

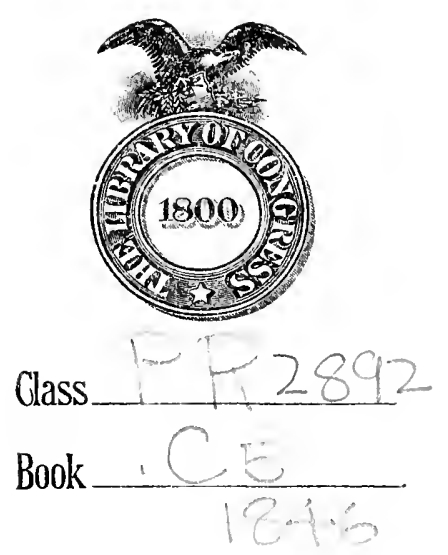




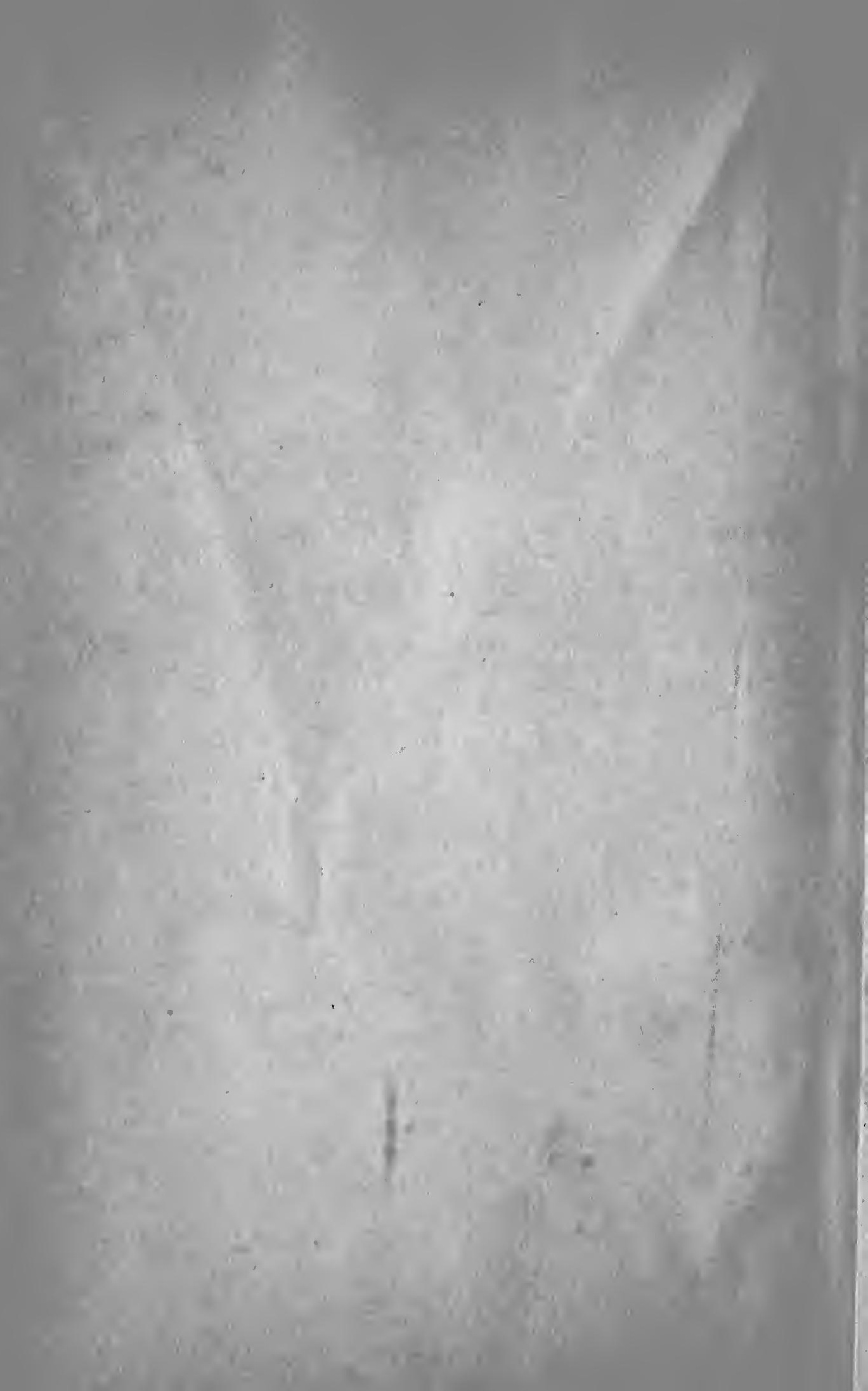



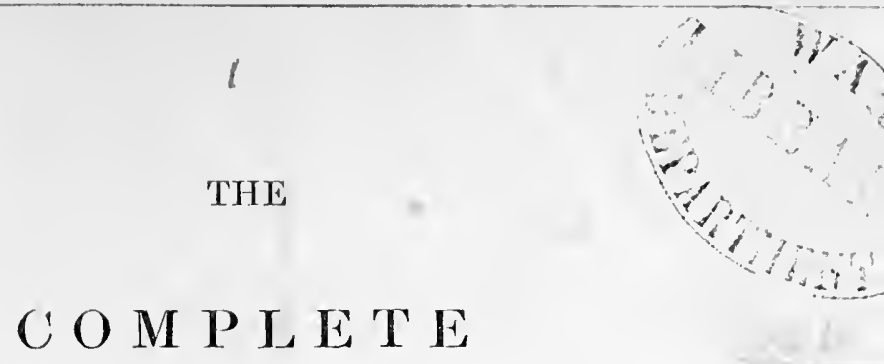

ONCORDANCE TO SHAKSPERE

IBEING

\section{A VERBAL INDEX}

To

ALL THE PASSAGES IN THE DRAMATIC WORKS OF THE POET.

135

MRS. COWDEN CLARKE.

ORDER GATE EACI THING TIEW.-SHAKSTPR:

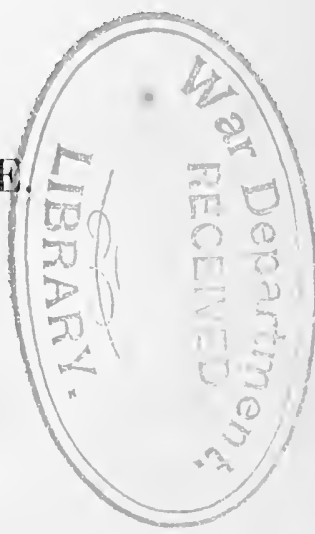

1

NEW YORK:

WILEY AND PUTNAM.

M.DCCC.XITI.

$1846 x$ 


$$
P R \frac{32}{0,24 b}
$$

LONDON :

I'rinterl by M. Mason, Ivy Lane, Paternoster Row. 
To

\section{DOUGLAS JBRTOLD}

The finst rit of the are,

$$
\text { 七拄的 }
$$

Concopance to

SHATEPLRE,

The enzat wit of everyt age,

is dedicated

by

IIARY COUDTIJ CIARIE,

$$
0=\text { a contain ace, }
$$

aind

Jo wit at pll! 


\section{PRE F A C E.}

SHarspepe, the most frequently quoted, because the most universal-minded Genius that ever lived, of all Authors best deserves a complete Concordance to his Works. To what subject may we not with felicity apply a motto from this greatest of Poets? The Divine, commending the efficacy and "twofold force of prayer-to be forestalled, ere we come to fall, or pardoned, being down;" the Astronomer, supporting his theory by allusions to "the moist star, upon whose influence Neptune's empire stands;" the Naturalist, striving to elucidate a fact respecting the habits of "the singing masons," or "heavy-gaited toads;" the Botanist, lecturing on the various properties of the "small flower within whose infant rind poison hath residence, and med'cine power," or on the growth of "summer grass, fastest by night, unseen, yet crescive in his faculty;" the Philosopher, speculating upon "the respect that makes calamity of so long life," "the dread of something after death, the undiscovered country, from whose bourn no traveller returns;" the Lover, telling his "whispering, tale in a fair lady's ear," and vowing the "winnowed purity" and "persistive constancy" of his "heart's dear love;" the Lawyer, discussing some "nice sharp quillet of the law;" the Musician, descanting on the "touches of sweet harmony;" the Painter, describing his art, that "pretty mocking of the life;" the Novelwriter, seeking an illustrative heading to a fresh chapter, "the baby figure of the giant mass to come at large;" the Orator, labouring an emphatic point in an appeal to the passions of assembled multitudes, "to stir men's blood;" the Soldier, endeavouring to vindicate his profession, by vaunting the "pomp and circumstance of glorious war;" or the Humanist, advocating "the quality of mercy," urging that, "to revenge is no valour, but to bear;" and maintaining that "the carth is wronged by man's oppression,"-may all equally adorn their page or emblazon their speech with gems from Shakspere's works.

To furnish a faithful guide to this rich mine of intellectual treasure, superadding what was defective in my predecessors, Twiss and Ayscough, has becn the ambition of a life; and it is hoped that the sixteen years' assiduous labour devoted to the work, during the twelve years' writing,* and the four more bestowed on collating with recent editions and correcting the press, may be found to have accomplished that ambition, and at length produced the great desidcratum-a completc Concordance to Shakspere.

* I cannot refuse myself the pleasure of mentioning that the day which witnessed the conclusion of this task, was the birth-day of the best of mothers-Miry Sabilla Novello; she who forms the glory and happiness of her children; she who first inspired me with a love for all that is good and betutilul, and who therefore may well be said to have originated my devotion to Shakspere. 
The appearance of a Preface with the concluding number of a periodically published work, though it possesses the advantage of affording an opportunity of commenting upon any thing that may have occurred in the course of printing; yet on the other hand, it involves a degree of disadvantage to the author, more especially in the present case, where there was judgment to be exercised in the admission or omission of certain words, and the right of that judgment to be vindicated and explained. The apparent inconsistency of omitting particular words when used in one sense, while they were retained in other instances, could only be accounted for by that discretionary power, which the author must claim in the Preface; where good and sufficient reason could be advanced why that power was not merely exercised for the sake of condensation, but likewise for perspicuity, and the especial benefit of the quoter. For instance, it might at first excite surprise to find so few examples of the word let; but by omitting it as an auxiliary verb (where the simple fact of its being universally joined to another verb of more importance, renders it less likely to suggest itself as a means of reference, as"let me remember thee what thou hast promised,") and retaining it merely in its more singular sense, the space gained is the enormous difference between 17 lines and 2184, or six printed pages of three columns each; while at the same time the few important instances in which the word occurs are thus rendered far more clearly apparent and easy of reference.

This was felt to be so valuable an arrangement, that, even cluring the course of printing, several thousand lines of MS. were cancelled-thus: well, omitted as an adverb, saves about 1550 lines, and leaves clearer the word as a noun, and where it indicates health; it is also retained where a pun is involved, as_-"would not this ill do well?"

It must be borne in mind that these omitted references are so frequent, as well as of such insignificance, that their retention would but have encumbered, and (so to say) hidden the other references to the same word of more distinct and unquestionable importance: as an example of this, "my lord," as a mere title, occurs in the play of Hamlet alone, no fewer than 192 times!

Come, look, marry, pray, truth, truly, and well, when used merely interjectionally, and still and well, as adverbs, are omitted. Like, as an adverb merely conveying a simile, as"he receives comfort like cold porridge," from the multiplicity of examples, and because such passages invariably contain words more striking-is omitted. Toward and towards are only retained when used peculiarly.

Titles: as master, mistress, lord, lady, king, count, don, signior, etc., when joined to proper names, are omitted; as are also lord and lady, when used merely as sir and madam. A few verbs and adverbs, as, to be, to have, to do; and beyond, some, never, etc., are omitted, on account of their insignificance, and frequent recurrence; also, oaths and exclamations of small importance, a fer peculiar ones only, such as aroint, avaunt, etc., being retained.

All nouns and verbs spelt alike are placed under one heading; and all plural nouns will be found under the same headings with their respective singulars. A few words, such as naught and nought, sallad and sallet, spelt indiscriminately in various editions, are placed under one heading. 
When a word recurs on the same subject, and with but little variation of context, in the course of a scene, or stands so closely repeated as inevitably to catch the eye in looking out the passage in the Play, as - "my poverty but not my will consents. I pay thy poverty, and not thy will;" the repetition is merely indicated by the word (rep.) in the Concordance.

The size of the Work has been selected with a vicw to its ranging with Mr. Charles Knight's popular and beautiful Pictorial Edition of Shakspere; but it will admit of being cut down so as to conform with the usual octavo volumes.

In Mr. Payne Collier's edition of Shakspere, he divides the second act of the Midsummer Night's Dream, into two scenes only; but as in most editions it is divided into three, I have adopted the latter mode of reference, merely pointing out the variation here, to avoid any confusion. I avail myself of the present opportunity to offer my thanks publicly to the abovenamed gentleman, for the lind and handsome manner in which he entrusted me with the then unpublished MS. of his concluding volume, when I took the liberty of applying to him, though unknown, for the purpose of collating his edition with the others, in order to complete my Concordance. Such a mark of confidence was a worthy type of the fraternity of feeling inspired by a close study of our immortal Poet; and it is one of the not least agreeable concomitants of my task, that it has been the means of my receiving generous testimonies of sympathy and encouragement from many of the cleverest men of our age, between whom and myself I could never have hoped for any assimilation, had it not been for the mutual existence of profound veneration and love for the genius of Shakspere.

Let me not likewise omit to acknowledge (after the fashion of dramatic authors in the preface to their Plays, towards the actors who embody their conceptions) my obligations to my "co-mates and brothers in "labour" "-the Printers; for though the public can juclge of the typographical beauty and accuracy of the pages of the Concordance which they have produced, no one but myself can appreciate their care, minute correctness, and patient assiduity.

Shakspere himself says: "Most poor matters point to rich ends,"-I trust my humble labour may tend to the "rich end" of furthering a universal study and appreciation of his genius; - in this hope, it only remains for me to take leave of those for whom $I$ have been working so many years (I cannot call them my readers), with an assurance that it has been a labour of love, and that it has been productive of many happy thoughts and aspirations to

Their faithful and obedient servant,
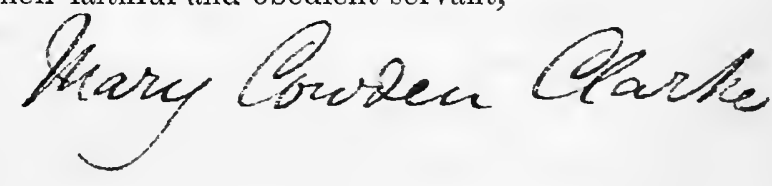


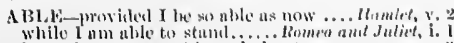

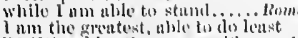

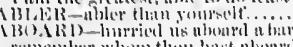
remember whome tlune fuast nbum

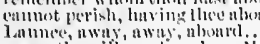

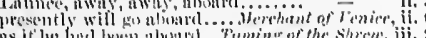

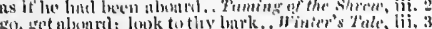

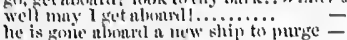

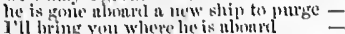
these lifind ones, nhourl him....

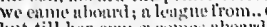

lut till her onenere cones shontri

that we were' satio and sommd ahroarl

theretore nwas, to get our stitti abourd

the wind thir, und we will nleserde

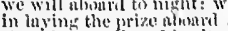

nhuarl my! salley, linvite join ait.

come, sir, will yin nbugred? I luse.

this nirlit; I must nhourd to-murrow

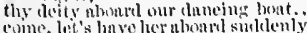

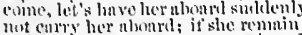

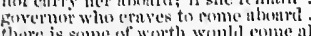

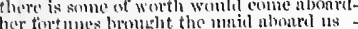

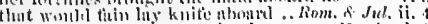

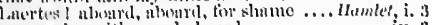

tempt thin with speet ahourd

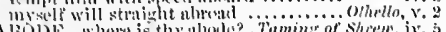

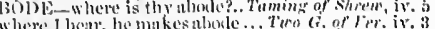

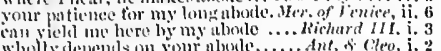

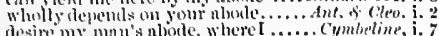

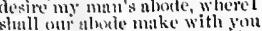

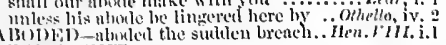

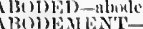

Tush man! nhotements .........3 Henry IT. iv. ABoMr.iBl.

firom their ahominuble nut benstisy tortelues.

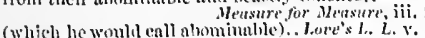

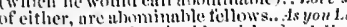

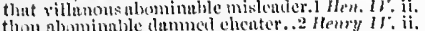

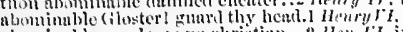

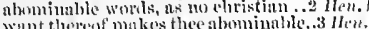

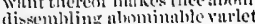

you vile abonitumble tents thus

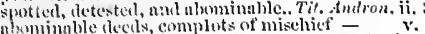
(Oabuminublis! sile make

ahmimalle villain! where is ie

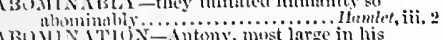

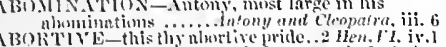

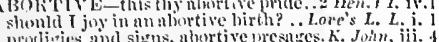

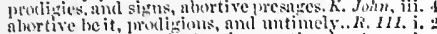

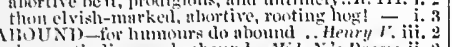

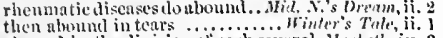

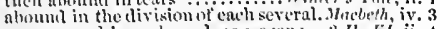

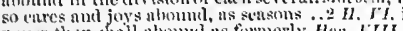

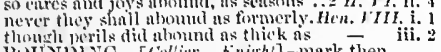

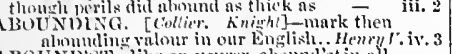

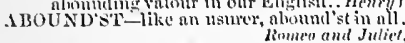

ABRAIIAM-consin Alraham Slender...M. Wires, i.

between master Alrralum nunt.

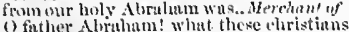

() father Alruhann! what these christians - i. s

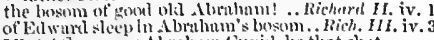

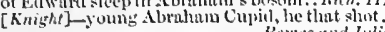

IBIREAST-then ffy nurenst; ns, in this- Ilenry

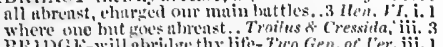

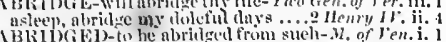

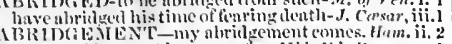

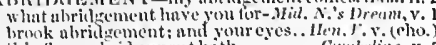

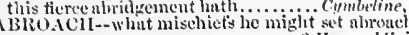

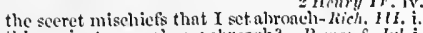

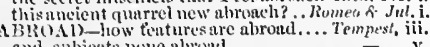

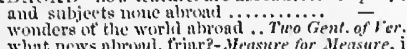

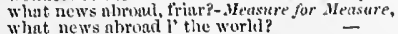
What news abroad ' the world?
there's villany alrond; this letter-Love's $\bar{L}$. Lost, i. duth noise abroad, Naviurre hatl

woult be with my hopes nhrond....Merchant of $y$ '

ventures he hath, squandered abroni

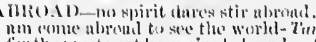

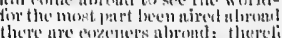

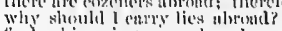

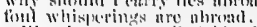

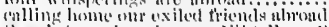

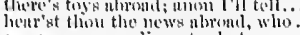

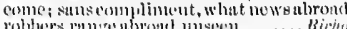

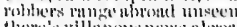

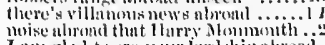

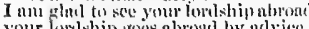

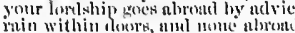

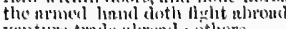

the 'Tulhot so muchl searest atronit-

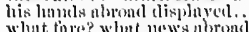

Hewny Iry.

What thre? whint new's shrobac.

mect thee, if thon stir atroud.

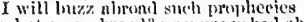

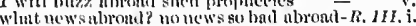

rear youn the news nimest?

monght with her soe cure abroud.. Hewry $1 . \overline{11}$.

is he retuly to come ahroats

whint new's nhimant?

what muke we aliroat

Tromitsand

Wnlk alnuml, nut reerente yourselves

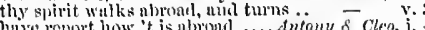

you shall know meen time of stirs alorion

there's nome nhroudl so wholesume. ... ('ymbetime, i. 3

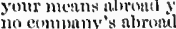

what emmlany aliserover you abroully.

fike silutits leaves, nhroad, and where's-

it you to stir nlrogal, go simed.

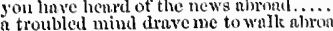

the Copulets abrond, and if we meet

the Capulets nitroed, and if we meet
at hume nbroal, [Kuight-time, work], alone,

that they so slirick abroad? "The yeoplo

and it is thought abroul, that 'twixt my... Othello $\mathrm{i}$.

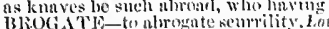

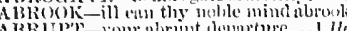

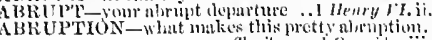

ABRUPTCX-lmoken from eompany abrult $1 y$, .

ABSENCE-nbence of thy frient,

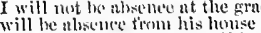

to take an ill : all vouttage of his absisene -

my indy will hang the for thy allwente. Foret

lori Angelo thakes it weil in his absenes

in the alsene ot the duke.... shon. . Yid

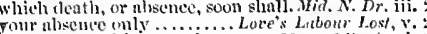

in bearing thus the unsence of your lort -

it you woild walk in ansecuce of the

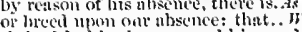

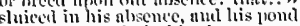

umberta'en to do in his alsene

my hest encleavours, in your absenee

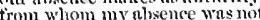

whose nbsenece is no less material... Com, of Es, i.

Whose nbsenec is no less material
his nusenee, sir, hay's blame upou.

the nelvantage of his nhenene to

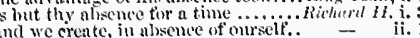

this alsenee of your tither's draws.. I Hewry $1 \mathrm{r}$. iv. 1

of his absenec make this use..........
with 0 wen (ileudower's absence thence

with subent chentes irs ausence well

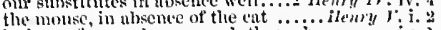

jenlous of your alssentee, scek throngh

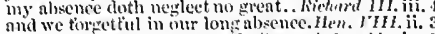

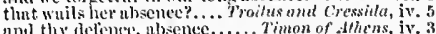

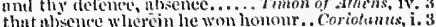

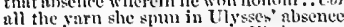

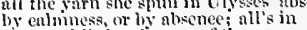

ever enol it the nisente of the......... - iv. 1 cannot endure iny ulsenece. Antony and Clopatra, $i .2$

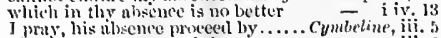

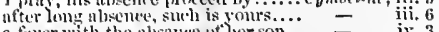

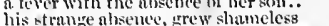

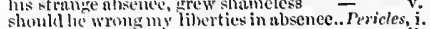
choipe $i^{\prime}$ the sllsence of your ling ......... strike sut this ly his dear abseme

AlsseNT-tir beint so long nlsent. Tirelifh Night, and mull please the allsent duke.. Meu. for M. iii. I would the dluke, that is absent, have
I never heard the absent duke much

I never hearl the nosent duke monch
how came it that the allsent duke

by a sured vow, and sliall be nibsent

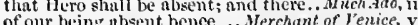

of our bus

mhen $I$ am absent, then lic with

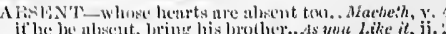

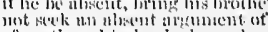

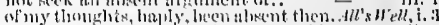

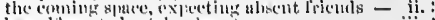

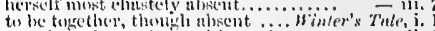

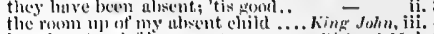
juy nhsernt, grited is present ........... Richert ir. i. 3

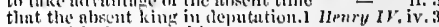
what with the absent ling ..

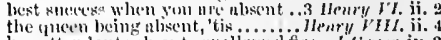

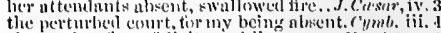

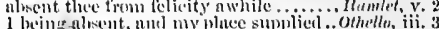

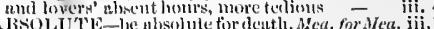
my nussolute pewer, nucl place.

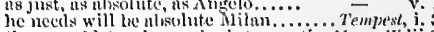

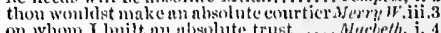
with ant nhosslute, sir, not I

I sqenk not us in absolnte fe................ - iv.

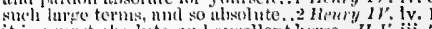

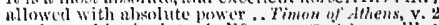

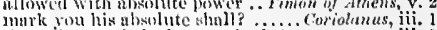

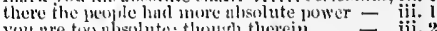

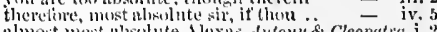

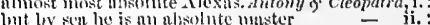

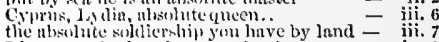

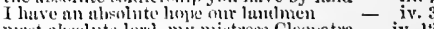

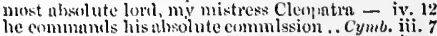

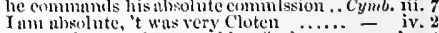

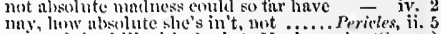

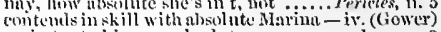
latijesty, to lim our alsolute fower ..... litar, v. 3 believe me, an nissolute fentlemm

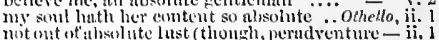
ABSOT,T'TELT-

hise shanl absolintely resolve your.. Mert for Mea, iv. 2

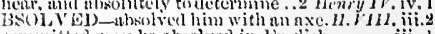

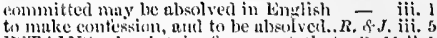

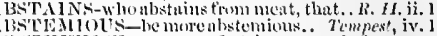

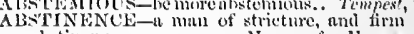

he doth with holy abistinence subulue

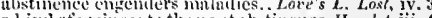
n kincl of casiness to the next abstinene. Hamlet, wii. 4

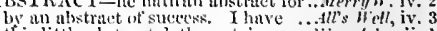

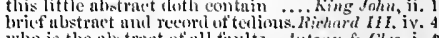

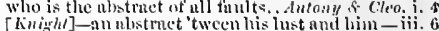

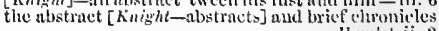
ABSURD-nature, to renson most alsurd. Ilumlet, i. 2

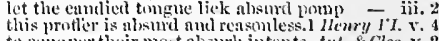

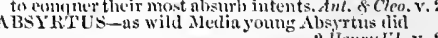
ABUNDANCE-with this abumlinec of surperfluon. Sim? Johu, ii.

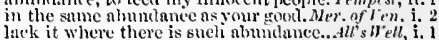

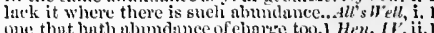
tor he hath the horn of nhundane c...2 Henry $1 F$. i. 2 that luve ulumulance, anul enjoy it unot

that you twe have not in aloundance?

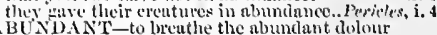
nucl thy ubumdant goolness shall Rexelcherel 11. i. 3

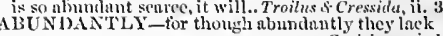
ABTSE-she does alume our enrs.......All's Well, v. 3

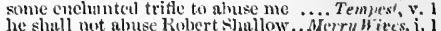
rejoice so mueh at the alruse of talstaif so did I almse myself, wy servant.. Twe fith $\lambda$. iij. 1 aul see how he goes about to abuse methis is a strunte aluse

to find out this almse, whenee 'tis

that nhuses our youm nlingnt....... is you $\bar{L}$ ike ih, iii.

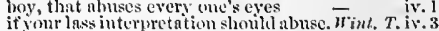
wickel drumns nlmse the eurtained ...Macieth, ii.

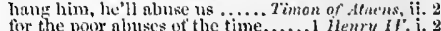
ert the poor almses of the thime....... turn their own nertection to sbise..... Heney IV ii. drive you then to contiess the wiltini nbuse

mobusc......................

well divest the almse of clistunec.. Henry $\bar{r}$. ii. (cho.) 
ABUSF-prarinn my aluse: I find..I Heury VI. ii. 3 clasti:elnent fior this alme own jermon answer thy nbine

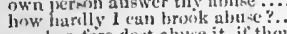
or wheretione dost abuse it, if thou the abuse dence to my nicce?

tnke no oflence at our abuse.

the abuse of greatness is, when ...

the times abuse, if these me motive Cleopratra to mot abuse my nirster with foul incest to abne your soll tliey do abme the king, that flat do mint alsuse me. Be com.

true hirth stumbling on abuie

nor prayers, shall purelsase out al

alsusts me to damn me: Tllowve

of ter some time, to abuse othelli,'s esio.

abuse him to the Moor, in the rank pur

my natire's plature to sisy into al,

opinion in my greatest abuse [C

least misusc

there be women do abuse their hushan

its honest, as you that thus alouse me

thiere was never man thus abused. T

never nian so notoriously abused

and by ny t'rienrls I an abused.i.

he harl your royal car abused... Hensure for $y e$

priuce anil Claurlio miglitily abused

of unother, therefore be abused.... Mid. N. prees

his bork-men; for here tis abused

nome could he so abused in sight.
this lorel, who hath almeel

are afiusel, and ly some putter

hat! abuzed and dishonoured me.. Corn. of Eirrors, y.

nuthe duxe hath been ton mueh aloned

numt be abused by silken, sly...... Michurd TII. i.

tin hear the city abusel.

thie nerple are abused; set on

the hath abised hour powigh authority abused....

you are alused beyond the mark.

$t_{1}$, be almsed by ome that looks on.

your are a great deal aluser in too..... cymbeting

you have abused me: his meanest girle

hut that my master is abotily

gool king! to be so mightily abused!. Tilus.tnd. ii. 3

as flatteries; when they are seen abused

to have her gentle they a resed.

being apt to have his ear ahused.......

the forod of thy abused father's wrath

the ford of thy abused freat breach in his abused nature?

I am mightily abused; I should even die

thy fuce is much ahused with tears.

pricess of mrdeath rankly abusen ....

ubused her delicate vouth with drugts.

she is al,used, stulen from me, and corrmited-

ont of self-trounty, be abused; look to

slie's gone; I am abused; and my reli

I swear 'tis better to be much abusent....

the Monr's abused by some most villannus - iv.
ABTSEP -an abuser of the world, a practiser- i. 2
A USSAG - the corruption of abusing time.

old ahusing of God's patiejce

Recheril int iii.

nll ahusing of God's patiemce ......Nerry Wres, i. 4

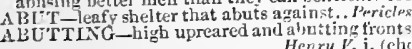
$\triangle B Y$-lest, to thy peril, thou aby it deur. AljY sil dark backwari and aly in of.

shot their fires with the abysm of hell.. ACADEME-our court shall lie a little academe.

the books, the academes from whence - iv. 3 the arts, the acarlemes that show

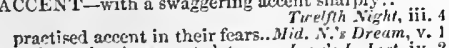
and so miss the accent; let me... L

action and accent, did they teach

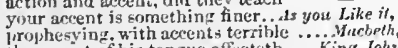

Vucbeth, ij. 3

that any accent breaking from thy

the heary accent of thy movin $t_{\text {ungue }} . \bar{\mu} . I L$

chort-winded accents of new broils.. I Henry it.

berame the accentsot the raliant.

enry $I V . \mathrm{i}$.

in second accent of his ordnance

cannot hrook the accent of reprorf. Rich. III

and with an accent tuned in. Troilus \& Cressida, i.

do unt take his rougher accents fior. Con inlanus, il

if but as well $I$ other aecents borrow... King lear

these new tuners of accents .. Nomen and Jatier,

with gorl arcent and grosd discretim ... Itaniet,
neither having the accent of elirixtiang

with like timorous geent, and dire vell... Othello, i.

CCEPT $\rightarrow$ hould reluse to arcept....

Denice,

your lorrlship to accept our ...

it you accept them, then theit wort

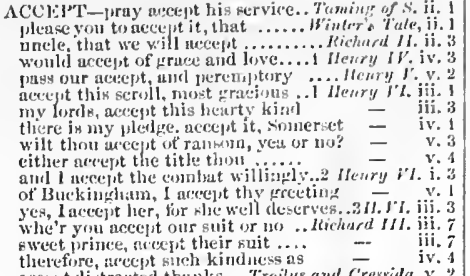

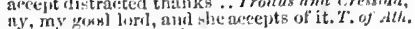

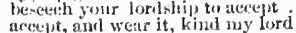

I shat\} acept them tairly …........

and cantort now accent, to grace

next, acecet my thanktulners......

which weleme ve'fl uecept.

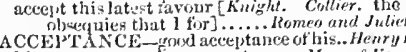

him to your frawious acceptince.. Ner. of yent. iv,

poured it to her acceptance; you

tell him our noble acceptance

thanks, but with acceptanee hountern

ACCEP'TED-not be accelted, nm in life... H.l

norught would be accented but the... Mer. of l' l'
I have done, in most accepted pain.. Troti.fy $C$.

ACCESS-noman bath aceess by day to he

shall you have access, where

he not denied acess ............. Tüelfh

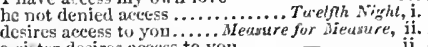

a sister desires aceess to you
we may yet again have access to .. Tuming of

nome shall have acecs nuto Bianca

and tree access and favour as the rest

from the access of gentle visitors ...

desires access to your high

stop uy the access and passaye to..... Wuctech i

we are denied aecess unto .......2 Heary $1 V$. jv. 1

if you cannot bar his access th....... Curiolenus, $\mathrm{y} .2$

may we not get aecess to her ........... Prericles, ii. 5

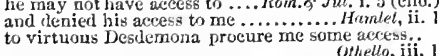

ACCESSARY_I am your acessary ..All's W'll, if. 1

Unth their rleatlos shult thou be accessary . R.III. i.
ACCESSIBLE-arcessible is none out Yiliford way

ACCIDENCE-some questions in his accidence.

ACCIDENT-hy accident most strange.. Tempert, i. a

of every these happened aceident

yet doth this accident and

$O$ ' $t$ is an acciclent that heaven...Mea. for Mets. iv. 3

this is an accident of hourly proci......
think no more of this night's accident

by what strange accident I chanced

by some aceiclent, should jass ... Wi
hut as the unthought on accident is
but firced by need, and accident..

nothing pleasetla but rare accidents.. Henry IV. i.

figns of future accident

prize oi accidest accident eut off'.. Richard III i.

prill accirlent, or purpose, bring you to 't $\bar{c}-\overline{\text { ins. }}$ iv.

are all but accidents unpurposed.. Ant.

plonld answer goleran aceidents.... Cy

the day was yours by accident....

by accident f hat a feigued letter...

friar John, was staid by accident.

that he, as ' $t$ were by accident, may here- Hitmlel, iij. 1

uneharge the practise, and call ji, acciden

are tongues, are liands, are accident

of moving accidents, by flrogl, and

the shot of accident, nor dart of cluance.

abode be lingered here hy sorne aceirent - iv.

ACCIDEA'AL give place to accidental evils.

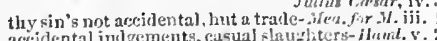

accidental julgements, ceusual lau

thus secidentally to encounter

which accidentally, or by the way...Lare's L. L.

ACCIT F-and what uccitis your most-2
we will accite, as I betore rememinerent

We will accite, as I betore rememireren a-

ACCLAMATION-in

safer kense will ne

IID-

a colderis better accommodater, than...2 II. I. mi.

accommudated by the plice, nore .. Cymbetine, $v$.

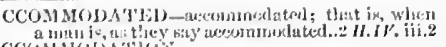

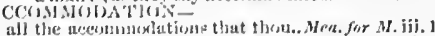

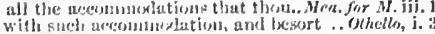

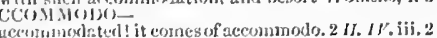

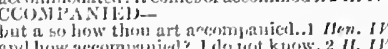

but a so how then art arempanict..1 Han. W

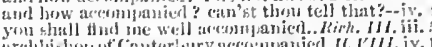

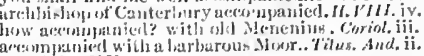

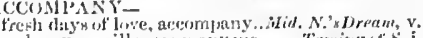

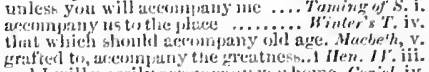

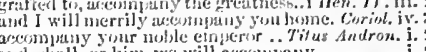

and gliall, ro him we will accouniany - i. 2

but ine accomnialying his declining. Timon of A.i.

auld happliness to lis accomplices !

CCunileIs li -

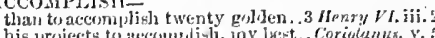

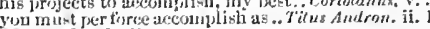

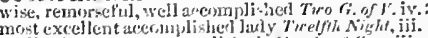

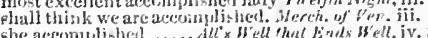

by them actomplishoig.. Foming of shrew, (Ind.)

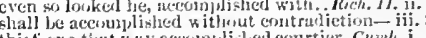

thief, or a that w uy arecompllishel courtier. Cymb. i.

at this instant is full accumplished.

the armmincrs, acemplishing .... Hen. $V$.iv. (cho.)

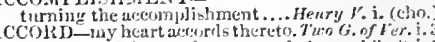

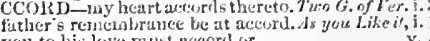

the ground of all ascord.. Traming of $s, \mathrm{ii}, 1$ (ganut

will attend on their atcords... Cornedy of Errors, ii.

to accord to fursish him with

and christinn-like awecord in their.....ect - v.

inclination accords not with the .3 Ilenry Pl. iii. 2

gentle and unforced uccurd of Llamlet sit..Ham. i.
CCORDANT-

ald if he tound her accordant, he... Nuch Arlo, j. 2

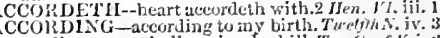
aceording to iny thallow simule skill. Two $\mathrm{i}$. if $\mathrm{V}$. $\mathrm{i}$. accerding tis his worth .......

accoriling to your ledy hip's impose.. - iv. 3

aceording to our meaning, ..........terry llices, i.

and kent according to commanis

I spoke it but according tw the trick
or tolier death; adcording to our law... Nid.X. Dr.

man by man, according to the scriy

and so every one acurding ty his cue - iii.

and aceordisg to ny description ...Verch of Ven. i.

for the young gentleman, (according to fates -

to for wwear; according as marriage. As you Lite
according to the lool b lowlt, pir....

our rcturned fortune, according to the - -1.

and weh, according to the fa

buy out his life. aceording to the Com. of Err.i.

remains to do, according to our orler $-\bar{J}_{n h n}$

acerne according to thy oath .... Richerd ll.

and formally according to our law...

shall we divide our right, according to - iii.

we will, according to your strength..2 2 Henryl $V$. v.

and merit, accurding to the weight ...Menry ${ }^{2}$ ii.

acerording to their firm yroproed natures

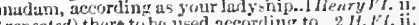

(repeated) there the we used accortling

lie mateherl accorrling to his state 3 ilm

not accorling to the prayer of the pern, le. Corm.
and bisthim, accorling as he pleaved. Jul. Corsar

weerrling to the which thon shait diseour se

must receive linin aceoriling to the laonour. rym. ii

I love your majenty aceording to my. king Latd, i.

acesrling to the phrate, or the aldition. Itzmel, it.

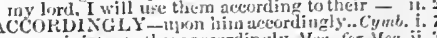

may minister tos them aceordingly. Weat for Weot

and heardede, and ureordingly valiant... Atl's Well,

which trut accorilinely, kind citizens. . K. J J het, is.

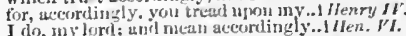

fortuic lim aceur line] y! Amen... Anlary \& Cleo. i

behold and bo proceed wecrorlingly

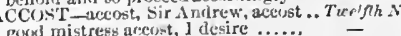

gexd mistress areont, 1 desire

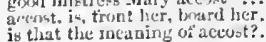


ACCOSTw1_should then have necostel. Tarl. N; iii.2

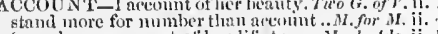

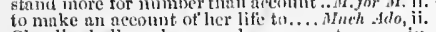
clawlio shall reneler me a drar accome -- iv. we may do it still without a+eont. . Lore's L. L. Y.

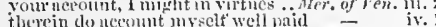

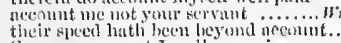

tixch nuy aceount I we
such I necount thy lose.

sinch I acount tlyy love.

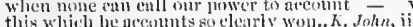
upou remander of a dear aceom ..... hichard coll him to so striet acemiut ....... H Hem by which necomet, our business valued

and in nevount nothing so strong ....

and sumuch the acoumt of chane..2 Ifenry

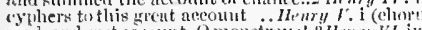
read, and ast account, O monsfrous!.2 Ilemely l. iy. by this acemint, then, Margaref.

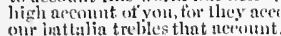

whose captain a aecount myrell"

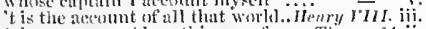
fakes no aecount low things go tromn..

I loright in my accounts laisl ....

that I areomit them blcssin:

Fon achunt a vice in lim .......... Coriolunus, i. I

tis a condition they atcount gentle

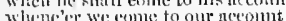

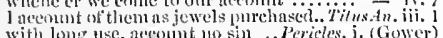

with lomg the, aceount 1 to sin

who ret is no dearer in my accumit.....ing Les, i. 1

O thear aecount ! my life is my . . Romeo o Jut. i. s

hit sent to my acentent with nll my .... Hamale, i. .

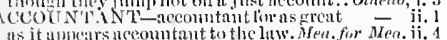

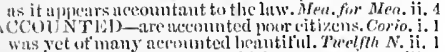

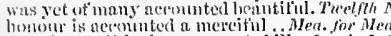

showting well is then accounted iil.. Lone's $L$.

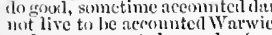

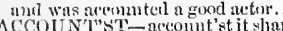

ACCOUN'L"T- accombtst it shame... Tum. of sh. iv. 3

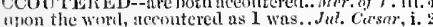

anon the Whil, acemt

all the actontrencent, complement. Mrroy $W$

print-de-vee in yourmentemencits.

extcrior tirm, ontwarl aerutroncut ACCRU

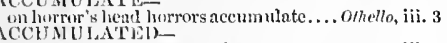

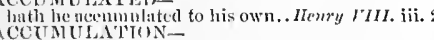
deculisw?

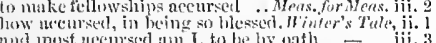
and inest uecersed am $I$, to be by oath - iii. 3 stand, nye, mecursed in the encentar

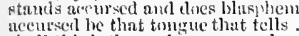

phall think themsedves aceursed.

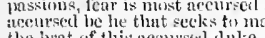

nom till I root out their arenrsed line $-\overline{\text { ine }}$ i.

$O$ my acciatsed weml, the beil of clesth

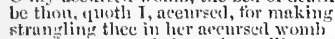

the minst mentrsed thou, thit stity

blessed, to be most aevured

iu lime (uecursed the mansion where) .. Cym
my aceursed sons, neenrsed, if the... Tritus .I

why acetrsed soms, neemrsed, if the....

ravenous tiger; this aceursed devil.

ravenous tiger ; this accursed devil .

aecursed time! nufortunate vild man... Rom. \& $\mathrm{J}$.

accursed, unhappy, wretehel, hatctil d

(O) thonghts of men mentst! past...

in second lussmant let me be necurst

ACCUSATION- rurrent fir an acensution.1 H.I I .

will sn youracensation overweigh?... Ned. for

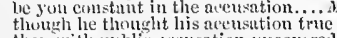

then witlo public nceusation uncovered

nine and my muster's false aecusation

which eontralicts iny acensition: and

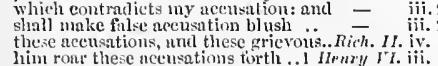
an honest man tor a villain's acecusation...2 H. VI. i. pone not by the way ot acensation

the accusations which they have ofte

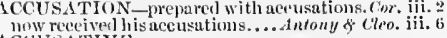
Accis. TIVE-

what is your aceusative case? ..... Merry Wives, iv. ACCISATIVO-Aceusutivin

accusli-lint the that aceuse hin $\quad-$ iv 1

the head of Alyelo aecuse lim ...Ate $a$. for $A$

arenes him of torviention, in self-same

which here you eome to aceuse.
to aceuse this wortly man......

they linow that do necuse ne

in the prince's name acen

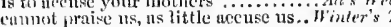

in this which you acense her.

ny cold words here aecuse my zenl.. Richerd II. i.

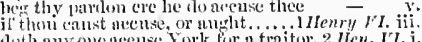

dow hany ouse arense York for a traitor.

whos e'ill acense me? wherein am 1 .

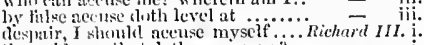

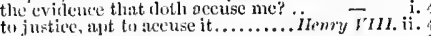
to justire, ahif fo aceuse it...

dite newse you boldty, more thin...

cet them necuse me by invention .. Coriolsues, iii.

him I aceuse, the city ports by .....

whom does he aceuse? Ciesar.. $\quad-\quad$ iii.

the lack of chatrity, (to aecuse myself) .. Cymbr. ii. 3

how dare you, ghosts, aceuse the thunderer

aceuse senine imocent, nud thrsweer. . Titus Anal. v.

will quieken, and acetse thee............ Letrer, iii.

so vul yarly and personally neeused. Mea. for Mta. might have beon aeeused in forniention

most wronertuly aecuse your substitute
what man is he you are necused of?.. M

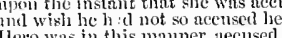

Ilero was in this uramer neensed....
my laty I Iero lias been finlsely acensed

ind chutio who accused her

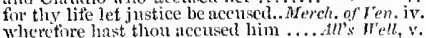
Ween publicly accused, so shall slie. IFinler's Tule, i. 3 Polixenes (with whon I am aceused) I do

the acenser ant the acensed, freely ..Richard II. 1. I

here is a man aceused of treason....2
I am tid] ${ }^{2}$ ety accused by the villain
who being accused a crafty murderer

if she be aceused on true report .... Richard $I I I$ i

than some, that have aceuserl them

peralyenture thout wert aceused by. Timon of

malicious, or be accused of tolly
nquinst the belly; thus aceused it

the wateh that are their aceuacrs

the wateh that are their aceurers... Nuch sdo, iv, my aceuser, an my the accused, freely ... Riphord $K$. slankers of lier fillse aceurers.

bring together yourself and your a.eus

my acensers be what they will .....
urit rash like his aceusers, and this

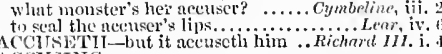

my most royal liege, nectsing it ...2 Henry II: iv. 4

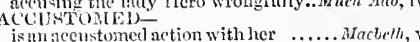

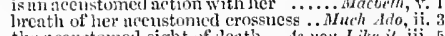

the neeustmmed sight of denth ...As you Like it, ini. 5
of your nccustoncd diligence to me.. I Hen. II. v.

soon reeover his accustomed health. Richrard III. i. 3

1 holl an olu accustomed tenst ... Romeo of Jul. i.
CE- lout an ace tor him: for he is but one. Less

the most colde the that ever turued up ace.. Cymb. ii.

ACliE-fill nll thy bones with aches .... Tempest, i.
nofurther, sir; nyy old lones ache $\ldots . .$.

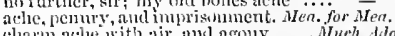

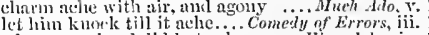

when your licad clid hut ache ....... King Johm,

never lat the ache in his shomlders. 2 Hen. II

aud such an ache in my bones. Troilus \& Cress.

my wonnds uche at you...............
their aclics, losecs, their pangs of love

their achics, losecs, their langs of love

aurl my soul uches, to know......... Coriolonus, ii

mine athe tir think on't............. Hetemlet,

for let our finger nehe, and it ind hes .. Ohello, ifi.

ACIILRON-

fir a s black as Acheron ...Mid. Nighi's Dream, it

CIIIEVE-some achicve greatuess. Twelfh $N$.

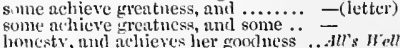

lromesty, und achieves her goolne'. . Alr's Hell,

beml thourlits and wits to achieve her -
AfIIfEVE-this feat, achicve the elcler.. T'am.of S.i. 2 hith them achicve me, and then sell ..Henry $Y$. iv. 3 amil to achieve the silver livery of .. 2 Henry $F I$. v. 2

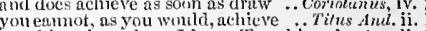
to achicve her whom I love. 'To achieve herl - ii. I experience is by industry achieved. Two Gen of $\mathrm{V} . \mathrm{i} .3$ your fortume achicyed lee mistress...Ner. of Fon. iil. 2 nucertainn life achieved by others..... King , John, iv. nll peasul, that lanst all achieverl! $\ldots . .$. - iv. they shall have mo sooner achieved... Henry IV i. 2 heaps of strange nehieved gold ...2. Ilenry $I F$, iv. 4 best garrlen he achieved (chorus) ...... Henry r. v. 2 which he achieved by the minute.... Ant. \& Cleo. Ai. I how achicvel you these enduwments ... P'cricles, v. 1 ACIIIEVEM MENT-

the soil of the achievement goes ..2 Henry $I F$. iv. 4 for achievement, ofter us his ransom.. Henry $V$. $3 i$. 5 nchievements, plots, orders, preventions - i. tikes from our achievements, though .. Itromlel, i. 4 CIIIEVER whin the achicer brings home finll.. Much Ado, i. 1 hide thy head Achilles; licre.. Love's Lorbour Lost, v. 2
the great Aclitles, whin oninion.. Troil. \& Cres, i. 3 Achilles; a better man thau Trotlus.

the large $A$ chijies, on his pressed bed

yet good Achilles still eries $\ldots$ i......

Achilles' horse makes many Tlietis' sons

strouger tlam Achilles' arm

blown ni in rank Achilles.

relates in purpose only to Achilies..

but that Achilles, were his brain...

those honours oft if not Achilles? .

that ever llector and Achilles meet

what glory our Achilies shares

plucks down A ehilles' plumes.....

this lort, Achilles, $A$ jax, who wears

yes, good sooth; to, Achilles! to, Ajax
when Achilles' bratls bids me, shall I

then there's $A$ chilles, a rare enginecr

what, hol my lorl Achilles!

Where's Aehilles? What, art thoun ilevout?

commands Achilles; Achithes is my lord

Achilles is a fon; Thersites is a ....

vliere is Achilles? Within his tent

Achilles liath invelgled his fool

tlut has his argument; Achilles
no Achilles with lim. The elephant

techilles bicls ine say, he is much ...

kingdomed Achilles in commotion rages

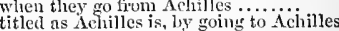

say in thunder, Aclitles go to lim.

must prepare to fight withont Aehill

the is not emulouts, achilles keeps thicket

lit Acliilles sleep; light bonts

Achilles stmints the entrance $\ldots$...it

these fellows? know they not Achilles?
thicix sniles before them to Achilles

tis known, Achilles, tbat you are

liefter yould it fit Achilles mucl

to this efiect, Achilles, have I mored you

f come from the worthy Achilles.
thongli the ureat bulk Achilles be

Arliniles bids you welcome..........

$\Lambda$ chilkes, sir, what is your name? If not

but for Achilles, niy own seareling eyes

and you, Aclities, let these threats none

art thought to be $A$ (hilles' male varlet

prouler than the eur Aehilles .....

great Aelitles is arining, weeping

Achilles hath the mighty Ilector slain

Achilles! Achilles!l Ieetor's slain!

to pray Achilles sce us at our tent.
clin

the pritice for my aching bones?. Rom. \&. $\bar{J}$ m. ii. 5 ACIITOPIIEI, a whoreson Achitophel l.2 H. IV.i.2 acknowledge then the king.

King John, ii. 1 this thing of darkness I acknowledge.. Tenpest, y. I if the encoltuter acknowlerlye itselt.

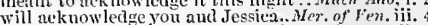
spirit, that will nut acknowledge it... Ail's Well, ii. lue, time claims, he does acknowledge of tanlt, I must not at all ackuowicdye - iii. thou sham'st to acknowledge me... Com. of Err. . 1

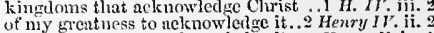
of my grentmess to acknowledge it..2 Henry $\mathrm{H}$.it. five best senses acknowledge thee..... Timon of $\mathrm{A}$. $\mathrm{i}$. that do acknowledge Cresar........... in \& \& Cleo. iii. il nature is asliamed almost to acknowledge . Lear i. by my soul, ['ll ne'er acknow letgre.. lom.\&.Jul. jii.s 


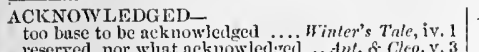

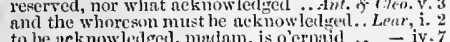
ACKNOWLEDGiLi HNT-

with this acknowledgement, that God.. Hen.V. iv. 8

[Collier. Knight]-he not acknown on't.. Ohella, iii. 3 A-COLD-(repeated) array; 'Tom's n-cold.. Lear, iii.

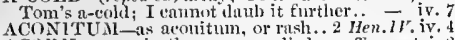
ACOR N-wnerein the aeorn cradler .... Tempest, $i$. ereep into acorn cups,

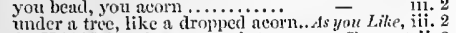
ACQUAINT-nisery aeciutints a man.. Tempest, ii. 2 nequaint her with the danger of ....Mea. for Mea. $\mathrm{i}$. 3 I will aequint my elaughter vithal... Much Ado i. . they disl entreat me to accluaint her of it thnd I eame to nequaint you with.... As you Like it, i. I speerlily to uequalint you withal .......A Al's Well, i. 3 to my house, aequaint my mother with may $I$ be bold to acquaint his graec

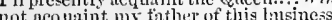

aequnint the king withal, I would do't

accuaint you with the pert

. Wing John, v. 6 I will aequint ho that I have ..2 Henry I Y. iv. but I'll aequaint our dutcons.

acquaint the princess with the $\ldots . . .7$ ive - indro. find means, and aequaint you withnl ....... Lear, i. aequaint my daughter no surther.... Rn $\overline{\text { a } J u l . ~ i i i . ~} 4$ eonsent we shall a c 1 ?

your cliest acquaintance cannot be .... Tempes', v .

.

that al together's aequaint:mee with.

I lesire more acquamtan

holl acquain tauce with the waves... Twelth $\mathrm{N} i$.

mistress 1 eecost, 1 desire better aequaintanec

I will wash off gross acquaintance...

to face ine out of his acinaintance ........

heracquaintance grew with this lewd. Much

shall desire you of more aequaintazee

I desire you more acquaintance, good

my best-esteemed aequain tance ......Merch. of V. ii.

have acquaintance with mine own..As yor
that on so little acquaintance you shuvil

small acquaintance, my sudden wooing

a desire to hold my ach siantance

is $\overline{\text { Well, }}$,

trlk logic with acquaintance that.. Taming of $\mathrm{S}$. i. I scape the true acquaintance of mine car. K. John, v. 6 agrinst acquaintance, kinlred ...... Hen

many of mine old acquaintance are dead.2 H. $\bar{l} V$. iii. let our old acquaintance be renewed.

must, perforee, be their acquaintance...Hen. $\bar{F} M l ., \mathrm{i}$.

grow from the king's acquaintance by this

time, acquaintance, custom, and.. Troil. \& Cres. iii. 3 how ereeps aecuaintance? Ilis father... Cymbeline, faith, my aequaiutance lies little

not grieve lending me this acquaintanee .. Lear, iv. whint sorrow craves acquaintince... Romeo o J J i1. [Collier. Knight.] sudden respect and acquaintance having been acquainted with.. Two Gen. of Ver. iv. 4 and be acquinted with you ........Merry Wives, ii. 2 like one that I am not aequainted withal to make myself ocquainted with you. you would lesires to be aequainted withal - iii. 1 I have acquainted you with the dear.... $\overline{\text { I }}-\overline{\text { iv. }} 6$ I pray you, be acquainted with this naid I am as wcll acquainted here

I have acquainted you withal..... Love's L. I.sst, v. 3 have acquainted me with their ....Mer. of l'en. i. 2 I acquainted him with the eause.... - (letter) iv. I have you not been aequainted $\ldots$ As you Like it, iii. 2 art not acquainted with him ..........Al's ${ }^{\prime}{ }^{\circ} e l l$, i nothing aequainted with these bu

made nue acquainted with a weighty

what need she be acquainted?.. Comedy of Errors, iii. belike, his wife, acquainted with his

face of right, acquainted me with interest...John, y. 2

I am well aequainted with your ..2 Henry $1 \boldsymbol{V}$. ii. I
well, I will be acquainted with him..

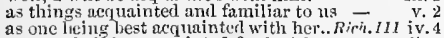
Queen shali be aerinainted forthwith...II. VIII. i. 2

we are too well aequainted with.. Troilus \& $\mathrm{Cr}$. ii. 3 doors that were necr acquainted... Timon of $A$, iii. 3 my lord, make me acquitinted with.. Jul. Cersar, ii. 1 I pray you, be lyetter arquainted .... Cymbeline, i. 5 my father shall be maleacquainted.

I will make them aequainterl with ..... Pericles, iv. 6 think he had been aequainted with her.. Othrllh, iii. 3
ACQUIR E-'t is sweet at first to acquire..II. VIII. ii. 3 by our deed acquire too high .......Ant, \& Cleo. iii. 1

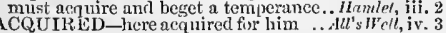
sc stale his palm, nobly wiquired Troit. of Cres. ii. 3

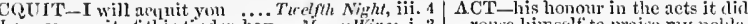

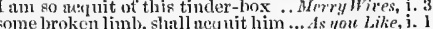
camnot cutreat you to acquit me..2 Heny $1 \mathrm{H}$. (opil. iod acquit them of their practices

by cirrumstance, but to acenit mysel .

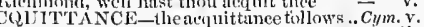
youl can prod nce aequittunces, for.. Lore's L. L. ii. enforement shall ac'quittanee me.... Rich. III. iii. 7 mult your conseienee my aequit tanee seal.
of sudden respect and acquitanee [Collie CQUTTTED-this dity acquitted........

no more tlan I am well acruitterl of

CRE-for nn acre of barren grount

Tempest, $\mathrm{i}$.

between the aeres of the rye... As you

ere with spm we beat an aere $\ldots .$. Winter's Tale,
over whose acres walked those blessed.. I Hen. IV

search every acre in the high grown ....... Lear, iv.

let them throw millions of acres ou us.. Hamle
ACROSS-has broke my head aeross... Tirelfth

this last was broke across.............. Mnech Aido, $\mathrm{v}$.

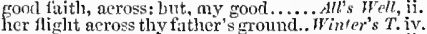

or I will break thy pate across.. Com. of Errors, ii. 1

C $\mathrm{T}$-restined to perform an act

deliente to act her earthly and...

Was i furtherer in the act...........

we do not act, that often jest...

beeme thee well to act niy woes... Tuelath $\bar{N}_{i g h t}$ iv.

he finisled, indeed, his mortal net

lives not to act another.... Nersure for. Neasn
puts the drowsy and nemlected act freshly -

puts the drowsy and netsected act fick out an aet..........
condemned upon the act of fortiention

his aet did not o'ertake his......

to the last hour of act.

thyself shalt see the act...

his acts being seren ages ........... As you tith it

and wore us ont of act...A $u_{\text {s s Well that Ends } W e l t, \mathrm{i} .2}$

from our acts we them dlerive
my reputation now in ans staining act

lavitul meaning in a lawful act

for, in an act of this importance.. Frinter

or in aet, or will, that way

the dignity of this a tow worth

to the swelling act of the imperia

in thine own act and yalour

guide his valour to act in safety

to crown my thoughts with acts $\ldots$........

the better act of purposes mistogk

my death were adjunct

this act is an aneient $\ldots$ ru...........

to this most cruel act, do but despe.

if $I$ in act, consent, or sin of thought..

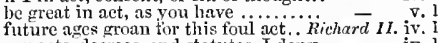
my acts, decrees, and statutes, I deny - iv. I still unfold the acts commenced..2 Henry $W$. (induc.) move to do brave aets $\ldots \ldots \ldots$......

and sets it in act and use $\ldots . . .$. .

teacli the act of order to a peopled kingdom.

sjeak freely of our acts .............

for his acts so muel applauded ....1 Henry $\overline{V I} .1 \mathrm{ii} .2$ thy acts in Ireland, in bringing .....2 Herry $V ., . .1$

would unfold his tather's aets......

the same to act eontrolling laws

before I would have granted to that act . $3 \bar{I} . V I . j$. I

until that at of parliament
by new act of parliament

of death hath Roseius now to aet?.

to make an act of tragic violenee

is cried up for our best act

the part my father meant to act

does pay the act of it

he acts thy act or two $\ldots \ldots \ldots \ldots \ldots . .$. (epil.)

and esteem no act but that of.

being mutual act of all our
the justness of each act suel

and the act a slave to limit.

of lions, and the set of harcs.

is ever the duller for his act ... Timon of thems ii.

any wholesome act established...... Coriolans,

brought to bodily net ere liome

when he might act the womin

the book of his good aets

their servants to an act of rage

and this our present ait, you sce.
commits some loving net upon

its some loving net uyon l.... -

never dirl urge me in his act ..........
our enditions so differing in their acts

further this act of griee
hath so betrayed thine act.

nay make ton great an act

to this great fairy I commend thy acts

thy limbs, actions, and spirit

in this action of swift speed ....... rouse limsclf to praise ny nohle
to see performed the cheaded act

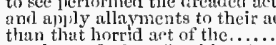

art thom a feodary tor this aet

in posture that acts my words

them, Pisanio, must act tor me

it is no ate of of tommon passagre.......

aetsuf'black night, abouninable deens.

fiew love to hear the sins the

can make his will his act $\ldots$..........

of a queazy question, which I m
this act porsuarles me, that thi

and did the act of darkness with

to quit this horrid act

opposerl a.gainst the act

smile the heavens upon this holy aict...

thy wild acts denote the unreasonable
my dismal scene I needs must act alone

almost to jelly with the act ot tear ...... Hum
in his particular [ $\mathrm{K}$ night-peculiar sect and

foree $]$ act and piace...........................

how socver thou [nursu'st this ant......

when thou sce'st that act $a$-font .......

an act, thant blurs the grace and blish.

to what it would, acts little of his will

it argues an act; and an act hath

but nutes or andience to this act

earnal, bloorly, and unnatwral acts ......
the native act and figure of my heart

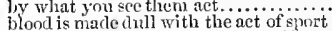

though I am bound to every aet

With a little net upon the blood..........

'tis a strange truth, O monstrous act! ....

the act of ghame a thousand times commi

this hervy act with heavy heart relate...

tor a wilful and secure Acteon ..... Aerry - Fives, ii.

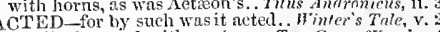

I so lively acted with my tears.. Two Gen. of 't'er. iv. 4
which must be actet, ere they may be.. Mrebeth, iii. 4

thall this our lofty scene be acted over... . Cresnr, iii.

true love acted, aimple modesty .... Rom. \& Jul. iii.

but it was never acted; or, if it was ..... Hrmlet, ii.
ACTING-acting this in an obedient... Tre?th $N$.

or that the resolute acting of your. Mea. for.Men. ii.

several crime, acting it many ways . M M incleth,

it is a part that I shall blush in aeting ... Corinl. ii. 2

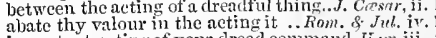

important acting of your dread command. Fitm.iii,

what dangerous action stond .. Tuo Gen. of ler. v.

I can construe the action of he:

I'll have an action of battery

more reasons tor this action

in hand, and hope of action....

have your action of slander too

in action all of precept, he did show

his actions show much like to mulness - iv.

you went onward on this ended aetion

and we will do it in action . Mid. N,'s $D$

do not fret yourself tao much in the action $-\overline{\text { iv. }}$
and long-during aetion, tires the .. Love's $L . L$. iv. 3

action, and aceent, did they teach...

how many actions most ridiculous.. As you Like, ii.

and waspish action she did use

in what particular action to try him....il's $w^{\bar{r} e l l}$, iii. 6

in this aetion contrives against his own. . (inalue.) i

gitit and action of a gentlewoman - (indur.)

'll bring mine action on the yroudect - , Tale, ii.

behold our human actions, (as they do)

pour actions are my dreans

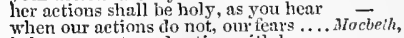

it is an aceustomed aetion with her.... - -

strong reasons make strong aetinns

makes ferrful action, with wrinkled

and on our actions set the name of

to underprop this action? is't not I -

and the general eourse ot the ation.. I Hen. IV. ii.
skimmed milk, with so honourable an action

wert not with me in this action...

vilely sinee this last action? $\ldots \ldots \ldots . .2 ~$
could restrain the stiff-borne action. .2

aid divide the action of their bodies.

for your quiet w'er-posting that action

incleed the instant action (a canse on font) -

laster fang, have you citcreil the action -

thy fare. thin thaw thy astion; emene
whun the inat of action is called on 
ACTION_are insinewed to this action.2Hen.IV, iv. 1 | ACTOR-

to the king, taste ot this action....

the manner how this aetion hath..

that action, hence lorne out $\ldots$......
(which is four terms, or two actions)

ill out of work, and cold tor action

so may a thousand actions.............

that this fitir action miny on for

I cannot give due aetion to my words.

that in your otitward action shows ... Rich. MI.

which aution's self was tongue to ...

must not stint our necessury actions

if my aetions were tried hy every tongne

no other spenker of iny living actions..

sith every action that lhath gone
with ridiculous and awkward aetion

smiles upon the forelsend ot this aetion

and whole earriage of this action rode

bring aetion hither, this enumot.

an effeminate $m a n$ in time of action

they are in action. Now Ajax

lie goes mon this present aetion .....
one voluptnously surteit ont of action

that best can aid your action

else your actions would yrow
he hath in this action outdone

in human action and eapacity

and lis actions in their hearts, that for

in such business action is e

that shall set them in present action........

Tou are darkened in this action, sir...

my partner in this action, you.

and labour of onr' great aet

the charges of the action .............
than thysclf, or me, in personal actio

action, nor utterance, nor the power

let not a leaner action rend us... Antony \& $C$ leo

partake in the glory of the action.

I never suw an action of snch shame

think'st his very aetion spenks in

than in my every action, to be

if' you will make' $t$ an action ........

hine

though his actions were not visible

the common men are now in action 'g

the action of my life is like it

in thy dumb action yill $I$ be a..... Titus And

wantiug a hand to give it action

partakes leer private actions to

nor never did my actions yet $\dddot{2}$ m........

action may conveniently the rest -

and witl continual action

what is done in aetion, more........

vice sometimes by action dignified...Kom

they are actions that a man might play...

in action, how like an angel

and pions aution, we dosugar o'er the devil

suit the action to the word, the word to...............

there the action lies in his true nature..

the nse of actions fair and good he likewise

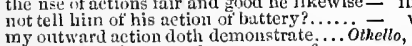

for if such actions may have passage free..

used their dcurest action in the tented field

soune aetion that may offend the isle

it were an honcst action, to say so .......

CTIOY-TAKI

a lily-livered action-taking knave... King Lear, ii

ACTIUII-the head of Actium beat..Ant. \& Clca. iii.

the most active fellow in Europe ...2Henry I 1
the

the most active fellow in Lurope ...2enry I V. iv. 3

libernl, valinnt, active, wealthy ....2 Henry ${ }^{\prime} I$. iv.

my speculutive aud netive instruments. [Knight

CTI

ICTISL-VALIANT-

more active-valiant, or more $\ldots . . . .1$ Henry $I V$. v. 1
C'T'CVITY-doing is activity; and he... Hen. $V$. iai. 7

the call your activity in question ... Troil. \& Cr. iii.

that your activity niay defent.. Timon of Ath

CTok-there our actors, as I foretold... Tempest, iv. I
the tault, but not the antor of it...Mea. for Mea. ii.

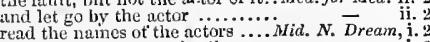

eull forth your aetors by the .....
an aetor, too, perhajs, if I see eause

and most dear actors, eat no....

the actors are at hand ................ - vo 1

I'll prove un busy actor in their play...ts you Like

a heareniy effect in an earthly actor.. All's Well, ii. 3

iu jest by counterfeiting actors

Henry ll. $\mathrm{ii}$.

author's pen, or actor's voice .... Trail. \& Cres. (pro.

hear it as our Roman actors do

Julius Casar, all aetor in Rome-The aotors are come... Humlel, ij. 2

each actor on his ass-The best actors in - iil. CTIJAL - other actual performances .... Mastheth, v.

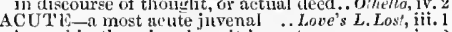

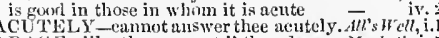
$D \wedge G E-l i k e$ the guor eat $i^{\prime}$ the adage . Murberh, i. unless the adage must he verificd ..3 Henry Vl. i. elapned on the slons are iny brethrent...Mach and called Adam

enrlowed with all that Alam liad leit.

a munth ald, when Arlam was no.. Love's $L$.

as I remember wam, it was ... As you Like

this is it, Arlam, that grieves me....
go anart, Adkm, and thou shalt hear

but the penalty of 'Adam, the seasons'

Why wow, Adam! no greater heart.

nome tue, but Adam, Raliph...Thming of Shrem, iv. 1

old Adam new appareled? ....... Com. of Errors, iv. 3

thou, old Adam's likents, set to ...Richard II.
since the old days of food-nan Adan...1 Hen. I

in the state of innocincy, Adam tell

and Adam was a gardener ........ Hemry H H

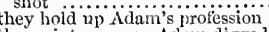

the seripture says, Adam digged...

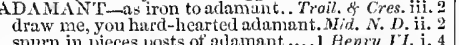

spurn in pieces posts of adamant.... I Henry II. i. 4
ADD-thcy that add moreover .... Thelfth Night, i. 3
she adds, moreover, that you should

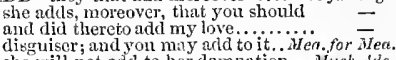

disguiser; and yoll mily and to it... Heat ador to her damnation. Huch Ado, iv.

it adrls a precious seeing to the

to our perjury to add more terror.... ${ }^{+}$could add a lie unto a fiult ... Merch; of Ven. v. 1

I'll add three thonsand crowns........All's Wrell, iii. 7

and I will add unto their losses

which you say, adds to nature...

adil thereto a tiger's elaudron
or add a rnyal number to the

of England add thus much tn

or add another line unto the....

good hap, add an immortal title

Macbeth, iv. 1
King John, ii. 2
-

it adds more sorrow to my want.

will add right worthy gains
mzist add unto your sickness

must add unto Your siekness .....2 Henry $I V$. iii.

to this add-defianee: and tell

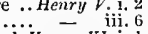

to ald to your laments

Would but add increase unto my ..2 Henry $v_{l}$. iii. 2

to add more measure to your woes.

I can add eolours to the can
eyes add water to the sea........
I need not add more fuel to

support, out of his grace he adds ... Henry $\bar{v}_{I I I}$ y. 4.4 aet will I add an honour.......... add to my clamours ....... Troilus a

may these add to the number... Timon of Athens, iii. 1 may these add to the number.. Tinon of Athens, in. which I will add to you, the liver, heart.. Cymb. v. unless $I$ add, we are honest.

nor come we to ardi sorrow to

thereto add such reasons of your own .... Lenr, i.

doth add more grief to too nuch.... Romeo \& Jul. i.

BDED-to have it added to the ...Mea. for Mea. il.

Ba, pueritia, with a horn added ... Love's L. Lost, v.

a gash is added to her wounds .......... Macleth. iv.

and acled years to his short $\ldots \ldots \ldots$ Richard $I I$, i. 4

twenty-six; added to these ........... Henry

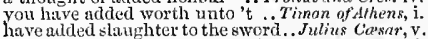

no; I rather added a lustre to it........ Cymbeline, i. 2
but he added to your laving.........

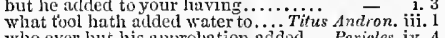

who ever but his approbation added ...Pericles, iv. 4
all ligve, and addat to the gall ........... Lear, i. 4
which, added to the goose, proves...Rameo \&. Jul. ii. 4

which, added to the goose, proves.. Romeo \& Jul. i. 4
ADDER - I am all wound witl adricrs.. Tempest, ij. 2

thou serpent, never alder stung ....... - iii.

or is the auder better than the cel.. Tuming of $s$. iv, 3
she longed to eat adder's heads.. Winter's Fale, iv. 3

tolnue ot dog, adder's fork ...........Macbeth, iv. 1

art thou, like the audcr; waxen deaf? ${ }^{2}$ H. VI. iii.
more poisons than the ailder's tooth..3 IIen. VI. i.

more poisons than the adder"s tooth...3 IIen. VI. i.
than 1 ean wish to adders, spider's ... Richerd III. i.

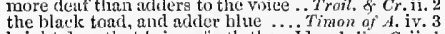

bright day, that brings forth the arder.Julias C. ii. I

wert't toad or adder, spider, 'twould ...Cymb. iv. 2
even as an adder, when she .. Titus Andranicus, ii. 3

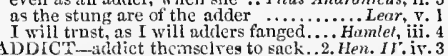

ADDTCTED_very wild; adlicted so and so. Mnm. ii. 1 being addlicted to a melancholy.. Tuelfth Night, it. what sport and revels his addiction leads ... Oth. ii. 2

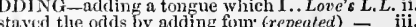
by adding one more L......... - iv. 2 (epitajh) this world: arding thereto, noreover
to England; addling withal, how ...Richnm II. iv. adcling further, thut, had the king.. Hewry VIII. i. DDI'TON-are devils' additious... Merry Wires, my troth, it is no aldition to her wit.. Much delo,
where great addlitions swell, and ....All's Well, where great additions swell, and ....All's Well, ii. and worth it wit.s addlition! but fair.. in which adilition, hail, most wortjy ... Macbeth,

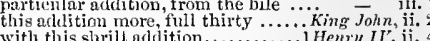
and with this addition in French ...... Henry $r$. beast.s of their narticular additions... Trail. \& Cres. his ardition yield to sinewy Ajax

a great addition earned in thy....

bear the addition nobly ever.........

bear the addition nobly every.......... Coriolanus, i.
to kndererest your good addition.....
with what addition! that by .... Julius Cresar, iv.
by addition of his envy!. Antony and Cleopalra, v. deny the least syllahle of thy ndalition - ii. [Coflier. Knight] -more than in your addition with swinish phrosc, soil our addition ... namiet i. and with no addition, we go to gain a litile - ir. and think it no addition, nor my wisli.. Othello, iii. the act that might the add whose want.

DDLE- beaten as addle as an egg.. Rom. \& Jul. iii. addle egg. Ii you love an addile erg. ... Troil. $f$. $\mathrm{Cr}$. i. adiress me to my appointment ..Merry Wires, iii.

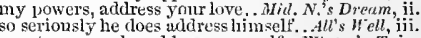
gnests approach: address yourself.. Winter's $T$. iv. dreadtinl lay! address thee instantiy..2 Hen. $V i, v$ let ns address to tend on Heetor's.. Troil. \&-C.ess. we first address towards you, who with and did address itself to motion, like ..... Hanlet, $\mathrm{j}, 2$ were all addressed to meet you ... Love's L. Lost, ii. I so have I addressed me: tortume ... Mer. of I'en. $1 \mathrm{i}, 9$ to this forest, addressed a mighty .. As you Like il, v. be is acldressed; pressnor and..2 Henry $I V$. iv. as von are addressed, will very well.... Pericles, ij. 3 your I might behold addrest the king ..... Love's $L . L$. y. 2 every thing adheres together ....T. Therfth Night, iii. 4
what to her allheres, which.. Winter's $T$, iv. (ehorus) nor place, did then adhere, and yet ..... Nacbeth, not living, to whom he more adheres ... Hamlet, ii. the sense of the adjacent wharfs....Ant. \& Clea. ii. demesnes that there adjacent lie ...Rom. \& Jul. ii. DDJOINING-adjoining to the eity..Ani.\& Cl. iv. 10 AOJOURN - we adjourn this court ..Hen. FiII. ii. 4 ADJUDGED-he adjudged your brother. $M$. for $M . y$. thou art adjulged to the deatli.. Comecly of Errors, i. by Gud's book are adjudged to death..2 Hen. $Y I$. ii. in thy nativity, adjudged an olive..3 Hen. VI. iv. AD.JUNCI-my death were adjunct to.... John, iii. 3 learning is but an adjunet to ourself. Love's L.L. iv. 3
ADIIINISTER leep the oatl that we administer ... Richard II. i. 3
ADMINISTEREDmedicine must he admininistered, or.. King John, v. and, in the administration of his law ..2 H. IV. v. 2 the knightts in admirable folling ....... it is admirable pleasures, and fery
but that my almirable dexterity of wit - iv. 4
iv. 5 howsoever, strange, and admirable ...Mid, $N$. D. . . most admirable: I have seen those....All's 'Well, ii. ot an adminable coneeited fellow... Hinter's Tale, iv. o ndmirable man! Paris? Paris is dirt admirable: how this grace speaks.. Timon of Ath
with admirable rich words to it .... Cymbeline, an admirable evasion of whoremaster-man.. Lear, an almirable musiciant o, she will ... Othello, iv. Jaques of Chatillon, admiral of France. $H . F$. that Riehmond is their admiral....3 Henry VI. iii. ADe Egyntian ndmiral, with all...... Ant. of Cleo. iii. bring in the admirntion; that we .....All's W' Whl, were very notes of admiration..... Winter's Tale,
that admiration did not whnop at .... Henry $V$. it is the greatest admiration in the ....

without the help of admiration

and not protraet with admiration what is -

this admiration is much o' the favour is $\bar{c}$ 
ADMIRATION-

at the heels of this mother's aclmiration?.Ham. iii. :

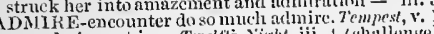
nor athuire not in .. Trelf'ti Night, ifi. 4 (chatlen that I thy parts adnire ...L

wh:ile we do admire this virtue
sec his weakmess, and admire our Taming of s. il. and, i' the end, admire......... Coriolımus, j. 9 iinIRED-adunired Mliranda! indecl. Tempest, iii. I that sle miglit admirel be. TuoG. of Fer. iv. 2 (song) wherein Rosalind is so admiret.. As you Like it, iii. 2 mecting, with most admired disorder... Nacbeth, iij.

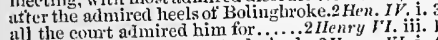
that dnth make them most admired...3Henry $V I . \mathrm{i}$. 4 settlest adumired reverenee in .. Timon of dthens, $v$. in thee, fair and admired!

by the mother's side, admired

celerity is nerer more adwired......

served with glory and admired success..$C_{y m b}$. i. i all the admired beanties of Verona.. Rom. \& Jul. i. DMIRE and admiring the nothing of it ... Winter's Tale, iv. 3 and from thy admiring daughter took - v. 3 shines seldom in admiring eyes.... Henry $I V$. iii. with modesty admiring thy renown... Henry $V I$. ii. 2 ADMIIRINGLX $\rightarrow$ of him, admiring

of this lord? Admiringly, my liege ... Te- - v. 3
DMIIT-kind of traffic would I admit.. Test. IDMIT-kind of traffic would I admit.. Tenupest, ii. 1 he will admit no kind of suit.... Twelfih Night, i. she never will admit ine.....

it ....Measure for Men. i. 1 admit no other way to save his life .. Much Adio, v. your answer, whether you'll admit..

whose title they admit, Arthur's, party do the towusmen yet admit?.. for the which the prince admits him..2 IIen.IV. ii. weli, by my will, we shall admit no parley - iv.

which supply, admit me chorus to..

therefore we nust needs anmit the

the latest parle we will admit

if sorrow can admit society.

admit him en trance, Grithith.

my love admits no qualitying ...
of this division admits no orifice

to strike at him admits a good.

a yielding; this admits no excuse

ans SDNIT TANCE-of great admittance. Merry Wives,i.2 or any tire of Venetian admittance

now, What admittance, lord?...Love's Labour L. il. do crave admittance to yourmajesty.. Henry $V$. ii. most desirous of admittance....

let them have kind admittance.

had I admittance, and opportun first admittance to the ambassador

IDMITICD-might not be admitted.. Tuelfin $N$.

you shall not be almitted to his sight

rou shall not be alnitted to his sight II' IV nneertain, should not be admitted

xcuses shall not be admitted.

admitted to your highness' council ${ }^{. .2}$ Hen.VI. iii. I that we ma he admitted where he is...Rich, III, i. I pray, let them be admitted ...Timon of Alhens, i. never admitted a private whisper .. Coriolanus, $\mathrm{v}$. not petty things admitted...

to be aclimitted to your presence ... Titus $\overline{A n d r o n . v}$. 1) MITTING-never admitting council... Coriol.v. 5 1)MONISH-spirits

thy grave aulmonishments prevail ... Henry VI. ii. 5 his eurs nighinst admonisbment . Troilus \& CrCs. V. 3

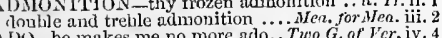
what ado bere is to bring.. Merry Wines of Wind. iv. I have mueh ado to know myself.. Merch. of Ven. i. to sec the end of this ado .. Taming of the Shrew, v. you had much arlo to make

here's sueh ado to make no stain no more aio; remember, stoned

with much ado, at length have ...................
now no more ado, lorave Burgundy

away : let's have no more ado

Richard II. IIleury $I V$. ii. Henry VIII. nor no more ado with that harsh.... Cymbeline, iii. not we be tired with this ado.. Tilus Andronicus, ii, make no more ado, but give

Romeo añd Juliet, iii. WVON Is-fetch the straight, Adonis. Tam. of S.(ind.) 2

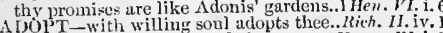
may not a king alopt an heir.........3 Hemry
for your best ends you adopt your poliey. Coriol. iil. 1 I had rather to adopt a child, than get it.. Othello, i. and an adonted nane of privilege ... Henry IV'v. this was he was lisis iulopted heir ....3 IIenry FI.j.
A1)(OT'TED-

? ? Rminn now adopted happily.. Tilus Andronicus, i, adenteclly as school-maids change.. Mea. for Hea. i. hint stand under the adoption of Herry Wives, her soln into tile adoption of the crown .. Cymb. v. ADOPTIOUSADORATION - the soul of adoration?...Henery $V$. iv. with adorations, witl fertile tears. Tuelfih Night, ADORE-and I do adore thee Two Gen. of Ver. ii. and adore filse shnpes $\ldots \ldots . . . . . .$. T'uelfth Night, ii. I do adore thee so, that danger....

I may command where $I$ adore (repeated)

I may command where thy sweet grace's slipper... Lore's $\bar{L}$. $L$. v. I adore the sun, thut locks ...........Alt's Well,

how dearly he adores Miar.

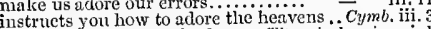
pretend to honour and adore...The gods, that warlike Groths adlore

now gods, that we adore, whereot.

wortip-I was adored once too.. Twelfth Night, ii. morshipped, lissed, loved, adlored.. Two G. of ler.iv. ADOREY I I profess myselt her adorer.

ADORER-I profess myselther adorer..Cymbeline, i.

ADORETH-let the solu forth that adoreth. W. Wh.

adorn lis temples with...

fashions to adorn my body

Richord III. $\mathrm{i}$.

funeral praises do adorn thy tonib!... Rom. \& J Jul. $\nabla$

dames so jetted, and adorned

AUORNING - their bends adornings. Anit.

with the adorment of my qualities

ADOR'ST-thou ador'st, and hast.. Titus Androu v.

ADRANLADIOADRIAN -which of them, he or Adrian, Tempest.ii. your name, I think, is Adrian

to Adriana vilnin lie thee

ADRIANO-

heat of duty, Don Adriano de.Armado.Love's L. L. i. or called Don Adriano de Armado

ADRIA'TIC-the swelling Adriatic seas. Tam of $S$. i. ADSUM-Adsum. Asmath, by the eternal.2H.VI. i.
ADULATION-blown from adulation?..Hen. $V$. iv. ADULATION-blown from adulation?.. Hen. possessed with an adulterate blot that adulterate beast, with witehera

that aduiterate beast, with witeheraft ...Hamiel, i. 5 DIULTERIES-that thy adulteries rates... Cear, i. DULTEROUS- adulterous thief. . Mea. for Mea only the adulterous Antony .... Anlony \& Cleo. iii. 6 ADULTERY - thy cause? Adultery ....... Lear, iv. 6 adultery with Polixenes all.

now shall we have wilful adultery .... Henry $r$. ii . 1 How! of adultery? wherefore write you .

win this ring by hers and mine adus . W'in
ADULTR ESS-she's an adultress. W
I have said she's an adultress; I have

she, the adultress; for the harlot king - ii.2 mother's tomb, sepuleh'ring an aduitress... Lear, ii. the fringed cmontains of thine eye advance

I must advance the colours of

that advance their pride against .....Much Ado, iii. advance your standards, and ..... Love's L. Los', iv. 3 will advance unto his several

towards which, advance the war $\ldots \ldots$ Macbelh, the signs of war advance; no king .... Henry $F$.ii. and never war advance his bleedir

advance our waving colours on the

a Henry $F$. $i .6$

I seek not to advance or raise myse

whose hopetul colours advance with our - iv

advanee thy hallierd higher than ... Richard III. i.

advance your standards, draw your $\overline{-}$ y.

he will advance thee; some little .. Henry VIII. ini so nuch, as to advance this jewel... Thmon of Am .

and advance the theme of our assembly - itice

to advance thy name, and....
if sat turnine advanee the queen of
to your wishes height advance you both

to your wishes' height advance you both

ere the sun advance his burning eye...Rom. g. Iul.ii. 3 $\Lambda D V \Lambda N C E D$-advanced their eye lids... Tempest, iv.

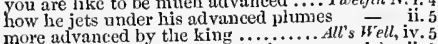
more advanced by the king ........... All's Well, iv.

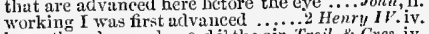
hung thy advanced sword i' the air. Froil. \& Cres.es, which, being advanced, declines; and then - il. I advinced above pale envy's threateving

to be advaneed to this lieight?...........

by this their elith slualt be atvanced...
ADVANCED-
one step I have advanced thee; if thou .... Lear, v. 3

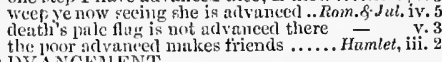
DVANCEMEN sleep were this fir your advancement!...Tempest, ii. I give you advancement; le it your ...2 IJenry $I V . \mathrm{v}$. . cndearioured my advancement to the. .1 LIen. FI. ij. 5 you envy my alvanement, and my..

disorders descred much less advancement. Lear, ii. 4 more that in
addition

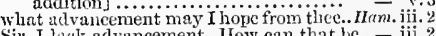

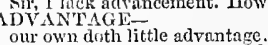

Tempest i. 1

the next advantage will we talke thoroughly - iii.

your good word cannot advantage him

her folly motion, and advantace... Merry Wives, iii.

glall advantage thee more than ever. Twelfth $\Lambda$.iv.

only reter yourselt to this advantage

for some advantarce to yourseif....

N. Drenm, iil.

do it in hope of tair advantares....... $-\overline{\text { s. }}$ it.

that's tor advantage. So is runuing.... -

where there is advantage to be given ... Macbeth,

the advantage of his alisence took the.. King Johnt

to cull the plots of hest advant

speed then, to take advantage of the ficld -

till this advantage, this vile drawing.... -

and with advantage means to par try lore - ini

the rich advantage of good exercic

as I upon advantage did remove .......

to take advantage of the absent time...... ii.

for our advantage, on the bitter cross... 1 Hen. IV.j.

shall be paid back again with advantage 二

let's awry ; adrantige fects him fat.. - iii.2

from this swarm or' tair advantages... nor lose the good advantage of his grace..2 4 . I iv. make road ujon us with all advantages... death is to him advantace; or not dying - iv. remember, with advantages, what fents - iv. low, with most advantage, they......1 Henry $V I$.1. and, in ndvastage lingering, looks

on that alvantage, bought with such...

and his advantate tollowing your decense - iii. slanjes with Protens, for advantages..3 Hen. VI. iii.
the swift advantage of the hours ...Richard $I I I$. iv. with lest advantage will deceive.... would not lose so rich advantage of.. Troil. of $\mathrm{Cr}$. if. do not ive advantage to stubborn eritics $\rightarrow$ v. and lose averantare, which doth ever cool - iv. advintage, more than do us wrong. $\ldots$...Julius $C$. iii.

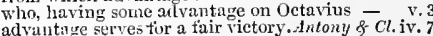
and hold on' best advantave..... _ iv. I0 with no nure advantage tlian the.... Cymbeline, $\dot{i}$. stand, stand! we have the adyantage of the $-\mathrm{v}$. Which gave advantage to ancient soldier $-\bar{v}$. taking ad vantage of oux misery ..........Pericles, j. 4 party to the advantages of France...

with this dream of lis advantage ....... Hamlel, i. bring them after in the best advantage... Othello, $i$. tive me advantage of some lnief discour'se - iii. with the least advantage of hone...... - iv. 2

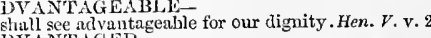
the poor NGEDADVANTAGEOUS-

here is every tlumg advantageous to life. Tempest, ii. ADVANTAGING-
advantaging their loan with interest... Rich, III. iv. ADVEN'T'RUUS -and advent'rous spirit. i $H . I V$. i. 3
ADVEN'TURE-will not adventure my. Tempest, ii. I bold Leander would adventure. Tüo Gen. of Ver. iii. the tear of your adveutiure wonkd.. As you hike it, ii. I'll adventure to borrow of a week..; Winter's $T$. i. will you adventure to save this brat's - iv. much less the atventure of ber lerson $-\mathrm{V}$. in this mist at all adventures go.. Comedy of Er. ii.
to try the tair adventure of to. morrow ..John, v.
he in this ad venture hath surprised... Henry $I \%$. i. such reasons fior this adventure, that - i. $\begin{array}{ll}\text { then will they adventure npon the exploit } & \text { i. } 2 \\ \text { in the adventure of this porilous day } & \text { v. } 2\end{array}$ 


\section{ADV}

ADYENTURE-

[Ki.ight.] my lite spakc'nt adventure..2 2 Ienry $I V$ i. 1

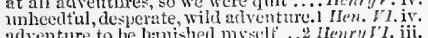

liave tound the adv'inture ery easy Richaril ni. it you fill in the adventure, our er.

not deatl on't, I would adventitre.

or die in the aldyenture, be my helips.

who looking for adventures in the worlel

adventure tor suel merethindize ..... Ro

ADVTETURAG-by alventuring boti

ADVENTUROOS-by report, adrentur.

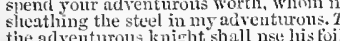

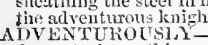

Alurst steal and thing alventurously. . IIenry $r^{\prime}$. iv. 4

ADVER tentrier of the adversaries

as adversaries do inl law, strive.ía
suggest liis soon-believing ad rersa

suggest lis soon-bclieving ad versa

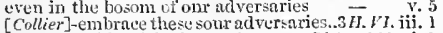

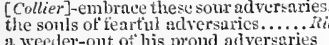

a weenter-out of lis proud artversaries
ancient knot if langerous adversaries

ancient knot of dangerouls adversares
they have been still my adversaries
the usuruing helmets of our adversarie

the usirping helmets of oux adversuries - vit. 3

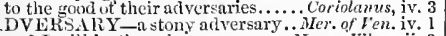

and I will be thy adversary ......

ot battle with mine adversiry
by reason of his advezsary's ou

by reason of his adversary's oddis....
thy adveraary's wite doth pray for.

the adversary I am to cope withal.......
the servants of your adversary...Ro

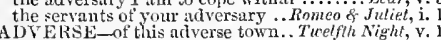
against me on the atyerse side... II eas. jor orght, v. this to what adyerse issue it ean ....Muneth dillo, ij.

time seem so adverse, and means ....

the adverse winds whose leisure I I. King John, ii.

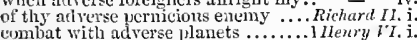

combat with adverse planets ..........1hen'y

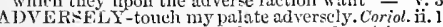

ADVERSELX-tonch my palate adverscly. Coriol. ï. 1
ADVERSITIES-embrace these som illversities...

[Collier-adyersarics]

ADVERSITY -

I am, eross'd with adver:

sweet are the uses of adversity ...As you Like il, ii.

to be patient; I am in adversit

ringed about with bold adversity ...1 Hern

well said, adversity! and what peed."'Troil. \& $c r$. $v$.

adversity's sweet milk, philosophy ... Roml.o. Jul. ini. 3

can my part in him advertise. Measure for Meas. i. 1
the king his lord advertise whether.. Hen.V111. ii. 4

please it your grace to be acivertised. .2Hlen.VI iv.

I bave advertised him by secret means

by triends ant well advertised....... Richarth 111. iv. 3

ail vertised, thcir grent general ... Troilus \& Cres. ii. 2

griefs ery louder than advertisement. AI Inch Aro, v. 1

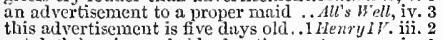
yct doth le give us bold advertiseme

as I was then advertising, and ...Merss. for Heas. v. 1

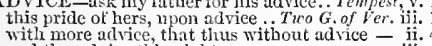

and thy advice tlis nightit.

the lists of all unvice my strength.... ineas. for $M$ MI. i. whote advice laath often stilled

and say by whose alivice thou cani.

yct did repent me alter more ad
upou more advice, hath sent yo

nuderstand what advice shal ...

siltre the adviee betwixt you.........
yout dili never lack advice so mizh.

inpon advice, it toucheth ns both

we need no more of your advice
easicr for adviee, or stronger for

etse have destred your tood advice..... Mtutceth, iii. 1

if you will take a homely man's adice

is banished npon good advice........ Rivithart ll $1 . \mathrm{i}$.

your lordship goes alsoand ly

on his more advice, we pardon hina ... Henry V. il. and Ifume's advice, your grace's title...2Hen. $l^{\prime} I$. i.
but with advice, and silent seeresy. thus high, by thy adviee, and thy... Riehard $\bar{I} I I$. iY. begin to relish thy advice... Troilus and Cressidn, i. 3 some contiort ont of your best advice.. Cymbeline, if you will elect by my advice.. Titus And drontices,
the Greeks, unon advice did biry $\mathrm{Ajax}-$ by my adviee, all humbled on your..
shall file onr engines witl advice.... shall file onr engines with advice.
by good adrice, mortal revenge..

will all suhscribe to thy advice......
nor ask advice of any other thought...
ADVICE - Te must have use of your advice. Lear, ii. I
and, by my advice, let us impart what.. Humlet, i. I by nyy former leet ture and acivice

she took the truits of my advice; and hi...

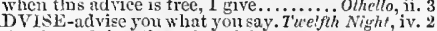
she thus advieses thec, that sirdh

I advise you let me not find you...Mea.fir. Mec. ii. I we shall tadvise thís wronged maid

and alyiec him tor a better placo.

I am come to adrise yon, eomfort you

good my lord, advise lim

uch Addo, iv.

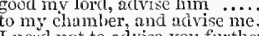

well dost thou advise: if Biondello...Taming of $S . \dot{i}$. .

I advisc you use your manners.

and this will I advise you; first teil me

co your dinty thoroughily, I advise you

I will aslvise you where to plant......

and that well night advise hin to
bid thy master well advise himself.

I advise you, (and take it from ..... Hen

can advise me like you.............

I shall anon advise you fiuther

what peace you'll make, ad vise me. . Tim. of $A$. iv

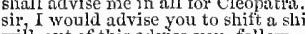

wili, out of this advise you, follow .....iii, 2 (lette

advise the emperor for his good ... Tilues Andron. $i$.

advise thee, Aaron, what is to be done

but yet, I know you'll do as I advise

advise your fellows so ..................

Lear, i. 4

advise yourself. I nm sure on"t

dvise the duke, where you are going

lay hand on heart, advise..... Ro

can you advise me? I am lost in it .... Homlet, iv. 7 be advised, sir, and pass good....... Merry Wives $^{\prime}$, i.

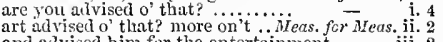
yet I'm advised to do it............ say you, Hermia, be advised, thir. Mid, N. Dream, i. if by me you'll be advised

and were you well advised...... Mror. of $V^{\prime}$ ? Y. 2

therefore be advised.................. - ii.

but art thou not alvised, he took .. Taming of $S$. i. 1

friendly, as thou hast advised me.. Wint
be advised. I am; and by zny finicy

I am addised what I say..... Comedly of Errors, $\mathrm{v} .1$

upon lutumour than advised respect

nor never hy advised purpose meet. . Richard II

good were advised, his flesh was.....2 2 Henry $I V$.

the advised head defencis itself at.......Henry $V$.

and bids your be advised, there's naught - ii. (elo.

are you advised? the east side of
and bid me be advised now I tread.

livery of advised age....
and bade me be advised

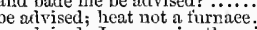

be advised; I say again, there i
by my frieuds in spain advised

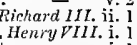

am advised to give her musie o, '. Cymbeline, ii.

general, be advised; he comes to bad..... Othell, , , i. 2

will never more break taith advisedly..Mer. of $V$. v. 1

fasten your ear on my advisings.. Mea. for Hea. iii. 1

an advecate for an impostor?

to be her advocate to the lourlest......... Wincer's Tules, ii.

What anvoeate hast thon to hith?

advocate's the court-word for a pheasant - iv. 3

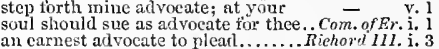

an earnest advocate to plearl........ Richord l11. i. 3

MVOCATION-

nyy ad rocation is not now in tune....... Othello, iii. 4
EACIDA -aio te, Dacida, romanos vincere

EACDES-

EDLLE- -the ediles, ho! let luim be.

seizc him, ediles. Down with him.....
scdiles, seize him. Yieln, Mareius, yield -
our xdiles smote? ourselves resisted?..

EGEON-laapless Exgeon, whom the... Com
doth Ageon wend, but to proerastinate

IEgeon, art thou not? or else his ghost?

speak, old NEgeon, if thon be'st
the same Jigeon, spenk and speak

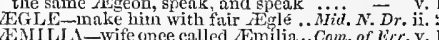

the sam-Wife once called AEmilia..Com. of L

DAILIUS - news with thee Enjilius. 2

ENmilius, do this message hounourably

as did Eneas old Anchises benr....
but then Inemi bare a bing load.
ENEAS-

Sheeds, from the feld to day? (rep.) Troil

but peace, $A$ Eineas, peace, Trojan.......

tis the Acneas, let me touch ........

lord Aineas. A valiant Greek, Sineas

Jove, let Acneas live, if to my
who's there? my lord AEneas?

and, my lord $A$ meas, we met by ehine

and bring 2 ineas, and the Grecian..

thus says 2Eneas; one that knows

Ajax hath ta'en

as Xneas, our great aneestor.........Julius Cersar, i. .

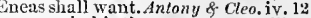

to bid Re Eneas tell the tule twice o'.. Cymbeline, iii. 4

'twas Aneas' tale to Dido; and thercabout. Ham. ii. 2

AER-we eall mollis wer; and mollis aer ... C.ymit.

ERIAI-the aerial blue, an indistinct... Othellh, ii.

WhC LAPIUS-Asculapins guide ns ..Pericles, iii.. 2

ESON-that did renew old . Esou.......Mer. of Ven. v.

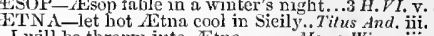

I will be thrown iuto IEtaa ........Merry Wives, iii.

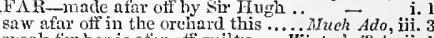

speak for her is attar off guilty....... Hinter's Tule, ii.

AEEARD-ateard now oit your four legs. Termpest, ii.

be not afeari, thy good triend

1 afenrd of him?

be not afeard; the isle is tull

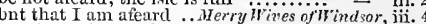

not the ladies be aleard of the lion? . Mid. N. Dr.

a knavery of them, to make me afearl

yet to be afeard of my deserving.... Mer of $V$. $l$.

I am balf ateard, thou wilt say anon - in.

then never trust me if I be afeard. Taming of $S$. $v$

Hortensio is ateard of youl. He that is -

I am but sorry, not afteard.

nothing afeard of what thyseif

Mracbeth, $\mathrm{j}$.

soldier and a feard? what nce

but, if you be ateard to hear

art thou not horribly ateard.......... King Honny $1 V$. i.

that shall make all France afeard. $.1 \%$ Henry $V$. iv.

name I oft have been afeard.......2 Henry $V I$. ii.

a virtucus sin), makes me afeard. Troit. \&. Cres. iv.

he is afeard to come. I will not..Antony \& Cleo. ii.

art not afeard? Those that I reverence.. Cymb.iv.

I am afeard, being in night....... Romeo \&s Juliet, ii.

I am ateard, you make a wanton of me. Hamlet, y.

affiability as in discretion yon ought ... Heniy $V$. iiii.

AFF ABLE-Baptista Mlinola, an affiable -

soft, and affable, why does the wrorld ....

valiant as a lion, and

attahle wolves, meek bears, you fools. Timong of $A$. iiji.

FFAIR - to eonfer of home affairs. Two $G$. of $l$.

in these affaiss to aid me

hope is a eurtail dog in some affairs ....Merry $w$. ini.

is right apt for this aftair ...... Twelfh Night, i.

so hardy io eome ngain in his affairs

give the mother notiee ot my atfai: ...Mea.for

my stay must be stolen out of other aftiairs -

save in the offiee and affairs of love ...Much $\bar{A} d o$, ii.

whiles I in this attrair do thee employ.Mid. N. D. iii.

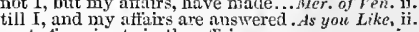

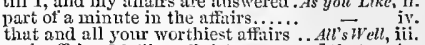

sneh affair's, [Collicr. Kinighl-a searre] that iv.

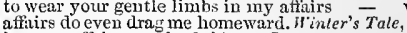

in your affairs, my lord, if ever $\mathrm{I}$.

what his happler affairs may be ......
and for the ordering your aftairs, to sing

and for the ordering your attairs, to sing
grown incapalle of reasonable atfairs?

your affairs there? what? with whom?

I command thee to open thy at......

best half of our attair. Well

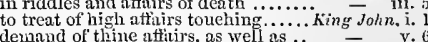

Macbeth, iii.

furnish us for our aftairs in band ... Richard Is v.

and, for these great aftairs do ask some

to order these affiuirs, thus thrust...ji
big upon the maidenhead of our affiirs. 1.

give even way unto my rough aftairs..

like a brother toiled in my affiairs

- iit.

and prosper your affairs, and send us peace - iii.

putting all affiurs else into oblivion

him dehate of commonvealth affairs..... Henry $V$..

other aftiairs must now be........ 1 Henry $V I$ I. iv. 1 my lord is cold in great affiairs.

take order for mine own altairs .......... iii. a packhorse in lis great attiairs ..... Richarll MII. i.

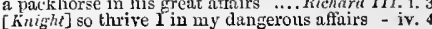


AFFAIRS-

diure look into these affinirs Henry VII. ji. 2 is this an hour for temporal aff their aftairs as righteous; but nll

gffuirs that walk (as, they say, spiritso do) -

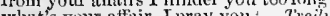

whe great sway of his affitirs with

the great sway of his affuirs with

my affairs nre servanted to other.

thy antairs are servanted to others.

there is a tide in the afficirs of

sis affairs come to me on the wind. Ant. $\overrightarrow{\text { s Cleo. }}$.ii.

to Jewry, on aftairs of Antony

if one of mean attairs may plod it... Cymbetine, iii.

assaul ted, for following lier aftair

freely gone with this affiair along

and start not so vrildly from my affai...

that elseleans on the affinir

( iv.

the state attairs, hath hither brought

still the honse afficirs wonld draw her.

your grace, on to the state nftairs ...........

beseech you, proceed to the afrairs of state.

let's to our affairs. Forgive us our sins

in their sleeps will mutter their atrairs

A have dealt most directly in thy aftais

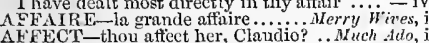

in Milan, here, whom I affect. Two Gen. of $f^{2} e r$. ini.

sir John afrects thy wife..............

Mlaria once told me she did aftect me. Turec

to atfect syeech and discourse.

of safe discretion, that does affect it - i. 1

I do affeet the very ground

I will something affect the letter.

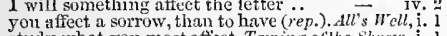

study what you most affect. Taming of the shreu, i. 1

if $I$ affect it more, than as........2 Henry $F V$. iv. 4

your yrace afficet their notion?

1 Hewry Vi. v. 1

how they afiect the house and claim..2 then. $V I$. iii. 1 and affect in honour honesty ......Henry VIII . i. 1

that I affect the un traded oath....

praise, but what he does affect.

to affect the malice and displeasure. Cor ioliness, i. 2

charge him home, that he atfects tyrannical -

stratagem must do that you affect .. Titus And. ii. 1

doth aifeet a sauey rougluness.

young affects, in my distinct and proper. Othello, i.

not to affect many proposel matches

spruce affictation [Collier-affection] figures

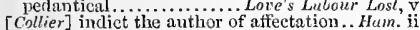

$\triangle F \mathrm{FEC} T \mathrm{TED}-$ stand you afiected to. Two Gen. of $\bar{V} \mathrm{i}$. 3

I stand affected to her............ Werry Wixes, iii. 4

and as I fud her, so am I affected.Merry Wizes, ini. 4

which we lovers intitle affected

that most are affeeted to these

I am in all afrected as yom self

have I affected wealth or honour..2 Henry $r$. $I$.

how he doth stand aftected to our...R Rithard III. which ever yet affected eminesee.

more affected than the performnice

nature but affected [Collier. Kinight-infected]

only affected greatness gnt by you .. Cymbeline, v. 5

for nught thou know'st, alfected be... Tilus And. ii.

no marrel then, though he were ill affected - ix
AFEECTETIl - of his tongue affecteth him. John AFFECTING-affecting one sole timrone. Coriol. iv. 6
such a drawling, affecting rogne... Merry Wives, ii. antick, lisping, affecting fantasticoes. Rom. \& Juh. ii. AFFECTION-aftection not gone fort

my affections are then most humnile.
fair encounter of two most rare afticet

your affections would beeome tend

affection elains thy tender days... Two Gen.of

but can you affection the 'oman?... Nerry $W^{\prime}$ iv to the vehemency of your affection.

hath answeret in $\mathrm{y}$ aftection (so far.

the ftock of all affections else that....

by vain thnugh aft atfection...

in the workings of your own affection

neither lieat, affection, limb, nor beaity -

yes. Has he affections in him.

I heard him swear lis affiction...

into a mountain of a

whatsoever comes athwart his affection

loves him with an enraged uffection ... -

hath she male her affection known to
seems her affections have their full bent -

rather die, tham give any sign of affection-
to wish him wreste with aftection..... -

no shape nor project ot affection, she i

contrining her anection unto benedick,$-\bar{N} ., D$

and tener praye for ooth, affection.

that war against your own affections. Lo
Rgainst the liumour of affection would

Rgainat the humour of affection would
have at jou then affection's men at arm
AFFEC'ION-

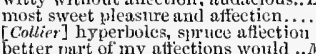

is there in your afficution

lovel at my atfection ................

and with alfection wondrous sensible

dimensions, senses, affections, nassions

and his affeetions dark as Erebus...

I will render thee again in affection. As

come, eome, wrestle with thy affectioms
my affection hath an unknown bottom

as fast as you pour affection in ......

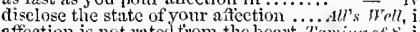

not removes, at least, afrection's edge.

of your entire affection to Biance....

of your entire affection to Bianca......

betwixt them then such an affection.

affection! thy intention stabs

I ain heir to my afiection.

with thought of such affeetions, step for

with all greediness of affection, are they.

gay vestments his affections bait?. Comed
strayed his affection in unlawfit love?

great affections, wrestling in thy bosom . $J \circ h$, v. 2

in affections of delight, in military $2 \mathrm{I}$

a better place in his afrection, than
with what wings shall his affections fiy

with the least atfeetion of a w

\section{it shows my earnestness of aftection.}

nor your affections, and your ap

with all my tinll affections still met. Hen.

my king is tangled in affection

be corrupted through affection.

weigh my friend's affection with

and your affections are a sick man's

gut, out, affection! all bond and privilege

not known when his affections swayed.Jul. Cops, v. 3

thou affections? yes, gracious madam.....

yet have I fierce affections, and think
Antony will use bis affection where it is

made weak by my affection...........
the iteh of his affeetion shonld not the

pitring the pangs of barred affection.

love and your affections on a strang
or your fore-vonched affection fall

to feel $\mathrm{my}$ aftection to your honoun.

measuring lis affections by my ow

his owu a ffection's counselior..

young affeetion gapes to be his heir..

affection makes him false, he speak

keep you in the rear of your affection ... Hamlet, $\mathrm{i}$.

the anthor of atfection [Collier-afitectation]

love! his afiections do not that way tend
dipping all his tanlts in their affection...

goes by letter, and affection, not by the
and poison this young maid's affections
of his salt and most hiddent loose afiectio?

and have not we affeetions? desires tor sport -

and your affectionate servant . Lear, iv, 6 (letter)

affectionately to you.... Troilus and Cresside
AFFECTIONED-an affectioned ass. Twelfth $N$. Th

AFEECT'ST as thou affect'st .....Aniony \& Cleo. 1.3

AFFEERED-thy title is affeered ..... Mncbeth

DFIANCE-the sweetness of affiance... Henr

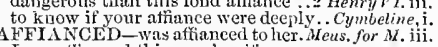

I am affianced this man's wile......
AFFIED-we be affied and such a

AFFIED-We be aftied and such ...Tuming

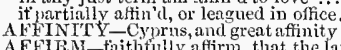

AFFIRM-faithitully afirm, that the land.i.ien.

and I must not blush to aftirn it.

renege, affirm, and turn their haleyon ..... Lear,

AFELRMATION-ot bloody affirmatio

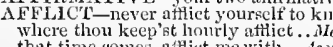

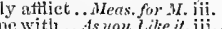

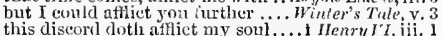

leave to aflict my heart ............2 Henry $V=$ ii.

whate'er you ean aftlict me with ....... I Ienry s

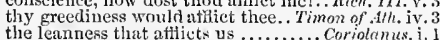

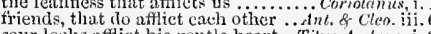

sour louks afflict his gentle heart... Titus . Andron

that dues aftlict our naturer

to us nuknuwn, afinets him this, that... IIremet, ii. 1

shall be any forther atflicted.... Therry Hicess. iv.
I come to visit the afficted spirits... Meas. for M. ii. 3

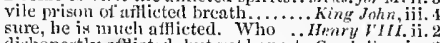
dishonestly aflieterl, but vet linnest... Cymbetine, iv.

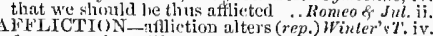

do not receive afliction at my

a feeling of their attietions as.

the affliction of my urind amends........

and sleep in the afliction of these

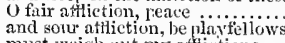

must weigh out my afficition
one of my greatest affictions

are made thy chictet afilictions .......

please to stop afiliction, let him tal

happier much by his affiction marle

man's nature eaunot carry the affliction

shake matiently my great afiliction
hencefurth I'll hcar affliction, till it

af' $t$ be the aftliction of his love

in most great affliction of spirit ...............

pleased henven to try me with afliction..

this commendation I ean aftord

praise we nay nfford to any lady.

and would afford nxy speechless visor half

nothing that my house affords. Tamin of $-v$

Padua affords this kindness

now Jove afford you cause

purest treasure mortal times.... Comed of of Krors, iii.

aftord no extraordinary gaze ....... I I I enry $I V$. iii.

see what physic the tavern afford

as my rapier's point affords.............

2 Itenry VI. i. 1

spacious world cannot again affurd.. Richare KII. i.

this dark monarchy afford filse $\ldots .$.

thou wouldst as soon afford a grase.

confort that the dark night can afford

as easy as a down-bed wonld afford it.. Hen. VIIL. i. 4

this brief rorld affords to such as..

Rome could afturd no tribune like... Titus $\bar{A}$ nd. iii. 1

Rome affords no prey but me and

can afford no better term than this... Rom. \& $\vec{J} u l$. jii.

these times of woe afford no tim
and strength shall help afford.

the world iffords no law to make the

WFORDETH-as soul to soul affordeth .. Othello, i.

AFFRGHT-Or ratherdid affright... Nid. $N$.'s Dr.v. I

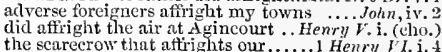

1 Henry l'I. i.

dotb death aftiright? Thy name affrights me -iv.

even to affright thee with the view thereof $-\mathrm{v}$.

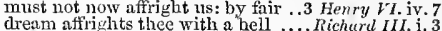

dreams aftright our souls..........

the one affights you, the other

these rone; let them affright thee...Romeo \& Jul. $\mathrm{v}$. 3

FFIIGHTED - have been so aftirighted.. Humlet, ii.

affrighted much, I did in time

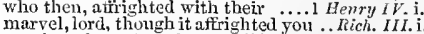

people and senators! be not aftrighted... Juchius $C$. ij. I

that the affrighted globe should yawn .. Othello, v. 2

your preparation can affront no less. Cymbeline, iv.

that gave the affront with them

may here affront Ophelia: her father ... Hamlet, iit. 1

EFY - daring to afry a mighty lord..2 Henry $\mathrm{Fi}$. iv. $\mathrm{t}$

Mareus Andronicus, so I do affy. . Tites Andron i. 1

-FIELD-who's a-field to-day?.. Troil

Eneas is a-field; and I do stand engaged

AEnRE-until our eity be afire

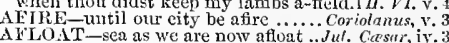

coor-have walked ten mile atoot... Muc cersic, iy. 3

I waw the tyrunt's power a foot.

were I tied to rum afoot, even to......... Michurd II. $\mathrm{i}$. I

before the game's atoot, thou

by the squire afoot, I shall ...........

bear nine own fiesh sa afoot with me

is so forward, and atoot too ...........

so tar atoot, $I$ shall be weary, love

but afoot, le will not bud

till these rebels, now atoot, con

how now, niy noble lord? what, ali afoot? $2 H . V I$.

went all atoot in summer's scaldi

mon, he's there afuot, and the re ..

mischivith know we were alcot.... Coriolenus, i.

were our witty empress well atoot... Titus . ind. iv. 2

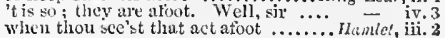


AFOREHAND-knowing aforeland.. Love's L. L.V.2 AFTERWARD_

AFORESAID-witl the atiorestid swain-i. 1 (letter)
or, as aforesaid, honest Lutueclot... Mer. of I'en. ii. 2 and, as aforesaid, Patrocius is a fool... Troil. \& $\mathrm{Cr}$. ii. 3 we are less afraid to be drowned

yon are afraid if you see the
I $\mathrm{am}$ hall afraic he will have

I am hall' afraid he will have.........erry Wires, i.

answer your master, le not afrail.. - iv.

be not afraid of greatne ss. Tuelfh Night, $\overline{i i} .5$ (letter;

be not afraid, good youth, I will not

be not atraid of greatness.......

am atraid this great lubher.. - iv

that iny daughter is sometime afraid.. Much Adtn ii. 3

be not afraid: she shall not harm thec

I am mueb afraid, my lady his... Herchant of ren. i.

not that I am afraid to die.............. All's $\bar{F}^{\prime}$ ell, ii. 3

I am afraid, sir, do what vou........... of o shing of iv. v.

these witehes are afraid of swords.. Com of Er.
I an afraid they have awaked ........ Macleth,
I aun afraid to think what I have doue

I ain afraid to think what I have doue

I will not be afraid of death and bare

thou'lt be afraid to hear it.............

he is afraid of me, and I of him....... King Jolnn, iv. 7

I am afraid; and yet I'll venture it.. am afraid, my daughter. iv.

I am afraid, of this gampowder Percy

I am afraid he rould prove the better.

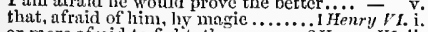

or more aftaid to figlit, than..........2Henry VI. ii. 3

are you all af raid? alas, I blame you... Rich. III. i.

I am afraid, methinks, to hear
what? art thou afraid? Not to kili...

good mv lerd, be net afraid of shadows

I am afraid, his thinkings are below.Hen.YIII. vii.

1o. Casar, is afraid? Pardon me ...Julins Cresar, ii. 2

is all afraid to govern thee nenr...Antony \& Cleo.ii. 3

are afraid of goose quills, and dare....... Hamlet, ii. 2

he not afraid, though you do see me

arc even now to be afresb lamented.. Winter's $T$. v.

then lave to't afresh. street Biance

their congealed mouths, and bied afresh. Ric. III. i. 2
AERIC-I would they were in

as when we put them on first in Afric. Tempest, ii.

better pareh in Afric sum
not Afric owns a serpent

A FRICA-I speak of Africa, and golden.2Hen. $\mathrm{V}$.

AFRICAN-lose her to an Af'ican..- .2 Tempest, ji. I

A-FIRONT-these four came all n-front..1 $H$.

AETER-ENQUTRY..

or jump the after-enguiry on your own .. Cymb. v. 4

A $F E R-H O U R-$ - left to after-cye him .. - i. 4

after-hours give leisure to repent... Richard III. iv. 4
atter-hours with sorrow ehide us not.Rom. \& Jul. ii. 6
AFTER-IOVE-to win thy after-love..Rich. II . Aenrm at first makes after-love .. TwoGen, of Fer. iti. 1
AFTER-AIETTING-

the main point of this our after-meting. Coriol. ii.

AFTERNOON-ride you this atternoon'. Wuci. iti.
'custom with him i' the af'ternoon to .. Tempest, ili.
the afternoon, Barnarline (note) Meas. for MIea. iv.

is to be executed in the afternoon?

Barnardine must dic this atternoon? $\overline{-}$

It must be done this atternoon.....

the rude multitule call the afternoon

and measurable for the afternoon

most vilely in the afternoon, when...Mer. of Ven v. 1

Ash-wednesda, was four year in the afternomn- ii.

we may eontrive this afrernoon .. Tuming of Shr. i.

this, till this afternoon, his passion... Com of Err.v. 1

at two o'cloek i' the afternoon

three of the cloek in the afternoon.

even in tbe afternoon of her best days. Rich, III. ii .

have the drum with me this afternoon

come you this afternoon, to know ... Rom \& - iv

to come to shrift this afternoon
this aftermoon, sir? well, sbe shail.

my eustom always of the afternoon ..... Hainlet, i. 5

our after-supper, and bed-time?. Mid. $N$. Dream. v. 1

Solnd the bottom of the after-times.2 Henry $I V$.

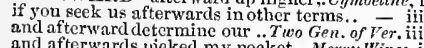

and afterwards pieked my pocket.. Merry Wives, 1 . 2

and we will afterwards ork upon...

cxeented, and sleep at'terwards...Meas. for $\overrightarrow{\text { Meas. }}$ iv. 3

lack of tempered judgement afterward

hang it first, and draw it afterwards. Much Ado, iii. reeount their partieular duties afterwards -
we'll have daneing afterward.

never to speak to lady afterward.

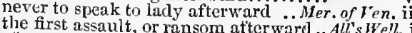

at'terwards consort you till bed-time. Com. of Err. i.

pardon, first; and afterward stand up...Rich. $I I$, v.

that afterwards we may digest our. Richard III. iii.

and afterward by substitute betrothed

syeak as mueh as thou afterward.. Troil.

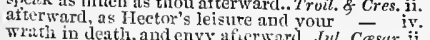

they not say atterwards, if they should... Homnlet, it 3 oft to seact a fai

we'll ery jt o'er again

they ill have nain, tlid $u$

which syemax tutald not again undo..... -

wo, it begins again ................

thy nerves are in their infincy again

ne'er again shall see her

thougl some east agrin

and it shall be said so again

perl your chaps again

Lo, to hain? by and by artain

to hearken once again the suit I made thee

W cried to dream agnin

whom once again 1 tender to thy hand.

Mars' hot minion is returned again

say again, where didst thon

to call her back given me again

and yet take this again ....
sinee unwillingly, take them again

could not again reply $\ldots . . . \ldots \ldots \ldots . . . . .$.

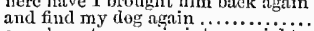

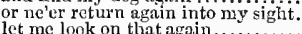

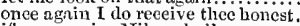

if once again, Milan shal

It I were young again, the

mine own great eliam

I'll never to sea again

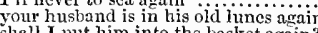

shall I put him into the basket again?

take the basket acain on your. .............

any way then to unfool meagain?

never trust me when I open agrin

in the way of waste, at tempt us again.

let out wires yet onee again ............

I will never take you tor my love agan

that strain again.................T.

thou mightst ncrer draw sword again

therefore, l say again, take ler wway.

todrown her remenglonganet again with more

we'll have the hewr again

I bade you never speak again of him

'tis time to smile again

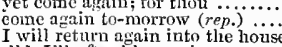

slid, I'll after him again

desire my dog again

till I come agail

to speak of, would offend a................... $\overline{\text { Meas. }}$ vor $\mathrm{i}$.

wive you three-1 pray you...

betore me again upon any complaint

why dost thou ask again?

to him again; entreat hing it bak again.

come again to-morrow..................

ere long I'll visit you again

the duke, we talk of, were returned again

my kisses bring again, bring again.

eall that same Isabcl here ouce again
return him here again: go with him...

see a bacheior of thrceseore again?

I would have thce henee, and here again

we'll hear that song agalin...

send her home again withort a liusiond...

nothing, unless you render her again ...

too few to wash her elean again

that fair again unsay; Demetrius. Wid. $N$.
to have his sjglht thither, and back again.
let lum roar agtain, let him roar again...

and be thou here again, ere the leviatban

that he heard, and is to eome again .....

lower! hark, again ...............

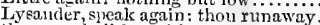

the man shull have his nare again

being sensihle, should eurse a...........

afflietion may one day smile aguin... Lo

and go wel satisfied to Franec again.

say the moral agai

fay the moral again .................

I will look again on the intellect

well proved artain on my side

immediately they will again be here...

but take it, sir, agnin.
AGAIN-

we are again forsworn; in will ...Love's $L . L$. v.

and the have me, or your pearl again?

let mole world again, eannot...

lest you be for'sworn arain

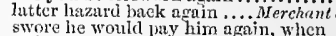

eall thee so arain, to spit on thee again

i. 2 that doth untreal again his tedions.

i. 2 I survey the inseriptions back again

ii. 1 for wooing here, until I sweat again

but, till I cone aqain no bed.

when we ineet atrain: I wish you weli

to eome again to Carthage ............

ever le go alone again, I'il never... As yo

I will render thee again in affection.
may'st in honour eome off again .......

may'st in honour eolne otf agan .....

giving her them agaiu, said with .....

shallow arain:

wonderful, and yet again wonderfui

when shalt thou see lim again? ......

I will be with thee again. Ay, go

if I sent him word again, it was not

restored to them agtin that were

what, pale again? ny tear bath.

to beir me back again. I call
to be young again, it we eould

to be young agtin, it we eould
why, there't serves well again

haste you atgain

we'll ne'er come there again

if I eould but meet again, 1 eare not ....

ont of it yon'll run again, rathe...

then hast thon all again

a letter? read it again

will speed her foot again, led.

come, let's return agnin, and suffice

and pay again, when $I$ bave found $\mathrm{it}$. .

hast thou to speak to us again?

or return again into France?

I will never trust a man again

I pray you, sir, put it up again

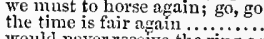

Would never receive the riug again
and bring again the count. I $\mathrm{am}$

and give me mine again ...............

and onee again, a pot o' the smallest

that we may yet again have access.....

nav, come arain, good Kate; I am ....

in the hole, man, and tune again

as he stooped again to take it up

eut out, and sewed up again; and that

and teteh our horses back amind

why, then let's lome again; eome.....

will take again your

time as long again would be filied $u u^{3}$

eame, sir, now I am tor you again

my rest miglit come to me again

spints of the dead may walk again.

never danee again after a tabor.........

whieh will shame you to give him agai

pureliase the sight again of dear

then recovered again with aqua-vita.

fit to slore them again, and

bless the bed of majesty again with....

break his grave, and eome again to me

when your first queen's arain in breat

he dies to me a quin, when talked of

then again worities he his dumghter...

until you see her die again

fairs, arain, it any Syracnsan borm...... Com. of

119y your worship those asain, perehanee -

go back agnin, thou sinve, and feteli $(r$ rep. $)$

so jest witl me again..................
thence that drop a gain, without....

come agaiu, when you may....

get you in again; eomfort my ..........
establish him iu his true sense again..

they are loose argain

bound again .......

brought him to his wits again

yet once ngain a foclaim it pub a gain

we eane agtin to bind them

when slunll we tluree meet again...

adriressed them again to sleep

but returns ugain to night

then eones my fit ofain

we'll hear, ourselves arain.

upon a tlought he will again be weyi.

but now, they rise again, with

being gone, I am a man atrain ....

V. 2

i. 1

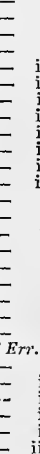

$$
\text { iv }
$$$$
\text { iv. }
$$ 
AGAIN-she'll soon be back aguin we may again give to our tables Ahal thou see thy to hed and asail see thy whe ....... the very ceho, that shouke appland again preferen

ellge, 1 shenthe amnium uniected.

were $\{$ to get ayain, matam, I would... King John

wear home thut husty blood again.

part your mingled colomess once again.

and she agin wants nothing, to mane

tell o'er thy ta?e again

then speak ngaiu; not ail thy former.

wonld live ạ

as now again to snatch our

and will again commit them to.

true, I shall sce my bov agat

atnd, rising so again, when 1

once arnin we sit, once is ain crowned

but nuw I breathe aurain alot

from them to me agairs. The spirit

in signs again parley with sin

hright, sir; put it up ngain?

my tongue shall hush again this storm

return tis me again, nfter they heard

u) onec acain; put spirit in the....

I say again, if Lewis do win

I say again, if Lewis do win $\ldots$.........

instantly return with me again.

are come home agnin, come the three.

bids, I should not bicl again............
return lack to their chairs again

return agitu, and take an onth

that speaks thy words again, to do

yet, again, methinks, s.me unbor

here part, that ne'er shall meet again.

stand upon my kingdom once again ...

till so much blood thither come again

speak again to alter this, for counsel is

and lands restmed again, be treel

restored again to all his land

rav that again : the shadow.

and wash him fresh again with.............

wilt know again, beiug ne'er so little.

give me mine ow m agtin; 't were.......
speak it again; twice saying pardon

and then again; it is as hard to com

then am I linged again; and, by and

come yourself with specd to us again
when he pleasc again to be himsclf ....

his nose, and took 't away again ...

urged the ransom once again if....

good if you have not, to't again;
to lift me up again, being down?

to lift me up again, being do
own flesh so tirr a foot again...

I say unto you again, you are

breathe awhile, and then to it agai

send him back again to my mother...

pick thee out three such enemics again

the moncy shall be paid back again.

the money is paid back again.

some surety for a safe return again.....

I must go write again, to other sriends

move in that obedient orb again

never to hold it up again

ha! again. Said he, young Harry

since we are o'erset, venture again ...

call him back again...........................

give us that king again, and take.

but I will have some of it out again....

whether I shall ever see thec again, or. no

$r$ will see you ag in ere I go

in all the inns of court again ............
till he roar again. o lord! good $\mathrm{my}$.

again would a'go, and again would a come-

thin our awful banks again

I never thought to hear you speak again

a fear to be again displaced........

and, again, sir, shall we sow the

a dozen of cushions again; you have ...

begin the battery once a gain

how shall I know thee again? Give...

onec more corne again for ransom...
once more back again; and be that ....

thrice up again, and fighting .

comest thou again for ransom? No ....

in my cap till I see him once again.

do always reasont themselves out again

my life, my joy, again returned.

again, in pity of ny hard distress.....

bctore he'll buy anatin at such a rate

Ill have a bout with you again, or else

to get the town again, or die

like to have the overthrow again .....

like a Frenchman; turn, and tur: again! scouts returned again, that dogged

flies so, will ne'er return again.
GAIN-

go, and he free agnin, as Suffolk's ... IIIenry $V I$. v. 3

I must trouble you arrain, no....

hope to eoncuer them a tain

delivered uy assain with peaceful.

$\begin{array}{ll}. . & \text { v. } 3 \\ 2 \text { Henry } & \text { v. } 3 \\ . .1 .3 \\ \text { i. }\end{array}$

I am pleased "totill. My lord........

restore this cripple to his legs

from hence to prison biek again

the workl may langh again..........
come to me aftin, and given mo

he doth revive again; madam

drove back argiu unto my nutive.
blush und beautify the eheck again.

alive again? then show me where

in eontempt, shall hiss at thee nga

I'll real it over once agaiu

farewell, for I must lience again....

and that will mike 'em rerl again.

are thy sovereign, clifford kncel again

go to bed, and dream again, to keep..

with this we charged again; (repeated)

bethink thec once agnin

never henecforth shall I joy again

again bestride our foaming steeds $(r e$.

take leave until we nuect again.

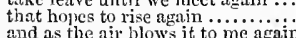

and as the air blows it to me again

chiet to bing him down again

and beat him back arain

and once again l, soeliim us $\mathrm{k}$

will issue out again, and bid ns battie

might recover all our loss again!

doth live again in thce ......................

take up the sword again, or take.

what if it conse to thee again?

shall be reconciled to him again..

win our ancient right in France again

until we meet agran in heaven .........

was urged to tell my tale agnin

here Catesby comes ngain; now Catesby -

call them again, sweet prince

call them again, $I$ an not made of stone -

let's to our holy work again

I say again, give out, that Anne

tell o'cr your woes again by viewing

shall never speak to thce again

and never look upon thy face again

shall come your be motber to a

and made his course again for Bretagne

whip these stragrglers o'er the seas again

perec lives argin; that she may long.

of his master he shall again relate. .

understand again like honest men

a measure to lead them once again..
when he was brought again to the bar

never found a gain bat wher

for it Erows again fresher than ......

I swear again, I wondd not be a aneen

therefore, I say again, I utterly alihor

that again I do refise you for my

then, stops agnin, strikes his breast

'tis well said again: and 'tis a kind ...

like Lucifer, never to hole again...

you are well met once again

paced back again to York-place ....

souls with modesty again

heing but a private man again

I'll unarm again; why should I war. Troil. $\bar{s} \cdot C r$

and such again, as venerable Nestor

thus once again 6ays Nestor from

what! nre you gone arrain

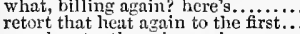

reverberates the voiee again

whd yet it may again, if thou..........

come you again in to my chamber...

where le answers again, beesuse....

when shall we see again? ............

when Helen is a maid atain

warm yet, let us fight ngain .........

stand again; think st thou to eateh..

take and take arain such preposterous
give't me again. Whuse was 't? (repeated)

thou never shalt mock Diomed ayain

age we void it ut agnin
AGAIN-

as it grows again toward earth

go, bicl all nuy friendls asain, Lucius.

dares to be hilf so kind again?.

and spleces to the April day atain $\ldots$

for showing me again the eyes of man

it' I thrive well, l'll vist thec again.

thon'dst courtier he again, wert thon

what else to do, I'll sce the again

I like this well, he will return ngain

go again; and after it again; and over and ove

go again; and after it again; and over and over
he comes, and uy again; catched it again. Cor

we shall be eharged again............

rather luve my wounds to heal again

an t were to give agitin:-but 'tis ....

and, now agiin, on him, that did not

to make road upon's again ........... -

my speech, and I will speak't again

he cannot be reined arnin to temper....

tbe very hour you take it off again? -

his crest up wonld make it flame again

we shall have a stirring world again.

thrusts forth his horns again into

may wish good Marcins home again.

you know the way home again

or capitulate again with Rome's

every noise be still: pence yet again. Julius Co

to him agilin; then he put it by again

when he eame to himsclt' again .....

get you to bed again, it is not day...

had thce there, and here again ......

he begins again to speak $\ldots \ldots . . . \ldots . .$. .

and thou shalt sleep again: I will not

and thoull I sce thee arrin

sleep again, Lucius: sirrah, Claudius! -

whether we shall meet again, 1 know not -

to yonder troops an, why (repeated)

$\checkmark$ will be here agaiu, even with

we wish it ours again ........Antony $\ddot{\&}$ cleope

words of Yompey, return it again ...

but yet hie you again to Egypt ......

I say again, thy spirit is all afraid...

if thou again say yes. He is married

sure he cannot weep it baek again
he will to his Eryptian dish again

I will employ thee back again

to him again; tell him, he wears...

being whipned, bring him again...

severed navy too have knit agnin ....i

ine my lord is Antony agnin, I will

Hie thee again: I have spoke alrcady.

I ans aggin for Cydnus, to meet ......

in the workl, that I may see arain

$O$ the gods! when shall we sec arain.

to the trunk again, and shut the spr

and now tis up again: it must be ....

which he, to seek of me again...

I thought you would not hack again

safe may'st thou wander, ante retnirn again-

kunck her back, fout her home again -

gave them first, has thern ngain $; \ldots .$.
again; and bring me word how "tis.

I have resumed itrain the part $r$.

nor bear arain, but end it by some

ceting the now throw

pr'ythee, valiant youth, deny 't again

I am down again; but now my heavy

I will not loose again, till ........titus Andronicu

these mischicfs be returned again

but, say again, how many saw.

taken them down again..............

this will I do, and soon return again

lil call my brother hack again

tarry with him, till I come again

how to knit again this scattered.

I were dead, so you did live again....

steeple, chireh, and parish, up again ...

but fortune's mood viries again ....

kindle agnin the over-pressed spirits
to blow mto life's flower again ......

my wedded lord I ne'er shall see again

walk, and be cheerful once again ....

I think you'll turn a cliild again....

again thwarting the wayward $\overline{4}$ iv.

aves Tharsus, and again embarks - iv.4 (Gover)

take ine home again, ind prostitute. - 
AGAIN-

father turn our thoughts again..

turn your eyes again nupon ine .......

at Tharsus, and found at sea agitin .

nothingean come of nothing. sneak again -

nor sliall ever see that taee of hers again
old fools are habes aguin, and must ..

measure your lubber's length a train .

bewreep this cause again, I'll pluek

he dies, that strikes again.

better counsel, wive ne nine again

and speak it artain, my lord; no more

I'd say, I had eyes again

I net laim back nain ..................

tempt me a ain to die hetiore sou please

let but the herald ery and I'th aplear again

if ever I returu to you arain

sound. Again. Again. Ask him his purposes - v.

if ever you disturb our streets arain. Lom.

come back again, I have remembered me

Romeo is beloved, and loves again $-\overline{\mathbf{i}} .5$ (cho

o speak again, bright angel....

I would it were to give again...

frank, and gire it thee again ..........
stay but a little, I will eome again

to lure this tassel-gentle buek airain..

with a silk thread plueks it back again

ere thou ask it me again ............

take the rillaim baek acrain, that

and then ageld min

ere I again behold my Romeo...........

that faith returu again to earth.......

God knows when we shall meet again

I'll call them baek again to comfort me

that I ask again; for vothing can be ill

here it is again, nor get a messenge

palace of dim night, depart again .....

if again this app)arition come .........

and let us once again assail your ears -

behold! lo, where it eomes again!

and wishes bend again toward Franee -

the henven shall bruit again, re-speakin

I shall not look upou his like again..

and narble jaws, to east thee up agai

dead corse, again, in eomplete stee,, re

it waves me forth again; Ill follow it

I'll speak to lim again: what do you rea

bring him to his wonted way again ...
take these again; for to the noble mind -

make us again eount o'er, ere love...

tempt you again to bed; pineh wanton

and, sponge, you shall he dry arain.

eore again? and will he not cone again? (song)

he never will eome again (song)

if praises may go back again ...........

fear I, this will give it start again.....

'twill away again, from me to you

withdrew to mine own room agai
a. very palpable hit. Well, again

nay, come again. Look to the qu

and let ourselves again but understand

therefore voueh again, that with som

haste, desprateh, she'd come again

at nine $i$ 'the morning here we'll meet again

which now again you are most apt to play -

yet again your fingers to your lips

yom as a henve

there should be, again to inflame it

will you hear it again? No; for I hoid him

eren as again they were. when you

I will ask bin for and he's yours

I will ask him for my place again...

music that may not be beard, to ' $t$ again -

by the front, to bring you in again

when I love thee not, chnos is come again

give it me again; loor lady, she'll.

I may agaiu exist, and be a meml

can ransom me into his love again

and is again to cope your wife.........

wurn, and yet go on, and turm again...

Othello and Desdemona return again to Venice

I ean again thy former light restore

I cannot give it vital growth again
I think she stirs agaiu: no. What's the

o lady, speak again! sweet Desdemona

is as

and ne'er was $A$ gamcnunon's brother. 3 Hen. $V$. $i$. ii.

Troilus, than Agamemnon and all.. Troi. \& Cres. i.

great Agamemnon, Nestor shall apyly

Agamemon, thou rreat commander

as Agamemnon and the hand of Greee -

great Agamemnon, this ehaos.........
sometime, great $A_{\text {ctamemnon, }}$ thy topless-
AGAMEMNON-

exeellent! 'tis Agamemnon just., Troilus \& Cres call A mamemon head and general ... which is the high and mighty Agamemnon sir, pardon; 'tis for $A$ gamennon's eur' we have a taste of it forthwith to Agamemnon

A gamemnol-how if he had boils? .. -

Agamemnon commands Aehilles; Aehilies

Agamemnon is a fool; Achilles is a fuol -

Agamemnon is a fool to offer to commund o A gamemnon, let it not be so!

general of the Grecian arony, Agamemnon-

conduet from Agamemnon. A gamemnou?

'tis Agamemuon's vish: aud great.

great Agrmemnon eomes to meet us

after we part trom $\Lambda$ gamemnon's tent

here's Agamemon, am honest fellow

like an a an agate very vilely cut .. Nuch Ado, iti. never manned with au agate till now..2 Ilen. $1 H^{\prime} . \mathrm{i} .2$ AGATE-RING-

nott-pated, agate-ring puke-stocking. 1 Hen. $I V$.ii. 4
AGATE-STONEno bigger than an agate-stone on the. Rom. \& Jul. i. 4 GAZLD_whole army stood agazed on.1 Hen. $F$.i. to excel the golden age

and as, with age, his body itglier grows

let me embraee thine age............... of $\bar{T}$ er. $\mathrm{i}$.

to elothe mine age with.....

the remant of mine a a

learn the humour of this ace .........Merry $W^{\prime}$ ives, $i .3$

well nigh worn to pieces with age.

like the old age.

Tuelfth Night, ii.

to see this agel $A$ sentenee .......... - ii. 1

thou bast nor youth, nor age

uruch Ado, 1.1

beyond the promise of his age..........

when the age is in, the wit

trust not my age, my reverence....

nor age so eat up iny invention

as under privilege ot age, to hrag

do not erect in this age his own

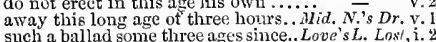

such a ballad some three age ssince.. Love's $L$. Los/, i.

the boy was the very stafi of my age...Mer. of Ven. ii..

and wrinkled brow, an ase th

the sparrow, be comtiort to my age!

therefore my age is as a lusty wi
two weak evils, age and hunger

his aets being seven ages.........

buckles iu his sum of age . $1 . . . .$. .

the foolish chronielers of that age

whose houghs were mossed with age
a ripe age; is thy name William?

on us both did haggish age steal on...
to whieh title age cannot bring thee

in what motion age will give me....

$r$ 'll have no more pity of his a

(verses) iii.

whose are and honou' both suffer

any woman in this waning age. Faming of $\bar{S}$. (Ind.)

stand back; 't is age that nomisheth -

in his waning age, set toot......

iv.
as well as revercnd age, I may
most ignorunt by age, or thon .... Winter's Tale, 1.
I would there were no age between ...
well you fitonr ages with flowers...

they are given to men of middle age.

indeed, tlian most of his age

your ages, of what having, breeding.

age, thou liast lost thy labour...

hath honely age the all uring beaity. Com. of $\mathrm{Er}$. ii..

I see thy are and dangers make

that which should accompany oild age

sweet proison for" the age's tooth
hut in this iron age, would do it..

a make-peace shinl become my are...
shall be extinct with age, and encless

to furrow me with are, but stop
unkindness he like erovked age.

that age and sullens have..........

who, weak with age, eamot $\ldots$.......

of woetid ages, long ago betid...

not be many hours ot age more.....

when his infant fortune came to age..1 Hen. $1 \mathrm{~V}$.

to the pupil age of this present
his age some fifty, or, by 'r lady

of the age of two and twenty, or thereabout

truth, in this fine age, were not

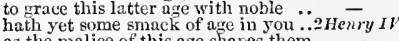

as the malice of this age shapes them
old with all the characters of $y+r e ?$

can no more separate age and covetoishess

(as, force perforce, the age will pour it in -
and weak age, of indigent fuint ...... Henr
$\Delta \mathrm{GE}-$ and see old age, will yearl

learn to know such slanders
old age, that ill layer-up of...
hereater ages may beliolel.

hereatter ages may beliolt...........
keepers of my weak decaving age..

in an age of eare, argue the end.

redcem the passage of $y$

fitter for siekness and for $\mathrm{cr} . . . . . .$.

when sapless age, and weak mable..

then leaden age, quickenerl.

I shall die with mickle age........

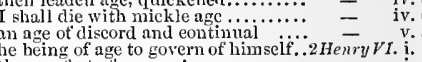

this dishort of my age! ....... in thine age wili bring

solace, and mine age would ease...

a bricklayer, when he came to age

shame thine honourable age with blood? -

unto the rrave with
livery of advised age

eternized in all age to come

slipped our claim nntil another age...3 Henry $V$. 5. o pity, God, this niserable age! $\ldots . . .2 \%$ ii. with the grossness of this age.
succeeding ages have re-edified...

successively trom age to age, he

that ever wretched agre bath looked

thy age confirmed, proud, subtle .......

mine shall be a comfort to your age...

youth, to wail it in their age......
plants, to wail it with their age...

children quit it in your age...

greater honours to his age than man

to rem whose age we void it un ... Timon of Athens, i. 2

but your age has forgot me

nolnoured age for ........... - iv. 3

his pupil age man-entered thus.
shall hardly in our ages see their

have been within my age

and your misery increase with your age!

groaning underneath this age's yolie...Jul. $\vec{C}$ es

age thou art shamed

when went there by an age

should do your age some inischief.....

how many ages henee, shall this $\ldots . .$. - iii.

in peace, lead on our days to age ..... - . v. 1 age cannot wither her, nor cllstom ...

well eorresponding with your stiff age -

he it is, that hath assumed this age..

wrong mine age with this indiguity.. Titus And. i.

his, that shakes for age and feeblewess

a staff of honour for mine age.

for pity ot mine age, whose youth ...
I brimg consuming sorrow to thine age

I ain of age to keep mine own......

nor age, nor lionour, shall shape

if my frosty signs and chaps of age.

complexion, height, age, with warrant.Poricles,

to outive the age $I$ an ................. - Lear,

balm of your age, most best

you see how full of changes his age is

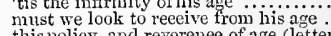

this policy, and reverenee of age (letter).

such men as may besort your age ...

as full of grief as age would not yield to......

whose age has charms in it

a pretty age. Faith I ean tełl her age.Rom. \&.Jul.

all christian souls! were of an age

fall baekward, when thou eom'st to age

tiuther woe eonspires against mine age?

as proper to our age to cast

so his sickness, age, and impotenee.... -

tor, at your age, the hey-day .......... -

than settled age his sables, and his weeds -

but age with his stealing steps (songs)
the are is grown so picked, that the..

I know, the drossy age dotes on .........

it yet has felt no age, nor known ...... Othello, ji. GED-their sinews with aged eramps.. Tempest, 1

thy blessed youth becomes as aged.. Mea. for $M$. to be aged in any kind ot course.

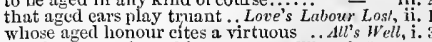
wothing so aged, as this seems .... minler's Tule, $\mathrm{y}$. Nestor like aged in an age of ...... 1 Henry $v 1$. ii. first lean thine aged hack.

forgets aged contusions and ail ........ IIsnry VI. v

dimmed your infant morn to aged night.R. NII. iv,

and take our goodly aged men by...Timon of $A$. $h$. 
AGED-

an aged interpreter, though young.. Timon of A. v. 4 aged sir, hands oft: Hence, rotten... $-\frac{\text { Henbeline, i. } 2}{2}$ and, being athed, dic of tris tolly filling the aged wrinkles in my .. Titus Andron. iti. [Calle aged [Callier- mrepare thy aged eyes]...
and fill this aged ear with golden.

as he regards Jis aged tia ther's lite. I thall with aged patience in the oppression of agted

and our aged tathur's right

AGENOR-the damblter of Agenor.. Taning of $S$. i. AGEN'T-the agent of her heart. T' this ungenitured atgent will.... and well become the agent: it ma beil up exh eorporat agent to this ... whiles night's blaek agents to their prey _- iii. 2 Gudes wrathful agent, do correct

(the agent of thy toud inconst

as the agent ot our carlinal.

thus is the poor agent despised!. Tr

the agent for his master

I will aggravate his stile; thon but I will aggravate n

atgravate your eholer

(GIn

AGILE-his arile arm heats down.. Rom. \& Jul. iii. 1

a

Henry $I V$. i. 3

aifright the air at Agineourt?

AGITATION - in this slumbry agitation ... IIacb. v. so now I speak
AGLET-BABY

to a puppet, or an aglet-baby ..... Taming of $S$. i. AGNIZL-1 do agnize a natural and prompt.. Oth.

he might have tonk his answrer long aro -

we made each other but so late ago

a great while ago the world...

tour days ago. Let's see the ........ our ago, sinee it.

past my garuut long ago. Taming of the Shrew, iii. twenty years ago, in Geu

we had the tune ou't a month a.r.

three nights ago on Goodwiu sands

woeful ages, long ago betid ......... Richard $1 I$. v.
fourteen hundred years ago, were ... Henry $I V$. i.

he is my lord, an hour ago

how long is it ago, Jack, sinee

no longer ago than Wednesday last.2 Henry $I V$. ii. that's fifty-tive year ago

ten days ago I drowned............ 3 Henry $I V$, ii. have hraved the east an hour ago .....Rich. III. v. 3 not long ago, one of his men ... Timon of Athens, iii.

over-roasted rather; ready long ago.
I read it in the grammar loug ago.Tilus Andro.iv. 2 is it two days ago, sinee I tripped ip ... Lear, ii. 2 his sou was hnt a ward two vears agoRom. \& Jul.i. 5 I would liave been a-bed an hour ago - iii. 4 O heavens! die two months ago ....

how long ago, and when he hath ....... Othello, iv.
AGONE-long agone I have forgot. Two Gen of $V$. iii. he's drunk, sir Tohy, an hour agone. Tuelfih $N$. v. 1 AGONY - ach with air, and agony with. Mueh Ado, v. 1 mirth eannot move a soul in agony . Lore's $L . L$. v. 2
take that to end thy agony ........3 Henry $V I$. v. 5 take that to end thy agony ..........

God knows, in torment and in agony $\vec{V}$ he was stirred with sueh an agony. G. of ter.iv. AGR EE-it agrees well, passant ....Merry Wives, i. I but, gentles, agree: the eivil war of. Love's $L$. $L$. . il. I notes agree. Tam, of $S$. v. slould well agree with our external.

I very well agree with you in the ...Winter's $T+i$. liow ill agrees it with your ... Comediy of Errors, ii. the gentlemen do not agree with..2 Henry IV. (epi.) higestions, does not agree with it

to France; agree to any coverants

style agrees not with the leannes

yees, I agree,

and so asree, the play may pass.. Henry $\overrightarrow{V I} L$. (pro

ere we can arree upon the first .... Timon of $A$. iii. 6
therein our letters do not well agree... $J$. C Cesar, iv. 3 full well, Andronieus, agree these deeds. Tit.An. i. nay, come agree, whose hand shall go

agree between you; I will spare.

an she agree, within her seope ...........Pereo \& Jul. $\mathrm{i}$. it best agrees with night ........... are you agreed? and there heard it agreed upon, that... Much $A d o$ iv. ${ }^{2}$ I am agreed; and would I had given.. Tom. of S. i. I eonelude, and be agreed; our doctors say..K.II. i. the traitors are agreed; the king..Henry, H. ii. (eho.)
agreed; I'll to yon corner. And I this.. 1 Hen. VI. ii. I it is agreed between the French $.2 \mathrm{HenVI}$. $\mathrm{i} . \mathrm{l}$ (art.) agreed between them; that the dutchies - 1. 1 the peers agreed; and Henry ...... Henry $\vec{V}$ III. v. $\triangle G R E E D-$

thus we are agrecd: I erave, our..... Ant. \& . Cleo. ii. 6
liave our two wagers reeorded. Agreed ... Cymmb. i. 5 What, nre you both arrecl? ............. Pe
AGREELNG $\rightarrow$ most of all, agreeing with the all ochreeination in earmestness to see him for Mersure, 1. mect, and agreeing with thine infancy. Tit. And. y. drugs fit, and time agreeing............. Hamlet, iit. upon some arreement, shall you find
with either part's agreement stand?.

upon atreement, of swift Severn's ..1

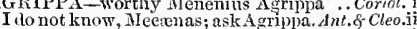
speak, Agrippa. Thon hast a sister.

say not so, Agrippa; if Cleopatra heard you
let me hear $\Lambda$ rrippa t'uther speak

power is in A $\mathrm{Arippa}$, if I would say $\mathrm{A}$ grippa

adieu, noble Agrippa. Good fortune

go torth, Agrippa, and berin the

AGROUND-We rnu ourselv

I will help his agut.

how does thine agre?

till fumine, and the ague, eat..

and meagre as an ague's fit........

how scapes he agues, in the de

an untimely ague stayed ine

like an ague, suhtly taints.. Troilus \& Cressida, iii. 3

as that same ague which hath .....Julius Cosar, ii. GUE-CHEEK

who, sir Andrew Aguecheek? ....Tu'elfth Night, i. 3 set umon A gueelheek a notahle report -

AGUE-FACE-sir Anurew Agueface.. Twelfth $N$. i. 3

AGUE-FIT-

this agne-fit of fear is overblown ...Richard II. iii. 2
AGUE-PROO -I am not ague-proof .... Lear, iv. 6

A-IIOLD-lay her a-hold, a-hold.......... Tempest, i.
A-HUNGRY - I an not a-hungry... Merry Wives, i.
as to drink wlien a man's a-hungry.. Tuelfth $N$. ii.

AID-by whose aid, (weak masters.

to aid me with thy aid

to aid me with thy eonnsel ....Twn Gen. of Irer. ii.

and be my aid for sneh disgtuise, as .. Tuelfth N. i.

should tender your supposed aid ...

by the good aid that I of you.

by thy honest aid, thou kept'st

didst connsel and aid them. Winter's ${ }^{2}$. iii. 2 (indic.)

omit nothing, may give us aid

their monld, hut with the aid of use . Nlacbeth, i. 3

the holy king his aid to wake

strongly sworn to give him aid...

strongly sworn to give him
to this we swore our aid

and surmise of aids uncertain

King John, ii. 2

in aid whereof, we of the spiritual

1 Henry I $V$.

her aid she promised, and assire

2 Henry $I V$. i.

renowned Talbot doth expeet my aid

our o'er-matched torces forth for aid

surecours that should lend him aid

York should have sent him aid.

$\begin{array}{ll}\text { appear, and aid me in this enterprize } & - \\ \text { eraves aid of your lonour from the.2 Henry } & V I \text {. iv. } 5\end{array}$

eraves aid of your honour from the.2 ffenry 7 . iv. 5

with aid of soldiers to this needful...3 Lenry $_{V I}$. ii.

Ill aid thee tear for tear

eraving aid tor Hienry .............

to erave thy just and lawful aid...............

be released from giving aid ...........
I firmly am resolved, you shali have ai $\overrightarrow{-}$

I firmly am resolved, you shall have aid -
how ean we aid yout with ........... Richard 111. ii. 2
expecting hut the aid of Buckingham
fear of that withlolds my present aid $\quad$ iv. 4
iv. 5

fear of that withlolds my present aid

ere $I$ could leud thee aic

never seek for aid out of himself....... Henry $\nu$ rII. $\mathrm{j}$.

that best can aid your action .........

if your refuse your aid uphraid un

to lend me arms and aid

will pray in aid tor kindness

it is for justice, and for aid.

to ue and to my aid, the blest ........ Pericles, iii.

go join with you some further aid ..... Hamlet, iv. I

AIDANT-he aidant, and remediate ..........ear, iv. 4

AIDING-heaven aiding, and hy the...All's Well, iv.
then deny her aiding hand therein... Richard III. i.

AIDLESS -aidless came off, and with. Coriolanus, ii.

your aiery buildeth in our aiery's nest - . - i. i.

aIG RE E
[Knight] like aigre droppings in to milk

AI - what does she ail, that she's not. All's Well, ii.

AIL'ST_-what aul'st thou, man?.. Winter's Tute, iii.
AIM-my jealous aim might err.. Twa G. of F'er. iii. hehold her that gave airn to.
AIN-that now I aim at

thin the aims and ends of biurning. Mea. for Hea. . . but it all aim but this be levelled false

a eertain aim he took at

from the hunters'

argainst the level of mine aim

fly with false aim; moye the

and my sweet hope's aim....
sister, sweet, for I aim thee

catest way is, to avoid the aim

not swifter toward their aim ...........

fleshed with conquest, aim to
with a near aim, of the main

with a near aim, of the main

as an aim or bntt, ohedience.

and aim we'at the best .........

your highness ains at, if $\mathrm{I}$ aim aright

my thoughts aim at a further matter.

gness that he doth aim at it?...... Richard $11 I$. iii.

know the Bretagne Richmond aims at

wander from the good we aim at.. Henry $\bar{V}_{I I I}$. iii.

the elief aim of his honour

not auswering the aim, and that... Troilus \& Cres. 1.

fame, at the which he aims.

we shall be shortened in our aim ......

even in the aim and very flash of it

thourgh enemy, lost aim ......... Antony \& Cloo, iv. 12
my lord, I aim a mile beyond ... Tilus dudron. iv. 3

give me aim awhile................

where the aim reports, 'tis of t with ........ Othello, i. 3

as my thoughts aim [Knight-aimed] not at iti. 3

my discovery be not aimed at.. Two Gen. of Ver. iii. 1
well aimed of sueh a young one.... Taming of $S$. $\mathrm{i}$. 1

this hird you aimed at, though you ...
seen in him, aimed at your hishness... Richard II. i. 2

in faith, it is exeedingly well aimed... Hen. IV.j.

I nimed so near, when I supposed... Romeo \& Jul. 1 . I

[Knight-my thoughts aimed not]......... Hathello, iii. 3

let all the ends, thou aimest at..... Henry $V^{\prime} I I I$. iii.

our soldiers, aiming at their safety..2 Henry $I V$. $i$.

aiming, belike, at your interior hatred... Rich. II I. i. 3

I' the air, of the air with sighs

with its sweet air.

the goddess on whom these airs attend

and sweet airs, that give delight

where thou thyself dost air ...............
are melted into air, into thin air

that they smote the ai

hast thou, whieh art but air

a solemn air, and the best

love ean feed before

than live in your air

i. 2

she purged the air of pestilence ... Tüelfth $\bar{N}$ irht, i.

between the elements of air and earth

more than light airs, and

lest the device take air, and taint....

which the air heats for vain........... - iv.

and so stop the air for wain ...Measure for Meas. 1i. 4

now divine air! now is lis soul.......... Iu $\overline{c h} . A d o$, ii.

eharm ach me into air

your tongue's sweet air more tuneable. Niü. N. D. i. 1 washes all the air, that rheumatie .. - ii. 2 and in the spiced Indian air, by night $\vec{i}$ ii. 2 playing in the tendemess of........... (verses) jiv. air quoth he, thy eliceks may blow (verses) iv. 3 all the other passions fleet to airs.. Mer. of Ten. iii. 2 bring four music forth into the air.
or any air ot music toueh their ears.

yet thou liest in the hleak air..... ss yau $\overline{\text { Like }}$ it, ii. move the still piereing air ..........

although the air of paradise did, fan.:
with her hreath shedid perfume the air.

with her hreath shedid perfume the air. Tam of $S$.
elimate's delicate; the air most sweet.Winter's $T$.

i' the open air, hefore I have got.

see'st thou not the air of the court.

purge all infection from our air.

there is an air eomes from lier

throngh the fog and filthy air.......... Nacbeth, i.

they made themselves - air .... - i. 5 (letter)

the air nimbly and sweetly recommends - i. 6

upon the sightless courier's of the air ..... Macbeth, $\mathbf{i}$.

and genernl as the casing

I and ger the air; this night I'il

I'll eharm the air to give a sound.....

infected be the air whereon....

howled out in the desert air....

as easy may'st thou the in trenchant air

leave them as naked as the vulgar air. $K$ in

moeking the air with eolours

being brought into the open air

cast forth in the common air 
AIR-hangs in our air, and thou art .. MicluerdII. i. 3 brooks your grace the air as higl $i$ 'the air as this

as high i' the air as this ............. Henry IV.i. 3 [Knight] the quality and air of our attemy
what is that honour?

eating the air on promisc $\ldots \ldots \ldots \ldots$....
give him air, he'll straight be well

give him air, he'll straight be
marry, good air; spread, Davy

aftright the air at A fincourt:
the air, a chartered libertine

the air, a ehartered libertine

up in the air, crowned withl

this your air of France hat

he is pure air and fire.

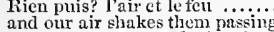

but stink, and putlefy the air

smell the air shall be perfumed .... IICnry $V^{\prime}$.

shall not breathe intection in this air

and eatch the air, blasplieming God.

breathe my soul into the air

foul contagious darkness in the air

if mine arm be heaved in the air ...

cherish weeds, but gentle air?......3 Henry $r I$.

the air hath got into my deadly......
and, as the air blows it to me again..

how to find the open air.

how to find the open air..............

those that hreathe them in the air.

his cnopty, vast, and waldering a

it yet your gentle souls fly in the air

the air will drink the sap

there's tresher air, my lord, in ..........

his person, and share the air witli us

carpenter, the air is sweet.

as talse as air, as water ...............
trom the lion's mane, be shook to air

that the applalled air pay........

through him drink the frec ai

a dedicated bergar to the al

all part into this sea of air............
below thy sister's orb infeet the air

hang his poison in the sick a
the bleak air, thy boisterons

promising is the very air o' the time

doth choke the air with dust

that do corrupt my air, I banish you

you are they that made the air unwhole

splitting the air with air...

my lips, and receiving the bad $a \mathrm{ar}_{\text {. ...juliu }}$

the exhalations, whizzing in the

the rheumy and nopurged air

whistling to the air, which, but for

music i' the air. Under the carth
fight i' the fire, or in the air.

and mock our eyes with air.

I am fire, and air ; my other elements

as soft as air, as gentle ................

but riding forth to air yourself

where air comes out, air comes in...

from the smallness of a gnat to
after, a wonderful swect air...

after, a wonderful swect air.............

nor know not what air's from lome..

and the air on't revengingiy enfeebles me

embraced by a picce of tender air ( $\left(r^{\prime} c p.\right)$

the piece of tender air, thy virtuous..

elipped about with this most tender $a i r$

lamenting doings in the an'?.. T

to stop the air would hurt them

should open to the lis

our woes into the air ..........

earth, sea, and air, were all $\ldots \ldots . . .$.
as fire, air, water, eartly, and beaven

I pray you, give her air............

the air is quek there, picreing
bird that tlies i' the purer air!.

bird that ties i' the purer air!...
you taking nirs with lameness!

choose to wage against the enin
that in the pendulous air hang

here is better than the open a

thou unsubstantial air, that I cmirace

would streteh thy spirits up into the aix

that wing the midway air

featlers, air, so many fathom...

spread his sweet leaves to the air .. Rom

which is as thin of substance as the air.

cails upon the bosom of the air

idle in the wanton summer air .....

with thy breath this neighbour air ${ }_{\text {the }}$ air [Collier. Knight-earth] doth drizzi

no healthsome air breathes in.....

for it is, as the air, invulnerable ...

the air bites slurewdiy; it is very cold

a nipping and an eager air

bring with thee airs from heaven........

methinks, I scent the morning air

out of the air, my lord? (repealed).

this most excellent cannpy, the air

nor do not saw the air too much

I eat the air, promise-erammed

and hit the woundless air....

go, vauisl into air; a way
AIR-light as air, are, to the jealous.... Otkello, iii. 3
hath blown his ranks into the air ... - iii. 4
O bear him speak as liberal as the air [Colier. Kint.-north] v. 2 your stately and air-braving towers. 1 Henry $\boldsymbol{H}$ l. iv. 2 AIR-DRAW N-the air-drawn dagger. Hacbelh, iji. 4 shortly after this world had aired them. II. VIII. ii. 4 AIRLESS-airless dungeon, nor strong...Julius C. i. 3 AIRY-that this airy

that thou shalt like an airy spirit go.Mid. N. D. iii. and gives to airy nothing a local

like an caglc o'er lijs airy tower.

with your airy wings. Rich. $I I I$. iv.

his ear full of his airy tame ... Troilus \& Cressido, i.

[Knight-lion's mane, be slook to airy nir] - iii.

brawls bred of an airy word....... home
would throngh the airy rection stream

and make her airy tougue morc hoarse

of so airy and lirht a quality $\ldots \ldots . \ldots \ldots$ hamlet, ii.

will be given to $\Lambda$ jax .............. - v. for sure, Eacides was $A$ jax ...... Taming of $S$. jii.

to Hector; they eall him $\Delta$ jax

Ajax is grown self-willed
let blockish Ajax draw the

brainless $A$ jax come safe off

Ajax, employed, plucks down

whocoever you take him to be, he is $\Lambda_{j}$ jax

this lord Achilles, Ajax, who wcars..

Ajax was here the voluntary

to Achilles! to Ajax! to! I sliail eut

shall the elephant $A$ jax earry it thus
what moves $A$ jax thus to bay .......

then will A jax lack nater

no, noble $\Lambda$ jax; you are as strong.....

your mind's the clearer, $\Delta$ jax

the steps that Ajax makes when

his addition yield to sinewy Ajax

the eminence of him the as $\Lambda$ jax ....

be ruled by him, lord $A$ jux ..........

their flower, $\mathrm{Nax}$ shall cope

good-norrow, A jax. Good-morrow

immediately the unknown Ajax

throw upon him, Ajax renowned

clap the lubber A jax on the shoulder

but our grcat $A$ jax bravely..
shall Ajax fight with Heetor?

Ill send the fool to $\Lambda$ jax

A jax goes up and down the field

You shall see the pageant of $\mathrm{Ajax}$

Jove bless great Ajax.

this A y thou dreadtul Ajax

stand by our $\Lambda$ jax: as you and lord.

now, Ajax, hold thine own! ........

let me embrace thee, A ja.

the issue is embracement: $\Lambda$ jax, farcirell -

Ajtx, your guard, stays to conduct....

A jax, against that dog of as bad a kind

bid the snail-paeed A jax arm for

Ajax hath lost a firieud

Ajax hath ta'cn Aineas

Thersites' body is as good as $\because$ iaxtony \& Cleo. iv. 12

did bury $A$ jax that slcw himselt.. Titus Andron. $j$.
and eowards, but $A$ jax is their fuol ....... Lear, ii.

AKIN-akin to foul redemption.. Meas. for Mees. if.

ii. 4 AYABASTER-monumental alabaster.. Othello, v. 2

within their alabaster innocent a'ms. Rich. III. iv. 3
AL $\Lambda$ CRI'TY - not that alacrity of 'spirit. Rich. III, y. 3

AL $A$ CRI'TY-not that alacrity of spirit. Rich. III. $\mathrm{Y}$.
I have a kind of alacrity in sinking...Merry $W$. iit.

with a bridegroom's fresh alacrity...Troil.\&-Cres, iv. 4

iii. 4 A-LAND - why, as men do a-land

(it' e'er this cotlin drive a-land).

Alarbus' limbs are lopped, and entrails

be ready to direct these home alarms. Richard Il.i.

when the angry trumpet sounds alarm ..2

arming to answer in a night a

as the steeping soldier, in the alarm.

Humlet, ii. 2

speaks, is it not an alarm to love? ....... Otkello, ji. 3 hark! what ner girum is this same?

sound, sound alarum ; we will ..... i Hevery

hearing alarums at our chamber

such fierce alarums both of hope

sound trumpets, alarum to the......2 2 nenry $V 1$. vi. our stern alarums changed to merry...Richare III. $\mathbf{i}$.

i'the sun, when the alarum were struck.. Coriol. ii.

and treason!

iii. 2 ring the alarum-bcill : blow, windi...... - 7.5

UNED-alorumed hy his sentinel

I thank God, and saint Alban
AYBANmore affected tho less loving son of Albany. Lear. i. to thinc and Albany's issue be this..

Cornwall, and Albany, with my two his party 'gainst the duke of Albany? efming, 'twixt Albany and Cornwall

LBEIT- atheit, I will confess ths. Merry $\overline{\text { Hives }}$ iv. 3 albeit the quality of the time.... Trelfin Nigh, iit fulock, albcit neither lend ...Merchunt of Ven. i. for more certainty, albeit I'll swcar.. $-\overline{\text { in. }}$. atheit, I confess, your coming befure. As you $L$. ire, albuit nyy wrongs might .. Comedy of Lrrors,

noble Dauphin, albeit we swear.

[Collier] albeit I make a hayard

alteit, $I$ conld tell to thee (as to one..2Henry $I V$. ii. 2

albeit against my conscience ....... Richurd III iii. 7

and shall, albeit sweet music

a worthy fellow, albeit he eomes on ... Cymbeline, ii.

albit unused to the melting mood . ..... Othello, y. 2

loosing ken of Albion's wished const..2 Ilem. VI. ii.

great Albion's queen in tormer golden.3 Ilen. FI.iii. 3

then shall the realm of Albion come $\ldots . \overline{\text { Lenr, iii. }}$

ALCUEMIST-and plays the aleluemist .. K. John, iii.
youl are an alchenist, make gold .. Timon of $A t h$. v.

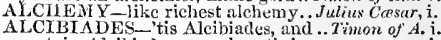

1 eaptain Alcibiacles, your heart's in ... -

We'll forth again, my Alcibiades
this is to lord Timon; this to Aleibiades -

Aicibiades is banished : hear you of it? -

drive back of Alcihiades the approaches wild

if Alcibiades kill my countrymen, let
be Alcibiades your plague, you his..

to prevent wild Alcibiades' wrath

trom Alcibiades to Timon's cave
AYCIDES-so is Aleides beaten by let it be more than Aleides' twelve... Taming of S.i.2

as grcat Aleides' shoes upon an ass... King John, ii. I

Where is the great Aleides of the field.1 Hen VI. iv. 7

nor great Alcides, nor the god of war. 'Titus And.iv.2

ALDERMAN.

crept in to any alderman's thumb-ring.1 Hen.I $V$. ii.4

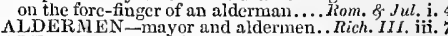

ALE-ro to the ale with a christian. Tixo $G$. of Ver.

sou brews gnod ale

you brew good ale

Twelfth $\bar{N}$ iij.

no more cakes and ale ........Twelfth Night, ii. 3

were he not warmed with ale..Tum. of S. 1 (indue.

on the score for sheer ale

once again, a pot $o^{\prime}$ the smallest ale -2 (induc.

for a quart of ale is a dish. Winter's Tale, iv. 2 (soln:)

all my fame for a pot of alc, and snfety $\mathrm{Hen} . \mathrm{V}$. iij.

in his ales and his angers, look you .

do you look for ale and eakes here...Henry $\bar{H}$ rII. $v$.

ALECTO-with fell Alccto's snake...2 Hen. IV . v.
ALL-HOUSE- to the ale-house with. Two G. of V. .i.

if thou wilt go to the ale-honse, so . - - in ale-house of my lady's house. Twel. N. ii.

call at all the alc-houses, and bid ... Nuch Ado, iii. 3

triumplh is become an ale-house gucst?.Rick. 11 . v. I
would $I$ were in an ale-louse in London... $H . V$. iii.

my image but an ale-house sign ...2Henry $V I$. iit.

ye ale-house painted signs ....... Titus Andron. iv.

to make tools laugl i' the ale-hinse ... Othello, ij.

the heir of Alengon, Rosatine her name - ii.

when Alengon and mysell werc down
lhe is a friend to Alencon and an cnemy

he's a friend of the duke or Alengon's

is take out of the hchmet of Alencon

that this is the glove or Alengon $\dddot{\ldots}$ - iv.

the ditke of Alengon fleth to........ IIenry VI.

but unto thee, Alemen, and the rest $=$ iij. Charles, Alengon, and that traitorous

and Burgundy, Alengon, Reignier ..

Calaber, Bretagne, and Alcngon .....2 Henry $v 1$.

the duchess of Alengon, the French ...Hen. VIII. iii that in Aleppo once, where a malignant. Öhello, v. 2 fouming bottles, and alc-washed wits .. Hen. $v$. iij. 6 the fat ale-wife of Wineot .. Trming of $\mathrm{S} .2$ (induc.) two holcs in the ale-wite's ncw petticoat. $2 H . \perp V$. ii. 2 the parish curate, Alexander .... Love's L. Lost, v. 2 is dismayed: procced, good $\Lambda$ lexander
Alexander lift his to the worthiest... Winter's $T$.

like so many Alexanders, bar in in ...Herry $V$. I think, Alexander the Great was born inif you mark Aiexander's life well .. -

as Alexander is kill his friend Clytus
Alexaniler Lden, an esquire of Kent .2 Hen. VI. iv. 70 
ALEXANDER

Alexander Idlen, that's my name ..2 Heniry VI. v. 1 as a thing made for slet; and Armenit. he gave to Alexander. Ant. \& Cleo.iii. 6 think Alexunder looked o' this fashion.. Hamlet, v. 1 trace the noble dust of Alexund

Alexander died, Alexander was buried

AIEXANDRIA-

ine news. Antony \& Cleo, when rioting in Alexandria; you did

in Alexandria,-here's the manner of it

tlurough Alexandria make a joli march $^{-}$iii. 11

ALEXANDRIAN and present our Alexandrian revels.

ALEXAS-Aleas, come, lis fortune

lord Alexas, sweet Alexas, most any thing

Alexas, almost most absolute Alexas

welcome, my good Alexas: did I, Charminu

go to the tellow, good Alexas; hid him

birl you Alexas hring me word

Alexas did revolt; and went to Jewr

testy mangistrates (alias, fools)

testy rangistrates (alias, fools) .... Coriolanus, ii. 1

thou liest! sir Alice Ford.

Madam. Alice nualam. or Joan (ind.) Tam. of S.
Alice, tu as été en Angleterre, et...... Henry $V$. iii.

excusez moi, Aliee; escoutez: de hand

AIIEN-be proved against an alien.Mer. of Ven. iv

and art almost an alien to the $\ldots . .1$ Henry $I V$. iii.

therefore eourage, good Aliena..... As you Like, i.

I'll tell thee, Aliena, I cannot be

I love Aliena; say with her, that she

when, your hrother marries $\mathrm{Aliena}$

ALIGHT-bidheralight (song) ....... Lear, iii.

e'en at hand, alighted by this .. Taming of 'shr. iv.

nobles of the senate newly alighted..Timon of $A . i$. 2

all men are not alike; alas, good........ueh Ado, iii.

where all alike do dote .... Love's Labour Lost, iv.

but looks on alike: wilt please

the odds for high and low's alike

male twins, both alike; those

the bill that writes them all alike.......Macbeth, iii. 1

both are alike; and both alike we like...John, ii. 2

will you have my power alike....... Henry $V_{i}$ it.

and good devil, were alike, and both..3 Hen.VI.

hlamed for it alike with us .

things, that are known alike ........

curses aud his blessings toueh me alike $-\bar{c}$

both alike: he merits well to.... Troilus \& Cres. iv.

serving alike in sorrow

at all times alike men are not.....

each in my love alike, and none

fetch him off, or make remain

all boats alike showed mastershi

our dungy eartli alike feeds beast ...Ant. $\overline{\text { g }}$ Clco

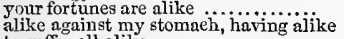

to suffer all alike.

disdains thee and the devil alike

pray not alike; though forfeiters ....

in dignity, whose dust is both alike..

creatures may be alike ......

every mother brceds not sons alike

both alike in dignity .... Romeo \&. Juliet (vrologne

bound as nell as I, in penalty alike.. $-\bar{i}, 5$ (cho

LISANDER-that I am Alisander.. Love's L. L.v.

'tis right; you were so, Alisander

away the conqueror, take away Alisander-

run away for shame, Alisander

ALIT-quod me alit, me extinguit

LIVE-he came alive to land

dead or alive?

that Julia is alive......................... Gentemen of Ver. ii. 6

I have one friend alive

you are the eruelest she alive ............ Tuelfth $\bar{N}_{i}$

there is scarce truth enough alive.HLa. for NIea. iii. 2

that might come if he were known alive $-\quad$ iv. 3
I have reserved ulive ...............

if 1 know more of any man ulive........nuch $\vec{h}$ do, iv.

(God rest his soul!) alive or dead?

and means, for every man alive.

(

of all the men alive, I never

what blessings I have here alize... Taming of Shr.

$O$ that he were alive, and here beholding -

not left a purse alive in the whole army -

a son, who shall be flayed alive ......

reme be alive again, and dare me to...
'twould have $e t h$,

'twould have angered any heart alive

young Arthur is alive; this .......... King John, iv

they heard young Arthir was alive?..

in you I see old Gaunt alive

that man is not alive, might

of more bold, is now alive........... - $v$.
ALIVE_if Percy be alive, thou get'st..1 Hen. IV. v. 3 AIIIIALLOWMAS-

bears not alive, so stout a ........

art thou alive? or is it fantasy $\ldots \ldots . . \quad$ v. - ALL-IIALLOWN

bad been alive this hour

which says the dead is not nilive....2 IJeury $1 \%$. i. 1 ALL-IIOLLOND

and is Jane Nightwrork alive? Slie iives - -

there's not a boy left alive

fight withal, if he be alive

be thou grneious to none alive

ah, York, no man alive so fain as I...2

alive ngain? then show me where

the brieks are alive at this day

ah, were the duke of Suffoll now alive

gronnd gape, and swallow me alive..3

why, then he is alive. Nay, he is

if that our noble father be al

for reverenee to some alive $\ldots \ldots \ldots \ldots$.

the greatest monarch now alive may. Hen. VIII.

wouldst not entomb thyself alive.

no man alive can love, in su

the cap of all the fools alive

Timon; who, alive, all living men

weil, to our work alive, what do you

shall ever take alive the nohle Brntus

or alive, ordead, he will be found like

our will is, Antony be took alive. Anto

Cymbeline dreams that they are alive .. Cymb. iti.

he is alive Ajax, when neither are

the same dead thing alive.

whom you Goths beheld andive, and dead

hither both thy sons alive; and that

the villaiu is alive in 'Titus' house

to killen bad, keep good alive
she is alive; behold her eyelid

put them i' the paste alive.........

ALr-lionoURED

summer

tnight.Merry Wives, i. 1

What

one tlay shall erow"rn the for alliameel... Anch Allo, ii.

and in his yarties, his allianee.

in love and dear alliance, let thin

that in alliance, anity, and oaths

as his allinnce will confirm our peacc

by this alliance to make void my suit

joined with France in such alliance.

by blood, and by allianee ............

infer fair England's peace by this alliance

combined. . Casar.iv.

LLIED-allied unto the duke ... Two G. of $\mathrm{Ver}$ in.

slie's nothing allied to your disorders. Twelfth $N$.ii.

kingdoms known and allicd to yours. Winter's $T$. $i$.

Deither allied to eminent assistants.. Hen. VIII. i.

hy the suggestion of the queen's ailies

your land, and love, and great allies

the passages of allies, ereeks, and.... Com. of Er.

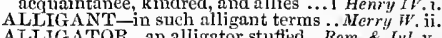

ALLIGATOR_an alligntor stuflied.. Rom

ALLONS-Allons! Allons! sowed.. Love's $L$. $L$. iv.

Allons, we will employ thee

pour une fois; Allons nous à disner... Herry $r$. iii.

five davs we do allot thee for
ALLOT'TED

ALLOT'TED-

thou art allotted

1 Henry VI. v. 3

give me the poor allottery my father. As you Like, $\mathrm{j}$.

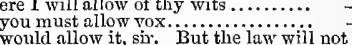

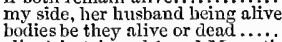

alive! in triumph! and Mercutio . Rom

ini.

there's millions now alive that night ly lie

to allay the gust he hati in

to allay the gust he hath in ....... Tweifih Night, i.

be moderate, allay thy ecstacy

I might be some aliay ...............

it would all:uy the burning quality ... K. John, in. 7

and when the rage allays, the rain....3 Hen. $V I . \mathrm{i}$.

or but allay, the fire of passion ....Henry VIII. i.

desire not to allay my rages ......... Coriolanus, v.
it does allay the good precedence $\ldots$. Ant. \& Cleo. i.j. of your pers

allayed their swelling griefs ........3 Henry $V I$. iv. 8

not a drop of allaying Tiber in't .... Coriolanus, ii. 1

ALLA YNENT-apply allayments to their.Cym. i. 6

AT-A-CHEERING G ali-eheering sun.Rom. \& -Jul. i. 1

ALL-DREADED-the all-dreaded.Cymb. iv. 2 (song)
ALLEGATION-reprove my allegation. 2 H. $Y$ I. iti. 1

false allegations to o'erthrow his state?

ALLEGE-reasons you allege .....Troil. 2. Cres. ii. 2

ALLEGIANCE-and allegianee cle

Macbeth, $\mathrm{ii}$.

I charge thee on thy allegiance

... Mueh Ado, i.

if they should have any allegiance in then , iii. 3

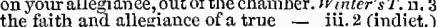

from his allegianee to a heretiek..... King John, iii.

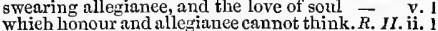

and sends allegianee and true faith of

I did pluck allegiance from men's... $\mathrm{Hen.} I \mathrm{~V}$. iit. 2

as if allegiance in their bosoms sat.... Henry $V$.ii. 2

then swear allegianee to his majesty.

keep the Frenenmen in allegiance .... - v. 5

hast thou uot sworn allegianee to me? - V.

subjects, sworn in all allegiance, will...3 H. VI. iii. 1

we owe allegianee unto Henry..........

cold hearts freeze allegiance in them. Hen. VIII. i.

a heart with less allegianee in it....... $-\mathrm{v}$. v.

on thine allegianee hear mel sinee thou ... Lear i. 1 .

ALLEGIAN' -but allegiant thanks. Hen.VIII. Hi.

ALL-ENDING-general all-ending day..R.III. iij. 1

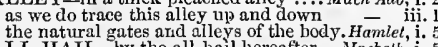

the natural gates and alleys of the body. Hamlet, $\mathrm{i}$.

in either side give the all-hail to thee. Coriolanus, v. allow it .................Mensure for Mea

the law allows it, and the eourt ...Her. of Ven. iv.

therefore allow me such exercises.......Asl's $\mathrm{Well}$, i.

of this time he will allow no speech..

I would allow him odds.....

and fearless, I to thee allow...

why, they will allow us ne'er a jorden. 1 Hen. I $V$.

I like them all, and do allow them well -

competenee of life, I will allow you..

allow us as we prove ....... Troilus a nd Cressida,
this is all a liberal eourse allows .. Timon of $A$.

allow their offieers, and are content. Coriolar

allow not uature more than nature needs-

if eonvenienee will not allow

allows itself to any thing .............

the time will not allow the compliment
for graee, and love for love ailow.. Romeo \&

of these dilated artieles allow ............ Hamlet.

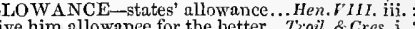

give him allowanee for the better.. Troil. \& Cres. i. 3

and syllables of no allowance,

and put it on by your allowanee

of safety, and allowanee, as therein.... Hromlet, $\mathrm{ji}$.

must, in your allowanee, o'erweigh a whole iii. 2
be known to you, and your allowance... Othelio, i.

of very expert and approved allowance $\bar{W}_{\text {ires, }}$ ii. 1

there is no slander in an allowed fool. Tuelfit $N$. i.

and allowed your approach, rather

and the worser allowed hy order of law - iit.

she is allowed for the day-woman ..Love's $L . L$. i. 2

go, you are allowed; die when you ... Wrin'er's 7 . i. 2

for once allowed the skilt'nl pilot's..3Henry I. $_{1}$. .

who, being allowed his way

scholars, allowed freely to argne
on all sides the autherity allowed

on ali sides the autherity allowed
almost, no grave allowed me ....

hy our permission is allowed to make.J. C.csor, jii.

and though it he allowed in mesur....

beinc done, but beiuer so allowed ....

yet here she is allowed her virgin cirant

sudden death, not shriving-timc allowed -

your patienee this allowing, I turn - iv. (chorus)

ALL-PRA ${ }_{\text {ISED }}$ all-praised knight...1 Hen.I $l$. iti. 2

AIL-SEER-

ATL-

and thou, all-shaking thunder, strike.... Lear, iii. 2

ALL-SlIU NNED-
I do allow this wen to be as fainiliar..

a substitute of most allowed sufficiency... Othello, i. 3 
ALI-SOULS this is All-tionls day, follows,
is it not? It is my lorth. Why, then $A$ Jl-

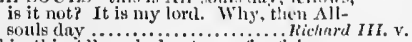

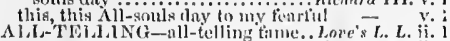

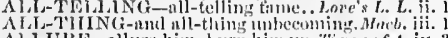
$a$ easement to allure fulse henrt

would allure, and make u laitter

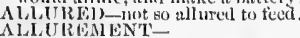

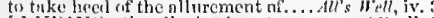

ALAURN

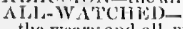

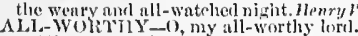

A All-worthy, villatin!............... ('ymberine, iii. 5 ALLYCIOHILY

methinks you're allycledly .. Tun Gen. of Fer. iv.

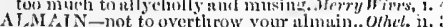
A GiliNick

the almnuark; find out monn-shine. MHit. N. D. iii. 1 licre ennes the almnnack of my trie. Cim. of

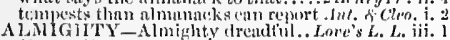

Mars, of lunees the atniphty, gave

Fou, in the nume of (inkl Almighty

ii mass by the Amighty km ... Troilus \&

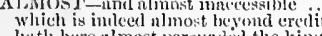

which is imleed nlmost beyomd ereidit

thy cyes nore almost set in thy head.

fincl muny, nuy, almost nuy

If think, 'tis ahmost daty . Tizo Gët. of rerono iv. 1

nhmost is well as $\mathrm{I}$ ho know

I mon almost out at heds...............

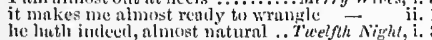

when 'tis ulmast an apple.

do show his deyys nre alu
I nmm almost sick for one

worn your eyes nlmost mit in the... Mea. jor Nea. i. 2

as like almost to Chumbio, as himself

I luve almost matter enomin inself nuch ato vo 1

you are nlmost enme to part almost a tray

in thughter, almost the coly of my chilil

I swion almost with fear. . Midsummer N. Dreum, ii.

'furgot your love? Almost I juad ....... Lore's

Wishla almost tama thost

hishone is nost past

th is almost murning, and yet, I am sure -

aud almost with tears I sjeuk it ....As you Like

atretch his leatheru coat nl most to bursting
till now almust firurseore here lived I

I fint nlmest to denth . . We........

and ulmost ehide (rod tor making yo

tlue por world is almost six thousini -

we liave almost molmost as great

the changed almost into another imun

lear thlumst as his life; which gratitucle

muy this, almost in miracle, he dion

they seened almost, with staring

il liust made me traitor to myselt.

I huve not lreathel almost, since I

he lins al hust supperl: why late

I hure aluost slipped the hour

gor about. Almost a mile ........

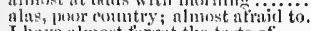

I have ulmost forgint the taste of . ...

nlmos ashamed to say what good.......

in the fickd, and almost lired or

aml art almost an alien to the hearts.in

no gentlemm nlmost forspent

which is almost, to plusk a kimgion dow

a)t clemel almost, my liege, to think

muld all lior almost kingly duketion

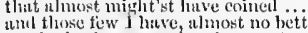

bentincls nlmost receive the secret.

tumle me almost yield mon my...
the French were almost ten to one

nwuy! vexution nlmust stops my
the duy is nlmost spent ...........

were nhmost like ne slarp cinilied .....

ur, ulmost slain, for he is taken.....3

troza'n almost to denth ................

firth almost overta'en him in

and almost shouldered in the swriliowing -

queth fiorrest, almost ehunget my mini

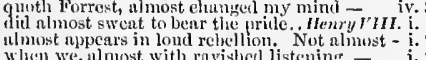
almost forgot ny prayers to content. .

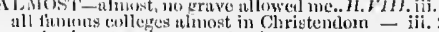
makle ulmost ench peng a ienth .......

Will almust give us a pirines . Troilhe

ancl ulmost, like the groxin of l'lutues'

the one nlinost as infinite as all.

lue liss almost charmed me troul.. Timon of . $1 / h_{1} \mathrm{i}$. I

it alunst turnu my gene from

nuy, these are alnost thoronghly .... Coriolun us, $i$.

cre slmost, Rome shoild kniw we

we will so: almist ull repent in their election

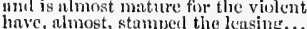

almost at joint to

that it had nlmost chokeil Ciesar.......julius $\bar{C}_{r}$ sur, $\mathrm{i}$.

crowel a feclile man almont to ricuth..

hath almost cneled his lite's history...

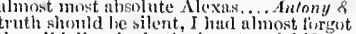

lee cricl almost to rouring.

art thou mal? Slmost, sil.

That nlimost forgot to entreat your grace -
almost midnitht, maimon. I have read -

it's nlmost morning, is't not? $3 . . .$.
that it dicl almost streteh the sides

aut am almost a man alrendy

reing goime, nlmost, spent with hminger

a gatliered lily almost withered. Tritus du

that, were his heart almost impregunbl
and almost broke my leart with ....

she swoumded almost at my pleas

a sea that almost burst the fleek

I have eried her almost to the nuil

her monment is almost finish

is ashamed nlmost to ack nowled ie hers

pothing almost sces miracle

I an almost mad myself; I lind $\mathrm{a}$ son

nimost too small fire siglit

tis nlmost mortring, I wonlil have... Rom. \& $\vec{J}$ ul. ii.

that olmost frewn wh the lient of lit

I cm almost af'rid to stanil ulone.

distillerl nlmost to jelly with the net of fen

with almost all the holy vow's of heaven

my hour is nlmost come when I

that's almrost in shape of a eanel?

to whet thy nlimost blunter prorpose.

for use almost enu change the stamp.

nnk yet it is almnst natinst my eme

whom love has turned nlmost the wronir side

my moncy is al must spent; I lave hee

could nimost read the though ts of pienple

rubber this ymming quat nlmost to the
he's almost slutin, and Roderigo deut

thes alost a

HMs-thoth her the alms of palsicel. Afea for Men

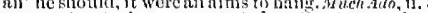
so give nlms ; pricy so; and for.. Winter's 'Tali, iv. 3 wherein he puts alms for.... Troilus of Cressida, iii. I have your alms ; adicu............. Corioltanes, by his own alms empoisoned

one lirel of alms, and fistered with...cymbeline, ii. who hatle reeeived your sit, fortune's alins .. Lear, i.

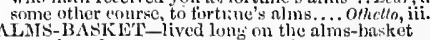

of words .................. inve's Labour Lost, $\mathrm{v}$ ALAS-DRINK-1hink nims-drink...Am, of Cleo.it.

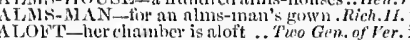
$A$ LONT-herchamber is aloft
breathe ntain nlogt the flood raise thlot the milk-white rose
that $y^{y}$ ou be hy her alott, while...

their mater loves to be aloit

to west on wine soaring aluf

and sits aioft, secure of thumler.

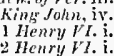

till thout nort with thy iniperiul

and reared alot the bitoody battle-n

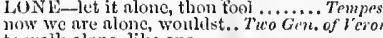

to walk alone, like one

she is alone ............

the firols are mnd, ifleft alone

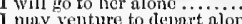

here enu I sit alon.

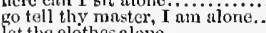

let the elothes alone.

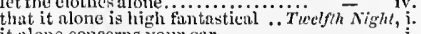

it alone concerns your ear
give us the place alowe

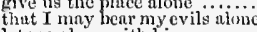

let ine alone with him

deal gently with him; lut me alone

ct me alone with him

nay, let unc alome t'ur sweariug some condemnel for a finlt alone .. Mert. for $M$. if. 1 Peelro and the Count Claudio alone... Much Ado, ii. 2

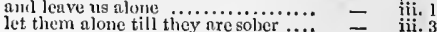
yen, even I alome

nnd she alone is licir to both of us....

I $2 \mathrm{~m}$ alone, when all the world... Nhil. N. Dream, ii. 2

thint mast needs be sport alone

let lier alone; speak not of Ifury

let your evilowie alono. The irun tomgue -

as, , for pralse alone, now seck to...Love's $\bar{L}$. $L$. iv.

fives not alume immuresl in the......

if $I$ be left alone, follow him......... - ini.

if ever he fo alone again, I'll never... As you Like, i.

then, being nlone, left and nibindou....

we are not all niome unhappy

poor men alone? no, no; the nolidet.

and show what we alone must think.

alone she was, and dirl communisate

gond alone is good, without $a$ name.

ii.

leave me and her alone .... Taming of $s . \overline{2}$. (indue.

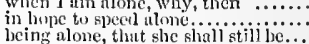

when men and women are alone

your love, and theu let me alone

"ivinter's $T$ iv.

would that alone, alone he would ...C Com of $\mathrm{Er}$. ii.

alone, it was the subject of $. . . . . . . . \quad=\quad$ it.

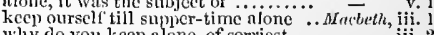

why do you keep alone, of sorriest ... - ii.

and not alone in habit and device.... King John, .

eatch your hide and you alone

we will alone upholil; withont no..

yet I nlone, alone, do me oppose.

using conceit alone; without eyes....

in spite of spite, nlone upliolds

yoursclves, and lenve us here alone...nichard in v. 4

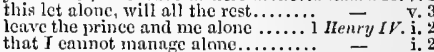

as well have met the alevil alome.....

so often when thou sit'st nione?

let them alone nwhile, nnd then

pr'ythee let him alone; we shall

pr'ythoe let her alone, und list $\ldots . .$.

let it alone; I'll make other

an' yout eould have jet me alone; my old - jii.

why dir you leave mo here nlone, ny lords? - iv.

then, would he were here alone ....... Henry $V$. iv.

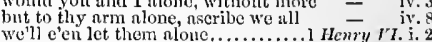

well then, alone, since there's no .... - ii.

not thut alose, but all the whole... - iii.

when my andry gumrlant stoni nione 二 iv.

we are alone; here's none but theo ..2 Henry VI. i.

lot me alone: to stand alone

anu live alone as seeret as I may

I am with thee liere alome

well eontent with that alone.

I am myselt alone: Clarence

Were best to do it secretly, alone ..... Richurd

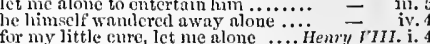

nay, sir Nichols, let it alone

thou art alone, it thy rare qualitic

let then alone, and draw the eurtuins

prile alone must tarre the mustifti on

were I alone to pass the difficul ties..

let these threthts alone, till .....

were ennigh alone to overcome lim.... Tim. of

I had rather be nlone. Why, fire....

all simgle and ulone, yet an areh viliain

let us alnne to guurd Corioli ...

he is himselt alone, to answer.......

let him. nlone, or so many, so minded

(o me nlonel make you n sword of une

nlono $I$ fought in your Corioli walls..

I know you ena do very little alone.

too infint-like, for doing much alone

know, Rome, that all alone Martius

alone he entered the mortal gate

though I go nlone, like to $n$ lonely

bear the palm alone. Anothor general.

is ho ulone? No, sir, there are more.

let me depart nlone, and, for my sink

revenge yourselves ulone on Cassius iv. 2

ii. 1

iii. 


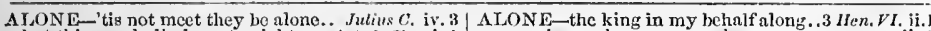
but thine and all alone, to niglit..... Ant. S . Clco. for not alone the death of Fulvia (lid sit alone, whistling to the air the senators alone of this great world he alone dealt on lientenantry ourselves alone; I'll write it.......... it portends alone the full of $\Lambda$ ton let lyim alone for I ret the curth ghe is alono the Arubian bird ...... let me alune with him to bring him here alone....

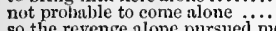

so the revenge alone pursned nie ..... she alone knew this; and, but she spoke it hot dreams, and she alone were cold

let his arms alone; they were not
when wert thou wont to walk alo

and then let me alone: I'll find

let me alone

why do you keep alone? how chance. . Peric'

$I$ am alone felicitate in your.

not alone the imperfections of

let me alone. Good, my lord, enter here who alone suffers, sutfers most it the

Ecarce awake; let him alome awhil

they are most alone. Rom. \&. Jut i.

for then she could stand alone

enll medlars, when they lourb....

you shall not stay alone, till holy clurur

too much minded by hersef alone

my lord, we must entreat the time alone -

to-morrow night look that thou lie alone -

I needs must aet alone: conre, phial.

now must I to the monument alone.

I am almost afraid to stand alone here

stny then, I'll go alone: fear comes

then all alouc, at the prefixerl hour of her

does not grow alone in thews, and bulk

some impartment did desire to you alon

now I am alone. within tre book.

let his queen mother all alone entreat

the cease of majesty dics not alon
never alone did the king sigh.....

in I alone became their prisoner

in a postseript here, he says, alone

your nalkin is too little; let it alone

leave procreants alone, and shut the door

ALONG-along, and do the murder first. Temp

had come along with me

in what habit will you go along?

regard thy clanger, and along with me

consent to go along with you
and as we walk along, I dare

and as we walk along, I dare

boy, go along with this woman

to go along with me.................

and bring lier along with you...

a servant comes with me alonir.

nay, tarry, I'll go along with th

and Egeus, go aloug: I must employ...Mit. $N$. D

came notling else along with thint.

and travelling along this const

with him is Gratinno gone along

bring your true friend along

with her father ran

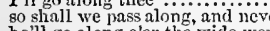

he'll go along o'er the widle world with

as he lay along lunder an oak

jumps along by him, and never stays to

we'll go along together; and ere we.

there lay he, stretched along, like....

en treat you written to bear along...

bring an tho whic...

bring along these raseal knaves
if along with ns, we shall be joyfi
eome, go along, and see the truth

You shall bear along impawned ...

come, go along; my wife is com

with him along is

bear not along the cloggin mother-queen.Jolen,

will you go alone witli us?

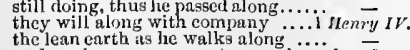
under whose government come they along? in Worcester, as I rode al

eome, go along with me, good ......... Henry $I$ and, as I came along, I nict ............ take all his eompany alongr with him

if they mareh along unfourht......... Ieary $V$. like a peacock swcep along his tail..t denry $V I$
as he marehed along, by your........ I shonld not thus be led alon and sorrow, go along witli you every borough as we pass along

towns as they do march alone
vengeance comes along with them

to go ulong with us; to

whut sity'st thou? wilt thou go along?

rge of Clarence sweeps along

every county as we go alons ...

as we pared along upon the gildy

I'll go along by your preseription

your lordship shall along: cone.

my eomfort comes alon:

as he passed along, how carnestly

strangeness as we pass along.....
along the ficld I will the Trojin

take the bonds along wi

and go along with him i.............

solemnness out o' door, and go along with us

will you along? Wo say ho aloie

eome, sir, along with us. I would they

when lie lies along, after for

these men, that come along with

Metellus, go along lyy him:

speak to great Casar as he comes aliong

thow on P'ompey's basis lies along

stand, ho! speak the word along ...

ii. 1 we'll aloug ourselves, and meet the in

espoused my brisle along with me. Titus sindron v.

along with me: r'll see what hole.
whose hand sliall go along, for fear.

and whith along with thee ahout

who shall cross?) along to go.

sirraly, come on; go along with

go along with me; and Montagie .... Rom. \&. Jut. i.

soft; I will go along; and if you

lay thee all a no such sight to.

therefore I have entreated him along ... Famlet, i. 1

freely gone with this affiair along...

sood guari, and go along with me.....

(iii. 3

ALONSO-thee of thy son, Alonso .... Tempest, jii. 3

most ernelly didst thou Alonso

. Twelfih Night, i. 4

one, aloof, stand sentinel. Midsummer $N$, Dream, ii. 3

the rest aloof are the Dardanian wives - iii.

must keep aloof from strict.

keep off aloof with wortlless

IIenryIV. iv.

stand'st thou aloof upon

rest stand all aloot, and bark at him... Henry VI. i. t

lience, and stand aloof; yet put ito

stand all aloof, and do not in terrupt.

and bid me stand aloof, and so I did

kecps aloof when we wonld bring him.. Hamtet, iii. 1

terms of honour, I stand aloof.

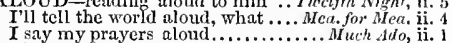

when all aloud the wind ................. $L$. L . v. 2 (song)

voices I desire aloud with mine........Mracbeth, y. 7

and crics aloud, tariy, dear cousi

even now he cries aloud for him...

ring leells, aloud; burn, bonfires...... - v.

and he shricked out alourl, Clar
fairly, shall bo spoke alond.

speak aloud to have her back

prompts me aloud to call.

and whine aloud for merey.Antony \& Clenpatra , iii. $1 \mathrm{t}$

singing aloud; crowned with rank......... Lentr, iv. 4

is hoarse, and may not spenk aloud.. Ron. \&. Jul. ji. 2
Romeo, he eries alond, bold friends

Romeo, he eries alond, hold friend

the Wind hath spolse aloud at land . vitus $\bar{A}$ ii.

ALPII ABETCAL-what should that alpha-

betical position 31 .............. T'velfih Night, ii. 5

ALPS $\rightarrow$ of the Alps and Apennines ... King John, i. 1
to the frozen ridges of the Alps..... Rirherd II. i.

to the frozen rilges of the Alps ...... Richercl II. i. t

on the $\Lambda$ lps, it is reporterl . Antony \& Clenpalra i.

already hatlı possessed them

you are already love's firm votary..... $\quad$ - iii. t

he is dead alrearly, if he be come ... Merry $\bar{W}$

'tis past eight already, sir............. - iii. j

he's out of his guard already $\ldots \ldots . .$.
slie's drowned, al ready, sir, witl $\ldots \ldots$
m, nicce is already in the belicf thit

has censured him already ......... Merts. for Meas. i. my gracious lord, wil't please you jiass along? iij.

ii. 6
iii. 5 ge fore lim: on, there; pass alon along: where's Jolabella

strnd aloof tiom the entire point...

and alrealy you are no stranger.. Twe'flh $\overrightarrow{\mathrm{Nigh}}$ iv, $\mathrm{i}$.
ALREADY-from nature stolen a man threaly

the imuge of it tives me content

told me too many of him alread $y$, sir

I have already dulivered lim letters

his cheek hath allealy stifferil tennis-balls

it is proved alrendy that you are
alrealy to their wormy heds are

for, you $\mathrm{sec}^{\text {, it is already in snuff }}$

so much, dear liege, I lave alrealy. Love'

well, she hath one o' my sonucts alre
the child hrags in her bully alrealy.

suitors that are already eome?

a quarrul, ho, alrealy? what's tic

they fay, he is alrcady in the forest. As you $J$.it
I have clime already: the bluslies...... Altl's

I have known thee alrealy

to what is past al rearly

I have toid your lordship alre......

gone already; inch-thick, knee-rlcep. Wiuter'

they're here with me alrealy:" whispering -

which I have given alrendy, but

the gentleman is half flayed alrcaly.

hut that, methinks, already - what was

he is already named: and gone to fic
expectation, already are i' the court.
with blood of thine alrealy

Arthur be not gone alrenty, even

breatl alreacly smokes about tho

that blood aluearly, like the pulican inichard 11 .

depressed he is already; and deposed

thon julgest false alrearly

men that we have already way-laid

and see alrendy, how he doth begin .

sone of them set forward alreidy?

take it already upon their salvation
so, two more alrealy. Their points.

your honour had already been at

thy my powers are there alretily ....

Perey is already in the ficld

the powers that you already have sent - ITenry $I V$. ii.

we have sent forth alveady

Our army is dispersed alrearly . $3 \ldots . .$.

is footed in this land alrealy

your ships already are in rcali

he hath learnt somich fence al tarly. a IIeñ.VI. ii.

methinks, already, in this civil liroil - iv.

thou hast spoke tno much alread
how now! is he dead already?...

ench one alrealy blazing by oin.

they are alrealy, or quiekly will bie, imoce

imagine I have said tarewell alreuly

my life is spanned already

he has banished me his bel already.

with these you bear already $\ldots . . .$.

one already of the privy eouncil

they are come already from the
but he alrealy is too insolent

why, even already they elap the

nay, I lave done already..

I am so fur already in your gifts...

we cannot, sir, we are undone alreitly

in whom already he is well grace

billeted, already in the entertninment

and have already o'crborne their way

which you deny already; yet we ..... -

the moved already some certalin... futus cresar, 1.3

gir, Oetavins is already come to 1

I have slept, my lord, already......... ine \& $\bar{C}$

some o'their plants are ill-rooted itready -

who, queasy with his insolence already -

he is already tradnced for levity

fix kings already show me the way

the faper hath eut her throat already ...Cymb.iii. 2

I have already fit ('tis in my cloak-bag)

Lucins hath wrote already to the ....
the powers that he alrealy hath in

has sorrow male thee dote alrearly?. Titus And. iji. 2

beat us down, which are down already...Pericles, i. 4

who already, wise in our neglis

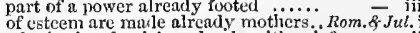

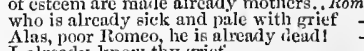

I alrearly know thy griet'...........

ii. 4
iy. 1
if. 3

we have sworm wyy lord, olready

they liave already order this night to play

those tiat are marrich aliesuly, all but on
yes, 'tis already garisoned ........... 
ALREADY - what to this was sequent thou

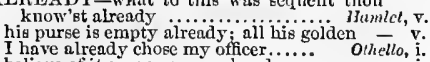
belicve ot it oppresses ne already.....

and rnet, are at the duke's already..

nut the woman hatli found hin al rendy

that who ii.

they hare given nie a ronke traty a

the Moor already changes with my poison - iii. 3

what already I have ioolistily suffered

A LsO-there is also another deviee...Merry Wives, $\mathrm{i}$. $\mathrm{i}$

You will also look that way.

because I know also, life is $\mathrm{a}$.

you were also, Jupiter, a swan ...... - v.

you shall also make no noise in the .Huch Aight, i. ${ }^{2} 2$

was wont to laugh is also missing...As you Like it, ii. 2

not 111 words only, but in woes also... Honry $1 \mathrm{~F}$. 1i. 4

vile seize on his lungs alsol..........

cury $V$. iv. 6

and also being a little intoxieates in his - iv. 7

fo also Harry Monmouth, being in .. $\overline{\text { I also wish it to you. I think .. Timon of Alh. iil. } 6}$

as in the duke himself also.

of that 1 shall have also eause to $\ldots . . . .$. ist mlet, $\mathrm{v} .2$

and hung over the altar ............. Mcrry I I ines, iv. 2

whose ingrate and inauspicious al tars. Tuctfin N. v.

from thy altar do I fly...All's $r^{\circ}$ ell that Ends $W$ ell, ii. 3 the alta at St. Edmund's-bury ; even on

the mailed $M$ Iar........................... King John, v.

let's to the altar; heralds

with modest paces came to the altar.Hen. YIII, iv

used to creep to holy al tars.. Troilu
think it an altar; and thy brother

to their nostrils trom our blessed altars ...Cymb.v. 5

and do upon mine altar sacrifice .....Pericles, $\mathrm{Y}$.

she that would alter services. . Twelfith $N$. ii. 5 (let.)

be that $I$ am, and seek not to al ter me.Mruch Ado, i. 3

but doth not the appetite alter? $\ldots \ldots . N^{\prime}$.

thy love ne'er alter, till thy.

no power in Veniee ean alter a deeree...Mer. of $V$.iv. 1

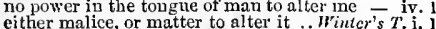

and whose heart together, affliction alters - iv. 3

to alter fayour ever is to fear

speak agin to olter this...

Richord II, iü.

auvment, or alter, as your

would please to alter the king's eourse. Coriolanus, $\mathrm{v} .4$

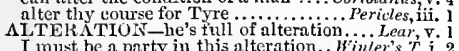

I must be a party in this alteration. Winier's $r$. i. 2

and settled project may suffer alteration

sone alteration in good-will

what an alteration of hono

ALTERED-life is al tered now.. Tro Gen. of Fer. ii. 4
but you, sir, altered that ........ Tu'elfth Night, ii. 1

brother Angelo wili not be aitered. Heas. $_{\text {for }} M$. iij. 5

finding myselt thus altered

delaycd, but nothing altered

our scene is altered, from a serious .. Rich orr. I will not have it altered ........... Renry $I V$. iii. he alteres much upon the hearing it.2 Henry $I V$.iv. ay, but the case is altered.........3 Henry r I. iv. 3 dow much her srace is altered on the sudden - iv. tities now are altered strangely with me - iv. 2 hath altered that yood picture?

thy speech had al tered it.........

were he in favour, as in humour, alterel. Othello, iii. 4

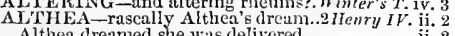

Althea dral brand Althea burned

ut each make not the altitude...

AlToGiwTHE

Leor, iv.

yet $I$ am not altogether an ass

yet I am not altogether an ass .... Mterry "ives, i. 1
that altogether's acquaintanee with...
my wite, master doetor, is tor you altogether ii. 2
iny

and al togetlier against my will

you are not al together of lis council this your request is altogether just.. Winter's $T$. iii. of joy, being altogether wantin

Richard II. iii. 4 you are altogether governed by

is altogether direeted by an Lrishman.. Iren. $V$. iii. 3 for I am she, and al together joyless... Richard $I$ i $I$. i. thou art not altogether a fool.. Timon of Athens, ii. 2 my quarrel was not altogether slight ....Cymb. i. my quarrel was not altogether slight

Lear, i.
ALTOGETIER-

, reform it altogether: and let those.. Hamlet, iii. AITON-lord Verdun of Alton, lord..1 Hen.VI. iv. 7 ALWAYS-they always use to laugh at Tempest, ii.

Iou always end ere you

you rould have them always play.... I would always have one play but oine thing - iv. 2 there they always use to diseliarge

for thill always count you my deer always obedient to your grace's . Mea $\mathrm{N}$, $\mathrm{JI} h l$, ji. thou art always figuring diseases..... for which sorrow is always toward ourselve

you always end with a jade.'s triek..... Much $\bar{A}$ do always excepted my dear Claudio...

you have been al ways called a mercifu

and justice always whirls in equal... Love's L. L. iv. I was always plaiu with you threes.. - V. 2 for always the dulness of the fool... As you Like, would always say, (methinks, I hear...All's trell i. 2 the always loved a great fire.

hefore the always wind-obey ing deep Com.of $E$ r. thinks a man alwass going to bed ... ear of youth dotl always listen ...... Richard $I I$, ii.

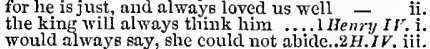
$O$, give me always a ittle, lean ....... they do always reason themselves ..... Henry $V$. . . 2 but always resolute in most extremes - iv. and happy always was it for that sou... 3 Hen. eommauded always by the greater gust - iii. 1

suspicion always launts the guil
such purple tears be always shed

the benefit thereof is always granted...Rich. III. iit.
your majesty has always loved .....Henry VIII. i. you are always my good friend........ I do not always follow lover ........;

I have observed thee always for a towardly - iii. I

always a villain's office, or a fool's

those senators that al ways faroured him Coriol. $_{\text {iij. }}$

he was always good enough for him ..

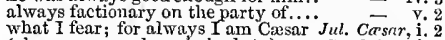

(always reserved my holy duty) .... Cymbeline, i.

it did al told you always, her

he al ways loved our sister most....

my custom always of the afternoo........

well........................ Mcrry Wives, ii.

AMat gave Anaimon the bastinado.. I Henry IV $\mathrm{V}$ i.

and here she comes amuin .. Love's Labour Los, , v.

from far making anain to us... Comedy of Errors, i. 1

from Ireland am I come amain

bid him eome amain, to say.....

no longer, make we henee anuain

at our backs; and therefore he

doth march amain to Loudon $\ldots . .$. ...

and erv you all amain, $\Lambda$ chilles ... Troil. . .

they hither mareli amain, under.. Titus.Andron. iv. 4

you do amaze her: hear the truth

amaze me: I would have thouglit .. Wuch Adto

you amaze me, ladies; I would have. As you Like,

it would anaze the proudest ...... Henry VI. iv

ye gods, it doth aniaze me, a man of . Kul. Cessar, i. and amaze, indeed, the very fienities... Hamlest,ii. 2

if he be not anazed, he will..........

stand not amazed: here is no....... Tu tand amazed; but le of comfort. Tuelfth $\mathrm{v}$.

be not amazed; right noble is......... - . -1

my lord, I am more amazed at

I an amazed, and know not what to say - Dr. iii. 2

zou are all lord? why looks your ... Love's

you are all amazed: here is a letter. Ner. of Ven.

there I stood amazed for a while.. Taming of $S$.

your strange eucounter much amazed me

that I, amazed, san from her.Comedy of Errors, iji.

who ean be wise, annazed, temperate ... Nacleth, ii.

behold the Frenel amazed my sight $\quad-\quad$ y. 1

why stand these royal fronts amazed thus? - ii. 2

$\mathrm{I}$ am aniazed, methinks; and lose....

and makes me more anaazed than had

we are amazed; and thus long have.Richard $\bar{I}$ l. iji. 3

be not amazed, there's nothing hid., I Henry II. i. 2

\section{$M A Z E D$}

what, amazed at my misfortunes?. Ilenry VIII. iii. 2 you are amazed, ny liege, at her. . Troil.\& Cres. .. 3 I am amazcd with mat, te. a the prisice wili...Rrm. of Jul. iii. to make heaven weep, all earth amazcd. Othello, $\mathrm{iij}$. 2 eome, stand not amazed at it, but go $\bar{M}_{a e b}$ iv. I shall reply amazedly, balf 'sleep.. Wrid. $N, D$. iv. IIAZEDNESS-little amazedness... Winter's $T$. two in treat amazedness will fly....ierry $\bar{W}$ ives, iv. in every eabin, I flamed amazement.. . - i wonder, and alnazement inhabits lere

put not yourself into amazement. Mea for NFer. iv. 2 or resolve amazement ean I qualify...... Nuch sdo, v. to the amazement ot mime eyes ........ Macbeth, ii. wild amazement hurries up nnd down .... John, v. will stike amazemeut to their ... Troilus \& Cres.ii. destruction, frenzy, and amazement, like

into amazement and admiration ........ Ilamlet, $\mathrm{iji}$. but, lonk! amazement ou thy mother sits - iii. a boun thon art an Amazod, aud fightest....... Hen.VI. i. AMAZONIAN-his Amazonian ehiu. Coriolanus, ü.
like an Amazonian trull, upon ......3 HenryVI. AMBER - their eyes pur ring thiek amber .. Ham. ii. her amber lairs for foul have amber, Love's $L$. L. iv. 3
with amber braeclets, beads .. Taming of Shrew, iv. 3 AMBER-COLORED

amber-colored raven was well noted Love's L. L. iv. 3 out of questious too, and ambiguities...Henry $V$. v. till we can elear these ambiguities ... Rom. \& Jul. . AMBITION-his ambition growurg ....Tempest, I have no ambition to see a goodlier man $=$ i. that entertained ambition

this is the period of my ambition........erry Wires, iii. of ambition, an envious emulator. As you Like it, i. 1
who doth ambition shun .......... the ambition in my love thus viagues.. All's sivell, $\mathrm{i}$. his humble ambition, proua numility art not without ambition; but ........ Macbeth, i. thriftless ambition, that will ravn ... $\bar{K}^{\prime}{ }$ ij. thoughts tending to ambition .......... Richard II. v. now beshrew my fathier's ambition!... Hcry $v$ v. choked with ombitiony ambition ..I Henry VI. ii. before, ambition follows lim......... Henry $V I$. and thy ambition, Gloster

at Somerset's ambition, at Buekingham -

fie on ambition! fie on myself .

$\because \quad$ iv. 10 ambition, thou searlet sin, robled .. Hen. VIII. iii. that, out of mere ambition, you have become a thee, fing away ambition . Bi -

pour in; his ambition is drr. Troilus o Cressida, ii. a beastly ambition; whieh the gods. Timon of $A$. iv. Caesar's ambition shall be glaneed at. Jul. $\overline{\text { Cassar, i. } 2}$ lowlines is youmg ambition's ladder..

stand still: ambition's debt is paid ... $\quad$ - iii. and death, for his ambition. Who is here - iif. 2 and ambition, the soldier's virtue .. Ant. \& Cleo.iii. ambitions, covetings, ehange of prides.. Cymb. ii. no blown ambition doth our arms incite. . Lear, jiv. y, then your ambition makes it one.Humlel, winch dreams, indeed, are ambition.

shows a most pitiful ambition in the fool -

my erown, mime own ambition, and my $\overline{-}$ big wars, that make ambition virtne!.. Othello, iii. 3 whose ambitious head spits in the ..Mer. of Ven. ii.

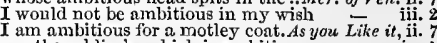
nor the soldier's, whieh is ambitious you Like it, iv. how that ambitious Constance would not..Jo/nn, i. if love ambitious sought a matcli of.. sky-aspiring and ambitious thoughts...Rich. II. i. Poole: farewelt, ambitions Richard.. - ij. 4

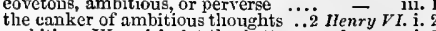
ambitious Warwiek, let thy betters speak = i. and, like ambitious Sylla, overgorsed with ambitious York did level at thy ....3 Henry $\bar{V} I$. ii. proud ambitious Edward duke of York - iii. 3 ike a subjeet, prour

free'd from his ambitious finger..... Henry $\overline{V I} I r$. i. you are ambitious for knaves'

ambitious past all thinking, self-ioving

and I have seen the ambitious oeean ....r. Casar, i. 
AMIBITLOUS-Casar wastambitious...Jul.Crrsu, iii. a 1 AM END-Edwarl, I will make amends..3II. FI. Brutus says, he was ambitious (repeuled) - iii. 2 dicl this in Ciesar scem ambitions? ...

tis certain, he wns not ambitious - iii. oppose notscythia to ambitious Rome. Titus . And i. proud and ambitious tribume, canst thou $\overline{\text { Finm }}$ i. for the very substanee of the ambitious

I am very proud, revencetul, ambitious A IIBITIOU SLY-ambitionsly tor rule. Titus dud. $\mathrm{i}$. as others would ambitionsly receive it.2 Hen.FI. ji. 3 AMBLE-you jig, you amble, and you lisp. In m. iii.

who time ambles withal

who anbles time withal

these time ambles withal ............ AMBLING - my ambling gelding ... Mcrry Wives, ii. a wanton ambling nymph. komeo \& Jullet, i. 4 IMBUSCADOES-ot breaches, ambuseadoes,

ANBUSH in the ambisili of ni... vame. Mea. for who would have snspected an ambushl. All' sirell, iv. 3 once did I lay an ambush for

in sceret ambush on the forest side.. 3 Henry $V I$. iv I fear some ambush: I saw him not.. Cymbetine, iv. A si EN-come, anen! I will pour .... Tempest, ii. I say amen, Gonzalo

amen! amen! Go on.Two Genllemen of Verona, $\mathrm{v}$. better than your thonghts! Amen. Merry irines, iii. marry, amen. I will, sir, I will .. Twelfih Night, iv. not the king of Hungary's! Amen. Mea for Meu. i. nmen: for lam that way going .......... Nuch $\overline{A d o}, \mathrm{i}$. cry, amen. God match mi............ (repeated

and atl grace say amen to it

amen, amen, to that fair prayer.Mia. N. Dream, i1. amen, so your be none

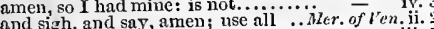

and sigh, and say, amen; use

give ns joy Amen. A man may. As you Like it, iii. 3

for my good amends I Amen. Tum. of shr. 2 (indne.)

amen, say we; we will be witnesser... Macbelk, ii. 2

I could not and amen, when they

pronounce, amen? I had mo

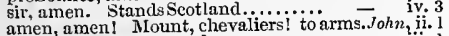

amen, amen! Alount, chevaliers! to arms. - iil. I

in hope, $\mathrm{L}$ ery amen.$\ldots \ldots \ldots \ldots \ldots$........ Rich

will no man say, ament well then, amen

to cry amen to that; thns we appear...Henry $v$ iv. $v .2$

to cry amen to that; thand and fair France. Anen! Now

God speak this Amen! Amen! Prepare - TII. i. 2

will searcely say, amen; yet, Stanley ...

Emen, and's worthy king! Amen

I say amen to lier. Stay, madam....

great God ot heaven, say amcn to all

long live here, acl say, amen!

now 1 pray God, amen! You bear.

my amen to t! All men's. There's

methinks, I coujd cry the amen .......
into whose hand I give thy life. Amen.

such scareity of youth! Amen ... Troil.

devil, envy, say, amen: what, ho

say, amen. Amen. Amen. Amen!.. $\quad$ ii. 2

mankind, high, and low! Amen

our entreaties, to amend your fauiti

to make amends, Tll give it to your

you make amends. He sits 'inongst.. Cymbetin

but your being by me eannot amend me

all the ablorred things o' the earth amend

make her amends, she weep

my faults to have amended

troth, that ease may be amended .. Romos o Jut iv

T-what hope is there of his ma

your amendinent, are come to... Tam. of $S .2$ (indue.

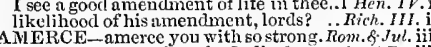

AMERICA-Ameriea, the Indies?. Comeedy of Er. iil.

AMFiS- $A$ CE-throw ames-ace for my life.

AMI - if he will come to Ami. As ynu Like it, ii. 5 (song)
AMIABLE-to lay an amiable siege.. Merry Wives, ii.

the orchard this amiable enco

while I thy amiable clieeks do

in no sense is meet or an

'twould make her amiable, and snbi.... king othello,

AMICNS-my lord of Anziens, tind. As you Like it, iv.

MINTAS Polcmon and Amintas. An/

that shall not he much amis

why 'tis not amiss, Pompey

for never any thing can be amiser

that did never ehoose arniss.Mer. of Fen. N.'s Dr.v.

tis not anniss; and I was about .....All's Well,iv.

impossible, I should speed aniss

drives our eyes and ears amiss .. Coinedy of Err. ii.

what is amiss! Your are, and do
sworn to do amiss, is not amiss

and all, are all amiss employed

it is not a hair amiss yet ............
great lords if I have done amiss

which is not amiss to cool $a$ man............

't were not amiss he were creat

something hath heen amiss ....T.

therefore, 'tis not amiss, we tender

what is amiss, plague and infeetion

what is now amiss, that Cæsar

it is not amiss to tumble

what's amiss, may it le gently hearr

have we done aught amiss? ..Tilus Andronicus, v. 3

twere not amiss to keep our door hatehed. Per

but here shows much amiss.

that's snid or done amiss this night

that's not amiss; but yet keep time....

and stand a eomma of aneient amities.. Lear, i.

All TY -thou and I are new in amity. Mitl. N.

conceit of godlike amity

I will pursue the amity. These things. All's II ell,

let in that amity which you have made...

is cold in amity and painted peaee .....

deep-sworn faith, peace, amity,

and the division of our amity
of our restored love and amity

join your hearts in love and amity.i Henry $v r$.ii.

in alliance, amity, and oaths

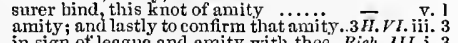

in sign of leaguc and amity with thee...Rich, MII. i.

the amity that wisdom knit not... Troilus \& $\mathrm{Cr}$. ii.

to hold yon in pernetual amity.

that which is the strength of their a
under two conmands hold amity?

AMLOROUS-encounter of my amorous...... Lear, ii.

sure, my brother is amorous on Hero.

Lorenzo, and his amorous Jessica... Ner. of $r e n ., j \mathrm{i} .8$ the amorous count solieits lier ........Al's I'ell, iii. a proper stripling, and an amorous! Taming of our fine musician groweth amorous.

the quaint mnsician, amorous $\mathrm{I}$ icio

to court an amorons looking-glass.. Rieharfl III. i. 1 amorons view on the fair Cressid

I liave chastised the amorous Troja

with Phobus' anlorous pinches blaek.Ant. \& $\mathrm{Cl}$. i. follow faster as amorous of their strokes

difference twixt amorous and villanous.

held, fetcred in amorous chans.. Tilus Andron. ii.

can see to do their amorons rites.. Romew of Jue i ii.

that unsubstantial death is ankorous

and she did gratify his amorous works... Othello, v. 2 what all amort? Rouen hangs loer

AMOUNT-do not amount to a man

Love's $L$. L. i.
AMOUNT-whereuntil it doth amount. Love's L.L. v. 2 upon my life, amounts not to fiftcen... All's ${ }^{\prime}$ ell, iv. 3

will but amount to five and twenty...3 Henry $V I$. ii.

ANIOUK-l'amour de Dieu, me pardonner!. $I . V$. iv.

Amplhimachus, and Thoas, deadly. Troil. \& Cres. v. AMPITTILL-from A mplithill, where. $H$.

sueh a mple grace and homour.... Meas. for Mens. i.

be eneountered with a shame as ample - iv. 3

as to my ample hope was promised

in very ample virtele of his futher

in large and ample enipery

the ample proposition, that $h$.

Henry $1 F$.. Henry $V$.

I do enjoy at ample point al

enjoy at ample point all..... - ii.

It.

now and then an ample tear trilled down

$A$ MPLEST-plead tor amplest eredenee Al' Twe

hug witl amplet

his fame unparallelen, haply, amplified.. Coriol. $v$.

to amplify too mucl, would mak

MPLY - as amply, and unneecssarily ... Tempest, 1. .

as amply titled as Achilles is . Troilus \& Cress. ii.

ANURATH-not Amurath an Amwath suceeds,
but Harry IIarry ..............2 Henry IV. v. 2
ANA'SOAIZE-let them anatomize Regan. Lear, iii. 6 to anatomize in the vulgar. Love's L. L. iv. I (letter)

should I anatomize lim to thec ....As you Like it, i. I

the wise man's folly is anatomized .. As you Like, ii. 7

have him see his company anatomized. All's Well,iv. 3

I'll eat the rest of the anatorny ... Twelflh Nighe, iii. 2

what vile part ot this anatomy doth. Rom. f J Er.

and all his ancestors, that eome.......Merry Hives, $\mathrm{i}$.

bequeathed down from manyancestors. All's Well, iv. 2

of six preceding ancestors, that gern ith. Rich. II. I. 3

from the fliglit of all th 5 ancestors... Henry $\mathrm{lF}$.iii. 2

I am sleeping with my ancestors ...2 Henry $I I^{\prime}$. iv.

bring in to any of your ancestors....... Henry $V$.i.

censor twiee, was his great aneestor.. Curiolnnus, ii. 3

as . Eneas, our great ancestor, did ...Julizes Casar, i. 2

my ancestors did from the streets of

thou mine ancestor, thy rage ...Antony \& Cleo. iv. 10

my liege, the kings your aneestors .. Cymbeline, iii.

nppears, he hath had good ancestors.. $-\overline{\text { iv. }} 2$

as erst our ancestor, when with ..........

my derivation was from ancestors who.Pericles, v. 1

by the honour of my ancestry..T To Gen. of Ver. V. 4

nohle ancestry from the corruption ...Rich. 211. iii. 7

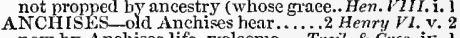

now hy Anchises life, welcome ... Troil. \& Cres. iv. 1

not my tongue, anehors on Isabel ... Mera. for M. 1 ii. 4

mneh ado to make his anchor hold. 'Winter's Tale, i. 2

whilst our pinnace anchors in the ...2 Henry $I T$. iv. 1

the holding anchor lost, and halt..... 3 Henry $l^{\prime} l$. $\nabla$.

say, Warwick was our anehor

great anchors, heaps of pearl......... Richard HI. i. 4

there wonld he anehor his aspect. Antony \& Cleo. i. 5

all safe, the anchor's in the port.. Titus Andron. iv. 4

an anellor's eheer in prison be my seope. Himlet, iii. 2

my nails were anehored in thine eyes. Rich. III. iv. 4

NCHORING-yon tall anchoring bark .. Lear, iv. 6

a pair of anehroling hooks. Tue Gen. of Veronn, iii. 1

a very ancicnt and fish-like smell..... Tempest, ii.

my ancient skill beguiles me ....MPa. for Mea. iv. 2

I beg the ancient privilege of Athens. Mid.N.Dr.i.

and will you rent our ancicnt love asumder? - iii.

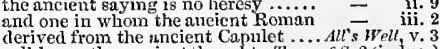

call home thy aneient thoughts. Tam. of S. 2 (induc.)

your ancicnt, trust $y$, pleasant servant - i. 2

a sobcr ancient gentlemm by youmr... Vinter's $T$. iv. 1

my life uefore this ancient sir...

is as an aneient tale new told .......... King John, iv. 2

if ho appeal the duke on aneient malice. Rich.II. i.

hath he fincl tor ancicnt quarrels 


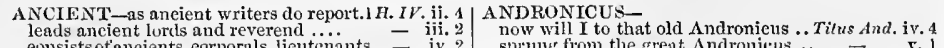

raggerl than an old fiaced ancient $\ldots . .$. Hen $\overline{\overline{1}} \mathrm{~F}$. new lamenting ancient oversights... Henry

may thee, go dowih, good ancient...

he gone, good ancient; this will grow

ecrtainly, ancient, it is not a thing

wien the true and ancient prerogatifes

will you moek at an aneient tradition?
and cxempt from ancient gentry? ... Henry

mo nueicut incantations are too.

in tlie timous ancient eity,

the nncient proverb will be effeeted

had recovered your ancient treedom.

I'll win our ancient right in Franee...

pity, you ancient stones, those tende

our ancient word of courace, fair saint

a eourier, one mine ancient friend. Timon of $A / \%$.

they, upon their ancient mulice

and they stand in your ancient eourage?

to thee, and to thy ancient maliee

a root of areient envy.............. -

gave advantage to an ancient soldier .... Cymb. v. 3

from ashes ancient Gower is eome.

dissolntions of aneient anities $\ldots \ldots . .$.
this ancient ruffian, sir, whose life $i$.

you stubbor'n antient knave, you reveren

you stuborn antient kina

let us then determine with the ancient of war - $-\mathrm{v}$

made Veronas aneient eitizens cast by

who set this aneient quarrel new :ab
this same ancient fenst of Caunlet'

groans ring yet in my aluient ears.

ancient dannent lady; farcwell, lady -

be borne to that same aneient vaul

as in a vault, an aneient receptaele

is no aneient gentlemen hut gurdeners.. Hamlet,

hisent, what ancient......

ancient, eonduct them; you hest know

plense your grace, my ancient; a man.

good aneient, you are weleme ........

lieutenant is to be saved before the aneient -

this is my aneient; this is my right hind

ANCIENTEST-
ere ancientest order was .
ANCIENTRY

ANCIENTRY - wronging the ancientry

a measure full of state and ancientry huch Adw, ii.

ANCUS- whenee enme that Aneus Harcius?Cor. ii.

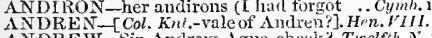

ANDRE W-Sir Andrew Ague-cheek?

for here comes Sir Andrew Ague-lace -

sweet Sir Andrew

an' thou let part so, Sir Andrew, would -

approaeh, Sir Andrew; not to be

shall we not, Sir

mnst needs yield your reason, $\mathrm{Sir}$ indrew

there is no way but this, sir Andro

for Andrew, it he were opened $\ldots \ldots .$.
sworn enemy, Andrew Aglie-clieek - iii. 4 (chai.)
go, Sir Andrew; seout me tor ........

come, Sir Andrew, there's no remed

wealthy Andrew doeked in sand...... Mer. of
ANDROMACHE-he chid Andromache, and

struek his .................... Troilus \& 6 .

Andromache, I am offended witli fou

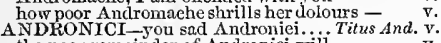

the poor remainder of Androniei will

ANDRONICUS-chosen Andronicus

returns the good Andronieus to Rome

the good Andronicus, patron of virtue

Andronicus, stain not thy tomb with

and let Andronieus make this his latest

Andronicus, would thou wert shipped to $\bar{r}$ ell

Andronicusi to gratify the good Andronieu

Titus Andronieus, for thy favours dome

tell me, Andronieus, doth this mo

come, Andronicus; take up this good

this day all quarreis die, Andronicus

but fierce Andronicus wonld not xel
the unhappy son of old Andronieus

Andronicus himself did take it up .
Andronieus, I will entreat the king.

Andronicus, I will entreat the king

I go, Andronieus, and for thy hand.

die, Androniens; thou dost not slumber

farewell, Andronieus, my nohle father

revenge the heavens for old Andronieu

I greet your honours from Andronicus

she wnuld applaud Andronieus' coneeit

wilful sons of old Andronieus...
of Lueius, son to old Andronieu

of Lueius, son to old Andronieus ... spruir from the great $A$ ndronicus

I will eneounter with Andronieus ... -

but would it please the us do, Andronicu

what says Andronieus to this deviee?

frewell, Andronicus; revenge now goes

why art thou thus attired, Andronieus?

it was, Andronicus. Your reason.

$\triangle N E W$-make him tell the tale anew
weep o'er my fatlier's death anew...

weep o'er ny father's death anew ....All's Hell, i.

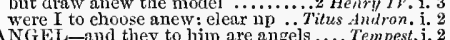

now, good angels, preserve the kin.

say they have angels' faces.... T'wo Gen. of Jer. in. i

himnotur ne the angel

I had myself twenty angeis given.....

as nake the angels weep...Measare for Heusure,

let's write good angel on the devil's horn -

ngel on the out thard side.

nohle, or not I for an angel ............. $u \bar{c}^{-}$ddo, ii. 3

in angel whiteness bear away those. $-\overline{\text { iv. }}$

for that angel knowledge you cau. Love's L. Lost, 1. 1

an angel shalt thou see.

the figure of an ancel stamper

but here an angel in a golden

in his motion like an angel sings ....

what angel shall bless this un worth

What angel shall bless this unworthy - iii. 4

like an evil angel, and bid you.. Com. of Errors iv. 3

here are the angels that you sent for.

appear to men like angels of light.... - iv. 3

some holy angel fy to the conrt.....
angels are bright still, though....

and let the angel, whom thou stili

when his fair a ging John, ii. 2

if an angel should have com

a glorious augel then if angels fight

[Collier-fire, that's God's angel]

as if an angel dropped down

this buttle makes an angel

there is a goof angel about him......

eonsideration like an angel came
God, and his angeis, guard your

an angel is like you, Kate (repeated $)$.

a shadow like an angel, with ........

good angels gnurd thy battle! .......

Good, and goud angels, fight on Riehmond'

good angels keep it rom us!

ye have angels' faees, but heaven....

by have angels' faees, but heaven

as I have a soul, she is an angel ... $.6 \%$

now are angels ; ont of which frailty.

women are angets, wooing.

Brutus, as you know, was Cæesar's angel .Jul. $C$. iii. 2

some god, some angel, or some devil
thy angel beeomes a fear, as being...Ant. $\&$ cleo. ii. 3

though this a heavenly angel ....... Cymbeline, ii. 2

by Jupiter, an angel! or, it not......

the old man and his sons were angels - v.3

to betray, doth wear an angel's faee ...Pericles, ir. 4
eroak not, black angel ................. Lear, iii. 6

o, sreak again, bright angeli

Rom. \& Jul. ii. 2

her immortai part with angels lives. . Knight

with tears distilled by moans]....

though to a radiant angel linked

in action how like an angel!

help, angels, make askay ! bow

a ministering angel shall my sister be

$\mathrm{o}$, the more angel she! and you the ....

ANGELIC enrse his better angel from his side $-\bar{\xi}$

ANGELICAL -fiend angelieal! dove-feathered-

ANGe with angel-like perfeetion.. Two Gen, of Ver.

it is lord Angelo...................

hold therefore, Angelo.................

I have delivered to lord Angelo

than in lord Angelo ....................

lord Angelo is precise

governs lord Angelo...................

go to lord Angelo, and let lim ......

or what art thou Angelo

hope of pardon from lord Angelo?... there is no evil angel but love.

issued from my other angel husband
ANGELO-
Angelo, having affairs to heaven.. Mca. for Mea. iii. I the princely Angelo? ...............

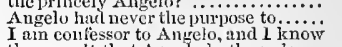
the assault that Angelo hath made ..

monould wonder at Angelo .......... her should this Angelo have married

ean this be so? did Angelo so leave her? haste you speedily to Angelo ......... and dispateh with Angelo, that it may they say, this Angelo was not nade..

twiee treble shame on Angelo...

with Angelo tonnight shall lie ........

lord Angelo hath to the publie ear ...

now in the government of lord Angelo

doliver than Angelo who hat

his head borne to Angeio.

this is a thing, that $\Lambda$ ngelo knows not

the hour draws on pretixed by Angelo

send the head to Angeio. (repeated).
we shall proeeed with Augelo .........
his head is off and sent to Angelo...

injurions world! most danmed Angelo

notice to Esenlus and Angelo ........

here is lord Angelo shall give you...

Angelo's forsworn; is it not strange? (rep.) -

it is not truer he is Angelo, that this

as Angelo; even so may Angelo, in ail

try her graeious tortume with lord Angelo -

eomplaint intended 'gainst lord Angelo

come, eonsin Angelo; in this I'll be.

and that is Ancelo, who thinks he knows face, thou eruel Angelo, which, once thou -
set these women on to slander lord Angelo -

an Angelo for Clauciio, deatli for death

then, Angelo, thy fault's thus manifested -

and so wise as you, lord Angelo, hiuve

by this, lord Angelo perceives he's safe
well, Angelo, your evil quits you well

love her, Angelo; I have confessed her

signior Angelo, you must excuse. ..C

iv

NGER - with anger so distemper'd ..Tempest, iv.

but I fear'd lest I might anger thee .. - iv

urge not my tather's anger .......... in the contempt and anger of his lip! both pleaseth men, and angers them $\ldots . . . M$. whieh not to anger bent, is minsie .... Love's $L$. $L$.
with his eyes full of anger ......... As you Like it with his eyes full of anger ............. too far in anger, iest thou hasten ......All's Woll, pill tell the an ${ }^{\prime}$ rer of $m y$ heart ........ to my red-looked anger be the .... let grief convert to anger.............. Macbeth, i to keep his anger still in motion

this is the dendly spite that angers m.

by the mass, I could anger her to the heart in his a e or mirth, or anger ......... Henry/ not for fear, but anger, that thy cheeks.l $\bar{H}$. VI. my heart fur anger burns

whose looks bewray her anger

out of anger he sent command

Henry $\frac{-1}{1 I I}$

the queen is put in anger

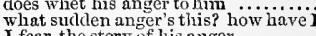

I fear, the story of his anger

that were we talking of ancof his a

nay, but yon part in onger

thon should'st, tlioust anger ladies .... Timon

to be in anger, is impi

and answer the vantage of his ninger...

that leads my use of anger, to better...

all's in anger. Only fair speech .......

and lament as I do, in anger, Juno-like

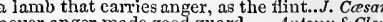

and had no hely of anger ....

thy tongue move anger to our face?...... Pericles,

his rage and anger be forgot

toueh me with noble anger! $\ldots . . . \ldots . . . \quad$ and take the ehanee of anger.......

thou wilt anger him. This eannot anger him :

$I$ anger her sometimes, and teil her...

more in sorrow than in anger .......... Hamlet,

Hamlet,

't would have angered any heart....... Masieth, iii. 


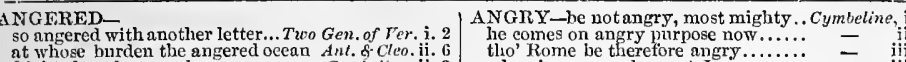

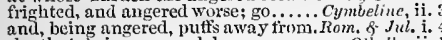
and, being angered, putss away trom.
she that, heing angered, her revenge $\ldots$ olhello, ii.

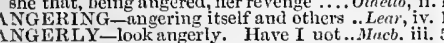
nor look npon the iron angerly............ John Jin, iv. ANGLERS-before Angiere well met.. King John, welcome before the gates of Angiers, duke to the walls these men of Angiers.

men of Angiers, and my loving subjects,

you men ot Angiers, open wide your...

you men ot Angiers, open wiee, you meir of Anviers

lord of our presence, Angiers, and of you -

these seroyles of Angiers flout you..... -

now, citizens of Angiers, ope your ...

ANGLE-10 an odd angle of the isle

so angle we for Beatrice

and did angle for ne, madding my

the hearts of all that he did angle for

to angle for Jour thought

give me mine angle; we'll to..... Aniony \&-Cleo ii.

ANGLED-angled for mine eyes..... Winter's Tale, $\checkmark$.

ANGLER -angler in the lake of Darkness. Lear, iii. 6

Aliee, tu as été en Angleterre, et tu... Henr

aussi droiet que les natifs d'Angleterre

roy d'Angleterre, heretier de Franee

$\triangle N G$ IING - pleasantest angling is to. Much Ado, iii.

I am angling now, though you..... Finler's Tale, i. 2 wNGL You wagered on your angling. Ant.

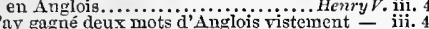
rort bon Anglois. Dites moi en Angloi

meilleur que l'Anglois lequel je parle
A AGRIL - how angrily I tanght. Tro

ANGRX -breasts of ever angry be
nay, good my lord, be not angry

nay, good my lord, be not
except an angry word..

what, angry, sir Thurio

her father will be angry....

good George, be not angry.............

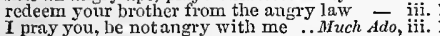

ort thou sick, or anggy? ?........
I think he be angry indeed

the eliliding autumn, angry winter...Mid. $\bar{N} . D r$

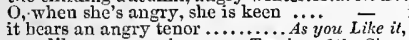
rage like an angry hoar ....T Taming of the Shr
i'taith, you are too angry ............ bite the lip, as angry wenehes wiil

be not angry. I will be angry; what
Apollo's angrv and the heavens. Winter's $\vec{T} a$

Are angry, and frown upon us.........
heavens, taking angry note, have left

to appease an angry God ................Macbeth, iv. 3

bring the angry lords, with ail.............ing John, iv.

may never lift an angry arm against. Richard I1. $\mathrm{j}$.

who, therewith angry, when it next...1 Henry IV $I$.

I should be angry with you if the ......

this pale and angry rose; as
and digest your angry eliole

but when my angry guardant

nay, be not angry, $I$ am please

and shows an angry eye

but angry, wrathful, and inclined to blood-

I am so angry at these abject terms..

when the angry trumpet sounds

whom angry heaven do make

when angels are so angry

When angels are so angry
stabhed in my angry mood at
be not angry with the child..

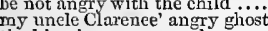

......3 Henry $_{\text {VI. }} \mathrm{ri}$.

Richard III. i.

the king is angry, see; he gnaws....

in the Lethe of thy angry soul thou.. - -

pray God, he be not angry

what, art thou angry, Pandarus?..... Troil. $\&$ Cres.

makes me smile, make Heetor angry?

whs he angry? So he says here ...
what, is he angry too? Who, Troilus?

as angry with my fancy..............

that $I$ had no angry wit to be a lord... Timon of $A$.

I am angry at him, that might have...

but who is man, that is not angry $\ldots . .$.
will you not be angry? Welli, well...Coriola

and be angry at your pleasures

and, being angry, does forget that eve

so would do, were he more angry at it
lcap in with me into this angry tlood.. ul. Coss

the angry spot doth glow on Casar's..

be angry when you will, it shall .....

not think, you conld have been so angry tho' Rome be therefore angry.

wherein you made great $J$ wajo angi......

haply, be a little angry for my so ....

farewell, you are angry. Stin going?
in tempest of thy angry frown. Titus

the augry northern wind will.

shalt thou ease thy angry
an angry brow, dread lord

resolve your angry father if my

why art thon angry? That sueh...........
which oft the angry Mab with blisters. Rom

once, when, in an angry parle, he smote. Haild

we be angry? I have seen the eannon (rep.) -

matter in't indeed, if he be angry
what, is he angry? Mar he the Jetter

nlmost to the sense, and he grows angry

the words would add more tinguish

whose power will close the eye of

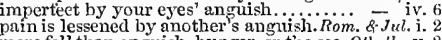

More fell than anguish, hunger, or the sea. Othello,
ANGUS-Murray, Angus, and Menteith. 1 Hen.l $V^{\prime}$

AN-HUNGRY -they were an-hungry.... Coriol.

ANIGHT

those pampered animals that rage ...Auch Adda,

he is only an animal, only sensible
that souls of animals infinse

his animals on lis dunghills are $\mathrm{ar}$. As yo

to fright the animals, and to kill them

a poor, bare, forked animal as thou art. Lear, iij. 4
the paragon of animals! and yet to me. Hamlet, ii. 2

ANIMIS-Tantæue animis cælestibus ire...2H. $V h$

and Ireland, Anjou, Touraine, MIaine

for Anjou, and fair Touraine, Maine

Poietiers, and Anjou, these five provinces - - i

duke of Anjou and Alaine, $y$ et is be

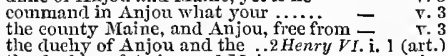

Anjou and Maine! myself did win

Anjou and Maiue, hothe given unto the

NNA as Anna to the queen of.. Tai

NNALS-have writ your annals true .CCoriol.

mistress Anne Page? ................ Pa-

O heaven! this is mistress Anne Page
the very point of it; to mistress Anue Page

here comes fair mistress Aun

I will wait on him, fair mistress Anne =

acquaintance with mistress Anne Page

master's desires to mistress Anne Page =

heaven seud Anne Page no worse fortune -

Anne is a good gipl, and ..................

in love with mistress Anme Page

dat I shall have Anne Page for myself

I vill myself have Anue Page...

by gar, if I bave not Anne
Yknow Anne's mind for that

knows more of Anne's mind

how does pretty mistress Anne?........

you are come to see my daughther Anne?

for a jack-a-naje to Anne Pas

where mistress Anne Page is..

thy adversary towards Anne Pa:

to bring me vere is Anne Page

to dine with mistress Anne ...............

first motive that I wooed thee, Anne

Thad a father, mistress Anne...

mistress Anne, my eousin

now, good mistress Aune

I would my master had mistress Anne

nothing but about mistress Anne Page

love I bear to fair Anne Page
if Aune Page be,my daugliter

if Aune Page be,my daughter

if $I$ did not think it had been Anne Page=

as Anne and $\mathrm{I}$ hrd appointed (rep.).

who hath got the riglit Anne?

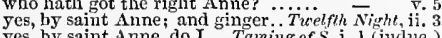

res, by saint Anne, do 1 ...Taming of S. i. I (indue.)

his eldest sister, Anne, my mother..̈ichard III, î. 2

but, gentle lady Anne, to lenve this..

that Anne my wife is very grievous..

that Anne my queen is siek. $\ldots \ldots . .$.
and Anne my wife hath lid the.

and Anne my withee wer good aunt Ani...

of the queen's, lady Anme Bullen.....̈Hen. $\bar{V} I I I$.

Anne Builen!' No; Y'll no Anne Bullens

last, that the lady Anne, whom the king

and behold the lady Anne pass

ANNEXED-had annexed unto '.......... \& chero. iv. 12

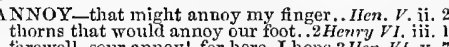

guard thee from the boar's annoy. Richard III

tretel so fax, as to annoy us all Julius Cesarar.

I fear, was root of thine annoy ... Titus Antron. iv

ANNOY ANCE-means of all annoyance, Macbeth, $\mathrm{v}$. any annoyanee in that precious sense...

doing annoyance to the treaeheroug. Richnrd 1 I . iti.

N NOY ED-she shall not be annoyed...Tom. of $S$.

ANNUAL-to give him annual tribute, . Tempesi,
about their anmual reckoning .... Love's L. Lost,

thousand pound a year, annnal support. L. VIII

three thousand erowns iv annual fee ..Hamlet, ii.

for the purpose, I'll anoint my sword. Hamlel, iv. Hive
ANOINTED-anointed sovereign of. Love's L. L. iij.

anointed, I implore so muncli expense
that had struek anointed lings.... Winter's Tale
broke ope the Lord's anointed temple.

broke ope the Lord's anointed temple... Afacbeth,

his deputy anointed in his sight heaven! Richord ili.

eommit'st thy anointed body to the cure -

because the anointed king is hence? ..
wash the balm from an anointed king

deputy elect, anointed, crowned, planted-

you stand against anoirted majesty... Hen. $I V$. iv.

stooped his anointed head as low ..2 Hen.r. H. (induc.

off, wherewith thoul wast anointed... H Henry VI. jii.

I was anointed king at nime months old - in. III. iv.
anointed let me be with deadly venom. Rich.

rail on the Lord's anointed ; strike..

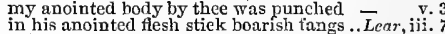

ANON - thou wilt anon, I know it...... Tempes', ii.

I will furnish it anon with .............

you shall see sport anon ........... $=$, Hii.

it strect end; he will be here ano

I shall find you anon

and anon, sir 1 will awake it ano..........

I will awake it anon

I will eall upon yon anon. $\ldots$ Measure for Nfeasure, iv.

you slall anon over-read it at

greet us here anon, my gentle $\mathrm{v}$ arrius

the friar and you must have a word anon-

anon, his Thisbe must be answered..

cover thou anon with drooping fog ..
of this discourse we more will henr anon

anon comes Pyramus, sweet youth

and anon falleth like a erab .... Love's L. Lost, iv.

and ever and anon they made a doubt

desire Gratiano to eome anon to my.Mer. of Ven. ii. 2

I will anon f first let us go to .......... $=$

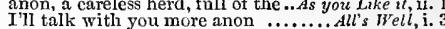

I'll speak with you further anon

you shall hear one anon
hear of your lordship ano...

I shall weep anon; good Tom Drum - iv.

anon I'll give thee more instruetions. Tam. of S. (ind)

and anou swallowed with yest and froth -

we'll buy the other things anon
we'll have this song out anon by

may think anon it moyt

avon, $I$ an sure, the duke............

anon, 1 wot not by what strong......

Paddock ealls : anon. Fair is foul

anoun, anon; I I pray you remember

be large in mirth; anon we'li driajk

well, more anon; eomes the $\ldots \ldots . . .$.
townd Birnam, and anon metiouglit

tumbleil about, anon becomes.........

up the heavy

which ever and anou he gave his nosc.1
what ostler! Anon,

Anou, anon, sirl score a pint of.......
tale to me may be nothing but

Alnon, anon, sirl(repeated ) Look down

the prinee, and weaster Poins anonon..2Henry this will grow to a brawl anon

ome sack, Franeis. Anou, anon, sir

Y'll give you a lealth for that anon..

Thi be with you anon; most sweet sir $-\bar{v}$ v.

anon, fiom thy iusultine ty?anny... Henry $y^{\prime} I$ iv.

shall heat you thoroulghing anon ...2 Hern'y ${ }^{2}$. . .

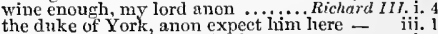

I alall anon advise you turther ....IIenry VIII. i.

I told your grace they would talk unon

close we shall hear more anon. ...

you'll leave your noise anon ye raseals

Troilus; you shanl sce anon. . Troilus \&

and, anon, hehold the strong-ribbed.:

she slall enme anon. Where.......
gnon lie's there afoot, and there they

but thou anou shalt hear of me

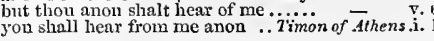




\section{$\mathrm{ANO}$}

ANON-I'll sneak with you anow.. Timun of Ath. ii. 2 ANOTHER I'll tell you more anou ........

Fou anon do mect the senate........

I'll have you talked with anon

forbear me till anou . ….....Antony f Cleopatra, it. ask him one thing; Til renlenber't a

a retire; anon a rout, confision thick shall I hear from you onou?

ndron. $\mathrm{i} . \mathrm{1}$

Whd then onou druns in his

Rom. S.Jul.i.

non, good uuxse! sweet Montague.

Peter! Anou? II tan Peter (repecie

anon comes one with light to ope the

anon he finds lim striking too.....

auon the dreadful thunder do

you shall see anon (repeated)......

bade him anon return and here spea

get you away; I'll send for you anol

pr'y thee, hie thee; he'll come anou.

ANOTHER-is another way so high.

give me the lie auther tims.

in such another trick.

there's another garment for $t$

but I'll prove it by another....

so angered with auother letter

and yet another yet.

I'll write your ladyship another

as one heat another

send her another; never .................

I'll get me one of sueh another lengtb

now of auother thing she may

what cur is that? aays another

shall tell you another tale........

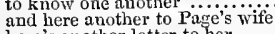

here's another letter to he

it is such another man .............

but I have another messeuger to ...

but I have another me mether into the register...

built upon another man's ground....

and another gentleman from Flogmore

another hope, to betray him to another

if I be served such nnother trick.

I lave reeeived from her another crmbassy

to mike another experim

aud by that we know one anoth

will be paid, one time or another.Tüelfh $\overline{N i g}$

will be paid, onc another jest

but, would you undertake another suit -

they will kill one another by the look

she loves auothe

grant me another recuest .............

to be a double-dealer; there's another $-\widetilde{\text { Nuea }}$. for

lives not to act another ...............

mather rejoicing to see another merry
thou believ'st there is another comfort

there is another friar that set ..

I have betlought ine of auother fauit

this is another prisoner that I saved

or else make another courtsey .........Nuch

seeing how mueh another man is ....

one an opinion of another's dotage ...

will not bite une auother, when they meet -

thou art another; Inch wear non

I pray you clioose anotlier subject (

that when I note another mim inke him -

here's another, writ in my cousin's hand

I will wed thee in another key

to choose love by another's eye .......

(as I can take it with another herb)..
should, of another, therefore be abused

therefore, another yrologue must tell

then there is another thing; we must
as one come uot within another's way

but wc are spirits of another sort

as little patienee as another man.....

'twill be thine another day

an' I eamnot, another cum

one drunkard loves another of the nam

tcll thee more of this another time.

and scaled under for another $\ldots \ldots$.

one wooer, another knocks at the door
to Tripolis, another to the Indies ....

another time you called me dog.

here comes another of the tribe

one hy another: this making of christians - iii.

is there yet another dotes upon....As you $\bar{L}$ ike $i t, i$.

thou liadst told me of another father

\section{ii. 3
iv. 3
iv. 5}

one another down his innocent.

I an shepherd to another main

that is another simple sin i..........

they were all like one another

the reation

but they asked one another the reason

there is, sure, another flood toward...

as creatures of another place.

sense saves another way $\ldots \ldots \ldots \ldots . . . .$.

you are not worth another word

thither they send one another............

not to know what we speak one to another

and buy another of Bajazet's mul.

he changed almost iuto another man

light on such another herb

another bear the ewer...Taming of Shrew, $\overline{1}$ (induc.)

I think, 'twas in another sense), I am

to help me to another, a fine musician

one buckled, auother laced; an old ..

another way I have to man my liaggard -

to take upou you another man's nax

another dowry to another daughter.

sometimes on one side, some another.

this cheat bring out another ..........

a kiss to choose, who loves another best -

here's auother ballad, of a fish ......

shake off one, to take another......

unless another, as like Hermione as is

with stariug on one another, to tear..

one joy crown auother; so, and in such

another elevated that the oracle...

another ship had seized on us.

and purchase me another dry bastin

the lost hair of another man

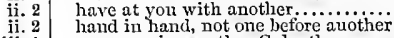

or memorize another Golgotha $\ldots \ldots \ldots . . .1$

and I another. I myself liave all the other

and $I$ another, so weary with disaste

another yet? a seventh? I'll see

add another hue unto the rainbow.

whisper one another in the ear

another lean unwashed artifieer

sound but another, and another sha

behold another day break in the east

stay yet another day, thou trusty ...Richard II. ii.

two'er so little urged, another way to pluck -

aud fill another room in hell..........

cannot be true to one another! ...1 Henry

strangled with a halter, as another

I have more flesh than another man

I fear, thou art another counterfit

meeting the cheek of such auother day

or it will seek me in another place . .

cannot one benr with anotler's eonfirmitich

marry, there is another indictment upon

as men take diseases, one of another
and let another half stand laughing by.$\overline{H e n}$.

endure cold as another man's sword wili -

to cut one another's throats.

if I should take from ano ther's pocket

here's my glove; give me another

I have another leek in my pocket...

quarrel will drink blootl anotlier day

imperious in auother's throne?

belt so fist at oue another's pate ....
turn thy edged sword another way.

twiukling another counterfeited beam

files from amother coast.

to purchase such another isiand

let them kiss one another, for th
or pick a sallet another while

or pick a sullet another while ..... . iv.
making another hearl to fight again..3 Hen. $v i$. i.
slipped our claim untit another arc..

one the better; then, another hest
and yielding to another when it blow

an, but, I fear ne, in anotlier fen

like a Sinon, take allother Troy ....
here another anehor? Aud Somerset another -
he might infect another.............

i. 2
iii. 2
iv. 1
iv. 1
v. 1
v. 2
ii. 3
iii.

\section{to-monow you'll serve another master}

such another sleep, that 1 might ( $r e p$.)

woo another wife, when Imogen (rep.) Cymbeline,

to exchange one misery with anotbe
and he's another, whatsoever he be

the cutter was as anotlier nature ....

it doth confirm another stain ............

many Cresars ere such another Julius

one sand another not more resembiles

but I'll deceive you in another sort.,

Tilus And.

another hue, in that it scorns to bear another - iv

to find another that is like to thice ...

like one anotlier's glass to trim ......

in pace another Jumo .................

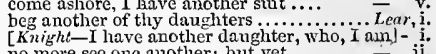

and here's auother, whose warped looks

another way the news is not so tart...

liere, friend, is another purse .........

but another, to amplify too much....

another's burning, one pain is lessened hy

another's ...............................

theu dreams he of another benctiee

to lay one in, another out to hive...

I dare draw as soon as another man..

I rith a ladder

the label to nuother deed, or my true

turn to another, this shall stay them

heap not auother sin upon my head..

must not put another seandal on him ... Itamlet ii.

and you make yourselves another: you jig - iij.

true love doth wroud another one?

I'll wot another question to thee ....

why he more than another?

possible to understand in another ton rue-

come, another hit; what say you? :..
comet w

another of luis tathom they have not ..... Othello, i. I

some one way, some another; do yuu know
this very night, at one another's hecls

here comes another troop to seek for you

that not auother comfort like to this.

Clarence hath not another day to live. Rich, III.

as for another secret close intent

O, but remember this another day..... -

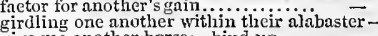

give me arother horse; - bind up ...... 'tis such another fitcher monry o verfumed you must tell us another tale......... I have another weapon in this chamber aud here another; the one of them import
2

v. 4

i. 2

iii. 1

.

ii.

v. 3

v. 3

v. 4
v. 4

v. 8
i. 2

ii. 5

iv. 3

i. 4

ii. 3

iv. 5

ii. 2 
ANSELAIE-county Aiselme and his heauteous

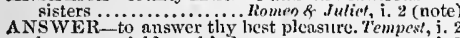
who never yields us kind answer to anser yther linsiness

on this a silly answer, and fitting wcll.. Two Gan of $\bar{v}$ er. a thousand times it answers, 11

answer not; the tide is now...

I will answer it straight

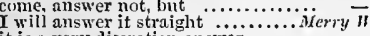

me shall have our answer

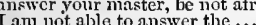

handmaid do return $t$

iv. 1

g roud lenten answer.

good my mouse of virtue answer ine...

to shall answer for lier .................

lye might lave took his answer long aro

I will answer you with gait....

stir on the youth to an answar

I can no otlier answer make.

yes, nightingales answer daws
with as much safety you miglit
aud on the answer, he pays you.

aud on the answer, he pays you.......

I pray you, answer him.... Measure for Aleo

from brakes of vice, and answer none answer to this, $I$, now the roic

and nothint of your answer............

answer his requiring with a plausible

and the place answer to convenien

to make your answer before him ....

ind yield me a direct answer

as you will answer it at your peril...

you'll answer this one da

be the hetter prepared for an answer..

in that kind, you know your answer

when the dance is done! Answer clerk -

thus answer $I$ in the name of Benedick

if their singing answer your saying
to have all things answer my mind..

to have all things answer my mind

if thew it would be your answer $\ldots$ you not then the better answe

will never answer a calf when he bleats

I will owe thee an answer for that

bid her answer truly

to make you answer truily to your naine -

if you are a maid answer to this

how answerou for yourselyes? and $_{\text {let }}$ it answer every strain for strain -

let him answer me: come, follow me

that dare as well answer a man ......

let me go no further to mine answer

your answer, sir, is enigmatical

$I$ answer to that name
answer, as I call you

that ron answer to Pyrannu................

and dares not answer, nay

will you tear impatient answers from

Hermia should give answer of her choic

eall me, and I will answer; my next is

I I say, thou art quick in answers...
they will not answer to thiat epithet

attends thy answer there

shall I know your answer... Merchant of Venice,

your answer to that.................

doth teach me answers for deliverance

thou art come to answer a stony :...

I'll not answer that: but say

now for your answer: as there ....

not bound to please thee with my answer

you will answer, the slaves are ours (rep.)

stand for judgement; answer; shall I

we will answer all things faitlifully.

answe

is more than to answer in the...

you are full of pretty answers

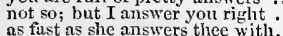

never take her withont her answer.

for I must bear answer back how

good wits have much to
a geod answer; art rieh?

he would ans; art reh? ................

while 'tis vendibie; answer the time."

he bath armed our answer, and Florence

(repeated $)$ an answer will serve all men.

Marry, that's a bountiful answer...
urge her to $\mathrm{a}$ present answer back...

must answer for yonr raising?

of pity : sjeak; thine answer .........
but to answer you as you would he..

bids you answer to what I shall ask.

shall I set down your answer so? let me answer to the particular of the

let me answer to the particular of the
would neep forth, and answer, thanks

Yll answer him lyy law: I'll not. Tam. of Sh. $\overline{1}$ (ind.)

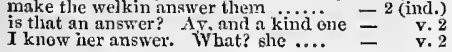

$\triangle$ NSWERRmile you do, we'll answer; if you. Winter's Tale, he makes the maid to answer, wlioop

and stand in hope of answer.

my lite may last to answer ..............

and answer to his part performed in as $I$ am a clnistian answer me.. Comedy of Ér

niadly thou didst answer me? what answer

may, answer my good-will .....

whe'r you'll answer me, or no .......

all the metal in your shop will answer

any man to answer it, that breaks

that clogs ne with this answer

Macbe

(howe'er you come to know it), answer me

answer me to what I nsk you. (rep.)
would I eould answer this comfort with

for controulment; so answer France.. King John
answer like an ABC-book; $O$, sir (rep.)

ere answer knows what question wonl

stay for an answer to your embassy.

let me make answer-thy usurping son

why answer not the double majesties.

to charge me to all answer ................

$O$ answer not: but to my closet

how we shall answer him: for....

or my divine soul answer it

as your lives shall answer

ny lord, my answer is-to Lancaster

and noble lords, what answer

for your days of answer: little

his answer was, he wonld uuto the stews -
sent for him to answer this............ 1 Henry $I \%$. i.

to answer all the debt he owc

come, come, you paraquito, answer me

are you not a coward? answer me to that -

shath I give him his answer ...........

send him to answer thee, or any mau

in such a parley wonler the coinage

shall I return this answer to the king

on their answer, we will set on them

he himelf will answer. Here comes. 2 Henry $I$

let him be brought into his answ

the answer is as ready as a horrower's

answer, thou dead elm, answer ......

he shall answer it; some pigeons ....
in answer of which claim, the prince

arrest them to the answer of the law..

to answer royally in our defences...

to answer matters of this consequence

fire nnswers fire, and thro' their paley

the king is not bound to answer the.:

hear $m y$ former answer bar

quite from the answer of his degree..

no answer made. Well then, (rep.)................

pass our nceept, and percmptory answer -

how answer you, la plus belle Katharine -

come, your answer in broken music.

of my mirth, if $Y$ answer you for that
and 1 will answer unpremeditated
answer you so the lord protector? The

Gloster, thou'lt answer this before the

and answer was returned, that he will

purpose to answer what thou

let me know, and then I'll answer you

I ronld that you would answer me...

to give thee answer of thy just $d$

will answer our houe your groce

shitl make answer to such questions...21len.

tremblest at, answer that I sthsil ask

these foul offeuders to their thy abits

an answer from the king, or we'll.

nay, answer, if you can: the Frenchumen -

what answer makes your grace .....

matters they were not able to answer

prose greatncss answers words

whisper you, my lords, and answer...3

here I stand, to answer thee.

before you answer Warwick

but auswer me onc doubt ........

and tell what answer Lewis and the barly -

what answers Clarenee to his sovereign's -

thou would'st liave me answer to.

could all but answer for that peevisili.. Rich.

his answer was,-the people were not..

still answer nay, and take it .................

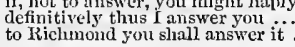

ANSWER-

to make ye suddenly an answer .. Henry rJIJ. iii.

lay upon my credit, $I$ answer is most false

sorely tainted), to his answer, lie fell

which will require your answer

this woman's answer sorts.... Troilize \& resside

his pretty answer. What was his an

fire to answer for his love ............

and wake him to the answer, thing

farcwell, who shall answer him? .... -

and bring his answer presently ......

your answer, sir. Fare you well

where he answers again, because

hence, I'll answer to my lust ........

we'll, answer it; the issue is .........
whom mnst we answer? The nohic.

great spirit flew : answer me, heaven

to answer such a question...........

that answer might have hecome............

answer in a joint and corporate voice

with their faint reply this answer join

ay, but this answer will not serve.

now we shall know some answer ....

while yon have mere nature

no answer? what is this? Timon is dead -

pell, sir, at heaviest answer

your belly's answer: what the
what could the belly answer? inil

a while, you'll hear the belly's answer

it was an answer; how apply you this?
but fome was realy to answer ns....

alone, to answer all the city..........

and shall answer as traitors do

and follow to thine answer $\begin{aligned} & \text { whe....... } \\ & \text { where he shall answer, by a lawfui }\end{aligned}$

arm yourself to answer mildly

I will answer in mine honour
answer to us. Say then; 'tis true

Coriolanus he would not answer to

his answer to me was, he colld d

and answer, such high things $\ldots \ldots . . .$.

stay not to answer me, but get thee gon

with reasons answer you

answer every man dicectly

answer every man directly, and bricfiy

no, Cesar, we will answer on their

no more light answers: let olu

no more light answers: let our . .
I shall entreat him to answer like

possess it, Till make answer: but

is this his answer? $\Lambda y$, my lord.

and answer ne delined, sivord against

the full Cresar will inswer his emptin
lives he? wilt thou not answer, nutin?

we anstrer other's merits in our nane

youl shall answer me witl your sword

deliver with more openness your answers-

the of your

doublet; hat, hose, all that answer to them-

and there's no answer that will be given -

ho! no answer? then I'll cnter

and put us to our answer

should answer solemn accidents....

ii. 5 great the answer be Britons..........

give answer to this boy, and do it freely -
answer I must, and sliall do witlt.. Tilus $A n$

to answer their suspicion with

draw him but to answer thee in aught..

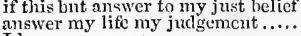

Lear,

the fitult of it $I$ 'll answer.

In answer that. My sister may receive

fetch me a bctter ansirer. Iy clear lor

than to answer with thy uncovered body

his answer was, the worse

craves a specdy answer; 'tis tron ...

craves a specdy answ

I should answer tiom a fuil-fiowing stomac

why you answer this present summons?

wast not bound to answer an unknown ...

Romeo will answer it.................
answer a letter. Nay, he wil answer the -

good, or bad? answer to that; say eitlicr -

eyes shut, that malce thee answer....

to answer-I'll not wed, I cannot love

to answer that, were to confess to you

answer me like men.................

but answer made it none: yet once.......

iii. 2

ii. 1

ii. 3
iii. 3
iii. 3
iv.

iv. 4

v. 5

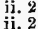

ii. 2

iii. 4

iv. 3 
ANSTER-

answer me: let me not burst in ignorance.Ham. i. we'll read, answer, autl think upon this

Thave nothing with this answer,

a wholesome answer; my wit's (repeutcul)

conne, you answer with an idle tongue

would vouchsafe the answer? How (rep.)

or quit in answer of the third exehange.
this thou shalt answer; $I$ know thee, lioderitg.

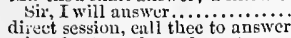

eries-haste, and speed must auswer it

niglat-lirawler? give ne auswer to it

a dug, than aliswer my waked wrath

make questions, and by them answer

AYriver.

ail tinings answerable to this portion. Tam. of $S$.

the eie men, he shail he answerable ...l Ilesry r $r$. ii.

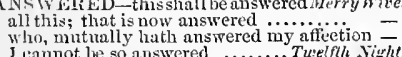

1 camnot be so answered

must she not then be answere

since been answered in repaying

- ii. 4

hail answered for his deed ifeasure for $\overline{\text { Measu }}$

would have durk deeds darkly answered
no more words, the elerk is answered.Much $\bar{A} d o$

no more words, the elerk is answer he

anon, his Thisbe must be answered.

I nu answered, sir .......... Love's L Letour Lost, it.

is it answered? what if my

what, are you answered yet? some.........

suit agginst him: are you answere
low a beggar should be auswered.
noteirs are answered. An' will $r e p$.

atfairs are answered. An' will (rep.). . As you Like,

Jou h:lve auswered to his reputation. All's $\bar{w}^{2}$ ell, iif. 3

slould lave answered heaven boldly. Winter's $T$. i. . 2

I must be answered; dost then hear.

thou hast answered lim well. Cormedy of Errors, iii. 1

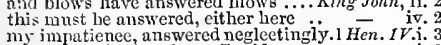

my impatienee, answered neglee

I answored indirectly, as I said...

rolilet $y$, lad, how is that answere
with geril I have answered; for al
lie answered thus; young Talbot

le answered thus; young Talbot..1 Henry $V^{V}$. iv.

finits are easy, quiekly answer
for measure muist be answered

who onswered him, they enme f......3Henry VI. ii.

lie answered, tush! it ein do me no..Hen. VIII, i.

fairly auswered; a loyal and obedient

to-morrow be answered inl this chill
the belly answered, - well, sir, what.
like his acensers, oud thus answered

like his acensers, and thus answered
whieh being answered, and a petition

I insisted, yet you answered not .. Julius Cesar,
and grievously hath Cesar answered it -

and grievously hath Casar ans

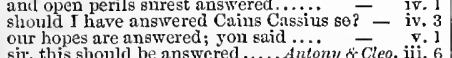

ean her eontempt be answered? .... Cymbeline,

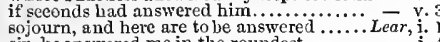

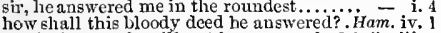

but jealons souls will net he answered.. Othello, iii.
ANS WERING - answering us with our. own. Cor. v.

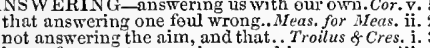

he professes not answering; spealiing

answering before we do demand of...Jul. Cassor, v.

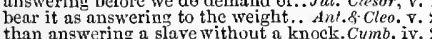

who, even now, answering the letter ot

fame answering the most strong. Pericles, iii (Gow (G)

and answerest not? Dremio.. Comedy of Errors,

thou answerest, she is fair. $\ldots$ Troilus \& Cressidn

ANT-10 the moldwee to sehool to an ant.... King Lerr, ii.

ANTEKOR-that's Antener; he has.. Tro

Helenus, Antener, and all the .....

a Trejan prisener, ealled Antenor....

for the enfreed Antenor, the finir Cressid

our Antenor delivered to $11 \mathrm{~s}$...

A plague upon Antenor! (reppe
thou art ehanged for Antenor.

thoich oh Anted or we deliver you
which for
ANTENORIDES-Trejan, and Antenorides,

with massy.......... Troilus \& Cressida (prologue)

dolour................ Tur Gentlemen of $\nu^{\prime} e r$

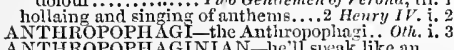

ANTIROPOPHAGINIAN -le"ll sleak like an

ANTIATES - - 'the vaward are the Antiates

set me against Aufidius, and his Antiate

Iio less honour to the Antiates

ANTICIP ATES-whose footing here antieinates

ANTICIPATING onr thesh and fair........ aticipaling

time with starting ........ Troilus $\delta$. Cressido
ANTICIPATION- so shii my antieipation

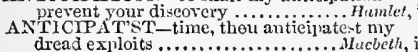

ANTICK-drawing of an antiek.... Aluch Ado, iii. I ANTONIO-

or pageant, or antick, er firework... Lore's $L$. Lost, v.
we will lave, if' this tadge not, an nutiek - v. I

werc he the veriest antiek in, a..Taming of $\overline{S h}$. (invi.)

anl there the antick sits, seoffing.. Richard II. iit.

three suit antieks do not anount... Henry $b$

thou anticks death, which langhiest... H Henry $l^{\prime} i$. iv. 7

witless anticks, one another meet.. Troil. 5 . Cress v.

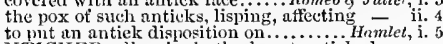

ANTICKED-disgnise hatl almost antieked

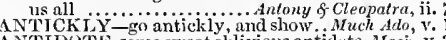

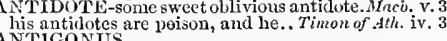

Antigonus, I charged thee, that slie.. Winter's $T$. ii. 3

good Antigonus, since fate, against thy - iili. 3

and s:icl, his name was Antigonis

ns my Antigonus to break hus grave.

beeane of Antiromus, that earried henee
N'TIOCll-Antioch the great .. Pericles,

Antioel, farewell! for wisdom sees .
at Antiuch, whose arm seems fur too

and went to Antioel, where, as thou
being at Antioch-What from Antioch? -

as friends to Antioel, we may fenst..

int Antivelh, and his daughater, you.

that would be son to great Antioelius
Antioehus, I thank thee, who hath taught-

I wait the slinrpest blow, Antiochus
nor tell the world, Antioehus dotl sin -

nor tell the world, Antioehus doth sin
great Antiochus ('gainst whow $1 \mathrm{am}$

Antiochus you fear, and justly too
royal Antiochus (on whnt eause $I$.

lord Thaliard from $A$ ntioehus is weleome-

Antiocluns frem incest lived not free
Antiochus and lis denughter's dend

ANTIOPA - A riadne, and Antiopn?

$\because$ iii. (Gower)

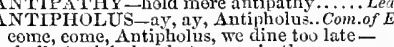
shall, Antipholus, hate, even in the

master Antipholus? Ay, that's my name-

is growing to me by $\mathrm{Antipholus}$......
well met, well met, master Antipholus

now out of doubt, Antipholus is mad
signior Antiphelus, I wonder much that -

Your grace, Antipholns, my husbuand

yeur mane, sir, ealled Antiliholus?

yave I been 1ratron to Antipholus....
hilike
these two Antipholus', these two solike

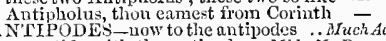

noon-tide with the antipoles. Mid. N. Drear
should hold day with the antipodes. . Mer.of $V$

we were wandering with the antipodes. Rich.II. iii.

ANTIOUALY Y the antiguary times.. Troil. \& Cres. . .i. 3

never may believe these antique fables. Mid. N.D.

an oak, whose antique root peeps out.
constant serviee of the antigue world

while you perforro your antique reumd. Mucketh,

in this, the antique and well-noted...King John,
the senators of the antique Rome.. Henry $V$. v.

the dust on antique time would lis.

his anticue sword, rebellious to his arm.. Ham,

an antique token my tather gave .........

ANTIQUIUS-et quo antiquins. . Pericles, i.
ANTLUITY-and of intiquity too. Mena. for
bigh top bald with dry antiquity. As you Lik

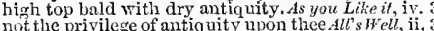

about you blasted with antiquity? ..2 Henry I $F$

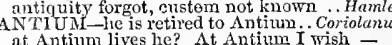

at Antium lives he? At Antium I wish -
a soodly eity is this Antium .........

a coodly city is this Antium ........
is he in Antiun? He is, and feasts

theAntoniad, the Egyptian admiral.Ant.\& Cleo. iii. did Antonio open the gates $\ldots . .$.
what thing.

know you don Anttonio ... Treo Gen. of Ver

You must know of me then, Antonio.. T'eelf

my kind Antonio, I ean no other....
Antonio, $I$ arrest thee at the suit of..

Where's Antonio then? $\ldots \ldots \ldots \ldots . . .$.
this is that Antonio, that took the ..

Antonio never yet was thief

Antonio! O my dear Antonio

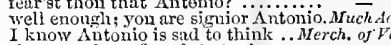

sinee you have found Antonio, we
yourleok not well, gignior $A$ nutonie

I tell thee what, Antonio, 1 lo
Ony Antonio, I do know of

'tis not unknown to you, Antoinio, how

to you, Antonio, I owe the most........

Antonio shall be bound. Antonio shall =

Antonio bound. Your answer $(r e p$.$) .$

Anay I speak with Antowio?..
tlis is sirnier Antonio

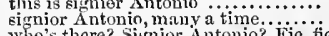

who's there? Signior Antonio? Fic, ic

let goed Antonio look he keep his day

I thought upon Antonio, when he told
to tell Antonio what you hear........
I saw Bassanio and Antouio part... Aler. of $V$ the good Antonio, the honest Autonio whether Antonio have had any loss at sea my master Antonio is at his bonse .. there eane divers of Antonio's ereditors but Antonio is certainly undone

tuat royal merchent rather hive Antenio's flesh, than .... it will go hard with poor Antonio...
that this $\Lambda$ ntonio, being the bosom..

what, is Antonio here? ..................

good cheer, Antonio! what man? .

Antonio and old shyloek, both stand

tell her the process of Antonio's end

Antonio, I am married to a wife
ior half thy wealth, it is Antonio

wh, tor the state, not for Antemio ..... -

if thou ean'st, unto Antonio's house...

this is $\Lambda$ utonio, to whom I am

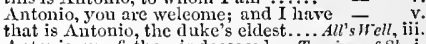

old Antonio's son: my father dead ...

Petruchio is my name. Antonio's son

Antonius. Cirsar, my lord (reperted)

he did bid Antounins send word yto ou
is Ciesar with Antonius prized so .. Ant. $\overline{\text { CCleo }}$.

slie is new the wife of Mareus Antonius

ANTONY-brotherAntony-hold you.. Much Ado, v.

gut, brother Antony, -come............ L i. I (letter) an't shall please yout; I am Antony Dull

said, Mark Antony's was hy Casar.. Macter/h, Autony duke of Brabant, the brotler

man of worslip, Antony Woodville.. Richard III he loves noplays, as thou dost. Ant tony -

I saw Mark An tony offic lim a erown

it is not meet, MIurk $A$ ntony, so well

let Antony and Casar fall together

and for Mratk Antouy, think not of him -

We'll send Mark Antony to the .......

good-morrow, Antony, so to most noble

where's Antony? Fled to his hinise
of Antony's. 'Tius Brutus (reported)

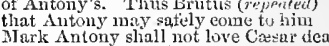

so says my master Antony ........... We -

o Antony? bets nut your death of us

Mark Antoly, pardon me, Cuius Cassius -

were you, Antony, the sou of Crear..
you shall, IIark Antony. Brutuss..

do not consent, that Antour speak.

Mlark Antony, here, take you Casar;'s bouly

do you not? I do, Mark Antony...

for my sake, stay here with Antony -

till Antony have spoke. Stay, ho! (rep.) -

noble Antony go up. For Brutus' sake -

not a noller num in Rome than Antony 二

we will hear it, Antony; you shall .. -

room for Antony; most noble Autony

I Brutus, and Brintus Antony (repeated) -

hear Antony, most noble Antony.... -

prick him down, Antony $\ldots \ldots \ldots \ldots \ldots$ -

come, Autony, and young Octarius

and Mrark $\Delta$ ntony, eome down upon us -

Octavius, Antony, and Lepidus, have

Miark Antony, shall we give sign of battle?

$\Lambda$ utony, the posture of your blow"s
for you have stolen their buzzing, Antony

come, Antony, away: defiunce, traitors
whilst we by Antony are all enelosed..

Mark Antony is in your tents.........

as Cassius' legions are by, Antony

safe, Antony; Brutus is sife crough...

more than Octavius, and Mark Antony

nay, hear them, Antony. Fulvia....Ant.s. Cleo.

thou blushest, Antony; and that hloos

the foel I am not; Antony will bu himself -

still should go with Antony.......... -

hush! here eomes Antony, Not he...

Anteny, thou wouldst say, 0 , my lord 1 -
but here eomes Antony. $1 \mathrm{am}$ siek..

quiekly ill, and well: so Anteny luves -

my oblivion is a very Antony, and I am -

set must Antony no way exense his

gap of time, leave thy laseivions wassels iii. ?

i. 1 
ANTONY-the weight of Antony! ....Anl. \& Cleo . i. 5 how mueh uulike art tliou Mark Antouy! how goes it with my brave Mlark $\Delta$ utony!
when I forget to send to Antony .... unother emphasis! 8 y, the hrave Mintony Ml:rk Autony in E:ypt sits it dimer in Rome togetlyer, looking for Antony Mark Antony is every lowu in Rome the ne'er lust-wearied $A$ is to Catsin and $A$ utony shall well grect.

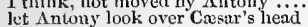
liere comes the moble Antony

creat llark Antony is now a widowe

take Antony Oetavia to his wife ..... not tifl he hears how Antony is touched when she first met Mlark Antony. (1, rare for Antony $\}$ Her geutlewomen Aistuny, enthroned in the market-place uloun her landing, Antony sent fo her our courteous Antony, whom ne'cr can scttle the heart of Antony, Oetavia therefore, $O$ Antolly, stay not by $\ldots . .$. sir. Mark Antony, will en hut them every one an Antony nuidam, raadam,-Antony's dea yet if thou say, $\Delta$ ntony lives, is well. jrating Antouy, Thave dispraised Co no. Autonr, take the lot ..... Autmy will use his atfiection

raod Antony, your hand

0 Antony, you have uny father's hou so thy grand eaptain Antony shall

thou wilt write to Antony.............. what's Antony? The God of Junite o Antonyl o thon Arahian biad he loves Antony: ho! hearts, tongues sing, number, 10, his love to Antony most uoble Antony, let not the ....... vilien Antouy is gone through whom between her brother and Milong Where 8 Antony? He's walking iu the
hwing me to A itony. Come, sir .... the wife of Antony should have an army ray lord, Mark Antony, hearing on the adulterous Antony youx presence needs must puzzle Ant
ruin of her maric, Antony, claps ou yet tollow the wounded chance of An tony let him appear that's eome from Antouy such as $I \mathrm{am}, \mathrm{I}$ eome from Antouy fir. Antony, I have no ears to from Antony win Cleopatra $\dddot{3} . . . .$. Antony, or we, in fault for this? Anto so, hajly, are they friends to Antony that you embrace not Antony as you you had let't Antony, and put yourself hive you no ears? I $\mathrm{mm}$ Autony ye portends alone the fall of Anton. sinee my loril is Antony agaiu ....... personal combat, Casar to Antony earned the waste: poor Antony
elapped up together in an Antou elapped up together in an Anto

single fight! Then Antony,-but now

the gods make this a happy day to Antony our will is, Antony be took al

that Antony may seem to speed $\dddot{h}$ is

to Jewry, on affiurs of Antony

and leave his master Antony

Enobarbus, Antony hath after thee seut = O Antony, thou mine of bonnty,

Antouy! o Antouy! Let's spee

Antony is valiant, and deject

say, that the last I spoke was Aitony

here I am, Antouy; yet eaunot $\ldots .$.

spike was, Antony! most noble Anton

groan did break the name of Antony

where's Antony? There, Diomed, there

0 Antony, Antouy, Antony! Charmian Done but Antony should cone uer Antony but come, eome, Antony! help me

Mrark Antony, $\mathbf{r}$ served, who best

I say, o Cosar, Antony is dead ...... o Antony! I lave followed thee to tlis Antony did tell me of you, bade

yet to imagine an Antouy, were

Ay taking Antony's eourse, youk shill

for Cydnus, to meet AIark Ant

if she first meet the curled Antony...

as slie would catcli another Antony

she shall be buried by her Antony :.

AN'TRES and Potpan! Ay, boy..Romeo of - $\bar{J}$ ution ANTRES_of antres vast, and desarts idle. Ohell

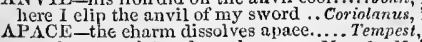
APACE-the eharm dissolves apace..... Tempest, v.
are pleasant, sir! and speak apace .. Alea. for $M I$, iil. $\triangle P A C E-$

our nuptial hour draws on apace .Mid, $N_{i}$ Drm. i. I stayed an hour, and talked apace. Lore's L. Lost, v. 2
quickly, and speak apace: I would.Asyou Like, ii. 2 come apace, sood Audrey; I will.: $\bar{p}_{\text {s }}$ oll iit. 3 aplruaches noce; I would gladly.... All's Well, iv. sunday eomes apree: we wifl

iv, 3

ii. $)$ now spun's the lated traveller apace ...MFacbeth, iii. 3

ii. 1 the holy legate eomes apaee ..........King John, v.

the kip conce

ii. 2 great weeds dogrow apaee........... Richard 11 i. ii. 4

ii. 2 Bratus, eome apace, and see how .Julius Corsar, v. 3

ii. 2 ereeps apace into the hearts of.... Antony \& Cleo. i. 3 thou bleed'st apace. I hat .......... - iv. 7

ii. 2 allaee, Eros, npaee. Nounore a soldier - iv.12

ii. 2 O, come; apace, despatch: I partly $\ddot{\text { in }} \overline{\text { Lear, }}$ iii. 2

ii. 2 powers o' the kingrom approach apace $-\overline{\text { ive }}$ iv.

ii. 2 [Knight.-anon? Beforo, und apace].Rom, \& Jul. i1.

ii. 4 APAR T-go apart, Ad:m, and thou. As you Like $\dot{i}, \mathrm{i}$.

ii. 5 why, thy godlhead laid apart, warr'st - iv. 3 (letter)

ii. 5 therefore I keep it lonely, apart; but here - v. 3

ii. 5 stay, stand apart; I know not .. Com. of Errors, ,

ii. 6 all reverenee set apart, to him ...... King John, iii. 1

and lay apart the borrowed glories..... Henry $V$. ii.

to lay apart their particular tunetion

and Henry put apart, the next for me.2Hen. $Y I$. ini.

irs, stand apart; the king sliall know - iii.

all apart; cousin of Buekingham ... Nichard III. iv.

get thee apart, and weep ........Julius Cass?

to lay his cav comparisons ap:Irt. Ant. \& Cleo iii. 11

I lave kept apart for Listia...

away; ayart upon our knees ...... Cymbeline, iv. 2

to draw apart the body lie hath killed... Hamlet, iv.

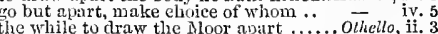

come, go with me aprart; I will witlidraw - iij. 3

PE-sumetimes like apes, that moe ... Tempest, ii. 2

turn'd to barnacles, or to apes........ Measure, iv. 1

like an angry ape, plays... Measure for Measure, ii. 2

so deliver I up my ape

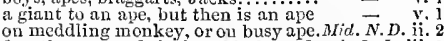

fox, the ane, and the humble-hee.. Love's L. L. iii.

the ape his keeper, the tired horse.. this is the ape of form, monsieur .. iv.

more new-fangled than an ape... As you Like it, iv. 1

so perfectly he is her ape.......... Winter's Tale,

no, $X$ am an ape. If thou art... Comedy of Errors,

have not transforned him aipe....

alas, poor ape, how thou sween'st.

because that Ian little, like au ape... Rich. III. iii.

from slaves that apes would heat? ..Coriolanus, 1 .

for apes and monkeys, 'twixt two

is jollity for alyes, and grief for boy

like the famous ape, to try conclusions. 2 . Jul. ii.

he keeps them, like an ape ........... ${ }^{-}$iv. 2 APEMANTU

glass-faeed flatterer to Apemantus. Timon of $A t h$, $i$. you know me, Apemantus

thou axt proud, Apemantus.

wilt dine with me, Apemantus?

how dost thou like this jewel, Apemantus?

do then, Apemantus? Even as Apemilntus -

art not thou a merchant? Ay: Apemanis

why, Apemantus? should'st have kept

good dich tlyy good heart, Apenantus

mow, Apemantis, if thou wert not sulien

are we, Apemautus? Asses. Why?

how dost thou, $\Lambda$ pemantus? Wrould.

Apemantus, retd me the stperscriptio

where feed 'st thou o' days, $\Lambda$ pemantus

thou do with the world, Apemantus.

APENNINES-the Alps and Apeunines.

APEX-me pompe provexit apex .......

a month's length a-piece, by an .......

bonds of forty pound a-pieee, and..... Hen Hy $\mathrm{IJ}^{\prime}$.

APISH-apish, sliallow, ineonstant ...fs you Like, it
this apish and unnanmerly approach . King John,

still our tardy, ajish nation ........ Richerd $H$. $\mathrm{ii}$

Freneh nods, and apinh eourtesy........hichard III. i. 3

A their mamers are so apish........... Lear, i. \& (song)

APOLLO-Apollo flies, and Daphne..Nijd. N.'s D.ii. 2 are harsh atter the songs of Apoilo .. hark! Apollo plays and twenty ... Tam.of $S .2$ (ind.)
sight shall sad Apollo weep ......
POLLO-Delphos, to Apollo's temple. Winter's T. ii. the great Apollo suddenly will $\ldots . . .$.
great Apollo, turn all to the best $\ldots$.
tlus by Apollo's great divine sealed up

the rate ; A Apolio be iny judge.

delivered of great $\Lambda$ pollo's priest

jollo's'angry, and the heavens (rep.) -

and that A pollo would, this being indeed -

作 $A$ pollo, a pour liumble sy

tell me, Apollo, ther thy Dapiline's love. Troil. $\&$ Cr.

though Apollo knows, tis dry enough

unless the tiddler Anollo get hals.

Anollo, Pallas, Jove, or Alerenry...Titus Andron this to $A$ pollo; this to the god of war

now, by Apollo (repeated) ............. King Lear POLUGY -I will have an apology.. Love's L. L. v.

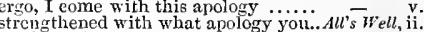
ny lord, there needs no sueh apolngy. Rich. III. iii. AP shall we on without apology?... Romen \& Jutiet, PED-that sense is apoplexed. Hamlet, his apoplexy is, as I take it apoplexy.2Hen. 1.1 . peace is a very apoplexy, lethargy... Coriolanus, iv. by the apostle Paul, shadows ...... Richard IIIT v. 3 I'O'TIECARY-bid the apotheeary.2Henry $/ I$ I. iii. 3 I do remember au apothecary ...Romeo o. Juliet, v. what, ho! apothecary! Who ealis so loud - v.

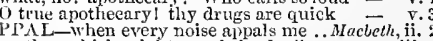
on that which night applal the devil . $-\overline{\text { ing }}$ - iii. make marl the guil ty, and appal the tree. Itomle', ii. that the appalled air may pierce. Troilus o cryess. ir. I'AREL - women in nen's apparel.. Nierry "I: iii. fur all he was in woman's ajparel.

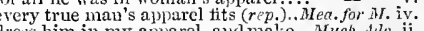
the infernal Ate in good apparel

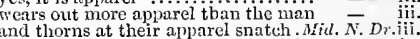
get your apparel together; good strings - iv, and snore, and rend apparel out.. Mcreh.of $I^{\prime} \mathrm{cm}$. and in man's apparel? Looks he as.. - iii. 2 by wearing his apprarel neatly.........All's Well, iv. what ajparel he will wear.. Taming of Sh. 1 (indue.) costly apparel, tents, anil eanopies a very monster in apparel; aud not like money and appurel ta'en from me... apparel vice like virtue's harbinger. Com. of Er iji. ny say apparel for an alm's-men's. lichardII. iit. but in vile apparel, and seud you back. 2 Hen.IV. i. for his apparel is built upon his baek

and I will apparel them all in one..2Hen'y $V I$. iv. is my apparel sumptuous to behold.. $\overrightarrow{J u l} \overrightarrow{\text { Casar, }}$ i. hring this apparel to my cliamber .. Cymbeline. ifi. 5 for the apparel oft proclaims the man ... Hamiet, $i$. are appareled thus, like Muscovites. Love's L. are appareled thus, like Muscovites.. Love'sL.L. . . not so weil appareled as I wish you..
of old Adam new appareled?.. Comedy of Errors, iv. 3 on my side it is so well appareled ... Henry VI. ii. see, where she comes, appareled like.... Pericles, i. 1
APPAREN'T-is it now apparent?.Mea. for Mea, iv. 2
without apparent hazard of his.. Tuo Gen, of $V$. i. 3 is thy strange apparent eruelty......Mer. of Fen. iv. I he's apparent to my heart ..........Winter's Tale, i. 2 (for, to a visionso applarent, rumour... $\bar{J}_{\text {it }}$ is apparent foul-play; and 'tis sliame. some apparent danger seen in hin ... Richard II. $\mathrm{i}$. although apparent guilt be seen in .. $-\overline{\text { iv }}$.

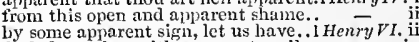
by some apparent sign, let us have..1 Henry if death he so appareut, theu both fly - iv. as harm apparent, in my opinion... RichardIII. ii. his apperent open guilt omitted....

no less apparent to the vulgar eye... Coriolanus, iv if you ean make't apparent............ Cymbeline, if. you zce, it is apparent: who found ..TilusAnd.it.
APPARLNTLY-if he should scom ime so
auparently ............... Comedy of Errors, iv.

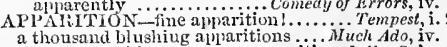
a thousand blushiug apparitions .... Much Ado, iv.
that shapes this muastrous apparitiou.JuliusC. iv. if agnin this appurition come.......... Hamlet, i. 1 MPIde truo alld good, the apparition eomes $\bar{T}$. 1. twenty times my son, I would appeaeh him $-\mathrm{v}$.
APPEACI ED - to the full appeached.. All's $W e l t, \mathrm{i}$. APPEAL-duke, and appeal to him... NIea. for $M$. i. thus to retort your manifest appeal.

I appeal to your own conscience... Winter's Tale, iij. 2 make good the boisterous late appeal. Richardil. i. 
APPEAI_to appeal each other of high..Rich.II. i. I of Hereford that appeals me...

is gruilty of my trite apjenl

whenever yet was your appeal denied.2 Ifen. $I V$. iv. I do appical.. Henry $r$.i. to heaven I do appeal, how 1 have ..2 Henry $r I$. ji. appeal unto the $P^{\prime}$ ope, to bring .....ilenry FIII. i to call back her appeal she intends

and your appeal to us there make

upou his own appeal, seizes him ... Ant. \& Cleo. iii. APPEAIED - as for the rest appealed.. RichardI

APPEAR-than he appenrs by speech ... Tempest. i. appear, and pertly - no tongue....... - iv. 1 for it appears by their...... Two Gen. of Ferona, ii. 4 and appear fresh ........ Twelfih Night, ii. 5 (letter) let it appear in thy smiling : - ii. s (letter) why appear you with this ridienlous

on purpose that I may appear stubborn - ili. 4

must needs appear offence..... Measure for $\bar{M}$ ec

thus wisdom wishes to appear more lorishit -

as it appears aecountant to the law $\ddot{\text { heil }}$

that appears not foul in the truth.

and lie shall appear to the envious.

to make the truth appear, where it $\ddot{0}$ -

and there appears much joy in him ... Much Ado, i.

as a dream, till it appear itself

craees will appear, and there's an end

that no dishonesty shall appear in me

as it appears he hath, he is (repealed)

let that appear hereafter, and aim bet

let that aypear when there

as it way appear unto you ...........

now thy image doth appear in the rar

as it appears in

as it appears in the true eours

hy and by I will to thee appear........ -

in their nativity all truth appears

it apprears, by lis small light of .......
while these visions did appear....
(epilogue)

one more fool, appearl .... Love's Labour Lost, iv. 3

there is no eertain princess that appears
ridieulous appears, to eheck their folly

ridieulous appears, to check their folly $\overrightarrow{v_{1}} v e n . \dot{j}$.

in sueh eyes as ours appear not faults

there doth appear among the lmezzing

besides, it should appear, that if he had -

honour more appents, than any .......

it must appear that malice bears .....

it doth appear you are a worthy judge

it must appear in other ways than ...
well in thee appears the constant ...
if it apou Like, ii. 3
v. if it appear not plain, and prove untrue. $A l l_{\text {'s }} H^{r}$ ell, v. 3 my wrong, the more my spite appears. Tam.of $S$. iv.

will have the truth of this appear....

I have strained to appear thus

the causes of her death appear, unto
nor shall appear in Sicily-my lord.

(where we offenders now appear) ...

but it appears, she lives, though yct
so it doth appear by the wrongs.. C

and yet the eiglith appears, who be

does appear, there is nor flying hence...
king Richard doth himself appear.. Richard $I I$. iii. 3

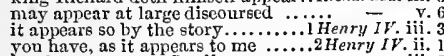

let them appear as I eall

for your part, it not appears to me ...

and wherein it shall appear that your

till their conversations appear more wi

thus doth it well appear, the Salique..

swallowed, and digested, appear lis

so appears this flect majestieal

and water nerer appear in him

and when it appears, it will bate .....

he appears hut a man; and thongh

to ery amen to that, we thus appear....

the better I shall appear: my..........

that he will appear in his true appear naked, and blind.

mother deigned to appear to me

the truth appears eo naked on. . i i....

appear, and aid me in this enterprize

as may appear, by Edward's good..3 Henry $V I$. iii. [Col. Knt. - so it appears by that I]. RichardIII. iii.
iu that very shape he shall appear... Henry FIII. i. almost appears in loud rebellion (rep.)

wherein he appears, as I eonld wid

how sleek and wanton ye appea

see you do appear before them.
that shall from mine eyes a!n?
appear it to your mind, tbat..
APPFAR-to appear this morning ...Trnil. \& Cres. somelime, it appears like a lord... Timon of
how fairly this lord strives to appear foul how fairly this lord strives to appean

can ever anicar in your impediment. Corio who's yonder, that does appear as he never would he appear i' the market-place call for Coriolanus. He doth appear
Hob and Diek, that do appear, their. Aufidius will appear well in these war but I appear not like a guest

intends to appear before the people

when you saw his chariot but appear.
which would appear offence in us.

which would appear offence in us ....
shall no whit appear, but all be buried

though now we must appear bloody..

that you have wronged me, doth appea

let it appear so; make your raunting

him appear: these strong Egyptian...A

thou would'st appear most ugly....

we shall appear before hin

When it appears to you where this

will appear there for a man: speak

how appears the fight? on our side

1 will appear in blood: and

that dar'st appear thins to us?

I will leave to appear hereaf ter.......

that, which to appear itself, must not

mist needs appear, unkinglike

with 't I may appear a gentleman

he appears to have practised more

diamonds of a most praised water appe

and am no other than I apuear

it appears not which of the dnkes...

since tlins thou wilt appear, freedom

a great ahatement of kindness appears

and bitter fool will presently appear
upon the beach, appear like mice........

upon the beach, appear like mice..........

let but the herald ery and I'll appear again

if none appear to prove upon thy....

let him appear at the third suu

in thy likeness thou lipess of...

tush! tush! 'twill not appear

(as it doth well appear unto our state)
eap-ì-pié, appears before thicm, and, wit

why, it appears no other thing to me

it well appears; but tell me, why

prizes the rirtue that nppears in Cassio.. Othello, ii. three times glain the appearance of ... 2 Henry $I V$. three times slain the appearance of

out of appearance? I do contess my.....

deny the appearance of a naked blind bos - iv. and quick appearance argues proof'.1 Henry $V I$. v. 3 appearamee make in any ot their.. Hen
for not appearanee, and the king's late

thou hast a grim appearanee, and... Co

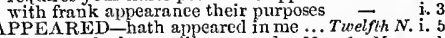
lord $A$ ngelo, have still appeared ...Mea. for Mea. in her eye there hath appeured a fixe. Much Ado, iv. is our whole dissembly appeared.

than formerly he hath appeared.

appeared upon the coast, on Wednesday

cf wouder appeared in them...

damned commotion so appeared.....2 Ilenry $I V$.

dappeared to me but as $n$ common ino ...

well appeared in his liueaments

cited by them, but aplinared not...

it seemed, appeared to kome

the favour is well appeared by your $\overline{\text { the }}$ -

there she appeared indeed; or ny ...Ant. . Cleo
of the goddess Isis that day appeared

like a pair of twins appeared
she hath not appeared hefore thi

upon his eagle baeked, appeared to me Cymbeline, iii. what, has this thing appeared again

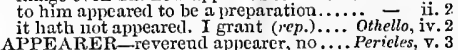
APPEARETH-here appear'eth due. Mi... of Ven. i as well appeareth by the eause you. Ricoard II.
APPEARING-not appearing what. Winler's T. iv already appearing in the blossoms of..
we sec the appearing buds ..........2 Henry I on the earth with yet appearing biood $V$. iii. (elio. 1 one appeariag hirir, that win not. Hen. deep prayers eannot appease thee ... Richard III. $\mathrm{i}$. so ehildren temporal tathers do appease... Cymb. . mutiny there he hastes t'appease. Pericles, iii. (Grow.)
APPEASED-he appeased with slaughter.Cymb, v. 5
APPEASED_rebels wonld be soon appeased

3 Hen.VI. iv. till we have appeased the multitude...J. Crsar, iii. the summons of the appellant's trumpet -

the appellant in all duty greets

arc the appellant and defendant .....2 1 Ienry $V I$. ii. APPELLE-qu'ils sont appelle de fingres. Hen. $V$. iii. Escoutez! comment estes-rous appellé?

APPELLEE-elle est appellee, de hand comment appellez-rous les ongles....

comment appellez-vous le col?

comnent appellez-vous les pieds et li
APPELLONS-les ongles? les appellonsde nails - iii. 4 APPENDIX_agninst you come with your
appendix.................... Taming of Shrer, iv. APPERI, Collier. Knight.-.iet me stay at thine

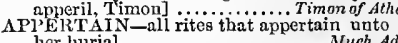

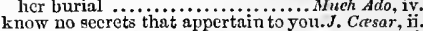

What most nearly appertains to us botls.. Leur, i. 1

a congruent epithetou, appertaining .Love's $L . L$. i. 2 APpertaining rage to such a greeting. Rom.

appertainments, visiting .. Troilus \& Cressida , ii. 3

your old .................. Love's Labour Lost, $\mathbf{i} .2$

other gift appertinent to man $\ldots .2$ Henry $I V$. i. 2 APPETITE-the appetite of her eye. Aferry Wives, i. appetite may sicken, and so die .. Twellfh Night, i. their love may be called appetite ..... f $\overrightarrow{\text { or }}$ ii. fit thy consent to my sharp appetite - ii. both right and wrong to the appetite $-\overrightarrow{\text { ii. }}$ s witl that keen appetite that he.........Mer. of Ven. Ii. 6 now, good digestion wait on appetite .Mracbeth, iii. 4 cloy the hungry edge of appetite $\ldots$. Richard $I I$. i. 3 and your appetites, and your digestions. Hen, V. V. I to breakfast, with what appetite you. Flen.VIII. iii. 2 into will, will into appetite (rep)... Troil.\& Cres. i. 3 to curb those raging appetites that ... $\quad$ - ij. 2 dexterity so obcying appetite ......... $\overline{\text { coriol }}$ ₹. 5 a sick man's appetite, who desires..... - i. 1 digest his words with better appetite.Jul. Cessar, i. 2 cloy th' appetites they feed; but she ${ }_{\text {nor }}$ ' the appetite; slutterly......... Gymbeline, i. 7 nor i' the appetite; slutterly......... Cymbeline, i. 7
weak with toil, yet strong in appetite... - iii. 6
staunch the eartli's dry appetite.. Titus Andron.jii. I
messes to gorge his appetite............... Lear, i. I goes to't with a more riotous appetite..... iv. 6 as if increase of appetite had grown by.. Hamlet, $\mathbf{i} .2$ to please the palate of $m y$ appetite.

and to give satiety a fresh appetite...

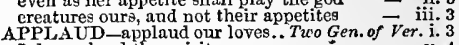
I do applaud thy spirit ....................... till thou applaud the deed ................ Macbeth, if. and blows, and groans applaud our..1 Henry $1 \mathrm{i}$. 1. 3 Rome's best citizens applaud.

she would applaud Andronicus' conceit $=$ i. 2 by the gods, I do applaud his courage.. Pericles, ii. 5 APPLAUDED-so much applauded..1 Henry $V I$. i.. 2 APILAUDING - great triumphers in their

applauding gates .............Timon of Athens, $\nabla .2$
sounds together, applauding our.... Ant.\& Cleo. iv. 8 APPLAUSE-with all the applanse and... Coriol. i. 9 not relish well their loud applause. Mea. for Mea. 1.12 true applause, and love; yet such .... As you Like,
with what lond applause didst thoir...2Hen.IV. this gencral applause, and eheerful...Rieh. III. iij. the applause and approbation .... Troilus \& Cress. i. 3 who broils in loud applause

lis silence drinks up his applaties = ii.

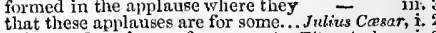
voices and applause of every sort... Titus Andron. i.
with joy, revel, pleasure, and applause. Othello, with joy, revel, pleasure, and applause.. Othello, ii. 3
APPLE-give it lis son for an apple.... Tempest, ii. I when 'tis almost an apple ......... Twelfih Night; i.
an apple, eleft in two $\ldots \ldots \ldots \ldots$. sink in apple of his ey'e!. Midsummer Night's $D$. ii. 2 laugh upon the alple of her eye? ... Love's L. L. . . 2
a goodly apple rotten at the heart ... Mer. of Ven. $\mathbf{i} .3$ there's small choice in rotten apples. Tam. of Sh, $\mathbf{i}$. ns mineh as an apple doth an oyster... Hen $\bar{r} y$ V. iii. and fight for bitten apples............ Henry . I ear,i. 5

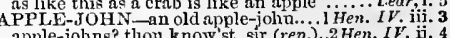
apple-johns? thon know'st, $\operatorname{sir}($ rep. $) .2 \mathrm{Hen} . \mathrm{Ir}$. i. 4
ence set a clish of apple-johns before him -4
PIPLET ART-like an appletart.. Taming of $S h$. iv. 3 APPLIANCEto tender it, and my appliance, with..All's Well, ii. I 
APPLIANCE - that's thie applinnee onty, II.VIII, i. 1 A APREIENSTON -

by good alpliance was recovered....... Pericles, iti.

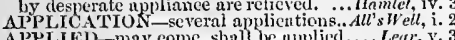
A P'PLIED - may come, shan be uphlied..... Lear? anil balns anplied to you, yet dare I... Coriolanus, $\mathrm{i}$.

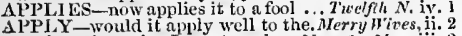
eralt against vice 1 must apply ...Mea. for Neat

gest about to apply a moral..........nuch sido, i. the power thereof it doth apply ... Love's L. Lost, v. philosophy will I apply, that treats. "uming of s. let your remembrance apply to Banquo... Macb. iit. Nestor shall apply thy latest words. Troit. \& Cress. i. 3 how apply youtluis? The senator:

these does ghe apply for warnings....jul. Cresar, ii. if you apply yonrself to our inter.

to alnt to his bleotling face............... Lear, iii. 7

APT

at de place I did appoint?..............
for I'll appoint my neen to carry

appoint a meeting with this old.....

appoint her to look out of. $\ldots \ldots . . . .$. Anch $A d$.

to appoint myself in this vexation?. . W'inter's ' $T$. $\mathrm{i}$.

he does-lie did appoint so ............. Macbeth, ii. 3

to : appoint some of your ecouncil........ Henry $r$. $\mathrm{Y}$.

to appoint who should attend on him Hen. IIII.
I do appoint lim store of provender., Izl. Casar, $\mathrm{i}$

Lareius, and appojut the meeting.. Tilut Andron. iv

Al'POINCED boing then appointed.... T'empess, i.

lie hath appointed thent contrary places

this is the place $I$ appointed

We have alpointed to dine

the hour sice appointed me
hath appointed that he shall likewise

as yon told me you had appointed?..

as Ame and 1 had appointe

oatl, and the nuptial appointed...M. Mea. for $\overline{\text { Mea. }}$ iii. 1 pluee thon hast appointed ne.. Mid. N. Dream, i. 1 here is the place appointed tor......As you Like it, i. my master hath appointed me to go.. tis lave

and such officers appointed to direet. Richard II i. i. 3

as is appointed us, at Shrewsbury... Henry $1 \%$. iii. if I be appointed tor the place $\ldots . . .2$ Henry VII. i. 3 this is the day appointed lior the combiat

ten is the hour that was appointed me.

thou has som

appointed this conduct to convey... Riehard $\bar{I} I I$. i.

nyy lords, you are appointed for that. Cymbeline, iii.

you may be anmed and appointed well Tiltus.And.iv.
to some retention and appointed gnard....LARr, V. 3

missing your meetings and appointments

I will then address me to my appointment = jii. 5

therefore your best appointim
to stead np your appointmen

and my appointments hare in them....A All's well, ii. 1 i. 5

in best appointment, all our regiment

our fair appointments may be well. Richard II. iii. 3

here art thou in appointment....Troilus \& Cress

where their appointment we may....Ant.\&. Cleo. iv. 10

Warlike appointment gave us ehase Hamlel, iv. 6 (let.)
A PP R E

in private brahble did we apprehend. Treelfth $N$. v. 1

a nan that apprehends death......Mea.for Hea.

that apprehends no further thing this world $-\mathrm{v}$.

youl apprehend passingt shrewdly... Much Ado,
splreened nore than cool reason. Mitl. N.Dream,

that if it would but apprelend some joy
apprehend nothing but jollity... Winter's
Tale,

he apprehends a world of figtures...... Henry $I V$. i. 3 eneotunter any such, apprelicnd him... Henry

in his najesty's name, applrehend him

will apprehend you as his enemy..3 Henry $V I$. iij.

O let my lady apprehend no fear. Triol. s. Cress. nii.

striving to

I will apprehend him: stop....... Romeo of Jutiet, v.

eondemued villain, $\mathbf{I}$ do apprehend thee
$[\mathrm{Col}$. Knt.] appreliend thee for a felon

do yon know where we may apprenchend.

APPREHENDED-let him be apprehended.

like to be apprehended for the witch Merry $H_{i v e s, \text { iv. }}$

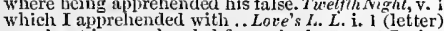

nerchanut is apprechended for arrival... Commof $E r$. i. 2 they shall be agyreliended by and by... Henry $V$. ii. whom we have apprehended in the fict $2 H$ Hin. $Y T$.

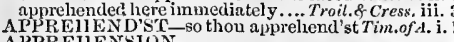

death is most in apprehension.... Mea.for Mea. iii. have you professed apprehension..... Mruch Ado,
the ear more quiek of appreheusion Mid. N. Dr. oljjeets, ideas, apprehensions.......... Love's $L . L$. iv. iv. 0 no! the apprehension of the good.... Riehurd $I I$. $\mathrm{i}$. how snel an apprehension may turn 1 Hen. $I V^{+}$i
if the English had any apyrehension. Henry $V$. to seourge you for this apprehension. I Henry VI.
to question of his apprehension...3 Henry $V I$. cannot outfly our apprehensions... Troil.\& Cress. that's a lasciviours apprehension Timon of Athens, $i$ took frow you the apprehension.... Coriohenes, ii,
APREIENSTON -

he may le ready for our apprehenensions.... l.eerar, iii. 5 in apprelension, how like a god! 1 in this brainish appreliension, kit...

hut some uncleanly apprelaensions keep.othello, ivi: 3

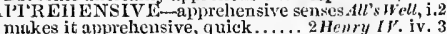
flesl and hlood, aud apyrehensive. Jutius Cresar, iii. je ne doute point d'apprendre par la ... Henry $V$. iii. a long apprenticehood to foreign .... Richard $11, \mathbf{j} .3$ APPRIS que vous m'avez apmiris........Herry $V$. iii. do not approach till thou dost

approach, rich Ceres, her to entertain

by thy approach thou makest.. Tuio Ge
let her approach.........Merry Wives of

gives intelligence of Ford's approach -

let him approach ; call in ,.......

approach, sir. Andrew; not to
mark his first approach beture

mark his first approach beture my lady

at whose approach, ghosts, walldering.
by day's approach look to be visited.

let him approach

no woman may approach his silent...L Love's

Navarre hrad notice of your fuitr approạchl
love dotl approach disguised .........

eve dothen soot approach

holla! approach. This side is

approach, here dwells my father, Jew

my labour by his own approach

Orlando did approach the man ...As you Like it, i.

if they do approach the eity, we shaili. All's Well, iii.

my approach be shunned, nay, hated.

she did approach iny eabin where I lay

and let lim approach singing

- 7 iii. 3

be stone no more; approach; strike ali

my wife with your approach........

approach the chamber, and destroy.....

solne danger does approach you nearly

let them appreach; - Our abbeys a.....Ki
but for our approach, those sleeping ston

your king and England's loth approach

shall hear of your approach, if that
this apish aud unmannerly approac

nothing but his majesty's approach .
and approach the ragged'st hour ....

and approach the ragged'st th

to desire the approach of day

for our approach slall so mucli dare.
by whose approacls the regions.....

and death apmo

. death's approach is seen so terrible!.2Henry $r I$. iii.
witle thy appruach, I know ........ Henry $Y$ III. ii. the approaelh of this wild river break

they approach sadly, and go away. Timon of

his expedition promises present approach -

like a shepherd, approael the fold.

than that which is to appproach
of horse to tell of her ayproacl

approach, and speak. Such as 1

approach, there: ay, you kite..........
sounils to together, a pplauding our appros

sounds together, applauding our approa
approael, ho: all's not well : Cxesar's

at the first approach you must kncel

now begin our sorrows to approach.
approach, thou beacon to this under

powers o'the kingdom approach apace

close fighting ere I did approaeh ...
that thou hear'st something approac

that thou hear'st something approaa
warning, something doth approacl

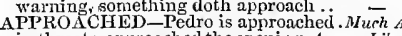

in threats, approached the opening. As you Like i

approachled too late; the capon burns. Comn of E
expected then, but not approached . Cymbeline
and

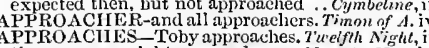

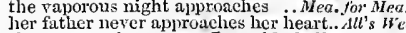
that approaches apace; I would gladly

near approaches the subject of our.
the time approaches, that will with

for England his approaches makes .... Henry my boy Mlarcius approaches

he approaches, you shall hear him ..... Ant. $\overline{\text { o }}$ Cleo.

makes his approaches to the port of Rome
the queen apuroaches; her licad's declined

APPROACILETI - wlicn he approacheth to

your presence ...... Two Genllemen of Verona, v.
period of thy tyraniy approaclictli..1 Heary $V I$. iv.

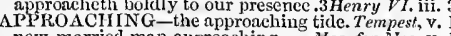
new-married man approaeling.... Mea. for Hea. . . signify the approaching of his lord. Mer. of Ven. ii.
red hot, approaching near these eyes, King o heat the approaching Carsar $\ldots$. Antony \& Cleo. iii. 7
APPROB AION-gives nanhood more

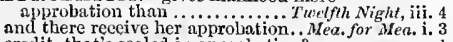
credit, that's sealed in approbation? naught for approbation, hut only.. Winter's Tale,
drop thuir bluod in ajprobation of...... Henry $V$. learned approlintion of the judges ... Itenry VIII.i. 2 applause and approhation the which... Thool. \& $\mathrm{Cr}$ i. and with most prosperous approbation of Coriol it. to meet anon, upon your apjurobation

on the approbation of what I have

whucver but his approbation added ....Perjeles, o in approof lives not his epitaph .... All's Well, i. and of very valiant approut ............ APPROPRIATION-a great appropriation

to his own good parts...... Werchant of Venice, i.
APPROVE-noway approve his. Twelfh Night, iv. on whose eyes I miglit approve this..Mid. $N$. Dr. ii. 3 which well approves you are great ....All'swell, iil. 7 approve Henry of Ilereford, Laneaster... Rich, MI, i. 3 my growth would approve tlie trati...2Henry $I V$. . .2 to approve my youth further $\ldots \ldots \ldots \ldots$ i Henry $F$ I. i. 5 approyes her fit for none ............ Henry $F I$. v. 5

I muse, my mother does not approve

that he approves the common liar...

thon dost approve thyself the very

which must approve thee honest..
my sword upon thee shall approve

speeches may your dceds approve.

this approves her letter, that she would

which approves him an intelligent party

if you did, it would not mueh approve.

I do approve in fearful sense $\ldots \ldots \ldots$.........

consequence do but approve ny drean

my love doth so approve him, that even iv. $\overline{3}$ (song
blame him, his scorn I approve....

of approved ralour, and confimed ...Much $\mathrm{Ado}$, ii.

not knit my soul to an approved wan tort

his love and wisdom, approved so...

there is a remedy, approved, set dow

my best beloved and approved frient

they have approved their virtucs. Winler's $T$ ale, iv.

to more approved service and desert...Richard II. ii

that ever valiant and approved Scot..1 Henry IV

he be approved in praetiee eulpable. 2 Henry T. Hil.

very noble and approved good masters

and he that is approved in this offence.

I have well approved it, sir. I drunk I...

APRICOCK -feed him with apricocks. Mid.N.D. ii.

APRIL-spongy April at thy hest...... Tempest, iv.

glory of an April day. . Tu' Geutlemen of terone

he smells April and Hay

men are April when they wo

rchant of Yen. ii.

the first of April, died your noble ... King John, iv. 2

an 'twere a man born in April.... Troilus \& Cress. i. 2

the April's in her eyes $\ldots \ldots$...Antony \& Cleopotra, iii.

when well-appareled April on the ...Ropi. \& Jut. i.

two of our jerkins and aprons .........

think scorn to go in leather aprons .

where is thy leather apron, and thy rule.J.Carsar, i.

mechanie slaves with grensy aprons. Ant. S Cleo. v,

APRON-TIEN - and your apron-men..... Coriol. iv.

apt in good faith: very apt!.......
how apt the poor are to be prouil

and I, most joeund, apt, and willingly

madam, I am most apt to embrace... - var vin veas.

I find an apt remission in myself

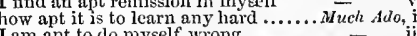

there is not one word apt ......... inid. N. Drearn, v.

and my saying ajt? or $\mathrm{I}$ apt........

wherefore apt? And therefore apt..

delivers in stch apt and gracious words

ghe's apt to learn, and thankful... Taming of Shr. ii.

vilany, apt, liable to be employed ... King John, iv.

is she not apt? our tongue is ........ -

stubborn to justice, apt to aceuse it. Henry $^{V} I I T$. ii. 4

glae is young and apt: our.own.. Timon of $A$ thens, $i$.

I have a heart as little apt as ...... Coriolmas, iil

I sliall not find myselt so apt to

slow to the apt thoughts of men

being apt to have lis ear abused

you will tind ine apt enough to that 


\section{A.PT}

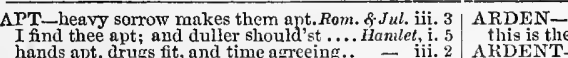
you are most apt to play the sir in. othello, ii. loves him 'tis apt, and of great credit so kind, so apt, so blessed a disposition APTER - apter to do than to confess true $\overline{7}$. is apter than thy tongue to tell $\ldots . . . .2$ Henry $I V$. $\mathrm{i}$. APTEST-every man the aptest way..2Hentry $1 . .1$. that part was aptly fitted.... Taming of Sh. 1 (imdule.) prettily and aptly taunts himself.. Richard $I I I$. iij.
verse which aptly sings the good .. Timon of $A$ h $h_{0}$ i. verse which aptly sings the good...Timon of Alh.
that you nptly will suppose.... Pericles, v. 2 (Gower or livery, that aptly is put on

APTNESS-they are in a ripe aptuess. Ciolanus, iv.

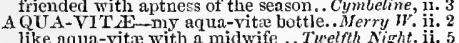
he aqua-vita with a midwife...Turelyth Night, ii.
reeovered again with aqua-vita... Winler's 7 ale, iv. oil, the balsanum, and aqua-vita... Corn. of $E r$.

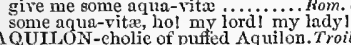

AQUII. ON-cholie of puffed Aquilon. Troil.

AQUITAIN-surrender up of Aquitain. Love'
the plea of no less weight than Aquitain

one part of Aquitain is bound to us
we will give up our right in Aquitain

to have his title live in Aquita.

or sield 12 A Aquitain. We arrest your

I'll give you Aquitain, and all that is
IRIBI -in Arabia there is one tree..

and the vasty wilds of Arabia are ...Mer.

all the perfumes of Arabia will not.

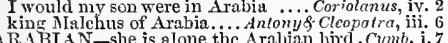

ARABIAN - she is alone the Aralian bind. Cymb. i.
OAntony! O thon Arabian bird!..Ant. \& Cleo. iit. as fast as the Arabian trees

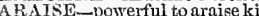
ARBITRATE-bloody issue arlitrate. King. lone process could not arbitrate

certain issue strokes must arlitrate.... A Macbeth, v. can arbitrate this cause betwixt us.
your swords and lanees arbitrate

ARBITRATING-arbitrating that which the

commission of ................. Romee \& Juliet, iv. I arhitrator of desnairs, just death.... I Henry VI. ii. 5 even to a mortal arbitrement.... Twelfh Night, iii. 4 if it come to the arbitrement of swords. Henry $V$. iv. 1 be nut to the arlitrement of swords ... Cymbeline, i. AlibOUR-hide me in the arbour.

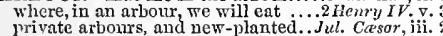
Mrivate arbours, and new-planted..Jul. Casar, iii. 2 Joan of Are hath been

tire most arch deed of piteous...... Richard $1 M L$
the

the most arch deed of piteous....... Richard III. iv

a most arek heretic, a pestilenee........

ne'er through an areh so hurrie

the wide arch of the ranged empirc.... Antriold s c Cleo, y. 4 to see this vaulted areh, and the rich
my worthy arch and patron, eomes

\section{$\underset{\text { archbishop latc of Canterbury }}{\text { ARCH.. }}$}

the archbishop's grace of York, Douglas $y$ iifi. 2

Richard $I I$. ii.

Northumbcrland, and the arehbisloop

and the archbishop are stion

fain would I go to meet the arcibibion
you, lord arclibishop, whose see is

goold-day to you, , gentle lord areh
and you, lord archibishop, and you

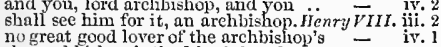

no great good lover of the archbishop's
tlie archbishop is the king's laand.

I have brought my lord the archisichop

my lord archbishop; and has done half

good lord arehbishop, I am rery sorry
thank youl, good lord archbishop: what
o lord grchishop thou host made me

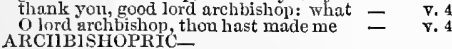

the arhbilihopic of Toledo ........ Henry VIrI. ii.1
ARCHDEACON-the archdeacon hith divided

ARCHED-ates of monarch......... Herenry IV. iii. 1

ARCHED-Tates of monarchs are arched...Cymb. iii. 3
thou hast the right arehed bent of. Merry Wizes, iji. 3

to sit and draw his arched brows .........All's Irell, i. I
ARCHELLAUS-Arehelans, of Cappadocia;

Philadelphos …….... Antonyy \& \& Cleopatra, iii. 6

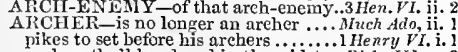

archers thall be placed in the midst ...Rich. III. v.

you are a good archer, Mlareus . Tilus Andron. iv.

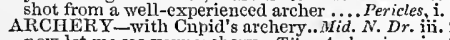
now let me se your arehery. Titus Andronicus, iv.
ARCHHERFTIC-hand of that arehheretic Joln, iij. ARCHIBAIDD-and brave Archibald.1 Henry $I V$ ARCHITECT-architect and plotter.. Titus And. V. ARCII-VILIAAIN-be an areh-villain. Mea. for MI. $\checkmark$ v an arch-villain keeps him eompany. Timon of $A$. v. ARDE-the vile of Arde. [Col. Knt.-Anderen]. ARDEN-in the forest of Arden......As you Like it,
[Col. Knt.-my uncle in the forest of Arden $]$ this is the forest of Arden (rep.)...As you Like it, ij. 1 MDENT-under ardent zeal. Timon of Athens, iii. then the compulsive ardour gives
SRAI -argal, she drowned herse

argal, he that is not ginity of his own

ARG ARTINE-goddess argentine, I will...

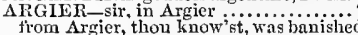
AlGO-Argo, their thread of life is gnun. 2 ARGOSIES-Your argosics with portly. MI
three of your argosies are riehly come to no less than three great argosies..Taming of $S h$. . .i.
ARGOSY - he hath on argosy bound.Mer. of Ven.
lintl an argosy east away coming....

lintli an argosy east away coming.
besides an argosy, that now is....

have I choked you with an argosy? .. - ii. 1

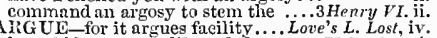
have bid me argue hike a father $\ldots \ldots$. Richard II i.
regues but the shame of your offence.2Hen, $V$. iv. argue the end of Edmund Mlortimer.1 Henry $r i$. ii. and quiek appearanee argucs proot
this argues what lier kind of life ...

a death ar'gues a monstrous life .....2Henry $V I$. iii. 3 her looks clo argue her replete with.3 Henry VI. iii. $m y$ lord, this argues eonscience in...... we are too open here to argue th.
allowred freely to argue for her.

it arcues a distempered liead.... Romen of Juliel, ii.

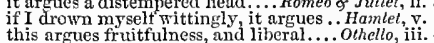
ARGUED-well have you argued, sir...Rich. II. iv.
argued betwixt the duke of York ... H H r r VII iv. Which argued thee a most unloving, 3 Hen. $V$

greater themes for insurrection's arguing. Coriol. i.

AR arging makes ns sweat ...........ulius Cesser, v. tang arguments of state... Turefth Night, ii. 5 (letter) this was a great argument of love in he
the rather by these arguments of fear

have given us bloody argument.

thy tongue tang with arguments of state $\overline{\text { prove }}$ notable argument...Much Ado, i. i.

hold longer argument, do it in notes.

nor no great argument of her folly

would not make me such an argunient

is a great argument of falselhood)..... Lov

how did this argument begin?

thus came your argumcnt in .........
the world cennot lold argument

finer than the staple of his argument

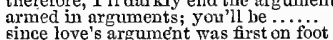

since hove's argument was first on foot
this fool to cut off the argument?

grounded upon no other argument .... = i.

in orment of proise, or to the worth

is the argument of Tipe ... Winter's Tale, iv. (choris)

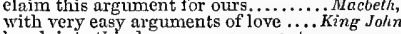

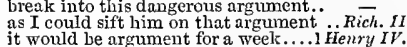

it would be argument for a week .... Henry IV.
content; and the argument shall be 3 .

as a seene acting that argument.
but our argument is all too lieary

for lack of urement;

he will maintain his; disonour not.. Henry $V$. iii.

way of argument, look you, and friendly
and my horse is argument for them all

when blood is their argument? now.

(good argument, I hope, we slall not fify) $=$

the argument you held, was wrong... Henry
now, Somerset, where is your argument

in argument upon a case

in argument and proof of which contract -

nothing but an argument, that he ..2Henry $V I$. i. inferring arguments of mighty force..3 3

well steeled with weighty arsuments...Ricl. IIII. i.

their arguments, be now producet. . Hen.
like conditions as our argument. Troil.\& Cres. (prol.

I cannot fight upon this argument

al the argument is, a euckold..
lost his argument. No; you see

good argument for kissing once (rep.

pard the gon and your argument.

so it may prove an argument of iaughter

as if he had but proved an argument
an argument that he is plucked...Ant. \&

mueh like an argument that fell out.

the argument of your praise, balm of...

to occupy the argument no longer ...Rom. $\delta$ - Jul . ii.

no money bid for argument, unless
this slow imports the argument of the play

have you heard the argument? is there no

ARGUS - t without great argumen

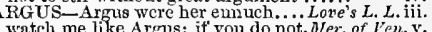

purblind Argas, all eyes and no sight. Troil. $\delta$. $C r$. i.

with Ariadne, and Antiora? . . Bid. N.'s Dream,
ARIEL - approach, my Ariel; come .... Tempest

ARIEL-approach, my Ariel; come
task Ariel, and all his quality..........

but ure they, Ariel, safe?
Aricl, thy charge exactly

Aricl, thy charge exnet
my quaint Ariel, hark
ARIEI_delicate Ariel, I'll set thee free. Tempest, i. thou liast done well, fine Arjel!

Aricll my industrious servant Ärieii...

dearly, my delicate Ariel.

I thank you: Ariel, cone......

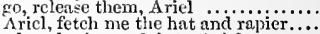

why, that's nyy dainty Ariel

A IIES - gave Arics such a knock... Titus Andron. iv.

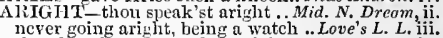
thou last harped my fear arighlt ..........Arebellh, iv. would you represent our queen aright. Titus And. $v$. to un I am known aright, yout shall not... Lear, iv. me and my eausc aright to the nnsatisfied. Hamlel, y. AllioN-Arion on the dolphin's back... Turelfth $N$. j.
ARISE-now I arise:-sit still .......... Tempest, arise, and any how thou...

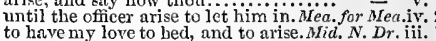
to have ny love to hed, and to arise.Mid. N. Dr. iii. arise more great; arise, sir Rielard ... King John sudden mischicf may arise of it …..... Henry $y$, iy. factious emulations shall aris

Suffolk arise; welcome, quecn ........2Henry VI. i.
Edward Plantagenet arise a knight..3Henry VI. ii.

- iv.

see, see, what showers arize ...............
if he arise, be mocked and wondered

arise, dissembler; though I wish .... Richard III. i. arise, and take place by us....

pray you, arise, nuy good and gracions

most nuble sir grise, the queen $A n$ tory \& Crsar, ii. and Plocbus 'gins arise ...........mbeline, ii. 3 (song) my lady sweet, arisc; arise, arise - ii. 3 (song) arise, my knimhts $\omega^{\prime}$ the to ar

ere 1 arise, I will prefer my sons $\ldots . .$. . eome sir, arise, away: I'll teach you ....... Lear, i. arise, fair sun, and kill the envious ...Rom. \&.Jul. il.

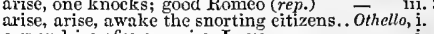
a gandsire of you; arise, $I$ say.......... - i. arise, black yengeance, from thy hollow cell - iii. AIISTOTLE- to Aristotle's checks. Taming of $S$. i. whiom Aristotle thought unfit to hear. Troil. $\&$ Cr. ii. that hath CIC - a tapster's arithmetic

but now tis odds beyond arithmetic.. Corialanus, iii. spare your arithmetic; never count... Cymbeline, ii. WRIII dizzy the arithmetic of memory. Hamlet, , $A P K$-are coming to the ark! . ....As you Like it, v. his good arms in lusty stroke ........... - ii. and his fins like arms ................... like a soldier, at arm's end........ nserry Wives, iii. pinch them, arms, legs, backs..... and hug it nime arms .......easure for Measure, iii.

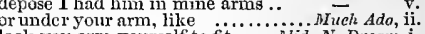

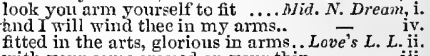

lord of folded arms, the anointed .... affection's men at arms

arm, wenehes, arm! eneounters.

and lay my arms before the leg.
leere comes Hector in arrus

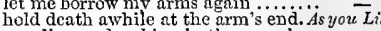
mewling and puking in the nurse's arms -

and here upon his arm the lioness had

will you take him by the arm? .......

lend me an arm; the rest have............ All's ${ }^{\prime}$ rell, $\mathrm{i}$. garter up thy arnis o' this tashion? ... $=$ ii.

so may you lose your arms.... "thming of Shree,

why then, no arms. A herald ... Winter's Tale

holds his wife by the arm, and little - i. but quick, and in mine arm

opening his free arms, and weejing $=$ iv.

joy to see her in your arms $\ldots \ldots \ldots . . .$. .

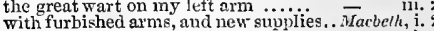
point rebellious, arm 'gajust armi........ whose arms are hired to bcar

my arms such eelscius stutted ............ing Joh

not think of home, but follow arms ...

resign them, and lay dowi thy arms?

and then our arms, like to a muzzled

lay down our just-borne arms (rep.).

in arms to spill mine encmies' blood (rep.) -

arm, arm, you heavens. against these -

than arm thy constant and thy .......
father, to armal U pou thy wedding-day= 
ARM_-go not to arms against mine uncle..John, iii. I | ARM-my arms torn and defaced

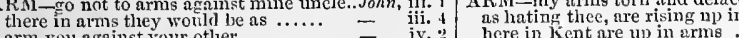

$\ldots 27$

arm you against your otlier.

unto the erest of nurder's arm

go, bear him in thine al'ms and base truee, to arms in

let us, my liege, to arms..............

flatly says, lie'll not lay down his arms

here in kent are up in arms ........

ARM-Titus, flourishing in arms .. Titus Andron. i.

the gallunt monarch is in his arms...

my arm shall give thee help $\ldots \ldots . . .$.

the three corners of the world in arms - v.

this arm shail do it, or this life

comnand our officers at arms....

never lift an angry arm a
of his arrival here in arms

thres knghtly elad in arms o......

ask yonder knight in arms .........

who ready here do stand in arms

and fold bim in our arms

and with uplifted arms is safe

our native peace with self-born arme

ostentation of despised arms?

how quiekly should this arm of mine

in hraving arms against thy sovereign

plueked from ny arms perfor.

falter under foul rebellion's arms

than this weak arm; diseomfort

in stiff unwieldy arms against

gentlemen in arms upon his party

to lay my arms and power ..........

his glittering arms he will commend

is not my arm of length

$\begin{array}{ll}\text { iv. } 3 & \text { never have given out these a } \\ \text { iv. } 3 & \text { his arms are only to remove. } \\ \text { y. } & \text { and now is York in arms........ }\end{array}$

v. 1 and now is York in arms...........

$\checkmark .1$ and if mine arm be henved ............

v. 2 hut if thy arms be to no other end.....

thus he mareheth with thee arm in arm? -

and so to arms, victorious fatlier

is hoarse with ealling thee to arms .

theretore, to arms; and tather do

such merey, as his ruthless arm......

i. 2 at mountans with ont intered by the iretinl arm....

devotion with revengeful arms?.

suppose, this arm is for the duke

i. 3 these arms of mine shall to

i. 3 to shrink mine arm up .................

while life upholds this arm, th
well, I will arm me, being thru

ii. 2 but why come you in arms?..........

ii. 3 serupulous wit! now arm

3 naked, foil a man at arms

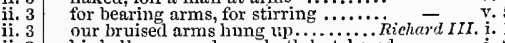

ii. 3 his hell-governed arm liath butehered the quarrel from his powerful arm...

with his vietorious arm, and charged

and from her jealons arms pluck

witlin their alabaster innocent arms

and when this arm of mine hath ....

my dangerons attempt of hostile arms

my liege, in Yorkshire are in arms .
fellows in arms, and my most loving

send out a pursuivant at arms

whose arms were moulded in...

send out a pursuivant at arms

our fortunes in our own stroug arr.

to meet nie in arms by the ninth ....

and great name in arms, hold

all furnished, all in arms, all plumed

men of estimation and command in arm

contident against the world in a
or an arm? No. Or take away

haughty arms this hateful name $(r e p$.

to gentle exereise and proof of arm

the arms are fair, when the inteut

never did sueh deeds in arms

and rebels' arms triumph in massacres

Stafford, and Blunt, are in my arms

thy name in arms were now..........

like a fire ont of his keeper's arms.

the oceasion of our arms (repe
what a maidenly man at arms

what wrongs our arms may do
put us in these ill-beseeming arm

put us in these ill-beseeming a
more perfeet in the use of arms

our powers to the arm of peace

this little kingon, man to arm......

strength into one giant arm

and do arm myself, to welcome.

we must not only arm to invade.

yokefellows in arms, let ns
most meet we arm us gainst

most meet we arm us 'gainst ...........

look, you strongly arm to $\mathrm{m}$

de nails, de arm, de bilbow

'tis miduight, I'll go arm myseif .....

those legs, and arms, and heads...

God's arm strike with us!

he threw his wounded arm, and kissed

expressly against the law of arms

thy arm was here, and not to us (rep.)

we'll offer up our arms; since arms.

are the flower-de-luces in your arms

the devil was in arm

their arms are set, like eloeks.......

with a baser man of arms by far....

from my shoulders erack my arms

despairing of his own arm's fortitude

arm, arm! the enemy doth make ...

since first in followed arms..............

chain these legs and arms of thine....
sinews, arms, and strength, with which

sinews, arms, and strength, with wh
and pithless arms, like to a withered

and pithless arms, like to a withered (before whose glory 1 was great in arms)

direct mine arms, I may embrace...

take up arms like gentlemen

will take thee in their arms.....

this arm, that hath reclaimed...

the law of arms is sueh, that ......

servant in arms to Jlarry lking

and lay him in his tather's arms ......

for his rare sueess in arms the most

ii. 3 in this doubtful shock of arms

arm, fight, and eonquer, for fair ....

that he was never trained up in arm

arm, arm, my lord; the foe vaunt

God, and your arms, be praised ....

ehallenged the noble spirits to arms. Henry VIII. $\mathrm{i}$.

lay kissing in your arms, lord cardinal

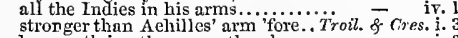

her worth in other arms than hers.

Greek did compass in his
eall some knight to arms

what, alas, can these my single arms?

disciplined thy arms to fight....

and with his arms outstretched

thou hast lusty arms

worthy of arms! as weleome ........

I come to lose my arm, or win

bid the snail-paced Ajax arm

be happy, that my arms are out of

execute pour arms $[$ Collier-aims]
(though his right arm might... Timon of Athens,

to take his fortune by the ario

whom fortune's tender arm with....

shall know, we have strong arms too. Coriolanus,, i.

your knees to them, not arms, must help -

sir, the Volces are in arms (repeated)

O let me clip you in arms as som

in's nervy arm doth lie .............

arm yourself to answer mildly

mine arms about that body

or lose mine arm for't
what an arm he has! lie............

Italy, and her conferlerate ar'ms...

your infants in your arms.............

and sighing, with yorw arms across

sluin manfully in arms ...............

tenfold grief with folded arms

lit ts she np her arms in sequence thus?

wrap and fumble in thine arms.

dispose this treasure in mine arms

arm, arm, my lords; Rome never

it one arm's embracement will

oped their arms to embrare me
whose arm seems far too short.

bring arms to princes $\ldots . . . .$.

the virtue I have borne in arms...

jewel holds his biding on my arm ....

my education heing in arts and arms

since they love men in arms ..................

take in your arms this pieee of your.

sir, lend your arm. Come................

threw her o'erboard with these very arms

a second time within these ar

weapons! arms! what's the matter here.

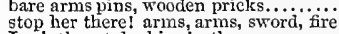

stop her therel arms, arms, sword,

bind fast his corky arms............

give me thy arm; poor Tom shaili...
I must ehange arms [ Knt.-names]

no blown ambition doth our arms ineite

let go his arm. Ch'ill not let go, zir........

thy arm may do thee justiee $\ldots . . \ldots \ldots \ldots$

the law of arms [Knt.-war], thou wast not

nor ar'm, nor faee, nor any other part. Rom. \& $J u l$. ii.

I was hurt under your arm.

igile arm beats down their fatal.

Romeo leap to these arms, untalked of

sinee arm from arm that voiee doth us

with arms encumbered thus, or this

a little shaking of mine arm ...........

to give the assay of arms against your

sword, rebellious to his arm, lies where.
or to take arms a

or to take arms against a sea of troubles

thus wide I'll ope my arms ...........

could he dig without arms.

caught her onee more in mine a.ms

for since these arms of mine had seven ... Othello, $\mathrm{i}$.

love's quick pants in Desdemona's arms

from his very arm puffed his own brotlie

and this good sword $\bar{E}$.

ARILADO-that Armado hight..... Love'sL. Lost, i.

Armado is a most illustrious wight ...

heat of duty. Don Adriano de Armado-

and Don Armado shall be 5our keeper..

this Armado is a Spaniard, that keep

or called, Don Adriano de Armado ....

that put Armado's page ont of his part..

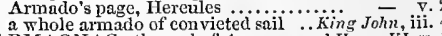
ARMAGNAC-the earl of Armagnae..1 Henry $\mathrm{FI} . \mathrm{v}$. the emperor, and the earl ot Almagnac?

ARMATHO-Armatho o' the one side.Love's L.L. i and sent me from Don Armatlo....... $\because$ 's Dream, ii. brought with armed men back to....Much Adn, v. appronch disguised, armed in arguments - v. I am armed, and well prepared ......... - iv. he hath armed our answer...............All's trell,i. but she is armed for him and keeps..... - iii. am armed with his good-will.. Taming of Shreu, $j$. our arms, in strengtin of malice.

the arm and burgonet of men?

to lend me arms, and aid ....

be thou armed for some unhappy worc

though thy little finger be arrned in ... of $\overline{E r}$. iv. with valour armed, compelled these..... Hacbeth, i. the armed rhinoeeros, or the hyrean..... ${ }^{2}-\bar{n}$, iil. thinking lis voice an armed Englishman $=\quad$ v. their thimbles into armed gauntlets..... proved armed soldiers ere her........... - iji. white beards have armed their thin... - irenry $I V$. with the armed hoofs of hostile ....l IIenry $I V$. $i$. I gallantly armed, $\rightarrow$ rise from the ground - iv. his armed heels against the panting..2 henry I ii. their armed staves in eharge........... while that the armed hand doth fight... Wenry $V$. i. like soldiers, armed in their stings...... $\quad$ iverk out their armed heels at their dicad amongst the troops of armerl men.... Henry $V I$. ii. armed as we are, let's stay within.....3 Henry $V_{I} . \mathbf{i}$.

whose overweening arm 1 have plucked eay, I moved him to those arm 


\section{ARM}

ART

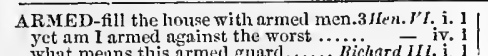

A HN Y-army, a weak and siekly guard.Hen. ${ }^{\prime}$. iii. 6
the hum of either army stilly sounds - iv. (('ho.) the hum of either army stilly sounds whint menns this armed guarl....... Richard 111 . i. 1

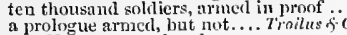

was Hector, armed and gone $\ldots . .$.
with ny armed fist I'll pash him.

w would fain have armed to-day

when I meet you armel, as black

and he is arincl, and ut it, roa

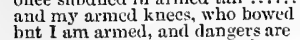

for $I$ am armel so strong in honest

\begin{tabular}{rr}
- & v. 3 \\
$-\quad$ i. 2 \\
\hline
\end{tabular}

should dishearten his army
an army have 1 mustered.....

all the whole army stood agazed......

- iv. (cho.)

that dogat the mighty army of

now dismiss your army when

assail them with the army of the king.2 Hen. $y$

his army is a ragged multitude ....

until this army lic dismissed from him

eheered up the drooping aring

the army of the queen nean to

the army of great Buelsingham.

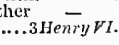

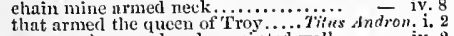

you nuy be armed and appointed we
an armed knight that's conquered...

go armed. Armed, brother!..(repened) Lear, i. 2

thou art armed, Glo'ster: let the trnmpet - v. 3
when I was armed, not sin'e, though hoping - v. 3

I come hitlier nrmed against mysulf.. Rom, jo jutl. v. 3

comes armed tlurough our wateh..........

arnerl say you? Armerl, my lord.

but then, in his Armenia, and other - jii. 6

ARM-GAUNT-[CoL. Knt.-an arm-gaunt steed] - i. 5

ARMIES-retire of both your armies.. Kin
where these two cluristinn armies night

on our behalf, armies of pestilenee.. Kichard $\mathbf{I}$. iii. 3

in both out armies, there is many ... Ifenry $I V$. v. 1

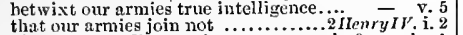

his grace just distance 'trieen our........ armies?

and here between the armies, let's drink
stickler-like, the armies separate .. Troil.

how far off lie these armics?

the eyes of both our armies here...julius Casar, iv. 2

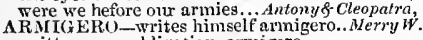

quittance, or obligation, armigero

arming to answer in of the verity...All's Well, iv. 3

by this, is arming him in Troy.

great $A$ rehilles is arming, weepin

ARMIPOTENT-armipotent Miars... Love's L.L. v. 2 linguist, and the armipotent soldier.. All's Well, iv. 3

ten mile afoot, to see a good armour... Much Ado,
give me my armour. "Tis not needed... Nacbeth,

give me my armour. "Tis not
come, put mine armour on

come, put mine armour on

their armour, that marehed henee

whose armour eonscienee buekled
unto my armour with thy prayers.

and bring away the armour that is there

Our armour all as strong, ou entse.
like a rieh arnour worn in heat........
tut! I have the best armour ...........

you have an excellent armour

yon talk of horse and armour..............

the nrmour, that I saw in your tent
heads had any intellectual armour

the sun doth gild our armour...

with my armaur on my back

went tlurough the army, elicering

frown and lour muon our arn

an army cannot rule them ............. Henry $\bar{V} I I$

general of the Greeiny army, Agamemn

for the remove bring up your army

the Volees have an army forth ....

before our army liear me

have you an army, ready, say you? ...

more than the instant army we can make -

the army marvelled at it

comes his army on? ............

Jutius Cars

king's son's body before onr army... Ant $\& \overline{\text { Cle }}$.

should have an army for an ush
distract your army which doth

and feast the army! we have store

'tis a brave army, and full of ....

$O$, I am known of many in the army. Cym

pray, sir, to the army: I and my brothe

the Goths, and raise an army th

the army of France was landed .........

how near's the other army?

her army is moved on. I thank your

within the lists of the army...... - $\because 3$ - iv. 6

ROINT-aroint thec, witeh! .............. Macbeth, i.

aroint thee, witch, aroint thee! ..... Lear, iii. 4 (song)
ROSE-when he arose again? .. Taming of Shr. iii.

thereupon these errors are arose .... Com. of Er. v.

sudrlenly arose, and walked nbout...Jul. Ccesar, ii.
AROUSE--wolves arouse the jades ..2 Henry VI. iv.

A-ROW-beaten the maids a-row .. Com. of Errors, v.

and then go I toward Arragon

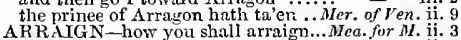

that we may arraign our most ... Winter's Tale, ji.

it shall be done, I will arraign them

not thine: who shall arraign me for

our person to arraign in ear and ear : Homle

high $\ldots \ldots \ldots$...... Wnter's Tnle, iji. 2 (indictmont)

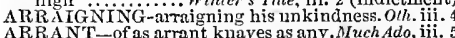

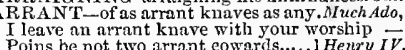

Poins be not two arrant eowards.....1 Herry IV. ii. 2

that Visor is an arrant knave

no, thou arrant kunve; I would I I might -
this is an arrant gounterfeit rascal .... Henry $V$. iii. 6
'tis as arrant a piece of knavery.....
iv. 7

lis reputation is as arrant a villitin

sblud, an arrant traitor.............

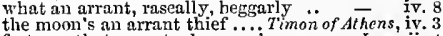

fortune, that arrant whore, ne'er ........ Lear, ii. 4

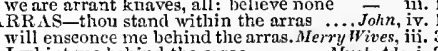

will enseonce me behind the arras. Merry Wives, iii. 3

in eypress chests my arras .... Taming of Shrer, ii.

tast asleep behind the arras

- ii. 4

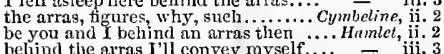

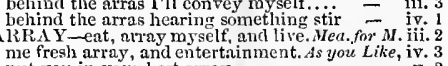

put you in your best array

poor furniture, and mettu ariay...

thou wolf in sheep's a aray

Henry I: iv. 6

stund we in good array

i Henry VI. iv.

set not thy sweet heart on prond array ... Lear, iij. 4

in all her best array bear lier to eluneh o futiel, iiv. 3

ARRAYED-is he arrayed? $A y$, madam .. Lear, ip. 7

ARREARAGES-send the arrearages ...eyml. ii. speak so wisely under an arrest ...Mea.for Mea. i. 3 I do arrest your words

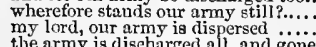

my lord, our army is dispers
the army is discharged all,
when he shall see our array.
ARREST-we arrest your word.... Love's L. Lost, ii.
well, offieer, arrest him at my siit.. Com. of Er. iv. well, offieer, arrest him at my suit.. Co
arrest me, foolish fellow, if thou (rep.)

suborned the goldswith to arrest me.

of eapital treason we arrest you

under our arrest proeure pour

we must arrest sir John Falstaff...2 Henry $I V$

sir John, I arrest you at the suit
I do arrest thee, traitor, of high

arrest them to the nnswer ............

I do arrest thee of high treason here. 2 Henry $V$

eliange my eonntenance for this arrest

I arrest thee, York, of capital treason

sends out arrests on Fortinbras (rep.)

death, is striet in his arrest............... - v.

Hunlet, v. 3

there's one yonder arrested .......... Nea. for Mea. i. 2

I am him arrested.................

what, is he arrested? tell me (repeatei)

whose suit is he arrested at?...........

iv. 2

and he is arrested at nyy suit

he is arrested, but will not obey

ARRIVAL-my arrival, and my wife's. IV' VIII. iv. 2

is apprehended for arrival here. Comedy of Errors, i. 2

the cause of his arrival here $\ldots \ldots \ldots \ldots$ Richard $I H$. 1.

hearing of your arrival in this realm.I Hen. Vl. iii. 4

SR soon as youltril where 1 arrive, ... Hinter's Tole, i. 2 or arrive where I may have ......... I ITenry $\boldsymbol{V}_{\mathrm{I}}$. v. 5 many so arrive at second mastcrs... Timon of Ath. iv. where he arrives, he moves all hearts ..... Lear, ir. 5 too swift arrives as tardy as too slow. IRm. \& Jul.ii. when I arrived, and heard thee ........ I have since arrived but hither........ Telfth Night, ij. 2 this gentleman is happily arrived... - i. father is arrived in Padua.

happily I have arrived at last......... - ${ }^{-}$. I being well arrived trom Delphos... Winter's Thle, ii. 3

we miss, were safe arrived ........... Mncbeth,

that they are all arrived................

either past, or not arrired to pith. Henry $V . \overline{\text { iii. }}$ iv, 2 where ne'er from France arrived more - iv. 8 being thus arrived from Ravenspurg . 3 Hen.VI. iv. cardinal Campeins is arrived ........... Henry $\vec{V} T I I$. it. I he is arrived: mareh gently on ...... Hulizas Casar, iv. 2 is arrived here where his daughter. Pericles, v. (Gow.)

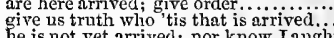

unon certain tidings now arrived.....

ARPIVING-arriving at place of potency. Coriol. ii. O monstrous arroganee! thou liest. . Alt s Well, ii. I not you for her proud arrogance....Richard III. i. 3 ye endure to hear this arrogance? ... Ien. VIII. iij. supple knees feed arroganee..... ARROGANT-arrogant Winehester?.. I Henry VI i. 3 thy proud ehild, arrogant man. Timon of Athens, iv. arrogant pieee of flesh threat us...... Cymleline, iv. that your arrow hath gianced ..... Merry $W^{\prime}$ ives, v. some Cupid kills with arrows ..... Much Ado, ili.

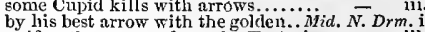
swifter than arrow from the Tartar's - iii. 2 to shoot another arrow that self...Mer. of Senice that love's keen arrows make..... As you Like it, iii. hath ta'en his how and arrows .. swallow, an arrow, or a bullet?

as many arrows, loosed several
draw your arrows to the head!

arrow, shot from she'll not be hit witl Cupid's arror....... Rom. \& Jul. i. so that my arrows, too slightly

that I luve shot my arrow o'er

$\rightarrow$ if by your art

sueh provision in mine art

for the liberal arts, without...

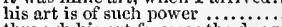

throngh his art foresces the danger

some vanity of mine art...

which by mine art 1 have.

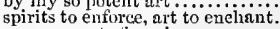

use your art of wooing ............
boys of art, I have deccived

ohad I bnt followed the arts!........

as thll of labour as a wise man's art

she hath prosperous art frlien

all her donble vigour, art, and notiure $\overline{-}$

nature here shows art, that through...

and contermplative in living art ... Love's L. Lost, i. 


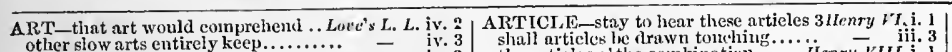

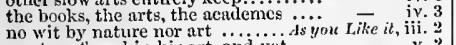

most protound in his art, and $y$

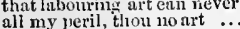

all my jeril, thon no art

nursery of urts, I am arrived ...Taming of shrew, i. I

ints of art

there is an art, which in their (.. Winter's 7 ale, iv. 3

that art which, you say, adids (rep)

but the art itselt' is nature.

ns we are moeked with art

let it be an art lawf

eling together, and choke their

there's no art, to find the

tell me, (it your art can tell

the grut ast of art

invest their sons with orts.

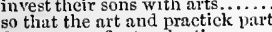

dear nurse of arts, plenties
untrained in any kind of ar

contrived by art. and haleful

naturat griees that extinguish art in , iii. 1 (so

so exeellent in art, and still so

swelling o'er with arts and

Tronil.s Cres. iv. 4 on objects, arts and initutions ...julius Cersar,

Thare as inuch of this in art as yo.

be it art or hap he hath spoken

the art o' the eourt, as hard

those arts they have, as I couli juit

temper him, with all the art I

art hath thus decreed, to make .........

my education heing in arts

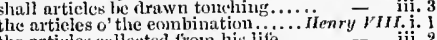

the articies collecter from his lite.

I vet remembir some of these article

euctures not artide tying him to nught Coriol ii.

you have broken the artiele...Antnay \& Cleopatra, ii.

the article of my oath-To lend

that's an article within our law

Piricles, i. 1

the scope of these dilated articles ailow.

take him to be a soul of grent article

hut the main article I lo anprove
I'll perform it to the last article.

othello, i.

for to deny each articie with oath

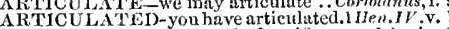

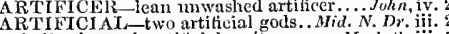

shall raise sneh artifieial sprites

wet my cheeks with artificin tears...3 Henry

two stones nore than his artificial on

that thy prosyerous artificial feat can ...Pericles, v.

MR'TILLERY and heaven's artillery. Tam. of Sh. i. 2

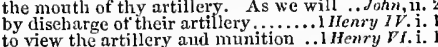

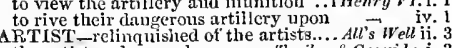

the artist and unread ........ Troilus \&. Cressida, i.

ARTLESs so full of artless jealousy . Hamlet, iv. 5

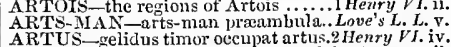

AR'TUS gelidus timor occupat artus.2 Henry VI. iv
ARUNDEL-Richard, earl of Arundel . Rich. II. ij.

ARVIRAGUS-Cadwal, (once Arvirgurus).Cymb.iii. 3
my Cadwal, Arviragus, your younger...

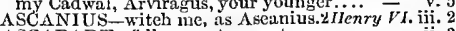

ASCAPART-fell upon Ascepart........

the $[$ Knight-aslant a] brook.......... Hamlet, iv. 7

her ehamber-window will ascend. Two Gen.of $V$. iii. 1 aseend my chambers, search ....Merry Wives, iii. bleed France, and peace ascend to heaven.John, ii. 1 ascend his throne, descend

Bolingbroke aseends my throne...

Bolingbroke asceuds my thron.

it aseends ine into the brain
would a seend the brightest

wouid ascend the brightest heaven..Hen. $V$. i. (chio.)

aseend, brave Talbot; we will follow... Hen.VI. base degrees by which he did aseend. Jul. Cosor, ascend, fair queen, Pantheon..... Titus Andronicu ASCENDED-Brutus is asceaded...Julius Casar, iii. 2

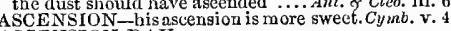
ASCENSION-bis ascension is more sweet. Cymb. v.
ASCENSION-DAYere the next Aseension-day at noon. Ki
on this Ascension-day, remember well

on this Ascension-day, remember we.)

ASCENT-his aseent is not by sueh easy...Coriol. ii. 2

to thy arm alone, aseribe we all...... Herry V. iv. 8

aseribes the glory of his conquest ... Henry $V$ H

ASl. r-where against my grained ask... Coriolanes,

be thou ashamed, that I have took

are you not ashamed

(repealed i... - - iv. fie upon thee! art not ashamed? but are you not ashnmed? Nay......Love's $L . L$.

to be ashamed to be my tather's ehild. AIer. of $v$. ii. 3

invention is ashamed, against

All's well, i. 3

ashamed of me? No, sir, (rrp.) . . Tuming of Sh. v. 1

I am ashamed: docs not the stone. Winter's Tale

art not astamed? but, sirrah .......... Heary IV. i. 3

poeket up wrong; art thot not asliamed? - iii. 3

are you not ashamed, to enforce

I need not be ashamed of your majesty. Hen.

are you not ashamed, with this ....1 llenry VI. iv.

I an ashamed; O henveus!.. Troilus \& Cressida, iii. 2

I am ashamed I did yield to them . Jul. Casar, ii. 2
it is ashamed to bear me!. Antony \& Cleopatra, iii. 9

it is ashamed to bear me!.. Antony \& Cleopatra, iil.

a wreteh whom nature is ashamed almost.. Lear, i.

art not ashamed to look upon this beard

upon his brow shame is ashamed... Rnm. \& Jul. iii.

[Knight? you'll be ashamed fur ever.... Othello, ii. 3

eonfine yourselt to Asher-house ..IIfnry VIIK. iii. 2

ASIIES-and thou shalt turn to ashes.....John, iil. 1

and strewerl repentant ashes ou his head - iv. I

not in ashes, and suckcloth..

not in ashes, and suckeloth...

2 Henry IV it.

her ashes, in an urn ............... IIfenry VI. i. 6

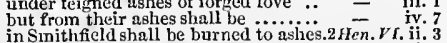

my ashes, as the phoenix, may ......3Henry VI. i. 4

pale ashes of the house of Laneaster!.. Rich. MII. i. 2
modesty, now in his ashes honour.. Menry VIII. iv. 2
ASIIES-her anhes new crente nnother. Hen. VIII. $y$.

frum the sacred ashes ot her honvur .
through the ashes ot my chance.. Antony focteo. v.

pole, asales ancient Gower is emme. Perictes, i. (Gowe

lins and eliceks sliall farle to paly ashes - iv.

where's Diek, the butcher ot Ashtord?
se iv.

here shall I die a*tore ashore

since I was cast ashore

shore at Windsor? like a duek ..................

thou wert come ashore, we........... Thiming of Sh. i.

to the leviathan to come ashore ........Henry $r$. iii.

hear lim ashore: I'll pledge it...........Ant.\& Cleo. ii.

threw him ashore, to give him....Pericles, ii. (Gower)

I must tetch lis necessaries ashore ..... othello, ii. I
ASII-WLDN ESDAX-

on Ash-Wednestay was four year. Mer. of Ven. ii.

SIIY - of aslyy sembianee, niearre..2 I Ienry VI. iii.

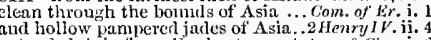

extended $\boldsymbol{A}$ sia from Euphrates $\ldots$ Antony \& Cho. j.

ty he flung aside ...Tempest, ji.

the attraetion of my good parts aside...Merry $1 \dot{V}$. ii. 2

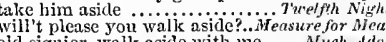

old signior, walk aside with me ..... Much sto, iii.

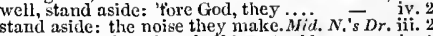

our purpissed hunting shall be set aside - iv.

staud aside, good bearer

stand aside, good Pompey

go, draw aside the curtains..............

my sister, reading; stand aside ..As you Lilic it, iii.

therefore stand aside : this ring ........An's ${ }^{r}$ ell, y. 3

Lianca, stand aside: poor girl 1

Kate, Tet's stand aside, and see

casting their saviageness aside ....WWinter's Tole, ii.

not cast aside so soon.................. Maebeth, i.

to lay aside the sword which sways ... King John, i.

and lay aside my high blood's royalty

to lay aside life-harming heaviness iHen $\vec{r} I V$. ii.

stiand aside, nobility $\ldots \ldots \ldots \ldots \ldots \ldots$.

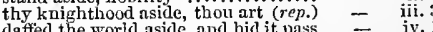

daffed the world aside, and bid it pass - iv.

knigh thood and my soldiership aside..2 Hen.Ir. i.

peace, fellow, pence; stand aside; know 二 iji.

go to; stand uside. And good mister
set this unaccustomed fight aside. .1 Henry $/ x$. iii.

pity, must be laid aside .

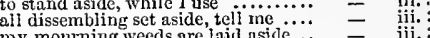

your seorns, and your mislike aside $e^{-}$iv

or brothers beat aside the point ...Richard $1 M$. i.

or hedge aside from the direct. Troilus \& Cres.

setting his fate aside, of eomely

come lay aside your stitchery.......... Coriolanus, i.

boy, stand aside: Caius Ligarius! hew? - ii.

soplease you, step aside; I'li know. Romeo \& Jiul, i.

with one hand beats cold death aside

hath rushed aside the law.

wht soft! aside; here comes the king .... Tramlet, v.

that I must ask my child torgivenes .. Tempest,

and ask remission for

ask my dog

and ask of Doctor Caius $\because$ house..........

that it pleases your good worship to ask $-i$.

you may ask your father

I pray you, ask him some.

and ask him, why, that hour ...........

what shall other dowry with

makes

and for his cowardship, ask Fabian .. - iii.

ask him what this man did.....

I beseeh your houour, ask me

and ask your heart, what.

let me ask my sister pardon........

what is he that you ask for, ni

ask my lady Beatrice else.

irst, l ask thee what they have dome (rep.) - iij.

that will ask some tears in .......Mid. N. Drean, i.

but ask me not what; for, if I tell..... - s. iv.

Was it then to ask the question........
the hour that fools should ask
Rosaline they eall her: ask for her...

it is not so; ask them, how many...

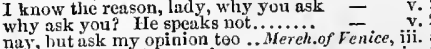

nay, but ask my opinion too ...Mereh.of Fenice, iii. 
ASK-I'll ask him what the would .. As you Like it, did he ask tor me? where remains he? you should ask me, what time think not I love him, though I ask and ask me what yor

might ask you for your eommission

let me ask you a question ............

free for me to ask, thee to bestow

ask me if I am a eourtier

rather muse, than ask, why I critreit

and sing; ask questions, and sing....

to what I shall ask youl out of a note

what does he ask him of me?

good my lord, ask him tipon

good him what apparel he will.. Tilm. of

ne'er ask me what raiment

ask Marian Hacket, the fat

let me be so bold as to ask y

when $I$ shall ask the banns.................

should ask, if Katharine shor

his weleomes forth, asks thee

then asks Bohemin forgiveness

some devils ask but the paring

answer me to whit I ask

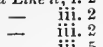

All's Well,

二

nay, ask dirnerer ask it you a gain

meantime, but ask what you would..

we do no firther ask, than ...

I do not ask you much; I be

in arms: ask him his name.

great affairs do ask some charge....

yet ask. Anil shall I have? ...........

directly to this question that $I$ ase

ask me when thou wilt, and thif

bade me ask for it to day

ask me this slave in French............

neighbours tel, Kate? Ihou eanst.

go ask him, whither he goes..................

ask what thou wilt: that $\mathrm{I}$ had

I ask but this; ean he, that speak

and ask him, what's the

Clitford, ask mercy, and obtain

canst do what I mean to asl.

why ask I that? my mangled.

that your lordship please to

ask God for temperanee; that'

ere you ask, is given ......

that seal, you ask with suel a

may I he bold to ask what that

ay; I ask, that I might waken

ask me not what I would be.....

that you ask me what you are

what do you ask of me, my friend.....

tell me one thing that I shall ask

the priee is, sir, to ask it kindly....

who shall ask it? the tribunes

or, if you'd ask, remember this

pet we will ask; that, if you fail.

I should not then ask Cosca what ......

why ask you? Hear you aucht of her....

not know Meemas; ask Arrippa ...Ant.

do so far ask pardon, as befits.........

to be sure of that, I will ask Antony

he did ask fivoutr...............

can we, with manners, ask

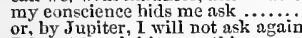

or, by Jupiter, I will not ask a

and ask, what news, of mel.

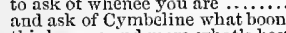

and ask of Cymbeline what boon ....

religiously they ask a saerifiee.

I ask your voiees, and your suftirace
you shall ask pardon of his maijesty

you shall ask jardon of his minjesty

nor ask advice of any other thought

for faith, not ask thine oath........

he asks of you, that never uxel to hed

my tongue that hent, to ask your heip

let me ask one thing .....................

in, and ask thy danghters' blessing.....

if he ask for me, I ain itl .................

let me ask you one word in private .......
ask me blessing, I'll kneel down, and

ask me blessing, In kneel down, a.

in wisdom, $\mathbf{I}$ should ask thy name ......

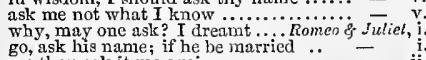

ere thou ask it me again.

ask for me to-morrow, and you shali find
that I ask again; for nothing can...
ASK-when they ask you, what it means. Uamlet,
without in lieart? Whiy ask you this? .. whithout a heart? Whe ask you this? Zound, sir

I wonder in my soul, what you couli i...

why dost tlou ask? But for a satisfaction - ii

gend for the man, and ask him .........
Cassio did tup her; ask thy husband else

I do believe it, and I ask your purilo

SSENCE-eanst not look askance. Taming of sh. ii.

when your hushand asked who ...Merry Wives,

who usked them once or twice.

you in doubt, sir, that you asked her?.. Much Aclo, i. 列 but the loske askel, to say, we are

asked thee merey for't ...All's I'ell that Ends $W^{\prime} e l l$

he asked me for a thousand mar
I thought to lave asked you

hath he asked for me? ...........

hlackberries? a question not to be asked.inen.1

and take purses? a question to be asked

he asked the way to Chester..

he asked the way to Chester...

and never asked for restitntion

was granted ere it was asked.

was granted ere it was asked......... Henry YIII.

have pardons, being asked, as free .. Coriolanus, iii. no question asked him by any

and when I asked you what the ...Julius Casar, ii. 1

as much as to have asked him pardon. Ant

that whoso asked her for his wife
this was well asked, 'twas so well

I asked his blessing, and from tirst to last.. Lear, $\mathrm{y}$. 3 my young lady asked tor, the nurse

called tor, asked for, and sought for

when you are asked this question next.. Hamlet, v. I AKKETH-my business asketh haste.. Tam. of $S h$, ii. 1

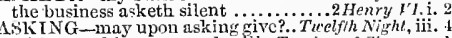
without asking my good-will.. Taming of Sire asking every one for Sir Joln ......... Hemry VI. iij. at his asking, the arehbishoprie ....Henry ${ }^{r} I I$. ii. 1 down the field, asking for himself. Troil. \& Cres. iij. yet dare I never deny your asking ...

in asking their good loves............

not be my offer, not thy asking............ Homlet, $i$.

first asling your pardon thereunto - iv. 7 (letter

thou ask'st me such a question

$\Lambda \mathrm{SLEEP}-\mathrm{I}$ have left asleep ............. T tempest, i. 2

will you langh me asleep

to be asleep with eyes wide open

and yet so fast asleep

I'll yield him thee asleep

within this half hour will he be asleep

the mariners asleep under the hatche

I was fast asleep..................

I told him you were asieep............ Titelfih $N i g h t, i$. how if the nurse be asleep, and will.Much dido, iii.
I'll watch Titania when she is asleep. Mid. N.D. ii.

sing me now asleep? then to you

dead? or asleep? I see no blood

this is my daughter here asleep

asleep, my love? what dead, my dove

though credit be asleep, and not... Hintcr's Tale,

and upon my life, t'ust asleep

find him when he lies asleep

Falstafft tast asleep behind $\ldots . .$.
the other night I tell asleep liere

ï̈еnry $I T$.

now their pricle and mettle is asl

sulijeets are at this hour asleep

may well be charmed :, sleep 0 ......

when others be asleep, to pry ........2. Ifenry

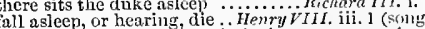

sle is asleep: gool weneh, let's sit..... - - iv. 2

I think our feliows are aslee

fast asleep? it is no matter ........J

thou hast been all this while asleep ...

to bring her babe asleep.......... Titas Andron. ii.

I espied the panther fast asleep

got tween aslcep and wake! ...........

athwart men's noses as they lie asleep

tickling a parson's nose as a hes asleep

low sound is she asleep! I needs must

when he is drunk, asleep, or in his rage.. $\bar{H} n$ m. iii.

'fith, half asleep. Good madann...... othello, iv.

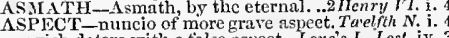
ravish doters with a false aspect . Lor' $' s$. Lost, other of sueh vinegar aspeet, that

they work in mild aspeet.As you Like i', iv. 3 (letter) with an aspect more favourable.. Winter's Tele, ii. know my aspeet, and fashion your.. Com. of $\mathrm{Er}$.

mistress hath thy sweet aspects
deelining their rich aspeet to tlic
SPECT_save in aspeet, have all offence ... John, ii. thaking uote of thy al,horred aspect..........
do hate the dire aspect of civil ....... Richard 11. i. thy sad aspect hatl trom the Henry $I V$. i.

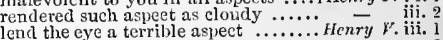
with an aspect of iron, thet

wor his grim aspect, and large......... Henry VI. ji. 3 shamed their aspeets witli store shamed their aspeets with store .......
that sweet aspeet of prinees......... $\overline{\text { Henry }}$. i. 2
'tis lis aspeet of terror: all's not well 2 corrects the ill aspeets of planets .. Troilus \&. Cres. i. put on a most importunate aspect.. Timon of $A t h$. ii. 1 my young boy hath an aspeet of .... Coriolnmus, v. 3 under the allowanee of your grand aspect. Lear, ii. distraetion in's aspect, a broken voice...IItanlet, ji. 2 ASPFRSION-no sweet aspersion shail.. Tempest, jv. I ASPICIOUS-two aspicions persons.. Much Alo, iii. SPICK-have I the aspiek in my "...Ant.
this is an aspiek's trail: and these (rep.)

this is an aspliek', trail: and these (rep.) othello, iii. 3 ASPIR frion-aspiration lifts him. Troil. \& Cres. iv. whose flames aspire, as thorghts
whIn

to aspire unto the erown

digs laills because they do aspire...

gallant spirit hath aspired

rill. ii.

gallant spirit hath aspired ..... Romeo of Jaliet iii. his aspiring rider seemed to know dame Eleanor's aspiring luumour ....2 Henry VI. i.

will the aspiring blood of Lancaster.3Henry $V I$. v.

the nspiring flame of golden ......Richard Kou so looked but a-squint... Lear, $v$. away ass; you will lose......... T . I $\ldots$ Gen. of Ver. away ass; you will lose.

\section{what an ass art thon!...}

that sueh an ass should owe them. TüoGeñ. of $v$.v.

vet $I$ am not altogether an ass....... Herry Wives, $i$

that I am niade on ass

I an not such an ass, but $\dddot{\mathrm{I}} \ldots \ldots \ldots \ldots \ldots$ Ta...

weleome, ass. Now let's have ...... - ii. 3

nould make lins an ass. Ass, I doubt = ii. 3

an ass of me; norr my foes tell me (rep.) $\overline{\bar{T}}$. $\mathrm{v}$.

for, like an ass, whose baek with. Mea. for Mea.

away! you are an ass, you are an ass.....

an ass! but nasters, remember that (rep.) -

O that I had been writdown, an ass...

plaee shall serve, that I am an ass....

you see an aiss' head of your own ... irid. N.D.

this is to make an ass of me..

and straightway loved an a...

and $I$ an sueh a tender ass

methonght, I was enamoured of au ass

man is but an ass, if he go ...

yet recover, and prove an ass .........

you must send the ass upon the horse

as he is, an ass, let him go.

for the ass to the Jude.................

every braggart shall be found an ass...

0 this woodcoek! what an ass it is!.. Tum. of Sh. i.

prepesterous ass! that never read...

my ox, ny ass, my any thing ......

an oss "Tis true; she rides me (rep.)...Com. of $\mathrm{Er}$.

I think thou art an ass

my heels, and beware of an ass

or thy name tor an ass .............

and so is an - ii.

upon an ass: but, ass, I'll take .......King John, ii. 1

yct $I$ bear a hurtlen like an ass...... Richard $I I$.

come, you virtuous ass, you............ Hen. $v$. iii.

thou seurvy valiant ass! .... Troilus \& Cressida, ii.

that I might water an ass at itl......

thint that same young Trojan ass .....
like a dog, the heels of the ass .. Timnn of $\overrightarrow{A t h}$.

and th' ass, more enntain than the lion -

by the ass: if thou wert the ass

when I find the ass in compound ..... Corriola

or to be entombed in an ass's packsaddle -

what an ass it is! then thou..........

like to the empty ass, to shake .......

might hear thee call grent Cxäar, ass - v.

unless it had been the fall of an ass .. Cymbetine

should yield the world this ass ....... Titus $A$ nd. iv. 2

thou borest thine ass on thy back

may not an ass know when...

why, what an ass am I?........

Hamlet, ii.

for your dull ass will not mend his.............

whieh this ass now o'er-reaehes ..........

for making him egregiously an ass ....... 
ASSALL-he ascails: and our virginity...All's Well, i. 1 assail them with the army of the

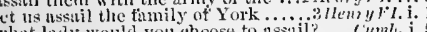
Whit lady would you choose to

it be siul when violence assails to ben kilyen riolence assils $\Lambda \triangle S A I L, N^{\prime} T$-thy ussalant . iny ruin and ussililet ot none

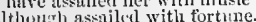

although askatchl woison whie.

AS.ALING-to heat assailing deatl... lle

ASSASTINATIUN-if the asia

A is IUL'T-it assaults merey it tict

the assindt, that Angelo liatl
invineible agtinst all assanlts

as. jor ir. ili.

in the tirst ansalt, or mansom...

il's stell, i. 3

against your vain assaul t.

Macueth, i. 2

of nen, beran a fresh assa

. Rich. $M$, v.

What mans death in this ridi

With shot, or with Rssanlt....
the enemy toth make assituit

in which assitth we lost twelve

- cres ivi

ao sooner mareh to assauit thi........ eoutry - v.

and the assault you haved of thy assault -

such gesulults as would take in

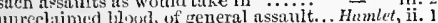
ASSAULTLD-assiulted, for following her. Lear, ii. ASs.1Y - in this manner assay me?...Merry itives, ii. bid lerselt assay him

anly lie hath malo an assi............

et us assaty otu plot

u's

I will asay ther; so dect thesclf. I would assay, proud queen...........3Itenry VI. i. I
let us make the assay upon him...T Timon of Ath. iy. 3
winulaces, and with assilys of bins....... Ifumlet, ii. I

to uive the assay of arms arainst

did reu assay him to any pastime?

hclp, angels, muke assay! bow, stubborn - itiello i. 3

the assay of reason.

assilys to lead the way $\ldots . . . . . .$.

hare assayed to wiu the Tower

performance, 'twere better not assayed... Hizmlet, iv.

等

to the Enylisly eourt assemble now ...2 lien. IV. iv.

let them assemble; and on a safer.

asscmble all the poor men of sour sort. Jul. $\bar{C}_{r}$ sar, i1.

assemble we rmmediate council .

Sotu tluck, assembled by the bell ..2Henry IV. iv.

we have in head assembled them
should be rointained, assembled

our former fiavour, you are assembled -

with their chicf assembled strength. . IIIenry $V I$. 1. $)$ assembled such troops of citizens... Then hath assernliled Boeehus, the king...Ant. \& Cleo. iil. 6 SSENBLLIES- to haunt assemblies ...Mea.for M. i. 4 in private. And in assemblies too .. Com. of Er. v. 1 good-morrow to this fair assembly

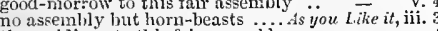

these tidings to this fair assembly

honourable? Is your assembly so? 2Henry $\mathrm{V}$. iv. 2 .)

whom this great assembly is contrived. Henry V. v.

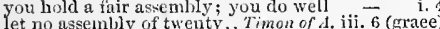

you, the great toe of this assembly?

and advance the theme of our assembly

if there be any in this assembly ...Julius Cossar, iii.

my oath betoire this honourable assembly. Lear, ini.

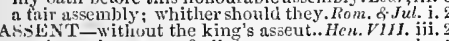

by the main assent of all these

AsisES-send ministers to me, asses...Trelfuh $N$. iv. 2
one lion may, when many asses do..Mid. N. Dr. v. 1 which, like your asses, your dogs. ...Mer of $i^{-2 n}$. iv. asscs are made to benr, and so are..Taming of 'S. ni. there's nome, but asses, will be..... Comedy nf Er. i1. what are we, Apemantus? Asses. Timon of Ahh. ii. thy asses are gone about 'em .............. Leur, i. 5 be led by the nose, as asses are.

ASS-IIEAD-will you help an ase-hend. Turelfh $N$, v. $\Lambda$ SSIGN-to assign our trial-day
till we assign you to your days

with their assigns, as girdle, hangers.... II $\overline{\text { Iamlet, }}$ v. 2

gis, and three liberal-conecited

to Tis eonveyanee 1 assign ny. witc

and

and east, is to my part assigned ....1 Henryl $V$. iii.

to Ptolcmy he assigned syria ...... Ant. \& Cleo. ii.

ASSINEGO_an assinego may tutor.. Troil. \& C Cr. ii.

let us assist them.

gentle girl, nssist me......... Tu. Ge Gen. of Verona, ii.

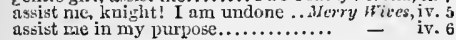

S.IST the hot-blooled gods assiat .. Momy H:

Jill ans

mithight, nssist our moan .....

your cumning can assist me

we'll all assis your he, that flic.

the uods assist you! amel keep

shall assist the decds of just

nssist, gout fricnds. O quiek, or I...
clo not assist the storm: here's all.

jour voice, to assist my simpleness

to the end to erave your assistane

that I to your nsistanee do make love.

without the assistanee of a mort
ly your assistanee win the da

towarls our assistanee, we do sei

swore him assistance, and perform
we hat his assistanee by the hand

ny gnin of it by their assistances...

by thy advice, and thy assistane.

you present assistance therein. '?

SSISTANT-assistnit, or

neither allied to eminent assisttunts. Heury $\mathrm{VIII}$.

and convoy is assistant, do not slcep ..... llamlet i.

let me he no assistant for a stute......... Thiter ii. 2

I an assisted by wicked powers

ith terrihle numbers, assisted by ..........acbelh, i. 2

SOCIATE-friends should associate.

o associnte me, here in this eity.. Ro

SOCLATED_associated with Au dius. Coriol.iv. 6

SIAGE-Goon gods assuage thy wrath - v. 2

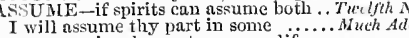

Iny very visor began to assume life $\dddot{\text { I }}$ er. of $\bar{V}_{\text {en }}$. ii. 9

but ascumes some mark of virtue...

these assume but valour's exerement $\bar{z}$ iii. 2

this shape of sense assumes.... Troil

and loss assume all reason without

do not assume my likeness..... Timon of Athers, iv.

to assume is semblonec thant very dogs

if it assume ny noble father's per'son.

hath power. to assume a pleasing shape.

ASSUMED-hath ossumed this not

ASUNING-assuming man's infirmities. $P$ -

for more assuranee that a living

and my assurance bids me search...... - v.

give me modest nssurance, if you.. Tuelfih Night, i.

plo

plight me the full assuranee of

fur the more better assuranee tell....Much Ado, ii. ver futher make her the assurance. $T$. $N$. Dr. ili. if yon make this assurance $\ldots \ldots . . . .$.

and give assturanee to Baptista Minola

to pass assuranee of a dower in marriage

and sueli assuranee ta'en, as shat.

counterteit assuranec: taike you assturnnce

and therefore, for assurance, let's each -

thy now unsured assurnnce to the e

procure him better assuranee than ..2 2leary $l$

else his head's assurance is but frail ...Rich. III.

nor no more assuranec of equal ....Henry r'111, ii.

the way which promises assurance Ant. \& Cleo,

by an auricular assuranee have jour.

to give the world assuranee of a man ...Humlet, iii.

Which scek out assurance in that

out o' the moon, I do assure the

assure thyself, my love ....... Tu To Gen. of ver. iv. 2

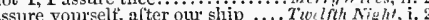

and 0 youre thpself there is no....

yon'll find it otherwise, I assure y

as Heetor, I assure yoll: and in the ...Much Ado, ii. 3

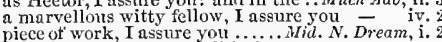

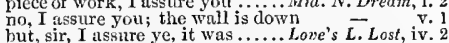

I do assure you, sir, I do assure $\ldots \ldots . .$.
I do assure you, very good friend $\ldots . .$.

you cannot beg us, sir, I can assure... - v.

I assure thee, and almost with tears...As you Like, i.

I lo assure you, my lord, he is .......... All's $\mathrm{W}$ ell,

nay, I assure you, a neace ennelucled

Tll assure her of her willowhood.. Tan
that ean assure my daughter greatest

Grumio, what can you assure lier?..

I dare assure you, sir, tis almost two

I do assure thee, fither, so it
the min, I do assure you.......

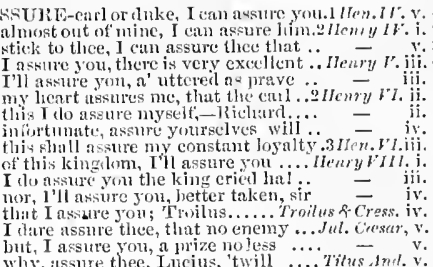

never 1 lumket yet, I can
nor, I assure thee, licgan
thy carliness doth me as

thy carliness doth me assure ....

assure rourself, I will scek satisf

he assured, my pnise, my person.....
be assured, you may, I will (repeate
bc assurei, thou shalt have justice..

as 'iwere, a man assirred of

swore, $Y$ was usstured to her .
well assureel, that I did so, wh

well assured, that I did so, when

assured loss, hetore the match .......... - in wi.

be assimed, will ensily be granted . ...111/en,y! $V^{\prime}$

wilt have me die assured of it

I bid you lie assured, I'll be your fit

assured I love sou not. I me assir

betore thy most assured overthrow
she promised, and assured suecess

she promised, and assu
but this I am assured

but this I am assured .................
well assured you put sharp weapo
or, be wcil assured, adventure to

be well assured, her taetion will ....3 Henry $r_{I}$.

be you, gooul lord, assured, I hate....Richurd III. $\mathrm{i}$.

he assureal, we go to use our hands .

(which, well I an assured, I have not - v.

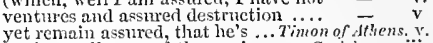

resting well assured they neer ..... Coriolin us, iit.

but, bcing assured, none but myself... $\bar{C}_{\text {that }}$ v maly rest assures, whether.. Jutius

no, be assured, you sliall not find me... Cymleline, i.

shall be asstured to taste of too

shall be asstured to taste of too
languish for assured bondage?

perfeet goorlness her assured credit

were I well assurcd she came of ger

would I were assured of my condition.

be assured, he eloses with you in this
be thou assured, it words be made ot

[Knight.] - be assured of this, that the

be thou assured, good Cassio, I w

but be yout well assured, no more than

SSURLDLY_assuredly the thing..As you $\bar{L} i k e$, ii.

yet to reax; I shall, assuredly ....... Henry HIII. iv.

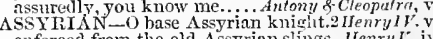

enforeed from the old Assyrian slings...Henry $r^{\prime}$. is

ASTERN-[Knt.] we are strong in astern. Pericles, iii.
ASTONISH - can so astonish a nother.. Haml,t, iii.

whose beauty did astonish the survey. All's $W$ cll, v. 3

drearful heralds to astonish us....Julins Cossir,

ASTONISHED-have astonished him .Henry F v.

beauteous niargaret hath astonished me -

terras Astriea reliquit; be you . Tilussudran.

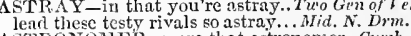

AS'TRONOMER-were that astronomer.. Cymb.

ho performs, astronomers foretel it... Troil. Cre
AsThONONICAL-a sectary astronomieal. Lea

you rent our ancient love asunder...M Mid. N. D. iii.

they whirl asmer, and disinember me...

narrow ocean parts asunder

could not live asuuder day or night.

haek their bones asunder $\ldots . . . . .$.
clapperl ur close, and kept asuniler.

to rend his limbs asunde

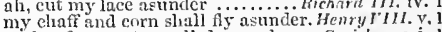

eurbs of more strong link nsunder ..Corinlamis, 1.1
that we two are asunder, let that .. Cymbeline, iti.

and he are many niles asunder...... Rnm. g. Inl. in.

$\triangle T \Lambda L A N T A \rightarrow$ of Atal

A talauta's betterpar

an Até, stirring him to blookl......... King John, ii.

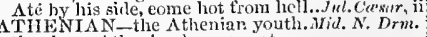

the sharp Athenian law exunot...

by the Athenian garments he batlo on

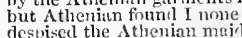

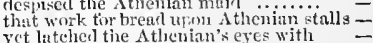

yet latcher the Atlowian's eyes with -

and the Atluenian woman by his side
this is the same Athenian.

$\dddot{\mathrm{D}}$ 
TIIENIAN-

by the Athenian garments he had on. Nid.X: ofl the head of this $\Lambda$ thenian swatin..

withont the peril of the Atlenium

to lie sung by an Atheuian eumuch .

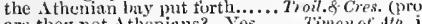

to knick out an lionest Atlienian's.. tholl art an Athenian; theretore

sow all the Atlienian bosoms

is this the Athenian uninien

and promise to the thenians, to speak

spare thy Atheninn cradle

come, good Atheniun. No words.......
ATHEN-ancicut privilege of Athens.

of else the law of Athens yields yo
trom Athens is her house remote
geemert $\mathrm{A}$ thens as a paradise to me

through Athens' gates have we devised

and thence, trom Athens turn away

through all Athens, to play in o

weeds of $A$ thens he doth weor.

and help from Athens ealls ..........

and llelent of $A$ thens will I lene my fook y liack

back to Athens shall the loyers wend
that I may back to $A$ thens, by daylight

may all to Athens hack agaiu repriu.

away, with as, to $\Lambda$ then

you have not a man in all Äthens...

wit of uny hanclicraft man in $A$ thens

men, that wurk in $\Delta$ thens here

hare to the port of Athens sent... Troil. \& Cres. (p

of $A$ thens here, my lord. Go to...

free-hearted gentleman of Athens....

Athens ceutain thee, attend ou

that $\mathrm{f}$ may strike at Athens $\ldots . .$.

sink. Atheus! heneetorth hated be

in the carth, and fence not $A$ the
henp ou $\Lambda$ thens, ripe for stroke!

herl on $\Lambda$ thens, ripe for stroke!
how enrsed Atlens, mindless of thy.

proud Athens on a heap, - warr'st (rep.

strike up the drumn towards $A$ thens.

what wouldst thou have to Athens?.

the common wealth of Athens is
to Atheos, go, break open shops

let us firt see pere in Athens...

shall see him a pam in Athens again

hest in all Athens: thou art, indeed.

the senators of $A$ thens greet

aud of our A thens (thine, and ours).

sword against the walls of Athens

but if he sack fitir $A$ thens

befure the reverend'st throat in $\Lambda$ then

tell Athens, in the eeruence of degree
but say to Athens, Timon hath made

before prond $A$ thens lie's set ilowu

my lord, in Athens. No, my most

a private man in $A$ thens $\ldots . . . . .$.

A'TIIVERSARY-yon, the athversary
marry', th' athversary was have possc

the perdition of the athversary hath.

what soever comes athwart his

what soever comes athwart his lay his wreathed arms athwort his. Love'

quite traverse, atliwart the he

when, all athwart, there eame ....... H ${ }^{2}$

winged thoughts, athwart the
athwart the lane, he, with two

athwart [Collier-over] men's aoses... Rymbeline, v. 3

ATLAS-You are no Atlas for so great.3 Henry $V^{\prime}$.

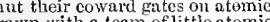

drawn with a tenm of little atomics. Rom. \& Jal.i. 4

ATONY - the atomy, thoul .......2 HenryI I. v.

since we canjot atone you ........... Richith

he and Aufidius can no more atone. $C o$

the present need speaks to atone you. $A$.
l was glad I did atune my countryman

I would do mueh
ITONEIIEN'T-

tu make atonements and compromises. Merry $W$

now male our atonement well ...2 Heury $\mathrm{I}$.

'TROPOS-come, Atropos, Y sayl 2 Hem?

iTwACH-attach the hand of his ..Love's $L$. $L$. iv

desires you to attach his son....... Winter's Tale

I woulel attuch yuu all, and male you. Rich. 11 . ii. 3

treuson I attach you both..........2 Henry I

myself attach thec as a traitorous.. Coriolinus, iii.

do at tach [ $\mathrm{Col}$. Knl.-apprehend] thee. R
some of you; whne'cr you find, attreh

therefore appreheod and do attach thee ... othello, i.

I should be attached in Ephesus ..Com. To prt, iii. 3

durst not have attached one .......2 Henry $1 V$. i1.

durst not have attached one $\ldots \ldots \ldots . .2$ Hen
my tather was attaehed, not attainted.1 H
hath attached oir merchants' roods. Hen

he is attached; eall him to present trial
he half attiched with that which ... Troil.

A'TTACHMEN'T-attachment to thy senses

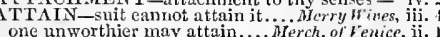

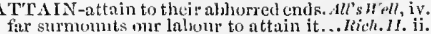
cre he attain his caseful western ....3 3 Henry $l^{\prime} l$.
the gods grant thee to attain to!.. Timon of $A$ th. by this vile eonquest shall attian unto

to attain in suit the place $\ldots \ldots . . .$. Cymbelin
A'T'ATNDER-struds in attainder..Love's $L$.

with the attainder of lis sland'rous. Richard $I I$. iv.

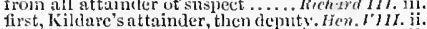

TTAINED-attained the effect.
ere his youth attained a bearl

which once attained, your hirlinct.

nore mire attained, than by a wlace

TTA INT-you are attaint with taults. Lore's $L . L$. v. 2

simple thief urags of his own attaint? Com.of

was never yet attaint with any...

roilus ores. i. 2

i. 1 NTTAINTED - not thon attainted... Henry F. i. 4

my tather was attached, not attainted
I must offend, before $\mathrm{E}$ be attainted.2 IIenry VI. ii. 4
ATTAINTURE-and her attainture..

ATTASKED-more attasked for want ..... Lear, i.

ITTEMPT -attempt us again .....Merry iVive

by tearing to attempt .......

and make fit for his attempt

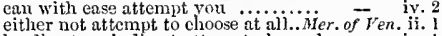

by direct, or indirect attempts, he seek

must attempt you further.

you $\overline{L i k e}$ it, i. 2

and give over this attempt ..........

pray God's blessing into thy attempt

I will graee the attempt for a worthy...

but the attempt I vow $\ldots \ldots \ldots \ldots \ldots \ldots$. $\frac{1}{-}$ iil. 6

prepares for some attempt of war...... - iii. 6

till my attempt so unch be glorified......John, v. 2

and hair of our attempt brooks

that your attempts may overlive.

in this haughty great attempt.

iHenryIY. iv. 1

will fillow ine to this attempt....

3Henry Irtiv. 2

filse traitors from the like attempts.. Rich. 1II. iii. 5

the ransom of my bold attempt shall

the gain of uny attempt the least of you $\overline{\text { VIII. }}$.ii. 2

this man of thine atteng on him ... Fenry

but with his last attempt he wiped it out. Coriol. v. 3

bid thee do, thou should'st attempt it

I durst attempt it against any lady

thourh your attempt, as yuu call it

this attempt I'm soldier to, and will abide - iii. 4

for whieh attemyt the julges.... Tilus Andron. iii.

ing wooed a villain to attempt it.... Perictes, $y$.

neglecting an attempt of ense, and gain.. Othello

therefore I will attempt the doing it.

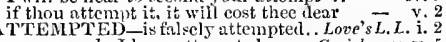

prosperowsy I have at tempted ...... Coriolamis, y. 5

TWMPTING-lyy attempting it ..2 Henryll, ji. 1

for him attempting who was self-subdued. Lear, i. 2
TTEND-dost thou attend me?

the goddess on whom these airs attend..

shall step by step attend you $\ldots . . \cdots \cdots \cdot \ldots$ = iii. 3

do now attend the queen? ........... iv $-\overline{\text { iv }} 1$

we'll both attend upon your ladyslip

I but atteud on teath ..............

the dimer attends your sir ........ Brerry Wi

attend your office, and your.......... - iv. 6

stre will attend it better in thy..... Tuelfih $\mathrm{N}$ ight, i. 4

he attends your ludyship's plensure.. $\quad$ - $\quad$ iii. 4

shall I attend your lordship?
but I will attchd you awhile

I shall attend your leisnre

rive thee tairics to attend on thee...Mit. N.'s D. iii

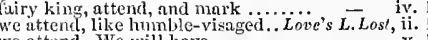

what lumble suit attends tijy

our leisures to attend an yours. ...

and happy hours, attend on you

he attends here in the forest on the.

I minst attend the duke at dinner

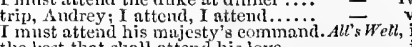

whicht but at siant attend his love

sliall more attend uyon the coming space -

you presently attend his turther...... $s . \overline{1}$ ii. 4

how thy servants do attend on thec.. - 2 (induc.)

I pray you do; I will attend her her

oley the britie, youl that attend on her

i' the garden; shall's attend you... W'inter's Tale, i. 2

and brought up to attend my sons. Con

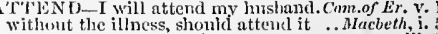
attend those men our pleasure?
6ay to the king. I would attend his leisure awikl better heaith attend his majesty. let our just censurcs attend the truc event as they say, attend the steps of wrong) is mode attend to neither, strike ul' .. Richard $I I, \mathrm{i}, 3$ in the base court he doth attend to speak - i

when you are better tempered to attend

lord Bardolph duth attend him here..2 Henryl $I$.

and conquest to attend on us............ Henry $r$.

shall I attend your grace? $\mathrm{N}_{\mathrm{N}}$.....

upon a wooden coffiu we attend........ i Henry $V I$.

will attend on ler; will not your $\ldots .$. - ii. 2

I will attend upon your lordship's leisure - v. honourable peace attend thy throne.2Henry $Y$ T. il. attend me, lords. The proud .........3 Henry Vl. ii. 1 and all their ministers attend on him

attend [Col. Knt.-Wait] upon your grace -

to-morrow then we will attend your grace

thy life, and doth thy death attend . Henry VII iv. i. some attend him. You have now a broken you, he bade attend him here ........ - iii. it is my duty to at tend your hishness; $\quad$ - v. fulfilled, and I attend with paticnce.. $=\quad$ v. 2 attend me where I whecl: strike not. Troil. \& $\mathrm{Cr}$. V. thy lower hath conjurcd to attend. Timon of Ath. $i$. attends he here, or no? - Lueilitis? jadies, there is an idle banquet attchids you we attend his lordslaip; '1ray', signify
attend our weightior judgment ...... attend our weightier judgment ....

attend upon Cominius to these wars..

where grcat patricians shall attend

the market-place, I know, they do attend -

We'l attend you there: where .......
away, the tribmues do attend your; aim
let at guard attend us through the city

with graeeful eyes, attend those wars. $A$ inl

there I will at tent what further eomes

good queen, I must attend on Cxsar

I'sl attend your lordship

I will attend the queen

I'll attend your lordship ............

to your mistress, attend the queen .

Which attends in place of greater state
that did attend themselves, ind hakd
willingly attend your ladyship.. Titus

willingly attend your ladyship...T

connot induce you to attend my words

move you to atiend me most

attend me then: I went to Antioch

Pericles,

thend me then: I went to Antioch.... - i.

, attend, my daughter; princes..... - ii.

a nicee of mine shall there attend you $\overline{\text { ind }}$ ii.

messengers from hence attend despatch
vigilanec, does not attend my taking......

and attend the leisure of their answer.

shall attend you presently at your

if you with patient ears attent... Roment $-\mathrm{v}$.

this lody and attend our will ...... - iii.

use that word in hell; howlings attend it - iil.

my betossed soul did not attend him conser.

attend: where are my switzers

that you attend him in the hall..........

the genticwoman that attends the general's - iii.

by yom invited, do attend your lirescuce

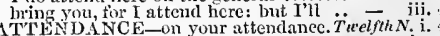

TTENANCE-On your attenda. Taming of $S$. i

I danced attendance on his will.......2 Henry Ir . i. 3

dance attendanee on their lordships'. Hemry YIII. $v .2$

wait attendance till you hear...Timon of Athens, i. 1

TS EN DANT - have I few attendants. Tempest, v. her attcndants of her chamber, saw...ts you Like, ii. means, and attendnnts, and my loving. stll's Well, i. and brave attentants near him. Tam. of $S$. 1 (induc.) to $p u t$ apart these your attendants.. Winler's T. ii.
thant his attendant, (for his case .. Comedy of Err. $\mathrm{i}$. with his mad attendant and himself. the tury of my thrce attendants .... Henry Hiv her attendants absent, swallowed fire. J ul. Carsar, iv. her attendants are all sworn ......... Cymbeline, ii. reason, he must have some attendants

dismiss your attendant there; look .... Olkello,

a fair young man, and well attended.. Tuelfh $N$. i.

only attended by Nerissa here...Merch. of Fen. in.

as the lark when'neither is attended... 


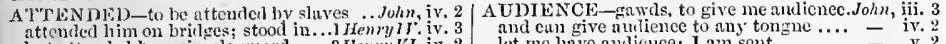
nttended lim on brilges; stood in...1 Hennyly. iv. hit attenderl by a simple guard who attended him in secret ambush.. - iv. attended to their sugared worls .. Richard III. iii. I am attented at the eypress grove.. Coriolumus, i. i 10 thint lave so long attended thee....... Cymbeline,

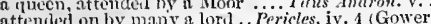
he is attended with a desperate train...... Lear, ii.

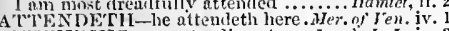
$A$ 'T ENDING-an attending stur.. Love's $L$. L. iv. 3 by this, I know, is lere attending ..... All's well, v.
with a free desire, attending......... Richurel $I I . \mathrm{i}$. nitus \&-Cress ij. than attending for a cheek; rieher.. Cymbeline, iii. attcuding $y^{\prime}$ ou here at Milforl Hare he stayed, attending nature's law. to lave-sick Dido's sad attending ear. Tilus.trd. v. like sof test music to attending ears!. Rom. \& Jul. ii their hearts attending on themselves.... Ohello, i. ATTEN'-be attent, and time.. Pericles, iii. (Gower) for a while with an attent ear ATTENTION-letter with attention. Love's $L$. $L$. i. amend the attention of your ears....2 Henry $I V .1 .2$ bold with time, and your attention....Hen. MII. ii. my heart, and lend my best attentio

Cymb. v. reason is, your suirits are attentive.

cinse on the attentive bent.

列 A'ex not his prescience; be attentive. Ant. \& Cleo. wounded his daughter..........Win'er's Tale, v. 2
ATTEST-crooked figure may attest. Hen. $V$. i. (elho.) now attest, that those, whon ........

invert the attest of eros and ears......
ATTESTED-attested by the holv. v. 2
ATTIRE-my masculine nsurped attire I'll show thee some attires............Auch $\overrightarrow{\text { Arlo }}$, iii. in poor and mean attire, and with .. As you Like, and so wild in their attire; that look ...Macbeth stern looks, diffused attire, and every.. Henry $V$. thy wife's attire, have cost a mass....2 2 Henry $V i$. i. 3 low itself, attire me how you can.....

lo you now put on your best attire?...Jul. Crescr. leap thou, attire and all

gou will say, they are Persian attire ..... Lear, iii. 6 ay, those attires are best .......Romen \& Juliet, iv. for my part, I am so attired in wonder. Much fdo,

were ther but attired in grave weeds. Titus ind. iii. Why art thou thus attired, Androniens

ten oroats for the hand of an attorney. All's $W e l l$, ii. vill have no attorney but myself.. Comedy of $\mathrm{Er}$. to be mine own attorney in this case.1 Henry VI. v.
be the attorney of my love to her .. Richard III. iv. I, by attorney, bless thee from thy

the king's attorney, on the eontrary. $\dddot{H}_{\text {enry }} \bar{V} I I I$. have heen royally attorneved...... Winter's Tale, ATTORNEYSHIP-by attorneyship.I Henry VI.V ATindy atturnies to their elient woes. Richard $I$ bis attormes-gemeral to sue........ Richard $I T$ ii. AT'TRACT-attracts my sonl ..... Twelfich $N$

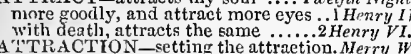
ATRACTYON- setting the attraetion. Merry $w$ and with his great attraetion robs. Timon of Alh. iv. 3 ATTRACTIVE-and attractive eyes.Mid. N. Dr, ii. 3 here's metal more attr:uetive. O ho! . Hamlet, iii. 2
A'TTRIBUTE-the attribute to awe. Mer. of Ven. iv. it is an attribute to God himself...... swear by Jove's great attributes, I loved $-\overline{-}$
mueh attribute he hath; and much. Troilus $\$-$ 5ou not find out that by her attributes? and for an honest attribute ery out.... Pericles, iv. 4 A the pith and marrow of our attribute.... Homl ATTRIBUTION-such attribution... Henry IV, A'TTRIBU TrVE-that is attributive [Col. $\mathrm{Kn}$ AT BREY - the lord Aubrey Vere....3 Irenry VI.iii. 3 A BURN-her hair is auburn.. Teo Gen. of Ver. i $\Lambda$ UDACIOU'S audacious eloquencc...Nid. $N$. Dr. away with that andaeious lady.... Love's L. Lost, v. 1 his duteous land audaeious crueity... Henry $I V$.iv. 3 perish ye, with your audaeious prate.. _ - ivenry

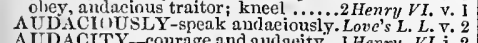
a rm me audacity, from head to foot... Cymbeline, waking, audible, anl full of vent ..Coriolanus, iv. 5
AUDIENCE-thou have andienee.. Tuelfth Night, i. 4 let the audienee lonk to their eyes...Mitl. N. Dr.i. 2 shall I have audicnee; he shall vouebsife me an audience for one word give me audience, good madrm .. As you like il, iii. let me have andience for a word . .i....
was worth the audienee ot kings. . Trinter's Tale, v. 2 get me have audicuce; 1 am sert
give me audience for a while.

i that he will give you andice...

unon that iustant, eraved audiene.

we'll give them present audlienee

three-pence to a second day of anlienc

hardly gave audienee, or vouchsatic

oft before gave audience, as 'tis reported

the queen, of andience, nor desire, shal

your audience been most free

sir, in this audience, let my diselaiming.

and entl the andicitee to this act....

AUDIS-tam lentus andis scelera?. T

to kIT-to make their audit at

yet $I$ ean make my audit $u$

our ... Mrachelh i.

and, bow his audit stands, who knows. Hamlel, iii. 3

a kind of auditor; one that hath ...... Henry $I V$. ii.

call me bcfore the exnetest auditors. Timon of $A$. ii. 2

UDREY-Audrey; I will fetch (rep.). . As you Like, iii. 3

we shall find a time, Audrey (repeated) -

sir Oliver, Andrey, a most vile (rep.).

trip, Aulrev, trip, Audrey ............

mend your voices! Come Audrey

benr your body more seeming, Audrey

so, your opinion is, Aufidius, that.

noble A A uidius, take your eommission
see him pluek Aufidius down by the

see lim plnek Anfidius down by the

there is Auficlius, list what

the man of my soul's liate, $A$ ufiding

to Aufidius thus I will appear .....

oer them Anfidius, their very heart
set me arainst Aufidius, and his

bear against the great Aufilius a sicield

but then $A$ unfidius was within my vicw

fought together, but Aufidius got off

Tulns Aufidius then had inade new

your voble Tullus Aufidius will appea

where great Aufidius lies: is lie in ...

Mrarcins, jomed with Aufidius, leads

be and Auficlius ean no more atome

assoeiated with Aufidins, rages....

and is Autidius with him?

this man, Aufidius, was my beloved

A ufidius, though I cannot make ( $(\mathrm{rep}$.

less? or granted less, Anfidius?

his own impatienee takes from Aufidiu

AUEIDIUSES-six Aufidiuses or more

by aught that I can speak.. Two Gen... of Tempest, $\mathrm{i}$.

respect not aught your servant doth..

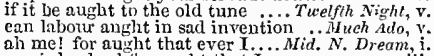

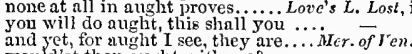

nor liazard, aur hit for lead

threatenest, thin dost promic........

or hers, for aught I lnow

(for aught I see) two and thirty.... Taming of Sh. i. 2

it thou ans ass thee from me. $\ldots .$. Comedy of Er.

or are you aught that man ma

if he see nuglt in you, that makes ... King Joln, ii.

before I make reply to auglit you........ Richar - vy. ii.

for anght I know, iny lord, they do

art thou anglit else but place, degree.. IIeny $V$.

or aught that we could do

that you have aught but Toibot;

or aught intend'st to lay um to .......

never dreamt on anglit but butcheries. $R_{z} h_{h}$.

be will not be won to aught against him

in anglit pertains to the state ......Henry VIII. $\mathrm{j}$.

heard him at any time speal anglit? - i.

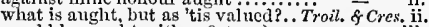

would he aught with ns? (rep.).......

indeed, in anght he merit not........... Coriolanus, i. I

artiele tying him to aught $\ldots . . . .$.
and never of me aught but what is ...

it be aught toward the general good...Jul. $\bar{C}_{e s a r}$

hear you aught of her in yours?....... $\overline{\text { no }}$ iv.

no pleasure in aught an eunueh has. Ant. \& Cleo. i.
my lord that I kiss sught but he .... Cymbeline, ii. give me andience, friends

nor is he dead for aught that $\mathrm{I}$ can .. - iii.

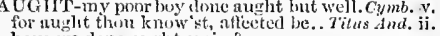
have we dome anght amiss?
auglit eseatjen bit himself

(who, firr anght I know to t

in aught you vortli, resolye

if anght within that little, seenit

do you hear and the sir, of a battle

nor aught os gowl, hut strained from. Rn

that you know auglat of me.

whether aught, to us unknown, artilicts

mo, nut I, I never gave yout aught ..........

in' my love thou hold'st at aught..

if that his majesty wolld anght with is.

it anght of woe, or wonder, eease your...

neither my place, nor aught I leard
nor know I aught but that he's well

nor know I nught, by me that's said

my lord, for anght I know

i)or set down anght in malice
UUG

to ratify, alument, or alter. as yent it... Alocbeth, ii.

insceming to angment it, wastes it?. Henryl III.

With the aumentation of the Indies. Twetfh $N$. iii.

what he is, augmented, would run.Julins Crrsar, ij. I
every stage with an augmented .....Ant. 5 Cleo. iii. 6

swift brook, angmentiug it with. . As you Like it, ii.

with tears augmenting the fresh. Romeo \& Jalirt i.
AITGRE-intio an augre's bore ...... Corinlamus, iv.

AUGRE-HULE -an augre-hole may rush. Mact, ii. AUGURS-aud trees to sneak; augurs . - iii.

the persuasion of his augurers may.Julins Cosar, ii.

what say the angurer's? they wonld not $-\overline{\text { ii, }}$,

AU, sir, you are too sure an angurer .o - v.

AUGURING-my auguring hope says.. - ii.

not a whit, we defy angury ............ Hamlet, v.

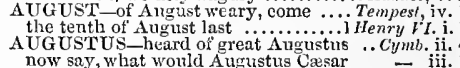

that I am to pronounee Angustus, Cæasar

Aurtus lives to think on't ........ - v.

A ULD-thine auld cloak about thee.. Oth. ii. 3 (song

my noble cousin, lord Aumerle: not siek - i.

you h A amerle, how far bronght.... - i. 4

are my lord Aumeric, lord Salistury - ii. 3

Aumerle, thou weep'st; my tender-hearted

there is my gage, Aumerle, in gage

to the like, forsworn him hom

the very time Aumerle and you did."

Aneryerle is guilty of my true appeal

that thou, Aumerle, didst send two.

here comes my son Aumerle. Aumerie

strikc him, Aumerle: poor boy....

$\triangle$ ÛN'T-maid's aunt, the fat woma

it is my mad's aunt of Brentford. Werry Wives. iv.

I have a widow aunt, a dowager ...Mid. $N . D_{\text {rm }}$.

songs for me and my aurts. "Hinler's T. iv. 2 (son
and thine aunt, great king; "tis I.... Richard II.

and thine aunt, great king; 'tis I.
rise un, good aunt. Not yet, I thee

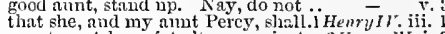
sweet aunt, be quiet; 'twas agninst ...2 ilenry $F_{I} . \mathrm{i} .3$ al, a yout, yom wept not fur our..... Richard $I I X$. ii. the hand of her kind aunt of Gloster?

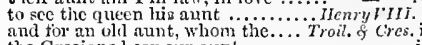

the Greeians koen our aunt

nake ny aunt nerry witl sonic....

my noble aunt loves meas dear.

but my uncle-father, and aunt-mother ... It $t m$, ji.

AURICULAR-by an aurienlar assurance. Lear, i. 2

shady eurtains from Auror's bed ... Rom. \& Jut. $\mathrm{i}$.
AUSPICIOU'S-a most auspicious star .. Tempest, $\mathrm{i}$.

ealm seas, anticicicus gales...........

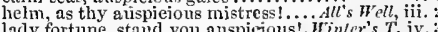

to stand lis auspicions anspictres

Lear, ii.

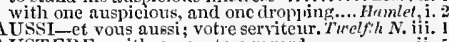

USTERE-with an austere

if this austere insociable lite...

ve's L. Lost, v. 2

as of grave and anstere quality.. Timon of Athcns.

mirht'st thou perceive austerely. Com. of Errors, iv.

ATSTEREN
AUSTERITY - anistereness of my...Mlen. far.h. ii. 
AUSTERITY-austerity and single life.Mil.N.D. i. I with such ansterity as 'longeth. Taming of $\$$, ir. 4 before An trom our cousim Austria $\ldots$ ill shel, i. I

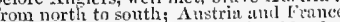

o tustria! thon dost shame that blood

A A the leses. dewree, stand iu anthentic plate. aUTuths authentic anthor to he coten know the grounds aud authors of it ... where is any anthor in the workd ...Loe's L.L. the author's of these women ... our humble author will continue.2.ienry IV. (epij.) of anthors tinithtiny

our bending anthor liatb pursued..

列 as trutli's authentic author

hut at the author's drit't

as if a man were author of himself .. Coriolinus, v. I should be anthur to dishonour you!. Titus. fad. $\mathrm{i}$. tell you what miue anthors say..Perictes, i. (Gower) violent nuthor of his own just rumove

ITHORI'TEs-his rewarls his anthorities - iv. and re-deliver our nuthorities......hea.for Men. iv. 4
must fill out to him, or our anthorities.. Coriol. ii. 1 when two anthorities are $11 \mathrm{p}$............. still would momage those authorities ........ Lear, i. 3 thy speech serves for anthurity ... Tirelfth Night, Witls full line of his authority
drest in a little brief authority

becisase anthority, though it errlike

for their robbery have anthority

for my suthority bears a eredent bujk

save base antlority tron olhers'. Lo

0 , some anthority low to proced

if law, anthority, and power deny

Wrest once the law to your autho

by his authority he remains here

it is in mine authority to command.. Wiat

great anthority; close with him

in any breast of strong antliority

to bim, and his usurped anthority

on the winking of anthority

your soverei,rugreatness and aut

I gave hold way to my anthority

a man of great authority in Frau

neither in

in sulsstance, and authority, retain.

of such grcat autlority in France.. Hesry $r$ r. iii.

that hath anthority over him

on all sides the antherity allowed.. IIenry HII. ii.

cannot carry authority so wcigh

bifold authority?

'gainst the authority of manners

What autlority surfeits on ...........

or let us stand to our anthority

rather discredit my authority

if our eyes liud anthority, here ....

authority melts from ne ...........

my anthority shall not see thee........

faiu call master. What's that? A

hy his anthority I will proclaim it
might th behold the great innge of auth

power and corrigible authority of this

AUTIYURIZED-winter's fire, authorized.Macb. iii.

e call him Autolyei

AUTUMN-the ehilding antumn.Mid.N.Dream, ii.
in the end ot autumn tumed to ....Mer. of Ven.

when the clouds in antumn crack. Taming of $S h . \dot{i}$.

foemen, hike to autumn's cor

an 'twere a cloud in aut unn....... Truthes 8 Cros, i.

ay, and fur laying autumn's dust ......... Lear, iv. 6 V.IIL $-0 f^{\prime}$ this can she avail?. . Mea.for Mea. iil. I

ror your avails they fell: to-morrow ${ }^{-}$' since arms a cail not, now that ........ I Lenry $V 1$. i. 1 will it best avail your majesty .......... Iacbeth, iv. 3

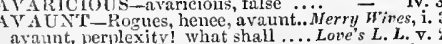
avaunt, perplexity! what shall .... Love's $L . L$. . . avaunt! and quit my siglit!

John, iv. 3

Wou hunt-counter, lence, avaunt....2 Henry $I$

[Col. Knl.]-dogs! avaunt, you chllions.. Hen.

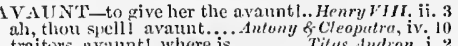
avaurit, thou damnerl door

avatint, rou curs! Be tlyy muth

Lear, iii. 6 Taunt. be gone! thoul hast set me on...

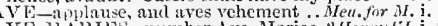
IVE-A AliEs-number Ave-Mari

Avr Ave-Mlaries with our beads?...3 Henry $I$. ii. AVENGED-not live to be avenged... 2I Ienry VI. i. 3 but thou wilt be avenged on my....Richurd III. i. 4 twenty wounds be well avenged ...Julius $C$

and be uvenued on cursed Tamora. Tilus Andrm. v. I VVERIING-averring notes of chamber... Cymb. v. 5 VEP'T-avert your liking a more worthier, Letr, i.
VOID-well tome; avoid; no more ...Tempest, if. that you might avoid him ..........Merry lie camnot by the dnello, avoid it.. Twefth $\overrightarrow{N i g h l}$, iii. s le will avoid your accusation..... Mea. for Mcca. iij. for either he avoids them with.... i. him red, that would avoid dispraise.. Love's L. Lost, iv. no wise remerly how to avoid it ...As you Like it, $\mathrm{i}$. 1 been all this day to avoid him

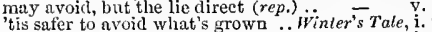
let us avoid. It is in mine

Sutan, avoid! I charce thee.. Comedy of Errors, iv. 3

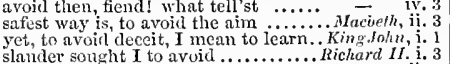
no shelter to avoid the storm

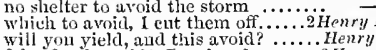

false fiend, avoid! Lay hands upon...2 Henry $V t .5$.

because he would avoid sueh bitter..3 Henry II. it.
avoid the censures of the carping .. Richard III. ii

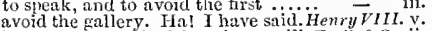

how may I avoid, although my will. Troil. \& $\mathrm{Cr}$.

no place for you: pray you, avoid

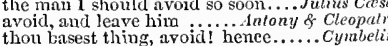

and did avoid a puttock

hapce, and avoid my sight! ...........

out-Herod's Herod: pray you avoid it ...
what's past; avoid what is to come
AVOIDED-men else I have avoided thee. AIa

siuee not to be avoided it fillis

what eamnot be avoided, 'twere childish
true, when avoitled grace makes .. Richar

it cannot be avoided, but by tlus ( $(\mathrm{rep}$.)

what can be avoided, whose end is.JuliusCasor,

VoDDING $\rightarrow$ avoiding, fortune's ualice. $3 \mathrm{H} . \mathrm{VI}$. iv.

if the duke avoudh the justice of...Mea. For Mea. iv.

aud in the stocks avouch it...Winter's $T$. iv. 2 (song

bid my will avouch it; yet............. Macbeth, iii.

avoueh the tholnghts of your heart........

if you'll avonch, 'twas wisdom .. Troilus \& Cres. ii.
I dare aveneh it, sir; what ............. Letr, ij.

without the sensible and true avouch of.. Hamlet, $\mathrm{i}$.
A VOUCHED- prove what is avouched .... Lear, $\mathrm{v}$. this avouclies the shepherd's son.. Winter's Tale, v. this avounches the shepherd's son.. Winter'
AVOUCIMENT-testimony, and witnes

Avow -I dare uvow (and now I ....... Henry IIII. iv.

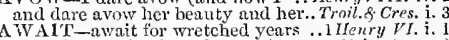
what ficte awaits the duke (rep.).2 He.r.IT. i. 4 (naper) thou hast sleit well, awake

why, hrw now, ho! awne?

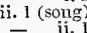

if he awake, from toe to erom

being awake, enforce them
if I did think, sir, I werc weil awa......
master ford, awake; awake.......Mer...

to awake your dormums valour.......

I will awake it anom.................. for $\bar{M}_{\text {net }}$, $\mathrm{ii}$.

tell him, he must awake .......... - iv. 3

now will he lie ten nights awake ....... Wuch Ado, ii.

so awake, when $I$ ann gone

if you live, good sir, awake......

will canse Demctrius to awake ....... -

why then, we are awake: let's follow
awake, sir; if you love the maid.. Tuming

with the clamour keep her still awake of $\mathrm{sh}$. i.

but what your jealousies awake... Winter's Tale, iii. 2

being noy awake, I'll queen it no.....

awake! awake! ring the alarum-beli...Macbeth, y.

awalcel awat awake! shake of thi

We inlist a wake endeavour for tlefence....John, ii.
he will twwake my merey, which lies dead - iv.

awakes my conscience to coufess ........
W A K E-death itself awnkes ....2 $\mathrm{H}$ nry $\mathrm{I}$. iii. $\mathrm{I}$

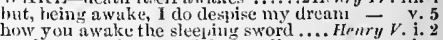
awake, awake, Englisi nohility?,.... Ijenry $Y I$. $\mathrm{i}$. there awake God's gentle-sie ping... Richaril11. i. 3 awake! and thiuk, our wrongs (rep.) .. - v. quict untroubled soul, awake, awake! . - v. 3 now. Trojan, he is uwake $\ldots \ldots \ldots . .$. - i. Icetur, thou slecp'st; awake thee! ... $\quad$ none, awake your dangerous lenity... Coriol, iii. will aw ake him, and be sure of him...Jui.Cresur, i. awalke, I say; what Lucius! $\ldots \ldots . .$. ..

and awake your senses, that you may sirs, awake! Clatulins! The strings meins, awake. Hy lord! Dat thou wake, awake, sir; speals to th ....... and ery myself awake? that's false.

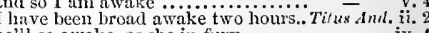
they may awake their helpy.

and will awake him from his melaneholy

- iii. awake, and tell thy dream ........... - v. he's scarce awake; let him alone ........ iv. 7 awake, as from a pleasant sleep ... Homeo of $\overrightarrow{J u}$ l. iv. i

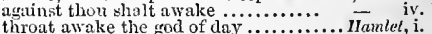
roughly awake, I here prodaim ........... v. ve 2 aWake the snorting eitizens with the bell.omello, i. we have very o.ten awaked hin........... I wonder, if Titania be awaked...AR.d.N. Drenm, iit. and woukl not be awaked ............Mer. of Vere. v. his equal had awaked them ............All's I' $e$ ell, $\mathrm{i}$. our knoke awaked the sleeping rheum ............. Richart 11. i. 4 awaked you not with this sore....... Richar $\vec{d}$ III. i. 4 timorons dreams was still awaked . Wimon of $A$ iv. ii. 1 rend the garboils she awaked ....Aniony \& Cleo i. 3 I offererl to a wakeu his regard for .. Coriolanus, v. AWAKENING-of her a wakeuing . . Rom. of Jul. v. nourish the cause of his awaking. Winter's Tale, ii. 3 AWARD-the court awards it (rep.).Mer. of Ven. iv. and award either of you to be ...... Richard IIl. ii. wrench awe from fools ..... Measture for Measure, i. 4 awe a man from the career of his .... Mnch Ado, ii. 3 the attribnte to awe and majesty.Ner. of Venice, iv. that doth with awe and terror.........2 Henry $I V$.iv. creating awe and fur in other men ........ - iv she holdeth thee in awe .............. i Henry $r$ r.i. Frenchmen might be kept in awe? ..2HenryVI.i. domestic awe, nigitt-rest, and ... Timon of Alhens, iv. keep you in awe which else would feed ...Corint. i. live to be in awe of such a thing.

shall hone stand under one man's awe? - ji. I to keep her still, and men in awe. Pericles, $\mathrm{i}$. (Gower) thy free awe pays homage to us.........-lamtel, iv. WEARY - I am aweary of this moon.Mid. $N . D$. v.

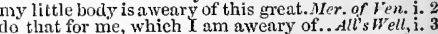
I begin to be aweary of thee............... not an eye but is aweary ............ Henry $\mathrm{I} Y$. iii. 2 are you aweary of me? 0 Cressidai. Troil. . . Cies. iv. 2 I an aweary, give me leave awhile.. Rom. o s / $/$ ul. ii. 5 AWED - created to be awed by man ... Richard II.v. 5 awfin! rule, and right supremacy..Toming of Sh. v. 2 to pay their awful duty to our ..... Richard Il.iii. 3 justice from your awful beneh …....... $-\bar{v}$ v. not to grace an aw ful priuce from sceptre.2Hen. AWKWARD-nor no awkward elaim.. Heary $V$. .ij. 4 by awkward wind from England ...2IIenry VI. iij. 2 rifliculous and awkward action .i.Troil. \&. Cres. i. 3 to the world and awkward casualities...Pericles, v. I Unt with awl [Collier. Knight-all]..
AWLESS-the awless lion could ...... King John, i. I upon the innocent and awless tluroue... Rich. MII. ii. 4
A-WorK-for tlat sets it a-work ..2Henry $\mathbf{W}^{\prime}$. iv. 3 set a-work by a reproveable badness .... Leur, ii. 5 eyed awry, distinguish form ......... Richard 1. i. ii. 2 looking awry upon your lord's......... $\bar{H}^{*}$ ii. ${ }^{2}$ merely awry: when he did lore..... Corialanus, iti. vour crowa's awry; I'll mend it...... Ant. \& Cleo v. 2 their eurrents turm awry [Kal.-away]. Hnmet, iiv. is the axe apon the block .............. of ven. iv. 1
not the haugman's axe, bear half...Mer. of ven. 


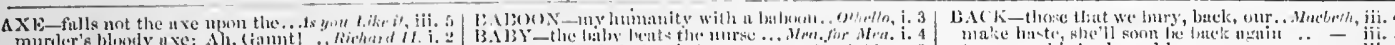

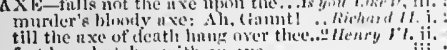
政

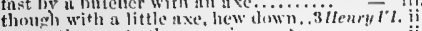
we set the are to thy usurping rot

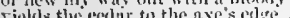

riekls the ecelar th the

二 $\mathrm{iii.}$

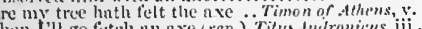

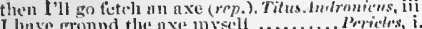
ent'st my hend cot' with a golden uxe. Re... of Jul. jii. let the giveut axe tinl

not to stny tlue grinding of the axe......... $\bar{t}$. strony as the axle-tree on which $\because$ Troil. \& Cres. $i$ i f 1 - the perpetnal wink for aye might. Tcmpest, ii. tir aye thy foot-licker

tor aje to be in slualy eloister......Mid. N.
to protest, for nye, ansterity and single

itiul aye ape

iud homur I for a ve nllow.

tri feed fior aye her lany? .... Troilus

and live aye with thy name? .......

tim mink vost Neptune weep for aye

that learnet elrarty aye wears. Perwes, v. 3 (Gower)

hit my king ant master aye gond-night .. Lear, $v$.

this world is nut for aye................ In meted, jii.

I\% 1 is-the azure vanlt set rouring ... Tempest, White aml azure, laced with blue .... Cymbetine, ii.$$
\text { B. }
$$

3.1-pronf will make me ery hn. . Two Grn. of Vir. i. 1

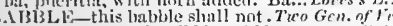
政

ing

1.1]:1?LED - a babbled of green fields... Menry '

B.11313LI Y YG - make the babbling gersip. Tuel.

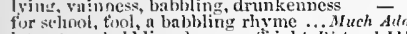

lit not our labbliling dreanis a firight. Richard 11

n lomg-tongucel bafibling gossi

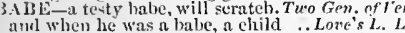

balkes luth judgement slanw (rep.) .. Ant's $W^{*}$

an routh, and woo not

amd a foodly babs, lusty and like. Finter's $T$,

dares trust me with her little babe

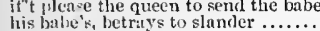

look to your balie, my lord

eme on, poor babe: some............

come, poor babe: 1 have heard

the thrower-ont of my poor babe

liteous plainings of the pretty babes. Com. of $n$

like a nakerl new-born babe

timger nt' a listh-strangled babe

his wite, his bnbes, and all

wile rul bahes, havaly

matly think, a bulse of elouts ...... King Joh

mothers' moist ey'es balies shall snek.1 Henry

his mane the mrithers still their bahes

in the mouth of every sueking babe.

as looks the mother in her lowly babe - iii.

nor more will their babes ..........2 Henry

upon the lips of this sweet bahe ........
to slay that bahe, and the most ..... Richerd Jul

those tencler babes, whom env

ali my tender bahest my tonblown

inlr mecer with two tair bahes

think that thy babes were fairer

mike labes were destined to a finirer

spare not the babe wluse dimpled..

or

the king, he takes the balie tol lis ...... C. Bmbelin

foint notling liur a babe [Col. Knt.-bribe] -

iii. 3

to bring her bale asleep..........

the erving labe entrolled with thi...

even thus he rates the bate

knows them art the empresg hala.... -

loss of maitenhead in halge is monla!erl - - iii.

a inore blust' rous hirth hud never bahe

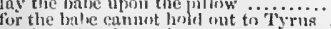

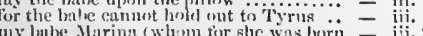

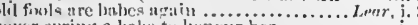

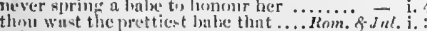

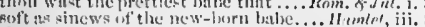

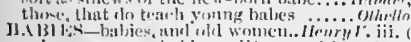

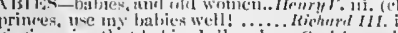

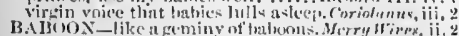

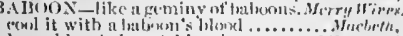

lang him, babom! his wit.............. thenryl

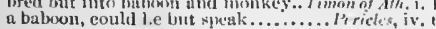

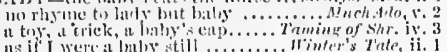

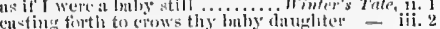
protest une the bulw of a rirh............ Nutheth, fii. 4

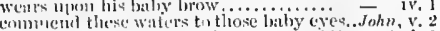

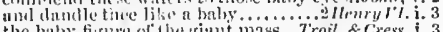

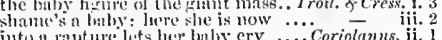

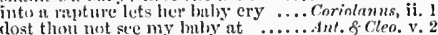
I am no balsy, 1 , thit, with base... Titus dutron, v. 3

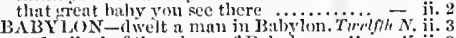

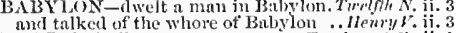
BACCARli-paceare! yot are.... Trming of Sh. ii. 1 BACCLANAL-the tipsy Bacelamals . Mit. N. D. y. 1 BACCIU S- dainty Paceluts gross . Jores $L$. L. iv. 3 BACHELOR- lismiss, bachelor hoves Tampest, iy. I if the mum be a bnchelor, sir......... Mere, for Wea iv.

never gee a bathelor of threeseore ..... Much dido, i.
I will live a bachelor

he shows me where the bacliclors sit

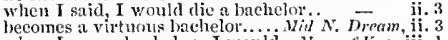
when I was a bacliclor: I wonld.. Mrr. of Fen. iii. 1

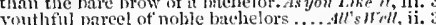
me ont contracted bachelors........ in in? n. II. iv.

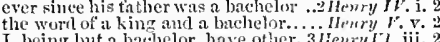
I, being but a havhelor, have other..3 Iremry It. jii. 2

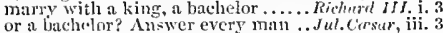

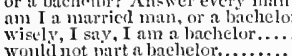

marry, hachelor, her mother is .........Rom.. . Jul. i. 5

the tirst fruit of my baehelorship..., I Itenry 1 I, v. 4

BACK-sighing hack nanin

measure us baek to Naples?.

break my baek, than $\ldots \ldots \ldots \ldots \ldots \ldots$ - ii. $]$

on the bat's back I lo fly ........... v. 1 (song)

to eall her back again .....Two Gen. of lerona, i. 2

my penanee is, to eall Lucetta back.
bere have I bronght lim baek agitin

Thurio give baek, or else .......... - v.

when gods have hot hacks.....

the fane will baek descend ........... $=$

like Arion on the dol phin's baek... Tuelfth $\mathrm{N}$ ingt, i. 2

I conld hardly entreat him baek

buek you shall not to the loouse...

take, and give back, affitirs .......... - iv.

may eall it back again

gentle my lord, turn back (pep.
whose baek witl ingots bows

or elothe a back, from such.

lives behind the baek of such ......... visch $A$ do, iii.

there, Leonato, take her hack again.

brought with armel men back to

on a dnlphin's back, uttering such.

keep hack the clamorous owl

to $A$ thens will I bear my tolly back.

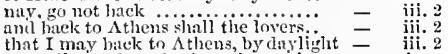

maly all to $\Lambda$ thens bnek ggain repair - iv. 1

carried the town-mates on his back .. Lam 's $L . L$. i.

fair, I give you bick again ........... - ii. I

that ever tiuned their backs to mortal

anter linzard baek ngain.... Herchan

surver the inseriptions

of late so huddleel on his inack........

behink lier baek

do not draw baek your latm

lay sleeping nn lis back

twice difl he turn his taic

I must bear answer back

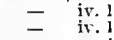

urge her tir a precent a

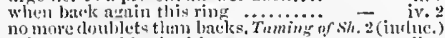

skiplyer, st:antl back: 'tis nuc

eomes with him on his buek

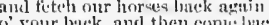

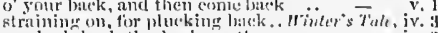

or plutek meck thy lusiness there .... - ir.

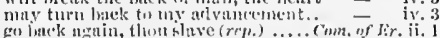

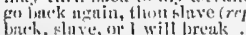

the liours coune batuk!

a' turns lantk fir very feur.

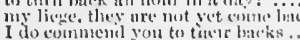

make haste, she'll som he bask $n$ wal ... - iii.

but get thee brek, ny soul

(1)

jirthrights pronel]y on their lincts .. - ii.

kliall not drive me back, when

stand hack, lorr salishury, staini buck

gladl pardon me I will not latek

minst I back lyseause that Jolu
the lords nre atl eosne latek ...

muybreak his finning courser's iack.

and both return back to their chairs:
save haek to Lngland, all the world's

beats lnek the enyjous siege

a keeper hack of deat $k_{\text {, who gently }}$

being plueked from ot their hack

shull we eall bacis Northumberlain

Northumberliand comestraek from

on the back of such as have before

that Bolinglroke was on his lnek!

proud man, that did usury) h

and he eame baek fiom linverisi...

you care not w'lo sees rour liok

cane at mot back, and let lrive at ine

and send lim back agair to my mothe

the money slall he prirl back nian

a dozen of shirts to your baek

paid lnek ngain. I to not

bring romr luggage nohly on yuur ${ }^{2} .$.

turned me brek with joyful tilli

of those that turned their backs........
und send you laek again to your mater

eall lim litek again........
he leaves liis back unarmed

eomes the kin: back from wales

thousnde reasons holn me hack

pou knew 1 was at sour liack...

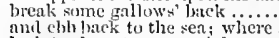

lonk back muto your mighty
and bring you liaek, elaimin

and bring you liaek, eliaiming.........

full intent b:ek to our broli

turn thee back. and tell thy king...

mistress shrewdly shook sour back

once more back a fain; and he thit
strajght back again to france.

with my armour on my back

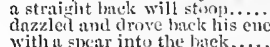

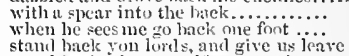

stand back you lorels, and give us loa
stand back, thou manitest conspiratos

not slar thee, but l'll drive thee back
drives baels our troops.

leam thine aged back neininst

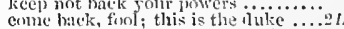

she bears a dnke's reventmes on her lack

toward I ondon, back ag gain, to look
from henee to mison lonsk ngain.

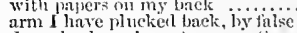

drove back a gain unto my native.

the tempest beat us back, I stood ....
let them lireak yomr hacks with burden

but now is Calle Iriven back .......

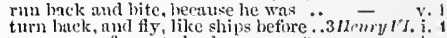

your mess of sons to baok you now?..

that sets his foot upon her back ......

an envious mountain on iny back...

to keep them back that eon

and beat him back agrain

for blood thou ne er mut'st

some weight, or brenk my biuk .......

my lorel, stunel hack, and let....

I'll brek to the dnke of labster.....
go baek again, and I will send you

lonk back, nut pry on erery side.

lowle buck, defend the, here are enemies

wook back with me. om the the Towe.....

unresolven to bent them lane

power hen, to broke their lare

ceremony it' bringing bark the prisis....

I kutw yentr bask will bear a duejess

mulim, you are calles baek

to cull lutek her apreal

thout the giving loark the great seal.

come hate: whut nean yoll? (reperated)

when they pass hack tirim ............

whe turit not lmok the silks

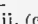


B.ACK-and renders Lack his figure... Froil. $f$ Cre
a wallet at his baek.................. pats back leave-taking, justles kads o' gravel i' the back, lethargies is ominour; therelure, come baek .

with the sleeve, laek $t$ s the dissembling mast not break my liak, to heal. Timon of the fool hangs on your back nlready.

when my indispositim put you back

let me look back their thes

rather than reuder hack..........

as we de turm our backs from .......

and wonld serid thein bek the plagrie

somn we shall drive back of Aleibiales

do lack resive the flower of all .....

Titns Lartius, nust to Curioli haek.

be delivered back on good eonditi

stanil, and go back. You guari like

therefure, go back (repeated) ........

baek, thint's the utmost of your (rep.)

for keeping your greatness

unjust, and spurn me baek ............

a hetter witnes back than worls .....

he then unto the ladder turns his back

ne'er looked but on my baek
never shall turn back, for I wili slay
thou shalt not back, till I have borne

pause till it come back to me

a tool that brought my answer baek.

him there, these people at our baek.

ensign here of mine was turning
le came not baek: he is or ta'en.

the hand eould pluek her back.

carry back to sicily much tall youti

and bear back our targe undinted

sure be eannot weepit back again ...

I will employ thee back again
looking back on what I have left

sent our schoolmaster, is he eome b
cet thee baek to Ciesar, tell him
let us score their baeks, and snateh

and o'er green Neptune's back witlı..

they showed his back al

what have I kept back? ...............

goest thou back? thoul slinit

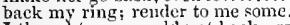

I thought you would not back again

if you'll baek to the court.

I'll knock her back, font her home

and but the backs of Britons
but to look batk in frow'n.

and I'll soon bring her back. ....... Tit

not be denied: sweet heart,
thy sons to baek thy quarels

do not draw baek, for we

whilst she playeth on lier baek

to the rery baek: yet wrung

ruturn those back as are righ

to turn thy hated biek npom $\ldots . . .$.

eall the clot troll beic

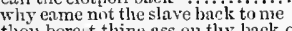

thou borest thine ass ou tlyy back ore

aud not gend baek my mestenger
who hath had three suits to his back

the foul tiend bites my back....

hack, Elinund, to my

so suddenly gone back

strip thine own back .................

i will back thee. llow? (rep.)

when mairls lie on their baeks

turn lack, dull earth, anil find

that fall baek to gaze on him .........

forgot why 1 dicl eall thee back

driving back shadows over lowering hills -

ms hack o' t'other side,-O my baek! (rep.)

the furious 'Tylualt back agtain

take the rillain lack agai

but by and by eomes baek to Rome..............

thas new snow on a raven's back

back, foolish tears, baek to your native

and eall thee bick with twenty hnndred -

that he dares ne'er eome back ......

prite, being spoke belind your liack.. upon thy baek hangs rayged misery

is empty on the back of Mlontague

yesternght returned niy letter bael:.

if praises may go back again ...............

should have a back, or second.............

right welcome laek to Denmark........

Tho brings back to him, that you atten

when I came baek, (for this was brief)...
BACK-I pr'y thee, eall him back (rep.).. Othello, iii. 3
I do beseceli your lordship, eall her baek - iv. I I do beaent tor

? 'tis a lost fea

BACK-BITE-knares, and will bask-bite.211.LF. v. I

BACK-BITTEN-thuy are baek-litten F- v. I having found the baek-door open.... Cymbetine, $\mathrm{v} .3$

he means, baeked by the power ot ...3 Henry $V$

wben tis backed with Frane

and Buekingham, backed with.......hichrord III. iv. 3 it is backedl like a weasel.

BACK-FlRI END-a buek-tricind.......... Hamedy of Er. iv. a

B.ICKING-eall Fon that backing (rep.).i Hen
baeking of the duke of York....... 3 Henry

Bick-1 to kn-till Jarry's bnek-retnrn

9 BACKSIDE-went the backside the towi... Cymb. i. 3

iii. 3 BACK WARD-the dark baekward.

his backward voice is to utter...

what is wotld spell him back ward.. Much Ado, iii.

that Dobbin's tail grows baekward.Mer. of

2
$\mathrm{v} .2$ you go so much baekward ..............

doth baek warl pull our slow designs..

demonstrate them now but goers back ward -
and beat them back ward lome $\ldots . . .$. ...

when the English measured back ward.....John,

whose mind is baekward now $\ldots$............ Henry $V$. iv. 3

an' you draw back ward, we'ii puit....

that will fly with his face back ward

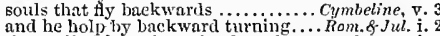
thon wilt fall baekward, when thou (rep.) - i. if, like a crab, you eonld go baek wart... Inamlet, it.
do ther re-stem their lnekward eourse.. Othello,

do they re-stem their baekward eourse.. Othello,
BACK WARDI, - loes he think so backwardly.

back-wounding ealumny .... Timosure for Men. iii

BACON-hang hog is Latin for bacon.. Herry $W$. iv.

I have a ganmon of baeon, and two.

on, baeons, on! what, ye knaves?
BACON-FED-baeon-fed knaves.

$B \Lambda D$-good womls have borne bad sons... Tempe

to eall her bad, whose.

so mueh of bad already ......
harsh, untunable, and bad

prevents a bad marriage ...

it were a bad recompen

your bad entertainure
onc that serves a bad

to make bad, gool, and good provoke

for being a little bad: so may

and, with his bad legs, falls into

his bad voice hode no misehief

which is as bad as die with tiekling.

an' bad thinking do not wrest. ...

for whieh of my bad parts didst thou

else your memory is bad, going o'er. Love's

there I have another bad match

the enckoo, by the bad voiec

the tree yields bad fruit

As you Like it, iii.

among nime bad it one be good...All's irell, i. 3 (song)

to produce so bad an instrument.

even as bad as those that rulgars ... Finter's $T$. ii. of good and bad; that make ....... $\overline{-}$ iv. (ehorus) did I tell him it was vile and bad

those that would make good of bad.....Macbeth, ii.
things bad hegum, make strong ........ iif.

bad world the while! this must

KingJohn, iv.
Richard II. $\mathrm{i}$.

and ton bard to live; since...

Richard $\mathbf{i}$ i.

doubly divoreed-B;

overfow of good converts to bad $\cdots .$.
rebellion hat ball $[$ knt.-ill] luek $\ldots 2$ HenryIV.

is as bat as to smell a fox...........

the king hath run bad liumours

but his few bad words are mateh

for our bad neighbour makes us

letters full of

not half so bad as thine to England's.2IIenry $V I$.

so grod a quarrel, and so bnd a peer

so bad a death argues a monstro

Henry $r$.

counting mysclf but bad, till i. .

no news so bad abroad, as this .....R R

Which renders good fior bad, blessings

bal is the world; and alt wili.

when sueh bud [Col. $K n t$-ill] iealing

gnod news or load, that thoul (repeated

no, to their lives bad friends were $\ldots . .$.

slept upon this bold had man .......Henry

now good, or' bad, 'tis but the
sans eheek, to good and bar..

sans eheek, to good and bar..........
of good or bad unto the general

nor fear of bal suecess in a bad cause

thut art too bad to enrse....... Timo

thonst not paint a enr

brafe death outweighs bad life ....... Coriolanus, $j$.
B.AD-gomd, or bad? Not neeording to. Coriolanus, ii. 1
is as bad as that whicls he dislikes... is, indeed, sir, a mender of bad soles...Jul. $\bar{C}$ ersnr, $\bar{j}$. I and receiving the lad air. But, suft.

that oureh erentures

or his bad verses, tear him tor his bad

the nature of had news infeets..... Antony \& Cleo. i. 2

the good and bad togrether......

for so bad a praver as his was

a thing too bacl for bad report

to lose so bid employnient

from one bad thing to worse $\ldots \ldots \ldots$

in a bad yuarrel slain a virtuous son.

bad thather! to entice his own..... Pericles, $\bar{i}$. (Gower)

you were not so bad, as with foul .... - ii. (Gowe.)

tortume, tired with doing lyad...... $=$ - ii. (Gower)

are yet so bad as thou art ................ $\overline{\text { Lear, ii. }}$ i

it is too bad, too bad. Yes, madam ...... Lear, ii.

bat is the trade must play the fool ...... ${ }^{2}-$ iv.

it was barl enougl, befure their spite - iv. 1

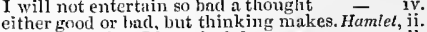

you were better have a bad cpitapl1.... -

thus bad begins, and worse remains.... - iij.

be advised he eomes to bad intent ....... othello,

not to pick baul from bad; but, by bad.... -

BAD-CAUSER-the bad-causer worse. Rich.III. iv. 4

who bade you eall her? ....Two Gen. of Feronn, ii. 1

love bade me swear .............. - ii. 6

earried mistress Silvia the dog you bade $\overline{\text { ive }}$ ive bade me tell rour worship. Merry

the lady bade take away the fool... Twelfth Night, i. 5

sir, I bade them take you

I bnde you never spenk again of him $\quad$ - ii. 1

he barke me store up as a triple.........Alt's Well, ii.

when I gave it lielen, I bade her ....... - ing of sh. i.

he loves (he bade me say so)...... Winter's Tale, v.

nor bade farewell to him

he bade me, from him, enll

your lighness bade me ask...

tempered thee, bade thee stand un

you bade me ban, and will you

and barie me be ndvised!

- ini.

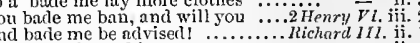

I bade them, that did love their....... - if.

you, he bade attend him here ..... Henry $V^{\prime} \bar{I} I$. jii.

he bade me take a trumpet .. Troilus \& Cressida,

1 bale the vile owl go learn ...
Hector bade ask. Whieh wa

but barle me not commend ber

spite of cunning, bade lim win ali $\overline{\text { pulius }} \bar{C}$ asar,

that bade the Romans mark him

bestow these papers as you bade me... - i.

being prostrate, thus he bade me say .

tell me of you, bade me trust you

for so he bade me sny ........Titus Andronicus, iv. done his sacrifice, as Dian bade.Pericles, v. 2 (Gower) my young lady bade me (repented) .....

that Romeo bade thee feteh

a madman's merey bade thee run awa

ary sionify Hamiet, v.

very moment that he hale me tell it .... Othello, $i$.

revenge being nigh, bade her wrong stay

bande him anon return, and here speak

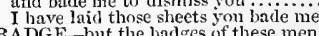

ADGE - but the badges of the

without a badge of bitterne
bearing the balge of faitl t
blaek is the ballge of hell

.......Much Ado $\mathrm{i}$.

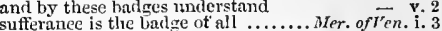

the badges of his grief and patience... Richard Il. v. 2

whieh is the balge of pusilianimity..2Henry 17. iv.

took exceptions at this badge $\ldots . . . I$ Henry $V I$. iv.
that he wears the badge of Somerset...

me with murder's erimson badge ..2̈Henry $\overline{V I}$, iii. 2 thy householl badge (repeated) ......... - ve Andron. i. I

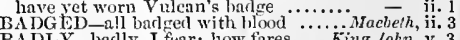
BADGED-all barlued with blood ........Macbeth, ii. 3
BADLY-badly, I fear; how tares ....King John, v. 3 set a-work by a reprovenlld badness....... Lear, iii. 5 MiDEST -and, as thou baxlest me ......... Tempest, i. 2 and badest me bury love ........ Roneo \& Juliet, ii. 3 a lamb, indeed, that baes like a bear. Coriolanus, ii. BAFFL_-I wiil baftle sir Toby ...Tuelfh Night, ij. 5 eall me villain, and baffle me........ Hen Hy $\mathrm{H}$. i. 2

impenched, and bafled liere.......... Richurd II. i. 1 BAG-I bave a bag of money here ....2Hery Jives, it. 2 
;A(r-or sumns in wciled bars

n hich ge pudding? a lan of haix

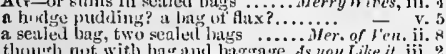

moul thut lis butes shall wrove

the enemy with bag and baggaga... Hinter's Trule, i.

detiy the bar of yola

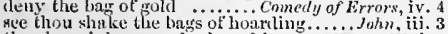

the cleryy's bags are lank anl lean ...

here is the bag of goid

tie my treasure up in sitken bags....... Pericles, iii. 2

entreasured with bags of spices fuli!

your dauthiter, and bags.......

Lecar, ii. 4

then luat up your pipes in your bag

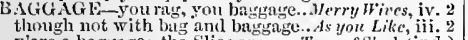

y'are a bagrage: the slies arc.... Tamof $\$$. $\$$. 1 (ind.)

thou baggige, let ne in....... Comedly of Errors, iii. I

that lay with the little baggage..........

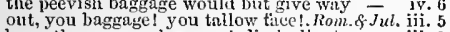

hang thee, young baggrage! disohedicnt
BAGOT-ourself, and Bushy, Bagot lere. 23

ly Bushy, Bagot, and their complices.

call forth Bagot: now. Baggot, frect

Bagrot, forbear, thou sizalt not

B.1GPIPE-baglipe singsi' the no.

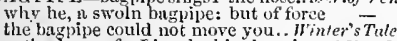

I F thedrone of a Lineolnshire bagpipe. 1 Heal IV. $\mathrm{i} .2$

B.IIL-I cry bail: here's a genteman..Mea. for M. iil.

your good worship will be my bail ..

you will not bail ine then, sir

let me bail these gentle three
I'll put in bail, my lierfe.........

I'll put in bail, my liere. . . . .
fetel my bail; stay, royal sir

and that shall bail me: hie thee.

to be your bail, hy Dromio

slinll be their father's bail

here cones Clittorl, to deny their bai

yet let me be their bail

ihou shalt not bail then .................

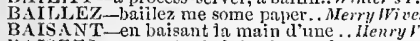
BAISEES-pour estre baisées devant

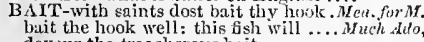

devour the treaclerous bait.

the false sweet bait thant we

to bait me with this tonl
with this melancholy bat

to bait fish withal: it it wili

gay vestments his affiections brit?

yountenelness doth bait myself. . Richurd II. i

young dace be a bait for the
we'll bait thy bears to death.

with cantelouts baits and practis

$[$ Col. $k n !$.$] Brutus bait not$
but worn, a bait for ladies

but worn, a bait for ladies ................
more dangerous, than baits to fish

the one is woundled with the bait

love's sweet lait from fearful.. $R$

BAITED-and baited it witb all... Tuelfin Night, iii.

how hath he been baitedl

to be baited with the rabble's curse.... Antucbeth, v

why stay we to be baitel with on

BAITNG-and here ye lie baiting...Henry 1 III. v.

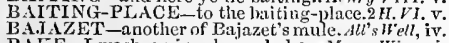

BAKE-I wash, wring, brew, bake... Merry Wiree
in the canldron hoil and bake ......... Macbeth,

and bakes the elf-locks in foul ........... Ro of Juliet,

BAKED-when it is baked with frost .. Tempest

then to be baked with no date....... Tronil.\& Cres. i.

are both, baked in that pie.

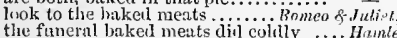

[Knight $]-2$ most instant tetter bukel about

BAKen amd impastel with the parching.. - ii.

BAKER-away to balkers' wives ..... Henry IV, iii.
the owl was a laker's danglter ....... Hanlet, iv.

the owl was a laker's rlaugliter ......... Homlet, iv.
BAKING - the oven and the baking. Trill.\&. Cres. $\mathrm{i}$.

B.ALANC E. - Tensons in her balanee ... Mucit Ado, v.
a mote will turn the lalanee.... Mid. N. Dreom, v.

are there balance lere, to weigh 3 ...Mer. of I ' en. i

hung so tot tering in the balanee

in the baliance of great Bolinghroke. Rishord $I J$ iii. 3

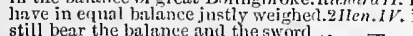

still bear the balanee and the sword

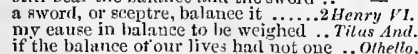

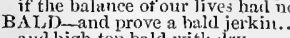

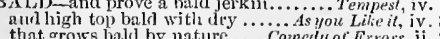

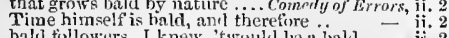

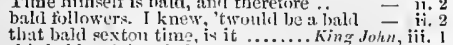

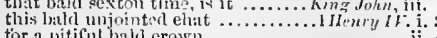

for a pitiful balel crown

lean, old, ehapped, bald slint

a curled, late will grow balld :.....
make curl'tl-pate rustians bali

II $m$ ry $1 Y$ iiti. 2

some anthurn, snme balil

people do with these bald tributin
but they stand bald betore lim.

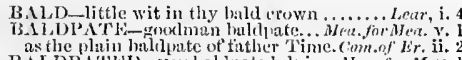

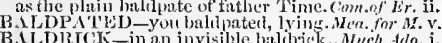
BALE - the one sile must have bale ...Coriolum B.LLEUL -art, and buleful soreery y illenry Vl. ii.

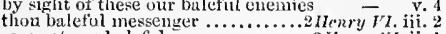
recount uur balefil news
with moss, and baleful mi

the story of that balleful burning night
with baluthl weeds, and precious. Riomeo of

BALK - Knighted balk lugie with... Trtm

BALKED-ballked in their own blood.1 II'cring IV.i.

ALL-witl two pitch balls
rilling on the balls of mine

why, these balls botund
that two-tild balls and

Alit's Well, ii.
it.

that two-tilld balls and treble sceptres, Mracteth, iv.

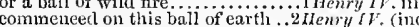

matched our rackets to these balls ....Henry

turned his balls to gun-stones..........

the seeptre, and the ball, the sword

spluru thine eyes tike balls before me. $A n t . \&$

hath male the ball for them
as swift in motion as a ball ...

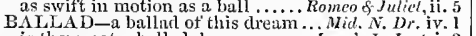

is there not a ballad, boy ............ Love's L. Lost, i. 2

was guilty of sueln a ballad some three

for I the ballad will repeat

tradneerb by odious ballads
ns he had eaten ballads.

I love a ballad but even too w..... Winker's Tale, iv. 3

here; ballads? Pray now, buy (rep.)

and sung this ballad against the lard

the ballad is very pitiful, and as true

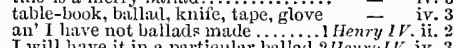

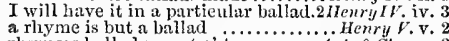

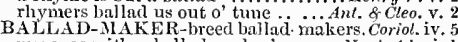
my eyes with a ballad-maker's yen. Much Ado, i. 1
that ballad-makers cannot be able. Winter's Tate, v. 2

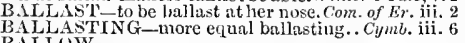
[Col. Knt.]-your costard or my ballow .. Lenr, iv. 6 balm his foul head with

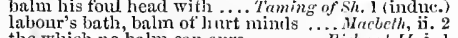
the which no balm ean cure .......... Richered II. i. 1

ewatears I wasli away my balm

be drops of balm, to sanctify.
'tis not the balm, the sceptre.

thy baln washed off $\ldots \ldots . . . . .$.
pity hatl been balm to heal

I pour the helpless balm

instead of oil and balm, ................ ... Hemy Ir: iv. 4

as sweet as balm, as soft as air Richurel iv. i. 8

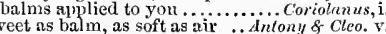

BALIMED-balmed and entreasured............ericles, iii. 2

this rest might yet have balned thy .... Leer, iji. 6
BALMY - to have their balmy slumbers .. Othello, ii.

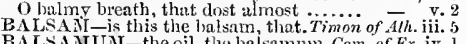
BALAAMUNI-the oil, the balsumum. Com, of Er. iv. 1
BALTHAZAR-come, Ballthazar, we'll.Mruch id o, ii. 3 dost thou hear, Balthacist? I pray thee $\bar{c}$.

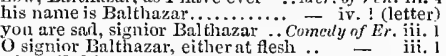

Where Balthazar and I did dine together $-\bar{v}$ v. 1

BAN -asked twice on the lans ...... Henry IIV.

and ban thine enemies, both m
should seem to curse and ban

you bale me linan, and will you

I, her husband, contrantict your bain

with IIecitte's bon thriee blatted .......ilumet iii.

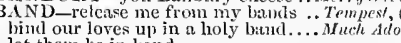

let them be in land

eaptain of ourr fairy bancl...

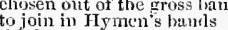

think us some band of strange

chitrse you in the band of the
to turn lim out o the band.

on a band? Not on a band

accorling to thy oath and bant.

gently wonld dissulve the banils

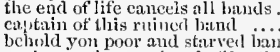

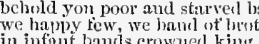

nl infant bands crownerl kifg...... - v. 2 (cho.)

will you le:ul a hand of uen .......

nourish a mighty banel ...

with a band ol thirty thousant? neir

some few bands of chosec soldieri

furth with in holy wediock bands!

revolt in my penurions
hie you to your bitnls..

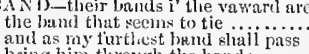

and as my fiuthest bend sliall $\mathrm{I}$
bring him thitough the bands.

mot mustered anung tlie band

all his threatening band of 'Ty

towarcls Rome a band of war
with all bands of law, to our

BANDIED-well handied both
BANDING-and landing thet
BANDITTO-and handitto sla

BANDITTO-and bandifto slave.

to ban- will bandy with the As you I Tle

I will not banily with thee word......3ilenry 1.2.

one fit to banly with thy lawless sons. Tilus 4 nd. i.

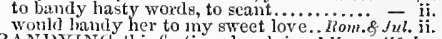

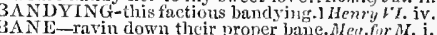

not be afraid of death and bane.

'twill be his bane; he eannot

lest Rome, was the liomans' bane... Cymbeline. iv.

BANED- ho have be hane unto herself. Titus $A$ ind. v.

ANG-you'll bear me a bang for that.J Jul. Cossar, iii.

tempest hatll so banged the Titrk

that banish what they sne for

and banish hence these abject. Taunity $-\mathrm{v}$.

therefore, we banish you our territuries. Rich. M. i.

six years we lonish hourselves.

think not, the king did banish the

as 'trere, to banish their efrects.
banish us both, and send the kin

him keej, with, the rest banis

till then I banisli thee......

good unele, banisli all offence

banisly the canker of ambitious. ...

I banish her, my bed, ant eompan .

the bansh thee for ever (rep.)... Timon of $A t h$. iii. 5

crrrunt my air, I banish you.
still to banish your defenders.

to banish him that struck.....

thou dist injustly banish said 'twas

Leonatus' jewel; whom thou diast banish - v.

BANISLED-thou lonord, but kill me not . Othello, v.

were pou banished thence?

is to be banished trom unself.. Trino rien. of Fer.

banished trom her, is self from self

doth silvia know that I am binished

Valentine is banisherl from her sight

bnt were you lanished for so smal
myself was from Veroma hanished....

because you are a banished man

I bear unto the banished Valentine..
a man disgraced, banisher Valentine

these banished men, that $\mathrm{I}$

my remembrance clearly banished.. Torelf!h $N$.

teach me to forcet a banislyed fatlier.

thy banished tather, haul banished thy

is daughter to the banisbed duke.
when your highness banished him

passed upon her; she is banished ...

your brother that hath banished you.

two of the banished dnike's pages

whose banished sense thou liast.......

whose banished sense thon liast........All's Well, if.
liave banished me from Scotiand....... Macbeth, iv,
O tair return of banished majesty... King John, ii.

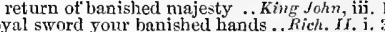

int the iir, banished this frail

firom the number of his banis

thy son is banished upon good

alties and rithts of banished i........

by the robbing of the banished duk

the banished bolingloroke repreals.

why have those banished ant forbiclen.

thou art a banished man, and here art

besides, I hearl the banisherl Norlink say
many a time liath banished Nurbolk fory

your banished howours, and restore. $1 / \mathrm{Hem}^{\prime} I \mathrm{I}$.

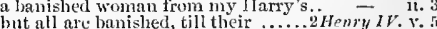

hath banished moody diseontented.i Henry $r$. iii. i

lis lady lanished, and a. limb Inpled.2 Henry $r 2$. if

by the sround that I am bauished fin

to be banisheil nirselt: and banished

thus is noor suttilik ten times banished

a king, beeme a banished man ....3 Lenry $/ \%$. iij. 3

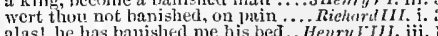

alas! he has banished me his bed.. Henry

I late not to be hanished ......... Timm of Ath

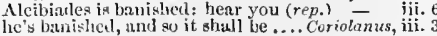




\begin{abstract}
BANISIIED-lmt he is banishet our enemy's lanislacd: he is Emie.

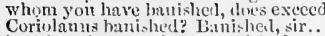
but that thou art thenee banisisel. ... so lated, and so banishecl: but he has go, you that bmuishel him, a mile . when we banished him, we respected not being banishell tor't, le came nuth alakk, good nun! and therefore banisheil his mistress, titr whin he nitwe is banished Leonatus! a bunisined riscen to enjoy thy bantished lort

indecel, a hanisheel man; I kuow not

Belarias wham you anmeti stands my other son, a bruishell min thy other banished sun with this che myself unkindly thanished, the gates Kent banished thus! and Fronee in now, banislicel lient, it than eanst surve why, this tellow hats batis thet two of the porir banisheth mun! thon say'st, the
they say, Edgar his banisheil son

ant liomer banished (rep, ).......... bathished, that one worl - hanilined

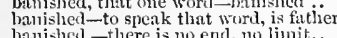
lenec from Verona art timou banished bunished is banithod thom the world but Romeo may not, lie is bisnished.
but $i$ am hanished and say'st thou but banisleed-to kill me; banished? though thou art banisheil. Yet banish whure that same bnnished runagate

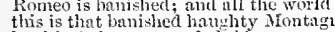
banifhed the new-made bridegroo
\end{abstract}

B.LNISLLLFN'thesty, and not to limishment...ds you the stranger pathls of banishment.... cach other other's love in lanisliment with weleome home from lanishiment
addled years to his slort linnishment added years to his slort linnishment
slatll call him home from buaishument cating the bitter breacl of binisisment my banishmeut repealed, and lands. the sentence of clread bamishment on left me in reputcle ss lanislim thus forward in his banishment

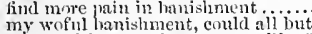

ha! banishment? it comes 11 ot iil.. Timo

for to b,art the banislument of that

healing of our slarcins his thane ant then his bauislument.....
so, followed iny banishment these ehildren upon my banidinent mye everlast ting duom of banishment.
Liteitits banishanent was wrongtully from him, as this of Kent's banishment ditfillences, banishnent of friencl

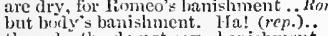

than cleath: (li) not sily-banishment
binfishment is denth mis-termed (rep.)

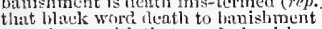

mingle me with that word-banishunen

() thou wijt speak again of banislment $\overline{-}$ B.XKk -sitting on a bank, weening
thy lanks with ne nied nol liticd

liriathes upon a bank of violets..Tireifh Nigh I know a hank whereon ti.

monnlight itceps minon this bink

lipon this bank and slual of time. I'll set a bank of rue

on the gentle Severn's seilg...........

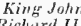

l:1 the lunllow hank blood-stained

Richard II, il.

that rlijicles the banks of Englaud
thrice from the banks of iV ye.......

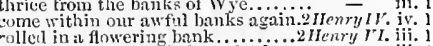
from England's bank drove baek.... Wichard III. iiv.
to ask thuse on the banks..........

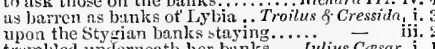
trembled underneath her banks .... Jutlius $\bar{C}$ Cosar, $\mathrm{i}$. draw them to Tiber banks ............. Cymbeline, it.

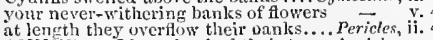
BANLED-28 liave bauked their towns!...John, v. 2 Bankrout

[Knt.] poor trankrout, break at once. Rom. \& J Jul. iiji. ? BANKRUPT - your wit tyankrupt. Turo Ger. of $r$ ii. 4

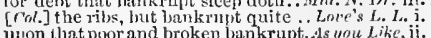
upon that poor and broken bankrupt. As you Like, ii. 1
BANKREPT-a hankminf, a prodigal. M
cut the fortciture from that bankrupt

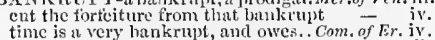
thie ne:st that must be bankrujt sol. Richard 1 il. ji. the king's grown bankirupt, like

bic Mlars seems bankrupt in their..... Henry $r$. jv. bankrupts, hold finst: rather than.. Timon of $A$. iv. 1

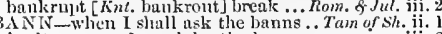
invite, yes nud proclaim the banns... F. pii. 2 BANN MR-the Norweyin banners flout. Nacbeth, hang out our bunners on the outward upon the dnneing hanners of the lrenel...John, ii. 2 I will the bamner from a trumplet tak and nobles bearing hamers, there
our eity with thy bunners syread..

in our ages sce their banme

with concluering banner slusok .....Antony of Clen o.

his lanners silble, trinmed with...I

at point to slow their onen bouncer

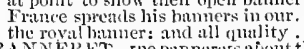

Oilhelt?

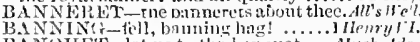

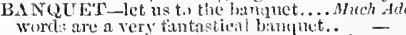

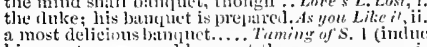

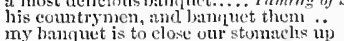

it is a banenet to me ................... Aracteth

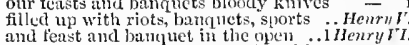

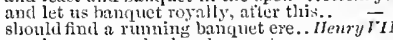

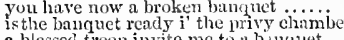

a blessed troop invite me to at ancluet
besides the running bann

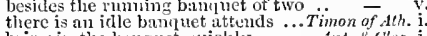

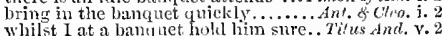

and this the banyuet sle sltall surfeit on - v. 2

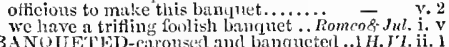

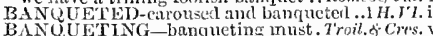

BANQUETING - banqueting must. Troil

$\Lambda$ NQUO-Hacbetha and Bmino? ........ Macbeth, $\mathrm{i}$.

hail iNrebetl, and Banquo! Banquo
noble Bunquo, that hast no less deserved

true, wortlyy Bauquo; he is fill .....

Banquo, and Donalbain! Malcolin

o Banquo! Banquol as our royal master's =

our fears in Banntno stiek deep
for Bancluo's issue have I tiled

kings, the seed of Banquo kings

say, thus did Banquo ........................

it is concluded: Banquo, thy

let your remembrance apply to Banquo

that Banquo, and his Fleance, live

'tis Banguo's, then. "Tis better.

the grnecul person of oul. Bang goud present =

and the right valiant Banquo walked

shall Banquo's issue evereign .......

for the blood-boltered Banquo sniles
I tell you yet again, Banquo's burjed

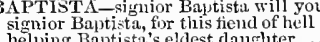

indeed had Baptista's youngest daughter =

her father is Baptista Nlinola ........ is

this order hatth Baptista ta' ell .........

to old Baptista as a schoolmaster.....

to Baptista Minola, I prumised ........
the house of simnior" Bantista Mlinoli?

Baptista is a noble gentleman.

yet erer see Baptista's daughter?
good-morrow, neighbour Baptista.

signior Baytista, my business asketl.

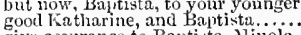

give assurance to Baptista Minole

signior Baytistil mar remember me..

done thy errand to Bantista?

Baytistal; set your eountenance $(r e$.$) .$

signior Baptista of whom I hear so ...
signior $\mathrm{B}$ aptista, shall I learl the way

Baptista is sate, talkin: with ......
help, son! help, signior Baptista ...

help, son! help, signior Buptista!
fallier Baptista, I charge you, see...

take hecd, signior Baytista, lest you

his wife, Baptitista: yout shall sce anon.. Hamle

young maid that yct wants baptisin, llepentrylt

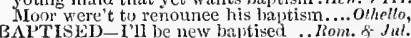

BAPTISED_i'll be new baptised. .Mom.

we will bring the device to the bar.. Treelfth $N$.

any bur, any cross, any impediment... Iurct iddo,

nay, but 1 bar to-night

is no bar to stop the tireign.....

put nars between thic owners ..........
B.AR-with 1 1is hinds, bars me the jlace. As you Like, i.

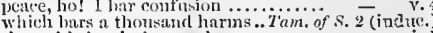
since this $\ln r$ in law makes us .... Winter's Tale, we it thar the titum suecession....

that law bati jis wrong

shunld, or should not, bar is in our

there is no bar, to make against...

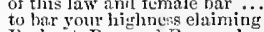

Bralyant, Bar, nut Burgundy

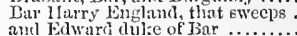

unte this bar and roval interview

a secret gate of iron birs in

and dlite hars agein t me

to bar tuy nuster's heirs in

and fortune, lar me haply hours....

thront tot the bar, erying all, guilty

brouglit atain to the bur, to liear.

it' you cammot lar his access to

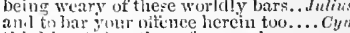

thinling to hat thee of sureesion.

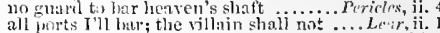

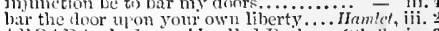

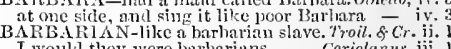

I wonlil they were barbariuns .......
hetwrixt an erring barlanian and

Othrilho, i.

ARBARISII-for barburism spok
barbarism, making me the precede

Picherd or v begin to prelaim barbarism

Troilus 8.Cress. art barbarous intimation! aves...Twelfth $\mathrm{N}$. iv. We will be singled from the barbito ns choke lis days with bartharous ignoranee. Iolm, jv. give ourself to barbarous lieenee ...... Henry $O$ barbarous and bloody spectacle! ..2Henry $\bar{\nu} I$. ah, barbarous villains! hath this lovel

receive 11 for barbarous and ummintral.. Cymb.
wars against the barbarous Goths.. Titus Anthon.

Was ever seythia haly so barlaruns?
thou art a likman, be not barlaruss

aceom art a koman, be not barbarens

nay, barbarous Tamora! for no name

O barbarons, heastly villains!.....

pirates (not enongh barbarous) had not. Pericles, the llarbarous Seytlian, or lie that makes.o Leir, i. I

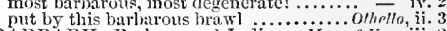
BAIRBARY - Burbary and India ...Ner. of ' V' $\neq$. iii.. 2

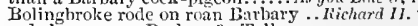

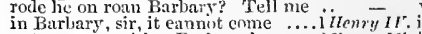
not swarger with a Barbary hen ....2.2 Henry Ir.

Wngerer with him six Barhary liorses
six Barbary horses against six French..

iii. 4 covered with a Barbary horse.

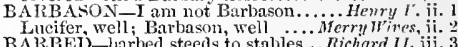
BARBED - barber steeds to stable.... . Richard II. iii. 3 instead of mounting barbed steeds.. Kichard III.
BARBER - firfeits in a barber's shop. Mea. for 31 . seen lim at the harber's? (reperted)...Nurch A Ho, ifi.

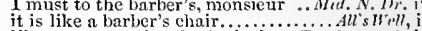
like to a censer in a barler's shop. Triming of sh. for a barber slall never earn ........2Herry BALBERED - barbered ten times o'er. Anl.s-Cleo.

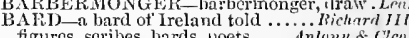

figures, scribes, bards, poets ....Anlony f. Clen I will entertain Bardolp
Bardolylin, follow him ...

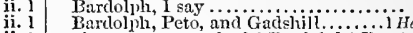

ii. 1 plague upon you both! Barloiph! Y.... Peto!

so did you, Barrlolph; your are lions....

bardalph, am 1 not fallen away viluly

you lie, hostess: Bardiol ph was sliaveil..

Bardolylum - mo lord Go, bear this letter

Bardolph, get thee before to Coventry
that the lord Bardolyh dantl

what news, lord Pardolyth?

better assurance than B:

where's Barlolyllh? He's gone into ....

'tis very true lord Bardoly

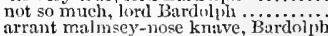

arrant malmsey-nose kn:

keep them oit, Lardolph...................

by the mass, here cones Biardol lit.
and your's, most noble Bartolnth

and yours, most noble Barrolnh

sirrth, Jou boy, and Bardolyh; no word

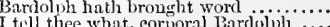

quoit him down, Bardoly l, l, like.

pricked dow u bardolih irrecoverable 
BAR DOLPH-master corporate Bardolph.2 H.W V. iii. 2 a caliver into Wart's liand, Bardolph. on, Bardolph, lene the ments low wow Barlolyh? The army the lord Bardolph, with a great... give me your hund, master Bitrlolph Bardolyh, look to our horses rive master Bardolph some wine $\ldots . . .$. . fie merry, master Burdolpli honest Bardolph, welcome I'll drink to master Bardoli $\ldots$, and to i.... away, Bardolph; snddle my horse. come, Burdolph; I shall be scnt for

good-morrow, licutenant bardol porporal

gnod bardolph, mit thy nose between
Bardulph, he blithe; Nym, rouse thy

saw a tea stiek nyon Bardolph's nose

for Bardwin-ine is white-livered

Barlolylu stole a lute-ense.

Nym and Bardolph are sworn brother's

Baribolph, a solklier firm and somnd ...

Fartmete is Bardloph's foe, and frown

Bardolnh, if your majesty know the ma

Barilulph and Nym, hal ten tim

angears ly their bare liveries

which is mineh in a bare cluristian

lyy the bire scal

from the seedness the bare fallow

therefions, Iny bare your bosom

than the bare brow of a bachelor.
hut his rirht cheek is worn bare

that liare eycs to see alike

I bare home unom my shnulke

meeting were hare without it.

stand bare amd nakerl, trembling

bare [ $\mathrm{Col}$. Knt.-base] and rotten

exceetling poor and bare; too be

exill threc fingers on the ribs, h

Genrge Bare, anil francis l'ickbone.

steril, and bare land, mamirerl

from this bare withered trunk......

C:esar ant his fortune ba

whom with my bare fists .............

but then Theas bare a living loat

our head shall go bare, till ...Troit

especially upon bare firiendship

whose bare unhoused trunks.

show bare hearls in congregations...

it was a bare petition of a state

dawning may bare the raven's eye.
and left me bare to weather.........

thon hast stuck to the bare fortine

and male thy boly bare...... Titus A

but such a ponr, bare, forkel anim

with such a storm as his bare hear

art thon so bare and full of wretchedness

who hare my letter then to liomeo

his quietus make with a bare bodk

rather use, than their bare hands..

wear thy gnond ripier bare, and put it

BARED-to be so bared before his.Med IenryI IV. ii. 4

lave hared iny bosom to the thunder.. Jul.Crsar,

BARE-FACED - will play bare-faced. Nitl. $N . D r$, i. 2
and though I conld with bare-faced... Hacbeth, iii. I

BARE-FOOT-in my bare-foot way . Tempest, ji. 2

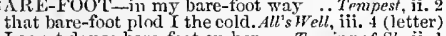

I must dance bare-foot on her.... Taming of Sh. ii.

going to find a bare-foot brother out. $R_{0 m}$. \& $J u l . \mathrm{v}$.

run bare-foot up and down, thren tening. Hamlet, ii. 2

would have wal sed bare-foot to Palestine. Oth. iv. 3

BARE-IIEADED-Alack! bare-headed

turning, bare-healed, lower thau his. RichordIII. v. 2

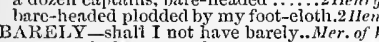

BARELY -shall I not have barely...Mer. of Ver. iv. 1

you barely leave our thorns.
barely in title, not in revenue.

iricharth II, ii.

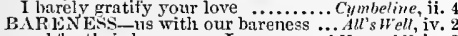

and tor their bareness, I am sure ..i Henryl 1\%. iv. 2 BARE-JIBBED-bare-ribhed deatl, whose

B.RFU I, - ret a barful strife!..... Twelfh Night, i. 4 BARGAIN-seal the bargain with. Twn Gen. of $Y$, ii. to sell a bargain well, is as eunning.

nake a frorld-withont-end hargain.

thwarted my barcains, conled my triends of to solemnize the bargain of rour thit

so is the bargain

As yon Like

upon what bargain do you give it me. Com. of

no bargains break, that are not this. King John,

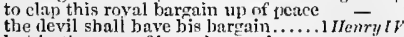

but in the way of hargain, mark ye.

I, hy bargain, should wear it mysel
BARGAIN-bnrgain for thcir wives. I Itenry VI. go to, a barrain male

lest the bargain shoutd citch cold

a duteless hargain to engrossing
too foll of her most filthy barrain

Cymbeline,

ton fond of her most filthy barrin ...... Othello,

lands are bargained for and sold

BARGE-barge stays: your lorilshij..IIenry VIII. i.

they have left their barge, and landed

see the barge be ready; and fit it

barge she sat in, like a burnished

trom the barge a strange in

sir, there's a barge put off from llitylene $-\mathrm{v}$.

BARGULUS-Bargulus the stront .2 Inenry $Y r$. iv.

BARK-they hurried us aboard a bark..

the watch-dogs bark ...............

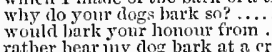

and neigh, and bark, and grunt.Mil. N. Dram, iii.

as sure as bark on tree.

the scarted bark puts from her.

and in their larks my thoughts...

carving liosalind on their bark.

look to thy bark; rll not be fo

what became of his bark, and his.

if any bark put forth.............

master, there is a bark of Epidammum

you sent me to the bay, sir, for a hark

thongh lis bark cumot be lost

the fox barks not, wben he

even as a splitted bark

.

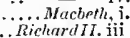

RickardII. jii

that dogs bark at me, as I halt ....

like a poor bark, of sails and trick

loss, bark, and part o' the timber
bark when their fellows do ....
reep-drawing barks flo there

hope, our convoy, and our bark
the strong-ribbed bark through

leaked is our bark ...........

swell, billow, and swim bark!

Henry $\mathrm{V}$. iii.

$o$, as the bark, that hatl dischar

n their skins, as on the ba
Pericles think this the bark.

ver. (Gower.)

and yon tall anchoring

thou coumterfuit'st a bark .....

rocks thy sea-sick weary bay

the bark is ready, and the wind at help. Hamlet, iv. 3

tet the labouring bark elimb hills of seas - Ohe - i. 1

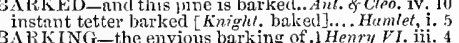
as of teu beat tor barking............ Corinlanus, ii. BARK'ST-thou burk'st at him ..Troil. \& Cres. ii. BNRLEY-leas of wheat, rye, barley .. Teinpest, iv. 1 their barley broth, decoct their

BARN-barns and carners never. Tempest, iv. 1 (son. see he shall jack no barns ............. Much Adlo, jii. 4 my field, my barn, my horse. Taming of Shrew, iil. 2 set fire on barns and haystaeks ...Titrts Andron. v. BARNARDINEcall hither Barnardine and Clavilio.

where's Barnardine. As fast locked up - iv. what is that Barnardine, who is to

let this Barnardine be this morning.

'sirrah, bring Barnardine hither

(marnardine! what, ho, Barnardine -

pray, master Barnariline, awake till

both Barnardine and Clandio...

what's he? Ilis name is Barmardine

BARNE-mercy on's! a barne (rep.). Winter'sT. iii. 3
BARNET - ilway townds Barnet ....3 IIewry VI. v. 1 the best at Barnet fiel

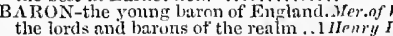

great primes, barons, lords, and...

twelve larons, ans twenty and

are four barons of the Cinoue-ports denry

BARONY-I'll give my barony

BAl?REU-whieh was before hitrre

things hid and barrerl, you mean... Lore

inspired merit so by brenth is larrel...th's s'ell, $\mathrm{ii}$.

swect recreation larresl, what dotll... Com. of Er. v.

in a ten times barred np ehest

purpose so barrer, it fi, lows.
the pangs of harreyl atliction

Coriolemes,

be barred his eutence
BARRED-nor have we herein harred ..Hamlel, i. 2 BAPRIRLN-1) an aere of harren ground.... Tempest, $\mathrm{i}$. lurren ynes, and fertile................

I let go your haukl, I am birren.. Thelfth $\bar{N} i g h t$,

takes delight in sueh a barren raseal

Why laugh you at such a batren rascal

shallowest thiek-skin of that barren -

$O$, these are barren tasks, too harl... Love's $L . L . \mathrm{i}$.

and sueh barren plants are set before us

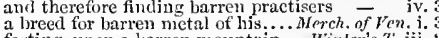

of that lind our rustic garden's barren - iv. 3

and put a barren sceptre in my gripe... Mrolueth, iii.

anfeeling bor

small model of the barren earth ....... - jii. 2

no, on the barren nountains let ... 1 Henry I $F^{\prime}$. i.

wished him on the barren monntains - ii.

barrell, barren, barren; leggrars all. .2 Heñy VI. i.

evermore sueceels barren winter...2.2 Henry $V I$. if.

oll barren llants to wal it witli
were his brain as barren as bank

I need not lie barren of areusations... Coriolanus, i.

the barren, tonched in this

that beanty that made bnrren the

some quantity of barrcin sy cetators ....Inmlel, iii.

BARREN-SPIRITED-

DARRICADited fellow ...........Julius Casar, iv.

no barricarlo for a belly; know it.. Hinter's Tate, i.

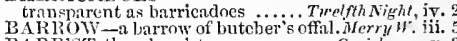

ART'ST-thou barr'st us our prayers. Coriolun u., $\mathrm{v}$.

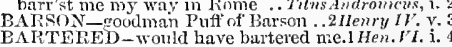

BARTHOLONEW-

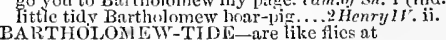

Bartholomew-tile, blind .............. Ilenry $F^{*}$.

BASE-with your unruly hase.
indeed I bid the base for Proteus

lest the base earttlis siould .............

go, base intruder

or base treachery

the more degenerate and base art thou - vv.

$O$ base Gongarian [Knt,-Ifungarian]... Merry W. i. .

base Phy no base humour

on base and ground enough ........ Tueifin Night, v.

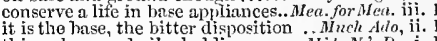

things base and vile, holding no ...Mid. N.'sDr. j.

that base minnow of thy mirth.... - i. I (letter)

which the base vulgar do eall tirce..; -
as it is base for a soldier to love (rep.)

as it is base for a soldier to love (rep.) -

to the wille fields too base to be mine

( $O$ base and obscure vulgar)

to think so base a thouglit ....................

or with a base and boisterous sword. As yon tike, ii. 3

the base. The base is right (rep..........

most of them means and bases .. Winter's Tale, iv.

thou art too base to be aek nowlelged ${ }_{\text {to }}$ most base, and vile concluded ... King Jokn, ii.

parley, and base truce, to arms ........

or sound so base a parle ...........

base men by his endowments....

my lord in the base court he....

in the base eourt? Basc court

shall I make to this base man?

shall I make to this base man?
though being all too base to stain

make glory base, and snyereignty

fawn on rage with base humility

permit the hase contagious clouds ...1 HenryI $Y$. i. 2

or base sceond means, the corcis.

sounded the rerv base string of....

tired thyself in base comparisons....

pick-thanks and base newsmongers.
througle vassa] fear, base inclination

You poor, base, rascally, cheating
I'll ne'cr bear a hase mind; an't

in lase and ahject routs, led on .......

most reereant coward bi

for the world, and worldings base.

is in hase durance, and eontagious ...

hase tike, calt'st thom me host
base is the slave that pays

and jutty his confinntel base

or art thom hace, common, and popilä

dust thuu thirst, bise Troja 


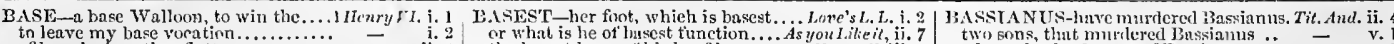
of love my base vocation. or what is he of busest tunction.... As youl Like it, ii. 7 perisb, base prinee, ignchle duke .... - iii. 1 bring noblest ninds to basest ends... Tim.of Ath. iv. 3 one o' the lowest, busest, poorest bo will this base and envious discorl I vowed, base knight, whell contaminuted, base, and misbegotten of all base passions, fenr is most ....... decrepit miserl basc, ignoble

so abject, base, and poor, to elioose

base dunghill villain, and meehnnieal tis but a base irnoble mind

when their basest metal be not mo prostitute me to the basest groom as basest and eontemned'st wretehes....

Jul. Caesnr, i. to tnke the basest aml most poorest Lear, ii, 2 BAsE-VIOL-went like a base-viul .Com, of $\vec{E}$ ii. 4 shewed basliful sinecrity, and comely . Tempest, i

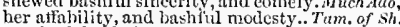
you bashfinl fool, must you

ne'er yet flid base disl anour blur.
base siave! thy words are blunt.

omall things make base men frongi

and you, base peasants, do re believe

only my tollowers base and ignominion

base, fcarful, and despairing llenry..3Henry $V I, \mathrm{i}$.
base deelension and loathed bigamy. Rich. III. ii. a base foul stone, made precious.

and base laeqney peasants

Henry $\ddot{Y I I}$.i.

enry and base opinion set arainst

0 theft most base; that we .. Troilus of Cressida,

on terms of liase eompulsion

but the strong base and building of ....

liave here her base and pillar by

lwen tonehed, and found base metal

it' 'twill not, 'tis not so base as

wrong, right; base, noble

these base slaves, cre vet the fight...... cor - iv.

it makes the consuls base.......

their base throats tear tongue :......

for the base matter to illuminate... $j$

scolning the buse degrees by which
who is here so base, that would be

cven at the base of Pompey's
our fingers with base bribes?

make bold her basifull yeirs

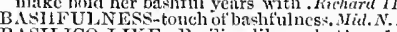

BASILICO-LIKE-Banilico-like: wlint! ... John

of basilisk of ownon, culverin ....iHenry I $V$.

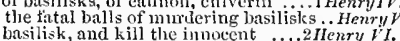

basilisk, and kill the imnoeent 1.2 IIenry $\nu^{\prime} x$.

slity nore gazers than the basilisk. 3 Inenry $V$ l. ili.

it is a basilisk minto mine eye ……. Chmbeline, ii. 4

BASI MI ECU-Monsieur Basimed ...2 Henry ${ }^{\prime}$

B.SIS-0'er lis wave-worn bgsis bow'd. Tempest ii. 1

lay thou thy basis sure.............

Troy, yet upon his basis

Henry $I^{\prime}$.iv.

and now on Pompey's basis lies

BASKED-him down, and basked... As you Like it, ji.

look, here is a basket ...............

have I lived to be earried in a basket

being thus crammed in the baske
what they had in their basket

searehed for him, in a basket

shall I put him in the basket ag

I'll cone no more i' the bask

to carry the basket again to meet....

what they shall do with the basket .

take the basket again on your
set dowu the basket, villain.

set dowu the basket, yillain.

buse and unlustrous as the smoky
ewil thou seek'st; as base, as strange

you pretenel with that base wreteh

thou wert too hase to be his grooti...

nitt base things sire base $\ldots . . . . . . . .$.

more like to rum the country hase

hure's the base fruit of his hurning.

with base prayers, $I$ should repe

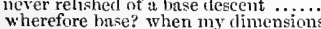

why brand they us with base? (repealert)
Eilinund the base shall top the legitimat

you base foot-ball player.

hase, proud, shaltow, beggarly, three-suite

tr keep base life afoot

the dram of bise [Col. Krit.-iii] doth ....Hamlet, i.

witl flaming top stoops to his base

are base respeets of thirift, but none...

among a mineral of metals bise, shor

to what base uses we may returu

and all indign and base adversities.....

prerogatived are they less than the base.

some base noturious knave, some

BASE-BURN-base-born eallat as she.2IIe

ten thousand base-born Cades miscarry _ $T$ i. 3

thy tongue detect thy base-born leart.31len. II. if. 2 B.LELES - like the baseless falbrie

BA:AEA,Y - but basely led by flatterers.
lunt basely yielded upon compromiso

to spend that shortness basely
that lasely fled, when noble

that liasely fled, when noble.

1 Henry 1 i. 1

out of my house yesterdny in this basket
this was his basket

umpeg the basket on the honse's top ...IIamled . . 2

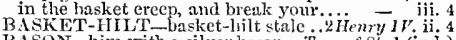

B. SON him with a silver bason. Tam.of Sh. 1 (ind.)

I dreant of a silver basom mul cwer. Timon of $A$. iii. 1

BASS-it did bass my trespass.......... Tempest, iii.

my lorel Bassanio, sinee you hi

yes, yes; it was Bassanio; as I think

mark you this, Bassanio, the deril

signior Bassanio,-Gratiano! . . ......

difference of old Shylock and Bassant

We are staid for at Bassanio's teast

I saw Bassanio nuder sail ..........

were not with Bassanio in his ship

I saw Bassanio and Antonio pa
business for my sake, Bassanio

he wrung Bassanio's land, and so they

Bassa niv, lord lnve, it thy
upon the rack, Bassanio?

then be bold to say, Bassino 3 '.......

ny lord Bassanio, aurl my gentle laty

with leave, Bassanio: I an half...

sweet Bassanio, my ships have all

pray God, Bassanio come to see me

in place of lord Gassanio and myself

like the lurd B:ss?nitio's wite?

the lord Bassanio live an upriglit.....

give me your hand, Bassanio .........

my lord basianio, let him lave the rin

my lord Bassanio, upon more au

my lord liassanio gave his ring away

liere, lord Bassanju, kwar to keep this

Assil mús-Bassianus, Casar's so

so Bassianus, you lave played yo

for you, prince Bissiantu, I lave passed

or Bizssianus so degenerate

though Baysianus be the cmleror's
than this Lavinia, Basaimns' love

this is the day of dom finr Lassianus
wash their hands in Dassinnus's blone

more, grent empress; Bassianus connes

poor I was slain, which Eassianus died

this deep pit, poor Bassimus gere

to find thy hrother Bassianus dead

where is thy brother Bassianus?...

Bassianus "tis, we mean, do tlonk ...
where we dececed to bury Bassiaul two sons, that mirlered Bussianus ..
where the detud corse of Bassianus...

BAST A-Basta, content thee.... Taming of shrer., $\mathrm{i}$. MAR - for he's a bastard one..... Tempest, $\mathrm{x}$. muel as to say, bastard virtues.. T2no Gen. of $V$. iil.
drink brown and white bastard. . . Nea. for ifea.

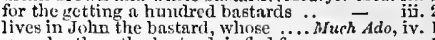

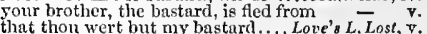
that thou wert but my bastard..... Love's L. Lost, 7 . thint were a kind of bastard hope .... sare, they are bastards to the English. All's Well, ii. 3 give her the bastard; thou, dotard... Winter's $T$. ii. take up the bastirt: take't ul, 1 say - ii. 3 the bastard brains with these my $\ldots=$ - ii. 3 this lostard's life; for 'tis a hastard = ii. $=$ ii. earry tlius female bastard henee...... $=$ ii. a bastard by Polixenes ............. 0 iii. gilliflowers, and do not eall them bastards - iv. 3 shame hath a bastard fame .... Com. of Errors, iii. them a bastard of the king deceased

thy bastard ghall be king

bastards, and clse. To verify ....... - ii.

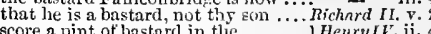

score a pint ot bastarl in tlie

ha! a bastard son of the king's? ...2ilenry $\mathrm{I} V$. ii. and a bastard, and a knave. and ........ Henry $y$. iij. new-store France with bastard warriors 二 iij. the bastard of Orlenns with him ....1 Henry $V I . i$. bastard of Orlenns thrice welcome

thou bastard of my grand fin ther...

now where's the bastard's brav

to make a bastard, charles ........

the ireful bastard, Orleans ....

sled some of his bastard blood.....
purposing the basturd to destroy

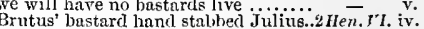

if that the bastard boys of York......

Tyrrel, I mean those lastaris

and not these bastard Brctagnes........

bnstard Margarelon hath Doreus ...Troil.

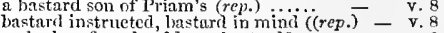

and wherefore should one bastard?

I lungh to think that habe a bastard. Timon of $A$. i. go, thon wast born a bastard ........

though but bastards, and syllables.. Co

bastards and all; goori man

what bastard doth not?

we are bastards all; and that most .. Cymbeline ii. liave me prove my self a bastard....... Titus And. ii. 3

i. 3 not the bringing iup of pon bastards .. Pericles, iv.

lore is to the bastard Eimund

now, gods, stand up for bastards $\ldots \ldots \ldots$....

thon mnpossessitig hastard!

Gloster's hastard son was kinder .........

that ${ }^{4}$ cy!m, proelnims me bastart

B.LSTAR1PLLNG - on my bastardizing....Len $r$, i. 2

BASTARDY - sIanilered me with bastardy..John

thou thyself was horn in bastardy ..2 IIenry $Y I$. iij. 2
the hastarity of Wetward's children.... Rich.III. iii. s

tonched yon the bastardy of Edward's -

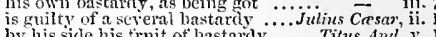

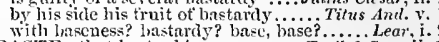

BASTE - that bastes his arrogance.. Troil. \& Cres. ii.
BASTED-are lut flightly basted on ...Much deto, $\mathrm{i}$.

BASTINADO-or in bastinado, .... As you Like it, v.

he gives the bustinarlo with his tongue ... John, ii. 2
thit gave Amainum the bastinado ..1 Henry $1 \%$. it.

BASTYNG - what's thut? Basting ...Com. of Err. ii.

BAT-toarls, beetles, bats, light on you ... Tempest, i. 2

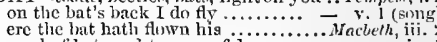

wrool of bat, and tongne of dog ........ - iv.

where go ron with hats and clnbs.... Coriolanus, i.
ready your stitt bats and elubs .......

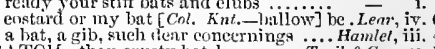

BA hat, a gib, sueh tear conecrnings .... Hamlet, iii.

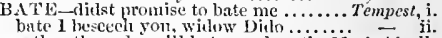

bather than she will bate one breath...Much $\overrightarrow{A d o}$, ii.
whieh shall bate lis seythe's kcen ...Love's $L$. $L$. i. 1

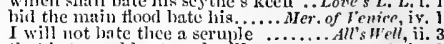

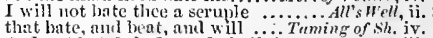

do 1 not bate? fo l not dwindle? ... Henry IF. iii.

and hreeds no bate with tclling ....2nenry 1 . il.

goofl bawcoek, bate tiny race

then it appears it wilituate

nenry $r^{\prime}$. iij.

too mueh of your own.

neither will they bate one jot
O let me bate, but not like me

ATED-liast thou nothing bate

Tempesl, iii. 3 
BATED-losses have so hated me... Mer. of Ien. iii. 3 those bated, thut inherit but. like a bated and retired flood.... hater like engles having lat no lejsure baterl, no, not to stay.... BATES-brother John Bate, BAT-FONLIn sore labour's bath, balm of hatr. jung John, $\mathbf{k}$ . Prricles, iv Honlet, $\mathrm{v}$. y) we'se, iii. enson the slaves for tuhs and hatjo... 7 imom of $\mathrm{f}$ iv.

BATHE-to bathe in fiery floods. and did bathe their hands in it.....Julins $C$ aesar, ii. let us bathe our hands in Casax's l, loot or bathe miy dying lionour is Jand I this eleek to hathe ny lips..... Cymbelinas

BA'TII ED-had most kindly bath
like eagles having lately bathed or hinthed thy growing with

BATIING-ehiste Dian, bathin

13.1 TIN-blood lating in my eheeks

B.TLET-and I remember the kissing of her

batlet [Col. Kut.--batler] 3 iil

B.TTAYIA-our battalia trebles

BATTALION-but in battalions
BATTEN-and batten on cold bit.

to feer, and batteu on this moor:

ATTER-with a $\log$ batter his skuli... Temp'st, iii.

the rnin that batters down

to batter the fortress of it.

butters all rebelling ensts

have battered me like roaring...... I Henry $I^{\prime}$ T. Hi

BATTERING-nould leave battering.

England mount their battering $\mathrm{c}$

mine action of battery on thee..

khall do more than hattery can...
if $I$ beain the battery onee again

if I begin the battery onee again.
best place to make oư battery next
will make a battery in his breast

will make a battery in his hum is a battery

and his him is a battery

minke battery the our ears ........... Anlony \& Clco.

else an easy battery might loy tat

milke raging battery... Pericles, iv.

and make a battery through his dea

BATTLE-the battle with the Centaur

give battle to the lioness........
perchance, he's lumt i' the batile

have I not in a pitehed battle lieard.. Tum. of Sh.

when the battle's lost and wo

lend our first battle: worthy Macdufi

and will in battle prove, or here

Treelith $N$.iv.

this fenst of oattle with mine.

to bloody battles, and to bruising ....ïienryI $V$. iii.

be seen to-morrow in the battle

Hal, if thon see me down in the bittic

that in the battle thus thou erosest.

haunt thee in the battle tlu

as many holes in an enemy's bat...

our battle is more full of nam
in sight of both our battles

a fearful battle rendered you in minsic

when Cressy battle fatally was struck.

each battle sees the other's.

our scene must to the battie fiy.....

chopped off in a battle, shal

0 God of battles! steel my soldiers

swarm about our squares of battle

the lite of such a battle in life $\ldots . .$.
limself is rode to view their battie...

are bravely in their battles set

might fight this battle out....

that ran from the battle, have

aud even play of battle, was ex

rushed into the bowels of the battle..

at the battle of Patay, when

leave the battle, boy, and fly .........

the clustering battle of the French

which fly befure the battle ends.

to die in ruffian battle

St. Alban's battle, won by famous

charged our main battle's front...

enconntered as the battle's jo

many a battle have I won in Franec

I saw him in the battle range about.

our battles joined, and both sides.

darraign your battle, fur they are....

have ehid me from the liattle .........

and battle for their dens $\ldots . . . . . . . .$.

and bicl false Edward battle ........

pitched battle against Wa

ein a

enough to bicl his brother battle......
and bid tliec battle, Edward .......

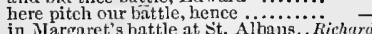

in Margaret's battle at st. Albains..
in the day of battle, tire thee more

a royal battle might be won.

the form aud model of our battle..
B.LTTLE-prepare thy lattle carly .. Riehard III good angels gourd thy battle

and in a bloody battle enrl thy days

in the hattle think on Buckinglam.. -

we ourself will follow in the main hattle

that find sueh eruel battle here... Troilus \& $\bar{C}$ Cre

the vale, to see the battle

as doth a lattle, when the

my great purpose in to-mo..............

men expose themselves to battle. Timon nf $A$ th. i

to Lirtius and to Mareius battle

how lies their battle? know you...
I do heseech you, by all the battles

I do beseech you, by all the battles..
the brunt of seventeen batles since.

and to the battle eame he .........

in puny battle slay une

noise of battle hurtled

their battles are at hand.

their bloody sign of battie is i..........

Oetavius, lead your battle softly
shatl we give sign of battle?....

nnon one battle all our liberti
it' we do lose this battle, then

it we do lose this battle, then ...........

and Flavins, set our battles on.........

do win the battle still of mine ...Antony

provoke not battle, till

the last of many battles we me

walled ... Cymbetin

and ymir three motires to the inittie..

the stroke of this yet searce-cold battl
suceessful in the battles that lie... Til

joinet your high-engendercel

I liad rather lose the battle, thian

before you fight the battle, ope this

the lattle done, and they within
nor the division of a battle kuows

than pertains to feats of broil and battlo

the hattles, sieges, fortunes, that I have

BATTLEAIENT - upon our battlements

seeurely on their battlements....

the castle's tottered battleme

un to walls and battlements........ Jum

fuller blast ue'er shook our battlement.

BATTY-lealen legs aud batty wil

a custard-eofin, a bauble.

how many shallow banble boats.

his shipping (poor ignorant bauble

an idiot holds his bauble for a god.

to hide his bauble in a hole

BAULKED-and this was bauliked

BAVIN and rash barin wits soon..ilifenr

BA WCOCK-why, how now, my baweoe

I' fecks? why, that's my bawcoek. Winter.
gnod baweoek, bate thy rage! ....... Hex
the king's a bawcoek, and a heart of goll

$B \Lambda$ WD-if it be not a bawd's hon

you are partly a bawd, Pompey
by being a bawd?
you need not to fear the bawds

you need not to fear the bawds

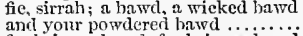

for being a bawd, for being a bawd

th bawd of eleven years eontinuanee

been a notorious bawd (reperfed) ....

more venitent trade than your bawd

come on, bawd; I will instruet

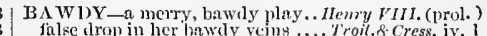

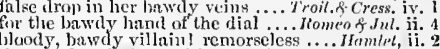

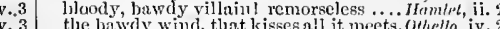

BAWDY-11OUSE - to a bawry-louse.1 IfenyI $V$. jii.

this house is turned bawely-hou:.

a ponr whore's ruff in a bawdy-hoü

we keep $\Omega$ bawdy-house straisht.

BAWL-those tlat bawl out the runs.2 Iemry $/$. ii.

BAY - why, it hath bay windows. Trelfit

fter three-pence a bay...... Measure for Mr M

like the bay of I'ortugal.

come to the bay of Ephesus .... Comedy of

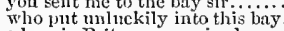

a bay in Br.tunny, received..

and chase thein to the bay $\ldots . .$.

in such a desperate bay of death ... Richard 21. iv.

what moves $A$ jax thus to bay at him

the other day bay courser.... Timon of Athens

a tog, ant bay the moon...........

set the dogs o' the street to bay me..

with precious lading to the bay.
let us make a bay, and wake

at suel a bay, by turn to servo...

of ehastity with rosemary and bay
to ride on a bay trotting horse...
bless this bay with his tall ship....

Tilus snd

gn to the bay, and discmbark my eoffers.

here wast thou bayed, brave hart...Julize

and bascd about with many enemies

BAYTNG-baying him at the heels ..2Henry I
BAYNARD-ling them to Baynard's.. Rich. III.

BAYONNE-the bishop of Bayomne. INenry $\bar{l}$ III.

EEACII-go stamd upon the beach ... Ier. of Fen. iv

let the pebbles on the hungry beach
stones upon the numbered beach

fishermen, that walk unon the heael $\ldots$. Lear, iv.

mENon the benehed verge of the salt .. Timon of A y.

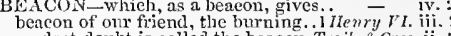

be, like a heacon fired, to amaze ........ Pericles, i. 1

Bipliroach, thou beaeon to this under globe. Lear, ii.

you bend, you aeorn .............. $N$. Dren

With amber bracelets, bendls
for

with these erystal beads bearen

give my jewels for a set of bead
tilat beads of sweat have stood

company, or at my beads.

King. Joh

number ave-maries on his bead

our ave-maries with our beals?
relininins men are at their beads

Henryli. ii.

seeing those beads of sorrow stand...

the beadle to her sin

war is his beadle, war is his renge.....

go fetch the beadle hither straight

the rumning banquet of two beadi

no better office, than to he beadle

3IIenry $r$ T. ij.

BEAD'S-11 EN - thy very bead's-men.... Rich. 11, iii.

and take thy bengles witl theo....

BEAk-now on the beak

kite soar with unhloodied beak

wing, and their halcyon beaks with
and turn their hen

somctimes the bean of her.

quenehed in the chaste beans.......

on Neptune with fair blessed beams

I thank thee for thy sunny beams

that little candle throws his beams...

but to the brightest beams distraetee

when lye hides his berms.

a rusl will be a beam to hang

and those his golden beams, $t$

ove's L. L. iii.

King John, i.

twinkling another counterfeited bean

reflex his beams upon ................

melts with the sun's hot beams

the glorious sun's transpare

thy very heams will dry thoe $\ldots . .$.
whose bright out shining berms .... Rielnrd III. i. 3

cast thousand beams mon me ... Henry FII, iv.

waving his beam, upon the past
sum, hivie thy beams $\ldots \ldots . . . .$.
down stretch helow the heam......

dhe benefit of his blessed beans

nold in the beams n' the sim so

Troil. dic

BAIVD-BORN - too; bawd-born...Ifen. for

withont bawdry, which is strange... Winter's $T$. iv.

BA's for a jig, or a tale of bawdry ...... Hremet, iv.

it is a hawdy planet, that will strike. Winter $T$. $T$.

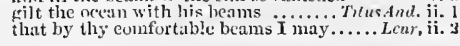




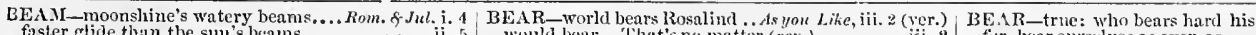

faster glide tiz:an the sum's bcams...

till our seale turn the beam

BCAN-pear and benns are as dank ...WHemlet

Bis.1R-to bear up agninst what shoukl... Tempes. ii.

the breasts of ever-angry bears...

how I mar bear me bere

to bear off any weather at all

and bears celestinl li, 1 nor
I'll bear him no more sticks

here; bear my hottle.

rll beitr your logs the while...

Oearth, hear witness to this sound

the refore beur up, and
bear with iny weaknes

help to bear this away

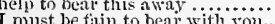

how do you hear witl me?

to bear my lady"s train.

bears no impression of the thing

to bear a lard opinion

to bear my letters to.

I bear unto the banished Valentine

to bear me eompany

he bears an hmourable mind.

hear witness, hearen ...........

it you see the bear loose

she bears the purse too...

go hear thou this letter ..............

you'll not bear a letter for me

if you will help me to bear
I pray you, bear vitness ......

lave you to do whither they bear it .

Iy ay ; I must bear it ............

disposition is able to bea

the dear love lear to tair Ann Page

let summer bear it out

that I may bear nuy evilis alone

that love a woman can bear me ........

will either of you bear me a ehallenge

same "haviour that your passion bears

as if beur were at his heels..

he will bear you easily.

ame

bear me to prison, where I am

in lierson bear me like a true.....

heaven, let me bear it

what lear in them one and

what s set in this, that bears..............

who the sword of heaven will bear

the provost, he shali bear them.

lor him bear it tur a difference.

if ever the sensible Benediet bear it.

whieh shall bear no less likelihood.

they say, I will bear mvself proudly.

tis a truth, I ean bear them witness
this is thy office, bear thee well in it.

and then the two bears will not bi

therefore bear you the lantern

in angel whiteness bear $[\mathrm{Col}$.

what? hear her in hand until

wake the drink to bear no barm... Wirl. N. Dra

(be it on lion, bear, or wolf..

or eat, or hear, pard, or boar

no, no, I an as ugly as a bear

hog, bear, tire, at every turn...

the hate I bear thee made me ........

to Athens will I bear my folly back..

they bayed the bear with hounds.

how easy is a bush supposed a bear....,

why, she that bears the how

before a lady, and to bear her fai

thy eye Jove's lightning bears, thy voice

and thus thy body bear

bear with me, I am sick

a heavy heart bears not
but that it bear this trial

and Tom bears logs into the

cubs from the slue bear.

who tìis inscription bears .......

once more what title thou dost bear

patiently to bear my wrath

whose souls slo hear an equal yoke...

a eertain loathing, I bear Antonio ....

not the hangman's axe, bear half

that maliee bears down truth ..........

the knowledge of my fitult bear witl ine -

to bear your briefs your

is comely envenoms him that bears it

I pray you, bear with me

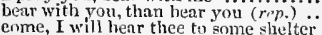

enme, I will hen thee to some shelter
the city-wouna bears the cost... and eould not bear themselves wittunt

for no ill will I betr you...

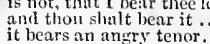

hear this, bear all: she says, I am...

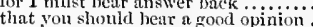

hear your body more seeming

the love you hear to women

to grow there, and to bear

more I'll entreat you written

We'll strive to benr it for your
how 'tis best to bear it .......

nnother hear the ereer.

Taming

he bear linselt' with honourable

for the love I bear my sweet.

for who shall bear your lint

to bear, and so are you (repeated)

she bears me fair in hand

mistress Kate, I'll bear you eoming......

my father's bears more toward ...

no halves; I'll bear it all myself.

nor parchment, bears not
if not, how best to bear it

which jou sliall bear along imp..........

bear the boy hence, he shall not

is not bis enough to bear a sehooliny.

it is but weakness, to bear the matter

$\begin{array}{ll}\text { iii. } 3 & \text { and that thou bear it to some remote. } \\ \text { iii. } 3 & \text { wolves, and bears, they say, easting }\end{array}$

so lono

to sce how the bear ture out

and the bear moeked him

I'll go see if the bear be gone....

and bear the sow-skin lingret........

if thou'lt bear a part

you shall bear witness to $t$....

so lies, that I must bear a pa.

good my lords, bear witness to lis oith

and those that bear them

will bear no credit, were not

he was torn to picees with a bear.

punishment that women bear

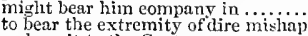

go benr it to the Centa ur..............

you would bear some sway

then she bears some bjealt

as from a bear a man wouli run...

no, bear't with you, lest I come

there's the money, bear it straight...

nay, I bear it on my shonlders...

and the rope-maker, hear me wituess

bear me forth with unto his

go bear him hence $\ldots . . . . .$.

and bear them to my house
and bear him home for his r

why bearyon these relukes

and every one dicl hear thy ........

under heavy judrment beurs thint life

not bear the knife myself

who shall bear the renilt of our

was never called to biear my pait

and bear his hopes 'bove wistiom.

who bears a glass, which ghows
and the lieart I bear, shill never....

a bongh, and bear't before him.

hired to bear their sta

bear mine to lim, and so depart.

diid after wedloek bear him....

from beneeforth bear his name....
some sins do bear their privile

like to a muzzled bear, save in

'gainst whom these arms we bear
nnd bear possession of our persum

nnd bear possession of our persun
well eould I bear that England

I hope, sour warrant will bear out

think you, I bear the

go, bear him in thy arms.

bear a way that child, and fijilio..........

would bear thee froms the knowled
I pray you, bear me hence trom

give thee help to bear thee hince...

go bear this lanee to Tlymu.

..nicherd 11.

and my nurse, that beais me

to bear the tidiugs of calsunit

weil, hear you well in this new

by man, wast horn to betir?

as a gib eat, or a lugig hear. fir, hear oursclves as even as...

'sblood, I'll not hear mine own

I do not heur these I bear your.

mark, how he bears liis coures.

gohyar this letter to John of.

his letters bear his mind, not

ay, hy my faith, that bears a fir

Good sir Michael; bear this sealed . $\cdots$ -

this earth that bears thee dead, huars

that shoula reward valour, bear the sin

and bears down all before him.

to hear a gentleman in hand...

you are too impatient to bear crosses.

tor a poor lone woman to bear.

a beast, to bear every knave's wrong.

bear with another's eonfirmities (rep.)

andl bear your ycars very well

peace, that bears such graee

that ail their eyes may hear tho

take me up, and bear me hence

but, bear me to that clianh

do hear themelves like fivolish justice.

let me but bear fonr love, I'll bea.

sword the still hear the balince....

swort that you have used to lear.
but you must bear; the henrt's all.

the bear our civil swords

that the powers we bear with us.

dear offences; bear them lienee

shall you bear nur full inte

your mistress bears well..

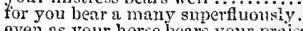

even as your horse bears your praise

into the mouth of a linssian bear

on the king; we must bear all

I pray thee, bear my former answer
now we bear the king toward Calais

and bear me witness all, that here.

bear henee lis body, I will help

your honours bear me compan

he hears hin on the place's privil weate.

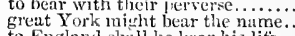

to England shill he liear his life

horse, thit hears me, fitl and die

that I bear them henee.......
bear her this iewel, pledige...

bear her this icwel, pledre.

bear that proportion to iny flesl...

while Gloster bears this hase....

bears lis thon the s revenue his faleon 8.

can I bear this siomeful yoke

with what a majesty he hears himscif

White, a rineorous mind he bears

lefs be firm to bear his body

more cur I name and port.....

more cin I benr, than you dare .....

mumentment of the vietory will I bear.

which I will bear in triumpl

to the stake my toro bramlih

are these thy bears? we'll bait thy bears

I am resolved to bear a greater storm

from thy bur oonet I'll rend thy bejor

the hearward that protects the bear

dost not hifle thee from the bear....

I, my lord, will bear him eompany

be theen thears tlee type of .....

or, as a bear, encomplassed romind

heneetorward will I bear upon....

nichisd, I bear thy name

'tis love, I bear thy gluries,

thlowe the

I'll bent the bear's the titie of a king

or an mulicked berr-whelp

will ulued trunk that bears th:

madam, hear it as rou may

and hear with miliness my

on the shimmeficed Ilenry, bear hiin...

the dearest hlow your bodies bear $\ldots$....

ive, to bear his image, and renew

bear her hence perforee (ripot....

I char ye, lear lier henee

the two litave bears, Warwick ...

he:ur with her weal the eorse, which

.lichard 111.

that a winged Merenry did bea

that bear this mitual heavy ...........
every horsc bears his eommanding... 
BEAR-I'll hear you comprny nnd thither bear your treasur. hnw to hear with him (rep.) ....

that you should bear me on your. the tencler love I benr your grnce me to the block; bear him my liead yielded to bear the golden yoke to bear lier burlen, whe'r I will .... to bear this tidings to the blondy king bear with ine; I am hungry

proud neck bears half my

hear her my true love's kis

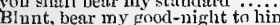

that bear a weighty and a

did almost sweat to bear............

and, to bear them, the bark is

that churchman bears a bounteous.

great respect they bear to

yet, heaven bear witness..........

the law I bear no malice for my

have you timbs to bear that load of title -

you bear a gentle mind

I nnow you back will bear a düchess

with these you bear already

and bear the inventory of your best.

business, which $T$ bear i the state...

to the little good you bear me.....

bear witness. all that have not

Who's that, that bear's the sceptre.

they, that that be clotin of honour...

their practices must bear the same .
churlish as the bear, slow as.. Troilus

my heart's content firm love doth bea

and bears bis head in such a rein.

shonld not our father bear

he slould not hear it so..................

let Diomed bear hiun, and bring...

a burden wlich $I$ am proud to bear.

shait bear a letter to lim straight (rep.

his bane; he cannot bear it .........

and bear hence a great addition...

that be'll bear on his helm

upon the love you bear me, get you in

go, bear Patrocius' body to Achilles..

one bear will not bite another..

it must not bear my daughter.

my lord, which bears that office.

who dies, that bears not one spurn

to revenge is no valour, but to bear

meek bears, vou tools of fortune

nothing 1 il bear from thee

the sear great fortune bnt by....

dragons, wolves, and bears

I, to bear this, that never $\ldots$

wert thou a bear, thou wouldst be kililed -

true; for he bears it not about

and there's all the love they bear us... Coriolan

as children from a bear ..........

that bear the shapes of men ....

able to bear agrinst the great....

bear the aldition nobly ever

that baes like a bear. “He's a bear, inileed -

though I must be content to bear with

your voices, bear of wounds two doze

charters that you bear i' the body....

bear him to the rock Tarpeian ......

and bear him to the rock. No; I'il d

ocr-bear what they are nsed to bear

armour on, which $Y$ can

will bear the knave by the volume.....

the wounds his body bears, whieh show

common chances common men could b
the wounds. that he does bear for Rome
and thy tace bears a command in't ...

displeasure which thou shouldst bear

he bears himself more prouldlier.

that he bears all things fairly ........

you shall bear a better witness

bear from hear my beating to.........

bear ton stubbom and too, and mourn

upon his shoulder the old Anchises bear -

and bear the palm alone

that I do bear, I can shake off

in his own hand bears the power

since the quarrel will bear no colour

every noble Roman bears of you...

bear fire ennugh to kindle cowards..

the ingrafted love he bears to Cæasar

and bears with ghasses, elephants ....

but bear it as our Roman actors do

but bear it as our Roman actors do

to bear my greeting to the senators...

f you bear me hard, now

bear with me; my heart is in the

you'll bear me a bang for that, $\mathrm{I}$ fea

but bear them as the ass bears gold.

offence slould bear his eomment....
should bear lis friend's infirmities.

BEA

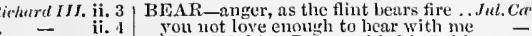
iii. 1 bear with him, Britus; 'tis his fashim
iii. 1 no man bears sorrow better: Portia is

then like a Roman bear the truth. ...

ini. 4 but yet my nature conld not bear it so

iii. 7 hear with me, good boy (repeated.

.

iv. to know the purposes I bea

iv. 4 when we do bear so great weight

iv. 4 to bear the weight of Antony?

iv. 4 and benr back ont targe undinted

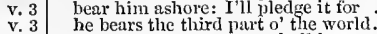

the holding every man shall bear...

bear the king's son's body hefore.

the mares would bear a soldier

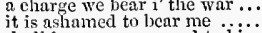

shall bear us an errand to him

bear our hacked targets like the

ii. 1 o, bear me witness, night.....

ii. 3 slatl upon record hear hateful .......

jike a bear, or lion, a towered

bear me, good friends, where cleopati.

and you bear it as answering

iii. 2 and bear her women from the monument -

$\begin{array}{ll}\text { iii. } 2 & \text { yon beat a graver purpose............. Cymbel } \\ \text { iii. } 2 & \text { and the prinroses, bear to iny closet } \\ \text { iii. } 2 & \text { the love I bear him made him ...... }\end{array}$

a woman, that bears all down

that will not bear your enemies' bont

justly may bear his betrothed from. Tit us. $\overline{A n}$ dron.

to bcar me down with braves

should let life heat his name...

bear thou my hand, sweet weuch...

the privilere your beanty bears

more than our backs cau bear.

\begin{tabular}{l|l} 
iii. 3 & more than our backs cau bear... \\
iv. 2 & and bear the faults of Titus' age
\end{tabular}

what hate they bear their emperor
for I must bear thee to a trusty Goti

and bear it from me to the empress...

more than auy living man con

Whose wisdom's strength can bear it.

he bears unon his shield is an armed

aged patience bear your yoke...

iii. 5 bear you it in mind, old Helicanus.....

he bears a tempest, which his nortal - iv, (Gow

omit that bears recovery's name

nature nor our place can bear

with such dispositions as he bears...

iv. 3 to the great love I bear you.

iv. 3
iv. 3
iv. 3

fool me not so much to

wherein the cub-drawn bear wonld conch.

thou'dst meet the bear i' the mouth....

i. 4

\section{r}

I'll repair the misery thou dost bear.

if I could bear it longer, and n

bear free and patient thonghts ....

thy great employment will not bear question - v.

a disgrace to thens, if they bear it...Romeo \& $\bar{J} u l . \mathrm{i}$. 3

nay, I do bear a brain ...............

and learns them first to bear

he bears him like a portly gentieman

=

but you shall bear the burden soou....

bear hence this body, and attend our will -
conld find out but a man to bear a yoison -

chain me with roaring bears

shall Romeo bear thee hence

best array, bear her to church.........
bear this work of heaven with patience

befitted to bear our hearts in grief

bear it that the oploser may beware

nature in thee, hear it not

but bear me stifly up $\ldots \ldots \ldots \ldots \ldots \ldots \ldots$

for who would bear the whips and scorns

who would fardels bear, to grunt and swe

ii. 1 make been too broad to bear with.

ii. 1 they bear the mandate; thes

ii. 1 and bear it to the chapel ...............

great love the general gender bear him

ii. $\quad$ whose griet bears such an emplansi

ii. 1 let four captains bear Hamlet

ii. i [Collier] to bear me to him ...

ii. 2 with inore fucile question bear it

iii. 1 he bears the sentence well, that (rep.).
iii. 2 but he bears both the sentence and the.

$\begin{array}{ll}\text { iii. } 2 & \text { but he bears both the sentence and the... } \\ \text { iii. } 2 & \text { east water on the burning bear, and cuench }\end{array}$

iii. 3 it is impossible they bear it out

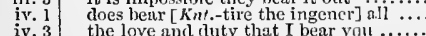

\begin{tabular}{l|l} 
iv. 3 & the love and duty that $I$ bear yout ........ \\
iv. 3 & that the probation bear no hinge........
\end{tabular} \begin{tabular}{c|c} 
iv.3 & BE AR-wonld bcar your misfortunes \\
iv. 3 & I prythello, iv. bear some charity to my wit
\end{tabular} she will sing the savageness out of a bear $=$ iv.
for the love I bear to Cassio ........... iv. yet could I bear that too; weil, very weli
either I must live, or bear no life ....... ns true licarts cannot bear

o tur a chair, to bear him easily henec...

0 bear him out o' the air ..............

think on thy sins. They are loves I bear
BEAR-BAI'TING-

in fencing, dancing, and bear-loaitiug. Twelfth $N$. i. 3

ii. 6 with my fady, about a bear-baiting here - ii.

BEARD-tears run down his beard
ay, by my beard, will we ... Tu' Gen

a great round beard.....................

like an icicle on a Dutchman's beard

put on this gown, and this beard

shave the head, and tie the beard.......

his beard, and head, just of his ....... iv.

not endire a husband with a beard ..
upon a husband, that hath no beard

hath a beard, is less than a youth ( $r$

than he did, by the loss of a heard

will smile, and stroke his beard $1 . .$.

what beard were I best to play it in..

French-crown-colour beard, your periect

good strings to your beards, new

good strings to your beards, new .....

a wife! $-A$ beard, fair health, and ....

what a beard hast thou got .......... - ii.

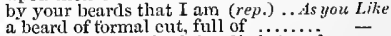

a beard? nay, he hath but little beard

stay the growth of his beard ......... -

your having in bearl, is a younger

courtier's bearl; he sent ine word (rep.) -

say, his beard was not well cut

as have good beards, or good faces.

or the baring of my beard.

- Tepilngue)

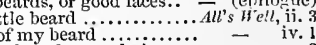

but that his beard grew thin .... Taming, of sh. iii.

so sure as this beard's grey .......Winter's Tale, ii.

will make him scratch his beard

whose beard they have singed of

dareful, beard to beard, and heat

Mucbeth, i. 3

plucks dead lions by the beard.......King John ii.

white beards have asmed their thin. RichardII. iii. 2

upon the ground, but I will beard him - iv. 1

I will sooner have a beard grow

merry in liall, when beards wag all - v, 3 (song)

fathers taken by the silver beards.... Ineniry $r$. iij.

and what a beard of the general's cut .. - ii.

a black beard will turn white.

and take the Turk by the beard........

priest, beware you beard

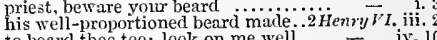

to beard thee too: look on me well... $-\overline{\text { iv }}$ is 10

I'll hide my silver beard in $\ldots \ldots \ldots . . . . . \quad-\quad$ i. 3

honoured age for his white beard. Timon of Ath. iv. 3

take our goodly aged men by the beards - y.
if e'er again I meet him beard to beard.. Coriol. i. ${ }^{2}$

the wagging of your beards (rep.)

yon had more beard, when I ast ......... - Cleo, iv. breeding, as his white beard came to. Cymbeline, y. 3 at snit of his grey beard .................. Lear, ji.

spare my grey beard, you wagtail.......... - ii.

art not ashamed to look noon this beard ...

if you did wear $a$ beard on your chin ....... - iii. 7

ha! Goneril! with a white beard ......... iv. 6

his beard was grizzled? beards ........... - ii.

comest thou to beard me in Denmark ..
it shall to the barber's, with your beard

plueks off' my bearcl, and blows it in

his beard was as white as snow....
can let our beard be shook witli dang

defeat thy favour with an usurved beer

did I to day, see Cassio wipe his beard ... - ii.

BEARDED-bearded like the pard ...As yon Like, ii.
such bearded hermit's staves ........2 lienry

such I dared, and bearded to my face? i I I H nry $V I$. i.

every bearded fellow, that's bit yoked.. Othello,
BEARDLESS- shall a beardless boy..King John,

BEARER-stnnd aside, good bearer.. Lore's $L$. $L$.

wast eat thy bearer np...............

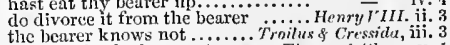

marrow, in the bearer strong . Timon of shens, v. 5 hearers of this greetiug to old Norwiy ...
slivuld the bearere put to suddcu deatlo 
BEATETII-fir the lowe he hereth. herd [Col. Knt.-luerr-wart] by trinsmutation a bear-herd. Tam. of $\$ h_{1}$. I (induc.) true valour is tumern bear-hiced the bearing of letter did.......... The The of le's i. I a smootl, discreet, and stable bearing

I know hin by his hearing

for shape, tor bearing, arsument ........

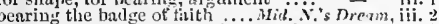
gonl repute, carti:lge, bearing. Low.s $L$. $L$.

well, we shall see your be: regia, betang thy port, eclsa senis. Taming of $\$$ ii. 1 thougl bearinus misery, F desire .....

in their houses, benrin, thence rings..... Cim of - v.

bearing their birthriglits proully. King John, ii.

bearing their own misturtumes.

when the intent of bearing them...... Hon Hry $_{\text {I }} I F$. v. either wise bearing, or iguorant ....2 Henry
by his blunt bearing, he will keep..... Iferry and nobles bearing bamners $\ldots \ldots \ldots \ldots \ldots$ ir. benring it to the blookly stanghter-liouse 2 H.F"T.iii. 1 bearing the king in my behalt along.s Henry $/$ I. Yi. I in bearing weight of goverminent

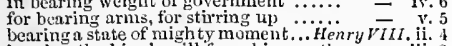
bearing the king's will from his mont

such valour in the bearing

at home, if bearing carry

their provand only tor bearing buxdens

sealing his present bearing with lis pist

be:aring hetters see bearing our woes . Th Antron. i.

Wath mates, and bearing fellowship........ Leur, iil.

bearing a Tartar's painted bow . Romeo of Julirt, 1 .

bearing with frank appearanee their purposes
BEARI

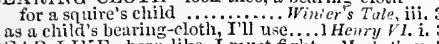

BEAR-LrkE-bear-like, I must figlit... Mickoth, v. 7

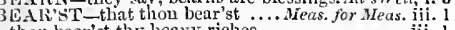

thon bear'st thy heavy riehe

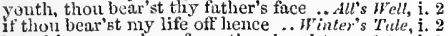

if thoul bear'st my life off hence .. Winter's 'Tule, i. 2

thou bear'st the lantern in the poop.1 Henry $I V$. iii. 3

see'st thou this, and bear'st so

bear'st thou her tace in mind

thou bear'st a woman's faee.

mEAR-WARD-C Col. that bear'st a cheek .. Lear, iv,

in earnest of the bear-ward ......... Huch Ado, ii.
manacle the bear-ward in their cliains .2Hen.VI.

the bear-ward that protects the boar

BEAR-WHELPS-these bear-whelps. Titus And. iv.

BEAST-beasts shall tremble at thy
he:Lveus keep him from these beasts!

any strunge beast there makes a man

eonspiracy of the beast Caliba

een a break fast to the beast

what a beast am I to slack it! .....

done first in the form of a beast

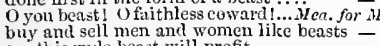

ere this ruxle beast will profit

$M u \overline{c h}$ Ado, i. 1

he would play the noble beast in love ... -

for loasts that meet me, run.......

for licasts tliat meet me, risly beast, which by nam

liere come two noble ben

a very gentle beast, and of a good

when beasts most graze, birds. Love's L. Lost, i.

not so, gentle heast; my lips a

he is little better than a beast ...Mereh. of Venice, i. 2

he be transtormed into a

the royal disposition of thint beast.

a pair of very strange beasts

how like.. Tam. of sh. $\overline{1}$ (indure.)

winter tarnes man, woman, and

taken the shapes of beusts upon them. Winter's $T$. iv.

a blessing he bestows on beasts

as a beast: not that, $r$ being a beast

二 iii. 2

then made...

as doth a raven on a sick-fallen berist ...... John, 1 v a king of beasts? A king of beasts. Richarl II. y. 1 a beast, to bear every knave's wrong.2Ileary IV. ii. I it is $\mathrm{a}$ beast for Perseus ............. Henry $r$. iii. 7 the ther jades you may call bea

even of the bonny beast he loved...2 $\ddot{H}_{\text {enry }} r$ r. v. 2 unt to the heast that would usurp

nin beast so tierce, but (repealed).......Richard III. robbed many betsts ot their

what a wicked beast was $\mathbf{I}$

Timon of Athens

the more beast, I say; I was..........

the unkindest bcast more kinder

give it the beasts, to be rid of the nien

and remain a beast witl the heasts?
what beast couldst thou be (repeafel)
I siall lo:e a stone by thec. Beas

ns beasts, and birls, and tishes ( $r e p$.)

some beast reared this; there does not

miture teaches beasts to know

the beast with many lreade butts

why birds, and beasts, fiom quality
not finl a heart within the beast

C.esar should be a beast withon
thon art tled to brutish beasts

alike teeds beast as man ..............

puldle which beaste would cough at

like beast, whicl you shun............ Cymbeline,
knew the betst, that I mirlit rail.. Tilus Anetron.

but throw lier forth to bcasts.

inght near to bets

the heast no hidle, the sheep no wool....... - jii.
whiat ho! you men, you beasts ...Romeo of Julet,

what a beast was I to chide at him!

the ull-beasonable fury of a beast....

O heaven! a beast, that wants discourse.

that adulterate beast, with witeheraft...

sleep, and tecd? a beast, no more

we are pictures, or mere beasts

let a beast be tord of beast

now making the beast with two

by and by a fool, and presently a benst

BE.ATI. ThST-the beastliest sense.Mer. for $\bar{M}$ ea. ii.

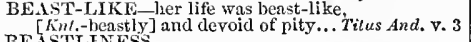

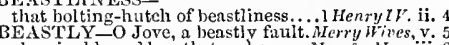

abominable and beistly touches.... Mea.for.Hea. iii. 2

see, how benstly she dotl court him. Tam. of Sh. iv.

being a very beastly creature .. Com. of Errors. in.

thou, beastly feeder; art so tull.....2 Henry IV.i. 3

not to relent, is beastly, savare ....Richare 111 . i.

in beastly sort, dragged through. Troil. \& Cress. V. II

a beastly ambition, which the golls grant
contumelious, beastly, mad-brained war

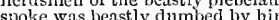

to expourd his beastly nind to $u$

We are benstly, subtle ns the for

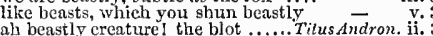

beastly villuins, like thyself

$[K n t$. $]$ her life was beastly, and devoid

BEAT-I sasw lim beat the surese

I could tind in my heart to beat him

beat him enough: aft him too

I am sorry I beat thee

then I beat my tabor, at which

or e'er your pulse twice bent

and hatl threatened to beat

he beat him most unpitifully.

he beat me grievously.

'slight, I could so leat the rogite......

the baby beats the nurse...

I shall beat you to your tent
which the air beats for vain.

or they shall beat out my hrains

they laugh at him, and beat lim

and you'Il beat the post ....

[Col.] whiteness, beat away those blushes

beat not the bones of the buried

I'll beat him, by my life (rep.).........

two hours younger, Ir beat the

how he bent me beeanse lier. T.......

bate, and beat, and will not be $\ldots . .$. .

knocks as he woukd beat down

that offer to beat my servant?.
he's beat from his best ward ......
who late hath heat her luusbain

healousy ! the, beat it lienee............

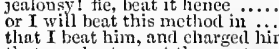

that I beat him, and charged hin

ii 1 beat the door down.............

and beat them backward liowe....

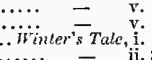

blood toth in the to leaven.......

it is to beat nsurping down

roeky shore beats back the envio
thrives to beat back Bolingbroke.

seope to beat since foes huve seope to beat

beat our watch, and rob our passengers
Tom, beat Cut's sarddle, put a few ..1Ilenr

Tom, beat Cut's sarldle, mit a few ..1Iten

didst thou beat heaven with blessing

your lulsidge beats as extraordinarily

that you and Pistol beat anion.........
BEAT-crowns to one they will heat .. Henry $r$ iv that beats upon the ligle shor to bent assailing death trom. auml thoughits heat on a crown

iIlenry $r$ iv. 1

from the shore the tempest jeat us biack -

$O$ beat away the busy meddling fiend

levy men, ancl beat liin back arain

or shall we beat the stones abo

.

pent heart may lawe some scope to beat -

and unresolved to beat then back...

power then, to beat lim back

yet to beat down these rebels .........

Will beat thee into han

therefore $\mathrm{t}$ heat thee. $\mathrm{L} \%$, io

more than he lias beat my bones

courage may beat down our foes

he beats me, and I rail at him

great Ajax bravely beat down him...

Polydamus linth lient dow'

and now he has beat it out of my. Timon of Ath.

with it beat out his brains.

I'lly beat thee, but 1 slinould infeet......

may beat thy gravestone daily

we'll beat them to their wives........

they had beat you to your trenehes?

so often hast thou beat me

are as often beat tor barking $\ldots . . . . . \quad$ - ji. 3

thou hast heat me out twelve $\ldots \ldots \ldots$ - - iv. 5

our enemies have beat us to the pit..Jul. Carsar, y. 5

the water which they beat, to follow. Ant. \&-Cleo. ji. 2

his quails crer beat mine, inlooped.

of Actium beat the approachini Casar -
as he harl power to beat me out of Egypt -

as he harl power to beat me out of Egypt -

we have beat him to lis camp....

we lave beat them to their beds......

the rain and wind beat dark December -

beats in this hollow prison. Titus Andronic

when thy poor heart beats with...

on the ragged stones beat fortly

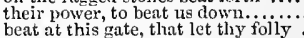

and beat thee, before thic king ............ - ii. 2

all teeling else, save whit beats there...... - iii. 4

strike! beat them down........... Romeo \&

and you beat love down $\ldots \ldots \ldots \ldots \ldots$.

with one hand beats cold feath aside

his agile arm beats down their fatal..
whose notes do beat the vaulty

but sureease to lieat: no warmth

I'll beat the knave into a twiggen (rep.). othello, as one would beat his offenecless do
a turbaned Turk beat a Venetian.

BEATEN-you have beaten my men. .yerry

is beaten black and blue. and beaten too

I was beaten myself into ali the $\ldots . .$. .

and would fain have it beaten aray... Much $A d o$,

if a man will be beaten with brains
I did think to have benten thee

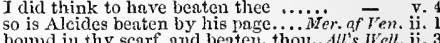
bomd in thy scarf, and beaten, thou... All's Well, ii. you were beaten in Italy for picking.. once heard, and thrice beaten ....... ii. beaten hence by your strange... Taming of $\bar{S}$. 2 (ind. was cver man so beaten?

I an robbed, sir, and beaten

and be new beaten home? ........ Comedy of Errors iv.

why am I beaten? (repeafed) .........

let us be beaten, if we eammot figlit .... Macieth, y. 6

are we not beaten? is not Angiers lost?.. Jolm, iii. 4

eldest son to beaten Douglas ........ 130 Henry $1 \mathrm{r}$. i. 1

hath beaten down young Ilotspur .2Henry IV. (ind )

like tle beaten flint...................

have in their own land beaten...... Richard III. v.

shake like a field of beaten corn ........ Troil. \& $_{\text {Cres. }}$ ii.

here, sir; I't have beaten lim ilize.. Coriolanus, iv.

nor walls of beaten brass .......... Julizs Crosar, i.
when thou once wast beaten fromi. Antony \& Cleo.i.

the poop was beaten yol beaten horse of Pärthia

ott our: coast, twice beaten ......... Cymbcline, iv.

beaten for loyalty excited me to ...... $\rightarrow \mathbf{v}$.

I'd have thee beaten for being old ........ Lear, i. 5

In hear the beateu drum ...................... intel, ii. 2 


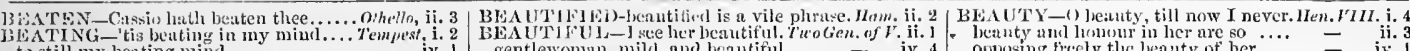
gentlewoman, mild, and beautif

with beating on the strangene

yet of many acemunted benutiful
lonks beantiful in the contempt

art as wive as thou art beantiful..... Whid. N. Dr.iii.

the highway: beat ing, and hanging. Winter's $T$, 'iv.

million of beating may come.........

nost beantitul pagan, most sweet... Her, of Ven. ii. 3

a lady tar more beautiful thann... Tuming of $s$. 2 (inil.

his youngest dangliter, beantitiul Bianca

becanse his feathers are more beautilul - $-{ }^{\prime}$ iv.

which was not half so beaure

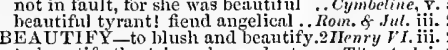

speak, beatiug your ofticers ......... Coriolen us, nili.

mist bear my beating to his grave. “itu

the bell then lenting one.............

will not mend his pace with beation.

that my larly Beatrice slanuld know ine

to beautify thy triumphs, and returif
grace thy marriage-day, I'll beautif

grace thy marriage-day, I'll beautif
to beantify hin, only laeks a cover.
BEAUTY - ondief, that's beanuty's canil

is the beauty of his daughter...

lady Beatrice, I will get you one .......

he slall fall in love witl Beatrice...

that her beauty is exquisite.

no mau counts of her beaut

let her beanty be her wedding-dower

upon the altar of her beanty

here comes Beatrice; by this day

fair Beatrice. I thank you tor you
find my cousin Beatrice proposing

when Bentrice doth come

now begin, for look where Beatrice.....

for beauty lives witl kindnes

in the holiday time of my beanty.... Merry Wives, ii.

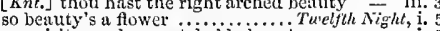

exquisite, and unmatchable beaut

give out divers scliedules of my beauty

never to let Beatrice know of it ....

as ever Beatrice shall couch upon?

fom all fashions, as Beatrice is ...

played their parts with Bentrice...

wsk my lady Beatrice else, here she coin

lady Beatrice, have you wept all

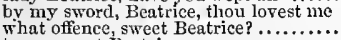

tarry, sweet Beatrice
Beatrice, -in faith, I wili go.

hearrice, in meatrice

nay but, Bentrice...........................

tefl thee how Beatrice praised thy wit.

helping me to tlie slecech of Beatrice

and so, I pray thee, call beatrice

well, I will call Beetrice to you......

an old instance, Beatrice, that lived....

which is Beatrice? I meswer to.......
his own pure brain, fashioned to Bea

his own pure brain, fashoned to Beatrice

BEAU-here eomes Mlonsieur le Bean. As you ike,, i.

bon jour, Alonsieur le Beau ............

BEAUFORT-Beaufort, that regards... Henry VI.i.

fie, uncle Beaufort! I have heard
mine uncle Beaufort, and inyself

Beaufort, the imperious churchman 7 a.

impious Benufort, that fillse priest

Beanfirt's red sparkling eyes blal $\ldots . . . .$.
Suffolk and the curdinal Benufort's mean

myself, and Benufort, had him in protection - iii.. 2

cardiual Beaufort is at point

cardinal Beanfort is at point of death

erowned the nompareil of beauty ....

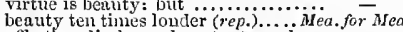

aftection, limb, nor bcauty, to make..
that is cheap in beauty, makes beauty

exceeds her as much in beauty
leretick in the despite of beaut

for beauty is a witch, against whose

$a$ sonnet in praise of my beauty

none, but your beanty; would. Mid. N. Drean ,

sees Heauty, thoungli but nean of... Love's $\bar{L}$. Lost,

benuty is bought by judgement
I thank my heauty, I an fair...

see, see, my beauty will be saved ....

ay, ny continent of beauty
hold, if not to beaut $y$ vowed

beauty doth varnish age, as if.

I may swear, benuty doth beanty iack

without the beauty of a woman's face

tCol. Knt.] eves of beauty's tutors.
[Cos

a light condition in a beauty das.

your beanty, ladies, lath much.........

veiling an indian beauty ........... As you

for honesty coupled to beaut $\mathrm{y}$

what though you have nore beau

youth, beauty, wisclon, courage .....
his wanton siege be fore her beauty

whose beanty did astonish the survey..... $=$.

I sarr sweet beauty in ber face...

virtues spoke of, and thy beauty
whereby $I$ see thy beauty

whangle heaven with such beauty

emblrace her for her beauty's sake....

ill-seeming, thick, bere th of beauty

never for a piece of beauty rarer. Winter
take the winds of MIarch with beauty

I'll hare thy beanty scratched
flowed with her beauty once

flowed with her beauty once
not so rich in worth as beaut

the alluring beauty took from my.....
best enamelled, will lose his beatity.

since that my bea uty cannot please..

love should go in quest of benuty....

such as she is, in heauty, virtue
can in this book of beauty read ....

as sle in benuty, edncation

chase the native beauty from his.....
proud with pure and princely beauty

or when he doomed this beauty ......
and stainer the benity of a fair .... Riel

tlieves of the day's beauty ...........1Henry I $\mathrm{H}$.

a stain uponi the beanty of all parts ..

that nl layer-up of beauty..

that bearity an I Ilest with

besuteous given $m e$, in thís beanteous face ....2Ilenry $V t$

thy beauteous princely daughter

her beauty, and the value of her

...̈̈ен

you arc a beanteous blossom, sure. Titus Andron. iv.

end his bcauteous sisters.... Romeo of suliet, i. 2 (note)

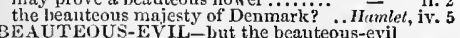

BEAUTEOUS-EVIL-but the beauteous-evil,
are empty trunks............... Tyelfth $N$ ight, iii. 4

BEAUTIED_beautied with ninstering. IIamlet, ii.

one that composed your beanties. Nitl. N. Dream,

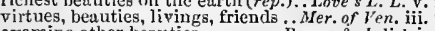

examine other beauties............ Romeo \& Juliet, i.

all the adinired heauties of $\mathrm{v}$ erona.

your good beauties be the happy cause. Inamlet, iji.

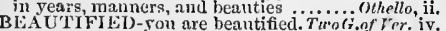

so seems this gor acous beauty...

ay; beauty's priucely majesty is

that for the beauty thinks it excelient

and beauty, that the tyrant of treclaim

'tis beauty, that doth oft make

fruit maintained with beauty's sun

your beauty was the cause (rep.) ...

thy beauty hath, and made them blind

but now thy beauty is proposed my fee

but twas thy beauty that provoked.
which, in their summer beauty kissed

her manners, stain her beauty $\ldots . . .$.
will be the beauty of this kingdom.. Henry rIII. i. 3

where this heaven of beauty shall

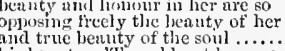

lis liesuty. "I'wonld not beenme.. Troil. \& Cres. i. 2

my mask, to dctivid my benuty

and dure avow her beauty and he:

pleasures such a beauty brings ....

gives us more palm in beauty than

the beauty tlat is borne here

$O$ beauty! where's tliy faith?

commend my service to her beauty...

by my once commended beauty.... Jul. $\overline{\text { Crssar, ii. }}$

whose lieanty elaims no worse a hisland -

if beauty, wistlom, modesty, can settle - ii. 2

her beauty and her brain go not.

no honour, where there is beauty

the privilege your beanty bear..... Tiin, $\overrightarrow{A n d}$.

the beauty of this sinful dame...Pericles, i. (Gower)

the purchase of a glorious beauty

which sliows that beauty hath

as my giving out her beauty stir up.

infect her beanty, you fen-sucked fogs..... \& $-\vec{J} u l$.

rich in beauty; only poor, that (rep.)

what doth her beanty serve ..........

her beanty [Col. it seeins she] hangs.

I ne'er saw true beanty till this night

thy beanty hath made me effeminat

power yet apon thy beauty (rep.

if she unmask her beauty to the moon... Hom the beauty of the world

no discourse to your beauty $(r e p$.

can trauslate beauty into his likeness....

tying her duty, beauty, wit...........

as having sense of beauty, do onnit

he bath a daily beanty in his life

BEAUTY-IVANING-beauty-waning.Rich. $\bar{J} I$ I. iii. 7 in charge, their beavers down ......2 Hen ry $I V$. iv.

I cleft his beaver, with a downright...3 Henry

is my beaver easier than it was? ...Richard III. v. 3

my silver beard iu a gold bearer... Troit. $\%$ Cres. i.
O yes, my lord: he wore his beaver up ... Hamlet,

the Frenchman became his surcty ... Mer. of Ven. i.

of her nature became as a prey ........All's Well, iv. 3

Jupiter became two spouts $\ldots$.... Winler's Tale, iii. 3

what pray you, became of Antigonus

became of his bark, and his followers $=\quad$ v. 2

at eigliteen years became inqui sitive of Errors, j.

when beame of them

Macbeth, i.

which became him like a prince ..... Henry $t$, ii.

became the accents of the val
became a bricklayer, when

2Henrytiv.

each following day became the next. Henry VIII. i.

in his spring became a harvest ....Ant. \&. Cleo. ij. 2

became the life o t the need ..............

became his guide, led him, begged ........ Lear, v. 3

Bo I alone becnms their prisoner.. Hamle, iv. 6 (let.)

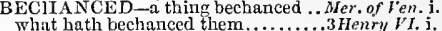

BECK - more offences at my beck thian... Hamlet, iii.

in his oftice ready at his beek.. Taming of Sh.2. (ind.)
when gold and silver becks me...... King John. iii

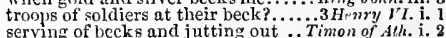

serving of becks and jutting out ... Timon of Ath.

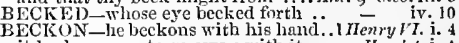

it beckons yon to go away with it ....... Honlet, i.
Iago beckns me: now he begins $\ldots$.... Ohello, iv.

BECKONED_one man beckoned .. Timon of A h. i.

BECONE-it would becone me as well. Tempest, iii.

your affections would become tender

should lecome kings of Naples? $\ldots . .$.
to become her tutor........ T'wo Gen.

my master is liecome a notable lo

my master is become a hot lover

to be fintastic may become a
will well beene such sweet

your falsehood elall become you.....

and now sbe is become as black as I.. ${ }_{\text {. }}$ iv. ives.

as it slall becone one that would.... - i.

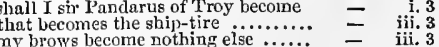

will become it well

become the forest better than

become the form of my intent
but it becomes me well enougl

Tuetrh Night, i. 2 


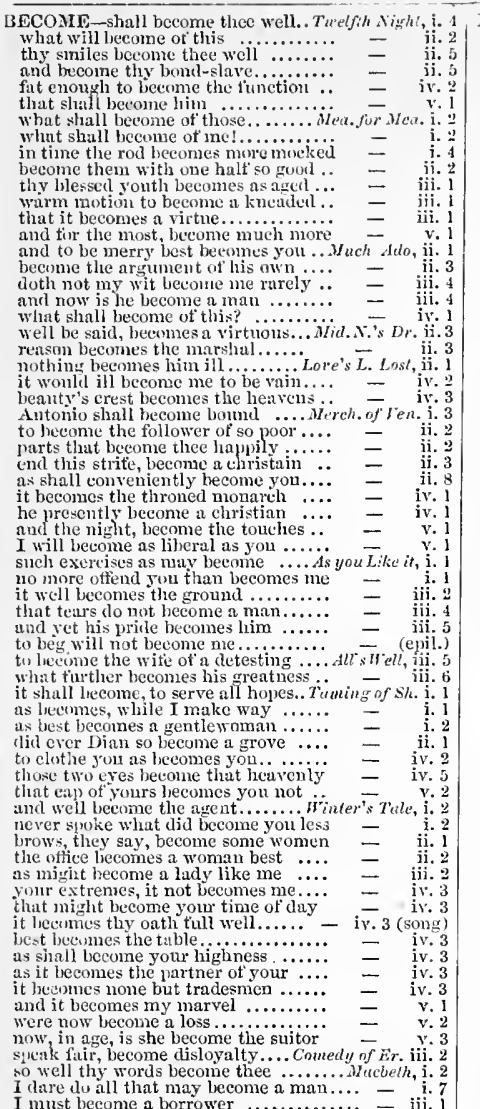

I must become a borrower

wonld well become a woman's story ..... $=$ = ini.

of your son, becomes a sun ...........

nor thou become thy great birth

anon beermes a mountain ..........

sheli he intendeth to becone the ficla -

and both beconje the grave ............

what o' God's name, doth
what is become of Bushy
shiall ill become the flower

when trimnim is become an alchoi....

and so become a rare liangman.

are now become your physicjan

doth this become your place.

if they become me not, he was a tool

maikleuly man at arms are you

William is become a good scholar

is the birth, becomes excellent wit

that he is become very hot

when gold becomes her olject.........
truth, it rery well becomes yoil
how ill white hairs become a fool

throne, and make you long becomi

there's nothing so becomes a man
in iny thoughts, becomes me best

this bccoms the great; Eorry an ì

ill-fitvouredily become the mornin

that should become our count
becomes it thee to tamnt lis...

and is become your foc.

wounds become hard-favored dcat

such commendations as become a mai

you shall become true liegeman ......
what shall of lim lecome. .2 Henry

no more than well becomes so good.

how insolent of late he is becone

our riglit valiant father is become.. .3 .

my soul's palace is become a pris
becomes it thee to be thus bola.

a king, become a banished man

should not become my wife

that king Lewis becomes your enemy

Where is Warwick then beco
is to become her husband

to see you are become so penitent
aud to myself become an enemy

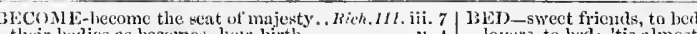

...Mil. N.'s Dren'n, v.

lacome as black as if besmeared ...Henry IIII. i,

what shall become of the great duke

whit's becume of of me now

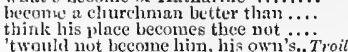

lis emiling becomes him better than

wlint's become of the wenehing rogues

does not become a man ........T

Athens is become a forest of beas
these words become your lips ....

ere we become rakes ..............

away, you fool! it more becomes a man

what is become of Marcius ...........

the wounds become liun on's brows.

this paltering becomes not Rome ....

sue as become a soldier

and this man is now become a god..... $j$

it doth become the month as well

it wonld become me better, thun to close

and is become the bellows

whom every thing becomes, to chide

does become the opposite of itself .
this lierculean Roman does become

say, this becomes him...............

and shall become you well

vilest things become themselves in her

thy angel becomes a Fear .i.

it nothing ill becomes thee

his captain enn, becomes his captain's

observe how Antony becomes his flaw

dime, whate'er becomes of me

more tenderness than doth become ....

satisfy me home, what is become of her

thingl valour becones thee we

a physician would this report becone

[Col. $]$ - would well liave become this pla

is Lavinia then become so loose

imnoeent, hecomes not 'Titus' broithe

thus it shall become high-witted

how well this honest nirth becomes

for mirth becomes a feast

no visor does become black villan.

mark how this becomes the honse.

most beloved, if all could so become it...

teath, becomes thy friend ............Roin. $\delta-\bar{J} u l$. iii.

for youth no less becomes the light

Hamlet, iv.

such a sight as this becomes the ficld ......

Whatever shall become of Mlichael Cassio. Othello, iii. 3
BECOMIED-might have well becomed.Ant.\& Cl. ii. 7

would have well becomed [Col.-become].. Cymb. v. 5

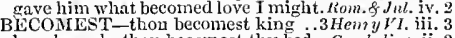

how bravely thou becomest thy bed... Cymbeline, ii. 2

so filled, and so becoming........ Winter's Yrie, iij. 3
becoming the actiou of good women. Heury VIII. ii. 3

becoming the actiou of good women. Henry VIII. ij. 3

since my becomings kill me.........Antony \& Cleo. i.

vith dimities becoming your estates.

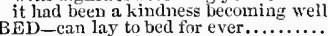

BED-can lay to bed for ever.
she will become thy bed.

bestrew the mimon of

in that oozy bed, whe

I was in love with my bed...

you hie you home to led .......... -

make the beds, and do all myself

go to bed when she list

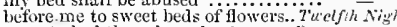

to go to bed then, is early (repeated)..

wit enough to lie straight in my bed

for this night, to bed, and drean

tis too late to go to bed now

biy enough fur the bed of Ware ........
wilt thou go to bed, Malvolio? To but?

get him to bed, and let his ....

I got possession of Julietta's bed.

if for this night he entreat you to lis bed

as tortunate a bed, as ever $\ldots . . . \cdots \cdots$ anch - v. 1

bill those that are drunk get them to bed -

till two, and then all to bed...........
she knows the leat of a luxurious bed

forsworn his bed and company...Mid. $N$.

to give their bed joy and prosjeri ty

one heart, one bed, two bosoms

here is my bed: sleep give tlice

wakes me from my tlowery bed

already to their wormy beds are gene

measure out my length on this cola bed -

sit thee down upou this flowery bet..
your' royal walks, your board, your bed - seek the weary beds of penple sick. Love's $L$. $L$.

in a grolden bed lies all within ....Mer. of len. ii. 7

mo hed shall e'er le guilty........... - iii. 2

let their beds be nute as silt

nor my husbantl's bed.................

or go to bed now, heing two

without candle may gor clark to beis.

(song)

to a long anil well-deserved lied...... - -

in your hed find tiliser turtume

raiscd me from my sickly leed?

I have sworn, I will nut beel her

the Tusem wark, and never bed her.

gave it to yourself in leed
that I husbanded lier leed

that I knew of their going

ny bed he hath rlefiled ............... =

to thy cold bed, and warm thee... Thin. of Sh. 1 (indi.

if he were conveyed to lied, wriplod = 1 (incl.)

gently, and to bed with lim......

the lustfil bed on purpose trimmed...

all this time abandoned fion your bid $\mathbf{2} 2$ (ind

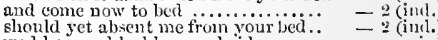

sweet Katlorine, in thy lied...

about the making of the bed

come, Kate, we'll to bed....

that goes to bed with the suin...

ïinter's $\bar{T}_{a}$

when you are going to bed

to die unon the bed my father...

as it becomes the partner of your bed

to bless the bed of majesty again .....

keep fair quarter with his lied....

to triant witl your hed....

nor to her bed no homage

and as a bed Inll take thee

always going to bed, and

didst make him master of thy hed...

his pendant bed, and proercant

-

re you went to bed, that rou did ic.

and again return to bed

who have died holity in their beds $\ldots . . . . .$.

room for him in my husbind's bed ... King Jo/

my bed was ever to thy son as true ...
from their fixed beds of lime had been

to die in beds that here con
shall gild her brital bed....

lies in his bed, walks up and down....

that bed, that womb, that me

broke the possession of a royal bed....$\quad$ iii.

send the hearess weeping to their beds

time enough to go ber with a canile.i Henry $^{-}$

a banished woman from my llarry's bed -

tell we, doth he iseep lis.

it grows late, well to bed

with the vile in loathsome beds.......

please it your grace, to go to bed

sit thou by my bed; and hear.........

come, corlon silence; and then to bed

very sick, and would to bed

...Henry $r$

as every sick man in his bed.

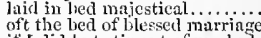

slcep upon their gniet heds............

on the sulden from their drowsy beds

I banish her, ny hert, and compiny.2 Henry VI. ji.

have youl laid fin the lies.

took into her blaneful bed some

died he uot in lis ined

you were best to go to hed, and drean

table, IIenry, and thy hed ............

what, will he not to bed?

attain his easeful western bed $\ldots \ldots . .$. .

go home to bed, and, like the owl....
what, is he in lis bed?...............

made her widow to a woful bed..................

necursed woml, the bed of death $\ldots$....

let sorrow lannt thy bed...

myself, as fulse to Wdward's hed........

$=\quad$ iv. 1

thy daughter to a conqueror's ied.....

8o went to loed; where eagerly

to him too, betore he go to bed .....
pr'ythec, to bed; and in thy prayers gravity out of his bed at midmight....

in sleeping on your leels ............ 
BED-her bed is India: there she lies. Thooil. \& Cres. upon a lazy led, the live-long in the fily beds preposed

a chamler and a bed, which bed

bed, clanuber, Pandar to ......

prythee now, to bed

mow lies thinking in his bed of the

this duinty bit, thus goes to bel..

maid, to thy master's bed

in different beds of lust .............

in the embracements of his bed

whose hours, whose bed, whose meal

when I went to bed. Get you to bed.

every man henee to his idle bed......

good Portia, go to bed

comfort your bed, and

to tumble on the bed of Ptolemy

great Cxsar lay his sword to bed

I drunk lim to his bed.

for the best turn i' the bed

we have beat them to their beds...

rim into 't as to a lover's be

than that runagate to your bed

to hed: take not away the taper

such the adornment of her bed

that your have tasted her in bed...

played the strumpet in my bed ...

filse to his bed! what is it

do't, and to bed then

have made the ground my bed

he'll make his grave a be

to make his bed with the definnct....

ny queen upon a desperate bed.....

in frcsh eups, soft beds, sweet words.

a hangman to help him to bed

in suit the plaee of his bed

over chance, in honour's bed...

died in honour's lofty bed.............

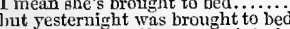

by the defiling of her parent's bed

to keep his bed of blackness...........

what inen in arms, as well as beds

what haste you can, get you to bed .....

he went to bed to her very description

not so to bed to her very descr

ere she had a husband for her bed.

within a dull, stale, tired bed

vouchsafe me raiment, bed, and food

ask for me, I am ill, and gone to bed

go to thy cold bed, and warm thee

my fool usurps my bed [ $\mathrm{Col}_{\text {. Knt. }} \ldots$ bedy]..

shady curtains from Aurora's bed... $R$

in bed, asleep, while they do

come on, then let's to bed

soon to bid good-morrow to thy bed...

Romeo hath not been in bed to night

made you for a highway to my bed

go you to her ere you go to bed (rep. $)$

go you to her cre you go to bed

this phial, being then in bed

eomes to rouse thee from thy bed

I'll not to bed to night

get thee to bed, and r

let the county take you in your bed.

with flowers I strew thy bridal bed.

why I descend into this bed of death

get thee to bed, Francisco $\ldots . . .$.

will sate itself in a celestial bed.

let not the royal bed of Denmark.......

in her eloset, ere you go to bed

I']! call upon you ere you go to bed...

or in the incestnous pleasures of his bed.

but go not to my unele's bed

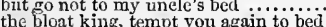

go to their graves like beds

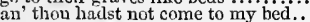

business, hattl raised me from ny bed ... Oithello,

my thrice-driven bed of down.

why, go to bed, and sleep

housewifery, and housewives in your beds

you rise to play, and go to bed to work

come away to bed, sir, for your hurts
his bed shall seem i school

nightly lie in those unproper beds..

strangle her in her locd, even the bed

lay on my bed my wedding-she

he hath commanded me to ge to bed

laid those sheets you bade me on the bed

will your eame to bed to-night, Desdemor

my mistress here lies murdered in her bed

look on the tragie loading of this bed

BEDABCLED-bedabbled with the dew Nrid. $\bar{N}$. BEDASHED-trees bed asbed with rain. Rich. III. i. BEDAZZLED-bedazzled with the Kum. of Jul. iii. BEDCLAMBER-your bedehamber.. Richaril II. i.

own hand, in his bedchamber ..... Herry VIII, iii.
BEDCIIAMBEl-of his bedchamber.. Cymbelin f will kecy, them in my bedchambe

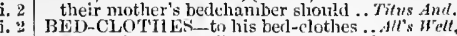
BEDDED-my son i'the ooze is bortled. Tempest, wedded her, not bedded her ...All's 'H'ell, iii. 2 (lette BEDE-where's Bede? [Collier-Bead KnightBEDECK should hedeek thy shape. Rom. \& Jut. iii. BEDECKING - with such bedeeking. Lore's L. L. ii.
BEDEW-.hedew her pasture's grass..Fichard II. iii. all the tears that slould bedew

nere you her berlfellow list night?

have that doctirr for uny bedfellow.

swreet doctor, you shall be my bedfellow

being so troublesome a berfellow?

the man that was his bedtellow
two tender bedfellows for dust

to leave so sweet a bedfellow?....

go, yon wild bedfellow

to scek her as a bedfellow......... Pericles, i. (Gower

my noble lord of Bedford, my dear lor

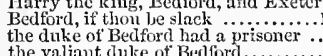

enry $V I$. i.

the valiant duke of Bedford...

couragens Berltord, let us now

the noble duke of Bedford, late
and did my brother Bedford toil

Henry's eonquest, Bedford's vigilinee

Ellen.Ir,ii.

BEDL AMI-Dellam, have done. I have....John
ha! art thou Bellam? Dost thou...... Henry

the bedlan brainsick dnchess

to Bedlam with him (repeated)

proof and precedent of Bedlam b....

get the Bedlam to lead him .............. - iii.

BED-PRESSEli-this bed-presser ..1 Henry $1 \mathrm{~V}$. ii.

BED-RID-sick, and bed-rid father..Lore's $L . L$. $L$.
lies he not bed-rid? ............ Winter's Tale

impotent, and bed-rid, seareely hears

BED-ROOM

BED-SWERVER-she's a bed-swer'ver. Winter's T. ii

afterwards consort you till bed-time. Com. of Er.
I would it were bed-time, Hal ..... 1 Henry IV.

BEDWARD-tapers bumed to bedward ... Coriol. i. 6

BED-WORK-call this-bed-work... Troil.\& Cres.

where the bee sucks there suek $\mathbf{I} \ldots \ldots \ldots$.

and kill the bees, that .....T Too Gen. of Verona, $\mathrm{i}$

when, like the bee, tolling from

for so work the honey bees

so bees with smoke like an angry hive of bees

iHenry

the bee stings, but I say, tis the bee's

they rob the Hybla bees, and leave
ron bees, that make these loeks

like stinging bees in hottest

BEEF I am a of henter of ....

she hath eaten up all her beef ... Icas. for Might, iii.

ot muttons, beefs, or goats.... Werchant of Venice, i. 3

a piece of beef, and mustard

why then the beef, and let th...

the you get ne beef of Grumio .... - iv. 3

0 my 8 weet beef, I must still ....... Henry IV. iii. 3

give them great meals of beef

in chines of beef, ere thou sleep....2. Henry IT. iv. I0

BEEHIVES-hut rob beeluves ......2 Henvy VI. iv.

BEER-vilely in me, to desire smali beer.2 Hen.I $V$.ii. 2

a pot of goed double beer, neighbour. 2 Henry $V I$. ii. 3

to suckle fools, and ehroniele small beer. Othello, ii.

BEER-BARREL-stop a beer-larrel .... Hamlet, v.

poor beetle, that we tread upon.... Nea. for Mlea. iii.

the shard-borne beetle, with his

filip me with a tluree- man beetle..

find the sharded beetle in a safer.

NIlemry $I V$. i. 2

aross as betles .... Cymtetine, iii.

that beetles o'er his base intu the sea....... Ilamlet, $\mathbf{i}$ :

\section{BEE'TLEHEADED-whoreson, heetlehearled,}

BEEVES-has he land and becves ....2 HenryIF,

BEF A -might befal your travel ....TwelfthN. iii. 3 than what betals myself

what doth befal you here ............... ilea.for Mea. i. 1

the worst that may befal me in ...Mill. N. Dream, i.

it doth betal, that I, one snout

now fair befal yonr inask

f:ir befal thee, rood Petruclio..... Taming of $S_{1}$. ofal my sour

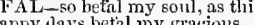

whom fuir befal in heaven 'mongst

no war, betal thy parting soul..

O let me stay, befal what may bet

more sucl days as these to us be
or what serrow can betal thee.....

what may befit him, to his harm

now fair betal you! he deserved.

...Rechard III, $\mathrm{i}$.

all joy befal your graee, and you

befal what nay befal, I'll speak. .. Cymletine, iii.

and ours with thine, befal what fortume $-\mathrm{v}$.

what hath then befullew, or what ...2Henry $I r$.

misfortume ins since then befallen

and Laneaster that had befullen us... Richard in

heartily wish this had not befallen ...... Othello, ii.

BEFEL-how heavily this befel .. Meo.for Mea. iii. I

lo, what befelt he threw his eye...As you Like it, iv.
what befel me on a clay .............3 Henry VI, iji

BEFIT-business that we say befits ....Tempest, ii.

a the tounder

it well hents you should be .......2.IIenry $I V$ iii.

it ill befits thy state.........

as befits mine honour to stoop......... Ant \& Clco,

as doth befit our henour ................ Pericles, i. 1

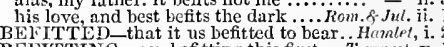

BEFIT'TING-nor befitting this first .. Tempest, v. I
BEFOREHAND-hath been beforeliand ...John, v. 7

BEFOR E-TIME-I have before-time. Coriolanus, i.

EFRIEND -thou mayst befriend me ....Johs, v.

and negligence beriend thee now..Troil. of Cres.

good Servilius, will you betriend.. Timon of Ath. iii.

I will befriend thee more with rain.. Tins And. iii. I

[Knt.] befriended with aptness ...... Cymbeline, ii. 3

BEG- boen than this I cannot beg. Tur Gen. of $V$. v.
that I do beg lis life, if it be sin.. Mea. for Nea. it.

and doth beg the alms of palsied eld - iii.

and sequent death is all the grace I beg $-{ }^{\prime}$ beg the ancient privilege of $A$ thens... Mid.N $D$. $\mathrm{i}$.

do but beg a little chasigeling ...... - ii.

place can I beg in your love .......

and beg lier Intian boy..........

I beg the law, the law, upon $\ldots . . . \%$ iv. 1

thou bid'st me beg....................

you cannot beg us, sir, I can......... $\bar{r}$ v. 2

you taught me first to beg............

wouldst thou have me go and beg.

but first begs pardon ....
therefore, to beg will not

I do beg your good-will in this.......... All's (epll $_{i}$.

you beg a single penny more .........

but first I leg pardon....

but that $\mathrm{I}$ mayes we

iVinter's Talc, ii.

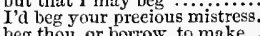

beg thou, or borrow, to make
I shall beg witl it from door

who neither beg, nor tear

find him fortune! and more I beg

upon my knee I beg, go not ......... King John, iii.

and to beg enfraneh isement ............. sichard II. iii.

I'll beg one boon, and then be gone.

and beg thy pardon ere he do..........

a begtgar begs, that never begged

his livery, and beg lis peace

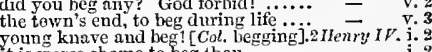

it is worse shame to beg than ........

my speech, to beg your parlon .......

on my knee, I beg mortality ........ i Henry $r$. ix.

make thee beg pardon for thy passed

I think lie means to ber a elicil....... - iij.

that love, which vintue bers, and ...

and at his hands beg mercy ...........

but beg one favour at tlyy graeious .. -

as you would beg, were you in m

Col.] none of you would ence be

purpose, thus to bes a kiss.. Trailus onry FIIT. iii.

purpose, thus to bec a kiss... Troilus \& Cresside, iii.

I beg of you to know me...

am bound to beg of my lord genern of sthens, i

the people, beg their stinking breatis

to bes of thee, it is my more dising 


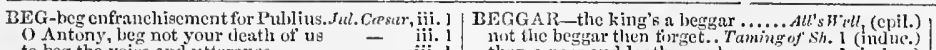

yea, beg a hair of him tor menory

bes often our own liarms.

not lie beggar tlien timget.. Taming of sh. 1 (indue. than a poor and loatlisone lregenr. ret wixt the prince and hegrgar ...Minter's Tale, ii. girt beside thy modesty enn be

no less hey than a kinglom.

I hes but leave to tir this jewe..

of kings, of beggurs, old men .......... King John, ii.

like it poor bergar, old th

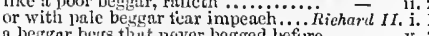

I do not bid thee beg my hi

'tis present deatly I beg

a beggar bees that never begged befuro
ehanted to the beggar and the king..

like silly begirars, who, sitting in

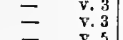

ulon my teeble knec l beg this boon

and his empress beg at the gat:

nor moody heggar's starving
beggars all, begrats all, six
ohn

thon command'st the bergar's kne

1 Henry $1 \mathrm{~V}, \mathrm{v} . \mathrm{s}$ to heg reliet annong Rome's en
be glad of hread, and beg tor $i$

neven used to beg. No, tric

to beg nt you, kind firiends

that beggars, mounted, run ..........

Henry $V$ iv.

spurn upon thee, begrar, for thy.
it begens any man that keeps it

else will take the thing she hegs...

on ny knees I beg, that you'll ....

aome reason, else he could not beg...

beg pardon of the prinee .........

fall prostrate here, and beg your parion

what wouldst thou beg, Laertes

we leg your bearing latiently....
virtue itself of vice must pardon be

i'll blessing ber of you

prinee what bege:ar pities not?

BEGGED-and begged he pardon?.Ant. S Cloo. iii, I thought to have begged, or buugbt. . Cynibeline, iii. not life that I liave begged so long?

led him, hegged tor him, saved bim Lear,

EGGING-begging but a beggar......... Tuelyh $N$. jii.

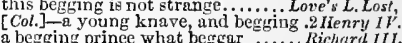
a begging prinee what beggar

I have been begging sixteen years... Henry $\bar{V} I I I$. ii. to trouble the poor with begring.... Coriolanus, ii. gets more with begging, th n we wi... Pericles, ii. I EGIN-no, it begius again ............ T'enpest, first begins to crovi $\ldots \ldots \ldots \ldots \ldots \ldots \ldots$..............

begin to chase the ignorint funver.

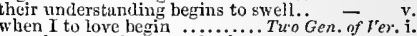

these thmishetl berrars weary..... - iii. 1

zou always end ere you begin........ - jen

made it a fool, and beggar ............. Henry FIHI. i. I

a beggar's book outworths a noble's ...

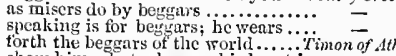

without adviee begin to love her

falls off, ere it begins $\ldots \ldots \ldots \ldots \ldots \ldots . \ldots, \quad$ v.

show him what a beggar his heart is
steal but a beggar's dog, and give it.

steal but a beggar's dog, and give
charitable men afford to beggars

begin, tool; it begins, hold ......... Tuelfin Nirht

I shall never begin, if I hold

why, that begins my name

to-morrow sliall I beg leave to see....
but wish and beg your sudden coming

I was so unfortunate a beggrar.

raise me tlis beggir, and clcnude...

learn to begin thy liealth.

the beggar native homour...........

now be fin; for look wherc............Yuch $\overrightarrow{A d o}$, iit.

I therefore beg it not, to please
BE.

be agois, wert thou not beggar .........

for the letter that begins them all.$\ddot{1}$.
Pyramus, sou begin; when.......Mid.N.

made senseless things begin to do.... - iii. 2

nyy very visol began to assume
my lungs began to crow like

this carol they began that hour
his good melanclioly of begrun

how her sistcr began to seold.

v. 3 (song)

I had rather be a beggar's dog

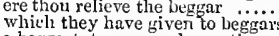

her dotage now I do herin to pity

come, thy l'envoy; begin ..........Love's $L$. Lost,

now will I begin your moral

peacc, the peal begins $\ldots \ldots . . . . .$.

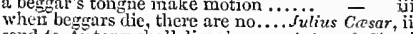

tlut ended when I but began
ot men, began a fresh assault

send to Antony shall die a beg

the begrar's nurse and Casar'

began to give me ground

woult have a queen his beggar
worth many babes and beggrs

thoul took'st a beggar

taking a beggar without no..............

bare tortume of that bergar Posthumus

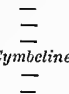

bergin, sir; your are my elde

the scene hegins to eloud
by the cuekoo:- Ver, bewin.

and beran thus: wonder of nature.... Henry $r$. iii

when the figlat began, ronsed on

rest where it began at first
begau her devilish mraetices...

is worse in kings, than berrars

why, are all your beggars whipped

a knave, begegar, coward, pander

your quarrel? how began it first? ...3 Henry $\nu_{I}, \dot{i}$. o then began the tempest.

first, I began in private with you... Henry ryII. ii.
low youngls he began to serve his.. Coriolanus, it.

continued to his country, as he began

stand in thine, began to water....Julius Cassar, iii.

he beran his stop is the ehase

our basest beggars, whe in the poorest

so beggars marry many

a poor unfortunate beggar

a poor unfortunate beggar .........

u'lio did end, the aninute $I$ begain.

Pericles, $\mathrm{v}$.

the strings of life began to crack ........... Lear, v.
were you by, when it began?

speak, who began this? on thy love .... Dethello, ii. 3
how this foul rout besni, who set it on .. - ii. 3

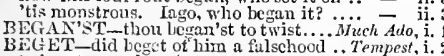

to beget more love in you...... Tho Gen. Tempest. .1 .

lis eye begets oceasion for his mirth. Lme's $L$. $L$.

it old sir Robert did beget us both.
and not love, bcgets lis penitence

and thcse two beget a generation

like the father that begets theun.

and doth beget new eourage.

I did beget lier, all the parisili........

is ikely to beget more enco..... $\rightarrow$

guarrol daily doth beget!

I will beget rine issue of your

live, and beget a happy race of kings - iv.

this one ehristening will beget...... Henry VIII. v

and beget youlug gibbets

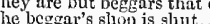

then are our beggrars, bodics............... Hamalet, ii. 2

beggar that $1 \mathrm{am}$, I am even poor.

a progress through the guts of a loggar ... - iv.

a begrar, in his driak, could not have.. Öthello, iv.

and beggared yours tor ever? .......... Metcleth, iii.

scems bankrupt in their beggared host. Henry $V$. iv. 2
it beggared all description ...... Anlony \& cleo. ii. 2

Wherein necessity, of matter beggared.. Hamlet, iv.

BEGGARLY - the beggarly thanks. As you Lite it, ii. 5
rest were ragged, old, and beggarly..T(tm. of sh. iv. I
poor and bare; too betorarly

peally, bre; too besfarly

Henry $V$. iv.

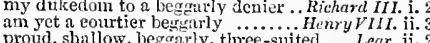
proud, shallow, beggarly, three-suited.... Lerur, ii. shake me off to beggarly divorcement.. Othello, iv.

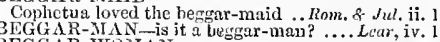
BEGGAR-NINN-is it a beggar-man? ....Lecar, iv. 1 was by a beggar-woman stolen ....2 Henry IT. ir. 2 learning, late deeeascd in beggary... Hit. $\mathrm{N}$. D r. $\mathrm{v}$. there is no viec, but beggary ........ King John, ji. 2 to emelude, reiroach, and bestury..2 Hen'y $I$. iv. impotent and snail-paeed beggary.....ichard 171 . iv. therc's beggary in the love that can... Ant.f cteo. depentlency but brats and beggary.

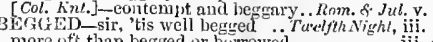
more of than begged or burrowed . Hril. $\bar{N}$. Dr. iv. 1 that begged it as a fee............. Ster. of tenice, v. mnto the judge that begged it.

and hegged the ring, the which I dici

$\begin{array}{ll}\text { I think you would have hegred the ring - } & \text { v. I } \\ \text { y. }\end{array}$ love I begged for you, he beggerl .. Com of Er. iv. 2 exactly begged your grace's pardon... Richard II. i. 1 hegs that never begged before ........ il - - v. in earnest what $\mathrm{I}$ begued in jest.... Richari III. $\mathrm{v}$. in all two worthy voices begged ....... and on her knee hath beared... whereon, I begged lios parton

there berins my sadness ............As you Like it, i.

within me, begins to mutiny

and there begins new matter

you must begin, - will you, Orlando

and $T$ 'll begin witl the womer

and ere $I$ do begin.

and $I$ begin to love, as an ol $d$ nian

they begin to smoke me

as it begins, stall so perseve

you might berin an impudent

go thy ways, I begin to be awears.,
to begin his wooing, that would

I must begin with rudiments of art..

now it berins to work

now I begin: imprimis, we enme ....

first begin with her (repeated).........

gasping to begin some specel

thought to begin from such a cottage

soul vexed, begin, and why to me!

would she begin a sect, might quendi

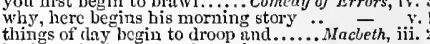

leaning on mire elbow, I begin ........ King $J_{0 h n}$

order the trini, marshai, and begin.

attending but the signal to begin

how he doth begin to make us ........ Henrry $I V$.

team begins his progress $\ldots \ldots \ldots \ldots . .$.
how bloodily the sun begins to peer...
begin to patch up thine old boily ....2 Henry $I V$.

begin to patch up thine old borly .....

doth obstrin to melt and drop $\ldots . . . .$. - ii.

then with Seotland first begin ......... Itenry $V$. i.

I have heard a sonnet begin so .......

yet my livod hegins to flatter.........

the ruin, there begins contusion...... - iv,

we shall begin our aneient hickerings.2 Henry $\boldsymbol{r}^{\prime} \mathrm{iv}$.

sweet York, besin; and if thy clain

this knave's trongue begins to doub

the rage allays, the rain hegins.

so young a thorn begin to priek.

for $m y$ uame berins with $a$.

inicharl IIl.

tyranny besins to jut upon the ........ =

and then agracious begin, and stop nguin

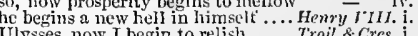

Ulysses, now I begin to relish...... Troil.f. Cres. i.

berin to lose their gloss...

all the Grceks berin to worship $\mathrm{A}$ j...

Tll begin. - So mueh tor Nestar.

the befure their strokes begin

I am not fnrnished likc a bergar ...

Greeians begin to proclaim ...... 
BEGIN-how the sum begins to sct.. Troil. \& (res. v. 9 nay, an' you begin to rinit on socicty.. Tint.of' sth. i. the gods besin to mock me

curse berin at every root of his hear

from whe jes shomill hegin, and end

to end, whero he was to be

any thing that other me

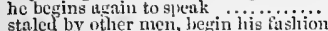

when love begins to sicken ant tleery

where I did begin, there shall I enel.

begin to throw Pompey the Grent

when it appeurs to you where this begins

mine honesty, and $f$, lierin to squar

when one so grent berins to ra

to be of note, begins betimes

and begin the fight; our will is

Miary-buds be din to

our song the whilst: bruther, berin ...

Ind remove him. So; begin the fashion, less withont

danghter's cbastity - there it

read, when mine begius to clazz

ay, now begin our sorrows $\ddot{\text { he }}$.

their mouths, if they begin to cry.

what they did begin, was, wi
now the winds berin to hilow

ready to hegin the trinm?

begin to part their frimges of
begin to tind an ille and fim

will pack, when it begin

he begins at curfew, and waiks till.

his wits begin to unsettle

my tears begin to take his part ......

let them legin. I will frown.... Ron
in the furtlest east begin to draw...

shall bitterly begin his ficariul date.

and Romeo begiu both with a letter

I know it bergius with some other....

if it live in your menory, hegin at

'tis not so; it begins with' Pyrrhci

begin, wurderer: leave thy (rep.)
in nause where I shall frst begin

thus bad begins, and worse renains behind -

ne'er begin [Cot. Knt. were ne'er lngan]

come, begin; and yori, the judges bea.

begin to heare the gorge, disrelish ......

my blood begins my siter guides to mile

BEGINNER-in the first begimers .. Cymbeline v.

WEGINNING-torgets tho beginning .. Tempest, ii. I

no great love in the beginnims

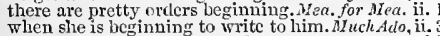

whe true beginning of our end.Mid. N.Dr. v. I (proi.

the true beginning of our end. Mid. N.Dr. v. I (prol.

well, the begiuning that is dead

a strange beginning: horrowed majesty ... John, i.

end of a fray, and the beginning of..1 Hem $7 \mathrm{H} / \mathrm{V}$.

weak beginuings, lic intreasured $\ldots 2$ Hemry $I V$. iii. I

we see yonder the beginning of the day

end of it muknown to the beginning. Coriolan

was an ill beginning of the night .Julins Casar, iv. 3

I will never fitil beginning $\ldots$........ Cymbeline, ii.

I eannot speak any beginning to this . Othello,

BEGNAW - conscience still begnaw.. RicirtrdIII. i. 3

was begot butween two stock-fishes. Mea. for $M$. iiii.

there's one whom he begot with child ,
these are bcgot in the ventricle..Love's $L$. Lost, iv. 2

these are bcgot in the ventricle...Lare's.

how begot, how nomrshed ...Mer. of Fen. iii. 2 (song)

snch i father legot villains

that was begot of thonght..........

were well liggun, and well begot ..... - v.

that $I$ am as well begot, my liege

and I am I, bowe'er I was begot
when Ricliard me begot, if thou

when Richard me begot, if thou...

what eannoncer begot this lusty

for nothing liath begot my something

the issue was not his begot ..........nichardrIh. iii,

I am a bastard begot, bastari...

exense be born or eer begot $\ldots . . .$.
grandsire, and begot a tather

first, know thou, $I$ begot him ..... Titus Antron. $y$.

you have begot me, bred me, loved me ..... Leur, i.

twas this flesh begot those l,elican

begot of nothing but vain fantas
tis a monster bergot upon itself .

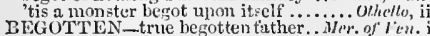

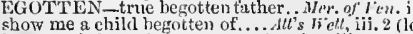

innocent babe truly begotten Wintcr's T. iii. 2 (nraele)

no heir bcgotten ot his body.

not me hegotten of a sliepherd.

BEGRINED_now begrimed and biack. ot hello, iij whites you bein and low heguile ..Mcrry Wires, 1.3 who dous heguile you ............ my ancient skill beruiles me............. for $\bar{M} e$. iv. $\mathrm{n}$ lat and bean-ted borse becuic....Hill.N.Dreain, ii. how shall we bewuile the lazy time $\ddot{2}$ eth liglit of light begule ........ Lire's L. Lork, i. I
BEGUII, - to beguile two hums in to beguile the supuosition of thint....

to bey nile the ohl folk

thint we misht begnile the old pant

would heguile nature of her enstom

in prosperity, thon clost beguile m

is't thou that think'st to beguile

1s thou that think st to begule me? Henry I $_{1} \mathrm{i}$.

rudely begniles our lips of all

the fox would beguile the .....

and so beguile thy sorrow, till thee. Titus $A$ en.

pions bonds the better to beruite

and fitin I wonld bertile the tedious $\mathrm{c}$

so let the Turk of Cyprus us beguile

but $I$ do beguile the thing $I$ a

to beguile many, and be beguiled by one

that beguiled him of a eliain

that begniled master Slender

in ehoice he is so of t beguilicd

Tuelfih

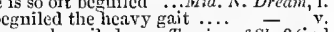

and how slic was beguled...... Taning of Sh. 2 (ind.)

very mueh beguiled the tediousness. Richurll II. ii.

in such distraction as beguiled all. Ant.

alls not well: Casar's heguiled

he that beguiled you, in a plain accent

not vanquislied, bnt eozened and beguiled

poor ropes, you are begulied, botil.

thus bestiled your daughter of herself ... othello, i.

to begule many, and be beguled by one - iv.
BEGUILING-beguling virins with.. Henry $v$. iv.

BEguiling them of emmendation 1 lienry $I V$. iii.

while ago the worlul begam. Tue efth Night, v. I (song)

were well besun, and well begot... As you l.ike it, $v$.

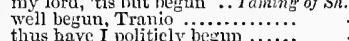

thus have I politicly begun $\ldots . .$.
since yon have begin, have at $y$.

since yon liave begnn, have at

thinges, bad begun, make stron.

all things begun eome to ill cul.

let this cue where it begun.....

begun upon an honounable respect

warrant, hegin through malice

since we have begun to strike $\ldots . .$.
all designs begun on earth below

when sueh time they liave

the ides of Nared begun ............ Juling
an end of what I have begun ... Antony
since first the world begnn ..... Ronie

since first the world begnn ....... Ronieo \& Jutiet, i. 2

[Col. Kint.] my joys were ne'er begun

the is begnn by time

BEHALF-thy voice in my behalf... Merny wives

Whet your gentle thoughts on his behalf - iii. 1
shall on her behalf ehange slander..Pnch Ado,

too offieions in her behalf .... Mid. N.'s Dream, iii. 2

his wise mother wronght in his behalf. Mer. of Ven. $i$.

in the behalf of a good play? .... As you Likie it, (epil.

in behalt' of the count Ronsillon?

suffer something in my behat

whisper hin in rour behalts.

right and true belsalt of thy deceased

on our behalt, armies liave challenged $-\overline{\text { ii. }}$ I

in your majesty's behalf ............ I klenrylt

both in an mis usist behalf...............

I have much to say in the behaif .....

even in thy behalf, I il thank ........ $v . \bar{v}$ v. 4

my behalf would pluek a flower (rep.).1 Henry I I. il.

every word you speak in his behali..2 2 curver.

the king in my behalf along ......... Henry $r t$. ii. i

the broker in minc own behalf

you in our lehalf go levy meu

from me to my son in youx behal
be eloquent in niy belalf to her......

prinees figlit in thy bchalf.

Troilus of cressida, iii. 3

to rob in the belialf of charity........

in my lord's belsalf, I eome ........... - iii. 1

we see, have sided in his behal

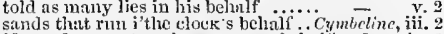

if you dare venture in your own behult ... Lear, iv. 2

will do all my abilities in thy bechlf .. Orhetlo, iii.

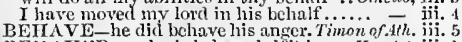

BEII V VD - as he is behaver, if't be ... Hamtet, iii. I

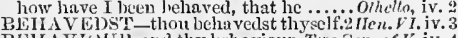

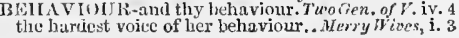

BEIIAVIOIIR-unweighed beliaviou
teach the childien tlieir behaviour's

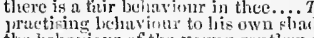

be dedicates his behavisurs tu love

hath in all outward behavicin's secmed

his general hehavionr vilin, ridiealous

and his behaviour everywlicie...Merch of $\bar{T}$.

ast, through thy wild behaviour........

so grossly shown in thy behavisurs
over-eyeing of his odd behaviour.

maid's milid bedrariour and sobriety..

qualities, and mild behaviour ........

in my hehaviour to the majesty......

borrow their beliavionus trom the

this loose behariour I throw oft

to hath my bchariour giren.... HenenryIV.i.

soil, perhaps, to my behaviours .... Julius Casar,

often the surfeit of our own lichariour.... C Cleo. it.

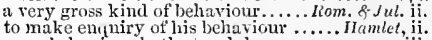

your behaviour huth struck her........... - - iii.
smiles, gestures, and light behaviour.

EHEADED-Clandio was beheaded. Meu. for Mera. v.

beheaded publicly for his offence

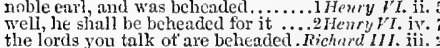

fell faults onr brothers were behearled. Titus . Anul. v.

that if yon now belicld them.

her picture I have yet beheld.

any madress, I ever yct beheld

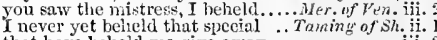

hast thou beheld a fresher gentlewomian $\overline{-}$ iv.

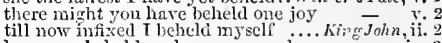

have sou behcld, or have you read . . Richtard $I I$. iv.

she hath beheld the man whose

of you have mine ey es beheld......

on his own part beheld ..........

those that have belield the doing

thou hast oft beheld heart-hardening

[hint - - beheld dissensious numbe

beheld this man; eommend minto
never be belicld of eyes arain

out-hustres many I hare belield.

beheld his tears, and laughed

strangers ne'er bcheld, but wondered

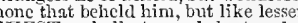

with eare perform his great beluest .. Cymbeline, v. EIIND-HAND

of my behind-haud slackness .... Winier's Tale, $v, 1$

behold, sir king, the wronged dinke......

behold her that gave aim to.... Tern Gen. or Ver. $v 4$

will you go with us to behold it
behold what honest clothes you .

shall not behold her face at amile. Firelfin Nivgh,

behold, how like a maid she blithes. Wuets duo, iv

behold the night of our solemnities.

when Phabe doth behold hier sil ver.

I o bint bchold the tears , Lore's $L$.

not to behold-once to behold (re

look on me, behold the window

behold, there stand the caskets

$O$, behold this ring, whose higit

0 , behold this ring, whose high ........All's Well,

and now behold the meaning ........ Winter"s $T$.

if powers divine beliold our human.

behold the sternness of his ji...........

any thing that rou behold the while
eic ther ean behold brimlt Plinebus.

where he is to belold hin, with nlics

bchold; and say, 'tis well; I li

if you can behold it, I'll ma
would behold in me this sham

we will belold his death.

jrythee, see there! behold: look

ean behold sizeh sights, and keep

behold, where stands the nisuryer"s

behold, the Freneh, amazed...............

nust I behold my lretty Arthur.

those eyes of yours behotd anotheriluy $=-$
there to behold our eousin Iereford.. Richard

like a king; bchold his eyc ....
yet look uy); heloold; that you 
BEHOLD to bchold the faee of that..1 Henry II: i. 3 if thou didst, then hehold that

do you behold these exhalations .....

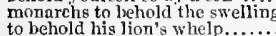

it is most lamentable to beholi .

and in them behold, npon the l

- iij. (eho.)

- iij. (cho.)

behold the ordnance on the

mean and gentle all, behold, as may - iv. (cho.)

mean and gentle all, behold, as may

do but behold your peor and starved

beloold the English herch

but now behold, in the quiek forge

are now glad to behold you

behold ny sighs and tears..

behold, my lord of Wineliester.

behold the wounds, the most unnatural

yon mav behold confusion

must I behold thy timeless cruel

behold and hear our exorcisnis?
your highness to bellold the fight

unworthy to hehold the same....

apparel sumptuons to behold

make king Lewir behold thy si

behold this pattern of thy buteheries.

to day shalt thou beliold a subject die

hehold, mine arm is like a blasted

[Knt.]-never more behold thy faee..

let's stind elose, and behold his

and behold the lady Anne pass ......

eheeks abashed behold our works. Troil.

and anon, behold the strong-ribbed.

when Helenns beholds a Grecinn

till he behold them formed

and to belolkl his visage, even to......

behold, I pray yon! Now ....
upon that sleeve; behold it well

beliold, destruction, frenzy

behold, the earth hath roots.....

let me behold thy face

behold! these are the tribune

and therein behold themselves ........ -

behold [Knt. beheld] dissentious

nay, behold us; this boy, that cannot

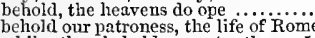

whiles they behold a greater than
when they behold their infants....

when they behold their infants.;

when you but behold our Cxs

a strumpet's fool: behold and see. A

to behold a foul knave un

didst thou behold Oetavia .....

behold it stained with his most noble

see, Cæsar! O, behold, how pomp

where is the queen? Behold,

onee more lct me behold it ..........

behold their quartered fires.

benold the poor remains, alive
behold, I choose thee, Tamora

behold, I choose thee, Tamora .......

once to behoid the thin

now I behold thy lively body so?..................

to behold our cheeks how they are

behold this ehild, of this was Tamora

the place where you behold us now

slie is alive, behold her eyehds

beloold him, sir; this was a goodly

not to behold this shameful lodging

there thon mightst behold the great onc of them we behold

to hehold this night earth-treading........

this night you shall behold him

till $\mathrm{I}$ behold him-dead-is my poor..

or, behold, 'twixt my extremes......

partly, to behold my lady's tiaee

but soft, behold! lo, where it comes.....

and now behold, $O$ Gertrude, Gertrude

and behold what innovation it makes

grossly gape on? behold her tnpped.

liehold! I have a pear

be beholden to his friend for a man. MIer

be beholden to his friend for a man. Merry ivives iv.

we be beholden [Col beliolding] to.. Mea. for MIea. iv. 3

you are fuin to be beholden to....As you Like it, iv.

you are fuin to be beholden to $\ldots .$. As you Like it,

been more kindly beholden [Col. beholding] little are we beholden to your love. Kichard II. yon are more beholden to the night .I Henryl
have been beholden to lim ......... Riehard 1II then is he more beholden to you......... my lord Sands, I am beholden to
have been beholden [ $\mathrm{C} l$, beholding]
BEIIOLDEN-belolden to a subject.. Hen ry VIII. $\mathrm{y}$.
good bretliren, I am mucli betiolden.. grutus' sale, 1 am mucli betiolde

he finds limself beholden to us ail ... Titus tudi. are beholden to you, good Andronie

I am beliolden to you for your ......... Pericles

BEIIOLDER-the beholders take... As you Like
but the wisest belolder, that knew... Winter's

did make beholders wink

Richard II.

to hurl at the beholders of my shame. I Henry
and the beliolders of this tragic play. Rich. II

to tell you, fair beholders ...Troilues \&ै Cres. (P

liere thou viewert, beholdest .. Love's L. $L$.

Eros, thou vet beholdest me?

BEIOLDING-[Col.] little beholding. Ntea, for $\mathrm{M}$.

[Col.] rest gencrally belolding.... Taming of Sh.

[Col.] more kindly beholding to you.. - ii. 1

pale before, beholding him

playing on the lute, beholding
I eloy me witl beholding it

JHenry VI, i.

Col.] should have been beholding. Richard IIX

sueh rich beholding as they have. Troil. \& Cres. iii.

an hour from ber beholding

Pericles, $\forall$. $]$

father, are not fit for your beholding .... Lear, iii.

BEHOOF-kings for your behoof
BEHOV - behore my knowledg

therefore it behoves men to be wary

preferment, behoves it us to labour ...2Henry ri.i.

perforce, behoves me keep at

ah, $\mathrm{mr}$ hehore, $O$ methorgli...

Hamlet, i.

BEHOV EFUL-behoveful for our state. Rom.\&. Jul.iv.

BEFOWVL-the wolf behowls the moon...Mid. N.D.

and influenee to their whole being. Timon of Ath.

took such sorrow, that he quit being.. Cymieline

to shift his being, is to exchange......

shatter all his bulk, and end his being.. Hamlet, ii.

BFL-sometine like god Bel's priests...... Otheh dello, ii.

BELARIUS -myself, Belarius........ Cymbeline, iii. :

an that Belarius, whom you

BELCH-sea hath caused to belch up ...Tempest, iii. 3 Belch! How now, sir Toby Beleh? .. Twelfth $N$. the bitterness of it I now beleh....

Cymbeline, iji.

when they are full, they belch us...... Othello, iii.

BELCHED-as hath been belched on ... Pericles, iv.

Bamps, the belehing whale ............Pericles, iii.
laLDAII - have I not reason, beldams. Naebeth, iii. old men, and beldams, in the streets. King John, iv.

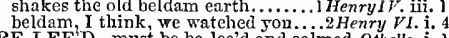
BELFRY-been that day in the belfry .. Pericles, BELGIA-where stood Belgia.. Comedy of Errors, iii. Edward from Belgia, with hasty ...

BELYC-Yet belie thy happy years.
to belie him, I will not, and more 3 HenryVI. iv.

thou art not holy to belie me so

King John, iii. 4

I should belie my thoughts ........Richard 1I. ii.

dost belie him, Percy, thou

doth helie all eorners of the world .... Cympry

we say, lie on her, when they belie her.. Othello, iv. I

BELIED-my cousin is belied a.........Much $\overline{A d} d$,

my soul doth tell me, Fero is belica.

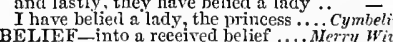

my nieee is already its the belief. Tuelfth Night, iii.

draw a belief from you, to do ....As you Like it, v.

within tbe prospect of helief .............Macbeth, i.

and let belief and life encounter..... King John, ini.

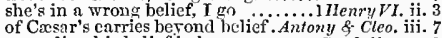

wounding his belief in lier remown .. Cymbeline, v.

but answer to my just belief . $1 . .$.

belief of it oppresses me already

. Tamlet, $\mathrm{i}$.

BFLIE V E-did belicve he was the diuk Much Ado, $\mathrm{v}$.

believe me, sir, it carries a brave form

I do well believe your highness .......

I'll believe both; and what does

believe that there were mountain

I do believe it, agrainst an oracle .........

will not let you believe things eertain...

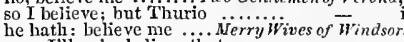

nay, I'll ne'er believe that

believe it, Page; be speaks sense

for, believe me, I hear the parson

I do believe the ss'earer

believe it, for you know it........
believe me, there's no sucli thing

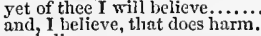

no, believe me....
BELIEVE-over-far believe that.. T'xelfth Night, ii. 1 that lie belicves himself, so do not $\ddot{I}$ will you make me believe, that I .. lielieve me, I am not .............. nay, I'll ne'er believe a madman ... believe me, this may be $\ldots \ldots . . . . . .$.
believe not that the dribling dart do not believe it................... belicve this, no ceremony ........... believe me on mine honour ........

who will helieve thee, Isahel?.......

I do make myself believe, that you

canst thon beliere thy living is a life

I ean hardly believe that, sinee you

let me exeuse me, and believe me...

I believe, there comes no eountermand

if she be mad (as I believe no other)

we did believe no less ...............

not $\mathbf{I}$, believe me ........ Nuteh Ado about Nothin

they will searcely believe this..........

surely, I do believe your fair cousin

that I believe, said she, for he swore

who, I believe, was paeked in all this

I'll believe as soon, this whol

I never may believe these antigu...

I beliere, althourh these antique... - y.

believe me sir, bad 1 sueh venture...Mer, of I'en. $\mathrm{i}$. .

believe me, no: I thank my tortune.

made her nejghbours believe she wep

and she believes, wherever they... As you Like it, ii. 2
believe I love. Me believe it? (rep.) - iii. 2
believe then if you please

dost thou believe, Oriand

I sometimes do believe, and sometime

I conot all believe: 'tis my slowness.

dost thou believe't? Ay madam ...

and believe this of me, there ean be..

and believe't the duke will lay upon

believe it, my lord, in mine own

I should believe you; for you have $\dot{x}$

wonld you believe my oaths, when $\dot{I}$

as, I believe you are, you must ......

could win me to believe, more than.

believe me, lord, I think ..............

believe me, sister, of all the men ....

I may believe, yet I mistrust .......

I must believe my master

not I, believe me; thus I'll visit ....

believe me, sir, they butt together

believe me, I speak as my ......... in

I must believe you, sir ..............

you would believe my saying ..........

I do believe, Hermione hath suffered

helieve me, thon talkest of an admirable

Ido well believe, exeels whatever

make us but believe, being ....... Comedy of Er. iii.

Thelieve, drink gave thee the lie ......... Macbeth, ii.

what I believe, rill wail (rep.) ............

as true, as, I believe, you think......

and I do fearfully believe, 'tis don

yet, believe me, prince, I am not ....

well believe thou art my friend .......

ichard II.

o king, believe not this hard hearted $=$ ii.

for I well believe thou wilt not .... Henry $1 V$. ii. 3

but he would make $y$ on believe it....
make me believe, that thou art only

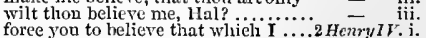

who shan believe, but you misuse.

believe me, I am passing light in

prinecs all, believe me, I leseeeh you

(n)

but, I believe, as eold a night as 'tis... - iv.

believe ny words, for they are certain. 1 Henry VI.i.

believe nue, lords, my tender years

believe me, lords, for flying at the

believe me, lords, were none more.

I do helieve that violent hands ........

well gruesed helice melieve him?

either not helicve the envious 1 . 
BEIIEVE-now they believe it...... Richard III. i. 3 could not believe but that I was in hell thy mind, nnd belicre him not $1 . .0$

or almost believe, (were't not, that

out of hone they may believe. $\because-\bar{v}_{\text {iii. }}$

I believe, not auy; we must not

they are brenth $I$ not believe in

helieve me, she has liad mueh wrong

relieve it, this is true $\ldots \ldots \ldots \ldots \ldots . . . . .$.

has the king this? Believe it........
shortly, I believe, his seeond marring

a royal train, believe me

helieve mc, sir, she is the goodiliest

I do belicve it; for they passed ...

to tell me so, I'd not believe thee

I rond Diomed, believe I eome to

I clo believe thee;-live (repented) ..... -

tye, no, do not believe it (rep.)

heliere' $t$, my lord and I have made

what then? believe't, that we'll do

of flesh, and not believes limse

I'll believe him as an enemy ........

helieve me, sirs, we shall be cliarged . Coriotanus,

thou'lt not believe thy deeds

and believe't not lightly

I'd not believe them more than thee.

believe it, $O$ believe it, most dangerously -

for, I believe, they are portentou

believe me tor mine honour (repeated)

believe it, till I weep too...

believe not all, or if tou must betinto

and believe, Casar's no merchant

but he that will believe all that....

I do well believe you ...................

I eould not but believe she exeelied...

I do believe, (statist tho' I am none

must first induce you to believe

poor fools believe false teaehers.......

he believes it is a thing most preeious

believe me, queen, your swarth... Titus

how eanst thou believe an oath

believe't I will: now, by your ........

believe me, la, I never killed a mouse

Perieles believe his daughter's dead -

you said you would believe me....

you'll searee believe me (repeat $\left.\dddot{d}_{d}\right)$.....

which to believe of her, must not believe a fool.

thoul't not believe, of how denraved

not I, believe me: You have daneing. $\ddot{R o m}$. \& $\bar{J} u$

shall I believe that unsubstantial...

I might not this believe, without...

fits your wisdom so far to believe it

do you believe his tenders, as you eall

for lord Hamlet, believe so mueh in him

Ophelia, do rot believe his vows

O most best, believe it. Adieu

powerfully and potentiy believe

indeed, my lord, you made me believe so....

arrant knaves, all; believe none of us...

I do believe you think what now you.

I pray you. Believe me, I eanno

no, believe me, 'tis very cold

believe me, an absolute gentleman

never belicve it, I am more

do not believe, that from the sense of ali. olitello and prays you to believe him

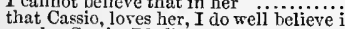

surely, Cassio, I believe, reeeived

heaven moeks itself! I'll not believe it

believe me, I bad rather have lost

greater reason to believe now than ever

BELIEVED-to be mueh believed. nfea.

not being believed, or wring redress ...

I lave too muteh beliered mine...Winter's Tale, i

I have heard (but not believed) the ..

these jugulliur fiends no more believed...Waebeth,

what he hear's may be believed ....... I Henry I $\mathrm{t}: \mathrm{i}$. 2

it I may be lelieved, so; if not........

that Bevis was believed............. Henry VIII. i.

which, being believed, it was mueh .

not strong enough to be believedi.... Cymbeline, ii.

you shouid not have believed me............ Leart, iv. my lord, this would not be believed..... Othello, to be saved by believing riglitly.. Twelfh Night, iii.

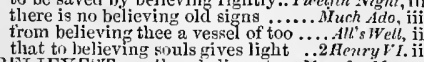
BELIEVEST-as thoul believest ... Men. for Mea. $\mathrm{V}$.
swear by? Thou believest no God .. Tilus And swear by? Thou believest no God ...T'ilus And. v
BELIKE belike it hath some... Tu' Gen. of Ver. belike, boy, then you are in love .... bilike, slie thinks that Proteus........ BELIKE-she's dead, belike ...Tu' Gen of ter. iv.
who belike, haviug reeeivcd....... Nerry Wives, iii.
belike, you slew great number

belike, this is n man of that quirk.... ord Angelo, belike, thi

this a good friar, belike

belike, for want of rain

some merry moelsing lord belike. Love's L Loam, i.

then, belike your hand is in...........

as thougla belike, I knew not what ..

more eomment

came to me; belike, you thought. Comcdy of $\bar{E}$.

belike, it is the bishop of Carlisle ...Richnrd $I I$. ii

belike tlien, my appetite was .....2HenryIV.i.

O then, belike, she was old and gentle.Henry $V$.
belike, your lordship takes us ....1 Henry $V I$.

then you, belike, silsneet these

belike, he means (baeked by

2 Henry VI. ifi.

twas odds, belike, when valiant ....

belike, she minds to play the Amazon

belike, the elder; Clarence will

that be? belike, unlooked-for fri....

O belike, his majesty hath some

aiming, belike, at your interior

belike, they had some notiee
then, belike, my elilildren shall...

belike, something, I know not wh.

belike, this show imports the arg

why then belike he likes it not

but that, belike, Iago in the interim ...... othello, $v$. in a eowslip's bell I lie..

Mest, i. 2 (song)
Merry 1 (song)
Wives,

or the bells of saint Bennet

hath a heart as sound as a bell....... Mueh Ado, iii. 2

but matched in month and

dont matched in month like beli

dong, bell. Ding, dong, bell. I

..Mid.N.Dr.iv. 1
of Ven.iii. 2 (song)

have with holy bell been knol

the faleon her bells, so man.......

twelve upou the bell, my mistress ... Com. of $\mathrm{Err}$. i.

she strike upon the bell

the bell invites me.

Maebeth, ii.

[Knt.] eountenanee this hor

ring your bells: king John........... King John,

if the midnight bell did shall not

strike upon my heart, whieh is the heil. $R$

as a sullen bell remembered knolling. 2 Hen

or a eommon 'larum bell?...............

and bid the merry bells ring

a warning bell, sings heavy

ring, bells, aloud; buru, bonfires

shall be thy fumeral bell.

worse than the scaring bell

no montrnful bell shall ring

chureh, steeple, bells, and all

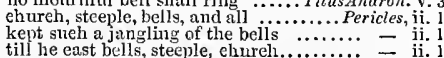

..1 Henry II. i. 6

Henry $r$ r.ii.

3 Henry $V I$ i. 1

our instruments, to melaneholy bells

this sight of death is as a bell

the bell then beating one ..............

the snorting eitizens with the bell

out of doors, bells in your parlours.

silence that dreadful bell, it frights

unless Bellario, a learned doetor

from Bellario? From both (rep.)

this letter from Bellario doth commend

you hear the learned Bellario, what he

eame you from old Bellario?

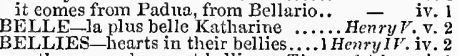
so they eome by great bellies ...Timon of dthens, i. 1 BELLONA-till that Bellona's bridegroom - i. 2 BELLOW-raven doth bcllow for revenge. Ham. iii. 2 and bellowed out as he'd burst... Love's L. Lost, y. 3 BELLOWING - burst of bellowin

fetching mad bounds, bellowing. Mer. of Venice, $v$. I flattery is the bellows blows up sin

BLLLOWS-MENDER-

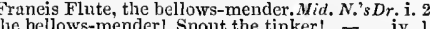
BELL-WETIITR

with a jealous rotten bell-wether. Nerry Wives, iii. 5 BELL $Y$-sometimes my portly belly. Merry Wives, i. 3 so many tuns of oil in his belly........ - ii. 1

my belly's as eold as if I had

dare not for my head fill my beliy. We.n. for $\overline{\text { sf }}$ iv. iv. 3 the ehild brags in her belly alrendy. Love's $L . L . \mathrm{v}$.

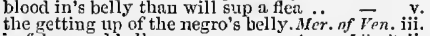

BELLY - put a man into your belly, As yot, Like, iii. 2
my heart in my belly, ere I .. T'aning of Shrow, iv no baricado fir a belly; know I would my face were in your beil am the fellow with the great beliy..2 HenryIV. ath something a round belly

substunce into that fat helly of his.

of tongues in this belly of minc.

an' I liad but $a$ belly of any inditfereney

wears his wit in his belly

the belly answered,-Well, sir (rep.).

I may make the belly smile, as well

your belly's answer: what!

by the eormorant belly be restrained

whint eould the belly answer?

your most grave belly was deliberate.

the senators belly), mark me

hath his belly full of fightin

and when I had been in his belly....... Pericles, ii. 1

HELLYance eries in Tom's belly $\because \ldots \ldots \ldots$ Lear, iii. 6

witll full eonsent helly'd his sails.. Troil.e Cres. ii.

crossed on your thin belly-doublet.. Love's L. L. iij. BELLY-PINCHED-the bely-pin-full ...Lerr, iji. BELMONT-Belman is as good..Tan. of Sh. 1 (indue.

wbieh makes her seat of Belmont...

I must go with you to Belmont...

will we both fly toward Belmont

run from Venice, as far as Belmont.. _ $\quad v$.

before the break of day be here at Belmont $-\bar{v}$. WLONG - what belongs to a frippery...Tempest, iv.

belong you to the lady Olivia....Tu"elfth Night, .

of sale a seller's praise belongs... Love's L. Lost, iv.

to our rose of youth rightly belong.... A Al's $W$ ell, i.

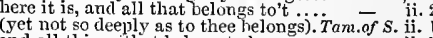

and all things that belong to house $. ., \bar{T}, \bar{c}$

not thy embassage belong to me....Richard II. iif. if there were it nounty shall belong.1 Henry $I V$. v.

particular belong un to the lodging

know the office that belougs to such... Hen. $V I$ iv.

duty that to us belong

judgement only doth belong to th

as I belong to worebip, and affect .. Henry $V^{\prime} I I I . j$

no great offence belongs to't, give your -

you not ehiefly belong to my heart. Timon of $A h, \mathrm{v}$.

no blame belongs to thee ............

the tears belong to Egypt..... Antony \&. Cleunis, v.

that belongs to this ............. Cymbeline, v.

your tributary drops belong to woe. Ron. \& Jul. iii.

indeed, belon-neessity belonged to't.. Tim. of A. iii.

ELONGING-and thy belongings... Wien... for Mea. $\mathrm{i}$.

appertinents belonging to his honour.. Henry $V$. ii.

give him with all his trim belonging. Coriolanus, $i$.

any other part bclonging to a man. Rrmeo \& J Jl. ii.
BELOVED-how well beloved .. Tu Gen. of Fer. i.

where they're beloved

of the love where he's belored...

to the ereature that is beloved ... Tueifth $\overline{N i g h t, ~ i i . ~} 4$

I am beloved of beauteous Hermia......Mid. $\bar{N}$. Dr. i.

fairly spoke by a beloped prinee ... Mer. of len. iii. 2

of all sorts enehantingly beloved

my best belored and approved firiend.. Tan.

so beloved of me. Beloved of me

one of us too mueh beloved....... Winter's Tale, iii.

break my oath to this my fair beloved $\overline{\text { iv. }}$ ivenly beloved, seeond to none.. Com. of

the Protetor's wite, beloved of bim..2 Henry VI. i.

am I then a man to be beloved....

Oxford, wondrous well beloved....

ever beloved, and loving, may .....Henry $\bar{V} I I I$. i. 1

that she beloved knows naught... Troitus \& Cress. i. 2

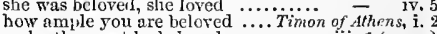

make the meat be beloved ...... - iij. 6 (grace)

didst thou ever know loloved .........

and come home beloved of : all the trades - iii. 2

Yas my beloved in Rome: yet thou..... - - y. 2

a bourn how tir to be beloverl......Antony \& Cleo. i. I

you shall be more beloving, than beloved

but, be sure, no less beloved .......... Cymbetine, iv. 2

nuy beloved brother, gracious triumpinier. Titus and.i.2

from the loss of a beloved daug pains.

live the beloved ot your brother ... Lear, i. 2 detter 


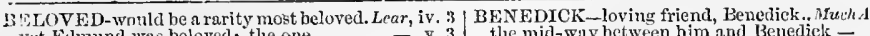
yet Edmund was beloved; the one

nuw Romeo is belovert ..... Romeo \& Jutiot, i. 5 (ch

the mornifico is much beloved

PSI.OV ING-1nore beloving than beloved.th

biLT-cause within the belt of rule

ne that buekles him in my helt

who's there, i'the name of Bulzchub? . . Mache

as Lueifer, and Belzelonb himsclf .... Henry

BEMADDIAG - and bemaddins sorrow ... Le

BHAOANED-so bemoanerl his son..3 Henry $J^{\prime}$

BFilOCK-bemoek the modest moon...C

BENOILLD - how she was bemoifed. Tam. of

BENCI-be the supporter of a bench. Tyelfth Nig.

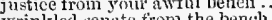

wrinkled acnat of the the

against a graver bench than ever.

olsellience tails to the greater beneh

Lear, iji. 6

cannot sit at etse on the old bench......... \& \& Jul. ii. 4

BE YCULD-meaner torm hisve bunched. Winter's T, i.2

$\mathrm{B}$ ENCHES-sheping upon benehes

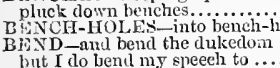

but I do bend my speech to

Heasime for 11 .

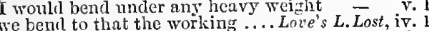

or shall I bend low, and in ...Merchant of Venice, i. 3

if yon love the maid, bend thoughts. Faning of s. 1 .

who for Bohemia bend, to signify. Winler's Tale,

homeward did they bend their course. Com of Er.

I am settled and bend up each eorporal. Macteth, i.

bend their best studies

why do you bend such solenin

or bend one wrinkle on my

flutter, bow, and bend my kne.

flatter, bow, and bend my

why dost thou bend thine eyes

towards York shall bend

and bend uy every spirit to his

thee stoop, and bend thy knee...

witch doth bend her brows...

in duty bend thy knee to me...

towards Corentry bend we our course

and humbly bend thy knee

to bend the fittal instrument ...

towards Lourlon do they benil the

that prouder than hlue

to our own selves bend we our needtin

bend like his that hath

whose bend cloth awe the worl

and made their bends adorni

exeept she bend her humour

whoze boughs did bend w-ith fritit

now to Marina bend your mind...

did all their thmoders bend

when that, whieh makes me hend, malses - iij. 6

bend you to remain here in the chec

that yon do bend your eye on vacaney

true joints bended he ...... RichardII $\mathrm{V}$.

helnet, and his bended sword...Ilenry $V$. v. (ehorus)

now npon my bended knee..........2 Henry Vl. i. 1

ny bended hook shall pieree..... Antony $f_{\text {Cleo. }}$ i. .

to the liat, bended their light on me.... Iramlet, ii.

fair knightliood's bending knee

but rny bending down reprieve

o...Richard $I$. iii. 3

some supportanee to the bending twigs - iii. 4

this prostrate and exterior bending

give place to flexure and low bending. IIenry $V$. iv.

our bending author hath pursued.

no bending knce will eall the

unarmed as bending angel

then hilf signior Benedick's tongue

melaneholy in siguior Benedick's fitce
this was signior benedick that said so

are not you simnior Benelick? .......

thus answer I in the nanne of Benedick

she were an exeellent wife for Benedic

to bring signior Benerlick, and the lady
and Benedick is not the unhopefullest

with Benedick; and I, with your (rep

see jout where Benediek hath hid himself

was in love with sismior Beneelick,...

espeeially against Benediek...
her affeetion known to Bemeli

she foumd Benedick and Beatrice between

$O$ sweet Benedick! God give me p:atien

it were gool that Benediek knew of it

I pray you, tell Benediek of it 130 .

I love Benediek well, and I eonld wish

how Benentick is siek in love with

that Benediek lores Beatrice so entirely

if they loved Benedick, to wish him

I will go to Benediek, and eounsel him

go rare a gentleman as signior Bened
gignior Beneliek, for shape, for bearin

and Benedick, love on, I will requite

be bold with Benedick for his company

signior Benediek, don John, and

unelel signor Benedick! friar

here dwells Benedick the marrieir....

good-morrow, Benedick; why, what's th

containing her affetion lunto Benedick -

how dost thou,

brought a benedietion to the buyer.. Winter's $T$.

he leaves the healing benediction

thou out of heaven's benediction coinest.. Lea

that stripped lher from his benedietion

hEld your hands in benediction o'er me

of this distilled Carduus Benedietns...Much Ado, iii. 4

Benedietus ! Why Benedietus? (rep.)
BENCFACTOR-two notorious benefnetors

Benefuctors? Well; what (rep.).Mea. for Mea. ii. 1

BEN Ereat benefactor's.. Timon of Alhens, iii. 6 (grace) the rays of the beneficial stun
the

for, besides these beneficial news, it is .. Othello, i

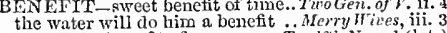

have $I$ the benefit of my senses. Tixelfth $N$. v. J (let.)

is likewise your own benefit.

is likewise your own benefit..........ea. for

the doubleuss of the benefit lefend

iner benents are mightily misplaced...As you $I$

bite so nifh as benefits forgot.

nothing benefit your knowledge

have done the time more bencit...

by the benefit ol his wished light.. Com

reeive at hope to make much ben

reeive at once the benefit of slcep

I erave the benefit of law of arm

bodies for their country's benefit..

of benefit proeeeding trom onu

the benefit thereof is always grant
this protered benent of dignity

give mine the benefit of seniory........

so noble benefits shall prove not
give me now a little benefit.. Tr.

for any benefit that points to in

no publie bencfit, which pou receive. Cor

may prove as benefits to the ........

give away the benefit of our levies ... -

shall reeeive the benet t of his dyin

you shall find a beneft in this ehange. Ant 8 -

With the next benefit o' the wind ...Cym
to have the benefit of his blessed beams

pains, and benefits, to langhter and

as the winds give benefit, and convo

distinguish a benefit from an injury

but to know so must be my benefit

BENETTED-thus benettel round

as - D b anks, benevolenees, and I wot..Richard II, it.

BENIGN-prince, and benigu lord. Pericles, ii. (Gow. BENISON God's benison go
to whom I give my benison

without oux graee, our love, our benison

the bonnty, and the benison of heaven....
BENNET- the bells of saint Beunet.. Tuelfin $N$. of Brocas, and sir Bennet seely .... Richard II.

BENT-bent [Kint.-beanty] of the brow. Merry 1.

her atfections have their full beat ...Much ddo, in

hare the rery bent of honour...

to a silcer bow now bent in heaven...Mid. $N$.
I see you all are beti to sct against me
BENT-which not to anger bent .. Love's L. Loft, iv. 2 to your own bents disyose you .... Winter's Tale, $\mathrm{Y}$. and, nadly bent on us, chassed ... Comedy of Err. v. . with tuyour, we are bent to henr........ are idly bent on hin that enter........ - v.

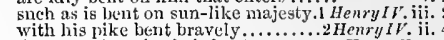
that met then in their bent .............. Henry $i_{\text {. }}$. . feree bent arginst their faces........ Henry $\mathrm{He}$. i.
all his mind is bent to holiness....... nanglity persons, lcwlly bent, under - ii. When Warwiek bent his brow ......3 3enry VI, y.
divinely bent to meditation...... Richard III. iii. set his senfe on the attentive bent... Troil.\& Cres. $i$.

why snch mplansive eyes are bent.

all gaze and bent of amorous view .. this preparation whither tis bent. Corinl. i. 2 (letter) and it is bent against casar...... - ii. 3 (pawer bliss in our brows' bent; none ...Antony f. Cleo. i.
their faces to the hent of the king's ... Cymbeline, i.
men bent to the spoil........ Titus Andromieus, iv. Thaliard eame full bent with sin. Pericles, ii. (Gow. but bent all ofices to hourur her .

and my best slirits are hent to prore .... Lear, y. that thy bent of love be hononrable.. Rom. \& Jnl. ii. they fool me to the top of $\mathrm{my}$ lent...... - iii.

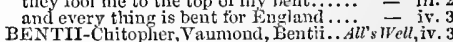

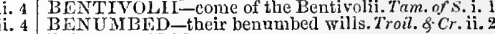
BEN VENUTO-

undertake your ben venuto .... Love's $L$. Lost, iv. come between us, tood Benvolio..... Tom. g Jul. come between us, good Benvolio .... - ii. Benvolio, who began this bloody fray? - iij. BEPAINT-maiden blush benint my cheek - ii. BEQUEATII-my horns I bequeatl. Merry Wives, $r .5$ your former hovour I bequeath ... As you Like it, v. 4 come away; beqneath to death. ..Winter's Tale, $v$. forsalse thy fortune, bequeath thy land ... John, i. for what can we bequeath, save...... Richard $\overline{I I}$. jii. at that time, bequeath you my... Troil. \& Cress. . $_{\text {. }}$ ] so I bequeath a happy peace to you.

my dead father did bequeath to me $\ldots \ldots . . \bar{J}$. ii. upon this fashion bequeathed me...As you Like il, i. her father bequeathed lier to me ..... All shell, i. 'longing to our honse,
BEQUEATHING-

his crown bequeathiug
bequeathing it, as a rich leyacy ...... As you lius Caksar, iii. BERAT'TLE-berattle the eommon stages. Ham. ii. 2 she'll bereave you of the deeds ...Troil. \& Cres. iii. bereaves the state of that integrity.. Coriolanus, iii. I'll not hereave you of youn servant .. Periclus, iv. 1
BEVEAVED - of life bereaved him...3Henry $F$. .ii. 5 in the restoring his bereaved sense $\ldots$. .. Lear, iv. madan, you have bereft me of......... of $\mathrm{Ven}$. iii. 11-seeming, thiek, bereft of beauty...Tam. of $3 \%, \mathrm{v}$. to pity him, bereft and gelded........ Richard $I I$. ii. are barren, and bereft of lyeuds...... ${ }_{\text {territories is utterly bereft yon } . . . .2 \text { Henry }} V I$. iii. tune bereft my rital powers $\ldots \ldots \ldots$ - iii. hath bereft thee of thy lite too late..3 Henr'y VI. ii. he that bercft thee, lady, of thy ....Richard III. i. 5ou have bereft me of all words .. Troil. \& Cres. iii. of wretehed sonl bereft.. Timon of Alhens, v. 5 (epil.) have bereft a prinee of all his fortunes.. Perictes, ii. has beed berctt of sims and mereft me...... othello, i.

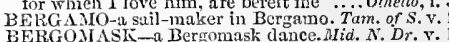

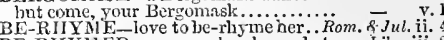
BE-RHY MLED-never so be-ihymed.As you Like, iii. 2
BERKLEX - at Berkley castle ...... Richard II. ii. far is it, my lord, from Berkley now? - ii. sent me o'er by Berkley, to discover
the lords of York, Berkley and Seymour it is my lord of Berkley, as $\Upsilon$ guess ... Tressel and Berkley, goalong witlime.Rich, III. i. 2 BERMIOOT FIE-still'vex'd Bermoothes. Tempest, i. Bernardo hath iny place (rep.) ............ these gentlemen, Mareelns and Bernardo $=$ 二

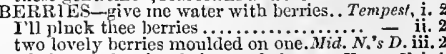
two lovely berries moulded on one.Mid. N.'s D. eannot live on grass, on berries ...T. Tilus ind. iv. BERRY - the dukes of Berry, and....... Henry $r$.ii. Orleans, Bourbon, and of Berry ....... $\overline{\text { int }}$ iii. 5 roughest berry on the rudest hedge...Ant, or cleo.
of bud, bird, braneh, or berry ..Perieles, v. (Gower) BERTR ANI-be thou blest, Bertram!...All's Well, i.
farewell, Bertran. The best wishes... earries no favour in it, but Bertram's
no living, none, if Bertram be away .. 
BERTRAM-good lord, young Bertram.. Al's Woll, i. 2 why then, young Bertram, take her.

kERow'st tliou not Bertran, what she - - ii. till they come to Berwick, whence.

towards lerwick post anuin ....3llenry VI. ii. 5

BWSEECH-beesecti yon, father! ...... Tempest,

beeseeen you, sir, be merry .

Bate, I beseech you, widow Dido

I do beseech you, ehiefly, that

I do beseeeh you that are of

besceh you confirm his weleome. Ty.

I now beseech you, for your.

I beseeeh you be ruled by............ Nerry Wives, i. 1

I beseceh you, heartily

I beseech you, follow

give me leave I beseech you............elfh Night, iv. ${ }^{2}$

and, I beseech you, come aguin

I beseeeh you, do me this ...........

and I beseeeh, look into ... Measurefor.Measure ii. 4

I beseeels you, sir, ask himi

I beseech your honour, ask me

nay, I beseech you, mark it well

I do beseech you, let it b.

when, I beseech you? that in lis

therefore, I beseech you, look forward

well, I beseech you; let it be proclaimed -

I beseech jour highness, do not marry me -

adieu, be vigilant, I beseech you ....

I beseech you, let it be remem

which I beseeeh your worship

but I beseeeh your graee, that I ....... irid. $\bar{N}$.

other men's secrets, I beseeeh you.... Love's $L . L$

I beseech you, a wor

I beseech you, read it.

I beseech your grace, let this lette

I do beseech thee, remember (rep.)

I beseech you, follow

madam, not so: I do beseech you, stay -

I beseeeh you, sir, go; my youug

I do beseech you, even at that time...

I beseech you, let his lack of years

I beseel you, wrest once the law...

most beartily I do beseech the court

res, I beseech punish me

I do beseeeh your grace, let ime...... - i. 2

I shall beseeeh your highness

I most unteignenlly beseeeh ......... - ii. 3

I beseech yon, let me answer

I do beseech you, whither is he gon

I do beseeeh you, sir, since you are

tell me, I beseech you, which is ..

for what reason, I beseeeh you?

indeed,-beseceh you,-Verily

press me not, beseech you so

but, beseech your grace, be plaine

beseeeh you all, my lords, with thoughts -

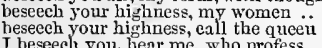

I beseecls you, hear me, who profess

beseech your highress, give us better
beseeeh you, tenderly, apply to her ..

at my petition, I beseecl your........

I beseeeh you, sir: I have a kinsman

soft, swain, awhile, beseeeh you...

beseeeh you, sir, remember sinee

beseech you, sir, were you present

I humbly beseceh you, sir, to pardon

whom I beseech to give ine am... Com

I shall beseeeh you-that is question

heseeeh your majesty, impute his

I beseech your grace, look on my ....

I do beseech your majesty, to have..

not yet, I thee beseeeh, for ever.

I beseech you, let not his revo

I do beseeeh your majesty............

I beseeeh yourr grace, I may

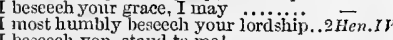

I beseech you, I may have redre.........

I beseeeh you, which is justiee Shuliow

let me see them, I beseceh you

I beseech your grace, let it be $\ldots . . .$. .

I beseech you, sir, to countenanec....

believe me, I beseech you, my father

wheh I beseech $J$ 'ou to let me have..
me worl more, I beseeeh you ........

Ine worl more, I beseed you ...........

I thee beseeh to do me tavouts.

I pray you, and beseceh you

I beseeeh you, take it for your own......

I besecel your highness, pardon $\mathrm{m}$

I bescech your majesty, clo nut cast

I beseech your mijest y, give me leave
BFSELCI1-I bescerle your grizes .
I bescech your grace to prarton me

I du beseuch you, cither not betieve.

that small, God, I bescech thee

I do beseceh you, send for some of' them

I rather do beseech you pardon me

take heed; yes, heartily beseech you. Inenry ${ }^{r}$ III. $i$.

I do beseech your grace, fur eharity

beseech your lordship, vouehsafe to speak -

I do beseech you, gracious madam

I do be secech your lordship, that.....

my lord, I do beseeel you, partou me

I do beseech you, as in way of taste..

which, I beseech you call a virtnons sin

I beseeeh you next to teast with me.
tell nie, I beseech you, in what place

riglit deadly; I beseech your go

which I do beseech your lordship...... Timon of $A t h, \vec{i}$. 1

I beseech your houour, vouchsate...

I do beseech you, good my lords

if I might beseeeh you, geutlenuen .

beseech your houvur, to make it

I do beseech yon, by all the battles

therefore, I beseech you...

I do heseech you, let me o'er-leap
therefore, I beseech you, I may be

no more words, we beseeeh you .......

therefore, beseeeh you, you that will
beseech yon, tribunes, hear me but .

yourself: be yone, veseech you

which is his honse, beseeeh you?

sir, I beseeeh you, think you ....

nay, I beseech you, sir, be not

二 $\quad$ i. 22

I do beseech ye, if you bear me hat

sweet Isis, I beseech thee! ....,.....

I shall beseech you, sir, to let

I earnestly beseech, touch you .....

I beseeeh you, sir, harm not yourself.

besecch your patience: peace, dear

but I beseech your graee ............

beseech you, sir, desire my man's

his health, beseech yoll yes, I beseech; or I shall short my wo...

guard me, beseeeh ye

beseech your majesty, forbear sharp

beseeh your highness, hold me your

cause it to sonnd, beseech yon

I do beseech you to learn of nee

I beseeeh your bou, do

I beseeeh your hounour, one piece

i. 2 reeount, I do beseech thee .............

ii. 1 therefore beseech you to avert you liking.. Le

I yet besecel your majesty

I beseech you, pardon me, my iord

$=\quad$ iii. $22 \quad$ I do beseech you to understand ....

I do beseech your graee-O ery you mercy - ii.

I do beseech thellow straight

what are they, I beseceh your ladyshin?

parclon, I besceeh you! henceforward

I beseech thee, youth, heap not anotb

I do beseech you, give him leave to go...

we beseech you, bend you to rema

I do beseech you, both away

I do besech you. I know no touch of $i$

ay, beseech you. Being thus bentted.

but I beseech you, it"t be your pleasure....

I co beseech you send for the larly

I hiumbly beseech you, proeeed

will I beseceh the virtuous Desdemona

yet, I beseech you,--if von
whereon, I do beseeeh thee

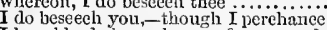

I humbly do beseech you of your parlon

hold ber fiee, I do beseech your honour.

I do bescech you, that hy your virtuour.

I do beseech you, sir, trouble yourseli' no

I do beseech you I may speak with you .. =

BESEECHED - the town is beseeched.. Henry $r$. iii. 2
beseerhed me to entreat your minesties. Ilantet, ji. I

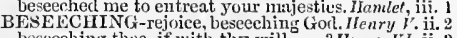
beseeching thee, if with thy will

beseeching you to give ber prineciy ...Piricles, iii.

BEsEEK-I bescek you now, aggravate.2 IIen.IV. ii.

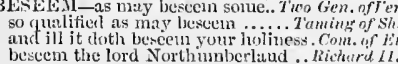

BESLEM-it ill bescens this prosunee. King Joln, ij.
more than well beseems a man more than well beseems a man
as beseenns their worth $\ldots . . . .1$.

as may beseem a monareh lik
how evil it bescems tliec.........

1 BESLENETH-ill bescemeth me.........

vet best beseming me to sichak wite. Two Got $V$. iii.

ill beseemine any commont man

these three in poor beseeming.

BESET - you are hard beset.... T' To Gen. of Ver, $\mathrm{i}$.

the thieket is beset

to defend him, when he was besct. Tuelfh Night, $v$.

I was beset with shame and courtesy. Mer. of I' $I^{\prime}$,

We're beset with thieves $\ldots . . . .$. Taming of Sh. iti.
BESLlREW-beshrew me, but ...Two Gen. of Ver.

beshrew me, sir, but it he

beshrew me, the knight'

marry, beshrew

now much beshrew my mauners. Nid. N.Dream, it.

and beshrew all klurews! .. Love's Labour's Lost,

beshrew me, but I love her heartily.Mer. of Ven. ii.

beshrew your eyes, they have

lunes o'the king! beshrew tbem! Winter's Tale, ii.

beshrew my soul but I do hand.

beshrew thy very heart! I dic not ..... King - J

beshrew thee, cousin, which didst .. Richard II. iii.

beshrew your heart, fair daughter ..2Henry $I V$. ii.

new beshrew my father's ambitiun.... Henry ${ }^{r}$. y. 2

beshrew me wimners, for they

beshrew me, I would, and venuie... Henry VIII. ii. 3

besiarew the witch! with venomou.

eome, eome, beshrew your heart!....

beshrew your heart, for sending nie... Rom. $\overrightarrow{\&}$ Jul. i. 5

beshrew my very heart, I think...

she will beshrew me moth. Anac...

but, beshrew my jealousy! it seems ..... IIamlet, ji. 1

beshrew him for it! how eomes this tirick - jv.

beslurew me, it' I would do sueh a wrong - iv. 3

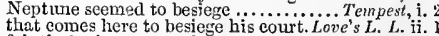

faintly besiege us ome houx

of the queen mean to besiege us..........

to eourt, the women so besiege us ... Henry $\bar{V} I I Y$. v.

except this city now by us besieged ... King John, ii.

thou know'st how Orleaus is besieged - i.

Paris was besieged, famished, and lost..2 Hen. VI. j.

BESMEAR--so much besmear it. Merch.of fenice, $v$. 1

BESALEARED-besmeared as biack .. Twelfth $N$. Tii.

they were besmeared and overstained....John, iii. I

BESMIRCH-doth besmirch the virtue . Hamlet, $\dot{j}$. 3

BESOM-I am the besom that must. 2 Henry $V t$. iv. 3

EESORT -men as may besort your age .... Lear, i.

BESOTTED -like one besotted.. Troilus \& Cress. it.

BtPA's neck, bespake them thas.... Richard II. v.
steed

see me an officer, bespeak him. Alerch. of

the eap your worship did bespeak. Taming of 's. iv. 3

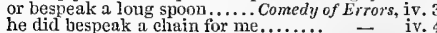

my young mistress thus did I bespeak... Lamlet, ii. 2
BESPICE-might'st bespice a eup.. H'inter's Tale. i.

BESPOKE-sir! I bespoke it not .. Com.of Err. iij.

then fairly $I$ bespoke the office

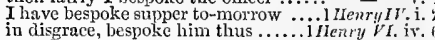

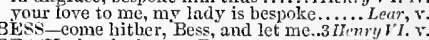

BES Y -o'er the bourn, Bessy, to me. Lear, iii. i (smig

thou best know'st wrlat. .......

and be quiek, thou wert best

I am the best on them that

best stand upon our guard

my best way is to creep.

have I eyed with best regard

are created of every creature's best

inver't what best is boded me.

and the best eomforte

the best news is, that we

you were best stick he

ot ming good I think him best

I think, best loves ye...

but she would be best plensed .....

best to take them up
whither were I best to send him

that fishion thou best likest....

how shall I best eonvey

the best is, sle bath no

the best way were to entertain............

and in such wine and sugar of the twest $=$ - ii. 


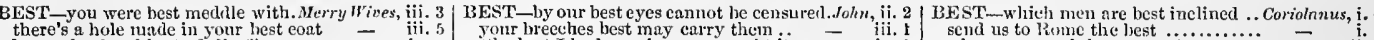
I im best pleased to be from sueh in me bend their lest studie

good worls, I think, were best...

have I not here thic best cards

the best part of my power ............

ven in the best bloud chambered....Rich Rud II. $\mathrm{i}$.

the best way is, to 'venge my

yet best beseeming me to speuk

confound the best part of an

from the best of all iny land

- iii.

to stain with the best blood that I

from the best tempered courare. . 2 Henry IV

seem best; things mresent, wo

and fame with the very best .........

bave you served with the best

as strong, our cause the best...

rank with the best governed nation

and ripen best, neighbo

the full fraught iman, and best indued

'tis best to

that men of few words are the $\mathrm{best}$....

therefore to our best merey give...

in my thoughts, beeomes me

it is the best liorse of Europe .............
whoss hours the persant best advantiages

share from me, for the best lope I have

and all bis brethren in best sort...

in this best garden of the world...

as your wisdoms best slall see ......

God, the best maker of all marriages

by which the world's best garden.

where is trest place to make

THenry 2 (eho.)

horses, which doth bear lim best

now will it best avail your majesty.

I were best to lit and saîest passage.

may live to be the him of .iil...

$2 \mathrm{H}$

that time best fits the work ............

where it best fits to be..............

to your wisdoms seemeth best.

there's Best's son, the tanner

ay, by the best blood that ever

she hath lost her best man

the best thing in him is his ...

put you in your best array .......

he cannot want the best that ..........

honours best tlirive, when rather

thon wert best set thy lower part ....

how 'tis best to bear it

drunkenuess is his best virtue
reputed one of the best that is

reputed one of the

wonld thy best triends did know

the queen

the better; then another, best .......

and undo, as him pleaseth best

and aim we at the best

I hope, all's for the best..........

but bad, till I be best.

were best to do it secretly, alone.............

for your secns best unt i your royal

best fitteth my degree, or your .......

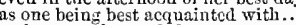

an honest tale speeds best

that is the best news; that the ear

with best advantage will dece

Were now best, now worst ..........

therefore, best not wake him from

what we oft do best, by siek....

is eried up for our best act

let's dream who's best in favour....

the best, she shall have; inn niny (rop.)

our eoutent is our best liaving ......

the inventory of your best graces

all thy best parts bound tingcther...

you, that best slionld teach us, have

nourishment, dare bite the best...

all the best men are olurs; for 'tis.....
or do his best to do it, he hath ... Troilus $\overline{\text { \& }} \overline{\text { Cress. }}$ (ep.

in taint of our best man

Ajax shall eope the best .............

- iv. 1

in qualitics of the lest............ Fimon of $\overline{\text { Athens }}$

I could wish my best friend at such.

the five best senses acknowledge ....

the best of happiness, honour

even to the state's best heal th........

the best half should have returned ..

ever at the best, hearing wil

serve bis mind with my best will .....

best state, contentless, hath.

the best, and trinest; for here it sleeps

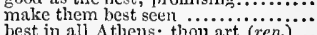

for thy best nse and wearing

see, our best elilers. Marcius.

the Antiates, of their best trust
that best can aicl your action when you siveak best unto the purpose

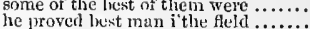

that our hest water liruugh

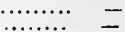

for your best enth, you adopt your poliey -

for his best fricids, it they should sny

best of my thesh, firrive uny tyraing

my bist and freshest men...

what dost thou with thy best apparei.sui. $\bar{C}$ os

do you now put on your best attire...

that your best friends shall wish .....

at your best leisure $\ldots \ldots \ldots \ldots \ldots \ldots \ldots$.

as I slew my best lover ...............

't were best he speak no harm

ay, and truly, you were hest .......

covert matters may be best disclosed

to see my best friend ta'en ...........

at the last, best; see, when ....... - i.

but this is not the best ............ i. - inen

no worse a lusband than the best of inen

let your best love draw to that (rep.)

best of comfort; and ever welcome

rell bceoned thie best of men .........

are not, in their best fortunes, strong

let our best heads know.

best that you safed the bringer

their appoint ment we may best discover - iv.

who hest was worthy best to be served 二 $\quad$ z.

milke your best use of this

some comtort out of your best a a dice. . Cymbeline,

best express how slow his sont sailed on

your lord, (the best teather of our wing)

equal disconrtesy to your best kindnes

madian, yeu're the best.

this life is best, if quiet life be best

first, with the hest of note..........

may the gods direct yost

I were best not eall

best draw ny sword; and if nine...

you Polydore, have proved best.....

that best eould deem lis dignity?....

whom best I love, I cross; to make...

think more and more what's best ...

and lend my best attention

and was the best of all amongst......

Rome's best clrampion, siccessful. Titus $\overline{-}$ v.

Rome's best citizens applaud ........ - i.

I have done as best I nay .......... - i.

prosectite the meanest, or the best ...
what pledge will nleasc him best $\ldots .$.

my eanse who best ean justify ..Pericles, i. (Gower

in Tharsus wis not best longer ..... - ii. (Gower)

all for specling do their be

that best know'st how to rule....... - ii. 4

throw their best eyes upon it ........

here to-morrow with lis best ruff on
sweetest, ani hest lies here.. - iv. 4 (Gow. inserij).

twere best $Y$ did give o'er................ Lear,

the best and soundest of his tirne $\ldots \ldots \ldots \ldots . . .$. i.

we hinve seen the best of our time ........... - i.

and the lest of

sirrah, you were best take my coxcomb ..... $=$ i.
tlise hetter? Best! this weaves itself $\ldots . . .$.

when he saw my best alarumed spirits

Which $I$ best thought it fit to answer

'tis best to give him way ........

lamentable change is from the best

who, with best meaning prel that I

and the best quarrels, in the heat...........

by me invested, he compeers the best ...... - v.

and my best spirits are bent to prove ...... $-\mathrm{v}$.

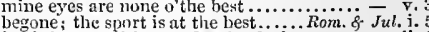

is this love, and best hefits the dark ...

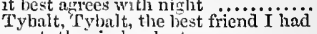

eontrts thee in her best array........

in thy best rolies uneovered on the

an, those attires are hest .............

hut she's best married, that dies

I she lie thine, and thy best graces...... Hamlet, $i$.

best saticty lies in fur....................

in France, of the best rank and station ...
inurder most foul, as in the hest it is ....

murder most foul, as in the hest it is .... - i. 5
that I love thee bust, 0 most best ....... 
BEST-the best aetors in the world ......Hamlet, ii, 2 BESTRA UG1LT-

where your wisdom best shall think

I pray yoll, pass with your best violence $-\mathrm{v}$.

conduct them, you best know the place

take up this mingled matter at the best.

of the place is best known to you

thou praisest the worst best.

liaving my best judgement eolilied

the best of you shall sink in my rebiike.

in best sumetimes torget: though Cassio

make examples ont of their best

their best eonscienee is $\rightarrow$ not to leave

as I have spoken for you all my

peace, you were best. Thou hast not.....

BEST ANED lis thin bestnined clonk

BESTED - a tellow worse bested

BEST-ESTELMED-

MY best-esteemed aequaintance. Mer. of Venice, ii. 2
BESTIA L-bestial appetite in change. Iich. IIF iii. whether it he bestial oblivion

and what remains is bestial ................

Othello, ii.

BETI BESTIR_-aground: bestir, bestir
BESTIR'D-bath so bestir'd thec

You have so bestir'd your valour.

BEST-MOVING - best-moving fnir ....... Lear, ii. BESTW-bestow upon the eyes of this. Tempest, iv.

and bestow your luggage

to bestow ber on Thurio

I may bestow nyself

bestow thy fawnug smiles

how ghould I bestow him?........... Merry $\overline{\text { Vives }}$

shall I feast him? what bestow on him? - iii.

to bestow it all of your worship ..... Much Ado, iii. 5
which they did bestow ........... Love's $L$. Losl, $\nabla .8$

sweet royalty, bestow on $\mathrm{me}$

that I would bestow upon
silenee bestows that virtue.

silenee bestows that virtue............ - v. 1

you will bestow her on Orlando... $\overline{A l l}_{\text {'s }}$ vell 4

to bestow them, as notes .......

All's IVell, i. 3

I will bestow some preeepts

iii. 1

not to liestow my youngest.........

a blessing he bestows on beasts .. Com. of Error

that ehain will I bestow $\ldots \ldots \ldots \ldots \ldots . \cdots \cdots \cdots$

ean you tell where he bestows himself? Macbeth, iil. 6

might we sec Falstaff bestow himself. 2 Henry IV

I will bestow a breakfast...

Henry $V$ ii. 1

we will bestow you in some better... i Henry $V I$.

and to bestow your pity on me

to bestow my bounties upon .....

bon you .... - iii.

swear you would bestow on me?....Troil.
what you bestow, in him I'll ... Timon of

bestow your suedinfor tongues

and so bestow these papers as . ...... - ii. 3

wilt thou bestow thy time with me...

weill you bestow them friendiy ...... Titus Andro

must needs bestow her funeril

bestow your love and your affeet

shall bestow on him f Col. Knt. - give him suel

an unaceustomed dram] so sure ..Rom. \& . J J hl.

will so bestow ourselves, that, seeing ... Hamlel,

I will bestow him, and will answer weil

bestow this place on us a little while

as of her tongue sbe oft bestows on me..

I will bestow you where you shall bave

BESTOWED-have bestowed on. Two Gen. of Ver. Hii. 1

I protest to you, bestowed muel. on her

so they shall be both bestowed!

that for had bestowed that time... Twelf

thitu ever she bestowed upon me

What, I mo not bestrauglat.. Taming of Sh. 2 (induc.) the best-regarded virgin

we will bestrew the ground.. Ttaming of $S h, 2$ (incluc.)

BESTREWED-lestrewer with flowers - 1 (indue

never bestril a horse, save one...... Cymbeline, iv.
BESTRIDE-bestride our down fallen... Naebeth, iv.

BET - the F renelh bet against the Danish. Hamlet, $\mathrm{v} .2$ betake you to your guard

betake thee to thy faith .................All's Well, iv. 1

makes me betake me to my heels ...2Henry VI. iv. \&

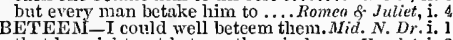
that he might not beteem the winds..... Hamlet, i. 2 and now I do bethink me .........Taelfth Night, v. I good, good my lord, bethink you ........ea.for Hea. ii. 2

and not bethink me straiglit...Aler

if yon bethink yourself of any crime ... Oihello, v. 2

bethought me what was past............

marry, well bethought: 'tis told me ..... Homlet
BETHUMPED-never so bethumped. King John,

of woeful ages, long ago betid

of woeful ages, ong ago betid ....... Richard $11 . \mathrm{v}$.
know I what is betid to Cloten .... Cymbeline, iv.
BE'TTDE-happiness betide my liege. Richard II. iii.

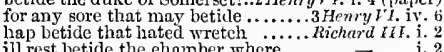

ill rest betide the ehamber where

so betide to me, as well I tender youl..

or woe betide thee evermore ..... Titus Andron. iv.
BETIDETH - else betideth here.. Tuo Gen.of Ver. $\mathrm{i}$.

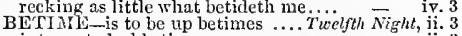

is to go to bed betimes.................. for Mea. iv. 3

but the rext morn betimes

let me say amen betimes ............. of verchice, iii. I

this diseased opinion, and betime.. Winter's Tale, i. 2

good God, betimes remove the means $-\bar{k}$ iv. 3

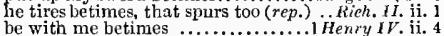

be with me betimes $\ldots . . .$.

away betimes, before his forces j

we rise betime, and go to it .

or betimes let's re-enforce, or fly ..... Cymbeline, v. 2

all this morning betime, and ... Hamlel, iv. 5 (song)

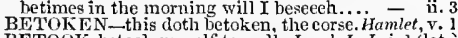

BETOOK-betook myself to walk. Love's $L$. L. i. I let.'
BETOSSED-when my betossed soul.Rom. \& Jul. v. 3

BETRSSED-when my betossed soul. Rom. \& Jul. v. 3

we'll betray lim fine?

have bestowed more contrite tears.... Henry $V$. iv. 1

have I bestowed on learned elerks..2 Henry Y $^{\prime}$. iv.
would not have bestowed the heir ..3 Henry $r$. iv.

whose life were ill bestowed... Troilus \&. Cressida, ii.2 on the heavens bestowed.. Perieles, iv. 4 (Gow. inse) his people eannot be weli bestowed ....... Lear, ii. will you see the players well bestowed... Hamlet, ii.

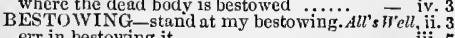
bestowing on him at his asking ..... Henry $\bar{v}$ IrI. it. yet, in bestowing, madam, be was.....

d do betray myself with blushing. Love's L. Lost, i.
Merchent of lenice, ii.

that thou so otten hestrid the

the bestrill an o'er-pressed Fomain

2llenry Vl. v.

bis legs bestrid the ocean ..........Antony \& Cleo. v.

he doth bestrilte a bleeding land

when I bestride liim, I soar ..........

and onee again hestrile our foaming.3 Inenry

wash

he doth bestride the narrow wooldi... Julius Casar, i.

lie bestrides the lazy-pacing elouds

All's Well, iv. 1

I will bethink me: come again

rwow I do bethink me, so it is ..Mid. N. No Dream,

0 , noble lord, bethink thee . Taning of Sh. 2 (ind.)

bethink you, father; for the diff

but I bethink me, what a weary
bethink thee on her virtues

as I bethink me, you slrould not be kin

Richard If. ii. 3

while we bethink a means to break it off

madam, bethink you, like .........Richard 111 . ii. 2

bethink yourself, wherein you may

bade him bethink bow niee .... Romeo \&-Juliet, tii.

bethouglat me of another fault .......10a.for Hea.

am bethought to take the basest....

Richard HI.

betimes i' the morn, I'll eall you

and stop the rage betime. ...........
would have lost my life betimes

come, let us sup betimes

let us pay betimes a moiety ..... Troilus of Cress. ii. 2

set on his powers betimes before...Julius Cosar, ii. 1

I will be with thee betimes $\ldots \ldots . . . \ldots \ldots$ othello, i. 3

iii. 3
Y. 3
Y. 3

BETRAY - did betray me to my own.Com.of Er, v. to betray us in deejest eonser neis.

doth betray to lose the eonquest

al, villatin, thou wilt betrily me....

why then should I betray thee?

to betray youldst thou betray me? .. Richard 1$] \mathrm{I}$. $\mathrm{i}$.

to betray me. Niy lorils, I thank you

wear them, betray with them..
will betray tawny-finned fishes

should not betray mine interest.

Ant. \& clen, ii.

live to betray this guilt of ours?

to betray doth wear an angel's ........Pericles, iv. 4

must die, else she'll betray more men, .Othello, v. 2

are we betrayed thus (rep.) .........

Camillo has betrayed me ......... Winter's Tale,

hath wilfully betrayed the lives of... I Henry I

he hath betrayed his followers

his dastard foe-men is betrayed......

Henry $V$

but dies, betrayed to fortune

either betrayed by talseli....

was by that wretch betrayed

2Henry VI.

he has betrayed your business ..... Coriolanus,

queen so mightily betrayed ..........Ant. \& Cleo.

thy tongue hath so betrayed thine art
this foul Egyptian bath betrayed me

betrayed I am; $O$ this false soul......
she liatl betrayed me, and sluall die.

in this relieved, but not betrayed

her painting, hath betrayed lis
those that are betrayed do feel

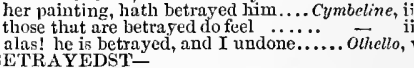

that thou betrayedst Polixenes... Winter's Tale, iii.

BETRAYING-and betraying me.. Timon of $A$. iv. 3

BETROTH-that betroths limself .....Much Ado, i.

thyself art witness, I am betrothed

you are betrotlied botb to a maicl. Twelfth Night, v.

my lord, was I betrothed ere I saw.Mid. $N$.'s $D r$. iv.

four highness is betrothed unto .... . Henry $I$ Henry $V I$. .

by substitute betrothed to Bona.... Richard IIf. iii. maty bear his betrothed from all ..Ti/usAndron. $\mathrm{i}$.

my true betrothed love, and now my wife

BETTED-and betted mueh money..2 Henry $\mathrm{kT}$. i

CTTER-that I am more better

no better than the earth he lies upon

- i.

has done little better than play'd...... $\overline{\text { send }}$ iv

wor thuth liath better deeds.

exebange the bad for the better

therefore, is she better than $a$ jade

he hatli staid for a better man

would better fit lis chamber

but better, indeed, when you

better bave none than plural fiith

'twere better for you, if it ....

upon better acquaintanee.

ay, for tanlt of a better $\ldots$...........

would you desire better sympathy - ii. 1 (letter)

Ilike it never the better for that

in better plicht for a lender than

better three hours too soon..........

I know not which pieases me better..

heaven make you better than .......

I seek you a better husband

he is a better seholar, than

there is no better way than thit

the better to denote her to the doctor..

better a little ehiding, than ..........

I desire better acquaintance...

under the degree of $m y$ better

ghe will attend it better in thy youth

for the better enceasing your foliy

no better than the fool's zanies

she were better love a dream

my legs dlo better understand me

how much the better to fall betore

but given unsought is better

you slall find better dealing
but $m y$ bope is be:ter, and

he hatll better betbought him....

if you be no better in your wits

may more betray our sense than... Afea. for Mea. ii.

the betray a nice wenches.....

the better for thy friends......

and the better for my foes

none better knows than you

and fortune shall better determine

would mueh better plense me ........ nature will betray its folly......... Winter's Tale, i.

his babe's, betrays to slander 


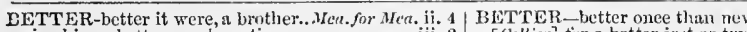

give him a better nuociamation.

love talks with better love

for my better satisfaction..............

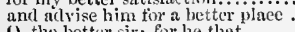

$O$, the better sir; for he that

the better, given me by so holy ........

it un be no letter.

nnt better than he, by her.

that life is better lite, past fearing you a better linstom

to brave no other, nor no better inain.....

beeome muela more the hetter for heing

to provide fur better times to come

indeed, better bettered expectation

is better than a beast of yours........
that she may be the better' prepied

and it hetter fits my bloul to be...

I lore you the better; the lienre

it were a better deatin than dic .....

I believe it better than reportingly.
and ainn lietter at me by that I now.

ant it would better fit your honour.

if they make you then the better answ

I think, sour other rabato we re better

you are little hetter than fulse k tarves

and for the more better assuranee.,.

desire lime and hair to sleak better..

which Pyramus, which 'Thisbe, is the better

yet a better love than my master..
were much better used on Navare.

better than remumeration
diil you erer hear better?

dil you ever hear better? ............

our copper buys no better treasire.

a bett, het ter wits have worn plain.

construe mr specehes botter (repeated)

and showed the bettur face.....

the better part of my affeetions .....
leare you now with better enmpany

ther would be ?.'tter, if well tollowed

better than the Neapolitan's;
he is bttle better than a beast.

thon muy'st with hetter tace exae

which is the better man, the greate:
and better, in my mind, not unciert

my prize? are my deserts no bette

but I will better

to wish myself muel better; yet .....

thrat stand in better place

You cannot better be employer

locomes the throned nunarel better

would be thought no better a nuusicin

we hove, the better for our words...

and I have better news in store for $y$ or

his borses are brerl better.

marry, sir, be better cmployed

ay, better than he $I$ am befure $\ldots . .$.

all the better, we shail be fhe more.

which may be better sunplied when

my better parts are all thrown down

limy better parts are all thrown town

take the part of a better wrestler th
were it not hetter, beeause tilat $I$

forthine cannot reemmense me be

at bome, I was in a better place.

Who ealls? Your betters, sir ........

that we have seen better days....

were I not the better part mace.

a better instance, I say; come........

desire we may be better stranger..

flefunce is better than no skill.

shepherdess, look on him better....

let ine be hetter acquainted.

I do love it better than laxl thing

at a better leer than you,

noy, you were better siveak first.

gool jlays prove the better by the.

in her they are the better tor the

your date is better in your pye

it was formerly better; mat like a naid the better....

no better, if you please ........

when better fall, for your avails....

lacly, have a better eheer

better "twere, I met the ravin hion better 'twere, that all the miseries none better than to let him fetch

air, been better known to you...

which better than the first ..................

esteemerl him no better than a pour

the better for lhim: would, I were so t

Pedascule, I'll watch you better yet

for Kate, and better for myself

to mut on better ere he go $\ldots . . . \ldots \ldots . . . .$.

he that knows better how to tame.

Your betters have endured me say....

or is the addur better thin the cel...

better be with the dead
[Collier] tior a better jest or two .......

win my wager better yet ...........

who have spled the better by ny...

is tove you better. An better

Jove send her a letter guiding spinit

frive us better credit: we have always

tor their better safety to fly

- i

much hetter than to be pitied

better not to have hatl thee than

sweet sir, much better tham I was...

yet nature is made better by no mean

what you do, stilinetters what is done

he eonld never come better: he shall

$\mathrm{my}$ senses, better plensed with madness

the swifter speed, the better...

and graced your kindness better .....

doth boast itself above a better

to sav, you have scen a better .......

better than thy dear self's better part. Com. $\overline{\text { ff }} \mathrm{Fr}$. ii.

better cheer may you have (rep.)

but I think him better than I say

go not my horse the better, I must...

good night, and better health attend

better Maebeth, than sueh

an older, and a better soldier, none.

cowel my better part of man!

manners give our betters way.....

I would not wisl a better father.

but butiets better than a fist of France

and hetter eunquest never eanst tho

uron which better iart our

fit it with some better time ............

any longed-for ehange, or better stute

any longed-for change, or bet
strive to do better than well $\ldots . .$.
make haste; the better foot iefore

jnake haste; the better foot befor

thon wert better gall the devil

each day stifl better other's happiness.

please me better, wouldst thou weep

thon little better thing than earth

I see some sparkles of a better boje.

persuades me I was letter when a

little bettex than one of the wicked..

when rou are better templerel. .......

he lowes his own harn better than...

I never iealt bet ter since I

I shall think the better of oryself ...

his health was never fetter worth....

i. 3 they'll fill a pit, as well as better.

ii. 3

oxcn at a stal, the hetter eherished.

miencls, better consider what jou

I better brook the loss of brittle life...

the better part of valour is discretion (rep.)

he would prove the better counterfeit
being better horsed, out-rorle me ....2H

you should proeure him better assiurance -

thoil wort better be hanged

a candie, the better lart bumt ont (...

I were better to be caten to death.

but gladly would be better satisfied..

Ihere is not a better wenc

the tennis-court keeper knows better

for fault of a better, to call my friend

keeps the road way better than.
better than I was; hem....

not geen a hulk better stuffed

anci ten times better than the inime

a better than thou: I am a gentlema

a soldier is better acconminolated ....
my lord of York, it better slowed....
I am, my lord, but is my hetters are

I am, my lord, but as my hetters
shall better speak of you than......

'twere better than your sinkediun.....

better quiet, better opinion, het

is better than a penny in pure ......

that no man conlel hetter command.
thou hadst better thou handet strued

this poor show doth better this

and to promise you a leitter.

King $\bar{J}_{o} h, \overline{\mathrm{i}}$.

better featred

it there is not better directions

when there is more better......

ainost no better tlan so many irenc....

by one that knows him better than you

you are the better at prnverlis........
were bettrer thay a churlish turf
BETTER-likes me better, since I may. Henry $\boldsymbol{V}$. iv. 1

then you are a better thim the king.
which likes me better, than to wish.

then hetter heed to re-sirvey them..

the princers is the better Englishoman -

the beter no better Engl

if thuu wear ne, better and ioti........

not all togethor; better far, I guess...inenry $V I$.

cljd look no better to thal weighty...

I'll prove on better men than Semper

his burial better than his life .........

will bestow youl in some better place

your diseretions better ean persuade.

her futher is no better than au carl.

but prosper better than ............. -

Was better worth than ail thy father's.2 Henry VI. i. 3

I saw not better sport these seven.

farewell, and better than I fare.

Which fear if better reasons ean supplant -

there is no better sign of a brave mind

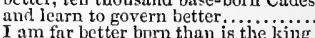

am far better bnrn than

my title's good, and better tar than...3

no, I can better play the orator

you love the breeder better than.
your legs clid better service than

now, one the better; then another best

to be no better than a homely swain

as are of better verson than gra eious

and better 'twere, you tronbied.......

than trusting -

she better would have fitted me........

better do so, than tarry ...............

better hushiud. His bek thy ........ nichardI11. $\mathrm{v}$.

the self'-same name, but one of better

wy an.

O, sir, 'tis better to be briet, than. ....

seldom comes the better: I tear.....

better it were, they all cane

iniglit better wear their lieadl...

the better, that your lordship (rep.).

and I in better state than ere I was.:

that, till thou bring better news.

a thing better men than they ean be.Henry $r$ III. $\mathrm{i}$.

'tis bettcr to be lowly born

who shall report be has a better wife

for your honour better, and your canis

your meditations bow to live better.

nor, I'll assure you, better taken, sir

does deserve our better wishes

ween you of better luek..............

for lietter trial of you

he had better starve than bit once......$\quad$ -

it' she be fair, 'tis the better for' licer.. 7 roil. $\bar{s}$. Cres. $\mathrm{i}$.

Troilus is the better man of the two

no, Heetor is not a man of the

twould not become him, his own's hetter -

(1)

Achilles; a better man any man .. -

the lustre of the better - Knt,-yet to show

shall show the betterf shall exceed -

we were better parch in Afrie sun.... -

still, that we have better men.

i. 3 all the better; thein fraction is...

ii. 1 better; I am the lord Pandaxus (rep.)

nothing, my lord. The better ......

and better wonld it fit Achill better she

the kiss you take is better

your fool no more. Thy better must

which better fits a lion

few things loves better..................

home wrought better, that made....

it our betters play at that game......

and eorme with lictter music.

twenty more better than he.............

not cluber your better remenbrance

may you a better fert ne.

who seeks tor better of thee

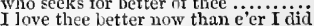

that never lnew but better ..........

thou shonldst have loved th

it was no better than, nor more...... Coriolanus, $\mathrm{i}$.

she will but disease our better mirth

of nn hetter rejort than a horye-drencl

they late minon no better a groumd

and to make us no better thinght of

ii. 1

ii. 5

iv. 1

iv. 3

i. 2

i. 3
i. 4
i. 4
ii. 3
ii. 3
iii. 2
iii. 2
iij. 2
iii. 5
iv. 4
v. 3
I. i. 3
i. 4

iii. 4

iii.

v.

j. 1

i.
i. 2
i.

i. 2
i. 3
i. 3
i. 3

ii. 3
ii. 3

iii. 1

iii. 3

iv. 5

v. $\frac{2}{3}$
s. 3
j. 1

i.

i. 2
ii. 1

iii. 6

iv. 2

iv. 3

iv. 3

,i. 1 
BETTER-this mutiuy were liet not unlike, escls way, to better your in a better hour, let what is mect

hy use of anger, to better vantage ... might have been much better. nature, that slupes man hetter....

you sliall bear a better witness back

yea, get the letter of them alluetite.

wife shall meet with better dret......

it would beeome ne hetter

that you may the letter juilge......

you say, you are a better soldier

not a better: are 1 say, better?

thou lovedst him better than

'tis meter that sorrow better .............

of force, give place to better...

of force, give place to better..........

will hope of hetter deels to-morr

I love long life better than figs ......

whose better issue in the war.

you can do better yet: but this is

given less matter a better ear

should be better, he hecame her guest

my better cumning faints under.

better leave undone, than.....

for better might we have loved ...

in Egypt cannot make better note

I have sixty sails, Casar none better

'tis better playing with a lion's whelp

have paid my better serviee.

but better 'twere thou fell's

in thy absenee is no better than a sty

does begin to make a better life...

I pray you, be better acquainted

I will consider your minic the be

our crows shall fare the better for $y$ you

mayst be valiant in a better cause.

all the better; your valiant

as 'tis no better' reckoned

or if not, nothing to be were bette

thin be so, better to cea

murder wives much better than

ret an I better than one that's sick

I cannot do it better than in gyres

this mau is better than the nau

live, and deal with others better

till you know better how to handl

better than he have yet worn .......

my lords: the better foot before.

they're better than the tribunes...

my youth can better spare my

deeper read, and hetter skilled .....

a better prince, and benion loal. . Pericles,

I would wish no better offic

if that ever my low fortunes betier

he had need mean better than...

he could not please me better.

ay, and better too; we oftend worse...

the better for yon that your resorter.

(nee they do better thee in the

any of these ways are bette

but her better stars brouglit her to

now I know you better

and sue to know youl better

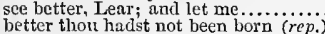

a better where to find

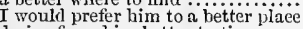

derive from him better testimon

I am better than thou art now

make servants of their betters.......

here to-night? the better! Best!

I have seen bettcr faces in my time........

fetch me a better gives th

vour state better than you yourself

thou better know'st the offices of natiw

be better at tlyy leisure.

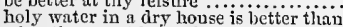

why, thou wert better ln thy grave

hath your grace no hetter compan

when we our betters see bearing

Whit better service have $I$ never

better thus, and known to be contemned

siniles ani tears were like a better day

and thou speak' st in better ture.

methinks, your are better spoken

better I were distraet: so should

be better stuted; these weeds are meinorie

no better. Well. sir. Say-better ..Rom. R- Jub

my, better, sir. You lie were better ended by tieir hate -

a better love to berhyme he

is not this better now than groaning

though his fiee be better than.....

thy disposition better tempered.....

anil all the better is it for the m
I love thee better than myelf..

I love thee better than my elf
barrerl your better wisdoms.

pious bonds, the better to begrilie
BETTER-that witl better leal

but, hetter looked into, he truly found it

in reputation and profit, was

5ou were better have a bal cpitapil ...

have letter commeree than witl homest

that it were better, my mother liad rust

I took the fur thy better ...............

- ii. 2 let Bianca take her sister's roon (rep.)

that Bianca doth fancy any other
your nistress binnea lover noue

forswear $B$ a fection to bialic .

ove for ever

give me bianca for my vatrimo

bic Binca make her rearly strui bat.

but, bid linnca farewell for ever

look not love made me exehing

fair Bianea, bid my futlier

be your half, Bianea comes..........

of your duty, fuir Bianea, hath cost..

pardon me, Bianca; I have this while

sweet Bianca, take me this work out
no, in good troth, Binumen

no, in good troth, Binnea.

now if this quit lay Cassio of Biane

how now, my sweet Bianca?

study his bias leaves, and makes. Trelfih Night, v. I

not unluckily arringt the bins. Taming of sh. iv.

this vile drawing bias, this sway

this same bits, this commodity

fortune runs arainst the bias
trial did draw biasand thwar...

Richard II. ifi.

till thy sphererl hins cheek .........

roil. \& Cres, i.

he's bettered, we have therefore odds

BETTERING-the bettering of my mind. Tempes

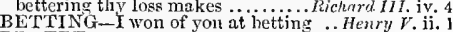

BETTRE-entendre bettre que moy..... - v. 2 with assays of bias, by indirections

Hamlet, ii. 1

from all hollow bias-clrawing ....Troil. \& Cres. iv. 5

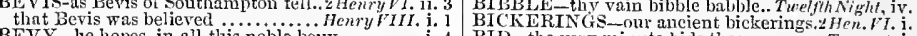

BEVY he hopes, in all this noble bevy - i. 4 BID-the very minute bids the

myself bawails good Gloster's case..2 Henry VI. iii. 1 BEWAILING-this hewalling land.Hem Coriolanus, y. 5

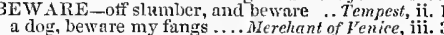

therefore beware my censure .... As you Like

beware of being eaptives, before you... All's $W$ 'll, ii. 1

waspish, best beware uy sting.... Taming of Sh. ii. I

and beware of anl ass ........ Comedy of Errors, iii. 1

like the parrot, beware the rope's end - iv. 4
Macbeth! beware llacdufưf; beware ... Macbeth, iv. I

my liege, beware; look to thy self ... Richard II. . . 3
but bewre instinet; the lion........ I RerryIV. ii. 4

priest, beware your beard.

Clareuce beware; thou keep'st......... Henry FI. v.
beware [Col.Knt.-take heed] of wonder dog.R.III.

beware of him; sin, death, and hell...... i. 3

beware, you lose it not; for us ....Herry HIII. iii. I

beat the messenger who bids bewre. Coriolanus, iv. 0
beware the ides of Mareh (rep.).... Julius Carsar, i. 2

beware the ides of Mareh (rep.).... Julius Casar, i. 2
Ciesar, beware of Brutus, ......... ii. 3 (paper)

young lords, beware! an' should the

beware ny follower; peace, Snolkin .... Lear, iii. 4

pray, innoeent, and beware the foul fiend - iij. 6

that the opposer may heware of

othello, iii. 3

$\mathrm{BE}$ W LEP-beweep to many simple gulls. Rish. II. i. 3

and I'll beweep these comforts.. Timon of Athen

old fond eyes, beweep this cause again .... hear, j. 4
BEWEPT-he bewejt my fortune.... Richard $1 I I$. i. 4

I have bewept a worthy husband's

Which bewept to the grave did go.Ifamlet, iv. 5 (song)
BEWET-with his true tears all be wet. Tilus.tud. iii.

BEWITCI-Words bewitch rour he

Warwick's words bewiteh your hcarts.2Hen.VI.i. I

BEWITCHED - he be not bewitched. Twelfth $N$. iit. 4

hath bewitehed the bosom of my. Mid. N. Dream, i. 1

yet I am bewitehed with the rogue's.1 IIenryI IV.ii. 2

look how I am lewitched

thout Sinon hath bewitehed ou ears. Tius bewitehed my d. v.

bewitulied by the clorm of looks

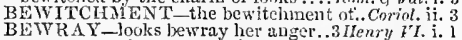

not bewray thy treason with

hewray what life we have led ....... Corintanus, y. 3

liel not thy hue bewray whose brat

Lear, ij.

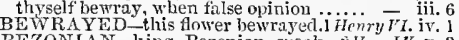

BEZON IAN - ling, Bezonian, sjeak. 2 Hen . I $F$. v. 3

BIANCA B Binnen, get youn in (rep.). Taming of Sh. i.

go in, Bianca; and for I know

more to commume with Bianta

the love I bear my sweet Bianea.

happy rivals in Bianea's love $3 . .$.

beautifnl Bianen, and her witihlold

zone sliali have access unto Biane:

seen in music, to instruct Bianca

a selnolinaster for fair Bianea.

one more may fiair Bianca have.....

in my sight? Bianca, get thee in

that love Bituea more than words $\ldots$.

greatest dower, shall have Bianca's love -

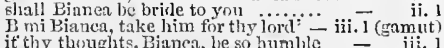

warry sweet Bianca, with consent unless he bia them ...................
drink servant-monster, when $\mathrm{I}$ bid thee

bids thee leare these

I bid a hearty welcome

and love bids me forswear

slie bids me think.

did not I bid thee still

wife, bid these gentlemen welcome...

and bill her tbink, what..

take bid you set it down $0 . \ldots . . .$. - iv.

bid the dishonest man mend ....... Trefth $\bar{v}_{i g h l}$

she is willing to bid rou farewe $31 .$.

bid him go? what an' if you do (rej).

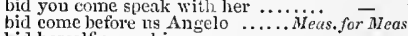

what I bid tliay do:

bid them bring the trumpets

you were not bid to speak.

until my hasband bid me

my husband bids me; now I will.

let me hid you weleome, my lord

sent to bid your conce in to dinner.......

bid her steal into the plencherl bower

you are to bid any man stand...

bid those that are drunk gret

call to the nurse, and bir her stili it.

and me a thousand times goodniglit

bid him bring his pen and inkhorn

come, bid me do any thing for thee

bikl him speak of patience ..........

he bath bid me to a calf's hearl

I camnot bid you bid my daughter lire

go. bid the huntsmen wake them

cuke was here; and bid us follow him
he did bid us follow to the .................

and bid them so be gome.................

in prive and I'll tid adieu.....

go, bid them preparc.................

as I can bid the otlien four .......... - i.

courareous find bids me pack

who bids thee rall? I to not lidili...

I am not hirl for love ..................

do as I bid you, shut kloors atter

have power to bid you welcume (rep.)

birl your friends weleonie, slow

go in, sirrah, bid them preine

biel them cover the tahie
bid the main flood bate lis

bid me tear the bond

bid her be judre, whether.

bit lim keep it better than

gut I wis bin to come for you

I will hid the duke to ................

good my lorl, hid him welcom

make court'sy, bid me farewell

when exception bid him speak

that he bid Helen come to yo
tlies where you bid it, I find.. law of frieudship hids me to conceal..

my assurance bids ne seare

depart when you bid me 


\section{BID}

BID-his taken labours bid hín.. All'swell, iii. 4 (let.) BID-to bid his brother batt

and sorrow bicls me speak.

our general bids you answe

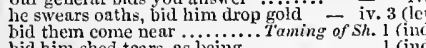

bid bim shed tear, as being

hew bid me knock him and rap him....

hid them use them well............
do bid me pack, I'll give her (rep.)

do bid me pack, I'll give her (rep.).

when I should bid good-mo

did I not bid thee meet me

you bid me make it order.

I birl thy master cut out (re

bid Bianea make her ready

but, bid Bianca farewell
to bid the priest be ready

bo, Biondello, bid your mistress.....

go, Biondello, bid your mistress.....
not come; she bids you come to lier

pray yon, bid these unknown.... Winter

with madness, do bid it welcome ....

bids the other grow, faster than

let's before, as he bids us

of who she but bid follow

we bid be quiet, when we hear ...Comedy of Er.

Dromio, go bid the servants spread ...

go bid them let us in .........

bid my wife disburse the sum

bid you forsake your liberty

bid the lady abbess come to me

bid the lady abbess come to me
gone before to bid us welcome

gone before to bid us well bid God yield us

go, bid thy mistress,

and bid my will avouch it...

but who did bid thee join witl

impress the forest, bid the tree ......

speedy messenger bid her repair

my throne, bid kings come bow.

that you have bid us ask his

ns bid me tell my tale in bloody toil, we bid good-night......

bloody toil, we bid good-night.........
none of you will bid the winter come

none of you will bid the winter eome
bid his ears a little while............. Richard II.

bids, I should not bid again (rep.
bid him, 0 what? with all good....

you would have bid me argue like

uncle, bid him so

a braee of draymen bid, God speed

bid him repair to us to Ely-house.

bid her send me present

and chity bids defend; the other

and bils me speak of nothin
yesterday, bid time return

yesterday, bid tine return
that bids me be of comfort

ere thou bid good-niglit.....................

no little reason bids us speed...

bid Butler lead lim my fort

and bid you play it off ..........

she bids you upon the wanton

bid my lieutenant Peto meet me

it' well-respeeted honou bid in
he bids you name your griefs

the king will bid you battle...

subjects, and time bids be gone........2 Henry 5

and bid me fetch thee thirty .....

hid mistress Tearsheet come .....

and bid the merry bells...

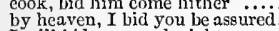

bicls youl be advisel, there's naught..... Henry $V_{\text {.i. }}$.

to comfort him, bid him, 'a should not

and bids you, in the bowels of the lord

bid him, therefore, consider of his.....

go, bid thy master well advise

on to-morrow bid them

bids thy ceremony give thee cure

bid them a hieve me, and then

bid him prepare, for 1 will $\ldots$..........

and bid me eat my leek..............
to bid henry $r I$ young son welcome......
bid me be advised how I tread ......2 Henry VI. bid me be advised how $\mathbf{Y}$ tread ...

bid them blow towards Eugland's

bid the apotheeary brin

go, birl her liirle him quickly

bid Salisbury and Warwiek, come.

and bid him arm himself ............

speak blasphemy ere bid you fly $\ldots . . .3$.

to bid the father wipe his eyes
retire, if W arwick bid him stay...

good fortune bids us paus

bid false Edward battle.............

I seal my truth, and bid adieu
out asain, and bid us battle.

as I can bid thee speak

bid them all home; he's

Dolahella, bid him $y^{\text {ield }}$ and bid thee battle, Edward and bid thee battle, Edward ..........
for warwick bids you all tarewell....
then bid me kill myself, and I will... Richard III.
bid me farewell. "Tis more..........

that God bids us do gond for evil

bicl Gloster think on this $\ldots$ my friend, tor.......

bid him not fear the separated

go, bid thy master rise and com
when he doth bid good-morrow

my good lord mayor, we bid farewel

so foolish sorrow bids your stones...

hath bid the world good-night

bid her wipe her weeping eyes

bid him levy straight the greatest....

bid lim bring his power before

for so the season bids us be

Harry the Sixth bids thee despair

thy nephews' souls bid thee.............

bid him bring his power; I will lead

bid him strive to gain the love

in mine arms I bid him welcome.......

and do as I have bid you ................

speak, sir, for heaven now bids $m$

when their ladies bid them clap...... $=$ (ep

when Achilles' brach bids ne.

Achilles bids me say-ke is much

bill them have patienee..........

Achilles bids you welcome

Ibid good-night: Ajax commind

ho! bid my trumpet sound!.

you bid them rise and live.............
and bid the snail-paced Ajax arm ....
enfranchised, bid him come to me.. Ti

to bid me farewell twice ..............

mightst kill 'em, and bid me to 'er.
you have bid me return so much

greet him from ine; bid him suppose

go, bid all my friends again...

like tapsters, that bid weleome

bid them flatter thee

bid them wash their faees.

bid them home; say, their great enemy =

do not bid me dismiss my soldier.

what he bids be done, is finished

bid them repair to the market-place

a soothsayer bids you beware the ides

for he did bid Antonius send

go bid the priests do present.

proeecding bids me tell you this

my master bid me kneel (rep.)

bid me say to you by word

bid them speak for me .................

bid them move away; then....

Pindarus, bid our commanders $\ldots . .$.

bid him set on his powers

bid me give ' $t$ thee? didst tho

bid me give 't thee? didst thon not

but bid farewell, and go; when

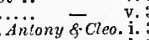

bid him report the feature of octavia

bid you Alexas bring me wor

do as I bid you. Where's this eup

let Neptune hear, we bid a lond

bid them all fy: for when (rep.).

and furtuues bid thy followers,fly

bid her have good heart

bids thee study on what fair

birl you do, get.

my conscience bids me ask

go, bid my woman search for a jewei

go, bill my woman teign a sicknes

do as I bid thee: there's no more
what villany soe'er I bid thee do

hoys, bid bim welcome. Were you

in honesty, I bid for yon,

I do not bid thee loeg my lis.

hole where Aaron bid us hide $h$

bid him bury it; more hath it....

to bid AEneas tell the tale twice.

bids thee ehristen it with
MTareus, loose wlyen I bid

bid him demand what pledge

and bid the owners quench ther.

and bid him come and banquet

and bid that strumpet

the feast that $Y$ bave bid lier to

bid him fareweli; commit him

being bid to ask what he would
TID_for if a king bid a man be a villain. Pericles, i. 3
low! do as I bir you, or you'll move...

Lyehorida, bid Nestor bring nie suiecs

bil Nicander bring me the satin

$O$ princes, bids you all adien
bid them farewell, Cordelia

bid farewell to your

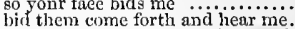

I do not bid the thunder-hearer sho

bids the wind blow the earth into

and bids what will take all.

do as I bid thee, or rather do thy

bid me farewell; and let me hear...... - iv.

am come to bid my king and master.... -

bid a siek man in sadness .......... Romeo of Juliet, i.

so soon to bid good-morrow to thy bei

bid her devise some means to come

bid him eome to take his last farewe

bil my sweet prepare to ehide (rep).

bid her, mark you ine, on Weduesday

or bid ne lưk where serpents are

or bid me go into a new-made grave

and do the thing $I$ bid thee do...

do as I bid thee, go. I am almost..

with wild looks, bid me devise
he early bid me give his father

he early bid me give his father and bid me stand aloof, and so $\mathrm{I}$.

of mo watch, bid them make haste...... Homlet,

and bid me hold my peace

no money bid for argunent

by no means. that I bid you do

not serve God, if the devil bid you

so was I bid report here to the state
brief: and bid-good-morrow, general

brief; and bid-good-morrow, general
which so often you did bid me steal...

seek him, bid him come hither

I have sent to bid Cassio come speak ....

bid her come lither, go: slie says enough $\vec{T}$ iv.

BIDDING-to thy strong bidding ...... Tempr'st, $\mathrm{i}$.

bidding the law make court'sy..... Mea for Mea. ii.

conld do nothing without bidding...Mer. of Ven. ii.

health, at your bidding, serve .........Alls $w$ ell, i1.

I shall not break your bidding .........

thou wilt perform my bidding

his person at our great bidding

bidding me depend upon thy stars. save bidding tarewell to so sweet....Richard II. ii.

his neigh is fike the bidding of ....... Henry $r$. iii. 7

is finished with his bidding .......... Coriolanus, v. 4

and I will do his

might from the bilding of the

but performs the bidaing of the fullest - iii. 11

do thou thy master's bidding

too slow to do thy master's bidding ...

perform ny bidding, or thou lis'st in ... Pericles, v. 2

dismiss me! it was his bidding.......... Othello, iv

BIDDY - aY, Bildy, come wit

can give no place, bide no denay

that would not let him bide..Mid. $\ddot{N}$ 's Dream iii.

and bide the penance of ench three. Love's $L$. Lost, i.

and though 'thou art not bonest.. Winter's Tate, i.

safe in a citch he bides

no spark of honour bides

or bide the mortal fortur.

Henry $I V$ iv.
ivenry $V$. i.

whe the mortal fortune.......... $-\overline{c l}$ ii. 2

whe ber live? or in my life. Cymbeline, iii

then, not in Britain must you birle.. - iii. 4

where you may bide, mintil your datc...Pericles, iii. 4

bide the pelting of this pitiless storm ..... Lear, iii. 4

nor bide the eneounter of assailing...Rom. \& Jul. .
BIDING-threats of billing there. TuoGen. of Ver.

i. 7 holds his billing on my arm.

Pericles, ii. 1

IID'ST-throu bid'st me beg ................... Lear, iv. 6

shall not marry, till thou bid'st... Winter's Tale. v. bid'st thou me rage? why, now.....3 3urnery VI. i.

thou bid'st me to my loss ........... Cymbeline, iii. 5 the bier at door, and a demand...... Cynibeline, iv. 2 Romeo, press one heavy bier..... Romeo $\delta$ f udliet, $_{\text {iii. }} 2$ bore him hare-ticed out the bier Ham/et iv 5 (songr)

ii. 3 bore him hare-taced on the bier.Hamlet, iv. 5 (song)
iii. I BI-FolD -itself! bi-fold authority!.Troil. s Cres. v. BIG-a dog as big as ten of yours. TwoGen. ofler. iv. 4
he's too big to go in there ........ Merry Wives, iii. 3 no woman's gown hig enough for him - iv. 2 no woman's beart so big, to hoid. Tuefth $\overline{N i g h t, ~}$ ii. 4 al though the sheet were big enough.. - iii. 2 big enough; if it be too big for ... Nea. for Mlea. iv. Pompey surnumed the big

his leg is too big for llector

. 


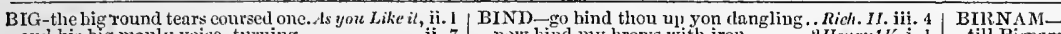

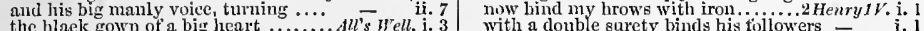
the hlaek gown of a big heart..........All's bell, i. my mind hath been as lify as une ..... sport herself with that she's big with. Winter'sT. ii. 1 sport herself with that she

$\mathrm{a}$ hoop of gold, to bind thy his tollower

anil surer bind, this knot...

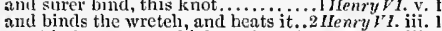
you hind me to your highness' serviee.3 Hen. $V$. iii. unother horse,--bind up ny wounds... Rich.III. v. your lordship ever binds him ... Timon of Athe

and bind up the putry difference. Cymbeline ii.

bind the offender, and take him ...... Cymbeline,
would bind me here unto the body... Titus And. mischance look big upon

witl forehead bold and big enougl

bnlk, and hig assemblance ot a man

big Mars seems bankrupt
glanll lessen this big look.

of oath, and big coinpar.

as thou

ienryl II

a earbunele entire, as big as thou.

thy heart is big; get thee apart

larty, big of this gentlenian .........

nn arm as big as thine? a heart as biy?

whilst I was big in clamo

a bump as big as a young.

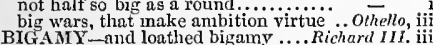

BIG-BELLIED - grow big-bellied......Mil. N.Dr. ii.

$\mathrm{BIG}-\mathrm{BONED} \rightarrow \mathrm{no}$ big-boned men. Titus Andm, iv. 2 the bigger bulk it shows

the bigger bulk it shows
the lnusband's the bigger

Tivelfich Night, iui.

his opening with this bigger kej.Mea. for Mea. iv.
a bigger. I'll have no bigger.... Taming of Sh. iv.

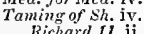

hearts in their bellies no bigger ...... R Renry $I V$. iv.

the spoous will be the bigger, sir ... Henry VIII. v.

a court no bigger than his eave.

Lear, iv. 6

he seems no bigger than his head

no less? nay, bigger; women grow ...Rom. \& Jul. i. 3

BIGGEST -and biggest tears............. ictes, iv. $\overline{4}$ (Gower) BIGGIN-with homely biggin bound.2 He
BIGNESS-legs are both of a bigness.

BIGNESS-legs are both of a bigress.. - ii. 1 lord Bigot, I am none................ - iv. 3
BIG-SWOL $N$-of my big-swoln heart.3 Henry $^{\prime}$. ii. the welkin with lits big-swoln faee?. Titus And. Hii. 1 BILBO-challenge of this latten bilibo

to be compassed, like a good bilbo....
BILBOES- the mutines in the bilboes

BILBOW-de arm, de bilbow

BIL -in any bill, warrant ..........

he set up his bills here in Mlessina.......Much $A d o$.

have a eare that your bills be not stol
being taken up of these men's bills

being taken up of these men's bills..,- iii.

with orange-tawny bill .......... - iii. 1 (song)

and as pigeons bill, so wediock....... - ili. 3

for I have bills for money .... Taming of Shrew, iv. 2

take thon the bill, give me

the neb, the bill to him? from the bill that writes them

manage rusty bills against

racbeth, ili. 1

that self bill is urged

this bill urged by the eommons?

take up eommodities upon our bilis.2 2 Henry $\overline{V I}$. iv. 7

had been cleft with a brown bill .... - iv. io

not your sums and bills . .... Timm of

all our bills. Knoek me down

proseription, and bills of outla

with charitable bill (O bill

fear no more tavern bills

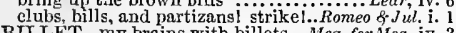

BILLETED-distinetly billeted ..... Coriolanus,

go where thou art billeted; away

Othello, ii. 3

BILLIARDS-let us to billiards.. Antony \& Cleo. ii.

BILLOW-methought the billows spoke. Tempest, iiti. 3

take the ruffian billows by the top..2 HenryI $\mathrm{V}$. iii. 1

on the inconstant billows dancing.Henry $V$. iii. (cho.)

the tumbling billows of the maiu ..Richard HI. i. 4

swell, billow; and swim, bark!

shakes on Neptune's hillow .... Prricles, iti. (Gower)

the brine and elondy billow kiss the moon

I never saw so huge a billow, sir
the chiding billow seems to pelt

othello, ii. 1

BIND-to lind him to remember. Two Gen. of Ver. iv. 4

provident in peril, bind himself .. Twelfth Night, i. 2

to bind our loves up in 2 holy.

二 $\quad$ iv. 2

to do what, signior? To bind me....

must sheaf and bind ....As you Like il, iï. 2 (verses)

according as marriage binds $\ldots \ldots \ldots . .$. . v.

we will bind and hood-wink him so....Alls $\bar{W}$ ell, iii. 6
$\mathrm{O}$ bind him, bind him, let him not.. Com. of Er. iv. 4

bind Dromio too, and bear them.

that we may bind him fast..

v. 1

and bind us further to you ................ Macbeth, v. bind up those tresses: 0 , what love... King John, iii. and bind the bov, which you shail tind

no chiders, sir; Biondello, let's away

hear'st thou, Biondello? I eannot tarry

fly, Biondello: hut they may ehance

pow

the singing birds, musicians

1 Henry $1 V$.

as bird doth sing on boing

Henry $V$, iii.

a quire of such entieing bird

yea, men and birds, are fain

if hird that will revenge upon that princely eagle's bird.

for both of you are birds of self-sane

such a pleasure as incaged birds

the haploss male to one swet hird

the rod, and bird of peace...

iii.

the hird of night did sit............Julius

why birds, and beasts, from quality.

she alone is the Arabian bird

the bird is dead, that we have made.

his royal bird prunes the immortal

the hirds ehaunt melody on every.

whilst their own birds tamish.

suffers little birds to sing

forth to beasts, and birds of prey

the meanest bird that flies i' the

$\mathrm{O}$, well fird, brineh, hird! ' $\mathrm{i}$ ' the clout

will sing like birds $i$ ' the cage.

no further than a wanton's bird.

I would, I were thy bird ....

this bird ot dawning singeth all night

hillo, ho, ho, boy! come, bird, come! ...

RD-BOLT_things for bird-bolts. Tud - ii

ellallenged him at the bird-bolt

Aluch Ado

thumped him with thy birl-bolt... Lnve's $L$. $L$. iv. 3

her husband goes this morning a birding -

is this morning gone a birding

BIRDING-PIECE-

二 iv.

to diseharge their birding-piece.

othello, iv. 2

BriN AM-until great Birnam wood .... Macbelh, iv.

near Birnam wood shall we weil

near Birnam wood shall we welt ....
make we our mareh toward Biruam. till Binum wood remove to Dunsinane. Macbelh, v. 3 The wood of Birnam. Let every ....

fear not, till Birnan wood do eome

though Birnam wood be come.

swore to that, Biron, and to the rest

go hom ike an envious sneaping frost

my lord Biron sce him dolivered o.er

a truth, Biron they eall him

that last is Birou, the merry monsieur Biron, to one lady

monsieur Biron, to one lady Rosaline

Biron. Sir Nathaniel, this Biron...

would the king, Biron, and Longavilie

What will Biron say, when that he
Biron, read it over. Where hadst

Biron, rend it over. Where had
it is Biron's writing, and here is

are then no eyes, nor I Biron

nay, I have verses too, I thank Biron

that same Biron I'll torture...........

this pert Biron was out of.

Biron did swear himselt ont of all.

quiek Biron hatl plighted faith......

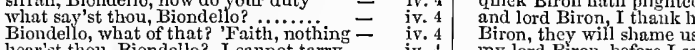

BIRT lord Biron, before I saw you

and robleness of hirth, wwo Gentlees.. Tempest, ii.

did govern Proteus' birth

what says she to my birth

doth object, I am too great of birth...... Merry rives, iii.

leep aecording to my birth...... Tuelfth Night, iv. 3

when Viola from her birth had

slie is no equal for his birth $\ldots \ldots \ldots$... Much Ado, ii. I

on this trevail look for greater birth.. - iv. 1

a month old at Caius' birth

I do in birth deserve her ..... Merchant of Jeniee, $\mathrm{v}$.

a gentleman of my birth ............. As you Like it, $\mathrm{i}$.

eivet is of baser birth than $\ldots \ldots . . . . .$. .

by birth a pedlar, by edvention. Taming of $S .2$ (ind.)

bethink thee of thy birth.......... - 2 (ind.)

wealthy, and of worthy birth ...........

of her breeding, as i' the rear of birth

this tyrant bolds the due of birth ..... Macbeth, iii. 6

sought a match of birth, whose veins. King John, ii. 2

virtue, birth, is the young

great birth, nor deserve a erown (rep.) - iii. I

famous by their birth, renowned...... Richard ir. ii. I

by fortume of my binth.

and at my birth, the trame ....... Henry $I V$. iiji.

thou art a summer bird

(yet likely of fair birth), should be...2 Henry $I V . \mathrm{i}$.

is the hirth,

and loathly births of nature.

in the derivation of my birth ......... Henry $r$. iii. 2

stands upon the honour of his birti...

I was the next by birth and parentage

of the garter were of noble birth

neither in birth, or for authorit

joined with her birth, approves

joined with her birth, approves ......

by her he had two children at one birth

ignorant of his birth and parentage

thy state, and birth, that

.....3 HenryVI. iii. your due of birth, the lineal glory..... Rickard 111 . iii. 7

ripe revenue hirth, your empery

burlen was and due of hirth

wrong not her birth, she is of royal

their budies as becomes their births

is not birtl, beauty, good shape....T

not name desert, before his birth

high birth, vigutr of hone, desert

residenee, and birth, searee is.... Tim

what's his riame, and birth?........... Cymbeline, $\mathrm{i}$.

above him in birth, alike conversant in - iv.

not seeming so wortlyy as thy birth..

a more blust'rous birth had never bade.

at her birth, Thetis, being proud - iv. 4 (Gow, ili.

a tempest, a lirth, and death ............ - v. 3

revolts from true birth st umbling.... - ii. a

lie himself is subjeet to his birth .......

of violent birth, but poor validity ...' b iii. wither all the abhorred hirths below

a mother to the birth of three .......

are our being and our birth... Pericles, i.

if not by birth, have lands by wit $\ldots \ldots \ldots$ Lear.

wherein onr Saviour's birth is eelelorated. Humlet, 
BIRTH-CHILI)Thetis' birth-child on the..Perieles, (Gow. inserip.)
BIR'IItDA $\mathrm{Y}$-this is my birtludaty ...Julins Cersar, v. is ny birthday: $[$ had thenght. Antony of Cleo, iij. 11 IIRTIIDOM - lown-fullen lirtlidom .... Narbeth, iv. 3 BIRTH-PLACE-lirth-plaes hate I

beriug their birth-rights loroudly honour of his birth-right to the ...2 2lenry $Y$. . il. deserved to lose his birth-riglit thus?.3 Henry VI. i should lose his birth-right by l
BIRTH-STRANGLED-

finger of birth-strangled b
Dis-simplieity, bis cootus

Alacbe/h, iv. 1

DIs-simplieity, bis coetus
BISCUIT-the renninder

uns a sailor breaks a lisenit........... Troil. \& Cres. ii.

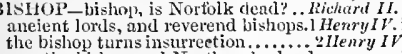

say, the bisbop mud Nortlinmberland

with you, lord bishol, it is even so
ay, see the lishoy be not overborne.

through malice of the bishop's men.

bishop and the duke ut Gloster

the bishop hath a kindly gird.
lord bishop, set the erown upo

the bishop will be overbone

burons, and twenty reverent bishop....2 Hen. rr. i. 1

is prisoner to the bishop here .....3 3enry $y$ iv. 4

to steal the bishop's deer

bislun, firewell; shield thee from

and from the bishop's huntsmen

IIenry at the bishop's pralate

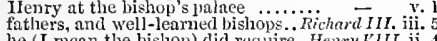

he (I mean the bisliop) did require... Henry VIIT.ii. 4 maimed the jurisdietion of all bishups

what two reverend bishops

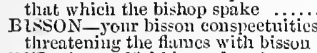

threateniug the flitucs with bis
BIT-the needtul bits and curbs

clainty bits make rich the
1 will not tonch a bit

Hamulet, ii.

Love's L. Lost, i.

with a half-checked bit 7 .... Taming of shrew', iii. 2

could be better bit than fiave been... Hemryl the in

their mouths with stubborn bits ........ Henry HII. v.

the bits, and greasy religue

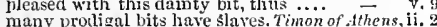

mo: and batten on eold bit

it had its head bit off by its young.......... Lear, i. 4

mine enemy's dog, thongh ho hat bit me... - iv. 7

BITCR - a bitch's blind puppies ..MTerry Wives, iji. 5

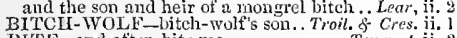

IITE-and atter, bite me ........

now 'gins to bite the spirits

slie bath no teeth to bite

it shall bite upon my nceessity..... Herry Wives, ii. 1

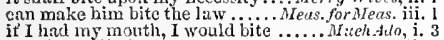

this fish will bite.

the two bears will not bite one..........

that bites the first-bom infunts .. Lnve's L. Lost, i. 1

that dost not bite so nigl

nor bite the lip, as angry........ Taming of shrew, ii.

thy beatity, as frosts bite the meads

lest it should lite its master

hath less power to bite $\ldots \ldots \ldots \ldots . . . . .$.

that frosts will bite them

and fret, and bite his tonrue

run baek and bite, beeaure he wa..............

and bite tlyy longue, that slunders

thou camest to bite the world
snarl, and bite, and play the do

fawns, he bites; and whe

but he would bite none

he bites his lin, and starts $\ldots . .$.

though you bite so sbarp at .

bites his lip with a politie...

one bear will

yot to bite his lip, and lium at

inad, I will not bite him....

ot thite the holy curds in tw

the foul tiend bites my baek

I will bite my thumb at then

not bite my thumb at you sir

the air bitcs shrewdly; it is very

Mich's T'ale, $\mathrm{i}$.

statutes, and most biting laws

lrere under some biting error........
where biting eold would never li

theu we are like to have bitin
culd biting win ter mars our.

this would have been a hiting je.
tor his biting is immortal ......

how she dicd of the liting of it....

with my good biting fituluhion.
BITTEN_-ight for lsitten apple

Henryl

BITTER-Ine with bitter fast.

you gave me bitter pills.

many bitter threats of......
it is a bitter deputy......

that's bitter to sweet e....... Wersure for. Weasure, iv. 2

the base, the bitter disposition of.......
BITTER-bitter on your bitter foe...11ic. $N$. Dr. iij. \& । do not be so bitter with me ........... too bitter is thy jest................ Love's L.Los', iv. 3

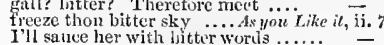

I will be bitter with hin

the tood of sweet and bitter fincy

but, $O$ how hitter a thing it is.......

in the most bitter touch of sorroy

the bitter past, nore welcome is

she eross thee with $: 2$ bitter wo
hicling his bitter jests in blunt

at $y^{\text {ou }}$ tor a bitter [ $\mathrm{Col}$. hetter] jest.

in that be matie more bitter

make heary, and vengeance bit

it is as litter upon thy tongue $\ldots . .$. .
and bitter shnme hath spoiled the ... King

bitter elamour of two eager tongues..
eating the bitter bread or banishment

our ac vantage, on the bitter eross

eaptain, these are very bitter word
consecrate commotion's bitter ed

consecrate eommotion's
this bitter tuste vield hi

swecten the bitter noek you sent

given me most bitter term

bitter injuries, which sumerset ....1 Henry VI. ii.
avuid such bitter taunts...........3 Henry VI. ii.
uphraidings, and your bitter scoffs.. Riehard III. i.

....1Henr?

ealled me all these bitter names.....

yet his punishment was bitter denth

will prove as bitter, black, and tragical

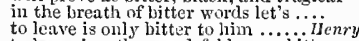

to leave is a thousand-fold more bitter

is it bitter? forty pence, no $\ldots \ldots \ldots \ldots$. .

too bitter to your eonntrywoman (rep.) Cres.

I sce a thing bitter to me as deith ... Cymbeline,

for thesc biter tears, which

a brine-pit with our bitter tears

stomachs with their bitter tongues

revenge these bitter woes of ours
leare these bitter dleep laments....

torment you with my litter tongue.

nor can 1 utter all our bitter grief
makes the world bitter to..........

a bitter fool! Dost thon know (repeated).. 2 (letter

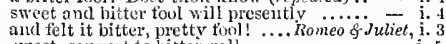

sweet, convert to bitter gall........
thy wit is a very bitter sweeting

'tis bitter eonduct, come unsavoury

and lack gall to make oppression bitter.

as the bitter day would quake to look on
power to make this bitter to thee.........

you shall yourself read in the bitter letter
be to him shortly as bitter as eoloquintida

BI'TTEKEST - to talk their bitterest. VInter's $^{T}$ T. iii. 3

oleak out to bitterest ennity

BI'TTERLY -wept bitterly.....
and she will speak nost bitte

andi she will speak nost bitterly...Meu. for Mea.

Which then blew bitterly against ....Richard II
bitterly to speak in , your reproof... Richard III.

more bitterly could I exjostulate.

vent reproaehes most bitterly on jou. Hen.VIII. $i$.

and it cried bitterly: yea, quoth.. Rameo \& Juliet, i. 3

shall bitterly begin his tenrful dat

but say not so in bitterness....... As you Like it,

contempt nor bitterness were in

ntught, but shame and bitterness ... King. John, it
the bitterness of your galls ..........2 Ilenry $I V$.

the bitterness of your galls ............ Richary hin

the bitterness of it I now belch .... Cymbeline, iii.
his trenzy, and his bitterness.... Titus Andron. iv.

despised time is nanght but bitterness ... Othello, $\mathrm{i}$.

as bitter-searching terms .........2 Henry VI. iii. 2

how close 'tis eaulked and bitumed...

BLAB-when my tougue blabs ..... Twelfth Night,
eyes blab his heart's maliee ........

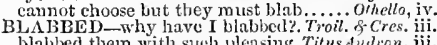

blabbed them with such plensing. Titus Audron. iti.

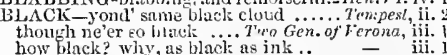

how black? why, as black as ink
now flue is beconite as black as I.

now the is beconte
my face is blaek .......
blick men are pearl

is beaten black ant blue

is beaten black and blue ..i
tell'st thou ne of black anit
iny doe with the black scrt

Mierry $\overline{\text { Wi }}$

fatries black, grey, gruen, and white

on my blaek cominilet i... Thelfh Night, ii. 4 (sonst) mot black in ny mint

besmeared as black ts vilean

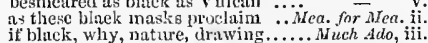

if blick, why, nature, drawing

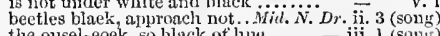

the ousel-eoek, so black of liue .... - iii. 1 (song)

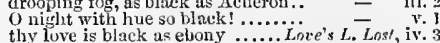

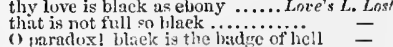

o jaradox! blaek is the liadge of hel
if in bluk, my' laty's ljow's be....
I A A CK-borm to make black fair
laints itselt black, to imitate her

arc chimney-sweeper's blaek

are but black to Rosalind.

your black silk hair, your bugre... ds you tike it, iii.

my cyes were black, and my hair blaek -

upon your graee's part; black and feaiful

the Black Prince, sir, alias, the prinee.. - iv.

were they filse as o'er-clycd blacks. Winter's Tale, i.

cypress, black as c'er wrts crow .... - iv. 3 (son:

or piuch us blaek anch blue .. Comedy of Errors, ii. 2

cre, to black fleente' summons............. -

whiles night's black aremts......

black spirits, and white................ iv. 1 (song)

how now, youl secret, black, and midniylit - iv.

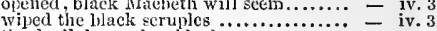

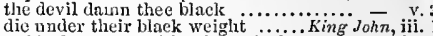

as black, way nothing is so black ... $\quad$ - iv. 3

in the blaek brow of night ...........

tliat tell black tidings...

(iv.

put on sullen black incontinent .... - v.

burne with black vapour............2 Herry $I V$. ii.

black George Bare, and Franeis....... Inenry $V$ iil.

as pross as blaek from white ........ - ii.

said it was a black soul burning fo... $=$ ii.

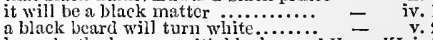

...1Henry $V I . \mathrm{i}$.

we mourn in black; why mourn we not -
whereas I was black and swart before

terror, and black Nemesis .........

Edward the black prince (repeated)..

but, see, his faee is black, and fuil ... -. iii.

from his bosom purge this blaek desinir $=$ iij.

covered with the night's black mantle

are dimmed with death's biack veil..

I sly a black, subpicions, threatening $-\bar{l}_{\text {III }}$

blaek night o'ershade thy day.

I'll join with black despair $\ldots \ldots \ldots . . . .$.

is bitter, black, and tragica

a black day will it be to somebody.... -

makes my whitest part hlack .......Henry $\boldsymbol{V}_{I I I} \mathrm{i}$.

as blaek as it' besweared in hell.

no blaek envy shall make my grave - ii. 1

armed, as black defiance.... Troilas \& Cressida, iv.

will make blaek, white; foul, fair. $T$ i
engenders the blaek toad, aud ndder

sume black, some aukurn, some bald. Coriolnnus, ii.

our black sentence and proscription.Jul. Cosar, iv,
with l'helous' amorous pinches black. $A n t . \&$ Cleo. $\mathrm{i}$.

they are blaek vesper's pageants ....

will have his soul black like bis faee.Titus.And. iii.

a joyless, dismal, black, and sorrowful

never twin a swin's liack legs ........

lowk, how the black slave sniles $\ldots . .$. .

ay, like a black log, as the saying is

incper palfreys, black as jet....

no visol does become black villany - iv. $\overline{4}$ (Gow.)

looked blaek upon me................... Lear, ji.

be thy montli or black or white ..........

black and portentons must ................ \& o Jutiet, i.

being black, put us in mincl........ - i.

stiobed with a white wenclis black cye -
this day's blaek fate on more days ..

sober-suited matron, all in li................

with thy black numble, till strange

and tiuned that black word death

turn fom their office to blaek tuneral

mor eustomary suits of solem black .... Hamlet $i$.

sable arms, blak as his purtose ........ - ii.

nay, then let the devil wear blnck ...... - iii.

0 borum, black as deuth! 'O limed soul = iii.

his soul may" lie as clammed, and black

on old blaek ram is tupping ..........

your son-in-law is firr viore fair thinn biaek -

to the health of the black Othello........

hinply, for I am black; and have not those

arise, black vengeance, from thy hollow eel!

BLACKANOOF-were a binekamoor.. Troil. \& $c$

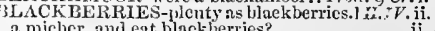

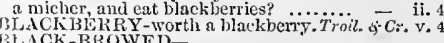

consort with black-browed njort .. Mid. $A$. Dr, iii. 2 
BLACK-BROWED-

comc, loving, black-browed night. Romeo \& Jul. iii. 2
BLACK-CORNEIED-

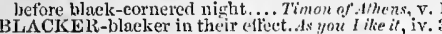

because your brows are blucker. . Whiler's Tale, ii. 1

piety does my deeds make the miack blacker than the night

ind you the blaeker dera

Pericles, i. 1

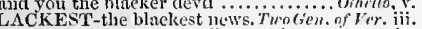

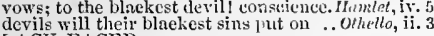

BLACK-FACED

when black-faeed Clifforl shook .. Richurd III. i.

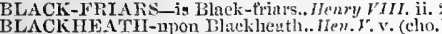

BLACKMIRE-Stringe of Blackmere.1IIen, $Y I$. iv.

BLACK-IONDAY-

a bleeding on blaek-Monday last... Aler. of $V$

more fiery by night's blaekness
his bed of blaekness unlaid one

a white that sliall her blaekmess fit ...... Prinello, ii.

BLACK-OPPIRESSING-

the black-oppressing liumotur.. Love's $L$.. L. i. I (let.) boys that swim on bladders

bladders full of imposthum

green earthen pots, bladders .... Romeo o \& Juliet,

ADE - as braggarts do their blades. Anch Adt

come blade, my breast immoric

Col.] done i' the blade of youth

Ill's trell,

let fall thy blade, and duigem

between two blades, which bear

and, with thy trencherous blade

fourishes his blade in snite of une ". Richard I11.

Spanish blades, of henlths five fathom

a very good blade! a very tall man!
BLADED-the bladed grass ..... Niil. $N$.

though bladed eorn be louge

B

or who ean blame me to piss.

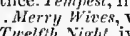

so far blume proves my enterprize...Mad. N.Dr.

truly, the more to blame he

truly, the more to blame he .....Mer. of Venice,

blame you me to love you (rep.)........ you Like it,

than I dare blame my weakness
he has mueh worthy blame laid

shall render you no blame

my ligh-repented blames ..............
whetlier I have been to blame, or

Whetlier I have been to blame, or no

fie! you are to blame: eome

eredit, the other miekle blame... Come

lays blame upon his promise.

the taints and blames I laid upon.........

who then shall blame his pestered.

I eannot blame him; was lie....

I cannot blame him; at my nativit

I feel me mueh to blame.

can you blame her then

or will you blame and lay tie ta.....ilinenry

his faney, blame him not

my youth be guilty of such blame?

Fannot b]ame them all...

I blame not her, she eould say litile less

let me blame your yraee .........

nor were not worthy

I cannot blane her, by God's looly

Riehard $I I I . \mathrm{i}$

the king my uncle is to blame for this

but wromg blame, and take thy office

I eannot biame his conseienee.... Ilenry

if the king blame me for't............ - v.

tis muel to blame; they say.......... Timon of Athens, i.

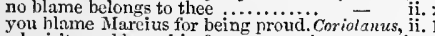

who is't ean blame lim? your enemie

the blame may hang upon your.....

I am to blame to be thus waited for..

I blame your not for praising Casar..-

poor knave, I blame thee not

by which I'did blame Cato.....

some men are niuch to blame

of what we blame him tor.

no blame be to yoll, sir: for ali was..

blume both my lord and a n

blume both my lord and me ...........

il part I understand them, are to blaine .. L

as elears her from all blam

tis his own blame; he hath puit .....

eanst thou blame him? his dinugliter

whiel men may blame, but not costrol

and, manners, blame us not

to lay the blame upon her owis desinir

you are to blame, my lord...... Rnmeo siffuliet, iii.

we are oft to blame in this ........... Hamlet, iii.

by eoek, they are to blame.......... - iv. 5 (song)
death no wind of blame shaii brenthe.. - iv.

the king, the king's to blame

othello, i.

whom let us not therefore blume.

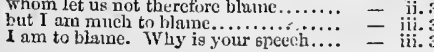

BI.AME-in sooth, you are to liame .... Othello, iit. 4

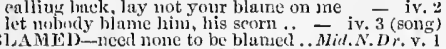
that was not to lie hlamed in .........All's s'rell, iii. be blimed for 't low you might .. Winter's 7'ule, ii. which I luve rnther blamed as mine own.. Lear, $i$.

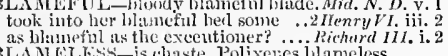
BladilLEtis-is chaste, Polixeries ilaneles

PLANC-from Port lo Blane, a bay ... livehard II. ii. the lady 13 huthet is netr to England.

find it finer then in Blaneh

richer blond than latly Blanch ......

Lewis minty blanchl oh? aud the

'Tray, minch, and Sweethent ........... Lear, ini.

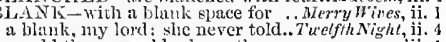

would they wore bianks, rather..

in the even roud of a blank verse .....

ont of the blauk aud level of my. W'inter's T'ale, ii.

at home shall have blank eharters ... Richard if. i. 4

a commission to a blank of dainger. Troil.\& Cres. iii. 3

the other blank as nothing $\ldots \ldots \ldots . .$. .

or the blank yot thine eses $\ldots \ldots \ldots \ldots$.... Lear, i. 1

that blanks the face of joy

within the blank of his displeasure ...... Othello, iii. 4
BLANKET-neep through the blanket

will toss the reegue in a blanket ...2. Henry IV , ii. 4

the smu from us with a blanket

nay, he reserved a blanket, else.

BLASPHEML-blaspheme the

brother of Englaud, you blaspheme in

bletsuling

blasphemous, ineharitali]e dog ........ Tempest, i. 1

BLAEPlHEMY hlaspllemy, that swear'st - y. I I wonld speak blasphemy ere bid...2 Henry VI. v. 2
BLAST-there he blasts the tree ...Merry Wires, iv. 4 blasts of January would blow ..... Winter's T
bolted by the northern blasts twice..

striding the blast, or heaven's eherubim. Nacbeth, $\mathbf{i}$.

but when the blast of war blows ..... Henry $V$. iif. I

general trimpet blow his bla

3 Henry $Y$ I. iv. 4

r'll hlast lis harrest.

eome, blow thy blast. Tulus

witle brazeu din blast you ...

from tell destruction's biast ....
blasts and fiogs upon thee! the vintented

blasts and figs upon thee! the untented

which the impetuous blinsts, with

owes nothing to thy blasts

airs from heaven, or blasts trom hell ...

if this should blast in proof

filler blast ve'er shook oum battienci...... ontello, if. 1

nbout you blissted with antiquaty

nine arm is like a blasted sapli
be men like blasted woods....

to see 't, mine eyes are blasted .

you wer'e half blasted ere I knew you

thus blasted, he will repent.

of blown youth, blasted with ecstice

BI STING-blasting in the buc

a blasting and a seandalous.......Mea. for Ntea. $\mathrm{v}$.

mildewed ear, blasting his wholesome
BLASTMENT-Contrgious blastment

BLAZE-the blaze [Col. blade] of youth. $\ddot{A} l l^{\prime}$ ' $\bar{W} e l$,

his rash fieree blaze of riot

for lleetor in lis blaze ot wratl.

the main blaze of it is jast .........

hlaze forth the death of prinees....... - iv.

find a time to blaze your marriagc. Rom. $\alpha$ oul. iii.

a speeeh of fire, that tiin

room hath blazed with lights... Timon of Athens,
BLAZING - but every blazing star ....

BLAZING--but every blazing st
each one blazing by otur needs.

BLAZON-with loyal blazon

I give thee fivefold blazon your blazon to be true

thy skill be more to blazon it ...R... Muchea of Auliot, ii.

but this eternal blazon must not be ..... Hamlet, i. 5

exeels the quirks of blazoning lens. ... Ohello, ii.
BLAZON'ST-tlyyself' thou blazon'st. Cymbeline, iv.
BLEACH-and maidens bleach.Love's L.L.v.2 (song)

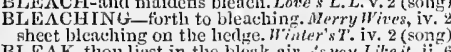
BI.EAK-thou liest in the bleak air. Ss yor Like it, ii. look bleak in the culd wind
BLE_AK-think'st thut the bleak air. Tim.of Alh. j7.

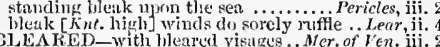
upposes bleared thine eyne.....Taming of $\mathrm{s} h \mathrm{~h}$. $\mathrm{v}$.

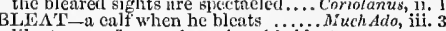
bleat sottly then, the butcher .... Love's L. Lost, v. 2 made the ewe bleat tor the lamb...Ner, of Ven, iv. BLEATED-Neptune a ram, and blcated lave not washerl my nose that bled... Coriolamus, i. BLEED-O my heart bleeds to thin!k.... Tempest, $\mathrm{i}$. if you priek ut, do we not bleed?. Mer. of Venice, iii. one shall swear she bleeds..... Taming of $\bar{s} h$. 2 (ind.) weep I cannot, but ny heart bleeds. Minter's 1 . ini. 3 hleed, bleed, poor country!

sword impress, as make me bleed

bleed Franee, and peace ascend

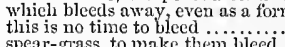

- iv. 3

fever, and we must bleed for it .......

for my opinion bleed ............... Henry $Y 1$. ii. 4

nad bleed todeath unon

thy wounds do bleed at many vents - Tiznon of Athens, i. alas, Cresar must bleed for it! ....Julius Casar, ii. did not great Julius bleed for justice;" sake

I do not see them bleed...... Antony s. Cleopretra, son's eye belold his tatiser blecd.. Titus Andron. v.

look, sir, I bleed. Where is the villain ... Lear, ii.

Regan. I bleed apace: untimely

at this time, we sweat and bleer

wife! look how our danghter bleeds...... \& $\&$ v.

they bleed on both sides: how is it...... Hamlet, $\checkmark$.

Ibleed still, I am hurt to the death ...... olhello, i. 3

nobody come? then shall I
I bleed, sir; but not killed.

BLEEDING_-nose fell a bleeding ... Mer. of Ven. ii.

to the hleeding, and the grim a tirm ...Mlacbeth,, .2

spit it bleeding, in his high disgrace... Richardil.

and bleeding, will we offer them.......

breathless and blecding upon the ground - $\mathrm{V}$.

advance his blecding sword,'twixt ..... Henry $V^{2}$. y. 2

lest, bleeding, you do paint..

the heifer dend, and bleeding fresh

of the mother's bleeding lieart. .. - iii.

the bleeding witness of her hatred... Richard iil $\mathrm{i}$.

ive unsearred of blecting slanghter.

pair of bleeding hearts; thercon engrave - iv.

dismiss the controversy bleeding ... Coriolonus,

the bleeding business they lane.. Julizes Cesar, iii.

pardon me, tion bleeding piece of earth
whercof lie bleeding in me.. Cymbeline, iii. 4 (letter)

than thy master in bleeding $\ldots . . . . .$. iv. 2

he hath returued bleeding to Rome ...Titus And, i.

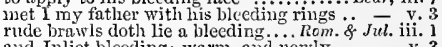

and Juliet bleeding; warm, and newly - v.
than Pyrrhus bleeding sword now talls. Hamlet, ii. 2
BLEEDING-NEW-

they were blecding-new, my lord... Timon of $A l h$. i. 2

BLEED'ST-thou bleed'st too mueh.1 Henry IV. v. 4
worthy sir, thou bleed'st ........... Coriolunus, i. 5

thou bleed'st apace, I had it wound. Coriof . Cleo.iv. 7

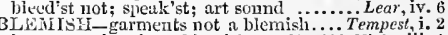
in nature tllere's no blemish .... Terelfit Night, iii. 4 Intlegrity stands Withont blemish. Mea. for Mea. vo 1

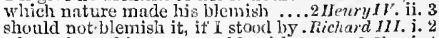
whom these things eamot blemisli ...Ant.o Cleo. i. 4
and blemish Casar's trinml] ...... sire blemished his graeions dam... Win'er's Tale, iii. 2 pawn the blemislied erown, wipe off. Richard $11 . \mathrm{ji}$. 1 eol'ruption of a blemikbed stoek .. Richard 1II. iii. 7 BLExi ISHWS-forget ny blemishes. $n^{\prime}$ 'inter's Tale, y. not my blemishes in the world's ....Ant.\& Cleo.i1. as constrained blemishes, not as deserved $\rightarrow$ ini. 11

eould man so blenej?? I must ...

do blench from this, and to stand ... Troil. of Cres. i. I

it he doblench, I know my eourse ..... Hannlet, ii. 2

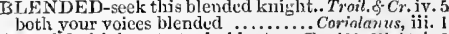
BLENT-'tis beauty truly lilent . Tuelfth Night, i. something, being blent together. Mer of lenice, i1i. go with me to bless this twain.

been thern (bless the mark.. Tre Gen. of Ver. iv.

heaven bles them, and make ..... Merry Hives, ii. 2
bless you sir. And you, sir......... 


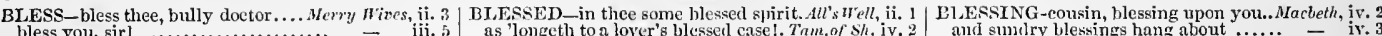

bless you, sirl bless you, fair slirew Titelfth Night, i.

Jove bless thee, master parson.

bless you, good father triar ......Meus. for Meas. iii. 2

I bless myself every way ......
God bless me from a challenge!

bless thee Bott

und bless it to all fair posterity

a paramour is, God bless us! ........

will we sing, and bless this plaee

Cind bless the king!

they did not bless us withione

who (Goil bless the mark!)

some sober brow will bless it

bless our poor virginity from
bless you ny fortunate lady

hless you my fortunate lad
bless him at home in peace

what anuel shall bless this

rod bless you captain Parolles...

better than the first, $O$ dear heaven, bless -

mistress Bianea, bless you with.. Taming of Sh. iv.

I bless the time, when ny good

bless me from marrying a usure

to bless the bed of majesty again .....

one eried, God bless us! .............

When they did say, Gi

bless you, fair dame! ...............

and God bless your expedition............

you would bless you to hear w
now the Lord bless that sweet

now the Lord bless that sw

Grod bless thy lungs, good knight!

the lord in heaven bless thee.....

and bless us with her former quatit

St. Dennis bless this happy stratagem.1 Hen. $V^{r}$. . ifi. 2

he's a good man! Jesu bless him

to bless a regal throne ......

O Jesus bless $u s$, he is born .........
God bless thee; and put meekne

God bless your graee with health

[Col.]-God bless the prince fro
if not to bless us and the land....

irod bless your gracel we see it

I, by attorney,

fortune falle, will bless the king

to bless your eye withal

ever God bless your highness

with the king, God bless him .......

both now and ever bless her!
bless me, what $a$ fry of fornieation
her own shall bless her; her foes

her own shall bless her; her foes

shall see this, and bless heaven ....... - $\quad \checkmark 4$

Jove bless great Ajax .............

so the gods bless me, when ali... Timon of Athens, ii. 2

assurance bless your thoug

break religions; bless the aceursed

heavens bless ny lord from fell....

you bless me, gods! Therefore.....

the gods bless you for your tiding

bless my lord and husband! (

make her thanks bless thee....

and bless the good remainders $\ldots . .$. . Cymbeline, $\mathrm{t}$.

now, the gods to bless your honour ... Titus And. i.

0 heavens bless my girl! but hark

pure Diana, I bless thee for thy vision - v. 3

bless thy five wital o pity

bless thee, master I Is that the

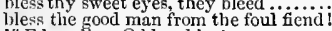

if' Edgar live, O bless him!

now, God in heaven bless thee... Romeo \&....

Gox in heaven bless ler! you are

(iod bless you, sirt Miy lord, the queen.
Givd bless you, sir. Let him bless tirce

Godl bless you, sir. Let him bless tirc
(Gorl bless the mark)! his Moorship's.

that he may bless this laay with

heaven biess the isle of Cyprus .........
is it out of the way? Heaven bless us

BLESSED_or blessed was't, we did

to estate on the blessed lovers.........
on this couple drop a blessed crow

a hlessed soul doth in Elysium. Tuto

with such grace hath blessed them

O, this blessed hour...................

tir all thy blessed youth beeomes....

then, ol, you blessed minis

hath blessed you with a good name....Mn

for sbe hath blessed, and attractive

on Neptune with tair blessed beams.

hath such force and blessed power

whiel by us shall blessed be

blessed are elouds, to do as such.........

it is twiee blessed; it blesseth. Merch, of

for, by these blessed candles

he blessed for your good comfort....... you Like it, i1. 7

is the single man therefore bfessed
0 blessed bond of board and bed. it is the blessed sun. Then (iod (rep.) now llessed be the great $\Lambda$ pollo how blessed are we, that are not simple we are blessed in this man (rep.) .... Pantina; so be blesscd nyy spirt the blessed gods, purge all infection..
and your tather's blessed (as le from

and your tather's blessed (a

I had lived a blessed time ............

and witl a blessed lour, by night ... King John,

the lialf part of $a$ blessed man.

and this blessed day, ever in Franee

and blessed shall lie be, that doth...

this blessed plot, this earth ........ Richard $I$

world's ransom, blessed Nary's sol
walked those biessed reet, whieh

and the blessed sun himself a fair...
shall the blessed sun of lieaven

iHerrylti. i.

shall the blessed sun of lieaven

the dove and very blessed spirit of peace -

we are blessed in the chance

the bed of blessed marriage

he was a king blessed of the King of..i Henry $V 1$.

more blessed hap did ne'er befol

blessed are the peace-nuakers (rep.)...2 Heñ?

blow townrds England's blessed shore - iii. the people of this blessed land

Richard 111 . $\mathrm{i}$.

York blessed his three sons of this peace

a blessed labour, my most sorereign

a be holy privilege of blessed sanetnary
the grace had blessed thee with a fairer

and blessed with beauteous wives....

thou full'st a blessed nuartyr....... Henry $\overline{V I} I I$. iii.

even now, a blessed troop invite.

thy person under their blessed wing

would diseredit the blessed gods.. Troil.

my dearest lord, blessed, to be most.

then was a llessed time............

whilst thou'rt blessed and free ......

O stand up blessed! whilst .............

be blessed for making up this peaee

we are blessed, that Rome is rid of..Jul. Cresar, iii.

Oetavia is a blessed lottery to him

0 , thou blessed moon, when men

Oblessed, that I miglit not!

blessed live you long! a lady to the.

far it is to tlis same blessed Nilford

thou blessed thing! Jove know

and make me blessed to obey

more sweet than our blessed fields.

to their nostrils from our blessed altars

make me blessed in jour eare .........

all blessed seerets, all you unpublished ... Lear, iv

[Col. Knt.] blessed my rude liand ...P
Iacly, by yonder blessed moon I swear

O blessel blessed night! I an a feard
dotli she not count her blessed .......

wife, we searee thought us blesse

and blessed are those whose blood ....Hamlet, iii. 2

and when you are desirous to be blessed - iiti. 4

blessed, she would never liave loved (rep.)

ii. 1

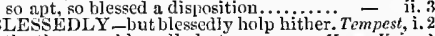

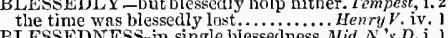
found the blessedness of being little. Henry WIII. iv. 2 leave her blessed ness to one.............

BLESSETH-it biesseth him that gives. Mer.of $r$. iv. BLESSING-marriage blessing.. Tempest, iv. ) (song)
Juno sings ber blessings on you .. - iv. I (song)

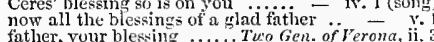

blessing of your heart...............

blessing on your heart for'ti ............ ierry Wives, ii.

blessing of his heurt! ................. Nuch .Ado, iv. $\mathrm{i}$. 3

for the which blessing, I am at him

God's hlessing on your treard! .... Lore's L. Lost,
and thrift is blessing, if men steat. Mer.ofl'enice,

give me your blessin

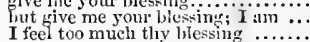

for, having such a blessing in 1 is jady

charged my brother on lis blessing... As ynu tike,
the blessing of God, till I have........ dill's Well, tions say, bearns ore ?

they say, bearns are blessints ..........

blessing upon your vows! ................

and blessing, against this cruelty .... -

and pray your mother's blessing

a blessing he bestows on beasts.. Com.or Errors,

I liarl most need of hlessing............. Hatbeth

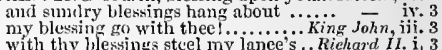
yet, blessing on his heart that gives . ${ }_{\text {hen }}-$ v. 5 blessing o your good heart
upon my blessing I eommand thee go. i Henry/ VI. iv. 5 and take my hlessing, good my girl . Hen - vI. $\mathrm{i}$. good for bad, blessings for cursings. Richard III. on my knee I erave your blessing

shall ery for hlessings on him .... IIenry $\bar{V} I I I$. ii.

his enrses aud his blessings toueh me
whieh, to say sootl, are blessings....

will fill sone blessing to this land

sleeps in blessijg $=$ i iii.

- iv.

this land a thousand thousand biessings -

that I aceount them blessings.. T'imon of Athens, ii.

your blessing, sir. Thongh you did love

did the third a blessing against his wiji ... Lear. i.

and ask thy daughter's blessing .......... - iii.

when thou dost ask me hlessing, I'll kneel $-v$.

I asked his blessing, and fiom first to last $-\mathrm{v}$.

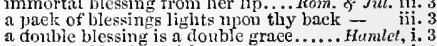

my blessing season this in thee

conception is a blessing; but as your... - ii.

BLEST - let me be blest to make. Two Gen. of Ver. v.

I an blest in your acquaintance.. Merry Wives, ii.

now with hymn or carol blest... inici. N.'s Dream, ii.

he was blest; and thrift is blessing..... Ner. of Ven. $\mathrm{i}$.

to make nre blest, or cursed'st among be thou blest. Bertram! and sueceed... Al's i.

weleome, and moloubted blest...........

now be you blest for it! I'll to.

how blest this land would be

the father of so blest a son ......

等

God's blest motherI I swear ........... - $\quad$ v.

that the blest gods -as angry....Troilus, \& Cress. iv. 4

away! and to be blest, let us with eare $-\overline{\text { vel }}$ y. 4

to have blest mine eyes............... $\overline{\text { in. }} 3$

BLEW - that blew this tempest up.... King John, v.

which then blew bitterly agrainst.... Richard II. i.

we blew the fire that burns ye ....Henry VIII. v.

BLIND-her, and her blind boy's....... Tempest, iv.

beeause love is blind........ Turo Gen.of $i$ erona,, $\mathrm{i}$.

wept herself liliud at my parting....$\quad$ - ii.

but I shall be blind ..................

drowned a bitel's blind puppies.. Nerry Fives, ivi. 5

phom the blind waves .......... Twelfth Night,
for the sign of blind Cupid ...........Much Ado

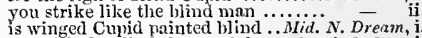

doth falsely blind the eyesight ... Love's L. Lost, i. I

and, strueken blind, kisses the ...... - iv. 3

will gaze an eagle blind..

so may $\mathrm{I}_{2}$ blind fortune leading........ of Veniee, ii.

but love is blind, and lovers cannot..
as the blind man knows the euel 0 .

as the blind man knows the euekoo...
as the boumtiful blind woman ....As you Like it, i. 2

that hlind raseally boy, that abuses.. $-\overline{\text { iv. }}$ iv.

these blind ones, aboard him ..........

for my rage was blind $\ldots \ldots \ldots \ldots \ldots$. King John, iv.

makes blind itself with foolish

strike the dauplin bind to look

the blind and bloody soldier

Henry $I V$. iii.

that goddess blind, that stands

of must appear naked and bli

as lore is biind, and enforces...

and she must be blind too..

glimmer thro' a blind man's eje.

a bliud man at Saint Alban's . .....

how long hast thou been blind

if thou hadst been born blind.

and called them blind and dusk

be blind with tears, and break.

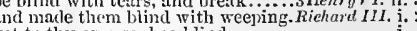

rend lis own soul so blind

into the blind eave of efernal night...

that blind priest, like the eldest son...Hen. $\bar{F}$ II ii.

blind fear, that seeing reason (rep.).Troil. $8 . \mathrm{Cr}$. ii

and blind oblivion swallowed cities up

and the blind to hear him sleak....

I'll wake mine cyebalis blind nurst... C.ymbeline,

are sometimes like our jodgments, bijnd

make them blind witl trilutiry tears 
B1.JN12-do make their children blind .... Lear, ii. d led by their eyes, but blind mon.

chanec to beur of that blind traitor ........ do thy worst, blind Cmpid .............. iv. 6 lie, tliat is strucken blind .......... Ronteo of Inliet, $\mathrm{i}$. blind is his love, nul best befits (rop) if love le blind, it best agrees....... - iij. lueing not defieient, blind, or lame ....... Othello, i.

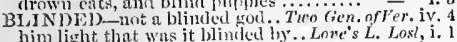
him light that was it llinded ly... Lnme's $L$. Los iv. no eves, the dust hath blinded them.2 Homry Vl.iii. BIINDING- lazed with blinding teurs - $\bar{L}_{\text {ii. }}$

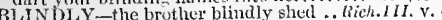

help him of his blimulness. Trofien. of $T$. iv. 2 (smg) love with some show of blindue

thank love for my

blind-worms, do no wrong

adiler's tork, and blind-wo... BLINK-to blink thronth with

BliNkING-of at blinking idiot

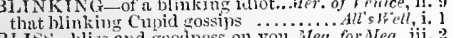
of 1 mire white, this senl of lylis.

bave hut a shalow's bliss...Her. of l'en. 1i. 9 (seroli)

hold your fortune for your bliss - ini. \& (scroll

heard me severed from my liliss .. Comedly of Er.

the contrary bringeth fortl bliss .... IItenry $I$. Y.

if thon think'st on hetuen's bliss ..2

the houe $I$ have of heavenly bliss

will prove our eountry's bliss

liliss in our brows' bent .....Antony se Cleopotra, i.

rom help as timbo is blis biss.. Titus Andron.

thou art a soul in bliss ................... Lear, iv.

hliss be upon you! tell me ............ othello, iii. 3

that cuckold lives in hiss, who........

BLis'LR-and blister you all o'er ...... Tempest, i.

a blister on his sweet tongue ...... Love's L. Lost,, .

let my tongue blister; and never.. W'inter's'Tule,

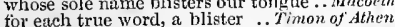

[Knl.]-powerful sun, to fill and blister .. Lear, ii.

the angry Mab with blisters plagues...Rom. . . Jul. i.

imnoeent love, and sets a hister there.. Hamlet, ini.
BLISTERED-blistered her report. Mra. for Mea. ii. 3

short blistered breeches, and those.. Henry $I_{11}$. 1 . 3

blistered be thy tongue, for sueh.... Rom. \& J Jll. iil.

BL1THE-blithe and bonny ....Much Ado, ij. 3 (song)

Bardol ph, be blithe ................ Henry

sweet emperor, be blithe again.... Tilus Ant on. iv.

BLITHER-blither tor their drouth - iii. (Gow.)

BLITHILD-descended of Blithild .....Henry V.i.

BLOCK-what a block art thon. T'wo Gen. of Ver. ii.

down on twenty bloody blocks ...Mea. for Me Me

sirrah, provide your block and your

him fallows; bring himu to the bloek

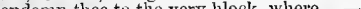

it erer clianges with the next biock

past the endurance of a block...

why, a llock moved with none ....... $\overrightarrow{\text { Like }}$ it, $\mathrm{i} .2$

a quintain, a mere lifeless block... As you Like it, i.

these traitors to the bloek of death...2 Henry IV. i

stoop to the block, than these knees..2Hen.VI.

what tong treless bloeks were tbey....

convey aie to the block of shain

like a block, hath denied my aeess. Coriolanus, v.

you blocks, you stones, you worse. Julius Ceesar,

this a good bloek! it were a delicate .... Lear, iv.

BLOCKKEAD-wedged up in a blockhead. Coriol. il, 3

BLoIS-Maine, Blois, Poietiers....... Henry HI. iv. 3

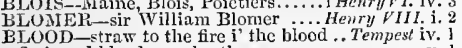

flesh and bloud, you brother

beats, as of flesh and blood.

mind to feed on your blood .....T Tuo Gen. of $\bar{V}$ er. it.

as then the milch-kine yield blood...Merry Wive

am I not of her blood?

- ii. 5 (let.)

you find so manch blood in hiser..

make some obstrustion in the blood

of this malapert blood from you

二 $\quad$ iii. 4

and let your flesh and blood ohey it.

$=$ iv.

had it been the brother of my blood..

right noble is his blood $\ldots . . . \ldots \ldots \ldots$.

whose blood is very snow-broth......

why does my blood thus muster...

fallen by prompture of the blood

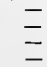

i. 4

ne'er issued from his blood .......... -

I thank God, and my cold bluod ....Much $\mathrm{A} d o, \mathrm{i}$.

prove that ever I lose more blond ..... -

whose charms faith melteth into blood -

wisdom and blood eombating
that blood hath the victory.....
BLOO1)-no true drop of blood in him. Mnehd turns abont all the liot bloods,

nore intemperate in yourbloud thinn

the story that is printed in her bloun

I will lie desli and blood.

this speecl like iron througli....... your libou -

that muster so their blook, to umicrso

I see no blood, no wound

I un not quilty of Lysander's blood

that cost the fresh blood clear

what, stained with blood! ..............

thisu heatest my blood

Alack, let it bloorl...................

in singuis-blood; rilie as ...ili

a fever in your blood! why, then

young blood will not obey an old

for native blood is counted painting.

no more man's blood in's belly than

sweet bloods, I both may and will...

your ofter made in heat of blood.

when blood is nipped, and ways be - v. 2 (song)

may devise laws for the blood....

to prove whose blood is reddest......

thongl I am a danghter to his blood

my own flesh and blood to rebel!

my cimighter is my flesh and blood ..

only my blood speaks to you in my.

blood, bones, and all, ere thon (rep.

one drop of ebristian blood, thy land

shed thou no blood; nor ent thon ....

which is the hot conclition of their blood -

takes not away ny blood, were there

hot and rebellious jiquors in my blood

this uapkin, dyed in this blood ......

as marriage binds, and blood

thy blood and virtue eontend...........

as you, and all flesh and blood are

our blood to us, this to our blood is born -

does it curd thy hlood, to say

mom torth the royal blood of France

that our bloods, of eolour, weight ...

I do wash his name out of my blo

workmanly the blood and tears. $T$

despite of the flesli and the blood of Sh. 2 (irid.)

much sadness hatls eongealed your blood -2 (ind

firiendship far, is mingling bloods.

thoughts that would thick my blood
give seandal to the blood o' the prinee

give seandal to the blood o' the

you have too much blood in him ....

the red blood reigns in the winter's

thind the true blood whieh fairly peeps

thit majkes her blood look out ....

and none of your flesh and blood

then your blood had been the dea

1 am sure, my heart wept blood.

rigorous statutes with their bloods..

a clrop of blood, a pin, a nut.

even for the blood that then I lost

make thick iny blood, stop up.........

gouts of blood, wh those sleepy two.

smear the sleepy gruoms with blood.

wash this blood clean fiom my hand
the fountain of your blood is stopped

and tices were all badged with blood

the ncar in blood, the nearer

there's blood upon thy face.

blood hath becn sherl ere now ...

thy blood is cold, thou hast no .......

bronght forth the seeretest man of blood

I am in blood stept in so rar

blood

pour in sow's blood, that hath ..........

here's the sinell ot the blood still
harbingers of blood and death

too mueh eharged with blood of thine.

great forerunner of thy blood, Richard

the market-place in Frenehmen's blood

you stain your swords with blood...

retirring lim to blood and strife ...

when living blood doth in these...

will bear lrome that lusty bluod agrain

and stalk in blood to our possessioa.

and as well-born bloods as those ....

hast thou yet more blood to cast awa
thou last not saved one drop of hluo

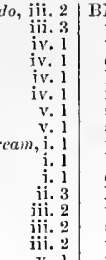

BLOOD-when the rich litoor of kings. King.John, ji. whosc veins bound richer blood the

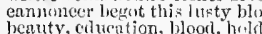

false blued to talse bood, joinerl

so lately murced of blond, so new ly

the smin's o'cresst with blood

ere our blome slrall quench

had haken thy lolood, and maile it..

steeps his sufity in turue bliod...

that blood, which owed the bried

where is that blood, that I have....
this confine of blood and $\mathrm{J}$ reath.

with the 'rimson spots of blowed.

frul imaginory eyes of blood
that leaves the print of blood

to stranger blood, to foreign rovalty

the blood of malice in a vin

full warm of the blood that ever fury

on unreprievable condenmed blood

the bloor is hot, that numst be.

aside his high bloot's royalty (rep.)...

told this slander of lisis linod

nearness trour saered blood should..

this eholer without letting blood

I had in Gloster's hlivor looth more

1)hials of his saced binod, or :

farewell, my blood; which if to-day
the earthly anthor of nty blood .....

rouse up thy youthin] blood.

even in our kindred's hlond

chasing the royal blood, with fur

that blood already, like the pelicen .

were guilty of no kindred's biood ...
of noble blood in this deelining land

to wash your blood from off ny hand

gentleman in blood and lin
near to the king in blood

near to the king in living blood

but now, the blood of twenty thousand

and, till so much blood thither come

moek not flesh and blood with

showers of blood, lained from.........

trrass with faithfid English blocd....

the royalties of both your b]cods

the blood of English shall manure

with the lking's blood stained

that blood should sprinkle $\ddot{m}$

that blood should sprinkle me ....

lins with her own children's blood .

balked in their own blood.......

eamest not of the blood royal

shed my dear blood drop by dro

that dead is, the next of blood? $\because . .$.

lost the fresh blood in thy eheeks...

swear it was the blood of true men.

doth not thy biood thrill at it

charming your blood with pleasing.

of my blood he'll breed revengement

all the court and princes of $\mathrm{my}$ blood

I will wear a garment all of blood

his altar sit, up to his ears in blood
while his blood was poor, upon ...

while his blood was poor, upon
to save the blood on either side

excuse of youth, and heat of blood

enn lift your blood up with persuasion

with the best blood that $I$ ean.........

even with the rebels' blood $\ldots . .2$ IIen
with the blood of fair king Richard.

a kind of sleeping in the blood

not have attuehed one of so high biood

therc is some of the king's blood spilt

and it

by this light flesh and corrupt blood

your ink to blood, your pens to lanees

by the honour of my blood, ny father'

doth so orer-cool their bloo

the warming of the lilood ...

for the cold blood he did naturaliy .

the united vessel of their blood

the blood weens from my lieart ....

when rage and hot blood arc his

and heary sorrows of the blood

which never quaffed but blood, would

infect my blood witl joy .............

shall drop their blood in approbatio

forta in blood of Freneh nobijity

the blond and courace, that renovened

as clid the furmer lions of your blood

with blood, and sword, and fire, to wi

ehased your blood ont of appearanee?
in suirit, not swerving with the blood

in spirit, not swerving with the blood
to suck, the very blood to suck $1 . . .$. .

ichned II.

$$
\begin{aligned}
& \text { i }
\end{aligned}
$$

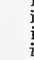

$$
\begin{aligned}
& \text { i. }
\end{aligned}
$$$$
\text { - }
$$

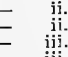

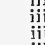

$$
\text { - iii. }
$$


BLOOD-the dead men's blood summon up the blood, dismuise fuir. whose bload is fet from futhers copy now to is beod .... pennons nainted in the blood of liarfleur tor the effusion of our blood ........ ground with your red blood dino when blood is their argumen issued furcet drops of hlood ............. their hot blood may suin in Fngli have them weep our horses' blood se:arec blood enotush in all their ..... to-day that sheds his blood witl me
as 1 suck blood, I will some.......... helmet to the spur, all blood be with blood he senled a testament neasunt limbs in blood of princes and gentlemen of blood and quality. yet my blood hegins to flatter me. and from her lolood rajse up issue... why mourn we not in blow

but, lords, in all our blood massaere yet lives guilty in thy bloo

quarrel will dink blond another dä at peace, cxeept ye thirst for blood... Let Riehard he (rep.) one drop of lilnod, drawn from lresume to boast of tentle blood .... trifle, that was bought with blood.. Englisb decr, be then in lilood ...... drew blood from thee, uny boy shed some of his bastard blood . 017 for that pure blood of mine ....... int that sea of blood my boy did ..... to stop eflusion of our Christian blood I was wront to feed you with

the guiltless blood ol inmocents

whose maiden blood, thus rigoronsiy he is the next of blood .............. proportion to my flesh and

red, master; red as blood

chaps be stained witl erimson blood clay with the blood of Englislimen see, how the blood is settled in .
his faee is bhek, and full of bloo. while I shed thy blond, if tirum king Henry's blood (repeated) king Henry's blood (repeated)
drones suck not earles'blood wrathful, and inclinerl to blood

ne'er shall this blood be wiped

his blood. And, brother (rep.) ..... drojs of blood were in my father's

in whose cold blood no slark of honou as I did. with my blood

the lizkewar'm blood of Henry's hear my father's blood hath stoplyed

let my father's blood open it again ..
son's blood, eleaving to my blade (rep. in blood of those that had eneounter with the blood that raliant Clifford. would not have stajned with blood

in blood of my sweet boy $(r e p$

to his captives-blood and death

therr blood rupon thy hend .......

growing with our lieated blood
thy brother's blood the thirsty

their fetlocks in his smoking biood .. e timnken with our bloor

his purple blood right well resembles

and with the of blood doth

the rust this sentence with thy blood

the dearest bliod your bodies bear

wh gave his blood to lime ...

now filled with blowd, were likenci.

ny glory smenred in dust and blood

would wash this eon

petitioners fin blood thou ne.

will the aspiring blood of Lancaster..

remnant of that royal blood! ......

this blood from eold and empty (rep.)

this blood madest, revenge his (rep.).

fanlchion smoking in his blood

his blood, I spilt nine own (rep.).....

the raultiess blood of pretty Rutland

garments are not spotted with our blood

bright hair dabbled in blood

in blonity thoughts, and not in blood destruction, bloog, and massaere!... are let blood at Ponfict castle...

our guiltless blood to drink.

true bloods, wlich, as thou know'st...

blood to blood, your right of birtl....
Henry V. ii. 4 BLOOD-I am in so far in hlow.... Richurl III. iv. 2 BLOOD-her hlood? if it be so to do..Cymbeline, iii. 2 made drunk with innocent bloud! .. - iv. 4 the frinedy blood flows in his cheek - iii. 3 and lap their gentle blord........... - iv. 4 Id let a jarish of sueh Cloten's blood - iv. 2 I have mo more sons of the royal blool - iv. 4 as rough, their royal blowd enchafed of roysl blood [ Col. Kitt. a royal jrine ss?] steepica in kut and s blood

iv. 4 to my lale elieek with thy blood .... mine issue of your blond upon..... swills your warm blood yike wail... one ralsul in blood, and one (rep. $)$ \begin{tabular}{l|l} 
iv. 4 & their blood thinks seorn, tinl it fly out \\
iv. 4 & the blond was eool, have threatencd..
\end{tabular} proncl horses liard, and ride in poor Lncland weep in streams of bleod outworth's a noble's blood HenrȳruI $\mathrm{i}$. then my guiltless blood must ery... ticel by blood bloot will make it' this salnte my blood a jot. their greatness, not by blood ehated .... Troilus of Cressida (prol.) when with your llood you daily paint a lord of Trojan blood, nephe with my three drops of blood
or is your blood so madly liot...

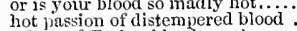
a drop of Trojan blood spent let thy blood be thy direction holis in his blood such swom. hot blood, and hot blood begets hot blood, hot thoughits, and hot deeds renew swifter than blood decays

give ns a linince of blood

no blood, no soul so near me

Ajax is halt made of Hector"s blood.

my mother's blood runs on $\ldots \ldots . .$. W'ill cost a dioplo of Greeian blood .... with too mneh blood, and too little art thon of blood, and honour have ronsed his drowsy blood

thou hast thy fill of blood and deatii

dip their meat in one man's blood. 7 .

tell out my blood. Five thousand

condem nushness in cold blood he forteits his own lilood

strange, musual blood, wheu.......
with mun's blood paint the ground

go suck the subtle blood (rep.) .....

through the rivere of pour blood

that art worst in blood, to run 0 .....

when it spit forth blood at Greeian

come not in the is rather physical

by the biood we have slicd together. a eliarter to extol hier blood the hlood upon your visage dries. he was a thing of blool, whose ..... for ny eountry I have sher my blood and the liazard of much lisood and the drops oi bloot shed for. and the man in blood, they will. our blood is eold, and then we pout and these conveyanees of our blood. lest I let forth your lialf-pint of blood her hand the grandchild to lier blood shed thy wife and ehildren's btood
be sold the blood and labour of.

ii. 1 in triumph over Pomney's blo
ii. 2 lost the breed of noble bloods

ii. 2 when every drop of blood 2 bundred spouts, did run pure blood your statue spouting blood in......... great liome shall suck reviving blood might fire the blood of ordinary men that Casar bears sueh rebel blood men are flesh and blood, and ....... who else must be let blood

the most noble blood of all this world as fast as they strean forth thy blood blood and destruction shall be so iu $u$ their naplins in his saered blood ... which all the while ran blood of speeeh, to stir men's blood and drop my blood for draehmas. when grief, and blood ill-tempered .. young bloods look for a time of rest. so in his red blood Cassius' day is set blood of thine is Casar's homager
higher than both in blood and ife higher than both in blood
pou'll heat my blood; no
laek blood to think on't.

cold in blood, to say, as $I$ said then. with Parthian blood thy sword is warm I will appear in bluod: $r$, and $m y$

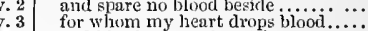
and blood of your begretting ........... blood and revenge are lammering $\ddot{0}$ - ii. leaves are drops a fearful siath of blood and dentl. by night lay bntled in maiden blood notwithstanding all tlus loss of blood all my hlond in Rone's great quarrel my son's sweet blood will make it shame refuse to drink iny dear son's blood...

see their blood or die with this reproach = execution on my flesh and blood

that receives your guilty blood ....... reeeive the blood: and, when that .... preserved her welfare in my blood..... wood from my chceks

wishing it on muel blood unto your life. may be as great in blood as 1 not consuine your blood with sorrowing mucli less in blood than yirtue

for flesh and blood, sir, white and red.... but are you flesh and blood

propimguity and nroperty of blood ....... - Lear. blood draw my flesh, my blood, niy dainghter.....

carbunele, in my corrupted blood........... our fiesh and blood, my lord, is grown

a son now ontlawed trom my blood

I smell the blood of a British man........ jii. $_{4}$ (song confliet be sore between that and my biood - iii. I am no less in blood than thou art........ - v. 3 atfections, and warm youthful blood now comes the wanton blood up .... hot days is the mad blood stirring.... ah me, the blood is spilled of my dear the priee of his dear blood doth owe? my blood for your rude brawls doth lood my unmanned blood bating in bedambed in blood, all in trore blood with blood removed but little from dry sorrow drinks our blood

blood is settled, and her joints....

Alack, alaek, what blood is this

.... Hamlet, $\mathrm{i}$. a fashion, and a toy in blood ............ - i. 3 frecze thy young blood; make thy two

must not be to ears of fiesh and blood....

the thin and wholesome blood...

a savageness in unreclaimed blood ......
horridily tricked with blood of father

blessed are those whose blood ...........

now contl I drink hot blood, and do blood?

the hey -day in the blood is tame

like the hectic in my blood he rage...

and my blood, and let all slcep?

ii. 2 that drop of blood, that's enlm.........

ii. peliean, repast them with my blood...

a treasou of the blood!...................

some mixtures powerfil o'er the blood

I do cont'css the vices of my blood.....
the blend and baseness of our natiues.

it is merely a lust of the blood

when the blood is made dull with the a

by heaven, my blood begins my sufer.

$O$ blond, Iago, blood! Patience, I say

or did the letters work mpon his blood.... sith lust's blood be spotied

BLOOD-BESPOTTED

o bloch-herpmtted Neapolitan .....2 Henry VI. v. 1 the blood-boltered Banquo smiles .....Macbeth, iv. 1 BLOOD-CONSUMIING-
blooi-consuming sighs recal his life..2 Hen.FI. iii. 2

i. 3 eognizance of my blood-drinking ..1 Henry Vr. ii. 4 letesteod-dinking sighs .........2Henry iii. 1 BLGOD-HOUND-starved blood-hound.2Hen.IV.v.4 if BLOODIED-to breathe his bloodied horse

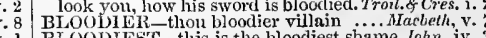
v. 1 BroODYEST - this is the bloodiest shame.John, iv. v. 2 that bloodily did yawn unon bis.... Henry I $P$. v. that bloodily did yawn upon his....... Henry $V$. iv, 6
at Pomfret bloodily were butehered...Rieh.III. iii. at a shot, so bloodily hast struck? at a shot, so bloodily hast struek Tuetrhn. Hamlet, 2 


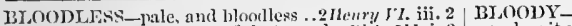
thou bloolless remmut of that royul... Rich. $I I$. i. 2 of pale and bloodless emulation .. Troil. \& Cres. 1.3 BLOOD-SACRIFICI

my body, nor blood-sacrifice, entreat. 1 II cnry I'T. v. 3 Rionstien) a deadly blowlshed.. King John, iv. 3 to gurarrel, and to lilou
BLOO1)-SHLDDING

are free trom guiltless llood-sliedding.2 Ylen. $F I$. iv. 7

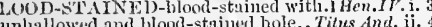
dnoys for

Bl,OOD-SLCKFR

blood-sueker of slecping men .....2Henry II. ii. $2^{2}$ knot jou are of dammed blood-suckers. Kic. K1. LI. the rising of blood-sucking sighs ...3 Henry rt. iv. 4
BloOD-TimRSTY to me, blood-thirsty lord; and ...... Uenery Fr. ii. 3 BIOOI 'Y'-mark so bloody on the husiness. T'empes', $i$. 2 I do hegin to have bloody thoughts ...... $\overline{5}$ iv. 1
lust is but a hloody fire ..... Merry Hives, v. lust is but a hloody fire ....Merry hives, v. 5 (song) have given us bloody argument.....

full of despite, bloody as the himer

in terms so bloody, and so dear

given sir Toby a bioody coxeomb too

if a bloody eoxemb be a liurt

you set nothing by a bloody coxeomb for Iea. $^{\mathrm{V}}$.

down on twenty bloody bloeks .Mea. for Mea. ii.

with bloody blameful blade (rep)

to-morrow to my bloody ereditor...Mer of Ven.

wolfish, bloody, starved aud ravenous

diverted blood, ant bloody brother. As you Like, ii.

he sencis this bloody napki

liut for the liloody napkin? ............ $A u^{-}$well, ii. 3

trom the bloody course of war......... - iii. 4 (let.)

so borrible, so bloody, must lead...Winter's Tale, ii. 3

to bloody thoughts, and to revenge

what bloody man is that?.............. Nac beth, i. 2

whieh smoked with bloody execntion....

that we but teach bloody

this most bloody piece of work

the near in blood, the nearer bloody

we hear, our bloody eousins are.

we hear, our bloody eousins

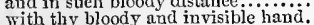

fensts and bampets bloody knives

be bloody, bold, and resolute.

I grant him bloody, luxurious. .

control of tieree and bloody war
with fearful, bloody issue arbitrate

all preparation for a bloody siege

for bloody power to rush uy

and bloods point to point.............

to mareh a bloody host, and make

bloody England into England gond
shall find but blondy safety ........

out of the bloody fingers' ends ......

the man should do the bloorly deed.

to break within the bloody house...

finding thee fit for bloody tillany

5oul bloody Neroes, ripping np.

to fierce and bloody inclination ........

hand, and murder's bloody ax

but blomly with the enemies

looks bloody on the earth......

and in outrage, bloody here...

the thousand bloody erowns.......

the bioody office of his timeless.....

we must have bloody noses, and cracked -

to bloody batties, and to brtising arms

my favours in a bloody mask...

many dearer, in this bloody fray ....

saw lhim in bloody state, rendering

eaeh heart being set on bloody courses

led on by blondy youth, gnarded ..

seal this lawless bloody book

seal this lawless bloody book
he would make this a bloody

unwind your bloody flag.

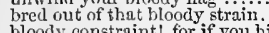

bloody constraint! for if you hide.....

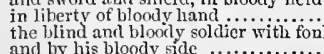

and by his bloody side ................

whose bloody deeds shall miake .....

dye your white rose in a bloody red.

nothing less thian bloody tyrrany .....

terror, and their bloody seourge......

turn on the bloody hounds

drops bloody sweat from $\ldots \ldots . . . . .$.

have found a bloody day of this......

the most blooly nurser of his harms

now bloody Tilbot's slain ..........

surjurised by bloody hands
with child, ye bloody homicides ...... muless it were a bloody murdere

niurler, indeed, that blockly sinc....... lakking the liloody dists .....

gomer dimce upon a blooty pole

rativer than blondy wai shal

Englands bloody scomrge $\ldots$ i.....

look, where bloody Clifford eomes.

after the bloorly fray at Waketicld .

let our bloody colours wave.........

O bloody times! whilst lions war

and bloody steel grasped in their....

butehy way out with atlains, blondy ennnibials -

to make a bloody supper in the

hath plaqued thy blooly deed.......
was stahhed with bloody daggers

who stahied with bioody daggers .....

a bloody deed, and desperately

nearer in lloody thoughts .....

o bloody Richard! miscrable En......

the tyrannous and bloody aet is dune

this tidings to the bloody kin

proud, subtle, sly, and bloody

bloody thou ar't, and bloody wili be.

bonglat love with such a bloody spoil

in the sty of this most bloody hoar

the wretehed, bloody, and usurping bo

that bloody [Col.-this guil ty] homicid

to the arbitrement of bloody strokes

dream on, of bloody deeds and deat

the bloody dog is dead .............

the dead temples of this bioody wrete.

would reduce these bloody days again

a ervel nature, and a bloody ...... Ulenry $\bar{\nu} 111$.

for I liave dreamt of bloody tu:bulenee
when I have the bloody Ilector found

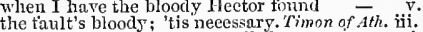

his bloody brow with his mailed

his bloody brow! O Jupiter..

set up the bloody flag against all .....

and with bloody passage, led your war

most bloody, fiery, and most terr

now we must appenr bloody and eruel

let each man rencler me his bloody hand

shaking the bloody fingers of thy foe
the eruel issue of these joloody men

whilst hloody treason flourished

o most bloody sight

should cndure the bloody spur

I will give thee bloody teeth

it' my shirt were bloody.

and send him some bloody sign of it

this bloody man, the care on't .......

yea, bloody eloth, I'll keep the

ere bloody hands were washed ........

quit the bloody wrongs upon her foes
unon his bloody finger lhe doth wear
thy whelps, fell eurs of blondy kind.

thy whelps, fell eurs of blondy kind

his heinous, bloody deed ...

I leave you both, like bloody villains

in bloody lines I have set do....

where bloody murder, or cletested rape

witb bloody vicws, expeeting

hide thee, thou bloody band

hold thy bloody band

the arbitrement is like to be $\mathrm{a}$ hioody

the bloody proclamation to escape...

romo began this by hand throw.

who began this bloody frity ...

eorse, a blocdy piteuns corse...........

where bloody Tybalt, yet but green

the gronnd is bloody; search abont

bloody, bawrly villain! remorseless
rash and bloody deed is this! A blooly

how shall this bloody deed he answere

my thoughts he bloody, or be nothing.

so jump apon this bloody question.
ot carnal, bloods, nnd umnatural act

the bloody book of law you shal

one at other's breast, in opposition blou

one at other's breast, in opposition bloody

ii. 5
iv. 2
iv.

where lie these bloody thieves?

$\begin{array}{ll}\text { iv. } & \text { where he these bloody thieves? ............ } \\ \text { iv. } & \text { these bloody aceidents must excise..... } \\ \text { iv. } 4 & \text { some bloody passion shakes your very frame }\end{array}$

o hloody period! All, that's spoke .......

iv. 7 BLOODY-F ACED-bloo

\begin{tabular}{l|l} 
iv. 7 & BL6ODY-HUN'TING- \\
iv. 7 & Ilerool's lloody-lumting slaughtermen. IIen. $V$. iii.
\end{tabular}

v. 1 BIOODY -MINDED-

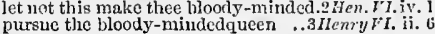

BLOODY-SCEPTRED-

an untitked ty rant blundy-seeptred ... Mrurbofh, iv. the bloom that promiscth n mighty... King. Iolu, ii.

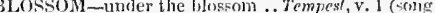

spied a bloscom passing farr.. Lope's

eannot so mich as a blossom yield... is you $L$ ike ii.

inler's Tale

in the hiossoms of their thrtune

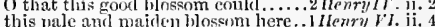

by this mailen blossom in my hand

my fearus, my blossom, in hís pride
thus are my blossoms binsted

5
i. 5
i. 5
5

yon are a blossoms, end bears.... Henry hl. iii.

ent off even in the blossoms of ny sin .. Harntot, i. .

BLOSBONING-as blossoming time...jea. for Mea. i. . their sweets on blossoming Casar...Anl.f Clen. jv. 1

3 BLOT -it is the lesser lilot .. Two Gen. of Veroma, v.

who ean blot that nume

and the blots of nature's hand .....Mid. N.'s $D r$. v.

then praise ton sliort doth blot... Love's L. Lost, iv.

posscssed with an adulterate blot.. Com. of $E^{\prime} r$ r.

to look into the llots and stains of right...John, ii.
that blots thy father. There's a good (rep.) - ii.

full of unpleasing blots, aud sightless .... - iii.

wime liath set a blot upon my pride... Richard - iii.

markerl with a blot damned .....

the realm of this pernicious blot ...

wear the detested blot of murd'rous..1 Henry I I'.j.

this blot, that they object a.............Henry

our sword we wiped away the blot..2 2 Henry $/$. iv.

all the imprure blots and stains.......Richard $I I I$. jii. 7

blot and enemy to our general name. Ti'us And. ji.

BLOTTED - ever-hlotted paper..... Mer. of Ven. jii. 2
my name be blotted from the book... Richard iI. i. 3 those eharms, thine eyes, are blotted . . Othella, v.
BLOTTING-blotting your manes .. 2 Flenry VI. BLOW -blow till thou burst thy wind..Tempest, a sonth west blow on ye.......

suffer the flesh-fiy blow my mouth

give him blows ...................

as thoughts do blow them............. how imagination hlows him ....T' Teelfh Night, ii. take you a blow o' the lijs then......

whonld meet the blow of justice ...Mea. for Mea. ii. thy eheeks may blow.... Lore's L. Lost, iv. 3 (verses)
though thev are lame with blows ....

and, when they relnir, blow like sweet - v. 2

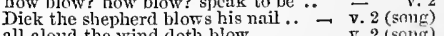

all aloud the wind doth blow....... - 7.2 (song)

would hlow me to an agne
the four winds blow in from

it bites and blows npon my body...... As you Like il, if.

to blow on whom I please.

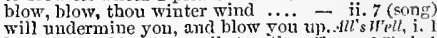

but we may blow onr nails together. Tam. of Sh. $\mathrm{i}$.

half so great a blow to the ear .........

will blow ont fire and all

shake not, thougl they blow perpetually $-\overline{\text { ij. }}$ may hlow no sneaping winds.... Winter's Tate,

a feather for eacly wind that blows . - ii.

of Jannary would blow you through - iv. 3

of every dead blow of it.

sixteen winters cannot blow away....

I eould too well feel his blows. Comedy of Errors,

an' you use these blows long.

and, in his blows, denied my honse

and the blows you gave were ink a...

well struck; there was blow for blow
and if the wind blow ans way.fom..
the merry wind hlows fair ..........

theel your blows. Thou art sensibie (rep.) -

for my service, but blows.........

that but this borts might be.

shall blow the horrid deed ......

blow, wind! come, wrack!

take pains to blow a born........

till then, blows, blood, and death .

shall blow ench dnst, eaeh straw .... - iif.

whieh his ancestors aehieved with blows- ii. 1

to ehange blows with thee........

so many blows unon this face..........
what wards, what blows

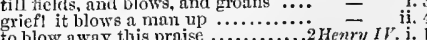

to blow away this praise $\ldots \ldots \ldots \ldots \ldots . . .2$ Henry $\mathrm{IV} . \mathrm{j}$.

that in the dole of blows your son....
kingdom, sick with eivil blows ......

wind which blows no man to good ...

let us but blow on tbem.... $3 \ldots \ldots \ldots$.

answer thee with words, but blows ...1 Henry ri i.
or else this blow should bronch ...... 


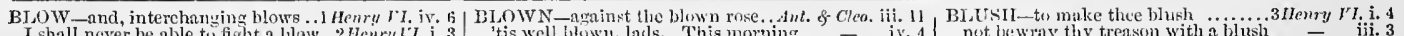

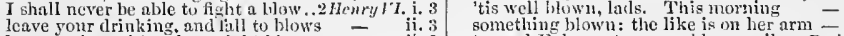

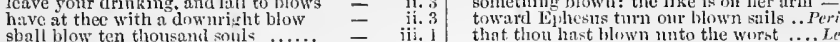
sball blow ten thousand souls . and bid them blow towards Englind's no blown ambition \&oth our arms form and fenture of blown youth
with all his crimes browd blown. gearernl trumpet blow lis blinst.... and blown [ knt.blowed] sumnises...... Othello, iii. 3

liy works, or blows, bere lit fur ragint wind hlows up incessint and minn blows repaid.......... ill blows the wind, that protit.
hemelht it with a hundred blowy

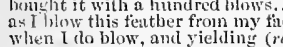
or groxl faitb, you'll eateh a blow

and blow it to the source

to enre that blow of thine .......

when it hath blown his ranks into the air BLOW's' T-then blow'st for Ilcetor. Troil. $\$$ Cres. iv. ELUBBELED-

[Collirer] she eomes blubluer is benten black and blue do tell'st thour me of black ind biuc.

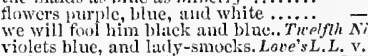
violets blue, and laily-smuclis. Love'sL.L. v, 2 (soug) garterert with a red and biue list. Tuming of $\$ h$. iii. their bluc coats brushed.

trumpet, blow lond, send thy .............

which cold lips blow to their
blow, villain, till thy splee red....

his livews are trell nisposed.

let the trimpets bloty........
thicse quiek blows of fortin

nose that has becr blue ............

or linels us black and blue ...Comedy of Errors

the lights burn blue, it is now ......... Richar

that prouder than blue Iris bend.

for every storm that blow

emic, blow thy blast

yet oft, when blows have male me

fortune's blows, when most struck

struck more blows for Fome

more noble blows than ever...........

words before blows: is it so

whow blow, wind: swell, billow.

the blow thon hadst shall make.
and your bruthers were at blows

and your hrothers were at blows
sigh of Oetaria shall blow the fire...

wind i' the world will blow them dow

when most she offer

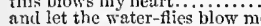

hark, how her sighs do

will blow these sands

Inaw the sharpest blow, Antiochus....

fattery is the bellows blows up sin.....
do you but strike the blow

do you but strike the blow ............

that were to blow at fire, in

now the wind begins to blow.....
wilt thou? blow and split thyself

wilt thou? blow and split thyself...

see, how she gins to blow into life's....

but a blow, which never shall be

a strong wind will blow it to

birls the wiusd blow the earth .........

blow, "ind, and erack your eheeks!

$n$ liich the rude wind blows in your fice.

that bear'st a cheek for blows

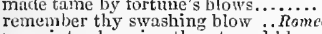

were interchanging thrusts and blow
this wind you talk of blows us from.

make it a word and a blow

wliut storm is this, that blows si contra....

and onr vain blows malicious moekery.
seeming to fuel this blow, with faming

my bearcl, and blows it in my

and blow them at the moon ........

may the winds low till they have

close together at blow and thrust ........

blow me about in winds! roast ine

BLOWED-lave blowed up the town...Henry

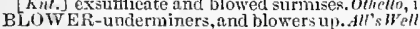

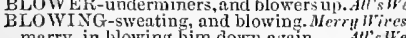

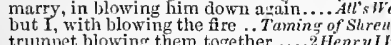

trumpet biowing them together ....2HenryI
the shepherd, blowing of his nails ...3Henry $V$
as

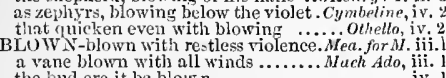

the but ere it be blow $\mathrm{n}$................

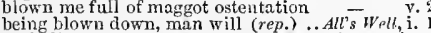

being blown down, man will (rep.) ...All's
with flies blown to death ........ Winter's T

with flies blown to death .........
our chimneys were blown down

and trees biown down; thon down castles.... Iacbeth, ii. 3

hath blown his spirit ont ...........

too huge to be blown out witli that

how now, blown Jack? how now .. H Henry $1 /$
rumour is a pipe blown by surnises.2 Henry $I V$

hath blown that viee in me $\ldots . . . .$. . Ilenry $i$.

with titles blown from adulation

so lightly blown to and fro ........
blown with the windy tempest....

it is You have blown this coal

Henry VIII. ii.

to this maturity blown up.....

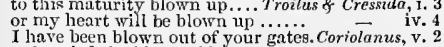

so hurried the blown tide... or blue promontory with trees...Anlonys Cleo. iv . 12
laced with blue of heaven's own .... Cymbeline, ii. 2

the yellows, blues, the purple violets... Pryteles,
or the skyish heud of bfue olympus.... Hamete

the main, and the aerial blue ........... Ohello,
B.,UE-BOTTLE-blue-bottle roguet.2 Henry $1 V^{\prime}$

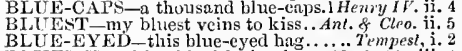

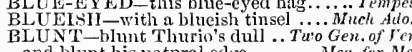

and blunt his natnral edse

yours as blunt as the feneer's foils ....

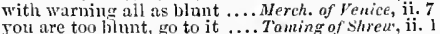

hiding his bitter jests in blunt behaviour

though he be blunt, I know him .....

convert to anger; blunt not the heart. Nacbeth, iv. 3

Spencer, Blunt, and Kent........... Richard II. v.

six Walter Blunt, new 'lichited ....... HeuryI $F_{\text {. i. }}$ I

weleome, sir walter Blunt......... - iv. 3

Westmoreland, and warlike Biunt...

his name was Blnnt; semblably
sir Walter Blumt; there's houno

the spirnts of Sliirley, Stafford, Blunt
that the blunt monster with....2 Herry $\bar{Y} \bar{V}$. (indue.)

and both the Blunts killed

Blunt, lead him hence: and see.
omit him not: blunt not his love

and blunt the sword that guard

by his blunt bearing, he will
thy words are blunt, and so art
Germans, and bIunt Hollander

Germans, and biunt Hollander

so harsh, so blunt, nnmatiral

murderous knife was dinll and blumt

good captain Blunt, bear

sweet Blumt, make some good means

good night, good captain Blunt....

whis tis: bhint weriges rive hard... Troilus $f$-Cres. $j$.

a plain blunt man, that lo

BLU TTED-blunted with

to whet thy almost blunted purpose .. Humlet, iii.

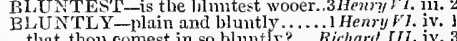

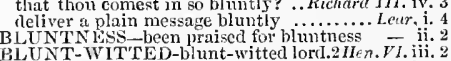

BLUR-ne'er yet did base dishonour bl

BLUR the grace and blush of modesty.. Hamlet, iii. 4

BLURTED_ours was blurted at ........ Pericl

her hlush is guiltiness, not modesty.. Much

but I should blush, I know....

come, sir, you blush; as is your.......
and torr you both did blush $\ldots . . . .$. iv.
Cupid himself would blush to see... Ner. of ven. ji.

I must blush and weep....

than with safety of a pure biush.

in the which hope, I blush, and hide.

make fo sny it, lie won me.

I should blush to sec youl so attired.

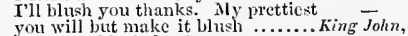

England, blush for shame

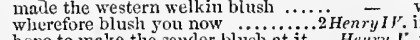

hope to make the sender blusli at it ...Hewry $i$. i. 2

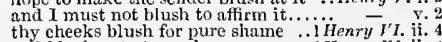
and blush not at nyy sliame $\ldots . . .2 .2$. Henry $V$. yet thou shalt not see me blush........ we blush that thou shouldat elioose ..All's sem. net hewrong thy trenson with a blush - ini.
blush, hlush, thou lump of finul .... Riehurd III. if 'ou can blush, and ery guilty ...Menry VIII. iii. the 1ns, it is, to gec a notileman..... sle does so blush, and fetches her.... - iii. conne, come, what need you blush....
whose liturh doth thuw ...... Timon of Athens, iv. you shall perecive whether I blush... Coriolanu, i. here do we make his frichds blush ... $=$ iv.

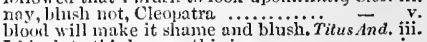
I blush to think upon this ignomy

say all this, and never blush

the beetle-brows, shall blush for me.... Rom. $\bar{g}_{\text {u }}$ ul

else would a maider blush bepaint
still blush, as thinking their own....

the gruce and blush of modesty....

O shame! where is thy blush
BLUSILED-I blusherl to hear

ever since thou hast blushed extemporc

and Irelen so blushed, and Paris ... Troil. \&.Cres. i.

that pates hlushed at hirn ........... Coriolomus, v. that her motion bhshed at herselt $\ldots . . .$. Othello, i. 3 prolixious blushes, thot banish 7 wo Gen. of J er. Y. how like a maid she blushes here ... Much Ado, iv. angel whiteness bear away those blushes $-\overline{\text { iv. }}$ iver

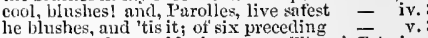
come, quench your blushes .......Winicr's $\bar{T}$ ale, iv.

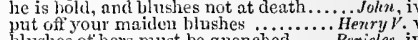
BLUShes of hers must be quenched ....Perieles, iv. BLUSHENG-blushing apparitions. . Mrach Ado, iv. I do long cheeks by faults are lred

will sit blushing in his foec........

as doth the bhishiug discontented.... - iii.

made a blushing eital of himself.... I IIenry I $\mathrm{F}$. v.

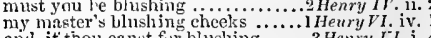

and, it thou eanst fur blushing.

turn my blushing eheeks; pardon in

for more than blume-faced spirit .. Richard 111 .

as from a blushing handmaid .....

bears lis blushing honours thick uyon - iij. what inu to be eneom tered .. Titus Andronicus, ii. 5 that will betray with blushing ...... in the blusters of thy wrath .. Trmon of Alhens, $\mathrm{v}$. a tempest, and a blustering day ..... Henry $1 \mathrm{~V}$. v. enrly, one blustering morn

BLUS'T'ROU's-for a more blust'........ birth - iii rage like an angry boar, chafed ... Taming of Sh. i. to night the boar had rased off....... Richard III. ii . to fly the boar before the boar (rep.) - iii. the boar will use us kindly

fear you the boar, and go so unprovicled

the boar clid rase his helm...........

in the sty of this most bloody boar
bloody, and usurping boar, that spoiled

gutarl thee from the boar's annoy.... - v v

who, hild boars roasted whole... Antony \& Cleo. .i.

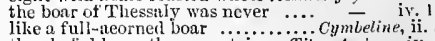
the chafced boar, the mountain ... Tilus Amedron. iv. BOARD-bear up, and board 'em...... T'empest, iil.
tront her, beard her, woo her...... Tuefh Night, i. that did the Tiger board............... to grapple, ns he was to board..... Lore'sL.Last, ii. but ships are but boards ..... Merchant of benice, $i$. bond of board and lied ...... As ynu Like it, v. 4 (song) I will boand her, though she chide. Taming of $\mathrm{S}$. at board, he fied not tor my.

eamnot lorlge and board a clozen

knecled dowil at the board

Hewry $y$. ii.

I would have left it ou the board ... Cymbeline, iii. I'll boarrl [Kut,-boord] him presently. . Humilel, BOARDED - I boarded the king's ship... Tempest, i. have bonded me in this fury...... Nerry Wives,

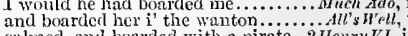
calmed, and bonarded with a pirate...2Ilenry $F I$. iv in the grapple I boarded them .. Hamlet, iv. 6 (let.

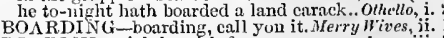
BOARINH-stiek boarsh fangs ......... Lear, BOAR-PIG-Bartholomew boar-pig..2 Lenry 11
BOARSPE come on, where is your boarspear. . Richard 111. my duty, will I boast of.... Tuo Gen. of I'erona, ii. why should proud summer boast.. Lone's L. Lost, $\mathrm{i}$. and make no boast of them ........ As you Like it, it. 5 it is no boast, being asked..............
boasts himself to have a worthy... iv. 3 , iv. 3

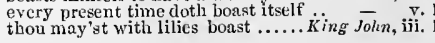




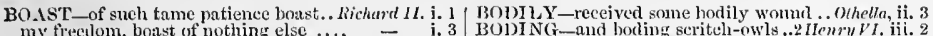
my freculom, boist of nothing el wander, boast of this I can

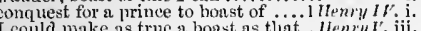
the a boast as tlat.. Henry $l^{\prime}$. iii. 7 that she may boast, she hath that nation boast it so with us presume to boast of gentle blod ennnot make boast to have.. Troilus \& Cressita, iii. 3

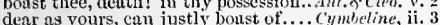
dear as you

further to boast were neitlier true

thrther to boast were neither true

. $\quad$ Y. 5

every thing doth make a gleetul boast. Titus dnd. ii. 3

where they bonst to have weil -............... Perietes, iv. 6

but, $O$ vain boust! who can control

BOASTED-oft have boasted to retain $\ldots$. Lear, iii. 6
BOASTFUI -and boastful neighs. Henry $\%$ iv. (eho.)

Bo

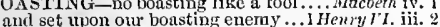
and set upon on boasting ener.

topping all other's in boasting

I know that bonsting is an honour ..... Ohello, $\mathrm{i} .2$ drive the bont with my sighs.. Tuo fien of lor. hung on our driving bont ......... Trelfh Night, i. 2 sought for safety by our boat. .. Comedy of Errars, i. 1 all our lives in one small boat ...... Henry VI. iv. 6 many shallow bauble bonts dare ....Troil.\&. Cres. i. 3 Where's then the sauey boat

all boats alike showed

all boats alike showed .............. Coriolanus, iv. 1 come, down into the boat

will not bear your encmies' bout

briugs in some boats that are not .... - - iv. 3

ahoard our lancing buat ............... Pejeles, hil.

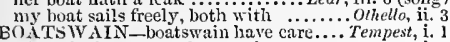

(c)

where is the master, buatswain?.
the swabler, the boatswain, and

the muster, and the boatswain

the boatswain whistles, the master cali.

not to seem senseless of the bob ...As . Nou

You shall not bob us out of.. Troilus \& Cressida,
BöBßBED-beaten, bobbed, and thunped. Ric.III.

gold and jewels that I bobbed from hin. Orhetlo

BOBTAIL-or bobtail-tike, or trundie-tail. Lear,

BOCCHUS-hath assemblet Bocchus. Ant \& Cleo. iii. 6
BUDEwhat should that bode?

What should that bode? .... it bodes. Tan. of Sh. v. 2
what it bodes, marry, peace it doth bode, Grod knows ....2Henry VI. i. 2

white'er it bodes, henceforward ......3 Henry IrI. ii.

Tould bode ...Troilus \& Cressida

my sight is rery dull,whate'er it bodes. Titus Anet. ii. I

this bodes some strange eruption......... Hamle

eves do iteh; doth that bode weeping?... Othello, iv. 3

What did thy song bode, lad

BODED-invert what best is boded me. Tempest, iii.

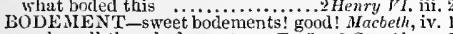

makes all these bodements .. Troilus \& Cressida, v. 3

BODGED-alas! we bodged agnin ....3 Henry $F I .1$.
EODIES-and you a curer ot bodies. Merry $w^{\prime}$ ires

nor I too: dere is no bodies.........

hale souls out of men's bodies? ....... IIuch . 1 do, ii. 3

with two seeming bodies

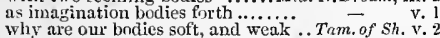

to the dead bodies of nty queen ... IVinter's Tale, iii. 2

save our deposed bodies to the ground. Rich. II. Hi.

the gibhets, and pressed the dead bodies - iv. 2

liave left their bodies liere in England.. Hen

their bodies to the hust of English youth

their nonr bollies must lie and tester....

and dispose of their dead bodie

give me their bodic

gold their bodies for their country,... - iv. 7

the bodies shall be dragred at my ...2Henry $V^{\prime} I$. iv. 3

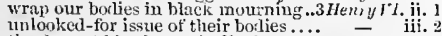

unlooked-for issue of their bolies...

the detrest blond your bodies bear....
whose budies Richind murdered ....
Richard

inter their budies as becomes ..........

the bodies of the dnke's confessor ..... Hens $\bar{y}$ VIII. i. I

state ot borlies womld bewray

du lance diseases in our buslies........ Antony $\bar{\delta}$ Clen. v. proxluce their bodies, be they slive or deal. $L$,

villanous shame to the dead bodies .. Roin. \& - Jul. vo

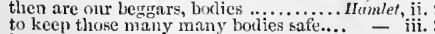

to keep those many many bodies safe.... - iii. 3

these borlies higl on a sture

take up the borlies $[\mathrm{Col}$. Lint hoily]

our todies are our gardens .............. othello, $\mathrm{i}, 3$

ol's bodikin [Cal. God's bodkin], man. . Itrmlet, ii.

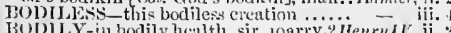

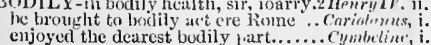

and fuirest boding dreams........... Michurd III. v. 3
and o'er the infected house, borling to inl ; othello, iv. cammot thrust a bodkin's point... W'Minler's Tale, iii. 3 [Col.] Godl's bodkin, man, much better..

BoD 1 -his budy nolier grows

I cminrace thy body

that 1 , unworthy body as I aiv...Two Gen. of Ver. $\mathrm{i}$

that winl endanger his body...

to come umler one body's hand

ol thy old body than I" hav

whether that the body puib.

give up your body to such......

lay down the treasures of your bod

ere I'd yield my body up to shame.

slsould her boly stoop to sueli....

the damned'st body to invest...

kecp the body of it ever fair .......
lath any body inquired for me...

and by an eminent body

ut by gift of my chaste body

this is the body that took away...

the body of your discourse is.....

combating in so tender a body

s your soul shonld with your body...

I'll prove it on his body

though the body pine.........
and body's fosternig parton
and thus thy body bear...

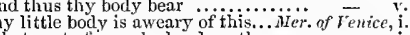

What part of your body pleaseth me.

so young a body, with so old a heal

no, not my body, nor my busbaul

bites and blows upon my body.

he piereeth through the body of.....

that one body should be filled.

ah, sir, a body would think this.

bear your body more seeming ...........

my poor body, madam, requires

our parting is a tortured body...

fock thy body with his ruffiri...

to deck thy body with his ruffing...Tam. of Sh. iv.

commits his body to painful labou...

continue the standing of his body.. Winter's $\bar{T}$

soul's peril, and thy body's torture...

or hoop his body more with

witches that deform the body.... Coin. of En

a very reverent body, ay, such

took measure of my body

for the dignity of the whole body

before my body I throw my.........

was levied in the body of a land

and part this body and my soul

sings his soul and body to their

my body shall make good be interred - Richard II. $\mathrm{i}$.

heaven's grace, and my body's valour

commit'st thy anointed body to

gave his body to that pleasant.

to undeck the pompous body of

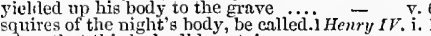

when that this body did contain ....... v.

all put forth; body and goods.........

we are a body strong enough..........

shew a weak mind and an able bodly.

it is hut as a body, yet, distempered..

hath ted ullon the bolly of ny..

your workings in a secomel body

make less thy body, henee, and mor.

commit my borly to your mercie.

no sonner lett his tather's body
len:ing his body as a paradise.

like little horly with a mighty....

althoush my body pay the price....

mit not my borly, pardon, sovereign...

with a binly filled, and yacant mind.

I lichard', ibody have interred new

bring forth the body of old Salisb

ontward composition of his body ....

my holy shall pay recompense ....
camnot my boly, nor bloor sacrifue.

my lody, soul, and all, before that

niy hody romm engirt witli misery.....

rear up his bolly; wring him by ...

graeions novewign, view this binly...
glould breatlic it so into tliy buily. that whishing well had not a

a hasty-witted body would say...
BODY - his head and lifeless hody lie.2 Heiry

where's the body that I should enobrace?

as I thrust thy lody in with my $\ldots . . .$.

his will in his old feeble body

that this wyy hody mi,rht...............

this body must be prey .....................

his body eouched in a curious

mire than my body's parting .........

sits retormity to mock my body...

ineans to make the lody follow

what is the body, when the head

my mangled braly shows, my bloo

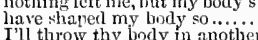

I'll throw thy body in anoth

fashions to adorn my body

Fll go hide the borty in some hole.

prevailed unon my body with their

frreys on the issue of his notler.

All-Soul's day is my body's itoom's-ilay

why anointed body, by the was punched -

panging as soul and boit

bod $y$ ' me, where is it?

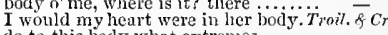

do to this body what extremes..........

in which part ot his body shall I.

bear P'atroclus' body to Aelilles .

come, tie his body to my h
which now the public body

which now the public body .... Timn of Athens,

i' the midst o' the body, idle ........
aftection common of the whole body.

and the shep of the whole boily

seven hurts i' the body, one in

motion towards the common body

to jump a body with a dingerous...

tirink on the wounds his bodv bear
twine mine arms abont that body

lury his reasons with his body

bear from hence his body.

and minst bend his body, if

prepare the body then, and follow

stanc trom the body,

his body in the boly

what villain touched his body.

and to Thassos send his body

this common body, like to ...Anter.
bear the king's son's hody before.

she shows a body rather than a lifi

the soul and body rive not more
thy captain is even smel a body

the arm of mine own body

some natural notes about her boil

ma body's marked witl homan

insultment ended on his dead bot

the lines of $\mathrm{my}$ body are as well ...

if we do fear this body hatli a tail..

Thersites' body is as good as A jax

a better hegl her glorions body fit...

make your hmonr of his body sts...

as any mortal body, hearing it

unto the hody of a dismal rew.........

some bring the mardered body .....

and made tly body bare of

belold thy living body so? $7 . . . . .$.

the steel in my adventurous body

to jrepare this body like to ther

J'li bring the body nresentiy..........

from her derognte body never spring.

he charges home my unprovided body

when the mind 's free, the bndy's delicite

with thy uncoveref body this extremity
all the rest of his hody cold

to lis body horse to

[Col. Knt. ]-my tool usurns a ry bul

for a hand, and a fort, and a hoily. . ko

not body's denth, hit hotly's bani.jument

inone hittle bonly thou enontericit'st.

the lark thy body is, sailing in this.

will overect thy teminest-tosect horly

her body slecis in Capel's minmment.

the voice and yielding of that body.

natural gint:s and alley"s of tive hoily.

the very age and bud of the time.

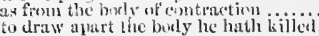

iv. 1
iv. 1
iv. 4
iv
ing

Y. 3$$
\text { iv. }
$$

\section{iii}

2

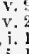

i. 1
i. 1
i. 1
i.

ii. $\frac{1}{2}$

ii. 3

iii. 3

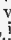

iii. 1

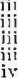


BODY_bring the body into the chapel. . Hamlet, iv. 1
donc, my lord, with the deal broty? done, my lord, with the dearl body?

vou must tell ns where the bodv i
the body is with the king, but the

sent to seck him, and to find the but

[Col. Knt.] take u] the bolly: such a sirht $-\bar{v}$ v.

Wher she is sated with his bod

had tasted her sweet boly, so I hid...

lest her borly and beauty tmmoride..

congh, and cry-hem, if any body con
lat in thus ensinared niy soul and body.

BODY-CUREli-and body-emeer...M
BODYlins-bolykins, master Page

BOG-sucks mp from los, fens, fints

through bog, through bush ..... Mid os Dram, ii: l

I found it out by the

EOGGLE-you boggle slinewdy

BOGGLER - have been a boggle

BoIL ENI I - to visit Bohemia....... Hin
betwixt our Bohemin and your sicilio

slow himself' over-kind to Bishemia

you are sure, all in Bohemia's well.

understand Bohenia stays here......

sky is nothin : Bohemia is nothing

and win feteh oft Bolremin for't...

with Bolsemia, and with your queen

Polixenes, king of Bohemin

touched upon the deserts of Bohemi

places remote enongh are in Bohemin

in tair Bohemia; and remember.

more than all the lawyers in Bohemin

not tor Bohemia, nor the pomp .......

who for Bohemia bend, to siguify ....

great sir, Bohemia greets yon ...
where's Bohemin? sjeak. Herc

as they speak: Bohemia stoys lis car

then asks Buhemia forgireness

BOFEMIAN - here's a Bolemian... \#crry $\overline{\text { Wix }}$ Brlaninian burn; but here nưsed. Mea.for Mea. iv. 2

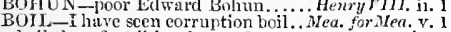

boil thou, first i'the cliarmed pot.

in the cauldron boil and bake.

ani sloth boil as trere fromb

boils? fnhl, al over, generally

thou art a boil, a yliague-sore

let me be boiled to death with... Tielifth Nivest, v. I

any but these boiled hrains...... Winter's Tute, iii. 3

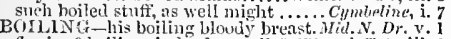

flaying? boiling, in leads, or oils?. Hinter'stule, iji.
for boiling choler chokes........... Henry $t$. v.

EOIS - son of sir Rownland tie Bois.

BOTSTElioTs-base and hoisterotis sword

what need you be so boisteronts ..... King John

make good the boisterous late sppeal ... Rich. $I$

the harsls, and boisterous tongue . 2 HenryI

honour snatehed with bijisteruus liand
o Ciiffurd, boisterous Clillord .......3llenr

swell before a boistcrous storm ...... Richard III

air, thy hoisterous chamberlain .. Timon of Ath. iv. 3

consernenee attends the boisterons.... IIa

BOFSTEROUSTY anderous expedition .... Othello, i. 3

Biter

BOLD make his bold waves trembie... Tempest

mis be bla to thine thesentins

may I be bold to think these spirits?

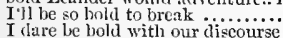

I make bold, to press uluo

I will first make bold...

I'll be so bold as to stay, sir.
may I be so bold to say so, sir?

\section{who more bold.}

and that you may be bold to say... Theteh sight, i. 5

vartue is bold, and goodness..........

I will only be bold with Benedick..Much -1do, iii.

by what jower I am made bo

bold of your worthiness.

making the boll wag .

Love's L. Los', ii.

too rude, and bold or voice.

Merchant of Vprice, $\mathrm{ii}$.

spirits are too bold fior your years... As you Like it, i. 2

may I be bold to acquaint ........... All's I'ell, iii.

durst make too bolit a heraiti

let me be thus bold with you... Tuming of Shree

let me be so bold, teli me

am bold to show my reli a torward

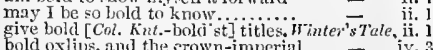

drunk, bath made me bold........... Mneteeth

I'll make so bold to call

ar, and a bold one, that clare look
BOLD-be bloody, bold, and resolnte . Nacbeth, iv. 1
he is boll, and blushes not at leath .. King John, iv. he is bold, and blushes not at death ... King John, i
Fienry llereford, thy bold son ...... Richard Il. a buld spirit in a loyal breast

sprifhtiully and bold, stays.

no person he so bold, or daring

i. 1
i. 3
i. 3 ten thousand bold seots bold conspiracy! - v veny $1 \mathrm{v} .3$

presence is too hold and peremptory

yet loth he give us bold advertisement $=$ iii.

such boln hostility, teaching ........ - iv.

the flame of bold rehellion..............

my grcedy ear with their bold deeds

to look with torehead bold and big

all these bold fears, thon see'st

I gave bold way to my uuthority

the like bolk, just, and impartial

his grace is bolil, to trust these.
I will be so bold as to tell you

I'll be so bold to take
madam, I haye been bold......

二 iv.

inst your bold vomicte.......

set a gloss upon his bold intent...

ringed about with bold adversity ....

dare you be so bold?

and therefore am I bold and resolute

dare any be so bold to sound retreat

to be thus and as buld in war....

and what makes roblers bold ...

in parlous boy; bold, quick

yet who so bold, but says.

$f$ am thus bold to put your grae..... - iij.

claring, bold, and vonturous

二 iv. 4

the ransom of $m y$ bold attempt.

Joeky of Norfolk be not too bold..... $-\overline{\text { v. } 3 \text { (seroli) }}$

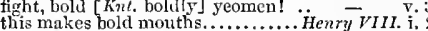

with bold spirit relate.

dare be bold to weep for Buckinghim

slept upon this bold had man .........

you are too bold; to to

you made bold to carry into Flanders

a bold, brave gentleman

bold languase. Do: remember your boll

for then, the bold and coward..Troiltes Cressi $^{-}$

state of war, bold as an ornele.

and make bold power look pale...... Coriolanus, $i$.

boll gentleman, prosperity be thy page

like a bold flood o'er-beat.

we are too bold upon your rest

Casar was mighty, bold, royal

abused in too bold a persuasion.

as I an bold, her honour will......

uncler the eondnct of bold Iachini.... - iv. 4

with the loss of many a bold one .....

be bold in us; we'll follow

be bold in us; we'll follow .........
like a bold ehampion, I assuire

unto a strmuger knight to be so bold

so rlebanched, and bold...

show too bold a malice again

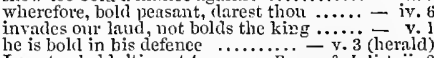

I am too bold, 'tis sut to me......... Romeo \& Juliet, $\mathrm{ji}$. 2

that I mean to make bold withal....

the bold winds speelless, and the orb. . Hamlet, ii.

$0 \mathrm{my}$ lord, if my duty be too bold ...... - iii.

making so bold, my tears forgetting .....

a maiden never bold; of spirit so ........

left int the conduct of the bold Iago....

gives me this bolil show of eourtesy

to be hold with yon,--not to affect

BOLD-BEA'TING-

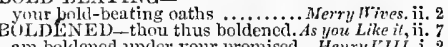
am holdencd under your promised.. Henry ${ }^{2} 111 . \mathrm{i}$. bold wag by their praises bolder.. Love's L. Lost, y. 2 of these bolder vices wanted less.. Winter's Tale, iii. 2 makes me the bolder to salute

bolder, but not so subtle.

Richard III, iii. 4 the most bolciest and best hearts..Julius Casar, iii. BOLD-FACED-bold-taeed victory..1 Henry $r$. iv. BOLDL Y - I will boldly publish her. T'melfth $N$. ii.
bolilly, at Ieast: but O, poor souls.. irea. for Mea. v. have answered heaven boldly .....Winter's Tale, i.

by heaven thus bolily for his king

se may boldly spend upon the hope. i Henry $I V$. iv. and boldly did outslare the dangers .

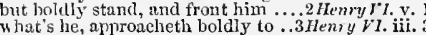

BOLDLY-boldly, and cheerfully .. Richard III. v. 3

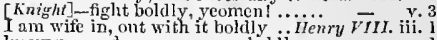
know many dare necuse you boldiy .... none but friends; say boldily ........ntony \& cleo. iii. 1

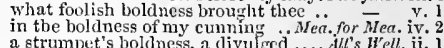
a strumpet's boldness, a divulged ..... ill's $W^{\prime}$ ell, ii. the boldness is mine own .... Taming of Shrew, ii. 1 as boláness trom my bosum, let it. ii. the bolduess of your speech

show boldness, and aspiring confidence ...John, v. upon thee, beggar, for thy boldness.. Richard III. i. will nake my boldness manners... Henry VIII. v. boldness comes to me now ... Troilus of Cressido, iij. 2 boldness be my friend! arm me..... Cymleline, i. 7 DOLINGBROKE-Bolingbroke, as low ...Rich.11. i. no, Bolingbroke; if ever I were traitor nor the prevention of poor Bolingbroke =-
the banished llolingbroke rcpeals himselfservants fled with Jim to Eritingluroke thinives to beat back Bolingbrok
than Bolingbroke to England.

than Bolingbroke to England

this traitor, Folinghroke, who all this

man that Bolingtroke liath pressed.

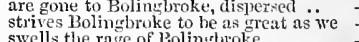

have made peace with Bolinglroke
our lives, and all are Bolingliroke's

proud Bulingbroke, I come to........

night, to Bolinghroke's fnir day $\ldots . .$.
Harry Polingtbroke on both his $\mathrm{knce}$

far off from the mind of Bolingbroke

tell Bolinghroke, (for yond', methinks

comes bable consin, flarry Bolingbrok

what says king Bolingbroke?

root and all by Bolinctroke...

Bolingbroke hath seized the wastetu.

the balance of' great Bolinghroke

the triumph of great Bolingbroke...

than Bolingluroke's return to Engla

standing before the sum of Bolingbroke

at last ont-faced by Bolingbrok

a prisoner by proud Bolingbroke ....

the mind of Bolingbroke is changed.

mounting Bolingbroke ascends my ..

God save thee, Bolingbroke ...........

preserve thee! welcome Boln sulpiect

till Bolingbroke have pardoned t

posting on in Bolingbroke's yroud joy

that Bolingbroke was on his back

and tired by jauneing Bolinghroke

incrate andi cankered Bolingiroke

to gall and pineh this Bolingbroke .

this king of smiles, tlis Bulingbroke -

hath Henry Bulingbroke made bead

where? which is Bolingbroke ..........

the admired hecls of Bolingbroke...

my cousin Bolingbroke aseends my...
when Harry Bolingliroke, and he...

from the breast of Bolingbroke

since misearried under Bolinghroke.

Roger Bolingbroke, the conjurer ....2
Henry Bolingbroke, duke of Lancaster

- ii. 2

BOLSTER-pillow, there the bolster. Tam. of $S h$ it. ever mortal eyes do see them bolster ... Ohiello, iii. 3 I'll make a shaft or a bolt on't....

Merry Wives, iii.

bolts and shackles! ..............Tuelfh Night, ii.

lay bolts enough unon him ............. aecording to the fool's bolt, sir......As you Like it, $\mathrm{v}$. a fool's bolt is soon shnt ............. Ilenry V. ini. charge thy sulphur with a bolt...... Coriolamus, v. aecidents, and bolts no change...

twas but a bolt of nothing Ant. \& Cleo. $\mathrm{v}$

to pick that bolt, then, tree for ever .. - $\mathrm{v}_{\text {. }}$ the thunderer, whose bolt you know

to oppose the bolt against

, Lear, ii. 4 OLinler's Tale, iv

so finely bolted, dirlst thou secm ....... Henry $V$. ii. 2 BOLTER-made bolters of them ..... Corllemry IV. iit. 3 BOLTING-the bolting. Have I (rep.).Trail.\& $C_{r}$. i i

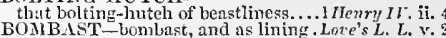

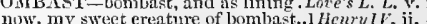
them, with a bombast eiriunstance .... Ohelio, i I BON-French lord, Monsieur le Bun?. Mer of trn. $\mathrm{i}$. que je suis le bon escolie 
BON-bon Dieu! les langues des lommes. Hen, $V$, y. 2 BONDAGE-an idle and foul bondage () their bons, their bons? ......... Romeo \& Jutiet, ii. 1

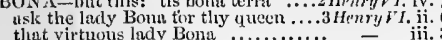
and liuly Bona, hear me speak
his love un to our sister Bonal

unless the lanly Bona guit his piain... that wona shall bevenge lis wrong to la.......... how shall Bona be revenged and mine, tair lady Bona, joins........ about the marriage of the lacly Bona what said lady Bona to my niarria

betrothed to Buna, sister to the king... Rich. IIT.

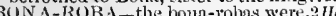
she was then a bona-roba.

BOND-his words are bonds Ti... G̈en. of Ver. ii. since bonds distraeed them .. T'elfh Night, ii.

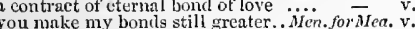
for everlasting bond of tellowship ....Hid.

I would, I had your bond (rep.)......

well then, rour bond; and let

scal me there your single bond

I'll seal to such a boind, and say....

three times the ralue of this bond....

ves, Shylock, I will seal unto this bund

dircetion tor this merry bond

to seal fove's bonds ney made

to his bond: le was wont to call (

fortititure, of justice, and his bond

six thousand, and defice the bond

my bond to the Jew is torfeit .......

that I will have my bond...

my bond; I will not hear thee (rep...)

no spcaking; I will have my bond

unt draw them, I would have my bond

the scal from off my bond.

do $y$ num conlicas the bond? I do

let me look upon the bond

why, this bond is furfeit.

I stay leare on my bond

liere appeareth dine upun the bond.....

go say's tlie bond; doth it not

camnot find it; 'tis not so in the houd

this bond dotl give tbee here no jot.

take then thy bond, take thon

have merely justice, and his bond

hau the natmeal bond of sisters.... As you Lite

my love hath in't a bond.

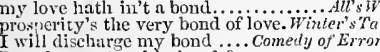

I am here entered in bond for you...

I will loose his bonds, and gain

that great bond which keeps me pale... Nacbeth, iii.

antl take a bond of fate.

I tore them from their bonds

King John, iii. 4

and rotten parclument bond

there is my bond of fiith, to tie

'tis nothing but some bond, that

with a bond that he is bound to

three or four bonds of forty pounds .j Henry $1 \%$. ii. 3

would not take lis bond and your

i Henry VI. iv. 7

cancel his bond of life $\ldots \ldots \ldots \ldots$ Richord 11I. iy. 4

notwithstanding that your bond of duty - iii. 2
should with a bond of air ... Troilus \&-Cressida, i. 3
tied with the bonds of heaven.......

the bonds of heaven are slipped

fir 'tis a bond in men ..........Timon of Athens, $\mathbf{i}$. 1

to trust man on his oath or bond...

t:ke the bonds along with you

all bond and privilege of nature break . Coriol

grace in waptive bonds his ehariot. . Sulies Cesur, $\mathrm{i}$.

what other bond, than secret Romans

within the bond of marriage.

I knew it fur my boud....... Antomy $\ddot{s}$ cleopatra, $\vec{i} .1$

from a next with bonds of death .... Cymbeline, i. 2

no bond, but to do just ones.

and cancel these eold bonds.............. -

think her bond ot chastity quite cracked -

Eave these.in bonds; let them be $\ldots$... bond. Lear,, i. 1

the bont cracked between son.

of nature, bond of eliildhood....

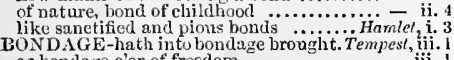

as bondage c'er of freedom............ - increase your bouduge.. Measure for Mensure, iii. 2

thy liberty into hondlage............As you Like il, v. 1

'tis a hard bondage, to become $\ldots . . . \ldots \ldots$. ${ }^{-}$' iii. 5

will also be the lyondage of certain.. Vinier's $T$. iv.

cast off his ehains of bondage......... Richrme II.

cassits trom

langivish for asssured bondaze?

lie Cymbeline

rows of women of no more

most welcome, bondlage your bondman, Dromio? (rep.)

cheeked like a bondinan; all
with Pindarus his bondman. bondage is hoarse, and may not.... Rom. o Jul. ii. BUNDSIAID- to make a londmaid.. Tum. of s\%. ij. BONDMLAN-in a bondman's key.Mer. of lenice, $\mathrm{i}$. with him his bondman, all as mad.. Com. of Err. v.

speak this betore a willing bondman

so base, that would be a bondman.....

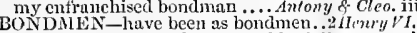

and make your bondmen tremble. Juitios

and bowed like bondmen, kissing Casar's - v, 1

for these base bondmen to the yoke.. Tins And. iv. 1

of law is bond-slave to the laty....... Richard 11 . ii

BONE-fill all thy bones with aches.

of his bones are cornl made .........
no further, sir; my old bones ache.

will never out of iny bones ..........
weave their thread with boncs ..

where my bones shall be thrown.

thy bones are liollow......... Me tesuref

and sing it to her bones..................

now, un to thy bones good night ...........

laus deo, bune intelligo. Bone? (rep). Love's L. I

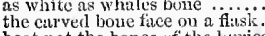

beat not the bones of the lurica

my flesh, blood, bones, and all

when virtue's steely bones look.... . iv. 1

the tomb of honoured bones indeed

to lay my bones there..............

my bones bear witness, that

thy bones are marrowless.

fuir fill the bones that took.

2 (song)

lay before this town our roy

kiss thy detestable bones ...........

for the bare-picked bone of majesty.. - iv. 3

womb inherits naught but bones.....Richari $I I$. ii. I

as paste and cover to our bones ......
no hand of blood and bone cuu gripe

upon thy royal grandsire's bones

goodman death! goodman bones..............

or lay these bones in an unworthy ...... $H$
desperate of their boues, ill-favouredily

achieve me, and then sell my bones.

fined these bones of mine for ransom.

till bones, and flesh, and sinews.....

to pieces, hack their bones as
by these ten bones, my lords

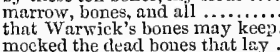

that his bones, when he bas run ...Henry $\overline{V I I I}$. 1ii. 2

to lay his weary bones among ye .... \& - i

tarre the mastiff's on, as 'twere their bone - i. 3

more than he has beat my bones ....

and such an ache in my bones

- $\quad$. 3

a goodly medicine for my aching bones -

not for me, yet for your aching bones $-\bar{T}$

I feel't npon my bones ...............

fiesh slide from the bone

or I shall shake thy bones out.

is oft interred with their bones... Julius Cusar, iii. 2

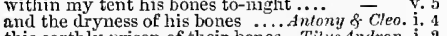

this earthly prison of their bones.. Tilus Andron. i. 2

thill Mutius bones be buried.

there lie thy bones, sweet Mutius.

go grind their bones to porder smail $\overline{-}$. v. 2

strike her young bones, you taking ........ Lear, ii. 4

and tear thy flesh and bones ............

my bones ache! what a jaunt (rcp.)
is this the poultice tor $\mathrm{n}_{k} \mathrm{y}$ acling bones

with dead men's rattling bones...

the bones of all my buried ancestors

with some great kinsman's bone

misery had worm him to the bones aith.. $\overline{\text { Ha }}$

eanst mutine in a matron's bone

nor hatchment, o'er his bones.......... - iv. 5

and hell gnaw his bones ............. Othello, iv. 2

incurable bone-ache, and tbe rivalled

BONELESS-from his boneless gums ... Macbeth, i.

way to the everlasting bonfire

honfires in France forthwith $\mathrm{I}$ am

ïMenry $1 V$. ii.

burn, bonfires, clear and brisht...

BON JOUli-bon jour, monsieur le Beati.... Ots you Like,

we'll give your graec bon jour ..... T'itus A miron. i.
si.ruior Romeu, bon jour] ....... Romeo of Juliet, ii
BONNE-le gentilhomme de bonue.

je snis gentilinomme de bonre matison - iv.

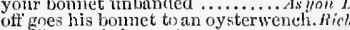

1 will wear it in my buntet.

your bonmet to his risfit al:e..................

in

fur my bonny kat

a cherry lip, a bonny ey

BONOS-bonos dies, sir Toby.

Bo NVILLE-ot' the lord Bom

BOOK-l knowing $\mathbf{I}$ loved my book

here, kiss the book $\ldots \ldots . . . .$.
swear to that; kiss the book.

I'll to my book; for yet........

remember first to possess his books

ii. 1

I'll drown my book.

ilpon some book I love

yout have not the book of riddles

I'll he sworu on a boyk, she

and a gond sthelent tiom his book.
mothing in the world at his book

wort ter worl, without book

that eons stite without book

I'll be supposed upon a book.............. fea. for Jen. ii.

the gentleman is not in your books ... Nuch stlo, $i$.

in my chamber window lies a book

a whiole book tiull of these quondan

painfully to pore upon a bouk ...... Love's $L$. Losi, i.

base anthority from others' books.... - Lost, i.

dainties that are bred in a book ....... - iv.

where is a book? that I may $\ldots . . . .$. - iv. ${ }^{2}$

eaeh of you hath forsworn his hook.. - iv. 3

wo have forsworn our books ........ - iv. 3

they are the books, the arts ..........
doth offer to swear mpon a book... Mereh. of ren. ii.

we turhed o'er many books together - iv. 1 (let.)
trees, books in the rumning brooks. As you like it, ii.

these trees shall be my bouks ........ - ii.

my books, and instruments, shall be. Tam. of Sh. i. I

and lily his book; welcome his friends - i. 1

poetry, and other books, frood ones... -

pand you the set ot books ........... - ii. 1

o puit me in thy books .............. - ii. 1

the priest let fall the book .........

priest and book, and book and priest ${ }^{2}$ iit.

is as a book, where men may read ......nincheth, i.

be blotted from the bokk of life........ Richard 11 . i. 3

dammed in the book of heaven

see the very book indeed where ....... I $_{\text {Henry }}$ iv. i. 3

by that time will our book, I think .. - iii. I

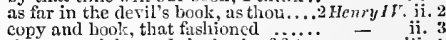

that one might read the book of fate - iii.

shut the book, and sit him down

seal this lawless bloody hook

how deep you were within the books in the book of Numbers. iv.

book our dead, and then to bury thern - iv.

I'll note you in my book of memory

youx names firom books of nemory...2 Henv'y $v i$. i. 1

such as by God's book are adjudged..

because my book pocket .......

what, at your book so hard?

made him my book, wherein......... Richurd 11I.

and, see, a book of prayer in lis ....
a book of prayers on their pillow lay

for, by the brok, he shuuld have braved

a beggar's book ontworth's a noble's. Henry r/II, i.

o like a bouk of sport thou'l t ......... - iv.

when comes your hook forth

is enrolled in Jove's ox'n bouk...... Coriolumus, iii.

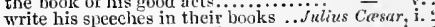

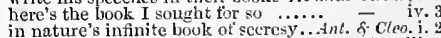

yet keep his book nnerossed......... Cymbeline, iii. 3

neck, sir, is pen, book, and counters... $\quad$ - v. $\quad$ v.

neck, sir, is pen, book, end colmers .

some book there is that she desires ${ }_{\text {Col. Knt. }}$ - what book? why lifts slic up -

lucins, what book is that she tosseth

her ficc, the book of praises .............
who has $a$ book of all that monarchs do

who has a book of all that monarchs do .. - i.

you have learnt it without book............. Lear, of Jutiet, i. 2 


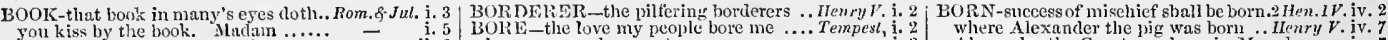

You kiss by the book. Matal

that fights by the hook of arithin

was crue book contaming sitch vile

writ with me in sour mistortune's book $\overline{-}$

rithin the book and volume of iny brai

real on this bonk; that show of sich .... - iit.

the blumly book of law you shatl yonrself. Othello, i. 3

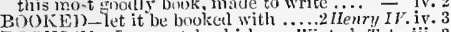

BoOkIsll-I am not bookish.... Winler's Tale, iii.

unless the bookish theorick, wherein ..... Othelln, $\mathrm{i}$.

BDUK-IIATE - and his book-mates.. Lore's L.L. iv

BOOK-MEN-Navarre and his bouk-17

Buok-0.ATH-now to thy book-oath. 2 Henry $\overline{I V}$. i. BoON-a smaller boon this this. Two Gen, of Fer. v, 1 to grant one hoon that $I$....

take execptions to my boun........ Richard JI. iv. I

I besceeh you, prant me this boon... Richard III. i.

a boon, my sovereign, tor my service.

my boon is, that this gentiem:

Tilus Andron. ii. 4

this, as my last bunn, give me.Pericles, v. 2 (Gower)

ny boon I mike it, that you know ...... Lear, iv.

Buoli-"wouldst thon have, boor?.. Herry Wire

let hoors and tranklins say it .... Mrinter's Tule,
Buoki] $-[$ Knt.]-]'ll boord him presentiy. Unmlet,

Bnol? Is] 1 - whiel in the berish is. As you Lil

BGOT-are over boots in love.... Tuo Gen. of $\mathrm{V}$

nay, give ine not the boots

I'll wear a bunt to make it

liquor fisherments bonts with

Herry Wives, iv.

all. Ju's llell i.

to rim will look upon lis bout and sing.

a pair of boots that have been

ofi witli my boots, you rogue

your stomachs, tor it is no boot
grnes to boot! of this make no

grnes to bont! ot this make no ...

yet liold tizee, there's some boot....

and the ricli East to boot.

it boots thee not to be con.

bore us some leatues to sea $\mathrm{O}$, that you bore the nnind that $\mathrm{do}$

slie bore a mind that envy ....... Tiuelgh Nimh, ii. 1 bore many gentlemen, nyself .......Mea for Men i. 5

and thy father bort it ..... As you Like it,

the love 1 bore your queen

bound me, bore me thence
that bore thee at a burcien

the queen, that bore thee ......
with a little pin bores through

as the soldiers bore deal

and thus $I$ bore my point.

a lute-ease; bore it twelve.
be bore him in the thickest.

some tarcly eripule hore......

obedienee he still bore your graee............

Errors, v. 1

Nacbeth,

Richard 11. iii. 2

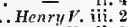

Richarl III. ii.

bars bore. Timon of dthen

mortal a purpose, as then eaeh bore... Cymbeline

or she, that bore you, was no

whom she bore in hand to love

whose towers bore hends so high...

the love I bore my cousin Tybait...12o.... \& . Jul. iii. 5

but he, which bore my letter.......... iv. $\overline{5}$ (soner)

too light for the bore of the matter
a while they bore her up ..............

he was the tirst that ever bore
BORE L

BOR ED-earth may be bored.... Mid. N.D

BORING-the ship boring the

where was she born

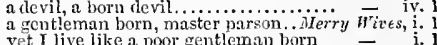

yet I live like a poor gentlc

for I was bred and born

were we not born under Taurus.......

both born in an hotw
some are born great

some are born great

why some are born great

where were you born, triend?............ fors. Meas. $\mathrm{ii}$

than iny son should be unlawfully born

usurp the heggary be was never born

say'st thou art), born under Sa

you were born in a merry hou

a star daneed, and under that I was hom

no, I was not born under a rlyyning

and vows so born, in their nativity.

every man with lis affects is bor
you were born to do me shane

theretore is she born to make

was for my service bort...............

or spleen, and born of marlness

wast born i' the forest he

that we, the poorer born $\ldots \ldots \ldots \ldots$
yon were born under a eliaritable

inust needs be born under Mlars.

a good woman born but every biazing

ehallenges itself howour's born

I was well born, nothing aequainted

born in Verona, oltl Antonio's son. Tan
his mane is Licio, born in Mlantua

I am he am born to tame you.... iife... Winter's $T$, ii.

have sinee then been born to us

than onestion how "tis born.....

o, thit ever I was borm ................

beenuse $I$ was no gentleman born (rep.)
if any, born at Ephesus, be seen.. Comedy of $E$ r

if any, born at Ephesus, be seen.. Comedy

in Syracusa was I born; and

wis lie not born of woman?......

no man, that's borm of woman

what's he, that was not born of woman?

must not yield to one of woman born.

being of no woinan born, yet

a. gentleman, born in Northamptonshir

was thy elder brother born

not such o oraeions erenti............

this aet, so erilly born, shall eool ...

were born to see so sad an hour...

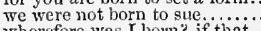

whercfore was I born? if that.
what, was I born to this

Richard

by man, wast born to bear

been born. I suy, the earth $($ rep..$) ..$ inenry $I V$. ii

Iny lorl, 1 was born about tiree.......2 Henry $I$

to brother born, a household cruelty
this Ilydris son of war is born........

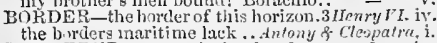

the b.rders maritime lack...4ntomy
BORDERLD-cannot be bordered..
Alexauder the Great was born in Macedon - iv.

Fenry, born at Monmouth (rep.) ... IHenry VI. jii. I

youn Talbot was not born afternoon

boin blink, an't plense your grace ...2 Henry $v I$. ii.

where wert thou bo:

if thou hadst been born blind.....

for you are more nobly borm ....... - ii.

this word sallet was born to do me...

$I$ am far better born than is the king 二

jike twas cre $I$ was born

and less than $I$ was born to

ay, thon wast born to be a plagne.... - iii.

bless $u s$, he is born with teeth.........

but I was horn so high .............. Richurel 1II. i.

she was dead ere thou wast born...... a stranger, born out of your dominions

an 'twere a man born in April .... Troil. \& Cres. $\mathrm{i}$.

wond thou born, his addition shall ...

we are born to do benefits ...... Timon of Aihens, $i$.

thon wast born a bastard ............. = ii.

keets and lactions were newiy born....

if thou hadst not been born ............

surely, this man was born of woman thongl you were born in Rome...... Coriolnn

I was born free as Casir ............Julius Cesur,

I was not born to clie on Brutus'

who's bory that day when I forget...Ant. \& Cleo v.

for the matter that is then born in it cymbeline, i.

let it die as it was born

timely knowing, the remedy then born =

why should exeuse be born or e'er begot -

fly born, where't grows; but worn..

went, and show them prinees born

in Cambria are we born, and gentlemen -

my briton born

they were not born for bonda.

Pericles, $\mathrm{i}$ (Gow.

for she was born at sea. I have named

may be mannered as she is born

ah me! poor maid, born in a tempest

when I was born, the wind was north

if you were born to bonour, show it now

she's born to undo us

born? and wherefore ealleri ifarina..... $($ rep. $)$ -

thou that wast born at wa born...

better thou hadst not been born

that thou wast born with

when we are born, younge

he was not born to shame

well-n-ilay, that ever I was born!.....

and to the manner born, it is a cistom.. Hamlet, $\mathrm{i}$.

very day that young Hasulet was born

been better have been born $a$ dog ...

where he was born, drew all sne..

would thou hadst ne'er bcen bor

have -have bortze bad sons ........... Tempest $\mathrm{i}$.

.. Merry Wives, ii.

when it is borne in high authority

hath he borne himself penitently

and lis head borne to Angelo....

he hath borne himself beyond......... Much $A d o$ iv.

the eonfcrenee was sadly bor'le $\ldots \ldots . .$. Love's $L . L . v$.

over-boldty we have borne ourscives. Lave's L. L.

[Collier] on the now borne bivef...... All's Well.

$i$ the love that I lave borme your father

which being violently borne upon. Com of Errors, i.

and borne henee for help

that he is borne about invisibie.......

how you were borne in hand

things have been strangely bor
he has borne all things well.

the tidings, which I have heavily borne

this must not be thus borne ...
what penny hath Rome borne

pereeives it is but faintly borne...

such wrongs are borne, in him

himself hat borne the erown .

truly borne betwixt our armies ......

like the sontin borne with black

ne'er had borne it ont of Coventry

that action, hence borne out

ber seeptre so fintastieally borne

threaden sills, borne with...........

the loses we have borue $\ldots . . .$.
they have borne life away.........
to have horne his bruised hem

to have horne his bruised heimet

hitherto lave borne in them against 


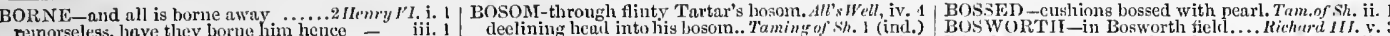

remoreless, have they bortue him hence - iii.

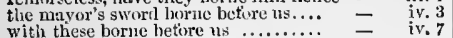
colours, often loorne in France ......... never borne thee son ................. inichardIII. i. 3 that is hardly borue hy any ..........

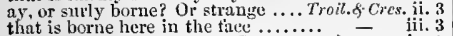
rather Troy were borne to Greece (rep.) O, it he had horne the business.

how plainly I have borne this business by the way, should have borne men cleoputra, i. 1 you have been nobly borne

the fool had borne my head

the fool had borne my head .............

borne her eleanly by the keeper's. Tilu

miseries are more than may

may this be borne? as if his.........

Thll show the yirture I have borne .......

aming of sh. 1 (ind.)

from botinty, fiertile bosom ........Winter's Tale, i. 2

a pastime to harder losoms

thou hast cleansed my bosom.

you bave your father's bosom there

shall deceive our bosom interest

still keep my bosom franchised ........

weep our sad bosoms empty.

not have such $n$ heart in my bosom

into this city's bosom

二 i. $\quad$ i. 2

lives in this bosom, dearly eherished.

Inon the bosom ot the ground

do take possession of my bosom

within this bosom never entered ....

wrestling in thy bosom, do make

so hot a summer in my bosom

through my burned bosnna .......... Richard II. $\mathrm{i}$.

sins so heavy in his bosom $\ldots . . . . . .$.

many miles upon her penceful boso.

and in my loyal bosum
from thy bosom pluck

write sorrow on the bosim of the earth

to the bosom of good old Abraham!.

from the traitor's bosom, king

into the bosum ereep of that same ... Henry $I V . i .3$

against the bosom of the Prinee of Wales - iv.

eren in the bosom of our adversaries

reign in all bosoms, that ..........2 Henry $L F$. i. 1

whose bosom burns with an incen
thy glutton bosom of the royal ......

there is a thing within my bosom....

as ifi allegiance in their bosoms sat.

turn into your bosoms, as dogs .

I and my bosom must debate....

accord in their sweet bosoms

feeds in the bosom of snch great

from his bosom purge this black
is erept into the bosom of the sea

throw in the frnzen bosoms of
issue from the bosom of the boy
I stabbed your fathers' bosoms

live one hour in your syreet boson.

Macbeth, i. 2

that mutinies in a man's bosom

of Ldward sleep in Abraham's b
all to pieces on thy roeky bosom

own points on their masters' bosoms

in your emboweled bosoms .........

let us be lead within thy bosom.....

hearts are great within

shook the bosom of my conscience..................

lie $i^{\prime}$ the bosom of our hard-ruled king

lift their bosoms bigher than ...... T

set fion doth your generous boson.

passion dotli embrace my bosom

to gratulate thy plenteous bosom

from forth thy plenteous bosom one

feed him, keep in your bosom.

no allowance, to your bosom's truti

whose double bosoms geem to wear

by and by thy bosom shall

tut, I am in their bosoms ...........

but in my bosom shall she never.....Ant. \&. Clro, ii.

whose bosom was my erownet

. Cumbeline, iv. 10

I found this label on my bosom ........ v - v. 5

sheathed my rapier in his bosom...Titus Andron. ii.

my dagger in their bosoms

from her bosom took the en

leaps to be gone in to my mother's bosom

shall to my bosom be as well neighboure

lay comforts to your bosom.

I know you are of her bosom a....................

the frozen bosom ot the north.... Rom
and sails upon the bosom of the air..

sueking on her nataral bosom tind ...

and the third in your bosom .........

my bosom's lord sits kightly in his

thy busband in thy bosom there lies

it mis-shenthed in my daughter's bosom - - -
those thorns that in her bosom lodre.... Ham

in liserellent istite bosom

soul of Nero enter this firm bosom

O bosomt blakk as death

to the sooty bosom of such a thing as...... othello it. 3

time to sijeak yolu bosom treely

your thought; it doth abnse your bosom

() WOILD-conjunct and bosoined wit

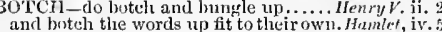
BO'TCllED-ruffian hath botehed. T'a elf: H Night, iv.

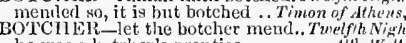
he was a boteher's prentice .....
as to stitfl a boteher's cushion as to stiff' a botcher's cushion

Borculy - not that a botishy corc? Troil BTII-botl, both, my rirl......... having botl the key ...... drop on rou loth

allaying both their fury, and niy

they let us both lither sudden.

that you shall hate it both

they were living both in $\mathrm{N}$ apl

may be both at once deliverer...
we'll both attend your ladyship.

they are both as whole as a fis
friar Laurence met them both

I will be chcater to them both

and I will trade to them

he wooes both higl and low...

may come and go between you

do you study them both

both, my good bost .........

both the proofs are extant..........

courage and hope, both teachiy

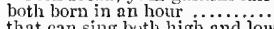

that ean sing both high and
this will so fright them both

both day and night did we

to make ns happy both.

you are betrothed both to...
thou shalt be both the plain

the glory of a creditor, both thanks. Mea. for.Yea.

visit both prince and people

hooking both right and wrong

sleep, dreaming on both

correction and instruction must boti

you are to do me both a present......

Angelo hath seen them both....

I know them both

in seeret holds, both Barnardine

and hearty thankings to you
both in the heat of blood

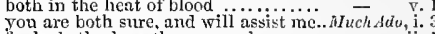

intend a kind of zeal both

both strength of limb

good che they are both in a tale...

good day to both of you................................

I came to seek you botb. .

but I pray you botlh, possess

some private sehooling for you botli. Hid. $\mathrm{N}, \mathrm{Dr}$.

unfolds both heaven and earth

and both as light as tales...

you both are livals, and love (rep.).

ereated both one tlower, both on on
both warbling of one song, both in

two of both kinds makes up four.

moderately, or to forbear both....

I confess botb, they are both

both in one, or one in both ......... i

writ on both sides the leaf.

well bandied both; a set of wit

I remit both twain,-I see.

to those tliat make us both

good signiors both, when shail we......

by adventuring botb, I oft found bot
or to find both, or bring your ........

one speak for both; - what would you

the power to steal both his

I fear sou are damnet both by father

well, you are gone both ways .........

from both, my lord; Bellario gree
and old shylock, both stand forth...
will we both fly towird Belmont

in both my eyes he doubly sees himsi

stand you both forth now $\because \ldots \ldots$. As you $L$

and your heart, both in an instant .
they are both the eonfirmers ........

and my grief were both extermincil... -

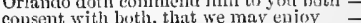

i'faith; and both in $n$ tume

but on us both did liaggish.

or where you both otr mothers............

that your bitm wis both her self

it both gnin all, the gift duth streteh

ii. 1

ii.

iii.

Night, i.

- ii. 3 (song)

iii.

v. 1

ii.
iii.
iii.
iii.
iv.
iv
iv.
iv.
v.
v.
ii.
ii

iii.

iv. 2

v. 1

ii.
iii.
iii.
iii.
iii.
iii.

ost, i.

1 (lette to whose flint bosom my eondem

and in his bosom spend my ........

both rich and poor, both young and old

did he send you both these letters.....

and so they shall be both bestowed

that have on both sicles past

tor he both plenseth men, and anger's

desires to speak with you both

wer auld death were both one thing

heart within her bosom......As you Like it, $\checkmark .4$ (vo
stall this in your bosom, and I thank...Alls IVell, shit his boson against our borrowing
seventcen poniarls are at thy losum
BUSON-[Knt.]-is the master, boson? .. Fiempre, i. 


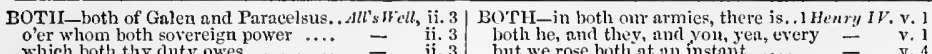
which both tlig duty owes

which of them both is dearest to ine

there both not sin, and yct a sinfiil
to thank both heaven and me.........

to thank both heaven and me.
damnable, both sides rogue

in the minority of them both

at one both the office of God

botls suffer under this complaint (rep.)

either hoth, or nome.

either of you both love Katliarina. Taming of $S$

our cake's dongh on both sides

it toucheth us both: that we may....

for my hand, both onr inventions..

or both? pras, what's the news .......

my reasons are both good and weighty -

and he, of both, that ean assure my.

thus pleasunt with you both ........

sweet masters, botli, I must be gone

botll on one horse?

and better 'twere, that both of i................

then both, or one, or any thing thou wilt -

or both dissemble deeply their ......
for both our sakes. I would that word

painful labour, both by sea and land

to save both, farewell, our brother. Winter's Tal

see gond and evil, inclining to them both

or botly younself and me cry, lost ....

in me both disobedienee

have been both at Delpho

if tortune please, both breed thee.

moeked him, both roaring louder...

try all: botil joy and terror ......
she was both pantler, hutler, cook; both

and remembramee, he to you both....

w'll buy for you botb; Pedler

till he had both tune and words.

having both their eountry quitted.

decreed; both by the Syracusans.......

had left to hoth of us alike

nay, master, loth in mind

ive me the ehnin both wi........

both one, and other, he denies me now

mistress, both man and master

speak'st false in both

and his man are both broke loose....

they are both forsworn ......................

you both of you remember me

and my chililren both ...

they smack of honour hoth; go, get...

or that with both he laboured

greater than both, by the all-

strong both against the deed

and yet voll would make both

good morrow, both! Is the king

ghall keep us both the safer.

bath been both grave and prosperous

hoth of you know, Banguo was

that are both his and mine.......
disjoint, both the worids suffe

present him eminence, both wit

on appetite, and heaith on both....

to he given, hoth more and less.

the tyrant's people on both sides .......

the worthiest, hold the riglit......... from

and retire of both your armies .... i.

both are alike; and both alike we like
and both conjointly bend vour

so strong in both, unyoke thi

with hot irons burn out both mine...

I will hoth hear and grant you ......

which both our tongues held vile

written down, botls they, and
high-stomached are they both

we thank yon both: yet one

is my life; both grow in one $\ldots .$.
slrovid violate!) both to defend.

ask yonder lnight in arms, hoth who

and reereant, both to defend himself

and both return baek to their chairs

riehly in both, if justice had...

hoth are my kinsmen...

ooth youmg and old reliel :....

by the rnyalties of both your bioods.

scope to beat both thee and m
am I hoth priest and clerk...

is my liehard both in shape .........

and hate turns one, or both, to worthy

yet, through both I see some

against them both my true joints....

"gage them both in an un ust (rep.)..1 HenryI

a plague upon you both

so majestically, hoth in word and matter -

both xhich I have lia]

and Glendower beiug both awe......

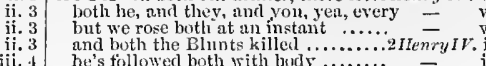

and so both the degrees prevent my

to pawn both my plate, and the tapestry -

you are botkl, in good troth

beenuse their legs are both of $a$ bigness

momnted, and both roukerl in their seats

members of onr cause, both here and.

and, both against the pare of heaven

then both parties nobly are sulyched

of capital trenson I attael you both

never come with both lands full.

that war, or pence, or both at once ..
for women are slirews, buth short -

I eharge you both go with me

gentlemen both, you will nistake.

which is both healthtil, and good...

as in kindness: prineely in both....

and they are both hangred .....

and there is salmons in hoth...

the numbers dead on both our parts

my luty to youboth, on equal eave...

they both eame swiftly rumning...

.............

i Hentry V.

w rong whereof you both complain.

gond eousins both, of Xork $\ldots \ldots . . . .$.

where both their lives are done

if we both stay, we both are sure to die

death be so apparent, then both fly

and may $y c$ both he suddenly .

alarnms both of hope and tear.

but I will rule both her, the ling

myself did win them hoth.

both together heaved it up re'll boti

thine enemies, both mine and thine.

but both of you were vowed du

and bring them both upon two poles.

of one or both of 12 the time is con

and yon both have vowed revenge.....

he is both king and lluke of Laneaster

injured both thyself and us?

be hated both of Gorl and man

mo inake me wipe off both.

of both the Sicils, and Jerusalem

and both sides fiercely tought .....

to frustrate both his oath

both tugeing to be

ere night yield both my life...

sinew both these lankls together.

here stand we both and aim....

wrongs both them and me.......

and our peers are both misled..

my talk and tears, both full of trinth

for both of youl are birds of ..........

What, if both and somerset both gone

give me both your lands ..............

soon persuade both him, and all his.

we'll meet both thee and Warwick

two of thy name, both dukes of Somerse

prineely nephew, brothers both not

besceeh your araees hoth.....

I fear me, both are finlse.

wear both of them, for both of them.

when we both lay in the field .....

alas! for me both; 1 do lament

both by his father and mother

ny brother mocks both you and me.
my gond lords botli, with all the heed

and we will both together to the Towe

the princes both make high aecount.

your good graees botb have well.

hid them prinecs both, but rill.

both in your torm and noblenes.

these both put by, a poor petitioner

God give your graces both a happy

henee both are gone with repe

both the prinees had becn brcathing. fare you well, gentlemun both .......

losing both beanty and utility....

purpose is botl good and reasonable.

to eall them both, a pair of ".........

so then both depiart to him
to resist both wind and tide

fair ereature; thou art both

there shall you find w hoth
BO'TII-we mist hoth give and take.. RichardIII v. 3 and being present both, 'twas said...Nenry VIII. $\hat{\mathrm{i}}$. or both, for he is equal ravenots....

Goud--day to both your grace

both of his truth and him............

'twill be mueh both for your hourur.

ye tell me what ye wish for hoth

ever couble, both in his words ant

have followed both my fortunes......

the progress both of my life and office

I shall both find your lordship.

fools, on both sides! Helen ... Troilus o Cressida, $\mathrm{i}$.

yet let it please both....................

Paris and Troilus, you have both said

both alike roins, you have

both merits poised

heart and hisnd both open, and both...

expeetance here fiom both the silles.

both taxing me, and gaging me ......

both to those that go, or tarry .........

I know them both............... Timon

my deserts to his, and join them bot

witl all my heart, genitlemen both
the Atlienians both within and out

but the extremity of both end

not thieves. Eoth too; and women's sons

my ladies both, good-day to you ....

that both our powers, with smiling.

calling both the parties kna

till we ealled both field and city ours

when, both your voiees blemleti........

may enter 'twixt the gap of botli .

swoln by, both divine and

simee that to more resleet $\ldots . .13 . .$.

in thy lying tongue both numbers

the gods preserve rour

are bound to pray for you both

a noble grace to both parts .....

peace, both, and hear me speak ........

we both have fed as well (rep.)

do so: farewell, both

betore the eyes of both our armies here

Cesar's, I would say? Both? ..... Antrmy s

hijger thin both in blood and life ... -

with his joy: but between hoth ...... -

join with beanty, lnst with both .... -

wer love to hoth, would (rep.) ......

plied them both with excellent praises

both he lores. They are lis sliards.

between, praving for both parts.

buth how your were wrong led.

so to them both. Fortune pursue thee
for both, my lord. I woold, they'l figlat - iii. 10

they were in Atric both together ....Cymbeline, i. 2

makes him both without and with

the wiuning both of first and list. ...

will be both noisome and infectious.

that tub both filled and running

what both you spur and stop

thint both nine ears must not...

no more be mad; that eures us botli.

proceerled but hy both your will ..

hath clone you both this cursecl ini iir.

in dignity, whose dust is both :

liave both their eves and ears so cloyed -

and brain not; either botli, or notlinis

in justice, (both on her, anit her

icei - v.

the and his larly hoth are at the lodge

hither both thy sons alive ...........

redeem my brothers hoth from death

I'll deceive them both; lent riae
that I intend to send them botli...

ii. 2 goids, confoumd you both ...

ii. 2 that you are both deciphered .........

iii 1 and tell them both the eiremustance

fown fell both the ram's liorns.

the bull and

that loth mine eyes were riny

loth her sweet hands, her tongue

why, there they are both, baked in

and both like serpents are..

hreak one, will sure crack bo

\begin{tabular}{l|l} 
iv. & that time of both this truth \\
iv. 3 & prove awinl both in deed and \\
iv. &
\end{tabular}

a man whom both the water

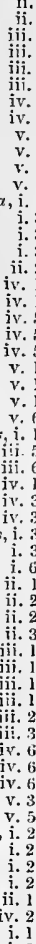

i. 2 
BOTI-Whatl are you buth pleased?.... P'ericles, ii. 5 | BOT'rOMI-let us hear, swect Bottom. Mril.N. Dr. iv. 2 are you both arreed? Yes, plense your makes her botit the hetrt

- iv. (Grower) we should have both lind and lown..... = iv. if both were justly weighed

equal mine if both were ojscued.....

so tiurewell to you both

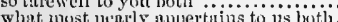

aud gavest away both parts

pared thy wit o botli fides

goinl-morrow to you both

sitli that both charge ani dange

grief as age; wretched in both...............

which both of then have borie anainst...

bring you where bots tire and foul is reudy

both botyle wolcome and groteetion horseway, a......

my lord: this let

to beith these sisters liave I sworn ...

both? one? ur neither? ncitho

housuholds, both alike in dim $\dddot{2} . . . .$.

both by myself, and many other trient

of honourable reckoning are you both

the more I have, for both are infinit
both are remedies within thy hily

gooi-nuorrow to you botli...

begin both with a letter (rep.)..........

happiness that both reeeive in either

a plagne o' both the houses! ( $r^{e} p$. $)$.

fither, or thy mother, nay, or both

you are beguiled, botli you and I.

ill-beseenning beast, in sceming buth

mis-shapen in the conduct of them both

or else beshrew them both

to auother, this shall slay them both

that we both wore in a house ........

as they had delivered, both in time... . Ham

oft loses buth itself and tiriend..............

extinct in both, even in their promise...

buth your majesties misht

but we both oliey; and here give up

both to my God, aud to my graeious

good inds, bow do ye both?

both in reputation and profit (repeaie.

mueh to do on both sides

way again, to both your honour's ........

whose end, both at the first, and

both here, and hence, pminsue me listing

where I shall first begin, and both neglect

when both contend which is the mightier

and skill, both countenance and exc
friends both, go join you witly some

Jet them know both what we mean to do
tbat both the worlds $\{$ give to negligence

you will draw both friend and toe

converience both of time and incans

I do not tear it; I hive seen you both....

they bleed on both sides...

both you ot my inelining, and the rest.

botín do learn me how to respeet you

but he bears b: th the sentence

being strong on both side

reely, both with wind and stream

have their palates both fin sweet and soitr

BOTS-beguawn with the buts.... Taminir of $\bar{S}$. Way to give poor fades the bots
ha! bots on't, 'tis come at last

BuTrLe-he shall taste of my buttle... Tenpsest,
it all the rine in my bottle will it all the rrine in my bottle will

over-board, by this bottie

I'll swear upon that bottle.

here; betr my bottle.................

a jox o' your bottle

ay; but to lose our botties in the pool

with my aqui-vita loottle

illing a bottle witl

hang me in a bottle like $\mathrm{a}$ c..........

a great desire to a bottle oi hay... Mid. N. Dre.zm, iv.

out of a narrow-muthed bottle.. As you Like it, iii.

the me buttle of sack...

brandish any thing but my botile.....2 ntenry $I F$. $\mathrm{i}$.

will do amung foaming bottles ....... Ifenry $V$. i

out of his leathern buttle .............

ITenry Vi. ii.

awry, you bottle-ale racal! ........2 Ilenry I $t^{\prime}$. ii.

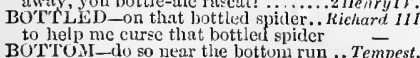

jerovirle to bottom it the bottom run .. Tempest, ii.

provirle to bot tom it on me .... Tru Gen. of Ver. iii.

most noble bottotn of uur fleet.... T'uelf'h Night, $v$

look into the bottom of my place...1\%u for Mea.

you, Nick Buttom, are set down

what say'kt thou hulty lottom? ….

what say you, Bottom?..

O Bottum, thou art changedi....

bless thee, Buttom! bless thee!

called Botton's dreann, becanse (rep.)

have you sent to Buttum
i sweet bully Botton!

bottum $1 \mathrm{U}$ unost comagevi............ are not in one lot ton trusted.....Mer. of lenice, i.

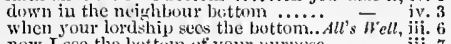
now I see the bot tom of your purpose - iii. 7
with at bottom of brown thread. . T'aming of Sh. iv. 3 but there's uo bottom nuove

bitt there s uo bottom, nove ..........Macter h, iy.

dive into the bottom of the deep...

rob me of so rich a bot tom here.

the very bottom and the soul of ho

to somd the bottom of the after-times

I'll pledge you a mile to the bottom
the voz anil bottom of the sea ........

knew'st the very bottun of my sou

draw the liuge bottoms throngh ...

wooed the slimy bottom of the decip

Bearches to the bottom of the wor

I myselt's see not the hot tom of it

bitt the bottom of the news is

drops i the bottom of a cows

who ever yet could sotnd thy bottom

my sorrow deep, having no bottom

one dead in the bottom ot a tomb...........

cliat sees into the bottom of my griet?

my massions bottomless with them
BUUCICUALT-Lestrale, Boneigual

BuUG1l-that hangrs on the bough. I

wing me to some withered bougl , "Winter's Tale, v. 3

that bearing boughs inay live.

richurd 11 . ini. 1

tell trom their boughs, and left. Fimon of A hens, iv.

bound with laurel boughs .... Titus Andron

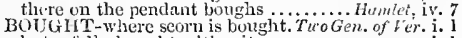

but a folly bought with wit............ Herry i. i. 1

for you th is bought niore oft .... Tuelgih Night, iii. 4
beauty is bonght by judgment .. Loee's L. Lost, ii. 1

the goose that you bought

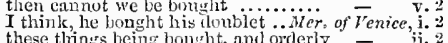

these things heing bought, and orderly
since you are dear bought .........

clavish parts, because you bought them - iv. 1

he hat li boutht a pair of cast lips....... As you Like, iii. 4

and he hath lought the eottage....... All's Well, ii. I

be might have bought me

at market-1)rice have butghit

to he boung bouth the oil, the baisamum

silks that lie had bought for me......

I have bought golden opinions ........ Macbeth, i. 7

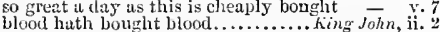

English, you are bought aud sold ......

would have bought me lights as good - iii. 3

I bonght you a dozen of shirts ......
they have bonght out thoir services..
to- iii. 3
iv. 2
i. 3

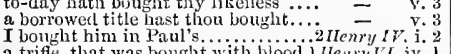

a trifle, that was bonght with blood.1 Henry VI. iv. I

alvantage, bought with such a shame

and boush his climbing very dear..2 Honry r I

poison that $I$ bonght of him

till I have bought a glass

having bought love witli such

Dickon thy master is buught and soli $-v \cdot 3$ (scivil)

have bought her dignities so

she liath bought the name of whore.. Cymbeline, i1. I

becuse I bought mime own... Tïus Andronicus, iii. I

the end ot all is bought thus dear

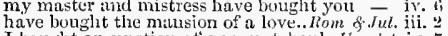

I bought an unction of a mountelink. If

BOULT-Boult, sir. Seareh the matk

it's no calling: but here con
Boult, has she any qualities.

what's her price, Boult?................
Boult, take ymu the unarks of hie

Boult's returnel. Now, sir, hirst

Boult, spend thou that in the tuw.

Boult, take her awny; use he
BuUNCE-fire, and smoke, and

bounce would a'say: and away ...2 Keng John, ii.

BOUNCING-the bomeint and

BOU ND-a confidence sants bound ....... Tempesi. ii. 2

bound sady home for Naples ........ - i. 2

slirits, as in a dream, are all

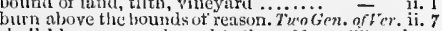

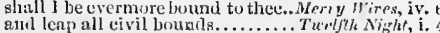

I aud bound to the count orsiuo... Turthls Night, i.
BOUN D.- whither you are bound.. Thelfh Nitght, ii. I iave litm in a rlurk nown and bound..

I shall be much hound to you for't ...

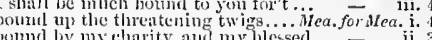

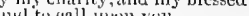

I am always bound to you

let these men ire berund and brought. Wuch $A d o$,

two of my lirother's men bound

past the bormels of maiden's jatience. Nir. N.D. i

I nm more boumd to you.... Lore's Labour

that and other sirceialitics are bound

am bound to served, hound.........

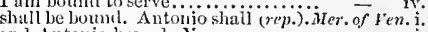

and Antonio bound. Your answer ". - i.

I am not bound to please the with.. = iv.

in liny mion, you are much boumel

gundo ballowingr

infinitely hound. Yum should in (rep.)

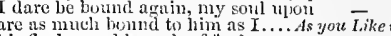

the cottage, and the bounds.

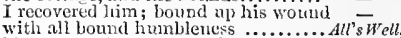

if' you were but bound to't

it ever thon be'st bound in thy sear'
shomlil sustain the bound and high curvet -

why, these billes bound;

to great Saint Jaques bound...

I'll huve them very fairly bound.. Taming of

when they are bound to serve, love . IVinter's

I am bound to you: there is solue sap

and whither they are bound

(1) other twins wats bound. $\dddot{C}$ om. of Errors, $j$.

cleath through the bounds of Asia....

but that $I$ an bound to Persia .....

they must be bound, and laid in some

more help, to have them bound again

onee dia $x$ get him bound.

and bound the doctor, whose beard .

and my man, both bound togetber

for lately we were bound

who are now bound to believe him

confined, bound in to sauey ............

thou other gold-boumd brow, is like... Macteth, i.j.

a soldier, and now boumd to Franee... King John,

glorify the banks that bound then

proud river peering o'er his bounds

hich $I$ alone, am bound to underbear

et me not be bound

iii.

England, bomd in with the .......... kichard 11 . ii.

to whose high will we bound cump....

heyond the bounds of patience ....... HenryI\%.

the thieres lave bound the true men
and bound them. No, no (repealed).

you bound them, and were masters.

ntmost bound ot alt our 'ort

in amgdom fior it was too small a bound - vound to thee, reverend Fechle.2 Hen. $\%$. iii.

brow, with homely biggin bound

no less for bounty bound to us.

the king is not bound to answer

like captives hound to a tritumpliant.. Henry Fl. i.

in dinty $I$ am bound to both..

I and lound to you, that you on ...

a hemet it was bound in with dianionds

but that he wis lound loy a solemu oath

both bound to revente ..............3 nirrsylrt, ii.

hath he set bounds between tineir love

boud with triuniliant garlonds

to nature note nore bourd

Henrytriti. $\mathrm{i}$

if you are bound to us, or no

all thy best parts bound together
but that I am bound in charity...

are you bound thither?

this sinister bounds in my futhers...

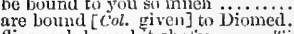

flies ench bourk it chaties ...... Timon of sthens, i. ,

We are so virtalourly beund

bound servants, stenl!

justice in your city's bounds

.........

bound to beg of puy lurd general Coriolanus,

if you will pass to where you are bound - iii. 1

what he would not, bound with an oath -

i. 3
ii. 3
iii. 5

i. 2

\section{ii. 2}

iv. 1
iv. 1
iv. 4

iv. 1

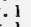

1 


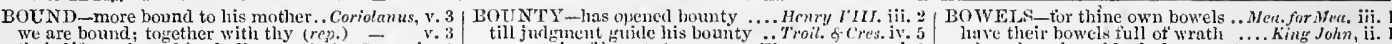

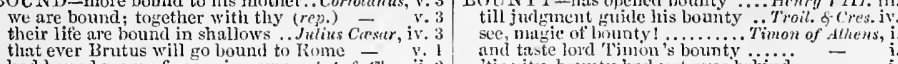
had bound me up from tuine ons le's botnd unto oetitria......................... often bound tor no less than my lifie. am boutud to load thy merit richly you are most burud to the kin you are nily be the king..... whither bound? Tro siliford inven a kinsman, who is bonnd tor Italy well, or ill; $I$ am bout

I dare be bound he's true .............

Andronicus, bound with laurel ...

like Nilus, it clisdaineth bounds....

and hers, are highly bound to thice.

is bound by the indenture of his onth.

whom I an bourd to $(r e p)$

where to being bound, the in

of all these bounds, even from the

to thy" aw my servees are bound

whereto our health is bount

the revenges we are bound to take

we are bouud to the like $\mathrm{I}$ am bound upon a wheel of fire

thou wast not bound to answer...

bit bound more than a mudiman is ..

sonr with them above a comnon boun

sueh vile matter, so fairly bouni?

not stenying o'er the bounds of moles

the survivor bound in hlinl oblitation.

speak, I am bound to henr ...........

the single and peculiar life is hound

embassador that was bound for Englain

re reuge should have no bounds 7 .......

to you I am bound for life, and edueation

bosom freely. I am much bound to

as $\mathrm{I}$ am bound, reeeive it from $\mathrm{me}$

I am bound to thee for ever...............

I am bound to speak; my mistress here

I am bound to speak; my mistress here...
BOUNDED-and bounded in a pale.. 1 Hen

the bounded waters should lift... Troilus of

BOUNDEN-much bounden to $y$.

I am mueh bounden to your maje

BOUNDING-to thy bonnding steed.1 Hon

a bounding [Col. Knt. abounding] valour. H. $V$. iv.

bounding between the two moist..
BUUNDLESS-ot boundless tongue.

.

the intiuite and boundless reach.

that the desire is boundless.

compass sueh a boundless happiuess! .. Pericl

my bounty is as boundless as the sea.Rom.\& Jul. ii. 2

how does my bounteous sister?

most bounteous sir, look ... Meazure for Measutre

the git't which bounteous nature .....hucbelh, iii. 1

bears a bounteous mind indeed

Henry III. i. 3

we'll share a bounteous time .. Timon of $\bar{A}$ the

mary a bounteous year............

the bounteous liousewife, nature

Le bounteons at our meal
ships, and hounteous win.

been most tree and hounteous ...........

to be free and bounteous to her min
bounteous madam, whatever shaIl

but with aeepptar
BOUNTEOUSLY

and I'll pay thee bounteously .... Twelfh Night, i. 2 Hector's bestow my bounties.. Hemry rif., iil. ? all that of his bounties taste... Timon

nor came any of his bounties over me

I'll pay your bounties; till then. rest..Perictes, ii.

BoUNTIPUL-bountiful fortune ...... Termpes, i. 2 marry, that's a bountiful answer ......ll's 's $W^{\prime} l l, \mathrm{ji}$. 2 theuntiful as mines ot" Indi

thy very bountiful good lord.. Timon of Ahens, iii. 1 thy lord's a bountifui gentleman

give it bountifully to the desirers ... Coriolan tull of virtue, bunty, worth

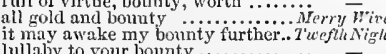

let your bounty take a nap..........

than cutstomary bounty ean......M. iler. of Veniee, iii. 4

from bounty fertile bosom

your lnck ot love, or bounty

stableness, bounty, perseverance..........nncbeth,

stands for my bounty ................. Rieharel 11. ii.

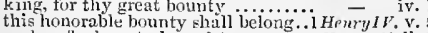

no less for bount bound to us ........1lenry $l^{\prime}$. ii.

your bounty, virtuc, titir luwility. Kicherdill. iii. 7 and taste lord 'Timon sounty bo......

O, he is the very soml of bounty! ...

tho thought is lowinty's toe passed

for bounty, that makes gods.

with his bomnty overplus ... inito

do not alise ny master's bount

for his bounty, there wits no winter

fitting my bounty, and nuy state.

who your their liounty on her.

eonsists in bounty, expect even fiere.. - v.

the bounty and the benizon of heaven

the more merit is in your bounty ...... Ham
BOURBIER-la truic live au bourbier. Hen

BOURBON-dukes of Orleass, Bourbo

John duke of Bourbon

lord Bourbon, our high ndmira.........

venture of Bourdeatux stutit Bourdeaux. Rich. II. v. 6

go to the gates of Boudeaux $\ldots \ldots \ldots$. Henry Vi.iv.

marehed to Bourdean with his power

Bourdeaux, warlike dnke! to Buurdeanx

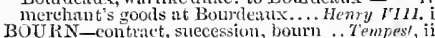

no bourn 'twixt his and mine .... Winter's Tule, $\mathrm{i}$.

ike a bourn, a lale, a shore.. Troilus ocresside, ii. 3

eorue o'er the bomrn, Bessy, to me. Lear, iii. 6 (soug)

eome o'er the bomrn, Bessy, to me. Lear, ii. 6 (soug)
the dread summit of this chalky bourn - iv. 6

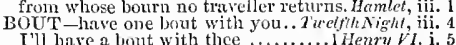

damsel, I'll have a bont with you ..... - ill. -2

as make your bout more violent
I'll play this bout first, set it by

BuW-at which end o'the beam shic'd bow. Tempest,

eaeh end of thy blue bow dost

whose back with ingots bow

like to a silver bow new bert

his love-shaft suartly from his bow

than arrow trom the Tartar.

why, she that bear's the bow

wide o' the bow hand

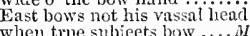

when true subjeets bow .....Merchant of 'enice, iij. 2

he hath ta'en his bow and arro
wlueh bow the head, and nod....

bid kings eume bow to it ........... King Joh

learn to bend their bows ............

flatter, bow, and bend

he drew a good bow.

wrest, or bow your reading.

hut, if I bow, they'll say.

than these knees how to auy

hath thy knee forest to bov?

bows unto the grave with in
and, lords, bow low to him.

and, lords, bow low to him

bow themselves, when he..Fenry $r$ HI
like loaien brimehes, bow to the earth

swords and bows directive.... Troilus of ciessidu, i. 3

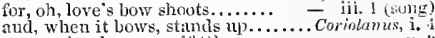

aud, when it bows, stanus up......

the gods that Romans bow betore...Julius Casar, ii. 1

ny knee shall bow my prayers. . Antomy o cleo. ii. 3

bows you to morning's holy office.

i'the eave, wherein the yow ho....

bow this ticeble

and be happy, by my the carth.

makes me beud, makes the king bow...

tellow handles his bow like a crow-keeper iii. 6

from love's wenk childish bow
a 'Tartiur's painted bow of lath

constrains a. man to bow in the hams

would have reverted to my bow again .. Hamlet s.

BOW-BOY -the blind bow-boy's.... hom. \& Jul. ii. I LOWED-his wave-worn basis bowed. . Tempest, ii. I to thee like osiers bowed ... Loce's Lalour's Lost, iv. 2

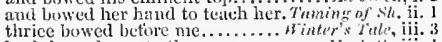
thrice bowed betore me.......
hath bowed you to the gruve

where I first bowed iny knce.

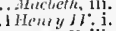

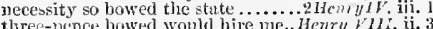

and bowed her to the people

who bowed but in my stirrus

Coriolemus, iii.

and bowed Jike bondmen

must he bowed as I would have yox ... Prricles, iv.

knoes humbly boved, could not ... Ram. of Jui. iii, 1 pursne me as you draw your bow. Taun ell, iv. Whose bowcls suddenly burst

out of the buwels of the harmiess...... nnenry $s . \mathrm{v}$. no mere weight than mine owu bowels $-v$ v. in the boweis of the Lord ............. inom $\mathrm{LI}$.

into the bowcls of the battle .......... i Honry

rushing in the bowels of the French

into the fatal berwels of the deep.............

thou thing of no bowels, thou! .. Troilus o Cre

no lady of more softer bowels ......... - in the bowels of unratetin Rome. Coriolanus,

tearing his eountry's bowels out ........

in his brinish bowels swallow ...
my bowels cannot hide her woes

Bow ER-ennupied with bowers .. Tirnlfh Nigh

bid her steal into the pleached bower. Minch deto

lead lini to my bower .........Mid. N. Dresm, it.

to bear him to my bower in fairylewd

a fair queen in a summer's buwer... In'nry 11 , iv.

than flatter him in a bower........ Coriolumes, iif. 2

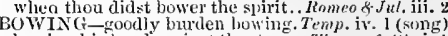
bowing his head against the steery. Thwon of Ath. i. challenge her to bowl...... Lure's Laborr's Lost, iv. roasted crabs hiss int the bewl...... - v. 2 (song

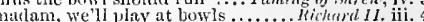
fill me a bowl of wine (ren.) ......... Ticherd 111. y. 3

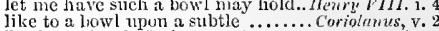
Lucius, a bowl of wine ............... Julius Cresar, iv.

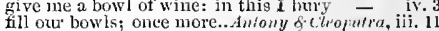
broke his pate with your bowl ...... Cymbeline, ii. your gravity o'er a gossip's bowl..... Rom. \& Jul. iii. 5 BOWLED-and bowled to death ... Merry Wres, iii. 4 BOWLER-a very good bowler.... Love's L. Last, y. 2 BOWSPPIT-the yards and bowsprit ... Tempest, $i$. enough: hold, or eut bow-strings...Mid.N. Drm. i. 2 Box-a box, a green-a box (rep.)..... Herry Hines, i. 4 bortowed a box of the ear..........Her. of Venice, i. that box? sir, there lies (rep.) .. Winter's Tale, iv. 3 Ior the box o' the car that ...........2 Henry I. i. 2 sworn to take him a box o' the ear...
purcliase him a box o' the ear....... iv.

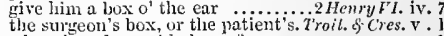
why, thou damnable box of enry.... nothing but an enjpty box.... Timon of Alhens, iii. I

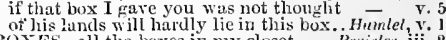
Boxps-all the boxes in my closet .... Pericles, iii. 2 a begarly aecount of enpty boxes...Rom. o. Jul. y. I when wo werc bors, who would......... - iii. and her blind boy's scandal'd company - iv. not so firir boy, as well-favoured... Tico Gen. of $F$. ii. belike, boy, then you are in love $\ldots .$.
no boy, but as well as I ean do them

ais' if thuu see'st my boy.

rejuice iu the boy's comection..........

the hangman's boys in the market-juace -
lusk to the boy. Wf lis boy! why war!

Where is that riog, boy?

more graee than boy ..............

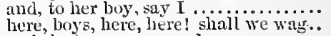

ind the boy never need .......

Hector ut Greece, my boy ........

0 yol are a flattering boy
why, this boy will carry a lett

to my wife, and Falstiff's boy

thou'rt a good boy: this secresy...

4 boy, thux hadst a tather

let the lroys leave to play

get you home, boy and she's a great lubi..........

aud 'tis a postmaster's boy

1ot In ne, but a postmaster's boy

a hoy; un juisan, by grar, a boy

lor young cuough for a boy

come hither, boy; if ever

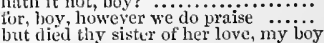

dicl she sec thee the while, old boy

a very dishonest paitry boy....

come, boy, witl nee 
BOY-boy, thou hast said to me .. Tuelfth Nizht, v, 1 , BOY-shames him so, poor hoy that $I$ wins und a little tiuy boy .... 'twas the boy that stole yiur ineat ...Much $A d o$, il. it thou kill'st me, boy loy; come boy, fillow me: sir boy.............. hoys, apes, bragirarts, Jaeks. $\dddot{l}$. fishion-mongering boys, that lie fiare you well, boy; you know bitl a lovely boy, stolen from itholus the loved boy, erowns hin slo but ber a little cliangeling boy. give me that boy, and I will go and beg her Indian boy. and rights, of this olyressed ho that yen green boy shall have
what say st thou, boy? $O$ boy, then where art thou .......... and at thy birth, dear boy! nat. Hubert, keep this boy: Pliplip ..... throw thinc eye on yon youn o lordl my boy, iny Arthur. and bind the boy, which you shail young boy, I must ........

ii. 2 I cun late

and I did purposc, bey, with this

forgot the duke of Hereford, boy.

why, foolish hoy, the king is
boys, with women's voices

dishonourable boy! that li

boy let me see the writing

wanton, and effeminate boy...

more authority, dear boy, name wore

is there not a hallad, bes, of the...

sing, hoy; my spirit grows heavy
his disgraee is to be cilled boy

by heart, and in heart, bor

the boy hath sold him a bargain

then the boy's fint l'envoy...........

domineering pedant o'er the boy

king Pepin of France was a little bo

play at push-pin with the boys

Yes, yes; he teiclies boys the hornbook
he bath been five thousand years a boy

the boy replied, an angel is not

the hedge-priest, the tool, and the boy

the boy was the very staff of iny age. $M$

yeu are not Launcelot, my boy

your boy that was, your son

noor buy, - not a poor boy, sir......

to see me thus transformed to a boy

in the lovely garnish of a boy.

why, all the boys in Venice follow him

the first boy, for a thousand dizcats

kind of boy, a little serubbed boy...

a prating hoy, that begged it

for that same scrubbed bo

for that same scrubued boy ...........
what, hoy? Come, eome, eider .....
but that I kiudle the boy thither ....

as boys and women ar

this but a peevish boy ...............

the boy is fair, of female fayour.

the boy is fair, of female favou

in this shepherd boy some lively

this boy is forest-born ...............

no more were broken than

All'swell, ii.

prond seorntul boy, unworthy this

to the wars, my boy, to the wars

twenty sueh rude boys might tend

a foolish idle boy, but, for all

pardoniug Rutland, my tra...

of mettle, a good boy, -by the

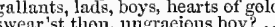

to laugh at gibing boys, and stand

mun by man, boy by boy, servant
o this boy lends mettle to us all

I have two boys scek Percy and thyself

ghall find no loy's play here ......

boy! Sir? What money is in $\mathrm{my}$

2HenryIV.

and the boy that $\mathbf{I}$ gave Falstaff

hath not the boy protited ...............

cood interpretation: there it is, boy..

sirrah, you bey, and Bardolph

rides the wild mare with the boys...................

ii. 8 e'er a scurvy young boy of them all

none, Ned, none; no, boys, none

for the boy, there is a good angel

now sir Jobn, a boy; and page

our watch-ivord was hem, boys.......

this same sober-blooded boy

any of these demure boys eome to...

eherish it, my boy; and noble offiees
boy, hristle thy courage up ..........

I ain boy to them all three

come bither, boy; ask me this.

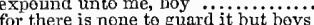

'tis certain, there's not a boy left $t$....

with wives, and boys, whose shou

your Frem boy, of such a boy

now, bey, de thou watch ................

therefore, dear hoy, mount on my ...

drow blood frem thee, my boy

from Talbot, my brave boy

to the peasant boys of France

my boy did drench his over mountili.

or he smiles, methink

we took him setting of boy's copies.2 Henry VI.

in whese time boys went to span-counter

if that the hastard boys of York.

ny surety will refuse the boys

in vain, thou speak'st, poor boy

3Henry VI.

so would I, faith, boy, to have the

fox is not so kind, my boy

why, Jack boy! ho hoy 1 ....

my boy shall fcteh the serivener

and yours, when you were boys ..Winter's Tale,

as to-day, and to be boy eternal

art thou my boy? Ay, my good. .

to say, this boy were like ne

go, play, boy, play: thy mother

take the boy to you; he so troubles

give me the boy; I am glad.....

hear the boy hence, be sliall not......

a boy? A daughter; and a goodly babe

fancies too weak for boys .

a boy, or a child, I wonder?...

why, boy, how is it. I would...

but look thee here, hoy .............

take thee here, boy

this is fair gold, boy, and "twill

we are lucky, boy; and to be so.....

eome. good boy, the next way home

for thee, fond boy, if I may ever....

come, boy; I am past more children

and so bave I, boy. So you have ....

my joungest boy, and yet my eldest care -

is troubled with unruly boys

in syracusa, boy, theu know'st ........

how goes the niyht, boy?

issue from the bosom of the boy...

thy minions, proud insulting boy..

ah, boy, it any life be left

my lieart, swcet boy, shall be thy...

peace wilful boy, or I will charm...

speak to thy mother, boy ...

scared the vin learus

thy fear, thou lily-livered boy? .......... - v.

thou unrevcrend boy, sir Robert's son. King Joht

a neble boy! who would net do........

till then, fair boy, will I not

make it subjeet to this boy $\ldots . . . . .$. .

and this boy liker in feature to his.

my boy a bastardl by my soul ...... and let me kiss my boy

ii. 1

did dissemble, granddam? Ay, hoy

a parlous boy: go to, you are too

come, eome, my bey, we will.

fools, and nnrespective boy

the boy is toolish, and I fear not him

should to thy ears not name my boys

wato weak ever to get a boy.......

and of a boy. Ay, ay, my liege (rep.)

among boys, grooms, and laequeys

a file of boys behind them ............

virgins and boys, mid-age and wrinkled -

if my lord get a boy of you ...........

and doubt thou not, brave boy

good boy, wink at me, and say. Timon of Athens, iii.

my boy Mreareius approaches

with spits, and boys with stones.

than boys pursning summer

and my young boy hatio an aspect

that brought you forth this boy.......
boy,-My lord. Know'st thou not any

it's ene e'clock, boy, is't
BOY-gpeak thou, boy; per
this boy, that cannit tell

name not the god, thou boy cf tears.

boy! false hound! if you have

alone I did it. Boy $! \ldots \ldots \ldots$.................

boy! Lucius! Fast aslcep? ............

I pry stind aside: Caius ligarius ....

yes, briug me word, boy $\ldots \ldots . .$.
hitrk, boy! what noise is that?

sure, the boy heard me
bear with me, sood boy

it does, my boy; $\mathbf{I}$ trouble thee

thy leadcn mace upon my boy ......

Varro! Claudius! .... - iv

'tis to be chids and wcinches .....

stood pretty dimpled boys, like smilin

then the boy shall sing; the holding

like boys unte a muss ...........

he calls me boy; and chides, as he had

to the Roman boy slie hath sold me.

young beys and girls are level now ..

some squeaking Cleopatra boy my

stoop, boys; this gate instructs ...
$O$ boy's, this story the world may

these boys know little, they are sons

divineness no elder than

beys, bid him welcome $\dddot{2} \ldots \ldots \ldots .$.
hark, boys. Great men, that had

boys, well go dress our bunt .......

blazon'st in these two prinecly boys.

a most rarc boy, of melaneholy

he was a queen's son, boys

the boy hath taught us manly duties

boy, he is preferred by thee to us ...

away, boy, from the troops

an old man, and two boys.

two boys, an old man twice a boy...

my boy a Briton born

boy, thou hast looked thyscif

nor whcrefore, to say, live, boy $\ldots .$.
the boy disdains me, he leaves me

on the truth of boys aud girls .......

what wouldst theu, boy? I I love this boy revived from deatl?

give answer to this boy

my boys, there was our erro

what, villain boy ! barr'st me.

ay, boy, grow ye so brave

there sjeak, and strike, brave boys ..

you shall know, my boys............

remember, boys, I poured forth tear

as for thee, boy, go, get thee.

come, boy, and go with me.

she loves thee, boy, too weit..

open them, boy; but thou art deeper

and kneel sweet boy, the Romau

lesson, then? boy, wbat say you?

ny, boy shall earry from me.

no, boy, not so; 1 th teach thee

ye sarguine, when this boy was got

sir boy now let lne w-liearted boys

here, boy, to Pallas: here, to Mereury

against the wind: to it, lo
good boy in Virgo's lap ....

good hoy in virgo's lap

to saye my boy, to nourish

come hither, boy, eome, come

[Col.-Knt.] why my boy? Why?

why no, boy; nothing can be made

the differcnee, my boy, hetween.
dost thou eall me fool, bey?......

in danger of kibes? $\mathrm{Ay}$, boy ..........

loyal and natural boy, I'll work

with you, goodman boy, if you please.

true, $\mathrm{my}$ good hoy: come, bring

but go in: in, boy; go first

a boy's love, or a where's anth

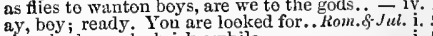

elicerly, boys; be brisk awhile

feteh me my rapier, boy ..............

you are a sauey hoy; is't so, indecd.

boy, this shall not cxeuse the injuries

give ine thy toreh, bos; hence.........

the boy gives warning, something

proveke me? then have at thee, toy

hitho, ho, ho, boy! come, bird, eome

do the boys carry it away? ...........

ii.
iii.
iii.
iii.
iv.
iv.
iv.
y.

iii. 3

iii. 6

iii. 6

iv. $\frac{2}{2}$

iv. 2

iv.

v. 3

$s, \mathrm{i}$.

ii. 3

iii.

iii. 2

1

iv. 1

v. 1

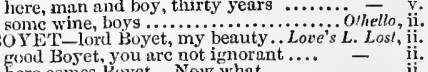

here eomes boyct. Now what

Hoyet, you can produce acquittauces 
BOYET-Boyet is disposed. Boyet, you can carve ............ Fon stijl wrangle witl her, B thy- news, Boyut? ......... know their minds, Boyet. Boyet. prepure; I will awny to-nigit

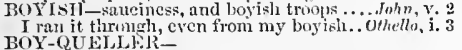

cotne, conte, thou boy-quet

of Brabant, and of Orlean

of Brabant, and of Brlcans $\dddot{3}$.........

Antomy duke of Bralant

BRABANTIO-signior Brabantio (rep.).. Othello, $\mathrm{i}$.

most grave Rrahantio, in simgle and

liere comes Brabintio, and the valiant...

Brabantio, take up this mingled ........
BRABBLE-in yrivate brable .. Terelfic

.

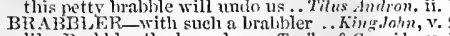

like Prabbler the hound .... Troilas

BRACL-but you, my brace of lords.... T'mpe
as will utter a brinee of worts .... Lone's L.

as will utter a braee of wrorts .... Lone's L. Lost. $\mathrm{v}$.

a brace of draymen bid God speed .. Richard II. i.

like a lirace of greylomis
with a braee of conrtezans

Tou lirace of warlike broth

twolit witl a brace of harlot.

discoser a lurace of unm

so, here comes a braee...........

I conld myself take up a brace $\ldots . .$. - iii.

your braee of unprizeable estion

have lost a bruee of kinsmen ...Rom

it stands not in such warlike brace....... Othello, i. 3
withort are a brace of Cyprus gallants .
it. 3

BRACED-a drum is ready braced ... Ki
BRACELF'T-hracelets of thy hair...Mii

with amber braeelets

lracelet, neeklaee-ambic
shnc-tye, bracelct, horn-r

this her braclet, $(O$ emning

the liraeelet of the truest prineess
SR AClI-brach Nierriman...Tumin

with the deep-mouthed hrach

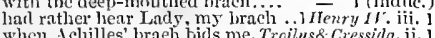

when Achilles' braeh bids me. Troil
when Lady, the hrach, may stand.

houml or spaniel, brach, or lym
BRACY - here was sir John Bracy

BRAG-thou shalt not live to brag.

liave hearl him brag to you

the child brags in her belly

C:esar's tlurasonieal brag.

is left this vault to hrag

to hrag, and stamp, and swear............ Matheth, ii.

for trive me, God, that I do brag thus..

were some of your brags dismountert

to brig unto them, thus I did

he brags lis serviee..............

either nur brngs were cracked...

if fortune brag of two she loved

Tilus Andron, i. 2

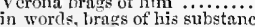

RRAGGARDISAI-what braggardism.Two $\bar{G}$.of 7 . ii. 4

ERAGGART-apes, braggarts, Jacks. Much -ido, v. as liramgarts do their blade

the braggart, the hedge-priest........... Love's L. Lost, r. see how mueh I was a braggart ... Mer. of len. iti. 2 and braggart with my tongue

Monry $r$. ii.

Gloraggart vile 7 ..................

by this mnholy braggart.

you reverend braggart, we'li teach you ... Lear, ii. 2

a liraggart, a rogue, a rillain .. Romeo \& Juliot, ifi. I
BRAGGED-the knave bragged ...Merry Wives, iii.

the whip nf your bragged progeny ..Coriolanus i. 8

like a fine bragering youth.

raw trieks of these bragsing $\mathrm{J}_{a c}$

the lrow nf liragging horro

King John, v.

like the bragging Spaniard ...

linder the correction of bragging........... Henry $\mathrm{F}$. v. 2

BRAfrLESS-yet bragless let it be. Trnil. \& Cres. v. io

BRAID-Frenchmen are so braid

BRAID_t $t$ would brain yourself..

my old braiu is troublei

eure tlyy lirains, now useless

lis Page any brains?

nor nowhere else, but in soul hrain

out of your hushand 's brai
have I'laid my brain in the

when liver, brain, heart ..........
till his brains turn ont o' the toe
I wear not motley in my brain Tuelflin Night, i.

that has no more brain than a stone

till I see his bruins

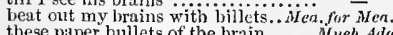

these paper bullets of the hrain

if a man will be beaten with brains... -

have such secthing hrains ..... Min. N.'s Rreqm, v.
a mint of plurases in Jis brain .... Love's L. Lost, $\mathrm{i}$.
BR. AIN-arta entirely keep the brain.. Love's L. L. iv. 3
Jives not alone iminumes in the brain - iv. Worm wood trom your fruitful brain

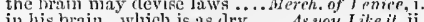
in his hrain-which is as dry .....

with pure love, and troubled brain..

woman's gentle lirain could not drop

his hrains are torf cit to the next

thic blimk and

the bastard lorains with these......

here is more matter tor a lot brain

my dull brain was wrought.

and dashed the lirains uut the warder of the hrain, shail

p ocecting from the heat oppressed brain

the written troubles of the brain

ant his pure brain (which sove ..... King $\bar{J}_{o h n}, \mathrm{v}$.

I conld brain him with his lady's...1 Henry I $V^{\prime}$ ii

and perturbation of the brain.....

rock his brains in eradle

it aseends me into the brain...

their brains with eare, their bones
but in gross brain little wots

a quagmire of your mingled brain

these conjurations in her brait...

my brain, more busy than

steel, to scar me to the brain ........ Richerd III.
beside forfeiting our own brains. Henry VIII. (y)

commotion is in his brain.

your brain, and every tunction

a young conception in my brain... Troil. $\bar{g}_{\text {Cress, }}$ iij.

were his brain as barren

no more brain than I have

it he knoek out cither of your lirains

and your brain so tempered.

no aritlmetie but her brain to set.
Ifector has knocked out his brains

little brain; these two may (rep.)
he has not so much brain as ear-wax

he has not so much brain as ear-wax

with it beat out his braius

scorn'dst our brain's filow

your eonversation would infect my bra

but yet a brain, that leacis my 1

enre draws nu the brains of men ... Jathus Ca

when from wis bram, and it gro

diminution in our eaptain's brain

her beanty and her brain go ust.....

that bears all down with her brain

which the brain unkes of tume

as madmen tourue, and brain not....

purse and brain both cmpty: the brain
the liver, heart, and brain of Britain

mine Italia.s brain 'gan in your.

beat forth our brains, and malk

it' a man's brains were in lis heels

lest my brniu turn, and the defieient...

bave a surgeon, I am cut to the bruins

through lovers' brains, and then ....

whieh are the children of an
youth with unsiuffud brain ...

dash out my desperate brains? .......

the book and volume of my brain

or else this brain of mine liuuts not

about my brain! humph! I have heard

whereos his brains still beating

sleep roek thy brain; and never come

O heat, dry up my brins................

could make a prologie to my brains

it plucks ont brains and all

and unhapyy brains for drinking .........

hadst shut up in thy lrain some horrible

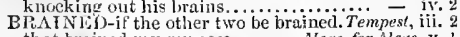

that brained my purpose ......... Neas. for Neas.

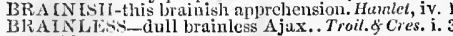
BRAIN-PANBRA BN-SICK -in brain-siek nien...1 Henry $r i$ iv. the bedlain brain-sick duchess

her brain-gick raptures cannot ...Trnil. \& C Cres. ii.

to feed his lirain-sick nits ....... Titus Andronicus, y.

RAKE-from brakes [Col,-breaks] of vice

$[\mathrm{Col}, \mathrm{K} n \mathrm{t}$. ice $]$
hicle me in the brakes, and leave ... Mid. N. Dr. ii.

this hawthorn brake our tyring-house - iii.

enter in to that brake; and so

and entered in a brake: when I aid... - iii. 2

his passion ne'er brake into extremity . Com.of Er. v.
tirlings of this broil brake off our ..... Hertry $1 \%$.

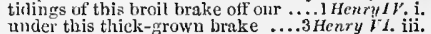

BRAKE-and even here brake off.. Richaral 11I. iii. 7
and the ronglh brake that virtue.... Henry VIII. i. 2 EIR AKENBƯRT-

please your worship, Brakenbury .. Richard III. i.

O Brakenbury, 1 have done these tliings -

Bir Robert Brakeubury ..............

BRAN-sup witl water and bran...Mea. forMea. iv. 3 finst a week witb bran and water... Lore's L. Lost, i. . and leave me but the aud bran! .. T'roilns Cres. i. neal and bran together he throws..... ili. mature hatl meal aud bran ........ Cymbetine, iv. that violates the smallest branch. Love's L. Lost, i. with any branch or imnere of thy sta te. All's Well, "Which eannot choose but branch ... Winter's Tale, a branel and parcel of minc oath.. Com, of Eir. one flrurishing branch of his most . Richard I in every branch truly demonstrative...Henry $V$. ii. as a brancl and member of this royalty - v. no hoineful branch niay sprug ...... - iii. adjudqed an olive brancle............. Whone top branch ovenpeercd Jove's..

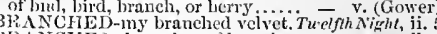
BRANCHES-branches of learning. Mer. of I $F$ en. ii. 2 or seven filir branches, springing ..... Richard $I I . \mathrm{i}$. 2 some of those branches by thie destinies

droops lis sauless branches.......... Henry why grow the branehes, wheu .......Richard III. ii. 2 reacth his branehes to all the plains .. - v. be lopped branehes (rep.) ..Cymbetine, v. 4 (scroll) aud thy lopped branelies poiut $\ldots \ldots . .$.
bare of her two hrancbes? BiAd an act hath three branches ......... Hamlet, y. these petty brands, that caluniny. Winter's Tale, ii. singel off with brands of fire.. Comedy of Errors, v.
the senseless brands will symathize..Rick.II. v. as flid the fital brand Alther.... a brand to the end o' the world wutting to my house the brand .....̈. eome, brands, ho, fire-brands......... why hrand they us with base? .............. Lear, i. 2 brands the harlot evon here................mamlet, iv. BRANDED-shonld be brande.............ham III. iv. 4 mever yet branded with sus]icion. Wenry Virl, iil. I AANDISH-nerer brandish more.. Richard 1 . iv. brandish anything but my bottle...2 IIenry $1 r^{\prime}$ i. $\mathrm{BRANDISIIED-his} \mathrm{brandished} \mathrm{stecl} \mathrm{...} \mathrm{Nacleth,} \mathrm{i}$. 2 bris brandished sword did blind men . I Henry VI. $\mathrm{i}$. his bloody sword he brandished over me - iv. Brakcnbury, and sir William Brandon $-\nabla$ v. BRASS-with characters of brass....... Mea. for Mea ctu any face of brass hota longer. Love's L. Lost

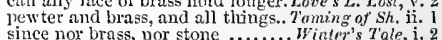
Wcre brass impregnable.............. Richard it. iii. like the brass eannon; let the brow... brass, cur! thou dammed (rep.)....... should hold up ligh in lons.. seull thy brass voice through .......... - i. nor wajts of beaten brass............... Julius Casar, i. lind them in brass, having called .... Pericles, iii. Bll ASSY from brassy bosoms ...Mer. of I'enice, iv. ndventure tis save this brat's life..... fur as thy brat has bcen east ......... - iii.

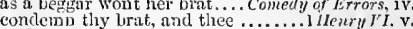
as for the brat of this aceursed........ 3 Ilenry VI. i.

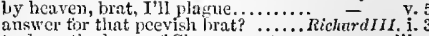
folluw him, arainst as liruts....... Coriolamus, iv. no more d cpendency but brats........ Cymbeline, ii. 3 BRAVE -a brave vessel ................. Tempest, i. my braxe splirit!......

the duke of Alilon, and his brave....... you are geutlemen of brave uettle......

o brave ranster! lead the way!.........

he were a brave monster, inded......... - iii.

he has brare nitensil

and bring thee forth brive brood

this will prove a brave kinglom to me! = iii.

thesc be brave splrit, indeedi

and hrave master shoe-tie. Measure for $\mathrm{H}_{\mathrm{c}}$ asure, iv. 3 'li devise thee brave puuishments ...Much delc, v. O biave turch! could not a worm...Mid. N.Dr. jii. theretire brave conquerors!....... Love's $L$. Lost, i. I
full merrily hath this brave minage 


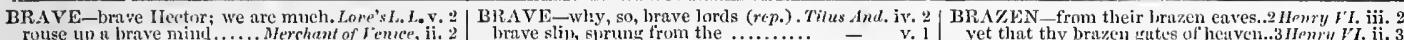

rouse up a brave mind....... Nerchant of rence, if. a bruve man! he writes brave (rep.)

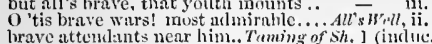

lorave atteudants near him.. Ttming

braved many men; brave not me.

Winter's Trale, iv

amity too, of your brave father..... - y.

hail, brave friend! saly to the king

well met, lirire sustri

acbeth, i.

darest thou brave a noblenian

silken wanton brave our fields

there end thy brave, and turn thy fire

latave soldier, parrlon me, that an

as when brave Gaunt, thy tinther.

Ilarry Perey, ankl bave A rehilnt
by the loril, I'll be a brive judge

rare words! mave world!

If die, brave death, when prinees

for Worms, hrave Perey

a rascal, $t$ ir brave ine

his brave thet witl silken ............. ${ }^{r}$, iii. (chorus)

O brave spirit! Via! les eanx $\ldots . .$.
take it, brave York: now, soldiers

give me crowns, brave erowns....

le plus lirave, valiant, et
the most brave, valorons

in mich array (loave soldier)

calier the brave loril Pouton...

this is a brave night to cool a eourteran .. Lear, iji.

Romeo, brave AIcrentio's dend... Reme

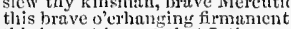

this is most hrave! that I, the son

adieu, brave Moor! use Desdenon:

to throw out onr eyes for brave Othella

O brave Inga, honest, and just, that liast

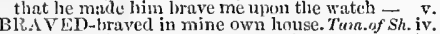

hast loratel many men (repeated)...

and my state is loraver ............... King John, iv.

one he loves; braved by his brother..Jul. Casar, iv.

BRAVELY-bravely the figure of this. Terapest, iii.

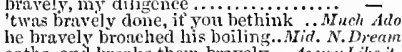

he bravely bronched his boiling.. Mid. N. Dreat

steal away bravely. I shall stay.......

and for our flight. Bravely, eoragio

revel at as bravely as the best.... Taming of Sh.

she came to it, (bravely conficsed.. Winter's Tale,

Obravel came we oft

eorne brother John, full bravely....... Kins John

fur to serve hravely, is to come (rep.).2 HenryIV

the Erench are bravely in their.

takes npon her bravely at first dasi... 1 Henry $r i$.

been dry, and bravely marching part. .2 Henry $J I$. ir

join bravely, let us to't pell-1uell .. Richard III.

now where's the Bast:urd's braves.

orave Burgundy, undonbted hope

take merey on brave 'Talbot's soul

it he be dead, brave Talbot.

force fom Talbot, my bra

weleome, lirave eurl, in to our territories

brave seers of England, pillars.

no better sign ot a brive mind

be brave thew; for your eaptain is i...

and clifford, are ye so breve?

wilt brave me with these saucy (rep.)

to the stake, my two brave bears ....

with thy lorave bearing....

brave warriors, Clifford and.

where your brave father breathed....

that thou, brave earl of Mrareh

why, then it sorts, brave warriors....
welcome, my lord, to this brave town

weleome, brave Warwiek

is Lewis so brave? belike, he thinks

thanks, brave Montgom
eome on, brave soldiers

and thou, brave Oxford

brave warriors, march amain

O brave young prinee! thy famous....

brave followers, yonder stands

forgot already that brave prinee..... Ric

when traitors brave the field

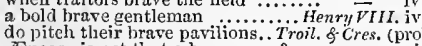

Rineas: is not that a brave man?...

a brave man, niece; O brave Heetor!

why this is brave now ...............

I presume, brave Hector would not lose

foot were on brave Hector's breast

this brave shall oft make thee......

welcome, brave Heetor; welcom

and doubt thou not, brave boy ......

little gold of late, brave Timon

ad any think, brave death outweigh

if any think, brave death outweighs..

you have done a brave deed

are yon so brave? In have you talked

tbat's my brave boy...

great Ajax bravely beat dowit him

thou diest as bravely as Titinius.

Cytherea! how bravely thou becomest. Cymbeline

a pieee of work so bravely don

sir; see you, do it bravely ..... Titus .

$\mathrm{BRAVER}$ - his more braver daughter

a braver place in my heart's love ... Henry $1 \mathrm{~V}$.

I do wot think, a braver gentleman

a braver soldier never eonehe

a braver warrior, lives not this da.... Titus And.
BRAVERY - and witless bravery...Mea. for Afea.

his bravery is not on my cost ..... As you Like it, ii. 7
double elange of bravery.... Taming of shrew. iv.

come down with fearful bravery ... Julius Cas

ii. 2 the natural bravery of your isle ....

BRA VEST-diseipled of the bravest.... All's Wel

the bravest questant slinink

from this most bravest vessel

$B R A$ VING-eontinue a braving war ${ }^{2}$.

braving arms against thy sovereigu.. Michord 11 . $\mathrm{ii}$.

BRAWL-adevil in private brawl. Tuelfh Night, iii. 4

but with thy brawls thou bast...inid. N.'sDream, ii.

win your love with a French brawl. Love's 1.L.

the brook that brawls along this...As you Like it,
I'll rail and brawl, and with... Taning of Sheree,

like a shrew, you first begin to brawl. Com.of Er. iv.

as the times do brawl

this will grow to a brawl anon......... $y$, ii. 4
in brawl ridiculous, the name of. Heary in brawl ridiculous, the name of. Herry
this brawl to-day grown to this faction.l Hen. (eho.) first begin to braw]; the secret...... Ficherd III. i. 3

a matter of brawl betwixt my unele.

three civil brawls [Kut.-broils] .. Romeo of $J u$

meet, we shall not 'seape a brawl ....

for your rude brawls doth lie a bleeding

those whom this vile brawl distracted.... Othello,

BRA WLED-brawled down the flinty ribs. $\overline{J_{o}} h n$, ii.

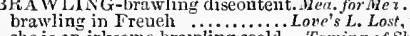

she is an irksome brawling scold .. Taming of Sh. i. 2

kept waking, and with brawling fed...

sir John? what, are you brawling here.2 2 cn.IV . i.
O hrawling love! O loving hate.. Romeo \&.Juliel, i. 1 BRAWN-and that damned brawn..I Henry IV. ii. 4

and Harry Monmonth's brawn

hut this withered brawn...... T. Th

the brawns of Ilereules; but his ..... Cymbeline, iv.

quateh-buttock, the brawn-buttock ..All's $W_{e l l}$. ii. 2

BRAY - trumpets' dreadful bray.

ichard Hanlet, i. 4

BRAXED-brayed with minstrelsy. Timon of Ath.ii.

BRAYING -shall braying trumpets. King John, iti.
BRAZED-that now I nm brazed to it .... Lear, i.

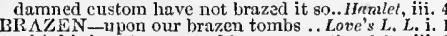

with bis iron tongue and brazen mouth...Jnhn, iti. 3

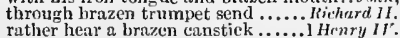

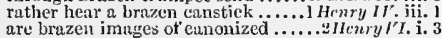
wert thou environed witla a lrazen wall

and split thy brazen pilie.... Iroilus \& Cressidn, jiv.

why nuch daily cast of brazci caunon .. Ilenalet, $\mathrm{i}$.

BRIZEN-kACE-

Well sidil, brazen-faee; hold it ont. Merry Wires, iv. 2

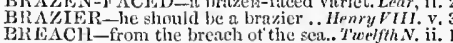

as honour, withont breach of honour. Love's L. L. ij.

to excuse your breueh of promise. Concedy of Wr

Waclueth, il. 3

to come off the breach with his pike.2 Henry IV. ii.

once more unto the breach, denr friends

on, on! to the lirewch, to the breaels.

before breach of the king's laws ..

which were the breach was...... Henry II. $_{\text {ii. }}$

danger for the breach of law........2 Henry VI, ii. 4

a breaeh, that craves a quick

no apparent likelihood of breaeh .. Richard I1I. il. 2

aboded the sudden breach on't....... Herery VIII. $\mathrm{i}$.

our breash of claty, this way

however, yet there's no great breach $\overline{\text { ive }}$ iv.

tainted with the breach of hers. Cymbeline, ini. 4 (let.)

the breaeh of eustom is breach of all..

more honoured in the breach than..... Hamlet, $\mathrm{i}$.

scapes i' the imminent deadly breaeb..... Othello, $\mathbf{i}$.

between him and my lord an unkind breach - iv.

of breaches, ambu seadoes, spanish... Rom. \& Jul. i. iL LD-maid as ever broke bread. is more to bread than stone .......̈Hea. for Mca. j. she smelt brown bread and garlick.. that work for bread mpon Athenian. Mid.N.Dr. iii. as the touch of holy bread.......... As youlike it, iii. the bitter bread of banishme

that jade hath eat bread

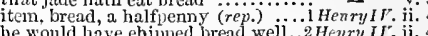
he wonld have ehilped bread well..2 Henry I $F_{\text {. ii. }}$ want ye eorn for bread?............ Henry ${ }^{\prime} 7$. iii. parts bread with him ............. Timon of Alhens, i. be glad of bread, and ber for it

eorn, to make your needy bread

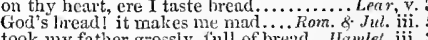
took my father grossly, rull of bread... Hamlet, iii.
buys herself lircad and elothes ........ Otkello, iv. call me pantler, and bread-ehipper..2 HenryIV.ii.

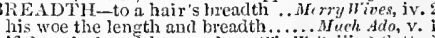
if there be breadth enough . Ali is Well, iii. 2 (letter) then she bears some breuth h?.Comedy of Errors, iii. owerl the breadth of all this isle .... King John, iv. it is as broad as it hath breaditl......Ant. \& Cleo. ii. tha: the longth and brendth of a yair. . Iramelet, $y$.
thempest, ii. if thou dost break her virgin knot

my eliarms I'll break.

I'll break my stafi .................

now can I break my first

I am to break with thee

which he will break, as easily

whieh he will break, as eas
for lovers break not hour's

they will break their hearts but... Nerry $\bar{W}$

and I would not break witl her

loreak their talk, mistress Quickly ... .
if one break, the other will hold (rep.). Ticelfth

and then to break promise with him

or we break the sinews of our plo

and the run trom breaks of ice. Mea. for M

break of thy song, and has

dis paved beak would break

will brenk with her, and with

after, to her father will I break

and instantly break with you of it...

to break with him about it ....

for my life, to break with him a

you break jests as braggarts do

witlt fair Aggle break his taith

he will seem to break loose...........

liere will I rest me, till the break of day

now until the break of day.

hreak it, and not lreak my trothi... Live se $\bar{L}_{\text {L. Lost, }}$

article, my liese, yourelf must break

and he, that breaks them in the leatst

why, will shall break

break up this capon

break the neck of the wax ........... 


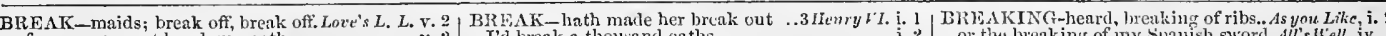

ah. would she break from leenec...

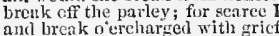

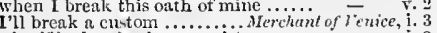

who if he break, thou may

anll break o'treharged with gricf ....

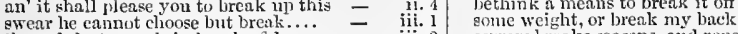

those dnlleet somuds in break of day

Will before break of day be herc.

sorrow treaks seasons, and reposing. Richur d $1 I X$.

their heads that break his law

wound of malice slould brealk oit ....

will never nure break fnith advisedls $\bar{L}$ ike it, $\mathrm{i}$.

and when I break that oath, let me.

you break not sanctuary in seizing him -

you break no privilege nor elarter

gainst the lady will suddenly bre

brave oaths, and breaks them brively

on one side, breaks lis statt'........

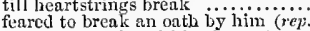

break an hour's proi

iii. 4 darkness breaks within the east.

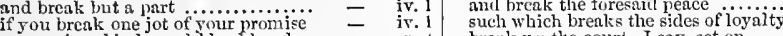

such which brenks the sides of loyaity
break vj, the court; I say, set on

the approach of this wild

go, hreak among the pres
livelong day breaks seurr
as a sailor breaks a biscuit

oer the ice that you should break

with sobs, aud break my licart

will yout go? you will break o.t.

but a plague break thy neck
but must not break my baek

I shall not break your bidding..........

if you break the ice, and do thi

my heart, concealing it, will break

to break a jest upon the eon

break up the seals, and read

but must not break my baek
will knit and break religion

anon did this breal from her .........

and break a foul gap into the

will knit and brenk religions
within this mile break torth

will brcak the back of man

to Athens, go, break open shops.
insolence shall break his wind

to break the heart of generosity....

we'll break our walls, rather th

do not break off so, for we mnas
or I shall break that merry seo

whieh will in time break ope

which looks witli us to break bis neck

or I will break thy pate across $\ldots . .$.
breaks the pale, and feeds from liome

break it withl a deep-divorcing vow?

none enter, lest I break your pate

well, I'll break in; go borrow

break out to bitterest enmity

that, which shall break his neck

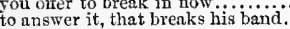

bond and privilege of nature, break
he returning to break our neeks..

I will not break away...................

that made you break this enterprize

doth not the day break here .......

if he do break the smallest particle

hreak un the senate till anotic....

fret, till your proud heart break

and break it to our hope ................ $\overline{\text { sold }}$, $\mathrm{v}$.

and fools break of your eonference..King John, ii.
that still breaks the pate of faitl ....

sinee kings break faith .............

Fgyptinu fetters I must break.

I shall break the eause of our expedie

whiteh break: themsel ves in s

if swift thlought break it not .......
dried with grief, will break to powder

did break the name of Antony

false housewite Fortune break her wheel -

Obrenk! O break! As sweet
wherefore brenks that sigh

to break it with a fearful dreani.......

might break out, and swear lae'
thy noble heart to lureak ... T

cattle break their neeks...........

and nephew, break the parle

who slumus not to break one .................

sought to make us break our vow

or the hreaking of iny spanish swortl. AUl's Well, iv.

the almy lrealking, my hulstrand hies

(ly

break any breaking here, and I'il break

it secms, thou wantest breaking.......

late tossiur on the breaking sens . Richard II. iij. by breaking throuth the till .........1 HenryIV, i. the horsemen offi from breaking in .... Henry $b$ and, lircaking in, were hy the swords.3

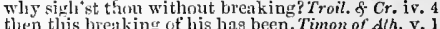
then the breathing of his hag been. Thmon of Anh. v. mitture for the violeut breaking out.Coriolanus, iv.
breaking his nath and resolntion .... did willikold our breaking forth. Antony 8 - Cleo. iii. 6

breaking forth in rimk and not to be...... Lear, $\dot{i}$. 4

BREAK-NECK - to me a break-neck... Winter's T. i.

most puthetical break-promise ...As you Like it, ip. 1 IIEAK'ST-1,reak'st thy instrument.Jul.Casar, iv. $\mathrm{s}$ BREAST-VOW - that daily break-vorw ..... Fohn, ii.

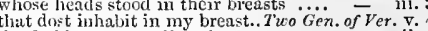
the fool has an excelient breast .. Twelf ih Night, ii. this erawling serenent from my breast. Mi id.N. D. ii. broached his boiling bloody breast

come, blade, my brenst imbrue ........

all about the breast: a eandle, bo!

a the base ground, with obedjent breast

v. 2

is from iny breast the innocent.. Winter's Tole, iiij.

if ny breast had not been made.. Comedy of Er.

$O$, my breast, thy hope ends

due to some single breast.

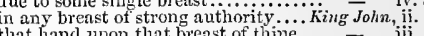

the mood of a much troubled breast.. $=$ iv.

a bold spirit in a loyal brenst.

eold cowardiee in noble breasts......

truth hath a quiet lreast

keep thy sorrow in my breast...

a thousand spirits in one breast.
his month, ours from our breast....

conjure from the breast of civil ......

from the breast of Bolingbroke ....2 IIfenry IV. iv. $I V$ iv.

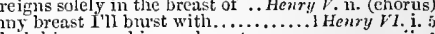

lock his counsel in iny breast...

engenders thunder in his sreast.......

thyself laast given her woetui breast..

beget new cournge in our breast
when thou suck'dst her breast

sharp dissension in my breast.....

eherot in your hreasts

iHenry $v 1$. Yii. 1

they break their faith to $\mathrm{Gol}$

head, shail break into corruption
weeping made you break the story

the door, or 1 will break it open......

und break the neck of that proud man ${ }^{-}$to break in to this woman's mood .... HenryIV. $\mathrm{i}$.

to break the pate of thee
further afoot, I sball break my wind

in faith, r'll break thy little

oftentimes brenks forth in strange....
and, withnl, break with your wives

and, withal, break with your
ere break the smallest parcel

I pray God, my girdle break .....................

of office did I break in Richard's time
breaks like a fire out of his keeper's..2 HenryIr

shall break into corruption ....

not to break peace, or any braneh of it

not to break peace, or any braneh of
will you thus break your faith....

or other break some gallowil break out
life looks through, and will breat

my officers, break my decrees .........

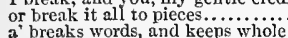

a breaks words, and keens whole............
their howls confused do break the clouds -

threak up their drowsy grave ........

break out into a secondl eourse

nor never break for urging $\ldots \ldots . . . . .$.
Katharine, break thy mind to me
break up the gates, I'll be your .......

contumeliously should break the peaee

and break our minds at larg

should they first break in ...............

will at last break out into a flame.

gond greybeard? break a la

lest it break thy neek with following

but this heart shall break.

it is, and my heart breaks at it

lanee of justice hurt tess breaks
break, heart; $I$ yr'y thee, break

Erudge break to new mutiny... Romeo
light through yonder window breaks?

obreak, my heart! poor bankrupt (rep.)

the break of day disguised from heuee

peaee, break thee off; look, where it ....

break we our watch up; and, by ny ädvice

break all the spokes and fellies .............

ealls me villain? breaks my pate aero
whit we do determine, oft we break

Whit we do determine, oft we bre
if sle should break it now..............

his head lie on my throhbing brea
this breast from liarbouring fuul.

that fire all my breast ..............3 Henry ${ }^{2}$

tugging to be victors, breast to breast

my sifhing breast shall be thy funeral
your fathers' bosoms, split nyy breast

infuse his breast with magnaninnity..

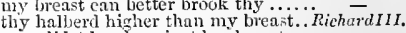

oflee didst bend a gainst her breas
please to hide in this true breast

cven so thy breast encloseth

ween so oft? and beat your

another s!read on lis breast.

Henry vIII

to tremble the retion of ny breast...

lie has a loyal lreast, for you have seen

ure ail uyan brerst, tor you have secu -

for sal upon her patient' brease .. Troll, g. Cres.

unmensurable, and infinite breast. Timon of $A / h$. iv. 3

the breasts of Ileculia, when slie ..... Coriolanus, i. a

to ease his breast with panting ...... = ii.

break not your sleeps for that............ o thello, iv.

or else break out in peevish jealousie.......

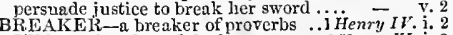

I'li be no breaker of the law ........ Herry $V$

BREAKFAST -relation for a breakfast. Tempest, $\forall$. 1

be mevded with a breakfast . Two Gen.of

to my bouse to breakfast .......... Merry Wives, iii. 3

go, make ready breakfast; love thy.

eat his breakfast on the lip of a lion

a sorrs breakfast on the lip of a lion 2 - iii. 7

a solry breakfast for my lord .........2 Henryy

to breakfast, with what appetite ...Henry VIIL. iii.

be at a break fast of enemies.... Timon

that breaks a stick of Gloster's gro
and glosts break up their graves

and ghosts break up their graves ....
my lord, break we off; wc know your

and so break off; the day is almost

from the king, or we'll all break in
my burdened heart would break

and do good, break open the gaols...

boars roasted whole at a breakffist...Ant.

which is oot worth a breakfast ........ Pericles, iv.

let them brenle his son-in-law's house

BIEAKING-iu breaking fitit

udden breaking out of mirth.... Love's $L$. Lost,

to break into my garde

so much I hate a breaking eause ....

blood ont of thy eountry's breast

my remission lies in Volcian breasts - iv.

this breast of mine hatls buried....Julius Casar, i. 2

and here my naked breast............ $\overline{-}$ iv. 3 dost thou not see my baby at my breast

here, on her breast, there is .......... Cymbelin

on her left breast a mole ............ Cymbetin

this tablet lay uyon his breast .... - $\quad$ v. 4

whose naked breast stepped before .. Titus - nd. iii. his loving breast thy pillow ........... all comfort in your snered breast

by the o'er-fed breast of this nust $t . .$. iii. (Gower) lie heavy in my breast ............ Romeo \& Juliet, $i$.

closed in mp breast, by some vile .....

thine eyes, peace in thy brenst.........

piercing steel at bold Mlerentio's breast 
BREAST-needs be treason in my breast. Itamlet, iji. 2 (BREATIL-so long as brenth did last..2 IIenry $V I$. i. I and tilting one ut other's breast .......... othello, ii.

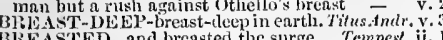
BlLEASTED-and breasted the surge . Tempest, ii. BRE ASTTNG-breasting the lofty. Henry Y. ini. (chn.) BREASTPLATE-stronger breastplate.2 Min. I. iii. their words are natural breath.

gentle breath of yours

Tu.........

incre's my mother's hrenth

in respect of her breath $\ldots \ldots \ldots \ldots \ldots$.......

and so sweet a breath to sing .... Twelfh $\overrightarrow{\text { Night }}$, ii.

a contagions breath

fy away, fly away, breath ........ - ii. 4 (song)

our very pastime, tired out of brenth $-\bar{v}$ iii. 4

and a scandalous'breath to full ou him

and words from breath, as there is sense

if her breath were as terrible as her...Muehtdo, ii.

that with thy breath hast killed

fonl breath, and foul breath is noisome $\vec{\nabla} \mathrm{y}$.

such dulcet and harmonious breath. $M$

$O, I$ am out of breath, in this fond

lay breath so bitter my dear

mockers waste more idle breath

the endeavour of this present breath... Love's $L$ iv.

vows are but breath, and brcath .01 - iv. 3 (ver.)
wished himself' the heaven's breatb - iv. 3 (ver.

that charge their breath against us .

with your sweet breatlis puffed out
of thy royal sweet breath as will

of thy royal sweet breath as will
own part, I breathe free breath

own part, 1 breathe free

in the converse of breath $\ldots \ldots . . . \ldots . . .3$.

lips, parted with sugar breath........

than any that draws breath in Italy

and breaths that I defied not

or sweet breaths, will, for my

made a moan of her last breath wanton with her breath.... Taming of Sh. 2 (induc.) heat outwardly, or breath within. Winter's Tale, iii. 2

Juno's eyes, or Cytherea's breath

5our first queen's again in breath....

and could put breath into his

they'll suck our breath, or pinch .... Com. of $E$ r

when the sweet breath of flattery

to the hot breath of Spain...

rnn this humour out of breath

how hast thon lost thy breath.

who, almost dead for breath.

that the heaven's breath smcli

of deeds too cold breath gives

pay his breath to time

give them all breath, those clamorons.....

alundance of superflnous breath ....

is but the vain breath of a common..

can task the free breath of a sacred

the latest breath, that gave the

the vile prison of afflicted breath

and stop this gap of lreath

for even the breath of what

nay, one quiet breath of rest .......

but with my breath I can revive

this confine of blood and breath.......

that sweet breath which was em

it was my breath that blew this......

the name of right, with holy breath first kindled the dead.

whose black contagious breath already

young, and cheerly drawing brcath.

my tongue from breathing native breath -

such is the breath of kings

thy kingdom cannot huy my breatli

nor strive not with your breath

sighed my English hreath in foreign

the breath of worldly men eannot...

allowing him a breath, a

pays death servile breath ............

by subject and inferior breath..

with mine own breath release all ....

giving him breath, the traitor lives

restrain thcir breath on some......

O for breath to ntter what is like

might draw short breath to day.

I was down, and out of breath

he sure means brevity in breath
true bed, and yielder up of breati.
by his gates of breath there lies...

and found no course of breatl within

and found no course of breath within

a night is but small breath ............
hold hard the breath, and bend up..
subjected to the breath of every ivol

my fading breatl permit ..............

pause, and take thy breatl $\ldots$ thy....... murder thy breath in middle of a word. $R$
give me some brcath, sone little pause

give me some brctth, sonc little palse

a breath, a bublilc; a queen in jest

despairing, yicld thy breath

kiss you twenty with a breatlin

your brenth with full consent

digestion sake, an after-dinner

than breath, or len, can give

not given so many good words breath

four own labouring breath

to the uttermost, or else a breath

seen thee pause; and take thy breath

I'll take good breath: rest, sword

I'll take good breath; rest, sword ....
and pledges the breath of him ... Timon of
Athen

to give it in a breath

the breath is gone whereof this prais

they have e'en put my breath from me

breath infect breath; that their socicty

poor suitors have strong breaths. ...

spend my malice in my breath ......
the people, be $g$ thcir stinking breaths

I am out of breath; confusion's near
whose breath I hate as the reek o' the

whose breath I hate as the reek

never man sighed truer breath

with such weak breath as this ..........
uttered such a deal of stinking breath.Jusar,

and having lost her breath... Antony \& Cleopat

our fortune on the sea is out ot breat

give liim no breatl, but now

in their thick breaths, rank of gross diet

motion and breath left out ............
whose breath rides on the postin

whose breath ricles on the posting
oit-sweetened not thy breath

on either side I come to spend my breath

his celestial brea th was sulphurous .

the breath is gone, and the sore ey

enough ; let your breath cool yourself . . $=$

fetch breath that may proclaim.........

and wanting breath to speak

[ love that makes breath poor.

I am scarce in breath, my lord

my breath and blood! fiery? the fiery duke? - ii. 2

- take ny breath from mo

if that her breath will mist or stain................

if that her breath will mist or stain...

have life, and thou no breath at all ........ v. 3

ipening breatl

breath? How art thou out of breatin?

breath to say to me-that thou

no warmith, no breath, shall testify ..

the trunk may be discharged of breath
bath sucked the boney of thy hreath

0 , you the doors of breath, seal

my short date of breath is not so long

windy suspiration of forced breatl.

words of so sweet breatl composed.

words be made ot breath, and breath of life

the gentleman in our more rawer brentli?

he's fat, and scant of breat

draw tlyy breath in pain, to tell my story

that their breatlo embraced together.....

thy words before thou givest them breath

BREATHE-the air breathes upon us.

while Stephano breathes at nostrils...

o breathe trice... ii. 2

pray thee, breathe it in mine.. Two Gen. of $\bar{v} e r$ ivi.

breatlies upon a bank of violets ... Tu'cfih $N$ ith

sighs shall poor Olivia breathe?.

mercy then will breathe within....Mea. for Mea. i. 2
I brcathe free breath............. Love's L. Lost, v. 2

I breathe free breath ............. Leve's L. Lost, y. 2

created for men to breathe themselves
doth he breathe? He breathes. Taming of Sh. 1 (ind.

here let us breathe, and happily. ....

our mother, breathe he

but now I breathe again

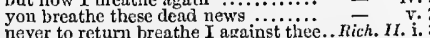

never to retum breathe I against thee... Rich. $I I$.
to breathe the abundant dolour........

that I may breathe iny last..... to the uttcrmost, or else a breath

he whose pious breath seeks to convert

not by his breath, that is more miseralle -

for the hire of their breath only....

is, every breatlı, a death...

and left me breath nothing to think on

with gentle with thy breatl........

unless the breath of heart-sick groans

o balmy breath, that dost almost persilad

but to breathe upon my love .......

for tbey hreathe truth, that hreatio
BIREATIIE-to breathe this news .. Kichurd 11. iii.

or drink, or breathe, or live...........

iinenryI $F$. i.

wlten you breathe in your watering.

no man so potent breathes upon

we breathe too long; come, cousin

stay, and breatle a while

to brentlie his bloodied horse

suffer you to breathe in fruit'ul

shall not breathe infection

i should breathe it so into thy hod

from their misty jaws breathe foul

their lives, breatlie out invcetives...
and, whilst we hreathe, take time

lay me down a little while to breathe

now breathe we, lords; good fortune

the traitor breathe out so proud words?

if she have timie to breat

Richard III. i.

his better doth not breat

those that breatle them in the air .

the worst that man can breathe.. Timon of $A t h$.

you breathe in vain. In vain? ......

breathless, power breathe forth.. Antony \& Cleo. ii.

to let hin brcathe between

to breathe the welkin dim

Cymbeline, y.

no breathe the welkin dim arest but to breathe

no mormth breathes [ $\mathrm{Cul}$.-warm breath]. Pericles, iii.

but thou dost breathe: bast heav

some say of breeding breathes

mouth no healthsome air breathes in

but breathes his fanlts so quaintly
the youth you breathe of, guilty

and hell itself breathes out contagion

no wind of blame shall breathe

I may not hreathe my censure

a man so breathed, that ecrtain.. Turelfth Night, v

when be breathed, he was a man .... - y.

heaven, breathed a secret vow ...Mer. of levice, iil.

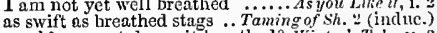

would you not deen, it breathed?. Winter's Tale, $v 3$

we breathed our counsel.

which breatlied this noison.

three times they hreathed

to be revived, and breathed in

Richard II.

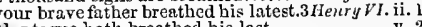

thus have you breathed your curse. Richard 1 III. $\mathrm{i} .3$

that breathed upon the earth ........ - iii.

and breathed our sufficrance rainly

this day I breathed first ......... Jitius Cesor, y.

breathed, and fight maliciously...Ant. \& Cleo. iii. 1

he breathed defiance to ny ears... Romeo ơ Jaliet, $\mathrm{i}$.

and breathed such life with kisses

will chide no breather in the world.As you Like, iti.

a statue, thian a breather .. Anlony \& Cleopatra, iii.

shake the head at so lon's a hreathing.. Machite, ii.

this mortal breathing saint... Merchant of Venice, ii.

no sighs, but o' my lireathing....

are sick for breathing and exploit ....d $d l^{\prime}$ ' Well, $\mathrm{i}$.

breathing to his breathless excellence

Four breathing shall expire.

a lireathing valiant man

be my last breathing in this mortal..2Heury $r l . j$.

cannot be quiet scarce a breathing while -

poor breathing orators of miscries

the princes had been breathing here

comes breathing at his heels. . Troilus f Cressida,

to give breathing to my purpoee... Antony \& Cleo.

tyraznous breathing that perfumes

a lady that wants breathing too......

it is the breathing time of day with in

breathica. ii.

all brcathless lies the mightiest .... Richurd II. . .

toil, breathless and taint, keaning . Henry IV.1.

here breathless lies the kin

I saw him dead, brcathless and bleeding - v $v$ v.

breatliless [Cot. Knt.-breathing] stoncs. Ric. III. iji. 7

now breatliless wrong shall sit.... Timon of Ath. v.

why are you breathless? ............ Julius Cosar, 1.

half breathless, panting forth from Goneril. Lear, ii.

BREATH'ST-livest, and breath'st.. Richarl II, i.

BRED-for I was bred and born ... T'uelfih Night, i.

would not a pair of these lave bred..

aguinst that power that bred it .... Much Ado, iii.

blushing cheeks by fiults are bred. Lore'sL. Lost, i. 2 
BRED-the dainties that are bred. Lore's L. l.ost, iv. 2 a neighbour, and near bred...Nerchen of $I^{\prime}$ enice, ii. the scull that bred them

she is not bred so dull

lis horses are bred better ........
from their cradles bred togetlier et am I injand bred, and kno

the raging fire of ferer bret

this calt, bred from his eow ..........

and he is bed out of that bloody

plainly say, our mettle is bred

the wound, that bred this meeting.

Like it.

thy summer bred used by necessity

hath bred a lind ot remorse in me..... RichardIII.

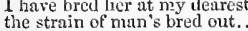

hut bred a do

0 true bred! Your eompany

and being bred in broils, hast not

your bred bim as my playfellow

one, bred oi alins, and fostered with cold

the flesh that slie herself hath bred. Titus

where were you brcl? (rep.).

you have begot me, bred me
a servant that he bied, thrilled witi

three eivil brawls bred of........Romeo of juliel, i.

BREECHEI-breeched with gore........ Macheth, ii. 3

BREECHES-make your brecenes. TieoGen. of $V$ ii.

pair of old breeehes, thrice turned.. Tam. of Sh. iii.

your breeches best may earry

short blistered breeehes, and those...Henry VIII. $\mathrm{i}$.

and put'st down thine own breeches ....... Lear, i. 4

his breeches eost him but a crown. Olhello, i1. 3 (song)

BREECHNG-breeching scholar. 7 am

use toth breed a habit in...... Two Gen. of Ter. v.

that my sense breeds with it....... Nea. for Mlea. ii.

in the oeension that brcels it........... Much Ado, i.
are these the breed of wits ...... Love's L. Lost, v.
I make it breed as fust

I make it breed as fast ........

take a breed for barien metal

virginity breeds mites, mueh like.

and these breed honour.

or breed upon our absenee

please, both breed thee, pretty .......

where they most breed and haunt

that in time will venom breed

unnatural deeds do breed unnatura

thousand hearts of England's breed.

what better matter breed
this happy breed of men

this happy breed of men ...............
feared by their breed, and famous

watehing breeds leanness

your chamber-tie breeds fleas ......i

breed a kind of question in our cause

and breeds no bate with tellin

to breed this present pence ...............

that island of England breeds very

shall breed a plaque in France

where I could not breed no eontentions

sudden foil shall never breed distrust Henry $l^{\prime} I$. iii.

when envy breeds unkind.........

in Fork this brceds suspicion

breed him some prejudiee...

the best breed in the north

breed a nursery of like ev

pleased to breed out your inheritors.

but breeds the giver a return... Timion
that feeds and breeds by a compesture

make war breed peace......................

hast lost the breed of noble bloods..Juli

powers breed serupulous faetion ..

Richend III.iv.

Henry VIII. i.

plenty, ard peace, breeds cowards

the imperious seas breed monsters.....

here nothing breeds unless.......... Tilus Andron. ii.
yct every mother breeds not sons alike
fiesh, which did me breed ........Pericles, $\mathrm{i} . \overline{1}$ (riddle)

yet they poison breed

a beart and brain to breed it in?

..

I would breed from hence oeeasion.

see what breeds about her heart.......... - iii. 6 this courtesy is not of the right breed

or breed itself so out of cireumstance...

worms were hallowed, that did breed....

doth affeetion breed it?

BRo-BATE-nor no breed-bate........ $\overrightarrow{\text { Merry }}$ wives, i. 4

these woolly breeders in the act. Merch of of $V$. ii. 1

you love the breeder better than ....3 Henry VI. Ii.
BR.F.EDER-the fairest breeders of. Titus
hath been breeder of these dire events

Wouldst thou he a breeder of sinners?... Hamlet, iij. 1 of good capacity and breeding ... Twelfth Night, iii. beneath your soft and tender breedingr

when green geese are a breecling... Looe's $\bar{L}$. Lost, $\mathrm{i}$.

may complain of good breeding.. As you $L$ ihe

of your breeding.

put you to the heiglit of your breeding. Al's 'W cll, ii.

to eon ider what is breeding father's .

forward of her brecling, as î' the rear of

of what having, breeding, and anything

generatiou ot still breeding thoughts. Richard I

gentleman, I know not your breeding

that you are worth your breeding.... Henry $V$. iii.

him to give her virtious breeding. Henry VIII.

much is breeding, which, like the ...Ant. of Cleo. $\mathrm{i}$.

in my exile the want of breedin

my breeding, was, sir, as your higliness

his brecding, sir, hath been at my charge

I am a gentlenian of bloot and breeding

these bunes cost no more the bieeding.........

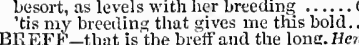

BREFH - that is the breff and the long. Heriry

cannot abide the old woman of Brentford

dress him like the witel of Brentford.

was't not the wise woman of Brentford

BRETAGNE-Arthur of Bretagne ... Kin

young Arthur, duke of Bretasne

Arthur of Bretagne, England 's king

turnished by the duke of Bretagne..Richard $I I$. ii.

dukes of Berry, and ot Bretagne....... Henry $V$. i.

I linow the Bretagne Richmond aims. Rich.III.

the Bretagne navy is dispersed .......

a scum of Bretagues, and base ......;

long kejt in Bretagne at our mother's - v. 3

and not these bastard Bretagnes .....

my friends, and brethren in these...2

his' greatness and thy other breth

and all his brethren, in best sort.. Henry

the mayor then, and his brethren.. RichardIII.

amongst my brethren mortal....... Henry VIII. iii.

good lord mayor, and your good brethre

brethren, and sisters, of the hold-door

some eertain of your brethren roared.... Coriol.

stay, Roman brethren; gracious . .

for their brethren slain, religiously they -

naught, but to inter our bre

for my brethren's obsequies. II........

he must be buried with his brethren

BREVIS that ira fuxor brevis est.. Timon of Ath.

BREVITY - Roman in brevity (rep.).2HenryIV. ii.

the rude bre vity and discharge.... Troil. \& Cres. iv.
since brevity is the soul of wit $\ldots \ldots \ldots$ Hamlet, ii.
BREW-she brew's good ale.Two Gen. of Verome,

you brew good ale

I wash, wring, brew, bale, seour.........erry $\bar{w}_{\text {ives }}$ i. or brew it to a weak and colder ... Trill. \& Cres. iv. 4 BREWAGE-in my brewage ...... Nerry Wives, iii. 5 sunshime brewed a shower for him...3 Henry $V I$, ij. 2

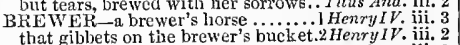
when brewers mar their malt.............. Lear, iji. 2 BREW ING-another storm brewing .. Tempest, ii. 2
come ill a brewing towards.. Merchant of V'enice, ii. 5 BRIARLUS- he is a gouty Briareus. Troil. \& Cres. i. BRlDE-I'll bribe you (rep.) ....... Nea. for Hea. ii. 2
that you took bribes from France..2 Henry VI. iii. 1 never had one penny bribe from France - iii. 1 to take a bribe, to pay my sword...... Coriolanus, i. 9 taking bribes liere of the sardians. Julizs Casar, jv. 3

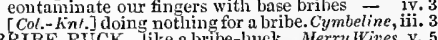
BRIBE-BUCK - ike a bribe-buek... Merry Wives, v. 5 if 1 should be bribed too........ Timon of Athers, i. 2 BIIBER -a sufficient briber for his life - iij. 5
BRICK-cireummured with brick. Mea. for Mea. iv. 1 be be set against a briek wall.... Winter's Tale, iv. 3 on a briek wall have I elimbed ....... = iv. 10 became a brieklayer, when he came.. $\overline{\text { iv. }}$ in I will bring thee to thy bridal ehamber - iv. I thy poor sire with his bridal day....3 Henry VI. ii. 2 make the bridal bed in that dim.. Romeo \&-Jul. iii. 5 our bridal flowers serve for a buried corse - iv. 5
with flowers I strew thy bridal bed.... for anch observances as fit the bridal ... Olhello, iii.
BRIDE-darkness as a bride .... Meas. for Meas.
BRIDE-take possession of the bride ...All's I' ell, ii. sluall Bianca be bride to you.. Taming of Shrew, ii. sce not your bride in these unreverent = bid cood-morrow to $m y$ bride.

and is the bride and bridegroom cuming obey the bride you that attend...

though bride and bridegroom wants

sweet bianen jractise how to bride it

in tikeness of a new untrimmerl bride ...John, iit.

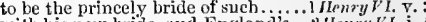
with his new bride, and England's ..2Itenry VI. i.

with him and lis new bride (rep....iv. 1) - iit.

- iv. 1

in your bride you loving bride..... - iv.

o' the youngest for a bride...... Timon of $\overline{\text { Athens, }} \mathrm{i}$.

I lead my cspoused bride along ...... -

your noble emperor, and his luvely bride = i. 2

I am not bid to wait upon this bride $\quad$ - i.2

joy, sir, of your gallant bride ........

wake the emperor and lis lovely bride - ii.

clothed like a bride, for the $\ldots \ldots \ldots \ldots . .$. Pericles, 1.

for your bride goes to that with shame $-\bar{j}$ iv. 3

may think her ripe to be a bride. Rome o Jutiet

shall not make me there 2 joyful bricle

sweetheart! why bride! what w......
come, is the bride ready to go to ehureh

in terms like bride and groom devesting. othello, iv. BRIDE-BED-the best bricle-bed.Mid. N. Dream, v. I thought, thy bride-bed to have deeked. Hanlet, v. IDEGROON-birdegroom's ear..Mer. of Ven.

you brides and bridegrooms all ..As you Like it, v. 4

bridegroom eoming home? (repeated)

though bricle and bridegroom wants

you shall supply the bridegroom's place - iii.

fresh as a bridegroom; and his ehin... Henry $I V$, $i$.

with a bridegroom's fresh alacrity... Troil. \& $\mathrm{Cr}$. iv.

I will be a brickegroom in my death. Ant.\& Cleo. iv. I

a gentleman to be her bridegroom?.Ron. \&.Jul.'iii. 5

when the bridegroom in the morning

the new-made bridegroom from this eity -

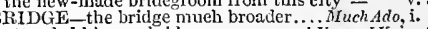

attended him on bridges........... HenryIY ${ }^{\prime}$. iv.

camest thou from the bridge? ......... - iii. 6

mareh to the bridge; it now draws ... - iji. 6

Cade hath gotten London bridge...2. 2 Henry I. $^{\prime}$ iv. 4

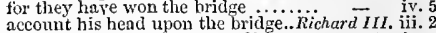

take the bridge quite away of him. Timon of Alh.jv. 3

trotting horse over four-ineled bridges ... Lear, iii. 4

does Bridget paint stili, Pompey?.Mea. for Mea. jii.

MRIDG, Bridget, Marian, Cieely. Conn. of Errors, jii.

our general forces at Bridgnorth shall - iii.

he is the bridle of your will .. Comedly of Errors, ii.

to bridle and suppress the pride ....2 Henry VI. i.

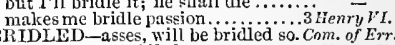

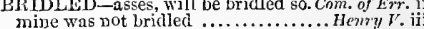
BRIEF-open the matter in brief. Tü Gen. of Ver.i.

be bilef, my good she Hercury ........erry wives, ii.

wrief, short, quick, snap...............

if you bare reason, be brief............ Tuelfth $\bar{N}$ ight, $\mathrm{i}$. .

be curst and brief: it is no ........... -

drest in a little brief authority... Mieas. for Meas.

my most stay brief in goodness...

be orief: here is lord Angelo shali...

in brief, to set the needless proeess $\mathrm{iy}$

briet, I pray you; for you see

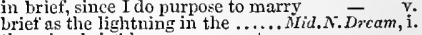

there is a briet; how many sports .... - v.

tedious and briet? that is hot ice......

which is as briet as I have known.... - $\mathrm{v}$.

to be brief, the very truth is.............. of $\overline{V e n i e e, ~ i i . ~}$

with all brief and plain convenieney $=$ iv.

how brief the life of man. As you Like it, ini. 2 (verses)

briet', I recovered him................. All's Well. ii. 3

crlodient on the now-bontous

in a sweet verbal brief, it did concem $=$ v. 3

in brief, sir, sith it your pleasure is

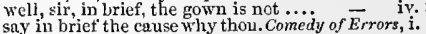

out, out, brief candle! life's but ....... Nacbeth,

in brief, a braver choice of dauntless. King John,

in briet. we are the ling of

must be brief, lest resolution ...........

a thousand businesses are brief in hand.. 


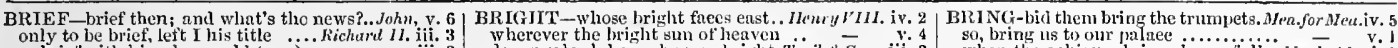
in wooing sorrow let's be brief bear this sealed hrief

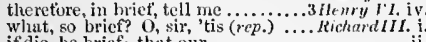

if die, be bricf; that our

we must be brict, when traitors brave

ii. 2 , 2

brief abstract anil reeord of tedions

and brief, good mother

be brief, lest that the process of

in brict, fior so the season bids us.. .

from spiritual leisure a brief span. Henry VIII. iii.

thon art too bricf

let your bricf pingues be mere

that this hrief world atfords ...Timon of dthens,

and to make it bief war ...............

this is the brief of money ...Antony \& cleonatra, v.

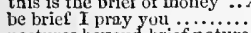

postures beyoud brief nature

to be bricf, my pruetise so .......
in brief, sorrow would be a rarit

list a brief tale; and when 'tis told

quiekly send; be briet in

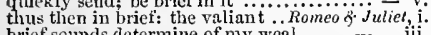

brief sounds determine of my weal .

then I'll be brief; O happy dagaer'

I will be brief; for my short date

briet'let me be: sleeplng within ...........

whieh he, in lirief, obeys; reeeives rebuke

and outward flonrishes, - I will be briet:.. $=$ ii.

'tis liriet, my lorl. As woman's

something that's brief; and bid...

aivantage of some brief

well, do it, and be brief

BRIEFER-gamut in a briefer sort.. Tam. of Sh. iii. 1 BRIEFLY -briefly, I do mean........ Aerry Wives, i. briefly, I have pursued lier

show me briefy how

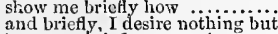

instance, briefly; come, instance.As you like it, iii. let's briefly put on manly

say briefly, gentle lork, we eoldi........ Nacieth, ii. question stands; briefly to this

briefly we heard their drums

speak briefly then; for we a......... Coriolan us, i.

speak briefy then; for we are peremptory - iii.

every man direetly. Ay, and brietly...ul.
directiy, and briety, wisely, and truy
for your dwelling,-briefly. Briefly..

pnt on thy defenees. Briefly, sir ...̈nt.\& Cleo.

priefly die their joys, that place ..... Cymbeline,

and time that is so briefy spent. Perieles, iii. (Gow.)

therefure briefly yield her...

speak briefly, can you like ................ Leareo of Jutiet, $\mathrm{i}$.

BRIEFNESS-briefness of your answer. Cymbeline, ii. reafuess sails are filled

briefness, and fortune, work! brother ..... Lear, ii
BRIER through tooth'd briers......... Tempest, iv

through brier, over park ................ N.D ream, ii. I

like the red rose on triumphant bries

for briers and thorns at their apparei

with the dew, and torn witl briers

$=\quad$ iii. i

how fuli of briers is this.............

when briers shall have leaves............1l's Well, 1v. 4

thy beauty seratehed witb briers. Winter's Tale, iv. 3

usurping ivy, brier, or idle moss.. Comedy of Er. ii. 2

from off this brier pluek Timon of Athens,

scratches with briers, scars to.......

covered with rude-growing briers. Titus Andron. ii. 4

wishes to appear most bright ........Mer. for Mea. ii.

wishes to appear most bright .... Men. for Mea. ii. 4

how came har eyes so bright ........ - ii. 3

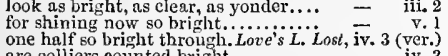

as bright $\Lambda$ pollo's lute, strung with.

vouchsafe, bright moon, and these thy - v. 3

the moon shines bright: in sitch. Mer.

iniaid with patines of bright gold .... - v. I

thou wilt show more bright $\ldots . . . . .3$ s you Lilke it, i. 3

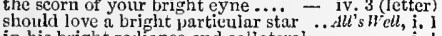

in his bright ralianee and eollateral ...

bright and goody shines the moon.. Tam. of $S h$. iv. 5
so bright. I know, it is the sun (rep.) iv. 5
ere they can bellold bright Phoobus. Winter's T. iv. 3

that e'er the sun sbone bright on

be bright and joviai 'mong your guests. Macbeth, iii.

angels are bright still, though.

your sword is bright, sir; put it up.. King Jolnn, iv. 3 with hard bright steel, and hearts.. Richard II, iji. 2 the track of his briglit passnge

as bright as is the eagle's ..............

to pluck bright honour from .........

than Julius Casar, or bright ....... i Henry $\boldsymbol{v}^{\prime}$. v

bright star of Venus, fallen down..... - i.

creature, bright Astræa's daughter.. - i. 6

burn, bonfires, elcar and bright ......2 Uenry VI. v.
whose bright outshining beams .... Richurd $I I . \mathrm{i}$.

with bright hair dabbled in blooi...

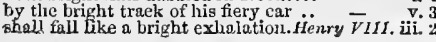

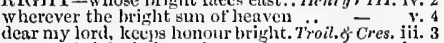
tear ny loright hair, and scrateh

more hight in zeal than ...............

thou bright defiler of it is the bright day, that brings ...Julius Cresar, ï. the bright day is done, and we are...Ant. \& Cleo. v. town with rejoieing fires bright .... Cymbeline, iit. I I will be bright, and sfine in pearl.

the morn is briglat and grev, the fields

to part their fringes of bright gold .....

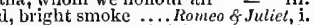

doth tenelh the torehes to burn bright

yosaline's bright eyes

$O$ sjeak aguin, bright angel..........

keep yp your briylit.swords, for the dew. Othello, $\mathrm{i}$.

a faggot to brigbt-burning Troy.. Titus Andron. iii.

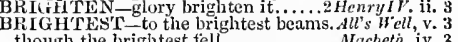

though the brightest fell...............Alacbeth, iv.

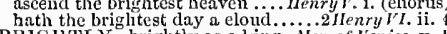

BRIGHTLY -brightly as a king....iver. of 'tenice, v. 1

BRIGHTNESS-ray and brightness. Troil. \& Cres. i.

the brightness of her eheek would.. Rom. of Jul. ii. 2
BRIGH'S-SHINING-

midst of this bright t-shining day ...3 Henry VI. .3
BRIMI-with peonied and lilied brims.. Tempest, iv. I

and pleasure drown the brim

with ample and brim fuiness of his .... Henry $F$. i.

a cup that's stored unto the brim.

bring me but to the very brim

with his eye brimful of tears

.... Lear, iv. 1

the people's hearts brimitul of fear..... Othello, ii. 3

and brimstone in your iiver.....

on ello, iv. 2

BRINE-pinnged in the foaming brine.. Tempest, brine pits, barren plaee

he shall drink nought but brine.

wis the best brine a maiden ean

with wire and stewed in brine.

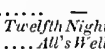

whe brine and eloudy billow

All's thell, i.

what a deal of brine hath washed ....... Rom. \& Jul. ii. 3 BRING-bring her to try

and then forth more island

than we bring men to comfort them

when you should bring the plaister

I'll bring my wood home faste

let me bring thee where erabs grow.
I'll bring thee to elustering filberds

canst thou bring me to the party?

and bring thee forth brave brood

wili bring us good warrant

go, bring the rabble, o'er whom.......

go, bring it hither rather than want

at least, bring forth a wond

I'll bring you to your ship ...............

w'll bring you where

to her let us garlands bring.

二 i.j.

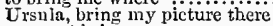

eome, bring ber away

must bring youl to our...

I will bring thee where nistress

he promise to bring me vere .......

I'll but bring my young man........

devise to bring him thitler

what ado bere is to bring you together

bring you the maid ................
we'li bring you to Windsor

I pray you bring your hand...

T....

to bring a overture of war ..........

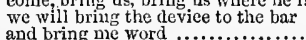

and bring her along with you.

I'll bring you to a captain .......

bring him hither

that we may bring you sumething......

and bring you back in happiness.

the bare thllow brings to teemirg.

bring him his confessor

I know nolaw; bring them away

and do bring in here before..........

bring them to speak

lie would never bring them to liggit.

my kisses bring again, bring again..

to bring you thins togethe

sirrah, bring Barnardine hither.

after him, tellows; bring him........
he shall bring you befure the dulce

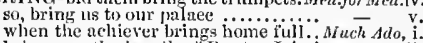

bring you the Jength of Prester John'
which is, to brint signior Benclick..

and bring then to sece this ..........
bring it hither to me in the orchard.

bring it hither to me in the oreh
I'll bring you thither, my lord

you'll be loade bring beformed forth

bid lim bring lis jen and inkhorn.

bring him a way ........................

bring hin yet to ne ..........

bring you these fellows on ............

deenest loathing to the stomach brings $N$.

that is to bring the moonitght

you never can bring in a
and bring him silently .

see thou bring her lere ...
good monsieur, bring me

go, bring them in; and tak

bring her to trial $\ldots . . . \ldots h$ ho

and that brings me ont...........

we will bring you on your way

who brings word, the prince

and brings down the rate of usanee

not in his power to bring to pass

cone, bring me unto my chance

that this same paper brings you
when it is vaid, bring your true....

bring them, I pray thee

to bring thee to the gallows.

and lring lim, il thou eanst

and I bring word, my mistress ....

if he be absent, bring his brother

to bring again these foolish rumaways
bring $n$ where we may rest ourselves

or bring it for food to thee $\ldots \ldots \ldots . .$.

bring lim dead or living

to bring the ewes and the

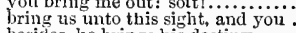

besides, he brings his destiny

on your riglit hand, brings you to $\dddot{0}$ this

if I bring in your Rosalind

will have her, when I bring her?

nature brings to join like likes

good Lateu, bring in the admiration

the sun shail bring their fiery torches

title age cannot bring thee

I will bring you where you shail

when we bring bim to our tents....

can bring this instrument of honour

come, bring forth this counterfeit

the time will bring ons sat in

to bring me in sonie graec (rep.)

to bling torth this diseovery $(v e p$. $)$
suffer under tlys eomplaint we bring

find him, and bring him linther .....

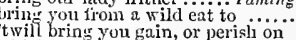

which, to bring to pass, as I before

bring along these rascal knaves

I will bring yon, viliains, bring it from

dress thy neat myselt, and bring it thiee

and bring our horses unto long lane en

if a man bring him a hundred pound

and brings your troward wives

to bring false generations......... Wiriter's $\bar{T}$

now, from the oracle they will bring all

I shail bring Emilia forth

within this hour bring me yord "tis done

ring fortb, aud in Apollo's name

iii. 4 pry thee bring me to the dead bodies

shall I bring thee on the way?

if I make not this eheat bring out.

pr'y thee, bring lion in

come, bring away thy pack niter me.....

I'li bring you where he is aboard.....

in pawn, till I bring it you

bring them to our enbracement..

will bring me to consider that......

to-morrow you vill bring it bome. Com of

bring it, I pray you, to the Porcupine

thell you will bring the chain.

that brings any man to ansive

I think, he brings the money

come, gaoler, bring me wher
let your servants bring my

let youx servallts bring my $\ldots \ldots . \ldots . . .$.
Promising to bring it to the Poreupine

iii. 1

etter

$\mathrm{v}$.

i. 3

iii.

iv.

v.

ii.

iii. 2

v. 3 (let.)

All's Well, $\mathrm{v}$.

iii. 1

iii. 1

ii. I

ii. 2

iii. 1 


\section{BRI}

BPING-he brings great news bring forth men-chikaren onjy! I'll bring you to him

bring them before us ...................

come, ming me whice they are....

front to tront, bring thou this ficnd .

bring it after me; I will not be

what brings you here to court so ....

I bring you witnesses, twi

will bring tlus labour to a happy

loves arain: bring them before me

bit to iny closet bring the angry lor.

and lorings from him such ottirs......

and bring their times about.

and bring away the armour that is .

bring lore these nien...............

elder days may happily bring fortli.

that brings me food, to make

spent with crying-bring in.......
to bring a slovenly unlandsom

bid the ostler bring my gelding out

and bring him out, that is hut woman's

to raise him, bring him hither

mine mole bring him our purposes

Douglas and Hotspur bring together

eannot chonse but bring him quiekl

man of them brings other news.2

they bring smootli conforts false

that time and spite dare bring

tood people, bring a resene or two

to see lus father bring up his powers

with hovey, we bring it to the hive

tidlings do I bring, and luek
what? I do bring good new

come, bring me to a justice

to bring forth so great an object.

with merry march bring home

and bring you hack, charming the

let me bring thee to Staines..........

to whom expressly I bring greeting.

into Ronen bring him our prisoner.

bring me just notiee of the numbers.

and bring him to my ten

there must we bring him $\ldots . . . . . . . . . .$.

sad tidings bring I to you out

a holy maid lither with me I bring...

spy'st any, run and bring me word

bring forth the body of old.

Johe so, bring the keys to me...

to bring this matter to the wished...

bring forth that sorceress ....................

gives gold, to bring the wite

will bring thy head with sorrow

whieh time will bring to light

than bring a buden of dishonour

bring me unto my trial when.......... -

therefore, bring forth the soldier

bring them both upon two poles

that brings his head un to the king

intencl these forces thou dost bring

darest bring them to the baiting-

brings a thousand-fold more care..

how many hours bring about

bring fortls that tatal seriteh-owl

what briugs thee to Franee?

will bring you many frieuds

bring forth the gallan

not barren to bring forth laments... Richare ${ }_{\text {III }}$ come, bring forth the prisoners

see, he brings the mayor along

we'll bring it to a heppy issue.

I'll loring thee to their sigh

till thou bring better news

comfort lring $I$ to your highness

bring his power bcfore sun-risin

every toncue brings in a several ....

they bring you to unrest

and the opinion that we bring.......... $r$ renry $\overrightarrow{I I I}$. (proj.)

may bring his plain-song; and liave.

to bring my whole cause fore his
that you bring a wretehed lady?

lying me a eonstant woman to

in spite of fortune will bring me off.

every thing may bring my ruin of

every thing may

some pains to bring together yoursel

the tichings that I bring will make
which time shall bring to ripeuess
MItcbeth, i. 5 | BRING-soon bring his particulars.. Troil. \& Cres. i. 2

i. 7 to bring, uncle, - ily, a token from

I bring bring the praise forth

be you $\mathrm{my}$ time to bring it to........

such a beanty brings witl it

bring aetion hither, this cannot..

and bring lis answer

comes to me now, and brings..........

and bring us Cressid hither

iii. 1 withal, bring word-if IYector........

you bring me to do, and then

I'll bring her to the Grecian ..........

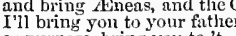

or purpose, bring you to 't $\ldots \ldots \ldots \ldots$......

Afinamemon's tent, to bring yon to the cates.

taken too, or bring him

little casket bring me bither .... Timon of $\bar{A}$ the

they laboured to bring nan

come, bring in all torether

wretehedness that glory brings us..

bring down rose-eheeked youth.

let it no more bring ont ingrateful

bring us to his eave

bring us to him, and chanee it a

and nothing brings me all things ....

muel hazard, if they bring niot Timon

bring me into your eity ..........

for the remove bring up you
and bring thy news solate?

and bring thy news so late?

brings 'a victory in his poeket?

ii. 3 should bring ourselves to be monstrous

I cannot bring my tongue to stich

bring in the crows to peek the eagle

v. 3 undertake to bring him where he

if you bring not Marcius (rep.)

bring me but out at gate ............

if the Roman ladies bring not eomfort

what conquest brings he ho

look in the calendar, and bring me word

brin wring him to the Capitol

bring ine their opinions of

the wind brings it from the Capitol..

and bring me word what he doth

bring him with triumpin home

bring me to Oetovius

bring Messala with you immedia.........

bring us word unto Oetavius' tent
bring in the banquet quiekly .....

seek him, and bring him bither.

your old smock brings fortl a $a \mathrm{vew}$

Casar, I bring thee word .............
bring it to that, the gold I give thee.

as a gaoler to bring forth some

as, that do bring the news, made not

never good to bring bad news .........

bid you Alexas bring me word

these the showers to bring it on ......

let it be; bring me to Antony

bring him througli the bands

follow me elose; I'll bring you

and bring me how he takes my deatl

bring our crown aud all

he brings you figs. Let him eome in

olle deed! he brings me liberty

to bring him to the haven ...........

if I bring you no suffieent testim

when thou shalt bring me word

bring this apparel to my chamber.

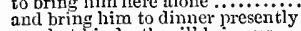

or what lis deatll will bring us

brings the dire oceasion in his arms.

and bring me word, how 'ti

of note; bring him to the kin

bring your prisoner to the kin

that I fring unto their latest.

and I'll soon bring her back ........

bring thou her husband...

straight will I bring you to...

some bring the murdered body

I bring the muered body ......

and bring you up to be a warrior...

to nourish, and bring lim up.

so, now bring them in, for I will

and bring our emperor gently in thy

may to your wishes pleasure bring. P'r

bring in our dalyhter, elnthed like...

gorrow never eomes, but brings an heir

they bring us peace, and come to us...
but bring they what they will .......
BRING-come, and bring away the nets. Pericles, ii. I
and I'll bring thee to the eourt inyself

f'll lring you in subjeetion.............

bid Nieander lring me the satin cotfer

we'll bring your graee even to

come, bring me to some private pince.

iv. 6

I will fitly bring you to hear ny ......... - i. 2 bring oil to fire, snow to thcir eolder ...... - ii.

come, bring away the stocks ............

come, bring us to this hovel.............. - iii.

and bring you where both fire and food.... - iil. like a thief, bring him before us $\ldots . . . \ldots \ldots$. bring some eovering for this naked soul .. - iv. lin hing him the best parel ............. I'll liring you to our master Lear............ - iv. 3

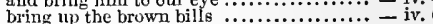
bring his eonstant pleasure $\ldots \ldots \ldots \ldots \ldots \ldots \ldots$ - v. 1 I'll bring you comfort. Grace go $\ldots \ldots \ldots \ldots \ldots$ - v. 2 sliall bring a brand from heaven $. . . \ldots \ldots \ldots-v-3$ and bring and bring in eloudy night immediately - iij. and she brings news; and every tongue

I will bring you thither............... conld to no issue of true honour bring tor shame, bring Juliet forth: her lord
dost thou not bring me letters trom... nor get a messenger to bring it thee.

lring it straight un to my cell (rep.)

bring forth the parties of suspieion
penee this morning with it lrings...
bring with thee airs from heaven

bring ti. Hamlet, i. 4

- 11.2

iii. 1 we would bring him to some confession.. - iii. 1

will bring him to his wonted way again

and bring the body into the chapel

of nothing: bring me to him: hide fox

bring him before us (repeated)

bring you, in fine, together, and wager

young osrick, who brings baek to him

state, to bring [Col,-bear] me to him
bring him away: mine's not an idle

he shall our commission bring to you...

bring them after in the best advantage

ii. 4 and bring all Cyprus comfort............

iii. 2 bring thou the master to the citadel

it $I$ can bring it to any opportunity

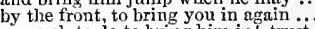

so mueh to do to bring him in! trust me

to bring them to that prospect .....

can bring you, for I attend here

4 come, bring away. Soft you; a word or two -

BRINGER -some bringer of that joy. Mirl. N.Dr.

snfed the bringer out of the host.Antony \& Cleo, iv. 6 from whom he bringeth sensible. Her. of Venire, ii. the contrary bringeth forth bliss....1Henry $V I$. v.
BRINGING-bringing wood in slowly..Tempest, ii. witness good bringing up.. T'wo Gen. of rerona, own ehildren in good bringing up. Taming of Sh. 1 . ehid you for not bringing it.. Comedy of Errors, iv. a plague on my bringing up.........henry I in bringing them to eivil diseipline..2 Henry VI. i. of bringing baek the prisoner $\ldots . .$. Henry Your eare in bringing up my child..... Pericles, tii. 3 tis not the bringing up of poor bastards - iv. 3 bringing the murderous coward to the.... Lear, ii. 1 pardon me for bringing these ill news. Rom.\& Jul.v. BRING'ST-- thou bring'st me out.. As you Like, iii, thou bring'st me happiness .......21henry I $V$.iv. unless thou bring'st them with thee.Jul. Casar, v. thou bring'st good news ............ Cymbeline, v. 4 thy sorrows which thon bring st........... Pericles, will in his brinish bowels swallow. Titus And. iii. BRINK-to the very brink of tears. Timon of Ath. v.
strength to pluek thee to the brink.. Titus And. strength to pluek thee to the brink. Titus And. ii. 4
BRISK-most brisk and giddy-paced.. Tuelfh $N$. ii. 4
to see him shine so brisk ........... IIIenry IV.i. 3 of wine, that's brisk and fine.2Henry IV.v. 3 (song) cheerly, boys; be brisk awhile .. Romeo \& Juliet, i. BRISTLE-as a bristle may euter... Trelfih Night, i. doth dogged war bristle his angry crest...John, iv. and bristle up the crest of youth ....1 Henry I $V$. $\mathrm{i}$. boy, hristle thy eourage uy ..........Henry $V$. it. ERISTLING - with bristling hair.....Mid.N.Dr. ii. raight to Bristol castle. Richurd II. ii

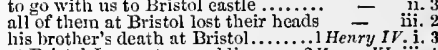
at Bristol I expect my soldiers ....2 Henry VI. iui.

they made Britain, India ........... Henry VIII.

sooner landed in our not-fearing Britain sonner landed in our not-fearing Britain - 


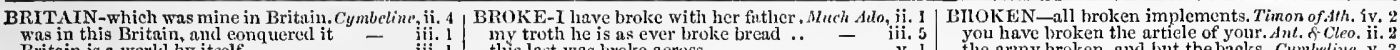

Britain is a world by itself

who was the first ot Britain.........

the heir of Cymbeline and Blitinin

hath Britain all the sun that shines

whence he moves his war for Britain

enough, that, Britain, I have killed thy
it thint thy gentry, Britain, go before

it thint thy gentry, Britain, go before
our Britan's harts die flying.........

in Britain where was he that could.
Britain be fortm nnte (rep. v. 5)...

Britain be fortu nate (rep. v. 5 ) ...
the liver, heart, and braiu of Britain

and not ' $'$ the court of Britain

away to Britain post I in this design

gan in your duller Britain operate..

BRITANY - a bay of Britany......... nichard II. ii. I

then to Britany I'll eross the sea........

we shall to Britany. Come therefore

too good, for any lady in Britany .... Cynueline, i. 5

BRT - placing of the British crow

sinell the blood of a British man...

sunell the blood of a British man... Lear, iii. 4 (song)
madam, news; the British powers are...... - iv. 4
upon the Britisla [Knt.-English] party .... - iv. 6

BRITON-liere eomes the Briton

whiles the jolly Briton reveur lord

and Britons strut with courage

your valiant Britons have their.

wars against the fallen-off Britons

my master, a very valiant Britor
must or for Britons slay us .....

mnst or for Britons slay us ..........
suit myself as does a Briton peasant

snit myself as does a Briton peas
but the baeks of Britons seen.

preserved the Britons, was the Romnn's

no more a Briton, I liave resumed

great the answer be Britons must take

great the answer be Britons must take
tribute; that the Britons have razed out

my boy, a Briton born, let lim

he hath done no Briton harm........... BRITTLE a brittle glory (rep.). . Riehard II.
metter brook the loss of brittle life...1 Henry IV
my kingdom stands on brittle glass. RichardlII.
BRIZE-annoyance by the brize.. Troilus \& Cres BRIZE-annoyance by the brize... Troilus \& Cress. i. 3
the brize upon her, like a eow... Antony \& Cleo. iii. 8 ever I did broaeh this business ....Henry $Y I I I$. if I would broach the vessels .. Timon of Atten B'll hroach the tadpole $\dddot{2}$...Titus Andronicus, iv. 2 that I broached in jest........ Tamin of Shrev. a portent of broaehed mischief..... Henry $\mathrm{IV}$. v. I best blood that ever was broached. .2 Henry

what hath broaehed this tumult..

lroaehed with the stecly point

the business she liath broached..
the business you have broaehed.

you have broached......

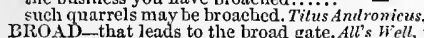

against those honours deep and broad... Macbet

as broad, and general

for from broad words, and 'eause...

in, by broad spreading, it disperse ... Henry F $_{\text {. }}$ i. 2

with a broad and powerful fan ........ Troilus \& - Cress.

as proud a place as broad Aebilies

it is as broad as it hath breadth... Antony \& c cleo.

I have been broad awake two hours.. Titus And.

fur and wide a broad [Col,-abroad] goose

for the world is broad and wide.

with all his crimes broad blown

his pranks have been too broad..........

whoean speak broader than he. Timon of Athens, iii. 4

BROAD-FRONTED hroad-fronted Casar, when thou. Antony \& Clfo. i.
BROADSIDE-fear we broadsides?..2 Hemy $1 \mathrm{~V}$. ii.
BROAD-SPREADING-

BROC $\Lambda \mathrm{S}$ - the heads of Brocas ..... Kichard II, iii. 1 BROCK-marry, hang thee, brocki Tuelfin $\bar{N}$ irg

BROIL the knowledge of the broil

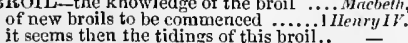

it seems then the tidings of this broil...

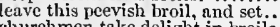

churehmen take delight in broils

more furious raging broils

in this civil broil, I see them..........

...2Henry $r$ I

here a period of tumultuous broils ..3 Hestry $F I$

and firstlings of those hroils.... Troil. \& Cres. (proi.

who broils in lourl applause

and being brel in bruils, hast not..... -

domestic and partieular broils are not ..... Leor, v. I

[Knt.] three civil hroils bred .... Romeo \& Juliet, i. ]

Blertains to teats of broil and hattle ....... Whello,

might have broiled and eaten him.. Coriolnnus,
BROILING

Bliok E-I have broke your 'hest...... Tempest,

son has broke his arrows $\ldots . . . \ldots \ldots \ldots \ldots$...

slender, I broke your liead.

as honest a maid as ever broke breai.

he has broke my lieal aeross .... Twelfth $\overline{N i g} h, \mathrm{v}$

who broke my liead tior nothing ........

which are as easy broke as they ...ileit.
which was broke off, partly, for that..

whe was the in sleep with thoughts

whose plots have broke their slee this last was broke aeross

vows that ever men have broke....Mirl. N. Dream, i. 1

the tlineshold, and broke my slin. Love's L. Lost, iii. I

vows, tor thee broke, deserve not

your oath onee broke, you f

and broke three of his ribs

thou hast not broke from comprin

so I had broke thy pate, and as

for she hath broke tbe

having broke your fast........ me

and his man are both brolie loose

murder hath broke ope the lord's...... IFacbeth, ii. 3

turned wild in nature, broke their stails

the nirth, broke the rood meeting

and ne'er broke his fast.

and bro broke with thec.

that late broke from the duke

of Woreester hath broke his staff

broke the possession of a royal bed

when time is broke, and no proportion
check time broke in a disordered ....

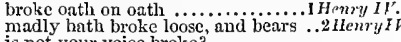

is not your voiee broke?............

that you broke your word.

for a' never broke any man's bead

why, all our ranks are broke

our windows are broke down ......

hath with Talbot broke his word

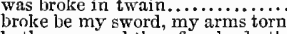

hath my sword therefore broke throing

a thousand men bave broke their fust

have youn not broke your oaths?

have you not broke your oat
the eable broke, the holding

.Richard IHI.
..Henry VIII.

when thou liast broke it in liave broke their backs

broke into a general prophecy

vou have broke it, coutsin,.... Troilus \& cressida, iii.

I would they liad broke 's neck!.... - ive iv. 2

jow has the ass broke the wail .

in excess hath broke their
liunger broke stone wall

a would have broke mine eye-strin

you have broke his pate with your
wit had been like him that broke

al most broke my beart with..... Titus Andron

broke them in the sweet face of heaven.. Lear,

the day is broke; be wary, look about

the doors are broke.........

the day had broke before we parted...... Ofhetto, iii.

BROKEN-are they broken? .. I'wo Gen. of V'er.ii. 5

niay heedfully bebroken

here's a Costard broken in a shin. Love's L.Lost, iii. I

that a Costard was broken in a shin

if broken then, it is no famlt ....

me without some broken limb.... As

that poor and broken bankirupt there

might exeuse his broken pronise

no more were broken than these
broken hilt, and elapeless (rep.)..

yon have broken trom his liking.
I make a broken delivery of the

of wonder is broken ont within this hour

our sides it never shall be broken ... King folkn, y.

our drooping eountry's broken wing - ji. 1

their points being broken .......... i Henry $I V$. ii. 4

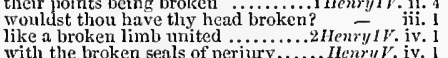

and thy English broken; therefore

in broken English, wilt thou have me

why hast thou broken faith with ine

any natl may be broken .............

iv.

the broken rancour of your high-swollen

ihy broken taith hath made a prey fir

amaze the welk

you have now a hriken banquet ...

moved, have broken with the kins

here is good broken music ..
with the sult if broken tears

as is Arachne's broken woot you have hroken the artiele of your. Ant. \& Cleo. if. 2

these broken limbs agnin into one. Tilus Anrlron.

broken a staff, or so; so let it pass....... P'erictes, ii.

might yet have balmed thy iroken seneo

for your broken shin

a broken voiee, and his whole function. Ithmin,

men do their broken weapons rather nse. uhello

this broken joint, between you and her. - - ii.

BROKER - a goodly broker.. Two Gen. of lerorci, $i$.

that broker, that still breaks.........

no broker; yet am I Snffolk (rep.). 21 2Ienry V1. i. 2

to play the broker in mine ......3 3 Henry VI.

for they are brokers not of that dic...... Humlct, $\mathrm{i}$.

and all brokers-between Pandars.. Troil. \& Cres. iii. 2

BROOCH-in a brooch (rep.) ... Love's L, Lost, v. 2

just like the brooch and toothpick .... dil's $W e h_{2}$.

pomander, brooch, table book.....Wiater's Tale, iv.

he is the brooch, indeed, and gem....... Hamlet, iv. 7

WOCHED-be brooched with me.An/. releo

ROOD-bring thee forth brave brood. Tempest, iii.

beeme the hateh and brood of time.2lonryll, iti.

why, what a brood of traitors

tomd of no seeond brood .........

threatening band of Typhon's brood... Tilus dud. iv.

which his melancholy sits on brood ...Hamlet, iji. I
BROODED—of brooded watchful day ..... Joln, iii. 3

sit brooding in the snow .. Love's L. Lost, v. 2 (song)

sit brooding in the snow ... Love's
BROOK-be the freslh-brook musel

Naiads, of the wandering brooks .....

how to brook this patiently..... Two Gen. of $\mathrm{Fer}$. v.

and tell him, my name is Brook ........erry $\overline{\text { Wives, }}$ ii.

and thy name shall be Brook

there is one master Brook below

such Brooks are welcome to me.......
my name is Brook. Good master Brook $=$

my name is Brook. Grood mast
speak, gøod master Brool

master Brook, I will first make.

want no mistress Ford, master Brook

master Brouk, thou shalt know......

I mon, master Brook, shalt know him

now master Brook; you come to
master Brook, I will not lie to

yery ill-favouredly, master Broo

No, master Brook, but the peaking (rep.) -

nay, you shall hear, master Brook

lissiug hot, think of that, master Brook -

master Brook, I will be thrown into

you shall have her, master Brook.

Y'll to him again in name of Brook

how now, master Brook? Master Brook -

I went to her, master Brook, as

devil of jealousy in him, master Brook

in the sliaje of man, master Brogk

strange things in land, master Brook

master Brook, Falstaff's a knave

paid to master Brook; his horses $(r e p$.

to Windser, to one master Brook.

or by rushy brook, or on the....Mid. $N$. Dream, ii.

or by rushy brook, or on the..... Nid. $N$. Dream, ii.
many ean brook the weather.... Lore's L. Lowt, iv. 2

as ver a brook, to see fair Portia ...Mcr. of len. ii. 7

or brook snch disgrace well as he....

books in the running brooks, serroons
vpon the brook that brawls along...

the extremest verge of the swift broo

painted by a in the brook.

my business eamnot brook...Tam. of sh. 2 (indlue.)

I cannot brook thy simlt this.. Com.of Er

how brooks your grnce the air...... Richard II. iii.

one England brook a double reign....

I better brook the loss of brittle lite

then lrook abridgenient

our late sovereign ne'er could
how ill we brook lis treason

business will not lrook delay.........

for flying at the brook, I say not....
the water where the brook is ilcees)

tieree, and eannot brook hard language

knowing how hardly I cau brook abuse

if they ean brook to bow a knee.
coild never brook retrent, eheer

for unger bunus, I cannot b

that makes small brooks to flow.........

that makes small brooks to fow ....

in that you brook it ill, it muk
a hark to lorook no miglity sea

ihut cannot brook the aceent of reproof

sinnull brook as little wrongs. Timon of
will the cold brook, candier with ice

will the cold brook, canclied witl ice 
BROOK-grows aseaunt the brook ...... IIamlot, iv. 7 (BROTIIER-for your brother's life. Mea. for Meu. v. 1 | BROTIIEli-embrace thy brother there. Com.of' Er. v.

your lordship brooked imprisonment... Rich. III.j. have brooked the eternal devil ..... Julins Cepsar, i. 2 I am sept, with broom, before ... Mid. N. Dream, v. came to the broomstaff with me ....Ilenry VIII.. . their barley broth, deeot their eold. Henry $r$. fii. BliU'THEL-is o' the brothel!. . Timon of Athens, iv. I Mrarina thus the brothel seapes..Pericles, v. (Gower) keep thy foot ont of brothels, thy hand...... iii. (videlieit, a brotltel),

up at the door of a brothel-house.......Aluch Ado, l. BKOTIEl-farewell brother.

Tempest, i.

niny brother, and thy unele

the government $I$ cast apon my brotier in uxy tialse broth it this might be a brother.

i.

my biother's daughter's queen of Trnis

you did supplant your brother Prosuero.

my brother's servants were then

brother, my lord the duke, stand to.

the king, his brother, and yours

thy brother was a furtherer...................

whom to call brother would even

and lerdinand her brother found

where ithe mo bister you.

here's the twin brother of thy letter...inerry Wives three of mister Ford's brotliers watch - iv. this debt ot love but to a brother

my brothe

Twelfthight, i. 1

as my brother ilved.......

hrother tor his sake

every month a new sworn brother...

reeoneiled to the prinee your brother

how now, brother? where is my...

late stood out against your brothe

the prince, your brother, is roy

are entering; brother, make good room

are very near my brother in his love

hath your grace ne'er a brother like you? -

go you to the prinee your brother

lord and brother, Grod save (rep.)

for my brother, I think he holds you

is this the prince's brother?

myself, my brother, and this grieved

the prinee's brother', was a villain

to eall a prinee's brother, villai

men ean couns

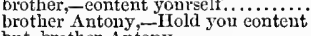

brother, away; I will be heard

Leonato and his brother

your brother, the bastard, is fled...

two of my brother's men bound!

Don John your brother ineensed me

my brother hath a danrliter.

office, brother; your must be

to maryy with my brother's danghter?

eall hei forth, brother, here's the friar

my lord, your brother Joln is ta'en in

would call their brothers, fools... Mer. of Verice,

my brother Jaques he

bars me the plate of a brother

yonder eomes iny master, your brother

I poor nuworthy brother of yours.

were there twenty hrothers betwixt.

wert thou not iny brother, I would

his younger brother, the new duk

your younger brother, Orlando ......

notice of my brother's purnose herein

against me his natural brothe

tyrant dike, unto a tyrant brother..

my eo-mates, and brothers in exil.

to his brother; fetch that (rep.)...

your brother's life falls into forteit

twist you and your poor brethend me to my brother.

I lave a brother is eondemned to die

his fault, and not my brother

your brother is the forfeit of the law

endemns your brother ( $r e p$ )

cannot weigh our brother with ourself

that's like my brother's fault

against my brotber's life.

Olet her brother live

your brother eannot live

a sentenee on your brother's life.....

to save this brother's life?

your brother is to die ................

as auch for my poor brother as myself then must your brother die

better it were, a brother died at one

sliding of your brother a merriment

my brother did love Jnliet

\& present pardon for my broth

redeem tily brother by yieldiug ap

brother die: more than our brother.

yes, brotler, joun may live

what aays my brotber?

what sin you do to save a brother's lif

I had rather my brother die by the law

redeem your brotlier from the angry

slie lost a noble and renowned brother

not only saves your brother but keeps

by this, is your brother saved

provost, my brother Angelo wiil not

if my brother wrought by my pity

I am a hrother of gracious

I eome about my brother.

it' yeugh her were my brother's pardon be eome

sent my brother's pardon

my troth, lsalel, I loved thy brother

was sent to by my brother

rer her poor hrothe

for my poor brother's head.

have weighed thy brother by himself

your brotler's death, I ken

but as he aujudyed your brother a diverted blood, not brother...........

find ont thy brother, wheresoe'er he

quit thee by thy brother's mouth ...

ii. 2 (Ganymede, my new mistress's brother

in beard is a younger brother's revenue

and browner than her brother

2 his brother, his elder brother (rep.).

ii. 4 eommitting me unto my brother's love

.4 how yon excuse iny brother, Rosnlind

God save you, brother ..........

for your brother and my sister.

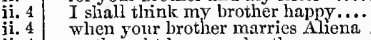

ii. 4 methought he was a brother ........

purnosely to take his brother here

bequeathing to his banished brother

eount Rousilon eannot be my brother. $A l l^{\prime}$ s $W$ ell, he must not be my brother

your son, were not my broth

he slew the duke's brother

your brother, he shall go along.....

the count Ronsillon and my brotlier

brother for a eoward, yet his brother - iv.

filled up, my brother witl our....Winter's The, $\mathrm{j}$.

we are tougher, brother, than you .

how is 't with you, best brother?

my brother, are you so fond of

and reconciled king, my brother .....

his sworn brother, a very simple

that I sbould eall you brother i.......

her brother, having both their country

called me hrother; and then (repeated)

with your crowned brother

dear my brother, let him, that was...

v. 1 look upon $\mathrm{my}$ brother...

reft of his brother, but retained

fie, brother! liow the forld...........

I would not spare my brother.

did eall me brother; what $J$ told ..... offer'st fairly to thy brother's wedding

iii. 1 what's his brother, the other eaptain

to save both, farewell, our brother

ay, good brother, or go about to think

and a brother, in quest of them. my glass, and not my brother.

if' Donalbain be with his brother

the brother Geftrey's son...King John,

to claim your brother's land?

your brotier did employ my father.

like thy brother, to enjoy thy land.

marlam, an' my brother liad iny shape

brother, take you my land

brother by the mother's side

Where is that slave, thy brother? ...

look liere upon thy brother Geffrey's

wan to the elder brother of this man.

first ealled my brother's father, dad

brother of England, how may we....

my brother, nay, ny kingdom's ( rep.)

thou seest thy wretehed brother die.
thus tlyy brother to be slaughtered

thy sonetimes brother's wite .........

wert thou not brother to great Edward's

my brother Edward's sou...

my brother Gloster, plain

eut off my head with my brother's

I am sworn brother, sweet

brother, the ling liath made

..1 Henry $v$

once again of my wite's brother.......

his brother's death at Bristol

farewell, good brother; we shiil ......

I tear my brother Nortimer doth stir

by thy younger brother is supplied.

Jolin of Lancaster, my brother John

younger sons to youmger brotbers...

nyself, my brother, and his son $\ldots$.

eome, brother, let's to the lighest.

your brother thus; so fought

ending with_lrother, son, and ali..

that I am in secoud brotber

John, with my brothers and sisters - ii. 2 (letter)

like a brother toiled in my affairs

Stafford and his brother's death.

therefore eomes my brother Montague as if he liad been sworn brother...

wy brother general (repeaied)......

is not his brother, Thomas of Clarenee

art not with the prinee thy brother?

in lis afleetion, than all thy brothers

I am here, brother, full of heavines

we left the prinee my brother here

brothers, jou mix your sadness. ...

yet be sad, good brothers

no more of it good brothers, than.....

your brother kings and monarehs.

all three sworn brothers to Franee

back to our brother of England.

are sworn brothers in filehing

were my brother, I would desire

ealls them brothers, friends.

brothers both, commend me.

go with my brothers to my lords

brothers; for he, to-day that sheds (rep.)

the brother to the duke of Burgundy

most worthy brother England

happy be tlie issue, brotlier England

brother, we shall; go, uncle (rep.) .

our gracious brother, I will go ............
this I have not, brother, so denied

this lav the not, brother, so denied

to slay thy brother Abel if thou wilt.1 Henry $I$ I. i.

and did my brother Bedtord toil

brother York, thy acts in Ireland...

Statiord and his brottier are hard by

iv. 2

good brother, as thou lov'st

nother, though I be youngest

now, sons, and brother, at a strife?

my brother Montague sliall post .... -

how tares my brother? .............

lord George, your brother, Norfol

and for your brother, he was lately

iv. 3 didst kill our tender brother Rutlan

was Agamemnon's brother wronged
thy lorother's blood the thirsty earth

revenge! brother, revenge my death.

brother, give me thy hand ........
that slew thy brother Rutland

that slew thy sire and brother

bour brother Richard marked

brothers, you muse what ehat.

well, jest on brothers. I ean te

go we, brothers, to the man $\ldots \ldots . .$.
my elder brother, the lord $A$ ubrey

sent from your brother, marquis

iv. 1 dear brother, how shall Bona be
v. 1 our brother made a worthy choiee?

iii. 1

iv. 1

iv: 4

iv. 4

$\mathrm{v}$.

iii. 4
1
1
1
1
1
1
1
1
1
1
1
2
2
1

4
2
6 


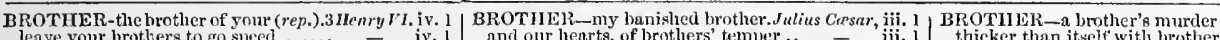

leave your brothers to go speed

not be tied nintio his brother's will...

Edward's brother, wero but a feigneil

brother being carelessly eneamped
how to use your brothers lrotluerly :.

be conveyed unto my brother .......
fell Wrick's brother, and by that..

our king, my brother, is prisoner.

brother, the time unl ease requireth

is eseaped from your brother $3 . . .$.

my brother was too ear

both him, and all his brother...........

brother, this is six John Mlontgomery

why, brother, wherefore stand you..

brother, we will proclaim yon .........

how far off is our brother Nontague?

gave the kingdom to thy brother ....
and thy brother both shall buy this.

to bid his brother battle.......

against his brother, and his lawful king

to deserve well at my brother's hands

sweet brother, take my hand

for, brother, if tlou didst ..............

eominend me to my valiant brother..

no loped-for mercy with the brother

exeuse me to the king ing brother.

thy brother Ei ward; and thyself.....
I have no brother, I am like no brother

princely nephew, brothers both

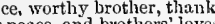

my country's peace, and brothers' loves
to set my brother Clarence........... RichartIIII.

brother.

brother, good day: what means......
Antour Woodrilie, her brother there
since that our brother dubbed them..

degree soever, with his brother .......
brotler, farewell ; I will unto the king

but that thy brothers beat aside.

the duke of Gloster and your brothers

my ehildren, brothers, and myself.

our brother is imprisoned by your
king ag:inst the duke my brother.

for my brotlier for his sake

my brotler's love, the devil (rep.)...

my brother, hate not me (rep.) . . ....

brother [Col.Knt.-Gloster], we have do

a tongue to doon niy brot

dear brother, live, and be a king?...

but for my brother, not a man

and brotleers, hanght and proud

I did grow more than my brother....

brother to brother, blood to blood...
unto his princely brother presently.

if our brother come, where shall we

ay, brother; to our grief

ay, brother; to our grief $\ldots . . . \ldots \ldots . .$.

the prince my brother hath oritgrow

my orother nosks both you and me

the king my brother was possessed.

that Edward is your brother's son .

depose the ehild your brother's son ..

your brother's son shall never reign

be married to my brother's daughter

murabeth, my brother's daughter...

where be, my brother

death of my poor sons and brothers?

in that safety died her brothers

didst thou love her brothers $\ldots$ by the man that slew her brother

by the man that slew her brother

sap from her sweet brother's bod

her father's brother would be her yor

he that slew her brothers, and her
thy brother [Col. Knt.-my husband] made -

brother slain [ Col. Knt. brothers died]

his elder brother, with many more ..

thy brother tender George be exeeuted

brother blindly shed the hrother's blood
marriage with his brother's wife. . Ilenr

marriage with his brother's wite.
learn this, brother, we live not to.

downger, sometimes our brother's

the heails of all thy brother eardinal
you a lirother of us, it fits we thus .

iv. 1 your brother too must die.............

iv. 2 low should I wrong a brother?

hear me, lod lrother

O my deur brotler! this was an ili

int, good brothe

iv. 50 and commeny brother Cassius...

against my brotleer lucius......

his brother warred upon him.

my brother never did we wars

to make you brothers, and to knit....

the heart of brothers govern

no brother dic ever love so dearly...

good brother, let me request you off.

v. 1 what, are the brotliers parted?

v. 1 my noble brother! The April's ....

v. 1 brother! lutsband win, win brother.

v. 1 of a war shall stain your brother

brother, good-night: to-morrow is
thou, my brother, my competitor

thiet-stolen, as my two brother
the younger brother, Cadwal

\begin{tabular}{l|l}
$\mathrm{v} .2$ & the younger brother, Cadwal \\
$\mathrm{v} .2$ & I'll love him as my brother
\end{tabular}

v. 4 if brothers? 'would it had been so.....

brother, stay here; are we not brotber
I yoke me in my good brother's fault

brother, tarewell. I wish y

I wish my brother make good time.

but sec, thy brother. This Cloten

howsoe'er, my brother bath done well

ny brother wears thee not

our son the whilst: brother, begin .

of bold lachimo, Sienna's brother.

and my brother are not kuown ....

0 my mentle brothers, have we thus met?

you called me brother (rep.) ......

i. 3 on him, her brotliers, me, her master

thou art my brother: so we'll hold.

lord Titus, my beloved brother...

brothers, help to convey her hence Tiin

unworthy brother, and unworthy sons
brother, for in that name doth nature

for thy sake, and thy brother's here

Lavinia is thine elder brother's hope

to save your brother from the sacrifice

speak, brother, hast thou hurt (rep.)

$O$ brother, help me with thy tainting

my brother dead! I know, thou dos

Lucius, tor thy brothers let me plead

to reselie $m y$ two brothers ..........

my brother, weeping at my woes...

Wiarcus! brother, well I wot

that to hex brother which I said to thee -

mine shall save my brothers' lives

redeem my brothers both from death

o, brother! speak with possibilities.

and thy brotleer, I, even like a stony

eome, brotber, take $a$ head

fie, brother, tie! teach her not

see, brother, see; note, how she quotes

brother, sit down by me.

the tribune in his brother's bearing.

will you kill your brothe

he's your brother by the surer side...

two of her brot brother.............

that murdered our emperor's brother
fell faults our brother's were beheaded

moonshines lag of' a brother?

it is a letter from my brother.............

I bope, tor my brother's justifieation.
the beloved of your brother, Edgar

the eharacter to be your brother's?

your indignation against my broth

I am thinking, brother, of a predietion.

a credulous father, and a brother noble...

set guard to take my brother

brother, a word; descend : brother, I say

fiy, brother; torches! torehes

'twas her brother, that, in pure kindnes

youx brother's evil disposition ..........

eould my good brother suffer you to do it.

and the exchange, my brother

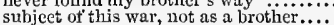

and eall itselt your lirother......

o my brother's cliild! unhappy.Roneo o. Juliet, iii.

for the sumset of my brother's son...

to find a barcfoot brother out..

brother, I'll goot lrother out.......

brother Montague, give me thy hand

of IInmlet our clear brother's dentl
thinking, by uur late clear brother's death

thinking, by wur late dear broth

sleepin's by a bruther's luand, ou' litio

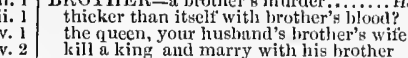

kill a king and marry with his hrother

counterfeit presentment of two brothers
blasting his wholesome brother

my brother shall know of it

her brother is in seeret come from France

forty thousand brothers eould not

oer the house, and hurt my brother
will this brother's wager frankly play.

will this brother's wager frankly pl

from his very arn puffed his own brother - iii.

BRoT is it, brothe ......................

ii. 2 Ehall comline, and brotherhood ........Ienry $V . i \mathrm{i}$

ii. 6 this deep disgrace in brotherbood...Michard 1II. i.

ii. 7 who spoke of brotherhood?

ii. 2 by my brotherhood, the letter was...lom. \& Jul. v.

ii. \& the king's brother-in-law (rep.).. Winter's Tale, iv. 3

but for our trusty brother-in-law ... Richard II. v. 3

brother-in-law, the foolish Dlortimer.l Henry $1 \mathrm{~V} . \mathrm{i} .3$

Clarence, this is brother-like.

iii. 3 IROTHER-LOVE- trie heart, and brother-love I do it. Henry VIII. v.

iii. 6. BRU'THERLY

I speak but brotherly of lim $\ldots .$. As you Like it, $\mathrm{i}$.
to use your brothers brotheriy $\ldots$...3ilenry $\mathrm{I}$ l. iv.

Polrdore, I love thee brotherly

was hither bropot with child

into bondage brought my too diligent

which brought thus tog hith

and were brought moping hither.

bave brought me to my love

here have 1 brought Lim back agaiv

Julia herselt' hath bronght it hitler.

youl have brought her into such
whatd's broughave brought ber to
whass under the

what's brought to pass under the...
when you have brought him thither

marriage would have brought upon her

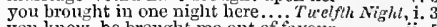

you know, he brought me ont of tavou
what foolish boldness brouglst thee to

has brought you to this shame... Meas. for Meas. ii. 3

that she brought me up, I likewise ... Much Ado, i.

ii. 3 be bound, and brought to Leonato

sliallow fools have biought to light

ii. 4 how you were brought into the orehard

ii. 4 brought with armed men back to

I thank it, brought me to.......Mid. N. Dream, iii. 2

I hare brought him a present.... Mer.of Venice, ii. 2

from beaven brought her (rep.). As you Like, v. 4(ver.)

that has brought his pardon ...

broulght you this letter, gentleme

she brouglit stone jugs.. Taming of Shrew, $\overline{2}$ (induc.)

his son, brought up in Florence.

who brought it? I. Tis burnt

his daughter is to be brought by you - $~$ iv. 4

I have brought him up ever since.

till I be brought to such a silly pass...
brought you forth a daughter..... Winter's Tale, ii. 3

from thence have brought this....... - iii. 2

times tbat brought then in $\ldots \ldots \ldots-$ iv. (cho.)

was brought to bed of twenty $\ldots \ldots . . .$. - iv. (c)iv.

and brought a benediction to the buyer - iv. 3

I brought the old man and his son....

why, sir, I brought you word .. Cam. of Errors, iv. 3

let him be brought forth...

they brousht one Pinch; a hungry

but I think he brought it not

rooks, brouglit forth the seeretest. ...

and brouglit oft the field; your eause ... -

have brought a counterclieek betore.. Sing Joln ij.

zeal and charity brought to the field

who brought that leiter from

brought in matter that should feed

this news was brought to Riehard

and brought prince Henry in their..

being brourht into the open air ......

brought hither Henry Thereford

now hath ny soul bronglit furti

ly me hither brouglit, Exton

and he liath brought us smooth

hath lorought three hundred mark

lath Butler brought those horse

that brougint you hone, and boldi!

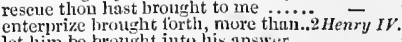

what the devil hast thou bruaght tlicre? -

have brought ourselves into a bminin.

ionuly bronght here, ant foolishly sei

are brought to the eorrection of your 


\section{BRO}

BROUGHT-may on foot be brourht so graeiously hath brought to light that erst bronght sweetly torth
had him brought into my power

had him brought into my power ..... Henry $V I$. $\mathrm{i}$. and safely brought to Dover

we have brouglat duke Humphrey in.2 Henry $v I$. be brought against me at my trial-day

and fuel be brought to feed it with

Thave been so well brought np .....

were brought me of your los $\ldots . . .3$ Henry VI ii.

brought your prisoner to your palaee

when nature brouglit him to the ....

brought desired help from Burgurd

the queen bath brought a piuissant

and yet brought forth less than .......
and untimely brought to light
who brought une in my master's hat

Who brought une in my master's hate

ichard IIt i.

he was brought to this by a vain.....

iii. 2

has brought with lier one care abroad
to him brought, viva voce, to his faee

when he was brouglit again to the bar

your grace conld but be brought to know

you brought the king to be your servant

and brouglit lim forward (as a man

and brought me garlands, Griffith ..

he brought a Grecian queen.. Troilus \& Cressida, ii.

he brought home noble prize

what have I brought you to do ......

poor honest lord, brought low by his

which with wax I brought away ...

lialf an hour sinee brought iny report

our best water brought by conduit

hath bronght me to thy hearth ......

say not, we broughtsit. How!

that brought thee to this world ( $(\mathrm{rep}$.

our spoils we have bronght

Jul

he linth brought many captives home

and having brought our treasure where
he was but a fool, that bronght my

he was but a fool, that bronght my
till he have brought thee up to youder

thongh daintily brought up.. Antony

Which thou hast brought from kome

Antony shall be brought drunken torth

simple eonntryman, that brought her figs

which brought them to be lamented

had I not brought the knowledge

I nm brought thither nmong the

and brought to yoke, the enen

that brouglit her for this high good tio

or brought a faggot to bright-burning

we are not lorought so low.

int resternight was brought to bed

I have brought you a letter, and a eouple

and brought him hither, to ase as you

till he be brought unto the empress' face

or who hatl brought the fatal engine in

contrary are brought your eyce

hath brought the bricle to bed.......

had pleased you had brought her hither

brought up some eleven, $\mathrm{Ay}(r e p$.$) ..$

have brought this king to Tharsus

y'et I was mortally brought fortli .....

but brought forth a maid-ehild called....

her better stars brought her to Mitylen

her fortunes brought the maid aboard.

they shall be brought yon to my house
who brought it? It was not brought me

of man, brought ncar to benst.

of man, brought ncar to benst.............

have his daugliters brought him to

when twat hound for him that hrowi.... it

I bronght my master news of Juliet' $s$. Rom. \& J J

so young days brouglst up with him....

from Hamlet? who brought them

received them of him that bronght tliem

to such wondrous doing brought lis hor

let the foils be brought, the gentlems

the state affairs, hath hithor brou

these legs, that brought me to a part of it

BROW-my brow to frown ...... Terofien. of Ver.i.

the right arched bent of the brow.....
my brows beeome nothing else.
my father had a mole upon his brow. Tuelfh

my father had a mole upon his brow. Twelfh
there is written in your brow ....Mfea. for Hea.

but speak you this with a sad brow... Ifuch Ado, $\mathrm{i}$.

honest, as the skin between his brows $\overline{\text { N. }}$. iii.

thees Hrows death-counterfeiting ....Mid.

these lily brows [Col. Knt. lips]

wanton with a velvet brew...

and she strikes at the brow

a state, a brow, a breast, a waist

the heaven of her brow, that is not .
in black my lady's brows be decked..
to imitate fier brow .................
BRU

BROW-help, hold his brows! .... Love's
the mourning hrow of progeny forbid

the mourning hrow of progeny forbid
some sober brow will bless it.. Merch.of venice, ii

hollow eye, and wrinkled brow ......

snenk sad brow, and true maid.

'tis not yeir inky brows, your black

sitand draw his arehed brows .........Al's ${ }^{2} \mathrm{rell}, \mathrm{i}$.

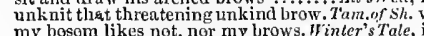

myd bardening of nyy brows

as if you held a brow of mueb

your brows are blacker; yet blaek brows

skin off' my harlot's brow

wears upon his baby brow the round of Errors,

would wear the brows of grace

ne'er pull your hat upon your brows.

against the brows of this resisting ... King John

these eyes, these brows, were moulded

a riot on the grentle brow of true

and put my eyeballs in thy vanlty b.
my liandkerchiet about your brows

why do you bend such solemn brows on -

witls wrinkled brows, with nods.......
and outtace the brow of bragging horror

in the black brow of night, to find...

and trowning brow to brow.

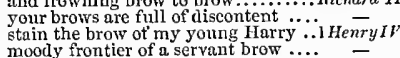

moody frontier of a servant brow $\ldots$ bear
beads of sweat have stood upon thy brow

tlis seening brow of justiee..........

now bind my brows with iron

it is not a eenfident brow, nor..........
whose brow, with homely biggin bound

-

and a jest with a sad brov

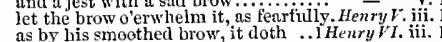

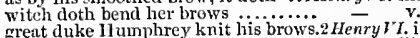

great duke lis lumphrey knit his brow.

aud Sutrolk's eloudy brow his stormy hate -

must round engirt these brows of mine

like a gallant in the brow of you th

ghe knits her brows

the wrinkles in my brows.

now are our brows bound with........ Richard III. i.

crown lis wrinkled brows with papes
metal, that must round my brow ...

metal, that must round my

to grace thy brow's withal .............

returned, his brows bound with oak... Coriolanus, i.

his bloody brow with his mailed hand
his bloody brow! 0 Juyiter.

his'bloody brow! 0 Jupliter.....

on's brows, Mlenenius: he eomes

prepare thy brow to frown: know'st
angry spot doth glow on Cæesar's brow. Jul.C
to $r$ so

all the eharnctery of iny sad brows

put on my brows this wreath of victory

take this garland on tlyy brow .......
bliss in our brows bent........ Antony \&

and make his eyes grow in my brow

did put his brows witlinin .

Cymbeïne, iii. 1

an angry brow, dread lord...

iny queen's square brows...................

stamp wrinkles in her brow of youth....... Lear iv.

that kiss fair ladies' brows
day before, sle broke her brow

day before, sle broke her brow
it had upon its brow a bump

upon his brow shame is aslamed to sit

but the pale reflex of Cynthia's brow

eontracted in one brow of woe $\ldots \ldots . .$.
with his other hand thus o'er his brow

what a grace was seated on this brow
between the elraste unsmirched brow

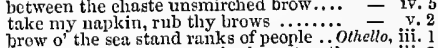

brow o the sea stand ralks of peorle...

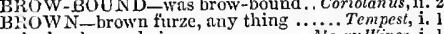

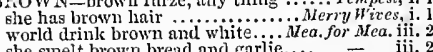

she smelt brown bread and garlie...

a commodity of brown paper and old

too brown for a tair praise.............Much Ad

with a bottom of brown threai

your lrown hastard is your only

been cleft' with a brown bill $\ldots \ldots .211$ erry VI. iv. 10

a broven favour, (for so tis (rep.).. Troil. \&.Cres.

but brown Faith, to say (rep.)

not that our heads are some brown...Coriolanus, ii. 3

her hair, what eolour? Brown

Ant. \& Cleo. iil. 3

do something mingle with our brown

bring up the brown bills ............... Lear, iv. something browner than Judas's...As you Like it, iii. 4 the woman low, and browner than her $-\overline{\text { iv. }} 3$
BROWNIST -as liet be a Brownist .. Twelfth $N$. iii. 2

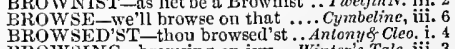
BROWSING-browsing on ivy ... Winter's Tale, iii. RUISE - and bruise to dea

Much Ado. il.

bruise me with scorn, eonfound me... Love'sL.L. v. 2

nor bruise her flowrets with the $\ldots . .1$ Henry $1 V$. i.
spermaceti. for an inward bruise
teel the bruises of the dags before ..2Henry $I V$. iv. 1
BRUISE-not good to bruise an injury. Henry $V$.iii. 6

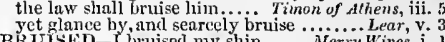
soul, bruised in adversity ...........Merry Wives, $i$. he was so bruisel, that the...........IIlenry IV.v. our bruised arms hung up for ....... Richar 1 III. $\mathrm{i}$. bruised underncath the yoke of tyranny

palamedes sore liurt and bruised...Troil. 8 Cress.v. that the bruised hicart was piereed ... O Cleo. iv. 1 BKUISING-against the bruising. Tư Gen. of $r, j$. battles, and to bruising arms ....... 1 Henry IV. iii.
thy bruising irons of wrath ......... Richard $I I I$. . sliall not be bruising to you ........... Coriolarus, ii. 3
BRUIT-the bruit thercof wili bring.3Henry/ $Y$. iv. 7 the bruit is - Ileetor's slain... Troilus \&. Cressida, v. 10 ns common bruit doth put it ... Timon of Athens, y.
the lieaven slall bruit agaiu............. Homlel, $\mathrm{i}$. 2 BRUITED - greatest note secins binited... Hacbeth, v. 7

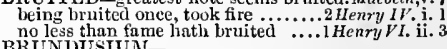
BRUNDUSIUM-

from Tarentum, and Brundusium..Ant. \& Cleo. iii. 7 BRUNT-in the brunt of seventeen.. Coriolanus, ii. with one winter's brush fell froni... T'im. of Ath. iv. BRUSHED - my mother trushed ...... Tempest i. their blue conts brushed ....Taming of Shreu, iv. I
BRUSHES- he brushes his hat ....... Huch Ado, iii. not yet the brushes of the war ...... Troil.s. Cres. y. it was a brute part of him to kill so.... Hamlet, iii. sensual as the brutish sting .... brutish... Tempest, my remembranee brutish wratli... . Richard III. i . brutish villain! worse tlian british! ........ Lear, i. RUTUS-daughter, Brutis' Por

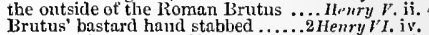
Brutus bastard hand stabbed

Sicinius, Lrutus, Coriolanus, citizens

than tliat poor Brutus, with himself

then, Brutus, I have mueh mistook.

tell ine, good Brutus, can you sce.

slenking of Brutus, and gruaning...
wished that noble Brutus liad liis ej.

therefore, good Brutus, be prepared.

that virtue to be in you, Britus ...

the fault, dear Bratus, is not in our
Brutus, and Casar; what should be

Brutus, and Cæsar; what should be
Brutus will start a spirit as soon as.

there was a Brutus once

Brutus had rather be a villager.......
thus much show of fire from Brutus

well, Brutus, thou art noble .........

he loves Brutus; it I were Brit

where Brutus may but find it...........

upor old Brutus' statue................

see Brutus at his house

Brutus, thou sleepest, awake (rep.)
full petition at the hand of Brutus

Brutus, do we trouble you?..........
this Decius Brutus. He is weleome

we'll leave you, Brutur..

ungently, Brutus, stole from

Brutus is wise, and were he not

is Brutus sick? and is it physical

wo, my Brutus, you hare some sick.

if yon were gentle Brutus (repealed)

a woman that lord Brntus took to wife

it suffieetl, that Brutus leads me on

here's Decius Brutus, he shall tell

the heart of Brutus yearns to think upon - ii.

Casar, beware of Brutus $\ldots \ldots . . . . \quad$ ii. 3 (paper

Deeins Brutus loves thee not $\ldots$

Brutus hath a suit, that Crsal

Brutus; he draws Mark Antony

What, Brutus! pardon Casar...

go to the pulpit, Brutus.............

thus, Brutus. did my master bid me

if Brutus will vouclisate, that Antony

so well as Brutus living ( $r e p$.) .....

now, Decius Brutus, yours; now your

Brutus, a word with you . I..........

the noble Brutus is ascended $7 . . .$. .

why Brutus rose against Casar .......

none, Brutus, none. Then nome have I

to Cxsar, than you should do to Brut
live, Brutus, live! live! Bring him..

shall now be crowned in Brutus

peree; silence Brutus sake, I am beholden (rep.)

'twere best he speak no harm of Brutn

the noble Brutus hath told you, Casar

under leave of Britus, and the rest ( $r$.
Brutus says, he was anbitious (rep.)

not to disprove what Brutus spoke...

I should do Brutns wrong, and Cassi
the well-beloved Brutus stabbed ....
$\overline{C e}$ iii.

$=$

i.

i.
i.
i.
i.
i.
i.
i.
i.
i.
i.
i.
i.
i.
i.
i.
i.
ii.
ii.
i.
ii.
i.
i.
i.
i.
i.

iii.

\section{ii:}

\section{位.}

iii. 

BRU'TUS-for Brutus, as you know..Jul.Carsar
I am no orator, as Brutus is..........

but were I Brutus, null Britus Antory -

We'then him say, 13rutus and Cassins

to Brutus, to Cassius; burn all

Brutus and Cassius, are levying powers -

that you are Brutus that your

Brutus, bay not me; I'll nut etulure it -

When Mlarcus Brutus grows so

brut Brutus makes nine greater thain

but mirth and laughter to his Brutus

O Brutus! What's the matter?

are over-earnest with your Brutus ,"

I cannot drink too much of Brutus' love -

let it not, Brutus. Every thing is well
good niglit, lord Brutus. Farewell.

good night, lord Brutus. Farewell -

in your bad strokes, Brutus, you give

now, Britus, thank yourself .........

I wis not born to die on Brutus' sw

now, most noble Brutus, the gods.

for ever, and for ever, farewell, Brtitus

Brutus gave the word too early

is overthrown by noble Brutus' power

as welcome to the ears of Brutus

thy Brutus bid me give it thee (rep.)
and I am Brutus, Marcus Brutus (rep.)

and I am Brutus, Marcus Brutus (rep.)
kill Brutus, and be honoured in his..

Brutus is ta'en. I'll tell the news (rep.)

Brutus is safe enough; I dare (rep.

and see whe'r Brutus be alive or dead

what ill request did Brutus make....

for Brutus' tongue hath almost ended

for Brutus only overcame himself.

so Brut us shoull be found (rep.) .....

at Philipoi the good Brutus ghosted.

Roman Brutus, with the armed rest

wheu at Philipui he found Brutus slai

lord Jnnius Brutus swrire for....

i' the Capitol; Brutus killed me .......Iambet,

seeking the bubble reputation .....As you Like

seeking the bubble reputation .....As you Like il, ii.
on my lite, my lord, a bubble....... All's Well, iit. 6
earth hath bubbles, as the water has ...Macbeth, i. 3

fire burn; and cauldron bubble (rep.) ... - iv.

of dignity, a breath, a bubble......

them to their trial, the bubbles are out... Hamlet, y.

BUBBLING-to a bubbling fountain.. Titus And. ii.

BUBUKLES-his face is all bubukles.. Henry $V$.
BUCK-buck? I would I could (rep.). Merry Wives,

buck, buck, buck? A , buck (rep)

it was a buck of the first hend... Lore's L. Lost. iv.

make a man mad as a buck... Comedy of Errors. iii.

bow shoots buck and doe. Troil. \& Cres, ii.

bow shoots buck and doe...Troil. \& Cres. iit. 1 (song)

they conveyed me into a buck-basket

buck-basket! By the lord, a buck-basket -

this 'tis to have linen, and buck-basket

BUCKET-dive like buckets, in concealed.J Jh/n

two buckets filling one another ..... Richard II. iv.

gibbets on the brewer's bucket ....2

a new link to the bucket must needs - v.

BUCKING-Were going to bueking. Merry Wives, tii. 3

Sork and Buckingham, Somerset ...2 Henry VI. i.

cousin of Buckingliam tluough

Somerset's and Buckingham's ambition -

slow some reason, Buckingham, why

lord Buekingham, methinks, you.

at Buckingham, and all the cre.......

of Suftolk, Buckingham, and York...

what, Buckingham, and Clifford ....

Buckinglam, is the traitor Cade

Buckingham, go and meet him

Buckingham, to disturl

Humphrey of Buekingham, I accept

O Buckingham, I pr'y thee, pardon me

Buckingham, I do dismiss my powers

Buckingham, doth York intend no

call, Buckinghaw, and bil him (rep.)

duke of Buekingham, is either.......
in Buckingham, Northampton, and.

ords of Buen, Northampton, and...

the duke of Buckiugliam and I ....

o princely Buckingham, I kiss........

she say, my lord of Buckingham?...

Stanley, Ilastings, Buckingham

sou Dorsct; Buckingham, nor you ...

whenever Buckingliam doth turn

cordial, princely Buckingham

my noble cousin Buckingham

train, my lord of Buckinghum?.

dukes, Gloster a

my lord of Buckingham, if my weak

and my good cousin Buckingham

and my good cousin Buckingham ...

cousin of Buckingham, a word with jou =
BUCKINGIIAM-cousin Buckinghan, Richlll. cousin of Buckinglam, and sage, grav al, Buckingham, now do I play .... why, Buckingham, I say, I would
high-rcaching Buckingh deep-revolving witty Buekingham than Buckinghum and his rash-levied expecting but the aid of bueking stirred up by Dorsct, Buekinglian

lickingham's army is dispersed

they came from Bnckingham upoi ..

the duke of Buckinghan is taken ...
Bnekingham be brought to Salisbury

3 in the bittle think on Buckinghan.

duke of Buckinglann's surveyor....H

ny lord the duke of Buckingliam

that gentleman of Buckingham's ....

out of the duke of Buckingham.

of the great duke of Buckingham.

be bold to weep for Buckingham

and, if he speak of Buckingham

constable, and duke of Buckingham

bewailing liund of noble Buckingham

the dukc of Buckingliam came from

a span buckles in his sum.. As you Like
cannot buckle his distempered cause.

...Macbeth, $\mathrm{v}$.

he that buckles himsclf in my belt ...

combat thou shalt buckle with me...i Henry $V I$. i. 2

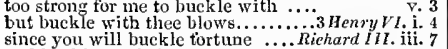

and buckle on their urmour.

and bucklc in a waist nost ............. Troilus \& Cress. ii. 2

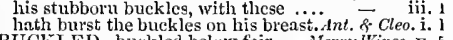

BUCKLED-buckled below fair.... Merry Wives, v. 5
one bucklerl, another laced .. Taming of Shrew, iii. 2

arlnour conscicnce buckled on...... King John, ii. 2

we have outr armours buckled

Troil. \& Cres. v. 3
Antony \& Cleo. iv. 4
.

I'll buckler thee the bucklers (rep.) MIach Ado, v. 2

buekler cut througl and through . .1 Henry I V.
the guilt of murder bucklers thce..2 Henry $V^{\prime}$.

now buckler filschoo
BUCKLERSBURY-

BUCKRAd like Bucklersbury .... Merry Wives, iii.

two rogues - -cascs of buckram

four rogues in buckrain let drive at

these nine in buckram, that I told

eleven buckram men grown out of twol - ii. 4

best -Wellilc with buck-washing... Merry Wires, iii. 3

BUD $D$ in the sweetest bud ....... Two Gen. of Ver. i. I

blasting in the bud...............

these lisping hawthorn buds

like a worm i' the bud .......

Merry Wives, iii. 3

when hawthorn buds appear

chaplet of sweet summer buds is
kill cankers in the musk-rose buds

which sometime on the buds was wont

masked are roses in their bud..... Love's $L$. Lost, iv.

as whirlwinds shake fair buds ...Taming of Sh.

i. 3 by bud of nobler race ............. Winter's Tale, iv.

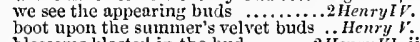

blossoms blasted in the bud ......... Henry Vl. ii
that kneeled unto the buds .... Artony \& Clen. iii

that kneeled unto the buds ..... Artony \& Clen. iii. II
shakes all our butls from growing.... Cymbetine, i.

of bud, bird, branch, or berry ..Pericles, v. (Gower)
ns is the bud bit by an envious.......Rom. \& $J u l . \mathrm{i}$.

aunong fresh female buds shall you

this bud of love by summer's ripcuing - it.

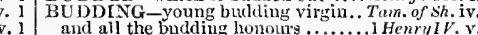
and all the budding honom

Tempest, $\mathrm{y}$

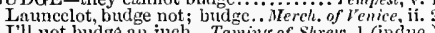

but afoot he will not budge a tout ... Herry $V^{\prime}$. ii.

I will not budge a foot

as they did budge from rascals $\ldots \ldots . .3$ Henry $V_{l}$. v.

must 1 budge? nust I observe ..... Hilius Casar, iy.

Yoil shall not budgc; you go not....... Hamlet, iti.

1 BUDGL' - she cries budert....... Merry Hives,

either your mint, or lier budget

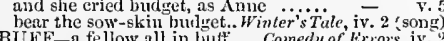

BUWF - a fellow all in butt.... Comedy of Errors, iv.

and is not a buff jerkin a most ....... 2 IfenryI $l$.

what a plague liave I to bo witli a buff

iii. 1 that he did buffet thec........ Conedy of Errors,

blows and lutfets of the world ......... Ilacteth, iit.

but buffets locter than a fist

if I might buffiet for my love...

King John, j.

Henryl:vi.2

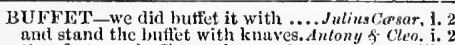

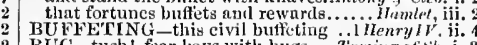
BUG-tush! fear loys with bugs . Traming of sh. $\mathrm{i}$.

the bug, which you would fright ... Wiater's $\%$

grown the mortal biligs o' the ficl

BUGBEAR-a bugbear take himl. Troil. $\&$ Cres, iv

BUGLE - or lang my butle in ........ Aruch Ade $i$.

burle bracelet, necklace-ami......... As you Like it,

BU ILD-to build upon a foolish ...Mrry Wive

sparrows must not build in his....Nea. for Mea. iii.

any model to build mischief on? ..... Mncec Ado, i.

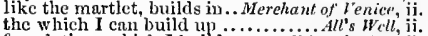

foundations which I build upon...........terter's Tale, ii.

When the kite builds, look to lesser.
when we mean to build, we first

at least, desist to build at all?.

bcyond his power to build it

plot, well chosen to build upon $1 . . . .2$. Henry $v$ is.

on thy shoulder do I huild my seat..3Henry $r I$. ii.

who builds his hope in that place. Richard 111. iit.

nor build their evils on the graves...ilenry $\bar{v} / 1$. ii.

build there, carpenter; the air .. Troil. \& $\mathrm{Cr}^{\prime}$ s. iii.

thou shalt build from nien

the cuckoo builds not for himself.... intony f.Cleo. ii.

[Col. Knightt.] build his statue.. Perictes, it. (Gower)

dare build so far to make your speed

bawds and whores do churches build

he must build churches then

nor build yourseif a trouble

do buila on thee a bettcr opinion

r aiery buildeth in the cedar's top...RichardIII. i.

BOur aiery buildeth in our aiery's nest

gaze upon the buildings, and then.. Com. of Err. $\mathrm{i}$.

luve, iu building, grow so ruinate... - iii.

stole thence the lite o the building
the singing masons building root's

thy sumptuous buildings

Henry ${ }_{\text {H. i. } 2}$

base and building of my love .. Troilus \& Cress. iv.

and the buildings of my fancy

mine cye upon the wasted buildin....

goodly buildings left without a roo

may all the building in my fancy
BUILT-and built so shelving..' $T$ u

a fiair house, built upon anotl
on whon I built an absolute

lifs apparei is built upon his lyack.

thou hast built a paper-niill.

from age to age he built it?.

as tairly built as Hector.... Troilus

you deserve to have a temple built.

who cannot be new built

Coriolunus, ii.

hath built lord Cerimon such $\ldots . . .$.
the gallows is built stronger than

BULk-the bigger bulk it shows

authority bears a credent bulk

spread ot lote into a goodly bulk...Nea. for Nea. iv.

spread of late into a goudly bulk..W'Winier's Tale, ii.

by our feeding to so great a bulk....1 Henry l V.y.
stature, buk, and bio assemblance.

within iny panting bulk ............ RicharilIII, $\mathrm{i}$.

can with his very bulk take......... Henry rIII.

though the great bulk Achilles.

monstrous bulk of this ingratitude. Timon of A. $\mathrm{y}$.

with, half the bulk o' the worlil....... Coriniony \& Cleo. iii.

not grow alone in thews, and bulk...... Hamlet, i.

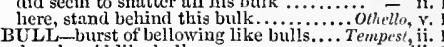

dew-lapp'd like bulls ................ iii.

thou wast a bull for thy Europa......... Herry Wires, v.

pluck off the bull's horns

when shall we sct the savage buil'.....$\quad$ - $\quad$ v.

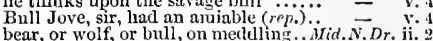

dew-lapped like Thessaliau bulls.... -

Jupiter became a bull, and ...... Winter's Tale, iv,

dried neat's tongue, bull's pizzle......

pouthfinl goats, wild as youll

from a god to a bull? Warwick rages like a cha..........

his brother, the bull ........ Troilus of Cressida, $v$.

now bull! now dog! ’oo, $\mathrm{P}$ aris, 'loo!

the bull being galled, gave Aries. Titus Andron. iv. 3
but where the bull and cow are ...... - y.

bull-bcaring Milo his addition. Troil. $f$ Cressida, ii. 3

BULL-BEEVES-their fut butl-beeves?. llen. II, i. 2

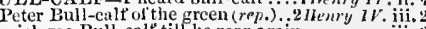

to frec Me Bull-calt till he ronr agaiu

hionldy, Bull-cale, Feeble (rep.

for your part, Bull-calt, grow till you - iit. 


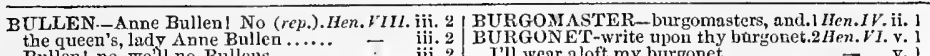

Bullen! no, we'll no Bullens.........
BULLET - inaper bullets of the brain.. nuch Aro, ii. 3 and the bullet, that's be ......... Love's L.Lost, iii. fleeter than arrows, bullets, wind instead of bullets wrapped in firc their drilt of bullets on this to
sir John, with two bullets

sir John, with two bullets
no proots, nor no hullets

a swallow, an arrow, or a bullet?

ike to the bullet's grazing

evebnlls into bullets turned......

BLOCK-so they sell bullocks ......Mueh Ado, ii.

yoke of bullocks at stamford fai

said I well, bully Il ector?..........

my hand, bully: thou sh
bless thee, hully doetor.

ha, bully i what eays my.

ha! is he dead, bully stale?............
our English tongue, is valour, hully

will clapper-claw thee tighty, hully

and, moreorer, bully, - but fir

bully knightl Bully sir John ......

what say'st thon, bully

Osweet hully Bottom? .............. Henry/ $r$. iv. 1

BULLY-ROOK-ny bully-rook?.... Mcrry Hives

how now bully-rook?

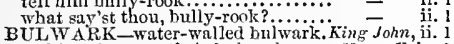

making the wars their bulwa

to seale their flinty bulwarks.

shake thy bulwarks to the rround

like high-reared bulwarks, stand... $\ddot{R i c h a r d} I I I . \mathrm{v}$.

be proof and bulwark against sense ...Hamlet, iii. 4

then slip I from her bum ....... Ain. N. Dream, ii

becks, and jutting out of bums!. Timon of Athens, i. 2

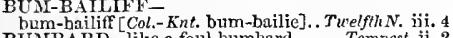

BUMBARD -like a foul bumbard...... Tempest, il. 2

that huge bumbard of saek.........

BUMP-upon its brow a bump as

Henry VIII. $\nabla$.

BUNCH - in the bunch of grape

lea. for Mea. ii. 1

BUNCHES_-bunches growing

BUnG $\rightarrow$ vou filthy bung, away!

BUNG-HOLE-stopping a bung-

pest, iv. 1 (song)

BUOY $\rightarrow$ buoy almost too small for

Ilenry $r$ ii.

BURDEN-under my burden groan

and, sweet sprites, the burden bear $\alpha$.. Tempest, $\mathbf{i}$.

with goodly burden bowing....... - 1.2 (song)

let us not burden our remembrances.... - v.

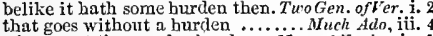

that goes without a hurden .......... Nutch Ado, iij.

set down your venerable burden...As you Like

1 would sing my song without a bur
the one lacking the burden of lean

knowing no hurden of heavy

All's $\mathrm{W}$ ell, ii. 3

as wealth is hurden of my wooing. Taming of $\mathrm{Sh} . \dot{\mathrm{i}} .2$

I will not burden thee: for, knowing - ii. I

my heart will be a burden to me..

with such delieate buxdens of dido

of sucl a huney-hags at a burden $\ddot{-}$ iv.

false, he burdens me withal.

bore thee at a burden two fair sons ...
heavy burdens are delivered [ Col.-burden

with burden of our armour here.......... King John, ii. I

that their hurdens may not fall this day - iii. 1

the elogging burden of a gutity

than a joint burden laid unon

their heavy burdens at his narrow gate. Henry $\dot{r}$. . 2

than bring a burden of dishonour...2Henry $V I$, iii. 1

let them break your baeks with burdens - iv. 8
unload my heart's great burden ....3 Henry VI. ii. I

and leave the burden of it all on thee

a grierous burden was thy birth to ine

the burden of my sorrows fall upon $7 e$

0 this a burden, Cromws ris a burden - iif. 1

willing to leave their burden: reach

of importless burden. divide...Troilus \&-Cressida, i. 3

'tis a burden which I am proud to hear - iii. 3

with burdens of the dead ....... The

only for bearing burdens, and sore...Coriolanus, it. 1

at whose burden the angered oce

thy biurden at the sea, and called

but you shall bear the burden soon. Rom. \& Jul. j. 4

most painted word: O heary burden!.. Hamlet, ifi.

but were we burdened with like weight - ii. I
my burdened heart would break ..2Henry VI. iii. 2

neek bears half my burdened yoke. RichardIII. iv. 4 BURDENING - with burdening griet..1 Hen.VI. ii.
BURDENOUS-his burdenous taxations. Rich.II. ii. BURGHER-that a wise burgher put. Nea. for Mea. i. and rich burghers of the flood. Yercle. of Verice, i.

native burghers of this desert eity. As you Like it, ii.
BURGLARY-flat burglary, as ever.. I Iuch Ado, iv.
I'll wear a loft my burgonet ............

tlie arm and burgonet of men.....Antony \& Cleo. i. 5
BTRGUNDY $-B$ ar, and Burgundy ... Herry $V$. iii. 5 the brother to the duke of Burgendy

duke of Burgundy, you pould the peace

my lord of Burguidy, we'll take your - v. 2

the duke of Burgundy will fast.......

no more ado, brave Bur, Burndy....

Brurgundy enshrines thee in his beart
wills lord Talbot, please th Burgundy

entiee tlie duke ot Burgundy to leave

brave Burgundy, undoubted hope of

of Burguudy. Shane to the duke (rep.)

from our unele duke of Burgundy ...

What! doth my unele Burgundy revo

Alencon, Orleans, Burgundy, and from -

duchess of Burgundy, with aid of soldiers

as he hears sinee to Surgundy $\ldots$....

bronght desired help from Burgundy
embarked to eross to Burgundy .... Richard

attend the lords of Franee and Burgundy.. Le

here's Franee and Burgundy (repeated)...

my lord of Burgundy, what say you

peace be with Burgundy! sinee that

come, noble Burgumdy. Bid farewell

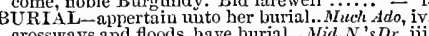

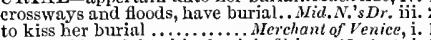

nor would we deign him burial of his ... Naebeth, $\mathrm{i}$.

the rest, and give them burial here...Richard 1 .
will see his burial better than his ...
Henry $V I$.

give them burial as beseems...........

earrion men, grc uning for burial. .

give him burial in his father's grave
no mournful bell shall ring hel burial

strength left to give them burial

[Col. Knt.] borne to burial in thy. Romeo o Jul. iv.

wedding cheer, to a sad burial teast.. - iv. 5

and finds it christian burial

been buried out of eluristian burial ........

BURIED-buried her grandam.. Two Gen. of $\bar{V}$ er.

I am sure, she is not buried............

and must be buried hut as.. Measure for Mcasture, v.

she shall be buried with her face

and be buried in thy eye

beat not the bones of the buried... Love's L.Lost, $\mathrm{V}$.

buried, as they say, it my gossip...Mver of Ven. iii.

that is dead and buried $\ldots \ldots \ldots . .$. As you Like it, 1.

lie with him when I am buried.

with his nearest; buried a wite

not to be buried, but quie

Hinter'sTale, iv.

Banquo's buried, he cannot come out... Nutcbeth, v.

that words seemed buried in

or I'll be buried in the king's.

and buried onee; why not upon

1 present thy buried fear .......

thou th buried in sour dunchilit.

Cour de-lion's heart was buried ...jHenry $l$ I. iii.

Edward's title buried ...............3 Henry III. jii.

too lag to see him buried

and huried, gentle Tyrrel? (rep.)

bricd this sigh in wrinkle of a smile. Troit. $\delta \mathrm{Cr}$. $\mathrm{i}$.

familiars to his buried fortun

hath buried thoughts of great value.JuliusCosar, i.

but all be buried in his gav

have biried them for prey!...

she shall be buried by her Auto.... - iv. 12

buried one and twenty valiant sons... Titus And.

he must be huried with his bret
till MIntius' hones be buried

ghall all be buried by my de

a man, pray see me buried .............

born at sea, buried at Tharsus

bones of all my buried ancestors. Romeos Juliet, iv. 3

with my child, my joys are buried ..

hath lain these two days buried...

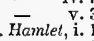

is she to be buricd in christian burial.......

who is to be buried in ' $t$ ? Une, tinat was

Alexander was buried

be buried quick with her, and so will I ...
BURIER-be the burier of the dead!..2

URIY-BUNED-

cut out the burly-boned clown....2IIenry VI. iv. 10 the princes, France and Burgundy

with burial auect and rites of burial...

burial, as becomes: give Mutius burial
BURN -and burn in many places ....... Tempest, i. 2

burn but his books ..........

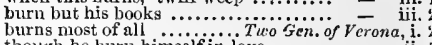

lest it should bum above ........ - ii.

with thy daring folly burn the world? = iij.

we buru daylight.$\ldots \ldots \ldots \ldots \ldots$....... Nery $\bar{W}_{i v e s, \text { ii. }}$

and burn him with their tapers....... - iv.

pinch him, aud burn hinn............. v. 5 (song)

I'll go burn some sack .......... Tuelfth $\mathrm{Night, \textrm {ii } .}$ to burn the errors that tliese ........ D. iv. and roar, and burn, like horse... Mid. N, Dream, iii. he meaus to burn the lodging ....... As you Like it, ii. o'erbears it, and burns on ............All's Well, v. 3 Trauio, I burn, I pine, I perish... burns worse than tears drown.....Winter's Tale, ii. I the fire, not she, which burns in't.... - ii. 3 better burn it now, than eurse .......
nor ny lusts burn hotter than ......
the capon burns, the pig falls.... Coned of your meat dotls burn, quoth $\mathrm{I}$.......... will burn a Poland winter (repeated) - iii. 2
will burn; ergo, light wenehes will burn fire burn; and cauluron (rep.) .......... Hacbeth, iv. thy ruge shall burn thee up.............. King $\bar{J}$ John, tii. with hut irons burn out hoth nine eyes - iv. I
irous nust I burn them out.......... very iron to burn them out

they burn in indigmation

this tyrant tever burns me

violent fires soon burn out ...........RichardII. i.

whose bosom burns with

whose zeal burns in his nos

already, and burns, poor soul! $\ldots . . .$. -

impatiently I buru with thy desire...1 nenry VI. i.

beholding the towns burn
burus under leigned ashes

that soreeress, condemned to burn... $=$ 二 iii.

O burn her, burn her ............... -

away, burn all the records.

buru, bonfires, clear and bright

lest by your heat you burn yourselves -

and burn me up with flames

here biưns my candle out.

lell burns, fiends roar

the lights burn blue

this cundle burns not clear ........... Henry - v.

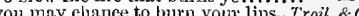

Paris burns us all (rep) your lips.. Troil. \& $\mathrm{Cr}$

when he burns with entertainino

burn, house; sink, Athen
allure him, burn him up

thou sun, that comfortest,,$\ldots$ urn!

let them hang. Ay, and burn too..Coriolanus, vii.

it' he could burn us all into one con

burn like twenty torches joined.....Julius $C$ ces

seek, hurn, tire, kill, slay .........

we'll burn his body in the holy place

how ill this taper buns

overplus of glupping will we burn...Ant. \& Cleo. ivi.

and tnpers burn so bright ........... Titus Andron. $\mathrm{i}_{\text {. }}$.

the corn, then after burn the straw .. - ii. 3

to live and hum in everlasting f......... $-\overrightarrow{3}$ (Gow.)

but thine do comfort, and not bonn ...... Luer, ii.

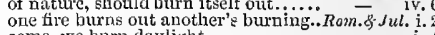

come, we hurn daylight $7 \ldots \ldots . .$.

there, where the toreli doth burn

where now it burns, Marcellus......

when the blood burns, how prodigal
frust itself as actively doth burn.

burn out the sense and virtue of

burn like the mines of sulphur......

$\ddot{0}=$ iii. 4

BURNED-hy that tire which burned...ik. $\bar{N} .0$. i. 1

maideu's heart hath burned?...As you Like, iv. 3 (let.)

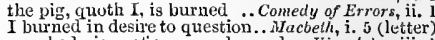

scorched viens of onc new burned ...King John, iii. 1

of my heart is erneked and burned

soon kindled, and soon burned ..... i Henry $I V$. iii. 2

halt' bis 'Troy was burmed.............2HenryI $V$. i. 1

the tatal braud Althea burned......2Henry

in simithfield shall be burned to ashes

your temples burned in their cement

no hereties burned, we water

BURNET-Cowslip, burnet, and green Heror, iii. 2

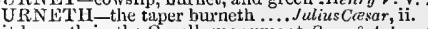
it burneth in the Capel's monument. Ronk. \& Jul. v. with liver buruing hot.

amss and ends of burning youth .. Mea. for Mea. $\hat{j}$. 
BURNING-is burning in my hall.. Ner. of Ien. v. is no mulice in this lumning coul ... King John, iv. I smokes nbout the limrning crest of

it would allay the buruing quality lurning cressets; and at my birth.. i iienry $\bar{I} V$. iii. the knight of the luurning lum]l.

he is in his robes, burning, burning..
the laud is burning; Perey stands on

ourselves into a burning fever...

shaker of a burning quotidiun.....
a black soul burning in bell-fire...

a black soul burning in hell-fi

the burning torch in yonder tury
to darkuess, and the burning lak

commeneed in burning Troy?

a burning devil take them.. Troilus of. Cressid $a$, $\mathrm{s}$

spoil of Phwbus' burning kisses .....

the taper; leave it burning.......... Cymbeline, ii.

by the burning tapers of the sk
I'll dive into the burning lake

the base fruit of his burning lust

story of that balefinl burning night

a hirning torch, that's turned

with eyne of burning coal..........

that burning slame detains him from

burning, scalding, steneh, consumption...

fire burns out another's burning. Romeo oै Juliet, i.

ere the sum advanee his borning eye..
made milel the buruing eyes of lieaven.

singeing his pate against the burning zon

to cast water on the burning liear
she's like a liar, gone to burning hell

BUR NING-GLASs-burning-glass. Nerry $\eta_{i z}^{-}$,

BIIRNISHED - the buruished sun...Mer. of ten. ii.

BURNT-the lightning bad burnt up.. Tempest, iii. pottle of burnt sack to give............ Terry Wizes, ii. 1 tis bumt; and so is all the meat. Taming of $S h$. iv. 'twas burnt, and dried away.

taper will be burnt and done

the better part burnt out.............2 Henry I I $I^{\prime}$ i. 2

we rast be burnt for you

you see, we have lournt our cheeks............

how Troy was burnt, and he made. Tit o deo. ii.

hereties, be burnt for liars...

night's eandies are burnt out

are burnt aud purged away

thou am a kind of bur ........Mea, for Mea. iv.

they are but burrs, cousin

these burrs are in my heart $\mathrm{t}$.

they are burrs, I can tell you ..... Troil. \& Cres. jii.
BURROW-out of their burrows ..... Coriolanus, iv.

BURST-blow till thou burst tly wind.. Tempest, $\mathrm{i}$. heard a hollow burst of bellowing

were great, 'twould burst at this ....... Ail's $W_{\text {ell }}$, iv. the glasses you liave burst..Taming of $\$ h .1$ (indue.) how ber bridle bus burst

how her bridle was burst ..............

the burst and the ear-deatening... Winter's Tale, iii. 1

whose bowels suddenly burst out...

and then he burst his head

will nake him burst his lead.

or we'll burst them open

passions of thy heart burst out

will burst, an' if I speak (rep.)......3 Henry $v_{1}$ iv. 1

a]most burst to belch it in.

Richard III. i.

then burst lis mingty heart.

Timnu of Athens, iv. 3
....Julius Casar, iii, 2

hath burst the buekles on bis breast.. Ant. 8 -Clea. i. 1

in his voiee, and burst of speaking.. Cymbeline, iv. 2
n sea that almost burst the deck ....... Pericles, iv. I
such bursts of horrid thunder........... Leor, iii. 2

Lear, iii. 2

$O$ that my heart would burst.

joy and grief, burst smilingly .......

let me not burst in ignorane

ill death, have burst their cerement

the instant burst of clamour that

vour heart is burst, you have lost

BURSTING-almost to bursting... As you Like it, ii. I

BURTON-HEATII-

old sly's son of Burton-henth. Taming of Sh. 2 (ind.) will I bury mine .... Tu'o Gentiemen of Teronest, v. 1 and lion are left to bury the dead. Mid.N. Dream, v. 1 we do bury the incensing relies of it...

we neerl no grave to bury honesty. W'inter's $\vec{T}$ ale, ii. any of him left, I'll bury it .

those that we bury, baek, our ......... Macbeth, ili. to bury mine intcuts, but to etleet.. Richard II. iv. our dead, and then to bury them ..... Henry $V$. iv. 7 at Bury the first of this next month.2Henry $V l$. Warwick, with the men of Bury

in your bride you bury brotherhoad.3 - iven your danghter's womb I bury them...Rich.lII. jv. 4 but yet I li bury thee ....... Timon of Athens, iv that hangmen would bury with ..... Coriolunus j. sball bury his reasons with his body

sball bury his reasons with his body - - v. in this I bury all unkindness, Cassius $-\overline{c l l}$ iv. 3 we't us bury him, and not protract .. Cymbeline, jv. yet bury him as a prinee
BURY-bury him where you eau .. Tilus
would you bury him in my despite? to pardon Mutius, and to bury lim.

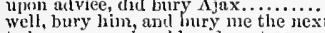
to himry so much gold under a tree

bid lim bury it; more hath it inerited

and bury all thy tear in my devices.

bury their parents'

and badest me bury love ..............

BUR bury thee in a trimmpliant grave

what is her burying grave....... Romeo of. Juliel, if. 3

heneeforth a buryin

BUSU-liere's neing-place to all..2 Hemry VI. iv. 1

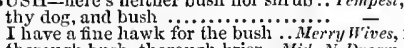

thorough bush, thorough brier...Aid.
must come in with a bush of thorns..

throngh bush, through brake

in some bush? where dost thou ......

dog, and bush of thorn, presenteth

wliere is the bush that we must.. Love's L. Lost,

closely shrouded in this bus

be married under a bush $\ldots$.............. As you

that good wine needs no bush.

myself bave limed a busll for hor

gives not the liawthorn bush

in a bush: with trembling wings

on eaeh busli lays her full mess...Timon of Ath.

by youn bush? pray, how far thither. Cymbieline, iv.

many miles alout there's scarce in bush ... Lear, ii. 4

BUSHELS-in two bushels of ehaff...Mer. of Ven. i. 1

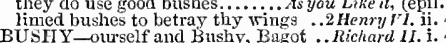

BUSHY - ourself and Bushy, Bagot ...Richarl iI. i.

go, Eushy, to the earl of Wil tshire
is leid by Iushy, Bogot, and their

is held by Bushy, Bagot, and their
bring forth these men; Bushy and

what is become of Bushy? where is..

Busby, Green, and the earl of Wiltshire

BUS1ED-they are busied about...Tan
who, busied in his niajesty, surveys.

who, busied in his majesty, surv
that England were busied with

that most are busied when they are.. Rom. \& Jul.

see how butsily she turns the leaves.. Titus And. iv
BUSINESS-to the present business.... Tempest,

a mark so bloody on the business

to do me business in the veins.

there's other business for $t$
to answer otber business

but this swift business I must uneasy.

widows in them of this business' makin

they 'll tell the clock to any business

for that's ny business to you ...............

there is in this business more than

on the strangeness of this busines

indeed, sir John, is ny business... . Merry i ives,

their business might be every thing...T2yelfth $N$. and that's my pith of business 'twixt

my business is a word or two with

to have hearing of this business....

in speeial business trom his holiness

when you liave a business for yourself

my business.in this state made me.

and holy to your business, not ehanging - v

about your own business, count............ .

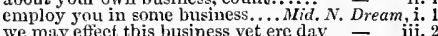

we kerious business, craving quick ...Lave's L.L. i i.

your own business ealls on you...Mer.

fare you well, I have some business.
slubber not business for ny sake

despateh all business, and be roone

in all your business and necessities. As you Like,

denrest friend prejudieates the business. A

and know her busiuess? that done, laugh -

does your business tollow us $\ldots$ kn..... -

an end, sir, to your business; give Hel

a very serious business ealls on him.

prepared I was not tor such a busines

at some great and trusty business.

seems to undertake this busiuess.

the business is not cuded, as, fenting

to whose trust your business was mor

her business looks in her witl an

my business asketh haste wi... Trming of shre

wateh our vantage in this business
if you knew my business, you would

till you have done your business

pass the business privately and weil

made his busincss more material.. "Winter's $T$

are to this business purblind (ref.)
I will whisper to the husiness.......
you smcll this business with a serse
BUSINESS-this business will raise us, Winter's 1 . it

what is the basiness? 0 sir, I shail .

howe'er the busincss goes, $y$ ou have..

to be so rid o' the business. Come, noor
for this ungentle business, put on thee

present partner in this busines

I not aequaint my thather of this business -

I muderstand the business, 1 licar it.

or toze from thee thy luasiness
to undertake the business for us.

are you a party in this business

a broken delivery of the business

unlawful business I am about...

present business calls me from you..
their business still lies out $0^{\prime}$ door...

besides, I have sone business in the

my business cannot brook this

and single business, to eontend against

in some words upon that businusme

it is the bloody business, which informs

what's the business, that such...

masking the business from the common

grcat business must be wrought ere noon

to consummate this business hapily. King John, v.

to see this business; to-morrow next. RichardII. ii.

full of eareful business are his looks.. - ii. 2

our business for the boly land

some heavy business bath my lord

in taith, I'll know your business, Harry

so hath the business tbat I come

by which account, our business valued

our liands are full of business.........

your place, your time, and bus

about thy business, Davy ..............
run betore our business; therefore

run betore our business; therefore .......Henry $r_{\text {. }}^{\text {i. }}, 2$

the business asketh silent secrey ....2Henry V1.i.

look into this business thoroughly.....

your censures in this weighty business

frath sounded Hastings in our business

let us eonsult upon tu-morrow's business - v.

why, all this business our reverend ... -

to look on the business present .......

as all think, for this business .........

with some other business, put the king

make youl know your times of busines

unpartial judging of this business.

ghail mcet about this weighty business

did debate this business, who deemed

nor ever more, upon this business....

wished the sleeping of this business.

i' the progress of this business........

if your business seek me ont

tor sucb men, or such business

to trust us in your business.

to think upon the part of husiness

the Lord inerease this business .....

all the business I writ to his lioliue

how goes her business! That $I$ can

some touch of your late business ....

speak to the business, mastcr seeretary

we have business of more moment

my business seeth. sodden business.

I have business to my lord

notling but heavenly business should

what business, lord, so carly

is't not your business too? it

one business does command us ail.

in debt to my impurtumate busiues.

our business is not unknown to

0 , if he had borne the basiness

but had he died in the business, madim

your are like to do sueh business ....

in such business, aetion is eloquence

you have merrily ended ny business

he has betrayed your business.

the bleeding

to gronsiness to my brother Claucius.

the end of this duy's business ........

the business she hath broaehed ......inio

it is my business too: tave brell

you do mistake your business.

despatch we the business we lave.... -
our graver busiuess frowns at this levity -

I find thee most it for busines.

thy businces? The ncws is true

the business of this man louks out

ii. 3

iii. 2

iii.

i. 1

i. 2
ii. 1
ii. 2

ii. 2

ii. 2

ii. 3

ii. 4

ii. 4

iii. 1

iii. $\frac{1}{2}$

iii. 22

iv. 1

vis

$\mathrm{v}$

iii. 1

i.

iii.

,

iii. ! 


\section{BUSINESS-partners in the business.. Cymbeline, i. 7 BUTCHERED-bloodily were butchered. Ric. II1. iii. 1 received command to do this business - hii. 4 whose children thou hast butchered to noc sleepy business; but must... \\ there's business in these faces.. \\ ïi. 7 \\ set abroad new busiuese for you ali. $\dddot{T}$ itus Andron. $\mathrm{i}$, \\ sounded you in this business? Never \\ frame the business after your own wisdom \\ eonvey the business as $I$ shall find means
I do serve you in this business. $\ldots \ldots \ldots \ldots$
I see the business: let me, if not by birth \\ this weaves itself perforee into iny busine \\ you have mighty business in hand \\ it is thy business that $I$ go about \\ eharged my duty iu this business \\ for this business, it toucheth us as Frane.......... \\ your business of the world hath so an end. \\ our present business is general woe ......
having some business, do entreat. Romeo \\ good DIereutio iny business was great of \\ hands full all, in this so sudden busines \\ thus much the business is: we have
personal power to business with the king \\ pusiness and desire, slall point you (rep.) \\ and think upon this business: meantin \\ my return, shall be the end of my busine \\ and do such business as the bitter day \\ like a man to double business bound ....
has this tellow no feeling of his busine \\ What is the issue of the business there...

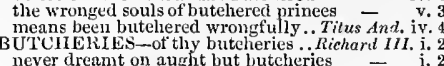

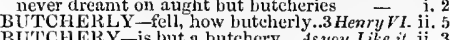 furious close of eixil butchery $\ldots \ldots$.... Henry $1 r^{\prime}$ i. 1 to do this piece of ruthless butchery.. Rieh. 111 . iv. both pantier, butler, eook.......... Finter's Tale, iv. 3 hath Butler brought those
bid Bntler lead him fortl \\ BUTT $-[\mathrm{Col}$. Knt.] earcase of a butt ..... Tempest, \\ I eseaped unon a butt of sarek.. \\ tell not me; when the butt is out \\ look how you butt yourself in ... Love's $\mathrm{L}$. Lost, $\mathrm{v}$. \\ they butt together well (rep.).... Taming of sh. v. 2 \\ I am your butt, and I abide your........ Henry VI. i

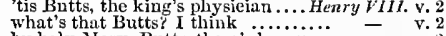 \\ by holy Mary, Butts, there's knavery $=$ v. \\ Why, uo, thou rninous butt........ Troil.s. Cres. v. \\ here is my butt, and very sea-mark of.. Olhello, v. 2 \\ BUTTER-Flemius with my butter.Merry Wives, ii. 2 \\ am as subject to heat, as butter...... \\ and eall for efrgs and butter \\ never see Tititu kiss a dish of butter?}

they have not to lead their

upon some present business of the state.

the business? The Turkish preparation.

my place, nor aught i heard of busines

disports corrupt and taint my busine
gentlemen, let's look to our business

converse and business may be more free

when I shall turn the business of my sou

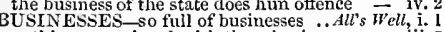
nothing aequainted with these businesses

despatehed sixteen business

a tho having made me businesses. Winter's Tale, iv. 1

a thousand businesses are brief....... King Joh
KKnt. needful counsel to our businesses. Lea
BUSK INED-your buskined mistress. Mid. N.D.

BUSK INED-your buskined mistress. Mid. N.Dr. ii. BUSS-and buss thee as thy w

wUSSE wanton tops do buss ...... Troil. \& Cress. BUSSING - knee bussing the stones. Coriolanus, iii.
BUSTLE-world for me to bustle in. Richard 1 il. i. come, bustle, bustle, eaparison

BUSY-he is very busy about it

have a eare this busy time
you see, 'tis a busy time with n.

[Col.] most busy, least when I. .

meddling monkey, or on busy ape..ivid. $N$ ?'s $s$. ii.

prove a busy actor in their play...As Aor Like it iii.
they're busy within, you were.... Tamingof $S h . v$.

that she is busy (rep.) .

to busy giddy minds with forcign ...2HenryI $F$. iv.

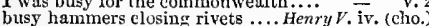

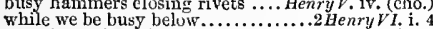

more busy than the labouring spider

beat away the busy meddling fiend. $-\overline{\text { iii. }}$

for lords to-morrowy days .......... Richard 17r. 1.3

we are busy; go. This priest......... Henry $\bar{Y} 111$. ii. 2

but that the busy day, wraked ....Troili. \& Crets. iv. 2
busy care draws in the brains .... Jutius Cirsar, ii, 1

do you busy yourself e braills

what, are you busy? do you need............. \& Jut. Iv. 3

to be too busy, is some danger ......... Ilamlet, iii. 4
let me be thouggtit too busy in my feers. Othello, iii. 3

did not call; lie's lusy in the pape

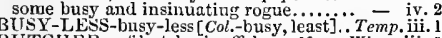

BUTCHER -ot butcher's offal ..... Alerry Wives, iij. 5

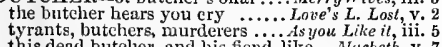

this dead buteler, and his fiend-ike .ike..Mucberh, v. 7

than to be buteher of an innocent .. King John, iy.
against tlie butelers of his life ...... Richard II.

against the butelers of his lite
stern murder how to butcher thee

that it may euter butcher Mowbray's $=1$ i. 2

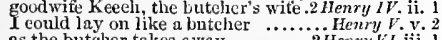

as the butcher takes a way

HenryVI. iui. 1

are yout the butelere sinttiik

and Diek the butcher, - then is sin.....
where's Dick, the buterer ot $A$ shtiord

for example, that an a butcher......

are you there, butcher? ..............3 Henry
butehers and villains, bloody eanibals!

butchers and villains, bloody canmibals!

you have no ehildren, butehers

next his throat unto the butcher's knife 二 $\quad$ v. 6

compelled, been butcher to the sire .. Rich. 11I.

butcher's eur is venom-mouthed ... Henry Y YII.

or butehers killing flies

but not butehers flies

meek and gentle with these buteliers!

the lamb entreats the buteher....... Cymbeline, iii. 4

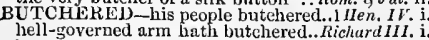

by you noy hopes are butehered....... as tit as butter. The man
such toasts and butter, witli heirts

theft lasth already nade thee butter - iv.

kUTCRED to his loorse, buttered his hay ...Lear, ii. 4
kindness

the wings trom painted butterflies, Mid. N. Dr. iii. 1

tor men, like butterflies, show not. Troil. \&. Cress. ili.

and lantgh at gilded buttertlies.
BUTTEKLY

and a butterfy; yet your butterfly was

BUTTERING - of tortune's buttering...All's $\bar{W}$ ell, v.

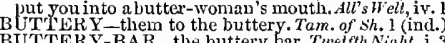

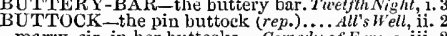

marry, sir, in her buttocks... Comeddy of Errors, iii.

more with the buttoek of the night... Coriolanus, ii.
BUTTON-'tis in lis buttons .....Merry Wives, iii.

pray you undo this button.................. Lear, v.
very butcher of a silk button ...Romeo 8 Juliet, i,
betore their buttons be disclosed......... Hamlet, $\mathrm{i}$.

fortune's eap we are not the very button $-\overline{\text { int }}$ i.

BUTTON-HOLE-button-hole lower. Love's L. $L$.

BUTTR LSS - no jutty, frieze, buttress., Macbeth,

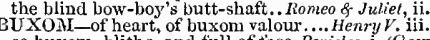

BU Y-will money buy them?

Tempest, v. 1

Ill go buy them vizards

money buys lands, and wives.

you will needs buy and sell
to buy you a better husband.

Would you buy her, that you (rep.)... Nuch $A d o, \mathrm{i}$.

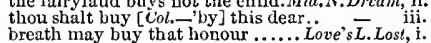

breath may buy that

did point you to buy them ............

may a man buy for a remuneration.

if so our eopper buys no better
shouldst have it to buy gingerbread

what buys your company?

that do buy it with much car

to bny his favour, I extend.....

I will go buy my tortunes ................. you Like it, i. .

in this desert place buy entertainment
whint is he that shall buy lis fluck ..

if it stand with honesty, buy thou.

and buy it with your gold rightit............

and let me buy your triendly help
to buy his will, it would not seem

you buy it? or who gave it (rep.)....
to buy apparel "gainst the wedding. Tam. of Sh. vi.

what ann 1 to buy for our.........W

I'd huve you buy and sell so s..........

buy of me, come; come buy (rep.).... - iv. 3 (song)

pray now, buy some, 1 luve a bal

being able buy out biy ti..... - iv.

go thou, and buy a rope's end. . Can.

Fo thou, and buy a rope's elld....

you slanll buy this sport as dear.....

otter me eommodities to buy

the curse that money may iuy out..... King Jochehn, ivi.

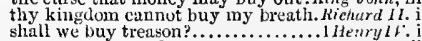

you nuay buy land now as cheap.......
shall buy maidcuheads as they buy butter-wonen's] rate to market...As you Like it, iii.

and buy another of Bajazet's mule

you buy it? or who gnve it

wenches, I'll buy for tos both

will you buy any tape
they throng who shall buy first.
BU Y - to buy your worship .........2 BenryIV.i. sell the pasture now to buy the ...ienry $\bar{r}$. ii. relio. to buy a slobbery and a dirty tarm .. - iii. and buy nothing of me but cuctgeis.

had sold my farm to buy my crown

cetore he'll buy again at . who would not buy thee dear?.......2 Henry $V_{1}$ y. $y$. shall buy this trearson even witi........ to buy a world of happy days ........ Richar $\bar{d}$ III. which buys to blay souls ........... does buy and sell his honour as .......

and he shall buy my daughter ..... - iii. dispraise the thing you desire to buy
did buy each other, must poorly as I would buy thee, view thee ....... meensenty nore better than he... Th in him, whieh buys buy this praise

is mine. I'll buy him of you

- iii.

my wealth would bny this for a liei... $=$

to

if you buy ladies' thesles at

to buy a present for the emiperor
'tis gold whieh buys adnittunce

I bic tor you, as I d buy .............

in the end to buy lim a wooden one?.. Pericles, iv.

shall buy this unprized precious .............ear,

nny man should buy the fee-simple. Rom. \& Jul. iii. that he did buy a poison in tesh

eostly thy bay a poison of a poor ..... - v

prize itself buys out the law ............ - iii. 3 BUYER - benediction to the buyer. Winter's Tale, iv. in's time a great buyer of land.......... Hamtel, $y$. BUZ - sliould buying any thing .. As you Like and buz these conjurations

yet look to bave them buz.
tor I will buz abroad such

2 Henry VI. i.

more wasps that biz about.......... Henry VIII. iii.

buz in the people's eurs ............ - iv. BUZ'LARD - and like a buzzard .. Taming of sh. ii. a buzzard take thee? Ay, for (rep.) .. Richār $111 . \mathrm{ii}$.

BUZZEDD-buzzed into lis ears? ....Richard 1I. ii. BUZZING - lot buzzers to intect lis ear.. Hainlet, iv. huslhed with buzing nighth-flies....2 HenrylV' iii. for you bave stolen their buzzing...Juliusceesar, $v$. with his pretty buzzing melody. Titus Andron. iii. BY - C Col. thou shat by this dear. Mid.N.Dr. iit.
BY AND BX-by and by it will strike.Tempesi, ii. we'll till him by and by argain.......... - ii..

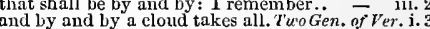
and by and by intend to chide myself

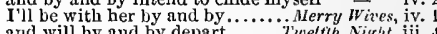
and will by and by depart ...... Twelfth Night, ili. I would by and by have some... M.eas. for $\bar{M}$ eas. iii. by and by: I hope it is some pardon 1 and. $\bar{N}$. iv. for in the tenple, by and by with us ${ }^{-}-\overline{\text { iv. }} 1$ that by and by, disguised they will. Love's L. L. v. 2
by and by: when from the first...As youL'ke it, iv. 3 I'll hear you by a but, by aud by, rude fisiermen ... Coneedy of 1. v. and, by and by, in as high a flow as..1 Henry $1 V$. i. shall be appreleaded by and by...... Henry $r$. i. will come this way by and by.........2 Henry vi.i.

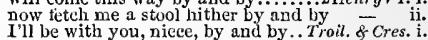
when by and by the din of war 'gan. Corivlanus, ii. by and by thy hosoms shall partake..jutitus Cassar, $\mathrm{ij}$. slall raise you by and by on business

I'll see you by and by $\ldots$...Antony \& Cleopatra, iii. I will embrace thee in it by and by... but by and by comes back to Romeo by aud by: God's will! what wiltulness - iii. that we may call it early by and by ${ }^{2}$ and, by and by, my master drew ou him $-\quad$ iii.
and I coine to my mother by and by ....... Hamlet, iii. 1 dare not drink yet, niadan; by aud by $=\bar{y}$ meet me by and by at the citadel ....... Othello, ii. now a sensible man, by and by a fool ... - ii. by and by, breaks out to savage madness
yes: 'tis Limilin:-by and by............ by ind by:-let me the curtains draw .. - - v.2
BY-1DELNDANCLESand all the other by-dependancies. .Cymbeline, v. 5

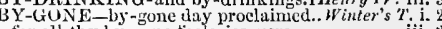

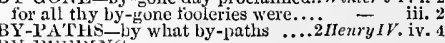

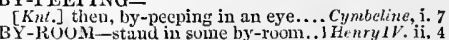
BY-ROUAl-stiud in soune by-ruom... IHenry IV, ii.,

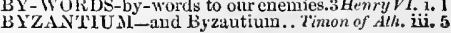




\section{c}

CABBAGE-worts! good callhage ... Nerry Wives, i. 1

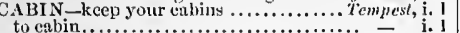

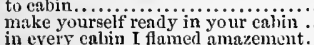

make me a willow cabin ut your ante.Tirelm $\mathrm{N}$. i. 5

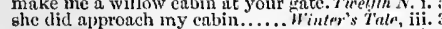
who trom my calin tempted me..... Richtarl III. $\mathrm{i}$. no, to my cabin: these drums ......tntony 8 Cleo. ii. 7 up trom my eabin, my sea-gown ........ Inanlet, v.

CABINED-I am cabincd, cribbed ........Hetheth, iii. CABLE-rope of his destiny our cable. Tempest, i. let me cut the eable ....... Antony \&-Cleppulra, i

with cables of perdurable tongliness

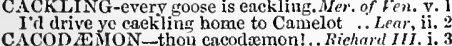

CACOD ASMON-thou cacodæmon!.. Richard III i. 3

CADDIS-GARTER

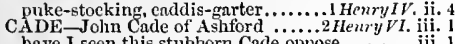
have I seen this stubborn Cade oppose

I tell thee, Jack Cade the clothier....
John Cade, so termed of our supposed

of stealing a cade of herrings $\ldots \ldots . . . .$.

Jack Cade, the duke of York linth
them traitors that are up with Cude.

will parley with Jack Cade their

Jack Cade proclaims himself

Jack Cade proclaims himself .........

how now! is Jack Cade slain?

Jack Cade! Jack Cade! Knock......

know, Cade, we come ambassadors ..

follow Cade, we'll follow Cade! Is Cade

is the traitor Cade surprised?

twixt Cade and York distressed ......

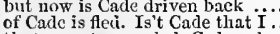

that monstrous rebel, Cade, wh

of Cacle, whom I in combat slew (rep.) $\overline{-}$ v.

CADENCE-golden cadence of poesy. Lore's $L$. $L$.
CADENT-with eadent tears fret ehannels.. Lear

CAINIUS_Hercules and Cadmus., Nid. N. Drm. iv. 1

CADUCEUS-craft of thy Caduceus. Troil. S Cres.

Carlwal, and I, will play the cook

but what oecasion hath Cadwal now

nadwal, I cannot sing; I'll weep....

this gentleman, my Cadwal, Arviragus -
CADWALLADER-not for Cadwallader. Henry $r$

CASAR-an emperor, Casar, Keisar. Nerry Wive
and prove a slirewd Casar to you...Mea. jor Mer.

and prove a slirewd Casar to you...Mea. for Men. ii. I
what, at the heels of Casar? ….....

the punmel of Cxsar's faulehion. Love's $L$. Lost, v. 2

and Cæsar's thrasonical brag of ...As you Like it, v. 2

Mlark Antony's was by Caesar .......... Macbeth, jii.

the times, since Casar's fortnnes ....2 HenryI $I$

compare witl Cæsars, and with Cannibals - ii. 4

than Julius Cæsar, or bright .........1 Henry F 7. i.

which Casar and his fortune bare at once

in the commentaries Cæesar writ

in the commentaries Cæsar writ .....

the Cæsar.3 Hen.VI. iii.

they, that stabbed Casar, shed no blood $-\bar{T}$ v. v.

that Julius Casar was a famous man

to see Casar, and to rejoice in his...Julius Casar

no images be hung with Casar's trophies -

feathers plucked from Cæsar's wing.:
peace, ho! Cæesar speaks. Calphurni.

ceace, ho! cæasar speaks. Calphur. Forget not, in your

when Casar says, do this, it is performed -

Cosar. Ha! who calls?

Cesar: speak; Csesar is turned to hear

come from the throng: look upon Cresar -

the people ehoose Cæesar for their king.

I was horn free as Cresar

Crsar said to me, darest thou, Cassius

Casar cried, help me, Cassius, or I ... -

if Cæsar carelessly but nod on him

new honours that are heaped on Cæesar

Caesar: what should be in that Casar?

what meat doth this our Casar feed..

are done, and Cæsar is returning ....

angry spot doth glow on Casar's bro

fear him not, Cæsar, he's not dangerou

fear; for always I am Cæesar.

to-rlay, that Cæasar looks so sail

becayse Casar refused the crown ( rep. $_{\text {. }}$ -

what? did Casar swoon? He fell down

no, Cassar hath it not; but you

if Casar had stabled their mothers...

for pulling scarfs off Casar's images..

Casar's ambition shall be glaneed at (rep.) brought you Casar home? ........... comes Cresar to the Capitol to-morrow
tis Cesar that yon mean: is it not .. mean to establish Caesar as a king....

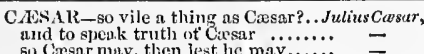
first did whet ine against Coesar.......

of Cissar, should outlive Ciesar

let Antony, and Cosar, fiull together.

Antony is but $\Omega$ limb of Caesn'

by Ciesar's suirit, and not dismember

harm than Capsar's arm, when Caesal"

whe'r Ciesar will come forth to-tlay..

help, ho! thicy murkler Cesal ........

wlut mean yon, Cresur? think

fiesar shall forth: the things .........

fice of Casar, they are vanished.

Cosar shall go forth: for these (rep)

tcrible, and Casar shall go fortl...

Cipsar, all hail! Gond-

Casar will not a lie? ...............

this day, a erown to mighty Cresar.:

lo, Cxsar is afraid? Pardon me, Casar

gooul-morrow, Cæsar. Wclcome

so to most noble Casar

Cxear, I will: and so near will I 7 be.

O Casar! the heart of Brutus........
Cosar, beware of Brutus ........

and it is bent against Cæsa

tand till Cosar pass olong

read this, 0 Casar, thou mayst live

take good note, what Cacsar doth....

thou hast some suit to Cæsar ........

please Cresar to be so good to Cxesar..

speak to great Cosar as he comes....

thiat Cosar will not grant...

ay, Casar; but not gone (rep.)

delay not, Casar; read it instantiy..

Cassins or Casar never sliall turn

he smiles, and Cresar doth not change

prescntly prefer his suit to Cesar..

most mighty, and most puissant Cassa

know, Casar dotli not wrong

sound more sweetly in great Cæ.......'

pardon, Cæsar; Cæsar, pardon

O Cæsar, - Hence! wilt thou (rep.)

et tu, Brute? then fall Crsar ........

so are we Cæsar's triends

bathe our hands in Cresar's blood...........

how many times shall Casar bleed

I teared Cæsar, honoured him ....

how Cæsar hath deserved (rep. $)^{\prime . . . . . . . ~}$

so fit as Cresar's death's hour .........

as here by Casar, and by you eut of

that did love Casar when $\mathbf{I}$ struck him

that I did love thee, Casar

the enemies of Cresar shall say this.

by looking down on Cæsar

and wherein, Cxesar was dangerous

you, Antony, the son of Casar .....

Ciesar shall have all true rites ......

Cessar's body. You shall not (rep.)

you serve Octavius Casar (rep.) ....

shall be rendered of Casar's death

any dear friend of Casar's $\ldots \ldots . .$.

why Brutus rose against $C$

not that I loved Casar less
had you rather Cæsar were living

had you rather Cæsar were living.

done no more to Cæesar, than you

grace to Cresar's corse (repeated)

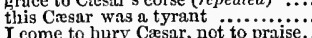

with Cesar. The noble Brntns (ve.

grievously hath Cæesar answered it

in Cesar seem ambitious? (rep.)

in the coffin there with Casar

Cresar has had grent wrong ..........

with the seal of Casar, I found it....

would go and kiss dead Cresar's woun

mect you know how Crsar loved you

you shall rearl us the will; Ciesar's.

a ring about the corse of Cæsar

the first time ever Ciesar put it on

wow the blood of Cxsar followed it .

was Ciesar's angel: jutige, 0 ye (rep.)

the while ran blood, great Caesar toll

the while ran blood, great Caesar toll

O noble Ciesar! $O$ woful day!

show you sweet Ciesar's wounds

a tongue in every wound of Casar

\section{二}

ii. I I anight, that I Ilial ferst witl Cicsur

10 you to Cresar's houre.

ii. 1 when Cesar lived, he durst not thus

cesar, we will answer on this...

i.. 1 in Casar's heart, crying ( $(r e p$.

ii. 1 like bondmen, kissing Casar's fect

ii. 2 Cranr's three and twenty wounds $($ rep. $)$

ii. 2
ii. 2 Casar thou canst not die by traitors
ii.

Cissar, thol art revented ..............
the ghost of Ciesar hath appeared

that they did in envy of grent casar

ii. 2 from Casar; therefore, hear (rep.)

is $C$ of thin

ii. 2 to marry me with Octavins Cesar...

joining their force 'gainst Cæasar

hath given the dare to Crsar

every hour, most noble Cersar.

that only liave feared Cæsar?

to-morrow, Casar, 1 sliall be furnishe broad-fronted Casar, when thou wast love Cesar so? O that brave Ciesar

the valiant Cæasar! By Isis (rep.)

Cxsar and Lepidus are in the field ${ }^{\circ}$

ii. 4 ennnot hope, Cæsar and Antony shail

dead, did trespasses to Cæasa........
if Cæesar move him, let Antony (rep.)

Antony. And yonder, Cresar.

my being in Egypt, Cxsar, what
her garbuils, Casar, made ont of

soft, Cæsar. No, Lepidus, let him '..

but on, Cæsar; the article of my

I am not married, Cresar

will Cæesar speak? Not tili he liears

the power of Casar, and his nowe

he made great Cosar lay lis sword

higher, Cæsar's or mine? Cxsar's

uningteleable, where Cxsar's is not..

or triends with Cæsar, or not captive

and riends with Casar (rep.).

Antony, I haye dispraised cosar....

since Jutius Casar, who at Philippi

that Julius Cessar. grew fat with ...

certain queen to Cessar in a mattress

then is Cesar, and he, for ever knit..

Octavia blow the fire up in Crear

the vessels, ho! here is to Cersar. ...

Casar, and Antony, have e
Ciesar is sad; and Lepidus

iii. i O how he loves Cresar

iii. 1 Ciesar? why he's the very Jupiter of

spake you of Casar? how? ............

but he loves Cirsar best...........

iiii.
iii. 1 but as for Cersar, kneel down..............
will Cresar weep? he has a cloud

iii. 1 will Cresar weep? he has a cloud....

iii. 1 Ciesar, and Lepidus have made wars

iii. 1 C:esar having made nse of him .....

navy's risger

whom does he accuse? Caesar.

iii. I you come not like Ciesar's sister

iii. 1 where Cerear fought with Pompey

iii. i in Cirsar's fleet are those ............

I have sixty sails, Cresar none better

Actium beat the approaching Cesar

Carsar las taken Toryne................

the hill, in the eye of Casar's battle

fly, and make your peace with Casar

Ciesar, 'tis his schoolmaster

Cresal; I go. Observe how Antony

power that moves. Cæasar, I shall

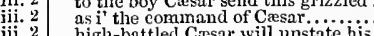

iii. 2 high-battled Cresar will unstate his.

the full Cresar will answer his (rep.)

a messenger from Crsar.

as Casar has; or needs not us (rep.)

we are; and that's Casar's

say to great Casar this

tributaries that do acknowledye Cresa

this Jack of Cresar's shall bear us.

be thoil sorry to follow Ciesar in

get thee back to C:esar, tell him

Cxsar sits down would you mingle..

personal conbat, Cassar to Antony

Casar must think, when one .........
that he and Cossur miglit determine

sir, he is with Casar $\ldots \ldots . .$.

to incline himsclf to Cæesar

ii.

iii. 3

v. 1

iv. 3

v.

v.

v. 3
v. 3
v. 5

v.

i. 2

i. 2 


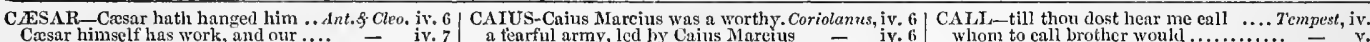
things he spenks may coneern Cassai:

their sweets on blossoming Cas

and blemish Cassar's triumpl cards with Caesar

has packed cards with Caesar .......
onr Casar tells, $I$ am conqueror

not me, 'tis Casar thou defiat'st

the whecled seat ot tortminate C.

she had disposed with Crasar.

not Casar's valour hath o erthrourn

of Ciesar seck your honour

none about Casar trust, but $($ rep. $)$

the pauses that he makes. Cies

I say, O Cxsar, Antony is dead.....

Cesar is tonched, when such

for Cresar cannot live to be ungentle

tis paltry to be casar

the beggar's nurse, and Caesur's..................

Cacsar scnds greeting to the queen

guard her till Casar come .........

than fou shall find cause in Cosar

last done thy master Cresar knows

what Caesar means to do with me?

make way there,-Casar .............
see, Cesar! O behold, how pomp

o Cassar, what a Tronnding...........

and believe, Cæasar's no merehant

I hear him moek the luck of Cxsar..

hear thec call great Cresar ass

Casar hath sent,-Too slow .......

Crsar's beguiled. There's (rep.) ....

away there, way for Casar!

o Ciesar, this Charmian lived

Angustus Casar with us (rep.)

famous in Caesar's praises

a kind of conquest Casar made here

to master Cassar's sword, made Lud's

there is no more such Cresars......

If Cxsar ean hide the sun from...
Cxsar's ambition (whieh swelled

we do say then to Casar

whose use the sworl of Casar hat

Augustus Casar, (Cæsar, that hatli..

thy Casar knighted me...........

we submit to Casar, and to the $3 \ldots . .$.

we submit to Casar, and to the Roman
the imperinl Cæesar, shonld again unite

if ever Bassianus, Casar's son, were... imperious Cæesar, dead, and turned

imperious Casar, dead, and turned.

Othello,, $\mathrm{ii}$.

the next Casarion smite!

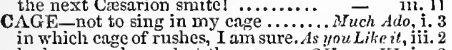

had never a honse but the cage ....2 Henry $V$ I.

our eage we make a quirc ............ Cymbeline, iii.
from torth that pretty hollow eage..Titus And. iii. will sing like birds i' the cage

Lear, Y. 3

I must up-fill this osier cage.... Romeo of Juliet, ii. 3
CAGED-twenty eaged nightingalcs. Tam,of Sh.2 (ind.)

CAIN-a month old at Cain's birth. Love's L. Lost, iv.
since the birth of Cain.............. King John, jii.

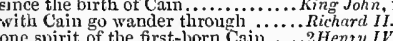

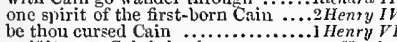

as it it were Cain's jawbone

Knt.-cance

coloured] beard.................... Alerry Wives,

I should do with this wicked caititit?

the wickedest caitiff on the ground ..
I went to this pernicions caitiff depnt

I am the caitiff', that do hold

a caitiff recreant to my coulsin

All's $\bar{s}$ 'ell, iii.

but

consnme you wicked eaitiffs left.. - - .5 (cpitaph)

caitifit, to pieccs shake, that under $\ldots$..... Lear, iii. 2 here lives a caitiff wretch would seli. Rom.\& Jul. v,

(1) the pernicious caitiff! how came you.. -

my master, master doctor Caius

and Cains, the French doctor...

sare you, good master doctor Caius

master doctor Caius, I am come.

master doctor Caius, the renowned

herc comes doctor Caius.

and firm for doctor Cains.

she is, by this, doetor Cains wife

espeeially againgt Caius Mrcius is

where's Cains MIarcius? Here

no, Caius Mareius; I'll lean upon ...

if tre and Caius Marcius chance to mect =

that Caius Marcins wears this war's
Caius Mrarcius Coriolanus (rep.)...

with fâme, a name to Caius Mlarcins

worthy Caius, and by deed-achieving -

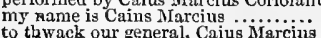

a tearful army, led hy Cains

ay, Mlareius, Cains Marcius, lost tion

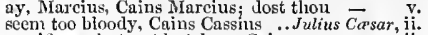

sacrificers, but not butchers, Caius .

Cains Ligarius, that Metellus (rep.)

what it is, my Caius, I shall mufild

Caius Ligarius, Ciesar was ne'

next Caius Cassins, do I tak

pardon me, Cains Cassiu

should I have answered Cains Cassius

and sce how I regarded Caius Cassius
she was the wife of Caius MIareellus.

the one is Caius Lucius................ Cymbeline, ii.

wos Cains Lueins in the Britain eonrt

thou art welcome, Caius

thon comest not, Cains, now tor tribute - iii. 1

2 Cains Lucius, although the victor . ${ }_{2}$ Tilus - nnd. iv. 3

2 come hither, Cains, and Valentine!

where is your servane, ay hands..

CAKE-no more cakes and ale ............. Lelfith Night, ii.

our cake's dough on both sides...

my cake is dough: b

stewed prunes, and dricd cakes ....2Henry IV. ii. 4

do you look for ale and cakes here..Henry 11. v.

the making of the cakc, the heating.

pack thread, and old cakes of roses...Rom. \& Jul. y.

CAKED-their blood is caked

2 CALAIS-on toward Calais, ho

of that receipt I had for Calais ........ Rich John, iii. 3

2 as far as Caliais, to my uncle's head

and in Calais they stole a fireshovel.. Henry $r$

we'll retire to Calais; to-night

we mareh on to Calais; and to England

now we bear the king toward Calais

some respite, will return to Calais.

is chancellor, and the lord of Calais..3Henry $V_{I}$ i.

CALANITIES-in his calamities. Timon of Ath. iv. 3

different plagne of each cal:mity

to bear togeticer in ealamity

to bear the tidings of calamity...... Richarari. iii.

shee my country from calamity...

you are transported by calamity

we must find an evident calamity

and thou art weddcd to calamity... Rom. \& Jul. iii.

CALCHAS-Calchos shall have ... Troil.\& Cres, iij.

to bring this Greek to Calchas '... Trouse

of the field doth Calchis leep?

he goes to Calehas' tent; I'll keep ...

and uses the traitor Calchas' tent .....

CALCULATE-did ealeulate my birth.2 Hen.VI. iv.

old men fools, and children calculate.. Jul. Cosar, i.

CALENDAR-a calendar, a ealendar. Mid. $N$. D. iii. I

he found in the calendar ot my past

you the calendars of their nativity

give me a calendar; who saw the sun..Rich.III. v.

look in the calendar, and bring

seratch it out of the calendar ........... Pericles, ii.

he is the card and ealendar of fentry...Hantet, 7.2

he hath bid me to a calf's bead

he clepeth a calf, caut: half, hauf.

is not yeal a calf? A calf (repeated)
then die a calf, before your liorns ....

more calf, certain ...................

and the calf, are all cailed, neat ........ Winter's Tale,

you wanton calf? art thou my calf? $\because-{ }^{\prime}-$

might have kept this calf, bred from. King John, i.

iniquity's throat cut like a calf.

as wolf to heifer's calf, pard to ...Troiluss Cres. iii.

never do beget a coal-binck calf ... Tilus And ron. v.

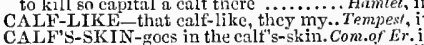

and hang a calf's-skin on those (rep.)....John, iii.

CALIBAN-yes, Caliban her son.
that Caliban, whom now I keep.

we'll visit Caliban, my slave

ii. 3 I had peopled else this isle with calibans -

to the most of mon this is a Calibain.

'Ban, 'bas, Ca-Caliban .............

we must prepare to meet with Caliban.

set Caliban and his companions free.

i. 2

ALIVER $\rightarrow$ my fair Calipolis ...2 Henry $I V$. ii. 4 put me a caliver into Wart's hand..2 Heury $I V$. iii.

i. 9 come, manage me your caliver ...... - iil.

I might call him a thing divine person. Tempes

I might call him a thing diving

ii. 2

ii. 2 that I may call men.................... - iii. 1

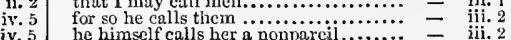

whon to eall brother woul

than you may call to comfort you

and I would eall it tair play............

it were a shane, to call her back again

mo renance is, to call Lilcetta back

who bade you call her?

sir, call ne what thou darest.

call her divine to call her bad, whose...

when I call to mind you.

which some call tears.

entreated me to call...
who ealls?...................

convcy, the wise it call .............Merry $\bar{W}$ ives, iv.

call him in: such Brooks ............. - i.

yet I wrong lim to call him poor ....

what do you call your knight's name

and when I suddenly call you

call your men, mistress Ford

she calls yon, coz

somebody, cail my wi............

go, knock and call

the knight may be robbed, Iil cail... 二

call in question the continuance.. Tuelflh $\overline{\mathrm{N}} \mathrm{ighl}, \mathrm{i}$.

to call his tortunes thine

call in my gentlewoman (rep.)... .6 -

constrained in't to eall thee knave... -

thou hast her not i' the end, call me cut 二

for many do call me fool ............

go call him hither.

I'll call sir Toby the wli ilst.

- iii. 4 (challenge

who calls there?.....................

who calls, ha?.......

call forth the holy father ...........

who's that which calis?

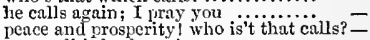

may call it back again

at that place eall vipon me

I am bound to call upon you

ary be, I will call upon you anon

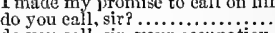

do you call, sir, your oecupation

the unfotding star calls np the slieplierd -

call your executioner, and you at yonr house

go, call at Flavius' housc ........
call that same Isabel here one

to him, till we call upon you

hear me call Margarct, Hcro

let us send her to call him in to........

well, you are to eall at all.

you must eall to the nurse $\ldots . . . . . . .$.

call un the right master constable.....

call me a fool; trust not my reading..

to call a prinee's brother, villain

the offender, did call me iss......

and so, I pray thee, call Beatrice .....

to call young Claudio to

eall her torth, brother.

you were best to cali them generally

jow, good Peter Quince, eall forth ..

those that hobgroblin call you...........

and help from Athens calls.........

to call me goldess, nymph, divine
when I come where he calis, then

Titania, music call; anil strike.

a torturing hour? Call philostrate.

elsc the Puck a liar eall ..................
which the base vulgar do call .... (eprii.)

Biron, they eall him

and Rosaline they cali her $\ldots \ldots \ldots \cdots \cdots, \quad \overline{-}$ iv. $\overline{3}$ (verses)

too peregrinate, as I nay cali it.......

which the rude multitude call ......

you were best call it, daughter-beamed

I dare not call them fool

eall them forth quiekly...

your own business calls on you.........

you call me nislseliever, cut-throat.

I am as like to call thee so egain ....

who bids thee call? (rep.)

Goouwins, I think they call the place

he was wont to call me usurer ...... 
CALL_to church, and call me wite.Mer. of f $\mathrm{cn}$. iii. \& / CALl,_call the lady Constance

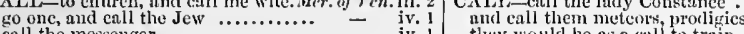
eall the messenger $\ldots . . . . . . . . . . .$. - iv. ! thy would he as a cull to train...

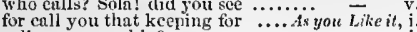

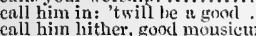
thity love, and eall it cumning cill it not potiencoll him call it il trayel that thou tukest the princesses coll high lleretord, it you call him did you call sir. sir................. - i. you have.... When time shall call him home. what shall I call thee............ look you call me Ganymed who calls? Your betters, sir call you them stanzas? ......... but that they eall compliment to call tools into a circle $\ldots . . . . . . .$. all things that thou dost eall thine it you would but call me Rosalind nay, you must call me Roealind good even, good master what ye cailit it pleases him to call you so. unworthy of her you call rosalind... she calls me proud ...

call you this railing?

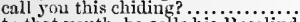

that youth, he calls his rosal.

neither call the giddiness of it

nuy lord calls for you.

and prime can happy cal

call before me all the lords in

a very serious business calls on him................

rights, call in the letters patent

nuless you call it good, to pity him
Earklonglnly castle call you this

0 , eall back yesterday, bid

shall we call back Northumberland

King Joh, ii. 2 | CAL, - no lending knee will call thee.3IIen.VI. iii. hould call you, thther. No more (rep.) $=$ iif. 2
iit. 3 eall roward king. Call him my

tather to, then call me husband...

tend upon, and call her

vell, call him lither

and call him, madam, do him. Taming of $\overline{S h} .1$ (ind.)

Christophero Sly; call not me

yon would call out for Ciccly Ilaeket -

not call me, husband? my men (rep.) -

wh hat must I call he

call him half a score knaves

what may I eall your name....

frets call you these? quoth she $\ldots . . .$. .

they call me-Katharine, that

call you this gamut? tut!.

he calls for wine

my haste doth call me hence.

who is that calls so coldly? ..........

they are. Call them forth

call them forth to credit her.

come, and know her keeper's cail ....

go, call my men, and let us straight

please it you, that I call?.

please to call it a ru

what a toolish duty cail you this?

which I'll not call a creature of ... i

beseech your highness, call the queen

our prerogative calls not your counse

I pray you now, call her

you'd call your children yours

Fll not call you tyrant

she durst not call me so......
kneel and call me father?...

not be long before I call upon....

Perdita, I pr'y thee, call't

whicl some call patpre's bastards

and do not call them bastards..

they call themselves saitier

call this, your lack of love

whom son I dare not call
desverate, sir. So call it

desperate, sir. So call it
that I may call thee somet
he would not call me son

lie would not call me son ..........

that I should call you brother.

business calls me trom you now... Comedy of

seonce call ron it?
thyself I call it, heing strange to me

how can she thus then eall us by....

cineer her, call her wite

why call you me love? cali my........

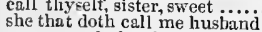

cvery one doth call me by......

let's call more help......

go call the abhess hith

yer sister here, did cali..........

Paddock calls: anon; fair is tio

to come at traitors calls, and

call Flward king, and at his hands..
enll Warwick putron, and be penitent

thou wilt, it Warwick enlls

were it, to call king Edward's.....

'his majesty doth call for you

ii. 1 and call us, orphans, wretches .......

thank you as you call me...........

Whom our manners call-the lrin
call them again, sweet prince....
well, call them again; I am not.

well, call them again; I am not...

go, call him hither, hoy

that calls jour beauteous daught

dear mother, (I must eall you so)

call up lord Stanley, hid him

yot must eall him Rutland now

dill I ever call for thee to pay......

.. IHenryIV. i. 2

whint do you call the place?.

we'll call up the gentlemen...

ean call them all by their christian...

by the Lord, so they call me...

dost thou not liear them call

I pr'ythee call in Falstaft.

an' ye call me coward, I'll stab (rep.)

all? I know not what ye call, all.

spit in my face, call me horse...

what a plague, call you him?

call in the sheriff; now

go, call hin forth. Falstaff!

which calls me pupil, or hath...

come, when you do call for them?

and I will call him to so stric

thou art a knave to cail me so

unless you call three fingers...
with him that calls not on me?

he calls lis rebels, traitors.

what, to York? call him back again.

and will you yet call yourse

cre long they should call me madam?

fou call honourable boldness

iii. for fault of a better, to call my friend

iii. 2 call him up, drawer. Cheater, call.

call me pantler and bread-chipper...

phrase, eall you it? by this good day

let them appear as I call

iv. 3 call in the powers, good cousi

that may do me good, and call it

doth the king eall? .............

now call we our high court

ii. 1 shall we call in the embass

ii. 2 he'll call you to so hot an answe

they will steal anything, and call it

the trumpet calls us to the breach

what do you call him...

all other jarles you may cail beasts

attached; call him to present

sir, it calls, I fear, too many .........

ii. 4 she's going away. Call her agrain

i. to call back her appeal she in tends..

you must no more eall it York-place

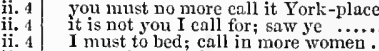

(when licaven shall call lier from

ii. 4
ii. 4
call here my varlet, I'll unarm ... Troilus \& $\vec{C}$ r

ii. 4
ii. 4 they call him, $\mathrm{Ajax} . \ldots . . . . . .$.

(which, slanderer, he initation calis)

our policy, and call it cowardic

when fitness calls them on ..........

they eall this, -bed-work, mappery

of Troy, call you yourself Eneas?

call some knight to arms

you may call it melancholy.......

shall i call you fatber?

to call together all his state.

if she call call for him at snpper ...

eall them all-Pandars

aloud to eall tor recompense.....

ii. 1 go call Thersites hither, sweet

I'll call mine uncle dow

which, I beseech you, call a virtuous

they call him Troilus; and on

Aineas, call my hrother Troilus to $\mathrm{m}$

who calls? Diomed. Calchas, I think

Cassandra, call my father to

call the man hefore thee.

why dost thou call them

and call him to long peace...

properer can we call our own ..........

to call upon his own ................

a way in a cloud: call him, call hin...

$\begin{array}{ll}\text { iii. } 2 & \text { call me to your remenbrances ...... } \\ \text { iij. } 5 & \text { vicious strain, and call it excellent }\end{array}$

call the creatures, whose naked......

I see him stamp thus, and call thus.

where is he? call him hither

call yon me? [Col.-Callino. Kut.-Cälen o]

what call poun the town's name

call him, with all tire applause

(I cannot call you lycurguses)

we call a nettle, but a ncttle

call him hither to me, soldie

and I call you, my queen

would call forth her flowing tide.......

speak, sliner in: but, first....

open the gates; it is Gloster that calls

of this princely train call ye thic

eall we to mind, and mark but this.

Talbot, captains, calis you forth
call my sovereign yours...................
conld but call these dead to life

call for Coriolanus. He doth

custom calls me to't; what custom....

call 't not a plot; the people cry

the rabble call our eares, fears ......

i. 3
ii. 2 go, call the people; in whose name ...
who was wont to call them woollen..

call me their traitor! thou

prythee call my mor. Cotus!

pret one time he did call me by my ...

call all your trihes together

who calls! Bid every noise $($ rep. $)$........

to call them both-a pair of crafty ...2Henvy

heard a voice to call him so.....

if it be fond, call it a woman's....

go, call our uncle to our presence

and call them blind and dusky sky.

sometime, he calls the king ..........

and calls your grace uviuper, olenly

and calls your grace yilur

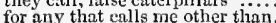

he'll never call you Jack .........

to call poor men before them ...........

king did I rall thee?

sirrah, call in my sons to be iny

look in a glass, and call thy image so

call hither to the stake my two

eall Buckingham, and bid him (rep.)

to call a present parliament

ean neither call it perfect day. .

when it is lighted, come and call me here

a hilcous trumpet calls to lariey

I'll call upon till we call

when none can call our power

what needful else that eali upon us

be George, I'll call him Peter

who is it, thou dost call usurper

call not me slanderer................. - ii.

iii. 1 .

and call in question our necessities

call Clandius, and some other

calls my lorl? I pray you, sirs

both? eall in the messengers ...... inton

call her winds and waters

call on him for't; but, to confound

for so be calls me; now I feed myself

say thon, shall call her mistres.

call the slave again; thongh I am (rep.)

will their caod thoughts call from ïim

that ever I should call thice, cast-away!

the emperor calls for Canidius.

call all his noble captains to my lord

he calls me boy; and ehides.........

call tor Enobarbus, he slall not..... 


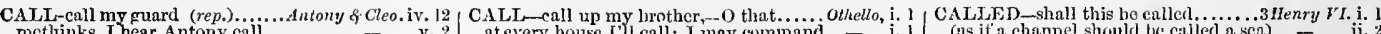

Dethinks, I hear Antony call ......... Dolabella sent from Casar; cell lim protection; calls lim I'osthumus .... Cymbelin

call my women: think on............

do ou call me fool? As 1 am mad

make ' $t$ an action, call witness to 't.'
which I did call my father

or robbery, call it what you will

call her before us; tor we have ......

I were best not call; I dare not call...
young gentlemen, that call me father

this geutleman, whom I call Polydore

call forth your soothsayer..............

raje, call you it, my lord, to seize. Til
go home, call for sweet water (rep.)..

and tair men call for grace.

to that I call: what, wilt thoü

or else I'll call my brother back again

and calls herself, Revenge ...........

doth your higlnness call? Thaliard.

for mine, if I may call't offence .......... Pericles

the good king Simonides, do youl call him? -

that calls me traitor, I return the lie

doth my lord call? Get fire and meat..

doth my lord call? Get fire and meat...
hundrcds call themsel ves your crcatures

the master calle, and trehles their confusion

and though you call my co th

well; call forth, call forth

call up some gentlemen (rep.) ...........

calls my gracious lord?

call and give them repetition ............
call Frasee; who stirs? call Burgundy....

let pride, which she calls plainness

most loath to call your faults ......

eall the clotjoll back

go you, call hither my fool

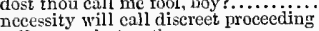

call my train tegether ......................

why dost thou call him knave?

which I must needs call mine

come when it will, I do not call it

from those that she calls servants.

but yet I call you servile ministers

Frateretto ealls me; and tells me $\ldots . . . .$.
bosomed with her, as far as we call hers

and call itself your brother

upon this call o' the trumpet

my master ealls, and I must not say.......

why call you for a stro

call her forth to me...............

call good Mercutio

2s maids call medlars, when they

that which we call a rosc, by auy.

it is my soul, that calls upon

forget why I did call thee back.

in that sense, may call him-man

thy fault our law cols death

then starts up, and Tybalt calls ....

but that a joy past joy calls out

but that a joy past joy calls out $\ldots$

all men call thee fickle ...............

thr eyes, whicl I may call the sea.

do thou but call my resolution

I'll call them back again to...........

they call for dates and quinces in.....
call Peter, lic will show thee where.

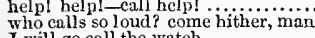

I will go call the watch ................

that calls our person from our

that calls our person from

believe his tenders, as you cali them?

ay, fashion you may call it ...........

so I call it, since not the exterior $\ldots . . .$.

the common stages, (so they cal tif

if you call me Jephtha, my lord ......

who calls me villain? brea

eall me what instrument you wili...............

I'll call upon you ere you go to bed...

you cannot call it love .............

call you, his mouse; and let him

who calls on Hamlet? 0 , here they come

the rabble call him lord

down a-down, and you cali him a-down

we may call it herb of grace o' Sundays.

and all that we call ours, to you

the practice, and eall it, accident

and that he calls for drink

maids do dead men's fingers cail them.....

why is this impawned, as you cali it?...

and call the noblest to the audier father, rouse him....

cull up all my people

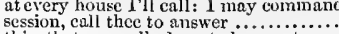

this, that you call -love, to be a sect.........

here at the sloor; I yray you, call them

known by, let ns call thice-devil!

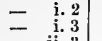

my crown is ealled coutent ...........

are you called [ $\mathrm{Col}$. Knt.-Lawn] forth -

wordy things, tis called ungratetul

I called thee then, vain flourish (rep.)

that ealled your grace to breaktast on
you hure a danghter called Elizabeth

nor cilled upou for high fieats....... Hen

let be called before us that gentlcman
you are ealled back. What need (rep.)

Katharine no morc shall be called queen

now the king's, and called-Whitehall - iv.

it be called the wild and wandering. Troit. $\overline{8}$ Cres.j.

a prince called Hector............... - i. 3

modest doubt is called the bencon... - ii. 2

have a Trojan prisoner, called Anteuor - iii. 3

hark! you are called: some say...... - iv.
unworthy to be called her scrvant....

that proot' is called impossibility ..... =

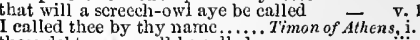

these debts may well be called........

till we called both tield and city .... Coriolrnus, ii.

we bave been calted so of many

as cause had called you up ............

called them time-pleasers, flatterers..

he called me, father: but what o" that?

called you, my lord? Get me...... Julius Cresar,

when he was called a king ...........
shall be called purgers, not murdcrers

a young Florentine, called ciaudio......Much Ado, 1 .

on the shoulder, and calicd Adann...

been always ealled a mercitul man

ii. 2

would'st thou come when I called

the knot of us be called the men ....

Cleopatra, as she's called in Rome ...Ant. \& Clco.i.

Cwsar's sister is called Octavia.....

to be ealled into a huge sphere

you have not called me so, nor

which is calicd supper.... Love's L. Lost, i. 1 (letter)

(so is the weaker vesscl called
his disgrace is to be called boy

then calied you for the l'envoy.

iii. 1

I have called the deer the princess killed -

nominated, or called, Don Adrian

and trow you what he called me?

as I think, so was he called.. Merchant of Venice,

another time you called ne dog......

it may well be called Jove's tree

is called the retort courteous (rep.)

give thee less to be called grateful.

at a place there, called
humbly called mistress

she callcd the saints to sirety ..........

for $y o u$ arc called plain Kate $\ldots \ldots . .$.
get a father called-supposed

Ajax $\rightarrow$ called so from lis graudfather

kuow, sir, that I am called Hortensio

my name is called, Vineentio...

and the enlf, are all called, neat...Winter's Tale

niy wars, and called them home ...

= $\quad$ ii.

the is called the Briton reveller

crown, and called himself a king......

the king his father called Guiderius.

Belarius, that am Morgan called ....
before I cnterca here, I called......

who called me traitor, mountaineer..

Fou shall be culled to no more payments -

cvery villain be called, Posthumus

a subject who was called Belarius....

you called ine brother, when I was but $\overline{-} \overline{\text { and }}$

not henceforth called my chíldren

if that be cailed deccit

a thing within thee, called conscience

what are they called? Rapine (rep.)..

this is called Pentapolis, and our king.. Pericles, ii.

huving called them from the deep! $\ldots$....

Marina was she called .
a king's daughter? and ealled Marina?

wherefore called Marina? called Narin

thy burden at the sea, anel cailicd Hi...ina

if thy name be alled ince Comedy of Errors, iii.

laid claim to me; called me Dromi

is not your name, sir, called Antipholus? -

how far is t called to Fores?........

was never called to bear my part ......

it caunot be called our mother
that thou art called a linis

- iij.

can you remember what I called the man

back to $\mathrm{mc}$, when I called him? .......... Lear, j.

Mover gave you kingdom, called you

informed him, then he called me sot $\ldots \ldots \ldots$. . iv.

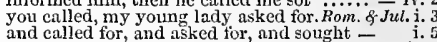

wered sought

still am I called; unhand $n$

but called it, an honest method...

Hainlet, $\mathrm{i}$.

since I first ealled my hrother's father

meritorous shall that hand be called . $-\overline{\text { ich }}$ II.

and this land be called the field of ...

you have been hotly called for $\ldots . . . \ldots \ldots$ othello, i.
with that he called the traitor-lown - ii.

I pray you, called wind instruments?.... 3 (song)

till Cassio be ealled to $\lim \ldots \ldots \ldots . . . .$. - iii.

and her friends to be called-whore?.... - iv.

my mother had a maid called Barbara... iv. $\overline{3}$ iv.

he called them-untaught knaves.

nay, my lord, he ealled you Jack

he called me even now, my lord ...... Henry $\mathrm{LF}$.

thou not ashamed to be called captain
when the man of action is called on..

you were called lusty Shallow (rep.)

here is two more called than your....

what is this forest called?

I cauld serusalcm, my noble ......

the king hath culled lis parliameut.

this day in Germany called Heisen

he is called, Ancient Pistol

my name is Pistol ealled. It sorts...

this day's called; the teast of Crispian
luis fatlier was called, Philip of Macedon

lis futlicr was called, Philip of Maced
it is called Wyc, at Monmouth .......

what is this castle called, that stands

a pu called me yesterday, mountaiu-squire - $V$

they called us, for our tierecness....

ealled for the truce of Winehester....

and called unto a cardinal's degree!..

as to be called but viceroy of ...........

and things called whips? a youu Venetian, called Roderigo -..... - v. the very debt of your ealling..... Mea. for Mea. iii. 2 the very debt of your ealling......Mea. for Mea, ii. 2 and would not change that calling. As you like it, i. as calling home our cxiled friends ......Macbeth, v. 7 do thou never leave calling-Francis.i Henry $I V$. ii. still, and hear'st such a calling ...... i - ii. but keep my wonted calling? ....... Henry

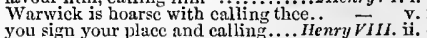
reverence to your calling makes....... calling both the partics knaves B...it.. Pericles, $1 \%$. mistermed: calling death ...... Romeo \& Julie, iii.
instrument of this your calling back.. Othello, iv. CALLINO-[Col.] Callino, castore inc! Hen'vy $Y$ iv. ALL'ST-call'st thou my love ....Lnve'sL. $L$. ii1. what, o' devil's name, tailor, cail'st thou - iv. with what thou else call'st th ne.Wine er' Taie, ii.

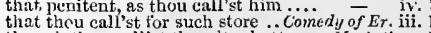
though thou call'st thyselt a hotter ...Macielh, v. call'st thou him a child?..............3 Henry $V I$. ji. 2 
CALL'ST-call'st thon that harm?. Timn of Ath. iv. 3 thou call'st on him that hates thee ........ Letr, iii. CALM-and promise you ealm seas ...... Tempest, v. be ealm, good wiud, blow not .. Treouen. of l'er. $\mathrm{i}$. unilerio for one calm look? the seas waxed ealm, and ............. they shoot but enlm words. we bound our calm eontent.. the cankers of a culm world.... KingrJohn, ii. do calm the fury of thiy mal-bred.2IIenry VI, iii. i de clures not ealin lis comtumelioms that led calm llenry, though he....3 Henry $\boldsymbol{F}$. ii. 6 with paticnee calm the storim....

a soul as even as a calm Henry $\bar{V}_{I I I}$ iii, 1 and marricd calm of statcs

Troil. \& Cres, i. 3

our blonds are now

let's be caln. 'The people are alus

when the sca was calm, all boats

thercin he was as calm as virtue) .. C'ymbetine, v. tribune speaks to calin my thoughts.. Filus And. o calm thee, gentle lord!

to ealm this tempest whirlin

calm thec, and bear the finult

with gentle breath, ealm look

Romeo \& Juliet, iii. 1

withont a sulden calm, will o

how mueh I had to do to calm his ri........

cAlater every tempest come sueh calmi.. Othello, A

is stratghtway calmed, and hoardcd.. provoket, soon calmed. Troil. \& $C$ res, iv. 9 though calmed, they give't again...... Perictes,

must be he-lec'd and calmed hy debitor.. Othello, $i$

CALMILY - the ealmest and most...tenery I $\nu^{\prime}$. ni.

calmly, I do beseeeh you ........... Corinimans, iii. 3

C $\Lambda$ LMI N Is

CALPIURNIA-Calplumia (rep.). Sulius Cessur, i. Antonius, to

Calphurnia here, my wife, stays me - ii. this by Calphurnia's drean is significd

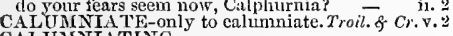
to envious and calumninting time

under more caluminous tongues ... I . At?'s Well, i. seapes not calumnious strokes ........... Hamlet, CALUMNY-and smell of calumny......... for Mea. ii. calumns the whitest virtue strikes Winter's Tale, iii. snow, thou shalt not esenpe ealnmny.. Hunlet, ili. 1 CALVED-thongh calved i' the porch ... Coriol. iii. I CALVES-SKINS and of calves-skins too $-\bar{V}$. $\mathrm{i}$. CALYDON-heart of Calydon ......2 Henry VI. i. welcome, good Cambio ................
it likes me well; Cambio, hie you.... Cambio. What say'st thou........... Cambio comes not all this while.

Cambio comes not all this while ....

CAADBR 1 A-I am in Cambria.. Cymbeline, iii. 2 (let.)

in Cambria are we born ..................

sharp neeld wound the cambric... Pericles, iv. (Gow.)

my lord of Cambridge, and my kind

though Cambridge, Scroop, and Grey

then Richard, earl of Cambridge $\ldots . .$.
my lord of Cambridge here, you know

name of Richard earl of Cambridge

Richard, carl of Cambridge, tor

carl of Cambridge, lost his head

married Richard, earl of Cambridgc. 2 Henry VI. ii. 2

CAAIBYSES-iu king Cambyses' veilu. 1 Henry $I V$. ii. 4

that we came from thence? .....

how came we ashore?

which now came from him

the rarest that $e^{\prime} e r$ came there

he came alive toland...

say, how came you hither?

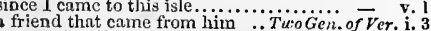

t came hardly off $\ldots . . . \ldots \ldots \ldots \ldots .$. - ii. 1

whence came you?

and I came no sooner into ............

unhappy were you, madam, ere I caine $\bar{F}_{\text {ives, }}^{\mathrm{v} .4}, 4$

even as you came in to me $\ldots$......... -

slip away ere he came................

but I came from her, master Brook... - iv. 5

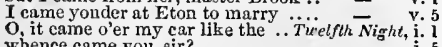

when came he to tliis town?

but when I came to man's cstate... - - v. I (song)

when I came, alas! to wive.......

this we came not to, only for.........hea.for Mrea. $\mathrm{i} .3$

gir, she came in great with child .... - $\begin{array}{r}\text { ii. } 1 \\ \text { how eame it that the absent duke... }\end{array}$

csine not to an uadoubtful proof...
C $\Lambda$ ME-I came to her from Claudio. Mea. for Mea. v. proportions came short ot composition

with slower toot enme on

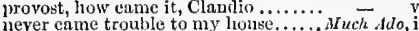

I came yonder from a great supper.

of passion came so near the litc

I eame hither to tell you

let me go with that I came for

how cane her excs so bright?

(so it came to pass) Titania waked

how came these things to pass?

tell me how it eame this night

hearing our in test, came here......

came with Hermia hither...

I from Thebes came last a conqueror

[Col. Kint.]-and then came Pyramns

gentle lady, hefore I came $\mathrm{unt}$ the groosc came out of door.

thus camc your argument in

he came, suw, and ovcreame: he came - - iv. 1 (lct.)

to came? the king why did he.. - iv. I (tet.

when be eame to tiveseore...........

madam, cume nothing else along

said, I came o'er his heart...........

that came hither in company of....

with one fool's head I came to woo

a day in April never canie so sweet

therc came divcrs of Antonio's creditors

came you from Padua...

that your messenger came, i i

and $I$ came to acquaint you with..... As

came hither to acculaint you withal

I am heartily glad I cume hitlicr to $y$

out of the wonder, betore you came
his fellow fault cante to mateh it

how I came into that descrt place...............

brag of, - I came, saw, and overeame

for thence wc came, and, after some...All's $\bar{W} c l l$, iii. you came, I think, from France?

they will sav, camc you off with

we came in with Richard .. Taming of Sh. $\overline{1}$ (induc.)

why came I hither, hut with that...

thougl Paris came, in hope to

that unly, came in well; sir, list

came you from the chureth? (rep.).

seeing this, came thence for

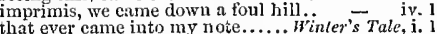

cast out it still came home

how came 't, Camillo, that he did stay?

fortnne it came to ns, I do.............

good my lord, she came from Lybia..

with the manner how she came to it.

but we eame to see the sta tne of......

alis, too soon, we came ahoard .. Com. of Errors.

but ere they came; O let me say.......

rom whence he cane, lest he...

nor goldsmith, came to m

together; and therefore came not ....

he that came behind you, sir

who came in haste for it..............

to-day came to my house $\ldots . . . . . .$.

we cane again to bind them

I never came within these.

I came from Syracuse..........

we came into the world, like $\ldots \ldots \ldots . . \overrightarrow{\text { Yacbeth, i. } 3}$

came missives from the kin

came they not by you? ...................
who was't came by? Two or three

when I eame hither to transport

how came she by that light

you came not of one mother..........

by this brave duke came early to...

which here we eame to spout against

in her right we came

whose conduct cane those powers.....

O bravely eame we oft; when with

half an hour since came from the

to-day as I came by, I culled there

letters came last night to ........

lately came from the king .

there came a post from Wales...

upon my sword came there a certain

when it next came there, took it in

when you and he came hack from

close, came in foot and hand

in Kendal green, came at my back

how came Falstaff's sword so hacked?

your unele Worecstcr's horse came
the inore and less came in with cap . $v .1$ tut, I came not to hear this

so iairly oue, cume not, till no.

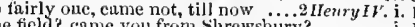

after lim, came spurring hared ...

so came sighing on atter the

and, as I came along, 1 met.

he came ever io the rearward of

it that rebcllion eane like itself'.

he caole not throush the

when I here came in, and foumb

how I came by the crown, $O$ God

consideration like an angel came. ...

on his untirnished kingdom eamie

as ever you came of women.........

who came off bravely, who was shot

all my mother came into mine eyes.

your majesty came pot like yourself

we came sir, but to tell yout ...........
in lis litter, sick, come to the field.

as we hither eame in peace

your highness came to England.

to Berwick, whence they eume
from whence she camc, and him

came he right now to sing

in England, since gentlemen came i...

a bricklayer, when he came to age

and full as oft eame Edward

like to lightning came and went

When cane George from Burgundy

cane on the part of York

therefore I came unto your majesty.

my father came uitimely

I came from Edward, as embassador

the post came from (repeated).

I came into the world with my legs.

never came poison from so sweet...

and I came hither on my legs....

murderers as yourselves came to you

that came too lag to see him buried.

you all came by his father

your lordship came to my mind

but since you came too late.

came to me, as I followed hay $\ldots . .$. .

and came I not at last to comfort yon?

they came from Buckinglam upon.

came to my tent, and cried, on! victory!

hut he came to whisper Wolsey.... Hen ry

the great duke came to the bar $\ldots . .$.

thus it came; give heed to't.

and eame to the ere o' the hont.

duke of Buckingham came from his trial

with modest paces came to the altar

wanc you roads, he came to Lcicester

I am glad, I came this way so haprily.

at length they came to the broomstait

she came to him the other day

shc came, and puts rue her white

how came it cloven?

for my own part, I came in late.

I came to kill thee, cousin, and bear

nor came any of his bounties. Timon
and came into the world when seets

how eame the noble Timon to

which ne'er came not my friend

there came news from him last night

aidless came oft, and with a sudden...

and to the battle came $h$

whence eame that Ancus Marcius

he eame unto me came to me

when he came un to hinseif?

when he came to himscli again ....

after that, he came, thus sad, nway

many lusty Romans came smiling

with her leath that tidings eame

Fulvin thy wife first came in to...

know then, I eame before you

we cane hither to fight with you

the messenger came on my guard ...

why came you from your master?

and so, I hope he came by

brag ot, came, and saw, and overcame

we came from

he came our enemy, remember ...

as his white beard came to

resumed again the part I came in....

came crving 'mongst his toes

\section{$=$
$=$
$=$
$=$
$=$
$=$
$=$
$=$
$=$
$\bar{z}$}

二

-

ii.
ii.
ii.
iii.
iii.
iii.
iiv
v.
v
v.
i.

i. 4

iii. 2

iii. 5$$
\text { iy. }
$$

iii.

iv.

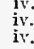




\section{CAM}

CAl

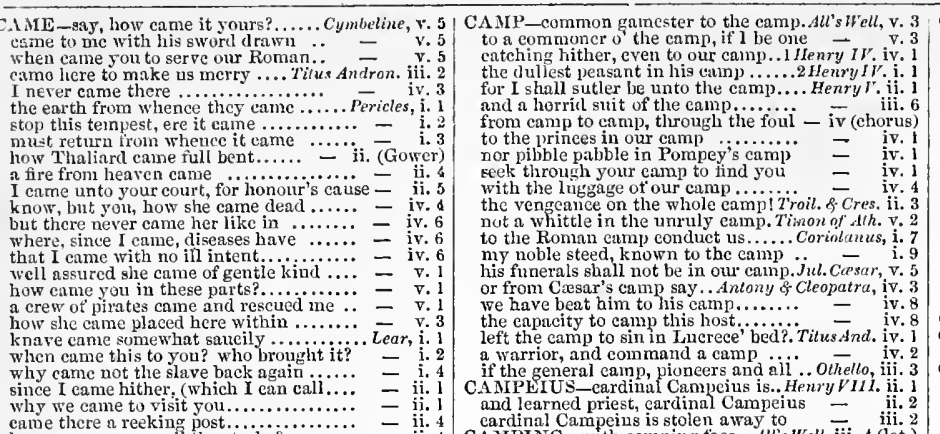

liow earne my man i the stoeks?

which eame from one that's of

my son came then into my mind

we came crying hither: thon know
came there a man, who having seen
it came even from the heart of .....

in the instant came the fiery ....Romeo \& Jutiel, $\mathbf{i}$.

cane more and more, and tought (rep.)

cume he not home to-night?

why the devil came you between us?
I dreamt my lady came and found me

and therefore came I

hour of her waking came I to take

but, when I camc, (some min

he came with flowers to strew his....

and therewithal eame to this vault

I came to see your fitlier's funeral

then came each actor on his ass...

it came to pass, as most like it was

low came he dead? I'll not be

how came he mad?" Very strangely

or cane it by request, and such fa

when I came back, (for this was

how came you thins recovered? .......

Michael Cassio, that came

Cassio eame hither; I shifted him away

eame in and satisficd him ...

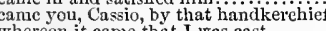

whEL_as for a camel to thread

a drayman, a porter, a very camel. Troil

of a camel? By the mass (rep.) ........ Hamlel, iii. 2

I is a kind of eameleon ..............

excellent, i'faith; ot the cameleon's dish. Ilamiet, iii. 2

what! Camillo there? Ay, my good lord

how came't, Camillo, that he did stay

I have trusted thce, Camillo, with all

have not you scen, Camillo..........

gouk-day, Camillo. Hail, most ......

Camillo, os rou are certain.

dost thou hear, Camillo, I eonjure
good Camillo. I am appointed (rep.)

come, Camillo; I will respect

his train? Camillo with him?

and Camillo is a federary with her

Camillo's flight, added to their

Camille and Polixenes laugh at me.

and coospiring with Carnillo to

CANIPING - with camping foes... All s Well, iii. 4 (l,
CANIEST-ere thou camest here ......... Tenipest,

how thou camest herc...

enipest, i.2 2 (a)

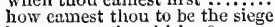

i. 2
ii. 2
ii. 2
ii. 2
v. 1
V.

by this bottle, how thou camest hither

how camest thon in this pickl

how camest thou by this ring?.. Two Gen. of

then camest in smiling, and in ... Twelfh Night, v. I

from whence thou camest..

thou camest l'rom Corinth first ....

camest thou by these ill tidings?

-

nor thou camest not of the blood

chard Il. iij.

camest thou here by chance ........

to tell thee whence thou camcst

eamest to bite the world: and if (

thou camest on earth to mak

yet camest thou to a morsel...........

before thou camest, and now, like

how camest thom hood her, tell me?

Cymbeline

why camest thou now to murder

Pericles, $\mathbf{v}$

iii. 3 CANARIES-into sucl a canaries...Merry Wives,

you have drunk too much canaries..2 Henry IV. ii. 4

and drick eanary with him.

cunless you see canary put it

and nuake you dance canary

invisible hand, cancel, and tear to...... Macbeth, iii.

the end of lite cancels all bandds..... H Henry $I V$. iti.
cancel his bond of lite, dear God...Richard III. iv.
the potwer to cancel his captivity...Julius Cosstr, i. the power to cancel his capts

proceed to cancel of your days $\ldots \ldots \ldots \ldots$......... Pericles, i.

concealed lady to our cancelled love.Rom.\& Jul. iii.

CANCER-more coals to Cancer. Troitus \& Cres. ii.

ANDICD-candied be they and melt.. Tempest,

the eold brook, candied with ice.. Timon of Ath. iv
let the candied tongue lick absurd .... Hamlet, iii.

C $\triangle$ NDLE_till candles, and starlight ...Merry W. v.
help me to a candle, and pen .... Tuelfth Night, iv.

help me to a candle, and pen .... Twelflh Night, iv,

dark needs no candles now ...... Love's L. Lost, iv. 3
what, must I hold a candle to ... Mer. of Venice, ii. 6

thus hath the candle singed the moth

we did nut see the candle

blameless, Camillo a true subject

recal the good Camillo; whom

I chose Camillo for the minister ....

puisoved good Camillo's honour ....

as thou lovest me, Camillo, wipe not

I have eonsidered so much, Camillo.

my best Camillo! we must disguise.

Camillo, not for Bohemia, nor the

now, good Camillo, I am so fraught
how, Camillo, may this, almost

how, Camillo, may this, almost

my good camillo, she is as forward

Camillo, preserver of my father, now of

thus we sct on, Camillo, to the seaside

who? Camillo? Camillo, sir; I spake

in the king, and Camillo, were very

seek him with candles of the night

than without candle may go dark

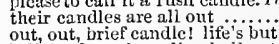

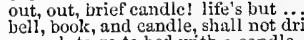

enough to go to bed with a candle... 1 Herry $1 V$.

a candle, the better part burnt (rep.)..2 Henry $I V . \mathrm{i}$.

here burns my candle out ..........3 Henry $V 1$. ii.

this cundle burns nut clear............. Henry VIII. ii

so, out went the candle, and we were..... Lear,

CANDLECASE-hure been candiecases. Tam. of S. iii.
CANDLEHOLDEE-a candluholder. Rom. $\$$ Jui. CANDLE-AINE-candle-mine, you..2 Herry $I V$. ii.

iv. 3 CANDLESTICK

$[K n t$.$] a brazen candlestick turned..l Henry l V$. iii.
sit like fixed candlesticks, with ....... Herry $V$. iv.

CANDLE-WASTERS-

drunk with candle-wasters .............Mueh Ado, v.
CANDY -her fraught from Candy.. Tüelfth

what a candy deal of courtesy …... I Heury $1 V . \mathbf{i} .3$

CANE-COLOURED [ [Knt.] a little yellow

CANIDIU'S-is't not strange, Canidius. Ant.\& Cleo.iii.

Canidius, we will tight with hin by sea

Canidius, our nineteen legions thou

iii. 7

the emperor calls for Canidius $\ldots . . .$. so his miud cualcers, beanty's canker., Tempest, i. 2 the cating canker dweils..... Two Gen. of Ferona, $\mathrm{i}$. is eaten by the canker .................. 1 huch $A d o, \mathrm{i}$. some to kill cankers iu the ...Mid. N. Dream, ii. 3

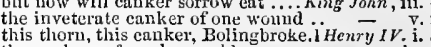
the cuukers of a calm world.......... iv. . Henry $V I$ ii 4 consuming eanker eats his falsehood... banish the canker of ambitious......2Henry $V I$. i. 2 full soon the eanker deatl eats... Romeo \& Juliet, ii. the canker galls the infants of ............ Hamlet, i. to let this canker of our nature come..... $\overline{\text { Lear }}$, v. 3 ANKER-BLOSSOM-

juggler! you canker-blossom!. Mid. N. Dream, iii. 2 ingrate and cankered Bolingbroke... Henry ${ }^{\prime}, \mathrm{ii}$. caukered heaps of strange achieved.2 Henry $1 V$. iv. cankered with peace, to part (rep.)...Rom. of Jul, iv. eankered with peace, to part (rep.)..Rom. of Jul. i. the hungry cannibals would not ....3 Henry $V I$. i. 4 and of the cannibals that each other eat. Othello ANNIBALLY - been camnibally given.. Coriol. iv. he reputes me a eannon ........... Love's L. Lost, iii. cven in the cannon's month......... As you Like it, ji. they were as cannons overcharged ....Macbeth, i. our cannon shalt be bent against

the caunons have their bowels ful

our cannons' malice vainly shall .... - ii. 1 he speaks plain cannon, firc, and smoke - ii. 2 now the devilish eannon touches.Henry $V$. iii. (cho.) like the brass cannon

sounded like a cannon in a vault.....3 Henry VI. v, 2

from the door with cannons ...... Henry VIII. v. why such daily cast of brazen cannon ... Hamlet, i. 1 but the great eannon to the clouds

if we could earry a cannon by our sides.. - - v.

I have seen the cannou, when it hath... Othello, iii.

that you deem cannon-bullets.... Trelfth Night, i.

the trumpet to the cannoneer without... Hamlet, v. 2

ANON - and continent canon. Love's $L . L$, i. I (let.)

the most inhibited sin in the canon.....All's Well, $\mathrm{i}$.

the canon of the law is laid on him.. King John, ii.
religious canons, civil laws are. Timon of Athens, iv. 3

against the hospitable canon...............

'twas from the canon ...................

CANONIZE-to come, canonize us. Troil. \& Cres. ii.
CANONIZED-canonized, and worshipped.John, iii.

thou shalt be canonized, cardinal....

why thy canonized bones, hearsed....... Hamlet, i. 4

WANO thy canonized bones, hearsed...... Hamlet, i. 4

now canopied under these windows.. Cymbeline, ii.

under the canopies of costly state..2Henry $I V$. iii

CANOPY - embroidered eanopy to ...3 Henry VI. ii.

hader the eanopy. Under the canopy?... Coriol. iv.

[Col. Knt.]-thy eanopy is dust ...Rom. \& Jul. Y. S

this most excellent canopy, the air .... Hamlet, ii. 2
CANSTICK-

CANTERBURY-archbishop of Canterbury $1 \mathrm{H}$. iii.

archbishop, late of Canterbury $\ldots . .$. Richard 11. ti. 1

pilgrims going to Canterhury with ..1 HenryIV. i. 2

is my graeious lord of Canterbury?.... Henry $V$.i.

installed lord archbishop of Canterbury

the archbishop of Canterbury.....

by the arehbishop of Canterbury

Canterbury? Ay, my good lord.......
good and gracious lord of Canterbury

stand np, good Canterbury ...........

promotion of his grace or Canterbiry

do my lord of Canterbiny a shrewd.. - v. 2

AN 1 E-a monstrous cantle ont .. I Henry I $\boldsymbol{F}$. iii. 1

CANTONS-write loyal cantons... Twelfth Night, i. 5

CANUS-that thrce-headed canns. Love's L. Lost, V.

I'll canvas thee between a pair

1 Henry Vi.i.

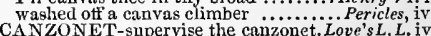

CANZONET-supervise the canzonet.Love'sL.L. iv.
CAP-will wear his cap with suspicion?. Mueh Ado

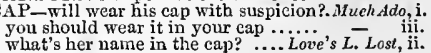

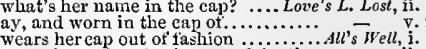

wears her eap out of tashion .........All's $\mathrm{Well}$, i.

wear themselves in the cap of the time -
put oft's cap, kiss his hand ( $r e p$.

coats, and caps, and goldeu ring

a trick, a baby's your

gentlewomen wear such caps as these

it is a paltry cap, a custard-coffin...

I like the cap; and it I will have

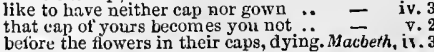




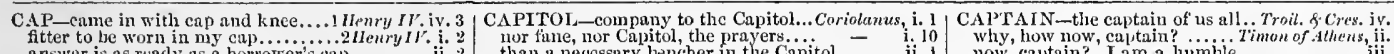

fitter to be worn in ny cap...........2 Heury $I F$. . . answer is as ready as a hotrower's eap

thou slialt liave is cap' to-morrow

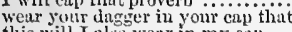

lleniy

this will $\mathrm{I}$ also wenr in $\mathrm{my}$ ea

weuring leeks in their Nlonnoutio....

why wear'st thou that glove in thy cal

if $I$ ean see my glore in his cap

aud stick it in thy cap...

I met this man with my glove in his eap -

wear it for an honour in thy cap

he ll make his eap co-equal..

throws not ns his enp for joy.

hurled up their caps, and some

dare us with his cap, like larks.

.2Henry W

3 Henry VI. it. 1

Timon of III. iii. 2

tine's flies, eap and knee slaves..

did you see my ean? (rep.).

thou art the cap of all.

they tlurew their caps as the

they thurew thelr caps as they ....... Coriolanus, $\mathbf{i}$.

take my cap, Jupiter, and I thank the

with their eaps, and slout

greasy caps, in hooting at Coriolanu.....

coxcombs, as you threw caps ul
I have ever held my cap oft to

ho, says a there s my cep ........

such gain the cap of him

if iny eap would buy a halter ...........

列 fortunc's cap we are not the very but
caps, hands, and tong ues, applaud it

a very ribband in the eap of youth

nor caps, nor any petty exhibition
CAPABILITY-capahility and godlik
CAPABLE-being eapable of all ill:

than a neccssury bencher in the Capitol
on, to the Capitol. All tongues sleak

you are sent lor to the Canpito

let's to the Capitol; and carry with

your number, repair to the Capital

thougl culved i' the porch o' the Cupitol -

as far as doth the Capitol excecd

shall us to the Capitul? O ay $30 . .$.

sce you yond' cotign o' the Capitol.

down that way towards the Capitol

against the Capitol I met a lion....

comes Carsar to the Capitol to-mori...

stands, as the Capitol, directly here.

hold him from the Capitol to-day

which drizzled blood upou the Capiti

run to the Capitol, and nothing else"

yet gone to the Capitol?

to see him pass on to the Capitol

cone to the Capitol. I wish...........

of his death is enrolled in the Capitol...
briefly, I dwell by the Capitol

or liere, or at the Capitol

to drencls the Capitol; but that........ Aniony \& Cleo the stairs that mount the Capitol .... Cymbelin this passage to the Capitol ...; Tilus.
and in the Capitol and senate's right .

thou great flcrender of this Capitol...

APITULATE-capitulate against us. Hen. $\mathrm{H}$. Hamlet or capitulate again with Rome's .... Coriolonus, CAPON-steals her capon's leg. Two Gen. of Ver. bid me to a calf's head and a capon ... Much Ado, v.
break up this capon ............ Love's L. Lost, iv. with good capon lined, with eyes...As you Like il, 11. malt-horse, capon, coxcomb, idiot.... Henry $I V$ iii. i. and a cold eapon's leg? .....

their danghters be capable.... Love's $L$. $L$. cicatrice and enpable inpressure. As you Like it, iii. so thou wilt be capable of a courtier's

if thou wit are capable of this ambition ........ King Jol fre capable of this ambition and and capable of fears his tlesh was eapable of wounds......2 Henry I ingenious, forward, capable ...... Richard III. iil. that's the more eapable ereature. Troilus \& Cres. iii. the means to make thee capabl

the means to make thee capable $\ldots . . . . .$. ... Lear, ii. I

to stones, would make them capable

till that a capable and wide revenge .OOthello, iii. 3

CAPACITY-you be capacity of it... Mierry Hives, i.

notwithstanding thy capacity ..... Tu'elf

this is evident to any tormal capacity
of good capacity and breeding........

speak most, to my capacity .... Nid.. N. Dream, v.

vour eapacity is of that nature.

the eapacity of your soft eheveril... Henry $\overline{V I I I}_{\text {. }}$

the capacity of my ruder powers.. Troil. o Cres. iii.

in liuman action and capacity

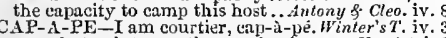

armed at point, exactly, cap-à-

caparison my horse; call u

here is the steed, we the caparison. Richard III.

CAPARISONED-I am caparisoned. As you Lilie,

for all the world caparisoned like.. Tann. of Sh. iii.

APE-with a small compassed cape - iv. 3 (note) or lace for your cape

what from the cape car you discern HenryI $V$. iii.

CAPEL - in Copel's monument ...... Othello, ii.

it burneth in

CAPER -he eapers, he dances ..... Merry wives, iii.

faith, I can cut a eaper...

is there here one master Coper ....ived. for $\overline{M e a . ~ i v . ~} 3$

run into strange capers .............

I have seen him caper upright

As you Like it, it. he capers nimbly in a lady

Richard III.

CAPERED the third he cajered........ Povericles, iv. Lost, $\mathrm{v}$.

CAPERING - capering tu eye her ...... Tempest
he falls straight a caplyering. Merehant of renice

CAPET-It ugh Capet also, that usurped...Ienry $V$. i.
sole heir to the usurper Capet.........

and Hugh Capet's claim, king Lewis...

CAPIIET-my horse, grey Capilet .. Twelfih $N$. iii. CAPITAINE-le grand capitane ...Wemy $V$. i CAPITAL - offences being so capital? Winters $T$, iv. 3 but treasons, eapital, confessed ........ Macbeth, i. 3
of cajital treason we arrest you here.RichnrdIl. iv. I of caljital treason we arrest you here. hichnrdII
and military title capital, throngh... IHenry $I V$. of capital treason I attach you both.2Henry $I V$. Wheu eapital crimes, chewed.............

enry $v$.ii.

of capital treason 'gainst the king ..2Henry VI. v. and in sueh capital kind, deserves...Coriolanas, iii. 3 due to this heinous capital offence...... Pericles, ii. Edmund, I arrest thee on capital treastm. Lear, v. to kill so capital a calf thcre ........... llomlet, iii. so erimeful and so eapital in luture... - iv. CAPITOL-here? to the Capitol ...... Coriolunus, i. item, a capon, $2 s$. $2 d$. I Item

you are cock and eapon to APliTCIO - this capricio hold in thee Ait's $_{\text {Well, }}$ i. 1 APRICIOUS-capricious poet .. As you Like

we must bring you to our captaiu

bring you to our captain's eave

a bawbling vessel was lie captain of

ill bring you to a captain in this.

to command the eaptain and ail ........ea. for Mea.

that in the captain's but a cholerick... - ii.

a phonix, cautain, and an e......Mid.

a phœnix, captai

good captain, let me be the interpreter

captain, I will. He will betray.

captain, we must be neat (rep.)

dismayed not this our captains .

pure soul unto his captain Christ
his captain, steward, dcputy elect
will you give me money, captain?

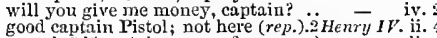

$o^{5}$ my word, eaptain, therc's none such

a dozen eaptains, bareheaded, sweating

my eaptrintains stay at door for you

Olord! good my lord eaptain

and good master corporal captain...

all to their captain, the licart

Seots captain, captain Jamy (rep.)

gud feith, gud captains bath .......
captain, I thee beseech to do me...

speak, captain, tor his life $\ldots . . . . .$.

under what captain serve you?

Gower is a goot captain

his pleasiure, captain, I peseeci rou.

and, captain, you mist needs be friends

enougl, captain; you have astonished

being captain of the watch to-night. 1 I

come hither, captain: you perceive

welcome, brave captain, and vietorious

a knight, a captain, aud a leader
Talbot, captains, calls you forth

Talbot, captains, calls you forth ....
whiles the lonourable captain there

liear ye, captain? are you not at leisure

nd our colours

captain, shall I stab the forlorn.

this villain here, being captain

for your captain is brave, and vows.

where's captain Mlargaret, to fence...

an thing captain, and persuaded. -

$U$ thou! whose captain I account mysclf

eaptain general of the Greci:tu... Troitus o" Cress. iii. you cannot feed capons

APPADOCIA - Cappadocia............ Hamtent, iii. 2

not told us of the did bring not

we shall, noble captain

captain? it eaptains were of $m y$ why, how now, captain? ..... Timon

pardon nuc, if $I$ speak like a cuptiin

senate pours into cuptains' wounls?

our captain hath in cvery figure sk
if thy captain knew I were here ...

come, iny caltstin knows you not

entreat your captain to soft and gent

1 do beseech thee, captain, and liear

so thy grand eaptain Antony shail se

than his captain cun, becomes ( rep. $^{\text {. }}$ )

eall to me all his noble cautains to $n$ y $\%$ lord

a diminution in our captain's brain
now thy captain is even such a body

my deur master, my captain

here is eaptain let him tel

come hither, captain; lork take thos Andronicus,

give it the captain. Haste thee ........ $-\bar{y}$.

go, captain, from me

let four captaius bear Humlet.

our great captain's captain, icft in

APTAINSHIP-the eaptainship. Timon of 11 il.

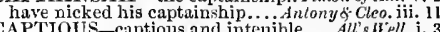

CAPTIVATE-husbands captivate..1Henry $V I$. ii. 3

liave been captivate ere now

their Woes, whom fortune captivates?.3 IIenry $I T$. i.
CAPTIVA'TED-captivated, bound. Love's L. $L$. iii.

CAPTIVE-the captive is euriclied

beware of being captives, bctore

whose rords took all ears eaptive .... - Y.

never did captive with a freer heart.. Richard $I$. i. 3

like eaptives bound to a triumphant..1 Henry $V I, 1.1$

and turned ny captive state to...

take away this captive scold

grossly grew captive to his honey..... Kichard III.iv.

when many times the captive Grecians ores.

as most abated captives, to some .. Coriolanus, iii. 3

brought many eaptives home to Rime - iti.

with Cesar, or not captive to lim. Antony \& Cleo. ii. 5

slaughter of you their captives.

came you to serve our Roman captive? - -

you have the eaptives, who were

CAPTIVED-all our princes eaptived....... Henry $V$. death, smeared with captivity! ..... Henry Vl. iv.

who kept him in captivity, till

2 Henry VI. ii.

to cancel his captivity capticy.

given to eaptivity me and iny nti..... Just... Olhello, iv.

CAPUCIUS- your name Capucius. Hewry VIII.

derived from the ancient Capulet.....

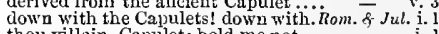

thou villain, Capulet: hold me not

you, Capulet, shall, go along with me

mine uncle Capulet, his wife .......

at this same ancient teast of Capulet

nay, sit, good cousin Capulet

and I'll no longer be a Capulet...

on the tair daughter of rich Capulet

the day is hot, the Capulets abroad

by my head, here come the Capulets

my tather Capulet will have it so.

run to Capulet's, raise up the Montagues -

CAR-to guide the heavenly car.. "woGen. of ter. iii.

be drawn from us with cars....... Terelfh . Wigh , ii.

Phibbus' ear shall shine from tar ..... Mid. N.1)r. i.
bound to a trimmphant car ....... Henryli. i. I

Phaton hatl tumbled from his car...3nenry

thy burmug car never had

bright track of his fiery ear.

Richard $I I I$.

[Col. Knt.] confessor Join de la Car.. Henry VIII. ].

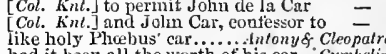

had it been all the worth ot his car... Cymabline, $\mathrm{v}$.

when thy ear is loaden with ... Titus, Andronicus,

CARAWAY - with a dish of caraways -1

wotehed him like a carbonado .... Coriolunus,
or I'll so carbonado your slianks ......... Lear,

lieads, and toads carbonaloed.... Winter's Tale, iy.

CARBUNCLE-rubics, carbuncles. Com. of Err. iii.

a carbunele of Plozbus' wheel ...... Cymbeline, y. 5

a plague-sorc, an embossed carbuncle ..... Lear, ii. \&

CARBU NCLED-were it eurbuneled. Int. \& 0 leo.iy. 8

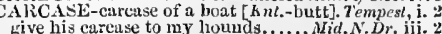

where the carcases of nany . iierch.of Venice, ii

sinakes the rotten carcase of old death. King John, ii. 
CARCASE-a earcase fit for hounds.Julius Cesar, ii. his body's a passable earease ......... Cymbeline, $\mathrm{i}$. CARD-faced it witl a card of..... T'aning of Sh. ii. know i' the shipman's card....

the best cards for the gam a cooling card

has packed cards witl Casa

KingJohn, v.

as sure a eard as ever won...

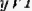
int. \& Cleo. iv.

he is the card and calendar of gentr.. CARDER - the spinsters, carders .... Henry VIII.

good father cardinal, ery thou, amen

to the cardinal? What should (rep.)

thour cardinal, I have heard you sa

brought that letter trom the cardinal?

the curdisial cannot make your peace

to the disposing of the cardinal

$\ldots . .1$ He
bat
law

ardinal, I'll be no hreaker of the law

and called unto a enrdinal's degree

onee lie come to be a cardinal.......

let us wateh the haughty cardinal ..

oft liave I seen the haughty eardina
and the eardinal, with somerset's ..
as I think, it was by the cardinal...

from the rich cardinal, and from
suftolk and the cardinal's broke

my lorl curdinal's man for teeping

college of the cardinals would choose

fancy not the cardinal, yet must we

lord cardinal, I will follow Elemor.

ay, my lord cardiual

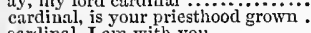

carlinal, I am with you

lord eardinal, be is your prisoner

but my lord eardinal, and you

lord cardinal, if thou think st on your grace ....

Richard III iii.

our reverend cardiual carried....... Ilenry

the eardinal's malice and his potency

this cunning cardinal the articles.

he privily deals with our cardinal

the o'er-great cardinal hath showed

my goorl lord cardinal, they vent....

menaced revenge upon the carding

the cardinal's and sir Thomas Loveil's =

to the eardinal's; your lordslip

you have found him, cardinal

Yll tell you, cardinal, I slould judge

good my lord cardinal, I have half

the cardinal instantly will find

either the cardinal, or some about him

the cardinal wili have his will ......

a man of my lord cardinal's

this is the cardinal's doing ..........

cardinal, pr'y thee, call Gardiner to me

even of yourself, lord cardinal

ord cardinal,-to you I speak

speak my cood lord cardinal to this point -

pcreeive, these cardinals trifle with me -

lord cardinal, the willing'st sin....

two reverend cardinal virtues (rep.)

cardinul's letter to the pope miscarried

how that the cardinal did entreat...
digest this letter of the cardinal's?

as the agent of our cardianl....

tis so. The eardinal-observe

my lords; saw you the cardinal?

the heads of all thy brother cardinal

into your own halids, cardinal

kissing in your arms, lord cardinal.

lord cardinal, the king's further

well, my little good lord cardinal.

this cardinal, though from a humijie

CARDINALLY_cardinally given..llea. for Hea. ii. 1
CARD-MAKER-a card-maker. Taming of Sh, 2 (ind.)
CARDUUS-Carduus Benedictus.... Whuch Ado, iii. 4

CARE-good boatswain, have care

what care these roarers for

witing hunan care; and lodged thee...............

if of lite you keep a care

and yet I care not

I care not though he 3 thank thee for thine honest care

what need a man care for

I care not for that neither .........

I care not for her $\ldots \ldots \ldots \ldots \ldots \ldots . . . \ldots$.

I care not for that ..................

lam sure, cares an enemy to life. Twelfth $\bar{N}$ ight,

an' he will, I care not

ay, ay; I care not for good life.........
CARE-I docare for something.. Tu'elfth Nishl, do not care for you; if that be to care

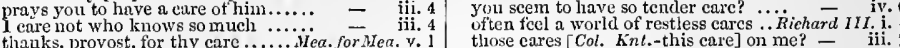

iii. 1 much overgrown with carc, here $\ldots . .$. - 4 - ii.

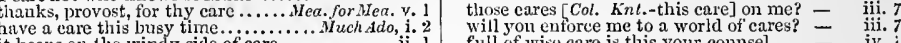

it keeps on the windy side of care.... $-\quad$ ii. $1 \quad$ full of wise care is this your counsel $\quad$ iii. $3 \quad$ a very caitiff crowncd with care.......

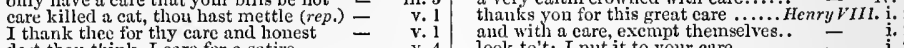

do:t thou think, I care for a satire

effect it witis some care.........Mid.. .'.'s D ream, ii.

liave a care the honey-lag break not ${ }^{\prime}$ would not care a pin if the.... Love's $L . \bar{L}$ ost, iv

you care not for me .........

past cure is still past cal

do buy it with much care...

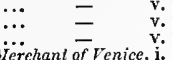

v. 2

bant my chict care is, to eome ....

I care not for my spirits............As you $\bar{L}_{i k e}$ it, $\mathrm{ji}$.

that little cares for buying any thing

naty, I carc not for their nam
but what care I for words?

I carc not, if $I$ have: $i t$ is iny study..

madam, the care I have had to even ... All's Well,

and I thank you for your honest care

I care no more tor, than I do for

throw thee from my care for ever

lose thee again, I cure not...

and with a care, exempt themselves.. -

brought with licr one eare abroad...

wave all the care 1 had, 1 saw

ii. 2 (letter)

filt's christian care enough...........

I care not, (so much I am happy .... - iii.

(of lis great grace and princely care ${ }_{\text {but what care I? I carc not .. Troilus \& Cressila, }}$

I do not care whether you do or no

swords? any thing, he cares not.

he cares not, he'll obey conditions

but alvantageous eare withdrew me

eareless force, and forceless care...... $\overline{\text { no care, no stop! so senscless... Timon of Athens, }}$.i.

nor resumes no care of wliat ....... - ii.

be t not in thy cire; go, I charge thee - iii.

and forteited to cares for ever!........ -

i. 3 if he care not for't, he will...

care of your food and living....

of Timon, that - rimon cares not $t$....

I cure not, and let lim take't (rep.).

most charitable care have the
who care for vou like fathers

who care for vou like fathers

all is done in reverend care of lier

I care not what, so it be wholesome..

one that cares for thee, and for

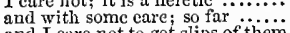

if you makc a care of happy...............

not little of his care, to lave.

it shall be so my eare to have

eare not for issue; the crove.

great care of goods at random ieft. Comedy of Er.

and yet my cldest care, at eightee.

I am dull with care and mclancholy

he hath great care to please his wite.

my teeble key of untuned cares

their counsels, and their care

neitlier to care whe ther they love

it he did not care whether he had

the rabile call our eares, fear

I neither care tor the world.....

what watehful cares do interpose...julius $\overline{C_{a}}$ sar,

which busy eare draws in the brains

if you did, I care not

nor neither cares for him .............. \& Cleopatra, ji.

in thy vats our cares be drowned.. - il. 7 (song)

I do not greatly eare to be deceived...

take thou no care; it sliall be heeded

very trutls of it, I care not for you...

care no more to elothe, and eat

this bloody man the care on't......

reserve my cracked one to more care

no care of yours it is; you lknow

and so much for my peculiar care.... - v

I care not, I, knew she and all .. Tilus Anuron. ii.

good quarter, and good care to-night
lives, but crosses, care, and grief .... Richard II

are now with me past care ....

iii. 1

drive away the heavy thought of care?

part of your cares you give me

kour cares set up, do not pluck ( $(\mathrm{rep}$.

so wan' with eare, find we............
I care not. Sir John, I pr'ythee....
I care not for thee, Kate ...........

1HenryI $\mathrm{r}$.

you care not who sees your back

二 ii. 3

have a reverend care of your healt

in good faith, a' eares not what

1 care not for lis thrust..................

well, sweet Jack, have a care of thysc

for mine own part, sir, I do not care

eare I for the limb, the thewes ......

perform with a most christian care

the incessant care and labolur........

perturbation! golden carc! that keep

my eare could not withinold thy (rep.)

the care on thee depending

bear your love, I'll bear your eares

for my part, I care not, I say little

alas, your too much love and care ...

and the eares of it, and the forms of it

nor eare I who dotin feed upon.

I care not who know it ........

aged, in an age of care, argue

be wary in tliy studious cure

speal, thy father's care

pcrplexed with a thousand ear.

noble lords, I care not which

so cares and joys abound, as seasons.

the reverent care I beer un

the care you have of us, to mow down

that care to keep your royal person.

in care of your most royal in his

for their tender loving care

or Walter, which it is, I ca

a thousand-fold more eare to keep...3 Henry $v l$. ii. 2 never with more care read to her sons
for this care of Tamora, herself ......

good sooth, I eare not for yon .......... Pricies, i.

have after nourishment and life by care
and cares it be not done; and so with me

which care of them, not pity.

but let your cares o'erlook what. ...

billow kiss the moon, I care not

and leave her the infant of your

no care to your best courses.............

and eare in us at whose expence

of territory, cares of state ......

half my care, and duty

no need to an my paternal care.

no nech to all

pinfold, I would not me thee care

what care I, what curious eve ... Romeo of Juliet ii. 7

where cure loùges, sieep will $(r \in p$. $)$

by my hecl, I care not $\ldots$..............

nor doth the general care take hold....... Othello, i. 3

the general does not greatly care ..... = iii.

CARED-none of us eared for Kate. Tenipest, ii. 2 (song)

and said, she eared not.....

Henry $V$. ili.

they ne'er eared for us yet ........... Coriolumus, i.

I shall meet your wit in the career

this brave manage, this career.... Love's L. Lost.

stopping the career of laughter...;. Winter's Tal

he pesses some humours and careers... Henry $V$.

down the hill he holds his fierce eareer? - iii.

as to say a careful man ...... Twelfih Night

hanging, yields a careful inan work. Winter's $T$. iv

more careful for the latter-born

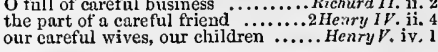

Richurd II eare not for me; I can go home alone.

I carc not for thy sword; Ill make thee - V v.

and careful hours, with Time's 


\section{CAR}

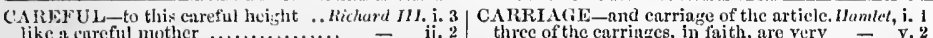

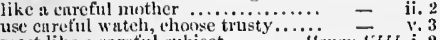
most like ut enretizl silbject and pray be carefin all, and hive. . Titus dud. iv. 3 till time heget some curetin remed $y_{.}$- iv. 3 and is not enreful whant they mean

I luve suen thec careful to obscrye

which the caretul 'Titus hath ordained $=$ v. 3 under the eovering of a eareful night ...pricles, $\mathrm{i}, 2$ there I'll leave it at eareful aursing

there 1 leave it at eareful hursing

the

C.AREEU1.LY - to enquirc carefully.. Tam. af Sh. i. 2 that $I$ fo carclully have dressed!

tend the emperor's per'son careful

do it earetily and sere

man bear him carefilly from hen

IRELESS- ns sound as carcless inf

eareless, reckless, and tearless ...... Hea for $\bar{\Delta}$ oa iv

a cureless herd, full of the pasturc. As you Like it ii

denuonstrating a careless desolation..

and the carcless lapsc

to Padua, careless of you

too careless patient as thou art hy sceming cold, or careless of his..2IIenry IV iv. 4

my careless father fondly gave ......3 $I_{1} n n y+7$. ii. 2

with such a careless force ......... Troil. \& Cress. v. 5

unkind, and carel ess of thine own. Titus Andron. 1.2

enrcless heirs may the two latter...

the light and earcless livery that.

brother being carelessly encamped...3Henry $V I$. jv. 2

like his raiment, carclessiy....... Timon of " 4 .

it Casar carelessly but nod on him. Jutius Cepsar, i. 2

be thought we held him carelessly..Rom. \& Jul.iii. 4

CAlREST-and carest for nothing.. Terelfh Night, 1ii.

CARET-focative is, caret

golden eadenee of poesy, earet .... Love's L. Lost, iv.

CARE-TUNED-my care-tuned tongue. Rich.II

CARL - or could this earl, a very drulge Cr. Cymb in. 1

CARLISLE-it is the bishop of Carlisle. Rich.1I. iii. 3

but here is Carlisle living, to abide

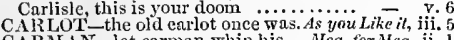

CARMAN-let carman whip his.

CARMIEN-the carmen whiste ....2 Henry IV ini 2

of carnal, bloody, and unnatural acto

CARNALI T - cornally, she says .. Mea. for Mea.

CARNARVONSHIRE-

I mysclf would for Carnarvonshire. Henry $I T H$. ii. 3

cnrnations, and streatiod gillyflowers.

cnrnations, and strealed gilly fowers. Hinter's T. iv. 3

this carol they began.......As you Like it, $v$. 3 (song)

CAROUSE-and quatf carouse..

carouse tull mensure to ber ....;

and carouse together like fliends

the queen carouses to thy fortune

all day caroused and bauqueted

hath to-night caroused potation

AliousING-aboard, carousing.. Taming of $\mathrm{Sh}$. iii. 2

faith, sir, we were carousing till ....... Macbeth, if. 3

do hourly carp and quaricl.

... Lear, j. 4

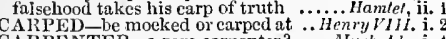

CARPENTER-a rare carpenter?

of wood; it is some carpente

Mrech Ado, i.

build therc, carpentcr

Cressida, iii. 2

the shipwright, or the earnenter?.... (rep.

CARPER-cunning of a carper.Tznon of thens, iv.

the carpets laid, and every thing. Taming of $N h$. iv. I

upon the grassy carpet of this...... Richarl rich

CARPET-MONGER

full of these quondam earpet-mongers. Muet Aclo, r. 2 [Col. Knl.] royalty, with carping fools.1 Hen.I $\mathrm{V}$. iii. 2 with envious earping $\forall$ ngue $\ldots \ldots$... Henry $I^{\prime}$. iv. 1 the censures of the earping world.. Richard III. iii. 5
CARRACK-armadas of Carracks.. Conn. of Es. iit. 2 to-night hath boarded a land carrack.. Othello i. 2 CARRAT-to the utmost carrat. Comedy of limors, iv. 1
CARRIAGE-upright with his carriage .. Tempest, v. 1 for easing me of the carringe........ Nerry Wimes, ii. than to fashion a carriage to rob.... Much Ado, i. 3 of good repute, carriage, bearing. Love's L.L.i. 1 (let.) and their rough carriage so ridiculuns

the violent carriage of it will ... Minter's Tale, iii. tcach sin the earringe of a holy... Comedy of $\mathrm{Er}$. unauy earriages he hath despatched.. Fing John, v. and a most noble carriagc.......... Henry $1 V$. the ordnunce on their carriages......enry ${ }^{r}$. iii. (cho this carriagc, the hearts of prinees. Henry VIII. iii.

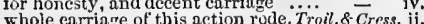
and honourable carriage, had . Timon of thens iii. become the earringe of tris ehafe ..Ant. \& Ch of your carriage from the court

women of good carriage.............Romeo of Julicl, i. 4 three of the carringes, in faith, are very $=\mathrm{v} .2$ the carriages, sir, are the hangers

AARRIED-carried mistress Silvia. Two Gen $-\bar{f} F$ v.

they carricd me to the tavern........Merry Hives, $\mathrm{j}$.

lave I lived to to be carrica in a

arrested, und carricd to prison .......eas.for $\overline{\text { Heas. }}$ i.

saw him earried away ..............

already lic hatl carried notice.

for we earried the town-gates

but that he is carried into

was carricd with mards Corinth ....Comedy or $\mathrm{Lr} . \mathrm{i}$.

carricd to Colmes-kill

Falstaff, you carricd your guts

and carricd you a forehand shaft...

they have burned and earricd

she has carricd hersclf toward $\mathrm{m}$

that kiss I carried from thce dea

Apollodorus carried

he was carricd from off our const

ARRIER - one of Cupid's carriers. Nerry H'

good-morrow, carriers..............1 Henry
sirah, carrier, what time do you ....

art not thou the earrier?...... Tilus $\ldots$ indronicus, iv. 3

and the tox carries the goose...
for the goose carries not the fo

why, it earries it: Remunerationi....ove's L. L. iii. I
which this promise carries ... Merchant of I'enice ii.

he earries his house on his head...As yout Like it

an unclean mind carrics virtuous

a very plansive invention that carries it - iv.

whore the judgcment, earries poor. Com. of Err.iv.

that earries no impression.

she that earrics up the train

the truth of the question earries

but carries on the stream .

the noblest mind he earrie

the greater he carries noise

wa do that carries anger...Julius Casar, iv.

a la stoceata carries it away ..... Romeo of Julief, iji.

CARRION-that foolish earrion ...Merry Wives, tii.

do, as the carrion does, not as ....Meas. for Meas. ii. out upon it, old carrion

a weight of carrion fles

and be a earrion monstcr lik

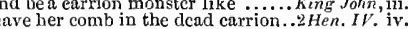

her contaminatcd earrion weight.. Tr
old teeble carrions, and such ....Juli

with earrion men, groaning for buria

more courtship lives in earrion $f$ l
out, you green sickness carrion!

a dead dog, being a god, kissing carr

I'll carry it to the pilc

go to, carry thi

lie cant fetch and your letters

he must carry for only carry.

nay, daughter, carry the wine

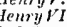

if you can carry her your

he will carry 't, he will carry 't $(r e$ )

earry them to the laundress in

to carry me in the name of

to carry the baskct again to

earry his watcr to the wise woman.. Twetfin

we may carry it thus, for our ......... for $\bar{M}_{0}$

if you think well to earry this

as if to carry him to exceution

daughter and her gentlewonan carry. Much $A d o$, ii. is valour cannot carry his discretion. Mid. N.D. $\mathrm{v}$. I am sure, cannot carry his valour...; L. Lost, iii. I but as a coach doth carry thee

no lawful means can carry me
resolves to carry her; let her

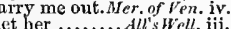

an officer: carry this

that thou carry this femaic bastard. Winter's $T$. ii.

why should I carry lics abroad?

go, carry them, and snear the slcepy.

your breches best may carry them.. King.John,

to, carry sir Joln

go, carry sir soln Falstaff to ...........

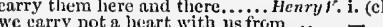

the inen would earry coals

to earry thee ont of this placc.......
sle curry armour, as slie hath begun

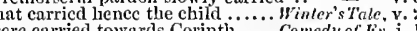
you islund carrions, desperate

carry him gently to my fairest.. Tam. of Sh. 1 (ind.)
CARRY-torbidilen late to carry any.1 Henry $1 \%$. lii. 1 an tist as horse can carry them

he'd carry it so to make the secptro..10

words cannot carry authority so weight

till in in to Flanders the great sea

the eleplant Ajax carry it thutle $\ddot{T}$.

glorious heaven, he shall not carry hii

stay at home, if bearing carry it.. Timon of $A t h$. ii
this will $\mathrm{F}$ earry to Rome

miss it, rather than carry

nd carly witl $11 \mathrm{~s}$ ears and eyes.

think you, hc'll carry Rome?

but he could not carry his honours even

and cariy back to Sicily much tail

carry me now, good fricnds, and hove

shall carry from me to the empres

only I carry winged time

shall carry half my love with hin

if our father carry authority with
may carry through itself to that finl

man's nature cannot carry the afliction

hardly shall I carry out my side

' my word, we'll not carry coals. Rameo \& juliet

do the boys earry it away?

that carry but half sense.

if we could carry a cannon by our sicle

CARRYING-carryin can carry t thus! .. Othello, i.

for carrying a letter to your lover.....

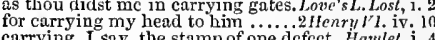

carrying, I say, the stamp of one defect.. Hamilet, $\mathrm{i}$. 4

CARRY-TALE-some carry-tale.. Love's I. Lost, v.
CART-to eart with Rosalind. As you Like, iii. 2 (ver.

to cart her rather; she's too rough. Taming of Sh. i. I
provide some carts, and bring ....... Ricliard II. ii.

provide some carts, and bring ....

when the cart draws the horse?

thennot draw a cart, nor eat ..............

CARTER-there is three carters.. Winter's Tale, iv.

when your carters, or your ......... Richord 11I. ii.

CARTHA GE-she was of Carthage ...... Tempest, i.

this Tunis, sir, was Carthage........

which burned the Carthage queen ......

to come again to Carthage...Merchant of Venice, v.

as Anna to the queen of Carthage.. Tuming of Sh. i. 1

if' I do not carve most euriously.........Much Ado

beyet, you can carve.......

Orlando; carve on every tree.......... you like il, iii.

but to carve a capon and eat it? ......1 Heary 15 .ii. 4

to earve out dials quaintly $\ldots . . . . .3$ Henry $V I$. i.

unvalued pcrsons do, carve tor himself... Hamlet, i.

CARVED-the earved bone face... Love's $L$. Lost

and carved upon these trecs? ...... Asyou Like il, iii. touched, or carved to thee ..... Tamedyg of Shrerr, iv. 3 like valour's minion, carved out his......1/acbeth $\mathrm{i}$.

for a pair of carved saints.......... Richard 11.

my knife carved in Roman letters ... Titurs And. $v .1$

be his own carver, and eut out....... Richarl Il. ii. 3

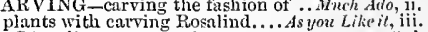

CASA-alla nostra easa bene venuto. Tamins of Sh. $\mathrm{i}$.

ay. Casca; tcll us what bath chanced

I should not then ask Casca what

but you, and $\mathbf{I}$, and honcst Casea

will youl sup with me to-night, Casc

good-night then, Casca: this disturbed

a Roman. Casca by your yoice

you are dull, Casea; aud those spark

now could I, Casen, name to thec....

no, it is Casca; one incorporate to.

come, Casca, you and I will, yet, ere das

this, Casca, this, Cinna, and this, Metel
good-morrow, Casca: Caius Ligarius

come not near Casca; have an eyc
Casca, be sudden, tor we fear jrevention

Casca, you are the first that rears.

and, my valiant Casca, your

what a rent the cnvious Casca made

.

$\mathrm{CAE}-$ our case is miscrable

for our case is as theirs....ii the

I am in ense to justle a constab

well, what is your accusative casc?

what is your focative case, Willinm?

(rep.) -

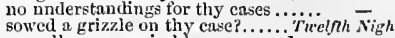

sowed a grizzle on thy case?......Ttelfh Night,
as well as a man in his case may do..

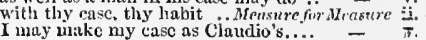


CASE_Yen, and a case to yut it into ... Much Ado, i. 1 | CASKET-depending on the caskets...Mer.of ren. i. 2 CASSIO-let's go see poor Cassio dressed. Othello, v. 1

the lute should be like the case..... - ii. 1 immeliately provided in that case ..Mid. $\bar{x} . D r$. i. t the worst tliat may befal nae in this ease - i.

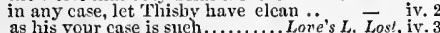
as his your case is sueh............ Lone' that superfluous case, that hic

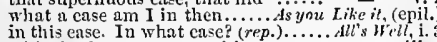
with the fox, ere we case him.... my lite, sir, in any case ............. iv. it this be not a lawful case for mie. T and hold your own. what case stand I in?

for, as the case now stands, it is ....... 0 that's the ease of the shepherd's son to tear the cases of their eyes ......... (for his case was like, reft of would not spare ny brother in this eas obserntion madest

plain case: he that went like (rep.).

would not be sir Nob in any case... my sworn duty in that case Richard $I I$. in any ense the offer of the king What, is it in the ease? Ay, Hal and my ease so openly know she hath been in good case. it was Jove's case: trom a prince a rotten ease abides no bandling make the case yours.$\ldots \ldots \ldots$..... in cases of defence, 'tis be no further of the ense, lives. no man answer in a ease of truth? the truth and plainness of the case in argtument upon a ease.

mine own attorney in this ease

pity my case! the spite of man

in any ease, be not too rongh...

ny, but the ease is alte

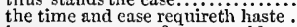

in ease some one of you would

your just proeeedings in this case... in this ease of justiee, $\mathrm{my}$ accusers.. Henry $V I I T$. v.

ay, ay; 'tis too plain a case ............ Timon of Ath.i. 2 wo, in a strange case was that........ to, in sueh a case the gods will not.. Coriolanus, and the case to be lamented Antony \& Cleo to eonsider in what ease thou stindest crack thy frail case

this ease of that huge spirit

jdiots in this ease of favoliv.

I yet not understand the case myself

an 'twere my ease [Kn!

her eyelids, eases to those heavenly.

and leave his horns without a ease

what, with the case of eyes?

your eyes are in a heavy case.

\section{gir further pleastre in the}

a case as mine a man may strai.

even in my mistress' ease just in her case

ince the ease so stands.

pitiful case, ay, by my troth $($ rep $) ..$ his cases, his tenures, and his tricks?.. Hamlet, as in these eases, where the aim reports.. Othello, as if the case [Knt,-eause] were his in such eases men's natures wrang

CASED -2 eased [ $\mathrm{Knt}$.-elhased] hion ... King Jnh $\bar{h}$, iij. I a eunning instrument caserl up.

Richard II. $\mathbf{i}$. jewel-like, and eased as richly

Pericles, v.

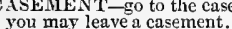

the moon may shine in at the easement

up to the casements then .....Merch. of

and it will out at the easement... As you Lik

thy casement I need not open

was it from a casement thrown me

you threw it him out of a casement

through easements darted their.... Richard $I$. look through a easement to allu
in at the ensement of my closet

CASH -in eash most justly paid.............. Lear,$i .2$ CASHIER-bully Hercules; eashier...Merry does his eashiered worship mutter?. Timon of $A$. iij. 4 bv that small hurt, hast cashiered Casso - ii CASING-general, as the casing air..... Macbeth, iii. 'CASION-go, zir, without vurther 'easion...Lear, iv. 6 CASKET-ehoose the right easket.Mer. of Venice, $i$. wine on the contrary casket here, eatch this casket

the several caskets to this noble prince What says this leaden casket?...

this casket threatens: men, that ....

there stand the caskets, noble prince

let me to my fortune and the casket

fortune stood upon the easkets ther

an empty casket, where the jewel ... King John

were not this glorious easket stored ..... Pericle

my easket and my jewels.

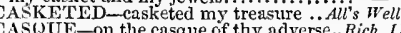
the very casques that did affich adverse.. Rich. 1

were it a casque composed by. Troilus \& Cressidu

not moving from the casque to ...... Coriolanus, jy. 7
CASSALIS G regory de Cassalis ... Henry VIII. ii.. 2
CASSANDRA-Cassandra's wit ... Troil. \& Cres. i. 1

and Cassandra laughed ...............

our minds, because Cassandra's nad?

visions Cassandra doth foresee.

Cassibelan, thine uncle ..............

can gripe as hard as Cassibelan.......

\author{
cy
}

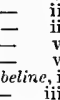

Cassio's a proper man $\ldots . . . . . . . . . .$.

but this same Cassio, though he speak

how say you, Cassio? is he not a most

ensnare as great a fly as Cassio

degree of this fortume, as Cassio does?

anger Cassio, either by speaking tooloud

but by the displanting of

that Cassio loves ber, I do well believe it

I fear Cassio with my nightcap too.....

to put our Cassio in some action that

the virtue that appe

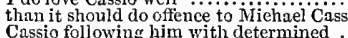

Cassio following him with determined

of swords, and Cassio high in oath

though Cassio did some little wrong

yet, surely, Cassio, I believe, received

to eomsel Cassio to this parallel eourse

my wife must move for (repeated)

my wife must move for cassio to her

one Cassio entreats her an litte favour

goon not doubt, Cassio, but I will have ...

whatever shall become of Alichael Cassio

Cassio parted from my wife? (rep.).

why, your lieutenant Cassio...

did Michael Cassio, when you wooed...

not that, when Cassio left my wife.

I think that Cassio is an honest man

observe her well with Cassio

it be fit that Cassio lave his place

will in Cassio's lodging lose this napkin

I found not Cassio's kisses on her lips

I lay with Cassio lntely...

to day, see Cassio wine his beard with

hear thee say, that Cassio lives not.
sirral, where lieutenant Cassio lies?

till Cassio be ealled to him

I have sent to bid Cassio come speak

I pray, let Cassio be received again

look you! Cassio, and my husband....

how now, good Cassio? What's the news

alasl thrice gentle Cassio, my advocation
go seek him: Cassio, walk hereabout .

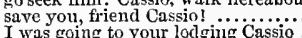

I was going to your lod girig

how now, Cassio? What is the matter?

such a man), Cassio came hither ......

now will a creation that dotes on Cassio

poor Cassio's smiles, gestures, and light

crying, O dear Cassio! as it were

I thenk you,

I thank you, how does lieutenant Cassio?

for the love 1 bear to Cassio...........

deputing Cassio in his government

you have sceu Cassio and she togethe

as the removing of Cassio.......

if Cassio do remain, he hath

the volee of Cassio: Iago keeps his word
here's Cassio hurt by villains. Cassio?

here's Cassio hurt by villains. Cassio?... -

Cassio, may you suspect who they

patience a faints, cassio! (rep.)

pow do you, Cassio? O, a ehair, a chairi

he that lies slain here, Cassio was my

alas, good centleman! alas, good Cassio! ij. 6 never loved Cassio, but with sueb......... - v.

like she comes to speak of Cassio's death - v.

Cassio killed?

heavenly true! Cassio did tup her.........

false to wedlock? Ay, with Cassi

that she with Cassio hath the act of

Cassio eontessed it: and she did gratify.

he give it Cassiol no, alas ..............

did you and he consent in Cassio's death

came you, Cassio, by that handkerehief.

is taken oft, and Cassio rules in Cyprus.

Cassius, be not deceived ..............

no, Cassius: for the eye sees not ....

dangers would you lead me, Cassiugs

darest thou, Cassius, now leap in ....

help me, Cassius, or I sink

bat, look you, Cassius, the angry ...

so som as that spare

so soon as that spare Cassius $\ldots . . . .$. .

your ear is good: Cassius, what night

that you mean: is it not, Cassius?

Cassius from bondage will (rep.)
0 Cassius, if you could but win

sinee Cassius first did whet me agains

'tis your brother Cassius at the door

will seem too bloody, Caius Cassius

alas, good Cassius, do not think of hi

Cassius or Cesar never shall (rep.).

and Cassius too. Where's Publius?

Caius Cassius, do I take y
pardon me, Caius Cassius.

passius, go you into the other street

those that will follow Cassius, go...

I will hear Cassius, and eompare .....

ran Cassius' dagger througl

Brutus and Cassius are rid like madine

to Brutus'; to Cassius'; burn all .....

Brutus and Cassius, are levying

is Cassius near? He is at hand ......

in general, are come with Cassius....

in my tent, Cassius, enlarge your...

the me tell you, Cassitts...

go to; you're not Cassius .............

is no terror, Cassius, in your threats

alone, on Cassius, for Cassius is....

o Cassius, you are yoked with a lam

hath Cassius lived to be but mirth

yes, Cassius; and, heneeforth, when

in this I bury all unkindness, Cassius

noble, noble Cassins, good-night

eommend me to my brotlier Cassius

if Cassius might have ruled.

this very day was Cassius born

no, Cassius, no; think not, thou

no, fassius, no; think not, thou

noble Cassius, fly far off ..............

o Cassius! far from this eountry

but Cassius is no more ..................

thou send me forth brave Cassius?

see how I regarded Caius Cassius.....

I shall find time, Cassius, I shall .

moved pale Cassius to conspire? ....... An

struck the lean and wrinkled Cassius

CASSOCK-from off their cassoeks - government I east upon though some east again

have me east my love on him?... Tu.o. Gen. of Ver.

thought your love not cast away

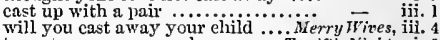
to east away my speech ......... Turelfth Night, i. my fortunes having east me ....... ii. 5 (etter) east thy humble slough $\ldots$, says she

to non-regardance east my taith $\ldots . . . \quad-\quad$ in. his filth within being cast hath an argosy cast away ...Merchant of l'enice, iij. I too precious to be east away upon...As you Like it, i. 3 and to east aws honesty upon

bought a pair of cast lips ais....

tis but one cast away, and so........ therefore, fire, fire; cast on no water - iv. ] thy brat hath been cast out.......... - jii. 2 east your good cuunsels upon his passion - iv.
(his dignity and duty both cast off).. not east aside so soon .................. Macbeth

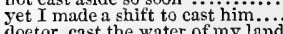

doetor, cast the water of my land.

hast thou yet more blood to cast away? ... John, ii. 2
dead, and cast into the streets ............ 


\section{CAS}

CAST_cast a way, and sunk, on Goodwin..John, v. dead, forsook, enst oll; and none of you

with a freer heart cast of his.

as to be east torth in the.

our states all at one cast? iinenryIrivi is

provokest thyself to rast liim up

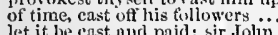

therefore I nust etest it up

be enst from possibility of ail

do not east away an honest nun

[Cot. Knt.] have enst in darkness.

I have set my life upon a east

your colt's tooth is not

asts such doulbts

and a non, he casts his cye ninginst...

and, saint-like, enst her fitir eye

how earnestly he east his cyes.

modesty again, cast none away ......

are we undone? enst oft?

would east the gorge at .......

Timon of sthens, iv.

our Rome will cast upon tliee.

you must cast your election on him...

from thence into destruction cast him

when you cust your stinising

and cast yourselt in

to cast into my teeth ..........

the city cast her people out

cast on my noble father.

harsh fortunc easts iljon my face.

they east their eaps up

though forteitcrs you cast in prison. Cymbctine, iii. 2

nnd cast from her his dearest one

the oceun, and cast your nets.

all headlong cast us down

one mountain, to cast up a highe

tlie sea lua th east me on the rock

poor men that were cast away before us

till he cast bells, steeple, church

hath cast utpon your coast (rep.)

nust cast thee, searcely coffined

did the sea cast it ur?

which even women have cast off

but cast their gazes on Marina's face

poor judgment he hath now east her off.

and cast you, with the waters...

think I hayc cast off tor ever

to east one's eyes so low?

for thee, oppressed king, am I cast down

cast by their grave beseeming ...Rnmeo \& $\ddot{j}_{\text {utiet, }, \mathrm{i} \text {. } \mathrm{I}}$

列

why sueh daily cast of brazen cannon ... IIamlet, $i$.

good Hamlet, east thy nighted colour off

and marble jaws, to cast thee up again!..

to cast beyond ourselves in our opinions

sicklied o'er with the pale cast

cannot with safuty cast hi.........

seems to cast water on the burning....... -

our general cast us thus early, for the

you are but now east in his mood

whereon it came that I was cast

ver I should call thes, castaways. Richard III. ii. 2

like a forlorn and desperate castaway. Titus And. $\mathrm{v}, 3$

CASTED-with easted slongh

CASTIGATE-castigate thy pride. Fimon of Alh. iv.

CASTIGATION-much castigation .... othello, iii. 4 CASTILIAN-art a Castilian king. Merry Wives, ii. 3
CASTILIANO-Castiliano vulgo.. Twelfh Night, i. 3 the casting forth to crows tha

the casting forth to crows thy.

there was casting up of eyes...........

his bouse, his castle, his atandinu-bed

search Windsor castle, elves, within.

though castles topple on tlieir...

the castle of Maeduft I will surprise

your eastle is surprised: your wite

our castle's strength will lau w

enter, sir, the castle. Why shoula $\dddot{\mathrm{I}}$ play

but Dover castle: London hath ....King Jo/n, y.

mect me presently at Berkley eastle. Richard 11. ii.

there stands the castle, by yon tus

please to enter in the eastie, and there

to go with us to Bristol castle........

Barkloughly castle call you thi......

bores through his castle wall ........

go, to Hlint eastle; there I'll jine...

this castle $y$ icld? The eastle is royaliy

of Hybla, my old lad of the castle .... Henry $I V$ iit.

at Berkley castle. You say true

girding with a castle, cock-stire...

from their sous, mock eastles down

what is this castle ealled

enry $r$.

to visit ler poor castle whe

an outlaw in a castle kceps

ii. 3
ii. 3
ii. 3

ii. 3

an a may catch your hide and you...

in the night to catch my horse ..... I Henryt $r$.

eatel ot you, Doll, we catch of y

traps to catch the petty theves.

and stare, and catch the air

set to catch my winged soul

or good taith, you'll catch a blow...3nenry VI. iii.

rearly to cotel ench other ly

souls may catch the king's. ...

RichordIII. $\mathrm{j}$.

to catch this food ocession most......ienry $\overline{F l l}$. y.

sooner catch the nge, thin what

you will cateh cold, and curse me
with great truth, catch merc simplicity

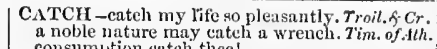

I will fuar to eateh it, and give way.

could $I$ but catch it for then

the very way to catel them ........ Coriolan

you may be pleased to eatch at... Antony \& Cleo. ti.

saucy lictors will cateh at us

as she would catch another Antony.

Col.] may gain shonid catch colr .. C.ymbetine,

canst thou catch any fishes then?

thou'lt catch cold shortly

catch in their fury, and make nothing of. Lear

ay, springes to eatel woodcocks

perdition eateh iny sonl, but I do love.

myen they are catched.. Love' $L$.

catched it again; or whether lli

cruel death liath catched it

we did kecp time, sir, in our catelie

and catches for his master .... Tamin ir achado,

A'TCHING - for cateling cold.. ? wo Gen. of tr

there's goodly catching of cold.

'tis eatching lither, even to our..... i Heriry $I r$.

their diseases are grow $\mathrm{w}$ to catcl.
lis infection being of catching.

massion, I see, is catching; for mine.julines Corsar, iij.

CATE- for dainties are all cates ... Taming of Sh. $\mathrm{Sh}$.

hut though my cates be menu. Comedy of Errors, iii.

wine, and sce what cates you

C A TECHISE-I must she not

and catechise my picked man you ..Turelf $h N$. i.

CATECHISING-what kind of catechising

CATECHISM - in a eatechism

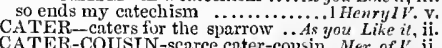

CATERPILLAR - the caterpillars ot... Richurd of 1 . ii.

al, whoreson caterpillars! .......... i Henry $1 V$. ii.

caterpillars eat my leaves away......2Henry VI. iii.

for every graft would scud a caterpiliar. Pericles

come hither, gentle Catesby

go, gentle Catesby, and, as it were .

good Catesby, go effect this

is my good frieud Catesly

well, Catesby, ere a fortnight make

and good-morrow Catesby ..........

Lovel and Catesby [Col. Knt.-Ratcliin

but, what, is Catesby gone?
Catesby, o'erlook the walls

yesternight by Catesby was it sent

now, Catcsby, what says your lord ...
return, good Catesby, to the gracious

hcre Catesby comes again (rep.)

come bither, Catesty $\ldots$.............

O truc, good Cateky, bid him...........
CATHEDRAL-cathedmal church of..2 Henry rI. i.

CAT-LIKE-with cat-like watch.. As you Like it, iy. 3

what say you, Simon Cating?...Romeo \& J Juliet, iv.

a soldier even to Cato's wish ........ Oerch. of Fenice, i,

well-reputed; Cato's daughter
by which I did blame C'ato tor.

and come, young Cat

ain the son of Marcus Cato (rep.

may'st be honoured as being Cato's son

AT-ONOUNTAIN-Or cat-o mountain. Tcmp.

your cat-o nom tall looks........... rerylnites, i. 2

what a catterwauling do you kecp. Treffh Night, ii. 3
what a cutterwauling dost thou keep?. Fitusstud.iv. 2

CATTLE-and takes the cattle.... Herry Wres, iv.

tor the most part eattle of this

men's cattle break their neeks

Promctheus ticd to Cancasus

AUDLF--the breast: a curdle,
ye shall have a hemren caudi

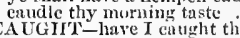

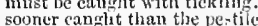

it he have ciutglit the Benediel.

We have canglit her, madom

Titus dudron. $v$

!. Lore's L. Lost, iv.

.........erc's L. Lost, v.

licenee of free foot hast caught ... As you Like it, ii.

we linve canght the woodeock

and it is caurlit of you (rcpeuted) Taming of sh. iv.

tor most it caught me, the celestial ....... 
CAUGIIT-mine eyes (eanght the.. Winter's Tale, y. whench caukght with ringing...

young was liucd, and caught 政 he has caught me in his eye . Timon of Alhens, iv. and we catre eaught it, he let

ort be cautght witlic cautelouts.

say, ah, hat you' re eaught ...........tonlo \& Cleo. ii.

a fiox, when oue has cuaglit her

Lear, i. 4

lave $I$ eaught thee? he, that parts us........ v. 3

in the alarm of feur eaught up ....... Hamles, it. 2

[Knt.] liath eaught me iu his elateh - v. I (song)

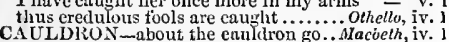

fire, burn; aud cauldron, bubble (rep.)

in the eauldron hoil and bake

for the ingredients of our enaldrou.

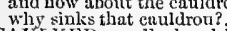

CAULKED_caulked and bitimed.......Pericles, iii. I CAUSE-you have cause (so have we ... Tempest, ii. Who hath cause to wet the grief ou

and that's lier cause of sorrow, Tho Gen... of $\bar{V}$ er. . v. afterwards 'ork upon the eause .... Merry Wives, i.

as I am from giving lim eatse
there is reasons, and eauses for

to give lum such cause of suspicioni

what eause of suspicion? what eause

- iii. 1

I suspect without cause, mistres....... $=$ iii. 3

our frailty is tlee eause ......... Twelfth Night,

find notable eausc to work

thou therctore hast no cause
drew your sword upou me without eause -

and the judge of complain of? (.... IIea. for Mea. i. I

hearing of the cause; hopiug (rep.).

the euase of his withdrawing (rep.)...

iii. 2

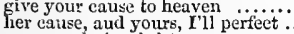

in cause doth ninister ...............

I would he had some cause to prattle

theu is your cause gone too.

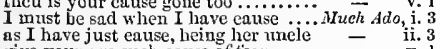

give your age such canse of tear..

last given me cause to curse ......

the birds have any eause to siug... Love's $\bar{L}$. Lost,

as the style shall give us couse ...

the first aud seeond cause will not

We eanuot cross the earse why

form all eauses to tlie purpose........

(as there is no such eause) you will... -

dotli cause me as my father

I aequainted lim with the earise in - $-\overline{\text { iv }} .1$ (let.)

1 am informed thoroughly of the eause

too unkind a eause of grief

and that a great eause of the night.. - iii. 2

not cause to weep? as good eause...

iiii. 4

upon the seventh cause (rep.)

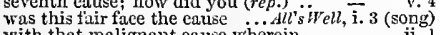

with that maltgnant eause wherein.

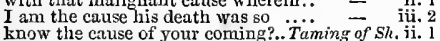

know the cause of your coming?.

to know the cause why music.........
no eause to stay. But I have eause..

know you not the eause? ..............

a weighty cause of love between
let me never have a zause to sigh

that las most couse to

there is no cause, when you sliall...

the earse were not in being (rep.).
nourisld the cause of his nowalking

nouris the cause of his a wath

to get the caulse of my son's resort

nowy Jove afiord youl cause!......

let him, that was the cause of this.

cause why thou departed'st (rep)

meek, that have no other cause
on her part some cause to you

on her part some caun
upon whint canse?

we shall have cause of state

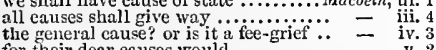

for their dear eauses would ....................

your eauge of sorrow must not be.

give you eause to prove my saying. King Joln

you shall have no cause to eurse

thou hast no eause to say so yet..
order in so fieree a cause doth

will pluck awny his natural eause

I had inighty eause to wish hin

put his cause and qured cau

appeareth by the cuuse you come...... Richarard $I I$

can arbitrate this cause betwix

in the justice ot his cause

as they eause it right, so be thy

heaven in thy good eause make
had I thy youth, and cause, I would

Eo the causes of our wreck

yct I know no canse why ...........
C.AUSE _well, that thou hast cause. Richard XI. iii. 4 , CAUSE_eause unborn, could never.. Coriolanus, iii. I wert eause of noble Gloster's death

thou hast no cause to tear

and for this eanse, awhile we

$\begin{array}{ll} & \text { one part does disdain witl } \\ \text { iv. } 1 \text { leave us to eure this cause }\end{array}$

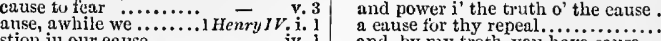

water-colours, to impaiut his cause.

God befriend us, as our cause is just!

but the cause that wit is in other men

Thave read the eause of his effects

IIenryI $V_{i} \mathrm{i}$.

action (a cause on foot)

as strong our cause the best.

all members of our eause, both here.

every slight and false derived cause

nor peer shall have just cause to say

turn lim to any eause of poliey
in regard of eauses now iu hand

your grace hath eause, and means

hand in a well-liallowed cause

we therefore have great ciuse of

and now to our French causes

so grossly iu a natural cause
when you yourselves are cause.

no great eause to desire the approach

his eause being just, and his quarrel

but, it the cause be not good, the kiu

be his cause never so spotless

meli more, and muelt more eause.

there is oceasions aud eauses why
these news would cause him onee

to know the cause of your abrupt....

and for that cause $\mathbf{I}$ trained thee

declare the eause my fitthe

more at large what cause that was.

I have, upon especial cause .......

for so slight and frivolous a cause

to forget this quarrel, and the caus
but eurse the cause I cannot aid

give me hearing in a cause

coufederates in tlis weiglity eause

as I was eause your highness came

that threat'st where is no cause.
the eause in justiee' equal seales

the eause in justiee' equal seaie
give you in this weighthy eause?

to determine poor men's eause

the cause why I have brought
thou hast no eause. No eause

thou hast no cause. No cause! ....3
for a thousand eauses, I would proion

with justiee of our canse ....................

from sueh a eause as fills mine eyes

this is the eause, that I poor Margaret

as he favours Edward's cause

upon what eause?
the cause of my imprisonment

Riehard III. iv.

thou wast the cause $(r e p$.

not the eause [Col. Knt.-mean] of my lord 二

pardon them that are the cause the

all of us have cause to wail. ...

go with you. You have no cause
indeed, had no cause to mistrust

the cause why we are met is,

[Col. Knt.] in this just earse coine i

who hatll auy cause to unourn

you have no cause to hold my

God, aud our good canse, fight upon

the eause he nay a little grieve at.. Ite
wlat's the cause? It seems ...........

what cause hath my behaviour given

to plead your cause, it sliall be

the full eause of our coming

and eomforts to your

and counsel, for my eause.

put your main cause into the ...........
for your honour better, and yoir cuis

put my siek cause into his hand...

upon what eause, Frong yout?..........
has left the cause o the king unhandle not wholesome to our ea

as I will lend you earse $\ldots \ldots . . . . . . .$.
good Griftith eause the musicians...

good Griflith eause the mus
the chief cause concerns his.

I take my cause out of the

what was his cause of anger?.. T.

he is melancholy without eause
I kuow the cause too; he'll lay

bad suecess in a bad cause

and on the cause and question now...

for'tis a eause hath no mean

sinee you refused the Grecians; cains

that cause sets up with and against..

a cause worthy my spleen
ay Timon, aud have cause

is the cause against your eity

or we had eause of fear, we sent
fight, as cause will be obeyed .

fight, as cause will be obeyed .......... Coriotan
in hearing a cause between
all the peace you make in their eause

he has more cause to be proud

with the least eause, these his new..

you know the cause, sir.........

I wish I had a cause to seek $\mathrm{l}$ iim......

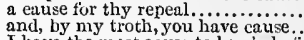

I have the most eause to be glad of
what eause, do you think, I have ...

stand to me in this cause

great cause to give great thank

.3 I know no personal equse to spurse. Julius Cec

i. 3 but our own cause, to prick us to redress -

unto bad eauses swear sueh ereatures

that, or our cause, or our pertorrnance

some eause, lest $I$ be langhed at (rep.)

nor without cause will he be satisfied
we will deliver you the cause, why..

hear me for my eause..............

not without cause; what cause.......
some worthy eause to wish things done
our couse is ripe: the enemy

ii. 2 between them and a great cause...... Antrmy $\overline{\text { \& }}$ Cleo. i.

ii. 2 they have entertained cause eupugh

having alike your eause"

your yartner in the earse " gainst which =

we have cause to be glad, that matfers

not ealled me so, nor have you cause

would obey it on all eause
for $\mathrm{f}$ have savase cause

never find more caulse to change

not as you served the eause

than you shall find cause in Cosar

projet nune own eanse so wcll
lest I give eause to be snspeeted

thou may'st be valiant in a better cause - $\quad$ iii. 7

that we have given him eause

of judgment is oft the cause of fear

the justice of my eause with an
undertook this eause of Rome.

commit my eause in balance to. ...

myself, my person, and the cause .....
valiaut doings in their country's eause?

died in honour and Lavinia's cause....

the cause, were known to them

[Knt.] an't were my cause, I sinould...

a thousand times more eause thian he

Antiochus (on what cause I know not

gives cause to mourn his fineral
try honour's cause for bear your

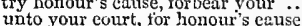

that is the cause we trouble you so early

to know the cause $[k n t$. -more of it $]$

beweep this cause again, I'll pluck

I have full eause of weeping

what is the cause of thunder

is there any canse in nature

some dear eause will in conceal
what was thy earuse? Adultery

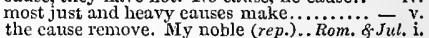

of the first and second eause

What unacenstomed cause procures lier

the eause of this effect; or, rather say (rep.)

John-a-dreams, unpregnant of iny eavi....

what cause he will by uo means speak

my tord, what is your cause of distempe

his form aud canse eonjoined, preaching

sith I lave eause, aud will, and strenstii

the numbers eanuot try the cause...
what is the eause, Laertes, that thy

for hy the image of iny ciause, I see

report me and my cause aright

I shall have also cruse to speak

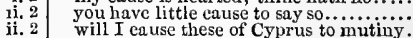

ii. 2 WKnt.] as if the eause wcre his ...............

$\begin{array}{ll}\text { ii. } 3 & \text { rather die, than give thy eause away....... } \\ \text { iv. } 5 & \text { (as worthy eause I lave, to fear }-I \text { am) }\end{array}$

(as worthy eause $I$ lave, to fear $-\mathrm{I}$ am)
sith I am entered in this eause so far....

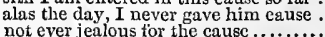

not the felt absenee now I feel a eause

v. 5 it is the cause, it is the cause (rep.) ....

ii. 6 dear general, I never gave you cause.....

ii. 1 hath eaused his death................ Richord II $\mathrm{i}$.

hath eaused every soldier to cout ....... Henry $V$.

ii. 1 thou hast eaused printing to be used.2Henry $V i$.

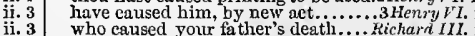

iii. 1 you have ealised your holy hat ... Henry YIII. iui. thou hast cause to rue can

'eause they take veugeance of suel

cause it to sound, 'beseech you

that the queen on special earse is here.

ause, they have not. No canse, no eause.. - iv.

the very cause of Hanlet's lunacy .... Han:

mine's not an idle cause ....................

my eause is heartedl thine hath no.... 
CAUSED-that letter, I cuused you. Ifrnry IIII. iv. caused our swiftest composition.

that caused a lessur villain ............. Cymbeliue. $v$

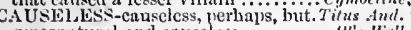
supernntural and causeless .............ll's Well, ti. with the rest, eauseless hnve laid

the eauser of the timeless denths.... Richarill I CAYSEST_eausest to be done............. for Hets. iji. 2 AUSTII-that which entseth it. Troil. of Cress. iv. 4 CAUTEL, 110 soil, nor cantel............Hamtet, cowards, and men cantelous ....... Julius Cirstrir,

advise him to a cuntion, to hold ...........Allisweth, for thy good caution, thunk

and pressed in with this caution ...Henry /'llI. ii. yet my eaution was more prertinent.. Coriolans,
with such cautions, that, it they come.... Lear With such cantions, that, if they comc.... Lear, i1.

and ench tilse be as a caut'rizing.. Timon of Ath. y.
CAVALERO-eke cavalero slender. Merry Wires, ii. to liel cavalero Cobweis to serateb. $\mathrm{Yid} N \mathrm{D}$. iv. CAVAlítions

to all thice caraleroes about London ..2HenryIt: v. 3

cavallo-justice, I say .............Merry Wives, ii.

AVALIER-

and chuiee-drawn eavaliers .. Henry $V$. iii. (chorus) shc'll clisturnish ns of all our eavalicrs. Pericles, iv. 6
C.IVE-to our captuin's cave.... Two Gen. of I'er. v. 3

mountains, and the barbarous caves. Tuelfth $N$. i

go to my cave and tell me ........... As you Like it, ii.

fo to my cave and tell me

to know at yonr abindoned cave

that cares and womby panltages .... Henry v. loosed them from their brazen caves.2 Henry nto the blind cave of eternal......... Richard 11$]$. bring us to his cave: it is our part... Timon of Ath. $v$ from Alciliades to Timon's cave.

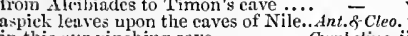 in this our pinch

(ymbetice,

there is cold incat ity ' the cave.

euturt no bigger than this cave.

that such as we cave liere.

as we cave here...

Tilus...̈rutronicus,

which way, shall I find revenge's eave

and cubin in a cave ......

and make them keep their caves $\ldots . . . . . \bar{L}$ ear, iti. 2 else would I tcar the cave where. Romeo $\&$ Juliet, ii. 2

CAVE-KEEIER-I was a cave-leeper ... Cymb. iv. 2

tind a cavern dark enough.

CAVETO-eaveto he thy eounselior ...llenry V. ii. 3 CAVIARE-'twas caviare to the general. Hamlet, that's but a cavil: he is old I'll cavil on the ninth part. Taming of Sh. ii. 1 you cavil, widow; I did mean

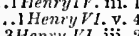

CAVCLING-not stand ctivilli

no more that thane of Cawdor shali.............

of Cawdor? the thane of Cawdor lives

no more than to be Cawd

all thane or cawdor too

and thane of Cawdor: the great

my worthy Cawdon'1 the prince

Gla of Cawdor, by wher

Great Glamis! worthy Cawdor

where's the thane of Cawdor?

theretore Cawdor shall sleep no more..........

CAWING-rising and cawing ............. - Dre CEASE-here cease more questions.

you said our work should cea

cease to persuade ...Two $G$

I pray thee, cease thy counsel

o nature, cease! [Knt.-cesse!]

hoth shall ecase without your

cease; no more: you smell...... Constance would not cease, till she ... King John, cease, cease these jars, and rest your..... Henry ${ }^{\prime}$. retreat, and ecase our hot purs

shall not cease to rage, until..........
nor cease to be an arrogrant controlie

cease, gentle queen, these execrations

cense to weep, but who ean

and letty sounds to ceasel cease to

and letty sounds to ceasel ............ iv. 4 ........3 HenryVI. i. nor ccase his fow of riot................... your importunacy cease, till....... let them not cease, but with

- ivi. to say, besecch you, cease: you bave...... $-\overline{\text { iv. }} 6$ Whieh are, or cease, as you shall give.Anl.\&. Cleo, i. 3
than be so, better to cease to be … Cymbeline, iv. than be so, better to cease to be $\ldots .$. Cymbeline, iv.
would eease the present power of life....
never was a war did cease, ere .........

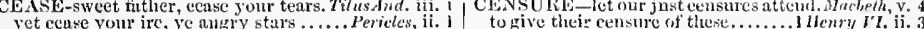
by break of day, it the winst cease patience, food sir, or here 1 'll ecuse we do exist, and cense to be or cense your quest ot love?
thint things unighit chnnge. or cense. fall, and cense! this teather stirs.......... which dotli cense to be.

to eeasc thy suit, and leave mi.........

the cense of unajesty dies not alone

CEASED-ceased, in heavy satistaction...All's Well, v. 3

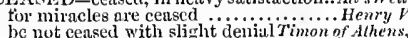

CEASETI-never ecuseth to enlarge... Henry $/ 7$.

as upright as the ecdar .......... Love's L. Lost, iv.

as on a mountain tol, the cedar

thus yields the cedar to the axe'

and, like a mountain cedar......

.2Henry $I^{r} I . v$ v.

a stately cedar shall (rep. v. 5) Cy

to the majestic cedar jomed

but shrubs, no cedars we ...Titus And inonicus, iv. 3

CEIDIUS_Epistrophus and Cedius.. Troil.\& Cres. and help to cclebrate a contrnet.

now witcheraft celelrutes pale.

to celebrate the joy that God

Michard $1 \mathrm{i}$,

Bacchanals, and celchrate onr drink i. Ant \& Cleo. ii

my queen, we'll celcbrate their nuntials. Pericles, v. 3
CEIEBRATED-contract celebrated. Winter's T. v. I

our Saviour's birth is celebrated

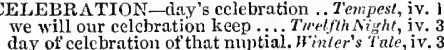

are ever forward in celebration. Henry VIII. iy.

CELERITY - his quick celerity ...Nen. for Mea. iv.

it was the switt celerity of his dcath..

as with celcrits find tector....... Troilus o. ini. (cho.)

she hath such a celerity in dying

celcrity is never more admired....
CELESTIAY-bears celestial liqu

now I worship a celestial sun.. T
celestial silvia's chamber-wivdow

give me thy hand, celestial, so.

give me thy hand, celestral, Bo..... Merry l'ives, iii. 1

celestial, as thou art, oh pardo

envelope and contain celestial spirits..Henry $r . \mathrm{i}$.

by inspiration of celestial grace

a pattern of celestial peace..

his celestial breath was sulph to

taste the fruit of you celestial tre
celestial Dian, goddess argcntine

will sate itself in a celestial bed
to the celestial, and my soul's ido

to the eelestial, and my soul's ido

Henry 11 . iv.

ay, Celia; we stayed her for you

neLI-a full poor cell

betore wc came unto this cell
lodged thee in mine own cell

retire into $\mathrm{my}$ cell .............

we are now near his cell ..il

which weather-fends your

fetch me the hat and rapier in my cell.

this cell's my court

and your train to my poor ecil

at friar Patrick's cell $\ldots .$. Two G

at Patrick's cell, should micet me ...

it is a cell of ignorance

sweet cell ot virtue and nobility

at triar Laurence' ccll be shinived.

hie you hence to friar Lauren
to dinner; hie you to the ccll

he is lird at Iaurenec' cell ...........

here comes the lady towards iny cell

the youthful lord at Laurenee
bring it straigbt unto nyy cell.

and keep her at my cell till $\mathrm{K}$

in my cell there wonld she kill herse

to keep her closely at my cell, till $I$.
feast is tow ord in thine ctcrnal cell

thy $[K n l$. the] hollow cell $[K n t$-hell $]$
CELI.A

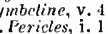

CELLARAGE-1ellow in the cellarage... .. Hamit

CELSA - sterat Priani regia celsa. Tan
eelsa senis, that we miglit begnile....

presums not; celsa senis, despnir not

may cement their divisions

as the cement of our love.......... - iii. 2

thou thin man in a censerl ........2 2henry I ${ }^{\prime}$

CENSOR-being censor twice........

CENSURE-should censure thus.. Two Gen. $\overline{\text { of }} \mathrm{V}$ er

which now you ecnsure him ....
when I, that censure him, do so

when I, that censure him, do so

in mortality can censure seape.

therefore beware my censure, and kecp

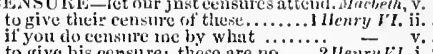

to give his censure: these are

give your censures in this weighty

your Wate censure both of his truth

uth - iii.

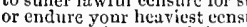

ccnstire me in your wistlom....... Jutius Cesur

fear not slaniler, ccnsure rash ...... - iv. 2 (song

the strongest in our censure ........... Pericles, ii.

lirst be known that are to censurc thein .... . .

the censure of which one, must, in your

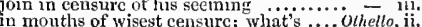

I. may not breathe my censure ........ - iv.

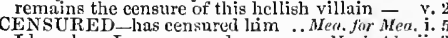

I licar how I nm eensured .............. Much . Ado

you two know how yon are censured. Coriolune

why, how are we ccnsured? Because

CENSUIRER-mnlicions censurers .. Henry i'it. $\mathrm{i}$.

CENT-donncray denx cents cseus ....Henry $V_{\text {. iv. }}$

go bear it to the Centaur, wherc.. Comedy of Err.

safe at the Centaur; and the heedfui

you know no Centaur? you reccived

home to the Centaur, with the gold.

and bloody than the Centaurs' feast.. TilusAnd. v.

CENTR E-through the centre crecp. Mid. $N$.'s D. iii.

thy intention stuls the centre! .... Winter's Tale, $\mathrm{i}$.

the centre is not big enough to bear.

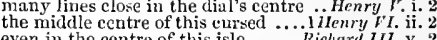

the planets, and this centre ...Troilus \& Cressidi

as earth to the centre, yct, aftcr all..

dull earth, and find thy centre out.. Rnm.\&.Jul. ii. I

it were hicl indecd within the centre.... Ilamlet, ii. 2

CENTIRION - the centurions, and

a century send firth.

CERBE liUS-club killed Cerbcrus.. Love's $L . L$.

damn thein with king Cerberus ....2 Henryl $F$.

as Cerhern!s at the Thracian poet's ". Titus And.

CERENENT -burst their cerements! .. Hamlet,

CEREMONIES

all sanctimonious ceremonies mas....Tempest, iv.

but atter many ceremonies done. Tuming of sh. nii.
shall find the cercmonies of the wars.. Henry $t$. iv.

his ccrmonics laid by, in his nakedness -

tuntasy, of dreans, and ceremunics.

all true rites, and lawful eeremonies

twenty popish tricks and ceremonies. Titus And. $\mathbf{v}$.

let us take a ccremonious leave ....... Richardil. i. 3

form, and cercmonious duty, for you - iii.

cou ceremonious, and the ceremonions vows of lore - v. 3

of Troy are ceremonious courtiers. Troil. \& Cress. i. 3

CEREMONIOUSI, Y -

CEREMUNY - and ceremony of it.Herry Wives, iv. to give onr hearts united ceremony .. $\overline{N i}_{\text {and }}$ iv. no ceremony that to grcat ones ....Met. fnr Meru. ii.

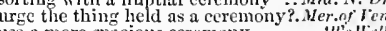

that I leave out ceremony ....... Winter's Tale,

save ecremony. save general (rep.)..... Her Het !

and bid thy cercmony give thee enre!

thrice gorgcous cercnony, not all these
and, but for ceremony, such a wreteh

but the cercmony of bringing back. Henry $\bar{T}$ III. it.

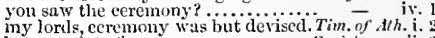
bate one jot of eeremony ............. Coriol han it useth an entirecd ceretuony ...... what, no more cercmony? .......Antnny\& Cleuo iii. I what ceremony else? then is (rep.).......... - v. approach rich Ceres, her to cntertain .. . iv, Ceres' hlessing 80 is on you........ - iv. 1 (song) Juno and Ceres whisper seriously....... the heal at Ceres' plenteous load? ...2 Henry $1 \%$ i. lord Cerimon, my lord; this mnn..... lord Cerimon hatli letters of good eredit - v. and gieddy censure will then cry ont...Coriolunus, $\mathrm{i}$.

the inmost centre of the earth .. Tilus Andron iv.

whe a more spncious ccremony.......... All's liell 
CERIMION-Cerimon there well. Pericles, v. 3 (Gow.) CERN-[Col. Knt.] what 'cerns it you. Tam. of Sh. v. 1
CFRTAIN-that's most certain......... Tempest, iii. 2 bury it certain fathoms in the earth.

will not let you believe things certain without you? nay that's certain. Tuo Gen. of ver. ij. 1 oome certain shot be paid . . 'tis most certain your hushnnd's.. Merry Wires, iii. 3 most certain, if you are she

most certain: let our catch be...

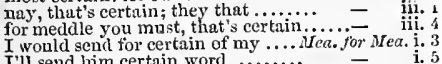

thon art not certain; for thy complexion - iii.

but it is certain, that when

for certain words he spake agains

Iuch do, i.

'tis certain so; the

rich she shall be, that's certain

nay, that's certain; we have...........

thy crazed title to my certain right

and ecrtain stars shot midaly from

be certain, nothing truer; 'tis no je

and ns a certain tather saith....
at the father's of a certain pupil

there is no certain $P$

some certain treason ...............

that certain he would fight, Jea ....

Lorenzo, certain; and my love, indeed

that's certain; 1, for ny part, knew

a lodged hate, and a certain loa thing

for bere I read for certain.

of a certain knight, that swore........ you $\overline{L i k e}$ it,, .

the cut of a certain conrtier's beard.. $\overline{-} \bar{W}$ ell, iii. 6

certain it is, that he will steal

she has; certilin it is, I liked ber

is ccrtain to me a break-neck

Hinter's Tale, i. 2

and to the certain hazard of ali

the bondage ot certain ribbands

most certain, to miseries enough

nothing so certain, as your anchors..

in a thing falsing. Certain ones then

(a thing most strange and ccrta.

for certain friends that are botb

for, certain, sir, he is not .............
but for certain, he cannot buckje

but certain issue strokes must arbitrate

most ecrtain of one mother............

by some certain king purged..........

came there a certain lord neat

why, that's certain; 'tis dangerous

why, that's certain; 'tis dangerous...

he is certain, ours is doubtfnl...

certain horse of my cousin Vernon's

to reform some certain edicts

no, that's certain; I am not ....

too trne, your fears too certain

I hear tor certain, nud do speak

I have received a certain instance

certain, 'tis very certain (repeated.)
but be old; certain, sine's old ..........

this apoplex, will certain be his end..

it is certain, that
it is raost certain

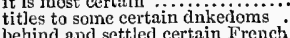

did claim some certain dukedoms

long as I may, that's the certain

falorous gentleman, that is certain

'tis certain, he hath passed the river

'tis certain, there's not a boy left

for they are certain and intalible

some certain dress of conscience.

the verity of certain words spoke...

from a dying man receive as certain

eertain, the daughter of a king

on certain speeches uttered by

'tis now too ccrtain

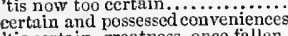

'tis certain, greatness, once fallen

call my thought a certain knowi

my lord, there are certain nobles

wy lord, certain half-caps ................

for certain money here,

so full of gold? Certain ............ Coriolan

yes, certain, there's a letter for you.

when some certain of your brethren

but this certain, that, if thou conquer

eertain, this is trme? (rep.) ..........

given up, tor ecrtain drops of salt..... some certain of the noliest minded. $\vec{C}$ ces nay, that's certain

send to you for certain sums of gold
CERTAIN-for certain, she is dead.Julius Copror, iv.
this is most certain that I shall ...Antony \& Cleo.ii. this is most certain that I shall ...Antony \& Cleo. ii. a certain queen to Caesar ........
by certain seales $i$, the pyramid is this certain? or I have no

most certain; sister, welcoine......

nay, 'tis most certain

nay, that is certain

at certain hours, such thoughts

as certain as I expect my revenge

to make ine certain it

dirl compound for her a certain stuff

some certain snateh or so would..

there are it wertain condolements, cert

this letter, and some ceriain jewels...

"tis most certain.

that's most certain, and with yo

if the matter of this paper be certain.

eannot be bordered certain in itself

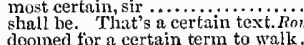

dooined for a eertain term to walk.....

that ecrtain players we o'er-ringht on

'tis certoin then for Cyprus

withont more certain [Knt.-wider]

\begin{tabular}{rr}
$=\quad$ ii. 6 \\
$二 \quad$ iii. 7 \\
\hline
\end{tabular}

HAFED-what, are you chafed?.... Henry VIII. ¿. so looks the chated lion upon the daring - iii.
their high blood chafed ..... Triolus \& Cressula (prol. so blushed, and Paris so chated .... Cressula (prol.) being once chated, he cannot be..... Coriolanus, iii. CHAFE in two bushcls of chaff'... Mer. of Venice, 1 . seared my choughs from the chaff...Winter's $T$. ii. cor'n shall secm as light as chaff ....2 Henry $1 \mathrm{~K}$. iv. where my chaft and corn shall fly ..Henry VIII. v. chiaft and bran, chaff and branl 1. Troilus of Cress. a pile of noisome, musty chaff ....... Coriolanus, v. You are the nusty chati; and you.... CII A I - howling, gingling cliains....... T'empest, v. affection chains thy tender days. Tuo Gen.ofver. $\mathrm{i}$. and have taken him by the chain... Merry Wives, $\mathrm{i}$. and slakes a chain in a must $\ldots . . . . . .$. beruiled master Slender of his chain I'll provide you a chain

go, sir, rnb your chain with crumbs...Twelfh $N$. ii. your neck, like a usurer's chain? ..... Much Ado, ii. the elain were longer, and the letter. Love's L. . v. and a chain, that you once wore. As you Like it, iij. and a chain, that you once wore. As you Like it, iii. he promised me a chain; would .. Comedy of Er. Ect y ou home, and fetel the chain
that chain I will bestow (be it for here is the ehain; I thought to (rep.) he had of me a chain; at tive (rep.)

a chain, a chain; do you not hear (rep.) -

for my diamond, the chain you promised -

more covetous wonld have a chain

for a chain, your husbaud bad ( $r$ cp.

did I mect him with a chain ...

protest, he had the chain of me .....

so to deny this shain, which now

to go teteh a chain prom

of him received the pronising

these people say the chain about

you, sir, for this chain arrested

cast off his chains of bondage.......

I will chain these legs and arms

the very shaking of their chain

their rotten coffins up in chains....

do chain my soul to thine.

if you had won it, certainly, you had ..... $J_{0} h n$, ii

the king is certainly possessed....... Henry $I V$.

certainly, ancient, it is not a thing ...

yes, certainly; and out of doub

Henry $Y . \mathrm{y}$

certainiy, the cardiual is the end ..Henry VHI. ii.

we'll hear you sing, certainly ...Troilus \& Cress.

nay, certainly, I have heard. Antony \& Cleopatra, ii.

nay, certainly to-night; for look ....... Pericles, 1i.

and, certainly, in strange unquietness. . Othello,
CERTAINTIES-with no certainties ..2 Henry I

I speak from certainties ............. Coriolunus,
certainties either are past remedies ... Cymbeline

CERTAINTY-but a certainty...Mea.. for MLeas.

we here receive it a certainty, voucbed. Al'sWell, $\dot{i}$.

upon thy certainty and confidence

with all certainty, to be the king's. Winter's Tale, $\mathrm{v}$.

the certainty of this bard life ...... Cymbeline, iv

. 4 CERTES tor eertes these are pcople Tempest, iii.

and certes, the text most infallibly. Love's $L$. L
certes she dic: the kitchen-vestal.. Com. of Er.

one, certes, that promises no ........ Henry VIII.

CERTIFICATE-this is a certificate. 2 Henry $1 V$. $i$.

ii. 1 CERTIFIED-certified the dnke...Mer. of Venice, in.

ii. 2 CERTIFLES-[Col. Knt.] then certifies. Rich. IIt. ii

CERTIFY-I go to certify her ...... Henry HI, i.

Who saw Cesario, ho! .............

now, good Cesario, but that piece.

once more, Ccsario, ret thee to yon

Cesario is your servant' $\mathrm{a}$ name

nor your name is not master Ccsario

be not offended, dear Cesario

Cesario, you do not keep promise

where goes Cesario?

fear not, Cesario, take thy

fear not, Cesario, take thy $\ldots$...........

a thrifty shoeing-horn in a chain.

to chain and restroin the yor.. Troit. \& Cres. v.

chain mine armed ncck... Antony \& Cleopalra iv.

and hang me up in cliains!

chain me with roaring ben.... Tilus dindronieus, ii.

in chains of magic wcre not

too long, if it were chained together. Com. of Er. iv

bear chained to the ragged staff ...2 2 Henry V

as I say, in a lower chair, sir.... Meas. for Meas.

fist to the chair; be heedfui: hence... King John, iv.

return back to their chairs again .... Richard il. i.

so hunger for my empty chair.

HenryI 1 . ii.

chair?..1 Henry VI. iii.

in that chair where kings and queens.2 Henry VI.1.2

even in the chair of state! ..........3Henry VI. i.

and, ocr the chiair of state, where...

his dukedom and his chair with me..

hadst kept thy clinin in peace........

ii. 1

resign thy chair, and, where I stand -

by the foil of Englind s chair in a rich chair of state ........... Henry $\overline{V I} I I$. iv. reach a chair;-so,-now methinks.. - - iv pant in your great chairs of ease... Timon of Ath anid the chairs or justree supplied. lay it in the prator's chair, where...julius $\bar{C}$ ceso and limself in chairs of gold.... Antony \& \&leo. iii. to this chiair bind him .................... Leur, ini. fellows, hold the chair: upon these eyes.. - iii.

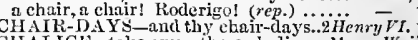
CHALICE-take away these chalies.. Nerry $\boldsymbol{W}$. the ingredients of our poisoned cbalicc.. Macbeth, i. 7 CHALICED-chalied flowcrs. Cymbeline, ii. 3 (song)

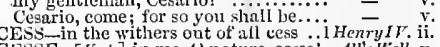

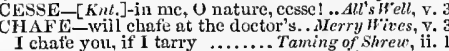
I chate you, if I tarry $\ldots . . . .$.
sec how it chaming of Shrew, ii. I who chafes, who frets, or where

fain would 1 go to chafe his paly

flies chle tinec, consin ..... Troilus gressida, iv. does become the carriage of his chafe.Ant. \& Cleo. $\mathrm{i}$. 3 on the unnumbered idle pebbles chates . Lear, iY. 6 an angry boar, chated with sweat?. Taming of sh. i. 2
Warwick rages like a chafed hull ..3 Henry $V I$. ii. 5
CHALK-grace chalks sucessors ....Henry VIII, $\mathrm{i}$. CIIALKE - for the ehalky elitts.. Comedy of Err. iti. 2 as I conld ken thy chalky cliffs ....2 Henry 1 . iii. to gar, it is a challenge ................ I'll writc thee a cliallenge ..........

bear me a challenge to him? uncle's fool, reading the challenge.... Much $A d o, \mathrm{i}$. 1 CILALLENGE-I combat challengc. Merry Wives, $\mathrm{i}$.

nere's the challenge, read it $\ldots \ldots \ldots$. matter I challenge thee for - ii. 4 (chai.

I will deliver his chalienge by word - iii. 4 (chal. 
CIIAILLENGE-I will eluhllenge him. Auech sto, iv. I / CUAMBER-show you a chamber do clullenge thee to trial of a minn.

Gorl bless ine from a chinlenge!...

Claudio undergoes my

i.ove's L. T. Tost, iv.

chen she shinl ehatlenge

Hector will clull ehatlenge th

by the sorth polc. I do ehallenge thee

Ponirey hath nade the ehallenge....

come chailenge, ehallenge me ly these $-\bar{T}$, y

challenges itsclf as honour's born

All'swerl, ii.

I am a subject, and chatllenge las.

Henry!l

in my life did hear a challenge

and ever dare to challenge this g

i know this: and thus I challenge $\mathrm{i}$

in thy enp, till I do challenge

not of any challenge of desert ....... i i Henry $r F$.

perfections challenge sovereinnty

why, and Ill challenge notbing but

these graces eliallenge grace: and.

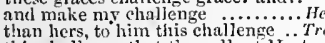

this challenge that the gallant 1Iector

I have a roisting chalienge sent...

to-morrow be answered in this challen
his spirit, that dares not cliallenge it

his spirit, that dares not cliallenge it $\vec{c}$

where merit doth most challenge it

-naturc loth with merit challeng
read thou tris challeuge; mark but

a challenge on $\mathrm{my}$ life.

dares ne'cr come back to chalienge you -

ho much I cliallenge that I may profess.. Om

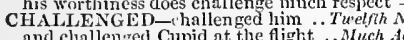
and ehallenged Cupid at the flight

and hath chalienged thee?

challenged Charles the wrestler ... As you Like behalf which we have cliallenged ...King John chalienged you to single fight $\ldots \ldots .1 \mathrm{Hem}^{2} \mathrm{IV}$. thy horn, it should be challenged... Troil. \& Cres. v these white flakes had challenged pity ... Lear CHALLENGER - the challenger's. As you

monsicur the challenger....

a style fit for challengers .

unhorse the lnstiest challenger.........

Richard IT. $\mathrm{v}$

cH stood challenger, on mount ot al] ...... Hamlet,

CHAMBER-me to my chamber. Two Gen. of I er. ii.

go with me to my chamber.

that is hanging in your ebamber

but all the ehamber smelt lim .

that's her chamber

hie home unto my chamber

would better tit his ehamber, than

mine own great chamber again....

and in the ehambers, and in the

step into the chamber, sir John

my husband will come into the chamber -

there's his chamber, his house

ny ehambers are honourable.

speak with you in your chamber.

come up into my chamber

come bs-and-by to my chamber........

come by-and-by to my eham

to bring moonlight into a chamber. $M i d . N^{\prime} . D^{2}$. must love a wall in the great chamber

her attendants of her chamber $\ldots$ As $y$ y u Like

go with ne to my charaber ...........All's Well, i

gently to my fairest chamber. Tam. of Sh. I (indue.

lay here in this goodly chamber.... -2 (induc.)

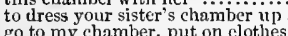

will bring thee to thy bridal chamber

in her chamber, making a sermon

perfume tor a lady's chamber

commanded out of the chamber ........ Macioth,

those sleepy two of his own chn
who lies i the seend chamber?

retire we to our chamber

alproach the chamber, and destro

those of his chamber, as it seemed
at hand, that ehamliers will be safe

at hand, that ehambers will be safe.

in your chambers gave you .........
sitting in my Dolphin chumber

venture upon the charged cham

bear me henec into some other chamber

he eame not through the chamber where -

depart the chamber, and leave

but, bear me to that chamber ........

unto the Temple, to his chanber .... inenry r'r. ii.

enter his chamber, view his.........2 thenry $r$, ii
capers nimbly in a lady's chamber.. kichard III.

rest betide the chamber where throu.

prince, to London, to your chamber... ${ }_{\text {a prisoner in my elimber........... Henry }}$ ii

time I was my chumber's prisoner

ready i' the livivy chaniber? .........

withdraw into your private chamber led, chamber, Pandar to provitl:

conse you agaul into my ('hanber
kecpl his ciamber, many (rep.)

lead me to my chimber..

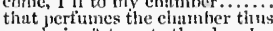

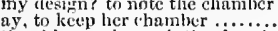

the chimney is south the chamber

deseription ot w-ut is in her chamber

sir, her chambers are all locked......

in his own chamber, I inean

Thaliard, your're of mur chamber

to the next chamber bear her.....

or at their cliamber door I'll heat ....

private in his chamber pens himself..

hic to your chamber: Ill find Romeo

light to my chamber, hol............

lady mother's coming to your chamber

thy nurse lie with thec in thy chamber

[Col. Knt.] was sewing in my cham
keep close within your chamber

now get you to my lady's chamber....

I found it in my chamber .................

how slie plucked him to my chamber.

that you should find it in your chamoer

I found it in my chamber

as well as my cham

hold the chanlher-coor, whilst by

alarums at our chamber-doors.....Henry Henry iv. 5

a lousy footboy at chamber-door?.. Henry IIII. v. 2

CHAMBERED-best blood ehambered. Richard II i. I

CHANBERER-that chamberers have.. Othell

chamber-lunging, pictures .......... Cymbeline, $\mathrm{v}$,

what hol Chamberlain. At hand..1 Henry IV. ii. 1

as much unto my good lord chamberlain

with a priest, lord chanberlain? ....

good lord chamberlain, go, give ......Henry $\overline{V I} I$ l.

say, lord chamberlain, they have done

my lord chamberlain, pr'ythec, come

thanks, my good lord chamberlain .

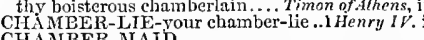

HAMBER-MIAID-
my niece's chamber-maid

my niece's chamber-maid .......Twelfth Night, i. 3
since possesses chamber-maids and ....... Lear. iv. 1

Worms that are thy chamber-maids.. Rom. \&.Jul.
CHAMBERPOT - tor a chamberpot... Coriolanus,
CHAMIBER-W

chamber-window .. TuoGentlemen of Verono,

he her chamber-window will ascend..

your lady's chamber-window ........

than to see me at lier chamber-window

in my chamber-window lies a book

the lady Hero's chamber-window

out at her mistress' chamber-window

with a ruffian at her chamber-window

knock at my chamber-window

All. Dr. iii.

CHAMP-Richard du Champ......... Cymbeline,

CHAMPAIG NE-Guienne, ChampaigneHenry $r$ i. i.

CHAMPAIN - with champains riched

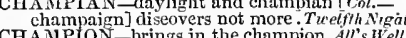

CHAMPION-brings in the champion.All's Well, iv. 2

thou fortune's champion.

to arms! be clumpion of our chiurch! the widow's champion and defence .. Richard II. $\mathrm{i}$.

why then, the champions are preparcl

dis new-come champion ..............

a stouter champion never handied...

his champions are-the prophets

the most complete chanpion that ever

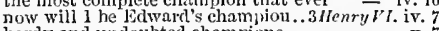

home's best clampion, suecessinl. Tritusandron.

Rome's readiest champions...

I cap produce a champion, that will........ Lear, $\mathrm{x}$.

CIANCE-chance to steal.. Tro Gen. of Frema, ii. 4
either in nativity, elanec, or sleath. Merry Wives, v. I

how chance you went not with

to comfort you with ehance

but it elances, the stealth. Mensure for iii. 4 (chal.)

though ny chance is now to use for leasure, 1.3

wherein if he chance to fail .......
but, by chance, nothing of wliat

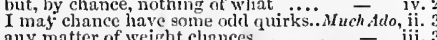

any matter of weight chances ........

make a pish at clianece and sufferanec.
how chanee the roses there din tidde.....Mid. $\bar{N}, D r . \mathrm{i}$

how chance moonsline is gone..........

I here am eome by chanec. and iay

you must take your cilance. .Merchun of Vinice, it.

by the view, chance as tair...... - iii. 2 (scroli.)
CII I NCE-if he ehanec to speak.. Tam. of Sh. 1 (ind.)

a gentle clinned twixt him alu you

a wil if she chance to nod, I'll rail.

hit they may chance to need the

by my fiurs, of what may chance

to be the slaves of ehance.............

howest, I am so sometimes by chane - iv.

it chance

set my life on any chance, $t o$ mend..

the chane, of goodness, be like

F'll tuke my chance; your f'ace hati... Kiag $\bar{J}$ ohn

madam, by chance; lint not by

and so, by chance, did grace

Rirchard Ill. i.

mithought of Harry, eliance to meet..

it may chance cost some of ns our.... - ii.

in the chance, throw me in the chance?

how ehances moek, and ehanges fill

against ill chasces, men are

how chance, thou art not with.

what ehance is this, that sudden
if it chance tlie one of us do tuil

and, now it is my chtnce to find...

for these woeful chances, misthink...

unless she chance to tall................

if you ever chance to hare a child that by cbance 1 found....

fo chance to talk a little wild ....... Henry VIII. i.

if they should chance, in charging you $-\bar{v}$ v. 1 .

or you may chance to burn your lips

how elanee my brother Troilus......

an act that very chance doth....

二 iii.

met by chance $\ldots . . . \ldots \ldots \ldots . . . . .$.

(as seld i have the chance) ............

and chance it as it may......... Timon of Athens, v. 2

if you chance to be pinched
of what we chance to sentence

that common chances common $\mathrm{men}$....

to each eiance that starts i' the......

by some chance, some trick not.
lest you sliall chance to whip

the disposing of those chances whic

some friend of Casnr's should chance.Jul.Cersar, iii. 1

faints under his chance .....Antony \& Cleopatra, ii.

give up yourselit merely to chance

I'll yet follow the wounded chance.

as things but done by chance...

think what a chance thou changest... Cymbeline

secnl to those which chance to find us

wilt take thy chance with me?

your conntry wars you chance to die

this was strange chance..............

$\begin{array}{ll}\text { by-dependancies, from chance to chance - } & \text { v. } 5 \\ \text { v. } 5\end{array}$

secure from worldfy chances...Tilus Antronicus, i. 2

though chance of war hath wrov

how chance my danghter is not witi ... Pericles, iv. 1

and chances in to an honest louse - v. (Gower)

thrown to my a in hone

how chance the king comes with so simail

it you do chance to hear of that.....

it is a cirance tbat does redeem ..........

this trick may chanee to scath you...Rom. \&.Jul. i.

he may chance to do some good.....

oft it chances in particular men

how chances it, they travel

if he by chance eseape your venomei ....
that look pale and tremble at this chine

[ kn/.] throw such chances of vexation.

I spake of most disastrous chances
well, I may chance to see yout...
shot of accident, nor dart of chance.

CIIANCED-chanced on this letter.

think upon what hath chanced
that what he feared is chanced...

the oceurrenees, whatever shanced. $\mathrm{H}^{2}$ Hcury II: i.

tell us what hatly chanced to dav... futius Coser, $i$.

how every thing is chaned.

chanced in the times of old... Titus Andronicus, jii. 2

it then they chanced to slack you ........ Lear, ji.

one Gijbert Peck, his ehancellor.... Ilewry III. i.
sir Giilhert Peck, his ehancellor...

is chosch lord chancellar in your place - iii. 2

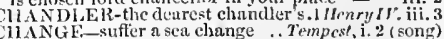

do you cbange colour? ....... TicoGen.of Vernna, ii. 4

revolt and cinange $y$ our mind........

ay, that ehunge is the spite.

women to change their shapes 
CHANGE_change her determ nation?. Nerry $w$. iij.5 $/$ CHANGE-change you, madam? why, here's a change, incleed ..... Meas. for Heas. i. 2 change your place, you need not change -

power change jurpose

as school-maids change their name

with boot, change for an idle plum

tis 1

if my passiou change not shortly .... - i. 12

maintained the change of words with

on her behalf change slander to
by this light be changes more and niore

angry winter, change their wouted...Mid. $\bar{N}$. Dr. ii.

will not change a raven tor a dove?.

what change is this, sweet lore? ...

this moon: would, he would change!,$\overline{\text { and }}$ change you favours too...... Love's $\bar{L}$ Lost,

do but vouchsafe one change ....

thus cliange I like the moou

therefore, change favours; and

the ladies did change favours.

these four will change habits ........

insociable lite change not your

I would not change this hue ... Merch. of Fenice,

between the change of man and boy

some power to change this currish ${ }^{2}$
for the time doth chnnge lis nature.

would not change that callin

As you Like it,

not seek to toke your change upon you

I would not ehange it.................

1 will not change for your best.

but the sky changes when they are..

but as we change our courtesies .....All's $\overline{\text { W }}$ ell, iij. 2

change it, change it; be not so .......

I can change these poor necontrements

and double ehange of bravery........

and the moon changes even as your.:

nine changes of the watery star

that you do change tlis purpose ...

that you must change this purpo

mend nature: changre it rather.......

role of mine does change iny disposition

change garments witl this gentleman

no jot hath she, to change our loves..

sorcerers, that change the mind... Comedy of $\mathrm{B}$.

the lips of unacquainted chen longed-for chang
with any lon

thimbles into armed gauntlets change

cea, but not change their spots.....

prophets whisper fearful change $\ldots . .$.

change the complexion of her.

change the complexion of her.........

for every one doth so against a change - in

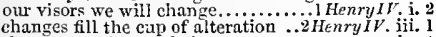

the seasons cliange thcir manuers.

his eye is hollow, and he change

and now my death changes the mode

we are blessed in the change

look ye, how they change! ....

I will not change my horse

I warrant you, or 1 will change it.....

shall change all griets, and quarrel

imparting change of times and states

she would change my shape...

to change two dukedoms for

nor change my countenance 3 and change misdoubt to resolution

is able with the change to kill and

change shapes, with Proteus........

Warwick now can change no mo

holy humour of mine will change... Richard $1 I L$. i.

canst thou quake, and change........

bestial appetite in change of lust

change, would give an eye to boot.

a son of Priam, in change of him pronomne the beggary of his change
but abide the ehange of time
covetings, change of prides, disdiain...

Cymbeline, i. $7 \mid$ CHANTFD- chanted suatches of old .. Hamlet, iv. 7

I'd change my scx to be companion.

he would change places with his office

hath wrought this change of cheer.... Titus

by this our change, these mouths.

they did cliange me to the meanest

you see how full of changes his age is

that things might cliange, or cease .....

the lamentable cliange is from thange arms at home......

hark in thine ear: change places........
advised by anght to change the course
the change of fourteen years....... Rome

montlly changes in her circled orb...

saint Francis! what a change is here?

all things change them to the contrary

I'll change that name with you

our loves should with our fortunes chang

this would changes, and hath abatement....

such changes [ $K n t$, - chances]

how say you by this cliange?

she must change for youth: when she is

she must have change, she must

to follow still the changes of the moon

the Moor already changes with my poison

your mind, perhaps, may change

when the change us for others?

be effeminate, changeable bongineta.Twelfth $N$. ji. report is changeable: 'tis time to look.... Lear, iv. these Moors are changeable in their wills. Othell, $\mathrm{i}$,
CHANGED-changed or else new-formed. Tempest, $\mathrm{i}$

fashion of the time is changed. Tu. $G$ Gen. of $\overline{V e r}$. iii. 1 the story shall be changed ....Mid. N.'s Dream, ii. but now slye's changed ….............. you are marvellously changed

.... $\vec{*}$ ii. 2

he changed almost into another man... All's Well, iv. 3

Cambio is changed into Lucentio

she is changed, as she had never been

your changed complexions are (rep.)

how the world is changed with ...Comedy of Er. ii.

if thou art changed to aught ........

oh, grief hath changed me

she is corrupted, changed, and won..King John, iii. 1 now changed to the bergar and the king $-v .3$ that he hath changed his style? ....1 Henry $V$ I. iv. our stern alarums changed to ....... Richard $I I I$. i. I my mind is changed; Stanley........ thou art changef for Antenor... Troilus \& Cres. iv.
delivers us thus changed, makes you. Coriolanus, v. delivers us thus changed, makes you. Coriolanus, v. 3
lord! how your favour's changed with. Pericles, iv. they shall not be changed yet.............. Lear, iii. but vever man so changed................. - iv. 2 thou changed and self-corered thing .....
in nothing am I changed, but in......... iv. art thou changed? prononnce this ... Rom. \&. Jul. ii. 3 to visit iny too much changed son....... Hamlet, ii. 2 he is mneli clanged. Are his wits safe? $\ddot{\&}-\overline{\text { iv. }} 1$

CHANGELING-sweet a changeling. Mid.N.Dr. ii.

I do but beg a little changeling boy
dicl ask of her her changeling child

this is some changeling: open't.. Winter's $\bar{T}_{a l e}$, iii. 3

but to tell the king she's a changeling - iv. 3

lis nature in that's no changeling... Coriolanus, iv

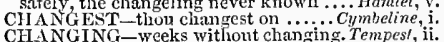

changing-weeks withont changing. Tempest, ii. I

not changing heart with habit ..... Mear for Mea. v.
but, in tbis changing, what is .... Love sL. Lost, v.

be quit with thee by clianging . Taming of Sh, iii. 1

I see, changing his property ......... Richard II. iii. 2

an hour in clanging, hardinent ..... Henry l $V^{\prime}$ i. 3

came the noble Timon to this change

sprung from change of fortune

but with them change of honours...

what I then change these garments?..

and shallow, changing-woinan
but are changing still one vice.

go, give that changing piece ...T

cymbeline, iv.

will elange to virtue, and to worthi

not conve, their minds may change

he smiles, and Cæsar dotl not change

now I chnnge my mind, and partly.

must change [Col, -charge] his horn.

would purge by any desperate change
what he cannot change, than .........

there is a change upon you

and did deserv his change ....

more canse to change a master ......

the miserable change now at my end

you shall find a benetit in this change ii. 1 shall leave his native channel

Tempest, iv, 1

trenching war channel her fields...

in a new channel, fair and evenly

a channel should be called a sea. 3 Henry $t^{\prime}$ i.

and make your cliannel his? ...... Coriolamus, iii. 1

fret channels in ber checks.

ii. 6 CIIANSON-of the pious chanson will ...... Herret, j. 4

tbat tirra-lirra chants.... Winter's Tale, iv. 2 (sung)

he so chants to the sleeve-hand $\ldots . . .$. . King.John, v. 7 the strain of strutting chan ticlere. Tempest, i. 2 (song) began to crow like chantielerc.... As you like it, ji.
CIIANTING-chanting faint hymns.Mid. N.Dr. $\mathrm{i}$. CHAN'TRIES - built two chantries....Henry $V$. jv. CII ANTRY - into the chantry by. Tuelfy Night,iv. I love thice not, chaos is cone again.... oihell Cl IAP-open your chaps again my knit'c in your mouldy chaps...
betore his chaps be staiued .......

King John, ii.

Worly. iji.

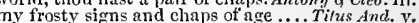

CIIAPE - in the chape of his dagrer. .All's Well, iv do, chapels had been churclies ... Mer. of Venice, $\mathrm{i}$. go with you to your chapel? ..... As you Like it, iii.
visit the chapel where they lie ... Winter's Tale, iii. guit presently the chapel; or resolve - v. as his queen, going to chapel......... Henry VIII. iij. thus in a chapcl lying! $\ldots \ldots \ldots \ldots . . . . .$. Cymbeline, ii. bear it to the chapel. Do not believe it.. - iv. CIIAPELESS-hilt and chapeless. Taming of Sh, iii.
CHAP-FALLEN-quite chap-fallen? .. Hamlet, $\mathrm{v}$. the chaplain -chaplain, away!

Joln de la Court, my chaplain

my chaplain to no creature lining......

rd III. iv.

by your teaching, and your chaplains - v. lady Worm's; chapless, and knocked . Hamlet, $\mathrm{y}$. shall as a chaplet [Col. Knt -carpet] . .Pericles, iv.
CIIAPIIEN-of chapmen's tongues.. Lore's $L$. L.i. Fou do as chapmen do, dispraise.. Troil. \& Cres. iv. 1 CHAPTER-what clapter of his bosom. Tuelfin $N$ i.

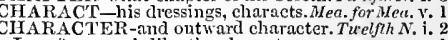
with character too gross, is writ on ... - i. you know the character, I doubt not $\quad$ - iv.

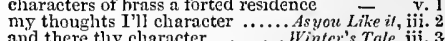
and there thy cliaracter ............. Winter's Tole, iii. which they know to be his character. razing the characters of your reuown.2 Henry VI. . grossness little characters sum up... Troil. \&-Cres. $i$. in characters as red as Mars his leart
the cliaracter I'l take with wax...Timon of $A t h . \mathrm{v}$. gleain ont of this character, if I ...... Coriolumus, ii. knew the stars, as I his characters... Cymbetine, iii. know you the charncter? It is my lord's - iii. in glittcring golden characters exjoress $-\overline{\text { iv. }} 4$ didst produce my verp character.......... Hamlet, i. 1 charactered and engraver.. Two Gen. of Verona, ii. 7
one scar charactered on thy skin ..2 Henry VI. iii. 1 CHARACTERLESSCHARACTERY - for their charactery.Merry $W . \mathrm{W} .5$ all the charactery of ny sad brows.JuliusCastr, ii. 1 CHARE-does the meanest clares ...Ant.\& Cleo.iv. 13 When thou hast done this chare ...... I charge thee that thou attend me

go, charge my goblins that they........

that is thy charge ........................

'tis a great charge, to come ........

not to charge you; for I mu
give your meit the charge.....

it charges me in manners $\ldots . . . .$. Merry Wives, i.

fither, I charge thee, by thy ......... -

and by me the

and charges lim, my lord, with...

eharges she more than me?

give them their charge, neighbour ....

is your charge; your shall eomlrehend

wcll masters, we hear our chirge.....

we charge you in the prinee's mame.
never speak; we charge you, let us ..

I charge you, on your souls....

masters I charge you, in the prince's

an you charge it against me.

what you lay to their charge ......... N. $\bar{D}$, v. 1

that charge their breath........... Love's $L$.

on your charge, to stop thie wounds .

must be hanged at the state's charge

I charge thee, be not thou more .. As you

he laid to the charge of women?

and so $I$ charge you, $O$ mct.

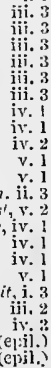
this chinos, when degrce is .... Trailus \&-Cressida, j. I contess, much like the character $\ldots \ldots$, for $\mathrm{Mea}$. i. he cut our roots in characters ......... 'tis Hamlet's character. Naked.......... - iv.

I charge her to love thee 
CIIARGE-I ehurge thee, as hcaven.....All's Well, i. 3 hail her breeding it iny tintlier's olharge whoever charges on his forward breast sir, it is a charde too heavy for $13 . .$. ... the charge, and thanking, shith the chare in we otr the crais, that yon do charge men with do they charige ne further?.

tell me true, I charge you............... wait ou him, I cluturge you, as becomes

here I charge thee, tell whom thou lovest I charge you, in the duke's nume.

futher Baptista, I charge jou, see

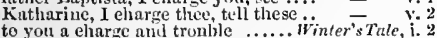

roun a elarge nind tronble

lay the old provert? to your cliarge

I do in justice cluurge the

have alwut me miny parcels of eliarse

to exeeute the clar

lay't so, to his elarige ................

thy clarge. Miy charge was but to foteh

and eharge you, in the dnke's name

Satan, nroid! I charge thee tempt

besides the elarage, the shame

speak, I eharge yot. The earti

do moek their churge with snores...

may reeoil, in an imperial charge.

jay not my trausgrcssion to my eliarg

to eharge me to an answer, as the pope

so feared he had a charge to do ......

great atfairs lo nsk some eharge ....

be it your charge to keep him safe
limits of the charge set down .....

at our own charge, shall ransom...

company, for they luve great charge

rogue a eliarre of toot...

yea, but a little charge will trencli

thou shalt have eharite, ant sovercign

charge an honest woman witl picking

procurcel thee, Jack, a charge of foot

but, to my ehargc; the king hath sent

every lender to his charge............

here, Pistol, I charge you with a cup

I will charge yon. Charre me?

he shall charge you, and discharge you

the lcaders, having eharge from you

come, I eharge you both go with me

or nieely charge your understanding

we eharge you in the name of God

and npen this eharge in

and we give express eharge, that

I'll to my charge: it we no more me

witb all expedience charge on us

I charge you in his majesty's name..

we eharire and eommand yon.I He

remember what I gave in eharge

utend"st to lay unto my charge

henceforth, I charge you, as you love

thy finther's charre shall elear thee..

I had in charge at my depart.

own proper eost and ebarges..........

so am I given in charge.

crimes are laid unto your charie

a eharge, lord York, that I will

and charge, that no man should ....

Icharge and eommand, that

and we charge and eommand

cry, ebarce and give no

we eharge you, in God's name

of marriage was the charge he gave...

coing what you gave in eharge ......

brother was too careless of his
the skilful pilot's charge

\begin{tabular}{l|l} 
iii. 3 \\
iii. 3
\end{tabular}

II AliGE-weary of thiseliarge . Timon of Ath. iii. 4 monl, and charge home

heard the charges of our fricnds

in this point charge him hone

need nut put new matter to his chiarge

the centurions, and their changes....

and yet to charge thy sulphur with.

the charges of the action

unluckily charge my t'antasy ........ Jilizus $\overline{C r}$ sar, iii.,

how to ent off some charge in legracies

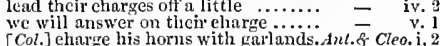

have tongue to eharge me with

a charge we bear i' the war.

go, charge $\Lambda$ grippa plint those thin

if slcep charge nature, to break it .. Cymbel

here's money for thy eliarse

this eharge [Col.-change] of thoug
with this strict eharge, (even is li

paticnee, goud sir, even fur this eharge

here 1 charge your charity withnl

he charges home my unprovided body

I charge thee in the prince's name.Kom. \& Jul. iii. 1

upon thy life I eharge the

hy heaven, I eharge thee, spcak (rep.) ... Hamlet, $\mathrm{i}$.

look to't 1 charge you: come your ways

as you may season it in the charge .......

eompulswe ardour gives the charge

this army, of such mass, and eliarge

go to answer this your charge?

ii. 1 began this? on thy love, I char.

iii. I $\quad$ Yon charge you, go with me...

CHARGED-my master charged... Tuo Gen. of $\bar{v}$ er.

she was eharged with nothing but..... Ifuch ddo, v

and, as thou say'st, chargerl my ...As you Like it

my father eharged you in his will.
therefore heaven nature charged

physieinns have expressly charged. Tain.of $\$$ H. 2 (ind.)

your father charged me at onr parting
since I am charged in honour.....W Whter's Tale, i. 1

Antigonus, I eharged thee, tliat she.

eharged him with a thousand. Comedy of Errors, iii.

camnon, charged to the mouths ...... King Jokn, ii. 2

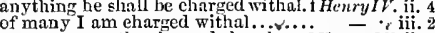

venture upon the charged elambers.2 Henry IV'. ii. 4

shall stand sore elanged for

with this, we charged again

eharged us from his soul to love

Henry Vi.i. 1

we klall be charged again

shall I he charged no fnrther thas.

but being hed him even as those ......

though the king hath eharged you.... Cymbeline, $i$. 2

or have elarged him at the sixth hour

charged me, on pain of their perpetua

my lady eharged my duty in this

I bave charged thee, not to haunt about. othello, i.

CHARGEFUL-chargeful fashion. Comedy of $E r \%$ iv. 1

the charge-honse on .............. Love's
the

CHARGETH-justly ehargetl them.... Com. of Err. v.

CHARGING-in eharging you with. Herry III. y. 1

CHARINGS-

CHARIOT-and in a captive eliariot... Henry $V$. Henry

did follow thy proud ehariot wheels. 2 Henry $V$ I.

in captive honds his ehariot wheels? $J$

set thee on triumphant chariots.... Ant. \& Cleo. iii.

follow his chariot, like the greatest.. - iv.

my sword, my chariot, and .... Titus Andronicus,

horse and cluariots let us have

bath strnightly given in charge......
we know thy eharge, Braekenbury
I'll be ot eharges tor a looking-

I'll be at eharges for a looking-glass

I lay unto the grievous eharge of ot

I eharge you, as you hope for any

to take on you the charare and kingly

each leader to his scveral cliarge

hie thec to thy cliarge.

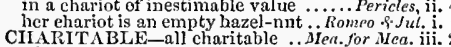

why had I not with charitable ...jlen.for Mea. iit.

born under a eharitable star ............Alt's Wel

a eharitable duty of my order.. Comedy of Errors, iv.

in such a just and charitable war.... King John, ii.

I come to thee for eharitable licence ..Menry $l$. i
to stop devoted charitable deed $\mathrm{N}$ ? .. Wichard III.

why have you that charitable title. Timon of Ath

hat charitable men affurd to beggars

most charitable care have the

do this and be, with eharitablc bill. Cymbetine, $\mathrm{i}$

for thou hast done a charitable deed. Tilusind. ii.

a charitable wish, and full of love

be tliy intents wieked, or elaritable..... IIt metet, $\mathrm{i}$.

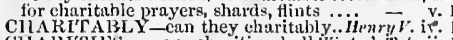

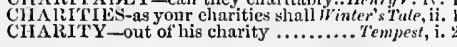

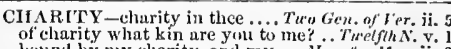
bound hy my charity, and my ..Met. for Mea. ii. might there not be a elarity in sin.

were eqnal poise of sin and elinrity...

tlyy love is my charity, and hearng

the love is far from eharity l...

he hath a neighbourly churity ...Mer. of

'twere good, you do so much for cliarity

elsuwhere they nuet with eharity

whom zcal and clarity brouglit

for 'twere no charity; yet, to wash...Richard 11. iii.

open as day for inclinir eharity...2. Henry 1

the dead with eharity cnelosed

fiel charity for shame! speak not

sweet saint, for charity, be not so...

Henrylitii.

lady, you know no rules of charity...

作

it not for eharity, urge ncither elarity

we have done dceds of churity ........

I do beseech your graee, jor charity...

I have more elharity: chat saty

I am hound iu eharity against it

a little earth for charity! so went.
to speak him, and 5 et with eharity

love, friendship, charity, are

it comes in the behalf of charity 3 i -

show eharity to none; but let $\ldots . .$. lain

and praise myselt' for eharity

O the charity of a penny cord!

I thourht it prineely eharity ..... TitusAntron. $\mathrm{v}$.

through Ephesus poured forth your eharity - iii.

the gods requite his clarityl .... - ii..2 (seroll)

that learned eliart ty aye wears.... - …, 3 (Gower)

with prayers, enforce their elarity........ Lear, ii. 3

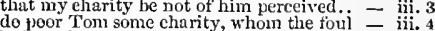

let's exehange charity ................. - v. 3

bear some charity to my wit ........... Othello, iv. 1

daughter to Charlemain, who was .... Henry $l^{\prime}$. i. 2

not Charles, the duke's wrestler ... As you Like it, i.

monsieur Charies, what's the new news
Charles, I thank thee for thy love to me

tcll thee, Charles, it is the stubbomest

with Charles, the duke's wrestier (rep.

howe you challenged Charles the wrestler?

or Charles, or something wi........

Clarles" wain is over the oew ...... I Inenry $I V$. ii.

Where Charles the Great, having....... Henry $V$. i.

and Lewis the son of Charles the Great

line of Charles tlie Great was re-united

Cliarles De la bret, high constable of

Charles, duke of Orleans, nephew to

the dauphin Charles is crowned of 1 Henrn iv.

here cometh Charles; I marvel....

Wheretore is Charles impatient

that Charles the dauphin may

the bastard's braves, and charles

cined witl Charles, the riahtfi..... -

with Charles, Alençon, and that

the bastard, Charles, and Burgundy

to Paris, roval Charles of Franee

command

Charles the dauphin is a proper mnn

since Charles es, and thee!

't w'as neither Charles, nor yet........

and, Charles, upon condition.

how say'st thou, Charles?

he is near kinsman unto Charics

and the French king Clarles ..........

Charles the emperor, under prctence. - i. 1 (article

Charles, I will play no more to-night

but little, Charles, nor shall aot.......

Charles, good-night.- Well, sir
CIIARM- with a charm joined to

all the charms of sycorax.......

my high eharms work, and thesc........

my charms eraek not ..................

your charm so strongly works them....

this airy eharm is for

the eharm dissolves apree ...............

now my charms are all o'crtirown.......

I have no otlier charms ..................

she works by charms, by spelï........ = iv. 


\section{CHA}

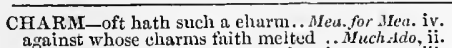

yet is this no charm for the tooth-aeh - iii.

ere I take this charm, and agony

nor spell nor charm, eome our

all the power this charm doth

but $I$ will eharm him first to $\mathrm{ke}$.

and charm her chattering tongue

peace, the eharm's womnd up $\ldots$........

provide, your eharms, and every

then the charm is firm and good

I'll charm the air to give a sound...

despair thy eharm; and let the ange
spirit: now with spelling eharms

therefore shall it eharm thy riot

or: I will eharm your tongue ........
have done thy charm, thou hatefui.

my body with their hellish char

I charm you, by my once
but all charms of love, salt

intoun \& Cleo.

I nin revenged upon my charm

tongue, charms this report out

nor no witehcraft charm thee!

that will charm Rome's Satmnine ... Titus. 2 (song

al charm to calm these fits..............

mumbling of wicked char

whose age has charms in it ....................

nor witch hath power to charm

Hamlet,

hast practised on her with foul charms

what drugs, what eharms, what eonjuration - i. 3

forth of my heart, those eharms, thine ejes

charm your tongue. I will not charm
CHAR MIED-so I charmed their ears..

My ontside have not charmed her! Twelfh. Night, ii.
I will her eharmed eye release .. Mid. N.'s Dr. Hii.
boil thou first i' the charmed pot! ..... Nacbeth, iv.

mas well he charmed asleep......... Henry $I V$.

has almost eharmed me from... Timon of dithens,

$I$, in mine own woe eharmed

Cymbetine, $\mathrm{v}$.

CHARMETH-such as charmeth.Mid. N.Dream,

eut my lace, Charmian, eome; but let

look, pr'y thee, Charmian, now this

O Charmian, where think'st thou he is

o Charmian, where think'st thou he is -

ink and paper, Charmian .............

eome, Charmian. Iy arm is sore.

I faint; O Iras, Charmian ............

pity me, Charmian, bnt do not speak

I think so, Charmian; du

more to ask him yet, good Charmian

O Charmian, I will never ro from hence

Charmian, help! help, Iras! help

how now, Charmian? my noble

now, Charmian? show me, my women

kind Charmian; Iras, long farewell.

Charmian, is this well done?

o Casar, this Charmian lived but now

you back, eharming the narrow., Henry $r$. ii. (cho ye charminit spells and periapts

set betwixt two eharming words ....Cy

more charming with their own nobleness -

CHARMINGLY-

and harmonious charmingly.

..Tempest,iv.

CHARNECO-a cup of charneco ....2Henzry

shut me nightly in a charnel-house. Rom. \& Jul.

CHARON-be thou nny charon .. Troil. of Cres. ifi.

CHARTER-light upon your charter. Mer.of Ven. iv. 1

at home shall have blank charters....

ins chartcrs, and his customary rights $-\bar{I}$ ii.

mother, who has a charter to extol...

Coriolunus, i. 9

and the charters that you bear i' the.., - ii. 3

CIIARTERED-a chartered libertine... Henry V'. i. I

sir, a Chartreux friar, his confessor..... of $\overline{V e n}$. ii.

CHASE-do chase the ebbing Neptune.. Tempest,

begin to chase the ignorant fumes.......

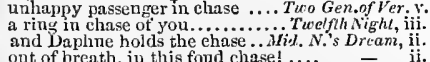

out of breath, in this fond chase .....

down his innocent nose in piteous chase

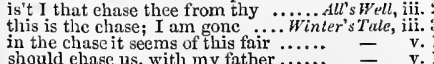

should elase us, with my father

and ehase the native beauty

King $\bar{J}_{o h n}$

and ehase them to the bay.......

Richard $2 I$.

France will be disturbed with chases .. Henry

you see, this chase is hotly followed
CHASE-enu chase away the first-

seek thee ont sume other chase
single out some other chase.......

where he did mean no chas.

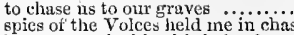

barren, touehed in this holy chase.

our valour is, to ehase what fies...
the proudest panther in the chase

the north side of this pleasant chase.
if thy wits rum the wild-goose chane.

if thy wits rmu the wild-goose chime. Rom. \& Jul. ii.

I do follow here in the chase, not like... Othetho, ii.

all sorts of deer ehased sleep.

Merry Wives,

more spirit elased than enjoyed...... Mer. of renice,

bent on us, chased us away ...Comedy of

so cowarded and clased your bloud .. Hetury $V$. ii.

when I have chased all thy toes...... I Henry I I I. i.

wharity chased hence by rancour's..2 Henry $/$ I. iii. 1

ten, ehased by one, are now eaeh ...... Cymbeline, $v$.

CHASETH-in armour, ehaseth them.1 Henry ${ }^{V I}$. i. 5

CWAS'TE-cold nymphs eliaste erowns. Tempest, iv. 1

ere one chaste nan ............

Isabel, live chaste, and brother die..iea for $\mathrm{M}$ ea. ii. 4

but by gift of my chaste bod

quenched in the chaste beams. Aidi. N. . s Dreum, ii. will your give horns, ehaste lady? Love's L. Lost, v,

I will die as ehaste as Diana ... Merch. of Venice, 1.
survey with thy ehaste eye......As you Like it, iii.
the fitir, the chaste, the unexpressive then let Kate be chaste, and Dian. Taming of sh. ii. as continent, as ehaste, as true .. Winter's 'Tale. iii.
Hermione is ehaste, Polixenes .. - ii. 2 (oracle

nor in a way so chaste: since. ...

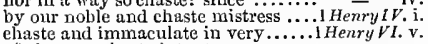

of virtnous chaste intents .....
the model of orur chaste loves.

I was a chaste wite to my grave.

as chaste as may be in the world ...Troil.\& Cres, i.
ehaste as the icicle, that's eurded ... Coriolanus, v.

virtuous, wise, ehaste, constant....... Cym

thought her as ehaste as unsunned sno

I was trught of your ehaste daughter.

of that chaste dishonoured dume

good report to a number to he elaste.

or your chaste treasure open to his...... o Jumler,

be thou as chaste as ice, as pure as snio

aud nany worthy and ehaste dames

secure eouch, and to suppose her chaste

not name it to you, you chaste stars?

CHASTELY-wish chastely, and love...All's $\bar{W}$ - $l$,

herself most chastely absen

CHASTISE-he will chastise me ...... Tempest, v.

and ehastise with the valour of $\mathrm{my}$.....Macbeth, i. 5

the palsy, chnstise thec, anci minister. Richard II. i1.

I will ehastise this high-minded ....
CHASTISED-this chastised kingdom....

this arm of mine hath chastised .... Richard III.iv. 4

have chastised the amorous Trojan. Troil. \& Cres. v,
nor once be ehastised with the sober.Ant.\& Cleo. v.

and chistised with arms our enemies. Tilus And: i. 1

in your chambers gave you chastisement? John,
for justice, and rough chastisement.. Richard II.

for justice, and rough chastiseme

very instruments of chastisement ...2 Henry $I V$. iv.

him chastisement for this abuse.

chastisement doth the forent.

IHenry $V I$. iv.
Richard $I I . \mathrm{v}$.

HASTITY - pure ehastity .... TuroGen. of Ver.

than our brother is our chastity. Meas. for MLeas. ii.

in double violation of sacred chastity

is not chastity enough in language..Much $1 d$ do, iv.

the very ice of chastity is in them..As you Like it, iit.

my ehastity's the jewel of our hutse. All's Well, iv.

Roman Luerece for her chastity. Taming of sh.

there's a palm presages chastity ...Antony \& Cleo. $\mathrm{i}$.

ere lie wakcned the chastity he wounde:

your daughter's chastity - there it begin

thy sons make pillage of her chastity.

her spotless chastity, inhuman traitors

if your peevish ehastity, which is not..Pericles, iv.

strong proof of chastity well-armed. Romeo of $J_{u l}$. i.

cold, my girl? even like thy chastity .. Othello, v.

then -a ehough of as deep chat ...... Tempest, ii.

let's hold more chat ..................

setting all this chat aside

what a tool am I, to ehat with you

for now we sit to ehat, as well........

this bald unjointed chat of his ....... I Henry $I \dot{F}, \dot{i}$.

no more of this unprofitable chat .....
what ehat we two have had ........3 - Henry $V$. iii.

what ehat we two have had .........3 Henry ${ }^{\prime}$. iii. CHAT-go and eliat with Paris . Romeo f Juliet, iv.
CHATYLON - uow, say, Chatillon ... King John, my lord of Chatillon may from England -

pause for thee; Chatillon, speak...... Jaques of Chatillon, admiral of France - iv. CHATTEL-my goods, my chattels. Taming of $S$. iji.

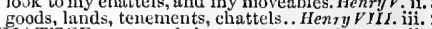
CIATTER-moe and chatter at me.... T'empest, ii. 2 the wind to make me chatter ............... Lear, iv. CFAT $T E R I N G$ - chat tering tongue. Tam. of Sh. iv. CHA U D-11 lait tort chaud............. Sterry Wives, i. CHEAP -that is cheap in beauty...Mea. for Mea. iii. is dcar in Sicily, he cheap in....... Winter's Tale, i. boy land uow as cheap as stinking... Henry $I V$. ii. so stale and cheap to vulgar company

when flesh is cheap and temales dear.2 HenryI $V . v$ and hold their manhoods eheap ....... Henry $V$. iv. 3 whu, in a cheap estimation............ Coriolanus, ii. I hope to see Romans as elieap as

which are as cheap as lies............

man's life is eheap as beast's

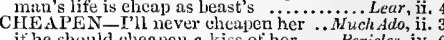
it he should cheapen a kiss of her ....Pericles, iy. CHEAPEST-the cheapest of us is ten. Richard II. $\mathrm{v}$. breakfast in the cheapest country ....Pericles, iv. 6
CHEAPLY - as this is cheauly bou CIIEAPSIDE- in Cheapside shall ..2Henry VI. iv. WhEA shall we ro to cheapside ....... my revenue is the silly cheat..... Vinter's Tale, you do not mean to eheat me so.. Comedy of $E r$. iv. 3 cheats the poor maid of thit .......... King John, ii. hatli cheated me of this island

cheated of feature by dissembling... Richard 111 . $\mathrm{i}$. disguised cheaters, prating to.....Merry Wives, i. 3 a tame chcater, he; you may........2HenryI $V$.ii.

thou abominable damned cheater.

I played the cheater for thy father.... Titus And. $\gamma$. CHEATING-base, rascally, cheating.2Henry IV. 1i. against, all ehecks, rebukes ........Merry Wives, iii. the haggard, ehcck at every teather.. you might keep that check for it..As you Like it, iv. eheck thy contempt; obey our will ..All's Well, ii. so devote to Aristotle's ehecks ..... Taming of Sh, i.
for goodness dares vot eheck thee!..... Macoeth, iv. a queen, and check the world! ......... King John, ii.

idly spread, and find no eheck? .... - $v$. the check of such another day....... 1 HenryI $V . \nabla .5$ hardly ean I check my eyes .........3Henry $V I$. i. 4 Phæton should check thy fiery steeds to check, to o'erbear such as are ..... cheek, and disasters grow in ....... Trouit.\& Cress. i. 3 sans check, to good and bad ............ i. seldom, nor no slight uhecks .... Timon of tithens, ii. worthy sinametul check it were........ Antony \& Cleo. iv. noblex, than attending for a check.. Cymbeline, iii.
check this hideons rashness ............. Lear, i. must be uscd with checks, as fiatteries...... - i.

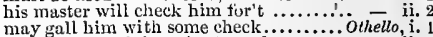
may gall him with some check $\ldots . . . \ldots \ldots$. othello, 1. to incur a private eheck $\ldots . . \ldots \ldots \ldots . .$. - iii. 3 his stubbornness, his checks, and frowns $\bar{w}_{\text {ell }}$ iv, 3 I have ehecked him for it............. Henry $L Y$. i. 2 cheeked and rated by Northumberland - iti.
unto nyself; and uot be cheeked ...2 Henry VI. i. other side, I checked my triends.. Richard ill.iii. 7 cheeked like a bundman .........Julius Cresar, iy. 3 make a checkered shadow on.... Titus Andron. ii. 3 CHWCKING-checking at [Col.-liking not]. Ham.iv. 7 the setting of thine eye, and eheek....... Tenpest, i. the setting of thine eye, and eneek...... of $\overline{\text { Ver. }}$ iv. my tears let fall npon your cheek..... v. I the old ormament of his cheek hath...Much Ado, iij.
why is your cheek so pale? while I thy amiable cheeks do eoy

these yellow cowslip cheeks, are gone $\bar{y}$ for blushing eheeks by faults...... Love's L. Lost, i. for still her chceks possess the .... that on my clieeks down flows...
thy cheels may blow; air, would - iv. 3 (vers.

that smiles his cheek in years.......

a villain with a smiling cheek. Mtrch. of Venice, steal the colour from Bassanio's cheek $\overline{\text { iii. } 2}$ a lean check; which you have not ...

iii. 2 
CIIEEK-meet in some fresh cheek. As yon like, iji. nur your eheck of cream, that cant ... tukes all liveliliood from lier cheek ....All's Well, $i$. and your norridge than in your
for, look thy eliceks contess i

here on his sinister clieek.

death sit on thy check firr ever ..... -

left check is a cheek ot two pile ( $r p$. $p$.) - iv. 5

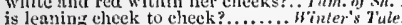

of his chin, and clieek

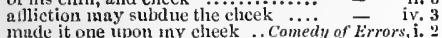

made it one upon iny cheek ... Comedy of Errors, $i$. शै

liculuty took trom my poor check?

those linen elaceks of thine are

Kasheth, iii. 4

uyou thy eleek lay I this .

King John, ii. .

anil struin their elceks to idle

the native beauty trom his chee

seen inlubit in those cheeks?

doth progress on thy
make pale our clseek.

...Bichard $I I . \mathrm{ij} .2$

made nie sour my patient chcek

the benuty of a fair queen's cheeks

upon the cloudy cheeks of her

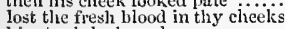

his cheek looks pale

let them eoin as heeks...............

the whiteness in thy cheek is apter

a vellow cheek? a white beard?

with kindly tears lis gentle cheeks.

their clieeks are paper

maresting lank-lean cheeks ........

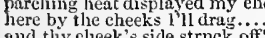

and thy cleeek's side struck ofif: ..........

meantime, your eheeks do eonnterfeit
that thy checks blush for pare sliame

when my lips do touch his cheeks

my master's blinshing eheels.

heek again.2IInnry VI. iii

these cheeks are pale for ............ 3 ivenry 7

give thee this to dry thy che
gave him, to dry his cheeks.

his pale eheeks, methinks, preseit

to my brother turn my blushing eheeks

rend that beanty from my cheeks..

red colour hath forsook his eleek $3 .$.

and kindly kissed my cheek .........

set the jaundiee on your cheeks?

do you with eleeks abashed behold

and bid the cheek be ready wit

and scrateh my praised cheeks.

heaven in your cheek, pleads ........
till thy spliered bias cheek out-sweil

her eheek, her lip, nay, her ..........

she strokes his cheel

let not the virgin's clieek make. Timon of Athen

in their nicely-gawded cheeks.

knaves tent in my cheeks.

Calphurnia's cheek is pale
else so thy eheek pays shan

.... $=$

else so thy eheek pays shame.......Antony \& \& Cleo.i.

to glow the delicate cheeks which

which pititully disaster the cheeks

you see, we have burnt our cheeks

put colour in thy cheek

had I this cheek to bathe my lips
princely blood flows in his.cheek

thint rarest treasure of your cheek

his right cheek reposing on a cushio
give colour to my pale eheek with

give colour to my pale eheek with

npon the dead man's eartby cheeks... Titus.snd. it.

yet do thy cheeks look red as Titan'

thlling the aged wrinkles in my eheek

on her chee

I will wijpe tlyy cheeks

no service on her sorrowfit cheeks

her sorrows, meshed npon her cheeks

and with dead cheeks advise the
blond from iny cleeks, musings.

our cheeks and hollow eyes do wit
something glows tupon my cheek

tears ret enanneis in her cleeks.e...

water-urops, stain my man's cle
crack your cheeks! rage! blow!

cruck sour chek tor rage

bear'st a cheek for hlows
tear trilled down her delicate cheek

hangs npon the cheek of niglth ...Romeos \& sutiet, $\mathrm{i}$.

brightness of her chcek would enanie

how she leans her cheek upon her
that I might touch that eleek?

a maiden blush bepaint my chcek.
washed my sallow clieeks tor liwsaline

washed my sallow clieeks tor liosalin

here pont thy cheek the stain
the wanton bloud up in your cheek

roses in thy lips and eheeks siant fade

farnine iy in thy cheeks

in thy lips, and in thy elieeks.........

in thy lips, and in thy eheeks...
the harlut's cheek, beartified wi.

pineh wanton on your cheek

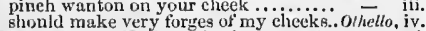

CIIEEK-ROS WS-those cheek-roses...Mea, fur Men. i.

I have good cleeer at home ................ Tempest Wives, ii.

besides your cheer you sha3i have sport -

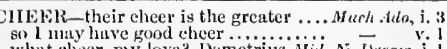

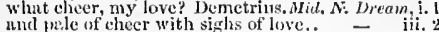
mud mile of cheer with sighls of lowe
that liked, thist looked, with cheer

Nerissa, ehcer yon stranger. Merchunt af houice, iii. 2

therefine, be of good clicer.

good clyeer, Antonio! what men?

lie of roout cheer, youth: you a man? $\bar{T}^{2}$ iv.

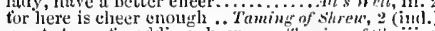

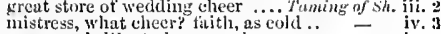

onle mess is like to be your cheer
likelihood, sonse cleer is townard

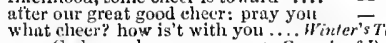

pray Good, our cheer may answer Comedty of Er
smail cleer, and great welcome....

better cheer may you have

here is neither cheer, sir, nor.

muth thanks for my good che

you do not give the elieer
come, sisters, wheer we up his sprit

receive what cheer you may

will clieer me ever, or disseat me now... =

cleer [Col,-lhear] there lor welcome ..Richard II, i.
my sovereign lord, cheer up........2HenryIV. iv.

and make good cheer, and praise...... - v. 3 (soll

whe sad, your cheer appalled

go, go, cheer up thy hunger-star

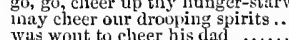

Was wont to eheer his dad ...........3tenry
doth not the object cheer your heart (rep.)

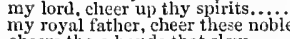

eleers these hands that slew...

this cheers my heart, to see
eheer his grace with quick and

now cheer each other, in eacli other'

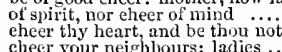

ehecr your neighbours; ladies .......Henry $\bar{r} I I I . \mathrm{i}$.

go in, and cheer; the town, we'll .. Troit. \& $\overline{\text { Cress. }}$.

he cheers them up .............. Timon of .1/hens,

ah, nhy good friend! what eleer?.

royal cheer, I warrant you......
Publins, good eheer; there is

eheer your heart; b you not
what, what? good cheer! why

be of good cheer; you have fallen
what theer madam? talse to his beal

go in, and eheer the king: he rages

you slail have better elieer ere yo
hath wrought this change of clieer

and cheer the heart that dies in .....

then cheer thy spirit: : for $k$

although the cheer be poor............. $=\mathbf{v}$.

with that part cheers eaeh part

welding eheer, to a sad burial feist.

here in the eheer and comfort of onr age. Huntet, $\mathrm{i}$.

an anchor's cheer in prison be my scope: $=$ inii.

still and anon eheercd up the heavy King John, iv.

I came, and cheered him up ........... Henry $V$, iv. 6

cheered up the drooping army

all the world is cheered by the sun...Richard 111 .

theretore be cheered; make not.......Anl.\& Cleo.
CIIEERER-merry chcerer of the heart. CIEERE UL-be cheerful, sir.

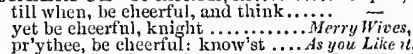

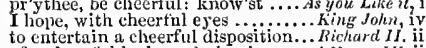

of a cheerfin look, and pleasing eye. 1 Henry $1 V$. $\mathrm{ii}$.

this had been cheertiul niter victory.2 21 enry $1 V$. iv.

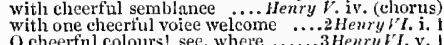

O cheerfnl colours! see, where ........3Henry rI. y.
applanse, and cheerful shout...... Richard III. iii. 7

be checrful, Richmond...

showers to bring it on: be cheerful... Ant s $\&$ cleo. iii.

be cheertul; wipe thine eyes
lies rolled in the cheerful sun

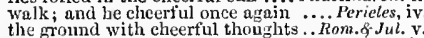

the gromnd with cheerful thought...

olli heart! thon speak'st cheerfully
said so, to make us fight cheerfuly

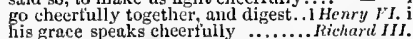

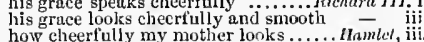
how cheerfully my mother looks. ..... Inamle, iiti: how cheertilly on the thlse trail they ery! $\bar{T}$, iv.
CIIEEEIING-eheering a rout of ....2leury

the arny, eheering up the soldiers... Richard $M T$. v.

CHEERLY - eheerly, cheerly, iny licarts. Tempesi,
ehreerly,
i.

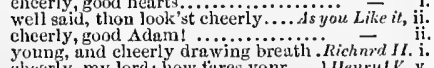

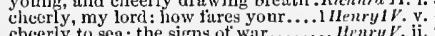

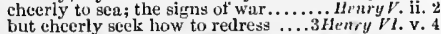

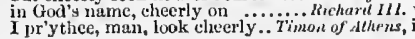

CllERR , Y checrly, boys; be brisk .. Rnm. \& Jut. i.

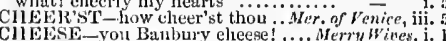
CllELSE - you Banbury eleese! ..... Merry Wives, i. there's yippins and cheese to come $\ldots . .$. 二 i.

lingl, the welshman, with my elheese.

lest he transform me to a piece of chesse

breeds inites, mueth like en che

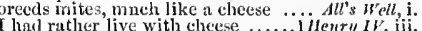

it will toast chese: and it will eniline

stinks with eating toasted cheese ...2Henry VI. iv.

why, ny clicese, my digestion. Thoilus \& C ressida, ii.

this picee of tonasted cheese will do't
the

Lear, ip. 6

MEQUIN-or four thonsand chequins...Piricles, iv.

CliEkE-notre très cher filz Henry ruy... Mlenry

CIIERISII-how you the purpose cherish. Tempest, it.

claerish thy forlorn swain!.. Tura Gen. of Verona, v.
if thou dost love fuir Hero, elherish it.

they cherish it, to make it stay ... Winter's Tale, iv.

his reign, but they will cherish it.

Richard II. ii.

to thy servants, cherish thy guests...1 Henry $W$. iii.

thy brothers: cherish it, my boy.

cherjsh duke Irumphrey's de
for what doth eherish weeds

sworn to cherisla and defend ............ Richrard $H I$ H. i.

with all duteous love doth cherish you $\overline{\text { you }}$ iif.
cherish those hearts that hate thee.Henry

outrages, and cherish factions.. Timon of sthens, iij.

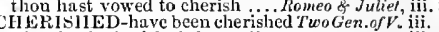

illnmined, cherished, kept alive....
if they were not clerished by our.... Alt's $W^{-} l l$, iv.

dearly cherished; give me thy hand.Kim! John, iii. I
so tame, so cherished, and loeked up. 1 Henry $l v . v .2$

cherer

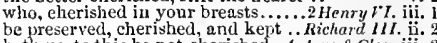

buth parts this be not cherished..Antony\& \&leo. iii. 2
CHERISHER-cherisher of my tlesh ... All's Well, $\mathrm{i} .3$

CHERISHES - that eherishes my flesh - i.

kill thee with much cherishing.. Rn nomeo \& Jutiel, ii.

CHERRY - - those kissing cherries..Mid. N.'s Dr. iii.

$m y$ cherry lips have often kissed
this cherry nose, these yellow

give it a plum, a cherry, and a fig.... King John, ii.

hath a pretty toot, a cherry lip ....Riehrard lil. i.

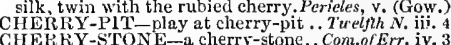

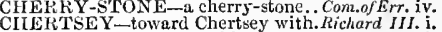
at Chertsey monastery this noble.... - i.

towards Chertsey, noble lord?......... Hamlet, iv.
CIIERUB I see a cherub

CHERU BII - O! a cherubim thou wast. Tempest,

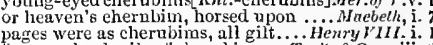

pages were as cherubins, all gilt... .Henry $Y 11$ H. .
tears make devils of cherubims . Troil. \&. Cres. iit.

for all her elerbbim look...... Timon of Athens, iv.
witl golden eherubims is fretted.... Oymbetine, ii.

thou young and rose-lipped chernbim .. Othello,
ClIE RUBINS-[Col. Knt.] quiring to the yonng-

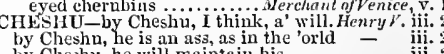

in the nanie of Cheshn Clirist, speak...

by Cheenu, I am your majesty's ......
CliESNUT-your chesnot was ever., is you Like it, iii.

as will a chesnut in a farmer's fire. Taming of Sh. i.

C11ES'T-neither press, conter, ehest. Merry Wives, iy.

what says the golden chest? ha!.....

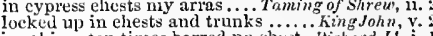

jewel in at ten times barred $\mathrm{qp}$ chest . Richard 1 i. $\mathrm{i}$.

are my chest 3 filled up with
from lis deen chest langhs out

come, stretcls thy chest, and let

sir, lis chests and treasure he........ Cariolanus, $\ddot{\mathrm{i}}$.

their aluns out of the emuyress chest.. Titus.And. ii.

we he elicst beneath the hatches ...Pericles, iii.

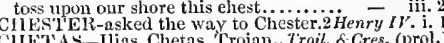

ClIExAs-Ilias, Chetas, Trojan.. Troil. . C Cres. (prol.

montez a elieval; my horse! valet! .

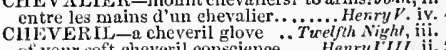

of your soft cheveril conscience..... HenryllIII. ii.

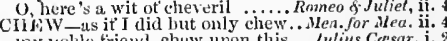

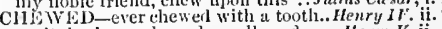

culital erimes, chewed, swalluwed ..... Henry $V$. ii.

ClinW

click-my Ariel; chick-that is ....... Tempest, $v$.

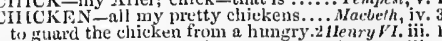

the porr cliscken shuald be sure of death -

y'on would eat chickens i', the shell.. Troit. \&. Cres. i.

tirtluwith, they fly like clickens . Timon o. cymbetine, y. 
CHIV-I chid Iucetta hence .... Treo Ger. of Fer. i. when you ehid at sir 1 roteus

when we have ehid the lausty-footed.Mid.N.Dr. iii. whiles you ehid me, I did ............ Lie Like $i, \bar{i}$ iv. 3 (let.) I should have chid you for not.. Comedly of $\mathrm{Er}$. he clitd the sisters, whicn hrst .............

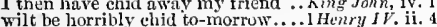
and elid his truant youth

thus upbraided, chil, and rated at...2Henry $F^{\prime} Y$ iii. 1 have chid me fron the battle ........3 3Henry VI. ii. 5 will you be clid? We will bear. Timon of . dthens, i. I 'tis to be chid as we rate boys ..... Antony \&. Clec, i. 4
he might have chid me so .............. Othello, iv. 2

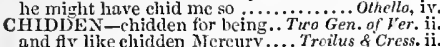
and fly like chidden Mcreury... Troilus \& Cress. [Col. Kn't] the chidden billow secms .... Othello, i. I CIIDE-Will make me elide the $\ldots .$. ... Tempest, $\mathrm{i}$.

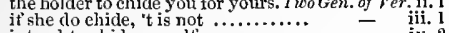

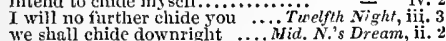
we shall chide downriglit .i. Mid. N.'s Dream, iil. ns well os I may etide you for it

you ehide at him, oflending twice. Love's L. Lost, iv. 3 I will ehide no breatler.

chide a year together (repeated)....
what hail he to do to chide at me?

what hal he to do to chide at me?
almost chide God for making you.

to ehide him from our eaves

it is no time to ehide you now. Taming of Shrew, $i$.

though she ehide as loud as thunder

not her that chides, sir, at any ...

the one he elides to hell, and oids

that chides the banks of England .. i i Henry $J V$. iii. 1

ehide him for fanlts, and do it.......2Henry $I V$. iv.

my lord of Warwick; chide him hithe
we'll chide this dauphin at his .........

shall chide your trespass, and return
and ehide the cripple tardy-gaited

then must I chide outright

and ehides the sea that sunders

and so I hide the means

to chide my fortune, and torment... Fichard III. ii.

it' he flineh elide me for it
guod Troilus? chide me for

good Troilus? chide me for it.......

and after teet-place; chicle me no more. Coriol. iii.

he'll think your mother chides

to chide, to laurh, to weep...Aniony \& Cleopatra, i.

with Juno ehide, that thy adulteries. Cymbeline, V. 4

I pray thee, chide not ........... Romieo o. Jutict, ii. 3

atter-hours with sorrow elide us not!
what a beast was I to ehide at him!

bid iny sweet prepare to ehide.

like death to chide away this shame - iv.

in her heart, and chides with thinking.. Othello, ii. I

do not you chide; I have a thing for you

and he does ellide with you

CHIDING-better a little chidin... Taming of $S h$. i. did I hear sueh gallant ehiding ...Mid.N.'sDr. iv. elurrlish chiding of the winter's...As ynu Like it, ij. mischievous foul sin, in ehiding sin

in thy not ehiding: for she was.... Winter's Tale, $\mathrm{V} .3$ a rock against the chiding flood .. Henry VIII. iii. 2 thou hast as ehidiong a nativity ....... Pericles, iii. I strike my gentleman for chiding of his.... Lear, i. 3
the chiding [Col. Knt.-chidden] billow.. Othello, ii. 1 in mod taith, I am a ehild to elhiding.
CHIIDEST-thou chidest me well ...Richard II. ivi. 2

in chief, tor that her reputation... Mea. of or Mea. $\mathrm{v}$.

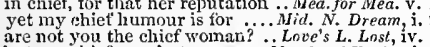

but my ehief care is, to cone... Herch. of Yenire, i.

father's gift stands ellief in power.....All's Welt,

chief nourisher in life's feast

King $\overline{J o h}$, iv. 2

hut, chiet ot all, your safety
from all soldiers chief majority

your grace do I in chicf address

and woe to my lord chief justicel...
my lord chief justiee, speak to that

their chief assembled strength $\ldots \ldots$ i ilenry

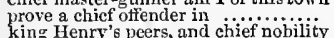

the chief perfections of that lovely

the chief perfections of that lovely .. - iv.

that his chief tollowers lodge...

the first of all your ehief attairs.......

the church the chief aim of his honour

are made thy chiet' afflictions.. Timonof Athens, iv.

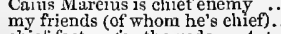

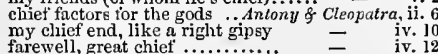

iv. 10

chief architect and plotter of ..... Tilus Andron.

were 1 chict lord of all this spacious ... Pericles, iv,
CIIEF - aud generous, chief in that .... Hamlint i. 3

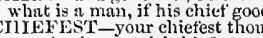

security is mortals' ehicfest encmy
for our ehicfest men of discipline Macbeth, iii. 5

sit at chicfest stern of publie

King John, ii.

their ehiefest prospect, murdering....

into this chiefest thiekset of the park

well winged with our chiefest horse. Richard $I I I . \mathrm{v} .3$

that's one of the cliefest of them..
that valour is the chictest virtue..

help three $o^{\prime}$ the chictest soldicrs . Witus Andron. v.
the cluicfest princes of the Goths..

built up for his eliefest scat ....Pericles, i. (Gower
ehictest courtier, eousin, and our son ... Hamlet, i.

CHIEFLY -chiefly that I night set it. Tempest, iii. I but, enify him youl termed

but chiefly by my villany $\ldots \ldots \ldots$........ Whech Ado, iit.

reeeipts he gave me; chiefiy one ..... All's Well, ii. 1
but clliefly, a villanous trick of and chieffy therefore I thank God...3Henry VI. iv and with you chiefly i' the world ...An of \& Cleo, ii.

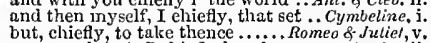

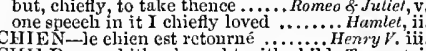

CHILD - was lither brought with ehild. Tempest,
seek to violate the lonour of my clild

him to yiolate the honour of my child

that I must ask my ehild forgiveness

that she is my ehild

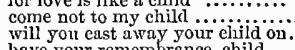

lave your remembrance, child

never name her, child, it she .......
you do ill to teach the child such.

now is Cupid a child of conseienee

madam Julietta with child ......
is there a maid with child by $\mathrm{him}$ ?

with child, perhaps?
he hath got his friend witli child

some one with ehild by him?

sir, she eame in great with
being as I say, with child

respeeted with man, woman, or child

she is with ehild; and he that got it

Kate Keepdown was with eliild by
lis ehild is a year and a quarter old

for getting a weneh with ehild o.d.
there's one whom he begot with child

no, for then were you a child . . ......
no clild but Hero, she's his only heirl

二 iii. 3

as to show a ehild his new cont ......

if you hear a clild ery in the night..
and let the child wake her with erying

do so, as thou art ray child

that so loved his child, whose
so wronged mine innoent clild

thou hast belied mine innocent ehild

thou hast killed iny child...

breatl hast killed mine innocent child?

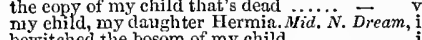

bewitched the bosom of my child ....

love-tokens with my child

therefore is love said to be a ehila.....
would have the child knight of lis trai

would have the child knight of

eome, thou child; I'll whip thee
ask of her her clingeling child.

this child of fancy, that Armado

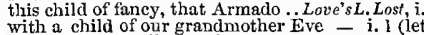

and sweet my ehild, let them
sweet invocation of a child

Warble, child make passionate........
of the foresaid child or pupil .....

her shoulder is with ehild ............

offered by a ehild to an old man $\ldots . .$.
when he was a babe, a child, a shrimp

the ehilu brags in her belly already.

all wanton as a child, skipping

that knows his own child ...Merch

the MIoor is with child by you .......

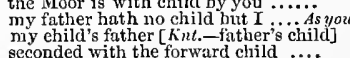

seconded with the forward child ...

a ehild begotten of thy ho..................

a ehld begoten of the hild towards
and thou
for gctting the sheriff's fool with ehil

All's Well, $\mathrm{i}$.

he got his wile with child.

a child shall get a sire...

Taning of Shrew, ii.

happy the parents of so tair a ehild.

it is a gallant ehild; , one that .

soften at the sight o the child ........
the child was prisoner to the womb.

my ehild? away with ' $t$ ! $1 . .$.
getting wenches with ehild.

a boy, or a chinid, $I$ wonder?

a bearing-cloth for a squire's eliild ...

till his lost child be foun

say, he found the child child

nided to expose the child, were even

left you wite, and child ................ Nacbeth, iv.

dispossess that child which is not lis? King John, iv

to thy grandam, child. Do child .
tlyy sins are visited in this poor child
CHIILD-relief of this oppressed ehild. King John, ii. 1 let wives witl child pray $\ldots \ldots \ldots . . .$.
give my ehild his kingdom liere $\ldots .$. beeause my poor ehild is ..............
Crin, the first male child ........... your child. Grief fills the room (rop.). pretty ehild, sleep dont bless, and seeure
corruption of a sweet child's denth .. before the child limself felt he.

to be bntcher of an inmocent ehild

if thou didst kill this ehild

bear away that cliid, and filiow...... = ive

a long parted mother with her child

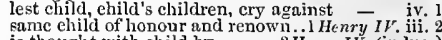

is thought with child by ........2HenryIV. (induc.)
neitlier woman, man, nor child .......

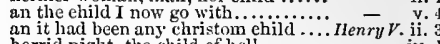

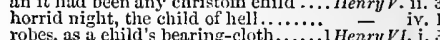

robes, as a elhild's bearing-cloth....... Herny

shall a child instruct you what.......

happy for so swect a eliid

the holy maid with ehild

my ehild is none of his ...............

murder not this innocent chilid.......3 enenry $\mathrm{V} I$. i.

hereafter say unto his elhild........... - ii.

means to beg a child of her

a ehild; and men ne'er spend $(r e p) . . . \quad$ =

if ever he have child, abortive.......... Richard III. $\mathrm{i}$.

like a child, told the sad story

I, as a ehild, will go by thy direction. -

that land, that's governed by a ehildi =

good maddum, be not angry with the ehiid -
lis master's child, as he worshipfully

loath to depose the child, your brother's =

eanst thou demise to any.

the tender temples of $m$ r child

if it eonceived a male child by me...Henry $\bar{V} I I I$. ii.

never, betore this happy child.......... =

to see what this child does ..............
whereot thy proud child $\overline{\text { chens, }}$,

indeed, la, tis a noble child ........ Coriolen us, i.

his mother, wife, his child, and this .

wife, mother, child, I know not

mother, witc, aud child, to see tlie son

requires nor child nor woman's face.

hatcful error, melunchioly's clild. Julius Cesar, v. let une have a child at tift5...Antony s. Cleopatra, i.

prevail under the service of a child $=$ iii. 1

a child that guided dottruds .......... Cyñzbeline, i.

sole child to the king? His only clild
how now, my flesh, my child?
for ne.er till now was I a clild ... Titïus Andron

for ne'er till now was I a clìld ... Titus Andron. ii.

how many women saw this child of his? -

his child is sike to her, tair as........

heard a ehild ery underneath ......

first, hang the child, that he may....

thy elilild shall live, and I will see....

my child shall live. Tell on thy (rep.)

like a loving child, shed yet $\ldots \ldots \ldots . .$. mother, wife, and yct his child. Pericles,

untinely claspings with your child...

his ehild, I wis, to incest bring.....
like beanty's child, whom nature gat

his queen with child, makes lier.. -

that e'er was yrince's child

in bringing up my child ..................

I think, you'll turn a child again....

she did disdain my child, and stood....

you not your clild well loving

as much as child e'cr loved...

there's father arainst child ...........
between the child andl the parent

in a child, than the sea-monster!

tootl it is to have a tlankkless eliildi!

the cliald was bound to the father.

will not trouble thec, my child

served you ever sinee I was a elhild ... 1 think this lady to be my ehild Cordielia.

my child is 5 et a stranger in ....Romeo of Juliel,

Ony brother's cliild! unhappy sight! $=$

before some festival to an impatient cinild -

a desperate tender of my ehild's love
thou hast a careful father, child ....

marry, my ehild, early yext Thureday

Grod chald! us only lits revivehild.

my child my only lite, revive ....

0 child 0 child! my soul (rep.)

my child is dead, and, with my ehild

an old man is twice a child iii. 1

iii. 4

iii.

iv. 5

jiv. 5
iv. 5
iv. 5
ii. 5 
CIIILD_speak like a good chi I hud rather to sulopt a child...........

fird at soul I have no other chitid , I am a child to chiding.

CHILD-BED-child-bed privilege. Winter's Tate, iii. 2 a terrible ehild-hed hist thou had .....?

nt sea in ehild-hed died she, but brought

CIIILDED-he childed, as I futhered!

CIILDERICK-which degused Childeriek in ${ }^{2}, r y$ r. $\mathrm{i}$. CIIILDHOOD-chilthood inmeence? arith

which in my ehildhood I did dote upou

I urge this chtildhood proot........Mrerch.oflenice, i.

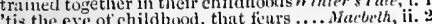
th the esc of chith now I have stained the ehildhod... Rom. S. Jul. iij, 3 CIIULDISH-toward chililish treble. As you Like it, ii. 7 but what he did being ehildish?.. Minter's T'ule, iv, 3 the seeptre in his childish flst. 'twere ehildish weakness to 1 with storc of chilclish drops our easiness and childish pity such ehildish triendliness to yield...

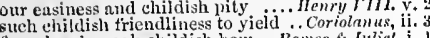
from love's weak childisl bow ... Romeo of

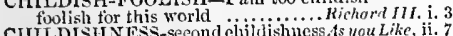

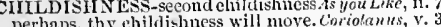
freedom, it does from ehildishmess. An'ony s $C^{\circ}$

CIIILD-KILLER-ernel child-killer..3 Hewry
CilILD-LIKE-child-like duty.. Tuo Gen.ofrer. the CIIILDNESS-his varying childness $I$
CIILDKENnot gond that eilidren shonld know
the children must be practised well. the children mast be practised well

teach the children their belaviours
to stick it in their children's sititit.. derry W. ii.

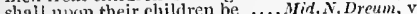
are to be laid upon the elcikiren...Mer of Vesice, iii. his kisses ure Judas's own children. .ts you

the world finll of ill-favonred children $\overline{\text { T }}$ Well, iii. own children in good bringing up. Taming of $S^{2}$ commonly, do ret their children

good hearing, when eluildren are toward - ' you'd eall your ehildren yours.

her ehildren not her

most precious queen and children.

(jewel of children) seen this hour

I am past more children; but .......

these are the parents to these children

my husband, and my children both $\bar{N}_{\text {acbeth }}$,

do you not hope your children shall....

throne and state, children and
and all my children? well too

my children too? wife, children

he has no children: all my pretty ones

my wife and children's rhosts will

doubt, as all men's ehildren mas

and leave your children, wives........

the sons and children of this

I mean, my ehildren's looks ........R

our lives, our children, and

which like unruly children

lest ehild, child's children, cry against

the children yet unborn shall feel this

in cradle-elothes our children where

that men yould telt their children.

the children are not in fanlt.

oHenry $l V^{2}$ it.

were all thy children kind..........Henry $V_{2}$ (cho.)

our children, and our sins, lay on....

and ourselyes, and children, have

that afirights our children so

our wives, and children, all will hot

he laad two children at one birth!

in their wives' and children's

madam, do you love your childien?

thou urong'st thy children mightily

and thou hast some clnildren ....

aguinst my children, brothers.

live to wail thy chilitren's loss $\ldots$ gail tless wife, and my poor chilidren!

leace, children, peace! the king

comtirt of thy childien lett thee

sanctuary children, neer till now

the bastardy of Edward's children

the bastardy of Erlward's child

name is ominous to childrent $\ldots . . . . .$.
wept like two child ren, in their deatly

villain-slave, where are ray einildreny

the little souls of Edward's childre

the a are as chilldren, one stej, below

jour children were vexation to your

the childiren live, whose parents thou

but thou dirlst kill my children...

Hastings, and Edward's children.....

when I was found talse to his chilitien

blest with many children by you ... Ii
our children's children shail wee this

our childrens children shath see this - v. obedience finil in ehildren!... Timon of essitn, iii. as children from a bear, the Volecs.. Coriolanus, i. towards her descrved ehilciren is
CIIILDREN-more basturd ehildren.

thy wite and rhildren's blood

fools, whoie children he huth stain

nien tiols, and children cal
into the law of chidiren.

men, wives, and children, stare.

put your children to thit dlestruction

put your children to that dlestruct
you with your children will he selu

that a king's childtren should be so .. C

so ehiluren temporal fatlicrs do mppease

I lost my children; if these be they"

not hencetorth called my ehildren.
that ravens foster folorn ehildren.

our wives, our children, or oursely

bear bags, see their children kind.

ealled you children, you owe me no
vengeance overtake such chiliren

which are the children of an ictle bruin

from her womb children of divers kind

an aicry of children, little cyases.

what? are they children?

my veins are chill, and have no more... Pericles, $\mathrm{ii}$

CHILLING -a chilling sweat

tis like a chime a-mending

only danceth at so harsh a ehime....... Pericles, $\mathrm{i}$

to Windsor chimueys shalt thou leap

the smoke out at the chimmey...As you

our climneys were blown dow

wain is over the new ehimney......

... Mucbeth,

he made a ehimney in my father.

rooked her on the chimney's top.....3llenry ri.

yea, to chimney tops, your iufants.
the chimney is south the chamber.

CIININEY-PIECE-the chimney-piece

CHINNEY-SWEEPLR-

are chinney-sweepers black .... Love's L. Los', iv. ChI - till new-born chins be rough .. Tempes', ii.

dancing up to the ehins

would

on old Hyera's ehin, and icy.....Mid. N.Dream, ii.

more hair on thy chin, than. Merchant of Venice, i.

wear yet upon their chins

stroke your ehius, and swe
or his ehin worth a beard?

the knowledge of his clinn ......

the pretty dimples of his chin..... Winter's Tale, ii.

it stood in her chin, by the salt. Comed of $^{2}$. $r$. iil

whose chin is not yet tedged

your ehin double? your wit sing

whose chin is but enrich

three or four hair's on

her white hand to his cloven chin

on his chin. Alas, poor chin

that Helen spied on 'Troilns' chin

fifty hairs on your chin, and one

which thou dost ravis't from my chin.... Lear, ii

if you did wear a beard upon your chin - iii.

CHINE-to mose in the chine... Taming of Sh. iii.

never hope to see a chine agaiu....1lewry III. . . 3

CIIN N-through the chink of a wali.,izid.N.Dr. uii.

ind through wall's chink, poox

show me tliy chink, to blink through

now will i to the chink, to spy

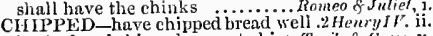

lincked and chipped, come to him. Troil. \& cress. $y$

Chiron, we hunt not. we, with horse

I take them, Chiron, and Demetrius

$O$ villains, Cliron and Denetrius!

that cursed (hiron and Demetrius were -

CHIlRRA-chirra! Quare chirra ..Lore's L.Los

i. 2 CHITUPIER-Chitopher, Vaumund. dil'swell CHIVALRY - the victor's chivalry

iii. 5 (tor Christian service and true chivalry) -

I have a truant been to chivalry...1 Henry IV
all the chivalry of England move..2 Heury I V

when all her chivalry guth been.

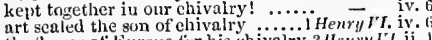

the flower of Europe for his chivalry.3 Heury $/$ 'l. ii.

Troilus! the prince of ehivalry! T Troils
on his fair worth and single elivalry

v. 1 to-day i' the vein of chivalry....

his deviee, a wreath of ehivary ....... Pericles, $\mathrm{ii}_{\text {, }}$

CIOICE-this is my tather's choice. Afrry Wive

a leavened and prepared choice.....MAfa, for.Mea. i.

choice of triends, to quit the .........Mreth Ado, iv.

or else it stood upon choiee of triciuls

if there were a sympathy of cluvice...

should give answer ot her choice?
CHOICE-singular und eloice epithet. Lote's L.L. Y.

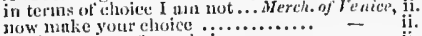

fail in furt tine of my choice............

while he rloth mulie lis choice........

so make the choice of thy own time.. - ii.

make clioiec, and sec, who sliums.... - ii. 3

this rins he holds is most rich choice - iii. 7

small shoice in rotten apples ..... Taming of

for flut wlich restetin in wy clacice - iji. I

pedler, let's lave the first ehoice. Wint

your choice is not 80 fich in worth

and twenty thousand men spirite... King John,

is sick of their ow choict.

and ye clioice spirits that admon
no portion in the choiec myself

with clusice of all delights .............

wur brother matc a worthy ehoice?.3 Henry Vl, iv. I

a choise hour to hear from him......Henry VIII, i.

(und of your chinge) these rever...... = $=$ ii. 4

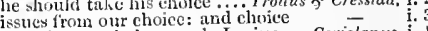

of their own choice: onc's Jnnius.... Co

distribution, at your only choice ....

at thy choiee then; to her of the .

choice and master spi rits of this age. Jul.Cersar, iii. I

firht for frectom in your choice... Titus Andron. i. I

pleased with this my sudden choice.

dost thou applaud my chojee?

to make sume meaner ehoice.

i. 2

and damned lier loathed choice!

to furbear choice it the absence $\ldots . . . . .$.
tis well your clioice agrees with imine

'tis well your chicice agrect

harmathy and other choice attractions

no better choice, and think me rare
ean make shoice of cither's moiety

most chuice, fursaken; and nost 1

men of choice and rarest parts..............

at your choice, sir. I pry the danghter - ii. 4 well, you have made a simple ehoice of

for on his choice depends the sirety ....

my dear soul was nistress of her choice.

reserved some quantity of wisest tricnds -

she will find the error of her choice...... Othello, $\mathrm{i}$.

CHUICE-DRAWN-

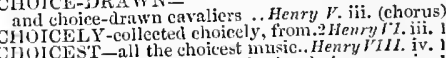

CHol R-to a preparcd place in the choir - iv.

Which performed, the choir, with .... for or Mea. v.

and choke a daw withal $\ldots$ gibing......... Love's L. Lost,

do ehoke their service up even .As you Like it, if. 3

cling together, and ehoke their art .... Macbelh,

for I doth choke the feeder........... Richard II. ii.

earthly parts to ehoke your clime ..... Fenry $V_{1}$. iii.

boiling choler chokes ...............

and eloke the herbs for $r$, $i$.

doth choke the air with dust

to choke it in the utterance .......... Coriolanus, iv.

prove untrue, Ill choke myself....... Cymberine, i.

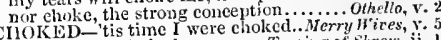

what, have I choked yon...... Taming of shreu, ii.

her tairest flowers ehoked up

gain proposed choked the respect ....2IIenryl $V$. i.

of Nortimer, choked with ambition -. - ii. f

give thanks to you that cloked it .. Henry VIII. i.

give thank it had almost choked Ciesar ...Julius Cersar, i.

all pity choked with custom

be choked with such another emphasis! $A n^{\prime}$. \& Cleo.i.

liokiNG-follows the choking.. Trilus f c'ress. i.

th choking gall, and a preserving.. Romeo \&. Tuhet, i.

IIOLER - cold water on thy chuler.... - it:

jow my choler is onded.

fin' it cugenders clwier......... Taming of Shrem, iv.

let s purece this choler without

chuter, my lord, if rightly taken ..... - ii.

I becek you now, agrravate your choler - ii.

tunched with chinler, hot as gunpowder $-\bar{v}$ iv

your boiling choler chokes

ler being over-blown

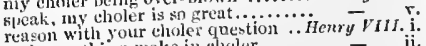

ant something spoke in choler ....... - ii. I

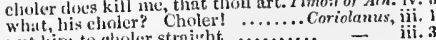

$\mathrm{I}$ 
CHOLER-to your rash choler?.... Julius Crosar and France in choler parted! ............... Lear, perforce with wilful choler meeting ... $-\overline{-}$ no, my lord, with choler. Your wisdom. perluaps, plunge him into more choler.

he is rash, and very sudden in choler ... Othello, ii.
CHOLERIC-but a choleric word... Hea. for Mea. ii. 2 ourseivcs are choleric ........ Tuming of Shrew, I fear, it is too choleric a meat

lest it make you choleric...... Comedy of Error before you

are you so choterie with Elcanor......2 Henry VI. to the choleric fisting of ench rogue.... Pericles, that infirm and choleric years ......
CHOLIC-with a kind of cholic out-swell the cholic of puffed

to be pinched with the cholic CHOOSE-I know thou canst not choose.. Tenpest I cannot choose but pity her. Two......... of yerona, you shall not choose, sir ............

that cannot choose but amaze him... thou shalt not ehoose but go....

they are glad to choose me .........Meas. for Meas. 1 pray you choose another subject.... Much .tdo, to choose love by another's eye !.......id.. N. Drerm if we choose hy the horns ......... Love ${ }^{\top}$ L. Lost, to choose me a husland (repeated).....
that I cannot choose one, nor......

an you will not hare me, choose $\ldots$....

offer to choose, and chow he will choose it

to choose at all, or swear (re
know if I choose the right?

if you choose that, then 1 am yours..

here do I choose, and thrive I as I

if you choose that wherein I am ....

that choose by show, not learning

that did never choose amiss

when they do choose, they have.....

swear he cannot choose but break
how to choose right, but then I am

let me clioose; for, as I am, I live

choose I; joy be the consequencel

you that choose not by the (rep.)

二

you cannot choose but lose by $1 t$

that cannot choose but lend and give...

thou hast power to choose, and they

if thou shouldst strive to choose

flower, choose thou thy husband .........

I think he cannot choose.......

I I hope, I may choose, sir

which cannot choose but branch.

not half a kiss to choose who loves.

the office to choose you a queen

this course I fittest choose.... Comedy of Error

whose way himself will choose.......

choose out some sccret place

why, it cannot choose but be

which cannot choose but bring him.....

to you choose for me, marry the

and let us choose such limbs of noble.

master Robert Shallow, choose what.

and rather choose to hide them in...... HenryV v. to choose for wealth, and not for $\ldots . .1$ Henry $V I$ v.
would choose him pope, and carry. .2 Henry $V I$ I choose Clarence only for protector.3 IIenry VI. iv.

I cannot choose but langh .......... Troil. \& Cress. I will choose mine heir from forth. Timon of $A$ th. $\mathrm{i}$. 1 I cannot choose but tell him....

they choose their magistrate

he cannot choose: I am most

the people choose Cesar for thcir $\mathrm{k}$

I rather clioose to wrong the dcad....

where would you choose it?... Antony

choose your own company

what lady would you choose to assait

What she cannot choose but must be.

that I would choose, were I to choose. Titus And. behold, I choose thee, Tamora ........

to fight when I cannot choose

and choose to wage against the enmity..........

yet I cannot choose but laugh ...Romeo

you know not how to ehoose a man ..

cannot choose but ever weep the friend - ii

I cannot choose but weep, to think....

choose we; Laertes shall be king

he shall not choose but fall..............
yo1s may clioose a sword unbated.

cennot choose but they must blab.

CHOOSER - might be her chooser...
CHOOSETH - who chooseth me... iI

who chooseth me, shall get as much.

who chooseth me, must give and hazard -
IOOSING-in choosing wrong... Mer.of Frnice, iii. 2
in choosing for yoursclt, you showed.3 ilenry VI.jv. 1 for choosing me, when Clarence is.
CIIOP-from the nave to the chops.. you will, chops? Hal, wilt..... and chop away that factious pate this hand should chop it off .......
I had rather chop this hand off
ehop off his head, man .................. Nuctbeth, $\mathrm{i}$. ifenry IV.i. 2 Ill chop off my man .............Richard III. iii. any one of you, chop off your hand..

wilt thou help to chop it off?

CHOPINE hy the altitude of a ch....... Othello, iv. CIIOP-LOGIC-how now, chop-logic! Rom.\& Jul. iti.
CHOPPED-head's to be chopped off. NIea. for ML'a. CHOPPED-head's to be chopped
her pretty cliopped hands had
aud heads, chopped off in a bat

aud heads, choppcd off in a battlo.

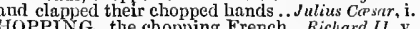
CHOPPYNG-the chopping French... Richard II. y. CHORUS-admit me chorus .... Henry $v$. i. (chorus) you are as good as a chorus, my lord ... Hamlet, iii. 22 whom rar chose to cross ....Two Gen, of Verona, iii. the word is well culled, chose; sweet.

no further, but chose here?.. Merchant of Veniee, ii. 7 Which casket 'twas I chose: next ..... for what dull part in't you chos

a deal of old irou $\mathbf{I}$ chose forth ....... Henry $r 1.1$.

have you chose this man?

they have chose a cousul, that will

$O$ what a time have you chose out

I chose an eagle, and did avoid

for she liad eyes, and chose me

CHOSEN-as they are chosen......
being ehosen the prince's wat

never be chosen by any rightly

..Mer. of Venice, i. 2

the chosen of signior Hortensio ... A Taning of Sh. i. 2

a guard ot chosen shot $I$ had

and holy; chosen from above

piot, well chosen to build upon!

hin that were to build chosen .3 3 Henry 1 . i. 4

to rank our chosen truth with ... Henry $\overline{I I L}$, iii. 3

I saw well chosen, ridden .........
sir Thomas More is chosen lord.

the servants of this chosen infant

then were they chosen; in a better

chosen Andronicus, sturnamed Pius

be chosen with proclamations to-dat
CHOUGH-a chough of as deep chat

chough's language, gabble enough ... All's s'cll,

scared my choughs from the chaff. Winter's $T$ ul,

and choughs, and rooks, brought forth. Macbeth, iii. 4

'tis a chough; but as I say, spacious .....Humlei, v. 2

up the town, so Chrish save me, la.

no time to discourse, so Chrish save in

nothing done, so Chrish sa me,

"so Chrish save me, I will cut off.
cHinIST-fought for Jcsu Christ.

his pure soul un to his captain

as to the sepulchre of Christ

the kingdoms that acknowledge Clurist? -

in the name of Cheshu Christ, speak..H Hary $V^{r}$. iv. 1

chall sup with Jesu Christ to-night...2 Henry ${ }^{\prime} I_{\text {. }} \mathrm{v}$.

by Clirist's dear blood shed for ..... Richtrel III. i.

tond, adoptious christendoms

lyingest knave in Christendom ... Tam. of $s h .2$ (ind.)

the prettiest Kate in Christendom .....

to do offence and scath in Christendom
all the kings of Christendom are led so

by my christendom, so I were out of .

there is ve'er a king in Christendom

any plot of ground in Cliristeudom ...

CHenryVI. ii. 4

the lyingest kuave in Christendom. 2 Hen

the biuntest wooer in Christendom.3 Henry VI. iii.

they liave worn out Christendom...Hem'y VIII. $\mathrm{i}$.

your scruple to the voice of Christendom

CHRISTENED-was christened.. As you $L$

be nevr christened in the Tower

[Knt.] on other g

in christening thou shalt have... Mer. of Venice, iv. 1 you must be seeing christeuings?... Henry VI
one christening will beget a thousind

when they pass back from the cliristening -
are come already from the christening
-

CHRISTIAN - of a christian ...Two Gen. of

Which is much in a bare christian.

as I $\mathrm{am}$ a christians soul, now .........

as foolish christian creatures,

no more wit than a christian..... r iefe Night, i. for there is no christian, that means
CHRISTIAN-good christians ought. Mea, for Mea.ii. I Thate him for he is a christian. Nerch. of V'nice, $i$. this if a chrian witian...

become a christian, and thy loving wife -

with ny new master the christian

to gaze on christion fols with varnished -

there will come a christian by $\ldots . .$. .

fled with a christian? $O$ my christiall

and summer, as a christian is?

a christian, what is his humility? (rep.)

and yield to christian intercessors

he hath made me a christian ....

we were christinns enough before ....
this making of christians will raise..

in converting Jews to cluristian

her be the christian husbands......

dost shed one drop of christian blood

and let the christian go .............

defies me, like Turk to Christian...As ynu $\overline{L i k e}$ it, iv. 3

the greatest in the christian world ...All's Well, iv. 4

as I am a christian, answer me .. Comedy of E'rr. i.

these two christian armies might..... King John, v.

some honest christian trust me with glorious christian field, streaming (rep.)

that in a christian climate, souls

if, like a christian, thou hames... i Henry $I V$. ii.

he had him from me christian $\ldots . . .2$ itenry $l V$. it. 2

perform with a most christian care ... iv. 2

the mirror of all christian kings ........ Henry (chorns)

upon no christian soul but

the christian prince, king Henry

no christian ear can endure to hear.2 Henry $_{V I}$. iv,

as I am a claristian faithful man.... Richaril $I I I$. i.

upon the earth a christian; made him

of virtue for a christian prince .......

breathe I in a christian land?.......

I could wish more christians.......Henry $\bar{v} l H$.

the learned ones, in christian kingdoms -

that's christian care enough...

jou have christiau warrant for them

this young one made a christ....

on my christian conscience, this one

God rest all christian souls!...... Romen of Julict, i.

accent of christians, nor the gait (rep.). Ilamtet, iti.

is she to be huried in ehristian burial..

finds it christian burial

anced out of christian bu.

christian [Knt.-christened] and heathen. O

for christian shame, put by this barbaruus

no, as I am a christian
CHRISTIAN-LIKE

ike fear........ Aruch dan, il.

nelghbourhood and christian-like

yet he, most christian-like ........2 Ilemry VI. iii. HRISTMAS-at Christmas I no.... Love'sL. Lost, i. I dash it like a Christmas comedy..... - Taning of Shrex, 2 (ind.)

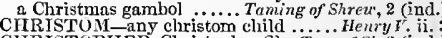
CHRISTOPHER-Christopher Sly. Tain. of Sh. .2 (ind.) I am Christophero Sly .. Taming of Shrew, 2 (ind not a tinker, nor Christophero Sly $-\frac{T a m i n g}{2}$ of Shrew, 2 (ind.) Hot a tinker, nor 'tristophero sly or fill up chronicles in time Taming of shrew, 1 (ind.) spoke your deservings like a chronicle $-1 V$ v. 2 your clironicle [ Knt.-chronicles] as rich.. Hen. $V$. i. as I have read in the chronicles....... his own trumpet, his own chronicle. Troil f $\mathrm{Cr}$ ii.

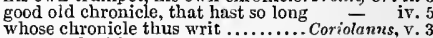
my sword will earn our chronicle.... Ant. \& Cleo. ii.. i1 abstract, and brief chronicles .......... Hamlet, ii. 2 CHRONICLED - chronicled for.. Two Gen. of Ver. i. this deed is chronicled iu hell ........Riehard 1i. $\mathrm{v}$. HRONICLER-foolish chroniclers...As you Like, iv. an honest chronicler as Griffith ... Henry VIII. iv. CIIUCK-how dost thou chuck?.. Tuetfih Night, iii. sweet chucks, beat not the bones...... sweet chucks, beat not the bones ..... use lenity, sweet chuck!............. Herry $V$, iii. no my chuck: Eros, come .......Antony \& Cleo. iv. 4 yray, clruck, come hither.............. iv. 2

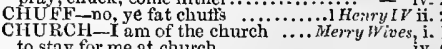
to stay for me at church............. - iv. if it liad not been i' the church ....... no sir, I tive by the churc

my house doth stand by the clitirch

the church stands by thy tabor (rep.)

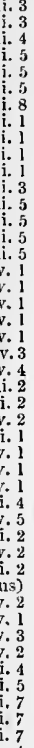 \\ i. 2
i. 1
i. 2
v. 2
v. 2
v. 3
i. 3
i. 2
v. 5
v. 1
v. 1 \\ 3
}

\begin{tabular}{l}
7 \\
1 \\
\hline
\end{tabular}

$\begin{array}{rl}v & 1 \\ v .1 \\ \text {,i. } 1\end{array}$ 


\section{CIIU}

CIT

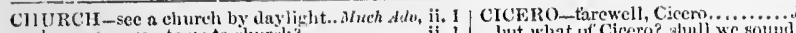
when mean you to tow to churcli?.

in the old church wimlow

are come to teteh you to church

should 1 go to chureh, and sec....Merch. of tern

go with me to ellureh, and call une

where bells have knolleyl to clatirch.

with holy bell been knolle: to chir

fet yuu to ch urch, and hare a gool...

lis time we were nt che go to elurel

letter ere he go to church...

at the yarting all the chureh did colio

at saint Luke's chureh is at your.
to the church; take the prie'st

to the chureh; take the priest

I have seen them in the church.

elop, ehureh, session, linating ... Winter's Tul

against the chureh, our holy motler

be champion of our chin

runsacking the chureh $\ldots \ldots . . . . . . . .$.

stood out agninst the holy ehurch. .1
the inside of a churel is made of

the inside of nerd; of the old elnurch ......... H He

and thou tollow'dst him like a clinur

testament have given to the ehureh...

and a true lover of the holy church

the chitreh's prayers made him (rep.)
throughout the year to churcli thou

throughout the year to church tho
or dignities of church, here by the

or dignities of churel, here by the

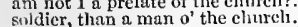

soldier, than a man o' the church....2H
in the cathedral church of Westminster

mikes the clureh the ehicf aim.. Henry $\bar{r} / 1$.

swallowed the whole parish church

hells, stceple, chiuch, and parish ......

lije you to church

till holy chureli incorporate two

nol so wide as a church door .......

by saint Peter's chureh, and Peter too

go with Paris to saint Peter's church

get thec to church o' Thurs

is the bride ready to go to eliureli?

liest array bear her to church

tu eut his throat i' the churcl $\ldots$........ Ham

CIIURCH-BENCH-

go sit here upon the church-hencli... Nach Ado, iii. 3 let them fight against the clurches ... Macbeth.

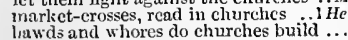

he must build churches then...

CIIURCH-LגKE-chureh-like humours.... Hamlet, ini.

CHCiRCHNAN-patient churchman ...Merry $W$. ii.

art thou a churcliman?

Beautort, the imperious churchman...2

ambitious churclinan, leave to afflict - ii.

that churchman bcars a bountcouls.. H

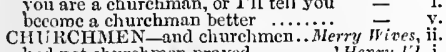
harl not ehurchmen prayed...

it holy churehmen take delight

churchmen so hot? good uncle...

and stand between two churchimenRichard III.

CIIU RCH-W A Y - chureh-'

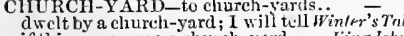

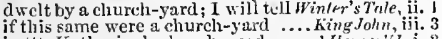

in st. Katharine's church-yard ........ Heving

like graves i' the holy church-yard. Coriolamus,

no foot upon the church-yard tread. io
to stand alone here in the clureh-yard

and strew this liungry church-yard

searer, about the ehurch-yard ........

we found him in the chureh-rard

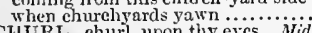

CIIURL-churl, upon thy eycs .. Mid. N.'s Dream thou churl, for this time, though. H'inter's Tale, iv. 3 that every churl aftords...

2 Henry VI. iil. ?

some sicrn untutored churl ..........2 the, thou art a churl; you have... Timnn of Athens, 1.9 though you left melike a churl. Titus. Andronicu,

CHURLIsH-churlish feet.. Two Gen of ferora me in this chmil ish meseenger. .. T'welfth Night, churlish chitling of the winter's... As you Like it, ji. 1 this is called the reply churli

interruption of their ehurlish drums.

though ehurlish thoughts themselve

and loud churlish druin

again unknit the clutelish knot ....3 Henry $1 r^{2}$.

waste for clurlish winter's tyranny...2HenryII

letter than a churlish tarl of Fance..Henry $V$.

churlish as the bicar, slow ts .. Iroilus of Cressida,

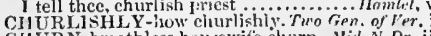
CfITR N-breathless houscwife churn..Mil.N.Dr. i

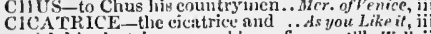
with his cicatrice, an enllem of war..Al's Well, ii. since yet thy cicatrice looks ray ....... Mramlet, is 3

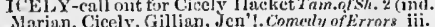

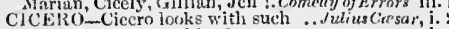
$\checkmark$ Cicero say anstline?

into your hand the circle of my glory
frum out the circle of his territorics

CIrCUM CIRCA

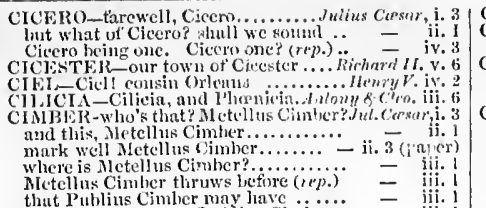

entranchisement for Publits Ciniber.

Cinilier should lie banished

CIMMERIAN_swarth Cimmerial. Thitus.tnrl show the cinders of my spirits. ......2ntony s

disth burn the heart to cinders. Tilus Andromicus
that would to cinders burn up modesty. Othello

CINN A-'tis Cimna, I do krow (rep.).Julias Casar,

am I not staid for, Cinna? (rep.) .....
good Cinna, take this parice
this, C'inna; aud this, Metellis Cimber

nuw, Cimna: nuw, Mletellus............
have an eyc to Cimma ..............
yours, Cinna; and, my valiant Casea

二 i. i.

my name is Cinna (repealet)

not Cimma tlic conspirator (repeated) ${ }^{-}$iii. 3

falls into the cinque-pace faster .... - ii.

CINQUE-SPOT'TED-

left breast a mole cinguce-spotted .... Cymbetine, i1. 2
CIRCE- have drank of Circe's cup. Comedy of Err. $\mathrm{y}, 1$

as if, with Ciree, she would change .. H Hewry ' l. Y. 3

obscured in the cirele of this forest

you must make a eirele; if conj ux

witli Henry's dcath, the English eirele ends

craves the circle of the Ptolcmis

the whel is come full circle

..terr, y. 3

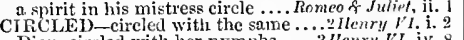

Dian, circled with her nymphs .....3 llenry VI, iv, 8

CIHCLIYG - cireling now thy head. Richard III. iv.

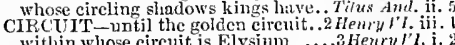

within whose circuit is Elysium ...3 Herry I'l, i. 2
circuit dost [Col. Kazl.-cauopy is dust]. Rom.t.dul.v. 3

about your infamy circum cirea .. Lone'sL. Lost, v.
CIRCUAICISED-the cireumcised dog .. Othello, v.

ClRCUMAEPE - the

in the eircumferenec of a peck....Merry Wives, iii.
invisible within the cireumference .Mid.N.

harbource in their

a garden circummured with brick. Meo for Mea. iv. 1

CIRCU MISCRIBED-he circumseribed ititus Aml, i.

must his choiec be cireu
CIRCUMSCRIPTION-

free condition put into circumseription .. Olleello, i.

Buckingham mows cireumspect .. Richard III. iv.

CIRCUNSTANCE

by your circimstance, yon call..
so by your circumstance, I fear....
that I can deny by a circumstance

that $I$ can deny by a circumstance

or unsafe circumstance.......... Tuelfth $\overline{N i g} h t$, iii.

but nothing of the circumstanec more

till each cireumstance of place, time f $-\overrightarrow{\text { Mea }}$. iv. 1

and, circumstances shortence ......... Nueh Ado, iii.

about my love with circumstance. Mer. of Yenice,
sixth, the lie with circumstance... As you Like

in all these circumstances....

to leave frivolous circumstunces .iv. -

ay oher circtinstances made un

so out of circumstance, and sudden

truth werc pregnant by circumstance

with circumstance, and oath.

cuts off more circumstance

thic circumstance I'll tell you

if your grace mark every circumstance - iti.

tell us here the cireumstance

not essentially, but by cireumstion
give me leave, by circunstance

give me leave, by circunistance (rep.)..Rich. $I I I_{1}$, . 22

indued hy potent circumstance

my cireumstance, expressly... . .

my circumstances, being so near

and I'll stay the circumstance .. Romeo of Jitliet, ii. 5

we crunot without circumstunce descry

iil such perilous cireumstance withont more circumstance at a hold

if cireumstauses lend me, I will find

$[K n t$.$] by no drift of circumstance$

comes nuar the eireumstance........

remember all tlie eireamstance

with a hombast circumstance

or breed itsclf so out of circlimstanec....

ingutation, and strong eireumstanecs
CIRUUMSTANCED-be circumstanced

CIRCIMATANTIAI,

go to the lie cireumstuntial ...... As you like il, v. 4
CIICUMY ENT-wonld circlimvent Gol . Hemlet, y.

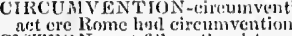

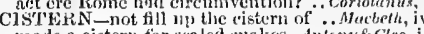

made a cistern for scaled snakes...

ITADEL, window of the cituld

theyered citidlel, a pendant rock...Ant of Clen.

bring thou the master' to the citudel

incet me by-und-by at the citudel

Enclia, non you to the eitadel, and teli

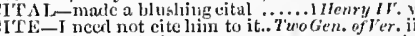

for we cite our fitult .............

whose aged honour cites a virtwous . .All's W'vt

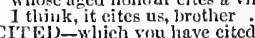

har I not heen eited so by then

and eited up a thousand heavy ..... Isichard III.

author to be citcd, as true .. Trmilus s Ciressidn,

the cities turned into a main.

so the maiden eities you talk

sec the cities and the towns defaced

and are the cities that I got witi

towns and citics for a dange

oblivion swallowed eitics up.......

Henryl

with ships made citics.... Antom,
O det those citics, that of Plenty

in eities, mutinies; in countrics
the fire is spicd in populous citie

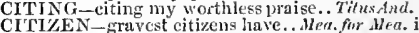

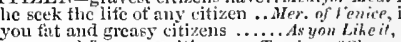

reslowned for gruve sitizens...Tuming of Shrew,

doing displeasure to the citizcns. Comerly of Err.

kind eitizens, and let us in
speak, citizens, for Eugland.

King John, ij.

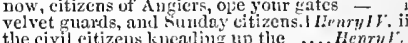

London doth jour ont her citizens $\ldots . .$. .

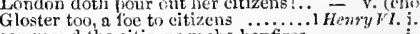

command the citizens make bonfir

the eitizens fly and forsake their

with the loving eitizens........

3Henryl't.

acquaint our duteous eitizens........

the citizens? Now by the holy' (rep.)

such troops of citizens, to come to him

consorted with the citizen

your citizens enticat you ..............
come, citizens, we will entreat no more

the citizens, I am sure ............ Henry $\bar{\eta} I I$.

the eitizens of Corioli hare issued

help, yc citizens. On both sides

tribunes, partrieians, citizens (rep)
lo, eitizens, he says, he is content.

when lie speaks not like a citjzen

When eame from several citizens.

to every Koman eitizen lie gives .... - iii.

and citizens to their dens ...Antony \& Clenpalra, $\mathrm{v}$.

but not so citizen a wanton........ Cymleline, iv.

ay, but the citizens favour Lucius

made Yerona's ancient citizens... Romeo of Juliot, $\mathrm{i}$.

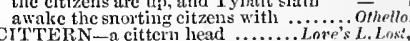

CITY-through the city gate...Two Gen. of Fer.

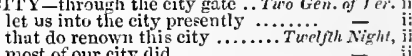

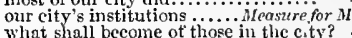

all the youth in the city

a leaguc below the city ...........

as of any man in the eit

....... Huch Aeln, iii.

to leave the eity, and commit yourecif - ii.

and profit of the city consistetly . Bar $r$.

burphers of this desert city

of the country, city. court, sea

Woursolyan in the city do 1 name..

if they clo approaish the eit

being a stranger in this city here

have done your business in fluc eity
to cozen somebndy in this city under

fostern, clear them o' the city .... Winter's $T a l$,

here in your city 1 now canie from..
up and ilown, 6 vicw the city. Comedy of Error

to none tiat lives here in the eity
and ull that know me in the city.

contront your city's tyes............... king $\bar{J}_{\mathrm{o}} \mathrm{hn}$,

save unscratrlyed your eity's threatened

harlonrage within your eity eall us lord

riks of this cointcmptuous eity '......

win $y^{n} u$ this city wit'sout stroke ...

so poremptery, as we to keep this city 
CITY-this city now hy ns besieged ...King John, ii. 2 a city on the inconstant ............. Henry $V$. iii. (chorus) before lime through the city........ - v. (choris) nanny would the peaceful city quit $=$ v. (chorus) cannot see many a fair French city
tower, to overpeer the city ........... Heury VI. i. 4.2

pity the eity of London, pity.........

these are thie city gates, the gates of.$\ddot{\text { Z }}$ iii. 2

sacks shall be a mean to sack the city

open your city gates, be hiumble ...... Henry $v$ vl. i.

when in the city Tonrs thou ran'st...

to spoil the city, and your royal court

to defend the city from the rebels
now is Mortimer lord of this city

now is Mortimer lord
that of the city's cost.

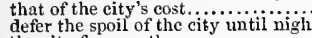

the city favonrs them......................
marreched through the city to
Warwick, wilt thou ope the city gates

Warwick, wilt thou ope the city gates
the city being but of sirull defence
his entorcenent of the city wives.. Ric

Rickard III. iii.

seems disgracions in the city's eye .

Priam's six-gated city, Darlan. Troiluss . Cres. (prol.

I wonder now low yonder city stands

make not a city fenst of it ${ }^{2}$ some high-viced city hang
his

that thou art out of the eity?

i' the canse against your

Timon to our city's love ...........
into our city with thy banncrs

into our city with thy banncrs........
regular justice in your city's bounds..

bring me into your city ..................

several places of the city you cry

they say, the city is well stored
should have first unroofc. the city

but issue forth their city ........

numlers to make good the city

and city, we render you the tent
go you to the city; learn, how ....

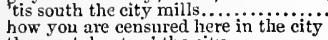

the mortat gate $0^{\text {the city }}$ cars

to unbuild the eity (repeated)

the people are the eity $\ldots \ldots \ldots \ldots \ldots$.

that viper that would depopulate the city

our good city cleave in the midst

the city, thus I turu my back

let a guard attend us through the city

a, theodly city is this Antium: city of kites and crows. $I^{\prime}$ the city

to melt the city leads upon your
who did hoot him out o' the city

who did hoot him out o' the city.....

the im hushed until our city be afire.....

that shall our poor city find $\ldots i . .$.
senators, patricians, a city fuli

they are near the city?

go tell the lords of the city. I a..............

your city Rome (I say your city) .
though in this city he hatl widow.

the city cast her people out...Antony \& Clcopatra,, ii.

din blast youl the city's ear.....

the hills adjoining to tlie eity.....

did you but know the city's usuries...

this day within the city walls...Titus Andronicus, $\mathrm{i}$.

this city then, Antioch the great. Perieles

a city, on whom plenty held finl
butt this populous city will yield
the city strived gnd Nejtune's ......

i. (Gower)
- i. 4 iv. 6

to rage the eity turn ................. (Gower)

west ward rooteti from the city's
all our whole city is much bound

here in this city visiting the sick

the new-made bridcoroom from tius eity $=$
delight in, the tragedians of the city....

estimation they did when I was in the city - ii.

three great ones of the city, in personal

many a beast then in a populous city.... - iv.
cITY-W ARD--the city-ward [Knt.-pittie-ward].

crTy-WOMAN-the city-woman. As you Like il, ii.

CITY-WOMAN-the city-woman. As you Like il,
CIVET-he rubs himself with civet ...Murh Addo,

bands are perfumed with civet ... As you Like it, iit. 2

give me an ounce of civet
civil

Lear, iv. 6

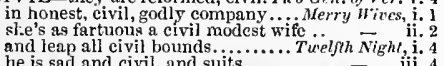

he is sad and civil, and suits .......... Murh $A d o$, iii.
but civil, count; civil as an orange

grew civil at her song ........Mid. Night's Dream, ii.

civil war of wits were much hetter. Love's $L$. Lost, , ii.
a civil doctor, which did refuse ... Mer. of Yenice, $\mathrm{v}$.

that ghall civil sayings show. As you Like, iii. 2 (ver.

like a civil war, set'st oath.

hostility and civil tumult reigns

of civil wounds ploughed up

should so with civil and uncivi
furious close of eivil botehery

Rieharl II. i. 3

trom the breast of civil peace

i Henry $_{I} V_{\mathrm{i}} \mathrm{i}$.

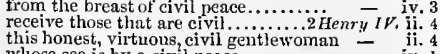

whose see is hy a civil peace .........
poor kingdom, sick with civil blows.
we bear our civil swords ..............
CIVII-the eivil citizeng kneading up...Henry $V$. i. 2 keep it from civil broils.

civil dissension is a viperous worin.... bringing them to civil discipline ....... Henry ${ }^{\prime} I$. i. 1 atready in this civil br

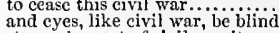

storms be past of civil enmity

3 HenryVI. i. I

now civil wounds are stopped...

Richart III. v.

either there is a civil strite in heaven. $f^{\prime}$ uld. Cossar, i. 3

domestic fury, and fierce civil strite.

shines o'er with civil swords. Anto
have shook lions into civil strect

if anthos lons inilo

our troy, our Rome, thie civil wound. Titus snd, v. 3

civil bood makes civili hands... Romeos. Juliet, (proi.)

tluree civil brawis bred of an airy word

come, civil night, thou sober-suitc

worthy Montano you were wont be c... Othello, ii. 1

and many a civil monster ...........

CIVILITY-civility, and patience. Merry Hives, iv. 7

in civility thou seem'st so empty? As you Like it, ii.

the show of smooth civility ti....

civility not seen from other
fron the sense of all civility

Cymbeline, iv.

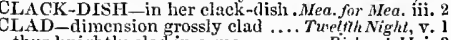

thus knightly elad in arms

Richard li. i.

CLAIM-I - claim the promise

I claim her not, and therefore.... Gen. of Ver. iv. 4

claim her witll a loving kiss.
the Jew may claim a pound...

in the forest lay's claim to you..... As you Like il, . . 1
thy duty owes, and our power claims...All's $w$ ell, ii. 3

as your due, time claims, he does ....
honour that good convenience elaims

hearen, and iny heaven's claim... Comedy of $E$.

wer.

Jaid clain to me; called ne

did claim me for her hushand...

that most naay claim this argument ... Macbeth, ii. i.

lays most law ful claim to this fair ...King Jolnn, i.

doth he lay claim to thine inheritancc?

my brother might not claim him

in right of Arthur do I claim of thee

make all the contradict his claim...

after young Artluur, claim this land.

and such as to my claim are liabie

personally I lay my claim

or should not, bar ns in our clatim

against your highness' claim to France

and Hugh Capet's claim

and conscience, make this claim

grandsire's tomb, from whom you claim =

gid claim some cortain dnkedo

nor no awk ward cluim, picked from

this is his claim, his threntening

when York shall claim his own ......2 Henry VI. VI. $\mathbf{i}$.

advantage, claim the crown ............

(from whose line I claim the crown)

as I have read, laid claim unto
claim the crown fiom John $(r e p$.

affect the house and claim of Yor

claim the English crown .............

whose beauty claims no worse ...Antony \& cleo. iii.
CI.AN1OUR-an liour in clamour ....Mrch Ado, v. 2 witls the clamour keep her still.. Tuming of sh. iv. contempt and clamour will be...

a savagc clamour? well may I get.... - iii. 3 the venr your tongues, and not a word $-\overline{\text { iv. }} 3$ make our griefs and clamoon roar...... Macketh, $\mathrm{i}$. loud clannours ot hell have brawled.. King John, ii. with the clamour of thy deam

bitter clamour of two eager tongues... Richard II. $\mathrm{i}$. with deafening clamour $. . . . . \ldots \ldots . .2$ Henry $I V$.ii. 4 why what tumultuous elarnour.....2 Henry VI. iii. canst but orngencious clamours!... Troil. \& Cress. shall dizzy with more clamour

the applause and clamour of the hos... Coringanus, with shouts and clumours. ....... Julius Carsar, iii.
can rent clamour from my throat can vent clamour from my throat .........Lear, $\mathrm{i}$. whilst $I$ was big in clamour.

lest, by his clamour (as it so fell out)..... Hamlet, , ii. Jove's dread clamours counterfeit ....... - iii. CLANG -and trumpet's clang? .... Taming of Sh. i. CLAP GOUR-dismal clingour heard.3 Henry $Y$ I. ii. to clap into your prayers ..........Mea. for Mea. iv. 3

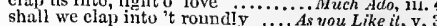

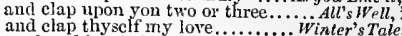
and clap thyself my love........... Winter's Tale i.

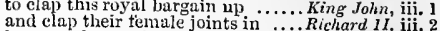
hostess, clap to the doors............. HenryI $V$. and so clay hands, and a bargain .... oll your leads clap round fines .....Henry $\bar{Y}$ III. v. they clap tle lubber Ajax ... Troitus \& Cressidan, ini. 3 if the tag-rag people did not clap him. Jul. C.eesar, i. .2 Antony, elays on lis sea-wing.. Anluny of Cleo. ili. \& what! fifty of my tollowers at a clap! ... Lear, i. 4

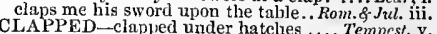
lct lim be clapped on the shoulder..... Muchs sdo, i.

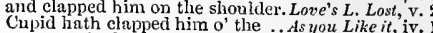
werd, clapped on the up so suddenly? Tam. of Sh. ï. of sugar, clapped even now ........ Henry HV.' ii. he would have clayped i' the clout...2 Henry $I V$. iii. let them be chipped up close $\ldots \ldots . . .2$ Heury VI. i. that's elapped upon the court-gate...Henry $\bar{V} I I I$, i. conpany clapped wings to me......... the sudden, clapped to their gattes . Coriolinu us, i. 4 and clapped their chopped hands...Jutius Crasar, i. and are most tyrannously clapped tor't. Hamlet, ii. CLAPPER-tongue is the clapper ..Muchddo, iii..
CLAPPER-CLAW-clapper-claw thee.Merry W. ii. 3
CLAPPER-CLAWING are clupper-clawing one another.. Troil. \& Cress. v. 4

clapper-de-claw! vat is dat? ....... Aerry Wives, ii. 3

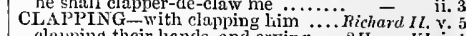
clapping their liands, and erying ...2 Henry $V I$. i. CLALENCE-Thomas of Clarence..2 2 HenryI $V$.

but well to thee, Thomas of Clarence
who saw the duke of Clarence? .......

and brother Clarence, and you

was Lionel duke of Clarence.......... i Hen $\overline{r y}$

duke of Clarence, the third son to king - ii.

duke of Clarence (from whose line .. - ii.

then, sentle Clisence, welconie unto

but, welcome, Clarence, $\mathrm{Edward}$ 's brot

yea, brother Clarence, art thou here too?
choosing mc, when Clarence is in place

that Clarence is so harsh, so hilt if $I$ claim by open war

had slipped our claim until....

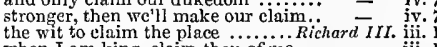

when I am king, claim thou of me...

Iny lord, I clain the gift, my due ...

that claim their offices this day

and claims to be high-steward

am your debtor, claim it when. Troil o $\overline{C r e s s}$ v.

were fit for thee to use, as they to ciain

for your claim, tair sister..................... Lear,
[Col. Knt.]-clains the conveyance .... Hamlet,

now to claim my vantage doth invite me

CLAIMED - your father claimed this son ..John, $\mathrm{i}$.

CLAIMING - your lighness claiming ..Henry $V$.

CLAMBER - clamber not you up. Mer. of Yertiee, ii.

her coronet weeds elambering to hang.. Hamlet,
CLAMOROUS-be clamorous, and leap Twelflh

keep back, the clamorous owl .....MIid. N.'s Dr. ii.

more clamorous than a parrot $\ldots$. ... As s you L Like ii, iv.
with slich a clamorous smack .. Taming of $S h$. iii.

those clamorouns harbingers of lilood .M.Macheth,, $\mathrm{v}$.

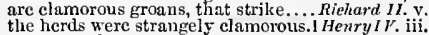

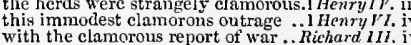

with the clamorous report of war... Richard 11I. i i.
clamorous denands of date-brole. Timon of $A$.

married the dukenel, duke of Clarence -

married the duke of Clarence' daugliter
from the duke of Clarence' house

let Georgc, of Clarence; Warvick..3 Henry

why, Clarence, to mysclf

is clarence, Henry, and his son

and as for Clarence, as my letters.

now brother of clarence, how like...

better would hive fitted me, or clarence =

alas, poor Clarence! is it for a wite..

Clarence will have the younger!

where Somerset and Clarence come.

cloosing me, when Clarence is in place -

answers Clarence to lis sovereign's will? =

and, Clarence, now then it is morc than

and thercin Clarence shall not want

anil, thou son Clarence, shatt atio...

well-minded Clarence, be thou fortunate

gutess, how nigh is Clarence now?....
then Clarence is at hand, I hear lis.

and lo, where George of Clarence sweeps -

good Clarence; this is brother-like.

What Clarenee, lint a quicksand

Clarence, excrise me to the king....
then, Clarence, do it thou

good Clarence, do; sweet Clarence

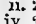

iv
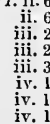

$$
\text { ing }
$$$$
\text { i }
$$$$
\text { iv }
$$

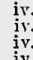

iv. 2
iv. 3
iv. 6

iv. 


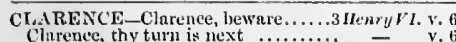
Clitrence, anil Gloster, love my lovely thanks, nuble Clarence; worthy .... this day shoutd Clurenee closely be... down to my soul! here Clareuce eones his wife, Clareuce, 'tis sice, that teinjers we are not sali, Clarence, we are not sute simple, plain Clarence! 1 do love thee and so shinll Clarence too ............. to urge his hitred more to Clarene Clarence linth not unother day his majesty agninst the duke of cliarenee murry, as for Clarence, he is well repaid for Clnrenee is well-ped, have monarehy atford false Clarence $i^{\prime} . .$. . Clarence is eome; fulse, fleeting ( $(\mathrm{rep}$ ) I woulli spenk with Clarenee.

the noble duke of Clarence to your... bitter sentence of poor Clarence' death? to take our brother Clatence ........
is Clurence dead? the order was reversed to my eloset: O poor Clarence! ;..... my teeble lands, Clarence and Edward dear lord Clarence! Alas, for both (rep.) haul we, but Clarence? and he's gone I tor a Clarence weep, so doth not (rep.) marry, my unele Clurence' angry ghust marry straight to Clarenee' daughter the son of Clarence have 1 penned. thou hadst a Clarence too ............. thy Clnrence he is dead, that thou madest away her unele Clarence pour Clarence, by thy guile...

CI.ARIBEL-fair daughter Claribel.... Tempest the next heir of Naples? Claribel.

how shanl that Clanbel metsure us...

CIASP-I am glad to clasp thee.. Troil \&

you clusp young Cupid s tables .... Cymmbeline, iu gold clasps locks in the golden......... Romer of Juleles, ii.

the gross cinsps of a lasrivious Mlour

CLASPING-untimely claspings with

elasping to the mast. endmed a

Clat

here comes signior Cland

why, how now, Claudio?

to her unhappy brother Claudio

see that Claudio be executed

it grieves me for the death of claudio

but yet, poor Claudio! there's no

business is a word or two with Claudio

dost thou think, Claudio, if $\mathrm{I}$ woul....

be ready, Claudio, for your death.

marry this Claudio is condem

marry, this claudio is conden

know how you find Claudio prepare

are to die Claudio and Barnardine

call hither Barnarline and Claudio

the warrant, Claudio, for th

what comfort is for Claudio.

huve you no countermand for cländ

and here comes Claudio's jardon.

let me have Claudio's he:d sent me

I may make my caze as Claudiös...

a man of Claudio's year

more like to Clandio

and how shall we eontinue Claudio...

buth Barnardine and Claudio..

unhapyy Clandio! wretehel Isabel!

am the sister of one Claudio...

Angelo for Claudio, death for death.

where Claudio stooped to death......

he dies for Clandio's dent

hnw eame it, claudio was beheaded.

when Claudio lost his head (re.)

she, Clandio, that you wronged.

the hearl of ha,gozine for Claudio's...

young Florentine, called Claudio ....... Iur $\overline{-}$

the company of the right noble

fignior Clantio, and signior Benediek

hear, comint Claudio

dost thou affect her, ciaullio?

and tell fuir llero I am Clandio

the prince discovered to Clandio.

who? the inost exiluisite Clumilio?

connes me the prince and Claudio...

and that is Clanclio

iil news with the ears of claudio

count Cla udio? Yea, the same

Thave brouglst count claulio.

here, Claulin, I have wood in ......

I warrant thee, Clandio, the time...

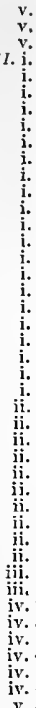

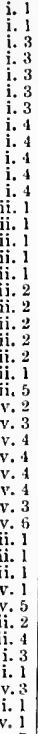

Macieth, v.

\section{v. 7}

i. 1 i

i. 1 i

i. 2

CLAUDIO-count Clandio shall marry. Anch.tio,

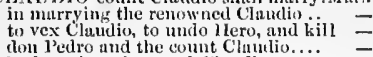
don 1 'edro and the count Clunulio.

[Cnt. Knt.]-slargaret term me Claudio

and such in man is Clandio ............

proposing with the prince and Clave

yet count Clautlio nany heur

the prince, Chuldio, and my master.

away went Claulio enrnger

the two priness lie? and Claudio lie?

unto the prince and Claudio

kill claudio

lio thine enemy?

count Claudio hath wronged ilero?

.

here comes the prince and ciaudio...

know, Clandio, to thy head.

dispose for heneetorth of poor Ciaudio

passed between you and ciaudio

the prince and Clautio mightily ubused

so are the prince and Claudi.

call young Claudio to a reckoning

and give her to young Clandio

from me, from Claudio, and the prince

here comes the prince, and claudio.

good-morrow, Claudio; we here
the prinee, and Claudio, have bee

they yere given me by Claudio....

1.AUDIUS.Clandius, and some........

Clandius! sirs, awake! Clamdi

CLAISE-reasons from this clause. Tuetsth $\overline{N i g h t, \text { iii. }}$

shall -elaw no man in his humour..Much Adn

shall hang out for the lion's claws.. Mid. N. Dr. iv. 2
if a talent be a claw, look (rep.)... Love's L. Lost, iv. 2

wounded with the claws of a lion...As you Like it, v.
CLAWED-clawed like a parrot ....2 HenryIV.'ii.

clnwed [Knt,-eauglic] me in lus.

was now a king, and now is clay

but gilded loam, or painted elay ...... Richard 11 . this toolish compounded elay, man...2 llenry IV
with charity enclosed in elay ........ Henry $V$.
to support this lump of clay

and temper elay with the blood

iHenry $V^{\prime}$

kingdoms are elay; our dungy ...Antony \& Cleo.

waters that you lose, to temper clay ...... Lear.

a pit of elay for to be made (rep.).Hainlet, $\mathrm{v}$. I (song

i. 5
ii. 1 CLAY-BRAINED-clay-brained guts. $\ddot{H}$ Henry $I V$. ii. 4
CLA

ii. I too few to wash her clean again $\ldots \ldots$ Mach Ado, iv.

ii. 2 to wash your liver as clean

for keeping his sword elean ..........All's Well, iv.

iii. 1 notling like so clean kept. Asia. Comedyof Err.i.

wash this blood cleau from my band?... nacbeth, ii. 2

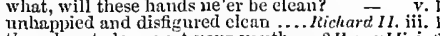

iii. 2 thongli not clean past your youth....2 HenryI $V_{\text {i. }}$ i. 2

iii. 2 will he wipe lis tribies elear

sweep the eourt ele:un ot such.......

......2Henry

domestic broils clem over-blowa ... Richard Iil. ii.

iv. 2 would thou sert clean enough ... Timon of Alh. iy. 3

and keep their teeth elean ........... Coriolanus, ii. 3

clean from the puipose

ere clean it o'ertlurow nature.......... Cymbeline, iii.

it is clean out of the Way ............ Ohe lle,

CLEANLY-not neat, but elcanly.. Winter's Tal

wherein neat and cleanly

and live cleanly, as a nobleman should

\begin{tabular}{l|l} 
iv. & and ive cleanly, as a nobleman should \\
iv. 3 & and borne her eleanly by ... Tikus Andronicu \\
iv. 3 & CLEANSE-
\end{tabular}

v. 1 cleanse the stuffed bosom of that ....... Hacbeth,

CLEANSI NG-in cleansing them... . Richard III.

CI

v. I l lector was not so clean-timbered.. Love's L. Lost, v,

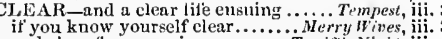
and clear from any image ........ Tuelfih $\mathrm{N}^{\prime} \mathrm{g} h \mathrm{~h}$, ili. let me be clear of thee....

given ine wireh elear lights of favour - v. it is almost clear dawn ........Meas. for Meas.

will make up full clear.

by fountain clear, or spangled....irid. N. Dream, ii. I how to get elear of all the debts....Mer of $\bar{T}$ enice, $\mathrm{i}$. thut clear honour were purchased.

this wrestler shatl clear all

slye looks as clear as morning ..... Taming ot Thth $^{2}$ ii.

posterns, elear them o' the eity
it they please, etn elenr me in

will cleur, or end, the business

shall clear that doubt.

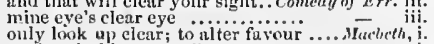

C1.EA Ji-tranchised, and allegiance elear.M acteth, ii. I It little water elears us of this deed

go foul a sky clears not witlout elear - v. so foul a shy clears not withiont

and offences with as clear excusc..

and 1, in the clear sky of tame

go, elear tliy crystals

Henrylt: iii.

- ii. 3

so elcar, so slining, ant so evident

eliarge whith alear the from

is Inaster, clear as diny....

that you will cicar yourselt from a....

proof's as cleal as tounts in July.... Henryllith.

by durkening my elear smi...

this eandle burns uet alear

that I shall clcar iny self

'tis clear, they' 11 say, tis naught ...

fountain of your mind were elcar.
craek my elear voice with sobs

villouies of more clear, what y past... - No

and nake a clear wny to the cletr. Thion of

you cannot make gross sins look clear

drop our clear juil

clear up, fitir queen, that clondy... Titus Andron.

see clear to stop the air would hint .... Pericles, i. 1

persevere stili in that to keep you clear

by ler own most elear reme
as clears her from all blame..

not yet thy sighs from heaven clears. Rom. o Jul. ii.

they got elear of our ship....... Haniel, iv. 6 (letter)

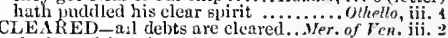

the imposition cleared, hereditary. Hinter's Tale, i.

see the coast cleared, and then...... Henry $r$. i. 3

by time let them be cleared ........ Cymbeline, jy. 3

till the ship be cleared of the dead ..... Pericles, iji. 1

CLEAREL-mantle their clearcr ruson. Tempest, v.

your mind's the clearer, Ajax...Troilus \& Cress. ii.

CLEARLY - clearly banished .... Twetfth Nighi,

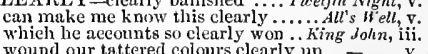

do not understand yourself so clearly ... IIamiet, i.

that I require a elearness .............. Alucbeth, iii.

that 1 require a elearness ............. Mucbeth, iii.

CLEAVE-thy thoughts I eleare to.... Tempest, iv.

to cleave a heart in twain .......Meas. for Meas. iii.

my tongue cleave to my roof......... Richar $\bar{d} I I . \mathrm{v}$.

cleave me to the girdle................ Rim on dthens, iii.

our good eity cleave in the midst.. Coriblamus, iii. 2

O cleave, my sides! heart, once
cleave to no revenge but lucius.. Titus Andron. 12

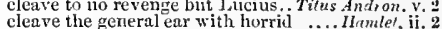

LEAVING-by clearing the pin, Love'sL. Los 1 , iv.

Ci.EFT-perjury eleft to the root. Tu. Gene of ler. $^{2}$.

have cleft his elub to make............. Much Ado, ii.

cleft the heart that conld......... Winler's Thle, iii. 2

cleft his beaver with a downright ..3Mlerry VI. i.

thou hast eleft my henrt in twain ...... Hounlet, iii.

CLEMENCY - to your clemeney ....... $\overline{\text { iii. } 2 \text { (prol.) }}$

more clement than vile men ....... Cymbelme, v.

before I came to Ciement's-inn ....... -

when I lay at Clement's-inn ........ - iij.

CLEOALNEs-Cleomenes and Dion. Irinier's $T$ ii.

Clcomenes and Dion, being well

go, cleomenes; rourself, assisted with - in.

most hononred Cleon, I must needs be Pericles, iii.

by Cleou trained in music, letters.... - iv. (Grow.

that Cleon's wife, with envy rare..... -

till cruel cleon, with his wicked wife..
she shonld have been, by sarage Cleon

she should have been, by sarage Cleon

she at Tharsus was nursel with Cleon :- v.

CI,EOPATRA-

Cleopatra's mujesty ....As ynu Like it, iii. -2 (verses)

Cleopatra's health to iluiui

name cleopatra as she's calleil in liome -

Cleopatra, catching but the least nuise

especially that of Cleopatia's

so netr the heart as Cleopatra this

salt Cleopatra, sotten thy waned lip!

if Cleopintra hearl you, your reprouf

jumy you, is he married to Cleopratra?

Cleopatrin liath nodded him to lier 


\section{CLE}

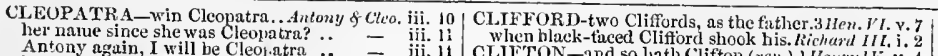
Auilt in again, I will be Cleopatrats sails their nests. ince cleopatia died, liovatia my mistress Cleopatra sent ine to the good friends where Cleopratra bides OCleopatra! thou art tuken, queen Cleopatra, do not abuse my master" Cleojatra,--think you, there was Cleopatra, know, we will extenuate. shall advise me in all for Cleopatra. nay, blush nut, Clcopatra ............. some squeaking Cleopatra boy

the story proud cleopatra ............ Cyme CLEPE - they clepe us drunk gipsy... Rom. f CLLPED -are cleped all by the name..... CLERGY $\rightarrow$ at one time the clergy yet ... as never did the clergy

the elergy's bags are lank and lean...2nenry JT. i. 3 CLERGYMAN an ill example .... Iermy IIII. ir. 2

you holy eler-among the clergymen

Jon holy clergymea, is there no. CLEl great clerks have purposed ..... Mid. N' 's Dretum, v. (riverianl of the judge's clerk! but well

the judge's clerk; a prating hoy.

then the boy, his clerk, that towk some

I'll mar the young clerk's pen

Nerissa there, her clerk.

the clerk, that is to make me (rep)

I were couching some good comforts ...

take the priest, clerk, and some.. Taming

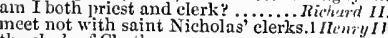
the clerk of Chatham ...............

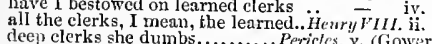
deep elerks she dumbs..........Pericles, ${ }^{2}$ (Gower thou art clerkly, thou art clerkly. Geriof thougl clerkly couched, as if slie...2 Hen Wirts, iv. CLIENT-counsellors lack no clients. Heat for Mea.i. 2 attornies to their client woes...... Rich wh
she should do her clients ber fitment..P

ii. 11 CLIIT TON-and so hath Clifton $(r e p)$..1 Henry/ $r . v$. CLIMATE

and four the quality 0 t the

the climate's delicate; the air...

our air, whilst you do climate here!

that, in a cliristian climate

is not their climate loggy, raw

Richartl $1 I$, iv.

unto the climate that they point

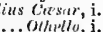

minto our climatures ..Hkmlet, i to climb celestial sil via's

one caunot climb it without

climb o'er the house to unlock...... Love's $\overrightarrow{L . L o s t}, \mathbf{i}$.

which they will climb incontinent

or else climb upward to what they...... inativeth iv. what, and wouldst elimb a tree?

and made me climb with danger

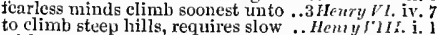

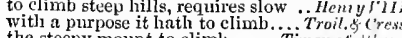

the steepy mount to eliml...... Timan of

whose top to climb is eertain fait

let our crooked sinokes climb

and climb the highest promontory top

nor I no strengtli to cling without

jon do climb up it now: look .................

are high, and hard to climb........ Rome o

let tle labouring bark climb hills of seas.

that chimbed unto tleir nest.

CLIMBER-washed off a canvas cliniber. Peric
CIIMBER-UPWARD-where to the climber-

CLINward turns his face ..........Jutius Casa

CLIMBING-still climbin trees.. Love's L. Los.

quartering steel, and climbing $\mathrm{f}$

and bought his clinibing very dear
climbing my walls in spite of me

climbing my walls in syite of
down, thou elimbing sorrow...

thou art flying to a fresher cliun

cold and sickness pines the clime.

to choke your clime, the smell

back again unto my native clime?..2 IIenry IT. iit. 2 matches, of her own clime, complexion. Othello iii. cliNG-that do cling together...

CLINK - eanakin elink (rep.) .... Ol

CLINKING-clinking of pewt
CLINQUANT $\rightarrow$ all clinquant

Hamlet, there is a eliff, whose high and bendin the dreadful summit of the eliff

a Clifturd! a clifford? We'll follow

and here cornes Cliffird to com

I thank thee, Clifford

we are thy sovereign, Clifford.

Clifford of cumberland, 'tis Warwick

Cliftord, I say, come forth (rep.).......
dear?ly-laneled Clifford slew my steed

I intend Cliftord, to thrive to day...

new ruin of old Clifford's house

and thine, lord Clifford

the hope thereof makes clifford........

true, Clifford; and that's Richard.

foor Clifford vows to fight in

o cliflord, how thy

look, where bloody Clifford comes!

ah, clifford murder not this innocent

ali, gentle Clifford, kill me with

sweet Clifford, hear me speal.
and, Clifford, cope with him

I bray; sweet Clifford, pity më!
bloody Cliftord, rough Northum

bloody Cliftord, rough Northumberlan

holld, valiant Clifford! for.......

warriors, Clifford and Northumberland

valiant Clifford, with his rapier's.

lurrl-hearted Clifriurd, take me

Clitford's and Northumberland

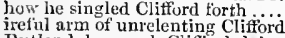

Rutland, by rough Cliffird slai

the stern lord Clifford done to death

thisn common fear of Clitford's rigour

with Clifiord, and the haught..

Clithord, were thy heart as hard.

but, Cliffurd, tell me, didst tho

'twas not your valour, Clifford, drove

upou that Cliftord, that cruel

that Clitford's manhood lies.............

now, cheen, and Clifford too liave chid

for 'tis Clifford wlio not contentei...

head, which Clifford placed there

syeak, clitiord, dost thou know ...

CLiflord, repent in hontless (rep.)

they mrick thee, Clifford! swear
when Clifford cannot siare his.
CLIP - wiugs elip dead men's graves..2 Her

enter the city, elip your wives .. Antony
the earth shall clip in it a pair so famous

will $\mathrm{I}$, my loved Marina, clip to form...

nts that clip us rond about! othello. CLIPPED-clipped in with the sea ...1 Henry I

clipped about with this most tender air
cliper

CLIPPER, nor clipped, but so ............ Lear, iv.

CLIPPETI - who clippeth thee abuut. King John CLIPPING - with clipping lier .... Hinter's Tate,
CLIPT_Judas Maccabous clipt ... Love's L. Lost,
CLIP-WVINGE CLITUS - sit thoe down, clitus $(. . .1$ Henryl $V$. iii, I ClITUS -sit thee down, Clitus
o Clitus! what ill request ( rep

a cloak as long as thine.

then let me sec thy cloak.

fastion me to wear a cloak?

let me feel tliy cloak upon ine

an old cloak makes a new jerkin ....Merry $\bar{T}$ ines,

or a hat, or a cloak, is notluing .......Much Ado, iii. 3

a scarlet eloak! and a copratain hat!...

not line his thin bestained elotk .....King John, iv. 3

Whe cloak of night being plucked ..Kichard $I I$. ii. 2
the
satin for my short cloak and slops?..2Henry $\mathrm{V} . \mathrm{i} .2$

give me my short cloak and slop

fike a wet cloak ill laid up

lend me thy cloak, sir Thomas

but cloaks aud gowns beforc thi

wise men put on their cloak

hats, clonks (doublets, I think)

Henry $r$.

what hast thou there under thy cloak

hault their faces buried in their eloaks

I lave niglit's cloak to hide me.. Rame of

tis not alone my inky cloak ........... Hamle'

ii. 2
ii. 3
CLOA th-BA thine auld eloak $\ldots . . . . .0$ otheilo, ii. 3 (sing)

("tis in my cloak-hag,) doublet, hat... Cymbeline, iii.

vat is de cluck, Jack? ................. Terry llives, ii.

the elock gives me iny eue

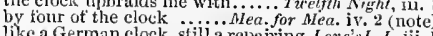

like a German elock, stili a repaining. Love's L. L. iii.

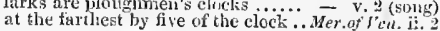

CLOCK-cver run hefore the clock. Mer. of Venice, ii.
there's no elock in the forest of time, as well as a fore

and his honour, elock to itself

thee not a jar o the clock behind...Winte's's Tale, $\mathrm{i}$.

the elock hath strueker twelve. Co....

should be your clock, and strike you

and now the clock strikes one............

by the clock, 'tis day

time

o' the clock this mo clock...hechard $11 . v$.

and eluclis the tongues of bawds ....... Henry IV.j. about three of the clock............ * IIenry $I V . i$. the clocks do toll, and the thiri... Henry $V$. iv. (cho. like clocks, still to strike on ......... Henry $/ 1 . \mathrm{i}$. count clock there; give me .......Richard III. v. canst aw'ake by four o' the clock ... Jutius Casar, ii. the sands tliut run i' the clock's behalf - iii. upou a time unhappy was the clock... CCUCK-SETTER-the clock-setter...King Joliet, ii. CrUCK-SETTER - the clock-setter..King John, iii. to a clod of wayward marl?............ Hisch Ado, ii. CLODYY -the meagre eloddy eartl....King John, v. CLOD POLE - from a elod-pole .. Twelfhi Jight, iii.

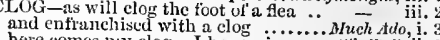

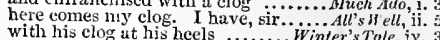
the tinie that clogs me wit

with clog of conseience, and sour....... Richard

to hang cloge on them $\ldots \ldots \ldots \ldots \ldots \ldots$.

CL.OGGING - the clogging burden.... Richard $I I$

my sister should the eloister enter.. Mea. far Mea.

steal, sir, an egg out of a cloister..... All's $\mathrm{Wr}+\mathrm{Wl}$,

and cloister thee in some religious... Richard 11 .

CLOISTER ED-lis cloistered flight ... Macbeth, iii.

to close prison he commanded...TwaGen.of Ter. iji.

close at the beels of her virtues.

to make this hapny elose.
close by the 'Thames' side.

doth of t close in pollution.

close, in the name of jesting

follows close the riurour............. - v.

hark! how the villuin would close now -

runs elose liy the ground...............

some treason vuasters; yct stand $\ldots . .$.

政

stand close; this is the same ......... - iii.

of death close up mine cye

for the close night doth .... Merchant of venice,

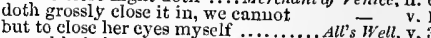
but to close her eyes myself ..........All's Well, v. 3 is to close our stomachs up.

to lie close ly his honest bones...Winter's T'ale, iii. or the close earth womls

of great anthority; close with him

killed it; she'll close, and be herself.'. Macbeth, the close contriver of all harms......

young princes, close your hands ....... King $\bar{J}_{o h}$, that cluse aspect of his does show ..... - iv. music at the close, as the last taste...Richard $I I$.
and furious close of civil butchery ... Henry $V$.

staud ear close to the ground $\ldots \ldots \ldots \ldots$ -. ii. 22

but I followed me elose, caine in ..... -

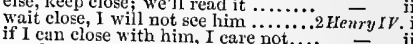

gentlewoman to close with us? $\ldots . . .$. . - ii.

as many lines close in the dial's centre - i. 2

keep close; I thee command

or close the wall up with our $\ldots$ English

when death doth close his tender

let's stand close; my lord Protector..2 Henry/ VI. i. 3

et them be clapped up close, and kept
in this close walk, to satisty nyself.

in this is close walk, to satisty myself..

ery ont f'or thee to close up mine eyes

these upes shall never draw (rep.).... -

that makes him close his eyes?

or else lold close thy lips..........

a sor another secret close intent ...Richard $I I I$ i.

temut unto a dose deudy ....... - i.

I will take order tor lier keeping close

let's staud have I penued up close.. - iv.

standaud close, and behold him ...Henry VIII. ii.

draw the curtain close; we slial $\ldots . . . \pm-$ iv.

keep the door close, sirrah

an 'twere durk, you'd close sooner. Troil. \& $\bar{C}_{\text {Cres. }}$ iii.

to bold youl: hand more close .. Timon of Athens, ii.

let your close fire predominate ...... - iv. 


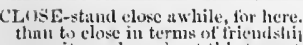

nuw sit we elose nuput this tul.er lle.

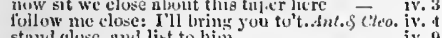
stund cluse, and list to him

down winlows close; mul golden...

prayed me to excuse her keeping ciuse

close villain, ril hatve this secert ....ï

the inarble pavement eleses

the narbe parement eloses.......

stop close their mouths

hinw close tis enulked and bitinieili.

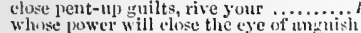

clase fithting ere I did ajpriach. Lioneo of

to himsclt so sceret amin so close......
[Kin.] to my ghostly friar's close coil

ho thou but close our hands with holy

gisread thy' close curtain

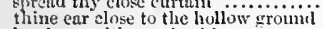

he eloses with you in this consequence. Hut

ciluses in the conse(juence (repl.).........

tillow her closes give her gowl watch

keep close witluin your chanubr.

I tivund them elose together .............

seci her fat tere's eyes up, close as ouk.

clous shall cluse prisoner rest

nat ture hath in him closed.

(ivi. 5

hath elosed these eyes of used

linth elosed these eyes of mine.
shill fortliwith be closed in our

of a despised life, closed in my r...Titus.st th ran, y. 3

living corse, clused in a dead man's tomb!

a cup, elised in my true love's hand?

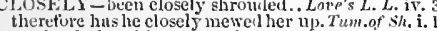

go elosely in with me; much danger. King John, i. .

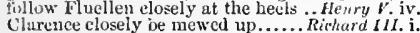

Clarence closely be metred up

as closcly to conceal what we impart
to keep her closely at my eell ... Romeo \& J Jutiet,

We lave closely sent for Humlet ....... Humlet, iij. 1

CLOSENESS-all dedicate to closeness. "Tempest, i.

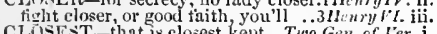

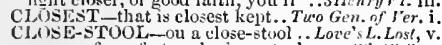

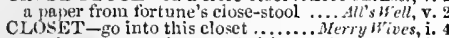

vetely me in my closet nu boitier..... ver' -

dere is some simplese in my closet

vat is in $\mathrm{my}$ closet?

do in my closet? dere is no honest

unlock her clocet, take forth pape
but to my closet bring the angry

when you come into your close

When you come into your clos
and, in thy closet pent up, rue

bed-work, mappery, closet war.... Rroit, . C Cress. ii. 1

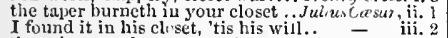

the primroses, bear to my clo-et.

I'l to thy cluset; and go read witi... Thus as And. iii. 2

hither all the boxes in my clo
at the casement of my closet

I have locked the letter in nny ciose

go with me into my closet, to hel
in my closet [Col. Knt.-chamber

dessizes to speak with you in her closet.. $=$ iii. 2

and from his mother's closet hath he

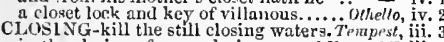

in the closing of some glorious ....1 Henry $1 \%$. iii. 2

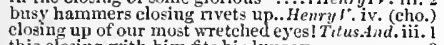

this efosing with him fits his lunacy.

CLiSURE-guilty closure of thy wali:.Rieh. TII. iii. 3

make a mutual closure of our louse.. Titus Amt. y. 3
Cl,OTEN-Cloten, whose love-suit.. Cymbeline,

'tis Cloten, the son o' the gueen....

Cloten, thou villain. Cloten thou double -

this Cloten was a fool an Cloten

cut off one Cloten's head, son to

he's the queen's son, Cloten: that 's ail
I'd let a parish of such Clotens blond

what Cloten's being here to us portends

I have sent Cloten's clot
for Cloten is quite forgot

Cloten, hast here eut otf my iord

tis he, and Cloten: malice and lucre

'tis he, and Cloten: malice and lucre
this is Pisanio's deed, and Cloten's

for Cloten, there wants no diligence..

newness uf Cloten's death.

though Cloten then but young.......

lord Cloten, non my lady's missing

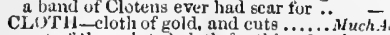

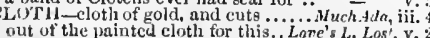

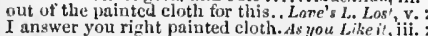

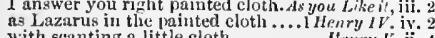

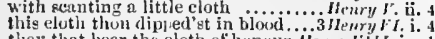

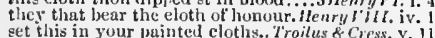

patched with cluth of any colour . . Corimlenus, iii.

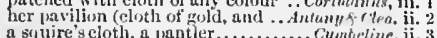

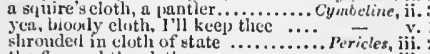

slronderl in cloth of state
the firc and the cloth:

the firc and the cloths
cLUTHA.............

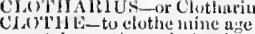

5o, take $u p$ these clothes her.:
in the name of foul elothes

mult anny went I for funl clotices.

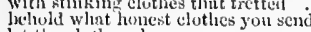

let the clothes alone

thesc clothes are good enour

or elotlie a lack, trom such

lonest in nuthing but in his elothic

to drown my clothes, and say

held familivitity with fresler cloithc:

Wrapped in swect elothes . Tamin
fillow Tranio stolen your ciotlies

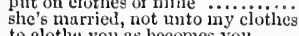

sce you thou as becomes you......

llotspor Mlars in swathing ciothes...

lay more clothes on lis feet.............. He ury $V$ ii. 3

their clothes are after such a parau. Lichend IiI. i.

at fiol in good clothes

i' the swathing clothes the other

I will execute in the clothes that she

know'st me not by my eluthe
he made tloose clothes, which

care no more to clotie and eat

and has excellent good clothes
through tattered clothes sinull

dressed! and in your clothes! .. Liom

good spirits, to teed, and clothe thee?

her clothes syread wide

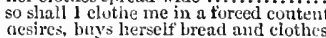

CLOTH THD-ilaurhter, clothed like a br
furtherance, $I$ an cluthed in stecl.

CLOTHIER-Jack Cade the clothier.:. Henry $T$.

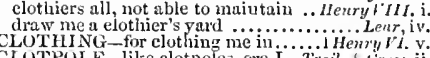

CLOTHING-for clothing me in ....... He
CLOTPOLE- like clotpoles, ere I... Troit.

I have sent Cloten's clo
call the clotpole baek...

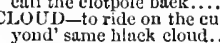

yond' same cloud cannot choos...........

the elouds, nuethought, would wpen

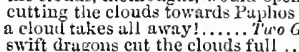

swift dragons ent the clouds ful

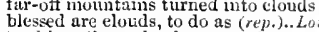

blessed are elouds, to do as (rep.)... Lo
to shine (thuse clouds removed upou

are angels vailing clouds,
the scene begins to cloud

let not the cloud of sorrow justie it

beams distracted clouds give way ....

like a summer's cloud, without

sits in a foggy cloud, and stays tior

the uglier seem the clouds thiat

my English breath in foreign cloud

is mustering in his clouds

base contagious clouds to sinot
dropped down from the clouds

subject to the weeping clouds.....

spirits of the wise sit in the clond

for my cloud of disnity is held

filthy and contagious clouds of
do break the elouds, as did the

up so suddeuly into the clouds

he'd be above the clouds
hath the brightest day a cioud

with the southern clouds contend
separated with the racking cloud

separated with the racking cloud
when dying clouds contend with

do cloud my joys with danger

black, suspicions, tlureatening cloud.

for every cloud engenders not..

the clouds, that lowered upon

the clouds, and enter hetveu (rep.)

When clouds are scen, wise men
du through the clouds behold this

even this instunt cloud puts on .
call her from this cloud of ilark

call her from this cloud of dark "ines

wanton tops do buss the clouds

one cloud of winter show
he goes away in a cloud

goes away in a cloud.

by yon clouds, let me deserve so ill. Cario
if Jupiter slould from you cloud spenk

exalted with the threatening clouds.
lowks in the elouds, seoning the base

that fret the elouds, are mesengers.

Warriors fight upon the clouds.

clouds, dews, and dangers, come

sometimes re see a cloud that'

to be encountered with a eloud. $\ddot{T}_{\text {; }}$

sometime clouds, when they do lug

Why cloud thicy not their sights...

they kissed the clouds, and strangers.

a hand environed with chouds
audding to clouda more clouds

he lestrickes the lazy-11ucing coloutls

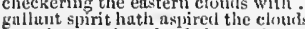

face the severing clowens in the clours

foce the severing clouds in yondur cht
is there no pity' sitting in the elunds

HenryIV.i.

Henry $V$. iii.

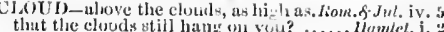

cannon to the clouds shill we

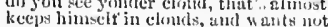

and tongues, aprolaud it to the clonds...

clutow secming ty pelt the clumel.

My sovereirn mistres cloulded

and Elwarel's sun is clonled..

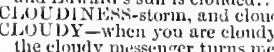

Rirharil Il. iit.

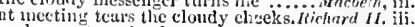

such aspect as cloudy men
and Sutfolk's cloudy brow

dark clouty death o'crisades

thy cloudy wrath hath in etering

2Henry bi iii.

coudy princes, and heart-sorruwin

Ilenry Vi. ii.

ueur, thut cloudy countenance .. Titus.tadron. ii.

my sileuce, and ny cloudy nelancholy?

bring in clondy niglint immediately. Rom of $J$, ii.

a dost, iv.

gavest the duke a elout, stecped.....Riehard III. i.

flome with clouts about their heads. Ant. \& Cieo. iv. 7

i' the clout, i' the clout: hewglt! ........ Lear, iv. 6

a elout npon that head, where late

phit my clouted brogucs from otf

LOVEN-into a cloven pine

stuck with cloves. Jo cloven... Love's $L$. Lost

makes amongst your cloven army ... Coriolanus,

CLOVER-burnet, and green cluver..... Henry ${ }^{\prime}$.

CLOWDER-couple Clowder.. Taming of si . I (i
CLOWN - a most simple clown!.. Lave's $L$. Lost,

sweet elown, sweeter fool, sweetest

the roynish clown, at whom so ott. As you Like

mcat nud drink to me to see a clown

therefore, you elown, abaudon

or, clown, thou jerishest

ny clown (who wants but ....... W'inter's Tale

the clowm shall make those laugh

let those, that play your clowns

LOY - or cloy the huniry edge

now I cloy me with bcholding
other women cloy th' nppetio

wing, and cluys his beak

whou he hath cloyed and graced

when they are cloyed with long

and ears so cloyed importantly

mine eyes are eloyed wit
CLOYLES-with cluyles

2Henryll. iv.

LOY IIENT - surfeit closment....Aat. o Cleo. ii.

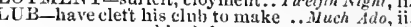

seems as massy as his club ....

is two hard tor Hercules' club...
not so big as the cnd of his club

Whose club killed Cerberu

clubs camnot part them.

wointn, who cricd out, elubi

Love's L. Losi, i.

where go rou cricd out, elubs!.......

make you reudy your atill bats ancic

tliat grasped the heaviest club..An/ony \& Cleo. iv i.

chubs! clubs! these lovers will not.. Tilus And.

great kinsman's bone, as with a club

LUE-you have wound a goodly clue... Coriolanus,

CLNG-how they eluag in their ...Menry :III,

liere come the clusters

CLUSTERING - to elustering fiiberds ... Tempest, ii.

iuto the clustering battle

CLU'TCH-come, let me cluteh thice.....Mreteth, ii.

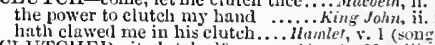

CLUTCHED_it clutehed?.

clutehel as nany millioas

CLY'TUS-kill his pest trienist, cly tus . Othello, ii.

Alexander is kill his triend

wut as a conch doth earry. Lore's 1 . Los ir. 3 (verses)

whe I am in my coach....

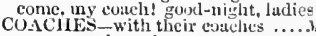

......erry Nives, ii.

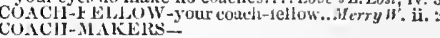

the fuiries' evach-makers........ Nomeo \&. Juliet, i.

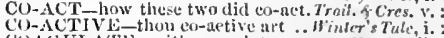

COAGULA'TE- with congulate gore.... Il'matet,

und all cyeser oll the evats.... Herch of benice,

no malice in this burning eual....... King John, iv.

the men would carry enals

llenry V. iii. 
COAT_hot coals of rengeance! ......2Henry F. v. 2 COCK-a cock that nobody can mateh. Cymbeline, ii, 1

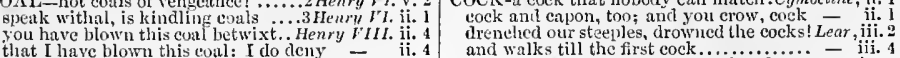
ald more couls to Cancer. Troilus of

than is the conl of tire upon

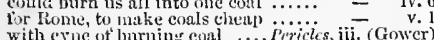
my wori, we'll not earry conls... Romeo of Juliet, $\mathrm{i}$. black, forsootla; contl-hluck as jet ...2 Itenry FT. wound about thy coal-black hair ...3 Hewry VI. coul-black is better than another lue

they never do beget a coal-hlack
co.tkSE- of whint coarse metal

COARSELY-reports but coarsely..... Ali's sF' COAST-travelling along this coust. I.ove fromevery coast renowned su

private fricuds, unon this cons

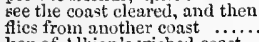

ken of Allion's wished const

Euglaad, for it is your nat

liave arrived our const ........

on the westerm const ridetll......

to show what coast thy sluggish.

ine landed on your coals $t$

batters all rebelling const

from coast to coast is tost ........
the sea hath east upou your coast.

mariner, say r'lat coast this is?

upon this coast, I warrant you

give a constin's welconeere it comes. Tredly of Err. i.

$\mathrm{cơ} \mathrm{AT} \rightarrow$ white luces in their cont..... Merry Hives, $\mathrm{i}$.

it is an old coat ................

the salt fish is an old cont........

if he has a quarter of your coat $\ldots . . . . .$.

and walks till the first cock............

diminisherl to her cock; her cock. a buoy $\overline{\text { iv }}$ iv.
the secund eock hath crowerl .. Romeo \& Julict, iv.

about to speak when the cock erew .... Hnmlet,

it thedel on the erowing of the coek .......

the snorning eock erew lond

cor cock, they are to blame........ - iv. 5 (song)

COCKATRICE-like cockatrices.. Fuelfih Night, iti.

the fleat in-rlarting eye of cockattice. Ron. \& Jul iii.

COCKERED-a cockered silken wanton, John, v.

tis a cockle, or a walunt-shell

sail seas in cockles, have ....Pericles, iv, 4 (Gower)

hy his cockle hat and staff....... Hainlet, iv. 5 (song)
Co' 'KLED-lorns of' cockled snails... Love's L. L. iv. 3

CUCKNEY-will prove : cockney.. Tuelfth Night, iv.

an the cockney did to the e
cock-PIGEON-

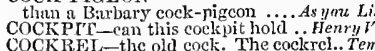

as big as a young cock rel's stone .. Romeo \& Jul. i. COCK-SHU' $\mathrm{T}$-abont cock-shut time. Richard II

COCTrTS-siniplicity, bis coctus!. . Love's L. Lost, iv. COCYTUS-as Cocytns' misty moutl... Tit us And. ii.
COD-your kas, and your cods ..... Herry Wives, iv.
from whom I took two cods....... As you Like il, ii.
change the cod's heal for the saimon's.. O/hello, ii.

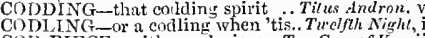

a cod-pice to stick pins on

for the rebellion of a cod-piece. Mens. for Meas. jii. where his cod-piece seems as massy. Mweth Ado, iii. nothing to geld a cort-picce of a purse Winter's T'. iv.
the cod-piece that will house .... Lear, iii. 2 (song) MELI'P, here's grace, and a cod-piece.... Instalment, coat, and several erest

I would not be in some of your coats.. Tweln!

as to slow a clild hif new coat..........inch A to in their gold coats spots you sce...

to make my small elves coits.....

I could shake them off my coat

did stretch his leathern coat alm

their blne coats brushed.......
Nathanicl's cont, sir, was not

Nathanicl's cont, sir, was no
with silken coats, and caps .

in my green velvet eoat....

may enter Alowbray's waxen cont ...Richard $11 . \mathrm{j}$.

shall make coats to deck our .......

torn my houselnold coat, razed out

flittcring in golden conts, like .... Henry $I V$

in his coats. Now, by my sword ( $r$ ap.)

等

spoil his coat, with seanting $I$ ind a hole in his coat, $I$ wil

lank-lean clieeks, and war-worn coats - iv. (ch.

gay new coats o'er the French soldiers' - iv.
of England's coat one half is cut ....1 Henry VI. i. 1

give me my stecled coat.

out, tawny conts! out scarle

the lions out of England's coat

down with the tawny coats!

for his cnat is of proof..

throw away our coats of steei ......... 3 Henry $V I$. ii.

in a long motley cont, guarded... Henry VIII. (prol.

your long eoat, priest, protects you.. pericles, $_{\text {ii. }}$ iif

when they have lined their coats.

COBBLE-Why sir, cobble yon. ...... Julius Casar,

thou art a cobbler, art thou? Traly,
Cor

thou art a cobbler, art thou? Truly, sir - i.
COBII.AM-Reignold lord Cubham ...Richnet II. ii.

Ed ward, shall unto my lord Cobham.3 Henry $V t$.

cot moble Warwiek, Cobham, and the rest

COBWEB-Peas-blosem! Cobwel)! . Wi

Cobweb. I shall desire you (rep.).

fuster than gnats in colnwebs ...Mer, of Venice, iil.

rushes strewed, cobwelss swept ... Taming of $\mathrm{Sh}$. iv. I

rhe old cork. The cockrel

to crow like a cock ........ Tü Gen of Ferona, ii.

by cuck and pye, you shail ............ Herry Wives,

of what kiad ghowld this cock come. As you Like, ii.

a coinbless cock, so Kate (rep.) .. Taming of Sh.
cock's passion, silence! I hear $\ldots \ldots$.
if tine springe hold, the cock's mine. ivinter's $T$.

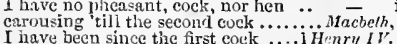

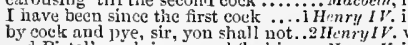
aild Pistol's cock is up, and Hashing ...Menry $V$. ii. and comntry cocks do crow ....... - . iv iv. (ehorus)

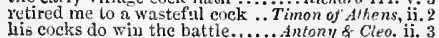

CCELIUS-and Coelins, are tor sea .. Ant. \& Clen. iii. 7
CGLLO-the ear of colo, - the sky. Love's L. Lost, iv. 2

he hath a trick of Coetrr-de-lion's face -

or the reputed son of Cour-de-liom .

God for'give you Conr-de-lion's death - ii
Coenr-de-lion's heart was buried ..1 Henry VI. iii
OFFER-cuckoldy rogue's coffer... Merry Wives, ii.

my cofters ransacked, mr reputatio
in the chambers, and in the coffers

neither press, coffer, chest, trunk ....
hold, there is half nyy cofter .... Titelfh
Night,

remaining in the cotiter of her.... . Mreas. for Heass. $i$.

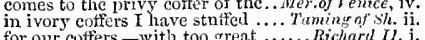

for our cutfers, - with too great.

shull our coffers then be enptied.

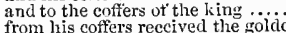

and all out of an empty coffer...Timon of Athen

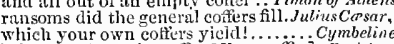

to the bay, and disembark my coffers .... othello,

ant the ducats in her coffin let. Tuelfth $N$. ii. 4 (son

within this coffin $I$ present thy $\ldots$. Richard $I I$.

upon a wooden coffin we altend...... 1 Henry $V I$.

my heart is in the cothin there..... Julins Casar, iii.
sons in coffins fron the field...... Titus Andron. $\mathrm{i}$.

of the paste a coffin I will rear
[Knt.] bring me the satin cofin

I oned the cotfin, and found there rich.. . Coriol. ij. 3
COFFINED-had I come colfined home

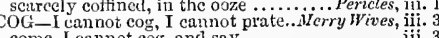

that lie, and cog, and fl sut, deprave... Much Ado, $\mathrm{v}$.

since you can cos, I'll play' no.... Lnev's L. I ost, y.
deceive, and cor, duck with French. Richnrd III.

and youl hear hin cog, see him. Timnn of Athens, v.

cog thcir hearts from them ......... Coriolanus, ili. 2
COGGING-cogging companion ... Merry Wives, iii. I
come both, you cogging Greeks.. Troilus \& Cress. v. 6

soine cogsing cozening slave $\ldots . . . . . . . . .0 t h e l l o$, iv.

great value, worthy cogitations.... Julius Cesar, i. 2

COGNITIUN-nor have cugnition... Troil.\& Cress. y. 2

cognizance of her incontinency....... Cymbeline, ii.

COGSCOYB-knave's cogscomb ... Merry Wives, iij. 1

COHERE-do cohere, and jump.... Twelf'h Nighi, v. 1

COIIERENCE-cohercnee of his men's. 2 Hen.IV .7 .1

COHERENT-may prove coherent
COHORTS-dissipation of cohort

... Lear, i. 2

by the four opposing coignes.... Pericles, iii. (Gow.)

CoIf-tlis coil would not infect....... Tempest, i. 2
here is a coil with protestation.. Turo Gen. of Ver. i. 2

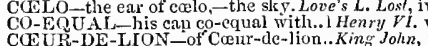

bring me the satin coffer [ $[K$

stand back, and let the coffin pass.. Richard III.

(it' e'cr this coffin drive a-iandi) $\ldots \ldots \ldots \ldots \ldots$ iin. $\overline{2}$ (scroll)

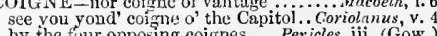

COIL-there is a great coil to-night... Much Ado, iiti. 3

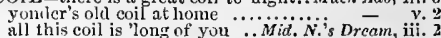
conmanded here, and kept a coil ..... All'sWell, ji. What a coil is therel.......... Comedy of Errors, what a coll's here!...................... Timon of Alhens, a retson tor this coit

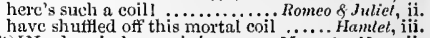
the face of an old Roman coin ...Mens, for Meas. ii. thcy have in England a coin ......Mer. of Fenice, ii. thousand marks of English coin ..... King John, ii. plate, coin, revenues, and moveables. Richard $I I$. ii.
so far as my coin would stretch ...... I Henry $V . \mathrm{i}$. lut them coin his nose, let them eoin

his valou, coin, and people .......2 2 Henry $\mathrm{HI}$. to be stamped on the king's coin.... Henry $/ 11$. iif. a slave, whose gall coins slanders...Troil. \& Cress, i. 3 why, the dog coins gold ........ Timon of $A$ hens, ii. mine lovour, shall not know my coin - iii. 3 so shall my lungs coin words ....... Coriolanus, iii. 1 I had rather coin my heart .......Julizs Cresar, iv. 3 his coin, ships, legions, may ...Anfony \& Clco. iii. ${ }^{11}$ COIN.AGE-I'll answer the coinage... 1 Henryl $V$. iv. this is the very coinage of your brain .. Humlet, iij.
COrNIDD-have coined me nitto gold.... Henry $V$. ii YCt, 'tis a life; you coined it ....... Cymbeline, y. no, ther connot touch me for coining .... Lear, iv. no, tlycy cannot touch me for coining ... Lear, iv.
CO-jOLN-thou muyest co-join with.. Winter's $\mathrm{T}$. i. COL-appellez-vous le col? ............. Henry V. jii. 4 nor sif (xuy, nor Colbrand..........Henry VIII. v. CoLD - must our mouths be cold? ...... Tempest, i.
he rceeives confort like cold porridge..
white cold virgin snow upon my heart $=$ iv.

to make cold liymphs chaste crowns ... $\overline{-}$ iv. my zeal to Valentine is cold .... . hope ny master's suit will be but cold $\overrightarrow{-}$ ii. for my helly's as cold as ...........

rather will suspect the sun with cold

old, cold. withered, and of intolerable $\bar{v}$

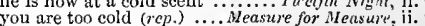
to lie in cold obstruction ...........

I thank God, and my cold blood........ M/uch Ado i

there's goodly catehing of cold ............ fling between the cold momn and - ii. measure out my length oil this cold bed $\overline{\bar{v}}$ iii. with some cold drops ot modesty.. $\overline{\text { ii }}$ ii. even till $\mathrm{I}$ shrink with cold ......... As you Like it, ii. in the cold wind; withal, full oft (rep.).All's Well, i. the list of too colil an adicu.......... iǐ. 4 (letter) and found lier wondrous cold ......... go to thy collt bed, and warm thee. $\mathrm{Tam}_{\mathrm{a}}$ of $\overline{S h}$. 1 (ind.) a bed too cold to sleep so soundly .... - 1 (ind.) a taller man than I will take cold.... for 1 have canglt extreme cold...... - iv. the day in cold, while tlou liest... Trameing of sh. $v$. with a scnse as cold as is a dead .. Winter's Tale, ii. the mon are not yet cold under water - iif.
was turned into a cold fish, for she .. is cold: the meat is colil. lest he catch coll on's feet
you stand here in the cold

aurl fan our people cold ........ 二 iii.

this place is too cold for hell.

thiy blood is cold; thou hast no ...........

and yet seem cold, the time you .......... your majesty doth seem so cold...... the instrument is cold, and would not -
with cold; I do not ask you (rep.) .. et not my cold words here ............Richard $11 . \dot{j}$

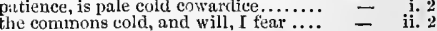
where shivering cold and sickness pines - v. my hlood hath becn too cold and....... -

with my wounds being cold

tis dangrerous to tuke a cold .....

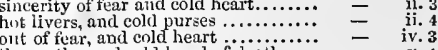
the earthy and cold hand of death..... = Poung Harry Percy's spur was cold ..2Hen'y $I \%$. i. he's like to be a cold soldier

whoreson cold, sir; a cong

We will have away thy cold $\ldots$..........

which before cold and scttled lett.......

by seeming culd, or careless of
how cold it stiuck my l.enrt! 


\section{$\mathrm{COT}_{4}$}

Cor,D-after this cold cousidernnec ..21lenry $1 r^{\prime}$ v. 2 COLD-MOVING-cold-moving nods. Timon of Alh. ii.

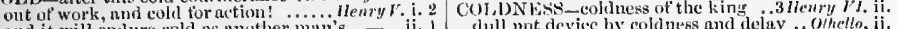
and it will endure cold as nother min's - it. and they were as cold as any stone ....
decort their cold blow to such ........ to every one thawing cold tear............. rain oucl cold iving

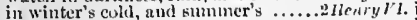
cold news for mc: for I late

with his wrathful nipping eold...

cold news, lord Somerset (rep)

cold snow melts with the sun's (rep.).

biting cold womld never let trass gruw

from the earth's cold fince

his cold thin drink out of lis

a cold premeditation for my jinrposei

cold biting winter mars our

cold bithe winter mars onr ...

that is too cold in thinking of it now.

when I nm cold in love, to you....

ity, cold, unwilling, be thou so too..

the air is raw and cold ......

cold fearful drops stimd on,

this cold corse on the earth's cold fuce

felt so mneh cold as over shoes......

and cold hearts freeze allegiance.....

placed together makes cold wle

and of an earthy colc

the morn is cold............ Troilus

the devotion which cold lips blow

lethargies, cold jalsics, raw eyes

cold statues of the youth
their blood is caked, 'tis cold ..............

cannot condemn rushness in cold bluod?

thun cold sciatica, cripple our

will the cold brook, candied witl ice.

ani drink cold water? no

sir, those cold ways, that
and batten on cold bits

our blood is cold, and then we pout

can both endure the wivter's cold.

can both endure the winter's cold...Julius Cre and straight is cold again.

or some devil, that makest my blood cold -

for I perceive cold demeanour ...

culd in blood, to say, as I said then!
Octavia is of a holy, cold, and still...

cold and sickly he vented them

cold upon dead Ciesar's trencher...
from iny cold heart let heurce

from $\mathrm{my}$ cold heart let heurch

Icst the burgan shouli catch cold

like Diana's priest, betwixt cold shects

it would make uny man cold to lose.

and fostered with colid dislies....

would show the Britons cold

there is cold meat i' the cave
on them cold dew o' the niyht

and cancel these cold bond

and she alone were cold

like a stony image, cold anil numb... Titus.And. iii.

warm kiss on thy pale colil lip

a man shrunk up with eold ........

she sent him away as cold as a snowbal

thou'lt catch cold shortly

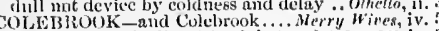

COLEBRAOUK and Culebrook .......err

shall you still be Colevile of the dal

top of it, Colevile kissing iny foot

name Colcrile? It is my lord (repde.

COLLAR-your neek out of the collar. Rom. \& Jul. $\mathrm{i}$.

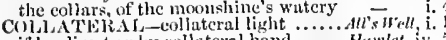

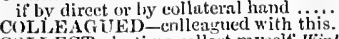

COLLECT -in time eollect myself:

goou old knight, collect them
made ine collect these dangers...
CoLLEC'LD-be collected ...

inler's Tale, iii.

COLLEC'TLD D-be collecte

the sums I have collected shall

..... Tempest, i.

our power collected, our substitit

assembled, and collccted, as were

a band of men, collected choiccly

. King John,

collected out of the dulie of

the articles eolleeted from his life
have you collected them by tribes

war -

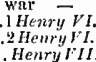

have you collected them by tribes?

collcetcd trom all simples that have

doth move the hearers to collection

Hamlet, 活.

a kind of yesty collection, which ca

Hamlel,

COLLEGE-college of wit-crackers
cougregated college have concluded

congregated college have concluded...All's Well

colleges almost in Christendom ....... Henry VIII.

having my best judgement collice

coldich-hang him, foul collerl.. Twelfh Night,

are colliers countcd bright......... Love's L. Lost,
no, for then $w \mathrm{c}$ should be collicrs. Romeo \& Juliet,

COLLOP-most dearest! my collop!. Winter's Tale, i.
thou art a collop of my flesh ....... Henry'r'. v.

COLMES-at stint Colmes' inch ............ Macbeth, i. 2

COLOQUINTIDA-bitter as coloquintida. Onello,

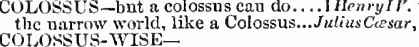

and stands colossus-wise ....Troilus $f$. Cressida,
COLOUR-with colours fairer painted .. Tempes

CoLOU $R$ - with colours fairer painted ... Tempest, i. 2
do you change colour? ........ Tu. Gen.of fer, it.

under colour of commending him . Merry Wives, it.

advance the colom's of my love
show no colour for my extremity.

show no colour for my extremity ..

I fear no coloure

by the colour of his beard.

and 'tis a colour sle abiors...........

in this fashion, colour, ornament ......

and head. just ot his colour

her hair shall be of what .......

of colour like the red rose on . Mid. N.'s Dream, iii.

the colour of lovers; but to (rep.).. Love's $L$. Lost,

wear his culoutrs like a tumbler's hoop

I do fear eolourable colours $\ldots . .$.

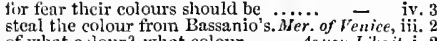

of what colour? what colour ....... As you Like it i.

most part cattle of this colour

good colour, an excellent colour $(\mathrm{rep}$ )

of colour, weight, and heat $\ldots \ldots \ldots \ldots . . .$.
whict holds not colour with the time

$\bar{Z}$
$\overline{-}$ Well,

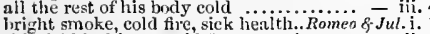

this tield bed is too cold for me to sieep

fhall rum a cold and drowsy humour

a faint cold fear thrills througl

out, alast she's cold

youth of a nation in his colour .......
scorned a fair colour, or expresscd

scorned a fair colour, or expresscd .

what colour are your eyebrows?.; Winter's Tale, iy. I

to colour the warden ples ..........

what colour for my visitation .......

most marble there, changed colour

my hands are of your colour ..............
stecped in the colours of their trade

stecped in the colours of their trad
to spread his colours, boy

part your iningled colours once...

the colour of the king doth com

the air with colours idly spread.

thy threatening colours now wind up

Ailis well, ii.

snow to their colder monds
CuIDEST-where hone is coldest

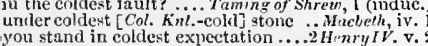
you stand in coldest expectation ....2 Honry IV. v. 2 from their coldest n
COLD-HEARTED

cold-hearted torrard me?...Antony \& Cleapatra, iii. 11 COLDL $X$-but yct so collly .... Turo Gen. of Ver. iv. 4
bear it coldly but till unidniglit .... Much diln, iii. 2 who is that, calls so coldly? (warm life, as now it coldił stimds) ... he would not plead an coldly..Comedy of Errors, we coldly panec for thce ............... King Jnhn coldly embracing the discolource....... kirtl -

the French fight coldly, and retir

she coldly eyes the youtliful .... Troilus \& Cress i.
but it liev as colfly in him as ....

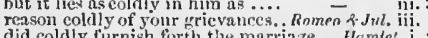
mayest not coldly set our sovereizn. wound onr tattered colours clearly up
under whose colours he had funglit..

and rotten policy eolour her worling. 1 llenry 1 .

no colour like to right, he dotl

that wear those colours on thicm

I have the wars for my colour .......2 Henry II.

in his true colours, and not oursclves -

but u coloir. A colour, I fcar (rep.) -

with patehes, colours, and with forms

twas a colour he never liked.

icclicate one jot of culour unto.... - iv (cluri.

by tinese colours: tor thy foes he's of the colour of the nutme

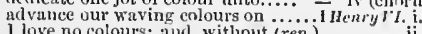

COLOUR-disgrueing of these colours.h Henry IJ. iii. the fungubtuc colvur of the leaves ..
grosper our colours in this dangerous

olir captains, aull our ecoloure

What colour is this cloak of"
what colmur is my guwn nof?

but yet we want a colour tor lis death 二 iii.

whose hopeful colours advanec with - iv.

and their colours, wften borne in France - i.

that have forsworn thy colmirs
let our bloody colours wave!

fintal colours of our strivine houses

I can add colours to the cameleon

$O$ cheertill colonus: see, where

but his red colvur hath forsook...... Wichard 111 .

unless I have mista'en his colours much - iti.

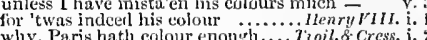

he having colonr' enough and the otlicr - i.

be patched with cluth of any colour. Corrolanus, iii.

buir no coluur fur the thing he is..... - ii.

not leave out the colour of her hair .. - ii.

What colour is it of"? of its own colour - ii.

put colour in thy cheek ...............

against all colvur, here did put...... - ii.

to guin his colour, ld let a parish of - iv.
give colour to my pale cheek .......

the colour of her hair, complexion ..... Pericles, iv.

a fellow of the self-same criluur ........... Lear, ii.
cast thy nighted culour off.

have not cratt enough to colour.............. - ii.

turned his colour, and has tears in's ejes - ii.

such an excrcise may colour your ..... 7 iii. 1

as it may luse some colour .............. Othello, i. COLOUKED-colvured pcriwig..Two Gen. of Ver.iv.
take my coloured hat and eluak.. Taning of Sh. $\mathrm{i}$. our wits are so divcrsely coluured .. Coriolen us, ji.

thou shonldst be coloured thus....... Cymbeline, y. I
COLOURING-as passes colouring. Winter's Fale, ii. OLT - like uuback'd colts ............. Tempest, iv. the hobby-horse is but a colt $\ldots .$. Lore's L. Lost, ii. 1 ay, that's a colt, indecd .....Merehant of Venice, i. for young hot colts, being raged.... Richard $J I$. ii. a plague mean ye, to colt me thus?... I Henryl $V$. i. CoLTED-thou art nut colted ..... Henry HIIT. HenryIV. she hath been colted by him ........... Cymbeline, ii. there's fennel for you, and columlines. Hamlet, iv. COMAGENE-kiug of Comagene. Antmy \&-Cleo. iii. CO-MATES-now, my co-nates.. As you Like il, ii. when the bee doth leave her with.. Taming of $S / h . i$.

comb down his hair; look! ........2 Henry VI. iil.

you crow, cock, with your comb on... Cymbeline,
COMBAT-I combat challenge .... Nerry tives, $\mathrm{i}$. Pompey is uncasing for the combat? Love's L.L. v. would by combat nake her good...'ininler's Tale, ii. 3 a noble combat hast thou fuuglit .... King John, v. combat witl aclverse planet

my courage try by combat ............

grant me the combat ..................

and wherefore crave yon combat?.. - iv.

single combat, in convenient place..2 Henry $r J$. i.

and $I$ accept the combat wiilingiy

the day of conbat shall be the last

to cumbat a poor fannished man.....

whom I in combat slew

to combat with the wind...............

invite the Trojen lords nfter the combat - iii.

dares me to persunal combat..... Aniony $\delta \bar{C}$ Cen iiv.

enulate pride, dared to the cumbat .... Hrmete i.

COMBAT.ANT-forward, combatants. Richard II. i. .

with thicse valiant combatants
you that would be conbatants

alurum to the combatants...

the head of the great cumbat

i Henryli, iv. 1

COMBATliD

OJI BATING-and blood conbating........ Hach Ado, ii.

wisdom and fortune combating. Aniony \& Cleo. iii. I

COMBED-be sleukly combed .... Tuming of sh. iv.

OMBINATION-solemn combination. Ficelfh $\mathrm{N}$. $\mathrm{Y}$.

the articles o the coubination .... Henry FHI, i.

two christian armies might combine. King John, $\mathrm{v}$.

and friendship, stull combine ......... Henry $r$. ii.

that they eombine not there ......... Coriolanus, iii.

save what thut must combine in ....... Rear. \&u. Ju.

whether le was combined with Nurway..Macbeth, i.

let pur aligance be combinet....... Julins Corsar, iy. 1

and :all combinat, save whint .. Remeo of Juliet, ii.

thy kntted aud eomlinel locks to part. H.tmle 


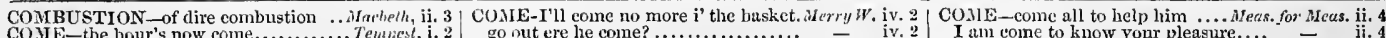

COMle - the hour's now come............ Tentiest, i.

come away, servant, eome $\ldots \ldots \ldots \ldots . . . . . .$. and hither eome in't

shake it oft: come on ........

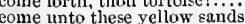

eome unto these yellow

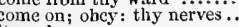

comes to the entertainer ...

what to eome in Fours and my dischio.....

ns thou got'st MIilan, I'll eome by Naples -

here comes a spirit of his
the storm is come again

if thou ineest Trineulo, come fortl

come on then; down, and swea

come on, Trineulo, let us sing

come to me, and I'll be sworn 'tis true

before you can say, come and go

well. Now come, my Ariel

to eome and sport... $\mathrm{I}$ know her.........

spring come to you at the farthest

come hither froin the furrow

of their plot is almost eome....

come with a thonght: I thank you (rep.)

come hither, spirit

peaee, here she comes..................... Gen of fe go, I come, I eome

now eome I to ny father $($ rep. $) \ldots . . . .$. .

far behind his worth come all the praises -

this gentleman is come to

here coines the gentleman

come on, you mad-cap .. .........

when you come to him

and this way comes he

every thing that he can come hy

could their master eome and go.....

but here comes Thurio

thus early eome to know

no griet did ever come so near

to come before their time.

see, where she comes

who's this comes here?

come not witlin the measire.....

his aneestors, that eome after him...

here comes sir John

never come in mine own.....

come, we have a hot venison pasty $($ rep. $)$ 二

here comes fair mistress Anne.

will't please your worship to come in

they will not sit, till you come...

there's pippins and cheese to eome ."

here comes my shall com

come, take-a your rapier, àd come after -

dat shall eome in my closer.....

to come under one body's hand....

eome near the house, I pray you

if he eome munder my hatehes

why, look where he eomes

ere sumuner comes

you'll come to dinner, George?

you are come to see my daughter

come a little nearer ther connes.

your worship, eome a listle...

you may eome and see the pieture
she hopes there will come a time

he may come and go between you both

now, could I come to her with any.

come yuld to me at night

and enckold, come to me soon at night

dat he is no eome; he has pray (rep.)

one, two, tree, fonr, come for?........

I am come to fetch you home.

come at my heels, Jack Rngls

we are eome to you to do $a$ good office

here comes doctor Caius

go home, John Rughy; I eome ano......

and come when yon are called forth

here eomes little Robin

is come in at your back door $\ldots . . . . . . .$. .

pray you, come near $\ldots . . . \ldots \ldots \ldots \ldots . .$.

I conen so speed me in my

ay, that $I$ will, eome ent and ............

may ask your father; here he comes

I come to your worship from........

onee more to come to her between

I like his money well: 0 here he come

you come to know what hath passed

comes me in the instant of o

comes in one mistress Page...........

clesires you to come suddenly

come hither William; hold up your (rep.) - go out ere lie coine?

we'l come dress you strajgit ...

youtl in a basket, come out liere!.

taie up yonr wife's elothes? Come away -

come you, and the old woman (rep.)

eome duwn, you witeh

should that be, comes so secretly?

they must come off

terrors in him, that he slinild not coine

how you'll nse him when he eome

let it not he doul

twenty thonsand worthier come to crave -

I come to spenk with sir John ......

there is $\Omega$ friend of mine eome to tow

dat de court is know to eome

it it should come to the ear of the eourt

eome up into my ehanue

I come to her in whit

I pray you cone; hold up the jest.

I pray you cone; hold up the jest ... - v. v.

for here comes sir Andrew $\Lambda$ gue-face

and eome home in a toranto?

here eomes the count

for here he comes, one of thy kin

how have you eome so early by

of that too, and therefore eomes.

come to what is important in'

unless perchanee, yon come to ine

but come what may,

so hardy to eome again in his affiars

here eones the fool, i'faith....

come kiss me sweet and twenty

that they come from my niece

come away, cone away, death

come by some notable shame?

here comes the little villain.

and I have heard herself come thus..

having come from a day-bed.

and then I comes behind

here comes my noble gull-cat
he will eome to her in yellow

construe to them whenee your eome.

every feather that comes hefore his eye

when wit cond youth is come to harve...

yet come again: for thon

the youngest wren of uine eomes $\ldots . .$.

he says he'll come.

hest have gaard about you, if he eome

and I'll come to thee...

I'll eome to him

oh ho! do you eome near me now?

ean eome between me and the

for it eomes to pass oft, that...

here he eones with your niece...........

I heseech you, come again

come on! 'To't $t . . . . .$.

this eomes with seeking

to bid you come speak with her.....

ii. 2 yon are well fleshed; come on.

come by and by to my chamber....

but here comes the lady........
willing it shall eome to note

till I eome again

here eomes the man, sir, thint

here comes sir Toby halting.

ii. 3 so eomes it, lady, you have been

hade me eome smiling

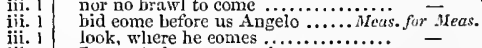

I eome to know your pleaswite...

where madam slitigation conies.

under her roof, as eome to

bere eomes signior Claudio
whence comes this restraint:

and notling come in partial

eome me to what uris clone

cannot come to that yet...

but you shall eome to it..........

the time is yet to come

what's eome upon thee

come hither to me, master Frot

I never come into any room

if sou hive to see this come to pass

he will come straterht

.

I eome to visit the aftlieted spirits....
I am come to know your pleasure....

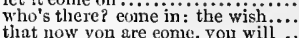

that now yon are eome, you will

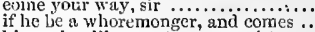

his neek will eome to your waist ....

eome your ways, sir,
but who comes liere?

a year and a quarter old, come Philip late come from the see, in special ....

the time is come, even now

the time is come, even now ..........

I eome about my brother ...............

what, ho! within! eome

eome hither, sirrah: can you cut .....

come on, bawd; I will instruct ......

now are they eome. This is a gentle

and here comes Chandio's pardon

fearless of what's past, present, or to come -

for, look you, the warrant's come ....

here comes your ghostly father

any thing to say to me, eome to $\mathrm{my}$.

from the danger that night eome...

the duke comes home to-morrow ....

come, we will walk ..................

the friar is come. Come, I have found

being eonle to knowledge that there.

now 1 eolne to't, my lor

to abide here till he eome

eome on mistress; here's a gentlewoman -

poor souls, eome you to seek

which here you come to accuse ........

come hither, Moodman bald lana: say, wast

eome hither, Isabel: your friar is now

and ehoke your good to eome ........

don Pedro of Arragon eomes this night. Much Ado

if you eome in her presence.
is it come to this, i faith?.

in their rooms eome thronging soft... -

comes me the prince and Clandio....

and then comes repentanee.

if a maid conld come by them...........

and whatsoever eomes athwart his

till all graces eome in one woman (rep.) -

eome what plagne conld have eome....

if I perceive the love come from her

here comes Beatrice: by this day....

I am sent to bid you eome in to dinner

been painful, I would not have eome

I'll make her come, I warrant you..

eome hither, neirlihour Sea-coal ....

but to write and readl comes by nature

and bid her eome hithe

are eome to fetch $y$.

incleed, neirlibour, he eomes too short

you eome lither; my lord, to marry.

come to marry her. Lady, you eome

comes not that blood, as modest...

come, let us go; these things eome .

eome appareled in more precion

come betore master Constable (rep.)..

let the watch come forth

here eomes the prinee and claudio...

man we went to seek

aimost eome to part almost a fray...

to-morrow morring come you to my

that no man living shall eome over it

to haye no man come over me? ......

and therefore will come...............

for here cones one in liaste (rep.)....

will you come presently? ..........

Where comes the prinee and Clandio...

here eome other reckonings ............

quick bright things cone to confusiun

all her elves eome here on.

the queen eome not within his sigit

but room, tilery, here eomes Oberon.

why art thou bere, eome rrom $\ldots . .$. .

and yon eorac to give their bed joy ...
progeny of evils comes trom our debate

my gentle $l^{2}$ uek, come hither $\ldots \ldots .$.
but who eomes liere? I am invisible

come not uear our fairy queen!

elarm, come our lovely lady nigh
weaving suiders, eome not here

never niay'st thon enme Lysand

if you think I emme hither as a
or else one must come in with

he eomes to disfig

that he heard, and is to come ngain..
here comes my messenger............

\section{$=$ iij.}

Mreus. ii.

iii. 2

iii.

iii. 2

iv.

iv. 1

iv. 1

iv. 2

iv. 2

iv. 3

v. 6

v. 1

v.

v. 1

v. 1
v. 1

v. 1

v. 1 


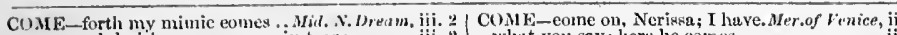
whit you \&ay; here he comes. l.ok, where thy love eomes ........... what, lave you eome by niglit let ine come to her $\ldots$.................... when 1 come wliere he calls come hither, I am here.

yet but three? eome one 1nor
hure she comes, curst, and sul come, sit thee down unon this flower. unt exposition of sleep eone upon m. but, us in health, eome to my

when my eue eomes, cull me

if he come not, then the play

here eome the lovers, full of joy ........

come now; what masks, What dance
where $I$ have come, great clerks have

we come not to oftend, but with

anour cond

yonder she comes. U wall, tull of ten

ticle death, I eome without delay....

here come two noble bensts in.

as lion eome in strife into this pilace.

he dares not come there for the caudle

hut silenee, here comes Thisbe

so comes [Col. Knt.-then came] Pyranms -

here she eomes; and her passion...

$O$ sisters three, come, eone to m

th:at no wowan shall come within...

liere eomes in embassy the Freneh

or vainly eomes the admired prineess

none spare that eom

like one that eomes here to besiege...

here eomes Navarre...

the packet is not eome ............

you may not eome, fitir princess $\ldots$. . I will eome to your worship to-morrow the princess eomes to hunt here...

comes a member of the commonwealth why did he eame? to see?

by the horns, yourself, eome near....

shall I come upon thee with

when it eomes so smoothly of

were eomes one with a

why, he comes in like a perjure

your mistresses dare never eome in

here eomes Boyet, and mirth is in his

we will do't, come what will come.

but what, but what, eome they

come ou then, wear the fave will ne'er come in.....

be masked, the maskers eome ......

how eome you thus estranged?

how eome you thus est

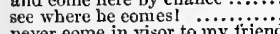

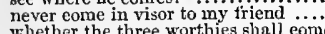

whether the three worthies shall eom

I say, they shall not eome

I here am eome by chance

ergo, I eome with this apology
here comes Hector in arms (rep.)

here comes Hector in arms come challenge

eome when the king doth to (rep.)

and milk comes frozen home in...

here comes Bassanio, youx most. Merch.of I

let old wrinkles eome.

many J sons come in quest of her

onpeifluity comes sooner by white hairs

princely suitors that are already eom

a tore-runner come from a fifth

you come to me, and you say, siiylock

eome on; in this there enn be (rep.).

truth will eome to light

father, I am glad you are eome......

to rare fortunel here comes

to eome anon to my lodging $\ldots \ldots$......

say, I will come

there will come a christian by ......

but come at onee; for the elose

what, art thou come? on, gentlemen

the wind is come about, Bassanio...

four coners of the earth they eome.
for princes to come view fair Portia

but they come, as o'er a brook

and eomes to his clection presenti....

comes to hazard tor my worthles

one that comes betore to signity

as this tore-apurrer eomes betore his

for here he eomes in the likcness.
that usel to come so smug upon

that usel to come so smug upon
liere comncs anotlier of the tribe.

with bleared visnges, enme forth $t i$.

whint demigod hath come so neur...

I come hy note, to give..........

to come with lim along $\ldots . . . \ldots . .$.

(i) not persuade you to eome...........

so find to come aloroad with lim..........

pray fod, Bassanio eome to sor me.
this comes too near the praising of nnd we will come in to dimer

he should never come to heaven
thou urt eome to answer a stony

at the door; he comes, my lord

to determine this, come here to-day

new come from Padue

eomes with him, at my importunity

doetor eome.

ather balf

other halt comes to the general stato

to come amain to Carthage $\ldots . . . . .$.

who comes so fast in silence............

Who eomes with her? None, but ....

but there is come o messenger hetore

that doetur e'er come near my hoinse

that doetur e'er come near my honse
it comes trom Padua, from Bellario.

are richly eome to harbour sudilenly

my ships are safoly eome to road ....

yonder eomes my master............As

that I should eome to sueh penury...

for my own honour, if he come in...
if he eome to-morrow, I'll give liiu

if he eome to-morrow, I'll give hii...
may'st in honour eome off agaiu

mistress, you must come away

hut I was bid to eome for you...

there eomes an old man, and his th

come on; sinee the youtb will not

look, here eomes the duke

did come to languish; and, indeed

your praise is eome too swiftly hame

ii. 1 no natter whither, so you come not here

bitt eome thy ways, we'll go along

look you, who eomes here.............

eome hither, come hither, eome hither - ii. 5 (sont)

an' if he will eome to Aim

who ean come in, and say

kind should this eock eome of?

or eomes of a very dull kindred.....

peacel here young master Ganymede

as wine comes out of a narrow-mouthed -

he eomes to kill my heart

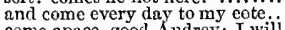

v. 2 eome apace, good Audrey; I will
v. 2 sluttishmess may come hereafter

here eomes sir Oliver $\ldots \ldots \ldots \ldots \ldots \ldots$.

who comes here? mistress, and ma:tel"

come not thou near me (repeated)

never come in my sight more (rep.).

so tardy, eome no more in

hut he eomes armed in his fortune

and so, come death. Two o' clock

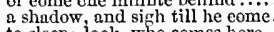

to sleep: look, who comes here

for here eomes more company

look you, here comes my Rosaliud ...

here eomes a lover of mine ...........

here eomes a pair of strange

who comes here? one that goes with

what's he comes here? It is the count

for the knaves come to do that ....

your marriage eomes by destiny

is for Helen to come hither.

i. 3 sce, that you come not to woo honour

farewell; coure bither to me

1.. 3
ii. 2
I eome to tender it, and nyy applinnce

ii. 2 come on, sir. I shall now put you

here comes the king

ii. 5 where I will never eome, whilst

ii. 5
ii. 6
save that he eomes not along with her

ii. 6 and when he means to eome

ii. 6 know it, before the report eome....

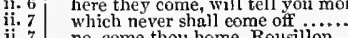

no, come thou home, Rousilion.....

ii. 7 come, nirht;

ii. 9 nay, enne: tor if they do approach.

ii. 9 they eome this way: if ynu will

ii. 9 now they come: that is Antonio....

iii. 1 every night he eomes with nusics

iii. 1 he enn eome no other way

come on, tholl art granted space

when midnight enmes, knock

iii. 2 not meddle with him till he cor he

Inodman enmes! Porto tartarns?a

for it will come to pass, that every

to conie into his presence ii. 1 here he eomes; I pray you, make us

comere the eames; to heguile two

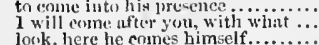

COME-but love, that comes too lute ...Ails Wall, v. 3

come on, my son, in whom

(where you have never eorne)

feary to eome into me..................
tor four or five removes, come short.

eome hither, eount

your reputation eomes too slior bid them eome near

you are come to me in happy time

nenee comes it that your kindred

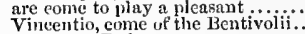

and am to Pudna come

if Biondelln, thou wert eome ashore

when Biondello eormes, he waits

here comes the rogue: sirrah ......

comes there any more of it?

after who eomes by the worst

signior Ifortensio, come you to part..

then had not Grumio eome ...........

come abroad to see the world (rep.)

nothing eomes amiss, so money eome

grieved as I? but who eomes here?

with some spirit when she comes

but here she comes: and now

nay, eome again, good Kate

es your father

that Lucentio that comes a wooing.

if it would please him eome and marry

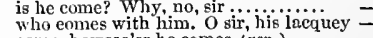

come, howsoe'er be comes (rep.)

not come; now sadder that you come so

away to-day, before night come

ere I should come by a fire to warn

sliall find, when he eomes home....

why, sile comes to borrow nothing

dagger was not come from sheathing

here are they eome to meet yon ......

to make her eome, and know her

and come to Padua, eareless of ...

heggars, that eome unto my father's

we may eome there by dinner time.

supper time, ere you eome the
but, sir, here comes your boy

here eomes Baptista ................
having come to Padua to gatje

to come against you come with your

eome on, o' Ged's name.....

sinee we have eome so far...........

Cambio eomes not all this while

that his father is come from Pisa.

come hither, craek-hemp (repeated)

mistress eome to ine, I go, son (rep.)

and sine caunot come. How! (rep.)

nay, then she needs must eome

not eome, she bids you eome ( $r \in p$.)

by my holidame, here comes Katharina!

thcre's a weneh! come on, and kiss me -

reign now! here eomes Bohemia.. Winler
the boy henee, he shall not eome ahout

said slie's goodly, come, between

when youl shall eome to elearer.

eredulity will not come up to the truth

please you, come something nearer..

might come to me again; who's there?

eommanded none should eome at hi.

I come to bring him sleep $\ldots$........

I say, I eome from your good queen

you, sir, come you hither

to the oracle, are come an hinur

ii. 3 but what eomes from myself ................

ii. 5 which who please to eome and icar

iii. I when I shall come to know them.

to me eomes a ereature sometim

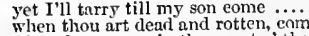

why, then eomes in the sweet o' the

for the life to come, I sleep out

whieh we two have sworn shall come

daflodils, that enme before the swallow

never come better; he shall enme in
thougth they come to him by the oross

come luy of me, eome; enme (rep.)

come to the vedler; monev's a medlar
let thein tome in; but quickly now..

but, enme on; contract us ....

come not hefore him.

thg for the time to eome "...........

let ony prispheev come liome to youl

if I may come tin the specels of him.

shill all eome'under the hangmun ..

his gru his daughter elrme into graed

his grave, ant like to his th ther's

they are come: your mother wa, most

(ini.)

2 (ind.)

i.

$$
\text { iv }
$$$$
\text { iv. }
$$$$
\text { iv. } 2
$$ 
CONE-will come on very slowly.. Winter's Tale, $\mathrm{v}$. herc comes a gentleman, that, happily here comes the lady Paulina's (lone good... there is an air comes from her nay, come away; bequeat Syracusan born, come to the hay. Com. of Error for what she saw must come Dromio, till I cone to thee here comes the almanack of my true come not home; you come not hom I from my mistress come to you come on, sir knawe, lave done thil you cone home to they'll go, or come here comes your man, now will you come lome? e? quothi I how comes it now, ny hushand ( $r e p$.) come again, when you may

wite? you might have come before hont evening, come yourself alone... put forth, come to the mart

lest I come not time enough ......... to prison till it come

that time comes stealing

that time comcs stealing on .......

will burn; come not near lier.

here cons

let him not come near me.......

come to the Centaur

and thereof comes it, that hi

won his grace to come in

see. where they coine.

and hid the lady abbess come

come Graymalkin! Paddock calis...... Macbeth, $\mathrm{i}$.

whence comtor

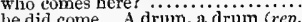

new honours come upon him

come what come may; time....

they are not yet come back

the king colnes here to-night

come to my woman's breast.

all our nights and days to come give

we'd jump the lite to come

o come in equivocator.

here's an English tailor come hithe

has awaked him; herc he comcs.

if there com tr

I'll come to you anon..

let it come down. O treachery!

then comes my fit again

catch it ere it come to ground

his message ere he coune

gomething wicked this way come

(howc'er you cone to know it)

come like shadows, so depart

can come a devil more damned

comes the king forth

sce, who comes here?

lo you, here she comes! ................

he cannot come out of lis grav

till Birnam forest come to Dunsimane..........

the cry is still, they come

do come to Dutusinane (repcated)

though Birnam wood be co

controversy, come from the country... King John,

goonl fortune come to thee!

and then comes answer like...

but who comes in such liste ...

at our importance hither is he come

along is come the mother queen.....

come to thy grandam, child.

troop of buntsmen, come our lusty

that bere come sacrifices for the.....

bid kings come bow to

all things berun come to ili end

here comes the boly legate of the
better part our prayers come in.

better part our prayers come in......

come hither, little kinsman (rep.).

yet it shall come, for me to do

look, who connes herel

young lad, come forth ..............

come forth. Do as I bid you do

let him come lack, that his....

of the king doth come and go

the tidings conc, that they are

this murder had not come into ......

grapple with him, ere he come so nigl where the holy legate comes apace

his spirit is come in

and come you now to tell me ..........

have dealt..

as to think I come one way of

the lords are all come back

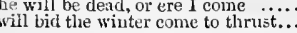

\begin{tabular}{l|l} 
v. & are come home again, come the three \\
v. & appearcth by the eause you come.... Richard II. \\
v. 2 & cone I appellant to this princely ....
\end{tabular}

v. 3 let him appellant to this princely.

come there, to seek

who hither come cngat

whether our kinsuau come to see...

if that come short, our substitutes

i. will the king come? that I may

all in vain comcs counsel to his

2 the king is come; denl uildly....

i. 2 here comes the dukc of York

ii. 1 whilst others come to make him

ii. 1 whin a tide of woes comes rushing

ii. 1 but who comes here? It is my son

here come the lorls of Ross ...

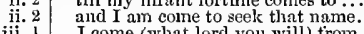

iifi I I come (what lord you will) from

iii. 1 and here art come before the expiration

iii. I but as I come, I come for lancaster

so much blood thither come again

humoured thus, comes at the last....

no worse can come, to fight

bolinghroke, I come to ehange ....

hither come even at his feet...

he is come to ope the purple .......

to come down. Down, down, I come

yet he is come. Stand all apart...

I come but for mine own ..............

duke of Lancaster, I come to thee....
this paper, while the glass doth come

torment'st me ere I come to hel

.

your eyes of tears; come hou
this way the king will come

liere comes my son Aumerle

be cropped before yourberle t........

never more come in my sight ........

she's come to pray for your foul sin..
his words come from his mouth......

it is as hard to come, as fo

where no man never comes

hut come yourself with speed........
indeed, you come near me now, $\mathrm{Hal}$

well, come what will, I'll tarry ....... -

let not his report come current for

and if the devil come and roar for.

here comes your uncle

come away, and be hanged, come away =

what time do you mean to come

Ned, pr'sthec, come out of that fat ..
dive away the time till Falstaff come

come hither, Franc

sir, it cannot come to so much

the rest, and then come in the other

of good feliowship come to you!
he says he comes from your father.

here comes lean Jack, here come

now Ilarry, whence come you?

now Inarry, whence come you? ....

but will they come, when you do ....

see, how this river comes me

here come our wives, and let

for the time will cume, that I shail..

the business that I come to speak of

letters conne from your father (rep.).
under whose government come they

the hope of what is to come in ......
let them come; they come like sacrif

let them come; they come like 8

lately come from swine-keeping .....

ii. 1 whose fellows are these, that come after -

cousin, stay till all come in. I come

ii. 2 comes not in, o'erruled by prophecies

$\begin{aligned} & \text { ii. } 2 \text { have not songlit it? how comes it then? } \\ & \text { iii. } 1 \text { durst not come near your sight ....... }\end{aligned}$

iii. 1 but who cones here? why stand'st...

iii. 3 if not, honour comes unlooked for

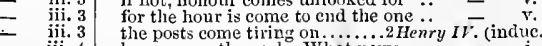

here comes the earl. What news....

what good tidings come with you

look, licre comes more news.

didst thon come from Slue wsbury?

here comes the noblcman that

you would not come when 1 sent

your life, to come speak with me ....
of this land-service, I did not come..

and come agaiust us in full puissance

past and to come, seem best.

an a come but within my vice....

he comes continually to Pye-corne

v. 2 so rough a course to come by her own?

v. 6 the butcher's wife, come in then

v. 6 the throng of words tliat come with...

is it come to that? I had thoughit....
CONIE-mass, here comes Bardolph. .2Henry IV. ii. how comes that? says he, that takes = they'll come in straight

to come halting off', you know; to conie -

rascal! let him not come hither...... -

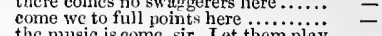

i. 4 the music is come, sir. Let them play =

\section{O Jesu, are you come from Wales?...}

wcaricd posts, conce from the north..

twenty-nine vears, come peascod time

ii. 1 bid mistress Tearslsect come to my ...
ii. 2 [Col.] comc, she comes blubbered (rep.)

the time shall come, thus did he $\ldots . .$. .

\section{of things not yet come to life ..........}

ii. 3 that comes hither anon about soldiers

ii. 3 here come two of sir John Falstaff's men

ii. 3 look, here comes good sir John ......

ii. 3 grow till you come unto it

ii. 3 come off, and on, swifter than he....

and come you in, and come you in

in goodly form comes on the enemy

this offer comes from nercy...........

and grect his grace: my lord, we come

some good thing comcs to-morrow

every thes is ended, then vou cone.

and, when you come to court.........

demure boys come to any proof....

hereof comes it, that prinec Harry...

now ligot, comes underneath …..... those that I am come to tell you of!
will fortune never come with both

will fortune never come with both..

lo, where he comes; come hither to me

for now a time is come to mock.......
look, herc comes my John of Lancaster

look, herc comes my John of Lancaste
William cook, bid him come hither..

here come the heavy issue of dead ..

now comes in the sweet of the night

fill the eup, and let it come

come from the court with vews (rep.)

O the Lord that sir John were comei

vell; of suifferance comes ease

ere they come from the coronation

will lcer upon him, as a' comes by
not to come near our person by ten.

it come unluckily home.

is come, to give him hearing

the weasel scot comes sneaking....... - i.

how he comes o'er us with our wilder - ii. (cho 2

here comes ancient $P$ Pistol and his wife - ii. (cho.)

you mint come to my master .........

of women, come in quickly to sir John

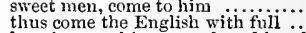

lest that our king come here hinself

mnocks go and come; God's vassals..

captain Flucllen, you must come.

here

here a conmes, and the scots captain
the Leviathan to come ashore

here comes the man. Captai

tell hime the will come on ...............

if it come to the arbitrement of
if ever thou come to me and say.....

if ever thou come to me and say

my penitence comes after all .......
and comes safe lome, will stand

ance more I come to know of thee

coine thou vo morc for ransom

a ton of moys! come hither, boy
all haggled over, comes to him

life is come after it indifferent

here comes his majesty

bid them come down or void the fiel

here comes the herald of the Frcneh

soldier, tou must charitable licence

I peseech you now, come apace

treason come to light, look sou
my licage, come from the heart

he is come to me, and prings me.

Why here he comes, swelling like....

at night when your come into your

when comes your father

and what's to come, she $\mathrm{c}$

then come o' God's name, I fear uo.

Tam come to survey the Tower.....

none, if that you come not quick

is come with a great power ....

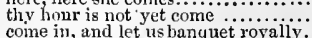

come hither, captain ................

message craved, so is lord Talbot come

well, well, come on; who else?
will my nephew come? (repeaced $). . .$.

conie to gather money for their ......

dare you come forth and meet us.....
like soldicrs, come and foht it out?.

like soldicrs, come and fight it out?..

ii. 4

ii. 4

ii. 4 
COME-eome hither, you that would. 1 Henry $V \%$ ịv. I there eomes the rinin, there begins

too late comes reteide..................

I come to knew whint prisoners thoi

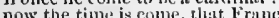

all your striet previsentss come to this?

to come tu cross the seus to England..

thou wilt ride.

gold eammot come amiss ..............

here a' comes, metlinks, and the que

come buck, fool; this is the duke 30.

could I come near your bennty
como Somerset, wc'll see thee

come, my masters; the duchess.......

holy uncle, would twere come

come with thy two-hand sword ......

here come the tuwnsmeu on processio

Simpeox come; come, ofter ut my slurine

come on, sirruli: off with $y$

tet it come $i^{\prime}$ taith, nud l'il pledge.

masters, I am come hither, as it were

but, sottl I think she come

cume you, my lord, to see my opei...

he should come about your highuess

that tiluu urt eome two soon...........

is the hour to come, that er I proved

spring-time showere, comes thoughit

and undiscovered come to me again...

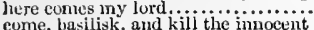

cume, basilisk, and kill the imnoce.

come hither, gracious sovereigll.......

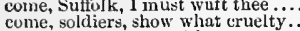

cone, soldiers, show what

therctore cone you with as

come, come, let's tall in wit] them......

come hither, sirrah, I must exumine

o'er whom, in time to come, I hope.

till I du come to hondon......

Englund may come out of your mont

coward! what, to come behind folks"

we come ambassadors from the king
York is newly come fiom Ireland...

Lork is newly come fiom Ireland...

proelaimeth, as he comes aloug ......

to come to rob my grounds

yet, come thou and thy five men.....

from thousand devils come

a messenger, or come ot pleasure?

Solncrset comes with the queen
Clifford; bid lim come amain

they come; I'll warrant, they (rep.).

and Warwick, come to me

Cliftord, I say, come forth and fight.

cone or both of us the time is come...

noble as he is, look where he comes

eternized in all age to come....

when the king cones,

come, cousin, let us tell the queen...

here comes tite queen, whose

you are come to Sandal in.

look, where bleody Cliffird comes!

and so he comes, to rend his limbs...

Plantagenet! 1 tome, Plantagenetl.

why come you not? What!

come make him stand upon

such comfort come to thee

I come to tell you things since then..

are come to join with you............

I come to pierce it or to give ........

away! tor vengeunce comes along .

come York, and Richard, warwick...

anon the deer will cume.

here comes a manl, let's stay $\ldots \ldots . .$. .

not a man comes fur redress of thec...

and come some uther time, to know.

1 come in kindness, and unfeignci lov

forbear this talk; here comes the king

where Sumersit und Clarence come

and come nuw to create you.

that be comes tourards London

come theretiorc, let us tiy

comes hunting this way .......

come hither, Lryand hope ........

come theretore, lets about it specdily

lrack that come to succour you

the lurds aud enentemen to eune with

in London, till we come to him......

is sportiul Ldward come?

cume, Warwick, take the

who is nigh? tome to me, trieni........

come quilkty MIontague, or I am dead
and lo, where youthfut boward connes

ii. 3
Conli-ere you come there, be sure ...3Henryll

no come to yon, thin yours 3.

v. 5 but wherefore dost thou enene

v. 7 come hillier, Bess, and let me kiss....

but who eomes here? the new-delivered -

in henven, where thou shalt never come
liere eome the lords of Buckinghum..

are come firom visiting his mujcsty

the day will come, that thou shmit

sott, here conic my exceutioners ....

and come to huve the warrant
Clarence is cone, talse, tleeting.

what, if it come to thee aguin?
wherefore do you come? To, to

a flutterer, come thou on iny side.

in goorl time, here comes tlie noble duke -

fiere comes a messenter: whit news?

the mayor of London comes to greet you -

that he comes not to tell as (rep.).

lere comes the sweating lord (rep) ..

it ou' brother come, where shall we.

let them rest; come hither; Cutesby

master rise and cume to me.

ii. 4 come on, come on, whe

in hilppy time, luere comes the duke

had you not come upon your cue.

thus tar come neur my person

the mayor then, and his bretiuren, come? -

are cone to have some couterence ... -

here cutesby comes arain: now
troops of citizens to come to him

we come to him in perfect love.....

in this just suit cume I to move....

here the lieutenaot comes: muster ... -
come hither, Catesliy; rumour it abroad -

open means to colve to thum

come hither, Tyrrel; go, by this token

come to me, Tyrrel, soon at aiter supper

wretched Miurisaret! who comes here?

the time would come, that bottled

shall come again transtormed........

by the time to come. 'That tho

swear not by time to

comes to be your liege, you cannot (rep.) -

mid of night, cone to my tent
means to come by what he hath...

means to come by what he hat
my lord, he dotli deny to cone

enrich the time to come with

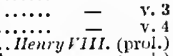

those, that come to see oinly a

only they, that come to he

grief comes throngh commissions...

and it's come to pass, that tractuble.

thade suit to come in his presence.

pr'ythee, come hither: what fair

thus far have come to pity me $\ldots . . .$.
of my long weary. life is eome upon $\mathrm{m}$.

of my long wenry life is eome upon me

acquninted torthwith, for what you come

for more thin blushing connes to .....

who comcs here? Good-morrow, ladies

nor could cumie pat betwixt two early

queen of Lingland, come into court (rep.) -

to wear our mortal state to come

pray their praces to come near

pray their graces to come near .......

not to come oft; in his displeasure

is he rendy to come abroad?...

where hight profits might come home

my endeavours luve ever come too short

政

you come to take your stand here.
when it comes, Cranmer will find

that comfort comes too late.

I am happily come hither.

come, come, give me yuur hand....

You shall this morning come before us

else no witness would come against you $\overrightarrow{-}$

let him come in. Your grace

but know, I come not to hear.

come lords, we trifle time away.

witls the great tool come to court ....

are come alrendy trom the eluristening

some come to tuke their ease ........
to Tenedos they come

Cressid counes into my thoughts ( rep.)

I cannot conuc to Cressid but by laandar
Truilus will not come far behind him

not come to't: you shal! tell me (rep.)

when eomes 'Truilus? I'll show you.

yonder comes $P^{2}$ ris, yonder comes $P$

what sneakin futlow comes yumer?

liere cume nure. Asses, fuols . $\ldots \ldots . .$.

that we come shurt vi' our suppose

conses from 'Iroy. Nor I troul Iroy come -

if any eome, llector shall honour....
of things to come at large...........
COME-Ajux come safe off.... Troilus
then wonld conne some matter tron..

ere 1 come any more to your tent

in time to cone, cunouize us

gond Phersiten, come int und anil

art thou come? why, nisy clicese

come in vitl me' Thertoten.

may easily uatie: here comes patrixilus =

we come to spenk with him $(1 / p.) . .$. .

come knights trom east to west

I come to speak with Paris from
tlicy are cone from field

thicy are coone from field

here he comes: how now, low now?

come your ways, come your way.

come druw this curtinil..........

boldness comes ti ne now

slaall, in the world to come

live to come in my behalf.

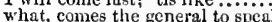

to come as humbly ..................

I come from the worthy Achilles.

my lord, come you again into.

pruy you, eome in; 1 wonld not......
to this valiant Greek comes fast upo

here, here he comes: ah sweet ducks?

have patienee; she slall come
good brother, come you hitlier

a coasting welcome ere it conic

yonder comes the troop ................

great Agamemnon cones to neet

whut's yast, und what's to come.

here eomes Thersites. How now
here comes himself to guide you

there will come some chave

she comes to you. Stand wher

Cressid eome forth to him

come hither once again

day is ominous; therefore, come

believe I come to lose ny arm .....

soft! here come Sleeve, and t' other.

hacked and chipped, come to hin.

come hoth, you cogging Greeks.......

wow ugly night comes brenthing .....

so 'tis: this comes off well

bid him come to me
look, who comes here

so they come by grtat beilies

I come to observic; I yive thee

tlat I might come neurer to you

there cones with them a fore

they unly now cone but to feast.....

what will this come to?....

it comes in charity to thee

what, you come for money?

stay, stay, lrere conges

no, tis to the lis" come fool

here eomes my nistress' yage.

when men come to bur

aside; here comes lord Timon (rep.)

the future connes apace

1 come to eutreut your honour.

is come aguin to supper to hin.

ha! bauishment?

he sent to me, sir-here he comes...

youder comes a poet, and a painter.

suspect still comes where an estate

may profit meet, and come too late

we are hither come to offer you...

by some course, and come to me

come not near him, if thuu would

come hither, cre my tree

thither come, and let mi.............

here come our brother

cone, come. Sot't who comes here?.... Coriohin

the lady Vuluria is connes, from

come on you wis to

over and over he comes, and up uguin

yonder comes news: a wager .........

come on; if you'll stund tust

we are come off like Romans.

come I too lute? Ay if you come not

he whs wont to connc home wounded

lad l come cothised hume

to Coriolunus eone all joy uini liminoms!

ho comes, and in the gown of humility -

liere comes a brace: you know

here colne hure volets-your voles.

cone away. This man lins marred .

he must come, or what is worst.....

come all to ruin; let thy moth

and cume home heloret or all

what, will he come? Ile's coming

wetl, here lie comes. Culumy, 1 do .

ii. 


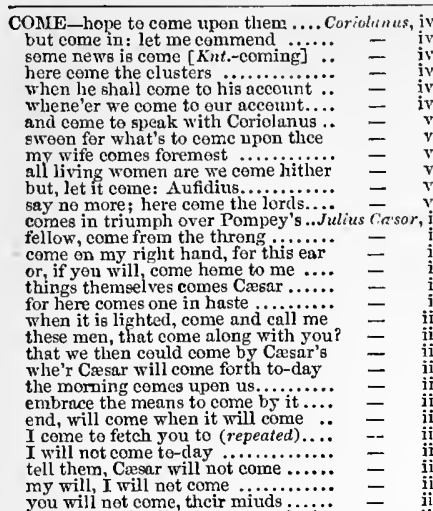

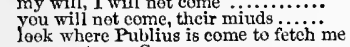

look where Publius is come to fetch me

come hither, tellow: which way

to great Cassar as he comes along....

say, I am merry; come to me again..

in the street? come to the Capit

that Anteny may safely ceme to him

so plesse him come unto this place.

but here comes Antony..............

write for him, to come frem Rome

I come to bury Casar, not to praise him -

come I to speak in Casar's funeral

I must pause till it come back to me

there will a werse ceme in his place

will you give me leave? Come down

a Casar: when comes such another?

Octavins is already come to Reme
to visit him; he cemes upon a wish.

to visit him; he comes upon a wis

in general, are come with Cassius

you shall not come to them.

come vourselves, and bring Messain

come in, Titinius: welcome, good

come en refreshed, nerr-added

never come sucl division 'tween ....

hal whe eomes here? I think, it is .

the enemy would not come down

and came down with fearful bravery

if you dare fight to-day, come to the field -

end of this day's business, ere it come?

let them all eome down.................

come dewn, behold no mere .........

come now, keep thine oath!

clouds, dews, and dangers come...

Brutus, come apace, and see hew I

Brutus, come apace, and see hew I $\because$ -

come hither, goed Volumnius

I know, my hour is come...

your dismission is come frem Cæasar

he comes too short of that great.......

hush! here comes Antony $\ldots . . . . .$.
but here comes Anteny. I am sick..

never given you leave to come
comes deared, by being lacked

says it will come to the full

not if the small come first

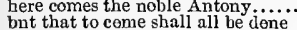

would $I$ had never come from thence

though it come tee short, the actor

theu shouldst come like a fur

that first we come to words ...........

in my besom shall she never come...

to come. Gold, ge to; come hither, si

might command it: come thou near

there's strange news ceme, sir

you come not like Caesar's sister
you are come, a market-maid to Rome
to come thus was I not constraincd..

and his affairs come to me on the wind -

here comes the emperor, is't not strang

triends, come hither: I am se lated

sent our schoolmaster, is he come back

him appear that's come from Antony

such as I am, I come from
$O$, is it come to this?

well said; come en: call.

Antony is come into the field..........

come on then. I'll halt after ..........

come on then; he may recover

when the exigent should come (rep.)

do't; the time is ceme ................

come then; for with a wound .........
draw, and come. Turn from me then

draw, and come. Turn from me they
fear of what bath come to pass .......

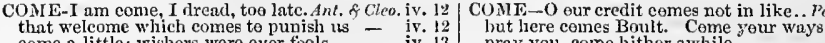
come a little: wishers were

come hither. Proculeius: no, and sny

gourd her till Cassar come...........

death? come hither, comel come, come

let lim come in: how poor $\ldots \ldots \ldots$.....

coune then and talse the last warmth

here comes the gentleman ...

where air comes eut, air cemes in....

ineuld they had not come between us

but hew comes it, he is to sejourn...

here comes the Britou to

if I come ofi, and leave her in such

here cemes a flattering rascal .........

comes from my lerd with letters

that's come to court te-night?

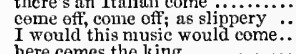

2
2
2 a worthy fellew, abbeit lie comes on...

wish that warmer days would ceme.

the stene's too hard to come by.

lo, here she cemes: I am ignerant ...

none dare come about him

where is she, sir? come nearer ........

stay, come not in.

fair youth, come in .................

we'll ceme to you after humtin

net probable to come alene

iii. 1 ordinance come as the gods foresay it

iii. 1 leek, here he cemes, and brings the
ii. 2 and worms will not come to thee

iii. 2 ceme on then, and remove him .

iii. 2 as chimney-swcepers, ceme to dust.. - iv. 2 (song)

all follow this, and come to dust.... - iv.? (seng)

censign to thee, and ceme te dust.... - iv. 2 (seng)

and they come under the coniuct of..

eome mere, for more you're ready

afainst the part I come wou, it seems, come from

I come to spend my breath

you come in faint for want of meat

of what's past, is, and to come...

I stand en fire: eome to the matter

past, in being, to come!

these staggers on me?

where you can, he comes not here..T

ceme on then, herse and chariots

great empress, Bassianus comes....

not by wondrous fortune come $\ldots . .$.

canst not come to me, I ceme to thee

make ns wendered at in time to come

come agree, wliose hand shall go

die before their pardon com

I slall never come to bliss

till Lucins come again, he leaves....

come hither purposely to peison me.

comes in tikeness of a coal-black

see, how swift she comes! .............
who comes here? Good-morrow

when you ceme to Pluto's region .....

and that it comes from old Andronicus

Marcus, the post is come

not come from heaven? and when you come to $\mathrm{him}$

but who cemes here, led by a lusty.

few come within the

ii. 1 uncle MI areus, and we wiji.......................

ii. 2 revenge is come to join with me ........

ii. 3 come down, and welcome me (rep.).

then I'll come, and be thy waggene

my ministers, and come with me

see, lhe, new do 1 come to thee

bid him come and banquet at thy house

till I come [Col. Knt.-tmrn] again

ready 'gainst their mother comes

iii. 6 from ashes ancient Gower is eome....

iii. 6 see, where she comes, aupareled like

iii. 6 hush, here come the lords of Tyre.

from lim I come with message

one sorrow never comes......

for what he comes, and whence be come

jii. 9 nor ceme we to add sorrow to your tears

iii. 10 here he comes; what shall be next...

they ne'er come but I look to be washed

princes and knights come from all parts

for comes to an honoured triumpl

voft, here he comes: I must dissemble....

iv. 12 here comes my daughter, slue can witness

iv. 12 weeping she comes for her old nurse's....

when he shall come, and find .............
come you between, and save poor me but liere cemes Boult. Come
pray you, come hither awhile.

coine your wnys; follow me.............. here comes the lerd I,ysimachus

here comes that which grows to the staik come your ways (repeated)

she had never come within $\mathrm{my}$ deors!....... every coystril that hither comes inquiring

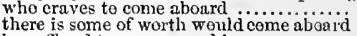
be suffered to come near him

0 come hither, then that beget'st him....

melanchely state, did come to see yeu... that he can hither come 60 soon.... - v, 2 (Gower)

to ceme betwixt our sentence.

come to me, that of this I may speak $-\mathrm{i}$. 2 (letter

ii. 2 and pat he comes, like the catastrophe

ii. 3 if yeu ceme slack of former services...

ii. 3 (so may it come!) thy master...

ii. 3 yeu sir, ceme you hither

iii. 2 o sir, are you come? Is it your wili?... iii. 4 geds, that we adore, whereof comes this? than comes from her demand

yield; come before my father n...

areh and patron, comes to-night

all ven neance comes teo short...

if they come to sojourn at my house

you come with letters against the raseal; come your ways

bid them come forth and hear

would soen be here: is your lady ceme?

who comes here? $O$ heavens.

half your train, ceme then to me.

if you will come te me

what, must I come to you
alack, the night comes on

come out o' the sterm

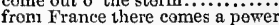

denied me to ceme in

of Albien come to net to tlirong

come not in here, nuncie, here's a spirit

grumble there i' the straw? come ferth.

and art theu come to this?

look, liere cemes a walking fire..........

burning spits come hizzing in upen them = iii. 6

come o er the beurn, Bessy, to me $\ldots$ - iii. 6 (sing)
why she dares not come over to thee - iii. 6 (sonig)

come hither, mistress; is your name .....

nay, then eome on, and take the chance

untimely comes this hurt....

but who comes here? my father

'parcl that I have, come on't what will.

madam, here comes my lord

wither and come to deadly use $\ldots . . . .$.

come with my lady hither

when shall what we are come

ceme shall we come to the top ..........

that we are come to this

nay, come not near the old man

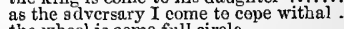

the wheel is come full circle...........

here comes Kent, sir. $O$ ! it is he .........

to this great decay may come.............

O thou wilt come no more; never, never
here comes two of the house .... Romen \& J

here cemes one of my master's kinsmen

old Montaguc is come, and flourishes

see, where he comes; so please yeu ..

at twelve year old, I bade her come...

nurse, come back again..............

come Lammas-eve at night............... =

madam, the guests are come

she comes in shane ne bigger than

sometimes comes she with a tithe-pig's -

supper is done, and we shall come too late -

am I ceme near you now?

this unloeked-for sport comes weil .

come Pentecost as quickly as it will

come lither nuree, what is

and rest come to thy heart

stay but a little, I will come agnin...

one that I'll procure to come to thee

madam. I come anon (rep.) .........

ceme between us, goed Benvolio

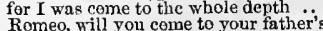

Romeo, will you ceme to your father's?

Jet she is net come: had she affections
she comes1 O honey nurse .......... only she comes too short

but who sir; here 's the place; stand still

whither should they come? 
CoME-now comes the wanton blood. Rsm. \& Jut amen, but come what sorrow can.....
here comes the lady; $O$, so light $a$ foot come, come with me, and we will liero councs here connes my man the furtons $\mathrm{T} y$ binit by and by cumes lack to Romco......... hore comes my nurse, and she bring and bid him come to take lits last lioneo, eome tortli; conne torth whence come you? whint 's your (vep) I eome from lady Juliet. Welcome
I'll tell my lady you will come

sweet discourses in our time to eime heer him and joy comes well in sucls.

and joy comes well in such ........... here cumes your tiather; tell him so. that he dares ne'er come bnek ...... come you to make confession shall $I$ come to you at evening mass come weep with mo; past hope in the morning comes to r

see, where she eomes from shirift

see, where she eomes from shl

die strangled ere my Romeo comes?

Romeo, comel [ $\mathrm{Col}$. Knt.-Romco.]

bring Juliet fortli; her lord is come.

at my cell till Romeo come...

is come to do some villanous.

for I eome hither armed against ....

fear comes upon me; $O$ much I fear

hold him in satety, till the prince

know how this foul murder comes.

he should hither come as this di

and I entreated her come forth

anou, comes one with light to ope.

if again this apparition eome

portentous firmre conies armed thronith

beholdl lo, where it comes againl

'grinst that season comes will

it is not, nor it cannot come to..............

the apparition comes; I knew your fut

would the night were come

but, here my tatlier come

look to 't, I charge you;

to what issue will this come?

my hour is almost com

conse from the grave, to tell us this

come you more nearer than your.

of horrors, he comes before me

defective, comes by cause

sadly the poor wretch comes reading

their inhibition comes by the means

and dare scarce come thither

haply, he 's the second time come to thiem

he comes to tell me of the players

for look, my abridgement eormes

say on: come to Hecuba

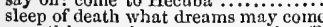

now this, overdoue, or come tardy off

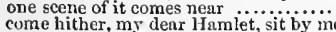

never come mischance between us twai

fores will I come to my motice

he will come straight; look, you lay
do you not come your tardy

avoid what is to come; and do not epreud

O Gertrude, come away! ...............

O come awnyl my soul is fuil

he will stay till you come.

let her eome in: to my sick soul....

young mon will do't, if they come ... -

is in secret come trom come not sing

no, let's come in. I pray you, give me

to negligence, let come whint comes .....

and will he not eome again? (rep.)..

he never will eome again

lct them come in: I do not $\mathrm{know}$

it comes from thic embassador that

bat my revenge will come.

but let him conse; it warms .......

quick $0^{\prime}$ the ulcer; Hamlet comes back

shall know you are come home $\ldots . . . . . .$. Gnt.] with fantastic garlands did sle con the toe of the peasant comes so near.

to this favour she milst come

dost thou come here to whine

when the baser nature comes between.

of our nature come in lurtlar evit?

peace: who comes here? Your lordshij.. sir, here is newly come to court

and it would eome to immediate trial.... to eame; if it be not to come (repea'ed)
the foils: come on. Come, one for me

come on, sir. Come, ny lord .....

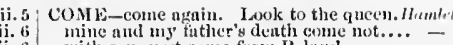
ii. 6 Why does the drum come lithur?

our atfinirs trom England eome too lint

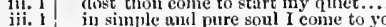

\section{iii. 2 I aur we come to do you service}

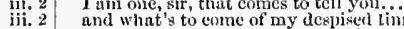

iii. 2 but, look! what lights come yonder?

here comes another troop to scek for
les advisesl: he eones to bad intent

iii. 3 he adviseat: Be conce to bad intent .......

\begin{tabular}{l|l} 
iii. 3 & ald, till she conce, as trnty as to heaven.. \\
iii. 4 & with haste despatch, she'd come agrain.
\end{tabular}

iif. 5 with comes the lady, let her witness it

iii. 5 as well to sce the vessel that's come in

iii. 5 the riches of the ship is come on shere

iii. 5
iii. 5
nothing, it not critical. Come on, assay

my invention comes from my pate .....

anid yeceive lim. Lo, where he comcs!

hard at hand comes the master and mai

whose qualitieation shall come into....

protit's yct to come 'twixt me and you
but here thicy come; if consequence
how comes $[\mathrm{Col}$.

how comes [Col. Knt.-came] it, Michacl
all's well now, swecting; conc away to b

pray you, come in; I will bestow yon.

iv. 4
iv. 5 when shail he heome? tell me, otheilo

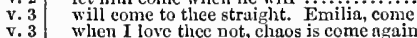

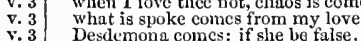

\begin{tabular}{l|l} 
v. 3 & Desdemona comcs: if she bo false... \\
v. 3 & look, where he comesl not poppy
\end{tabular}

v. 3 ny waked wrath. Is it come to this?

look wherc he comes, I will not leave..........

I have sent to bid Cassio come speak
a cause: is it come to this? w'ell, well

O, it comcs o'cr my memory as doth

here he comes-as he shall smile

before me! look, where she comes.

au' you'li come to supper to-night (rep.)

touch not you, it comes near nobod

bid her come hither; go: she says enough pray, chuck, come hither .......
or cry-hem, if anybody come

3 how comes this trick upon him?

there is especial commission come from ..

pr'y thee, hie thee; he'll come anon

to come in to the cry, without more (rep.

come in, and give sone help.......

she comes to speak of Cassio's death

shall she come in? Were't good?

if she come in, she'll sure speak to
$O$ come in Emilia; soft, - by-and-by

she comes more near the earth than she.

$O$, are you eome, Iago? you have done

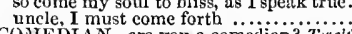

uncle, I must come forth ..............

CÓNEDY-prologne of our comedy...Mery

the most lamentahle comedy. Mil. Night's D

there are things in this comedy of.
heur them say, it is a sweet eomed

to dash it lik, it is a sweet eomedy ${ }^{-}$iv.

have made our sport a comedy

come to play a plcasant eomedy. Tan.. of $\overline{s h} .2$ (ind.)

either for tragedy, eomedy, history

for if the king like not the comed

COMELINESS-comeliness plucked.. Coriolnnus, i. 3

in most comely truth, thou deservest
what is comely envenoms him ... As you Like it, ii. 3

What is comely envenons him ... As you Like it, ii. 3

a happier and more comely time . Corinlanus, jy.
COMLR - as any comer I have.. Merch. of Fenice, ij.
the hand;

the hand; grasps in the comer.. Troilus f Cress. iii.

coward, why comest thon not? ...Mid.N.'s Dr. ii
thou comest to use thy tongue

thou comest thas knightly clad(rep.) Richurd $I I$.

thou goest, not whence thon comest.

comest thou because the anointed king

when thou comest to thy father

comest thou again for ransom?

comcst thou with deep
wlicn thou comest to the stake

when thon comest to kneel at.
why comcst thou in such haste?

why comcst thou in such haste?
why comest thou in such post?

that thou comest in so blumtly.

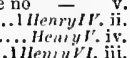

illenyy ${ }^{\prime}$ iv. 7

although thou comest to me... Timon of sthens, iii. I why comest thou? To teli thee...Juliuscicsur, iv, thou never comest unto a liappy birth - v. thou comeat not, $\mathbf{C} a$ ins, now for....... Cymineliti comest not to be made a scorn .... Tilus Andron. out of heaven's bencdiction comest to .... Lear, ii .
when thou comest to age ........ Romeo f. Jutipt, comcat thun to beard ne in Deumark?

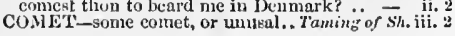

COMET-like a comet, I was wondered.I Hen.M $H^{\prime}$ iij.
conets, importing cliange

bow shine it like a eomet of revenge

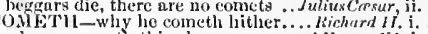

whenec cometh tlis alarum

here cometh Charles; I marvel...

ii. 1

COMET-LIKF-gazed on eomet-like . Pericts, y.

CONHOR'T-comfort trom this fellow

wipe thou thine eyes; have comfort

weigh our sorrow with our comfort.

he rceeives comfort like cold porridge.
than we bring men to comfort them

well, here's my comtiort

than you may cali to comfort you......

give him a show of comtiort in his.... - ii.

and thank you for that good comfort ..

God eomfort theel $\ldots \ldots \ldots \ldots \ldots \ldots \ldots$ - iii.

you stand amazcd; hnt be of comfort $-\overrightarrow{\text { iii. }}$ whose very eomfort is still...... Ners

what's the comfurt? why, as ali comforts -

dried not one of them with his comfort

I thank you for this comfort ..
I spy comfort; I cry, bail....

heaven give your spirits com

to advise you, confort you, and pray.

make her heavenly comforts of despai

make it your comfort, so happy is....

being gone, comfort sbould remain ... Nuch Ado, $\overrightarrow{\mathrm{i}}$.

have comfort, lady

go, comfort your cousin.

and speak comfort to that erief........ $\overline{\text { take }}$. Dr.

tarry for the comfort of the day

comert

God comfort thy capacity! ........... - iv.

I could put thee in comfort; not by two - iv. 3

some good comforts too for you . Her of Fenice,,

be comfort to my agc!................

live a little, comfort a little, cheer...

some

we make us eomforts of our losses!

distress in my smiles of eomfort

shall soon fecl, to thy cold comfort

you have an unspeakable comfort. 'H'inter's Tale,

nay, there's comfort in't, whiles

and comfort the gracious queen

the queen receives much comfort in't

my third comfort, starred most.

to greet him, and give him comforts

comfort, good eomfort; we must to .. -

the great comfort that I have bad of thee-

so much to my good comfort, as it is -

my comfort; when your words... Comedy of Err. i.

comfort my sister, cheer he

whence comfort seemed to eomc $\ldots \ldots \ldots$ Nacteth, i. 2

there's comfort yet, they are assailable - iii. 2

would I cold answer this comfort with - iv. 3

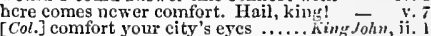

couragc and comfort! all shall yet...

good lady! comfort, gentle Constance

my widow comfort, and my sorroti's

being crente for eomfort. to be used.

be of good comfort, prince.........

and eomfort me with cold (rep.)

what comfort, man? how is't with

near the ticlings of our comfort is .

my comfort is, that heaven will.

nor with thy sweets comtort his

of comfurt no man speak .......

that bicls me be of comfort any more

a comfurt of retiremcit lives in this..
bring smooth comforts false ....2ilcon

is that all the comfort you give n

you shali bear, to comfort him

I am much ill. Confort, your majest

\author{
二
}

iii. 4

ii. 4

plucks comfort from lís looks.....

my comfort is, that old agc ....

as witting 1 no other comfort liase

the comfort of my age! thy deeds ...2nenry ri. i.

great is his comfort, in this cartily.

all comfort go with thce? .......

by erying comfort from a hollow iu enst

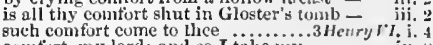

confort, my lord; and so I talie niy 
COMFORT-to comfort Edward with. Rich, lII. ii. I COMFORTING-if I tind him comforting.. Lear, iii. aud I for comfort have but one false and hast the comtort of thy clildre in him your comfort lives sister, have comfort; all of us have....

by their uncle cozcned of comfort.

but mine shall be $n$ comfort to your age

lines of faix comtort and encouragement

all comfort that the dark night

Henry's issnc, Richmond, comforts thec -

doth comtort thee in thy sleep

Henry $\bar{V} I I$

and comforts to yourg ....

as all my other comforts, fur hen

is this your confort? the cordial

pray, pray. Heaven confort her

take good comtort. O my good lord (rep.) -

keep comfurt to you; and this morling

all comfort, joy, in this most gracion

this oracle of comtort has so please

failing to him, periods his comtort. Timon of $\mathrm{A}$.h. $\mathrm{i}$.

$\mathrm{O}$, what a precious comfort 'tis, to have
and I'll beweep these comforts, worth

in that there's comfort. Doubt not... C

hearts dunce with comforts, conetrain

which is a comfort that all but we enjom

Roman ladies bring not com

at meals, comfort your bed .......Julize

thesc tidings will well comfort Cassius

thy spirits all of comfort!. Antony \& Cleopatra, iij. 2

gentle imadam, to him: comfort him

i spake comfort makes the rescue

once for thy spritely comfort

give her what comforts the qualit

have comtort; for, I know, your plight $\overline{-}$

honest wills, which seasons com

to our comfort, shall we find

or in my life what comfort, when $\mathrm{I}$.

or in my life what comfort, when

Ill make't my comtort, he is a man
socicty is no comfort to one not sociable -

Imngen, the greut part of my comfort

it strikes me, past the hope of confort
his comforts thrive, his trinls well are

but the comfort is, you shall be called

for they shall taste our comfort

dawning day new comfort hatl inspired -

why dost not comtort me, and help me

and rather comfort his distressed plight

was once our terror, now onr com

joy and all contort in your sacred

nnding little comfort to relieve then.

awake their helps to comfort them....

sake of it. be inanly, and take contort

then men must comfort you

but thinc do comfort, and not bur.

I will piece out the comfort with what

thy comforts cau do me no good at al

to you again, I'll bring you comfort

what comfort to this great decay may.

such comfort, as do lusty young men

I'll find Romeo to comfort you...

comfort thee, though thou art banished - iil. 3

her chamber, hence and comfort her

how well my comfort is rev

word of joy? sorne comfort, nurse......

some raerry dump, to comfort me...

in the eheer and comfort of our eye ..... Hamlet,

but the tree comfort which from thence.

though he speak of comfort, tonching

that not another comfort like to this

our loves and comforts should increase.

and I dote in mine own cornforts

expectations and comforts of sudden

a comfortable doctrine.

Twelfth Night, i. 5

for my sake, be comfortable

be comfortable to my mother

what comfortable hour canst tho

As you Like it, ii. 6

comtortable temper has forsook

Richard II. ii.

yourself in a more confortable sort... Coriolanus, $\mathrm{i}$

return to us, peaceful and comfortable.. Pericles, i.

am sure, is kind and comfortable

O comfortable friarl where is.... Romeo \& $J u$ tiet, v. 3

COMFORTED_must $Y$ be comforted ... All's Well, i. I

be comforted; let's make us medicines. Macbeth, iv. 3 not comforted tolive

be comforted, good madam

Cymbeline, i.

thou hast comforted me marvel lous. Rom. $\%$ ful. iii.
coMroRTER-it is a comforter ...... Tempest, ii. comforter

let no comfortcr deliglit mine ear.......... Much $\bar{A} d a$, v. to be your comforter, when ......... Richard III. i.
comforTING-comforting your evils Winter's T. ii. nature with comforting repose ....Henry VIII. $v$. comforting therein, that when old...Ant. \& Clea. i.
COM FORTING-if I find him eomforting.. Lear, iit. teartul, comturtless, and horrible.... King John, y.

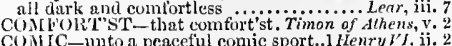

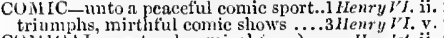
cu.11CAL pastoral-comical ( $r$ at the road expects my connis.

at the road exjects my comin
ny father stays my coming.

sir. $V$ alentine is couning

but, by my coming, $\mathrm{I}$ have

master, doctor Caius, coming

Tempest, ii.

I whs coming to you

youder he is coning, this way

she's coming; to her coz
but is my lutsband coming?

tarries the coming down of

your true love's coming .. Tiuelfth $\mathrm{Night}$, ii. 3 (song)

lie's coming; I perceive "t......... Mieas. for $\bar{M}$ eas. ii.

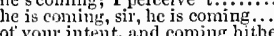

then I will expect your coming $\ldots$ Mid. Much Ado, $\mathrm{v}$.

the duke is coming trom the temple.

Thisby, coming first by night.......

to read the purpose of my coming. Love'sL. Lost, if.

I think, eoming from Nluscoyy ...
but there are worthics a coning will

cxchse me so, couning so short of thanks -

for your coming in to dimer,

for your coming in to dimmer, si

messenger betore, to signity their coming

your coming before me is nearc

yonder, sure, they are coming.

yondcr, sure, they are coming

more attend upon the coming space ...Al's Well, ii. 3

to make the coming huurs o'crflor

the king on he has the cramp

insuit coming with her................

know the calse of your coming?.. Taming of Sh. Hi.

coming? Is she comet (rep.).......

bride and bridegroom coming home?

I know, the rovit is coming

they are coming atter to warn them.

is my master and his wife coming...

away, away! for he is colning hit

what company is coming here

he is not guilty of her coming hither

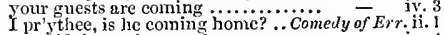

my wife is coming yonder.........

he that's coming, must be provided for.

that way are they coming

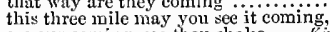

ere our coming, see thon shake ..... Khig John, ii

his coming is but for his own.........
his coming lither hath no furtier ..

our two cousins coming into London - y.
moncy of the king's coning down ..1 Henry IV. ii. 2

stand close, I hear them coming .... - ii.

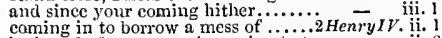

coming in to borrow a mess of .....2 HenryIV. il. 1

he is coming hither

coming to look on you $\mathrm{x}$................ Henry $V$

in fierce tempest is he coming.........

from Ircland coming, bringing ........ - v. (cho.)

the cmperor's coming in behalf of ....

wateh the coming of my punished...... Henry $r i$. ii. 4

the king, thou knowcst, is coming

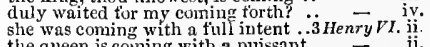

the queen is coining with a puissant

we were forewarncd of your coming... Riehard III. iv. ?

thicre attend my coming. ..........Riehard MI . .
the duke is coming; see, the barge.Henry VIL.ii.

I do not like their comins.

such a truant since my coming....

stand close, the quecn is coming

on all parts they are coming.........

they are coming from the field .... Troilus or Cress. i.

takc no warning by my coming .... - iii. 1

an intent that's coming toward him
hal Marcius coming home? (rep.)... Coriolanus, ii. 1

make way, they are coming $\ldots . . . .$. - ii. 2

[Knl.] some news is coming that turns - iv. 6

receive his letters, and is coming. $j_{\text {ulizs }}$ Corsar, iii. is thy master coming? He lies to-night -
coming tron Sardis on our tormer.. your husband's coming with half....

our thane is coming................. Macbeth, i.

the winter coming on, and sickness..
COMING-yet, coming from lim... Antony \& Cleo. i. 5 thyselt art coming to see pertormed coming and going with thy honey...Tilus $A$ nd. ii. 5 is not thy coming for my other hand? Pericles, yon have fiortunes coming upon you the king is coming. Attend $\ldots . . .$.

he's coming, madain; I hear him

I hcar my f'ather coping; pardon me...

this usage, coming from us .............

which tince his coming tiorth is thought = iv.

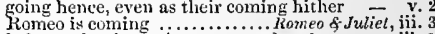
lady mother's coming to your chamber - iin. 5 not to question, for the wateh is coming -

and prologue to the omen coming ond $\overline{\text { Hanalet }} \mathrm{i}$ hither are they coning, to ofïcr you ..... - ii. Thear him coming; let's withdrav

they are coning to the play

wish and beg your sudden coming o"cr... - iv. 7 so guilty-like, sceing you coming.... othello, iji. sweet love, I was coining to your house.. cult, so, I hear him coming ............. of $\vec{V}$ en. COAIINGLED-so well cn-mingled. . Humlet, iii. to the coming-on of time ........ Macbeth, i. 5 (letter) in robustions and rough coning-on ... Henry $V$. iii. 7 COMINGS-IN-what are thy comings-in? - iv follow, Cominius; we must follow you

Cominius. come; half all Cuminius'

Cominius, Narcius your old enemy

will haste to general is gon

speak, good Cominius: leave nothing

worthe yon to hcar Comiuius speak?

proceed, Cominius. I shali lack voice

here is Commons? Cominius, I have been

Cominius, droop not, adieu ............

take good Colninins with thec awhile
it he coyed to hear Cominins speak

return me, as Coninius is returned.

and hum at good Cominius

the course. Fimon of Ath. $\mathbf{j}$. COMMAND-command these elements. Tamlet, v. 2 her earthly and abhorred commands .... - i. 2 I will be correspondent to command.

or dost unwillingly what I command.

nor liath not one syirit to command

Juno does command .....................
graves at ny command, have waked.....
and deal in her command................. write, please you command ...Two Gen..... of $\overrightarrow{\text { Ver }}$. cominand me while I live.

hy his master's command............

let us command to know that .......Merry $\bar{W}$ ives, $i$.

I may command where I adore... Tüelfth $\overline{\text { Nigh }}$, iv.

command where $Y$ adore (rep.)..

iii. 4

command her followers ................ this other doth command a little door

an express command, under penalty

command these tretting waters....

will your grace eommand ne....... shall I command thy love? Lore x L. Lost, iv. 1 (let.) piease it your majesty, command me of $\overrightarrow{\text { Venice, if. } 9}$

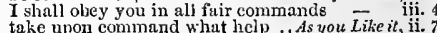
I have left you commands ............ Alts $\mathrm{Well}$, $\mathbf{i}$. ninst attend his majesty's command.. All's Well, i. as I command you? that man (rep.)

what more commands he? ...........

to be blamed in the command

if he had becn there to conmand ...

and at your inajesty's command ....

your honour will command?. Taming of $\overline{s h}$. 1 (ind.)

what you will command me, will

and whom thou keep'st command.

go forward, Kate, at thy command.

this gallant will command the sun

at your command at all hours

to command the keys of all ........Winter's Tale, i.

prevailed than so, on your command.

tardied my swift cominand...........

willingly obey your command

y his command have There touch $\ddot{d}-$ iv.

with thy command, let him le.. Comedy of Err. v.

I, sir, am Dromio; command him

he did command me to call timely .........acbeth, ii. 3

let your higluess command upon me..... - iii.

perform what you command us 
COMIIAND_tls her commund

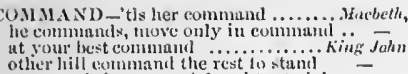
commind thy sim mond dather to join - if were not boru to sue, but to comminal - i. Garsal, commund our oflieers at aru let it ermmand a mirror hither

the king, conmands the contrary..... to command the devil.

of cstimution and command in arm

as word of excceding good command

will you coinmand me to use my legs

our vain command upon the enraged

yet my soldiers are in my command

's command

gegg'nr's knee, command the health of it? - iv.

and look st to coumand the prilice

dust thou command me to be slut out?

wec eharke and command you

this pluce commands my patience

on the king commands me stoop

your highness shall command a peace

upm my blessing I command thee go

with sucl a proud command spirit

command in Anjou what your hono

to be at your command; command

worldly pleasure ut command ......2H

used to command, untaught to plead

kings and princes, - command silenee

and do as I eommand $y$.

and we as

larley, when I command them kiil?

coinmand no more eontent than I?

Ilenry, conmand my eldest son....

Faukonbridge commands the narrow. 3 Henry $V I$. i.

command an argosy to stem the waves

what you command, that rests in me

I will do what your grace commands
but to command, to check, to o'crbear

to serve, where kings command......

entreat, (for I command no mo
stand thou when I command.

stand thon when I command .......
we will do, we do upon command...

we will do, we do upon command....

the king, that may command, entrents - iif.

sent command to the lord mayor ...Henry $\bar{\nu} / 11$. ii.

who command him, follows

Who eommands you to render up.

whose heirlit commands as subject. Troit. $\bar{c}$ C

Agamemnon commands Achilies.....

to ofl'er to command Achilles

the holy strength of their command.

and command him wholly

to him that victory comman

Ajax commands the grard to tend

he commands us to provide ...T $i$

or that which cun eommand
drugs of it freely command...

drugs of it freely command ........

thy fuce bears a command in't

under your grcat command ............

necessity of time commands our services -

through whom I might command...

command what eost your heart.

the bidding of the gods command $\mathrm{me}$

soon as i' the command of Casar....

worthiest to have command

on my command, thou then wouldst

service that $I$ sliall command you...

as thereto sworn by your command...

you have done not after our command.

of what commands I should be subject
suve when command to your dismission

command shall give t'lee opportunity

since I received command to do this

change eommand into obedience....

command, our prescnt numbers......

good servant does not anl commands

a warrior, and command a camp. Tit

which are now at your command

which are now at your command
get this done as I command you

better thee in their command...

sicuk, communts her service .

commands the minil to sufier with

many people, under two commands.

in all your dlaughters' hard command

own blialf, a mistress's command

in uur ey'es which do command them....
higher rate, than a eommand to yarley..

higher rate, thant a eomunand to jurley.. Hainle
lut, th you did eommand, his aceess to ine -

more into command thun to cutreaty .... =

wherc it falls, repugnant to comnumind
as I can make, you shall command...

thesc cannot I cummand to any uttera
like $\$$ lars, to tlureaten and eommand...
COMMAN1)- who enmmands them, sir?. Humlet, iv.

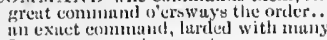

I may enmmind at most

mot! the man conmmands like

let him eommand, and to oley shinll be.

cmperor's side, and communt him task

power and your commind is tuken oif

COAMA D DED-commandel her. Tua Gemery

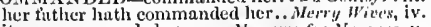

it was commanded so ...... Measure for Measure, y. I

I am commanded here, and kejt ....... All' s Welt, ii. 5

as Iluwer of commanded tears. Triming of $\overline{s h} .1$ (iliti.)

l commanded the sleeves should be cat $\bar{T}$ iv. 3

commanded none sifould come at.

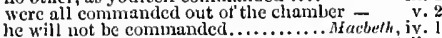

me where thou are commanded........... IIenry $/$ i. ii. 4

despatched the dukc, as he cominanded

chill be commanded

I am commanded, with your leave ..̈ichard $1 I I$ i i.

and he, that hath commanded is our

in the tnble of his law commanded

but to be com been commanded........

let silence be eommanded....

whoth commanded to-norro como.......

iv. 2 what you commanded me.

the arehbishop, as you commanded me

to be commanded ii. 3

comnanded by sucl poor passion.. Ant. \& Cleo. iv. 13

wheretore you have commingorant in what I am eommanded - iii. 2

for 'tis commanded $I$ should do so ...

second thing that 1 have eommanded - iii. 5

do what wc ure commanded....... Tilus Andron. v. 2

at your feet, to be commanded .......... Ilamlet, ii. 2

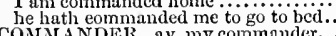

CONIIANDER-ay, my commander... Tempes
love thec as our commander... Tuo Gen, ofler

I was the world's commander ....Lov'c's L.Lost, v. 2

the commanders very poor rogues....

perfect in great commanders' names...Hcury $V$. iit. 6

a good old commander, and a most

bosom of such great commanders ... Henry $\mathrm{Vl}$. iy. 3

A a common. thou great eommander. Troil. of $\mathrm{Cr}$. i.

thy commander, Achilles....

ii. 2 bid our commanders lead ............... Julius Carsar, iv. 2

ii. 3 commander of nyy thoughts..............

COMIMANDING- eommanding love... King John if. 1

the great commanding Warwick ..3Henry It. iii. I

commanding all, obeyed of non

(the court of Rome commanding)... Henry VIII. ii. \&

comminding one another's fortunes. Tim. of $A, h$, i. 2

COMMANDMENT

to sea with the ten commandments. Mea. for Mea. i. 2

twas a commandment to command

'gainst your wife's commandment..

gainst your wife's commandment.... - iv. 1

I have express commandiment....... Winter's Tale, ii. 2

commandment on the pulse of life?.King Joln, iv.

England are at my commandment

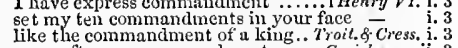

more after our commandment

thy commandment all alone shall live.. Hamtet, $i .5$

tell him, his commandment is fulfilled.

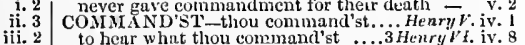

to henr what thou command'st ...3 Henry ${ }^{2}$ f. iv. 8
CUMIIENCE-wooer doth commenc. Much Ado, ii. 3

did you thesc arms commence......2HenryI

till sack eommences it, and scts

commence [Col. $\mathrm{h} n^{\prime}$. conduce] a fight. Troul. \& Cr. v. 2

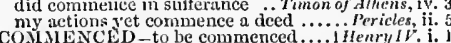

commencel on this ball of earth...2ilenry $I V$. (ind.)

commenced in burning Troy' ...2Ilemy r't. iit.

it was a violent commenecment $\ldots \ldots \ldots$ Othello, i. 3
coNMENCING-conmenciug in a trutli?..Macb. i. 3 COMMLND-

eommend thy grievance to...Two Gen. of lerona, i. 1 I'll commend you to my master

commentl, cxtol their graces

i. 3

to her beauty $I$ commend my vows...

that all our swains commeni her? .. - iv 2 (song)

womm, commend ine to her

commend me to them both

argument to commend themselves ... Twelsh $N$. ii.
COMMUNS

culiumleith

I ditl commente the black-oupressing

that well can the commend
the

signior Antonio commenting him to

conmend me to your lionomrable wif

I pray you, commend my counterfuiting - iv.

commend ine to my kinsmen, and.....An's Welt, ii.

commere the pajer to his grucisus liand $=$

commend me to thy mister ...........

comilia, commend my bost .............

commend them, and condconn them

I commend you to your own content. Com. of Err

Ido commend you to their backs

$O$ well dork! I commend your jainis.

commend me to one ilubert

commend me to my brother

Gaunt commends him to your majesty

will commend to rust his lartsed steed

to his gentle hearing kind conmunds - ii

commend me to my cousin ..........

my captain, sir, commends lime to you $=$ iii. 2

both, commend me to the jinines...... Henny $l$ iv.

my lord, commeud my scrvice to my I commend this kind sulbnission....2 Ifenry VI.

commend me to my valiant brother.3 Ilenry VI.

commends him to your noble lordship - iii.

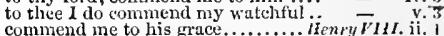

the king's majesty commends his goot - ii. 3

the repininis cnemy commends... Troilus \& cress. $i$.

commends himseli most affectionately

we'll not commend what we intend.

lade me not commend her to you...

commend ne to him: I will scud.. Timon of $t / h$.

commend me to your master ......... =

commend me to tlyy honourable ....

commend me to my loving combtrymen

commend me to them; and tell them $\overline{-}-\bar{a}$

commend me to my wife.

lct me commend thee first to th.

and commend me to thy lord

to this great fuiry 1 cormmend ... Antony o Cleo. iv. \&

commend unto lis lips thy favouring - iv. \&

commend me to the court........

ally way speak in his just commend ... Perictes, ii.

well, $d$ commend how commends itself

it is your grace's pleasnre to eommend .....

doth this instant so rnueh conmend itself. Letr, ii. )

I did commend your highness' letters ... - ii. t

comnend me to thy lady (rep.). Mlomeo of sutiet, ii.

eommend me to your daughter

let your haste commend your duty ..... $\overline{\text { Hamlel, }}$.

with all my love I do commend me to you -

commend me to ny kind lord

cannot be commendable: but who dare - ii

discourse grow commendable in ... Her.

nor more commendable...... Tamin of stren

and ever were, very commendable...2fenry 1. iii. 2

unto itselt most conmendible .... Coriolun us, is. 7

sweet and conmendalble in your nature. linulet, i. 2
coNIIENDATION-

a word or two of commendation. Tiro Gen. of Ver. i.

commendation from yreat putentates

urevai! in man's commendation. Fuetflh Nirht, iii.

the commendation is not in !is u it... . $^{\circ}$ ii.

praj' You, do my commendations. Lave's L. Last, ii.

high commendation, true applanse. As you Like it, i.
there commendations go with pity ...ill's Well, $\mathrm{j}$.

your commendations, manlam, get tears -

ictters of commendation to them....

in his commendations I am fed

in his commendations I am fed.......... Nacheth, i. 
COMMENDATION-
eommentations to my king? (rep.)..1 Henry I'T. v. 3

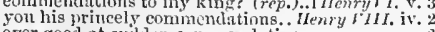
ever good at sudden commendation a mere saticty of commenclations.. Timon of 1 th. $\mathrm{i}$. I have your commendation.

turn all into my eomnendations

to express my enmmendations great
COMMENDED-much commenred. $T$

priest obthe town commender him. is

who commented thy yellow stoekitrs -

have eommended to his goodness. . H'nry thI

do his goodness. HinrythI, iv.

by my onee commended beaity

his maiesty eommended him to ........... Peric

COAMIENT - to enmment on your malady

a vugar eomment will be made. Concedy

by the adle eomments that it mates.

comment then upon his snden ..... Henry $\bar{F}$. iii.

rith the very eomment of thy soul... Hamke iii.

COMIIENTARIES

in the conmentalies of Caesar writ.2 Henry $\boldsymbol{Y}^{\prime} \boldsymbol{I}$.

that fearfinl commenting is leaden. Richard III.

peacent commerce trom dividable. Troil. \& $\mathrm{Cr}$

all the eommeree that you have had
better commeree than with honesty? .. Hamle

CONMLINGS-[Kot.]

OMLISERATION-

commiseration on thy heroieal. Love's L. L. iv. l (let.)
pluek eommiseration of his state.. Mer. of Yen. iv. I

lempling . Wour kind commiscration. Tilus Andron.

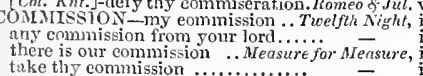

take thy commission.................

I leave you of your eommissions ...

give out a commission for more heads
ask you for your eommission ..... As you Like it,

you commission [Col. Knt.-heraldry]. All's H'ell, ii.
I'll give him my commisson .... Winter's Tale,
$\mathrm{i}$.

are not theye in eommission

are not those in eommission ye

Macbeth, i.

usience, in commission in his ntmost force - iii.

silence, iu commission with me ....2Henry It. iii.

with letters of commission..
the king's commission (rep.)
let lim see our eommission.

..2Henry I'I. ii.

there have been eommissions sent...

have yon a preeedent of this eommiss

by commied foree of this eommission.

highness' hand I tender imy eommiss

our eommission from Rome is read .

stay, where's your commission, lory
large commission to Greory

did my commission to Gregory de Cassalis

sents a commission to a hlank . Troil.

the your commission; hie you

mission with him

your eninmission's ready: follow me.
will do his comminission thoroughly..

he communds his absolute commissio

the words of your eommission will tie
his scaled enmmission. Ict in trust

my commission is not to reason.

the eommission of my place and ners

he hath eommission from thy wife and

whieh the commission of thy years, Rom.
his eommission, to employ those soldiers
your commission will forth
to uritheal despatch
grand eommission.......

here's the eomnission; read it at morc

he shall nur eommission bring to you

and is in full enmmission here for

CUM MISSION ER-late eommissioners?. $H_{m u}-$ iv.

COMNIT - as e'er I dict eommit. Tuo Gen.
to time, I will eommit.............. Tuelfih

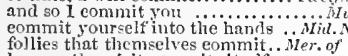

follies that themselves eommit

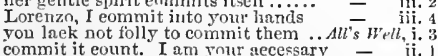

commits his body to painful labou
is for me less easy to eommit......

commit me for committing lionour....

with the dam, eommit them

and will again commit

to my authority, and did commit you

you did eommit me; for which (rep.)

where, inshipped, commit them ....1 Henry $y^{\prime}$ (epil.

never traitor in the land eommit..... 2 IIenry VI.ji.

we will eommit thee thither ........

moved his highness to eommit me now $\overline{\text { now }}$ i.

to commit you, the best persuasions. IIenry $\overline{Y I I I}$. v. 1
OMINIT-onr reiled dames eommit. Coriolanus,
tlus to enmmit your weak eondition.Jul.Cresar, thus to enmmit your weak eondition.Jul. Cresar,
which eommits some loving aet .. Antony \& Cleo. we do eommit muder in lealing ...

commit offenee to my inferiors....... Cymbeline,

commit my eause in balanee to be riius

of my eontritry commit myself.

commit him to the grave ..............

we eommit no erime to use

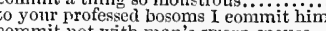

commit not with man's sporn spouse ........

OMMTT'ST-or else eommit'st thy...Mid.N. N. Dr. iit.

commit'st thy anointed body ......Richard In. ii.

have committed disparagements ...Merry Hives, $\mathrm{i}$. I

to prison, where I am committed.Meas. for Meas

there's many have committed it....

flat butact ii. 3

sir, they have committed false report

they are committed; and to conelude
I have eommitted to your worship. Winter

there his fury liad committed.

freason enough ........hacbeth, ii.

intended, or eomitted by your person .. Richard II. iv. I

oath on oath, committed wrong on.. I Henry IF. iv. 3

wilfui adultery and murdereommitted. Henry $r$. ii.l

eniarge the man eommitted yesterday

eomminted to the bislop of York ..3Henvy ${ }^{\prime} T$. iv. 4

have aufht committed that is .... Richard III. ii. I

whe nobles were eommitted, is all .... - ii. 4

I for thatis had been eommitted..... Henry $\bar{F}^{r}$ III. i. 3

that I committed the daring'st counsel - ii. 4

the willing'st sin I ever yet committed - iii.

throats that have eommitted them.. Titus-fnd. iii. I

what eommitted! eommitted! (rep.)

aet of shame a thonsand times committer

commit me, for committing honour. Winter's T? ii. 3

in eommitting adultery with ... - iii. 2 (indiet.)

comin eomitting freely your seruple..IIenry VIII. il. 2

COMIIXTURE-commixture shown. Love's L. L, . 2

thy tougl eommixtures melt........3 Heary VI. ii. 6

take un commodities nupon our bills.2 Henvy FI. iv. 7

onr mere defeets prove our eommodities.. Lear, iv. I

for a eommodity of brown paper.. Mea. for Mea. iv. 3

a eommodity in question, I warrant you - iii. 3

nol eommodity to raise a present. Mer.of Venice, i. 1

for the eommodity that strangers have ${ }^{-}$iit. 3

a eommodity lay fretting by yon. Taming of sh. Hi. 1

tiekling commodity, -commodity ...
this commodity, makes it take head

this commodity, this bawd, this broker

sinee kings break faith upon commodity - ii. 2

such a commodity of warm slaves....

I will turn diseases to eommodity ..2 Henry IV'. i. 2

coMIION_our hint of woe is eommon. Tempest, ii. I

all things in common uature should

thou eommon friend, that's.... Two Gen. of Fer. v. 4

make him a eommon recreation... Tuelfh Night, ii.

and the terins for common justice...Mea. for Mea. i.

use their abuses in eommon houses

do me the eommon right to let me...

a common executioner

ii. 3 .

my dear fliend to a eommon stale ....Much Ado, iv. 1

strike more dead than common sieep - D iv. 1

you menn, from eommon sense? .. $L$.

not jump with common spirits......... of Venice, ii.

to the common ferry, which trades to $\overline{\bar{L}}$ iili. $\mathbf{4}$

I am more than eommon tall ....As you Like it, i. 3

the common executioner whose heart
which in the eominon, is-woman ..

would slay in eommon sense ..........Alls $w$ well, ii. 1
and eommon speech gives him a worthy
and as in the eommon course of all ..

was a eommon gamester to the camp

$\begin{array}{ll}\text { bonght me at a common priee.......... } & \text { v. } 3 \\ \text { I think you now some eommon customer } & \text { v. } 3\end{array}$

rhetorie in your eommon talk.. Taming of Shreu, i, 1

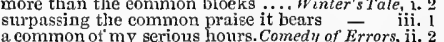

a common of my serious hours. Comedy of Errors, ii. 2

supposed by the eommon rout against $\overline{-}$ iii.

given to the common enerny of man ... Macbeth, iii. 1
the business tron the eommon eye ......

the vain breath of a eommon man ...King Jothr, iif. I

death is common in their mouths...
ONINON-forth in the common sir... Kichard $I I$. i.

the conmons hath he pilled with

and commons cold, and will, I fear

the liateful commons will perform

some way of common traul

二

the colnmons will not then be satisficl $-\overline{ }$ iv.

not in the roll of name to all men..1 Irenry

o common hackneyed in the eyes

but is a weary of thy eommon sight

make it too eommon .............2 renryl

so, thon eommon dog, didst thou .....

the nobles, and the armed commons

or a eommon 'larum-bell?

dith, in eommon sense, erowd us ....

of this bill urged by the eommons?

as 'tis ever eoinmon, that mea are....'.

ort our nobles from our common men

appeared to me but as a common man

beseeming any eommon man..... Henry $r$ iv. conimon grict of all the land .........2Ilenry $l_{l} . \mathrm{i}$.

the greatest favour of the commons..

and common profit of his eountry!

the eommons hast thou of Mclfor

hath he won the eommons' hearts.

the eommons haply rise to saye his life

the commons, like an angry hive

the eommons send you word by mie..

the commons, rude unpolished hind

all the reaim shall be in eommon $\ldots . .$. .

and you, that love the commons, follow

from the king unto the commons

the swords of eommon soldiers slain...3

grief more than common grief

the lightness of you common men.

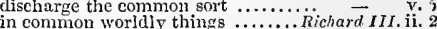

grieved commons hardiy coneeive... Henry VIII i.

as you resuect the common good

the common voiee, I see, is verified ... - v.

列

and that old common arbitrator, time $=$ iv.

tom Athens, 1 .

with inore than common thanks I will -

whieh I hear fiom eommon rumozus

with the eornmon common grace.. iii. 6 (grace)

thou common whore of mankind... - iv. 3

eommon inother, thou, whose womb
in the common wreck as eommon bruit $-\quad$ iv. 3

cieserve the common stroke of war ..

touching the weal o' the common.... -

hut for our gentlemen, the common file

stand upon my common part with

and the eommons made a shower .... -

proviug motion toward the common body -

they were the common muck o' the.. -
I have not been eommon in my love

the tongues $0^{\prime}$ the eommon mouth
passed the nobles [Col. Knt.-noble] and

the commons? [Col. Knt.-conmon]

ried, he not as eommon fool

right and strength o' the commons

you common ery of eurs!

eomnon chances conmon men could

your son will, or exeeed the common

in theirs and in the eommons' ear

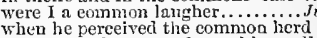

a common slave (5ou know him vell

so appearing to the common eyes....

of prætors, common suitors ..........

the commons hear this testament...

commou pleasures to walk abroad .

and common good to all, made one

he approves the common liar ..... Aniony $\bar{\delta}$ Cleo. $\mathrm{i} .1$

this eommon body, like to

with lips as eommon as the stairs....

it is no act of comnon passage ....... - iij. 4

the eommon men are now in action...

the common people love so mueh..... -

the eommon voiee do cry, it shall be so - Pe the eommon body, by you relieved....

the eommon hangman shall execute it .. - iv.

common sewers, of filth (rep.).

pilferings and most eommon trespasses ... Lear, ii.

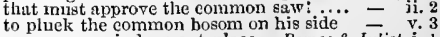

our common judgenient-plaee .. Romeo \& Juliel, i. 
ComnION-thou know'st 'tis common ... Ifamkt',

ny, malam, it is conumon................. whose eviumon theme is deatly of lit fiers eommon tor the rounger surt to lack and oo berattle the commons stages

grow themselves to common plingers at knave of common lire, al gondolicr. in our common renson, (suve that....

a thin for me? it is a common thing.... lie's a very dog to the eommonalty .. Coriolanus, i.

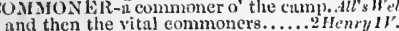
loubt not, the commoners

o thon public commoner Ooriolnmes, ii.

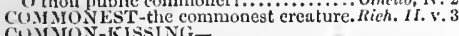

toucl of common-kissing Titan.

CUIMONL $\mathrm{X}$ - fathers, commonly. Tiaming of 's $h$. ii. as our sex commonly are

in women commonly is seen .....

Henry I. v.

coMnIoNTY-is not a coononty. Tam, of Sh. 2 (ium.)

COMAION-W EAL-a common-weal. Men. for Metr. ii.

kind a finther of the common-weal..1 Henry $V 1$. ii

the king and common-wenl are decply

it so with king and common-weal!..

to the loved for king and common-weal.. Titus And,

ripen justice in this common-wenl...

his shipwreck, and his common-weal's

i' the comnumwealth I would

Tempest, ii.

i' the com nimwealth I would ............

indeed, in the commonwenlth! ... Yeas. for $\overline{3}_{\text {cass }}$ i.

was known in the commonwealth ... Much Allo, iii. 3

a good member of the coinmon weal th

nimber ot the common weal th..Her.

thut better to the commonwealih

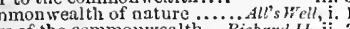

caterpillars of the com of

look too lorty in our commonwealth - iii.

the commonwealth their boots!

the common wealth is sick of their..2 Henry IT. i.

ny brother general, the commonw

lim debate of commonwealth afficir

the bowels of the commonwealth ... irenry

the common wealth hath daily run .2 Henry ${ }^{2}$. i. 3

cume to talk of commonwealth affin

means to dress the commonwealth ...
lord Say hath gelded the common wealth

this our commonwenlth guinst
the commonwealth of A theas..

the commonwealth doth stand

n place in the eommonwealth

3Henry VI. iv. I

if damned co-tempest or commotion

if damned commotion so appeared

when he please to make commotion. 2 Henry $V I$. iii.

to make commotion, as full well he can

some strange commotion is in his brain - iii. 2

what follows then? commotions.... Henry VIII. y.

commotion in the winds? .... Troilus o

Achilles in commotion rages, and batters - ii. 3 more to commune with Bianca ...Taming of Sh, i. 1

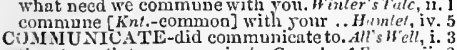

thy strength to communicate. Comelly of Errors, ii. 2 COMMUNICA'TEST-

communicatest with dreams ...... Wrinter's Tale, i. 2
cOMMUNICATION-minister communication of a most poor issue? ............. Henry VIII. i. I COMMUNITY - with community 1 Henry $M$. Aii. 2 COMPACT-this empaet sealed.. Tueifth Night, v. woman, compact with her that '....Meu, for Men. v.

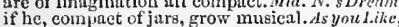
whiles our eompact is urged.

and drift of your compact? ... Comediy of Errors, ii.

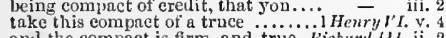
but what compact mean you ..... Julius Corsar iii. iny heart is not compact of flint... Titus diclron, v. 3

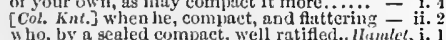

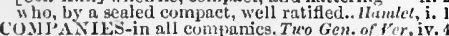
stranger companies [Cols-strange coinpaníns] discreetly in all kind of companies. Tuming of sh. i. throst thyscif in to their companies.. King John, iv. 2 Eentlemen of companies, slave

llenry ri. these villains from ynur companies. Ti... of Ath. v. I search what companies are near.... Cymbeline, iv. so by your companies to draw lim un. Whmlet, it. Bet Caliban and his eompanions free.

companion, youthful Valentine. Ta. Gen. $\overline{\text { F Fer. i. }}$ at his heels a rabule of his conun. this rour componion with the other confederate companion

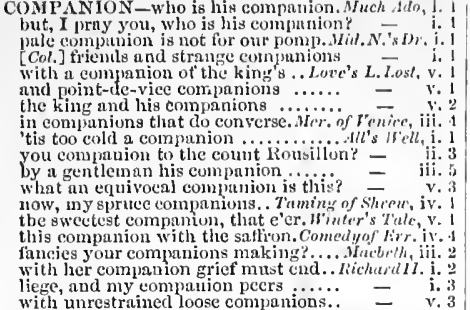

a tun of man is thy companion

grew a coospanion to the commion
a better companion! Ileaven (rop

Inys he, no swaggering compan

studies his companions, fike a strange

to be made companion with a king... I Ienry r w. v. 3

inust be companion of his nuptial....
why, rude companion whatsoe'er..2Henry $r$. iv. 10

liave you therein my companion.. Henry I'll],
our backs from our companions... Timon of. th.

gives entrance to such companions?. Corio

such jiggiug fools? companion

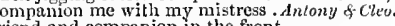

the fron

there is

to be companion with them.

I create you companions to our person $=\quad$ iii 6

never be her mild companion ........... Peric

sad companion, dull-eyed melanchioly...

none but $I$ asd my companion be sufferce

was he not companion with the riotous

as are companions noted and most .... Hanlet, ii. I

COMPANIONSHIP

twenty horse, all of companionship. Tinon of Ath. $\mathrm{i}$. 1

COIIPANY -all our company else leing. Temy

her blind boy's scandal'd company

to thee, and thy company, I bid .....

there are yet missing of your complin

good eompany; with them shail ...
kindly in your company ...........

to forbid gir Valentine her coinpany

forsworn $\mathrm{my}$

thrust fiom the company of awful men

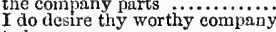

to bear me eompany

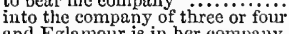

in honest, civil, godly company....

fither desires your worship's company

never laugh bit in that maid's complany

she was in his company at Page's house

torbear, here's compan

for want of company $\ldots \ldots . . . . . . . .$.

and requests your company

I shall make two in the compan

and the rest of their company.

he's drunk nightly in your company

not undertake her in this company.

ain best, when least in eompany ....

grace and good company $1 . . . .$. . Mers. for $\mathrm{N}$

his company at Mariana's house

your company is fairer than honest..

with me in your company?

none but to desire your good company

be bold with Benedick for his compaily

and steal out of your eompany.

we shall be dogged with company

Ihave fursworn lis bed and company

this wood lack worlds of company -id

nor longer stay in your curst compnuy

a while fiom uny own company

danee, between two of our company?

forbear till this company be past... Love's $\bar{L}$. Lost

slaall I send this; companyl stay....
keeping company with moon-like men

worse than the king's and lis eompany

leave you now with better company.

came hither in company

enough to teep his name compriny

creditors in my company to Venice.

in choosing wrong, flose your con pan

to keep his daughter company dinner

I camot live olit of her company.

doth part the flux of company

thit youth is surely in their company

he thou has inot broke from conpan

frieuls must woo your company?..
COMPANY - for your company ...As yon like

thy company, which crst was ou irksin

for licre comes more company...

pot then have his company to-nighit?

have him see his eompany ant
mine uwn company, Chitopher

good will, anl thy good com

Wint in this? Master ......

alse you like not of niy eompany.

wheretiore gaze this goodly eomptoy

and, honest comprany, I thank you ull

mistress Kate, I'll bear you eompuny

what company is coming here

jest upon the company you overtake?

with our company picee the rejoicing?

his company inut in the quest .. Comedly of

more eompany; the fiend is strong
in company, $I$ often glaneed it ...

and in his company, that gentlemin

keep us company, and we
that keeps him eompany

grace us with your roy com....................

brought prince Henry in their conylany. . Jo

your noble company (roped tet)

they will along with conpany......1 Henryl

necurst to rob in that thief's company

forsworn his company hourly ......

so duth the with the rogue's compau

often noted in thy company ......

and cheap to vulgar complany $\ldots \ldots . . .$.

a shirt and a half in all my company

wliat coming snch ving company ...2henry $I$

till time and vantage crave niy company -

discharge yourself of our company

those that kept me company .i...........

take all his company afong with him

and then I would no other company.

as in the king's company .............

would not die in that man's company

shall thine keep company to l

your honoul's bear me company.

sued a valiant company are fled

and so conduct me where froin company -

I be playish her my bed, and company

be playfullows to keep you eompany

my lord; will bear him comprovy...

and craves your company for speed

in my company, my brother Gloster. Richard III.

with our company?

so was I; I'll bear you colmueny

that ever graeed me in thy comp

nay, he must bear you company..... irenry $\bar{V}$ iII.

thought ot this tair evinpany clapicid

my lord, you'll bear us con

and to all this thir company

sir, mire own eumpay

let's have your company

'll keep yor compny an hour or two

I'll keep you company. Swcet sis .......

for he docs neither allect company

entreats your company to-morrow
what do you in this wise compauy

first mend iny conpany, take away.

the plingue of company liglit upon

an areh-villuin keeps him eompany

rll keep you company.....

and most glud of your connen

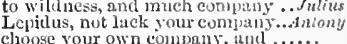

desires your lawn compans, and ......

your compn

no compuny's abroad. None ........

sir, the soldier that did cumpany these

thou art not for my compatuy. Tifus An tronious,

might have your company in liel

our king, and all lis company.. Perieles, v. 3 (Gov.

take you some company, and away ........ Litur
what, hath your grace no letter comfiny?

noble philosopher, your tompany.........
Edmund, kcep you our sister cuminuiny..

for thine to kcep lim cumpany

my dear son with such gour eompuny

lie shall soon keep 'Ty'balt conpany".

aloue, in company, waking or slecping 


\section{COM}

132

COM

COMP.ANY-company, at what expence.. IIamlet, 11 . jerceive in all this noble company my wife is fitir, feeds well, loves company $=$ ifi.
well, I must leave her compuny.........

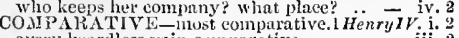
every beardless yain comparative... - iii. 2 malle comparative for your virtues... Cyinbeline, ii. 3 miake no compre between that love. . $-\overline{\text { ii. }} 1$ my love, shall I eompare thine eync?
she hath malle compare between our our weakness past compare Toun of Shreto, y. compare uur tices, and be jndge ..... King John, i. 1 stndying how 1 may compare this prison - v. compare dead luppiness with living...Rich. III.iv. nearest compare to thy flatterers?. Timon of Ath. iv. 3 finiling in him that should compur. Cymbetine, i. I I can eompare onr rich misers to
$i$ the justice of eonnure!

i' the justice of ennpare! ............... iv. yet they are 1 ust eompase.

comprine with him in execllence........ Hamlet, v. 2
COMPALED-I am compred to.. Love's L. Lost, v. 2 as a lamb, beilug compared with $\mathrm{my}$. Nucbeth, iv, 3 COMPARING-comparing to his. Timon of $A t h$. iii. eomparisous are odorous

fur 60 stands the comparison. Lore's $\ddot{L}$. Lost, $\overline{i v}$. 1 (let.) that the comparison may stand...Mer, of Fenice, iii. 2 in the cumparisons between Maeedion. Henr

but in the higures and eomparisons ot

enry $r$. v.

in whose comparison all whites are ink

O Jupiter! there's no eomparison.

after all comparisons of truth.

(a kind of hand-in-hand cumparivon

to compass her I'll use my. Tu'o fien. of i'erono,

that I may compass yours.

of that he conld not compass.
like to the Garter's compass....

that were hard to eompass.......

we the globe can compass soon. Mirl.N, s Dream,

too big, I hops

Whose compass is no bigger than

in good compass; and

to comprer, compross him about

to compass wonders, bne by

exeeds the compass of her wheel ...3IIenry $V I$. iv.

beyond thought's compass ............

compass [Col. -couple] in this arms.. Troil. \& $\mathrm{Cr}_{\text {ress }}$ ii.

to all points o' the eumpas

my lifi is run his compass ............ . Coriotiotan Casar,

within the comprass of my carse... Titus Andron.

past the compass of my wits..... Romeo \& Juliet,
lowest note to the top of iny compass.. Humtel, lowest note to the top of iny compass.. Humtel, iii. this is within the eompass of man'
is it within reason, and eompass?

co.t within reason, and eompass? ........ be compassed like a good bilbo ... Merry W'ives, iit. then he compasstil a motion. .... Winter's Tule, iv. 2 see thee compassed with thy kingdom's. Hacbeth, in to the compassed window... Troilus of Cressida, $\mathrm{i}$. COAPASSENG-compassing the crown!. Henry ${ }^{\prime}$. compassing of his salt and inost hid

that lis compassion may give lite that his compassion may give lite ... King John, iv. 1
in cumpassion, weep the fire out $\ldots$ Kichard 11 . y. 1

of mere compassion, and of lenity.

tenderness and mild compassiou ... Richard 11 . iv make mine cyes to sweat eoinjassi

not relent, or not emp

it boots thee not to be compassionate. Richard $I I . \mathrm{i}$. compassionate heart will not permit.. Tilus And. ii. COIHLL-it may compel him to...Hea, for Mea. iii. I
I can compel. Thou cau'st compel.Mid. N. Dr. Iii.

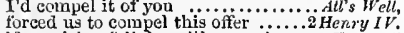
if requiring fail, he will compel which eompel from each the sixth....Henry $V_{1} H_{\mathrm{i}} \mathrm{i}$. eompel me then to read the will?...Jutius Casar, ii compel her to some second choiee ...... Othello, ii. 1
COMPELLED-our eompelled sins...Mea.for Mea. ii. 4 puts it off by a compelied restraint ...All's Well, ii. curse he eamut be compelled to......... Winter's Tale,ii. With valour armed, compelled these ..Macbeth, i. 2 greatness were compelied to kiss ..2HenryIV. iii. pertioree, compelled to banish him ... - iv.
CONPELILE-our ofter is eoinpelled.2 Henry I

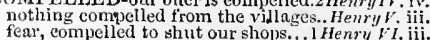
the son, eompelled, been butelier. .. Richard III (f) am I compelled to set upon

being thereto not compclled

we pit on a eompelled yalour. teeth. Hamlet, iii. 3

COHPELING-compelling oeeasion. Anl. \& Cleo. i. 2 COMPETENCE-for competence of lite. 2 Hen.I $\mathrm{H}$. v. 3 receive that natural competeney

a mPETEN'T-eompetent injury. Thefth Nirhl, iii.

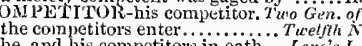

more eompetitors flock to the rebcls.. Rich. II

to hatc one great competitor. Antong

my competitor in top of all design.

cannot brook me a poor competitor. Tilus And. j.

COMIPILE-for her sake compile.. Love's L. Lost, iv,

two learned men have compiled .......

that he hath cause to eomplain
to whom should I eompiain?

thou camest here to complain

let us eomplain to them what fool.... Love's $\bar{L}$. $L$.

may eomplain of good breeding... As you Like it, iii. 2

shall I complain ont thee to our.. Taming of Sh. iv. I

we should ourselves eomplain

alas, znay I eomplain myself? ........ Richard 11. i.

what I want, it boots not to cornplain - in - ii. 4

wrong whereof you both eomplain?.1 Henry VI. iv.

if they did complain, what could

COMposed he must complain.. Romeo \& Jul. i. 5 (cho-) COMPLA INER-specehles eomplainer. Titus And. iii.

to his eomplaining names

snch sweet complaining grievanee

the nightingale's complining not.. - iii.

humbly complaining to her deity ... Richard $I I I . .1$.

adieu, I pity thy complaining
they vented their complainung

no less with thy complaining $\ldots . .$. . Coriolanuseline, 1 i.

to have a dispatch of eomplaints

that there was complaint intended

with complaint acainst the enild

the complaints, I have heard of you ...All's Well, $\vec{i}$.

what impediment this eomplaint. W. inter's Tale, iv. 3

that the eounplaint they have to the king - iv. 3

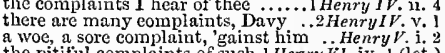

the pis late complaint will make but. .2 Henry $V I$. i. 3

trouble him with lewd complaints.. Richard III. i.

[Col. Knt.] to bring forth eomplaints $\vec{V}_{1 I}$ ii.

will now unite in your complaints...
given ear to our complaint.........
my lord, grievous complaints of you

my lord, grievous complaints of you - vo

each compliant, dislike, he may enguard.. Lear, i. 4

COMPLEMENT-

a man of complements $\ldots . . . \ldots$..... Love's $L$. Lost, i. 1

these are eomplements, these are humours - ifi.

$[K n t.] \mathrm{my}$ heart in eomplement extern.. Othello, i.
COMILETE-he is complete. Tu० Gen. of Vernna, if.

can pierce a complete bosoln ..... Meas. for Meas. i.

of grace, and complete majesty ... Love's L. Losl, i.

no, my complete master: but to $j$ ig.

every way complete; if not complete. King John, ii. in complete glory she revealed ..... I Henry VI. $\hat{i}$.

make the hour till complete

thand all the complete armour that. Ricnard $H I$. iv

this man so complete, whio was

thou great and complete man.. Troilus \& $\overline{c r}$ ress, iii., 3

a thousand complete courses of the sun! $\overrightarrow{\text { iv. }}$ iv

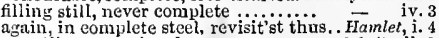

a pestilent complete knave $\ldots \ldots \ldots \ldots . . . .$. Othello, $\mathrm{i}$.

of what complexion soever ....... Merry Wives, iv.
drew to the complexion of a goose!
eye, forehead, and complexion... Twelfth Night, i.

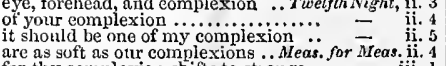

for thy complexion shits to strange - iii.
being the sonl of your complexion...
know love's grief by his complexioni. Much Ado, i.

womething of that jealous complexion , - i. Lost i.

of all complexions the culled sovereignty

and ethops of their sweet complexion

and the complexion of a devil...Merch. of Veniee, i.
mislike me nut fur my eomplexion..
COMPLEXION-of his complexion.. Mer. of ren. ii. gnod my conplexion! dost thou...As you Like $i$, iii. $\mathrm{g}$ between the pale complexion of true love too great testimony in your complexion

changed comptexions are to me.... Winter's

what eomplexion is she of ?. . Comedy of Errors,

judge by the complexion of the $\mathrm{kky}$. Richard $I$ ehange the complexion of her maid -pale - iil. 3 that you lose of my greatness ....2 Henry IV. ii. 2 with his smirched eomplexion, all feil $\overrightarrow{\text { in }}$ iii. 3 his complexion is higher than his .... too flaming a praise fur a good complexion - i. horsed with vuriable complexions .. Coriolumus, ii. reserve that excellent complexion ..... Perictes, iv. the by the o'er-growth of some eomplexion.. Hamlet, i. this dread and black complexion smeared - ii.

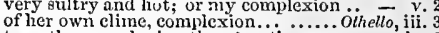
turn thy complexion there! patience.... fight with Glendower and his eomplices - iji. lives of all your loving compliees ....2HenryIV. I. thyself, and all thy complices ........3Henry $V I$. iv.
COMPLIMENT-ealled eompliment.Twelfin $N$. iii. valour into compliment, and men ..Much Ado, iv, stay not thy eompliment; I forgive thy - iv. but that they eall compliment.... As you Like it, ii. 5 with customary compliment ....... Winter's Tale, i. 2 come, come; sans compliment......... more meelanienl compliment... Antony \& Cleo. iv. 4 firthe will not allow the compliment............ vear, i. but farewell compliment! .......Romeo \& jutiet, ii.

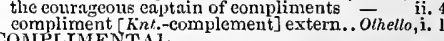
make a eomplimental assanlt. Troilus \& Cress. iii. their complot is to have iny life....2Henry VI. iii. will not yield to our complots? . Richard III. iii. the complot of this timeless tragedy. Tilus And. ii. 4 abominable deeds, complots of mischief - $\mathrm{v}$. to lay a complot to betray thy foes
COMPLOTTED-complotted and eon trived. $\bar{R} i c . I I$. i. he did comply with his dug, before ........ Hamlet, ii.
y. nor to comply with heat, the young ..... Othello, i. if we compose well here ..... Antony \& Clooputra, ii. with her neeld composes nature's. Pericles, v. (Gow.) whose eomposed rhymes should. Tu. Gen. of Ver. iii. 2 eomposed and framed of treachery ...Much Ado, v. 1 one that composed your beanties ..Mid. N. Dr. i. imitate that which I composed ....... Henry $V$. iii. well composed, with gitts of nature.Troil. \& $\mathrm{Cr}$. iv.

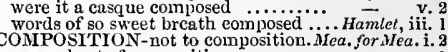
the composition, that your valour........Al's $w^{-}$ell,, $\mathrm{i}$. made in the unehaste composition ... - Macbeth, i. in the large composition of this man? King John, i. mad kings! mad composition! ......

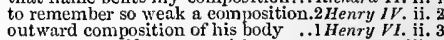
caused our swifter eomposition ..... Coriolanus, iii. our eomposition may be written ...Ant. $\delta$ Cleo. ii. nothing but the composition of a knave... - ii. there is no eomposition in these news .OHello, $\mathrm{O}$. COMPOSTURE-by a composture. Timon of Ath. iv. 3 thou art of sweet composure ........ - ii. as his composure must be rare. Antony \& Cleopatra, i. 4
COMPOUND -rankest compound. Merry W'ives, jii. 3 componnd with him by the year... Nea. for Mea. iv. I'll compound this strite .............. then behold that compound ........ Henry $I V$, ii. whoreson mad eompound of majesty.2HenryI $\mathrm{V}$. ii. 4 only compound me with forgotten ........ Henry $V$. ii. 1 ransom thon wilt now compound.....
I must perforce compound with mistful $=\quad$ iv. 6 componend a boy, half French......... $-\overrightarrow{\text { inenry } V I . \text { ii. } 1}$ let me compound this strife ........ Henry $V I$. ii. 1 wheu I find the ass in compound .. Coriolanus, ii. I these most poisonons compounds ....Cymbeline, i. 6 did compound for her a certain stuff $\overline{-}$ v. s than these poor compounds that. Romeo f Juliet, y. COMPOUNDED-compounded of. As you Like it, iv. I this foolish compounded clay, man..2Henry I $\mathrm{V}$. i. 2 weighed such a compounded one?... Henry VIII. i. eomponnded thee poor rogue.. Timon of Athens, iv. 3 she, of all compounded, outsells..... Cymbeline, iii. 5 my father componuded with my mother.. Lear, i. 2 
COMPOUNDED-compounded it with.. Ifamet, iv 2

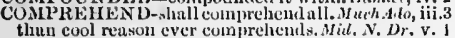
thiun cool reason ever comprehents. Miel.

that ort womld compreh

COMPREILENILLD-

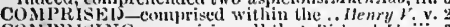
COMlPlISING-comprising all tlut. Rieherl M1. iii. 3 make compromise, insinution .... King John, v.
basely yiched npon eompromise .. Richart II. ii. the natter grows to compromise

CoMp'

theirs, in comyt, to make their nuelit

and have the dates in compt comp wit shall meet at compt, this look. Ohell COAIPULSATORY - nind terms compulsutory

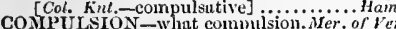
the highest compulsion of base fear...Ail's "I'ell, iji. by the compulsion of their ordnatice. King

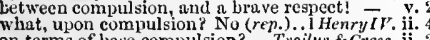
nn terms of base compulsion?
fools, by heavenly compulsion

COMIULSIVE-the compulsive ardoux. itamlet, iii. and compulsive course ve'er feels...... Othello, it CoMPUTATION-by computation. Comedy of $\mathrm{Er}^{-1}$ ii by just computation of the time... Richard III, iii. to be a comrade with the wolf and owl .. Lear, ii. new-batched, unfledged comralle ......Hamle CON-taken great paing to con it.. Troelsh Nigh

to con then by to-morrow night $\ldots$...ivid. $\bar{N}$. Dr. i. 2 but I con him no thanks for't
et de con. De foot, et de con?

and this they con perfectly.

All's Well, iv.

and this they con pertectly.

yet thanks I must you con ... Timon of tifens.il. made in her concave shores? ...... Julius Casar, iii. CONCAYITIES-the concavities of it. Henry $V$. ii. 2 not conceal them, sir. Couceal ...Merry Wioes, iv. conceal me what I am........
be shall conceal it, while

you may conceal her (as best befits... Mruch $A$ do, iv. I over' flights doth still conceal...Mid.N. Dream, i. conceal this dark conspiracy? ... Winter's Tale, iv. to utter them, or to conceal them....2HenryIV. v. 3 tis wisdom to conceal our mcaning.3 Henry VI. iv.

a conceal what we impart........... Richard II. ili. that which torments me to conceal... Cymbeline, $\mathrm{v} .5$

he, that conceals hin, death .............. Lear, ii. might'st pour this concealed mav. As you Like it, iii. like buckets, in concealed wells ........... King John, .. sorrow concealed, like an oven stopped. Tilus And ii. if you bave litherto concealed thome sight. Hamlet, i. CUNCEALING-by concealing it. TwoGen. of Ver. Hii. 1 rive your coneealing continents

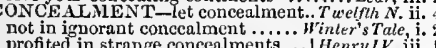

..IHenryIV. iii. will in concealment wrap me up axhile.

CONCEIT-the good conceit .. Two Gen. of Ver. iii. if he be so, his conceit is false......... Much Ado, ii. fuir tongue (conceit's expositor).. Love's L. Lost, ii . good lustre of conceit in a turf ...... with thy kcen conceit

sravity, profound conceit.................

as humours and conceits sliall govern
thy conceit is nearer to death..... As you

hy conceit is nearer to death ....As you Like init. 5

you are a gentleman of good conccit - v. 2 for thy conceit is soakin'........... Winter's Tale i. me my earthy gross conceit ..Comedy of Errors, iii. 2 pressed down with conceit; conceit. Without a tongue, using conceit alone....Juhn, iii. 3 elt' and vain curceit

no more conceit in bim, thin is HewryIV.ii.

to ravish an y dull concit..

approve tlie fair other likes him ... Richar, III. iii. whose conceit lies in lis hamstring. Troil. Heress. in. griefs were but a mere conceit.. Timon of Athens, $\nabla .5$ yet rich conceit taught thee....

bad ways you must conceit me...Jüius cesar, who if it had conceit, would die as.....'Pericles, iii. I know not how conevit may rob......... Lear, iv. 6 onceit, more ricli in thet force his sulle conceit of do th suiting with forms to his conceit? ........ ut your tablel Concit upon her father.. - iv. in thy brain some horribie conceit .....

dangerous conecits are, in their natures

CoNCEITED-humuur concitud?.. Merry Wives, i. 3 CONCEITED-horribly conceited. Trelfh Night, 111.
an admirable conceited follow ...Winter's Tale, iv. 3
well eonecited, Davy; about .......2Henry ${ }^{\prime}$, , 1

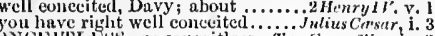

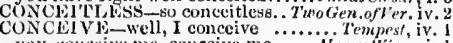

nuy, conceive ne, conceive me ......Merry Wives, i. 1

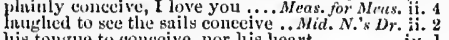

is foul os lo conceive, nor lis lieart - iv.

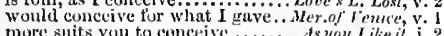

morc suits you to conceive .............

thus sle conteives her tale.............

that could conecive, a gross aud foolish

make coneeive a bark of baser kiud.

that takes upwer

rank, conceives by idleness.............len

pluasure as incaged birds conceive. 3iiemry $r I$ iv. 6

will conecive the tairest of me. Timon of Alhers, iii.

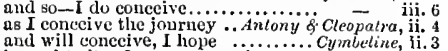

hrazed to it. I eannot conceive you ....... Lear, i. I

conceive, and fare thee well.

but as your daughter may conceive...... Hamlet, ii. 2

What does this geatleman conceive? .... Othello, iv.

that a woman conceived me

he hatli conceived a of spleen ...As you Like it, iv. 1

to serve all hopes conceived.... T'aming of Strew, i. I

if it conceived a male child by me. IIenry. ${ }^{\prime}$ III. ii. 4
tis coneefved to seope.......... Timon of Athens, i. 1

crror soon conceiycd, thou never..Julius Casar, v.

coneeiving the dishonour......... Winte

mnch more his own conceiving ....Cymbetine, iii.

having f'ull reference to one concen

ONCLPTION-my conception... Meas.for $\bar{M}_{\text {eas. }}$ ii.

I have ous conception iu this point.. Henry VIII. i.

joy had the like conception in...Timon of Alhens, $\mathrm{i}$.

conceptions only.proper to myself ... Jutius Casar, i.

have their first conception by misdread.

remember"st me of mine own couception... Lear, i.

conception is a blessing; but as your .. Hamlel, ii.

nor choke, the strong conceptions toy... Othello, iji. \&

ONCHRN - that it concerns..... T'u' Gen. of $V$.

it will not lie where it conecrn

it alone coucerns your ear ........Twelfh Night, i. it concerns me to look into.........eas. for Meus. i.

what I would spreak of coucerns him

how it muy concern my modesty... Mid Meh Ado, iii.

somethiug nearly that coucern ........

t concerns you something to know it...Ali's Well, $\mathrm{i}$.

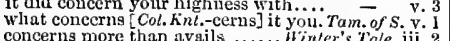

nor concern me the reporting

what coucern they? the genera!

what doth concern your coming?
more than carefully it us concerns

me they concern; regent 1 am of.

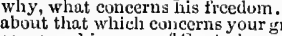

concerns his grace of Can terbury.. Heury VIU. $\mathrm{Y}$.

when it coecrn you vear ..... Timon of Athens, i.

or, being, concern you not

miay concern Čisur.

of nic, or what concerns

known to them it most coocerns.. Titus snetron. ii.

more conecrus the Turk than thodes $-\overline{o t h e l l o}$ iv. 3

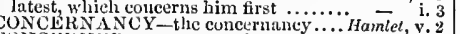

CONCERNETI1-love coneernetli us, Tam.ofsh. ii. 2 is concerning your martiags ........ Merny wives, i.

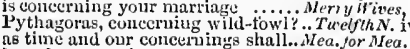

as time and our concervings shall...

as conecrniug Jaquenetta $\ldots . . . . . L$

as concerning some entertinment.... - v.

thoughts, concerning us and France . flemry $V$. i.

concening the rench journey ..... Henty

a gib, sueh dear concernings hide? ..... Hamlet, jii. 4

concerning this, sir, $-\mathrm{O}$ well-painted $\ldots$... - ivelio, i

CNCERT-

swect concert [Col.-consort] ..Tiro Gen. of rer. iii, 2 CONCLAVL-the holy conclave for.Henry $11, \mathrm{ii}$.

conclude, conclude, he is in love.... Much .tilo, iii. they are lying knaves.

to conclude, what youl ay to their chirge $-\overline{-}$ v. most intillibly concludes t $t$...... Love's L. Lost, iv. the other two conclucles it.

and to conclude, - we have 'greed. Taming of $\mathrm{sh}$. i
ONCLUDE-to entelute, thits drud,ge. Com.of'ir. iii.

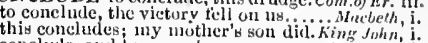

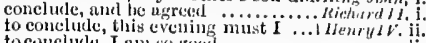

to conclude, I am so go

tili you conclenle, that ho

elull we at last conelude citting

if we conclude a peage, it shall

or clse conelude ny words eficet

and, to conchide, reproaclis iud to

and to enclude with trutli ..........

you conelude that lie is deud . .

to conclude, without the king........

Othen conclude, minds, swayed by. Troil. o cress.

I will couclude to but by the

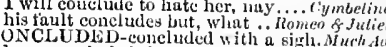

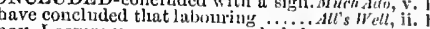

nay, I assure you, a peace

abide within; it is concluale

have a godly peace conclude

Suffolk concluded on the articl

iny presence mingt have bech eoncluded

the senate have concluded to Troilus of C'ressida, iv.

and wits at onec had not concluded all ... Leur, iv.
I had forgot: 'tis so concluded un

I had forgot: 'tis so concluded un .... If umlet, iti. I

CONCLUSION-in concinsion

the conclusion is then, that it

and the consions passed the careires...Merry Wires

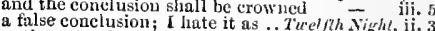

but in couclusion, put stan

the vile conclusion 1 uow be

the she shall be thine... Much do

in couclusion, dumbly have broke ...Mid. $\bar{N} . D_{1}$

beauteous as ink; a good conclusion. Lost, iv. I (let.)

try conclusions [Cot,-conlisions]

must make conclusion of the

of this make, she shall wateh all. 'T'aminy of ah. iv.

in conclusion, he did bent ne........

in conclusion, equivocates him in ...... Macbeth, ii.

draws towards supper in conclusion... Kirver John, $\mathrm{i}$.

there must be conclusions ............. Hewry $V$. iv. 3

and tell him, for conclusion, he liath

and, in couclusion, wins the king..3Henry $I$. iit.

modest cyes, and still couclusion...Ant. o cleo iv.

ny judigment ind conclusions infinite

jadie conclusiner conchusions?".

and, in conclusion, to opjose the bolt

in conclusion, nousuits my nediator

conduct us to most preposterous conclusion

main excrcise, the incorporate conclus

Concolinel-sweet airl .. Love's L. Lost, iii. ! (song)

this gentle coucord in the world... Wh $N$.'s Dr. iv.

we tind the concord of this discord:

his jarring concord, and his discorc

.

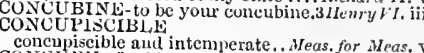

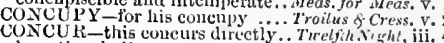

bounties shall concur together. Troilus of Cress. iv.

ONDENIN-at home condemn them.. Templest, iij.

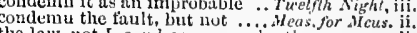

we do coudemn thee to the Urother - ii.

cannot greatiy condem our success. All's Trell, iii.

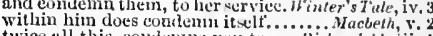

twice all this, coudemins you
thy words condemn thy brat.

1Henrylit.

not want fialse ritue coxdemms....2Henryl'l.ji.

that faultless my condernu a noblemun: - iii.

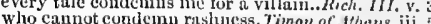

you night condemn us, as poisonons, criakun $\mathrm{v}$.

but must condemn it now...Antony of C'leopatra, ii.

away! I do contemn wime cars

though I condemn it not, y'ct

whose condenumation approof......Meas. for Meas. ii.

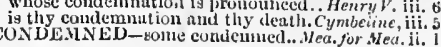


CONDEMNED-the man condemned..Mea.fur.Med I have a brother is conclemneil to die why, every fault's condemned
Clavio is comlenned for unt

condemned upou the act (rep.).......

on this man condeminet as if my brother

thou 'rt condemned; but, for tho

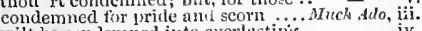
Whil be condenmed into everita

poor thing, condemned to loss $1 . . . . .$.

by law thou art condemed to die. Comedy of Err. on unrepric viable cundemned blood.. King John king stands gencrally condenued...

I shall stand condenned a wandering

my condemned lord is doomud a lirisiner $\overline{-}$

the poor condernned English .......

that sorceress, condemned to burn

tell you whom you have condemned

thus two fricnds condenned entbrace - iit.

truly is he, and condemted unon it.Menry

in your condemnct secomls $\ldots$.......

you are condemned, our general

you have condemned and noted...J
you yourselt are mucli coudemned

the condemned Pompey ....Anto

own tongue thou nort condemned.... Cymbelin
be pitiful to my condemmed sons. Ti/us Andron.

her brothers were condemned to

coudemned villain, I do apprehend. $. \ldots . . .$. Lear, $\mathrm{i}$.

mrself condemed, and myself excused - v

CONDE INING - condemning some..Coriolanus, i. 6

condemuing shadows quite.......Antony of Cleo. v. 2

if thou wilt condescend to be

CONDIGN-in thy condign praise........

never gave them condign pmishment.2 Hen.l'I. iil. 1
CONDTTION-mark his condition...... Tempest, i.

now the condition

I am, in my condition, a prince

the eat-log of her couditions. . Two Gcs. of V'er. iii.

leare her on such slight coudition of this present. Tuelfth

taint the coutition of this present. Tuelf $\mathrm{Night}$, v.

a light coudlitiou in a beauty .... Love's L. Lost,, .

as are expressed in the condition.

in the gentle condition of ulood.

forget the cundition of my estate
such is now the duke's condition

are words, and poor conditions ....... All's $\mathbf{W e l l}$, iv.

As you Like $i t, \mathrm{i}$.

but they know his conditions and lay - iv. 3

our soft conditions, and our hear

whose lieat hath this condition

my condition, which hath

King John, iii. 1

this same time's condition

what conditions we shall stand upon?

no conditions of our peace can st.lir

of what condition are your?

to welcome the condition of the

pry IV. iti.

despatched, with fair conditions.

his senses have but human conditio

this cord condition! twin-born with

this day shall gentle his condition

and my condition is not smooth

a hard condition for a maid...........

upon condition I may quiet

upon condition thou wilt swear.

shall our condition stand?

of so mean coudition, may pass ....2.2Henry $r$. v.

my derree, or your condition........

and those ot true condicion.

either (for so run the conclitious) ....

like couditions as our argument. Troil.s
condition, I had gone baref'sot to India

custom, and condition, made tume

you sue how all conditions $\ldots . . T$

well cxpressed in our condition.

I'l trust to your conditions
back on good condition. Conditio
eonditiou! what good condition

condition! what good condition .

'tis a condition they accou
to yield to his conditions

to yield to his enditions ...............

once more offered the first cond
on like conditions, will have

on like conditions, wilter the condition ot a mar

thus to commit your weak condition

much qrevailed on your conditiou...

upon conditiou Publius shall not live

our conditions so ditfering... Antony o Glenpa

I embrace these conditions ........ Cym

quiet and gentle thy conditionsl....... Pericles, iii.

nakes not un, un such cunditions..........

atars above us, govern our conditious....

Lear, i.

not my unhoused tree condition put .... Othello, iv. and the conditiou of this country stande - ii. 3

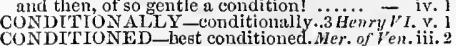
but thus conditioned............ Timon of A'hens, iv. let us condole the knight .............. Hen.'s $\mathrm{Wr} .1$. CONDOLEMENT-certain condolement $l^{2}$ rricles, ii. 1 persẻver in obstinate condolement .... Hitmlet, $\mathrm{i}$ CONDOLIN G-is more condoling. Mid. N. Nream, i.
CONDUCE-conduce to the hot ... Troil. \& Cress. CONDCE- conduce to the hot . Troil.
[Col. Knl.] conduce a fight of this strange
CONDUC'T-nature was ever conduct. Te

desire some conduct of the lady ... T'uelfith Night, iii. welcome then, conduct me thither... Love's $L$. L. í. 1 let us conduct them thither...

give him courtcous conduct ........... of Verice, iv. I
and I shall conduct you, if you... As you Like it, iii. 4 in his own eonduct, purposely to ..... All's $\bar{W}$ ell, vii 4 I will conduct you where you .......All's Well, iii. 5 pray you then, conduct me to..... Winter's Tale, ii. 2

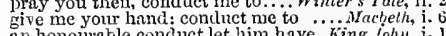
an honourable conduct let him have... King john, i, 1 under whose conduct came those

condinct me to the king

I will be his conduct

and in my conduct shail your......... I IJen $\overline{r y} I V$ ivi. 1 shall follow in your conduct speedily $-\frac{1}{\text { the }}$ ii. the conduct of young Lancaster ...... nenryI cunvey them with safe concl

conduct me to the Dauplin's whe whe froms

i Henry Henry i.

hast been conduct of my shane .....

this conduct to convey me to

I'll conduct you to the sanctuary........

Good lords, conduct him to his regiment - your fair conduct, crave...... Henry VIII. $\mathrm{i}$.

water side I must conduct youn grace - ii.

for you to conduct him thither........

to procure safe conduct for his person
safe conduct from Agamemuon......

stays to conduct you home

to the Roman cannp conduct us.

desire of yout a condnet over land ... Cymiveline, iii.

under the conduct of bold Iachimo ... -

provision give thee quick couduct

fury be my conduct now! ...... Romes

mis-shapen in the conduct of them bo

ancient, conduct them; you best know .. Olhello, i.

conduct us to most preposterous
left in the conduct of the bold Ia

CONDUCTED-shall be conducted. IIea. for Mea. ii. 3

I could wish you were conducted.... Coriolanus, i. 6

CONDUCTOR-conductor of his people?.. Lear, iv. 7
CONDUIT-weather-beaten conduit. Winter's Tale, v. 2

the conduits of my biood froze ...

from a conduit with three issuing. Titus Andron. ii.

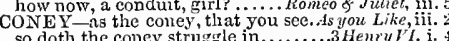

so doth the coney struggle in ........... Hemry

lest you he coney-catched in.. Taming of Shrew, v. 1

your coney-catching rascals ...... Nerry Fives, i. 1
you are so full of coney-catching. Taming of sh. iv. 1

CONFECTION - for my confections?.. Cymbeline,

that confection which

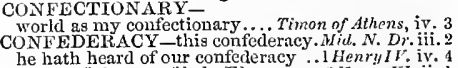
and contederacy of lady Eleanor....2 Henry $l i$. ii. 1

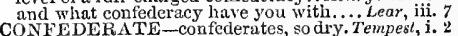

the beast Caliban, and his contederates... $\overline{M e}$

my wife and her confederates... Comedy of $\mathrm{Er}$

a rabble more of vile confederates...

heart is not confederatc with my ....Riehard II. v. nor any of his talse coufederates .1 llewry r $I$. ii. 2 with thy confederates in this weid

Italy, and her confederate arms

was confederate with the Romans... Cymbeli

nor thesc cont'ederates in the cleed that more than one confederate in the fact

confedcrate with the queen, and her
confederate seasun, else no creat ture.

CONFLR - and conter tair Nitin........Tempe

some secrets to confer abou.

conter at large of all that

may conter at large...............

and conter with you of somethiug ...Mid. N. Dr. i.

a parley, to confer with him
to conter about some matter

to ourselves: we must cont
did tou confer with him?.

on whom I may confer what $\mathrm{I}$.

3Henry ${ }^{H}$. v.

for a man and his gloss to confer. Timon of Athens, $\mathrm{i}$.

confer with me of inurder and of .... Titus And

where you shall hear ns conter of this ....Letur, $\mathrm{i}$.
CONFERENCE-in sad conference ....ifuch $A d \sigma, \mathrm{i}$.
CONFERENCE-words' conference...Much Ado, ii. the coufereuce was sadly borne...

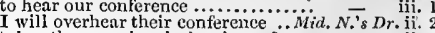
takes the meaning, in love's conference $-\overline{\text { intumes personal conference .. Love's }}$ L. Lost, ij. 1 so sensible seemeth their conference.. yet she urged conterence............ As yon Like it, j. 2 I must be present at your conference conference, about some gossips ... Winter's Tale, 11. 3 good to you in our last conference.....Macheth, iii. I break off your conference............... King John, ii. conference with your grace alone.... Richard II. v. 3 the nutunl conference that my .... Henry $1 \%$ ini. 2 not willing any longer conterence...3 3 Henry VI. ii. 2 no man shall have private conference... Nich. III. i. 1 forbear your conference with the noble - i. private conference. We are husy.. Henry $\bar{V}$ III. ii. ? to know the secret of your conference? sucli free and friendly conference..... - iv. 2 till we have done our conference ..... opportunity of a sccond conference ... Cymbeline, i. 5 not a man in private confereuce ....... Pericles, ji.
drift of conterence [Knt.-circumstance]. Hamlel, iii. in the ear of all their conference......... ill' $F_{F}$ iil , v. 3 hast thou as yet conferred with......2Hewry ${ }^{2}$. i. i. 2 CONFERRING-they sit conferring. Tam. of $\mathrm{sh}$. v. Conferring them on younger strengths .... Lear, 1.1 pou'll not confess, you'li not confess... Herry $W$. he doth in some sort confess it.....$\quad$ albeit, I will confess, thy father's... i though, I confess, on base and.... Tüelfi $\bar{N}$ ight, v. 1

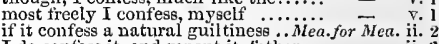
I do confess it, and repent it, father.. - - ii. 3 confess the truth, and say by whose..
till she herself confiess it ........... I do confess I ne'er was married (rep.) I must contess, I know this woman..

she would sooner confess; perchance - wueh Alo, iï. 1 I confess nothing, nor I deiry nothing $\vec{N}$ iv. I I must confess, that I have heard ... Mid. $N$. Dr. i. I must confess, made mine eyes water $\vec{m}$ sir, I confess the wench............ Love's L.Lost, $\mathrm{i}$. I do confess much of the hearing it... I confess both; they are both ....... $\quad$ - i. in so unsecming to contess receipt of $=$ ii 1 let us couless, and turn it to a jest .. $\overrightarrow{\text { confess what treason there is } \ldots \text { Mer. of Venice, iii. } 2}$

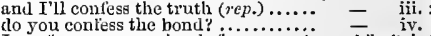
I confess, your coming hefore $\ldots \ldots . .$. As you Like it, than to confess she does............. thy elheeks coufess it, one to the other. All $^{\bar{s}}{ }^{-} W^{\prime} l l, \dot{\mathrm{i}} .3$ then, I confess, here on my knee

I will confess what I know owes ${ }^{-} \quad$ - ii. I may be done, so you contess treely .. - $\quad$ iv. 3

I do confess the ring was hers......... $=$ v. 3 in plainness do confess to thee..... Taming of Sh. i. I I must confess, your offer is the....... $=$ i. 1 confess, contess; hatl he not (rep.) it' thou wilt contess, (or else be .... Winter's Tale, i. 2

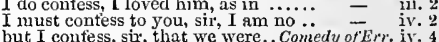
but I confess, sir, that we were.. Comedy of Err. iv. 4 heard you confess, you had ........... king John, i. aud though thou now confess, thou didst - ifi. I my conseience to confess all this .... confess thy treasons, cre thou fly .....
I must needs conless, because ........ i. 3 you contess then, you picked $\ldots . . . .$.$) Henry I V$ iii. 3 two things, I confess, I cannot lielp....

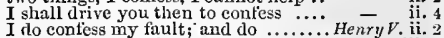
no wisdom to coufess so much $\ldots . . .$. - iii. 6 glad to hear you confess it brokenly $=-$ Hen VI. will not contess thy eitor $\ldots \ldots \ldots \ldots 1$ Henry $V I$. ii. I confess, I confess treason.........2 Henry 2 . iii. 3 yet I contess, that of ten ere this day - iii. 3 these news, I must eontess, are tiull ...

timorously confess the mauuer ..Richard. III, iii. 5 I will confess she was not Edward's.. ${ }_{\text {they all contess, there is indeed .... IIenry }}$ III. $\mathrm{i}$. must now conless, if they have any.. - ji. if you may contess it, say withal

for so 'tis, 1 must confess .... Troilus of Cressidu, i.

white hand, I must needs confess... -

if I contess much, you will

I Imast neets confess, I have... Fimon of Athens, iii. : 2 
CONFESS-they confess, toward. Timon of Alhws, either you must confess yourselv.
silent, and not confe'ss 80 much.

silent, and nol confess 80 much ti...

you slull contions that yoll 111. du you eonfess so in uch? give me.... - jv.

does confess thy greatmess. Antom

but do confess, $I$ have been laden

where, I confess, I slept not

Cymbeline, ii.

she did contess, slic hal for you to mortal -

here confess myself the king of Tyre ...Perickes, $v$.

I confess than 1 am old

Lear, ii. t

to answer that, were to confess to you

I will confess to you, that I love him

I must confess, thit cluty done...........

confi'ss yourself to licaven

Ime not to the purpose, confess thyscil

a doueh, a touch, I do confess....

that will confess-perfection so could err. ols

truly as to henven 1 do confess the vices

if she confess, that she was half...............

slwuld I do? I contess, it is my shame

confess yourself freely to her

I confess, it is my nature's plingue to spy

to confess, and ho hanged for his labour.

and then to confess: I tremble at it....

did he confess it? Good sir, be a man...

therefore contess thee freely of thy sia

hither, and let lim confess a truth
CONFESSED-if it be confessi

CONFESSED-if it be confessed ........ Mer

I have confessed her, and I know ..... -

cunfessed the vile encounters .........Much Ad

we hath confessed himself to Mor

(bravely confessed, and lamented. Winter's Tnte.

lut treasons capital, confessec

very trankly he contessed his treasnins ... Macuet, i. 3 he hath confessed; away with him .2 Henry $\bar{T}$. iv.

always have eonfessed it (rep.)...Timon of Athens, i.

what she confessed, I will report.... Cymbeli

me thing which the gueen confessed . Othello, Y.5

Cassio confessed it; and she did gratify.

wreteh bath part confessed lis villany

and lie himself confessed, but even now $=$ -

gentlewoman, confesses, that she . As you Like it, ii.

by her is poisoned: she confesses

CONFESSETH-which he confesseth. i Henry $I V$. iv.

not confessing their cruel parricide

by confessing them, the souls of.

CNFESION-holy confession. Turo Gen.of $V$ er.

she did intend confession at Patrick's - v.

let my trial be mine own confession a for Mea. i. 2

it appears not in this contession

the fairest is confession

the very sum of my confession...... Ler. of Feniee, iit. 2

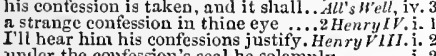

under the confession's seal he solemnly

mistress more than his contession. Troit. \&-Cress. i. 3

riddling confession finds but.... Romeo \& Jutiet, ii. 3

to make confession, and to be absolved

to make confession to this father?

a kind of confession in your look 6

he made confession of you: and gave you

handkerchief,-confessions $\ldots \ldots . . . \ldots \ldots$..... othell

I nm contessor to Angelo, and I know

and his confessor, gives me this instance - iv

sir, a Chartreux friar, his confessor..

confessor to one or two of these!

anil John Court, confessor to him

good even to my ghostly confessor... Rom.
a ghastly confessor, a sin-absolvar . .
CUNFIDLNCE-confidence sans bound..

U NF IDLNCE-confidence sans bound. $T^{-}$iii.

next time we have confidence ....Merry

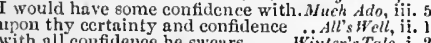

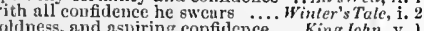

reposetli all his coufidence in the.... King John, v. I I renounce all confilcnce.

with a demure confidenec this ....IIenry PIII. i.

in confidence of anthor's pen... Troil. \& Cress. (piroi.)
your master's confidence was.. Tinton of dthens, iii.

your master's confidence was.. Tinton of Alhens, iii. 4 ,

wisdom is consumen in confutence. Julius Cresar, ii.

I do desire some confitenee with ..Rom. \& Jul. ii.

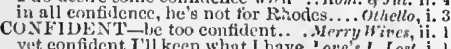

yet confident I'll keep what I have. Love's $L$ Lost, $i$.

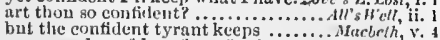

sceure and confident trom furcign..........ing John,

tis forecs strong, lis soldiers eou fident
lions more confident, mountains....

as confickent, as is the fulcon's ...... Richord IJ. i. n re confident agaius: the world....... HenruIV.

it is not a confident brow...........2nkenry 1. ii. confiden $i$ and over-lusty firencli. Hernery. iv. (eho.)
CONHIDENT-I am contlent

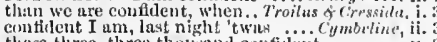

these three, three thousand confillent

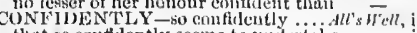

that so contidently seems to und
CONFINE- she did conthe thee

I have from their conflnes calt'

but you must confine yourseld....Tu"
conftne? I'll conflne myselt'no finer

in their own conthes, witls forked.

from our quiet confines tright fai

from our quet confines tright to
measure our coaflues with such....

the mure, that should conflne

here in these confines slily have I...Richari III.

shore, cunfines thy spincious.. T'roilus

confine yourselt most unreasonabl

till veath enlarge his confine.

on the yery verge of her confine $\ldots . . . \ldots \ldots$ Lear, ii.

ering spirit hics to his confine.

in which there are many confines

or conflne him where y'our wis

confined together in tho earne

cannot be measured, or confined.

free jerson she should be contined. Hinier's

as a fiend, confined to tyrannise ...... King

keep the wild food contined:

[Col.] to our purposes confincd

you and I cannot be confineri within

and the execution confined. . Troilus
whereon you stood, confinci into.

confined to exlhibition! all this done...

confined to fast in fires, till the forl ...... Hn

CONFINER-stirred up the confiners. Cymbeli

CONFINING - thy confining shorcs.. King John, ii. ,

in little room confining mithty.. Henry I. V.

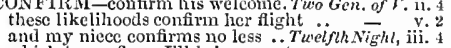

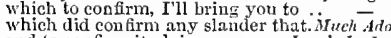

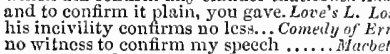

one part confirm the other's peace.

confirm to more approved serv

what she sny's, I'll confirm

alliance will confirm our peree

what we do establish, he co
confirm the crown to me

confirm the crown to me

thou dost confirm his happine

to confirm this too, cardinal $\mathrm{C}$

to coufirm his goodncss, tried it by

confirm my princely brother's... Iroil. \& Cres.

behalf, and thus far I confirm.

whose strength I will con firm with... Cy

and that will well confirm it

which to confirm, this coronet pa
they all confirm a Turkish flect

they all confirm a Turkish flect
CONFIRMLTIUN - the confirmo

and the particitar confirmations

better opinion, better coultrmation.

how dear $f$ hold this confirmation. Ifenry fr.

honoured with confination your.... Cymbeline, i.

confirmation; embrace him de:er Thaisa. Perieles, y. 3

jealous, confirmations strong as proots... Ohe

confirmed by mutual joinder

conting and confirmed honcsty ........Much

I will do witl ron firmet chat is stronger

until confirmed, sisned, ratified...Mer,ofl

faitlitully confirmed by the rector.....

alf is confirmed, my lord ...............Macbeth, v.

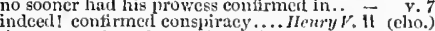

thy age confirmed, proutl, smbtle... Richure lif. i

he's not conftrmed, we may deny hiv

confirmet [Col. Kint.-conferred] on Goneri].
ONI-IRAIER-the confiners of

cad signs confium of thy words? Wing doh,

CoNFIRMITIE

lear with another's confirmities....2 IIpnry $I \mathrm{Y}$. ii.

dicst, and all thy goods are confiscute

your soods too goon be confisert

ull his linds and goods be contisente.311rnry

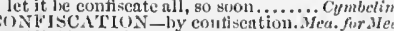

CoNEIXED-tor ever be confixed liere

in contlict that you get the suu........ Wuech $A$ do

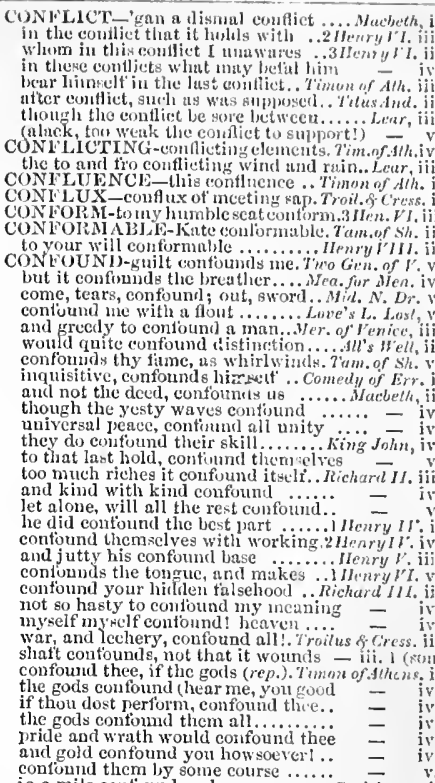

confound them loy some cours

let's not confound the time............

the gods contomd thee? ................

the Roman gods, confunind you both, Titus $\bar{A}$ nd.

interim, pray you, all confound. Pricles, $v: 2$ (Gow.)

appal the firce, confound the istorant.. Humlet, ii.

CONFOUNDED-form confounded.. Love's $L . L$

and module of confounded royalty ... King John

thy tiry spent, confounded be.Timon of Ath

liave confounded one the other....... Cymbeline

to your enntounding contriarie
fet them into confounding odd
CUNFRUNT-coufrom $[$ Col,-col

dunghill curs contront the llelior $]$ your. Jokn, ii.

INRONTED-controuted oflunce?.. IItrilel

lant in proot; confronted him

troubled, coufronted nowe

NF USED-a passion so confuse And ronicis, iv.

dire combustion, and confused events... Macle:h, ii.

injustice and confused wrony $\ldots$....Kiny Joln, $J_{\text {on }}$.

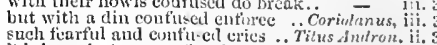

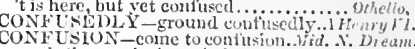

mark the musical contusion of hound

there is such contusion in my" powers
I bar contusion; 'tis I must innle.. As you

and live on thy confusion

clraw lim on to his contusion.

let confusion ot one part confiri

slow nothing but confinsion

of nell mell havosk at: con
belishld contision of your tio

the ruin, there begitis confusion.

henping confusion on the ir own
shame and cont usion! all is ont

make large contitsion; and,
fall in the confusion of men.

not as ouf confusion, all thy

I um out of breath; eonf ensien

while we strut to our contins
nay, to thy mere contusion

confuston titl-

calls,

hafrel denth! confusion! tiecy?........ Lear, it.

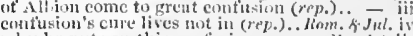

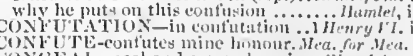

coNGEAl,-cool and comgeal ngain. 


\section{$\mathrm{CON}$}

CONGEALED-pure congealed white.Mid.N.Dr. ili. 2 as fiaws congealed in the spring ....2 Henry I $V$. iv. till thy blood, congealed with this

woul their congenled mouths .....
open thEALIIENT-

wash the congealment from your ant \& Cleo iv. CONGE'D-I lave conter CONGER-you muddy conger, linng. 2 Hen $r y ~ I V$. ii. 4 and eats conger and tennel; wnd drink

to congratulate the princess ....... Love's L. Lost, v. CONGREG TE-most do congregate. Her. of Ven. i. CONGREGATED-

and the congregated college have....A.Al's W'ell, ii. contered rocks, and congregatel sands... Ohello, if. ] before the whole congregatiou

show bare heads in congregations... Corinlanus, iii. 2
n foul and pestilent congregation ...... Hamlet, ii. 2 CONGRUENT-a congruent epithetou. Lore's L. L. i. 2 CONGRUING-

congruing [Col. Knt.-congreeing] iu ..Henry $V$ i. 2 CONJEC'TS-conjcets [Col. Knt.-conceits]. Othello,iti. 3 and give out conjectural marriages. Coriolanus, i. on my eyelids shall conjecture hang. Huch. Ado

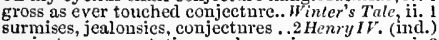
conjecture, expectation, and surmise by all conjectures; first, Kildare's.. Henry Vill. ii. conjectures in in nice conjecture. Troil \&-Cres. iv. coNJoIN-conjoins with my disease. 2 Henry $1 V . i v .4$ CONJOIN ED-shonld not be conjoined. Aluch sdo, iv. 1 I perceive they have conjoined.. Mid.N.Dream, iii. 2 two parts, is now conjoined in one... Henry YI. y. 2 CONJOINTLY-both conjointly bend. King Joln, ii. 2
prodigies do so conjointly meet....Julius Casar, i. 3 prodigies do so conjointly meet.... Julius Casar, i. 3
CONJUNCT-you have been conjunet .... Lear, y. 1 WONJUNCTION-echoin conjunetion. Mid.N. $\bar{D} r$.iv. 1 son, list to this conjunction ........ King John, ii. 2 with our small conjunction and Venus this year in conjunetioni.2 Henry $I V$. ii. and this dear conjumction plant $\ldots . . .$. Henry $V$. v. 2 smile heaven upon this fair conjunction. Rich.1II.v. 4 all my joy trace the conjunction!. Henry YIII. ii. 2
CONJUNUTIVE-conjunctive to my life. Hamlet, iy. 7 let us be conjunctive in our reveuge .... Othello, $\mathrm{i} .3$

mock not my senseless conjuration. Richard II. iii. 2 buz these conjurations in her brain..2 Henry VI. i.

an earnest conjuration from the king \&.. Inamlet, v.

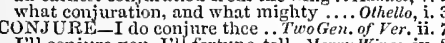
I'll conjure you, I ll fortune-tcll... Merry Wives, iv. 2 to colition would conjure her ..... my way is, to conjure you.......As you Like it, (epil.) dost thou conjure for utenches Comedy of Errors, iii $I$ conjure thee to leave me, aud be gone

I conjure thee by all the saints
I conjure sou, by that which?

I conjurc thee but slowly; run

Macbeth, iv. Barbasun; you cannot conjure me.... Herry $V$. ii. 1 I cannot so conjure up the spirit or devil's dam, I'll conjure thce .... Henry VI. i. 5 any thou canst coujure up to-day ..2 Henry VI. v. learn to conjure and raise dcvils.. Troil. $\&$ Cress. ii. I cannot conjure, Troilus ............ and conjure the to pardon Rome .. Coriolanus, v. 2 she conjures: away with her...........Pericles, iv. 6 I must conjure him: I conjure thee.

I eonjure only but to raise up him .. . Tamlet, ii. I

phrase of sorrow conjurcs the wandering - v. 1
CONJURED-conjured the devil...Mer. evils conjured to remembrance... Winter's Tule, v. 3 he iath conjured me beyond them

like an exorcist, hast conjured up.Julius Casar, ii. 1 with some dram conjured to this effect... Othello, i. he conjured her, she should ever keep it.

they will kill the conjurer

forsooth, took on him as a conjurer.

French conjurers, and sorcercrs
Roger Bolingbroke, the conjurer?

1Henry II. i.

with witches, and with conjurers.....

$\overline{\text { iv. }}$ ivear,

CONJURING-conjuring the moon

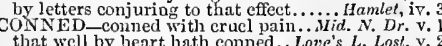
that wcll by heart hath conned... Love's $L$. Lnst, v. the heart that connet them
learned, and conned by rote Coriolanus, iv.
CONNIVE-gods do this year connive. Winter's $T$. lv. 3
CONQUER-of flattery conquers strite. Cmm. of Er. iii. 2 that was wont to conquer others..... Richard $I I$. ii. Kate, to conquer the kingdom .......... Henry $V$. v. the regent conquers, and the Frenchmen - v. were the hove to conquer them arain

the and

that I may conquer fortune's spite...3 Henry $V I$ iv. inchard's bosom will conquer

if we be conquered, let men conquer us

wast born to conquer iny country. Timon of Ath. iv. he hath been used ever to conquer... Coriolanus, iii.

we have used to conquer......... Aniony \& Cleo. iii. 7 conquer lim that did his inaster conquer

to conguer their most absurd intents

CNQUERED-you have conquered.. Al's $\bar{W}$ ell, iv. 2 grcat progenitors had conquered

thieves upon their conquered booty...3 Henry $V I$. i. peither. conqueror, nor conquered. by his prowess conquered all France

we be conquered, let mea........ Richard III. v. When thou hast conquered!. . Timon of Alhens, iv. and other have conquered, I grant. Ant. cleo. Mil. 6 not yiclded, but conquered merely.

in this Britain, and conquered it ... Cymbetinc, iii. wisdom hath her fortune conquered... Titus And. i. . thou art not conquered .......... Romeo \& Juliet, v. 3 their conquering Cæsar in.......... Henyy $V$. v. (cho.) in whose conquering name, let us

from hence a conquering part.

fis conquering banner shook

disputation I kiss his conquering hand - ii. 11

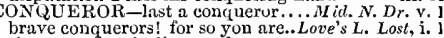

the conqueror is dismuayed

take away the conqueror, take away

a conqueror, and atcard to speak!...

like a Roman conqueror ..........ds you Like it, iv. came in with Richard Conqueror. Tam. of sh. I (ind.) at the proud foot of a conqueror

as his father here was conqueror . neither eonqueror, nor conquered ..3 Henry VI. ii. 5

the conquerors, make war upon ....... Richard 111. ii. 4 from this war thon turn a conqueror

lead thy danghter to a conqueror's bed

virtuous and holy, be thou conqueror

the conquerors can but make a tire...Jul. $\overline{\text { Cees }}$

much you were my conqueror ...Anion

Casar tells, I am conqueror of iny self

gracious conqueror, victorious.. Tilus Anstronicus, i. 2

done, if he return the conquero

stood seized of, to the conqueror .......... Humlet, i.

out-look conquest, and to win renown - -1 . 2

hath made a shameful conquest .... Richard $I I$.
faith, it is a conquest for a prince.... Henry IV
fleshed with conquest, aim to hit ....2 HenryIV

of the nature of a conquest ..........

sucess and conquest to attend oil us...Henry $V$. ii. 2 ascribes the glory of his eonquest got - iii. 4 think upou the conquest of my
the conquest of onr scarce-cold

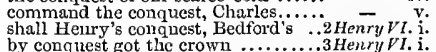

presageth happy gain, and conquicst
by my fall, the conquest to my toc

no conquest ot this conqueror ....R Richard III. iii. I

to whom witl I retain my conquest... - iv. 4

the conquest of thy fury............. Julius Casar, i. 3

what conquest brings he home?...

all thy conquests, glories, triumplis

and your signs of conquest.. Antony \& Cleopalra, v.

put we i' the roll of conquest .....
kind of conquest Cæesar made here.. Cymbeline, iii. I

and make a conquest of unhappy me ...Pericles, i. 4

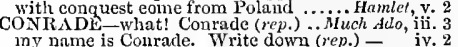

CONSANGUINEOUS-

CONSANGUINITY
no touch of consanguinity....... Troilus\& Cress. iv. 2

CONSCIENCE - thy conscience is so ..... Tempest
but, for your conseience...............

twenty consciences, that stand

you sufter for a pad conseience ....Merry Wives, iii.

now is Cujicl a child of conseience

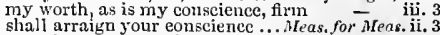

examnine your conscience .............. SIuch Ado, i. 1

the testimony of a good conscience. Love's $L$. $L$. iv.
CONSCIENCE-consciences, that will. Love's L.L. v. 2 my conscience says, no .............. of tenie, ii. well, my conscience hanging about... conscicnce says, Launeclat - ii. 2 to be ruled by uny conscience, say I - i1. give the lie to their eonsciences ( $(r e p$.$) .$ appeal to your own conscience... Winter's Tale, iii. in my conscience, the heavens with.. 80 much my conscience whispers in .. King John iv. 作 his purpose and his conscience, like. $\begin{array}{ll}\text { made it no eunscience to destroy .... } & \text { iv. } 2 \\ \text { betwcen my conscience, and my consin's - iv. } 2\end{array}$ awakes my conscience to contess all this - V. with clog of conscience, and sour.... - v. 6 the guilt of conscience take thou for - true faee, and good conscience.... Henry $I V$. ii. 4 now for our conscience, the arms .... - (evil.) $^{2}$ is in your eonscience washed as pure ... Frenry $\stackrel{V}{V .1 .2}$ may I with right and conscica

with conscience wide as bell

I think, in my very conseience, $\ldots \ldots$ is

in your own conscience now?

I will speak my conscience of the king wash every mote out of his conseience please your majesty, in my conscience ground and his earth, in my conscience yes, my eonscicnee, he did us great goot my own conscience tells me, you are whose conscience with injustice is .. - iii. and in my conseienee do repute $\ldots . .$. . v. 1 with God, her conscienee, and these.. Richard 111. i. 2 the worm of conscience still beguaw some certain dregg of conscience are. where's thy eonscience now?
our reward, thy conscience flies out ... my lord, this argues conscience ....... are gone with conscience and remorse every man's eonscience is a thousand $O$ eoward conscience, how dost thou my conseience hath a thousand sereral our strong arms be our conseience....

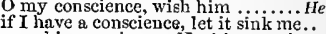
near his conscience. No, his couscience the quiet of $\mathrm{my}$ wounded couseience but conscience, conscience-O 'tis.....
soft chercril conscience would reccive my conscience first received a tendernes sbook the bosom of my conscience .. I meant to rectify my conscien o' my conscience, deserves a corner... I leave to your own eonscience........ a still and quiet conscience

I camnot blane his couscience

yet my conscience says she's a good.

as you do conscience in doing daily on my christian conscience, this one

o' my conscience, twenty of the dog-days - v. 3 canst thou the conscience lack.. Timon of Athens, ii. in my conscience, I was the first main fourth would return for conscience.. Coriotanus ii. 3 I may use with a safe conscience ... Julinus Casar, i. 1 my conseience bids me ask .......... Cymbeline, i. strongly as the conscience docs within heaven, and my cons seience, knows the virtue which their own conseience my conscience! thou art fettered more yet, on my conscience, there are verie a thing within thee, called conscienee. Tilus And.v. et not conscience, which is cold ......Pericles, iv. they're too unwholesome o' conscience ... Z - iv the conscience of the kin.... Hamlet, $\mathrm{ii}$. conseicnce does nake cowards of us iil conscience, and grace to the profoundest now must your conscicnee my acquittunce - iv, is't not perfect cunscience, to quit jim

Yet it is almost against my conscience. .

best conscience is--not to leave undone.

dost thon in conscience think, tell me... - iii. 3 ONSEC A this body, consecrnte to thce.. Comedy of Errors, ii. 2 eonsecrate commotion's bittcr edge? 2 He hryI . iy. seat, to virtue consecratc...... Titus Andronicus, i. to villany und my sword, my chario did I my soul and fortune consccrate... Othello, i. 3 underned th that consecrated roof. Tuelfth Night, iv. 3 


\section{CONSICRATEl)}

mect mo at the consecrutel fount. Mew. for MPa. Iv.

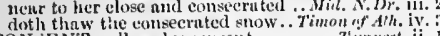
CONSENT-nll, ut hy eousent......... Temp'rst, i

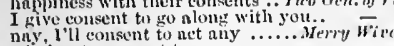

wiin her to consent to you............

waits on my consent, and my eonsent

now in the house, by your consent

thic inmid hath given consent to go . .

thy eoment to not ment, but my int reaty

I will not consent to die this diny

hath my consent to marry her... Mili.

before your grace conseut to marry

by your setting on, by your consent?

and me, of my consent; of ny consent -

here was a consent, (knuwing.... Love's L.. Lost, v.

are of consent and cuife cnough to consent

for all your writers do consent

consent with both, that we may

you ling my consent: let your wedidin

to my endeavours give consent .......Al

the matin consents are lian

that you cxpress consent, which we...

marry swect Bianca with consent.

with one consent to have her so.......
glinlt have my daughter with consent

slinlt have my daughter with consent
a husbanil take by my consent . Winter's Tate, v.
either consent to pay this sum.. Comedy of Err. iv.

consent to pay thee thet I never lad:

it thou didst but consen t to this.

Iacbeth, ii.

it I in act, consent, or sin of thought - iv. 3 thou dost cousent in some harge.

given here my soul's consent .......

flock together in consent, like so...

grows not in a fair consent with ours... $H_{c}-\mathrm{v}$.

to consent to winking. I will wink (rep.) - v. 2

by ny consent, we'll e'cn let them..

consent, (and tor thy hon

king llenry gives conseat .............

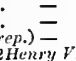

months concluded by consent

say your consent, and censure well

our authority is his consent.

ine swore consent to your succession. 3 Henry VI. ii.

yield consent to disinherit lim.

adopted heir by his consent ....

hadst thou never giren consent

couacil and consent is wantin

I yichd thee $\operatorname{mo}^{\mathrm{y}}$ free consent $\ldots \ldots \ldots$ - $\ldots$ iv. 6

give consent, his master's child ... Michard III. iii. 4

bay, have I thy consent, that ....... Henry ${ }^{r} / 11$.

and our consent, for better trial ....... $-{ }^{-}$

do not consent, that ever Hector.

your full consent gave wings .......

that all, with one consent, praise .....

by your consent and voice, which you

marriage my consent be missin

the senators, with one consent of.

and their consent of one direct way $\cdot$ Coned

by the consent of all, we were est

With the consent of supreme Jove....

do not consent, that Autony........
consent you. Lepidus? I do con sent.

not having my consent, bestow your

there's no going but by their consent ... - iv. 6

lics my consent and fair accordin voice -

than your consent gives strength to

give consent to marry Paris .........

do you consent we shall açuaint

do you consent we shall accuaint .......
upon his will I scaled my hard conse

consent to swer. Propose the oath...... - i. 5

flensure, and most wise consent ..........

dit you and he consent in Cassio's death CONSENTED-she hath consented. Herry Wives, iv.
'tis well consented; presently away...Mueh Ado, iv.
. pove conented to all terms of reason...llenry $V_{\text {. }} \mathrm{v}$. luve con cented unto llenry's deathl.inc ing

you all eunsented unto salisbury'a...̈.

CUNSEN TING - consenting to t...... Coriolinesers, iv.

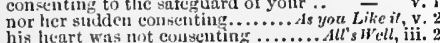

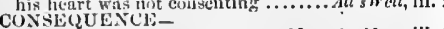

an unshiumetl corrsequence .... Mprs. for Meas. iii.

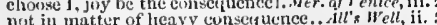

the conseruluence is then ...... Comedy of frrors, $\mathrm{v}$.

to betray us in deepest consequence.... Naebeth,

[Cal. Kat.] know all mortal conseduciences -

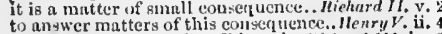

to answer matters of this consedrience...lenry $/$. i.

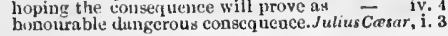

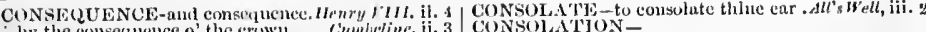

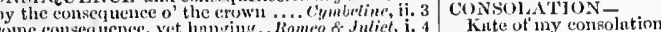

be eloses with you in this ensentuence..

at closes in the consequente. $\Lambda_{y}$, marry

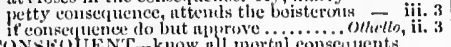

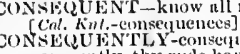

consequently, thy rude land to ... King John, iv.

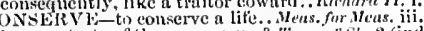

honour taste of these conserves?. Tam. al s/. 2 (ind.

any conserves, give me conse'ves of he othello, iii.

CONSIDER-most deeply to tonsido

considers ghe my possession.

Herry bivers.

consider, he's an enemy to mankind. Turelfth $N$. iit.

masters, you ought to consider

consider who the king your father. Love's L. Lost, ii. I

consiler, what you first did swear unto

be thy plea, consider this .....Merch. of I'enice, iv.

when 1 consider, what great creation...ill's Wre, ii.

consicter little what dangers ..........

consider, how it stands upon my. Comedy of $\mathrm{kr}$. iv.

consider it not so deeply

better consider what you have

you that are old, consider not the...

Hencheth, ii.

we consider, it was excess of wine ..... Henry $V$. ii.

we will consider of this further.
bid him, therefore, consider of

consider lords, he is the next of blood. $2 \mathrm{Henry} V \mathrm{VI}$. i. $\mathrm{t}$

we will consider of your suit .....3 Henry VI. ini. 2 to consider furtlicr, that what his ... Henry IIII. consider what you do: how you may

must consider, that a prodigal. Timon
consider you what scrvices he has

'tis for you; corsider of it ........

consider this; he has been bred i' the
warlike service he has done, consider
consider further, that when lie speaks

what you have said, I will cousider. $J$ ueliws $\bar{C}$ iii. 3

but if you would consider the true cau

not to consider in what case ...Anton!l \& Clen. iii. II

and then let her consider.

madam, you're best consider

consider, when you above perce

consider, sir, the chance of war...

consider him well: thou ow'

'twere to consider too curiousl g guest

We consider the importancy of Cyprus

I hope, you will consider, what is spoke

CONSIDERATE-considerate eyes. Richard $11 \%$. iv.

go to then: your considerate stone...Akt. \& Cleo. ii.
coNSIDER ATION-thy best consideration. Lear,

on carpet consideration

startles and trights consideration

considerations infuite do make ....1 HenryI $V^{\prime}$. v.

these humble considerations make me - -

would give it quick consideration ...Henry ${ }^{2}$ III. i.

come, and drown consideration... Antony \& Cleo. iv. 2
CONSIDERED-considered well.. Ttro Gen. of $\mathrm{F}$ er. i. 3

you will be considered...........'asure for Heasure, i. 2

I have considered so muel, Camill

being somethint gently considered

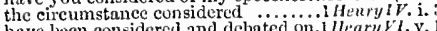

huve been considercd and debated
my lord, I have considered with

I have considered in my mind

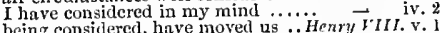

if thou hast considered, let us know. Jnt. Schen. ii.

there's more to be considered

if thine considered prove the

the play be then to be ensileren
CONSIDERING - considering the

many mazed considerings did.

not worth his sertous considerin

considering who thou art

CONSIGN-and we'll consign thereto... Sle Jutict? 11.

condition for a maid to consign to.....

CONSIGNED-and to our purposes, comsirnel

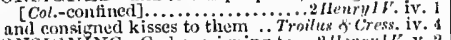

CONSIGN ING-God consigning to ..2Henryll. y. 2
CONSIS'T-do not our liyes censist. Tuelgth Night, ii. 3

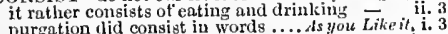

purgation did consist in words ..... As you Like it, i. 3

as our conditions shall consist upon.2flenry $/ V$ iv.
in her consists my happiness...... Richard 11. iv.

most consist of war-marked ....... Antony \& Eleo. iij. 7

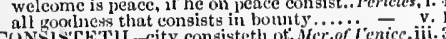

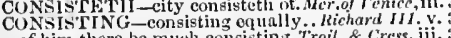

of him there be mueh consisting. Troil. \& Cress. iii.

consistory, yea, the whole consistory. Menry VIII. ii. 4

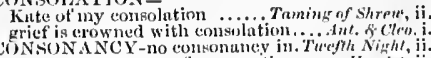

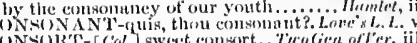

vilt thou

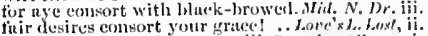

and at terwards consort you

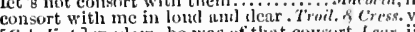

[Col. Krit.] minlam, he was of that consur

zound, consort1 We talk liere.

whio is it that consorts, so late

all the rest of that consorted crew... Kic

witch consorted with that hurlot.. Kichard

for this, consorted with the citizens ivize - ili.

to be consorted with the lumorous. Romeos Jull. ii.

ONSPECTU ITIES

can your bisson conspectuities glean . Coriolanu*, ii.

open-cyed conspiracy his time doth... - ii. I (song)

a pack, a conspiracy against me. Mrrry Wines, iv.
now, for conspuracy, I know not. Winter's linle, ii.

conceal this dark conspiracy? ...... Hicharel $11 . \mathrm{v}$.

strong, and bold conspiracy! o loyal ${ }^{-}$ii. (elo.

O conspiracy! shanest theu...... Julius Cresar, if.

scek none, conspiracy; hide it...

conspirney! sleep till I waked him....... Lear, $\mathrm{i} .2$
CoNSPIRANT-conspirant 'gaiust this high -

CONSPIRATOR-grand congpirator. Kichor $\bar{l}$.

back, thou manifent conspirator ...lllemr! $V I$, i.

tear him to pie cs, be's a conspirator

I am not Cinoa the conspirator......

all the conspirators, save only le.... Tim -

CONSPIRE-and conspirc arainst. Tioo Gen. of

or what conspire you, lords?

that do conspire ny death......... Richard III. iii.

I would conspire against destiny. T'roil. f Cress. y.

what further woe conspires arainst. . Kom, f Jul. $v$, 3

thou dost conspire aganst thy fricud.. Ofhello, iii.
CONSPIRED-have you conspired... Mid. N.Dr. ii.

they have conspired together.......er. of chere,

lightly conspired, and sworo.......... Henry $r$. ii.

conspired with that irregulous devil. Cymbeline, iv.

CONSPIRER- where conspirers are ... Wacbeth, iv.
CONSPIRING-

conspirior with Camillo. Winter's Tale. iii. 2 (inuliet.
CONs'TABLE-to justle a constable .. Tempert, iit.

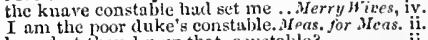

how dost thou know that, coustable?

do the constable's wite any' harni?

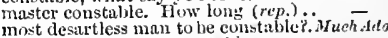

both which, master constable........ -

you, constable, are to present........
call up the riglt naster constable

master constable, you go not tic way

master constable, - pray thee, tellow

this learned constable is too cunning

nay, a night-wateh comstable . Lone's $L, \bar{L}$ Last, iij.

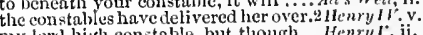

my lord high constable, but though ... Henry

thereforc, lord constable, haste on
forth, lord constable, and princes ali

my lord high constable, you talk.

my lord constable, the armonr....

my lort high constable, the Eniglish lie -

now! my lord constable! I Iark.

tell the constable, we are but warriors

I was lord higli constable ..........1knry VIII.

the constable's own word......... Rome'o oumbitious Constance. King John, i.

is not the lativ Constince in this trool

lady Constance, peace. Whar! Wart.

comfort, gentle Constuncel

my name is Constance $\ldots . . . . . . .7 i . .$.

CONSTANCY-my true constumey. Foofien of $V$. it.

men of such constaney put to $6 \mathrm{en}$. Tirelinh $\mathrm{Ni}_{\text {ith }}, \mathrm{i}$

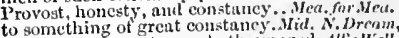

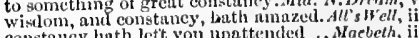

constancy hath lett you unattended ...Maebeth,
fellow ot plain and uncoined constancy. Menry

ant forec them with a eonstancy.. Mrenry $V^{\prime \prime I}$. iii. 2

find persistive constancy in men?. Troilus of Cress. i. 3

spirity, and formal constancy.......ulius corsur, ii. 


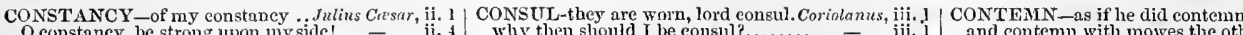

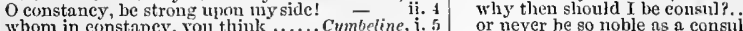

whom in constancy, you think ........ Cymbeline,

CONSTANT-Was so tirm, so

prove constant to myself ... Tivo Gen.of Verono,

or never be so noble as a

it makes the consuls base ...........

and . Coriolanus, ii.

were mas but constant.............

enter...

as I do know the eonsul's worthiness

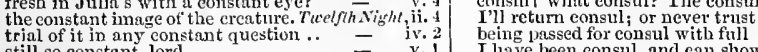

still so eonstant, lord

I lave been consul, and can show

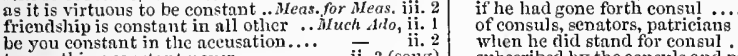

be you constant in the aceusation.... $-\overline{i i}_{3}$ ii.

to one thing constant never............

subseribed by the consuls and partricians
Hirtius and Pansa, consuls, at thy ...Ant f

sent by a consul to me............... Cymbet

the constitution of any constant man

the constant serviee of the antipue..As you

to this I am most constant ...... Winler's

arm thy constant and thy nob

constant you are, but yet a wom

and many of the consuls, raised, and met

I pray, your price o' the consulsbip?

I pray, your price o' the consulsbip?
CoNSUt'T-let's consult together..Merry Wires, ii. 1

lest they consult about the ........2 Henry I I. iv. 7

kiss thee with a most constant heart. 2 Henry Il:

with faith, and constant loyalty......

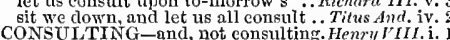

CONSU MLE-consume away in sirbs. Mich Adlo, iii. I

how terrible in constant resolution

shall nssure my constant loyalty ..3 Henry $l$ I. iii.

long as Edward is thy constant friend - iv.

bring me a constant woman ...... Henry FIII. iii. I
they are constant, being won ...Troilus \& Cress. iij.

sir it is, and $I$ am constant .......... Coriolanus, i.

sir it is, and I am constant ............

you keep a constant tem

do consume the thing that feeds. Toming of Sh. it

after that, consume away in rust.... King John, iv.

consume you wieked caitiffs. Timon of Ath. v. 5(epit.)

will it consume me? let me see .. Titus Andron. jii. 1

do not consume your blood with.......Pericles, iv, 1
which, as they kiss, consume

I am constant to the northerm sta. ... -

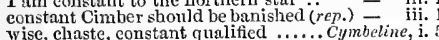

wise, cliaste, constant qu
g sly and constant knave

they are not constant, but are elianging

I divine, is this most constant wife . -

a constant will to publish ou daughters'

bring his eonstant pleasure

I am constant to my purposes...

is of a constant, loving, noble nature..... Othello, ii. CONSTANTINOPLE-

that shall go to Coustantinople .....IIfenry $V \cdot \nabla$.

I do constantly believe you ..... Neas. for Meas. iv.

I constantly do think, (or, rather. Troil. \& Cres.

to meet all perils very constantly..Julizs Cepsar, v. 1

since patiently and const constantly.... Hamlel, i.
his eyes upon you? most
CONSTELLATION-constellation is.. Twelfh $N$. i.

CONSTITUTION-excellent constitution

turn so much the constitution. Merch of Venice, iii.
CONSTRAIN-constrain me to tell..... Much Ado, i.

constrains them weep, and shake.

and eonstrains the garb, quite trom ....... Lear,

CONSTRAINED - be constraincd in't. Tuelfth $\mathrm{N}$.

I have constrained one to call me...

with him bnt constrained things ....... Macbe

constrained to wateh in darkness ..1 Henry VI. ii.

thus was I not constrained.

see it constantly consumed with fire. Alinter's T.ii. 3

have consumed with fire our town. . Richard II. y. 6
consuned his royal person ........ Richard III. i. 1

what else dear that is consumed.... Troil.\&. Cr

their way, consumed with fire....... Coriolanus, iv. 6
wisdom is consumed in confidence.Julius Casar,if. 2

Wisdom is consimed in confidence.Julius Casar,if. 2

WNSU MIING-consuming means ...Richard II. ii. 1
whiles thy consuming canker eats ... Henry VI. if. 4

whiles thy consuming canker eats ... Henry hi. il. 4

consuming sorrow to thine age ... Titus Andron.
CONSUMMATE-

Which consummate, return bim .. Mca. for Mca.
till your marriage be consummate ... Much Ado,
post to

post to consummate this business..... King John, v. 7

consummate our spou
CONSUM ITATION-

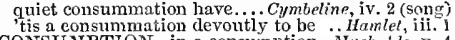

CONSUAIPTION-in a consumption. Wueh Adla, , 4
this consumption of the purse $\ldots . . .2$ Henry $I V$ i. 2

consumptions sow in hollow bones. Timon of $\mathrm{Ath}$. iv. 3

consming, scalding, stench, consumption. Lear, iv. 6
con'TAGION-dulcet in contagion. Tuelfih Nighi, ii. 3

strumpeted by thy contagion 7 Comedy of Lrr.

the vile contagion of the night? .. Julius Cassar, ii. 1

hell itself breathes out contagion...... Hamlet, iii. 2
I'll toncl my point with this contagion - iv. 7

a contagious breath (rep.) .........Twelfh Night, ii. 3
up tiom the sea contagious fors. Mid. $N$. Dream, ii. 2

up tirom the sea contagious foss. Mid. N. Dream, ii. 2

permit the base eontarions

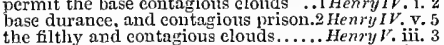

a most eontagious treason come to ...

I am glad to be constrained to utter .. TilusA $\overline{\text { nato }}$. v.

CONSTRAINETH-constraineth me. Aid. N. Dr. iii. 2

by love's own sweet constraint

confess what I know without con

it should be on constraint

bloody constraint! for if your lide....... Henry $V$. ii. 4

CONSTRINGED-constringed in..Troil. . Cress. y. 2

observe his eonstruetion of it .... Tweifin

o illegitimate construction! $\ldots \ldots \ldots . . . . . M$

the merciful construetion of rool. Heiriv VIII.

at him admits a good construction.

show bis skill in the construction..... Cymmelt

I can construe the action of lier

I will construe to them whence.. 'T'elf'h Night, ii

construe then. Hae ibat, as.. Taming of Shew, jii. 1

now let me see if $I$ can construe it.

construe $[$ Construc the times to ....2 2rien ry 1

construc any further my neglect..Jui

men may construe things atter their .

jealonsy must construe poor Cassio'

were he to stand tor consul

Were he to staud tor consul $\dddot{2}$..........

to desire the present consul, and last
and i' the consul's view slew three

well pleased to make thee consul ...

to nur noble consul wish we all .....

beseech you, I nay lie consul ..........

indeed, I would be consul.....
therefore let him be consu]

I would be consul, says he ..............

breathe foul contagious darkness ..2Henry VI. iv. 1

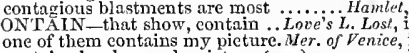

one of them contains my picture. Mer. of Venice, ii. 7

your own honour to contain the ring $-\bar{T}$ v.

this listle abstract doth contain ....King John, ii.

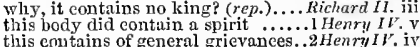

please ic you, contains at large

to envelope and contain celestial $\ldots . . . . .4$ Henry $V . i .1$

worst, this letter doth contain?

ever did contain a thing of worth..2Henry $V I$. jii. 2 contain yourself; your passion ...Troil. \& Cress. v. 2 contain yourself; your passion ..Troil.

two days' shine, Athens contain thee $-\overrightarrow{\text { ii. }} 5$
too great for what eontains it ...... Coriolanus, v. 5

your Italy contains none so.

dost contain [Col. Knt.-is dust]............. Leareo \& iii.

a paper, which containeel the name..All's Well, v.

CONT AINING-containing her affection $M u c h A d o$, Y. 4

but for containing fire to harm mine. King John, iv.

whose containing is so from sense ... Cymbeline, v. 5

as much containing in as all these .... Hamtel, iv. 5

ruffian lust should be contaminate?. Conz of Err. ii.

his fairest daughter is contaminate . ffenryl $V$ i iv. 5

CONTAMINIATED-

to a contaminated stale, such a onc.. Mrueh Ado, ii. 2

scruple of her contaminated carrions, Troil. $\&$ Cr. jv.

Which contemns its origin, cannot be..... Lear, iv.

plaster by contemned revolt ....... King Jolu, v.

to he contemned, than still eontemned ... Lear, iv.

penance for contemning love.. Tu:o Gen. of Ver. ii. 4 CONTEMPI ATE-must I contemplate. 3 Hen. $V I$, ii. ON'TEMPLATION

lenden contemplation a rare......Twelflh Night, ii. live in prayer and contcmplation. Mer.of Venice, iii. the sundry contemplations of my travels with contemplation and devout desires... John, v so sweet is zealous contemplation. Richard III. iii. slinped cont mplation were above. Hen.VTIT. iii. doth molest my contemplation? .. Titus indron. v. what serious contemplation are you in? . Lear i. CONTEMPLATIVEa contemplative idiot of him .... Tielfih Nighl, ii.
and eontenplative in living art ... Love's L. Losi, i. I
CONTENIPT-contempt of love. Tü Gen. of Ver. ii. will grow more contempt.......... Nerry Wines, i. at any tling more than contempt.... - ii. but turn him in to a notable contempt

in the con tempt and anger of his lip! - iii. contempts thereof are as touching. Love's L. Lost, $\mathrm{i}$. wlyy, that contempt will kill the .... you put off that with such contempt? check tliy contempt: obey our will.. = ii. - ili. ontempt and clanour will be .... Winter's Tale, $\mathbf{i}$. lip of much contempt, speeds from ... - i proud contempt that beat his peace... King Johm, ii. I or with much more contempt ...... Richard II. v. his tasking? seemed it in contempt? subjects to oppression and contempt... Henry $V$. i slight regard, contempt, and any thing - ii. who, in contempt, shall hiss at thee.2Henry $V I$. iv, under foot with all contempt ......... and the nobility held in contempt..... - i.

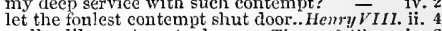
Walks, like contempt, alone . Timon of Alhens, iv. boint to misery and contem

the senator slall bear contempt.......
he did solicit you in free contempt.. that his contenpt shall not be bruising

forget not with what contempt he wore $\overline{-}$ into contempt the suits of princely... Cymbeline, iii. can her contempt be answered?...... meal, and bran; contempt, and grace - iv. justice, used in such contemut?.. Titus Andron. iv. or the best, for these contempts

to laughter and contempt; that she may $\overline{-}_{\text {Lear }}, \mathrm{i}$. in col. Knl.] contempt and beggary... Romeo \& $\bar{J} u l$. v. know all, hath a contemptible spirit.. Aruch Ado, ii. 3 to shine on my contemptible

King John, ii. 2

contemptuous hase-born callat as she.2 Henry ${ }^{\prime}$ l. $\mathrm{i} .3$
CONTEMPTUOUSLY trumpling contemptrously on.. Tu'o Gen. of Ver. i. 2

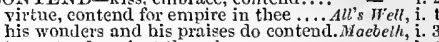
to contend against those honours
do contend about them, whether do contend about them, whether
two such kingdoms did contend

southern clouds contend in tears......Henry $V$. . i. when dying clouds contend with....3 Henry VI. ii. 5 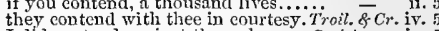 I did contend against thy valour .. Coriolanus, iv. for I will wend, out of our question... Anl. \& Cleo. ii. whom I am too little to contend......... Pericles, i. contend not, sir; for we are gentlemen - iv. (Gower)
this Pluiloten contends in skill... - - iv. when hath contend which is the ....... Hamlet, iv. 1 contended especially to know .. Meas. for Mlens. iii. 2 but $a$ foul eontending rebel .. Taming of Shreer, $\mathrm{T}$. 2 out, contending 'rainst obedience ......Alacbeih, $\mathrm{ii}$. blood at Grecinn swords' contending. Coriolanis i. contending with the fretful clement .... Lear, iij. furnish it anon with new contents

and rest myself content.................

that the contents will show .... Two Gen. of Ver.

are you content to be our general? - iv.

verefore sliall I be content-a? ......... 
CONTENT-I warrant, to your content, Nerry $H$, iv. $s$ of such contents as you your

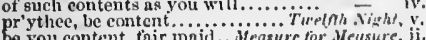
be you content, tair maid...Mecosure fin brother dies to-morrow: he eontent.

the image of it gives ne content alrearly

yet $I$ will be content to loc a laxtul... =

whose contents shall witneas to him.. _ - iv.

content yourself: Gool know日.........Mueh Adn, y.

as minding to content you, our true - v. 1 (prol.)

they are content to whisler............
what are the contents?

Lore's
Lits die

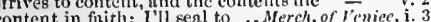

be content, and scek no new

ii. 2 (scroll)

your ladyship all henrt's content

I am content, so he will let me have

now go we in content to liberty ...As

light upon some settled low cont

hut travellers must be content $\ldots \ldots$

menns, and content, is without three

doth ny simple fcature content you?

I know not the contents

know not the eontents

I will content you, if what (rep.).....

if truth holds true contents ..........

I have had to cven your content....

and for the contents' sake, we are eorry

with very much content, my lord.

content you in my discontent .... Triming

gentlemen, content ye: I am resoived

this contents; the rest will comfor

Basta, content thee; for I have it....

content you, gentlemen, I'll compound

I am content Are you content (rep.)

O Kate, cont

his painted skin contents the eye?....

I am content in a good father's care.

we will content you, go to

content; what is the wager ...........

a hundred then. Content. A match
would they else be content to die?. Winter

more it would content me to have her

shatl the contents conter, somethis

$\mathrm{X}$ am content to look on (rep.)......

to your own content (rep.) ..... Comedy of E Errors, i.

our desire is got without content ........

be content. It thou, that bid'st (rep.)

not care, I then would be content
pardoncd, am content withal .......

pardonce, and content withal wound our ealm contents

cood mother, be content

thmughts tending to conteist, fiatter.

content to do the prolession sol

content; and the argument shall be

content. To-night, say I.

I could be well content to entertain

i) am content, that he slall tak

il est content dc vous donner
den it shall also content me.

I am it shantent; so the maiten cities

content; I'll to the surgeon's

a s you not content? Content.

so eontent? An if my father (rep.)

I could be wcll content to be minc

the fulness of my heart's conten

Work your grace's full content ......
I am content: provide me soldicrs ...
Iargaret; these words content me much

I am content he shall reigu

could commanil no tnore content than I?

shall he so; content thrscli ........3llenry

$\mathrm{my}$ crow $\mathrm{n}$ is callel content ............

with content, your crown content.

cry, content to that which griec

well content with that aloin

it to your honour's good contcit?....Richard III. iil. 2

next sabbath, and 1 will content you

with double ricles of content

cierlicates to fair content, ant you... IIen

our content is nur best having

forgot my prayers to content

these are the wholc contents .........

pruy you, content you...........
worsc, than the worst, conteit. Timon of sthens

peace and content lic herel

and could be content to give .......... Cor iol

soft-consciencert men can be content to
though I mnst be content to bear...

though I mist be content to licar...

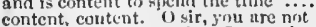

pray, be content: mother, I am going

are content to sutfer lawtil ceusure..

I an content. Lo, citizens (rep.).....

Cassius, be conttunt, speak your fricts

could be content to visit uther pluces
which drives o'er your content... Antor

which drives o'er your content...Antony \&
how 't will give oft. Content: 'tis strange

Dow $t$ uill give oft. Content: 'it shall content me best

and the contents o' the story of hENT_nf his content,-yet

of his content, all but in that! ....

arm's embernement will content the

that $I$ repair to lome, I am content .

all too little to content and please .....

I do commenil to your content

geemed so content to minish them
let your study be, to content your lord.

the contents, ns in part I understand

pray you, content: what, Oswali, hio

on whioso contents, they summoned

must be content to think you oli

see how one auother lcals content ...

I am content, so thon wilt have it so

if not, be you content to lend your

your soul to give it dne conten

on the view and knowing of these contents

you must therefore be content to siubi...

my soul hath her content so absolnte

I cannot speak enough of this coutent

nothing can or shall contcnt iny soul

first be ripe: content thyself awhile.

poor, and content, is rich, and rich enou

pray, be content. O blood, Iago, blood

so shall I clothe me in a forced cont

CONTENTA-Bperato me contenta $2 \mathrm{2Hen}$

art thou contented, Jew?.......Nerch of $V$

and all his contented followers.....As yon

if you he so contented, forswea

and will, if she be 89 contented

well contented. What will you do? ...Ararlor/h, ii.

are you contented to resign the crown?

none contented; sometimes am I king

I could be well contented to be.1Henry \& $Y$.

be ynu contented, wearing now

who not contenterl that he lopped.......Hen

must be contented to go along with is

from that contented hap which I .. Richnrd $M$ III. $\mathrm{i}$.

are contented to wear our mortal ... Henry IIII. ii.

we arc contented, Cresar shall.... Julins Corsor, iit.

privthee, muncle, be contented....

CONTENTETI1-contenteth me ..2Ifmr? $F I$. iv 10

contention, like a horse full ot high...

breed no contentions with him........

when contention and occasion ... Troil. 8

my arms coulcl mateh thec in

'Treat contention of the sca and si.....

CONTENTIOUS-contentious waves... Tempest, if.

CONTENTLESS-state, contentless. Timon of

CONTEST-do contest as hotly ....... Curio

CONTINENCE-to justice, continencc. Tilus
CONTINENCY - with contineney. Mrea. fur.

making a sermon of contineney.. Taming of
CONTHNFN - that orbed continent.. Turting

have averborne their contin

ay, iny continent of beaut

the eve heen as continentionary of ...Mer. of

my desire all continent impediments... $W$

the oppozel contincnt as muth......

be stronger than thy contincent.. Anlorey
I pray you, have a continent forbearance

rive your concetling continents, and cry

and continent, th hide the stain? ........
the continent of what part a genticman.
CONTINUAL-continual 'lirum...Merry

a man of continual dissolution and thaw -

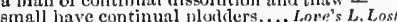

tongues continunl slanders ricle ...2/tenry $I$

l'sins, and other lis continual followers
kecp prince Inarry in continual laughter

entleavour in entinual motion
of discord anf continulal strife?

of diccord and contimulal strife.

repentanec, continual meditations. Ifenr

with

I lave heen in continual prutie

for they pray contininally to their

he comes eontinually to Pyc-eorncr.

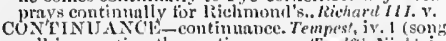

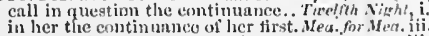

a bawd of eleven yeurs continumee.

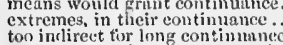

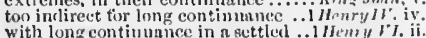

continuance of their parcits' ragc. $\ddot{B}_{0} m$. of Jul. (prol. ) ii. 2 CONTINUATE-

und contimnate goodnegs ..... Timon of Athe ns, i.

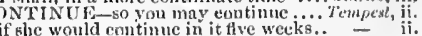

not long contimue love to him. Tur Gen. of tire iit.

if the duke continue these favours. Tueelfin Nighe,

to continue now, thou varlet $(\mathrm{rep}) .$. -

your ille scorns, contime them

and continue a braving war ............ All's Hith, $\mathrm{i}$

fhr the which, I shall continue thankfin -

the licare continue their lovest. Whinter's Tale,

ynul did contime funlt, and that yon
will continuc the standing of his body

ghnll contiuue our graces townrls.

Thave known her contimuc in this.....
jour pleasure, and contimue friends. King Jolu

author will continue the story ....2IIenry/l' (cepii.)

still continue peace and love ....... I llemry irl. iv.

pecrs, continue this united lcague .. Richaril III. ii.

did I continue in my liking

may he continue long in his highness - iij

your emperor continues still a Jove.. Ant.R Clno. iv.

will continue fast to your affection

Wils continue fast to your affection

Desclemona shnuld long con timue her love. Othello, i.

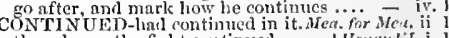

three hours the figlt continued ...... IIferyy I'T. i.

how long continuel: and what....... Cariolanus ii.

continued so, until we thought he .. Cymbeline, v.

CONTTNUING- wenther continuing. Winter's $T$. v.
CONTR

to mols this no contracts,

a contract of truc love to celebrate

help to celchrate a contrret of truc lore... - iv.

a truc

between which time of the con tract...

the contract of her marriage .....As you tike it, iii.

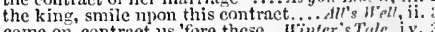

come on, contract us 'fore these...

will not have our contract celebrated

joyful am I made hy this contract!. I Henry $/ r$, iii.

and proof of which contract,
in the course of this contract

hiscouse with that with lady Lucy (rep.). Richard $\bar{Z} T$.

first he was contract to lady Luey

contract and starve your supple . Timon of Ath. $^{\prime}$

it is no cnntract, none no................ joy of this contract to-nigh. Jul. $_{\text {ij. }}$

it was very sweet, to contract.... Humlel, ro l (songs)
didst contrart and purse thy brow .... Olleello, iij.

CONTRACTED-since contracted...Merry W' Wres,

you wnuld have been contracter the.

extended or contrncted all proportions. Alt's she

enquire me nut contraeted bachclors. I Henry II: i

the articles of contracted peace.....2 2 lewryl $T, i$.

to be contracted to the brow of woe ....... Hamlet, i. 2

and perform an old contracting. Meas. for Meas. iii.

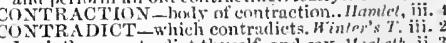

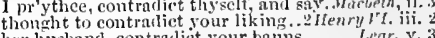

her husband, contraliet your banns ....... Jatar, v.

cower than we ean contradict ...Romeo nutied, v.

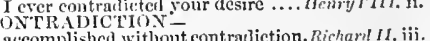

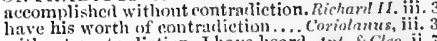
without contralliktion, I have lieard. An'. S. Cleo. $\mathrm{it}$.

of this contraliction you sllall now be yuit - y.

to soothe him in these contraries? Comerly of Rr. iv.

no entraries hold more antipathy......... icar, ii.

how ean these contraricties agree?..1 henry $/ 2$. ii. 3

than violentest eontrariety

and mot contrarions guests.... Meas for . Ueas, is.

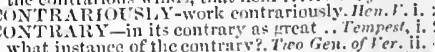

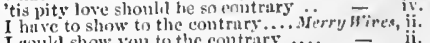

I could show you to the contrary a.je =

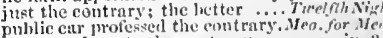

ou may lear to the contrary ..... - iv. 2 (nnte)

finl no infredinnent to the contimry $\bar{i}$ v. 2

he supaks the nere cuntrury. (rosices

woo contrary, deceived by these removes
winc on the contrary casket........Mer of renice, $i .2$ 
CONTRARY - to the contrary?.. Merch or Fenice, i. 3 CONVENIENCY-

to pull at a smack o' the contrary.... All's Well,ii. 3 brict' and plain conveniency ... Merch. of Venice, iv. 1 they have gone a contrary way ........ wafting his eyes to the contrary

to the contrary I have express.
thou, INermione, contrary to....

thould to the liearens 2 (indict.)

ghould to the liearens be contrary ....

thrust upon contrary fect ............. iv. 2 thrust upon contrary tect ............... Richnrel II. v. 5 in thy house, contrary to the la banding themselves in contrary

wherens the contrary bringetl........ - v. and, contrary to the king, his crown - iv. the prove the contrary doth make thee wondered at

the contrary doth make thee wondercd at $\overline{I I L}$. iv. bad friends were contrary............ $\vec{H} \bar{F}$ iv on the contrary, urged on the.....
his contrary procecdings are all

as i' the contrary the toulness is

the best persuasions to the contrary fail - iii. 2 six months, be quite coutrary.... Timon of Ath. iv. but tidings to the contrary arc... Pericles, ii. (Gower) for aughti kn trary the

you must contrary me! marry ...Rom
storm is this, that blows so contrary?

all things change them to the contrary

and fates, do so contrary run.......... Hamlet, jii. What in the contrary? Every day...... Othello, iv.

a trembling contribution! why ....Henry VIIL. $\mathrm{i}$. they have grudged

we would be contributors....... Taming nf Shrerv, i. 2
CONTRITE-more contrite tears....... Henry $V .1 \mathrm{v} .1$ CONTRIVE-he doth contrive.. Mer. of Venice, iv. in this uction contrives against his ...All's $H^{\prime} e l l$, iv. in this action contrives against

we may contrive this aftermoon . Trming of Sh.

that do contrive how many liands Troil. \&-Cress. i. 3 nor let thy soul contrive against.

suddenly contrive the means of meeting
CONTRIVED-contrived to bait. hast contrived against the very. iler. of Venice, iv. complotted and contrived in this land..Rich. II. i. 1 by whom this great assembly is contrised that hatil contrived this woful tragedy!

contrived by art, and baleful solcer

conscience, to do
CONTRIVEDST

thou that contrivedst to murder ....IIIenry $V I$. i. 3 the close contriver of all harms ........ Hacbeth, iii. 5 find of him a shrewd contriver.

the damned contriver of this deed ...Titus And.iv. I
coNTRIVING-our contriving fricnds. Ant. 4 -Cleo.i. 2 one that slept in the contriving of list

CONTROUL-would controul my din's. Tempest, i.

with an austere regard of controul. Tu....... subject, and at their controuls. . Comedy of Err the proud controul of fierce and without controul, listed to make...... Richard III. iii. for the ill which doth controul it .. Coriolanus, no more will I controul thy

to slack you, we could controul th

main bonstl who can controul his

vain boastl who can controul his fate?. Othello, v. controuled in that he frankly gave...Titus And. i. CONTROU LING ${ }^{2}$ controuling bounds. King $J$ ohn, ii. 2
lightens forth controuling majesty... Richard $I I$. iii. the same to act controuling laws...2Henry $V I$. v. CONTROULIER-an arrogan

conTrouller of our priva

you may do it withont controulment. Nuch $A$ do $i$ , controulment tor controulment...John, i.

controulment, justice, or revenge?. Tilus Andron. ii.
CONTROVERSY-all controversy. Mea. for Mea. i.
the cause in controversy.Mer. of Venice, iv. I (letter see the end of this controversy . Taming of Sh. $\mathrm{V}$.
for staying on our controversy.. Comedy of $\mathrm{Err}$. v. for staying on our controversy.. Comedy of Enh.
herc is the strangest controversy .... King Jnh
shall be swallowed in this controversy. Henry $\nu$.

the controversy of three-pence...

dismiss the controversy bleedin

it with hearts of controversy......

conTUMELIOUS

and scorns, and contumelious taunts.1 Henry $V I$. i. not calm his contumelious spirit ..2 Henry VI. iii. 2 thus contumeliously should break ... Henry $Y I$. i. 3 CONTU MELY-proud man's contum ely. Hamlet, iil. 1
CONTUSION-forgets aged contusions.2Henry $Y I . v .3$

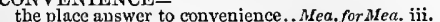
can meet him with any convenience.. All's Well, ii. 3 honour that good convenience claims $-\overline{\text { jii. }} 2$ which, if convenience will not allow .... Lear, iii. 6 for want of these required conveniences. Olhello, ii. kecp'st from me all conveniency ...... Othello, iv 2 and 'tis not convenient you should be $\overrightarrow{ }_{\text {con }}$ iv. 5 convenient is it: make a switt.. Meos. for Mens. iv. 3 I go with all convenient placel........ Mer. of venice, iii. we have most convenicnt convoy ....

if the time were convenient.

the garden here is more conveniewt... H Henry $Y$ i. it take convenient place that I .. Heniy $M T$. ii.

true wars, l'll frame convenient peach

it were convenient you had such.. Tilus Andron, y.

ander covert and convenient seeming.... Lear, iii.

tis most convenient; pray you, go with

we shall find him most convenient...... Hamlet, i. i

may be conveniently delivered.. Trelfth Night, iv. 2

conveniently the rcst convey ....Pericles, iii. (Gow.)
I conveniently could send to Romeo.Rom. \&ul. Jul.

I conveniently could send to Romeo. Rom. \& Jul. v.
CONVEN'T-golden time convents. T'wefth Night, v.

one of our convent, aud his the council board he bc convented.. HenryVIII. $v$,

convented unon a pleasing treaty ... Coriolonus, ii.
cONVENTICLE-your conventicles.2 Henry VI. iii. CONVERSAN $\mathrm{N}^{\top}$-nor conversant with. King John, iv

alike conversant in general services.. Cymbeline, iv. I
slould be so conversant with pain..... Pericles, iii. 2

OUt of my couversation

out of my conversation ..........Merry Wives,
from the conversation of $\mathrm{my}$ thouglits. All's W'ell, trom the conversation of my thoughts. All's I $\mathrm{Well}$, his conversation with Shore's wite. Richard III. iij.
more of your conversation would ..Coriolanus, ii. five times so much conversatiou.

as e er my conversation coped withal.. Hamlet, iii. those soft parts of conversation that ..O Othello, iii. 3 $I$ did couverse this quondam day still couverse with groaning wretches $-\nabla .2$ that do converse and waste the time of Venice, 1 . why dost thon converse with that ... Henry IV. Hi. 4 practice and converse with spirits ..1 Henry VI. ji. A converse with iron-witted fools ...Richard converses more with ..... Coriolgnus, ii. I to converse with him that is wise.......... Lear, i. that your converse and business may.. Othello, iii. I
CONVERSED-have conversed.. Two Gen. of Ver, ii. 4 any man with me conversed at bours. Misch Ado, iv. I hath he conversed with the enemy . - iii. Cooman, by conversing with him....1 Henry $1 V$. . . I
con too sociable for your conversion.

MNT - must convert to disdain... Much Ado, $\mathrm{i}$.

thy overfiow of good converts to bad

that shall convert those tears $\ldots \ldots \ldots 2 \mathrm{Hen} r y \mathrm{IV} . \mathrm{v}$.

pious breath seeks to convert you.....

sweet, convert to bitter gall....... Romeo \& Juliet, 1.

convert his gyves to graces .................

and how you may be converted...... was converted, both from his ....As you Like it, v. 4 CONVERTING-converting all. Much Ado, ii. 3 (song) CONVERTITE-these convertites. As you Like it, v.
since you are a gentle convertite .... King John, v. CONVERTLY - but so convertly that. Much Adv, ii. 2 chll convey thee through ............

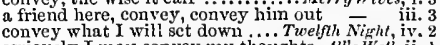
seriously I may convey my thoughts. All's Wetl, ii. I convey unto our feartul minds..

convey me to my bed, then to
convey him to the Tower. (rep.)

Michard 11 . ii. 1

lords convey my tristful queen ..... i HenryI $V$. ii. 4 convey them with safe conduct ........ Henry $Y . \mathrm{i} .2$ convey me Salisbury into his tent..$\overline{1}$ Henry Vl. i. kecpers, convey him hence .......... away, convey him hence ............ to convey me to the Tower .........Richard III. i.
convey me [Col. Knt.-lead me officers] how I convey my shame out of ....... help to convey her hence away .. Titus Andron. i. 2 $\begin{array}{lll}\text { help our uncle to convey him in } \ldots . . . & \text { - } & \text { v. } 3\end{array}$ some loving friends convey the emperor
conveniently the rest convey.... Pericles, $\mathrm{ii}$. (Gow.) but it shall be convenient, master YYum

my lord, with all convenient haste. Richart $I I I$.

abbot, with all his convent......... Henry VIII. iv, holy, cold, and still conversation. Antony 5 -Cleo. i borne ourselves in the converse of.... conversed with a magrician .....As you Like it, $\mathrm{v} .2$

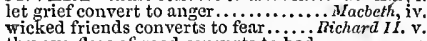
sure, there's no converting of them.. Henry VIII. i. 3
CONVEY-convey tliy deity aboard ..Pericles, iii. never could I so convey, unl less....
convey the business as I shall find ......... (Geow. into her womb convey sterility! that may convey my grectings.. Rameo \& $\ddot{J}_{\text {uuliet, }}$, iii. behind the arras $\mathbf{I}$ 'tl convey mysclf.... Hamlet, iji. CONVEY A NCE-of some conveyance.ilerry $W$. iii. I fear there is conveyance ......... Henry $V I$. i. 3 thy sly conveyance, and thy lord 6.3 menry $V t$. jit. these conveyances of our blood........ Coriolanus, v. Fortinbras eraves the conveyance .......lamlet, iv.

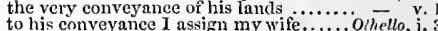
CONVEYED-be conveyed away. TwaGen.f Ver. iii. conveyed to my understanding........en, for $\bar{M}$ ea. iii. if he were conveyed to bed. Taming of Shrew, 1 (ind.) sir, I lave conveyed aboard. . Comedy of Errors, 1 ind. see him safe conveyed home .......... ivenry ${ }^{-} \mathrm{i}$. be conveyed unto the Tower..........Henry $Y$ H. iii. be conveyed unto my brother......... - iv. 3 suddenly conveyed from hence ...Richard. III. iv. 4 fortliwith you be conveyed .........Henry VIII. v. lord's of Gloster hath conveyed him hence. Lear, iii. CONVEYERS-conveyers are you all. RichardII. iy. CONVICT-convict by course of law. Richard III.i. CONVICTED-armado of convicted sail..John, iii. 4 wine and wassel so convince ...........Macbeth, their malady convinces the great..... . - iv. persuasion could but thus convince me $-\overline{i n}$ i. convince the honour of my mistress... Cymbeline, i. CONVIVE-in the full convive.. Troilus \& C Cress. iv. CONVOCATION-spiritual convocation.. Henry V. i. I a certain convocation of politic worms.. Hamlet, iv. 3 we have most convenient convoy ..... and crowns for convoy put into....... ivenry hope, our convoy, and our bark.. Troilus \& Cress. i. my convoy in the secret night... Rameo \& Juliet, ii. A CONVULSIONS-with dry convulsions. Tempest, iv. would the cook were of my rnind $1 . .$. ...Much Adn, $\mathrm{j}$. where's the cook? is supper.. Taming of Shrew, iv. where is the rascal cook? ........ winter's Talo iv. the cook help to make the gluttony.2HenryI $V$. ii. yea, marry, William cook, bid him.

let thine age be thy cook.............. Henry $v$. v. my cook and I'll provide...... Timon of Athens, iii. epicurean cooks, sharpen with .. Antony \& Cleo. ii.
will play the cook, and servant .... Cymbeline, iii. you ala fidele play the cooks ....... - iv. for $Y$ will play the cook ...... Titus Andronicus, $v$. things for the cook, sir ............. o. Jaliet, iv. COOKED- what we have kilied be cooked. $\overline{C y}$ mb. iii. 6 you be rendy for that, you are well cooked $\overrightarrow{\text { CoOKERY-tine Egyptian cookery. Antony of }}$. but his neat cookery! he cut ...... Cymbeline, iv. for pills to cool the reins ...

send me a cool rut-time, Jove...

let it cool the while. I love .........Muth Ado, ii. more than cool reason ever.....Mid. N.'s Drenm, v. my heart cool with mortifying ... Mer. of Venice, $i$. rust, sword! cool, blushes! ..........All's Weil, iv. warm, he cools me with beating. Comedy of Err. iv
cool it with a baboon's bloor I'll do, before this purpose cool ............ - iv. remorse, cool and congeal again .......... Jing $J o h n$, ii. as fire cools fire, within the scorched

the cool and temperate wind Hen'y $Y$ iii. 3 t will make them cool in zeal ....2 Henry VI. iii. to cool a man's stomach this hot... . iv. io etrike now, or else the iron cools.....3 Henry $V I$. $v$. to let the meat cool ere we can ... Timon of Ath. iii.

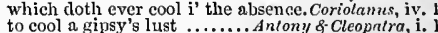
to cool a gipsy's lust ........An'ony \&-Cleopntra, i. I when the blood was cool .............. Cymbeline, now let hot Etna cool in Sicily lest your breath cool yourself $. . . . . \ldots .$. Pericles, of thy distemper sprinkle cool patience. $\dot{H}_{n \text { nniet }}$, iii. to cool our raging motions, our carnal .. Othello, i.
COOLED-and coolerl, glowing hot. Mferry Wines, iii. my bargains, cooled my friends. Mer. of Venice, it warmed and cooled by the same winter - ii my senses would have cooled to hear... Afacbeth, v. that must be cooled for this.......... Richard $T$. i. COOLING-whom I left cooling of the air. Tempest, i. my wind, cooling my broth..... Merch. of l'enice, i. you must stay the cooling too ... Troilus \& $\mathrm{Cress} . \mathrm{i}$. 


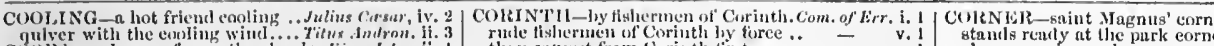

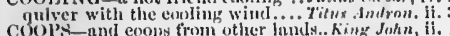
cool? -and eogp from other hands.. king John, it,

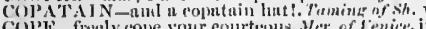

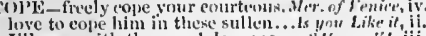
I'll eope with thee, und clo some... nal, Cliffure, eope with him 3 Hen? $Y 1, \mathrm{i}$ A jax shalt cope the best ....Troilus f Cressidn, ii.

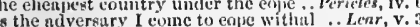
he hath, and is again to eoje your wifs. oihelln, iv

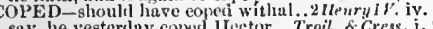
say, he yesterday copred IIeetor ... Troil. f. Cress

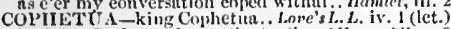
let king Cophetua know the truth 2 IIenry $1 \%$. v. coprip-let this be copied out ....... Kink Jnhn, y. Youth and observation copied there .... Ilametet,

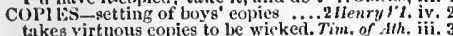
col'loUs-be eopnous in exclaims.. Richard HI. iv. Col'PRD-easts eoplyed hills tow'arls

thut hat ring wos eopier my ring was eopper. I say, $t$ is eopper - iti. with eunning gitd their eopper erow With eunning gill
COP'E

and master Colpler-spur .......Meas. for Meas. iv. 3 CoP'ST-fool thon cop'st with.... Winter's Tale, iv. that cop'st with death himself... Romeo of Juliet, CoPULA TION-the conulation of. As you Like, iii. 2 Copulation thrive, for Gloster's hastard .. Lear, iv. almost the eopy of my elitd that's ...Mnch Ado, might be a eopy to these younger .....A All'sWell, i. will you give me a copy of the sonnet - iv. 3 they say, it's a copy out of mine .. Winter's Tale, i. 2 it wus the copy of our eonferenee. Comedly nf Er in them nature's eopy's not eterne.... Macheth, iii. the eopy of your speed is learned. King John,

COPY-BOOK-B in a copy-book.. Love's L. Lost, v. 2 for our flight. Bravely, coragiol ....Ali's Well, CORAL - bones ore eorul made .. Tempest, i. 2 (song) I raw her coral lips to move .. Taming of Shrew, i. COR AMI - of peace, and coram .........Mern' Wires, CORAMBUS-Corambus so many....... Alt's Well, iv. 3 why, he's able to lead her a coranto... All's well, Involtas high, and swift corantos ..... Henry
CORD-the ladder made of cords. Two Gen. If $V$ er. quaintly made of eords

to your waist, a eord, sir ........... iteas. for Meas. ili. 2 hast in two my eords if thou want'st a cord, the smallest.. King John, the eords, the ladder, or $\ldots \ldots \ldots \ldots \ldots$. Henry $1 \mathrm{~V}$,

o the eharity of a penny eord! . .

Cynaline, v.

give me eord, or knife, or poison ........

oft bite the linly cords in twain ........... Lear

cords made like a tackled .......Romeo f $^{-J}$

cords, that Romeo bade thee fete
take up those eords; poor ropes....

come, cords, eome, nur

it there be cords, or knives, poison ..... othello, iii. $\mathbf{3}$ and with a corded ladder feter.

CORDELIA-What shall Cordeliä do?

how now Cordelia? and yet not so .......

and here $I$ take Cordelia by the hand

fuirest Cordelia, that art most rieh bid thern farewell, Cordelia, though

with wushed eyes Cordelia leaves you...

eome, my fuir Cordelia. Sister, it is not

how' ugly didst thon in Cordelia show 1

if now tis from Cordelia ..............

shume detains him from Cordelin.

this lady to be my ehili Cortlelia ..............
whieh he intends to Lenr and to Cordeli

upon sueh sacrifices, my Cordelia.........

the question of Cordelia, and her father.

on the life of Ler, and on Cordelin.....

to hang Cordelin in the prison ........

Curdeliu, Corlclia, stny a little: ha! as sweet us any were eordial .... Winter's Tale, i. 2 a plensing cortinl, princely fo.......... Richard $I I I$. it. 3 cordiul that you bring a wretehed...Henry I'II. iii. I to not know what is more eordial.. Cymbeline i. 6 wasfection whieh I gave him for eortial the cordial of nine age to glad.... Titus Andron. i. come, corlial, and not poison . Romeo of Jutirl, v. CUilE-cor: tutto il core bene trovato. Tam. of Sh. i. were not that a hotchy eore? .. Troilus of Cress. ii. most putrefiel eore, so fair without... I will wear him in my heart's core.... Mlamlet, iii. 2 O Corin, that thou knew'st how.. As yau Likeil, ii.
O

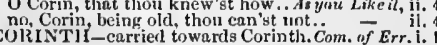
of Coril-carried towards Corintl
I eame lroin Corintl, my most would we enull see you at Corinti, Timnn of uh. ii.2 CORIOLANUS-

Coriolanus: weleome to Jiome (rop)

newly named, what is it? Coriolanus

therefore, for Coriolanus neither to

performetl by Caius Mareius Coriolant

the deeds of Coriolunts aliould not

eall lir Coriolanus. II doth (rep.).

there, Coriolanus. May I then....

sicinius Coriolanus deserved this ....

Coriolanus, patienee: speak, good

the eonsul Corivlanus. He good ii

hinisliment of that worthy Coriolanus
Coriolanus banished? Banished, sir..

his grent opposer Coriolanus being

entertninment, in being Coriolanus.
witness anay my surname Coriolanus

your Coriolanus, sir, is not mueh ....
we wished Coriolanus had loved you

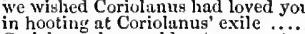

Coriolanus he would not answer

come to speak with Coriolanus .......

before you'll speak with Coriolnnus.

to his surname Coriolanus 'Iongs

$\begin{array}{ll}\text { stolen name Coriolanus in Corioli? } & \text { v. } 3 \\ \text { ns mueh as ever Coriolanus did } & \text { v. } 5\end{array}$ COR IOL I-nlone to guard Corioli .... Coriolanus,

are set down before their eity Corioli
the citizens of Corioli have issucd...

holding Corioli in the name of Rom

alone I fought in your Corioli walls
for what he did before Corioli, eall him

Titus Lartins, must to Corioli back..

for all the ehests in Corioli, and

Marcius did fight within Corioli's gates

before and in Corioli, let me say corioli

a sudden re-enforeement struek Corio

his wife is in Corioli, nnd his chi

I fluttered your Volees in Corioli ....
Co-RIV $\mathrm{L}$ ED-co-rivaled greatness?.. Troil. \& $\mathrm{Cr} . \mathrm{i}$.

CORK-take the eork out $\ldots . . . .$. ... As you Like it, jii. 2

CORKY - bind fast his eorky arms........ Lear, ifi. 7

insatiate cormorant, eonsuming ....Richard II. ii. 1
digestion of this eormorant wnr.. Troil. \&. Cress, if. 2

by the eormorant belly be restrained. Coriolanus, $\mathrm{i}$.

our eorn's to reap, for yet ........Meas. for Meas. iv.
playing on pipes of eorn ..... Mid. N.'s Dream, ii. 2

and the green corn hath rotted .. ${ }^{\bar{y}}$ ii. 2

sowed eockle reaped no eorn

Nacbeth, iv. 1

shall lodge the summer eorn

to gather money for their eorn

that come to sell their eorn

Henry rivivi in.

curse the harvest of that eorn

like over-ripened corn, hanging

like to autumn's corn, have we

where my ehaff and eorn shall
shake like a field of beaten eorn...

二 $\quad$ iii. 2

we'll have eorn at our own price

sent not eorn for the rich men only

the Volees have mueh eorn ..........
when we stood up about the corn...

when eorn was given them gratis

tell me of eorn! this was my sleech
to give fortl the eorn o' the...........

know, the eorn was not our

ompenso

first, thrubh the eorn, then atter... Titus Andron. ii.

seut tered eorn into one mutual
are stored with eorn, to make.
fed my country with your eorn.

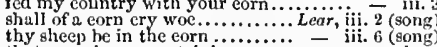

thy sheep be in the eorn .......... - iii. 6 (song)

unplugued with eorns, will hnve.. Romeo \&. Juliet, i. 5

forinELIA-Cornelia never with. Ti
Cornelia the mid wite, and myself..

Cornelia the mid wite, and myself.... $-{ }^{-}$iv. 2
ColiNELIUS-whnt's this, Cornelius?.

goorl Cornclius, and you, Vol timand.... Hometit, it. 2

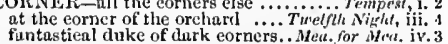

I mantieal duke of durk eorners...Mea. for Mart. iv. 3

from the wcst corner of thy. Lone'si.L.Lost, $\bar{i}$. I (tetter)

from the lour eorners of the earth...Mer. of $V^{\prime} n$. ii. 7 if you thus get my wife into cormer

unregarded age in corners thrown. As you Like it, ii. 3

hoodge' corner in the eoldest. Taming of Sh.1 I (iniluc.)

skulking in eornera? wishing ..... Winter's Fute, i.
upon the corner of the moon there..... Hucbeth, iij.

even till that utmost eorner of ........ King John,

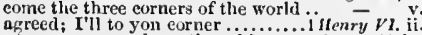

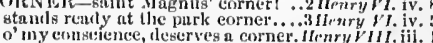

winds of all the corners kisked your. Cymbeline, if.

doth helie all comers of the werte

the eorner of his jaw .. llamter, iv.

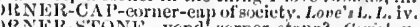

C)]

the green eorte-field rlid pass. As you Litis, y, 3 (bon

CORNISII-art tlou of Comiln erew?.. Henry $r$. iv

CORN W'TO-the genking cornuto.. Merry Nines,

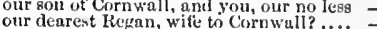

Cornwal, and Albany, with iny two ....
duke of Cornwall, and Kegan his duchess

$t$ wixt the dukes of Cornwall ant Allany
gpoken 'uainst the duke of Cornwill?

Id speak with the duke of Cornwal

the lsing would speak with Curnwall

eumning, 'twixt Albany and Cornwa

Albany's and Cornwall's powers you ...
that tlie duke of Cornwall was so slai

ColioLLARY-lring a corollary....... Tempest,

solemnly set down our eoronation... Kichs John,

in London streets, that eoronation clay

affairs, upon his eoronation day ...2ilenry $1 \mathrm{~V}$. iii.

our eoronation done, we will aecite.

in our eoronation take your place "i Hen

to sec unto your eoronation, a letter - iv.

first, will eoronation be performed ..2Iienry $/ 7$. i.

sojourn till our eoronation?

to sit $\mathrm{nbout}$ the eoronation

for his purpose in the eoronation

order fiven for her eoronation ......ienry $\bar{V} \| L$ iii.

published, and her coronation........ - iii.

voice is now only about her coronation - iii.

this day, by eustom of the coronation - iv.

to show my duty in your eoronation..... Hamlel, i.

CORONET-his eoronet to his erown cly Nigh,

imperial, erowns, and eoronets

doth deserve a eoronet of gold........ Henry Hen $^{\prime}$ I. iii.

their eoronets say so; these are ...... Henry $\bar{V} / 1 I$. iv.

this eoronet part between you ............. Lear, i.

my name is sir corporal Nym..... Merry Wives, ii.

in corporal sufferanee finds a pang......

I to be eorporal of his field ....... Love's L. Lost, ii

by earth, she is but eorporal............. All's Well, iv. 3

and what seemed corporal, melted ........ Huebeth,

bend up each eorporal agent to this ......

of aneients, eorporals, lieutenants ..1 itenry $1 V$ iv.

eertain, eorporal, that he is married....

good eorporal, be patient here........

pray thee,

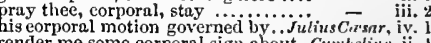

CORPORATE-corporate Bardulph...2 Henry I\%. iii.

CORPULENT-and a corpulent ...... Hilenry!'. i1. I

to eorreet yourself, for the example... Much ido, y.

do eorrect their proud eontempt....... King Jnhm, ii. I

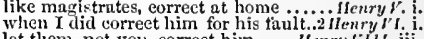

let them, not you, correct him .... Ifenry H H I iii.

what wouldst thoul? 1 wonlil correct him - v. 6

his sorrow, would eorreet himself..
CORRECTED-to your eorreeted son?.

CORRECTING-eorrecting thy stout - iii.

rejoiee in the boy's correetion......... Gen. of fer. ili.

correction and instruction must both ${ }_{\text {it }}$ shall follow in my eorrection...Lne's L. Lost, $\mathrm{i}$.

not so, sir; under eorrection, si

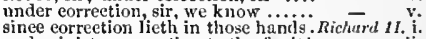

and ininister correction to thy fuut

to tie thee to my strong eorrection

and dread correction wait on us

langs resolved eorrection in the arm.2 HethryI

hrought to the correction of your luw
after the taste of mueh enreetion .... Itenry $V$

let a welch correction teach is

uncter the correction of bragging lit... - v

your purposed low eorrection is sueh ....Lear, ii. 2

you filthy fimishel eorrectioner!....2HenryI $V . v .4$
CoR RFSPONDEN'T-

I will he correspontent to eommand .. Tempest, i. 2

corresponcling will your stiff age .. Cymbeline, iii. 3

corresponsive and fuln nlling lolts. Trnil. $\delta \cdot \mathrm{Cr}$. (prol.)

the power and corrigible uuthority ....... Othelln, i. 3 
CORRIVAL-without corrival, all her..l Houryl $r^{\circ}$ i. a anil many more corrivals, and dear

colitosive-but rather corrosive.,ilienry

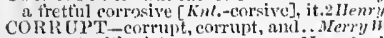
corrupt with virtuous season... had never the purpose to corrupt

and the corrupt deputy scal
so tainted and cormupt, hut

you eurrupt the song, sirmal $\ldots \ldots . .$.
or corrupt our hope, to prostitite

or corrult our hope, to prostitnte

my son corrtipts a well-derived nath
in sueh a suit corrupt the tender

to corrupt him to a revolt..........

art, inulewh, able to corrupt a saint
this light flesh and corrult blood..

as. for Meas. ii

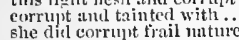

and I'll corrulut her manners

know to be corruyt and treasonous.. He Hery

once corrupt, they turn to

that no king can corrupt ............

corrunt minds procure knaves as corrupt

that do eorrupt ny air

fittest time to carrupt a man's wife

clisports eorrupt and taint my business .. Ot

it is the flesh of a corrupted heart.. Merry iW

sle is corrupted, ehangel, anil won. K
purclinse corrupted pardon of a man

attainted, corrupted, and

with injustiee is corrupted ........2 Herry $F \mathrm{l}$.

most traitorously corrupted the you

inderhand corrupted foul injustice. Rich

irt this law of tatire be correnest men

one of her women, being eorrupted... Cymbline

are not corrupted-as 'tis thought!

lrought hither a corrupted mind.....
carbunele, in my corrupted blood...

carbunele, in my corrupted blood....
in the corrupted currcnts of this worid.
and corrupted by spells and nuedicine

and corrupted by spells and nuedicine

would hatt have corrulted a votarist .....

away, corrupters of my faith $\ldots$...... Cymbeline, iil.

and more corrupter ends, than twenty ....LPar, ii. 2

CORRUPTIBLE-corruptible, grosse..Hen
CORRUPTIBLY - is touched corruptibly...
CORRUPTING - on heaps corrupting.. Hen

whom corrupting gold would tempt. R
CORRUPTIUN-corruption inhalits.

what corruption in this life.... Meas. for Klens. iii.

I have seen corruption boil and bnbble
but falsehood and corruption .. Comedy of

the foul corruption of a swect ........ Kirs , Jolin, iv. 2

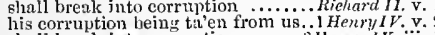

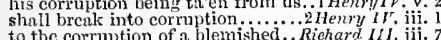
shall break into corruption..........

from the corruption of abusing time $-\bar{F}_{I 11}$ iii.

to keep mine honour from corruption

of Cassius honours this corruption.Juli
sword, fire! corruption in the place!

corruption from that particular tant
stewcd in corruption; honeying

stewed in corruption; honeying
rank corruption, nuining all $w$ thin

CORRUPTLY - derived cormutly!...Me
CURSE-greet my poor corse. Tuelfth Nigh

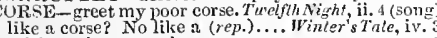

spirit again nosscss her co

upon whose dead corse ...............

nc'er part, till one drop down a corse
had only but the corse, but shadows.

man, hefore dead Ilenry's corse? ...

view his breathless corse ........2IIenry $V$ r. ii.

bear the corse, and set it down ..... Richerd $111 . \mathrm{i}$.

the corse; or, by St. Paul,
talce up the corsc, sirs

take up the corsc, sirs $\ldots . .$.
injury, to scoln his corse...
as $X$ followed lienry's eorse.

as $X$ followed lienry's eorse,

a tair corse, I'll be sworn .... Troilus 6 cressida, ii. 3

upon the pashed eorses of the kings

regarded as the most noble corse.

il the presence of thy corse?
till $I$ have borne this corse into.....

do grace to Casar's corse $\mathrm{a}$ a............

a ring about the corse of Casar.

the dead corse of Bassianus lay

whater must o' erwhere a eorse! most strang

piteous corse, a bloody pitcous eorse. Poin. \& $\bar{J} u t$. iii.

weeping and wailing over Tyhalt's cor

stick your rosemary on this, fair

follow this fuir corse unto her grave

poor living corse, closed in a dead....
from the first corse, till he that died

from the first eorse, till he that died.....
that thou, dead corse, again, in completc

we have many pocky eorses now-n-days

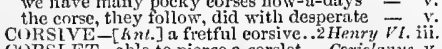

CORSLET-able to pierce a corslet .. Corrinlanus,
COSMO-Guiltian, Cosmo, Lorlowiek.. All's Well,

COSMO-Guiltian, Cosmo, Lodlowiek...All's Well,
COST-that cost me two slillings ... Merry Wives,
and at my proper cost............. Tuelfth Nigh,

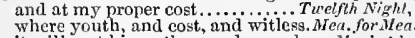

it will cost him a thousand
of the world is to avoid cost

of the world is to avoid cost ...........
thougl it eost me ten nights' watehings
COST_cost the fresh blood dear... Nid. N. Drntm, iii.
eost me two thousanl ducats.. Werch. of Venice, iii. how little is the cost I have.

the cost of princes on unworthy... As you Like it, ii. 7 not on my enst (thinking I mein him) and cost me the ilenrest groans ........ All's W' hath cost me a hundred crowns.. Taming of $\mathrm{Th}$. one yenny cost to ransom.

and leaves his purt-cented cons...

Illenryly. i.

and leaves his part-crenterl cost.

inilcel, sir; to my cost.

lingering wars with little cost

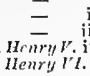

to thy dear cost, be sure.

own proper cost and charges...2irenry rr. $\overline{\mathrm{i}}$. I (art.)

command, that, of the eity's cost

these worls will eosi tc... thou...........

3 Henry VI. i.

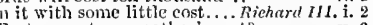

kept in Bretagne at our mother's cost?

will cost a drop of Grcesin biood .

armour thus hath eost thy life
bred her at my dearest cost ....

which will not cost a mun a doit ....

command what cost your heart. Antony \& Cloo.
whut pain it cost, what dunger! .... Cymbeline,

Forth all our munclane cost ... Perieles, iii. 2 (scroll)

Where thee he got, cost him his eyes ......

it would cost yout a groaning

his brecehes cost him but a crown. Öhillo, ii. $\&$ (song)

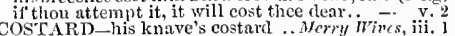

Costard the swain, and he slall be. Love'sL. Lnst, i. 1

not a worl of Costarl yet $\ldots . . . . . .$.
which as I remember,

With the rational hind Costard ....
thitt you kecp Costurd sate $\ldots \ldots . .$.
here's a Costard broken in a shin..

that a Costard was broken in a shin

how was there a Costind broken in.

sirral Costard, I will enfraneline thee =

Efgnior Costard, adien ...............

it was given me by Costard, and sent
good Costard, wo with me $\ldots \ldots . \ldots \ldots$
of Costard. Where hadst thou it...

your servant, and Costard

take him over the costard with $\ldots . .$. nich
whether your costard or my bat $\ldots \ldots$...... Lear,

regard in these costermonger times ..2 Henry/ $/ r_{\text {. i }}$.

COSTLIER - no costlier than would... Cymbeline

COSTLY - too costly to wear every day. Muteht do, ii.

be ready with a costly suit.... Taming of Sh. I (iuil.)

counterpoints, costly npparel .........

under the eanopies of costly statc .2 Henry $\mathrm{T}$. iii. I

to this last costly treaty.

with such a eostly loss of wealth.. Troil. \& Cre

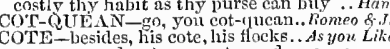

come every day to my cote, and woo me
COTED-foul have amber coted $\ldots$ Love's $L$. Lost

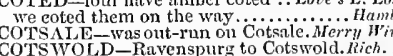

COTSWOLD-Ravenspurg to Cotswold. Rich.

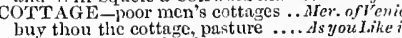

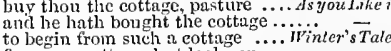

from our cottage, but looks on $\ldots . .$. ...

home to your cottages, forsake ....2 Henry $\boldsymbol{L}^{2}$. iv. 2

COUCII-there I couch when.... Tempest, v. 1 (song)
and his roft couch detile...........nerry ivives, $i$.

and his soft couch defile eouch i' the castle ditc

I'll wink and couch ................

but couch, ho! here lie comes.........All's $W$

we'll have thee to a couch.... Tamingr of Sh. 2 (ind.)

and leavest the kingly eouch ......2 Henry I

where souls do couch on flowers........Ant. \& Clen

cru couch for fear, hut $I$......... Titus A ullronicus, $y .2$

whercin the cub-cirawn bear would couch. Lear, iii. I

a couch for luxury and damned incest.. Hamlet, i. 5

couch we awhile, anil mark

the flinty and stecl eoucl of war

othello, i. 3

to lip a wanton in a secure couch ........ - iv. 1

COUCIIED, all couched in a pit..... Merry Wives, y.

with valourr couched in thine eye ..... Richard II. i. 3

though clerkly couehed, as if she ...2 Henry $V \mathrm{r}$, iii. 1

his body couched in a curions bed...3 Henry VI. ii. 5

these thes are couched.......... Timon of Athens, ii. 2

when he lay couched in the ominous ... Hamlel, ii. 2
COUCII ES-now couches 'fore... Pericles, iii. (Gower) OUCHING - that 1 were couching... Mer. of Ven. $v$. 1 lay couching, head on ground...

a couching lion, and a ramping cat. I HenrylV. iii.
these couchings, and these lowly...JuliusCasar, iii.
(1) (TI)F-et le eonde. De clbow a cough, sir; which I curght

conch, and spit, and with .....2 Henryl $V$, iij. pudille which heasts would congh at. Ant. \& Cleo. . . OUailing-coughing drowns. Lone's $L$. L.v. 2 (string) thet the col.... IIenry $\nu . v$. it is $C r L$-the couneil shall hear it.

the council, look you, shall

emptying our bosoms of their council..nru. - . . Dr. i. ther several eomeils they unbosom. Love's L.L. v. and, in onr inaiden council, rated ..... your ure not altogcther of his eouncil - Maebeth iv. in this day's council ; hut we'll take... Mraebeth, iii. yesternight our conneil did deeree ..1 II cury i $\%$. our eonncil we will hold at Windsor -

an old lord of the conncil rated me

appoint some of your council presently. - iii.

with alf the of the French council....

other of your highness' privy couneil

nay more, the king's council ....... -

we shall be of her council..............
wherein thy couneil and consent is...

what council, lords? Edward from . .

to-morrow hold divided councils ..... - iij.

there are two comneils held ......... - iji

not like these several couneils ...... $=$ iil.

nyy conneil is my shicld............... $-\overline{\text { ine }}$ iv.

a wise council to them of cvery realm - if

one, alrealy, of the privy eouncil....

inecinsed tlie lords o' the council

was sent to me from the eouncil....

why are we nict in comeil?

and wislom, of my counci] .............

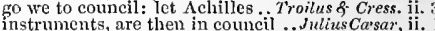
asscmble we immediate council ... intony $_{\text {\& }}$ Cleo. $i$.

private conferenee, or council........... Pericles, it. 4

in conncil! in this time of the night! .... - i. 2

my uncle from the council-board ... Henry I $V$. iv. 3

sat in the council-house, early ......2Henry $V I$ i: 1

ylotted, in the eouncil-house....... Richard K1. iii.

with a council-keeping cave ....Tilus Andron. il. 3

war with good counsel thou then counsel me to fiil ii lo......

I like thy eounsel; well hast thou ...

in counsel, his competitor.

if it were known in counsel

give me some comsell ........

=

i. 2

at the least, keep your counsel .......

drink and goorl counsel will amend... Twelfin

o you give me ill eounsel ...............

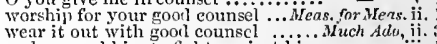

and connsel him to fight against his

have thy counsel, which is the best..

kecp your fellows' counsel

and let my counsel swry you in.......

give not me counscl, nor let

men can counsel aud speak eomitort.

their counsel turns to passion

the ill counsel of a desert place.Mid. N. s $\overline{\text { Drea }}$

all the counsel that we two have

commend this senled up comsel.. Love's L. Lost, iji.

meshes of good counsel the cripple... NTer. of Ven. i.

counsel well, fiend, say I, you counsel
to offer to counsel me to stay with

gives the more fricndly counsel hate....

would counsel you to a morc equal. As you $\bar{L}$ ike it

I do in friendship coursel you ...... - i.

I woutd give him some goot counsel

with me, and let me counscl the

$=\quad$ iii.

to your. sworn counsel I have spoken ${ }_{-}$iii.

toll in to counsel them.... Taming of Shrew, 1 (ind.)

counsel me, Tranio, for $I$ know .....
will comfort, for thy counsel's sound

will comfort, for thy counsel's sound
thank me but a little for my counsel

thank me but a little for my counsel -5 .

or connsel shake the fabrie of his filly

whose spiritual counsel had...........

didst counscl and aid them ........ iii. $\overline{2}$ (i

hold sone eounsel in such a business -

cast your good counsels upon his .....

all connscl, all redress, but (rep.)......... King John, 
COUNSEI-in rain comes counsel .. Richurd II. li. I COINT-here pomes the coun my hife's counsel would unt hesur. tou late comes counsel to be licur for counsel is but vain

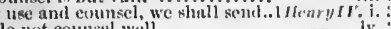
Y liold as little couned and comsel every man the aptest.... ly iny lenrnct counsel in the laws i will take your cunnsel the yery latest counsel thint ever i guel limbs of noble eominsel, that the by your own counsel is sulpressed. bear the key of all my eom

lork his counsel in my breast
friendly counsel ents ofl many toes and ali our counsel, die?

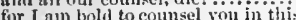
what counsel give you in this weingi

your company for spcedy eounsel .3.

gochl counsel, imurry; learn it.

georn me fir my gentle conmsel?

to eounsel me to make my penee

my countsel's consistory, my
with politic grave counsel.

if I may counsel you some day

care is this your counsel, madain

ghall be the neighbour to my eonnsels

are litreral of your loves, and comsels

he counsels a divorce

heaven keep me from sucli connseiti..

whose coupsel 1 will implore $\ldots . . . .$.

and counsel, for iny eause

any" Fing

vour griefs, and take my connsel...

is this your christian counsel

reverend fathers, hestow your counsels

and heavenly thoughts still comsel her

mydertakings, as your cour

and very courtly counsel

to counsel aleaf, but not to flatteryi. 7

yet he would emhrace no counsel.
thou givest me, not all thy counsel

morc counsel, with more money,

ot limme are entercd in our connscis

of limme are entered in our colussels
whoever gave that counsel, to give ..
never admitting counsel o' the war..

tell me your counsels, I will not...Julius Cirsar, ii. I

for women to keep counsel! ...........

things set down by lawful counsel.

that make these locks of counsell.
now for the counscl of my son...

counsel, lad, smells of no cowardice... Titus. And. ii. 1

close enacts and counsels of the heart!

I can keep lonest counsel, ride

this man hath had good counsel

hestow your nccdtui counsel to onr.......

Whell a rise man gives the better co

my Regan counsels well: come out.......
uniless good counsel may the cause... Romeo of Jut

in night so stumblest on my conri.....

he lent ine counsel, and 1 lent him
two may keep counsel, put ting one

to hear good counsel: $U$, what learning

crmtort me, counsel me: alack, alack

pive me some present counsel?

the players cannot keep counsel $\ldots . . . . .$.

that I can keep your counsel, and not

so I thank you for your gocd counsel....
we lacked your eounsel and your help

to counsel Cassio to this jarallel course.

he was of my connsel in my whole cour

turn the key, and kecp our counsel ........

pray, be counseled; I have a heart... Coriolmnus, iii. 2

coUNSEL-KEEPER

his note-lwok, his counsel-kecper ..2IJenryIV. ii. 4 to be an emperor's courasellor.. Turo Gen. of fer. ii. not for his counsellor....... Nerry Wives, ii. I (letter) gooul coumsellors lack no clients... Meos. for Mirks. i. eounsellors that feelingly persuade. As you Like it, ti. your most obedient counsellor.... Winter s Tule, and hot bloch are his counsellors ..2 lienry $l l$ : all your sage eonnsellors, henee? .... . Itenty $r$. well supplied witis noble enunsellors _ ii be a goon comsellor, or no? .......2lienry l'l. iv. norses had lecen counscllors to Peptn. Kenry you are a counsellor, and, by that virtue as he was a counpeltor to try him...

the counsellor heart, the nrin nur.... Coriolanus, i. fit counuellor, and servunt for a prince .. l'rricles, $i$. thou art a praye and noble counstilor. his own aflicetiong' counscllor .. Romeo \& Juliel, $\mathrm{i}$. go counsellor; thou aul my bosom

a most profine und lileral counsellin. Hiantet, iif. COUNT-other ont of all count. Twocien. of I'er. $\mathrm{ti}$. that no man counts of lier beauty

but cerunt the world a atranger ........ the duuph ter of a enunt that died. Jinelsh Nirht,

the coumt himself, here, hard by
she'll none o' the count..........

challente me the eorut's yout

the eount's gentieman, ol

to be marrieil to this c
know you any, eomnt?

and this ancererl count, $d$

und let this comnt kill me .......

I count it inut time lost to

the amorous connt solicits her
the count, he is my lusband

then must I count my gaing

I wolkd not be a young count

count wisdom as no member

as we count not worth the

whever f count his, beyond

doth she not count her blessed

are colliers counted bright.

in eountenance somewly

on him such a countenance as

lift "n your countenance

how he holds his countenane? il'it be a suit from the count ....
the youth of the count's was trect

more fuvours to the connt's serving-inu

to strve this noble eosunt ...

about your own busines, count

the count is neitler sad, nor sicl

cinnt, take of me my lunghter
sicak, count, 'tis your cue ...

these glotes the comnt sent me ......

how long is't count, since ............

As yon Lik

commit it, count. I am your .........

count; to all counts! to whint (rep.).

the french comnt has clone most

of the grent eount himself, she is

the count, he wooes your daughter

the comt's a fool, and foll of crold.

fur I knew the young count to be

that lascivions young boy the count...
nutl bring again the count ...........

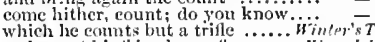

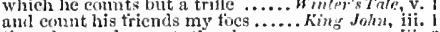

on you depending, eounts it your weal - iv.

go, count thy way with sols

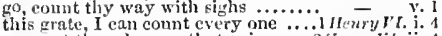

[Col. Kul] much count to violent theft

l count it one of my greatest.. Timon of Alhens, iii. 2

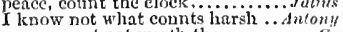

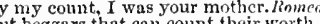

by this count I shall be much in yours

her father counts it dangerous ..... - iv. 1

make us again count o'er, ere lore

Why to a public count I might not go..... - iv. 7
I'll comt his favours: but, surc.........

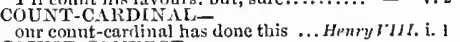

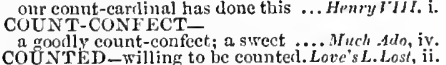

for nutive blood is counted painting.

thou nust be counted a scrvant ........ ${ }^{-}{ }^{-}$iv iv. $^{3}$

mine integrity, being counted falschood - iii. 2

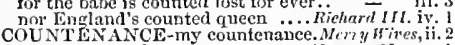

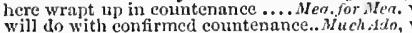

Biron was out of countenance.... Lne'e's L. Losl, v. 2

put the in conntenance (repealed $)$.....

the countenumee of steru commandment

making you that conntenance you are

their eflcet than in their countenance -

to countenance my mistress.............

in gait and countenance surely like..

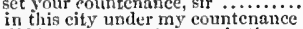

did bcar iny countenance in the town $-\bar{T}$

sprights to countenanec this horror! .. Mrabeth under whose countenance we steal .. WHevry $I I$.

and gave his countenance, against lis

dingerne countensnce of the king

the countenanee and grace of heaven

have soine countenanee at lits friend"

do but mark the countenance that he

grisly countenance made others fly.

grisiy countenance made nthers fly ...111enry

strangeness of his altered coluntenance?

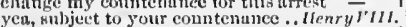

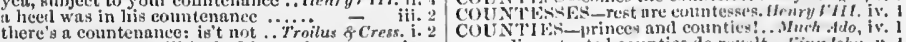
there's a countenance: is't not ...Froilus o-Cress. i. 2
thy countenance, still locked in steel
COLNTENANCE-confl rmerl eomntenance. Coriot. i. 3

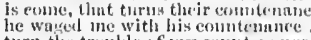

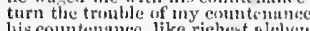

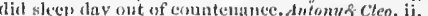

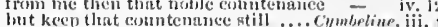

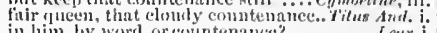
but you linve thit in your enuntenince.

lis combtenane hike's ne mit.........

a contutennnee more in sorrow than

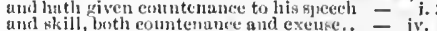

ir, that poaks anj the king s esmuntenance - iv.

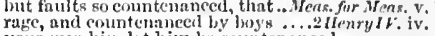

CiUNTER-what, for a counter ...As yor Like it, ii. 7 I cannot lo't without eomnters .. W'inter's Tale, iv. 2
a hound thut runs counter. . Comedy of lirrors, iv. 2 such rasenl counters from lis . Julius Cirsur, iv neek, sir, is pen, book, and counters. Cyml,eline, y, 4 COUNTER-CASTER
debitor and creditor, this counter-caster olhello, $\mathrm{i}$.

conunterehange is severally in all .... Cymbeline, v.

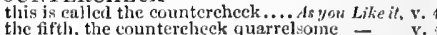
a conntereheck lefore sour gates .... King J $r h n$, ii.

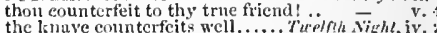
ne flo you but comterfeit? tir.......... o God! counterfeit! there never ( $(\mathrm{rpm}$.) $\overline{\bar{N}}$ ii.

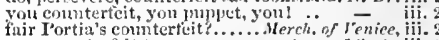
now counterfeit to swoon.........As you Like it, iii.

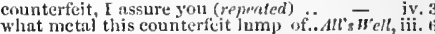
so curiously he had set this counter feit - iv.
bring forth this counterieit module..

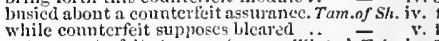
not a countcrfeit stone, not .......'H'inter's Tale, iv. slcep, death's counterfeit, and look on .Macbeth, if. 3 beguiled me with a counterfeit....... King.John, iij. 1 n true picce of gold a counterfeit.... Henry $1 Y$. ii. this is an arrant eounterfeit raseal.... Uenry $V$, iii. 6

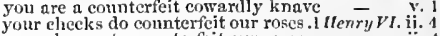

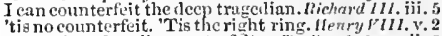
rememberch a gilt counterfeit ... Troilus f Cress, it. 3 strike me the counterteit matron!. Timon of $A$.
thou draw'st a commterfeit hest in all with his tools made me a counterfitit. Combeline, ii. 5

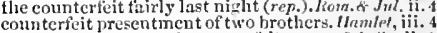
an eyc can stamp and counterfeit ....... othello, ii. I these mar be counterfeits; let's think't.. - v. I
COUNTERIEITEDhow I counterfeited to swoon, when lie - $-1 \%$ another counterfejted beam ......... I Henryll. v. 3 my counterfeiting the action of ...Mrry Wires, iv. 5

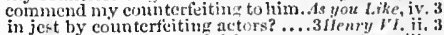

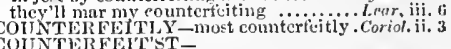

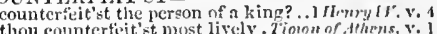

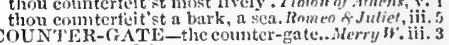
COUNTERMAND-

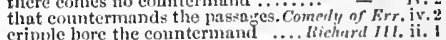
cripple bore the countermand ... Lichurd /ll. ii. 1 my arras, counterpoints, costly ... Taming of Sh, ii. 1 to whom I promise a counterpolse ...Al's Well, ii, 3 counterpoise of so great an olpositicm. Thenrll dis more than counter

cannot be counterpoised with such..2 flrwry IrI. iv. I

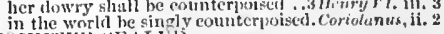

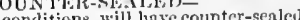

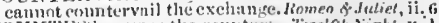

COUNTENANCEI -

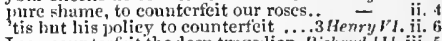

no countermand for Claudio......Meas. for Meas. iv, 2

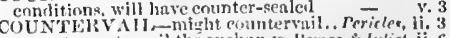


COUNTIES-soldiers up in counties.2Henry $I \%$. ii. I powers unto their several counties and those two counties ï - ivry $V I$. v. 3 COUNT ING-counting myselt but bai.3 Henry $/$ I.v. 6 enticetl thee to view a countless glory..Pericles, i. i that give heaven countless eyes to vicw... $\vec{i}$, i. 1 I could find out countries in her Comedy of $\mathrm{Er}$ iii 2 could cin out coun man ot countries. King John i. the rest of thy low countries have ..2 Henry $I V$. ii. 2 dismiss you to your several eountries.2 Henry VI.iy. 9 in countries, discord; in palaees, treason... Lear, i. 2 COUNTRY - one iu country footing ... Tempest, iv. 1 while I am king of this eountry guide us out of this fcarful country

guide us out of this fcarful country! .... lauglh this sport o'er by a eountry fire $-\bar{N}$, 5 know'st thou this country? ........... for $\overline{M I}_{\text {eas }}$, ii. and the eountry proverb known...Mid.N.'s Dr. iii. 2 boy, I do love that country girl ... Love's L. Lost, i. 2 a vessel of our country, richly ...iler. of Venice, ii. 8 the body of the country, city ..... As you Like it, ii. country, as the behaviour of the country -

the earliest fruit iu the country....

these pretty eountry folks would lie $-\overrightarrow{\mathrm{v} .} 3$ (song) the rest of the country copulatives ...

that chase thee from thy eountry...

if you could find out a country .......

follow him to his country for justice - $\mathbf{v} \cdot 3$ (petit.)

of that fatal country silicia...

having both their country quitted

he laboured in his country's wreck ........

to this our suffering country

bleed, blced, poor country! .............

yet my poor country shall have.

and my poor country's, to eommand

alas, poor country; almost afraid.

in our country's purge, eaeh drop. come from the country to be judged...King John, i. 1 our eountry manners, give our betters - - i. 1 which iu our country's eradle draws.

turn me from my country's light....'

the bay-trees in our country are

ntry's earth

to weep over his country's wrongs.. 1 Henry IV. iv. 3

in our marehes through the country...Ilenry $V$. iii.

the country coeks do erow ........

a member of the country's peace

enough to do our country loss...

weak list of a eountry's fashion.

the nice fashion of your country

our

wasted our country, slaiu our citizens

drawn from thy country's bosom....

wash away thy country's stained spots - iii. 3

and my country's weal. What!

or sack this country with a mutiny

sought every eountry far and near

upon the country where you mak
bodies for their country's benefit.

to ease your country of distressful

in duty love my king and eountry

your king, your eountry, and your iives -

youret is the country, beeausc full....

well you love your prince and country

for all the eountry is layed for m....

how will the country, for these ....3 Henry VI. ji.

here in this country, where we noy

strength and safety of our eountry

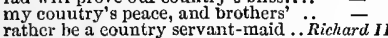

rather be a eountry servant-m

were you this country's king .........

here we waken to our country's good - iii. ?

your country's foes, your country's.. - v. 3

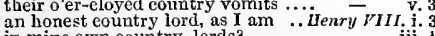

in mine own country, lords?

thou aim'st at, be thy eountry'......

in their country did them that.. Troilus \& Cress, iv.

born to conquer my country... Timon of Alikens, iv.

but vet I love my country

services he has done for his country?

say, it was for his eountry, he did it

eleven die nobly for their eountry
his country's dearer theu himsel

that's for my country; he, that has

deserved worthily of his eountry....

I got them in my country's scrvice.

have deserved nobly of your country -

received many wounds for your
wounds received for his country

youngly he began to serve his eountry
COUNTRY-your country's friend.. Cor
for my country I huve shed my blood
for his country; and whit is left (rep.) when he did love his eountry.

ncmy to the people, and his country being now in no requestot lis country I'll do his country scrvice

shed for my thankless eountiy

figlat against my cankered country

blood out of thy country's breast

thy country's strength and weakness

if you would be your country's pleader

tearing his eountry's bowels out

the conntry, our dear nurse (rep.).

read on thy country's ruin ............

destroyed his country; and his name

more infected with my eountry's love

vile, thint will not love his eountry?

rom this eountry Pindarus shall run

Brutus, my country's friend

most useful for thy country.....Antony \& Cleo. iv.

that ever country ealled his!

wars shall find I love my country

the prineess of this country

in doing this for his country ................

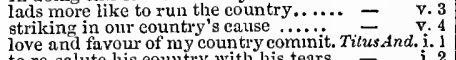

slain in your country's wars!.........

that iu your eountry's service drew...

led my country's strength success

this ungrateful eountry done the like

here's them in our country of Greece .. Pericles,

he's but a country gentleman ..............

next, he's the governor of this country

if he govern the country, you are bound.

who frichted from my country, did wed

shape his old eourse in a country new.

as the mavn of our proutry is komeo \& Juliet,

where is the country's pnge ............

or the addition, of man, and country ....

undiscovered eountry, from whose bourn

of country, credit, every thing .......... othello, i.

tis pride that pulls the country down - in

I know our eountry disposition well ...

may fall to match you with her country

her father and her

Antonio, your countryman? .. Two Gen. of Ver. ii.

is your countryman, according to

here you shall see a countryman ... All's Well, it what countryman? Born in Verona. Taming of $\mathrm{S}$

what eountryman, I pray?

my countryman; but yet I know ......... Macbeth, my countryman. By Cheshu (rep.)

Froissart, a countryman of ours ....

1 Henry $V I$

Charles of France, thy eountryman - iii. 3 dear countryman, bring in thy...Timonof Athens,

my helmet to my eountryman... Aniony \& Cleo. iv. 13

a simple countryman, that brought

one Aruliteus lives, my countryman... Tilus And. iv. 2 my friend, and my dear eountryman ..O Olhello, v. 1
COUNTRY MEN-and countrymen. Ner. of Ven. iii. 2 and to Chus, his eountrymen ........ Tamintr of sh.
visit his countrymen, and banquet. our well-dealing countrymen.. Comedy of Errors, i. thy seditious countrymen and us.. . Richard II. i. 4 with thanks my countrymen .........Richard 11. ii. 4 our countrymen are gone and fied

then, forth, dear eountrymen..........

brothers, fricnds, and countrymen

have we done, thrice-valiant countrymen - iv.

my friends, and loving countryme

1 Henry $V 1$ i. 5

joueth Rouen to her countrymen

thou fight'st against thy countrymen

stain to thy countrymen! thou hear'

ah, countryinen! if when you make

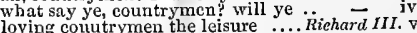

if Alcibiades kill my countrymen. Timon of Alk. v. 2

me to my loving countrymen...$\cdots$. criolanus, $_{\text {i. }}$.

Rome, and thy petitionary countrymen

Komans, countrymen, and loversi

my countrymen-peace, silence!

ii. 2 what a fall was there, my countryne

i. 3 stay, countrymen. Peace there ....

ii. 3 bet hear me, eountrymen: yct hear.

\begin{tabular}{l|l} 
ii. 3 & eountrymen, o yet hold up your l \\
ii. 3 & countrymen, my heart doth joy...
\end{tabular}
COUN'TRYMEN-countrymen are men.. Cymb. ii. 4 countrymen, my loving tollowers.. Titus Andron. i. 1
unto our climatiưes and eountrymen .. Hamlet, i. I COUN'TKYWOMIN

too bitter to your countrywoman. Troil. S Cress. iv. What enuntry woman? bere of these Pericles, v. messenger, the county's man ...TTureljth Night, i. a ring the county wears .............. All's Well, iti. 7 a poor esquire of this eounty $\ldots \ldots$...2Herry IV.iii. 2 the county Mlaine, and Anjou ...... Henry VI. v. 3
Anjou, and the county of ..2Henry ${ }^{2} . \mathrm{i} .1$ (articles) from cach county some, and try .... - iii. I in every county as we go along......3 Henry VI. v. 3 Juliet, the eounty stays........... Romeo \& Juliet, i. 3
best you unarried with the eounty ... - iii. 5 next be married to this eounty ...... - iv. 1

send for the county; go tell him $\ldots . .$. - $\quad$ iv. 2

be married to the eounty? [Col. Kni.-then to-morrow morning ?] $\ldots \ldots \ldots \ldots \ldots$
the county will be here with musie...

let the county take you in your bed.:
pitiful sight! here lies the county slain coUPE-coupe le gorge, that's the word. Hentry $V$. ii. 1 COUPER-de couper votre gorge (rep.) - Tempest, iv. 1 on this couple drop a blessed erown $\ldots . . .-1$ a prettily he couples it to his... Tuo Gen, of Ver have ta'en a couple of as arrant ....Mueh Aito, iii. 5
wood-birds but to couple now? ..Mid. N.'s Dr. iv. 1 these eouples shall eternally be knit - iv. so shall all the eouples three ........ these couples are coming to the ark!
and couple Clowder with ..... Taming of Sh. 1 (ind.)

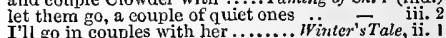
I lost a couple, that 'twixt heaven ... - v. as you, gracious couple, do! and then $\overline{\text { va }}$ v. a couple of short-legged hens.........2 Henry $r V$. v. 1 and a couple of pigeons here . Titus Andronicus, iv. 4

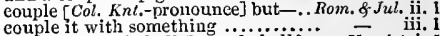
what else? and shall I couple heli? .... Hamlel, i. 5 for honesty coupled to beauty .......... is yua Like it. 3 with slaughter coupled to the name..KingJohn, iii. married in league, eoupled and linked $\overrightarrow{-1}$ VI. iv. 7 unremoveably coupled to nature.. Timon of Ath. v. 2 COUPLEMENT-royal couplement 1. Love's L.L. v. 2 that ber golden a couplets are diselosed .. Hamlet, $\mathrm{v}$. I
the COUR-je m'en vais à la cour ....... Merry Wives, $\mathbf{i}$. courage; there will be pity taken. Meas. for Neas. i. you have courage to maintain it .... iii. 2 what man? eourage yet!......Merch. of Veniee, iv. I what man? colvrage yet......Merch. of veniee, iv. but what though? Courage! .......... All's Well, ii. 1 beauty, wisdom, courage, virtue....... All's Well, i. and in that heart eourage, to make ....... courage mounteth with occasion............. John $n$, ii. 1 eourage and eomfort! all shall yet ... - iii. 4 ery, eourage, to the field! $\ldots \ldots . . . . .1$ Henry $I V$.ii.
show greatness, courage, blood ...... their courage with hard labour tame
best tempered eourage in his troops.. 2 Henry $I V$. i. 1 doth any deed of courage ............ $\overrightarrow{H e n} r y V . i$ iv. 3 boy, bristle thy courage up :........ - ii. with men of courage, and with means - ii. 4 mastiffs are of unmatchable courage - iii. greater therefore should our courage be -
may show what outward courage he will dout them with superfluous courage - iv. 2 my courage try by combat ........... full of liaughity courage, such as .... - iv. 1 her valiant courage, and undaunted.. - v. 5 fear you not lier courage $\ldots . . . \ldots \ldots \ldots . . \quad$ i. 4 thrice cried, courage, father $1 . \ldots \ldots \ldots$...... this soft courage makes your followers $\quad$ - ii. 2
this may plant courage in their...... this may plant courage in their...... $\quad$ which are so weak of eourage....... $\quad$ iv. 1

eourage, my masters; hong why, courage then! what canvot .... - v. 4 and children ot so high a eourage! ... $\bar{R}_{\text {ichord }}$ III. v. 3 the thing of courage, as roused ... Troilus \& Cress. i. 3 deject the courage of our minds.

whosc present courage may beat .... anticipating time with starting eourage - iv.

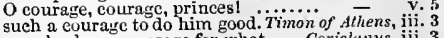
nor cheek my courage for what ..... Coriolunus, iii. 3

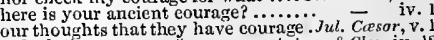
to lack the courage of a woman.Antony \& Cleo. iv. is my courage prove my title! ........... 
(1)IRABE-their courme worthy his (nuw mitngled with the il cuurages) pretty self,) to a w'uggisls eoturage thide it with a prines's conrmbe thought but thithfulness und eourage Hluall dri ve courange frem the stnt I to applaud his courny what courzzye, sir? God suve you (rep Suliwt, iii.

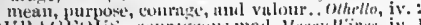

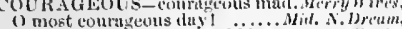
the most couragenus tiend lidx... Mher. of Jenin show it celf eourageouts to petticont. As you lihe

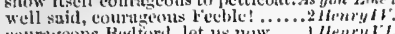

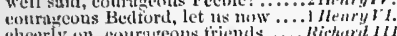
ehcerly on, comprageous triends ....ki courageous lifelmond, well hist thon - v. courageous, high, ummatetuble .Antony of Cho. ii.

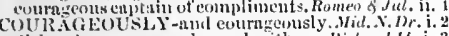
disloyal: courusconsly, ated with.... Kichard sh. 1 wet a couriter, one mine ancient. Timon of $A$, ciunt cer we

\section{Ci) Ulise-zet lier two esurses}

who slivild nut uphraid our course.

the swift coursc uf time.....Tu'o Gen.ofleron his finimeler not my course

lie did so course o'er my exteriurs.....ierry Wives, i. let him comtinue in his eourses.. Meas. for Mers. this being granted in course.....

the the

il pervert your course

- iv. 3

way unto this colurse of fortune .....Much Ado, iv.

Irem 1 on: this strange course .......

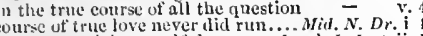
t) us sec'meth it a needful course... Love's L. Lost, if. uf all elements, conrses as swift as....

that in the course of justice .......... - iv. 1 not martel, llelen, at my course .....All's Hell, ii. as in the cumone 1. a te' the course the end is the

I could uot answer her in that course

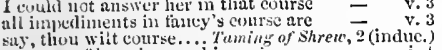

a eotase of fearmin:, and ingenious

as mine ow from conre requirul...

untess he take the course that yon

which sliall have due course,

what conrse I mean to hold ...........

a course more promising thall a wild
clid they bend their course .... Comedy of $\bar{E}$ r

what is the course and drift

this course I fittest choose.

grat nature's secund course

with course disturbed even thy confining -

all direction, purpose, course, intent

stays in his courici, and plays

the yeariy conrse that brings

it makes the course of thoughts

our rankness und irregnlar eonrse...

rivers take their eourse through......
are dried by nature's course .......
but by bad courses may be understood

kept on his coursc, while all .

kept on his coursc, while all ...........

and the general conrse of the

and all the courses of ny life.........

lieart being set on bluody courses.

tis so rough a coursti to cume by

tlieg take their courses cast, Wu'st...

and nukes it course from the inward

and nakes it course from the inwards

and found no course of breath

and found no course of breath .......

my liarry, be lt thy eourse to busy

the eutrses of lis youtli promised...

his addietion was to eourses vain

and oaths must have their cours

intu a second course of mischief.".

numbers, and due conrse of things

the full cumre of their glory .... - v. $\overline{2}$ (chorus)

persuade you take a better course. ..1 Menryll. iv. 1

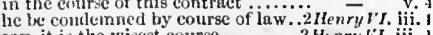

say, it is the wisest course.........3 Honry VI. iii. I

towarls Coventry bend we our course

keeps un upward course, and we are
hold their course townd Tewkesbury

bat kecp our conrse, thongli...

$\begin{array}{r}-\quad \text { v. } \\ 二 \quad \text { v. } 3 \\ \hline\end{array}$

Minos, that denied our eou

Richard III. i.

needs no indircet nor lawless course

prul may direct his course ay please

infirect and peevish conrse is thi

unto a lineul trec-derived coure ....

thin ath the course of justice wheeled

hend their eourte [Col. Knt.-poxer].

tin alter the king's course............. Ilenr

and is not this course pious?

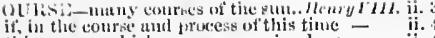
this comrse, which yen are rmming lere -

flow your envitus eotrese,

the stroug courac of thy atition

iuscunt from his comrse of grow th ...

to talie llut course by your cousent

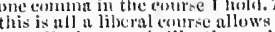

th posligal course is like the sun'

whose conrse will on the way it tiken, Coriolan

too vislent for a secund eourse of fight
the other coures will purve too bloud

ditermine ourse will porve to

When le doth run his rourse .......... Jitin

our conrse will secm two blosd

myselt resolvet upon a conse.

to cunrse your flying hags, and lour
tis your hoblest course: wisdom

which kent their coure, and lighted

by taking Antong's rour

you should tread a course pretty and

canst not in the coursc of gratitude.

if cach of you wonld take this course

a specdicr course than lingeri

in conrse of this revenge, to do

will shum no course to keep them

aiter thy course tor 'Ty'e ......

no eare to your best comres

he did not llow from honourable eourse.

though you call my course unnaturnal.

we must take anutlaer course with you

by monthly course, with reservation.

you shall rnm a certain course

to hold my very conrse.......

that yu protect this cuurse.............

been inturned of my obscured cour

to coured he is in his own course.

I will perscvere in my course of loyalty

meet the old course of deat

might liave the trecr course .......

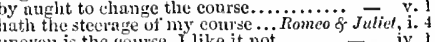

tue not intere cotr'se, like it not

the not interrugt me in my course $\because .$.

had made his course to illuuine that

is a course of ingions thiongly the naturnl gates...

if he do bleneh, I know my course

in our circunstance and colurse of thought - iii. 3

and Guildenstern hold their cuurse for- iv. b (let.)

with due course toward the isle of pihotes

now do they re-stem their back ward
deliver of my whole conrse of love

ind indirect and forced courses subdue...

or from what other collse you plents.

counsel Cassio to this parallel cours

compulsive course ne'er feels retiring ebb

[Col KuC] the sun to eourse two hundred

shut myself up in some other course

the lethiargy must have his quict course

and his own eomses will denote him so.

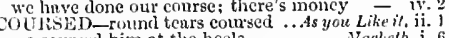

we coursed him nt the heels.............. Nacbeth, i. 6

their neighin' tuanimg comrer's back. fich

complosed to cunsers dar.

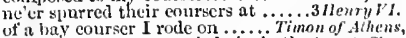

of a bay courser I rode on ...... Timon of A Ahens, $\mathrm{i}$.
Which, like the conr'ser's hair, hath. Alut. of Cleo. $\mathrm{j}$.

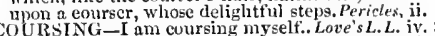

not mean the conrsing snatchers only.. Henry $r$. i. 2 CRT-if now 1 court 10

the emperor in lis royal conrt... Tu.......... of $\bar{V}^{\prime}$

with Valentine in the emperor's cunrt

with sir Proteus to the Imperial's eourt -

her company, and my court

and happy being at your

to leave our roynl court.

me after my heel to de court ..... Merry lives, i.

.

let the court ut Frauce show

and will be to-norrow at court

and his friends potent at court

it it shoudd come to the ear of thic court

bound to the count Orsino's court. Twelflh

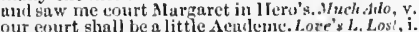

vilu liers in your court for three ..

shitll come within a mile of my ecoirt

as the rest ot the comrt can possibly thist ones here to besiege lis exurt

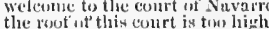

welsonc, malam, to my eome

that keeps here in cont; in pliantion

to parle, to court, und dane
the king will eourt thee for his dear.

to leas you to our esurt...............

come inton the conrt, and swear. .

I may disniss this conrt, unless

doctor to our conrt: Witer is he?
tlie comrt shall hear Bellario's leter

Jolds this present fiacetion in the con

this striet "ront of fenice must
I temier it for lim in the court

I do besecels the court to give.....
the const awarls it, mal the law

law alfows it, and the court nwards it

he hath retused it in the open court.

here in the court, of all he clics po

at the new court? There's no (rmp.).An you

and get you trono our court

so near vur public esurt as twenty

trom leril than the envious court?

the country, city, conrt, $y$ ea

not in the court, it is tedions

at your court? your renson (

good matmest at the court

mon sinlute nont at the conrt.

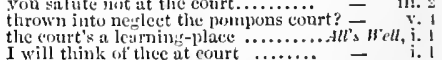

to those ol mine in enurt; I'll stay ...

but to the court. To the court! (rep.

sinec $l$ was at court: our old lings

some despateh in hand at conrt.

arive thee from the sportive comrt
let lis nobility romain in his tourt

I have seent you in the court of F rance

ast that ect I took her leatre at cour

to court lice at your pleasure. Taminir of shre

the knave doth court my luve

fce, how thicy kiss and eonrt!.....

how beastly she doth court limi

in courts and kingiloms $\mathrm{k}$.

1 must forsake the court ......

no court in Europe is too good for thie

appear in person here in court

why he lett your court, the gods ....

ecrtainly whipped out of the court .

no virtue whipped ont of the court

sun, that shines upon his eourt

scc'st thou not the air of the court ..

are they returned to the court?

is Banuo gone from court?

are $i^{\prime}$ the court. Ilis horses.

lives in the linglisle conrt

fy to the cuurt of England ...........

meet him in the court of hearen $\ldots . . . .3$.

lre liatla forsouk the court, lroken

kecps deatl his court; and there
my hord, in the base eourt he doth

unruly jades; in the hase euurt? ( $r$.

as well as waiting in the court

you must to the court in the mor...

You must to the court in the morning.....

trained $n p$ in the English cour

of all the court and prinees....

dismissed ny thether from the court.

the temnis const keeper knows better.: he si $_{y}$

yon must away to conrt, sir, presentiy

he must then to the inns of court

in all the inns ot court neain .........

I will with you to the court
was a mansion for him, a court

with seorn shoved trom the eourt

despateh we toward the court, my jords

to the linglish court assemble now

a friend i' the court is better ........

the English, not the Turkish court

the court with news. From the cuurt?

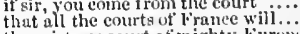

the mistress court of mighty liurope

know! edge at the conrt of guterd ..... Henry I"l. ii.

as princes do their conts when ........ -

alsentlering ot each other in the cuurt

minse oflice-hadge in coutrt ..........2 IJenry $V$

slie sw' 


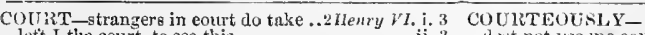
lett I the court, to see this all the court admired lim wimees courts be filled wit. and princes' courts be filled wit.
the city, and your royal court.

must sweep the court clean of such

thy force so neur the court

to call a present court of pariament

grief and sorrow, to the comt....

nor made to court an amorous.......

John de la Court [Col. Knt.-Car].....

John de la Court [Col. Kint.-Car]

Jolin Court [Col.Knt.-Car?, confessor to

by whose virtue (the court of Rom

heen begring sixteen years in court.

king of England, come into the cuurt -

queen of England, come into court (rep.)

appenrance make in any of their courts =

no revercnd per'son in this court

breuk up the court; I say, sct on

farcwell, the hopes of courtl

held a late court at Dunstable

my way, which is to the court ......

with the great tool come to
even to the court, the licart.

even to the court, the heart ......... Corialanus, $\mathrm{i}$

must return to the comt ot' gutard... A

let us bear him to the court of guard

Wived in court (which rare it is to do). Cymbeli

thou fraught the court with thy

cominend me to the court where you

a suncy stranger, in his court.

take my power i' the court for yours

that's come to court to-night?

cold dishes, with scraps of the court

i' the court; before her father.

of courts, of princes, of the tricks ....

the art $o^{\prime}$ the court, as hard to leave

you shall be missed at court ........

back to the court-No court, no fathe

suspected of your carriage from the court -

but our great court made me...

gieat men, that had a court no bigger

courtiers say, all's savage, but at cour

perhaps, it may be heard at court .....
Romans, and not o' the court of Britain -

rcmenber me at court, where

why fled you from the cuurt?

so clishonoured in the court of Rone

that knows to court it with words

the exuperor's court is like the bou the court may echo....

and I'll go brave it at the court.......

this tempest whirling in the court

shoot all your shafts into the court

in the emperor's court there is a quee

here pleasures court mine cyes .......
so this is Tyre, and tlus is the coirt

is his court distant from this shore?

guide me to your sovereign's court ....

the entertainment in our court

I came unto your court, for honours

to the court of king Simonjes.

long in our court have made their a

O nuucle, court holy-water in a dry

poor rognes talk of court news $\ldots \ldots \ldots$.....

though lewduess court it in ............

voughsafe your rest here in our court
shall we to the court? for, by my fay

thicy are about the couxt

sir, here is newly come to court, Laerto

watches on the court of guard ..............

it' I court no women, you'll couch - - iv. 3 (solls)

on thy baseness, court-c
COURT-CUPBOARD

remove the court-cupboard .... Romeo \& Juliet
COURTED-I am courted now ... Winter's Tulo

COURTEOUS - this courteous office.. Tuelfih Th

and courteous to this g
thanks, courteous wall

nds, aud courteous breath.M.Mer, of Venice, it. hint courteous conduct to this

we ficely cope your courteous pains. $\overline{\text { th }}_{\text {ike }}$ iv. 1

the first, the retort courteous .........

affible, and courteous gentleman .. Taming of sh. i.

pleasant, gamesome, passing courteous - ii.

my courteous lord, adieu .... Troilus \& Cressida,

parasites, courteous destroyers. Timon of Atheus, i

supple and courteous to the people.. Coriolames,
cuntteous lurd, one word .....Antony \& Cleoputra,

vur courteuus Antuny, wliom ne'er

a inost courteous exyosition .....Romeo of Juliet,

and a courteots, and a kind, and ....

with what courteous actiou it waves.... Hamled, $\mathrm{i}$. dinst not lue me courteonsly .. Troilus \& Cress, iv. 4

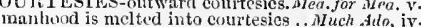
manbood is melted into eotritesies... Much . Alo, iv. 1 lves and clo him

for these courtesies I'll lend you... Mer. of Ienice $\mathrm{i}$. unwenried spirit in doing courtesies.

but as we cliange our courtesics

let thy courtesies alone, tley are

thesc lowly courtcsics, might fire. Julius $C$ ersar , iij. bcen debtor to you for courtesies ..... Cymbeline, $\mathrm{i}$. the courtercorn our courtes

the comrtesy of it is so fearful .... T'welfth Niyh

ii. $)$ present and a dangerous courtcsy. Mea for Mea.

then is courtesy a turn-

for lore and courtesy lie further of...irid. $\bar{N}$.'s $n r . j i$.

if you were civil, and knew conrtesy

but yet, in courtesy, in all reason

remember thy courtesy .............. Lov's L. Lost,

kissed away his hand in courtesy ...

the smiling cuurtesy of love

pleasant jest, and courtesy, in hombast -

money for a ehristian cuurtesy . Mer of of $\overline{V^{\prime} \epsilon}$

to offices of tender courtesy

I scant this breatling courtesy ......

the courtesy of nations allows you. As you Like

that courtesy would be uncleanly

lowly courtcsy, and say .. Taming of shrew, I (int.)

to do you courtesy, this will I do

with humble and tamiliar courtesy.

my unpleased eye see your courtesy

deal ot courtesy this fawning
yet $I$ am the king of courtesy

then I stole all courtesy from heaven

he shall shrink under my courtesy

a second time to do such a courte
if thou wert sensible of couvtesy

was more of his courtesy than your.2 Henry IV.
to prove this lady's courtesy ......... I Henry $\mathrm{VI}$

I proed not crave his courtesy

French nods and apish courtesy.

- $\mathrm{v}$

the mayor in cuurtesy showed ine.

Henry $_{\text {VIIL }}$

the mirror of all courtesy;-stay

which looks like pride, is courtesy ...

I do disdain thy courtesy, proud.

and all this colutesy! the strain. Timon of $\bar{A} t$

digest the senate's courtesy?......... Co

showed thy dear mother any courtesy

with courtesy and with respect enough -

the qucen shall than have courtesy. Ant.
dissembling courtesy! how fine this.: Cymb

to have the courtesy your cradle promised

how courtesy would seem to cover sin!.. l'er'

with such a graceful courtesy delivered?

$O$ sir, a courtesy, which if we shonald den

effects of courtesy, dues of gratitud

this conrtesy, torbid thee, shail the duk

jet our power shall do a courtesy to

a man may strain courtesy ....Rom

he is not the Hower of courtesy

this courtesy is not of the right breed.. Hamlef,
they do discharge their shot of courtesy. Othello, gives me this bold show of courtesy

that I did! but that was but courtes

COURTEZAN-shameless courtezau!.1 Hen $\bar{V}$ VI. iij. 2

fricnds, aud give to courtezans ......2 Henry $V$.

some Roman courtezan ............. Cymbeline, iii. 4
a brave night to cool a courtezan ....... Lear, iii. 2
COURT-GATE-upon the court-gate.Henry VIII. i. 3

COURT-HAND-wite court-band.2 2 Honryl'

now I see you'll be a courtier.

thou wouldst make an ausolute courtier

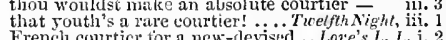

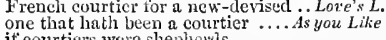

if courtiers were shepherts

do uot your' courtier's hands sweat
the courtier's lands are pertumel.

nor the courtier's, which is proud....

he hath been a courtier, he swears

the cut of a certain courtier's beard
'tis an unseasoned courtier ............
like an old courticr, wears her eap.

like an old courticr, wears her eap..

be capable of a courtier's counscl ......

- in, ii.?

ask me, if $\mathrm{I}$ am a comtier .............

I pray you sir, are you a courtier?...........

are you a courticr, an't like you... I' inter's $\bar{T}$ ale, iv.

taws cannot be but a great coutier $\ddot{2}$ Henry VI. iv. 3 to thin is an English courtier may ... Hewry Vlil. i. 3 (am yet a conrtier bestrarly)

thou'dst courtier be again .... T'imon of Alhrns, iv. 3 obey the lienvens than our courtiers. Cymbeline. ii. but rint a courtier, although they wear or in that way accomplished courtier
COURTIER-so accomplished a courticr. Cymbelne, i. $t$ comrtiers say, all's savare, but at court

you ure right courticr knirhts $\ldots . . .$. . Pericles, i. on courtier's knecs, that dream... liomeo \& Julict, i. she gallops o'er a courtier's nose...... courtier's, soldier's, seholur's, eye, tungue - it. a courticr; Which could say, govd the king, the gucen, the cuuticrs....... $-\mathrm{v}$ war-like court-like, and lcarned.. Merry Wires, ii a wOTThY - too cuurty a wit for. As you Like it, iit. 2 forth from courtly friends .. All's Well, iii. 4 (letter) in courtly company, or at my .....2Henry $V I$. i. and very couttly counsel ............ - iv. is most courtly and fashionable .. Timon of Ath. v.

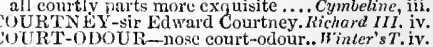
OURT'SHIP - full of courtshi]. .. Love's L. Lost, v. rated them at courtship, pleasnit jest

your chiefest thoughts to courtship. Her. of Ven y. one that knew courtship too wcll. As you Like i iii. observed his courtship to the common. Richard Il. i. courtship lives in carrion fics... Romeo \& Jutict, iji. I will gyve thce in thine own courtship. Othello, ji. I OURT'SIED-court'sied when...Tempest, i. 2 (solig) lay out their wealth on court'sies.. Timan of $A, h$. d'eam on court'sies straight .... Romeo \& Jul 'e!, ny cousin's duty to make court'sy ... Hueh Ado, or else make another court'sy .......... court'sy, swcet hearts: a:1d so ........ when I make court'sy, bid me... As you Like it, (epii.) let them court'sy with their left. Taming of Sh. iv.
heels aud court'sy at his frowns ..1 Henry $1 \mathrm{~V}$. iii. if a man will make court'sy $\ldots . . . . .2$ Henry $1 V$. il. my court'sy, last my speech (rep.)....... - (epil. nice custome court'sy to great kings . Henry $I$. H.?
is made; she seals it with $n$ court'sy. 3 Henry $V I$. iii. what is that court'sy worth? ......... Coriolanus, $\mathrm{v}$. worse, must court'sy at the consure. Cymbeline, iii.
whom mighty kingdoms court'sy to.. Tri usAnd. v. 3 the hams. Aleaning, to court'sy. Romeo of Julict, ii. the hams. A I aning, to court'sy. Romeo o-Jultet, ii. can you tell, cousin?

I will do as my cousin silialiow says

at your request, consin, in any reason

ay, I think my consin meant well ...

go, wait upon my cousin shallow....

Anise Page and my cousin Slender ..

your cousin, my lady, takes great. Twelfth $\mathrm{Nighth}, \dot{3}$.

cousin, cousin, how have you come so

saying, cousin Toby, nyy fortunes....

your drunken cousin rule over me.... - iii. 4

cousin Juliet? Is she your cousin?...Mea.for M Mea. i.

my very worthy cousiu, fairly met

you, lord Escalus, sit with my cousin

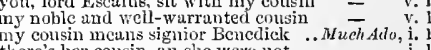

there's her cousin, an sile were not

cousins, you know what you have to do

good cousins, Jave a care this busy time it is my cousin's duty to mak

fault will be in the music, cousin.....

cousin, you apprelend pussing shrewdly -

speak, cousin, or if you çannot, stop

and so slie doth, consin

cousins, God give you joy! ..........

find my cousin Beatrice proposing ...

to stain my cousin wirl $\ldots \ldots \ldots \ldots . . . .$.

wake my cousin Beatrice, nnd desire

your cousin will say so. My cousin's

I am stuffed, cousin, I cannot smeil

why, how uow, cousin, whercfore sinl

0 , on my soul, my cousin is belied

believe your fair cousin is wrouged..

I ain sorry for my cousin

go, comfort your cousin .............

how doth your cousin? Very il

why, then my cousin, Marga ret

writ in my consiu's hand

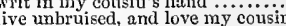

if my cousin do not look excceding

the duy cousin's hand, doctor ... Mer

shall we see this wrestling, cousin?

low now, daughter, and cousin? ...
gentle cousin, let us go thank him

gentle cousin, let us go thank him ...
why cousiu, why Rosalind ..........

theu there were two cousins laid up

they are but burs, cousir, thrown upon

you, cousin; withiu these ten days

thou hast nut, cousin; pr'rthee, be ii. 1

ii. 1

ii. 1
ii. 1
ii. 1

ii.

ii. I

iii. 1

iii. 4

jii. 4

iv. 1

iv. 1

iv. 1

v. 2
v. 4
v. 4

v. 4
v. 4
Y. 4
v. 4

i.

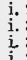




\section{$\mathrm{COU}$}

COIV

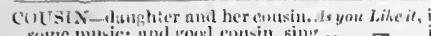
some muse; and goosl embsin, sing
there is more in it: contin,

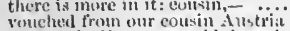

Alts $H^{-}$al,

our entisin Erance, wouth, in so just

lis eny cousin lerdinnel come hither

(I) valiunt cousin! wortly rentlemint.

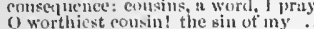

no, cousin, l'il

our blewly cousius ure hestoweil in

my pretty cousin; blessing upon $y_{\text {wil }}$

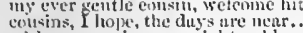

with my eonsin, your right uble soin.

cousin, go drew out

cousin, nway for Eingland

thewell, my gentle consin $\ldots . . . . . . .$.

fir England, contsin;

bear with me, esusin in..............

my conseicnec, und my cousin's death

iv cousin, thou, urt come to set

cousit of lleretord, what dost thon ...
whut doth our eousin lny to Mlowbruy's

cousin, throw down your gage ......

there to behold our eousin Ilereford

recreant to my cousin Ileretord!

my" nuble consin, lord sumerie .....

cousin, farewcll; and, umele, lid him

ue diil ohserte; cousin Aumerle

what said our eousin, when you .....
he is our cousin, consin; but 'tis doul

why, cousin, wert thou regent of

comc, sister, - cousin, I would sny

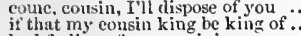

hid feeling of my cousin's wrongs

discomtormble cousin! know st thou

beshrew thec, cousin, which did
take not, good cousin, further
thy thriec-noble cuusin, Innry

his noble cousin is right weleome....

we do debase ourself, cousin

my tcnder-hearted cousin! ...........
fair cousin, you debase your princely

up, coisin, up; your heurt is up

cousin, I am two young to be your

towards London: : euusin, is tt so?....

cousiu, seize the crown: [Col. Knt.-(rep.) $]$

name it, fair cousin. Fair cousin?

our tho cousing coming into London

what is the matter with our cousin now?

my dunferous cousin, let your moth

my gentle enusin Westmoreland ......

a gallant jrize? ha, cousio, is it not?

comsin, un Wedplesiay next our council

canoo blame his cousin kiu

peace, cousin, say no more ............
good eousiu, give me tudicree for

hear you, cousin; a word ............

cousin, turewell; lo further go in thi

colsin, farthel of many men I do not bear.

teuch you, cousin, to command
slabll $f$ tell you, consin? he lolds....

my cousin Vernon! welcome....

coud cousin, be alviseil; stir n

this to my cousin scroup, ............

so tell your culsin, and bring me word

gool eousin, let not Ha

liere comes your cousin ...............
cousill, I think, thon art enamoured

conc, cuusin Westmoreland, our duty

I am the king's joor cousin, sir ...2

how doth my roasin, your hedfellow?

we shull ull tollow, cousin

$\mathrm{ha}$, eousin silunee, that thou hidist

now, cousin, wherefore gtands.

cousin Wratek. Good-ruorruw, coutsin

now sit down; come, cousin.

not yet, my cousin; we wauld be
plensure of our fitir cou

plensure of our far coust the man hath

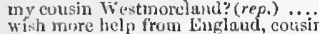

mo-t tilir and princely cousin Katharine -

$y$ et leave vur cousin Katinarine here

iny rovel erousin, teuch you our

my tiár cousin, how peffectly I love hier -

teuch your cousin to cunsent to win

cousins both, of York und somerset.

contsiu of York, we institute your.

cousin of York, we here dischur.
cousin of somerket, join you

cousin of someret, join you

well liast tian spoken, zousin

cousin of Exeter, frowns, words......

come, cousin, let us tell the ctucen ...

cousin of Exeter, what thinks your..

my pretty colsing, you nist

why, my young cousin? it is good

dear culsin, my thow! lite govereigu

i) my thir consin, I mist mit suy so.. -

give ny cousin. A greuter git!! (rep)

cousia ol buehingham, a word with jou -

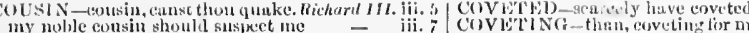

my nolle cousin should suspect me
farewell, gool wousin: larewell $\ldots . .$. .

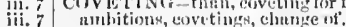

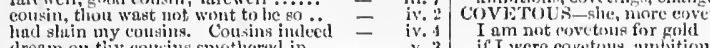

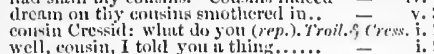

who, my cousin Cressida?
you huve broke it, cousti:

iny cousin will tidl ont witi you

huve you seen iny cousin?
your hutnd: here, my eousin?

cousin, all honour th thee

1 emme to kill thec, consin ...........
I would desire my fimous consin

give me thy hand, my cousin.......

he kilted my cousin IIareus

cousin, $\mathrm{n}$ word; where is your ..... Titus dut

you, cousins, shinil po sound the vecan

in sadness, cousin, I do love a woman

[Col. Knt.] an hour loatl been my cousin
Tybalt, my cousin! U my brother's

never more covetisus of wisdom.... Henryly, $\mathrm{v}$.

kintuess subtle covetury .... Froilus fo Cirrstidh, it,

in no way suy, lie is eovetoug.......... Coriolnumes. $i$.

coveToUsl, Y-covetousiy reserve it. Timonof. I. iv. 3

is the sin of eovetonaness

Turelfh Night, v. 1

why, that were covetousned

enfound their skill in eovetousness. Kimg, John, iv. 2

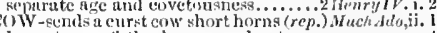

leaped your fither's cow, and got

this calf, bred from his cow........... King John, i. 1

that 1 wolld not for a cow

IlenryIIII. $\mathrm{v} .3$

where the bull and eow are both. Tilus indron. Y.

[Col. Knt.] O prince, $-O$ eousin

lay dear loved cousin, and my deare

kill my cousin? that villain cousin.

i. is but I miglat venge my cousin's death

I see my eortsin's glost sceking out

that murdered my love's consin
forgive me, consint al, dear Julict.

i. 1 chiefest eourtier, cousin, and our

ii. 2 consin IIanlet, you know thie wager?

ii. 3 you'l have coursers for cousins..........

ii. 3 COUSIN-GERMAN-a consin-rerman to great

iii. 2 Priam's sced .............. Troilus of Cressid

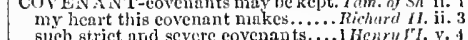

agree to any coveunints

let there be covenants drawn ........
your haud; a covenant: we will have

ii. 3 you lisust, if you keep covenart

iii. 3 Coves'IRY-at Coventry, upon..

thou gocst to Coventry, there to beliold

I must to Coveatry: as nuch goo

get thce beforc to Coventry ........

ne'er hal borne it out of Coventry..2 Ilewry $I \mathrm{~V}$. iv.

swcet lords; let's meet at Coventr
and lords towards Coventry bend

Warriors, mareh amain towards Coventry -
CoVER $\rightarrow$ the cuver of the salt.. TwoGen. of

the hair that covurs the wit ......... - iii. I

help to eover your master, boy!... Merm Wires, iii. 3
to invest and cover in princely.. Heas, fin .Yeas. iti. 1

to invest atud cover in princely

can eunning sin cover itself withal!..

death is the tair

why seck st thou then to eover
the starry welkin eover thou

the starry welkin eover thou anon..Mril. N. Dr. iii.

fait fall the fisce it covers! ..... Lore's L.

cower is the word. Will you eover

bicl them eover tic table.......

sirs, cover the while: the duike........

eover thy hend, eover thy head....

as paste and cover to our bones

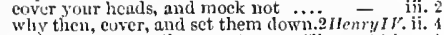

and cannot cover the monstrous .. Timones sth. v.

n garment nobler than that it covers. Cymbeline,
how courtesy would seem to cover sin!.. Pericles,

who cover fuults, at lust glame...

to beautify him, mily lacks $\mathrm{n}$ cover............

the cover. of the wines of grashoppers - i.

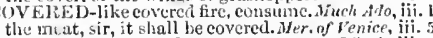

nry; pray be covered............. As you Like in.

as concuve as a covered goblet ........ - iii.

in the desk that 's covered o er..........

what gowt is envered with tlie fiec.... Wichard III. iv.

all covered dishes! royal cheer. . Tisnon of Ath. iii. 6

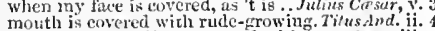

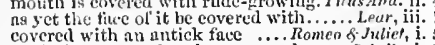
you'll have your daughter covered ..... Ohliello, i. 1 coVERING-the covering sky is. Minter's Tate, i. 2
Bolingbroke, covering your fearful. Ri'hard It. iii. 2 Bolingbroke, covering your fearful. Ri.hard It. iii. 2
Roman Drutus, eovering discretion .. Henry $r$. ii. 4 these covering heavens full on $\ldots \ldots$. Cymbeline, $v$. withont cuvering, save yon ficld of stals. Pericles, i.
fomme covering for this naked soul......... Lear, iv.

COVERLET-thisway the coverlet. Tuming nf Sh. iv.
COVEl\{T-wards of covert bosom. Mras. fir Mets. v. retire yourself into some covert.. Winter's Tale, iv.

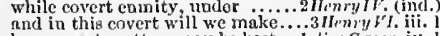
how covert matters may be beat ...Julize Cirsar, iy. I

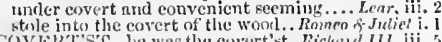

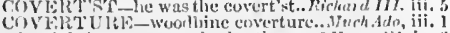
it light's caverture, thy hrother ...3Henryll, iv.

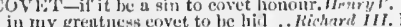

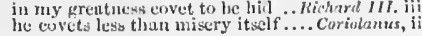

he is de cowarit Joek priest of

you are de coward, de juck-dog...

he's n coward and a eoystril...

Merry Hives, ii. 3

and nore a eoward thin a hare.

a eowart a most devout coward

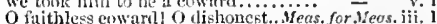

a fool, and a coward, ns you then

that knew me fir a tuol, in cowarh
I will subcerile him a cow ard ....

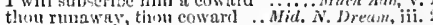

thou costarl, nire thon bragging....
ho, ho! ho, ho! coward, why con

hide your hcarts like cowitrds .... Lure's L. Lost, v.

who shut their cownri gates on a tomies - iii. 5

he's annst notable coward, an intinite - iii. 6

excels his brother for being a coward

nn I were not a very cownid

that way, thut art a cow urd ........ Winter's Tule, i.

then yieln thice, coward, nud live to be ... - v

a slauderous coward, and $n$ villain .... Richard I1. i. i

pale trembling corrard, there I thro

like a traitor coward sluiced out

[Col.] awake, thou coward majesty!.. - iii. 2

as true-bred cowarls as ever ........ i Heñyll i. .

what, a coward, sit, lohn Pinnch?..

and Poins be not two arant corards

to play the coward with thy indentime

a courard is worse than a eup of (rep.).

this sallyuine coward, this bed-presser

I wns a coward on instiuct

generally tools and cownrds..........

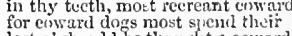

sir Juhn Fastolfe plisyed the eoward.
dogs! cowards! dastards! I w ould ..

cownerd of France! how much lie

let him thrt is no coward, nor no.

and make the cowards stand aloot

forfeiting a traitor and a coward

murderous coward, on thy knee...

proclamed a cowated through the wor'd

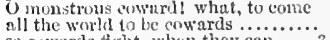

a dastard and a treacherous coward....

it a coward heard her speuk these .

fo, coward, as thou art

O coward conscience, Jusv doat thi....

conscience is but a word that
the bold, and eowari, the w

Troilas, thou coward 'Iroilu

Troilus, thou cowarl 'Troilus,
the devil take thee, cuward!

and thou, great-sized coward

old. roung; coward, valiant .. Timo

come on, you cowards: you were .....

made tlie coward turn terror into *ivirt

coward lips did from their colour.. Julius

tire cnough to kindle cowarrly .........
swear priests, anil cowards, nind imeil

swear pricsts, ant cowards, num ine

cither a coward, or a flatterer........

O eowaril that I siu, to live so long

and lave inc

ships, legions, may be n coward's.... - iii. it

plenty, and lenec, lireeds eowerils

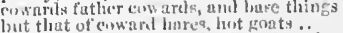

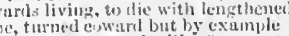

mul now, un cownels (like frnoments

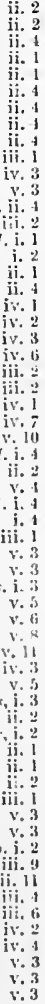

how many eowarls, whose hearts... Her.of jen, iii. 2

than e'er the coward hand of France. King Jots, ii.

and thou a natural eowarl

lest a" should be thoughtit of cowan 
COWARD-foul-spoken coward!.. Titusindron. ii. 1 bringing the murderous eoward to ....... Lear, ii a knave, beggar, coward, pander the louse witl loud and coward erie,

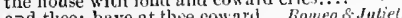
and thee: have at the coward illameo fom conscience does make eowards of as all ..
part wisdom, and, ever, three parts eoward COWARDED-Cowarded and ent Gen of when slie knows it eowardiee. or I will protest your eowardice.

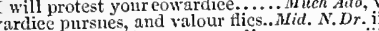
cold cowardice in noble brcosts ...... Ricliard $I I . \mathrm{i}$. pure fear, and entire cowardice HenryI $\boldsymbol{F}$. ii. balge of pusillanimity and eow with eowarlice a man halt dead? ..1 Henry $F$ r. iii. that slanders him with cowardice. soil the tact with cowardiee ... Timon of Athens, iit. gods do this in shame of eowartice.Jutius Cesar, counsel, lad, smels of no cowardiee.. Titus And, same eowarlly, giant-like, ox-beef.. Mid.N.Dr. not a more cowardly rogue in all. Winter's Tale, fellow had destroyed so eowardly. you are a shallow cowardly hind
and the cowardly raseals, that ran you are a counterfitit eowarily follow them) cowardy thed ........... no, he'l say, twas done cowardly. yet are they passing cowarilly ...... in our stands, nor coward nobles.... I do find it eowardly aud vile .....Julius Cassa not basely die, nor cowardly ...Antony \& Cleo. iv. 13 COW ARDSHIP-his cowardship. Twetfit Nigh, jiit. 4 COWV-DUNG - eats eow-dung for sallets
COWED-it hatl cowed my better part.

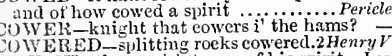
COWERED-sulitting roeks cowered.2 Henry OOWL-STAFE-the cowl-staff? ...Nerry Wives, iti. the eowslips tall her pensioners be.Mid.N.'s Dr. ii. and hang a pearl in every cowslip's ear

these yellow cowslip eheeks

violets, eowslips, and the primroses.... Chenry 1 drops i' the bottom of a cowslip ......... Al's

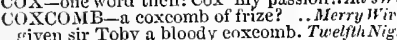
giveu sir Toby a bloody enxeomb. Twe
if a bloody coxcomb be a hurt........

you set nothing by a bloody coxcomb

and eoxcomb! $\ldots \ldots \ldots \ldots \ldots \ldots \ldots \ldots$. Much Ado, iv. the prince's officer, coxcomb........... ${ }^{\prime}$. Lost $^{\prime}$ iv. 2 by this same coxcumb that we ......... All' well, iii. 6 capon, coxeomb, idiot, pateh! .. Comedy of Er. and a prating coxeomb, is it mect wound, and your ploody coxcomb is goot for your proken coxcomb as many coxcombs; as you threw hire him too: here's my coxcomb you were best take my

there, take my coxconb ............

wear my coxcomb: how now,

rapped 'em o' the coxcombs with a stick.. - ii. 4 CO but she is nice, and eoy .......... $-\bar{c}$. lier spirits are as eoy and wild as.... Much Adto, il.
while I thy amiable eheeks do coy.Mid. $N$,'s Dr. were rolgh, and coy, and sullen... Taming of Sh.
COYED-it he eoyed to hear Cominius.. Coriolants, .1 COYSTRIL_-Coward and a coystril. Twelfh Night, i. 3

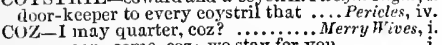
eome, eoz; come, coz; we stay for you

conceive me, sweet eoz

she's eoming; to her, eoz....

she ealls you, coz: I'll leave .........

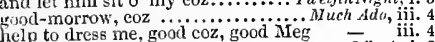
sweet my $\operatorname{coz}$, be merry .... i....... As you Like it, j. were I my tiuther, coz, would I do this? shall we go, coz? Ay: farc you well
will you go, eoz? Have with you. will you go, eoz?

O eoz, eoz, eoz, my pretty little eoz

my dearest coz, I pray you

coz, farewell. Come hither

and I can teach thee, coz

and, dear coz, to you the remnant

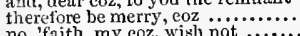

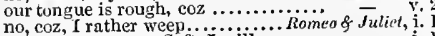
farewell, my coz. Soft, $\mathbf{I}$ wili go fair mark, fair coz, is suonest hit

COZEN-go abosit to cozen fortune. Mer of Venice, ii

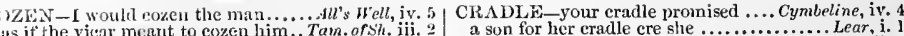

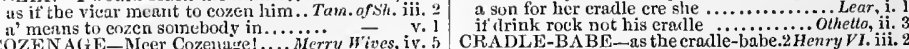

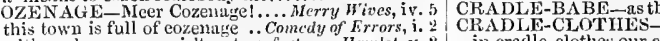
with such eozenage; is't not perfect.... Hamlet, v. ZLNED-eozened him of it that lins cozened all the hosts...

in eradle-clothes our chitaren where.I Horry $\mathrm{IV}^{\prime}$ i. CRAFT-loses the name of craft.... Mierry Wives, v. will not else thy eraft so quickly...Tuelfh Nigh, . . craft against viee I must apply

athe world might be cozeued (rep.)

that you have cozened of money ...

by gar, I am cozened; I ha' married

like to be cozened with the semblance. Much Ado, ii. trusting of the eozened thoughts ....AAl's lite how I was eozened by the way .. Winter's Tate, iv. asely eozencd of that true hand.. Titus Antron. hath eozened you at hoodman-bliud?.. Ham

COZENER - with the cozeners ..... Merry Wives,

sir, there are eozeners abroad . ... Winter's Tule

the usurer hangs the cozener ............ Lear, iv.

be at enmity with cozening hope.... Fichard $M$.
been dammed for cozening the devil... Henry it some cogging cozening knave

COZIER-out your coziers' eatches. Tueifth Night, ii. $\mathrm{R} \Lambda \mathrm{B}$-bring thee where crabs grow.....Tempest, ii.
I think Crab my dog be....Two Gen. of Verona, ii. 3 I the that's tied here; Crab my do

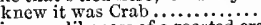

in very likeness of a roasted crab ...Mid. $N$.

when roasted crabs hiss in .......... v. 2 (song)

see a crab. Why, here's no crab... Taming of Sh.i1,
as like this as a crab is like an apple ....... Lear,

as a crab does to a crab

if, like a erab, you conld go backwa...... Hamlet, ii. RABBED-than her father's erabbed. Tempest, iii. I three erabbed months had soured. Winter's Tn

RABTREE-graft with crabtree slip.2Henry $V$.

fetch me a dozen crabtree stives
some old crabtrees here at home

Tempest, $\mathrm{i}$.

I had rather erack my sinew's

Fives,

my charms erack not ..................

my heart is ready to erack with ...Merry L.Lost, iv.

is sound, sans craek or flaw

wheu the clouds in antumn crack. Taming of Sh.

he eraek 8 his gorge, his sides......

overcharged witl double eracks
stretch out to the erack of doom

stretch out to the erack of doom.
shall

when he was a crack, not thus ...

by the mass, you'll crack a quart
from my shoulders erack my arms

King Joh

should erack their duty to you..... Henry VIII.

a' were as good crack a fusty nut

a' were as good crack a fusty nut

now crack thy lungs, and split

erack the lawyer's voiee, that he.. Timon of Alh.

thy continent, crack thy frail

should make a greater crack...........

voices have got the mannish erack... Cymbeline,

secure of thunder's crack, or lightning. Titus find

a heart that even cracks tor woel

crack the glass of her virginity

blow, wind, and crack your eheeks

and the strings, of life began to crack

so that heaven's vault should crack $\ldots . . . .-$
not to erack the wind of the poor plurase. Hamtet,

now eraeks a noble heart: good-night ...

CRACKED-so crackel and splitted. Comedy of $\mathrm{Er}$.

of my heart is eracked and burned ... King John, for there it is, eracked in a hundred.

bloody noses, and craeked crowns . i Henry $1 \mathrm{H}$. ji. are cracked in pieces by malignant. Richard III. ii.
for, now he has eracked the league. Hen y $I I I I$ il. for, now he has eracked the league.
their hours at a eraeked drachn!.

whom with a cracked heart I have.

mine eye-strings, eracked them...

my cracked one to more care

either our brags were cracked of kite

the bond cracked between son and father.. Lea my old heart is eraeked, is erackechl
gold, be not eracked within the ring

CRACKER-what eracker is this same. King John,

come hither, erack-hemp. I hope.Taming of $S h$. CRACKING-cracking the stones. Mrea. for Mra. ii. lest my heart, eraeking it, break. Winter's Tule, cracking ten thousand curbs

with a man for eraeking nuts... Romeo or Jutiet,

CRADI E- So near the cradle of the..Nid. N. Dr.

gives the cruteh the cradlc's infancy. Love' $L$. $L$. iv. 3
in the eradle where it lies. Mer. of V'enice, iit. 2 (song) bcing ever from their eradles bred.. As you Like i

in our eountry's cradle draws.........2 richary $I^{\prime}$ in cradle of the rude imperious surge.2 Henry VI.

was I crept out of my cradle........2 Henry 11 .

from his cradle, he was a scholur... llenry VII

though in her cradle, jet now promiscs

unveil in their dumb cradles.... Troitus \& Cress.
政'

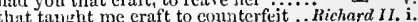
with the craft and patient underbearing - i. wherein cuuning, but in eraft? ..... Henry $1 \mathrm{~V}$.i1. unto an euciny of craft' and vantage. Henry $V$. iii. all the serlientine erift of thy. Troitus \& Cressida, 11. or wrath, or eraft, may get lim ..... Coriolanus, i. 10 and your crafts, you have erafted fairl - $\overline{\text { iveline, }}$ iv barbour more craft, and morc............. Lear, ii. your modesties have not eratt enough.. Hamlet, ii. not in madness, but mad in craft ..... RAFTIER-a eraftier Tereus hast .. Tilus Aril. ii. 5 or seem so, craftily [Col.-crafty]...Meas.for Meas. ii. . and that was craftily qualified too....

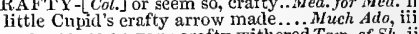
a vengeance on your erafty withered Tam. of Sh. ii. wherein erafty, but in villany?...... 1 HenryI $\mathrm{V}$.i..

a pair of afty knayes

who being aeeused a crafty murderer

like a shag-haired crafty Kerne...... - iii. of those erafty swearing raseals ... Troil. \& Cress. y. 4
such a erafty devil as is his mother.. Cymbeline ii. but, with a crafty madness, keeps aloof. Hamlet, iii. 1

but, with a crafty madness, keeps aloor. Hamlet,
CRAFTY-SICK-lies crafty-sick.2 Henry $I V$. (ivduc.) w what 'tis to cram a man ............ Meas. for Mleas. iil. cram us with praise, and make.....Winter's Tale, i. 2 or may we eram, within this .Henry $l$. i. (ehorus) crams his rich thievery up ...Troilus \& Cressida,
I'll eram thee with more food! . . Romeo \& Juliel, CR $A N$ NIED-erammed in the basket. Merry Wives, iii.
so erammed as he thinks........ Tuelfth Night, ii. so erammed as he thinks ......... Tw'elfth Night, il. hath strange places erammed with. As you like it ii. to rest, crammed with distressful .....Henry he iv. thoughts with this eramned reason. Troil. \& Cres. it. their storehouses cramned with grain. Coriolanus, i. I'll rack thee with old cramps

their sinews with aged eramps

I am not Stephano but a eramp

being taken with the eramp.......
in coming on he has the eramp CRANKING-comes mecranking i.... Henry $1 Y$. but, my lord, wheu returns Cranmer

heretic, an arch one, Cranmer ......

Craniner is returned with weleome..

the arehbishop's, the virtuous Cranmer -

when it eo!nes, Cranmer will find

till Cranmer, Cromwell, her two hands $\bar{N}$ CRANNI ES-ereep in craunies.. Comedy of Err this the cranny is, right and sinister

CliNTS-her virgin erants [Knt.-rites]. Hamle CR.ARE-coast thy sluggish crare.... Cymbeline, ClaASH-and with a hideons erash takes. Hamlet, does of Mareus Crassus' death... Antony \& Cleo. iii. worthier come to crave her ........ Nerry Wives, I crave your honour's pardon ... Meas. for Mees. I shall crave your forbearane

I crave but four days respite

if any erave redress of injustice......

that I erave death more willingly ...

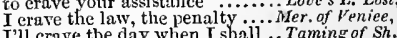
and eraves no other tribute ............ I erave your pardon; soon ..... Comedy of Errors,

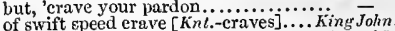
and eraves to kiss your hand ....... Richard for his designs erave hast

and vantage crave my company ....2 2 Henry 1 do crave admittance to your........... Henry 1 Hen
when ladies cra ve to be encountered.i Henry $V$. for my lady craves to know...

no other satisfaction do I crave ....... -

and crave I may have liberty

and wherefore crave you eombat?....

I need not crave his courtesy

well erave a parley, to confer......... fish witl eraft for great opinion...... - iv. 4 RAFTSMEN-wooing poor craftsmen. Richard 1 . my love was crafty love, and eall it... King John, iv pays this for Mareus Crassus
CR.iVE-this must erave (and if this ... Tempest, 


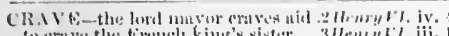

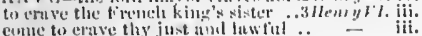
ente to erave thy just this

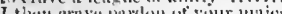

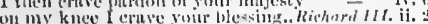

cruve lenve to view inese ladies.... Hemry $P, H A$. i.

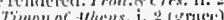

每

than ernve the hire which lirst........

I d e rnye a worl or two

the violent fit o the time craves it .

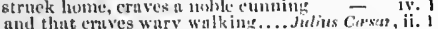

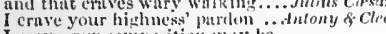

and of the erares the circle .......

the e erave to tre dentanded........... Cymbetine, iv.

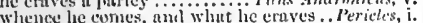

death in preace is anl he"ll crove

I liit tout eruve. But crave?

whint he will, not what the

Terave no more than hath yo
which craves the instant uge

mathm, ernes a spedy answer .......... $\overline{\text { iv. }}$ iv. 2

his help to erave, and my dear hap .

Which craves as desperate an execution - iv. 1

1 crave fit dieposition for my wite ....... Othello i. 3

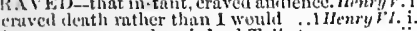

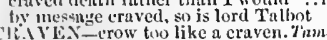

het is a craven and a villain eles.
tior his cruven heart, say thus

Henry fiv. in

to tear the gurter from thy eraven s leg

thint cravents my weuk hand........ Cymbeline, iii.

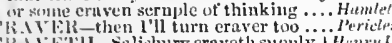

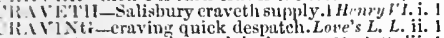

cause of state, eraving as jointly

in eraving your opinion of my title..2nlenry! $\mathrm{l}$. ii. 2 .

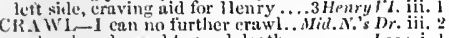

muthurdeled crawl toward death

CHe

crawling between earth and heaven?. Hamlel,

to in notion crazed, sny, thus did........ Mnederth, iii. i

fo mung miseries have erazed .........

the griet lanth erazed my wits.......... Lentr, iii.

CRLAKING-creiking ny shnes on All's Hel,

CRkA the edo cream, and matle ...Mer. of lenic

nor your check ut cream. .......... As you Like it
is tlie ytucen of eurts and eream. IInter's Tale

steal cream. I think to steal cream.1 Hearyllit

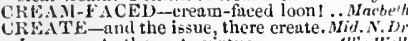

I can create the rest: virtue

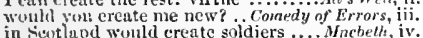

well ereate yuuag Arthur duke ...... King John, ii.

ly.ing ercute for comfort................

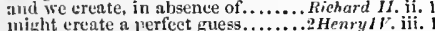
with hearts crente of duty and of zchl, Henryiy if. if here create yon earl of Shrewsbury.1 Henry $V I$. iii. 4
we here ereate thee tirst duke........2 Henry VI. i. I will create the duke of Gloster ...3Henry ' 1 . ii. 6

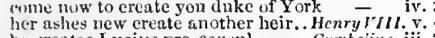

her ashes new ereate another heir... Henry
he ereate Lucius pro-eousn..... Cymbeine,

$I$ create you comprnions to unir person

we create, lord Saturninus, Rome's..

will create thee empress of Rome

teem, wreate her child of spleen ...........

tirst create [Col. Kint-created] .. Romeo ơ Juliet,

are ereated of every ereat thre's best

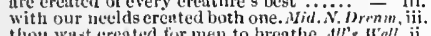

thon wast ereated ior men to breathe. All's well, ii.

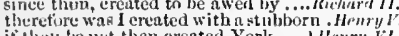

aut rise ereutedl princely duke ot ...

ereated, for his rare success in armi...

ercuted knightt for his good service...2Heñry $r$, iv.

whym heaven created for thy ruler...

to tlee end they p'ere created........3

thinus ereateel to lny und scil with. Corinhans, iii.

unil thou last reat tes a muther...... ('ymbolin

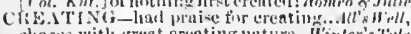

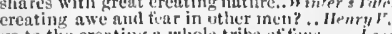

to to the crentin's a whole tribe of tivys ..... i.cin

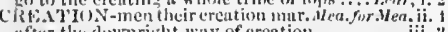
ufter the duspricht way of creation

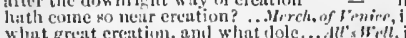

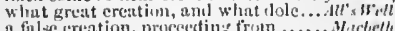

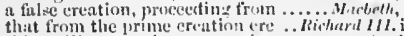

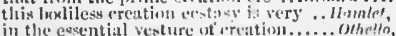

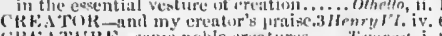

betid to any ercature int the itsoul
Chis Thlit:-creatures that were mine. lempest nio, preceious creat tus

he creates of every ereature's best

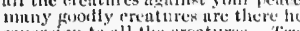

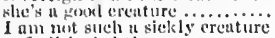

as fuolish christinn erent ures.....

the virtuous creature, that hinth . Tuefh

not more 1 win than these two ereatures $\bar{y}$

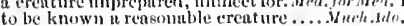

the ehunge of words with any creature - i iv.

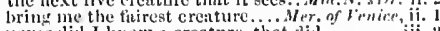

hath male a fair ereat ure o.......Asyou Like

madam, a wicked ercaturc, ns you

cunst like this creature as a mai! ....

a tinir creature; will you go see her?..

of his creatures not daring the reports
llelent tlatt's deal, was a sweet ereature

this is a fishd and de's perate erenture

she was the tuirest ereature. Taming of Shrem, 2 (intil

is tor n precious creature........... Winter's Tulte, i.

the sweetest, dearest creature's dend

fimmous for the ereatures of prey

to me emmes a creature, nonutimes her - $\mathrm{iii}, 3$

sulch a creatnre, would she hegin an sect - v.

majesty of the creature. in rescmblante
ant let no creature enter .... Cimned

teach me, dear ertature, how to.....
lheim a very beastly eveature, lays elaim =

leing a very beastly ereature, hays elaim -

not such a grations ereature born...

creatures of note for merey-lacking.. . - iv,

from the commonest creature placks. Richnod II. v. 3

then an 1 no two-legged ereature....jusenry $I F$. ii. I

how now my sweet creature ot bombast? -
un noble tarl, and many a creature else

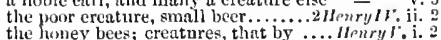

ingratet til, snvage, and inhuman ercatture!
breeds very valiant ereatures ...........

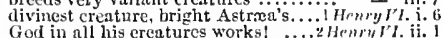

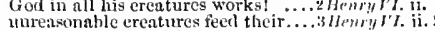

curse not thyself, fuir creature ..... Riciciard 111 i.

for the plainest harmless tereature..

there is no ereature loves me

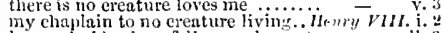

lienvenly blessings follow such ercittues

betore the primest creature that's...i.
a ervature of the quecn's, Anne Builen

sle is a gallant erenture, and complete

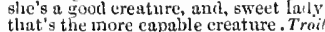

of plith and slippery creaturcs... Timon

this thy creature liy night frequents
they were the most needless creat

thay were the most needless creat
call the creatures, whose naked.

youl ille ereatures, get you hene ...

steh ereatures as men doubt

it is a creature that I teach to fight

amd kindidy creatures turn alt towint
by him, this ere tare's no surch thing

most sovereign creatiure, - Inis legs

on suenture such as, to seek ..........

two ereatures, lienrtily. Am I one, si

0 the dearest of creatire

and couk to honest creature

forhcar; erentures may be alik

only in killing ereatures vile

ereatures want our hands and eannot

they tave their erestures in abuudauce.

huntreds eall themselves your creature

finir ereature, rare as you seem to bel.
liut yet sle is a goodly ereature...

illt yet sle is a goodly ereatine.

we were never so nuele nut of erentiues.

proclains you to be a creatire of sul

notent to make this creatine fruitfuly

those wicked creatures yet do foo
hurts the poor erenture of earth...

and the ercuture ruat from the eur?

the fair ereature died, and here.. Nmmen $J_{u}$

und niek-name ciot?'s creatur

eunfedcrate season, clse no creat
we titt all creatures cles, to fit

or like a creature native nud infuci

she is a most fresh and ideliente creith

this wine is a guxd fimuiliar ereatut.

an call these delicite ercatures our

wring my haml, ery, $U$ swcet ereallu

it is a crenture that itutes on Cassio...

1) the worth hath not is swecter erea

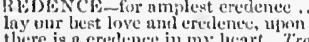

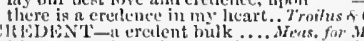

tis very eredent, thou may'st .... I'tint r's

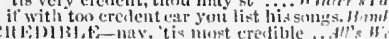

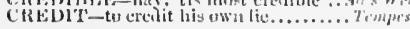

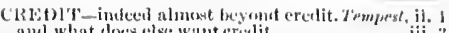
and what doe's cisser want eredit

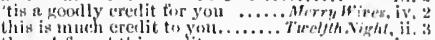
there $\mathrm{f}$ fimmel this credit....

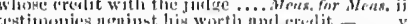

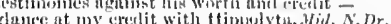

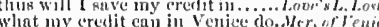

noul theres mut oatlo of eredit....

sir, 1 wrestlo for my credit ......... As you b.t.

how Bhuth they credit a phor

upen my reputation and crestit.

at I wit I lave with the dilk

I eall them forth to credit $h e r$.

wis name and credlit shall yout..........

give us better erellit: we linve al

will hear no credit, were
though eredit be asleep.

the one ne'er got me eredit .. Comerty of

being eompaet of ererit, that

edit infonite, hiclily bching

Is I and a fentleman, I eredit lim...Richard II. ii

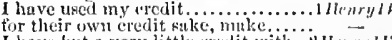

have frit a very little credit with... Hemryl

frown to creclit by the wars ........

and will you credit this lase drutlge

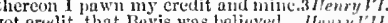

his taking lord ean lay ujon my credit

fracted dates lane smit my eredit. Timon

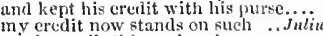

partly crectit things that in liresage
credit that thy lady lath of thue...

perfect gookiness lier ussureti crenli

our eredit comes uot in like

make my senses eredit thy relation

fi on my credit rou dare build so tir

in these news, that tgives them eredit..... Ohe hello,

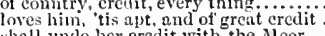

ylanll undo her eredit with the 1 oor ...

send for ecrtain of my creditors

my creditors grow ernei, ny estate

to-morrisw to my bloods cresitor

forthwith nuto his ereditor . Comedy tef lirrors

is a soul, counts thee her creditor ${ }^{2}$ king. futh

his creditors most straight

the slaves: Creditors!-devili..........
no true debitor and ereditor but it ... cymbelim

debitor ant ereditor. this counter-caster. Othell

CJEDO-liand credo (rop.)........ Lore's L. Lost,

CritDULOUS- pooreredulous monster. Ternuts

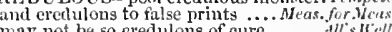

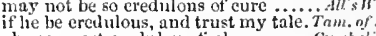

ah me, most credulous tool........... Cymbeline.

and, being ercedulons in this mad.. Titus ob

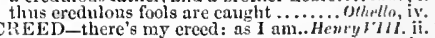

CREEK-creeks, and narrow lands.Comedy rf lis. iv.

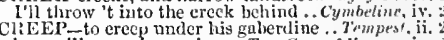
ove will creen in service. Two Gen, a lown

he may ereep in here

let me erep in herc..................
he eannot crecp into a half-penny purse

he eannot crece into a hall-penny purse - iii.

creep into the kiln-hole.

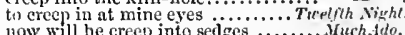

sliall swectly ereep into his stuly........

for fear, creep into acorn enps ...Miil. N. Drearn, ii.

may through the eentre ereep.

mouse that ereeps on floor

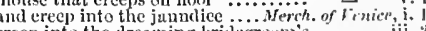

creep into the drenming hritlegrimum

that ereep fike shado

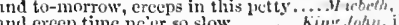

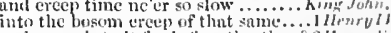

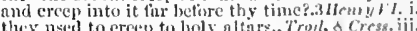

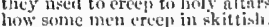

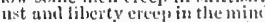

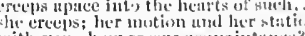

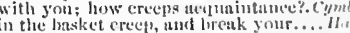

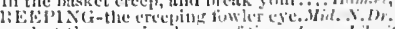

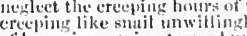

of harm is ereeping toward ne .... Wintary's Tet

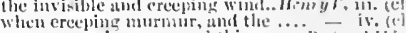

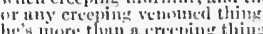

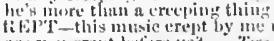

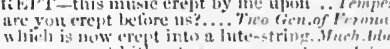




\section{CRE}

CREPT_erept jnto any alderman's....I Henry II.ii. . is ercpt into the bosom of the sea ... is crept in to the palaee of our king no souner was I erept ont of my

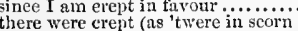
the crept (as twerc.

crept too near his conseience (rep........ mulation in the army erept.. Troilus \& oressid $^{2}$, were slily erept into his lyman.

my porrer's a crescent, and my. Julius Creser, iv.
iid. $N$. Drom, v.

he was then of a crescent note......... Cymbetine, i.

for natire, eresent, does not wiow alone. Ham

ClessETs-of burning cresset;

I am Creasid's unclu, that dire leuve.. All's

lazar kite of Cressin s kiml.

I tell thee, I am mad in Cressid's

I cannot come to Cressid

what Cressid is, what Pnndar, nind what

and fly with me to Cressid!....

T'roilus shall he such to Cressid.....
why was my Cressid then so haru...

your leave, sweet

as false as Cressin...

desiret my Cressid in right grent .....

the enfreed Antenor, the fiir Cressid

than Cressid borne from Troy

o foolish Cressid! I might have stili

you maid! where's my eousin Cressik

Cressid. I love thee in so stramed ....

name Cressidl, and thy lit'e shali be

fair lady Cressid, so please you

anorous view on the tair Cressid .

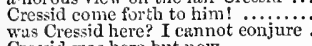

Cressid was here but now .............

hy Cressid's rule: rather this

Cressid is mine, tied with.

is ninueh as I do Cressid love $\ldots$ Cressid! $O$ false Cressid! fal

the fair stced to my lad $\mathrm{Cressid}$, fulse

RESSIDA - to bring a Cressida .. Tivelf $h \overline{N i}$

Cressida was a begga

who, my eousin Cressida?............

with my disposer, Cressidn.

why should you say, Cressida?
thy master? at my eousin Cressidis?

$O$ Cressiria, how oiten have I...

to Diomedes' hand the lady Cressida

was this Cressida in Troy?

no, this is Diomed's Cressida
CRESSY - Cressy battle fatally

'tis not the devil's erest .......

'tis not the devil's erest .....

Alerry Wives, $\mathrm{v}$. a erest ere thou wast born... As you like it, jv.2 (song) what is your erest? a eoxeomb? .. T'aming of Sh. ii. 1 thy blade on vulnerable erests

the erest, or erest unto the erest.

the burning erest of the ald snarleth.

the burning erest of the old, feehle

budding homours on thy erest I'

ing Joh

shown upon our erests to-day

When from the Dauphin's erest thy...i Henry $V I$. iv.

Franee must vail her lot'ty erest

on whose bright crest Fame with

his erest up again, and the man.

Corinirinus,

cven thon luast struek upon my crest. Titus And.

CREST-FALLEN

us erest-fallen as a dried pear .... Nerry Wires, iv.
shall I seem erest-fallen in my fatlier's. Rich I .

and let it make thce crest-fallen....

CIET.LN-kissed the Cretan strand. Taming of Sh. i.

in Crete, in Sparta, nor in Thessaly.

thy desperate sire of Crete........

Henry Hon iv.

peevish fond was that of Crete ......3 Hewry VI. v. 6

CREW-bring thee to our crews. Two Gen. of ter. iv. 1

a crew of patches, rude meehanicals. Afid. N. Dr. iii.

to support so dissolute a erew........

.

art thou of Cormish erew?

2 Henry Vi. ii. 2

to Londm all the crew are gone ...3 Henry VI. ii. I a crew of pirates came and reseued me.. Pericles, v. 1 about to speak when thic cock crew........ Hamlet, i. i

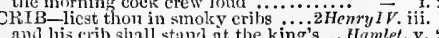
and his crib shall stand at the king's ..Hamlet, v. IIICK $\mathrm{E}^{\prime} \mathrm{T}$-Cricket, to ivindsor.... Merry Wives,

yon eriekets shall not hear it .... Winter's Thale, ii. the crickets -ns merry as cricke

the crickets silng, and man's,..... Cymbeline, ii.

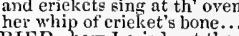
How $I$ eried out then

eried, hell is empty .................

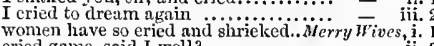

eried game, said I well?..............

ericd lime and honour on lain

and his thunb, ericd via! ............

and never eried, have patience..........

he crierl lupon it at tlie merest. Taming of Sh. 1 (ivi.

how f eried; how the horses...

how lie eried to me for help..........Winter's Tale, iii, 3

one eried, God bless us! and, amen

Zacbeth, ii.

who was it, that thus eried?

and eried aloud, $O$ that these hands. King John, iii.
while all tongues eried, God save ...Richard II. $v$.

no inan eried, Grod save him!

I eried humph, and wel], go to

they say, he cried out of saek

his tail between his legs, and eried ..2 Henry VI. y.

thrice eried, courage, fither!

lac eried, like to a dismal elangor
the night-crow eried, aboding.

ii. 3

who eried [Knt.-spake] alond

and soine ten voiees eried, God save.

as he eried, thus let be.......

the king cried, hat at this.

hit that woman, who eried out, ehilis!

he used me kindly; he eried to me.... Cnrioton ii.

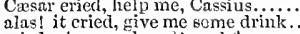

alas! it cried, give me some drin
eried, alas, good soul! and forg?

when that the poor have cried,

he eried almost to roarime cried, Cwar

cried he? and bersed he pardon?

a German one. cried,

but eried, good seamen, to the sailors... Pericles, iv.

and her through the market? (re

eried, sisters! sisters! slinme of ladies!

and it eried bitterly: yen, quoth... fim

in such matters, cried in the top of

and then cried, eursed fate! that gave..

who is't that eried? Who is't that cried? thou criedst, indeed? and didst thou criedst, indeed? and did

hear the erier. What the devil art ... Kinu John, ii. 1

I had as lief the town erier spoke ........ Hamict, iii.

eries, ah, ha! to the devil.. Twelfhi Night, iv. 2 (song)
mercy of the law eries out most.. Meaw. for. Meas. v. I

mercy of the law eries out most..MPC.N. for. Meas. y.

he murder eries, and lielp from

O Jove! the other cries .............. Love's L. Lost, iv. why, who eries out on pride ......... ss you Like it, ii. our own love waking eries to see........A Al's s well, v the lapwing eries away ....... Comedy of Errors, iv. the eries for $y^{\circ}$ ou and row

witeh! the rump-fed ronyon eries........ Nuceteth, i. that which eries, thus thou must do..

harper eries: 'tis time; 'ti: time..........

a widow eries; be hushand to me ...King John, iii. and defence, eries out upon

tor wisdom eries out in the streets..... Richard Henry 11. . i.

cries out upon abuses, seems to ...... - iv.

the widows' tears, the orphans' eries . Henry it.

upon his faee; and cries aloud

cries out for noble York...........

even now he cries aloud for
and dead men's cries do fill

and evcry drop eries vengeane

Henry $V I$. Iii

flled it with eursing cries

thy plaints, and drown thy eries?

ret rool Achilles still cries exeell Troil. \&

sir Valour dies; crícs, 0 ! enourh ....

with her loudest $O$ yes eries, this is he

eries, of itself, no more ........ Timon of Athen

was timed with dying eries........... Coriolants, ii.

which great nature cries, deny not ...
he eries out, no more........ Antony \& cleopatra, ii.

cries, fool, lepjdus! ini thireats .... . . Cymbrline iji.
CRIES-so cries a pig, prepared .. TitusAndron. iv. 2 the hear what pitiful cries they made .. Pericles, ii. Hop-danee eries in Tom's belly for .

Romeo he cries aloud, hold friends! Romeo of $\bar{J}$ ul. iii. 1 thy form eries out, thou art

my tate eries out, and makes each petty.

eries euekold, to my father

this quarry eries on liavoek

whose noise is this, that cries om inurder

cou trom erimes would .. Tempest, (evit.)

know the nature of their erimes...Meas. Jor.

how may likeness, made in erime

rows guilty of detested crimes Love's $\bar{c}$.

and our erimes would despair, if they. All's Well, iv. impute it not a crime, to me. W'inter's Tnle, iv. (ehis.) mingled with the erime of lust. Comedy of Err

and these eaeh several crime

when eapital erimes, ehewed.............

ichard II.

Wines the crime of it out of us...
of thy vile outrageous erimes....

hut miglitier crimes are laid....

weigh but the erime with this. Timon of dihens, iii.

if by this erime he owes the law.

erimes, like lands, are not inherited.

flashes into one gross erime or oricles,

hast within thec undivulged erimes

our pether erinles so speedily can ver

with all his crimes broad blown, as flusi $=$ iii. 3

if you bethink yourselt of any crime ..Othello, v.
CRIMEF UL-soerimeful and sn eapital. Hamlet, iv.

CRIMIELESS-true, and erimeless . 2 Hem? $Y$. ii.

more eriminal in thee, than it ... Winter's Tole, iij. 2

even this, so criminal, and in suel. Coriolanus, jii. 3

painted with the erimson spots ....King John, iv. 2

in drops of crimson blood.

yet rosed over with the virgin eriminn

be stained with erimson blood ....2Henry $1 \%$.

like the crimson drops i' the l.

a crimson river of warm blood

wretched stump, these erimson line

yet is erimson in thy lips......... Romeo \&. Juliet, v. 3 CRINGE-you see him eringe ... Antony \& Cleo, iii. 11 ehide the cripple tardy-gaited . Henry $\dot{V}_{\text {. }}$ iven. (ehorus) re=tore this eripple to his legs again?.2 Henry $V^{\prime}$. ii some tardy cripple bore ........... Richna ra III. i1. CRISP - leave your crisp channels .... Tempest, iv. hid his erisp head.................. HenryI $r^{r}$. i. 3

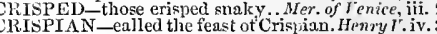
rouse him at the name of Crispian

and Crispin Crispian shall ne'er'go by -

CRISPIN-Wounds I had on Crispius day -

and Crispin Crispian shall ne'er go by

on the day of Crispin Crispianus

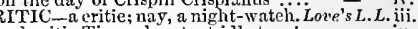
advantage to stubborn crities .. Troilus \& $\bar{C}$ ress. $v$. for I am nothing, if not eritical ......... othello, y. I would croak like a raven .... Troilus \&. Cress. v. croak not, blaek angel; I have no ...... Lear, iii. CROAKING-the croaking raven doth.. Hamlet, iii. 2
CROCODILE-the mourntul croeodile.2 Henry $\%$.ii. of your sun: so your croeodile ..Antony d Cleo.
what manner o' thip or is your croeodile? eat a erecodile? I'll do 't .............. Hnmlet, v. 1 drop she falls would prove $a$ erocodile... (thello, iv. 1 CROMWELL-Crouwell of Winglieli.1 Hewry $I$ I. iv. 7 Cromwell, gave it you the kiug? .. Henryl'III. il so truly happy, my good Cromweli.. tis a burden, Cronwell, 'tis a burden

go, gct thee from me, Cromwell

with what a sorrow Cromwell leaves

Cromwell, I did not think to shed ..

Cromwell, I charge thee, tling away

O Cromwell, thon fall'st a blessed

Thomas Cromwell; a man in muel

Crammer, Cromwell, her two hands.

as for Cromwell, beside that .......... ClRoOK-erook; the pregnant hinges... IIomlet, iij. 3 -BACK-valiant erook-baek...3 Herry VI. i. ay, crook-brek; here I stand...

CRoOKED-if erooked fortune.. Tuo Gen.of $v e r$. iv. 1 he is defornied, erooked, old.. Comedy of Errors, iv. 2 unkindiness be like erooked age .... Richard II. ii. bypaths, and indireet erooked ways.2 Henry $I V$.iv. 4
a erooked figure may attest .... Henry $V$. i. (cliorns) to imbare their crooked titles. 2 Henry YJ. v. let hell make urooked my mind .....3 3lenry $r$. . 


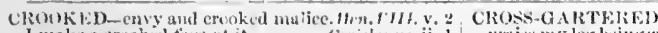

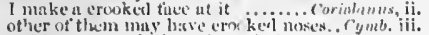
numl let nur erixikel snokes climb. C12(0)

列

crook-kneed, and dew-lapped .... Wid. $x^{*}$ s. Dr. iv.

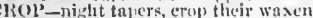

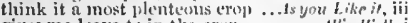

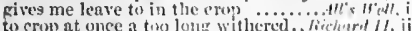
to crops ance a tiro long witherel on thy crest Th eropl, to mithe

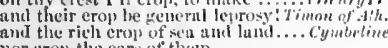
mor croyg the enrs of the in...

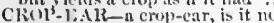

Clivel'lel-lest you be cropiped cropyed are the tlower-ile-liwe a plant have you untimely (rop thut eropped the golden

must or nnw he cropped

he plonghed her, and she cropt.

lest my life be cropped to keep

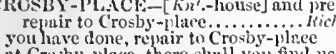
nt Crosby-place, there shiml you fint us

I rather ehoose to eross iny triend

rather ehoosc to er

he would never clso cros.............

terptation where pruyen's usos. Veas for

to cross this in the smallest
if I can cross lim any way

I can eross it. Any bar, any tross

how can st thou eross this marria

beross? tho ligh to he cutlirulle

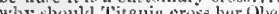

we cannot eross the cance why

never dire mistortune eross her.

lest the devil eross my prayer...

As you Like it, it.

you and youn no cross shail part .......

pleasure to be cross in talk ........

I cross me for a simer ............

here delivered me to my sour

ander whose blessed cross we

advantage, on the bitter cross...

liegeman upon the cross of a W Welsi hook

consin Perey! how you cross my father!

when you do eross his humuir

to cross the seas, and to be crowincili.itenn $\bar{V} L$ iji.

whiles they each other cross ........

to come to cross the seas to England

to Britany I'll eross the sea

to cross nic from the golden..............

shall eross the seas, and bid taike...

my lore of York will stili be cross...

go cross the seas, and live with

what eross devil made me put

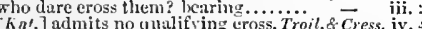
ere they lacked power to cross you.. Coriotanus, iii. and when the cross blue lightming...Julius Casar, i. 3 cross me in this exigent? 1 do not cross

gire him way, cross him in nothing ...Ant.\&.Cleo. i. whom best I love, I cross ............. Cymbetine.

be eross with him; and Y'il go..... Tifus . Imelron. ii. 3
(which who shall cross?) ...... Pericles, iii. (Gower) who can cross it, unless you pluy

it is not good to cross him............... - v. $\mathrm{k}$ now'st, is cross and till of sin.. Romeo of Juliet, iv. to cross my obsequice, and true love's Closs-Buw-master of the cross-bows. Hesry

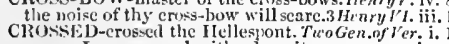
a man I an, crossed with adversity - ive iv. I

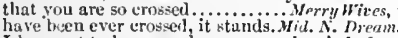
have ben ever crossed, it stunds.Mid. N. Drequ, i. 1
I love not to be erosed. ............ove's L. Los', i. 2 but hadst thou not erossed ye ... Tiuming of Sh, iv. 1 but hadst thou not crossed me ... Timing of Sh, iv. 1
haul then not crosserl the eses .... Winter's Talc, i. 2 we have erosistl to execute the charite their hopes pronlitiously be crossed.. King John, iii. he'd be erosesel then, an' he condil... Timon of d' he crossed himselt by $t$ : and I camot leing crosect in cunferene by some. futiers

"scajket I killing, when I erossed you so? I erosaed the seis on phrpove ........ Cymbeline, i. 7 this forl's speet be erosisei with alowness -

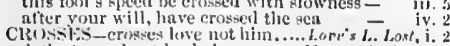
doth : tray abuut by holy erosses.... Wer. of ienice, nuthing lives, but cromses, eure...... Bichard 11 .

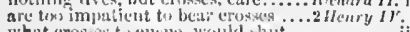
what eroses ter ellsue, would shut but our eresess on the way have.. lichar.t tht iit. yect, that after nll nyy crowey .......... Irerictrs, ii.

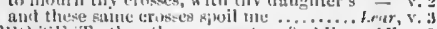

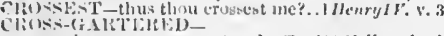

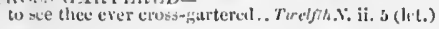

prase my leg beingerops-gartered. Turlfhw Night, cross-garterel, a fishion sle detest

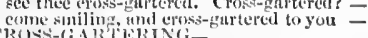

in tlie tisur this aross-gntering

CROSSING-un rrosing the plain...Mer. of $t$

I bo nit bear thene eronsings.

is no erossing lim in lis him

by crossing their himl will ........

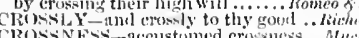

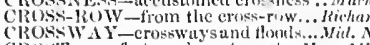

CROsT-my fortute be mut crost... Mer.of

creronere crost, and erost (rep.).. Thaning of

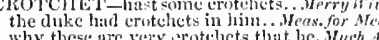

Why these are rewy srotelicts that lac. Muth A

and fin-to eroneh in litter of..

must I stand and cronch mulce

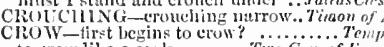

to erow like a crek ........ Tizo Gr..... of reron

rather hear my dog burk at a crow . Whe

and crows are fiatt ted with.

meet me ere the first entk crow

nyy lungs berging an sicectiy...jerch. of

you crow too like a craven...............

enting kirth to erows thy baby... Winier's
cyprus, black as e'cr was crow.... - it.

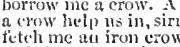

and the erow makes wing to

at the crying ot your nation's erow.. King $J_{\text {t }}$

thy trunk for crows to feerl uyom.

a prey for carrion kites and erow.

crows and dawe, erows and daws.

and bring in the crows to pee

ravens, crows, and kites, fiy o

have made him as little as a erow.... Cymbelin

and you crow, coek, with your comb on
our crows shall fare the butter for you

above perceive me like a crow

what erow's have pecked then

the urows and chonghe, that wing......... Leur, iy.

make thec think thy swan a crow ...hom. \& Jul. $\mathrm{i}$.

a suowy dove trooping with erow

chowD - crowd to his presence... Mceus, for Merts. it.

in common sense, crowd us .....

among the erowd i' the abley

Henry VIII. iv.

CROWDED-so crowded humours.. Troil. \& Cress. i.

erowding in their heavy burlens.......Nenry $l^{\prime}$

cROWED in their heavy burlens .......

CROW-FLOWER- of crow-fowers..... Hemlel,

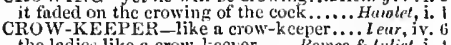

the ladies like a crow-kcener ..... Romeo \& Jutiet, i. 4
CROWN-his coronet to his crown ...... Tempest, i. 2

sees a crown droplying upon thy head...

to make eold nymuls chaste cros

do make eold nymphs chastec

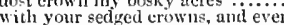

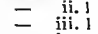

from toe to crown he'll fill ............

and crown thee for a finder...... Fuelfin Night, iij.

one day shall crown the allianec on't

a Freneh crown more........ Meature for

for, from the crown of his head ......Much dfo, iit.

some of your F renth erowns lave no. Hit. N.Dr. i.

chin, and icy crown, un oblurous

of a hundred thowsand crowns

crowns; and not demands $\left(r p_{0}\right) . . . .$. .

monarch better than his crown.

hut a pour thousand erowns ........As you like it, i.

and yet give no thetsand crowns incither

Thave ti we hundred crowns, the thritty $\bar{v}$ it.

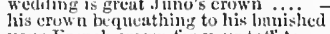

your Freneh erown tor your tatfita ...Alliswell, ii.

still the func's the erown ............ -

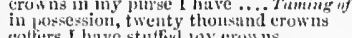

colters I have stufteil iny crowns

thenty erowns. Twenty erowns!

hath cost me a hinulied erow sas sinec $=$ v.

plot nyainst any lite, ny crown "riner's Tatr, ii.

irowns what y'sus are doing

the crown wifl find an lecir

ayatiut thy crotin, uly oat

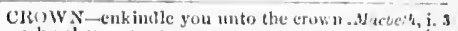

why chance muy crown me.

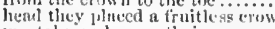

thy erew no dincs star minc eyebalis.

to erown my thonghts with art

which owe the erown that thon.

doth not the trow of of linglanel pireve

now mased assuranes to the crown

kleulul deliver up yente arown.

I shall yele up my crews

this easy mateh player for a crowin.

atdel an immortal title to your

flatterers sit within thy erown ......
from broking pawn the blemi het

steel a fininst wur golden crown

unvidelely armos ag atinst thy "rown.

threat the glery of nuy ircioms

erown le looks for live in $p e$
himscl' had liorne the erou'n

offer of a humbed thousantl crivin

and if you crown him, let me pron
and crown to Ifenry Bolinglirol

this golden crown like a deep weil

cares you give me with your rows

the crown, yet still with me (rap.
own hands I give away iny erown

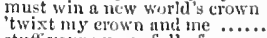

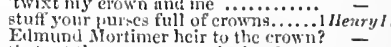

that sct the crown upsn the heud

blonk noses, and critcked crowns

and this cushion my erewn ..........
rich crovin, for a pitiful buld crowii.

of your cyelids crown the god of slec

crowis's worth of gow interpretition.2

give crowns like pinas lave we not

ton slillings in Froneh crowns for you

set me the erown ulon my pillow here

from thee, is this inn lie there upo

where is the crown? who took it

wherefure did he take aw ay the crown?

therc is yourcrown: and lie $(r e p)$.)....
I slake minto the crown, as having selise

crooked ways, I met this crown

how I came by the crown, U God forgive!
to the crown and scat of France........ Ifenry

to the crown of France (rop.)

reminted to tlic erown of

shall strike his thether's crown int

with crowns imperial, crowns......

for a few light crowns, lightly cons'ired

the crown, and all wide-stretichet.

then resigu your crown and kingdein

for if you hide the crown even in

of the Lord, deliver $\mathrm{w}_{1}$ the crow
twenty Freneh erowns to one...

to eut French crowns; and, to-morrow

the mace, the crown imprial .........

and erowns tor convoy put into...

unless thou give me erowns (rep.)

hundred crowns. Tell him (rep.) ....

give him the erowns; and, eaytain ..

to crown limself king, and supiress

I will divide my crown with her

What a seandal is it to our crown $\ldots$....

they may uybraid me with ms erown

his capl co-celual with the crow
and set a precious crown upon.

become true liouseman to his crown

erown of England: thou, nor tliy (rep.)

heir-applarent to the English crown.

cluim the erown, tor that's

humours fit not for a crown.......

was riglateul heir to the crown

and set the triplc crown unon his lient

rithtful heir unto the Englisl "rown

heat on a crowr, the treasire of thy".

iufallible, to England's crou no.

got the homse ot fameaster the erown

read, titid clain unto the erow

buing heir unto tle erown, nurried

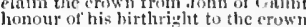

a thousand crowns, or else lay down

to pay two thousanl crow na, anl les

for I am riohthul heir tuito the erowi

went to sinan-comter finc lrenhl croun

the king, his erown, and dignity.

and get at theusand erewns of the king

to phek the crown from feclite

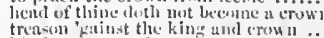

tis for a crown thou tiont
cluim the Finglista crown

...3 3 Heñy r. i. 
Clow $N$-to aspire unto the erown $.3 H_{e}$ nry $l$ to the crown. Exeter thou art (rep.) show our title to the erowu?..

tear the crown from the ustruer's.

by concuest got the crown.

resigned the crown to Ileury

twere prejudicial to his crown? (rep.)

Henry of Lancester, resign thy crown

the crowis to thee, and to thine heirs

untel his leirs unto the crown

the cost in ut wow and,

how sweet a thing it is to wear a crown

and cried, a crown, or clse a glorious

the crown; and with the 5 ork.

to be encomparsed with your cromn.

York dinl level at thy crown .......
draw it as apparent to the crowi

thongh he do wear the crown.

wilt thou yield the erown?

unless thou yield the crown............

sedition on lis crown at home

some store of crowns; and I, that...

where is thy crown? My crown is in

crown is called content; a crow

sour crown content, and you .........

to accomplish twenty golden erowns!

to drean upon the crown

a glorious erown. And yet (rep.).

I do this, and cannot get a

title to the crown be wenk

impale him witl the regal crown?

the chief that raised him to the cro

now sinall wear the English crow
true heir to the Englisli crowu

to set the crown onee more on

priv that I may repossess the crown.....

my head still wear the crown.....

by nature framed to wear a crown

if Edward repossess the crown

stute tor Henry's regal crown .......

now forget our title to tile crown.....

fearless minds climb soonest unto erow

might'st repossess the crown in pence

on Edward's jarty for the crown
when thou didst crown his warlike.

lost his lite to get the crown.

dost thou mean the crown?

this crown of mine cut from (rep.)

my path were even to the crow

looks proudly on the crown

that forelsend with a golden ci........

the prince that owed that crown ....
my george, ny garter, and my crow
thy crown, usurped, disgraced his...

for England, here to clam the cro

I, that helped tliee to the crown.

for high feats done to the crown.

there 'longed to the crown no more

did crown lis word upon you ......

Edward Confessor's crown, the rod

prerogative of age, crowns, sceptres. $\ddot{r}$

opinion crowns with an imperial voice

till merit crown it ....................

Cressid's name the very crown of
with cumning gild their copper er

with cumning gild their copper cr.
the end crowns all; and that old

the end crowns all; and that old

mine's three thousand crowns. Timon of Athen

five thousand erowns, my

now the gods crown thee! .......... Coriolm
why, there was a crown offered him

was the crown offered him the
who offered hin the crown

the crown: yet, "twas not $i$ erown......

because Cresar rcfused the erow
was glad he refused the crown

and he shall wear his crown, by sea.

crown him? That; and then, I grant
this day, a crown to mighty Cresar

this day, a crown to miglity Cxsar ..
I thrice presented him a kingly crown

he would not take the erow

to lay my crown at his feet ...... Antany

the erou's o' the earth doth melt

in his livery walked erowns, and

bring our crown and all...

give me my robe; put on my crown

yom crown's awry; I'll mend

by the consequence o, the crown

his brows within a golden crown .....
have the placing of the British crown

son into the adoption of the crown

crown him, and say, long live our.. Titus Andro

crown you king of this day's happiness. Pericles,

did vail their crowns to his supremacy

would set on the erown of Tyre....

their doom, will take the crown
to scatter lus crowns in the sun....

to scatter lus crowns in the sun

two crowns. What two erowas shail

two crowns of the egg. Wh
httle wit in thy bald erown...

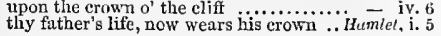

CROWW $N$ - of life, of crown, of queen .... Hamlet, i. 5 three thousaud crowns in annual fee.

my crown, mine own ambition

in Denmark's crown have worn..........

0 lowe, thy crown, and hearted throne -3 iii. 3

you were erowned the nonpareil.. Tuetfh Night, i.

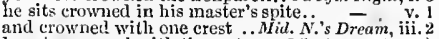
love is crowned with the ... As you Like it, v. 3 (song) were I crowned the most imperial. W'inter's Tale, iv. 3 vouclisafed, with your crowned brothe

we invite to see us erowned at Scone.

we invite to see us erowned at rou were crowncd before, and that hioh - iv. in the presence of the erowned king. 1 Henry $I V$ iii. 2 Harry the art crowned....

crowned with faitl, and constant........Henry $r^{\prime}$ iv. 4

up in the air erowned with the

in infant bands erowncd king

v. 2 (chis.)

the Da

forsooth, the king of Scots is crowned

iii. 1 in his infancy been crowned in Paris.?

where kings and qucens are crourned.2 Henry VI. i. 1

iii. 2 crovrued by th

iii. \& I am uot your king till I be crowned

a queen, and crowned with infany! - ii. 2

grcat Plantagenet is crowned so soon.

who erowned the gracious duke ....
to be crowned England's royal king

if you be a king crowned with content $\overline{-}$ iii.
lct lim be crowned: in him your.. Richard

to be crowned our king ............. - ii. 2

may it please you to be crowned

to be crowned Richard's royal queen

a very caitiff crowned with care.......

. $\mathrm{Cr}$. ii.

incertaia pomp, is crowned before

for aye be crowned with plagues

better parts shall now be or that ..Julius

Whe'r lhe have not crowned dead Cassius! - $\quad$ v.

this gricf is crowned witly consolation
like a fury crowned with saakes

with thy grapes our hairs be crowned $-\bar{i}$ i. 7 (song)
for the erowned truth to dwell in...... Pericles, v.

and crowied with joy at last.......... Perices, v.

crowned with rank fumiter, and furrow. . Lear, iv.

CROW NER-the crowner hath set on her. Hamlet, v.

CROW NER'S-QUEST-
zy, marry, is't; crowner's-quest law .

CROWNET-their crownetsregal. Troit. $\ddot{\&}$ Cres. (proi.) whose bosom was my crownet.. Anlany \& Cleo. iv. in
in his livery walked crowns, and crownets - v. 2 CROWN-IMPERIAL -

oxlips, and the crown-imperial.. Winter's Tale, iv. 3
CROWNING-crowniug of the king. Richard III. iii. 4 CRUDY-dull, and crudy vapours ..2 Henry! $\%$ iv. 3 I am slain by a fair eruel maid still so cruel?

were not you then as eruel as ...........

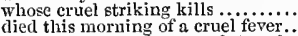

this is that tace, thou cruel Angel.

sat smiling at lins cruel prey.

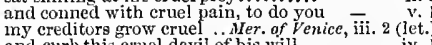

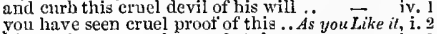

tis a boisterous and a cruel style

what a cruel tather's he! ....... Taming of Shrew, i.
but this most cruel nisage of your. Winer's Tale, it.

a death as eruel for thee................... Macbeth, ii. 3

not confessing their cruel parrieide

hut cruel are the times

producing forth the cruel ministers..... $\overline{\text { this }}$ vost eruel act, do but despair.. King John, iv.

I do see the cruel pangs of death.

thon cruel, ingrateful, savage
liath, by cruel fate, and giddy....

wasting ruin of the cruel foe!

behold thy timeless cruel death

rens at thy too cruel hand!

but is $t$ not eruel, that she sho

out of the gripes of eruel men . .......

thou hast a cruel nature, and a bioody

and instruments, of eruel war. Troilus \& Cress. (prol.)

make eruel way throull rancs

civil laws are eruel; tlien what. Timon of Athens, iY. 3

to a cruel war I sent him ............. Cariolanus, i.

von cruel men of Rome, knew you.Julius $\bar{C}$ cesar

we must appear hloody and eruel...

bow the people take the crucl issue... - iii. I a father cruel, and a step-dame false. Cymbetine, i. 7

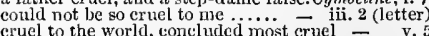
cruel to the world, concluded most cruel - v.

the eruel fither, and his traitorous sons
till cruel Cleon, with his wicked wifc.. Pericles,

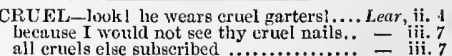
0 cruell O ye gods!

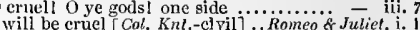

and erucl death hatl catched it from

by cruel cruel thee quite overthrowu

I must be cruel, not unnatural

must weep, but they are cruel tears ... othello, $\mathrm{v}$.

she loved thee, cruel jloor: so come $\ldots . . . \quad$ - .2

dil not this cruel-hearted cur.. Two Gen. of Ver. ii. 3 RUELLEST-the cruellest she alive.. Twelfh $N$. $\mathrm{i}$. R UELLY_most cruelly didst thou.... Tempesl, v. becanse I love thee cruelly

none hut tyrants use it eruelly.... Timon of 1 th - tirewell, fair cruelty!. Twelfth Nighl, i. get thee to you same sovereign cruelty the heart with vour stern cruclty ...Mid. $\bar{N} . \overline{D r}$, iii. 2 the state of hellish cruelty? thy strange apparent cruelty

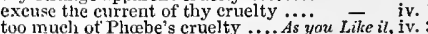
arainst this cruelty, firht on....... Avinter's Tale, ii. top-till of direst cruelty! .................. Hacbeth, i. born an household eruelty...........2 HenryIV.iv. for when lenity and cruelty play for... Henry $V$ iii. show what cruelty you ean ..........

'tis a eruelty, to load a falling man. $\ddot{H}_{\text {enry }} \bar{V} I I I$. v the eruelty and euvy of the people. Coriola nus, iv.
to lay on me a cruelty, by taking.. Antony s. Cleo. $\mathrm{v}$. if there be any cun he that keeps nor erust nor erum.......... Lear, i CRUPPER-crupper of velure .... Taming of Sh, jii. how I lost my crupper; with many .. - iv. the saddler for my mistress' crupper. Cam. of Er. i. crush this herb into Lyander's cye... Nid. N.Dr.iii. quail, crush, conclude, and quell! ..... let nature crush the sides o' the.. Winter's Tale, iv. to crush our old limbs in ungentle ... HenryI H. v.
crowd us, and crush us, to this.....2 HenryIV. iv.
that they may crush down with.... Richard III. v. our muiu opinion crush in taint... Trail. \& Cress. i. when lie hath power to crush?......... crush him together, rather than......... cymbeline, i. come and erush a cup of wine....Roneo \& Juliet, $[K n l$.$] that is but a crushed necessity .. Henry V$. his valour is crushed into folly.. Troilus \& Cress. i. CRUSHEST-crushest the snake!... Love's L. Lost,, v. CRUSHING-then crushing peuury.. Richard II. v. that he could gnaw a crust at two... Rieh. of V III. ii. infinite malady crust you quite o'er. Tim. of Ath. iii.
he that keeps nor crust por erum.......... Lear, i. with vile and loathsome crust ..........Hamlet, $\mathrm{i}$. CRUSTY-thou crusty batch of nature. Troil. \& Cres. v. hesce therefore, thou nice crutch ...2 HenryI $Y . \mathrm{i}$. king Henry throws away his erutch.2Henry $V I$. iil. as give a crutch to the dead ............ Henry VIII. i. he is thy cruteh; now if thou lose.. Trail. \& Cress. v. pluek the lined erutch from... Timanof Alhens, iv. turned my leaping time into a crotch. Cymaeline, iv. a crutch, a erutch! why call you. Ramea \& Juliel, i. that went on crutehes ere he ....... Hinier's Tale, desire to live on crutches till he had one $-{ }^{2}$ i.
plucked two crutches from my fechle. Richard $I I$. ii. ChI $Z$ DDUES - purse full of eruzadoes.. Othello, iii. RY-the ery did knoek ag:inst my ..... Tempest, i. whicli thou heard st ery
will erv it o'er arain

to ery to the sea that roared to us....... every cuthit seems to ery out ........... 1.2 (song and breathe twice and hry $\ldots$. - ii. 2 (song) I couch when owls do cry............. v. -1 iv. will make me ery baa.

Why dost thou ery alas?..............

I have a great dispositions to ery......

all my neiglıbours shall ery aim...... - iti.

if I cry out thus upou no trail $\ldots . . . .$. - iv.

I come to her iu white, and ery, mum $\overline{\text { hablling gossip of the air cry out.. Tuelfth Night, i. }}$.

Sowter will ery upon't, for all......... -

I ery bail: here's a gentleman.......... fors. $\overline{\text { Mleas. }}$ iii. 2 I cry you merey sir; and well conld - Auch Adv, iv.

sit in a corner, and cry, heigh-ho!

If you licar a clild cry in the night

earthly thing ery shame upon her?.

cry, sorrow, wag! and hem, when he
my griefs cry loider than advertiseme

my griefs ery loitder than advertisement -
though he cry, euckoo, never so?

I cry your worship's mercy, heartily

I cry mure tune mutual cry

a cry more tuneable was never ...... 
CIR Y-you mus ary: well dene ... Lone's L. Lost, Y.

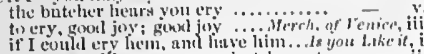
if could ery hem, ambar but 1 minst - ii. and to ery like a woman

that fume muy ery you lomi............t!'s Well, ii.

(t) you erv, oloml, sir, at your.

ii.

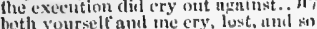

nearent of kin erry, fle ujus my arave!

1), the most piteots ery of the puser

n, the most piteotus ery of the phor

be quiet, when we hear it ery.

youll ery for this, minion

good master, cry, the devil ......... $\overline{\text { ive }}$ iv.

of the rark, to cry, hok, hold!

serem, anil the erickets ery

new orphans ery new aorrows.

the ery is still, they com

it is the ery of women .

to ery aim to these ill-tuned iepetitions ..

ery, havock, kings! back to the

linving hrenth to ery ..........

in hope, I ery, amen

cre, woe, destruction, rinin, loss

dial they not sometime ery, all hail

Enpulinut makes this eager ery?

ery, evourage, ti) the ticla! ........

they ery, hem! and bil you.......

rather ine a kitten, mul ery new.......
lork of Westmoreland, I ery you mere

upon this charge, ery, God for llarry.

let lim ery, praise and glory on his
num ery ull-we died at sueti a plute

tivery umen to that, thus we alpenr

I ery, a rope! a rope! now leat....... tenry $V I$.

wery - i.

the ery of Talbot serves.................

I ery you merey, madam, was it you?.2 Henry 1

the time when seritel-owls cry..........

and therefore do they ery, though ....

pinched $\mathrm{a}$ few, and maile them ery...3 IIenry

and ince ugain cry-charge.

goul father; cry st. George! .......
cry, content, to that which gricves.

the drum; cry, colrage! and thay..
I cry thee inerey then; for I lid..... Richas
and ery, OClarenee, my unlampy son!

iny mother, I do ery you mercy

you live, that shall ery woe.......
cry, God save Richard. Englind's

crs, God save Richard, England's ...

ery inercy, lords, and watehtul ......

my ruiltles bloot must ery agr.....

ehinl ery tor blessines on him

and let him ery ha, lnuler!..........

now, if you eni blush, and ery guility
methinks, I conld ery the amen.

1 cry your hounur merey.

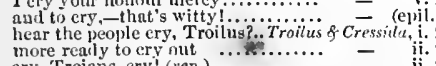

more really to cry nut $\ldots$.............
cry, 'Trojans, cry! (rep.).............
infiney, that nothing eanst but cry.

cry cry! Troy borns

the deith tokens of it err, no......

these luvers cry, oh! oh! they die!.. - iii

the ery went once on thee $\ldots \ldots \ldots$ i
and all cry-llector! Ilector s deadi

and ery you all amain, Achilles ....

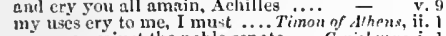

you ery against the noble senat
will then ery out of Wareius

will then ery out of hareius

in to a rapture lets ainst the recturship

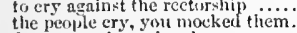

do net iry, havock, where

say, fine. ery fine; if death, ery death

say, fine, ery fine: if denth, ery death
soch time they luve legun to ery

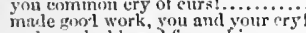

anil ery, he blessed fir mufin?

ery, welcome, laties, weleome?

eliriter than all the musie, cry ....... Julius

What was the last ery fir? . .
ery it atwat the itrects (rep.)

ery it alkmt the entreets (rep.)........

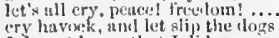

I den not know that I diil ery

why did yom so ery ont, airs.

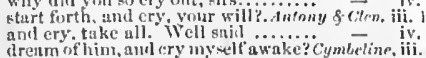

ery out for service................
will ery to the sthining syoul

will ery te the shining syenel.......... -

their mull

the eommon voice dlu ery, it shall be

and rave unt ery fur timf ............

and ory be thist will riye

cry mit, she died by find pluy

ery to it, numele, as the cerkiney......... t.m.

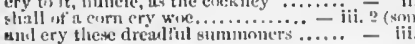

CRY-ery sou merey, noble whits

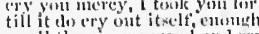

stnell the nir, we wawl und ery

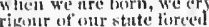

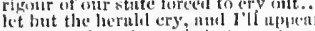

ery lut $\rightarrow 2$ h me! cory

I ery you nersy? you are the singe......

the people in the atrect ery-kan

get me a fellowship in a ery of $y$ layer

they ery, chousc we; latertes slatli h

low eluectinl?y on the fielse trail the

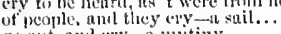

goout, and ery-a mitiny

but one that fills up the ery ..........

filith, my lithl, (ry, $O$ sweet crenture.

"ough, or ery-liem, it auy bouly exime

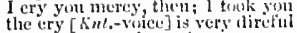

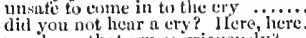

did you not heur a ery?

I ery you mercy! here

alus! what ery's that? Thiit? whint?

all, all, ery shame against ine...

sister erying, onr maid howling. Tre.... Teme of I" te

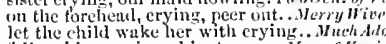

follow him, crying - his stanes ...Mer. of tent

somr oftence, crying, that's good . W....All's W'

leave it erying, and for the balse. Winter's Tale,

and spent with erying-bring

like to whelps, we crying r

.llenryl.

by erying comtont fiom a lioilow

2Henry

crying-Viliageois! unto all they me

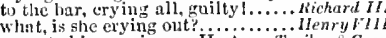

conse to him, cryiug on II eetor... Troilus \& Cress

abont the strects, erying, contusion. Coriotenus,

that prayer, by erying out as loud... Ant. \& C C $r^{2}$,

came erying 'mongst his foes........ Cymbeline

we caine erying hither, thou know'st .... Luar.

the pretty wreteh lett erying

to think it should leave erying....

myself the crying tellow dit pursu

othello, ii.

Crying, Odear Cussio! as it were

sitt'st still, and cry'st, Alack! why does.

CRYSTAL-in her erystal looks.. Tiro Gen or'ter. ii. 4

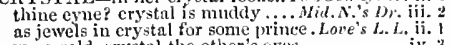
were gold, crybtnl the other's eyes

these crystal beads lieaven shatl ..... King John

the elore hiir and erystal is the sky...nichard 11.

branilish your erystal tresses.

illenry

bit in those erystal seal
CRYSTAL-BUT'TON-

this lenthern-jerkin, crystal-but ton.1 Henry $/$ : ii.

CRYSTALLINE-pubaee crystalline..Cymbetine,

young sucking eubs from the... Mereh. of I' rnic

ii. 2 CUBICUIO-call the at the enbieulo. Tietfh $\mathrm{N}$ CIBIT-whose every eubit seerns to cry. Tempest, it. CUCKOLD - the euckold's horns .. Merry
know lim tor a knave and a cuekold

but cuckold I Wittol cuekold! .......
tie, fie, fle! cuckult! cueksld! cuckold!

tie, fie, fie! cuckutel cuekold! chckold

you shill cuckold ford

now, sir, who's a euckold now? .......

in moking me a enckold... Neasure for Mpensure,

like an old cuckold, with horns .....Wuch Ado

whin, are we cuckults, ere we hine..Ver. of tien. v.

the elerk, thut is to make me euckold? tit' $^{-} W_{r}$

the cuckolel to lis horn, as a scolding -

much decuiver, cuckolds ere now.. Hinter's Tule, i. 2 and made Luciture ekekold

and made luciter wickold ........... Henryly. ii.

lie or she, cuckuld or cuckold-maker.. Tren.

what, does the euekrld scorn me

like a puting cuckold, woutd d

the cuckoli, and the cuckoli-in

pence is a grent maker of eurknl,ts. Coriolum

their li:enests tio niake me a citckolid...

cleng thou lust miule me euckold...

rries, euckold, to

that enckust curekuld him, thou dost.....

I will chop, her into messes: cuckuld me

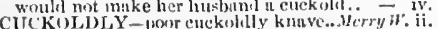

the key ot the euckolilly rogue's cotler

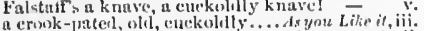

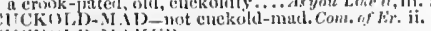

ICK(H,D-.I.1KER-

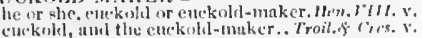

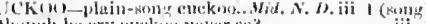

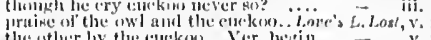

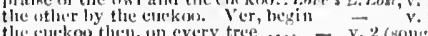

the rlurkoo thes, , mevery tree ...

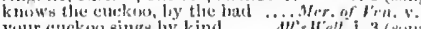

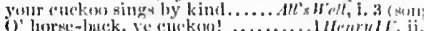

he was but us the culckon is in bune.

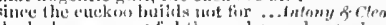

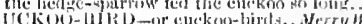

CUCK() - Bul) -

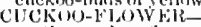

nettles, elaskow-llowery, darnel, and at

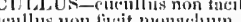

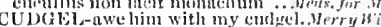

to thy husband's endlgel; and the

his cullgel, and twenty pounds of

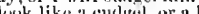

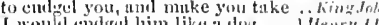

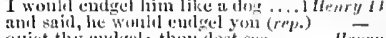

guict thy eulgel; thou slo

not theretione hamble an linglish cuiring

to hase struckes foim with a culd

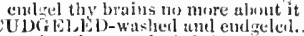

I miglit have toudgeled the out..
onr ears are endireted; not a word

my weury limbs lonour is eurl

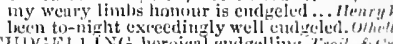

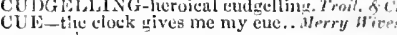

remenber you your ene.

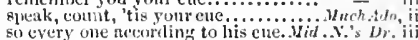

cacs and all. Pyramis enter;
when mo ele comes, eall me

deceiving nue is 'Thishy's ete

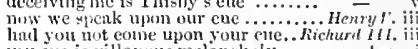

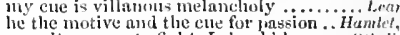

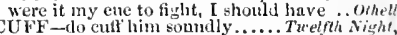

I swear, lll cutt' you, if you

and this euft was lout to knoc

with rutfs and cuttis, und fartbingale

tu tug it, and to cuif Fou sonndly

C

aud cull the shall cull forth out.... King Joth, ii.

and enlt the infected fortl .... Troilus of C'ressictu,

do you now enll out a holirlny?.... Jutirs Cirsar

the word is well culled

and udled thcse tiery spirits from .........John, $v$.

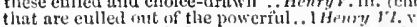

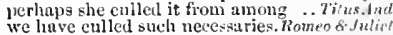

CULLING- $[K n$. $]$ bee, culling from.2Hemy $11 \%$

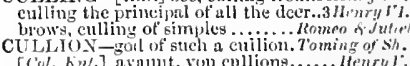

awiy, hare cullionts! suffolk

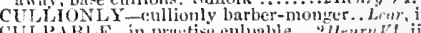

CULPABLE-in prutise eulpalie ..2lleury $/ 2$

COAIBER-let it not cumber your. Timon of oth. iii.

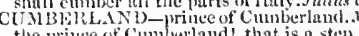

the minte of C'umberlan

northern lord, clitford of cumberiand -

that lig his cunming huth chented me

with all the cumming man

nyy eunning drift exeds.................

the eumning of her jasion invites.....

out so cunniur in tionce.

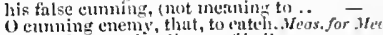

0 , 'tis the cunnion livery of hell

hut in the bobluess of my e'unnin

be emming in the working this .

and my ctinning sl:all not shame

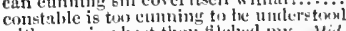

with eumning hust thom fileled my ... Mi

adranee your cunning more nn

is as eunning as filst and lok

your cumning eatn nsivist me

to eunning ment l will le very ki!nt

elmining rching

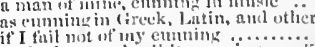

ernfty love, ant eall it, enming

trust not these enuming wenters of his cy

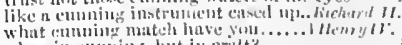

wherein emuing, but in erilt

whatsecerer cuming an profestation 
CUNNING-is this thy cunning ...1 Henry $Y^{\prime} L$. ii. I / CUPTD-I should out-swear Cupid

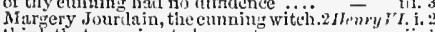
think that curning to he grea

a cunuing mina did caltulate my birtis

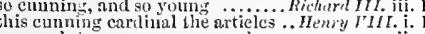

courtly, and thou art too eunning. Wroil. \& $\bar{C}$ Cres. ifit. 1

with cunning gild their copper erov
in very spite of cunning, bute him

puttiry on the enunine of a carper. Finon of

that they wanted cunniu

she is cumning past mann's the

this connot be enuning in her

my better cunning faints under his...

try thy cunning, Tliyreus; make tline 二 $\begin{gathered}\text { iii. } 10 \\ \text { ii. } 30\end{gathered}$

her braeelet ( 0 cunning how 1 got it! Cymbeline,

I'll find some cunning practiee ... Titus. Andron.
virtue and cunning were endowmeuts. Periels, ii.

un fold what plaited emming hiles.

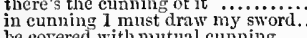

be exored with mutual cunning

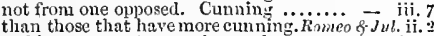

go lire me twenty eunning eooks.

witl as much modesty as cunning

by the very cunning of the
esstasy is very cuunlng in

wamer on your cumnings $[K n t$.
of deatlis put ou by cunning

of deaths put on by cunning ......
to find ont praetices of cunning bel

in ignorance, and not in eunning ...

took you for that cunuing whore of Venice = iv. 1

it there be any clunning ernclty, that can
CUNNINGLY - so cunningly... TroGen of

neer so cunningly you smother it ... 1lleury I'

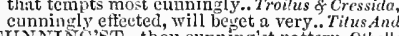

CUNNING'ST - thou eunning'st pattern. Ohello,

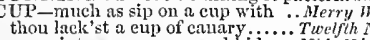

ereep into acorn eups, and hide ..Mid. N.'s Dr. ii. 1 poured ont of a cup into a glass... As you Like it, v. take it to you, trenchers, cups, and oll

nightest bespice a eup, to give.... Winter's Tale, $\dot{i}$. 2

may be in the cup a spider steeped ...

unless hours were cups of saek

let a cup of saek be my poison

give me a cnp of sick, boy

$O$ villain, thon stolest a cup of sack.

give me a cup of saek, to make $\ldots . . .$. Henry $I$

all the eup of alteration $\ldots \ldots \ldots \ldots . . . \quad$ iii.

a eup of wine, that's brisk and fine... $-\mathrm{v} \cdot 3$ ( song)
fll the eup, and let it eome........... v. 3 (isly!s)

'twould drink the cup and ail

being in his ales and his cup

I drink to you in a cup ot sack

neighbour, here's a cup of charneco.

viands sparkling in a golden eup

keeper? give me a cup of wine
one that loves a cup of hot wine

one that loves a cup of hot wine
till the wine o'er-swell the cup

Where's this cup I called for?

fill, till the cup be hid

eup us, till the world go round

scant not my cups; and make as
hides him in fresh cups, sott bed

of Plenty's eup and her prosperities.

here with a cupj that's store
the curp of their dcservings

the clip of their deservings:

by the operation of the of wine................ Leareo of Juliet,

What's liere? a cup, elosed in my

give me the cups; and let the kettile.

give him the cop. I'll play this bout

It is the poisoned eup; it is too late

one cup: I'll drink tor you (rep.)

if I can fasten but one cup upon him

everv inordinate cup is unblessed
ever

CUP-BEARER-thou, his cup-bear
Iam lis cop-bearer; if from me he

CUPBOARDING-still cupboarding
CUPID-is one of Cupid's carriers...

CUPID-is one of Cupid's carriers.
now is Cupid a child of conscienee

subseribed for Cupdd and chello...Much Alo, i.

to tell us Cupid is a good h

tor the sign of blind Cupid

nay, it Cupid have not spent all.......
if we ean do this, Cupid is no longer

is little Cupid's crafty urrow made

some, Cupid kills with arrows

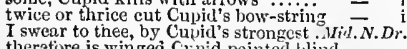

theretore is winged Cupid painted blind -

and the earth, cupid all armed

young Cupid's fiery shaft quenched

hit with Cupid's arcliery .....

Cupin' is a knavish lad, thus to
Dian's bud o'er Cupid's tlower

saint Cupid, then! and, soldiers
was fain to seal on Cupid's name

shall play the cur with him

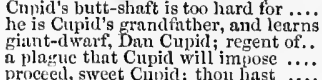

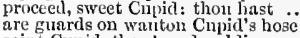

saint Dennis to saint Cnipid

if they could, Cupic himself wout

I long to see quick Cupild's post.
why Rosalind; Cuplid havemercy

that Cupid lath clapped lim
that blinking Cupid gossips .

us all. O Cupid, Cupid, knoeked out $\overline{-}$ iii. 2

from Cupid's shoulder pluek his

in all Cupid's pageant there is

and the weak wantou Cupid shall

dimpled boys, like smiling Cupilds.

were too winking Cupids of silve
you clasp young Cupd's tables.

no, do thy worst, blind Cupid.

slie's not be hit with Cupid's arro

we'll have no Cupid hood-winked

young Adam Cupid, he that shot so

theretore hath the wind-swift Cupid
lirnt-winged toys of teathered Cupid

Uh-hang, cur, lingl........

when a eur eannot
what cur is that?

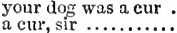

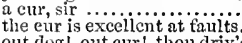

a stranger en over your threshold.

is it possible, a cur can lend...
it is the most impenetrable cu.

to he cast awa. y upon cur's .......

mongrels, spaniels, eurs, shiough

slall dunghinil curs confront ......

thop priek-eared cur of Teeland
foolish curs! that run winlsing

yield, cur. Je pense, que
brass, cur! thou damned

follow me, cur. Snivez vous

and make the curs stand alo
small curs are not regarded

astonish these fell lurking curs

when a cur doth grin

that this carnal eur preys on

this butcher's cur is veuom-1no
like to villnge curs, bark when
two curs shall tame each other
you whorcon cur?

you cur! Mars his idliot! do...

you whoreson indistinguishabie eur.

enr, A jax, against that dog (rep.
what would you have, you eurs

you eummon cry of eurs

minst give this cur the lie
spurn thee like a cur out

like a cur, bhind, struek
fell curs of bloudy kind, $h$.

you whoreson dog! you slave! you ..Titusts dit. ii.

avanut, you eurs! Be thy mooth.

and the creature run from the enr?
CUR AN - save thee, Curan. And your

CURATE-art sir Topas the curate. Twelfith Night, iv. sir Topas, the curnte, who come.

the parish ewrate d exnoder.

CURB-the needftil bits and curbs........ and curb this eruel devil of his will. Mer. of $V$ en. iv. 1

the horae his eurb, and the falcon... As you Like, iii. 3

Tll curb her mad and headstrong. Tanin

reverence of your highness
with the rusty curb of old

and curbsh himself even of his

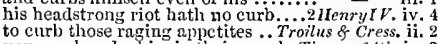

your curband whip, in their rough. Timon of Alih. iv. 3

to curb the will of the nobility

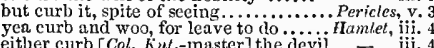

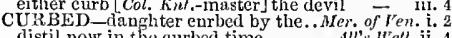
from corbed licence plucks .......... Henryl $V$.

yet you are eurbel from that ............ Cymbelin

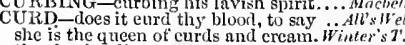

she is the queen of curds and cream. Winter's ?'
the shepherd's homely curds.......3Henryl Vi
and feed on curds and whey .... Tit us Andron.

and feed on curds and whey .... Titus Andron,
it doth posset and curb, like eager ...... Humler.

it doth posset and curb like eager ...... Itumlet, i.
CURDDED-that's curded lyy the frost. Coriolan us,

cure thy brains, now useless

were past cure of the thing you.....ifeus. for $\overrightarrow{\text { IEeas. }}$ ii.

and the curre of it not only saves your

and severity must cure it .............

strangely they strain the cure .......visue $A d d o$,ive

for, past eure is still past c.

did you ever cure any so?...............
CURE-cure the flesperate languishings. Al's $W^{\prime} \mathrm{cll}$, i. 3 may not be so eredulous of eur.

past eure. Art thout so eonfident? (rep.) ehildness, cures in me thoughts.... Hinter s Tule i. sinis, that stay his eure

the mere dcspair of suryery, he curcs

enre her ot that; canst tiou not......

give her sadness very little eme...

widow eomfort and my surrow's cur.....

to the cure of thosc ph chre.

bid thy eeremony physicians.......

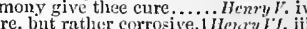

can cure their to kil and cure....2llenry Vi.

to cure that blow of thine

for my little eure, let me alone..........II ${ }_{\text {enry }}$ VIII.

thou art a eure fit for a king

政, to remove

is there no way to cure this

must lites the wor:

Troilus s... Cressida, iii.

leave us to cure this canse.

to eut it oif; to cure it, c.sy ...........

the cure wherens, my lord, 'tis tim.

natiure works, and of her cures......

his nestanir, is done to cure it ............

O you kind gods, enre this great breach..

one desperate grief curcs with
past hope, past cure, past hel

confusion's cure lives not in these....

blood he rages, and thou must eure inc. Hamlet,

to death, stand in boid enre ............ Othello,

wonld do mueh to eure him of this evil =

are not so punished and cured ..........

and thus I cured him; and this way

will you be eured of your inflimity?...AM's " well, ii.

be cured of this diseased opinion .. Winter's Tale,

the king has cured me....

giventhe, hall cured

you see, is enred [ $k$ it.-killed] in him .... Lear, iv.

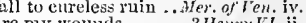

is a eurct of souls (rep.). Mnry thes, ii,

I'll be a curer of madinen.... Troilus \& Cressida,
CUREEW--to hear tle solemn curfew. Tempest,

nunc, sinee the elurtew rung ..... Meas. for Meas. iv.
he hegins at eurfew, and walks till the .. Lear, iii.

che cintew bell hath run

betore the euring of a strong disease. Kine Jnhn,

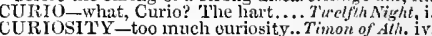

that curiosity in neither can make clooice.. Lear,

and permit the curiosity of nations....

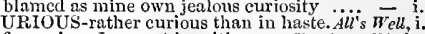
for curious 1 eannot be with you.. Toming ofshls. iv. body couched in a curious bed ........3 Henry $Y I$. $\mathrm{i}$ What too curious dreg espies.... Troilus \& Cress.

though you be thereill curious ... Aniony \& Cleo. ii

and $Y$ am sometling curious

was lapped in a most cnrious niantle nothing but curious pleasures ..........

what eurious eve doth quote

What eurious eye doth q
CURIOUS-KNOTTED-

thy curious-knotted garden.. Love's L. Lost, i. 1 (let.) whereiu so euriously he had set this.. All's $W^{2}$ el, iv. the sleeves curiously cut .. Taming of Sh. iv. 3 mote

URL-it will not curl by nature... T...... Haifth Nigh,

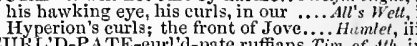

CURL'D-PATE-eurl'd-pate ruffians. Tim of athl.

a curled pate will grow bald

if she first meet the curled Antony........ Hi. s. Cleo,

or swell the curled waters 'bove the.

shunncd the wealthy curled darlin

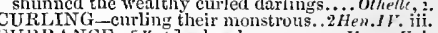

CURRANT-five ponnd of currants. Winter's Col $^{\prime} V$. i.

URRENT - the current .... TuroGen. of Verona, ii.

like an impediment in the current. Mea. for Mlea.

the current of our right run on? ...... King Jolnn,

thy word is current with him........ Richard II.

Your bloods, eurrents that spring from - iii.

pardon, as 'tis current in our laud ...

come cin'rent for an acensation

as to o er-walk a curreut $\ldots \ldots . .$.
it holls current, that $I$ told yo

and poss them [Knt,-current]

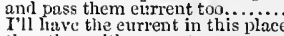

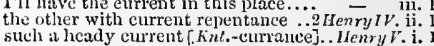




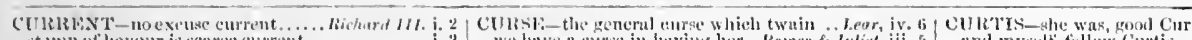

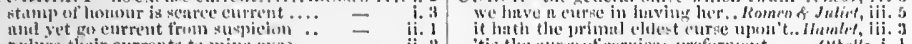

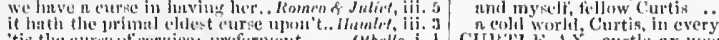

reliuce their chrrents tos mine eres

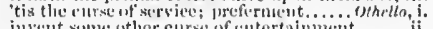

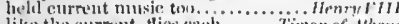

like the current, flies cheh .......Timon of $1^{\text {then }}$, i.

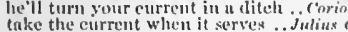

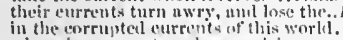

wh, ise in enrrent, $n$ in

CIRlRISil-currish thanks is.. Tre Gen,

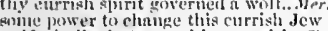

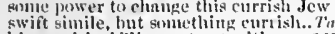

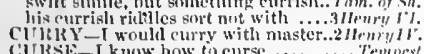

clissli- I know how to curse

ilo cirse the grnce that

I enrse myself, for the

s $\Leftrightarrow$ curses all Eve's dnughiters ..........

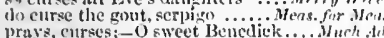

prays, curses:- $U$ sweet Beisedi
give him curses, yet he gives

heing gensible, shmulal curse agitin

the curse never foll upon our nation. inter of

but you will curse your

it is a curse he camiot be..

burn it now, than curse it the..........

thouth my tongue do eurse .. Comndy of

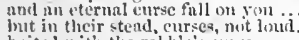

un enuse to curse the fair procedings. king Joh

mo enuse toschrse the fair proted

the neril of otur emescs ligh

it is the eurie of kings to be ........

my skill were subjert to th

invent sume cother curse of cutertaiminent = ii.

refuite it with the serpent's vurte...

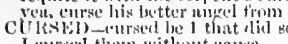

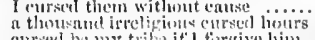

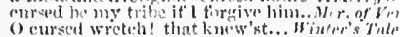

retrain in me the curtect thoughits.

stand curterl, und exemminumieate.. Kin

if thon stand exemmuniente, atsel cursed - iii

ever fell maon this euried enrt

musing nut enssed nuelanclusty?

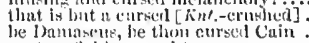

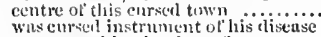

now eursid he the time of
deny thy finther, cursed ilrab?

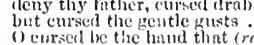

enred the bloul, that let this holowi...

circuinstance, to curse thy cursed self

cureel she llistings, then cursed (rep.)

unless th inan were cursed, I cannot. Froil. $\vec{\AA}$.

nothing level in our cursed in

he pllocket his enrsed steel away.

cursed be that heart, that forced.... Titus dus iv.

and he nvenged un cursed Tumura.....

that curscis Cliten nut Demetrin

and cursed binge le that will not ...

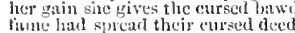

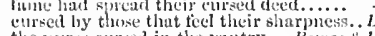

the wurse curbel in the pantry ...Rome
as that name's cursel hand murtered

what cursul toot wenders this wry

with juite of enrsed liethenon in a viad

what if this cursed hand were thick

ten times treble on that cel'sed

slatl we entric the planets of

but curse thi cauve I cannut

to curse awhitic. Cure, mine:
with wlum I leave ins cursc

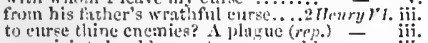

to etrse thine cnemies? A plasue (rep)
every joint should seem to curse and ban

wonld brenk, should I not curse them

and these dread curses, like thic sun..

well could I curse away a wi

God's curse light upon you nil

may England curse my wretelsed reign

the curse of her that bare thec.
anil, witly the erown, my curse

anil, with the erown, my curse

I'll muke thec curse thic
to curse thy cursed self

the maetise of a elirged [Cot.-i]:mneil] shave

curse not thyself, fitir creature..... Richard HI. i.

with curses in her mouth

the curse iny noble tis ther laid on.....

his curses, then from bitterncs

can curses pierce the clouds (

can curses pierce the clouds (rep.)....

hrenthel your curse ngainst yourself
curse this poisonous huach-liackel (rep.)

of niv curse. Nor no onc here; for curses -

stand on end to hear her curscs

now Margaret's curse is fillen upon
now thy heavy curse is lighted on poor

now thy heavy curse is lighted on
die the thrall of $\mathrm{M}$ argaret's curse

cre I can repeat this cursc again.

suljject of mine own sonl's curse.

help me curse that bottled spider
in curses, star awhile, nnd tewch

in curscs, star awhile, and terch (rep.)

take with thee my most henvy enrs

yet much less spirit to eurse shides.

their curses now, live where their

too many curses on their heads ......
lis curses and his blessings touch me

lis curses and his blessings toucti me
all your studies make me a curse .....
is the curse dependant on those.. Troilus o $\bar{c}$.

the common curse of mankind

you will catch cold, and curse mic....

hearen's curse upon thee...... Timon of Athen

if thou wilt curse, thy fatlier.........

thou art too bal to curse io..........

inte ali, eurse all; show charity......

if thou hatest curies, whts not.

pass by, and curse thy flil........
when you curse them as ener

and curse that justice disl it..........

a curse legin at very rowt of his henr

voicen might be curses to werurselves.
and did curse against the Volecs ....

but to confirm my corrses .............

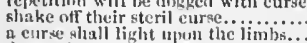

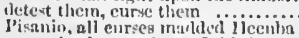

curse the day (and yot I loink (ro $\because \mathrm{i}^{-}$iv.

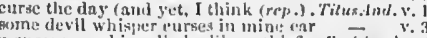

a curse npon him, die lie lihe a thite .. p

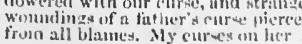

CURSIN( $x-b$ a cursing hypoerite

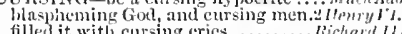

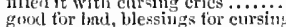

wecping, cursing, vowing ventgense Troit \& i. beating, your officers, eursing

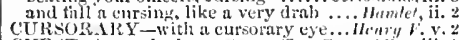

0 time most she is eur

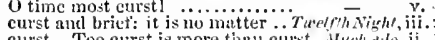

a curst cotr shurt horns (rep.)

so by being too curst, God will ench

mor longer curst, Thave no fift .....Mit. N.Dr. iij.

here she comcs, curst, and s:ul

curst be thy stones for thus deceiving do not curst wives hold that v.

curst and shrewd as Socrates Xnutiple -
slic is intolerubly curst and slirewd ...

till Katharinc the eurst have got $(r e p)$.
will undertake to woo eurst hatharine

will undertake to woo ell'st h

if she be cur'st, it is for poliev...
she shatl still be curst in compun

ghe ahatl still be curst in company ..

they are never curst, but when... ininter's $\overline{7}$ ale, iii.

as eurst, as harsh, as horrille to....2 Itenryl' l. iii.

with currt specch I thiren.tenerl to

CIRATER-curster thun sle? why .. Tum. of Sh. iii.

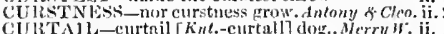
she hal transtionnet ine twa curtuil.Come of lir. iji.

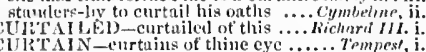
thesc gitts n curtain betore them? Tirelfith Night, $\mathrm{i}$. thesc gitts al curtain betore th
but we will ilraw the curtuin

draw aside the curtuins, and

draw the curtains straight.

eone, Iraw the curtain,
ilo unt draw the eurtain

I'l? Iraw the curtain

the curtain? 11", nut these twenty year

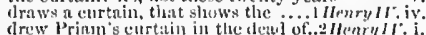
their ragaed curtains poolly are....... Menry $r$ iy. and is raw the curtuin elose

IInmylli. v.

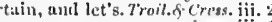

drnw the curtains: so, so, 80
slinty curtuins from

sprtad thy clusc cortain, tove-pertiormint

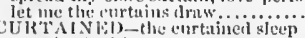

Wherllo, v. 2

durtaned with a conteil-hecping. Fitus dudron, it.

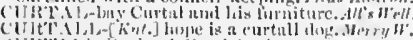

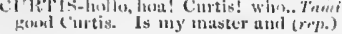

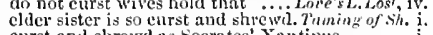

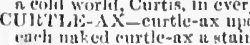

calli unked curtle-ax a stain

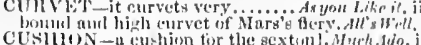

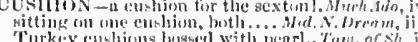

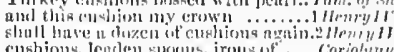

as tos stull u lutecher's cushions, or

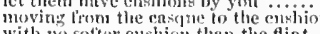

With no softer cushion than the fliot
I'il have then slecp om cushions...Juliu

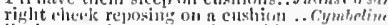

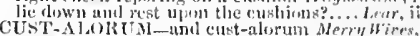

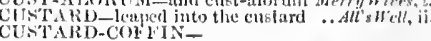

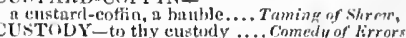

UsToDY $-t$ thy custudy ..... Comedy of lirrors,
a cluree from thine own custody?

nor shill not, whil-t tis in my custody, omeello, jif.

tis a custom witls him $\mathrm{i}^{\prime} \mathrm{i}$

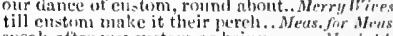

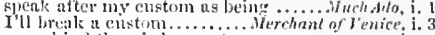

more kind thitu is her custon.

slaull hop, witlout my eustorn. Taming of shret, iv,

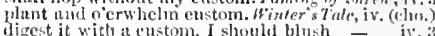

(y).

buit as a thinz: of contum ...

Okate. nice customs court'sy
new eustomin, themgh they be

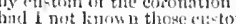

othere, int sust m, in ull line.... Troilus s. Cress. iv

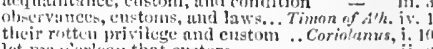

let me cierleap that enstom

to fit you to the eartum...

curtonn ealls me to't; what custer..... wills -

a:ted custom, but by your voices

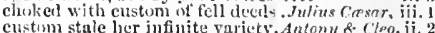

is but a custom in your tongue. ..... Cymbeline, i.

by custom, what they did betin.. I'tericles, i. (Gow.)

you'll lose nothing hy eustom

as the custom is. in all her best................ Lear i. o g

is it a custom? Ay, marry, is't.
it is a custom more honoured in

my custom niwnys of the atternoon

firgone all custom of exercises ........

that monster, custom, who atl sen

antiquity forgot, custom not known
nat ire lier eustom bolds, let shame

custom hatl made it in him a property... - iv.

the t5rant custon, most grave senators... Othello, i. 3

CUSTUNARY - it is a customary...Mid..... Dream, i.

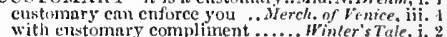

chanters, and his enstomary riglits.. Richard II. ii. 1

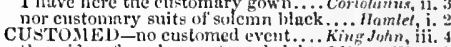

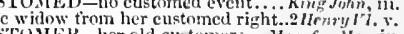

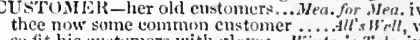

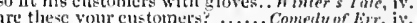

would but wive wny to eusiomers ..... Pericles, is. 6

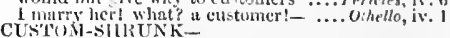

luserty, I mo custom-shrunk ...Mens. for sreas, i. 2 UJT-cut his wenzamil with thy knife.. Trmpest, iij.

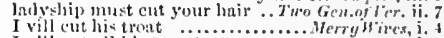
I vill cut all his two stones

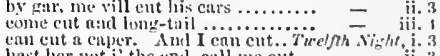

hast her not i' the enil, eall we eut o. ii. 3

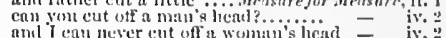

ent off hy curse ot justice:
nnd not hinve cut limin whl

see the fish cut with her goiden ........ vush stow, iii.

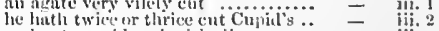

ame ent and laced with sivet ... vid. $x$ - iij. I

it' l'nt my finger, 1 shall............ - iii.

cut threat, nut thrum .............. =

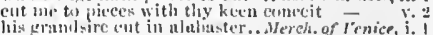

to be cut off aul taken in what

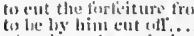

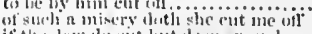

and gaut anst eneugl. 


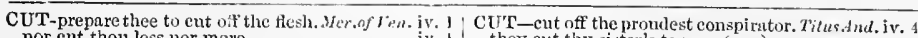
nor ent thou less nor more $\ldots$ we.........

this fool to cut off the argument?.. As yon $\bar{L}_{i k}$ it other means to cut you out..

and beard c

dislike the eut of a certain courticr's $(\mathrm{rep})-$.

and cut the cntail from all

cut off all strife, here sit we flowi..........m. of sh. iit.

nip, and cut, and slish, and slash ....

ent ont the gown: but I did not (rept?

the sleeves curiously cut..........

o cut my lace; lest my heart ... Winter's $\bar{T}_{a l}$

I picked and eut most of their festival

could ever yet cut breath?..............

we will draw cuts for the senio

I should cut off the nohles for.....

but gentle heavert, cut short ali......

but gentle henver, cut short all.........
their elmurlish drums cnts off more ... King Jot
his lawfinl king, eut off the sequence

if you will, cut out my tom

cut him to pieces. Keep the pes.....

the king hal cat off my head

and cut out his way, to find ovt...

like an executioner, cut
this festered joint cut off

knife, no more shall eut lis master...1 Henry

rob them, cut this bead from

down with them; cut the villains'

my buckler cut through and tlirough

and cuts me, from the best ot all

cut me off the heads of all the...

that he ents me from my tale......

of a wheel have his ears cut off

wluch to avoid, I ent them off

I will cut thy throat.

knives to cut one another's throd

will eut their passage through .......

and there is throats to be cut, and
save me, I will cut off your head

save me, I will cut off your head
vital thread be cut with edge of

beard of the geveral's cut..............

would have all such offenders so crit off

no English treason, to cut French

for I will cut lis throat.

every soldier to ent his prisoner.....

besides, we'll cut the throats of ......

coat one half is cut away.

flint doth cut my tender feet

flint doth cut my tender feet

iniquity's throat cut like a calf

war shall cut them short .........

or cut not out the burly-boned ......

into as many gebbets will I cut it...

shall warwick cut the sea to France

I'll cut the causes of

whiles the head is warm, and new cut off -

in his youth to have him so cnt off .̈̈icharl

to cnt off those that have offended ....

Ill have this erown of mine cut from

ah, cut my lace asunder!

the fearful time cuts off the ......

through liguid mountains too ........Henry VIII. i. 3

I shall cut out your tongue.

and cut off all fears attending..

thy guard, I'll cut thy throat

cut my heart in sums throa............

and cut your trusters' throats!

pronounced thy throat shall c
there's more gold: cut throats

mine own use invites me to eut down

a disease, that must be cut away

mortal, to cut it off; to cure it ....... -

our general is cut i' the middle

cut me to pieces, Volces...................

you'll rejoice that he is this cut off...

and offered them his throat to eut.

to cut the head off, and then hack ...
that cuts oft' twenty years of life, crits

by Cæsar, and by you ent off

how to cut off seme charge in

advantage shall we cut bim off....... -

eut my lace, Charmian,

he conld so quiekly cut the Io.........

paper hath cut her throat already
thy garments cut to pieces before.
he cut our roots in characters.

cut off one Cloten's head, son t $\theta$....

hast here cut off my lord

I ent off' 's head; and am right glad....

of a eut loa to stea! a slive... Titus Andronic

who twas that cut thy tongue.

that mean is cut from thee

lie hath cut those pretty fingers off

the one will help to cut the uther... they cut thy sister's tongue (rep.).....
she was wnshed and eut and trinmed

my hand cut off, and marle a merry..

ravished lier, and cut a way her tonguts

destinics do cut his thread of life
half the flood hath their keel cut

half the flood hath their keel cut ..

ay, he offered to cut a caler at the

wash his fnce, nor cut his hairs

why, ast things be cut the egg.

to cut off my train, to bandy.

preferment talls on him that cuts hin of

a surgcon, $I$ am cut to the brains

I will eut off their heads ............. Romeo

and cut the winds, who, nothing hurt

euts beauty off from all posterity

that hand that eut thy youth in

to cut lis throat $i$ ' the church

I had rather have this tongue cit.

away, you cut-purse rascal!

and something lean to cut-purse

a cut-purse of the cmpire and the rit.

CUTTER-cntter off of naturc's

the eutter was as another nature. .As you Like il, $\mathrm{i}$.

thou art tla best o' the cut-thruats. of l'enice, i. 3

UTTING-deity cutting the clouds... Trmpest, iv. 1

I would the cutting of my garments. All's Well, iv. I

by cutting off your heads.

2 Henry VI. iii. I

and cutting the web ......... Troilns \& Cressida, it. 3

CUTTLE-play the saucy cuttle $\ldots$. $^{2}$ Henry IV ii. 4
CYCLOP-framed of tine Cyelop's size. Titus And. iv. 3

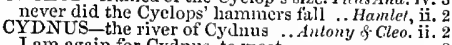

I am again for Cydnus, to meet.

CYGNET-I am the cyguct to thi

the swan ber downy cygnets save ... Henry J'l. v.
the cygnet's down is liarsh . Troilus \& Cressida. $i$.
CYMBAILS-tabors, and cymbils .... Coriolanus, v.

Cynbeline, ii.

swore to Cymbeline, I was confederate -

nor Cymbeline dreams that they are

the heir of Cymbeline and Britin .

Cymbeline! heaven, and my co

hath to Cymbeline performed .......
ask of Cymbeline what boon thou wilt

eedar, royal Cymbeline, personates the
in favour with the racliant Cymbeline

CYNIC-how vilely doth this cynic..Jul. Cirsar,

CNTHIA-by the eye ot Cynthia hath. Pericles, ii.

CYPHER-cypher of a function... RIea for $J$ ul. iii.

to prove youl a cypher.....

As youe's Like Lost, it.

like a cypber, yet standing.........W'inler's Tule, $i$.

CYPRESS-and in sad cypress.. Twelfth $N$. ii. 4 (song) in cypress chests my arras.... Taming of Skrea, ii. 1

I am attended at the cypress grove... Coriolanus, i. 10
CYPRUS-a cyprus, not a bosom. Tuelfh Night, iii.

cyprus, black as e'er was.. Winter's Tale, iv. 3 (song)

the proof, at Rhodes, at Cypria

such loud reason to the Cyprns wars

something from Cyprus, as I may divine

the importancy of Cyprus to the Tyrk

their purposes toward Cyprus

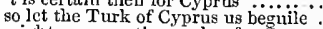

mighty preparation unakes for Cyprn

and bring all Cyprus comfort!

men of Cyprus, let her have your knee.

yon shall be well desired in Cyprus...

cause these of Cyprus to mutiny

without are a brace of Cyprus gallants

thello, i. 1

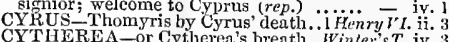
and Cytherea all in sedges hid. Taming of Sh. 2 (ind. Cytherea, how bravely thou becem'st. Cymbeline, ii.

D.ABELED-hair dabbled in blood .. Richard 111. $\mathrm{i}$. DACE-if' the yound dace be a bait ..2 llenry If. iti. WHED wont to cheer his dad in ........3 Henry VI. $\mathrm{i}$. D.FF_-can'st thon so daff me?.........Much Ado, Y.

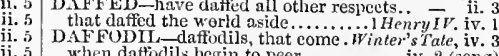
ii. 5 when daftiodil begin to peer ....
CUTLER-like cutler'............
CUT-PUEtry.

and sol a cut-purse...

cutting a smaller hair than may he.. Love'sL.L. v. 2

heaven bless the isle of Cyprus ............ tirst called my brother's futher, dad... King john, ii. 2
wat wont to cheer his dad in ........3 Henry $V I, \mathrm{i}$.
AGGElR-throw your darger o'er. Twetfth Night, iv. I whos with dagger of lath

the rapier and dagger man........ Meas. for.Heas. iv.

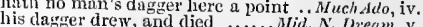
thou stick'st a dagger in me ........Mer. of Venice, and wear ny dagger with the braver in the clrape of lis dagger .............All's Hell, iv. 3 and Walter's dagger was not come. Taming of Sh, iv. I my dagger muzzled, lest it should. Winter's T'ute, i. 2

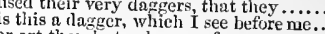
or art thon but a darger of

why did you bring these daggers from

give me the daggers; the slepping
so where their. .0

their dagters unnannerly

where we are, there's daggers in men

thy kingdom with a daferer of lath ... Henry $\bar{L} V$. this dagger my sceptre, and this eusinion -

thy golden seeptrc tor a leaden dogger

now is this Vice's dagger become ...2.2 Henry 17 .

do not you wear your dusfer in your.. Henry

pare his nails with a wooden daggrer

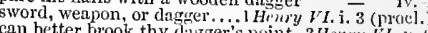

stabbed with bloody dagger's point. .3Henry ${ }^{\prime} I$.

give me this datger. Ay dagger, little - i

I know where I will wegrer....... Ilenry IrII

the honourable men, whose dagrete

ran Cassitus' dagger through
there is my dizgser, and here

sheathe your dagaer: be anery whion

when your vile daggers liacked one.

oy, with my ciagrer in their bosouth. Cymbeline,

ay, with my adagger in their bosoms
christen it with thy dagger's point

lay the scrving-creature's dagger.. Rameo \& $J u l$.

wit, and pnt up your dagger

oh dagger! this is thy sheath.

will speuk daggers to her, but w..... - - - Y. these words like daggers enter in

rapier and dagger. That's two of bis
DAGONET-then sir Dagout

DAII Y how daily graced by ...Two Gen of $V^{2}$ er. i. 3

what men daily dol sighs

so long I daily yow

Much Allo, iv.

nade daily motions for our home... Comedy nf , iti.

that daily break-yow ................

they suly new exactions are......

King Johu, ii.

being daily swallowed by men's ...ïHenry $\bar{I} r$, iii. 3

we lose, thcy daily get
as

Henry VI. iv. 3

as are daily scen by our

quarrel daily doth beget! $\ldots . . .2$ Henry $l^{\prime} I$.

for hunting was his daily exercise ....

slowered on me daily, I have bcen. Renry VIIL.iii.

conscience in doing duily wrongs

to heaven in daily than

doth daily make revolt in.

Troilus \&-Cressidcu,

may beat thy gravestone dhil

provide more piercing statutes daiij

which out of daily fortune ever......

daily slie was bound to protter......... Cymbeline

why such daily cast of brazcn cannon ... Hrimlet, $\mathrm{i}$.

DAINTIER - hath the daintier sense..... Hamlet, v.

DAINTIES-fed of the daiuties

for dainties are all cates ...... Taining of Shrew,

I hold your duinties cheap, sir .. Comedy of Err. iii.
DAINTIEST-the daintiest last....... Richard if.

gall, the daintiest that they taste...2Henry $V I$. iii.

their mother daintily bronght up ..Ant. A c Cleo. i.

DAINTINESS-the daintiness of ear. Richard II.

DAINTRY -innkeeper at Daintry....1 Henry IV.iv.

by this at Daintry, witl a puissant...3 Henry $Y I$. v.

O dainty duck! O dear! .........Afid. N. Dream,

and dainty bits make ricli the ribs .. Love's L.L.

were much too dainty for such treadi

proves dainty Bacehus gross in taste - iv.

my dainty duck, my dear-a? IVinter's $T$ in of sh. ii.

makes searec onc dainty dish in Comedy of Er. iii.

king is weary of dainty and such ..2 HenryI\% iv.

but his ean please your dainty eye... I Henry $F$.

grows dainty of his wortl. .... Troilus \& Cressida, i.

gives memorial dainty kisses to it ....

your laboursome and dinty trims.......

you thither then this dainty dne.. Titus andron. ii.

slue, that makes dainty, she...... Romeo of Juliel, i.

DAISIED-the pretticst daisiet jiot. Cymbeline. 1v.

nettles, daisies, and long pnr.. Love's $L$. L. v. 2 (song)

DAISY - there's a daisy; $l$ would give you - Hamlet, iv.

in dale, forest

the doxy over the mead

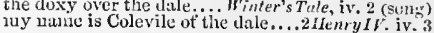




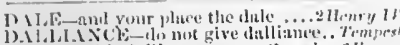

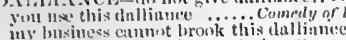

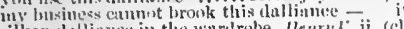

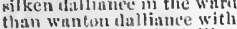

than wunten tualtiante with

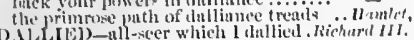

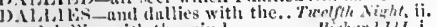

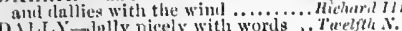

D.ALIS G anly nicely with

thus, datly with my exercment........

dnlly not with the gods ...... Tuming of

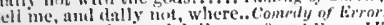

is $t$ a time to jest and dally

Hlenrillt.

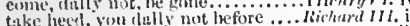

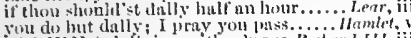

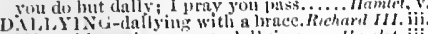

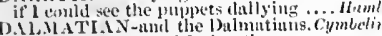

the P'unuouians and Dalmntian

D.A.I-him:elf upon thy wicked d

it woold esmetronl my dani's gowl
no more dlams I'll make for fist

but only syetrax my dum

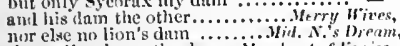

them all to leare the dam........erehant of lenice, iii. 1

thoul lay'st in thy unluillowed clam
you may go to the devil's dam.... Taming of sh

a devil and the devil's dam........

can clyy dam? may't be ...

tugether with the dum, comminit.

she is the devil's dam .................. Fe E Frror

pretty ehiekens, and their diem ......... Mtecbell, iv.

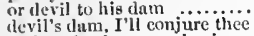

and as the dum runs lowing

now will 1 dam up this thy............
neither like thy sire nor dum $r$ in.........

carries no impression like the dlarm...

a

Coriolanus, iiti.

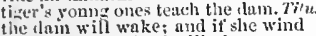

why then slee"s the devil's dan

lulf ine, and halt thy dam?

eursed hell-howds, und their dam!

Your unhallowed dam, like to

Det the devil and his daun haunt youl... Othello

DAMAGE-growth may damage me. Richard IMI.

nud all damage else, as honour.. Troiltus \& Cress. ii. 2

D.MISCUS-this be Damaseus...... Hesry VI. i.

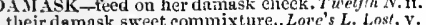

eunstant red, and mingled damask. As you Lilie,

as sweet as danask roses.. Winter's Tale, iv. 3 (song)
the war of white and dumask ...... Coriolanus, ii.

D.MASK-COLOURED-

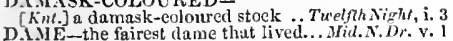

the tairest dames, that ever ...... Love's $L$. L. Lost

how now dame! whence grows.... Taming of sh. ii. I

unroosted by thy dame Pirtlet ... Hinler's Tale, ii. 3

both dame and servant: weleomed all of $\overline{\text { Errors, ii. }}$, 2

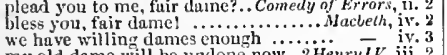

we have willing dames enough
my old dame will be undone naw

for my old dame's sake, staud ........

non pour les dames d'houneur d'user. Henry $r$ ?

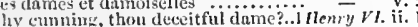

to wou so tair a lame to be his wife..

perftetions of this lovely dame ...

presumptuons lame, ilf-nurtired...2Hcary S'T. i. marriage with a dame of 'Frunce ...3 Henry $\%$ \% iii.

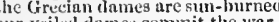

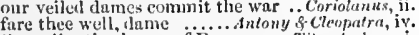
the gallant'st dames of Rume

that chaste dishonoured dame

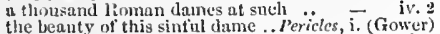

whose men and dames so jetted....

behuld yon simpering dame.

shut your mouth, dung.

Lear, iv.

and many worthy and chaste ditume.......

flanmed with dead men .............. Cymbthl

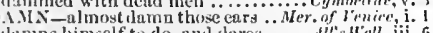

dlaning himself to do, and dare

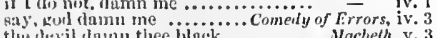

the resther the

thanin others, and lot this daun youi. Tim. of Ath. iv. 3

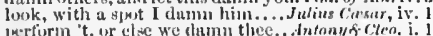

jertorm t, or che we ktamin the...

Cymletine, iii.

thin shith mot tamn my himl.

Hambet, ii.

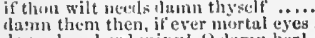

- iii. is

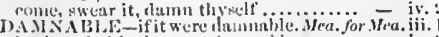
in tlus mind be is, vered

in the mind he bs, were dimlintile...

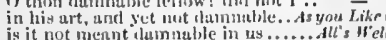

dammalie, buth sides rogne 1

Il's W'ell, iv.

deed you undertuke iy dumbible .. Rerhard $1 \mathrm{il}$. $\mathrm{i}$.

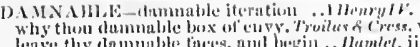

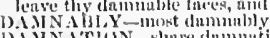

LIN ATION-slure dammition.

she will not ald to her clammation.

$t$ were damuation, to think

is sin, and sin is damnation........As y sutike it,

witness against us to damnationl .. King John, i

bmigle up damnation with patches

the author of the eervunt's dummution

the king guilty of their dammution

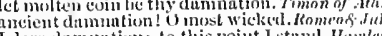

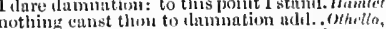

death nud dimmintion of it were at tedions -

a torment to by nuon the damised

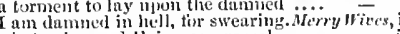

whit a dammed Epicurean rascal
the devil will not huve me dumnei

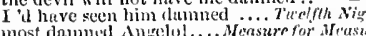

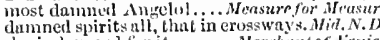

she is damned for it.......... Mer

I tor ty, fhink, you are elamned

$O$ be thou dinned, inexorable dis

art damed. Nay, $\mathrm{I}$ hoje (rep.). Asyou Lite it,

wit thou thest damned? God heip

though many of the rieh are dumned.. $A l l^{\bar{\prime}} \mathrm{W}$ ell, $\mathrm{i}$.

where dust, ant damned oblivion

where is th:t damned villain.. Tamint of

some putter-on that will be danned. Wiln

fortume, on his damned quarrel smilin:-

and damued, all those that trust them

can come a devil more damm

out, damned spot! out, I say!

it is a damned and a bloody work. . King John

by some dimmed hanl was rolbed

untread the steps of damned fligh

thon art danmed to hell for this

with a blot, damned in the book

damned for keeping thy word (rep.)

and that ilanmed brawn shull play

I'll see thee damned ere I call thee.

an old host that I know, is damned -

lhou abominable damned the glutton

damned first; - to Pluto's damned ink

if damned eommotion so ajpeared

thou damned tripe-visaged rascal.

vile, and dumned turious wight ......
prevented trom a damned enterprize

a damned death! let gallows gape

die and be damned: a figo for .......

that witeh, that dummed sorceress.. I Henry I"I. ii

die, damned wreteh, the curse ...2 Ifenry I'l. iv, 10

but to be lammed for killing him

outrage, end thy damned spleen ....

devilish plots of damned wituheraft.

protector of this damned strninpe

O thou damned eurl I sholl. Troilus \& Cresin.

fly, damned baseness, to him that. 'T

come, damned earth, thou comm

when dumned Casen, like a cur

a true election, she is damned n........

sithould I (danned then) slaver with lips -

O damned paper! black as the ink

danned Pisanio hath with his (rep.)

in war, danmed in the first berinners?

reveal the danned contriver of this ..

and damnel her loathed choice .......
dumned [Col.-and] as he is, to witness

justice done to Aaron, that damned Noor -
avaunt, thou damned doorkeeper...... Peric

thou'rt the dlamned dourkeeper to every

suggestion, plot, and damned praetise.... Lear, ii.

like dommed gnilty leeds to sinners

like dommed ginity deeds to sinner.

by doing rlamned hate upon thyself?

a spirit of health, or goblin danmed ....

villuin, villuin, sunilimg, danned villui,

a tyrannous and a danned light to their

it is a lammed ghost that we have

that his soul nuty be as dimmel

if dammed eustom lave not brazel it so..

in $y^{\prime}$ our noek with his dimned fingers.
is't net to the damnel, to let this cumk

inecstuons, murderous, damned] Dane

a fellow almost dumned in a fair wife...

what damnel minites tells he o'er ......

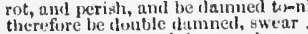

() damnerl Ingo! " inluman dor .......

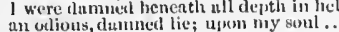

M.MiNlon-for 'Lis a tamnet slave ...... othello, v.

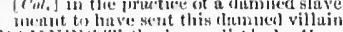

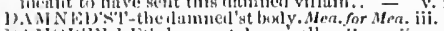

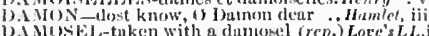

B. NUSE, -tnken with a dantomel (rep.:

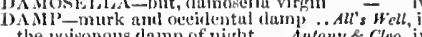

the prisonous damp of night..... Antony \& Cleo. iv.

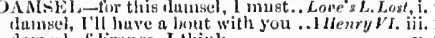

damed of l'runce, I thin

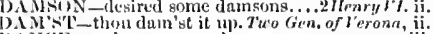

DANCE-to dinee on sambls..........

lie capers, he dances, lie has

onr dance of eustom, roinil ubotit.

I will clance and ent plutns.

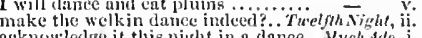

acknowlerge it this night in a dance...Much ado

out of my sipht, when the dunce is done
do you sing it, and I'll dance it......

let's have a dunee, ere we are ......... -

if you will patiently danee in nur...

with dantes and delight; and there - ii.

What masks, what dances shall we have

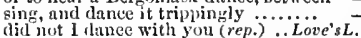

for rovels, dances, masks, and merry

and let them dance the huy

but shall we dance, if they desire........

we will nut danee. Why take we

wish the never mure to dance.

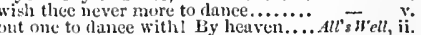

burthen of my woong dance ... Timing of Shrets.

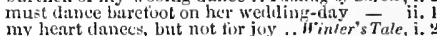

would sing her somg, and danee her turn -

when you do danee, I wish you a wave

Which dances with your daught ter?
she dunees teatly. So she does any thing

you would never danee ngain after ...
they have a danee which the wenclies

a delirhtiul measure, or a dance.....

und rnfbans dance and leap, the one
madam, we will dance. My legs

swear, drink, dance, revel

to dance out ot your debt

or to danee for your sake, Käte.

that I may sing and dance

I dance attendance here: I $t i$

there they are like to dance

ce $\ldots \ldots \ldots \ldots$.

those, that dance before me now... Timon of Ath. i. 2

more danees $\mathrm{my}$ rapt heart
hearts danee with comfort

make the sun dance. IIark you

very well become a soldier's danee.

ghe dances us goddess-like to her.... - v. (Gow.

of you all will now deny to danee?

the's there, that would not dance

some fo dance, some to make bontires... Othello, ii.

DANCED-that daneed with her....... Wuch sulo, ii.

but then there was a star danced........ $\overline{\text { in }} \bar{T}$ ir iv.

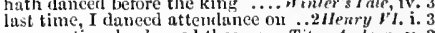

muny a time he danted thee on . Titus Andron.
even now of one I daneed withil. Romeo of Juliet,

D.NCER-me pith a good dancer.... Much Ado, ii.

kept his sword even like a daneer..Ant. F Cleo. iii.

DANCING-anly danceth at so harsh

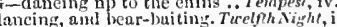

we'll hure dancing afterwards ........ Yuch Adn,
the dancing horse will tell you

other than tor dancing measnres.. As you Like it, y. I

the daneing banuers of the French ... King John, ii. 2

more than my daneing sou

therefore, no dancing. girl...........

on the meonstant billows slaneing. llenry foiii. (cho.)
with dancing is a little heated

say, I am dlancing; it in mirth ..... Hntony o Cloo. i. 3

thy deity abont onr daucing boat..... Tericley, iti. 1

you nut 1 are past our dancing duys.. - i,

DiNCiNi-scinocis

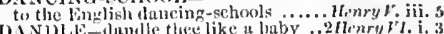

let the emperor lamble him tor . Tilus Inelrou iv.

aul liefumen to the Datie. Give yon.... Itamlet,

you cannut spenk of reason to the Dame.

king, fither, ruynt Dime: 0 , answer me..
tlis is 1 , llamlet the Dame ..............

danued inue, trink otl' this potion.

ann mare an antigue loman than a bume - v.

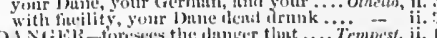


DANGER-run into no further danger. Temprst, iii. 2 il thy danger, if ever diznger regard thy danger, and along......... I do not without danger wal

into the danger of this adver

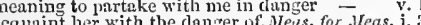

to save me from the langer that.

let the danger liplit upon your. iver, of

You stand within lus danger, do you not:

thou hast incurred the danger formerly

what danger will it be to $n$........

have lett of the danger to its

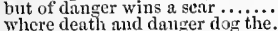

no death and danger dog the....

in a main danger, fail you

hare I run into this danger...........

save him frmm danger, do him love .o

what dangers, by his highness' fail of

age and dangers malke thee dote. Comedy of Err. v. 1

I doubt, some danger does approneh..... - iv.

mueh dauger do 1 undergo for thee..

nor tempt the danger of my true .

the therns and dangers of this world

toven in the javs of danger and of death

to find this danger ent ............ v.

some apparent danger seen in him

and unevoided is the danger now....

to worthy danger, and deserved death

tell us how near is danger

for I see danger and disolee

out of this nettle, danger .............

without the taste of danger and repr

where most trade of danger ranged

meet with danger there.

and with what danger, near the hear

ruminate the morning's danger.. Henry $V$. iv (eho.

a terrible and unavoided danger.... Henry $I^{*}$. iv.

climb, with danger of my life $\ldots \ldots .2$ Henry VI. ii. 1

but I in danger tor the breach of

your grace's person be in diulter

still where danger was, still there I .
not on thy danger and dishonenr ..3 $H_{\varepsilon} n r y$

with danger and with sorrow (rep.)

foretold-that danger lurks within.

men's aninds mistrust ensuing dange

daring an opposite to every dauger

and danger serves among them

and there seatters dangers, doubts.

I weighed the dlanger which my realims

a precipice for no leap of clauge

sover rounded in with danger...

address their dangers in..

luis heart to bring it int.............

was pleased to let him seek danger...

the extreme dangers, and the drops...

we'll deliver you of yeur great danger

when they are in great danger .... Jut

and dangers are to me indifferent

lis will he may do danger with......
danger knows full well, that Cæasar.

clouds, dews, and dangers come
the sides o' the world may danger

and we in negligent danger.

only seems to seek out danger i' the

only seeme to seek out danger i' the
nay prove his travel, not lier danger

what pain it cost, what danger!

nor seek for danger where there's...

her purpose was of more dinger.

your danger is ours. And our good.

the danger of the task you under

and danger, which I feared, is at

or my life iniply her danger?

the comodity woges not with

and to ne other pretence of daugu...

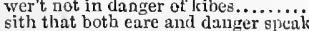

come to me (for now I spy a dangur)

so much fear and danger, that his person

neglecting it may do much danger. Ko

out of the shot and danger of desire.

and the diselose will be some d

fortune, death, and danger, dare, even

and ware a denger profith d

slie loved me for the daagers i had pa.... Othed

worthy othelle, I am hurt to dange

DANGEROU's-dangerous to wass. Two tien. of $V$.iv. what dangerous action, stood $j$..

for the revolt of mien is dangerous. Merry Wires, $\mathrm{i}$
D.ANGEROUS-dangerous eourtesy. Mra. for .Me'c.iv. 2 DAPPLE-dapples the drowsy east .....Much Ado, y. 3 with dangerous sense, might, in ihe.

speak ott half a dozet) dangerous words they are dangerous weapons tor maicls

dangerons rhyme, master, against

bethink me straight of dangeruus.

a very dongerous flat, and fital...

the guiled shore to a most dangerous sea - ili.

oaths that are not dangerous....As you Like il iv.

to be a dangerous and lascivious lio

ordanents of te, too dangerous

betimes; for 'tis most dangerous

semetime, neeounted derorous foliy. Macheth, jv.

to this dangerous argunent ...... King John, iv

know the meaning of dungerous majesty

feli] and dangerons to Grod of heaven

makes upon my land, is dangeron

my dangerous eousin, let your mother

read you matter deep and dangerous.1 11 ary $/ \mathrm{W}$. i. 3

tis dangerous to take a eold

to lay so dangerous and dear a trust

ventured on such dangerous seas . .

whose dangerous eyes may well be

diseovery of most dangerous treason... nenry $r$. ii.

brought to light this dangerens treasnn - ii

delays have dangerous ends....

our colours in this dangerous figlit

pernicious proteetor dancerous peer

as I do, in these dangerous days, wink
what's mere dangerous than this foud

these days are dangerous! virtue is..

more lonour, because more dangerou

induetions dangerous, by drunken..

it is a dangerous thing, it makes .....

would be so much the more dangerous

whieh you want, were dangero

dangerous and unsuspected Hastings

the aim of every clangerous shot

and dangerous suecess of bloody war

thrive I in my dangerous attempt ..

note this dangerous conception ......

new opinions, divers and dangeron

'twixt the dangerons shores of..

this place is dangerous; the time

my wind pipe's dangerous notes. Timon of Alt

turns my dangerous nature wild

rather physieal than dangerou.

if none, awake your dangerons lenity

a body with a dangerous physi.

than fear thy dangereus stoutness.

the rout, then hold me dangerous.

sueh men are dangerous (rep.) ......

honourable dinagerous eensequence..

Casar is more dangerous than he...

and wherein, Cwsar was dangerous .

a mourning Rome, a dangerous Rome

lovers and imen in dangerous bonds .

unfold a dangerous speeeh, thourlh

think you not how dangerous.... Titu

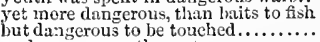

as dangerous as the tout.

lianied at home; "tis dangerous

stay with us; the ways are dangerous....

with turbulent and dangerous lanacy.

how dangerous is it, that this man gous.

for she may strew dangerous conjectures
vet liave I in me soncthing dangerous

tis danferous, when the baser nature...

I have fost him on a dangerous sea .....

DANGEROUSL $Y$-upon it dangerous

have practised dangerously against.

most dangerously you have with him.... Cor

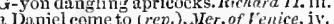

a seeontl Daniel, a Daniel, Jew! $\ldots$...
a Daniel, still say I; a secopd Daniel
A VISII-red after the Danish sword.

DANISII-red after the Danish sword .. Humter

from me greet the Dunish kin

O, this is counter, you false $D$

the Freach bet against the Danish

DANK - on the dink and dirty ...Mid. N. Dream, ii.

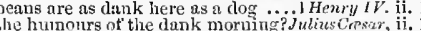

and viyht's dink dew to dry.... Romeo \& Julic

DANKISII-dark and dankisl vault.
D.INSKERS-Dinskers are in Paris

D.PIINE-Daphne holds the chase... Mirl. N.Dr.il.

or Daphne, roaming through.. Tam. of sh. 2 (induc
$\Lambda$ yollo, tur thy Daphne's love. Troilus \& Cresside, i
DAPPLED_poor dalpled tools.... As you Like it, ii. I Dardan, and Tymbria, nia, Chetas - (prologite)
DARDAN IAN-Dardanian wives...Mer. of Ven. ii. 2 DARD $A$ NI US-hark thee, Dardanius Julius Cresar, y. 5 DARE-that dare not ofter what I desire. Tempes!, iji. I

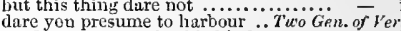
we dare trust you in this kind ...... - iii. now I dare not say $T$ have............ I dare be bold with our discourse ...... the folly ot my soul dares not present for his love dares yet do more than .. - iii. yet reason dares her? no ........... - iv. I dare swear he is mo hy pocrite ....... Nuch Ado,, $\mathrm{i}$. but who dare tell her so?........... - ii.. if you dare not trust that you see.. - iij. I dare make his answer, none (rep.)...

you dare easier be friends with me

that dare as well answer a man (rep.)

how you dare, with what you dare (rep.) - v.

and still dares me on .............. - iii.

eagle-sighted eye dares look upon....

your mistresses dare never coune in ...

and never dare misfortune eress her...Mer. of $V e n$

who dare searee show his head on the

I dare be bound again, my soul........

she thought, I dare vow for her .......All's Well,

that dare leave two together $\ldots . . .$. .

what I dare too well do, I dare net de.

nor dare I say, 'tis mine ..........

great ones I dare not give..............

she stands, touch her whoever dare..Tam. of Sh. nii. 2

I dare

1 dare swear, this is the right .........

(rep.) ...Winter's T'ale, i.

and cannot say, you dare not

to prove, I diu'e not stand by

to prove, I dare my life lay down, and wili....

if she dares trnst me with her

yet that dare less appear so ............

whom son I dare not call ....................

nor dare to know that which I know
$I$ slare, aud do defy thee ...... Comedy of

I dare do all tinat may oeeome (rep.)

look on't again, I dare not ......

'tis much he dares; and, to that....

what man dare, I dare

now did you dare to trad

I dare not speak mueh furthe...

who dares not stix by day.

who lives and dares hut say...

and dares him to set forward

how dare thy joints forget $t$

how dares thy harsh rude tongue.....

if I dare eat, or drink, or breathe ...

what my tongute dares not $\ldots . . . . . .$.

that they dare not meet eaeh.......... Henry 1

a thou art hut man, I dare.
and I dare well maintain it.

so dace we venture thee, alleit .......

that time and spite dare bring.
[Col.] and dare speak the truth

I dare say, my enusin William is.

and I dare swear, you borrow not....

I dare not fight, but I will wink...... IIenry

you must not dare, for sliame..

I dare say, you love him not so ill

shall so much dare the field

and ever dare to ehallenge this glove

by which honour I lare not deed ..

what these dastard Frenchmen dare...

dare no man ans

an uproar, I dare warrant ...........

dare you come furth, and meet us...

1 o no, no, no no, you dare not .. Twelfth Niglt, ii.

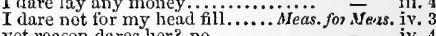

and ever not come there for the eandie $\bar{\gamma}^{\prime} L, L$.

1 klare, aud do defy thee ...... Comedy of Error

leart would tiviu deny, and dare not .... $=$ v.

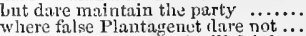

I dare say, this quarrel will drink.... 


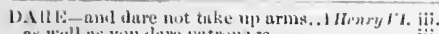
as will ns you liure patrimlage...

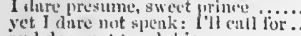

ind dhre not tunch his own...

intienry VI.

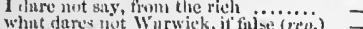

thongh suthilk lare him ................

than you dare exeeute

as would (hut thet they diure net)

dare any lue so bait to somul retreat
ay, here be they thut dure, and will.

or diure to brili tily firce so near

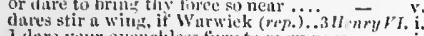

I dure your quenchless filly
Wharwick? dare you spenk?

dare he presume to seern us

witlout your speria! parilon dare not

yes, Warwick, Fitward dares, and leads

wren may prey where eagles dare not.. kith. $11 \mathrm{~L}$ I dare atventure to be rent ......... -

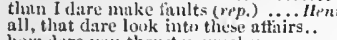

how dure you thrust yourselves.

any Englishmun duri give me

a womm (1 dure sny, without
my lord, 1 dare not muke myself

my lord, 1 dare not muke my'self so.
who dare cross them? heariag the.

I dure, and must deny i

and mate a sominder mun than ...

speak on, sir; I dire your worst.

my weak-hearted enemies dare ofitir

is all I dare now call mine own.....

who dare spenk one syllable (rep.)....

no man dare aceuse you

lic

fints dare sail upon her

lare avow her beauty and her worth

thme dare maintain. I know not whint

without a heart to inre, or sword

think we dare nut move.

thent dares not ehalleuge

but flure all imminenee........... - v. 11

we must not dare to imitate them... Timon of .1/h. i.

do rouder, men dare trust themselves

who then lares to be half so kind

who dures, who dares, in purity of

yet dare I never deny: your........... Co
whith, I dare vouch, is more than that

Wit cannot be, the Volees dare break..

for I dare so far free him

I dare be sworn, you were.

to dlare the vile eontacion of

it yout dare firlat to day, eome to

I ilare assure thee, that no enem

of 'Jewry dare not look upon you

for he darea ns to't ...................

if that the tormer care but

ant dare not speuk their knowled

1 lare not, dear (dear my lord (rep.)

I dite the dare come to us?

I dure, thereupon, pawn the moiety

I dnre you to this mateh

they clure not tignt with ne, liee.......

thit not dares to stride a limi

I the not call: yet famine, ere clea.

I dare speak it to myself

the lies low dares not deseive me

wlyo dares not stand bis foe

how dare you ghosts, nccuse

dare I undurtake for good lord.

peur the emperor's palaee dare .......

if Jove seray, who dares say

I lare dare the plants look up to to

dare avonch it, sir: what, fifty

itire, "njon the warrint of iny art...

thy she dare's nut come over to thee

if yout thre venture in your own behaie..

e thut dares apuroach, on him, on you

whyst! dares the slave compe hitlier

we can do, that dares love uttempt"

letwe's master, how he clares being dured -

chere lluw as soon as another man

hat he dures ne'er evenc back to ....

I dlure $110 t$, sir; my master knowg no
I dare stay no longer. Go, get thee

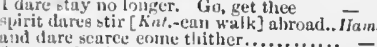

a!d dare scarce ente thither.

1 dare dnmution: to ther, dare.

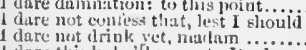

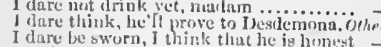

prunks they diare not ohow their husbund

linre not say, he lies any where
nore 1 will thin tor myselt I dare

beds, which they dare swear peeal
ay, ir you dare do yourelt a wroft

ny, if you dore do yourself a jrofit ....... iv. iv. 2

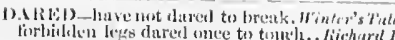

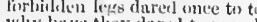

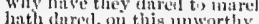

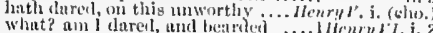

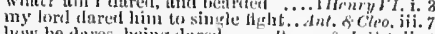

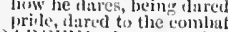

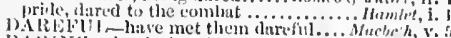

DAlit

henrt most daring on the carth.
not daringe the reports of my

so buld, or daring lutsdy, as t.

more daring, or more buile

eosursers dlaring of the slur.

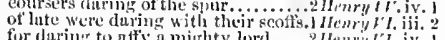

fur daring to affy a mirhty lero.

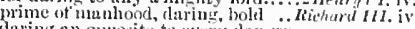

daring the everut of the teeth

DUpon the claring huntsmm that ha:

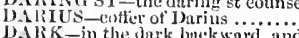

in the dark out of my way

we'll liave him in a durk room... Tuelfin

suy st thou, that house is dark?
I say to you, this louse is dark

ns rlark as ichoranee (

kept in a dark house .............

but oniy a repair i' the lark
funtastical duke of durk cormer

fartly by the dark night, which

that fallen am I in dark uneven way

a dark nirht too of half the day ... Lo
your light grows dark by losing

dark neels in eandles now, for clark

what's your dark meaning, mouse

rou do it still i' the dark .......
it grows dark, he may stumble

his afiections dark as Erebus......Mtr. of

1 shonld wish it dark, that I were.... -

may on durk to bed .

to the dark house, and the deteste....... $l^{-}$well, ii. 3

for, with the dark, poor thief

Inl kcep hin dark, ant sately locked

ind a dark and dankish vault.

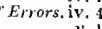

and yet dark night strangles the

tor a dark hour, or twain

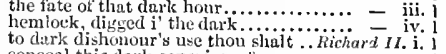

coneeal this dark eonswiracy.
fur it was so dark, Ifal, that

when it was so dark thou couldst .... IIenry IV. ji.

the poring durk, fills the wide .. Henry $b^{\circ}$. iv. (cho.)

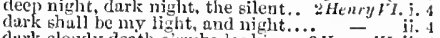

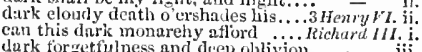

dark forgetfulness and deepr oblivion

eomfurt that the dark night ean altord

death, thut dark spirit, in's

is done, and we are timothe diark.... Antrony

rain and wind beat dark Deemb

iij.

this so darks in Philoten ull. Pericles, iv. (Gower)

here stoorl he in the durk, his sharp......

child Rowland to the dark towe

all dark and comfortless ..........

all's cheerless, dark and deadly

lore, and hest betts thic dark

which the durk night hath so diseovered

fi bird's nest soon, when it is durk

kecps thec here in thark to be hi

in the dark groped I to fiud ont them ... Hom

kill waen $i$ ' the dark! where lo the

D.13KEN-dnaleon not the mirth.

their blaze sliall carksen lim for

enrugh to durken all his gond he
than gain, which darkens him

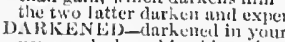

D.11k are darkened in this action ..... Curiol

darkening [ [nt.-darking] of the sun. Trail.

D.RKER-somewhat darker than 1luken's

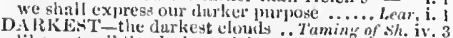

bike a star i' the dnrkest night.

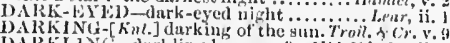

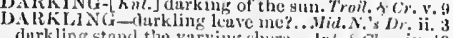

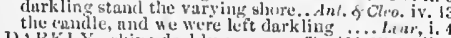

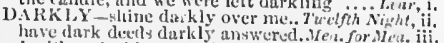

I will godarkly to work with her .... for dle

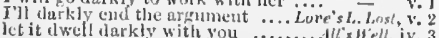

I spake durkly what l purposed........king dohn, iv.

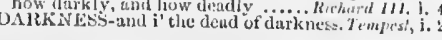

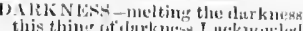

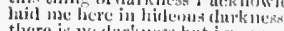

reme is no clark ness but ignoran

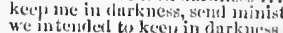

thingh you luve mit me juto darkne

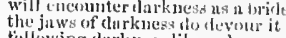

follewing dimtoness like a lirenin

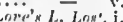

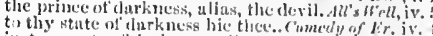

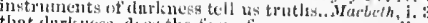

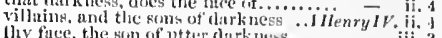

and let darkness of the the burier of .....

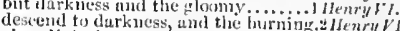

gives light in darloness, comntiort in ..

brenthe foul cumtariuus darkness in... - iv.

whom I, incleed, liave latil in farknes:

nuld flaky darkness breaks within
call her from this elond of dint:

hide their faeed even from durknes. Wenry $\% / 11$. y.

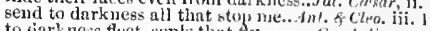

to atark gess flect, souls that hy

if she'd do the deeds of datknes

darkness and devils! saddle niy horses.

and did the nut of darkness with her

there's licll, there's derk a the gentlemun - iti.

feeked darkness like a drunkard reels. lime $-J$ iv

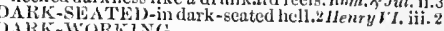

the eye, dark-working soreerers.. Comrdy of Err.i. 2
DARI NG

of his old experience the only darling...2ll's $H^{\prime}$, iii.

where is your darling Rutland?

Censorinus, darling of the people...... Coriolamus, ii. 3

curled darings [Kut.-dearling] of our .... Othello, i. .

make it a darling like your precions eye - - ii. 1

twas full of darncl; do you like...... incnry VI. iii. 2

DARRAIGN-dar'raign your buttle..3 Henry ri.ii.

for I know thou dar'st

call me what thou dar'st .. T'ro Gen. of revona, ii.

dar'st thou die? ........... Measure far . Weregtire, iii.

abide me, if thou dar'st; tor well ....... -

and dar'st not stand, nor look........ $=$ iil.

what dar'st thou venture?............... All's swell, yi.

swedr, if thoth dar'st. Nay, I dare. Taming of sh. v.
how dar'st thou trnst so ireat.... Commdy of Eirr. i.

arrest me, foolish fellow, it thou dar'st

ont dung st not say so, villain.............ng John, iii.

dar'st with thy frozen admunition.... hichard iv

thon thou, thou little better

seize it, if thou dar'st...........

but, Franeis, dar'st thou be bo
dar'st thou be as good as thy

dor'st thou be as good as thy

if ever thou dar'st ack nowledy
thou dar'st as wedl be longul

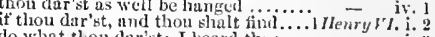

dar'st thou minutuin thet'ormer

marry, when thus dar'st........2nenry $V$. ii. I

suy, it thes durst, jirmul lord.......

this presence then dar'st go with ine = jii.

which dur'st not, no, nor cansi not rule =

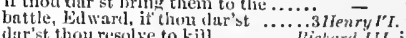

it' so be thou dur'st ne i this ......... Alichard III. iv.

dur'st thou, C'ussius, now leap in ..... Jutius Casur, $\mathrm{i}$.

that dar'st appear thus to us? ........

thy weapon nothing dar'st perfirm...... Titus Anel. ii.

if the the sur support a published traitor ...Lea's iv.

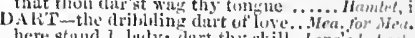

here stund 1 , luly; dart thy skill... I.ore's 2. Los',

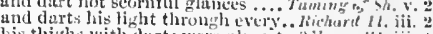

lis thighs with durts were almo
shaking the blowly clarts, ans he

aficl durts, we prove thas

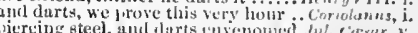

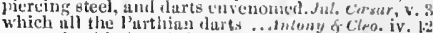

not is death's lart, being lanshed... Cirmbetase, iv,

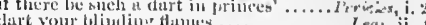

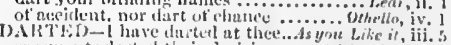

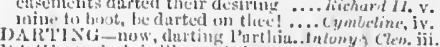

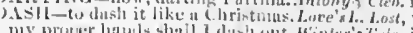

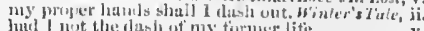

luad I not the dash of ny tormer life - v. 
DASH_unon her bravely at first dash.1 Henry I and would not dash me with their..2 Henryll1. ii. dash our late decree in

they dash themselves to pieces..... Richard III. $\mathrm{i}$. all your thunderbults, dasln him ...Julius Cresur, iv. DASHED-and dashed all to pieces....... Tempest, $\mathrm{i}$. look you, and soon dnshed! ............'s L L Lost, v. 2 作 and dashed the brains out, lum y $80 . . .$. Harteth, 1 . that we have dashed them to the.... Kint $J_{0} / h$, ji. reverend heads daslied to the walls .. Menry $l$. ini. 3
this hath a little dashed your spirits ... Ohello, iij. 3 DASHES-dashes the fire out ........... Tempest, i. 2 DASIING-dishing the garment ..Henry VIII. i. 1
run on the dashing rocks......... Romeo of Juliet, v. 3 ASTAR this out-llarn dastard?.. Richard II. i. 1 dogs! cownrds! dastards!.......... - i. 2 what these dastnrd F reuchinen dare

this dastard at the batt.

you a re all reerennts aud dastards..2 Henry $/$ I. iv. like a dastard, and a treacherous....3 Henry VI. ii. 2 permitted by our da

of foul clothes to Datchet-lane ...Merry Wives, iii. 5 by your two men to Datehet-mead

to the laundress in Dirtehet-mead.....
DATE-whose date till death shall... your date is better in your pre your date is better in your, py

's Tale, iv. 2 the almanack of my true date. Comed ly of Errors, i. 2 and will weep my date of lite out .. King John, but their clate is out

time thou gavest new date... .1 HenryI $\mathrm{V}$.i. 4 telling than thy kindness' date...... Richord III. iv. no date in the pye; for then (rop.). Troil. \&-Cress. 1 . reliances on his fracted date

and have the dates in compt ........ r. ritus and. i. 2 mas bide until your date expire...... Pericles, iii. 4 the date is out of such prolixity. Romeo of Juliet, i. 4 they call for dates and quinees

for my slort date of breath $\ldots$....... delst, broken] bonds........... Timon of Athens, ii. with a righteous kiss a dateless... Roineo \& Juliet, v. 3 and daub the wall of a jakes with him ... Lear, ii. 2 poor Tom's a-cold; I cannot daub it furtler - it. I DAUBERY _such daubery as this. Merry Wives, iv.
DAUGHTER_thee my daughter!...... Tempest, i. 2

she said-thou wast my daugh

of the king's fair daughter Claribel ....

the marriage of your daughter ..................

1 wore it at your daughter's marriage $\ddot{\text { would }}$ had uever married my daughter

not bless our Europe with your daughter
my brother's daughter's queen of T'unis

is the beauty of his daugliter

lis daughter and I will be king and queen = iii.

take my daughter: but if thou dos

use ine, and my dalnghter.

a daughter? O heavens?

when did you lose your daughter.

now, daughter Silvia, you

to steal away your daughter

whom your gentle daughter

sir Thurio, to my daughter............
stich a wife as your fair daughter...

the love I ever bore my daughter...

my danghter takes lis going grievouisly

baw you iny daughinter?

for your daughter's sake ...........̈.

not kissed your keeper's daughter?

nay, daugliter, carry the wine in ....

love him, daughter Anne...

my daughter is disposed of $\ldots \ldots \ldots \ldots$........

my claughter will I question

so curses all Eve's danght

nember, son slender, my daugliter

$m y$ daughter is in green

the doctor's marrying my daughter.

it Anne Page he my daughter.

how you should know my daughter..

turned my daughter into green......

my fatiler liad a daughter loved a man

1 am all the daughters of my father's
't is mect so, daughter ..... Measure for
nor gentle daughter, fear you not ....

to yuu, fair and gracious daughter

show Four wisdom, daughter

I think, this is your daughter..... ......Much $A d o$, iv.

with IIero, Leonato's short daugh te

that he loved my niece, your daughte

I will acquaint my daughter withal

daughter, remember, what 1 told you

for I have heard my daughter say

you heard iny daugliter tell you how
DAUGIITER_so your taughter says. Much Ado, ii. 's a pretty jest your daughiter to.jd us of niy daugliter says so: and the ecstacy hear fiurther of it br your daughter. your daurhter and her gentlewoman give yue this maid, your daughter? lut more one question to your daughter heart is sorry for your daurhter's death the old man's daughter told us all you, prinees, for' ny daughter's denth
I cannot bid you bid my daughter live my brother hath a daughter, almost well, daughter, and you gentlewomen be fither to your brother's daughter to marry with iny lrother's daughter? my child, my daughter Hermia .....Mid made love to Nedar's daughter, IIelena this is my daughter liere asieep ........ - iv. tell him, the danghter of the king pray you, sir, whose dauthiter? Cato's danghter, Brtus' Portia.. Mer will of a living daugh ter curbed by for his gentie danghter's sake....

fiuther, you a daughter, lost...

my daughter! O ny dueatsl (rep.).

stolen from me by ny daughter

stolen by mydanghter! justiee!....... his stones, his daughter, and his ducats = my daunghter is my tesh and

my daughter were dead at my foot.. that he liad of your danghter for that you are not the Jew's daughter because $I$ am a Jew's daughter 1 have a daughter; would, au his son Lorenzo, and lis daughter the duke's daugh ier, be bauished.. As you $\overline{L i k}$ for the dukc's daughter, her cousin. of her uncle than his own daught the two was daughter of the duke.... his daughter, the other is daughter to to keep, $h$ is dauthter company thou art thy father's daingter your daughter, and her cousin lively tougheres of my daugh (rep.) ..... he was a brother to your daughter.. good duike receive thy danghter even daughter welcome in no less
the daughter of Gerard de Narbon why? that you are my daughter?. but $i$ your daughter, he must be my mean it not! daughter, and mother. poor physician's daughter my wifel.. the eount, a poor physieian's daught. but that your daughter, ere she seerns instruct my daughter how she

to be your daughter's dower.......... what says he to your daughter?.... in the spirits of my daughter, thot

to bestow my youngest daughter...Tu eldest daughter to a husband, we set indeed had Baptista's youngest daughter his youngest daughter, beautiful ... Leda's fair daughter had a thousand you yet ever see Baptista's daughter?
the youngest daughter whom you a daugliter ealled Katliarine (rep. a suitor to your daughter, unto Biane toward the edueation of your daughter lead these gentlemen to my daughters if I get your daughter's love my daughter prove a good musician send my claughter' Kate to you? how speed you with my daughter? how now, danghter Katharine? (rep.)
Baptista, to your younger daughter assure my danghter greatest dower if $Y$ may have your dangh ter to
my daughter' Katharine is to be..... my daughter' Katharine is to love beween your dauthter and himself he beareth to your daughter, and ..... and pass my daughter a sufficient .. send for your daughter by your.
his daughter is to be bronght by

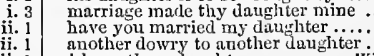

$\begin{array}{ll}\text { ii. } 1 & \text { another dowry to another daugh } \\ \text { ii. } 1 & 1 \text { have tluree daugliters } \ldots \ldots \ldots . . . \\ \text { ii. } 2 & \text { a daughter; and a roodly babe.... }\end{array}$ a daughter; and a goodly babe $\ldots . .$.
DAUGHTER-daughter of a king. Winter's Tule, iii. 2 a great king's daughter, the motlier
here beholding his daughter's trial.

ii. 3 forth to crows thy baby daughter...

ii. 3

ii. 3 fie, daughter! when my old wife whieh dances with your dauthter? lie says, he loves my daughter
read, as 'twere, my daughter' but, my daughter, say you the like I give iny daughter to him, and will your hand; and, daughter, yours ..... have married a shepherd's son $\ldots$ lave his daughter come into graee! nome of your daughter, nor my sister whose daughter his tears proclaimed might I a son and daughter now have and with a shepherd's daughter...

the king's daughter is tound

certainty, to be tlie king's daughte... for joy of his tound daughter ........

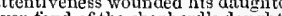
over-tond of the shepherds daughte that which my daughter caine to and from thy admixing daughter took graees upou my daughter's liead!....
is troth-plight to your daughter.

your wives, your daughters, your

command thy son and daughter.

'tis true, fair daughter $\ldots . \ldots \ldots \ldots \ldots$.

my daughter weeps: she wili not part beshrew your heart, fair daughter

ancl your f'airest daughter, and mine _- iii

which was daughter to king Clothair.. Henry ${ }^{r}$. i. lady Lingare, daughter to Charlemain deseend unto the daighter

ofter him Katharine his daughter... his fairest daughter is containinate... his daughter, first; and then ........ thereupon, give me your daughter
hy birth a sheplerd's daughter ....... nor yet saint Philip's daughter. proffers his only doughter to

pry name; and daughter to your Reignier, see tlyy daughter prisong. daughter shall be wedded to my king gained thy daughter princely liberty my daughter shall be Henry's, if' le
ah, Joan, sweet daughter Joan ...... a poor earl's ditughter is unequal ..... daughter un to Reignier ......2 Henry
dnkedoms for a duke's fair daughter gave two dukedons for his danghter daughter unto Lionel, duke of Clarenee she was, indeed, a pedlar's daught ter married the duke ot Clarence' daunghter nay, bear three daughters ...........3 Heury VI. ii. 1 than when my daughters call thee.. only Warwick's daughter shall be thine will hence to Warwick's otler daughter my daughter shall be thine .........

When he sacrificed his daughter........ unto their servants, daughters, wives dnughter, well met. God give your. danghter, well met. Cod give your.. marred to my brother's danghter young Elizabeth, ny brother's danghter for my daughters, Richard, they shill you have a daughter, called Elizabeth -
confess she was not Edward's danghter I love thy danghter. My danghter"s thy daughter, aud do intend to make her not the way to win your daughter .. -

ii. 1 your blood upon your daughter ......... your daughter is made queen ......... calls your beauteous daughter, wife. thy daushter to a conqueror's bed.... not thy beauteous prineely daughter l in your daughter's womb I bury them shall I go win my daughter to .....
slall espouse Elizabeth her daughter ravish our daughters? Hark, I hear.
sir Thomas Bullen's daughter .... Henry certain, the daughter of a king ....... duke of Orleans and our daughter Miary whether our daughter were legitimate a knight's daughter, to be her mistress'
our chiaste loves, his young daughter a queen grace, or a daughter a goddess. Troilus \& Cresside with one of Priam's daughters

Dionned, with Calchas' daughte

and daughters of the game $\ldots . . . . . .$.

a token from her daughter, my fair.
where's your daughter? she comes 


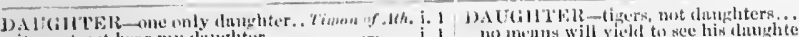
it mant luot bear my ding liter.

proy you, duwshter, sing

Numn's dhughter's son, who, atter great -

lulp to ravish your own danghter

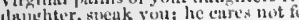

liek

cento duurlute rlink

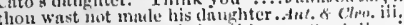

his danghter, unt the heir of his .... (ymtrelios,

not find me, dluginter, ufter the slamice

would I were at mothoril's dimglite

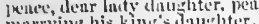

marrying his king staluhter.

aml hataghter whing he mit respect

thent nuy prefier yout to his dangh

where is one thoghter? she linili

your lluughter, whom she bore in hand

your ilumber,

thint parigen, ehy dwughter.

my dnughter! whint of her

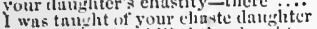

l'osthumis, that killed thy daurhter

of tenter air, thy virtuous daughter

thy uangled danghter here.

you tubl my claughter

(1) slny his dutughter with his own right

sluin thine only daughter thus?

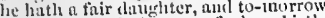

our chungliter, in huneur of whose birth.

nuw your honour, clnushter, to explain..

(for daughter, so you are), here tuk

se:ated, and his dlughter with lim .....

iroun my daugliter this I let $y$ und

mew to my dampler s letter ...........

what do rou think, sir, of my elauglater?

my daughter, sir, thinks very well of you -

theu hast bewitcherl my daughter

eones my dnughter, she can witness it ..

Antiochus um his daugliter's dend - iii. (Gow )

sle was the daughter of a king

hath our Cleon one dunghter........

hims chanee my taughter is not

perfurm to your sole daughter ........

se his daughter, all his lice's delight-iv. 4 (Gow.)

tw fiteh his daughter hume ........ - iv. 4 (trow.)

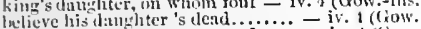

display his daunter's woe unit.

display his damghter's woe anil
lice where his daughtor dwells

lose where his dalughter dawer and $n$.

loss of a belorel danghter and a wife....
surh a ove ny daughter mi lit lave been

a king's daughter? and called Jarina?

my mother was thic daughter of a king

this cannot he; my daughter's buried.

I am the danghter to king Perieles...
is it no more to be your duughter..

is it no more to be your you are my diangliter

with thy dungter's, call, and give then

Irevail, were it to woo iny daughter

the fair-betrothed of your daughter...

son and daughter shall in Tyrus reign .

Antioeh and his dalyhter you have -

hit quecr, and daughter, seen

our danlgliters several dowers
rivals in our youngest daughter's love

tell me, my duugliters, sinee now we

what says our second daughter...

as thou, my sonetime duughter.........
my two duughters' dowers digest thi

yeungest daughter does not love thec....

fith rivalled for our daughter

thy dowerless daughter, king, thrown

you, sirrah, where's my duughter? ....

yay, my lord, your daughter is not weil

thic duke him:clf alsu, and your daughter

tell my dumister I would ypeak with

lists banished two ot his daughters

two enxeombs, and two dalls

mulest thy daughters thy mother

What kin thou and thy inughters are

how now, danghter? what makes
are you our daughter? Come, sir

are you our daughter? Come, sir
false persuated I ladi duaghters

yet have 1 lett a daugliter (rep.)

and such a daughter, shoulil sure to thic

acquaint my dumbter no further.........

not to give it away to lis daughter

buth lie and she, your son and daugiter

sont and daughter fount this trespass...

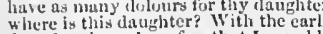

where is this dalughter? With the earl

I pr'ythee, danghter, lo net make me nal

my tlesh, my bluok, iny daughter

if it be you that etir theec daughter

wish, thunder, flre, are nuy daughter

with two pernicious laughters joinci

given ull to thy two dlugghters? .........

on thy daughters i fe hath no dunglite a louncs, fut his unkind daugliters

this tlesth berot therse felicun tiuughter

in all your daughters harl com
his daighters oeck his deuth

prince lonuthin, rou shall stay with lins mems will yedel to see his dimghter.

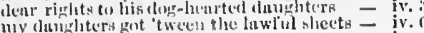

nir, your mont thear dunghter ............

theu hast one thinghter, who recto

hath lost, he and his dimghters ta end

your elikest dampliters have fore-iloomeal

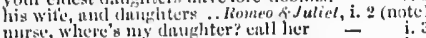

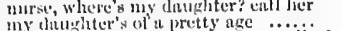

Imy churhater's of thet pry age ....ilied -

on the far langliter of rich Conpulet

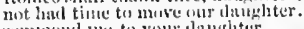

(4) muend me to your danghter......

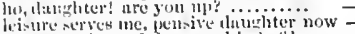

hohl, limghter; I lo sug a kind of hoge

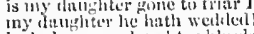

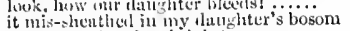

this is my thanditcre jointure........

these blazes, denuhter, giving more light

[Kut.] from tlis time, dawhter, be ......

in obedience, hat th my dninghter shown ine -

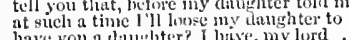

have you a thushinter? I have, my lord

still harping on iny linght

meeting between hins and my diugliter.

onc fair daughter, and no more $\ldots \ldots \ldots .$.

still on my daughter. Am I not i' the....

blood of fathers, mothers, daughters, , on
they say, the owl was a haker s daughter

they saly, the ow was a hakers dumghter
stewaril, thith stule lis master's daughter

look to your house, your daughter .... oinello,

hearll me say, my ilumhter is not for thec -

your daughter mol the Moor are now ....
that your fair diughter, at this odd-even

your duughter-if you have not giveu her
trust not your claughters' minds by what

where hast tlsou stuwed my daughter?

iny elaughter! O my daughter! ilead?

charged withal), I won his daughter with -

this tale would win my laughter too...

I am hitherto your daughter

D.

you might be my daughter-in-law

All's Well, i.

Youre sent you a daughter-in-law

DAUNT-a little diu enn damt.... Tuming of $\mathrm{Sh}$. $\mathrm{j}$.

discontent daunt all your hopes.

itus. Antrort. i.

unspotted is not casily daunted ...

What, are ye damnted now? now will - iv.

a braver ehoice of dauntless spirits. King John, ii. I

put on the dauntless spirit of re

DAULIIN of Lewis the Dauphin ... King John,

is the young Dauphin every way .... =

speak then, prinec Dauphin ............

O noble Dauphin, go with me to

of the Damphin's love, is much morc

away toward Bury, to the Dnuplim.

the pauph ad the Dauphin.

the powers led by the Dauphin .......

the Damphin is ton wilful opposite

shalt find it, Dauphin, do not dout

where is my prinec, the Dauphin?...

the Dauphin is preparing litherwarl
the Dauphin rages at our very hecls

sinee came from the Dauphin

the messengers sent from the Dainl hin. Ifenry

Detr

tell us the Dauphin's mind

tell us the Dauphin's mind ........... -

glad, the Dnujhin is so pleasant with us -

but tell the Dumplain, I will keep

gtrike the Dauphin blind to look ..... -

re'll chide this Dauphin at his father's -

and you, prince Dauphin, with all

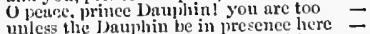

for the Damplin, I stand here for him -

the Jamphin, whon ot succour we

the Dauphin longs for mornimit.

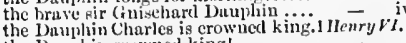

the Dauphin erowned king!...

to win the 1)amphin's grace........

I'll hale the Douphin headlong ......
either to quell the Jauphin utterly.
where's the printe Druphin? I have

Where's the printe banhin? I have -
stum! thes us I ta uphin in my place.. -

where is the lounshin? cone, come from -

tis the r rench louplain sueth to.... =

the lauphain, witls me Joad la

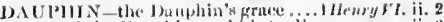

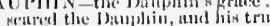

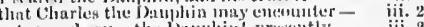
enter, mul ary-the lhupling! presently the Dumphin, well-appointerl ........

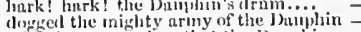
inighticer irosps than that tho Jayphis

when from the B:mphin's erest thy.

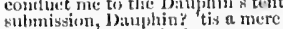

Chorles the butuphin is a proper min

nud the Juyphin bave bet jugpling

smel here at hand the Dunbun, and his - v. 4

be wom into the Dauph thing hasids.

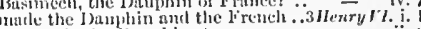

athil made the Jumphin stsel .........

Wy Jav? Here, sir (repo)

sunte bigeons, invy; a conple

well conceited, Lasy; ulunt thy (rrp.)

there ure many eompluints, Bavy

sprend Davy; spread Davy (rep.)......
five master Bardolph some wine, Davy

an' fmight ree you there, Davy......

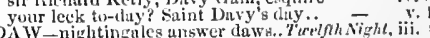

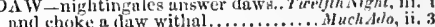

and dawe, and muldens..... Love's L.Lost, v. 2 (song)

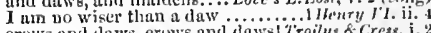

erows and daws, erows antl daws! Troilus d Cress. i. 2
then thou dwell'st witl daws too?. . Coriolasus, iv. 5

upon ny sleeve for daws to peek at....... Otivelin, i.

next day, ufter dawn, doth rise .........Hehry V. iv.

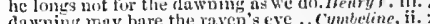

but dawning day new confort.... Tilus Andron.ii.

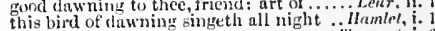

D I Y - O woe the day! ................ I'enpert, $i$.

what is the time o the day?........... - i.

that burn by day and night.............

once a day belold this

as fiesh tis the first dlay $I$ wore it

as I lope for quiet day's, fair issue

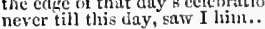

how's the rlny? $\ldots \ldots \ldots \ldots \ldots \ldots$..............

atfection ehains thy temler clays. Taro fien. of $r$.

that every day with parle encounter me

uucertain glory of an April dity........

that hour o'erslips me in tlae day

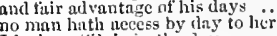

I look on Silvia in the day

there is no day for mic.

have you been these two ilitys hivitcrin

$=\quad$ i.

the other day with phating yours $\ddot{y}_{0}$

by day or nicht

this ray rlicumatie day

and you shall one day tinl it

my sins at the day of jutloment...

alas the dny! Good heart

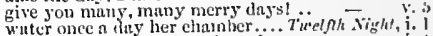

lie liath known you liat three days... - i.

put down the other doy witl

alns, the layl d...........................

o the twelfth day of Deecmber

his eyce do slow his days are almost

both day aud night disl we wiö....
antl died that day when Viola

that day, that intede my sister

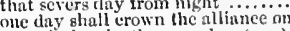

the rain it raineth every dny (rep.)

we ll strive to please you every lay

this day my sister should the cloister

numd those eyes thic brenk

I lave sat liere all day ................

ii. 4 many times a day, if not many iliy

I erave but four days respite $\ldots . . . . . .$.

within these two thys he will he here
for he this very day receives letters.

nay sleep the sommler nil the mext

well, you'll answer this one lay.....

1 hane to see you one day thted with

your yrace is the contly fow weur every day -

presently go learn their day of narriage -

uhy, every day to tomerrow; eome...

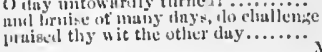


DAY - the gentle day, before the wheels.Much ddo,v. 3 DAY -once a dluy I'll visit the.... Winter's'Tale, iii. 2 this day to be eonjoined in the

but, by this good day, I yield upon.

happy days hring in another moon. Nid. $\overrightarrow{N .}$.' $D r$. i. four days will quiekly steep themselves

uson thatl sy erther prepare to die in the shape of Corin sat all day

and tarry tor the eomfort of the day

interded for great Thesens' nuptial day

not so true unto the day, ns he to me

effect this husiness ret ere day .....

corne, thou gentle diny! tor it but ...

wy day's approach look to be visited

since we have the vaward of the day

is not this the day that llermia should

a day during his life: he eould (rep.)

gixpenee a day, in Pyramus, or nothing

joy, and fresh days of love, accompan

joy, and fresh days of love, accompan

now until the break of day, through

one dav iu a week to touch (rep.......... Love's L. Lost,

not be seeu to wink of all the day....

make a dark night too of hali the day

four days ago. Let's see the penalty.

aftliction may one day smile agai

appertaining to thy youug days..

the merry days of desolation that $I$.

what time o' day?..

'twill be thine another day

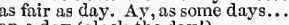

nek the day!).

I did conferse this quondam duy with

in the pasteriors of this dity...

the posterior of the day, most ........

in the posterior of this

(to the manner of the days)

I have seen the day of wron

a twelvemonth and a day $I$ 'll mark.

from day to day visit the speeehless.

you shall seek all day ere you... Mlereh. of Venie

you spurned me such a day

if hou repay me not on sueh a day

come home a month before the day .

alack the day, I know you not .........

sloke with me this day, and hat

a day in April never eame so sweet

pause a day or two, before you hazard

been this day acquitted of grievous

and be a day before our husbands...

it sounds mueh sweeter than by da...

if she sheuld sing by day, when every

if she should sing by day, when ever
'tis a day, such as the day is when...

tis a day, such as the day is when...

being two hours to day (rep.) .........
gent lemen flock to him everry

so young and so villanous this day living -

thus men may grow wiser every day

within these ten days if that

all this day to look you (rep.)

that we have seen better days

I was seven of the nine days out

alas, the dayl what shall I do
as he did the day he wrestled?

ask me, what time o' day

and $I$ set him every day to woo me...

and corne every day to my cote

and a day. Say a day, without the...

to-morrow is the joyful day, Audrey

that every day men of great............

by our remembrances of days foregone. $A l l^{-}$s $W e l l$, by such a day, and hour

'twill be two days ere I shall

will, day by day, come here for.........

come, night; end day for, with

and writ to me this other day............

this exceeding posting, day and niglit

made the days and night

I do hope good days, and long... Taming of $\overline{\text { Sh}}$ re

and every day I cemnot come to woo

I'll crave the day when I shall ask.

this is the 'pointed day th

ere three days of mass; which whith......

be wooed and wedded in a day

looked for him this day in Padua.

farewell for ever and a day.

the night in storms, the day in coid.

such a day to-morrow as to-day .. W
in those unfledged days was my wife

he makes a July's day shor't as

departure two days ago

one of these days; and then you' $\dddot{d}$...

nor night, nor day, no rest ..........

this ill day a most outrageous.....

shall his day's hard journey
I never saw the heavens so dim by day -

'tis a lucky day, boy; and we'll do ...
sir, it is three days, since I ........

your merry heart goes all the day - iv. 2 (son.

as it were the day of celebration......

take on me the hostess-ship o' the day

might become your time of diay

iii. 2 the lottest day prognostieation proclaims

to firht with me this, ever sinee.

I'll linit, thee this day, to seek ........

this very day, a Syracusan merehant

passage of the day, a vulyar eomment

locking me ont of my doors by day

turn back an night and day

O most unhoppy day?...

this day, great duke, she shut.

ne'er may I look on day ...

neither night nor day, hang npo ....

so foul and fair a day I have not

o' the self-same day, he fiuds.
runs throurh the roughest day.

where every day I turn the leaf...

they met me in the day of succe.

by the elock, 'tis day; and yet

or the day's shame, that darknes.

in this day's eouneil ..................

good things of pitiful day

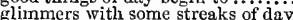

under coldest stone, days and nights

see thy wholesone days again?

died every day she lived

the days are near at hand

petty pace from day to clay.

the day almost itself professes.

so great a day as this is elaeaply.
by night, or day, when I was got

who dares not stir by day....

commander of this hot malicio

in favour she shall give the day day

will quake and tremble all this day.

and this blessed day, ever in ........

二 ii.

$=$

$\begin{array}{r}\text { v. } 1 \\ \text { i. } 3 \\ \text { i. } 3 \\ \hline\end{array}$

stand full fure of this for forilous day

as I have done this day .............

the fortune of the day quite turned...

the eheck of such another day ......

your lordship good time of day ......

join not in a hot day it be a loot day, an'...............

alas, the day! take heed of him.....
fubb'd off, from this day to that day

the other day; and, as he said to me

cannot go but thirty miles a day ....

abridge my doleful days !............

aud the very same day dia 1 fight...

by this mad days that $I$ have spent!.

upon his coronation day, sir

O the days that we have seen! $7 . .$.

the bruises of the days betore .........

open as day for melting elarity......

congealed in the spring of day .....

sings the lifting up of day $\ldots a . . .$.
worn in heat of day, thut seaids......

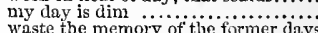

lost the other day at Hinckley fivir?.

Harry's happy life one day ..........

welcome these pleasant days! ........
lie woukl make this a bloody day

as it were, to ride day and night

is at this day in Germany the kings of France unto this day

comes o'er us with our wilder days ...

worm-loles of loug-vanished days..

the pronise of his greener days

our expectation hath this day an end

and on that disy at noon .............

two long days journey, lords, or e'er
whose office is this day to feast .......

how goes the day with

be lords of this loud day

it Lewis do win the day, he
behold another day break in
feeble, and day wearied sun

feeble, and day wearied sun....

by your assistance win the day

the day shall not be up so soon $\ldots \ldots \ldots$.

each day still better other's happiness

upon saint Lambert's day ........

we have stayed ten days, and hardi $\dddot{y}$

stay yet another day, thou ..........

one day too late, I fear, my lord (rep.)

and death will have his day $\dddot{\text { li.......... }}$ like an unseasonable stormy

blows with thee for our day of doom

state and inelination of the day....
nirlit, to Bolingroke's fair day

night, to Bolingbroke's fair day
alaek, the heavy day, when suel

that honourable day shall ne'er...

assigu you to your days of trial

keep him safely till his day of triai.

senties tor your days of answer........

alack, the heavy day, that I ........

shall feel this day as sharp

shall show us all a merry day ......

like Hallowmas, or shortest of day $\ddot{3}$

gay apparel, 'gainst the trinmph day

which elder days inay lappily bring

never see day that the happy sees.....

thy head by day nor light..............

on Holy-rood day, the galliant.

to demand the time of the duy

..1Henry $I r$. i. 1

thieves of the day's beauty .

rated me the other day in the
well then, once in my days $\Gamma$ 'li $\mathrm{b}$.

we these days, or fill up elironieles as you shall see in a summer's day..

ma foi! the other day methought ...

will it never be day? I will trot ....

your dagger in your cap that day....

join together at the latter day
jos.

he let lim unt live that day to sec....

wiuding up days with toil

twice a day their withered bauds...

the day, my friends, and ull things

this day's ealled the feast of (rep.)...

pleasest, God, dispose the day! .......

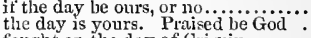

fought on the day of Crispin,
wear the leek upon St. Tavy.'

as you shall desire in a summer's day

by this day and this light, the fullow
your leek to-day? St. Davy's day is

I will peat his pate four day

of this good day, and of this . gracious
that this day shull change all griets..

yield day to niglit! coinets

haleyon days, since I have cintered...

to survey the Tower this day .......

I will have for this day's work........

this day is ours, as inuly more ......

by whom the day is won
after this golden day ot

the dily begins to break, and vighit is

live asunder day or night

this das ink blood another day.

this day, in argument upon..........

his days may finish ere that ........ on which day, my lord of Burguncly

by whom the day is won ..............

huviug all day earoused

ii.

iii.

iii.

iii.

ili.. 3

iv. 1

iv. 1

iv.

v.

v.

v.

v.

v.

i.

i. 22

ii. 4

ii. 4

iii. 4

iii. 2

iii.. 2

iv. 1

iv. 3

iv. 3

iv. 4

iv.

v. 3

r. 3

Henry V. i. 5

i. 2

ii. 4

iii. 4

iii. 6

iii. 6

iiii. 7

iv. 1

iv. 1

iv.

ivi

iv. I

iv. 3 


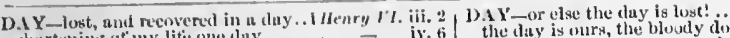
ollorkeniang of my lite one dluy

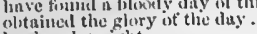

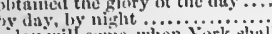

a tay will eme, when York shiil

mongst her miniens t'inther clay ....

correct him tirr fis timls the uther day

and the day of eombers shat be the last

Ix-ter sport these sevell yeurs' day

lit nerer elny nor night iut

clenr ns bay; 1 thank tood ...........

gows ns, lxeture this day, a many (rep.)

in these dauteruus duys, wink at.

sliatl one dlay muke tlic eull ot

ufter three days" open jemune

prite divg in lier youngese clay.

hith the brightest day u elond

my light, and night my day

crery one will give the time of diay

the biswns each day revolted

these day are dawigerous

thich ha here all iny

vithin tomutken dily's, at Bristol...

thece days longer, on the pain of

if, after iluree day' spate, thou .....

blathing and rem these two lases

whipled three minket days toretion

nre alive ut this duy to testify it......

theses tive days liave I hitl ne

I have tat no meat these five dayo
this dayy Ill wearalolt my hurgouet

flames of the last day, knit
we will live to see their day

we will live to see the dany .....

a glorions day: st. Alban's battle..

nul more such days as these to

live fin prison all my days.....

tell day's ago 1 drowned

no hope to win the day ..............

have kept that gjory to this day

tly poor sire with his bridal tay ....

neither eall it perfect day, nor night
brins about the day, low many days

so miny day's my ewes have

huturs, days, weeks, months, and yeurs

and this day hadst kept.

ten days wonder at the least (rep.).

tuten in former golden days .........

often ere this day, when I.

ghall be the day, if Warwiek ......

luse, that now hath won the day

in devotion spend my

the rnidst of this bright-shining day

like the owl by day, if he arise

will surt a pitchy day for thee........

days, $f$ am determined to (rep.) .....

from wheace this present day.

good time of lay un to my gracious

good time of hat unto my

my day, my life. Bluek night (rep.).

good time of day unto your royal....

Eorne two days sinec, were worth $\ldots . .$.
those busy clays, wbieh here you urge

thy happy days before thy cleatl. ....

the day will eome, that thou

1), hut remember this another da..........

to buy a world of happy day"s.

now have I done a goud day's work.

I every day expect an enbassage...
of tay? Huppy, indeed, as we (rup.).

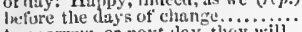

to-morros, or next lay, they wili....

aceursed and unumiet wramgling days! =

With health and happy or two, your highnes.........

evea to the gencral all-cuding day

this bame very lay, your cuenles.

the Tower? the day is s]jent

this day thonse cnemiea are pult

gy,

not yet set dinwn this dily of triumph

this clay laal plotterl

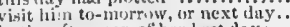

in the afternonon of her test days

a joyrul timse of duy! ........

abstruct and resord of tenlious days

the nightst, and fint the ri:ly

wa lave many goorlly lays to

duy, yield me not thy li, hit..........

this is All-souls' duy, fellow's (rep.).. is the day, whereio I wishet to tall. this $\mathrm{All}$-souls' day to iny fearful ...

thither, is but oue day's mar

fior tu-morrow is a busy da

to lier of a goxdly day to-morruw ....

awake, and win the day! ............

it is nut vet near clay ..................

did you not of late disys by

sine the this lay

whit time o day is $t, \Lambda$ perminth

leat on our slays to age!.........
7 plenty, these blowily day's agnin ........

cvery day it would infect his e

by lay nnt night, lie \& traitor

I have this day reecived a traitor make tlem one day groan tor

the king will know will one day onen.................

ndjourn this eourt till further day

the third day, eomes a frost.....

in eeleliration of this day with shows

thit cham their othees this day ...

this day they has been lost..........

businded, this day, sir, I may telt

astw this tate days, our neighbours

like to dance these three days

many duys shall see lier, and yet no day -

this itay, no man think he has

swore the other day, that Troilu

the livelong day breaks.

were your hays as green is $\dddot{\Lambda} \mathrm{jax}$

alis, the day, how loved you night and day

as suin to day, as turtle ......

ay, and good next day too

a whole weet by days...................

doth this day lic on lis fair worti

t $t$ is hut carly days ......................

never 's my day, and then

you inay have every tay enough

prove onivous to the day $\ldots . . . . . . .$.
I shall lenve you one o these days

now is my day's work done.

to close the day up, tector's

the other flay of a bay courser I rorle

suctestion of new disy this month

die then, that day thou art hamsed

ay, hut the days are waxed...........

his days are foul, and his drink.
if after two days' shine

the root time of day to you,

your lordship this other day serit....

he gave me a jewel the other day $\ldots . .$.
one day he gives us tianonils, next day -

we have seen better days

spiecs to the April tay again.......... -

where fecl st thou o day a

the tortunes of his furmer da

once a day with his embossed.......

' $t$ is not fuur days gone, since........

when for a day of kings' entreatics

as when our nuptial day was dune

to a second day of audience...

in that day's teats

but with a grain a day ...............

could I meet them but once a day.
well saved me a day's journey

the day serves well for them now

os finr as day does night.

a merrier day did never set.

there have sat the livelong

upon a raw und gitsty day ........

glike hay, see Brutus at his house.

and ere day, we will awuke him

it is the bright day, that brings...

get yout to berl again, it is not duy

$U$, then, hy disy, where wilt thou.

that firet the clouls, are messengers of day -

two lions littered iu one day

this day, a crown to mighty Cessur

and drawing dilys out, tiat nen

o woetiul day! $U$ iraitors, villains

Getavins, 1 huve seen mure days than

the enemy incereaseth every day

as this very day was Cassius born....

the entel of this tlay's business (rep.)

this day 1 breathed tirst

Cassilus duy is set (rep.)................

I Elall have ptury by this losing tain

jorn that diny when I forget........ Intony s.e.

my salaul days; when I was green....

but, next tlay, I tuld him of invielt.

we did sleep day ont of' coumbeitance

Jon'll win tho lays upon me.

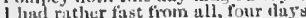

the gexldess Isis that day apmenred

the gordess isis that day apper

muke this a happy day to Antuny! .

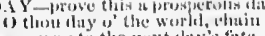

this last day wiss al slirewil one

most heury day! Nay, kond ny

ghown to thee such a declining dus.

the bright day is dence, am we

and, withan the dhy, your with

ant every day that comed (ripeaimil) -

almost mornmg, is't not? 1ny, lay tom

make pastine with us nday or t

may not i gline thither in a day?

a gooklly day not to keeplitistas

day, night, are they not but in tsritioin

hath tendered the inty of the du

fircest:a! him sit the costing chat

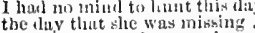

it is a day turned strangely......

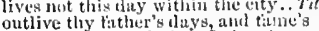

in our election this day, $t$ pive thee.

the dismal'st dlay is this, that e'er...

rll tind a day to maseacre them all ..

but dawnine day new comitort ....
this the day of doon for Barsianus

pass the reinuinder of our hateful days? -

see that $y^{\prime}$ ou take no lontorer days
by doy and night to uttend linin.

to press leaven in my young days

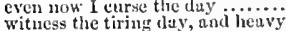

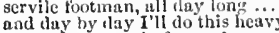

proeectl to eancel of your days.........

in the disy's glorious walk

day serves aut light more faithiful ,.ib
would have been that day in the beliry

if it be a day fits you

marry, sir halt' a day's journey a...iii".

until this day, to seour it in the dust

crown you king of this day's happiness

what you will, the day is your

and weleone: Trangy day, ny iords.

never whore to view nor day nor light.

as a fair day in summer; wondrou
by hreak ot day, if the wind eease.

while summer days do last ....

we every day expect him

in that kingelom spend our foilowing ding

tive days we do atlot thee........

a predietion I read this other day.

by day and night! he wrong's ne

for the rain it raineth every day...... $.7 i j$.

alaek, alack, fhe day!...........

as this day's buttle's fought...
the opposites of this day's striti

the opposites of this day's striti......

is the day 30 Joun.

ame odd days. Even or odd, ri ati day's -

days of the year, mpon

geek happy nights to hum

in vain, like lamps by day ..........

I have seen the day, that I lase wor

youls trom tortli day's patinway, made

his burning eye, the day ti) cheer.

eunsent to innrry to dhy

the thy is liot, the Capulets abroad

this tlay's black tate on inore days doth

Romeo! eome, thou day in nifting

su tedions is this dny, as is the night
alack, the day ! he's tone, lic's lifilled

it did, it did: al:as, ho dhy; it did.

or by the break of flty disguised frrsin
whit dety is this? Alomlity, my lord.

it is not yet near duy: it was the

and joeund day stunds tiptoe on

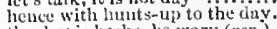

the diay is broke, be wary (rep.). .

gorted out a sudilen diny of joy.

in happy time, what diry is that?

day, night, late, early, int home...

ghod fuith, tis diny: the eounty

Pamentable day! What is the (re

alack, the day Aluck, the day!

woctin! dny! most lamentable day! (

Oday! Oday! O day! O hateful (rep.)

all this fay an macenstomed spirit

the niglit joint labourer with the day

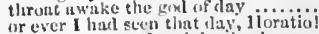

orever I had seen that diy, lioration

anyl, for the day, conflued to fist in fires

trimes, done int ins days of nature.

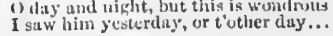

i. 2

iv. 3

v. 1

$\therefore 2$ 
DAY - being of so yonng days brought up. Hamlet, if. 2 DEAD_she is deal; which nothing.... All's ' ell, v. 3 day is lay, night, nlght, and time (rep.) how does your honnur for this many a day the repose. lock from me, day, an

us the bitter day would quake to look on

'tis sitint Vulentine's day

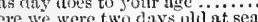

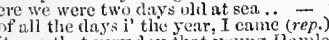

it was that very day that young laml

\section{whe and}

it is the brenthing time of day with me....

why, no; the day liad broke before

lnt let it not exteed three days ...........

diats, the day! I never gare him cause

Seven days und nights? eight seore . ...

lo not weep, do not ween; alas, the day?

every das thou dontst ne with some

Thue seen the das, that, with this little

D. $x$-BLD-conie from a ding-bed. Twelfth

DAY-Licite - We hurn day-light.. Berry Wires

hy-light and champian discovers. Tocelfh Night, ii.5

it'

back to Athens, by day-light, from these - iii. 2

methinks, is but the day-light sick. Mer. of $\vec{t} e$.

how loth you are to uffend day-light! Troil. \& Cr.

lucks fair day-liglit out, and

those stars, as day-light doth a lamp

YOn light is not day-light, I know it , $\overline{\text { Yit. }}$ it.

DAZLLE-I will dazzle all the eyes.....Henry $V$. i.

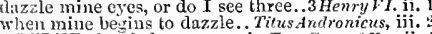

D.IZZIED-dazzled my reason's. Two Gen. of Ver. ii. 4

clazzlcl and drove back his enemies.. I Henry VI. i. 1

D.LZZLING - who dazzling so .... Love's L. Lost, i. 1
DEAD-and i' the dead of darkness....... Tempest, $\mathrm{i}$.

Col. Knt.] now he's like, that's dead

dead or alive?............

I liad ne under the dead inoon-calf"

wich I serve, quickens what's dead

we were dead of sleep.

the night's dead silence

the night's dead silence.....
but slie is deal.........

but she is deal ....................

she's lead, belike w..........

till my mother be dend ...............

by gar, de herring is no dea

is lie lear, my Ethiopian? is he dead

is he dead, bully stale? is he dead?.

I would thy hinsband were dead.

and he's hit a dead man

to season a brother's dead love.... Tivelfth $\bar{N}$ ight,

dead to infliction, to (rep.) ..............

the law liath not been dead though.

tis now dead midnight, and by eight

for the old women were all dead .....
dead, I think; lielp, unele ...........MuchAdo

here the prinees lett for dead

and publish it, that she is dead indeed

I must say she is dead, and so farewell
and she is dead, slandered to death by

and she is dead, slandered to death by

slmost the eopy of ny child that's dead

graves, yawn, and yield your dead

the form

on the ground! dead? or asleep?

so sliould a murderer look, 80 dead

nor is he dead, for aught that

whether he be dead or no...

and strike more dead than common...

now am I dead, nor am I fle

for he is dend; he is nothing..........
what dead, my dove? O Pyramus

what dead, my dove? O Pyramus

quite dumb? Dead, dend? $A$ tom

for when the players are all

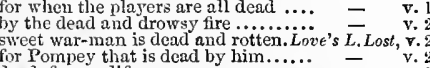

dead, for my life ..................

(God rest his soul!) alive or dead?

I would my daurhter were dead

some dear friend dead.

beginning, that is dead and burice..... As you $L$ it

brit one dead that is willing to be so..

strikes a man more dead than.

dead sheplierd! now I find thy...

on nothing that doth seem as dead

when you are dead, you should be

to marry me, when his wite's dead

I am supposed dead; the army breaking -

II Ielcn that's dead, waz a sweet.

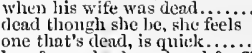

one that's dead, is quiek.............

my father dead, my furtune

as eold as is a dead nurtune nose....... Hinter's Tale, ii. 1

is dead. Apollo's angry

inter state, iii. 2

sweetest, denrest creature's dend

I say, she's dead; I'll swear't ...
bring me to the dead bodies.

spirits of the dead may walk agibin
on when thou art dead and roten.

on when thou art dond and rot
one being dead, $I$ sliall have

fion the slead blow of it

attd all eyes else, dead coals

so her dend likeness, I dos well believe

your crave when you are dead......... Comedy of Err. iii.

aliving dear nan; this pernieious...

Who, almost dead for brenth.............
nature seems dlead, and wicked dreams

ant tlie dead, are but as pietures

and grace is dead; the wine of .....

marry, he was tlead; and the right

father is not dead, for all your (rep.).

it he were dead, you'd weep for

the ciead man's kuell is there

then he is dean? Ay, and bronglit off

whose valuur plueks dead lions

or ald a royal number to the dead

my merey which lies dead

nust not know but you are dead

whiels you demand is gone and dead

my mother dead! my lord, they say.

to wish lim dead, but thou

shame, I'll strike thee dead.......

they tound him dead, and cast in to

he will he dead, or ere I come

dead, forsook, east or

you breathe these dead news in as de.....

is not Gaunt dead? and doth not...

lords, the duke of Laneaster is dead.

'tis thonght the king is deat.

hearing thou wert dead, are dead.

not reason to look pale and deal?

and the earl of Wiltshire, dead
what, are they dead? 'They are

of Golgotha, and deal men's sib.

think, $I$ am dead; and thiat even

though $I$ did wish bim dead...

upon whose dead corjse there.

as the soldiers bore dead bodies by

by Richard that dead is, the nex

and in England did repute hini dead.

insensible then? Yea, to the dead ...

Percy, though he be dead ...

what friends are livinot who are dead

so dull, so dead in look ...............
Priam's eurtain in the dead of night

Priam's eurtain in the dead of
brother, son, and all are dead

brother, son, and all are dead ........

say not that Perey's dead

the dead; not he, which says the dead

think, my lord your son is dead......

wouldst eat thy dead vomit up

answer, thou dead elm answe

certain instance, that Glendower is dead

mine old aecuaintance are dead!

and is old Double dead.

after I am dead, between his greatnes

leave her comb in the dead e
crowned, not that 1 am dead

thinking you dead (and dead almost

I hope, not dead. He's walked ...

come the heavy issue of dead Harry

yet weep, that Ilarry's dead....

whatl is the old king dead?

remembranee of these valiant dead

for Falstaff he is dead

the dead inen's blood, the pining

Encland, as dead midnight stil

though we seemed dend, we did

though definct and deact hefore......

to book our dead, and then to bury ..

armed heels at their deml masters.

and dispose of their dead bodie

of the numbers deald on both $\ldots$ ille dead numbered?....

there lie dead one lumelred

is the number of uur Enrlish denit?. or, how stoion from the dead

but dead, thy gine thend...

in that dead time wlien Gloster

this earth that bears thee dead
DEA D-the dead with elsarity enclosed.Henry $r . i v .8$

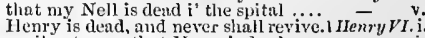
avnil not, now that Henry's dend.... -

before dead IIenry's corse? ..........

contrivedst to murder our dead lord.

when she is clead, her ashes

piteh a licld; when we are dead........ thith cowardiec a in

that, ' ralbut dead, great York.........

if' he be dcad, brave Tulbut ...........

to revenge nyy death, when I am dead

to survey the bodies of the dead........



I an dead and gone, may lonourable

so he he dead; for that is good deveit
but I would have him seed, my lord

which nuw is dead, in faee, in gait ..

ay, my good lord, he s dead, as

dear in his bed, mr lord ( $r e p$.)

the king is dead. Rear up his .......

that he is dead, good Warwiek

who finds the heifer dead ......

may ima rine how the bird was dead

lis me, thon art but de:a ...........

if that $I$ had been dead

never saw, and strutek them dead ....

oce my tomb, when $\mathrm{l}$ am dead
let me view his visate being dead

and deal non's cries do fill the .......

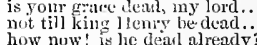

take time to do him dead.

'wonlt I were dead: if God's gooci.... wil

wheresocer he is, he's sur.

I know by that he's dead.

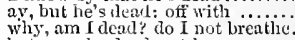

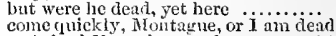

see! dead llemry's wom open .... Richard III.

not deal; [Col. Knt-slain] bnt ileul..

nay, he is dead; and slain by Edwird's

it he were dead, what would betide

some lay in dead men's skulls...

and mocked the dearl horres that

that the gentle duke is dead? ...

Who knows not, he is dead! ...
is clarence deal? the order was..

tell us, is our fither dead?

you conelude that he is dead

solrow in dead ditwar!'s grave

yes, the king's dead. Inl news......

I fear no uncles dead. Nor none

encrease the number of the dead

and that dead [Col. Kint - -denr] saini.

but didst thou see then dead?.......

Plantatenet, why art thou dead?

dead lite, blind sight, poor mortal....

thy Clarenee he is dead, that stabbed

live to say, the dog is dead!
compare dead happiness with

compare dead happiness with .........

is the king dead? the empire ........ = it is now dead midnigh

the bloody dog is dead.

as give a cruteh to the dead............ Henry $\bar{V} I I$

than the grave does to the dead

of honour, cardinal Wolsey, was dead

whenl 1 am dead, good wench .........

there's many a Greek and Trojan dend

Whector! Hector's dead! o Hecto

he's dead; and at the inurderer's hor

Hector's dead; there is a word will

all thy living is 'mere is no more to say

now his friends are dead, doors $\ldots . .$. .

would 'twere so; but not till I am dead

Timon is dead, who hath outstretehed.

Timon is dead, who hath outstretehed
dead, sure; and this his grave ........

Timon is dead; entombed upon

as the dead carcases of unburied....

and

our fathers' minds are dead ......... Julius $\bar{C} e$ s

huve yawned, and yielded up their dead -

tyranny is dead! run hence, proelaim

slith not love Casar dead so weli as.

I rather choose to wrong the dead......

would go and kiss dend Cresar's wounds

Portia is dead. Ha! Portia? she is dead

ay, Cicero is dead, and by that order

for certinin she is dead, and by strange

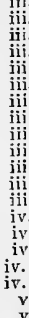

iii
iii.
iii
iii
iii
iii
iij
iii
iii
iii
iii
iv.
iv
iv.
iv.
iv.
v.
v.

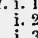

i. 4

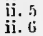

iii. 6

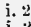

i. 2

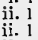




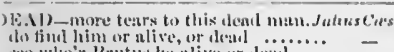

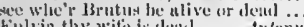

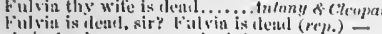
plec's deat. my queen: leok leere

Antony s dieat? if thon stay so, villuin

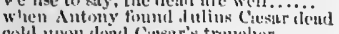

cold upm deal Ciesar's treneles

deal then? Je:ul Fros, umarin

linw! not yet dead? not ilearl?

let him thit hoves me, strike ne oce.iul

sle sent you worl she wats tem ....

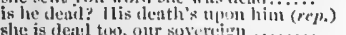

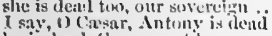

he is leud, Ciessir' not by

the diatem con her leat inistress.

your unjaragonedl mintress is deal

Yil give lut notice yon ure dent

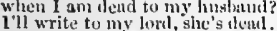

insulturent ender on his dent iovily.

the birt is deut, that we linve.........
or deud, or slecying on him? but iewi

or sleven unon the deart.

pass wns tammed with deail me.....

heing deact many years (rep). v. (5)...
than a Litoler: no bolts for the ilewi

lrent searched among the dead nud living -

I must report the 'I ween is dead ...

but wec sow him deai ...

most like I did, for I was deail

lmingen, thy mother's ciend

entlure our law: thou art dend

fir many yeurs thought dead

pousilence, as the deall are wont

youm (inths belneld alive, and deail ....

ile:ul, if you will: but tot to be his

nud inake his deal trunk pillow to.

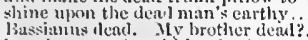

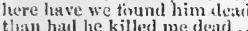

thish hall he killed me deatr.

where the dead earse of laksianis lay

ift hetse I digtred up tend ment

sorrow die, thoush in ain deatl.

with dewal cre dead, so you diu live

unless thon syy, prinece l'erieles is deaid.

till Perieles he deat, my heart e:u

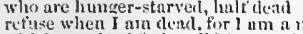

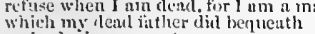

or dead, ivives wause to montrn

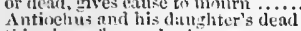

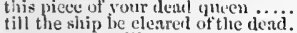

Fuur master will be deat ere you

Bycluorida. our nurse, is deteil

I"ll swear she"s detul, and throw
the pronr Transilvanian is deud

that she is dead. Nurses are not

linw she eame deact, rorr nume

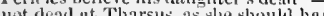

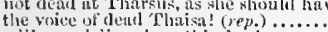

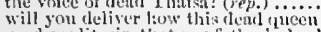

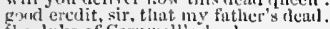

the dluke of Cornwall'y detul.

ninongst then fellem lian deat

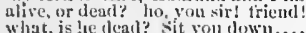

lie's readi I am vnly sirry

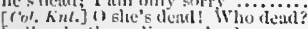

furlies, be they alive or de:at

I kuw when one is deat, and wien

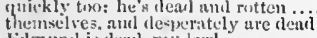

do 1 live deal, that live to teii.................

ti) strike hion deanl 1 hold it not...

the ape is deawl, and i nnust conj.....

many feign as they wore tlent.

lirave sereutio's dearl; that guiliaiti..

hro sleal, he' deal, he's deat!

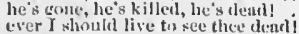

c.ver Ihould live to see thee dearl

Tybalt's sleul, that would here shain

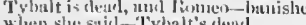

hiluen sles satil-Tybait's dead .

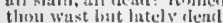

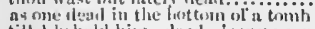

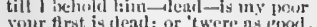

oer-revered cyuite with theml menty

and hide ne with a dearl inum in his.

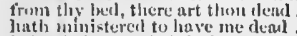

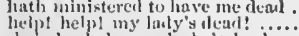

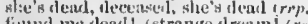

fimul me learl! (strange dream!
the liti-oweary taker may fall deut

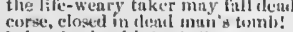

laing cleasl, witl? [col. knt,-tostrew il

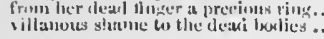

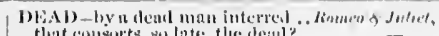
thint consiserts, sol lnte; thec deat

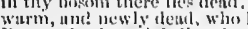

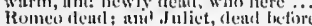

fit to onen these dent men's tombs

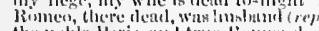

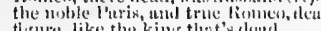

Honle, like the king that's sem

and the shected dead disl squenk

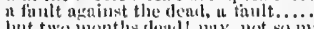

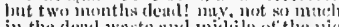

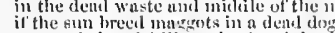

when thy tiret lord ix dend

a rut?' Detul, fir' a dur'at, dead

wollere the my learl boty is hestowed

lu is ane aud

where is my thther? Deal

low calne he dead? I'll not be jugroled

maicls clo dead men's fingers eall the

tis for the dend, aud not tor the
lunt, rest her' sout, slue's dend

lutt, rest her sout, sle's deatd .............

Fiore decayer of your whoreson deat body

implerions Ciesar, dend, and turned to elaty
we slould profane the serviec of the deat

pile yout dust mpont the quiek ant dend

Tfollow thet; I andend, loratio
Iloratio, I am dead; thou liv'st

Rosencr:untz and Gitildenstern are dead.

Ony dautulter! Dead? Ay, to me
witli facility, your Dane dead drumk

Iaro, that lowk'st deal with grieving

mr trient is deat i ' tis done, at your
minion, your dear lies ileml, and your

he's nlmost slain, and Roderigo leatd
be thus when thou art tlead, and I wil .

what, is he dend? Had all his hairs been

not ilead! not yet quite dead? I, that an
she's slearl "Sis like she eomes to sueak

I ann glat thy tather's dleat

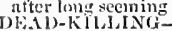

ii. 1 swoon with this dead-killing news. Richard IIJ iv. to fly his ileadly doom.

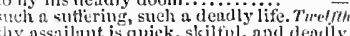

the dertly seren it is the least... Meas. for . Me

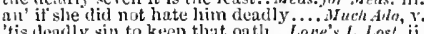
'tis deadly sin to keep that oath. Love's L. Losh' ii. I and prove untrne, deadly divorec step.

twere deatly sickness, or elsc

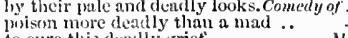

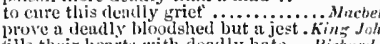

inlls their hearts with deadly hate.

shanl exense this deadly blot in tlyy.

working with such deadly wounds ... HeñryI

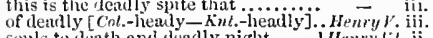
souls to denth and deadly night

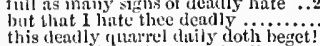

this deadly 'tlarrece ditily doth heget!
the air hat th got into my deally wounds

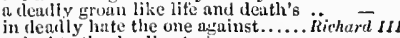

naked to the dendly stroke

no slecp close up that dearly eye of thine -

warke deadly web ensilireth the about? -

on cach of licr, and lonked deadly pale

smuinted let tine he witle dendly ven

"ins punched full of deadly holc

beally gatl, and theme of all .. Troil. fo Cr

the time right deally; I beseech you, go

and Thons, deally hinrt ...........

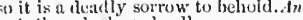

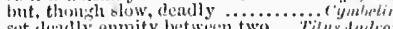

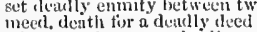

ii. 1 wither, ant come tor deanly use

turns deally point to point..................

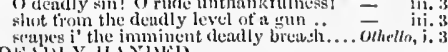

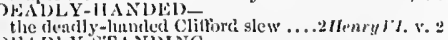

WADIY-SCANDING-

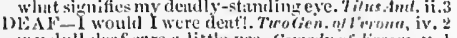

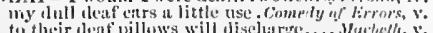

dents our eary with this abondan

in mot linlt so deaf, lions more.

in rittle while te deat? till i

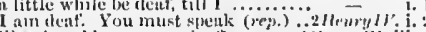

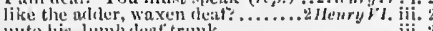

unto his , lumble deen' trunk

cars more deat than atcleor.

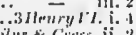

the gosts are deut' to het and piecrisla.

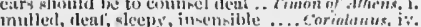

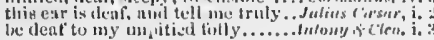

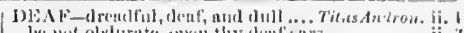

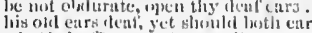

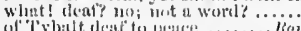

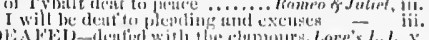

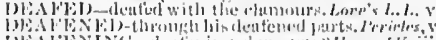

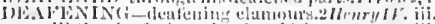

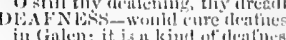

ifs grilen; it is al kint of deather.

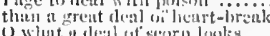

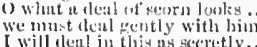

let me deal in this...........

an intinite fleal of nothing

the ficllow hats a t?

As yim lake il vel

sos shentel 1 be at great cleal

Fike a fit the you will deal witio... Fianin

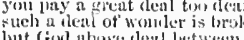

lut God above deat hetwee

What a deal of world f wander.
the kine is eeme; deal mildly

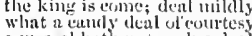

a weacel liath nut such a dea

such a deal of skimble-skamble...

cott of a dent of oid iron 1 chose

never able to deal with my master

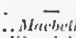

kine Jullat

He'zry

औcnryl in. i.

master..$\quad$ ii.

and loubt not so to deal, as ail .....

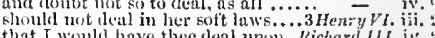

that I woulth have thee deat uponi... Richard HI. iv.

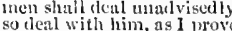

he pivily dcals with our curdinal $\ldots H_{\text {enry }}$ VII. i.

cren so a great denl of your wit.. Troil. \& Cress. it.

aud undo a great deal of hoviour?

as rieh wen deal gifts, expecting ..... $=$ iv.

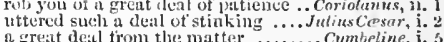

ng great de:cl from the matter

live, and deal with others bet

that weep duth ease some deal . Tilus,andron.

show me a inurderer, $\mathrm{Yll}$ deal with him -

have you that a nuu may deal witial.. - iv,

and put upen him such a deal of man..... Lear, ii.

heavens, deal so stiili........................ = iv.

startel uway to deal with frief alone .... - iv.

Maria! what a cleal of brine ............. o Julief, ii. :

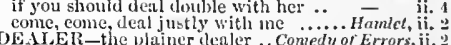

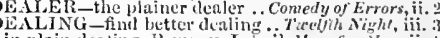

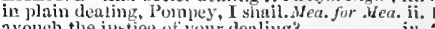

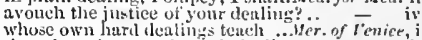

there is no lunesty in such dealing...jenryth. it.

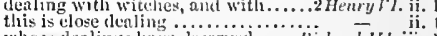

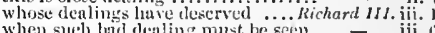

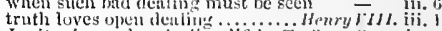

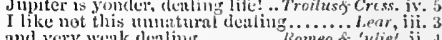

and very weuk deal hint............ Romeo of suliet, ii.

DEAL'S'T-that thou deal'st justly witi me

DEALT-how you have deait fur him. King Joh

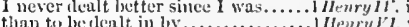

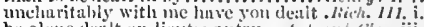

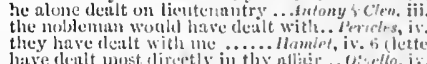

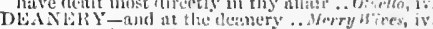

is now with the cloct or ut the
DEAli- of thec, my ciear me!

deer, they durst int

now my deat liats, hith

awake, dear heart, awnke!
O, cleur taflect, matse not

thy cease, deear lriemil, shat

You, foos trient, and

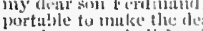

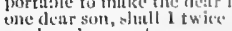

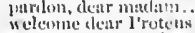

is intale to one so deatr

whut dear foosh will i beat

fir whose fene suke then dicl

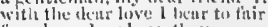

for whuse dest lowe, tley say

witls diecourse of my dear foitio...

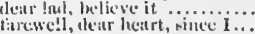




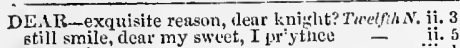

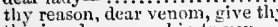

this is a dear manakin to you

I lave been dear to him, latd

that $I$, dear hrother, be now ta.......

be not offended, denr Cesario

in terms so bloody, and so dea

be rasle of our dear souls

dear sir, ere lonr l'll visit jou

low doth my dear morsel

and now, dear maid, be you as fiee

U my dear lord, I crave no ot
dear Isabel, I have a motion

what, my dear laxly Disdain!

a deur hajpiness to women ......

not till Mondey, my denr son.

always exeepted my dear Clandin

that any villany should be so dear.

to link my dear friend to a comm

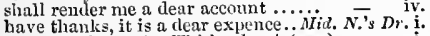

my lover dear; thy 'Thisby dear' (rcp.)

when thou wakest, it is thy dear

thy breath, my dearest Thisby dear.

that eost the tresh blood dear.

dear: look, where thy love $\left(r r^{\prime} p\right)$.

and most dear actors, eat no...

and the death of a dear friend.

and the death of $a$ dear friend.........

so mucl, dear liege, I liave already.. $L$

one and the self-same thing, dear imy

more authority, dear boy, name more
wlio was Samson's love, my dear Moth?

who was Samson's love, my dear
of all dear graee, as nature (rep.)

hear me, dear lady; I have sworn.

dear princess, were not his re

will court thee for his dear ..........

lord Biron, I thank him, is my dea.

tidll of diar guiltiness; and therefore
the clamours of their own dear groan

your worth is very dear in my...Mer.

some dear friend dead; else nothing.

and yet, dear lady, rating my selt

is it your dear friend, that is

is it your dear friend, that is

how dear a lover of my lord ....

which is as dear to me as life itself .

dear sir, of force I must attempt...

the very life of my dear triend
dear Celia, I show more nuittl

dear Celia, I show more nirth

Rose, my dear Rose, be merry ....
then, dear tuncle, never so much a

dear sovereign, hear me speuk

dear master, I ean go
O, dear Phœbe, if eve

good day, and happiness, dear Rosalind

pardon me, dear Rosaliud

ala $\vec{n}$, dear love, 1 cannot lack.

o my dear Orlando, how it ........

a traitress, and a dear; his humb

my master, my dear lord he is.

the honour of ny dear tather's

dear sir, to my endeavours give.
thy life is dear; for all, that life.

your dear son may $h$ ie

it wonld not seem too dear, howe'

I'll lend it thee, my dear, but have
a desired office, dear almost as his.

whose dear perfection, hearts

makes the rememlurance dear

$U$, my dear mother, do I ree you

as ceeret, and as dear, as Anna

thou canst not love so dear as
while you, swect dear, prove

purdon, dear fiather

you pay a great deal too dear......

dear gentlewomau, how tares our

as mourn tise of our denr services

softly, dear sir; good bir, softly

(1) but, dear sir, your resolntion
fur my lads to give their dears

my dainty duek, my dear-a? .......

dear, look up; though tortune......

clide me, dear stone; that I may .

dear my brother, let hin

tor from him dear life redeems you ...

clieap, and your welcome dear.

teacli me, dear, creature, how

my dear heart's dearer heart

anywhere; dear Duff, I pr $\dddot{y}$ thiee.......... Macketh

full of scorpions is my mind, dear wife!..

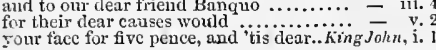

DE.AR-my dear sir, (thus, leaning on.
thou art the issue of my dear offeuce
and, out ofmy dear love, I'll give....

and at thy birth, dear boy

divers dear friends slain?

of your dear mother England.............

where we swore to you dear amity...

deardear lord the purest

then dear miy liege, mine

but Thomas, my dear lord, my life

with that dear blood which

limit of thy dear exile.........................

dear souls, this dear dear land, dear...

dear earth. I do salute thee

to $a$ dear friend of the good duke............

in torwarding this dear expedienee..1 Henry $\mathrm{IV}$

shed my dear blood drop by drop

dcar coz, to you the remnant ........

dear mien of estimation and command

the lord of Stafford dear to-day .......

so dear [Knt.-great] a show of zeal . $\because$ Henry
licart's dear [Col.-heart-dear] Harry.

we would, dear lords, unto the

shall, $O$ dear father, pay thee ........

when flesh is cheap and females dear $-\bar{v} .3$ (song)

God torbid, my dear and faithful .....
let their bodies follow, my dear liege

moek out of their dear husband

in their dear care and tende

of all your dear offences..........

unto the breach, dear friends

for us, dear uncle, the winter ........

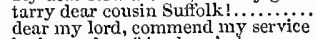

he is my dear triend, an' please

dear nurse of arts, plentie

I naid so, dear Katharine $\dddot{2}$ and while thou livest, dear

v. 2 and while thou livest, dear Kate

in love and dear alliche

to thy dear cost, be sure ............. Hen

as dear as mine, and they shall find dear

therefore, dear boy, moun

and bought his elimbing very dear...2 Henry

who wonld nut buy thee dear?

wast thou orduined, dear father

withhold revenge, dear God!.
dear brother, how shall Bona

in Clurist's dear blood slied for

broke it in such dear degree?

said dear brother, live, and be a king?

image of our dear Redeemer

widow had so dear a loss (rep.)

comfort, dear mother

my dear cousin, 1 , as a child

welcome, dear cousin, my thouglits'

I hold my lite as dear as your

be satisfied, dear God, with our true

so dear I loved the man,

right well, dear madam ...............

[Col. Knt.] that dear soint which then
made me by my dear lord's death! .

some little pause, dear lord .........
his bond of life, dear God, I pray

[Knt.] with dear heart's love

therefore, dear mother (I must

liave bonght her dignities so dear

ont of dear respect, his royal self

thew dear brothers, are able to endure

what else dear that is ........ Troilus \& Cressic

hath been as dear as Helen

lear lord, go you and greet bim......

dear lord, you are full of fair ........

Troy holds him very dear.

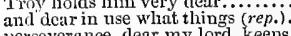

jerseverance, dear my lord,

strungles our dear vows eve

in lond and clear petition

holds dear: but the dear man (rep.).

theretore, dear sir, let me not shame

my dear lord, - What it' it.

O, a root,-dear thanks! dry up......

left to us in our dear peril

then, dear countryman, bring in ....

and noue less dear than thine and iny

ah, my dear, such eyes the widows ..

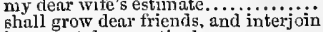

in a most dear particular ...........

hangs on Dian's temple: dear Valeria

the country, olu dear nurse; or else..
DE $A R$-dear my lord, make me ...Julius Cresar, ii. I as dear to my dear, dear love to your proceeding -

any dear firiend of Cresar's

O my dear brother! this was......... - ii.

dear goddess, hear that prayer.......utony $\delta$ Cteo. i. 2

help me away, dear Cliarmiau

last thing he did, dear queen

good-night, dear lady. Good-night, sir =

from Rome are all too dear

hail, most dear Cæsar!

nothing more dear to me ............

do, most rear qneen. each heart.. - iii.

ah, denr, if I be so, from my cold hieart - iii. 11

be comforted, dear madam. No....... $=$ iv. 13

I dare not, dear, (dear my lord, pardon) - iv. 13

no, dcar queen; for we intend..........

peace, dear lady daughter, peace ..... cymbin

ny ring I hold dear as ny tinger....

what, dear sir, thus raps you?....

the walls of thy dear honour

our dear son, when you liave given

whose tailors are as dear as yours..... -

dear lite, take mine; and though (rep.)

to whom I sued for my dear son's life

refuse to drink sovereign, and oux.....

is dear Lavinia, dearer than my soul

patience, dear niece: good Titus $\ldots$

do then, dear beart; for heaven.....
with this dear sight struek pale

loves me as dear as e'er my mother..

upright at their dear friend's doors ...

speak, Rome's dear friend...........

the end all is bought thus dear....

O dear Diana, wlore arm I

shill not be more dear to

take from you the jewel you hold so dear - iiv.

speak would own a name too dear.....

embrace him, dear 'Thaisa; this is he ..

dear sir, for higlness' love ..................

the gods to their dear shelter take thee..

folly in, and thy dear judgment out!

liear, nature, hear: dear goddess, hear!

the dear fatler would with his quality

dear daughter, I confess that I ...

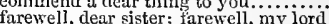

ah, dear son Edgar, the tood of thy ......

my most dear Gloster! $O$, the difference.

gave her dear rights to his dog-hearted

O, dear father, it is thy business.

sir, your most dear and our aged father's

Omy dear father! Restoration

kind and dear princess! .................. - iv. 7

O then, dear saint, let lips do

O dear account! my lite is my......

my name, dear saint, is hateful to myself -

dear love, adieu! anon, good do not

dhree words, dear Romeo, and good-night -

[Col.] Romeo! my dear! At what o'cloek -

and my dear [Col.-good] hap to tell.:-

whom thou didst love so dear.

what say'st thou, my dear nurse?....

receive in either loy this dear eneounter

the blood is spilled of my dear kinsmau! -

the price of his dear blood doth owe?

this is dear merey, and thon see'st it not

the white wouder of dear Juliet's hand

thy dear love, sworn, but bollow perjury -

help afford: farewell, dear father....

full of charge, and dear import $\ldots . . .$. .

ah, dear Juliet, why art thou yet so fair? -

of Hamlet our dear lyrother's deatl....... Hamlet, i.

by our late dear brother's death

if thou didst ever tliy dear father love

dear Rosenerantz and Guildenstern!

he tells me, my dear Gertrude...

cear Ophelia, $\mathrm{I}$ am ill at these $\ldots$ ii, $\overline{2}$ ji.

然. 2 (letter

or my dear majesty your queen he

dear friends, my thanks are too dear.

by what more dear a better proposer ....

in what, my dear lord? I am but mad.

the son of a dear father murdered .......

come hither, my dear Hamlet, sit by me

dear my lord. $O$, my offence is rank

a gib, ouch dear concernings hide?

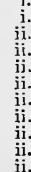

ii.
ii.
ij.
ii.
ii.
ii.
iii.
iii.




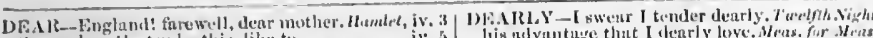

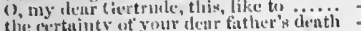

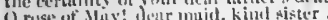

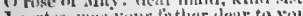

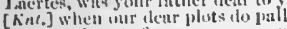
are very lear to truty, very restemsive. (n)

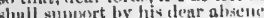

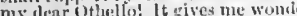
to Desicmena a most dear linshand. entue my den love; the purchase made he held them sixpenes nil too dear what's the inather, deur? All's well 1 in man, and woman, denr my tort lier jesses were my i how mow, my dear (1) hellu? yomr erying, () dear Cansio! ns it were.... minion, your denr lies dend, tansio. alas? my friend, and iny dear countrin slain lere. Cassiu, was ny tear thicish. if thou attemyit it, is DEAR-13ELUVEIJ-

of theme our dear-beloved solemuized.. Tempest, v. DEAR-BULGIIT

and England's deur-bought (1ueen ..2renry fri. i. 1 concs deared [Col. Knt.-fuared] liy...Am/. s. Cleo. i. 4 DE. RRER-dearer than an triend. Tiro fien. of t'er. ii. knowledge with dearer love.

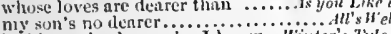
nyy son's no denrer...................... Ant site elt, 1.

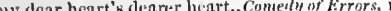

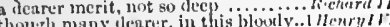
though nany dearer, in this blowly . that his country's learer than

to earn a denrer estimation of thein

grieve thee, denrer than thy denth.

is clearer, in my respeet, than all.... Cymbeline, ii. 3 Lavinia, dearer than my son1..... hit leaves his pledges denrer thin

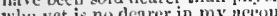

learer than evesfolnt, syace, and liberty

lowed him, frient, nin tather his sonde

shalt flud a dearer finther in my love ....

comsin, and my dearer lort?.... Romeo of Jutiet, iil.

an is the denrest of tise los

worth what's dearest to the workii

my mistress, dearest.

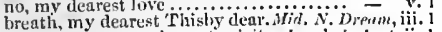
summon uj your dearcst spirit in the dearest desirn ot indust $\mathrm{r}$

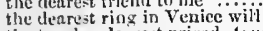

our dearest friend prejudicates ...

my dearest madam, let not your

as the dcarcst issue of his practice

which of them both is dearest to $\mathrm{n}$

cost ine the deurest groans of a mother

mest dearest! my eoliop! can thy

the sweetest, dearest erenture's dead

throw awny the dearest thing

iny dearest vartner of greatiess.

my dearest lore, Duncun eomes

of the knowledye, dearest eh

the blond, and denrest valued blood.. King John, iii. ny nearcst and dearest enemy? .... Inenryll.

wc were the first and dearest of you

bend you, with your flearest speed

should broach thy den rest blood.... i i Ifonry $V I$, iii. have left thy denest heart-blood ....3 Henry ${ }^{\prime}$ L. i. deep truitors for thy dearest friends!. Richard III. i. 3

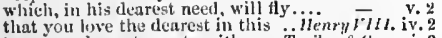
thate our denreit repute with

bred lier at my dearest cost. my dearest lord,-blessed

my deurest master! Awayl what art - iv. now, iny dearest queen, pray yoll...Antony o Cleo $\mathrm{i}$. farewell, my dearest sister, fare thee well known to patience: my dearest sister!

ing dearest husbunt, I gomething...

enjoyed the dearest bodily part of....

hitrike $-i$. () the dearest eff erestures ....... - iii. 2 (letter) since deatla of iny dearest muther .... - iv. 2 ame cast trom her ham .............. Pericles, iit. 3 my dearest wife wus like thi ............... . verid gecond dnughter, our dearest kepan ...... Lewr, 1. [ $\mathrm{knt.]}$ ] iny rlearest cousin: and... Monpo öjuliel, iii. gurged with the dearest morset

that which dearest fiatlaer benrs his gon... Hamble $\mathbf{j}$. would i had met my denrest fie in heaven - i.

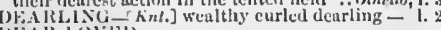

my dear-lisved fort, thou:h.... Timon of Alicens, ii. 22

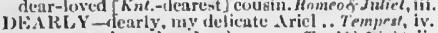
iny master loves lier dearly ...... Turtgh, wiohi, ii.

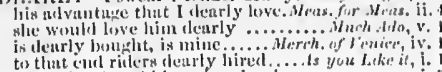

my futher leseel his izther ileurly

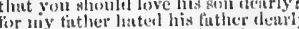

which 1 teuder dearly, though 1 say

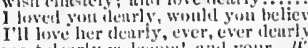

how dearly would it tumble these.

in this bosme denty gheris

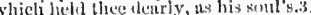

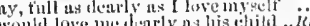

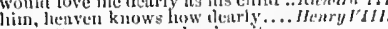

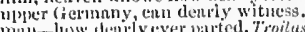

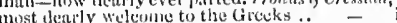

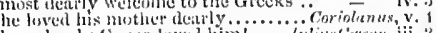

if your did taye him loved ling

niv lotheter diel cerer love so deenty

nut grets your hiolntess deurly.......

rubics mingragoned, how dearly they

bold the dearly for thy mother's. Titus Andron.

kept, I so dearly loved it ... H............

winc loved i deeply; dice dearly

I teulur as dearly as mine own. liomeo of Jul

she loved her kinsunan 'Tylalt dearly - iii. 1

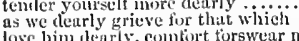

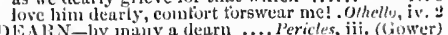

1)EAliN-lyy many a dearn ... l'ericles, iit. (liower)

make a tearth in this revoltiug.... Richuid $1 /$

make men expect a dearth

tor the denrtli, the gods, not the.

the dearth is great; the people .... - i. 2 (letter)

death, dearth, dissolutlons of ancient .... Lew, i.

DEA'Tl]-I would tain die a dry death.. Tempe

this were denth that now hath

bite hin to death, I pr'ythee
worse than any deatli can be

worse than any dentin can be at once

destived to a drier dentl on

Ind, why not death, rather

I Hy nut death, to fly his.....

whose death I much repent

stood it next to denth.......

upon his death's bed ................

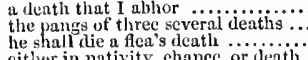

take the death of her brother thus?. Tucln Night $^{-}$

good fool, for my lrother's death

till the pangs of death shake him..... $-\overrightarrow{\text { ii. }} 4$ (song)
come away, come away, death.....

my part of deatl no one so true $\ldots . . .$. - ii. 4 (song)

but hy pangs of death and scpulelire

out of the jaws of death.................

a thousund deaths would die

than fall, and bruise to death ............ for $\bar{M}$

judgment puttern out my death .....
it grieves ine for the denth of Claudio

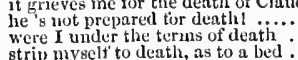

die the death, but thy unkindness (rep.) -

and fit his mind to death ...........

ahsolute for death dercly, thou art death's fool

yet grossly fear'st tlyy death

and death unloads thee ................

and seeking deatla, tind life.

but fetter you till deat

sense of death is most in appreliension.

for your denth to-morrow
death is a feurful thing.

to what we teur oi denth

therefore pregare yourselt to death...

whut an merit were it in clenth, to take

for the entertainment of olest th.....

a man that upprehends deatl no more

in the delaying death.

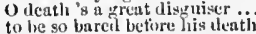

perchance, of the dluke's cleath

to rise and be put to dleath.

unprepured, uminect fior fleath

and sequent de'uth, is all the grace

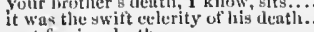

past faring denth.

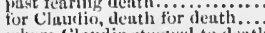

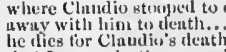

u thousand prayers for thy death....

that I eruve deati inore willingi......
1) W.ATII-is pressing to death ..... Meas. for Meras. v. I to the rleath, my lord .................. press me tis eleath with wit

it were a lecter rlenth than die with.

hethtin is the bil rest cover for tic

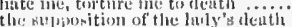

slaserered to death by villains........

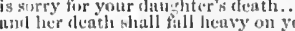

rather sen! with my deuth, than rejeat

any detrighters dent

denth in gherthon wet ler wrungs

lives in leath with flerions far

tell $y+1$ lar'wely of thir Ilere's death.

to this gentleman, or to her death

to denth, or to at vow of sinule lite.

and inost eruel denth of $l^{2} y$ ram

either death, or you, l'tl tind

und will dos to my dea

whose rlate till death shall never cou

I datll sing it at her detath

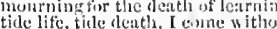

awd the deat! of a dear iriend.

an elitarin on the deat is of th

sick to death, wished hingestt'.....

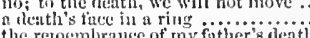

the renembrance of my finther's dent

wild lauphter in the throat ot denth?

at their death, have foosh....
be married to it deat fir's head

she wept for the death of a third ...
it' 1 minht but see you at ny death

mectese for death; the
lest lic do bleerl to deat

speak ane tair in deuth

to rencler it, upon his death, unto...

nfter his derith, of all he dies ...........

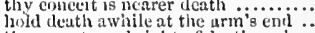

the acustomed gist or de

and sin, conce death: two o' clock

ler and cleath were both one thing

wecp o'er my fitloer's dentle ancw ...

lcath should have play tor lack of work -

it woulf be the death of the king

as one nenr denth to those that wish.

not lelping deatls deay fec

uncertain life and sure deatl

I am the wite death sit on thy cheel.

where death and dauger dog the liecls - - jii.

anter tor death and

or let me see iny death!...............

it was the death of the most virtuons

since I heard of the rood lndy's death

are almost frozen to death
'tis death for any one in Muntia.

or else lresent death; I pr'y thee ifo.

and beat me to deatis with a botton of -

not only be deatle to thy"self.

though a present death had

look down, and see wlut death is doing

thourh I with death, and with rewurd

the death of the young prince.

the causes of their denth alpeas.

either for lifo, suffered death

a dleatle to grant this ...............

not yet on suminer's denth, nor on

I will devise a denth as eruel for

but that death is too suft tor him

allenths are too few, the shorpest

with thies blown to denth

instant of their master's dewil

at the relation of the qucen's deutio.

ever since the death of Ilermione

ins ever still sleep nocked renth.

by the doom of ileath, enil woe's

warrunt of immed iste dentli

were I in my timely denth, coulilili

thou nrt adjuklyed to the that
lie gains ly desth, thint hath

the place of dentli und surry

ve viti

gi", promotmee his death..........

strunge imates of lutath.

hath been sturlical in lis denth

he, as in in death, whist cement

that deuth and nature do contend.

that

$A d i, i$

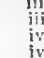

iv.
iv.
reer
(red

N. Dr. i.

二 
DEATH-strange screams of deat

death's comnterfitit, and look on
which in his deatli were perfiect.

the least a death to nature ....

in ridilles, and attuirs of death

to add the death of you

toath of thy soul! those linen cheeks.

I will not be afraid of death and bane.

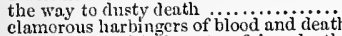

I would not wish them to a fairer death

and took it, on his death, that this ... King John

Tll follow you unto the denth.....

now doth death line his dead eliaps.

till then, blows, blood, and death!

industrious seenes and aets of deatl.

no, not denth himself in mortal

the rotten careasc oi old death .......

that spits forth deatl, and mo

would live again by death of need....

though that my death were
death. NIy lord? A rrave

death, death: $O$ aminble lovely death.

corruption of a sweet ehild's death .

we heard how near his death

yomng Arthur's death is con

and talks of Arthur's death $\ldots . . . . .$.

broke with thee of Arthur's death...

o deatl, made proud with pure ....

bold, and blushes not at death

if thou diost this deed of death $\ldots$ o...

a bare-ribbed death whose office

wounded to death. Fly, noble...
hare I not hideous death within

hare I not hideous death within
see the crnel pangs of death.

see the crnel pangs of death
death, having preyed upon

strange, that death should sing

a doleful hymn to his own denth

did plot the duke of Crloster's death.

despite of death, that lives

ineasture to thy father's deatio.

to 'venge my Gloster's denth ....
in his siglit, hath eaused his deati

on pain of death, no person ..........

upon pain of death [Col..-life] till twice

but speechless death, which robs my

and blindtold death not letme see....

word is current with him tor my dea

happy then were my ensuing deatli?

though death be poor, it cnds ...

not Glostur's death, nor fler deatis.

a keeper back of deatil, who gently

forerus the death or fall of kings

to the death; see them delivered (rep.)

throw cleath lpon thy sovereign's.....

have feit the worst of death's destroyin

nothing can we call our own, but

sad stories of the denth of kings.

is death destroying death (rep.)

$O$, I am pressed to death, through

when Gloster's death was plotted

in this your cousin's deat

the rnanual seal of death ..........

will kepp a league till death.................

the true man's put to death

death in this rude assault? (rep.).

on iny tiace he turned an eye of deati.l Hew 1

and fur whose death, we in the ......

the bloody payment of your deaths...
his brother's death at Bristol . $\ldots \ldots .$.
of oats rose; it was the death of him

of oats rose; it was the death of him
to dic a fair death for this....................

to dic a fair death for this........

and I know, his death will be.........

as many a man doth of a deatly's head

why, thou owest God a death .....

if die, brave death, when princes

that will revenge lord Stafford's death

whose deaths are unrevenged

the earthy and eold hand of death lies

death hath not struck so fat a deer

I'll take it upon my death, I gave....

bear Worcester to the deatl, and Vernon -

head as low as death............

where hateful death put on

and I my Perey's death, ere thou......

in tew, his death (whose spirit

I were better to be eaten to deati with

led his powers to denth, and, winkin

do not syeak like a deatl's head

with the luurly, death itsell' awakes?

very sure; death, as the Psalmist saith

death is certain. Is old Double of you

We owe God a death; I'll ne'er bear.

to strord, and life to denth

guard these traitors to the bloek of death
DEATII-they weep for thy death
beyond the hour of death...

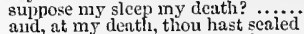

and now my death chauges the mode

Goodman death! Goodman bones!

I banish thee, on pain of death ......

sovereign's life to death and treachery!

repent my funlt, more than my denth

the golden cart,

ny, or go to death; and aile pay it.

a damned death! let gallows gape

hath given the doom of death.

for they purpose not their death

where they feared the death, they....
dying so, death is to lim advantage

their prayers, and they stay for death

ii. 2 here was a roval fellowship of death!

HenryIV.iv. 3 DEATII-hunt this deer to death ...2 Henry FI. v. 2

and be it death proelaimed through

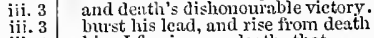

iii. 4 him I forgive my denth, that ......

with Heury's death, the English ....

heneeforwarcl upon pain of death.. $-\overline{-}$

for fear of sudden death.

manner of his mournful death

as Sevthian Thomyris by Cyrus' deat

thousand souls to death and deadly night

the pursuivants of death, $\mathbf{N}$

just death, kind umpire of,$\ldots . . . . .$.
upbraid me with my father's deatl.

and deatl approael not ere my tale.

my fainting words do warrant death

humble serviee, tlll the point of deatl

run a tilt at death within a ehair?

when death doth elose his tender

draws a sword, 'tis present denth

banish thee, on pain of death

and fearful owl of denth, our

caust not enter but by deat

friends greet in the hour of death

to bent assailing death from

fly, to revenge my death, if I be slain

upon my death the French ean

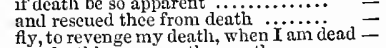

my death's revenge, thy youth

thou antick death, which langhest

wounds beeome hard-iavoured deatl

brave death by spealing, whether $\ddot{\text { th }}$ -

had denth becu rench,

thy timeless cruel death?

altho' yc hale me to a violent death.

and the gloomy slade of death $\ldots \ldots . .2$ Henry

outlive, and die a violent denth (rep.)

of king Herury's life and death
after Ldward the third's death
shall find their deaths, if York

by God's book are adjudged to death -

will take my death I never

for, by lis death, we do perceive

till the axe of death hang over...

devise strange deaths for small

if my death misht make this...

mistrust, that shows him worthy death -

hath more reason for his death
clicken should be sure of death

clicken should be stue of death

of death, I shall find joy (rep.)

this get I by lis death ..................

comment then upon his sudden death

I see my life in teath................

who should do the duke to death....
of dive Humnlurey's timeless death

of duke Humplurey's timeless death

Suffolk straight be done to death....

with grievous lingering death,$\ldots . .$. .

in hir dislike, or you of denth.

days louger, on the pain of death....

Beaufort is at point of death

Were torture more than

if thou be'st death, I'll give the

when death's approach is secn

so bad a death argnes a monstrou

doth death affright thee? (rep.)

at good duke Humphrey's deat

I must waft thee to thy death.
that this my death may never

mourning tor Suffolk's death?

his brother's death hath given ......

iii. 2 injured, that ye scek my death?

iii. 2 lead you to your deaths?

or unto death; to do my cuuntry good

we'll bait thy bears to death
I am resolved for death, or dignity
3 HenryVI. i.

v. 4 pray hefore I take my death .........

pray before I take my death $\ldots \ldots . .$.
born to renown, by life, or death...

eyes can water for his death

ii. 2 ean fall for Rutland's death? .........

mounted, run their horse to death

eries vengeance tor his death

licre's for my fa ther's death ............

I'll venge tly death, or die renowned

hlood and death, I cannot judge...

that quarrel use it to the denth .....

in the very pangs of death, he eried..

till either death hath elosed thesc....

that triumphs in their denth ....

for a father's death, take on

no mourning widows for our deathi...

like life and death's departing

nothing sung but death to us (rep.)...

which in the time of death lie gave..

my love till death, my humble than

bronght him to the door of death?

tather came untimcly to his denth?

are dimmed with death's black vei

I'll pardon thee a threefold

what seene of death hath Roscius....

for their parents' timeless death

to purge his fear, I'll be thy death

wretched by the death of thec $\ldots$ mo...

more miserable by the det this ( (rep.)

the timcless deatlys of these Plantagen

kill me with a livingr death ............

the sad story of my thers my knee

though I wish thy death $I$ will not...

to both their deaths shalt thou be....

banished, on pain of death?...

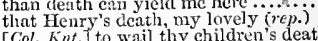

thy hapny dows before thy death

tooth will rankle to the deatl

sin, death, and hell, have set their ..

leisure in the time of death

sentence of poor Clarence' dentli ....

to thrcaten me with death ............ 'tis death to me, to be at enmity ....

a tongue to doom my brother's death

yet his punislment was bitter death

frozen almost to denth ...............
when they did hear of ciarence' death?

to lose him, not your father's death..

eracked in pieees by malignant deatl

you wept not for our tather's death.

of good king Edward's cleat

to look on death no more! ............

which by his death hath lost muci

I will not do it, to the death

this day those enemies are put to death

the second here was hacked to death

the hour of death is expiatc

that do eonspire my death with ......

my lord, they have deserved death...

he deserved his deatl...

us in him, and wail his death...... .

how Edward put to death a citizen ..

if thou wilt outstrip dog thee ....

aceursed womb, the bed of death .....

by iny dear lord's death! .............

into a close exploit of death

shall tell the process of their cleath....

drop into the rotten mouth of death

and the dire death of $1 n y$ yoor sons.

thy life, and doth tlyy death attend..

in suels a desperate bay of death

my father's ceatl, - thy life hat 11 .

death, desolation, ruin and decay.

owls! nothing but songs of death?

to rmin, shame, and death

of bloody deeds and death $\ldots$.......

death $1 \mathrm{my}$ lord, their clothes are

I do not think, he fears death....

I bear no malice for my death

nothing but death shalt ent's de.......

lis physie after his patient's death.

OGriftith. sick to death

after nyy death I wish no other .....
tell him, in death I blessed him....

ii.

ii. iv. 4 defended me from immincnt deati

Will hunt this woll to death

son, so rued a father's death

thy day, and death thy lite!

my son, now in the shade of death

bewept a worthy husband's death

$\begin{array}{r}\text { i. } 2 \\ -\quad \text { i. } 3 \\ \hline\end{array}$

i. 4

i. 4
i. 4
i. 4

i. 4

ii.

ii. 3

ii. 6

ii. 6

iii.

iii. 3

v. 2

$\mathrm{v}$.

v. 6
v. 6

v. 6

i.

i. 2 


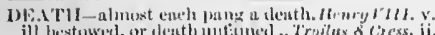

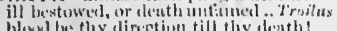

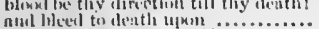
chut the deuth tokerus of nectar? teath. I te:tr me

preses it to dent

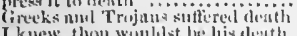
I knew, thum wushlst be lis death time, fisce, and denth, do to this tonty

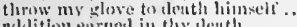
mlilition earneal in thy teat

cho I met thee, fill as ileat th ir' in lisis clenth the ginds low

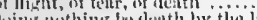

thes slute fimish, a dong's cheuth

by whose death, lie's stepreet into...

when he is sick to slenth, let not ....

secing his reputation toucherl to denth

inen's works; and deatly their gain?.

lyy lesinution, unt in tithed death...

eindemning some to denth

and tent themselves with denth.

denth, thant dark spirit, in's nervy

his sword (tleath's stmini?) w

this deserves death. Or let us stnigd

Iliscius is worthy of preseut ienth.

that erer he heard the mane of le:ith

kepis him liere, our eertuin death

present me denth wn the wlieel

fir death, tor tine, or butishucit (rep). sat twenty thonsind denths.

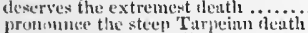

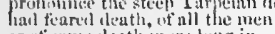

or of some cle:th inore long in

humiour in one eye, and flenth in

ot honum more than I

it must le ly his death i..........

blaze forth the teath of prinec

letire their dentlis, the valiunt (r...p.

cringit a feeble man alinost to deatl

yeurs of temring denth (rep.)

uhrihlyed his time at fearing denth

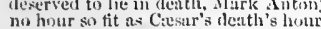

no metm of deuth, as here by casir.

OAntomy, beg not your death or a

grieve thee, dearer thin tliy de:th

Hinw the rensom of one Cesiar's denth

stud death, for his umbition.

the question of his death is cnrolled

entoreed lor which he suttered tleath

though he had wo hand in hix deuth
fleuse ny count ry to need iny death

we'll revenge his death

nothing but death shall tay me...

for with her death that tidings eatue

have put to death a hundrel senator
blame cato for the death which lic.

blame Cato for the death whic
and be honomreal in his death

noman clae hath humure by his deat

though in his tale lic deat

inr departure, death's the woril.......

for not alone the fleatlo of kulvia

I see, in inlvia's deatl, low miac.

if Marrus C'rasus' denth make me .

till lleath enlar: his cunfine

mand dentla will seize her

stay till denth love me

victorious lite, than dentlo and

the husd of deatlh lath raugint him

for one death unishat the presented

bring me how he tukes ny denth.

shall die the death, Dettl of one

which, ly ber death, our Caesar tells
escape the sorrow of Antony's teath

I will le: a bridegroom in niv deatis.

death and firtunes bitl thy fillowers

give ine sulfieing strokes for death .

I here inumortume death awhile

seerce houst of death, ere denth dare

aidi rnake sleath jrouil to take us.

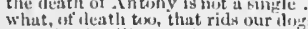

your leatli will never let come (rep.).

atroke of iteath is as a

the nanner of their deathis?

truno a next with bunls of ileith!.....

there eannet be a princh in leath mor

the movers of a lanirnishing aleat
in wort show of death it mukes

five tines rerleemed trum teuth

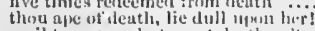

peril to my nuslesty, mot ileatlo onit..

anil strukes deat io her

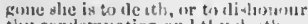

thy ennlemuation and thy clezthi...

or what his death will bring at.
since death of my dearest incther

not as death's dart, leving laurricil ut

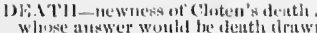
whe answer would be

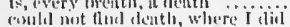

ii. 3 Tir ute, my rousutmes denth

iii.

come, sir, are you revily tir destli?

yentr denth his eyes ins herth the

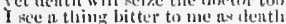

is not this loiy revived trom denth?

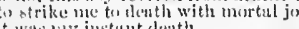

te

yinu chont ponde.

in nyy leurt, teath in my hum

lenve me tis this miseruble denth

tis present elenth ton

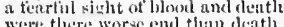

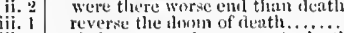

their tomiraes demn men to deatli...

my two lirothers fiom their deuth
this way to deatle my wreteded sons

this way to deatle my wreteded son

for his teath, thy hrothers are

reileem my brothers both from ileatl

remembrince of my" hither's deat

that ever denth shouid let life bear.

n deed of death, done on the innocent

in his ruge will dom her denth

or else derise his derith

so sweet udenth, as hanging presentily

of murcler and of aleath........

her brotlers were comtemmel to ileat

meed, denth tor a deatly deed

think death no hizarrl.

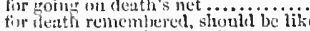

tur the way of lite or death

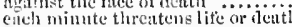

to think on, hut ensuing ileath

a shiche 'twixt me and lenth

Whase sleath s, indeed, the stron
ns a whisper in the eurs of deat

to pilease the fool and death. ...

dentle mity usiorp on nature many

wherein my death misht yichl her protit

an twuyest, a birtli, and death?

mahndenel erawl toward deatl

ent is thy denth

death, deurth, dissolutions of aneient ..

ife and death! I am aslumel that ...

profits of my slenth were very preginat

renreance! plarne! death! confusionil

denth on my stite! where
till it ery sleep to deuth.

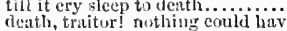

his rlaughters seek his death $\ldots \ldots \ldots$.

have o'urheard a plot of teath npon him

meet the old eourse of death

pours in the ranks of death

() untimely dettli: I know thee ................

that of thy deatl and business I can tell

rith the pain of denth we'd hourly die .
do, with their death. bury.... knomeo of $J$.

on pain of sleath, all meu depart

and the pluce death, considering who

my deuth proroguet, wanting of thy

to eateh my death with jumti

love-devouring death do what he dare

a cat, to serateh a man to detath!
the prinee will doum thee desth

with one haud hents eold deutl nside

worsce than Tylualt's death

a renrward followine Tybalt s dinti

incisure, \}rnund, in thut word's reteth

loe hoty s death, hut hody

in his look, mus:h more thain ileath.

crile is death: then lanishment (rep.)

yct, thut exile is mot denth?

no sudalen menn of alentis.
well, ilenth's the cmet of ail

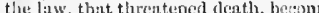

let me be put to death...............

cone, llenth, and weleome! inter

thus werp'st not so minch for lis death

but I might venge my cousin's death!

deatl to shisle away this shame (rep.)

like dently when he Houts up

the horrible eoneeit of dently und night

lenth thent bath

hath denth luin with thy his

denth is my sour-in-luw desth is iny ine

life leuving all is death's

nnil eruel denth hath entelied it from

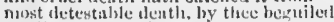

met lite, bint lones in tleatli! . .

whose sale is present desth in Muntuik

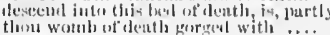

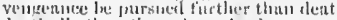

cleath, lie thenil there, hy al dewal man

point of stenth, bave they

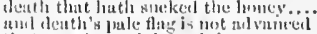

thint uningsemtiul ileath is semorous

a dateless ligeryain to engrosinger denth

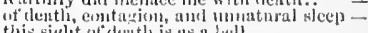

and lend youl coven to dent

whase antinely death burishem.

my manter news ot Julict's deuth.

the tidinges of her seath: and hor

they say, you stirits ot thalk in leati. . II, mulet,

brother's dleathe fur state to be disjoint

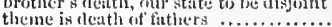

learsed int death, have lumst their

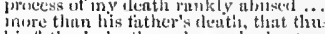

his fittler's leath, and our o'er has

alter your death, you were letter

for in that sleep of dentli what dreanis.

the dreat of something after ileath

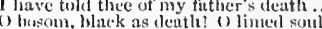

will answer well the death 1 gave him

nll that fortune, denth, and langer

I ste the imminent flenth of twent,y
it springs all from her tuther's (leuth

pestitent specehes of his tather's death

gives me sulertloous death! .............

the certininty of your dear father's death

mueh haste as thou woulset fty death

and for his death nu wind ar

falll lim sightly, it may he death.......

luet guilty of his aiven de:ath, shortens not

put to sulden lleath, wat slriving-tinue.

as this fill rergeant, lleath, is strict .....

gave eommandment tior their death

of deaths put on by eumning

iny houes not surticited to death of

I bled still, I an hurt to the deuth

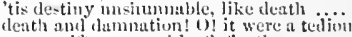

sume swift meins of death tir the ........

nobudy cone! then shall a hleel to deati

slic comes to speak of Cassio's destin

C......................

the death of Cassio to he the

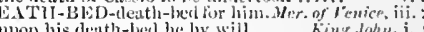

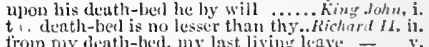
on thy cleath-bed phy the living leave desire doth in his death-betl lie.. Rom. . . Jul. i. 5 (cho)

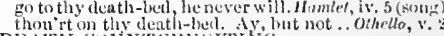

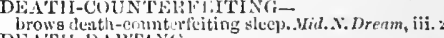
the death-darting ye of cockatrice..Rom. no Jul. jii. for deuth-like dragons l'erictes

iii. DEATI-MARKE] - - Romeo \& Jutiet, (urol, ) DEA'TI-PIRAC'I'LED

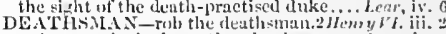

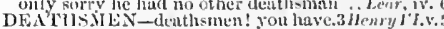
DEBA.SE - we do aleluse ourself .... Richard 11 . iii. gou debase your prinely knce ...... - iif.

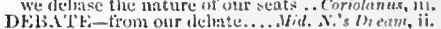

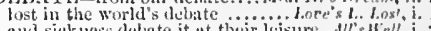

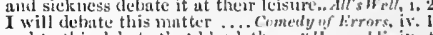
I will debate this mut ter ... Comedly lirers, ix. hear him debate of emmmonseateh .... Henryl i i. and my bosim muat debute al hile - iv. thut did delute this lussiness ........ Henry' ril. ii.

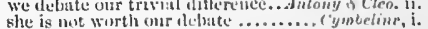

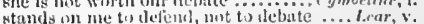

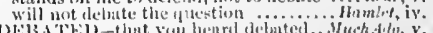

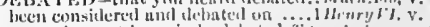

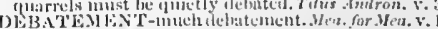

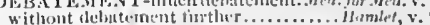

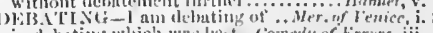

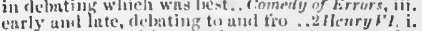
whist talk you ot ili.luting

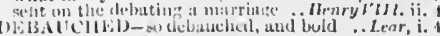




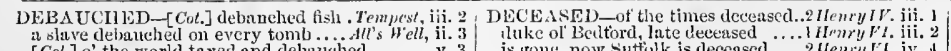

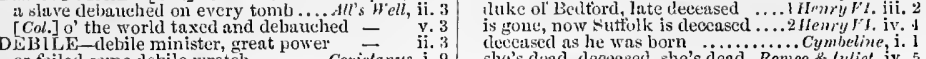

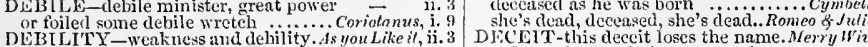

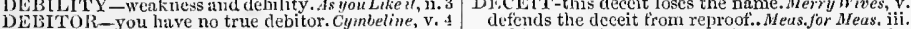
by lebitor and creditor ................ Othello, i. DEBORAII- the sword of Deboral

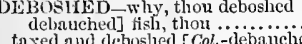

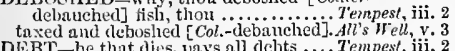
to pny the that debtes, lay's all delts .... Tempest, it tor debt, Pompey? or how? ineasure for Meustire, the very debt of your calling for dethe that will not die in debt from the great debts, wherein.......... clear of all the debts I owe to pay the petty debt twenty to sce me pay lis debt, and then
repents not that he pays your debt lie ne'er pays after debts .....All's Wrell, iv. 3 (letter) to gather in some delits, my sonl.. Tain

too little payment for so great a debt ${ }^{2}$ to hence in debt; and thicrefore .. Winter's Tale, $\mathrm{i}$. . shoull he in debt; tell me ... Comedy of Errors, iv. as if time were in debt!
if lie be in dcbt, and theft if he be in dctt, and the
the debt he ows, will be knowing how the debt
has paid a soldier's delt

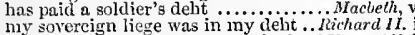
and pay the debt I never promised ... I Henryltr. i. th answer all the deht he owes
will alwars think him in our debt

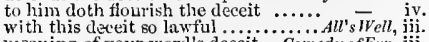

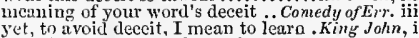
must lose the use of all deceit?
tongnes of mon are fiul of deceits?

best to quittince their

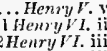

a shaje, that neans dece

grood deceit which mates him first.....

but from deceit, bred by necessity...3 Henry $V I$. iii. Clarence, but a quicksind of decit?
ah, that deceit should steal sueh . . Richard
HII. not yct dived ine drew not this deceit

it that be ealied deceit, I will be.. Titus Andron.

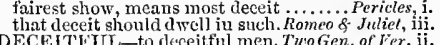
deceiving father of a deceittinl son. Tam

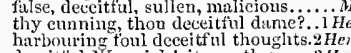

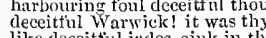

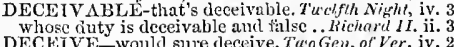

no more in debt to ycors than thou

pay lier the debt you owe her ......2 Henry $I V$. ii

to clance out of your deht
upon the debts they owe

Henry $r$. Iv.

our debts, our careful wives.
mimwillingness to repay a debt...

Richard III. ii. 2

reynires the royal debt it lent you

I iun iu your debt for your las

what nearer debt in all humanity. Troil. 4 Cress. ii.

Ill pay the debt, and free him.........

that what he spcaks is all in debt. . .
[Col. Knt.] clamorous demands of deb

dctention of long since due de
and your great thow of delts.....

to pay your present debts.

and fawn upon his debts $\ldots \ldots \ldots \ldots . . . .$.
he should the sooner pay his debts

these debts may well be
and be in debt to none

ind debt to nyy importunate business

swrallow them, debts wi
aubition's delit is prid

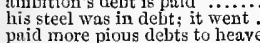

prid more pious debts to heaven ....

paid as debts, and not as given...Perictes, $\overrightarrow{\text { ive. (Gow.) }}$

or else die in debt

my life is my foc's debt.....

pay ourselves what to ourselves is debt. Hamlet, iii. DEBTOR-I am yet thy debtor.... Merry. Wives, ii. 2 how? let me not die your debtor.. Love's $L$
rest delitor for the first ....... Merchant of

and not my master's debtor......... As you $L$

as most dchtors do, promise you. 2 Heary $L^{r}$, in. ii.

I am your debtor, claim it .. Troilus \& Cressida, iv.

when I lave been a debtor to you.... Cy moeline,

a prison fur a debtor, that not dares.
who of their broken debtors take...

till then, rest your debtor.

DECAY - to be the decay of lust............ Purry Wives,

this muddy vesture of decay doth. Mer. of Ven

presage ot your own decay

destruction, ruin, loss, decay

must perforce decay; you cast

Richard II. iij.

fronting peril and opposed decay ..... - - -

gnair hope must linder lifc's decay,..3 Henry $V$ Henry

denth, desoliation, ruin, and decay... Richart III. iv.

full of decay and failing?.

coin words till their decay.
love begins to sieken and d

decays the thing we sue for

comes to decay a day's work ............ Cymbeline,

DECA YED-like a poor dicayed ...........il's

my decayed fair a sunny look ...Comedy of Err. ii.

that takes pity on decayed mer
of life had not so soou decayed

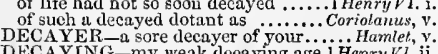

DECAYING-my weak decaying age... i Henry $V 1$.

enjoy the kingdom after my decease...3 Henry 1 II.
DECEA

is indeed, deceased; or, as you ... Mier. of le nice,

Antonio, my father, is deceased. Taming of Shire,
and he knew my deeeased tather well
true behalt" of thy deeeased brother .. King John

a hastard of the king deeeased ......
tells us, Arthur is deceused to-nithi

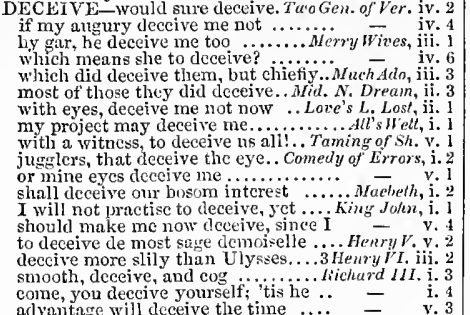

adrantage will dcceive the time
thyself and all our Troy deceive. Froilus \&
\& in knave, that mightily deceives you. Timon of $11, \mathrm{~h}$.
the fel low dares not deceive me .... Cymbeline, iv. I'll deceive them bot

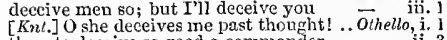
she dild deceive her father, narrying you
DECEIVED-deceived so many. Tuo Gien.opt"

it he have deceived me...............Merry $W$

I have deceived you both

how have you deceived me!

are you therein, by my life, deceived. Tuelfth 0 sir, you are deceived
thou art deceived in me, friar

I have deceived even your very eyes... Much $A d d o$, and Clandio, have been deceived ....

woo contrary, deceived by these renoves

get thce, $I$ am mucis deceived............ of of $v$ en

world is still deceived with ornament - iii. or I am much deceived, of Portia,... yoll are deceived, sir; we kept time ..Al' $\overline{\text { Fe }}$ th, iji. yon are deceived, my lord; this is....

or I am deceived by him that in your worship, is deceived: the gown is
and, hut I be deceived, signior Baptista
or I am much deceived, cuck olds.. $W$ in

or 1 am much decest

you liave dcceived our trust . .........

you are deceived, my substance is ... Henry $V I$. î.

friend, unless I be deceived ..........

but he's dectived, we are in readiness _- v.

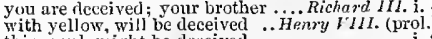
you are deceived, 1 think of no... Troilus \& Cress. iv. 2 Cassius, be not deccived: it I have...Jul. Casar, i.

I do not greatly care to be deceived... Ant. \&. Cleo. v.

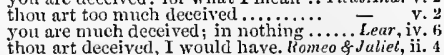
thou art deceived, I would have. Romeo \& Juliel, ii. 4
tush, thou art deceived; leave me .... and aunt--notlece are deceived ......... Hamlet, ii. 2
I loved you not. I was the more deceived - iii. I she has deceived her tather; and may ... othello ${ }_{i}$ i. I an sorry, that 1 am deceived in tay

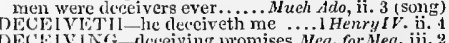

$I$ be deceived, our fine nusician. Taning of $S h$.

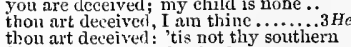
confess, that you are both deceived ver.. Tempest, (epil.)
DECEIVING-thuns deceiving me!...Arid. N.'s Dr. v. 1

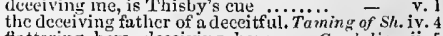
Hinttering, hers; deceiving, hers ....Cymbeline, ii. 5 DECENBER - lay of Decenber... Twelfiri Night, it. of Nhay doth the last of December.... Much ddo, $\mathrm{i}$. they woo, Decenber when they wed.As you Like, iv.

or wallow naked in December snow. Riehard II, i. rain nnd wind beat dark December.. Cymbeline, ili. 3 DECEPT TIOUS-deceptions functions. Troil. o $\mathrm{Cr}, \mathrm{y} \cdot 2$ DECERN-that decerns you nearly .. Huch Ado, il the swords which must decide it....2/Ienry $I V$. iv DECIMIATION - by decimation. Timon of Alhens, $\mathrm{v}$. DECIPUER - white will decipler...Merry Wires, v. the spirit? Who deciphers them? Comedy of Err. $y$.
DECIPITERED-seen deciullered there. I Henry VI. iv.

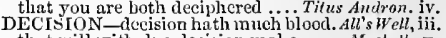
that will with due decision make.......Macherh, v.
the voice of any true decision.... Troitus \& Cress. ii.

this Decius Brutrus IIc is wolcome too Decius, well urged: I think, it is not

tell them so, Decius. Say, he is sick..

Deeius, go tell them, Cusar will not..

now, Decius Brutus, yours; now yours

some toDecius house, and some to Casca's when he has a house, he'll deck withal that deeks a thing divine!.. Tun Gen, of Verona, ii. to deck his fortune with his .. Taming of Shrew, i.

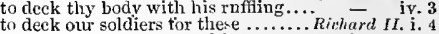
that now must deck our kings... Heurry $r$. i. (ehorus)

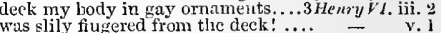
stand on the dying deck ...... Timon of Athens, iv. upon whose deck the sen-tost......... Pericles, iii. (Gower) from the deck you may discern the place $\vec{v}$. ECKED-when I have decked the sea o. Tempess, my lady's brow's be deskect........ Lore's L. Lost, iv. decked with five flower-dc-luees not decked with diamonds ......... Flemry III. iii. find thent decked witl ceremonics... Julius Casar,
thy bride-bed to have decked .......... Hamlet,

DECKING-decking with liquid pearl. Mid, N.Dr. i. -scutchcon phin declares... Love's s.... v. with a ready gness, declare, before .....Henry $\mathrm{V}$.i. and now dceiare, sweet stem from ...1 Henry $r$. 11. please you to declare, in hearing .... Henry $\overline{V I I I}$. ii. be it so; declare thine office..... Aniony \& Cleo. iii. 10 read, and declare the meaning ....... Cymbrline, $y$. [Kint.] to a bull? a heary doclension? 2 Henry Ir' ii. by this declension, into the madness .. Hamlet, ii.

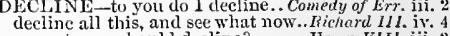
a great man should decline? ....... Henry VIII. iij. not letting it decline on the deelined 5 ivess. decline to your contounding .. Timon of Athens, iv.

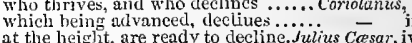

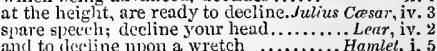
and to deciine upon a wretch ......... Hamlet, i. Winter's Tale, ii. what the declined is, he shall.. Troihus \& Cress.

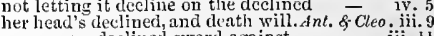
answer me declined sword agninst.. - iii. if [Col.Knt.] perfect age, and thethers declined. Lear, $\mathrm{i}$, I am declined into the vale of years .. Othello, ifi. declining their rielh aspect.... Comedy of Errorss, iii. noblc blood in this declining land ... Richurd II. ij. 1 accompauying his declining toot... Timon of 'Ath, i. 1
shown to thee such a declining day. Ant. \& Cleo. Y. 1

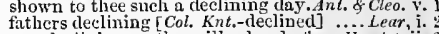
Was declining ou the milky head of...... Hamtet, ii. DECOCT-broth, decoct their cold ....Henry V. iii. 5 DECORUMl-goes all decorum..... Hieas. for Heas. i. 4
keep decorum, and fortune lim. Antony \& \&leo. $\mathrm{i} .2$

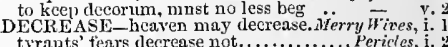
DECREASED-rather than decreased. Tam. of $S$, it. 1 DECREASING-a decreasing leg? ..2Henryl 1 . i. firce, dispense with this deeree ... Love's L. Lost, i. will not obey an old decree ................ leaps over a cold decree $\ldots \ldots . . . M e r c h$
no toree in the decrese of Venice can alter a decree established..

and on our quiekest decree iv. 1 and on our quiekest decrees ..........All's Well, v. my acts, deerees, and statutes, I deny - iv. 1

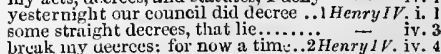




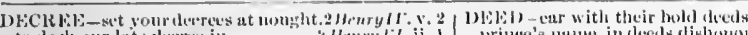

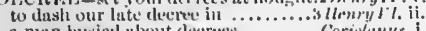
a nan busiel ubent deerees........... ('orinhanus, i.

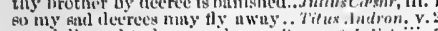

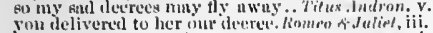

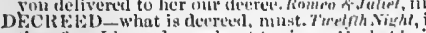

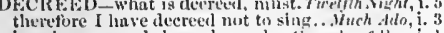
in solemn gynuls been leereed .. Comedy of kirr. it is deereed-l lector the sreut... Troitusis erows. v. therefore, it is decred, he dies....'('oriolumus, iii. tis llevered, is these betore tine.

nrt luth this deereed, to make some.

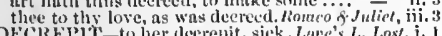
DECR Ril'l'T-to her decreplit, sick. Lare's $L$. Lost, $\mathrm{i}$.

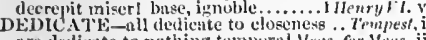
are dediente to nothing temporal. Mets, for Meas. ii.:

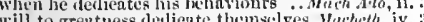

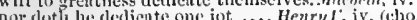
he that is truly dedicate to wi... .... Hestery i.t. v.

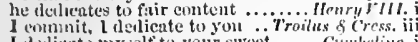
I itedicate myself to your stect

of miril myself I'll dedieate ............ DEDICATEI - [ Col. Kut.] nll derlicaterl to. T'ent a derliented heggar to the air.. Fimnon of , ihens, $n$ wild dedieation of yourselves. Winfer's Tith singe dediention to the sreat lord... Tmon of Ath. j. both in word and dew

for truth hath better deeds. Tivo Gon..... of ironona, ii. twere as good a deed, as to ...... Ticelfh Night, ii When evil llects have their

most good in deed

dispenses with the deeil so fur

hasc dark deeds clarkly answered

this deed unshapes me yuite $\ldots . . .$.

hand you a speeinl warrant for the deel?

xith your high and wortly douds......

in the doing of the dew o.... Love's L. Lost, ii.

to render the diceds of merey

my deeds upon my hend:

send the deed utter me, anil i...

give him this deed, and let him...

tus deed will be well weleome

so slvines a good deed in a mang

better pleased me with this deed

by doing deets of hospitality.

my deed slanll mateli thy dieed

is lignified by the doer's deed

wicked meaning in a lawful deed

to the future our pust deeds

till your deeds gain them .............

his fortune with his virtuous deeds

and that my deeds shall prove

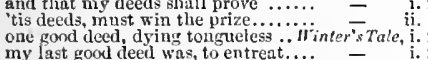

to do this deed, promution tollows

eireumstanees made up to the clewr $\mathrm{i}$

in more than this deed does requ
dnes my deeds make the blaeker

that's a goot deet; if thou mays

and we"ll do good deets on 't

the present deeds, that all your

to sires your deeds; not little

strome botle against the deel ....

word a to the heat of deeds too coid

and not the lecel, con

these deeds must not be thoming

a little water elenrs us of this deed

to knuw my deed, 'twere best.

who did this more than blond yeel

puts upon them suspicion of the deer .

be done a dced of drenilful note.

till tliou applaud the theed .

a deed without $a$ name

unless the deel go with it
this deed I'll do, before this.

umnatural deeds do breet unnaturn.

your sharpest deeds of malice on ...

your warrant will bear out the

phe man slould do the a deed .......

deets, makes deeds ill [ Knt,-ill decds]

signed, to do a dleed of shume

the deed. whieh both our tongues.

had not a hole to hide this ileed.

renowned firr their deeds as far

huinoms, black ob=eene as far

o, would the dees were goorl: ........

nought $a$ deed of slumpler........

whose higl decels, whose $i$

exchnnge his glorious deeds for my....

to engrexs up glorious deets on...

never diul such deecls in arms.

how to clierish such high dleed.

to set a gloss on faint deeds ...............

onr deens nre dlone?

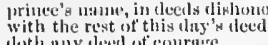

loth uny the'el of courure

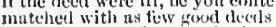

itare not avouch in your deets any

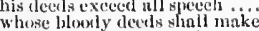

() let no wortis, but deeds, revenge

thy noble deeds, as valour's .......
deverls of ruge, and stern impatienee.

your deeds of war, and all bi

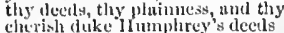

secing the deed is neritorions.

and eensure well the deed

reward you tin this venturous deed.

hallow thee for this thy deerl

to do a murilerous deed, to rob

impudent with use of evil diceds

olown it flinty by thy deed

my son my virtious deets behini.........

I'll make thee eurse the tlect .........

art fortunate in all thy deeds...

ithis fonl deed were by

to stopr devoted charitable deeds:
delight to view thy leinous deed

thy dced, inliuman, umnatural

hath plagued thy bloody deed

O 'twas the funlest deed, to slay

the deed you undurtake is dammable

sinke did I that ill deed?.........
will be nvenget tor the deed

to do this deed, will hate you (rep.).

bloody deetl, and desperately desimtehed!-

it they have done this deed ...

most ureh deed of piteous massaere

n letter of thy noble deeds.

nud be a hapy mother by the died.

tor hateful deeds eommitted by .......

that I gainsay my deed, how

goorl deed, to suy well (rep.)

no day without a deed to crown

do a deed that fortune never.. Troilus
valiant and magnanimous deeds

but in the deed, devours the deed in

hot deeds, and hot cieeds is lor

ald hot deeds? why, they are vipers
give her deeds, but she"ll bereave

what, are nyy deeds forgot?........

whose glorions dects, but in ...........

speaking in deeds, and deetless

do deeds worth praise, and teli

but edifies another with her deeds

that's a deet thou'lt die for

forgetting thy great deed .

wonder of good deeds evilly bestowed.

now we'll slow 'em in deeds

outdone his former deeds doubiy.

without any other deed to heave

rewards lis deedls with doint thei

tell us hisdeeds, we are to put

as his worthy deeds did claim no les

let deeds express what's like to be ..

thou hast done a deed whereat

quite througl the deeds ot men .......

by men's voiees to commend

hath done this deed on C:esar.

choked with eustom of till deed

that this fint deed slably smell

they, that have done this deed

it is a deed in fashion!

I do sneh a deell O Dardanius i

hope of better deeds to-morrow

assist the deeds of justest me

'tis a worthy dect, and shall become.....

than by our fleed aequire too high

to lament our most persisted deeds

I aprove tour ends all uther deecls.

an inetrument may do a noble deeil

te our gots deted, though liome

thou hinst robbed me of this deed
this is Pisanio's deed; and Cloten.

such preeious deeds in one that

I would not thy good deeds sluinilifiom -

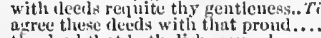

arree these deeds with that proin

iny nephew llutius' deeds do plo.....

in all hiscleeds, a fither, and a triend

leave to pleal iny deeds.

they would not ilo so fonl in ieed....

at heed of teath, thine on the inumeerit

thou hast clone a edaritable decd....

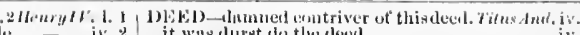

perfiommers of this heimens, hilooly ileced? -

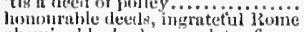

ubouminable ter:1s, complots of

bitt a clecel of clarity, to tlat

let my ilecls be witsess ot my

80 rry for these heinous
tell, who dicl the decrl?

die, frantic wreteh, tir this ace........

meech, weath tor a deadly leerl.

uwt'ul botle in decel and wort.... l'erisles,

to plate uperin the volume of

not to reason of the deeel, mit do $\mathrm{i}$

if give it to thathe deet.......

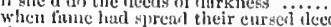

large specelice may your devds aplurove $\because-i$.

dithmed guilty decels to simers'. Romen \& Julict, ii

foul deete will riouther deerd........

rany give his saying deet

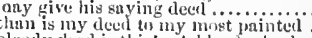

0 , such a deed, as thos thendy decel

$O$ heavy deedil it had been so with is

and this vile decel wo must, with all our

Ilamlet, this clectl, for thine espeeial

to show yourselt in deed your father's

Öhetlo, iii.

modesty, did I but spreak thy dueds.

in tiscourse of thought, or actual deet

I have no great devotion to the dwe.

0 who hath done this deet?

hates the slime that sticks on filtili. deeds $=$

thon hast done a deed of thine is no...

when you shall the unluck y deeds reläte - v.

by deed-achieving honour newly .. Coriolanus, ii.

EEH-you deen eanon-bullets. Truelfh Night, $\mathrm{i}$.

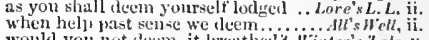

would you not deem, it brenthed?. I'inter's 'I ale v.

may deem that you tre worthily. . Richord 11 . Iv.

that $I$ deun you an ill husband ..ilenry ili. iii.

what wieked deem is this? .. Troins "Cresside, iv.

[ $\mathrm{knt}$.] of himself, I cannot deern of ..... Inmtet,

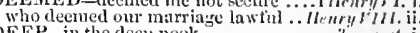

EEP -in the deep nook ..................

to tread the ooze of the salt deep ....

that decp and dreadful organ-lipe ..... $=$ ii.

that's a dew story of deep love.. Two Gen. of'ter.

sad sighs, deep troans

forsake unsounded deeps to...........

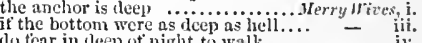

a pond as deep as hell ................. for for $\bar{M}$ eas. iii.

and so deep sticks it in ny .......... $-\mathrm{v}$.

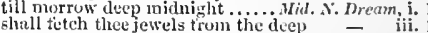

1) 1 uluge in the deep, and kill me too. - iii.

that will not be deep searched

get a deej rlass of am of the diep - iv. 3 (verses)

it the Jew do ent but deep enuugh ... of

many fisthom deep I am in love!. As you Like it, iv.

how deen? Thirty fathom ............Ath's well, iv.

to plunge him in the deep ....Taning of Shrea, i.

al ways wind obeying deep gave.. Conedly of Err. i.

and took deep sears to save thy life... - v.

set firth a thep rmes and great...... - -

see my black and deep desires........... -

arimst those honours deep and liroud

our tiers in banque stick deep.

curses, not loukl, but clete..

deep shame had struek me dumb......... Joh John, iv.

thrust thy land as deep into the pintse -

olcep incision, $\boldsymbol{k}$

a fo

erown like a deefi well, that owes... - iv.

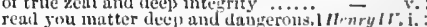

the botton of the decp .....

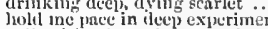

- ii

slmll not wind with such a deep indent - iii.

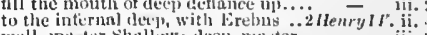

wel, mitster shithow; tleck, master.

a place levels enongh

with snch a deep flemensinur in........

this would driuk derp

iret fethek deep in gore.

yeomen from so decp u ruot? ........ 
DEEP-comest thou with deep

received deep scars in France.......

deep night, lark night, the silent....
the water, where the lirook is deep.

of deep decit

that is to see how lecp my grave

was troubled with deep melancliol

whenee springs this deep despar.
in the deep bosom of the ocenn....

this deep disgrace in brotherhoo

eursing eries, and deep exclaims ...

and take dcep traitors for thy

upon these secrets of the deep?

o God, if my deep prayers eannot....

in that sin he is as deep as I........

a virtuous visor hide deep vicel .......

guilty of so cleep [ Col. Knt.-great] a sin
into the fatal bowels of the deep ....

I can counterteit the deep tragedian

in deep designs, in matter of great

but meditating with two deep divines

torgetfulness and deep oblivion...

two deep enemies, toes to my rest....

repays he my deep service with such
too deep and dead, too deep and dead

of state was a deep envious one....

wish him ten fathom deep $\ldots . . .$.

so deep suspicion, where all faith
in how many fathoms deep they.
from his deep chest laughs ont

from his deep chest laughs ont .

bottom in the uncomprelensive deeps

would I were as deep under the eart 1 .

one may reach deep enough .. Timon
tis muels deep: and it should seem

fill deep in love with thee ...........

the deep of nith t is crept upon.....

and wrinkled deep in time? $\ldots . .$. Antuny o cleo.

but said so, twere as deep with me.. Cymbeline, ii.

womb of this deep pit ........ Titus Andron

my heart's deep languor, aud my soul's

this sight should make so deep

whose loss hath piereed him deep....

sound deep our woes into the air.

thunder above, and deeps below.

having called them from the deep!

deep clerks she dumbs

natures of such deep trust we....

looks fearfully in the eonfined deep....

like monsters of the deep

deep dread-bolted

more clouds with his deep sigh

of heal ths five finthom deep

as boundless as the sea, my love as deep

no, tis not so deep as a well...........

why should you tali into so deep an
w'il teach you to drink deep. ..........
i' the throat, as deep as to the lings?

o! this is the poison of deep grief.........

to-night caroused potations pottle deep.
DEEP-CONTEMPLATIVE-

should be so deep-cont
DEEP-DIVORCING-

with a deep-divorcing vow? .. Comedy of Emors, ii,

and the deep-drawing harks.. Troilus \& Cress. (prot)

DEEPER-I'll seek him deeper than .. Tempest, ini. 3

deeper than did eve

a deep story of a deeperlove ....Twa Gen.of Fer. i. 1

the conceit is deeper than you. Taining of Skrew, iv. 3

this avarice stieks deeper

Richard II. iv.

face of mine, and made no deeper wounds - iv. I

dogs, which hath the deeper mouth...1 Henry VI. ii. 4
touches me deeper than you can.... Riehard III. i. I

touches me deeper than you can..... Richard 1 .

or something deeper, whereof, perchance. Lear, iii.

the deepest loathing to the stomach.Mid. N. Dr. M. 4

to betray us in deepest consequence ......Macbelh,

and with the deepest malice of the.. Coriala nas, iv.

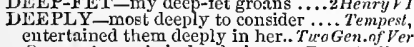

entertained them deeply in her.. Tü Gen.of Ver. y. 4

O peacel now he's deeply in .... Twelfth $N$.
yet not sodeeply as to thee belongs. Taming
or both dissemble deeply their afrections

declined, drooped, took th

eonsider it not so deeply ................ Mtrchoth, ii. a

solut $I$ will deeply put the fashion

are deeply indebted for this...........2 $\mathrm{Hen}^{-} \mathrm{V}^{\prime} \mathrm{v}$.

as deeply to effect what we intend...... Richard III. iii. I

if your uffiance were deeply rooted ... Cymbeline, i. 7

she's with the lion deeply still in. Titus Antron. iv. 1

wine loved I deeply; dice dearly

'tis deply sworn.
DEEP-NOUTHED-

with the deep-mouthed brach. Taming of $s h$. 1 (ind.)

out-voice the deep-mouthed sea... Henry $V$. v. (cho.)

DEEP-REVOLVING-
deep-revolving witty Buekingham. Richard III. iv. 2
DEEP-SWORN

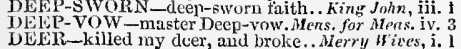

DEER-my deer? My male deer? ...M

seek to spill the poor deer's blood. Love's $L . \bar{L}_{\text {Lesl }}$,
and who is your deer?.................

the deer was os your ki....

haud eredo for a deer. I said, the deer

an epitapl on the death of the deer?

Thave called the deer the princess killed -

the king he is hunting the deer.......

and ceer, quoth he, thou makesing deer -

the noblest deer hath them as...

to set the deer's horns upon his

he have, that killed the

like any deer $\mathrm{i}$ the herd .............

ns 'twere the mort o' the deer...... Winter.'

too unruly deer, he breaks.... Comed ly $_{\text {of }}$ Err

not struck so fat a deer to-day ........ Нелry

herd of England's timorous deer....

if we he enctish ceer

they shall find dear deer of us...

mist hunt this deer to death ........2 Henry

the prineipul of all the deer

close, to stenl the bishop's deer?

how like a deer, stricken ....... oulins Cae

the elected deer before thee? .........

it was my deer; and he, that wounded

why, let the strucken deer go weep.... Ham

DEESSE - très chere et divine deesse?.... Hemry

DEFACE-and deface the bond...Aer. of Fentic

and not deface your honour with..... He

my arms torn and defaced

and defaced the precious image of...R

her face defaced with scars of infamy
DEFACER-that foul defacer of God's

DEFAcers of a public peace .......... Henry $V I I I$.

DEFACING-detiacing monuments ...2

DEFAULT'-in the defuult, he is a man. All's Well, ii.

are penitent for your default to-day. Cum. af Err.i.

perisheth by your default.

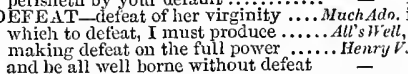

sharp reasons to defeat the law ....Henry $\bar{v} 11$.

activity may defeat and quell ..... Timon of Ath. iv.
ye gods, you tyrants do defeat .....

ye gods, you tyrants do defeat
some mortal stroke she do defeat

and damned defeat was made

my stronger guilt deteats $m y$ stro.

their defeat does by their own ins

DEFEATED-thereby to have defeated. Hid. $N$.

if these men have defeated the law....Henry $\mathrm{V}$.

DEFEAT', wT-Cresar thou defeat'st.Ant. $\&$ -

DWF

DEFECT-hut some detect in her...... Tempest, iii. 8nying thus, or to the same defect ... Mid. N, Dr. iil.
this is the very defect of the matter. Mer. of Ten. it. for those defects I have before.. Taming af Shre
our will became the servaut to delect.. Macbeth our will became the servaut to delect.. Macbeth, and so many, my defects, that $\mathrm{I}$...Riehard III. iii. the faint defects of age must
whether defect of judgment

by laying defects of judgrnent to

[Knit. for defect of juldyment, as oft.. Cymbeline,

I say, the stamp of one defect........... Ham

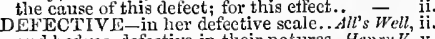

and hedges, defective in their natures..Henry $V$.

our state' a defective for requital .... Coriolanus, ii.

all which the Meor is defective in ....... Ohling, ii.

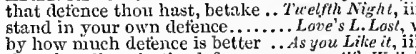

though valiant in the defence .......... All's Well, i.

keeps her glurd in honestest defence $\overline{-}$ iif.

put up that womanly defence; to say....

we must awake endeavour for defence

the danger of my true defence: lest I

rescue, and dutence, eries out

well sinewed to our defence..........

and prepared defunce, whilst....... Henry $1 r$. (ind.)

to answer royally in our defences.

ii. 4

in eases of defence, 'tis best

so the proportions of defence are filled

or, guilty in defence, be thus destroyed? - iii.

in defence of iny lord's worthiness.. Henry $V I$. iv.

vows to fight in thy detence...........3 Henry $F I$

those that fight in your defince.....
the city bein: but of small clefence.
DEFENCE-not cooped here for defence. 3 Henry VI.y. 1
spent more in her defence... Troilus \& Cressitu, ii, Epent more in her defence... Troilus \& Cressilla, ii.
in defence, by mercy, 'tis most .. Timon of $A$ th. iii. in defence, by mercy, tis most $\dddot{\text { Tim }}$.

for the defence ot' a town, our general Coriola

lolicy, strength, and defenee, that Rome -
full of rest, detivee, and nimbleness.Jal. Ceesar,

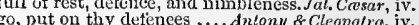

soft, soft; we ll no defuce........... Cymbelime, iii.

dismembered with thine own defence. Rom. \& $/$ ul. iii.

for art and exercise in your defence.... Humlet, iv. 7

she drowned herself in her own defence? - y. defend your reputiation, or bid.......... Tempest, ii.

defend your reputiation, or bid... Merry Wives, iti. pray God defend me! a little.... Tweifh Night, iii. the benefit defends the deceit ............ fors $\overline{\text { Mers. }}$.ii. for God detend, the lute slould be ...Much ido, ii. for God detend but God should go betore - iv. and God defend the rifint! .......... Luve's L. Lost, i. gain shouldst defend mine honour? .. King John, i. Dut yet I dare detind my innocent life $-1 v-1$
let this defend my loyalty ........... Richard 11. in myself I boldy will defend........... so detend thee heaver, and thy vriourl

as I truly fight, defend me heaven!.:

thy lance, and God defend the right!

both to detend himselt, and to approve

and God defend, but still I should... I Icner.y $_{1} V^{\prime}$

I winl assay thee; so defend thyseif

to defend against the scot .......

the advised head defends itselt.

cannot defend our own door trom

to defend the city from the rebels................

their helps only detend ourselves.

but to defend his person from....

iv.

sworn to eherish and defend

marry, God defend his grace should say

and waking, $O$ defend me stilt:

and waing, o defend me still!...

to defend my honesty; my (rep.) iroil. $\overline{\text { f }}$ Cres. i.

that detend her (not palating

what shall defend the interim?...... Timon of $\mathrm{A} t h$. î.

or defibund yourself by their vulgar.. Coriolunus, i.

the mighty gods defend thee!.Jui.....

the gods detend him from so great ..... \& $\overline{C l}$. v.

defend the justice of my cause .... Tik

protect thee from? it may defend thee

seen to detend yourself: now quit

deterd you from seasons such as these?....

and all that offer to detend lim, stand

the gods dofe to defend, not to debate...

augels aud ninisters of grace defend nsi.ilamlet, $\mathrm{i}$.

0 , set detend me, triends, I an but hinrt

and to defend ourselves it be a souls

of all my tribe detend from jealous

DEFENDAN'T-ot the defendant..Mer. of Venice, iv. are the appellant and defendant 2 Henry $V$. ii. DEFENDED-to have defended it. Mier. of Fenice, v. not only well defended, but taken .... Henry

when Helen is detended...... Troilus $\&$ Cressida, ii. DEFENDER-banish your detienders Coriol ron. iii. your gates the very defender of them - v. DEFENDING-the ring detendiug it. Mer. of Ven. DEFENSIBLE-did seem derensible..2 Henry II. $\mathrm{ii}$. 3 tor we no longer are deftensible ...... Henry $V$. iij. holy Joan was his defeusive guard... 1 Henry $Y I$. ii. soldiers, defer the spoil ot the city. 2 Henry ${ }^{\prime} I$. iv. of my triends .................. Richard III. iii. then take my king's defiance......... King Jaln, i. I and send detiance to the traitor.... Richard II. iii. I have thrown a brave detiance in.... seorn and detiance, slight regard....... Henry $V$. ii. greet England with our sharp defiance - iii. 5 as black detiance, as heart can.. Trailus \& $\overline{\text { Cress. iv. }}$ defiance, traitors, hurl we in your.Julius Casar, v. DEFICIENT-the deficient sight topple.. Lear, iv.

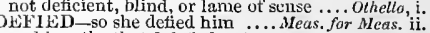
and breaths thiat I deticd not ....3s you for Like it, (epil.) thus defied, I tliank thee for myself. Cymbeline, iii. DEFIES-she deties me, like Turk. As you Like it, iv, 3

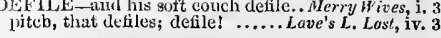




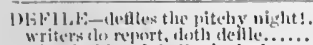

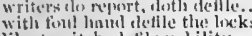
like to pitoh, eletile nobility

whone wrong thought dethles the Di:Th, li, p-pitels will be dethled

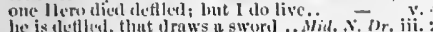
my bel he lintls defiter

his sourvest, und defiled himselit' ny, tletlet land, my lore

nis louses are defiled tir want of umon of . Ithens,

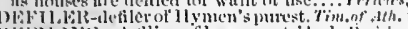

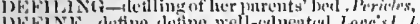

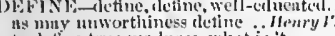
ns my nuworthiness detine . llo

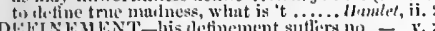

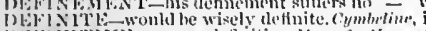

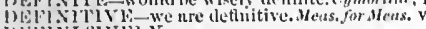
DEF IN I UV ERT-

Alefinitively thus I nnkwer you.... Richart III. iii. 7

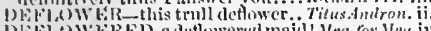

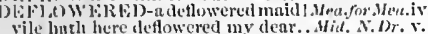
vile buth here deflowered my dear... Mit. Ni. 1) some Terets hath deflowerel thee.
entimecel, statined, and deflowerel?

as sle was, deflowered by him... Romen of Juti

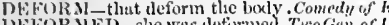

liow lom liath she leen defirmed?

low" long hath she lxen deformed?

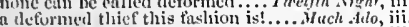

I kuw that Dutormed; he has becen

I say, what a cluformed thief this.

tmal one Detormed is one of them....

Fu

low deformed dost thou look! ... Lore'sL.Lost, iv.

hath mineh defornsed ass, ftishionime...

rith "Yime's deformed hund have.... - v

deforned, mintinished, sent betore.... Richard IIT.

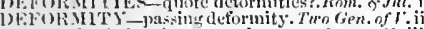
where sits deformity to mock

descant on mine own deformity.

proper fleformity seems not in the tiend.. Leer

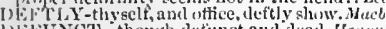

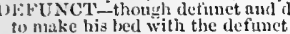

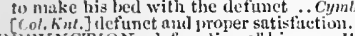

1) E U UCTION- defunetiun of king

bit 1 ilefy all angels

... Teropest, iii.

leahery I I defy lechery.

what inun! dety the

for lim dety you $\ldots \ldots \ldots \ldots \ldots \ldots$ - iii.

and do defy thee for a villuin.. Coned of

I clis tefy thec, Franec.....
whiv, then defy each otlier

no, if lefty all counsel

I do defy him, and I spit at him....... Richarm ul

I defy thee: I was never

det' $h$ im by the lord of Westmorelaind

I lice defy a grin: O lround

lefty us to our worst......

and I d defy them all

defy them then, or else hold

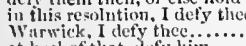

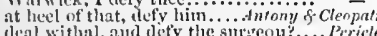

and clety the foul tiend

then I lety you, stars!........

Bomeno.... Lear, iii.

not a whit; we defy augury............. Inanlet v. 3

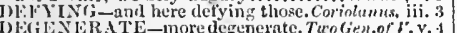

you icgenerate, you ingrate revolts.. Kintr Jo th.

reereant and most degenerite traitur. Richard

most degenerate king! but, lord .

show how muth degenerate thou art.i Ifenry $/$.

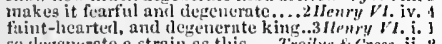

or dewculate a strain as this . Troilus f. Cres.

degencrate bastard! I'll not trouble thee... L

most harbaroua, most dereneratel........ - iv.

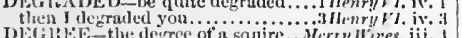

will not match above lier dewree.. Tuelfth Nishl,

unler the tlegree of my bettery

mi-jrision in the higlsest degree!

tir hye's in the third degree of crink..

that's a cheree to love...............

I'll reyuite it in the hirhest depree.. -

now to have no sacessive degrees. Mea, for Mea, ii.

that break s them in thic least degree -

Ill leave it by derrees

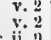

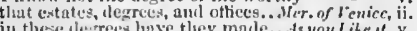

in these de rees have they maile.

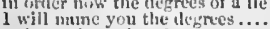

weleome in nu, less degre

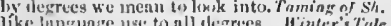

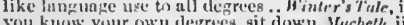

answer the in any fair degree...... Hirbarrl il.

our suljucts next degrec in liolic .....

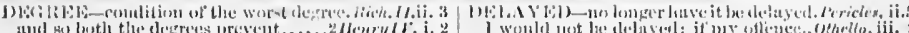

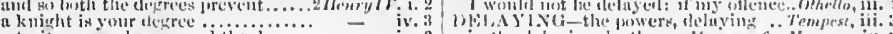

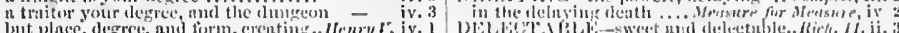

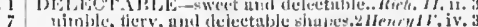
quite from the muswer of his cle

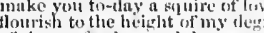

of thy profession, nut alepree

intalles rot bit hy leprece

calles muto a enritinal

called? and what is thy deuree? ...2

of whith degree sucver, with

bruke it in such denr degree! .............

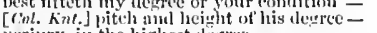

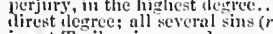

is not Tritilus, in some dectres.. Troilus

observe clegree, priority, and place
obser

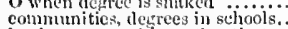

by degree, stancl in authentie (rep.).

when derree is suffiseate (rep.)

the sweet deres, observanees $\because$ Timon of

in the sequente of degree ..........

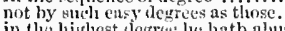

in the highest degree he hath nutsed -

pre-ordinance, and first de

ofience nust be of sueh uninatural deny of Cleo.

f any nous of

eminently in the degree of this fort une. Oinallo, ii. )

what wound lid ever heal, but by degrees? - ii. 3

DEIFYING-leitying the nanie.. As you $I$

DE[GN-not deign my lines.... Tiro Gen. of Ver.

silee thon dust deign tos woo ....... Henry I'T.

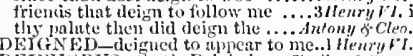

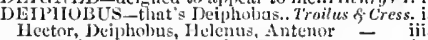
Hector, Deiphobus, I elenus, Anterwo
and Deiphobus, the Greeian Diomed

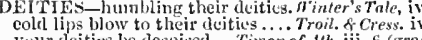

your deities be despiscd... Timon of Ath. ini.

DEI'TY - I teet not this deity in my

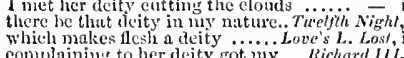

conplaining to her deity got my ... Richord $I i T$. i. 1 by rod of the rest, against thy deity... Combeline,

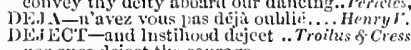

of ladies nost dejeet and wretelied

DEJECTED-I an dejected....

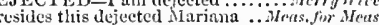

Antony is valiant, and dejected

and most dejected thing of fortming

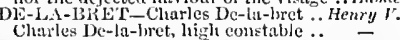

DELATION-[Col. Kul.] eloze dulations. Othello, jii. 3

of 'my people hold him in delay?... Twelfh Nigh, i.

in delay there lies no plenty ........

life, ticle death, I come without delay - v. 1

if thou delay me not the kniswiedge alse

now, Goil delay our re deluy

to seek delay's tor them and ine... Comcdy of Err. i.

to tarry for the hoy, Delay

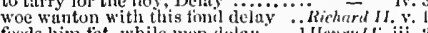

feeds him fat, while men delay ..... INenry/r. ii

lenvo ofl delays and let us raise .......
no time, delitys have dantrerous ents

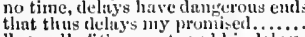

that thus delays my momised....... =

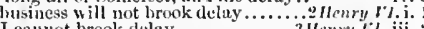

I canrot brook delay ............... 3 Henry il. iij. 2

therefore delay not, give tlyg
their suits with slow delays
if we use delay, eold biting

not ta'en tarly by unwise delay .....jichard $11 /$. iv.

makc no delay; tim, lords, to-mortrow

make no delay; fir, lords, to-molrow

that $y$ ou not ilcluy the present ...... Corioloms, i. ti

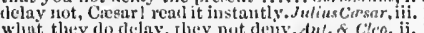

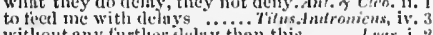

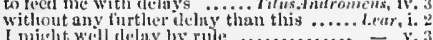

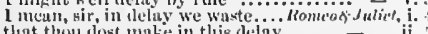

that thes dost make in this delay

leluy this marriage for a month

the law's delny, the insolense of of
witli speed alsoard, delay it nut .

with specel alsoard, delay it not.
abatements and delays as many

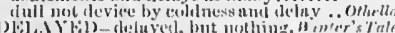

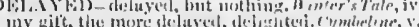

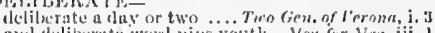

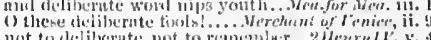

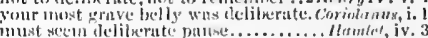

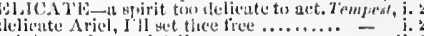
anbtle, tender, and alcliente temperance... = i i.

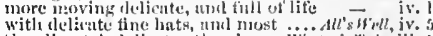
the climate's lelieate; the air.... ïinter'stide,

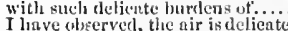

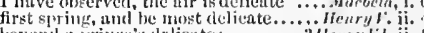
beyontl a minee's delicate

to glow the delicate clicels ......... Intony yeteo. ii.

our semee in soft and delicatc l.ethe $.2-$ it.

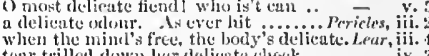

tear trilletl down lier delicate clicek .... - iv.

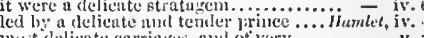

abliscul her delicate youth with drings.... Othello, i. her delicute temelernesin will lland itselti... - ii.

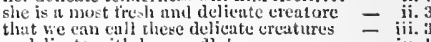

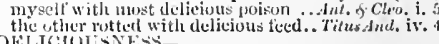

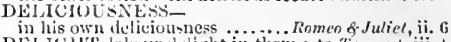

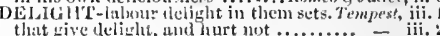
you delight not in music .... Iuo Gen.ofVeromu, ii.

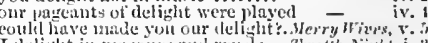

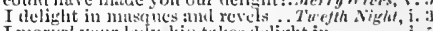
lacty vlivia's father touk mucls delight $=$

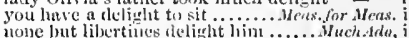

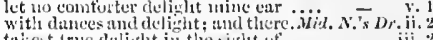
takest trice delight in the sight of"...

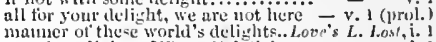
to vain dellintit. Why, all delighits are - i. how you delight, my lords, I know nut - i. ine I, delight in jerjured menc..... - $v$ I tesire no mere dulight than...Mrach, of benice, ii. will talise little deliglit in it ....... As you Like it, $\mathrm{i}$. whom henven delients to liear ........s's slie tnketh most delight in music.. Taming of st. j. 1 teach her that wherein slie delyghts ..

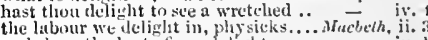

and delight no less in truth, this

ean kcep no nuedsure in detignt..... Kichard 11 . iit.

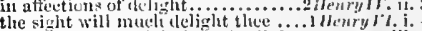
clunrelumen take deliolat in broil: nud delight to tis delights

now un to live in savery to......

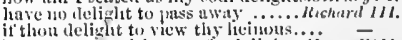

besotied on your sweet delights . . Trol. o C're'ss. ii.

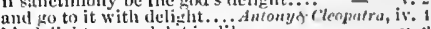

the silken strings telirht to k Rs.. Titus Andron. ii.

tuless the govls delighli in tragedies! $\overrightarrow{\text { iy. I }}$

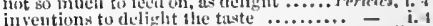

in eutrse of true dulingt than to be ...... - iii.

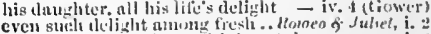

fimel delight writ there with beanty"s - i.

the druige and toil in jomedelight

if' sour we delights in tellowslith .....

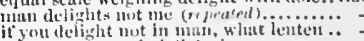

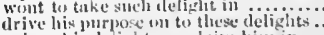

poison lis tedight, proclam him in Dencilite - ii.

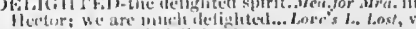

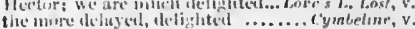

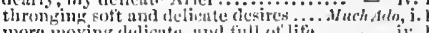

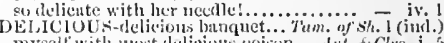
the labour we delight in, plysick
and show the best of vor ilelithts

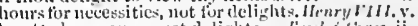


DELIGHTED-no delighted beauty lack. Olhello, i. delighled them in any other form......... than a delightetul mensure ........... Richichard it. marches to delightful measures..... Richlarl III that delightful engine of her thou
whose delighttul steps shall mak

whose delighttul steps shanl make ....

DELINQUENT-two delinqtients tear. Wacteth, iit

DELIVER-I'il deliver all

I am going to deliver them... Two Gen.of verona,

If his enemy deliver sent to deliver him

deliver it to madam Silvia

deliver to a joyful resurtectionsi.......

and did deliver to our age

some hideous matter to deliver Tuielfh Nigh

or I'll duli ver thy indiguation to him

but you'll not deliver it..................

but sir, I will deliver his challenge

When the fool delivers the madman.:.

to deliver his head in the view of Angeio

and to deliver us from devices hereafter

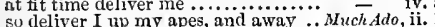

deliver me from the reprobate..... Love's L. Losl, i.

delivers in such apt and gracious words

deliver this paper into the royal hand

to this devil. to deliver you

deliver all the intelligenee in hi........ $A l l$ 's $\vec{W} e l l$, iii.

in fine, delivers me to fill the

pray you, sir, deliver nee this paper... $\quad-\quad$ v.

and must here deliver them.....

and so deliver, 1 am put to sea

as from your father shall deliver.
the old shepherd deliver the manne..

he cin deliver you more...

didst thon deliver to me on .............

angels that you sent for, to del
some blessed power deliver us

the sum that may deliver me

thought good to deliver thee...... Hacbe
sinee he lelivers ow offioes, and what

to deliver sweet, sweet, sweet
should deliver up your erown

deliver $\lim$ to safe

care-tuded tougue deliver him

deliver them up without ranson

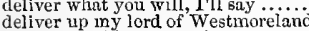

and deliver him up to his pleasure.

eaptam, and deliver to the army.

that would deliver up his greatness so

I priythee now, deliver them like a man
but truth. I will deliver her...........

to her laws wo do deliver you

let 18 deliver our puissance into....

I shitl deliver so: thanks to

deliver up ny title in the queen .......

when he delivers you from this earth'

from your graee I shall deliver to him

eardinal, deliver all with charity ...Hen
deliver this with modesty to the queen

do not deliver what liere you have heard

and to deliver, like free and honest
to deliver this to my lord the king

1 could not personally deliver to her
this ring deliver them, and your appeal

this ring deliver them, and your appeal
deliver Ifelen, and all lamage else. Troil. \& $C$

now to deliver her possession up

to this hand from a spicter $I$ deliver her.............

but, an't please you, deliver .........

as is the wind: deliver him, Tit

deliver you, as most abated captives.

the sorrow that delivers us thus ehanged
deliver them this paper: having read it

deliver them this paper: having read

and we here deliver, subserilied by the

from bondage will yoliver Cassius.. J

then we will deliver your the cause..

most eertain that I shall deliver..Antony \& Cleo. ii.

I pray you, sir, deliver with more openness -

I pray you, deliver him this petition

deliver the pigeons to tlie emperor ( $r$
with a grace deliver a suppication?.

then deliver up your pigeous ...
safely from this plaee deliver

great with woe, and shatl deliver weeping

will you deliver how this dead queen

will you deliver how this dead queen
and deliver a plain message bluntly

and deliver a plain message bluntly
loathed warmth whereof deliver me

loathed warmth whereof deliver me - iv. 6 (let.

till I may deliver, upon the witness of .. Hamlel, $\mathrm{i}$.

shall I deliver you so?.

a round unvarnished tale de
thouver of mo........ from me. to deliver to Desdemona
Your deliverituee with an unpiticd.Mea. for Mea. iv.

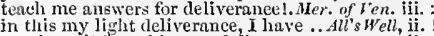
you have it trom lis own deliverance

desire deliveranee from these ofticers.2 2 Itenry 2

and heartily, for our deliverance .. Henry $V$ III

mother rejoieed deliverance more..... Cymbeline
DELIV ER KDD-most learnedly delivered T'empes

nay be both at, once delivered... Two Gen.of Yer.

delivered by a friend that cann.

shall be delivered even in the..........
she loved me well, delivered it to me

uniad vised delivered you a paper that

of an old woman, delivered me ...Merry Wires
not be delivered to the world

it lte may be couveniently delivered.
not mueh, when they are delivered

Ine him delivered, Fabian

Thave delivered to lord Angelo... Bea
not either delivered him to bis liberty
I bave already delivered lim litters

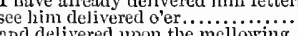

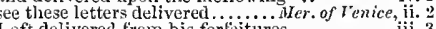

I oft delivered from his for deitures .". Al's $W^{-}$inl $\mathrm{i} .3$

back again this ring shall be delivered $=$ iv. $\frac{2}{3}$

before lher time, delivered .......... Winter's Tale, ii. 2

by the hand delivered of great Apollo's
given already, but not delivered......

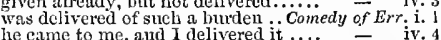

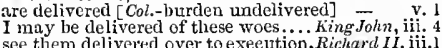
care my greetings be delivere

have liere delivered me to uiy sour cross = iv.

as is delivered to your majesty ....... Henry $I V \cdot$ i. 3

sle was declivered of a firehrand ...2 Henry $I V$. ii. 2

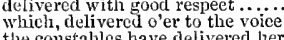

the constables have delivered leer o

and delivered to the ring

delivered up again with peaceful words?

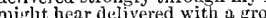

this present day he is delivered?

hie delivered his gracions pleasure....

delivered sueh a shower of peibles....

and our Antenor, delivered to u
'twill be delivered back on good
lave delivered the matter well

and more, more fearful, is delivered.

is delivered, lords, she is delivered ...
no one else but the delivered enpress
thley shall be ianmediately delivered..

of this was Tamora delivered

sueh a graceful courtesy delivered

whether there delivered or no, hy the holy

hath oft delivered weeping .............

delivered letters, spite of intermission.....
delivered to her our deeree?

delivered to her our cleeree? .... Romeo of.Juliel,
as they had delivered, hoth in time..... Hamlet,
contl

cond not so brosperously be delivered of othello,
of time, whichl will be delivered
my nuse laibours, and thus she is delivered DELIVERING

dneat for delivering your letter. TwoGer
I, delivering you, am satisfied ...Mer. of

in delivering my son from me

DELIVERY $-a$ broken delive

All's $W e$ ill,

that he would labour my delivery......

DELPHOS to sacred Delphos..... Winter's Tale, ii.

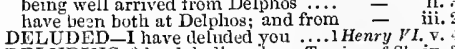

DELUDING-talse delnding slave. Taming of Sit

DELUGE-provokes this deluge .... Richiard III.

DELVE--delve him to the root.......... Cymbeline, $\mathrm{i}$.

it shall go hard, but 1 will delve one... Hamlet, ill. 4

DELIAND_is't thou can'st demand?.... Tenipest,
upon any reasonable demands ..... Merry I'ives,

you will demand of me, why 1 do.........
than to demand what tis $\ldots . . . . . . .$.

agree with lis demands to the............
demand to have repaid (rep.) ..... Love's L. Lost, ii. 1

what yisor? why demand you this?..
of flesl, whieh I demand of him...Mer. of Venice,

shall he paid her, than she'il demand... All's Well

languase to deny when they demand
(for that is her demand) and know her

(for that is her demand) and know her
manke thy demand. But will you....

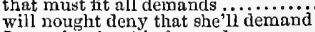

will nought deny that she'll demand $=$ iii. 7

first demand of lim liow many (rep.) - iv. 3 (note)

each one demand, and answer to... Winter's Tale, v. 3

speak. Demaud. We llt answer ........ Mucbeth, iv.

impatient of your just demands ..... King Joh
religiously demand, why thou against

innoeent, I do demand of thee ......

why may not 1 demand of thinene.
DEM AND-demand of yonder ehampion. Rich. 11 . i. 3

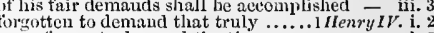

and of him 1 did demand, what news.2HenryIV: i. 1 in grant of all demands at large ...... Henry $V$. ii.

if 1 demand, before this royal

aceord to all our just demands

in, or out of, our demands; and we 11
she is our capital demand, comprised

where your najesty demand

give thee answer of thy just demand.1 Hemry $V I$. v. liatl ty yielded unto thy demand.......... his demand springs not from Edward's shiall answer his demand ..............

the late demand $[$ kint $t$-request].... Richard 1 III of me demand what was the speech... Henry VIII. my good lord, not your demand ......
nilke that demand of the prover. Troilus $\&$ Cress.

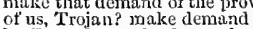

let Patroclus make demands to me... aspeet, a visage of demand .... Timon of Athens, ii. 1

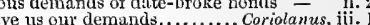

a good demand, If it be honour...... - iii. if then that friend demand ....... answering before we do demand of them $\& \bar{c}$. Yii. 1
kingdoms, I demand the like.... Antony he'll make demand of her, and spend

your answers to my demands........ Cymbeline, i. 7 anannerly demand thee of thy story - Mii. 6 thongh thou do demand a prisoner... $=$ v. nid him demand what pledge ...Titi.es Anitron. iv. willing you to demand your hostnges - $\overline{\text { v. }}$. than comes from her demand out of ..... Lenr, i. . for no more can I demand wii to. Romeo \& Suliet, v. of our demands, most free in his reply
for the demand of our neglected tribute

I pray, demand that demi-devil ........... othello, v.

DEMIANDED-well demanded, wench...Tempest, i. . in your highuess' name demanded ... Henry I $V$. i. 3 amoug the rest, demanded nay prisoners $-\bar{l}$. muel more, should be demanded
being demanded that, she would sit... porictes, our pleasure might have been demanded.. Lear, v. but, to be demanded of a spunge! ...... Hamtet, iv. 2 ere it be demanded (as like enough ..... Othello, iii.
DEMANDING-clemanding of king..2Henry $V$. ji. I DENAEAN-never so demean himself . Com.of Err. iv. 3

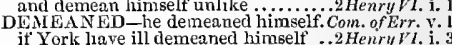
they have demeaned themselves ...3 Henry $r$. i. 4

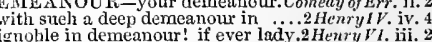
cold demenzour in Octavius' wing... Julius Cresar, v. 2
DENERIT-not for their own demerits.,Maebeth,iv. 3 shall of his demerits rob Cominius ... Coriolanus, i. and my demerits, may speak, unbonneted. Othello, i. 2 demesues that there adjaeent lie... Romeo \& J Juliet, ii. DEIIETKIUS-stand forth, Demetrius. Nid.N. Dr eonsent to marry with Demetrius.

Delnetrius is a worthy gentle
if I retise to wed Demetrius

or else to wed Demetrius, as he woull

you have her father's love, Demetrius

it not with vautage, as Demetrius' .

Demetrius, I'll avouch it to his head

with Demetrius thoughlit to have spoke
but, Demetrius, come; and come tiveus

Demetrius, and Eqgeus, go along......

Demetrius loves your fair: O happy
were the world mine, Demetrius being

sway the motion of 'Demetrius' heart

good luek grant thee thy Demetrius!
you on him, Demetrins dote on you!

what of that, Demetrius thinks not so ere Demetrins looked on Hermia's eyn Demetrius, the more you beat me....
fie, Demetrius! your wrongs do set.

thouglh thou kill me, sweet Demetrius

though Demetrius, do as a monster.

a sweet look from Demetrins' eye

ah. good Demetrius, wilt thou give."

will eause Demetrius to awake .......
Demetrius loves her, and he loves

you are unkind, Demetrins............

niadc your other love, Denetrius.

in love unto Demetrius, I tolc him

With Demetrius. Be not afraid
Demetrius up with bitter wrong $(r e p)$

where art thou, proud Demetrius?

I'll find Demetrius, and revengo

this Demetrius is, this Helena .....

and I have found Demetrius tike

Demetrius, thou dost over-ween...T.
stuprum -Chiron-Demetrius...-

had he not reason, lord Demetrius?.

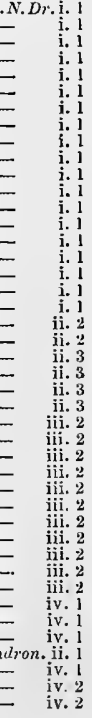


Jist:Tillit

I tnke tluem, Chiron, andl Demetrin

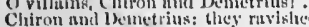

eursed Cliron mul bernctríns were they

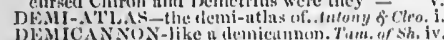

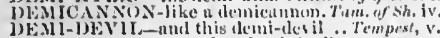

you, I prav, demasud that denin-devil

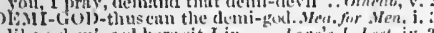

like a demi-goul here sit $I$ in .... Lorers. L. Lost, iv. 3

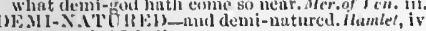

DEMI-P AJADISE-

this other belen, demi-narulise

.

Richurd Il.

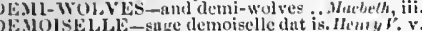

H:sloN-if thint same demen, thant lat th

thy demom, that's thy spirit which...tnt. of Cleo. ii.

max.

demonstrmte the life of sueth a batth.

thit shanll demonstrate these guick.

my out ward netion doth demonstrate ... Ohinel

inther pronfs that do

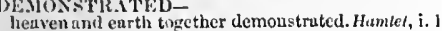

DEMONSTIATING-

You demmentrating a careless .... As you Like il, iii. 2

demonstrution of the working .... Love's L. L.ost, i. 2

the queen to my demonstration of griet?. Lear, iv. 3

in everr branch truly demonstrative. Henry $V^{\prime}$ ii.

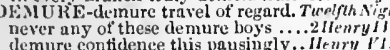

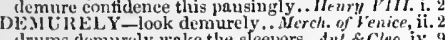

1) Hrums di I $\mathrm{NG} \rightarrow \mathrm{no}$ honour demuring upon

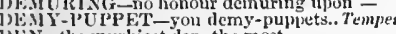

1)E N-the murkiest den, the most.........
his rage, repasture for his den .. Lore's L.Lost,

at your den, sirrah, with your

sliull they seck the lion in his dein?

from choin den with fell

beast thint would usurp their den ....3 llenry $V$.

and battle for their dens.
and citizens to their dens

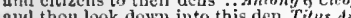

slould nature build ro foul a den

DENAY-110 place, bide no denay. he's fortified tugainst any denial... Tirelfih Nights, in your denial 1 would find no sense

thut gracious denial which ....Mcas.for Mens.

never muke deni:ll, I must and will. Trams of Sh.

viur grant, or your denial ........3Henry!'

nuy never be beld by you denials .. Coriolnnas.

mi:NIED $\rightarrow$ all these matters cenied. Merry Hives,

he not denicd actess

welly Night,

(n)

it must not be duried but $\mathrm{I}$ am..........

thou wouldst have denicd Beatrice

thlough so denied fair harbour in...Lore's L..Lost,

how if the kiss be denied?......... As you Like is iy.

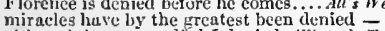

although 'twere needlul I denied.. Winter's $\bar{T}_{\text {al }}$, $\mathrm{i}$.

lest she should be denied

vou denicd to tight with me thisother

Y. 2

in his llowe denied my house fur his

and 1 denied to enter in to my hou

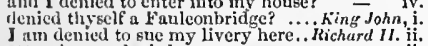

attornies are denied me.

int faintly, and would be denied ...

not with such strength denic
we are denied aceess nnto lli

of encer yet was your appeal deniell? - iv.

so denied, but your request.

Mlinos, thit denied our course

mun thint lias denierl the fore

illenryl't

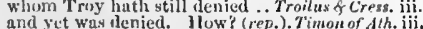

and yet way nenied. Jluw? (rep.). Timon of Ath. iij. 2

slould ne'er have deniect lis oce

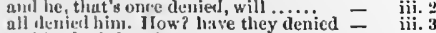

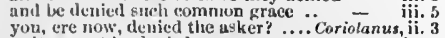

so it cemm'st be denied

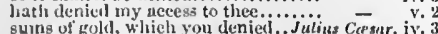

par my fegions, which you dented ne

I that denied the gulil, will pive

the wlsich You both denied ...Antony of Cleopatra, iv. thourh it cannot le denied wliat .... -

presently lenied him rivality.....

will not be denied vour hipliness'.... wonld l ixe denicd of your fair courtesy... I'ericles, ii. demunding after yoi, denied me to emene. Lear, iij.

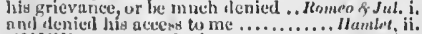
DEL IE 1 - no, not a denier. Taining of Sirrer, 1 (int my dlukedun to a beggarly denicr... Hiehard i $\mathrm{i}$.i.

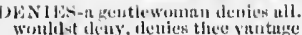

she not dentes it: why seck'st ....... Nurh fito, iv.

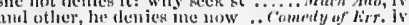

tiac goldswinith here denies that sayin

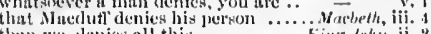

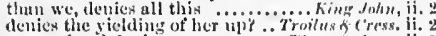

womnnhood denies my tongue .. Titus dudran. ii.

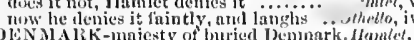

is the throne of Denmark to thy father.

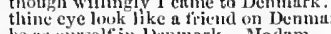

foe ourself in Demmark. Mndum

the unin voice of Denmmrk gnes withal

is rotten in the statt of Deninurk.

not the royal ied of Denunark he a coin.

I ain sure, it may be so in Denmark
llwellini in all Densnark, but he's al

prison, my lord! Dewurark' a yrison

for my uncle is king of 1 e wors

come st thes to heard me in Derminitiv

himself for your sucecssion in Dennark?

why, here in Denmark ..........................

reasons, importing Demnark's hea
is right welcome baek to Deumark

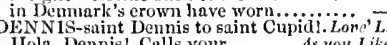

IIoln, Dennis! Calls your ............. you Lite

between St. Dennis and St. George

gologer on saint Dennis will we ... Henry $1 \%$.

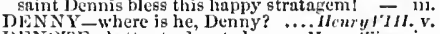

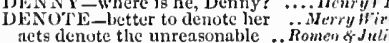

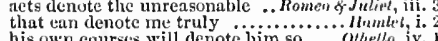

his own courses will denote him so ... Othello, iv.
DENO'TED-denoted a foregone conclusion - iti. 3

denotement [ $\mathrm{Col}$. $\mathrm{K} n \mathrm{l}$-devotement] of ho

DENose denotements [Col. Kint-delations].

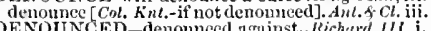

[Col. Knt.] if nut deaounced against. Ant.o cleo. iij. 7

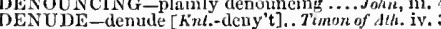

WEN do the denuniation lack .....Meas. for Meas. i. 3

to be your follow, you may deny me..... Tempest, i. 2

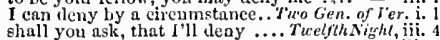

will you deny me now?
do not deny: heshrew his soi.

ay husband; can lie that deny?

You must not now deny it is ......... for for - v.

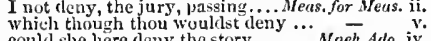

could sle lice deny the story ....... Nae

you kill me to deny it...............

more, masters, than you

1 would not deny you.................

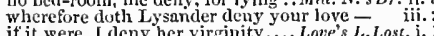
if it were, I deny her virginity .... Love's L. Lost, $i$.
tnd deny himself for Jove ...... iv. 3 (verses) if you deny to danee,

if this thou do deny, let our han

or more than this, 1 would deny
yout must not deny me........

the stute, if they deny him justice.

authority, nnd power deny not ......
the duke eannot deny the course of law

not to deny this imposition........

if you deny me, fie unon yon Taw

not to deny me, and to pardon $m$
in love shall not deny me this...

not for my heart deny it him..........

I would deny it, but you see my finger
the whieh I did deny him, and sutfered

I'll not deny him nny thing I have

or dse by him my love deny

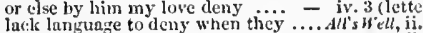

do all they deny her? anl' the
will noughit deny thut she'l

Incithere tan, nor will deny bit.

if she deny to wed, Ill crave.......
yonder he is; deny him, forswear.

if they deny to conne, swinge me

if 1 tlen deny it, 'tis none of..........

Which to deny, enterns more than.. -

that 1 did deny my wite and louse

though most ilislonestly he dotin deny it -

so to deny this ehain ..............

enn you deny it? I think, I had
I think I did, sir, I deny it not

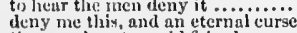

the puor heart would fain deny.

as laithfully as I deny the devil.
to do ne wrong deny their oflice

to do me wrong deny their ofit
nund deny his youth the riels

Bu ungruteful, you deny me that

son unpruteful, you deny me that

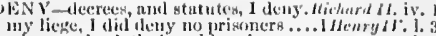
"a wivementer, that I utterly deny..

I deny your mujur; if your will devis

anl woukl as at would weny

"mint thou deny it? dijh not ........2

do you think, i wosuld deny licr?

if she deny the aspenrance of.
she will sleny thy suit, betore

Itinery $S^{2}$.

wilt thou deny thy parentage?

deny me not, 1 pry yhee.

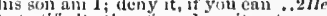

to) teny their hail .............

in justee canthot woll deny

em you deny all this?.....

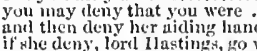

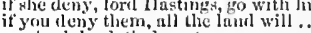

nyy lorel, he doth deny to come

not to deny her that a woman

1 dare, anil nuust deny it

suit which you must nut de.e...

does deny him, in respect of his.. Timon of $A$ th. $\mathrm{iii}$.

yet.j this beggar, and reny 't that ... ive

vur voices, we ought nut to deny hiin $=$
we may deny hin yet. And will deny $=$
ii. 3

which great nature eries, deny not .. $=\forall . .3$

which you deny already
more strength than thou hast to ile....

though thou deny me a mutter... Antony $\overline{\text { of }}$ Cleo. $\mathrm{i}$. 2

the wise, they not deny ............. - ii. 1

there I detuy my land service .....

if thou dost deny thou hast (rep.) ...... Cymbetine, ii. 4

valiunt youth, deny te agin ......... - v.

who should deny it? come, young one. Pericles, iv. 3

which if we should deny, the most just.

would he deny his letter?

to deny thou know'st me?

delly to speak with me? they are sick?.. - ii.

you all will now deny to dance ... Komeo foldich iij.

deny thy father and refuse thy name

fuin douy what I have spoke

do not deny to lim, that you love me

riend... Namlet,

your griel, or you deny me right ......... - i

I will deny thee nothing $(r e p)$. ......... - iii.

for to deny cuch article with oath

DEN Y ING-and denying lin ... Ticeinh Night, iii.

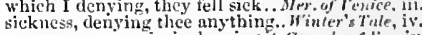

wrong me more, sir, in denying it. Cunetly of lirr. iv. I

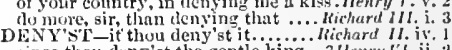

since thou deny'st the gentle king ...3llenry li. ii. to dogs wlat thou deny"st to men. Timon of Ath. iv, 3
if thoin deny'st the least syllulble........... lear, ii. DEU-laus deo, bone intelligo ..........' ' $\quad L$. Los', v. at iny denart, I gave this .............. $\mathrm{a}$ pr'y thee, fortish Greek, depart from me when you depart from lim .... YHas for Meas. iv.

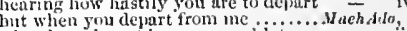

why then, depart in jeace, and let

sipnior, und dejart when you bir

therefore 1 will depart unkissed

we shall be riels ere we deznrt .........

mbrtet the weension to depart...Merch of Jenice,

therciore, tremble, and depart ......ts you Like it,

whets you chepart, and save your ... Mryaler"s

d'liart, and yet purtake no

ruled by me: lepart in patience....... Conedy of Err. iii

not 1 in rnge depart from thence?.....

he rutict, ant depart leave lim

conc like sludows, so depart

nuy, yet depart not so .............

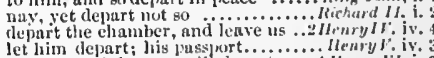

..., Macbeth,

eleured, and then we will deprirt ...... I llenryl it. i. 3

now, guict snil, depart when heuren - iii. 2

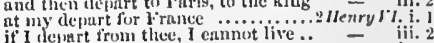

if I deyst irom the I entinnot live,

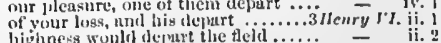

highne

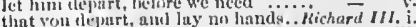

if thilupart in slenee, or bitterly ..... - ii 
DEPART-ere we depart, we'll share. Timon of $J / h . \mathrm{i}$. 1 DEP()SED-lier Ilenry is deposed a fool of thee: depart

with this

wood countrymen, let me depart alone

the loathness to depart would grow.....

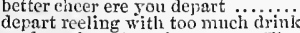

madan, depart at pleastire.... Titus Andronic

of your loves, he would depart

he mulst hence depart to Tyre .......... - iit.
slould so ciepart trunt home, and not sent. $L$

ere I clepart

for this time all the rest depart

on pain of death, all men depart

your grievanees, or else depart

teach you to drink deep, ere you de
DEPARTED-from thee departed..

lath willingly departed with a
fare witl your deprarted souls?

christian peace to souls departed.

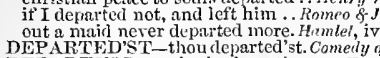

DEPARTING-praise in clepartin

the first departing of the kin

Dike lite and cleath's departing..

gave it him at his departure.

grant thein a fair departure.

this morning your departure hence. All's $W^{\prime}$ ell,

did expect my hence departure.... Winter's Ta

knew of his departure, as you know
whieh is another spur to my departure

on their departure most of all slow. King John,

awry upon your lord's departure.

more than your lord's departure
licence your departure with your

your wives of your departure hence.

cause of your abrupt denarture.

shall ring thy dire departure out ....

if they suffer our departure.

needs must know of her departure ... Cymbeline, iv.

and laughs at nyy departure
DEPECHE-

DEPEND $\rightarrow$ my zenith doth depend upon. F'emper
that more depends on it than ... Meas. for Meas.

there's more depends on this.... Mer. of Venice, iv. 1
whereon the likelihood depends ... As you Like it, $\mathrm{j} .3$

biddling me depend upon thy stars.. King John, iif. I

your right depends not on his life.

he that depends upon your tavours

we on, and not depend on you?

but our jealousy does yet depend

poor wretches that depend on great

fate on more days doth depend... Romeo....... $j$. Leatiet, iii.

for on his choice depends the safety
upon whose weal depend and rest.

if I depend on the issue?

and wit depends on dilatory time

DEPENDANCE-dependance upon. Troil.

him your sweet dependancy $y$...MIeas. for Meas. $\mathrm{v}$.

Whom there is no more dependaucy.. Cymbeline, ii.

thereon dependant, for your brother

is, rewarding my dependants.... Love's L. Lost, iii.

the curse dependant on those that. Troil. \& Cress. i

as well in the general dependants

of Ath. i.

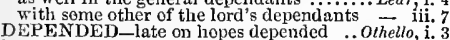

DEPENDER-to be depender on....... Cymbeline, $\mathrm{i}$.

lite, so stinkingly depending?.. Tro Gen. of Ver. i. 3

depending on the caskets..... Merchant of lenice, i. 2

on you depending, counts it your ... King Jonn, iv
the care on thee depending, hath ..2 Henry IV. iv
whom depending, their obedience... Coriolanus, ii

nicely depending on their brands
DEPLORE-tears to you deplore.

DEPLORING-deploling dump. TuoGen. of Ver. iii. 2

DEPOSE-I'll depose I had him...Ilers. . For Moros. vi I

to our law depose him in the justice.
possessed now to depose thyself....

cannot depose the deputy elected by

may my glories and my state depose

lives, that Henry shall depose ( $r e$.

loath to depose the child...

DEPOSED-king purgerl and deposed King III. ïi. 7

our deposed hodies to the ground?. Kichard II. iii.

been deposed, some slain in war (rep.)

must he be deposed? the king.

be deposed? Depressed he is $($ rep. $)$...
say, king Richard is deposed?

deem that you are worthily deposed

be deposed, and, shortly, murdered ...

short time after, he deposed the king

二 iii. 1

deposed his nephew Riehard....

deposed the rightful king

and hashliul Henry deposed.......... the king, king Elwwrd hath de

by you deposed, you quake like.... Richard III. i.
trinmvirate shonld he deposed...An'ony of Cleo. iii.

containing the deposing of a king

for the deposing of a rightful kin.

$\overline{\text { Leur, }} \mathrm{\textrm {i }}$.

DEPRAVATION-for depraration. Troit. \& Cress. v. 2 that's not depraved, or depraves. Timon of Athens, i. 2

of how dlenraved a quality.....

DEPRIVE-euriosity of nations to deprive. Lear, i. 2

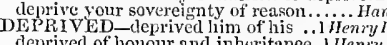

deprived of honour and inhuritanee..

is wretchedness deprived that ben

deprived of supple goverument...Romeo\& Juliet, iv.

most ingenious sense deprived thee of!.. Hamlet, v. 1

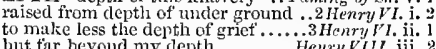

but fir beyoud my depth

sounded all the depths and shoals

which is past depth to those that. Timon of Aih. iii. 5

damped beneatl all depth in hell ...... Othello,

hy deputation could not so soon be..1H

thy topless deputation he puts on. Troilus f Cres
DEQU'TE-to depute Cassio in Otliello's. OHello,
DEPUTED-nor the deputed sword. Mea. for Hea.

DEPUTING-deputing Cassio in his.... Ohncllo,
DEPUTY - and the new deputy... Neas. for Meas.
make friends to the strict deputy ....

make friends to the strict depu
this outward-sainted deputy
and the corrupt deputy scaled

he must before the deputy, sir ......

What is the news from this good deputy?

sworn to the duke or to the deputy?

hath yet the deputy sent my brother

great deputy, the welkin's. Love's

our own great deputy.................
his deputy anointed in his sight

cannot depose the elected deputy

be the deputy's wife of the ward

. King John, ii.

defore master Tisick, the deputy

whose far unworthy deputy I am

then deputy of Ireland

you sent me deputy for Ireland.

DERACINATE-that should de

rend and deracinate the unity ... Troilus of Cress.

DERCETAS-I am called Dercetas..Ant. \& Cleo. v.
DERIDES-at last shame them derides .... Lear,
DERISION-scorn, and derision ...Hea. for Hea. iti.

in a poor maid's eyes, with your derisio

all this derision shail seem a dream.

DEZIVATION-in the derivation of...Henry $V$. ii.

my derivation was from ancestors

DERIVE-indignation derives itself.. Tuelfth $\mathrm{t}$, iii. this ghame derives itself from ....... Much Ado, iv. this doetrine I derive (rep.) ........ Love's L. Lost
or, if we did derive it from $\ldots \ldots$. . . . Like you she derives her honesty, and achieves.. All's Well, things that would derive me ill wili..

free face put on; derive a liberty.. Winter's Tale,
derives from heaven his quarrel ...2 HenryIV. dend blood, derives itself to me

derive this: come............. Troitus $\&$ Cressida,

of the war derive some pain from you

till you can derive from him better

this abuse, whence 't is derived...Mieas, for $\bar{M}$ Ieas. v. $\mathrm{v}$

I am, my lord, as well derived as he.Mid. N.Dr. i. I

a wretched Florentine, derived from...All's Well,

coneeit is still derived trom $\ldots \ldots \ldots \ldots$. Richard $I I . \mathrm{ii}$.

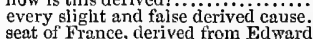

evenly derived froin his most ......

derived foom famous $E$ dmund $I 0 n$ Tiey $I$. ii.

of whom derived, were shame enough.3 Henry VI. i. 4

from whose help I derived liberty... Timan of Ath. i.

brave son, clerived from honourable. Julius Corsar, ii.
DEROGATE-yon cannot derogate .. Cymbeline, ii.

being foolish, do not derogate......
and from her derogate body ney.

DEROGATION-un derogation in't?......... Lear

DES

DESCANT - too harsh a descant. Tu'a Gen. of Ver. 1 .

descant on mine own detormity.... Richard $I I I$. i. 1

DESCEND

the flame will back deseend...........

move indeed; descend, and take.. Winter's Tale, v.
DESCEND_'t is time; descend.... Winter's Tale, v. 3
we will deseend, and told him...... Richard II. i. 3 we will deseend, and told him ....... Richard II. i. it shall deseend with better quiet ...2Henry $Y V$ iv. I descend, to give thee answer descend to darkness, and the buning. 2 Henry $V t$. of ' York, descend my throne .........3 3 Henry VI. our Henry lineally descends ......... - iii. descend, and keep your words

shall I descend? and will (rep.)...Julius Cresar, iii.

a word; descend: brother, I say.......... Lear, ii.

one kiss, and r'll descend ..... Romeos.... $j$ uliet, iii.

DESCENDED-oaths descended inte. Two Gen.ofV. v.

hadst thou deseended from another. As you Like it, i.

being descended of Blithild ..............Henry $V$.

a gentle

my wife descended of the Lacies .... - iv.

descended from the doke of Clarence; - iv.

teseended of so inany royal kings. Antony \& Clo. $\mathrm{y}$.

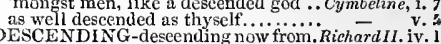

DESCENDING-deseending now from. RichardII. iv.
thou camest from good descending?... Pericles, $v$.

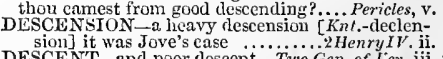

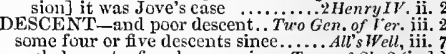

some four or five descents since...... All's Well, iii. by the glorious wortll of my descent.Richard II. i. ming, the third of that descent ........ i Henry $V$ r. ii. 5 whence you spring by lineal descent - iii.

that he is near youl in deseen

a preachment of your high descent?..3 Henry $\overrightarrow{V I . i .}$

that I was not ignoble of descent .....

nyy muster's heirs in true descent.. Richard 1II. iii. 2
Neptune's ear in lis descent .... Troilus \& Cress. v, hov of descent as good as we? ....... Cymbeline, $y$.

to the descent and dust heneath thy feet... Lear, $v$. DESCRIBE- - I will describe t.... Romeo \& Juliel, v. 3 how he describes himself! ....Troilus \& Cressida,

by that the poet lere describes ..Titus Andron.

and fear I wos descried: wait you. Taming of sost, and fear I was descried: wait you. Taming of sh. who hath deseried the number of . Richard IHI. y. we have descried upom onr neigh houring. Pericles, $i$.

a right description of our sport ... Love's L. Lost, v. and, according to uny description. Mer. of Veniee, $\mathrm{i}$. I should know you by descrintion. As you Like it, iv. for this description of thine lonesty? . All's Hell, iv. and undoes description to do it ...Winler's Tale, a most excellent description of fortune. Henry $V^{\prime}$. iii. vour wondlons suit itself in ....

his description. He; I know lim. Timon of $A l h$. by all description, this should be

person, it beggared all description. Antony $\bar{\xi}$ Cleo. deseription of what is in her chamber.Cymbeline, ii. rery description of their meetingr-place

or his description proved us unspeaking - v. 5
he went to bed to her very deseription. Pericles, iv. 3 a maid that paragons description ....... Othello, ii. 1 IIelican - to come, she can descry ..... Henry H Y I. i. 2 moreover, to descry the strength............ Lear, iv. 5 cinnot without eireums on the hourly.... - iv. 6 'twixt the heaven aud the main, descry.Othello, ii. Knt a - Knt.] sweet Desdemon ...

Knt. prayed to-night, Desdemon?
Knt. . poor Desdenon! I am glad thy Knt.] O Desdemon! dead Desdemon? DESDEMONA - the gentle Desdemona ...othello, 1 . would Desdemena seriousiy incline.

adieu, brave Moor! use Desdemona weil

Iago, my Desdemona must I leave to the Desdemona should long continue her love letting go safely by the divine Desdemon love's quick pants in Desdemona's arms
come, Desdemona, once more well net.

Desdemona is directly in love with him

prove to Desdemona a most dear husban thus early, for the love of his Desdemona to Desdemona hath to night caroused.... will i heseech the virtuous Desdemona.. easy the inelining Desdemona to subdue. that she will to virtuous Desdemona some brief discourse with Desdemena....

not now, sweet Desdemona $\left[\begin{array}{l}K n t . \text { Desdemon] } \\ \text { farewell, my Desdemona: }\end{array}\right.$

I do not think, but Desdemona's lionest

Desdemona [Kint.- look where she] comes

1 heard him say - sweet Desdemona ....

how do you, Desdemona? Well, my good

ply Desdemona well, and you are sure

O Desdemona, [Knt.-Desdemon] away!
from me, to deliver to Desdemona ......

, 


\section{DES}

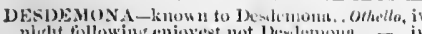
niglit following enjoyget not Deselemonit

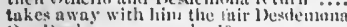

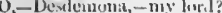

frum lim as gifts to benlemon

who's there? athello" As, Desdemome....

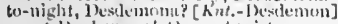

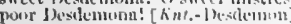

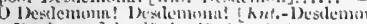
Desdeanon] ilead? dead? of UI U!

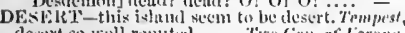
desert fo well reputed...... Troo Gen of ferome, ii. iny paticue more slum thy dewert

she sigh of gooul destert

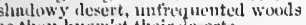

as thon know st their cherer

Oyour derent speaks lotel.

"irelen $\overrightarrow{x i g h}, \mathrm{ii}$

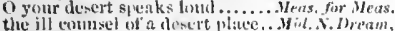

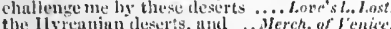

I will issume desert

are my deserts no better.

mative burglaets of this hlesert ..... As you Like it,

an iu this descrt place biy

if there five any thing in this desert

why should this desert silcut be

how I came into that desert ploce - me. 2 (velse

how I enme into that desert plice $30.4{ }^{-}$iv.

sluekle up my love, atud her desert.

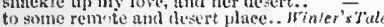

tonched uron the deserts of Bohcmia?

Gut, I lirutest, Without desert)... Comedly of Rir. jii. I

be howled out in the desert ai

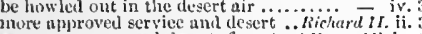

any way your good deserts forgot

Richard tr.

hnie right, and let desert mount

thun guittance of desert and meri
nule to lead him with his desert!

for these good desertw, we bear

any challenge of desert. or we....

gnerconed for there good descrt.

hir ruy desert is honiour

that all without desert have frowned

but my desert ummeritulsle ..jil.

mit my doserts, but what I will...
the ainke by law founti his descrt

we will not name desert ....Troilus on cit 7 .

desert in service, love, friemiship

is ranked with all deserts......Timon of Athess. $i$. 1

take my deserts to his, and join
own desert. Your own desert?

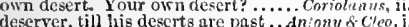

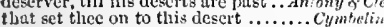

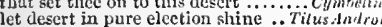

good and great deserty to Rome...

plead your deserts in perce and...

thanks in part of thy deserts ........

none of both but are of high desert

descrt must gain; and which (rep.)
pleasure to commend, not my desurt

less know how to value her desert

use thera aceording to their desert.

antres vast, and leserts idle, rough........ Othell

well deserves the honour aur

only deserve my love

ond truly, she decerves it................ Merry Wines, ii.

I know not how I may deserve to be

kecp in that mind; I'l deserve it... $=$ iii. 3

as ever thou wilt deserve well at. Tuelfh Night,

when it deserves with clinarieters

slandering a prince deserves it

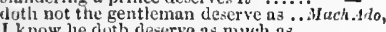

- iii. 1

others say thou dost deserve ........

Mlargaret, descrve well at my hands. - iv. 1

huw pitiful I deserve ............... $\overrightarrow{\text { vid. }}, \vec{v} .2$ (song)

nor never can, deserve a sweet look

hind Costard; she descrves well ... Love's L. Lost, i. .

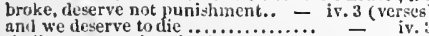

shall get as much as he de............... of tresice, ii. 7

as much as he deserves?

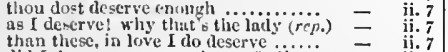

lid I deserve nu mure than a fool's

doth he not deserve well?

I tell you, deserves as well .............
no, he deserves no pity .......
and your virtue, whll deserve it.

have him, till Y lo dererve hi

or will dexerve at my liund ..........

only to secen to deserve well

descrves a nume a\& rank as any

whe terery worrl deverves to taste.

(well he diserves that name)

that life which le denerves to ligen

something you may deverve of hum

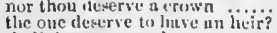

shalt eleo(rve your lisve (rep.).

desere the semrge of grentine
gueak of you timu you deserve
doth deserve a eorunet of gohl.

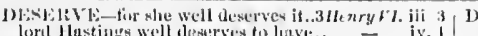
loril flastings well deser'sers to lave...

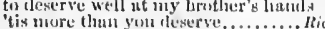

deserve not wore than wretilgel .....

tult me what they deserve, thut do

your love neserves my thanks

the subject will deserve it ......

your grane must needs deserve ail

what he deserves of you and ne

he will descrve nure.................

(Hot will alewerve, for tirtue

dowes cleserve our bet ter wishe...

(fow of you deserve that title)

gentlem:in, that well deserves a

and nyy estate deserves an heir ....

who deserves grenthess, decerves.

your benrds deserve not so lonourable

we prov the gorls, he may deserve your

diel net ile

this deserves death. Ur let is stimi

kind, leseryes the extremest death
the people deserve sueh pity of lum.

ladies, you deserve to have a temile.

and did deserve lus change

attemit, as you call it, deser.

hath of thee, deserves thy

doth ill duserve by doing well

neither cheserve, und yut are steeped...

to deserve my mistress' grace
and he deserves so to be called

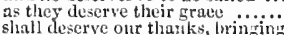

which way thow minglit'st deserve.

the less they deserve, the nume merit.

goon Roderigo: ril deserve your pains. Othef,

for thou hast deserved her $\ldots$. Thofich.

mneh deserved on his pirt.

he would liave deserved it.....
well I liave deserver this ring

well I liave deserved this ring

we euckolds, ere we have deserved it?

sir, you have well deserved ........As you

I have not, my lord, deserved it....

how I have deserved to run into my.

his heels have deserved it.

Murth Ato i.

Your mistress has deserved prison. $W$

very nobly have you deserved

would thou had'st less deeerved.

what hath this day deserved? .......

have I deservel at your higliness"
worthy danger, and deserved deat

vary deserved pruise on my palftey ...Hen

liath lie descrvet to lose lis birthright

at their hanels, I have deserved no jity

whose dealings liave deserved ..... Lichard

neither elaimed it, nor descrect

my lord, they hinve deservelideatl

betil you! lie deserved his deati

I have deserved this hearing ...

deserved nobly of your country (,

gratitude towarils her deserved ciilderen -

give him deserved vexution ........

shoule do tlat lad deserved his hate

into one coal, we have deterver it

Casar hath sleserved to lie in death. Jul. Carsor,

were well eleserved ot rashous... Antong

which worthily deserved notin

when you lave well deserved ten times

lie hath deserved it, were it eurbuneted

king hath not deserved ny survice... Cymbedine

who deserved so long a breeding ....

that he deserved the praise o' the world
question, thou ladst well desurved it ...
lits own disorders deserve? mueh less ...

deserved at the hands of furtune $\ldots . . . . i_{\text {amtent }}$ ii.

DI.SERVEDI, Y deservedly contlneil... Tempes

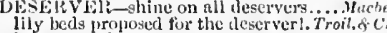

is never linked to the deserver ... Antony fo Ch

in mest comely truth, thut deservest. Yuch i in,

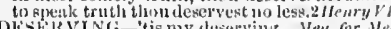

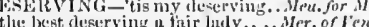

to be afeard of ny deserving

unlike my hopes, mand my denervinge...?

let his deservings, and my tove withat

Fonl the clearness of our deserviniss

ocme cuvy your great deservinis . Illenry $l$.

spoke your deservings like a chronticle

virtue he had, deserving to conmund.1 Henry $b^{\prime}$

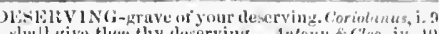
Gluth give thee thy deserving ....1me is whing tlan in his feuts

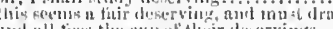

I eonliess me knit to thy de. erving with...

endist thon bestaw on a deserving woman -

without morit, and lase without deserving -

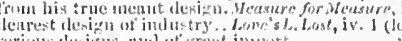

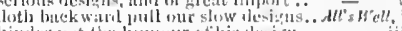

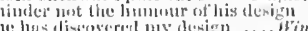

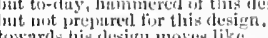

cowart his lesion moses like ......... Marbesh,

leave there sul designt ti, hin ....

in deepriglesigns, in matter

pevish found in great tle-ign

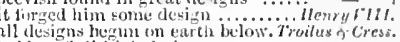

latder of all hight designs.

lises mocking opr designs .........

lithe the font of our derign

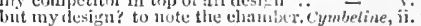

a voluntiry mutc to my design.

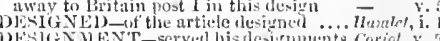

the Turks, that theje desigumenc inalts ofiell, ii.

ot:ary to tumb lesirus

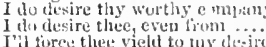

ghall desire to hear.
an just as you will desire.
and desire a marriage betw.

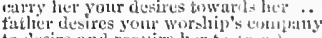

to desire and require her to

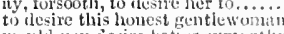

mistress I'age would desire yoli

I desire more arquaintine of

my desires had intanee ast th

you would desires to he aeculti

I desire you in friculshi].

I desire you, that we maty be frichits

she desires you once nore.

Inistress ford desires you to
ereatures an 1 would desires.

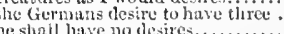

he shanil have no de

kintlle! with uncheste desire

serve Got, nnd leave your desi
winere I will desire the to lin

my desires, like iell and

desire him not so di.

if you desire the slicen ...............

some toy you have desire to mareluse

and give lim his denire

do not desire to see thi

in recompense, desire my do dastin.

I shall desire yon, gir, to g
why I deire thee to give

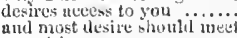

not with more tame a tongue
shall we desire to ruze the

chatl the desire to raze the shleturery

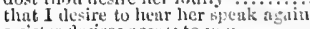

n sister clusires neeess to $y$

desire $y$ ou to make your an

I do desire the like

say, it was the desire of ilie.............

truiy, sir, l would desire

I elesire his eomulny ut Mariun!

and deliente desures, ufl promenting me..1

antl desire her to rise ................

1 would heside they we

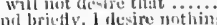

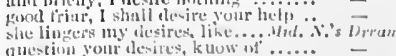

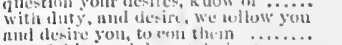

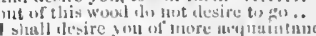

devire you of hore nequantule too.. 


\section{DES}

DESIRE-never did desire to see thee.SHd.N.Dr. iii. 2 , DESIRE-desire the valiant Ajax. Troil. \& Cress. iii. 3 , DESIRING-their desiring eyes upou. Richard II.v.

can keep no pace with ny desires ... - iii. 2 who most humbly desires you

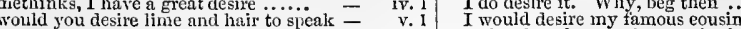

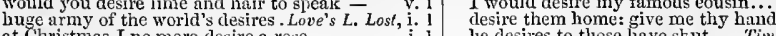

at Christmas I no more desire a rose

I would take desire prisoner

sweet health and fuir desires consort

1 desire her name. She

peeping through desire

he desires to those liave stiut.... Timon of thens,

thou shouldst desire to die

would you desire more? dance, if they desire us to

how many months do you desire?

and desire Gratiano to come anon

I desire no more delight than........

shall gain what many men desire.....

many men desire, bccause $I$ will not

desires to speak with you both

I do desire you, not to deny this
for thy desires are wolfish, bloody

for thy desires are wolfish, bloody

your heart's desires be witl you!...... As you
I shall desire more love and knowledge

acquaintance with mine own desires

I do not desire you to please me (rep.)

I do desire we may be lect

as good cause as one wonld desire....

wore giddy in my desires thau a monk
when he had a desire to eat a grape..

do desire it with all my heart (rep.).

I desire sou of the lik

madam, I desire your holy wishes.......Al's ${ }^{\prime}$ Vell

only, he desires some private speech

seems as won, desires this riug ....

give thyself unto my sis.

till we have sealed thy full desire...

and the desine of the nobles...

to desire the present consul, and .....

you must desire them to think upon

not mine own desire (rep.)

that shall say, yea, to thy desires...

desire not to allay my rages and

gave him way in all his own desir.

not hinder, Cassius, your desir
who doth desire to see you

Trebouius doth desire you to o.er......

be it so; I do desire no more

list night you did desire

so your desires are ours....

of audience, nor desire, sliall fail ...

did desire to burnt this night

that should desire you to touch him

desires your highmess' company....

preferment sucl as thou'l desire .....
miserable is the desire that's glorious

should make desire vomit emptines

that satiate yet unsatisfied desire...

thy master's bidding, when I desire it
present yourself', desire his service...

present yourself, desire his service

will a handmaid be to his desires.. Ti

it foul desire had not eond icted yon?

when you have the honey you desire

there is that she desires to see .......
desires to be admitted to your presence

have inflamed desire in my breast
adventurous by desire, tell thee with

since my desires run not before.......
only therefore desire to breed by me

adventurous by desire, tell thee with
w'e have no reason to desire it............

this we desire, as triends to Antioch
tulfil his prince' desire, sends word

filfil his prince' desire, sends word

and further tell him, we desire to know.

and further he desires to know of you
makes her desire (which who shall ..

welcomed, to his own desire

I desire to find him so, that I

such pay as thy desires can wish........

I pray, desire her call her wisctom to her. Lear, iv. 5

mistress, as badness would desire

now olil desire doth in his. Romeo \& Jutiet, i. 5 (cho.)

I desire some confidence with you

it is most retrosrade to our desire ...... Ilamlet, i. 2

some impartment did desire to you alone - i. 4

and desire, shall point you (rep.)

your desire to know what is between us

return of greetings, aud desires

she desires to speuk with you in her closet - iii. 2

had my dicsire; fingered their pack

the queen desires you, to use some gentle - v.

the gallan ts desire it. Where are they?

thiat he desires you, of all loves, to make
by selling lier desires, buys herself bread

by selling lier desires, buys hes

iii. 4

tur I desire nothing but odds with
I would desire the duke to use his

I would desire the duke to use his ...
anon, desire them all to my pavilion

no grent cause to desire the approa

outward things dwell not in my desires

in mercy, the constable desires thee..

where that his lords desire h

a little piece of my desires .........

I would desire you to eat it.

I will desire you to live in the.

impatiently I burn with thy de
swift-winged with desire to get
with proud desire of bold-faced

spirit, winged with desire

which wrought to his desire. ofool!.... v. ve

finding yourselt desired of such... Mers. for Meas. ii. 4

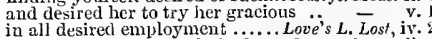
under which Loreuzo desired us. Mler. of Venice, I dicl him a desired office.............. All's Well, should have else desired your good . . Macjeth, whieh hath desired to see thee nore. I Henry $I V$.
great honours, as ean be desired....... Henry $V$.
redeemed I was as I desired ........ Henry $V I$.

aceording as your ladyship desir
my wife desired some damsons

desired help from Bturguudy

$\ddot{2 H e n r y} V L$

the duke desired to him brought

Henry VIII.

never desired it to be stirred .

and desired your highness most heartily - ii. desired my Cressid iu right great..... $-\bar{H}_{\text {ii. }} 3$ begs to be desired to give ........ Antony \& Cleo. ili. 11 which hurts and is desired

queen thut most desired the ma.teh....Cymbeline, i. i

gJves, desired, more tlian constrained

be then desired by her, that else.............eor, $\mathrm{i}$.
when I desired their leave that I mighit

you shall be well desired in Cyprus.... oucello, ii

DESIRER-bountifully to the desirers. Coriolan us,
DESIREST-if thou desirest to be. Tuetflh $N$. i. 5 .

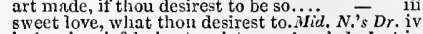

in love's grief desirest society.... Love's $L$. Lost, iv.

justice, more than thou desirest.. Aler. of Venice, iv.

DESIPIN G-not as desiring more...Meas. for 1 Ieas.
desiring thec to lay aside the sword.. King John, in heart desiriug still ............... Henry VI. iv. DESIROUS-my nice is desirous. Tuelfin Night, iii. that is so desirous to lie with his.. As you Like $2 l, \mathrm{i}$. not been desirous of their wealth ...3Heury VI. iv. and how desirous of our sight.... Tilus dndron. v. when you are desirous to be blessed ...Hamlet, iii. DESIST - at least desist to build at all? 2 HenryIV. i. 3 condemn it now: desist, and drink.. Ant.\& Cleo. ii. I will desist; but there is something....... DESK - in the desk tliat's covered. Comedy of $\overline{E r}$. iv. the money in the desk?

it' I hud played the desk, or table-book. Hamlet, ii. DESOLATE - in this desolate isle .... Tempest, iii. poor lady! desolate and left!.. Two Ge desolate, desolate, will I lience ....... Richard II. i. 2 in a moment makes them desolate... 1 Herry $V I$. ij. 3 and makes them leave mae desolate. .2 Henry $V I$. iv. 8 merry you bave lived in desolation here ..... his whole kingdom unto desolation....... Henry $V$.ii. wherc thov art not, desolation. .2 Henry $V I$. iii. death, desolation. ruin, and decay. Richard III. iv. desolation does begin to make... Antony \& Cleo. v. 2 and seen the desolation of your streets.. Pericles, $\mathrm{i}$. DESPAIR-my ending is despair..... Tempest, (epil.)
lieavenly comforts of despair .. Areas. for Meas. iv. 3 and rash-embraced despuir. Alerchan of Venice, ifi. eoldest, and despair most sits $\because \ldots . .$. All's Well, ii. and our crimes would despair, if they - iv. celsa senis, despair not ...... Taming of Shrew, iii. should all despair, that have....... Winter's 'Tale, i. betake thee to nothing but despair .. $\overline{\text { to }} \overline{\text { itim }}$ and comfortless despair.. Connedy of the mere despair of surgery .......... Macbeth, iv. but, in despair, die under their..... King $J_{0 / n}$, iii. do but despair, and, it thou want'st.. . pichard $1 \%$ iv. $\mathrm{i}$. not patience, Gaunt, it is despair...... Richard 11. . despair not madam (rep.).... speak of nothing but despoir

sweet way I was in to despair! ....... arbitrotor of despoirs just denth....

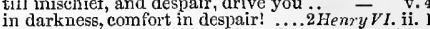
his bosom purge this błack despairi - iii. 3 whenee springs this deep despair?... reseue him from foul despair?

rather wean me from despair .......... $\begin{array}{lll}\text { I'll join with black despair against... } & \text { ii. } 2 \\ \text { despair therefore, and die! (rep.) .... } & \text { v. } 3\end{array}$ I shall despair. There is no creature - $\overline{-}$ y. 3 fan you into despair! .............. Coriolanus, iii. 3 fan you into despair! ............... Coriolanus, il. 3 past hope, and in despair ............ Cymbeline, i. 2 then why should he despair....... Titus Andron. ii. 1 why I do trifle thus with his despair .... Lear, iv. 2 begged tor him, saved him from despair.. merit bliss by making me despair. Romeo \& Jutiel, i. 1 DESPAIRING - - thoughts .. TwoGen. of Ver. iii. I despairing of his own arm's $\ldots . . . . .1$ Henry $V I$. ii. I base, feartul, and despairing Henry!.3Henry VI. i.
by despairing, shalt thou stind .... Richard III. despairing, yield thy breath! ......... v. 3 not effected; so, despairing, died .... Cymbeline, v.
DESPATCH-I will despateh him. Two Gen.of Ver. $\mathrm{i}$. despateh, sweet gentiemen ............. obey him; quickly, despatel. ......Merry wives, iv,

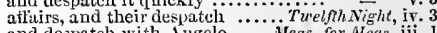
and despatch with Angelo ...... Meas. for Meas. iii. I desprateh it presently; the hour......
quick, despatch, and send the head...

to have a despatch of complaints $\ldots . .-$ iv. deraving quick despateh, importunes. Love's L.L.ii. I to duy we shall have our despateh ... 0 - iv. 1 mistreso, destuteh you

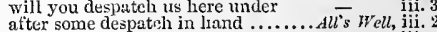
despatch the most convenient ....... - iif. 4 between these main parcels of despatch $\bar{T}$ ale iv. 3 nay, pr'y thee despatch ........... Winter's Tale, iv. 3
I jray you, sir, despatch ..... Comedy of Errors, iv. I great business into my despateh $9 \ldots . .$. Matbeth, $\mathrm{i}$. I will be sudden, aud despatch............. John, iv. my lord, despatch; read o'er these...Richord $I I$. iy. some music: despatch; the room ..2 HenryIV. ii. the eoronatioul d we toward the eount

with all switt despatch, to line......... Henry $V$. ii.

I will despatch the horsemen ....... i Henry $V I$. iv. despatch, this knave's tongue begins.2Henry $V^{\prime} I$. ii. bear me hence, despatch me here ..3Henry $V^{\prime} I$. v. . nay, now despatch; 'twas I that...'

go, go, despatch. We will, my uoble iii. 3 
DESPATCI-despateh, my lord .. Ri

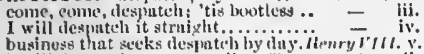
I vill dessuteh youl screreslly. Thenn of fihens, ii.

and hetr how the tesputs is male... C

if 1 do semul, lesputeh these contur

to despatch this viperous traitor

yet give us our desinte
with werils: despateli

desplateh we the buiness we hiuve...int. of Clen. ii.

clespintels; from Antony win ('leoplatia

despruteh: O) love, that thin conlulst see

hime- men: Wros, desputeh.......

Clumminn, we'll dessnteh indeed

be aungry, and desputels: 0 conlds

ajace, desinteh: I partiy fecl the

prythes, desisatels: the lumbe

my sword slaall soon desplehteh it.. Titus indran.

terrible desintel of it into your poeket?

nemain umeaught; und tound-despatel

messengers trom henee at tend

it would desprnteh you straight ... Romeo \& Jalit, $v$.

we liere desgrated you, good Cornetius ...It zmlet, i. a

your commssion will forthwith despateh - iit. as she conld with haste despateh

your uystery; nay, despntel

prythes despatch. Shall I go feteh your - iv. 3

have you desputched? despatehed! Merr!l Wines, v. 5

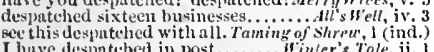

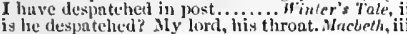

despatcherl him in an embass

see them desputeher: unite,

I huve despatched with letters say

withitehed.

a fleld should be despatuhed

we have despatehed the duke

sirs, have you despatched this thing?

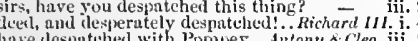

litve desputehed with Pompes...Antony \& Cleo. iii. 2
I bid you do, get them despatched .. Cymbeliap. i. I what shull be, is despoteh
they 're well despatehed..

of erown, wit queen, at once despi........... Hamet,

DESL'ERATE-ot them are desperute. Tempesl, iit. 3 anl desperute of obtaining her. TtroGen. of fer. iii. my suit then is desperate ......... Merry Wives, iii. 5 state is desperate for iny master

desperate of shame and state

afraid she will do a desperate ontrage.....uch d do, ii. 3 of many desperate studies..........As you Like it, $v$. a disperate oftendress against nature...All's Well, i. I to cure the desperate languishings

this is a fond and desperate erenture

venture madly on a desperate .. T'aming of sh v. 3

this is desperate, sir. So eall it ... Hinter's Tate,

two desperate men, which ........... king John, iii. I

as dissolute as desperate ............ Richart II. v. 3

yen istaud earrions, desperate ......... Henry $r$.

Salisbury is a desperate homicide.

iHenry VI, i.

mondy mad, and desperate stags

unheedful, desperate, wild adventiure

thy desperute sire of Crete

so deswerate thieves, all hopeless ......3 Herry $\mathrm{V}^{\prime}$

needrul in this desperate case.
drown desperate sorrow in clead

fright tfol, desirerate, wild, and fth
in suchs a desperate bay of death

to rlesperste ventures of death

in desperute manuer daring

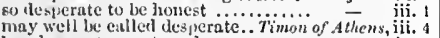

las de-jierute want nate ............ - iv. 3

purge by any desperate change .........

my' quein upon a desperate ber

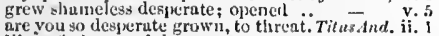

like a forlorn and desperate castaway

attended with a despurate train

go after her, she's desferate; govern her... Lear,

one lesperate griet eurcs wit

lold thy desperate hnew

as desll make a desperate tencler...

dush ont my desperate Irains?

in the thenghts of tlesperate

tempt nut a desperate man

thon desperate pilot, now at once run

he w'u

he waxes desperate with inagination ...

desperate grown, by defperate appliance

a kister triven into desperate terins

with desperate hand furdo its own life.

1 um desperate of iny fortunes

sight would inake du a desperute turn....

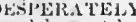

and desprerately mortal ... Measure for Meusure he rerately he hurried throughl... Comedy of Rirr. . . i nud desperately deamtehed........ lichurd iil $i$.

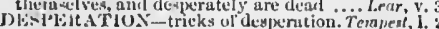
lesperation is all the policy ........ Coriolunus, it. 6

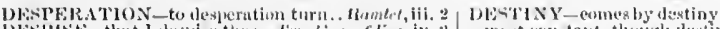

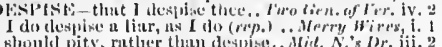

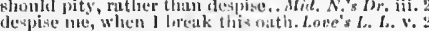

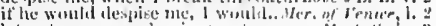
let not your cars despike my tom
a wake, f to despise my dretm.

my lord, despise her gentle sutit

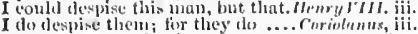

but comfirts we desirise. Antony $x$ - clropatr

the grent, nur llo the low desinise ....... Pericter, ii.

in thy hate. Jespise me, it' $I$ do nut

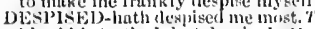

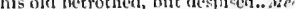

such as are despised in nativi

ostentution of despised arms.....
toul weather witl despised tear

nephew, late despised Riehtird.
say-of lute thou wert desigised?

say-of lute thou wert desypisec?

the state of our desplsed nobility...ilenry r'Mll. iii.

thus is the poor agent despised!. Troilus is cress. v. 11
lest your deities be despised. Fim. of ath. iii. 6 (graee)

but art despised for the contrary

is yen clespised nnd ruinous man $m$

our tinther's tents despised

a poor, intirm, wetk, and despised old inan - ii.

despised substanee of divinest show!

despised, distressed, haterl, martyred

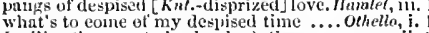

I will rnther sue to be despised, than .....

DESPISET -

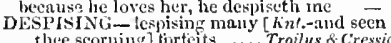

despising, tor you, the city, thus ..Coriolums, ini.

full of derpite, bloody as the .... Tirelfth Night, iii.

is gruce, despite of all controversy...Mea. for Mea. i.

heretic in the despite of beauty
that in despite of his quick wit

only to despite them, will I

and

despite his niee ton

we come but iu despite... Mid. N. Dream, $\bar{v}, 1$ (prol.)

hnve the graee, despite of suit .... Looe's L.Lost, v.

yesterday in despite of my invention

in despite entoree a watery. Taming of

keep nine own, despite of all

in despite of mirth, mean to be..

my fair name, (despite of death
on whom, as in despite, the sun

on whom, as in despite, the sun
hag of nll despite, encompassed

sword, despite of tate, to my

in thy despite, shall seape

proteetor, despite dnke IInimplire

m despite of the devils and hell.....

all contempt, despite the beurward. .3 menry
set the duke up, in despite of me ${ }^{2} . .$.

the gracious duke, in high desp
that $I$ in all desinte might rail

in despite of all that shall

wreteh! tespite o'erwhelm thee! .. Coriola

in your destrite, nion your purse?.... C'ymbetin

openerl, in despite of heaven and men - v.

would you bury him in my despite?.. Titus And. i. 2

despite of mine own nature

in despite, I'll cram thee with. . Romeo of Jutuet,

no, in despite of sense, and secrey.... ham

DESPITLF UL-to seem despitcful. As $y$, ou $L$ ib"

his despiteful Juno, sent him. .. All's 's'll, iti. I' (let.)

his despiteful Juno, sent him .. All's will, iii. d let.

despiteful tidings! U nopleasing... Richard

ingratitikle that despitetul Kome . ilal. of

despitefini and intulerablowrongs?

[knt.] most despitefull'st gentle. Troiluso Cres.

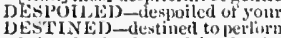

being destined to u drier rleatlu. 7 wo $G c n$ of $V^{\prime}$

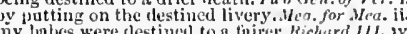

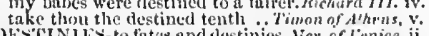

or ns the destinies derec............ you Like

those branehes by the dentinies e...... Mischari 11 .

or destinieg do cut jis thread of hife..... Pericles, i.

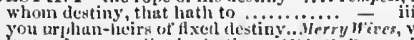

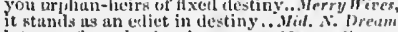

lottery of my destiny bars me ....Jer. of l'ence,

lumping and wiving goes by destiny..
he brings lais desting with him ... will come to know lis delestiuy

un't he shems of destiny?......... king Joh, iv. 2

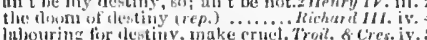

I would connpire ayninst destiny

he painted witls hombes dentiny

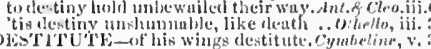

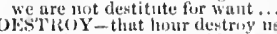

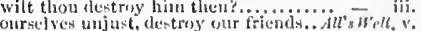

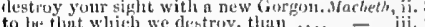

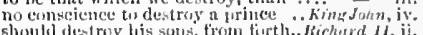

teteld pardon pardon to dentroy?......

poveresing and destron the reath

he that ecuts us to destruy you ...... Richart III

to fright them, cre destruy .......
warilestroy what lies betore thein

thercby to ilestroy the Volces whom

porys, and dostroys the minger..

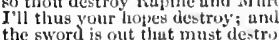

own enactures witl themselves destroy. . Lear, in.

destroved the swectest eompaniog

a world ransomed, or one destrayed

the sentenee my own life ilestroyed.. Richard $I I$. $\mathrm{i}$.

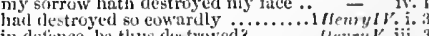

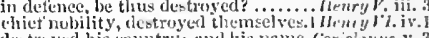

destroyed his combry; and his nanc. Coriolanus, v.

DSTIIOYER-eourteous destro

DisT TOY ING

and die, is deatl destringing deatin

EsThUCTIUN-hy dictruction
even till destruction sicken, answ

send destrution into this

to push destrmetion, and perlectual shame $\bar{v}$

destruction straight shmll dog them.. - $-{ }^{\mathrm{v}}$

like to men proud of destruction ......Hemyl: ii

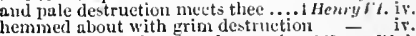

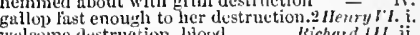
delcome destruction, bloud

death and destruetion does the

ventures and assureif destruction ....̈.

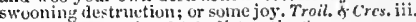

to great destruction [Col.-distraetion] ]

linger not our sure destructions on! .. $\quad$ - vil

suituble for destruetion. Timon of dih. iii. 6 (gr:

destruction fung mulkind!.... Tmon of Athens, iv.

our good wills; a sure destruetion . Coriola aux, ii.

from thenee into destruction cast him $\bar{C}_{\text {arsar }}$ iii.

ineenses them to send destrutetion... Julius

your ehiluren to that destruction ...

destruction on the enemy's castle? :- - iii.

halt' the woocr, elestruetion on ny lical.. (jethello, i.

DE' TAIN-muy detain us longtr.........Meh ido, $\mathrm{i}$.

detain you here some month...herch of lenire, iit.

not sickness should detain me.... Antony o cleo. il.

that we detaill all his revenue

burning slame detuins him from Cordelia - iv.

DETAINED-lere cietained by lier, As you like it. i.

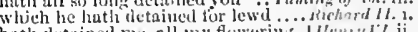

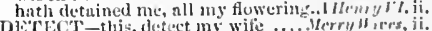

cheCI-this, detect iny wi

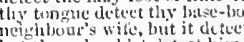

lest thon shoulvist de'tect thin

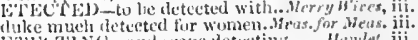

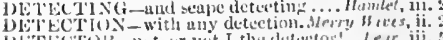

1)

IILLAHIATLE-

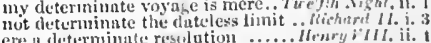

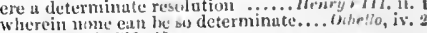

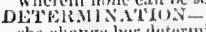

she ehunge her determinntion? ...Mrry Wires, iii.

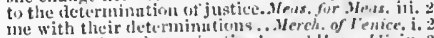

you were of ond deterninution! ... Il/raryll: iv. 3

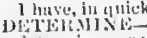

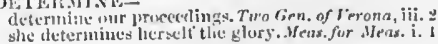




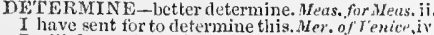
I will deternine this determine what we shall do ........ Kins Joh abmiutely to determine of what....2 Ineriry $H^{\circ} \mathrm{i}$ and yet 1 determine to fight lustily go we to detcrmine who they shaili.i 3 , to chetermine of the eorons tion. determines turther must all determine here?

\section{..Henry} determinc on sone eourse.

witl deternine how to ent off ....Jutins Cassar it will determine one way ......
night determine this great wir.

low letertine this sreat wor.

the laws of Rome cetermine all ..Titus.4ntron.

let us then determine with the ancient

this shall cletermine that ...... Romeo \& Jutiet.

brief sounds determine of my weal

be it as you shall privately deternine ... Othello,

sou have determined to bestow her

you lad, to a determined seope. Meas.

yet determined to-day tw mar

from his own determined aid....

my dete rmined time thou

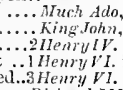

ni determined to prove a villain ... Richard $\mathbf{I I I}$.

it is determinel, not eoncluded yet.

that may be determined at the one

is the determined respite of my wrongs -

are you then determined to do?

ct determined things to destiny. Anlony \& Cleo. iii.

have governed our determined jest?. Titus 1 ind. $y$.

DETEST - we detest such vile.. Two Gen.of Ver. iv. I $I$ do detest false perjured Proteus
nut, I detest, an honest maid

hut, I detest, an honest maid ........Merizrives, $\mathrm{i}$.

a fashion she detests ...........Twelfh $N i g h t$. ii.

wost thou detest her therefure?

I will detest myself also...

these that my poor eompany detest. Hicl.N. D

thac the gods detest sueh bacencs.

write against them, detest them
DETESTABLE-detcstable things

I will kiss tily detestable hones.... King Joh

nakedness, thou detestable town!? Timon of $s t h$,

most detestable death, by thee.. Romeo \& Juliet,

thm detestahle maw, thuu wom

ETESTED-ah me, detested!... Tuelfh Night, v. 1

Ginws guilty of detested erimes.. Lore's L. Lost, iv.
the dark house, and the detested wife. All's Well, ii.

sross rebellion, and detested treason. Richard II. ii. 3

Whou the detested blot of

1 HenryI ${ }^{\circ}$

smontl, dictested parasites

Timon of.Ahens,

a barren letestet yale you ree, it is -

this lekested, dark, blood-lininking jit
yet detested life not shrink thereat..

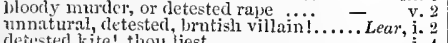

deîusted kite! thou liest

and sumpter to this detested groom.........

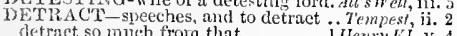
DETRACTION tron that

(1)

thore detraction at your heels.... Twelfth Night, ii. 5 unspeak tnine own detraction.

detraction will not suffer it.......
SEUCALION-far than Deueal

Four predecessors, sinee Demealion.. Coriolanz

DEIJCE-ACE-sum of deuce-ace .. Lone's L. Lost, i. 2 je vous donneray dear cents escus . DFVICE-O excellent device!

\section{marr, this is our deviee}

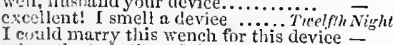
taken the infection of the devi

lest the device take air, and taint...
we will bring the device to the bar

we will bring the device to the bar
set this device against Ml alvolio.

set this device against Malvolio...... - $\mathrm{v}_{\text {. }}$

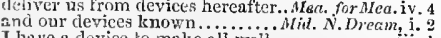
I have a device to make all weil .....

an exeeltent dievice! so, it any.... Love's I.. Lost,

but I will forward with my device...

thiee by some treaeherens device ...As you Like it, i. letter of your own device.

of the maicl: that's your device.T.7.... soine device or other, the villain .. Comedy nf $\mathrm{Fr} r$. Rmi not alune in halit and device..... Kiag John, i. to hear his inonstrous deviees.... some odd gimmals ur deviee
DEVICE-it was thy device by this.. 3 Henry $l^{\prime} l$. iii. 3 eamot see this palpable device?...... perish muter device and practice ....Ienry III. i. I by deviee, let blnekish Ajax.. Troilus \& Cressida, i. 3 ne with mine own device ....... Timon of Alhens, $\mathrm{i}$. 'tis plate, of rare deviec; and jewels.. Cymbeline, i.
whether by deviee, or no the heavens. I'itus Anet. whether by deviee, or no, the heavens. I'itus Aut.j. 2 blot some device of further miscre

plot some device of further miscry

bury all thy fear in my deviees .....

'er-reach them in their own deviees

the device he bears upon his shield $(r e p$.

and his device, a wreath of ehivalry

an exploit, now ripe in my device......

dull not device by coldness and del
doff'st me with some device, Iago

EVIL_anit all the devils are lie

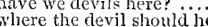

and thes" are devils.

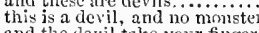

and the devil take your finger

are worse than devils

as many devils entertain.

picked (with the devil's name) ont .

the devil himself hath not

what devil sugrests this imagination?
but, lest the devil that guides him

and the devil guide lis eudge?

if the devil have him not in fee-simple

the devil take one devils

hath the finest mad devil of jealousy

no man means evil but the devil
and the Welch devil, llugh?

I think the devil will not have

that ever the devil conld have.

the devil a Puritan that he is......

if all the devils in hell be.

what man! rlety the devil

an' you speak ill of the devil....

why, man, he's an private braw.

have persuaded him, the yonth 9 s a devil

that will use the devil him

eries, ah, ha! to the devil .........

but he's the very devil incardinate

on the devil's horm (rep.)... Hease
is yet a devil; his filth being.
nay, if the devil have given the

nay, if the devil have given thee $\ldots . .$.
you bid me seek redemption of the devil
and let the devil be sometime honoutred

make a voyare with him to the c
and there will the devil meet me

but the devil my master knew she

one sees more devils than vast hell. Mid.N. S Dr. v. 1
love is a devil, there is no evil angel.. Love's L.t.

devils sonest tempt, resembling
nodevil will fright thee then

some quillets how to eheat the devil

feared her had she been a devil.......
if the devil be within, and that
and the complexion of a devil, I had

and the complexion of a devil, I had
the Nazarite, conjured the devil into

the devil ean eite seripture for .......
(God bless the mark i) is a kind of devil -

the devil himself: eertainly (rep.)

lest the devil eross my prayer; for liere -

if the devil may be her judge...

sarbifice them all here to this devi

why then, the devil give hin good of itt -

nay, but the devil take moeking ... you Like it,

he must needs go, that the devil drives. Ali's Well, i.3

though the devil lend the measure

the devil it is, that's thy master
what the devil shonld move

the prinee of clarkness, alias, the devil

both the uffice of God and the devil?
from all sueh devils, good Lord ... Taming of Sh. i. 1

you may go to the devil's dam ........ -

he's a devil, a devil, a very fiend (rep.) $=$ iii. 2

your queen and $\mathrm{I}$ are devils ........Winter's Tale, i. 2

a devil in an everlastint $\ldots \ldots \ldots \ldots$.

it is the devil. Nay, she is (rep.).Comedy of Err. iv. 3

some devils ask but the paring......
the devil will shake her chain $\ldots . .$.

cry the devil. God help.............

that fenrs a painted revil ............. = ii. 2
who's there, $i^{\prime}$ the other devil's name?

who's there, $i$ the other devil's mame?
that whirh might apyal the devil..... - ii. 3
- ii. 4

would not betray the devil to his feijow - iv. 3

the devil himself eould not pronounee - $\quad$ v. 7
DEVI1,-faithtully as I deny the devil. King John, i. the devil art thou? One that wili $(r$. $p$.) that sly devil; that broker, that still the devil temints tliee here, in likeness some airy devil hovers in ............. that you shall think the devil is eome the devil got ten devil, iv. 3 for now the devil, that told me what a devil hast thou to do witl...... Henry $I V$. $\mathrm{i}$. how agrees the devil and thee about the devil shall have his bargain (rep.) as well liave he had been ( $r c p$.)....

0 , the devil tal come and roar for.... but, as the devil would have it ....... and swore the devil his true liegeman there is a devil ham ts thee.........

heigh, heiglit the devil rides upoin...

'scapes he agues, in the devil's nane

recomitge the devil understauds Welsh 二

it that the devil and mischance look big what a devil dost thou in warwickshire? he will fisin like any devil ..........2 Henry what the devil hast thou bronght there? a mere hoard of rold kept by a devil = why the devil sliould we lieep knives. Henry and said, they were devils inearnat

'said once, the devil would have him -

grive the devil his due............... with-a pox of the devil

mee wolves, and fight like devils...

than this roaring devil i' the old play

the devil take order now!........... -

the devil was in arms................ Henry $V l .1$. devil, or devil's dam, I'll conjure thee = i. wonders, but by help ot devils $\ldots . . . . . .=$ $=$ v.

my lord, let's see the devil's writ..... - i. this devil luere shall be my substitute - iii. the devil make a thixd!............ - iii.

let ten thousand devils come $. . . . . . . .{ }_{3}-$ iv. 10

where is that devil's buteher........... 3 Hen ry VI. v. 5

cannot endure the devil; avaunt .... Richard ${ }_{\text {HII. }}$. o wonderful, when devils tell the truth but the plain devil, and dissembling

with a bell of ugly devils! ............

a saint, when most I piay the devil..

brother's love, the devit, and my......

bit, $O$, the devil, - there the villain ..
of the devil thus? $A y$, if the devil tempt

the devil speed him! no man's pie. Hevry

not from hell, the devil is a nigitard..
why the devil, upon this French ....

by the devil's illusions this monk...

the devil fiddle them! I am glad....

what cross devil made me yut this

the devil was amongst them, I thiu

learn to conjure and raise devils ....

and devil, envy, say, Ainen...........

the devil take Antenor! :...........

sometimes we are devils to ourselves

how the devil luxury, with his $\ldots . .$. .

buruing devil take them

he devil take thee, coward! $\ldots . . .1$ v

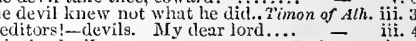

he's the devil ...................... Coriolanus, i. 10 some angel, or some devil............. if the devil dress lier not

these same whoreson devils do the....

tisdring thee and the devil alike

that such a erafty devil as is his

his garment? now the devil-
$O$, all the devils? this yellow

the very devils eannot plague .........

pray to the devils; the grods have. T'ilus And

a devil. Why then she's the devil's daw -

bring down the devil

if there be devils, wond 13 .............

all hell afford you such a devil? conveniunt you $^{-. . .}$

his aeenrsed devil; let him receive...

ome deril whisper curses in

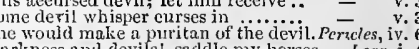
darkness and devils! saddle my horses ... Lear, i. the devil should this 2 umeo be?. Krmeo \& Jutiel, iv. 4 


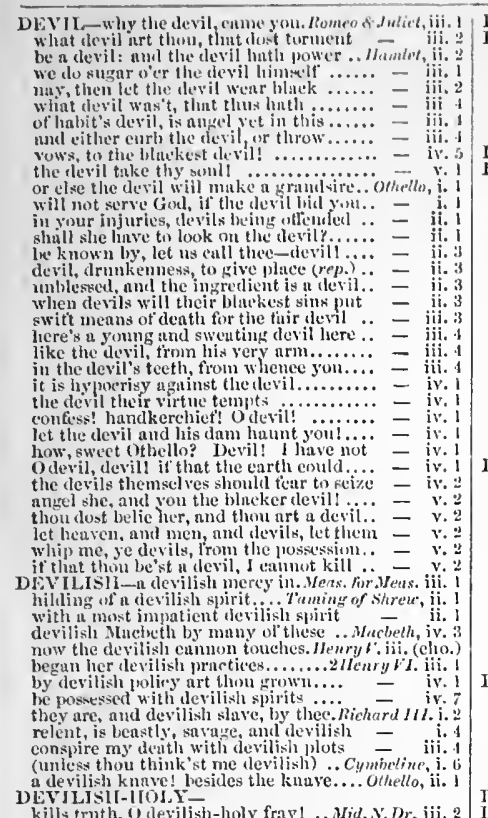

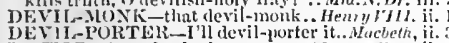
DEVISE-then she devises.......... Merry Hincs, ii. good henrts, devise smmething....

devise but how you'll nse him let us two devise to bring him thither

let us two devise to bring him thisher

truly, 1 'il derise some honest sinuders

ind devise thee brave puislunents

falls ont better than I could devise...Mid.X. Dr. iii.2

rest of the court ean possibly dev

let

the brain nay devise laws tor ... Merch of $\vec{F}$ enice iv.

I will, eoz, and devise spirts....... As you Like it, 1.

therctore devise with mo,

I sliall devise something

I will devise a death as erinet..........

can'st not, curdinal, devise a nam

out of your grace, devise, ur
or thou caust wor'se devise

what eport shall we devise here....

whaterer I shall hupuen to devise

I will devise matter enougls out ....

and withal, devise sinnetling to do.

等

this doth fonn what

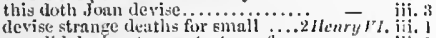

you dial deviee strunge tor bure:

well devise a neun to reconcile.

Cliford, devise excuses for (rep.)....3/

vistre to devise inu ji.

mistreds to devise imjosition
see, and hear, devise, instruet

see, and hear, devise, instruet $\ldots \ldots . .$.
fit the honours which we devise

devize with the where thou

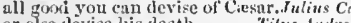

or else devise lis death

Titus dudronsats,

devire his specty taking off ................ Lear, y. I

love thee better than thou canst devise

hid me devise sume rocaus tis rit

if you could devise it so, that 1 .

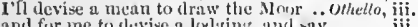
and clevise engines for my life

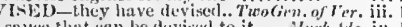
no Eallee that ian lie deviscd to it

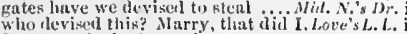

fir a new devized enurt's

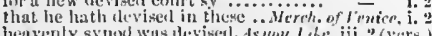

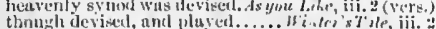
new exactiuns are deviset ............. Richarllit. ii.

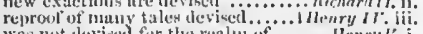

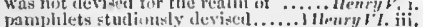

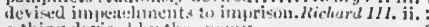
a thing devised l,y the enemy ........ - v.3

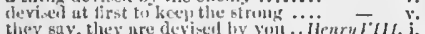
they say, they ure devived hy yoll. .Henry III,

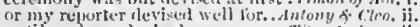
nntil we have devicul sume ...... Titus indron. ii. revised a new eomminsing

limmlet, v.

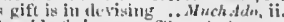

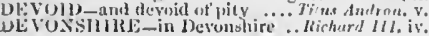

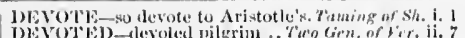

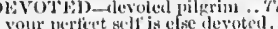

iompliments of devotel and Love's

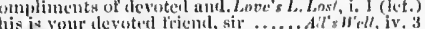

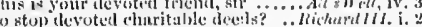
minl if thy poor devoted servant inay - i. 2 lie hatl devoted and riven mis himself.. (Nakllo, ii. 3 DEVo'Tlislist - [Col. kut.] devoloment of - ij. 3 政

lowliness, derotion, paticnee, cournge..y

in the devotiun of a sulyjeet's love

my devotion. It duth...

devotion, bo this holy slinine? (revp.).2.

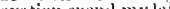

the in tevotion spent my latter days $\bar{y}$ iv.

upon the like devotion ay yourkelves

the inter

he derotion whieh cold lips .. Troilue of Cross is.

with greater devotion than they cun. Cor

mumnerly devotion shaws in this. Rome's
(iod shicld, I shotald disturb devotion!

that with devotien's visage, and pious. 11 m

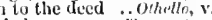

thold-they devour their reasur

rechity devour the trenelserons ..... Much.sto

devents up ull the fry it timels ....... All's if ell,

nut devour incertain lonkers-on.. Winter's Tal

to devour so many as will to .........Mutherth,

devours the deed in the praise.

ay, to tevour him; as the humigry.

and at last devours them all ..............
the gonjeres shath devour them, fesi

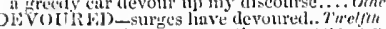

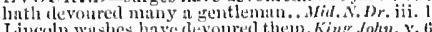

all mw wrily, devoured by the........ King Joh, 8.6

forsook me, liutli devour

in sorrow all devoures

DEVOUIR $\$ G-i t$ hat, devouring

or sumpose, devonring jestileuce.

minler his devonring jaws

out of this fielt aevouring recepitaci

contemplation and devout desires... . kinis Jwh

which men alevont by testanent have... If ury $I^{\prime}$. i.

huly and devout rel igious men.... Richtert $\$ 11$. iii.

what, art thou devout?....... Troilus o cressid
the devout religion of mine cye.. Rome o f luth

mich castiyation, exereise devont .... Ohe flo, tii.

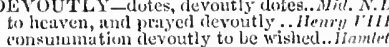

DE I - to fitein dew from the..........

as wicked dew as e'cr my mother

t.) lew her orhs upon the grted. . Mid.
beflatblud with the dew, and torn...

and thit same dew, which somet
that sweep nway the morning de

tiurfully o'ertrip the dew ... Merchun/ of Jenice, v.

rotes newly washed with dew. Thming of "shreu', ii. 1

the want of which vain der.

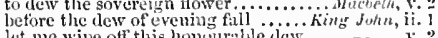

let me wipe off this honemrab

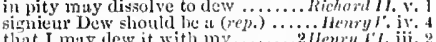

crell us the dew th tire

enjoy the golden dew of sleep....... Richard 111 . iv.

which Grul's dew quench

the dew's of heaven fill thiek

melted away with rotten dew.

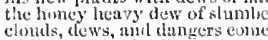

Whiles yet the dew's on gromind
have on them cold dew o' the vinht.

have on them cold dew of the uight
fall on their heals dike dew! .........

as doth the lumey dew upon ..... Tilus Autron. iii. $t$

atymenting the fresh morning stew. Nom. of Jul. i. I

the air doth drimale dew

[Cul. hint.] water nightly I will c

trings eft tire ancl dews of blom

thaw and resolye itself int! a rle

the morm and liquald dew of youtl

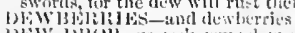

a rlew-\{lyop frem the lion's muse. Troil. of Crus. iii. 3

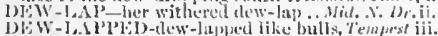

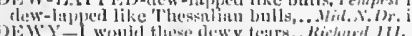

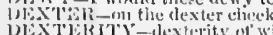

with :

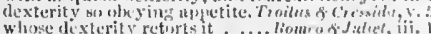

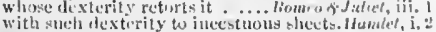
With such dextrity

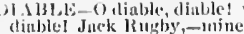

diublel Juck lumby, - mine .......

1)] A131.(1-rlinble, las! the town will rite (1)

.

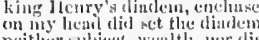

neither suliject, wealth, mer cliadien... - iv.

und rob his temples of the diarlem ...3 Ifenry J' i.

und set thy diaten nom iny heset

trimming upt the diallem an her... Ansony f clon.v.

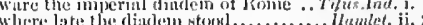

troms a shelf the precions diatem stole... iii.

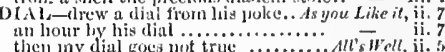

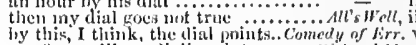

my this, I think, the dial points.. Comedy of firr.

dinls the signs of teaping-hou

did ride unon a dial's point
close in the dial's ectre

to earve out diuls gutintly.

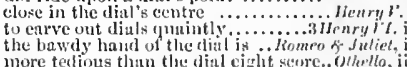

more tedious than the dinl ciglit semre.. Ohe mo, iii. A

to go ont of my dialeet, which you ...... Lear, ii.

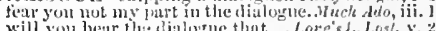

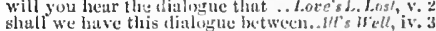

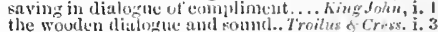

dust clialogne with thy sharlew.

D) A $M$ LER - the world's dianc

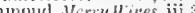

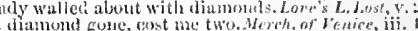

for $n y$ dianond, the ehuin youl. Comeity of kir. iv. 3

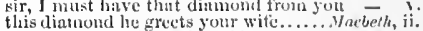

set this diumond sate in golden .... l bewn r I. .

aot dicked with dianjomess

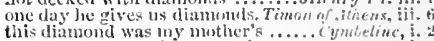

as that diamond of y mustike

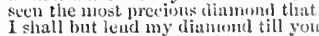

so is your diamond tian: if I conce oft

must be married to that your diamond

to me lie ecems like dianoml to glas

the diamonds of a most prisecel wh

ing pearls from diamonds dromped....

Inime bud o'er Cunjif's fluwer lat

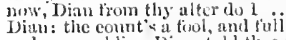

and say a solditer, Dian, told the

theu Dian, and fet her be hit

stow that lics on Dim!s lap!.

and hangs on witn stemplic

yet my mother seened the Lian of thu

or is it Dian, habited like hie.....

the power, that, some say, Dian lind

vail to lier mistress bjan

eelestial Dinn, goddess argentine

done his sacrifice, as bian lade

iumortal Dian! Now I kinow

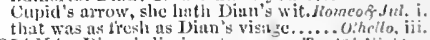

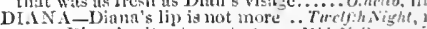

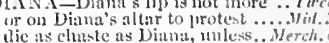

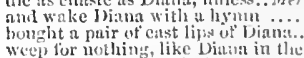

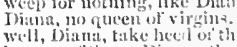

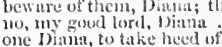

one bithe, to take heed uf

you, binua, moler my porer instruetion

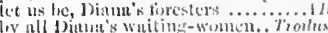

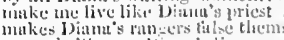

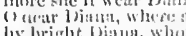

ly luright biats, whom we honte

Hian, aid uty nury
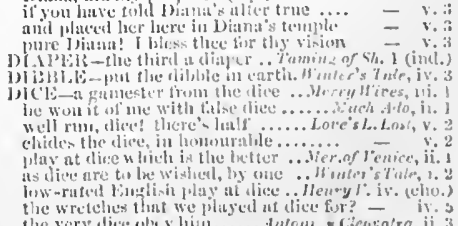
DICE-wine loved I deeply; dice dearly .. Lear, iii. 4 DICED-dicel, not above seven

Henryll, inte DICl - good diels thy good heart. Timon of Athens, $\mathrm{i}$. 2 DICK-llid'st see Diek surgeon, sot?. Tuelfhh Night, v. some trencher-linight, some Dick.. Love's L. Lost, $\mathrm{v}$. and Dick the shepherd blows his

THenryIV. ii. 4 and Dick the butclier 2 Henry VI. iv. where's Dick, the butcher of Ashiford? - iv. 3 and thou, mis-slapen Dick, I tell ...3 Henry VI. y.
to beg of Hob sud Dick, that do.... Coriolanus, ii. 3 DICKENS-the dickens his n:me is. Merry Wives, iii. 2 ICKY I icky, your bov, that, with..3 Henry II. i. DICTION - to make true diction of lim.. Hamlet, v. 2 Dietynu: goodman Dull (rep.) ... Love's L.Lost. iv. 2 DIDO-not since widow Dido's time.... Tempest, ii. widow IDido! What if he had said

widow Dido, said you? you make.

'bate, I beseeen you, widow Dido $(\mathrm{rep}$. $)$ - ii. I when he to madding Dido, would..? Inemry It. iii. Jido and her Anens shall want ...Ant.' \& Clco. iv. 12 the wandering prince and Dido onee. $T$ to love-sick Dido's sad attending ear
to be-rhyme her: Dido, a dowdy. Romeo \&.Juliet, ii. 4 DIE-I would fain die a dry deatl

thou lett'st thy fortune sleep-die rather - ii. I for else his project dies

what I khall die to want

if not. I'll die youx maid

he that dies, pays all debts

to die, is to be banishid....

let him die: but first

why, now let me
vou die, sir Jolnn

he slall die a flea's death

lie that speaks to them shall die

may sicken, and so die...

they to perfection grov

Ronos clies, sir 'Toby

when we drink, we die ..... Measure for Measur

sir, he must die.

and he to die for it!..................

I have a brother is eondemned to die

must he needs die?

your brother dies to-moirow

he die?

must die to-morrow! - O injurious love

yet he must die...

your brother is to di

redeening him should die for e......

else let my brother die .......

Ine must not only die the death

Isabel, live cliaste, and

I find, I seek to die.....................

as when a giant dies ..............

if I must die, I will

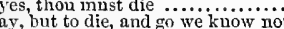

take my detines anow

to-nlorrow you must die

had rather iny brother die by the law

die to-morrow, or no? Why (rep.)

and now is he resolved to die...

are to die Claudio and Barnaxdine

I will not eonsent to die this day............

I swear I will not die to-day

unfit to live, or die: o gravel
this rude wretel willingly to die.

this rude wreteh willingly to di.

he dies for Clandio's death

is it possible, clisdain should

I shall see thee, ere I die, look pale.

she will die, for she says, she will die
die ere she nake her love known (rep.)

that she will rather die than give

when I said, I would die a bache

than die with moeks (rep.) . . .

thou would'st not quickly di

hence from her; let her

therefore, I will die a woman..........

and so dies my revenge.

I will live in thy heart, die in thy lä

gives her fame which never dies ..
either to die the duath, or to...... $\mathrm{v}$ (seroil)
. Dream, i.

grows, lives, and dies, in single.

upon that day either prepare to die..
she, being mortal, of that boy did die

to die upon the hand $I$ love.

thow, die die, die, die, die $\dddot{N}$, the...

wealth, to pomp, I pine and die die ${ }^{2}$ ' $\bar{L}$.

and we cleserve to die...

how? let me not die your debto

i.1 privite with you, ere I die
DIE-that will not die in debt .... Lorc's L. Lost, die when you will, a smoek.

and the contents die in the zeal....

I will die as chaste as Disna ... Merch of $\overline{\text { Venic }}$

and die with grieving...

with gazing fed; and fancy dies...... - iii. 2 (song

of nll he clies possessed, unto hi

I'll ilic for't, but some woman

of all he dies possessed of

As you Like it

in the greatness of my word, you die,

O I die for food! aud, not my master's

I'll give thee lcave to die

thou slinlt not die for laek of ....

answered with reason, I must die

I to live and die her slave....

that lives and dies by bloody drons?

did what he eould to die before

then Ill study how to die........

should $I$ die the hour after .......

though therefore I die a virgin .....

and so dies with feeding his own

and with his vassal die: he must not

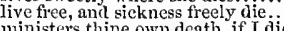

ministers thine own death, if I die ...

I'll live and die a maid ........

not that I $\mathrm{am}$ afraid to die ....
you must die: the general says

therefore you must die ................

in hope I shall see him ere I

may not young men die, as well.

I should die with laughing..............

whieh now shall die in oblivion.........

would they else be content to die?...Winter's Tale, $\mathrm{i}$.

with die, and drab, I purchased this

pale primroses, that die ummarried

might die within this hour (rep.)

until you see her die again

to the bay of Ephesus, be dies. Comedy of Errors, $i$.

then thou art doomed to die

away, and weeping dic

that hath sucil means to die...

we shall not die, so much we

with one that saw him die

the man would die, and there an end.

at least we'll die with harness on

and die on mine own sword?

sorrow how to make ine die...

in the very meeting, fall, and dic....

in despair, die under their black ....

make my mother die with grief.

and so he'll die; and, vis.

even at that news dies ..............

that I must die here, and live.

I live, and for that will I die...

will I hence, and die

there lives, or dies, true to.

leased ont (I die pronouncing it) .....

but die not shame with thee! ..........

and let the shame with thee

fight and die, is death destroying.

leave to live till Richard die?.

lives when his dishonour dies.........

they eannot, die in their own pride...
sinks downward, here to die ........

in peace, die free from strife

nuy reasonably die, and never.

but to die a fair death.

and I will die a hundred thousnd.....

thousand rebels die in this

doomsday is near; die all, die merril

to die, is to be a counterfeit

let order die! and let this world no...2 HenryIr.

thourh that be sick, it dies not

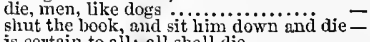

is certnin to all: all sh

a man ean die but onee

he that lies this year, is quit for

let me ln nyy present wildness die...

I shonld not die but iu Jerusalem....

whieh king, Bezonian, speak or die

I would I might die, that I might

Falstatl shith die of a sweat........

seemed to die too

When the son dies, let the...........

this grace of kings must die.

die and be dimmed; and figo tor.....................
OIE-not die any where so contented .. Henry $V$. iv.

it these men do not die well, it wili..

die in many irreconciled iniquities...

then if they die unprovided.

if we are marked to die ................

not die in that man's eompany (rep.)

English, or else die witli fame $\ldots . . .$. .

base Trojan, thou shalt die

cheerer of the heart, unpruned dies..

that I shall die is true $\ldots . . . \ldots \ldots \ldots . . .1$

would I were to die with Saksbury!

here dies the dusky torch.

to get the town again, or die

and mi whtiest potentates, must die...

that thus we die, while remiss ......

he dies, we lose; I break my

but dies, betrayed to fortun.

we both are sure to die ...............

my followers here, to fight, and die?

for live I will not, if my father die

if I to-day die not with.

that bears me, fall and die?

to Talbot, die at Talbot's foot.........

eominendable proved, let's die in pride

.

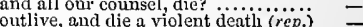

by water shall he die, and take (rep.)

$a n$ ' if I die, $I$ give thee my apron

that he should die, is wortlyy poliey

by this, you would not have him die

a hundred times to part than die....

and in thy sight to die, what were ...

where should he die? ean I make....

he dies, and makes no sign

for die you shall; the lives

to revenge it, shalt thou die...

that I should die by sueh

great men oft die by vile
and Sutfolk dies by pirates

not find him guilty, be shall not die

go for ward: therefore yield, or die

should not mourn, but die for thee

die, clammed wretch, the curse

thus to die in ruttion battle?

he that flies, slanl die.......................

and die in bands for

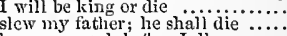

here me speak betore I dle

slew my father; therefore die.......

or die renowned by attempting it.....
burns ny eandle out, ay, here it dies

take 13, we are sure to die

how we can, yet die we nust .........

no more; die, prophet, in thy speeeli $-\overline{\text { and }}$ must not die, till George be.... Richard III.

that I might die at onee

die in his youth, by like

long die thy happy days before........

die neither mother, wife.

come, he dies; I had forgot ...........

with God, for you must die, my lord

if die, be brief; that our swift-winged
make me die a good old man!........

or, let me die, to look on death.

of the queen must die at Pomfret....

'tis a vile thing to die my gracious..

shalt thou beloold a subject die .....

had we not determined he should die

and die, ere unen can say-God save

my queen is sick, and hike to die
cither thou wilt die, by God's just

and nust she die for this?............

despair therefore, and diel (rep.)

and, if I die, no soul will pity me....

after the battle let George Stanley die
and $\mathbf{I}$ will stand the hazard of the die

for that die is on me, which makes..II

the king should without issue die...

and by that name must dic

when the bird ot wonder dies...........

but she must dic, she must; the saints

at this sport, sir Valour dies.

ery-oh! oh! they die!.....

let him die, with every joint

die I a villain then!.

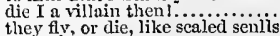

deereed-Hector the or areat must die...

that's a deed thou'lt die for .... Timo

who dies, that bears not one spurn ..

there will little lcarming die then....
a bastard, and thou'lt die a bawd ...

i. 4

iii. 3

iii. 2

iii.

iii. 3

iv. 1

iv. 1

iv.

,

Heñry r. i.

i. 2

i. 3 
DIR-'tis neeessary, he sisuld dile. Thion of Ath. jii

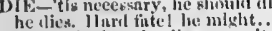
we are for law, he dless nirge it........ thon shouldat devire to die, heing long live so, and so clie! I mun yuit . ait the spetted clic. let slie the spotted

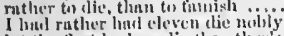
let the first huslyer dio the ather's advanced, declines, and then men dio getter it is tir the, licter to starve....

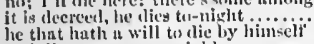
and dic mume unr neiphlours ....... let him die for t.

take thomglt, and die for Ca.......... Julius Corsar let him not die; for he will live... when begatars die, there are no

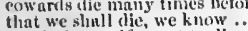
that we shinll die, we know
nut find miyself so apt to die. were living and die all slave

well follow him, we'll die with him

glall die: their names are prickedl (rep.) -

his voiee who slomuld be prie

we mist die, Mlessala (rep.).

thom conlust not die more lowour.....

only I yieht to die: there is so mueh

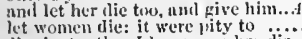

dies instantly; I have feen her die

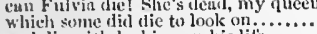

Which some did die to look on.

to Antony, slunll die a beggar.

think, and die. Is Antony, or

I hive minny other wuys to

same diteh, wherein to die the...........

slue dies tor't: Eros, ho.

and shall die the death
thy moster clies thy selooln.

die, where thou hast lived

anci do now not basely di

noly, I woulul dic. Nost noble ci......

sny, I woulli dic. Mrst noble empres

those, that do die of th seldon...

lint it die na it was born

I must die much your dehtor.

which dies 't the sureli; and hat

why, I must die; nud if 1 do not ...

swent of indusiry would

to seem to die, ere sick

nnd a demund who is't shali ilie

die the death; when I have slai

that I never did see man die?.........
in your eountry wars you clanee to die
so I'll die for thee, 0 Imogen .........

to die with lengthened shame...

our Britain's harts die flying ....

those, that would die, or ere resist

I am merrier to die, than thou

that lie nguinst their wills
briefty dic their joys, that plaee.

thas clie ere I hear inure

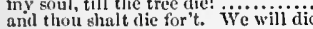

and die he must to appease... Tilus

hononr thee, and will do till I cli

that dies in tempest of thy angry .....
this day all guarrels dic, Antronieus

full mail, or clse die sudilenly

for fear they die before their parion

die. Andronicus; thnu dost not.

or die with this reproaeh

it shall not die. Anron, it must
he dies upon my scimitar's ....

let not your sorrow die, thongli......

for he murt not die so sweet...........

clice, frantie wrutch, for

so for her nany a wight dij die...Pericle

of lie in the alventure...

ant the por worm doth die for't .........

theretore in tantly this prinee must die

wie, nirst alsalt die to lengthen

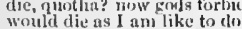

lis hands, where I was like to ilie

a enrse thom him, the he like a thice

asc ane ald wies! hould do........

be flice, that strikes nenin. .................

if I die fur it, as no less is threntenei no

awny, nnil let me die ...................

thon fhalt not die: ilie fir uluiltery! no.

to will ile bravely, like a britegrools.

when du you die? still, stiil, fur widei.

\section{I should you lie with pity.}

hurbly slie, rather than die at oncel.

when slie dices, with bu

the rank pison si the olili will die...

often ilruwied, conlel never dic ......

arment in ther, and would ali

the trutli, ir lict lenvolion

ant when he shall die, take hin

I, a mairl, die nuilden-willuweol.

take hetil, fur such dlie mixcrable....
well, we were born to die .............

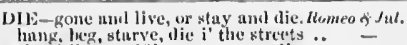

clac finl, myself hine powee to lise

I long torlie, if what thou spenk'st

there die strangled cre my Rem

lonk ull, or I will die with the

hest marrien, thut dies murres young

for thum imust die. I must, indeed...

thus with a kiss l dic ..................

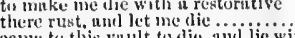

eame tis this vault to die, and

ull that live, must dic, pussing

to die, - to sleep, no more.....................

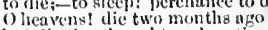

Oheavens! dic two months afo w.....

the ecuse of majesty dies not alone

a plenrisy, dies in his own too-much

faith, it lae be not rotten before he die...

t) I dic, lloratio: the potent poisol
then lanve we a preseription to die

if it were now to llie, twere now
I am lurt to the death; he dies.

his sonl light: he dies upon his motion.

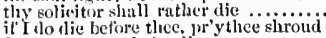

forth, my sword; he dies ..........

she must die, else she'li betriy more me.....

thy cleath-bed. Av, but nut yet to die

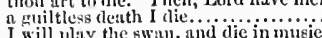

go speaking as I think, I die, - I die.....

gor, in my sense, 'tis happiness to die

DI lid -within which time she diel......... Temperst,

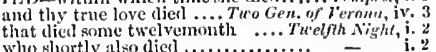

but dicel thy sister of her love

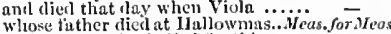

who is it that hath died for this

hetter it were a brotlier died at

the thing for which he died...

by private otrler else have died .......
that slould have dicul when Claudio

hear slie died upon lis worls .......Wuehth

and upon grief of this, suddenly diex

so the lite that lied with shame..

lis dagger drew and lied

v. 3 (scroli)

his dagner drew, and died .......Mid. N. Dream, v. I

bave been a grandam ere slie died....

or have died to stay belind her..... As you Like it, i.

men liave died from time to time.

the plyysician at your futher's died?....All's Well,

die upon the hel my father clied.. i

not a month 'fore your yuten died.

he died as one that hath been

fiet, died every day she lived.

feet, died every day she lived
who have died holily in their beds

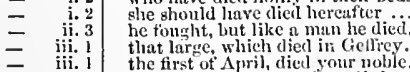

l,efore I came, the duchess died .....Richard 11. ii. 2

lie that tied o' Werlnestay .

frandsire, Ed wart, sieked, and died

whin lied within the yerr of our

Nenryll

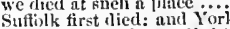

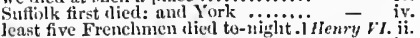

and there died iny Iearus.

death of Jlim thut died for all .........

black prince, diet hefore his father.. - ii. 2

of I Iatfield dicel without an licir

bet how lie died, God krows

by him the gool duke I Iumphrey died

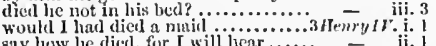

gay how he dicd, for I will hear.......

when holy blitry' died, ant iny sweet - ivi 1

only in that sntety dietl her brothers

Rivers, thit dien at l'onfret!...

that be ran wasl, and died.

or thed where they

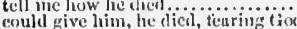

he might have dicd in war.... Fituon of Athers,

lut luud lie diecl in the businesg....... Corrolank

and died so? liven st....................

how diet my master, Strato?

where died she? In siryen... tutriny of Cleopatra, i.

since Cleoputra died, l have livedi.
DIl:D-she rlied of the biting of it...A tutany f Cico. v.

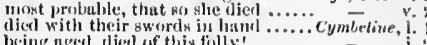

bcing ngett, tlient of this filly:

tronk liecel to do't, and set ified too? ..

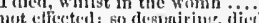

rosy laul, who dical, aud was loidele

continues so, until we thanglit be died

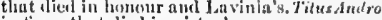

was slnin when Bassiunus diecl

they died in howour's botty beel
thint died by law for murder of

who rliet und lett a female hoir... Perietes, i. (Givw.

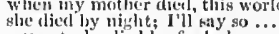

ery out, alie rivel ly foul play...
who clied the very minute I s

at $\mathrm{sect}$ in child-bed diet she

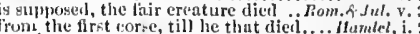

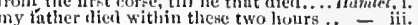

they withered all, when my fatleer died.. - iv.

her fortune, and she died sincinu it wathello,

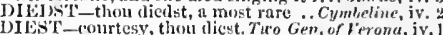

eonceal them. or thou dieat ........Merry Wives, iv.

'tis best thint thou diest quickly...... for - iii.

thou diest, and all thy fouls......Mer. of Fenice, iv.

but if thesu diest before 1 come ....... - ii.

to thy better unlerstanding, djest.....

thon dicst within this hour ............

thu diest, thourl I the sicker be ... Rickard Ji. ii.

thun diest on point of fox ............ lleary $V$. jv.

locik, how thou diest........... Troilas \& Cresside, v.
why, now thou diest as bravely ...Julius Copsar, v.

why, now thou diest as bravely ...Julius Cepsar, v.

witli thy unworthiness, thou diest .... Cymbeline, i.
let go, slave, or thou liest................. Lear, dv.

Iet go, slave, or thou liest ............... Lear, iv. 6
villuin, thou diest. That thrust....... Othello, v. I

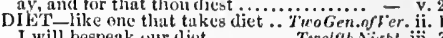

I will bespeak uur liet ........... Tueelfh $\mathrm{Nighh}$, iï. 3

may justly dict me ..............

be his nurse, diet his sickness.............. Aedy of Err. . . I

for your diet, and by-drinkings.... 1 Henry $1 l^{\prime}$. iij.

or are they spnre in diet

kept an evil rliet long

your diet slialt be in all place
to the tub-tast, and the diet.

Richard $1 \mathrm{i} i \mathrm{i}$.

the thos, rank of gross diet.

for food and diet, to some enterprize..... Humlel .

your worm is your only emperor for diet $-\overline{\text { intly }}$ iv.

or feed upon such niec and waterisi dict

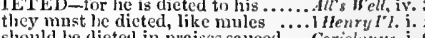

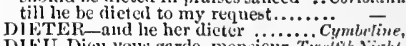

ILU-Dieu vous garde, monsienr. Tuelfh.Tight, iii.

d'apprendre par la gruee de Dieu....

O geigneur Dieu! ees sont mots.....

Dieu de battililes! where liave.

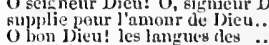

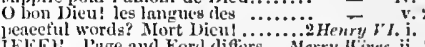
IF El:-l'uge and Ford difters...... Werry Hires, ii. that dificrs not from the stullinis... As you Like il,

Jothing llitlers hut the outward..... Richard IIT. i. but elay and elay differs in digrity... Cymbeline, iv. to make dillerenee of men's liking. Werry wires, ii.

lot him hear it for a diflerence........ Much.t/

there is more differenec between your

thou shalt kee the difterence of onr spiril

'twas just the diflerenee bretwixt the

yet stund otf in difliterence so miglite

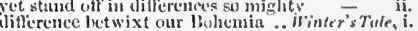
to me, the diflerence forges dread.... for the ditlerence is, purehase of a lienry - iii.

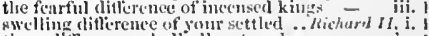
these differeness shall all rest under

making such olitferenee 'twixt (rep.). I Jenry $1 \%$, dii.

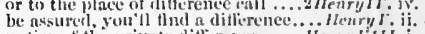

mitire ut the lirivate diflere ue

in the verighty dilference betwee.....

whilst twixt you there's dillierence

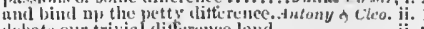

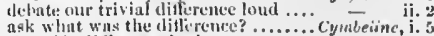

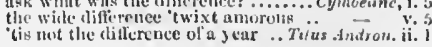


DTFEERENCE-the difference of all...Pericles, iv. 3 DIGNITY-this new-fallen dignity. As you Like if $\mathrm{v}$. I'll teach you differences; awn , away. art thou know the dinterence, iny boy

whant is your difference? sl eak?...

from your first of ditlerence and decny

ehoice, to serve in such a diflerenee.... Hamlet, iti

roul may wear your rue with a
till of most excellent differen

the aim reports, "tis oit with ditie rence.

DIFF ER E.YT - for difterent numes . . Corinhanus, $y$. but either it was different in blood ... Whil. N.Dr. i.

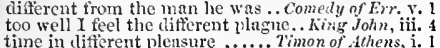

Athens, 1.1

in different heds of lust

could not beget such different issues

remble in their difterent greeting

the scas, and countries different

DIFFERING-differing in the owners. Timntet, iii.

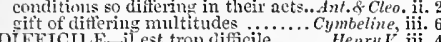

DIFFICIlE-il est trop difícile

Henry $V$. ï. 4

[COl. Knt.] Iull of poize and difficult .. Othello, iii. 3

all dificulties are but easy when. Men. for Mea. iy.

DIFFICULTY - be of any dificulty ...Al's $w^{\prime}$ ell, iv. 3

undergo any diffeultr imposed.. Troil. \& Cross. iii.

it were a tedious diffetulty. I think ..... - iii.

of thy cunning had no diftidence .1 Henry 7 . iti. 3

DLFF USE - that can my speech difluse
DIFTUSED-some diffiused song ...

stern looks, diffised attire, an

DIFFUSEST-litusest hene

and clig my grave thyself

wing, but I conld dig his gra

as these nocr pickaxes ean dig

tis $y$ must dig with mat
for who dirs hills because tl

could he dig without arms?

Henryll. iv.

what man dost thou dir it for

will difest the harsh indignity. Tereifih Nirht,

other things I shall discet it..

do digest the poison of thy flesh
well rligent the abuse ot distan
and digest your angry choler

nary di

will the king dixest this letter
digest things rightly, touching t

Julius $\bar{C}$

by the gods, you sliall digest the werom
$\mathrm{m}$, two dnughters' dowers digest this

DIGESTED-nme must be di
chewed, swallowed, and digest
the disgrace we hove digested

the diggrace we have digested
what may be clige ted in a pl:
that matters are so well dige

that inatters are so well

now, gnos ditrostion wait on appet

your apjoctic

in not digestion of this

for your liealth andion, why hinst.

DIGGED-hemlock, digged i the lark. I acb

tpro kinsmen, digged tlicir groses ... Richard II. iij.

and with my nails digged stones.

no, if I digged up thy fore

no, if I digged up thy forefathe

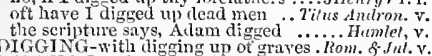

1GGrNG-with digging up of grayes. . . Kom. \& . Jni.

O thus, auth Dighton, lisy th
when Dighton thus told on

DIGNIFIED-dignified with
the place is dignified loy the
thou wert dignified enough,

thou wert dignified enong
smmetime's by antion dis

DIGNIFIFS-dignifies an inpais.

that dignifies the renown of a baw
DRGN

to dignufy the tines since Ciesar's
DrGNITIFS-nore mature dignitie

and the late dignities, lieaped up.

double-charge thee with dignities

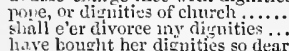

have bought her dignities so dear.
the ways you have for dignities....

the ways you have for dignities....

nur joint and several dignitics.. Trooilus \& $\bar{C}$ ress. ii.

in the disigosing of new rlignities...Julius Casar, iii. 1

this dignities, upon his son.

DIGNTY - being so reluted in dignity. Tempest, $\mathrm{i}$.

can tramspose to form and dignity. Nid. N's 's $D_{r}$ nyy cirnity would last but till . Winter's Tule, iv.

(his dignity and duty both cast off)

mis act was worth

my erown, my oath, my dignity.. Comedy of Err.

for my cloud of dignity is heid

hicar your own dignity 60 much

advantageable for our dignity

still enjoy thy regal dignity.

...... Yacbelh, $\mathrm{Y}$.

I Hewry I!

thought, but thinks on dignity

intlenry

lis erowu and dignity, thou liast

tris proffered benefit of dignity

a sign of dignity, a breatl, a hubble.

what state, what dignity, what honou

hirgh promotious, and grent dignisy

by my life, and kingly dignity

this liath uot a finger's dignity ..Troilus o $\bar{C}$ re

holds his estimate and diguity as well

clay and clay differs in wirnity antony \& Cleo

that best conld deem his dignity?

both alike in dignity .... Rontes \&.Juliet, (prologne)

after your own honour and dignit

DIGRESS-part enforeed to digress. Triming of $\bar{s} h$. ili. 2

OIGRESSING-in thy digressiug son. Richurd ll. $\mathrm{Y}$.

digtessing from the valour of .. Romeo o Juliet, iil.
OIGRESSION-my digression by .. Love's L. Lost

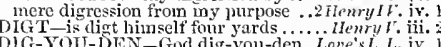

DIG-YOU-DEN-God dig-you-den. Lone's L.L.iv.

DILATE-to dilate at full what... Com
that I would all my pilgrimage dilate

DILATED-more clinted tarewell... . . Othello,

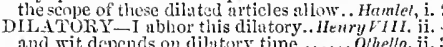
and wit depends on dilutory time ...... Ohello, ii. presently pen down my tilemmes...tlis s $\mathrm{Well}$, iii. hravely, my diligence

most guilty diligence in action................... Heas. iv. true diligence, lie is no less .. Taming of Sh. I (ind.)
of your ticcustomed diligence to me... 1 Henry VI. there wants no diligence in seeking. Cymbeline, iv. 3
with all due diligence, that horse. Pericles, iti. (Gow.) and the best of me is diligence .........

Dil, with nil ditigenee of thou see'st how diligent 1 am.... Taming of sh. iv. but be a diligent folloner of niue... Cymbeline, iii.

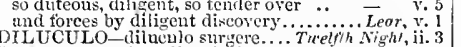

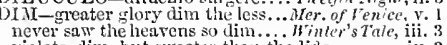
violets, dim, but sweeter tlan the bils $\overline{\text { ing. }}-3$

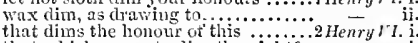
that which seoms to dim thy sight? ... i $\overline{V I L}$ i. not Erebus itself were dim enough.Julius Casar, ,ii. in that dim monument whlere... Romeo s.Juliet, iif. 5 DIMENSION-in dimersiun, and.. Twelfh $\overline{N i g h t, i .}$.

his dimensions to any thick sight ..2 2fonry 1 r. iii. when my dimensions are as well compact. Lear, i.
DIMINNISH-as diminish one dowle that renson wonder may diminish. As you Like il, $\mathrm{v} .4$
DIMINISIED-diminished to her cock .. Lear, jv.

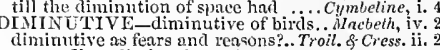
Water-flies; diminutives ut natire! ...
shown tor noorest diminutives.. Anlony \& Cleo. iv. 10 DINAMD-and dimmed nine cycs ...

these eyes that now are dimmed ....3 Henry I. it. v. is the sun dimmet, that gnats do. Titus snd Inon. iv. 4 DYYPLE-pretty dimples of his chin. Winter"s. DIAIPLED-you know, 'tis climpled. Troit. \& Cress. i. 2

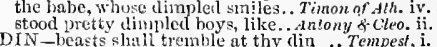
DIN - beasts shall tremble at thy din .. Tempest i.
O, twas a din to fright a munster's ear - ii. might hardly endure the din?.. Taming of Shrew, i. when by and by the din of war........ Coriolanus, ii. with brazen din blast you the ....iniony \& $\overline{\text { Cleo. }}$ iv. 8 no further with your din express.... Cymbeline, v. no din hut snores, tire houlse ... Pericles, iii. (Guwer) minstrelsy, and pretty din ...... - v. 2 (Gower) we have appointed to dine with..Aierry Wires, jii. liable to our crown and diunity

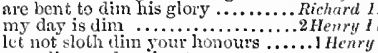
but am in that dinension grossly clad DrAI IN ISHING-or diminishing. Comedynf Err. ii. 2
DINE-study where I well may dive. Love's L. L. i. I if do dine to-day at the father's ....... if it pletse you to dine with us ...Mer. of Venice, $\mathrm{i} .3$
think to dine with nre to-day ... Taming of Sh. $\mathrm{jit}$. dine with my father, drink.......... iii. to my inn, and dine with me?.. Comedy of Errors, i.:2 good sister, let us dine, and never fret -

I'll dine above with you to-day

Antipholns, we dine too late

there will we dine: this woman

to day did dine together

where Balthazar and I did dine to.....

which of you two did dine with me... - v.

there to-duy; he dines in London ..2 Henry $I v$. iv.

will not dine until I see the same. Richardy $V I$. ii.

we must needs dine together .. Timon of Alhens, i.

wilt dine with me, Apemantus?

you must needs dine witl me

will you dine with me to-morrow?.JuliusCasar,

I shall not dine at home: I neet ... DINED-I have dined ...... Tro Gen. of I Ierona, ii. hast thou dined? the tailor. Tanin of sheret, iv. bear lalt dined on the centleman. Fiuter's Tale, iii. I have not dined to-day .... comedy of $\omega^{\prime}$ ?ors that is where we dined, where........ - i

I dined at home! thou villain

that he dined not at home

yott say, he dined at home $\ldots \ldots \ldots . . .$. . teast, having fully dined before he had not dined: the veins unfilled.. - $\quad v$. and when my lust hith dined.......... Cintuteline, iit. 5

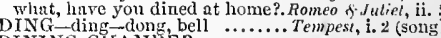
INING-CHAMBER

Tu'o Gen. of I'erona, i the tapestry of my dining-elambers. 2 Heury $I V$. ii.

is it near dinner time?...... Two Gen. of J'erona, $\mathbf{i}$.

it was presently alter dinner ........ - i.

why muse you, sir? 'tis dinner time... $\bar{F}_{\text {ives }}$ ii.

the dinner is on the table....

I will make un end of my dimi.......

some of you go home with me to diiner

to dinner with me.

will you walk? dinner is ready ........ Much .Ato, ii.

et us send her to call him in to divner - ii.

sent to bid vou eome in to dinner.... -

yonr reasons at diuner have been. Lnve's L. Lost, v.

my exhortation after dinner. Merchent of Veniev, $\mathrm{i}$.

atter dinuer your hazard shall be made

then bid them premare dinmer

and we will eome in to climme

for your coming in to dinuer, sir .....

first, let us go to dinner...............
entreat you home with ine to dinuer

shalt not die tor lack of a linner

attend the dyke at deuping hours

$x$ must attend the duke at dinner....

I were as sure of a good dinner ... Taming of sh.. .

and then to dinner; you are passing - i.

forward to the bridal dinner..........

as you sit at dimer: I from .... Comedy of Errors, i.

to dimner; my mistress, and her sister

somuwhere gone to dinner: gool sister

desired him to come home to dimuer

of a mistress and a dimuer....

that at dimuer they slionld not drop in

go bid the servants silread tor dinner

come, sir, to dimner; Dromio, keep ..

wherefore? tor my dinner

let us to the Tiger all to dii...
to her will we to dinner.......
we'll mend our diuner here.

the ring of mine you had at diinuer.

ocked me out this day from dinner....

our tlimer done, and he not eoming

ne for you to-dny at dimner.......... - v. he's indited to dimner to the shall $I$ entrent you with me to dinner? - ii. 1 go in with me to dinmer $\ldots \ldots \ldots . . . .$. go with me to dinuer; come, lieutenant - v. v. 5 eome, let us four to dinner: I dare... Henry $F I$. enough, for I stay dinner there.... Richard III. my lork; the duke would be at dinner - iij. of enemies, than a dimner of friends.

importumacy cease, till after diuner.

our dinner will not recompense.....

hazard thy life for thy dinner.

in till after dinner. Coriolanus, $y$

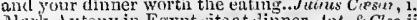
and bring lin to dinuer yresently.. Cymbeline, iv, 2 


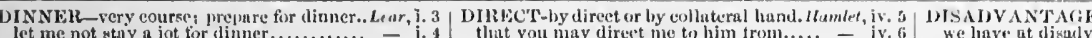

let me not stay a jot for limuer.

no worke after dliner, 1 will not part $($ rep. $)$ - i

go, I'll to slinner; hie you to the enll

tarry for the mourners, and stny dim

to-morrow dimner then. I sliall not.... othello, iii.

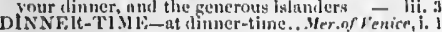

we will lenve you then till dimner-time

may come there by dinner-time. Thming of Sh. iv.

tis dinner-time, juoth 1 ; my
but say, sir, is it dimner-time?

by to-morrow dioner-time, Bend him. 1 Herury $1 \%$. ii. 4

niles to ride yet ere slimuer-time

DINT -and by clint of wworil .......2henryl

proul feel the dint of 1 jity.......... Sulitex Cassur, iii. let bisuned bear him, and bring. Troil. $\delta$ Cress. iii. 3

how Diomel, a whole week by dayy

the one and other biomed embrated

finir Diomed, vout do ts chapmen (lio.

the Grecian biomed, and our Anteno

welcome, sir Diomed! here is the lady

rnel to Diomed you sinall be inistress

I'll tell thee, Diumet, this brave

it not yoll Dioned, witli Calesis ....

since first 1 saw yourself and Dinmed

there Diomed dioth teast with him

you ton, Diumed, $k$ ecep l Iectur compran

thut same Diomed st thelse-hearted.

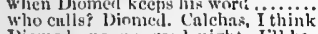

J)iomet-no, no, goryl-night: Ill be

lsere, Jiomed, keep this sleeve

1 ir'stlee, Diomed, visit me no mor

thou never slant mork Dimned a.....

faith, are boumd to llimmed.

by weight late I her Diome

sworl falling on Diomed ..............

would I could ineet that rogre Diomed!

pronel Diomed, belicve 1 come to lose

laste we, Diomed, to rcinforcement.

O truitor Diomed! - turn thy fulse fiu

fight with him alone, stand Diomed

there, Diomed, there. 1

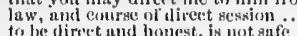

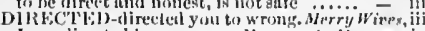

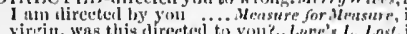

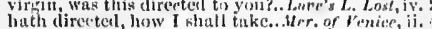

tis yours to he directed, as frons her loril

the rest to whom they are direter
alcogether direeted liy un l risime

placed, und morlently directed

等

I was directed hitlier.......... Tімон of Alhers,

you must either be directerl by gome. Cymbeline,

Whish directed him to seck her on the

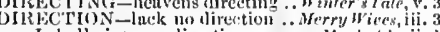

as I slall give you direction........... Murh difn, ii.

by nice dlirection of $a$ maiden's eyce

just as iny master had direction.. Framing af

to the direction just

I pot my elt to thv dipection

trom all direction, purpose, contrse . King John

then with direction to repair $t 13 . .$. .. kichard It.

than givin" direction doth irom

your well-practised, wise directio
if there jo not better directions

he lias no more alirections in the true

particular knowledge of his direction

according as 1 trave direction.

will indirectly, gave direction

time to arme men of sound rlirection

a good lirestion,

ket thy blood be thy ar

of worldly matters and direction.

fit to stand liy Caesar a
DIR LCIIVE-and bow
1) IRLCTION-GIVER-

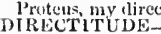

lie's in rlirectitude. Directitudel ..Corin
DIRECTLY-this concurs direetly. Tretflh

you would say, dircetly interes
that indireetly, and directly too

will slie go now to berl? Direeti

Which shall directly lead thy foot

to answer them directly, low far
but direetly, to say-I Yove you

would swewar directly, their very
that you directly set me against

he was too hard for him

trakle art thou? answer me directly.julin

as the Capitol, directly here

directly and biefty, wisely aind truly

proceds directly. Dircetly, I am going

that matter is answered directly

give me directly to understand

rather, direetly fly
to pertorm it, directly and truly

dircetly seasons him his enemy

Dosilemona is directly in love with lim.
par:illel course, directly to his torl?

parallel course, rifectly to his gom
which lead directly to the door of truth...

I have dealt mast directly in thy
DIRliv UL-the diretul spectael

sturms and direful thunders brea

more direful hap betide that

some direful slaughtering deatl... Titus sndron. $\mathrm{v}$.

ne, of this dircfui murter ...... Rames of Jutien,

DIREN WS-

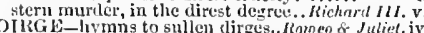

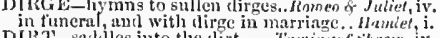

waled threugh the dirt to plick ....

whose filth and thirt troubles .......

mutch us ill comparisons with dirt.

gold and sitver rutlier turn to dirt

bortst thine ass on thy laek over the
to luave lis fine pate tull of fine dire?

spacious in the possession of dirt

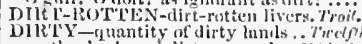

Dll'l' $Y$ - quantity of dirty lunil.
on the dank and dirty grounil

a sloblery and a dirty tirm.

1 kiss his dirty shoe

abont the seone with a firty shovel .. Hame, il.

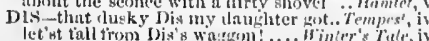

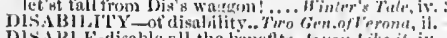

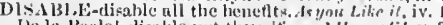

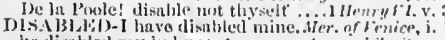

be disablet! my julgment

DisAjViNTAfi:

hideous genl of war in disad vantage..2/lenry $W$, ii. 3

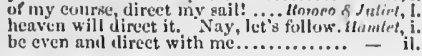

OSAIVVAN'TARE--
We lave at dixalvuitage fouglit

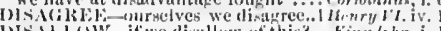

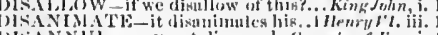

F.N N I - may not disumul..

Warwick lisannu

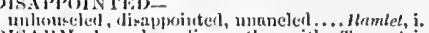

DSAkM-1 cun here rlikan tlece witli... T'mpest,

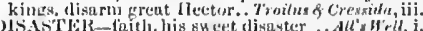

it was a clisaster ol' war that cathur - ii.

eent it us upon her greut disaster

disasters grow in the vens.... Troilue o. Crrysida, i.

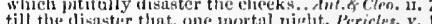

[Knt.] to shield thee from di inasterg ot........ Lear,

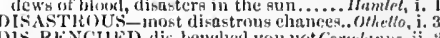

DL-BliNCIIED-dis-benched you not Cortuthens, ii.

IHSISURIENEDD-ere't be disturdened.Rich. R. ii. I

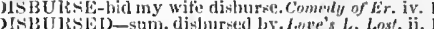

till he disbursed, at saint Colmeg ineli, Herbeth, i.

[Kn?] hy the diseandering of this. Ant. \& Cteo, iii. 1$\}$

1).SC.INbY lo diseandy, nelt their - iv. io

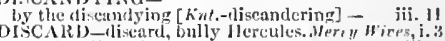

to ofl'; 1 discard yona............. Thentgh Night, iti.

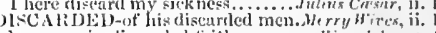

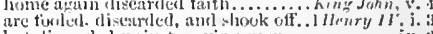

hut discarded najut serving-men the - ir.

to be discarded thence! or keep it as .. (j)hrllo, iv.

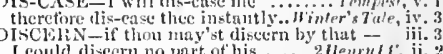

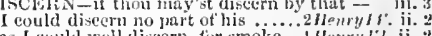

what weck discern you in me

from the deck you mat diseern $\ldots . .$.

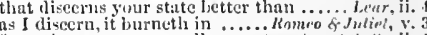

from the cape can you diseern at rea? . Whello, ii. I

DISCERNING-discernings are letlargicd. Lear, i.

an eyc disecrning thine homour trum ..... IsCIIARGE-I will discharge thee.... Tempest, i. what to eome, in yours and my dischar

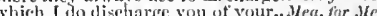
go, I discharge thee of thy prisoner... Much ofdo, $v$. I able to dischurge $1^{\prime} y$ rumus, but he . iv is he not able to disedarge............ iv. I that their discharge dist streteh ........ As you tike it, ii. I I will discharge my bond .... Conedy of therron iv. to their deat fillow, will discharge .....Machelh, y. I discharpe my followers, let them licnee - iii.

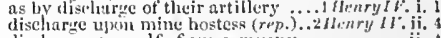
hinll charge you, and dlsellariog.

if this may please you, discharge your

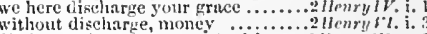
discharge the eommon sirt with pay.3 Henryll y. rude hrevity and cliselarge of one... Trnil. of Cr. iv.

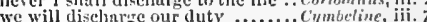
past, is, and to eome, the discliarge

have in my name tirok their disehurpe..... Lear. y.
thev do discharge their shot of courtesy.orhello, ij.

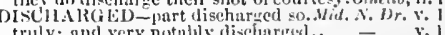

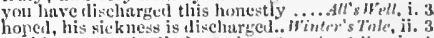

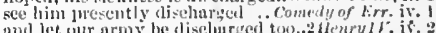
the army is clischarget all, and gone - iv. 3

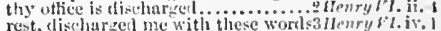
hest, discharged me kith these wortsanenry three times was his nome discharged..

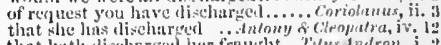

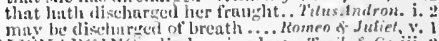
mav be disedured ot breath .... knomeo of whet, y. 1)

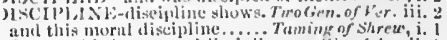
enr our chieftest men of tliseipline.... hing John, $\mathrm{ii}$. and their discipline, were larboured in mecireling ton the clisciptines of the
true dirciplines of the wars

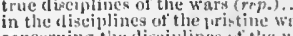

conecrning the disciplines of the har
the dircetion of the militury discipline 


\section{DIS}

DISCIPLIXE-the disciplines of wass, Henry $\gamma$. iii. 1 know the diseiplines of war valizuntly, witl cecellent discipline,
for disciplines onglat to lwe for disciplines omght to lw ysect Aringing them to eivil distipline Yet's wascipt ne diocipline, make no discipline come not near thes!. their disctpline (now minsted wit tom lond, or thinting his thiscipline

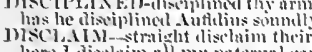

here f dischim all my patermal tare.

mature dis.laims in thee s tailor

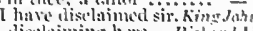

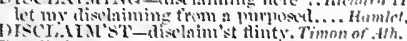

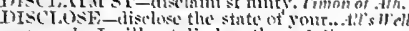

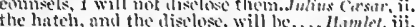
the hateh, and the disolose, will which his eyo hath disclosed: I oul

onee dischloset the liulies tid chang

II I ean, I hare dischosed

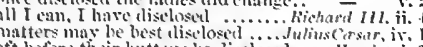

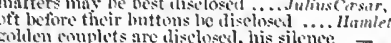

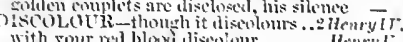

with rour red blexi disoleur......... Hrnry

blokl stain this discoloned shore, .2 Herne l I I

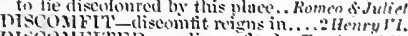

DLCONLE TED - so iliscomitited.. Taming of sh.

the earl of Dunghs is discomfitid.

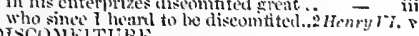

DIsCOMl: lTUkl-

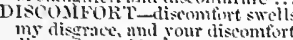

Itenryll. i. 1

discomfirt guites my tongue

returned with some distomtort

iichord II . iii.

you do discontingt atl the host.

.llenryIi

Discomtort you, my lont, it nothing .. Hamkt, jii.

diseomfortatle eonsin! know'st.... Richord II. iii. a

1) IscoNiol ATE-all disconsolate.Jul

I) SSCONTENT-brawling diseontent.M

make no nse ot your tliscuntent?

comtent you in my discontent.. Taming

move the murmuring lips of discontent

from home, and diseontents at hom

your quick-conceiving diseontent

perer discontents.

heart's discontent, and sour ant? Zilenry $M$. iii. I

full of sorrow and heart s discontent.3neary

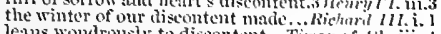

le:ans wondrously to discontent...

to the ports the discontents rep

sir. to the worst of discontent..... Cym focline ii. 3

lot uob diseontent daunt all your.. Tihs a
dissemble ant your griets and discontents

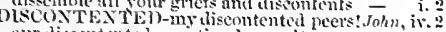

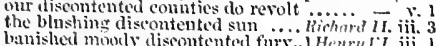

I know a discontented gentieman. Richur / I I i ii. I

lends atiscontented steps in foreisn soil

ii that your mody discontented souls - y i

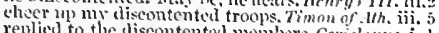

replied to the discontented men

twill tic un lly disconented

misw here's minther discontented l'ajer.. Othello, r. 2

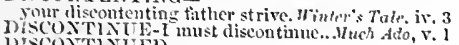

DISCONTLNUED-

hise discontimed sehool ahove. Mer of

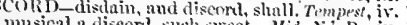

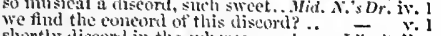

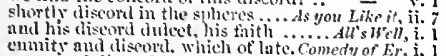

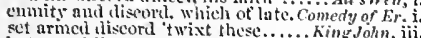

set armal iliscord t wixt the

but you fall to some discorl
(), how this discord doth atflict

this base and eurions tisecret hreed..

private diseonl keep away.

an nge of distord and contimunt.

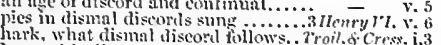

know this discont s sround. . Tirus . Indronicus, ii.

in comntries, diserort; in palaces, trenson. Len

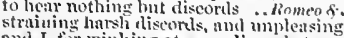

mil I. for winking at your cliseorls too

my suml is full of fiscorrl. and dismay.. Lhamlel, iv.

Discorid the greatest diseonds be

oliscorlant wavering multitude

ill wiste with inch discourse

2IIenryIF. (ind.)

hear swect discourso, conive.

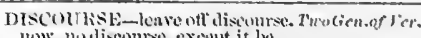

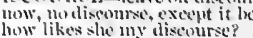

when liliscourse ot love and $\ldots$.......

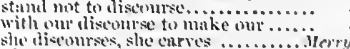

mumirable discourse, of great aciunittanes

with discenrse of my dinr tith

to sflect spevely and discosurs.

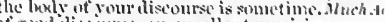

of mond discoms an exeellent musicism

of this tiscourse we more with hien

misters. 1 am to disconrse womder

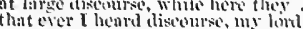

sweet and volubis is his disconiss. Le

it is nu cpilogrne or cliseourse, to make

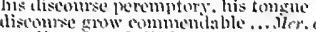

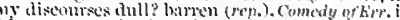

1 kmow a weneh of excollent cliseoure

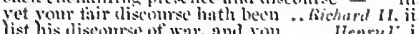

it is no time to disc war, and you .... denryl: i. I

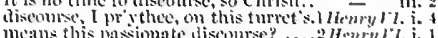

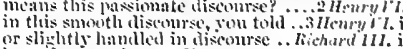

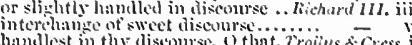

gimalest in thy discourse o that

gorsh shane, discourse, manhow

C malues of diseourse, that ea

White o' the eye to his discourse.... Coriolan

discourse is lieary, fitsting

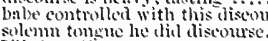

her eye diseourses, I will answer.

woes shall serve for sweet discourse

a beast, that wants disemurse of reason.. Humlet i

put your discourse inte some trame

Will disconre most elequent minsic...

that made us with such larige discourse.

a gredy ear devour ul, my discourse...

of some briet discourse with Desdemont

ather in diseonres of thonght, or actuin - iii.

cliseoursed in this paper lisere

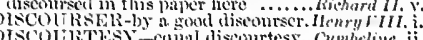

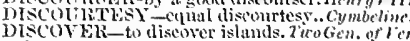

that might her mind discover..

that max discover such intergity ....

shell iliscover a thing to you.......Mrry "ires, ii.

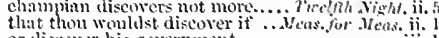

or cliseorer his government.

nand will diseover the timour ........ - iy.

any impediment, I prity you diseover

what your wisdoms conlt not discorer $=$ iii.

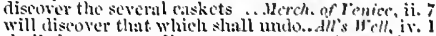

shall the entents discover...... Hijuters Tule, iii. I

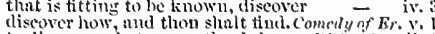

to diseover what power the duke.... Kicinath 11 , ii. 3

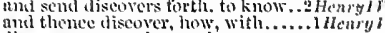

dincover more ut larise whint camse

your puintel gloss discorers to men. Himp $\overline{1}$ lll. $v$

the toreh may not distover us .. Troilts o cress..

that inay fully iliseorer lim their

by no means I nuy discorer them liy

aprointment we niay best uiseover.

disever to me what both .............

what company discorer you abroal?

Will diseverer nanght to thee... 2ritus dndon.

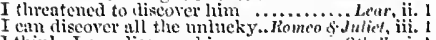

I think. I enn diseover him ............ Othello, i. 1

the mine discovered to elaulio ..... Much dto i. a

that have so traitorously discovered....In's " in, iv. 3

he has discorered my design ... Minier's Tale, ii. 1

justly hath discovered and I repent... Henryl: ii. 2

to lie discosered, that can do me... hicherd III. iv.

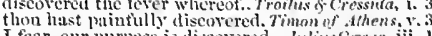

I fear, our purpose is discovered... Julins cresur, iii.

how ensily muter is discorered... Titus thetron. $\mathrm{ii}$.

will have discorered tor revenge .... - iv.

d:urk night hath so discovered ... Romeo of Julist, it. 2

DISCOVERIES-

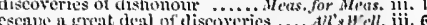

suchl prepostcrous cliscorcries... Troilus of Cress. v. 1
DIscovelis-doubts discovery there.. Tempesl, ij. I tis an othe of aliseovery lowe ... Mer of Fenice ii. 6

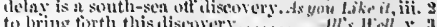

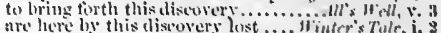

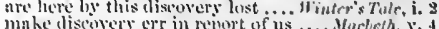

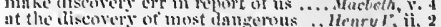
discovery of the inthite thatceries.. Timan of $A, h$.

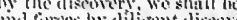

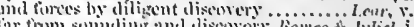

(n)

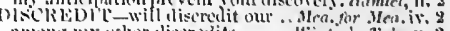

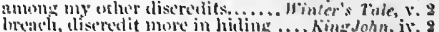
wesken and iscerdit our exposure. 7 roil. of Cres. $\mathrm{i}$.

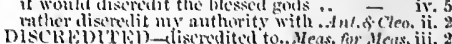
luve discredited vour travel......... Anfony \& cleo. $i$. (1)

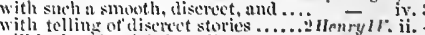

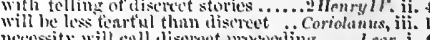
recessity will call disereet jueceling .... Leen, i. lef not the discret herert thimk it ...... Othello. ii. DIse vour manners diseretly in. Faming of shesc, 1 .

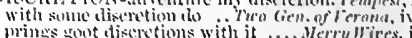
prings gont diseretions with it ..... Merry llires, $i$. old tolks, you know, hane diseretion

think the man of safe rliseretion.. Mcas for Mcas.

wombl have no mere discretion ...Mhid.N. Dream, $\mathrm{i}$.

for lis diseretion. Not w $(r e p),, \ldots .$. .

his diseretion, ! tum sure, cammot...... =

appears, by his sumall light of diseretion -

thou pigew erg of discrefion...... Lote's L. Lost, v.

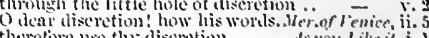

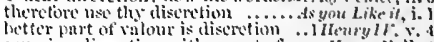
curering diseretion with a cout of ..... Henryl\%. ii.

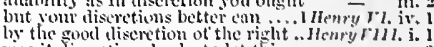
whs it discretion, lords to lat this num - v. roilus oress. i. abunduntly they lack liseretion ....... cortiotanns, i. 1

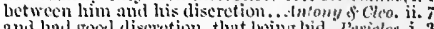
and had gooul discretion, that leing bid.. I'ericlos, i. 3 and led by sonnd discretion, that tisechs. Lear, ii. tor the younger sort to lack tiseretion ... Item/ct, i.

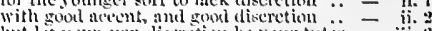

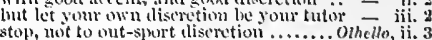

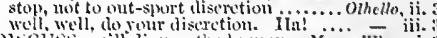
spenk, brenthe discuss the humour...Merry Nires i. You may diseuss unto the dinke....... llenry r. jii. what is thy mame? disems

diseuss the same in French usto him - ive eontemptuonsly on thy distaim. The Gen of I err. 1 .

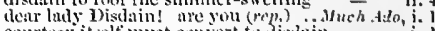
courtesy" itselt must comvert to dischin

dist:m and seorn ride slnarkling in... - iii. glow of scorn nud prous disclnin ..As you l.ike it, iti. " dischin rather corrupt me ever!....... - ii. thet te not tly disdinin, but presently - ii. these are, therefore I'll not dislain. Winters 7 . iv. 3 to see if they'll disclain me c'antely of Frrors, iii. i holding in distum the German ........Menry i.: i. 2

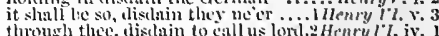

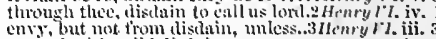
ut tered with mild dist?in

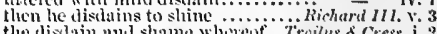
the disdain mind shme whereof. Triphs o Cress. i. 2 jea, himselt, Timem disthins.... limon of Ath. iv. 3 they do distain us mueh leyond .... - i. which we distain shombl tetcer

where ome part do's disclain with sause $\overline{-}$ iii. 1 that disdinins thee and thederil a like. ('ymbrline, i. 7 clinuge ot prites, disdatin, nice lomgings

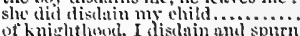

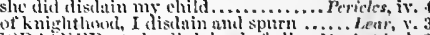

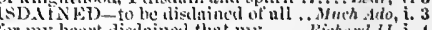
ns if lie distnined the gromel .......... - v. 5 voniselt so by a son disdnined .......2 He'my Ir. צ.

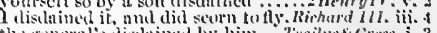

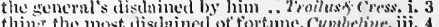

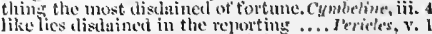
a semblane that rery dogs disilan ........ Lew v. 3

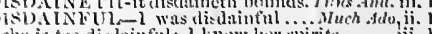
she is too diskinful: l linuw leer spirits - ini. I is in love with a distainful youth. Ast. $A$ "s. Dr. ii.

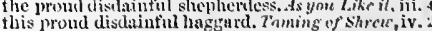




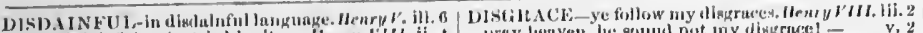

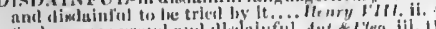

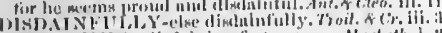

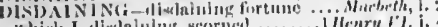

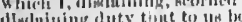
divinlnimg me, anul tlirowing IJ)

Jislisisti:

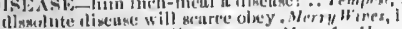

purehased as dumy diveasey ....

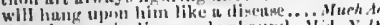

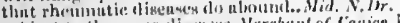

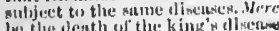

the king's diserase, - nily jrojeet

his ludy though she liave as many diseuses tha.

have the dipeane, unit feel't mut

lint ! enunot nime the discuse.

this sliseame ts leyoud iny prac

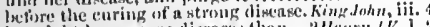

lie might hinve more dineares th

you are fallen into the clisease

it is the dimease of not thits

I will turn diseases to esmmolit

plutumy ami cliscases muke them.

what rank discases grow

what risense hnat thou? $\mathrm{A}$ whoreso

of which dlixease our late king, livinural -

conjofins with my diacase, uni lie lps

un ment take aliseasen, one of anst

pursed lnat rument of his disen

fuil of sirk ness and dimares.

only, which your diteuse regulires.

he rotten disenses of the gouth.

time berducuth you my discases....

O inny dixenses only work upon't

his clisense of alt-shunned poverty

give them disedres, leaving with thiee

may diseases lick up their false lolowd

poimonous where the difease is violent

a disense, that muat be eut awny (rup.) -

we do lanee discases in our bodies...Ant. A . Cleo. $\mathrm{v}$

diseares have been solil denrer

fee bestow on the fonl disense ............

shleld the from disefines $[K m$. - til

rather, a disense that' a in my lesh ..........

disenes, desperate grown, by desperate

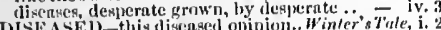

thou mot minter to a inind dirested... Mercleth

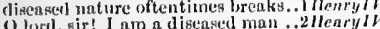

Oloril, sir! I am a d

hug their disessed perfimes.............

with diseased ventures, tlut phay.... C. Cymbeling

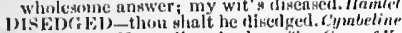

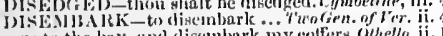
go to the hay, und dliscmbark my colfers. Om. lie comen to disflures or urcesnt

Cupill's hose: disflyure not his stop. i.one's L.L. iv. 3

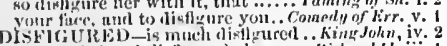

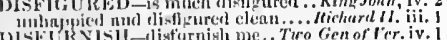

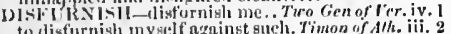
to disfurnish my aclf against such. Timon of A Ah. iii. 2

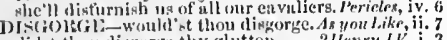

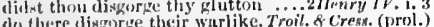
dis there diagnorge their whrlike. Troil. Cresn. (prot.) DISGIRACE-is not only disgrace....... T'rmpent, iv. unworthily disgrace the man.. Turo firn. of Ter. iit. 1 will juin with thece to digorace lier... Murh Ado to clingrace llero before the whole.

that did their owit stingrace bewail Mirl. N.Dr. iv. 1

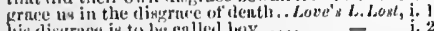
fis disgrace is to be calleal hoy

eurea all dingruce in me

or brook such difgrace well as lic...ts you tike it, $i$. 1

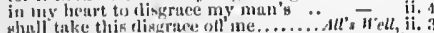

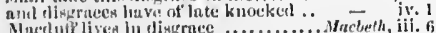

it would be my clisingee, ani your........

int his ligh own divgrace, neglected .

nor iny own disgraee, huve ever.

whiut a disgrnce is it to me, to

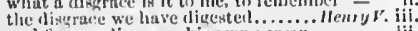

tud hive

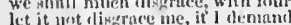

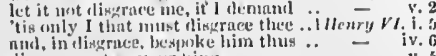

thingruec not wh your king .......?

- verult.

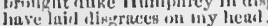

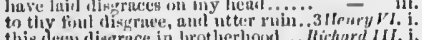

this deen disgrace in lirotherhook .hichard

sustain inore new distreces

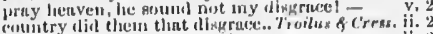

dilagrue tis your prent worthow

foll bil our ifingruse with a tale.

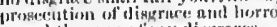

an! ntately lame's dispruse.

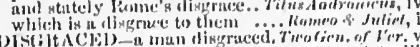

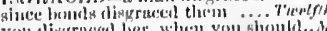

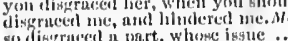

I mon disuruced, inipenchers.

iliseracerl we in my linery v

be disgraece? by an inkhorn-mate.. ïhrory Vr. jii. I

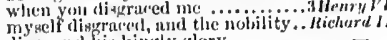

dispricecel fiis kingly glory

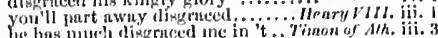

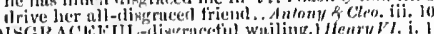

D)

Istikiclotsi-becms clisgracis

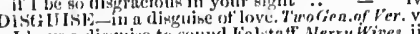

I have a disglike to sound lalstaff. Merry Wives

lin whish diaguise, whilc otler jest

my aicl for such disguise as, hinply. T

ara

fuliey thut lie liath to stramed dinguises -

dikguine us at my lodping ... Merchant of renice,

in this diones

thut seorn to live in this disguise. Taming of sh. iv.

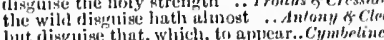

blut dinguise that, which, trappear.. Cymbeline, jit. 4

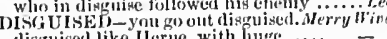

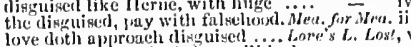

by-ant-hy, disguised they will be here

as well known, as disguser...........

jere, but even now, disguiserl? ......

to come in disguised a gainst me....... s you Like it, i.

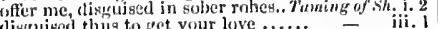

deform the body ; disguiser?, eheaters. Con on Er.i.

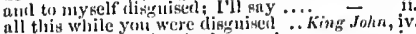

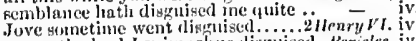

comes the lord Jysimachus disgnised.. l'erieles.

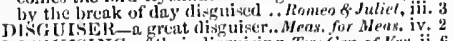

DISG U ISING-of their disguising. Twa Gen.of Vmr. ii. 6

JisII-ner wasli dish............ Jempers', ii. 2 (song)

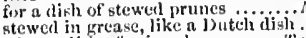

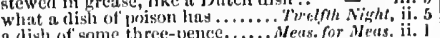

a tish of some three-sience.

and having but two in the dish...........

kir, here's a dish I love not ............. Wurh Adto, ii. 1

four wookcocks in a thish! ...........neve's L. Lost, iv. 3

gool meat into an unclean dish... As you t.ike it, iii. 3

it dish that I do love to fecd.

h velvet dish; fie, fie! 't is iewil...

a plutrt or ate is a lish fur. Winter's Trate, iv. 2 (amg) goblets for a dish of wood

moviug sueth a dish of skimmed.........

never sce 'Titun kiss a dista of ' l
she hul a good dish of prawns

once set a ilish of apple-jolus ........

with a disle ol enrruwnys, and so forth
there is a distl of leather-eoats for you

fruit in an yuwluslesone dis

friencl, that clips in the same dijis? Timn of

a wornan is th dish fort the gods

the dish poys the shot

marry come us, my dinili of chastity ..Perieles, i

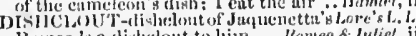

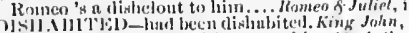

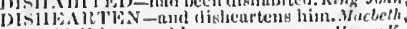

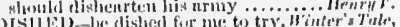

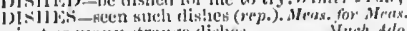

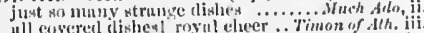

ant fisstered with cold climhes

Ilmmlet, ive

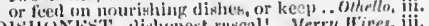

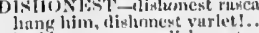
besides, you grow dislouest

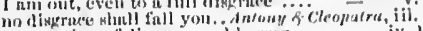

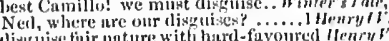

disk uise hitir nature with haded-fuvoured lenry $r$. iii. I

will to his as a dikl fic for the gors. in knuce tlay disties. The nidalio...

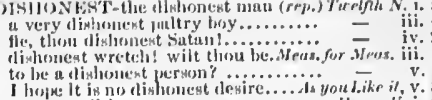
firr anne dinghoment manters

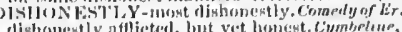

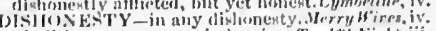

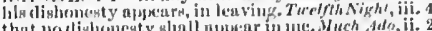

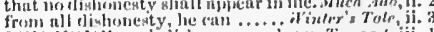

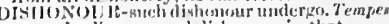

not only dingrace and cliphronour in that -

111 her, inseoveriss at rishomulir...

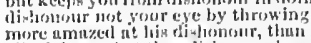

all of theon, that thus dlishonour her...Murh Ado, y.

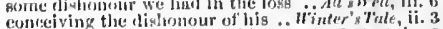
not ny jealousies be your dishonours... burberth, iv. thall 1 Ho muc? dishosour my

his dislumour dies, or my slamed (eеp.) -

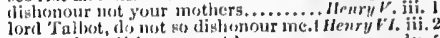
my nuther, disbonour not leer

thip alislonour in thine age will ....2 Heary't. ii.

lring a burden of dishonour lirme $\ldots$ - iii.

it were dishonour, to deny it loer ...3Henry $1 \%$ iij. 2

with dishongur langer and lishe on the ground =

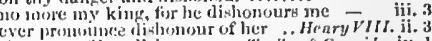

the taste of her rlishonour . Troilus \& Cressidn, iv.

kince dishonour traffics with man s. Timon of ah,

ili in nom more dlishonours you at all"

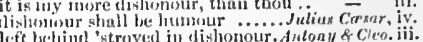

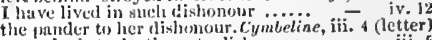

gone she is to dleath, or to dishonour - iit.

ny soms would never so ilshonour me - i

confolerates all, thus to dishonour me

hath breathed in ny dishonour fiere

may dislsyour him: and what may.....Perieles, i.

none so rank as may dislonour him.... Hamtet, ii.

my lofd that would dishonour him.

dishonourahle hoy! that lic slanll lie. Richnrd /I. iv. ten times more dishonouruble...... I Ileary $1 \mathrm{~V}$, iv. 2 and death's disholsourable vietory .. Illemy Vl, i. 1 find ourselv ea dislionourable graves. Jalius cursur,i.2 DISIIINUL:RED-

I tecivind a dishonoured life..... Meas. for Meas. iv. seorned; dishonoured my kiuswoman? - iv.

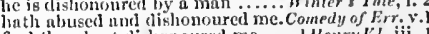
find thin hast dishemoured me hatli dishomonirel Gow

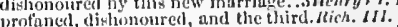
thy life liath that di-honoured

I am so flishonoured, that the very.

your wives dishonoured to Your noses - is

that lintla dishensiured all our fianily

to be dishonomed by my sons in Romel -

and those, that have dishonoured me

be sn clishousoured in the court of Rome

That ented dithonotred dame

lie should be dishonoured ....... Momon of Jutiet, iv.

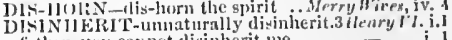

father, $y$ ou cannot lisinherit me

yield ranent to nfinherit him .....

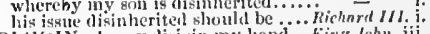
DISitoIN I may dixjuin my hand.... King John, ii When it disjoins remorse from power.Jul. Cassor, ii.

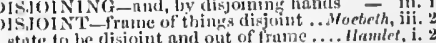

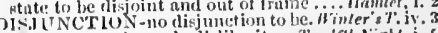

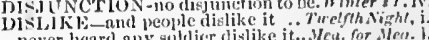

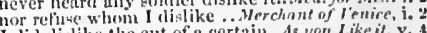

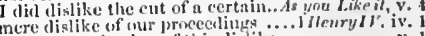
not sought ule day of this dislike....̈.

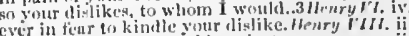

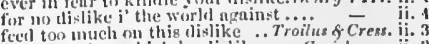

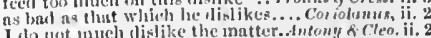
not miludiug whether I distike or nu?.. Pevirles, if. is he tislike [Col. Kn'-distante] it ....... Lear, i. 3 what most lic shoulis :lislike, sems..... = iv. cither thee dislike [Cont.-displeasc]. Kumen of Jul, ii. 
DISLIKE-I'll do't; but it dislikes me.. Othello, ii. 3 DISLIKEN-disliken the truth ...Winter's Tale, iv. DISLIMN - the rack dislimns DIELOCATE-enough to disloeate and tear. Lear, iv. DISLODGED_Volees are dislodged..Coriolanus,
DISLOY AL-disloyal man!....T TwoGen. of Ver. the lady is disloyal.

arraign the word is too good to .... iii. arraign our most disloyal lady ... Winter's Tale, ii. his sovereign, and to dim, disloyal..

that I have been disloyal to thy bed..

O disloval thing. that

disloyal? no: she's punished for her - iii.

dishonour, and equally to me disloyal - iii. 4 (let.)

give me a living reason she's disloyal.

become disloyalty; apparel vice. Comedy of Err. iii.

'gan a dismal conflict; till that...........Macbeth, $\mathrm{i}$.

[Col. Knt.] unto a dismal and a fiatal end

would at a disinal treatise ronse..... -

inform fou of a dismal fight ......... I Henry $F T . i$.

whose dismal tune hereft my

like to a dismal clangour heard

like to a dismal clangour heard ....3 Henry $F I$. ii. 3

pies in dismal discords sung

so full of dismal terror was the .......

more slander to thy dismal seat.

und the this dismal sight the elosing.

a joyless, dismal, blaek, and sor

that makes me look so dismal
should be roared in dismal hell. $\ddot{B}$.

myould be roared in dismal hell

with heraldry more disma

the sight is dismal; and our affars from

[Col. Knt.-dismal and a fital] end ... Hacteth

al st day is this. Titus And. $\mathrm{i}$.

DISMANTHE-dismantle you..... Win'er's 'T

to dismantle so many forms of favour!.

DISMASKED-dismasked their damask $L$ ror

DISMAY of sorrow and disinay
no, she shall uot dismay me...

th this there can be no disnzay.

with much much more dismay $\ddot{I}$ viev.

dismay not, princes, at this .......1 Henry

my soul is full of diseord, and dismay.. Hamlet,
DISMAYED-as if you were dismayed. Tempest,

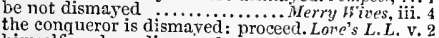

the conf ueror is dismayed: proceed. Lore's L. L. v. 2
himself, and ran dismayed away...Mer. of Venice, v. I
dismayed not this our enptains ..........Macbeth, i. 2

be not dismayed, for succour

heart, and be thou not dismared......

be not dismayed; these are a sile.

do you go back dismayed? 'tis a lost ... Othell

DISMIENBER dismember Casar!.Julizs Cisar, ii.
whirl asunder, and dismember me.. King John, iii.
DISNEMBERED -

dismembered with thine own defence. Rom. \& $J u l$. iii.3
DISMES-many thousand dismes.. Troil. \& Cress. ii.

DISMES-many thousand dismes.. Troil. \& Cre

for the present, and dismiss

I may dismiss this court, In

promised to dismiss tho power........

ere the king dismiss his power

enlargement doth dismiss in
so, now dismiss your army

I do dismiss your to your

I do dismiss my power

please you dismiss me, either with...3 Henry $V I$. iii.

will you dismiss the people?

dismiss them home. Here enmes his

never lacks power to dismiss itscl
dismiss your followers, and, as su

dismiss your followers, and, as suitors. Tite sar,

dismiss your attendait there frieuds

and bade me to dismiss you. Dismiss me.....

which a dismissed offence would. Meas. For Mest, iv.
from your Sieilian shores dismissed

that hath dismissed us from our

in rage dismissed my father....
ere they be dismisscd, let them
until this army be dismisscd f

dismissed me thus, with his

DISAISSING-dismiseing half

DISAISSING-dismiseing half your train

cominand to your dismission tends.. Cymlelel

I will dismount, and by the wargon. Tilus

ISIIOUNTED-brags disinounted. . Henry

dismolnted from your snow-white.. Titus Ane
DISNATURED-dinatured tornent to her. Lee

DISNER-allons nons a disner ......... Henry

for disobedience to your father's will.Mid. N. Dr.

which is most infallible disobedience.. All's W $\mathrm{Wll}$, and disobedience in thine eye $\ldots . . .1$ Henry I to wilful disobedience, and rebel? ... I Henry $V I$. my disolbclience 'gainst the king ... Chymbeline, iii. I

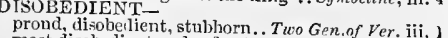
most disobedient and refractory.. Trnil. \& Cress. ii. 2
DISOBEDIENT -

DISO $\sin$ of disoledient opposition. Romeo \& Juliet, ir. whom to disobey, were against all.... Henry $r$, iv. make a disobey, nor be relsellious. .I IIenry IFI. v. IS-ORBED-a star dis-orbed? Troilus \&

DISORDER-allied to your disorders. Twelfh $N$. ii. meeting, with most admired disorder. Mrativet $/$, iiti. 4 disorder, that jath spoiled in

fear frames disorder, and disorder

to disorder wander, what plagnes.

and all rivinous disorders

his own disorders deserved much

LORDERED-but all disordered.Mid.

hath suffered this disordered spring....

time broke in a disordere

men so disordered, so debanci...ed...

DISORDERLY - thus thrust disorderly. Pich, $\bar{I}$. ii. DISPARAGE-I will clisparage her... Huch Adr, iii.
disparage not the faith thou dost ...Mid.N.Dr. ii. PPAAGENT.

to our honour's great disparagement. Com. of $\mathrm{Wr}$. i.

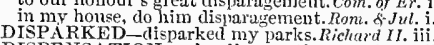

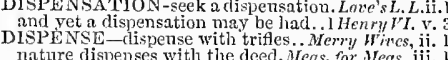

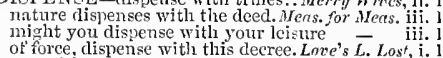
enu with such wrongs dispense.
how shall we then dispense ......

canst thou dispense with heaven

learn now with pity to
DISPERSE_away, dispe

spreading, it disperse to nough

gale will soon disperse that

sing, and disperse them, if thou cans

and, friends, cisperse yourselves .. Julius Cosar, ii.

DISPERSED-I have dispersed them ... Tempes

which I dispersed.

and dispersed the lousehold of .... Richard $I 1$.

gone to Bolingbroke, dispersed, and fled

we learn, the Welshmen are dispersed
our army is dispersed already.......

scattered and dispersed, and lay ne

army is dispersed and scattered

navy is dispersed by temp

ning dispiteons torture.. John iv.

a fear to be again displaced $\ldots . . . .2$. Henry $I V$. iv.

DISPloster be displaced, he'll be......2 Henry VI. i.

DISPLAX-display to the night....Merry Wires, $y$

did display them wheu we first.........King John, ii.

and here risplay, at last, what God.. Titus.And. iv.
dieplay [Cnl. Knt.-must play]. Pericles, iv. 4 (Gow.)

DISPLAYED-being once displayed. Twelfih Night, ii.4

than heauty eould disp ayed .... Meas, for Meas. ii.
with visages displayed, to talk.... Love's L. Lost, v.
are at hand triumphantly displayed. King John, ii.

are at hand triumphantly displayed. King John, ii.

displayed the effects of dispositiou...Henry III. ii.

the rery fellow that of late displayed .... Lear, ii. 1
DISPLEASE-displease her brother's.. Nid.N.Dr.iii.

and let it not displease thee...Taming of Shres, i. 1

[Col.] if either thee displense $\ldots .$. Romeo of Juliet, ii. 2
we must not now displense him........ Othello, iv. 3

ISPLEASED-who's displeased. Two Gen.of $V^{\prime} \epsilon r$. ii. 7
my mirth it much displeased .. Meas. for Meas. iv. 1

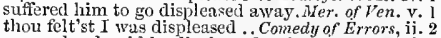

reason he should be displeased at it... HIenry I'I. i. I

as he pleased, and displeased them. Julius Cassar, i. 2

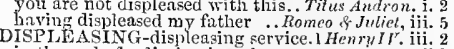

in the end of a displeasing play ..2 Henry $1 V$. (epil.)

take a displeasure

take a displeasure against you.........Tempest, iv. 1

the strength of your displeasure...NI... of $\overline{F e n i c e, ~ v . ~} 1$

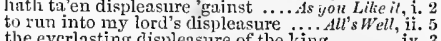

the evcrlasting displeasure of the king - iv. 3
to stop up the displeasure he hatll....

strong displeasure. Truly (rep.) $\ldots . .$.
the nnelean fislupond of her clispleasure

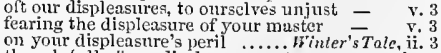

on your displeasure's peril ...... I'inler's Tole, ii. 3
though full of our displensure, yet we - iv. 3

doing densure to himselt?.. Comedy of Errors, iv.

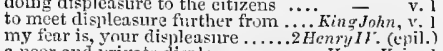

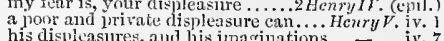

DISPLEASURE-in your displeasure. Heriry VIII. i. 2 behaviour given to your displeasure

is your displeasture with the king...

ii. 2 on height of our displensure. Timnn of ditens, and ispleasure of the people.$\ldots$. . Coriolanus, $\mathrm{ii} .2$ the maltce and displeasure which thou - iv. 5 turn your displeasure that way. Antony \& Cleo. iii. took some displeasure at him .... Cymbeline, i. 2 gain her love, or your displeasure....... Pericles, with our displeasure pieced, and nothing.. Lear, i. found you no displeasure in him, by word -

I shonld win your displeasnre to entreat

and flattering lis displeasure, tripped me - ii. on pain of their perpetual displeasure .. urged withal your high displeasure. Ron. \& Jul. iii. wrong stay, and her displeasure fly ..... Othello, ii.

a man that languishes in your displeosure - - iii. stood within the hlank of his displeasure
DISPORT - way to disport himself ...3 Henry onrselves fools, to disport ourselves. Timan of dile. $\mathrm{i}$. that nyy disports corrupt and taint...... Olhello, i.
DISPOSE-leave at thy dispose. Tu' Gen. of Ver. $\mathrm{ii}$. all rest at thy dispose.............. - iv. dispose of her to some more fitter...Miea for MPa. ii. 2 dispose for henceforth of poor Clandio. Much $A d o, v$ to your own mats dispose of her.. Mid. N.'s D confiscate to the duke's dispose... Comedy of Err. $\mathrm{j}$. ] lay gour heart at his dispose .......... King John, i. come, cousin, I'll dispose of you...... Richard II. ii. your grace, I may dispose of him..... HenryIV charitably dispose of anything

Itenry r. iii. pleasest, God, dispose the day!

the stream of lis dispose. Troitus s-c. - iv.

please you to dispose yourselves...Timan of $A t h$. $\mathrm{i}$.

there to dispose this treasure.. Timus-Indroniens, iv. dispose of them, of me; the walls ......... Lear, v. a person, and a smooth dispose............ Othello, i. I find not myseli disposed to slecp..... Tempest, ii.

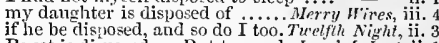
Boyet is disposed-But to speak. Love's L. Lost, ii. my lady laugh, prhen she's disposed.. you are disposed to be merry ......As you Like il, iv.
the children thus disposed ...Comedy of Lrrors, $\mathrm{j}$.
how thou hast disposed thy charge.... a speed with such advice disposed...King Joln n, iii. to see how fortune is disposel to us. 1 HenryI $V$. iv. your father is disposed to sleep ...2 Henryl $V$. iv.
right ill disposed, in brawl ....Henry $t^{r}$. iv. (eliogrus) he's disposed as the lateful raven..2Henry H. iii. 1
shall prove not well disposed ...... Hemry III. i. his blows are well disposed. Troilus \& Cressida, iy. be wrougth from that it is disposed.Jutius Cosar, i. he was disposcd to mirth.... Antony \& Cleopatru, i. suspect she had disposed with Cesar - ix-12 when a gentleman is disposed to swear $\overline{\text { in }}$ ii. Cressida? no, your poor disposer's sick - it
DISPOSING- the disposing of the cardinal.John, to fail in the disposing of those .... Coriolunus, iv. ISPOSITION - sworn lis disposition.Merry $w$. inconstancy of mun's disposition guiltless and of free disposition. . Tüclfh $\overline{\text { Night, i. }}$ iv. 5 good disposition 'tend your lady yhip ! - iii. do it not in evil disposition..... Meas. for Meas. $i$. of what disposition was the duke?..$\quad$ iii. the bitter disposition of Beatrice .... - ii. a cisposition to conie in discuised. my master is of churlish disposition - ii. in a more coming-on disposition ... $=$ iv. her dispositions she inherits ...........A Al's $n e l l, i$.

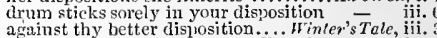
against thy better disposition. ... Winter's Tale, in.
robe of mine dues cliange my disposition - iv. even to the disposition that I orre ..... Macbeth, iij. of his own royal dispositiou ......... Richard III. i. 3 the bitter disposition of the time.Troilus $\&$-Cress. iv. I give your clisposition the reins $\ldots . . .$.
knowledge he has in their tiisposition the thwartings of your dispositions. awar, my disposition, and possess me anether by the disposition. a car i. o ling his goatisli disposition to the charge but let his disposition have that scope... wose disposition, all the world we Ynur brother's evil disposition made
I fear your disposition; that vature

\section{2}




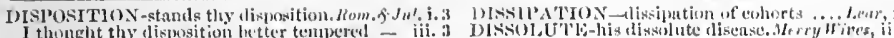

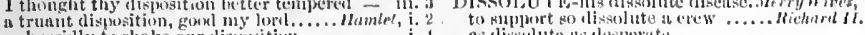

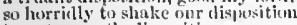

to put an antic disposition bil....................

lut with much torcino of his disinesition

l crave tit dispessition for my wite

I knww on rountry lisposition weil ..... il.

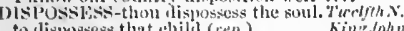

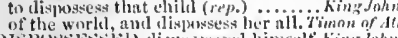

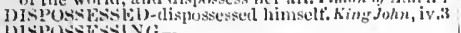

b) MossLSSLN

dispossessing ill my other parts.3/uns. for . Mects in.

in worth you dispraise sir Valentine, -

that would avoicl dispraise...... Lowe's $L$. Lou

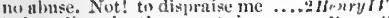

to her, ilisi rise those parts in me..... Henryt

dispruife the thing that you tesire

whint, my lorl? bispraise?...... Timon of Jihen

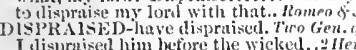

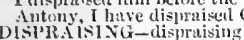

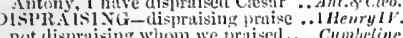

nut alisprusing whom we pratised .... Cymbly tin

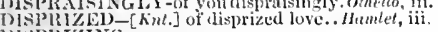

DISPRIZING-

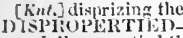

and clispropertied the
J) isplopolion-

to disproportion the in every part...3 Jfenry $/ 2$. iii. D)

is as tlisuropartioned in his manners.. Tempest

indeed, they are disprenortioned

and Warwiek shall clisprove it .......3 it tenry $t$

I speak not to disprove ythat Brutne.

disprove this viliain, if thon he'st ....

Dind

DINU NGE-dispnn I lipon me

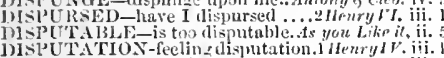

a tew disputations with you........ Henry

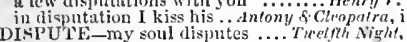

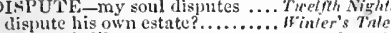

dispute his own estate?

vea, or no, dispute not thit.

2 Jenry, $V$

dispute not with her, she is lumatic. Richard 1I

Displyte with thee of thy estate.. Mome

DIN1 UTEST-thou dispntest i ike.. Love's L. Los

DISPUTING-are disputing of your.. Henry $r$
I)TSQUANTITY - d squantity your tran.. Lea

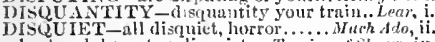

hustuand, be not so disquiet

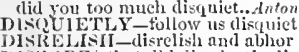

DISROBE-that did disrobe the lion.

disrobe the images, if you do find... Sutios Con

'lil disrobe me of these Italian weeds. Cymobction,

DISSEAT-me ever, or disseat nis

love t best: see thou disseuble not. Tuming of sh. ii. or botl dlissemble deeply their aftections so help me God, as I dissemble not!. I Henry $1 \%$, iii. gent hiun, sure: I must dissemble.

disemble not your hatred, swenr... Richard 11. my uncle did distemble, grandum fin dissemble, know his gross. Timon of ith. yi. I 1 would dissemble with my pature.Corintanss, liere he eones: I must dissemble it .... P'ericles

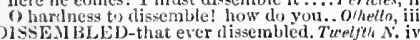
whose fury, not dissembled.... Titus dudrontezs, i.

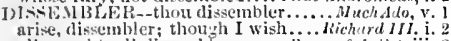
nll naurlit, all disemblers....... Romea f Jutim!, iii.

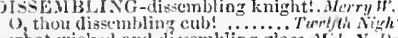
What wicked and dissembling glass. Mrl. No
liair is of the tissembling colonr...1s you Like

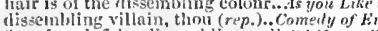
tivind sucl false dissenuling guite?.1 Henry all diswembling et aside, tefl ine ...3Henry $V$ l. of feature by thisimbling nature....lkcherd ili. $\mathrm{j}$. I the plain divil, and disembling looks
dissenthling abominable varlet .. Trnitus o

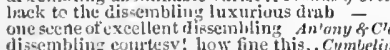
disenbling eontusy! low fine this.. Cymbeline

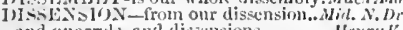
and quarrels, and disseusions.........lenryly civil dissention is a vipurous worm... this late diss:nsion, growin betwixt.

let this distengion first ne tris.

if they perepive dinsen-jum in our livics - ivi

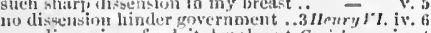
min a Jiswencion of a dlut, brcak out, Coriolanus, iv. I with smets elisuentious rtmours

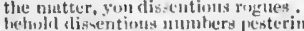

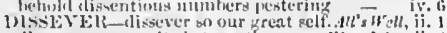

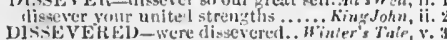

1)

most distolitely spent on T'uestiy ...1 I/

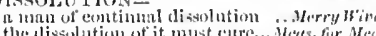

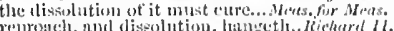

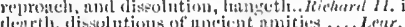

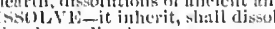

the eliarin alissolves a thuce

that nothing emu clissolve

gently would alisenlve the band

retermines, so clissolve my life

dissolye, thick elombl, and rain......

Almont reany to dissolve, learing of this.

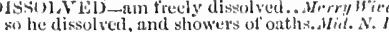

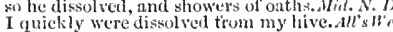

were all tisselted to tears

they nre lissulved; hang em!........ Coriol tom

DISSUADE-dissuale him trom lict... Much deln

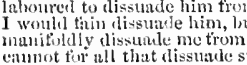

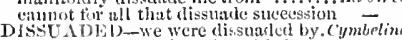
when I dissuaded him trom his intent.... lew

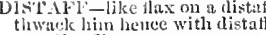

Pea, distaft wonnen manage rust

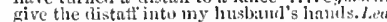
OIST

of maise listuns his worth. .... Preilus o Cress.

in these times you stant on distunce

thy distanee, thy montint

is will holl a long distance........Ait's

in such bloody distance, that every

folle what distance his wisdon ....... - iij.

the abmse of disteme, while we ...ipenry / ii. (cho.)

ner yet the other's distance eonfont me. In'

lime, thictanee, and proportion... Rometo of Juliet, if. I

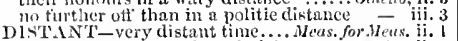

so fir be distant; and good night....Wid. N. Nr. ii. 3

his eourt distant from this shore?...... Pericles, ii.

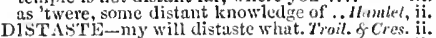

camot distaste the goodness ot

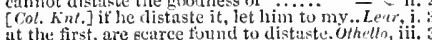

DISTASTED-distasted [Col. Kut. - distusting]

With the salt ............... Troilus s Cressidu, iv. 4

DI Cot. Kul.] flistasting with the salt. Troil.f. Cress. iv. I

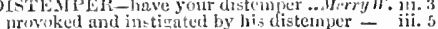

to this his distemler he is in no

night, lerhaps, distemper yours.. TirelghNi

faults proceeding on distumper

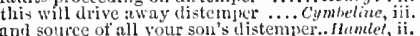

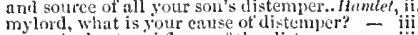
mylond, what is your eause of ditemper? - ii. 2
ujom the heat arid flame of thy distemper - ii. 4
DISTEMPERATUKE-

of pale distemperatures, and foes. Comonly of or.

having this distemperature .......... Thenry

DIjpoused by some distemperature

this distempered messenger of we
buckle his distemnjered cause with

Tenupest,

no distempered dag, no eon

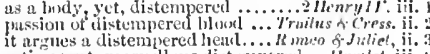

DEtirement, murvelluus distem]nere

visper, and distcmpering dranghts

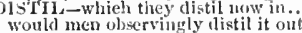

Othello,

make pertumes? distil? presery

DisTHLA'TiN

in, like a stron distillation .........4erry Wiwrs, iii. s

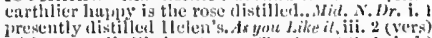

with warn thistilled wnters . Thming af sh. I (inil.)

anan dlistilled out of onr virtues.

(col tine with tears distill ing oneo

[Col. hat. With tears distilled hy mons

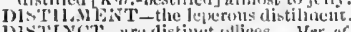

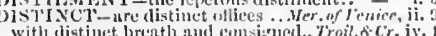

the fanl' is in the 'ort thisulute

what grom looks pale at his distempicrature

t:lste with a distempered appetite.

buckle his distenglered canse withill... Wacbeth,

few distillet on dlowers?....

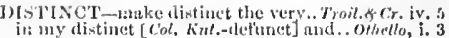

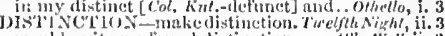

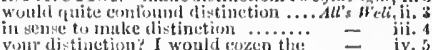

distinstim, with a loroul and.... Troilus of Cress. i. 3

les throws withert elistinetion

grunts searce listinetion
doth matio distinction of

DIS'INCTL - I Iame dist

Coriolam, ii. ]

Temmess

did distinetly his fuil function

all, which yet slistinctly ranges.

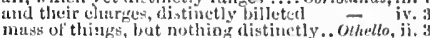

met, in position, distinctly spenk ol her..- iii. 3

DISTINGI Isil-clistinguisfi torm

sight may distinguish of colours

cye or ear listimenial him trom

lears that which enan dis

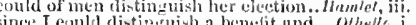

sinee 1 emld distimuiyl a benelit and .. Othelte, i.

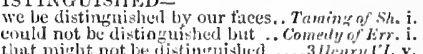

that mirlst not be distinguislicd

the valued nile listingishes the swift. Utebeth, iii.

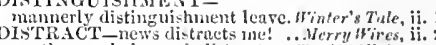

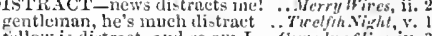
fillow is distract, and so am

fixed on end, as one thistrast.
with this she fell distrnet, and

oflewryll. iii.

listract your army, which inth. dn'ony $\delta$ Clto. iii.

to sce thy noble unele thus distract?. Titus smel. iv.

distruet; Her noud will needs be pitied. Whamet, iv:

DSTRAC TED-all the distraet

uneven and distruted manoer

tetel my poor distracted hushand. Comedy of Fr.

joverty hath distracted her ..........

epeak trom your distructer soul...Tinon of $\mathrm{A} t h$. Hii.

a sut in this distracted globe....... . Samlel, i.

does confuss, he feels himselt distracted
he's loved of the distracted multitude

those whom this vile brawl distracted.. on $\overline{\text { otho }}$, ii. ISTRACTEDLY -

did spleak in starts distractedly.. Trelfh Night, ii. IS'TRLCTION - in their distractions. Thmpest, iii.
und Ford's wife's distraction ......Merry Wives, iii. this savours not much of distraction. liclil it brow of much distraction... Winter's Tale, $\mathrm{i}$. with a countenance of such distraction $\bar{r}$.

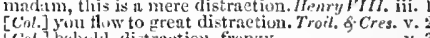
power went out in such dietractions...int.o Cleo.iii. tears in his eyes, distruction in s s.......

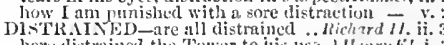

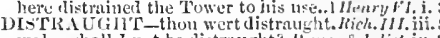
wake, shall 1 not be distrumght? fioneo of Jutiet, iv. 3

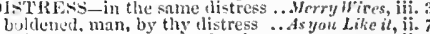

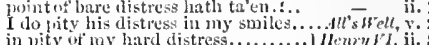

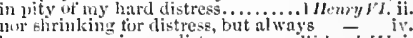
beg, were you in my distress ....... hichard HI. i.

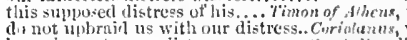

dir not upbring us with our distress.. Curiolans,

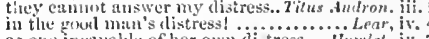

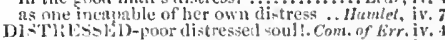

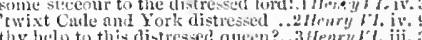

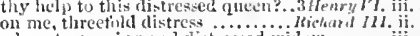
a beanty-waning aud clistressed widlow wite, th most distresket widlow

this youth, how er distresed

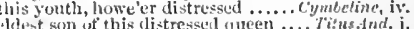
r:ther sonfurt his distressed plighti.. - iv. a stranger and tistresed gentlemain ...... - ii.

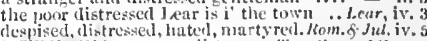

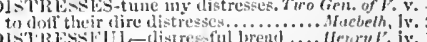
ease your eountry if alistrestul war.illenry $\%$. iv.

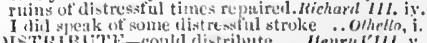

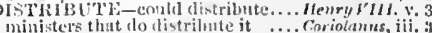

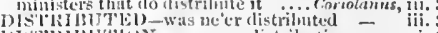

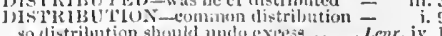

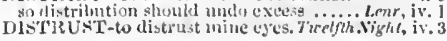


DISTRUST-fear, and sud listrust foil shall never lired clistrust....... i llenry I 2 . iii. a

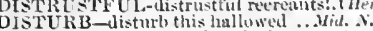
shall we disturb him, since he kiegs.. Henry $r$ i, $i$ : ould disturb your rist disturb him not, let him pass. that dar, and will disturb thice Buekingham, to disturb me? most unnt time to distmb him

it ever you disturb our strcets . Fomed
crenl shield, I should disturb devotion!

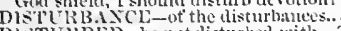

DLST KBED - be not disturked with..

to be disturbed, would mal or ...

neither disturbed with the affict.

bubbles in a late disturbed streai

this disturbed sky is not to wnl! iu.dulins Ceesar.

nor we listurbet with prodiri

hare thrice disturbed the ynist of. Romeo o-Juliet,

these disturbers of our peace ... 2 Yifus d milron. iv,

DISTCKBSE

DISINATE- fool eould disunite. Troiltw
DISVALUED_dismalued in levity. M/e/?.

DISVUTCHED-writ huth disvouehed ITCH-it in the muldy diteh......Merry Wires, iii.

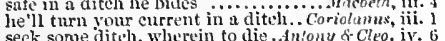
seck soane diteh, wherein to die...

bathe, ditch-delivered by a drab ....... ifucbeth, iv. 1
pirci-Dog-old rat, wind the diteh-dog...Lear, iit. 4 DITCH-DOG-old rat, ind the di
DITCIED-by the battle, ditehed

DITCHER-ditehers nnd grave-1uakers..IJumlet, $\mathrm{v}$. and ditehes grave you all!.... Timon of thens, iv. 3 dites moy en Anglois, le bias

DITTIES-sing no unore ditties. .ruch-4do, ii. 3 (song) as sweet as ditties highly penned

and this dittr, niter me, sing... Uidi. $\mathrm{X}$. Dream, $^{2}$. no great matter in the ditty.....

musy an English ditty
DIURX.....

HenryIt. ii.

DIVE-to dive into the fire

All's Hell, ii.

to dive, like buckets, in eonee:licd

or dive into the bottom of

dive, thoughts, down to my souli ..... Richord III. $\mathrm{i}$.

Richard II. i.

dive in tle eartb. and fenee not... Timon of th. iv.

as a duek tor life that dives.... l'erieles, iii. (Gower)

OIVED-Fet dived into the world's.. Rithard

I will give ont divers selpelules .. Therth $h$ Night, i. 5

eame divers of Antonio's ereditors. Mer. of ten. ili. 1
divers paces with divers nersons...As you Like it, iii.

threatens them with clivers deaths. Winter's Tale, v. 1

divers dear triends slain?
whieh-for divers reasons

whieh-for divers reasons ....

alteration witl a divers liquors?

mysclt, and divers gentlemen

for divers unknowi reusons.....

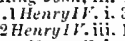

new opinions, divers, and dangerous.. -

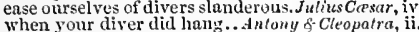

elildren of divers kind ......... Romeo o $J$ tuliet, ii. 3

with diverse-eoloured fans.. Antony di Cleopalra, ii. DIYERSLY - so diversly culunred .. Coriolanus, ii. IVERT - to divert the Euglish ..Henry V. ì. (eho.) and divert his grain tortive

DIVERTED-of a diverted biood....... As yor Like it, ii. 3 eould have well diverted her intents. All's Well, iii. 4
pI VES-and Dives that lived in .... I Henry $I \%$. ii. 3 DIVEsT-that you divest yourself $\ldots . .$. Heny $r$. ii. A DIVID.ABLE-from dividable shores. Troil. f. Cres, i. 3 DIVID AN'T-searce is dividant
DIVIDE- sometimes, Yd divide

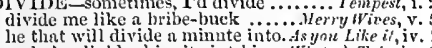
and o"er divides him 'wixt his ... Winter's Tale, iy. 3 Wlinding tears, divides one thing....
though he divicle the realm, and give

though he divide the realm, and give
o, I could divide myseli, and go to.
shial we divide our riglit, aecording

that we divide our power............ - - v. a thousand parts divide one man.. Henry $l^{r}$. $\mathrm{I}$. (cho. therefore doth heaven divide $\ldots . . . . .$.

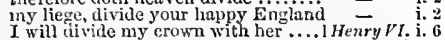
yourself in twain divide
then to divide the times

3Henry $r$ ii. 5

valour's worth, divide in storms ... Troil. $\delta$ Cress. i. 3

burden, divide thy lips

insepurate divides more wider

and you shall divide in all with us... Coriolanus, i. 6 will sometimes divide me from your. Ant. S Cleo. ii. 3 divide our equalness to this

brothers divide; in cities, mutinies.

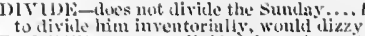

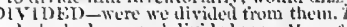

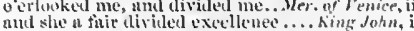
must we be divided? must we purt?

the untion king in throe siviled ${ }^{\circ}$

the English army, that divided was.

theught of this divided firiendship
we to-nurrow hold divided eoxneils

this tivited fork and latuedster, diviled -

breatl of lim in a divided dranght. ?

the three-fold world diriled

it was dividel between her.. Intony o chopers, in know, that we have divideel, in tlure
poor Ginelia divided trum hersedf...

DIVI pereeive here a divided duty.

DIVINATH - tor sle divideth us: kome d. Jnliet, iii.

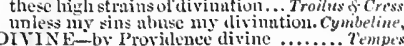

I INE-by I'rovidenee divin

I night eah lim a thing (livine .........

eall lier divine

it not divine, yet let her be

of such divine perteetion $\ldots$ he furnished with livine

I know him tor a man divine
like power divine, hath looked

now divine air! now is his soul

goddess, nymph, pertiet, livine!.ivit. .t. Drean,

nymph, divine, and rare, precious

$\mathrm{O}$ wood divine! a wit

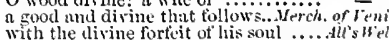

by Apollo's great divine sented up... ii
if powers divine behold onr human...
for has not the divine A pollo suid...

more divine, the masters of all.. Comedy of Er

more than earth divedse the divine, thinn..........

my divine soul answer it inl hear

as tho

your tongue divine to a loud

mon tres chere et divine deesse?

she is not so divine, so full.

that makes them seem divine
love, which greybeards call divine

divine perfeetion ot a woman

by a divine instinet, men's miuds...

meditating with two deep livines

hath an operation more divine..
Oyou gods divine! mnke Cressid's

with most divine integrity

whieh our divines lose by them............

from ron cloud speak divine thing

bound to divine of this unity.....
thou divine Inogen, what thou

there is a prohibition so divine...

fly from so divine a temple ..............

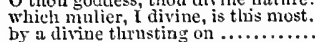

by a divine thrusting on .......................

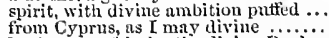

Mucbeth, $y$

letting go sufely by the divine Desdemoma

DIVINEL $\rightarrow$ most dirinely vowed King Johm ii. I

DIVINENESS-behold divineness.. Cymbeline, iii. 6

IVINEST-divinest ereature ....... Henry 1 . i. 6

despised substane ot divinest show $!$. Hom. \&o Jnt. iij. 2
DIVINING-my divining thoughts..3 HenryVI. iv. 6

DIVINITX-there is divinity in ...M. Miry Wives, v. 1

we will hear this divinity

nor divinity, if this sweet lady........ Nuch Ado. iv.

hear him but reason in divinity ...... Henry $V$. i.
but to have divinity preached therel. Pericles,

ay, nnd no too was no good divinity .... Lear, iv. 6

there's a divinity that shapes our cuds.. $-\bar{y}-2$

DIVISION-I'll make division .. Twetfih Night, iii.

how latre you male division of yourselt?
and in his own division: and .........Mueh deto, v. 1

division of the twentietl part .......... of lemice, iv.

but the wathe division prove ...Richard It.

with ravishing division to her lute..1 HenryI $V$. jii.

of our attemyt brooks no division.

and the division of our anity.

cnvy breeds unkini division.

iHenry $\mathrm{H}$ -

divided, in their the division.......Richard IIT. $\mathrm{v}$

them in the lieat of their division... Coriolamm, iv.

never come such division ' $t$ ween... Juthes Cosa
may eement their divisions....... Antony of $C l$

unhtrpy tady, if this division ehance

but now, in the division of the kinglam ... Lear, i. ? thesc eelipses do portend these
divisions in state, menaees and

there is division, nlthough as ye

there is division between the aukes...

二 iii.

the lark makes sweet division...Romeo s. Juliet, iii.

nor the division of a battle knows mure.. Othello, i.

IVOIRCE-diroree his memory ... Love's L. Lost, v.
dcadly divorce step between one ....... All's Well, r. 3
DrVilice-mirk your divorec .. Winters Tule, in: 3

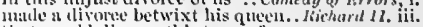
that would divorec this terrer from ..

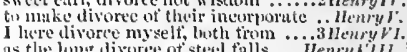
as the long diroree of sted falls...... Henry inh. ii. to divores it trom the benrer........

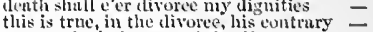
to stay the judgment o tlic divorce.. that weep this lnnuentnble divoree cumbelin. iv of the divorec hed make! ............ ii.

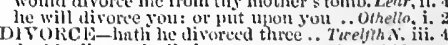

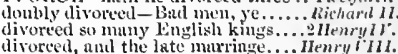

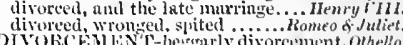

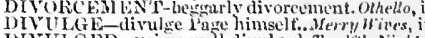

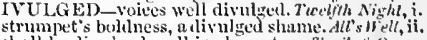
shall be divulged well in characters. Troil. si Cr. $v$ DI U DIZZY-dizzy with hore clmour. Troil. of Cress. $v$.

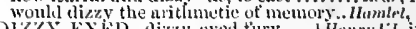

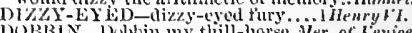
DOBB $N$-Dolbin my thill-horse.sler of lenice, ii.
that Dobbiu's tnil grow's buekwart? (OCK -0 iocks, or mulluw's ....... Tempest, ii. hitteful ducks, rough thistles.............. Henryl. v.

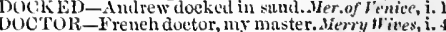
and Caius the French doetor

bless thee, bully doetor ...

he is the wiser mun, muster doctor. thangh we ure justices, and doetors.

I will bring the doctor alsou

ndicu, good muster doctor................

so do you, good master doetor.
sliall I lose my doetor? No...

but iny wife, master doetor, is for...

thut's my nuster, naster doctor.

the doetor is well monied

three doetor finustuses

here, master doetor, in perplexity

to clenote her to the doetor

master doetor, my daughter i

at the doctor's marrving my daughiter

she is now with the doetor ...........

why went you not with master loctor -

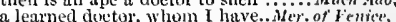

with letters from the dector.

at young and learned doctor $\ldots . . . . . . . .-\overline{\text { iv. }} 1$ (let.

here $I$ take it, is the doetor come.... - iv.

reverend doctor, hire it is.............

to give the worthy doetor (rep.)......

the same I gave the doet

the doetor's elerk, in lieu

thut Portia was the doetor ...........

you tlie doctor, and I knew you not?

sweet doetor, you shall be ny bedtellow

why, doctor she; my lord, there 's one. All's Well

for so your loetors hold it. Taming of shrew, 2 (Ind.)

good doctor Pinch, you nre .. Comedy of Errors, iv.

good master doetor, see him safe

bound the doetor, whose beard .......

rookl-night, grood doetor.

Doctor, the thanes ty trom me ......

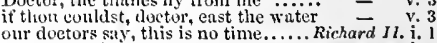

what says the doetor to my water?.2 2henry 15 i. 2

of the lund, und doctors lenrned ... Henry rill. ii. .

do wonder, (loetor, thou nsk'st ine.. - i.

no turtlier service, foetor, thistil I send = i.

yet death will seize the doetor too.... I - Itamle?, iii. 5 DOC'TRIN E-eomfortable doctrinc. Tineirh Night, i. 5 this doetrine I derive: they spnrkle.. embowelled of their doctrine ......... Atr's Well, i. show a worse sin than ill doetrine. Henry VIII. i. 3 hitl ly learn a doetrine of obedienee. Ant. \& Cleo. y.

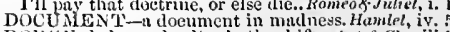
DOUGL-dodgend palter in the shifts.Ant. \& Cleo.iii.9 my doe with the black sent? .......... whiles like a doe, I go to find .......As you Like il, ii. hust thou not full often struek a doc. Titus.And. ii. 1 


\section{DOE}

DOF:-to pluck a dulnty dine to gmund. Titus Aad. if. 2 DoBlf-Jove, not I, Is rloer of this. Tirelfh, Night, lii. all preat deren in our trale ....Mras. for Mran, iv. now juatice on thas derers now juatice on the dirers Richare III, i. 3

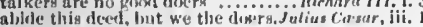
thesn dreal it to the thoer's thrift..... C'vmbeline, y. to floff thele dire dintreskes. Ioff it for shame, and lang and roale un loif our easy role driff thy harneas, Youtl, 1 am in plenee to doff"t for ont re
deof thy name; and for that.

政, wro-blasphemous, inchiaritulile dog ... Tenpest, $j$.

the wateli-dings lark

thy dog, and busil

liut you'll lic like dings

rrpj., Two Gen. of Verona,

1 an the dos: no, the don lo lifinsicif

nnd I am the dog: (1, the dog is me.

now the dog nil the while

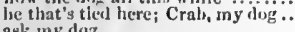

ask my dog to

his I kould tearlis a dog

to Ire, as it were, a dions sit aili ithings...

man-like dogrs

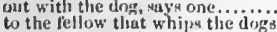

You mean th whip the dog $\ldots$..........

ghe says, your dog wus a eur

but alie reveivel my dog? ............

Who is a dog ga big as ten of yours ...
and find my dog again ...............

lie's a groml dog, anid a fuir do

hat not have a liark 80 ? ...........

hope is a curtuil dog in some alfuirs

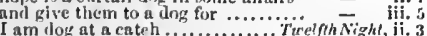

and worne (logs will eatch weli

$\ldots=$ ii. 3

to give a log, and, in recornpense (rep.) - y - y. I

nu' lie had been a ding, that should

I would not liang a dog by my will.. - $\begin{aligned} & \text { ii. } 3 \\ & \text { to be used as you use your dog..... Misl.N.'s Dr. ii. } 2\end{aligned}$

with lantern, dog, and bual of thorn

my thorn-bush, and this dog, my dog -

the dogs dirl yell ....... Lore's L. Lort, iv, '2 (epitaph)

eut-throat dog, and spit upon my

hath a dog money? is it possible

anther time you called

as the dog Jew did utter ............. -

und your $\operatorname{dog} s$, and unules, you use

O, he thou damned, inexorable dog!
not one to throw nt a dog ......... ds you $\overline{\text { Lil }}$.

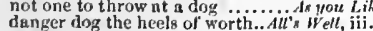

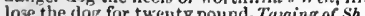

I take lim for the better dog

than a mad dnes's where is ...... - iv.

than a mad dner's tonth ...... Comediy of Errors, y.

and tongue of dngs, adeler's fork

throw phraje to the doys; I'll none.

maids of thirteen do of puppy dogs!. King $\overrightarrow{J_{v} h n}$,

and like a dog that is eompenled .....

dogg, easily won to fawn on.......... Richard $1 J$. iti. but that sad dog that lirings me foor

are as dank here ns a ing........ I I Ienry $/ V$. ji.

I would curlgel him like a dog

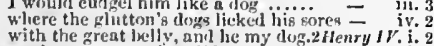

so, thou cominon diog, dicht ...

as familiar with me as iny ring .....
dowu, down, doga! down, fititors

die, inen, like dogs; give erows

and the wild dong shall flesh.

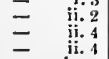

pish for thee, Itedand dop

solus, egrezionts dog? o vijer vilei

and lioldirst is the only dog............ iny

for eoward dogs most нjencl..........

[Col. $K^{\prime} n t$.] up to the preach, $y_{\text {oul iogs: }}$

lisciplines, than is a pup,

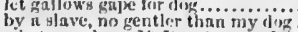

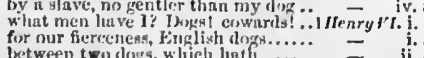

between two dons, which liath
in quiekly found to leat a dog.

to inake ing s leather of .............

ïLenry $v$. iit. 1

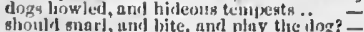

that dogs burk at me, au I lialt .... Jichard II

unmannered dog! stumil thou ...

stay, dog, lour thisu shalt irear

leware of yonder log; look............
and destruetion dog thee at the liceli

feahed villains, lilooly dogs, melting

that deg, that linl lis teeth.

live tn say, the dog is d
the blowly dog is dend

the blowly dog is dend .................

is whoresou dog, that shall pailier.....

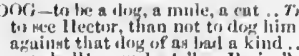

aquinat that dog of as Inal a kind ,

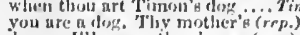

ilog, or I'll sliurn thee lience ( $r e p$,

but a lreggar's lisg, and give it (rep.)

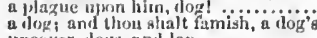

uncover, dozs, und laj

dont wot keep a doug uhom i would

never elasped; but bred a dog.

some metns to keep a dog.

away, thou issue of a mangy deng!

give to de,ges what thou deny'st .....
make gold ol' that: out, raseal doge?

he's a very dog to the commonalt

as easy as tos cat; that, meat..

muke them of no mere voice thisn do....

I'd have benten him like a do

I hal ratleer be a dog, and bay.

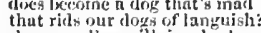

that richs olt dow of languish

Hhoreson doy I I give him
lay liands on limi a dor

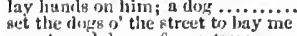

as ests and dogs, of no e;teem

and therein, hellish dog, thou.

as true a log as ever tought..

uway, inhuman dog! unhaliowed

you whioreson doge! you slave! you cur!

knowing naught, like dogs, but followi

dogs, and teerr, by the neck

the little drogs and all, Tray, Ilanc.

logs leap the hatch, and all are flet.....

they flattered me like a clo

keen a farmer's dog bark

mine eneny's dog, thougli he harl

a semllanee that very dogs disclaince.

$\mathbf{a}$ dog of the house of Montague.. Iiomeo

a dog of that house shall move $\ldots . . . .6$

because he hath wakened thy

zounds, a dog, a rat, a mous

every cat, and log, and little mouse - iil. 3
if the oun breed maggots in a leat dog. Humlet, ii. 2

will is counter, you talse Onnish log

will mew, and dog will have his day.

as one would beat his offeneeless do

better have been forn a dor

O inhuman dog? 0 ! 0 ! 0 ! Kill men

Itook by the throst the cirumcised $\ldots-$ v.

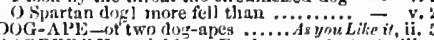

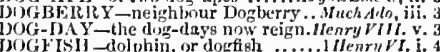

JoG-Fox-doghin, or dogfish ...... Ulenry VT. i. 4

DOGGED-I have dogged hin ... Tuetfly Night, iii. ?

we shall be dogged with company...Mid. N. Dr. i.

that dogged the mighty army .......julenry VI. iv.

and dogged York, that reaches at ..2 Iferery $F I$. iif.

Whose repctition will be dogged

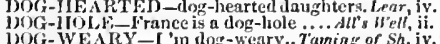

DOG-WEARY - I 'in dog-Weary.. Taming of Sh. iv. 2
DOIt;T-les doigts. I Le doigts? (rep.).. Menry $r$. iit.

DOIT-will not give a doit to relieve .. Tempesi, ii. 2
nnd take no doit of nsanee...... Merch. of J'enice, i. 3

little John Doit of Statiord sij.

which will not east a man a doit ... Timon of $A$ th. $i$.

irons of a doit, doublets that

I'd not have given a doit

[Cot.] poor'st dimin utives, tor doits. Ant. \&- Cleo. iv. $]$

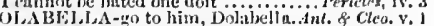

Where's Julubclla, to second (rep.).

Dolaledla inadam, as thereto sworn
Dolabella, I slaall remain your delitor

there's Jolabella sent from Ciesar

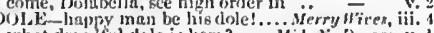
what dreadful dicle is liere? ........idl.. . D ream, v. I

making such pitiful dole over ....As yons bike it, i, 2

liaply man le his dole!

I'inter's Thle, i. 2

liajly inan le his dole, say i ....... I Henryl

(omit we all their dole and woc). Pericles, lii. (Giow.)

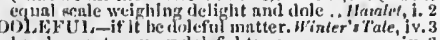

liere's one, to a very dol eful tume .....
whin chants a doleful hymn to his ... King John, v. 7

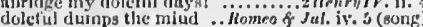

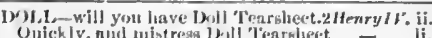

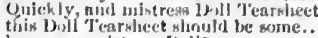

how now, inlatress Doll? ............

Yout make fnt ramenla, miptress Diti.

liark tlice lither, mistreas $\mathrm{b}, 11$......

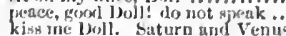

furevell, Jolli; you see, goorl wenches

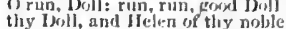

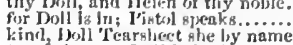

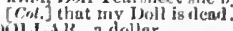

to threc thou dol lar foll..................

to three thousasel dollars a year. Aleas. for Meas.

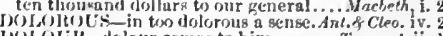

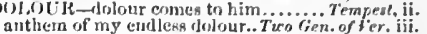

oule sign of diblour to another

Macbeth, iv. 3

$t$, lireathe the afundant dolour of ....Michard $i I . \mathrm{i} .3$

Anlromache phrills her dolours. Troilus of Cress. v. 3

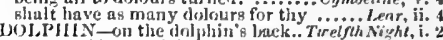

a merintid, on a dolplin's back..... Shil., N. Pr. ji. 2

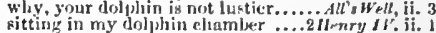

lucelle or puzel, dolphin or dog-fisli. I Henry vi.i. A

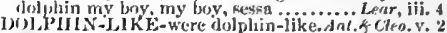

DIJ]'T-asoes, forsls, dolts! .... Troilus \& Cressida, i.

diminutives, to dolt [ Col.-fur dioits]. Ant. f Clen. iv. io

DOMESTIC-malice domestic, forcign. Wacbeth, iit. 2

vomestie broils clean over-blown ... Hichare III. ii. 1

justice, truth, domestic a we... Tinon of Athens, iv.

equality of tuo dometic powerg...Antony f Cleo. i. 3

fervants, than tlyyelf domestic officers... Cymb. iii. I

to manage private and domestic quarrel. Othello, ji. 3

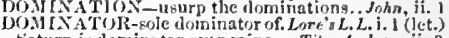

saturn is domisator over mine .. TilusAndron. ii, 3
marne Dominatur poli, tam lentus... iv. 1

Do.TIN E-a verse; lege, domine.. Love's L.. Losl, iv, 2

DOSINEER-revel and domineer. Taming of Sh. iii. 2

domineering pedant o'cr the boy. Love's L. Lost, iii.

DoMINION-out of our dominions. Winter's Tnie, ii. 3

shall tythe or teil in our dominions. King Sohn, iif. I

born out of your dominions.......... Henryly. II. ii.

trunk be found in our dominions........... Lear, 3 .

Dour dominions for this enter rise .... Hamlet, ii. 2

DON-what! should I don this rohe Titus Andron. $\mathrm{j}$. 2

ONALB.IN - chamber? Donalbain...Nacbeth, ij.

Banquo, and Johalbain! Maleolm! ...

and for Donalhain to kill their gracious - iii, 6

Who know's, if Donalhain he with ....... - vest,

put my wealth into donstion.. Timono of Alhess, iii.

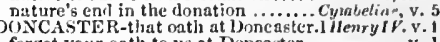

forgot your oath to us at Doneaster.. $\overline{\mathrm{c}}$. $\mathrm{v}$.

I3O NNE- lonne inille reroercimens ..... Henry $V$. iv.

he rose, and donned his clothes.. Viamlet, iv. 5 (song)

DONNEP-ile vons donner la liberté .. Henry $V^{2}$ iv.

D(3NNEIRAY - donneray deux cents esens -
DOON-to fiy his deally doom.. Turo Gen. of

she hath offered tos the doon

stand tilf the perpetial doonn........ Merry llires, v.

hath repented o'er his doom ....... Hevess for steas, it.

firn and irrevocable is my domin.. As you Like it, i.

and see the great doon's innge.

alter not the doxe crick of thoom

the thee remains al henvier doom

King John, iii.

How' with thee for our day of doom - fij.

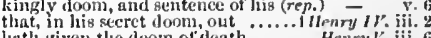

hath yiven the dem of death ........... Henry $r$. ii. 6

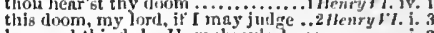

luw, and this duke In Inmplirey's dooin

greatly who insuugns our doom...

revoke that doom ot merey...

.......

thumpla, finry, in thy diny of doon - Y. 6

to doom the offunders.............. - iii.

all unsoided in tho down of destiny - $\quad$ iv.

and the gods dom him stter!......... Corintanus, i. \&

the denth of $A$ ntony is not a single deom - y.

this is the day of drom for Bassiantus. Titus .

with their tumgues donm men to death

ing lis ruge, will doom licr deatls.

this is our duom: some stay....... 
DOOM-obedient to their doom.. Pericles, iii. (Gower')

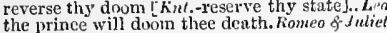
somnd the general doom!

what is the prince's doom?.....

prince's doom. What less than (rep)

displant a town, reverse a prince's ctoom - iii. as against the doom, is thought-sick .. Ha mlet, iit.
Doonten-art doomed to die .. Comedy of Errors i. he doomed this beauty to a grave ... King John, is doomed a prisoner learn our........ Cymbeline, donmed for a eertain term to walk......

ghe lives till doomsday

doomsday is near; die an .

anil run, as it were domsday

leave tu play till doomsday

murriace-day was Tybalt's doomsday

sick almost to doomsday with eclipse ..

louses, that he wakes, last tiil doomsday

DoOR-turn my merey ont of doors .. Tempesl,

ay, hut the doors he lock d.. Tu' Gen,of lerona, ii

shall turn your head out of my door

jealous knave their master in the door

watch the door with pistols

to meet him at the door with

your master is hard at door
out of my door, you witcls!

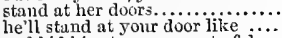

and bid him turn you ont of

doth command a litile door ............. for . Hens.

watel about signior. Leonato's door...

came out of duor, and stayed the... Love's $L$. $L$. iii.

came out of door, staying the odds

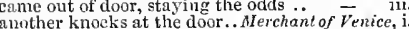

loek up my doors; and when you hear

I will make fast the doors, and gild.

he's ready at the door ...

eome not within these door

well, push lhim ont of doors....

make the doors upon a woman's wit
knocked too often at my door......... Alt's Woll,

ye were beaten out of door.. Taming of Sh. 2 (indu

the door is open sir, there lies

thint eone unto my father's door

sir, here's the door, this is Lucentio's
and is here at the door to speak......
hence with ber, ont o' door .......

some behind door work................

why, they stay at door,

still lies out os door ...

eitlier vet thee from the door

go, get thee from the daor $(r e p$.)

since mine own doors refuse

locking me out of my doors by

shut the doors against his way

sliall beg with it from door to door

upon me the guilty doors were
were not my cloors locked up

were not my cloors locked up

agrainst his murderer shut the door

the doors are open this is the door. I $11 . \ldots . . . .$.

now to the door, and stay there.

at mine hostess' door, teach us . .....

meet displeusure further from the doors

eren ot your door, to eudgel you

out of the weak door of our ..........

open the door, or I will break it open

pity me, open the door

at the door, shall I let them in (rep.). i Henry IV.

hostess, clap to the doors .............

a most monstrous wateh, is at the door

shut the door; there comes no

swaggerer eomes not in my doors...
have you turned him out of doors?
so loud at door? look to the door...

a dozen captains stay at door for $y$ ou

debate that bleedeth at our door

how now? rain within doors..........
this door is open; he is gone this way

look who's at door there: ho

as 1zail in door: the things I speak

chide this Dauphin at his father's door

up for example at their doors ......2 Henry $V_{I}$, iv. 2

up for example at their doors ......2 Henry VI. iv

shame to make me wait else at door..

who holds his state at door, 'mongst..

and at the door too like a post.........

keep the door close, sirrah ...

keep the door close, sirrah ............

a fellow somewhat near the door.

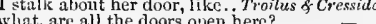

who's that at door? good uucle
DOOR-will you beat down the door? Troil. of $\mathrm{Cr}$, iv. 2
have thee thirust me out of doors.. Timon of $\mathrm{Ath}, \mathrm{i}, 2$ men shut their doors against

doors, that were ne'er acquainted

what, are my doors opposed against.

turn thy solemness out o' doo

pray, go to the door...................

as rushing ont of doors to be resolved

to wander forth of doors

cucius and Titinius guard our door

that is out of door, most rieh!........

attend you here the door of our stern
her doors locked? not seen of late?

the bier at door, and a demand who
with iny sword I'll keep this door safe. Titus dnd

knock at my door, and tell me ......

upright at their dear friends' doors

not amiss to keep our door hatelied....................

to me the very doors and windows savour

she lad never colne within my door
and kcep in-a-door, and thou shalt

or at their chamber door l'll beat

your doors, my lord; 'tis a wild night.

than this rain-water ont $o^{\prime}$ doo

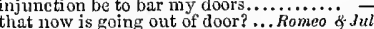

nor so wide as a church door

$O$ sliut the door, and when thou hast

sealed up the doors of and would weal with

for out o' doors he weut without

let the doors be shut upon the door upon your ow

bar the door upon your own liberty.......

the doors are broke. Where is this king?

I thank you: keep the door...

yeu are pictures ont of doors, bells in.....

lead directly to the door of truth $\ldots$.....

speak within door. O fye upon him!

come, guard the door

avaunt, thou damaned doorkeeper! .... Pericles, iv. 6 thou't the damned doorkeeper to every $\bar{Y}-$ iv. 6
DOOR-NAIL-dead as a door-nail..2 Henry DORCAS-those flowers there, Dorcas. Winter's T. iv. 3 DOREUS-hath Doreus prisoner .. Troil. \& Cress. v. might fear, $\mathrm{my}$ Doricles, you wooed me

they call him Doricles; and he boasts

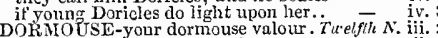

DOROTHY - mistress Dorothy ......2 Henry $I V$. ii

I know you, nistress Dorothy

to Dorothy my woman hie thee ........ Cymbeline,
DoRSE' $\mathrm{i}$-Rivers, and Dorset ......

[Knt.] to be revenged on Rivers, Dorset -

Dorset, embrace him; Hastings

look I so paie, lord Dorset

the marquis Dorset, as I liear, is tled

Dorset is fled to Richmond ..........

Dorset your son, that, with a fear

stirred up by Dorset, Buckinghain

and lord marquis Durset, 'tis said...

and hdy marquis Dorset; will these

DORSETSHIRE-in Dorsetshire ..Richnrd III. j

hold one an opinion of another's dotage

banish your dotage; banish usury. Tim. of $\mathrm{A} / \mathrm{h}$.
but this dotage of our general's ... Antony \& Cleo.

or lose myself in dotage.

that scope his dotage gives it...

ind may enguard his dotage with their.

Lear,

or voluntary dotage of some mistress ...Öthello, i

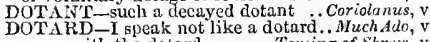
away with the dotard ........ Taming of Shrew, v.

a ehild that guided dotards $\ldots . . . . . .$. . Cymbeline,
DOTE-to dote thms on such luggage?.. Tempest,

seest me dote upon my love.... TivoGen. of Ver.

how shail I dote on her.......

you dote on her, that cares

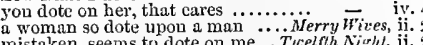
and dote upon the exchange ......... Aluch Ado, ii. she should so dote on signior Benedick -

if he do not dote on her upon this ...

as you on him, Demetrius dote on $y$ on!

which she must dote on in extremity

how I love thee! how I dote on thee!

which in my childhood I did dote upon
where all alike do dote ............ Love'sL. Lost,

when wit doth dote: since ail...........

but I dute on his very ahsence... Merch. of l'enice,

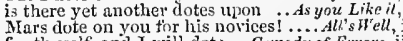

fur thyself, and I will dote ... Cumedy of Errors, iii.

thy age and dangers make thee dote.

as much they love and dote on.....Henry $V^{\prime} / 11$. ii.

and the will dotes, that is .. Troilus \& Cressida, ii.

three, that Rome should dote on $\ldots$. Coriolanus, ji.
lias sorrow made thee dote already?. Titus And. ii
DOTE-so old, to dote on her for any thing. Lear, i. 4 I know, the drosssy age dotes on........ Hamlet, y.

DOTED-whom they doted on $\ldots \ldots . .2$ Henry $^{\prime} V^{\prime}$ iv. DO'CER-should ravish doters with. Lone's L. Losl, iv. 3 DUTING-with a doting observance. Merry Wives, ii. 2 pence, doting wizard, peace .. Comedy of Errors, iv. doth gape, and doting death is near .. Henry $v$. ii. $]$ than is the doting title of a mother. Richurd III. iv. that same scurvy doting foolish.. Troil. \& Cress. Y. and they thein tor fear and doting ... iil. fur doting, not for loving, pupil mine.Rom.\& $\mathrm{Jul}$. ii. : Tybalt murdered, doting like me.... ... $\bar{O}_{\text {thello, }}$ i. 1 DOUBLE-a thrice double ass was 1 .....Tempest, v. is double your folly ....... Two Gon. of Verona, ii. double gilt of this opportunity ... Tu'elfth Night, iii. double and treble aumonition, and still - iii. being criminal, in double violation... there's a double meaning in that ..... there's a double tongne, tliere's two
snakes, with double tongue ...Nid.N.Dr. ii. 3 (song) pays the hearing double recompense - iii. like to a double cherry, seeming parted - iii. to cvery power a double power.. Love's L. Lost, iv. you have a double tongue within.... double six thousand, and then ...... - iii. swcar by your double self.................. you do me double wrong .... Taming of Shrew, iii.

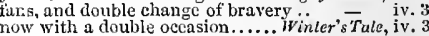
for then you kill her double........... 't is double wrong, to truant... Comedy of Errors, iii. ' and then done double, were poor...

he's here in double trust ..........

palter with us in a donble sense......

why answer not the double majest... some reasons of this double coronation - iv. whose double tongue may ...........Richard $I I$. iii. paying back, 't is a double labour..' Henry $I V$. iii. as if Jie mastered there a double.....

I an not a double ma

who with a double surety binds $\ldots . . .2$ Henry $r V$. i.

rumour doth double, like the voice.. $\quad$ iii.

and is old Double dead! ............ - iij.

this is and shall double gild ........... Hen $\bar{y} v$ iv.

a pot of good double beer, neighbour.2 Henry VI.

this knave's tongue begins to double - ii.

a double shaiow to Henry, 3 body ..3Henry VI. iv. 6
with donble riches of eontent .... Richard III. iv. with donble riches of eontent ....Richard III. iv. be ever double, both in his words .. Henry $\bar{V} I I I$. iv. this double worship, where one ..... Coriolanus, iii. make the greatest king doublei......... Cymbeline, i. as if a double hunt were heard....Titus Andron. ii. sorrow flouted at is double death .... - iij. fifty yet dotl double five-and-twenty..... Lear, ii. a donble blessing is a double grace....... Hoinlet, $\mathrm{i}$. 3 like a man to double business bound.... - iij. his double vouchers, his recoveries $\ldots . . . .=$ v. a double knavery, how? how?.......... DOUBLE-CIIARGE donble-eharge thee with dignities ..2 HenryIV. Y. 3
DoUBLED-11l deeds are doubled.Comedy of Err. foul words doubled down his throat. Riehard II. $\mathrm{i}$. shall still be doubled on her........ Henry FrII. v. when straight his doubled spirit.... Coriolanus, i. the last of inany doubled tisses ... Antony \& Cleo. i. 5
DOUBLE-DEALE -

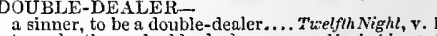
to make thee a double-deajer ...........Much Ado, v. it would be donble-dealing, sir .. Tuelfh Night, v. DOUBLE-HEN NEDDUUBLE-MEANING-

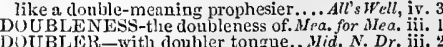
DOUBLER-with doubler tongue... Hid. N. Dr. iii.
WOUBLET-is not, sir, my doublet as fresh. Tempest, ii. my jerkin is a doublet .... Tu'o Gen. of Verona, ii. 4
in your doublet and hose ........ Merry Wives, iii. I shall make thee anew doublet and hose - iii. carving the fashion of a new cloublet. Much d do, ii. trom the hip upward, no donblet.... 


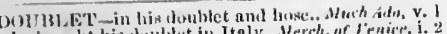

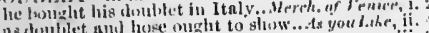
na doublet anut hose ongh to

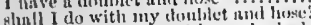

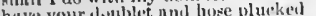

he

a silken dublbetl a velvet hoset......

your white ensusas doublet will ...ilnenryo

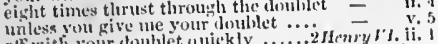

off with your toublet iquick $k$ ly

fon in their hose nnd donblets...........

disublets thut hangunen would

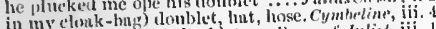

in my thak - hisg new doublet.... Romeo \& Julict, iil.

with his doublet all unbracel........... Hitemlet,

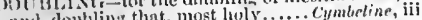

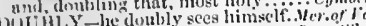

be mine, now you nre desubly won? .. All's llidth,

sis they doubly redoubled strokes

let thy bisws alembly redonbled

my tongue doubly porteullised

on disihly seconded with wili.

outilene his firmer deuts cloubly

Jichard 11 ,

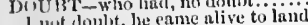

lust doubts distovery there

and, no douht, mirketable

slie makes no doubt of that. Tico Gen of inon

ghe mikes no not well

he will print them out of doubt.

dectors dowibt thit

ass, I derubt not .............

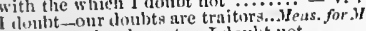

You know the eharneter. I loubt

were you in doubt, sir, that you

and l rombt not lint to fashion it

ilinilit not but sucess wils washion

haul we timght, I doubt, we should . F. Drea

no donbt, they rose up early, to

I lingt doubt but to hear them say

fine, when he should say doubt.

they male a dnulst, presence

cut of cloubt woukl make me

l do nut dinut, as I will watch....

will, no dnubt, never be elusen.

in a doust whither those peals

ta make these doubts all even.

if any man dnubt that, let lim .......

loubt not but henven hath hrought...All s

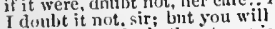

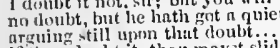

if thom doulbt it, thoum mayst shicle.

lint tliat's past iloubt; you lion

then, "t were past alt doubt.

I lowbt not then, but innoeen

arrive, shall elenr that donbt.ii.
and doubt not, sir, bnt she wili.
notorious slume, i doubt it not.

now, nut of doubt, Antipholus in

I doubt, some danger does ap

where I did find my doubts............

shall never sagg with

and hegin to doubt tlie equivoention

of that I doubt, as all men's childreu. King Jo

ay, who doubts that? a

hang no more ill doubt .................

ant eye of doubt upon my fitce.

find it. Dauphin, du not doulit $\ldots$.....

I doulst, he will be dead, or ere
but 'tis dnulst, when time slanl

urge dunbts to them that fear
ard dejosed, "tis doubt, he wili
I doubt not but to rigle as fast....

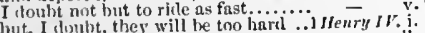

wroll, I doubt nut but to die ...

demlit not, my lurd, they shail.

to culd one doublt by deith.............

in,tle which, we dontbt not but your.

will, I loult, prove mine own marring

ms dusts, grew like the sunmer-gras.

we dowbt not of a firir and lueky war

We doubt not now, but every rub.

your breeting: which I dimubt not

out of duult, be of the same relisli....

cut of foubt, and out of questions too

1 doul, not, lut with honour

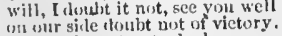

ary $I V$ iv.

I luubt not, unele, ot' our $v$

but answer ine one doubt...

why stanit $y^{*+a}$ in a doubt?

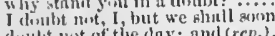

douldt wat of the doy ; and ( $r p p$.$) ....$

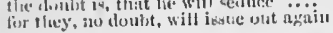

OOUH'L-no doubt, no doubt

there's no doubt, his majesty witi..

himself, no douls, slall then .......

I1w) doubt, he is, my gractus (rmp.)

nowloubt, no lowe

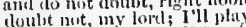

no doubt we'll bring it to a finpy issue

mo rloubt, shortty be risl of we........

will, no doubt, tempt him to unything

no doult the inurderons knife was

1 doubt not, hut nils friends lord.

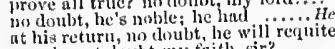

You do not toubt my faith, sir?......

iloubty, wringitug of the enmseien

coutsel which had, to doubt ......

no roubt, in time witl fiud their

no donbt, shall thank you ... ii c......

deserve mnte. Yen, without at do litte doubt, as yon do

room, no doubt, left tior the ladics.

but modest doubt is called the

and dontht thu not, hrave boy.........

would not liold tiking, I doubt me.

doubt not that, it money

for I must ever doubt, though neer

in whose breast doubt and

we never yet made doubt but Ron...

) doubt not that; I sleak trom.

(as it were sin to dlonbt) that love.

thing wanting, which I douist not ...

stay, past cloubt, fur greater..........

that yon make doubt of it?

such ereatures is men doubt

and will, nodoubt, with reasons.

I do not doubt, but that my noble

I I will be even with thee, doubt it no

I doubt not, a great deal from the

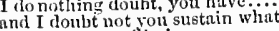

I doubt not you'll give me

anl will, no doubt, be found

this is, sir, a doribt, in such a time

and slonild he doubt it (as no that doulit, he'll till this

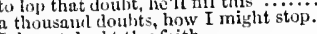

flo not doubt thy fuit

I dion, we doubt but this nopulous city

I doubt not but I shall find th

t ly lough doubts did ever sleep

nay more, I doubt it not ........

I doubt it nnt; and all these woes

I will do it without fear or doubt .....

we doubt it nothing; heartily farewetl.

do you doubt that? For IInmet....

doubt thou, the stars are fire, doubt ..... ii. 2 (let.)

doubt truth to be a liar, bnt ( $r p p$.)

I do cloubt, the hateh, and

speaks things in doubt; that car.............

do not roubt that; before Emilin licre

who dotes, yet doubts; susprects, yet

to be onee in doubt, is-once to bu

I'll see, before I doubt; when I doubt

nor loop, to hane a rlowbt on

DOF13TED-let it not he doubted... He

let it not be tonbterl I slanl! do good.

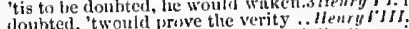

is not doubted: a word, Lucilius..

and to be doubted, that your lloor .. T'ilus.tut. ii. 3

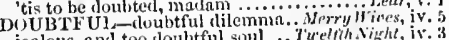

jealone, and too toubtinl soul ..J'relfh Nizh,

as tloubtfol though t 8 , and .... Merch,
doubtfiul whetlier what I see be true

an doubtfut of your inodestiee. Taming of shy 1 (int.)

a doubt'lul warrant of immediate. Comed y of Rr.

fy ciestruction, ch well in donbtfinl joy

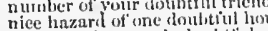

nice hazard of me dintoultitul.

be unfire in this soulute ul stri
by doubtful tear my joy of line

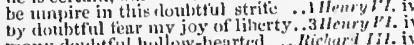

many donthtill hullow-hearted . Nicliarl
no anse to hold iny friendship donbtlul -

and nicl thee in this doubtiul shoek.

our doubttul hope, our convuy ... Tr

but it is itoulat ful yet, whe'r Cesenr. $j$

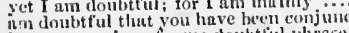

in doubtful thut you have heen conju

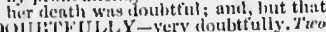

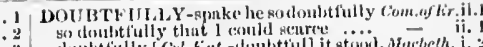

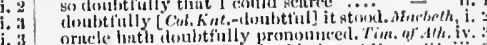

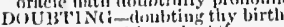

I apenk not this as clouliting any

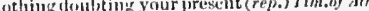

Fince donbting things go ill.......... C'ymbeline, i. 7

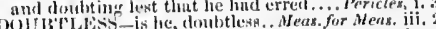

sleep, loubtless, and secure, that.... King John,

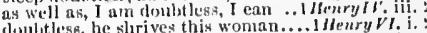

conbtlest, he slirives this wontan...

rombtless, he would have mut

ctoubtless, witf joy lie wili enibric...... C'ynbelise, jii.

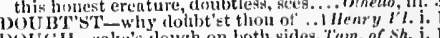

DOUGil-cake's dough on both sides,

ii. 2 DOUGITTY-IINNDED-

for doughty-hanled are you. Antrny \& Cleoputra,iv.

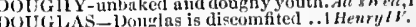

and eldest son to beaten Dougtr

make the Douglas' son your ouly

where you and Douglas, and our

that sprightly Scot of Seots, bouglas

against renowned Douglas

aganst renowned bout Douglas

gruce of York Duustas, Nortime......

Douglas, and the English rebels, inct

attribution sliouid the Douglas liave

you need not fear; there's Douglins

the Douglas and the llutspur both

know then, my name is Dougla

o Donglas, hadst thou fought........

I an the Douglas, fatal to nlf t?

who, Douglas, gricves at heart

insulting hand of Douglas ove

at my tent the Duuglas is

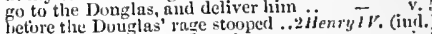

killed by the hind of Dungla

so fonglit the nuble Douglas ...........
Dounflas is livint, and your brother..

that furious Scot, the bloody Douglas

doth ill the noble substance often dont.

[Kut.] but that this folly douts it ......... $-\overrightarrow{\text { iv. }}$

DOVE-his dove will prove............ Merry Wires, i. 3

a raven's heart withim a dove .... Trelfth Sighl,

as gently as any sucking dove

as gently as any sucking dove purstes the griffin............ =

What dead, my dove? O Pyramms . . of - Yenice, ij. 2

not froward, but modest as the dove. Tum. of Sh. ii. I

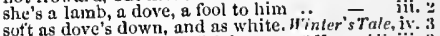

soft as dove's down, and as white. Winter sTale, iv.
as valiant as the wrathtul dove...2 Henryll. iii. 2

ns valiant as the wrathful dote ....2

was Iahomet inspired with a

and doves with noisome stench ....... $-\bar{y}$. 1.5

sucking lamb, or larmiess dove...

secms he a dove? his feathers.........

and doves will peck, in safeguarl.....

those doves' eyes, which ean make.. Coriolnnus, y. 33

the dove will peck the estridge. Antony
with the dove of I'aphos miglit. Pericles, iv. (isuwer)

so shows a snowy dove trooping with.hom. $f \cdot J_{u l}$. $i$.

couple but-love and dove $. \ldots . . . .$.
nimble-pinioned doves draw love...

fare you well, my dove! .....

DoVle-coTE-eagle in a dove-cote...cerinlanus, 1.5

O)V liNRAWN-lier son d

D) 1 E-1IOUSE-under the dove-hunse

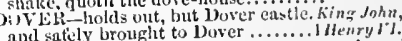

and sately brought to Dover.

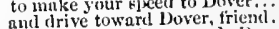

are gone with him towards Dover

let lim ormell his w' to to

a mile or twain, i' the way to bover

know'st thon the way to Dover?

dost thin know bover? Ay, master ...ikt.s. is.

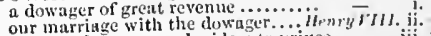

princess downer, and widow to

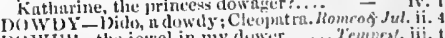

Dow kh-the jewel in my duscr...... Tempest, is.

and she, is fier ow nduwer

to be your danghter's dower ...... - iv.
thy hinghand, and I'll pay thy diswer

assure my dnighter grentes flow er.. Tom,nf $\mathrm{Sh}$. ii. I

pos assurnuec of a fower in natringe - iv.

lass my dunghter a suthicient dower - is:

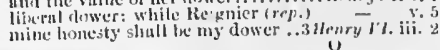


DoWER-our daughters' several dowers .. Lear, i. I DRAB-ditch-delivered by a drab.

... Macbeth, iv. J wo daughters" dowers digest this third..

require in present dower with her...

$\left[K^{\prime \prime} \mu l.\right]$ if this suit lay iu Bianca's dower. Öthelio, iv. DOWERLESS-thy dowerless daughter.

Dow LAs-clowlas, filthy dowl

DOWL Dow $N$-one dowle that sin my plume. Tempest, iii. 3 soft as dove's down, and as white Winler's Tale, iv. 3

HenryIV. iv. light and weightless down pertiorce.2Henryl the eygnet's down is harsh.... Troilus \& Cressida the swan's down feather. . Antony \& Cleopatra, fii. 2 sloth finds the down pillow hard .. Cymbeline, lii. 6 my thrice-driven bed of down $\ldots \ldots . . . .$. . Othello, $\mathrm{i}$. 3 DOWNFALL-divine his downfall?. Richard II. iii. in the downfall of his mellowed.....3 Henryvi. iii. 3 that wish the downfall of our house! - v

DUTWN-FALlEN

Titus dndron. v. 2

bestride our down-fallen birthdom ...Macbeth, iv.

DoWN-GYVED-duwn-gyved to his ...Hamle

shall chide downright, if I longer ...Mid.N.Dr.it. 2

they'll mock us now downrisl

sleep, and downright languislied.. Winter's

bis beaver with a downright blow....3 Heury VI. i.

with downri, ha panent, slowed...

bruther's sou, it rains downrislit.. Romeo \& Jul. ii. 5

my downrim violence and storm . Othello, $i$

down-roping trom their pale-dead.... Henry $V$. iv. 2 industry is-up-stairs and down-stairs.1 Hen. $V I$. ii. for this down-trodden equity
DuWNWARD-the wist dow 政, and downward look on us

ivnaris, to behold there lies a downy feather............... Hacbeth, ii. the swan her downy cygnets save ..1 Henry VI. v. DOW WILE-gold, and dowries, with ..2 Henry $V$, v. and ask no other dowry with her. Tuelfih

for the half ol my dowr

that perished vesscl the dowry.......... feus. for $\bar{M}_{\text {Meas. }}$ iii. I a dowry for a queen ............... Love's L.Lost, ii. 1

a lice take jeer dowry witl this. Tuming of Shrew, i.

what dowry bill' 1 have with ler

for that dowry, l'll assure her of

another dowry to anther daughter..

give with our niece a dowry ......... King J

with her, to dowry, some petty...Henry $r$. $\overline{\text { ui }}$ (eli. 2

with a large and sumptuous dowry...IHenry ${ }_{\text {HI. }}$.

charges, without having dowry.2 Henry $l^{\prime} I$. i. I (art.)

nature this dowry gave, to glad

rove the this plague for thy dowry.

DOWSABEL-Dowsabel did elaim.Comedy

DOXY-doxy over the dale.. Winter's Tale iv. 2 (song)

DOZEN-remain a dozen years ......... Tempest, i. .

the dozen white luees in their coat... Merry Wives, i. 1

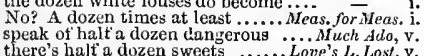

faith, there's a dozen of 'em. All's Well, iv.

esteem him worth a dozen sueh.. Tam, of $\mathrm{Sh}, 1$ (ind.)
if but a dozen French were there ... King John, iii. a dozen of them here here there

sir John, with half a dozen more ...1 Henry $1 V$. ii.

some six or seven dozen of Seot

at halt-sword with a dozeu of them..

we four set upon some dozen

a dozen eaptaius, barehcaded

a dozen captains stay at door for you

half $u$ dozen sufficient men?

1 must a duzen mile to-night....

he knave; and take this drab away.2Henry VI. ii.

say, he keeps a Trujan drab.. T

than he for a commentious drab .......

cursing, like a very drab, a scullion

DRACHA-at a cracked diaclum!

DRACHNA-seventy-tive draclimas.Jul. Cosar, ii.

and drop my bloud for druclima

from -still swine eat all the dratf. Merry Wives, iv.

from eating dratf and husks....... I Henryl $V$. iv.

drag back our expedition

or I will dras thee

Hewry rt. i.

jades that drag the trayic melancholy

drag hence her husisaud ....... Tit

sirs, drag them from the 1
go, drag the villain hither

DRAGGED - sliall be dragged at $\ldots 2$ Henry $/ T$. iv. 3 dragged through the shanneful field. Troil. \& Cres. v.l1 DRAGON-night's swift dragons cnt. aid. N. Dr. iii. scale of dragon, tooth of wolt .........Macbeth, iv. 1 St. George, that swinged the dra spread wider than a dragon's wings ..1 Henry VI. i. dragon wing of night o' erspreads, Troilus \& Cress. v. like to a lonely dragon .......

swift, you dragons of the night! ..... Cymbeline, ii.
for death-like dragons liere affright .....Pericles, for death-like dragons liere affright .....Pericles, i. under the drabon's tail; and my nitivity DRAGONIBII thiat's dragonisl, Antony \& Cleo. iv. I2 DRAIN-I will dratn him dry as hay $\ldots$ Macbeth, i. 3 eouldst thou drain the life-blood...

did drain the purple sap from ......3 Renchard III. iv.

as he drains lif draughts of Rhenish . Hamlet, i.
DRAINED-sword be drained!.. Troilus \& Cress, iv.

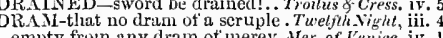

empty frosn any dram of merey.Mer. of $V^{\prime}$ encice, iv. I

ay, every drain of woman's fiesh, is tal

may make some dram of a seruple .2He iv. 3

tram of a seruple..2 Henr'y $I V$. i. 2

a dram of this will drive away

camnot a dram of worth be drawn.

by the queen's dram she swallowed... let me liave a dram of poison....

the dram ot base doth all the noble ..... He $\overline{\text { Hemlet }}$, i. 4

DRANK-thy tather drank wine .......... Ot's $W^{\prime}$ ell, ii. 3

I ne'er drank sack in nuy life. Tuming of shl. 2 (ind.)

I have drank, and seen the spider....
you all have drank of Circe's eup. Comedy of Brt.

neverdrank with him in all my lite. Tilus dnd. iv. 3

one drauglit above heat makes him. Tuelf

for shallow draurtht, and bulk........
which draw

taken my last draught in this world.2HenryVIIII. 3

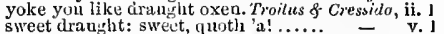

breath of him in a divided draughit. Timon of $A l h$. i. 2

with liquorish draughits, and morsels

on him so sure a druught [ Knt.-give bim such

an unaceustomed drum J... Romeo of Juliel, iii. 5

of supper and distempering draughts.... Othello, i.

and drave great Irars to fiuction. Troilus \& \& Cress. iiti. 3

the fist encounter, drave them . Antony \& Cleo. $i$.

$a$ trgubled mind drave me to walk.. Romeo of Jul. i.
DR $A$ w-draw thy sword: one stroke .. Tempest, ii.

draw together: and when.

please you draw wear...

good slould draw from me. Two Gen. of Verona, iii. 1

he sliall draw; he shall tap

the hour clraws un

thou might'st never draw sword... T.uelfh Night, i.

I would 1 might never draw sword again -

that will draw three souls out of

so soon as ever thou see'st him, draw

therefore diaw, for the supp
but never draw tliy sword

me furtlier, draw thy sword......

they will draw you, master Frotl

draw with idle spider"s strings

the hour draws pretixed by ingelo

draw it. llang it! .........

it is in my seabbard; sliall I draw it?

draw, as we do the minstrels; draw.. 二 v.

our null drial hour alraws on ap

that in a dozen passes hetween yourselt..
liave sent a dozen sequent messengers ..

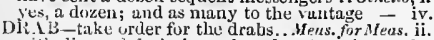
his rery of your house

have heard him swear downright. As you Like it, iii. 4

downight oaths, which 1 never use .Henry $V . \mathrm{y}$.

that is the dowry of his wite ......As you Like it, ifi. 3

your dowry igreet on................. with tigers, dragons, wolves ... Timon of Alhens, iv.

you draw me, you fiaril-heatel $($ rep. $) \quad$ - ii. 2
R.AW-leave you your power to draw.Mid.N.Dr.ii. 2 he is defiled, that draws a sword on thee

Pyramus draws near the wall $\ldots \ldots . . . \%$ of $\overline{v e n i}$ gentle riddance: draw the em'tains

I pray thee, draw the curtain straight

I would not draw them, I would have

elerk, draw a deed of gift ..............

do not draw back your liand

and draw her home with music

pray you, draw homewards..........s you Like $i t$, iv. 3

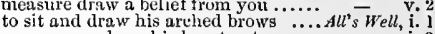

a man may draw his leart out .....

Grumio, draw forth thy weapon.......................

pursue me as you draw your bow. Taming of $S h, v .2$ will draw in more than ..........Winter's Tale, $\mathrm{i}$.

'll draw the eurtain; my lord's .....

draw witlin the compass of suspeet. Com.of $E$ and yet draws dry-toot well

good sir, draw near to me ...........

nor ever didst thou draw thy sword.

as palpable as this which now I draw...Macbeth shall draw him on to his eonfusion...

it draws towards supper...............King $\bar{J} h n$

to draw an answer from thy artieles?

not his mother's shames, draw those

cousin, go draw our puissance together

draw near, and list, what with .......Richard $\overline{\text { vat }}$

draws the sweet infant breath of....... - i.

your tather's draws a curtain ........ i Henry $Y V$ iv. 3

he cannot draw his power this ......

and here draw I a sword, whose .....

hall we go draw our numbers..... .

draw, Bardolph; cut me off......... =

you do draw my spirits from me .....

and $\mathbf{l}$ come to draw you out by

wind, draw the huge bottoms. . Henry $V$. iii.|(chorus)

it now draws toward night: beyond - iii.

and draw their honours reeking up....

blood will I draw on thee.....

that, who so draws a sword......

traw conditions of a friendly peace -

the curtain close .......2 Henry $v I$. iii. 3

I'll draw it as apporent to the crow. 3 Henry $V 1$. ii.

raw near, queen Margaret; and be - iii. :

wilt thou draw thy forees hence .....

to draw the brats of (']arence out.... = iif. 5

to draw him from his holy exereise.

yet to draw forth your noble

iii. 7

draw, arehers, draw your arrows

as draw the eye to flow........... Henry $V \overline{I I} I$. (proi.)

poverty could never draw them from me-....

and draw the eurtain elose .......... -

trial did draw lias and thwart... Troilus \& Cress.

or sword to draw, when Helen

though greater hulks draw

an' you draw hacks draw decp

eome draw this curtain, and let's

from my weakness draws my very

your passion draws eurs hither

so, so, we draw together...............

draw nemer, honest Flaminius.......

worthy friends, will you draw near?
draw trom the earth rotten ............
shall quiekly draw out my command. Coriolanus, i. 6

draw near, ye jraw a swor

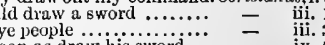

acheve as soon as draw his sword.... = iv.

which busy care draws in the brains

he draws Mark Autony out of the way

I draw ray sword against..............

loves to both, draw atter her ........
I did not think to draw my sword

if we draw lots, he speeds...

my purposes do draw me much..........

let your best love draw to that poini

draw the inward quatity

aecidents uupurposed: draw, and.....

draw thy sword, and give me......... and to draw it out in length ........

draw our throne into a sheep-eote!...

thou draw not on thy danger .......

I'll draw the form and model of our

that I was tain to draw nine honour -

\section{$\frac{2}{7}$ \\ ii. 9 2
1
1
1
3
2
1
3 3
3
3 v. 3 \\ v. 2 1

ii. 7 


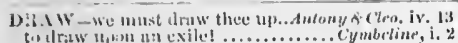

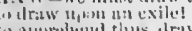

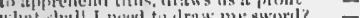

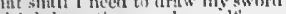
hest low proy, diraw near (rep).

(line

trax

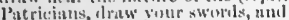

the coupreror's palice dare you draw

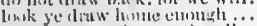

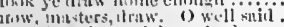

lout, lune,

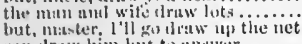

sul clraw him hit to answer

I must draw my sworl a;om youl: draw

the liill, let lim ilraw the ufter

draw mue that which my tuther loses

draw me that

draw me a elothier's yand.

please yon, ilraw near.

elsemy sin view; draw up your power.

leamot draw in cart, yor eat dried outs.

in wh thy sworid; that, if iny

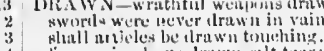

platl micles be il rawn tomehing......3

[Cnt, Knl.] are you ilruwn liorth anong

年

jow long lace tiuce is d rawa?

why drawn alsut this yuestic

when you have il rawn your ming

dritwe thes of hiloud ont of thy .......

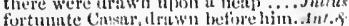

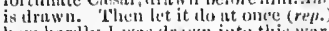

liow hatrilly I wis drawn into this war

will soon be arawn to luein

eamut a iletm of wertl he drawn

lemy hody are as well drawn as his.

be sleath drumb on witl turture.

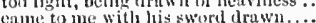

thon with thy weapm irawn.... Tilus andron. iii. i

ny weipun drawn, I rusled upon hion

I have draw'n her pieture with iny vo....

who having drawn, a erew of pirites...
the bow is bent and drawn, make from

some blood drawn on me would be

forse, drawn by the powerful sun ........

thou drawn amomg these heartless. Rom of Jul. i.

drawn with o tom of lite and talk

druw, if you be men ................

$\left[\begin{array}{l}k n t, \\ \text { besin to drat? }\end{array}\right.$

ne"ll draw thee from the mire .....

nimble-finimed doves draw love....

druws it on the drawer, when, indeed

thereture turn, and draw. I

cre 1 cenlle drais to part thein.

it then druws neur the seuson ..........

a unl clrus you into analness? think of

of my fince, ns he would draw

doth draw what's near it, with it

to clraw toward an end with you

to chrar a part the hody he hath kilied

von will draw loth friend and fue

where it draw's blood, no cataghlasm....

whose voiee will draw on mor

the house atfitirs would draw her tine

the next way to draw new misehief on

the while, to draw the Hoor apart

levise a mean to draw the Muor out ....

that's but yoked, may draw with you...

DR IV BIR I DGE-the drawbrilge....R Richarıl $11 I$. iji. 5 swirn brother to a leash of ilrawers.l leney $1 V$. ii. while I question my piny lrawer

male with this jest of the drawer? ... Menryl

call him ulin, drawe Chenter.....

I am a gentleman, thou art a drawer

Ir:aws if m the drawer, when ..Rmer \& Juliel, iii.

DRA IVETI I-tiat traweth .. Lnoe's L. Lost, i. I (let.)

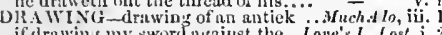

if drawing ay sword ataiust the.. Low's $L$. Lost,

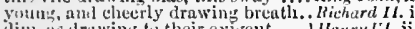

dim, ds drawing to their exigent..... Inenrylt. ii.

dratsing their massy irolns ...... Troilus $f$ Cress. ii.

the tiunc, and drawing days ont ... Julices Corar, iii.

Dil. IV N - it hath draw ne rather .... Tempes

why are you dirnwn?

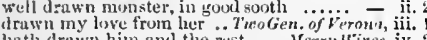

lath drawn him and the rest .....Merry inives, iv.

DR. WW'ST-as thou draw'st, swear. Tirelnh Nirhl, iii. A

i. 5 DIRAYMIN-Achilles? a drayman. Troil. f C Cress.

DRE.AD-yen, his them trideat shike .. Tempest,

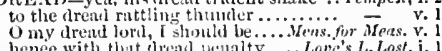
henee with that head penalty ..... Love's L. Lost, i. I

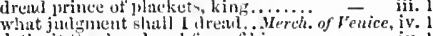
doth sit the dre:d und tear of kings . $-{ }^{-}$iv. 1 this crack $t$, lue in nyy drend mistress - i. 2 he dreach his wife. So, I wonld, you did
to me, the ditlerence, finges dread ..

thon antieiput'st my thear expluits ....Matereth, iv

if guilty dreath hath left thee so muck. Kichard K. ?.

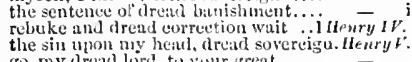

gh, my drend lord, to your great.
therefore, dretul kint, we yield

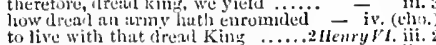

dread lort. the commons send you .. - iij.

and these drebl eures, like the sun.. - iii.

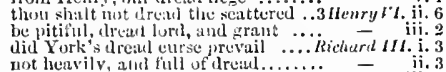

well, my druld luri, so must i eili 2 - iii. I

and consequence of ilrearl, that f.. Ifenry rart.

dread sovereizn, how mueth are we bound

yet, dread triam, there is uo lady. Froil. \& Cress. ii. 2

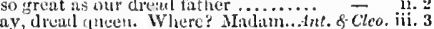

a

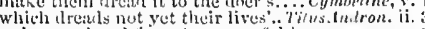

an ansry brow, dlecud lord.

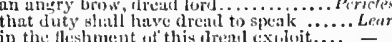

rou the dreat of

my dreall lord, your leave and tavour .. Ihumle

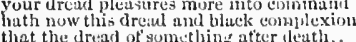

that the dread of somethin: at'ter leath.

Joses dreal clanours counterfeit ..... othello, iii. 3

the deep dreul-bolted thmider?.........Lenr, iv.

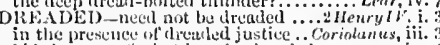

bits lewere of whit is to be drealiat

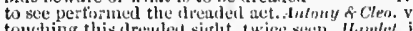

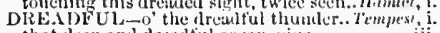

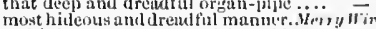

and it in you more dreadful would. Ne:a. for . Ne

I to fear, tim rlreadrul

ladies, is a most dreakltul thi
what drealful ilole is here?

his almighty drcarifu! likele

thy voice his dreadful thumiler

the drealfisl tuuch of nerchant. .iver. of fentere, iii.

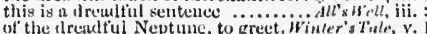

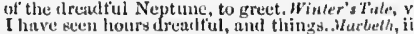

shall be dlise a deed of slreaditul note...

twixt two drealliyl bateles set

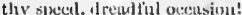

the dremalful motion of at murilurisus = iv.

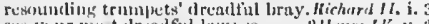

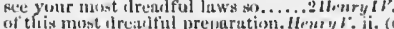

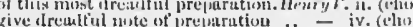

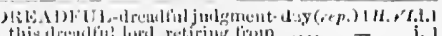

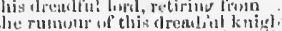

turemer a dietaclitut onth, swisris witls

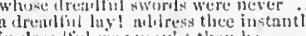

iii. 2

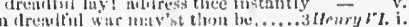

or lizar!'s aldewlins stings.......... - ii.

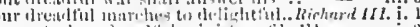

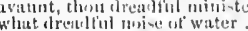

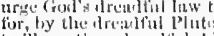

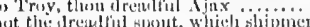

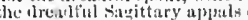

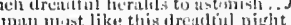

between the actiof of a drrethlingling

.

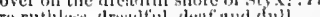

lone a thoustand drealful thind

heir ears tell them my drearltinl ni....

hy deatening, thy dreadful thunders.. Perich s, iii. keep this il readhil pother veer our luewds.Letar, iii. athers samphire; drendful trub! $\ldots .$. - iv. tisen, dreadful trumpet, soumd. . Komera of Julip, iti. or to the drealful summit of the eliff.... - i. anon, the drealful thumder dheth rend.... D. DREADING - ireuding the curse......... King John, iif. dreadin' that her purpose was ....... Cymbeture, v. 5 ny spirits, as in a tircam, are all ..... - i. ried to drean agnin ................ even iu a drean, were we............. then never dreum on intamy ........ - ii. 7 how like a dretm is this $I$ see........... is this a drean? do I aleejp? bhe were better love a drean ..... Twelfh Nighi, ii. 2 and tream on the event ........... - ii. 3 or else this is a dream it be thus to dream, stili liet.......... whant is't I dreum ull? : .............. we will holil it us a dream.............. such $A d o, i, 2$

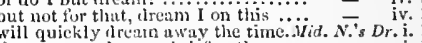
short as any dectul; brief as the .0 for pityl wlist a flream was here shali scem a dream, and fruitless.

as the fieree vextion of at dity

yy the way, let us recount our dreams

it he go about to expound the $(r, p)$. .

to report, whint my dream was $\ldots \ldots .$.
of this dream: it shall be e:lleal $(r e p$.

following darkness like a dream

no more yielding but a dream

can yom still dream, aud pore.....Lone s L.Lost, iv. if that I do not clenm, or be not ... As you Like is, i. that canst nut drean, we, poisiag ......t/'s Well, ii.

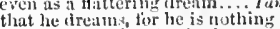

renee these abjeet lowly dreams.

years you have been in at dream...

c lou to tinl into my dreams...

ro nete was ilream so like a wakimg

arear -

more than you cum dream of yet .... -

n:tried to lser it my dretul.. Conedy of Errors, ii.

if this be nut a drealin, I see, and ben

wicletl at reuns nouse the eurtained

these terible dremos that shake us.

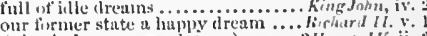

Athen's dream, aw ayl $(r c p$,$) .....2Henry 7$. .

intereption which they drem not of.. Henryb. ii. ?

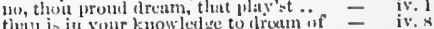

waking, nid in iny drunps

mintronlous dream this night ....

felearsal of my mornimges stream.

but her drean? uext time ( $r^{2} p$.

I ilid drean to night, the duke

to drean uysu the crown,............. Richard HII. i. 1 hearkens ufter prophecies, und il reams 
DHEAM-so full of fearful dreams.. Richard III. i. 4 What was your dream, iny lord? impression made my dream. and for his dreams-I wonder, he's so Stanley dill dream, the boar did
with his timorous dreams was stil with his timorous dreams

a dream of what thou wast .............. dream on thy eonsins smothered in. dream of success and happy victory..
drearn on, dream on, of bloody deeds soft; I did but dream

I have dreamed a fearfiil dream and fitirest boding dreams that ever. the remembrance of so fair a dream. and then let's dreain who's best ... such good dreams possess your fancy my dreams will, sure, prove ominou live but in a dream of triendship. Timon of th. fantasy, of dreams, and eeremonies.
this fream is all amiss interpreted by Ca! phurnia's dream is signified ditlst thou drean, Lucius, that thon

he dreans; I know, they are in... nno so fairly shows, dream of impediment?
that he shonld dream, knowing all.. or women, tell their dreams let her lie still and dream ............ cymbeline brcak it with a fearful dream of him
I hope, I dream; for so, I thought ...

drean often so, and never fillse many dream not to find.

'tis still a dream; or else

thid you ever dream of such a thing

awake, and tell tlyy dream

yes, that on every dream, each buz

I i reamt a dream to-niaht

while they do dream things true

then they dream of love (rep.)

dreain on fees;

then dreanis lie of another benefice

then dreams he of cutting foreign

true, I talk of dreams.

all this is but a drean, too flattering

strange dream! that gives a dead man

or did I dream it so? or am I mad.

colleagued with this dream of his ....

bad dreams. Which dreans, indeed

a dream. A dream itself is but a shad

in a dream of passion, could foree his...

what dreams may eorre when we ha

this accident is not unlike my dream...

consequence do but approve my dream ...

way, this was but his dream .....

DREANIED-I have dreamed to-night.Merry $W$. iii.

news that yon yet clreamed not ol .... Mhuch $\mathrm{A} d \mathrm{ln}, \mathrm{i}$.
she hath often ilreamed of unhappiness

or have I dreaned till now.... T'aming of Sh. 2 (ind.)

that I have dreamed tnd slept above - 2 (ind.)

I but dreamed it: as you were .......

I hy lord, Althea dreamed she ......2

what dreamed my lord? tell me
(or long dreamed a fearful dream
(or have dreamed so) .........

2 Henry VI. $\mathrm{i}$.

Henry VII

one that ne'er dreamed a joy beyond - iii. 1

such a man as this I dreaned of?

now sir, what have you dreaned

dreamed, who thought of such .. Pericles, iti. (C)
spoke so well; ne'er dreamed thou eouldst -

DiEA AlER-thou idle dreamer .... King John
of the dreamer Herlin, and his ..... IHenryI of the dreamer Alerlin, and his......IHenryIV. iil. 1

DPE AMIN 6 - and then in drearining... Tempest, into the dreaming briclesroom's. Mer. of Venise iij. no longer dreaming of renown ...3 Henry VI. ii. their dreamilsg on this fond exploit. Richard III. v. dreaming night will hide our joys.. Troil, \&C this fool the dreaming, superstitious girl -
it's past the size of dreaming. Antony \& Cleopat
DIIEAMI'ST-thon dream'st not of .. 1 Henry look, how thou dream'st! .........Richard III. iv. DIREANTT-I dreamt last vight of the.. Macbelh, dreamt on anght but buteheries

dreamt to night the boar had .... - reant of a silver bason and ewer. Timon of $\mathrm{Ath}$. $\mathrm{jii}$. sie dreant to-night she saw my. Coriolanus, iv. I dreamt to-night that I did feast..... I dreumt a dream to-night ........ Romeo of Juliet, $\mathrm{i}$. 4 1 dreanit my master and another

than are dreant of in your philosophy... Hamlet, DREARY - out of these dreary .... Tirus Andron. i. DREG -thic dregs of the storm be past.. Tempest, ii. sume certain dregs of conseience .. Itichard H1. i.
what too carious dreg espies .. Troilus \& Cress. iij. the lees and dregs of a fiat
DREG $\rightarrow$ friendship's full of dregs. Timan of Athens, i. 2 DRENCli-my roan horse a dreneli... I Henry $1{ }^{\prime}$. ii.

so do our vulgar drench thei

boy did drench his over-mounting..I Henry $V I$. to dreneh the Capitol .......Antony \& Cleoprut ind drenehed me in the sea.. Two Gen. of Verom and drenehed me in the sea..T $w$
slcep their drenclied natures lie.

spout till you have drenelsed our steeples. l.por DRESS-dress meat and drink

Wet's go dress him like the.....

we ll dress like urchins

help to dress me, sood coz...

and heln to dress your sister's. Tomini of sireu.

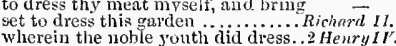

prove that ever I dress inyse

todress the ufy form of $\ldots \ldots \ldots \ldots$.

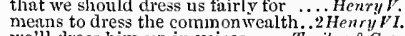

we'll dress him up in voices .... Troilas s Cress.
see you in your soldier's dress..... Aniony 8 Cleo.

see you in your soldier's dress.... Antony
for the gods, if the devil dress her not

DRESSED Lo dress our hunt . ..... Cymbeline, iij, because we'll be dressed together $\ldots \ldots$ of
to be dressed in an opiuion of....Merch. of Venice see him dressed in all suits ... Taming of Sh. 1 (ind.) lope drunk wherein you dressed $\ldots .$. Macbeth, i. 7
so trimmed and dressetl his land ..Richard II, iii. 4 hor'se, that I so carefully hive dre

neat, and trimly dressed, fresh as .... Henry $I V$. j. dressed! and in your clothes!... Romeo \& Juliet, iv. the abilities that Rhodes is dres.
lct's go see poor Cassio dressed..

DRESSER--from the dresser... Taming of Shrew, iv.

DREST-drest him with our love. Meas. for Meas. drest in a little hriet authority

DPE drest to some oration

drew on my side ...................

Troilus \& $\bar{C}_{\text {ress. }} \mathrm{i}$.

you drew yo:u sword upon me

lis danger drew, and died .....

then he drew a dial from his loke. $A s$ you

so drew the rest of the herd to me. Winter's Tule,

that drew him oft from home

I drew my sword on you

before I drew this gallant head...
drew Priam's eurtain in the

he drew a good bow; and cead

that drew blood from thee

wonder why I drew you hither
from my duirs he drew not this....

the articles 0 , the eombination di...

that drew the swords with you. Antomy $C^{2}$.

which he with ferveney clrew up

eountry's service drew your swords.. Titus Ant

drew sleep nut of mine eyes

drew from niy lieurt all love....

mare mak than wit about me, dre

I drew to part them ............. Ro
by and by, my master drew on him

born, drew all such humwurs from him. othello

the dribbling dart Mea, for Mea

DREDD_erest-fillen as a dried jear. Nerry $W$
latid my brain in the sum, and dricl it

and dried notone of them with his. Mea. for

a handful, or two, of dried peus ...Mid. $N$.'s $D$.

in a ncat's tongue dried ....Merchant of Veni

great seus have dried, when miracles.. All's $W e$

'twas hurnt, and dried a way.. Taming of Shret",
are dried by nature's course ........ Richerrd 5 .

you dried neat's tonurue.

i HenryI $\mathrm{l}$

my mercy dried their water-flowing.3 Henry

which, being dried with grief
d raw a cart, nor eat dried oats.

his roe, like a dried herring

irralh, feteh drier logs .......... Romen \& Juliet

DRIES-tries me there all the foolish.2 Henry I ${ }^{2}$.

my eurrent runs, or else iries up ....... Othello,
DIIFT-the sole drift of my purpose .. Tempest,

wit to plot this drift!
in his intended drift

my eunning drift excei

o, understand my dritt! ...................

keep you ever to our speeial drift.Mea.for Mea.iv.

and rlrift of your eompact..... Comedy of E, rors, ii. 2

vet the king not privy to iny drift..... Kineriry VI. i.

lut at the author's drift

Timon of Athers, i.

we know your drift: speak what ... Coriolanus, iii.

good son, and homely in thy drift. $R$ or

nempy my letters know our drift .. Humlet, ii.

inarry, sir, here's my drif

and can you by no drift ot conferenee.

that nur drift look through our bad

DRINK-sea-water slialt thou drink
but that the poor mouster's in drink
RINK-will arink water, not a drop. Tempest, iii. 2 gervant-monster, drink to me

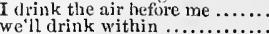

I hope we shall drink ilown ail.................

that's meat and drink to me now.....
he was gotten in drink...............

he was gotten in drink

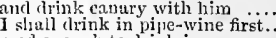

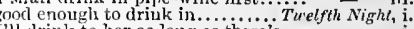

I'll drink to her as long as there's .. - i.

and wrink in will not drink to my nice........ - i.

to the buttery-bar, and let it drink... -

for five the elry tho drink of drink... -

let. us therefore eat and drink........
as ti) drink when a inan's a-hungry..

forgt to drink after thee.. Measure for Measure,

shall have all the world drink brown

1 drmik, I eat, array myself, and live

iv.

make the drink to bear no ljarm.....Mill. N.'s Dr. ii.

fonls would fain have drink ....Lrm's L. Lost, ii.

eat with you, drink with you,...Aferch, of $F_{\text {crice, }} \mathrm{i}$.

that I may drink thy tidines........ - iii.

that clrink, bein' poured out of a eup - v.

lordship drink a eup of sack? Taning of Sh. 2 (imi.)

but eat and trink as friends ....... -

dine with my fither, drink a health

not clioose but drink hefore eomes.

re will give you sleepy drinks.... Winter's Tale,

and one may drink; depart, and yet . Macbeth,

therefore, mieh drink mrovoker

I believe, drink gave thee the lie.......

I drink to the general joy....

these eyes, would drink iny te:

and three times did they drink.

King Johln, iv

sooner than drink, and drink sormer.

ani twere not as good a deed as drink

that I can drink with any ............

I do not speak to thee in drink
but to taste sack and drink it?

constrained, as men drink yotions ...2Henry $I V$. ii. 4 drinks off eandles' ends for ilapdragous -

-

- iv. 2

but that's no marvel, he drinks no wine -

for thin drink doth so over-cool their

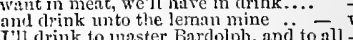

'll drink to master Bardolnh. andi to all -

this would drink derp. 'Twould drink. Henry $l^{\prime}$. $\mathrm{i}$.

I drink to you in enk of ........2 Henry $Y I$. ii.

drink, and fear not your man......... - ii.

I thank you all, arink, and pray for me -

poison be their drink ............. -

the silver spring where Englind drinks -

iii. 2

all shall eat and drink on my seore.. - iv.

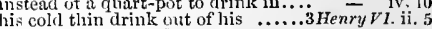

I drink the water of my eyes ........... $-\overline{\text { Richard } I}$ II. iii. 2

we give up our guiltless biood to drink - - iii. 3

to drink to these fair ladies.............

shatl have desire to drink............ - iii.

throngh lim drink the free air.. Timon of Athens, $\mathrm{i}$.

I should fear to drink at meals .......

sreat men should drink with harness

to drink those men, ypon whose age

he ne'er chinks, but Timon's silver
are foul, and his driuk dangerous...

drink wine, lie soft ..................

if the drink you give me, touch ..... Co

and by ; bot we will drink together -

me some drink Titinius......Julius Casar, $\mathrm{i}$.

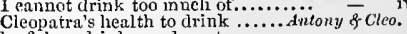

he fishes, drinks, and wastes $\ldots \ldots . .$.

ha, ha! give me to drink r andragora

they have made him drink

condemn it now: desist, and drink

drink thou; increase the reels

than drink so much inl oue ............

and drink carouses to the next day's$$
\begin{aligned}
& 2 \\
& 2 \\
& 3 \\
& 5 \\
& 1 \\
& 1 \\
& 2 \\
& 3 \\
& 5 \\
& 2 \\
& 1 \\
& 3 \\
& 5 \\
& 2 \\
& 2 \\
& 1 \\
& 1 \\
& 1 \\
& 1
\end{aligned}
$$

3

4
4
4

\section{3
4 \\ i. 3
i. 3
in}

i. 3

1 1

4
2
2

3
2
2 10
5
4 


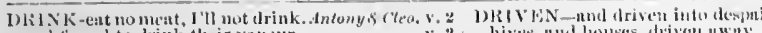

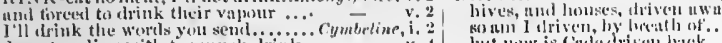

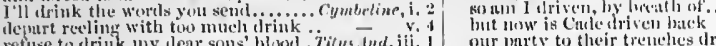

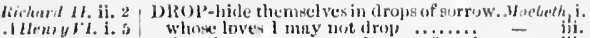

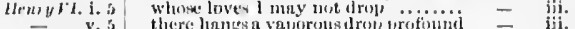

either leil or driven, um we point

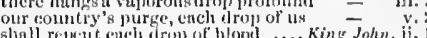

refuse to drink ny tear sons $\mathrm{h}$

We hail driven then heme...dnto

glial repent encit drins of blood bi... King

a silver (lrop hatli talleu (rep.).
lest resolution drop out at mine

she drinks no wther lrink but tetire.

linve no more gentlemen driyen

elfusiou of such manty "l rops 8 ......

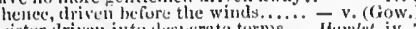

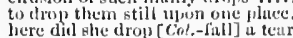

we ritik this stumling-bowl of

a sister driven intendesperate terms..... Thomert, iv. 7

drinks the green mantle of ....

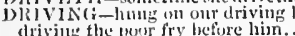

me dear blood drop hy drop.

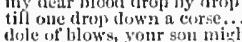

driving back shudows oser...... Konco \& Julict, ii. \&

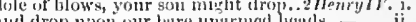

they are droys of thy lovers
that it will quickly drope

the uir duth drizzle dew ......... Romea o Julie', iii.

() churl! drink nll nuth leave no triendly $=$

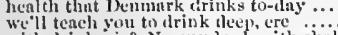

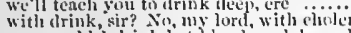

now eould I trink hot blowl, and

garments, lienvy witls their drink ....... - iv. ?

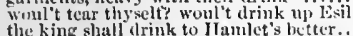

the king shall drink to IIanlet
now the kiog drinks to Ilumlet.

rtay, give me drink: Ilumlet $\ldots \ldots \ldots \ldots$

Gertrude, do not drink. I will, my lord
I dare not (lrink yet, madam; by and by

I dare not (lrink yet, madam; by and by
the trink, the drink, -0, my deur ( $r e p$.)

the urink, the drink,

think off this potion she drinks is ma................

why theu, let a soltier drink....... $\overline{\text { ii. }} \overline{3}$ (song)

ho are nothing to youm enghtish

Why, he drinks you, with fatility........
u dhuble set, it drink rock not lis crudie

"I levgar, in his drink, could not have lail - iv. RINTLNG-saek, und drinking do .. Tempest, tii. 2

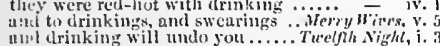

with drinking henlths to my nicee ...

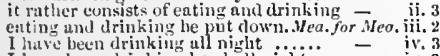

I h:ve been driuking hard ull night... $-\frac{1}{3}$ iv. 3

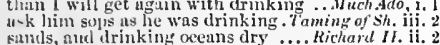

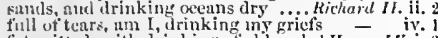

fit-wittel, with drinking of old saek.l Henry IJ i. 2

they call, drinking deep, dying

glasses, glasses, is the only drinking 2 menry
with excellent endeavour of drinking 1

cone, leave your drinking, and fall...2 Itenry Fr. ii. 3

and made the night light witl drinking

and made the night light with drinking - ii. 2

ay, or drinking, feneing, swearining.... Hrm/el, ii. 1

poor and unhappy lrains for drinking.

DRIFK'S' $F$ - what drink'st thou oft

Ocarth, which this blood drink'st.. Richard WI. by stren - could drive the boat. $T$

I could irive drives out anoth

drives une to these habits ........Merry Wives, ii.

and drive the gentleman (as i know

to drive liking to the name of love

here s that shall drive some of them - iii.

himbleness may drive unto a fine ..

this drives no, to entreat you

is it 1 that drive thee from ............
what error drives our eyes and ears. Cam. of Frr.ii. 2
and eandle slull not drive me baek. King $J_{\text {ohn }}$, iii. 3

and ubert! drive these men away ..... - iv

to drive away the lienvy thought .... Richard II. iij.

exploit drixs him beyond

and drive all thy subjects afore the

rogucs in buckrin let drive at me.

("tument my back, and let lrive at me

should drive the irinee of Wales

my lord, he will drive you out

and irive the English forth.........

glay thee, laut $I^{\prime \prime l}$ drive thee ianck....

like 1 Iannibal, llives back

and clesmir, drive you to brenk....... - $\begin{aligned} & \text { i. } 5 \\ & \text { y. }\end{aligned}$

so som we shall drive baek..... Timan of Athens, v.

one fir drives out one firc...........

and drive away the vulgar ......Jalius Castr, i. I

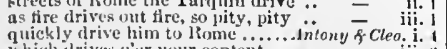

H hich il rives o'er your eontent

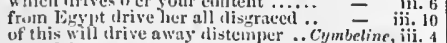

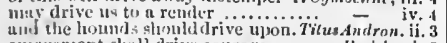

mazenent shull drive conrage $\ldots \ldots$...... P'erielcs, i. 22

81) ul and rlown the poor ship drives - iii. (Gower)

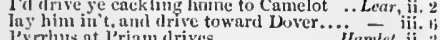

l'y rrhus at l'riam drives ................ Iramlet, ji.

un if you would srive me intas a tuil? .... - iji.

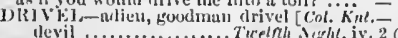

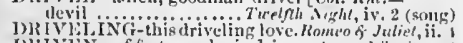

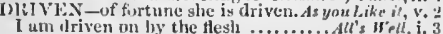

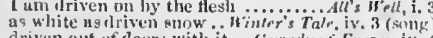

JROICT-nussi droict que les nulifis .. Henry 1 . iii.

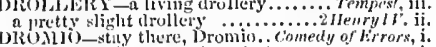

come, Dromio, come, these jests are.
the gold l gave to Dromio is laid up

I could not steak with Drouliu, since

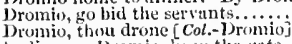

to dinner; Dromio keep the gate.

Dromis, play the porth

lren Dromio to-day in my jiace

Dromio, who are those at the gate
why, how now, Dromio? where.

ant i Dromilo? und 1 your man? ( rep.)

called me Dronio; swore, 1 was

where is thy master', Dromion?

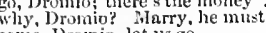

eome, Dromio, let us gom.

bind Dromio too, and bear them .

is not that your boudman, Dronivo?

now am $I$, Dromio, and his man

I, sir, nim Dronio, commant $\left(\mathrm{rej}_{\mathrm{j}}\right)$

and the twin Dromio, all were take took Dromio, and my

and these two Dromios, one in
liy Dromio, but I think he ...........

ay Dromio, but I think he
and Dromio my man dit bring

Dromio, what stutti of mine

Dromio, thou drone, thou snuil ... Merch. of l'

yea, or the drone of a Lineolnshire.

the lazy yawing drone

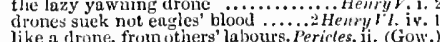

we would purge the land of these drone
DROOP-fortunes will ever after droop.

that inalses your will ever after droop.. Tempest, i.

berin to droop and drowze

but wherefore do you droop?
sick now! droop now! this sici.

that droops his sapless brunches

Nacbeth, iii.

droops my lord, like over-
thus droojs this lofty pine

droop not, adieu; farewell

DROOPETll-thy glory droopeth..... Hentery It.

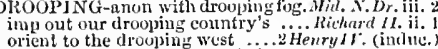

thy father to lis drooping chair....1 Hesery $V t$. iv.

may cheer vur drooping spirita

checed up the drooping army $\ldots \ldots . .3$ thenry $v l . i .1$
words revive my drooping thoughts

who had not now been drooping here

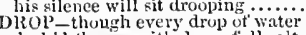

Himtine, $\because$

deck'd the be'a witly drops finl salt

be drops of balin, to sanetify

whosepriltles drops ure
Whot's vassals drop und die

frosty people sweat thops of gillan.....

he'll drop his heart iutu the silk $\ldots . .$.
trom it issued forced drops of blockl..

every trop of blood was druiv?

the arop of blood, draw n from thy

than drops of bluod were in my......3n

uld every drop cries vengeunee for . Kichard III. i. 2

droji [Col. Knl.-full] tears.

the lichuid drops of tears that you ....

the nure nust pity drop upon her...ienry $\bar{v}$ lll. ij.

ny drops of tear's r'll turm ............

I would not wish a drop of 'Tojan .. - ii. "

that any drop thon borrow'st from

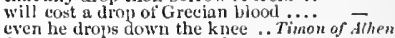

fire thousand drops pays that ......... coriolanus.

wine with not a drop of allaying Tiber

have I heurd groan, and drol........
dangers, and the drops of blood sici

the arops that we have blet tugethe
at a few drojs of women's rheum...

for eertain drops of salt

when every drop of by lott

as are the ruddy drops that visit iny

these are graeious drops

will turn to redder drous

in our own filth drop our clear..........

race grow where those drops falj

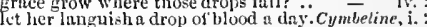

like the erimsou drops $i$ the bot tom

as small a droy of pity as ......

uurelenting flint to drops of rain. Titus dudron. ii. 3

whose leaves are drojs of new-bled..

these sorrowful drops upon thy

shed yet come small drops from thy $\quad$ - $\quad$ v. 3

your tributary dropss belong to.. Kameo of Juliet, iit. 2

that drop of' blood, thut's caln ....... Ilom/et, iv,

she let it drop by negligence ........... Othello, iii 3

each drop she fulls would prove a erocolile - iv.
some part of my sonl a drop of patience

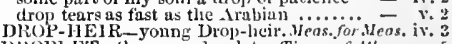

DIROPPED_they dropped, as by ...... of . Thpest, y.

hast thou not dropped from heaven?

under a tree, like a dropped acorn...As you Lilie, iii. 2

as if un anget dropred down from... Henryit iv.

my heart dropped love, my power. Henry $/ 11$.iil.

tongue of roaring Typhon dropped. Trnil. C Cress. i.

instigations have been often dropjed. Jul. Cersar, ii. I

as plates dropyed trom his pockit ...Ani.\&-Cleo. $v$.

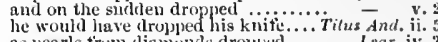

ns pearls trom dianonds drophed ........ Lear, iv. 3

by the letters that thou wilt drop..... - ii. 3

that the wide sea hath drous too tew $\bar{N}$ iv. 1

morning drops upon the rose. Lore's $L$. $L$ iv. 3 (vers.)

no rlroj but as a coach doth

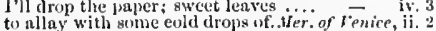

these fonlish drops do somewhat

weakest kind of truit drops enritivit

it thou dost sthed une drop ot christian
fuir laulics, you drop manna in the ..

wijed our eyes or'tirops that

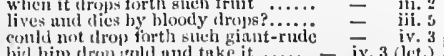

bil him drop pold and take it....... - iv. 3 (let.)

alie irops lurstics in my montl

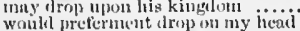

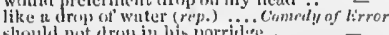

should nut drop in his polritloge.....

a lair, a drop ol blowl, a lin

ROPIING-drouping unon thy lead.. Tempes, ii,

dropping the hides and hips ...........Henry $l$.iv.

through a tempest dropuing fire.

one auspricions and one dropping eye ... Hamlet, i. 2

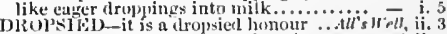

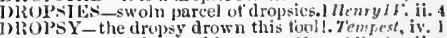

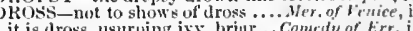

it is dross, usurping ivy, briur ... Comedy of krr. it. 2
merit of vije gold, dross, dust ...... King John, iil. 1

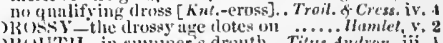

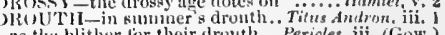

its the blither lor their druth ... Pericles, iii. (Gow.)

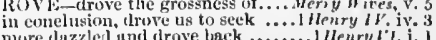

more dazzled ind drove back.......... Illenry l\%. i. I

Chitlord, drove me thenee..............3enry Yi. ii.

Irove lim int this meluneholy... Timan of Ath. iv.

one inortul wight, drove lim to this.... Irricles, $v$. 


\section{DRO}

DROVER-like an honest drove

DRoWV the ser eannot drown me

men hang and drown their proper seives - iii. 3

the dropsy drown this fiooll.

and a third drowns him ...............eifth $\overline{\text { ivght, }}$ i.

coughing drowns tie parson's. Lore's L. L. v. 2 (song)

somewhat drown my manly spirit.. Mer.of Fen. ii. is

and pleasure drown the brim ......
or to drown my elothes, and say

we drown our gain in tears!.

burns worse than tears drown ..... Winter's Tale, ii.
to drown me in thy sister's.. Comedy of Errors, iii.

that tears shall drown the wind.

and drown the weeds; make we

the silver rivers drown their shores. Richard II. iij.

ranlting sca refused to drown me..2 Henry $r^{\prime} l$. iii. 2

my sighs or tears E blast or drown...... $\frac{-1}{\text { ive }}$ iv 4

What pain it was to drown you in the Malmsey-butt

thy plaints, and drown thy eries?

plenteous tears to drown the world

thus will I drown your exclamations

thou drown the sad remembrance.

and drown themselves in rioti

drown them in a drauglat ..............

eome, and drown eonsileration.. A niony o Cleo.

drown the lamenting fool in sea-salt

floods of tears will drown my oratory

and would drown the stage with tears

that this folly drowns [Knt.-douts] it.
if $₹$ drown myself wittingly, it argues

and drown him, he drowns not himself

I will ineontinently drown myselt.....

drown thyself? drown eats, and blind

DROWNED-less afraid to be drowned.

does remember my drowne

but he's drowned and thes

hut art thou not drowned stephavo?

all our eompany else being drowned

all our eompany else being drowned

my man-monster hath drowned lis
he is drowned, whom thus we stray.

whom they suppose is drowned

the mean is drowned with ... Two
in the sen, where I am drowned...

have drowned a bitch's blind puppies

perchance he is not drowned

like a drowned man, a fuol.

was my sister drowned

she is drowned, already, sir.......

is't not drowned i' the last rain?. $\dddot{M}$ era. for $\bar{M}$ tea iii. stands empty in the drowned ricld.Mit.Ns.Dr. il. 2 he is drowned in the brook........As you Like il, iii. being taken with the cramp, was drowned $-\overline{\text { iv. }} 1$
being light, be drowned if sne sink 1 Com. of $\mathrm{Er}$. iii. 2 pluek up drowned honour by... they will look like drowned mice.... I Henry $V^{\prime}$. iv. 7 my heart is drowned with grief..

wouldst have me drowner on shor

I drowned these news in tears...

while heart is drowned in cares? .....

there iny hopes lie drowned.. Troilus $\$$ - Cr

for his wits are drowned and lost. Timon of Ath. iv.

ho vats our eares be drowned.Ant. 6 Clro. il. 7 (song)

a deluge, overflowed and drowned

who drowned their enmity in my...

my drowned queen's name

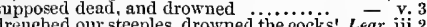

often drowned, eould never die the cocks!. Lear, iii

sister's drowned, Laertes. Drowned
she is drowned? Drowned, drowned

unless she drowned herself in her o

than to be drowned and go without her... Othello

our wars are done, the riurks are drowned

DROW NING $\rightarrow$ mo drowning mark
'would thou might'st lie drowning

'would thou might'st lie drowning

I have not 'zequed drowning

then, to 'scape drowning tlirice... Mer of of Ver. iv.

a more delieate way than drowning.... othello, $\mathrm{i}$.

a pox of drowning thyself! it is elean out - i. 3

no more of drowning, do you hear ...... $\overline{\text { i. }} 3$

DROWSE- -gin to droop and drowse. Macbeth, iil. 2
DROWSED - but rather drowsed....1 HenryIV' iji. 2
DROW SILY -thou speak'st drowsily?Jul.Crsar, iv. 3

DROWSINESS - a strange drowsiness.. Tempest, ii. 1
DROWSY - drowsy and neglected. Meas. for Meas. $\mathrm{j}$.

DROWSY -drowsy and neglected. Meas. for Meas. $\mathrm{i}$.
sleep when I am drowsy, and tend .. Much Ado, $\mathrm{i}$.

dapples the drowsy east with tend

by the dead and drowsy fire ..Mid.N.'s Drram

makes heaven drowsy with ...... Love's l.. Lowt, iv. 3

unto the drowsy race of night............ Kurbeth, iij. 2

vexing the dull ear of a drowsy man mong iii. 3

third hour of drowsy morning ...Henry $V$. iv. (eho.
break up their drowsy grave $\ldots \ldots \ldots . . .1$ iv.
the sudden from their drowsy beds..i Henry $V I$, ii.
DROWSY_with their drowsy, slow..2 Henry VI. iv. 1 ever entered in a drowsy head ..... Richard III. y.
amazement to their drowsy spirits. Troil. \& Cres. it.
have roused his drowsy blood .........

run a eold and drowsy humotr.......... \& $\overline{\text { Jutiet }}$ iveo nor all the drowsy syrups of the world. Othello, iii. 3 if I be his enek old, he's my druige

you whoreson malthorse drudgel ?

this drunge, or diviner, laid clam.. Com. of Err. iii. these paltry, servile, abjeet drud
eredit this base drudge's words

this carl, a very drudire of nature'.... Cymbeline, v. 2 I am the drudge, and toil in your.Romeo \& Jul.

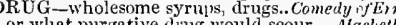

passive drugs of it freely command. Timon of Ath. iv. 3

passive drugs of it freely command. Timon of Ath. iv.

have you brought those drugs? ...... Cymbeline,
with a drug of such damned nature.. -

he hath a drug of mine $\ldots . . . \ldots . . .$.

the drug he gave me, whieh, he said

such mortal drugs I have ...... Romeo
true apothecary, thy drugs are quiek

hands ant drus, thit and time quek -

abused her delicate youth with drugs ... Othello,

What drugs, what charms, what conjuration - i.
DRUG-DAMNED-

that drug-damned Italy hath.

DRUGGED_drugged their possets .... Mnrbeth, ii.

be still, drum! for your manager........ Love's L. Lost, $\mathrm{i}$.

and when you hear the drum ...Her. of Veric

a lover of thy drum, hater of love

to let him fetch of his drum (rep.).

to undertake the recovery of this drum -

he has led the drum bef

a plague of all drums!

he's a good drum, my lord

a drum, a drum; Macbetli doth eome... stae

interruption of their ehurlish drums. $K$ i

trumpets, and loud ehurlish drums.

eome tripping after drum

of thy drum, and even at hand a drum

the noise of threatening drum.

Richnid IS. i.

of guns, and drums, and wounds ..... Henry $1 V^{\prime}$.i.

eould wish, this tavern were my dr.

2Ifenry $I$ V. iv. 2

a rout of rebels with your drum

Henry 1 i. i.

did sound, or drum struck up..

the Dauphin's drum, a warning beil

let your drums be still .......
sound, drums and trumpets

sound drums and trumpets

I hear their drums; let's set our men

3 Henry ri

at hand, I hear lis drum. It is not his

the drum your honour hears

strike up the drum; ery, courage

sound, drums, and trumpets!........

strike alarum, drum

strike up the drum. I pr'y thee, hear
sound, drums, and trumpets, boldly

hark, I liear their dran

peace, druma. Achilles!

Troit.f.Cress, v. 10

follow thy drum; with man's hlood ...

beat thy drum, and get thee gone....

the enemies' drum is lieard, and fearful

each other's leech: let our drums strike

the swords, and hear liusliand's

our drums are bringing forth our youth

when drums and trumpets shail

ran from the noise of our own drums

quired with my drum

you shall have the drum struck up

beat thou the drum, that it speak.

honours, lords, with trump and drum.Tilus And.i.

where's thy drum? Franee sureads

methinks, I hear the beaten drum

let the drum strike, and prove my tit

on, lusty gentlemen. Strike, drum
why does the drum eome hither?

wpirit-stirring drum, the ear-piercing... Olhele, i ii. 3
DRUMBLE-how you drumble!... Merry Wives, iii. 3

DRUMMER-drummer, strike up ...3 Henry $\boldsymbol{V}^{\prime} \mathrm{I}$. jv.

DRUNK NG-I'll no more arumming. All's h'e $^{\prime}$

if he have never drunk wine afore

that liath drunk so much sack ........ - iii. 2

and made me drunk...................

what L did when you made me drun

the gentleman had drunk himse

drunk nightly in your eompany..Twelfh $\bar{N}$ ight,

dy mine honour, half drunk

$O$ he's drunk, sir Toby

he would be drunk too ...ileasure
drink many times a day (rep.)....
DRUNK-he was drunk tben..... Meas. for Meas. y. 1 bid those that are drunk get them.. Siuch Ado, iii. 3 make misfortune drunk with ........

he hath not drunk ink ........... Love's L. Lost, iv. when he is drunk, when he is.....Mer, of Venice. i. 2 wilt not be drunk; but $\mathrm{L}$ (rep.) ... Winter's Tale, y. $\mathbf{2}$ was the hope drunk wherein you.....

intelligence bees drumk?

teeming date drunk up with time?... King John, iv. 2 what, drunk with eholer? ........... Heary $1 V$. i. 3 be else; I have drunk medieines

but the sack that thou hast drunk $m$ me

the raseal's drunk; you have liurt him

by the mass, I have drunk too murt him -

against a post when he was drunk .. Hen $\overline{r y} V$.

the thirsty earth liath drunk ......3 3 Henry Vi. ii. 3 unlawfully made drunk with ....Richard III. iv. 4 to-night, shall be, -drunk to-bed.Antony \&-Cleo. i. 2 I druink him to his bed

the third part then is drunk

my father, sir, has drunk to you........ pericles, have not jet drunk a hundred........... \& \& Jutiet, ii. 2 when he is drunk, asleep, or in jis..... Hamlet, iii. 3 with that which he hatl drumk to-night with ficility, your Dane dead drunk.... - ii. do not think, gentlemen, I am drunk... - ii. 3 you must not think then that I am drunk eome, eome, you're drunk. Drunk!.......
drunk? and speak parrot? and squabile? I drunk? You, or any man living (rep.) DRUNK A ion-our lives by drunkards... Tempest, i. to make a wonder of a pour drunkard.
to take this poor drunkard for a god.

this Flemish drun and I will, like a true drunkard..... Mueh Ado, iii. 3
one drunkard loves another .... Love's L. Lost, iv. 3 eensure, worse than drunkards... As you Like it, iv. to the drunkard's chanber...Taming of $\$$ Sh. I (ind.) to hear him call the drumkard, husband - 1 (ind.) rivo, says the drumkard but like a drunkard must I voritit.. Titus And. iii. drunkaris, liars, and alulterers ...........

darkness like a drunkard reets.. Romeo of Juliel, ii.

now 'mongst this fluck of' drunkards
he shall tell me I am a drunkard!

DRUNKEN-a drumken monster.

and not with drunken knaves $\ldots .$. Merry Wives, $i$. I hate a drunken rogue ............. $-\bar{v} .1$ (let.) still liad drunken head ............. $-v .1$ (song) but as a drunken sleep ... Measure for Measure, iv. practise on this druuken man. Taming of sh. 1 (ind.) let the anth slare, 1 sent thee. Comeny of Err. iv. by drunken prophecies, libels

lives like a drunken sailor on a mäst

wept with drunken spilth of wine. Timon or Ath. ii. sliall be brought drunken forth... Antony \& Cloo. v. 2 what a drunken knave was the sea.... Pericles, it. I Do slight, so drunken, so indiscreet .... Othello, ii. must amend your drunkenness.. Twelfth Night, ii. 5

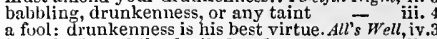
a fuol: drunkenness is his best virtue. All's Well, iv. it hath pleased the devil, drunkenness.. Othello, ii. DR $X-1$ would fain die a dry denth .... Tempesi, $\dot{i}$. their joints with dry eonvulsions ...... - iv. write till your ink be dry............. or his dry nurse $\ldots \ldots \ldots \ldots \ldots \ldots \ldots$ Merry W'ives,

but $\mathbf{I}$ can keep my händ dry -

go to, you're a dry fonl .......................
give the dry fool drink, then (rep.)

ay, dry your eyes; one of our.Meas. for Mens. iv. here's his dry hand up and down....Muech Ado, ii. I this jest is dry to me $\ldots . . . . . . . .$. Love's $L$.

as dry as the remainder with...Mer. of Venice, iii. 2 high top bald with dry antiquity.... you Like it, iv. 7 with udders all drawn dry .......... - iv. 3 none so dry or thirsty will deigu.. Taming of Sh. Y. the colour's not dry

so many summers dry; searee any ..
then 'twill be dry. If it be, sir .. Cumedy of Err. ii. 2 purchase me another dry hasting.... - ii. I will drain him dry as hay ............Mrcbeth, i. nay, dry your eyes; tars show....... Rickard - iii. or a dry wheel grate $\ldots \ldots \ldots \ldots \ldots \ldots . . . \ldots 2$ HenryIV.i. 2 these six dry, roumd, old, withered ... - ii. as rhemmatic as two dry toasts ...... - ii. 4 


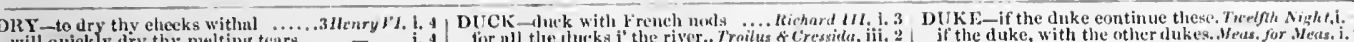

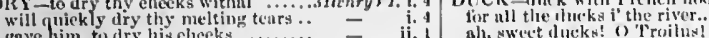
Dersick iii, gave him, to dry the elicek.

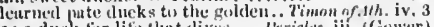

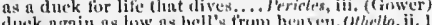
my sea shill sinek them dry.

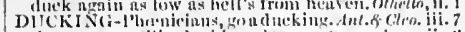
anil then, to iry them, fils'st than twenty silly dilueking ob-ervunts.... Leter, ii. "2

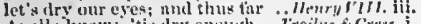
A pollo know

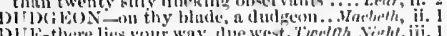
now the dry serpigo on ..........

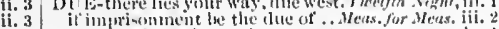

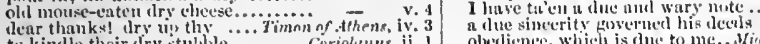

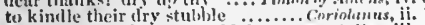
the sweat of inclustry would ilry .. Cymbeline, iii. stuunch the carth's ilry nlpetite. Tilus Andron. yet not dry with miry slime

Find Titus, dry thine eres ...........

eturt holy-water in a dry house

as due to bove, as thenghts ............

for fuul words is more than che...

the due and forticil of my hond... M

which as your due, time eluims .......All'swen, ji. 4

which shall liave due eourse

a saying, sir, nut due to me........... - $\overline{\text { iii. } 2}$

I im the to a woman

since l'entecost the sum is dine

say, how grows it due? Due for.
more is thy due than more than

dry up your tears, and stick your.... . Humlet, iv, 0 heat, dry uin my brains!

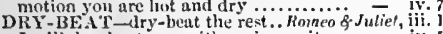

I will dry-heat you with an irum wit - iv. 5

DRY - FUO' F-draws dry-tont weil. Comedy of $\mathrm{Er}$.

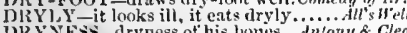

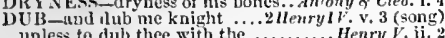

unless to duh thee with the ..........Henry $V$ ii.

DUIBISEl)-dubbed with unhacked. Firethh. Tight, iii. 4 what! I am dubbed

were but yesterday dubbed kniqhits ... Henry $l^{2}$

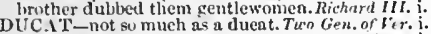

three thousand ducats a year.

not lose the dues of rejoieing $\ldots . \ldots$.

a fier-gijet, lue to some singhe lre
that will witl due deeision inake

with all due expedience

and form, ant dne proportion.

no; I'll give thee thy due
he will give his devil his duc

tis not due yet; 1 would be loath.

thy due, from me, is tears.

d due from thee, is this imperint.

holding due course to l larfeur. llerry $v$. iii. (ehorus)

numbers, and tue eourse of things $-\bar{v}$. (ehorus)

thy enemy, due thee withal......... I lsenry $b^{\prime}$

ere yon tan take due orders ...........2llenry

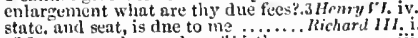

to put a ducat in her elack-dish. Veas. for Mlens.

carned of don John a thousant dueats - iil

received a thousund dueats of don John $\bar{F}$ iv.

three thousand dueats, for three nonths -

three thousand ducats: 1 thin

ay, ay: three thousand dueats

chree thousand ducats, 'tis a good...

go and purse the duents straight

there is a ducat for thee...

fild myelf with some more duent

O my dueats! O my daughter

O my ehristinn dueats! Justiee (rep.)

bags of dueats, of duuble dueats stoleu

the stones upon her, and the

two thousand dueats in Frank fort $!$

two thousand ducats in that

and the ducats in her coffint

one nicht, fourseore ducats $i$............

the first boy, for a thousand dueats

of fortune, and your due of birth

the rine revenue, and due ol
the git t, my due by promise

grave's due by life usurped
and blame the due of blane.

carries the due o' the v'erlict with it. Ulenry VIII. v.

with due observance of tlyy. Troilus fo Crrssida, $i$.

primogenitive and due of birth .......

nature eraves, all dnes

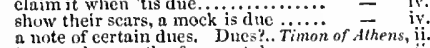

to stop the month of pris iastant due

give thee tliy due; - and ene that knows
the due of honour in no point omit.. Cymbel

with admiration what is now due debt

the hazard therefore due fall on me.

the graees for his merits du

for me, three thousand dueats ......

for me, three thousand to receive three thousa

dueats here is six. If every ducat (rep.)

should arnin do their due finctions.....

due to this heinous crpital offence
with all due diligenee.............

lust the dtre and just reward.......

abode make with you by rlue tin

dill refuse three thousand ducats of ne

two thonsand dueats by the year.

two thousand ducats by the year ....

there is purse of duent

the kingdom may lave due note of hin.

to thee a woman's services are due

your sonl to give it due content.

stering with due eonrse tow lor

Itromlet, iv.

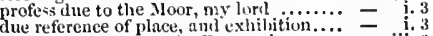

hath of mine wortl forty ducats

for forty ducats is too mue

to her fur a purse of ducat

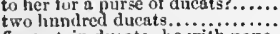

fir certain ducats; he with non

but kecps due on to the l'roprontic

in the due reverence of a sacred row .... $\bar{J}$.

there ducats paw'n I for my ...........

I will lay you ten thousand ducats .. Cymbe

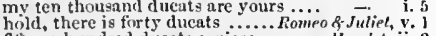

fit $y, a$ hunilred ducats a-pece ......... Ilualet, ii. 2

to pry five dueats, five, I would not....... =

twenty thousand ducats, will not debate
DUCD.MiE-duedame (rep.). As you like il, ii. 5 (songt

what s that duetame? Tis a Greek - ii. 5

be fire the duke and duchess.....Mid. ...'s Oreann, i.

would fright the duchess and the ladics

befure l came, the luehess died .... Richnral II. ii.

make merry withe to undernine the duchess. 2 Henry

hiren will he the luehess'

the duehess, I tell you, expeet

the erning of my punished il ueliess

whilst 1 , has fistiora duchess

like to a duchess, and duke 17 imipliney's -

the duehess, $b y$ lis summation

what think gou of a duchess? …..Henry $\bar{V} u I$. ii. 3

I know your back will hear a duehess - ii. 3

1) Fo with ine to the duehess .............. Lear.ii. s

DICK-swam ashure, man, like a duek. Tempest, ii.

thou h thou eanst swira like a slink .... - ii. 2

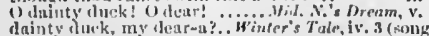

is the only dot, my duck............... icenry's, ii.

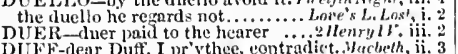

DUG -and the cow's dugs that her.. As you Like i, ii. i

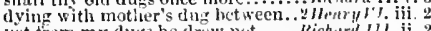

yet trom my dugs he drew not .....Nichart Mii.i.

on laill wormwod to my dug.. Komeo o Juliet, i. 3

tetehy, and fall out with the dug

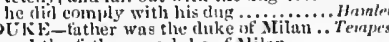

ani thy father was duke if Dlilan

and Prospero the prime duke.

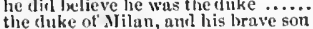

the lluke of Wilan, ani his more braver.

my wrol the dlike, st:thd too

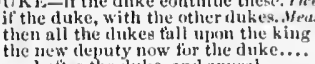

the new deputy now for the duke...

the duke is very strangely gone.

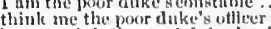

low mulh is the gorod luke dereived

whet news, friar, of the duke?

forl Angelo liukes it well in his.
wisuld the duke, that is alsent

never heard the abicnt duke much

Who? not the duke? yes your
the duke had crotebcts in hisa

of the suljeet held the duke to be wise

sut, if ever the duke return.

you hope the duke will return no more
I would, the duke we talk of, wcre...

the duke yet would have dark deeds

the duke, I say to thee again

with child by him in the che e tim
of what disposition was the cluke?

how came it that the absent cluke..

if the duke avourh the justice of ...

here is the hand and seal of the duke

perchince of the dluke's death
the duke comes home to-merrow

grace of the duke, revenges to........

he shall bring you betore the duke.

but they say, the duke will be here.
if the ofl fintustieal duke of tark

sir, the tluke is marvellous little

can tell thee pretty tales of the duke

such vantage on the duke he shall not

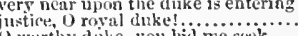

O worthy dike, you bid me seek
O aracisus duke, harp not on that

most villamous speeehes of the duke
where is the duke? 'tis lie should (repos

is the duke gone? then is your (rep.)

from him tu the duke himselt.....

in the absenee of the duke

and wat the tluke a fleshmonger

love the cluke, as I love myself

first knave, that e'er nade a luke ..

We are the pour dluke's offieers...... Wuch Ado. iii.

my gracious duke, this hath

my graciuss duke, be it so she wiil...

that I will make the elnke say

at the duke's onk we neet $\ldots$ wo......

do not you think, the duke was..

masters the duke is coming from the

which is the duke's own person?.......

to stmlin three reare with the duke.
sir, the iluke's jleasure is, that you

vow-lethws with this virtwons cluke?
the duke of Saxuny's nephew? ...Mer.

with outeries ruived the lluke

he plies the duke at morning

wenty merehants, the duke himself

the duke shall grant me justice.

the duke eannot deny the cours

and beg mercy of the duke...

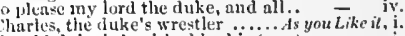

the oll duke is banisled by lis (rep.)

flosalincl, the rluke's daurbter

no, fir the duke's daughter, her cousin -

wrere will the old luke live?.........

with churles, the duke's wrestler....

we will muke it our suit to the duke
ret such is now the duke's contlitiun

the duke is humorous; what lie is

danghter of the cluke that here

of lite this duke luth taten dispileasir

from trant duke, unto a tyrant ...

look, here comes the duke $\ldots . . .$.

the bony juriser of the humorous duke?

the duke will drink under this tree..

I um the dluke, that loved your........

danghter to this fummis dake of Milum

near allicel untos the duke .. Tro Gen.of Verona, iv. I

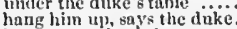

lere eomes the duke

it is my tord the duke.....

I must attems the duke at dinner....

let's gresent him to the duke ........
he led me to the gentle duke, who gave

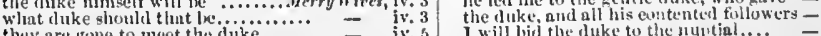

jrejaration for $n$ duke de olurinany... - iv.

dere is no duke, dat de cuurt ........ - iv. 3 kecp voun your word, 0 duke, to give

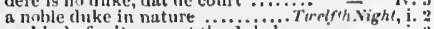

no kind of suit, no, not the diuke.... -

Hexh duke reweive thy daughter.

trom lelow your duke, to beucath,....A Alrs siell, ii. 
DUKE-the duke will lay upon him., Al's Well, witli his own hatsd he slew the d
Antonio, the duke's eldest sol the duke sluali both speak of it ....

he met the duke in the street, sir

the cuke hath offered him letter...

how many horse the duke is stron

what credit $I$ have witl the duke...

what his reputation is witli the duke

with the duke? the duke know

this is not the duke's letter, sir

to his reputation with the duke.

and the duke (tor private (rep.).. Taming of $S$

of your duke to merchants.... Comedy of Ev

his goods confiseate to the duke's dispose

chalge you, in the duke's name.

I am sure the duke himselt...

kneel to the duke, before lie...

justice, most sacred duke, against

therefore, most graeious duke.........

justice, most graeious duke, ol, grant

most mighity dukc, vouchsnfe me..

most mighty duke, belold a me...

renowned duke, beid a ma...

the duke, my husband, and iny...

by this lrave duke came early to

before the gates of Angiers, duke

appeal the duke on aneient malice... Richard 1

for now his son is duke..............

but by robbing of the banished duke

the nohle duke hath been too........

the noble duke hath sworn

where is the duke my father $\ldots . . .$. .

as I suid, the duke oreat Bolingbroke

where the mad-cap guke his unele..

either earl of duke, I can assure
be mertiful, great duke, to men

abate thy rage, great duke!..

tell you the duke, it is not so........

you nay diseuss unto the duke.......

high dukes, great princes, $b$

I wouke will hesire the duke to use his

your majesty, the duke is a prave man

lave patience, noble dnke

thitt hat ls ineensed the duke

the duke lath bauished moody....

thanks, gentle duke: but where is

wcleome, brave dukel thy friendsiop

to Bourdeaux, warlike duke!.

Charles, nor yet the duke I named

the new-made duke that rules ......2 Henry

tor a cluke's ftir daughter

my Humphrey, my sweet

she bear's a duke's revenues on her back

tlie duke yet lives, that Henry (rep.)
injurious duke, that threat'st where

father, the duke hath told $\ldots . . .$.

eollect these dangers in the dike

hath your hirhness seen into this duk

the duke is virtuous, mild

[Knt.] Suffolk's duke, thou sihait not see -

sirs, take away the duke, and guard

we have despatched the duke, as he.

althourh the duke was enemy

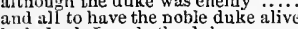

be judged, I made the duke away

the lite of this thriee-famed duke.
who should do the duke to deatlly?

had the good duke to keep

these rags are no part of the duike...........

the meancst of you earls and dukes?

of this most renowned duk

ean set the duke up, in despite of me

made that savage duke thi

and the duke, enforced me is made proteetor of the reain -

may she be on that hateful duk

the brat of this accursed duke

who erowned the gracious duke

his name that valiant duke hith

he, but a duke, would have his son

here's the duke. The duke! why
to serve a king, and not a duke...

to serve a king, and not a duke...

the king agaiust the duke my brother

there sits the duke asleep............

the duke shall know how slack.......

I repent me that the dulke is slain
till that the duke give order for

in good time, here eumes the noble duke dukes, earls, lords, gentlemen

mighty dukes, Gloster and Buckingham -

instalinent of this noble duke in ...

most in ward with the noble duke
and in the duke's belaulf I'll give

in hapry time, here cornes the duke
DUKE-the duke would be at dimer. Rich
nothing like the noble duke my father being not like tire duks. thus saith the duke, thus hath the duke the duke will not be suoke withal good Catesby, to the gracious duke. fly to the duke. I wiñ, my lorl.

here, und goest not to the dinke?

as the duke said, the will of heaven. Henry $\vec{r}$ III the duke being at the Rose.

presentty the duke said, 'twas the fear

the duke slall govern England ( $r e p$.)

列, hy the devil

servant, the duke retained him his.

at ter-the duke his fatleer ........

which the duke desired to lim brough

this duke as much they love and do

if th.e duke be guilt less, 'tis tull...

my father-iu-liw, the duk

the duke by law found his deserts

not all the dukes of waterish Burgnudy

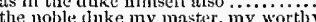

hillk, the fluke's trumpets

the duke inust grant me that

the duke's to blare, in tha

you know the fiery quality of the diuk

this renotion of the duke and her

tell the duke and his wite, I'd spenk

here is clivision between the dukes....

torbid thec, shall the duke instantiy $\mathrm{know}$

advise the duke, where you are going...

the sight of the death-practised duke..

now of the duke, it his last purpose hold - v

Gone, and the duke her husbated

voice potential as double as the duke's.. Othello, i.

the duke does greet youl my lieuter.

and met, are at the duke's already

how may the dnke be therewith satisfied

how! the luke in eound in this

the duke himself, or any of my brotliers

most sracious duke, to niy unfoldin

the duke and semators of Veniee greet you

DUKEDOM-was tukedom large enough. Tempest and benu the dukedon yet

that $I$ prize abuve piny dukedoun

iii. 3 thy dukedom I resign....................

and require iny dukedom of thee

my ankedom since you lave

Prospero his dukedom in a poor isle...

sinee I have lny dukedom got
your highress took his lukedo

at large, a potent dukedons

of Grunt, dukedom of Lauenster....

twere better than your dukedum...2Henry IV.

all her almost kingly dukedoms

did cliam some certain dukedoms.

some petty and unprofitable dukedo

but I will sell my dukedom, to buy

chane two dukeduns for his daughte

his dukedom and his elanir .........

for chair and drkedom, throne and...

enter, as into our dukedoin ...........

ehallenge nothing but iny dukedom

is not a dukedon, sir, a roodly gift?

my dukelum to a bejrarly denier.. Richord 111. $\mathrm{i}$ ulucest ind harinomiousion.. Twelfh Night, ii. as are those duleet sounds .........'rch. of Fenice, und los discord duleet, his fiuth........All's Well, a dulcet and a heavenly ...Taming of Strew, 1 (ind.) DUIL-dull thing, I say so ............ Tempes', $\mathrm{i}$. and worship this dull fool.................. upon the duil earth dwelling . . T and dull to all procedings .... Heas. for. Hers. iv. of dumps so dull and lieavy she was in her dull and sleeping ....M $i d$. grace's officer, Antony Dull

Dull; Dietyng dull, and slow?

via, goodman Dull! thou hast

most dull, honest Dull, to our.

she is not bred so dull but sh

of his spirit are dull as night

or eomes of a very dull kindred...

designs, when we ourselves are dull

for what dull wart in't yuu chose. H'..All's Well

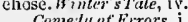

my diseourses dull? barren my wit?

but moouly and dull melaneholy ... ii. 5 vexin-my die dull brain was wrouglt .....Macbeth i, 3

dull, unfectings, barren ignorunce.... Richnri I I. i. fits a clull fighter, and a keen $\ldots \ldots . .$. i Henry $I F$, iv. 2 like dill aud heary jeal

$O$ thou dull god, why liest thou with

of hetven, and our dull workings....

should not so duil a kingdom

foggy, raw, and dull? on whom

piercing the night's dull ear

able to ravish any dull eonceit

Henryl $\%$. i.

give way, dull clouds, to my quid

with dull unwillingness to repay ....

servitor to dull delay $\ldots . \ldots \ldots \ldots . . . . .$.
my words are dull, 0 quieken thein.

murderous knife was dull and blunt

dull nnmindful villaim ...............

in this dull and loner-continued Troilus \& cress.

if the dull brainless $\mathrm{Ajax}$.......

fur the journey duIl and lueavy...

Where the dall tribune.

you are dull, Casca; and those..........

dull of tonere, and dwartish! ..... Jnlony \& Cleo. jii. 3

with the sober eye of dull Oetavia.... - v.

will stuyify and dull the

not too dull for your good wearing.... - ii.

my sight is very dull .................

that e'er dull sleep did mock ............. Pericles, v. 1

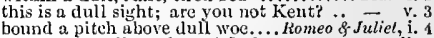

turn back, dull earth, and find ....... - - - iamlel, i.

but do not dull thy palm $\ldots \ldots . . . \ldots . .$. Hamlel, i. 3

a dull and muddy-mettled raseal........

my spirits grow dull, and fain I would ...

and spur my dull revenge! ..............

for your dull ass will not mend his pave.

this odd -even and dulI watch o'the nightothello, if.

when the blood is male dull with the aet - ii.

duil not device by coldness and nelay

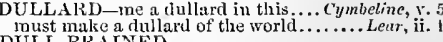

rebel, dull-braines Bnckingham... Richard 11T. iv.

DULLED $-[C o l$. $k n$ l.] he hath dniled...IIrnry $r$.i. only sensible in the duller parts.... Love's L.L. iv. timon of Alheis, and duller slouldst thou be that

ULLES $T$-the dullest seent.. Tuming of Sh Hel, $i$. that may strike the dullest nostril. H'inler's I'ale, i.

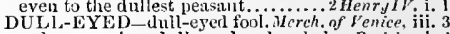
sad companion, dull-eyed melancholy.. Pericles, i. DULLNESS-tis a good dulliness ......... i. always the dullness of the fool.....As you Like rt, i. 2
thy dullness would torment thee. Timnn of . 1 th. iv. even till a Lethe'd dulluess ..... Anlony \&-Cleo. ii. DULLY - dully sluggardized at.. I'wo Gen. of Yer. i. the time shall not go dully by us ..... Much A Alo, ii. I duly an informed his innjesty is ...All's $W$. disbursed $I$ duly to his highness'.... Richard 11. i. as duly, but not is truly ........... Henry $V$. iii. are not worls luly hallowed ....... Henry VIII. ii, 3 rather than unfold his ineasure duly. Cymbeline, i. i [Col.] duly quench thy nimble .......... Pericles, iij. 1 my loving lord, Dmmain is mortified young Dumain, a well-aceomplished Dure my wish; thy love is fat from charity

0 tell me, good Dumain?............

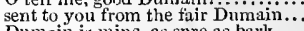

one captiain Dumain be i' the...Al $l^{\prime}$ 's $\dot{w}_{\text {ell }}, \overrightarrow{\mathrm{iv}} \mathrm{3}$ (note) do you know this eaptain Dumain?..

the other eaptain Dumain?

U MB - of excellent dumb discourse... Te - iv. 3 strikes poor lover's lumb. .Two Gen. of Verona, ii. dumb jewels often, in their

I ean be as seerct as a dumb nign.......... which will be merely a dumb shuw.. - ii. 3 praising her when I am dumb...... $\bar{N}$.' v. 3 (seroll) one of these same dumb wise men. Mer. of Venice, $i$.

who cin converse with a dumb show?
I ain dumb. Were you the doetor..

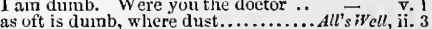
a dimb innocent, that could not say $\ldots$..... iv. 3 deep shame had struck me dumb ... King $J_{o h n}$, iv. in dumb simifieants proslaim

to-nirht, the duke was dumb ...

unto his clumb deat trunk

like dumb statues, or breatliess.. Richard 111 . iij.
thuuults unveil in their dunb.. Truilus o Cress, iii. 


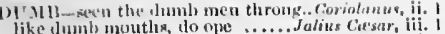
like tumb moutles, to one .......

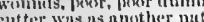

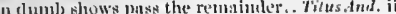
in thy dlumb action will I he us.

siturs cun witness, (lumb nitho they are -

rath be inute, and fiury duml

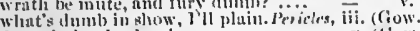

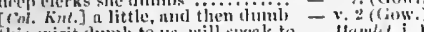
this spirit clumb to us, will sigenk

wy luert a working, mute nul clunib.

my henrt a working, mite mint hime.

in thine ear will make the dumb - iv. E (letter)

I) in thine ear, will minke the

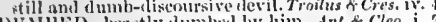

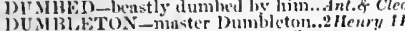

Dit Iibl. Y-d umbly liave liruke oft.

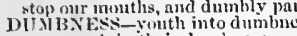

Tueleth $\mathrm{v}$.

was speech in their jumbnes

inter's Tialc, $\mathrm{V}$.

the choss. iii.

Il oblhiliclanee, prince of dumbincss ...... Letr, iv. I

of tluups so dull and heavy ... Much dilo ii. 3 (sulne)

in your dumps? Call you me. Tamine of shrem, ii.

step ont of these dreary dumps.... Titus A nitron. 1 .

and loleful dumps the mind oppress - iv. 5 (song

Di: N-tut! llun's the mouse (rcp.). hom inuneul comes lere to-night

le'silles, this Dumean bath borne hij

when limean is asleep (where'tio the

perform upen the ungunriled 1) une:

wake Dunean with thy knukling!

here lay Dunean, his silver skin face

and Dunean's horses (a thing most

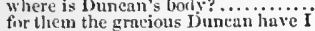

Douncun is in his grave

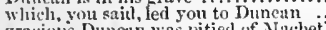

gracious Duncan was pitied of Niacbeti"
had he Dunean's sons under his key

the son of Dunean, from whork.

1) I. . F- palntes more the dung...... Intony \& Cleo. $v$ . GEON-the hue of dungeous .. Lore's L. L. iv. 3 and the dunceon sour within a louthsome dungeon

2 Henryst'iv. 3 fome dungeon. Your bedehamber... Riehryrd III. i. mor airless dungeon, nor strong. shace i the dungeon by a snuft? many live unson the yapour of a dungeon. Othello, iii. 3

DUNG-HIJ.I,on dung-hill shine...Merry Wives, i. 3 thou hast it at dung-hill, at the..

false latin; dung-hill for unguem
his animals on lis dung-hills are... As you Like

his animals on his dung-hills are.. As you Like
out dung-hill! darest thou brave... King John

slall dunghill curs eonfront the.

Henry 1 l

though buried in your dunghilts

Henry $V_{\text {.iv. } 3}$

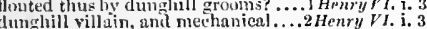

untos a dupghill, which shall be thy grave - iv. 10

throw this slave upon the dunghill

ont, dunghill: Ch ill pick your teeth
DISig $x-$ of the whole dungy earth. H

Dirr dung carth alike fueds ...... Anton! f ( Co

DINSINANE-rood to hioh Dunsinan

till Birnam wood remove to Dunsinane.

to Dunsiname. Were I from 1)unsinane

k(eps still in Dunsinane, and will enture
t11 Dutsinane; now a wood comes (rep.)

Jirnam wood be come to Dunsinane.

DUNSTABLE-court at Junstable. Henry VIJl. $\mathrm{v}$. DUPPE.S-dupued the chamber.. Himlel, iv.

peristual durance? ay $(r e p$.$) ....$ set thee from durance ........... loore's L. Los', and gives 'em suits of durance... Comedy of Eir'. iv. jerkin a most 8 weet rube of duranee? I Ifenry If

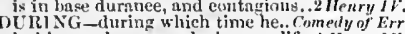
in lits own languaze during my life.. Henrylr. of nuself, and the during my life.

during the time Edward the third .... Henry during whose reign, the Pereies...

time have dimgring the life.

timen, dis dich during all guestion he the geutle. Truil. \& Cress. iv. revolte during their use................ Cymbeline, we will resign, during the life of this .... Lear,

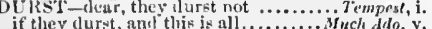
iretty soll! s she durst not lie near....3rid. N.Dr. dursi chou have lokkt upon him.... never turst 1 wet thich a pen .... Lnere's L. Last, iv.

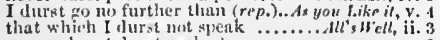

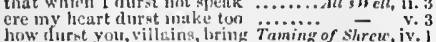
you that linet swear that your..... slue durst not 'all me 80 , if the........ - ii. I clurst liave denied that .... Concdy of lirrors, ii. 2

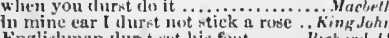

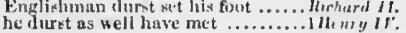

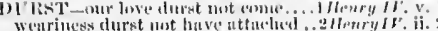

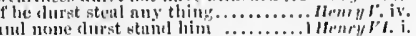
and nome slirst stant him ....

none durst conne neur

or durst not, fur his criveiri lieart.

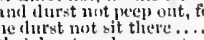

lin, durst the truitor brentic ionit

and who durst smile, When Warwi

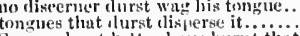

surrey durst better lave hurnt that

mid durst cennumend a secret

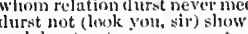

mud durst not conce peep nut

I lurst not lungh, for fear of .........julizes Carsar

lurst not thus hure moved me $(r<p)$. - iv. 3

durst 1 have dine iny will

I durst attemit agafist any laijy...... Cymbelin

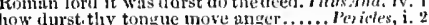

I durst wager, wonld win kone work

I whicht we durst never yct), and wit

they durst not do't; they eould no...................

I clurst, ny lord, tu warer she is hone..... om

USkY'-dusky Dis my damyliter tot... Tem

bere of the nirht

and when the dusky sk $y$ legan

smotheret in their dusky graves.. Kichard 11 r. iv.

DUST - I lay the dust with my.. Tuo Grn. of bir. ii. 3

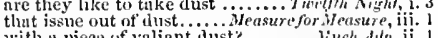

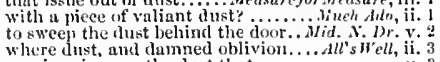

and after weep their dust: our own....

where no priest shovels in dust ... Wivter's 7 sle, iv. 3
vile gold, dross, dust, purehase...... King John, jii. I

of brenth with fulsome dust

dust, eneh straw, each little....

a grain, a dust, a gnat, a wandering - iv.

erumble uy to dust

wipe off the dust that hides our ..... Richar
dared once to touch a dust of England's

make dust our paper, nnd with rainy

dust and rubbish on king Richard's.

but dust was thrown upon his

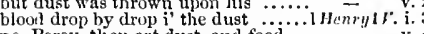

no, Perey, thiou art dust, and food .....

complound me with furgotten dust

nor from the dust of old oblivio

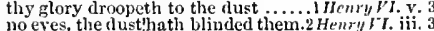

write in the dust this sentenee

rule, reiun, but earth and dut?

give to dust, that is a little gilt. Troilus \& ('ress. iit. 3

the ent

and throw their power i' the dust.

they to dust should grind it, and throw

ges alnng, no worthier than the dust. Jul. Cersar, iii.

the dust should have ascended ...An/onj \& Cleo. jii. 6

rotting together, hisve one dust $\ldots . .$.
as chinmey-sweepers eome to dust $\ldots=$ iv. 2 (song)
all follow this, and come to dust....

eonsign to thee, and eome to dust ... $=$ iv. 2 (sung

in the dust I write my hicart's. Tilus Andronicus, ill.

blows dust in others' eyes, to spread..... Pericles, $\mathrm{j}$.

to scour it in the dust.

ay, and for laying the autumn's dust... - iv.

to the deseent and dust benenth thy feet - v. 3

f Col. Knt.] thy eanopy is dust and... Romeo f Jul, y.

to me, what is this quintessenee of dust? - ii.

compountedit with dist, whereto tis kin - iv. 2

Alexnnder returneth to dust; the dust is - v.

DUSTY-the way to dusty denth ........ Masbeth.

are grated to dusty nothing ..... Troilus \& Cress. iif.

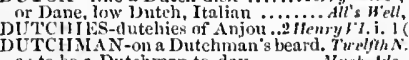

as to be a Dutchman to-day ...........Mnrh Adto,

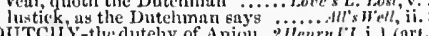

DUTClY Y-thedutelyy of Anjou ..2 Inenry I.i.l (art.)

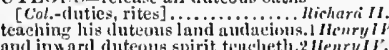

and inward duteous spirit teucheth.2 Wenry $1 l^{2}$.

I will purelase with my dutenus service

be hat duteont, and true prefirment. Cymbelin

as duteous to the viees of thy mistrus ... Lear, iv. 6

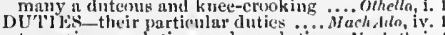

to reccive nur durtes; and our hinties...1nabeth,

my" duties are with a mont
our thuties and the pledge

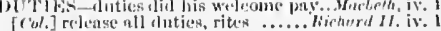

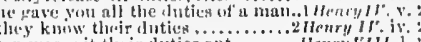

tonglues ntit their dutieg out.

Iirnry flll,

keep your dlutieq, as I have set....... Coriolumms,

the hoy hath taught its manly dutices

loy all the duties that I owe to Rume. Thus

I return those rlutics luak ns are......

prescribe not 118 our sluties

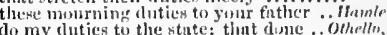

say, that they slack their lytic

Fou know me dutitul; theretion. Troitus of ress.

aid duty never yet did wait.

my dluty pricks ine on to

stubiorn, lacking duty.

by leer chilil-like duty

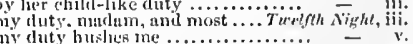

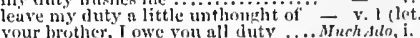

it is my consin's duty to make courtsey $\overline{\text { with }}$ ii.

with eluty, and desire, we follow..... Mid,
when simplersess and tluty tender it..

and inty in his service peristing

and what poor dinty cannot do

er-esteemed duty pricks me on. Love's L. L. i. t (let.

I forrive thy duty; adieu duty

I know ny duty, so infinite........

with all respect and duty ......... As you Like it, i. 2

all aloration, duty and observance.. $\overrightarrow{\bar{F}}$. vis

thanks and duty are your majesty's .. Al's H'cll, i. 2

which I held my duty, speetlily

brith thy duty owes, and our nower.. $\quad-$ ii. 3

my mofher did hut duty; snch, my lord in. iv

sueh dity tir the drumkard let........ -1 (inil.)

may show her duty, and make known - 1 (inll.)

be belind in duty to fair Bianca.

bo well I know my duty to my elders

no regard? no duty? where is

now ilo your duty thorunghly

fool you, for laying on my duty.

what aluty they do owe their lord

wen duty as the subjeet owes

his dignity and duty both east off. Winter's Tale, v.

where you were tied in duty...

to pay that duty, which you trily... King Jahn, ii. I

nttend on you with all true duty....

the one my duty owes $\ldots . . . . . .$.

the appellant in all duty greets.

swear by the duty that you owe
shall tender duty make me suffer.

nad duty bids me defend .................

hose duty is deceivable and false

ny stooping duty tenderly sholl

thicil a whil duty to our presenee?

and show fuir duty to his majest

our duty this way lies ................

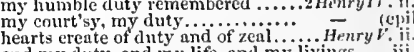

and ny duty, and my life, nnt my livings - iii.

my duty to you both, on enual love $\ldots \ldots . .$. -

how mere in duty to forbear

in reguerdon of that duty done.

and as my duty springs, ko perish....

to do my duty to my sovereign .....

as I in duty love my king .........

in chity bend thy knee to me

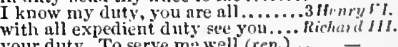

your duty. To serve me well (rep.)

thy brother's love, our duty, and thy

eharity, obedience, and true.duty!
for truth, for duty, and for lovelty

as he male semblanee of lis dinty

our breaeh of duty, this way.

or my love and duty, a gainst your

all the workl shoilia crack their fluty

yet my cluty, as doth a rock agralls:

to strengtye to atterel your

receive of us in duty, gives us ...Trailus f çess. jii. 1

duty and zeul to your unmutches of . Whens, iv

of thy deep dluty nore impression ... Corinlunus,

ansl unproperly slyow duty, as mistaken
that thou restrain'st from mo

it is my duaty, sir. 1 shomid (rep.).Julius Carser, iv.

Freent thertight. by dluty ruminated.And, o cles. ii. 2 
DUTY-lay my duty on your hand.Ant.\&.Cleo. iii. 11 DYE-flower of this parple dye .. Mid.N. Dream, iii. 2 EAC1I-each substance of a grief latl. Richard II. ii. 2

may be, it is the period of your duty

always reserved iny holy dut

more made of malice, than of duty.....

she should that duty leave unpaid

wo wild force me to my duty

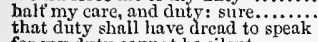

fhat duty shall have dread

all particulars of duty know ...........

twas my duty, sir. 1le did bew ray...

that showed my duty kncelin

my lady charged ny dinty in this busines

needtul in our loves, fitting our dity? .. Humlet, commend your duty. In that (rep.).

my duty in your coronation (rep) ........

our duty to your honour ................

I hold my disty, as I hold my soul ........
what duty is, why day is day, night, night

who, in her duty and o

if my duty be too bold

we shall express our duty in his cye

in forms and visages of duty

not I for love and duty, but seeming ....

tying her duty, beauty, wit, and fortune

with his free duty, recommends you thus

I do perceive here $a$ divided duty

you are the lord of duty, 1 am hitherto..
and so much duty as my mother.........

a knave! teach me my duty!

forgot all sense of place and dity $! . . . . . .$.

the love and duty that $I$ bear you

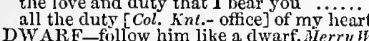

get you gone, you dwarf .......Mid. Herry Wives, ili. 2

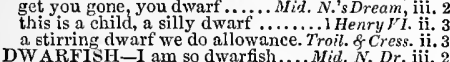

giant's robe upon a dwarfish thief ...... Nocbeth,

to whip this dwarfish war

dwarfish pages were as cherubims... Henry VHi. i.

dull of tongue and dwarfish! $\ldots$ Antony \& Cleo. iit.
DWELL-nothing ill can dwell in such. Tempest, $i$.

good things will strive to dwell with't

she that dwells ten leagues

dwell in this bare island ............... - (epil.)
the eating canker dwells...Tiro Gen.of Verona, i.
there dwells one mistress Quickly.Mferry Wives, i. 2

I myself dwell with master...

slie dwells so securely

if a beggar dwell near

what graces in my love................. Mruch selo, v. 1

'll rathes in my love do dwell . MFid. N. Drecom, i.

that dwells with him, dwell with him

that you see dwell where slie is... As you Like it, iil. 2

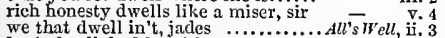

we that dwell in't, jades

and dwell apon your yrave.. Comedy of Errors, jii. 1

scek out sorrow that dwell

to dwell in solemn shade

such ontward things dwell not in ...... Henry 5 . iv. 3

to all that do dwell in this house..2Henry VI. iv. 10

eirpty veins, where no bicod dwells. Richard III. i. 2

pity dwells not in this eye ...........
sumdered friends should dwell upon

time forbids to shoul

v. 3
$\mathrm{v} .3$

should still d well in his musing
my lopes in heaven do dwell

when I shall dwell with worm

in the trial nucli opinion dwells. Troilus \& $\overline{\text { Cress. i. }} 3$

but value dwells not in particular

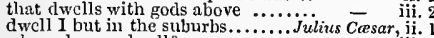

where do you dwell? ..................

briefly, I dwell hy the Capitol

blest the hons that dwell in vegetives. Pericles, iii. 2

why, the house you dwell in, proclaims.. $\overline{\text { ive }} 6$

for the crowned truth to dwell in

dwells in the fickle grace of her ............. Lear, ii. 4
fain would I dwell on turm ..... Romeo \& Juliet, i.

sleep dwell upon thine eyes..........

and hereabouts he dwells.

though he in a fertile climate dwell .... Othello, $\mathrm{i}$.

DWELLING-upon the dull earth dweling

dwelling in a continual 'larum .. Herry Wives, iii. 5 not for dwelling where you do... A Heas. for Meus. ii. assigned and native dwelling place.As you Like, ii. I purchase in so removed a dwelling . .
my dwelling, Pisa; and bound .. Taming of Sh. iv. 5
the plite the place of your dwelling

a goodly dwelling, and a rich

.2Henry $1 V . \mathrm{v} .3$

ne'er a villain, dwelling in ali Denmark. Hamlet,

DWELLING-1YOUSE-1rnil dwelling-house John
DWELLING-PLACES-repair to your several

DWELLST - where dwell'st thoury r. . Coriolanus, iv. 3 (proclam.

then thou dwell'st with daws too?....

dwelt by a churehyard $\ldots$ an.......... Twelfht Night, ii.

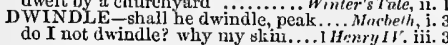

shall dye your white rose

...Tempes

this napkin, dyed in this blood.......... As you Like it, iv. 3

with purpled hands, dyed in ........ King John, ii. 2

and it was dyed in mummy

Tuelfikh Nigh

is still a dying horror! .....Measure for Measure,

one good deed, dying tongueless.. Winter's Tat

thou met'st with things dying......

dying, or ere they sicken .....

dyed in the dying slaughter

the tongues of dying men

Macbeth

should dying men thatter with those

where fearing dying, pays deatl

the lion, dying, thrusteth forth.

talk not of dying; am out of fear

but to counterlicit dying, when a man

in Franee, dying like me

how dying Salisbury doth gro

undaunted spinit in a dying breast 1 .

doth elose his tender dying eyes.

when dying clouds contend
for Edward pays a dying debt....

for Edward pays a dying debt

this from a dying man receive

so dying love lives still... Trailus \& Cress.

stand on the dying deck ...... Timon of theres, iv.

notion was tim with dying cries.. Corinlanus, ii.

shall receive the bencfit of his dying

hath such a celerity in dying .....Antony $\overline{8}$. Cleo. i. 2

than with an old one dying.

I am dying, Egypt, dying

dying, Egypt, dying; give me

madly dying, like her life

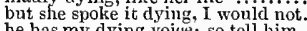

he has my dying voice; so tell him ..... Hamlet, y.
she, dying, gave it me; and bid me .... Othello, iii.

mbeline, iv. 13

EACH-each pinch more stinging ...... Tempest, i. 2

each putter-out on five for one

and with each end of thy blue bow

think of each thing well

I'll kiss each several paper.

a pastime of each weary step
she excels cach mortal thing

she excels caeh mortal thing

each fair instalment, cont

the vows we made each other

till each circumstance of place

swear down each purticular saint..$\ldots$ Ieas for $v$.

masters; each his several way......... Nuch Ado , v. 3

and from each other look thou ........

to each word a warbling note

through this house each fairy stray

and each several chamber bless .......

and bide the penance of each three..

each to other hath so strongly s
a beam do find in each of three

a beam do find in each of three....

while "tis spoke, each turn away her face -

take each one in his vein ............ $\overline{\text { in each }}$ v.

that we may enjoy each other.....As yout Like it, v. 2

marry, to each, but one?

two hundred and fifty each ...........

each in his office ready $\ldots \ldots . . . \cdots \cdots . . .2$ (ind.)

by eack particular star..............Winter's Tale,, $\bar{i}$.

do sigh at each his needless heavings

weeds to each part of wind

she would to each one sip.

each your doing, so singular in each

二 i. i. 3

leisurcly each one demand .......... $\overline{\text { vomedy }}$ v. 3

did meet each other's man

by each at once her choppy.
our free hearts each to other

bend up each corporal agent...

did wake each other.

the denth of each day's life

violent sea, each way other....

eaeh new morn, new widows.

and each new day a gash is....

esish minute teems a erime

in our country's purge, each drop of us.

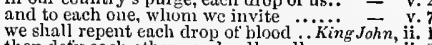

then dety each other; and pell-mel

Austria and Frauce shoot in each

the difterent plague of cach calamity

each day still better other's............

to apyeal each other of high treason
embrace each other other's love...... three Jutlases, each one thrice worse - iii. 2
the variation of ench soil betwixt....1 Henry $1 \%$. i l

they dare not mect each other; cach

let each man do lis best

each several artjele herein rediressed

like a selionl bryke up, each hurries.

you will mistake each other

We shall have each a hundred

(cho.)

- iv. (cho.

with envy of eitch other's happiness - $=$ v.

each hath lis place and function $\ldots . . .1$ Henry $V I . \mathrm{j}$.

with five flower-de-lnces on each side

this shouldering of each otlier

whiles they

whiles they each other cross .........
and ench of them had twenty times.2Ienry $V I$
the towns each day revolted......

and, 'twixt each groon, say

three glorious stins, each one

each one already blazing by

my masters, each man take his stand $=$ ii. I

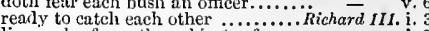

live each of you the subjects of .......

and Hastings, take each other's hand

now cheer each otlier, in each other's

we know each other's faces.............

and each hour's joy wrecked ......... =

limit eacl leader to his several .... other - iv. 3

all used in each degree $. . . . . . . . . . . . . \quad-\quad v .3$

succeders of each royal house ........ Henry $\overrightarrow{V I I I}$, $\mathrm{i}$.

order gave each thing view

pricle peep through each part of him

which compel from cach the sixth

a slave to each incenscd wilt $\ldots . . . .1$.
sixth part of each? a trembling.....

free parlon to each man that ..........

made almost each pang a death......

each Trojan that is master of . . Troilus \&

each thing mcets in mere .............

each thing mcets in mere

two curs shall tame each oth

there is a law in each well-ordered

so do each lord; and either greet ....

salutes each other witl each ..........

each weighs nor less nor more $\ldots . .$. ...

that in cach grace of these there

extremity pursue cach other
flies each bound it chafes

each man to his stool, wit

Timon of Athens, i.

let each take some; nay

- iii. 6 (grace)

nature, on each bush lays her.........

each man apart, all single and alone

for each true word, a blister! and each

make each prescribe to other, as each

a dozen sons, each in my love alike.

what each of them, by th' other lose

wild exposture to each chance

fisting each other's throat....

and each in either side give..........

till each man drop by lottery..... Juilius $\overline{\text { Cassar }}$ y. 5

let each man render me his bloody hand

in each thing give him way ....... Antony \& Cleo. i. 3

on ench side her, stood pretty dimpled 二 ii. 2

we'll feast each other, ere we part ...

each heart in Rome does love.

forth, each minute some

whose several ranges frighted each other? - iii. is

mortal 2 purpose, as then each bore... Cymbeline, i. 5

each on one toot standing............ - ii. 4

with ills, you would take this course

are now cach one the slaugliterina....

we may, each wreathed in the other's. Titus And. ii. ${ }_{3}$

mity turn me to each one of you ....

where each man thinks all......... - ii. (Gower)

the labour of each knirht.

therefore each one betake him

(Gower)

fisting of each rogue thy ear ..........

excess, aud each man have enough ....... - iv.

my love; eacl jealous of the other

with that part clieers each part..Romeo \&. Jutiel, ii. 3

eacl part, deprived of supple.

each word made true and good........... Homlet, $\mathbf{i}$.

take each man's censure, but rescrve.... $=$ i. 


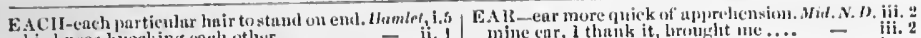
his knees klocking each otlier at cuch car a hicurer....

etor on his ans

each oplesite, thimt binks the fiure if joy

when

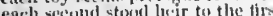

the ennnihus that such other ent ....

cuch mun to whint sport and res

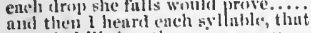

cach clo kill tlec uther, ciery way

fur to deny eltelh article with orth

with eager feceline foul dititl.

suppliant inakes this cneter ery?

to be more cager: of ohl i
followers to the enger foe.

thenrylti. i.

ii. 6

it is a nipping anil an enger nir

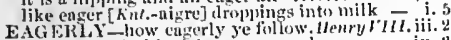
where eagerly lis sickness pursued... $\overrightarrow{\text { iv. }}$

on Cetavius, took it tou eagerly ...Iulius Cansar, v. 3

EAtiRNES-mudding my engerness, All's It"ell, v. 3 yes; as sparrovs, engles; os the hare

like an engle o'er his tiry

as bright as is the cagle's .......... hishtrit II. iii.

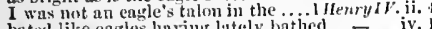
tir

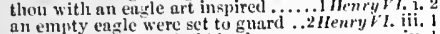

drones suek not erurles' bloud....

like an empity eagle, tire onl.

be that princely cagte's birl....

gave shelter to the princely easle .... - v.

wrens may prey where eagles didre not - i. 3

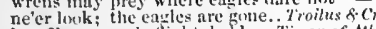

but flics: the eagles nre

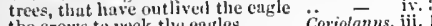

the crows to peck the earles.

two mirhty eagles fell...............Julius Casar, y. 1

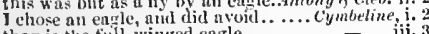

than is the full-winged carle...

the Roman eagle, winged from the
the way which ther stuoned eagles

mount, en rie, to my palace crystalline

the holy eagle stonyed, ns to foot us.

freat J upiter upom carle, from sonth to.

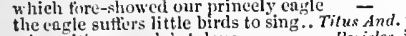

seize with an endrle's talons .......... Perictes, iv.

EAliLE-sigil TED

peremptory eagle-sighted eye dnres. Love's $L$. L.iv. 3

EAGLE-WhNGD-
we think the eagle-vinged pride.... Richart II. i. 3
E.INING $\rightarrow$ did in eaning time fall. Mer.of Venice, i. 3
.

EANLING- that all the eunting

EAR-lids thee ope thine car
to what tume pleastl his ear

hark in thine ear

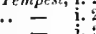

you eram these words into mine

a din to fright a monster's ear

brought my too diligent ear

will hum ahout mine ears

they priek'i their ears

so 1 eharm'd their ears

wlieh must take the ear strangely

my ears are stopued

.

you have a

ye hears with ears

he hears with ear?

give ear to his motions

w tell you in your ear

and let me tell you in

let-a me speak a word vit your ear...

if it shomild come to the ear of the eourt

it came o'er my ear like the...... Twelfth $\bar{N}_{\text {ight }}$,

it alone coneerns your ear

to your ears, divinity.

go shake your ears ....................

as tiat and fulsome to mine ear.

perpeut, my princess, and give ear

strewed it in the common ear ...Mras. for Mfeas.

if he took you a box o the ear.......

fasten your ear on my advisings

hath a stury reudy for your ear.
hath to the public ear protessed.

hath to the jublic ear professict.

that want no car but yours ...........

and in the wituess of his proper ear.

if you'll a willing ear ine

witls the ears of Clautlio $\ldots . . . . . . . .$. .

tells him in lis ear, that lie

that her ear lose nothing of the false

what fire is in unine ears?

a worl in your eur, sir; I Iny to you

fills into nine cars as protitless...

let no comforter delight inime enr..
fliall I eneak a word in yum ear?..

they say, he wears a key in his ear...

my ear aluulis eateh your voice

hang a peurl in every cowtift's ear .
mine ear is muels enamoured of .... mine car, a thank it, lirugh

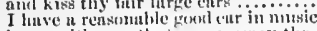

hinng with ears that awe' nwiny the

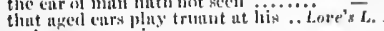

and cory one give ear a............

und rentling! ligten, (an ...........

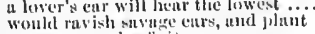

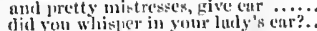

dial you whispler in your ludy's ent.

hest pierre the enr of gerief..

then, it rickly enrs, dented witi... .

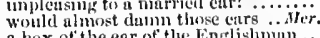

a box of the ear of the Englishmu

stop my house's ears, I nean my....

into the dreaming britlemroom's enr.

sounds of musie creep into our cars.

any air of musie touch their ear
tell you friendly in your ear

the broken ears after the man

Florentines and senoys are by the eurs. $A l^{\bar{t}} \mathrm{~s}$ Wrl,

senttered not in ears, but gralted...

he, that ears my land, spares my team

her own words to her own ears.

vowed to thee in thine ear, Parulles
may help me to his majesty's ear.

whose wor

a little din can damit mioe cars?

a blew to the car [ $\mathrm{Col}$. Knt.--]ie

was but to knock at your ear

jiteliers have enrs, and I have

o'er head and ears a furked

and give't me in mine ear $\ldots$ and......

and all men's ears grew to his
their other senses stuck in cars

to have an open ear, a quiek eye ....

Bohemia stops his ears, and threatens

be asleep, and not an ear open

the told his nind upon mine

words were nusic to thine ear

error drives our eyes and ears aniss?

and teael your ears to listen witi

twill sound harshly in her

and let it feel your ear

these ears of mine heard you confess

my dull deaf ears a little

pour my spsirit in thiue ear .............

too terrible for the ear ..........

let not your ears desios

a title more hateful to mine enr....

keep the word of promise to our ear

my eonscience whispers in your

that in mine ear I durst not .........

a faithless error in your

rounded in the ear with that same

wear me without thine ears.....

vexing the dull ear of a drows

her ear is stopped with dust

whisper one another in the ear

the true welkin's ear, and moek

these dead news in as dead an ear....

hid his ears a little while be deaf...

in vain cumes eounsel to his ear.

inay yet undeat his ear ......

quickly lnzzed into his ears

mine car is open, and my hem

let them go to enr the land ...........

into his ruined ears, and this deliver

heart plant thou thine ear ............

and licre have I the flnintiness of

and he the ears of profiting.

lend no car unto my purpeses ......
and in his ear l'll liolta-Mortimeri

tying thine enr to no tongue but

liny thine ear elose

whiel of the ear of grentness.

on his altur sit, yp to the ears in blood

open your cars; for which of you...2inenry $l$

stulling the eurs of men with

stoplyint my greedy war witla their

for the box of the car thint

I can henr it with my own ears
of a wheel hase his ears uut off

bit the nerry betls ring to thine eur to eonsolate thine ear.................

these ears of nine, thou knowest

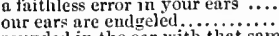

i come to draw you tult by the eirr.

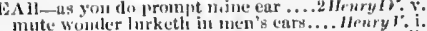

Working witls the "ye, nithout the enr

finia be alwout the s'ars of the Ensylish

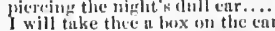

to tuke lin a box a' the cur......

hy will enter at a luely

cyes be withess with nine curs.

int"ury l't. ii.

un no ehristis
five him an

whose w urlike cars cumbl never

3 Itenryll.

late cutering at lis licedfii ears

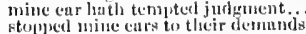

二 iii. :

beat the stones about tline cars?

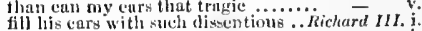

ircadtil moive of water in mine eard

luwled in mine cars sich hideou

lind favourable enr to mur request.

rise, and lend an enr: there is $110 \ldots . .$.
should to thy eurs not name ny boys

prepare her cars to liear a wooer
in hearing of all these curs...

ilenry $\bar{T}$ III

left to some ears anrecounted

suffered, gave mear to't
commonid a seeret to your

given eur to our eomplaint .......... \& cressida,

laving his ear tull of his

a tuir message to lis kingly

I bring a trumpet to awuke his car.

his cvasions have ears thus long

luwe ears nore deat than adders

invert the attest of eyes and ears.

Neprtune's car in lis descent.
your passiom draws curs hither

to stop his ears against adnonisiment?

sacriticial whisperings in his ear.. Timon of $A$

0 that men's ears sliould be to

feast your ears with the musie

put armour on thine ears, and on...

thou gavest thine ears.................

carry with us ears and eyes i........

we do request your kindest car

than one of his ears tu hear it?
let them pull all about mine ears.

let them pull all about mine ears...

that's worthily as any ear ean hear.

of' Rome gates by the ears.............
shake your Rome about your ears

my name hath touehed your ears

mine ears against your suit
stopied your ears against.

hereafter will I lend car to

in theirs and in the commons' ears

rire your own eyes and ears?

their hats are plucked about their ears

more sweetly in great Cæasar's ear.

lene nu suur ears; I come to bury

to shake his ears, and graze.

thrusting this report int his ears.

I ennot serateh mine enr...Antony $\tilde{f}_{\text {citeopo }}$

mincear must pluck it thenee

thy fruittul tidings in mine ears

the pack of metter to mine ea

make hattery to our ears with the loud

I'll tell rou in your car.

aequanted my grieved ear withal

I lave no curs to his request

have you noears? I nm Antony $\%$

with this eye or car distinguish.

ii. thint both mine care must not.

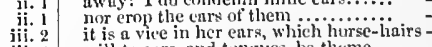

iii. 2 will to enrs, and tungues, he theme

infection is fullen into thy ear?

aliould render lim hourly to your ear

if that his heucl hove enr in music

have botli their cyes and ears so cloyed

mine curs, that licard her flittery....

full of tongues, of eyes, of ents ......

he not obdurate, open thy deat cars.

varied motes, enchanting every ear...

haz in the peoples cars..............

lis old ears deaf, yet should bot ly eas

and in their che then ...........

t) love-sick lide's fnl nttending ear

tit plual your ear, and please .... P'erictes.

ahould fet their ears liear their faults.

the reat (hark in thine ear) as hlack
my ears, I du protest, were never...

v. 1 
EAR-as a whisper in the ears of death. Pericles, iii. 1 EARLY_makes us early stirrers......Henry $r$. iv. I fir the gods are quiek of ear your ears into your ezes

- iv. 3 you are early stirring: what news.. Richard III. ii.

and whispers in mine ear, go

to my sense bend no lieentious ear

give ear, sir, to my sister

heing apt to have his ear abused.

light of ear, bloody of hard.

look with thine ears: see how.....
hark, in thine ear; change plac.

that ererear received

it you with patient ears attend.......

as he hreathed dcfiance to iny ear.

wherein thou stick'st pp to then nun drums in

a whispering tale in a fair läy's ear

rich jewel in an Ethiop's ear . . .......

sottest music to attending ears.

groans ring yet in $\mathrm{my}$ aneient ears

shot throngh the ear with a love-song

hy the ears? make haste (rep.)

I see that madmen have no ears ....

piereed the fearful hollow of thine eir

this, which startles in our ears?

let us once again assail your ears ........

nor shall you do mine ear that violence.

if with too eredent ear you list

give every man thine ear, but few
mulst not be to ears of flesil and hloo

so the whole ear of Denmark is by
and in the porehes of mine ears did

and in the porehes of mine ears did ....

nieans, and plaee, all

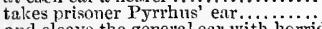

and eleave the general ear with horr

the very faculties of eyes and ears

to split the ears of the groundlings

ears without hands or eyes .......

like daggers enter in mine ears

a knavish speech sleeps in a foolish ear

war person to arraign in ear and ear

I have words to speak in thine ear

heard, and with a knowing ear, that he..
the ears are senseless, that should give

with a greedy ear devour up my diseours

bruised heart was piereed through the ea

abuse Othello's ear, that he is too familia

pour this pestilence into his ear.

makest his ear a stranger to thy thought

pish! noses, ears, and lips: is it jossible?
or that mine eves, or ears, or any sense
EAR-DEAFENING-

ear-deafening voice o' the oracle.. Winter's Tale, iii. l
EAR-KISSING-

but ear-kissing [Col.-bussing] arguments?. Leor,

de earl, de knight, ele lords

those suggestions for the you

henceforth be earls, the fir
kept the earl from henee?

二 v. 6
v. 1
v. 1
v. 3

prepare thy battle early in

the early village eoek liath . ........... $\bar{v}_{\text {n }}$ v. 3

betwixt too early and too late....Ilenry VIII. ii. 3

Wlat business, lord, so earl

whlat news with you so early?

tis but early days.........

are you stirred so early ton?

Julius Corsar,

Brutus gave the word too earl

early though it be, have on...Antony \& Cleopotra, iv. 4

that's the reason 1 was up so early . Cymbeline, ii.

why do you stir socarly?............. Pericles, iii. 2

should at these early lours shake off

early, one blustering morn

marred are those so eirly mate.

I fear, too early; for my mind

too early seen unknown, and known

what early tongue so sweet salutetli me? -

we may call it early by and by

marry, my elile?, early next Thursday -

late, early [Col. Knt.-hour, tide]

on Thursday early will

early in the morning see thou deliver

warly up, to see thy son and heir $($ iep.
carly letter he early bid me give his ...

our general cast us thus early

I ear'n that I cat, get that

I ear'n that I eat, get that
a barber shall never earn sixpe

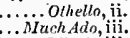

to earn a dearer estimationt ......... Coriolanus, ii. 3

As you Like it, i1i.

the aet that might the adldition earn ... Othello, iv. 2

ARNED-itself would have earned. Twelfh $N$. iii.

tlie one for ever earned a royal......... irinter's Tale,

betore you have earned them ....2HenryIV.ii. 4

though Marcius earned them not.... Coriolanus $i$.

and they have earned the waste.Aniony \& Cleo. iv. 1

EARNEST-perceive her ear.

sixpenee in earnest of the bear-herd... Much Ado, i.j. in earnest. In most profound earnest forbidl in earnest, shall I say?...Mid.N. Drenm, iii. but love no man in good carnest. . As you Like it, i. 2

et us talk in good earnest ...........

that it was a passion of earnest ........ - iv. 3

are you in earnest, sir? I smell .........

I have had earnest, but I canmot with

now your jest is earnest....... Comedy of

and, for an earnest of a greater honour. Macheth, $i$.

given me earnest of sueeess, commenein
pleads he in earnest? look upon ....Rich

tell me now in earnest, hoy

my plate, in good earnest, lo

the golden earnest of our death....

in earnest of a further benefit

stumble in mine earnest words

an earnest advoeate to plend.

importune with earnest prayers $\ldots$, earnest in the service of

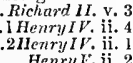

look to be either earl or duke

where is the earl? What shall (rep.)

tell thou thy earl, his divination

Eweet earl, divorce not wisdom .....
full fitteen earls, and fifteen hundred

an earl I am, and suffoilk

weleome, brave earl, into ou

rare description, noble ear

a poor earl's daugh ter

no better than an earl, al th

seven earls, twelve barons............

with all the northern earls and lords. 3 Henry $V I$. $i$

tor a poor earl to give ..............
dukes, earls, lords, gentlemeit.

desire the earl to see me in my tent

with the earl, sir; here within ......
let's follow the old earl, and get.

be married to this noble earl.

Richard III. ii.

given in earnest service of my God

given in earnest what $I$ begged in jest

must be an earnest motion made ..Henry VIII. ii.

nay, stay thou out for earnest.

in earnest, it's true; I heard ...

the nobles, in great

it is an earnest of a further good ..... Cymurline, $i$

we are strong in earnest [Knt.-astern].Pericles, iii.

if not, I nave lost my earnest

an earnest eonjnration from the king ....Hamlet, $y$.

draw from her a prayer of enrnest heart. Othello, i. 3
so earnest to have me fileh it?............ - iii. 3

MARNEST-GAPING-

he wishes earnestly ...... Winter's Tale, iv. (eliorus)

have carnestly implored a general..1 Henry VI. $\mathrm{V}$

earnestly he east his eyes upon me!. Iienry VIII. v. 2

how earnestly are you set a'work. (the rather, for I earnestly beseeeh)..Ant.\& Clco. ii. $_{2}$

as I earnestly did fix mine eye . Titus Andron. v. 1

why so earnestly seek you to put up ..... Lear,

all agreeing in earnestness to see him. Coriolanus,
with a solemn earnestness (more than .. Othello

With a solemn earnestness (more than .. Othello

in the reinso' the earth

thou earth thou! speak

nor no sound, that the earth owes.

all the corners else o the earth let

no better than the earth he lics upo...
$O$ heaven, $O$ earth, bear witness

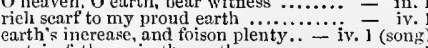

by this brave duke eame early to his . King.John,
by four o' eloek, early at Gadshill .. I Henryl

in the morning early shall mine unele - as in an early spring we see ..........2 Henry
EARTII-no sueh joy on earth!

lest the base earth should from

as heaven from earth

upon the dull earth dwelling

is nor of heaven, nor earth

as positive as the carth is firm ......... Merry Wives, iii.

the elements of air and earth ........ Tivelfth Night, i.

so in heaven, but not in earth ............ for $\overline{\text { Meas. }}$.i. 4

men of some other metal than earth... Much stdo, ii.

between the cold moon and the earth -

round about the earth in forty

this whole earth may be bored

heaven to earth, from earth to heaven - v.

goul's eartl's God, and boly's.. Love's L. L. i. I (let.)

a good lustre of conceit in a turf of earth - iv.

which on my earth dost shine .... - iv. $\overline{3}$ (verses)

hy earth, she is but eorporal $\ldots . . . . . \quad$ - iv. 3

heart most daring on the earth....Mer. of Venice, ii. 1

a kinder gentleman treads not the earth

here on earth, and, if on earth he do not to iii.

that she's in eartlit from whence......... All's Well, ii.

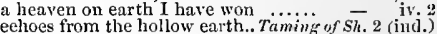

as heaven sees earth, and earth ...Winler's Tale, i. 2

uponeten of the whole dungy eartl.

I'll not put the dibble in earth to set

the earth, the lieavens, and all $\ldots . .$. .

or the elose carth wombs

the most peerless pitee of earti, I think =

as is the spring to the earth ........
they kneel, they kiss the earth

iii. 3

- iv. 3

another earth that the oracle was.... $-\bar{v}$ v.

in earth, in sea, in sky: the beasts ..

our earth's wonder; more thin earth

my sole earth's heaven, and my

like the inhabitants o' the earth .....

thon sure and firm-set earth, liear

does the face of earth intomb.

eonfound all unity on carth

do bear their privilere on earth...... $\overline{\text { sino }}$ iv iv

and eartly! Thou monstrous (rep.)... -

that sways the earth this elimate....

the meagre cloddy earth to glittering

the earth had not a hole to bide ....

ving earth's good hap, add an...... Richard $11 . \mathrm{i}$.

shall rake good upon this earth

from the tongueless caverns of the earth
when he sees the hours ripe on earth

our kingdom's earth should not be soiled -

this earth of majest $y$, the seat of Mar
this earth, this reajm, this England

and we are on the earth, where notling

fall to the base eartl from

dear earth I do salute thee (

all thy happy days on earth .........

sorrow on the hosom of the earth .....

earth I rain my waters; on the earth

a pair of grayes within the eart
to make the base earth proud...

I take the better thing tha the like

in earth as quiet as thy father's..............

to that pleasant country's earth.

if this rebellinis earth have any

wounds the earth, if nothing else

a god on earth thou art ..............

the sovereign'st thing on earth

and lards the lean earth as he.

forgot upon the faee of the earti

and the foundation of the earth shaked

I say, the earth did shake when I....

oft the teeming earth is with a kind ot

hures the old beldan earth

for, heaven to earth, some of' us.

two paces of the vilest eartli (rep.)...

commeneed on this lall of earth ..2 He

let heaven

$O$ earth, give us that kiug a...........

whose nemory is written on the earth

goes with me into the earth.

proud hoofs i' the receiving earth...Hen

he bounds from the earth, as if ......

the earth sings when he touches it

trod upon Got's ground and his earth

so in the earth, to this day is not ...

Venus, fallen down on the earth
pitchy mantle over-yeiled the earth 


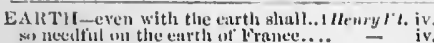
sis nectiful unt the earth of l'ramee..

exceedin!' minteles on carth

2llenryrl. i. 2

prostrite, mele grovel on the earth

blesserl are the pemeenukers on enrti

aul eursing men on earth

ii. 1

theirs fir the curth's inerense.

thy grave is dighed already
find a hurbour iu the eartli?

knit eurth nut henven together

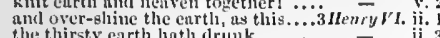

then let the earth be drunten

rise from the earth's cold fice........

in leaven, or on carth

car never had seorehed the carth
sitiee this carth aflurds

sitiee this carth aflurds no joy
must yield niy boly to the enrti

must yield ny boily to the enrti
rule, reign, but eurth ant dust?

rule, reign, but etrth ant dust?

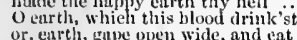

or, eurth, gupe open wide, and ta

doth nint brenthe unon the carth

trum this enrth's thrallom to the jo

that breathed upon the earth ........
on England's luwtul earth, uniawtul

excellent grand tyrunt of the eartl

thou eanest on earth to mnke the ear

imperial ty'le of this earth's glory

num keep it from the earth ........

I had never trol this English enrth

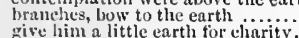

give laim a little earth for eharity.....

designs begun on earth below
shuking of eartli? commotion.

sh earth to the eentre, yet .....

wind, or sundy eartli, as fox

as deej under the earth, as I

the very centre of the curth.

wiler than the sky and earti.

wiug of night o'erspreads the earth

no spuce of earth shall sunder our...

dive in the earth, and fence not Athe us!

draw frowu the eurth rotten humidity

earth, yield me roots

thou eommon.

behold, the carth hath roots.

the earth's a thiet, that feeds

that of all things upon the earth

leaveu will not have earth to know

not of stronger earth than othe
sink, my knee, i the earth
fulds in this orts

fulds in this orts o' the earth...

when all the sway of earth shakes.julius $\bar{C}$ crsar, $\mathrm{i}$. 3

known the eartl so tull of faults.
nor heaven, nor earth, have been

nor heaven, nor earth, have
thuu bleeding pieee of earth

shall smell above the earth with

find out new heaven, new earth ...Anionys cleo. i.

our dungy earth alike feeds bea

levying the kings o' the earth for wi.

standing on the earth, and fishting toot

breatlue between the heavens and

music i' the air. Under the earth....

that heaven aud eurth may strike

the 'ruwn o' the earth doth melt

no grave upon the carth shall elip

mure vexagh at anything in the earth.

the abhorred things o' the earth ament

the abhorred things o' the earth ament -

teirs of joy shed on the earth

as 'Titan's rays on earth, and ripea...

into this gaung hollow of the eartis

stauncli the enrth's diry appetite

and bow this feeble ruin to the carti

thith not the earth o'ertlow?

the weeping welkin, I the carth

crough written upon this carth...

the immost centre of the earth

no justice in earth nor hell.

wet him breast-deep in eart

to see him fistened in the carth.

my rielies to the eurth trom wh.
the eurth is wronged by man's

kings are carth's gods: in viee

we'li mingte bloods together in the earth

of' late, earth, sea, a od uir...............

wonter, earth, and heaven can make.
showk, as the eartli did cillake .........

equal uny single erown o' the earth..

some part o' the eartl (rep.)..... iv.

shall be the terrors of the eartli..........

blow the eurth into the sen.

and hurts the poor ereuture of earti

she's dead as eurth; lond nie

the earth hath swallowed (rep.)............ S Juliet

lor use, for earth too deur! ............
turne buck, elull earth, and find thy

the encthe that earti, and muther

wil the earth duth live, but to the cart

too untimely here did scorn the cartl
li.MIRII-vile curth, to earth rexign. $k$ eartli? gimes birth, mind herstal curth [Cat.Knt.] the eurth doth drizgle dew my huslund is on earth, my titit]
returu aguin to enrth, umlens that

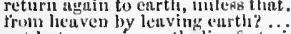

yict but green in earth, lies festering

the dearest inoriscl of the eartl

lienven and carth togetler flemon

in sea or fire, in earth or ai

we liray you throw to enth this

thenen and earth! must I remenher?

O eurth! what else? und shall I couple.

canst work $i$ ' the earth so f:ist?

more things in heaven and enth, iloritio -

this goodly trume, the enrlh, secms to m

nor eurth to me give food, nor heuve

examples, gross as enrth, exhort

a man lie i' the earth ere he rot?

lain you $i^{\prime}$ the earth three-and-tw

the dust is earth, of earth ห'e make $^{\prime}$ ion...

$O$ that that earth, which kert the worle

lay her i the eartli; and from her finir

the heaven to earth, now the king alrink

if that the cartli could teem with woman's

zushed within the hollow mine of earth

EAliTH-BOUND-

the tree unfix his earth-bound root?... Macbeth,

EARTIIEN-green carthen pots.. Komco s.Julit, $v$

EArthly happier] is the rose Cii Mid. N.'s Drecm,

EARTHLY -her carthly and abiorred.. Tempest, i. a

but she is an earthly paragon... Two Geat. of $\mathrm{l} e \mathrm{er}$

there were no earthly mean

doth not every carthly thing ery.........uch fitlo

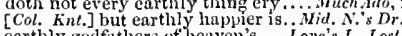
earthly godfuthers of heuven'

with sueh an earthly tong

the wager lay two earthly women. $\bar{M} e r$. of $($ Ven iii.

and eartily power doth then show

a heaveniy effeet in an earthly actor. Al s. Welse)

$\mathrm{I}$ am in this earthly world

what earthly [Col.-earthy] na.
o thou the earthly author of

Wichard II. i. 3

a world of eartly blessings to oke..Henry V iv.

great is his comfort in this entriliy vale

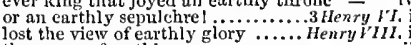

the queen of earthly queen

to keep your earthly audit

a peace above all earthly dignities ... - iii. 2

if thou darest be, the earthly Jove... Ant.6 Cleo. ii. 7

this earthly [Col. Knt,-earthy] prison. Tilus, And, i.

gripe not at earthly joys, as erst......

Pericles, i.

again, se-speaking earthly thunder .... Harnlet, $\mathrm{i}$. EARTH, re-speaking earthly thunder .... Hainlet,

I look for an earthquake too then.... Much Ado, i. I

blazing star, or at au earthquake

do make an earthquake of nobitity

since the eartbquake now eleven .... Romeo \& sui.
EARTH-TREADING-carth-treading stars

EARTH-TREADING-carth-treading stars - i. 2
EARTHI-VEXING-earth-vexing snurt.Cymb. y. 4

EAR'THY-earthy gross eonceit.. Comedy of krr.

soon lie Riehard in an earthy pit1.. Richard II

to survey his dead and earthy image.2Henry $Y I$.

she looks, and of an earthy cold?.. Henry 1 III.

[Col. Knt.] before this earthy prison
upon the dead man's earthy check

EAR-W AX -brain as ear-wax .. Trnilus \&- Cress, it.

EASE-do it with much more ease ..... Ternpest, iii. I
ean with euse attempt you .....Meas. for Mleas. iv. 2

to ease the anguish of a torturing . Mid. N. Dr. V.

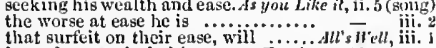

All's liell, ini. I

is ready, may it do him ease.. Taming of Shreer, $y$.

whom youtli and ease have taught.. Richard 11 . ii. 1

they find $a$ kind of ease, bearing.

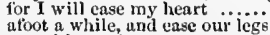

got with much case...

shall I not take mine ease in ........
vaulted with sueh case into his geat.

ineurytr.i.

in yoiny, and ease, whilist

to euse your cowitry of

rusted with easc, thut slunli $i$

mine ire, nor case my henrt

enjoys the honour, and lits case

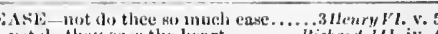

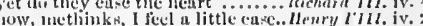
at whut euse might eorruyt minds

pome cume to take their case ........ $\overrightarrow{\text { (epii.) }}$

beculse these eunst not euse thy smart - iv. A

and seek ubout for eases ............. Trinon of thens. v

sit aud jaut in your great clinirs of ease - v.

as he he never ut leart's cuse... .... Julins Corar, $i$.

to ense oursel ves of divers slunderous
probution, I can with case produce. . Cynbeline,

ruil at hin to cuse ny mind.. Tilus dwdronicus

$O$ could onr foumring case thy misery!
some simn how I may dos thee ease ..

to eace their stomatis with the
that weep doth ease seme denl.

to ease the gnawing volture of

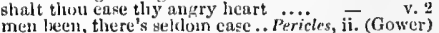

troulhle, for a minute's ease ............ - it.

emunt sit at ease on the old bencli. Romeo of $J$ hl. ji.

be dome, thint may to do thee ease ....... Hamlet, $\mathbf{i}$.

so that, with eare, or with a little shuftling - i

tor my ease, in gool faith.

neglecting an attempt of ease .............. Othello, i. 3

E.ISED-till he be eased with being.. Kirbird 11 . v.

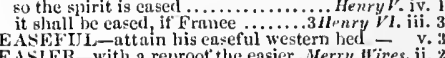

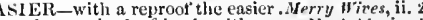

you dure easier be friends with me...Much Ado, iv. 1

I cun easier teach twenty wliat. Yerch. of Fenice, $\mathrm{i} .2$

your spirit were easier for advice. Hinter's Tute, iv.3

for a friend: 10rego the easier .............. John, Jii. 1

you think, I am easier to be played on. Hamlet, jii.

EASIENT-in whose casiest passaye. Hinter's Tale, jij. 2

EASILIEST-easiliest harbonr in? ..Cymmetine, easily as I do tear. TucoGien. of'er. iv.

pat off my opinion so easily

he will bear you easily..........Tteelfh Night, iii.

very easily possible; he wears his fuith. Nuch Ado. i.

your wit anbles well; i it goes easily.. -

for my great suit so easily obtuined ..
for the one sleeps easily, because... As you $\overline{L i k e}$ it, iii. 2

he may easily put it off at eourt........Al's stell, it.

came the posterns so easily open?. Winter's Tale, ii.

I will enforee it easily to my love.....

dogs, easily won to fawn on ....... Richnerd II. ini. 2

bring this prize in very easily .....2.2Henry $/ Y . j$

you eannot easily purge yourself...... - - iii.

folly may easily untie........ Troilus $\&$ Cressida, ii. 3

he will supply us easily ........ Timon of Athens, iv. 3
whieh casily endures not article ..... Coriolanus, ii. 3

in Rome, as easily as a king ........Julius Carsar, i.

not easily, I think ................. Cymbeline, ii.

craeked as ensily 'gainst our rocks . ̈us Andron. iit.

by and by is easily said ................ Hrmet, iii.

of one, not easily jealous ...............

shall lead a kind of easiness to ......... Hamlet, iii.

madle it in him a property of easiness......

a spendelerift sigh, that hurts by easing. Itrmlet, iy, 7

EAS' $\mathrm{S}-$ be my enst and west Indies... Nerry Wires, i.
dajples the drowsy east with spots ... Yuch Adw, v.

sline, eomforts, from the cast... Mid. N. Drram, iii.

first opening of the gorgeous enst

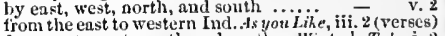

from east, west, north und suth... Hinter's Tate, i. 2

by enst and west let Franee ...............ng John, ii. 2

anther day break in the east ......... richaril 11 . iii.

rising in our throne the east.......... inchan - iii. 3

danger from the east unto .......... llenryll. i. .

hegins his golden progress in the east - - iii. 1

on the east sille of the grove (rrp.)..2llenry li. ii. 1

larkness breaks within the east an hour - v.

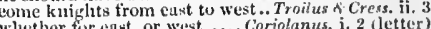

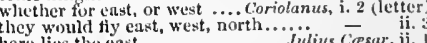

here lies the east................... Julius C'asur, ii.

and the high enst, stamis, as the Capitol $-\bar{\delta}$ Cleo, i.

fir my pence, í the eust my plensure lics -

the heds $i$ 'the cast are soft

W'e must luy his head to the east.....

Inay way.

the goldlen wintow of the cast. . Romeo of Juliet,

phonlal in the furthest east begin

the severing cloude in yonkler east $\ldots . \overline{-}$ iii. 5

even from the enst to the west! ........ Ohhello, iv. 2

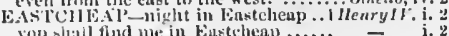


EASTCHEAP--lads in Easteheap

my noble lord, from Eastclieup

at the old place, my lord: in Eastcheap 1 Henry 1 . ii. I

EASTER-new doublet before Easter? Rnin. \& Jru. iii. 1

EASTERN-with the eastern wind...Mid
even till the eastern gate, all fier $y$-red

the proud tops of the eastern pines. Richard II. iii.

uj) to the eastern tower

O eastern start Peace, peace....... Antony of Cleo. v.

eheekering the eastern elouds ... Romeo \& Juliet, ii. 3

e'er the dew of yon ligh eastern hill. Hamlet, i. 1

how ensy it is to be sueh ........... Merry Wives, ii. 2

as easy as a eannon will ...........

tis all as easy filsely to take... Sleas. for Neas. ii.

which are as easy broke as they.......

all diffeulties are but ensy when

how easy is a bush supposed.....Nid. N. Drean, v.

and how easy it is to put years.... Love's L. Lost, $\mathrm{i}$.

if to du were as easy as to

it is as casy to count atomies.

youlike it, iil. 2

rou shall as easy prove that 1

is tor me less easy to eommit..

are too few, the sliarpest too easy

my Jove, as easy may'st thou tall. Comedy of Er.

how easy is it then? your const
which the false man does easy

as easy may'st thou the intrenchant

with very easy arguments of love

to win this easy mateh played for.

an easy task it is, to win were an easy leap, to pluek

made us doff our easy robes of...... Henry $I V . i$.

and of so easy and piain a stop ...2 Henry $\overline{I V}$. (ind.)

its not so easy on easy yielding.

sits uot so easy on me as you .........

a soul so easy as that Englishman's... Henry $V$. these taults are easy, quiekly

found the adventure very easy

is it not an easy matter to

Richard III. iii.

easy penance! Faitl, how easy (

at last, with easy roads

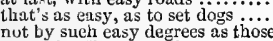

to eut it off; to eure it, easy

with the easy groans of olu women....

with a suaffe tound easy tines

with a suaffle you may paee easy....̈itony \& Cleo. ii. 2

at this tirne most easy 'tis to do't

infinite of easy ways to die

else an easy battery might lay flat ... Cymbeline v.

not a whit, your lady being so easy.. - - ii.

as jewels purehnsed at an easy price

my praetiets ride easy!.................... Lear, i. 2

the next more easy; for use .........

for 'tis most ensy the inclining ........... othello, ii. 3

do it with gentle means, and easy tasks - iv. 2
EASY-BORRowED-

whose ensy-borrowed pride dwells in .... Lear, ii. 4
EASY-HELD-

EASY-MELTING-

IHeary VI. v.

Wrought the easy-inelting king

it eats and sleeps.

I'll eat nothing; I thank

..... wives, i.

still swine eat, all the dratt

thor shalt eat a posset to-night.

danee aud eat plums at your wedding
let us therefore eat and drink.... Twelfth
Night, ii. 3

I'll eat the rest of the anatomy...... for $\bar{M}$ eos. iij. 2

I promised to eat all of his killing......M Much $\mathrm{Allo}$, i. I

aid lie hath holp to eat it.

ent when I have stomach.................

he eats his ment without grudging

nur age so eat up my invention.

and I will make him eat it, that says

will you not eat

what thou desirest to eat

most dear aetors, eat no onions....

he liath not eat paper, as it were. Love's L. Lost, iv. 2

but I will not eat witls you

and eat husks with them?

learned, played, eat together .........

it I bring the not sometling to eat..

forbear, and eat no more (rep.) .....

when he laad a desire to eat a grape...

grapes were made to eat, and lips to

it looks ill, it eats dryly...

true gait, eat, speak, and move under

will you teat no grapes, my royal.

to eat with us tu-night, the charge ...

but I will eat and drink, and sleep ä
I will hencefurth teat no fish of ......

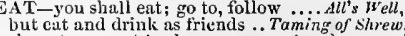

she eat no meat to-day, nor none (rep.) -
if I should sleep, or eat, 'twere deadly

eat it up all, Hortensio, if thou ......
Kate, eat apae; and now, my honey

as well as eat. Nothing but sit (rep.)

I

that inust eat with the devil

'tis said they eat each other

ere we will eat our meal in

sir Robert might have eat his part... King John,. .

now will eanker sorrow eat my bud - iii.

that jade hath eat ink, or breat

$a$ micher, and eat blaekberries? ....... Hen $\overline{\text { y }} I V$

I would make him eat a piece of $\mathrm{my}$ -

wouldst eat thy dead vomit

desire to eat some; whereby made a shitt to eat up thy holiand...

make lim eat it. That's to make (rep.) -

and eats conger and fenc

we will eat a last year's pippin ........

havock more than she ean eat

to eat the English. I think

that dare eat his breakfast

only stomachs to eat, and none to

and bid me eat my leek: it was......

petitions, to eat, look you, this

the mean-time, and eat your vietuals

ean moek a leek, you ean eat a leek
make him eat some part of ny......
I eat, and eat, I swear. Eat, I pray you -

thy cudgel; thou dost see, I eat...

eonsuning eanker eatshis falsehood.1 Henry $V I$. it.

all shall eat and drink on my seore.

but I'll make thee eat iron like............

I have eat no meat these five days

open wide, and eut him quiek

Richard LII, it.

would eat ehiekens i' the shell .. Troilus $\&$ Cress.

he that is proud, eats up himself

he eats nothing but doves, love.................

live in fire, eat roeks, tame ......

I will go eat with thee, and see

I eat not lords. An' thou (rep.).

what a number of men eat Fimon

rieh mon sin, and I eat root ...

keep't, I canuot eat it.

in this! thus would I eat it.....
or, rather, where I eat it ....

there's a medlar for thee, ent it.....

eat, Timon, and abhor them

ean you cat roots, and drink cold...

that, dors must not up

that, dogs must eat; that ..............

umatural dam should now eat

it will not let you eat, nor talk ..JuliusCesar,

for what his eyes eat only

it eats the sword it lights with.

sir, I will eat no meat ................
will it eat me? You must not (rep.).

as the wolf, for what we eat

but that it eats our vietuals

look you eat no more

please you eat ot" it

will't please you eat? will't please

the eat those little clarlings........

the great ones eat up the little ones....

and to vionds that $I$ eat do seem

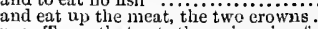

poor Tom; that eats the

I cannut draw a eart, nor eat dried oat.

canker death eats up that plant. Romeo \&

I eat the air, promise-crammed ....... Humlet, ii.

who all semse doth eat of habit's devil

not where he eats, but where he

list, eats not the flats with more

driuk up Esil? eat a croeodile?

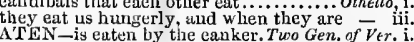

hath eaten up my sufferance. ....Merry Wives, iv.

having eaten the rest, as I said

how nany latl he killed and eaten... Much $\overline{\text { ini. }}$.

thy master hath not eaten thee ... Love's L. Lost, vy.

aid wurms have eaten them ..... As you Like it, iv.

and low much he hath eaten.... Winter's Tale, iii. 3

he utters them as he lrad eaten bullads - iv. 3
EATEN-better to be enten to deatlu..2Herin $I V$. i. 2 suftiering flesh to be eaten iu thy house - ii. 4 some ravenous wolt' had eaten thee!..l Henry VI. v. 4 he eats, but where he is eaten him... Coriolain $s_{\text {, }}$ iv. 5

I see, sir, you are eaten up with passion. Orhetto, iii. 3 and she an eater of her mother's flesh EATING - the an meats ...............

so eating love inlabits ............. $\bar{v}_{i}$ i.

eating and drinkine be put down...Yea. for Mea. iii. let it be an art lawful as euting ... Winter's Tale, v. 3 eating the bitter breud of .

trom eating draff aud husks. iнenry $\lrcorner V$.iv. 2 eating the air on promise...........2 Henry IV. i. 3
stiuks with eating toasted eheese ..2Henry 2 . iv. 7 your dinner worth the eating....... fulius Cosar, i. EAU A - via! les eaux et la terre....... Andron. v. AVE_drops from eaves of reeds ........ Tempest, v. not bnild in his louse eaves..... Heas. for Heas, iłi. 2 EAVES-DROPPER R I'll play the eaves-dropper ......... Kiehard III. y. 3 do so: to etb, hereditary sloth
make flows and elbs

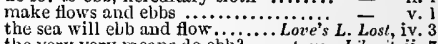

the very very means do ebb? ..... As you Like it, ii.
doth ebb and flow like the sea ...... Henry $I \gamma^{\prime} . \mathrm{i}$.

as low an ebb as the foot of

as low an ebb as the foot of

thrice flowed, no ebb between.

$\ddot{2 H e n r y}$ IV. ii. 2

and ebl back to the sea $\ldots \ldots \ldots \ldots \ldots$ ebb - v. 2

his ebbs, his flows os their ebi

in the ebb of your estate ....... Timon of $A$. Thens, ii. 2

that ebb and flow by the moon ...Antony \& Cleo. ii. 7 do esb and flow with tears? ..... Romeo \&..Juliel, iii. 5 eour'se ne'er t'eels retiring cbb........... Othello, jii. 3

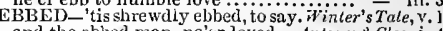
EBSING-ebbing men, indeed, most ... T \& Cleo. i. 4 do cliase the ebbiug Neptune........... EBON-COLOUREDthe ebon-coloured ink.... Love's $L$. Last, i. 1 (letter) as blake as ebony. Is ebony ...Lore's L.Lost, iv. 3 CCE- - a Jew else, an Elorew Jew .) HenryIV. 1i. 4 ECCE-like a hand-saw, eee signum
ECHE-fancies quaintly eehe ... Perieles, iii. (Gower) CHO_cives a very eehu to the seat. Twelfhl Night ii and echo in eonjumction........Mid. N.'s Dream, iv. all the ehurels did echo

Macbeth, v. 3

applaud thee to the very eeho

Heng John, y. 2

all the court may eeho ........T

thilst the babbing eeho mocks .... - -3

ECHOES-fetch sluill echoes.. Taming of Sh. 2 (ind.)

he echoes une $[h n t$-alas! thou eehoest!.. Othello, iii.

ECLI'SE-in the moon's eelipse ........Mocbeth, iv.

these late eclipses in the sun and moon ... Lear, $\mathrm{i}$.

these eelipses do portend these divisionsl -

sick almust to doonsday witli eelipse... Hamiel, i.

it sliould be now a huge eclipse ......... Othello, v.
ECLIISED-is halt' ecliused

terrene moon is now eelipsed...Antony \& Cleo. iij. 1

ECST ACY - what this eestaey may.... Tempest, iii.

eestacy hath so mueh overborne her... Nuck Ado, ii.

he trembles in his ecstacy! .. Comedy of Errors, iv.

sorrow seems a modern eestaey............ - iv.

sorrow seems u modern eestaey ........

this is the very ecstaey of love ......... Hanlet, ii.

blown youth, blasted with eestaey......

and laid yood seuse upon your eestaey. othello iv.

EDEN-this other Eden ............. Kichard 11. ii.

EDG AR-Edgar, I must have your land ... Lear, i. 2
the beloved of your brother, Edgar - i. 2 (let.)

my son Edgar! had he a hand.

my tather named? your Edgar? ......

something yet; Edgar I nothing am

dear son Edrear, the food of thy abused...

if Ldgar live, $O$ bless him

say, Edgar his banished son......... - iv.

my name is Edgar, and thy father's son - v.

-take away the edge of that ....Tempest, iv.

gall bate his seythe's keen edge... Love's L. Lost, i.

whose edge hatb power to eut ....... - ii.

apon the cage of youder coppice.

with the edge of a feather-bed...Merch. of Venice, ii. to the extreme $\in$ dge of hazard ..... Al ${ }^{\prime}$ ' Well my pugging tooth on edge. Winter's Tale, iv. 2 (song)

with an unbattered edge, I sheatbe

eloy the hurrury edge of appetite ... Kichard $\boldsymbol{I}$. would set my teetli notling on edge 
ED(ab-OM an edre, more likely to full.2 Ifenry $I l^{\prime}$, level ut the etge of n menknife $\ldots . . .$.

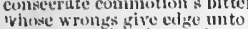
- me say, knives have ed ges he eut with calse of luenty eori

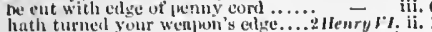
if thou turn the elyge, or eut not...... iv - 10

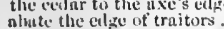
his sword hith a sharp ed

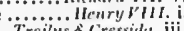
[col.] or edget aside from the direet chall to the edgate of all extremity

rice fur his edse, tall down

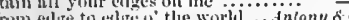

trom enlige to enge o' the worli

have elige, sting, or operution.

slumler; whose culge is sharper

thy' wit wants edge, aud manners

even to the exlye $u$ ' the slure.

give lim a further edac, and divive

cost you a grostuing, to take ott ny eil

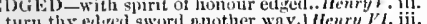

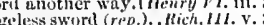

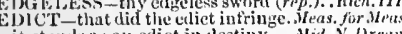

it stmols a an ediet in testiny

ctrongly stand.. Love.

preluimed ediet and continent ...

such il straight edict

2 Itenryll, iii.

spurn at his edict, and rulfil a min's? $h$

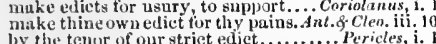

EDIFICE-1 have lost my edifice... Merry Hires,

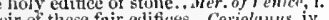
Muny an heir of these fuir edifices.. Coriolamms,
EDIFIED to be well edified .... Tuelfth. Night,

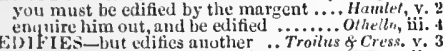

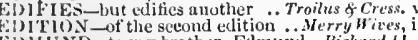

EDNEND_to my brother, Edmund... Richard l.

lord Edmund fortimer, my lord

the end of Edinund Slurtimer...

from fanious Edinund Langley

heads of Edmund dnke of Somerset...2 Henry $l$

the fifth, was Edmund Langley

Ednund Mortimer, eurl of March (rep.) -

Edmund, Anne, and Elean

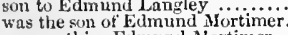

marry, this: Edmund Mortimer

know this noble gentlemun, Eumund? .

lowe is to the bastard Edmind, as to .....

Edmund the base shall top the legitimate -

heaven and carth! Edmund, seek him out -

find out this villain, Edmuni

how now, brother Edmand?

Edmund, I hear that yon have shown

you, Edmund, whose virtac and obedience

alack, Sdinund, I like not this unnatural

Edmumb, keep you wur sister company

Edimund, furewell: go, seek the traitor

Where's my sun Edmund? Edh
back, Edmusk, to my brother....

back, Edmunk, to my brother..............

Elmund, 1 think, is gone, in pity of

II ist samaking louks to noble Edrami

billumul and I have talked.

t) Edinuml earl of Gluster; seek him ont

Himuthe 1 arrest thee on capital treason

what's he, that speaks for Edmund earl of

no less in bloud thme thou art, Edmand.

speak, limmund, where's

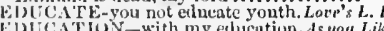

Dith my erheation. As you Like in

hy educution a card-maker. Tumin' of shretr, 2 (inil.)

toward the erlucation of your daughters

as blic in beuuty, teduetion, blood

Pericl's, ii. 3

gained of edluention all the grace.

find eclucution; iny life, and elacention .. Omhello, i. recived of the inast pions Edwurd

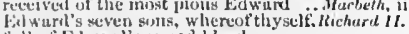

lull of Eilwart

ny lirsther bilwarl'y bun (repestedi.

my losther Ealwarl's bon (repeated)..
resuect'st not spilling Edward's blood

the last of noble Edwurd's sons

trundsire, Edward, sicked and diedizinenry $W$.

y our greut uncle's, Fil iward the black

tu) till king Elwarl's tunge with ....

of funous ancest, rs, Erlward the thirel -

and Your great uncle bilward the plack

Gilwara the duke of York, the carl of

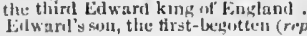

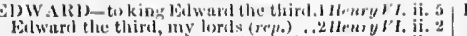

fod ward tlue black prine, clicel foctiote

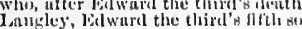

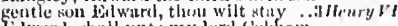

Ealwuri, shall unto my lore cahisan

chward, and kirelitre, you shall stay

wnitom Eilward, uul the lusty

king wl ward, valimit dicliard

stay, biwitred. No, wrangling woman

and belwarl's gum is cloumed ........

blwarl aud Richurel, like a braee

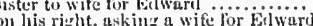

and suys, his lolwircl is instulled ...

and support king Elward's place.

true subjects to the king, king lidward

it he were seated as king bilward is..

Ellwarl, will uso wonen honourably

Llward's title buried (ropeated).
while proutl anditious Edward.

prince Edward, llenry's heir

our earl of Warwick, Edward's greate
from worthy Edward, king of Alban

yet licre prince Edward stands

prince Edward, and Oxford, vouchisaf

is Edward your trae king?

to Edward but not to the Engiisi.

as may appear by Edward's good suceess

I an eleur from this miscleed of Edward's

Edw:1rd, thy supposer king (rep. iv. I)

and bid talse Edward battl

ill Edward full by war's mischance

but seek revenge on Edward's inockery

or long as Edward is thy constant riend -

that young prince bdward marries
I stay not for the love of Ed ward.

as he fivours Edward's cause! .......

may beat down Edward's gnard
but fullow me, and Eetwond shall be

that Edward needs must duwn.

Edward will always bear limself.

his mind, be Edward England's king

misfortune is betinlen king Edward?

for love of Edward's oftspring in

king Edward's fruit, true heir ......

gave at least the heir of Edward's right

shaken Edward from the regal scat.
that Elward be pronounced .......

that Edward is escaped from you

ay, for it' Edwurd repossess the erow

yet Ed ward, at the least, is duke of York

for Edward will defend the town ....

now will I be Edward's ehampion (rep.) -

Edward the fourth, by the grace - iv.
whosoe'er gainsays king Edward's riglat -

long live Edward the fiourth!..
Fdward from Belyis, w'th basty

Fidward from Belgis, with hasty
tlye power, that Ed warl luath in field

should they love Edward more than me?

is sporttul Edward cone? Where slept

Warwick's king is Edward's prisoner

pardon me, Echard, I will make

what is Edward, but a ruthless sea?

for Edward is at hand, ready to fight

and lo, where youthful Ed ward cons

Elward, whut satisfaction eanse

lascivious Edwurd, and thou, perjured

sweet boy, tby brother Edward...
that Edward shall be fearfal of li

if king Eilward be as true and just.. Kichare 11

to cull king Edward's widow, sister.

God take king Ellward to his mercy.

breathes; Ear ard still lives, and reigns

wite to thy Erlward, to thy sla

these l'luntugents, I Ienry, and Eilward -

"hen iny futher York and Edwurl wch

that brave urince, Edwurd, her lorel

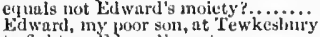

to firtit on

to flyht on lidwaril's larty $\ldots . .$.

my lovely Eilwird's death

bilwart thy soo, that now is (rep.).

against my soul, tur Edward's sake
fior Edl ward, for my brother, for his sake

thun Eclward will for tielings of iny

to eomfirt Elwurd with our colnum
Eilwarl. my lurd, thy son, our king

my fecble hands, Clarenee and Edwar

tis winy alcur lord lurenes

Fil wird and Clarcued What stay $(r, \ldots)$ -

whe fir an bilwarl weeps, and 80 dh I
I tim un lotwarl weep, so do not they

deud belward's gituve, and plunt (rip.

dews holl of gingl king Edwarl's lenth? -

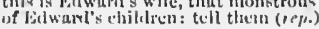

W. AlD-that insatiate Eilwarl. Richard HH, ii, s

the tusenrdy of Ldward's elailusen?

ii. 2 that Edwaril jo your bristier's sin (rep.) $=$

he got this lid ward, whom war manuers -

tis so; but bidurerd lives....

that blward still slusald live........

the sont of diwerd slece in Xbraliming

I hau on lid ward, till a l kichard ( $r p$.

he is dead, tlyat stablsed iny Fidward

as fille to bilwaril's beal; throw over

confess she was not Edward's letugh

thereon engrave Lilward nnd York.

Iftstings, and Ewoluri's childen, Rivers -

thy fuir son El wiurl, Vutughan ...... =

Edward's unhappy sons do bid tlee.

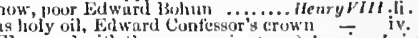

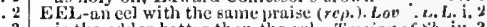

ii. 3 shall not so awake the bed of eels.... Pesirles. iv.

1. 3 as the eockney did to the eels .............tar, ii.

ii. 3 all his apparel, into an eelskin ....2 Henry 11 . iii.

ii. 3 one man, -e'en one poor wnn .... Love's L. Lost, v.

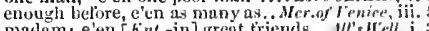

e'en as soon as thou cinst

what have we here? E'en that you hiave - iii. 2

is our master. E'crat hand.. Tuming of Shrerr, iv.

and one, e'en at turning o' the tide .. Henry! ii.

iii. 3 We'll e'en let them aloue.............i itenry .1.

she's e'en setting on water to seakl

and e'en as if your lord should wear
and

I am e'en sick of slame, tlat.

gusod e'en to your Horships............ Coriolanne, ji.

iii. 4

cood e'en, good fillow (rep.) ........... Homeo of Julict, i.

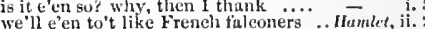

iv, 3 Horatio, thou art e'ers as just a wun .... - iii.

iv. 3 'tis e'en so: the haud of little employment - v.

why, e'en so: and now my lady Worm's

the king's jester. This? E'en that

e'en so. And smelt so? pah! E'en so

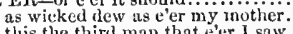

this the third man that e'er 1 saw

and the rarest that e'er came there

deeper than e'er plummet sounded

return or e'er your pnlse twice beat

as strange a thing as e'er 1 looked on.

if e'er you know her

as e'er 1 did comnit

e'er sinee pursue me

than e'er 1 shall love wite.

v.

the first knave, thint e'er made.

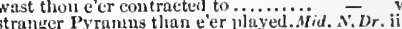

if e'er l loved her, all that love....

ar shal, my iord, thit

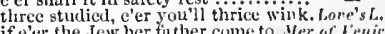

if e'er the Jew her futher com

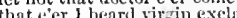

the first truth that e er thine

tell times more than e'er I ilid...

as willingly us e'er I enme tron

eyprus, black as e'cr was crew.

as you have eer beell my tintier.

the sweetest complnuion, that e'er man

that e'cr the sum slone briglit on

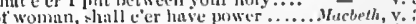

he judined lay yon, that s'ur 1 henral. King Joh

than eer the coward hand of Frane

the dragon, and ex since, sits on his

if e'er thuse cyes of yours behwli

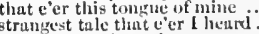

Mirhard II. iii.

better than I love e'er a seury

I/lenryl!

as loul as e'cr thou canst.

the greatest miriele thut e'er ye

lltury iti. i.

as ecer thy fiather Ifenry inade.

2Henry ri, y. 1

that dinit thut e'er 1 wrester

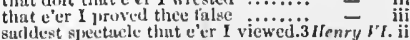

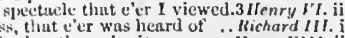

a!rain, fresleer thun e'er it was ... Henry FIII. ii. 


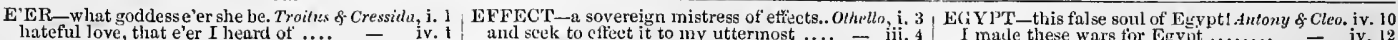

lhateful love, that e'er I heard of '.... - iv. $t$

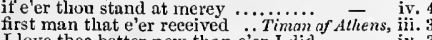
I love thee better now than e'er I did - iv. 3 if $e$ 'er again I meet him ..............
more a friend than $e^{\prime} e r$ an eneiny.

lip lath virgined it e'er since

repent, that e'er thy tongue ... excuse be born or e'er begot?

as dear as e'er my mother did...

vanquished, e'er they do resist.

if my tongue did e'er solicit...

to understand, it e'er this eofiin...

the rarest dreain that e'er dul .

as much as elilild e'er loved

Tilus Andronicus, $\mathrm{i}$.

of despatch, ettected mariy nicer nceds

my lord, and I wish it happily effected

we'll sce these things effected to
ancient proverb will be effeeted

that has but effected his good-will ... Corrota

vils she hatehed were not effected.. Cof Cleo. iii.

Which, eumingly effeeted, will beget. Titus
EFFETLES - served me to effectless use

Sure all's efiectless; yet nothing we'll.. Peric pleasint, pithy, and effectual... Tamin. of $\mathrm{F}$ ' else conelude my words effeetriai ...2 Henry $V I$. iii. reason, nighty, strong, and effectual. Tilus And d. v. 3

EFFEMIINATE-be effeminate .. As you $L$

young, wanton, and effeminate boy. Richard $I I$. y.
like but an effeninate prinee......... Henry $V I . \mathrm{i}$

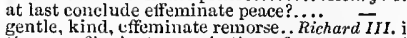

gentle, kind, effeminate remorse.. Richard III.

than an eftem mate man in time of. Troil. \& Cres.
beauty hath made me effemiuate..Romeo\& Jut.
EFI'IGIES-his ethgies witness most.. As you Like,

EFFUSE-much effuse of blood doth.3 Hetry $V^{I}$.

EFFUSED-thus rigorously effused..1 Henry $V I$.
EFFUSION-the mere effusion of. Mea. for Mea.

this effusion of sueh manly drops.... King John, v. 2

stop effusion of our ehristian blood..1 Henry VI.
EFTEST-that's the eftest way ....

EFTSOONS-eftsoons I'll tell thee why. Pericles,

EGAL-of egal [Col.-equal] justice. Titus Andron. i

EGEUS-thanks good Egeus......Mid. N.'s $\overline{\text { Dream, i. }}$ i

and eome, Egeus; you slall go with

Demetrius and Egens, go along......

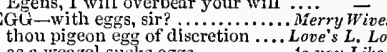

as a weazel sucks eggs .............As you Like it, .ii.

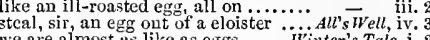

we are almost us like as eggs...........inter's Tale, j.

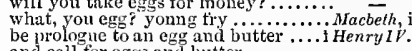

and call for eggs and but ter

and so sucks her princely eggs .........Henry $y . ;$

finch egg! My sweet Patroclu

some triek not worth an egg
think him is a serpent's egg

oriolanus,

give me an egr, nuncle, and I'll .......... Lear,

the egg $i^{\prime}$ the middle, and eat up (rep.).. - i. 4

thou hadst shivered like ang e...

of quarrels as an egg is full of meat. Rom. \& $\bar{J} u l$. ii

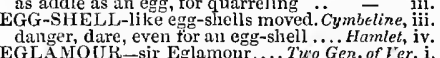

sir Eglanour, a thousand times.....

O, Eglamour, thou art a gentleman
sir Eglamour, I wonld to Valentine

urge not my fathur's anger, Eglannon

go on, goud Eglamour .............

whe Eglanour is in her company...

more to be revenged on Eglamou

EGLANTINE-and with eglantine... iria. $\bar{N} . D r$. ii.

no, nor the leaf of eglantine ........ Cymbeline, iv.

EGREGIOUS-egregious indignity.... All's Well,
solus, egregious dog? o viper vile!... Henry $V$.

solus, egregious dog? O viper vile

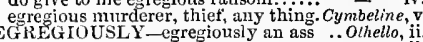

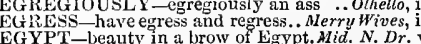

against all the first-born of Egypt. As you Like it,

Ior all the mud in Egypt . B......... Herry VIII. ii.

know there were a heart in Egypt

and say, the tears belong to Egypt

sovereign of Egypt, hail! How inueh

the firm Roman to great Egypt sends
his remembratee lay in Euypt with hi

greeting, or I'll unpeople Egypt ....

can from the lap of Egypt's widow

my being in Egypt, Casar, what was'

at Rome miglit be to you in Egypt.

Fulvia. to have me out of Egypt

welcome from Egypt, sir ........

you do wish yourself in Egypt?

but yet hie you again to Egypt .......

melt Egypt into Nile! and kindly

so half my Egypt were submerged

we have used our throats in Egypt
your serpent of Egypt is bred now

three in Egypt eannot make better $\ddot{n}$

yon ribald-rid nag of Egypt ........

O whither hast thou led me, Egypt?
Egypt, tlou knew'st ton well.........

requires to live in Erypt ............
from Egypt drive her all disgraced ..

I hear the doom of Egypt ........... and hath, in his ; after what flourish $\ldots \ldots$.

some dram conjured to this effect........ - i. i. 3
I male these wars for Egypt ........ - iv. I ann dying, Egypt, dying (rep.) ..... grecting to the queens of Egypt - iv. 13 to give me eonquered Egypt tor my son rather a ditch in Egypt be gentle.... when is the queen of egyp

mo the juice of Egylt's grape shall $=\quad$ v. 2 EYPTIAN - than the Egyptians. Twelfh Nighl, iv. like to the Egyptian thief............. rare Egyptian! Upon lier landing ... - ii. yonr tine Egyptian cookery shall have dance to his Egyptian dish again let the Egytians, and the Phenician the Antoniad, the Eryptian admiral ther with my brave Egyptians all poor Eqyptian hath betrayed me - iv. 1 a poor Egyptian yet: the queen my $=\quad$ v. have heard of an Esyptian .......... Pericles, iii. EIGIIT-tio-morrow, eirtit o'cloek...ierry Wives, iit. to come to her between eight and nine

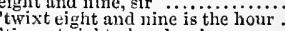
tis past eiglit already, eyes were set at eight i' the inorning.. Twelf $h N$. v. thourrow thoust.. Meas. for heas. iv. it shall be written in eirlt and six. Mid. N. Dr. iii. let it he w'ritten in eight and eight ..
I'll rhyme you so, eight years ... As you Like it, iii. hrere's eight that must take hands.... with eight tall ships, three ........... i i - ienry $I V$. ii. eight yards of uneven ground ....... I Henry $I V$. ii. I am eight times thrust throush ....

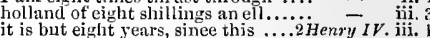
in the year eight hundred and five...... Henry $v$. i. you'll pay me the eight shillings about the hour of eiglit........... than an eight year otd horse

caght, 'tis strueken eight t.....

ïrnry $\overline{V I I}$ iv. dry-beat the rest of the eight ..................ear eight score eight hours? (rep.) $\quad$.......... Othello, , jii. EIGHCEEN-at eighteen years. Comedy of Errors, i. a cup of sack eighteen years ago.... I Herry $I V$ i i for eighteen months concluded

for his heart, and leave eightcen..... Cymbeline, ii. EIGHTH and yet the eighth appears. Macbeth, iv. 1

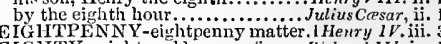
EIGHTY-eiglty odd years of .... Richard III. iv EKE-I to Ford shall eke unfold ...Merry Wives, i. and eke cavalero Slender ............ to peize the time, and mine, to eke out hers .......... As you Like il, $\mathrm{j}$. nbservance seek to eke out that.........All's Well, ii. and eke ont onr performance.... Henry $V$. iii. (eho.) ELBE-the floods of sala and of Elbe $\quad-$ ELBOW - and my name is Elbow. Meas. he's ont at elbow. What are you sir?

this mistress Elbow, being, as I say..
what was done to Elbow's wife ......

lone to Elbow's wife, ouce more?.

come hi. one rubbed his elbow, thus.......... Lave's L. Lost, $\mathrm{y} .2$ the fiend is at mine elbow ......Merch. of Venice, $\mathrm{ii}$. thus, leaning on mine elbow, I berin. KingJohn, $i$. now my soul hath elbow ............ go, plnck lim by the elbow............2Henryl $V . i$.

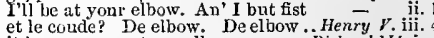
it is even now at my elbow ......... Riehard 1II. i. than I have in mine elbows .....Troilus \& Cress. ni. a sovereign shame so elbows him ........ Lear, iv. I'll be at thy elbow; it makes us ........... othello, v. beg the alms of palsied eld .......Meas. for Meas.

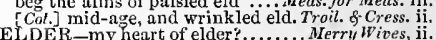
the woman take an elder than ... Tuelfih Night, ii. yon are my elder. Well (rep.). . Love's L. Lost, v

ii. 3 how mueh more elder art thou...Mer. of Venice, i ii. 3 come, come, elder brother, you are..As you Like it, i.

ii. 5 it was his brother, his elder brother.

her elder sister is so curst and shrew

until the elder sister first be wed

iii. 3 achieve the elder, set the younger free

iii. 6 I know my duty to my elders........ - i. 2

has an elder sister, or I mistake .. Winter's Tale, i,

not I, sir; you are my elder.. Comedy of Errors, v. I

Geffrey was thy elder brother born

son to the elder brother of this man.

Whieh elder days shall ripen.........Richard 11. ij. 3 

EI.DE12-the withered elder hath not.2uenry $11:$ il. i

the elter I wax, the better...

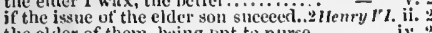

the elder of them, heing jut to nurse

my elder brother, the ford Aubrey...3 Henry $V^{\prime} l$. iii. 3

bishop of Exeter, his eider brotlier. Wicharid IST. iv.

he is elder. P'urdon me ....... Troilus $\delta$ Cressida, j.

wrinkled elders [Col.-eli $\mathrm{kni}$.-old] .

lover, elder brother, and woutul.. Thimon of th. ii. 2

see, our lest elclers. Nhreius .....

for our elders say, the burren.......

and I the clder itid more terrible...

I snid, an elder soldier, not a betier..

or rather ours the elder.....Antony $\delta$ Cleopato

nnd let the stinking eliter, grief..

with ills, each elder wor

Lavina th thine elder brother's hape. Titus.And. ii.

nmong the nettles at the elder tree

some year eliler than this

his son is elder, sir; his son is ................. Julie

til] by gome elder masters, of known . . Hamtrt,

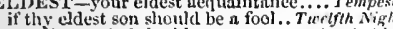

two like my lady"s cldest son ......... Much Ado

you are my eldest brother ........As you

the eldest of the three wrestied with.

played a farmer's eldest son.. Tamin

in the prelerment of the eldest sister

the eldest is eleven; the second ... Winter's Tale, ii.

yet my eldest eare, at eighteen ... Comedy of Eir.

upon our eldest, AInleoln

and eldest son, as I suppose...............

and cldest son to beaten Douglä...... i Henry $I V$.

that her eldest son is like you ......2 Henry I $\mathrm{V}$. ij.

bis eldest sister, Anme, my mother

l'll join mine eldest dau, nhte...

like the eldest son of fortune

3Henry Vl, $\mathrm{Yit}$

the eldest of them at three years-old.. Cymbeline.

ereate your emperor's eldest son

your eldest daughters have foredoomed ...Lear.

it hath the primal eldest eurse upon't.. Homlet, iii.

ELEANOR-nay, Eleanor, then must.2Henry $1 \%$.

with Eleanor, for telling but ...........
dame Eleanor gives gold, to bring

knowing dame Elcanor's aspiring

strike dame Eleanor unrevenged rep.

of iady Eleanor, the protector's wife

issue-Edmund, Aane, and Eleanor

Eleanor, the lnw, thou see'st, hath

thus Eleanor's pride dies in her
ELECT-deputy eleet, anointed

that you eleet no other kirt

yea, the elect of the land ...........

the deputy elected by the Lord ...

Troilus \& Cred M. iij.

whose power we were eleeted theirs. Coriolanus, iii.

the elected deer betore thee?

to stay you from eleetion

thy trank eleetion make ................ Al's ${ }^{\prime}$ Well, ii.

and merit her election

ull revoke your ignorant eleetion.

mnst east your election on him

almost all repent in their election

if it be $a \sin$ to make a true election.

in the election of a sir so rare

desert in pure election shine ...T

name thee in eleetion for the empire.

in our eleetion this day, I give thee

and leaves us to onr free election...... Periclien

could of inen distinguish her eleetion.. Humlet,

between the election and my hopes..

buit, he sir, hud the eleetion: and I

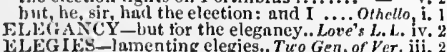
LEGIES-lamenting elegies.. Two Gen, of Ver. iii. 2 ELE.MENT - command these elements. Tempess

the elements of whom your swords.

beyond our element: we know ....Merry wives, iv.

the clement itself, tih seven.......Turelgh $N$ ight, $\mathrm{i}$.

our lives consist of the four elements?

I might suy element; but the word...

of the melancholy element in lier.........Much 1 do, ii. than the elenents of fire and water. Mirhard II. iii. 3 dotis the einders of the clement $\ldots .2$.llenry $/ \mathrm{V}$. iv. and the dull elements of eartl

the element shows to lim, us it doti $\mathrm{h}$. iv.

between the two inoist elements ... Troit. \& Cress. i.

to the eonflicting elements exposed. Tim.of Ath, iv.
by the elements, if e'cr again 1 .... Coriolanus, $i$.

and the complexion of the element. Jutius Corsar, i. 3

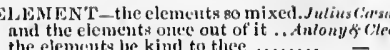

above the cleme't they lived in ....

the unlriendily elements forgut thee.

contending with the fretfiul element

I tax not you, you elements, with

native and ind ued unto that element.. Hamtel, is. 7

the very elements of this warlike isle.

yon elements thut elip us round ahoint:

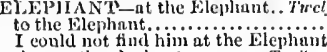

I could not find him at the Elephint
slow as the elephnt........ Troilus
shall the elephunt $\Lambda$ jax carry it thus

shall the eleplunt $A$ jax carry it thus?
the eleplunt hat joints, but none for

with flnsses, elcphiants with holes, Juive cor ii. 3

ELEVATLD-another elevated ..."Winter's Tal

ten and eleven; woman, commeni
slatl be with her between ten and

eleven o'eloek the hour ...............

what's o'ctoek, think you? Eici..Ten. Hea. Nor Hea. ii.

$n$ bawd of cleven years eontinumee
eleven widows, and nime maids...Mer

twill be eleven; and so, from.

'the

seven of the eleven I paid (rep.) .....1 Herry I

you have but eleven now ............ Henry if

by eleven o'eloek it will go.. Troilus \& Cressida,
I had rather had cleven dic nobly .. Coriolamio,

brouglit up some eleven- $-\Lambda y$, to eleven. Perieles, iv.3

entliquake now eleven ycars (rcp.). Rom. \& J J

till the bell hatl told eleven............ Othello, ii. 2

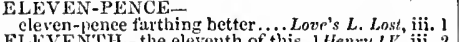

in the eleventh year o' the Inst kin's lienry $1 \mathrm{~F}$. iii.

in the eleventh year o' the lnst king's...Jenry $l$. i.

Eltall my hair in knots ................. Rar, ii. 3

ELF-SKIN-You elf-skin, you dried.1 Honry

a daughter ealled-Elizabeth, virtuous

let Richmond and Elizabeth, the true

princess of England, Elizabeth I .. Henry $V /$

LI - an ell and three quarters . Comedy of Err. iii. 2

au inch narrow to an ell broad... Romen of $J$ uliet, ii.

ELLEN-my god-daughter Ellen?..2Henry IV.jii.
FLA-the barky fingers of the elm. Mid. $N$.

thou art an elm, my husband ... Comedy of Err. ii. 2

ELOQUENCE-aged eloquenee.. TumGen of J'er. Hit.

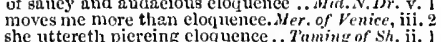

she uttereth piereing cloquence.. Taming of
his eloquenee, the pareel of $\ldots . . . .1 \mathrm{H}+n \mathrm{ry}$

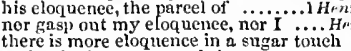

there is more eloquence in a sugar touch -
action is eloquence, and the eyes... Coriolan

to try thy elounenee, now'tis time...Ant.8-Clen. iji. 10

spenks hea venly eloquenee ..... Komeo of Jutiet, iii. .

turn the sands into eloquent tongues. Menryl
be eloquent in my belialf to her... Richard WII

it will diseourse most eloquent music.. Ilumlet, iii.
ELSINORE-is your nttiuir in Elsinore?.. Hamlet

friendship, what make you at Elainore?

till night; you nie veleome to Elsinore.. - ij. 2

the king from Eltham I intend

at Eltham plnee I told your mnjesty $\begin{array}{r}\text { iii. } 1 \\ \text { LIVWS-ye elves of hilis, brooks .......Tempest, v. I }\end{array}$

elves, li-t your names.

Aierrybires, v. 1

and all her elves eome here anon. Nid.N. Drcam, ji.

that an their elves, for tear

uod to lim elves, and do him

like elves and fairies in $\mathrm{n}$ ring ......... Whebeth, iv. 1 ELVISII-MALKRED-

ELY -my lord ot Ely, when I was last

chardlll.j.3

Ely with Riehmond troubles ........
LLY-IOUSE-lies he? At Ely-house.

my brotber he is in Elysium. Two Gen. nf Vernna, ii. 7

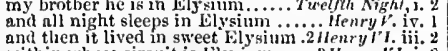

within whose circuit is Elysium
poor slindow's of Ely'sium, lience

SIBA LINNG - an emballing

Cymbeline, $\mathrm{y}$. 4

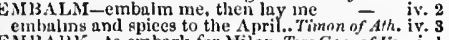

MBARK-to embark for Milan. Tro Gen. of Ier. i. 1

leaves Tharsus, and arnin embarks . Pericles, iy. 4 EAB ARKED - the embarked traters.Mill.N.Dr. ii. 2 of mine hast thou embarked?. Comedly of krrors, v. 1

he emburked at Milforl.............. Cymbeline, iii. 6

my neessaries arc embarked; farewell.. Haratol, i. 3
hes enbarked with sueh loud reason .. Othello, i. I cmbarquements of all fury
EMBASSADF-in my embingarle .3Henry Vt. iv.

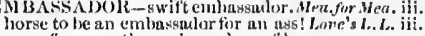

your finvours, the conbassadors of love

the French embassalor, upon thia

fhall we eall in the ernbassalor.

question your craee the late embas $^{2}$

thet, enll the embassadors.

my lords embassadors, ynur severa

we eome embasearlors from the king

Iny lord embnssalor, these letters...

know not how to use embassadors.

embassadore from toreign prinees...
ot Bayende, then l'reneh embassado

you went en then lieneh embassador

you should be lord embssalor

like you, sir, embasenulors from

the embassudor, Jueius the limanin.

the embassadors from Norway

to the embrasadors of England gives this -

do you any emhassage to the Pigmies

not thy embassage belong to me.... Richard it. v.

EXpect an embassigge frum ........ Richard ITI. ii.

fresh embassies, and suits
EIIBASSY - another embass

onee more hear Orsino's embinsy. F'u'elfh Night, i.

and what's in embassy the fresch.. Love's I.. L. $_{\text {. }}$.

hear the embassy. I'hilip of Franec... King John, $\mathrm{i}$.

the furthest limit of my embas.

stay for an answer to your embassy

dauphin's meaning, and our cmbiss

great stite he heard their embassy

down the stream, in embas

Cymbeline,

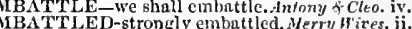
that were embattled and ranked.... Kine John, iv. 2 the English are embattled............ Herry $V$. iv.

MIBELLISHED- -

nll o'er embellished with rubies. Comedy of Err. iii. 2

EMBER-EVES-on Ember-eves...pericles, i. (Gower)

AIBLEMI-cieatrice, nn emblem of war. All's Well, ii.

and all suel emblems laid nobly ... Henry VIII.

EMBOLDENS-emboldens sin so.. Timon of Ath. iit.

a soul enboldened with the glory .......Ppricles, i.

but we have almost embossed him ... Ait's II ell, iii. 6
the poor eur is enbossed... Taming of shretc, 1 (iud.)

impudent, embosecel rascil

once a day with his embossed froth. Tinon of. Ath. y. 2
of Thessaly was never so embossed. Ant. 8 Cleo iv.

a plague-sore, an enbossed carbuncle ..... Leur, ii. 4

MIBUWEI - if thou emborel

embowelled will I see thee by and by llenry

embowelledl if thou embowel me tri-day

in your entow elled bosoms

let me embrace thine age
still embrace his heart, that doth

now kiss, embrace, conteud.. Two Gien. of lerona, $\mathrm{i}$

or else enibrace thy detht .............

I uin mest apt to einbraee your offer.

she did embrace ne as a husburicl.

O let us embruce! as trie....... Lov'r's L. $\vec{L}$ ost,

you embrace the oceasion to depart.. Wer.of i

to embrace your own sutety .......As you Like il, i.

sweet Kate, embrace her jor her.. Thming of sh. js.

his body more with thy enabraces. Winter's $\bar{T}$ ale, iv. 3

embrnce but my threetion

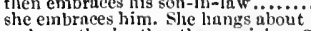

embrace thy brother there, rejoice.. Com. of Err. v.

embruce him, love lim, give him ... King John, ii.

and we mist enbrace this gentle offer - iv.

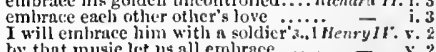

and I enbruee this fortune jatientiy

together friendly, nud emlorace ...2 Amry I I. iv. 2

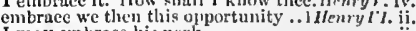

I may embruce his neck ............

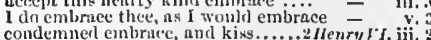

the body that I s!lonld! einbrace?

the king, nnd will emlirace lis pardon - iv.

Pluntagenet, embrnee him ...........3 Henry $r^{\prime \prime}$. i. 1
tliey join, embrace, and scem to kiss 

EMBR ACE-let me embrace thee....3 Herry $V l$.ii. 3 EMPEROR_tis the emperor, madan. Aul.\& Cleo. v. 2 | EMPLUYED-thou art employed.As you Like il, iii. 5 I employed, was pre-employed ... Winler's Tale, ii. Dorset, embrace him; Hastings ... Richard III. ii. 1 to buy a present for the emperor how he employed my mother ........ King John, i. \begin{tabular}{l|l} 
& \\
no more ado, let all embrace him....Henry VIII. v. 2 & the tenor of the emperor's writ \\
the Roman emperor's letters..
\end{tabular} and all, are all amiss employed ....... Richard II. ii. 3 our late deceased einperor's sons... Tiitus Andron. till saturnine be Rone's emperor... in Seotland beilig thus employed ..i Henry IV. i, 3 create your emperor's eldest son

the one and other Diomed embruces

let me embrace too: O lieart

let me embrace thee, Ajax

and say, long live our emperor!

the wide world's emperor, - do I

where is the emperol's guard?

lestore Lavinia to the emperor

and yet he would embrace no connse

when tirst I did embrace him

your noble emperor, and his lovely bride -

must advise the emperor for his good

my word and promise to the emper

I embraee these eonditions: let

with joy he will embrace yo

nay, nay, sweet emveror, we must all be

to embrace ine as a friell

T embrace you, sir; give me my rolies.

so near the emperor's palace dare...

emperor's eourt is like the house of fiu

wake the emperor and lis lovely bride

to tend the emperor's person caretull

the emperor sends thee this word ....

O fracious emperor! O gentle Aaro

that good hand thou sent'st the emperor =

emperor's trumpets flourisly th

received for the emperor's he

let the emperor dindle him....

the will afflict the emperor in his

deliver the pirgeons to the emperor

an oration to the emperor with a gr
give your pigeons to the emperor.

when thon hast given it to the emperor

an emperor of Roine thus over

wished that Lucius were their emperor

thou emperor, I will enebant ........

and now, sweet emperor, be bitilie aga

what hate they bear their emperor

thou might'st have been an emper

let the emperor give his pledges.

the emperor himself, and all thy queen

the emperor and the empress too teasts

I tear, the emperor means no

show, the emperor is at hand ........

my lord the emperor, resolve me this

muxdered our emperor's brother (irep.)

Lueius, all hail; Rome's royal emperor! -
frlends convey the emperor henee.....
I revived, and was an emperor. Romeo s.
worm is your only emperor for diet.... H H

worm is your only emperor for diet.... H H cmlet, iv.
she might lie by an emperor's side .... Othello iv.

MPERY in large and anple empery. Hen?y $V$ i. 2

and fastened to an empery ............ Cymbeline, i.

in election for the Roman emper

shalt obtain and ask the empery ......
EMPHASIS-such another emphasis!.Ant. \&leo. i. 5
.

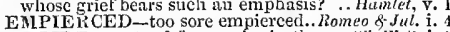
NMPIRE-eontend tor empire in thee...All's Well, i. 1

for the contempt ot empire ....
got an empire by his marriage

the empire unpossessed?...........Richard III. iv. 4

may have the world in empire!.. Timon of alh. iv.

eommands the empire of the sea ....

as when mine empire was your fellow

to Cesar, and to the Roman empire. Cymbeiine, v.

name thee in election for the empire

from their watery empire recollet ...... Pericles, if.

a cut-purse of the empire and the ruie.... in -4

EMTPIR IC-past-eure malady to empiries $A l l ' s W e l l$, i.
CMIPIR ICUTIC-is but empirientic. Coriolanus, ii. I

EMPLOY-she'd employ me in. Two Gen. of I'er. iv.

and will employ thee in some........ -

we shall employ thee in .. Measure for Measure, $v$.

in this affair do thee employ ........... ${ }^{2}$ in iii.

I manst employ thee: as thou wil

was employed in passing to and fro.I Henry $V I$. ii. 1 that luek $y$ ruler be employed.....2.2Henry $V I$. iii. i were glad to be employed, to slow how - iii. thyself shalt highly be employed... Richard III. iii. how is the king employed? I left ...Henry $V I I I$. ii. 2 Ajax, employed, plueks down ... Troilus \& $\overline{\text { Cress. i. } 3}$ a sword employed is perilous ......... - ii. 2 must be employed now to guard... Timon of $A$ ih. iti. 3 I remember now how he's employed. Ant.\& Cleo. y. 1
slialt be employed in these things .. Titus And. iii. 1 she is so employed, he thinks........ - iv. 3

EMPLOYER-enployer of panders ....Much Ado, $\mathrm{v} .2$

fit for great employment .. Tvro Gen. of Verona, v. 4 When tis upon ill employment! .. Merry Wives, v. 5 what employment have we here?.Twelfih Night, ii. 5 his employment between his lord.... - iii. 4 proud of employment, willingly...Love's L.Lost, it. ladyship's in all dusired employment

not inueh employment for you ........ detained tor lewd employments $\ldots$. . Richard II, i. 1
is there not employment? .........2 HenryIV. i. 2 being upon lasty employment and tire, crouch for employment... Henry $V_{\text {. i. }}$ (eho.) will find employment, and far ....Henry VIII. ii. 1 to lose so bad employment ........ Cymbeline, iii. 4 underco those employments, wherein $\bar{L}$ ini. $\overline{5}$ thy great employment will not bear....... v. v. $\mathrm{v}$ the hand of little employment hath.... Hamlel, v. 1 EMPOISON ED-ove to this employment ... - v. 2 IPRESS-for an empress' love. Tzo Gen, of Ver. ii. 4

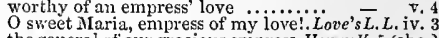
the looks of an empress; take me .... more like an empress, than duke .....2 Henry $_{V I}$. i. 3 madam, O good empress! ........ Antony o Cleo. iii. 9 ruyal Egypt! Empress! Peace, peace - iv. 13 most noble empress, you have heard - v.

Lavinia will I nake my einjpress.. Tilus

rise; my empress liath prevailed...

to wait uponi this new-jnade empress

our empress, with her sacred wit....

their alms out of the empress' ehest...
hark, Tamora, the empress of my soul

no more, great empress, Bassianus comes

under your patience, gentle empress

prond Saturnine and his empress beg from me to the empress' sons presents

our empress' shame, and stately Rome's the empress sends it thee.... what shall I say unto the empress?

but the delivered empress? The empress -
go to the empress; tell her, this I said secretly to greet the empress' friends

empress I am, but yonder sits.;...... the pearl that pleased your empress' ere bear it from me to the empress ...... = told the empress of this sport... I know thee well for our prond empress like the empress' sons they are! (rep.) the empress never wags, but in her

I will bring in the empress and her sons the empress too feasts at my house

forbear, we are the empress' soms

Your highness, and your empress $\ldots . .$. - v. 3 as meet to be am emperor's counsellor

thou'rt an emperor, Casar ..........Merry W $W$ the emperor of Russia was my .. Winter's Tale, iit. my innoeent life against an empero to the tent-royal of their emperor

as good a gentleman as the empero

the emperor's coming in behall of $-\overline{-} v$. (elorus)

Charles the emperor, under prete

the emperor paid ere he promised ..... to revenge him on the emperor ....... -

you went embassador to the emperor

employ your chietest thonght

Ill for her, employ them all

your brother did employ my father.. King John, i.
employ the countenance and graee.2 Henry $I V$. .i. employ thee then, sweet virgin ....1 Henry $V I$. iif whatsoe'er you will employ me

I will employ thee baek again.......... Antony \& $\bar{c}$ cleo. iii. if you'll employ me to hin...

when it pleased you to eraploy me... Cymbeline,,$i$. to employ yon towards this Roman

Hañlel, ii.

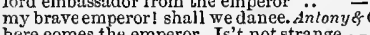 ore comes the emperor. Is't not strange

my brave emperor, this is fought indeedl -

Othello, i.

what ho! the emperor's guard!

EMPLOYED-shall be employed. Two Gen. of Ver. i. 3 you cannot better be employed.. Mer. of Venice, iv
EMP'CIER-the emptier ever daneing. Riehard II. iv.1 as they say, the emptier vessel ......2 2 Henry $I V$. ji. 4 Whoso empties them, by so much .. Richard Il. ii. 2 Corr will answer lis and emptiness!. Ant \& Cleo ii il should make desire vomit emptiness. Cymbeline, i. 7 barns and garners never empty .. $\ldots$ iv. 1 (song) and there empty it in

empty the basket, I say............. $\overline{\text { iv. }} 2$ heaven hath my empty words. Neas for Near. fold stands empty in the drowned ...Mid.N.Dr. ï. 2 I shall find you empty of that.... Love's L. Lost, v. within whose empty eye there...Mer. of Venice, il. 7 when I have made it empty ........... As you Like il, i. 2 n eivility thou seem'st so empty?.. - ii. 7 now is sharp, and passing empty. Taming of Sh. jv. 1 we empty casket, where the jewel ...King John, v. 1 


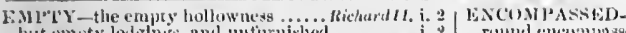

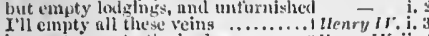
in court-enty the the jordin

ém a weak enpty vessel isenr

po hunger for my enspty ehair whenry Wi. ii.

leing empty of ilefence, huth

a voice isstue from so emplty a heart.

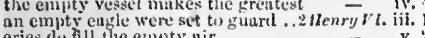

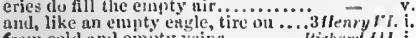

from eold and emitty veins ........ Isithard
to seek the empty, vast, and wawlering -

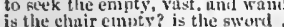

nuore worth than empty vanitic
behold that clasir stanl empty.

政

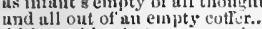

filth, nothing but an eimpty lowx ....

1 returned you an emplt

like to the enputy ass, to shake ..... $j_{\text {tititu }}$

lave enuty left their orly ...

tis enuty of all things, but grief ... Cymber

an emplty purse, there was

purse anil brain both empty.........
einpty old reeeptacles, commoi

her ehariot is an empty liazel-nut.

a beggarly account of empty boxe.

his louse is empty on the back of ....

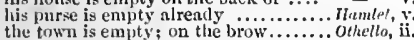

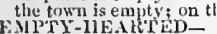

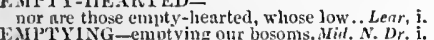
ENP'T ING-emptying our bosons. Mit. N. Dr. í. listh been the untimely emptying.

W.1 ULATE-emulate the dliamonds. Merry Hives, iif. 3 prieked on hy a must emulate pride .... Intumlet $i$ faetious emulations shall arise! .... ulenry $r^{\prime}$. iv. for emuth worthless emulation .......ichard rn iii. of pale and bloodless emulation. Troilas o cress. $\mathrm{i}$. Whilst emulution in the ariny erept.

for emplation linth a thonsand sot.

a gory emulation tirixt us twain.... - iv. mine ont of the teeth of emulativan....Justius Cerear, ii. 2

EMIU LATOR-an envious emulator. As you Like it, i. hu LOUS-emulous factions. .. Troilus o ch

he is not emulous, as Achilles is

made emulous missions 'monst

in inine emulous honour, let liim clie

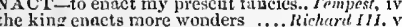
the close enacts and counsels of . Titus And ron. iv.

ENA what did you enact? I did cnnet.. Itamlet, enaeted wonders with his sword ..... Henryly. i. hath bcen enacted thiro your en

and the rest, it is enacted thus

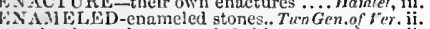
snake tlirows her enamaled skin...Mid. $N$.'s Dr.

the jewel, best enameled, will lose. Com. of Err. ii. mine ear is enamoured of thy note. Siden Ant, il. methought, I was enamoured of an ass - iv. hecome enamoured on bis grave ....2 Rearyly I i. affliction is enamoured of thy parts. Rom. of $J u$ l. iii. 3

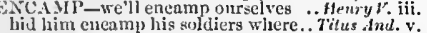
foes encrimp tluem still in nan...Rnmen or Juliel, ii. 3 EDA.IPED-the king encamped?..1 Hearyly' iv. 2 FCELUDUS-uot Euceladus Tilus Andron

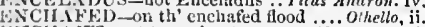
XCIIANT-urt to enelanat ........ Tempest, (e) and enchant lim with tly words... I Henry Vi. ii. 3

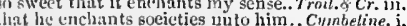
will enchant the old Andronicus. Titus Andron. ravid. NTE D-some enchanted trifle. Tempesi, v, ravish, like enehanted harmony..

gatlered the enehanted herbs ...Herch. of T'enice $^{-}$

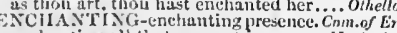
enchanting all tlat you put in ........ Marbeth,

Your white enchanting fingers.. Troilux \&. Cress. iii,

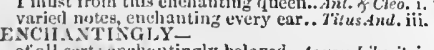

of all sorts enchuntingly belored...As you Like it, i. 1

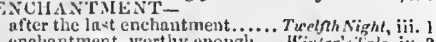

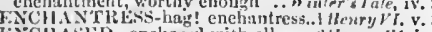
ENCIRCLE-eneircte him ab a H.NCIRCLED-eneircled

ENCLOSEl)-that lies enelused

Herryllioes, iv. with charity cuelosed in clay

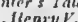

enelosed were they with their ........ Illenry fit.

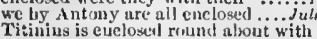

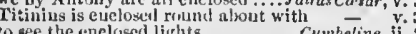

ENCLC

for enclosing- the commons of . 21 tirnry I't. i. 3 (pet.) EXCLOIPAEDED

Lave I encompasscl you?

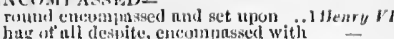

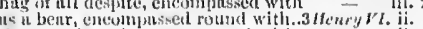
that sengyld to be eneompassed with

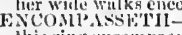

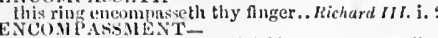
ly thisconcompassment and dritt

ilenumble, ii.

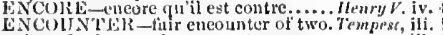
these fresh mymph escounter every on

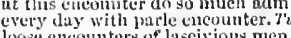

in the instant of our eneonnter .. Merry HFires, iii.

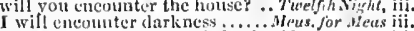

if tle eneounter acknowledere itsclf..

strong cuevinnter ot' my amurous tiile

in the orcilurerl this aminble encounter

eoniessed the vile cueounters .........

Wenches, arm! eneounters mounted
the eneounter of two dog-upes.... As

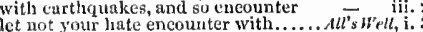

appoints lim an encounter ............

give you over at this firstencounter. Taming of sh
with your strange encounter.

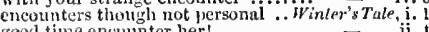

gand wilt cneounter with my wrath.

with whit encounter so uneurrent ...

they ereounter thee with their hearts "s

let beliet : and life eneounter so...... King Johm, iii,

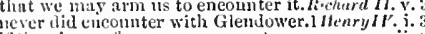

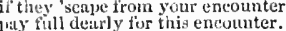

to cheounter you, myt lord

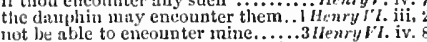

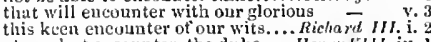
at our last eneounter, the duke.... Henry IIII. iv. I

We cucouinter as often ns we cat ..... Co
they shull eneounter stuch ridiculous

they shill eneounter siteh ridiculou
thus uceideutally to encounter you

dreamt of eneounters 't wixt

upon the next eucounter, yields ....Jutius Crasar, i. upon the urst encounter, drave ...Anlony \& Cleo. i. 政 th orison

innl she should from encounter guar.

I will eneounter with Andronicus.

nor bide the encounter of........ ilomeo
und is he a man to encounter Tybalt?
in either by this dear encounter

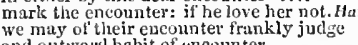

men of peace well encountered

at home be encountered with shame... All's 'sell,

were encountered by a mighty

ladies erave to be encountered with... $t_{t}$ thy $r$ t

I soon encountered; and, interchan

once I encountered him, and thus

sinall be encountered with a man

I encountered as the battles joined ...3 Henry $/$. i.

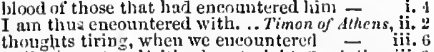

well eneountered! 'tis almost night. Cymbetion

to he encountered with a eloud .. Tilus.smilron. ii.

ENCOUNTERERS-these encounterers, so

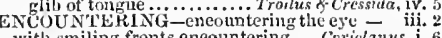
with smiling fronts coeountering ..Cnriol nus is i. my dilenmus, encourage myself in..Alt's Well, iii.
did threaten and encournge him. Winter"s Tule, iif. traetable to us, encouraus him .

ENCOIiRAG ED-and encouraged.JuliusCesor, iv. tor tlae cneouragement of the like. Men. for Men. i. 3 uf fuir cunffirt and eneouragement. Richard III, y.

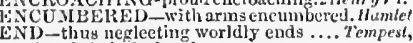
painted their finl cinds .....................

at which enll o' the benm she 'd how
the latter end of lis comsnonwealth.

porm matters point to rich ends ........

in the very end of liarvest..............

shortly shall all my labours end ...

二 ii.

I will and there an cund ....?

and tiere an cond ...........

yon always end ere you
still an cral, turns wive.

to the west ent of the wood.
tike $n$ sollier, at nrm 's end .

like n soliter, at nris s end ...........

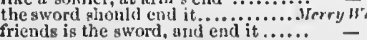

to hear it, and end it tetween thein.

I will make an end of my dinner...

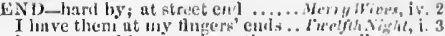
journeys end in liowers merting

if throu last her not fi'the end.

and of shill end, 1 hog

attends thee at the orcliari end

this slunll end without the perdition

he holds Beelzctub at the stave's end

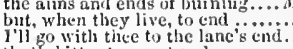

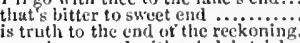

you ulways end with a jude's trick... Mach sdo, $i$

cre youn nout old ends nuy longer.

graves will appear, and there's ail
any service to the world's end?

to what end? le woulk but $\mathrm{m}$
this is the end of the elatirge..

and then end tife, when I I cind loysut

Ihose date tili death shall never end

and her passion ends the play

and her passion ends the phiny.........

whint is the end of study?.......... Luve's $\bar{x} .$. Lot,

at the fingers' euds, as'they say

to the end to erave your assistance
not so big as the enil of his elub.

therefore, I'll diskly end the argunient

and so the measure ends..............

my wit is at an end

or the latter end of lis name

at the twelvemontl's end

doth not end like an old play ........
nad then 'twill end. That's too leng

followed in the end of our show
I'll end iny exhortation ufter

in the end of autunn tulteded
but in the end, trutly will out

I shull end this strife, become...

prove the end o o his losses

tell her the proeess of Antonio send

and to that end riders dearly hircd. As you bike il, i.

ee the eud; for the hest.

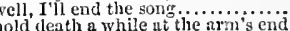

that ends this strange eventful....

or at every sentence ene be...

no end of his goods (repented)

as we do trust they'll ent, in tr.

an end, sir, to yotur busin
$[$ Col. $]$ end, ere L do begin

at the later eud of a

they attuin to their abhorred end

ends well: still the fiue's the crowni $(r e p$.

and if it end so meet, the bitter pa.....

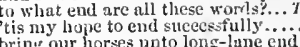

bring our llores unto long-lune end
and sce the end of this controversy.

to see the ent of this nd

und there an end. Now, liy my.......
from the cnds of opposed winds....

not weithing well the end $\ldots . . \ldots$
where clianee may uurse, or end it

will clear, or end, the lusiness

wit upper end o' the table, now

every lane's end, every shop, churcin
of death, end wo's nut all ... Conmetly of Frrors.

that my cud was wroughlt by inuture

at either end the mast..........................

but to procrastinate his lifeless end...

to the world's end, wiil hase
go thon and buy a rope's end

end. You gent me, sil , fur it rone's cud

end lid I bid thee hie thee lome? (rep.)

your enu; or ratier the liropheey (rep.).

loves for his own ends, not for you

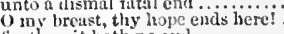

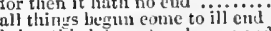

bring tiis labour to a lanpy end

but that which ends all connsel $\ldots . .$.
nut of the hloody fingers' ends of John

there end thy brav

列

grief mist ent her life in it........... -

列

and in the end, having my frecdun.: =

more ure men's euds marked ........

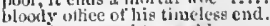

to mike my end tha kudacn

to whit end he gave me .........

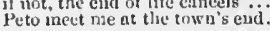


END-to the latter end of a fray and they are for the town's end.... unlooked tor, and the

to end the one of us ................

but in the end, to stop nine ear ....2 HenryIV

let the end try the man...

do not bid me rememher mine end

drinks off eandles' ends

let time shape, and there an end ....

the question stands, briefly to this end

and either end in leace, which beaven

give suceesstul end to this deibate.....

this apoplex will, certain, be lis end

even there my tife end to

lately here in the end of a displeasing

once afoot, end in one purpose

Col. $k n t$.] and there's in end.....

made a finer end, and went away

to that end, as matching to hi

diseiplines ot war; and there's an end

hath this day an end, the Da

we shall never see the end oi $\because \mathrm{it}$

ere it is made an end and finished

verses have eon trived his end?

death, the English eircle end

argue the end of Edmund

for that's the end of human misery

bring this matter to the wished end.

here let them end it, and God

and, in the end heing rescued....

my hair he fixed on end, as one.
which fly before the battle ends

thy arms be to

let the vile world end, and the premised -

outrun you, father, in the e

ovcr to the end they were created.....

my suit is at an en

take that end, I shortly mind to

and ends in-Margaret

...ichard III.

doth stand on end to beer her curses

with old odd ends, stolen fortl

I see, as in a map, the end of all

outrage, end thy damned spleen

your lordship came to see his end

and to that end we wished your

when my oratory grew
at lower end o' the hal .

he wonders to what end you have

his piteous and unpitied
bloody will be thy end
unto her fair tife's end

and in a bloody battle end thy days!

to as much end as give a cruteh

and to what end is this? nay, ladies

like good angels, to my end....

old time shall lead him to his end

who nndertakes you to

see this main end, the French

brought to know, owrends are hones

mine own ends have been mine so
drawn together for mine own ends

any private malice in his end...

let all the ends, thou aim's
she'll with the labour

and the end was ever, to do well

I see your end, 'tis my undoin

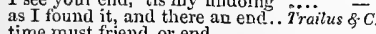

time must friend, or end
to end a tale of length

as near as the extremest end of

be ealled to the world's end after...

I reek not though $\dot{i}$ end my life.

but, in the end, the villanies... Timon nf Athen

my lord and $I$ have made an end.

bring noblest minds to basest end

words go by, and language end

and slung, i' the end, admire

from where he should begin, and end

for an end, we must suggest

to spend the time, to en

a lirand to the end o' the world....................

and the end of it unknow

- which, for your hest ends, you adopt

he'd make an end of thy poster

st table, aod their thanks at end

only their ends you have respected

than seek the end of one

great son, the end of war's nncertain

and, to this end, he bowed his natur.

fame which he did end all his....

but there to end, where be was .......
whose end is purposed by the mighty.

a neeessary end, will come, wh

might lnow the end of this da.......

the day will end, and then the end:

where I did begin, there shall I end
END-of Romans serve your ends! Antony f-Cleo.iii. 2 I was of late as petty to his end

left us ourselves to end ourselves

O make an end of what $I$

the miserable change now at my end

- iv. 10

but resolution, and the briefest end

that thing that ends all other deeds.

not for sueh an end thou seek'st
to what end? why should I write

son, let your mother end

I see into for youl and there's an end

and my end can make good use

lut for the end it works to

lack, to what end? who dares not

Posthumus end his miseries (rep.)

failing of her end by his strange absen

let me end the story; I slew

unto my end of stealing them

was wise nature's end in the donation

I kept it to a worthy end

will this tearful slumber have an end?

brought up a neck to a tair end

yet the end of all is bought

yet the end must be as 'tis

and have not money enough in the end

who did end, the minute I began.....

more craft, and more corrupter ends

and, in the wholesome end, as clears.

benefit, to end itselt by death?

business of the world hath so an end ...

is this the promised end?

these violent delights have violent end

but berins the woe, others must end
the law should end, the life of Ty tralt

to earth resign; end motion here

when every thing is ended

our simple supper ended.

and, now the battle's ended

and our sharp wars are ended.. Troilus \& Cress. v. 10

you have ended my

.... iv. 3

ufter my speech is ended .............ulius Casar, iij. I

hath almost ended his life's bistory ...

your service for this time is ended ... Cymbeline, $\mathrm{i}$.

how ended she?

were better encled by their hatc.. Roneo \&.Juliet, ii.

was woe enough, if it had ended there -

the griets are ended, by seeing the worst. Othello, $j .3$

NDING-my ending is despair .... Tempest, (epil.)

for ending thee no sooner .........Meas. for Meas.

very ominous endings: no, I was.... Much Ado, v. 2

a good l'envoy, ending in the goose.Love'sL.L. ini.

still ending at the arrival of $\ldots \ldots \ldots 1$ HenryIV....

this praise, ending with-brother...

particular endings of his soldiers

this day to the ending of the world.. Hexry $r$. iv. 1

the passion has ending ....Pericles, v. $\overline{3}$ (Gower)

ENDLESS-my endless dolour. Two Gen. of Vtr. iii. I

a $\mathrm{Col}$.$] thou and endless nighit$

in solemn shades of endless night..... Richord

extinet with sge, and endless night.. Henry $_{\text {ing }}$ i. i. 6

heaven, from thy endless goodness. Henry VIII. v. 4

between whose endless jar justice. Troil. \& Cress. i. 3
CNDOW-endow a child of thine...Richard III. iv.

within endows a man but he ......... Cymbeline,

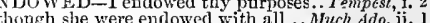

thongh she were endowed with all ... Much ddo, ii. I

ENDOWNENT-by his endowments. Richard II. ii. 3

the catalogue of his endowments bad. Cymbeline, i. 5

half a dozen friends, and there an end
poison, I see, liath been his timeless end

all his bulk, and end his being

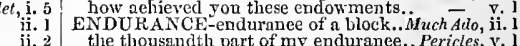

to what end, my lord?

ENDURE-would no more endure .... Tempest, iii. I

this I endure for thee!......Tuo Gen. of Verona,. . 3

youth's a stuff will not endure....

I eammot endure my lady Tongue ....

she cannot endure to hear tell of ....

when he shail endure tlie like

could endure the tooth-ach patiently

I should endure, I would not yield . Love's $L . L$. i.

I will no longer endure it ........... As you Like it, i. 1

irksome to me, I will endure ........ = ii.

I conld endure any thing before....... All's well. iv. 3

miglit hardly endure the din? .........

hardly will he endure your sight. Winter's Tate, iv. 3
and will endure our setting down ..... Hacbeth, v. 4

let wne endure your wrath, if't be .... - . v. 5

not able to endure the sight of day. Richard II. iit. 2

endure this tempest of exelamation?,2 Henry $I V$. ii. 1

cannot endure an apple-john

it will endure cold as another man's... Henry $\nu$.

give you patience to end

the substance shall endure the like. Henry $_{\text {VII }}$.

breved, and must perforee endure it!
for more I hardly ean endure.......2 Henry VI. i. 4
may she endure the flinty streets ....

I am able to endure mueh

as no christian ear can endure to hear - jv.

shalt I endure the sight of Somerset?

these eyes could not endure that beauty's -

do me wrong, and I will not endure it

ye endure to hear this arroganee?. Henry $\overline{V I} I I$.

to endure more miseries, and greater

I did endure not seldon...... Timan of $A$

and not endure all threatenings? .....

which easily endures not ar tiele

can both endure the winter's eold...Julius $\bar{C}$ cesa

will shake him or worse days endure

they should endure the bloody spur..

ye gods! must I endure all this? ....

patience, to endure it now (rep.) $\ldots . .$. .

cannot endnre my absence... Anlony se cleopalra, 1.2

and could not endure a further view - jil. 8

sir, will not endure tis yoke ....... Cymbeline, iii.

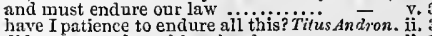

did endure to have his princely paws

shall I endure this monstrons

iv,

too rough for nature to endure

pour on; I will endure ................ I never shall endure her; dear my iord... 


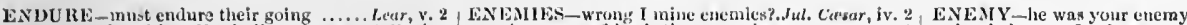

Fli not endure him. Ile shalli....Ronien f. Juliet, i. 5

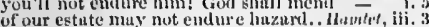
howlieit that I emdure hin not ......... Othello, ii. I

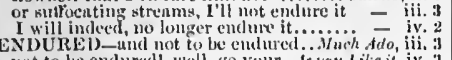
not to be endured! well, fro your your betters have emburel me. Titming of shree, iv. 3 intoleralle, not to he enthred till now endured all weathers..... irinter's Tale, v. what extremities lie endure Richerd 11. v. 5

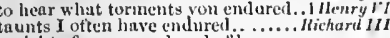
un night of groans enciured of lier

such men my triends tlum enemies

will not bear your encmieg' luats ..Cymbrime, iii. elustised with urms our encmies. Filus Anthon. bromplit to yoke, the enenies of

work contusiou on his enemies

to be is torment to mine coemics?

lenst, make them his enemies.

sent her eneuies unt is the grnve
to bes relict among livme's encmi

to wage urainst mine enemics

to know our enemies' minc

subjects, cuemies to pense
where be these conemies?

makes triends of encin

clusping to the mast, endured $a$ sen.....

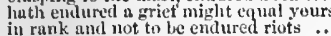

in rank and not to be endur

EN

thon

till mine eneny has mure power

it his ememy deliver it

I will nut be your tricnd, nor enemy

wherein the pregnant co............. mu moes mu

sworn enemy, Andrew Ague-che

ground enough, Orsino's enemy

o cumning enemy, that, to catch. Meos. for Meas ii.

lend it ruther to thine encmy (rep........ Mer.

engaged iny friend to his mere enemy

I did find him still mine enemy... is you $L$ inc

the encuny of all your grmes lives .

snooth witli mine enemy.

be able for thine enemy rallier

eaptain, nad an enemy, a guide...

any drum of the eneiny's.

friend, and then mine enemy

to give mine enemy a lasting wink

visible an enemy, should clase us....

given to the eommon enemy of man...Macbet

know, Banquo was your ener

being no turther enemy to

to offer service to your enemy

thy ndverse pernicious enemy

80 iar us to mine enemy
in to despair an enemy's hope

proportionable to the enem

and, thougl mine enemy, restored

for thongh mine enemy thou hast

art my nearest aud dearestencmy?.

so are the horses of the enemy
stand agninst ns like un enemy

not so terrible to the eneny as it

as many holes in an enemy's battle.

presents no mark to the enemy......

plucking to unfix an enemy

furious kniglıt, aud valorous enemy

iii. 1

thut he your fixed encmy, und revote

khow thine cnemy in a flery fult .

the people's eneny is gone (iep.). . .

nyy, their grent encany is gone .....

more a friend than e'er al enemy
given your enemy your alicit.

uns ne'er so nuch your ench

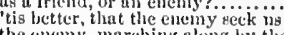

the cuemy, marchine along hy them

the enomy would not eome down.

the enemy comes on in enllant.

trops he to mine own turned enemy -

that no enemy or enemy

my glory unto an encmy's triomph. int. \& Cleo. iv. the could not

for his unaster, and enemy to $\mathrm{my}$ son

thine encmy; receive it from me, then
thus mine enemy tell; and thus I ect

I must report ye my master's enemy

forth I wear it as your enemy ......

though he eame our enemy, remember

the enemy full-hearted, lolling

destruetion on the enemy's east

besides, this sorrow is an enemy
ghe is thy eliemy, and $I$ thy friend

from her bosom took the enemy's ...

enst thou wish thine enemy to bont $-v$.

prot'css myself an cuemy to all . . Perces, iv.

mine enemy's dog, thomgh he had bit me - iv. eombine together gainst the enemy..... - iv. followed his enemy hin und did him.... - v. the only son of your greut enemy. Romeo s Juliel, $\mathrm{i}$ that I must love a loathed enemy

bceausc it is ane, eme is my cnemy

I have been feasting with mine enemy

I would not har your enemy suy so.... Hamlel, i.

lis muduess is poor Ilamlet s enem..... - iti.

urainst the general enemy ottoman

that men should put un enemy in their.

that thrust had been mine enemy indeed - ii.

NFEEBLE-revengingly eutectles. Cymbeline, v.

or with light skimisles enfeebled ..I Ifenry irt. i. I

NFETCE RED-soul is so entettered... Othello, $\mathrm{ii}$.
NFORCE-enforce them to this place. Tenpest,

spirits to enforce, art to enchant $\ldots . . .$. ... (epil.)

bo to enforee, or cualify the laws. Meas. for Heas. i.

and enturce them against him ........ iv. -1 (letter) to entorce the pained impotent ....... on sword, chiforce a thievish living... As you i.ike in, ii.

I will no more enfuree mine oniee.....All's "I'ell, ii.

in despite enforce a watery eye.. Tam. of sh. I (ind.

spleen than powder can entorce.

men entorce uttention, ike ......... Riehurd 11 . ii.

to entoree a poor widuk..............

lack of means enforce you not to evil -

and liumer vill entores .............

could it uot entorce them to relent....

will you entorce me to a world....Richard 111. iji. 7

be evils, and entoree us kill . Timon of . thens, iii.

enforce his vricle, and his old hate... Coriolanus, ii.

entores him with his enry to the people - iii. 3

enforce the present execution of ..... $\bar{\delta}$ iii. 3

to enforee no further the griefs bitween - ii.

we will extenuate rather than entoree $-\bar{y}$ we

with frayer's, enforee their churity. ...... Lewr, ii. :

with all his might, to entoree it on....... Uhello, i.

the place, the torture-0 entorce it! ...... - F

thant eufored the law against it!...Men. for .hea. iv.

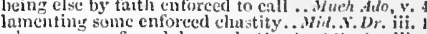

where mene enforeed do speuk. yerch of lenice, iti.

I wus enfored to send it after hin

tiorgive me this entored wron

disl, my $=$ cilt enfored him to

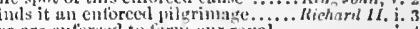

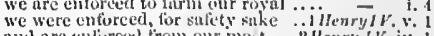

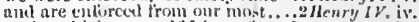

to is enteresel to retire, and the duke. Henry $r$. ivi.

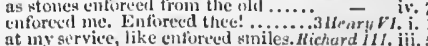

entureal us to this excention? ...... Juins Casar, iii.

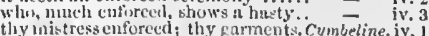

garments, wivich he entorcal from mo 
ENFORCED-she was enfored .. Tilus Andron. v. 3 ENFORCEDLY-dost it entorcedly. Timon of $A t h$, iv. 3 ENFORCLIENT - let gentleness iny strong

by what rough enforement you got...All's $H^{\prime}$ ell, v. 3 upon enforeement, flies with

his enforcement of the city wives.. Richard III. iii.

mere entorcement shall acquittanee

FNHORCEST-enforeest lanthter.Love'sL.Lost, iii. 1

I will enfranclise thee .... Two Gen.of V'eronn, iii, Costard, I will enfrunehise thee. Ln*e's $L$. Lost,

pertorm it, to enfranchise you...... Richard III. i. I

ENFR ANCHISHD

she hath entranchised them. Two Gen.of Verona, i and enfruncluised with a clog ............Mucth ddo, i.

Hipparchus, my enfranchised... Antony se Cleo. iii. II

ENFRANCHISEMENT-

request the enfranchisement of Arthur ...John, iv. 2 uncontrolled en franchisement

and to beg entranelisement immedinte

Henry $\mathrm{Vi}$. v. 1

ENFREED - the enfreed Antenor. Troil. \& Cress, iv. 1 enfreedoming thy person.

Love's L. Lost, iii.

NGAGE-I do engage my life.... As t/ou Like it, v.

engage it to the trial, if thou

I I liere engage my words

...1Henry IV. ii. 4

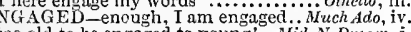

too old to be engrged to young!.. Mid. N. Dream

to thee engaged a prince's word.. Comedy of Err. v.

hithicr come engaged by my oath.

[Col.Knt.] to be engaged in Wales...

Westmoreland, that was engaged.... - v. 2

we all, that are engaged to this loss. 2 Henry $I V$. i. 1

I do stand engaged to many $G$. $T r$

tis all engaged, some forfeited. Timon of Athens, ii.

than honesty to honesty engaged.Jutius Casar, ii. 1

strugrting to be free, art more engaged Hamlet, iil.

ENG AGEIIENT-all my engagemen ts.Jul.Ccesar, ii.

ENGAGING-engaging andredeeming. Troil. of Cr.V. 5
ENGAOLED-engaoled my tongue .. Richard II. i. 3

ENGENDWR-engenders maladies. Love's $L$. Lost, iv. 3 for it engenders choler, plauteth.. Taming of $S h$. iv. of a king engenders love amongst.

engenders the black toad...... Timon of Athen

ENGENDERED-is engendered Her.oflen. iii.2 ison 17

that sacred pity hath engendered. As you Like it, ii.

the mother that engendered thee...Julizs Caesar, v. 3

ENGENDERING -

ENGILD-more engilds the night.aris. $N$. 's Dressida, ii. 3

and

and all these engines of list

like an engine not portable.

All's Well, iii. 5

Colamus, y. 4

that del our engines with advice. Titus Andron.

hath brought the fatal of her thougints

like an engine, wrenched

0 you mortal engines, whose $r$

and devise engines for my life

ENGIRT-my body round engirt....2 HenryVI. Hii.

ENGLAND-were I in England

Tempest, ii. 2

the young baron of England?... Merch. of Venice, i.
a fourth tor England,-and other.... - i.

they have in England a coin

from Mexieo, and Eugland.

the old Robin Mood of England ........ you Like $\overrightarrow{\text { int, }}$ i.

where England? I looked for. Comedy of Erro

are bestowed in England, and in Irelan

ty to the eourt of England, and untol
is fled to England. Fled to England?

from gracious England, have $I$ offer

since iny here remain in England.

the borrowed majesty of England..........

even till that England, hedged in...

may trom England bring that right

England, impatient of your just

to England; if that war return (rep.)

England was Geffiey's right .......

'tis France for England. England for

we are the king of England's subjects

doth not the erown of England prove

heartz of England's breed............
Arthur of Bretagne, England's king

Enirland, thou liast not saved one....

for Fngland; who's your king? (rep.)

speak Errgland tirst; that bath beer being enfranchised, bid him come... Timon of $t$ th

ilorty freedom, and enfranchisement!

I have engnged myself to (rep.). Mler. of Venice, iii.

every eloud engender's not a storm...3 Henry $V I . v$.

as any man in England............. Merry Wives, i. 1

WNGLAND-brother of Englan

from the mouth of England add thus

brother of England you blaspheme

away for England; haste before

tor England, cousin.

bloody England into E................

well could I bear that England had

to England, it you will ..............

Faulconbridge is now in England

for England go; I will whet on the king -

my soul, and England keep $\mathrm{m}$ p bones!

easy dost thou take all England up!

of your dear mother England, blush

to the revolts of England here .......

of the part of England. Whither....

it' England to itselt do rest but true

as were our England in reversion his

this England, this nurse, this teemion

pel ting tarm: England, bound ia

for sleeping Engiand long time have

nol' England's private wrongs

to touel a dust of England's ground?

my lords of England, let me teli ....

become the flower of England's face

if my word be sterling yet in England

gallows standing in England when ..

sworn upon all the books in England

three good meu mbianged in England

shall the son of England prove a thief

that chides the banks of England

that all in Lingland did repute him dead -

nor can one England brook a doubie

is not a better wenel in England ...2

is the foulmouth'dst rogue in England

whiles England shall have generation

England shall double rild (rep.)

never king of England had noble

that their bodies here in England ....

once the eagle England being in prey

divide your happy England into four
never valued this poor seat of England

all the Jouth of England are on fire

no king of England, if not king of

if we lieard that England were busied

from our brother Englind? From him

back to our brother of England.

nothing but odds with England

leave your England, as dead...

whose limbs were made in Eng for Harry! England! and

let him greet England with our sharp

and let him say to England, that

bring us word of England's fall .... England shall repent his folly

alas, poor Harry of Eugland he longs

my brothers to my lords of England

that Engiand shall couch down in fear

ten thousand of those men in England

wentlemen in England, now a-bed.

dost not wish more help from England

or in Franee, or in England

to Calais; and to England then........

to England wiil I steal, and there I'll

most wortly brother England, farly

great kinirs of France and England

I cannot speak your England........

sooner persuade Harry of
is't so, my lords of Enetiand?

kingdoms of Franee and England

sword twixt Englind and fair Fran

crowned king of France and England

and made his England bleed

England ne'er lost a king (rep.) ....1

England all Olivers and Rowlands bred

or tear the lions out of England'

third Edward king of England.

the sen from England to Franee

from thenee to Lingland; where I...

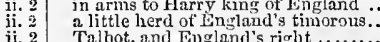

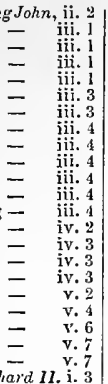

i. $\begin{aligned} & 4 \\ & \text { ii. } 1 \\ & \text { ii. } !\end{aligned}$

so bad as thine to England's king

England knows thine insolence

sovereign Riehard, England's king!

king Tenry govern England's helm

as I hope tor fertile England ........

that England was defamed by

I will stiv up in

by awkward wind from England's bank -

I lost fair England's view .......... -

or banislued fair England's territories =

the silver spring where England drinks -

in England, sinee gentlemen eame up -

for thereby is England naimed.

only, that the laws of England may

spare England, for it is your native

may England curse my wretelied reig

ne'er be said, while England stands.

of Naples, Eingland's bloody scourge

rightful heir to England's royal seat

what good is this to England ......... -

the crown of England, father, whichi is

George from Burgundy to Fngland?

degree is, England's royal throne (rep.

dwell, when I was king of England?

fair queen of England, wortlyy MIarga

to England's king in lawful marriage

then Lngland's messenger, return ...

that of itself, Engiand is safe, if true

his mind, be Edward England's king

come hither', England's hope

once again proelaim us king of England -

sit in England's royal throne ..........

mother, wife, nor England's queen

thenee we looked toward England..

the ron thit.

O bloody Richard! miserable England!

the peace of England, and our lersous
save Riehard, England's royal king!

happy were England, wonld this

nor England's counted queen.

thy unrest on England's lawfiul earth

intend to make her queen of England

he makes for England, here to claim

who is England's king, but great Xor

and conquer tor fair England's sake!

preeious by the foil of England's cliainen of England! fight..

make poor England weep in strenms

not a man in tingland ean advise. Henry $-v$

betwixt England and Franee, might

the duke shatl gorern England...

Henry king of England, come into

Katharine, queen of England (rep.)

in England, but little for my profit

mighty princess of England, Elizabeth! -

he shall with speed to England ...... Ham

if she find him not, to England send him

I must to England; you know that?....

but, eome, for England! farewell $(r e p$.$) .$

and, England, if my love thou hold'st...

do it, England? for like the hectie ......

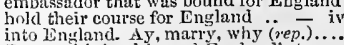

into Enchland. Ay, marry, why (rep.)...

as Eneland was his faithfui tributary

nit.

(art.) 
EN(BLAXI)-cubassudors of Finglinul .. Humlet, v. live to heur the news from Enghind our atfairs trum England come too late.

and you from Englamb, are leere arrived

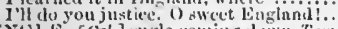

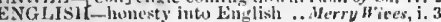

and the king's binglish

[Col.] trights Einglish o

and hack our English

they speak English? ........

to woo her in gowd English ...............

be a list of un Enclisth kersey

poor pennyworth in the English..

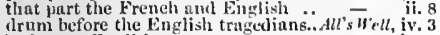

he his an Enplishmume

here's an English tailor come tither... Macbelh, ii.

lives in the Euglish court

the English power is near, led on

thingle with the English epieurc.

would seour these English hente?

thy nunntural uncle, Englisin John.

nll these Engtish, and their discipline

for tears in many an English nother

come our lusty English, all witi

now hear nar English king.

fly, noble Englisti, you are bought

when the English measured backward

the Endish lords by his persunsion

surveyed by English eye............ thichard $I I$.

my nntive English, now I must forego -

and sighed my English brenth

grass with fiththil English blnod....

from the restful English eonrt.
from

the blood of English shall inanure - iv.

forthwith a power of English shall... Henry $/ V$. i.

never spake other English in his

muzy an English ditty, lovely weil

muny an English ditty, lovely

my wite can spenk no English

the triek of onr English nation......

great pored so many English kings

to the English court assemble now
this is the English, not the Turkisl

0 noble Eoglish, that could entertain. . Henry $V$. i, 2

winged heels, as English Mercuries - ii. (chorus)
seek to divert the English purposes - ii. (chorus)

these tinglish monsters!

English with fill

neglected Englisl upon our fields

take up the Engkish short wa........

on, on, you noblest Enylish

to the lust of English youth

to the English daneing-sehoois.

upon one pair of English legs did.

fain be abont the ears of the Engtisi

he longs to eat the English

the English lie within fifteen hundre

if the English had any apprehension

ay, but these English nre shro

the poor condemned English

be triends, yon English fool

may spin in English eyes............

a bounding valour in our Englisl....

offer up our lives unto these
to smother up the English

the number of our English dead?

behold the English beach pales in

not speak Engish in the native ( $r e p$.)

prinees English, every one

English princes all, I do salute you....

brokenly with your English tongue.

thou canst speak no better English

half Froneh, half Enelish.

and for my Finglish moiety, take

in true Engliss, I love thee, Kate...

thy English broken; theretore (rep;

twaeh you our princess English? ....

that Einglish may as lireneh

awake, awake, English nobility !....

the English army is grown we

the famished English, like pale...

and drive the English torth.

am $I$ to lie the Englialh peourye.......

Thenry's chenth the English

how the Ginglish, in the suburbs elose

called, for our tierecness, Einglish dögs

is Orleans from the Finglish wolves.

for the right of English llenry

watehmen of our English weal

the troops of English after lim.

luit English IItenry will he lurd...

English John Talhot, captains ........

no christian soul but
if we be English deer
ENGI,IsIf-lender of aur linglis
the linglish arung that tlivided

heir-Hymarent to the Englimb erown

elieim the English crow

so wealthy us an Jenglish yeoman

to cuteh tho Winglish erown

wite to the Euglish king (rep.) ....

now shatl weter the Wuglisli crown

true heir to the linglish erown
these linglish woes shall muk.

shome down the Euglish .............
is no Engliwl sonl nore stronger

all the gool onr English have got.

think an English courticr mily be
becantse they sileak no kinglish.

mruy, suenk in Euglish

I had never trod this En:lish earth.

When she has so muels linglis]

ure notling to your English E........... Othet

ENGLISHLI)-be englished rightly.
ENGLISHA $A N-$ as de Englishnam.

his voice an armed Englishman

ny grandsire was an Englishm

Enghishnan durst set his toot.........

a soul so eusy as that Englishunan's

an Euglishman? An't please your majesty

that any Enurlishman dare give me. Ulenry VIII iii.

is your Euglishmas so expert

Wounds of slaughtered Englishmen. Nichard 11. iij.
have each a hundred Eaglishmen.... Henry $V$. iii.

Eng henthe receive eaeh other...

with the bliod of En Entishmen

prineess is the better Englishwoman...Henry $\boldsymbol{V}$. y

ENG LUTS-it engluts and swallows ..... Othello

peasants, this night englutted!. Timon of Alhens, ii.
ENGRAFFED-so much engrafed ..2 Ifen'y $l \mathrm{~V}$. ii.

ENGRAVE-thereon engrave ....... RichardHI. iv.

ENGRA VED-and engraved. Two Gen. of F'eraza, ij. 7

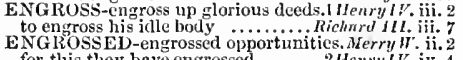

for this they have engrossed ........2 Henry I $\mathrm{W}$. iiv. 4

ENGROSSEST-it' thou engrossest all. All's Wett, iij. 2

ENGROSSING-to engrossing death! Romeo of Jul. v. 3
ENG ROSSIENT - his engrossments.2nlenry $t:$ iv. 4

ENGUARD-he may enguard his dotnge .. Lear, i. 4

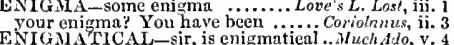

ii. 1 ENJOIN-weight that he'll exjoin me to - v.

enjoin thee, as thou art liegeman. H'inter's Tale, ii. 3

cnjoined me to write some lines.

and it was enjoined him in Rome.....

1 am enjoined by onth to observe. Mer. of 'enice, ii. 9
of enjoined penitents there's four or...All's Well, iit. 5

to be by oath enjoined to this .. Finter's T'ale, iti.

am enjoined by holy Laurence.. Romeo of -Juliet, iv. 2

if you will, enjoy Ford's wife .........

let me enjoy my private

... Much Ado, iv.

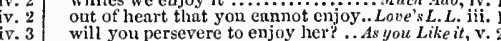

that we may enjoy each other........ -

yon may enjoy your mistress ..... H'inler's Tale, iv.

that you might well enjoy her.............

o'er liim, ankl all that he enjoys.......

to lose what they enjoy (repeated) ...Richard $I I$. ii. 4

your majesty shail soon enjoy....

kings neglect, that private men en

of the country's perce, enjoys it

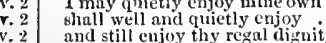

and may enj, that enjoy the sun?...2 Henry VI. ii.

enjoy the kingdom atter my decease. 3 IIenry r t. i.

therefore enjoy it now.

gecure and swectiy he enjoys

to cujoy thee for my love...

enjoys the honour

enjoy, were you this country's........Ricfined ive

I eujoy, being the queen thereof ( rep.)

shall these cujoy our lands?

went it, elsoy it, and make meh of it

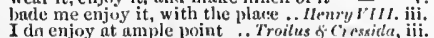

a denjoy at ample point ... Troilus of cissicta, iii.

enjoy the honey heavy dew of slamber

more thun the world enjoys...

I was nbout to say, enjoy your...

to eniny a seeond night ot such sweet

a valiant son-in-luw thou shit enjoy, Titus. fud, $\mathrm{i}$.

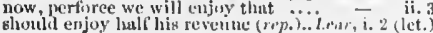

ExJoY-menn you to cujoy him?
thon Nhalt enjoy lur; therctore ma

I.rur. v. 3

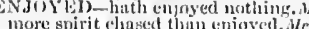

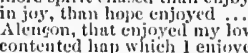

I have enjoyed the denrest borlijy
le hath enjoyed her: the cogniza

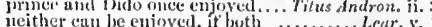

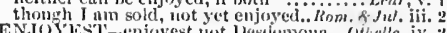

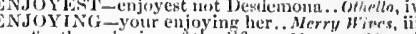

as tor the enjoying of thy life.... Meas. for Meus.

thy world, enjoying bot this lasel.. Richurd $1 i$.

ENKINDI,E-might y'et enkindie yon... Macbulit, i

enkinlle all the sparks of nature

my will enkindled by nine cyes. Tyoilus of Cress. ii. 2

Which secmed ton mueh enkinlled...'ul. Crryor, ii. I

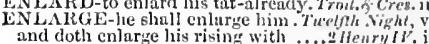

uncle of Exeter, enlarye the man ...... Jenry $V$.

we'll yet enlarge that uan, though ...
never eeaseth to enlarge it seit ...... i Henry r. i. 2

should enlarge itselt' to wrathfiil. Troil. \& Cress. v.

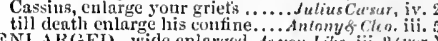

ENLARGED-wide enlaried...is you Like,

as far enlarged as we haye warranty

give enlargement to the swain ... Love's L. Lost, iij. 1

which, fur enlurgement striving ... I Ilenry II, iif.

sweet enlargement doth dismis

enlargement by the eonsequence.... Cymbeline, ii. 3

NAINKLD-enlinked to waste.... Heury $r$, ii. 3

EN 1 EW-follies doth enmew . . W ...... Onhello, if. 3

ENII'CIES-how lesser enmities. Anluny \& Cleo. ii.

by hate, and fear no enmity? ...Mid. N. Drenm,

the enmity and cliscord, which .. Comedy of Err.

while eovert enoity, under the ...Richard 11 it. 2

been enaeted thro' your enmity ..... Henry $I^{\prime} l$. iii. I

harmless lambs abide their enmity.3 lenery $I^{\prime} l$. ii. 5

storms be past of eivil enmity

'tis deatls to me, to be at eromity

loog hath l'rowned upon their enmity?

the push and enmity of those ... Troilus Cress.

thine enrnity's most eapital

set deadly enmity hetween two... Titus Andron

agniast the enmity o' the uir

proof against their enmity. Romeo \& Jutiet, ji. 2

Inmlet, i. 5

ENNOBLED-Who, so ennobled, is ...At's Hell, ii.

ENOBARBUS-Enobarbus, - Madam

how now, Enobarbus?' What's your

good Evobarbns! We have cause to be

Good Enobarbus, make yourself my..

why, Enobarbus? When Antony found -

call for Enobarbus, he sliall not iear

[Col.Knt.] despateh: Evobarbus! ....

Enobarbus, Antony hath after thee..
mock me not, Enobarbas: I tell you

loor Enolsurbus did before thy (rep.)

NOUGII-if room enongh!.

there's wood enongh witinis

space enongh have I in such

I know that well enough.

enough; I read your fortu

is goot enough tor sneh a present...

if we recover that, we are sure enongh

I have had tord enough.

they'll do fust enough of themselves
no womnn's gown hig cnough for him

we exmot misuse lime enong

but long enough to say my pruyers.
white will deciplier her well enougli

this is enough to be the deeny of ....

enough; no more; 'tis not so....... Tirelfh vight,

but it becomes me well enough......

ay, he (lnes well chough, if lie bo

hut 1 have renson gool enough ...
this feltow's wise cuourith to plny.

of your reeeiving, enough is slown.

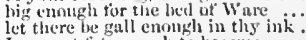

I am not int chougl to beenme
nor lean chough to be thutuglit

on base nnd ground enough.

are not these large enougli?.3

having wate gromend enongli $\ldots . .$. ...

there is seirce truth cyongh alive...
but security enough to make fellowerips -
this news is old enough, yet it is .... 
ENOUGH-thlnks it big enough. Meas. for.Heas. iv. 2 , ENOUGH-enongh to purge this field..Henry your thief thinks it little enough ....

enough, my lord

is't not enough, thou hast suborned.

we are enough to do our country loss

we are enougl yet living in the fleld

enough, cantain; you have astonished

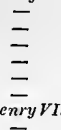

rench enough to deceive de most

revercntly worship thee enough? ..... Henry

I have almost matter enough in me

and money enough in his

I am sure you know him weli enough

proof enough to misuse the prince .

thou sing'st well

it were enough to fright the reali...

yes, there is remedy enougl, my lord

it is enough; I'll think nough

the king is old cnough himself to give

gallop fast cnough to her destruction

neighbour, you shall do well enough

that's bad enough, for I am but

a wilderness is populous enough

Eugland's treasure, enough to purchase

is't not cnough, to break into my garden -

you are old enough now, and yet.....3 Henr

'tis prize enough' to be his son ......

with force enough to bid hi

you shall have wine enough

cousin, were it light enough .......

being now seen possible enough ..... Henry VIII.

that's christian care enough

sharp enough, Lord, for thy justice!

whave told you enough of this.

having colour enough, and the other

Apollo knows, tis dry enough ......

rievisc imposition chough

princes, enough, so pleasc you

Agamemnon, an honest fellow enough

tis not enough to help the teeble.. Timan of Ath. $\mathrm{i}$.

and thou know'st well enough, althougl

onc may reach deep enough, and yet

as your waiting, 'twere sure enough

wcre enough alone to overcome him

now the gods keep you old enough

lend to each man enough, that..
cnough to make a whore forswear.

all the whips of heaven are large enough

I'll give you gold enough

you's one lionest enough: 'would

they say, therc's grain enough? ....... -

that I ain knowni. well cnough too?
cnough too? Come, sir, come (rep.)
enough. Enougl, with orer-measu

enough. Enougl, with over-measure

you might have been enough the man

he was always good enough for him
and room enough, when there is ...J

not Erclons itself were dim enough to

bear fire enough to kindle coward

that is enough to satisty the senate

courtesy, and with respect enough

this hill is far enough: look .........

wine enough, Cleopatra's health... Antony $\dot{c}^{\circ}$ Cleo

evils enough to darken all his ...

make space enough between you

I have donc enough; a lower place

all may be well enough. I warrant you

yes, like cnough, high-battled Cæsa
but late, enough to tetch him in ...

you have land enough of your own

were wealth enougl for the purchase

gentlemen, enongh of this: it came

thou wert dignified enough, even to

sun and sun, madam's enough for you

thy favour's good enough.............

though valour becomes thee well enough

'tis enougl, that, Britain, I have killed
is't enough. I am sorry? So children

returned with similar proof enough to

there is enough written upon this earth

look ye draw home enough

I know thee well enough; witness this

it is enough you know

enough; lest your breath cooji...........

courage enoughi ; I do not fear the flaw

what tis to (not enongh barbarous).

and have not money enough in the end

for a king, thou art pour enough

and each man have enoug

do cry ont itself, enough, enough, and die

I remember thine eyes well enough..

Iknow thee well enough; thy name.

put strength enongh to it ...................
enough of this; I pray thee ..... Rom
it is enough I may but call her name
ENOUGH-find me apt enough. Romea \& Juliet, iii.

marry, 'tis enough. Where is my page?

was woe enough, if it had ended there

for it was bad enough, before their spite

chamlet $i$

the not craft enough to colour....

heard of zour know well enough ........ $=$ iii. I

not rain enough in the sweet heavens

with modesty enough, and likelihood to

to judgment .. othelto, i. 3

put moncy enough in your purse ......... -

I cannot speak enough of this content ... -

stand well enough, and speak well enough -

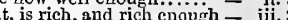

it were enough to put him to ill thinking - iii.

she says enough; yet she's a simple bawd - iv.

ENQUIRE-enquire you forth.. T'wo fien. of Ver. ii.

go cnquirc for my master.................. Much Wives, i.

prescntly enquire, and so will I.......... of Venice, i.

enquire the Jew's house olit............ sirrah, enquire further after me.........All's Well, v. 2 tell the king, he may enquire us out. King john, iv. enquire at Londou, 'mongst thic taverns - v. enquire me out contracted bachclors 1 Henry IV. iv. 2 enquire me out some mean-born.. Richard IIT. iv. 2 you must enquire your way......... Coriolanus, iii. I did enquire it; and have ......... Antony \& Cleo. ii. the most strong cnquire......... Pericles, iii. (Giower) first did prompt me to enquire.. Romeo \& Juliet, ii. 2 young lady bade me enquire you out
look you, sir, enquire me first what

can youl enquire him out, and be QUIRED-enquired for me... Meas. for Meas. iv. 1 you lave oft enquired after ....As you Like it, iii. have you enquired yet who picked. I HenryIV. ini. 3 ENQUIRING-cnquiring tor his tib .. Pericles, iv. ENQUIRY-made enquiry of you. Dleas. for Mers. Y. to make enquiry of his behaviour...... Hamlet, ii.
ENRAGE-question enrages lim...... once enrage the gentle Thetis .... Troilus \& Cress. i. the rude sea's earaged aud foainy Tu:elfin of $N$. loves him with an earaged affection...Much $A d l$, ii. away went Claudio enraged ........ never saw the giant world enraged... being now enraged with grief.......2 HenryIV.i. that hath enraged him on to offer...... $\overline{\text { Henry }} \bar{F}$. iii. 1 upon the enraged soldicrs in their..... Henry $F$. iif. 3 whether his fall emraged him. Coriolanus, i. 3 who, thereat enraged, flew on him ....... Lear, iv. ENRAPT-suddenly enrapt... Troilus \& Cressida, v. 3 revenues enrich the new duke.... As you Like it i. Henry is able to enrich his queen ... Henry VI. . I. 5 praying to enrich his watchful soul enrich the time to come with.... . . to enthenrich the hand of yonder...... Ramea fybeline, ii. NRICHED - hath enriched any...Meas. forMeas. i. the captive is enriched.. Love's L. Losl, ir. 1 (ictter)
tutors have enriched you with?...... tutors have enriched you with?..... Which, more en riched, shall be your love $-\overline{\text { ii. }}$ if thy pocket were enriched with ...1 Henry whose chin is but enriched with. Henry $V$. ii (cho Whose chin is but enriched with. Henry . ili. (cho.) her gift, and yet enriched it too .... Cymbeline, ii. 4 ENRICHES-which not enriches lhim.. Othello, iji. ENRING-enrings the barky fingers. Mid.N.Dr. iv. 1
ENROBE-enrobe the roaring waters. Mer. of Ven. i. 1 ENROBED-shall be loose enrobed. Merry Wioes, iv. I hope well, is not enrolled there. Love's L. Lost, I liope, is not enrolled there.

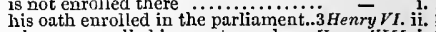
who was enrolled 'mongst wonders.. Henry VIII. i. 2 question of his death is enrolled...Julius Casar, nit. 2 ENROOTED-so enrooted with his..2 HenryIV. iv. I cnrounded him............... Henry ${ }^{F}$. iv. (ehorus) NSCONCE-will ensconce your rags Merry Wives, ii. 2 I will ensconce me behind the arras - ii. 3 ENSCONCING - ensconcing ourselves. All's sell, ji. 3 ENSEAR-ensear thy fertile...Timon of Alhens, iv. 3 ENSEIGNEE-je rous ay enseignee ?.. Henry $V$. iil. ENSHIELD-an enshield beanty...Mea. for Nea. ii. ENSHRINE-enshrines thee in his..1 Henry VI. jii. 2
ENSIGN-the ensign of the christian. Richard II. iv. I 
ENSIGN-an ensign there at the pridge. Henry fil. 6 hang our former eluin two mighty......Julius Cotsur, v. this ensign here of mine was.

a Roman and a British ensign wave. Cymbrline, mine honour's ensigns humbled. Tilus.tndronicus,

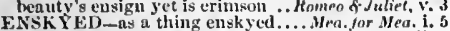
ENSNARE- will I ensmare as great a fly othello, ii.

ENSNARFTII-web ensmareth thee. Nichard III, i.

EN'TEEP'ED-traiturs ensteelied to clag. Othello, ii.

why, then, let kibes ensue ..............Try Wiwes', i.

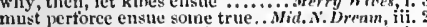
doth it therefure ensue, that youn... As you Like il, i. 3 what of' her ensues 9 ..... irinter's Thite, iv. (chorus)

a kind of light, what would ensue... King John, iv. 3 or overthrow ineurable eusue

to-morrow then cusue to-day

what will ensue hereol, there's none - ii

what erosses to ensue, would shut..2 Henry $V$. iii.

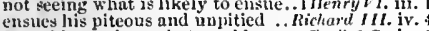

foretold you then what would ensue. Troil. $f$. $\mathrm{Cr}$.jv.

nor here, nor what ensues.

what now ensues, to the jud gment. Pericles, i. (Gow.)

and what ensues in this fell storn

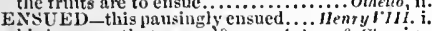

lis haseness that ensued?........ Anlony \& Cleo. iv.

ENSUING - a elenr life eusuing ....... Tempesi, iii. 3

the next ensuing hour

then were my eusuing death!...... Richard 11 . ii.

of Nuy next eusuing .....2 Henry it. i. I (articles

the ensuing night nade it a too ..... Henry rWI. i.

give you inkling of an ensuing evil.. - ii. 1

nothing to think on, but eosuing death. Pericles, ii.
eTAIIl-eut the entail from all .... All's Well, iv

I here entail the erown to thee

to entail him and his heirs unto.

EXT.MIE-ean entane my spirits. As you Like

ENT. NGLES-cntangles itself Antnuy \&
ENTANGLED-nore entangled by..Corio

ENTENDL with those mouth-made. Antony $\%$ Cle

EN'TER-to enter human hearing ....... Tempes

one moise, and enter .................. of $\bar{v}$ er.iii. 1

so wide as a bristle may enter..........

my niece is desirous you shouid enter = ij. 5

I mean, to go, sir, to ent

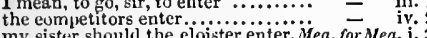

my sister should the eloister

I am bound to enter publiely

he ought to euter into

your speech, enter into that brake....izid.N.Dr.

Pyramus, enter; your eue is past

she is to enter now, and I ain to spy
before we enter his forbidden gates.. Love $\bar{\top}$ 'L. L. ii.

to let you enter his unpeopled louse

his enter and exit shall be strangling

shalluw foppery enter my sober...Ner. of Venice, ii.

let it not enter in your mind or love

rear it, do not enter it ..............As you Like il, ii.

too little for pomp to enter ............All's Well, iv.

let no creature enter: eome .. Comedy of Errors,ii.

ay, and let none enter, lest $\mathcal{X}$

and I denied to enter in my honse?...

ter, and lay hold

saw'st thou him enter at

enter, sir, the castle

and to prochaim..... Macbeth, 7 .

it may enter butcher Nowbray's.... Richurd 11. i.

at all point 8 ; and longs to eu

please to euter in the eastle....

bent ou him that enters next

that no man enter till my tal
if uut, let him enter ...............

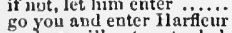

go you and enter liarficur........

i Henry $I V$ ii.

here's Gloster tbat would enter.

enter, go in; the market-bell is rung

enter, and cry-the Dauphin!

canst not enter, but by death.....

enter his chamber, view his....
where thy words should enter

view his …2Henry $r$ iv. ji. 3

that

or foul means we must enter in.

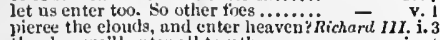

thanks; we'll enter all together...... $\bar{V}$ iv. 1

an ye none enter, since Plent?... Henry $\bar{V} I I$. iv.

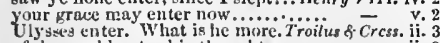

of the wurld enter his thoughts...... - ii. 3
as is A ruclune's broken woof, to inter

they enter my mistress' houlse.. Timon of $\overline{A t h e n s, ~ i i . ~}$

and enter in our ears, like great....... -

the very heels, with them he enter.

may enter twixt the gap of both ....

Tll enter; if he slay me, lie dues ....

almost at point to enter............
ENTER-let them enter. They nre.Julius Carsar, ji. 1 enter the eity, elip your wives...Antony s.cleo. iv.
shall enter nee with him...........
let instruetions enter where folly.... Cymbeline, j. 6

no answer? then I'll enter

good my lord, enter (rep.)

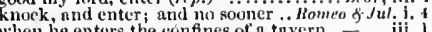

$O$ misehict! thou art switt to enter

the soul of Nero enter this firm bosun.

like luggers enter in mine ears

see lier elamber-window enter

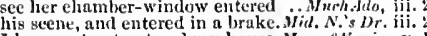

1 have not yet entered my hous. Mer. of fenice

within this bosom never entered yet. King Jifn

gone bond, that he is entered into...Richart $1 \%$. .

have you entered the aetion
I have entered lim and all

sinee my exion is entered, and

that war hath never entered .......... Henry $V^{\prime}$.

Pueclle is entered into Urleans......

here entered Pncelle, and her practisants

that would have entered Troy.....

but, being entered, I doubt not.........

of my conscienee, entered me...... HenryVIII. ii.

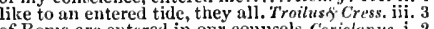

of Rome are entered in our connse
alone he entered the mortal gate

are entered in the Roman territories

the eity ports by this huth entered

your native town you entered like a post -

before I entered here, I ealled...... Cymbeline, iii. 6

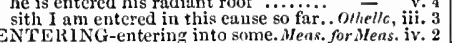

proelaim it an hour before his entering

the revellers are entering; brother...Mnch Ado, ii. 1

for entering his fectsimple......... Hen ry $F^{\prime} l$. iy. 10

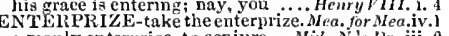

a manly enterprize, to eonjure ..Mid. N. s Dr. iil. 2

you to a more equal enterprize .. As you Like it, i. 2

be magnanimous in the enterprize ...All's $\bar{F}_{\text {ell, iii. }}$

made you break this enterprize to me?.Macbelh, i. 7

to line his enterprize: but if you ... IIenry $W_{\text {. }}$.1. 3

the very life blood of our enterprizes

a larger dare to our great enterprize

Eworn to us in your younger enterpriz
this present enterprize set off his head

this bold enterlrize brought forth ....

prevented from a damned enterprize

the enterprize whereof shall he to you - ii.

and aid me in this enterprize!......

whet on Warwick to this enterprize..3 Henry $V I$. i. 2

he offers in another's enterırize. Troilus \& $\&$ Cress. i. 2

of any bold or noble enterprize..... Julizs Cesar,

an enterprize of honourable dangerous

speed thee in thine enterprize

your enterprize to day may thrive (rep.)

death no hazard, in this enterprize.

as an enterprize of kindness

through your domini ons for this enterprize - ii.

ENTERTAIN-Ceres, her to entertain. Tempest,

entertain him to be my .... Tu

for this I entertain thec.............

I will entertain Bardolph

to entertain him with hole

I'll entertain myeelf like one ........ - ii.

a wilftul stillness entertain ...Werchea i of I'enice, $\mathrm{i}$.

then entertain him, then forswear. As you Like il, iii.

to entertain it so merrily with ........ Alt's Wett, ii.

to entertain them sprightly...... W'inler's Tale, iv.

John should entertain wn livur..... King John, iij.

and entcrtain a eheertul disposition. Mirhard $I V$,

to entertain the entertain no more of it ............

that eould entertain with half thei

I clid not entertain thee of thou art.. $\overline{1}$ Heury (chor

for here we entertain a solem

to entertain my yows of thanks and.e fienry $/ 2$. iv.

entertain great England's lawful kin

to entertain these tair well-sploken.

for Grod's sake entertain good eomitior

there's few, or none, will entertain it

pray, entertain thein: give them. $i$ in

to entertain me as your sterard still ofsens, i.

but entertain it, and, although ... Antony \& Chro. ii. 7

so please you entertain ne........... Cymbeline, iv.
ENTEIR AIN-your entertain shall be.. Periele's, $\mathrm{i}$.
I entertain you tor one of my hundred .. Leur, fii. 6 not entertain so hasl a thought .. Rome of Jnliel, iv. 3 that entertuined anbition.

thoul hast entertained a fox to be

and entertained them dceply in...

being contertained tor a perfumer

returning; entertaincd my convoy

not, how thou wert entertained....... / Henry $h l$, i.

entertained me with mine own.. Timon of sthent, i.

sce them well entertained.

lave entertained canse enough ........ Antony \& Cleo. 11 i. 1

him be so cntertained amongst you . Cymbeline, j. 5

but newly entertained revenge... Inmeo of Julief, iii.
ENTERTAINER-to the entertainer.. Prmpest, ii.

minTINEST-if thou entertainest. Ty

ENTERTAINING-

NTERTAINMEN'

no, l will resist such entertainment

luve a cure of your entertainments

Tcmpest, $\mathbf{i}$.

I learned tiom my entertainment. Tuelfh Night, i.

pardon me, sir, your bad entertainment

him tor the entertainment of cleatl.

- iii. 2

concerning some entertainment of time

desert place buy entertainment ... As you Like il, ii. 4

gave me treeh array, and entertainment - iv.

him not John Jrum's entertainment

the adversary's entertainment .... - iv.

ac entrance to iny entertainment.. Tuming of Sh.ii. 1

our entertainment shail blame ns. Win

entertainment may a tree fuce put on

give en tertainment to the night of it. 2 Herry $I V$.iv. 4

entertainment to dny prineely queen .2 1enry

set a fair fashion on our entertaimment

pruvided to show them entertainment
already in the entertainnent ...... Coriolanus, iv. 3

1 have deserved no better entertainmeut - iv. 5

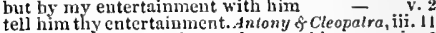

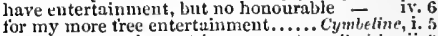

as if the entertuimment in our court...... Pericles, ii.:

she inay" not be raw in her entertainnent $-\overline{\text { iv. }}$
shall be needful for your entertainment ...ear, ii. 4

with entertainment of caeh new-hatehed. Humlet, i. 3

what lenten cntertainment the players

appear like entertainmeut than yours..

sume other eustom of cutertainment .... Othello, ii.

if your lady strain his entertainment ... - iii. 3

from my enthralled eyes ..Twa Gen. of I'erona, ii.

too higl to be entliralled to low!.Mit. N. Dream, i.

bo is mine eye enthralled to thy shaje being evthralled as $I$ am.... Winter's Tale, ir. 3

ENTHRONED-it is enthroned... Her. of lenice, iv. 1

many courses of the sun entluroned. Henry VIII. ii.

enthroned in the murket-place... dutony s. Cleo. ii.

chairs of guld were publicly enthroned $\overline{\text { Th }}$, iii. 6

will entiee the duke of Burgundy...irsury $V_{1}$. iii. 3

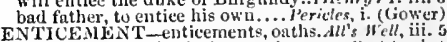

ENTICETH-renticeth thee to view ... Pericles, i. 1

a yuire of such ent teing birds........2Itenry $V I$. i. 3

your catire aftection to Bianca.. Taming of sh. iv. 2

pure fiur, and entire eowardice ....2Alenry $1 \%$ ii. 4

and the man entire, upun the next. Jutius Corsur, i.

that stand aloot trum the eutire point ..... lear,i.

EN'une entire and perfeet ehrysulite.... Ohitite, v.

Benedick loves Beatrice so entirely? Much Ado, iii. 1

they are entirely weleome... Merchant of I'enice, iii.

you love your gentlewoman entirely...All's Well, i.

so tenderly and entirely luves hinn.......... Lear, $\mathrm{i}, 2$

all the duty of nyy heart, entirely honcur - iii. 4

in mean men we entitle patience.... Kichard il. i.

ENTITLING-in so entitling unc... Winter's Tale, ii. 3

ENTUMBED-entombed upon the.. Timon of Ath. $\mathrm{y} .5$

EN'TRAll, s-the in his knotty entrails. Tempest, i. 2

md of intolerable entrails............... Macbeth, iv.

as if his cutrails were hairs ............. Jenry $l^{\prime}$. iit.

fiery leart so parched thine entruils,3 itenry $1 . \mathrm{i}$.

to revel lin the entrails of my lanibs - iv.

plucking the entrails of an ottering..Jul. Casar, ii.

our swords in our own projer entrails - vo 3

the ragged entrails nt this pit .........

their exits, und their entrances .. As you iikr it, i. 7 


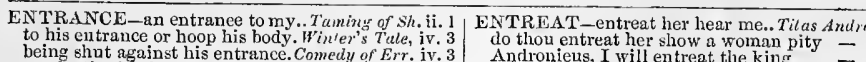
eroaks the fatal entrance of Dnncan ... Nacbeth, i for ruin's wasteful entrance.

and lineal entrance to our own! ..... King John, it

and give you entrance; but, withou

[Col. Knt.] thirsty entranee of this ... Richard II. iii. make our entranee several ways

admit him entranee, Grifit

stands i' the entrance of his tent. Troilus o cres.iv.

gives entrauce to such companions? Cori

be barred his entranee he

the prompter, for our en trance... Romeo s. Pricles, ii.

the stony entranee of this sepulchre

beware of entrance to a quarrel.....
ENTRANCED-been entraneed above

a golden mesh to entrap the hearts.

utrap thee by some treacherourts.

a to entrap me by intellisenees you Like it, i.

seek not to entrap, my graeious lord

ENTREASURED - and entreasured ...Pericles, iii. would AT -do entreat thou pardon

would entreat thy company

conid hardly entreat him baek... Twelfth $\overline{N i}$ h

I must entreat of you som

and en treat him to a peace

to him again, entreat him .............

if lor this night he eutreat you to...

we shall entreat you to abide here

tis my deserving, and I do entreat it

they did entreat me to aequaint ..... Much $A d_{0}$, iii

I do entreat your graee to pardon...iH

and I am to entreat you, request you

entreat, I ean eompel (repcoted

one thing for me that I shall entreat. Love's L. L. iii.

shall I entreat thy love? I will.

and entreat, out of a new-sad soul...

he did entreat me, past all saying

so she eould entreat sotne power
sir, I entreat you home with ime

and doth entreat your company

shall not entreat him to a seeond.. As you $\overrightarrow{L i k e}$ it, iv. 2

unless thon entreat for her

this drives me to entreat you

Andronieus, I will entreat the king

onee more I entreat of you

he will not entreat his son for us $(r e p$.

to play upon, entreats you pity him

let me entreat to know at large....

displeasure to entreat me to

entreat you to bring, do not, sir.....

my lord, entreat hirn by no means ......

whom I'll entreat to lead me...

do entreat her eyes to twinkle............ \& 8

my lord, we must entreat the time alone

he beseeched me to entreat your majestie

all alone entreat him to show his grief..

and her hosband, entreat her to splinter

one Cassio entreats her a little favour.

entreat you then [Col. Knt -that your wis

I might entreat your honour to scan th

I do entreat that we may sup together
ENTREATED-entreated to it.. Two Ge

madam Silvia entreated me to eall

but he will not be enterated

fairly let her be entreated

whom of sueeour we entreated

which she entreated........

whieh do not be entreated to Aniony \& Cleopalro

and I entreated her come forth.... Romeo \& Jut

therefore I have entreated him along .. Hamlet,

the eutreaties of our most (rep.)

not temporize with my entrea

Richard III. iij.

penctrable to Jour kind entreatios fault!

if entreaties will render you no .... Henry $\bar{V}$ III

might in entreaties find sule
tor a day of kings' entreatic

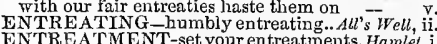
ENTREATMENT-set your entreatments. Hamlet, then she pats you to en treaty....As you Like

upon entreaty, have a prese

use no entreaty, for it is in vain...

my mild entreaty shall not make..3 Henry $V I$, v.

by the entreaty and grant ot

reconciles them to his entreaty... Antony \& Cleo. ii. 7

more r'll entreat you written to bear

let me entreat of you.. Taming of shre

let us entreat you stay till after $\ldots . .$.

let me entreat you. It cannot be (rep.)

marry her though she would entreat

how to entreat, nol

and entreat my wife to eome (rep.)

yet when we can entreat an hour

nor entreat the north to make his

to entreat your majesty to visit

use it oft, let me entreat you

master Gower, shall I entreat yo

and my speech entreats, that I may

by me entreats, great lor

entreat you to your wonted furtherance? -

did I purpose as they do in that..2Henry $V I$. ii.

$O$, let me entreat thee, cease.

my gracious lord, entreat him

some holy bishop to entreat.

write unto them, and entreat them...

came to yout, for I command no more -

and entreat for me, as you would beg

first, madam, I entreat true peace

he doth entreat your grace, my nobi

your citizens entreat you.

either be patient, and entreat mi.....

either be patient, and entreat me fair

entreat an hour ot revels with them.

and did entreat your highness to this

I do entreat your highness' poline:s

and heartily entreats you take good

entreat her fair; and, by my soul.

can searce entreat you to be od
dost thou entreat me, Hector?

coneur togrether, severally entreat him

I must entreat you, honour me. Fimon

lord Lucullus, entreats your company
I come to entreat your honour to supply

entreat thee back to $\Delta$ thens

at my entreaty, forbear his presenee ....... Lear, i.

iii. 2

so with love I might entreat you.... Coriolanus, ii.

so with love I might entreat you ... Julizes Casar, i. 2
shall I entreat a word? Here lies....

I do entreat you, not a man depart.

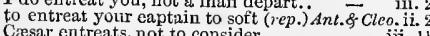

good queen, let us entreat you

to entireat your grace but in a small... Cymbelin

the lamb entreats the butcher ...... -
this one thing only I will en treat.....
let us entreat, by hononr of his name. Titus And.
i. but entreat of thee to pardon Mutin
ENTRENCHED-sword entrenehed it. Ali's $\bar{W}$. $l l$, ii. 1

ENTRY-at the south entry; retire we . Macbeth, ii. 2 ENVELOPE-night envelope yon. Nea. for Mea.
envelope and contain celestial spirits. Henry $\mathrm{V}$.

envelope and contain celestial spirits.. Henry V. i.
ENVENOM-comely envenoms him. As you Like, i. 3

envenom him with words

ENVENOMED-

whose envenomed and fatal sting..2 Henry $V I$. iii. in thy hand, unbated, and envenomed.. Hamlet, v.

the point envenomed too!.
ENVIED-you envied him

that envied his receipt

from time to time envied against......

ENVIES-star now envies thy.

I hope, is none that envies it
ENVIOUS-appear to the en

drive him from the envious plea. Mer.of Venice, iii.

envious emulator of every man's...As you Like it, $i$.

free trom peril than the envious eourt?

like envious fioods, o'er-ran.. Taming of Sh. 2 (ind.)

this base and envious diseord breed...

the envious barking of your sancy

with envious carping tongue

the envious load that lies upon

to make an envious mountain

the envious slanders ot her false...

but still the envious flood kept ...

of state was a deep envious one

to silence envions tongues

grows to an envious tever..... Troth
to envious and calumniating tim

neeessary, and not envious......... Jutius $\overline{\text { Cas }}$ sar

and $k$ ill the envious moon

be not her maid, sinee she is envious

can heaven be so enviops

look, love, what envious

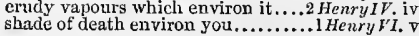

ENVIOUS-appear to the envious. Nea. for Mea. iii. 2
Biron is like an envious sneaping, Love'

the envious clouds are bent to dim ....

when some envious surge will. Tilusindronicus, iit.

an envious sliver broke............... Hamlet, iy EN VIRON-do environ thee ....T Tuo Gen of $\bar{V}$ er. $\mathrm{i}$. \begin{tabular}{l|l}
.3 & ENVIRONED-lamb, environed with.3 Henry $V I$, i. I
\end{tabular} envirowed he was with many foes ..
of thou environed with a brazen wall - ii.
ii. environed with a wildermess of sea... Titus And. iii. a hand environed with elouds .........Pericles, ii. ENVironed with all these hideous. Komeo \& Juliel, iv. that envy could not but eall fair.. Tuelfth stands at a guard with envy.......... for for $\bar{M}_{\text {eas. }}$ either this is envy in you, folly....... - iii. the keenness of thy sharp envy...... eny yo non's happiness......... As you like it, iii. but now I envy at their liberty .... King John, iii. ...Richard II. against the envy of less liappier

in envy that my lord Northumberland 1 HenryIV. those envy, therefore, or misprision

if he some envy your great deserving

with envy of each other's happiness . Heñy when envy breeds unkind $\ldots \ldots \ldots . .1$ Henry $V$. V. as leall-faced envy in her loathsome.2 Henry $V I$. iii. exempt from envy, envy

you envy my advaneement .......... Richard III. i. whom envy hath imp; to feed my.... - iv. no blaek envy shall make my grave Henry III. ii. enry and base opinion set against them - iii. turn the good we offer into envy .... - iii. that makal ye are moulded,-envy

and his diseiples only envy at .......
as full of envy at his greatness.. Troilus $\$$ - $r e s s$.
and devil, envy, say Amen ...........

as what envy ean say worst......... = iii.

why, thon damnable box of envy.....

with poisonous spite, alld envy. Timon of Athens, $\mathrm{i}$.

enforee him with his envy to the..... -

a soldier, rather than envy you..... - iii. 3

from my heart $a$ root of aneient envy $\quad-$ iv. 5

Wrath in death, and envy afterwards. Jul. $\overrightarrow{C a}$ sar, ii.

by addition of his envy! .....Antony $\&$ Cleopatra. $\mathrm{v}$.

even to the point of envy ..........Cymbeline, ii. 3

here no envy swells, here grow no. Tïus Andron. i.

above pale envy's threatening reach.. - ii.

but alaek! that monster low despise.. Pericles, ji.

Cleon's wite, with envy rare....... $=$ iv. (Gower)
pluek such envy trom him...... (Gower)

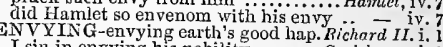

I sin in envying his nohility ........ Coriolanus, $i$.

ENWOMBED - were enwombed mine..... All's Wello, il.

ENWRAP that enwraps me thas . Twolfh N. 1

what eompany? Ephesians, my lord.2HenryIV.ii.

PHESUS - any born at Ephesus. Comedy of Err.

earse thou camest to Ephesus ......

coasting houneward, eane to Ephesu.

try all the friends thoul hast in Ephes

sir, I shall have law in Ephesus.

has through Ephesus poured........... Perieles, ivi. 4

my temple stands in Ephesus .......... at Epheses the temple see, our king - - v. 2 (Gow.)

EPICURE-with the English epicares..Macbelh, . . 3
else lie is a very epieture.... Antony \& Cleopatra, ii. 7

epienrean cooks, sharpen with...Anlony \& \& Cles, ii. 1

EPICURUS-Y held Evicurus strong.Julize Casar, v.

a league from Epidamu to Epidamnum. Coms. of Er. i.

you are of Epidamnum, lest that your - i.

there is a bark of Epidamnum ...... $=$ iv.

by men of Epidamnum, he, and $\mathbf{I} . .$.
they left with tlose of Eyidamnum.

they left with those of Eyidamnum.
EPIDAURUS- of Epidanrus this .

EPIGRAM-a satire, or an epigram?...Much $A d o$, v.

EPILEPTIC-upon your epileptic visage!. Lear, i. 9

PILOGUE- to see the epilogue. Mid. N. Dream, $\mathrm{v}$

et your epil i pray you

it is an epilogne or discourse ............. 's L. Lost, iii. that a good play nologue .....Asryou Like it, (epil.) neither a good epilogilognes ...... - (epil.) EPISTLE-obseuro epistles of love. Twelft $\mathrm{Nighl}$, ii. 3
as a madman's epistles are no gospels the kings Epistrophus and Cedius. Troil. \&. Cress. v. 5 hang her an epitapournful epitaphs. Much Ado, iv. hent an extemporal epitapli on... Love'

live still, extemporal epitaph on... Love's $L$. Lost, iv. lives not his epitaph, as in your ........ All's 'Well iv. of graves, of worms, and epitaphs...Riehard II. iii. not remembered in thy epitaph! ....1 Henry I $V$, v. 


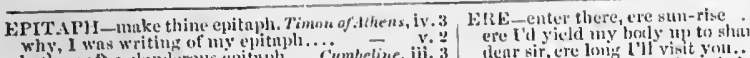

luth in of a slunclerous cpituph .... Cymbeline, iii. and her epitnilst in glittering golden ... I'rricles, iv. the evitajph is for Morinn writ

you were better luse al but cpitaph .....intemlet, ii. :

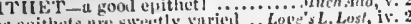

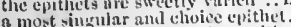
they will iot nnswer to that epitliet

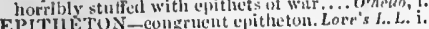

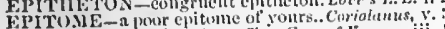

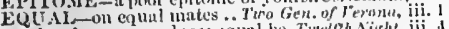
saul and merry mulness equml be. Turelfh Night,

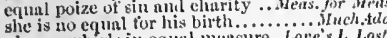
glic is ao equin for his birth.............'s L L Lost, ir. 3 nominated for an equal poutnd...Merch, of tinice i. 3 whose souls do bear an ehual yok

you to a more equal enterprise ..... is you like

have fought with equnl fortune 3 ifiem

fuiled to crunl uny treat fortune ...... iv. (chortis)

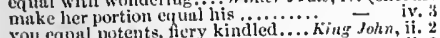

you equal potents, nery kindlen.

on equal terms to give him.......

in quantity equals not one of.

to equal with the king ......

in equal runk with the best governed

to you hoth, on equal love

his wrong linth equal mine

Richurd $I$. iv. 1

thic eause in justice' equal senic

Ilenrylr. s.

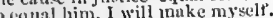

thy cumgue be equal with thy leatrt

so is the equal poise of this fell war.
wishing his foot were equal with

and strensth eoulil equal thom

grul strength eould erghat the by, to equal it ........

the two kings, cifual in lustre..... It
for lie is eyual ruvenous as le is subtle

two ergual mell. The gueen slatl

of equal friendship and protecedind

le misted with a

this, and nyy fowd, are erguals...

s this Mareins? He lins to equal ..Coriolanus, $i$.

thouyht tocrush him in an cqual Antony \&-Cleo, iii.

tlint this world did equal theirs.

and honours waged equal with him..

did but $\mathrm{my}$ fortunes equal my desires.. Pericles, $\mathrm{ii}$.

to equal any single erown o' the earth

endured a rrief might equal jou

good purentage-to equal mine! .......
thought'st thy griefs might equil mine

in equal scale weighing delight and dole. Hamlet $\mathrm{i}$.

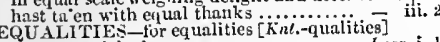

EQUA so weighed ........................... Lear, i. equality of two domestie powers. Anlony \& Clea. i. 3
EQU ALIED not to be equalled.. Winter's Tale, y. I else, surely, bis had equalled.. Timon of Athens, iii,
EQUALLY-you weigh equali y...Mcas.for Meas. iv equally remembered by Don Pedro ...Much Ado, i. I heneeforth be bestuwed equally.... As you Like into three limits, very equally....... Richard III. iii. 7 consisting equalty of horse and foot $\because n t-\&-C l e o$, jii. 4 and equally to me disloyal .. Cymbeline, iii. 4 (letter) and our safity may equally deternine ..... Jear, v. 3 EQUALNES-divide our equalness. Ani. A Cleo. $y$ EUUINUCTI.A the equinotial of.. Twefnh N.ii. 3 EQU LNOX-to his virtue a just equinox. Ohello, ii. 3 EQUTY-this down-trodden equity . King John, ii. cowards, there's no equity stirrulg ..1 Henry IV. ii. 2 and equity exiled your hishnes

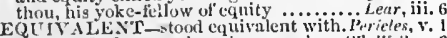

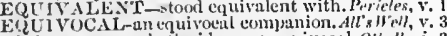

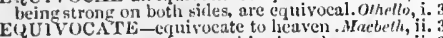
in eonclusion, equvocutes him in a slecp - ii. 3 in eOnelusion, equvocates him in a shect -

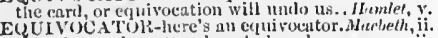
comc in. e'guivoestur; knock, knock

sairl to be an envivocator with lecher

this is Ercles' vein, a tyruit's vein

Elik-re thou eamest hore.

and melt, ere they nuslest

for yet, ere supper time 1 co....

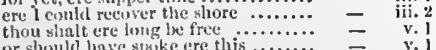

oraten by the eanker ere it bluw. Fino Gen. of Jer. i.

this hour ere I have dome weeping

you always end cre you letin....... -

unhappy were you, madam, ere $\mathrm{i}$ ex...

fulls vit, ere it be fins .................

ere summer eunce, or enck (u) - hircls ..

into the Thames, ere twill lesc

- iv.

you might ale sleep, lias thrike

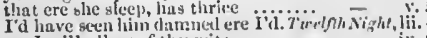

ere I will allow of thy wits .......... Fo. iv. 2

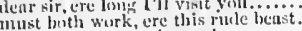

cre be wombl have hanged a mun

you shinl hear more ere morning

ire twice the sum hath male

a thousul the thut ny report ......

I shull see thee, ere 1 dic, look pale

ere you flout old ends any longer

and she will die ere she muke her....

did earn it, cre be had it

arink some wine ene ere it be

und yet, ere 1 go, let me go

let's late a clanee ere we are marri

nud ere 0 man hath power to sny

finir llermia, ere I to ...........

for ere Demetrius fooked on ..............

be thou here again, ere the levintlan

and ere I take this eharm oft from

meet me ere the first eoek crow

hat th made my eyes water cre now

effect this business yet ere day . .

we will make ameuds, ere long .

so, ere you find where light in

we shall be ricli ere we depart.

we shall be rich ure we depart........

Birom l't torture ere I go $2 .$.

seck all day ere you tind .....

anythini. Nerissa, ere I will be

ere 1 ope his letter, I pray you

saw the lion's shadow ere himseif'....

my mister will be here ere mornin

we cuckolds, cre we have deserved it?
unto entreuties, ere he shonld thus.ds you Like

and ere we liare thy youthful wages

you'll be rotten ere you be haiti

it was a erest ere thou wast born

unnoted, ere they ean hide their........ $[$ in 1

his heart out, cre he pluc

lending grace, ere twice ................

of the bride, and, ere I do begin

with the fox, ere we case him .........

your daughter, ere she seems

a thousand salads, ere we light

I hope I shall see him ere I die.

steals ere now, sir, been better.

upon her, ere my heart dur

or, ere they meet, in me, 0 nature

sir. a word ere you go ...........

better ere he go to elureh .................

in my belly, ere I should come by...

time, ere you come there (rep.

went on erutehes ere he was boin. . . inter s $T$ ote.

a thousand furlongs, ere with spur

ere I could make thee open thy .....

come between, ere you can say

shed water out of fire, ere don'
the same I am, ere aneientest

spent time worse, ere now ........ - iv. (clorus)

spenk, ere thou diest

but ere tley came .......

Camedy of Erro

gres ere the weary suu set.

ere I learn love. iojt wim

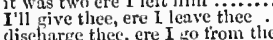

that will be ere set of sun

friend, ere you went to bed.

sutier, ere we will eat
ere the bat hath flown

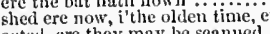

acted, ere they may be seaniled

I'll cateh it ere it come to ground

unfold lis message ere lie come......

dying, or ere they sicken $\ldots . . . .1$.

and so, ere answer knows what..

to ashes, ere our blood slail

and ere our eoming, see thon siri

our sorrows, and ere ling, I doub

grupple with him, ere he eome

, or ere I come

(so please my sovereign) ere I move... Richard st.

but ere I last received ........

confess thy treasous, ere thou fiy.........

ere the six years, that he ..........

ere further leisure yichl thisn

perhaps, they had ere this

werhaps, they had ere this

iii. 2
Meas. ii. 2 ERE-but ere the erown le looks for. Nichard 1/. iii. 3

to liell ....

ere thou bid pons-nighlit

purdlon, cre I rise or speak.

twas, villuin, ere thy liand did

I"I] it:are ere ['ll robs

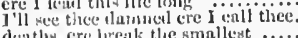

deathw, cre lreak the smallest

lour days ere I set forth

fitst been whole, ere he by siekne

thrive not, ere the king úfismiss

yet onee ere night l $l$ will embrace

found the fire, ere he his tongue $\ldots . .2 .2$

perfiunes the blool ere oine cas say.

I will see you aguill ere $1 \mathrm{go}$

long ere this, we ofterel to

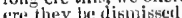

ii. 2 rebuke, cre you with griei lini

to sed Isuden onee ere I die .....

it will be two o clock cre the

ere he take ship fir lrance.

by the mess, ere these eyes
to hazard, ere you have th
yot

yet ere night they'll be in
ere it is make an endl and finished

I intend to have it, ere long

prove not maseuline ere lov

ere that we will suffer such $\ldots \ldots \ldots . .$.
his heart out, ere tbe priest shouli ever

nuny finish ere that liapless time....

there will we be too, ere it he long

but, ere we go, regard this
where $I$ hope ere long to

for ere the glass, tinte now.

sprak to thy fatlier ere thou

of England, ere the thirtieth

Franee will be lust ere long
ele thou go, give up thy staff.

rumedy this gear ere long

my lort of Suttolk, ert you ean take

great pin, ere thou and I part

I know, ere they will liave ne go.

speak blusplieniy ere bid you $11 y$

but twas ere I was born .............

made thee faint and ty ere this

bat ere sun-set. I'll make the

and, ere my knee rise from ......

may yet ere night yield both

ere I enn place my'self

uncrown him ere't be long (rep. iv. i)

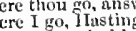

ere he at tain his ensef ul

hewn up ret cre night.

ere you were queen .............

what you huve been ere

deul ere thou wast borm

long ere this have met ns.......
from rou, Catesby, ere we sl

well. Catesby, ere a firtnig!

will lose his liead, ere give consent

die, ere men ean say-Gol save .

the prime ereation ere she framed

cre from this war thou turn

misused cre used, by tines a.........

I dien for hope, ere 1 contd lend thee

ere he jromised; whereby his (rep.) Henry ${ }^{2}$ UI

the other moicty, ere you ask ....

this business, ere a determinate..

gone, ere ye eame to llium? .. Troilis

ere I come any more to yaur tents

inust be watehed ere you be mnde.

figlit your hearts out. ere I part you.

though they he lont ere they are

you'll do him wrong ere you are

lorthwith, ere the first snerifice
a consting weleome ere it eones.

my office, ere that eorreetion

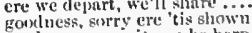

made nway ere it ean be born!

wheretore, ere this time ............

to lat the mest cool ere wo

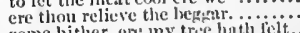

come hither, ere iny tree hath lelt...

ere tikes, ere we leceme rakes.

the city. ere bo prevailed with me

ere stay belitind this binsiness

erc, nlmynt kome should know .

to our tent; where, ere we do repose
Richaril HI.

$$
\begin{aligned}
& \overline{ } \\
& = \\
& \overline{ } \\
& = \\
& = \\
& = \\
& \bar{z} \\
& \bar{C} \\
& \text { Cressi }
\end{aligned}
$$

iii.

- iii.

iolanus,

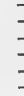




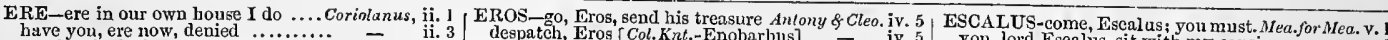
- iii.

ere you go

iv. 2 Eros, ho! the shirt of Nessus is upon meshe dies for't. Eros, hot ....

to be excented, ere they wip

I shall ere long have knowledge.

ere he express himself..

good knaves yo.

but ere we could arrive the point.

slie, Eros, has packed cards witl Cæ...

ere day, we will avake him

ere I can tell thee wliat thon

Eros, weep not, grentle Eros $\ldots \ldots . . .$.

apace, Eros, apace; no more a soldier

Eros! I come, my queen: Eros! stay

zet ere night we sluali try for it com

thou art sworn, Eros, that when

yct, ere we put ourselves in arm

Bros, wouldst thou be windowed

next norn, ere the ninth hour

I have a mind to strike thee ere thon

we'll feast each other ere we part.

you were half blasted ere I

or less, ere left to after-eye him...............

ore I could tell him, how I would.

ere I could give him that parting kiss

many Cresars, ere such another 3 ilius

ere willuess vanquish my

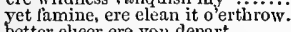

better eheer ere you depart

to seem to die, ere sick ...............

than die ere I hear more.

here's my knee; ere I arise....
ere thic stroke of this yet scaice
war did cease, ere bloody hau

war did cease, ere bloody haud
ere half an hour can pass...T

some scrvice, ere I come to the

yet, ere you shall depart

dead ere you return.

wreath of flowers, ere the sea na........

now, Eros. Why, there then

ii. 5 my queen and Eros lave, by their hra

ERPINGH thy master dies thy scholar

old sir Thomas Erpingliam ....

under sir Thomas Erpingham $\ldots . . . .$.
ERR-my jealous aim might err. Tu. Gen.
authority, though it err like...

authority, though it err like......Meus. for Meas.

and as he errs, doting on Hermia's... Will. N. Dr.
to me religious; else, does err ........ All's Well,

shall borrow, err in bestowing

these old withesses ( cannot err).

Macbeth.

who eannot err, he did it ...........Henry VIII. i.

whiat error lcads, must crr ..

Crymbeline, $\mathrm{i}$.

as they are men, for they may.

Pericles, i. 2

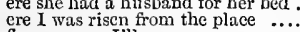

flaws, or ere I'll weep .............

I'll speak a prophecy ere I go

ere long you arc like to bear

ere they have done their mischief...

beard, ere the black ones were there

demanded, ere you had spoke so fin

on thy lieart, ere I taste bread.
close fighting ere I did approach

for nature so prcposterously to er.........

errs in ignorance, and not in cunning

ERRAND-he came of an errand.....

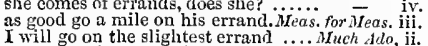

but hast thou doue thy errand. $T$.

so meet for this great errand

upon which errand I now go toward

my errand, due unto my tongue. Comedy of $\mathrm{Err}$. i1

thy tongue to tell thy errand $\ldots . . . .$. King John

I know thy errand, I will go with thee. Henry $r$. iv

I'll say an errand for you ....

meet to be sent on errands

ere we may think her ripe to be.......

ere once in our five wits.....

cease to be, ere one can say ware.

shall bear us an errand to

yon shall know my urrand ....R Romeo \& Cleo. iii.

now ere the sun advance his hurning

I'll tell thee ere thou ask it me again

when it hoars ere it be spent

be about your ears cre it be out.

for ere I could draw to part them

ere I again behold my Romeo.

must wed, ere he, that should be

erc this hand, by thee to Romeo

I have watclieo ere now all niglit

a little ere the mightiest Julius feil

or ere those shoes were old

ere yet the salt of most unrighteous teach you to drink deep ere you depart

teach you to drink deep ere you depart
[Col.Kut.] ere ever I had seen that day

ere this, I shopld have fatted all :

in iner eloset, ere you go to bed ....

I'll call upon you ere you go to bed....

ere we were two days old at sea....

by the margent, ere you had done..............

ere I would say I wonld drown myself... Othello, i.

ere the next pottle can be flled........... - ii. 3

EREBUS-dark as Erebus

with Erebus and tortures vile ........ HenryIV. ii. 4

not Ercbus itself were dim enoing

I'll erect a tomb, wherein

and there ercets thy noble cleeds

erect his statue then, and worship..2Henry $V I$. iii. 2

ER hCTED-where I erected it ..... Merry Wives, ii. 2

walls of ours were not erected...Timon of Athens, v. 5

ERECTING-erecting a grammarschool.2 Hen. VI, iv.7
ERECTLON-mistook their erection. Merry Wives, iii. 5

we rate the cost of the ercetion $\ldots \ldots .2$ HenryIV 1.3

is bad, foing o'er it erewlile ... Love's Dream, iii. 2

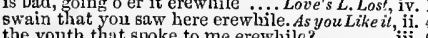

erewhile mad [Col.Knt.-o'erwhelmed]]... othetln, iiv.

ERGA-tanta est ergà te mentis.... Herry'rIII, iii. I

will burn; crgo, light wenches.. Comedy of Err. iv. 3
ER INGOES-and smow eringoes ...Merry Wives, $\nabla$.

LRRED-in your life erred in this..Veas. for Meas. ii.

ERREST-madman, or sinned

ERR ING-this erring love .. TüuGen of Vight, iv.

the extravagant and erring spirit ....... il a

and yet, how nature eriong from itself

ERRONEOUS-erroneous, mutinous.3 Henry $V t$. i

erroneous vassall the great king .. Richard III.

that this may be some error .... Thelfth Nigh

but thou art full of error ............Meas. for Me
to burn the errors that these prives. Much $A d o$.

guilt less here under some biting error
upon the error that you heard debated

to take from thence all error ..Mlid. N. Dream, iii.

pardon sir, error: be is not

the error that love makes

what damned error, hut some sober.iter. of $\bar{V} e n$. iii.

and many an error ............... iv.

error i' the hill, sir; error i' the... Taming of Sh. iv. 3
make, and unfold error .. Winter's Tate, iv. (clorus) what error drives our eyes and ears. Com. of Err. ii. 2 and therenpon these errors are arose

thed one day's error.

wrangling Somerset in the error?.... King John, ii. thy tongue will not contess thy error - ii. 4 the error of our eye directs (rep.). Troil.

mountainous error be too highly.... Coriolanus, ii. 3 o error soon conceived, thou never ... - v. 3 make us adore our errors... Antony \& Cieopatra, iii. 11 my boys, there was our error ....... Cymbeline, $\mathrm{v}$.
but breath; to trust it, error............ Pericles, $\mathrm{i}$. mischance, on plots, and errors, happen. Hamlet, I do not secure me in the error........

it is the very error of the moon.......... RST - which crst was irksome ............ Likeit, iii.
that erst brought sweetly forth........ Henry $V$. v. as Tarquin erst, that left .... TitusAndronicus, iv. as erst our ancestor, when with ....... as erst they did; so I bequeath …...... Perirles, i. 1 ERUPTION at such eruptions ... Love's L. Lost, v. I areals forth in strange eruptions ...1 Henry IV. iii, hodes some strange eruption to our stnte. Hrmalet, i. SCALUS-Esealus, -.... Measure for Measure, old Escalus, though first in question 'tis one thing to be tempted, Escalus

10 thanks, good friend Escalns, tor thy

ESCANES-no, no, the Frenchrnan?...All's $W^{e l l}$, iii. old Escancs, whom Itelicanus late.... Pericles, ii. ESCAP'DST-then low thou cscap'dst. Tempest, ji. and a kerchief, and so escape .... Mterry $\overline{\text { ines }}$ ii. minc own escape unfoldeth to $\mathrm{my}$. Twelfih Night, i. give him liberty to escape ....... Meus. for Meas. iv. for a week, escape a great deal of.....All's IVell, iij. I for my escape liave put on his..Taming of Sh, $\mathrm{i}$. to tell the king of this escape .......... I wot not by what strong escape. Comedy of $E r r$ iv. in him that escapes, it were not sin..Henry $V$. iv. happy tidings of his no, tis impossible he sliorld escape.
but how made le escipe?

even he escapes not language ......... Henry $\bar{V} I I I . \mathrm{i}$. 2 thus I do escape the sorrow .......... despise her for this foul escape... Titus Andron. iv. 2 if he by chance escape your venomed...... for thy estape would teach me tyranny... Ohello, i. 3
ESCAPED-I escaped upon a butt ....Tempest, ii. 2 sailors that escapcd the wreck...Mer.of Tempest, ii. well-mounted, hardly liave escaped..King John, v. I wonder, how the king escaped our..3 Henry VI, i. the blood that has to day escaped......Ant. \& Cleo. iv. 8 CSCAPEN ESCHAPPER-d'escliapper la force .Henry $V$. iv. 4
ESCHEWED-cannot be esehewed. Merry Wives, ESCOLIER-que je suis le bon cscolier. Henry $V$. iit. ESCOTED-how are they escoted? ....... Hamlet, ii. 2 excusez moy, Alice; escoutez; de hand
escoutez; coinment estes vous appellè? pour les escus que vous l'avez promis - iv. CSPECI $A$ L-npon especial cause. I Henry VI. iv I I (let.) this deed, for thine especial safety .... Hamet, iv. 3 there is especial commission come from..... othelth, iv. 7 SPECI ALLY - especially, against his very friend.................. Two Gen. of Verona, iii. 2
espccially to know himself........Meas. for Meas. iit. 2 and especially, when I walk wway .... Nuch Ado, ii. I and especially of my own people.. As you Like it, i. 1 especially he hath incurrerl the everlasting - Aels, i. I Richard right; especially for those........Macheth, $V I$. iii. 1 especially, since Charles must father it - v. especially to you, fair queen!. Troitzs \&-Cressida, iii. I proceed especially friendship... Timon of Ath. iii. I especially in pride ..................

especially that of Cleopatra's ....Antony $\bar{f}$ Cleo, i. 2 of it especially, where he speaks ........ Hamlet, ij. 2
ESPER now,-esperance ! Percy !............. stands still in cspcrance................. Lear, iv. by your espials were discovered ...... lier fatlier, and myself, law'ul espials... Hamlet, ivi.
ESPIED-we are espied where I espied the panther fast........ our Tyrian ship espies he espies ..Mid. N. Dr. ii. ESPOUSE-by name, and her espoure.. Henry $V$ ii. he shall cspouse Elizabeth............2 Richard III. iv. 5
in the sacred Pantheon her esionse..Titus And. i. in the sacred Pantheon her esponse.. Tilus And, i.
ESPOUSED-and so, espoused to death.. Henry $V$. iv. my task, and was cspoused.............Henry Vi. $\mathbf{i}$. I ESPY - when his love he doth espy. Mid. N.'s Dr. iii. 2 he doth espy himself ............... King John. ii. 2 ESQUIRE-Robert Shallow, esquire. Merry Wives, i. 1 a poor csquire of this county ......2 Henry $t V$. iii. and two hundred good esquires ........ Hentry $V$ i. i. and two hundred good esquires ....... Henry $V_{\text {. i. }}$.

Alcxander Iden, an esquire of Kent. 2 Henry $V I$. iv. 10 a poor esquire of Kent, that loves .... . . Tenry V. i. 2 but as an essay or taste of my rirtie........ Lear, i. 2 his glassy essence,--like an........Meas. for Meas. ii. 2 her honour is an essence that's not seen. Othello, iv. ESSENTIAL-in the essential vesture SSENT LALLY - essentially mad ...1 Henry IV ii. that I esscutially am not in madness ... Hainlet, iii. 4 ESSEX-power, of Essex, Norfolk.....3 Henry I't. i. 1
ESTABLISH-establish him in .. Comedy of Err. iv. 4 but to establisl here estate

ant to establisl here a pence

inenry $I V .17 .1$

mean to establish Cazar as a ling.Julius Ccesar, i. 3

established proclaimed edict... Love's L. L. i. I (let.) ean alter a decree estahlished ...Mer. of Venice, iv. 1

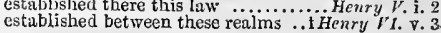


ESTA[BI,ISHED-

and oue in blewe entalilished

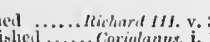
any wholesome net citublinhei

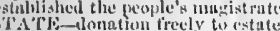

veciston mellow, what my entute is .. Treelfit $\mathrm{A}$.

meither in estate, ycars, now wit

prat when I cume to man's estat

$-v \overline{1}($ (soniz)

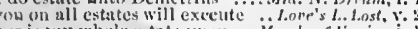

lisule

(1) that entntes deuretes sud willies

letter there will sicus you his astate

nyy esinte is very low, iny looul.

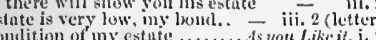

will I estute upon you, nul here....ts yoth totie it, i.

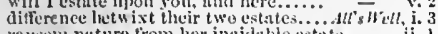

lansolu nature from lier inaidal

if not to thy estate, a balanee.....

thengh my estate be tallen, I was

shame to your estufe, an

dispute his own estate? lies be not

leiug in so prosperous estate as we are
wo will entnblish our estate upou our.

aud wish the estate o the world were now

walks my estate in France?

hin John, iv.

kns in a molel, our tirm estate? .... Rirherd 1, iil

what thinks he of our estate? .......... Henr

to shine un my eontemptible estate... Henry l\% . .

stur now envies thy estate

ilenry iri. ifi. 3

kuew in what estate he stunis.

by how muclu the estate is gree

hy this so sickencol their estate.

Richard JIJ. ii.

this way, is business of estat

remembir the extate of my poor queen

aud my entate deserves an

he's stephed into a great estate....

and his csiate shrinks from him

supported his estate; lay.

still turee owe their estates unto him

we sin arainst our own estnte.

nn estate of sever ours'

should we slifit estates, yours woujil. Ant.\& Cleo. y.

would I had put my estate, and niy

with dignities becoming your estates

so, think of your estate.

we could jick uj some pretty estate....

in time to great and higli estate

dispute with thee of thy estnte.. Romeo \& Juliet, iii.

the terms of our estate may not enclure.

'twas of some estate: eouch we awhile

aud my possessions she estcems not.

go high in his esteem, because I am. irid, $\bar{x}$ iii. 1 this their jangling I esteeln a aport..

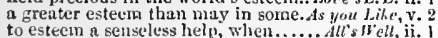

our esteem was made much jourer

I wonld estecm lim worth. Trming of $S h .1$ (ind. she is of goud esteun, her infowry.

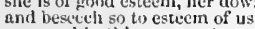

a eowarl in thine own estecm...

the yoor state esteem him as

thy weary stejs estcem a foil.......

five hundred yrisoners of esteem

esteem none triends, but such

unto another ludy of estem

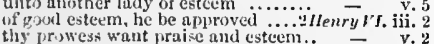

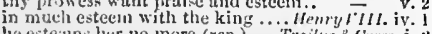

he estecuns her no more (rep.) ...

things again most denr in the esteen

a.4 eats nod dogs, of no citeen

my noble lort eoteems me honc:t ....... Othello, is. 2 but, most estecmed greatness, will you L. I.osl, ii. I with me estemeer alove thy lite. Her of éenice, iv. 1 the world estecined thy thether .....As you Like it, i. 2 lusth estemed hitn no more.. Tainizy of sh. I (ind.) m., testeemed friend, your brother. Troil. of Cres. jii. ther shalt he no less esteerned... Timon of .therss, ii. 2 they should be estemed nothing.. Antony f clem. i. foction

side of our known worli estcemed him.. Ilamlet,

Wher

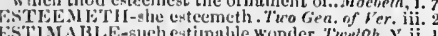

is not on estimable, profitable ... Aereh. of ientice, i. else of nanie, and mblc estimate .. Richari $I I$. it holds his estimute andulignity . Troilus of Cress. if.

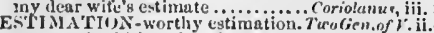
camot pleal his estimation..... Meas, for Mros. iv. whore estimation do you mighitily ..17ueh Ado, ii. lunring, and estimution ...Lore's. Lo. Lod, I. I (letter) to let him lack a reverculul extination

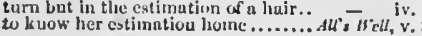

LSTIMATIOS-Mngalled estimation

deur nen of estimntion, and conment

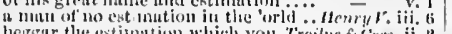

hergar the citionation which

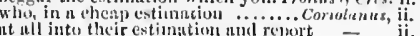

to curn a deurer estimation ot chemente

he wonld use me with estimation...

mice of unjurzalule estinsutions

do they hold the alue estimation.

agminst my ustinution] [Col.-reputation] othello, i. 3

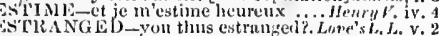

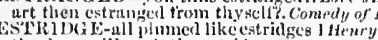

the dave will jeck the estriche Antony o cho. iil. I

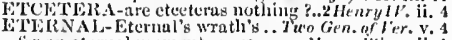
for an eternal moment, or so.......... Merry

give eternal fowl to his jeulousy ....

stands in attainder of eterial shanc. Lore's $L$. L.

and sworn to make the not eter........

as to-day, and be boy etermul .... Winter's Thte, $\mathrm{i}$.

and mine etermal jewel given

Muebeth, iit. 1

holding the etermal spirit

thy lingers for eternul peace...

Asmath, by the eternat Gorl

Henry ?

of thou cterual mover of the

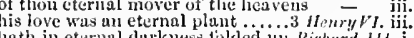

inth in etermal durkness tolled up. Richard 11 . $\mathrm{i}$.

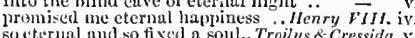

socterual and so fixed a soul.. Troilus \& Cressida,

would be etermal in our triumpin. Antonys Cleo.

no noisc, but silence and

may slumber in eternal siee

keep cternal spring-ime on thy fice. - iii.

but this eternal blazon must not be ..... Humlet, i. 5

teast is towurd in thine eternal eell .......

ETERNALLY-eternally be knit... Nit. $N_{i} \vec{D} r$ iv.

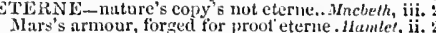

ETERNITY - heirs of all eternity Love's L. Losh, i. I

who, had he himself eternity ..... Hinter's Tule, y. 2

but eternity, and n heaver............ Coriolunzts, v. 4

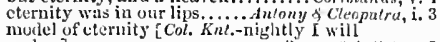

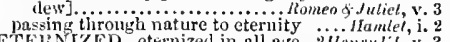

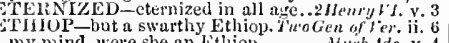

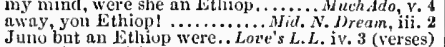

and Ethiops of their sweet comple s. L. iv. 3 (rerses)

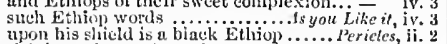

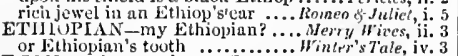

or Ethiopian's touth .................

so ooou as I came lieyond Liton.

Ind with him at fiton

EUNUCIl-present me as a eninuch. Turelgh

be you his ennuel, and your mutc $\ddot{B}-$ i. 2

sthing by an Athenianl ennuch ... Nird. N. Dream, y. 1

to the Turks to make en

into a pipe small as an cuncheh

no pleusure in nutht at e......... Antony of Cleo. i. 5

thin witle an sumuch played.

that L'hotitums an cunueli...

roiet of uninved emuch to hout...... Cymbetine, ii. 3

EUPIIRA ArES-Asin from Euphrutes. Ant. \& Cho it.

by good Euriphilc, our mutler wast. Cymbetime, iii. 3

suve that Euriphile jnust be ridele

EUROPA-a bull tor thy Euro..........

all buropa shull rejoice at thee (rep.) Huch wo

no eourt in Europe is too good ..."Winler's Tole, ii. 2

the dearest eliandler's in Lurope...11/enry $1 \%$.

the most active tellow in Eurolic.

pistress

it is the best horse of Europk

infenry vii.

shall make all Lurope quake $\ldots \ldots . .1$ Ifenry $V J$. i.

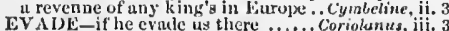

E furpuses, cvalcs them, with a bombast.. Ohnello, i. I

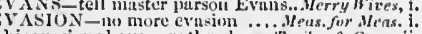

his evasions have cur's thus long. Troilus of Ciess. jit.

there can be no evinsion to blench.
but his evakion, winget thus sw if

an admiralse crasion of whoremaster man. Lear, $\mathrm{i}$.

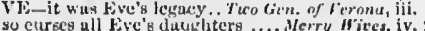

LV fi-ns witty u piece of Eve's tledh, Ticelfh Nirfh, i. "

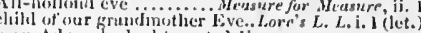
wech Allim, he hasl temptenl live .... - v. whint fire, what terpent lath .... Richard $11 \%$, iii. cwern now, we hearla hollow.

even here I will put off ny liope.

with such like valour.

cren to roaring: come

cven socislife to the slow of thite.

where, but evein now

thrive thereiu covell as I woulil..........

eren so lyy lowe the young $\ldots . . . . . . .$.

even with the speediest expedition...

even she; and is she not.....

even as one heut unother.

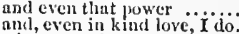

why, even that tuslion
even in the milk-w.....

even yow abuet it
my will is even this

even for this time I spend

cven from a leart as full

atrick 8 cell this even.

who cven now gave me good eyeb... Herry Hives, i.

an old fut woman even now with me -

her mother even st rong against........ - iv.

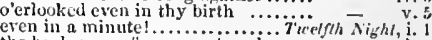

the book even of my seerct soul...... - i.

sing them loud even in the dead of...

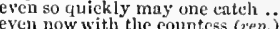

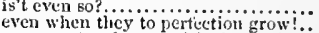

cross-gartered even witl the swiftiess

ven such, and so, in favour was

even for the vows we male.

unhappily, even so ................... her seasure, i. 1

even so har o ergrown lion.

even for our kitelicus we kill

and even so the general, subject to

even so? Heaven kecp your honouri

the time is eomc, cven now .......

paralleled even with the strokic..

most audible, even from his projer

your highness said even now ....

theretore $I$ will wen take sixpence

who even now is eoudhed in ........

even she. Lcunato's Ilero, your llave

a very even way, but no surly fricad

I have deceived even your very eyco

in

and even for thent to I love you. $\because \cdots i$. . . D

tell true, cren tor ny sake ........
pat in two scales, will even weigh

who even but now did spurn me.

may tread, cven till the easterl gate $\overrightarrow{\text { iii. } 2}$

liere, hut evenl now, disguised
dead, fur my life. Even so

finslioning our himours even to

lut even now worth this...... Hrehehin

shall be racked, even to the uttermost
he rails, even there where merehants

even for that, I thank you ..........
so are $y^{\circ}$ ou, swect, even in the lovely

reigle thy value with an eren hand.

cren there, his eye being big with
the ontward wall, even in.............

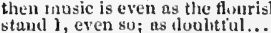

even now, but now, this house

even such a linsibud hat thou of me

even from the gullows did his fill...

even lie that hind held up

I sweur to thee, even by thine own

is it even so? lxyin you to grow........ Bs you Like

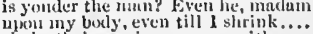

ehoke their sorviec uperen with ...

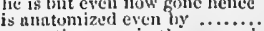

reputution even in the camonis.

cven at toy in hashd here, sir......

to make nll this matter even

cartily tlings male even .............. - v. 1 (verse 


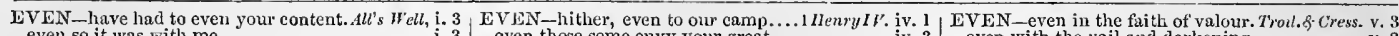
even so it was with me

but will you make it even?

find in you, even to the world's......

his greatness, even to the utmost

who had even tuned his oonnty....

true, even to the point of her .........
to make the even truth in pleasure.

\begin{tabular}{r|r} 
i. 3 & even those some envy your great...... \\
ii. 1 & followed him, even at the hecls \\
ii. 4 & even those we love, that are misled..
\end{tabular}

iv. 3 even he drops down the knee .. Timon of $\overline{d t h e n s, ~} \mathbf{j}$.

even as a flattering dream.... Taining of Sh. 1 (iv. 3

with her breath, cven as the waving of -2 (ind.)

is't he you mean? Eve

good sooth, even thus 1 will be free, even to thic.........

and even in thy behalf, I'll thank....

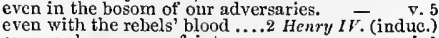

even such a man, so foint ...

make sacred even his stirrup

lent a fire even to the dullest peasant

even so my limbs, weakened with

a body strong enough, even as we are

he ealled me even now, my lord

even like that are kin to

even as your mind; what you (rep.)

give even way unto my rough

do even drance, even such, a woman - v.

many a man there is, even at this....

how vilely did you speak of me even now -
yea, for my sake, even to the eyes ..

dost advise me, even so is mine........

even now I met him with customary

I eyed them even to their ships....

even thou, that hast a heart so tender

something xare, even then will rusli.

we pronounce, even puslies 'gainst

love had spoke, even since it conld.

ay, my lord; even so as it is here set

are even now to be afresh lamented.

I will even take my leave of you

even now I tremble to think ...

even here undone! I was not rauch

Camillo. Even he, my lord

then, even now, I might have looked.

that even your ears should to hear me

I thought of her, even in these looks

the child, were even then lost...........
thus she stood, even with such life.

even now, even here.......... Comerly of Evr

i. 2 denied access unto his person even by

i. 2 with you lord bishop, it is even

ii. I laud be to God! even there my life

how smooth and even they do bear

even those, that were your fatlier's

a'parted even just between twolve.

weighs time, even to the utmost grain

from morn till even fought.

even as your horse bears your the puissant pike? Even so; what are

even as roen wrecked upon a sand

and even play of battle, was ever

the even mead, that erst brought

iv. 3 even so our houses, and ourselves....

v. 1 and fully even thesc thrce days.

is it even so? Nay, then. I see...

uc.) even as Apemantus does now

my lord, you take us even at the best

such as do even enemies exceed......

$\begin{aligned} \text { i. } 3 & \text { even so thon ontrun'st grace .......... } \\ \text { ii. } 2 & \text { of whom, even to the state's best } \ldots . . . \\ \text { ii. } 2 & \text { naught but cren the mere necessities }\end{aligned}$

ii. 2 even so, sir; as I say: and, for tliy

ii. 4 ay, even such heaps and sums of love

which he is, even to the altitude of... Coriolanus,

but even thus, (for, look you

even so most fitly as you malign..... -

thou wast a soldier even to Cäto's wish -

even there against the hospitable....

even when the navel of the..........

even this, so criminal, and in such.

we, even from this instant, banish

sir, even by your own. I cannot

but he could not carry his honours even -

and I an out cven to a full disgracic

even he, your wife, this lady .......;

even in theirs' and in the commons' ears -

even like a man new haled from

good even, Casca: brought you .......fulius $\bar{C} a s a$

in a moment, even with the carth.

i. 4 even in the aim and very flash of it.

even as I have fertile England's

Antipholus, hate, even in the spring.

even my soul doth for a wife

even just the sum, that

even now a tailor called me...........

invisible: even now we housed.
even for the service that long

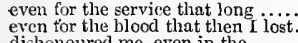

dishonoured me, even in the

the sin of my ingratitude even now.

both sides are even : here I'll........

you make me strange even to the

and even now to crown my.....

perchance, even there, whe

even so? To bed; to bed .................

and makc us even with you.....

even till that utwost corner....

while they weigh so even, we hold.

with course disturbed even thy .......
upon these jades, even till unfenced.
lay this Angiers even with ...........

made to run even, upon even grouid

and even bcfore this truce, but new.

hath fallen, even to that drop

for even the breath of what

even at that news he dies .............
even in the matter of mine innocence

my cyes are out, even with the fierce.

is braved, even at my gates.......

and even there, ncthinks, an angel ..

and to win renown even in the jaws.

had the strength, even at your door.

even at the crying of your nation's

brought to Richard but even no....

even on that altar where we......

but even this night, whose black.....

run on in obedience, even to our oce...

even so must ruw $I$ on, and even so

even from the tongueless caverns

a loyal gentleman even in the

shame doth harbour, even in ..........

and make us wade even in our.....

uncle, cren in the glasses of..

for even so looked he, accomplishi...

not so; even through the hollow eyes

hither come even at his fect....

all must he even in our government

rue, even for ruth, here shortly
and that even here thou takest

even so, or with much more eon tempt

even such they say, as stand

owes to you, even with the hioody...

bear ourselvcs as even as we can

that's even as fair as -at liand.........

lorsc, my lord, he brought even now

thou said'st but two, even now

the: he runs straight and even

enrbs himself even of his naturai....

even in the presence of the

and even as I was then, is Per'ey ....
yea, even the slightest worship ....

and cren as willingly at thy fcet

even so, remorseless, have they borne

even so myself' bewrails good ......... -

even so suspicious is this tragedy....
away even now, or I will dray thiee.

ancl even now my lumeng the..

even now be gone; o go not yet!

even as a splitted bark, so sunder we

may, even in their wives' and children

even the presence of lord Mith you

even to affight thee with the vicw
even of the bonny beast he loved

even at this sight, my heart...

rehel sits, even in the chair of state!.3 Henry $v I$. i.

be dyed, even in the lnkewarm blood

even with those wings which sometime

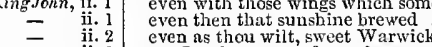

ii. 2 am I stolen, even of pure love

tell me, even upon thy conscicnce

ii. 2 'tis even so; yct you are Warwick still -

hide their faces even from darkness.

walk whow it, even in thi

even at the base of Pompey's statua..

even so great men great losses shouid

cren so, Lucilius. Now, most noble..

even by the rulc of that philosophy.

even with the sword that killed thee

it runs over even at his eye

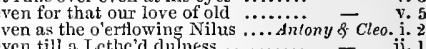

iii. 1 even now forsake me $\ldots . . . . . .$.

iii. 4 even so? and please your worship.... irichard III. $\mathbf{\text { i. }}$

and even with the word, this hand

zounds, it is even now at my

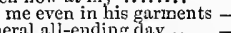

even where his raging eye

and even here brake off, and came away -

my path were even to the crown

even when you ploge since best.

even when you please, since you $\ldots .$.
even in so short [Col. Kut. - within so smail]

even all I have; ay, and myself and all

even he, that makes her queen

even so; what tlink you of it, madam?

lics now even in the eentre of this...

whose figure even this instant........Henry $\bar{V} I I I$,

even

even to the hall, to hear what shall.

i. 3 even of her, that, when the greatest..

sprcad then even of yourself ...........
i. 3 iii.

iii. 2 even till a Lethe'd dilues

I will be even with thee, doubt it not

- iii. 7

give me a kiss; even this repays me.. - iii. 9

he's hunted even to falling .......

even here do we shake hands
a horse, even with a thonght

a howse, even with a thonght $\ldots \ldots \ldots . .$.

i. 2 now thy captain is even such a body - iv. 1.

ii. 2 I honour him cren out of yoir report. Cymbeline, i.

ii. 6 make her go back, cven to the yielding

iii. 3 even to the point of envy .............

for even to vice they are not constant

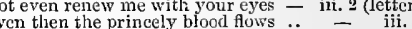

to read would be even mortal to me.

but we'll even all that goor time ,....
will pursue her even to Angustus' thro

even there, thou villain Posthumus ..

but even bcfore, I was at point to sink -
I'll foliow those that even now fled lienee -

he went hence even now 3 . $\ldots . . . . .$. .

even to the note o' the king ...........

who, even now, answering the letter - - varcus, cven thou hast struck Tilus Andronieus, $\mathrm{i}$.

even at thy teat thou harlst thy ...... -

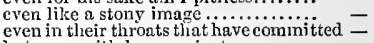

but even with law, against $\ldots . . . . .$. -

even by my God; I swear to thee......

even when their sorroprs almo.........

even from Hyperion's rising in

even at thy solemn feast.

the embracements even of Jove límself.Pericles,

even such our griefs...........

east away bcfore us, even now

(cven as he left his life) keep it

iii. 3 no? saw you not, even now no........... co-rivalled grcatness?... Troilus \&.Cress. i.

even so doth valour's how ..........

perspicuous even as substance

even so? a great dcal of your
even such a passion dotl

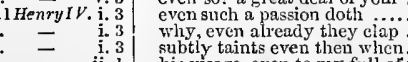

ii. 1 his visage, even to my full of view.....

ii. 4 strangles our dear vows even in the.

iii. 1 is this the lady Cressid? Even she

give even, or give none

odl, and he is even with you .........

even in the fan and wind of your...

shriveled up their bodics, even to loathing

even in his throat, umless it ......

patience, good sir, even for this charge

even at the first, thy loss is more

we'll bring your grace even to the edge

even ripe for marning time

pity, which even women have cast off...

and even good as rotten

that even her art sisters.... 
WVPN-Ven from this line to this khe, thut even but now wis yourt het
but even tor want of that, for which which even but now, demand he was met even now ns nul

methinks, the grominl is cre

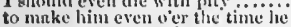

a mane him evell oer the

going hence eve as the

evell so; eover thicir taces

even such delight nmons ini................... Jutien even or odd, of all days in the yeur

for even the day betore, she hroke....

who won's even now the trozen hoson
a rhyme I learned evel mow of one

who even in pure and restul mole

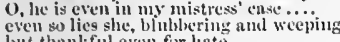

is it evenk so? then I dety you, sturs!

whose imige eren but

and

why sle, even she,-O heaven! a benst

but, even then, the morning eock erew

went hind-in-hund even with the you

eut off even in the blossoms of ny

I am eren joor in thanks; but 1 ........

be even and clireet with me, whether.

cven thrse you were wont to take such
even with the very eomment of thy goul

ferr too mueh, even as they love .........

even our loves shondd witli our firtunes

even to the tectlis and forelieal of our.

even now, ont at the portel?

to kear all smoth and even

and clanger, ditre, even for a e..........

brands the hurlot even here, letween.

nut eren his mother shinl minch

why, cyen in that was heaven ordinant.

eren while men's minds are wild

even now, very now, an old bl

appearance, even on the instant

I run it through, even from my boyish

henr's subdued even to the very quality

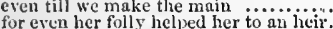

even as our days do grow?

for, even out of that, will I cause these

tupon his peace and quict even to madne fipon his peace and quiet even to madnes even as again they were, when you....

even so ns one would beat his offenceles

even as her appetite shall play the god ...

ereu so this forked plagie is tated.

tis even so: fur let our tinger aclie.

healthful nembers eren to that sen

even thus nll guiltless meet reproach.

the addition, whose want even kills me.

you was here even now; she haunts ine.

you gave me cren now? I was a fine

that quicken even with blowing

that erom this intal on the

that eren his stubbormness, his elieck
hark! 'tis even so. O help! ho! liaht!

even he, sir; did you know him?

eold, my girl? even like thy chastity

but even now, that there lie dropped it

and $\mathrm{cyen}$ but now he spake, after lurn

E;EN:IIAXDED-] am evened with him - ii. 1

this cven-handed justice commends ...Vacbeth, i. 7 this eve-some evening music. "'o Gen.of ter, iv.

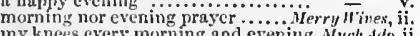
my knees erery roming and evening.

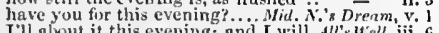
I'll alwut it this evening; and I will. All's Woll, it. cud likesise with the crening sum. Comedy of $\mathrm{B}$. Irefiore the dew of evening fill ....... King John, ii. I this evening must I leave you

this evening, on the east side of .....2lenry $1 \mathrm{l}$ l. ii. 3 mude an evening ut the noon-tide ..3 lenryliti. a hright exhalation in the evening. Ilenry VIII. iii. delay than this v'ry evening ................ Lear, i.

ecome to you ut eveniug mass?.. Honeco $\dddot{f}$ Jutiet, iv.

EVESL - ranges evenly witi nibe...Much dilo, ii. in u new chanel, fuir und evenly ...ilinnry t' iji. 1 Fy EVENT-lis condition and the event .. Tempest, erown whint I proties with lind event - iii. I these are not natural events ........... come, let's see the eveat ...............
but leave we him to his events... $\overline{\text { iil }}_{\text {ii. }}$ is as the everit stamps tlem ............Much Atlo, i. and nost preponterous event... Lovers L. L. i. I (let.) not satisfied of these events tit full. Mer. of $y e n$. $v$. of these most strunge erents....... ds you of ike it, v. a to the event of the nome-sparing uar? All's Hell, ili.2

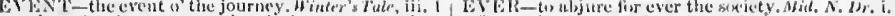
let our just event un sustomed event, but they will .. King John, That the erents can never ful. futh $n$ liand in these event

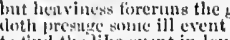
.

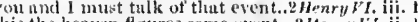

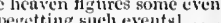

thes, besting suelt events! …..... no other than event doth form it. Froiluts o cress. ii.

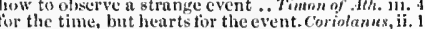
all strante and terrible events are. ir, the event is y'et to mike those.. dire eve........

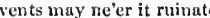

nay then-Well, well; the event.

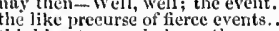

thinking too preeisely on the event

there are many events in the woub

EV WTYUL, eventful history ...As you Like it,

will ever atter droop.

penetrute the breasts of ever-a..............

for nothing natural I ever saw so noble
we have lost your son, I fear, for ever..

can lay to beil for ever ........

emperor that ever trod on

W'at there cyer man a coward

let me live here ever.

make this island thine own for

than did ever plunmet sound

youth have ever homely wits ...

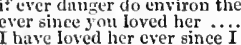

was there ever heard a better?

that ever any man tied ..........

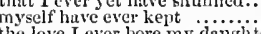

the love I ever bore my dainghiter.....

no grief did ever come so near

didst thou ever sec me do

I have my wish for ever

as lonest a naid as ever broke bread

dic you ever hear the like?

you are undone tor ever

or bid farewell to your good life tor.... ever

any madness, I ever yet beheid.

let me for ever be your

more wit than ever I learmed....

that ever the devil could have ma.....

doth ever make the better fool ... Tutelfih $\bar{N}$

if ever thou shait love .............. - ii.

can ever believe sueh impossible

and thanks, and ever thanks........

more aplrobation than ever proot itself

Will it we ever thus? $\ldots . . . . . . . . .$.

as ever thou wit deserve wel

having sworn truth, ever will be true -

how I have ever loved the life $\ldots \ldots . .$.

it ever I was respleeted with her.....

by redeeming him, slould die for ever

should keep the body of it ever fair.

it peradventure, he shall ever return

in his love toward ber ever most kind

ever your fresli whore, ant your

I hine hestrd it was ever his maniner

hold you ever to onr speeinl drift.

or clse fur ever le confixed here.........

it ever chinnges with the next binck...

the sweetest lady that ever 1 looked on

prove, that ever I lose more blood.

well, if ever thou clust finli from...

but if ever the sensible bunedick.....

and not ever sal then; for I have...

inea were decuivers ever ...........

- ii. 3 (somg)

the fraut of mon was

more than ererit

as cver lieatrice shall couch upon?

ever gince you left it

as ever broke bread...................

why ever wast thou lovely in my eyce

if ever love had interest in his liver.. link ever men have broke (rep.)...

it ever I thy lace by daylight sec.

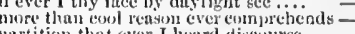

Grartion that crer I heurd disemurse

this is the silliest stutf that cever I heard -

there crente, cver shall be fistumate

buse entinul pluclars ever woul

but the bet that ever I heard.

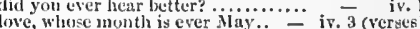

for all tle wealth that ever I clici see - is.

nud ever and anon they made a cloubt

tlut ever turned their eyes to........

henee ever then my heart is...

your father was ever virtlous lyerch of $\bar{t}$.

of all the went that ever my foofisi.

for lovers ever run lotiore the clock.

I will cyer be your head........... -

unpleasintest words, that ever blotted

as I have ever found thee houes

she would not hold out chemy for ever

did make him swear to kecp for ever

heing ever from their cradles bred. As you Like it $\mathrm{i}$.

it is the first time that ever I heard.

ns true a lover as ever sighed upon

that ever love did make thee rur into

well then, if ever I thank ary man..

if ever sat at any good man's feast (rep.) -

wist creu in eourt, shepherd.

Your chestnut was ever the only

if ever (as that ever may be near)....

who ever loyed, that loved rot ......
for ever, and a day. Say a day (rep.)

did you cver liear such railing? .....

if ever 1 narry woman

if cver I satisfied man.............

the first time that I ever saw ...........

hy being ever kept, it is ever lost.
who ever strot'e to show her merit

wilt thou ever be a foul-mouthed.
did ever, in so true a flame ..........

did speeial nothing cver prologues

mny serve long, but not serve ever

sit on thy eheek for ever

fortune, if you ever wed
my service, ever whilst I live.
disclain rather corrupt me ever

throw thee from my care for ev

anel forfeited to eares for ever!

my lord is gone, for ever gone.........

will for ever do thee all rights of ...............

and ever, my love, as it berins

nor you, mistress, ever a frichd

I speak of, crer keeps a good fire...
it her fortunes ever stoud necessitic

prove this ring was ever hers ............

I'll Jove her dearly, ever, ever deariy

nor no man ever sa w..........

dicl you yet ever see Baptista's .....
was ever gentleman thus grieved

did ever Dimu so become...........

was ever man so beaten? was.........

Peter, didst ever see the like? ........

linve you ever been at l'isa?...

will repute you ever the patron...

manter, if ever I said loose-bodied ..̈

brought hio up ever since hie was..

that ever eume into ny note .......

the one for ever earned a royal

it ever fiartil to do a thinis.

by a mun which ever proteseril to him

un gross as crer tumelicil conjecture

ny crer chik, wr stone, was soumel..

the elase: 1 un gone fir ever.

if erer you have spent
o that ever 1 was born?

I'd Jiare

that you might "ver do nothing...............

the linirest youth thit erer mude

if ever, nencefiurtly, theru these

[Col.] for I do fient eyes ever.....

(1) thit aver I had spunsed me.

ii. 1

(1)

$\forall$.

$\forall: 2$

i. 2 stitl a repairing, ever out of tirane

for ever to be true to those

and slall do so ever, though I took

lats, that ever run on the greenisward 


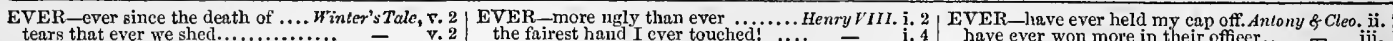

as ever still sleep mocked death......................

searce any joy did ever so long live.

was there ever any man thus...Comedy of Evr.

for ever houscd, where it onee get.

and ever as it blazed, they thre

nor ever didst thou draw thy

your servants ever have theirs....

\section{beggared yours for ever ?}

shall Banquo's issue ever reign in..

more sundry ways than ever.......

enrs despise my tongue for ever

this push will eheer me ever...

the first that ever Scotland........

have I not ever said, how that $\ldots . . .$.

and this blessed day, ever in Franee..

(it' ever I remember to be holy).

that ever wall-eyed wrath, or staring

that ever spicler twisted from he

that ever was suryeyed by English... Richard II.

if ever I were traitor, my name.

have ever made me sour my.

we ever have been near the

that ever fell upon this cursed.

the emptier ever dancing in the.

for ever may my knees grow

for ever will I kneel upon my.

mine enemy thou hist ever been
that ever valiant and approved

did I ever eall for thee to pay...

cowards as ever timned back

whieh ever and anon he gave his nose

veriest varlet that ever chewed

and a good jest for ever

a good plot as ever was laid......

and roared, as ever I heard bull-caif

and ever sinee thou hast blushed

harlotry players, as I ever see........
as ever offered foul play in a state

as ever offered foul play in a stat
making you ever better than his

that ever said, I belrkened for .....

thus ever did rebellion find rebnk
sounds ever after as a sullen bell
well I eannot last ever.................

whether I shall ever see thee again

prove that ever I dress myself.......

good phrases surely, and ever were

when ever yet was your appeal .........

agninst ill ehances, men are ever mer.

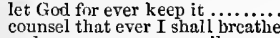

and ever among so merrily

as 'tis ever common, that me...

as ever you eame of women.

and murder, ever kcpt together.....

if ever man went to Arthur's bosom.
then if ever thou darest aeknowledge

if ever thon eome to me and say
if ever I live to see it. I will

if ever I live to see it, I will..........

as ever his plack slioe trod upon.......

Was ever known so great and litt

who ever saw the like? what men.

thian Rhodope's, or Memphis',
will I for ever, and my faction

will I for ever, and my factio
should ever get the privilege

should ever get the privilege
beeause I ever found them as
for ever should they be expul

for ever should they be expul

no hope that ever I will stay

ever marquess gave, the fairest $($ rep. $) .2$ Henry $r$ I. i. 1

nor ever had one penny bribe...

didst ever hear a man so penitent?

that ever did contain a thing ....

was ever feather so lightly blown ......
was ever king that joyed an earthiy
best blood that ever was broalsed..

clumpion tliat ever I heard.

and to thine heirs for ever...

it ever any malice in your heart

ever beloved, and loving, may his.

be eommanded, for ever by your grace

tongue could ever pronounce dishonour

which ever yet affected eminence.

ever in fear to kindle your ............

When was the hour, I ever contradic
who ever yet have stood to charity.

no, nor ever more, upon this busines

whether ever I did broach this

or ever have to you, but with thanks

plants, and flowers, ever sprung

ever easts sneh doubts, as false eoin.

that for ever mars the honey of

ever God bless your highness!

my endeavours have ever come.

my loyalty, whieh ever has, and ever

my ever royal master, dare mate

stream, that must for ever hide me.

my prayers for ever, and for ever....

the sweetest forward in celebration

woman that ever lav by man........

ever ranking himself with princes.

ever witness for him those

Christendom shall ever speai

so may he ever do! and ever flouri....

and not ever the justice and the truth

and the end was ever, to do weil

you were ever good at sudden...

ii. 2 prosperous life, long, and ever happy

fairer than ever I saw her look... Troil

hath ever sinee kept Hector fasting

if I ever saw him before, and knew him -

than ever Greek did comunss....

with ever Hector and Achilles meet.

if ever you prove false to one

how dearly ever parted.

the man's undone for ever

your lordship ever binds him.... Timon of Athen

I gave it treely, ever; and there's

bat yond' man's ever [Knt.-very] angry -

my heart is ever at your service .... -

as good a trick as ever hangman

have $I$ been ever free, and must...

we banish thee for ever..........

I'll ever serve his mind with

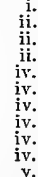

ever son, so rued a father's deat

what man didst thou ever know unthrift -

didst thou ever know beloved?

grant, I may ever love ..............

than ean ever appear in you

we have ever your good word...

was erer man so prond as is

we shall ever strike till one ea
bear the addition nobly ever!

ever right. Menenius, ever, ever ....
their blaze shall darken him for ever

ever spake against your liberties

over will be ruled.

does forget that ever he beard the

does forget that ever he heard the...

whieh doth ever cool i' the absene

than erer thou wise words

pluck from them their tribunes for ever -

since I have ever followed thee with hate -

as ever in a mbitious strength

he was ever too hatrd for hin .......
I ever said, we were i' the wrong

of daily fortune ever taints
for I have ever veriffed my

for I have ever verifled my .........

that ever lieraid did follow to.......

as ever trod upon neat's leather......julius $\bar{C} a$

who ever with their likes .........

the first time ever Cæesar put....

you, and to your heirs for eve

if ever he have wife, let her f..........
dost confirm bis liappiness for ever. -
ever woman in this liumour wooed? $($ rep. $)$

ever woman in this liumour wooed? (rep.) -
so do I ever, being well advised.......

if ever any grudge were lodged

traitor that ever lived

which ever sinee [ Col. Knt.-litherto] ] iath -

and for ever let them last!

that ever yet this land was guilty of

ever you or yours by me were harnedt

shall that title, ever, last?

that ever entered in a drowsy head ....

one that hath ever been God"s enemy

and ever oinee a fresh admirer that ever Brutus will go bound....

for ever, and tor ever, farewell (rep.)

my sight was ever thick...............

no enermy shall ever take alive .......

whom no brother did ever love so dearly

and his quails ever bent mine.

let him for ever fo ${ }_{\text {and }}$ he................. ii. I ever not, Lueilius, when love begins

and he are greater friends than ever ii. I that ever I slould call thee, cast-away! -

. 1 pray you, be ever known to paiticnee

ii. 3 you have been a bogrler ever

\begin{tabular}{l|l}
1.3 & who? onc ever near thee $\ldots . . . . . \ldots \ldots . .$. \\
i. 3 & of the full-tortuned Cæsar ever sliall
\end{tabular}

if there be or ever were one such.....

ii. 4 Thieh I will be ever to pay........... Cymbeline, i. 5

was there ever man had suel luck... - i. 1

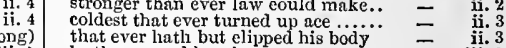

be theme, and hearing ever..........

to kill the marvel, shall be so ever

hardness ever of hardiness is mother

and so shalt be ever, this youth......

searee ever looked on blood.

piek that bolt then tree for ever!....

of Clotens had ever sear for...

truest princess, that ever swore hier foith -

if ever Bassianus, Cæsar's son.. Titus Androni

if thy sons were ever dear to thee...

was ever scythia half so barbarous?..

if ever Tamora were graeions in those

that ever ear did hear to sueh effect.

o Tumora! was ever heard the iike?

expecting ever when some envious.

that ever deatll should let life bear..

by this our mother is for ever sliamed

was ever seen an emperor of Rome.

as mitch as ever Coriolanus did......

sure a card as ever won the set.

dog as ever fought at head

as from thenee sorrow were ever rased...Pericles,, .

thus knit, a kingdom fortunes better

iii. 2 I held it ever, virtue and eunning.

iii. 2 I ever have studied physic .........

iii. 3 odour. As ever hit my nostril ........

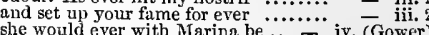

to toster it, nor ever to preserve ........ - iv. (Gower)

did you ever hear the like?

did you ever dream of such $a$ thing?

out of the road of rutting, for ever ....

tharry, liang her up for ever?

hereditary ever, remain tbis ample.... $\overrightarrow{\text { Lear, }}$ v. 1

whom I have ever honoured as my king

yet he hath ever but slenderiy known

should enjoy laalf his revenue for ever

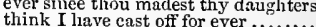

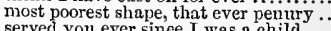

was a chila......

if ever I return to you again

way, where they shall rest for ever

that ever ear received

$O$ she is gone for ever

now she's gone for ever?

her voice was ever soft

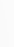

if ever you disturb our streets agnin whot ever would have thought it?..... = did ever dragon keep so fair a cave? was ever book, containing such vile.

iii. 1 think'st thou, we shall ever meet again? I eannot ehoose but ever weep the friend heneeforward I am ever ruled by you that ever, ever, I did yet bebold! ...

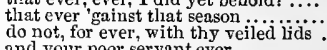

and your poor servant ever ...................

that ever I was born to set it right!...

if, onee a widow, ever I be wite!

let not crer the soul of Nero en

and, ever, three parts coward ............

I loved you ever; but it is no matter

if thou didst ever hold me in thy heart

iii. 1 if ever I did dream of such a matter.... othello lawful prize, he's made for ever........

iv. 2 ever as she could with haste despateh

ever as she could with haste despateh...

she tlat was ever fuir, and never proud.

was a wight , if ever such wight were

what wound did ever heal, but by degree.

to him that ever fears he shall be poor..

I am bound to thee for ever...............

ii. 2 he eonjured her, she should ever keep it

ii. 5 for ever, farewell the tranquil mind!.

ii. 5
i. 6
[Knt.] what bloody business ever ........

iii. 1
iii. 6
iii. 6

iii. 3

iii. 1

v.

จ. 5

v. 5

i. 2
i. 2
i. 2

ii. 3

ii.

iii.

. 2

4 3

iii.

2 (let.)

$$
\text { iv. } 2
$$$$
\text { iv. }
$$ 


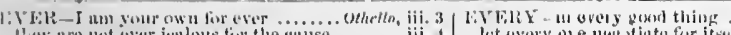

lley are unt iver jenlous fint the enuse

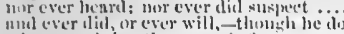

二

ctery ore nug inte for itsulf

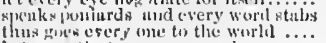

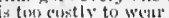

in every thing, lout in loving Iseneitior

tilles sle every mint the wrom

well. "very onc cun muster $n$ gr

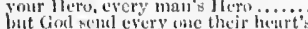

whe doth not every earthly thing

pitied and excued if every heme

antl e

and let it answer every struin for stru

in every lireament, litanshe, flane

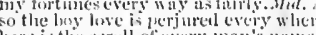

here is the seroll of every man's name

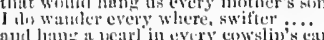

gnd lomp a pearl in every enwslips's ear
have evory polting river made so....

cone, sit down, cvery nutherers som.

and so every one areordin
weres every little flower

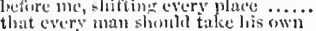

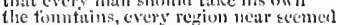

and every thing secms double.

every mull lork o'er lis part

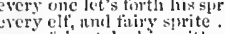

evcry fairy tike his grait

the me rical or every day hesiole.......e

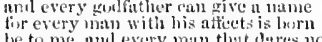

for every oljoct thit the one lonth

thy own wish wish I thee in every plate

and every jost liut a word

and my hart on thy every jurt.

in every power; and gives to crery power

then, lonewari, cyery man attael .

and every one his love-fed
we will ciery one be nnsked

that smiles on every me
fur every onc purscints three...

o every vuried object in lis gla.

the cuekno then on every trce .... -

how in from every eos renowi......

lie is cyery nam in no man

and his belavionr every where

you may tell every finger I have

where every something, being blent

and every word in it a gaping

low every fool ean play alon.......

if every lucat in six thousand ducats

and cvery part a clueat

when evely goose is cackling

gentiemen flock to him every day......

meu may grow wiser every dny!

in stones, and good in every thing

witnessel every where; ran (rep.)

tongues I'll hing on every trce.

or at every sentent every sprite.
the quintessence of eving every minute, and ( $r$.

cvery one rault secuting monstrous

every thime about you demonstrating

and I set linevery day to woo me.

and cory passion someting.....

betray themselves to every inolern...

that uluses every onc's ey'co, hecause.

to 11 ymen, gonl of every town.

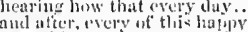

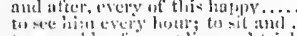

lom lut

yes, goos thitl, cvery dram ol it

and every man slimil beat thee...

in crery thing I wait upon his will

every night he eomes witl musics of
therefure we unst every orse be a man

can lave erery thing in him..

he liak every thing that inl lomest.
that every bragust shall he found...

and neans, for every man alive..

and nod ut crery num

warped the line of every other........

by my olil beard, ant every hatir.....

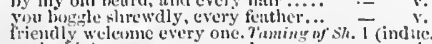
at the highti-toss every mornilir.

and every duy I (munet eonse to wos.

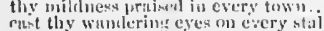

rint thy wimlering eyen on cory stalc

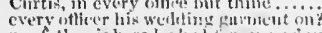

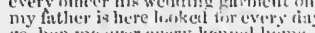

go, hop me: werer crery k(onnel lam

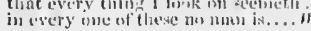

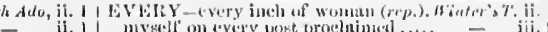

ii. I mysell on every font proch himad

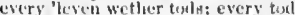

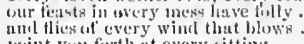

prsint you forth at every sitting .......

i will tell the king all, every word

J Lernionle, as every preent time
every wink of un eyc, some sucw

your exultation partake to cvery

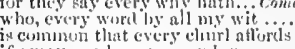

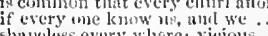

and every one lothe in wions

and every one slid bear thy jinis

by doing every thing satic toward

in crery grint twice bene...

when every note apjuls me?

letery mal

that every mintite of his being.

your charms, and every thins

every orse tluat dioes so is a truitor...

sincking of every sin that lias

cet every soldier haw lim im

I'd give it every toot to have his liz

since all and every part of what.

surrow that ilwells every where.
nay, rather, every tedions stricle.

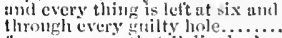

for every man that bulingbroke

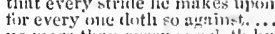

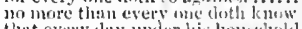

thent every thy under his hou-chold:

num the soul of every man.

the push of every letardless vain......
fin every homour sitting on his l:eim.

it promises le kept on every haml...

stop all sight-lutes, every lould for

it every owner were well placel ....
vea, every man, shall be my friend.

therefore, every leader to his clarere.

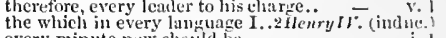

every minute now should be ...........

and every part ahout you hlasted.

to bear every knave's wrong..........

John Falstuir, kuiglit; every main....

for in every thing, the purpose

asking every one for sir John ........

examples of every mimute's instance

every thing set oft that might 80 .

thas every slight and lalse (repseted)..

whenery thing is ended, then you.

puts forth her olive every where...

with every conrse, in his particular..
toling from every flower the virtumis

from every region, nyes of illcucss!.

'tis all in every part. "Tis so inte....

are every one a woe, n sore ...............

in the bieast of every man.......
donbt not, but every rub is smootien.

in every branch truly rlemomstrative.

and bend ule every sjirit to lis ....

tihnt every wreten, fining .........

cvery subject's chity is the king's $\left(r+r^{\prime}\right)$.

cis certain, crery mas? that dies ill...
subjected to the lreatl of every fol.

that every one may bare his...........
then every soldier kil! his prisemers.

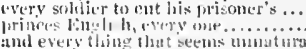

the king huth granted every artiple

here, there, ami every whice emingto

I can count eviry [Col. Knt.-cath] on]

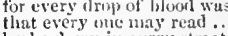

broke down in every treet

if your grate marl cecry eireimsta....

in the mouth of every sticking late.

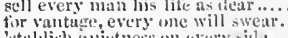

butnlikh (1)ietness on crery

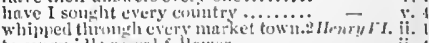

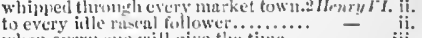

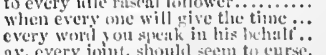

as, every joht, should seem th curse.

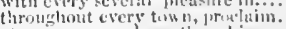

auve pay, and esery thing yos wisi.

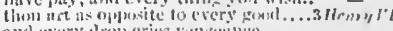

a

but evely thilgh is riglit............. iii. $\frac{1}{3}$

i.

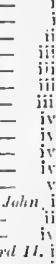

iii.

(1)

4

iii. $\frac{2}{2}$

iv. I

ii.

ii. 2

iii. : 

EVERY-as every loyal subject ought.3 Ienry $I_{J}$ iv. 7
for every coud engenders not........ augmented in every county as wings misdoubteth every busli. since every Jack becanse................. every jack-slave hath his belly full. but not every man patient astonion that but not every man patient after some flattery for this evil............ - iv. 3

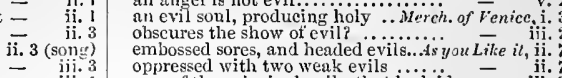

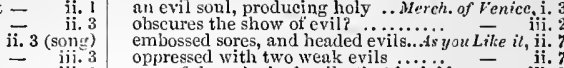
and every day do honour to her grave from every one the best she hath....

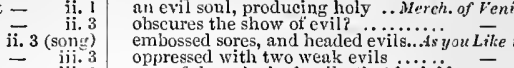
and every man that means to live. where every horse bears lis.

ready with every nod, to tumbje down my life is, every breath, a death

they weigh not every stamp ..........

with roices and applause of every sort. Titus and v.

shall be thy usage every way ......... -

my toes $I$ do repute you every one

when every thing doth make (rep.).. -

my aunt Lavinia follows me every whe
blazoning our injustice every where?

blazoning our injustice every where?
come, come, be every one ofticious

of every virtue gives renown to ment any of the principal evils, that he laid ${ }_{\text {yet these fixed evils, sit so fit in him. }}$ iii.

we must do good against evil ........ ey'es at once see good and evil ....... Winter's Tale, $i$. in comforting your evils.

forget your evil; with them......... - v.

every tongue brings in a several ( $r$

erery man unto his clarge.............

the traet of every thing would $\mathrm{by}$..... every man, after the hideons storm.
trom every tree, lop, bark, and part.

to every comty, where this

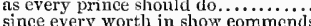

are doubled with an evil word.. Conedly of Err.

every day it would infect his speech.

his dews fall every where .......

lead in your ladies every one......

news are every where; every tongue $(r e$

every thing that heard him play.

Were tried by everv tongue, every

such news as this once every hour...

rc appear in every thing may. ...

in her days every man shall eat....... -

where every flower did, as a prophet

with every action that hath gone ...

then every thing includes itself ...

oo every step, exampled by

and evcry Greek of mettle, let.......

and railest every hour on Achilles....

every tithe soul, 'mongst many ......
knows almost every grain of Plutus'

sith every joint a wound

for every seruple of he

at every joint and motive of her.

to every ticklish reader!..............

t'll kill thee every where.............

you may syllable that here was spioke.

but vows to every purpose, nust n

here, there, and every where,
in every thing illegitimate.

in every thing illegitimate.

Timon of $\overline{A l h e}$

when every feather sticks in

erery man has his fault, and honety

of the same picee is every flatterer'

every man here's so: what would....

bare for every storm that blow

that speak'st with every ton
hath in every figure skill.

with every minute you do ehange..... Coriola

tongue fiom every meaner man's...

every gasl was an enemy's grave....

and rebulie from every ear that heird it -

and rebuke from every ear that heatrd
whose every motion was timed with

wherein every one of us has.

let every fechle rumour shake

Id with thee every foot....

standing every flaw, and saving....

to every new pe still: peace .....Julius $\overline{\text { Caesar }}$

every time gentler than other ( $r e p$.

so can $I$ : so every bondman in hi

yes, every man of them; and no (rep.) -

and every man hence to his idle bed

when every drop of blood, that every
and so, good-morrow to you every one

and so, good-morrow to you every one -

that every like is not the same

give to every one that eomes $\ldots . . . . . .$.
and every one with claps 'gan sound - ii. (Gow.)

we every day expect him here

conscience to be used in every trade

the dammed doorkeeper to every coystril

for every graff would send a caterpill
every hour he flashes into one gross

upbraids us on every trifle

pierce every sense about that on every drean

smootl every passion, that in the nature.

with every gale and vary of their masters

when rain it raineth every day.

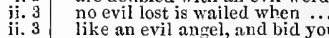

more enned in evils, to top $\ldots . . .$. Macbeth iv.

these evils, thou repeat'st.

exils, that take leave, on their (r.ep.). King $\overline{J o h n}$, iii. 4

to acquaint you with this evil .........

turning past evils to advantages .... $\quad$ jv.

of means enforce rou not to evil .... - . - v. 5

some soul of goodness in things evil.. - iv. 1

what a sign it is of evil life............

imptent witls use of evil deeds ......3 Henry $F I$. i.

how evil it beseems thee

at thy birth, an evil sign .............

of these supposed evils [Knt.-crimes]

God bids us do good for evil.

som eyes the evidence of their evil.

were he evil used, he would out-go. Henry FIII. i. 2

nor build their eviss on the graves

madam, men' if it fall ...............

to say ay, and no, to every thing $I$ snidi

they told me $I$ was every thing

every one hears that, which can distinguis

examine every married linearnent... Romeo of $J u l$. j.

and every thing in extremity.

but every man betake hin $\ldots \ldots \ldots \ldots$....

and suffer every knave to use me.....

that every part about me quivers...

and every eat, and dog, and little

from time to time every good hap

hear from thee every day $i$ the hom
every one prepare to follow this fair corse

without more motive, into exery biain................

where every god did seem to set his seal

to you yourself, to us, to every one

for every thing is sealed and done

ratifiers and props of every word.

eannot you tell that? every fool can

at every honse I"]l call; I maty eominand -

good-night to every one: and, noble.

for every minute is expectancy of.......

and on every hand, enwheel thee round

every man put himself into trium!

every inordinate cup is unblessed...

I am bound to every act of duty

so help me every spirit sinctified ......
every bearded fellow, that's but yoke

that dwell in every region of his face

she ham ts me in every place.

every day thou doft'st me with some

but every puny whipster gets my sword

the 111 aspects of planets evil.... Troilus \& Cress. i. 3

breed a nursery of like evil.

wrongs be evils, and enforee us kili... - iti. 5

by nitht when evils are most free? Julius Casar, ji.

if you give place to aceidental evils.

iii. 2

thy evil spirit, Brutus ............. iv. 3

not think, there are evils enough.Antony 8 ceo. i.

repent the evils $I$ have done.. Titus Andronicus, v. 3

to entice his own to evil ........Pericles, $\mathbf{i}$. (Gower)

heaven and men suceed their evils! I'll tell thee, thou dost evil.............. Lear, i.

and all that' we are evil in........................

of our nature come in further evil?......... Hamlet, $\bar{v}$. 2

it is too true an evil; gone she is ........ olhello, i. 1 in Cassio, and looks not on his evili....... - ii. 3

EVIL-EYE EVILLY - this act, so evilly born..... King John, iii. 4 of good deeds evilly bestowed! Timon of Athens, iv. 3 $\mathrm{EVE}$-whereof the ewe not bites ....... Tempest, y.
for the ewe that will not hear......Much Ado, iii.

the ewes, being rank

before the tulsome ewes...............

made the ewre bleat tor the lamb....

we are still handling our ewes... As yon Like it, iii. 2

to bring the ewes and the rams........

but milk my ewes, and weep .....Winter's Tale, iv. 3
of ewes now? Thereatter as (rep.)..2 Henry $I V$. jii.

so many days my ewes have .......... Henry $V i$. ii.

is tuplyng your white ewe $\ldots \ldots \ldots \ldots \ldots$ othello, 1. basons and ewers, to lave her dainty

dreamt of a silver bason and ewer. Timon of dth. iii. 1
EXACT-my power might else exaet.... Tempest, $\mathbf{j} .2$ thon art too fine in thy evidence.

and many other evidences.

All's Well, $\mathrm{v}$.

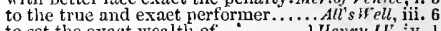

to set the exact wealth of ........... Henry II. iv. I

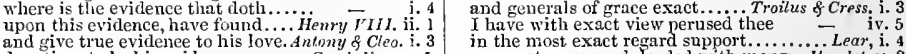

ay, every man a way: Brutus shall.. $=$ iij. $\quad$ and give true evidenee to his love. Antomy f Cleo.

EXACrED-have I aught exacted at.2Henry $P I$. iv

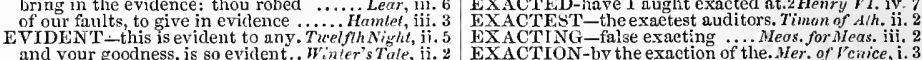
and your goodness, is so evident.. W'nier's Tale

a tomb so erident as a hair.

EXACTION-by the exacting ...Meos. for Meas. ini. daily new exactions are devised ..... Richard II. ij. I as putter-on of these exactions....... Henry VIII. i. 2 these exactions, whereof my sovereign

EXACTLY-exaetly is performed ....... Tempest, i. 2 sign about her, more evident than .. Cymbeline, to bring this woman to evil ............. Tempers Wixes, to bring this woman to evil ........Merry Wites, iii. 5 but then exaetly do all points of ... no I do it not in evil disposition..... Meas. for ileas. i.

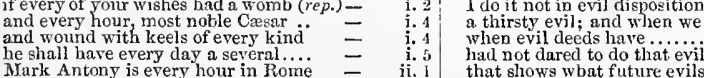
be so rarely and exactly wrought.... Cymbeline, ii. armed at point, exactly, eap-a-pe ...... Hamlet, i. 2

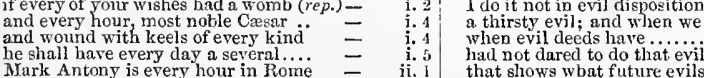
he shall have every day a several.....
Murk Antony is every hour in Rome every time serves for the matter .....
I'll think them every one an Antony the holding every man shall bear. in every power that moves and pitch our evils there?

for in every ten that they malie. repent me, as it is an evi..

and questioned'st every sail.......

enception.

ii. 2 EXALT-he doth exalt himself, more than. Lear, v. 3 unfold the evil thou causest to be done kiss the most exalted shores of all.Julius Casar, i. to bc exalted with the threatening clouds

EXAMINA'TION-their examination. Much $\bar{A} \bar{d} o$, iii. 5 e are now to examination these men - iii. 5 and show him their examination ..... ll ' $^{-} \bar{w}_{\text {ell }}$, ii. 6 ha? where's his examination?...... Henry $Y I H$. i. 1
urged on the examinutions, proofs .. 


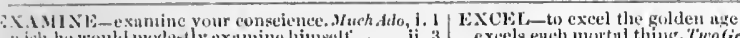
"isht he would moclestly examine linuseltWe have the exilition to exumine.

jura you, exumine him uxun tlaut point know of your youth, examine well ... Vhit..... Dr. i. I

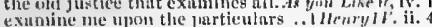

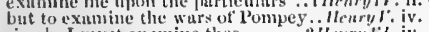

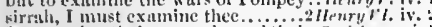
firr examine their counsels, and their. Coriolsues, $i$. to thine cyes; exumine other.... Homeo of Juliet, $i$.

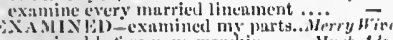
exismiled betire your worship........Wheh Ado, jii.

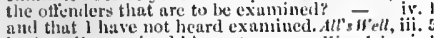
listli well exumined his part

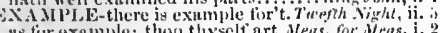
as tin example; thou thy

to muke him an example.......... no such example linve we

roursulf, for the examule

thot I niuy example iny of others ....Vuch Ado, v. I thint tofure been sain. I will eximnjle it - ii. I ill, to example ill, would from in

sufferance be by duristian example? ijer. of $\bar{V} e n$. iij. by the sume example, will rush in to

alul the misery is, cxample, that so.. All's 'W'ell, iii. s it I eoult example of thousanis..

hang him, he'll be made als example - iv. 3

grow great by your example, and put - v. the examples civery minute

lest of late exumples left by the.

love their presint pains, upone......

he hanget up for example at their..2 Itenry $b^{\prime} J$. iv.

in ingselt, for exanple, that am a butcher -

things done without example

they are set here for examples .....

before me, happily, for ny example

there's much example for't .... Timon of Athens

Tis example yom with thievery .......

three cxanules of the like have been

he las given example for our fight.Ant.f Cleo. iii.

turned coward but by example...... Cymbeline v.

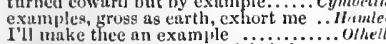

must make exmples ont of their best .. - iit. 3

for hear her but exampled by herself. . Henry, $V$. i. 2

so every ste1, exampleil by the first. Troil. \& Cres. i. 3

EXAS1'ER ATE-to exasperate yon.. Tuelfih $N$, jii. 2
report hath so exasperate the king ... Wuebeth, jii. 6

report hath so exasperate the king ... Mucbeth, iii. b
why art thou then exasperatc. Troilus \& Cressida, v. I

to take the widow, exasperates, makes . Lear, y. I

no fur exceel all instance........Twe Thin N N irhi, iv. 3

your wwn science, exceeds, in that. Mt'a. for. Mea. i.

0 thut exceds, they say ................

livings, triends, excecd aceds exced all speech.

flialt fiul that I exteed my sex .........

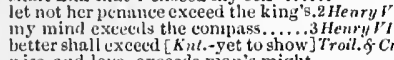

sisc, and love, exceeds nian's might

such is to even enemines exced. imon of dithens, $\mathrm{i}$.

or execel the common, or be ca aght. Coriolanus, iv. I

as doth the Capital exceed the meanest
whon you have banished, does exceed

it exccels jeace as for as da
not exceed the prescript of th

my mistress execeds in goodne

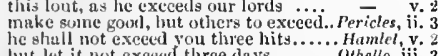

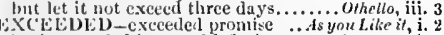

hath cxeceded law, and left thee.....2Henry ${ }^{\prime}$. i. 3

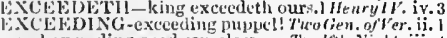

and execerling good senseless .. Tuelfh Night, jii.

and she is exceeding rise...............
for my heart is excceding ieavy!
by my trith, I ann exceeding ill

do wot look exceding narrowly to thec - v.
is excecding funtastical.......... Love's L. Lost, v

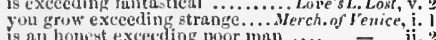

is ar honest exceceding poor man ........

hut this excecling pusting .............

parents were exceceling poor.. Comediy of Ërrors i.

they are execeding loor and bare .. MhenrylV iy.

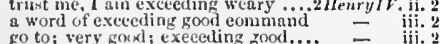

iii. 2

exceding well, his carcs are now ali Z

to work execeding mirac'es on..........

plagne ill store, exceeding those.... Michard III. i. 3

), very mail, execeding num

Menry VIII i.

the glwer a return excecding ali ... Timon of $\mathrm{Ah}$. i. excowling pleasant; nunc a stranger. Cymbeline, l.
this fillow of exucding houesty ExCLEDINGLY-

exceedingly well met ...........love's L. I.ost, iii. faith, it is execelingly weli aimed ... ll lestry it. i. a worthy gentleman excecdingly well - $_{\text {excelingly, }}$ exceedingly, my lord; it is very sultry. Ih met, v.
to-niglat exceediugly well cudgeled .... Othello, fi.

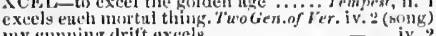
Irty emming drift exeels

how fiur dust thou excel

Love's L, Lost, i, 2

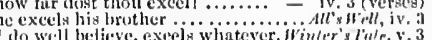

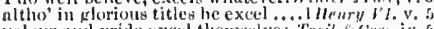

ralenr mal pride exed themed ves, Troil.

yet his leg exeels all men

Julite ii.

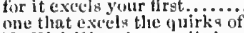

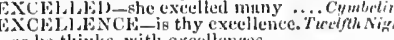

us lie thinks, with execllences

his extellence did carn it, ere lie liakl. Mur. Mra

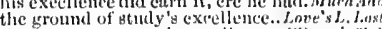

the more onr curver's excellence.. H'inter's That

got the voiec in hell tor execllenct.....henry !

sue minto your execllenee, to lauve .. i hen

as procurator to your execllence .....

to be protector of his exeellene?

that loves lim with that excellence. .ien ry $\bar{r}$

to sach ncat excellence opposed...... Cymbeline $\mathrm{i}$. 7

Fou are not ignorant of what excellence.

I shonld complare with hin in excellence
ExcEL.LENCY -on the excelleney. Herry
is there not a louble excelleney in this?

it is the witness still ot excellescy ...Much $\mathrm{Ads}$, ji.

all excelleney [Knt.-tire the ingener]

a kind of excellent dumb dis

is an excellent pass
() execllent motion!

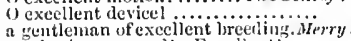

uy, dat is very good! - Extellent
would give an excellent motion.

would give an excellent motion....
thant will be excellent. I'll go biy.

hadst thou had an excellent head.. I' etrin s

by the exedlent constitution of thy leg

higher: hal ha! excellent

so excellent a tonch of modesty...

excellent! why this is the best fooling

excellent! I smell a devio.

cxeellent weuch, say

the cur is execllent at fanl to.

nost excellent aecomplished laif.

and witl sonc excellent jest ....

why, this is excellent ............

he hath an execlleut stomach

he were an excellent man, that were

your futher got cxour excellent wit?

she were an excellent wife ior Benediek -

good discoursc, an excellent
get us some excellent music.

ghe's an excellent sweet lady

luving so swift and excellent a
he hath an excellent good name

graceful, and excellent fashion

they are an excellent pertume.

oxcellent! swect, do not scorn.... vid.

they may pass for excetlent men ......

none at all in nught prover exce

an excellent device! so, it any.......

young men of execllent growtis... As you Let

0 excellunt young exen!

an excellent colour: your ehestuit.

very good, very excellent gout.. ...

there was an excellent command!.....

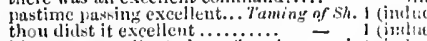

'tis a very excellent piece of wo

piece of ext motion! Icllowa.

at wench of exellent discourse.. Comedly of Lir

this is excellent sport, is tith!.

let it be an excellent good thing.
it will be an execllent stratagei

your are in an excelient tempiernlity...

which is un cxcellent thin

ha, ha, ha! most excellent, i faith!

becomes execllent wit. 'The seconl ( $r e$,

lixeellent, madnme. C"est assez pour.

the re is versexedlent setvice........

exeellent de-cription of tirtune (refi.)

a most alsolute and exeellent hor.....

excellent $l^{p}$ ueelle, if thy nume be

or the lieanty, thinks it execellest...2 Ileney i.

execllent device! and make a sop. Hichard his.

an execll tont und umnatelied wit $\ldots$.. i

fro execllent is urt, aud still so rising..

here, lere's an execllent place.... Trnil
erics, excellent! 'tis Agamenumou just.

dehilles still cries, execllent?

this comes off well and exrelient. Iimo

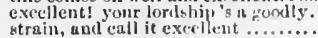

EXCEIALENT-an exrollent picee.. Ti
rxecllent wolkmm thou cant not.

ifl tell you exeellent now of your

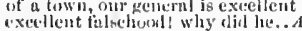

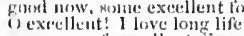

plical them both with excellent praises

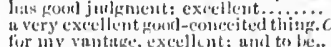

for my vastage, exedlont; and to

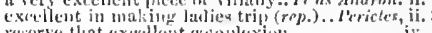

resorve that exeellesit complexio
and has execilent grotel clothes.

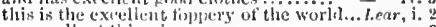

un excellent thimg in woman

muny fur numy virtues excellent ....

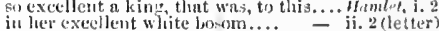

excellent well; you aro a finlimonger ....

thy most exectlent cansur, the air

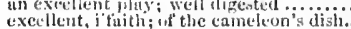

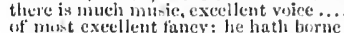

of most execlent fancy: be hath borne. - iii. 2

luil of most excellent diffurencet........ - v.

fore heaven, an exellent song

and speak well enongh. Exrellent weil.. - ii. 3

excellent wretch berition catel my sonl = in.

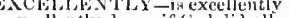

this letter, being so exeellently iwmorant - jii.

interpreter toes it well. Excellently. All's Hell, iv. 3

EXCELI, NG-isexecling. Tuogen.of Ver.iv.2(song)

eumning'st pattern of execlling nature.. Olletle, v.

exeept an anyry word

except my mistress

excent thou wilt cxcept against my love

execut 2 be by silvill in the niriont.

change this hue, except to steal.... Ver of Venter, ii.

I knuw not: exeept, in that eountry. All's "ell, iv. 3

to none of thesc, except it he.. Comedy of Errors.

upon the tue: excelt they meant to yacheth, i.

except this city now by us besieged ... King - it

not reverence, makcs thice to excejut..Richard $11 . \mathrm{i}$.

$\begin{array}{lll}\text { to touch the lists; except the marshal } & - & \text { i. } 3 \\ \text { by me: except the north-east wind... } & - & \text { i. }\end{array}$

except, like curs, to tear us all ...... then - ii.

goest, except it be to pray against ... Henry $y /$.

mourn not, exeept thou sorrow for...

more than I do-execpt I be provoked?

yield Winchester; except you mean - iii.

at peace, cxcept ye thirst tor blood . .

exeept so much were done.......... Henry 27. iil.

except I cannot do it .............3leary I'l. iii.

(cxcept immortal ceasar, speaking. Julius Casur, i. ?

after, exeept slic hend her humour .. Cymbeline, i.

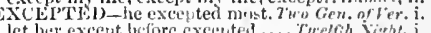

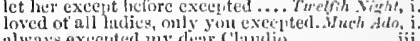

and sleping hours excepted ..... a you like it, iif.

is it excepited, I elould know no... Julius Cersor

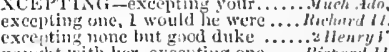

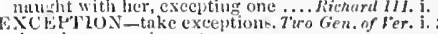

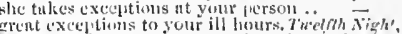

the true mimute when exception biel...Alls $\|$ cll, i.

gaimst all exceutiens, loris.

took exeeptions at this bulge

thke exceptions to $111 y$ hom

taken aghinst me a mot ju

buns nut with sueh exees.

nor by giving ot exeess, yet...

the exces nukes it som nort:

$t$ was

in exces luth broke their.

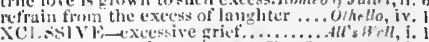

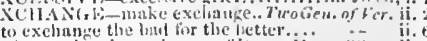

if your time in exchunge ot it ......ierry siver ii.

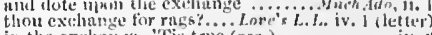

in the exclumge. "Tis truc (rep.)

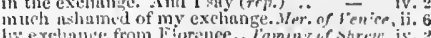



EXCH ANGE_exchange my state. Taming of Sh. v. 1
would not excliange fiesh with one H'inler's Tale, iv. 3
we must make an exehange.......... what an exchange had this been withiont- iv. 3 I have got, in exchange of a lumired thave got, in exchange of a I'd exchange for this one $\mathrm{nish}$. Timon of Athers, iv, my poor self did exchange for you ...Cymbeline, i. 2 is to exelange one misery with another - i 6 and the exchange, my hrother! there's my exebange; what in the wor the exehange of thy love's faithful. it eannot countervail the cxehange of joy in answer of the third exchange.

EXChan me for a goat, when I shall... othello I was exchanged and ransumed EXC ILEOUET they shall be exehequers

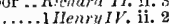
tis going to the king's exehequer.

his exchequer is too poor
ExCITE-reason excites to this the alarm exeite the mortified fif $^{2}$ Night, ii. those this quarrel would excite!. Troilus \& Cress. ii. EXCITEM-for loy excitements to the field .......Troilus \& Cressida, i. 3 that er I to exclaim on you. Merch. of Jenice, iii. 2 than your exelaims, to stir against... Richard II i. and Franec exelaims on thee......

what makes you thus exclaim?

or to exelaim on fortune's ficklenes

eursing eries, and deep exelaims

despatch; 'tis bootless to exclain

his drum; be copious in

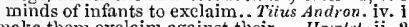
well used; exclaim no more aramst it. Hamalet, ii. 2 CXCLAIMED-the French exclaimed.I Henry $V^{\prime}$ i. i. 1 when she exclaimed on Hastings.. Richard III. iii. 3 that we shall stop her exclamation.. King John, ii. 2 endure this tempest of exclamation?.2 He will I drown your exelamations ... Richard $I I I$, iv. LXCLUDE-excludes all pity.. Comedy of Errors, i. 1 to set down our exeommunieation ... Nuch,Ado, iii. 5 assume but ralour's excrement.. Mer. of 'T'enice, iii. $\bar{z}$ assume but ralour's excrement... Mer. of Tenice, iil. 2 it is, se plentiful an excrement.. Comedy of Err. i1. 2
stolen from general exerement ... Timon of $A l h$, iv. 3 iike life in excrements, starts up...... Hamlet, iii. 4 E.XCUSE-exense it vot, for I .. Two Gen. of For. i. 3 the vantage of mine own excuse
thy tempted subject, to excuse it I will not hear thy vain excuse..... 1 must exeuse myself', master Ford . in way of thy excuse I sornething do cxeuse the thing were best soraething do cxeuse the thing...Mea for $\bar{i} e$ i. with excuse that which appears .....Much 4 do iv. hear my excuse; my love, my life... Mrid.N.Dr. iii. your own good thoughts excuse ine.Love's $\bar{L}$. $L$. ii. transgression some thir exense

exunse me so, eoming so short of....

to excuse the current of thy eruelty..

would be a good excuse lor mc

that you night exeuse his broke........

stands for my exeuse... Taming of 'sh

I will so excuse, as you shall wel

if there were no other excusc.

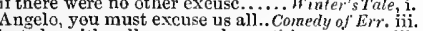
but she will well cxcuse why at $t$
to excuse your breach of promise...

exeuse; it is to beat usurping dowu.. King John, ii. 1 fault the worse by the excuse

with as clear excuse, as well as

inichard II., 3

it hath the excuse of youth

pleading so wiscly in excuse of it .

you must exeuse me, master Rober

to armit the exeuse of timitt

thnow it will excuse this .........

devise exeuses tor thy fauits.......

Clarenee, excusc me to the king

leisure to exense myself

no excuse eurrent, but to hant......

my lord cardinal, I do exense meu.. Henry $\bar{\Gamma} I I$. ii.

Henryti.

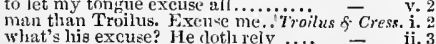
ot supper, you will make his exense

you'll remember your hrother's exeuse?

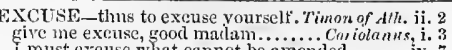
Imust exeuse what eannot be amcnde a yielding; this admits

but you patched un , rour

to exense their alter wrath .......... - v,

to exeluse: but first, how get (rep.). Cly

mine own. exuse it how she ean

she ean witus dud. iy.

speen be spoke for our exeuse?.. Rome
the exeuse, that thou dost make $\left(r \ell^{\prime}\right)$.)

doth much excuse the appertaining rugge

deat' to plealing and cxeuses

skill, both eountenance and cxeüe.... IItenlet, iv.

EXCWSED-may hold exeused. T'e
pitich and cxensed of every lieare
well cxeused: that thou dilst...

pist do stand excused in this

you shall not be excused (rep.).

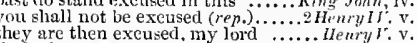

slat thou stand exeused; for doing. Richurd III. $\mathrm{i}$

condemmed and myself excused. Romeo \&. Juliet, v. 3

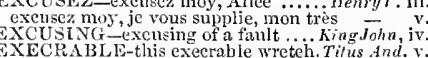

EXECRABLE-this execrable wreteh. Titus And.

issue of my spiteful execration

you have a warrant to execute
you on all estates will execute

Tempest, ii.

you on all estates will execute... Lore's L. Lost, v.

that thyself excente; to make. Toming of sirew, $\mathrm{i}$.

inust either stay to exeeute then

to exeente the noble duke at

a husiness that this night may exeente Henrylr. i.

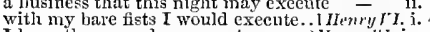

I bear, than you dare execute ......2 Henry $l^{\prime}$. iy. 1

the way, and tlon shalt execute...

yet exuchte thy wrath on me
your office, sergeant: execute

Richard III. $\mathrm{i}$.

wen think, or comragc exeeut

in fellest manner cxeeute your arins

whe execute in the elothes thint she.

the common hangman shall execute it. Pericles, iv.

EXECUTING-exeeuting the outward.. Tempest, i.

EXECUTED-had been executed. Tuo Gen of Ver.

and commands shall be executed. Tu'clfih $\mathrm{N}$.

that Claudio be exeented by nine.Mea. for Mea. ii. 1

who is to be exeeuted in the afternoen?

Barnardine be this morning executed

awake till you are exeented, and sleep

and see our pleasure herein executed

to be excented for robbing a ehureh..
his nose is exeeuted, and his fire's out

for treason executed in our late ..... Heary $Y I$. ii.

hecause his purpose is not exeeuted.2 Heary I'I. iil.

he shall he cxeented presently. Timon of Alhens,

that end upon thein should be execu
what is written shall be exeented

XECUTION-cxeention of it.. Tw

that wait tor execution in the morn... -

hath a warrant for his execution

When, ifter exeention, judgment ....

hereof the excention did cry

therest execution sworn .........

smokcd witl bloody exeentio

whose execution takes your enemy of

like lightning in the execution...... Rish

delivered over to execution and the hand - iii. I

present execution of our wills

doing the exeention, and the act.......

my father's execution was nothing...1
and then do exeention on the watuh

ay, ay; away with her to exeentio
this sudilen cxeeution of my will

thy eruelty in exceution....

thenee unto the pluce of excention.....

execution of my big-swoln heart , 3 Hem - r $r$. ii.

enforced us to this uxecution? ....... - iic

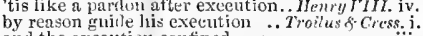

and the exeeution eontined.

mad and fantastic excention

enforce the present uxeeution of what - Coriolanus, ii.

and prepare for your cxecutio

and stay unon exeurtion. Is't possible

why, one that rode to his execution.

unroll to tho some fital excition?

flo execution on my flesh and blood.
do shanneful exceution on lierself

as desperite an execution as.... Romeo \&uliet, iv.
EXECUTION-the exention of his wit. Olhello, iti. 3 our prison a common excentioner. Nea. for Mea. iv. eall your execntioner, and oft with. I would not be thy executioner....... like an exeentioner, eut ofl the liends. nichardII. iji. exeeutioner, unsheath thy sword...... 3 Henry $V I$. ii. 2 think st thou, I am an executioner?.. as binent thon art an executioner $\ddot{R}_{\text {ichard }}$ v. 6 I will not lie thy executioner.

1'lay judige, and exectitioner ........ Cymbeline, iv. lut's cloose cxecutors, and talk .... Richard 1I. iii.

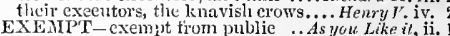
you are from me exempt .... Comedly of Errors, ii. not quite exempt from envious... exempt from envy, but not from ..2 Henry $V^{\prime}$. iv. 1 yourself are not uxempt in this.... Richard III. il. I not wish to be trom wealth exemit. Timon of 11 . 1 . EXENPTED-exempted be from me.. All's ' ' ell. ii. EXERCISE-all exercise on thec ....... Tempest, i. for any or for all these exercises. TiroGen. of ler. i. anch exereises as may become........... A you Like it,. . bear up with this exereise, so long.... - iij. rich advantage of good exercise..... King John, iv. 2 to gentle exercise and moot of arms... I Henry IV. v. 2 with arts, and martial cxereises...2. Henry $1 \%$. iv. 4 in your debt for your last exereise. Richard IIK. iii. swelliug o'er with arts and exercise.. Troil. $\mathrm{f}$ Cr. iv. thy exereise hath heen too vio!ent .... Coriolunus, j. 5
whose meal and exercise are still .... show-place, where they exereise. Aniony \& $\bar{C}$ Cleo, iii.
wo longer exereise, upon a valiant no longer exereise, upon a valiant.... C.jmbeline, $v$.
now starved for want of exarcise........ Pericles, $\mathrm{i}$. for art and exereise in your dutence........ Inach castigation, exereise derout.......... - ini. uncle of Exeter, enlarge the man...... He', ry $7:$ ii. 2 come, uncle Exeter, go you and enter the duke of Excter doth love thee... but Exeter hath given the doom ..... the duke of Exeter has very gallantly
the duke of Exeter is master of...... my good lord Exeter, and my kind...
Bedford and Exeter, Warwick and..

go you with me, uncle of Exeter.

go unele Exeter, and brother.

that Exeter doth wish his days....... Hen - . Y. cousin of Exeter, frowns, words ..... 3 Henry $V I$. i.

art thou against us, dukc of Exeter?..

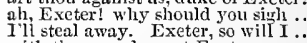

vith thee, good sweet Exeter............

eutsin of Exeter, what thinks your.. $=$ iv.

when iast 1 was at Exeter............ lichard $I I$ I. iv.

EXIIALATION-natural exlialation. King $\overline{\text { John }}$ iii.

do you behuld these exhalations?...1 Hemyll i.

exhafations whizzing in the uir ...Jutius Ceestre ii.

thy presenee that exhaies this............hichard III. i.

some ineteor that the sun exlaales. Romeo s. Iul. iii. 5

XHALES-an exhaled meteor ..... I Henry $I V$. v. 1

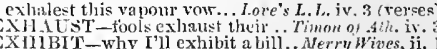

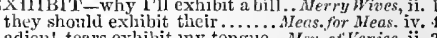
adien! tears exhibit my tongue... Mer. of '́enice, ii. 3 wXe do exhibit to your majesty...... Henry VI. ifi. 1

like exhibition thon shalt have. Two Gea. of Ver. i. we have the exhibition to examine...Much -Alo, iv. confined to exhibition! all this done ....... Lear, i. 2
due reference of place, and exhibition ... Othello, i. 3 mor eaps, wor any petty exhibition .... $\bar{r}$ iv. 3 gross as earth, exhort me, witness ..... Hamlel, iv. 4 I'il end my exhortation after.. Merch. of Venice, i. I Why do you cross me in this exirent?.Jul. Coesar, v. 1 Whin the exigent should eome..Antomy \& Cleo. iv. 12 let them be reealled trom their exile. $-\overrightarrow{\text { v. }}$, 4 put themselves in to voluntary exile. As you Like it, i. 1 sle woutd have followed her exile.... - i. klatcless limit of thy dear exile ....... Richard $I I . \mathrm{i}$. fitur years of my son's exile.......... - i. some to deatl and some to exile ....Coriolanus, i. 6 Turpeian death, vagabond exile...... loug as biy exile, sweet as nyy

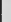

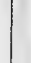

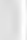

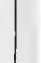

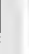




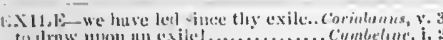
toilraw upgn an calel.

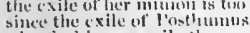

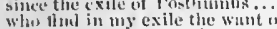

thos thic in me.

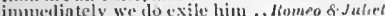
num world's exile is eleatle.

Nes'st thent yet, thut exile is not remitis?

ming turns it to exile.

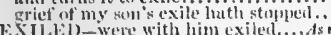

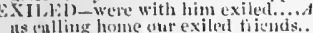

us ('ulling home our exild tor

equity exilcd your higliness' haid....

to be cxilerl, nind thrown trom

E.Xox-since my cxim is cuter

C.Als-fron whon we do cxist .

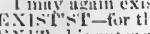

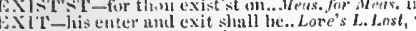

kecel some stute in thy evit.

they hise their exits, and their........ you to

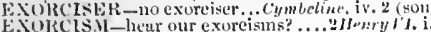

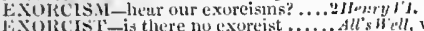

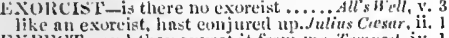

EXPl:CT-and they expect it from me. 'Tempes', iv.

at the roart expects my comning. Fro

thin you mist expect or me to tall

I lis expect rettun of thrie

we ull expeet a rentle answer, jeiv.

let's in, nut there expeet theil com

its sture fis you, than you expect ....

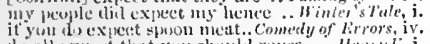

do al! expect that you shubla

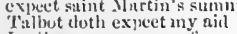

I tell yom, expects jerturmance of

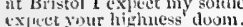

and direxpect him he

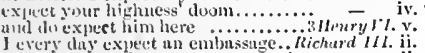

luate in those where I expeet most luve! - 111 . ii.

milke men expeet a deurth

dake of york. anm expect him liere

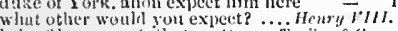

Troilus o cilcos, i.

sure the thanks this prince expeets - iv.

gero l: l will expect you

racher I'll expect victurious lifio

and at the port exyect you

what shalt thoa expect.

as certain as I expect $m$.

comfurt is too far for us to expeet

mure than you expeet, or more thani s fit

we crery duy expeet lim here.

in bounty expet even here ............

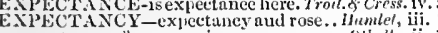
expectaney of more urrivanee ..... Olhello, ii.

bule TATION-

. Wuch Ado, i. 1

I will uever trust iny expectation.

oft expectation fails, and most

within the note of expeetution

xinctation troubled not the ........ - iii.

frients, and full of expectution ....1 Henry $\%$. ii. 3

the hope and expectation of thy time

conjecture, expectution, athl s

thou hast sealed up my expectution.

youstant in eoldest expectntien aid

now sits expectation in the air

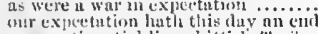

exicetutiou, tickling skittisli.

exinectition whirls me rount

with

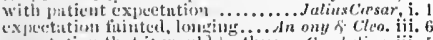

wir prepmention rtame in cxpectatiom.... Lirar, iy.

were no expectution of our lrosierity ... Ohe tho, if.

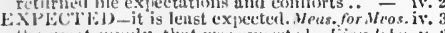

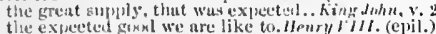

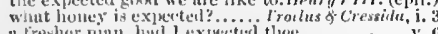

at fresher nian, ham lexpected thee

pualin when it was less experted

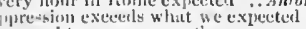

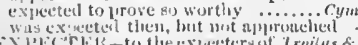

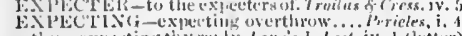

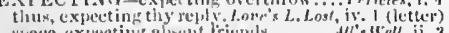
slace, expecting absent frierds .......Alls sell, ni. deal gift ox exesting in return... Tunon or dhens, iv.

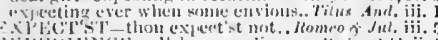

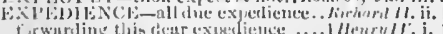

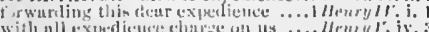

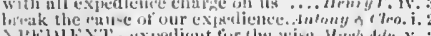

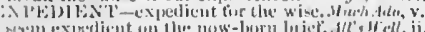

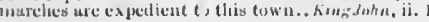

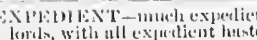

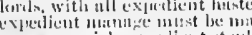

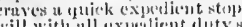

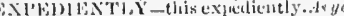

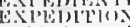

with the slecelient expculition.... The a Gen.offer, i. 3

(1) hasten on his expertition.

so much tluy sinu their explellition.

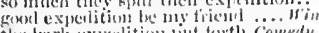

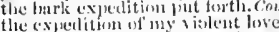

slall puy this expertition's charge

much milloked for is this experticin

drato batk ontrexpeslition

betore your experlition to slirewsing

motion, the experlition ot thenglat?

give further:ture to our experlition

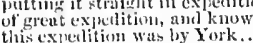

this expentition was by Fork .........

expedition lox wing wichart

who intereepts ne in $10 y$ expedition?

besides, his expedition promises
he haul, hefore his last expedition

more stuhborm ant hoisterous expentition.

l.XPEL - unother hent expels.. Ttro (ipn.

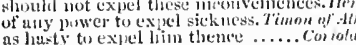

shall expel this sonething-sctilicd .... Homlet,

E: lateh a wall to expel the winters

EXP'ENCl-the (xipence of so much
being galled with my expente

hold, there's expences for the'.. T'wetfh Nigh', iii.

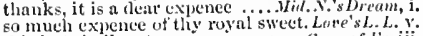

this jest shall eost me some expence. Com. nf Er. iii. 1

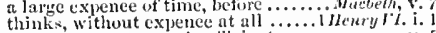

for your expenecs and sulficient

what expenee by the hour secuns......

so senseless of expence, that he

so have rated ny expene,

eare in us at wluse expence tis done

sable, trimmed with rich expence

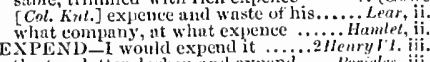

the two latter darken und expend ... P'ericles, iit.
as to expend your time witl us awhite.. Humlet, ii.

would time cxjend witl such a buipe... Othello, i. 3

EXPERIENCE-experic
but his experience old

but his experience old .......

umless experience be a jewei............ Hery n'ives, ji.

gained my experience (rep). . .... As you Lihe it, iv.

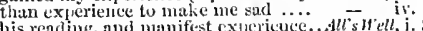

and of his old experienes the only.

1 have sinned against his explerience - ii.

where small experiente grow's.... Thming of sh. i

long experience of her wisdom... Cometly of Err. jii. 1

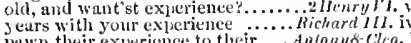

puwn their experience to their...... An/ony f cleo

experience, manlsoud, honto

expertence, 0 thou disurovest repert! - iv.

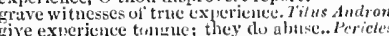

have so much experience tor my paius... Othello, $\mathrm{ii}$

elerklike, experieneed, which no.. Winter's Tule,

curs to his experienced tomegue ... Troilus $f$ Cress.

as lest thou art experieneed

nut me, make an experinent

hold me pree in decpexperiment ...ilitemy $/ 1$.

singled lintle to try

which with experinental seal .......huch dibo, iv.

liacing therein some ex, ert ol

expert [Cal.Knt-exhuisite] in his drinking - ib.

what say you to hin expertues in war? - iv.3

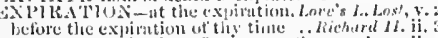

it, till the expiration of your phonth....... I.ter, ii.

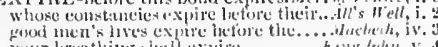

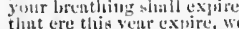

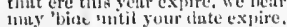

expire the term ot a dcosised lice

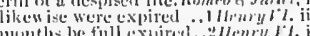

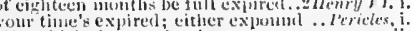

in whe tine exjire, lie not return

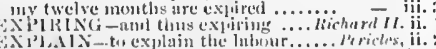

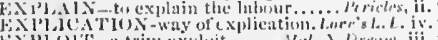

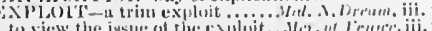

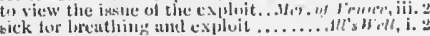

1:X1P.OrT-for a worthy exploi

do nore exilnits witl his mis

thos antieisat'st my dreml

of tome great exploit drives hin

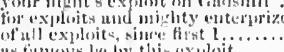

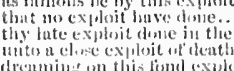

what exploit's ill lumb?

crplovit worthy the nam

cif this dreat explosit.

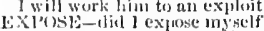

ind expose thine temeler limbs

whicli aficed to expmese the elding

expo:e thyselt to lied what wrete

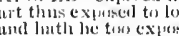

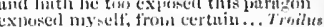

"1, som glath be exposed, my lord.

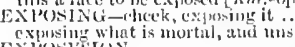

(y) of slee

your exposition on the holy

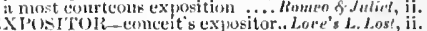
XPUSTUATL-

my, stay not to expostulate .........3 Herm? r\%. ji.

to exe bitterly conldt 1 expostninte.. Kirhard III. iif.

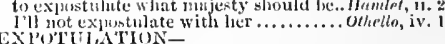

M.ust use cxpostulation kindly.. Troilus $\delta$ Cress.
EXPOSURE-1nore than a wild exposture

EXInt.-exposure] to ench........... Coriolamus, iv.

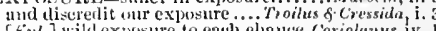

[Kinl.] Wild exposure to each elinnce. Coriolanus, iv. to exponnl the meaning...... Taming of shrer, iv.

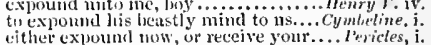

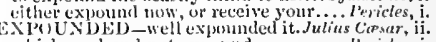
which read and not expound.

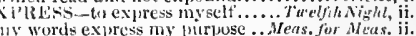
slitl an express conmand.

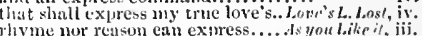
riyme mor ronson ean exiress......ts you hike il, iij. mate leisure shinll express.

that you express content ............. - (epii.

I have express commundment ..... Hinter's rate. it.

shall, as lexpress it, lie su ree

sums thave collected shall expro

tell my tale in express words ...
and we give express charee, th

1 have express commund nent
let we have your cxuress opisi

I can express no kindler sigh....

justice and trife right express

He mirlit cxpess some part... In

these well express in thee thy latter..

or express yourself in an more.

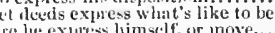

e lie exprens limsclf, or move,.
whl best exymes liow slow his

ing

ti) express my commendutions treat.... Prericts, ii.

guldent characters cxpress a general

xives her goollicist.

to cxiress his love and friculine to Jolo.

w3 express and admiralsle!

We shall express ourduty in his cye..... - iv.

in his ese pride expreseteth........ Lare's L. Lost, ii.

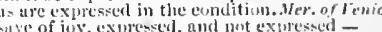

it is not so expressed; but whint at cliat?

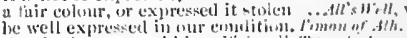

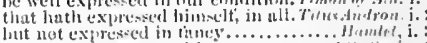

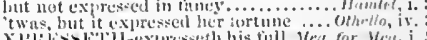

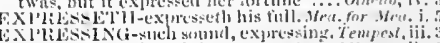

past all exuressing: it is very ...Wer. of lemec, iil.

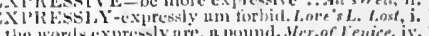

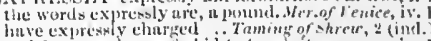

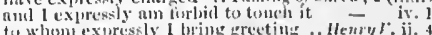
a

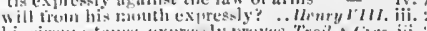

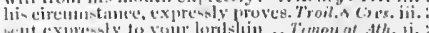

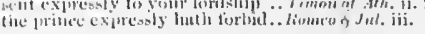


ETPRESSURE-

the expressure that it hears

or pen. cun give expressure Wi.... Troilus \& Cress. jii. 3

EXPULSED-exptisel from France.l Ilenry VI. it

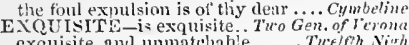

exquisite, aml umatehabi

thy exinuisite renson, dear

my nost exquisite : ir 'Toyas?

lord, my very exipuisite friend. I

jewels, of rich and excuisite form

call hers, exquisite. in yule
she's a most exeruisite laul

[Col. Knt.] so exputisite in h

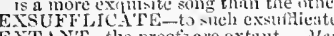

ENTAN'T-ilie proot: are

but in this extant moment.

the storv is extant, and written

EXTENPORA1,-extemporal gol...Love's L. Lost, i. 2

will you lear an extenthoral egit.
sudden and externporul speech

comedians extemporally will stage us. Ant f f Cleo. v.2

EXTEMIPORE-may do it extempore. Hid. N. Dr. i.

we may do any thing extempore

ever since thou hast bl ushed extempore

EXTEND-doth extend not a frown.

may not extend so far as to the

thint would not extend his migh

and extend to you what furtlier

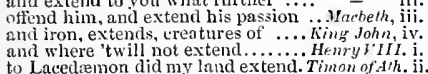

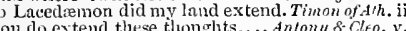

I do extend him, sir, within himself. Cymbetine,

are wonderfully to extend hin

on us we must extend onr notice

Lear, i. 1

good Iago, that I extend iny manners... O hello, ii. I

no worse of worst extended ............ All'sWell, ii. 1

report of her is extended more. Winter's Tale, iv. 1

uxtended Asia from Euplirates .. Antomy \& Cleo. i

EXTEN'T-unitust extent against. Turelfih
make an extent uyon lis house.. As you $L$

for the extent of egal justice.

of my offending hath this extent....... Hamlet, ii.

EXTENUATE-so extenuate his. Mieus. for Meas. i and so extenuate the 'forehand sin...Mrach Ado.

gy no means we may exten iate.

will extenuate rather than enforce.. Ani.\&. Cleo. v.

nothing extenuate, nor set down aught... Olhello

5.XTENUATIUN-snel extenuation.1 Henry 1 V. iji.2 E. XTERIOR-oer my exteriors .....Merry Wives, $\mathrm{j}$. a maid, by these exterior shows? . .Much ddo, iv. prostrate and exterior bending! ...2 Henry $\mathrm{V}$. iv. nor the exterior nor the inward man ... Hamlet, ii. 2 IXTERIINED-hoth extermined... As yoo Like, iii. i IXTERN-heart in eompliment extern... Othello, i. I agree with our external parts? ... Taining of Sh. v.

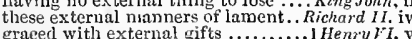
graeed with external gifts ........... Henry $F_{\text {t }}$. EXTINCT -be extinct with age...... Richard II EXTINCTED-to our extincted spirits... Ohallo,

EXTINGUIT-me alit, me extinguit.. Pericles, EXTRPATE-presently extirpate me.. Tempes EXTOL-extol their graces. Tu o Gen. of lerona, of you, that you extol me thus?. Meas. for Meus. to extol what it liath done

EXTOLLED_for't as 'tis extolled... Timon of Ath EXTOLAHENT-the verity of extolment. Hamiet,
ExTON-sir Pieree of Exton, who .. Richard II.

Exton, thy tieree hand hath.

EXTORT-will not extort from me.

do not extort thy reasoiss from

and extort a poor sonl's patienee.

EXTORTED-up with extorted gold?.2 Henry $I$ I. iv. 7

tinv 1 fe extrirted treasure in the womb .. Ilamlet, i. 1
EXTORTIUN-with thy extortions ...2 Hewry $V^{\prime} I$ i. 3

own humds, cardinal, by extartion. Henry $\nu_{111}$. iii. 2

EXTRACT-extract one syark of evil ...H. nry
EXTRACTED-simples, extracted. Ax you Like

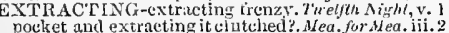

pXeket and extracting itci

I mean not to sweat extraordin: 1rily..2 Henry $1 \%$. i.

EXTRA()RDINAIRY

something extruordinary in thee.. Aerry wives, iii.
EXTRAORDINARY

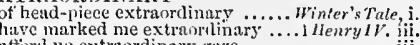

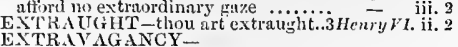

EXTRAYAGANT-

the extravitant

in an extrayagnt and wheeling stranger. othetto, $i$

EX'TREME-fire's extreme rage. I'wo Gen. nf ' 'er. It

the extreme purts of time

Lone's L. Lo

to the extreme edge of liazard .......All's W'sl, iii.

yet extreme gusts will blow out fire

ol. I have caltght extreme cold ......, - iv

to be nsed in undeserverl extremes. King Jole, iv.

fierec extremes, in their continunes

dry with rage, and extreme toil ...

inwars to the parts extreme

always resolute in most extremes ..1 He'n,

Who cau he patient ju such extrem

that the is the wonder in extreme

grict and extreme age shall perish

puiulul [ r

between the extremes of hot and cold. Ant. \&

no mid way twixt these extremes at a
breal in to these dleejextremes. Tirus

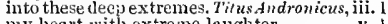

broke my heart with extreme laughter - Y.

twixt twu extremes of passion

wixt my extremes and me this biondy - 5 (chorts

heing wrought, perplexed in the extreme.

of time extremely form all causes. Lor 'es $L$. Los

he sweat extremely, and something. Henry VIII. ii.

to hear the city abused extremely

nay, urged extremely for't.... Timon of Athens, iii.
EX'R'R

my extremest means, lie all...Merckant of t'enice, $\mathbf{i}$.

stood on the extremest verge.
on thee to the extremest point

yery extremest inch of possibitit

in her heart's extremest hate

the extremest ends of parallels .

deserves the extremest death

from the extremest upward of thy head ... Lenr, $y$

but when extremities speak.......... Coriolanu

the the and these extremities.JuliasCasar, ii. I

EXTREMITY - auy extremity

hy extremity .

that are in the extremity of cither..As you Like it,iv. I

turned into the extremity of love.... - iv.

save your life in this extremity.. Taming of Sh. iv. 2

extremity of weather continuing $\ldots$...

ne'er brake into extremity of rage

o time's extremity! hast thou

fulse hope lingers iu extremity

tempers him to this extremity

Pichard II. i. 1

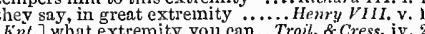

to the edge of all extrenity pursie.

in the extremity of great and little ... - iv. 5

but the extremity ot both ends. Timon of Athens,

now this extremity hath brought.

nowy talie off some extremity

extremity of griefs would make...Titus Andron. iv.

and smiling extremity out of aet ....... Pericles, v. 1

make much more, and top extremity......

and every thing in extremity....Romeo \& Jutiet, i. 3
I snffered much extremity for love ..... Hamlel, i. 2

in neither aught, or in extremity

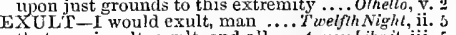

that you insult, exult, and al $\ldots$... As you Like il,

EYASES-little eyases, that ery out .... Hamlet, ii.

EYAS-HEUSET-

EYE-wipe thou thine eyes ................
it is a hint, that wrings mine ejes.

i. $\overline{2}$ (song)

those are pearis that were his eyes

who witll mine eyes, ne'er......

they have ehanged eyes
with an eye of green in't.

is banished from your eye

I wish mine eyes would ...............

the settiug of thine eye.

thy eyes ure alnost set in thy head

upon the eyes of this young eouple.

no tongue, all eyes; be silent...

mine eyes, even soeiable .......

our master eapering to eye her............

that not an eye, that sees you.

0 that you had mine eyes.

my grandam having no e

luve hath twenty pair of ey

love hath not an eye at all ............

I read your fortune in your eye...
EYE-mine eye [Knt.-her mien]. Tso Gen. of Ver. ii. 4

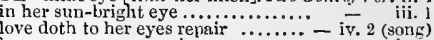
her eyes are grey as glna...

pearls in beauteour unseeing cyes..

such pearls as put out ladies es.......

nonglit but mine eye conlal

in Julia's witl a constant ey

who even now gave me good eyes......ierry $\bar{W}_{i v e s}$

a wart above your eye?

as long ns $I$ have an eye to make

as you have one cye myon....

leud mine eyes, or eye your....

he lias eyes of youth, he writes

no man their works must eye....... - iii. 3

$O$, when mine eyes did see.

then let mine eyes not see!

item, two grey eyes, with lid...

to creep in at mine eyes.............

mine eyes will tell tales of m
there it lies in your eye...........
her eyes had lost her tourue

her eyes had lost her tougue ...........

his eyes do show his days are almost

the expressure of his eye, forehead

to hit him in the eye!............

every feather that comes before his eye

let us satisfy our eyes.

haply, your eye shall iig

ready to distrust mine eyes

$\begin{array}{lll}\text { more than I love these eyes } \ldots \ldots \ldots . . & - & \text { v. } \\ \text { his eyes were set at eight } & \text { v. } \\ \text { v. }\end{array}$

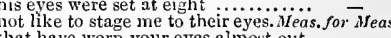

ald houre worn your eyes almost out

and those eyes, the break of day..... $-\bar{v}$, ii.

I will to him, and pluck out lis eyes

nay, dry your eyes

these freting waters from your eyes

to see thine eyes so red

shall you lear disproved to your eyes

in mine eye, she is the sweetest ......... nuch Ato,

pick ont my eyes $w$ ith .....................

I have a good eye, unele $\ldots \ldots . . . .$. .

and see witli these eyes? $\ldots \ldots \ldots . . . . .$.

look with your eyes as other women do

do not ope thine eyes

why ever wast thou lovely in my e.....

and in her eye there hath appeared.

out of all eyes, tongues, minds

Thave deceived even your very eyes

let me see his eyes; that when

with an eye of frour. That eye......

I do with an eye of love requite her

with my eyes. Rather your eyes. Mid. N. Dre

to ehoose love by another's eye I

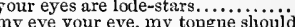

tongue sliould

doting on Hermis's eyes

let the audience look to their eyes..............

drop the liquor of it in her eyes...

anoint his eyes; but do it.

in thy eye that shall appear..........

on whose eyes I might ajprove ......

upon thy eyes $r$ throw all the powe

hereyes so bright? not witl (rep.)

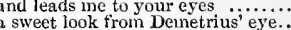

so is mine eye entliralled

and gambol in his eyes ..................

light them at the fiery ghow worn's ey liath made my eyes water ere now

looks with a latery eye

neese that the ereeping fowler e........

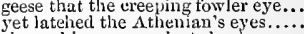

charm his eyes, against she do appear

siuk in apple of his eye! .............

that from the eye his function takes

thou art not by mine eye, Lysander

all yon fiery oes and eyes of light...

my nails can regeh unto thine eyes.

that I have 'nointed an Athenian's eye

crush this herb in to Lysander's eye.

that sometime shuts up sorrow's eye

I'll apply, to your eye, gentle lover..

in the sight of thy former lady's eye

this hateful impertection of her eyes

0 low mine eyes do loath this .......

with thine own fool's eyes peep......
and the pleasure of mine eye, is oniy 


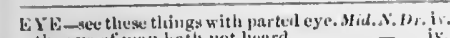
the eye of nan hath not lieard the puct's eve, in at fint frenzy ...... 1 must confess, male mime
eyen do you see? low can it les?

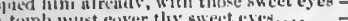
his uyes were green ns lecks........... by lusing of your eye's ...............Lol'e's T.. Los', i. how to please the eye indeet (rep.) jungment of the eye. will you jrick't with your eye? diselused with eyes, leceive ine not. to the eourt of his cye, peepil

were licket in his eye, as jewels were locket in his eyc, as jewels .... hint all cyes saw his eyes enchanted o'er the shop ot your eyes............. pitel balls stuck in lier face for eye king Cophetun set eye $u$

and inakes lis howk thine eyes.....

thy eye Jove's lightning bears

0 , but lier eye,- by this light (rep.). yes, tor her two gyes

the womler of a mortal eye!

rystal the other's eyes ........

gour eyes do make no eoncli

a late, an eye, a gait, ustite ........

my uyes ure then no eyes, nor ...

lixiking in her eye

carn not of lier eye to look

were paved with thine eyes .............

in that forth s eyes this doctrine

teaches such leauty as a wontan's cy

when ourselves we see in ladies eyc

as the prompting eyes of hea

seeing to the eve; a liorer's eyes will

rom tomen's eyes this doctrine

I thuught to close miue eyes some

their eyes, villatu, their eyes ( $r e p$.

with your sun-beamed eyes (rep.)

best cail it, daughter-beamed eye.

the virtue of your cye must break .

wise and rich; for in my eye...

and eanglit it of your eyes ....

litugh ugun the apjple of her eye? ....

furmed by the eye, und, tluerefore (rep.

as the eye doth roll to every ............

those heavenly eyes, that look

laud of death close up mine eye

the window of my heart, mine eye

evermore peep tlirough their eyes..lier. of $\bar{l}_{e}$

within the eye of honour, be assured

that ever my foolisl eres looked upon

nice direction of a maiden's cy'es...

I would outstare the sternest eyes

nay, indecd, if you liad your eyes....

and in such eyes as ours appear.

houd mine eyes thus with my

will be worth a Jewess' eye...

if that mine eyes be true

witlin whose emoty eye there is ....

his eye heing big with tears.

than tlie fond eye doth teach .......

beshrew your eyes, they have o'erlowker

my eye shall be the stream

it is entendered in the eyes .....iding

but her eyes,-hisw could he see to

he hatlo done sell in perople's eyes

my eyes my lord, ean look as.

gelancing an eye of pity on his.........

their savaye eyes turnel to

even by thine orn thir eyes.........

saw yoursulf witli your eyes ........ As

hut let your fair cyes, und gente

with his ejes full of anger

with a hek-lustre eyc, says, very

with eyes fevere, and lheard of.

sans teeth, wns eres, sans taste.
and an mine ere dirth his effigies

iurvey with thy elaste cye

that every eye, which in this forest.

of many fuces, cyec, unal heurts.

a blue cye, and sunken; which you.

there is murder in mine eye

that eyes-that are the frui.

mine eyes are murderers (rep.)

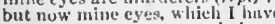

no furee in eyes t:ut ean clo hurt ...

to tanglu: my eyes tim.

his eye did heal it lip.................

to lat ve ricli eycs, and poor lumis.....

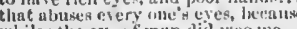

w.hiles the eye of mun did woo me

if that an eye may protit by ............

it is, but with the eves of a laly.
CI E-througle another inan's eyes! A you latie o, to set her betione your eyes to-lnorrow ${ }^{-} \bar{T}^{*} W^{2}$, her eye is sick on't; I observe lier now many-colesured fris, romks thes shown as a trible cye, sufer than mine.

send forth thine eye: this youtliful.

that tlanes in your fair cyc

the lielp of mine own eyes

where thou wist shot at by fair eyes

es...................

hid twtomish the

was in mine eye the dus .

for milte cye, white I was speaking.....

lut to close her eyes myself..

the truer oflice of mine

mine cyes sment onions ................

jut finger in the eve, und she juct

no mort eves to see withal that

to make mine cye the witness of

youth, in ladies eyes that floturisheth
to cast thy wanderiug eyes on erery

and sinee mine cyes nre wit

as those two eves lectume that

pardon, odd father, my mistakit

Ecornful glances from those eyce

look on me with your welkin eye

to have nor eyes, nor ears....

that eaust with thine eyes sece at onee

that bare eyes to see alike mine.

the abhorred ingredient to his ese...

potless i the eyes of leanen

of the tather; eye, nose, lip ..........

vet with eyes of pity ............

her eves became two sponts..........

that I have eres under my service

real, as 'twere, in my daughter's eyes

fairest youtli that ever mate

guick eye and a nimble haid ...

looking with a southward eye upon him

looked ypon my queen's

and all cyes else, dearl coals!

as is her pisture, aftront his eye

when she has obtained your eye.

your eye lath too much youth

there was casting up of eye

she hind one eye deelined for..

that which angled for mine

every wink of an eye $\ldots \ldots \ldots \ldots \ldots . . . .$.

the axture of her eye has anotion in

fixing our eyes on whom our enre. Con

situate under licaven's eye

I know his eye doth homage

pleasing in thint eye ...............

put the finger in the eye, and weep.

let not my sister read it in your cye.

a fault that springeth from your eye

in his eye thut he did plead...

herein others eyes were worse

hath not else lis eye otrayed

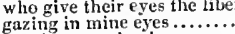

or mine eyes deceive me.

haste looks through his eyes!

the eye rink at the hand

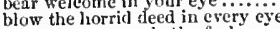

mine eyes are made the fools

which informs thus to mine eyes...

la! they pluek out nine ey

th the amazement of mine eyes

from the eommon cye, for sundry.....

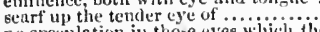

no speculation in those eyes which thon

eye of newt, and toe of frne
show his eyes and grieve lis licurt...

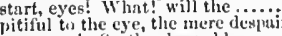

yaur eve in Scotland woul

I could play the woman with mine eyce

you see, her eytu are open.

and still keepeyes upon her...........

as lightning th the eyes of lined

mine eye fimth well examined

heaven-moving pearls trom lis poo

before the eye and prosp ect of your

confront your eity's eyes ............

whose equality ly our best eyc

in the flattering talise of lier cye (rep.)

on the out ward cye of thekle.............

witts splendun of his preciuns eye

keep men's eyes, und train.

without eyes, cark, und lismiful soind

throw thime cye on yon younk ......
EYS-with a thruseninu cye

Kin John, itis 4

both mine eyes?"

will you put nut minc eyes?

approaching near these

fire to harm mine e

Ilubert siroulil put out min

my cyes are out c.ven with

want plending firs a patir of eyes.

verchmee, will sparkle in your

I vill not suscls thise exes ............

lusked upon, I hope, with eliecrfinl

finult lives in his cre...

a feartul eye thou hast .............

with nols, with rolling eyes

or turnet in cy'e of donbt.

thove cumaing waters of his eyen...

covern the motion of a kinely e

startes mine eres; and makes me...

these wiagers to those baly eres.

if ent thuse eyses of yours behold.

of denth right in thine eyce

cver was surveyed liy linglish ey.

leave of thee tikes my' weclying

with voluoble cye profane

for our ey'es do hate the dire.

all piaces that the eye of heave.

ii. 1 rith u lirnluet's eye, seen how ........

for sorrow's eye, glazed with.

miny wrongs with an indiflicent eye

with the eyes of heny mind.........

drawn from her eyes by your full.

searehing cye of heavenis hid..........

by ny dull aid hieary eye

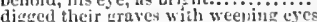

that my umpleused eye see..........

mine eycs ure fill of tears.

if I turn mine eyes upon mysuif

of surrow, and your eyes on thars.

the eyes of men, atter u rell-grae....

men's eyes did scowl on Ricliad......

his eyes do drop no tears
tinine eye begins to sjeak

thuse opposed eyes, which like

and attract more eves, than that

111

and disobedience in thine eye......

hast thou never an eyc in thy head?

bend thine eyes upon the earth.

do stop the flrodgates of her ey.

a villanuus trick of thine eye.

a pleasing ese, and a nust nob

liackuey ad in the eyes of men........

fect but with such ey'es as...

seldom shines in admiring eyer.

wlience the ere of reas or

uo eye liath seen such scarecrows.

suspiciou sliall be all btuck full of ey

nothing confintes me but eyes

knowledge from others eyes.

strange contession in thine eyc...

a moist eye? a dry hand?

at last, I spied his eyes.........

seal up the ship-boy eyes

with his eye brim-full of ter.

their eycs ut tire sparkling throing

whose dangerous eyes niny well he.

that all their eyes may lar tho
his eye is hollow, und lae ehange

dazzle all the eyes of' Franee

how shull ue sireteh our es.
my eve will seureely tee it

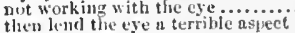

nut noble lustre in your es es...................

with a mufther betiore lier eses........

have at the very we of thit

his liberal eye doth give to
sweats in the ese of Phelus.

blood mys spin in Euglisls 6

from ther ghatericad eyes............

perfirec compound with mistlal eyes

are liumbler than

amt your eyes abline atter your

tince to linc, and rosal ere tue

with a eurvorisy atye o'erglaneed....

let thine eye be thy enok 
EYE-though they have their eyes ....IImry Jis smourling eves replete with. at thicir mothers moist eyes halies. wit' of thy eyes, ant thy chech silo

"II" eye thou hast to look to heav' thin wonld mine eyes be wit

Whel hath the merriest eye
that any surblime eye may find

will glimince tliro' a blind man's ove

these eyes, like lamps whose was
thoth close his tender slying eyes

these eyes, that see thee now

but his ean pleate romr clainty eye
this gor geuus beauty to mine eyes

and dimned mine

why are thine eyes fixed to the.

thine eyes and thoughts beat on

let ree see thine cyes: wink now

mine eyes are fuli ol tcars, my hen't

iny tear-stained ejes to sec hic

and shows an angry eye

red sparkling eyes blab his

hem with dimmerl eyes look after him

o, llemry, olle thine eses! ...........

on me, for thinc eye are wound
and birl mine eycs be presting...

mine eyes should sparkle lik.

for thee to close up mine eye
lie hath no eyes, the dust hit
luok with a gentle eye upon

look with a gentle eye upon
elose $u_{1}$ his eyes, and draw.

I lost mine eye in laying the...

sight of me is odious in their eyes.
thy steadfast-gazing eyes to mine.

these eyes shall never close...

that makes him elose his ey
I throw mine eyes to lacaven

and, if thine eyes can water.....

the father wipe his eyes withal ...
liardly can I eheek ny eyes from

dazzle mine eyes, or do I see..

latth closed these eyes of min.

minc eyes, my heart to thee.

luearts, and eyes, like eivil war

throw up thine eye; sec, see

with tiery eyes, sparkling for very...

toot were equal with his eye

my eyes too quiek, my heart

gracious in the people's eye? .

with tearful eyes add water

I drink the water of my eye

many an orphan's water-standing eye

the helpless balm of my poor eye

and murtal erres eannot endure...

inteet mine eres. Thine eves...

those eyes of thine fro'n unine.

these eyes, which never shed remorseful

my manty eres did scorn an hu

will she yet abase her eyes on me...

thy scorns drew'st rivers from his eyes

cluse up that deauly eye of thiue

your eyes drop milstrmes (rep.)
of ugly death within minc ey'es!

of ugly denth within minceyes!
where eyes did onte inhaljit (rep.)

your eyes do menaee me

if thine eve be not a flatterer .........

many of you have mine eyes beheldi?

then be your eyes the wituess

scems disgraeious in the

price and purchase of his wanton eye

whose unavoiled eye is murderous!

look into me with considerate eyes

pity dwelts not in this eye ..........

in galled eyes of weepiar souls

[Col.kn'] be so disgraeious in your ey

my nails were aneliored in thine eres

wipe her weeping eycs withal.

the windows of mine eyes.......

scenes as draw the eve to flow

nim in eye, still him in praise $\ldots . .$.

and his eye reviled me, as his aljoct

will one day open the king's eyes.

every eye saw them, envy and b

he easts his eye against the moon...

to bless your eye withal

as if ruin leapet from his eye ; ........

let's dry our eyes: and thus

mark you her eyes? slie is goin.

mine eyes grow dim: farewell $\ldots . .$.
earinestly he east his eyes upon me!...
lier eyes, her lair, her cheek.. Troilus of Cressid Argus, all eyes, and no sight

ot her eyes; did her cyes rum o'er too?

to ehange, would give an eye to boot
could live and die i' the eyes of Troilus

have you any eycs? Jo you know .

whose ned'cinalle eye corrects EYE-from eyes of other mortils? Troilus
when she eoldly eyes the youthiful ...
I see them not with my old eyes .... the pride and salt seurn of his cyes
as will stop the eye of I Jelen's needie enkindled by mine eyes nud cars... lem me ten thousand eyes, and $I$ will practise your eyes with tears.

minwares cineonnterin the eye of

il my fears have eyes .............
such unplusive eves are bent

as suon rearl in the eves of other....

commends itrelf to vthers' eyes (rep.)

but eye to eye opponed

pliny the idiots in lier" eyes!

things inl uotion sooner catch the ey

the lustre in your eye, heaven

and let thy eyes spout blood

there's language in her eye ...........

I have fed mine eyes on thee

so olpress ne with thine ey

green sarcenet fity for a sore eye

one eye yet looks on thee (rep.)

minds, swayed by eyes, are full ....

invert the attest ol eyes and ear

swagger limself out on's own eyes!.

look, how thy eye turns pole.

at rheum in mine eyes too

and iny proeeddings eyc.........

in mental power this eye shoots... Timon of $\bar{A}$ hen

whoc eyes are on this sovereign

minc eyes cannot hold out water..............

the like conception in our eyes.

now come but to least thine
butnty had not eyes belind....

and set mine eyes at how.

showing me again the eyes of man!.

window-bars tore at men's eyes.

the tongues, the eves, and hearts of

, the in his eye.

ii. 5 undone lord, than mine eyes for you..

it ojens the eyes of expectation.....

a fool's heart, and a woman's eyes.

the vigilant eye, the eounsel

marked you his lip and eyes? ...........
that yon could turu your eyes toward

whither do you follow your eyes

elambering the walls to eye lim ....

earry with us ears and eyes for the...

so planted his honours in their eyes.

and the eyes of the ignorant more

and renomous to thine eycs.

has the porter his eyes in his head

turns up the white o' the eye to his.

go whip him fore the people's eyes to the vilgar eye.

his eye red as 'twould burn home.

or those doves' eyes which ean make.

and saving those that eye thee.

to pierce a eorslet with his eye...

fore your own eyes and ears?.

I have not from your eyes

for the eye sees not itself...........

that noble Brutus had his eyes........

and that same eye, whose hend doth..

such ferret and such fiery eycs.

betwixt your eycs and night?........
so anpearing to the common eyes

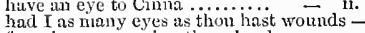

fur mine eyes, secing those beads.

poor scul! his eyes are red as fire...

a friendly eye could never see..

weep my silitit from nine eyes?

eanst thou bear np thy heavy eyes

it runs over even at his eyes.

night hangs upon mine eyes.

I know by that salne eye ...............

ii. 2 when they do not eye well to you...

and make his eyes grow in my brow.

tended her i' the eyes.

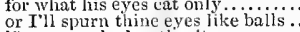

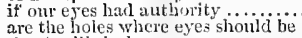

the April's in her eye

this in the publie eye?...............

to see 't, mine eyes are biastei

mine eyes did sicken at the sight .....

my sliame out ot thine ey's..........

woutd you mingle eyes with one thin

whose eye becked forth my war

Octavia, with lier morlest eyc.
EYE-to wash the eyes of kings ... Antony of Cleo. v. with the sober eye of dull Octavia...

my nails are stronger than mine eyes

beheld of eyes again so royal

abide the hourly shot of angry eyes.... Cymmeling v.

and with mitre eyes I'll drink the...

have turned mine cye and wept......

the sun with as firm eyes as he......
hath nature given them eyes to see.

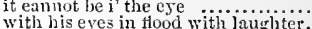

with his eyes in flood with laughter.. then lic peeping in any eye.

then lie peeping in an eye $\ldots . \ldots . . . .$.

may bare the raven's eye

it is a basilisk unto inine eye

remembrance yet lives in men's cyes

first kill lime with your eyes

no single soul can we set eye on........

drop of pity as a wren's ere

be cheertul: wipe thine eyes .......

fruitful object be in eye of Imogen...

your deati has eyes in 's head then

a mian should have the best use of eye

me not in fault.

which strikes the eye:-I stand on fire

throw's her eye on him, her brothers

gracions in the eyes of royal Ron
tliumplyer in the eves of Rome!

gracious in those princely eyes of thine -

full of tound to Aaron's charming eyes

shadowed from heaven's eye

what sirnities my deadly-standing eye

that ever eye, with sight, made.

suspects more than mine eye ean see

will not permit mine eyes once,.....

whole months of tears thy father's eyes?

prepare thy noble eyes to weep

closing up of our most wretelied eyes?

the tears that thy poor eres let fill.:

mine eyes are eloyed with view of

I would hide from heaven's eye...

the as earnestly din tix mine eye. that both mine eyes were rainy....

mentakng eyes...

$\ldots \ldots \ldots-$ v. 3

to the judgment of your eye I give - i. (Gover)

because thine eye presumes to ....... - i. 1

blows dust in other's' eyes.

and the sore eyes see clear to sto
hits the mark his eje doth level

pleasures eonrt mine eyes, and mine eye

her face was to mine eye beyond

and seen with mistful eyes

our eyes do weep, till lungs............

like a beacon fired, to umaze your eyes

contrary are brought your eyes

that all those eyes adured them

this by the eye of Cyutbia hath

hither, to have blest mine eyes!.........

which did steal the eyes of young and old

your ears unto your eyes I'll reconcile
that neer betore invited eyes...........

turn your eyes again upun

ii. 1

[cot. $K^{\prime \prime \prime}$.] slumber langs ujo............ eycs a still-soliciting eyc, and suel a tongue... with washed eyes Cordelial leaves youl.

where are his eyes? either his notion ....

hluw firr your eyes may jieree. $\mathrm{n}$............

deavy eyes, not to behold..............

tlimes inito her seuritiul eyes!............

spluints the eye, and makes the hare-lip

wants thoces at the trial, madam?

eruel nails pluck ont his poor old eyes

upon these eye of thine I'll sct my tivot..

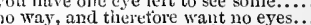

an eye diseerning thme honour......

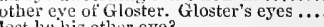

when they did take ixis eyes?.................

the kin:, and to revenge thine eyes.....

the holy water tiom her heavenly eyes.

and bring him to our eye

will cluse the eye of anguish

Gloster's eyes being out, to let

and dizzy 'tis, to east one's eyes so low....

alack, I have no eyes: is wreteled ness

I rementuer thine eyes well enough..... 


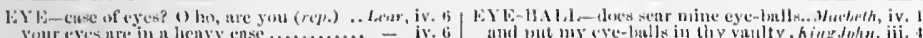

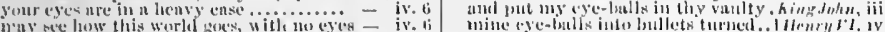

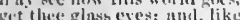

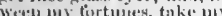

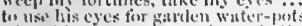

wipe thine eyes: the ponjeres sluti

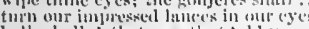

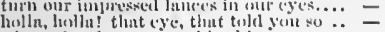

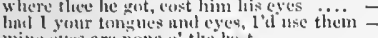

mike eyes are none of the best ......... o Juli

a firesporkling in luvers cyes ......

by ris ing liberty to lhine eyes

and, with unat tnintel cye, eompare her -

desont relision of mine ves nulutuins

poiserl with herselt ind

writfen in the maring of lis ejes .

in many's eyes dontl slute the glory.

what rurious eye sloth quate ........

fy latsaline's liright eyes, by her high

hirr cye disenorses, J will answ
do entrent her eyes to twinkle

what it their eves were there

her ere [col. eyes] in heaven wowili

the white-spturned womlering eyes

there lies more peril in thin

[tol. Kint.] to hirle me from the

comnsel, ant! I lent lim eye

slew dwell upon thine eyes ........

his wnteh in erery old mant

their learts, hut in their eye

With a white wench's litack eye.

hise, a grey eye or so, but not ....

here all eyes gaze on us (rep).

thint runina seyce mat wink.

or those eyes shut, thut mnke.

I suw it with mine eyes ...............

when that wise men have no eves.

you grey is not the murning's eye...

in my eye so do you

still thy eyes, which I ma.......

so itir an eye, as puris hath...........

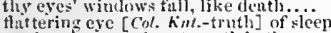

flat tering cyc [Col. Knt.-truth] of sleep

eyes, look your last!

lie miny apirove our ey

anil true asoueh of mine

me anspicious, anal one drupuing eye

let thine eye look like a firent in .

nor the fruitful river in the cye...

in the cheer and eomfort of our esce.

in my unind's cye, Iloratio

ompressed and fear-surirised cy
and fixed his eves upon fon?

earth oerwhelm them, to men's exes

$[\mathrm{hul}$.] ese which their investments show

innke thy two eyes, like stars, start..

to find his way without his eyc

their eyes puring thick amber
nuy, tien thave an cye of you

with eyes like carbuncles.

the herning eyes of liea

and has teurs in 's eyes............

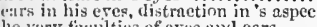

the viry fuculties of eyes mul ea
suldicers, semolar's, eye, tongue

I mine cyes will rivet to his face

an eye like Mars, to threnten.

lase you eyes?

eirs witlout hands or eves

thrm turn'st mine cyes into my very soul t! Int jou clo bend your eye on vacancy

forth at your eyes your spirits willly

not in thicir juignent, but thejr eye

ns day dnes to your cye ................

lnwl lave to see your kin-ly eyes -

heitler motion, yourcl, nor eye

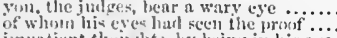

impaticnt thuights, hy beine in his eye.

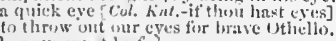

lier ere must be fed ......................

we she has! methisiks it sounds (rep.)

for glie hat eves, and chose une

vour eve [ $h^{\prime}$ 'it.-eres] thus, nut jealous....

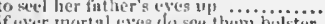

my futher's cye should holither loathis

a ilarling like your precioun eye

ld me ree your eyes..........
or that mine eyes, mine ears

mine eves de itch .....................

lo you perceive the thinstmess of her cyce

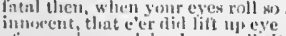

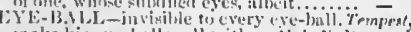

make hiseyc-balls rull with ....Whl, N. Hrom, fii.

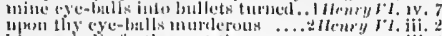

balls fiurtlaer out than

T'll wake mine eye-lulls blind tiret. Cymbetime, iti. I

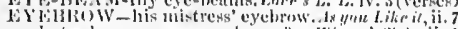

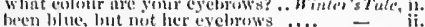

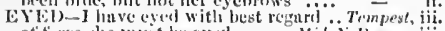

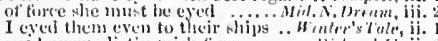

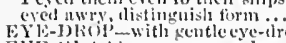

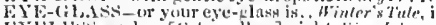
Ex lildisteyeless [ rol.-endless] night. King John, v. b

unil eyeless venomed worn.... Timon of dhess,

losts, with eyeses rage.......

thint cycless heurl of thine was tirst tramed -

E

atvanecel their evelids

on wy cyctids shinll conjecture hing.... Wuch sde,

turbid sleep his sent on thy eyelint.... -

with turmm un your evelids .. Lore's L. Lost

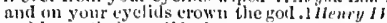

and hung their eyclids down ........ iii. -

eyelids, eases to those heavenly jewels,

EYE-0F cyelids will no Ionger wa:... Mamlet,

rombl with eye-oflending brine.. Twelfh Night, i.

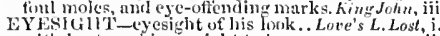

with haste in his eyesight to be.

fantisy that pity upon our eyesipht?.1 Henry/W.

treasure of his eyesight lost ...... Rnme

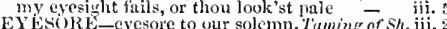

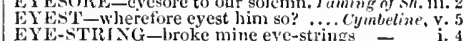

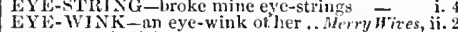

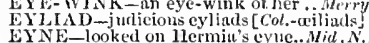

EYNE-looked on llermiu's evle...Mid. N. Dream, i. 1

my love, shall I conpare thine eyne?

upon our watery eyne...................

seorn of your bright eyne........... Like Lit, iv. 3 (letter)

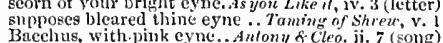

the eat, with eyue of burning eoa!. P'ericles, iii. (Gow.)

FABIAN-thy wnys, signior Fabian. Trelfth Night, ii. 5 I will do so. Signior Fabian, stay you - iij. 4
Fabian can searce hold him yonder..

and for his euwardship, ask Faliau..

good master Fabian, grant m

FABLE-these antique fables.

by the world I recount no fable . Mrd. N. Dream, v. 1 sans fable, she herself reviled .. Comedly of Err. iv. 1

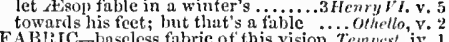

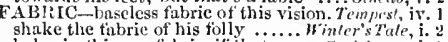

when it stands agamst $n$ falling fabric - ii.

that former fabulous story ........ Henrylli, il. 1

ICE-the outward face of royalty $3 . .2$ Tempost

no wuman's face rementier....

for breathing in their faec's

say they have angels' faces.

this taee of nine were tiull a

my face is black.................

he in the renl ficce had it

(1) wee fine...

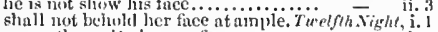

come, throw it o'er iny face...

thy tongue, thy face, thy limbis.....

he does smile his liuce into more
ns a sad fince, a reverend carriaue

tunght liun to face me out

one fice, one voice, one

must not show your face ( $r$.

but as she spit in his fince...

doth your honemr mark his fice

pec any harm in his titce?.

if his fure be the worst tliin

let hor show her fice; nutl, witie

this is that fince thonerne.

show your shecp-hiting fine

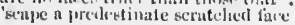
he fables not, I hear the...

but, eliefly, for thy face

to negotiate with ny tac

all they can in face me out of my

I will not show my fitce, until

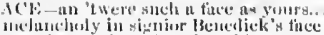

ulasband with at leard on his fuce.

when wits lie wemet to wensh his face

flaili be buriecl with her fice upsards

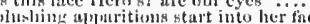

klall fuce to fuec be brouglit to Alargare

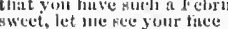

lic wio more pece your fice .

min' I may hide iny face, let me......

and halt' his fince most be aeen tluroig

and pruise my eyes and fuce?

if ever I thy fuec by thalighit se

I an narvellows hairy about the fure

to sipy an 1 'an hear ny 'Thibly's fince

fris facces own margent did quite.

I must sigh in thy fice: most rude.

falleth like n erult on the fues of $t$ ierra

as rluth thy fince through tears

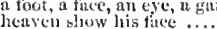

nu fize is fair, that is not

It find a fairer taec not waliced

withont the betaty of a womats tuc

fist not looking on a woman's fitee

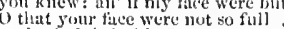

and mirth is in his fince.

to sce a ludy's fuce ..........

to show the sumshine of your the

my face is but a menom, and cluskded too

und showel the better face

Can any lase of brass hold .

a denth's the in a ring. The fuece of

the curved hone finee on a flask

or a jainter; for he nakes finces

belter tice exact the penalty . Merch of $\bar{r}$

loristiun fiouls with ramich

spits in the fise of heaven

and let him stand before our fi...

ne'er wear hair on his tiee, that hid it

a kind ot unber smireli my fice ... As you

no fare be kejt in mind........ - iii. 2 (ver.

or good taces, eyes, and heurts.... - iii. 2 (ver.

outh, thun bear'st thy father's face....An's $\|^{-} \cdot l_{l,} i$.

was this fair tave the cause
that the tirst finee of noither

and it shall be read to his fuee

with a pateh of velvet on's fuce...

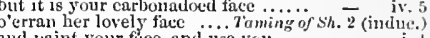

and yaint your fuce, and use you

I saw swect benuty in her face

distinguished by our faces, for ma...

that special tioce which I could fancy

what, y'su mean my face?

limis with uaths to fince the natter

y, ahe hath a fuec of her own...

fice not me; thou last braved

may a tree fince pret on .................

looking on the lines of iny boy's titce

l learncel it out of women's faces

the fice to sweeten of the whole
lier face o fire will labour .

matso fir fitces, ant tor nose

where they should hear their faecs

muthle yonir fice; dismantle you

how inmatience low reth in your tice:

hurl the lanne of husbund in my fitec

changed thy hine tor a name

ay. mud break it in your tace

hut her fire nothing like so cle.un...

to seoreh your face, and to disfigure

strunge elefteatures in my fuce.

this grminct fite of mine he hicl

your fice, ny thume, is as a hook

fuloo five must hice witus face.

I'll gild the finces of the sroon.

their hamde and thees Were all takiged

does the fuec of eart in intminb.......

there's hlowl unes thy fiue..

Why do yon natke such faces?

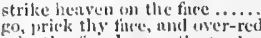

ty rant, shew thy face ........................

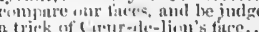

wy tites so thin, that in nine iii. 3

i. 8

(rili,

- iii.

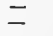$$
\text { i. }
$$

i.

ii. i

iii. 2
iv. 1
iv. 3

i. $\frac{2}{-}$

iii. 2

iii. I

v. 1

, i. 1

i. 7

ii. 3

iii. 2

iii. 1

iv. 3
$\forall .3$

צ. 3

i.

i. 1 


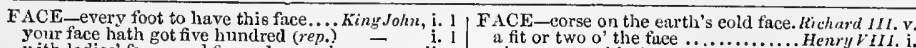

npon thy brother Geffrey's face

stand in his face to con's sace

turn face to faee, and bloody point to

and well-noted fice

and well-noted finee of plain old........

turned an eye of donbt upon my fice

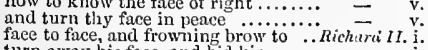

turn away his face, and bid lis

doth harbour, even in Mowbray's taee

blew bitterly against our fives

his face thou hast, for even so.........
did triumpli in my tiaee and they

did triumpli in my taee and the

then set before my face the ior

Elrow me what a face I have

destroyed the shadow of your $f \in p$.

his faee still conbating with tears.

for love, speak treason to thy face

look upou his face; his eyes do

to look upon my sometimes master's five
and on my filee he turned an eye .... Hen ${ }^{\prime} / 2$

to behold the face of that ocession....

and in thy fice strange motions....

never wear hair on my face more

give me them that will face ni
spit in my tiee, call me hore.

spit in my tiee, call me horse.
now nly masters, for a true faee...

now nyy masters, for a true faee.
slept in his face, and rendered

do thou anend thy tiee, and $\mathbf{I}$

my face does you no liarm

I never see thy faee, but I think (rep.).

look npon his faee; what call you rich?

and, by this faee, this seening brow.

to face the garment of rebellio

no, I know this face full well $\ldots \ldots . . .$.

not stick to say, his face is a taee royal.

not a white hair on your faee
go, wash thy faee, and draw
or to

could diseern no part of his faee from

colne, let me wipe thy faee ...........

and his faee is Lueifer's privy-kitchen

and face them in the fie.

before my faee murdered my fatlier..

till bis face be like a wet eloak

borrow not that faee of seeming sorrow

in thy nost marrellous faee

his faee is all bubukles and wilielks...

way sliall be paved witl English faces
sees the other's umbered faee....

sees the other's umbered faee ....
upon his royal face there is no vote -
tanning in his faee with

bloodity did yawn upon bis faee....

he smiled me in the face

behold your faee most worthy brother

whose faee is not worth sun-burning

a fair faee will wither.

ean do no more spoil upon ...... fiee

though I speak it before his taee

sun, fierce bent against their faees
presume to look orice in the face

presume to look orice in the facc
beard thee to thy faee (rep.)...

beard thee to thy faee (rep.) .........

destrnction meets thee in tle tace.

night shoot them at your faee
doth not flatter, faee or feign

in this beauteous faee, a world

in thy face I see thy fury

my ten commandments in your face

gazing on thy face, witli envious ...
in thy faee I see the map of honour.

in faee, in gait, in speeeh ......
tnrn away, and hide tlyy face?

to drain upon his face an oeean

tu drain upon his face an oeean .......
how the blood is settled in his face

his faee is black, and fnll of blood

hath this lovely face ruled

and daughters before your faees

stand, and front him to his faee.

canst for blushing, view this tae

to bear a woman's faee?

that faee of his the lungry eaunibais

larighed in his faee

that spoils her young before lier tace

though man's face be fearful

let his manly faee, which yromiseth

0 God! it is my father's face

is this our foeman's faee !...............

red rose and the white are on his faee
before his face I speak the words

blow this father from my face.

frame iny face to all occasions

thy heavenly face that set

smile in men's face, smooth
we know each other's faees

we know each other's faees ..............

her faee defaced with sears
I looked on Kiehard's faee

never look upon thy face again

covered with the tace of
stand before our faces.

\section{viva voce, to $h$}

ye have angels' faees, but beaven .....

had their faces heen loose

whose bright farees east thous............

how long her fuee is druwn?

he should be a brazier by his fai......

I'll pash bim over the faee...... Troilus $\& \overline{C r}$

borne here in the face

will fly with his face baekward ....

thou boy-queller, show thy face

sprinkles in yonr faees.
that see I by our faces....

hurse nay mire npon your faee

let me behold thy faee........................

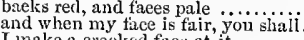

I make a erooked face at it......

you unake taees like mummers.

from tiee to toot he was a
bid them wash their faee

thy taee bears a command in $t$

by his lice that there was something $(\mathrm{rep}$.$) 二$

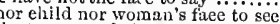

the tartness of his faee sours ripe grapes

enn you see your face?

the climber-upward turns hice again

half their taees huried in their eloaks

if not the faee of men, the sutferanee

hide their frees even from darkness.

when they shall see the faee of Casa

at Philippi we do faee him

thinking, by this face, to fasten in

and

Titinins' face is upwrard
Tha

liadst thon Nareissus in thy faee

all men's faces are true (rep.).......

he lias a eloud in's face

from that great taee of war....

you see him cringe his face

his face subdued topent?

and would gladly look him i'tlie face

lits faee was as the heavens $\ldots$.

he fled forward still, toward your face

eut to pieees before thy fae

upon their faces: you were as flowers

his Jovinl face-murder in heaven

to the face of peril myself l'll dedieat

with faees fit for masks

whose face I never saw?

there's business in these fice

wonder greatly tbat man's face ean.

thou turn'st away thy face for shamei

thy eheeks look red as Titan's face ...
keep eternal spring-time on thy face

have his soul black like his faee

the welkin with his big-sivoln faee?

nyy seal be stamped in his fae

brought unto the empress' faee

drops upon thy blood-stained faee

her thee, like heaven, entieeth

tongue move aliger to our tace

\begin{tabular}{l|l} 
iii. 2 & against the fice of death, I sought \\
iii. 2 & lher faee was to mine eye beyond
\end{tabular}

iii. 2 she has a good fine, speaks well.

to betray, doth wear aus angel's tae

never to wash his tace, nor cut

to stink afore the faee of the gods...

nor shall ever see that face of hers a...

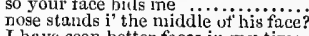

I have seen better facese in my time.

my faee I'll grime with filth

athough as yet the faee of it be eovered.
broke them int the swreet faee of heaven

to apply to his bleeding face

which the rude wind blows in your fa........

wast this a the then her forks yre

even so: cover their tiposed...

eumpare her faue with solne .....Romeo o Jul

dost thou fall upon thy faee? (rep.).

his face to the dew-dropping
covered with an antick tace..

nor arm, nor fnee, nor any other part

to hide her taee; for her fau's.

playing it to me with so sour a faee.

he will make the face of heaven so fi

out, you bagtage! you tallow face!. whom thy upward faee bat

rlooked her in the face..............

burom, blythe, and full of faee.
FACE-rever after look me in the tace. Rom.\&. Jul. iii. 5 to your tice. Poor soul, thy face is ...
spake it to my faee. Tliy faee is mine

to see this morning's taee..............

partly, to beliold ny lady's fae

of heaven visit her thee too roughily ..... In Inmle

then saw yuu not his taee

he fallis to sucl2 perusal of $m$
that their fices are wrinkled

thy faee is valanced since I saw.

iii. 3 God hatl givent you one faee [Kni..-paee $]$

I mine eyes will rivet to his

leave tly damuable fiees, and begin

lieuven's face doth glow .................

of a surrow, a taee without
come, let ine wipe thy tiace

knavery's plain tace is never seen, tili

I have no judgment in an loonest faee
begrimed and black as nine own fince

dwell in every region of his face

let me see your eyes; look in my face.....

ween'st thon fur him to my face? ........

thou hast faced many things

that faced aud braved me.....

ill taced, worse bodied

this the tace that faced so many.......itichurerd 11 .

ragged than an old faeed ancient .. 1 Hensy $1 \mathrm{~V}$.
for tear I should be faced out of

FACERF-facere, as it were .......... Hoves L L Losi, i

keep it still as a face-royal..............
FACILE-with more faeile question

Othell,

for the elegance, taeflity, and golden
why he drinks you, with facility ...... of hello,

FACING-stands for the faeing..Meas. for Meos, iii.

FACIT-euenllus non facit monachum. Tuelfth $N$.

cucullus nou faeit monachuin . Meas.
FACT-and, indeed, his fact, tili now

in mercy of this fact, her hrother's

all shame (those of your faet are so). Winter's $T$. iii.

this faet was infamous, and ill ..... M Macbeth, iii.

and a fouler fact did never traitor...2 Henry $V t$.

whom we have apprehended in the fact

soil the faet witly cowardice .... Timon of $\mathrm{d} t h$. iii.

than one confederate in the fact. Titus Androno, iv.

will bandy with thee in faction Turo cien.of l'er. iv.

of the revolting faction, traitors?. . . Richard 11 . ii.

[Knt.] gentlemen in arriss upon his faction

you maintain several faetions .......1 Henry $V$.

for ever, and iny faetion. wear.

to this taetion, in the Temple-garden

forsaken your pernicious faetion - iv. 1 (lette

or any of your faction? a plong as...3 Henry $V 1$.

they upon the adverse faction want .. Richard

so many hollow fietions...... Troilus \& Cressido

to draw emulous faetions, and bieed

more our wish, than their taetion.

conthe outrages, and cherish faetions

let them ens, and give out conjeetural. Coriolanus, is

poyers breed

iii. 1 polvers breed serupulous faction... Antonty \& Cleo. i.

my faction if thou strengthen with....

thou and thy faction shall repent

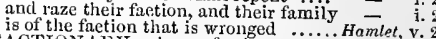

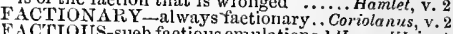
his foU S-sueh factious enulations. 1 Henry $V I$. iv.

make up no factious of their

chop away that faetions pate of lis....

thou factious duke of York, deseend.3 Henry $F I$. i.

you have been frctious one against ... ii.

inakes faetious feasts; rails on. Troilus \& Cress.

be tiutious for redress of all these... jutiut $\overline{\text { Cacsar, }}$ i. ACTOR - till my factor's death. Comedly of Err. i. Perey is but my taetur, good my lord.I Henry IV. iii.
or lowly faetor for another's gain...Richard 111 . iii. only reserved their factor, to gain.

chief tactors for the gods.... Anlony \& Cleopalra, ii.

FACULTIES-wlose faeulties inelusive. All's sine, i. hath borne his taculties so meek ........Macbeth, sueh other gambol faculties he hath.2. Henry $1 V$. i. natures, and pre-formed faculties.. Henr'y VJII. natures, and pre-tormed faeulties. . SuliusCresar,
how infinite in faeulties! in form.

the very theulties of eyes and ears.......... - ii.

FACULTY -yet creseive in his faenlty. Henry $V$. i. .
FADE-the roses there do tade so tast?. Hid. $N, D r$. i. rise and tadel he shall be lord ot $\ldots$.... Cymbeline, v. thy lips and eheeks shall firde... Romeo o suliet, iv. old, wrinkled, faded, pageant faded.. Tempest, jv.

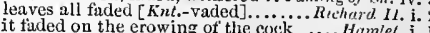
FADGE - how will this fadge? .... Treigh Nithlet, ii. WAD will have, if this fadge not

swan-like end, tadiug in musie. Mer. of Venice, iii. 2 
F.1 Ind

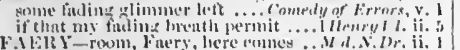
ure glat nmel finis ling tliglit fo.........

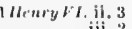

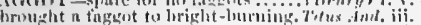

F.til. - or elie my provect tinils

und biris, are fain of climbing high.2

ah, York, mo man alive non fitio as 1 .

und finin to go with at aul

would hin that all were weil.

she will not firit

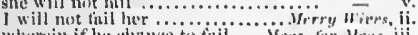

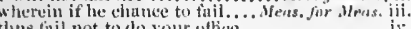

thas thil not to do your whic

how hitit, like l'iltte, would

the tencler prince wobld fitin have eome

thet luns tinin to trow

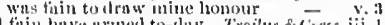

we will not fuil. T'on-light, i'li

iiiv

I would finin see tlesen moter

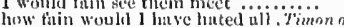

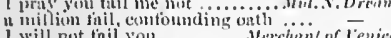

he would fin have hat it ....

yom might finil of the knewwing nee

which I wonld fitin eull master

but it you fiail, wh ithont more

anul wnst thour tain, pour fither.

if $i$, if thil in tortine of my.

thut woukd fain lay knific alwsud

l'll not foil if l live wil...

oft expeetstion fails, imi mont oft

I would firget it fitin; hut, O, it presses -

liath there been such a time ( $l^{\prime} d$ fain....

and thim woukd begnile the terlions day - iii. 2

that would fan have a measure to

FAlN' - which is nost finint ......

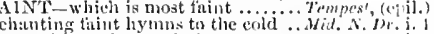

ulou fimt primrose-bels wate wout.
you faint with wandering in the wood

than my fint manderwing wild graut...Mer of ii. 3

I thint ulmost to dentl wo............. you L L

but I nm fuint, iny gasles cry .........Macteth, i. ?

possessuth ioe, and I am thint

the evgnet to this jale faint swan

but if you funt, as furing

With heavy nothing faint and shrink

preathless and timit, leaning upon..

so taint, so spiritless, so dill

rendering faint quittunee, wetiried

of indigent taint souls, past.............
of his kingdom too faint a number

nrmy is grown weak and fint ....
why fuint you, lomels, my title's good.

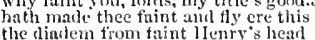

soft eourage makes your fillowers tain

eftuse of blood woth make me finint ..

and warriors faint! why, 'twere ....

it fuints me, to think what follows. Henry l'III. ii.

the fuint defects of age, must.. Troilus geressith, i.

to set a gloss on thint deeds ..... Timgin of $\bar{A} /$ hen.

lias triendship sweh a faint and milky

witls their faint reply this answer join

$\mathrm{U}, 1$ grow thint: rum, $\mathbf{i}$ ucius

euming faints under lis ehanee. Antony o' Cleo. ii.

viluint; o las, Charmian,- tis no

you come in taint for want of meat

give me letve; I thint

if fear lath made thee faint.. Tilus Andronicus, ii. 4

he faints! my lord, my lord-Break.

or I slall faint: a lilagne o' both. Romeos duliel, iii.

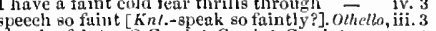

alas, he faints: O Crissiol Cussio! Cassio:

AINTED-and now he fuinted ...As ynu Like it, iv. 3

nnd expectation fainted.... Antony \& Clenputra, iij. 6

AINT-HEARTED-

filint-hearted degenerate king him. I Henry/VJ. i. 3

fuint-hearted bov, arise, and look. Titus dus

F.INTING-and eried, in fuinting.As you Lrhe,

the weak door of our fainting land .. King Jenth

kindly give one fuinting kiss......... I fenery $r t$.

fninting, destrair; respairing, yicld. kithar, $J \Gamma$.

FAINTLY-I fainty broke witl thee. King John,

pereeives it is but finintly borne...... kir

faintly through a rusty beaver peeps...Isenry $r$

like fulc ghosts, fuintly beniege...... I Henrybl.

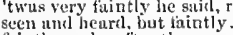

fuintly spoke after the prompter............. Jethe

now he denies it fuintly, and inngh

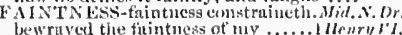

FAlli-and eonfer fuir Milan

.. Temptest,

it the ill-spirit hicve so tinir a house.

the marriage of the kimg's thir da

of of

quiet days, fair issue, and long 1

and I would call it tair play

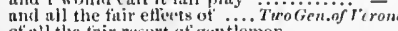

of atl the thir resort of gentlemen.....
think'st thou of the tair sir Egiainour?

not so tuir, hoy, as well-favoured

angenter the fair

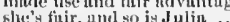

to love fuir silvin

thint intude her fuir

I would fink fin shent ont

we wovill finin have either Comerly of firm

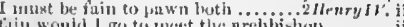

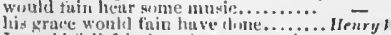

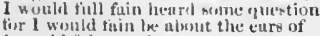

when his fuir nours

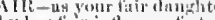

but Silviat is toos fine

holy, fuir, and wise, is slie

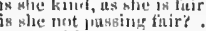

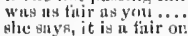

but jearls are tiair

fir my ruced, but one tiari lixik

he's a gowd dog, and a tuir ther.

lece comes titir mistress . Inme $\ldots \ldots . .$.

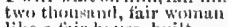

like a tiur house, built

What is finir. William?
the dear lase I lear to

each finir instulment, coat

helow fair knightion

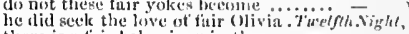

there is at firir belasviour in thee......

liess yon, juir shrow

'tis a fin young think you lave.

if you were the clevil, you are tair.

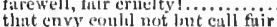

whuse tair tlower, being ance displayed

is your scrvint's name, filir pri
for the fair kindnesg you have

but 1 bespake you tair

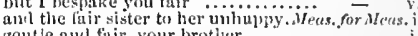

by your fiti: prayer to.

reflent yull fuir oue ot the sis

low now, fitir maid?

my mother play ed my father finir!

the hind that liath mule you finir

to you, fuir that grncions daushter

poompting tor a hair praise

if thou dost love tair Ilero ...........

tha tell tair Ifero I am Clandio
but by the fair weather that you

aud fair Ilero is won

one woman is fair; yet $I$ ami wel

they say, the lady is fair .

ly this day, slie's a finir latily

fitre thee wetl most foul, most fii

good-morrov to tuir eousin is wronged

f'll tell you largely of fair IIern's death

soft and fnir, thar. Which is Beatrine?

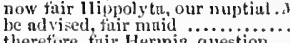

therefore, fuir Hermia, question
for you, fair IIermia, look you

syeded, fuir IJelenal

fair? that fiuir again nnsay (rep.)

I am thought as fuir as she.......

nnd make him with finir fliglé brenk

at a fair vestal, throned oy the west

where is Lysander, and fair Ilermia?
do I speak you fair? or, ratler.......

fair love, you faint with wandering.

amen, anen, to that fair prayer......

if 1 were fuir, Thisby, I were only

that would not let lim bisle, fair IIelen -

I un as fuir now, as I was crewhile...

opening on Neptune with fuir blessed

and kiss thy finir large ears...

we will, fuir queen, up to the

my lord, fitir Ilelen tisld me of

iị Helena in fancy following me

my next is, most fuir l'ynum

for phrting my finir Pyramus and $\mathrm{me}$

as onr hest-moving fitir solicitor

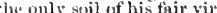

Which his fair tongue (ennecit's expositor) -

Nnvarre hal notice of your fix aly roach -

fair primess, welcome to the eotirt (r

now thir toffll your mask ? Fir fail

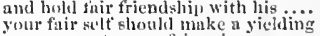

thengh oodeniesl tair harbour in $\mathrm{my}$

sweet heulth and futir desires comsolt
to feel only locking on thirent of tair

I non finir that shent, and thercujom.

not tinir' alack, tor whe? Yes, mulnm, fir

tilir payment for tonl words.

nothing but tuir is that which you

Olieresy in tair, fit for theese days!

thant tom urt tixir, is most intinllili

then thou, titir sun, whicls on iny...

ay fuir us iny

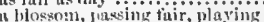

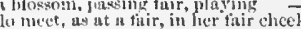

im fure is fair, that is not ........... 
FAIR-I'll prove herer fair, or talk.. Lore's L. Lost, the hand of lis fair mistress .

an' if my faee were but as fair is.....

compared to twenty thousand fuir..

fair as a text $B$ in a coply-look ...

fair lady,-say you so, fair loril (rep.)

at calf fair lady? No, a fair lord calt

fair ladies, masked, are roses in.
fair sir, God save you! where is.....

mectings, markets, fairs $\ldots \ldots . . . . .$.
and tair time of day! Fair, in all

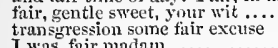

I w'as, fair madam

all one, ny fair, swect, honey wionar....

tor nll your filir endeevours..........
for your fair sakes have we negleetud

make us both - fuir ladies, you .......

a beard, fair health, and honesty.
sle is fair, and fairer than that...

I did receive fair specehless messages
to Beimont, to fair Portia ...........

God grant them a finir departire.

was the best deserving a fiur lady....

rest you fair, good signior...

say this, fair sir, you spit on $\ldots \ldots . .$.
ni equal pumad of your tair flesii

I like not fair terms

then stood as fair as any comer wite.
in futh, tis a fair lamal; nnd whiter

is the fair land that writ

was not that letter from fair Jessict?

mind fuir she is, if that mine eyes

do it in lope of tair alyantages.

to come view fair Purtia
as o'er a brook, to see fair Porti

as o'er a brook, to see fair Portia ....
and such fair ostents of love as shail

the grosstness with fiar ornament

find I here? fair Portia's counterfeit?

ehanee as fair, and eloose as true!

a gentle scroll; fair lady, by yonr...
so thriee fair lady, stand 1 , even so.

a thousand times more fain

I was the lord of this tiir mansion

I got a promise of this tair one here..

tair thoughts, and happy hours.......

speak me fair in deatly; and, when

tair sir, you are well overtaken ........
even by thine own fair eyes, wherci

even by thine own fair eyes, whe
where the ways are fair enough.

fair ladies, you drop manna in.

that they are fair with their .......As $y$
those that she makes fair, she scarce

when nature hath made a fair ereature

tair prineess, you have lost mueh

no, fair princess; he is the yeneral ...

flare you well, fair gentleman ...........
tair sir, I pity her, and wish for her sale -

if ladies be but young, and thir

in fair round belly, with good ........
the fair, the ehaste, and mexpressive

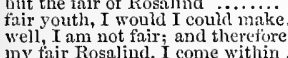

would bave lived many a fair year

my errand is to you, fair youth .......

goud-motrow, fair ones: pray you

the boy is fair, of female fravour....

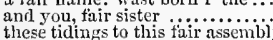

these tidings to this tair assem
whicl make fair gifts fairer.

save

was this fair face the eause, quotio sio

now, fair one, does your busines

to eaeh of you one fair and virtuous

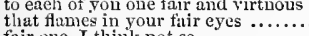

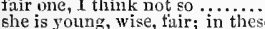

where thon wast slyot at by fair eyes

he is too good and fair for death
sle's a fair creatture; will you go

but fair soul, in your fine.....

the time is fair arain

storncd a fair eolom, or expyressed

your amorous token for fair MIandlin

I will buy graee and speeeh of .

to see fair Padna, nursery of arts.. To

have access to unr tair mistress

to fair Bianea, so beloved of me.

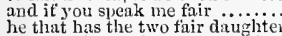

tain Leda's dangliter laad (rep.)

have (iremio to keep yout tim.
Katharina, fair, and virtucus?

unto Bianca, fair and virtumus

the jaeks fair within, and the jilis tih

she jetrs me fair in hand....

young budding virgin, fair, and fresi

the parents of so fair a child

fair sir, and you my mery mistress..

my fair Bianca, biù my father $\ldots . . ;$

wisdom of your duty, tair Bianca.

as whirlwinds shake tiair buds

but love, fair lookss, and true obedicitue
AIR-shond not produe fair issue. Winter"

or I'll be thine, my tair, or not

shepherdess, (a fair one are you)

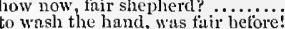

nothing else but fair posterity

yourself, and your fair urincess...

all that you speak, shows firir....

and your fair prinecss, godaess! ....

please you to interpose, tair madam.

at any Syracusau marts and fairs. Comedy of $E$

my decayed far a sunny look of his

keep then fir league mui trueu.

plead you to me, fair dane?....

bear a fitir presence...................

but her fair sister, possessed with.

would refuse so fair an offered chatin

wind blows tail trom land

they speai us thir, give us

and this fair gentlewoman, her sist

so foul and fair a day I latve not seer.

things that do sound so fair?

bless yon, fiir dame! I anı not

most lawful elaim to this fair island... Kimg $\bar{J}_{0}$ h

at least from fair five hundred.

tail fall the bones that took.

and slie a fair divided cxcellence....

for Anjou, and thir rourane, Maine

when his firi angels would salute

but thou art fair; and at thy birth

to tread down fair respect

tis true, fais daughter

to curse the fair proceedings of .......

$O$ fair return of banislied majesty!

for your fair safety; so I kiss.....

in the fair multitude of those........

my Arthur, my fair son!

knew you of this tair work?

tale fait wenther in your blustering

having our fair order written down..

of this most fair oceasion

to try the fair adventure of to-morrow

the more fair and erystal is.......

I'll answer thee in any fair degree

or seven fair braneles, springing

quiet confines fright fair peaee .....

the fluwers, fair laulies; and thy steps

whom fair befal in heaven 'mongst

but by f'in: sequenee and suceession?

the wind sits fair for news to go

stained the beanty of a fair queen

Riehard's night, to Bolingbroke's tairday -

the news is yery fair and good

our filir appointments may be

should stain so fair a show

so poorly, and to speak so fair?

so poorly, and to sis to bis majesty

so muel dishononir my fair stars

in so fiair a tioop?, to read

name it, fuir consin. Fair consin!

do not see, my fair rose wither

pluck my fair son from mine a

a fair hot wench in flame-culoured...inenry

that's wandering as - at hind

to die a fair death for all this

and slow it a fair pair oi the

these promises are litir; the partie

the noun shines fair, you may

sumg by a fair yueen in a smmer.

where you did give a firir and natural
from this swan of fair adyantages.

we offur fair, take it advisedly .....

tic arms arc lair, when the intent

2 for doing these fair rites of tenderness

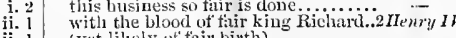
(yet likely of fair birth)
tap for tap, and so part fair

ii. 1 tall for tap, and so lart fair.........

iv. 2 then feed, iand be fat, my tiir Calipolis

iv. 5 good yoke of bullocks at Stamford filin?

iv. 5 heahth and thir grecting from um....

$\checkmark .2$ lost the other day at Hinckley fair?.

v. 2 now speak sir John Fulstalf tui

v. 2 The this fiur proceenling of the king'

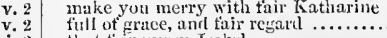

full of grace, and tair retsarl .........ntury $f^{\prime}$.

F. I li-the pleasure of on: fair cousin ...Menryl: i. as I may, in fair terms ................

now sits the wind for terms $: \mathrm{iil}^{\circ}$ that grows not in a fair ennsent...... we doubt not of a fair and lucky war. say, if my father render fair reply. disgnise fair yomir fresh fair virgins, and your...
and your finir show shail suck away and your fair show shall suck away to our most fair and prinecly cousin wilir Kout fitirine, sud most fair? will yo O tair Katharine, if you will love me What says she, fair one?

sleak, my tair, and fairly, I pray thee what say st thou, my fair flower-ile-luce? I would have her learn, my fair consin y a toir Fench city, tor one fitir take her, fair son, anl from her (s) ood

your fair minds let this aceeptance finir nuid, is't thoul wilt do be not dismared, fair lidy

firewell, and tair be all thy jopesi...

by fitir persuasions, luixed
niy leave of thee, filir son

to woo so fair a dame to be

fair Margaret knows, that sitfi,ili

v. 2 (chro

lath pulled fair England down

have you laid fair the bed?

I lost firir England's vicu,

entreat lim, speak him fai

but I must shake fir weather.

and entreat them fin; eome .........3 Henry VI.

lpon my target three fair slinining suns -

fair queen of England, worthy Miargaret -

why, say, fair queen, whence springs

that our fair queen and mistress

thy news? and yours, fair queen.

son Edward, she is fair and virtuous

till then, fair hope must .............

by fair or foul means we must
fair lords, take leave, and stand

curtailed of this tiir proportion ....... Richard $111 . \mathrm{i}$.

to entertain these fair well-spoken..

in Jears; fiir, and not jealous

sline out, fair sun, till I have .......

lielp you to many fair preferments ..

(lity

O my fuir cousin, I mast not say so... -

in air of your titir [Col. Knt.-guod] louks -

now, fair befal you! he cleserved .....

bolker-on of two fair

only mocked with two fair babes.....

and entreat me fair, or with

this fair alline, royal and gracions

infer tair Englaud's peace

king Heury and thy fair son $\ldots . . .$.

lines of fair comfort and eneouragement

and conquer, for fiuir England's sake!

word of comage, tair saint Georam..

reseue, firir lord, or elsc the day......

upon this fair coljmetion

plenty, and fair prosperons diny...... -

with treason wound this fair land's pence-

than ever they were fitir............. Henry $l^{\prime}$ I1l. $\mathrm{i}$.

dlie very thought of this fiar eompitiny

a sweet society of fair ones

ladies puss away

rise in their tuir cheeks, my lord ...

so noble and so fair assembly ........

you hold a fair assembly

cone hither: What fair ady's tliat?.

licalths to drink to these fuir ladies

that you may, fair lady, perceive....

laith married the fair lady

there is more in it than fair visage.

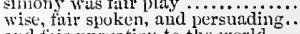

atd tair puryation to the world.....

as if we kcpt a fair liere? ............

of wislom, and tair virtue, than........

to tell you, fair beholders.. Troilus \& Cressite, (proi.

and when tair Cressid comes.

if she be tair, 'tis the better for lier.

so itir as llelen: au' she (mpealed). 
F.1IR-suy I, she is mut fitir? .. Truilus fo cirssitu, i.

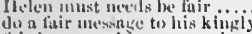
fiar leuve, and harte security

tair lurel A, He'ns, let me tomel.

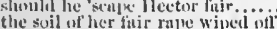
the) urt a fitir curs.

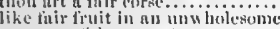
ulual our this renuest, mitent tiir le to y'su, niv lorst, und to (rep.) thir theen! fuir thoughts be (rej,

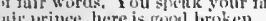
Hiil yrince, here is goon
fiw words to fuir tinith

if (t)-monrow be a fair diay. the enfreed Antenor, the tin Cressid merits finlr llelen best.

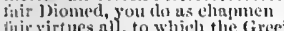
entreat her aisir; and, by my soul, fui fiip luly cressid, so pleuse you in your ehcek, plemls your finir usage in appointment tresh asid fair. inat winter from your lips, fuir inily stulu fuir, I proy thee; let me. umorms view on the fair Cressid trom her dinughter, ny tair lov.

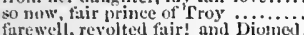
and wind of your fair swor 1" tis fuir play. Fool's play . present the fuir stecl to my lady tite matid is tuir, o' the young laults that are rich, are fair....
unch gruee, fair ladies, set a fai inteh gruee, fair ladies, get a fair
reecived, not without thir reward with a noble fury, and fair spirit to make an unly deed look fair has ilune tiur bervice, and slain tinul, fitir; wrong, right.

now the tuir goldess, fortui. anul when my tace is finir my us tuir us noble lullies. on fair ground, 1 eould he:t fort clueak tuir: you muy salve only fuir speeeh. I think ' $t$ wi w at the priee of one fair word. many an heir of these fair edific.......... he does fair justice; it he give. you have made fair work (repealed)...
fair hands! you, and your crafts! (rep.) with our firir entreaties haste...

yours is as fair a name

it was a vision, fair, and fortunate.....

in thee, fair and admired?......... Antony have fair meanings, sir. And tiir words -

but there is never a fair woma
give liglit to thy fair way!......

the morn is fair: good-morrow ....

on what fair denc

I do not think, so fair an outward

to be more fuir, virtuo

something too fair, aud too goo.....

get ground of your fair mistress.

a. lady so fair, and fustened to :t cimpery that temple, thy fair iniud

ths record of tuir act.

tir she's fuir and royal

ur'y the firir youth thini..........

fuir youth, eome in: dixcour is ..... this forth

inoulded the stuff so fair

how fair the trihme iluenks......

clear up, fuir queen, that clous

accend, tair queen, Pantheon

Jistis werds, hitirlooks, and lit

tair P.lilomelat, she but ?ost

and fitir men call for grace

lorought wp a neck to a fair eic.

stnootli and speetk him fair

hetore thice stands this fair II

fire flass of likht, I lovel you

from so fair a tree as your fuir sel

wie hath a fuir daughter, and ti-morr

woul she is fair tho, is she not? (repeated).

as yole are as virtuous as fair

(1) hear your fate, fair crcatu

weleume, fair one! is't not u givorliy

fiair one, all gondness that consists

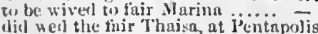

yet was his incther tinir......................

queen of us, of ours, and our fiur lirane.

some, name, fuir rentlewoman?

there was never yet tair wollan...

this eecelly a fair deservill:

eh to wakes ant tairs.

where am 1 ? fuir daylight

fur your claim, fuir sinter ...................

thy out-1ide lowk so fair and warlike...

in fair Verona, where we lay... Jomen of
litir I love. A right fair mark, fuir eas.

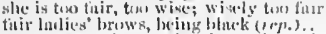

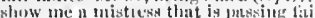

Whe pussed that possing fitir

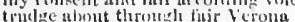

IIIy fing niece lion

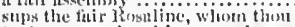

thit! you saw her fuir, none else.

for fitir without the ftir within

the fume was necer su fitir .......

thew a e

that fitir, which love gronnet for (rep.)

my inveration is tair mnt lisonest

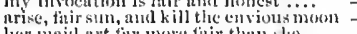

meither fair it cither the wislike

in truth, fiar Mlontagne, I am too fond

set on the fair dum ther of rieli Cagumet =

God ye groul den, fitir gentlewoman.

clicl eser dragon keep so fuir a cuve?

of fiair demesnes, youthtul, and uelily

so quick, so duir an eye, as Paris hath

stick your risemary on this fuir eorse

to fillow this fair corse unto her

tail Julict [Col. Kul.-or winting] tia

it is sulpused, the fair ercature died

the with that fuir and warlike form. Jamber

take thy fair huntr, laerter..........

most finir return of gretetings ....

soft you talu

are you dair? What means

monk far, you shonid athit

that's a fitir thought to lie between

slanlt live in this fuir norld behind

could you on this tair mountain leave

to the use of aetions tuir and good

fair, and bring the body into the elsapel..

from herselt, and her fuir judgment.....

and from her fair and umpoll uted

wrote it fair: 1 onee dill hold it..

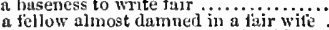

that your fuir daughter at this odd-eve

so tender, fair, and hizply

nnd sueh fair question as soul to soul...

your son-in-law is far more fair than black

if she he fair and wise, -fairness and wit
finir and foolisl?? Slie never y'et was (rep.

fioul prauks which tair and wise ones do

she thut was ever fair, and never proud.

not 1 , for this finir island

other things grow fair against the siu......

to say-my wife is fitir, ficeds well.

how is it with you my most fair $\mathrm{Bizi}$....

a fine woman! a finir woman!

meli st so sweet

what nume, fail latly? Sun as, slie says

takes away witl him
F.MIR-BETROTHED

the fuir-betrothel of your dnughter....

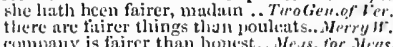

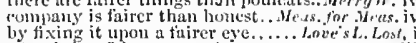

Mily it is a farer name thin

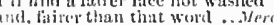

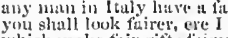

which make fail gifts luimer

in your besl find titirer firt the

lis dughter tairer than ylu is. Taming of $\bar{s}$ 'an

mot wish thent to a fitirer death....... inacbeth

the cover of a fitirer milut.............. John, ii.

unon the in a more fitirer sort ........

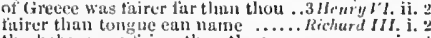

thy babes were taifer thun they were

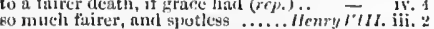

she leroket yesternight fairer thim... Troil. f.c'ress. i. I a latly wiser, fairer, truer............ - i. 3

thist nyy lady was fairer thinil his

and your virtues the fairer ............

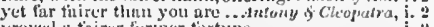
proved at finirer former fortuile

or rather fitirer than those for ...... Cymbetine, v. 3

tor her fiun's the tivirer of the tw........ o fut ii.

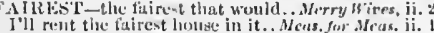
the fuirest grant is the neeessity ........ I uch.tio $\mathrm{i}$.

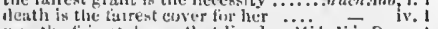

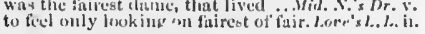

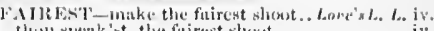
thous speak int, the finirest shont

lowy parcel of the finiret dounc

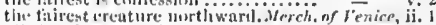

ull the pietures, fuirest lined. Ax you Like, iii. ? (ver.)

Iint

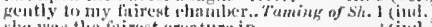

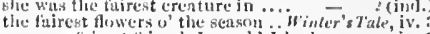

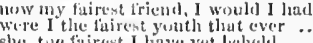

Incek the time with finget held

Mactisth i.

lier fairest flowerts elusked us.

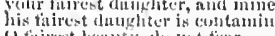

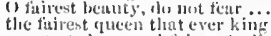

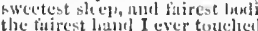

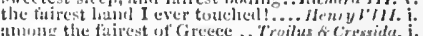

will enecive the tisirest

nind swectert, tairest, ns 1 my por . . Cimbeline, $\mathrm{i}$.

thatuke, fuirest ladly: what! tro

your luty is on firest sister; your swect

with fitirest fliwers, whilst bummer last -

the fitirest lireencrs of our eline..

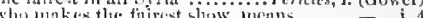

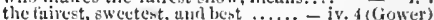

all silhapeny as of all the fairest.

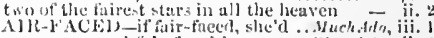

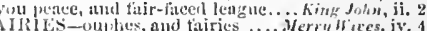

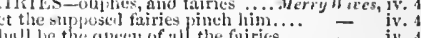

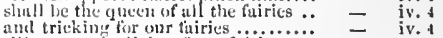

till we ece the dight of our fintres.

alyl her tromp of faries?

fuintes, bilek, grey, green, and wilitc

thicy are fairies; he that speaks to thetn - v.

alsut hiln, fairies; sing a scorntul .. $\quad v$.

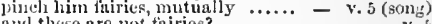

and these arc not fairies?

in the thought, they were not fairies
rly'me and reason, that they were fuirics

and fuiries will not linse you

itipies, away: we shall chide.. Mit. $\Lambda$.'s Dream, ii. 2

firies, the fuiries to attend on thee - iii.

nutl we tairies, thut do run by... 二

sloull be rich by the fairies .....Winter's Trale, iii, i

frum fairies, and the temuters........... Cymbeline, ii.

with female fuiries will lis tomb.

What fuiries haunt this gromul? $\ldots$-... v.

fartes, and gods, prosper it with thee.... Lurar, iv.
she is the faries midwife......... Rnmeo of Jutiet, $\mathrm{i}$

time out of mind the firies conehmakers - i. A AlliLY-tairly spoke, sit then ..... Temprst, iv.

so it be fairly clone, no matter

goes as fuirly, ns to say ..........
thut they may tairly note this

Merry liress, ii.

my very worthy cousin, fuirly met. _.

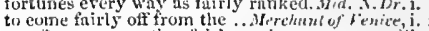

as, atter some oration finirly spoke, . - iii. 2

and fust it fairly out: our cake's. . Tommes of sh. i. i

i'tl have them very tuirly bouml

there it is in writing, fuirly drawn

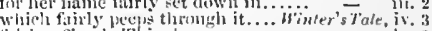

tiren thirly I beepoke the oflice.........

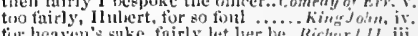

unt soldiers stund full putirly tor

tilen dest this uttice tidirly

should dress us tinirly for our end.

hrother Enfland: fairly met: bo atre

of Gueh looks, we timily hope, have lost
speak my fiar, and titirly. Pray thee

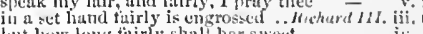

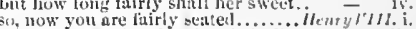

fuirly nowered; a loynd and ohicient

ton let the troop pass fuirly; or l'l
slow as fairly in the musk. Fro

what Troy' means thirly, shait ......

turnish you tinirly for this interehange

as firirly built as II Iect 11 .

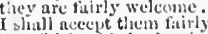

luw fuirly this lord strives to anica.

thit lic bears all thimes fairly ...... Coriolanus, iv.

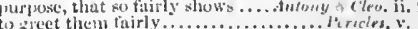

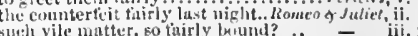

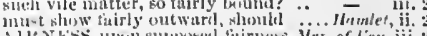

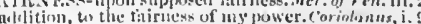

that hook of wiving, fuirnes......... Cymbelene, y.

finirness, alul wit, the one's for use...... Hethelle, ii.

aceorling to the fisir-gluy ol the world - 
FAIRY-your firiry, whiel, you (rep.)..Tempest, iv. 1, FAITU-by my faith, this league.... King John, ii.

yet this is your harmless fairy ....

sweet Nan present the fairy queen

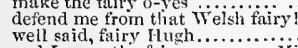

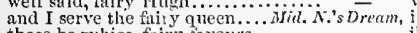

those he rubies, fairs farours.........

thou hast stolen a way trom friry land
the fairy land buy's not the child ....

the fairy land buy's not the child....

weed wide enough to wrap a fairy in
come, now a roundel, and a fairy song

eome not near onr fairy queen .....
so near the eralle of the fuiry queen?

eaptain of our fitiry bant, Helena is

iny fairy lord, this must he done ....

I have a venturous tairy that shail seek

and her fairy sent to bear him (rep.)

fairy king, attend, ajrd mark

antique fables, nor these tairy toys...

'tis almost fairy time. I tea-

every elf, and fair sprite...

hand in hand, with faicy

this is fairs gold, boy, and 'twili......

this is the fairy land; $O$ spite.. Comedy of Errors ii.

a fiend, a finiry, pitiless and rou

some night-tripring fairy had

to shouf think here were a fairy .. Antony $\&$ Cleo. iv.

are no fairy? no motion? [Col.-fairy motion?]

[Knt.-fairy-motion]................ Pericles,
no fairy takes, nor witch hath power. .. Hamlet

FAIRY-LIKE-fairy-like, to pinch. MIerry Wives, iv. 4

FAIRY-A1O'CION-
[Knt.] and are no fairy-motion?

Pericles, v. 1

FAITH-brealing faith with Julia. 7 iu oGen.of $r$.iv. 2

to praise his faith and honour..............

rend thy faitl into a thousand oaths

thou hast no faith left now

better hare none, than plural

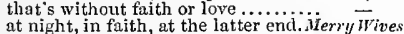

good faith, it is sueh another Nan

as firm as faith

with diseonrse of my dear faith...T. Tuelf $\bar{N}$ Night, i. apt in good faith: very apt!

that it is his ground of fith

in faith, they are as true of heart...

the tull assuranee of your faith

hold little faith, though thou

upon my faith and honour. Measure for Measure, v.
he wears his faith but as the $\ldots \ldots \ldots$. Much Ado,
in faith, my lord. I spoke mine (rep.)

if ever thou dost fall from this faith.

in faith, she is too eurst..............

by my faith, you say houestl

in faith, lady, you have a merry heart

in faith, I will go...

in faith, I will go.......................

in faith, my hand meant nothing...

with iair As Asé break his faith ...Mí

bearing the badge of faith, to prove..
disparage not the faith thou dost not

and all the faith, the virtue of .......

never faith could hold, if not to beaut
for paradise break faith and troth

for paradise break faith and troth

a faith infringed, which
and our faith not torn

and our faith not

yes, in good faith .....................
Biron hath plighted faitli to me.
my faith, and this, the prineess

content, in faith; r'll seal

in faith, tis a fair hand .............

to keep obliged faith unforfeited!

mean good faith? Yes, faith, my lord

almost makest me waver in my faith

with many vows of faith, and ne'er.

in faith, I gave it to the judge's.......
rivited so with faith unto your fles

now, in faith, Gratinno, you give...

but, good faith, I had as lief ......As you Like

now, by the faith of my love

as, by my faith, I see no ...............

all made of faith and serviee

hy my faith, he is very swift

that your true faith doth merit....

his faith, his sweet disaster

good faith, across: but, my good lord

now by my faith and honour, if serious

yes, good faith, every dram of it

betake thee to thy faith, for seventeen

I'll pheese you, in faith .. Taming of sh. $\overline{1}$ (indue.

You lie, in faitli; for you are called..

which, on my faith, deserves ligh speech - ii. 1
contrary to the faith and allegiauee - iit. 2 (indiet.)

burn hotter than my faith

adventure to mingle faith with $\mathrm{him}$.

but by the violation of my faith.......
as, in faith, I mean not to see him

you do awake your faith: then

at no time broke my faith... Comedly of Errors, iii. iv. 4

that still lireaks the pate of fuith
since kings break taiti upon.

yea, faith itself to hollow falsehood.

but ly the death of faith (rep.).

the fitiths of men ne er stained ......

keep our faiths firm an

welcome home again disearded faith

show now your mendel faitls .....

and true faith of heart, and sends...

[Knt.] the faith itself against the

I a thief? not $I$, by my faith ..........

in haithed, hast no fitith in thee?

stnfi as puts me from my faith .....

in faith, he is a worthy gentleman.

there's no more faith in thee than in

ay, by my faith, that bears

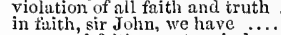

our royal faiths martyrs in love
will you thus break your faith?

your faith, and serviees, to this

erowned with faith, and constant..

by my faith, sir, but it is

do you in faith? I wear ont my suit

good faith, I Im no wiser than.

among professors of one faith

or feared thy faith.

ay, br my faith, the fiejd is...

why hast thou broken faith with me

now by my faith, [Col. Knt.-hand] lords

or good falth, you'll catch a blow. $3 \mathrm{H}$

With thy hand, thy faith irrevocabl

ay, by my faith, for a poor earl

good faith, good faith, the saying... Richard

your honour and your faith is pawned

thy broken faith hath made a prey

renouncing clean the frith ...........

where all faith was meant

if there be faith in men...

few words to fair faith

and yet, good faith, 1 wished myself

I do not eall your faith in question...

in faith, I eannot: what would you.

in faith, I do not; eome hither

in faith I will, la; never trust me else

O beauty, where's thy faith?

reliques of her o'er-eaten faith

I must not break my faith

a fine spot, in good faith

yet, by the firith of men, we have

untrod state, with all true faith..

no tricks in plain and simple faith ...

our fith mere foll

a way, away, corrupters of my faith!

fits thy faith: thy faith, thy name

I do not doubt thy faith.

Pericles, i.

a'll take thy word for faith .............

iii. 2 of truth, of faith, of loyalty............. 3 (Gower)

must be a fuith, that reason ............... Lear, i. 1

lest faith turn to despair

with him, that is renowned for faitli?

on earth, my faith in jeaven (rep.).

no money, on my tuith ..........

but what, in faith, make you from.....

in taith, my lord, not 1 . Nor I (rep.)

for my ease, in good faith ................

in faith, are very dear to fancy

by the faith of man, I know my price

in faith, 'twas strange, 'twas passing

in faith, too much; I nind it still .........

good raith, a little one; not past a pint .. - ii.

FAITII-BREACH-

revolts upbraid his faith-breaeh $\ldots \ldots$ Macleth,, .2
FAITHED - make thy words faithed?... Lear, ii,

FAITHF UL -a faitliful verity.......... for MLeas. iv. 3

pairs of faithiful lovers be wedded... isia $\Lambda \bar{D} D r$. iv.

to thee I'll faithf'ul prove ...... Love's L. Lost, iv.

ny blaek gown for a faitliful friend..

will your very faithful feeder be. As you Like it men's faiths are wafer-cakcs

my faith, sir? The secret is so (rep.)

if thy taith be not tainted

princess, that ever swore her faith FAITHF UL-a faithful shepherd. As you Like it, v. 2
to this most faithtul shepherd? do taithful homage, and reeeive free...Macbeth, iii. iii. 1 inseparable, frithful loves, stieking.. - iii. 4

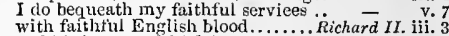
and his heart to faithful serviee...... - iil. 3 never did taithful subject more iejoice - ii. 2 your faithrul service, and your tuil. Henry as 1 am a christian taithful man .. Rickard $I I I$. i. 4 With your faithful love to me.......... $\mathrm{H}$ be not faithful $\bar{V}$ III. ii. i are all these your faithful friends.....
'faith, we hear faithful news ...... Coriolanus, iv. 6 my friend, fuitluful and just to me.Julius Casar, iii. 2 and my faithful friends, I have... Titus Androm, v. 1 of thy love's faithinl vow..... liomeo of Juliet, ii.

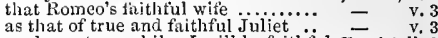
as that of true and faithful stay awhile; I will be faithful. Hamlet, ii. as of a man fit thful and honorable ...... - ii. 2 the fuithfullest offerings hatl .... Twelfh Night, y. 1
FAITIIFULLY - so faitlifully been.Love's L. L. ii. I I'll serve the true and faithfully $\ldots$ w $\widetilde{V e n i c e}_{\text {will }} \mathrm{v}$. as you have whispered faitlutully... As you Like it, it. was faithrully confirme.

as faithfully as I deny the devii.......... King John, i. their own authors faithfinlly affirm ..... Henry $V$.
both my fortunes faithfully ...... Henry VIII. iv not urge it half" so faithfully ... Timon of Alhens, iii. dost love, pronounce it falthfully.. Romeo \& Jul. ii.

thought but faithfulness and conrage .. Pericles, i.

for your faithtulness we will advance you - i.

she is issue to a faithless Jew...Mereh. of Venice, ii.

to make a faith less error in your ears. King foltn, ii.
umnatural and faithless service! .. Henry VIII. ii.

FAITORS-down faitors! have we not.2 Henry $1 \mathrm{~V}$. ii. 4
FALCON-as faleon doth the fowl.. Mea for MIea. iii. 1

and the falcon her bells........... As you Like it, iii.

my falcon now is sharp................ Aning of Shrees, jiv.

a falcon, towering in her pride

as is the falcon's light against ...... Richard II. i. 3

his theuts

so doves do peck the falcon's ..........3 Henry VI. i.

the falcon as the tercel, for all.. Troilus \& Cress. iii. 2

FAL' ${ }^{2}$ to to the Freneh falconers..... Hamlet, ii.

to fall it on Gonzalo

fens, flats, on Prosper fiali

mount their pricks at my foot fail

cannot ehoose but fall by pailfuils.

else falls upon your heads ...........

the blind mole may not hear a foot fai - iv.

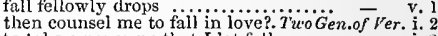

to take a paper up that I let fall .... -

$\begin{array}{lll}\text { growing ruinous, the building fall .. } & - & \mathbf{v} .4 \\ \text { ineonstaney falls off } \ldots . . . \ldots \ldots \ldots . . . & \mathbf{v} .4\end{array}$

rivers, to whose falls (rep.). Merry Wives, iii. I (song)
it had a dying fall ................ Tweelfh Night, $\mathrm{i}$. 1

but fills into abatement

if' both break, your gask

if this tall into thy hand

I should my tears let fall upon

tears let fall upon ......

the king...Meas. for Meas. i. 2

your brother's life falls into forfeit ...
than fall, and bruise to deatb $\ldots \ldots \ldots$.
another thing to fall

and some by virtue fall ..........

if any thing fall to you upon this....

lalons breoth to fall on him.... - iv. 2

falls into the dust fall from this faith.... Mueh $A d o$,

that she shall fall in love faste

thall fall in love with Beatriee....

for it so falls out, falls, weeps, sobs

falls into mine ears as profitless.......

her deatb shall fall heavy on you....

didst thoul first fall iu love with me?

frosts fall in the fresh lap:

here o'er and o'er one falls ...........

- iv.

you shall see, it will fall pat.............

submissive fall his princely feet.......

the people falls straight a capering ............ iver. of Venice, i.

an' the worst fall that ever fell .......

in eaning time fall paity-coloured... iii. $\overline{2}$ (scroil)

since this fortune falis to you....... - iii. 2 (scroll)

I fall into Cliarybdis, your mother

or it will fall to cure!ese ruin ........ $=$ iv.

disguised against me to try a fall...As you Likc il, j.

jou shall try but one fall ............ $=$ i. 


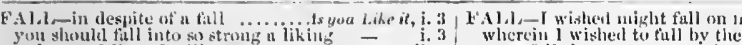

ii. ?. as sofily as foot c:an fall.

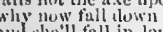

nul slectll fall in love. with iny

do not fill in love with me

gone fintl into our rustic reselry.

in jor, to the mensures fall.

pluck down, whll on thy lienti
that inlierit but the filli of the

one fair and virtuons mistress filil

when better fall, hut your avail

you shall see his finll to-nigint......

furteit to the next tile that falls $1 \ldots \ldots$.
because I would not fall out witli tiree

well thanked, whate er fiull more

lowe'er the matter fall, shall titx
I wonld be loath to full. Tuming of

fill to them, as you fiud your.

the priest let full the

that, frighted, thou iei 'st inil ........ïinter's Tale, iv

Solinus, to proeure my thll........ Conedy of Errors

the pig falls from the spit

as ensy may'st thou fall a drop
1 will full

1 will full prostrate at his fect.

'erleaps itself oud folls on the........

the sovereignty will fall on the other side

lout wail liss fill whon 1

and an cternal eurse fall on youl.

and fill of many kinge

let fall tly blade on roune.........

fiur fill the hones that touk

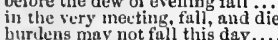

burlens may not full this day.
now fall over to my foes?

England, r'll fall trom thee

then Arthir needs must fal

unlecard, fall on your l:ead.
the truth will fall out so

and till betore his feet ....

grief boundeth where it fails

reluubled, fall like amazing...

ean never fall out good

firerun the death or fall of kings

fall to the base earth frorn

weuk men must fall for heaven

met with the fall of the leaf....
to make a second fill of eursed

to make a seeond fall of eursed
[Col.? here did slie fall a tear

rise thus nimbly by a true king's fall

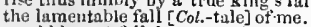

would he not fall down (rep.)

he never did fall off, $m y$

if le fall in, good-nigh

- i.

low would thy guts full about thy knees- iiii. 3

since not to he avoided it fills on me
tnore likely to fall in, than to get o'er.2HenryI $F^{\circ}$

but you fall to some diseord

shall we fall foul tor toys?
might not full in love with

and though we here fall down

that they fall into a kind of
mayy they fall as tloose that....

may" they fall as those that.......
how quiekly nature talls into

falls upon thee in a more fairer

old man: fall to thy prayers
without much finl of blood

and thus thy fall bath left $a$ kind

is like another fall of man

pure maidens fall into the hand

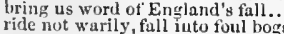

sone of thern will tiall to-morrow

I pray you fall to: if you ean.

if all things fall out right

and tall on my side so agains

we lyall to it with our teeth ..........

and flesh, and ginews, fall away.

a prophet to the fill of all our
lety full his sword before your

to fill down with a pinch.

that lears me, fall and die! .........
ard let her heal fall into England

from wondering, fall to weeping joy

at taint ure will

a fall vif of a tree $\ldots \ldots \ldots . . .$.
drinking, and fall to blows

sheould you fisll, he is the next....

to frame our sovereign's fall.

this way fill I to death

come, eome, let's fall in withi thein.

for our enemies shall fall before us

must Edward fall, which peril heuven

now I tall, thy thugh commixtures ..

unless she ehanee to fall

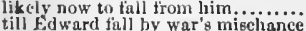

till Edward fill by war's michlance
and, hy my fall, the eonquest to.....
untimely fall of virtuous

and is: sounculant into a ulower

that fall out in sharing that....

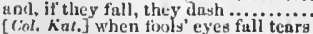

come, shall we fall to work?

when great leaves fall1, then winter..

and so falls it out with livers.
gtay him from the fall of vanit

stay him irom the fall of vanity ....
Ly sudden fluods and fall of waters.

with a heavy fifll the uanryius.

event as the uxe fill

arch of the ranged empire fill
dear Charmian, I shall fall.... and fall thy edreless sword (reph

with guilty fear, let fall thy lusiee!

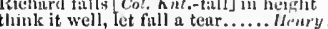

in your furturee of stect finlls on mic.

if it full, greater than this........

the greatest stroke orl' fortune falls..

tall anlece, or, hi

burdent ony sorrows fall upon ye
will fall sone hlessing to this land

tor a foul to fill by to

exhanlation..

and then lie falls, as 1 do .............

when he falls, he falls like $\mathrm{L}_{\text {ueife }}$

the dews of heaven full thick in.

or I full into the trap is laid
may hourly fall ulpon ye ?

and make him sill his erest .... Troilus cressiela,

stand till they fall of thernselves
my eousin will fill out with you

must fall out witll men too

which, when they fall, as being

would linve them fall upon him

the fall of every Plurygian

the eaptive Grecians tiall, even

Troy on thee, fall all together
fall down before him, ijke the

so, Ilion, finll thou next

or fortune fill into my keeping... Timion of $A$ th

that now they are at fall

and the gods tall on you!

wouldst thou have thy'selit itili

ours is the fall, I fear, our foe

whose fall the mark of his ambition

and sehools should fall for private

inust fall with those that have

for reproof, fall, and no more

or whether his tall enraged him

fortune, fall deep in love with thee

must fall out to him, or our author
he fall in a rage with their refusal

stop, or all will fall in broil.

a mile before lis tent fall down

but the fall of either makes the.
and $I^{\prime} l l$
renew me in his tall

your houses, fall upon your knees...... ullius $_{\text {incesar }}$

let Antouly, and Cosur, fall together

as low as to thy foot doth Cassius fall

et tu Brute? then fall, Cæsar........
Mark Antony, bild me fult down

still falls slurewdly to the purpose

here didst thou falls; and litere tly

what a fall was there, my

What a fall was there, my countrymen!
they fall their erests, and, like deccitti

for fear of what iniglit full

put off, fall to their tlysoats..................
titke leed you tall not: Henes, ini not

no disgrace shall fall you for $\ldots \ldots . .$.

portends alone the fall of Antuny

grace gruw where those drops fall!
and I I till under this phot.............

it smites me bereath the falli $I$ have

and, when we tall, we answe

unless it had been the fill of ani.......

if you fall in the advent ure.

some falls are means the happier

note o' the king, or I'll fall in them.

the hazard theretore due fall on me..
that's love, to have them fill no more

with Mars fall nut, with Juno ehicle

my tears, that fall, prove holy $\ldots . . . .$.
beavens fall on thiir heads like dewi

should straight fall mad, or clse.. Titus

confusion fall-Nay, then I'll stop.
hast thou hiut thee with the fall?

doth rise and fall between thy

tears that thy poor cyes let fill

come, let's full to; and, gentle girl
hand in hand, Lucius tund I will fail

for by his fall my lionour

ere their fall, scorn now thecir....

will soon to ruin fall, your ..............
doth fall in travail with laer fur

people's prayers ttill fall ungur you

wislles fall out as they're willed -...

Knl.] when majesty falls to fully

aftection fall intes taint

griendshin falls ofl, brotlyers divide.

of king falis trom his lizus of nature.

to fall and blast her pritel

why, then, let fall your horrihil
FAlLL-younger rised, when the old doth fall. Lear, iii. und not full to quarrel with your.

fill, ant rense! This teather stirs....... - iv.

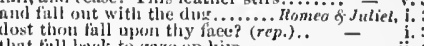

women may fall, when there's 8 .......

it beats as it would tall in twenty pieces -

and yet not till, so light is vanity

tear thy hair, and full upon the oround

Why should you tiall into so deep an $O$ ?

cries, ant then dow'n falls arain

to fill prostrate here, and beg.

that the litie-weary taker may fail dend

lics wherc it falls, repal of my face ..... Mantits,

Jever disl the Cyelops' hami..............

and fall a cursing like.....................

Jit tiall, unshaken, when they mellow be

when it tills, cach small annexment

oftence is, let the grént axe fall

hit shall not ehoose but fall ....................

$u$ trehle woe fall ten times trchle on

providence in the fall of a sparrar

[Knt.] What a fall Furtune does the thiek. olnello, $i$.

ven fall upon my lice

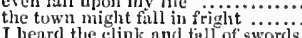

I heard the clink and titl of swords...

may fall to mutch you with her country

such drop she fall my neck

wo a erocodile - iv.

your attempt, shd lon to tall oult between - iv,

husbands' faults, if wives do fall

from his side, and fall to reprobation..... $=\mathrm{v}$.

the woman falls; sure, lie has killed $\ldots \ldots-$ y. 2

FALLEN-hiad not tiallen flat-lone.... Terapest, ii. 1

why she- $O$ she is fnllen into a pit... Mueh dous o iv.

that fallen am I in dark ....Mid. N.'s Dream, iii.

grieve not that I am fallen into. Mer. of lenice, iv.

thint you are not tallen from the....... All's Well, v,

that has fallen into the unclean.

master and mistress lathen out.. Taming of $\mathrm{s} h$. iv.

jersuasion, are again fallen off

(likenry IF: iji. 3

Inink you are tallen into the diseave

hath fillen iuto the liands of ......... Alenry $v$.

mischief never could have talleu....... ne - ij.

mow Margaret's eurse is faile.......... kichard $I I$ iii. 3

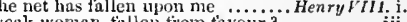

weak wothan, falhen from favour? ?

once fallen out with fortune.... Troilus \& Cress. iii.

like a gallant horse tallen in first.... - iii. 3

jour friends fallen otf..

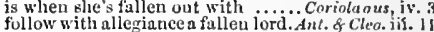

the star is fallen

the soldier's pole is fallen.............

you have fallen into a prinecly hand - vo :

infeetion is fillen into thy ear ... Cymbeline,

$\mathrm{I}$ an fallen in this oftence

but now lier priee is tallen

tallen ...............

but have i tallen or no?

things have fallen out, sir....... Romeo of Jaliet, iii. 4

purposes mistook fallen on thic

there's fallen between him and my lurd

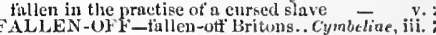

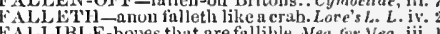

but this is most fallible........... Antony of Cieo. $y$

ALLING - falling in the fiames....... Areas. for Meas. ii. 3

of his own seorn by tinling in love........uch dido, ii. 3

which falling in the land .....Mlid. . N.'s Dream, ii. 2

falling out thut year on $A$ sh- ...... Mer of lence, it.

falling a lip of much collemint... Hinter"s Tale, i.

falling there to fund his fiellow. Camedy of Errars, $i$.

is held trum fulling witl so weak ..2 llenry $1 \%$. iv.

and, in fallings, struek me..........kechard 111 . i.

and, somctimes, lalling ones ........ - iv. 1

a cruelty, to luad a fuliting man ......

promuted sword falling on Diomed. Cresida,

It stancls againt a lin!ling tabric.... Cnriolantus, iii.

certain fialling, or so slipluery (rep.). Cymbehue, iti. ,

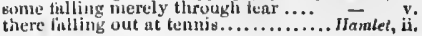


FAUTING-FROM

the falling-from of his friends. Timon of thens, iv. 3
FALLING-UFF-a falling-off was there!. Hamlel, $\mathrm{i}$. 5 FILLING-SICKNESS-

he hath the falitug-sickness (rep.)...Julius Cors $n$ r, i. 2 the bare fallow brings to teeming...Aerry Wives, her fallow leas the darne

FALL

all'st, $O$ Cromwell, me so lucki

fall'st thou upon thy fou tall'st ..Hemry $/ M$. iii.

FAlO

in un false false uncle-

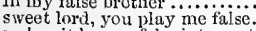

or my false transgression

elready lizve I been talse to valentine

he plays false, father

but yet so false, that he ................ -

thou subtle, perjured, false disloyal man!

and adore false shapes

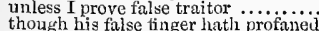

thau have false Proteus rescue me.

I do detest false perjured Proteus .....

it is talse, if it is a piek-purse

a false conclusion; I hate it...... T'welfh Night, ii. 3

and words are grown so false...

wiser souls to thy false seeming?......

to make a false one................
and credulous to false prints

my false o'erweiglis your true.....

pay with falsehood false exacting

rum with these false and most

and hide the false, seems true

what he doth know is true, and false

he wou it of me witl false dice

lose nothing of the false sweet bait

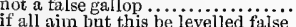

little better than false knaves........

in a false quarrel there is no true.

sir, they have committed false report

mine and my master's false accusation

and uot a false turned true

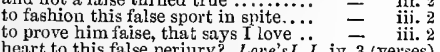

heart to this false perjury?..Love'sL.L.iv. 3 (verses)

ravish doters with a f

false; we have given thee faces

false; we have given thee faces .......
ourselves prove false, by being once false
played false with a smith....

phose hearts are all as false as stairs

even so void is your false heart

is the very false gallop of verses.......

and play false strains upon thee! ....

fly with false aim; move the........

the story then

get theegone, thou false deluding. Traming $n \bar{f} S h$. iv. 3

false as o'er-dyed blacks (rep.).... Winter.

that faise villain, whom I emploved

every dram of women's flesh is fals

$=$ ii. 1

shall make false accusation blush ....

I am false of heart that way

if it be false, son? If 'it be ne'er so failse

from my false hand cut the ...

mufile your false love with some

thou speak'st false in both

and pluek out these false eyes........

as this is false, he burdens

and this is false you burden me.

wouldst not play false, and yet woinli

a false creation, proceeding from the

which the false man does easy

avaricious, false, leceitful ...

my first false speaking was.......

then fly, false thames, and mingl

if thou speak'st false, upon the
if she dia play false, the fault.

false blood to false blood joined

you think them false that give.
fill these dogged spies with false

fill these dogged spies with false, or false, I know not..

whose tongne soe'er speaks failse

Wike a false traitor, and injurious...... nichard 11.

fetch from false Mowbray....

through the false passage of.............. -

'tis with false sorrow's eye ...........

whose duty is deceirable and false

what thou hast said, is false.

as false by heaven, as heaven .........
his prayers are fall of false hypoerisy
thou judgest false already ..........

(for recreation sake) prove a false thief

have it, as you are a false thief

sb!ood, my lord, they are false

they bring smootl comfurts false ...... -

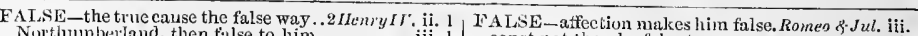
Northumberliand, then fulse to linim.

as a false forcurite doth lis...

now, fie upon my false French!........ Herry $r$ iv. 2

will I trust, if slie prove false .......... Henry $V I$.

nor any ot his fulse confederatos.

study and my books be fals

where talse Plantagenet dare not he. it is the false ste ward, that stole his......

canst not then be false to any man .... Hambet, i. 3 what! frighted with false fire! .......... - iji. $z$ as tatse as dicers' oaths: $O$ such $a$ deed ... — iii. 4

tissembling guile?

is an idle and most false imposition...........

as for your spitefine, the trust

false fiend, avoid! Lay hands

by faise accuse, doth level at

I shall not want false witness....

the winners for thation

al2, that nuy for they played ine talse!

that e'er I proved thee false.

return we to the fialse duke
or thou not false like him?

it my susject be false, forgi
it false Suttolk dares him?.

I would, fial se murderous co
muless talse Suffolk strainlit.

sueh fell serpents as false suffoli

that's talse. Ay, there's the question

they call false caterpillars

false king! why hast thou broken....

by Warwick, that false peer...........

and thy lore woman, as

tell false Ed ward, thy supposed

such things, in a false disloyal kua if she he false, $O$ then heaven mocks..... - iii. 3 ha! ha! false to ine? to me? ... ...... false as hell. To whom, my lord? (rep.)... iv. 2 she was false as water. 'Thou a....

and bid filse Edward batcle

I fear me, bot false, and treachtrous... Richard $\mathrm{h}$ in

the envious are talse..

afford false Clarence? and so he

Clarence is come; false, fleeting...

for false forswearing, and for nurder

for comfort have but one false glass.

to from such false triends! (rep.)...

slauder myself;, as false to Edward

never was, aud never will be false....
when I was found false to his children
by the false faith of lim whom .......

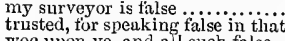

woe upon ye, and all such false.
such doubts, as false coin from

such doubts, as false coin, from

if I be false, or swerve a hair.

from false to false, among false maid

as false as air, as water, wind ........

if ever you prove false one to another

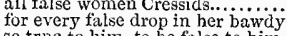

for every false drop in her bawdy...
so true to lim, to be false to him

$O$ false wench, give ' $t$ me again
$O$ false Cressid? false, false, false

turn thy false face, thou traitor

methinks, talse hearts should never. Timon of Ath.i. 2

leave their false vows with him

never more false title plead.

you should have teared false time

diseases lick up their false bloods

would you have me false to my

his elothes made a false report

boy! false hound! if you have

the strings, my lord, are false....

who have been false to Fulvia?........

tis false. From Silvius, sir......... - i. 3

false, false, this, this. Sooth, la........ - iv.

and false played my glory uinto

and false plaved my glory unto.....

that the false housewite Fortune

to try your taking a talse report.

to allure false hearts, and be false with

O abore measure faise!

what false Italian (as poisono
whose talse oaths prevailed

false to his bed! what is it, to be false? =

like false Aneas, were, in his time (rep.) -

shall be false, and perjured, from thy

mine ear, therein false struek

that, wlich I fear, prove false!

true to thee, were to prove false.......

with them, since Leonatus false ....

dream often so, and never false

and my false spirits quail to remember

if it be talse shadows tor true.. Tilus andron. iii. 2 if it be true that I inter'pret false $\ldots . .$. Pericles, i. false of heart, light of ea.

true, or talse, it hath marle thee
false justicer! why hast thou let

when false opiniton, whose wrong

政

thou may'st prove false .................. Juliet, ii. 2 iii. 1 1

my husband say, that she was faise?......

but did you ever tell him, she was false?
she false with Cassio! did you say ......

Folse-boding woman. Rich. $I I J$. i.

FALSE-1EEART-a false-lyeart traitor.2IIenry $/$ l.v. I

Diomed's a false-hearted rogue.. Troilus \& Cress. $v$.

slander Volentine with falsethood. Tü ...Tempes', i. 2

she twits me with my falsehood to .. - iv.

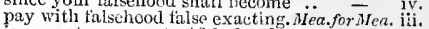

is a great urgument of tiulsehood. . Love's L. Lost, i. 2

goodly ontside falsehood hath!. Alerch. of $\overline{\text { Verrice, }}, \mathrm{i}$.

being counted fal sehood, shall... Winter's 'Tale, iii.

shall proceerl; this is mere falsehood and falschood falsehood cures; as fire - iii. truly as a man of falselivod may... Richard $I I$. iv. consuming canker eats his falsel.... Heod.1 Henyy $V$. 1 .i. buckler falsehood with a pedigree?.3 Henry $V I$. jii. confound your hidden falselioud ... inichard III. ii. and worthily my talsehood? ......IIenry YIII. ii.
in love, upbraid my talsehoodi. Troilus \& Cress. to stick the heart of talkehood ...... - iii. my husbandry, or falsehood .. Timon of Athens, ii. 2 exeelleut falsehood! why did he.. Antomy \& Cleo, i. I and falseliood is worse in kings...... C.

your bajt of falsehood takes his carp ... Humlet, ii.

'tis all as easy falsely to take ... Meas. for Meas. ii.

lady Hero hath been falsely accused. Mruch Ado, v.

truth the while doth falsely blind. Lone's L. Lost, i. 1
true love, which is falsely attempted? thou speak'st it falsely, as I love ....All's $\overrightarrow{W r}_{\text {ell }}, \mathrm{v} .3$ had falsely thrust upon contrary ... King John, iv. 2
most falsely doth he lie ............ Richart II. i. I most traly falsely, must needs.......... Henry $r$. v. 2 falsely to draw me in these vile ..2 Henry VI. i. 3 England's chair, where he is falsely set laid falsely $i$ ' the plain way ....... Coriolanus, iii. 1 the witness, and he's indited falsely.... Ohello, iii. O falsely, falsely murdered! Alas ...... FAL'y tice speak; talseness caunot come. P'erieles, Y. I and that I dare not, fal ser........ Julues Cersar, ii. 2 if sir John Falstaff have committed..

is sir Joln Falstaff' her'?

Falstaff will learn the humour of.....

for thee to fight, John Falstaff........ - ii. 1 (letter)

Falstaff loves your wife.

sir John Falstaff, sir John Filstiff! !

and Iralstatf's boy with her ...........

there I shail find Falstaff.

that Falstaffi is there; I will go.........

what, sir Joln Ealstaff? are these .

special suspicion of Falstaff's beirg here -

amother errand to sir John Falstaff .

as Falstaff, she, and I, are newly met

go, send to Falstaft straight..........

wherein fat Falstaff hath a great scen

rejoice so mucl at the abuse of Falsta

I liave removed Falstaff's horsc......

dri re away the time till Falstaff come

Falstaff and the rest of the
I pr'vthee, call iu Falstaff

and Falstaff, you carried your guts...

how came Falstaff's sword so haeked
remember me, his name is Falstaff. itself to hollow falsehood change!.. King Jork, iij. shall winnow the truth from talsehood - v. FALSING-in a thing fulsing, Comedy of Frrors, ii.

a diszuise to sound Falstaff.........

Falstaft's a knave, a cuckoldiy knave

sir Joln Falstaff, serve Got, and lcave
Falstaff, Bardol ph, Peto, and.........

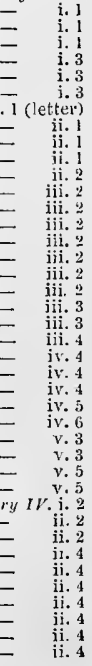




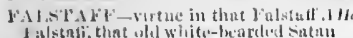

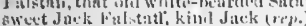
to sny in heluilt of thint $k$ ulstatl.

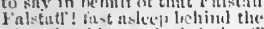

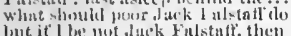
lint it I be mit aluek fiulstaft, then

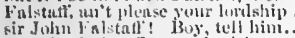
sir Jolin lenlstatt, a wold with you, sunre, Wcmist arrest sirduhn lenlsta and sis inuel congralled to l'ulstat and the tue enot 1 gnce loustut John linktutt, kmight: every mu Juek Julstati, with my tuniliurs.

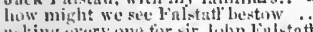
askinge every one fir sir Juhn ladstati Then was Jack leaktats, now sir Juhu here coine two of sir Jolin Falstall's. my eaptuin, sir dulun Fnlstati

1 think, you are sir Johu falstati.... now, ralstatr, where li

you must now squen sir johin Falvi a in go, enri'y sir Johin l'alstall to the l'leet

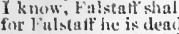

fir talaif he is dead

FAl.T.

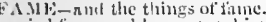

(riw) fance and houou on him ......

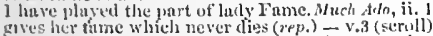
gless her time whicls never dies (rep.) let tume, that all hunt after.

tu know nought but fame............

when, for fime's sake, for praise....

when, for fime's sake, for prais.
thut fame may ery you loud.

that set him in high taine.

glane lutli a bastard fame... Comedy or firrors. iii. 2

l uni in grod name and

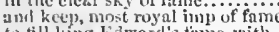

to fill hing Ldward's twe with....

cheth win immortal tam

would sive all my fame for a pot of ald

these Enghish, or else die with tame.

how mueh he wrongs his fame

thuu art no less than fame hath....

his fume lives in the great

thy yoliti, and England's fäme.....

lift, aud slay bright fame

enneelling jour fame.................

where fame, late entering at his....

my meed hath got ne fume

whthing difters but the outward fimo

without eharncters, fame lives lon

of ereat fume coll hin

havilitg heard by tame of thi

as great in fimo as sle was.

full of his airy" ftwe

shat s their fitne in peace.

nud farme, in time to eur

when fume shall in our is lut

my tame is shrew dly gored ........

fail, fame; howour, or go, or st

where he was like to find fame.

more than thy fame and eny.

with fume, n nome to Cains inreius.

read his fume mimaralleled, lujply.

lulp torenp the fame, which he
muth his. fouse folds in this orb

disy jim cockery shall have the fame

hy our tlect aequire too high a fame.

muregistered in v'ulgar fimie.

the nane of fune, and lumour...... Eizmbeline, alul tane's etersinl cate

rurvive, and you that siecp in fitme.

rejerec in fame; none basely

he lives in fume that died int

Fante answering the mot stron
und set $111^{2}$ your tume for ever.

whe a fame hacl sprend their eursed -

anil triek of fame, go to their graves.
varnish on the faine the Firenghuman.

paragon's deserijtion, and wilu fame.

Fill biv-lie was much famed.

frum lis mest fatned of famous....

they slall be fimed; for there

as he is famed tor mildness

\begin{tabular}{l} 
Cress. i. \\
$=\quad$ i. 3 \\
$=\quad$ i. 3 \\
\hline
\end{tabular}

fimed he thy tutor virtums

but it was fumed with on parts. Troil. 4 Cress.

the famed Cassilyclan, wh.. Wits ince. Cymbeline, iii.

FAll],IAl -it is a familiur beast... Merry Mioes, $i$.

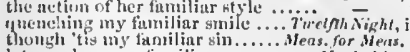

thongh 'tis my faniliar sin......

ly a familiar fletomstration.

iovere's L. Losi,

weve is a familiar; love is a tevil.

ant my fumiliar, I do assure you.....

direness, fumiliur to my slangh trutis... Shebeth,

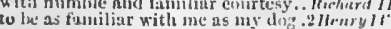

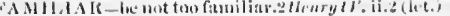
things nequainted ams fumiliar to y

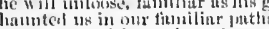

as fumiliar with men's poekets

then shull our narues, tamiliar

1 think, here vild fmuline is aslee

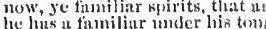

and most fiumiliur to my nuture,
it is familiatr; but int the anthor'

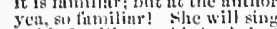

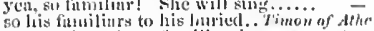

thant we luse laces tamiliar, ing

but nut with soleh fandiliar instand

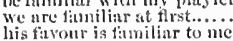

mavle fimuilin to

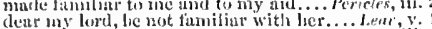

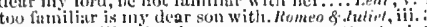

ine thum fimiliar, lut by numeans...... Ilambet, i.

that he is too fumiliar with lis wife.

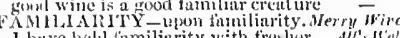

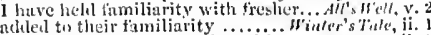

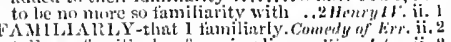

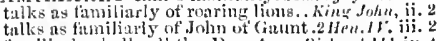

tiuniliarly shall call thy lorset ... Richard Mi.jv.

$\Lambda \perp I 1,-$ and win your tum

eome they of nolde family?....

Hewry it. it

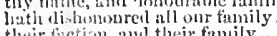

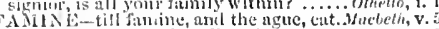

humg alive, till fomitie cling thee

shonli lambe, sword, and fire.. Menery ${ }^{2}$. i. (chorus)

lean limine, yustrtering stee

fumine, alud no other, lath slain

o'erthwing Nilus presagetis fam
at thy lacel did tamine tillow ....

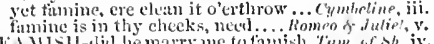

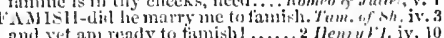

or else you fumish, thant's

rather to the, thin to timish

sullir us to fimish, and their ........... Corrolusus,

whilst their own bircls fimish in..... Pituts tndron. if

breust-deep in the earth, atrl famis

F.AllsILED - I am famished in... Mer.of

the fanished English. like pale

I see, this city must be famished..... - i. 1

ould to eombat a poor fumished man - iv. 10

with a single fimnished kiss. Troilus of Cressiche,

FANOUS-to this fanous duke of MIilan. Thmpest,

he was famous, sir, in lis profession

the one as famous for a scoldin

this place is famons for tine
by that most fanous warrio.

upom my head, and all this tamous jand -

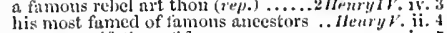

your grizndfatlier of famous memory - iv

Henry the fittlh, too fitmols to live. .
I shall as fimomis be by this.........

then derived trom famous Eilomind

so, in the fimonts ancient city.........
made the wizarl fanous in his death

made the wizard famous in his
won by timous York, shall be..

were he as fannous and as bold

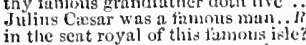

finmous ['lantagenet, most gr'acious

nll famous colleges almost in ....

though unfinishel, ret so tumous...

would desire my fumous consin to. Froil. forms.

and Nenas, fanous pirnt

thine uncle (fantons in Catsing

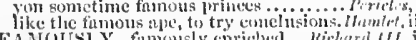

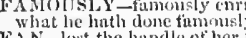

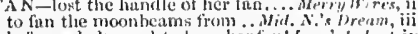

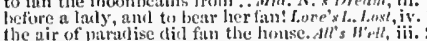

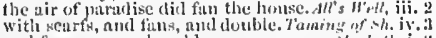

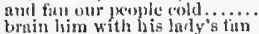

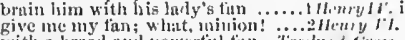

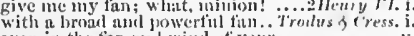

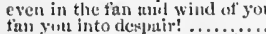

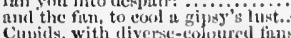

mase me to tan yirn thus

my tinn, l'eter. 13r'y tlice, dio (rep.)

tis fiteli her fiul, her glover, her mas

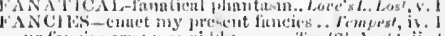
war fancies are more chldy .......

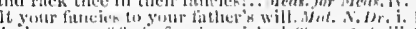

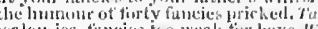

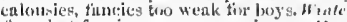

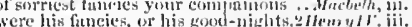

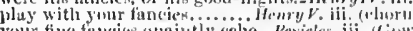

he it as your fameies teach you ........ Oherlo, iii.

his figity flould hunt uffer new funcies -

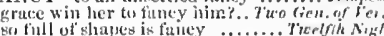

that should she funcy it sho
let fincy still my semse in

and Jis fancy's quect.

us funcy values then .......Mecturefor Metasure.

no sppestrance of fincy in him

lie is no fuol for formey, as rous.

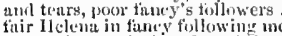

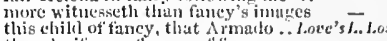

the veluriferous flewers of there

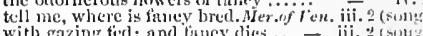

with gazing fed; and luney dies

ct us all ring tancy's kncll
tresh clieck the lower of fim

the food of sweet and bitter lat
thy faith my fancy to thee fiot

my idolutrous faucy unst sultify...

for I subnit iny fancy to your cy'ts.. - ii.

every one to be a mun of his own fancy - iv.?

or worthless fimey; then talie. Thmong of s/to I (imi.)

could fancy nore than any other..

that dijuen doth finey nny otlo.

your own weak-hiuged faney........inter's Tale. ii. 3

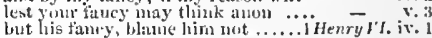

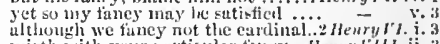

nirth with your lurticular fancy... Henry $l^{\prime} / 1$. it. 3

such good dreams posacs your fincy - iv. 2

roines \& Cress. iv.

and the buildings of my fines'...... Corioimus, it. I

to vitey ont-Work nature...Antomy geteopatra, it.

to vie strange forlas with tuney

by your taney's thanktul boun. Perictes, $v .2$ (cions.

ealch buz, each fancy, each coinglant...... tect it.

lut not expreavel in fancy; rich........
infinite jest, of inest excellent fancy

are very dear to faney very resuey

what luerible funcy's this? Sume of .... Othetlo, is.

is maden meditation, fancy-free .. Mhd.N.Dr. ii.

I emll meet that tancy-monger...s yoa Like t, iii.

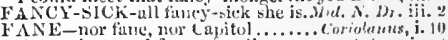

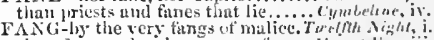

sinee 1 am a dog, leware my fangs. Mer ant lin. ili.

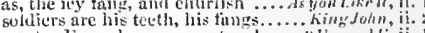

master Fang, have yout entered

good umster Fang, hold him sure.

destruetines, master Falf.......... ii.

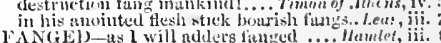

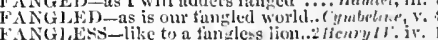

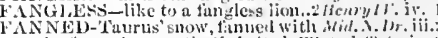

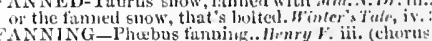

with fanning in his face ............ it.

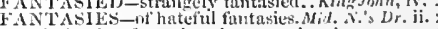

anch shaping fantusice, that upprehene

many leyiuns of strange fiantusies . King John, $\mathrm{x}$

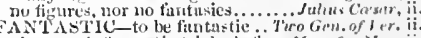

plays such lantastie tricks hetore. Ween, for Meet, i

man anil fantastic execution. T

funtastie garlands did sla inake ...... Hismet, i

that it aloure is high fantastieal .. Twrigh . vight, $i$.

it whs n mud tuntastical triek... it

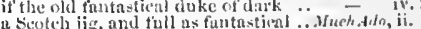

his word are a very funtustical bamplue -

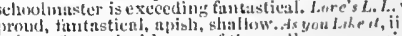

ue'er a fintastieal konve of them all

more molic in theing lantastical.. Wmeter's 7 al,

are ye fint:sticul, or that indeed ....... vacteth, $\mathrm{j}$.

whise merder get is but fintusticul..... oshato, it.

FANTANTCALAT-

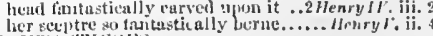

FANTAsTicosis-

isping. alfecting fantastienes.... Kome of Juli.t, ii.

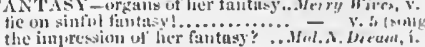


FANTASY-drawn to Jiy thy funtasy. As you Like, ii. I to be all made of fantasy, all made

or is it fantasy that plays .............. Henry $I V$.
than $I$ have drawn it in my fiatasy .2 Henry $I V$. fantasy, of dreams, and ceremonies, things unlnekily charge my timtasy.

ar, ili. 1

begot of nothing but vain fantasy.

iii. 3

IIoratio says, 'tis but our fantasy........ Hamlet, i.

is not this sometlung more than fant
for a fantasy, and trick of time...

nothing, bit to please luis fantasy

FAP-and being

know thus far tionth

who is so far from Itair removed .

... Othello, iti.

but she as fur surpasscth Sycorax..

catch your royal fleet far ofl

for fiur behind his wortl.

far fir from the ground

far from the ground.........

$a$, i. 3

slanl far exceed the love............. $=$ iii. 1

that's fur trom granting...

that's firr worse thau no
he's as t:ur from jealousy

Mierry $\overline{\text { Tives, }}$ ii. 1

so far forth as herself night...........

for I am now so far in offence.

so far exeecd all instance
so far beneath your soft.

tongne far from heart...................

thus far can I praise him .

Much Aio, î. $\mathrm{t}$

so tar be distant, and good night............

and so far hlameless proves my

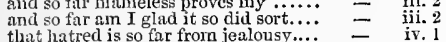

requests so fur from reason's

thy love is tar from eharity.............

I will run as fiar as God has.. Blerchant of Venice, ii.

yet look, how far the substanee...

so fur this sliadow doth limp

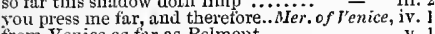

from Venice as far as Beimont.

to travel forth so far?

As you Like it, i. 3

had it stretehed so far, would have.

do not plunge thy self too fiar in ange

whilst 1 from far, his name.

I am so far dceeived in him?

let me buy your friendly help thus far $=$ iii. 6

out-villained villany so far ........
know how far I may be pitied

a lady far more beautiful ... Taming of Sh. 2 (ind1ue.)

it shall be so far forth friendy

sinee we have stepped thus far in...

were my state far worser than

travel you far on, or are you .....
up further; and as far as Rome

since we have come so far

mingle friendship far, is mingling. Winter's Tale, i. 2

'tis far gone, when I shalt gust

so far, that I have eyes under my...

is it not too far gone? not our kin, far than Denea........

not our kin, far than Dence
for being so far officious...

sorry, sir, I have thus far stirred you

I'll not seek far, (for him, I partly.

ships from far making amain ..

far from her nest the lapwing

thus far I witness with lim

how far is't ealled to Fores? ..........

is't far you ride? As far, my lord.
stcpt in so far, that, should I wade

or far off, well won is still well shot..... King John, i. i

art so far, that thou hast underwronglit

and now 'tis far too huge to

Norfolk, so far as to mine enemy ....

Riehard II. i.

sinee thou hast tar to go

how far brought you hi

as far from home, tor Christian
York is too far gone with grief

he is gone to save far off...........

how tar is it, my lord, to Perkley, now?

and far surmounts onr labour.
how far off lies your power?

how far off lies your power?
Richard, not far from henee

how far off from the mind

so far be mine, my most redoubted...

court as far as Calais, to my

better far off than near, be ne......................

is far as to the sepulchre of Christ.... Henty Ir. i.

[Kni.] tar more uneven and unwelcomc
so far as my coin would stretch......

to be delivered as far as Charing-cros

niure own flesh so fir afoot again

so far afoot, I shall be weary, jove ....

in a windmill, far,

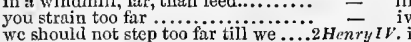

thou think'st me as far in the.......

how far forth you do like.

heard the eoluse of it so far

fire, as far as france.................... Henry $r$. . . 2

FAR-to tlireaten, rnns far before them.Henry $V$.ii. 4 , FAlR-well, you may fear too far. so tar my king and naster........... - iii. 6 [Col. Kni.] safer than trust too fin.

ny office hath so tiar prevailed....

this far, with rough, and all unabie - v. 2 (ehorus) far more glorious star

hetter man of arms by far.

better fur, I guess, that we.......... - ii. 1

cvery country far and near...........

fiur truer spoke than meant..........

whose far unworthy deputy I am.

far be it, we should honour sueh......

I am far better born than his.

fur be the thought of this

and creep into it far before thy time?

of Greeee was fairer far than thou.

elangour lieard from far.

is far heyond a prince's delicates....

wish the crowm, being so far off.

yet thus fiar fortnne maketly

how tar licnee is thy lord.

ill a far truer love, to both...

Richard III

far be it from my heart.

and as it were far off, sound thou....

toul this sparingly, as 'twere far off

how far I aun trom the desire...

but I inm in so far in blood ............

thus far into the bowels of the earth
low tiar into the morning is it........

0 , you go far. As I belong ....

to ruminate on this so far......

as fin as I see, all the good our

you that thus far have come.

yet thus far we are one in

how far I have proceeded, or how far

and thus far clear him.....................

trutli and him (which was too far)

as all my other comforts, far hence.
far from his suceour, from the kin

press not a falling man too far

but far beyond my depth ............

and thus far lear me, Cromwell.

yet thus far Grifith, give me.

bid ye so far forget yourselves?.......

this far, my most dread sovereitio...

will not eome far behind him.. Troilus \& Cressidct

short of our purpose so far.

as far as toueheth my........

holds honour fur more precious dear..

and thus far I can confirm.

will you befriend me so far, as to
if it be so far beyond his health.....

$=\quad$ iii. 2

Henry VI.

et him fly tar; not in thi

dare build so far to man

Knt.] mareschal of Franee, monsieur le Far

far off, methinks, I hear the beaten......

bosomed with her, as far as we call hers = $\mathrm{v}$.

demanded, ere you had spoke so far...... $J \overline{\text { atiel, }}$. 3

far from sounding and diseovery.

wert thou as far as that vast sho....

proves thee far and wide a lroad goose

yet so far hath diseretion fought. ...

your wisdom so far to believe it..........

ii. 2 he is far gone, far gone ..................

so sick of late, so tar from eheer ........ - iii.

o far he topped my thought

free ine so tar in your most

free me so far in your most generous ... - $v$.

Fill not be far from you...........

FARCED-the farced title running .... Henry $r$. iv.

RDEL - that in this tardel, will. Winter's 'ale, iv.

the tardcl there? what's i' the fardei? - iv.

sucli secrets in this fardel, and box.. = jv. 3

at the opening of the fardel, heard

I heard them talk of a fardel.

FARE-how fares the kinut and swent. Hamlet, iii.

thes thest,

be free, and fare thous sir.

fare thee well; eommend ...........13ervy wives, ii.

should be cozened: tiare you well.....

fare you well, sir .....................

fare you wetl: 1 thank you........... - i.

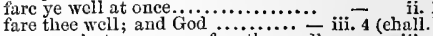

come again to-morrow; fare thee wenl - iii.

f thy grandam; fare thee weil ........

so, fure you well ...........Measure for Measure, i.

I tlinnk yon, fare yon weli

Pompey, fare you well

to my housc; tare you well ..........

furc you well, good father............

to visit the prisoner; fare you well

I shall sir: fare you well ..............

you go: fare rou well MruehAdo, ii. 3

but fare thee well, most toul ........ -

so will it fare witly Clandio

well, tare you well, my lord

then is spoken; fare jou weli now....

and leave us; tare you well .............

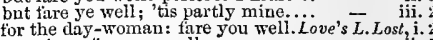

monsieur, tare you well............. - i will do it, sir: fare you weli..

how fares yonr majesty? and Lorenzo: fare you weil......... Nerchan of $\overline{V e n i c e, ~} \mathrm{i}$.

fure ye well, a while fa.................

but fare thee well; there is a dueat..
fare yon well; your suit is eold

fare yon well; your suit is eold
so fare you well, till we shall ......

ii. 7 (seroli)

I will set this foot of mine as far......ulius $\overline{\text { Casar, }} \mathrm{i}$.

may well streteh so rar

press not so upon me; stand far off.

tar from this country Pindarus.

a bourn low far to be beloved.......... Antony $\&$. Cleo. i.

yet far filirer than you are ............

tempt him not so too far .......

do so far ask pardon, as hefits........

there, my musie playing far off.....
so far as we lave quarter............

we have engaged oursclves too fä.

so far preter her 'fore ours (rep.

only thus far you shall ans

so far I read aloun

who is as far from thy report

and tell a journey twiee as fil

how far it is to this same blessed Mifilford -

my name was not far ofi

Why hast tholl gone so far

so far as thou wilt speak

madness could so far have raved $\ldots . .$.
pray, how far thither? Ods pittikins!

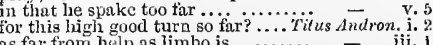

as far from help as limbo i

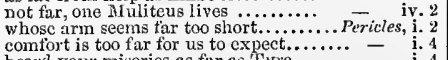

heard your miseries as far as

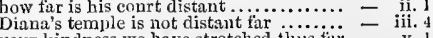

your kindness we have stretched thius tiur $=$ v. 1 fare you well, fair gentleman gallant

much bounden to you; fare you weili

to thee, shepherd: fare you we

- iti.

I must not liear thee; fare thee weil ${ }^{-. A l l} 6$ Well, ij. 1

of lattice, farc thee well ............
at his prayers; fare you well. my lord $\quad$ ii. 3
ii. 5

an impudcut nation; fare you well.. $\overline{-}$ iv. 3

how fares my noble lord?.. Taming of $\$$..$\overline{2}$ (induc.)

how fares my Kate?....................

then fare the well; I must go ....... $\overrightarrow{\text { iv. }}$.

a merry man, sir; fure you well. Comedy of Err. 1ii.
tare thee well, my lord............ Nacbeth, iv

fare thee well! these evils

madam, fare sou well; I'll send .......

fare you well; liad you such a loss... - iii. 4

how fares your majesty? .......... - v. 3

how tares your majesty? Poisoned... ${ }_{\text {hich }} \overline{\text { vard }}$ II. ij. 7

Harry, how fares your unele? ....... - ii. 2

so, fare you well; unless you.........
how fares your grace? sir Nicholas.. Henry $V$. v. 4

brave Percy: far' the weil, great....

tare yo-well; go: this Doll Tear-sheet - ii.

well, fare thee well; I liave known..
fare sou well, gentlemen both ...... on yon: tare you well, Jessica......... - iii. 4

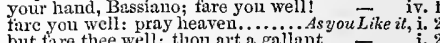

have with you: fare you well ........ 


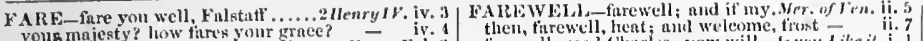

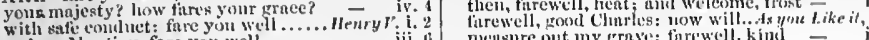
and si, Mlontjoy, fare you well and si, Mont wy, fare you well on fure the well: thou never sliuit. Englisls eondition; tare ye well so fare ny limbs with lome
how dost thou fire? wilt thoil hrewell; and better thelp lords.

frow fares my, gracious lord? Conifirt it bow wonta tire with your lepurted - is whut fore" what iucw's abromin? this bnttle fures like to the mornings' - ii. then fire you well, for 1 wil

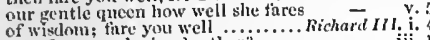
how fares our loving brother?
how fares our eonsin, noble loril or York mother, how fares your grace?

ny lord Alwergn'ny, fise you well...

ent, my little good lord - iit

fare you well, witl all my leart

二

fure you well. All hrppiness to.7'imon of $\bar{A}$ thens, $i$.

well fare you, gentlemen...

fare thee well, fare thee well ..........

gay, thou saw'st me not: firre thee we

fentlemen both: and how fure you

it thes will fine so harshly on.....

why, fare thee well: here's some

. come, fond...... Coriolnnus, i.

hath yet not warned me; taw
fare you well. Ile has it now

fare ye well: thou hast year ".

fare you well: there was more $\ldots . .$. Julins $\overline{\text { Cessar }}$

fure you well. What-said Popilius Lena

to this little measure? fare thee well

of all the Romans, fure thee

so, fare you vell at onee $\ldots$ ili.....

your hand first: fure yon well, my lord -

$\mathrm{m}$ v learest sister, fure thee well

determine one way: fare you well

fare thee well, dawe, whate er $\ldots .$.

fure thee well, Pisanio; think on...

vet to name the winuer: fare you well = iix.

how fnes my mistress? ..............

you shall fare well; you shiali liave ... Pericles, iv. 3

fare thee well, king: sinec thus

in time: fare you well, sir $\ldots \ldots . .$.
how fares your graec? What's he.

conceive, and fare thee well............... iv. 2

how fares your mnjesty? You do me wrong - iv. 7

why, fare thee well; I will o'erlook....... - - . 1

how fare you well: upon the platform..... Hamlet, i. 2

God be wi' you; fure you well ............

God be wi you; fure yout well

fare you well, my lor liamlet?

how fares $\mathrm{mr}$ lord? Gire o'er ..........

fare you well, my liege: I'll eali upon you - iti. 3

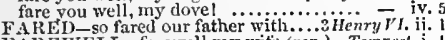

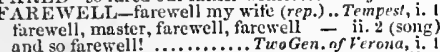

Julia, farewell! whati gon

at snint Gregory's well. Fareweli.

beeause thoul lorest her. Farewell

well, farewell! I am in

fare kell to your worship

the horn. fary, farewel ..............

larepell, iny hearts: I will to my.... -

or bid farewell to $y^{\prime}$ onr good life for ever -

farewell gentle mistress; farewell, $\dddot{N}$ an $=$

farewell, mistress Page

to the count (Ursino's court: firrewell

anil diceam on the event. Farewell

a gon! royage ofl' nothing, furewel
farewell. She that wouldialter...

of $\mathrm{it}$, master Froth: furewell.............. or or seas. ii.

hold $y$ on there: farewell $\ldots \ldots \ldots \ldots . .$.
farewell: go; sty $I$ sent thee thither

farewell, gowl lompey; commend mo

farewell therefore ylero!

do so; farevell. Come hither, Leonito

enntempt farewell! and maiden pride

farcwell, thou pure impiety

You kill me to deny it; farcweil $\ldots$.....

lords, farenell. Farcirell, my lords ..

furewell, sweet play fellow; pray....

farewell, thou lob of syirits, I'll be .

and farewell, friensls; thus Thisby ends -
and so farewcll. Fair weather.... Love's $L$. $L$.

thoughts excuse ine, and firewell.....
farewell to me, gir, and welcome to you

furcye!l. mod wenches; you have

farewell, worthy lord! a heavy heart

as I ean bisl the other fint firtewell..

do it seeretly, and so firew cll........

his words were, furewell, inistress... nethsure out my grave; furewell, kind
no longer with you; firewell, good..

furewell, gool muster oliver

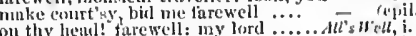

onthy hems him! farewell Bertrain

fincewell, pretty lady: you must hold

makes thee awny; threwell.........

use him as lie unes thee; so farewell

and take in more dilated farewell

monsenr? tirewell; go thou towa

will suhseribe for thee; farewe

aud so farewell: Kathurim . Taming of Shree,

and so farewell. What, with uy tmugue
furewell, sweet inasters, botb; 1 must

hence, and farewell to you all

bid Bianca fureweh for cver ant a diny

so, so; farewell; we are wine $\ldots \ldots \ldots . .$.
enjoined to this: furewell! the dity..

cone, lady, eome; finewell my friend

farewell till then: 1 will to lose. Comedy of Err.

shook to thy heart, and farewell..

father, farewell. God's lienison

Pembroke, look to't: farewell..........King John, i.

farewell, my gentle eousin. Coz, farewell

and so, farewell. Stay yet, lord Sal isbury $\overrightarrow{\text { iv }}$ iv

and loving farewell, of our several

eousin, farewell: and, unele, bit him

then, England's ground, furewell

the worrl fircwell have lengthened.

my liege, farewell: what will en
save bidding furewell to so sweet

farewell: if heart's presages be not.

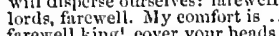

farewell king! eover your heads
uncle farewelt; and cousin too.

farewell : you shall find me $($ rep. $) .. .1$ Henry $l \mathrm{r}$.

cousin, furewell: no further go

farewell, you muddy knave

furewell, and stand fast..............

I will, captain; farewell. If I be not

our purposes; and so farewell.

say thy prayers, and farewell ..........

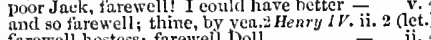

farewell hostess; fareweil Doll .......

I thee command. Farewell, adieu

farewell, good salisburT; and good linek - iv.
fiarewell, my masters; to my task ..1 Henry VI. i.

mayor, farewell: thou dost hut.

Talbot, farewell; thy hour is not....
atdd so farewcll, until I meet thee (rep.)

so farewell; and fair he all thy hopes

if he miscarry, farewell wars in France

farewell Tabot, France, and England's -

so, farewell, Rei mier! set this

farewell, my lord! good wishes.......

farewct, good king: when I am dear

and so, sir John, farewell (rep.)....... -

yet now farewell; and tarewell life..

and so farewell, for I must hevee nisu

farewell; and be proud of thy vietory
farewetl, faiut-hearted and...........

furewell, my gracious lord; I'll to my

onec more, sweet lords, farewell! .....

brother king, farewell, and sit you list

for a while farewell, food duke.....
bishop, farewell: shicld thee from

fircwell, my sovereign. Farewell...

one more a happy farewell. Farewell

bills youl all farewell, to meet ngain in

farewell, sour annoy! for here
farewell: I will unto the king

I must perforee; jarewell. Go, tread

bid ne farewell. "I'is ninre than ....

malato farcwell. Stay, I will

fireweli, until we meet atain in heavel

my good lorl mayor, we bid farewell

firewell, thou woful weleomer of glory!

farewction whor welcomer,

fnrewell, till then. I humbly tuke ing

farewell, York's wife; aml queen of
my true love's kits, and so furewell.

resolve him of my mind. Furewet

my ulear atm: my lord, farewell .. I

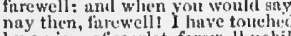

l,y a piece of searlet, farewell mohility

sis threwell to the little gens (rcp.).
furewell the hopes of eourt! farewell, my liege; now, no way
AREWVLL, farewell, my lorl(rep.) Hen.VIII.iv. 2 gontagious sickness, farcwell, all physiek -

furewetl, sweet queen .............

and lurewell gues out sighing......... -

Ajux, furewell. It l inight in entreatics -

why then, furewell; thwu never shalt

furewell till then. (iond-night $\left(r e p_{*}\right)$

furewell, revolted fair! ami Diomed arew -

furewell, yct, soft: 1lector, I take.

farewell: the gots with safty $\ldots$ me -

a loul, to bill me farewell twiec.. Timon of Athens,

ingen; it I thrive well ...

and 60 , farewell, and thrive. 0 let me

muels mirth. Well, then fares'ell....

placeth highegt; so, tarewell.......

furewell, my wife! my mother!

bid me farewchl, and smile ..........

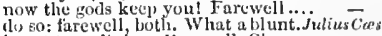

is not to walk in, Farewell, Cicero
why, farewcll, Portia: we must ilic

Why, farewell, Purtia: we must ate
furewell, good Alessala; good night.

good night, lord Brutas, Farewell..

our everlasting firewell, take (rep.)..

furewell, good Strato: Casar, now be still -
but bill farewell, and go .... Antony f. Cleopat

my business too: farewell. Farewell
whieh will become you botl, farewell

sir, good suecess! farewell ............
we bis a loud farewell to these great

fortune, worthy soldier; and farewell

farewell, my dearest sister $\ldots \ldots . . . . .11$.

farcwell. 'Tis said, man; farewell (rep.)

get thee henee; firewell (rep.).......

ay, tarewell. Look you,

furewell, kind Charmian (rep.) ....... Cymbeline

thus far, and so firewell.

brother, furewell. I wish

fareweli, you are angry. Still goin.

farewell, my sons: see, that you make

now, farewell, fattery: die, Andronieus

farewell, proud Rome! till Lucius

farewel, Lavinia, my noble sister ..

and sweet revenge, farewell ...........

bid him farewell: commit him to

Antioch, finrewell! for $y$ isdon sees....... Pericles, i.

thourfh loatl to bid furewell

whiles I say a pricstly furewell to her

furewell: thou art a piee of
bid them turewell, Cordclia.

bid furewell to your sister

so furewell to you both ..................

torehes! so, tarewell. Some blood ....

fhrewell, dear sister; furew'ell, my lord

farewell, sweet lord, and sister (rop.)

gone, sir? turewell. And yet I know not =

preserving sweet: farewell, my eoz.lioneo fo subet

but farew thou eanst not teach me...

fnrewell, ancient lady; fareweil (rep.)

farewell, be trusty, and I'll quit thy

vilinin am 1 none: therefore farewel!

thy hand; 'tis late: farewell...........

so bricf to part with thec; farewell.

agrainst this welling-day; furewell..

firewell; I will omit no opportinity

help aflitd : farewell, dear dather ....

fircwell, buy tood, and get thygelf in flesh -

good-night. 0 furewell, homest soldier... $\overline{H a}$

we anout it nothing; heartily farevell

your loves, as mine to you: faressell.

my neeessarices are em

farewell; my blessing season this in thee! -

farewell! how now, Ophelia?

bitt farewell it, for [ will use no art.

get thee to a munery; fireweli (vep.)

for Englaml! furewell, dear nother.

furewell. Ile that thou knowest.

farewell, for 1 must lewre you:

It is too true an evil ...

go to; fnrewell. Im you hear (rep.).

farewell my lord. Farewell, my ....

furewedl, threweli ; if more thou dost

0 farewell! firewell the ncighin: steed =

firewell! (ithello's oceupation's gone!

firewell: emmend ne to (rep.)....... iii. 3

ii.

v. 2 
FARAl-to fam on royal real m....... of Wiltshire hath the realm in tarn a slobbery and a dirty fitrm in that...
hiad solin iny tarm to buy my crown ind sold my farm to buy ny erown
from low firms, foor peling villages.. but keep a f:urm, und carte

five duents, five, I would not firm it (induc.) as will a chestuut in a furmer's fire? thou hist seen a tirmer's dog bark ........ Lear, iv. 6 $\mathrm{AR}$-OF - fal"off mountains turned.Mid.N.Dr.iv. dicl but glance a far-off look........2 Henry $Y I$. iii. and spies a firmoft slore where........ 3 Henry FI. iii. 2 Fetween lis limmess and Farrara.Henry $/ 11$. iii. 2 I AR'ST-how far'st thou, mirror of.. I Henry $V I$. i. 4 how far'st thou, soldier? well..... Antony \& Cleo. ii. 6 and for me, I have no farther gone.. Henry rill. $\mathrm{j} .2$ from the farthest inch of Asia.

be realy at the farthest by five... Mer. or Venice,

mine as fur, as who goes farthest... Julius Casar.
$F .1$ TIIING -for three farthings (rep.) Love's L. $L$.

marry, sir, laal fipenny farthing

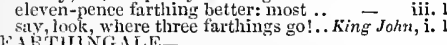
you wear your farthingale?....Two Gen. of $\mathrm{F} e r$. ii. ug: inst a gentlewoman's farthingale?

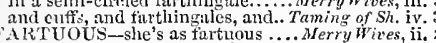
FitroN-in the same fashion as your. Tempest,

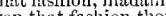

the fashion of the time is chinged....

iii.

how shall I fashion me to wear......

tis no de fashion of Franee........Merry Wives, iii. 3

a fashion slie detests ............... Tuelfh Night, ji. 5

and he welt still in this fastion....... $\mathrm{Arch}$. iti.

the fashion of the world is to avoid ...

than to tashion a earriage to rob.

and I doubt not but to tashion it ....

I will so fashion the matter............

and from all fashions, as Beatriee is.

thou know'st, thiat the fashion of ...

mean the fashion. Yes, the fashion (rep.

and see, that the fashion wear's out

thyself giddy with the fashion too...
into teling me of the fashion?....

your gown's a most rare fashion.

graceful, and excellent fashion

but sueess will fashion the event in - iv. I

in all the world's new fashion planted. Love's L.L.i. I

ot fire-new words, fashion's own knight

linconfirmed rashign, to insert again
observed your fashion; saw sighs reek

turns the fusluion of the days

iv. 2

in their own fashion, like a merriment

not in the fashion to choose me ....

upon this fashion bequeathed me...As

art not for the iashion of these times

passion is mueh upon my fashion.

hat yet, for fashion sake, I thank....
it is not the fushion to see the lady

it is not the fushion to see the
wears her eap out of fashion

expire before their fashions .......... - i. 2

it is my fashion, when I see a crab. Taming of

old fashions please me best.............

pricks lim to this fashion, ................

accorling to the fashion, and the time iif. 2

Why, here is the note of the fashion...
'lowgs to women of all fashion.... Wiziler's $\bar{T}$ itle, iii. 3
.

that mourued for fashion........ Comedy of $E$ inle, iil. 2

fashion your demeanour to imy looks

and chargetul faslion; whield doth

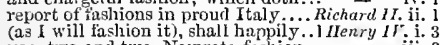

yea, two and two, Newgate fashio

this is the old fashion: you two......
ever in the rearward of the fashion

the wearing out of six fashions

I will decply put the fashion on

appear a little out of tashion...........

it is not a fashion for the maids..... - v.

the nice fashion of your eountry

thee and thy fashion [Col. faction] ... H Henry VI. ii. 4
study fashions to adorll my body .. Richurd III. i. 2

or let ne lose the fashion of a man! Henry VIII. iv.

in this fashion all our abilities. Troilus \& Cressida, i. 3

wit would be out of fashion.

to hang quite out of fashion ..........

notling else holds faslion ........... T.

and in what fashion, more than his..Coriolanus,

he dirl faslion atter the inveterate.... $\overline{-}_{\text {a }}$ i. 3

after his sour faslion, tell you ....Juliu
eonstrue things, after their fashion...
for the thing he is, fashion it thus...

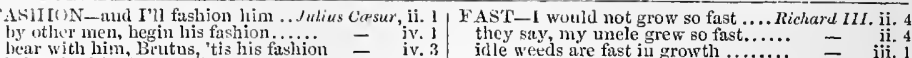

it is a deed in fishlion. Ilark thee.....
after the higl lioman fishion... dniony \& Cleo. iv. stale, a garment out of fashion........ Cymbeline, iii. I will berin the fashion, less without

meet, that I ean fashion fit...................

is it the faslion, that disearded fathers

do not like the tashion of your garment

in honourable fishion. Ay, faslion

these are now the fashion...............

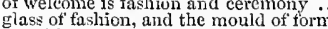

puts him thus from fashion of himself

I prattle out of 'tashion, and I dote

which I will fashion to fall ont between

Which I will fashion to fall ont between - iv.

most eourtly and fashionable.. Timon of Athens,

and fashioned by the hand .. Merchunt of Venic

never saw a better fuslioned gown.. Tam. of $S h$.

that self-mould, that fiashioned thee. Richurd II. copy and book, that tashioned others. 2 Henry $I V$. ii. and fashioned thee liat instrument.1 Henry FI. iji. was tashioned to much honour

is firshioned tor the journey .... Timon of Athe

faslioning our humours

ASHION-MONGER-

Romco \& Juliel, $\mathrm{ii}$.

FAIION-MONGIRING

out-facing, faslion-mongering boys.. Murh Ado

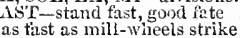

and yet so fast asleed

penished with bitter fasts....

judged me tast asleep.

whither way so fast?..

fellows, stand fist

whieh ther"ll do fast eno

not too tist:- soft! soft ! ........... Therry Wives, iv.

surfeit is the father of lauch fast.Mess. for Meas. i.

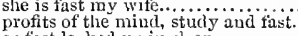

as fiast locked $u_{1}$ in sleep
was fast beloeked in thin

the roses there do tind

I followed fast, but faster he did

tis but a three year's' fast

you shall fast a week with bran.

but a'must fist thee days a wee

I will tast, being loose (rep.).

it speeds too filst, "twill tire...

whither away so fast?

to fast, to stmely, and to see no

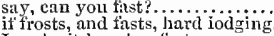

I make it breed as fiust.

I will make fast the doors

who comes so tist in silence.

as fast as she auswers thee.

that as fast as you pour affecti

and fitst it fairly out .......
sine vied so fast, protesting
that both of us did fist ...

that both of us did fisst

we'll fast for company ...............

hroke your fast (rep.)........... Comedy of Errors, i.

she that doth tast, till you come home

by rumning fast. Where is thy

iii.

thint we may bind liur fast

yet all this while in a most fast sleep

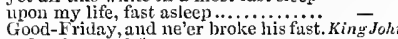

0 fewis, stand fast

play fast and loose with faitli?

with me, fist to the chair.

that spur too fiast betine

hath kept a tedious fast

loulst not but to ride as fist as Xork firewell, and stand fast

Falstaif! fast asleep belind

do pelt so iast at one another's ...... ïenry $\bar{r} r$. iii. I

the duke of Burgundy will tast.
and York as fitst upon your

I think. I have you fast.

sle'll gallop fast [Col. Kat. tar] euough.2 Herry VI.i.3

as fast as horse can carry them

and sees fust by a buteher with an a... = iii. 2

wut that thou art so fast mine enemy -

thousand men have broke their fasts.3 Henry VI. ii. 2
and sit you fast, for I will hence ....

the gates male fast! Brother

tlis hand, fast wound about

now, Mlontague, sit fast: I seek

whither away so iast! I pronise .... Kichard 111. ii. 3 they say, my unele grew 80 fas

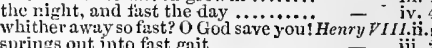
all fist! what means this? hoo

vur main of power stand fast. Troilus \& Cressida, ii.

comes fast upon: good my brother... - iv. 3

staud fast, and wear a eastle on...... - v.

bankrupts, hold fast ............. Timon of Athens, iv. if you'll stand fast, we'll beat ...... Coriolanus, $\mathrm{i}$. whither do you follow your eyes so fast? -

staud fast; we bave as many friend...

than in our priest-like fasts

boy! Lucius! Fast asleep? .........Juli

as fast as they stream forth thy blood

stand fast Titinius: we must....... - iii.

hath, at fast and foose, begniled .... Cleopatra, ii. 7

as we do air, fast as 't was ministered. Crymbcline, $\mathrm{i}$.

will the liand fast to her lord

I fast, and prayed, for their intelli.. - i.

I espicd the panther fast asleep.. Titus Andron. ii.

my niece, that flies away so fast?....

and tis our fust intent to shake all ....... Lear, i.

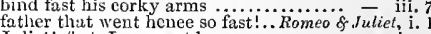

Juliet! fist, I warrint ler $\ldots \ldots \ldots \ldots . . . .$. Hamlet, i.

caust work i' the earth so fast? ........... - i.

then into a fast; thenee to a wateh....... - ii.

npon another's heel, so fast they follow.

but, I pray, sir, are you fast married..... othello, i.

drop tears as fast as the Arabian trees.... $-\overline{-}$ v.

FAST-CLOSED - oun fast-elosed gates. King John, ii.

to fisten in our thoughts that they.Julius Cresar, $\mathrm{v}$. 1

if I ean fasten but one cup unon him .. Ohello, ii. 3

took it deeply; fastened and fixed. Winler's 7 'ale, ji. 3

fastened ourselves at either...

cymbeline, i.

and fastened to an empery.............. Cymbeline, i. 7

to see him fastened in the earth .. Tilus.Andron. y.

he fastened on my neek, and bellowed.

ASTER-bring my wood home faster. Tempest, ii.

into the cinque-paee faster aud faster. Huch Ado ii. I
I followed fast, but faster he did fly. W I id. N. Dr. ili. I

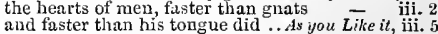

several tumes, faster tlian you'll. Winler's Tule, iv.

grow, faster than thought, or time . ${ }_{\text {trodden }}-$ iv, the faster it grows..... i Henry $I V$. ii.

fiaster than spring-time showers...2 Henry $V I$. iii. I

then thou wouldst sin the faster. Timon of Alhens, i.
to follow faster, as amorous of .. Antony \& Cleo ii.

to follow faster, as amorous of .. Anlony \& Cleo. ii.
faster bound to Aaron's eharming .. Titus And. ii.

but grow faster than their years.........Pericles, .

FASTEST - he that runs fastest, gets Taming of Sh.

like the summer-grass, fastest by night. Henry $V$. 1 .

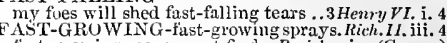

fast growing seene must find.. Pericles, iv. (Gower)
FASTING-not to be kissed tasting. Two Gen. of $V$.iii. 1

fiom fiasting maids, whose minds. Meus. for Meas. ii.

express my true loye's fasting pain.. Love's L. L. iv. 3

fasting, upon a barren mountain. Winler's Tale, iii. 2

to keel' my paek from fasting.

a fasting tiger safer by the tooth ... King John, iii. I

give their fasting hor'ses provender .. Henry $V$. iv.

while pride is fasting in his

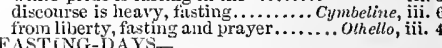

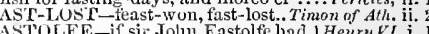

ii. 2

FT-Rolin Houd's fut friar. 2 wo Gen. of Verona, iv.

I shall think the worse of fat men. Merry Wives, ii. I

I am glad the fat kniglat is not here..

a meting with this old fiat fellow

hat woman, gone up into

the coming down of thy fat woinan.

an old rint woman even now.........

wherein fat Falstatit hath

I am not fint enougl

...Tielfth $\overline{N i r h}$ ive

int and bean-fed horse .............. N.'s Dream, i.

gross, gross; fat, fat..................

i will teed tat the aneient grudge...... stand fast; we have as many friends
friends now fost sworn, whose double

wilt tlou be fast to my hopes, if I dejend - i. 3

ASTEN-fasten your ear on my. Meas. for Meas. iit.
I will fasten on this sleeve.... Comedry ferrors ii.

ten times faster Venus' pigeons..Mer. of Venice, ii. 6

kept Hlector fiusting and waking. Troilus \& Cress. i.

tisl for fasting-days, and moreo'er .... Pericles, ii. 1

the treacherous Fastolfe wounds

at paunehes have lean pates .... Love's $L$. Lost,

liet me see a fat l'envoy; ay, that' $\ddot{a}$ a fat 


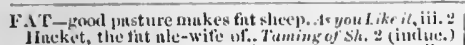
Iincket, tlie fitt nle-wifie of.. Tut

to a fut trim, thely broilery?

muke us as fit na tume thing

.ivinter's Tule. i. 3

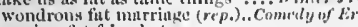

there is a fat friend at your

the fit rills of peace must by............ king John, iii. 3

Mith fat purses'.

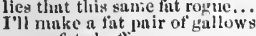

no, ye fint chuttis

and out of them is fat. und grows old

zounds ye tiat paumeth ..............

it to be fat be to be hated.

An gross fut man. As tint as...

advantage feeds lim tiat

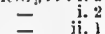

Why, you are so fat, sir Jolin

not struck so fat a deer to-day
tell me, thije fint man was doud?

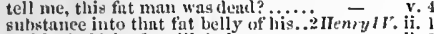

and look, it the fat villain have not.

you make tat rascals .......
then teed, and he fat, my fair calipolis

how? you fint fool, I seorn you
too muels eloved witl fint incat

too mucle eloyed with fit
is turn away the fat kniglt

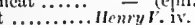

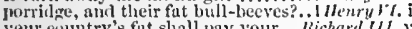

your country's fint slall lay your. .. Richarel 111.

luxury, with lis tint reim

have men aboat me, that are fiat ....Juliuscipsar, $i$

grew fat with feasting there ..... A Attony \& Cleo. ii.

how this villung doth fat me with. Thtus.lnutron. iij.

thiu the fit weed that rots itself........ Hamlet, i. .

Wour tit king, and your lean beggar

he's fitt, and seant of breath

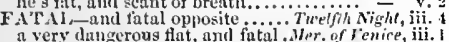

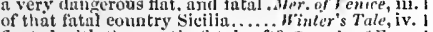
flouted with thee on the fiatul raft? Comedly of ${ }^{2}$, I. $\mathrm{Y}$.

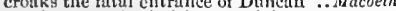
art thou nut, futtul rision, setsib]

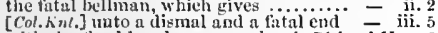

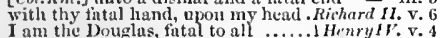

by the fital und neglected Engiish...... Henry $F$. ii. 4 with fintal moutles gaping on girled - - iii. (chorus) fiuld up l'urca's fatal web?

the fintal halls of murdering basilisks

aeeursed fatul hand, that hath ...
aud now I fiear that fatal proplicey

of piteh upon the fatal

Henrytr. i. 4

an did the fatal brand iitlie........

二 v. vii.

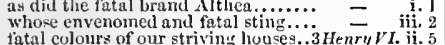

fatal colours of our striving louoes...3 Henry VI. ii. 5
bring tortin that fatul scritch-owl ....

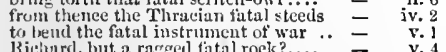

hatel nuw ominous to noble peers!...Richard $11 I$. iii.

intu the fattil bowels of the deep .....

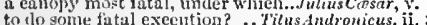

to to some fatal exention? . Titus An
give the king this fittal plotted stroll

the nightly owl, or tatal raven

a very fat thl place it seems ............

hath bronght the fatal cugine in ....

from forth the fatal loins of . Romeo \& Juliel, (proi.)

mulueky manage of this fatal brawl..

liarry from the fatal cannon's womb

so sweet was neer so tatal

FATAL1.Y-luattle fatilily was struek.Jlenry $v$. ii. 4 FAT-11,IR FADY-fat-already pride. Troil of Cres. ii. 3

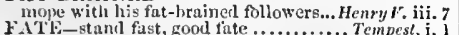
I anl my fullows, are ninisters of fate Tempest i. . Lut fate, orduining he sloulal ..... Merry Mives, iii. 5
wives are sold hy fate............... fite, show thy force ......................... the malignaticy of my fate might... - ii. 5 (letter)

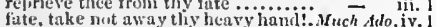
make and mar the foolish thies..Mid. N.'s Drean, i. 2 like Ilelen, till the fates me kili ..... be my fisol, und I lis fate ........... Love's L. Lost, v. 2 accorting to futes and destinis..... is re of $y^{\prime}$ trice, ii. 2 fince fate, aguints tliy letter ..... Mincer's Tale, iii. 3 whom the thites huve marked.. Comedy of Firrors, i. i which fate und metaphysical aid ....... Macbeth, $\mathrm{i}$. where our fute, lide within an............. -

come, fute, iuto the livt.

innst cumbrace the fate oil that......

he sliah spurn finte, seorn death......... - iji. 5

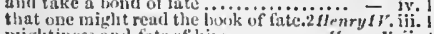
miglitiness and fute of him............. Ienry $r$.ii.

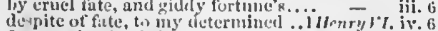

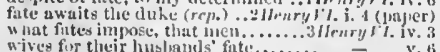

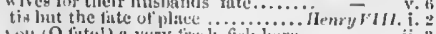

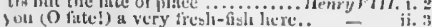

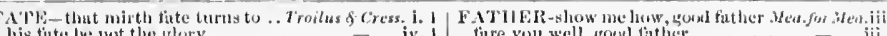
is finte le not the gtory.

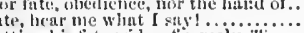

sctting his fittensitle, of eomely jimon of

arc musters of their tiutes............ Juliuscapsur, i. 2

it not, the fintes with trators do......

where I will oplnese his tite.... Antony fo Cleo. iii. il

carouses to the next diny fite

and make us weep to henr your fate.

the strict fates had pleased you...

bluck fute on more days doth ... Ro

harbingers preceding still the fates

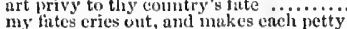

who, certuin of his fate, loves mut....... - iii. 3

cursed finte! that gave thee to the

anil your fate hies apace.

Wlo can contrual his fate? "tis not so inow - v

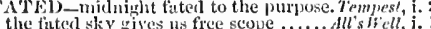

as it liath filted her to he the

Leor, iii. 4

then this torked plague is lated to us... Othello, iii. 3

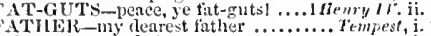

thy no greater fatlier

sir, nre not you my father?

again the king nyy father's wreik .....

fill finthom tive thy tather lics.... - i. 2 (song)

docs remernber my drown'd father
belield the king my father wrek'd

why speaks my tather so ungently

move my fither to be inelined my
$O$ dear father, make not too rasli.....

beseed1 you, finther

my rather's loss, the weakness ....

my father's ol a better mat

my father is hayd at stuly

0 , my tither, 1 have broke your............

and my father's preeents

so rare a wonder d fither, and a
your father's in some passion...

your father's in some passion.......

ask my father for his advice

my father at the road expects ... TüoGen,of i

and your father stays..............

Inteared to show mon fatler Julia's letter -

your father calls for you.

my fither stays iny coming.
my father wailing, my sister

this shoe is my father.

no, this left shoe is my fiatlicr.

now eome I to my father.....

father, your blessing

now, should I kiss my father.

your father's in good heal

the honour and regard of sueh a father -

my lord your father would speak.

thin hive tather likes fatjer notiee.....

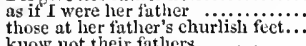

know not their fatlic
he plays false, father

nor how my father would enforce

urge not my father's anger

ay, and her father is niake $\ldots . . . . . . \%$

I have your good will, finther Pagre?..

thy fatlier's wealth was the first

yet seek my father's love

this is my father's eloiee ............

how my fiuther stole two geese

your father, and niy now your fatlier

you may ask your fatier.

her fatler wint be angry ..............

her father hath commanded her to slip -

meane she to deceive? I ather or mother? -

whoo, ho! ho! father lage!..........

f have heard my fatlier namu lim. TwelshNigh

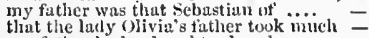

my futher lind a claugliter loved

all the daughters of my father's
then lead the way, good filler.

eall torth the holy tather

weme futher! lather, I cliarge thice

my fither hasl a mole upon his brow.

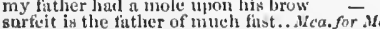

no, holy father, throw awiy

now, as fond fatliers liaving boind up

therefore, inklecel, my tantlier, I lauve

whore fatler dieth at Jlailowmi..........

ath repest it, tather ...............

my mother plikyeuf my tither lair: . fiure you well, gond fiather

good brother fither: what oilicine

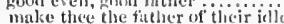

take the enteryrize upon her, fintlue

most gentle Clantio. Welcome fisther

pardon nile, good futher; it is asuin:t

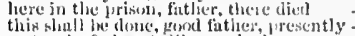

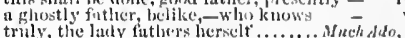

with her finther, and thon slunt have
then, after, to lier lather will I break

I trast, you will be rulcal iny your finther -

and soy, fither as it please you

and sidy, father as it plouke me...

I have broke with lier father, nud his -

rather liave one of your father's getting -

Your father got excellent husban

oh, my liather, prove you tliat any
bring inc a finther, thint so luvet his.

you must be futluer to your lirother's

your fatlier should be as a gul.. Mint.

wanting your finther's voice, the oth

if you yield not to your fither's clisice

you have

to fit your tincies to your tuther's will

steal forth thy tather'e house to-morrow -

and to master l'eascod your tintleer..

yea, and my father. And I) ippolyta

wall is down that jartel their fatliers

tuther's wit, and my motler's tongac

who the king your father senils......

nagdan, your tather here distl intimate

dishrursed by ning father in his wars.
if then the king your tiather will

and have the money by our fatlier lent -

you do the king my father ton mnch
speciul ofbcers of Churles his father.

for her father is but grim

a certain father saith-sir, tel

at the father's of a certain pupil......

hilhe a joy ful father wouldst
the ling your fintler-dead...

the rememhrance of my fiather's deat

eurbed by the will of a dead

refuse to perform your tather's wiii...

other sort that your father's imposition -

in your fatlier's time, a Tenetian..... =

0 fither $A$ braliam, what these cliristians -

iny father did something smack...

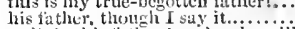

well, let his tither be what he will..

do yon know

do you not know me, father?

it is a wise futler, that knows....

to him futher, for I ans a Jew.

to him fither. God bless your

a desire, as my tatler shall speify

as my rinther, being I lope

go, fithere, with thy son.

Father, in; I eminot get a service...

gorry, thou wilt leave my tather so.

asliamed to be my tather's eliild!.

take lier from her tiuther's house
it e'er the Jew lier fatlier come to

I bave a father, you a dangliter, lost.

the sins of the father are to be iaid.

hope that your father got you not.

nud the spirit of my finther

I have ns nucl of iny father in ni... .. -

for your finther's remenbrunce lee at..

ny tather charged you in his will.

the spirit of my tather grow's stronis.

dallghter, be bunishell with laer tuther

to forget a banished therer, yols must

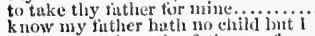

taken awny tronu thy father purtiorce

you must come away to your fatlect.

their fither, making sich pittin! do

world cstemed thy tither homurable

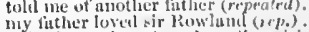

fither's rough thml envious dispositio

pity her for her goon finther's take....

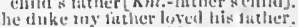

tor my fintleer luted his fiotluer desarly

i.

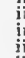$$
\text { iv. }
$$$$
\text { 'n. }
$$

like an lonourable futher (rep.) ....
with her finther, and thon shut have

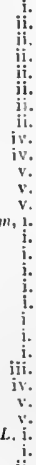$$
\text { ii. }
$$ 
FA'THER-my father was no traitor. As you Like it, i. 3 FATHER-your father's temper.. Winler's Tale, iv. 3 |FATHER-vow made to my father..1 Henry $1 V$. iv, 3

whth her father ranged along wil......
wilt thou change fathers? I wili give

fol my father scek nnother heir...

I was about to call his father.

hire I saved nnder your father

the duke, that loved your father.

on the duke your father .....

thy finther's father wore it $($ rep. $)$......

my father's house, and all the reveuue

weep o'er my father's deatl anew .....A Al's $W^{-}$ell, $\mathrm{v}$.

you, sir, a father: he that so.........

the remembrance or her fitther never

nnd succeed thy father in manners.

of your father. O were that all! (rep.)

thy fiatlier's moral parts may'st tlion

as when thy father and iny

mere fathers of their tarments

the physician at your tinther's died?....

you know my tather left me some....

more than my father's skill

Gerard de Narbon was my father...

sovereign power and father's voice.

not one of those, but had a noble fat

had her breeding at my father's charo

that I am father too, then call

a the 2

and my father first, a merchant of

I will wish him to her father.

though her father be very rich .....

what a cruel father's hel

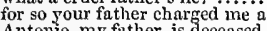

Antonio, my father, is decensed

tell mer fier father is Baptista Mame Minola...

her father, though I know not ( $r e p$.)

to whom my father is not all unknow

lier father keeps from all access

you knew my father well

your father hatli consented

here comes your father ........... 'tis thus, -yourself and ail

provide the feast, father, and bid the

father, and wife, and gentlemen, adien
I am my father's heir, and only son..

I am my fatlier's heir, and only son...

nid let your father make her

supposed Lucentio must get a fatlier

fathers, commonly, do get their ehildren -

mistress, your father prays you leave

to add her father's liking

the narrow-prying father, $3 i$ inola.....

dine with my father

father, be quiet; he shail stay...........

and countenance surely like a father

he is my father, sir; and sooth to s

my father is bere lciked for ....

will we return unto thy father's house

we will unto your father'

.

that your father was at Venice

I am content in a good finther's

that like a father you will

Lucentio's father is arrived in

the deceiving father of a deceitful sui

once more toward our father

ere I journey to 5 our father's house.

pardon old father, my mistaking $1 . .$.

entitle thee my loving father.

my futher's bears more toward ti...

that his father is come fiom Pisa

his fathor? Ay, sir, so his mother suy

good father, I am able to maintain

father Baptista, I charge you, sec ....
sweet father. Lives my swectest son

sweet father. Lives my swectest son (re
pardon him, sweet father, for iny sake

thy father will not frown.

bid my father welcome, whilie I

I will respect thee as a father....... Hinte
the whole matter and copy of the father
k neel and eall me father..............

no father owning it ...........................

upon the earth of its right fither

my father named me, Autolycus

my futher hath made her mistress

made her flight across thy fatlier's ground

your father, by some accident....

welcome, sir! it is my father's will
we.

my father and the gentlemen are in

have you a fatlier? I have.

methinks, a finther is, at the nimi......

is not your father grown incapable

the father, (all whose joy is nothing..

not acquaint my father of th

why, how now, father? speak
die upou the bed my father died i. 3 your discontenting father strive to .. as 'twere $i$ ' the fiather's person.

\begin{tabular}{l|l} 
ii. 3 & sent by the king your father to \\
ii. 7 & as from your father shall deliver.
\end{tabular}

iii. 4 you have your father's bosom there.........

preer

phall satisfy your father..

should I now noet my father

stealing away from his father........

no houest unan neither to his fatier...

comes not like to his fatler's grcatues
she did print your royal father off....

your father's image is so hit....
amity too, of your brave father

i. 2 mity too, of your brave father
i. 2 the charge my finther gave me.

i. 2 you have a holy futher ...............

thed from his father, from his hopes

i. 2 the father of this seeming lady ........

i. 3 by your good father's speed....

i. 3 slould chase us, with my father......

my father will grant precious thing

i. 3 gentleman born betore my father

ii. 3 called my father, father; and so we...

how found tily father's court? ......

Inever saw my father in ny life ....

for my father here. It shall not

your roval father's mindered father, thou see'st.....

father, farewell. God's benison.

and father of many kings........................

than is his futher's, must embrace

i. 2 to kill their gracious father

. 2 sirral, Jour father's dead; and what..........

my futher is not dead, for all your (rep.)

Was my father a traitor, mother?

1. 2 thy royal tather was a most
i. 1 and, as I tlink, one father

ii. 1 and, as I think, one father ..............ing

ii. i he hath a half face like my father

ii. 1 my father lived, your brother did ( $\ddot{\text { rep }}$.)

ii. 1 between my father and my mother.:

my father's land, as was my futher's
your finther's wifc did after (rep.).

ii. 1 my fatlier gave me honou

ii. Richard Cour-de-lion was thy father

ii. I I would not wish a better fathe
ii. I I thank thee for my father:

iii. I liker in feature to his father Geffrey

iii. 2 his father never was so true
iii. 2 boy, that blots thy father.

iii. 2 first called my brother's father, dad

iii. 2 in our foresaid holy father's name.

iv. 2 good father eardinal, ery thou, amen

jv. 2 my reverend father, let it not be so.

iv, 2 father, to arms! Upon thy wedding-day? -

father, I may not wish the ............
dear be to thee as thy father was

shall wait npon your father's fumeral

iv. 3
iv. 4 seem crest-fallen in ny father's sight Pichar

iv. 4 seem crest-fallen in my father's sight
iv. 4 some large ineasure to thy father's deatla

\begin{tabular}{l|l} 
iv. 4 & the model of thy father's life. \\
iv. 4 & have bid me orgue like
\end{tabular}

that some fathers feed upon

that I was his father Edward's son...

of whom thy father, prince of 'W ales

brave Gaunt, thy father, and myself

sou are my father, for, , a pethinks ( $2 e p$.

Where is the duke my father with....
my father hath a power, enquire ...

I am too young to be your fathe

O loyal father of $a$ treacherous so

sons their scraping father's gold

ny soul the father; and these two

with the rusty curb of old fither

I think his father loves him not ...

is there not my father, my uncle

these lies are like the father that

sir John Bracy from your father

sir John Bracy from your father
thy father's beard is turned whi

when thou comest to thy father

do thou stand for my father.

for me father. how he holds his

that father ruffing my father....

to meet your father, and the scotisish

my futher Glendower is not ready yet

good fnther, tell her, that she, and my

I am good friends w th my father.

these letters come from your father.

your father's sickness is a main....

this wour father liad been here

my tiather and Glendower being bot

my father, and my uncle, and myself

my father gave lin weleome to the.
my father, in kind heart, and pity. iv. 3
iv. 3
yet this

upon my head, and on his finther's :

iv. 3 where Hotsur's father, old ....2HrnryIV. (induc.)

where Hotspur's father, old ....2HrnryIV. (induc.)

should be the father of some stratngem

for liking his fin ther to a singing-luan

their fathers being so sick as yours..

warest hi. 2

.

to see lis father bring up his ........

the king your fatber is at Westminster

not much ot the father's substance

you, reverend father, and these nolie
tinther's? What thing, in honour (rep

nothing could have staid my father..

ample virtue of his finther, to hicur

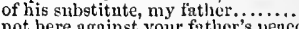

my father's purposes have loeu.

I hear, the king my fither is sore sick

he did naturally inherit of his finthe

O my royal father! My sovereirn.

my rracious lord! my fatller?

shall, $O$ dear father, pay thee.......

engrossments to the ending fittier

thy wish was father, Harry, to that...
hatly fed npon the body of iny father

before my face murdered my father..

win the more thy tather's love ......

I'll be your father and your brother too =

did use the person of your fath

be now the father, and yropose $a$ son

to speak my father's words ...........
you shall be as a futher to my youth

my father is gone wild into his ......
which your fatler, slabll have foremost

no sooner left his finther's body ......... Hemy

shall strike lis tather's crown into

this Danphin at his father's door

those, that were your tather's enemies

my most redoulted tather, it is most

and by French fathers liad twenty

and, if your father's lighness do not

if my father render fair reply
is fet from fathers of war-proor! finthers

whom you called fathers, did beget you! -

and by my father's sour, the work ...

the emptyiog of our tiatlier's luxury...

the father of his son, nor the master..

think not upou the fault my father made

his father was called, Plitip of....

now beshrew my fatlicr's umbition....

tather, I know; and of tiave shot...... Henry $V$

father, I wrrant you; take you ......

was not thy father, Richard, earl....

upbraid me with my father's death..

for my father's sake, in honour of....

his tarther Bolingbroke, did reign $(r$ cep.

my fatler's execution was nothing..

so kind a father of the commonweal

so shall his father's wrongs be....

I do remember how my futher said ...

think upon the conquest of my father

in travet toward his warlike fat!ier..

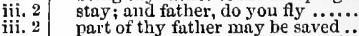

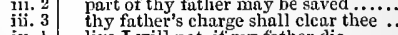

$O$ twice my fatler! twice am

it warmed thy father's heart...........

speak, thy father's care $. . . . \ldots \ldots \ldots . .$.

by thy father's side.......

and lay him in his father's arms......

an' if my father please, $I$ an content

at your,father's castle walls...........

thou art no father, nor no frieud......

deny thy father, eursed drab?.......

her father is no better than

her father is a king, the king of

to the king ber father.......2 Henry $/ 1$. i. $\overline{1}$ (artic

Ofather, Mlaine is lost....

iii. 1 main chanee, futher, you meant........

worth than all my fatlier's lands ...

father, the duke hath told the truth

then, father Salisbury, kneel we.....

so termed of our supposed father.......

my father was a Mortimer........

fillain ther had never a house...

made a chimney in my fatler's house
for his father's sake, Henry the fitth

honours not his father, Henry the fifth $-\quad$ iv. 8
this small inheritance, my father lett me - iv. 10 
FATIIER-for their truitur tather....2 sluill be their fiether's buil..............

victorious futher, to quell thie reibels.

wast thou orduiticil, tear finther.

my nohle father, three tines tu-dhy ...

that this is true, fintlier helichl

he slew thy futice; ank thitio

sit there, liad your fither lived
thy futher was a traitor ti) the

slew your futhers, and with colveriry

hlood were in my father's veins......

thy father was, as thon urt, thike of .

my grandsire, and my futh

kneel to him thut slew wy tither?.

liast proved so unnatural a futher:

father, you cannot tlisiuherit m

the erown of Englans, fatiser ........

luther do but think, how sweet a ...

with flve hundred, finther, tor a need
whose fother slew niy fiuticr (rep.)

whose fother slew nyy iuther (rep.
my father's blood hath stopped.

my futher's blood hath stoppen

then father hath. But 'twas ere

courage, fatherl inght it out!

payment, showed into my fitther...

thy futher lrears the type of

to bitl the tather $\left.w^{\prime}\right)$ pe his cyes...

queels, a hajless fiuther's teurs, $\ldots . . . . .$.

how our princely fitther 'meaped...

our right valiant futher is becone....

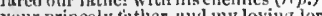

your princely tather, this

your brave father breathed hiig lastest

arguel thee a most unloving futher

lose his birthright hy his futher's tinul

iny eareless fither fondly gave ar

whose father fior lis hourdiog .........

wonld $m y$ father huve left me nin

my graeious futher, by your kingly .̈.

undicath your sword, good father....

who should sueced the father.....

I slew thy father: call'st thou him..

whose futher bears the title ot a kid
lis father revelled in the heart of...

that washed his father's fortunes.

that stablied thy futher York.

0 Godl it is my father's face........... -

and pardon, father, for I knew not thee!

thy father gave thee life too soon...
how will my mother, for a lather's death -

so rued a father's deatli? (rep.)

so obsequious will thy father be...

fly, father, fly! for an your frienils..
or us thy father, and his father, did..

or as thy father, and his father,
I stabbed your fathers' bosoms.

our prineely father, duke of York.....

in the olace where your futher's otanis

my lather, and my grandfather were -

to be the father unto many sons...

the ghostly fither now liath done...

because thy father lienry

you have a futher able to maintain...

my father came untimely to his......

father of Warkick, know yon what.

I will not ruinate my fatler's house.

that thy father liad been so resol veil..

nsurp'st my futher's right and mine.
thy father, slinos, that denied.

as the fatlice and the ton, and two...

lieignier, her father to the king of....
and her father? the reallicat (rep.)... Kichard 11

warlike father, like a eliild (rep.) ....

the curse my nolle futher lail on the

the eurse my noble father laid on the
loathed issue of thy father's loins!...

tell us, is our father dead?.

if' that our noble tinther be ailive.

to lose him, not your fatlier's death..

guess who eaused your fatlier's death

bade me rely on him, as on my fatlier

wept not for our futher's death........
ah, for our fatlier, for our dear lord.

both by his juther and mother ( $\mathrm{rep}$.)

he for his father's sake so lores.......
my princely father, then lial wirs

nothing like the noble rluke my fatlier

with reverend fistlicrs, and well-leurned

being got, your futher then in l'rnnce

being the right idea of your futher

witli two right revere tul fith

he hates me for my fatler warwick.

I thank Gisl, my father ancl vourelif

her father's brother would be lee lond

my father's death, thy lifi linth.......
[Col, $K n$. ] the chilitren live whore father

receise we from bur fitlier stmiley..

be executed in his fatlicr'b sigh ،

the father raslily mlaughteren his

the fart my father meant to act....iten, y $v 11$.

the dake his futher, with the

he would out-go his father ..........
forgive me, I had it irom my filiter..

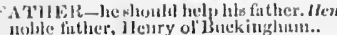

my tather's losn. Jike a must royul..

hulplicer than wy wrotehed father.
the king, your futher, was reputed

lecrliubut, iny fither, ling of spain

hy all the reverend tithers of the lund

conne, reverend fathers, bentow your.
nyy futher loved you: he snit, he did

my futher loved you: he suit, he lid
learmel and reverend linthers of lis
lere will be fitther, gixlfather, and

lere will be fither, ginlfather, ant .

ufool to stay belind lier futlec

should strike lis tather der.

ealled Ifector, (J'riam is lis fittlier).

gur great as our drend futher ...........
ghoukl not our futher bear the great.

shant I call you futher? $\Delta y$

thon must to thy fittlier, and begone.

I have forgot tisy futher.........

my futlier's sister's son, a cousin-german -

this sininter bound in my fat

cull my futher to persuade ...................

do not, dear father, Andromache .....

the aorls rementiner niy fitther's age

Timon has been this lord's fintlier....

thy liather, that poor rag, nust be... - $\quad$ iv. 3

' ny word the f'uthe fathers....

one of his father's moods.

was not a man my fither?............

no wor'se than tlyy oftl futher Hlonenius

and the fintlicr, tearing his cosuntry ${ }^{\prime}$.

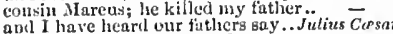

our futhers' minds are dead.

rieh in his father's honour ........... \& \& Cleopatra, i.

wherefore my father should revengers

o er-count me of ny father's house..

thy father, I'omicy, would ne'er have

whom they eall my fatlier's bon

Ciesar's father of't, when he hath

if that thy father live, let him

their father, (then old and foni of issue)

I something fiar my fatlier's wrath.

who to my father was a friend
your gon's my father's friend .

comes in my father, and, like ........

lis father and were soldiers tofether

a fither eruel, and a step-dame false

betwixt a futher by thy stej-dame

obelience, which you owe your fither -

befure her fither: I'll do something

man, which I dicl eall my futher

justice, and your father's writh

say, she'll home to her father

they take for naturnl father .......

disobedience 'gainst the king my fatlier

that they had been my fatlier's sons!

gpurn her home to her father .......

I'd say, my father, not tlis youth...

eowards father cowards, and base...

I am not their father; yet who this.

that let their futhcrs lie witliout

my father hath a reason for 't.........

and ratier father thee, than master.

whose fatlier thcu (ns men report (rep.)

then, sivare not the old father....

gentlemen, that eall me lath

you are my father too; and did relieve

then let my fither's hnours .. Titus
see, lord and tather, low we liave...

see, lord and tather, low we linve.

ontlive tliy futher's day

yoble 'Titus, father of my lifel ........

futher, and in that name doth nature

dear father, soul and sulsstance...

ii. 2 cruel tather, and his traitorous sons.

for my father's sake, that gave thee life -

iii. 5 make thy futher bliml; for sneh (rep.) -

iii. 5 mase montlse of tents thy futher's ey'us?

inoble fither, you lament in vain.

handless in thy futher's sight?

iii. 7 sweet futher, ceuse your tears...............

and, for our fint should be thoughit..

remeinhrance of my father's death

furewell, Andronicus, my noble fittlier

it that fiy lind a fittler and mother?.

futher, of that ehante clishonoured

thy fatler hath full oft for this.

the brey out of his father's hands...

a sight to vex the fiuther

wrote the lester that thy fitther found

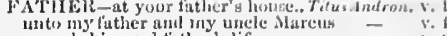

unto my' lather and my unele
regards his aged tatlier's life

ii. I since 'tis ny futher's roind, that I

belobld his latlier bleed?

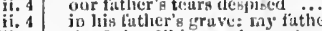

the father likiog touk $\left(r{ }^{\prime} p.\right)$..... P'eriel

nnw you 're both a futher and a son..

the sinful fatlier heemed nint to

whicli my deud father did bequesti.

since I liave here iny futher's gil't...

of spurta, my renowned futher i.....

what is it to me, my father?

alas, my fiather, it befits not re..

resolve your andery futher.
I love the king your futhe

niy father, as nutret stid, did never.

licarkened to their fat

my fatlier, and a king..

another lifie to Pericles thiy fither

king, my father, gave you sucla a rin
credit, sir, that my fither's detud...

e'er loved, or fatlier found .......
my sisters, to love my father ail

I give her father's heart from lier?
loverl as my father, as my nuster.

you have so lost a father

the jewels of onr fath

I think our fatlier wili henee to-ni

on father's love is to the bastard

our father s love is to the bastard $\ldots \ldots \ldots$. i. i. $^{2}$

anc fathers declining, the father should be - i. 2

eracked between son and tatlier.............

there's on against futher.
there's futher aqainst elilid...

ny fatter compounded with ny mother

a eredulous father, and a hrother noble.

did my father strike my gentlemin.....

my ludy's fatler. My lady's father!.....
which they will make an ohedient father

woundings of a father's curse pieree...
so kind a father! be my loorses read $y$ ?

I have been with your father.

my fiuther hath set guard to take .......

my futher wateles; $O$ sir, fly this place.

come before my futhe

father! fatherl stop, stop! no help?

my futher's godson seek your life? (rep.)

riotous kaights that tend upon my father?

you have shown your futher a child-like
our finther he hath writ ....

against the royalty of her futher .........

fithers, that wenr rags, do make (rrp.). .

I pray you, father, beios weak, seem so.

must draw me that which my futher loses

Gonerill me that which my

disearled fathers should have thus iitile

loved litm, friend, no finther lis son deurer

seek out where thy father is

slue kicked the poor king lier fitt lov.

bound to take upon your traitorous fi.

my father, poorly led? world, world

the fiod of thy abused father's wrath!

beaved the narue of father pantingly fort

Kent! fatlier! sisters! W' liat? ' i' tlie storm?

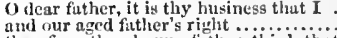

therefore, thou happy father, think that

well pruy rou father............

well pruy you, father ..............
sit you down, fatlier; rest you

come, father, I'll bestaw you with a friend

wind uy of this child-changed father....

O) my dear father! Restoration

and wast thou fuin, poor futher.

the, fatier, take the shartow of this

the question of Cordelia, anil her father.

iny name is El gar, and thy father's son

it'ever I did hate thee, or iny father!

mot I $20 y$ father with

threw him on my thtser

was that ny fat her that went liene........

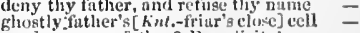

good-10orrow, futher? Bencelicite!

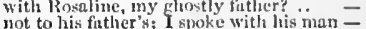
hath sent a letter to his futher's liouse Romeo, will you esme to your futlier's? -
tliy fither, or thy mother, nay, or lwothi is tather, notlyer, Tybalt, Ruvien, Julict where is my fatluer, and my motice... futher, what news? whut is the prince's tell my lord and fither, mudam, I will here comes your fither: tell him so
good futher, I hesecelt you on my knees -

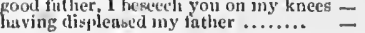

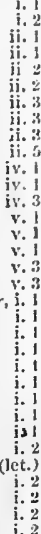

\section{.}


FATHER-father counts it dangerous.Rom.\& Jul. iv.1 FATHOM-LINEto make contession to this father? are yom at leisure, holy father, now
hely afford: farewell, dear father! is ny father well? how tares my Juliet? deliver it to my lord and father to press before thy father to a grave

forestid lands so by his father lost......... lost by his tather, with all bands of law have you your fatlier's leave? what say seek for thiy noble father in the dust these mourning duties to your father. your father lost a father: that fatlyer lost whose eommon theme is deatl of thather think of ns as of a father; for let the... that whieh dearest father bears his son but no more like my tiather, than I my father, - methinks I see my fathe the king your tather. The king my father! It figure like your futher, armed at point it it assume my noble tather's person. my fiather's spirit in arms! all is not weil IIamlet, king, father, royal Dane.. I am thy futher's spirit; doomed for that did sting thy fither's life, now I know lis fither, and lis friends more than his father's death, that thin still hast been the father of good new
his father's death, and our o'er-hasty his father's death, and our o'er-hasty make montlis at him while my finther live with blood of fathers, mothers, danghters the unnerved fither fills

the son of a dear finther murdered

something like the murder of my fithe

her father, and myselt, (lawful espials toid thee of my father's deatl

my father died within these two liour...

a villain kills my father; and, for that.

thy father much offended, frep.)

my father, in his hahit as he lived

that have a father killed, a mother stained slie speaks mueh of her father

eonceit upon her father. Pray, let it

first ber

pestilent father slain; next, your son ...

give me my father. Calmly, good Laert

where is my father? Dead. But inds the

revenged most thronghly for my finther

the certining of your dear fatlier's death

they withered all, when $m$ father died.

he which hath your noble father slain

and so have I a noble father lost

I loved your father, and we love ourself

think, you did not love your fo you

your father's son more than in words...

requite him for your father

Thad my father's signet in my purse

call up her father, rouse him... not...

here is her father's housc; I'il cali aloud

who would be in father? how didst thon
fathers, from lenee trust not your

fathers, from lienee trust not your ...... -

let her speak of me before her fiathe

her father loved me; oft invited me.

preferring you before her father, so mugi.

preferring you bease, bet her father

to put my tather in impatient thoughts

she has deceived her father, and may thee

to seel her father's eyes up, close asig you

subdue my father entirely to her lore...

my father's eye should hold her loatli $y$

it, haply, you my father do suspeet

good father! how foolish are our minds

food father! how foolish are our minds!

token my father gave my mothe

being so fathered, and so husbanded Jul. Macbeth, iv. 2

he childed, as I fithered! Tom, away. .. Lear, iii. 6
FATHER-IN-L WW-

my great father-in-ław, renowned.. Richard IlI. i. 4 thy person, noble father-in-law!

ot noble Buekinghum, my tiather-ın-Law - ini.

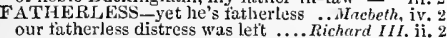

FATllERLY -by that fatherly and...Mnch.ddo, iv. shown a tender fatherly regard.. Taming of sh. ii. I
this serviee I have done, titheriy ... Cumbeline, ii. 3

FATHOM-fathom five thy father. Tempest, i. 2(

certain fathoms in the earth

how many fathom deep I am in love!..... $s$ s you $\bar{L}$ Like, iv.1
thirty fathom. Three great........... All's Well iv. thirty fathom. Three great............All's Well, iv. 1

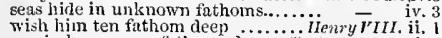
nor in how many tithoms deep...... Troihus of Cress. $\mathrm{i}$. so many fathom down precipitating..... Lear, iii. 4 of healths five fathom deep ....... inomesos Juliel, i. 4 looks so many fathoms to the sea ...... Honter, i.
another ot his tathom they have not .... Ohello, $\mathrm{i}$. FATHIOILLSS

buekle in a waist most fathomless, Troü.f TFis. ii. 2 where fathom-line could never touch.l HenryI $\boldsymbol{V}$. i. 3 I FATIGATE-What in the

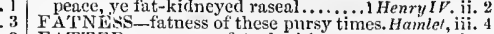
FATTED-ernws are fatted with ...Mid. N.Dream, should have fatted all the region kites. Iremple, in FATTER-would he were fatter ....JuliusCresar, i.
FATTEsT-and the fattest, I thiuk. Merry Wines, $\mathrm{y}$. is the tint test soil to weeds........2 2 Hewry $1 \%$. FATCING-fatting for his pains ...... Richard III. i. FAUCONBERG-

Roussi, and Faueonberg, Foix

Henry $r$. jii. 5

FAII Russi, Faueonbers, and Foix F'A ULCHION-of Casar's fanlehion. Lone's L. Los,

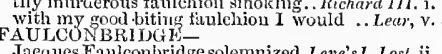

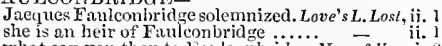

I suppose, to Robert Fauleonbridge... Kins

be a ranleonbridge ...................

go, Fanleonbridge; now hast thou thy

hast thon denied thyseif a Fuleonbridge? -

the bastard fatheonbridge is now in

do, renowned rauleonbritl

your valiant kiusman, linleonbigige

that misbegotten devil, Fauleonbridge

stern Haulconbriclge commands .......3 H Hry

AUL'-the finul's your own.

and frees all fanits..................

pardou the fiult I pray .... Two Gen of lerowa, i. 2

and prav her to a the fory tault

that fanlt may be mended..........

that word makes the faults graeious.

were you banished for so small a fiult?

tor wake a fanlt noun me...

that one error fills him with failt.....

'tis your tault, 'tis your fa

but nobndy but has his tault.

ay, for tault of a better.

what a world of vile ill-favoured faults -

good heart, that was not her fault...

a beastly fault l and then anotlier finit

a beastly, thult and then another fituit $=$ v. 5

two fuults, Madonna, that

reproves my fault (rep.)

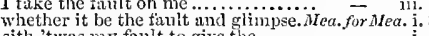

sith 'twas my fanit to give the
for I luve had sueh faults.

condemned for a

condemn tlie faul $t$, but not the

every finult's condemned, ere it ...

to find the raults, whose fine.

is this her fitult, or unine?

have it added to the fiauts of mine....

than fitults may shake onr trome

free from our fuults, as fimlts
kills for finults of his own liking.

that for the fault's love, is the ........

should pursue fantts proper to limself

then $A$ ngelo, thy inult's thus mamifested -

I have hethourht mee out of faults

I thought it was a finult ..................

the fault will be in the musie.....

Margaret was in some fault for thi

no fault of mine (rep.)........

her partly will ne'er be kno...........

it is no fault of mine ......... - iv. 3 (verses)

I made a little fault, in, great from.

that look into these til, great.

are attilint with fanlts and perjury..........

find you empty of that fiult............

such cyes as ours appear not faults. M.
lose a hair through Bassanio's fault..

if I could add a lie unto a fault

pardun the kuowledge of my fault.....

I know most faults (rep.).

one fiult seeming monstrous (rep.)

eamnot make her fiult her husban
we'd find no fault with the tythe

such were onr tioult

vow my furdts to hia................. ii. 4 (letter)
that's all the tault: I spoke with her

that's all the tault: I spoke with her

our rash faults make trivial price..... - v.

cormer in the coldest fault?.. Taming of Sh. 1 (induc.)

her only fiult, (and that is finuits enough -

have yoll told him all her fault

some kndeserved fanit r'll find
F A ULT-you did eontinue fault.... Winler's Tale, i. so foreing fanlts upon Hermio

you lave made fault i' the boliness.

all fiults I nake, when I shall come

for" thy mother's fault art thus exposet

to pardon me all the fanits I have...

for she will seore your tault upon.... Com. of $\bar{F}$. that's not my fault, he's master of niy it is a fault that springeth from your eye a grievous fuult; say, woman

false, the fault was hers; (rep.).

your fault was not your tolly ........

excusing of a fault, dotl make the fiult = iv. !

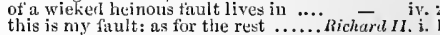

which marle the fault that we...

minister eorreetion to tly fault!

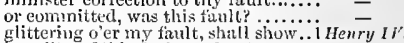

is guilty of this fant, and not my son

if suck and surrar be

neither, 'tis a woman's fituit...............

the children are nut other fiults... - $\quad$.

for fault of a becter, to call my friend -
chide him for faults, and do it.............

seouring tanlts; nor never............ Henry $l$

if little finylts, proeeeding on distemper

ido conliss my fault; and do submit
their fanlts are open, aurest ..........

my fault, but not my body ...........

au! that's a foul tault................

ii. 2

a iii.

blame and Yay the fault on me?....... i Henry $r$ iv. correct him for his fault the other day. 2 Henry $v i, i$. : hese are to those fauls............... - ii. lity was all the fault that was........ my lord, these fuults are easy ......... iii. 1 shall for the fault make forfeit ...... tis not iny fault, nor wittingly have I
lose his lirthright by his father's fault exeuses fior thy faults (rep.).....

and quite forget old fanIts....

that fuult is none of yours............. Richard $111 . . \mathrm{i}$.

onn' duty. and thy fault provoke..... - i.

entreaties, to antend your fault ! .... $=$ iii. ?

it is your fault, that you resign ...... ${ }^{-}$iii.

more than I dare make fauits......... - ii. I

his fanlis lic open to the laws....... - iii.

like, or find ficult.......... Troilus \& Cressich, (urol.)

tis Troilus' fault: eome, eume.......... $=$ iv.

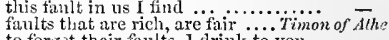

to forget their faults, 1 drink to you..

the fanlt's bloody: 'tis necossary......

in him, which biys out his fanlt .....

must neetis say, you have a little fault

should fall for private faults in them

lie hatli faults, with surnlulus...

shall be tle general's fiult
and all his tiualts to Marei

he's yoor in no one fanlt ..................

lay a finuit on us, your tribuues......
lay the finlt on us. $A y$, spare us not

so can 1 name his fanlts.............

i. 2

iii. 5

inlt, assemble all the poor. Jutius $\bar{C}$ osar, i. 1

known the earth so finll of fants

1 would it were $m y$ fiault to sleep

were so, it were a grievous frult...... - iii.

taunt my fallts with sueh fuli..........

of all feults that afl men follow.....

his faults, in him, seem as the spots..

I have mide no tanlt ................

for our fiults ean never be so equal.

the flint and liardness of my fault

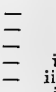

iv.

all fuul ts that mav be named...........

if you kill me for my finlt...........

yoke me in my good brother's fault..

ta'en vengeance on my faults.........

these young men's heinons faiit......

fitult of my atchesed sons (rep. ....
shinil be the ransom for their fiult

and bear the linults of Titns' age..... 1 2
2
3
3 i

i. 2

i. 3 2

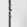




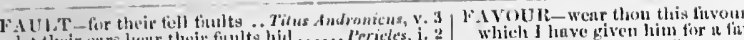

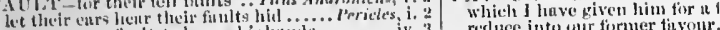
the mare my liult, to sempe his lumbls

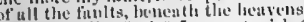

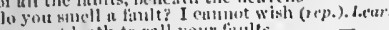
IIM nuse lenth to catl your finls...

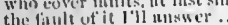

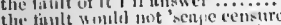

() bust small timli how unly didst fint.] whent is his fintt?......... hnug fated cier men's tank

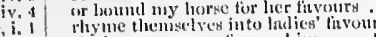
hyme themsetres into hathes fivours tirtune, in fisour, makes hitn lit.

as you lone our fuyour, yuite

i. I all fur this grent tavant flume........

this the emumon people fin vonr lim

iii. 1 at the fassurs of the world?..........

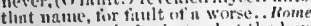

his fnut comelinles hat, whint the luw

thy finte our law enlls deatli.

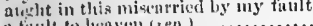

corruptim from thent porticular finile

iii. I justaut with fincour liave 1 al ways done

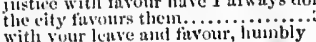

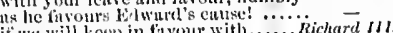

if we will keep in favour with....

since $l$ am erept in finvour with.
inyself scture in grace and favour

pray, give me fiswur, sir ...........

then let's dreant who's aest hing favour
generally whereer the king favours

tied ly blool and tivour ta her . $7 . .$.

muth joy and favour to you ........

fortmes, mul his hightess' fitvours
woman, fallen from taveru?

crawlecl inte the tinvour of the king

that liangs om priness finourt.......

and so near oi

fir a brown fingul, ftor so 'tis

richus, favour, prizes of aceilicht.....

I know your fisour, lord Ulyste

then, unkler fivour, purfon nie.

he that dounds upout rour fol......

but your ia vour is well apreared .....

as 1 do know your outwarcl tinsour. Julius
[Col. Kut.] in tavour's like the work we

by auy mark of tavour ...............

by the minute, lost his favour

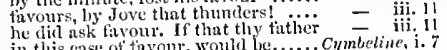

in this cast of favour, Would

methinks, thy favour's good emongh =

nothing blurred those lines of favour

that defreud on greatness' tit

his favour is lampiliar to me............

mgain unite his fitvour with the radiant,

to the love and tinvour of my eountry.

Titus Andronicus, for thy tavours done

receive him then to favour, Sat irnine

ay, but the eitizens f:lvour Lueits

voiec and favour! -you are, you are

so many fulds of favour! sure ...........

dalking onc's part that is out of fivour

o' the finvour of other your new pranks

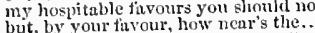

but, by your favour, how near's the..... \&

Iatest tiusour [Col fint what I for thec]

my favour were us great ................

this favour thon shalt wear

and change yout tavours too......

wear the furours most in sight .......
out of your tuvours, lheuvenily spirits

therctire, change fivours.....
the ladies clid change favours

the ladies clit change favours ........
wears next his heart, for a tavour

wears next his heart, for a favour $\ldots .$.

therefore, if yout iny fit vour mean ....

I sny, to buy his tivvour........ Mrexchant of $\bar{T}$ en

I sny, to biy his favour........

the ingy is fitir, of tem daughter's favou

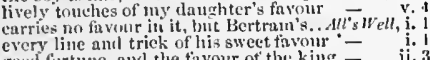

gow firtune, and the tavour of the ki
to fly the fitvours as so good a king ..

to flat himelf into a main's fitvour

l'll reasl it tirst, by your fastur.

the line of every other fuvour......

give a favour frum $y^{y}$, tus starkle... . v.

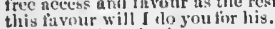

anil fivour of the cilimate...

your livour, J do eive lost ........

O, what more fiavour ean 1 do to the

for I amlet, and the trifling of his titvour -

or in the midde of her tavers

to this favour she must con

count his finvours: but, sure, the bravery

defent thy tinvour with an usurped beard

entreats her a liktle favour of spech

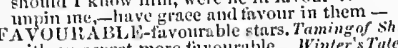

with an aspect more fiwourable .. Winter's Tate,
some dull nut tavouralle land ...2Henry I'

lemi favournble ear to our requests. Kichori III

FAVOURABLY - more fitvonmbly minister

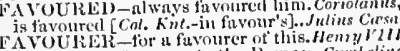

A VouliEk - tor a fuvourer of this. Henny

heing now a fitvourer to the Roman. Cymbetime,

FAnt cont to us as finvourers, hot in toes. P'ericles,

whto his lips thy faveuring lumbl. Antony \& Clin

ye favourites of $u$ king: Hre we not. Richari if 1 .

as a fulse tavourite doth his prines.2Jenty

bandying of their fuvouritcs........ I thary

his sons, his fuvourites, and hi

you mark, his tilvourite flies ..........

how I would nuke him fawn .... Loa? s...

1 am ton olil to finwa upon a nurse .. Riclared $I, \mathrm{i}$.

easily won to tawa oul any min!

rii.

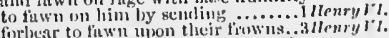

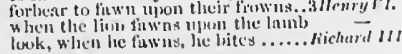

ripens in the sumsline of his favent..
A WN-fitwn mkn his deht

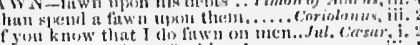

mind proy, and fiswn, fir litin, 1 spur

A N N

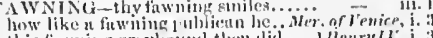

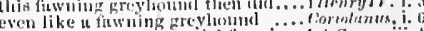

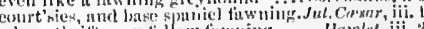

where thrift may tollow fiwning...... Nambe, iii. 2

by uy fuy, it waxes late ......... Koneo of Juliet, i. ?

F lis l.

lasting fealty to the new-mule

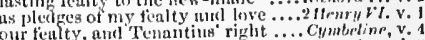

our fealty, and Tenantius riglit ....Cymbrline, v.

Romans, forget your fent y to me. Tilus imaron. is

unve lost your son, I fiear, for ever .... - ii.

by their own fear, or
tion fiar if the storm

faith, sir, you noed not feisr...

faith, sir, you noed not felir.

that, I tear me, will never
I shiall not finr fly-thowing

I fear you'll prove..........

I fear, w1y Julia would not ...........

the one that fears roblims

I fine me, it will make.

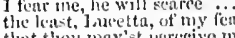

that thon may's pereeve my fear

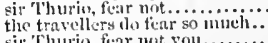

sil 'Thurio, fear not ynu.
i festr, I am attended hy

fear not; the forest is not $\ldots . . . . . . . . \quad \mathrm{v}$.

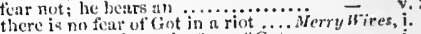

shall desire tw larar the fear of Got .

leaving the tear of hewen on the .... $=$ ii.

and i fear not mine uwn shame $\ldots . .$. 二

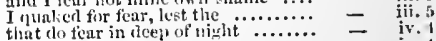

fear not you that: goo, get us

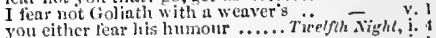

newds to fear no colours........

of, I tiar no rolours....

and fear to find mine eye

my servant, and I tear me, you.....

and fiar to kill a woorlenck

it is the Laselzess of thy fear
fear not, Cezario, take tliy

though thou hast tou inuch tien........

I do tear not youl....

he, (to rive fear to we ancl liberty.

you need not to fear the bawds.....

liti is we stand in tear .............

yct death we fear, that riake

to what we fear of dentl

I fear yout not.........................

fien me not. Nor, gentle dimgliter, fear -

her wits, I fear me, are not firm......

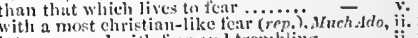

into a quarrel with tear and trcmbliug - ii.

tear you not my part of the dialingue = iij.

give your ase such canse wi fear .... -

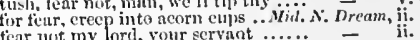

fear not my nord, your servat

run awny for fear: therefore $\ldots . . . .$.
look, how I do quake with fear....

I swoon almost witl fear.

hy'r lukin, n parlous fenr $\ldots . . . .$.
this will put them out of fear.

$I$ finr it, I promise you

not to tear not to their fears, thus strong.....

I fed them on in this distractel tear

for thou, I feur, hust given me ciuse
for temr lest day shumbl look their...

by lute, and fitar no cumity?

their proctied neecent in their feitr.

I fear any 'Thisby's promise is forgot!
whose fentle heurts do fear the smillest

whose fontle heurts ds fear the smnllest
I fear, we shall out-slecp the coming

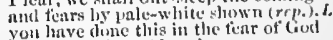

I flo fur colourable eolmurs............

your Erace needs nut tear it..........

yet, fiar not thou, hut sipresk

() worl of lear! mupleusing to ..... -

muke me fear misturtme fo my......er. of Veme, i.

theretere, for four of the worrt .....

you need not tear hady, the lavin

which mukes me fear the enjoying. ii. 1

i. 4

ii.
ii.
ii.
ii.
ii.
ii.
v.
.
ii.
v.
v.
ii.
ii.
ii.

ii. 3

$$
\text { 二 iii. }
$$

anil gracel whth grincely fivours. 
FEAR-ay, but I fear, you speak. Mer.of Venice, iii. 2 FE.AR-fears might have wrought fears ...John, iv. 2 FEAR-true nobility is exempt from fear.2flen. VI. iv.

make it less, for tear I surieit! ......

truly then I tear you are damned.

you need not fear us, Loreuzo

no telitales, inadain: fear you not...

'll fear no other thing so sor

what woman's fear there will.......

Ass you Like

abhor it, fear it, do not enter it

as those that fear they hope (

when fcar proposes the safety

二 $\quad$ iii.
$=\quad$ iii.
$=\quad$ iii.
$=\quad$ iv.
$=\quad$ v.
$\bar{L}$ Like it, $\mathrm{i}$.
$=\quad$ i.
$=$

your vatour and fear makes in you....

my fear hath catched rour fond $\ldots . .$.

bis majesty seldom fears: I am

eubmit ourselves to an unknown fear

ear me

the lighest coinpulsion of base fear.

my heart hath the fear of Mars...

makest conjectural tears to como.

shall tax my fenrs of little

fear not my lorl; we can .. Taming of $s h . \overline{1}$ (induc.)

you shall never need to fear ........

fear boys with bugs. For he fears...

for fear, I pronise you, if I look pale

now I fear thee not; sirral

I tear, it is too choleric a meat

fear you not him; sirrah

tut! fear not me. But hast

my life, Hortensio fears his wido.... -

I am questioned by my fears ..... Finter's Tale, $^{\text {v. }}$

his negligence, his folly, fear, amongst

fear o'ershades me oft inects the wisest

you need not fear it, sir: the child

do not sou fear: upon mine honou

that I should fcar to die?

with mere conceit and fear of the queen's -

and fear we have landed in ill time.

but I fear the angle that pluck

I fear, sir, my shoulder-blade is out

hath not been used to fear

wisdom I might fear, my Doricles

as little skill to fear, as I have purpose

endure your sight as yet, I tea.

fear not, man; here's no harm

fear thou no eyes over you)...........

ignorant what to fear........... Comedy of $\overline{E r}$.

1 greatly fear, my money.

for fear you ne'er see chain

fear me not, man; I wili not

stand by me, fear nothing

feear of death doth make

neither beg, nor fear, your favour

present fears are less than horrible

which the eye fears, whon

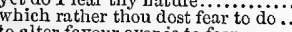

to alter favour ever is to fear

for fear thy very stones prate

listening their fear; I could not say

fears and scruples shake us ...

and I fear, thou played'st inost...

our fears in Banquo stick dee

is none, but he, whose being I do fcar

to saucy doubts and feal in fear...

the very painting of your f

(impostors to true fcar).

when mine are bianched with $\ldots$ ear...

is the initiate fear, that wants

thou hast harped my fear aright.

thou hast harped my fear aright..

that I may tell pale-hearted fear it lies

our fears do make us traitors.

ill is the fear, and nothing is the love

from what we fear, yet know (rep.).

thou'dst never fear the net.

but fear not yet to take...

yet do not fear.

what need we fear who know

to Dunsinane, I cannot taint with fea

fear not, Macheth; no man ...........

with doubt, nor shak

cheeks of thinc are counseliors to $\ldots . .$.

hang those that talk of fear...........

almost forgot the taste of fears...

like truth; fear not, till Birnam

such a one am I to fear, or none.......
kinged of our fears; until our fears.. King $\bar{J}$ o.
sick, and capable of fears (rep.) ......

I fear. Ay lord, I rescued her (rep.)

I fear some outrage, and I'll follow.

why then your fears, which as thicy.

what they fear, but full of $f c a r$

to possess me with these fears? let not the world see fear ........

the king, I fear, is poisoned

which tear, not reverence, makes..... Richard II. i

motive of recanting fiear.

urge doubts to them that..

and will, I fear, revolt on Ilereford's

the one, in fear to lose wliat...

fear not, my lord; that Power

to fear the foc, since fear oppresscth.

this ague-fit of tear is over-blown ...

converts to fear; that fear, to hate...

I fear, I fear. What should you fear

fear, and not love, berets his penitence

will rid imes for tear

will rid me of this living fear?.

and indent with fears $\left[\boldsymbol{K} n t_{0}\right.$-feres $]$

very sincerity of fear and cold heart.

I fear, my brotler Mortimer dotly stir

and not in fear of your nativity......

I fear thee, as I fear the roaring of...

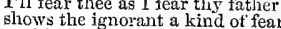

is this term of fear of .....

such as fear the report of a caliver.

tut, never fear me; I am as vigilant

1 fear, we shall stay too long

you speak it out of fear

in the battle, which of

and $I$ fear, sir Michael, what with

you necd not fear; there's Donglas...

yet needful 'tis to fear; and to prevent

a prodigy of fear, and a portcnt .......
vear your sight, for fear of swallowing

at London, I fear the shot here

I fear, thou art another counterf
all is inen upon the foot of fear

he that but fears the thing he...

and hold'st it fear, or sin $\ldots . . .$.

such lightness with their fok
stumbling in fear, was took

fear we broadsides? no, let the

pure fear, and entire cowardice...

irom mercy, not from fear

admittance to a thought of fear.

fear you not that: if we can make...

the people fear me; for they do

might lodge a fear to be again displaced

alas, I fear, all will be overturned....

fear not your advancement...

first, my fear, then my court'sy (rep.)

shake in their fear; and with

as provident as fear may teach

- ii. (chiris)

youth, that fear attends her not..

let us fear the mightiness and tate

for fear I should be faced out of my wa

to every one, thawing cold fear.... d-

creating awe and fear in other inen?

possess them not with fea

shall couch down in fear

I fear, thou'lt once morp to die .......

whorn we wont to fcar................. Henry r r $I$. i.

since Henry's death, I fear, there is ...

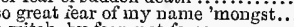

for pale they look with fear.

not for fear, but anger, that tii. cheek

and me, for fear, if thy thought

ay, but I fear me, with a lollo...

and now I fear that fatal prophec $y$

I fear, we should havc seen deciphered

(hey'll say-it was for fear...

do not fear, nor fly

alarums both of hope and fea

v. 3 ay, grief, I fear me, both at first..

v. 3 and no great friend, I fcar me ..........

v. 3 nay, fear not, man, we are

what else? fear you

madam en nour her coura.

and fear not. neighbour, you shail do

drink, and fear not your man...

jii. 1 Peter, and fear not thy maste

iii. 4 call it a woman's fear; which fear...

iv. 1 fear were false (rep.)....................

iv. 2 to rid us from the fear we have
iv. 2 let pale-faced fear keep with..

in him they fcar your lighness' death

in him they fcar your lighness' death
tis thee I tear (rep.).................
I fear neither sword nor fire (rep.)....

fear not that, I warrant thee.

f fear, my love, it that I had............

and not fear, provoketh me

- iv. 3

ear frames disorder.

think'st thou, that we fear them.......3 Henry $V I$. i. 2

a woman's gencral; what should we fear? -

what! multitudes, makes him

more than common fear ot clifford's

cheer them that fear their wreck, ....

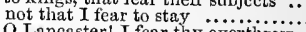

my love, and fear, glucd namy

ay, but, I fear me, in another....

go fear thy king withal

fear not that, my lord....

by doubtful fear my joy of

what! fear not man, but yield ........

ii.. 3
iii. 1 die thou, and die our fear...........

the thief doth fear each bush

mistrust no parcel of my fear ........
neither pity, love, nor fear...

his physicians fear him mightily.... Richard III, i.

I fear me, both are false............. -

I fear, our happiness is at the height -

as well,the fear of harm................ =

come, come, we fear the worst..... -

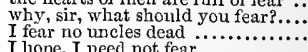

bid him not fear the separated...........

fear you the boar

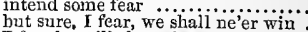

I fear he will: here Catesby comes

he fears, my lord, you mean no $73 .$.

I'll rid you from the fear of them....

and fiy to him, I fear

but who are friends for fear........

with guilty fear, let fall thy lance....

What do I fear? myself? there's none
Fatcliff, I fear, fear, - nay, good......

his fears were, that the intcrview .... Henry $\bar{V}_{111}$.

in the fear to cope malicious.........

exempt themselves from fea

'twas the fear, indeed; and that he

your grace, I fear, with dancing is (rep.) -

it calls, I fear, to fears death.

I fcar, he will indecd; well, let him

wringing of the conscience, fears

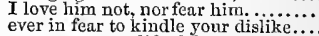

(more near my life, I fcar) $\ldots . . . . . .$.

wrong the king's love with these fears

your fears are worse

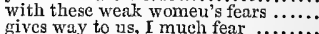

, fear him not; his spell in that.....

I fear, the story of his anger..........

be just, and tear not................

I fear nothing what can be said

morc than, I fear, you are provided

then would seek you, not their fears.

but those, we fcar, we have frighted.

fears his peril (repeated)...... Troilus

- ii. 2

diminutive as fears and reasons?.....

stolen what we do fear to keep!.....

we fear to warrant in our native

all fears attending on

death, I fear me; swooning............

if my fears have cyes. Fears make

stumbling without fear: to f.....

$O$, let my lady apprchend no fear.

I fear, we shall be much unwelcome

fear not my trut

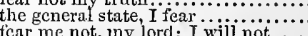

ferr me not, my lord; I wili not.....

but that of fear, of death

Timon, I fear me, thou wilt

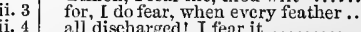

.

I fear, 'tis deepest winter in..

iii. 1 piety, and fear, religion to the gods......

I will fear to catch it, and give way..

ours is the fall, I fear, onr foes tire snare

ii.

3

iiti: 1

iii: 2 
FEAR-or we hal canse of fear.. Timon of athens, to atone your feurs with iny more...

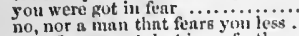
they fiear us not, but issue fiortl. pule with flight, anul ngued fitar. if any feur lesser lis person tha. fear not mis cur

and in true fen tlieg gnte us...

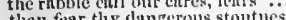
neitlier need we tien him reu lave mole nir work i fear me. but I tear, they'll mar him in again so scem to fiar: go home

feses it not trom another ............

and shake with feur and sorrow.

do fenr, the people choose Cresar

fenr him uot, Cessar, he's not daugerous

I fear him not: yet it iny name $\left(r r^{1}\right.$.

what is to be fenred, thinu w

for fear of openimg my his

it is the part of men to fesr and tremb

put on fear, and cust yourselt' in wonter

to nake them instruments of tear....

yct I do tiar lim: for it

liever fear that: if he be $80 . . . \ldots . . . .$.

heyond all uee, and $I$ do fenr them

most strange that men should
glould stay at home for fienr

enll it no fear, that kceps you.......

much that I fear may elaniee..

I fear, our purpose is diseovered

be sudden, for we fear prevention

a mind, that fears him much .........

multitude, beside themselyes with fear

joull benr ine a bang for that, I fear

have in their hearts, I fear, malions

for tear of what might tall

the fear of ns may eement ...........

thy angel beconnes a Fear ......

cause for what you secin to fear

and they them for fear and doting .

to be frighted out of fear ............

fear of what linth eome to jass.

into a princely hand, fear nothing

hat you did fear, is done

I something fear my father's wrath... Cymbeline

subdues all pangs, nll fears ............

oome religion in you, that you fear

come religion in you, that youl fear
my lord, I fear, has forgot Britain

1 lodge in fear

fear it not, sir .........................

and we will fear no poison

into a "haviour of less tear...

where, if thou fear to strike
fear not; 'tis empty of all thing..........

fear not; tis empty of all things.

that which I fear, prove fnlse !

if mine enemy but tear the

I fear some ambush

to thy further fear, nuy $\ldots \ldots \ldots \ldots . . . .$. .

those that I reverence, those I fear

for we do fear the law?

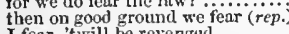

I fear, 'twill he revenged ..........

tear no more the heat o' the sun ...

fear no more the frown o' the great.
fear no more the lightning-tlash.

fear not slander, censure rash

good faith, I tremble still with fe
we fear not what ean from Italy
but the villainy of our fears .......

some falling merely through fear

my lord, now fear is trom me

fear not, lords, and you, Lavinia... Tiitus And

surprised with an uncouth fear...

to fear I know not what

if fear hath made thee fuint

fear not thy sons, thicy sliall ..........
for fear they die before their pardoil.

do not fear thine aunt

fear her not, Lueins.

and rape, I fear, was root of thine..................

why should you fear, is not your eity

bury noll thy fear in ny deviees

can eouch for fear, but I will ........

ghun the langer which I fear.......

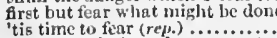

'tis time to fear (rep.)................
and tyrant's fears decease not

Antiochus you fear, and juitly too (rep.) -

that's the least fear; for, lyy the semblance-

What need we ficar? the grouml's .

I do not fenr the flaw.

pure surprise and fear maile me to quit

fear not, ny loril : your grace .......
did never fear, but ericd, good seanen

nor fear to loge it, thy aafety

that's my fear : I pray you, linve a
to fear judgment; to thght, wlien I

to fear judgment; to tlght,
well, you muy tiear tou fin

well, you muy tear to tar a ..........

take away the harms I fear, not fear
inform her full of my particular fear "fisli-never more be feur of thoing harn.. I

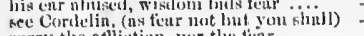
eurry the anlietion, nor the len

in esperume lives not in tis

l fear your dispusition; that anture

so much fear mul, lunger .......

iii. I fear me not : she, nul the tluk

whom I fear, most just and lienvy .jome- -5

I teur, toot early; for my mint

ay, sn I feur; the more is my
vengeance for it, tiar thou nut

vengeance for it, fiar thon wot
I will do it without fear or doult

tuy, nol womunisl fear, abnte

I have a faint cold fear thrills

I tier, it is; nud yet, methinks

1. 2 environed with all these hillenes tiars?

his looks I fear, and his intensts.

for lenr of thint, I will still sttey $\ldots$

fear comos upon me; $O$, much in fear

it hirrows me with fear, and woud

i. 3

alchost to jelly with the act of fear ....... -

fear it, Ophelia, fenr it, my dear si
luest safety lies in fiear; youth to

O, fine me not, I stay too long

why, what enould be the fear?

ii. 2 in the alum of fear eaught up $\ldots \ldots \ldots . . . .$.

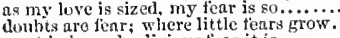

most holy and religious tear it is.

we will tetters put ipon this fear...

do not tear our person; there's such.

dangerous, which let thy wisdom fear....

my fenrs forgetting manners .............

to fenr, not to delight...................

for, I fear, my soul liath her content ....

I fear, the trust Othello put: him in

the people's hearts brimful of fear

to him that ever fears lic shall be poor

the smullest fear, or doubt of her revolt.

trust me. I fear it has. I hope ............

too busy in my fenrs, (as worthy (rep.).

devils themselves should feer to feize

yuick, quick; fear notlling; Ill he at
and yet I fear you; for you are tatal

my fear interprets then, -what, is lie dead?

this lost iear; man but a rush.....

FEARED-but I feared lest I might ... Tempest, iv. j beeones more mocked, than feared.M.'. for Men. i.

grown feared [ $\mathrm{Col}$-seared] and tedious

I am fenred in field and town.. Nid. N. Dream, iji.
I should have feared her, had she. Love's L. Lost, v.

this aspect of mine hath feared... Mer.of fenice, ii. 1

hoving vainly feared too little....... All s s eh.

reigns that which would

indeerl, we feared, his siek $\ldots$.........

teared by their breed, nnd fimaous ... hichard $I$

to monarehize, be fearesl, and ki

to be feared

he was much feared by his plyysicians

the respect of likely peril feured

and echo, the numbers of the feare

been then more feared than harmed .. Henry $r^{*}$.

never was monarch better feared

$\begin{array}{ll}r .5 & \text { where they feared the denth } \ldots . . . \\ \text { i. } 2 \text { less hapy heing feared, than the }\end{array}$

made thee feared, and honoured ....2 ten rev $\mathrm{VI}$.

proved thee false, or feared thy faith
prow

I, that never feared any.

for one being feared of uti

Richenrylll. iv.

thoul hat st feared to breuk an outh (rep.) $\bar{r}$ iv.

men fearel, the French would prove

and feared, slic'll with the in

should have fenred tilse times. Timon of thens,

that lis fen makes feared

innde him feared, so haterl, niil so

rather tell thee what is to be teares.

say, I feared Casar, honoured him $: .9$
those thut only have fearet Casar:.A

[Cot. Knt.] comes fenred ly lowing lacked

in these feared [ $k$ nt,-sentet] hope.... Cyrobeline, ii.

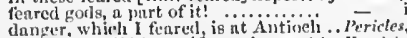

I feared, lie did hit trifle, and meant to. IInmint

With wlint she feared to louk on?.

guile us out of this ticarful country !.....

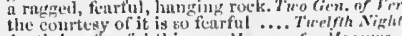

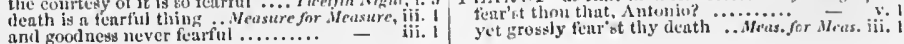

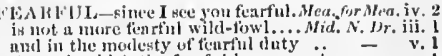

throngh which the fearful lovers are to $\overline{\text { vo }}$.

left in the fearful guard of an... Nerrh. ar tenire, $i, 3$ if' le were of a fenriul heart ........ As you like if, iif. I be segligent, fiolish, ancl fearlint... irin!er's T'ali, i. to the fearlul usave a thing.

convey unto vur feurful uiusls .. Comedy of Frr. i

the fienrful diftirence of ineensed kings - iii

he, that heyrs, makes learful action... - iv. 2

black, furful, emmfortless, and lorrille - v.

we henr this teartul tempest sing ... Michord 11 . ii.

whisper fearful chitme? ; rich with

to wateh the fenr'til bending of thy .. - iii

a mighty amd a feartul hend........

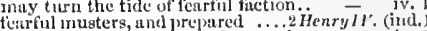

and fearful mceting uf thcir opposite - jv,

a feartul battle rendered you in.......... flenry $l^{\prime}$.

conspiraey with fearful France .. - ji. (chorus

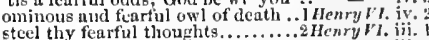

after nll this fearful lomage done..

the fearful Freweh, whom you late... - iv.

the fearful king. and this the regal.. 3Henry $\%$. i.

having the tearful flyiug hare in sight - ij.

vilid I but suspect a tearful man..... - v.

lidward shall be fearful of his life ... Richart IIt. i.

so full of feartul dreams .......... - i.

while my fearful lical is on.......... = iv.

with a fearful soul, lenis diseontented
All-souls' day to my fiearfit soul ....
and the fearful time ents off the ....

cold tear'iul drops stand on ny trembling -

I an tearful: wherefore trowns he? Ilenry FIII. v.

fearful seouring doth choke.... Timon of Athens, y.
will he less fearful than discrect .. Coriolanus, jii.

more, nore fenrful, is delivered (rep.) - iv. 6

a fenrful army, led by Caius Moreius $\overline{\text { Casar, }}$

and fearful, as these strung

and come down witl foartill bravery $-\bar{y}$ ।

to lireak it with a fearful dream.... Cymbelin ", iii.

hath been to me as ficarful as a siege

when fearful wars point at me ........

see a tearful sight of blood and death

when will this fearful slumber have

and by those fearful olyjects to prepare... Pericies, $i$.

how feartul and dizzy 'tis, to east one's eves - iv.

the fenrtul paseage of their..... Nomeog. Jutict, (proi.)

shall bitterly begin his fenrliul date..

there's a teartinl point? shall I not

n guilty thing uyom a fearful summons. Jitunte.

dithenty, and fearful to be granted

FEARFULLY - tetriuly o ertrip. Ner. of benir

and I do fearfully believe, tis done. Kinerom

as feurfully, as doth a galled rock..... hem

youks fearfully in the eontined decp........ lecr., iv.

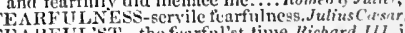

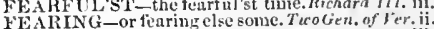

but fearing lest my jealous.....

hy feariur to att ir were ........... for veosure,

past fearing death

fearing to hear of it liereafier.

All's well, iv,

feuring you would not come.. Taming of sherre, iit.

fenring to do so, stay, ant be seetret...

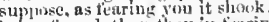

leng fenred, than they in fenring

fenrel of all, now fearing one.

and, ferring he would

he died, fitang find iolit.

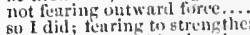

so muny years al tearing death

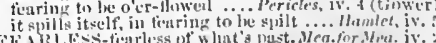

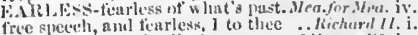

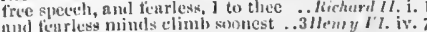

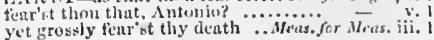

with fenrful hlowely issue arlsitrate........ king John, i.

face be fearfil to their eyes $\ldots \ldots . . . . . \quad$ - ij.

eome forth, thou fearful unan; aflietion

fearyng sinee how it might work an' felro. iv. I2 


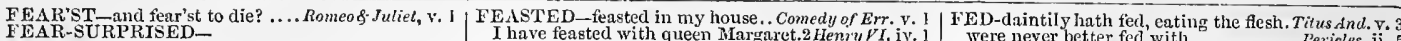

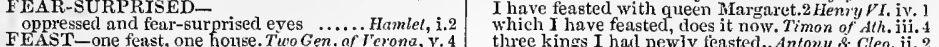
EAST-one feast, one holse. Two Gen. of Ierona, y. 4 three kings I hal newly feasted..Antony \& Cleo. ii. how shall I feast him.......... Tweth Night, iji. and least upon her eyes?

EASTING-at a farm-louse a feasting. Nerry W. ji. 3
no mind of feasting forth to-night...Mer. nf Ver, ii. s

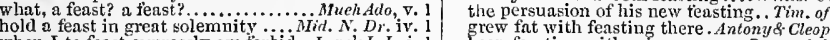
no mind of feasting forth to-night....Ier. of

when I to feast expressly am forbid..Love's L.L.i. 1 been feasting with mine enemy.. Romeo \& Juliel. ii. at a great feast of languages ......... - v. 1 there is full liberty of feasting

FEAST-WON-feast-won, fast-iost. Timor or who riseth from a feast, with that

who riseth from a feast, with that ...
we are staid for at Bassanio's feast ..
our feast shall be much honoured...

ever sat at any good man's feast... As you Like it, ii. 7 and sat at good men's feasts...

$F E \Lambda T$-the feats of a lion................Much Ado, i.
got a ealt iu that same noble feat ....
do this feat [Col. Knt.-seek] . Taming of the solemn feast shall more attend.......All's $\bar{v}$ ell, i1. 3 provide the feast, father, and bil... Taming of

go to the feast, revel and don

wence forthwith to feast and sport us

of all,--but my share of the feast

to buy tor our sheep-sheering feast?

hath made her mistress of tbe fea

but that onr teasts in every mess
darken not tle mirth o' the feast

darken not the mirth o' the feast

promised them agaiust the feast
makes a merry feast .........

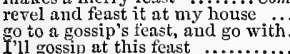

that eannot do that feat........... Winter's Tale, ij. 3

each eorporal agent to this terribie feat. A
and the feats he hath done about ..2Henry

your puissant arm renew their feats ...

what feats he did that day.

wilt do these wondrous feats?

in that day's feats

tell them your teats

than in his feats deserving it ........

so feat, so nurse-like
beeoming well thy fea

if that thy prosperous a. .17 ifial feat

what feats, what shows $\ldots . . . . . .$.
proceeded not against these feats....

were never better fed with............... Iericles, ii. your graee, that fed my country..... - iii. 3 had grown by what it fed on............ Hamlet, i. eat of the fish that hatli fed of that worm - iv. K Knt.] slept the next night well, fed weli

EDLARY-Camillo is a ferlerary. Winter's Tale, ii. and thy fee is a thousand ducats..... Mueh der. ii. 2 pleading for a lover's fee.......Mini. N.'s Dreain, iii. as a tribute, not as a fee $\ldots . . . \ldots . .$. - jv. that begged it as a fee; I eould not...

1.ii give them hin without a fee.... . death's [Col. Knt.-see] thee to stand up. $\mathrm{All}^{\prime}$ ' Well, it. so you shill pay your fees ........... Winter's T'al chall take iee; arrest him...... Comedly of Err. iy. rob the deathsman of his fee $\ldots \ldots . . .2$ Henry VI. iii. a deer whose skin's a keeper's fee...3 Henry VI. jii. thy beauty is proposed my fee...... Richard. III. $\mathrm{i}$.

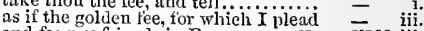
and fee my friends in Rome .......Henry $\overline{V I I I}$. iii. are the proud man's fees.... Troilus \& Cressida, iii. 3 the rest of your fees ...... Timon of $A$ ih. jii. 6 (grace) rob my sweet sons of their fee ..Titus Andron. ii. 3 and the fee bestow upon the foul.........

who straight dream ou fees ....... Romeo \& Iuliet, i.
set $m y$ life at a pin's fee ............... Hamlet, i.

FEATER-mich fenter thau before ..... Tempest,

cATHER-brush'd with raven's feather. Ten
cheek at every feather that eomes. T'uelfih $N$;
a feather will turn the seale.

chief nourisher iu life's fenst.......
been as a gap in our great feast.

fail not our teast ..................

a teather will turn the seale .....Meas. for Meas.

the feast is sold, that is not

free from our feasts and banquets... - iii. 6

now he feasts, mouthing the flesh ...Kin

with fortume other than at feasts.

to feast upon whole thousand
lo, as at English feasts, so $I$.

lo, as at English feasts, so I.
this feast of battle with mine.

by bare imagination of a feast?

but sumptnous showed like $a$ feast... 1 Hen $r y, \bar{I} V$. iti. 2

of a fiay, and the beginning of a ficast

great friends, did feast together.

called, the feast of Crispian

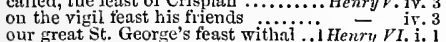

and teast and banquet in the open

to feast so great a warrior.....

would not feast him like a triend ...2. Henry $V$ I. ii

where the feast is held

what plume of feather's is he

s L. Lost, iv.

every teather starts roun.

fancies prieked in't for a feather.. Tamin
because his feathers are more beautiful

I am a feather fors are more beautiful -

when fowls have no feathers.. Comedly of Errors, iii. I

a erow without a feather

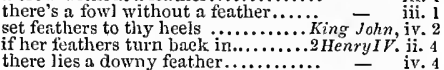

add more feathers to our wings

in his face with a peacoek's feather

his feathers are but borrowed ....... 2 Henry $V I$. iii. 1

their feather, many more proud birds.

as I blow this feather from my face.

these remnants of fool aud feather... Henry

I am not of that feather .........Timon of Athens, i. 1

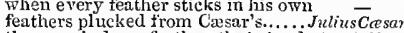

the swan's down feather, that stands Ant. \&.Cleo. iii.

the best feather of our wing ........ Cymbeline, $\mathrm{i}$.

feathers, air, so many fathom down...

this teather stirs: she lives!

Diomed doth feast witl hin to-

art going to lord Timou's teast. Timon of sthens,

feasts are too proud to give thanks

now come but to feast thine eye

what need these feasts, pomps

I'll onee more feast the rascals

feast your ears with the mo

make not a eity teast of it

may you a better feast never behold

all feasts, societies, and throngs of men

lere, 1 will mend thy teast .

false times, when you did feast

aud feasts the nobles of the state

the feast smells well: but I.........

you know, it is the feast of Lupercai.

the libertine in a field of feast

more monstrous matter of feast

goes to the feast.

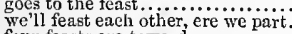

four feasts are toward.................

since Pompey's feast, as Mrenas says

done; and feast the army

shall be the lord of the feast

king and queen moult no teatlier.

ii. 2

ranker rate, should it be sold in fee. $-\bar{G}$ iv.

in ercors, feeble, shallow, weal. . Comedly of Err. iii. 7

cannot liear a lady's feeble voiee....King John, iji.

ot the old, feeble, and day wearied sun - v.

mine honour with such feeble wrong. Richard $I I$. i.

Franeis Feeble! here sir

well said, eourageous Feeble!

let that suffice, most foreible Feebie.. $=$ iii.

1 am bound to thee, reverend Feeble - iii.

Mouldy, Bull-ealf, Feeble, and Shadow - iii. 2

the siek and feeble parts of Franee.... Henry $r$.ii.

and with a feeble gripe, fays $; \ldots \ldots \ldots$. 3 .

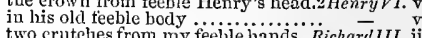

two crutehes from my feeble hands..RichardIII. ii, 2

a man of such a feeble temper......... Coriolius Cosar, i.

old feeble earrions, and such suffering

will crowd a teeble man almost.

upon my feeble knee I beg this ... Titu
and bow this feeble ruin to the earth

ii. 4

EEBLED-victorious hand be feebled. King John, v. 2

FEEBLENESS-age aud feebleness...Thilus dnd. i. 2

FEED - to feed my innoeent people .... Tempesl, ii. 1

to teed on such sweet honey Two Gen.. of verona, i. 2

more mind to feed on your blood .... - ii. 4

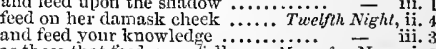

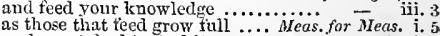

sueh meet food to feed it, as ......... Much $1 d$ o, $_{\text {, j. I }}$ I

unless we feed on your lips ........... Love's $L . L$. ii.

to feed upon the prodigal christian.... - ii. 5

if it will feed nothing else, it will feed $\quad$ - iii. I

he lets me feed with his hinds .............

as pidgeons feed their young .......... - i. 2

and he that doth the ravens feed, yea

and bounds of feed, are now on sale

there is nothing that you will feed on
sit down and feed, and welcome to ou

sit down and feed, and welcome to our
and let hin feed

and let hin feed feed yourselves with questioning..........

ii. 4
ii. 4
i. 4
i.

for fenture, laming the shrine.......... Cymbeline, $\mathrm{v}$.

form and feature of blown youth........ Hamlet, iii. 1

FEATURED-how rarely featured... Much Ado, iii. 1

FEBRUARY - sueh a February faee ..

unebaste desire, fed in heart. MIerry Wives, v. 5 (song)

he hath never fed of the dainties.... Love's L.L. iv.

with gazing fed; and fancy dies

a good knave, i'faith, and well fed

and with brawling ted

at board, he fed not .......... Comedy of Errors, $v$

in his eommendations 1 am fed......... Macbeth, $\mathrm{i}$.

whilst you have fed upon uny.

and being fed by us.....................

Rilenry $I V$. V

fed from my treneher, kneeled

Who fed him every minute..........

HenryliII.

of this most pompous marriage feast - - ii - (Gower)

at this same ancient feast of Capulet's

show you, shining at this feast

ill-beseeming semblanee tor a ficast...

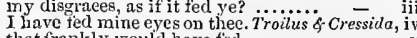

that frankly would have

Corinlames, iii.

shall be the frujt to that great feast .... Hamlet, ii.

whit feast is townerd in ther.......... eternal eell -

we hoth have fed as well

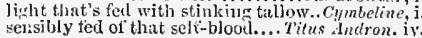
the thing that feeds their fury ............ing of Sh. ii. that $I$ do love to feed upon. feeds from home, poor I ..... Comedy of Errors, ii. to feed, were best at home ............. Nacleth, iii. in matter that should feed this fire....... King $\overline{J_{0} l \text { nn, }}$. that some fathers feed upon..........Richarl II. ii. we shall feed like oxen at a staji....... to feed eontention in a lingering....2. Henry $I \%$. doth the old boar feed in the ........ - ii. who fed, and be fat, in I was wont to feed you with my........ word sallet must serve to feed on .... - iv. thy trunk for erows to feed upon........ to feed my humour, wish ti..........3 Henry as frritinl as the land that feeds us. Henry HIII. i. $^{2}$ to fied for aye her lamp and flame Trilus f Cress. il. see, and cannot feed mine eye ........... than feed on eates, and have ......... i Henry $I V$. iii. as your oppression feels ....I Henry VI. iv. I (letter) 
FEE1)-supple knees feerl arrognuce. Troil.s ('res. iii. 2

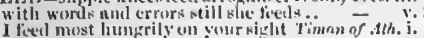
lavpier is he that has no friemil to fic

influite breast. teems, numl fecels all

on what I hate I fied lout ............. of athens, iv. buser temple, than where sin

clse woskld feesl an one another?...... Coriolunus,

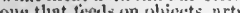

iniong for Cleo. i.

alike feeds beat os jert

now J fied misclt with nuost jelivious

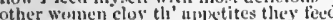

feed, arul slewe; our enre and pity.

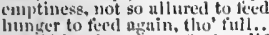

shovild by the minute feed on life

entruils feesl the sneritieing fre .. Titus

feel on herries, and on routs, nulfecl

and? feed his hamour $k$

to feet me with de!ays .................

tor tied lis brain-sick fits

will' please your highness feed?........

though they feed on swectest flowers.

not so misel to fied on, as delight.

whll starves tize ears she feed

gixol spirits, to fical and elothe thec?... nam

that live, nnd feed, uाкu your majesty

you on this thir nombintain leare to te

let it leerl even on the pith of lite

feeds ton his womler, keeps hinself in.

feerl upon such niece and waterish diet

which toth mock tlie meat it fecels on

倓. 3

feet every sliglat oecasion

Inuse I lieep a servant feed

Treth Nirht, i.

thon werlat be teed, I sec, to niake 3herty hl. i.

I will you very for

torlers disest it with a custom ... W'inter's Tale

fisesl doth chuke the feeder.

the tintur atil the fecler of uny riot

Rllemrliti.

the tintur atil the feeder of my rints..

by one that looks on teeders........ Anony on cleo. iii. I

1. LEDE.Tll-ftedcth those in love. As you

ulies with fecding his own stomaeh....All's Well, i.

limself to have a worthy feeching. Winter's Tal

with eager feeling. food doth ehoke. Richard 11 .

like o lerse full of great $\Omega$ bulk

and so shall starte with feeding

of our blood with wine and teeding

feeling from our soldiers' hands .. Julius Corsar,

in feecling them with those my

for it is not worth the feeding

this woe, in feecting life ...... Tilus Indronicus, iii. ]

where feed st thou o' day's.... Timon of then

FEL-GliLF - or is it a fee-grief ....... Machelt

1.EEL-thic weakness which I feel ........ Tempest

but I frel not this deity......

let nue feel thy elonk upon me.Tuo Gen.nf Jer. iii. 1

miethinks, I feel this youtls's...... Tu'elfh Night, i

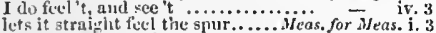

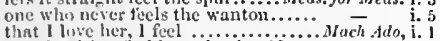

that I meither leel low she should..

which they thenselves not fiee

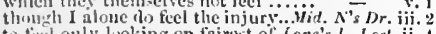

to tect only linking on fairest of. Lore's L. Lost, ii, 1

lisere fiecl wo but the penalty........As you Like

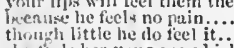

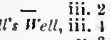

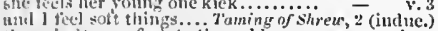

then shalt sown feef, to this cold

this is tos feel a tale, not to hear

have the disetive, and feel't not

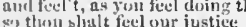

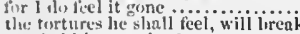

the tortures lie shall feel, will lireak
wot lietl his meaniny? (rep.). . Comed

that I night not fiec your blow

let me feel your 1 mise (rep.)

but 1 ioust a!so fiet it as a nan

wus dive he fiec his title haj

1.6. well I teel the litfierent

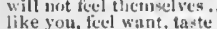

like your fed want, faste

le, th lue fiel it?

lieel, master , how I slake

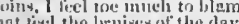

tos feel other men's minus.............

Iii) muse can f(w) but his own

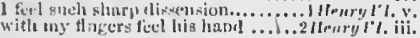

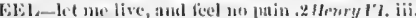

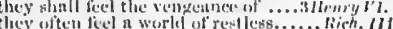

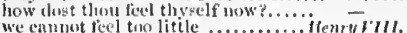
thint she should feet the smart of this?

which I then dial feel full sick $\ldots . . .$.

(fior I ticel the lant fit of 2 .

jow I feel of what toorse metal......

thom should'st feel iny sword i' the

Ifel my leart new opened

ont of a firtitule of sonl I fed

I feel a litte case

whist than not lacur? fecl then. Iroulus \& Cressidn

ns teet in his own fall.

nor fiels not whint he owes $\ldots$.

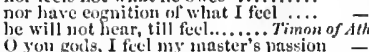

I fecl't gots, I feel my master's jotssion - iii. I

walk, feel, and nutitually participate... Coriolanus, i.

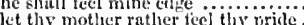

(whiels fiuds not, till it fect

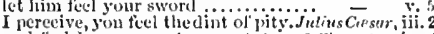

and feel 1 um so nost ....... Antoing of Cleo

but 1 elo fied, ly the reboumi if

I partly fect thee. Aproach, ho

do tecl the treason sliarply $\ldots . . . .$. Cymbe

he that sleeps fiels not the touth-nelie

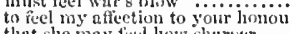

expose thyself to fecl what wretehes fect

lie'll not tiel wrong

If fect this pin prie

by those that feel their sliarpre........

speak what we feel, not what we

this love feel the

young men feel when well-apparcled

speak of what thou dost not fecl.

so shall you teel the loss

he feels himself distraeted

cannot but feel this wrong .............

to the felt absenec now $I$ feel a cause

but set, I feel, I tear

FEELEY-won!d fore the feeler's sutil. Cymbeli

EELING-a fceling of their afflietions. Tempe
and frame some feeling line.. Tieo Gen of $\mathrm{fer}$
with

with most painful fecling of .....
he had some fecling of the sport...

thou hast no fceling of it, Aloth...Love's L. Last, iij. I

(which we of taste and feeling are)

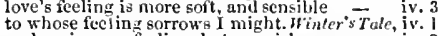

no hearing, no feeling, but my sir's song

no henring, no fecling, but my sir's song - il.

sensible to fueling, as th sight

then, feeling what small things .......... King John, iv. 1

I have had feeling of my eousin's wrongs -

this earth shall have a teclin:

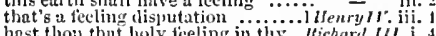

feeling in itself a lack of 'imon's.. Timon of $\mathrm{Alh}$.

andiprove it in thy deeling .......... Cymbeting

see hetaven. bat tiecling wee uripe not bericles

from my sense s tale all teeling else.

by the art of know'l and fecliag sorro
iogenious feeling of my lumge sorraw.

weep for such a tecling loss.... limmeo of Juliet,

eyes without feeling. fleling without... Ha

has this fillow no fecting of his butiness?
FEELJNGIY - I syeak felingly ... Mer.

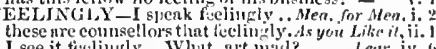

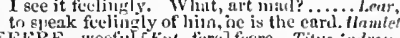

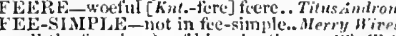

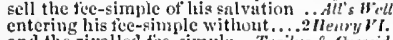

and the rivalled fee-sinple.. Trailus \& Cressida

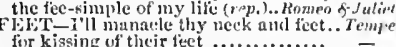

fir kissing of their feet
lake o'tr-stunk their feet

at her father's ehurish feet ...Tirn Gern. of 1

as surely as your feet hit the.... Tree?h Night, iii.

eanary to it with your fiet.

lier feet w'ere niucis too dlaint

as lat treuls on them, kiss his feet.

ect then the

tise fect minht bear the veries (rep.).

no more sluses than licet (rep.) Tam. of sh. $\mathbf{2}$. (indlic.

I will tall prostrate at his fect........

lier knees than ou her fiet................ Netereth, iv.

faliely t lirust ujon eontrury feet . . Ning Johr,

and lull before his feet; for, if the....

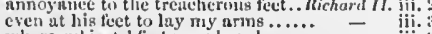

where suljects' feet may hourly

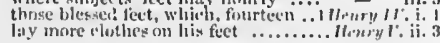

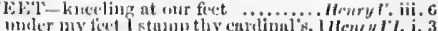
vet are these feet, whuse ntreug hiles - ii. his sworil lretire your hiplenew fect.. $=$ ii. thes ems'st to knecl at llewry's fect.. as willingly at thy fect I leave it ..... - ii.

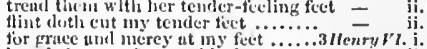

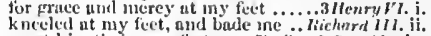
mist kiss their own feet .... Troilus of Cressila, suceess lic strewed betore your fect! .. dut.f Cleo. i. 3 to lny dny erown at his fect. my clouted brognes from ofl iny fect. Cymbeline, iv. and at thy fect I knecl, with teurs... Titus Ant. i. at the Thracian poet's fect $\ldots . . . . . .$. = on the litme fect of ny rlizme.. Perictes, iv. (Gower) that going fhall le neel with fect........ Lear, iii. dust fiencitth thy ficet [Col.-below thy toot] 二 v. to lay our serviee frecis at your feet .. Mambl, ii. 2

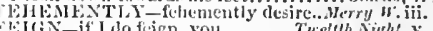
the yet dir feign that orplicus... . Merch of tert. v.

sume hene thou didst fieign.............

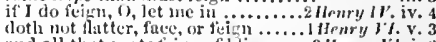

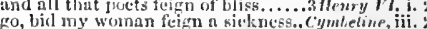
many feipn as they were lowel ... Homeo f Jutiet, it. J feigned ashes of forged love ......... If lenry 1 . . iii. were but a figmed triend ..............3 henryl. iv. 2 feigned Fortune to be tlironcel.. Timen of sthens, i. hast feigned him a wortlyy fellow' (iep.) - i.

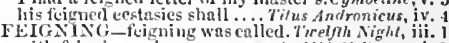

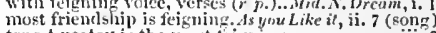

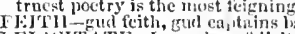

EI,ICITA

FLLJCIT Y-of snel woul were futicity. Low $\approx L$. L. Liv.3

like fell and crucl hounds .............. Teremp Tight, ij. how tell you besides .................. Oberon is passing tell and wrath..Yid.N. Dream, ii. Where the bolt of Cupid fell: it fell..
everything, right as it fell out..... ii. a lim fell, nor else no lion's dam .... ye furits fell! O fates $\ldots$.............. on the toe, and town he fell............ that my nose fell a-bleeding ....... - ii. the enrse never fell upon our nation = ij. 1 they fell sick and died ............. - iif. 4 my prisle fell with my fortunes.... As you tike it, i. for there he fili in love............ - ii. Who yuickly tell before him .......... that down fetl priest and bonk... Taming of sh. iii.
how her horse fell, and she under.... they fell upon me, bound me.. Comedy of Errors, v. ? buke uny fill purpose nor kecp

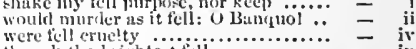

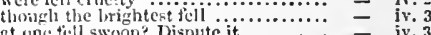
at onc fill swoop? Dispute it

my fielt of hair would at a disnil.......

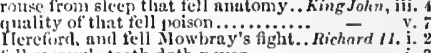
fell sorrow's tooth dowh never....... - i. 3

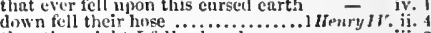
the other niglit I fell asieep hiere

syeh $n$ thod of greatiness fii on yo..... llary Mlanmouth fell umler...2 Hetry from ebon den with fell Alecto's snake = v. ull tell leats enlinked to waste......... Henry $r$. iii. ill whice, or fell jealonsy ............. i llenry $/$ I. ii. tell, haming hag! enciantress........

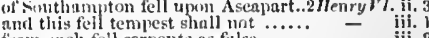
from snels fell serpents as fulse.

stand, of I']l fell the flown......

sifficed with the bear's fell paw ...... liew rlown and fell the hardest-timlicred fell pently town, as if they str
the equal poise of this tell wax

strutuge-uns, how fell, how hutcherly.

fell Winrwick's brother $\ldots . . . . .$.

but lie ficls to limself ausin.

ikicheret Itt iii.

both fivell tit trial fill

ii. 
FELL_that is sad, speak how I fell.Henry VIII. ii. by that sin fell the angels...........

since the cardinal fell

he fell sick suddenly ................

one of which fell with him foresceing those fell misehief.

porringer fell off her head......

they fell on; I made good $m$

and fell so roundly to a large. Troilus \& Cressida, iii.

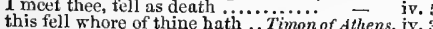

fell from their bourhs

all, save thee, I fell with c...

and shortly must I fell it ...........

so men oheyed, and fell below hi

then the people tell a slouting.

be swooned, and fell down at it...
he fell down in the market-place

but, I an sure, Cresar fell down..

marry, betore he tell down $\ldots . . . . .$.

among the rognes; and so he fell
choked with eustom of tell deeds

ran blood, great Casar tell

and all of ns fell doivn

two mighty earles fell

his soldiers fell to spoil

he fell upon me, ere admitted.......... Antony \& $\overline{\text { Cleo }}$.i. 3

the rest that tell away ..............

with bira, you say he is so feli

- iv. 2

fell bravely, and were slain.............

thy whelps, fell eurs of bloody kind..

that this fell fault of my ...............

ii. 4
ii. 4
ii. 5

down fell hoth the ram's horns

ensues in this fell [ Col. self] storm. Pericles, $\overline{\text { iii }}$. (Gow.)

preserved from fell destruetion's blast - v. 3 (Gow.

how fell gou, with his prepared.....

which thou hast perpendiculinly feli

devour them, flesh and fell, ere they
as he fell, did Romeo twrn and fly. 20 .

as he fell, did Romeo twrn and fly. Riomeo of $\mathrm{Jul}$. iii.

article designed, his fell to Hamlet

a little ere the mightiest Julius fell

the whiff and wind of his fell sword.

it so fell out, that certain plasers...

and herself fell in the weeping brook

(as this fell sergeant, death, is strict..

by his elamour, (as it so fell

her salt tears fell from her ....

Humlet, i. 1

and amongst them felled him dead ........ Lear, iv. 2
FELLEST-

fellest manner exeeute your arns. Troil. \& Cress. v. 7

so, fellest foes, whose passions

FELLIES-fellies from her wheel.......... Hamlet, ii.

he hath lost his fellows ...............

ii. 1 .

fellow Trinculo, we'll fill

to be your fellow you may ...........

fellow ministers are like invulnerable

thou and thy meaner fellows your last

two of these fellows you must $\mathrm{know}$.

fellows, stand fast.

this fellow were a king for

to the fellow that whips the dogs........

'trias a good sensible fellow

made yon four tall fellows skip

a meeting with this old fat fellow.....

ii. 2

my shonlders for the fellow of this walk

am a fellow of the strangest mind. Twelfth $\vec{N}_{\mathrm{g}} \mathrm{h} t$,

madam, yond young fellow swears he

O, fellow, come, the so
shall this tellow live?

steward still, the fellow of servant.

I warrant, thou art a merry fellow

this fellow's wise enough to play

good Maria, let this fellow be looked

nor after my degree, but fellow

thou art but a seurvy fellow.

no words with him, good fellow.

how dost thou, my good fellow?......
bnt for thee, fllow, thy words are....
fellow, why dost thou show me... $-\overline{\text { Meas. for }}$ Meas

next, this is a respected fellow $\mathrm{I}$ am a poor fellow, that would hive.

1 am a poor fellow, that wo
a shy fellow was the duke.

ignorant, unweighing fellow that fel....

instruction from my fellow partner

here's a fellow will help you to-morrow
after him, fellows; bring him ........

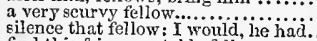

silence that fellow: I would, lie had.

such a fellow is not to be taiked withal

What muffied fellow's that?

bath the fellon any wit, that told

the fellow is distract, and so am $\mathrm{I}$......

the fellow finds his vein ...............

cannot my fellows had the spect

betray the devil to his fellow

many worthy fellows that were out..

God-a-mercy, fellow; and if his....

what becomes of me? fellow, be gone

a fellow by the hand of nature

go, fellow, get thee home, provide.... Richard II. ii.

fellow, give place; here is no longer

poor fellow! uever jozed sined

each takes his fellow for an officer

that ever this fellow should have fewer

a fellow of no mark, nor likclihood..

a mad fellow met me on the ........

fellows, soldiers, friends, better consider

this is the strangest fellow, brother John -
he was some hilding fellow.........2 Henry

he wa some hilain f fllow...........
I am the fellow with the great beliy
stand from him, fellow: wherefore.

stand from him, fellow: wherefore

that $I$ am a proper fellow of my hands

a good limbed fellow; young, strong

peace, fellow, peracc; stand aside

well said; thou'rt a goot fellow.

and this same half-faced fellow, Sha

a tittle quiver fellow, and a would

see such a fellow. These fellows will do -

with the hook-nosed fellow of Rome

but thou, like a kind fillow, gnvest.

and weleome, my tall fellow

v. 1 and such fellows are perfect the .....

peevish tellow is this king of England

should they mock poor fellows thus?

when thou meet'st the fellow ........

here is the fellow of it; and he, that
give it to this fellow; keep it fellow
. Nuch sdo, ji. I FELLOW-no petter than a fellow .... Henry $V$. v. it 二

-

iv. 2 for these fellowrs of infinite tongue...

for these fellows of infinite tongue ... not tellow with the best king $($ rep. $) \quad v$.

this fellow here, with envious..... I Henry $V I$. iv.

follow, lewlow? wouldst any thing.2Henry Vt. i.

I never saw a fellow dost thou proclain? -

fellow, thank God worse bested.

and innocence of this the good wine -

come, fellow, follow us for thy $\ldots . . .$. .

with Pembroke and his fellows....3 Henry $\bar{V} t$. iv.

I tell thee, fellow, he that doth ....... Rickari $I I I$. j.

first, I'll turn you fellow in his grave

spoke like a tall fellow, that respects

go, fellow, go, return unto thy lord..

gramerey, fellow: there, drink that..

All-souls' day, fellows, is it not? ...

fellows in arms, and my most loving

the a fellow in a long motley.. Henry $\overline{V I I}$. (proj.

this top-proud fellow, (whom from...

noble triends, and fellows, whom to..

I find him a fit fellow................

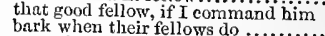

a worthy fellow, and hath ta.en much

you aregance? and from this fellow

but this fellow let me ne'er see .......

a fellow counscllor among boys....

ye have made a fine hand, fellows....

you great fellow, stand close up.....

there's a fellow! go thy way.. Troilus
what snenking fellow comes yonder?

a paltry, insolent fellow ............

what incan these fellows? know they

a strange fellow here writes me...

an hone thellow enough, and one...

strike, fellows my service to her..

wbich were his fellows but of late... Timon of $A t h .19$

this fellow here, lord Timon $\ldots . . . . . \quad-\quad$ i. I

a brave fellow! he keeps his tides.

these old fellows have their ingratitude -

[Col. Knt.] the fellow loaden with irons

more of our fellow, what should I say

we are fellows still, serving alike

good fellows all, the latest of my

'fore me, this fellow speaks! .........

come on, my fellows: he that retires.. mareh ou, ny fellows: make good

a brave fellow, but he's rengeance proud -

and nake me your fellow tribune

what fellow's this? a strange one

what have you to do here, fellow
where is this fellow? Here, sir....

come, we are fellows, and friends

but reason with the fellow ran a.......

and this brave fellow too, we are the

therefore, fellow, I my general is my..

pr'ytlice, fellow, remember my name

a noble fellow, I what's the matter?...

this fellow liad a Voleian to his.......

fellow, come from the throng...........

come hither, fellow: which way ....

What, is the fellow mod?

there is no fellow in the firmament...

how now, fellow? sir, Oetavius is...

aaucy fcllow, hence. Bear with him

Clandius! fellow thou! awake .......

that ever Rome should breed tliy fellow

fellow, wilt thou bestow thy time

let this fellow be nothing of........... Antony of Cleo

there's a strong fellow, Alexas

wrent to these great fow

the fellow has tood judrement

what.art thou, fellow? one, that but

whip him, fellows, till, like a boy.

tond a fellow that will take reward

well, my good fellows your fellows..

as when mine cmpire was your fello.

good fellow, cut thine yas your fellow

see'st thou my good fellow?

nay, good my fellows, do not please..

here is a rural fellow, that will not

and that she should love this

a worthy fellow, albeit he com

profanc fellow! wert thou the son of

the suits of princely fellows............ 
FEL,

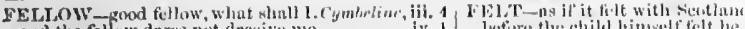
and the fellow dnes not deccive me.. $\rightarrow$ iv. i lefire the chilal hintelf felt he yes, inteed, (di) I, tiellow ... I tell thee, fiellow, there inte the lich, anil tielt them or filt tlut juin which I did wis $J$, that feit tligtyrann one that never in his life felt 80 dangerots fellow, hence! brenthe not

how now, good fellisw? woullikt.. Tilus. A miron not need, niy fellow peces of 'P 1 re

honest! goot felluw, whut's thit'?

now, nfore une a lianisome fellow

sir, this young tellow's mother coniili...

you and your fillows; l'd have it.....

udvery hourst-hearted felluw

dost thou know me, fillow....................

whit salys the fellow thene? eili the.

I thank fluec, fellow; thon serest me.
why this fiellow lias butishel two ol...

thesu wast a pretty lillow, when

titluw, 1 know thec. Whint llost

why, what a monstroms fellow nart
thon art a strunge fellow; in tuilur

whine, are thou mad, nlid fillow

this is some fellow, who having
this is a fellow of the selt'-sume

leing the very fellow thint of thte

slie will tell you who your tellow

where is this straw, my fellow?.....

sonthe hin; let him tuke the fellow

fellows, hold the clitir itpon these.

fellow where ginest? Is it a bergar-
night's storm 1 such a fiellow saw.

is thit the nakent tellow?

sirrul, nuked fellow. Poor Tom, a-co

now, fellow, fure thee wetl. Ges his bow like

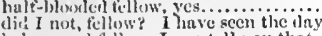

he's a poral fellew, I cur

stay, fellinw; I can real.

yonder lity oer her fellows show

am l like sueh a fellow? come, coing

now, tellow, what's there? things firr

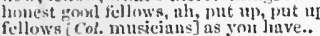

prosperuns, and furewcll, gionl fellow

what should suchi fellows as l do crawl

periwig-pated fellow tear a passion to

we slull know by this fellow

or tict the flitteries thut grow ..... Wienry $\bar{V}$. vour gifte, aud bwectly felt it .. Timon of $\overline{A t h e n s,} v$.

telt ...Ant. B Clro. ii.

which i hul ruther you felt

(y)mbline, ii. 3

ns within me; mot imagined, felt

lere they're but felt ..............

our woes, felt several years.

to slowe o trun ot hore with ici

all Eorrows that ever I hat ve fict

jests at sears, that never felt a woun

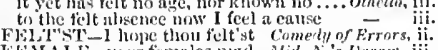

W.MALE-poor females nut Wid. N.'s Dream, iii. 2

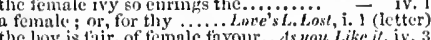
the boy is lair, of temale tavour.. As you Like of this fomale, which in the common.

abundon the socicty of this femele i...

are this terate bastard

and clap their fiemale joims

my hran l'll prove the feroale to.......

flesh is elseap, and femules detr...........

of this law and female har

in riolt anl title of the firmale.

your highness elaiming trom the female
with fermule foiries will his tomb

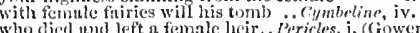

anous tresil femule buds shall

as patient as the temale dove, when .... II meter, v.

FEN-from unwholesome fen

is, as 'twere perfumed by a fen

as reck o' the rotten tins

that his fen makes feared

FENCE-with a master of fence.......... Herry Hives, i. 1

alns I sir, I cannot fence ............. i. 3

despite his nice fence, and his active Much Ado, v.

I'll whip you from $y^{\prime}$ nur toining fence.

tence with some fence ! sirral

or all my fence shall fail............2Henry VI. ii. 1

captain Maraget, to tence you now? 3 ileary $V /$. ii. 6

thint dil cyer tence the right

he hath given for fence impreguabic .

Which fence the roots they grow by ....Pericles, $i$.
FENCWD-sheep-cote, fenced about is you Like, iv.

FENCER-been fencer to the Sophy Tierlfth

Your's as blunt as the fencer's foils ... Much dd

this is the right fencing grace $\ldots . . .2$ Hen $r y I \%$. ii. 1

witlout any more virgmal fencing i... Fericles
drinking, feneing, swearing, quarreling llumle

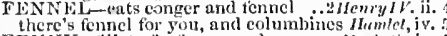

FEN Y - illet of a fenny snake .....

FENTUC-master' Fenton, I ll be sworn . Merry

what suy you to yontug naster Fenton?

und how does good master lenton

what does mister lenton here

good master lenton, come nut
no, gool master fenton ............

You wronf me, master Fenton ........

look on, master Fenton this is

but specionsly for master fenton

master l'entoin, talk not to me

I will hear ynu, master tenton

Fenten, lenven five thee joy

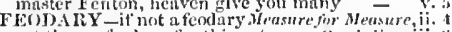

art thou a foodary for this ac
FE1t-Fer, he fays lis name is

FElt-Fer, he fays his name
the French for ter, and terr

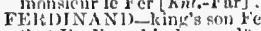

thut Ferdinnn! is drowned"...

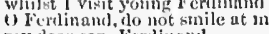

ney dear son, Ferilinant...

ard lerdinatul, Jer brother.....

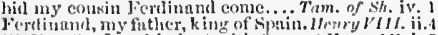

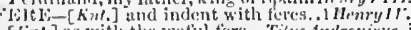
WEint.] as with the woful fere.. Tirus Antronerus, i

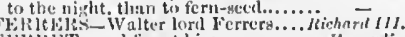
firlis: $T$-and ferret him

with wutl ferret and such flery eyes.Julius Corsar, i.

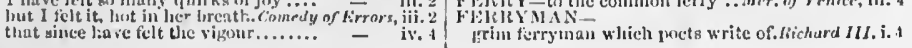

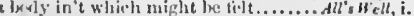
1 have felt so muny qnirks of joy..... iii.

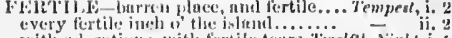

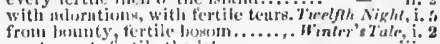
nust swect; fertile the list: and all the fertile lant within ....... ilenryll. fiil.

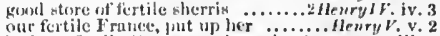

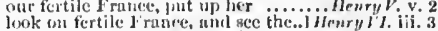
ths I lawe of firtile Finglunt's

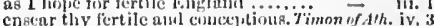

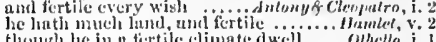

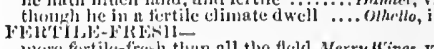

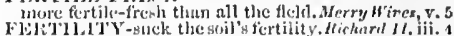

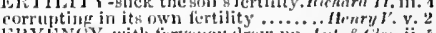

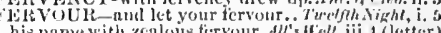

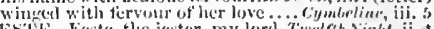

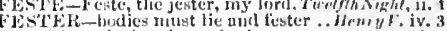

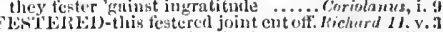

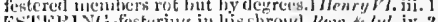

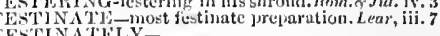
hring lim festinately hither .... Loece's L. Lorl, iii.

nor 1 cannot woo in festival terms. ...Much addo, v. 2 ant most of their festival jurses.. Winter's Tule, iv. 3

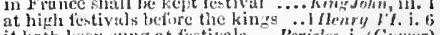

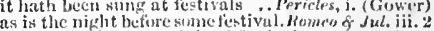
all things, thut we ordained festival nory $v$ ivi. LC1]-to fetuh dew from............... Tempest, i. 2 fetch in our wood...

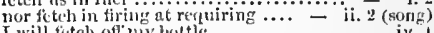
I'll fietch them. sir..........

fetch me the hat and rupicer........... v. 1 she can fetcli and carry

a hor fetch it you ......................

I am come to fetch

go fetch me a quart of sack

I will fetels you light and pai.... Tuefth . .ight, i. s

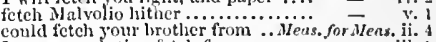

I ean a resolution fetel from .

go in to him and fetch hin or.

and he muy teteh him.

go, fetel him hither................ wuch ddo v.

I will fetel you a toothpicker...

fetch you a hair of the grcat...

arc come to fetch you to church...... $\overline{\text { iii. }}$.

to teteh me triscs, and returi...MAid. ...'s Bream, ii. 2

f.t.h me this lacb................... =

slanl teteh the jewels from the decp

and fetch thee new nuts...............

to lis brother; fetel that gailant. As you Like it, ii. 2

I will feteh uly your gonts...............

let him fetcli his drum ....

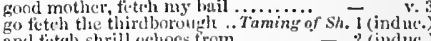

and fetch shrill echoes trom $\ldots \ldots \ldots . .2=2$ (induc.

go, and fetels my supler in

my woy slintl fetch the serivence.......

go, feteh them hither .......................

whut he is, futch me to the sight......

thou slave, nint titech him honie.

pratine peusant; fetch thy master.

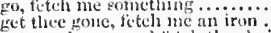

get you home, and fetch the chain...

to my wiff, and ficteh your money...

come to the Centaur; feteh our stuft

toot sullir us to fitcily lim out...

to go fetel a chrin ....................

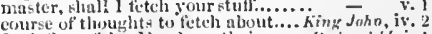

fetcin from lithe Mlowbray their...

to feteh his quen..................

sune of you, nand feteh a looking-glas - iv:

or tlicy will ficteda it from saplact

as 1 return, I will feteh will these justices - iij.

1eteln forth the linzar kite of
I wiln tieteh thy riml out at tliy

I will fetedi him. My lord of .

二 iv. 4

gen forth und fetelh their contuering.. - vo (cho.

sirr: h, go feteli the licadle (rep.) ....2Henry ill. ii.

so few shesuld feteh the prince

lichurdill. ii.

teli fere

I'll tith lier: it is the prettiest. Troilus of Cress. iit. 2 
FETCH-yet go fetch him hither. Troilu let's fetch him off, or make........... Coriotanus, all of us be there to fetch him.........ulius Ca'sar, ii 1 I come to fetel you to the scilate-house
look where 1 ublius is come to fctch me I'll fetch lim presently. I know ... go, fetch fire. Pluck down benches

cten the will in to Mlcrcury should fetch thee up .......

go fetch my best attires ................ I will fetch niy gold, and lave our two and swear he'd fetch us in

pray you, fetch him hither.

il' you'll go tetch him, we'll say....... now will I fetch the king to find ....

then I'll go fetch an axe

go, fetch them hither to us presently

or I'll fetch thee with a warnnion ....

to fetch his daughter home .... - iv. 4 (Gower)

fetch forth the stocks, ho! (rep.).

Lear, ii. 2

go thou; I'll fetch solne flax, aud whites

eten me my rapier, boy........... Romeos Jutliet, i. 5

to fetch a ladder, by the which your love

go, villain, fetch a surgeon

the cords, that Romeo bade thee fetch?
go, I say, and feteh him hither .......

kirrah, fetch drier logs; call Peter....

I believe, it is a fetch of warra

and fetch me a stoup of liquor ...........

1 fetch my life and being from men ..... Othello

must fetch his necessaries ashore: farewell -

fetch' $t$, let me see it. Thy, so I can ...

to fetch her fan, her gloves, her mask

shall I go fetch your night-gown

I'll fctch the general's surgco

Ludlow the young prince be teteled... Rich. III

ETCHES-how hard he fetches breath 1 Henry 11

she fetehes her brcath as short as

FE'C HING-fetching mad bound

ETLOCK - fret fetlock deep in gore... IIe

FETTER-with reason fetter.

but fetter you till death ...Aseasure for Measure, ii. fetter strong madness in a silken ..... Much Ado, v, these strong Egyptian fetters

fetter him, till he be bronght ..... Tilus Antron, v.
we will fetters put upon this fear...... Humlet, iii.
FETTER ED-our wretches fettered in...Hcury $l^{r}$. i.

their chaius fettered the kingly lion...3 Henry II. v. 7

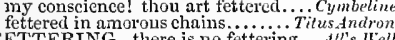

FETTERING - there is no fettering 0 Alls $\mathbf{W}$ ell, ii. Rien puis? J'air et le feu ............. - iv. 2 FEUD-made of our rank feud...Troilus \& Cress. go great a fever on goodness ..... Neas. for Meas. iii. 2
there died this morning of a cruel tever - iv. 3 sick, $m y$ lord, of a strauge fever

but a fever she reigns in my ......Love's L.Lost, fire of fever bred: and winat's a fever. Com. of Er. v. at'ter life's fitful lever, he sleeps ...... Macbeth, iii. this fever, that hath troubled

this tyrant fever burns me up.

ourselves into a hinning fever.

tiever of pale and bloodless (rep.). Troilue \& Cres. the fever whereof all our power ...... - i. 3 potcnt and inficetious fevers heap. Timon of $\bar{A} t h$. iv.

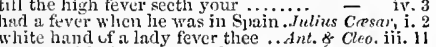
a fever with the absence of ...... Symbeline, iv. 3

FEVEROUS-f'everous life should'st iea.forMea. ifi. 1 the eurth was feverous, and did shake . Macheth, ii.
thicker than a feverous pulsc.... Troil. \& Cress. iij. 2 as if the workd were fererous
FEV

the wretch, whose ferer-weakened ... Fenry $I V . \mathrm{j}$.
FEW-in few, they lumried $115 .$. tew in millions can speak like

here have $1 \mathrm{fcw}$ ottendants

faith, sir, few of any wit ill such. Meas.for $\bar{M} e$

in lew, bestawed her on 1

but few of any sort, and none of name. Much iii. 2

liatl drops ton few to wash her...... - iv.

the liker you: few taller are ........

trust a few, do wrong to none

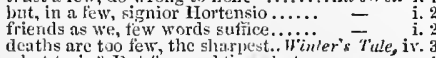

his leisure for a few words.............. Marijeth, iii.
there's few, or none, do know me ... King Jwhn, iv.

I have too fiew to take my ........... Richar'l it. i.

and some fiw ravities tingt in.

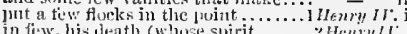

atier so few, ant neter yet nor
FLW-which, after some few hours ..2Henry $I V$. thus then, in few, your lighnes

that men of few words are the best his few bad words are matched ( $r p p$.)

a few disputations with you.........

and those few I have, almost no betie

and those few I have, almost no bette

we few, we happy few

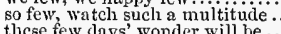

who having pinched a few......

with some few bands of chosen

noletters, and few words.

for few men rightly temper

in few words, if you'll not.............

meet so few should fetch the pring

I took the vantage of those few

but few now give so great oncs...

you few that loved me, and clare ....

and capable of our flesh, few are ange

(but few now living can behold

few words to fair faith ...... Troilus \& cressida, iii.

that few things loves better....

at a few drops of women's rhem....

here's a few llowers, but about

few come within the compass of ...... Thilus

freat king, few love to hear

these few precepts in thy memory

in few, Ophclin, do not believe

FEWER-should have fewer words

[Knt.] Chesliu Christ speak fower

the fewer men, the greater sliare.......
FEW EST - the fewest roses..........
if I have fewest, I subseribe in silence

1 Henryl'l.j.

3 Henryl $V$

ii. he doth fill fields with harne

he doth fill fields with harne

..1HenryIV. iii.

FEWNESS-fewness and truth ... Meas. for Meas.
FICKLE-eye of fickle France........ King John,
please the eye of ticklc changelings... Henry $1 l^{\prime}$.

please the eye of ficklc changelings...1 Henry $I V$. y.
fortme's furions fickle wheel......... Ienry $r$. iii.

amongst a fickle wavering nation

all mcu call thee fickle (rep.)..

FICKLENESS-fortune's ficklcness 't Henry $V^{\prime}$

FICTION - an improbable fiction Twelfh $N$ ight, iii.

but in fietion, why, thy verse Timon of Ahens, v.

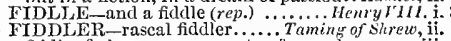

FIDDLER-rascal fiddler....... Taming
fiddler forbear ; you grow too forward

unless the fiddler $A$ pollo gethis Troilus \& Cress. nit.
FIDDIE-STICK-apon a fddlc-stick I IIenry $1 \mathrm{~V}$. ii.

here's my fiddlestick ........... Romeo \&-Juliet, iii. I

FIDELE - what is your name? Fide

you and Fidcle play the cooks: I'll sta

poor sick Fidele! I'll willingl

summer lasts, and I live here, Fidel

save that Euriphile must be Fidele..

Fidele, sir. Thon art my good youth

lad, wlio died, and was kidele $\ldots \ldots .$.

IDELICET-

and there is myself, fidelicet, myscli 1 ....

FIDELITY - by my fidelity ..........

FIDIUS'D - been so tidius'd for all ... Coriolanes, ij. I

go about the felds with me ........... - ii. 3

than all the field to sec $\ldots \ldots \ldots \ldots \ldots \ldots$.

stands empty iu the drowned field Mid. N's.D. ii.

I an feared in field and town

neans to lodge you in the field ........

and welcome to the wide fields too hase

and soldiers, to the ficld!

this ficld shall hold ine

thit oft in field with targe

that won three fields of sultan Merch. of Venice

in respect it is in the fields .......As you Like it, iil.

they fill: to-morrow to the ficld

heard great ordnance in the field Tam

the field is won. Well, forwar.

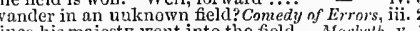

ay and lought of the ficld the fied

of Coenr-de-fion linishlited in the

back to the stainerl ficld, you equial.

that here come sacrifices for the field

whics he intendeth to become the field

sour majesty to leave the field

sore sick, hath left the field........

the noise and rimour of the field....

five summers have curiched our tields

be called the field of Golgotha.

clinmel her fickds, nor lruise lier.
in thrye holy fields, over whose

till fields, and blows, and groan........
cry, pournge, to the ficld! and thou hast seck Percy, and thyself, abont the field

let's to the highest of the field .....

in a bloody field by Shrewsbury ..2 2 Henry $\bar{I}$.

and Staffurd, fled the field

sew you the field? came you
their safety, fly from the field

to abide a ficld, where nothin

the windmill in saint Georse's $\mathrm{Field}$

and face them in the field............

the on to ligher fields, and draw no - iv.

pavilioned in the fields of France...

and a' babbled of green fields..............

neglected English upon

of gallant youtl in our rich fields

than your swords, hie to the field...
to purge this field of such a hilding.

approach shall so much dare the ficid

ill-favourcdly become the morning ficld

from the field: I will the banner.....

marching in the painful ficld .........

yct keep the 1 rench the ficld

glorious and well-foughten field ....

may wander o'er this bloody ficid

peer, and trallop o'er the ficld

then eall we this, the ficld of Agincourt

whilst a tield shoukd be despateined.. 1 Henry $v$ I. i.

for refuge in the field

shall pitch a field when we are .......

came to the field, and vanquished ...

the great Alcides of the field .........

so of ten lodge in open field..........2 Henry

which eliased you from the field ....3 Henry

shall plead it in the tield

return with victory from the field.....

army of the queen hath got the field

highusss would deprart the field........

vide the mortal furtume of the field?

himself keeneth in the cold field?....

power, that Edward hath in field ....

having now the best at Barnet field.

in the ficld by Tewkesbury

in the field at Tewkesbury
when we both lay in the ficld ...

is in the ficld, and still his jower

spoiled your sumer the field

even here in Bosworth field

the foc vaunts in the field $\ldots \ldots$.....

that once was mistress of the field. Henry $\bar{Y} / 11$. iii.

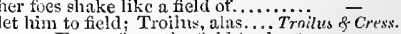

news, Fneas, from the tield to-day?

and to the field goes he ...............

excitements to the field

Achilles will not to the field to-moriow

they are come from field ............

but in these fields of late.............

Ajax goes up and dow' the field ....

to the field. "Tis Thoilus' failit ( $(r p$.

any voice or order of the ficl
let us see you in the feld ....

in what place of the field doth

a thotsand IIcctors in the feld

yet are we masters of the fielc

dragged througli the shameful field..

your heart's in the field now.... Timo

our army's in the field.

are $y$ ou lords o' the field?...

if we lose the field, we cannot..........

shall i' the field prove flatterers. ....

called both ficld and city our
the left-hand of the even field

tell me what thou not'st about the fieid

cet us to the field: Labeo, and Flavius

proclain $m$, name abont the field...

so, call the field to rest: and let's away

thy wife first came into the field.. Anton

show ourselves i' the field.............

tie np the libertine in a field ot feasts

we have jaded out o' the ficld.

Antony is come into the fie

the fleld: well leave.

are grows the mortal bugs o thic field - v. by my faith, the field is lonourable

to-morrow in St. George's field .........

saddle White Surrey for the ficld....

he proved best man i' the ficld 


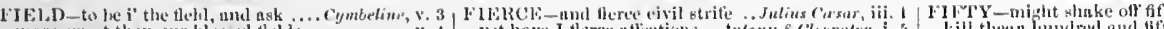

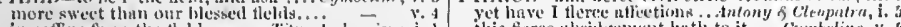

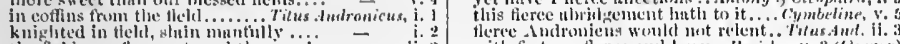
政,

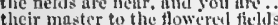
anve yoll ficld of stars, they here

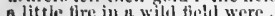

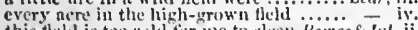
to befure to field, lie'll he toul the

the sweetest fiower of all the ticlu.

such a sight as this becomes the fielii .. Hambet that never set a sijtudron in the ticlel .. Othelln dearest aetion in the tentet fleld....

aecidents by thool mil field

FI 1F.4

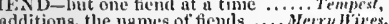

- bov hollow the fiend spenks.. Tuetrin with"

the fiendis rough, and will not...

flerece Androniens wesuld nut retent. Futus ant. ii.

more eomposition and fieree quality

heres ure ileree, lint thine do enmtiot

her eves ure ileree, bint thine do enm
nor thy nicee sister in bis numbinted.

more fierre, unil more inexorable. Romeo of tutirt, $y$.

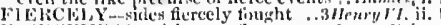

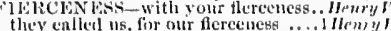

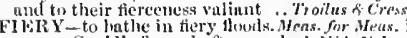

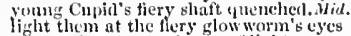

aif $y$ on hery oes and wos ot li hit.

hest secing heuven's fery eye.

shall bring their fiery torelier ...........

S's L. L. iv. 3

fors's fiery steed; to other regions! - ii. 3 alas, how fiery and how sharp.. Comedy or

inemsiderate, fiery voluntaries..... King John, ii. ] equal potent, fiery kinclled spirit

and euend these fiery spirits from

from out the fiery portal of ........

of heaven was full of fiery shapes

to turn and wind a fiery Pegasus
and look whether the fiery Trigon.
full of nimble, fiery, and delectable.

the fiery tever will go out with

hath thy fiery heart so part

with fiery eyes, sparkling.

tien fiery expedition se wa......

the bright traek of his fiery ca.

beekoning witl fiery trunclieon. Troilus \& $\bar{C}$ ress

follow thine enemy in a fiery gulf..

proud cedurs gainst the fery sun.....

most bloody, ficry, and most terrible

wixt the fy night's blackness ... Antony \& Clen.

sou know the fiery quality of the duke... Lear,

tiery? what quality? why, Gloster ....

in the instant came the fiery Tybalt.Rom. \& Jul. $i$.

and outbreak of a fiery mind ........... Hamlet, i. .

send thee hence with fiery quickness...... - iy. 3

FlERY-FOOTED-

spurring, fiery-red with haste ....... Richard 11 . ii.

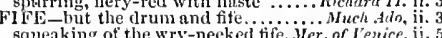

squeaking of the wry-neeked tife..Her. of Jenice,
from Fite, great king, where ........... Macbeth

no, eousin, I'll to Fife.

seize upon Fife, give to the edge

the thane of Fitio hat a witc

aone but Morlake, the earl of Fife

the ear-piereins titi, the roy al bans. Carinlar

the ear-piereint hite, the royal banmer.. Olhelo.

blind puppies, fifteen it the litter

alas, fifteen wives is nothing ..... Mer.of ren

mounts not to fifteen thotrand....All's Hell, iv.

these fitten years! by my tion aming of sh. 2 ind.

above some fiftecn years and more... -2 (ind.)

and odd slilling: fiftcen hundred shorn

twice fifteen thousand heurts

full fifteen earls, and fifteen hindred.............

full fifteen lundred, besules cominon

pry one and twenty fifteens......... Henry

FIrTII-repeat them, or the tifth. Lore's L. Los'

eone from a fifth, the prinee of. Mereh. of Venice, i.

the fifth, the comtercheck..............

third, or fourth, or tifth ...... Toming of sh. 1 (ind.

Itarry the fifth is erowned..........

llarry the fourth or fiftl

Ijenry the fitth, tho fanons io

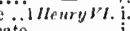

Ilenry the fifti he first trained

when Ilenry the fifth, sucecelling...

time of I lenry, named the fifth.

IIenry the fitti did sometime prophes

the fiftl, was Edmond Lankle

Ifenry the tlftli, in whuse tine jo....

lienry the tifth, that made oll Frine

the son of Ilenry the fitth, that thus

the name of Ileury the fifth lales

I am the son of Ilenry the fifth.

IIenry the fiftl, who by his lirowe

Col, Knt.] the tlfth lionr of tile sun. Troil. \& $\mathrm{C}$ iii.

the titth, a hand environed with $\ldots . .$. l'erecles, $i$

FIlTY - hundrerl and fifty poumls. Merry Hiers, iii.

yes, your beggar of fifty...Mensure for dileasure, ii wash my fieree hand in lis lieart ....

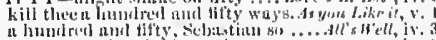

two limulred and fifty ench

diseases us two and fitty horste.

thugh remoyed fifty times.

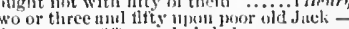

his age some tifty, or, by'r lady .......

hundred and stfty tatterent prodigats

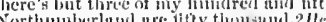

Northamberland are iffy thousand.2 Henry l!' iis.

that two and tifty kingloms hom.

liere g but (me and fifty huits

let the requent be lifty tatenty... T

let me hawe a chilul at fifty ....... dutony \& Cleo. i. '2

Whe, difty of my foll wwers at.............. Lear, i.

What, fitty tollowers? is it not well?.... - ii.

give twenty forty, fifty, a hundred ....Inmle, ii.

le cannot want fifty-five hundred. Timon of $A$ th. iii.
FIFTY-FOI.D-fifty-fold a euckold.. An'

$G-$ green figs, and mulberries. Wid.N.'s Dram, ii. I

and fig me like the brugring

Nenryl iii. 6

and a fig tor Puter !................2heury 7. il.

presence, he brings you firs

presence, he brings you figs $\ldots . . . . . .$.

virtue? a fig! 'tis in ourselves .......... Othello, i, 3

hIGIIT-1'll fight their legious o'er..

I slew him manfully in fight.. Two Gers of ${ }^{2}$ er. Iv. I

for thee to fight................erry Wires, ii. I (letter)
rather hear them seold than tight - ii. 1 (letter)

pursue, up with your fights

if you slionld tight, yni.........

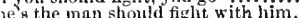

me the count's youth to fight.... Tuelyth Night, iii.

he will fight with you for his onth sake - iif. 4

und eommsel him to fight against.....Mueh Alo. iif.

than fight with mine enemy ......... iv - iv

these lovers seek a place to fight .... $\overline{\text { and }}$ iij.

and every man that dures not tight!...Love's L.L. i.

I will not fight with a pole .........

but the fight of two rams ...........As you lilke it. y. 2

go so much backward, when you fight. $A l$ 's $W_{e l l}$

this eruetty, fight on thy side......... - ii. 3

you denied to fight with me....

pretence I tight of treasonous.

will fight, her young ones in.....

make our wonen tight
I'll fight, till from ny bone

beaten, if we eannnt fight ...........
bear-like, I must fight the course

people on both sides do fight.

cour hope: I'Il not fight

Nacbeth, ii. 3

o parley, or to fing

then, after, fight who shall be kin

that dost never ight but when her

the french fight enldly, and retire.
if I bo trator, or unjustly fight!

llerefurd, and fell Iluwbray firght...

ant as 1 truly fight, defend me heaven

do I with Nlowbray fight

as to jest, go 1 to fight..................
dares him to set forward to the fight

where one on his side fight

fight with (itendower aigh his co

fight against yourself: fear (rep.).

ict's fight with gentle worls....

to fight against the irregular and wild

if he fight longer thun he sees reuson

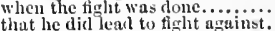

currents of a heady titht

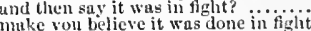

to fight ngainst me under I'erey's...

We'll fight with him to-niglat
try fortune with him in a single figlit

to figlit with Glendower...

and the shows of men to fight ....

intury

and they did fight whtll gueasiness...

anil true order of the fight .......

I lare not tight, but I will wink

gaces it out, but fights not

ike wolves, and tight like devils...

I deterinine to thlit iustily for him.

to make us fight elieerfully
and after fight with them?

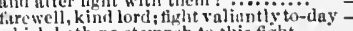

which liath no stomach to this fight..

might fight this battle out!

the wat i gitio...... 
FIGHT-I"ll fight for France if thou be slack, I'll fight it more than three hours the figlit contimued firht till the last gasp............... Ill comtirm: we'll tight it out........... either relight not orsee in for when the fight beinn, roused on the.. set this unwenstomed fight aside... and children, all will tight this tisension fint bo tight it out strong enougls to issue ont and fight colours in this daurerous firht with his power, to tight with Talbot York set lime on to figlth

my tollowers here, to fight, and die? and victory! fight, solviers, tight the maidenhood of thy first fight it thou wilt fight, figlit by thy

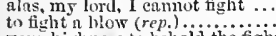

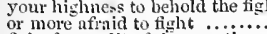

fight for credit of the prentices

fight for credit of the prentices . .
those which we have lost in figlt

fight for sour king your country...

come then, let's go fight with them..
my foot sliall fight with all the streu

hew up roeks, and fight with fliut...

come forth and fight with me

You"ll nor fight, no: fly .............

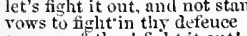

eourage, nther! fight it out!

so cowards fight, when the

naking another head to fight agai

be it with resolution then to fight.

learteu those tliat fight in your

hand to hand I slew in fight

and let them fight that wil.

why should we figlte, if you pretend

I challenge him to single figlt

leave the town, and fight

march on to fight with us..............

ready to fight; therefore, he resolute

give simnal to the fight

you fight in justice (rep.)

to fight on Edward's party ....

..̈ichard 11. $\mathrm{i}$.

Warwick, and did fight for me?

prayers on the adverse party fight

to fight against that bloody homicid

to fight against that bloody honnicide

good angels, fight ou Richmond's side

our good cause, fight upon our

then, if you fight against God's enemy

if you do fight against your country

all on toot lie fights .......

as fool and fight is

as fights and fireworks

Heni y $V \overline{I I}$. (prol.)

and fight for bitteu apples ............

fight, uncle? Helenus? (rep.)

for whom he comes to figlit

to fight for and maintain

you must prepare to fight without

nay, you sliall firms to fight .........

nay, you slatl fight your hearts out

I'll fight no more 'gainst Troy

shall Ajax fight with Hector...

he must tiglit singly to-morrow

not warm yet, let us fight agai

I'd fight with thce to-morrow.

a figlit of this strange nature .....

meanest thou to fight to-day?

I would not have you fight to-day

now here he fights on Galathe

I'll fight with him alon

in the son of $a$ whore fight for $a$ who

and slain in firght many of your. Timon of Alhens, one crutch; and figlat with the oth

and flght with hearts more proof

tore yet the fight he done, pack up.....

thus I will appear, and fight

the business in some other fight.

I'll fight with none but thee $\ldots . . . . . .$.

saw him fight, when with his

for I will fight against my ...........
fights dragon-like, and does achieve..

but then I'll fight

fierce fiery warriors fight upon the.julius $\overline{\text { caser }}$ if creature that I tcach to

if you dare fight to day ................
we shall try fortune in a second fight

we shall try fortunc in a second fight

and to fight, I should ....................

and we shall talk before we fight ...

we came hither to fight with your
FGHT-we will fight with him...Antanys Cle. iii. 7 I'll tight at sea. I have sixty sails.

Onoble emperor, do not higlit by sea

i'the nidlst o' the fight, when vautage

leaving the fight in height

brenthed, and fight malieiously

it ents the sword it tivl ..... with

iii. 1 it eats the sword it the last of with wany battles we menin to

he will not figlit with me, Domitius.

by sen and land I'll fight

wou, that will tirht, follow we close.

determine this thent $u$ in sinsle fight

to make me tight at land! . . i .......

I fight agninst thee! No: I will

like the Parthian, I shall flying tight. Cymbeline, i. 7

and to fight against my lady's kingtom

so I'll fight against the part I come with
stand, stand, and fight! Away, boy..

fight, will no more, but yield..........
ancl, Romans, fight for freedome...
suceesstul in the battles that he tights

SI if to fight for king and common weal

ripe for marriage fight [ $\mathrm{Col}_{\text {- }}$-sight $]$. Periclus, iv. iv.(Gow.) betore you ticht the battle

he tights ts you sing prick-song. Romeo of Juliel, ii.

a villain that fights by the book

fight for a plot whercon the members .. Hamlet, iv.

why, I will fight with him
woul't fight? woul't tast?

were it my cue to tight, I should have ... othello

um no fighter a .......... Tuelgh Niwht iii.

contess to you, sir, I am no figliter.. Hinter's T. iv.

ii. 1 fits a dull tighter, and a keen guest..1 Henry $1 v$. iv,

ii. 2 thou fightest against thy countrymen

i. 5 FIGH'ETH-l thou fightest

i. 5 IGITING-stealing fig one weary.l Henrylli.i.

have twelve thousand figlting men. Riehard $I I$. iii. 2

leave fighting $o^{\prime}$ days and foining ..2Hevery $Y$. ii. 4

of tighting ment they have full.

some among you have beheld me fighting. $\overline{\text { Coriol. }}$ iii. 1

and tighting foot to foot .......... Antony \& Cleo. iii. 7

close firhting cre I did gang........ Cymbeline, ii. 1

step between her and her hightin
there was a kind of tighting

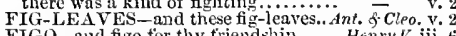

FIGO -and figo for thy triendship .....Henry $F$. iii. 6

the figo fin thee then! I thank you ...

she wooes you by a figure.. Two Gen. of rerona, ii. 1

what figure?

is as a tigure trenclin in ice..

by the figure, and such danbery ..... Merry Wives, iv.

it it be but to scrape the figures out .. $-\overline{\text { iv. }}$.

and so great a figure be stamped.......

doing, in the figure of a lamb $\ldots . . . .$. Mnth $A d o$, i. 1

and no eyes, tigure unheedy haste....

a most fine ignre?.....................

what is the figure? What is the tigure
spruce affect:ation, figures pedantical

spruce affectition, figures pedantical

shall see mine own figure.

for it is a figure in rluctoric .......... , w. 1

he will throw a figure in her face... Taming of $\mathrm{sh}$. i.

resolveth fiom his tigure 'gainst. .... King John

shall the figure of God's majesty ... Richard 11 .
apprehends a world of figures here ..1 Henry I'

we see the figure of the louse

whose white iurestments figure innocence -

sivee a crooked figure may attest...Henry $r$.

I speak but in the figures

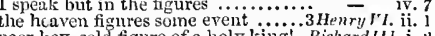

whose figure even this instant ....... Henry VIII. i. I unbodied figure of the thought..

the baby figure of the giant inass ...

renders back his figure and his heat $-\bar{t}$ iii. 3

in thee the fignures of their love

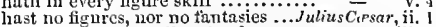
tongues, figures, scribes, bards ...tntony d Cleo. iif.
arras, firures, why, such, and such.. Cymbcline, ii. arras, figures, why, such, and such.. Cymbeline, ii. 2 in as like a figure, strikes life...

take pieces for the figure's sake...

desery a figure of truth, of faith:Pericles, v. 3 (Gow.)

no figure at such rate be set ..... Romeo \&. Jeatiet, $i .4$

in the same figure, like the kiug .........Hamlet,

that this portentous figure comes armed -

a firure like your tather

a foolish figure; but farewell it ......

figure of my heart in compliment

but (alas!) to make me a jixed tigure

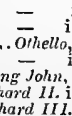

i. 2

my figured goblets for a dis

Richerdin, $\mathrm{y}$.

FIGUTING-figuring diseases in me...Michard III.

ii. 6 all men's lives, figuring the nature 2 Henry $/ Y$. iii.
F(1,Cly-eamest to have me fileh it ...orhello, iii. Fil.CI ks-but he that filehes firom me. Othello, iit. FluclIING-his thlehing was like ...Merry Wizes, i. 3

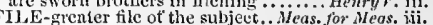
I put myscl' into thy file...............Al's 'well, iii. it is upon a file, with the duke's.....

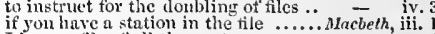

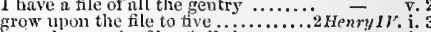
he nakes up the file of all the.......... Henry iny. $\mathrm{i}$. but in that fite where others tell

are lis tiles as full as thy report?...Timon of . Ath, v. the conumon file, (a plagne !........ Coriolanus, i. 6 let him choose out of my files.

the files and musters of the war..........

within our files there are $\ldots . . . . . . .$.
for three pertormers are tlice file .... Cymteline,

she shall file our engines with .. Titws Audron, ii. 1
FILED-more sharp than thled sted. Twetjh Night, iii.3 us tongue tiled, his eye .......... Love's L. Lost, v. I I woukd hare tiled ke,s off .......Winter's Tole, iv. yet, filed with my abilities......... Jenry VJII. iii. 2 filial ingratitudel is it not is this mouth. Lear, iij. 4 bonnd in filial obligation for some term. Hamiel, i. 2 Ili_-fill all thy bones with aches ..... T'empest, i. we'll fill him by and by again

lic'll fill our skius witli pinches.....
shortly fill the reasonable shores

my sails must fill.

a monn to till your song..........

that one error fills him with fault

in his emincuce that fills it up...Meas. for Meas i.

I dare not for my head fill my ........

many inches do till np one ..... Love's L. Losh, V. 2

I fill a place, I know"t

delivers me to fill the time ............. of $\overline{\text { shrew }}$ ii. $\mathrm{i}$. 1

come; I'll till your grave up...........

Macbeth, i

give me some wine, fill full

could nct hill up the cistern....

foisons to fill up your will

griet' fills the room up of my

and fill up her encmies' ranks

by so much fills their hearts.

and fill another room in hell

he doth fill fields with harness

to fill the montll of deep definuce....

such liave 1 , to fill up the rooms of

they'll fill a pit, as well as better ...

changes fill the cup of alteration ..2 Henryl $\boldsymbol{V}$. iii.

fill the cup, and let it come...

to fill king. Edward's t'ame

fills the wide vessel of the

here, uncle Exeter, fill this glove

whose glory filts the world...

to fill the world with vicious

or I will fill the house witll...

henec, where I may weep my fill

- v. 3 (soug)

- ii. (chorus)

cause as fills mine eyes with tears...

to fill the world with words............ Richard III. i. 3

it tills ons ear's with sucli.............

only to fill the scene

now fills thy slecp with perturbations $=\quad$ v. 3

and he fill up one monument! ........ - ii.

I will fill them with prophetic ... Troilus \& Cress.ii.

we'll put you i' the filis...............
behold thy fil. Nay, I have....... iv.

thou hast thy fill of blood and death - v.

his lobbies fill witl tendance.

fill me some wine............

pass by, and curse thy fill... - -.. v. 5 (epitaph) ransoms did the general cotfers fili Julius Cesar, iii. fill, Iuvins till the wine o'erif he fill his vaeancy with............. fill, till the cup be hid

lie will fill thy wisbes to the ........ - iii. 1 should fill the bores of hearing .... Cymbetine, iii. and fith his aged ear with golden. Titus Andron. iv. be poor, 'twill fill your stomachs you do love, fill to your mistress' lips fill thy purse with money

but oue that fills up the ery $\ldots \ldots \ldots \ldots . . . \cdots=$ - ii.

rather than filled with me

morris is filled np with mud.......iii. N. Dream, ii. 2
slould be filled with all graces... As you Like $i$, 


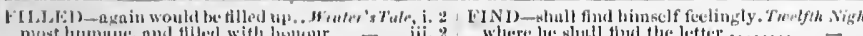

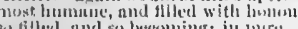

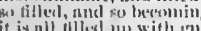
his lours lll ul with with riuts. ence are filleil. hnve tllled their courts be flled with my reprond .. 2/lenry 1\% iii, 2 a sail, fllent with a fretting gust lhy place is filled, thy reept re tilled it with ewring wies

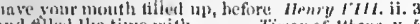

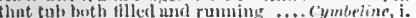

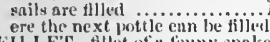

VII.I.E.T-fillet of u fermy anake.

r IJI,ING-filling a buttle with by liting the oue doth empity ....
filling their henrers with strange

two buckets fllting one unather

for Mpus iii. in flling the wliole realm bul, filling the air with sworil

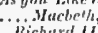

metronicus, iii.

FII,I,IP-it' I clo, flliti, nue. yeut thllip me o' the lieat .... Troilus of Cressirth,

FII, X-in likeness of a filly tont Mil. N.Drom,

Fil.sI-the lash of film ......... Nomen f Juliet

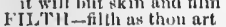

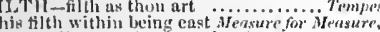
whose filth and clirt irouble

the flith and seum of kent .

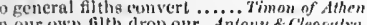
eammon sewers, of filth.

my foe I'll grine with tijith.

Filth, thou liest. By Jenven, I lo vot .. Ohetlo

hi, Th $-i$ ' the filt ly mantled poot... Tempest, elothe a back, from sucli a filthy vice

old, filthy, seurvy lord! well, I must. All's ${ }^{\prime}{ }^{\prime}$ ll a filthy otfieer he is in those sugge-tions
fle, fie! 'tis lewd and filthy .. Fuming of

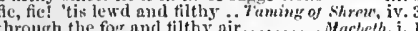

throllgh the fog and filthy air...

Wash this fittiy' withess from

and sumg to filt liy times.

- ii. 2

you filthy bung, nway! ............2ilenry $\bar{l} \mathrm{~V}$. ii. 4 you lilthy famished eorrectioner

knave; and contagious elouds ..... Henry $r$. iii. 3 vet be's but a filthy picee of work. Timon of dilh. $\mathrm{l}$. fith, for the worst is filthy

filthy worsted-stoeking knav

1) fil thy traitorl umnereiful larly

the slime that stieks on filthy deeds ..... othelto, $\mathrm{v}$.

too find of her most tilthy bargain -

Fi $z$ - notre trits cher fiz. Henry roy..... Honry $t$.

no fenthers, and fisl have no fing. Comedy of Err. iii.

for a fish witsunt a fin...

la fin eouroune les wuvre.

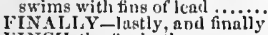

2Henryl.

Coriolanu, i. ]

F INCI-the finch, the sparrow. Miti. N.Dr. iit. I (fong)

out, gall! Fincli egg! $\ldots$..... Troilus \& Cressida, v.

what torment 1 did fint thee in

and atritys about to find them.....

I find not $m$

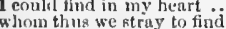

you should find inany.

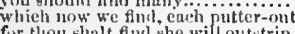

fi,r tlou shat find she will outstrip

there shalt thou find the mariners.....

where shemld they find this grand linuos

thus tind I by their loss.... Tivo Girno of tiron

him we go to fint.

go firral, find him out.

whilfibel my dog ngain......

O) sir, I flud her milder than...

sir, yon minll titul me reasmalie..... Nerry Wive and tind anybrry ir: the house ...... -

you shinl finel it o great cliarge

welt, I will find you twenty.

if I lo flum it, woll

if I thol her honcet.............

and you alull one dny tind it

kenreh, feck, findl out .................

I cannot tlot him....................

gearch for you, und enuld not fiud you?

if you find a mun thace.

if you find a minn there.

if they ean find in their hen

your denial I wouliI find no kellee. Tirelfh Night, i.

and fear to find mine eyc tom. he it his that fluds

will iny revenge find nutable eause... ne'ce tluid sily frave....

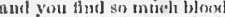

you whulal the better tealin

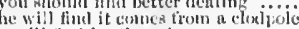

you'll thut it wherwise.........

and he finds that mew seuree to bo.

I enuld not fint him at

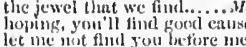

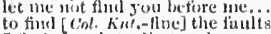

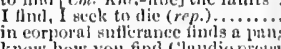

know how yon find Clandioperpuseil

for I lo finl, your hangman..........

you shind thit me yare

where you shatl ynd, within thace.

yow sir, how do yoll find the jurisoner?

to find out this alone

we shall find his firiar to be

I find un apt renissiom in mysel.

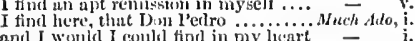

you shall fiul her the infernal

go then, find me a mert lour

I tonlat time in my heart to bestow it

but they shall tind, awaked in suel.

then we fint the virtue, that posesc

I cun fint out no rlyyme to lusty

le it so, 1.ysander; find you ont a bed.Mid.

[kmt.] hut Athioniat tingl I mone

ceath, or you, rin find immediutely.

Ilelent of A thens look thou tind

I'll find Demetrins, and reveuge this

fespiteh, I ray, anel fiod the forester

c:mless you can fiml nurt in their .ib

and finds her lover? slre will find him

you find not the apostroplaes

but presage find; that the lo

I'll find a fairer fitec not

lose our ouths, to find oturselves.....

i light th your metming out

seck all day ere $y$ you tind them. Merch. of Ven

or to find both, or hring your

fust bind, fust find; a proverb.

let us go, and find him out.......

hear of her, bint cammol find her.

what find I here? fuir Portia's

be finds the joys of hea ven hiere on...

I eannot find it; 'tis not in the bond

and find it out by proclamation
there you shall find, that P'ortia

there you shall find, three of your

which thou dinalt find 1 will.

but I did find lim still mine...

finds toogues in trees, books in......

I eould find in my heart to disgraee

little recks to fisd the way to heaven

I go to find my fawn ................

look to it; find out thy bristher.

sweelest rose will find, mint find

now I hind thy aaw of might

we shall find a time, $\Delta$ whe re

you shall find of the king a himibind.. Alt's Well, i.

and finds no other arlvantage in the.. $-\bar{i} .3$ (son:

wed find no fuult with the tythe

Lo as mueh love as fhe finds

that seeks not to find that her acurej

the hrevest questant shrinks, fin

in your bet find fairer fortune

I find, that she, which late was.....

ditl you find me in yourelf (rep prou

mnch finol may you tind in you...

find you that there?

if your lordship find $\mathrm{him}$ not....

what a sirrat you shall fond him

devoury up all tle fry it finds.

if you could find out a country where

and you shall find yourself w be

where ditl you find it then?

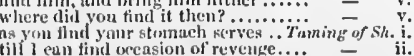

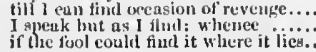

which you slath find by crery sylluble

so, ere you tind where light in.... Love's

and so much to find the thief.........

and find your grace in health.........

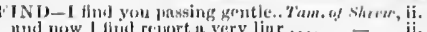

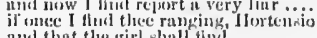

iii.

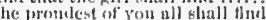

finult I'll find utwolt the inaking

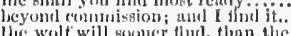

lice wolf will gomer fluth than the

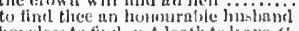

hopeless to find, ret loath tolctive. ('o

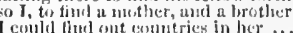

but I pould fired no whiteness in

the fellow ind hip vein ..........

and thon shalt frorl me just.........

there's no urt, to find the mind's
do yoll find your patience ro.

if it lintl heaven, mast find it out.

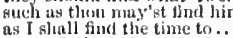

where I rlil find my doolitis...

long, that never finds the doy.

do we but find the tyrant:

lel me find $\mathrm{Jim}$, fortune! .....

where slomld he find it fairer.

find liable to our erown............

and in lier eye I flud a wond

8o we conlil find some pattern of ...

shall fiud but bioody sufcty..........

and find the inlieritanee of this joor

I find the peojle strangely .......

and find no cheek? let us, my liege.

of night, to find you out

fimts brotherlesod in thee $30 . \ldots . . . .$.

which finds it an cintureed pilgrimage

ancl I mast find that litle in

to find out right with wrong

there shonlast then find one loeinous

therl myselta lraitor wi

with eare, find we a time for

you ghall find me in Easteheap.

there thou shalt find him;

I eould find in my heurt .....

find pardon on my true now find out

you shall not find it so; and God ...

thou shalt find ine tractable

want

they'll find linen enough on every.

avd find a time to punisl this offere

and thou shalt find a king that will.

nuy, you shall find no boy's play here

noul it; you know where to find me.2 Hrary $I$. $\mathrm{j}$.

if we fud ont weighs ability $\ldots \ldots \ldots \ldots$

and find nic worse proviled

nst fiud out Sucak's noise.

should r:ot find a grountl to root upon

good from bal find no partition

find him, ing Jord of Warwick

be assured what grace to fincl

and you shall find, his vanities.

when you find him evealy deriver
be assured, you'll find a difterence

if I tind a hiulc in his coat .....
then we shatll find to-morrow

you shall find the ecrembinies of the wars -

seck throngit your camp to find you

you shali find: in the emmparions

that shall find himself' ag reriefed

son find it otherwise; an, hencedorth

Wouldst tind me such a ptnin king ..
shalt time the best king of yoid fillows

and thun shalt find that 1 ixiced.....

I fiul, thus not no less thin fane.

well, l'll find friends to wear iny

ay, thou shalt find us realy

find thou hast distowoured me -

and that we find the sothful watch.. -

my chanee to find thee ont

we shall not find like oploremily

yet I do find it so....................

we must have you find your...........

kinall tind their leaths, if yor

shule of clenth I luall finu juy

who finds the heifer deast

who finds the partrid te in tio

an Iris that shell fine thee ont

unless I find him quilly

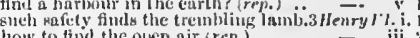


FIND-here find his hiends with ....3 Henr? $Y I$. he'll som find means to make to find us unprovided.

that, who finds Edward, shail............ she tin !s, althongl I eannot........ Richard III. i

but I do find more pain in banishment

[Col.Knt.] to find the empty, vast, and

there shall you find us both

and hopes to find yon forward upon

and firds the testy gentleman so ho

you shall find me well accompanicd

may here fiod truthl too ........ Henry $I^{\prime} \bar{I} I$. (prol.)

my counsel, rou't find it whol

cruld not find his hour of speech

should find a running banquet er

they should find easy penance

woild have your grace find out...

instantly will find employment

I find him a fit tellow .................

your graces find me here part

madam, yon'll find it so ............

which I tind at such prould rate......

till I find more than will, or word.

Crammer will find a friend will not..

that it may find good time ......

the king may never find a heart

yet should find respect for what

of $m y$ conneil, but I find non

and find a way out to let the troop $(r e p$.$) -$

and ye shall find me thankfil

like, or find fault .......... Troilus \& Cressida (prol.)

that find such cruel battle here.

to find persistive constauey.......

find Heetor's purpose pointing

could you not find ont that by her

finds safer footing than blind

finds bot tom in the not worth $\ldots$.....

you did not find me here ..............

shall find him by his large

this fuult in us 1 find, the error........

but find supply immediate.

ceep enough, and yet find little....

men daily find it sueh

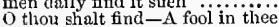

where my stomach finds meat.

find that thou want'st by free.

thus you still shall find him

where he should find you lions, finds

you'll find they have not prepar

can a treaty find i' the part that is

where I find him, were it at home

when I find the ass in compound

whe hope to find you our friend

which finds not, till it fecls

the Volseian state, to find yout out there -

look pale before youl find it other

and his, find something in him ....

we must find an evident calamity

we must proceed, as we do find the people -

if you do find them deeked with ...Julius C

to find ourselves dishonourable graves

you shall find that heaven hat

where Brutus mar but an

to Pompey's porel, where you sliall find -

they conld not find a heart with...

I shall not find myself so apt

what, shall I find you here?..........

Cassius' sword, and find Titinius' heart

Whall find time, Cassius (rep.) .. ...

find me to marry me with...

if you find him sad, say, $Y$ am

you shall find there a man

and did find her welcome friendil

but you shall find, the band...

you slall not find, though you be...........

I find thee most fit for binsiness ......

should I find them so sauey with the

what she says, and how you find of her

and you shatl find a conqueror

further than you shall find cause

you shall not find me, daughter......... Cymbeli

and shall find it so

when you shall find you need it not.

eould I find out the woman's part.

su Caesar shall not find them ..........
yon sliall find us in our salt-water girdle -

Jon sliall find us in our salt-water.
shall we find the sharded beetle.....

and you shall find me wretehed man

halt hereafter find it is no

and find not her whom thou pursues

sloth finds the down pillow hard ...
FIND-cannot find those runagates .. Cymbelinc, iv. 2 FTNDER-OUT-a finder-ont of oceasions. Othello, ii. I scem to those which chance to find let us find out the prettiest daisied plot wars shall find I love my country.... what pleasure, sir, find we in life .....

who find in my exile the want

well, I will find him; for, being now

so graze, as you find jasture.

wake, and find nothing (rep.).

he shall be happy that can find him

than I did truly find her, stakes

till I find the stream to cool.....

tetch the king to find them here...

if you ean find the himntsman out

what would she find? Lavini

that I may this treason find! $\ldots \ldots \ldots . .$.

you may find [Col.-catch] her in the

but $I$ will find thein ont

I'll find sout mpreerers in their

to find onother that is like to the ...

and now I find it; therefore bind ...

whom if you find, and win unto return. Perrete.

who finds her, give her burying... - - iii. ${ }^{2}$ (scroll)

must find at Tharsus .............

how dost thou find the inclination

ret I find, it greets me, as a

I desire to find him so $\ldots \ldots \ldots \ldots \ldots . . . . .$.

in my true lieart, I find, she name...

and ind, I am alone felicitate......

l find it not fit for your overlookin

$I$ begin to find an idle and fond....

yet nature finds itself and aequaint

find ont this villain, Edmund.

let him be whipped that first finds it so

thou shalt find, that I'll resume.

that he, which finds him, shal

all's not offence, that indiscretion find ..

you shall find some that will thank....

find ont their enemies now

If I find him eomforting the king...

villain thou shalt find

if you do find him, pray you, give...

as we shall find their merits and our

find those persons ont (rep.)..........

dull earth, and find thy centre out

any of my kinsmen find thee here

sncking on her yatural bosom find

sncking on her yatural bosom find.

where I may find the youn

you will find the shall...

you shall find me a grave man

till we can find a time to blaze true

I'll find out your man, and he shail

madam, if you could find out but a man -

a head, sir, that will find out log

choer you find, attat brother

heaven finds means to kill your joy

we shall find him most convenient .... Hamien

find thee apt; and duller should'st thou be -

by indrections find direetions ont

that we find out the cause of this effect

anon he finds him striking too shor

nor do we find him forward to be sounde

to seek him, and to find the body .......

if you find him not within this m...

greatly to find quarrel in a straw ........

and finds it christinn burial

till he find it stopping a bung-hole?

in the dark groped I to find out them...

(as partly, I find, it is) that your tair

I must se din surely find him

if you do find $\mathrm{m}$ found out practise...

prompt alacrity 1 find in hardness

and let me find a clinter in your poice.

I find it still, when I have list to sleen

find a white that shall her blackne

do you find some oceasion to anger

whe this mapkin, and let him find it

now I find, I had suborned the witnes

that you should find it in your ehamber

I do not find, that thou deal'st justly

lespect and acquittance: but I find $\mathrm{n}$

(Gower)

stops the months of all find-faults ....Henry $V . v .2$

FINDING-finding yourself desired. Hea. for Mea. ii.

ard's nest... Much Ado, ii. take a toste of my finding him in this alteration, find thyself thus. Winter's Tale, i. finding it so inclined ............... Macbeth, iv. finding thee fit for bloody villany ... King John, iv. finding his usurpation most unjust... Henry VI. ii. finding wh 'twas that

Lear, v. 3

finding him, the searchers of the town.Rom.\& Jul.v.

and finding, by this eneompassment ... Hamlet, ii.

FIND'sT-fires thou find'st unaked. $\bar{M}$ rerry W'ives, $\mathrm{v} .5^{2}$

word how thon find'st him...... Tuelfth Night, iv. 2

letters which thon find'st about me...... Lear, iv.

FINE-fine apparition! by ........... Hamlet, iij.

spirit, fine spirit, I'll free thee

these be fine things, an if they

master is ............

a fine volley of word and fine.. Two Gen.of Verona, i.

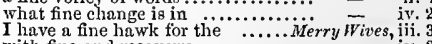

wonld whin me with their fine wi..... -

hath a heart of that fine fiame..... Twelfih $\bar{N}$ ight, $\mathrm{i}$.

finely touched, but to fine issues. Meas. for Meas. i. find [Col. Knl.-finc] the faults, whose fine - if. a but for a fine, quaint, graceful

\author{
- iii.
}

fine i' faith! have you no modesty. the poet's eye, in a fine frenzy rolling

it would hare been a fine tragedy ....
where to meet some mistress fine... Love's.

a most fine figurc?

dout, fine, when he shonld say, doubt

like a fine bragging youtl ............... of Fench $\overline{-}$

humbleness may drive unto a fine

to quit the fine for one half of $\ldots . .$. .
let her, in fine, consent, as well....... $\bar{w}$ ell,

in your fine frame hath love no...

still the fine's the crown

witl delicate fine hats

a finc musician to instruet evidenee $\overline{\text { she }}$ y.

be sure, my Katharine shall be fine..

and eanopies: fine linen, turkey

onr fine inusician froweth amorons...

there were none fine, but Adam

O fine villain! a silken doublet! .....

what fine chizzcl could ever yet cut ... the fine of rated trcaehery (rep.).... King John, y. 4 if spealing truth, in this fine a

rebellion with some fine eolour

]ess fine in shoot: Joln of Gaunt.2 Herry $I V$. iii. but thou, most fine, most honoured...

cup of wine, that's bris and fine.

to fine [Col. Knl.-find] his title .......... Henry $r^{\prime}$ i.

your free purses with large fines ...... i ilenry VI. j.

ye have made a fine hand, fellows. Henry $\bar{V} I 11$.

on your heads elap round fines ...... thou hast a fine forehead .. Troilus \& Cressida, iii. 1

the grief is fine, full, perfeet..........

a fine spot, in good faith ............. Coriolan us, $i$.

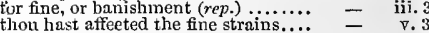

might have found easy fines....... .

in respect of a fine workman ......Jutius Casar, i.

a very fine one ....................

that makes them fine ............... iii.

with your fine fancies quaintly.Pericles, iii. (Gower)

sir, in fine, seeing how loathily............

prince of darkness is a fine gentlcman ... - jii.

the gentle fine [Knt.-sin] is

$I^{y} l l$ amerce you witl? so strong a fine

ma the

but settle your fine joints 'gainst....

very much more handsome than fine...

nature is fine in love (rep.) ............

bring you, in fine, togcther.......... - iv.

is this the fine of his fines $\ldots \ldots \ldots \ldots . . \quad v=v$

in fine, withdrew to mine own room $-\mathrm{v}$.

was a fine fool to take it............. Othello, iv.

INE-B ITTE: a fair

him on with a fine-baited delny... Merry Wives, ii.

the nobles be perdurably fined? Men f for Mea. iii.

that $I$ have fined these bones of ........ Henry $V$. iv.

FINELESS-but riches, fineless ........ Othello, jii. 3
FINIIX -me a bottle of saek finely.Merry Wives,iii.5
finely attired in a robe of white...... - iv. 4 


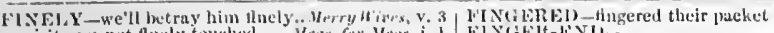

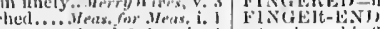

touch me his linger-end

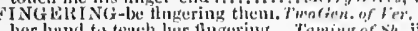
her hund to teuch lier 1 hering...

FfNGRli-lingres; oby, de timb

eome nenr. Finely put on, indeedl.. we will trin it fing thely broiled?

such and so finely bolted

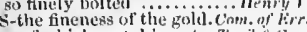

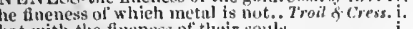

that werth the flneness of their souls.

(i)

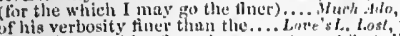
aeent is something there than you. . As you tike il, iti. 2 is't, but of the finer natures?

Herry? ii.

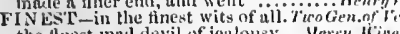

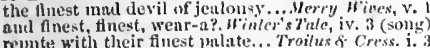
nothing but the finest part of pure...Ant. f c C

1Nus - the derlo t.

put some lime upron your th

his tulse tinger hath jrofined.. Tion Gen, of I l'll ne'er put my tinger in the fire... . my fluger itehes to make one

with the finger of my substinte.

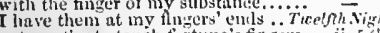
not worthy to toneh fiotume's fingers - ii. 5 (letter dare nomore streteh this fingur of., Mea.for. Ved

or I eut my finger, I shall make.......

at the fingers' ends, as they say.... Lor

and with his royal tinger $\ldots$ ö........

another with his nimser and

wa may tell every tiuger I have. iver. of té

when this ring parts from this tinger

le lami, de tingres, de nui

INISII-shall that thish the jest? Lome. Lean, ii.

we net, and these things finisil

his duys man finish ere that

days will thish tap the year

finish, yood lady; tlue bright

and might have inale you finis

the

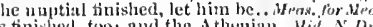

left to be thisisied by such a she .... Kinu . Dr. iit.

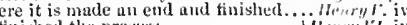

tinished the process

thou hast finished juy ........ (iy

were present when she finished

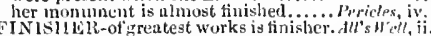

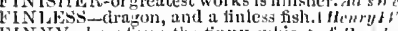

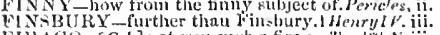

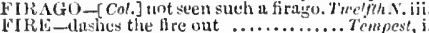

to dive into the fire.

the fire and eraeks of ....

then all a tire with me.

are straw to the fire i the lilood........

slumbed the fire tor tear of

for you gave the fire $\ldots \ldots . . .$.

kindle tre with now.

quench the tire of love

qualify the fire's extreme rage

at the latter end of a sea-coal tire.......erry

ne'er put my finger in the fire
till the wieked tire of last have....

give fire; she is my prize ....
run through tire and water

should set hell on fire.

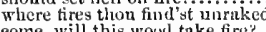

eome, will this woud take fire?

last is but a bloody fire............. - v. 5 (sony with sighs of tire.

to put fire in your hear

the fire that severs day from night ...

have eleft his club to make the tire.

what fire is in mine eurs? ...

hith appeared a fire, to burn

and by that fire whieh burned.......id.v. $\overline{\text { Drcum }}$ iv.

thorough fire, I do wander

a headless bear, sometime a fire...

hog, bear, fire, at every turn

by the dead and drowsy fir

fire enough for a tlint.

is misie, and sweet fire.............

stand between her back, sir, and the fire

where Phobus' fire searee thaw w. .Hor.

the tire seven times tried this

'tween snow and fire, as trea

is to wet, and fire to burn.

- ii. 9 (scroli)

where a tinger conld not be wedged in - iv. 1

this hath not a tinger's dignity... Troitus of

do not, my tinurers if h

white enehanting fingers toueled.....

fat rump, and potatoe timger ..........

cainbric were sensible as your finger.. Coriolatus, i.

ahout with his finger and thumb...

to displace it with your little finger.

very lint the bloody ningers of thy fous

eontaminate our tingers with base bribes? - iv.

iny ring I hold dear as iny fing

then lie wore npon his honoured finge

the fingers of the powers above .......
upon his llloody finger he doth wear. $T$.

lnath eut thowe pretty fingers off.

from the lazy finger of a maiti... Rnmen f Jutiet, i.

do not wers hisgers, who straight dream -

try il they can lick their fingers.....

his own fingers: therefore lie $\left(r e p_{\text {. }}\right)$....

from ber dean finger a preeions ring.

not a pipe for fiurters on your lips....... Itumlet v.

quvern these ventuges with your finger

my your neek with his dumned flngers... - iij.
naiks do dend men's tingers eall them...
take thy tingers from my throut..........

kisserl your three tingers an oft............. outhe vo,

vet arain your fingers to your lips?.

for let our finger nelae, and it indu's our

in point his flow unmoving lluger nt .... - ivi.

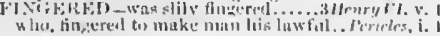

upon the violent speed of tire

if the quick tire of youth lighit

a great fire; and the master (rep.)

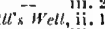

when broad onte, nud the great tire

ns will a ehestmut in a farmur's fire?.. Tam. of

where two ruging fires lneet together

little fire grows grent with

a tire to that me $(r \rho p$,

110 wuter

nnd therefore fire: do thy iinty

there's fire ready; anl therctive...

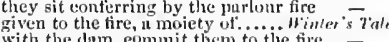

with the dam, eommit then to the fire

see it instantly eunsumed with tire...

go, take it to the fire

raeks? hres? what flaying?
woulch have slied water out ol fire

her fiee s'tire with labour ........

the rnging fire of fiever lired.

stals hiclu with bra

at a winter's flre, unthirizg..........

insteral of bullets wrappeel in fir
rich lrlood of kinfos is set on tire!

riel hood of king ins on tire!

camben, fire, nut smoke, mul bouse: yet, in his idle fire, to bny

fire hurn; starl cubletron bilulsle
TRk:-slanll quemis that thre.

fior containing tire to lingm
llie il re is dean with gried".

whicl fieree tire, and irm, extends

its red $a y$ new-conkindled fire

mater that should fiet this the

resolveth l'rom his figure 'gniust tlic fî.

aratinst this flre flo I shrink upt

as the sea, hasty as tire...............

0 wlio can lield a fire in his have

he fires the prosul tous of the

thun the elements of the and water.

hit by the fire with good old folk

il compassion, weep the fire out

with fire our tow a of Cicester

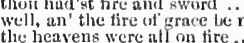

as hest lord I'erey

my oath should be, by this tire

that salammeler of yours with fire.

num on fire, to hear this rich
but Prian found the dire ...

whose spirit lent a fire

twok fire and hert awny ...........

with an iucensel fire of injuries.

by a sea-cont tire, unon Weckerday.

no, let the fiend give fire

sworly, and native tire, as fur

() for a muse of fire.............

sword, and tire, to will your riglit.

youtl of fingland are on fire

is gone, that maintained that fir.

and tames of fire; and his lings

lie is lure air and fire

wers tire; and throush

by their watchiful fires sit
replete with wratliful fine

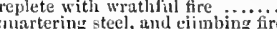

crest thy sword struck fire
when 'l'roy wis set on fire

prove a raging fire, if wind aid fuel.

ourns with revenging fire.

he should stmul in fear of fire

and set Londen bridge on fire...

even as the dew to fire..........

as red as fire: may, then lier.....

I need not add more finel to your

the fire thut mounts the liquor

inichund II.

but allay, the tire of passion

blew the tire that burns

there was a more temperate fire... Truilus $\bar{\delta}$ Cress

come in; I'll go get a fire.

live in fire, eat rocks

as eoldy in him as fire in a fint ...

hey-day! spirits and fires!
the fire $i$ ' the fiint shows not

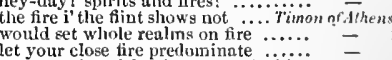

and her pale fire she snatches ........

thev'll sit by the fire, and presume

or, by the tires of heaven

will be his tire to kiudle their try

consumed with fire, and took whit

one fire drives out one thre.............
forged himself a nume i' the fire of

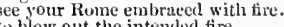

to blow out the intended tire

thou art prepin. as I know the sun is fire

praise the gols, and make trimmphant fires -

through a tempest drupping fire.

not sensilile of tire, remumed unseorched -

they saw men, all in fire

whe a mighty fire.

bear fire enough to kindle cowards .
might fire the blumb of ordinary meit

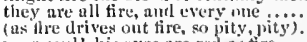

wor soull his eyes are red as tire

with the brands tire the traitors' house

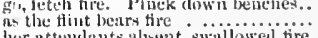

her atteudents ulsent, swallowed tire

cuin but wake to fire of him...........

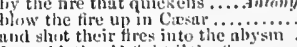

I would, they il iglit i' the fire ......

yot the tire of rage is in him............. cymbeline, $i$.

tow'n with rejoieing lires brifht ....

I stand on flre: come to the matter.

nul make a fire stripht ...... Titus dndronicus,

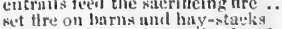

(1) live and lum in ererlating tire

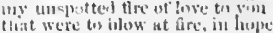


FIRE-the which hath fire in darkness..Pericles, ii. 3 FIRMLY_I firmly am resolved

a tirc from heaven came ...............

as light, no tire: the unfitiendly.

ret fire and meat tor these poor men

and yet the fire of life kindle again.

well suid; the fire and the cloths

if fires be hot, knives sharp.

may stand by the fire and stink ......

bring oil to fre, snow to thcir cold

sulphurous and thought-exccuting fires

spit, tire! spont, rain! (rep.) ...........

led through fire and through flame...

now a little fire in a wild field

look, here comes a walking fire..............
bring you where both fire and food is ready

arms, arms, sword, fire!

and quenched the stelled fires

stood that night against my fire
$I$ am bound upon a wheel of fire

and fire us hence like foxes...................

quench the fire of your

Romen \& Juliet, $\mathrm{i}$.

cold fire, sick health!...............

as firmly as yourself were still .......
and here I firmly vow, never to woo

and here

as tirmly as I hope for fertile .....2 HenruV $L$. iil.

at last, I firmly am resolved

my truth and honour firmly...

FIRMINESS - uustooping firmness of my. Rich.II. i.

FIRMI-SET-aure and firm-sct carth ... Mricbeth, i

FIRST - it was the first, and Prospero... Tempest,

was the first man that

when thou eamest first...

which first was mine own kin.

the first that e'er I sighed for....

as when we put them on first in Afrio

as fresh as the first day I wor

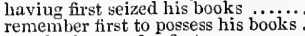

and do the murder first...

when first I raised the tempest

nor befitting this first meeting

as wheu we first put out to sea

first, you have learn'd, like.. T

one fire burns ont another's burning

at first $I$ did adore

and quench the fire, the room is ...

and quench the fire, the room is $\ldots$

is set on fire by thine own ignorance

stars with trains of fire and dcws of
whether in sea or fire, in earth or air

you must not take for $f$

confined to fast in fires .................

and 'rins to pale his ineffect

thy first best love.......

yourself shall go first....

let thine inherit first .....

I will first make bold with

but first, master guest ...........

I shall drink in pipe-wine first with him -

roof fretted with golden fire.

roasted in wrath, and fire.....

and melt in her own fire: prociai.....

time qualifies the snark and fire of it
I lave a speech of fire, that fain.....

first, an iutolerable fright...

I'll first direct my men

a fault done first in the form of

in the first of his heart ..........

all the battlements their ordnance fire $\overline{o t h e l l o, ~} \mathrm{v}$.

give renewed fire to our extincted spirits - ii. 1

poison, or fire, or suffocating stream

nay, but first, Iet me see $\ldots . .$.
mark his first approach before

best, first, go see your lodging

I would I were the first that eve.............

that did bring me first ou shore...

it was she first told ine

it was she first told me

first, an' it like you, the hou

so you must be the first......................

first, that your stay

first, here's young master Kash....

but send me Flavius first

first his integrity stands without

first, for this woman; to jus

first, for this woman; to jue

thou art the first knave, that e'er (rep.
whipped first, sir, and hanged after.

whipped first, sir, and hanged art.

the first suit is hot and hasty

sinee summer first was leavy .......
she may wear her heart ont first

you must hang it first, and draw

first, who think you the most.

I should first tell thee, how the prince
by his oaths, which first possessed them

well be fri, which fir

and write God first; for God depend

first, I ask thee what they have done

in the rare semblance that I loved it first -

Troilus the first employer of panders

didst thou first fall in love with

dirst, $o^{\prime}$ my word; therefore, play, misic

first, good Peter Quince, say what... Mid. $\bar{N}$.

first, Pyramus must draw ...............

on the first view, to say, to swear

but first I will release the fairy que

which your highness will see first....

first, rchearse this song by rote ......

why, villain, thou must know first

Fhat, what? first praise me, and
it was a buck of the first head
am I the first that have bcen .

at the first opening of ................

consider, what you first did swcar
but love, first lcarned in a lady'

but be first advised, iu confiic

first, from the park let us.

there is five in the first slow

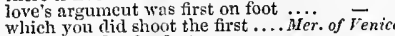

rest debtor for the first

first, there is the Neapolitan prince...

first, forward to the temple

that he did pace them first?..........

first. never to unfold to any one ....

we'ti play with them, the first boy

when I did first impart my love

first, go with me to church

every offence is not a hate at first.....

bath tbe frmament more firmarment

this lorave o'erhanging firmament...... Himlet, ji.
FIRST - with your wife's first. Merchant of Venice, $v$. it is the for the first time that ever I ..... ls $_{\text {you }} \bar{L}$ ike it,, 1.2 mightily persuaded hin from a first first, for his weeping in the ncedless

till he be first sufficed a fir...

at first, the infant mewling.

borrow me Garagantua's mouth first

but first begs pardon

that loved uot at first sight?

nay, you were better speak first...

When from the first to last, betwixt..

the first, the retort courteous

first, in this forest, let us do.

in frichishy

lend it you, shail lack it first .........

at the first view; to you that

the was first smoked by the old lord...

first, give 1

since the first tather wore it

this is the first truth that e er.....

nay, $T$ 'll read it first $\ldots$..............

remembrance, did first propose

the first thit found me (repealed)....

the first view shall kill all repetition

which better than the first, $O$ dear

that turned off a first so noble wife

I gave it his first wife.

and my fatber first, a merchant........ Taming of $S h$. i.

I will charm him first to keep.........

I should knock you first, and then .
I had well knocked at first ...........
give you over at this first encounter.

the elder sister first be wed

on Sunday first. Hark, Petruchio

your neighbour, and was suitor first -

first, as you know, my house

take it on you at the first so

first, know, my horse is tired...

read you? first resolve me that ......

for our frst merriment hath made

first kiss me, Kate, and we will ......

come on, I say; and first begin ..........

what was my first? it has ............ -

first hand me (rep.) ................. -

than to pertorm it first

second joy, and first fruits of my body

but, first, how the poor souls roared..

pedlar, let's have the first choice

thcy throng who shall buy first

when your first queen's again in breath

I sec, will kiss the valleys first .........

but yet speak: tirst, you my liege.....

since first we were dissevered ..... Winter's Tal

since at first $I$ sent him from the. Comedy of Err.

why, first, for flouting me...

tirst, he denied you had in.....

first, he did praise my beauty

thou cam'st from Corinth first

till then, lead thou first...

when first they put the nam

at first, and last, $a$ hearty welcome.

boil thou first $i$ ' the charmed pot ...

more potent than the first............

is like the first, a third is ....

now protest their first of manhood...

lead our first battle ...............

the first that ever scotland in.......

therefore, hear us first; these fiags .... King $J$

when we first marched forth.........

since 1 ent to last the ond

when I was first assured

thy vow frst made to heaven, first be

against thy first, is in thyself rebellion

cain, the tirst male child of............

your breath first kindled the dead

but when it first did help to wound

irst, the fair reverence of your

their first head and spring

physicians that first wounded the

that first wounded tbee

prince of Vales, was first.

the first departing of the king

iii. 9 my horse, and I will first be there

iii. 2 had you first died, and he been

iii. 2 if but the first, how heinous ere it be

but pardon, first; and ufterwards...

that they are not the first of fortune
tastc of it first, as thou art wout..... ii. 1

ii. 7

iii. 5

(1).

ii. 6

iii. 7

iv.

iv. 3

v. 3

3

i. 1

i. 2

1. 2

i. 2

ii. 1

iii. 2

iv. 1

iv. 5

v. 2
v. 2

i. 2

ii. 3

iii. 2

iv. 3

iv. 3
v. 1

v. 1

v. 2
v. 3
v. 3 i. 2

iii. 1

iv. 1

v. 3

v. 1
v. 6

v. 7

ii.

ii. 2

iii. 2

iii. 1

iii. 4

iv. 2
v. 2

II. i. 7

i. 1

ii. 1

ii. 1

ii. 1

ii. 3

v. 3
v. 3 
FIRsi-first, to thy sacred state Richoml 1/: v. 6 likst-ere the first sacritice were $x$ frst bowed ing knee ......... I'll see thee haugeal tirst

first purdon me, my hord ..............

\section{二}

列

the state of time hind first leen whol

we were the thrst und dearest of your

to speak so true at first?..........

yet the fint hringur of unweles
ginee I perevived the first white.

and first, lord marshal, whint sny

we first survey the jlot, then draw

fint let them try themselves

I'll see her dlumbel nirst

the first human prineiple $\because$ would

working I wns first allanced ...

tirst, my fear, then my eourt'sy.

then with sevt land first legin
he thut strikes the first stroke.

he that strikes the first stroke.
lie that makes the first thrust.

those roots thut shall first spring .

you must tirst go yourself to hazurd

tis not the first time you wer

his danghter, first: and then, in se....

but, first, ro try her skill ...........
ghe takes npon her bravely at first ilus

Henry the fifth he first truined

since first I finllowed arms ......

didst thou nt first, to flatter us .....
or which way, should they first briak in

sinee Henry Mlonmouth first hegan.

first, lean thine aged back a

conquest got, first to iny Give ..........

first let me know and then I'll

and he first took execptions...........

disscnsion first be tried by flight

rest where it began at first

if', the first hour, I shrink.....

the life thon gavest me lirst $\ldots \ldots .$.

you shall tirst receive the sum of money

ghe was the first fruit of $\mathrm{my}$....

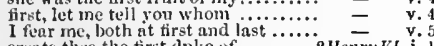

"reate thee the first duke or
Poole first duke of suttiolk

1 lll be the tirst, sirre; come biack

first, for I cannot fatter thee in priale

hrst, of the king. What shall of hin -
the first, Eiward the blnck prince ..

Richnrd, the first son's heir........
be we the first, that shall salut

be we the first, that thall salute $\ldots .$.

tirst, note, that he is near you

hail I first been put to speak .........

wich inotes him first, that first in tus -

first let $\mathrm{my}$ words stab hin

the first thing we do, let's kiil

rine this first year of our reign
but, first, go and set London ?

first, let ine ask of these, if they.

the tirst I warrant thee, if dreims

Plantagenet sliall speak first.

no, first shall war unpeople...
how began it first? No quarrel

first; will I see the eoronation

first, to do greetings to thy royal

ay, that's the first thing that we

the first of all your ehief' aftairs.

when first thou didst presume

but, first, I'll turn you fellow

ane first tlat there did greet

first, malam, I entreat true peace

by your first order died

first, he commends him to your....

and to avoil the first; and then.....

for first he was contract to lady Lucy

first, nighty liege, tell ine

the first was I, that helned

devised at first to keep the strong......

but, tell me first, is young ...........

requires slow paee at first.

the red wine first with thim

first, Kildure's attainder, then deput

who first raised head against usurvili

than tis awect at first to aequi

my conseicnce first received

first, methought, I stoorl not in...
first, I legan in private $w$. itl you

reek, when I first moverl you

the ciuestion ilid at first so rtauger mie

and the first lie vicwed, he dud it with

the duke of suftiolk is the tint

since first you knew me....

noble lad $y^{\prime}$, flrst mine mw...............

tow ard the
whea we fir

cxampled by the tjent pace . Troilus o cressida, i. 3

showing the worse first [ $h t_{\text {, }}$-shall sliuw

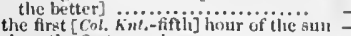

since the firnt aword was.

he elouklal cent swords first...

with the first gisnee that ever

men's privileye of spreaking in rat ....

2 gullant looro tallen in the throt rank the flrst was Heneluus kiss.
since tirst I saw yeursclf anc

first, all you jecers ol (irecete

sing noy mitul at frst sight

ceremony was but devised at fir Timon of , when

might hive woued me flrst

I was tha dirst man tlant e'cre........ red

ure we ean nerce unou the first place

more whore, wore misehict first

from our first swatl...

first mend my eompany .........

let us first see peace in Athens
monn their tirst loril's neck

when thy first grietis were but.....

motives that you first went out

first, you know, Crits a very lo

receive the general tiod at first

the rubble shomld lave first wnroofed

thime by a place belesw the tirst .....

first hearing le was at niall-child ( $\mathrm{rep}$ )

in finvouring the first compluint

the Volces stand but ns at first

we'll proceed in our first way.

thee first a soldier.

my first sou wither wilt. say........

know thou fir'st, I lovel the maid....

iet ne eommend the first to thuse

when first I did embraec him....

first he was in noble servint...........

onee more offered the first eonditions

'tis the first time that ever I was

of a dreadful thing and the first motion

he first presents his fire.

read mine first; for mine's a suit

turm gre-ordinance, and first degree

Irst, Mareus Brutus, will I shak

the first time ever Casar put it on

give me your hand first: fare you weil

thy wite first eame in to the ficli... Int

upos the first eneounter, drave them

not if the small come first ............

Whes she first met Nar
first, madam, he's well

most mect, that first we ce

but, first, or last, yonr bine Egyptian

and the first stone drop in my

if' she first meet the eurled Antony.

the winluing both of first and last....

we are familiar at first
uyom him will I first work

which, first, perelunee, she ii jorove on

ravening first the lamb, longs aiter.
first, a very excullent good-eonceited

first, a very excullent good-eonceited
first, her bed-chimber (where I conf

witli shame (the first that erer .......

Mulnuntius, who was the firet of Britain -

but, first, how get hence may steal

ras once first with the best of note

he, that strikes the venisun first...... -

ne er longed iny mother so to see me first

first, make yourself but like one

the firet serviee tlou dost me (rep.
tirst kill him, and in her eyes.

the ground that gave them Arrst...

but, first, an' $t$ please tire gods.
damned in the first beginners!

first, she eontessed she nerer loved you

not too lot; tirst pay me for the nursing

and at first meeting loved.

your brothers? how
but, your ring firs

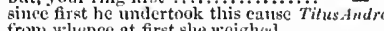

from knence at first slue weighed

first, thrash the corn, then
that first eave life to you.

at the first approach, $\mathrm{You}$

i. I first, hang the elitd, that he

the womb that their first being

luve their first coneertion by

and what was first but tear what

who flrst shall die to lengthen life ....
who is the first that loth prefer fimeti

even at the first, thy loss is more

fis daugliter hone, who first is gone -

first, I woulal lunve you note

pr'ythee tell me one thing fir

flrst, sir, I pray, what is your title?

but $I$ an for other service fir'st

bereech you, ti rat to last resolve you.

Goueril, cour clutest-born, sixe

We thrst aderess towurds you $y^{2} . . . . . . .$.

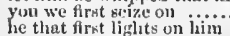

he that first lighlits on him .................

ilrst let me talk with this pluiliosingier
Ilis'f-I'll soe their trial th it

lec him first answer that

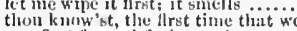

whis first framed llesh to ruise
jleasures firnt le known tlue

lileasures firnt lie known thut are.
we are not the first, who, witli bent

We are not the first, who, with linet.
weep: we'll see thein staire first

and from first to last toid hin m

of nothing tirst create! 0 heavy.

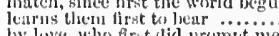

by love, who first lid prompt me

fout leman wh the ve

execls your flrst: or if it ilid not

cuouire me first wist till he that died.

give first adinitane to the enilassadors

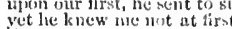

the first row of the pious clanson

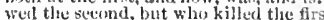

u.hen thy first lorel is deat!

in muse where I shall tirst begin...

first, her futher slain; next, your son...

he was the tirst that ever liore aring

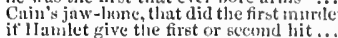

it II minlet give the first or second

first, I must tell thee this-Desdemona

she tilst luved the Moor

do sugrest at first with hear.i...............

fruits that hlossem first, will first be rijo

hedich, from first to last: "Wy dost

thut the dl oor first gave to Destemona...

which, at the first, are esuree found to

first to be hanred, and then to confes

ay: 'twas he that told nue brot

ii. I Flalge of love, which

ii. 2 Eilwards son, the tirst-begotten ....1Henry $V I$. ii.

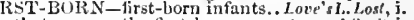
in that you are the first-born........As you Like it, i.

i. 2
i. 3 I an spirit wis the first-born Cain .....2 Henry It: i.

spare my first-bom son. I'atient yourself FInST-CONCEIVED-cun elase away the - iv. first-conceived sound?...........2 heny $F l$ iii. 2
6 11 FIRSTLING-the very firstlings (rep.). Macbeth, iv. . 7 anil firstlings of those broits. Troilus of Cress. (prol. a man or a fisli? $\ldots \ldots \ldots \ldots \ldots \ldots \ldots, \ldots \ldots \ldots$ ii. 2 a very aneient and fish-ike smell

and hind but this fislo..........

this is ne dish, but an islander

l'll tish for thee, and get .........

why, thou deboshed rish thou
being but lialt a tish, and lialf

one of them is a plain fish $\ldots . .$. ....

the luee is a fresh fish; the salt fish is . Herry

this fisi will bite.................... viuch .jh, ii.

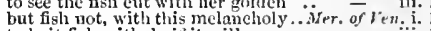

to bait fish withal: it it will $\ldots . . . . . . d m$ s $\bar{w}$ ell, iii. 6

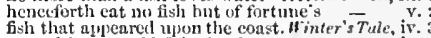

fin that alpeared upon the const. Iminter's Tan, iv.

eaught the water, though not the fish

than tish and fow 1 s............. Comedy of Errors, ii.

either at flesh or fish, a talile....

no licatlers, and fish

a dragon, and a finless fish

the lether fish nor flesly: a man... - iii.

up Fish strect! lown suint a pond ..2Henry $1, i$.

政

as is the osprey to the fish

poor tributary rivers as sweet fis

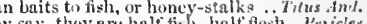

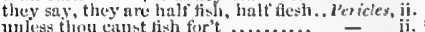

lore's a fish hangs in the net

and to eat no fisf. What art thou

tis well thou art not fish
the figh lives in the eta

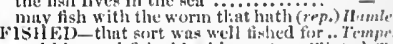

nnd his pond fistled by his next ... Winters's

the fisct the flsthers of their prey.Com, of Eirr.i.

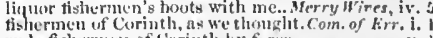

rude fisluermen of corintl by furce .. - y

at your labour, honest tishermen ...... Pericles, ii. I

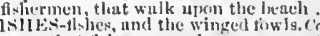

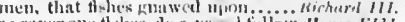




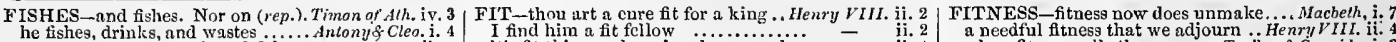
1 will betray towny-fimed fishcs.... ii. 5 it's fit this royal session do procecd.. how the fislice live in queen's son... Cymbetine, iv.

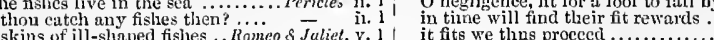

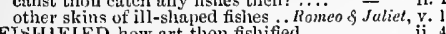

nor fitness for the world .............. Coriolanus, ii.

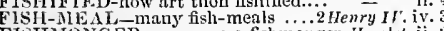

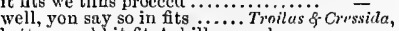

a woman's fitness comes by fits....... Cymbeline, iv. which bonld it fit Achilles much .... - iii. 3 all night, I am not fitted for

all night, I am not fitted for $i$....... for Meas. ii. 3 and I hope, here is a with a husband. Much Aclo, ii. not one word apt, one player fitted ... - y. well fitted in the arts, glorious .. Love's L. Lost, ii.

nor is he fit for it, indeed ...... Timon of Athen he said I was a fishmonger ........... $A r_{s} w$ ell, $\mathrm{y}$. ISTan' I but fist him once .............2 IIearyI 1 .

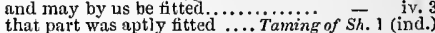
tell Valeria we are fit to bid her welcome give me thy fist, thy

Heriry iv.

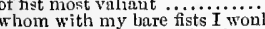
with measure fit the hononr

go fit you to the custoin. she better would have fitted me....3 Hevry VI. iv. she had fitted you with her craft .... Cymbeline, y. 5 fitted by kind for rape and villany. Tilus And. ii. the sceptre in his childish fist........2.

is but a finger to my fist .............. iv -10 pun thee into shivers with his tist. $T$ roil.

with my armed fist I'll pash him ....
FISTING-fisting ench other's thro:t.

to the choleric fisting ot each ro:

were fit for thee to use....

tis fit yout make strong party.
and when the fit was on him

well are you fitted, had you but a Hoor - v.

a disl fit fibr the gods (rep.)

FITTER-some more fitter place. Meas. Jor Meas. ii. but fitter time for that

zour son, there is no fittex inatter......All's $w^{r} e l l$, iv.

here is no hour so fit as Casar's deat

your son, there is no fitter in

2 Henry I $V$. i.

FIT-if' now 'twere fit to do't

he's in his fit now...

find thee most fit for business

there are other men fitter to go ont.

better placc, fitter for sickness...... I Henry $/$ I. iit.

the fonlest hest fits

and in these fits I lcave them

you an officer fit for the place... Tü Gen. of Ver.

fit me with such wee
that fits as well, as....

an engine fit for my proceeding
would better fit his chamber

served me as fit, by all

and fit for great employment

as in state tis fit

as the fits and stirs of his mind

the fitter for the King of heiven.... Richard III. i.

were fit, that all the plagnes

fitter then the gods should have her... . Pericles, iv.

if he shall think it fit, a saucy

it is not fit, your lordship should ....

ay, it is fit for your lordship only....

ay, it is fit for your lordship only

than would fit a t'ranklin's housewife

and fit you to your manhood

it fits ns therefore ripely

that he wisely show not fit me

how fit his garments serve me?
made the tailor, not be fit too?

a woman's fitness comes by fit

thy name well fits thy faith.
with faces fit for masks.....

a young man more fit to do ............ for. Jeas. ii.

fit thy eonscnt to my shar

and will fit yon with dignitie

and ht his mind to denth ......

every true man's apparel fits your..... thief

so every true man's apparei

I thought your marriage fit.

is fit; 'tis once, thou lovest (rep.).........uuch $A d a, \mathrm{i}$.

and it better fits my blood to be.

the fit and apt construction of thy nam

one fit to bandy with thy ............

$I$ am as able, and as fit, as thou

a charm to eain these fits.

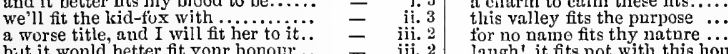

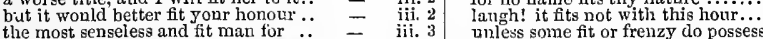

the most senseless and fit man for to fit your fancies to your.....Mid. $\bar{D}_{\text {ream }}$ ii. $\mathrm{i}$. 2

which is thought fit, through all Athen

how fit a word is that vile name

unless some fit or frenzy do po.....................

why, sir, that is as fit as can be ......

closing with him fits his lunac

which pleasure fits a husband

it fits thee not to ask the reason...

fits kings, as they are men

and $I$, as fits my nature,

how both did tit it $1 . . . \ldots$...........

none so fit as to present the nin.

is fit for treasons, stratagems... Merch. of Venice, v.

it fits my hnmour well

evils sit so fit in him ...................
nay, I'll fit $y$ on, and not be all day
[Col.] coldest, and despair most fits.

[Col.] coldest, and despair most at

that fits all questions (repeated) $(\ldots . .$.

it were fit you knew him .

if it be a day it should be so; for princes

than you expect, or more than's $\mathrm{fit}$

some other is more fit...................

I find it not fit for your over-looking

take a lodging, fit to entertain...... Taming of Sh. i.

by any means light on a fit man

was it fit for a servant to use......

and behaviour, fit for her tur.

this doth fit the time

what fit is this, good lady?................

no milliner can so fit his

where it fits not you to know......... - iv. 3 (song)

which "tis not fit yon know

if he think it fit to shore them........ iv o 3

what's a fever but a fit of $r$

thy jealous fits have scared .........

then comes uny fit again

the fit is momentary

meet, that 1 can fashion fit .............

thought it fit to answer from our home

the indisposed and sickly fit...

provided for your fit welcome............
make content with his fortmes fit $\overline{2}$ ii. 4 (sni)

are not fit for your beholding ...........

it fits, when such a villain ....... Romeo \& Juliel, i.

with instruments upon them fit to open

it fits your wisdom so fur to

as fits a king's remembrance

if you hold it fit, after the play

when he is fit and seasoned for his........

you must translate; 'tis fit we und

would not nnderstand what was most fit

botch the words up fit to their own thought

it' such a one be fit to govern

und fits the mounting spirit...........

may fit ns to our shape .....................

hither, and siy, you are not fit.

till fit time of law, and course of dircet... Othello, $\mathrm{i}$.

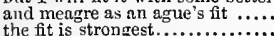

I crave fit disposition for my wifc.

he is $a$ soldier, fit to stand by Casar....

if you think fit, or that it may be done

mapatient of his fit

2Henry $1 \mathrm{~V} \mathrm{i}$.

mapatient of him, and make him fit to go

fit that Cassio have his place..........

if I do tind him fit, I'll move your suit

it tits ns then, to be as prow
is it fit this soldier keep.

this is his second fit; he had one yesterdlay
FITCHEW-a fitchew, a toad.Troilus \& Cressida

prize, fit for the devils ir

the fitchew, nor the soiled horse.......

Tiv.

fit to be made companion with a king

approves her fit for none.

humoirs fit not for a crown........... Henry $V I$.

a state fit for his liolincss

FITF UL-after lite's fitfin fever

Othello, iv.

where it best fits to be.

i. 3 even so most fitly as you inalign

that can judge as fitly of his worth...

Coriolanus, i.

sec the lists and all things fit $\ldots \ldots \ldots . . .$.
not fit to govern and rule multitudes

may fitly like your rrace................

Lear, i.

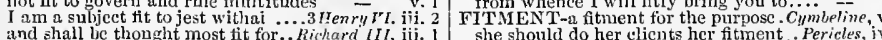

a fit or two thonght most fit for... Richard III, iti.

and fit it with such furniture.............

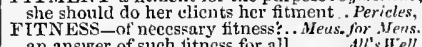

FITTEST- devise the fittest time............ I ear,

this course I fittest choose.... Comedy of Errors, iv,

fittest time to corrupt a man's wife.Coriolanus, iv.

madam, do you, 'tis fittest .............. Lenr, iv. 7

it fitteth not a prelate so to plead ... Herry lost, best fitteth my degree ............. Richard III. iji. 7 FITTING - fitting well a sheep...Two Gen, of Ver. $\mathrm{i}$. news fitting to the nitht, black........ King John, y. 6 as fitting best to quittance.......... Henry $V I$. ii. nothing, fitting for your purpose... Richard $M I$. iii. fitting for a princess descended ...Anlony \& Cleo. v. 2 needfil in our loves, fitting our duty?.. Humlel, $\mathrm{i}$. needfin in our loves, fitting our duty?...Hamlel, i.
FI'T'WA'TER-Fitzwater, thou art. Richard II. iv. lord Fitzwater, 1 do remember.

FIV $\mathrm{E}$-hains, Fitzwater, shall not be forgot $-\overline{\text { nor }}$ or five women.... Tempest, $i$. full fathom five thy father lies $\ldots \ldots . . . \mathrm{i}$. 2 (song) continue in it five wecks witlout...... - ii. five and thirty leagues ................ each putter-out on five for one ........ ve verona, ii. 5 shalt have five thousand ............... it is his five scnses ................... - i. among five thousand, and five bundred - iii. 3 besides your five wits? .............. iv. 2 was worth five thousand .............. for Measure, i. 2 Claudio's head sent me by five ...... - iv. 2 and five he made five marks

since which time, of five years..... . four of his five wits went halting off ... Much $A d d_{0}$ i. . five shillings to one on ' $t$, with any ... that's not five weeks old as yet? ... Love's $L$. and raut tre wo to five weeks ........ - Love's $L$. L iv. 2 the third of the five vowels ........... $=$ v. for he hath been five thousand years = $=\mathrm{v} .2$ cammot prick out five such............ $\overline{\text { verchant of }} \overline{\text { venice }}$ v. 2 by five of the clock ........... Merchant of Venice, ii. 2
I have five hundred crowns ........As you Like it, ii. 3 five and twenty, sir ..................... some four or five descents since....... five or six thousand.................
five or six thousand horse, I said.... who hath for four or five removes.... past cure of the fives ........ Taming nf Shrew, iii. 2 five pound of currants............... - iv. 2 and tive or six honcst wives .......... five justices' hands at it................
could meet by twice tive leagues.. Comedy of Err. i. . five summers have I spent $\ldots . . . . . . .$. = at five o'clock, I shah receive........ $=$ iv. five hundred ducats, villaim........... at least from fair five hundred ....... King John, $i$. got five hundred ponnds a year...... $(r e$. $)$ i. i my lord, they say, five moons.......... $=$ ivichard $I I .2 .3$ forsooth, five year, and as ............ Richard HIV. ii. this advertisement is five days ol ol .... our present five and twenty thonsand

What! is the king but five and twenty

thfteen hundred foot, five hundred horse - ii.

worth five of Agamemnon, nnd ten... - ii. 4 let me have five hundred of my ........ Hen ${ }^{2} y, r .1 .5$ with four or five most vile........ - iv. (chorn five hundred poor I have in yearly

thou hast unwished five thousand mine

of the which five lnundred were but. of all other inen, but five and twenty 
FIVE-with five tlower-de-luee at lenst five Frenchmen died beside flve hundred prisoners these five days have i hid me

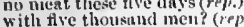
fle men to tweity! though the will but amount to flve and twenty.

nnd Oxfore, with five thomsaut men - iii.

five have 1 slain tri-duy, instend......

the five lest senses acknowledige...

and late, five thousaud to Vurro

which minkes it five and twenty.

I elenred him with five talents....

I elen red him with five talents $\ldots . .$.
to be rememhered w ith those tive.....
the thousand mine..................

five thousund crowns, my lord. Fise

five times, Jiareius, I have fougli

five hundred voices of thit soln

with five times so much eonversnt

linth the king five times rexleemed

five thues he hath returned... Titus Andron

Romans, of five und twenty valiant sons

this monument tive liundred years

were you a gamester at five...

flve rlays we do allot thee ................

I entreat you to bring but hive anil twent

neel you five and twenty, ten, or five...

neess thy firc wits! Tom's a-cold.

bless thy five wit

some five or six nnd thirty of his linights

five times in that, ere unee on

some five and twenty year

I have in my whole five ....

to pay five duents, five, I would
from this present hour of five
FIVE-FIVGERED-TIED-

FIVE-FI. AERED-TIED-

FIVE-FOLD-thee five-tidd blazon. Twelf hizh, $\mathrm{j}$

withered hermit, flescore winters worn

IX-and enyy: hix thy foot....

Tenrnestly did fix mille eye

FIXED-the hour is fixed, the miteli....... Why ly

you orphan heirs ot fixed destiny.

an ass's nowl I fixed on his hearl.

that give a name to every fixed

yet these tixerl evils sit s

but my intents aee fixer
fastened and flxed the shame

the statue is but newly fixed

eyes on whom our care nas tixed. Conedy of Brr. $\mathrm{i}$.

fixed his head upon our battlements..... Mrarthe/h, i. 2

rom their fixed beds of lime.

four fixed: and the fifth did whirl .

fright the fixed stars of heaven ...... Richart $/$. ii.

to which is tixed, as an aim or butt.

that the fixed sentinels almost

sit like fixed candlesticks

thine eyes fixed to the sullen........

my hair be tixed an end

in venry $r$ iii.

and be not fixed in doom perpetnal. Richard III. iv.

and fixed on spiritual object...... Henry $/ h$. iit.

and so stand fixed: peace, plenty ..... -

is, as a virtue, fixed, to-day was. Troilus \& Cress. i.

nay, that's most fixed ..............
on this sovereign lady fixed

that he's your fixed enemy.

of nature from the flxed place

how unremoveable and fixed he is

gainst self-slaughter.Hamlet,

and fixed his eyes upon you? ...........

to make me a fixed figure............. olhetlo iv.

FIXES-that fixes no bourne "twixt. irinter's Tale,

fixing our eyes on whom our eare. Comedy of Er

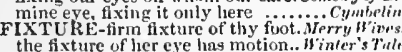

the fixture of hier eye has motion.. Winter's Tate,
FIXURE-quite from their fixure!. Troilus \& Cress
Fin

unwind your blorl fran

Nene John, ii.

unwind your basmly flag ............. Henry ${ }^{\prime}$ i.

a garish flag, to be the aim ........ Wichurd III
pet np the bloody flag against ...... Coriolanus,

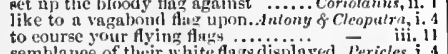

gemblance of the ir white fags displayed. P'ericles, i.

I muct show out a flag and sign of love... Ohello, i. I

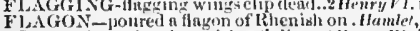

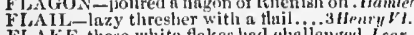

FI, $\mathrm{K}$ C-these white flakes had ehallengel. Leor, iv.

FLA.IL-wonld [ flume rlistinctly...... Tempesi, $\mathrm{i}$.

the flame will buck rlesend............. Herry Wres, $v$

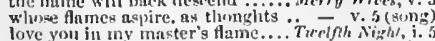

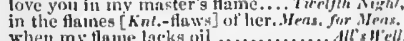

when my tlane lacks nil ...
in so true a flanne of liking

that fanes in your thir

throw into the flame.................urereth, iv
FL, A l:-in flames, like to the prince ., Henry sut knobs, und flames of flre

und through their paly flame
at last hreak out into o flame

iv. (chorris)

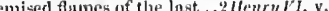

and burn me up with func o

the aspiring flame ot golde un day

uye lier lnmp und dames of love.. Tront.

wy the thime of yomler glorions henven

a smalt thing would make it flatio.

fire your city is realy to flume in

did flane ant hurn like twenty.

flame o' the taper bows tinwarch he

dart your blinding flames into lier...

to sulpluarus and tormenting tlames

threatening the flames with bixion r
the luat and tame of thy distemper.

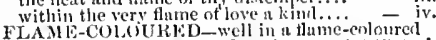

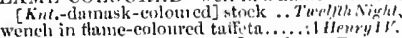

F L.A. ED_in every cabin. I flume

La Mr biN-anil hoar the flamen.

seld-shown thunens do press amon
LAMING -shull to my taming wrat
is too flaming a praise for a gotal..

witli flaming top stoops to his base

firming youth fet virtue be as wax..

if I quench tlae, thou flaming minister.. Othello,

Flaminius, honest Flaminius :........

Flaminius, I have noted thee ulway

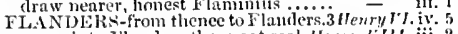

carry into Flanders the great keal. ifen $y$. $T /$.

FLAP-DRAGON-

atser swallowed than a flap-dragon.. Lore'sL.L. . . 1

FAAP-DRAGONED-

FCe how the sen flap-dragoned it.. Winler's Tate, iii. 3

F LAP-JACK-puddings nnd flap-j:
F IARING - rihands pendant, flating

the 1 -in the aim and very flash ot it.Jal.

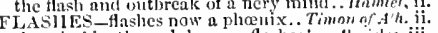

thy nimble, thy sulphurous flats?

Sour flashes of merriment, that were..... Hamlel,
ASIIING-flashing fire will follow... Heary

FLASK-carved bone faee on a flak .. Love's L.L.

sueks up from bors, tens, flats

and fat meads thatch d with stover

nay, now you are too flat.... Tro Gen. of Verona

the flat transaression of a school-hoy. iruch Ado, ij. why, this is flat perjury

flat burglarly, as ever was committed,$\overline{\text { iv. }}$ ivove's $L$. Lost,

a goose, that's flat....

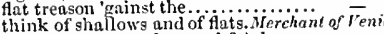

think of shallows and of tats. Merch

why, this is flat knavery
rebiellion, flat rebclion I

rebelion, flat rebclionl $\ldots \ldots . . . . .$. . King John, iii.

passing these thats, are takeu .........

through Coventry with them, that's flat

the flat unruised spirit .......... Henry/ $Y$. i. ehnrus)

and dregs of a flat tamed piece.. Troilus \& Cress.
with the nose, down with it flat .. Tianon of Ath.

the eity, and to lay all tha

that is the way to lay the eity flat.

I'll trend these flats. Consider

strike flat the thick rot undity

marle of stuff en flat and dull ............

FLATIY - he tells me flatly ... Merch. of Vr

tells you flatly what his mind is.. Thming of

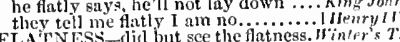

FLA'TNESS- disl but sce the flatness. W'inter's $T$. iji.

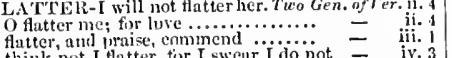

think not I flatter, tor I swenr I do not

desire him not to flatter with...... Furelfin, Nigh

to flutter up these powers of mine.... me's $l .$. Las

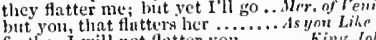

further I will not flatt

great kint, to flatter thice

to insinuate, flatter, low (ji.........

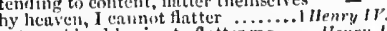

yet my blool beyins to flatter me .... Venry $1 . y$.

doth not slatter, face, or feign

give consent to flatter sin
to flut 1 .er Ilenry, and forsake

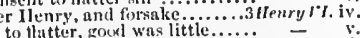

teach me how to flatter you ......... Richned II.

beaure I cammot flatter, and speak fair

flatter my sirrows with rejort of it

for I shnild ne're flatter thee

I fiatter not; but sny, thou art in enitiff
Fl.ATTLR-flutter beneach abhorming. Cord
to flatter them for their love .......

multiplying apa wn how ean he llute
I will, sir, flatter ny gworn brother.

regard me as I do not tatter.

he would uot flatter Nepti

lepinlus thatters botl

to flitter Caesar, wonla you mingle eyes - iii.

Aintromisos, I do not fliatter the

he flatters yon, makes war upon

nay donot think I flatter

l'ericles, $\mathrm{i}$.

I liave finttered a lardy

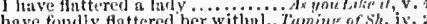

try his friends thut flatteres! him . Richarit $I i$, ii.

hemling peers thint flattered thee?.. Richard hil.

they never flattered thee: what hast

men that liave flattered the
lreing then most flattered

I hear him as he flattered .......... Juny \& C C'eopatra

flutters both, of botls is llattered .

than still eontemmed and flattered

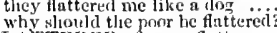

Why sliotld the poor he futtered
FLATERER - for imy flatterer

Hamlel, iii.

too great a fintterer for my mind Tuelnh Nigh', i.

but basely led by flatterers..........

he is a flatterer, a parasite, a keeper
flatturers were then but subjects (rep.)

from the glinss-fac aterer the

to be flattered, is wortlyy o' the fintterer

the same picee is every flatterer's spirit

the sanc picee is every flatterer's spirit -
and say, this man's a flatterer?..........

thy flatterers yct wear silk, drink wine -

haclis been a knave, and flatterer.

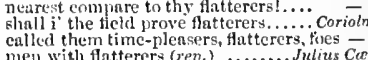

either a coward, or a flatterer $\ldots . . . . .$. .

thou art no flatterer; I thank thee...... Pericles,

1 know, sir, I an no flatterer ............ Lenr, ii.

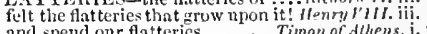

stuck and spangled you with flatteries - iii.

the infinite flatteries, that follow

FINTTERING-are a flatterinteries

to be a thattering honest mun

even as a flattering dream.. Taming of sh. I (intulue.)

honours in these flattering streams .... Wacteth, iii.

math ot her flattering sounds ........ Richard $I i$. ii. I

Oflattering glass, like to my followers - iv. 1

thou dost give me fattering bnses .. - ji. 4

for all this flattering gloss he will ..2Henry I' i i ?

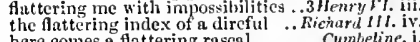

here comes a flattering raseal

fiatterimg mysclt, as if it ..... Tilus Andronicus, iit.

and fluttering his displeasure, tripperl.... Lear, ii. 2

if I may trust the flattering eye of sleep. - v. 1

not that flattering unetion ta your soul. Hant 1 , ii.

thou flatter'st misery. I flutter not Timon of $A$ th. iv.

FLATTERY-by thy flatters .. T'uoGen, of ler.

and say, this is no flattery.............. As ynu Like it. ii.

brenth of flattery conquers strife Comedy of Err. iii.

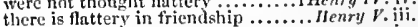

but poisuned fattery? ............... =

hase insimating fattery, I pluck ....i Henry 'ly. ii.

cume hot to hear suels fluttery now Heary

let none think flattery. for thie's'll .

to eounsel deaf, but not to thattery! Timon of $d / h .1$.

his new plants with dews of fhittery - ...

I kiss thy hand, but not in futtery Julius Corsar, iii.

mine cars that heard her thittery.....

so well as sott and tenler tatle up?.

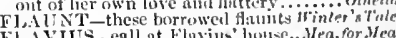

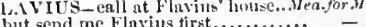

Timon of thene, $\mathrm{i}$.

Gurullua and Flavius............... Jufins Cersar, i.

Luben, and Flnvins, set our buttles on - Yeas. ii.

sans crack or thw.................. Lure x l. Lost, v. 2

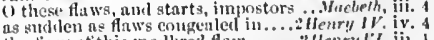

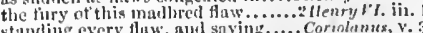

how Antony heennes his flaw...An/mny ficlen, iij. In

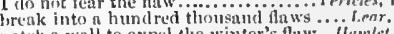

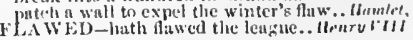


ELAWED-hath Hawed the heart ...Henry VIII. i. 2 but his flawed heart, (alack, too weak.... Lear, v. 3
FLAX $\rightarrow$ bar of flax? FLAX-a bag of flax? .............. Merry W"ines, ₹. 5 to my thaming wrath be oil and flax.2 Henry VI. v. 2
I'll fetch some flax, and whites......... Lear, iii. 7 I'll fetch some flax, and whites....
FLAXEN-al? flaxen was his poli. $H$.

FLAX-WENCH-as any flax-wench. $I$ ind

FLAY-her nails she'll flay thy wolfisl FLAYED-is half flayed alrcady.. Winter's Tate, iv. 3 a son, who shall be flaved alive remember, stoned, and flayed alive...
I hope I shill not be flayed out of it.

F LAY ING-what flaying

vagabond, exile, flaying................ Corioln - iii. 2

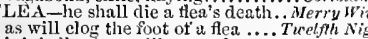
as will clog the foot of a flea .... Twel.ph Night, iii. in's belly than will sup a the in all London road for fies breeds fleas like a loach

FLEANCE-goes Fleance with you? .. Mncb Fleance his son, that keeps lim company Banquo, and his Fleance, lives.
tyy, good Fleance, fly, Hy, fly

that did the like for Fleance

most royal sir, Fleance is 'senp

so should Fleance; but, peace! why then, she's fied unto. T'wo Gen.nf

we'll follow him that's fled

do not say, they be fled $\ldots . . . . . .$.

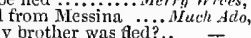

and fled he is upon this villany

who is fled and gone.

and, as she fled, her mantle she di

now am I fled; $\mathrm{my}$ soul is in the sk

my daughter! fled with a ehristian

some two months sinee, fled from.

the treachery of the two, fled heuce.

fled from his father, from his hopes

then they fled into this abbey. Comeaciy of Error

are stolen away and fled ................. Waebeth

the son is fled..............

Fleance killed, for Fleance fled ...

Maeduff is fled to Eogland. Fled to

that fled the snares of watchfu.

of all this realm is fled to heaven ...
powerful friends, are fled to him... R

servants fled with him to

the nobles they are fled...............

our countrymen are gone and fled.

to Bolinghroke, disperscd, and fied...

they are fled, and till so mu

and Stafford, fled the field

that arrows fled not swifter

the rogue fled from me like quicissilver 二

I would ne'er have fled

and night is fled, whose pitchy

such a valiant company are fled

could not, if he would have fled.

that basely fled, when noble...
you fled for vantage, every one

for that which we have flcd

with his soul fled all my ............Henry

what, is he fled? go some and follow

he's fied, my lord, and all his power

not enough our foes are this time fled

the king is fled to London

oo fled his enemies my warlike...

belike, when valiant Warwiek flut

so much before, and yet you fled

for all your friends are fled.

and fled, as he hears sinee, to Burgundy

with Oxford, ffed to her.

is fled to Riehmond, in the prits...

Dorset is fled to Riehmond,
Morton is fled to Riehmond.

a pardon to the soldiers fled.

either to harbour fled, or made. Troilus \& Cres

all are fled, save the gods only. Timon nf Athen

I fled from words: you soothed not.. Coriolanus, iii. 3

ned to his house amazed.

thou art fled to brutish beasts....

towards Peloponinesus are they fled... Ant.\& - Cle
I have fled myself; and have instructed -

what although you fled from that

'tis certain, she is fled: go in, and chee

follow those that even now fled henee

why fied you from the court?

Marens, she's gone, she's fled..... Tilas Andron

miv lord, prince Pericles is fled

fled this way, sir: when by no means.. Lear,

full suddenly he fled li.................

leap the hateh, and ali.... aled ....

and then Tybalt fled: but by me Romeo \& Jutiet, $\mathrm{i}$.

fled from her wish, and yet said ........ o o/hello, ii
FLEDGED-the bird was fledged.Mer. of Vereice, iii. 1 FLEE-thunp then, and I fiee............ we have won the flecee (rep.)

not sheer the fleeces that I graze. As you Like il, ij. down with them, fleece them ......1 Henry I ere I shall, sheer the fleeee fl......... 3IIenry VI. ii. 5 harmless sheep doth yicld his floee...

my fleeee of wonlly hair that now. Titus Andron.

FLEECED-flceed poor passengers.2 Henry ${ }^{2}$. ii.

to fleer and scorn at our solemnity. Romeo of $J$ ito,

mark the fleers, the gibes, and notable . Othello,
FLEERED-and fleerel, and swore .. Love's L.L.

FLEERING -is no fleering tell-tale..Jutius Crsar, i. 3

and for the rest o' the fleet $\ldots . . . . . .$. . Tempest, i. 2

shall eateh your royal fleet far off........

I am sure, he is in the fleet ..............Much $1 d$ d ,

all the other passions flect to air. Mor of Verice, iii. 2

and flect the time carelessly ........As you Like it,

if Echo were as tleet, I would. Taming of Sh. I (ind.)

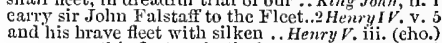

so appears this fleet majestical

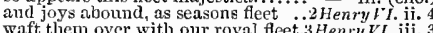

in Cosar's fleet are those, that oiten. Ant.\& Cleo iii 7

and flect, threatening most sea-lik

my fleet hath y ielded to the foe......

all confirm a Turkish fleet, and bearing. Othello, $\hat{i}$.

there injointed them with an after fleet.

that the Turkish fleet be not insheitered

and sufferance on most part of their fleet 二 ii. 1

FLEE perdition of the 'Turkish ffeet....

ay, fleeter than the roe . Taming of Shrew', 2 (iin.
FLEETING-false, flceting, perjured. Richard III.

and $I$, hence fleeting, here remain. Anlony \& Cleo.

now the flecting moon no planet.......
FLEGMATIC be not so flegmatic..Merry

FLEMING-a Fleming with my butter
FLEMISH-hath this Flemish drunkard

FLESH-at them wallets of fle

beats and blood, you brother.

methinks, his flesh is punishcd .......... wives wives iv

it is the flesh of a corrupted heart .... $\quad-\bar{T}-\mathrm{v} .5$

and let your flesh and blood..........

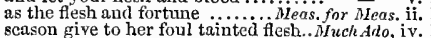

as pretty a piece of fiesh as any

I will be ffesh and blood.

his own person in flest and biood. Love's'L. Lost

of man to hearken after the flesh

which makes flesh a deity

an equal pound of your fair flesh.

a pound of man's flesh, taken......

thou art mine own flesh and blood

is my flesh and blood. There is (re?

thou wilt not take his flesh

he would rather have Antonio's flesh

apre a pound of flesh to-morr

the pound of tlest, which I demand..

the Jew shall have my flesh, blood

balance here, to weigh the flesh?

a pound of that same merehant's flesh

and you must eut this fiesh from off
of flesh; take then thy bond (rep.)

prcpare thee to cut oft the flesh

but just a pound of flesh: if thou ....
riveted so with faith unto your fiesh

of a good piece of flesh ............As you Like it, iii.

I am driven on by the flesh; and he .. All's Well. i. 3

as you, and all flicsh and blood are

if she had partaken of my flesh.

in despite of the fiesh. . Tam

ever dram of wanted' fesh $\ldots . . . .$. - iv.

se would not exchange fiesh with one

either at flesh or fish, a table.....................

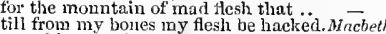

mouthing the tlesh of men ........... King John,

and fin this wall of flesh there.

of flesh, as now our flesl is . Richord II.

as if this flesh, which walls about.

mock not flesh and blood with solemn

bear mine own flesh so far.

why? she's neither fish nor flesh

I have more flesh than another man

worse than thy sword my flesh .......

his flesh was capible of wounds....2

by this light flesh and corrupt blod

says that which his flesh rel,els arginst
shall flesh his tooth in every........
FESH-when flesh is cheap $\ldots 2$ HenryIV.v.
for thou lovest the flesh.............. Heniry till bones, and flesh, and sinews

did flesh his puny sword......

thou art a eollop of my flesh

roportion to my flesh and blood .....2 IIenry

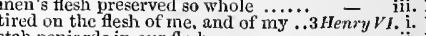

drop stand on my trembling fie....... Richard

capable of our flesh, few are angels. Henry VIII, $v$

good trader's in the flesh.... Troilus \& Cresside $\mathrm{v}$ i

arrainst the quality of flesh ...Tinon of Alhens, iv.

what in flesli was futigate ........... Coriolunus, ii.

best of my flesh, forgive my tyranny - and men are flesh and blood....... Julius Cepsor, iii.

he means, in flesh .................. Jutony \& Cleopatra, i.

thou didst eat strunge fiesh

if you buy ladics' flesh at a willion

to let an arrogant piece of flesh threat

how now, my flesh, my child? ......

in thas fiatrum saerifice his tiesh.. Tilus And. i.

execution on my flesh and blood

yet I teed on motlier's flesh .....Pericles, i. 1 (riddie)

half fish halt' flesb; mother's flesh

and we'll have tlesh for holiday

tor flesh and blood, six, white and red..

but are you flesh and blood? have you
look, who kneels there! flesh of thy flesh

my flesh, my blood, my daughter (rep.).

merey on their flesli? ( $(\mathrm{epp}$.$) . ..............$

in his anointed flesh stick boarish .....

and teur thy flesh and bones

devour thin, flesh aud tell, ere they .... - v

makes my flesh tremble in ....... Romeo \& Juliet, i.

O flesh, flesh, how art thon fishified!
paradise of such sweet flesh?

paradise of such sweet flesh? buy food, and get thyself in flesi.... - $\quad$ ii.

stars from this worli-wearied flesh..
this too too solid fiesh would melt ....... Hamlet, i. 2

to ears of flesh and blood .............. - i.

man and wife is one flesh..............

FLESBED-you are well fleshed.. Twelfih Night, iv. I

tull bravely hast thou fleshed .......1 Hexry 1. . v.

princes, fleshed with conquest $\ldots \ldots . .2$ HenryI $\dot{V} . \dot{i}$.

of him hath been flcshed upon us......Henry $V$. ii. 4

albeit they were fleshed villains .. Richard $I 11$. iv. 3

FLESHFLY -the theshfly blow my mouth Tempest, iti. I

FLESHAIEN'T - the fleshment of thís dread. Lear, ii. 2

and was the duke a fleshmonger. Meas. for Meas. v. I

FLEW - wings she flew withal ... Alerch. of Venice, iii. I

pitch she few above the rest: ...... Henryl' $I$. ii. 1

whereout Hector's great spirit flew. Troil.o' Cres. iv.

thereat enraged, flew on him $\ldots \ldots \ldots \ldots$ Lear, iv. 2

FLEXIBLE-pitiful, and flexible ....3 Henry VI, i. 4

makes flexible the knees of ..Troilus \& Cressida, i. 3
FLEXURE-give place to flexure ....Henry $r$. iv. 1

legs for neeessity, not for flexure. Troilas \& Cress. ii. 3

this is the toul fiend Flibbertigibbet .... Lear, iii. 4

FIibkertigibbet, of mopping and mowing - iii. 4

FI, IERS - not for the fliers............ Coriolanus, $i$.

tollowing the fliers at the very beels
he stopped the fliers; and, by his rare

you, it seems, come tom the fliers ... Cymbeline, ii.

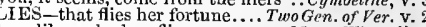

love like a shaduw flies......... Merry Wives,

pursning that that flies................ ${ }_{\text {Apollo flies, and Daphne holds } . . . M}^{\top}$. $D r$. ii.

cowardice pursues, and valour flies .. - ii. my taxing like a wild goose flies.. As you tike it,

of honour, flies where you bid it .......All's Well, ii. 3

with flies blown to cleath

what, with worms and flies?............ Macbeth, iv.

upon enforcement, flies with greatest.2 Henry $r$ r.i.

are like flies at Bartholo........ Henry $\nu$. ini. (chorns)

which flies the higher pitch....... . i Henry $V I$, ii.

gold, flies from wnother coast..........2Henry VI. i. 9

assist you; he that flies, shall die.....3 Herry VI. i.

swarm like summer flies ........... $=$ ii.

never then had sprung like summer flies - ii.

reward, thy eonseienee flies out .... Richard III. i. 6

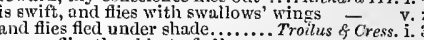

renson flies the objeet of ali............ - ii.

hut flies the grasps of love $\ldots . . . \ldots \ldots$.

but flics an cagle flight, bold $\ldots . . . .$.
showers, these flics are couched.....

trencher-friends, time's flies ........ - ii.

or butchers.killing flics ............. Coriolunns, iv. 6

so abides and flies, that thou ......Antony \& Cleo. i.

the fight in height, flies after her..... - iii.

to chace what fies; our cage ........ Cymbeline, iii. 
FL, ES-thy spite on mortal flies .....'ymbrline, v. Flock-buy his thock und parture? my nicee, that fies nwy so finst?. Tlus that winter kills the flies.

that llies i' the purer air

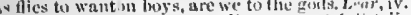

aflicted with these strauge flie's. Romeo o Jutich

mies may do this, when I from this

you mark, his tievourite flics

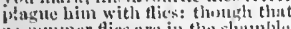

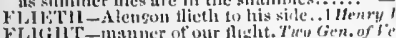

ancl pretendecl tivetit

and when the flight is imalo

Thesus' periury, und unjust flight.

cuntirm her thight

labour st hy thy thight to shin : .

your brotler dohn is ta' en ill thight

thut luvers' fliglits woth still..... .

tell him of tiuir llermia st flight ......

ant in our tlight, tell me how it can

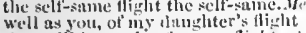

well as you, of my dinghter's inght
that will be imule ufter my fight...

away. and lior our flight. Bratel

rumour may report nity flight.

her flight acruss thy liatluer's 'rroumb

resolved for tlizht: now were 1 hitply

may be to the llightit of ny master

Baniquo, thy stsul's flight, if it

his-elsistered flight : ere, wo black
his flight was muluess: when our

where the flight so runs agninst

new fliglit; and hathy newness

$a s$ is the litleon's fliglit against

quite from the flight of all thy

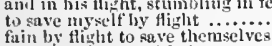

irom the liberty of night

flight eanuot stain the honour.

remowned nume; shall flight

then talk no more of fightt....

they have used with fearful flight.

bontless is flight, they follow

our soldiers put to flight

I like not this flight of Eilwurd?

come, to our flesek

as your gook thock shiil pronper..

were if your tock und mily

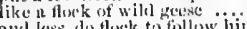

and less, do flock to fiollow him

that they flock toucther in eon

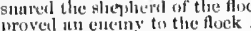

guthered llicks if friends.

hours must I teml my flock

ginlity people thek to him.

minre competitors thock

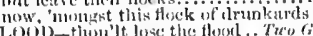

in losing the food the flowe

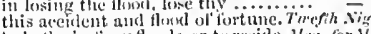

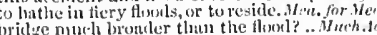

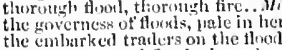

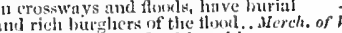

and bid the main food hate h

surew trees, stimes, nind ford

great flookls have flus'n from simple

ike cuvious tonds o'erran her. T'aning of' sh. 2 (in)

Noati's flond could not dis it.

I breathe nasin aloft the flool

devoured by the unterested thom.

ot swit' Severn's thod ............

imperisus tloot hat h left a wit

shail mimgle with the st:te of flowel

never eame reformation in a flogl

let floods o'erswell, and frie
pales in the flood with men

pales in the food with men
theretore, with a flood of tea

whuse flod berins to fow with
sometime the flood prevails

satilors swallowed in the floo

bat still the envious flood

by suldencholy flood, with that grim

a roek against the chitling flood ... Heary $\bar{V}$ HI. iii.

the wild and wandering thood
his youth in flood. I'll prove

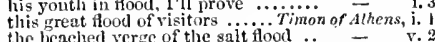

the beached verge of the sait
likc a bithl flood o'er-beat....

with me intu this angry flood

by an age, since the great flood

taken at the flood, leads on to fortum

shine left on them by a flood?

lave them hourly in the floou

hut floods of tears will drown .........
half the flood hath their keel cut. Pericles,
iii. (Gow.)

what, if it tempt you toward the flood.

moving accidents, by food and field ..... Othello, i. 3
it is a high-wrought flood; I cannot...... ii. I
like molestation view on the enchafer fiood - ii. I

LOOD-GATE

do stop the flowd-gates of her eyes .. Itenry / 1 . ii.

of so flood-gate and o er-lsearing natme...

look, how the floor of heaven is...Mer. nf lenice. $Y$. I

had tound gold strewel o' the floor

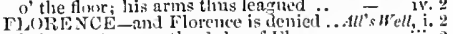

towaris Floreste is he? $\mathrm{dy}$, maxl:m

a young gentlewinan here in Flurence

to a proper maticl in Florence. onc oian

in Flurence was it from a casement...

atole from Florenee taking no leave
broutht to in Florence........ Thm

from flotence, ant mist here deliver

is lie nut in town? Ife's now in Florence. Othollo,

FLCRENTINE-on a young Florentine. Mueh. $\cdot l^{\prime}$,

that the Florentine will nove ws $\ldots$....

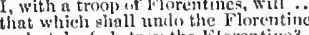

undertake fo betrity the lorentiue?

liere's a. petition from a Florintine

one Michacl Cassio, at lorentine..........

I never knew a florentine more kimk - iii. I

which Florizel I now name.

I have kerved printec florize 0 ......

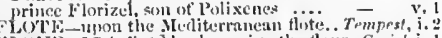

f. LilR [ Col. Krut.] butk reecive the llow

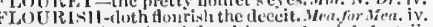

nceds unot the painteil flourisly

lenl we the flourish of all gentle

even as the flumish when true... Mer. of lenice, iii.

or Alusing to the heirht of my a

vain flourish of my fort une?

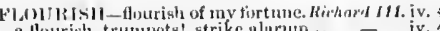
a llowrish, triunjets! strike alurum.

in thy slceg! live, and flowrisls! (rrp.

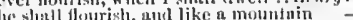

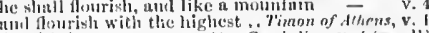

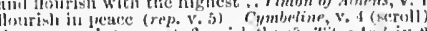

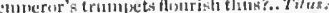

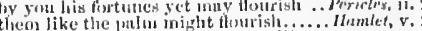

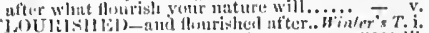

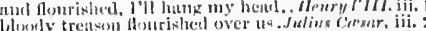
to hin that flourished for leer.. Thitus Andronicus, $\mathrm{i}$.

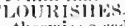

'therwise a seducer fluorishes. . . lll's Well, v, 3 (petit.)

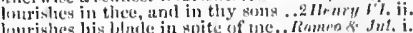

mina

I, UURISIILT)

is ladies cyes that flourisheth .. Taming of Sh. ii.

i better brook than fourishing. . TeroGrnof ter. v.

renowact Titus, flutrishing in urms.. Titus dud. $\mathrm{i}$.

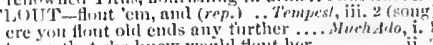

to one that she knew would funt hor $\quad$ - ii.
fior I should flunt him, if he writ ....

and cos. und flout, deprave and slander $=$ v. 1

why will you suffer her to flout me thus? - iii. 2

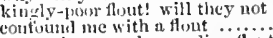

comparisons, and wound line flowit

given us wit to flont at fiortune .... As you Like it. i. 2

her silenee flouts one, and l'll be...Takainz of sh, i. I

jecr, and llout me in the tecth?.....

these eeroviles of Angiers flout you ...King Juhn, ii.

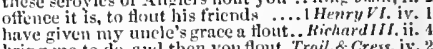

bring me to do, anul then you flout. Troil. $f$. Cress. iv.

so flouted in this royal presence? Richard III ii.

certuinly, he flouted us lownright ... Coriolanus, ii.

but sorrow flonted at is flouble scath. Tilus And, iii.

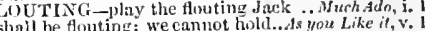

why, first, tor fonting me ... Comedy of Errors, ii.

I. otv - I'll teach you how to flow .... Ternpest, it.

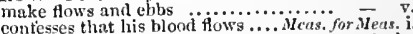

bcing that $\mathrm{I}$ flow in grief'............... I uch .Ado, iv.

that on my checks llown flows. Love's L. L. iv. 3 (ver.
the sea will ebb and flow ............. iv.

doth it not flow as hugely as the sca.ds yno Like, ii.

the even truth in pleasure flow ........ Alt's Well, y.

if wit flow frum it, as boldness.... Hinter's Tale, i1.

in as hizll in flow as the......

and fow heneeforth in formal ...... illerryly. v.

whose food besing to flow within ..2 Hewry r. iii.

scenes as draw the eye to How ...Henry I"111. (prol.)

whom from the flow of gall I

scems to flow from him! ........... iit. -2

you flow to great destruction $\ldots \ldots . .$. .

nor cease lis flow of riot ............ - ii.

nor cease his flow of riot

finl sct mine eyes at flow

seornd'st our brains' flow, anil thise

should make onr ey fluw with jor Corio

they tuke the flow o the Nile ..jolony of cles, ii.

that it flows over on all that need

princelv blord flows in his cheek

dirl not flow from honourable courses the

that chb and flow by the moon. . .

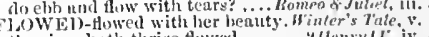

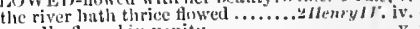

promily flowed in vanity ............

mumbers that l'ctrarch fowed in...Romes o Jul. ii.

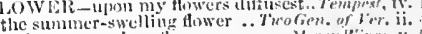

and every lrecious tlower .....

intiries use flowers for their chin rietery -

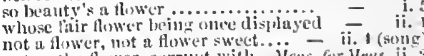

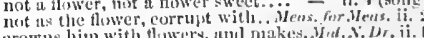

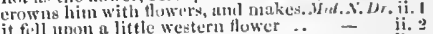

fetch me thut thower ......

linlled in these flowers with dinize.

this flower's firec in stirring love..

while thou on presaed flowers dost sle
wecpe every listle flower, lamenting

weeps every little flower, lamenting
flower of this purple dye, lit with

of tresth beth one flowitr, bith

orer cuphil's dower bath such liorec.

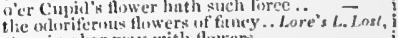

strewing her hong with flowers
this is the flower that siniles on

I ain that fluwer, - that tinint

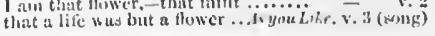


FLOWER-a fresh uncropped flower...Al's well, ${ }^{2}$ and bestrewed with flowers... Tamung of Sh. 1 (ind.) give me those flowers there.

fit our ages with flowers of winter.
the fairest flowers o' the season nre.

here's flowers for you; hot lavender.

these are flowers of middle summer..

O Proserpina, for the flowers now...

come, take your flowers; methin

before the flowers in their caps...

the flowers, fair ladtes; and tihy steps. Richard II. i. 3 a too long withered flower........

from thy bosom pluck a flower 3 .

fertility trom wholesome flowers

her fairest flowers choked up
we pluck this flower, safety

we pluck this flower, safety

and play with flowers, and smile...

on my behaif would piuck a flow

that the paleness of this flower

because sweet flowers are ow alsy.3Hen

my unblown flowers, new-appearing - iv.

misic, plants, and firew me over with mide..Henry

strew me orer with maident towers . - iv.

he's one of the flowers of Troy

and cull their flower, Ajax shall cope - $\quad$ i. 3

receive the flower [ Col. Kn'l, -flour]
flower of warriors, how is't with

strew flowers before them: unshout.

do you now strew flowers in his way. $J_{\text {ulius }}$ Crpsar, $\dot{i}$.

where souls do couch on flowers...Anlony \& Cleo. iv. 12

gather those flowers; make

on ehaliced flowers that ]ies ........ ii. 3 (song)

with fairest flowers, whilst sun
thou shalt not lack the flower.

thou shalt not lack the fower........

here's a few flowers; but about midnight -

you were as flowers; now withered

your never-withering banks of flower

morning's dew distilled on flowers?.

though they feed on sweetest flowers

to blow into life's flower again!
to strew tliy green with flowers.

to strew thy green with flower.
give me your wreath of flower

not such a flower (rep.) .................

may prove a beauteous flower when...

the infant rind of this small flower

pink for flower. Right. Why, then .. -

he is not the flower of courtesy, but I'll -

flower as she was, deflowered by him

our bridal flowers serve for a buried corse -

give me those flowers; do as I bid thee

with flowers to strew his lady's grave

larded all with sweet flowers.... Hamlel, iv. 5 (song)

the flower-de-luce being one! .... Winter's Tale, iv. 3

sayest thou, my fair flower-de-luce? .. Henry $V$.

are the flower-de-luees in your arms.1 Henry

FLOWERED - to the flowered franee.2 Henry WI.v. 1

then is my pump well flowered.. Romeo \& Suliet, ii. detained me, all my fowering youth. 1 Henry

snake, rolled in a flowering bank...2 Henry VI. iii. 1

hid with a flowering face l....... Romeo \& Juliet, iii. 2
ELOWER-SOFT-

of those flower-soft hands.. Antony \& Cleopatra, ii.
Fl.OW ERY-flowery tenderness?

wakes me from my flowery bed.Mid. N. Dream, iit. 1

wit thee down my fowery bed.Mid.

and the y'll be for the flowery way....All's $\vec{W}$ ell, iv. I 5

low ING-be in their flowing cups.

would call forth her flowing tides..... Henry $V_{I}$. i. 1

no less flowing than marchioness ...Henry VIII,

to-night flustered with flowing cups.... O/hello, ii

Low $N$-floods have flown from simple...All's $W$ ell, ii.

having flown over many knavish.

ere the bat hath flown his cloistered.. Macbeth, iii. 2

she's flown to her desired Posthr

$O$, well flown, bird I $\mathrm{i}$ ' the clout

FlOWRET-nor bruise her flowrets... I Henry I $V$

I say, gud-day, captain Fluellen

low now, captain Fluellen

how now, Fluellen? camest thou from

what men have you lost, Fluellen? $\because{ }^{\prime}$

eaptain Fluellen! So! in the name of

they did, Fluellen. Your majesty.

what think you, captain Fluellen?

follow Fluellen closely at the heels

for I do know Fluellen valiant

FLUENT-a theme as fluent as the sea
FLUNG-Whose enmity lie flung aside

broke their stalls, flung out

............Macbeth, ii.

from lin

Hexry VIII. ii.

he's flung in rage from this.... Timo nof Alhens, iv.

FLUSH $\rightarrow$ now the time is flush. . Timon of Athens, $\mathrm{v}$.

and flush youth revolt ........ Antony \& Clopatra, i. 4

FLUSIMNG-flushing in her galled eyes - i. 2

flustered with flowing eupg
FLUTE-Flute, the bellows-mender... Mid.N.Dr. i. 2 FLY-horse, beeause I will not fly .3HenryVI. ji. Flute, you Thisby ..............

iv. 1 fly, father, fly! for all your friends...

to the tune of flutes kept stroke...Anlony \& Cleo. ii. 2
these trumpets, flutes! what! ............ ii. 7
FLUTTERED-

FLUtted your Volsces in Corioli .... Coriolames, y. 5

the very uncleanly flux ot a cat...

Tampest, i. 2

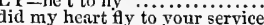

her peacocks fly aminin

and whither fly the gnats............

no way to fly, nor strength to.

what are they that fly there?

ah, could'st thou fly! $(r, p$.)

fly, lords, and save yourselves.

some one of you would fly from us...

the boar, before the boar..... Bichard $I I I$. iii.

disdained it, and did scorn to fly

wilt thou, 0 God, fly from sucl

Catesby, fly to the duke. I will......

and fly to him, I fear..............

but, fly $I$ hence, I fiy away

in great amazedness will tly

then fly, what, from myself?.........

der.Henry IIII. v.

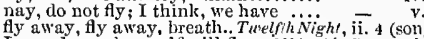

Lysander and myself will fly ...Mid. N.'s Dreum

thou shalt fly lim.

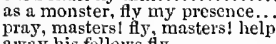

and fly like chidden Mercury... Troilus of Cress.

deliver a fly from a spider....

ii. 3 arms outstretched, as he would ty

but faster he did tly.

hut faster he did fly..................... $\overline{\text { Love's }} \bar{L}$ Lost, iii.

as they fly by them with

will we both fly toward Belmont

how we may fly, whither to go...

it will not kill a fly

from your sound parts shall at

Like it, i.

from your sound parts shall fil

that can fly from us...

to fly the favours of so good a king

anci that yrou fly them as

I Hly, Biondello: but they may. Taming of Shrew,

to fly away by night.... Winter's Tale, ihi. 2 (indict.)

so fly $\mathbf{I}$ from her that would.. Comedy of Errors, jii.

fly pride, says the peacock............

fly, good Fleance, fly, fly, fly........

some holy angel fly to the court of
to make him fly the land?

Macbelh, iii. 3

from whenee himself does fiy

whither should I fly? let them fly all; till Birma.....

then fly, false thanes, and min
doetor, the thanes fly fiom me....

I cannot fly, but, bear-like

them........ing $\overline{J o h n}$, iv,

y, noble English, you are bonglit...

seem the clouds that in it fly

Richard II. i.

on his side fights, thousands will fily

be safe, fly from my side

a rendezvous, a home to fly unto....

to fly out of your sight
their safety fly from the fiejd

will fly with his face backward...

I do not fly, but advantageous....

and there they fly, or die, like...
why then, fly on, I'll hunt...

why then, fy on,
I will fly, like a dog...............
his promises fly so beyond his
fly dammed baseness, to him

Timon - v.

Ay damned baseness, to him that.

if I fly, Marcius, halloo me.

do they still fly to the Roman?

save your lite, fly to your house

coward lips did from their colour fly..

fly not, stand still; ambition's debt..

look, the villains fly!

fy therefore, noble Cassius, fly far off

fly, fly, my lord, there is no tarrying..

thoughts may not fly forth of Egypt.Ant. $\bar{y}$ Cleo

and never fly off our loves again.

the shelters whither the ronted fly....

flitli all their sixty, fly, and turn

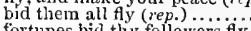

fortunes bid thy followers fly

his spirits fly out into my story.......

it wovld fly from so divine a temple.

soft! what are you that fly me thus?.

as some fly had tickled slumber

or betimes let's re-enforce, or $\mathrm{fl} 5$

torthwith, they fly chick

he'll quickly fly my friendslip too

I have killed, my lord, a fly.. Titus . Andron

have but kilied a fiy. But how, if that fly -

twras a black ill-favoured fly

we can kill a fly, that comes in

sweet scrolls to fly about the fly

dimuned, that gnats do fly in it?....

willingly as one would kill a fly....

so my sad decrees may fly away...

a mou wilt live, fyy after

wrens of Tharsus will fly hence

ant fly to him ! o whither shall we fily

go back one foot, or fly ....

countenance made others fiy

as you fly from your oft-subdued.....

for fly he could not (rep.)........

fly to revenge 0 , it you love...

and, father, do you fly; your loss....

death be so apparent, then both $\mathrm{fy}$

from France to heaven fly............

are saved, if thou wilt fly away ......

an' if I fly, I am not Talbot's son.

men fly, now help.

your grace eould fly to heaven?

the lame to lenp, to fly awny...

and, fly thou how thou can

ty, fly, fy!! sir IIumphrey Stiffird....

those, which fly before the

the citizens fly and forsalke........

the wing wherewith we fly to hica.....

no home, no place to fly to.............

sou'll nor fight, nor fly

ere bid you ty; bre but fiy...

ere bid you ty; but fly you must.....

and trumpets, and the king wili fiy.

ah, whither sliall I fly, to scape

when they can fly no further?

nade thee faint and fly ere this......
never once again turn back, and fily.

king, and many fly to hin

counsel give you? whither shall we fly?
0 , sir, fly this place; intelligence

let him fly far; not in...........

$\ldots$

gives strength to make it fly $\dddot{2}$. Romeo o Juliet,

when I from this must $f$.

fly at any thing we me; think upon.. than fly to others that we know not of?.. my words fy up, my thonglits remain .. - iii.

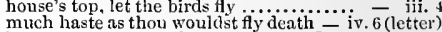
mer wrong stay, and her displeasure fly.. Othetlo, ii. will I ensuare as great a fly as Cassio .... - ii. FLY-BLOWING-not fear fly-blowing. Tempest, $y$ FLY-BLOW N-stinking, and fy-blown. 1 Hen $V L$, i FLYING-that send then flying. Two Gen. of Fer.iii. the justice of my flying hen and flying what pirsues................ Nery Wires, ii. there is nor flying hence .............. Macbeth, $\mathrm{v}$. tholl art flying to a fresher clime..... kirhord 17 . for flying at the brook, I saw not....2 Henry $V I$. ji. either turn my flying soul $\ldots \ldots \ldots . .3$. on heaps the enemy flying .. Troilus \&-Cressida, iii. 2 to conrse your flying flags ..... An'ony \& Cleo. iii. il all fying thrian, I shall flying tight. Cymbeline, $\mathbf{j}$. our Britain's harts die flying

images of revolt and flying offi

Lear, נi. 3

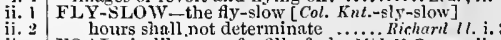
O $\mathrm{AL}$-in likeness of a filly foal...W. Wid.N. Dream, ii. i and the small gilded fly does lech...... - ii. flying for succour to his servant.....Henry $\%$ HI ii. foals me, straight, and able horses. Timon of . $\mathrm{th}$, ii. 1 
FO.AM-nul finums at mouth. . Troilus d Cressids, y. the bark, and plouglint the ton

and rage, and fom, $\mathrm{to}$ be exalted...julius Corsar, i. the angered oceun toams......tntony o. (Venpatra, ii.

Fo.xit:D-and timmed at month .. Julius Cirsar, j.

finmet ut the month, al:al swore

Cylius Cirsar,

Cymbrline, y.

o.

Nicterditi.i.

among fouming luttles, and

aguin bestritle our founing steels ...3Herny ri.

do imit stand upont the foaming shore ... Othello,

Fob-rives them a tob [Col. sob]. Conedy of hr.

to fob off our disgrnce with a tule.... Cariolanns

FOBblid-and resolntion thus tobbed

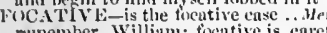

remember, William: focative is, earet -
luDDER-the sluevo for toduler.. Tu*o Gen, of for.

VOE-'montst all fou's.

two such friends should be long foes... - $\quad$ v. 1

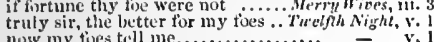

so that by uny toes, sir...

and the bettur for huy foes

so bitter on your hitier toe

strangers, ainl foes do sund

Mid. s $_{\text {s }}$ Drem, iii. 2

with emping tives to live....

redoublet strokes upon the foc

guol of bal, and friends of foes

we hase met witl foes that

in the dying slaughter of their foes...King $J_{0}$

now fall over to my fies? .......

our party mav well meet a prouder toe - il.

the harty mave werlier to $n$

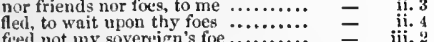

the foe, since fear omyre foe $\ldots . . . . . .$.

sinec fies have seope to beat

the glittering helmet of my foe! ...

the king's friend, and will

his foes are so enrooted with........2 Henry IV

fortune is Bardolph's foe, und frowns

to purge the field of such a hilding foe -

to pray agninst thy toes.............

Giluster too, a foe to citizens

by these colnurs, for thy tives ....

our bodies slaughtered by thy foes ...

a od so thrive Richard, as the

to the field, and vanquished his fises

wasting rain of the eruel foct

was not the duke of Orleans thy foe?
and stek how we may prejudice the fo

and none your foes, but sueh as...

behold confusion of your foes...

but not to fly the foe

isarzine him a Frenchman and thy foe

in Paris, in despite of foes

seek prevention of thy foes

preserve my sovereign from his

were vowed duke II wmphrey's ioes.

our foes are this time fled.....
that seeks to make them foes

to the eager foe turn back

yea, even my fues will shed...........

on the helmets of our foes tell our

our foes are nigh; and this sot' cournge -

whiles the fore doth rage

that to my foes this body must

the foe is merciless, and will not

if friend, or toc, let him be

Henry your foe is taken

the stronger grows our foc

return his sworn and mortaj foe.................

I rather wish you foes, than bollow..

or by his tae surprised

so otlier fues may set up...............

proclaim myself thy mort

irielid, or toe, and tell me............

frisoner to the foe; his state

or urnng surnise, hold me a foe

do figlit agaisust your conntry's foes.

the fore valuts in the tielul.

set ujon our foes; our ancient

a farnace for your foe so hot.

her foes shake like a fiell of

the welcome of a noble foe..... Troilus \& Cross

comat thouglit is bounty's foe .. Timon of the

he rlid oplowe his five

and let the foes quictly eit

if there were no loes, that were.

I fear, our foes the snare.

I'll leave the foe, and mak

fast foe to the plebeii

a foe to the public wesl.

(1till your own foes, ) (leliver y

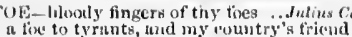

my theet hath jielded to the foe. Antony of $c$ c

such a foc, good heuvens! ........... Cymbeline, iii. g

ontr the was princely; and

cunce erying 'mongst his toes.

aterror to our foes, lunth yoked ... Tilun Andron. i.

the thenly wrongs upon her fixes

wreukful vengeance on thy tix

the emperor himselt, and all thy foes

to lay a eomplot to betra

eme to us as tavourers, not as foes

mearecly think our miseries our foes

and all foes the enp of their deservin

stir one foot to scek a toe

my life is my toe's debt.

but to his foe supposed he must

heing held a foe, he may not l.... - t. s (elio.)

two such opposed fues [Col. Kut.-kings.

met my dearest foe in lieaven. .

you will draw both friend and foe

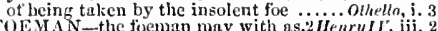

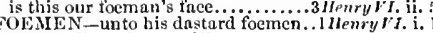

what yaliant toemen, like to..........3Herry $v_{1 . \text { v. }}$

than fomen's marks upon his.. Titus Andron, iv.
FoG-the Egyptians in their fog... Trelfh Nigh, i

sucked up fom the sea eontagions fogs. Afid.N.Dr.ii. 2

coser thou anon with drooling fog

to lose itself in a tog

but have a fog in then
stain the sun with fog

stain the sun with fog $\ldots . .$.
blasts and fors upou thee.

Cymbeline, ili.

you fen-sucked fors, drewn by

sits in - like foggy south, puffing.......... L youk it, iii. 5

is not their climate foggy, ra

ma foi! the other dort chau

par ma foi, peasant. unless

blunt as the fencer's foils.

blunt as the fencer's foils, whild be lotls to foil him.

that did but lately foil the sinewy......

cstcem a toil, whereiz thou art

five most vile and raged set......... Henry $I V$. i. 2

one sudden foil shall never ......... Heriry $V z$ iii.

England give the Freneh the foil

naked, foil a man at arns

3 Henry $r$

[Col.] Antony no way cxcuse his foils.Ant. \& Cl.

Col. must not foil the 1 recious .... Cymbeline, ii. 3
knight shall use his foil, and target ..... Hamlet, ii. 2

will not peruse the foils .............

give us the foils; come on

give them the fiils, young osriek

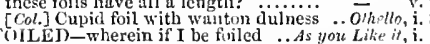

if he were foiled, why, then

FOIN-to see thee foin ...

he will foin like auy devil

come, no matter vor your foins ........... Lear, iv.

fighting o' days and foining o' nights.2 Ilenrylt. ii.

, e'est assez pour une fois allos

earth's inerease, and foison plenty .... Tempest, iv. I (son

fallow brings to teenting foison ...MIeas, forkerss, i.

if dearth, or foison, follow ...Aniouy o. Cleopar

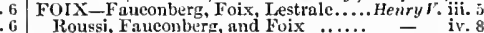

FOLD-thus will I told them..TwoGen. of lerona, i. 2
the fold stands empty in .......Nhd.N.'s Dream, ii. 2

take forth paper, told it

descend, and fold him in our arms....... Bichard $I i$. i. 3

to have me fold up paren's ........... Hrnry

a thousand fold it doth $\ldots \ldots \ldots \ldots 3$ Herry $l$. $l$ ii. 5

unloose his amorous fold

approach the fold, and euli.............. Timon of $\overline{\text { Athens, }} \mathrm{y} .5$

and his fame folds in this

tisld down the leaf where I .......... Cunbeline vi.

that mun's face ean fold in pleasing

so many folds of titin th

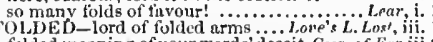

folded meaning of your words' deecit. Cons. of Err.iii.2
ealm words, folded up in smoke ..... King John, ii. 1

hath in eternal darkness folded yp... Rich hord $\mathrm{Hi}$. i.

folded the writ up in form of the other.. Hanlet, y.

FOLIO - for whole volumes in folio. Lone's $\&$. Lant, i. 2

old folks, you know.....................

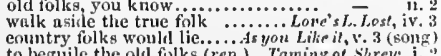

to beguile the oll folks (rop.). Thaning of shere, $\mathrm{i}$.

likes Gremio these yniek-witted rolks?
by the fire with good old folk. ....... lichard $I I$.

and the old fulk, time's floting

2llenry!!

whint, tn come lsehind folks?

will yoor folks lie. that have........ Cymbeline, iii.
old folks, many feign as they were. Romenof Jul. ii.
F) $\mathrm{K}$ - r reat folks should lave

that these follies ure within you

Humble, v.

and follita doth enmew . Measure for Measure, iii.

the pretty tollies that themselves....... Murr. of Ven.

thus so tender o'er his follies ..... Winter's Tale, ii. 3

the faee, that fued so masy fullieg . . ${ }^{-}-{ }^{2}$.

und all that love his follies..........henry VIJI. iii.

ony tollies! then Eilgar was abosed .... Lear, iii.

wherein the acorn eradled: fillow

come, tillow; speak not for him...............

nn more oticks, but fnllow thee $\ldots . .$.

the sound is gening away : let's follow
wilt come? I'll fillow, Stephano

follow then swiftly, and linder....

follow, I pray you ...........
finllow, anil do me service...

the slicep tor forder follow.

for food tollows not tlie sheep

thy master for wates follows thee not

it follows not that she will

, and follow

tes her fortune when it follows her.

and 1 will follow, more tor follow, more to cross

Moyses and Valerius follow him

let lin follow: let me see

I am at a word; follow

Bardolph, follow him

follow my hecls, Rugby ..........
I follow, mine host, I follow

follow me, lad of peace; follow (rep.)

iray you, follow

than follow him like a dwarf

follow your triend's eoun

nay, follow him, gentlenicn

and not follow the imaginations of

will you follow, gentlemen? ( $r$

follow me: I'll tell you strange ......;
follow: strange things in land (rep.;

let's away f fillor me

than any one clse that follows lier. Tuetfi $\overrightarrow{\text { sight }}$...

than any one else that follows ler. Tretfih Night, ii.
what tollows? The numbers altered:

$\Lambda$ should follow, but $O$ does...

suft, here follows prose $\ldots . .$.
if you will see it, follow ine

laugh yourselves into stitehes, folinw me - iii. .

I'll follow this good man ............ $-\overline{\text { in }}$ it. 3

but I sliall follow it .

being grinted in course, now follows.

we must follow the leaders ............ Nuch

the laulies follow lier, aud but one....

if you will follow ine. I will show you

I thought, there would a stab follow.:

come, follow me, boy; come. boy, follow $\bar{*}$.

the more I hate, the nore he follows..

get thee gone, and follow me no more

unworthy as I am, to follow you ....
nr if thou follow me, do not believe..

I'll follow thee, and make a heaven

as in seorn, to follow me, and praise.

take on. ns you would follow

now fillow, if thou darest, to try

follow? nay, I'll go with thee...

follow me then to plaiver grou

and bid us follow him?

bid us follow to the temple (rep.

as it shall follow in my corretion.

and do you follow with my l'envoy..
Mnth, follow. Like the sequel ......

1 beseech you, follow

what follows is pure innocenee.........

to follow mine own terching

the boys in Vunice follow bin ........

I'll follow hin no more with

strange natire is the suit you foliow...

Which, if thon follow, this strict court

go on, I will follow thee, to the last. A you Like it,

with effects of them follow our triends. Ali's $\mathrm{W}_{\mathrm{e}}$

I follow him not by any token

thet follows it, my lord, to bring me

go to, follow. 1 lrajse God for you .. - v. 2

and follow him to his country..$-v$. 3 (petiting
then it follows thus, thou slalt. Taming of shree, $i$.

I follow you, Cambiol

husband, let's follnw, to *ee the end ...

but rution follow our forceful instigation? -

come, follow us, we are to

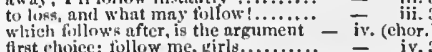


FOLLOW CD-it was followed.... T'melnh Night, ₹.

FOLIOW-That follows this?........

my words; follow us to the court ....
this follows; if you will not change

's Tale, iv. 3

FOLLOW-follow to thinc ans
or what is worit will tisllow .....

rather follow thine enemy in ..........
follow lim, as he hath followed you.

I'll tollow thee a month, devise.....

follow your function, go.............

that ever herald did follow to his urn

tributaries follow him to Rome... Jutlius $\bar{C}$ ersar,, $\mathrm{i}$.

I plunged in, and bade him follow...

for he will never follow any thing

I follow you, to do I know not what

leads me on. Follow me then.

but will follow the fortunes and affairs

prepare the body then, and follow us
tlien follow me, and give me andience

that will follow Cassius, go with him

betimes before, and we will follow.

hence; I will follow thee. I pr'y the
then take him to follow thee, that did

and let worse follow worke (rep.)..Anlony $\bar{s}$ Cleo

of all fimlts that all men follow.

which they beat, to follow faster...

commission's ready; follow me .......

and what may follow to try a larger.

if dearth, or foison, follow

I'll never follow thy palled fortunes.

the fingitive Parthians follow

why should he follow? the itch of hi

I'll write it, follow me...............

to tollow Cresar in his triumph

follow the noise so far as we have....
you, tliat will fight, follow me close.

tollow his chariot, like the greatest.

pray, let us follow 'em.

out of this, advise you, follow

-.. ii. 2 (letter)

son, I say, follow the king .......

will follow mine, if onee the

broke, and ruin follows us

they follow us with wings............

that love me and Warwick, follow we

in person will straiglit follow you

jou, that will follow me to this .....

I'll follow you, and tell what answer.

menns to make the body follow......

all those frieuds that deign to foll

it follows in his thought..............
go you before, and I'fl follow you

go you before, and I'il follow you

incense the boar to follow us.......

that love me, rise and follow me ...... -

they tollow, for what is he they follow

I'll follow, and out-w in the main

now this follows, which, as I take it

do a vessel tollow that is new trimmed

command him, follows my appointment -

heavenly blessings follow such ereatures -

then follows, that I weighed the dainger

how eagerly yc follow my disgraces.

follow your envious conrses, men of..
sir, what follows? sir, I have brought

sir, what follows? sir, I have brough
right sorry to repeat what follows.

and what follows then? commotion

bark, what diseord follows.... Troilus

degree is suffocate, follow

who knows what follows?.............

on, lord; we'll follow you ...

your heart before, this follows

follow me, sirs, and my proceedings.

on the moment follow his strides... Tim

I do not always follow lover .........

f'll follow, and enquire him ont.....

the infinite fatteries, that tollow youth

follow, Cominius; we must follow... Coriolan

nay, let them follow: the Volsces...

puts well forth: pray, follow ..........
[Col.] us to our trenches follow......
his disposition, and follow Marcius.

his disposition, and follow Marcius..

whither do you follow your eyes so fast? -

these in honour follows, Coriolanus.
therefore follow me, and I'll direet.

it follows, nothing is done to purpose
I'll follow those thiat even now fied

must all follow this, and eome to dust

leaving so his service, follow yo

counters; so the aequittance follows

follow, my lord, and r'll soon bring

see, thou follow me: some bring

let's so: Publins, follow me

we'll follow where thou lead'st

follow me then: lord Helicane

hell, follow me my masters.

performance shall follow ...

follow yur ways: follow me

so that it follows, I am rough

what should follow these eclipse

i. 3 follow me; thon shalt serve me........

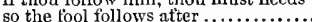

commanded me to follow, and attend ....

- iv. 2

- ritus And. i. 2

- ii. 4

foll that follow their noses, are ied

I would have none but knaves follow it

and follows but for form

to follow in a house, where twice

away! the foul fiend follows me! .......

follow me, lady; turn out that eyeless
let's follow the old earl, and get the ....

let's follow the old earl, and get the

go, follow them to prison; one step
follow straight. We follow thee.Ro

what's he, that follows there .........

follow me this jest now, till thou

follow me close, for I will speak

to follow this fair eorse unto her grave

and it must follow, as the night the day

it waves me forth again; I'll follow it

let's follow; ' $t$ is not fit thus (repeated)

nay, that follows not. What follows then

very well: follow that lord; and look you

where thrift may follow fawning

look you now, what follows .......

follow her close; give her good wateh

let 's follow, Gertrude: how much $\mathrm{I}$ had

start again; therefore, let's follow

but to follow him tlither with modesty

the corse, they follow, did with desperat

they follow the king's pleasure ........
is the union here? follow my mother

is the union here? follow my mother.

I would tot follow liim then (rep.).....

follow these wars, defeat thy favour.

i. 6 to follow still the changes of the moon...

ii. $)$ EOLLOWED -thence I have tollowed it. Tempesi, $\mathrm{i}$.

ii. 1 they my lowing followed...

\begin{tabular}{r|r} 
ii. 3 & followed her with a doting......... Merry Wives, ii. 2 \\
iii. 1 & O had I but followed the arts! ... Tutelfi Night, i. 3
\end{tabular} go on, I'll fullow thee (repeated) that you followed not to Leonato's?..M/uch Ado, i.
he followed yon; for love, I followed.Mid.N.Dr.iti.

I followed fast, but faster le ....... - iii.

dhem.. iv.

it shonld have followed in the end .. - v.

would be better if well followed...MIer. of Venice, i.

you are thave followed her exile. As you Like it, $i$.

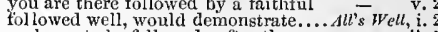

such are to be followed: after then

must be even as swiftly followed...W'Winter's Tale, $i$. but I tollowed me rollowed should be

a hue and ery hath followed certain

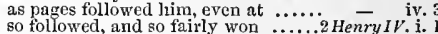

followed both with body and with nind -

this chase is hotly followed, friends .Henry $r$. ii. 4

since first I followed arms

2 Henryli. ii.

we followed then our lord...

Richord III. $\mathrm{i}$.

as I followed Henry's eorse.......

thronging troops that followed thee?

followed with the general throug. Herry $V \overline{I I}$. (prol.)

be unmanly, yet are followed....

followed both my fortunes faithfilily

iv. 1

lollowed both my fortunes faithfully $\overline{\text { hiv }}$ iv. 2 us to our trenches followed [C Col.-follow]... Coriol. i. 3 follow him, as he hath followed you

how the blood of Cosar followed iti.jul. Corsar, ini.2 I followed that I blush to look upon. Ant. \& Cleo.iij. 9 I little thonght you would have followed - iii. 9
would have still tollowed thy heels OAntony! I have followed thee to this
behold, how pomp is followed!.

followed him, till lie had melted ....... Cymbeline, $\vec{i}$. so, followed my banishment ......... - iii. 3 as my master followed, as my great patron. Lear, $\mathrm{i}$. G]oster? Followed the old wan forth .... $=$ ii. 4 that followed me so near ............... decay, have followed your sad steps...... $-\mathrm{y} .3$ why followed not, when she said... Romeo \& Jul. iit. 2
slie followed my poor father's body ..... Hamlet, i. 2 indeed, my lord, it followed hard upon - i. nor all masters eannot be truly followed. oinello, i. 1 he that you followed with your sword? . - ii. 3 treasure to give your followers. Two Gen. of $\mathrm{Ver}$. 1i. 4 you were wont to be a follower ....... $\overline{\text { Twelfh }} \overline{\text { Night, iv. } 3}$ command her followers, take.... Twelfth Night, iv. 3 a gentleman, and follower of my lady's and tears, poor faney's followers. Mid. N. Drean, i. 1 to become the follower of so pour.Mer. of Venice, ii. 2
duke, and all his contented followers As you Like, v. 2 duke, and all his contented followers As you Like, , 2 became of his bark, and his followers?
will have bald followers....... Cumedy of Errors, ii. 2 will have bald followers ..... Cumedy of Evrors, ii. 2 your persol, and your followers....... - iv. 1 like to my followers in prosperity.... $-\overrightarrow{2 H e m}$ iv. 1 and other his continual followers.... - jv. 4 of time, east off his followers ........ to Harry and his followers..... Henry $V$. ii. (chorus) le hath betrayed his followers ......
to mope with his fatbrained followers wilt mind thy followers of repentance -
ourselves, and all our followers ..... IHenry $r$ iv. 3
iii. 1

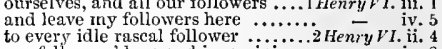
to every idle rascal follower ........2 Henry and I to Norfolk, with my followers.3 Henry rl. i. I and all my followers to the eager foe - i. soft coruage makes your followers faint = ii. 2

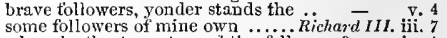
Where be thy tenant 3 , and thy followers? $-\overline{\text { iv. }} 4$ dogged witli two strange followers. Troil. $\delta$. Cress. i. I seemed his follower, not partner to make his tollowers weep. Antony \& Cleopalra, iv. - iv. 12 to wear all your true followers out ..

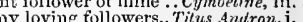
Romans, friends, followers, favourel's dismiss your followers, and, as suitor

what, fifty of my followers at a clap. restrained the riots of your followers ...... Lear, $\mathrm{i}$. 4 him gladly but not one follot wer. to feld. he'll be your follower.. Romeo \&. Ju $\overline{l i t}$ iij. to field, he'll be your follower.. Romeo \& Julict, iii.
FOLLOW ING-following her womb. Mid there is no tollowing her in this fierce - iii. fair Helena in fancy following me .. $\quad$ - iv. following darkn manner and form following, sir. Love's L. Lost,, $\mathbf{i}$ following her into the park (rep.)....

and then we, following the signs, wooed $\overline{-}$ v. walk with you and so following.. Mer. of Venice, $\mathrm{i}$. not following ny leash unwillingly. Winter's $T$. iv. following the mirror of all christian. Hen. $V$. ii. (cho.) 


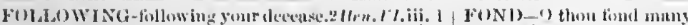

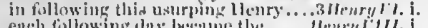

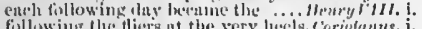
fillowing the lliers at the very lioclsot toriolunns, i.

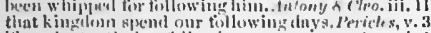
if on the tent h day tollowing.............. teere, i. ! knus ing neught, like dogs, but fislowing asanulted, for following lier aflisir

kit it lsesk thy neek with following it.. - ii. rearwnre fullowing Trbalt s deatl. Rom. see suitors following, ind not look lehind and Casso following bim with determined

the next night follow ing enjovest not.... - iv.

firr whes follow'st thy muster. Tuo firn, nf Per. i.

lut in folly bouve wits wit.

or clise a wit hy tislly vampushed

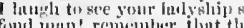

fond rum!n! rementher, ilint them

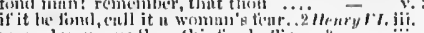

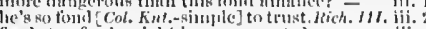

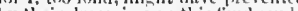

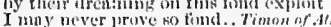

why do fond men exprece them

fist fond to wnil inevitni

be not fime, to think tlint

(then old and find of isst

an ialle und tond bondage.

I am a very fislisla fond old man

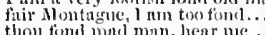

thon fond mat man, hear me .......

to see what folly reigns in us

through the most fond unl wi

it is my slame to be so fond , $\ldots . . . . . . . .$.

all my fond love thus do i blow to hica
slie was too fond of her most fillity

your own piresent folly ....

hew quete you my folly?........

With thy daring folly burn the worlit?
that the fuily of my soul clures ...

he gives her tully motion.
why this is ynur own filly

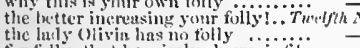

for filly, that he wisely show's, is tit

vent my tilly? Ifi has hear

vent my folly! 1 am afruid

lly, or mistuking. Yeus. for Meas. jii. 2

nor nil grent uryument of her folly ... Such dis, ij. 3

to Athens will t hear my folly back

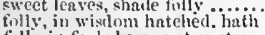

folly in fouls beurs not so st rong.............

to eheck their folly, massion's snienn

remember' not the slight

most galled with my foll

the wise man's folly is anntomized

most loving mere folly

FoNiLY - I hate fondly flut tered.

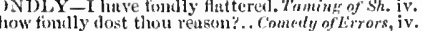

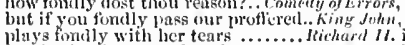

Eleaks fondly like a frantic man.

how timblly dost thou spur a forward - $\overrightarrow{\text { iv. }}$.

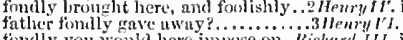

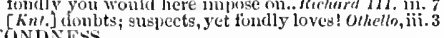

in obseruivus fondness erowd..... Neas. for Neas. ii. 4

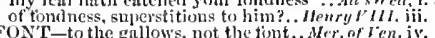

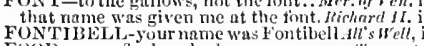

FoOD-some foud we had .............. Tempes
thy food shall be the fresh-irook miscles

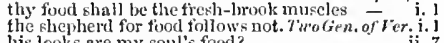

his looks are my boul's fond?

yount ravens must have tood ..............

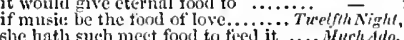

she hath such mect food to tied it .... Muth
this may prove fiod to my displeasure -

from lovers' food, till morrow deep

did I loatl this food: but, as in ....... - iv. 1

food for his rage, repasture for his den

fed with the same food .... Nerckent
hard food for Midas, I will none of ..

have me go anil heg my food? ..... As yuu Like it, ii. 3

if he for gold will give us any food? ..
sceking the food he eats............

s, I die for foodl here lie I

be food for it, or bring it for food to...

as I do live by food, I met a fno

then but forluear your food a little...

elewing the foud of sweet and bitter

did he leave him thu'e, tool to thee.. - iv. 3
what, so it be wholesome food.... Taming of sh. iv. 3
food, my tortme, and my swect. Comerly of Err. iit.

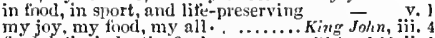

tood doth choke the feeder.....

food for pow der; food for low
thou art dust, and food for

a stomaeh, and no food .....

and tiends for food howl on!....................

andic the tid

lie said, "twas folly, for one poor grain - v.

theretore be eleaf to my unpitied folly - i

does make mur faith mere tolly ....... iii. 11

being aged, rlie of this folly

like lions wanting food

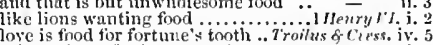

this, and my food, are equals ... Timon of Ciths. iv. 5

core of your food and living ............
linnger for that thod, which nature

reecive the weneral food at first.

music, moody food of us that trade... Ant. S cleo.

hetween them all the food thou h
I was at point to sink for ford .

who wanteth fiod and will not sa

thy very fisod is ench au hanth been.

this hand, for lifting food to " $t$ ?

rricles i.

Ful. turned to filly, and she

Tirelfth Night, iii.

lint wise men, filly-falle

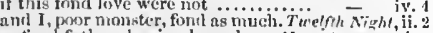

as tind fatlers laving bound ..... Meas. for Yeas.

not with fond slackele of the tested golil

when men were fond. I smilen! ......

he may preve: more tond or her

I am out of hrenth, in this fond chase

shall we their fond papeant are?

you sce how rimple and how fordl $1 \mathrm{~mm}$ - iii. 2

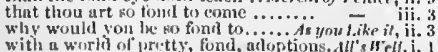

fond done, lone toril ............... - i. 3 (nomg)

my lord, this is o fond and desperate...
are you so timul of your young .... Winter's Tule, i. 2

tior thee, foul boy it $I$ inay ever.

been 'Tom's fom for seven long year
where botl fire and food is ready

where both fire and food is ready ........ - iii.
black angel; I have no food for thee..... = iij.
the lood of thy abused father's wrath .... - iv.

kept without my ford.............. Komeo o Jutiet, i. 2

buy food. and get thyseit in flesil .

for ford and iliet, to some ente

nor earth to me give food ............... - iii.

ati but stomachs, thes we all but fiost

I am a fool to weep at

thumgh fools at home ermilemin thiein

you fools! I mul iny fellows

let it alone, thou fiol $\ldots . . . .10$
the ilropgy drown this fouli

and worship this dull fiool

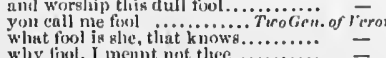

for why, the fixsla are mat

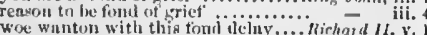

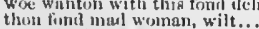

away fond woman! werc lie twenty.

I an bint a foul, low mail

alas, noon tois!

from in pentlaman to 2 fool

thold him bitt $u$ fiocil

do not musy ine to youml' tion.

will voul cist awe to your for .........

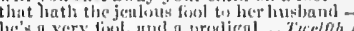

(lo you think you have frois in ianim?

umd those that are fosis, let them...

lis very oft prosete fors

take the tool a way :............

give the dry find lrink, then in the fivol

the lany lithe take awhy the forl

coorl thol, fir my brotlier's deat 12

take uway the fool, sentlemen

doth ever make the better fio

for two-pence that you a re no fiol

the rither lany with an ordinary fool
set kind of fools. no better than the fnol's -

for thou speak'st well of fools.

as if thy cldest sm should be a fio

W fios s a drumken man like.

ant the tool shall leok to the madman

here comes the fool, i"fuith

the tinol htts an excellent breast....... -
so sweet a breath to sing, as the fuol has -

berin, fonl; it berning, loold thy

and let the fool make a third

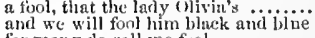

for many do call me forol

art thoun not the lady olivia 3 sool?.

and fools are as like husbands

I am, indeed, not her foul.

Wut the fool slould be as oft
fellow's wise enough to play the fool

for now I am your fool ................

and now alullies it to a foo

these wise men, that cive fools money

fool, I say; - slie loves another (rep.)

fool, there was never man so

as well in my wits, fool, as thou a......

fool, fool, tool, I say ................

good fool, some ink, paper .......

fool, I'll requite it in the highest ....

when the fool delivers the nastman.

noor fool: how have they baffed thee?

by the lord, fool, I ain not mad.......

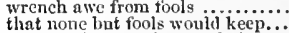

merely, thou art death's fool

the vanity of wretehed fools

a fleshmonger, a fool, and a eoward.

my unele's fool, reading the ehallenge..surh ddo, $\mathrm{i}$.

what is he for a fool, that betroths

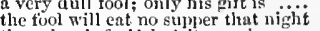

the prince's fool ! hat it may be ....

I thank it, poos fool, it keeps on the

secing how much annther man is a fool

he is no fool for fincey, os you.......

my consin's a fool, and thon art another

What nrems the fool, trow?...

I am not such a fool to think........

I speak not like a doturd, nor a fool.

ther school, fiool, a babbling rlygme....

sweet suvours for this lintefil fool...

with thine own fool's cyen

but man is but a patehed fool.

the hour tlunt fools should ask ... Lore's $L$. Lost,

the fool said, and so say $\mathbf{I}$, and 1 the fool

the fool sent it, and the larly lath it

(t)e more fool, alujenr

what fool is an

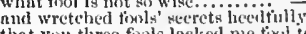

that you three fooss neket me toxil to

yon will prove ferls.................

they are worse fools, to pureliase........

they are entelied, as wit turned fool..

owil graec to grace a learned ferol ...

complnin to thers wlut tosls were here

I dare not calt them fould ............. drink

are thirkty, fools womld fain have drink

all the fiol mine?

the leetlete-prisest, the fini, inil the bing

lamphim herers give to fools ........

ii. :

ii. 4

iii:

iii.

ii 

Foor,-eall their brothers, fools ...Mer. of Venice, i. 1
for this fool's gudgeon, this opinion..

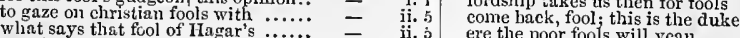
may be meant by the fool multitude deserve no more than a fool's head?. thiere be fools a!ive, I wi

still more fool I shall appear by

with one fool's head I cam

O these deliberate fools! ............

a soft and dull-eyed fool, to shake

how every fool can play upon the word!

the fool hath planted in his...

many fools, that stand in

the dullness of the fool is the whetstone

where learned you that oath, fool?

the more pity, that fools may not.

since the little wit that fools

you are a fool; niece, provide yourself

to steal the clownish fool out of.....

and thus the hairy fool, mucli marked

the more fool I; when I was at home

peree, fool; he's not thy kinsman!

gross fools as he, an' if he

a fool, a fool! I met a fool (rep.

as I do live by food, I met a fool

yet a motley fool: good-morrow, fool

when I did hear the motley fool thi.

fools should be so deep-contemplative

wohle fool? a worthy fool!

$O$ that I were a fool! I am ambitious

so fools have; and they that are

he, that a fool doth very wisely hit

out, fool! For a taste ................

peace, you dull fool; $i$ fonnd them

either a fool, or a cypher ............

'tis sueh fools as you, that make

I had rather have a fool to make $m$ e

for she will breed it like a fool

you are a fool, and turned into.....
the fool doth think he is wise $(r e p)$.

which in all tongues are ealled fools

according to the fool's bolt, sir

good at anything, and yet a fool

I will be a fool in question.

entertain it so merrily witl a fool.

thou art a witty fool, 1 have found

this dialogue between the fool and

for getting the sheriff's fool with child

ii. 9

why, what a peevish fool was

fool, fool! thou whet'st a knife ....... Richard III. i. 6

why, fool, he shall never wake $\ldots$ w.....

relenting fool, and shallow, changing

fool, of thyself speak well (rep.)

Hexiry $V \overline{I I}$. (prol.

made it a fool, and beggar...............

he was a fool; for he would needs be

a fool to stay behind

fools on both sides! Hel faither...Troilus \& $\vec{C}$ ress.

asses, fools, dolts! chaff and bran

the wise and fool, the artist

I know proclaimed a fool, I think.

peace, fool! I would have peace $($ rep $)$

and leave the faetion of fools

a fool. You raseal! Peace, fool.

a fool to offer to command Achilies ( $($ ep. $)$ -

inveigled his fool from him

composure, a fool could disunite

see, we fools! why have I blabbed?

will leave, to be another's fool

I'll send the fool to Ajax

I'll be your fool no more

and wine heat heaven, Hector.

we make ourbelves fools. \begin{tabular}{l|c} 
Henry $V$. iv. I & FOOL-a bitter fool, and a sweet fool!...... Lear, i. 4 \\
Henry $l^{\prime} l$ iii. 2 & the sweet and bitter fool will presently ...
\end{tabular}

the sweet and bitter fool will presently... dost thou eall me fool, boy?

this is not altogether fool, my lord........ $=$ i.

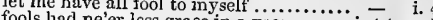

fools had ne'er less graee in a year........ i. 4 (song)

that can teach thy fool to lie $\ldots \ldots \ldots \ldots \ldots \ldots \ldots$ i. 4 (song)

rather be any kind of thing than $\mathrm{a}$ fool...

this your all-lieensed fool

more knave than fool, after your

so the and take fool with thee........

thon wouldst make a good fool

if thou wert my fool, nuncle.

and cowards speeches, as I were a fool

why, fool? We'll set thee to sehool

naves follow it, sinee a fool gives it

turns fool, and runs away; the fool no

fool me not so much to bear it tamely.....

ii. 1 fool, I shall go mad! ................

ii. 3 pities neither wise men nor fools

3 that's a wise man, and a fool

3 turn us all to fools and madmen part...

ad is the trede must play the fool to

ny fool usurps my bed

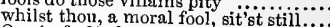

O vain fool? thou changed

I am even the natural fool $\ldots \ldots . . . . . .$.

part fools; put up your swords nome... v. 3

and felt it bitt

and pretty fool, it stinted, and said-ay -

stay, stay, hare comes the fool with

the fool hangs on your back already

speak to 'em fool (rep.)

fool, I will go with you to lord Timon's =

three usurers' men? Ay, fool

what is a whoremaster, fool?

thou art not altogether a fool

come with me, fool, come ...

amongst the lords be thought $a$ fool.

you fools of fortune, trencher-friends

ducks to the golden fool

fols exhaust their mercy

a madman so long, now

always a villain's ofiice, or a fool's

lend me a fool's of all the fools alive

away, you fool: it more become

and the faults of fools, but folly

rather than fool it so, let the high.
are learned, be not as common fool

ay, fool; is that a shame? (rep.).....

and perish constant a fool

and patient fools whools $\ldots$ i.......

why old men fools, and children

as to say, they are fools that marry

he was but a fool, that brought

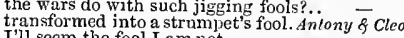

I'll seem the fool I am not..

out, fool; I forgive thee for a witch

when it concerns the fool, or eoward..

cries, fool, Lepidus! and threats

wishers were ever fools

wishers were ever fools
to fool their preparation...

poor venomous fool, be angry

measured how long a fool you were... cymbeline.

she shines not upon fool

you are a fool granted.

fools are not mad folks (rep.)

thus may poor fools believe foij.

for, when fools shall-who is her?

this fool's speed be crossed with slowness

thou art some fool; I am loath

this Cloten was a fool; an empty

the fool had borne my head

ah me, most crerlulous fool

and are ye such fools, to square... Titus Audron.

what fool hath added water to .....

drown the lamenting fool ...........

to please the fool and deat

did mock sad fools withal

for chiding of his fool? Ay, madan are

where's my knave? my fool? (rep.)

三 iii. i

a fool go with thy sou

other shift; you'll be a fool stili..............

lighten thee, thou art a great fool! $\because \ddot{\text { you bashful fool, must you be blushing? - }}$

thus we play the fools with the time

they are fenerally fools and eowards

why, 'tis a gill, a fool, a fool

a fool's bolt is soon sliot.

and $a$ fool, and a prating coxconb

iv. 3

where's my fool, ho? I think the world's

the fool hath much pined away

go you, call hither my fool

why fool? [Col. Knt.-my boy] why?....

he will not believe a fool. A $\ldots$ bitter foolit.. would the fool were married to lier grave -

peace, you mumbling fool! utter your fool, a whining that he may play the fool nowhere but

they fool me to the top of my bent......

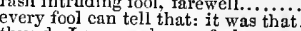

to suek fools laugh, 1 the aleliouse ......

how my sick an toronicle small beer

by and by a fool, and presentiy a beast!

$O$ wretehed fool, that livest to make.....

for honesty's a fool, and loses that it

fools as gross as ignorance made drunk .

I was a fine fool to take it...................

you are a fool; ;oo to. O good Iago .......

fool! fool! fool! 'There is, besict

OOL-BEGGED-this fool-begged Comedy of $\vec{E}$ rr.

OOL-BORN-with a fool-born jest...2 Henry IV . v. 5

that you are fooled, discarded......... I HenryI $I V$. i. 3 she is fooled with a most false effeet... Cymbeline, j. 6 OOLER Y - see his own foolery.. Winter's Tale, jii. be bold to say in your foolery .... Twelfth Night, $i$. a fancy to this foolery, as it appears. Much Ado, jii.

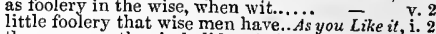
thrown upon thee in holiday foolery!
being fooled, by foolery thrive!...... All's Well, iv. too much homely foolery already...Winter's $T$. iv. there rest in your foolery.... Comedy of Errors, iv. 3 as much foolery as I liave...... Timon of Athens, ii. 2 was mere foolery, I did not mark it.Julius Co sar, $\mathbf{i}$. 1 there was more foolery yet, if I could - i. it is but foolery ; bit it is such $a$ kind... Hame, iii.

ii. 4 FOOL-HARDINESS-fool-hardiness; not Coriol

iii. 5 FOOL-HARDY-is too fool-hardy.... All's Well, iv. the door, secure, fool-hardy king ....Richard II. y. 3 put me into good foolingl......... Twelfth Night, i. thou wast in very gracious fooling last - i. this is the best fooling, when all is done - ii. the knight's in admirable fooling.... - ii. have no more fooling about it... Merch of Measure, i. while I stand fooling here............ Richard $I I, \mathrm{v}, 5$ I do not like this fooling ........Troilus \& Cressida, v. 2 way ward is this foolish love. Turo Gen. of Verona, $i$. my foolish rival, that her........... - ii. 4 shall we send that foolish carrion $\bar{M}$ erry $\overline{W_{\text {tve }}}$, iji. 3 to build upon a and of a foolish knight, that you.. Tu'elfth Night, i. your time with a foolish $\mathrm{kni}$.

go to, go to, thou art a foolish feliow

I pr'ytliee, foolish Greek, depart....

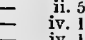

a foolish thing was but a toy....... $-\bar{v} \cdot 1$ (song) ii. 2 and none but fools do wear it......... -

ii. 2 we fools of nature, so horridiy to shake... Hamlet,

a most pitiful ambition in the fo..........

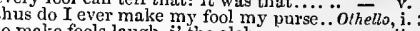
foolery, sir, does walk about the orb - iii. than a foolish wit................ 
FOOLISll-so pluy the folish .... Mrus, for .Heas. ii. I

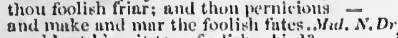
and make and mir the foolish futes...
would wet his wit to so foolish at bird? foolish extruvent suirit .......Love's L. Lost, iv , your wit mukes wise things foolish . wise things seem foolish. nud rich things a foolish unild mun; an honest....... ever my fonlish ejes lonked mpon. Mer.of bring usenin these footisl ronawy

and the tionlish edironiclers of that age

to hear such in foolists song

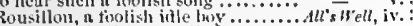

imgenions, foolikh, ruseally knuve.... a toolish duty calt you this (rmp.)....

a gross and toolist sire blemished his

let foolish fuats inuke sport .. Corsedy of Frrors, ii.

arrest me, footish fellow

a foolish thought, to say a sorry sight, Macte

ame, foolish oroked, surart King Joht,

how now, fool ish rleum! turning...

why, foolish boy, the king is loft.... Richerd II. ii.

and a foolish hanging of thy nether hip - ji.

brain of this fool ish eompounded elay.2 Henry $/ \%$ : i.?

but for these foolisil otheers.

what fiolish master taunht yisu...

the foolish, anil dull, and erutly yapours -

for this the fontish over-careful fathers -

do bear themselves like fortis i justice

foolish ears! that run winking

come, "tis a fonlish saying............. -

too full of $f$ ol

illenry rly ii. 2

tut, that's a foolish observation.......3 Henry $y^{\prime}$. ii. 6

the boy is foolish, and I fear not him

of ool ish Cressid! I might.. Troilus $\AA^{-}$Cressida

this foolish, dreaming, superstitious girl

and the foolish fortune ot this girl.

neitl:er foolish in our stands.....

how foolish do your feurs seem......... Julius Cersar,

they are frolish that are so. Antony \& Cleopatra,

tirou foolish thing! they were aga

your issues being foolish, do not derog

if 1 eould get this foolish Imogen..........

no, foolish tribune, no......... Titus sndronicus, i. 2

you are a young toolish sapling ......... Pericles,
why are y.u so toolish? ..............
on whose foolish honesty my praetiees...

on whose foolish honesty my praetiees.... Lear, i. 2

I am a very foolish fond old man...........

forget and forgive, I am old and foolish $=$ iv. 7

have a trifling foolisls banquet ...Romeo \& Julint, j. 5
baek, foolish tears, back to your ........ iii. 2

a foolish figure; but furewell ............. Hantet, ji. 2

who was in life a foolish prating knave

a knavish sneeeh sleeps in a foolish ear

and foolish? There's none so foul ( $r$ cp. $)$

to have a foolish wife. $O$, is that all?...

to see how he prizes the foolish woman

good father! how foolish are our minds!

OOLISrILY_thus foolishly lost...Meos. for Meas. i. 3

doth very foolishly, although he smart

fondly brought here, and foolishly...2 Henry $I V$.

whbnt alreat l I liave foolishly suffered . Othello,

FOUIISIN ESS-done your foolishness. Com. ol Er.

Foor-foot it featly here and there. Tempest, $\mathrm{i}$. 2 (song)

what, I say, my toot my tutor!
mount their pricks at my toot-fail.

moll kiss thy ticic

the blind mole may not hear a foot ins

with printless foot do ehase ............

her view gilded iny foot.

the firm fixture of thy foot wotili...

are something rank on foot

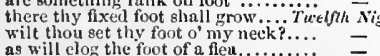

as will elog the foot of a fleu.......... - ii. 5

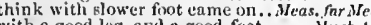

bring you the length of ['rester Jolin's funt

one fuit in sea. and one on shore

of his head to the sole of his foot

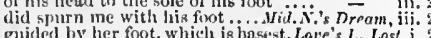

guided by her foot, which is basest. Lave's $L$. Lost, i. 2

a hand, a foot, a fince, an eyc....

my foot and her face see.

we will not move a lim
know' my lady's foot by

love her by the fiot by the squire

love's arguinent was first on foot

and foot me, as you spurn..............

would n:y daughter were dend nt iny foot -

would she were heursed at my tiot ... -

licence of free fhot hast eanglit...... As you Like

foot of time, as well as a cli

go as bonty as fint enn fall
which were on foot, in lis ow

the tread of a man's fiont.
will gpeed her foot agrain
FOOT-noiseless fuot of tlme stenls

age, ret foot unsler thy table.. Taninh of Sheu,

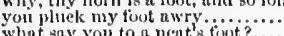

we mount, and thither walk on $f$

that bauble, throw it under foot.

your hinnds below your husband's font

horsing foot on foot? skulkin. in eorner

twetre foot nud in half by the squire.

no longer from liend to toot

oorrow on the fint of motion

awift, and sule or sof

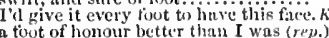

whose fout spsurns lnck the ceenul

leak thy foot to Eingland's throne.

I see this hurly all on thot

when I strike my forst ung

the better foot hetore

nor attend the font that leaves..........

lie gently at the foot of perae.

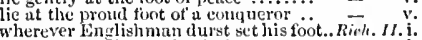

this overweening traitor's fout

drend sovereign, at thy foot...

ns low an ebb as the foot of

I am joined with no foot land

if I travel but four foot by

and mend them, und fort them tou

elose, cume in fout and liand

this fat rogue a charge of foot

when I from France set foot at

and all his metl ack, a charge of font

(a enuse on foot), lives so in hope ...2 Henry

fifteen hundred foot.

tove and life under my coot.

Colevile kissing ny foot.

aetion may on thot be brought $\ldots$.......

and her foot, look you, is fixed.....

swear by her font, that she may
sees me go baek one foot, or fly

I will not budge a toot

and set your knee against my foct.

die at Tnlbot's foot

until thy foot be snared

my foot shalt fi thit with all the

and tread it under foot with all

won one foot, if sarisbury be lost

spurz hin with his foot away?

wishing his foot were equal....

Shore's wife hath a pretty foot.........kichard III. i. I

consisting equnlly of horse and foot

the leading of this foot and horse

and all on foot he fights....

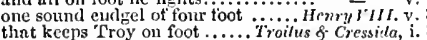

didst iteh from head to foot.

as if his foot were on brave

aecompanying his declining foot. Timon of $\overline{s t h e n s, ~ i v . ~} 5$

have seen the foot above

set but thy foot against our

fix thy foot. Let the first

I'd with thee every foot

and to be on foot at an hour's warning

Wh have a power on foot........
1 lame the fuot of our design

1 lame the fuot of our design .........

impatiently stamped with your foot.

as low as to thy foot doth Cassius fnii

at whose foot to mend the petty ...1nt

our foot upon the hills adjoinin

now from henel to foot I a1

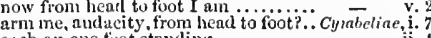

and thus I set my foot on lis neck

knoek her back, foot her home agnin.
his foot nereurial; his martial thijh

the better foot beture.

keen thy foot out of brotieis

T'itus disuroni

these thy foot out of brothels

Lear, ini. 4

you gre now witin a foot of the

near, and on speedy foot......................

not stir one foot to seek a foe

give romm, and foot it, girls ....

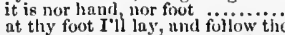

for a hand, and a foot, and a boxly

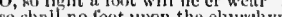

what cursel forst wunders this winy

my lord, from head to toot .........

follow him at foot, tempt him.

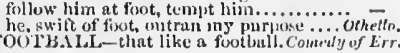

3. lOGTISAI, - you base foothall player

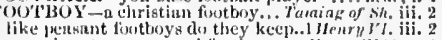

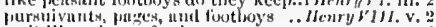
wait like a limsy fuothoy

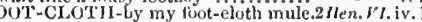

thou dost ride on a fuot-eloth

my fout-eloth horse dial atnmble .. Richarri 1/1. iil.

part of a power alsumly foot this land.. Lenr! $h^{2}$. nit.

taint Withohl footed thriese the wold - iii. 4 (sollg)

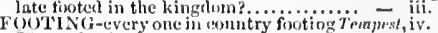

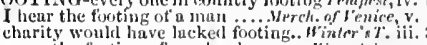

charity would have lacked fo
mpon the forting of our lausl.

hath set footing in this land....
on the unstearlfust footing of

Rechas II:

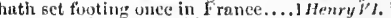

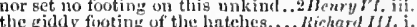

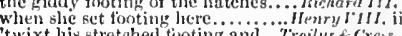

swixt his stretehed footing and

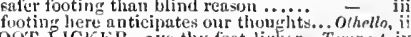

FOOT-S.ICKER-aye thy foot-lieker.. Tempes,

should be footman, by the garment

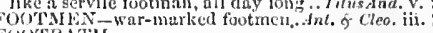

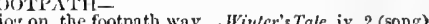

joy on, the footpath way...Whisr's Tale, iv. 2 (song)

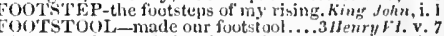

()P-creating a whole trilie of fups........ hear, it. 2

lict have the folpery of freedom. . Neas. for Neas. i. 3
sound of sluallow folmery enter...Mer. of t'enice, it 5

this is the exellent topjery of the worlu! Lear, $i$. 2

ORAGE-from forage will incline. Lore's $L$. L. iv.

forage, and run to meet displeusure... King John, $y, 1$

FORAGEli-joragers shall all repair. Troil. Cress.

forbade my tongae to sucak house. Merry lf ires, iv. 2

forbarle all names ...1i P.............. Coriolanus, y.

villuio, forbear $\ldots . . .$.
sirrah, I fuy, forbear

jutience to furbear awhile

forliear, I say! it is my lor
firlicar, here's eompany.

can hardly forbe ....................... - iv. I

forbear it therefore; give your eanse. Mea, far Mea. iv. 3

to hear? or forbear hearing?........ Love's L. Lost, i. I

forbear till this comyny be yast

peace, peace, forbear; your onth onee -

forbear, and eat no more........... As you Like it, ii. 7

then, but forbear your food a litile... -

for bear; your wrow too forward.... Faming of sh. ili

either forben'; quit presentily the thanel

I would forbear. P'ntience, ninmoved. Crm. of Err. ii. I

eanst thou not forbear me halt...

it were your dut $y$ to forbear

2llenry H. iv

gersuade you to fortear a while ...... - ii.

ah. Nell, furbear; thou aimest all....2nenry Vl. ii.

liands on me; forbear, I say.

you cunnot but forbear to niurder me -

feport what speceh forbears .......... - iv in

forbear awhile; we'll hear a
my lords, forbear this talk

ny love, forbear to fawn upon their.. _ - iv.

and, withal, forbear your conference. Nichard II

turbear me: there's a great spirit gone!.Aml.g Cleo

Iny precious queten, forbear; und give

forbear me till anon....

forbe:ur, seleueus. Be it $\mathrm{known}$

forbeur: here eomes the gentlemin . .
bescech your majesty, forthear sliarp

ghist unlaid, forbear thee! ...

fornins, forbear; we ure the

forbear your sulling (rep.)
to forluen elioiee i' the absel

(torbent

forbear his presence tili some $\mathrm{jit}$ it

Ill forbear; and am finllen unt with

for slame forbeur this outrnge ... Rmmeor Juliet, iii.

for love of God, forbear him
I did tull hard torbear him.

no, furhenr: the lethargy must iuve
FURBHARANCE-

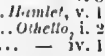

crave your forbearanee a little...Veas.for .Yers. iv.

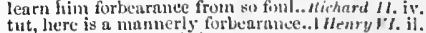

lcurn. heing taught, furbearauce ..... Cymbetine, ii,

frnyet me, the, fortsearance.......... - is

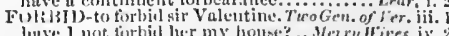

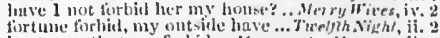

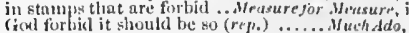

firbid the sun to enter $\ldots . . . \ldots . . . . .6$ 
FORBID-and forbid him to wear it.. Auch Alo, iii. 2 | FORCE-I should force you to

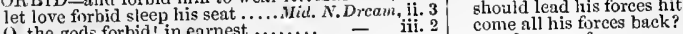

0 , the gods forbid! in earnest............

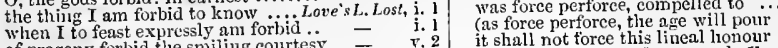

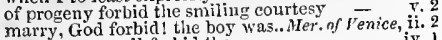

marry, God forbid! thie boy

on your imagiuary forces work. Henryl $r$ i. (chorns)

with half the with hices the full

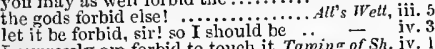

I expressly ain forhid to

never went with his forces into France
and brim fulness of his force ........

their passage tlurough the force of France

a force de ton bras?

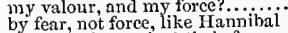

1 Henry $\begin{gathered}\text { iv. i. } 5 \\ \text {. } 5\end{gathered}$

no sir, God forhicl; but ashamed........

as well forbid the sea tor to obey

by fear, not force, like rise against. their force....

occasions, uncle, were ot force......
but gather we our fores ont .....
$\mathrm{my}$ tiores and my power of men

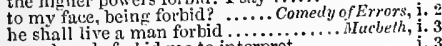

how caus the lav forbid my tongue.. King Jolkn, iii. I

obedience I forbid my sou

all our general torce night ............

not the force of France $\ldots \ldots \ldots \ldots \ldots$
which thou dirlst force from Talbot

now God in heaven forbid!
the King of hearen torbid....

Richart II. i1.

marrv, cool forbid! worst in this
O forbid [ Col. Knl.-furfendl] it God

treason that my laste forbids me show

did you beg any? God forbid! $\ldots . . . . .14$

and heaven forbid, a slallow scratch 2 Hor

and God forlid, my dear and faitlful... Henry $r$. 1 .

he forbils it, being free from … God forbid, any malice should prevail.2 INenry $r I$. iii., though you forbid, that they will....

for God forbid, so many simple.

by main force Warwick did win wiel
force perforce, I'll make him yield
of no little force, that York is most

of nolittle force, that by foree..........
which now they hold birn the force of them upon thyself

turn the force of them upon thysel
are hard by, with the king s forces

to bring thy force so near the court

intend these torees thou dost bring

we have broken in by foree...........

arguments of mighty force $\ldots . . . . .$.

and force the tyrant from $h$

God forbid, your graceshould be .....3 Henry 1 . i.

as God forbid the hour God forbid that! for heil take vantages -

secure from force and traud ...................

no, God forbid, that I should wish them - iv. 1 did leave him with hores hence.

be lere, as God forbid! let him......
God in heiven forbid we should... Richard III. iii. 1 which the king's King forbids....

him that does best; God forbid else Henry

the Lord forbid! marry, amen!.......

and Jove forbid, there should be done

Jupiter forbid; and say in thunder.

which you do liere forbid me........

Whicetor? the Gods forbid! He's dead
with mie to forbid him her resort. Timo

with me to forbid him her resort. Thinon of Alhen

nowinkles torhid! Vex not his....... Antony \& Cleo. i.

the gods forbid! Well, my good

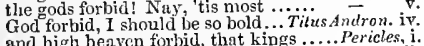

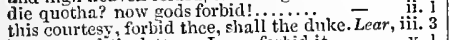

this courtess, foride thee, shall the leter. I was forbid it.. Lear, v. 1

expressly hath forbid [Kut. forbidden] = iii. 1

no, no, this shall forbid it: lie thou... . Famlet, i.

and therefore I torbid my tears..........

which heaven hinth forbid the Ottom.
marry, heaven torbid: Reputation.

marry, heaven forbid! liglit, gentlemen.:
FORBIDDEN - his forbidden gates.. Lowe

ORBIDDEN -his forbidden gates.. Love's L. L. ii.

those banished and forbidden legs.... R Ilchary vi. jii.

nay, if we be forbidden stones, we'li.

[Knt. Thath forbidden bandying. Romeo s. Tuliet, iii.

FORBORNE - forborne the getting. Ant. \& C Clen . iii. 11

stands in effectual torce................
muth the force of heaven-bred presy

'gainst the nature of tove, force yoy
ill foree thee sield to my desire.

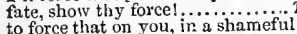

to force that on you, in a shameful $*$ iii.

but in the force of his wili............. Huch ddto, i.

with the force and strong encounter of
this flower's force in stinring love. Mid.N. $\overrightarrow{\text { Drcam }}$, ii. 3

and thy fair virtue's force perforce dotli - iii. 1

when he waked, of force she must

edict shall strongly stand in force.

we must, of force, dispense

you force not to torswear............

but of force must yield to such....

there is no force in the derees......
his sceptre shows the foree of tevi

dear sir, of force I must attempt

your geittleness shall force (rep.).
there is no force in eyes that ..

their foree, their purposes........................
too strong for reason's force, 0 erben

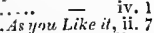

will you go yct? force me to keep.. Win/er's Tale, i. . .

force her hence. Let him, that inakes
had force, and knowledge, mure.......

who of force must know the royal.

by force took Dromio and my soucomedy of $E r$ r. $v$.

the English force, so please you..........Mincbeth, y.

of no more force to dispossess me

unmatched force the awless lion ......

his forces strong, his soldiers..........

his forces strong, his soldiers..........

our commission in his utmost force. - iii.

what force will have us do........... Richard Jl. iii.

our general torces at Bridgnorth

1 Henry $1 \%$ ii. 3

denied the force of this commission

force should he right; or, rather.. Troilus $\delta$ - Cress. i. 3

force him with praises..........

with all my force, pursuit, and policy
time, force, and death, do to this body

time, force, and death, do to this body - iv. 2

with such a careless force .............

old love made a particular fore

, i. 10

not fearing outward force............................

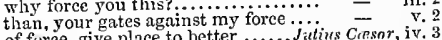

of force, give place to better .......Jatius Crsar r, iv.

with his Parthian force ..........

and to night I'll force the wine peep

for his best force is forth to

yea, very force entangles itself .......

wonld force the feeler's sonl $\ldots \ldots \ldots . .$. . i. 7

this secret will torce him think I have - ii. 7

and strike her home by force.. Titus Andronirus, ii. 1

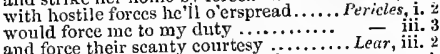

and force their scanty courtesy ........... Lear

guess of their true strenged [Col. Knt.-sinail I
must I of fore be married [

the potion's forre should cease ......

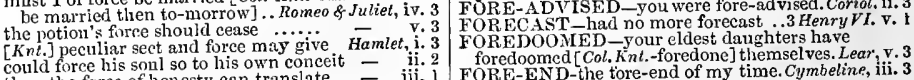

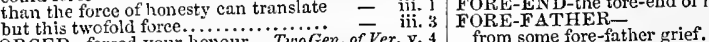

Richard II. ii. 2

FoRCED-forced your honour... Tu. oGen. of Ver. v.
which forced marriage would....... Merry ivives, v. which forced math forced me to tell him........ Meas. for Meas. iii. that I am forced to lay my reverence. 31 uch Ado, $\mathrm{y}$ by that freed baseness which he.. Wintcr's T'ale, ii. Perdita, with these forced thoughts ...

a visitation framed, but forced by need
what to fear, forced me to seek.... Comedy of $E r r . \mathrm{i}$.

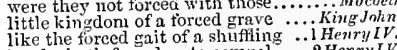
like the foreed gait of a shuffing ... HenryI IV but he hath forced us to compel ..... Henry/ 1 .
from it issued forced drops of blood.... Henry $V$.
stweet manner of it forced those waters

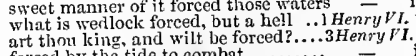

foreed by the tide to combat............
forced to retire by fury of the wind

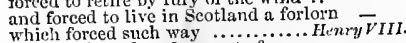

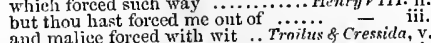
and malice forced with wit ... Trailus of cressidn, 1 were forced out!........ Timon of Athens, that ever I was forced to scold............ do stand but in a forced a flection .. Iulizscresar, iv. and forced to drink their vapour ... . . - viven forced in the ruthless, vast

traitors you constrained and forced

rigour of our state forced to cry out

nor windy suspiration of foreed breath.

pyt indirect and torced courses subdise

so shall I clothe me in a forced content - iii.

our fore-fatluers had no other books. 2 Henry $V I$. iv. if I digged up thy fore-fathers graves. 3 Henry VI, i. 3

play with my fore-fathers' joints?. Romen \& . Tul, iv. now heaven forefend: the holy maid.I Henry $V I$. v. 4 marry, God forefend! God's secret..2Henry 1 I. iii. the gods of Rome forefend .... Titus Andronicus, $\mathbf{j}$. 2 heaven foretend! I would not kill ...... Othello, v. 2 murdered in her
murd

FOREFENDED- m to the forefended place.. Lear, $\mathrm{v}$.

FOLE-FINGER-Tom's fore-finger ...A $l^{\prime}$ ' Well, 'ii. 2 agate-stone on the fore-finger.... Romen \& Julict, FOREGO-forego the purpose that Jou. Tempest, i11. for a friend: forego the easier ...... King John, 1 i. rents, revenues, I forego.............. $-\overline{\text { Henry }} V I$, iv. I and let us not forego that $\ldots \ldots \ldots$..... Ilenry VIII. iii. : I am unarmed; forego this vantage. Troil. \& Cress. v. 9 quite foregn the way which promises. Ant.\& Clen. iii. 7 FOREGOER-than our fore-goers ....All's $W$ ell, ii. Or. FOREHAND-extenuate the forehand. Much Adn, iv and carried you a forehand shaft....2 Henry $1 V$. iii. the forehand and vantage of a kroilus crassido i. 3 FOREHEAD-foreheads villanous low.. Tempest, iv. ay, but her forehead's low.. Tro Gen. of Verona, iv. 4 buffets himself on the forehead..... Merry Wives, iv. 2 a rechent winded in my forehead ..... Much Ado, i. 1 


\section{FOR}

FOREILEAD-frum my forchead wipe. Lotre's $L . L$. iv , so is the forehend of a nurried man .. the trick of his trown, his foreheat. Winter's Tate, ii. In her torehead; armed ...... Comeily of kirrors, iii. 2 and in his firchead sits a hare-ribbed. King John, hid'st thou that forehend with.... Richard III. as amiles nipn the forehend. Troinu

thro lleitor's torehein

than wish the forchead of the morting

and her forehend is as low as she. dntony \& Clea, ifi.

to the teeth and farehead of our faults. Ilam

from the fuir forehead of $n$ imnocent love

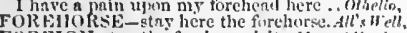

FOREIGN-stop the foreign spirits. Mer.nf lenic

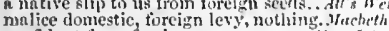

confident from forcigri purnoses

for uny foreign prefiaration

with ranks of foreign power

to stranger blood, to fureign rornity - iv

serve a fong apprenticehoud to firceig

giddy nimis with foreign cunrels.

lur in foreign purse, so set

more thun streams ot foreign tore

when foriem prinees shall

galust forcion storma kings.

Farwick $x$ itls his foreting

discontented steps in foreign in

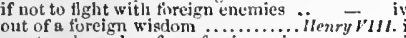

preat emhasurndors from for

or else to toreign prinecs, Ego et

must as a turein recreant

with more than foreign heart.

turned her to forcign easualties...

dreams he of eutting foreign throats. Komeos-s
and forcign mart for implements of war. Hamlet

and foreign mart for implements of war. Hain/e

FOnd pour our treasures into foreign laps. (thetho,

when adyerse foreigners atfriglit

haphily, foreknowing may aroid ...... Hamlet,
FoREK

hor seems to have a foreknowledge. Tre fth Nigh

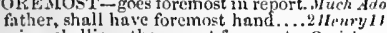

wise rebellion, thou goest forem

ny wife comes foremust, then.

the foremost man of all this rorld. Jutius Corsar.

FORENAMED-forenamcd maid Neos tr Veur.

FORENOON-at any time forenuon
wear out a good wholesome forenoon

to three kiligs in a forenoon....... Antony \& Cleo. $\mathrm{i}$. FUREPAS - my forcpast proofs.......All's Well, s. FOIE-RECITLD-

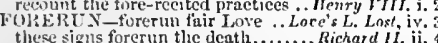
these sigus forerun the death.

Keve is furerun with woe

hut heariness foreruns the good ....2 Henry $I Y$. iv. 2

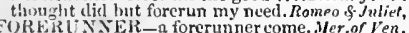
the grent tisermuner of thy blood.... King John, ii. FORERL

forerumuing more requital....... Meas. for Meas.
FURES-how far is't enalled to Fores?. . Maciseth, FORESIIY-the toresaid prunes. Meas. for Meas. the parents of the foresaid chilk . . Love's L. Lost, in our foresaid holy father's name. . Ning John, ii

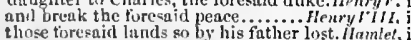
FORES.LY - as the gods forcsay it . Cymbeline,

FORESA W-What it foresaW... Troilus o C'ressita, 1

that you foresee not what.......... Henry IF. iv. Warkiek! I forese with grief....... Henry Hery II that his particular to torcsee.... Timon nf but foresee. Pray then, foresce me..Ant. A. Clen.
FoikEstit. FURE Itif

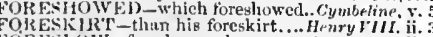
FORFSLOW-foreslow no longer.

FORE.T'E.NT-lis vanities forespent ... Henry $f^{\prime}$

his gondness forcsent on us ....... Cymbeline,

tOREST-the furest is not three. Fern Gen. of Ver.

wanderch through the forest.

a kecper here in Wind or forest........erry Fives, iv

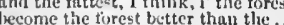

to trane the furests wild.............idid. . . Dream,

in dale, forest, ne mead.............. -

is already in the torest of Arden...... is yn tike

to seek my uncle in the forest of Arrlen -

if this uncouth forest yield iny thing

I met a tool i' the forest, a notley..

or no, lat the fint julpe

or no, ict the forest jurlge....

the forest. 'Then there is nu true (rep.)

in the skint of the forent

there is a man liannts the forest ......
telf me where in tlee forest jonl live..
lOR.

IOlkEST-in this place of the fores in the purlleus of this forest, sturicl

fracing throu the thest, ehe'wing ...

wist born in the forest her

absenred in the eircle of this firsent.

ofter

in this forest, let us do those.

Tho enu inpress the furest! ........ Worbe

till Bironm forest come to Dunsinane -

what is this torest callerl? (rep.).

west of this forest, scarecly ofl.

sceret anbush on the torest side.......

inenry

A thens is hecome a forcut of hessts Timinn of $\mathrm{Ath}$.

forest walks are wille nnd sprieiou

the general hunting in this forest?.... . -

this, sir. and a forest of fenthers.........

forestal prescience

may this night forestni him

forestal their repair hither.....

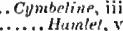

forestalled this dear and deep

2 HerryIr. iv.

rafored and forestalled remission.

FuR EST-BOR N- woy is forest-born. As yon Like it

one of you, find out the forester

then, tureater, and find

do you hear, forester?

Lne's L. Lost,

no sung, forester, for this jurpose?

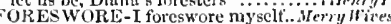

foretels, the grent Apollo

foretel the ending of mortality

expiring, do foretel of him ......

Winter's Tale,

a title-lenf, foretels the nature

whose heary looks thretel some

FORE'TELIS

Richardll. $\mathrm{i}$.

so wept on, forctelling this same ..2 Henry 15 .

ORWTHIN-toretlink thy fult ...Memry iii. 2

FORE'TIJUUGiT-

not the doom forethought by he
FoRETOLI as I foretold you

are well foretold-that dan
which he himself foretold

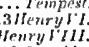

I forctold you then what ............nilus h-Cressid

FOPEVOUCHED - forevouched attection.. Lear

FOREWARN-forewarn him, that. Winter's Tal

we were forewarned of your coming

RFEIT-life falls into forfeit.. Meas. for Meas.

all the souls that were, were furfeit.

and still forfeit in the same kind?

is no grenter forfeit to the law than
like the furcits in a barber's shoy.

remit thy other forfeits........

our states are furfeit, seek not...........

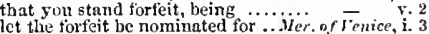

I will not forfeit it $\ldots . . . . . .$.

I am sure, if he forfeit, thou wilt
have the heart of him, if he forfuit
mr bond to the Jew is forfeit ..........

$\mathrm{my}$ bond to the Jew is forfeit ....... - iii. 2 (let.)

the penalty and forteit of in thend

on forfeit of my hands, my henel

thy weal th beine firt and lawfilly

my sont upon the finfeit, that your

With the divine forteit of his soul.
his brains are forteit to the next tile

forteit, sovercign, of ny gervane's... Richard III

to forfeit all your gonds, lunds.... IIrnryt $I I I$.

he forfeits his own lilood...... Tizuon of Athers,
I haviug ta'en the forfeit............ (ymbeline

shall pay the forteit of the peace. Rome'o of Julie

some vile forfeit of untimely death
lid forfeit, with his life, all those lis.... Hamler,

FURFEITED-forteited to eares for ever:.All's Helt, ii.

his vows are forteited to me ........ - v. 3 (petit.)

hare lost and torfeited thenisel
witlront ransom to lic forfeited

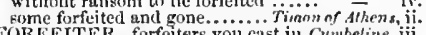

FORE EITER-forfeiters you cast in. Cymbeline, iii.
FORFliti

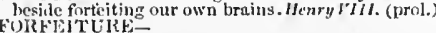

by the exaction of the forfeit

never elious plea of fir fiture

thou wilt not only loose the firfeiture

to ent the forfeiture from that bank riupt

chalt have nothing hat the forticiture

thas due on forfeiture, my lorl.. T"imon of Ath. it. 2 FORFEND - [Cal. Knt, ] U forfund it. Richard II. iv. Which peril, heaven forfend

forgave him with nll their hearts. Juliu fonces?

FURGE - to the forge with it then...Merry H'ires, iv.

to me, the difference forges dreal. Wintr's Tale, iv.
FOl\{lik-that I should forge quarrels... Masbeth, iv. 3

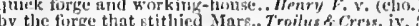
what lis breast ferges. whinte'ur $t$ forge, to feed his. . Titus Andronicur, v. I should make very forges ol" my chleeks. Othells, iv. ORG ED-best wiehes that ran be forged. All' a Hell, $\mathrm{i}$. it was forged, with my rapier's .... Kichurd II.

of torged rebellion with a Real......2 2 Henry $I V^{\prime}$.

that thercfore I have forger

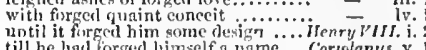

I'jannio hath with his firged letters. Cymbicline, i

Minrs's armenur, forgel fir pronf eterne .

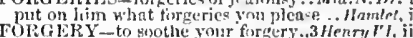

in forgery of whapes and trick ........ Ilwalet, i

his commonwealth forgets the beginning

I forset: but these swet thonghts

I will forget that hulia

make the girl finget the love .......
that his changing thouglate forget...

I here lorget all former griefs........

of Herne the hunter, let we not forget

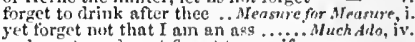

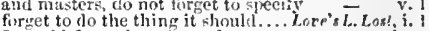

I wenld forget her; but a fever ......

unless youl teach me to forget .......An you Like it, i.

meantime, forget this new-fallen ....

I could not forget you for I never saw

you of whit you should forget... Winter's Tale, iii.

I cannot forget my blemishes in them -

I do forget; do not muse at ine .......harbeth, iii.

we like not this; thou dost fromet tly'self - iii.
should forget myself; 0 , if I eonld (sep.)

mad, I ehould forget my son

would not have you. lord, thrget yourself $\overline{7}$ iv. 3

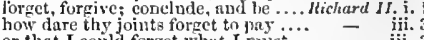

or that I could forget whit $I$ must... $\quad$ - iii. 3

forget to pity him, lest thy pity.....

a prince of my great hopes forget so.. =

pleased to forget my place.............. Inenry r. ij.

vld men forget; yet all shall be...... - iv.

let's not forget the noble duke ...... Henry $r$. iii.

forget this grice. Ah, Gloster (rep.)..2 Henry rI. it.

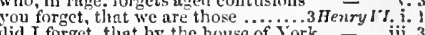

and I forgive and ituite forget old faults - iii.

they quite forget their loss of liberty

if you forget, what rou have heen... Riciard $\mathrm{HI}$. i.

shall I torget myself, to be myself? . Benry VIrI.
bid ye 0 fir forget yourselven?....

forget that thou art "Jove the king. Troil. \& Cress. ii.

O forpet wbat we are sorry for........ - $y$.

I would tliey would forget me ....... -

besilles, foryet not with what contempt $=$

forget not, in your siced, Antomins.Julins Carar, i. 2

you forget yourself, to hedge me in .. - iv.

when I forget to send to Antony...Aniony \& Cleo, $\mathrm{i}$.

to torget them quite, were to rememher - ii.

you must forget to be in woman

you must forget that rarest treasure..

torget your labnnrsome and dainty trims -
when $\mathcal{I}$ do formet the least (rep.) . Tirus sndran

when it we so forldet forget we lind no hands - iii.

teach us to forget our owr forget mo

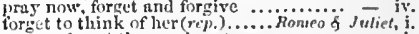

cannut forsect the precious treasure

Y never shall forget it, of all the days
thousand yeans. Inever slmuld forget it -

thousand years. Inever shmuld forget it -
shall forget, to have tluee still stand thene -

to lanve thes still forget, furgetting

IIoratio, or I do forret imyeli.

- ii.

that we or 1 do forget myel .......... Hamlet, i.

din not forget; this visitation is but ...... -

how to forget that learuing

general will forget my love and service... - - iit. nay, you nust torget that ................ - is. forgetful in our long ahsence...... ifenry $1 / 1$. ii. 3

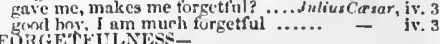

for my love's forgettiulness. TirnGen. nf l"erowa, ij, 2

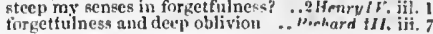


FORGE'TFLILESS

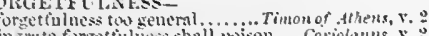
in minte forget

quich, firgetive, full of nimble .ellenry fl: ir. 3 and wh s - which thou forgetst .... Tempest it.

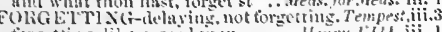
forgetting, like a gexil min

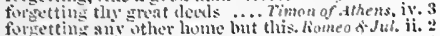

my rentr forgettims mamers.

1 do forgive tlice, ummatural.

tho forgive thy fankest timl

forsive me, that l du not....

besilen timgire me!..........

well. hescen forgive you

bestent firgire our sins?

furgive that sime gou the praise

good Antimis, torrive ine your trumble

thy slauters Iomive

thy slmers I for tive ................

why then. (renl forsive me?

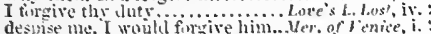

emred be my tribe, it I forrive lim.

forgive a moicty of the principal ....

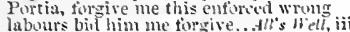

royal sir formive s tolish woman. Minters 7 (leter

with them, forgive yoursel

it he sempe, heaven

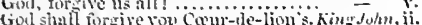

then coud for ive the sin of all

and I.ll furtive you, whnterer torment

forive the eomment that my lnssion - iv.

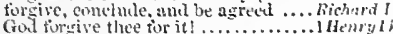

Goil tor ire me! sood uncle

and Goil torgive them, that so mineli

hostess. I ringive thee: so make sem

I besech your highness to for rive....
ret, forgive me Gid, that 1 do brag.
him I forgtre my death..............

forgive me, comitry, and sice

he false, forgive me, frod .

I forgive and quite forget old fimlts.3 Henry ${ }^{2}$, iii. 3

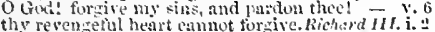

thylk a lifle wild, forgive me ...... Henty $[M J]$. i.

I heartily forgive the's ...

to for give me trankly (rep)

pras, forgive me. if I have used mysels

heaven forgive me! ever Goul bless your - iii.

unapt to give or to forgive.......... Cor of

forapt to give or to forgive .......... Corioltmus,

I fortive thee for a witeh.

but, sir, forgive me; sinee ny

forgive me in thine own proticular

malice towards you, to forgive rou.. Cymbe

pray now, torget and forgive: I am

If thou art nob!e. I do forgive thee
God forgive me, (marry, and amen?

forgive me, eousin! ah, deur Jaliet

forgive me my foul murder

forgive me this my virtue........

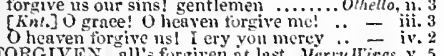

I hGIVE. all's forgiven at last...Merry Wires, $v$.

of your youth are forgisen you... ininter's rinte. iii. 3

gentlewomen here have forgiven... Hewryn. (egil.)

thy low grave, on faults torgiven.. Timon of .tih. v, 5

COLGIVENESS

that I must ask my eliild forgiveness! . Tempest, $r .1$

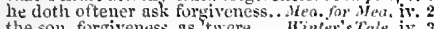

the son, forgiveness, as twere.
them asks Bohemia forgiveness

Hinler's Tale, iv.

for this for siveness, prosped may.... Hichard $\boldsymbol{H}$. v. 3

ask her forgiveness? do you but mark.... Lear, ii. 4

and ask of thee forgiveness: so we'll li

exchange furgiveness with me...

FORGONE-my mirth, forgone ali eustom

hast thou forgot her? $\ldots . . . . . . . . . . . .$.

I have forgot to eourt...... Tiro Ger.

worthless Falentine shali be forgot..

out upon't! what have I furgot? ...... Aerry w'ives, i. 4

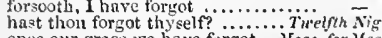

once our grace we have forgot..... Ireas. for ifea.
speals troth. I have forgot our way. Mit, N.'s $D$.

speak troth. I have forgot our way. Ma
0 , aud is all forgot? all selnool-(lays'

lieur iny Thisby's nromise is forgot!
wlyy, this was quite forgot ........ Love's I.. Lost, $\mathrm{i}$.

the hobby-horse is forgot......

- iii.

I hinl forgot, three months ... Merchant of Yenice, i. 3

ko nigh as benefits forgot ...As ynu Like ii, ii. 7 (song)

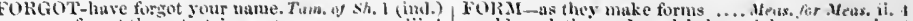
som forgut the entertsimment

what luave we twizin firget?

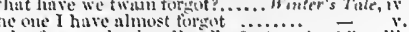

quite for

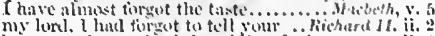

have you forsot the duke of fiere ori

1 had forpot myselt: am I not kim

the not forgot unson the face.

i Henty 1 r. ii. i

I have firgot the map.

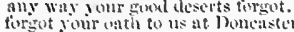

trespess may be well tionsot

but he latlif forgot that ..............

vet anll shatl be tionget

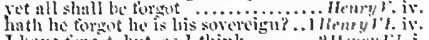

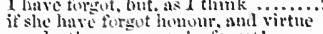

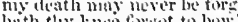

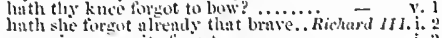

my pains are quite foryot ........... i.

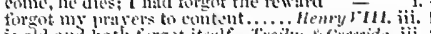

is old and hath forgot itself. Froilus o cre'ssita, iii.

stmanely by him, as it he were forgot

二 ili.

forgot as som as dome.

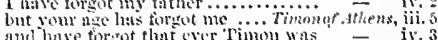

have you tirgot me, sir?

by Jupiter, fursot: I am weury

truly ing fore forgot son.

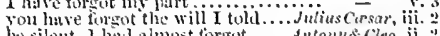

be silent, I had almost forsot ...... Antonys cleo.

my hord, I find. hass for

sle hath not yet forget lim..........

- $\quad$ ii. 3

f rorgot to alsk him one thing.

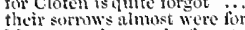

lis rage and anger be torgot

untriemily elements forgot thee nit terly

half o' the kingdom hast tlou not for $r$ ot. . Lear iii.

grent thing of us forgot!..................

I have forgot thint name...

Hamlet, iii. 2

hine you tirgot me?

alinck, I had forgot ..........

that to finertes I furgot myself

Yon forgot all sense of place and duty?... othello,

I would most gladly have fortrot it......

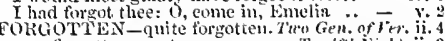

on a forgotteu mater we etu .... Terelfin Sight ii. 3

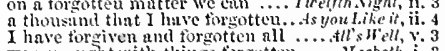

was wrought witly things forgotten ..... Hacbeth, i. 3

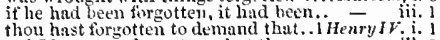

an' I have not forgotten what the....

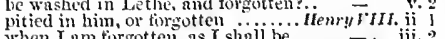

when I um forgotten, as I shall be ... cleopatra, i. 3

die two montlis ago, and not torgotten. Ilamlet, iji. 2

adker"s tork, and bind-worm's sting. .. Nacbeth, iv.

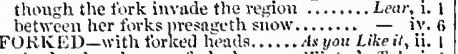

oer head and ears a forked one ... Minters Toli i.

with forked tongue, that glided ....2 Hemy $1 \%$ iit. 2
the forked one, quoth he...... Troilus of Cressidu, i, 2

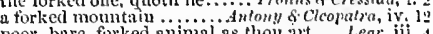

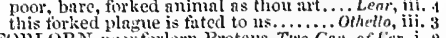

cherish thy for form sw 1 roten

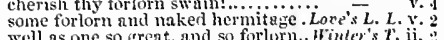

well as one so grent, and so forlun. Finker's $T$. ii.

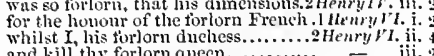

and kill thy forlorn queen..........

shall I stab the forlorn swain?.

foreed to live in Scotland a torlorn... - iii.

the forlom soldier, that so nobly .... Cymbeline, y.

thongh summer, set fortorn ald wat Jus dmi. ii. 3

long liave I been forlurn, and atl for the

like a forloru and despernte eastaway.... $-\bar{c}$,

nor M-it enrries a lrave torm ........

nor can imagination form a shape.....
and duth lose his form...... Tro Ger. of lerona, iji. I

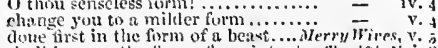

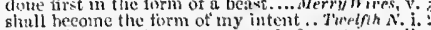

women's waxen heurts to set their forms! - ii.

to read him ly his torm ................. - iii.
cen assume toth form nid stit .........
ant in such forms which here wure..

oplace! U ferm! how often..... Meas. for Meas. ij. churacts, fitles, forms, be an arch-villatio

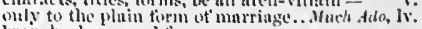
minch, shave, all form.

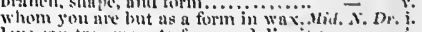
fore can transpose to form and dignity

in monner the forms of things.

sitting with her uon the form...

for the firm, - ith some form,

mont with his torm, in lis ey.........

full of torms, tigneses, slanes, vijocets

their form continumled mules nosi. firm =

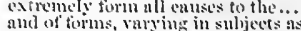

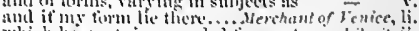

Whith he vents in mangled torms. as y in Lihe it, it.

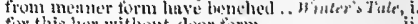

thou hast thine ow u form .... Comedy or forors, ij.

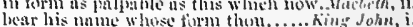

exterior form, outward aseoutrement

all torm is tormless, mder ordertess.

valunt garments with his form

of plain olld form is num.

sinndered nature in my torim

-

wove the farour and the thm of this -

to set in firm ulum llat indigest.

distimrnislt form; so your sweet...... Richard IJ

radition, form, ancl ceremomious dity

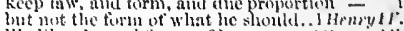

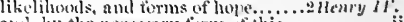

in growly form comes on the.

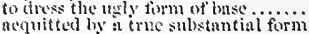

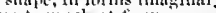

and with firms being fetehed from..... Henry r: ii,

and the torms of it mul the soluriety of it - iii.

degree, and formu, creatine awe und fiear -

nume your higluess in this torm...

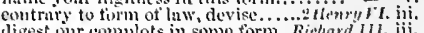

digest our complots in some form.. Rirhard IJ]. iii.

both in vour torm and nolileness of.. - iii.

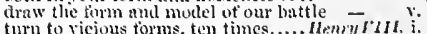

and niplear in furms inore horrici.

no

and put on a form or strungeness.

form, but that lic is.

tout shapes and forms of slunghter.

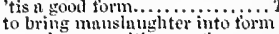

your honour with your form.

hew on this tardy form. Jutirs $\bar{C}_{\text {cesar }}$

to

life without the form of justiee............ it.

finin would I dwetl on form ............

who stund so much on the new form

thy noble slinpe is but a form of war

it wrought on her the form of denth..

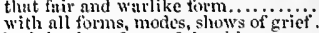

both in time, form of the thing.......

the form of plansive mumers.

in forms, and pressures past, that youtli..

suiting with forms to his conceit?

of faslion, and the monld of torn

whint he spuke, though it lacked form...

bouy of the time, his form and presstin.

a form, indeed, where every god uiil see.

his form und cause empoined, prenching

the writ $11 \mathrm{p}$ in form of the other $\ldots . . . . . . .-\gamma$

.

what form? what likelihood?

FoRA AL - to any tormal enpacity. Tivelinh Nighe, ii. and beard of tornul cut ...........As you like it, it.

make of lyim a formal man ngan........ Comety of Er.

fow henee forth in firmal mujesty .,2 llenry $1 \%$.

with snakes, not like a tormal man.....sut. \&. Ciro. ji.

no noble rite, nor tormal ostentution ... Humlel, iv. s

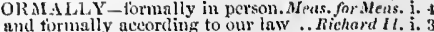

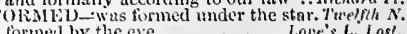

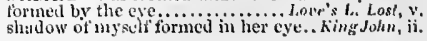

rush us, to this monstrous form.

squadrons, and right torm of war....
pluek down forms, windows, anything

this sober torm of yours hicles wrongs $-\overline{\text { iv. }}$

and follows but for torm, con to for

. are you so formal, sir?... 


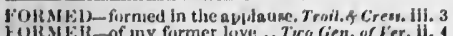
URA MVil - of iny former lovi

I here furgut all former griefy .........

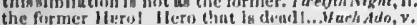

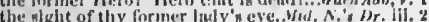
voll to yuur furnier hullow

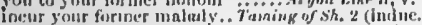

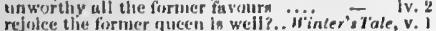

the dasli of iny furuer life li mo

and with fin firmer title greet Mailieth. Macbelh, 1.2 night liatin trifeyl former knowing

my former njeceches have but hit

a thind is like the fiorso

Gering not ali thy former tale

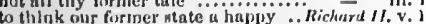

waste the memory of the furmer daye

turnesl uway roy forme

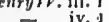

henryr. i.

bear nit former answer buck

and blews un with her former çaalition

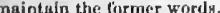

ail his gloss of former honour

thought o'ersan iny furmer time.

queen in former golden

replant J

never more

male former wonders it"s

that former fabulous atiory

of his former lays the forme....

former agents, if they fid compluin.

it in vour former uremias

in thit action out hone his former sleeds

I'll work

on our former v. proved a falree former fortune Antony of Cleo

must not take my former mharpness...

if that the former dare but what it cun

with those my firmer fortuice

friends o'erborne $i^{\prime}$ the former

immortality atternd the former.

so, by my former lect ore and advice...

and from your former state, that

madam, my former suit: I do bresecel..

三

or scant our former huving in deesit

I can apain thy former light r
Foll 1 L R - the danger firm

it was formerly better: marry

the

never they ahall abonnd as firm
but what is like me formerly

letters he had formerly wrote...Antirny of

FORALES. - all furm is formless.... Kints Johin,

and formleng ruin of oblivion. T'roilus f Cressida, iv.

have been accused in fornication. Mers. for Meds. ji.

condemned upon the act of fornicntion -

whe that accuses him of formication formication is at door!. Vicnry $\bar{V} I I$. $v .3$

FOKNICATRliss-

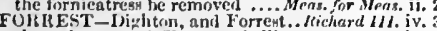
thus, thus, quoth Forrest, girlling one

Whieh once, quoth Forrest, almo

and they none to fursake

All $\bar{v}$ wer.

that we'll furnake ouraclves: give me ${ }_{\text {I }}$ mubt forsake the conrt

bid you forsake your liberty. Comedy of Errors,

Kiit thou forsake thy fortane........ King John,

if you forsake the offer of their

see! they firsake me

to your eot tagres fursake this.......... stoom - v. 3

fly and forsake their housca

that will firsake thec, and go home... - iv. 8

manors that 1 had, even now firrakit me - v. 2

how the poor soul clid forsake.

I munt not yel forsake you ...........ilenry $\bar{V} I I I$. i. A

I must now forsake ye; the last...... - ii.

would forrake the gowd .. Timon of Aith. iii. 6 (grace)

forealse thy seat, I do leseech thec.. Ant. Ff Cteo, ii. ?

mul firmake thin room, and gor with us Othello, iv. 3

forraken your pernicious ... IIPnry

art then furnakern, as thou went'st...3lienry Vl. iii. I

most clicice, forsaken: and most loved..... Lear, I. 1

love si itrar, nos soon formaken?

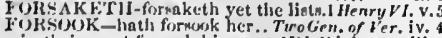

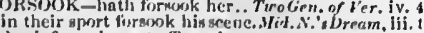

dead, formok, cant off; and none.... King John, v. 7

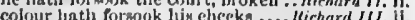

temuer has formouk him eliceka ..... Wichard hi.

who hiave all forsook me

Coriolanus, iv.

has nine furnork man many nollle ma telien. Jthello, iv.

not a-hungry, I thank you, for sooth

aj, formonth

no, forsonth: hie liatii but...

as, formoth: but he je aa tail

ay, formoth, l'll fetein it you

ay, formoth: and I pray how doc.

ay, forsooth; and then you may
OIRSouT H-1 had rather, formooth. Sierry Wives, lil. 2 to the laundres, forsonst the

formosth, 1 lave forgot

frant the $t$ wos particin, loresenth.

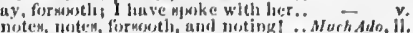

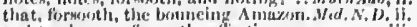

und temater me, forksoth, aflection

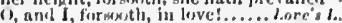

ail formonth, reilying the name... Aryau lik

I um going, formenth: the buriness.... Ali's Wril

110, no, formenth; I dare not, for iny life

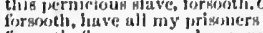

formath, flve yearn, and un triveji.

and now, fersosth, thken on him to

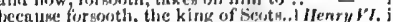

the klug, forsooth, will have it no ...2 lienry $v l$, i.

forsosth, a hind Juan at haint Alhan's

formostl, hud the goos duke to keco

that 1, firmusth, am stern, and....... Ilicharit Ih. $\mathrm{j}$.

formosth, an inventory, thä impersting - jii

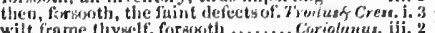

yes, forgocth; I wish you joy

yes, forsoth, an' your nintership ...'Tilas And. iv.

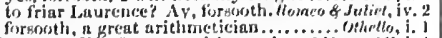

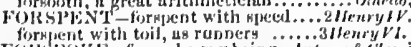

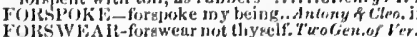

love bils me firrwear............... Tuelgh Night, it. 3

or forsweur to wear irom about you .. _ _ iii. 4

you'll forwerw thin usain.
bat was fain to form wear it

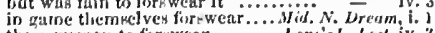

these women to for wear

entertain him, then forkwent hị.......

to swear, and to furswees

if it be not, forsweur't, ............... All's We

but do forswear he

deny him, forswear him.

forswear themselvey uy of ten ay they speuk

to deny it, or furswear it: .... Comedly of s.

cees reanon, I'll forywear arm

I'll forsw'ear keeting house

I'll forswear half kirtles.

thou usent to forswear thyse if ...........

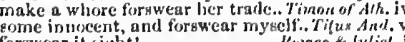

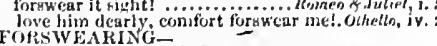

fornwearing that he is forsworn...... Henryl $r$ : $v$

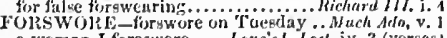

a Woman I foreswore ...... Love's L. Lost, iv. 3 (verser)
I forswore not thee .......... iv. 3 (verses)

he forswore most monstrously.

did, sir: and forswore it tors.

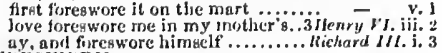
FU'RSWURN-

Fcaulul'd company I have foreworn... Tempest,

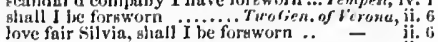

I shall be much fornworn

if Silviu liave forsworn mel

forsworn iny company

gow swectly were forsworn..Meas. for Meas. iv. i f (sung)

that $A$ ngelo's for w worn

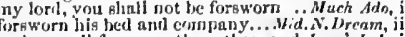

make us all fortworn threc thougand. Love'd..... i.

$1 \mathrm{am}$ for $w^{\prime}$ orn on mere uccessity

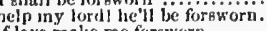

if love make me forsworn

ah, ne! I am forsworn

that I am forsworn for thee

of all havds must we be forsworn

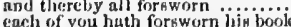

you have in that forsworn the use of

it is religion, to be thum fivrn worn

prove jlagnes to men fursworn

We are aguin fornvisrn...........

lest you be firaw'orn again

hut then $I$ an forsworn .... Mcrcharil of Venice, iii.

that I had heen forsworn .............

you are not fursworn ................

Wut he, had quite forkwomi . Taming of Shrew, jv.

though yct forsworn he were.. Comedy of Errort, iv.

they are both forsw orn

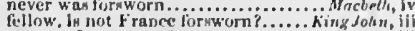

you are furesworn, firsw worn............
svear only to be furs worn $(r e p.) . . .$.
FORswoie - he la foroworn, if e'er... King Solin, $v$.

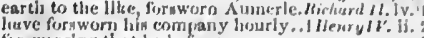
fornwearing that he in firs worn

that have fioreworne thy

forlid, your goure hicould be fou

Hrnsyl.

you are forenwrorn............

I lave fors worn tor grast

bhe hath firsworn tos love ........... -

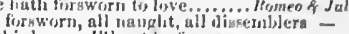

bethink you, I'll nete be lorss or

SI'T-ma fiji, il fuit fort cliued.

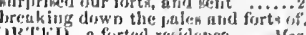

oistrif-know thus fur forth

come forth, I say.

come furth,

and your affeetion no.............. forth

but risture eloakd bring fisti

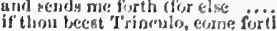

if thou becest 'I'rinculo, eorne forth
and brisg thee forth brave lirsod

and lict them forth

which was thrust forth of iiliur

that bave hiof forth a wonder.

put lirrth their souss to beck.. I T"u $\ddot{G}_{e n}$, of terona,

her hushasu, will be forth ...............

were ealled frorth by their sny jua oce - iii, 3

conce, etme forth ij................ = iv.

come forth, pirrah.................. - iv.

bot fur forth as lierself might be lier chioser - iv.

one chin, and $p o$ forth............ Tuelfth Sight,

set forth in your furrowit ..............

call forth the lis ly father............. = vilu

lead furth, and bring you back

did witter linth u voice! ...............

tentimonicd in his own bringing forth

eannot but yicld you forti ..........

you'll be male bring Deformed forth. Wueh Ado, iti.

you must cuil forth the watch ...... - iv.

eall her forth, Jirotler..................

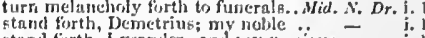

stand forth, Lysander; and iny gracious =

eall forth your actors by the scroli...

HJk'ak, Jyramus: Thishy stand forth

as imarination berlies forth the for...

every one lets forth his anrite......

now step I forth to whip liyjocrisy.

call them forth quick ly...............

to tind the other forth.

I arn bid forth to supier, Jessica.....

no inind of feasting fortli o-night.

well, j'll wet you forth ................

and old Sliylock, both staurl firth.

bring your mosic forth into the air

stuml $y+u$ britl forth now

to travel forth so far?

when it drops forth such fruit.

he rent but forth to wasli him

could not drop forth such giant-rude

fair maid, gend forth thine eye.

liath much bivod let forth.

sent him forth from courtly...... -

bring him forth: he lins sat in .......

so stand thou forth, the the is ......

aend forth your amorous token.

to liring forth this discovery .........

draw forth thy weapon, we's
call forth Natiante, Joeeph.

call them forth. Do you hear, ho?

1 eali them forth to credle hes

an he forth walked on his way

lay forth the gown; what new s

swinge me them roundly forth wi....

等

I wall bring linilia forth

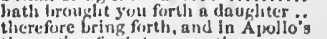

the custing forlh th erows thy........

he kuow'n, when 'tim brought fort

whall point you forth, at every rition 

FORTH-to find his fellow forth.. Comedy of Err. i. 2
is wandered forth, in care to seek.... F ORTH-forth toward Phrygia.Troilus \& Cress. (prol.)
I think, he went not forth to-day saj, he dines forth, and let no crenture I think, he went not forth to day

if any bark put forth, come to $\ldots$ ingit? Knt. . youth, liberality, and so forth thou lock me forth to-day

bring my husband torth

iv, 3 as 'twere from forth us all ............ when thou art forth in the incursious Cressid come forth to him!............

set forth a deep repentance shrills her dolours forth! behold ...

bring forth men-children only!

we'll forth, and fight; do deeds worth

and sent forth great largess to your....

when comes your book fort

was setting forth; now we'll together..

an eagle flight, bold, and torth on

comes the king forth, $I$ pray you?

we'll torth again, my Alcibiade

is my lord ready to come forth?.

produciing forth the cruel ministers...

we'll set forth, in best appointment.. King $\bar{J}$ oh

when we first marehed forth

that spits forth death, and mountrinis

.

and seud forth to us, to mals.

sighed forth proverbs; that, hun

arise forth from the couch.

rush forth, and bind the boy

and throw for th greater themes.

young lad, come forth; I hav

come forth. Do as I bid you do

from forth this morsel of dead royaity

as to be cast forth in the common ...Richard $11 . \mathrm{i} .3$

i sent thee forth to purchose

of their powers are forth already

then wiping, forth he goes

indeed, I will not forth. In trutl

the Volsces have an army forth

our drums are bringing forth our..... youth

to he ta'en forth, before the common

to give forth the corn o" the storehouse

the world thrust forth a vanity.

my soul brought forth her prodigy

from forth the ranks of many

which didst lead me forth of that...

if the time thrust forth a cause

lightens forth controlling majesty

call forth Bagot; now Bagot

cousin, staud forth, and look ........

from whence, set forth in pomp......

elder days may happily bring forth.. $-\begin{array}{r}\text { v. } 3 \\ \text { in setting forth? Why, we will (rep.).I Henry IV.i.2 }\end{array}$

did set forth upon his Irish

to-duy will I set forth, to-mo

go, call him forth. Falstaff! .......

vill set forth to meet your father....

earl of Westmoreland set forth to-day
four days ere I set forth...............

the king himself' in person is set forth

the prince of Wales stepped forth before - is walked forth into the orehard $\ldots .2 \mathrm{~V}$.

go forth: and none of this, though

come, we will all put forth

thousand pound, to turnish me torth?

if he had gone forth consul

lest I let forth your half pint of blood

no, I an promised forth.....

that brings forth the adder

whe'r Cesar will come fortl to-day.

blaze forth the death of princes (......

to stir forth to day; plueking (rep.)

do not go forth to day.

look well, for he went sickiy forth

then walk we forth, even to the

what, shall we forth? .............

to wander forth of doors (rep.

for, from this day forth, I'll

be'st a Roman, take it forth...........

why didst thou send me forth

brings forth a mew petticont.

no vessel can peep forth..............

that you already have sent forth

how tar forth you do like their articles?

but peace puts forth her olive.

and breathless, power breathe forth.

did withhold our breaking forth

and throes forth, each minute.

kings would start forth, and cry

call forth my househol
he goes forth gallantly

but, till the king come forth, and not - ii. (cho.)

feteh forth the lazar kite

and of Orleans, shall make forth

tis meet we all go forth, to view ...

for forth he goes, and visits all

go forth, Agrippa, and begin the fight

his force is forth to man his galleys

your death will never let come forti

shall be brought drunken forth

were hut riding forth to air yourself.. C

but from this time forth $I$ wear it...

put forth disordered twigs ...............

would call forth her flowing tides....

it sendeth forth to skirmish .......

step you forth; give answer to

call forth your soothsayer.

$a$ deal of old iron I chose forth .......
bring forth the body of old Salisbury

point thy two sons forth

till from forth this place $r$ lead....... Titus And ron. $_{\text {. }}$

I poug forth to ty experimeuts.

i. 2 forth, my sword; he dies $\ldots . . . \ldots \ldots \ldots \ldots . \ldots . \ldots$
i. 2 forth of my heart those ebarms

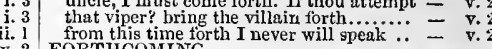

For'THCOMING

see, that he be forthcoming .. Taming of Shrew, v. I

your lady is forthcoming yet at London - ii.

FoRTHRIGH'T-through forthrights.. Tempest, iii. 3

aside from the direct forthright. Troilus \& Cress, iii.

we will hence forthwith to feast.. Tamirıg of Sh. iv.

bear me forth with unto his creditor. Com. of Err. iv

for you must part for thwith ......... Richard $I$. v.

in France forthwith I am to make ...1 Henry $V I$.

go victual Orleans torthwith ........ -

and now forthwith shall art

see that forthwith duke Edward be.. - iv.

I'll hence forthwith un to the sanctuary - iv. 4 forthwith that Edward be pronounced - iv. 6

forthwith from Ludlow the young. Richard 11 iv. ii. 2

shall be acquainted forthwith.... Henry VIII. ii. 2

iii. 1 of it forthwith to Agamemnon...Troilus \& $\overline{\text { Cress. }} . \dot{\mathrm{i}}$.

iv. 1 for him forthwith, ere the first sacrifice - iv. 2

forth with, they fly chickens ........ Cymbeline, $\mathrm{v} .3$

commission will forthwith despatch ... Hamel, iii. 3

I will be returned for thwith ........... Othello, iv. 3

FOR'IIF IED-he's fortified against. Tweiffi Night, $\mathrm{i}$. hath won, that hath he fortified ...... King John, iii.

we are well tortified, and strong ...... 1 Henry $V I$, iv. 2

2 FORTIFIES-he strongly fortifies.......... Hacbeth, $\mathrm{\text {val }}$.

fortify it strongly 'gainst the French. Henry $V$.

view the Frenchmen how they fortify. 1 Heury $\dot{V} I$.

ii. 4 and theretore fortity your hold........ 3 Henry $V I . \mathrm{i} .2$

iii. 1 be it hut to fortify her judgunent ...... Cymbeline, i. 5

FORTINBRAS-Fortinbras of Norway...Hamlet, i. I

to the inheritance of Fortinbras......... -

now, sir, young Fortinbras, of unimproved -

iv. 3 Sou know, young Fortinhras............

Norway, ancle of young Fortinbias, who
sends out arreste on Fortinbras, which he

the nephew to old Norway, Fortinbras.

young Fortinbras, with conquest come.

the election lights on Fortinbras......... v. courage, fortitude, I have no relish.....Macbeth, iv.

despairing of his own arm's fortitude.1 Henry VI. ii.

(ont of a fortitude of soul I feel)... Hen'y Vinl in.
Othello, the fortitude of the place is best. Othello, $\mathrm{j}$.

FORTNIGHT-a fortnight a fore..... Merry Wives, i.

a fortnight hold we this solemnity...Mid.N.Dr. v.

majesty hath heen this fortnight ill.2 Henry $I V$.

ere a fortnight make me older.... Richard III. iil.

they have had inkling, this fortnigh t. Coriolanus, i.

a fortnight, and odd days ......... Rioneo o \& Juliet,

God is our fortress; in whose........ Henry

FORTRESSES - fifty fortresses ....... Henry VI. iii.

FORTUNA - fortuna della guerra.. Loze'sL. Lost. v. 2 si fortuna me tormenta, sperato ....2 Henry l 1 . ii. 4
FORTUNATE-the Fortunate. Tweifin $N$. ii. 5 (letter) hung upon with love, so fortunate...Miuch $A d o$, iit. there create, ever shall be fortunate.. - v. bless you may utter forth the venomous ....... -

calls you forth, servant in arm

our captains, and our colours, forth.

bring forth that sorceress, condernned

contrary iringeth forth bliss

put forth thy halid, reach at the ....

bring forth the soldiers of our prize

duly waited for my coming fortls?
to sloot fortl thunder upon these paltry

come forth and sight with me!

and issue forth, and bid them bittle.3 $\mu_{t} n-\overline{r y}$

may bring fortil a bird that will

his father's fortunes forth of France

by the king was I pressed forth....
when his leaves put forth.........

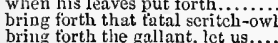

bring torth the gallant, let us.
yet brought forth less than .......

that let forth thy life ...............

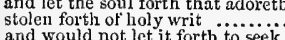

are you called forth from out.......

not barren to bring forth laments.

may send forth plenteous tears

zet to draw forth your noble aneestr

from forth the kennel of thy womb..

to breaktast once, forth of my company $=$

vomits forth to desperate ventures . Henry -

stand forth; and with bold spirit ...
to-day he puts forth the tender leaves

no sun shall ever usher forth mine.

embalm me, then lay me fort

v. 4

but throw her forth to heasts .........

put forth to seas, where when men - - ii. (Gower)

disgorges such a tempest torth

walk forth with Leonine

well; call forth, call forth.

yet I was mortally bronght fortb

but brought forth a maid-child ......

fetch forth the stocks, ho! (rep.)

ii. 2 ganting forth from Goner mervant forth

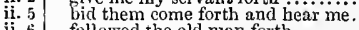

followed the old nian forth

grumble there i'the straw? come fortli

which since his coning forth is thought.

a century send forth, search every acre

but are my brother's powers set forth?
from forth the fatal loins .... Roneo \&

peered forth the golden window...

\begin{tabular}{r|l} 
i. & call her forth to me ........... \\
ii. 2 from forth day's pathway.
\end{tabular}

Romeo, come forth; come forth ........

they are all forth forth in lamentation

for shame, bring Juliet forth ........ -

bring forth the parties of suspicio

and 1 entreated her come forth ......

from this time forth, have you so slander

forth at your eyes your; spirits wildly

forth at your eyes your spirits wildly bless you my fortunate lady!.

fortunate mistress, let my prophecy. Winler's $T$. iv. 3

nothing so strong and fortunate ..... I Henry $I V$. v.

and France be fortunate! ...........

well-minded clarence, be thou fortunate - iv.

most fortunate, thus accidentally... Coriolan us, iv.

as he was fortunate, I rejoice at it.....

wheeled seat of fortunate Cæsar. Antany \& Cleo.iv, 1

less gracious, thee more fortunate. Tilus $A$ ndron. ii.

who hatl most fortunately been informed. Lcur, ii.

most fortumately: he hath achieved...... Othello, ii. m T NE-bountirul fortune.......

thou let'st thy fortune sleep, die rather.

content tender your own good forture? ... -

for all is but fortume....................

me with him, partner of his fortune.

I read your tortune in your eye.......

do want my servant's fortume........

nothing but my fortune.

which heaven and fortune stili.........

good bringing up, fortune, and truth

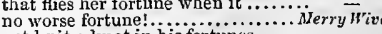

not knit a knot in his fortu

now heaven send thee good fortune!

master's fortune to have her or no (rep.)
to call his fortunes thine .......... Tivelnh Night, i. 


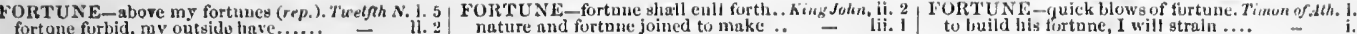

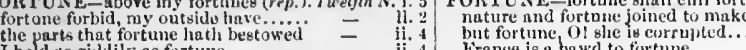
ii. 5rance is a bawd to tortume.

ii. 5 thou fortune, and thy strengtli?

thun fortunes before you................ - ii.

not worthy to touch fortune's tingers - ii. s (let.

build ne thy fortunes upon the lasis

I may not wish the fortune thine.

fortune lics. There where my furtune

when tiortune means to men most
with fortune other tlun at fensts

well for a servint with my fortunes.

iii. 4 with fortune other tlun at feust

however heaven, or tortune, cast

patient underbcaring of lis firtun

of place, time fortuni, ilo coliere.

rile in fortune's womb, is eomling

all the oceurrence of my tortume since

fortune hath concey

as my fortume ripens with thy love.

of her fortune, her murriage-dowry.

to thy good all furtune gues.

un prince, by tortume of my birth ....

more than thanks and good frrtune

and with her my fortunes....

and that my fortune runs arainst

given way unto this eourse of fortuno.

thieir fortunes both are weighed.

nor fortune made such havoek

not the first of tortanc's slives
who is sweet fortune's nuiuion

for the fortune of us, that are $\ldots . . .$. .

tu iny fortunes and me............. Love's L. Los',

1 thunk my fortune tor it .......erch

When this infunt fortuse eane to age
to bear our fortunes in our own strong

to see how fortune is disposed to $1 \mathrm{~s}$.

that s.ll my fortunes are at sea .....

utmost bound of all our fortunes...

abundunce as your good fortunes are

may turn by fortune from the weaker

good fortune then!

8 rare fortune! here comes the man.

I slall ha re good fortune.

well, if furtuile be a woman..

and if my fortune be not erost ......

fortune now to my heart's liope!

go about to eozen fortune .............

let fortume go to liell for it ...........

me to my furtune and the enskets....

since this fortune finlts to $y$ ou $\ldots . . .-$ iii. 2 (seroil)

and hold your fortnne for your bliss - iii. 2 (scroll)

provided that your fortune achieved her

fir hercin fortune slows herself more

I will go buy my fortunes .........

thou goest from fortune's office (rep.) -

may she not by fortune fall into the fire? -

is fortune too hard for nature (rep.)

this is not fortune's work neithes.

as wit and fortune wili ........

ouc out of suits with fortune

translate the stubbornness of fortume

many their fortunes seek

fortune cannot recornpense me better

my fortunes were rnore able to relieve
ruiled on lady Fortune in food terms

railed on lady Fortune in good te

to question you nbout your fortunes.

the residne of your fortune

all jour fortunes waderstand

what straits of fortune she is driven...

shure the good of our returned fortune

have fuught $w i^{2}$ th squal fortune

firtune, she said, wins no goddess

lose malle your firtunes twenty

in your bed find fairer fortune do thine own fortunes that obedient.

gond fortune, and the fayour of .

to have nine own good fortunes.

upon thy promising fortune

fipon thy promising fortune .........

approves you are great in fortune

if her fortunes ever stood necessitiel

to mine own furtune deck his fortune with his virtuon...... Taminir of Sh. i. 1

it rained down fortune showering...

and I embrace this fortune patiently

when he saw the furtune of the day.

dignify the times since Casar's furtune

may the weneh have no wor

i. 7 whom fortune would then liave smiled?

ready are to try our fortunes
will fortune never come with both

i. 9 not take a knighthood for my fortune

what thou wilt, I am fortune's steward $-\overline{-}$
giddy fortune's furious fiekle wheel .. Henry

fortune is painted plind

of furtune; fortune, louk you (iep.)...

doth fortune play the huswife with.

fortune made his sword; by which $-\overline{1}$

fortune, in favour, makes liim las

betrayed to fortune by your strife

eornmit thein to the fortune of the sea

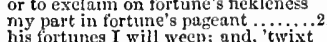

witness the fortune he hinth had ...

thy fortune, York, hadst thou been..

the bottom of all our fortunes

this breaeh now in our fortunes mide

their day, aud them our fortune give
their woes, whom fortune captivates.

which proniseth sueessful fortune.

Jeave us to our fortune (rep.)......
bide the mortal fortune of the field?

father's fortunes forth of Franee

or fortune given me measure of revenge

take like seat unto my furtune ......

than mysclf have had like fortune

though fortune's malice overtlurow.

I may eonquer fortune's spite (rep.)

their fortuncs furtlier than at lione..
by good fortune, I liave lighted ......

my torture lives for me ..........................

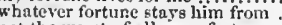

not the worst of all you

\begin{tabular}{l|l} 
ii. 3 & for on thy fortune $I$ repose nyseif \\
ii. 3 & thus far fortune maketh us amend
\end{tabular}

ii. 4 if fortune serve ne, I'll requite

iii. 5 with patience to my fortun

vain flourish of my fortune!

.....Richrd /11. i. 3

put iny furtunes inine ...........

as by strange fortune it eame to us ..

quit his fort unes here ..........

O lady tortane stand you anspieiouisi

myself, and fortune, try for the time

my fortunes do all

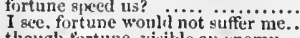

though portune, visible an enemy

in the blossoms ot their fortune ......

my fortume, and my sweet hope's

to this fortune that you see me in.

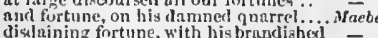

our sepurated fortune shall keep

which hell you so under fortune $\ldots$

tugged with fortune, that I would set
malevolenee of fortine nothing takes

let ine finil lim, fortune?

ehicle my fortnne, and torment myself?

the right and fortune of his happy stars

You will buckle fort une on my linek
Riehmond, and good fortune guide thee?

vain flourish of my fortune

and height of fortune [Col.-honour. $]$

fortune and vietory sit on thy helm.

and pint thy fortune to the arbitrement

thus far we are one in fortune

ii. that state or fortune fall into my

long may he live in fortunes!

ure ye to my fortunes, than my fortunes -

hosour, and furtumes been with you

and men's fortuncs, eonld I trankly use -

that 'l'men's fortumes inong hige fricinds =

it jlcanses tine, and fortune, to lie beavy

to take his fortune liy the arm

a kiscll unto our master's fortones

thy yreat fortunes are made thy chice

can bear great fortune, but by

tor every grize of tiort nue is smoothed

but fior tliy sword and fortune

sprung from elhange of fort une

oflering the tortunes of his tormer day

now the fuir yoddess, fortune, full decp -

that he would pawn his fortines

else would put you to your fortune.

tortune's blows, when most .........

which out of daily tortune ever taints

1 purpose not to wait on tortune.

put in mind of his blind fortune

joy, tor his fortunes and aftairs .JulinsCesar, iii.

fortune is merry, and in this mood will - iii.

we shall try furture in a seeund fiune - iv.

good sir, give nie good fortume ...Anlony f Cleo.

proved a fairer foriner fortune

but a working-day tortune (rep.)
of fortune better than she (rep.)

and fortune him aceordingly! Ä....

and make thy fortunes proud: the lijow

to try a larger fortune. You have made -

this day laugh away his fortune

lield my eap off to thy fortanes

now pleased fortune does of Mlareus

gour fortune lies upon this jumi...

uur fortune on the sea is out of breath

making, and marring fortunes..

lord of his fortunes he salntes thee.

fortune pursue theel Bring lim...

are not, in their best fortunes, strong

ot his fortunes yuu should make a stati

ii. 2 wisdom and fortune combating togethe

being twenty times of better fortune

my fortunes lave corrupted honest inen -

his fretted fortunes give him hope

fortume and Antony part here .......

death and fortunes bid thy foilowers fly

not being former fortune, he's but furtune's

I am his fortune' hassal .............

(O riglot fortune!) to master Casg.; Cymbet

as low, as were thy firtunes $7 . . . .$. .

a mind dark as your fortune is ......

stur'k to the pare fortune of that

fortine, put them into nyy haud!

inform us of thy fortunes ....................

to my fortunes, and the people's...T

honour and with fortme is returned

your fortunes are atike in nll .......

wisdom hath her fortune conquered

safe out of tortune's shot $\ldots . . . . . . . . . .$.

thine, belal what fortune will.

lereft a prince of all his tiortuni.

when the greatest stroke of tortune fills -

Yet, if that quarrel, fortune, do divorec

yout have hy fortune, and bis highues

in spite of fortune will briut me off.

dirl but my fortunes equal iny desires

thanks, fortune, yet that after all.

by you his firrunes yet may flonrisi

all fortune to the good simonides?

is not found in fortune's lio
divide in storms of tortuno

divide in storms of fortun

do a deel that fortune never ilid

conveniences, to doulstful fortwes

onee fallen ont with fortume

furtune and I are frients.

creep in skittish fortune's hali

sweet love is foorl tor fortune's tooth
and the foolish fortine of this girl.

till when, go seek thy fortume

him large tortume, upon his good. Fimon of . Theres

whom Fortune with her irory hani

gond fortune eome to thee!

a hazaril of newe furtunes here.

wheu Fortune in her thift aud cliauge

but fortune's mood [ $k^{\prime} n t$, -fortune moved]

it is a gonl constraint of fortume

your shinfts of fortune.

stood between her and her fortuies

to be orderel by limly fortune ...

most ungentle fortune hath placed ...

though waysard fortune did malign

her fortunes hrought the maid aboard
although assailed with fortune fieres $-\mathrm{v} \cdot \overline{3}$ (Cower

lest it may mar your fortunes ............. Lear, i. 
FORTUNE_reeived you at fortune's alms. Lear, i. I keeps our fortunes from us.

when we are sick in fortune.
briefness, and fortune, work

briefness, and fortune, work grow out......

Fortune, good night; smile once more

Fortune, that arrant whore, ne'er turns.

make content with his fortune

how malicious is my fortune............

if thou wilt weep iny fortunes.............

I am even the natural tool of

made tame by tortune's blows ...........

lest that the infection of his fortune take

machination ceases: fortune love you! ..

could else outfrown false fortunes

and fortune led you well

sword, and fire-new fort hast this fortume

if fortune brag of two she loved and hated

mine own fortune in my misery...R

hie to high fortune! honest nurse.

O! I am fortune's fool
pout'st upon thy fortune and thy love

pout'st upon thy fortune and thy love

be fickle, fortune; for then, I hope

in her fortume's tender, to answer ..

heing nature's livery, or fortune's star...

fortune's cap we are not the ver

in the secret parts of forts fortume

ont, out thou strumpet Fortune!

gainst fortune's state would trenson linve

slings and arrows of outrageous ortune.

not a pipe for fortune's finger to sound

even our loves should with our fort
love lead fortune, or eise fortune lo
hitherto doth love on fortune tend

if the rest of my fortunes turn Turk

for thy better; take thy fortune...

to all that fortune, death, and dancer...

the queen carouses to thy fortune, Haml

with solrom I embrace my fortune ......

beanty, wit, and fortunes, in an $\dddot{1} \dddot{\text { liav }}$

to as proud a fortune as this that I have

the battles, sieges, fortunes, that I haves.

cannot be preserved when for fortunes

violer the storm of fortunes...

did I my soul and fortune consecrate

so eminently in the degree of this fortun

I am desperate of my tortunes..............

down the wind, to prey at fortune......

founded his gnod fortune on your love

some other course, to fortune's alms......
would bear your fortunes [Knt.-fortune.

it is my wretched fortune

knows not yet of his honourable fortum

it expressed her fortune, and she died

un the fortunes of the Moor

FORTUNED-what hath fortuned. Two Gen. of $v$

FORTUNE-TELL-fortume-tell you .. Merry

FORTUNE-TELLING-

the profession of fortune-telling, Merry Wives, iv.

FORTY-hnd rather than forty shillings - i.

I had rather than forty pound

and, I think, forty more.. Measure for Meastre, iv, 3 round about the earth in forty. Mid. N.'s Dream, il. 2 humour of forty fancies pricked. Taming of Sh.

of mine worth forty ducats .. Comedy

for forty ducats is too mueh to lose ...

I have learned these forty years ....Rich R

king's name forty [Col. twenty] thourk

forty let it be; my father

you shall have forty, sir

I will have forty moys............... Henry $V$. iv

is it hitter? forty pence. no ......... Henry VIII. ii. 3

within these forty hours Surrey durst

I could beat forty of them

Coriolanus, iii.

I saw her once hop forty paces....Antony \& Cleo.

I lave been thy soldier forty yenrs. . ... Pericles, $\mathrm{i}$.

forty days longer we do res

hold, there is forty ducats............

I loved Ophelia: forty thousand mine, a hundred and forty.

and mine, a hund
that the slave had
FORTY-EIGHT-

I have years on my back forty-eight ...... Lear, i. 4 FOR WARD_his forward voice now is.. Tempest, ii. 2 now, forward with your tale........... you'll still be too forward.............. but let our plot go forward .......Merry Hives,
look forwurd on the journey $\ldots$.... a very forward march-chick!......... Mrech Ado i. it goes not forward, doth it?..Mid. N.'s Dream, iv. and now, forward; for we have ... Love'sL. Lost, v. 2 but I will forward with my device $\ddot{2}$. of $\overline{\text { Yenice, }}$ ii. first, forward to the temple......Merch. of lenice, ORW ARD_with the forward child. As you Like, iii. 3
whoever charges on his forw ard brenst. All's Well, iii. 2

take the instant by the forward top .. $\overline{\text { The }}$.

go forward; this contents .... Taming Baccare! you are marvellous forward how fiery and forward our pedant is! gew flery and forward to the bridal

they shall go forward, Kate ........

forward, I pray, since we have come - iv. 5 she is as forward of her breeding. Winter's Tale, iv. 3 nay, forward, old man ....... Comedy of Errors, i.

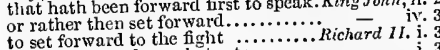

to set forward to combutant

Richard 1. i. 3

fondly dost thou spur a forward horse - iv. I
when a jest is so forward............. Henry $I V$. ii. 2

some of them, set forward

I will set forward to-night .

what need $I$ be so for ward with him

bending forward, struck his armed

in God's name then set torward.

go forward, and be choked with
thus forward in lis banishment

if you go forward, therefore yield .....

most out of order; come, march forward - - iv

promised knighthood to our forward s

if that go forward, Henry's bope is done -

ah, torward Clarence.

nor forward of revenge, though they

in to the world with iny legs

inigentous, forward, capable....

and hopes to find you forward .......

I mily not be too forward

let lim on; go forward ............

drive this forward: prove and dare us

they are ever forward

but when goes this forward

hath made us forward...

set we forward: let a Roman

been thus forward in my right. Tiitus Andronicus, i.

can I go forward, when my heart. Romeos. Humlet, $i$. 3

FORWARDING-

FORWARDNYSS-

his own peril on his forwardness

As you Like it, i. 2

I will requite thy forwardness.

my heart, to see your forwardness . Cymbetine, iv.

FORWEARIED-forwearied in this.. King John, ii.

FOSSET-SELIER -

an orange-wife and a fosset-seller ..Coriolanus, ii. 1 my blood that fosters it.............

to foster it, nor ever to presery

FOSTERED-infiuence fostered..
like a lion fostered up at hand

dear blood which it hath foster.

and fostered

FOSTER-NURSE

to be my foster-nurse

to be my foster-nurse............ As you like il, ii.

OUGHT-fought with a warre is a fray to be fought
there

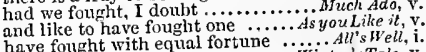

was fought in Paulina! ............. Winler's Tale, v.

good and bardy soldier, fought 'gainst.. Macbeth, i.

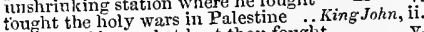

what a noble combat hast thou fought - v.

colours he had fought so long.........

what, fought ye with then all?

by'r lady: you fought fair.............

fought a long hour by Shrewsbury clock - v.

fought, so tollowed, and so fairly won.

hath safely fought to-day .

from morn till even fought .......... Hcury $V$. iui. I

and if he be not fought withal $\because \cdots$ day

fought on the day of Crispin Crispianus

that God fought for us ...............

a ficld should be despatched and fought -

fonght so long, till that his thighs..2 Henry $V I$. iii.

well hast thou fought to-day $\ldots . . . .3$ bloody fray at Wakefield fought.3 Henry VI. ij.

and both sides fiercely fought........

when I have fought with Pembroke
by the way they be not fonght.... Richard $I I I$. iv.
thy

0 , well fought, my youngest brother! - voriolanus, i.

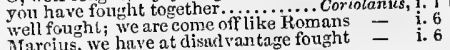

FOUGHT-wherein we have fought ...
alone I fought in your Corioli walls

Marcius, I have fought with thee...

he fought beyond the mark of otliers

for your voices I have fought ........ $-\mathrm{ii.}, 2$

in the cause gainst which

that often have 'gainst Pompey fought - iii.

emperor, this is tought indeed!

and have forght not as you scrved.... - iv.

rather played than fought ........... cymbeline, $\mathrm{i}$.

rather played that that the heavens fought
all was lost,
the poor soldier, that so richly fought 3

soldier, that so nobly fourlit..........

as true a dog as ever fouglit at head..

that fouglit Kome's quarrel out .......

lurt in parting two that fought $\ldots . .$. . Pericles, jv.

or ill, as this day's battle's fought......... Leor, i .

and fought on part and part

I dreamt my master and nnother fought $\overline{-}$ Hamlet, i. 3

discretion fought with nature .......... Hamlet, i.

OUL - what foul play had we w......... Tempest, i.

by foul play, as thou say st.

painted their foul ends..................

it is foul weather in us all...

loul weather"? Very toul .....

is to utter foul speeches .............
for which foul deed the powers...

for which foul deed the powers...

that the foul lake o'er-stuuk

thit now lie toul and muddy

foul mischance torment me. T'wo Gest of Verona, $\ddot{i}$.

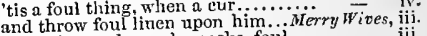

foul shirts and smocks, socks, foul - - iii. 5

and away went I for foul clothes..... - iii.

think on t, Jove, a foul fault..........

I am a foul way out...

hang him, foul collier!................ - Measure, ii. ?

answering one foul wrong.
but, in the less, fonl protanation

nothing akin to foul redemption...

that appears not foul in the truth.... $=$ iii.

drawing of an antick, made a foul..... Mruch $A d o$, iii.

fare thee well, most foul, most finir! ajesh! -

only foul words; and thereupon.

bait me with this foul derision? . Mï. N.'s Dr. iii.

fair payment for foul words is ....Love's $L$. Lost, iv.

though foul, shall have fair praise....

your lips grow foul

defile? a foul word..................

is foul, as I conceive..................

played foul play with our oaths ......
is nipped, and ways be foul $\quad \bar{v} \cdot 2$ (song)
cleanse the foul body of the infected.As you Like, ii.

most mischievous foul sin.............

I thank the gods I am foul ..........

as your pearl, in a foul oyster

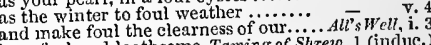

and make foul loathsome. Taming of Shrew, 1 (induc.)

balin his foul head with warm...... 1 (induc.

be infused with so foul a spirit! $\ldots$ oul as was Florentius love - i.

and all foul ways! was ever man .... - iv.

wh came down a foul hill .............

lead on to some foul issue .........Winter's Tale, ii. 3

break a foul gap into the matter ....

fair is foul, and foul is fair ................ nacbeth, i.

so foul and fair a day $I$ have $\ldots \ldots \ldots \ldots . .$. - i. 3

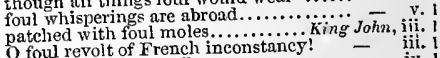

Hubert, for so foul effect ........... - iv. 1

the foul corruption of a sweet.........
so foul a sky clears not without.....

and foul imaginary eyes of blood ..... - iv.

ah, foul shrew traitor's name stuff I..... Richard 11 . i.

men, hate so foul a liar ......

my soul from such foul sin. ..........

from her eyes by your foul wrongs ..

falter under foul rebellion's arm

we'll make foul weather with......

forbearance from so foul a wrong .....

is a foult tror this foul act.

ere toul sin, gathering head...

she's come to pray for your foul sin...

will she hold out water in foul way? - ii.

without boots, and in foul weather too! - iii.

for nothing can seem foul to those $\ddot{\text {. }}_{\text {Henry }} \mathrm{V}$.

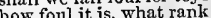

how foul it is, what rank

that foul sin, gathering bead $\dddot{2} . . .$. -

it you grow foul with me, Pistol ........ Henry $V$. ij. 1
Au! that'e a foul fault .............. 


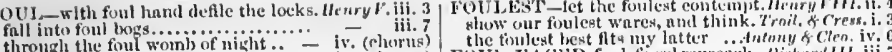
who, fike a foul and nigly witels.

- iv. (churus) 年

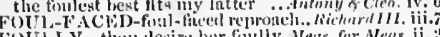

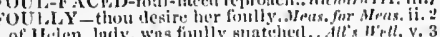

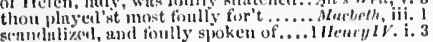

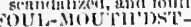

wul fient of France, anul has and take foul secrn, to finwn iilienry I't. iii. thon finl aleenrsel minister. enil these forul oftendit

virtue is ehoked with foul aimbition. foul sulornation is predouninant (the agent of thy foul ineonstuney) all the foul tcrrors in dark-seated. breathe foul contugions darkness. harbouring foul deceittul thomghts herap of wrath, foul inctigested him to thy foul disgrace, and utter ruin. inany seorns, many foul tnunts...... $\mathrm{m}$ foul despair? resette him from foul desplair?... plngue thee for thy foul mislending in if this foul decd were by, to equal it. Riehard II foul devil, for God's sake, hen

thou lum of foul deformity , ...... liest

[Col. Knt.] in thy foul thront, thour te. foul chume unon youl.

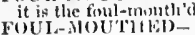

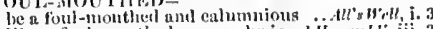

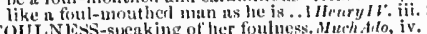
be the golls for thy foulness! .... As y/nn like $i t$, iii. murder or fouluess, 10 unchaste action Ft)UL,-Pi,A $Y^{\prime}$-is apparent foul-play.. King John, iv. foul-suoken coward! that thunder'st. Titusind. ii. FOU ND-her brother found a wite

iii. 3 We have sufely fotmd

where you found it

till I have found each letter ...Two Gen. of Ver. i.

for in print I found it............

it will be fiund $\mathrm{so}$, master Pabo

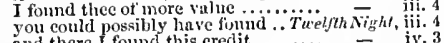

a legion of foul fiends environed me

see the erown so foul misplaced.

that toul hunchiracked toad.

tis tiil of thy foul wrongs

by unclerhand corrupted foul injustice

this foul swine lies now even .......

a buse toul stoue, male precious...

and there I found this eredit .........

found out the remedy

for we have found upon $\mathrm{him}$

you hall not found me here so inusieal

I lnow You do; and have found it

let this frinr be found...............

I found him here as melanching

she found Benertick and Bentriec.

not by minc eyc, Lysander, found

that 1 sleeping here was tount

I think, now 'tis not to be found... Love's $\bar{L}$. Lost

you found his mote; the king

have foumd out such ficry numbers

rejoice at friends uewly founct

eanght it, gound it, or enme by it.Mrer of renice, $i$.

sinee you have found $\Delta$ ntonio

hast thou found my daughter?

as I have ever found thee homest ....

they found the bed nintreasnred of

I found them on a tree ............... -

I tound him under a tree.

for a fool, when I found you

and found the quarrel was upon the

may be ten times found: by being ....A Al $\bar{s} w$

I wish might be found in the calendar

in what he did protess, well found

a witty fool, I have found thee .......

since I have found myself in my

found her wondrons coll; but I sent

and pay again, when I have found it

rou were the first that found

find it then. I found it not

I found yon wondrous kind...

till I found it to be truc, I never.. Taming of $S h$.

I found the effect of love in idleness..

you'll be found, be you bencath . Winler's Tale, 2 . 2

show those things you found
till his lost ehild be found?

the mnnner how he found

say, lie found the child .........

has the king found his heir?

letters of $A$ intigonus, found with it

for joy of his tound daughter......

our Perdita is found. You gods

how found thy fither's court?....
that's never to be foumd again....

that's never to be forme hag how

can be found ty him not ruined?. Comedy of $\mathrm{B}$

I firund it out by the hogg....

I found it hy the barreminess

you have found the goldsmiti

we found upon their pillows

lic not found here; hence ........

whom I found with many hundreds. King John

found it too precious

they tound him deal ..............

there are found luseivious metres...
will be found in liess and willoughy

he should hitwe fouml lis uncle fantit

in twelve, found truth in inl but one

to Grod, my lorils, he might

null you hinve fonnd me

nothiug but roguery to be founil

lay in his way, and he found it

but Prinin fomml the thre........
for he hath fisuml-to ent ond

for he hath fisund-to ent one $\ldots \ldots . .$.
as the year hat found rome months.

as the year hat found aone months.
my lors, I found the prinee..........

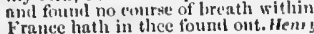

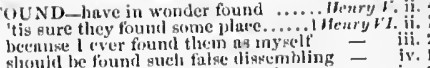

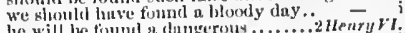

19 will lie forme to hent a dog

'tis well seetr, he fomsal an enemy... - iit.

thum here be'st found on nny ground - ifi.

if thou be found lyy me, thom art .... ne-

of gold, that by chunec 1 found..... Nichard $H I$.

not peevish found in great desimns... - iv

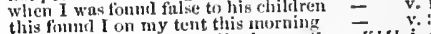

you have found lim, cartinal.......Itenry $V I I I .1$.

is lie timnd guilty? yes, truly, is lie... -

linve found him guilty of high trenson
never found again but where they.

but that slunder, sir, is found a trutil
have great eare I be not found a talker

have grent care ibe not fount a talker

nnd wot you, what I found there....

I now pronounce, you have found tru

the duke by law found his desert... - iii.

and found the blessedness of being little - iv.

is not found in fortune's love........

the nature of the siekness found, Ulysses -

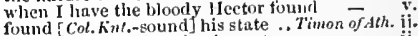

you found them in mine honesty....

have found time to use them toward

I would therein have found issuc.... Corintann

but you have found, sealing his present

gone forth consul, found it so

might have found easy tines............. -

if it be found so, some will dear.....

I founl it in his eloset, tis he fund like Brutus

I found no man, but lie was true to me -

so Brutus should be found ............

when at Philippi he found Brutus slain

I found you as a morkel.

(whieh never shall be found) $3 . . . . .$.

but found their conrage worthy

found no opposition but whint he

how found you him? stark, as yon
bave I not found it murderous

and will, no doubt, be tound

having found the back - cloor op
but none of them ean be found

but none of the prof, eannot be found

I fomm this label on any besom.......

nud I have foond the path

here have we found him dead...

0 , thus I tound her, straving in.

the old mam thath foond their guilt ..

I wrote the letter that thy tather found - -1 (riddie)

ne has finmd the meaning (rep.

at Tharsus, and tound at sere acain!

at found there rich jewels.

I long to hear how you were tol.nd

be shown you all wins found with her

cer loved. or fatler found

I found it thrown in at the ensement...

found you no displensure in him

motley here, the other found out there

to luve found a safe redress.........

Lnenlight; and fom - despact

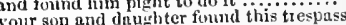

when we have found the king....

there I found them ......................

here, that means not to be found. Romen

wint hast thon foumd? No hare, sir

when he's found, that hour is lis last

we found him in the churchyard

that 1 linve found the very canse .......

he truly found it was anginst..
why, tis found so. It inust be

why, th found so. It inust be.

I must be tiund; my parts, my title

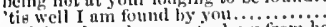

and tound gond means to dirn from he

I never found a man that knew how ...

and the woman hath found him alrcitly

I foum them elose together, at blow

I nm glnt l huve foumul this napkin

at the tirst are searce found to dis tnite

1 finund not Cassio's kisses on

I will he found most cunning.............

he furnd it then; I never gave it him.

what he found himself w 2 a a pt and true

huntkerehice thou Epeak st of, I finnd.

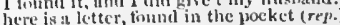

I loumel it in my clumber.

FoUXil). 


\section{FOUNDATION-}

Whose foundation is piled upon .. Winter's Tale, i. 2 those found

slope their heads to their foundations.Macbeth, iv. I and the foundation of the blood... King John, iv. and the foundation of the earth ..... HenryIV. iii. 1 to bring the roof to the foundation... Coriotanus, iii. I I think, foundations fly the wretched.Cymbeline, jii. 6
FOUNDED-founded as the rock........Macbeth, jii. 4 founded his good fortune on your love. Ohello, iii. FOUNDER - the founder of this law. idly supposed the founder of this law in this point all his tricks founder. Henry $\bar{V} I I I$. iit. foundered nine-seore and odd posts. 2 Henry $I V$. iv. FoU NT you are the fount, that makes .......3 Henry $V I$. iv. 8 as clear as founts in July Henry VIII. i. 1
Mid.N.Dream, ii. 1 FOUNTAIN-by in Jul

by paved fountain, or by rushy brook

like Diana in the fountain ......As you Like it, iv. I the fountain of your blood is stopped.... Macbeth, immaculate, and silver fountain ....Richard II in the fountain of our

would the fountain of your mind

like a fountain, with a hup bubbling fountain stirred with wind. Titus And. sit round about some fountain

and in the fountain shall we gaze so long

fountain from the which my veins... Romeo \& Jul. i .

FUR-had I not four or five womeu...

to be afeard now of your four legs.

some monster of the isle, with four legs.

four legs, and two voices

Tempest, $\mathrm{i}$.

or four of his blind brothers. Two Gen..... of

three or four gentlemen-like dogs

I would have made you four tall... Merry Wives, ii.

one, two, tree, four, come for?

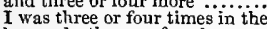

I was three or four times in the......
he speaks three or four languages. Twelf $\overrightarrow{N i g h t}$, i.
it's four to one she'll none of me ....

some four, or five attend him

our lives consist of the four elements?

if your fonr negatives make.

I crave but four days respite

-coloured satin

four happy days bring in another off .. Much A do, i.

four days will quickly stee

four nights will quickly dream away

two of both kinds makes up four

been proclaimed? Four days ago... Love's L. Lost, i.

of all the four, or the three (rep.)

and stayed the odds by adding four..

staying the odds by ndding four

four woodcocks in a dish....

true, true; we are four

we four, indeed, confronted...........

if these four worthies in their first (rep.) $\bar{v}$

the four strangers seek for you, madam -

'tis now but four o'clock

was four year in the afternoon

Was fon year in the afternoon
from the four corners of the earth...

some three or tour of you go give...

I have had four gurarels

or four and twenty times the pilot's....Al's ${ }^{r} e$

there's four or five, to great saint

some four or five descents since.....

houses three or four as good...Taming of Shree

tour pound of prunes, and as many ...

any time these four hours

four fixed: and the fifth (rep.).......King Jolin, iv.

he shortens four years of my wan's

y four o'clock early at Gadshill ....1 Herury iv i.

heigh-hol an't be not four by the day

if I travel but four toot by the
sirs, you four shall front them

sirs, you four shall front them ......
with three or four loggerheads ( $r e p$.)

there be four of us here have ta'en

a hundred upon poor four of $u$

we four set upon some dozen

four rogues in buckram let drive

saw you four set on four

that $I$ borrowed, three or four time

lent you, four and twenty pound

three or four bonds of forty pound

he did. my lord, four days ere I set. .

you must have but four here, sir ....

four, of which you please

sir John, which four will you liave?

I should make four dozen such.....

which is four terms, or two actions..

until four hundred one and twenty

our redemption four hundred twent

Gour happy England into four
FoUR-digt himself four yards ander..Henry $V$. iii. 2
that treads but on four pasterns ... with four or five most vile and ragged - - iv. (cho.) eiglit thousand and four hundred.

I will peat his pate four days.......

four of their lords I'll change for ......। Henry $V I$. i. i

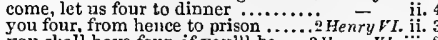

you sliall have four, if you'll be.

3Henry VI. iii.

upon the stroke of tour

their lips were four red roses on a stalk

what four throned ones could have...Henry $V I I I$. $\mathrm{i}$.

are four barons of the Cinque-ports.

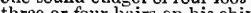

to you four milk-white horses. . Troilus o Cres.

tis not four days gone, since .........

to wheel three or rour miles about
which of you but is four Volsces?

and four shall quickly draw out

three or four wenches, where I....Julius Casar,

rather fast from all, four days.

eanst awake by four o' the clock...... Cy $y$ mbeline,

by the four opposing coignes ... Pericles, iii. (Gower)

three or four thousahd chequin

be it spoken, I have but four
he walks four hours together

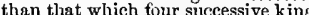

let four captains bear Hamlet

FOUR-INCH four times seveu years ..... Othello,

FOUR-INCHED-over four-inched bridges. Lear, jii.

a man of fourscore pound a year...Mea. for Mea. ii.

one night, fourscore ducats. Merch. of Venice, iji.

almost fourscore here lived I ..... As you Like it, ii. 3

but at fourscore, it is too late $a$ week

Wednesday the fourscore of April.. Winter's T. iv. 3

from fourscore to thirteen .... Timon of Athens, ii. 2

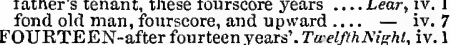

which for these fourteen years.. Meas. for Meas. i.

wetween fourteen and five and thirty? Ifuch Ado, iii. 3

I am not fourteen pence on... Taming of $s h .2$ (ind.)

fourteen they shail not see ...... Winter's Tale, ii. 1
full fourteen weeks before the course.King John, i.

which, fourteen luundred years ago.. I Henry $I V$.

some fourteen, an hour afte

need his help, these fourteen days

ii. 4

a fourteen and fourteen and a half. $\ddot{2}$ Henry $I V$. iii. a dozen or fourteen gentlewomen .....Henry $V$. ii. within fourteen days, at Bristol....2 Henry VI. iii.
sir, March is wasted fourtcen days. JulizsCaesar, ii. whom at fourteen years he sought .....Pericles, v. am some twelve or fourtecn moonshines .. Lear not seen the change of fourteen ...Romeo \& Juliet, $\dot{i}$. she's not fourteen. I'll lay fourteen.
she is not fourteen: how long is it

FOURTH-fourth turned on the toe. Love's L. Lost, a fourth for England-and other.. Mex. of Venice, i. the fourth, the reproof valiant .... As you Like it, v.
third, or fourth, or fifth borough. Tam. of Sh. I (ind.) a fourthe start, eyes! ...............Macbeth, jv Henry, of that name the fourth .....Richard II. iv.
Harry the fourth, or fifth? (rep.) ...2Henry IV. Henry the fourth, grandfather.

Henry VI. ii.

being but fourth of that heroic ......

John of Gaunt, the fuurth son $\ldots . . .3$ - - ii.

resigned the crown to Henry the fourth

Henry the fourth, whose wisdom

Edward the fourth, by the grace of - iv. 7 (procl.)

long live Edward the fourth $\ldots . . . .$. Coriolanus, ii. 3

there was a fourth man................ Cymbeline, v.
what is the tourth? A hurning iorch ..Pericles, ii.

What is the fourth? A hurning torch . Pericles, i.

FO foutra for thine office!...............

we kill the fowl of season.. Measure for Measure, ii.
Whe

as falcon doth the fow

stalk on, stalk on; the fowl sits

Much Ado, ii.

fishes, and the winged fowls .. Comedy of Errors,

ay, when fowls have no feathers

worse than a struck fowl

your man put up the fowl so suddenly.2 Henry $V I$. ii.1

a fowl? and yet, for all his wings (rep.).3 Henry $V I$. y.6

ii. 4 fowl a flight of fowl scattered by..Titus Andron. . .

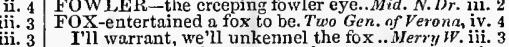
will be sworn, that I am no fox ... Tuelfth Night, i. 5
iii. 3
iv. 1

to seek the lamb here of the fox? .....

this lion is a very fox for his
and the fox carries the goose

for the goose carries not the fox........ royal fox? yes, but you will (rep.)......All's Well, ii. 1 make you some sport with the fox ...
an old Italian fox is not so kind... Taming of sh. ii. 1 than in thee, than in a drawn fox ..1 Hen ry $1 \%$. iii. is hut trusted like the fox

2 HenryIV. i.
Fox-thou diest on point of fox .....Henry $r$. iv.
fox barks not, when he would steal.2Henry $r$. jii. die in that he is a fox yor.

but, when the fox liath once..........

holy fox, or wolf, or both .........Henty VI. iv. as wolf to.... Troilus \& Cressida, iii. the fox would heguile thee..... Timon of Athens, iv. subtle as the fox, for prey ............ Cymbetine, iij. a fox when one has caught her............. Lear, i. hog in sloth, fox in stealth, wolf ........ - iit. hide fox, and all after

OXES-where toxes, geese

Hamlet, iv.

and fire us hence like foxes

OXSIIP hence like foxe............... FOY - les doigts? may foy, je oublie..... Henry $V$. uil. laissez, laissez; ma foy, je ne veux ... $-\overline{\text { Henry }} V$. my reliances on his fracted dates. Timmon of Athens, i. 2 the fractions of her faith ............ FRAGILE-nature's fragile vessel doth - v. RAGMIENT-guarded with fragments. MuchAdo, i. from whence, fragment? Why.. Troilus \& Cress. v.
the tragments, scraps, the hits........ it is some poor fragment ...... Timon of Athens, iv. yo, get you home, you fragments! .. Coriolanus, i. (like fragments in hard voyages).... Cymbeline, $\mathrm{v} .3$ thousand fragrant posies (rep.). Merry $W$. iii. I (song) the fields are fragrant will drown the tragrant meads .... . inhabits our frail blood ........Twelfh Night, iii. we are all frail ............ Measure for Measure, ji. nay, call us ten time to....

the soul's frail dwelling-house

is this frail and frail sepulchre is this frail and worthless trunk...... Henry $V$. iii. 6
she did corrupt frail nature $\ldots \ldots \ldots$ Henry $V I$. jii., 2
his head's assurance is but frail $\ldots$ Richard $I I I$. iv. 4

King John, v. 7 her trail son, amongst my brethren. Henvy VIII.iii.

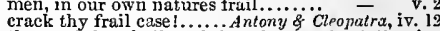
the one is but frail, and the other.... Cymbeline, $i$. or loss of that, you term her frail ...

Perirles, i. 1 if sanctimony and a firail vow ............. Othello, $i$.

FRA that in wisdom never was so frail .... - ii. FRAILTIES - our naked frailties hid... Marbeth, ii. 3
been laden with like trailties.... Antony \& Cleo. v. let her consider his frailty ............ - iil. 5 alas, our frailty is the cause........... Thelfth Night, ii. 2 by the instruction of his frailty....... from the organ-pipe of frailty ........King Johus, . . 7 which frailty, and want of wisdom, Hewry $V I I I . v .2$

tempt the frailty of our powers. Troilus of Cress. iv. 4
frailty, thy name is womant
is't frailty, that thu errs? for sport, and frailty, as men liave?

TRA NE-frame some feeling line. Two $G e n$. of Ver. iii. 2 hath a heart of that fine frame.... Twelfth Night, i. I than faults may shake our frames. Nea. for Mea. ii. 4 nadness hath the oddest fi............ - vense of frame the season for your own harvest. Mruch Ado, i. 3 toil for that at frugal nature's frame?

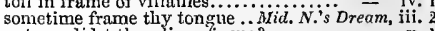
nature, didst thou lions frame?.

ever out of frame ...................... ove's $\bar{L}$. Lost, iii. I in your fine frame hath love no...... $\overline{\text { iv. }}$. therefore frame your manmers ....... - i. very mould and frame of hand ...... Winter's Tale, ii. 3 but let the frame of things disjoint ...Macbeth, iji. 2 the frame and the foundation....... I Henry $I V$. iii. I the whole frame stands upon pins...2 Henry $1 V$. ifi. 2 in peace, which heaven so frame! were the whole frame here .......... Henry fear frames disorder.................. and frame ny face to all occasions... Henry $V I$. iii. 2 but you frame things .............Henry VIII. i. 2 perse tlian I could frame employment - iv. 3 thou wilt frame thyself, forsooth ... Coriolanus, iii. 2 my warrior; I holp to frame thee.... I'll frame con venient peace............ preparedly may frame herself .........
tirame yourself to orderly solicits... Cymbeline, ii. 3 slould frame them to royalty unleumed $-\overline{i v}$ iv 2 made many princes thither frame.Pericles, i. (Gow.) frame the business after your own .......... Lear, $i .{ }^{2}$ wrenched my frame of nature $\ldots \ldots \ldots \ldots \ldots$ Hamlet i. 4 this groodly frame, the earth

二 ii. 3

put your discourse into some frame...... - iii. bloody passion shakes your very frame. Othello, v. 2 never framed a woman's heart....... Mu ${ }^{\prime} /$ Ado, ili. I
save this of hers, framed by thy villany - v. I 


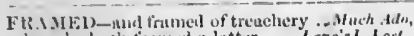

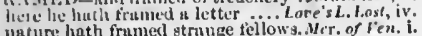
uacure hath frumed strumge fellows. Mir' of ren, f.

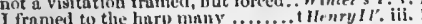
I framed to the hurl many .... Henery to iv. 3

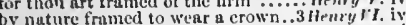

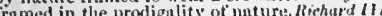
from the prime eruighos

from the prine creaton ere she trined $\bar{p}$ th wherein this trumk was framed .... Coriolanus, v. a young had framed of another lecer.. Tilus . Ind.'iv. frnmed of the cyelop'y size

when Nature frumed this piece ericles, iv, 3 was first trumed flesh to raise iny

he's fromul is fruitfin as the free eleinents -

FRA IING - in fruming artist

ERA N t $t^{2}$ OLD-a very trampold life. Wer

KANCE-let the court nf F rance show

110 de fasthion of France: it is not (rep.) -

and go well satisfled to trunce ngain

on saturduy we will return to Fra

to a laly of France, that he ealled

wh woo these girls of Franee?

rs, ii. 3

of this sweet lass of Franee

his round hese in France .... Merchan of 'enic

from finth the royal blood of France.

I liave nothing in France (rep.)

you tame, I think, from France? ...

ie stole from France, as tis repro

his lorkship will next morning for Frane -

to my lord lafeu? I am for France.

I am fur France too; we shall speak

I have seer you in the court of Frunie

where France? In her forehead. Comelly of Err. iii.

that ran between France and it.

what would France with us? (rep.).... Kins John, i.

for contrnlment: so answer France

as lightning in the eyes of France

till she had kindled Frunce..............

we must sjeed tior France, for Fra

peace be to Franee; it France in peace

if nust, bleed France, and peace ascen

whr return trom France to England

this great commission, Fra

I lo defy thce, F rance; Artiinr of

the coward hand of France ean win

these flars of France, that nre

these flags of France, that nre
who, by the hand of France,

remured by a staff of Franc

France, hast thou yet more blood.

more tlinn we of France; rathe

I like it well: France, shall we knit

Austria and France shost in each

better than a fist of France ........

a philip of France, if thou be pleased.

and France (whose urmour conscien

the outward eye of fickle France

France friend with Englnnd:...

France is a bawd to Fortune...

fellow, is not France forsworn?......

Pbilip of France, ou perit of ........

and raise tlic power of France upon.

pale, Franee? do not let go (rep.)...

France, thou shalt ruc this hou

France, I ain burncd up witli.........

when I was in France, young. ......

how goes all in France? Irom in France

in Frane? under whose eonduet ( $r(?)$.)

count Melun, a noble lord of France

lui! , woble prince of France?

FliA.YCL-theretore to l'sunce,

take you one quarter into frumee..
France being ours, we'll beiul it to

large und ample empery, o'er France

ately sending into france, dicl elain

alt the court of France will be disturbed

rance hath in thee found out a nest

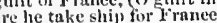

and thenee to france shutl we convey

all three swim brothers to

we must to France together..........

sworn into the practices of lrance

id not seduce

now, lords, tor Franes; the entermize

let us to France! like horke-lecehes

the sick and f'eeble parts of France

and womby vaultuges of France ....

your own losses, it he stay in Fance?

devant les seigneurs de France

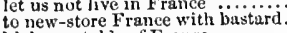

tigh constable of France $\ldots$ mo......

this your air of France hath blown...

the nost active gentleman of Frunce

better than a churlish turf of France

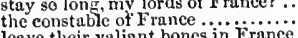

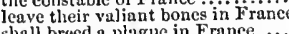

shall breed a ptague in France ......

a most prave pattle here in France

or in France, or in England.

ne'er from Franee arrived more happy

coming in behalf of France $\ldots \ldots . . . .$.

straight back again to France

i' the spital of malady of France...

unto our brother France, and to our

onr fertile France, put up her hovel

from France too long been ehased....

the friend of France, for I love Fran

when France is mine, and I (rep.)

quaud j'ay la possession de France ...

Ireland is thine, France is thine

il n'est pas le eoutmne de France ...

for the maids in France to kiss

that the king of France, having :.....

contending kingdoms of France and

'twixt England and fuir France .... - v.

crowned king of France and England - v. 2 (elo.)

of Franee: give me my steeled coat (rep.) -

France is revolted from the lingli

whom all France, with their chiet

bonfires in France forthwith .......

the finglish forth the bounds of in race -

France, triumph in tlyy glorieu

all France will be replete with .......

before the kings and qucens of France

la Pucelle shall be Franee's sai

cownard of France! how much ......

applauded through the realm of France?

is this the scourge of France? the seas, and to be crownerl in France

mareh in England, or in France

France, thou sliat rue this treason.

we escriped the pride of France

woul fend of France, and has of aii.

base muleteers of France! .............

public wrongs, sustained Here po place for Henry's....

be expulsed from France, and not

undoubted hope of France! stay

look on fertile France ..............

the pining malady of Franec . . .......

'Talbot hatl set footing once in Frnuce

Charjes the rightful king of Frane

the sen from lingland into Franee...

and lost the realin of France?

our regent in these parts of rince

if he miscarry, furewell wars in France

else, firewell Talbut: Trume $\ldots . . .$.

we mourn, Franee smiles

from thance to henven fly

to the ruge of France his sword

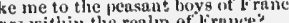

to fright the realin of France..........

that shall make all l ranee a feird....

the realums of linglund anct of l' rame

a man of grcat autionity in Fratice.

transportecl uresently to

on, my londs, and France be tirtiuni

never went with lis fores into Frurice
sll her chivalry lath been in Fravee

whom she dirl seud to France interruption, spite of France?

we will, in France, hy Gerl's truce

of France: Jagues of Chatilion (rep.)

that they lost France, and made.

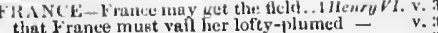

now, franee, thy glory droopeth to.

lieignier of linume, I give the kingly

truce slall be proclaimerl in F rave

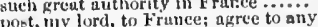

post, my lord, to Frunce; a ranee......2 thenry

presence of the kings of France and sicil -

deup

how France and Frenchmen mirtit be

momuments ol conguered France.

for linee, 'tis ours; and we will keep

staict in France, and starved in France

prophesied-France will be lost ere long -

which I will win from France

which $I$ will win from France

Einglund, France, and Ireland

your regent in the renlm of France.;

for soldier's puy in France

what news from France? .............

that you took bribes of France

ever had one penny bribe from France

the fort une he hath had in France...
would have stuid in France so long..

to France, sweet suftoline were soli to France

message from the queen to france

which sold the towns in France.

giving up some more towns in France

that inale all France to quake ...... -

to France, to Franec, and get what ..

muny a battle have 1 won in France
she-wolf of France, but worse thau (rep.)

revelled in the heart of France ......

cut the sen to France, and ask the .

and, having France thy triend ...

and son, are gone to Franec for aid ...

if France can yield relief

peers of France should smile at that

the alliance that he seeks with France

lewis of France is sending (rep. iv. 1)

nocking marriage with a dame of Fruce

as well as lewis of France, or the Earl

baeked with France (repeated)

letters, or what news, from France?

the friends of r rance our shrouds...

to the king of France hath pawned

our ancient right in France again... Richard 111 . iii.

his contract by deputy in France...

vour tiuther then in France...........

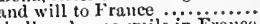

shall make me smile in fraice....

since lust we saw in France?.......

us well in France as licre at bónc..

hetwixt Englaud and France...

is nimed, your wars in rance.....

the spells of France should juggle men

and teather, that they got in F runce

the rurest our ladies in France....

being so fur provoked as I was in Frauce -

for the rest, have done in France .....

attend the lords of France and Burgundy

vines of ranee, and milk of Burgundy

call Franec, who stirs; call Buraundy

queen of us, of ours, and our fair France

thou hast her, Franee; let her be thine

of leave-taking between Frunce and him
France in eholer parted! and the king

since ury ynung lady's gning inte I rance

are to France the spices ant speeulations

from France there comes a power...

piaty th the udvantases of pol

letters liad you late from Franee?

France sprends his banners in our

theretire greut Frunce my mourning .

um I in Tahec? in your int

it toucheth us as Fince invades .......

ant wishe's bend aguin tosward France

in France of the txist rouk and stution

is in suert ente frum $\mathrm{F}$ rance. ill demeaned himself in France.........

sent rance be won into thance.

Thess the flower-de-luee of France - iv

colours, often borne in Fraoce .......

What brings thee to France?

the queen from France hath brough

why the king of Frunce is so suddenly

v.
v.
v.
v.
v.
v.
y.
i.
i.
i.
i.
i.
i.
i.
i.
i.
i.
i.
i.
i.
i.
i.
i.
i.
ii.
iij.
iii.
iii.
iii.
iii.
iii.
iii.
iii.
iii.
iv.
iv.
iv.
iv.
iv.
iv.
iv.
iv.
v.
i.
i.
i.

i. 4

ii. 6

ii. 6

iii. 3

iii. 3

iii. 3

iii. 3

iii. 3

iv.

iv.

iv.

$\mathrm{v}$

ii. 5

iii. ? 
FRANCE-since he went into Frunee ..Hamier, y. 2 FKEE-thou shalt tre long be fiee

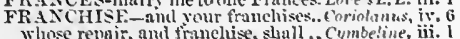
Fhlinse repain and frin

domner la literte, le tranchisement. .. Henry $r$. iv. 4 FRAXCY - -et heres frawcic come, frim Fruncis be trief.

Frances tute, the bellows-mender... vrit. . . D. i. Watertom, and Francis (Sunint...........kirhurd li. ii. I Tom, Dick, and Prancis. They tis

never leave ealling - Franeis, that

Frme look to the door there, Fruncis . sir.... and Francis liekhore, and Will sinele - iii.

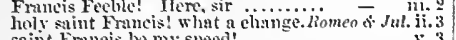
saint Frneis be my speed:

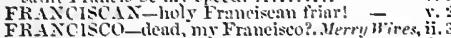

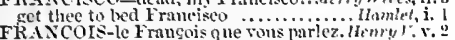

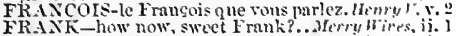

R.ANk-how now" sweet Frank?
thy fither's fince; frank nature

thy trank election make $\ldots \ldots . . . \cdots$.

with frank and

the native of our so frank long

but to be frank, and give it thee. Romeo

bearing with frank aplearane

FR.L g god hamd. a framk one

Ger.

FRANK ER-bear you with frnoker spirit. Othello, iii.

FRAXKFORT

FRANKLIN-boors and frankfint.Mer. of 'pen. iii.

FReres a franklin in the wild of Kent.I Henryllyi. 1

would fit a franklin's housewife.

very frankly he confessed his trenson. for. Moctie

now to forgive me frankiy ....... Ilenryllill. ii. 1

that frankls would have fed

could I frankly use.................. on of Athens

controlled in that he frankiy gare. Tilus tnd ron
of their encounter frankly jugde ...... Hamlet,

this brother's wager frankly pias.

to make me frankly despise myself ..... othello,

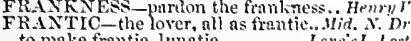

to make frantic, lunatic .......... Lore's L. L.ns'

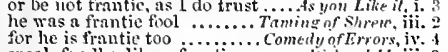

Comedy of Errors, iv.

speak fondly, like a fiantic man ...

let frantic Talbot trimmph

woman, end thy frantie eurse....... Richard lil. i. 3

$O$ preposterous and frantic ontrate.

[Col. Kne.] beholders of this frantic pliay -
sly frantic wretch............ Titus tudronic

die, frantic wretel, for this accursed

FRANTRELY-low franticly I squnre

FRATRUNI-ad manes fintrum .. Tilus Andron

the frand of men was ever so...Mnch Ato, ii. 3 (song)

seenre from force and fraind

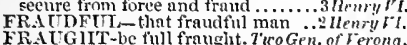

FR.A tGilT-be full fraught. 7'zoGen. of Terona,

vessel of our eountry, riehly friught. Mitr' of t'

so frnught with curious business. minter's Tale, iv, 3
fraught with the ministers...Troilu \&. Cress. (prol.)

thou franglit the court with thy ..... Cymbeline, i.

that hath discharged her fraught. Til us t indron
wisclom whereof I know you are fraught... Lea

wisclom where of 1 knotw you are
swell, hosom, with thy fraught

FRAUCIIT-AGE-onr franghtage, sir..... othello, iii. 3

disgorge their warlike fruughtage. Troil. $\&$ Cr. (prol.)

Col. $K n$.] the franghting souls within. Tempest, i. 2
FRAY-there is a fray to he fought. Merry Mirps, ii. I

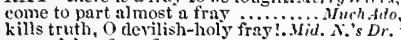

are quicker for a fra .................

shield Lysander; if they mean a fray!
thon partest a fur fray $\ldots$.......... Lore's L.. Lost, v.

than thou that maliest the fray......Mer. of Jertice, iii.

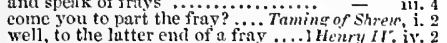

many dearer, in this bloody ti: $\ldots . . . .3-$.

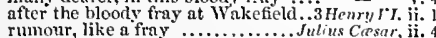

glad I am, he was not in this fray... nomeo of Jul.

O me! what fray was here?

where are the vile beginners of this fray?
Benvolio, who began this bloody froy?

Benvolio, who began this bloody frny?
FRAYED-as if she were frased.Troilus fress. iii. I
FRECKLE-in those freekles live ...Mil. N. SDr. ii. I

FRECKLED - a freckled whelp ......... Tempest, i.

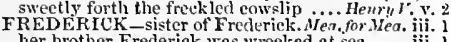

her brother Frederick was wreeked at sea - iit.

to be adopted heir to Frederick.

dirke Frederick, hearing how that FIEE - what a torment I did free thee?.. Tempest,

thou shalt be as free as inownia..........

thought is free.

iii. 2 (son

be free, and tare thou well?.

und trees all tinults

sul of the disposition

I will be thee trom thes.

free from our fiults, as fimit

who is ns tree firm tonch or soil.

you ure not tree, fior the Lord's

I brenthe ties imenth.

let them the tres, marry them...........

the time is free: I see the

and free trom other ntisbegotten

to my inheritance of tree descent...

tree from

let ninn go free, and let not.....

making God so fiec an offer...

being free from rainness.

thke with you free power ......
free my country from ealnity

o'ereharging your free purses
they set hinn free, withont

my hand would free her, but
for prinees should be free.......

England's roygl king be free ....
free from oppression, or the stro
she hath been libernl and free.

is not so free from mud ............
free lords, eold snow meits wit]

to free us from his Father's...

free from a stubborn opposite.

these hands are free from in

to set him free from his enptivity
thou sct'st me free, and ehjelly.

yield thee my free eonsent

inexamined, free, at liberty
if you do free your ehildren

if you do free your ehildren.
with free partlon to each man

$I$ as free furgive you, as I......
and free us from lois slavery

that I am frec of your report

throurh him drink the fiee a

I'll may the debt, and fiee lin

want'st by free and oftered light.....

be shmuld be free, as is the winc

as free as vords to little purpt...

as frce as words to little purpose thou shalt be fret. .....................

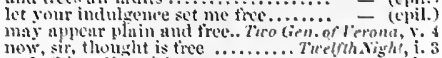

frue, lestred, mul valimt.

nim the free minils, that weave

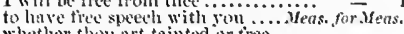

Whet her then art tainted or tree
and fiee pardon, are ot two liouses

that will free your life

he youn as tre to us

Foluble and tree of grace! ...... Lowe's L. Lost, iii. I

Tempest, $v$ | I'REE-for I dare so fin tree him...

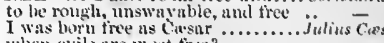

when evils are most the?

fo live afl free men?..............

so, I min free: yet would net so.

fec fom the bumlange you ure in... -

if . nutury be free and lyulth

nuil thou sures

when I dial inake thee fire ............

for my more tree entert nimment.

cymbeline, iv. 12

will his free heurs langilish tior

I could tree tI or I; whate'er it he

piek thut holt, then, free for ever!.

here we set our prisoners free... Titus.indronicus, $\mathrm{i}$.

Antibehus from incest lived not tree .. Pericles, ii.

and lowes us to our free election $\ldots$... - ii.

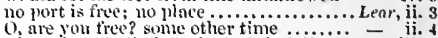
when the minul's free, the hody's delicitio - iii. 4 lemving tree things, and happy shows .... $-\overline{\text { iii. }} 6$ are the men, but I mim bansiced.. Romeo o.Ju. iv. I heen most tree and bounteous .......... Hamlet, i. 3 is it a tree visitation? come, come........
make mat the gnilty, ant appal the tree of our clemuncls, most tree in his reply...

and we that lmve tree souls.............

strugaling to be free, art more engnged
aml thy free nwe pays homate to us....

generous, and free from all contriving

fice me so tar in your most generous

revuld not my unhoused free eunditiou.... Oshello if sale actions muy have plassnge frec $\ldots . .$.

but the fire contiort whiel from thenee he -

lut to be fiee nmel bounteous to her mind

the Mloor is of a tree and open mature....

when this advice is tree, I give, and honest

tramed is truittul as the free elentents .

not bouml to that all slaves are free to

is tree of sprecth. sings, plays .............

nold her free, I do beseech your honour.

the next night well, whs free and merry.

free from our fiensts thal bnnquets

of his displetsure, for my free specen!...

.. Richarel Hi. i. i

reins and spurs to my tree speech.

and with a tree desire, attending

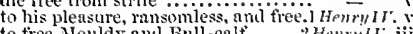

go, and be tree angin; as sutiolk's

pronounce free pardon to them ail

from that torment I will free myself. $3 H_{e n r y}$

Richard $1 /$ t. iii.

have their free voies .............

Henrn rill.

speak this with as fiee a soul as I do?

courtiee and honest men, our just ..

than to make up a free determination

to be a speaker tree; when I am whe.

too gentle, and too free a man

my free drift jalts not ......... Timon of Athen

out of his tiree love, hath presented

being free itself, it thinks all others so

liave I been ever frec, and must my
fly, whilst thou art blessed and free. 'd and entranchised.... Winter's Tale, ii.

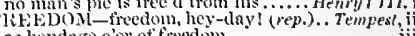

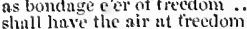

but yet thou shalt have tieedom $\ldots . . .$.

I phy my freedom ne tras-trip... Thelfh Night, ii. lief have the foppery of reedom...YMeas, for Meas. i. charter; and your eity's freetom ...... gained my treedom ........... Comedly of Errors, $v$.

gim frestom, buast of nothing else ...Richart $11 . \mathrm{i}$. what eonecrns his fiedtom nuto me? Illenry ri. v. lial reewerel your ane ient fredom.2 Henry 1. iv a keeper with my freedom trimon of th. i. 2 (graee) Liberty! Freelom! 'Ty'nnmy is dead! - iii. Liberty frectom! Tynmyy is dead

liherty, freedom, and enfranelisement

folly could not give me freedom... Aniony \&. Cleo. i. courtiers of beanteous freedum ....... if of my freedom 'tis the main part ... v. tight for freedom in your cloice... Tilus Andron. i. I FREE-FOOTED_-goes too free-footed......... Lear frec-hearted gentleman of Athens. Timon of dth. iii. FREELIER-I should treelier rejoiec.. Coriolants, $\mathrm{i}$.

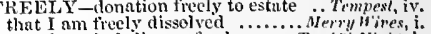
and thou shalt live as freely n..... Trelih Night, $\mathrm{i}$. nost freely I eonfess, nyyselt' ........ as freely, son, as God dill wive her me. Much Ado, iv. Yom have no renson, 1 do it realy .... iv ifreely told you, all the we freely eope your conrteous.......... It - iv. in the Tusen serviee, freely have ....All's $\|$ ell,. . so you contess treely, therefore ...... too dear, tor what's given fieely ... Winitr's 'ule, j. slicak, from an infant, freely ....... pale, at whit it rlid so trecly............ Afreleth, i.

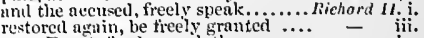

now, Bagot, freely spenk thy

hefire I freely speak my mind ........ you would drink freely

ryeak freely of our acts ................ Henry $\boldsymbol{V}$.

this prisoner treely give I thee....... 2 Honry $/$ I. iv.

this urisoner frecly give I thee......2 Honry VI. iv.
thy husband's lands I freely give ...3 Henry Y. iii. my his highness live in freetom... Henry FIII. i. to give uny por host freetom........ Coriolanus, i. and disprepertied their freedoms ...... 


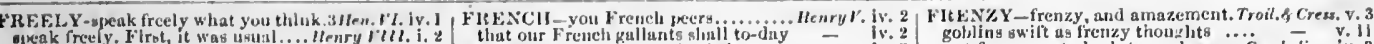

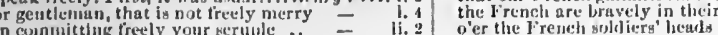

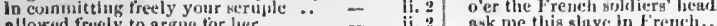

allowed frecly to argue tor lier ...... - it. 2 sak me this slave in French

opposing freely the beauty of her ferson - iv. 2 discuss the same in rench

licar ine spouk. Freely, fisot fülier. Timon of Ath. i. i

1 gave it frecly ever; and there's non

and cume truely to gratula

the French have reinforied thicir

here coincts the heralis ot the Frisusth

it lo spoke trecly out of unany

of ten ther of the statigh

the lamentation of the French.

hall hear the olise frety. Antony of Cleopalm,

and sing onr bondage fredy .......... Cymbeline, iii. 3

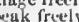

princes French, and peers, liealth

love ne soundly with your French licurt -

more F reneh I thall never (rep.)

leave tin sjeak, freely I'll sicak

who frecly give to crery onc that.

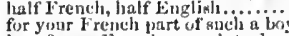

wh lay our service frcely at your fect

and the ludy sliall say her inind freely

for your French phrt of such a

now fle upon my talie French ........

fit French city, for one fair Fremel

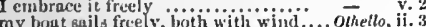

I think it freely.

with this adlition in lirench $\ldots$

not frenzy, not alssolute mal in 's .. Cymbeline, iv. 2

time to apeak your bosing fred

we think the subtle-witted French

wounds I will lend the French

the strut lori Talbot and the Firench

three and twenty thousand of the
the French excluimed, the devil

the honour of the forlern French .....

'tiy the French Dauphin sucth to thee

remember to arenge me on the french
the french tiave gatliescd lical.....

the Freneh have gathered licad ......

all F'rench and f'rance excluins

ten thousatid rench liave ....

yelpiog kennel of French curs?

the elustering lrattle of the French

rushing in the towels of thic Fre.uch.

tis a mere French word

turn astin nnto the warlike Fretich.

I shall be rescierl by the French.

our sovereign and! the J'retich king ..2 Henry re. i.

the French king, Cliarles $\ldots \ldots \ldots . . . . . .-i$. I (articles)

Somerset be regent o'er the French...

your grace lord regent o'cr the French -
went to span-counter for French crowns -

can speak French, and therefore

the Dauphin ald the French to stooj.3 Henrylrl.i.

to crave the French king's sister

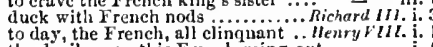

the devil, upon this French going-out

the French journcy; I replied

you can speak the French tongue.....

one your French crowns have no. Mid, $N$. L.

comes in embassy the French king's. Love
ransom him to any French courticr for

a fairer name than French er

how sny you by the French lord...Mer. of $\bar{V}$ enice, i. 2

neither Latin, French, nor Italian

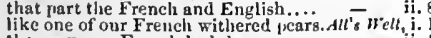

they say, our French lack language..

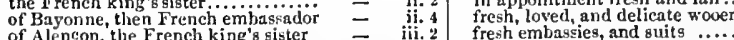

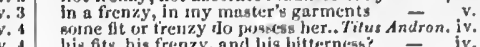

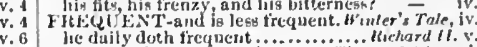

he duity doth frequent ................ liechard 11 .

Frelist that some fresh water...

ficod shall lie the fresh torook muscles

our garments are now as firbli

our garments feem now as fresh

'tis frekh lingrning with

as when they are free

and these fresli nymply
more fresh in Julia's

the luee is a fresh fish.

Hithered bering-man, a fre
of the yrodigal, treeth and new

how quick and fresli art thoul.

and then "twas fresh in murn

humble slough, und appear fresh $\cdots$ - ii. 5 (letter)

and salt waves fresh in love ......... Me- iii. 4

full in the tresh lap of ........ Mid. $N$, ", Dreum, ii.

that cost the freeh blood dear ........

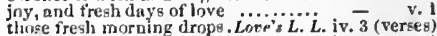

when their fresh rays have mote - iv. 3 (verses)

you incet in some fresh clicek.... ds you Like st, iii. 5

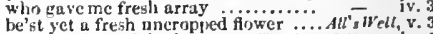

virgin, fair, and fresh........ Taming of Shrpu, iv.

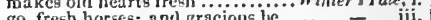

go, fresh horses; ant gracinus lic

kissce the hands of your fresli princess $=$ jy. 3

of men, begull a freeh assault ..............Facbeth, i.

fresl expcctation troubled not ..........

the fresh grecn lap of fair ..............

fresh as a bridegroom.................

some six or seven tre oh men $\ldots . . . . .$. -

as many fresh streams run in one $\ldots$.... Henry $v_{i}$ i. 2

mowing like grass your fresh fair virgins - jii. 3

casted slough, and frerh legerity

dinners, and fresh spits

thy friendship makes us fresh

dead, and hleeding fresh

under a fresh trec s shade .....
shall follow with a fresh supply

shall follow with a fresh supply

ïHenry VI. iii. 3

fresh and yet unbruised Greeks. Troil.f. Cress. iv.

fresh kings are come to Troy

with a bridegroom's fresh alacrit

fresh embassies, and suit

look fresh and merrily.

do you know the French knight ........Pericles, iv

we'll e'en to't like French falcoders.... Hamlet, ii.

French, and they can well on horseback -

the F rench ne'er got them ..........

take heed of this French earl.

Italian, or French, let him speak

against six Frencli aw pon

to he am fresh of elinit.....

to he more fresh, reviving...............

resh thy and whiter than the slieets! - ii.

tis their fresh supplies. It is a day.. -

he hides lim in fresh cups ...........

FRENCH-CROVIN-COLOUR-

by these F rench confront your city'.... Kinacbeth, ii.

the dancing thauch, amazed, vouchsate

the dancing tauners of the French
$O$ foul revolt of French iuconstancy $i$

if but a dozen Frescle werc there.

the Freneh, my lord; men's mnn
many thousand warlike Fredch

go meet the French

or your French-crown-colour heard. Mid.N. Dr. i. 2
FRENCIIMAN-

then fresh tears stood on her cheeks

tilt the fresh taste be taken .....

for look, how freen she looks.......

therefore let's have Presh ones....

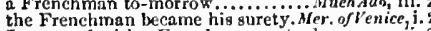

I reasoned with a Frenchman yesterday

which is the Frenchman ....

dit's $\bar{l}$ 'ell. iii.

go I to make the liench lay down.

upon whole thousands of the French

pot spirit in the Freneh.............

Who's that? a Frenchman? Faith, sir
before the Frenchman speak a word

done like a Frenchman............ iterry $V 1$. iii.

imagine him a Frenchman and thy foe -
stoop unto a Frencliman's mercy.. 2ltenry $l$.

there is a Frencliman his companion.

and hear him mock the Frencliman.

the rusks of many thonsand 7 rench

speuk it in lirench. king ...............

one fower against the French.
the french ant..... W clsh baying him.
who is sulstituted gainst the Frenel

FIENCIIIEN-of worthy Frenclinicn. IIt $^{2}$ Wel

since Frenclumen are so braid .........

market-place in Frenchmen's blond. Kin
return all gilt with Frenclimen's blood

did march three F renchmen

and view the f'rciclimen ..............

lenry $V^{\prime} \mathrm{iii}$

the Freneh embasaulor .....

the French unjustly gloze

try what thice dastard Frenchmen dare

at leust flve frenchunen died to-night

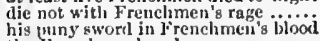

did seat the French beyond

who on the French ground plinged

not only arm to invarle the French

the French, advised by good intelligence - ii. (ch

and now to our Frencli causes

embassador from tlie French conies

and the I'renchmen fly; now help

shall the Irenclimen gain thereby

and keep the l'renchmen in allegiance - v.

fortify it strongly 'gainst the F'reueh

none of the French uplisaided

almost no better tlian so many Frenei

your l'rench hose oft

the fuhenen might be kept in ake?

we put fresh garments on him ............ Lear, ir.

the fresh mnrning's dew amnnt fresh femalc bnds ghall you... Romeo of Juliet, i.

and to give ratiety a fresh appetite..... Othello, ii. I

she is a most fresh and delicate creature
of the moon with fresh suspicions?....

her name, that was as fresh as Dian 8 visage - iii. 3
the fresh gtreams ran by her ..... - iv. 3 (solig)

FRESIIER-but fresher than bufure .... Tempes, i. 2

held familiarity with fresher clothes.. All's ${ }^{\circ}$ ell, v.

beheld a fresher gentlewoman?.. Taming of sh, iv. 5

they'll be in fresher robes; or they.... Henry Viv. 3

for it grows again, fresher than e.er.

much more a fresher man.... Troilus \& Cressida, y. G
FRESHES-the quick frcslies are..... Tempert. iil. 2

FRESIEST - my freshest reputation... Winier's $T$, i.

ii. I to the freshest things now reigning Coriolanus, $v$.

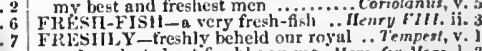
FRlill, Y-freshly beheld our rojal .. Tempest, v. lorks he ay freshly as he did ..... An yout like il, iii. 2 bit freshly looks, and overbenrs... yet freshly pitied in our meunorics..Henry 'tIIt. v. 2 Flts:

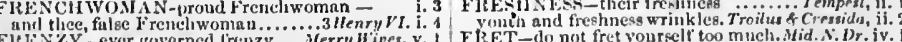

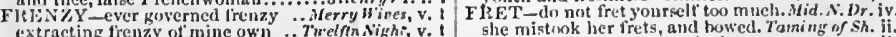
extracting frenzy of mine own . Twelftn Night, v.
poct's eye, in a finc frenzy rolling. With. N. s. Dr.v. poct s eye, in it finc frenzy rolling. Mirt. N. s. Or. v. humours well his trenzy ... Commely no Kirrors, iv. 
FRET-that struts and frets his hour ... Hacbeth, and he frets like a gummed velvet.. 1 Henry $1 \%$. ii. fret fetlock deep in gore.............. Henry sit, and fret, and bite his tongue $\ldots . .2$ Hen $y$ VI. i. 1 stamp, rave, and fret, that I may....3 Henry VI i. 4 that would fret the string ........Henry VIII. iii. grey lines, that fret the clouds... fret, till your proud heart break .... $5 \overline{\text { Cleo. iii. }} 6$ with cadent tears tret channels. though vou can tret me, you cannot .. Hamlet, iii. 2 though parting be $\mathrm{f}$ fretful corrosive...2 $\mathrm{Hen}$ ry $\mathrm{VI}$. iii. 2 nding witl the fretful element .... Lear, iii. I

FET

RET $F E D$-fretted in their own grease. Merry till they lave fretted us a pair .... Richard II. iii. 3 his fretted fortunes give him hope.Ant. \& Clco. iv. io this majestical root fretted with........ Hamlet, ii. 2

FRETTEN-[Col.] Jare fretten with. Mer. of I'enic a commodity lay fretting by you. Taming of Sh. ii. he may well in fretting spend his.

filled with a fretting gust ...........3 3 Henry $V l$. RIAR-Robin Hood s fat friar. Tu'o Gen. of $V^{\prime}$ er. what's your will, good friar?

adieu, trusty Pompey. Bless you friar what news abroad, f

what news, friar, of the duke? ..... something too erabled that way, friar

thou art deceived in me, friar... farewell, good triar; I ply'y thee.....

so please you, this friar lrath

good triar, I know you do...................

good even! Friar, where's the pro

fricr, thou know'st not the duke

Opeace; the friar is come

this a good friar, belike!

let this friar be tound.

and that friar I saw them (rep.).

gooxl triar, let's hear it

is this the witness, friar? ............

thou foolish friar: and thou perniciou

there is another friar that set them

thon nireverend and unhallowed friar!

for the friar and you 1
do yon the oifice, friar

vour triar is now your prine

there was a friar told me of this man

friar, advise him; I leave him........

to be married to her

uncle! signior Benedick! friar

friar, it cannot be, thou see'st ....

let the friar advise you .................

in which, good friar, I shall desire your

here's the friar ready

before this friar, and swear to marry her

betore this

sott and fuir, friar; which is Beatrice?

whom he supposes to be a friar

the friar of orrlers grey. Taming of Shrew. iv. l (song)

priests and friars in my realm ....... Henry III. i.

[Knt.] my ghostly friar's close cell. Romeo \& Jul. ii.

O friar, the damned use that word.

o tell me, friar, tell me, in what vile

I'll ti the friar, to know his remedy

tell me not, friar, that thou

whis the friar e

holy liraters me lettrom the friar? (rep.)

holy iranciscan friar! brother, ho! ...

here is a friar, tliat trembles, sighs

a creat suspicion; stay the friar too.

a riar, and slaughtered lioineo's man

FRIDAY-eat muttion on Fridays. Neas. for Meas. iii. 2

will I, Fridays, and Saturdays .. As you Like it, iv.

FRIEND-the wreek of all my friends.. Tempest,

thy case, dear friend, shall be.

that these, his friends, are in ........

is to speals well of his friend

thy good friend Trinculo

my goorl friends, hark

first, noble friend, let me

welcome, my friends all
in ahsence of thy friend

he leaves his friend

I leave myself, my friend

delivered by a friend that cane

he from his friends receives...........

the secret nameless friend of yours...

a letter from your friends.

jour friends are well

om dearer than a friend.......

s a sweeter frien

sir Valentine, my friend

to eross iny friend in hi
FRLEND-letters to my friends. TwoGen of Fer. iií. I ton my riend, sir Thurio...

triend Valentine, $a$ word

and from me thy friend

whom she esteemeth as his friend.

being entreated to it by your friend.

for your friend's sake

my friends-

my talsehood to my friend ....

your servant and your triend.

thou counterfeit to thy true friend

in love, who respects triends?

thou common friend, that's without.

(for such is a friend now)

that a friend should be worst

two such friends should be long foes..

Got's plessing, and your friend...

he speaks but for his friend

and one that is your friend

grated upon my good friends for .....

and friend simple by your name

that we may be friencs

but, if you have a friend here.

there is a gentleman, my dear friend

follow your riend's counsel.

and his friends potent at court

and so we'll all be friends.

what country, friends, is thi

now, good-morrow, triends...

save thee, friend and thy greet

Twelfth Night, i.

thy friend, as thou usest him

in leaving his triend here in

belong you to the lady olivia, friends?

and the worse for my friends...

the better for thy friends

and by my friends I am abused....

why, then, the worse for my friend
please you to be one of my friends

one word, good friend ....... Mteasure for Measure

remaining in the coffer of her frien

I thank you, good friend Lucio.

he hatl got his friend with child

where were you born

a gentleman, and a friend of mine

when the steeled gaoler is the frien

his friends still wrought reprieves.

there's other of our friends will greet

our old and faithful friend,

thanks good friend Escalus.......

my dear friend leonato, hat

0 , I ery you mercy, iriend

will you walk about with your

and his friend's reputation

give not this rotten orange to your friend

to link my dear friend to a common.

and chnice of friends, to quit me of them

a very even way, but no such friend.

be friends first. You dare easier be friend

or that I had any friend wom

never love that which my friend hates

come, cone, we are friends: let's h.

it stood upon the choice of friends.

to seck new friends, and stranger

but. gentle friend, for love and courtesy

and good-night, sweet friend

neighbours will not make them friends

good-morro w friends. Saint Valentine

joy, gentle friends! joy .........

and farewell, friends; thus Thisby ends

sweet friends, to bed. $-A$ fortnight .

Five me your hands if we be frends

then forester, $m y$ friend

he's a good triend of mine $\ldots \ldots \ldots . . . .$.
very good friend: for what is inward

you'll ne'er be friends with him

only to part friends: court'sy, sweet

never come in visor to my friend

since, to wail frends lost.............

my black gown for a faithful friend

worthier friends had not prevented. $M$

the ripe wants of my triend

ii.
ii. I
Ii. 4 wourren metal be friends with you
i.

ii. 4 my honest friend Launcelot........... sir for we have friends that purpose

friend Launcelot, what's the news?.

sweet friends, your patience tor
our friends all stay for you

cooled my friends, heated mine enemi

should sunder sich sweet friends ....
RIFN D-beauties, livings, friends. Mer.of Fen. iii my old Venetian friend. Salerio?.... - iii 2 tell me how my good friend doth.... - iif. 2 some dear friend dead ............ - 111.2 the body of my friend, and every word = your dear friend $(r e p$.$) .............$ away to Venice to your friend...... 二 iii. 2 bid your fiends weloome... hear the letter of your friend ........ that you shall lose your friend $\ldots . . . .$.

$I$ and my friend, have by your wisdom

a friend. A friend! what friend? (rep.)

my friend Stephano, signify

in the hearing of these many frieuds

if we dil derive it from our friends

of his velvet friends [Col. Knl,-friend]

good even to you, friend .............

ii.

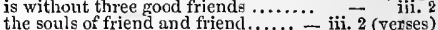

how now! back, friends $\ldots \ldots \ldots \ldots .$. - iij.

a hard matter for friencs to meet.... - iii. 2

good even, gentle friend...

bid your friends; for if you wili be...

I have been politic with my friend ...

and a mistress, and a friend...........
with effects of them follow our friends

remember thy friends...............

I am out of friends madam (rep.) .....

such friends are thine enemies (rep.)

my friends were poor, but lionest....

make us friends, I will pursue ....... $\quad$ - ii. 3

forth from courtly friends..........

and take leave of all your friends.... $\quad$ - iv. 3

ever a friend, whose thoughts........ $=$ iv. 4

destroy our friends ..................

guch friends as time in Padua... Taming of Shrew

in law makes us friends...

welcome his friends..

my friends in Padua (rep.)

and tell me now, sweet friend

thou'rt too much my friend...........

now sliall my friend Petruchio do

'st me so, friend?

but eat and drink as friends ..........

make friends, invite, yes ...........

neighbours and friends...............

is't possible, friend Licio

the other, for some while a friend... Winter's Tale.

now my sworn friend, and then

good expedition be my friend.........

and toward your friend...........

unknown friends to ns welconie (rep.)

now my fairest friend I wauld

and, fitends unk

'er been my father's honoured friend

farewell, my triend. Adieu, sir......

assisted with your hououred friends.

desires, I am friend to them....

in the behalf of his friend.

try all the friends thou hast...........

done wrong to this my honest friend

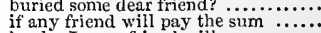

haply, I see a friend will save.

hail, brave friend! say to the king......

who's though: come,

was it so late, friend, ere you went

good of bad, and friends of foes!....

tor certain friends; that are both ....

to all our friends; for my heart.

sit worthy friends; my lord is

your noble friends do lack you ......

and to our dear friend Banquo

as 1 shall find the time to rriend ...

I would the friends we miss..........

in sooth

be friends aw hile, and both conjointly

gone to be friends! shall Lewis have

and count his with England..........

ii. 2 the light loss of England for a friend

ii. 2 do your pleasure, and continue friends

my goou friend, thy voluntary......

ii. 6
ii. 6 divers dear friends slain?......

iii. 1
iii. 2
gee and know our friends in hearen. 


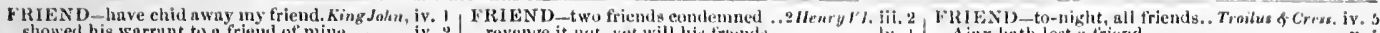
showed his warrunt to a frient of mine

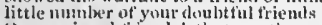

(I) mot prieverl triends! thint we, the sons -

not think the king sostored with trietzls -

a thencl: wilut urt thou?

thou art ny friemt, that know...........

we conmot to to muke you friends .... Richurd II. i.

return'st no grectime to thy triends?

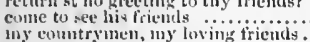

atil not arainst his triends

with ull their powertul triendi.........

now shnll he try his friends thut ....

a som remembering my good riends

thy friends are tled to................

in substanee and in friends [Col.-power] -

neal triems: suljected thus

netl friemals: subjected thus
with some few private friend

harren, and berctit of friends ........

to a deur friend of the good duke...

the loye of wieked friends

for being Rithard's friend

I am the king's friend, and wili rid.

tell me, gentle friend, liow went he..

theretore, friends, as fur as to....... I
nnd true indastrious firiend, sir Waiter

and true indostrious friend, sir W
never hold that man my friend....

never hold thut mas my friend ......
the friends you lave numed, uneertain - ii. 3 (let.)

our friends true and constant.

gool friends, and tull of expectation

yonr tenants, friends, and neighbouriug
to any well-deserving friend .........

and made a friend of thim, to fili ....

and made a friesd of thim, to fill

and that his friends by deputation

I must go write again to other friert
the first and dearest of your friends.

yea, every man, shall be my frien

and fellux's, soliliers, friends

your retirement do amaze your friends

knolling a departed friend

and make friends with speed.

most noble frienils, I prizy you ail

for fanlt of a better, to call my friend
conse, I'lt be friends with thee, Jack

the part of a careful friend.......

young, strong, and of good friends

that thy friends shall ring for the

stnnd my friend, and here is four

a desire to stay with my friends $\ldots$...
finr my old dame's sake, stand ny friend -

tis well done, my friends............

his foes are so enrooted with his

prove a slielter to thy friends

prove a slielter to thy friends.....

till his friend sickness hath.

thy friends, which thou mast (repi....

a friend i'the eonrt, is better ....... =

the knave is mine honest friend, sir.. -

you have lost a friend, indeed...

I am thy Pistol, and thy friend...

are antient $l^{\prime}$ istol and you friends...

a brenk fast, to inake your friends....

nu' thou wile be triends, be friends

dear friencls.

there stands, your friend tor the devil

brotlier: friends, ami countrymen

qui va lit? A friend. Diseuss nnto me
art thou his friend? And his kinsmau

who goes there? A friend

be friends, you Englitilt fools, be friends

my friends, and all things stay for me

fenst his triends $k$ nt, - ne
spuiled us, friend us now.

8pwiled us, friend us now?
kill his pert fricnd, Clytos

never killed any ot his friends .......

lie is a dent

he's a friend of the duke of Alengon"s

you must needs be friends will
I will tell rou, as my triend

you shoud love the friend of i......

shull be the raskom of my

thuu urt so friend to God ........... I Jenty $F /$

and Picarry, are friends to us..........

thad friends to wear my hleeding roses

for theare my triends, in spite ot thee

my triends, and hoving eountrymen

his subjects, und his logal friends..

by a sign give notiec to our friends..

the beseon of our friend .............
Burgimuly, and ull his trieide
esteen none friends, but sueh (rep.)..

ostence it is, to thout his triends....

good my lorth, be triends ..............

thall find dear deer of us, my friends

that sundered friends greet iti.

revenge it net, yee will his frendy
thut be the king's fritumls, follow me

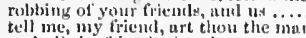

muld all the friemis thom lust
his furourites, and his friend

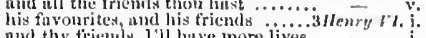

gathered llocks of fricuel

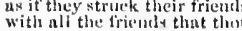

woulil thy hest firiends flid kuow

for ull your firiente ture tled

il frietnl, on for, let him be gently a...

cannot spare his fiends an oath

of Warwick, filward's orentest frietid

sovereirn, and thy vowed friend
lewis was demy's friend (rep.)

lewis was llenty'g fricud (rep.)

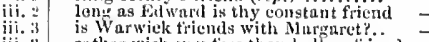

rather wish youn fives than hollow friends

but a ficigned tricul to onr proecedings

for wurwiek and his frie

king kilward s triends masi dow

here the his firicnds with borse .....

what news, my friend

hither will ony friends repair to us.....

we are king lienry's friends

our trusty fricnd, unless I be deeeived

whill bring you many friends

shalt muster nut thy friends.

belike, untooked-tor friends

come tond and tide thy friend

we are adiertized by our loving friends

our slaughtered friends the tackles

I never sued to friend, nor enemy...Whenart $I I I$,

and I no fricuds to baek my suit witha

elvy my advancement, and iny triends -

thy friends suspect tor traitors (rep.)

my friend, I spy some pity in thy looks

since I have made my fitiends at peace

a friend, and most assured that (rep.)

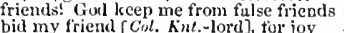

wour triends at Pyonfret, they do need

be patient, they are friends

the loving haste of these our friends

thanks, gentle eitizens, and friends..

very worshipful und loving friends .

the other side, I cliecked iny friends

good cousin; tarewell, gentle fric
resolve to kill a friend of mine?.

bad friends were contrury.

many doubtfit hollow-hearted friends

friends are in the north. Cold triends

I 3 innster up my friends................

any well-arlvised ficnd proelaimed.

and $m y$ most loving friends...

his friends will torn to us (rep.).......
so long sundered tricnds should divell

your friends are up, and buckle on..

will our friends prove all true?

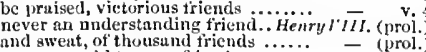

as you wolld to your friends

freely merry, is not my firicin

his noble friends, and fellow

for those you make friend

Which of yon ficnds have I not strove

till I may be by my friend in sipain

your hopes and friencls are intinite

or be a known friend

my friends, they that must weigh out

sinee virtue hinds no friends $\ldots \ldots . . . .$.

jeacemakers, frieuds, nnd servunts..

to me, your friend, than any

Cranmer will timd a friend will not...

and truly a worthy friend

i. 4 atund these poor pople's trieni.

five your triemd somute tone

you are alwuy's my good friend

be frients, for slume, iny lorts

and he is your friend tor ever.

time must friend or ead ...... Troilus \& cressid

wnunds, fricuds, und w'liat elice dear.

frient: you! prity you, a word
friend, know me better....

yrace! not 80, frieud; honour

fricm? at mine, air, and theirs (rep.)

no grcat friend, I fear me....

purthase friends, and give to courtezan

it is known we were but hollow frie
wnuld not feast him like a friend...

and most estemed friend, your brothe

fortune and I are friends...........

and roll grow friend wish dauks.

to shuke off iny friend when he. Fimon of Athe

r.hut have you there, my firlend?

niake thy recinests to thy fricni

wish my best friend at suel a feast

O no doubt, my good friends

what need we have any friends

than the riches of our irienda?

to their graves of their friend s gift?

hupvier is he thint hus no friend to tied

I weigh my fricud's aflection with ..

could deul kingion

nine honest friend, I $\mathrm{j} r \mathrm{j}$ thi

eontain, thyself', good friend .
do so, ny triends: see them wei

do so, my friends: sec them wel

friends, you shail perteive (rep.)......

gome good neecesity touches his trien.

fortunes 'mong his friends eall sink.

he is my very good friend.

lord, my very exuluisite friend $\ldots . . . .$.
who cun call him liis friend, that dip

to mark me for his fricild.

his friends, like physicizus, tlirive...

whut do yon ask of me, iny friend?

go, bid all my triends again.......
to lie letavy upon a friend of nis

to lie heary upon a friend of nis
triend, or brother, he forfitits his

in the trial of his several friends

ah, my good ricnd. what cheer? .... - iii.

tor these my present fricndy...... - iii. 6 (grace)

all gone! and not one friend

ungrateful eent of unonst rous friends

I um thy friend, and pity thee ....

than friends, who can bring noblest..

been but a try for his frieu

cour friends fallen off..........

for ull this, my houest-natured fricnds

tell my friends, tell Athens

ter ancient friend

and made us spenk like friends....

gond friends, mitne honest neiglibuu

note me this, my good liriend.....

my good friends (this says the belly)

our greatest friends attend us...

to help onr tielded friends! .........

breathe you, my friends; well tourï

we have heard the charges of our friends

vows we have made to endure friends

you have been a rod to her fricuds.

we hope to find you our triend

nake him good riend to the pople!

my nobler friends, I erave their pardions

truly your country striend ..........

Ijr'y thee, noble frieud, home to thy

and my triends, at stake, required .

any masters, and my common triends

nid my friends of noble tooth....

shull grow dear tricuds, and interjoin

what would you lave, triend?........

and more a friend than e'er m enemy

come, we are fellows, and friends $\ldots$...

lis triends, wliilst he's in directitu

ii. not much missed, but witl his triends

ii. 4 hut as a discontented triend, grief-sloo

good my titients (rep.).................

not with sucls friends thut thourht

nor from the state, nor private friend

friend, art thou eertuin,

over your triend thint loves youl ....... Juluse

but let not theretore ny good riends be

a tricul: Cinna where hos yon thas

gentle friends, let's kill him boldly .

hest friends shall wish 1 had been (r.p.) =

like friends, will struightway go twether -

wlo comes here? a fricm of $\mathrm{int}$ towy

that we shall have him well to trien

then, in u friend, it is eold moslenty.

pripkel in number of our fricunds...

triends am I with you all, and love you -

bive me audience, frienel

nny dear friend of Casstr" to him i say =

wus iny friend, faithtul and $\ldots$ just to.....

luse putience, gentle triend

gond triends, sweet triends, let me not

blunt met. thent to to ateul.

2 (grace

i. 


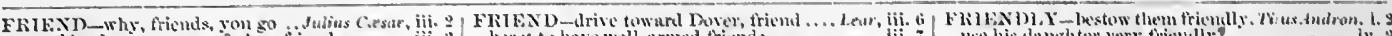

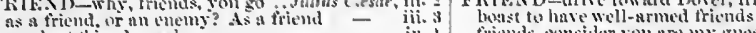
thou liast described a het triend enoling such rasul counters from his triends

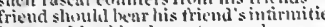
love, and be trienthe as two snch men tried ane tits yomu thrips are frient or encmy .... did l not meet thy frients? ........... friends. I owe more tears to this devid

to fyrants amd my country's trient.

Brutus, my comntry striend

such men my frients than enemies.

come, phor remmins of triend

that's not un ofties for a fricul. my lima

many of our eont tixing friends in.

gond friend, gheth he, saly .

my homourable frieml. Asrifyna

is well, or tricmls with Ciesar

prothee friend. pour ont the rack...

Priends witl Casar: in st:te

hut what? we ane frichls: comine, down

how nuw, thend Eros? ..............

friends. come hither: lam so lated in

friends, come hither: 1 am so lated in -

friends, be sone: yom shall have (rep)

friemes, considler you nre my goust

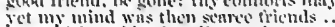

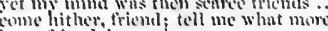

here, frient, is mother purse ...........

tahe that of me, nuy trient

trentions

tither, Ill hestuw you with a friemi

the tricul hath less his tiend.

"ou loris, mut nothe triemds

all frisuls shall taste the wage

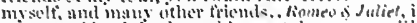

miv very frieme, liath yot his mortat

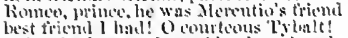

a sin-nbselver, and my ritemd protessed -

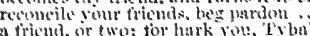

some halfin-doeen trichds .....

my lowe my lend! my friend!

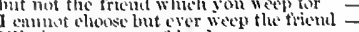

the world is not the friend

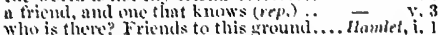

lowk like a firichd on Demmuth

my geod fricmet; Ill ehonge that name

none but friends; say tholelly (rep.)

mine honest friends, i turn you not away

my hearty friends, Fou take me in too

Four wives your thenes, tetl them

like friends long lost 1 iij, trieuds

bear me. gend tiriends..........

earry ne now gool friends..............

assist, good iriends, O quick, or 1

we liave no friemd bu

friend and companion in the front.....

heur me, aod frictsts. hut low he the

as we greet molem friends withal

that we remain your friend.

who to my fisther was a friend

buy my" injuries to he friencls

as a noble friend of mine

milmittance. and opportmity to tivend

nor las no friends, so muth as but

bolduess be my friend! urm me.
mrself, and other noble friends.

myrself, and other noble friends......

we mist not contimue trients.

for you fult mongst friend
sav, his mame, goul frienl

my triends, the buy hath tanglit is

for trients kill friend

Eome, their treuls o erborne ithe

is he thy kin? thy friend?

Romans, ficuds, followers...... Tit
strive hy fictions, and by friens

strive by factions, and by fiends...

friends, that have been thus forwer

whose friend in justice thou hast.

if thou strengthen with thy triends.
bones, sweet Intius, with thy friend

a fisther, and a friend, to thee

have reconeiled your friends and yon

swect emperor, we must all be frient

I foum a triend; and sure as leath.
my guest, Lavinin, and your friends

despernte grown, to threat ronr trien

for shanc, the friends; and join ....

and purchase us thy hating f

secretly to greet the empress' friends

my* fith ful fricnds, I have reecived

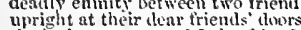

she is thy cnemy, nnd I thy fivend

the ambinsh of our triends be strong.

spenk, Rome's denr triend.............

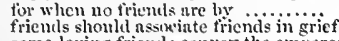

some loving friends convey the empero
as friends to. Antioels, we inay feast...

no, triend. enunot you heg?
hark you, ny fricnd, you sid you.....

O not all, my friend, not nlt; for if ail

an armour, friends! I nray you..........

ay, but hark you, my triend ..........

whirring me from iny friends ...........

What were thy fricnts? didst thou not
thy fricuds? how lost thou them?

well, my compmnion fricnds...........

hereafter as ny honournlle fricnd

banishment of friends, dissipntion ......

how now, my nolsle triend? sinee I

cood dnwning to the, fricnd

I 11 tell thee. friend, I nm ainost mai

of loses losh itselt and friend.

his friends, mut in port, him.

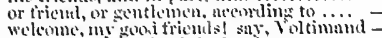

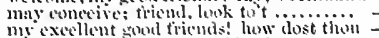

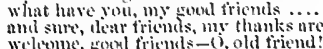

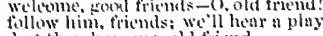

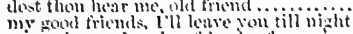

pix) sulvamed makes triends at enemia

never lack a triend: and who in (rep.)

lave me, friculs, tis now the very.
frimels loth, go join you with somic.

wo'll eall up our wisest friem

rou will draw both friench mat

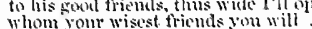

must put me in your luent fior tricues....

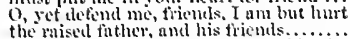

Fondness of the night uprom you

I have professed me thy friend

our triends, nt. lenst. I pray you, sir.......

news, friends; onr wars are dome

O they nre our friencls: but one cuy

my lomest fricnd? nu, I henr wot (rep.

do, gool my friend: in happy time, It

Cassio's ny wortly friend: my lered, I see

friend is denl; 'tis done, at your request

this is some token from a newer fricnd

and her country, and her triend

good fitowl, go to him

such noble sense of thy friend's womy

shin here, Cassio, was my dear friend.

myr triend, thy lushoud, honest

not triended by bis wish.............. Jenz sea.

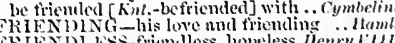

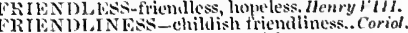

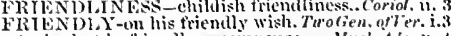

traly, min in friendly recompence ..Much tho

gives the nowe trichlly counsel. Werchor bphic

let me buy your triendly heip ........At's Iteti, ii

give them friendly weleome.. Taming of $\$$.
so fur forth fiendly muntained .......

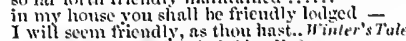

(a will seem friendly, as thou hast.. Inters sout

this friembly treaty of our threatenel. King John,

lot's drink together fricndly .........

conlitions of a friendly pence .........

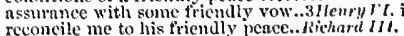

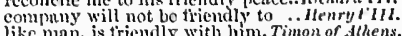

lo sny, thou'lt enter friendly. ........

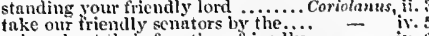

take our trienkly senntors by the...

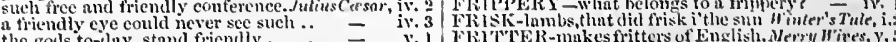

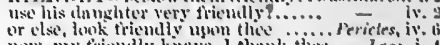

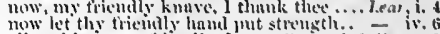

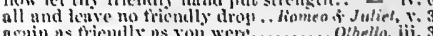

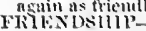

the law af triendshiy bids me.. Tero Gen. ar Jer. iij. I

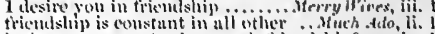

is there any wny to sluw such frichlship? - iv.

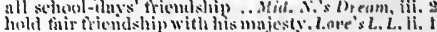

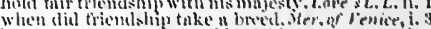

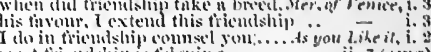

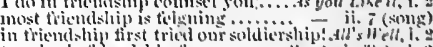

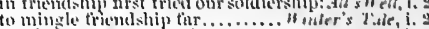
us trienilship wears at feost

protit therein the leaping tricuibilipe - iv.

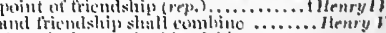

there is thattery in friendslai

lut join in thiondship, th your
thy trientshit mokes ns thesh

hey une linkint in fii.

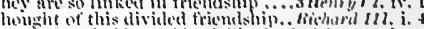

no cinse to hold my triendship donbtrul - iv.

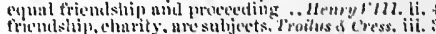

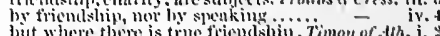

trisenel

especinlly unon hate friemilshif........ -

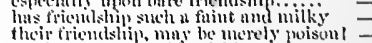

the in a dream of triendshipes.

what firemelshis may I do thee?

momise me fricutsliph, but performinome -

of triendshin with thine onemies. Julius Cersur, iii.

scems to tie their friendship tegether - ii.

he"ll quickly tly my tricndslip too.. Cymbeline,

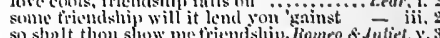

in the benten wny of triendship........ Plamer, $i$.

[Knt.] if your friendship were at leisure.

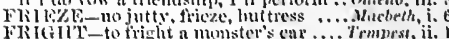

or tright me with urehin shows ........ - ii.

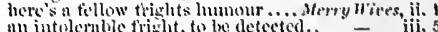

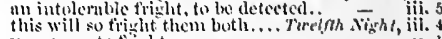
you come to fight us a................ if that you singuld fright the halies.. - i. to tright me, it they eould .......... no devit witl firght thee then so $\ldots .$. iv. 3

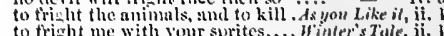
to fright me with your sprites.... Winter's Tule, ii. the bug, which you would fright me - iii. her chain, und frirht us with it. Comedy of firr. iv. to firght you thus, methinks.............arteth, iv.

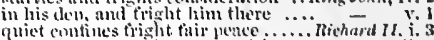
nud tright our native penee with ..... - ii. and meteors tright the fixed sturs.... his uglicst mask, to fright our party.2 lemry

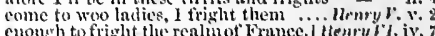

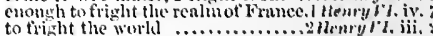

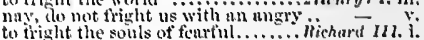

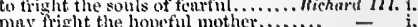
mis fright the hopeful mother....... ${ }^{-}-$i. to fright them, ere destroy .......... Coniolamus, iy. eremenies, yet now they fright me..Jul. Corsar, ii. mat in firy, tright nyy youth .... Thims Andion. iv. it frithts the isle fiom her propriety.... Othello, it.

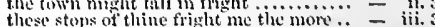

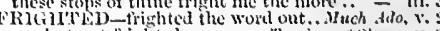

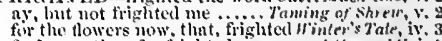
find we a time for friglited pence ....1 tlenry $l i$ : clumorous to the frighted ficlds......
how have I firiglited thee, that thou.

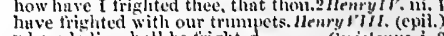
where linties shall be trighted......... Coriolanus, 1 .

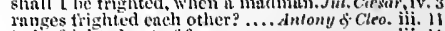
to be friglited out of fenr. frighted and angered worse ........... cymbeline, ii. 3 Who, frighterl from my country, did wed, l'ericles,y.

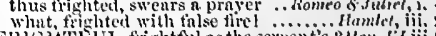

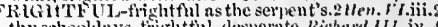
thy sehooldays, thightthl, (lesperate. Richarel III, iv. frighting her mle-faed viluges.... Richard Ii, ii, thy neck, for frighting me! . Troilus of Cressita, 1 . to murt their tringes of briglit gold ..... Pericies, iii, FRINGEj)-fringel curtnins of thine eye Tempest, i. \&

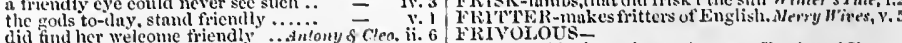
receive her weleome triendly ...Antony \& cleo, ii. 6 FRTVOLOUscome hither, frient; where is the kingr...

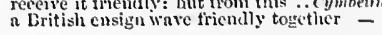
tor so slight nad fivolous a eauso... Henryl\%, iv. 


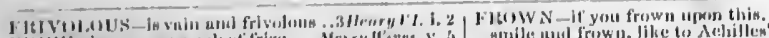

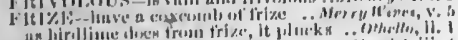

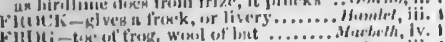

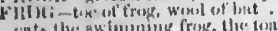

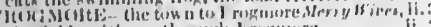

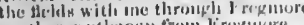

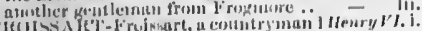

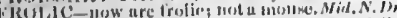
thereliare frobles we will hence. . Taming of sh. iv

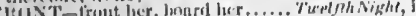

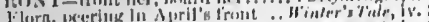

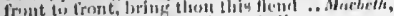
ay, on the frost. Why the'1, (') ".

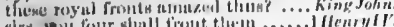
sirw, you four shall tivent tläm

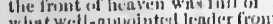

whintwellow uprearest and ubutting trist

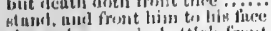

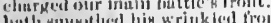

and frent bot in thint ille wiliere

that jertly frumt your tow ll.. Troili

of their view upw a taw

(1) frunt this present tim

In flickering !'lacelous tront

the front of Jove himmelf

the very heas and front of

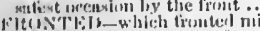

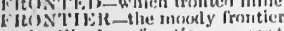

of pallinaluen, fruntiern, jarryect

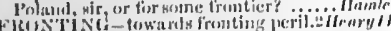

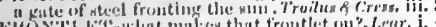

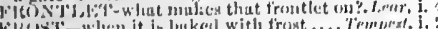

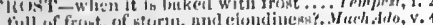

tull of front, of kfersit, the

like an envions rncaping fircyt.....

if frosten and lasts, luerl foulgoin

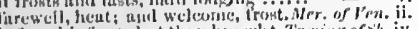

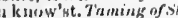

thy lecuaty an lirants fite

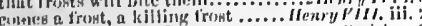

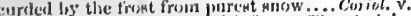
lueng the head an fluwers with frost.. Titus And, iv. 4 like un untincly frout

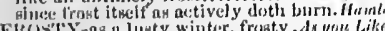

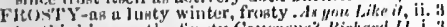

loy thinking ont the frowty

thut leurs in frosty sound ...........

whiles a more truaty fersple sw

hanimled from the frosty heor

fior all the frosty nights that I .. Tilursor

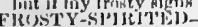

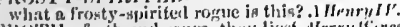

(te)'Tll-froth and seum, thenl liest.

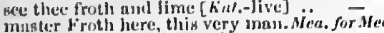

as you know, muter lirot.

aister froth hicre

was' not ut finlowinas, master froth?

gonsl manter firoth, lissk ujo

hi1 mes, master f'reth. Mruter Firoti:

they will draw you, muster firuth.

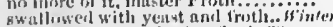

fiver secth your lolowl tu firsth. Timen

leliciv siti)

otarl

utul frowerel; so heyouil all mensure

for slie's not frowuril, hut monlent....

and if alse les froward, theis liast thoii

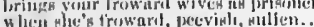

cone, youl froswal and unuble worm.

harti henring, when women are frow's

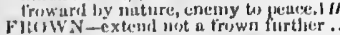

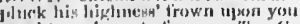

tinilitit tuy linow to l'rown

i1'slac do trown, 'tis nist in

If frown the while ....... Totjo

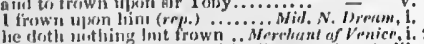

now I do frown an tluse witis ull, ds yon Like il, bii.

leer frown miylit kill me

suy, that she frown, Itl say... Training of stirew, ii. I

them centet mot frow

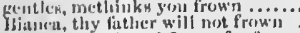

word finr worrl, und frown for firown

trick ot his frowis, lis forelicud

tritk of his frownd, lis foreticud .......

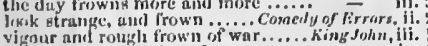

never wall wo muels as frown on you

if then, jerchance, it lirowny inore

and heuven itselt doth frowin uje....

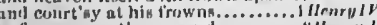

fown

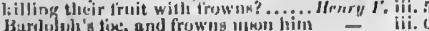

arrile unl frown, lilie to $\lambda$ delille

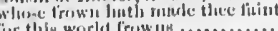

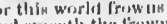

ins of war witl.

$k$ Iros an ut lifis

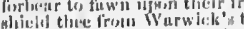

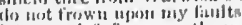

let my arlefia frown on tlac ily ger

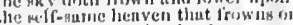

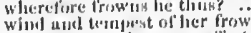

liownon, s'oul heusens, reflict

how you can frowli, thith

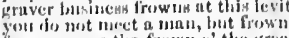

feur no more the frown o' the foreut

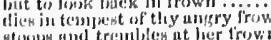

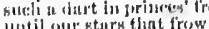

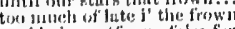

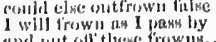

und fint ofl' thene frowss.

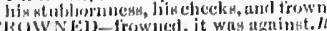

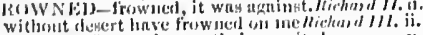

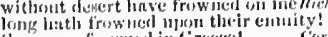

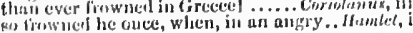

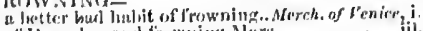

of Tlerealew, and frowuing Mlar

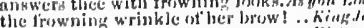

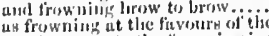

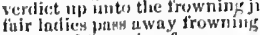

hie purted frowaing from
their courage worthy lii
he pack lience frowning

he pose licnde frowning ..............

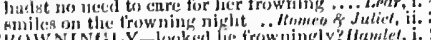

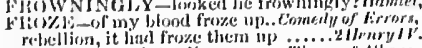

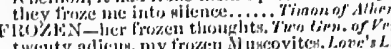

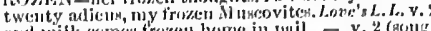

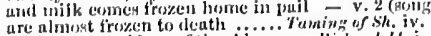
are nlmust freszen to death $\ldots \ldots . .$.

bix fromen winters spent, return

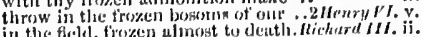

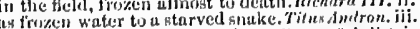

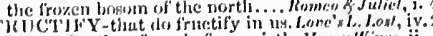

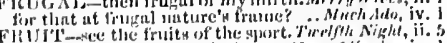

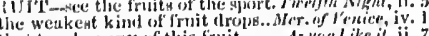

that tomelack any of this fruit .....

the earlicht fruit in tlac country.

and first fruits of iny linely.

the rijest frubt first thils.

he to taste tlieir fruits of diuty .......

by the fruit, as the fruit by the tree..i nom

I jruy toul, the fruit of her womb

killing their fruit with frowns?

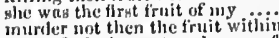

whose fruit thou art, und never of
fruity ot love I meast. The fruits....

- iii.

fruits at love I mean. 'The truth

Ifmrul'tiii.

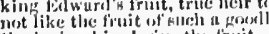

the loving kish 1 five the liruit

tree listli left us royal torit

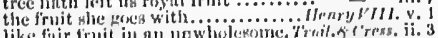

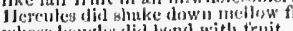

whose fondlis did lend with tru

the fasc fruit of his loring lunt.

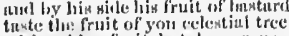

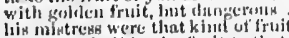

iny news thall be the fruit to hiut.

slat took the fruits of $11 y$ urlvi

which llow, like fruit unripe

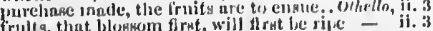

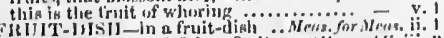

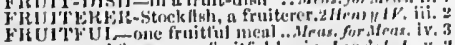

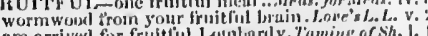

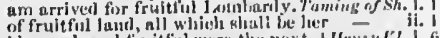

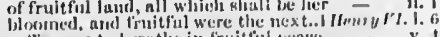

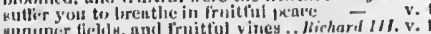

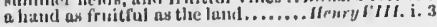

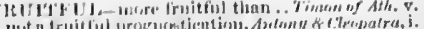

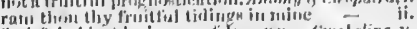

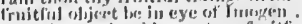

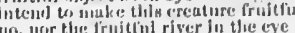

frumed 98 trinitiul an the fres: element

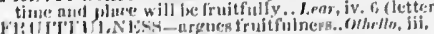

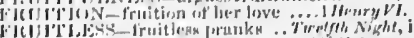

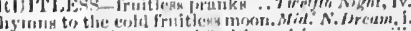

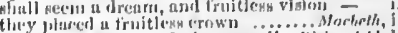

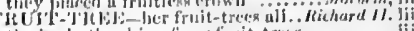

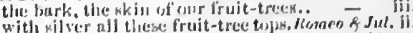

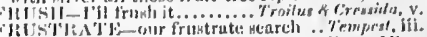

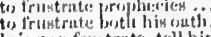

lecing $k 0$ frust rate, tell him....

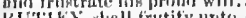

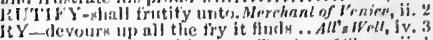
but thine doth fry: kkipper .. Taming of sherem, ji. 1

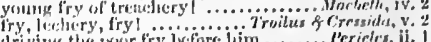

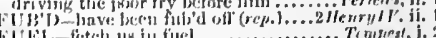

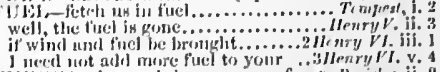

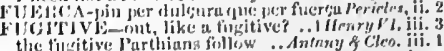

the filcitive lardhina follow ...An/nny o cleos. iv.

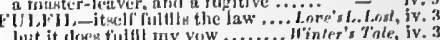

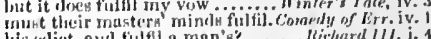

and toncke, fulfil sonr pleagure.. Sulins Corsor, ili,

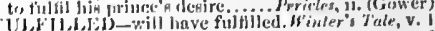

the orn.le is fulfuled ................. - v. 2

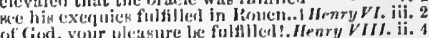

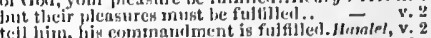

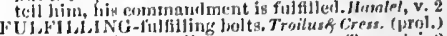

YUi, a lialt poor cell

to bute ine a full year.

fill futhom the tliy futher lieg ....... - i.2 (onng)

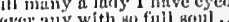

I am full of pleasure

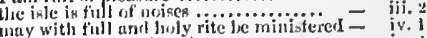

go full of valour, that they ...........

is fult of jealonsy .i....... Turn fien, of lerona, ii. A

I nuw um full in full of virtue

blustle be finl fremglit with.......

a licurt as full if yorrow's

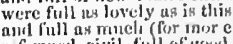

reformerl, civil, full of poest

I have my lielly tull of forri

atul finl! ret giber and viontly!

lie is fill of lecheril' and inioguity . - v.

sofinll of shupes is taicy

iny Wurds are as full of je:

this is a prostiec, an finl of laboin a...

betwecil me and the finl prosperet it

plipht une the rull nissuraned it ........

but thout art full of cerror

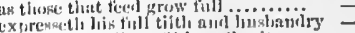

amil with fiull line of his anthorit
you glutl have yessr f'ull time of

le says, to veil full pur
will make up full ticar

briugs home fiult numbers

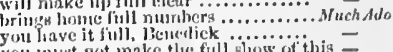

you must not inake tlue full blow of this -

ns a socasure full of state nnil ancientry -

her uflections Juve their fill lient

deserve us full, as fortumate a licd....

more moving dediente, und fill
thou are fulf of piety, aH hlall.

and very fiull if proof ................

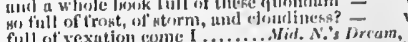

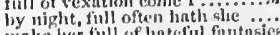

ninke her fiull of liatciul furtosic

ent the elouda tiull foit

thic Invera, full or joy asid miriti

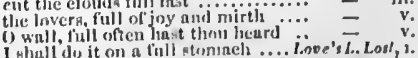

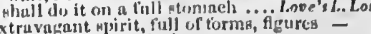

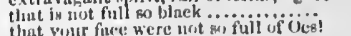

you tork the inom at full...

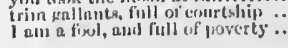

i. 3
ii.
ii. 1
ii. 3
iii. i
iv. 1
iv.
v. !
ve

ii. 2

V. 1 iv. 2

iv. 3

v. 2

. 
FULI-full of maggot ostentation.. Love's L. Lost, full merrily hath this brave manage

as love is tull of unbefitting.......

like the eye full of strange shapes....
received your letters, full of love

periured much, full of dear guiltiness

so full of unmannerly sadness... Merch. of $\overline{\text { Ven }}$

of full three thous

but the full sum of $\ldots$ is is sum of

hath full relation to the penalty

with his hurn full of good news...

not satisfied of these events at full

full of ambition, an envious ....... As you $\bar{t}$ ike

thou lovest me not with the full weight

with his mouth full of new

how full of briars is this working-di.

with his eyes full of anger ...........

for then he's full of matter

full of wise saws and modern instance

that my full life doth sway...

jou are full of pretty answers

forswear the tull stream of the world

his kissing is as full of sanctity.......
make the world full of ill-favoured.

withal, full oft we see cold wisdom.

I $\mathrm{am}$ so full of businesses.........

which nien full true sliall find .... - i. 3 (son

but, what at full I know ............

to the full arming of the verity

the count's a fool, and full of gold

silver bason, full of rose-water. Taning of Sh. I (ind

a mad-brain rudesby, fiill of spleen

the fashions, full of windgalls

carouse full measure to her maidenhead -

she must not be fill gorged

that I have, to be full like me.

it becomes thy oath full well...

though full of our displeasure...

the king is full of grief

looked upon my queen's full eyes...

there was not full a month between..

this town is full of cozenage

a table full of welcome makes scarce

to make thee full of growing

he is full so valiant.......

it is too full o' the milk...........
$O$ full of seornions is my mind

the table's full. Here is a place.....

give me some wine; fll full

I have supped full with horrors...

told by an idiot, full of sound and fury

into the world full fourteen weeks

have their bowels full of wrath

this addition more: full thirty thousand

with wrongs, and therefore fill of fears

and tin full of

more ill news, for it is fuil

more ill news, for it is full

men's mouths are full of it

at feasts, full warm of blood

are they both, and full of ire :...

o fill of careful business are $\ldots . . . . .$.

and lie full low, graved in the

the world is full of rubs

with full as many lies.

unseen, and full of water

mine eyes are full of tears. ..

Four brows are full of disconten

his prayers are full of false

as full of valour.as of royal....

I protest, my soul is full of wo.

stuff your purses full of crowns...

good friends, and full of expectation

and our induction full of prosperous

giutted, gorged, and full

thy looks are full of speed

our hands are full of business........

the better part of ours are full of res

shall pay fult dearly for this encounte

suspicion silall be all stuck full of eyes

Know this face full well

our soldiers stand full fairly for...

like a borse full of high feeding

this is the news at fut

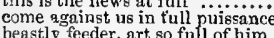

heastly feeder, art so full of him

come we to full points here........

our battle is nore full of names.....

hath the prince john a full commissio
for fuli well he knows, he cannot....

as much as the full mon doth

quick, forgetive, full of nimble

never come with both hanes fuli ...
FULI,-king's honour, full fifteen earls.. Henry $r$. i. I FULL-too full of the wars' surfeits..Coriolanus, iv. 1

the king is full of grace
making defeat on the ful power..........
forces the full pride of France forces the full pride of France $\ldots . . . . .$. . congruing in a full and natura having full reference to one concent

rise there with so full a glory

the English with full power unon

shall you know our mind at full...

every spirit to his full height

injury, till feign hearl some question

they have full threeseore thoisand.............

he is as full of valour, as of kindness.

he was full of jests, and ripes

giving full trophy, signal, and ostent -

witl full aceord to all our ..............

tongues of men are full of deceits?

starts the full course of their glory

these letters, full of bad mischail

..1 Hen' 2 (chorus)

having full scarce six thousand

their pockets tull of pebble stones.

'twas full of darnel .................

ofull replete with choice.

see these things effected to the fuli

by the interpretation of full time.....

a city full; of tribunes, such as you (rep.) -

known the eartli so full of faults ........ulius $\overline{\text { Cecs }}$

thou receivest thy full petition ...

danger know's full well, that Casar.

our reasons are so full of good regard

such as he is, full of regard

now is that nobie vessel full of grief.. - iv. 3

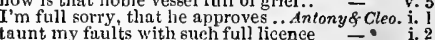

taunt my faults with sueh full licence - i. 2

full surfeits, and the dryness of his..

say it will come to the full $\ldots \ldots \ldots . .$.
stands upon the swell at tull of tide..

o'er my spirit thy full supremacy

the full Cæsar will answer his emptiness - iii. Il

a brave army, alld fith of purpose....
make your full reference (rep.)

hath his belly full of figlting...... Cymbeline, ii. I

hunger to feed again, tho' full $\ldots . . . .=$ ii. 4

are full weak to undertake our wars - iii.7

gods are more full of mercy ............
his full fortune doth contine $\ldots . . .$.

at this instant is full accomplished ... v.

full well, Andronicus, agree these. Titus And

full well shall thou perceive low.... - ii. I

for that I am prepared and full resolved -

the palace full of tongnes, of eyes....

I have heard my grandsire say full of -

a charitable wish and for this....

be it known to you my full intent

port is just, and full of truth

whom, plenty and finl of face.Pericles, $\vec{i}$. (Gow-)

their tabies were stored full.........

yet glance full wanderingly on us.....

and a wench full grown, even ripe.. - iv. (Gower)

full well hath Clifford played...

ay, full as dearly as I love myself.

mine, full of sorrow and heart'

you see how full of changes $\dddot{h i s}$ age is .... Lear, $\mathrm{i}$.

to that full issue for which I raged .......

wont to be so full of songs, sirrah? .........

inform her full of my particular fear

her fiction will be full as strong

so full of tearful dreams

so full of dismal terror was

$I$ have full cause of weeping..........

\begin{tabular}{l|l} 
iii. 2 & treacherons, and full of guil \\
iii. 4 & my soul is full of sorrow ...
\end{tabular}

iii. 4 and, in his full and ripened years

ofull of danger is the duke

heavily, and full of dread

twas tull two years ere I could get

tis seen, our mean secures us.... - iv.

full soon the canker death eats...Romeo \& Jutiel, $_{\text {ii. }}$

that was so full of his ropery? .i... - ii.

slialt remain full two and is full...

thou know'st, is cross and full of sin

I am sure, you have your hands full

art thou so bare and full of wretchedness -

not nice hut full of chare

a feasting presence full of light ........ $=v$.

acen there? Full h:lf an hour ...... $\overline{-}$ v.

of unimproved mettle hot alıd full...... Hamlet, 1 .

in the full bent, to lay our service freely -

grossly, full of bread Phobus' cart...... - iii.

his liberty is full of threats to all ..... - iv.

$\mathrm{my}$ soul is tull of diseord, and oismay.... - iv.

so full of artless jealousy is guilt ......... - iv.

full of most excellent differenees

what a full [Knt.-fall] fortune does the... othello,

now, in madness, being full of supper.... - i.

and is in full commission here for cypo... - i.

the man commands like a fuil soldier

she is full of most blessed conditions

and there is full liberty of feasting

and, $Y l l$ warrant her, tull of game......- ii.

- ii.

I know thou art full of love and honesty = iij.

lost my purse full of cruzadoes .......... - jii.

and when they are full, they belch us.$\ddot{\text { - }}$ - jii.

iii. 1 speak, for my heart is full..............

ii. 3 FULLAM-gourd, and fullam bolds. Merry Wives, i. 3 ULL-CHARGED -

level of a full-charged confederacy.. Henry VIII. i. 2

LLER-spinsters, earders, fullers. .i - i. -2

youths are full of quality.

wby, thou full dish of fool

bladders full of imposthume

i. 3 by eyes, are full of turpitude

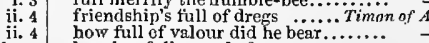

iv. 1 lays her nill mess before bour...

iv. 1 full of decay and failing?

- iv. 3 FULL-HEARTED-

are his files as full as thy report?..... - $\quad$ v. 3 full-hearted, lolling the tongue.....Cymbeline, v. 3

till we have sealed thy full desire....

did but fill Ithaca full of moths....... Coriolanus, i. 3 FULL-WING ED-full-winged eagle. Cymbeline, iii. 3 
FULLX-informed her fully, I could not. Al's W'ell, v. 3 to instruct her fully in thos

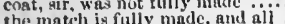

here had the conquest fully been

and fully erent these thiree doy

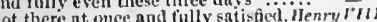

had you not fully laid my state. Tinnn of. Hehen,

the fenst, having fully dinch lefor
that may fully diseover him their

to opyose his hatred fully.

whose cvery passion fully strives......

our hour is fully on

it will stuft his suspicion more filly .

tear, it.

fubiess of pertiction lies in him

and brim nillness of lits force

to luve in tulness is sorer

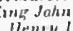

Minmy to

to lupe in fulness is sorer

Cynbeline,

hetore the fulsome ewes, who ...Yerch. nf to

this gap of brenth with fulsome dust. King fohn

Washed to lleatli with fulsolno

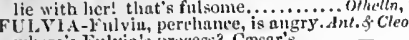

where s Fulvia's process? Casar's

why did le marry Filvia, and not love

Fulvia thy wite first eame into the ficld

rail thou in Fulvia's phr

Fulvia thy wife is dead is dend. Sir? Fulvia.......

if there were no more women but Fulvis -

for not alone the denth of Fulyia

my roin. is folvia's death.

cuin Fulvia die? She's dead

I see, in Fulvia's derth, how inine

so Fulvia told me. I $\mathrm{pr}^{2} \mathrm{y}^{\mathrm{t}} \mathrm{ee}$, turn

FUMBLE-tumble with the sheets .... Henry

lie fumbles up into an lnose adieu. Troilus f Cress.

vrap and fumble in thine arms?. Titus Andrn

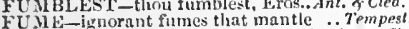

quoth she: I'll tune with them.. Taming nf Sh,

ghall be $n$ fume, and the recuipt of

her fume cun need no spurs

raised with the fume of sighs ....R Ramen of Jutic

FUNIING-keep his brain tuming... Antony s clen.

FU IITTUR $\bar{Y} \rightarrow$ and rank funitory...... Henry

FU XCTION-the function well

sealed in my funetion, by $\mathrm{ms}$

all the very eypher of a function

have paid the heavens your function -

from the eye his fiunction takes.Mid.N. Dream

above their funetions and thei

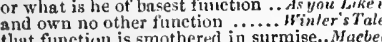

that function is smothered in surmise.. Nacbet

their particular functions and

his pluce and function to attend

touching thy spiritual funetion

lid distinctiy his fuil funetion

organs had deceptions functions. Trimilus \& Cress.

follow your function, go.............

should again do their llue functions... Cymbeline

his whole function suiting with forms... Llamlet,

powers their functions lenve to do

play the god with his wenk fuuction

\section{FUND.IIENTIL}

the fundamentul renson of this war.. All's I"ell. iii.

FUXEERAL-sing at a man's funeral .. Fempesi, ii.

turn melancholy forth to funerals...ivid.N.'s $D$,

shall wit upon your fatner's tiunera

Ienryli.

only, give order tor my funeral

Hentyl. ii.

speak in the order of his ftuteral

not in your speak in his fumeral ...

lave nity liand at nll about his tumer

come I to sleak in Cresar's funern

I am going to Ciesar's funeral

fis fmernts shall not he itl onr...... - iii.

solcmu show, attend this funeral. Antony f clen.

Ernciously pleud lior lis lunerals

mo funeral rite, nor unn in mournful

gives cause to mourn his funeral ......

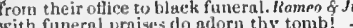

with futireth

I eame to sec your finther's funeral

the funcral buked meats did coldly firmish -

his obeure fuutral, - no trophy, sword

FUR-fur your gloves with reason.. Trailus \& Cress. il. 2

Holf krep their fur dry, unbonneted

FURBISHED-with fiarbished nrms. icharilil.

FUR

and of furies, and $i$ know not what.

las thy head in Furies lap.....

All's N'ell, v.

atud his furies, and his w ratis.

llenry $V^{\prime}$ i

FURIOUS-if you see him furious. Trelfh Nixh', iii.

and furious, loyal, and nelitral.......... Incbeth,

and furious close of eivil butchery ... Tharyl

a most furious knight, and viulorou

vile, and dumned furious wight!..... Inenry $V$.
FUIRIOUS-fortune's turiou

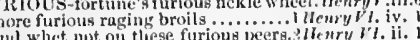

desperate, wild, and furious ....... kichnorl lli. il.

to be furious, is, to he friglited........ Antny of Cleo, iii.

you are most hot, and furious

iv. 2 (snug)

how turims and impaticut they

FURLONGS-thousnnl furlongs of sea.. Trmpes!,

a thinand furlning, cre with
heat not a furmet fik your fise

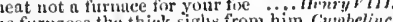

FURNACE-BURNIN

to quencls my furnue-burning heart.3 thenry J. ji.

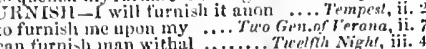

the best to furnish me to-morrow..... MrtehAla,

to timplish thee to Belmont ...

of iny trile, will liurnish ne

we linve two honrs to furnish us ....

ift shall furrish me to those rtalian - ii. 3

the revenuc whereof shall furnigh us. Richard $f$

to turnish lim with all appertine

vouchsate to furnish us with some..3 Hetery $V$ J. iii.

that he may furnish and instruet ..Henryl' $M$. i.

good Diomed, furnish you fuirly. Trnitus \& Cress. iit. 3

sent to your lordships to furnis.

as you think fit to furnish me .. Romea \& $\overline{J u}$ lie

colilly furnish forth the marriage tables. Hamlet, $i$.

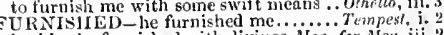

let him be furnished wewels, she is furnished witl. Mer. of Fenice, ii. 4

and jewels, she is furnished with.Mer. of Tence, il.

he was furnished like a hunter

furnished with plate and geld. Taming of shrem, (evil.)

not furnished like Bohemia's son. "W'inler's Tale, iv.

not furnishicd with the present .. Comedy af Err. iv.

all furnislied, all in arms $\ldots \ldots \ldots . . .$.

he is furnished with no eertainties

that is not lirnished in this sort....ililemy $\nu$

ridden, and furvished
my Wolsey, see it furnisied

tis furnished well wing

less furnished than now he is.

if she he turnisled with a mind......

FIRN ISH ING-these are but furnishings. L'ar. iii.

URNITURE-nnd his furniture .... All's Well, ii. 3
for this ponr furniture....... Tain ing of Shew, iv. 3

money, and order for their furniture. Henry $/ V$. iii. 3

fischarge, money, or furuiture

FURNIV AL-F urnival of sheffictd.. Henry I'l. iv

FUROR-that ira furor brevis est. Tintan of $A$ the

to travel with her furred pack ......2 Henry I I. iv. 2

robes, and furred gowns, hide ail .......... Lear,

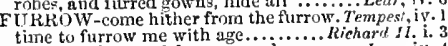

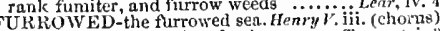

FURTIER-inlorm thee further

please you further

hear a little further.

make further search for $m$

run in to no further danger ............

I'll go further off'.............

stand further-come procced

I can go no further, sir

doth extend not a frown further.

will look further in to't $t$.............

purwae hiun with any further

well, I will muse no fur the

trip no further, pretty sweeting.
I will no furtier chide you .....
if thou clarest tempt me turther...

if thou clarest tempt me fiurther.

it may awake my boninty further

you nuns no further privileges?

and by me this further charge

I will go further than 1 meant $\ldots \ldots$

ere you llout old ends nny further..... Mtich

we'll hear further of it by your dain
wonder not till further warraut

let ine go no furtlier to mine answer

lie further off yet, do not lie ...Mfid.
for love and courtesy, lic further of

and follow you no further ............

What if I strayed no further

use no further means, hut.............

I will no further offend you than.. As you Like

nor no turther in sport neither

I cannot go no turther, $\mathrm{I}$ ile for foo foo

do not look for further recompense.

I durst go no further than the lie.

vive us a further lase to be made.

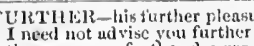

there were no furtier dumger known .. =

and, to requite your further, I will besiew -

extend to you what further

know not liow I whall mante you furthe

pr'y thee, get thee liurther. Pray' you

we'll sift this nutter firtlier

importune me nofurtler................... no shing she

scek their furtunes further thim at home

but then up fiurther; and as fur as ouncr tale iv.

I'll queen it nos inch further.

but cond afflict yon furtier.

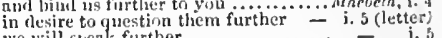

We will pricecd no surther in this...

of work, porter it no further

and went further, which is now our point -

nothing, can touch lim further?

1 dare not speak mued further

$\bar{J}, \bar{k}, \mathrm{ii}, \dot{i}$

further I will not flatter you, my lord - ii.

and run to ineet displeasure further from -

and be no further liarnuful than in show $-\overrightarrow{\text {. }}$

ere further leisnre yield them firther

uncle, further than you sliou

in more shame, be further spoken..... 1 Henry IV.

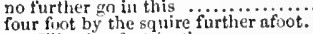

ere I'll rob a foot further

not an inch further: but hark you

never watk'st further than Finslung
and further. I have learned, the king

procceded fiuther; cut me oft' the beads

to npprove my youth further .......2 Henry I $J^{\prime}$ i.

lifow no further now.................

did push it out of further question .... Hen1y $V$. i.

or us, we will consider of this further

if you urge me further than to say
my lords, no further of the case

in earnest of a further benefit

(a)

it is further a areed between them ....2 Henry

until your further time of trial ......

persualed lim from any turther act - - ii.

when thes ean fly no further? ......3Henry $V I$. i.

while I use further conference with:. - iij. 3

then further-all dissemining set aside

and as I further have to understand

no further than the Tower ....... Rishard III.

eonsider further, that what hishigh. Henry $l^{\circ}$.

benefit no further than vainly longing

advise you further in the procesting

canst thou say further? I can, my liege -

for furtber life in this world I ne er.

proceded, or court till further day

till vou hear further from his lüghness

the kin $r^{\prime}$ s further pleasure is

till further t

heard you without indurnee, turther

not medille nor make no turther. Troilus \&-Cress.

what further sou will do ............. Timon of Athens,

till you hear further from me...........

come, sermon me no further...

hefore we proceed any further.

withont nny further deed to heave them -

and so troulhle you no turther.

pass no turther. Ira! what is thï? (rpp.) =

not poison any further. Shall remaiu! -

trinl than the

shall turn $y$ on to no further hurm äher -

my mother does not applrove me furthe

cun do i the way of flattery, further
shall t be charged no further than

consiler further, that when he speaks

1'll know no further; Jet them

eonitrue any further my neglect

entreat you, lye any further noved...

I urged you further; then you seratehed

tempt me no further. A was .......

fly further on, my Jork, ny further on - iv.

pray you, stand further from me.. Amlany o clen. i. 3

to enlurec no further the griefs

tet me hear Agrippa turther speak ..

1 urther this act of gnce................

say-lingar: go no further. Indeed

no further, sir. You take from me

there I will attend what further conmes

thou staud'st, furtier than be is Cæesar 


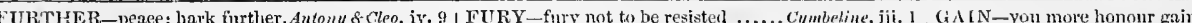

(urther on, where tleir appointment $=$ iv. in

turther than rou shall tind cuuse.

I an no further your enemy

no further serviee, doctor, until ....

I grant we were to question turther.

it you seek for further satisfying

no further laalting: satisfy me hom

to thy further fear, nay, to thy mere

no further witl your din express...

neace, pence! sce further; he eyes us not

be silent: let's sec fiuther.

became of him, I further know not...

some device of further misery. Titus

it firther yet you will be satisfied

and further he desires to know of you

and tior a further grief, God give you joy

there's no further neeessity of qualitios

let us beseeeh you further, that ...

we sloall further think of it

witlout any further del it................

I will look further into't: but where's.

acquaint my daugliter no further witl

I cannot daub it further. Co

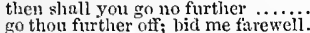

no more, till further settling

no further, sir; a man may rot

to-morrow, or at further space
to know our fiurther pleasure

and yot no further thon a wanton Romin s. $J_{u}$

in whint I further shall intent to so

vengeanee he pursued further than deatl 2

what further woe enspires against.. to snppress his firther gait herein ...... Hamlet,

giving to you no further personal powe

speak, I'll go no further. Mark ine....

how may we try it further?

give him a further edge, and drive his .

lave you any further trade with us?
go join you with some further aid

without debatcment further, more, or les

canker of our nature come in further evis?

no further off than in a politic rlistanee.

of my thought; no further harm .

to sean this thing no t'urther: leave

tronthle yourself no further. O pardoin me

you to your wontcd fưtherance?....

FUT YOHERER furtherance, I am elothed ..... Pericles,

furthermore, I pray you, show... Mer.of Venice, iv. 2

Furthermore, we'll have the lord ..2 Henry $b$,

brother-in-law was the furthest oft. linter's $T$.
lave 1 spent in furthest Greee.. Comedy of Err.

the furthest limit of my embassy.

to the furthest verge that ever was ... Richard II. $\mathrm{i}$.

as my furthest hand shall pass... Aatony \& Cleo. ii .
should in the tiuthest east begin.. Romeo of Julict.

FURY wallaying with the furthest sed

Tempest, i. 2

fury, fury! there, tyrant, there!.

"gainst my fury do $I$ take part

the fury of ungoverned youth.. Tuo Gen. of $\bar{v}$ er. iv. 1
skill, fury, and impetuosity .... Tuelfh Night, iii. 4

she were not possessed with a fury..... Whrh Ado

a vessel of thy law's fury..Love's L. Lost, i. l (lett

a vessel of thy law's fury.. Love's L. Lost, i. I (letter)
what zeal, what tury bath ......... - iv.
oppose my patience to lis fury...Mer.of Venice, iv.

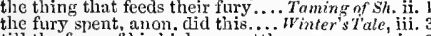

till the fury o his higlness setth

thast here and there his fury had. Comedly of Err.

I do repent me of my fury

full of sound and fury, signifying

in mortal tury haif so peremptory

as doth the firy of two desperate

and fury shall abate, give me thy.

tell him, my fury shail abate, and ${ }_{\mathrm{I}} \cdot \mathrm{H}$

tempt the fury of my three

and wrathful fury, makes me weep.........

dizzy-eyed finty, and great rage...

in thy taee I see tliy tury............

or oxen could I spend my fury

is as a fury to torment my so

ne'er snend their fury on a child

lost in the labyrinth of thy fury? Troil, of cress.

with a noble fury, and fair spiri

worthy my spleen and fury

the quality of lord Timon's fury?.....

thy fury spent, eonfounded be tliyself:

ernharquements of all tury

domestic fury, and ficree evil ....... Juliuscionsar, iij.

come like a tury erowned...Antony of Cleopatro, ii. 5

thon fill'st into my fury

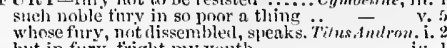
but in fury, friglit my youth

dreal fury, to iny woful hous

wrath be mute, and fury dunb?

ii eateh in their fury and make notling .. Lear, jii. firc-eyed fury of his heart

the unreasonalle fury of a beast

in her prophetic fury sewerl the work.. othello, iii. 3

I understand a fury in your word

tooth'd hriers, sharp furzes ............. - iv. - iv.
FUS'T-reason to fust in us unused .... Homlet, iv.

STIAN- fustian riddle! .... Twelfh $N$.

cannot enclure such a fustian rascal!.2 Hem

FUSTILARIAN-you fustilarian! ..2 Henryl

FUSTY -at this fusty stuff.... Troilus \& Cressida, i.

erack a fusty nut with no:...

that, with the fusty plebeians ...... Coriolon

that shows what future evils.... Meas. for Meas. ii. 2

present eomfort, and for future good. Winter's $T$.

and now the future in the instant...... Hacleth, i.

give me signs of future aceidents!. . Richard Henry. $I$. $\mathrm{v}$.

provide tor thine own future safety. Henry I $^{\prime} I I I$.

on the present; in finture, all

the fiuture comes apace
lie'd lay the tuture open

that future strife may be prevented Cymbeline, iii.

FUTURITY-purposed merit in futurity. Othello, iii.

$\mathrm{G}$

GABBLE-wouldst gabble like a thing.. Tempest, i. 2

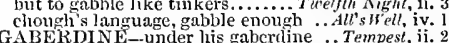

under the dead moon-calf's gaberdline... Tempest, ii. 2

spit upon my Jewish gaberdine ... Mer. of renice, i. 3

GAD-and with a gad of steel.. Fitus sudronicus, iv

GADDING-yon been gadding?.. Romeo \& Jutict, i

four occlock, earty at Gadshill ....

Geto, and Gadshinil, shall rob those men

good-morrow, master Gadshil .

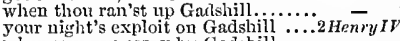

when you ran away by Gadshill ..... - ii. 4

GAGE-you shall not gage me. Merchant of Venice, ii. 2

luur] lown my gage npon

the lnke of Nortolk's gage

give me his gage; lions make..................

Cousin, throw down your gage

there is my gage, Aumerle, in gage to

there I throw my gage, to prove

differenees shall all rest zunder gage.

give me any gage of thine ..............

'GAGE-gage them both in an unjust.1 Hew

moiety competent was gaged by our king. Inumlet,

GAGGED-oeeasion to him, he is
an' your smile not, he's gagred

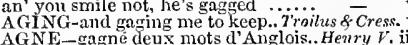

GAGNE-gagne deux mots d'Anglois.. Herry $V$. ii
GAIN-perhaps a hapless gain. Tto Gen.of $V$ erono,

if' study's gain be thins ............. Love's L. Los

What should I gain by the
shall gain what many men

mocked at my gains, scorned $\mathrm{my} . \cdots$ - $\quad$ ii. 7

I, his brother, gain nothing under...As you $\bar{L}$ ike it, i. 1

we rlown our gain in tears

till your deeds gain thein

gain, or perish on the seas (rep.)...Taming of Sh.
the loss, the gain, the ordcring ... Winter's 'Tale,

think he gains by deatl...... Comedy of Errors, iii.

and gain a husband by his liberty ..

to gain the timely inn

every one shall share i'

that for thine own gain shouldst $\ldots . .$. King John, i. 1

gain, be my lord; for I will wors

your care is-gain of care....

will add right worthy gains.
for the gain proposed choked

by no suit gain our aulience
wherein, to gain the language

wherein, to gain the language...

partakers of a little gain

if they can gain your liberty

shall the Frenchman gain thereby.

my mind presageth happy gain

then must I count my gains.....

for the crain thereof.............

uncertain way ot gain: $\ldots \ldots . . . . . . . .$.

ten times double gain of happiness

incleed, to gain the popertom and denth, their gain!.

T... Newryrill. v. 2

anything, we hope to gain hy you .. Cortolumus, ij. 3

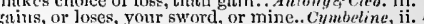

gans, or loses, your surord, or mine.. Cymbetne,

to gain lis $k m$.-guins $]$ the eap of

not gain so great a happiness.. Titus Andronirus, ii.

glory, whieli desert must gain ........... l'erirles, $\mathrm{i}$.

he gains the name of goorl............ - ii.

a rlced might gain her love

- ii. 5

thy mister would gain anght by me - iv.

her gain she gives the cursed bawd ..... v. (Gower)
which serves and seeks tor train ......... Lear, ii.

we go to grin a little patch of ground...Hamlet, iv.

an attempt of case, and gain, to wake..... olhello, i. 3

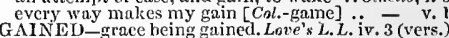

yes, I have gained my experience. As you Like it, iv.

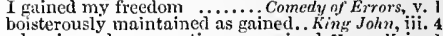

wherein such preparation was gained. Henry $r$, iv. I

hath gained thy daughater ......... Ilenry $r I . v .3$

so gnined the sur-aildition, Leonatus. Cymbeline, i. I

own gained knowledge should profane ... Othello, .

AIN-GIVING-a kind of gain-giving.. Harlet. $\mathrm{v}$.

GAINSAID - to be by me gainsaid...2HenryIV.i.

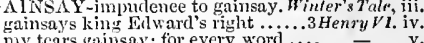

that I gainsay ny deed ............. Henry $\bar{\nu}$ III. ii.

but the just gods yainsay .... Troilus o-Cressida, iv

G $\triangle I T-1$ know her by her gait ........ Tempest, iv.

and strut in his gait? $\ldots$............. Nerry in ives, i.

the manner of his gait ............. - ii.

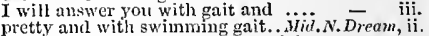

well begniled the heavy gait of night

everv fairy take his gait! ................

his gait majestical, and his general .. $\mathrm{L}$. Lost, iv.

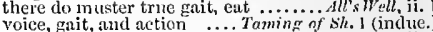

this chamber with her prineely gait? - ii.

hath not my gait in it ...........Winter's Trale, iv. 3

the forced gait of a shuffing ........ 1 Henry $1 V$. iij.

no legs, than praetised not his gait..2 Henry $\mathbf{L}$. î..

in face with his lion gait wrik...........Henry V. 1i. 2

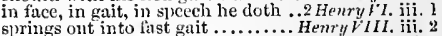

her cheek, her gait, her voice... Troilus \& Cressina, i.

I ken the manner of his gait........... - iv.

I do know him by lis gait .........Jutius Crsar, i. 3

what majesty is in her gait?. Antony \& Cleopalra, iii. 3

good gentleman, go your gnit ............. Lear, iv. 6

to suppress his further gait herein ........ Ilamlet, i.

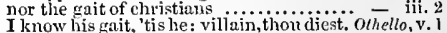

GALATHE-he fights on (ialathe. Troilus \& Cress. v. 5 WLE-calm seas, auspieious gales ....Tempest, v.

a little gale will soon disperse ........3 Henry r $^{2} . \mathrm{v} .3$

with every gale and vary of their masters. Lear, ii. knowledge in Hihocrates and Galen iii.

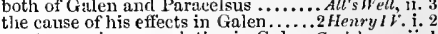
most sovereign prescription in Galen. Coriolanus, ii. 1 most sovereign prescription in Galen. Coriolanus, i1. I to strike, and gall them.....Ieasure for Measure, $i$. a dismissed offence would after gull..

can tic the gall up in the slanderous $\overline{-}$ iii. 2 thou grievest my gall. Gall? bitter. Love's $\mathrm{L}$. Lost, v.

gall of coat, and slips of $y$.

gath of goat, and slips of yew .........

save how to gall and pineh ........... Henry I $V$, i.

with the bitterness of our galls ......

for the gout galls the one $\ldots \ldots \ldots . . . .$.

have steeped their talls in homey.......Henry $F$ ii.

in fretting spend his gall $\ldots \ldots \ldots \ldots .1$ Hemry VI, i. 2
gall, worse than gall, the daintiest..2Henry VI. ii.

from the flow of gall I name not... IIenry J'HI. i. I

Whose gillt eoins slanders like. Thoil

the honey still, but these the gail.....
0 cieadly gall, and theme of all $\ldots . .$.

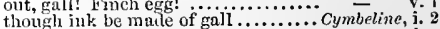

a jestilent gall to me! $\ldots . . . . . . .$.

all love, and added to the gall.............. $-\overline{\text { ind }}$ i.

sweet, eonvert to bitter gall........... $\overline{\text { Hamlet }}$ the canker galls the inf

and laek gall to make oppression bitter

if I gall him slightly, it may bc death

heel ot the courtier, he galls his $\mathrm{k}$

to slgar, or to gall, being strong on both

- v.

let it not gall your patience, good lago

GALI we have galls; and thongh we have - iv.

our royal, goud, and gallant ehip

to show keep your way, little gallant....

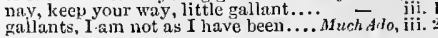




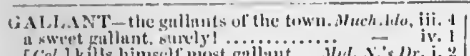

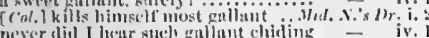
never diil I liear sted gallant chiding 每, anil this misst gullint, til ustrite. the

the gullnots are it humb.

this gallant pins the wenches.on

trisus gallants, full of courtship.

emme, where is this youmg gullunt...is you tiku

thull art a gallnit youth

a fallunt eurtle-nxe upon my thighi

freteh thent gullunt hithes

"tis a most gulthint fith

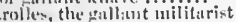

come, where las these thillnuts?..

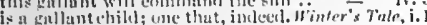

arew this gallume luewh of ow

know, the gallnnt monureh is

the gallant llof-iur there

n mallant prize? la, cousin, is it not?

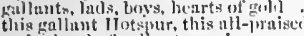

and a heut of zallant warriurs

at gollunt knight lue wats, his n:tuc.

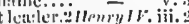

sweut drops of

is gullant and most prive prissices

of lay lady, he's a gallunt

to hinrse, you pallant prille's! ........

1) "tis a gallunt king!

citpuires, and galliut toutlume

guenl-morrow, gallints! want

gatlant Wurwiek. do but unsw

bring forth the gallunt, let us hear. .

rete is a gallant erenture, and emulete

lleretor's a gallant man

is't uit a yallant mun too, is t not? ..

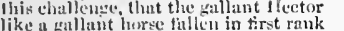

like a gathant hirec fallen in tirst rank

gallant show and promise of their.. $f m$

the enemy comes an in gallant show

Hive you joy, sir, nt your eallant bricle.

hear, and you are

sure he's a frallant pentlet

Nlityiene is tull of gallint

that gallant spirit hath aspired .Romeo

gallant, youner and noble efentlemn - iii.

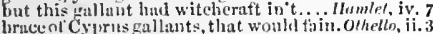

the gallunts desire it. Where are they?.. - ii. 3

ALLANTLY - kills himself most gallintly

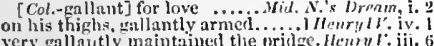

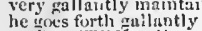

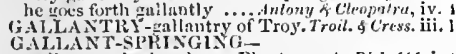

Gallant-8primying, lrave Plantagenet...Rich. III. i. 1

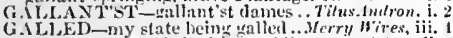

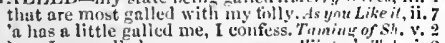

lisw I an galled

lave you becn iralied hy the king?..2 Henry $/ \mathrm{V}$. iv. 1

as doth a galled rock o'erhanir.

in walled eyes of wepping souls.

huntsmant thut has galled him.... Henry VIII. iti.

soine palled gonse of wineticter. Troilus feres. V:

the bull heing galled, gave Aries. Tílus.hulron, iv. 3

left the fusling in her gallel

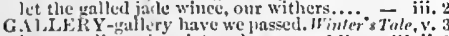

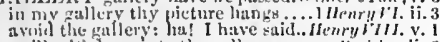
we'll uitharaw into the galler

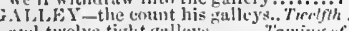

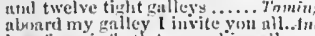

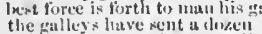

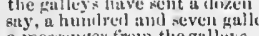

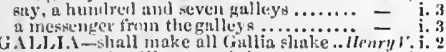

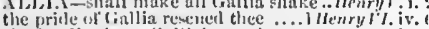

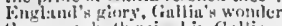

the quen hath ruinel in Gal! ia

the lerions now in tiallia.

that he alrealy hath in Gialia

the lepians now it trallia are fiill weak

the lerions yarrisonesl in (inili

Gilima all from finllia trawn

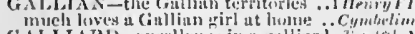

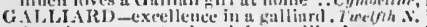

last thou not go to elurels in a galliard

can le witl a nimble galliurl won .... Inory $r$

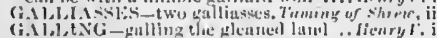
gleching and gulling at thi- ifontlemair

gallinu his kingly hames with hauling.liorioles, iv

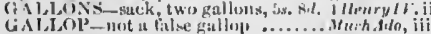

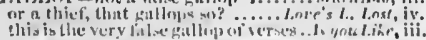

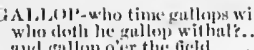

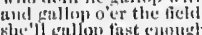

gally gin tlue zudiac in hi

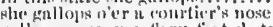

frallip unuec, you tlery-finted steei

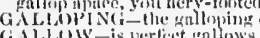

if a gnllows were an fand

what with the gallow's...... Hearese for Meas

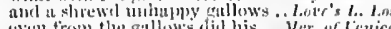

tis lising the tos the gollows

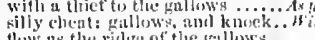

flow nx the rillge of the frallize

Ill make $n$ tat gisir of gillow

time ur other loresk surne tail

let galloxis gale gor the

murkesl for the

beling to the rallowes, and be hameci. ilenry

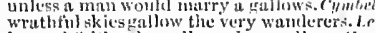

sices well.... lteml

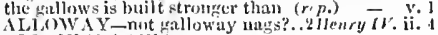

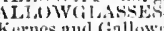

Kernes anl Gallowerasses is supplied... Mforbeth, $i$.

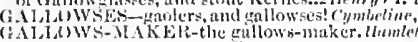

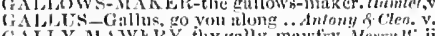

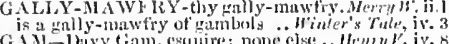

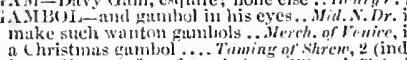

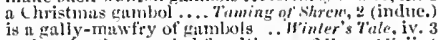

und such other gambil faculties....2 Ilemyll. ii.

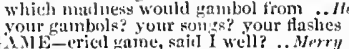

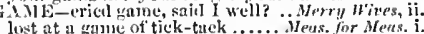

lowt at at gume of tick-tuek ........ Veus. for Neres. i.

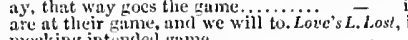

moeking intencled rame.

patime here, and filensant game .......

so thrive it in your rame!..........
the hest eards for tlac game, to win.

betore the game's aftuit.

the gane's atout; follow................
wear at the olympian games

he knows the colour of his usual game

nor play at subtle ganes.

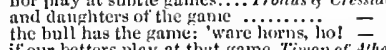

if our betters play at that game. Timon of Athen

followed the sugared gane betur thee $\bar{c}$ the games are ilone, and Ciesar is.Julius $\bar{C}$.

dost play with him at any game... dn tony foleo. ii.

for natural fatlier. The game is up.

follow where the came nakes way.."Tilus ind. ii.

the game was ne'er so fitir a..... Momeo of Juliet, i.

[Col.] every Hay makes ny game ......... - y. 1

I am not gamesonne: I lo lack.... Julius of sh. ii. I

so merry, and so gamesome............ Cymbeline, i.

you are a gentlemen. and a gamester. Lore's $L$. $L$. i. 2

now will I stir this gamester........s you like it, i. I

Wou a common gamester to the camp...Al's sell, v.

young gamester, your father ....Taming of Sh. ii. I

you are a merry gamester.

G Ali
there was he gaming; there oertook in... -

at raming, sweuring; or about some aut

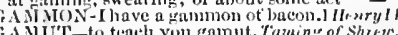

pist my gamut long aso (rep.)

eull you this, gamut? that! I lik

(iAN-'san passage find... Lone's L, Los!, iv. $\overline{3}$ (versi.

the thane of Cuwilor, gan a dismul ....ivicbeth,

the diu of war 'gan pierce his ......en eningmus

mine ftalian brain "gut in your

GiNy one with claps 'gan somml. pericts, fii. (Gom.)

i.N Y MLDE-call me, Giunymeile. As

here comes yound master Ganymede

there is more in it: cominin! fanymete!

G.AOL, - pen and inkliorn to the gusl... Iuch aldo,

and meet me at the gaol

carry this mid knave to
carry me to the gnoll

thint would have sent ne to the gaoi.

break open the gnols, and let out .

my retentive enemy, my gaol? Trimonof dfhe

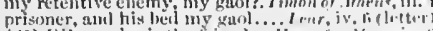

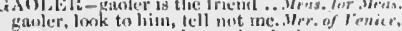

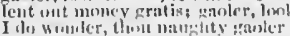

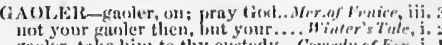

fursler, take linin to thy elistody.. . Comedy of Fer. i.

thon, gowler, thisu, I an thy frr

is mate my uniler to nttepel

his injury the pasoler tos lis pit

but yet is a funder to

hint your gnoler slumll aleliver you.

1) there were denslation of gasl

performed in this wide rajp of time.

tharl been as an gup in enr freat

stauds in the gunund tratle of

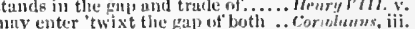

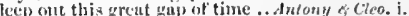

and matle at pou in nature.

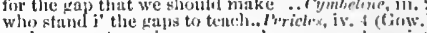

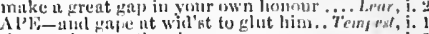

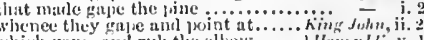

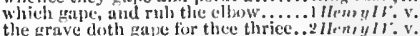

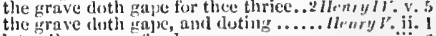

let gallows gape for dog.............. - iil.

or, eartl, gape npen wide ............ Aichurd III. $\mathrm{i}$.

or, earth, gape ngen wide

young aftiction gapes to he. Romeo \&-Julict, i. 5 (chiri.)

though hell it sefit should gaje ........... Hawlet, i. 2

the stpervisor, grossly gaje on? .......thello, tii. 3

every word in it a gaping wound...lyer. of $V_{\text {ent. }}$ iij.

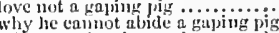

grievous, ghastly, gapping wounds ...

mouthy gaping an girded Hartlenr. Ileury l. iii.(rlio.)

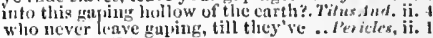

borrow me Garagantua's month...As you Lihe it, iii.

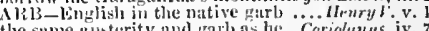

and emintrains the garb, dinite from ....... Lear, ii.

let nue eomply with you in this garb .... inmer, ii.

GARB.AGE-ntter for the garbayc.... Cymbeline, i.

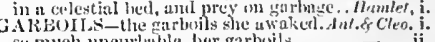

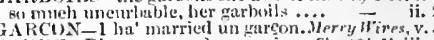

AlibE-Dieu vous garde, monsicur. 7netfh $x$. iii.
ARDEN-let the garden dour be slut

from the vineyard to the garden leats - iv.

thy curious-knot ted tarden...Lore. $L$.Lost, i. 1 (let.)

the pleasant gn rilen of great Itujy.. Taming of Sh. i.

us she went to the gurden tor jarsiey iv.

of that kind, our rustic gurelen's barren - iv.

make your garden rieh in gillyflwwers - $\overline{\text { iv. }}$

when our sea-walled guriten

dressed his land, ns we this garden:...

set to dress this garden ............. n. - itil.

in this best garden of the world ...... - v.

the world's best gurden he aelieved $-\bar{v}$. (eho.)

the gurden laere is more convenient..

climied into this sarilen

withenk into my gurden ............ - jv, 10

wool strawberries in your garden. . Bichusal IIT. ii.

he's walking in the garden........Antwny of cleo, iij. 5

to use his eyes for garden katerpots...... Lear, iv.

"tis an unweetlell garden .................Humler, i. 2

our lotics are our gardens ............... Ohello, i. 3

gardener, for telling me this uews.... H - iii. I

as gardeners do with ordure

illenryli.iv.

no ancicht pentlemen lut warleners.... Mumlat, y. I

to thDEN-1101:SE-

in his gurrenthouse, he knew me...

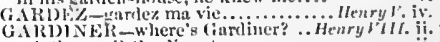

come bither, Ginrrliner to me ........ = ii.

Stokesly anil (iarliner ...............

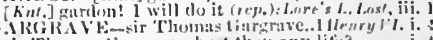

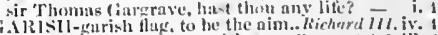

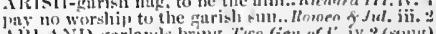

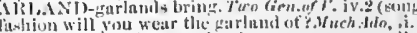

either to muke him a garlumi.

a rul the gurtume two; for the gurland

1 luek, to make you garlands of.. Hinter's Tale

to muke a garlanil for my heal ..... Henry I

Henrin: now the gurland, to have a molt -

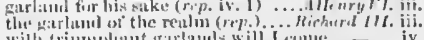

wilh trumplumt girlands wile come 


\section{GAIRLAND - that was your garland}

Mareius wears this war's garland....

third time home with the ouken gurland -

take this all swords o' the garland. .

change his horns with garlands!...Antony 5 Cleo, $\mathrm{i}$.

and put garlands on thy head

fautastic garlands did she muke .... Hamlel, iv. 7 fantastic garlands did she make

green willow must be my garland. Othello, ir. 3 (song) ARLICK - breed and garlick ...Mras. jar Meas. iii. ent no onions, nor garlick.....Mid. N.'s Dream, garliek, to mend her kissing ....'Minter's Tale

GARLIC-EATER o f and garliek. I HenryI

GARMEN' -pluek my magie gament.. Tempest, i. 2

with rich garments, linens ..........

on their sustaining garmen

that our garments, being as they were

our garments are now as fresh as when

how well my garments sit upon me....

二

there's another garment for't

if the garment bad beea made.

wo Gen. of $\overline{\text { Yer. iv. }}$

my daughter by her garment

.Merry Wives,

court Miargaret in Hero's gainents.... Mruch Ado,

by the Athenian garments.... Mid.

what notes and garnents he doth...Mer. of ven.

sueh garments, and siteh year's ...As you Like it,
are mere fathers of their garments .....All's Wel

are mere fathers of their garments

be proud, our garments poor.. Taming of Shreu,

elhange garments.witlithis gentleman

his garments are rich, but he wears.

known by garment, not by favour .. -

if your garments were thin .. Comedy

in everlasting garment liath him

Nectelh, i.

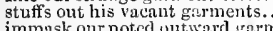

immask onr noted outward garments.] Henry $I V$. i.

and then to beslnbber our garunents
when I will wear a garment all of

when I will wear a garment all of

this new and gorgeous garmen

if men my garments wenr........
your garments, your lowliness

thy garments are not spotted.

SHenryIV. v. 2

did lap me even in lis garment

Richard $I I I$.

dashing the garment of this peace.

his meanest garment, that ever hath. Cymbeline, ji.

his garment? now, the devil (rep.) . .)
his ineanest garment? aly, I said (rep.)

a garment out of' tishion

master's garments in tlyy possession?
I would, these garments were come..

she held the very garment of Posthuinus -

how fit his garments serve me! .......

thy garments eut to pieces be

the girments of Posthum

in my master's garments

made up this gament through tle ......Pericles, ii. ?

give me fresh garme!its

do not like the fashion of your gurmeuts. $\overrightarrow{\text { ear }}$, iii. 6 am I changed, but in my yarm

remembers not these garments

GARNER-barns, and garner's.. Tempest, iv thet, iv.

rats thither, to gnaw their garners ... Coriolanus, i.

GARNERED-garnered up iny heart ..Othell, iv. 2

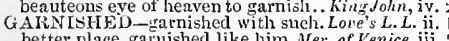

better place, garnished like him.Mer. of Venice, iii. 5
garnished and decked in modest...... Henry $V$. ii. 2 garnished and decked in modest......
GARRET -in the garret one niglit

GARLISON-of one towns of garrison. 1 Henry Vl. y.

GARRISONED-garrisoned in Gallia. Cymbeline, iv. 2

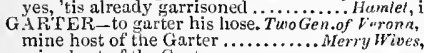

mine host of the Garter

his lorses to mine host of the Garter

does he not lie at the Garter?........

good mine host o' the Garter

be judgment by mine host of
hear mine Jost of the Garter

companion, the host of the Gar

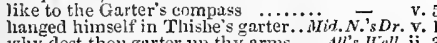

why dost thou garter up thy arms.... d ll's $l^{\prime} e l l$, ii.

garters of an indifferent knit.. Tameng of shreu, iv.
in thy own heir-apparent garters! .. I Henury $1 \%$. ii.

unloose, familiar as lis garte
to tenr the garter trom thy.

knights of the garter were of noble...

George, my garter, and my erown. . Richard III. iv. 4

thy garter, blemished, pawned his

lend me a garter: so; -0 tor a chair
GARTERED-gartered with a red. Ta

Lear, ii. 4

GARTERED-gartered with a red. Taming of Sh. iii.

perilous gash, a very limb lopped off. I Iewy $l \%$.

perilous gash, a very limb lopped off. Ilemry $l$. iv.

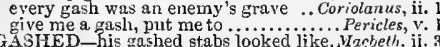

witl

the gashes do better upon them

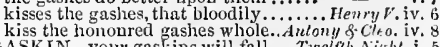
GASKIN-your gaskins will fal

nor gasp ont my eloquenee.

tight till the Jast gasp.

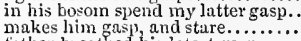

makes him gaspl, and stare.........

and to the latest gasp, eried out..

ant his uame is at last gasp............

a gasping new-delivered mothor. Winler's Tale, iii. 3

a bleeding land, gasping for life

iz Hemyll. $\mathrm{i}$.

GAT-Whom nature gat for men to see.. Pericles,

thee through the eity gate.. Two Gen. of Veron

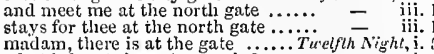

what is he at the gate,

there's one at the gate.

you were sauey at my gates....

make me a will low eab

men shut their gate.................... $\bar{v}-\bar{v}$. (song)

prepare to meet him at the gate

bid them bring the trumpets to the gate

no; but to the gate: and there.

I'li loek up all the gates of love....

through A thens' gates have we ... Mrid.

through Athens gates have we ...Mrid.

ven till the eastern gate, all fiery-red $\bar{g}$.

as thou did'st me in carrying gates

not come, lair princess, in my gates.. $\overline{\text { it. }}$ it

shut the gate nuon one wooer.

whieh stays for us at the park gate....

their coward gates on atomies.... As you Like it, iii.
for the honse with the narrow gate ...All's Well, iv.

that leads to the broad gate.....

the raseal lnock upon your gate

knock at the gate? 0 heaveu

with-knocking at the gate?

have gates; and those gates opened. Winter's Tale

Dromio, keep the gate; husband
shall I be porter at the gate?

who are those at the gate

the abbess shuts the ga

without the palace gate .....
from hence to the palace gate...

from hence to the palace gate
there's knoeking at the gate.

welcone before the gates of $\mathrm{Angiers.}$.

your city's eyes, your winking ga

rammed up our gates a gainst.

open wisle your gates, and let joung

open your gates; and give the vietors way -

to our fast-closed gates ....................

ope your gates, let in that amity

who keens the gate here, ho! .........

break Slkogan's head at the eourt gate

by his gates of breath there lie

heavy burdens at his narrow fate......

enter our gates; dispose of us

open your gates; come, uncle Exeter -

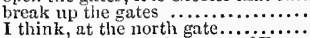

are the eity gates, the gates of Ronen
go to the gates of Bourdeaux .........

open your city gates, he hum

for vengeance at the gates of
broke through London gates.

set ope thy everlasting gates ...........
the poor well pleased trom my gate

through the city to the pala

open thy gate of mercy

the morning opes her golden gates

and on the gates of York they set...

from off the gates of York feteh....

prisoner to your palace gate.
lefore the gates of York

the gates made fast.

apen the gates, we are king He
the gates sliall then be opened

these gates must not be shnt

whe thou ope the city gates ............

let's shut our gites, and sleep. Troilus \& Cressid

or like a gate of steel f'ronting

he shall unbolt the gates ..............

I'll bring you to the gates............ -

no porter at his gate........... Timon

agrainst our rampired gates
our gates, whici yet seen shut...

our gates, whicil yet seen

upon the sudden, clapped to their gates -

henee, and shut your gates upon us ..
Mareius did fight within Corinli's gate
GA'TE-the mortal gate o' the eity ... Coriolanus, ii. 2

they would not thread the gates .... = iii. I

go, see him out at gates ..............

let us see him out at gates

bring me but out at gate $\ldots \ldots \ldots \ldots \ldots$ 二 iv. 1

the porter of Rome gates by the ears = iv. 5

when you have puslied out your gates - v. 2

than your gates against $\mathrm{my}$ toree .... -

as the reeomforted through the gates - v. 4

go to the gate; someborly knoeks.......ulius $\overline{C r e s a r}$, ii.

like madmen through the gates of Rome - iii. 22

$\begin{array}{ll}\text { this gate instruets you how to adore } & - \\ \text { the gates of monarchs are arehed .... } & \text { iii. } 3 \\ \text { iii. } 3\end{array}$

aud on the gates of' Lud's town set... = iv.

open the gates, and let me in... Tilus Andronicus, i.

before the palace ante to brave

the gates shut on me, and turned ....

sin within, will touch the gate $\ldots \ldots . .$. Pericles, 1 . .

at thy gate howled that stern time ....... - iii. 7

Po, thrust him ont at gates .............. \& o Juliel, ii. 5

the natural gates and alieys of ijue body. Hamlel, $i .5$

and keep the gate of hell; you! ....... Ohello, iv. 2

and I of him will gather patienee.... Much ddo, v. I

will lead thee on to gather from.....All's Well,

by this we gather, you have tripped. Winter's Tale, t.

gather the sequel by that went. Comedy of Errors, i. 1

thus may we gather honey from........ Henry $V$. iv. 1 the rest, I wish thee, gather.......... - ii.

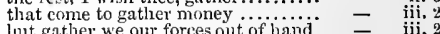

but gather we our forces out of hand
then gather strength, and march unto

to smithífeld, and gather head $\ldots \ldots$ Henry $V I$. iv. 5

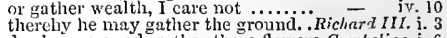
dew's on ground, gather those flowers. Cymbeline, i. 6 by them gather their several virtues $\quad . \bar{L}$ ear, iv. 5 hangs one that gathers samphire ........ now gather and surmise now gather, by laim, as he is beliaved...... - ii. and gather by laim, as he is belaved ... Venice, y. I than may be gathered by thy shape... - ii. 3 my soldiers, gathered floeks of....... 3 Flenry $V i$. .ij. 1 they had gathered a wise couneil ... Henry VIII. ii. 4 of him I gathered honour ......... Cymbuline, iii. I upon a gathered lily almost withered. Tilus And. Iii. I
the Goths have gathered head........ GATHERING-sin, gathering head.. Richard $I I$. y. GA UDEO-video, et gaudeo .......Love's L. Lost, v. 1

ii. 1 therefore thou gaudy gold... Merchar th of Veniee, iii.

therefore thou gaudy gold...Merchat rt of Veniee, iil. 2

have one other gandy nirht ...Antony \& Cleo. iii. 11
rich, not gaudy; for the upparel oft .... Hamlel, $\mathrm{i}$. 3

GAUI-I say, Guallia and Gaul!...Merry Wives, iii.

Ah, Gaunt! his blood was thine.

eall it not patience, Gaunt ........
farewell, old Gaunt; thou goest...

knew the name of John of Gaunt....

how is ' $t$ witll aged Gaunt? ...........

old Gaunt, indeed; and gaunt (rep.)

my liege, old Gaunt commends him

nor Gaunt's rebukes, nor England's

as not Gaunt dead? and doth not (rep.) -

as when brave Gaunt, thy father .....
in sou, I see old Gatunt alive .......
he should have tound his unele Gavnt

I am not John of Gaunt ............. I Henry the seat of Gaunt, dukedom of Laneaster - v. 1 tahn of Gannt loved him well ....2 Henry $1 \%$. iii. 2 told John of Gaunt, he beat his own - iii. 2 from John of Gaunt doth bring .... I Henry VI, ji. 5 John of Gaunt, the duke of Lancaster 2 Henry VI. Th. son and heir of John of Gaunt

all the line of John of Gaunt ......3 Henry FI. i. I disannnls great John of Gaunt ...... - iii. 3 GA UNTLET -into armed gam tlets.. King John, v. sealy gauntlet now, with joints...2 Henry IV i. hy Mars his gauntlet, thanks!.. Troilus \& Cress. iv. 5
there's my gauntlet; I'll prove it ....... Lear, iv. 6
. L

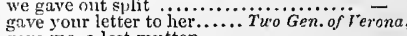
gave me, a lost mutton

fhe gave me none...

yon gave me bitter pill.

whieh gave me first.

this ring I gave lim

his Julia gave it him ait his departure

the ring I gave to Julia..............

that gave aim to all thy oath
who even now gave me good 


\section{GAV}

GEN

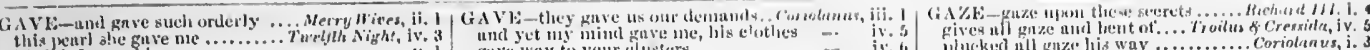
this jearl ble guve n

ueth Allo, ii.

ind I gnve him use lior it .

Which straight the gnve me ...Mid. . S Drem, iv.

prokligally gave them all

that fure tluse tokens to $1 \mathrm{~s}$

you gare me this: but tuke it....

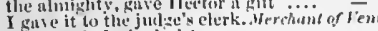

gave it $r$ judge's elerk:

I gave it io a youth, a kinil it lio

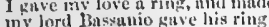

iny lorid anse you lord

I give the ring, ir you did knyw (r

I give the ring, il you diti know

her worthiness thant gave the rits:

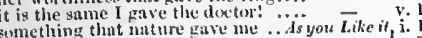

who gave me fresh array ........ii. ivell, $^{\mathrm{i} .} 3$ (song)

and gave this bentence then

that gave him out incurnble .......

and, when I gave it llelen, I lidde

unless she gave it to yourself in bed

for all thint, he gave it to a commone

and this was it 1 gave him

huy it? or who gave

I gnve it his flrst wite.

gave me iny being, and iny father. Tuming of sh i.

gitve order how it should he done (rep.)

the eharge my futher gave me... Winter'

the ortere gave hole thon wast in beme

dicp gave any tragic instanee

ictt the money that I gave you?

where is the gold Y gave in ehirr
the thousand marks I gave thee

the golut I gate to Dromio

the entar, nith the gold you gave me

something that you gave me for

Ind the blows you gave were ink .....

why, sir, I guve the money for.

drink gave thee the lie last night
ny fither give me honour (rpp.

that gave the sound of words

your chambers gave you ehastisement?

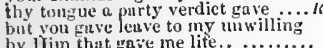

at Yenice, gave his boty to that.

no joyful tongue gave him his

to whut enil he gave me the sugar

that gave Amaimon the hastinad

and gave the tongue a helpfol

and gave his counteuance...

my fither gave him

gave him their heirs ........

I gave him this wound in the thigh.

he gave his able horse the head.......

the irince gave you-lie gave it like

and the boy that 1 gave fulsta

proportion that we gave them out

give that, which gave thee

wore it, kept it, gave it me ........

give thee no instance why thou

and gave me up to tears

that 1 gave it to in ehauge ..........

remember what I gave in charge
I gave thee life, and reseued thee

"tis true. I gave a noble

the inilk tliy mother gave thice

gin that ever mariuess

I never gave them condign punishment -

aceording as 1 gnve diretions? ........ iii. 2

the ruthless giteen gave him.........3
my eareless tather find ly gave away!

geitlenian gave up the ghost ......

lasted. gave king IIenry lirbt.

time of death he gave our finther ....

narringe was the elarge he gat
doint wh hat you guse in cliarge

that gave the kinglom to thy hrothe

who guve his blent to lime the

the thing you fave inclimse.

all indirety gave dircetion

nay, guve notice he was from the....

this gave to me many a gromuing th

cromucll. gave it you the king:

with his own hunf gave me.

the king, that wave it. It mist

(1) wlioun he gave these words. .

he gave his hismurs to the worli......
ant gave the elergy an ill examplic.

that guve us sueh a prince

I gave ye jower as he wa.

whe thut gave thee anck.

if I gave them all my livis

Whas the oftenee yon gnve hich

Gave me cold looks: mud neeting.

guve hin wy in all his ow in ile: ire.

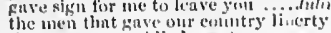

that guve me jublic lease to
rissh fumour, which my unt

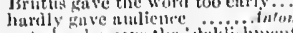

anto her he gave the simblishment

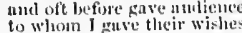

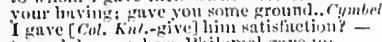

turned dewn, where l'hilomel guv

and it gure ame presut himer to ticed

the man that gnve them the

maded loeula gave the Greeks

the drug he gave ne, which, he said

that guve the atiront with them

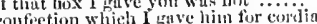

entrolled in that je frankly gave. Fitus dmen

gave you a dancing-rajicr hom sic

chyt first gave life to you

gav'e Ariey sneh a knoe

Geve hiventy kines

glail lic

I gave you all-and in good time

whose frank hieart gave al

guve her dear right to his .........

I gave thee mine betore thou . I

you gave us the counterfeit fairly

gave him what beeomed love I might

Inever gave you augh

gave us not that capability

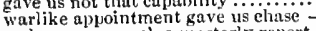

and rave you such a musterly report

and fave you the Frenchman gave you

subseribed it; gave't the impression.

beiner gave conne gave mer my pains

that the Moor first gave to Desdemona

eursed fintel that gave thee to the

I gave her sueh a one: 'twas my... .

gave away my heart. A liheral (rep.

she, dying, gave it mes and bid mo

alas, the diyy! I never gave him cause

same handlkerchief, you gave me even

she gave it him, and he hath given it ...

I never gave him tike

pleige of love which I first gave her

antique token my father gave my nothe

dear generai, I never gave you eause

she whom thou gavest to me .. Cosnedy of Lrrors.

singur thou gavest me ...

the life thon gavest me lirst

illenry

time thou gavest new date............

mercy on the fault thou gavest ..Henry/lll. iii.

gavest thine ears, like tajsters. Timon of the

thou gavest me poison

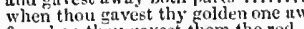

for when tlom gavest them the rod

that late thou gavest me........ Romeo of Julies,

aW D_rings, gawds, eonceits......Miti.

an idle gawd, which in my childiood

and too fitll of gawds to give me .. hing John, iii.

gratse new-born gawds ..... Troilus f Cressula,

to Clidton, l'll to sir Nichulas Gawsey - - Y.

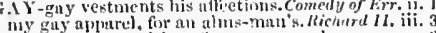

that he is entered into tor gray apm

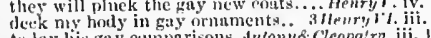

to hay lis gay emmprisols...1nionys cleopntrn, iii,

G.A Niss-our gayese, and our pilt ... Inenrys"

his eyes enelunitul with gazes.... Lore's L. Lost, ii. I

to gaze on christian fool
turned to a modest qa\%

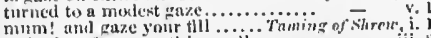

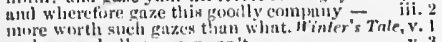

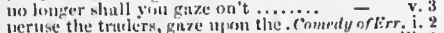

guze where you wheshli, and that will

the sluw ard gare o' the time

nthind no extruordinary kare

it' Mes, gaze on, fund grovie' on

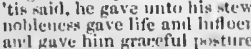

anl guve him graseful inst plucked all gaze his way

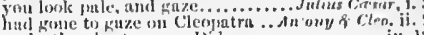

make the ghasts gaze: Diano.......... - iv

cust their yukes on Mlurina'k fuec ....... Perirles, iv.

thint full btok to gaze on him . Roveo of Julice.ji.

guze on us. Mlen's ryes were made (rep.) - Thello, $i$.

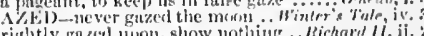

right

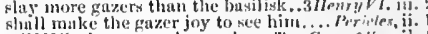

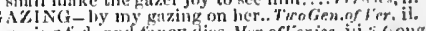

atill gazing, in a doubt whether ....

at length the sun, gazing upon .. Cumedy of Err.i. I

for pazing on your thams.............

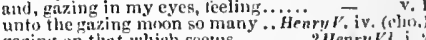

jeople, gating on thy face ..........

anwl leave his navy gazing. Anlony fo cleopatra, iii. I

like Patiente, gazing on kings prives.. Pericles, v.

a goul wench for tlis gear .......... - ii.

I will remedy this geur, ere long .... - iii.

will this gear ne'er be mended?.. Troilhs \& Cress. i.

come, to this gear ............Tilus Andronicus, iv.

here's goodly gear! $\mathrm{A}$ sail, a sail.Rmeo of Jutiet, $\mathrm{ii}$.

Gleh soon-s]jeeding gear as will dispere - - wight,

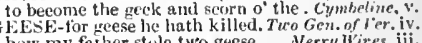

how my father stule two geese......Merry lit ites, iit.

sinee I plueked geese .................. prean, iii.

when green geese are a breeding .. Lore's L. Lnst, $\mathrm{i}$.
there ix tint thourand-Geese, villaiu?... Macbeth, y.

like a flock of wild geese............. i Henry 1. . ii.

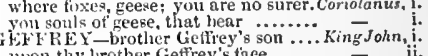

mpon thy lrother Geffrey's faee ......

that Geftrey was thy elder brother $(r e p)=$. ii.

liker in teature to his father, Gettrey $=$ ii.
I was Geftrey's wife: young Arthur

ny fault that I was Geffrey's son? ...

by mine honour, I'll geld them all. M'inter's Tale, ii.

twas nothing, to geld a cod-piece of - iv 3

hereft and gelded of lis patrimony. Richind II. ii. I

Say huth gelded the commonwealth .2 llemry $/$ l. iv, 2

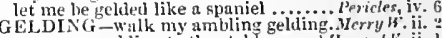

to see my geldin to the stable...... Henry $V$.

to bring iny gelding out of the

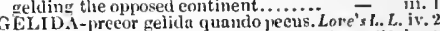

GELIDUS-gelidus timor ocenuat ..2Uenry $r l$. iv. GLI'T-Would he were gelt ...Merchant of Venice. $v$

never so rieh a gen was set. Herchant of Penice, ii.

thut gem conterred hy tertament ..... Ail's If irl, v. 3

reflecting gems, that woned ........ Hembllll, ii. 3

and by a gem of wonen...Antony \& Cleoprtra, iil. 11

indleet, and gem of all the nation...... Hamiet, iv. 7
GEMIIN

love the general genter bear hin...... Hamlet, iv.

supply it with one gender of herbs ........ Olhelio i.

GENEKAI-- to be our general?. Pico Gen, nf $\bar{i}$ er. iv.

and even so the general... Meusure for Measure, ii.

to your lieart, and general hirinour.....

and gient general of trotting pa

half cones to the general state. Herch, of Ienice. iv.

he is the generul challenger $\ldots . .$. .. As you like 1 , i.

disgorge intos the general worki.......

thou art a genural otienee.......

the general of our horse thou art .....

you are a merciful generul : our general

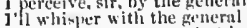

the genernl says, you, that hic

as hars to mir fenernl the the meing

as ariuk to the peneral jov of the sine

the general cause? or is it a lece-prict

much more gencral than these line. King John,

and the peneral eourse of the aretinl.. Inrary)

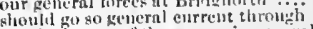

are the horses of the enemy in general

grectiug trusule genera

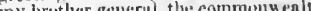

all the eountry, in a perueral volce....

liere come I frum our prine ly teneral

contains of pereral grierance

combans of generalgriesance
this will 1 bhew our geseral. 
GENER AL-here eomes our general.2Henry r.iv. 3 did, as heir gencral, being descended

and what a beard of the general's cut

werc now the general of our wincins - iv.

than a general petition of munurchs

vou are disputing of your generals... Henry $r \cdot 1.1 .1$

simmon their general unto tlie wail

all our general torce right

success un to our valiant general

implored a general peace bet wixt...

parley with Jack Cade their renera

a woman's general; what shonld

wocs are parcelled, mine are general.

this general inpulatwe, and elieerful siout

this general applatise, and cheertul sho

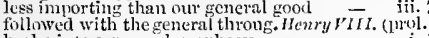

broke into a general propliecy

liatl sent one general tongue uito $\mathrm{u}$

offered sorrow; this, general joy...

with a general taint of the whole statc

wijen that the general is not like.
the general's disdinet by lim

severals and generals of grace exoct.

call Agamemon head and general

it is spread in general name.

good or bad unto the general

did not the general run then?.

our noble general do not do so

please it our great general to eaji

what, comes the general to speak

my lord, anght with the vener
that takes me for the general?

holvured captain general of the Greeian

by Priam, and the general stat

our general doth salute you with a
better, she were kissed in general ...

after the general, I beseech you next

the general state, I fear, can scarce...

to square the general sex by Cressid's

I knew it the most general way. 7 imon

to gcneral filths convert o' the instant

and their crop be general lepros

plunged thyself in general riot

stolen from general excrement

my general and exceptless rashness.

foryetfulness too general, gross

though in general part we were opp

I receive the general food at first ...

miscarries shall be the gener
Cominius the general is gone

say, has our general met the enemy?

o general, here is the steed

I thank you, gcneral

am bonnd to beg of my lord general

welcome home. and welenme general

and last general in our well found

by the yea and no of general ignoran

rather show our general low ts how you

my sometime general I have seen.

defence of a town, our general is ex.

our general. Cains Mareius (rep.)...

general himself makes a mistress
which was sometime his genernl

our general will no more hear from thence -

heard your general speak of Roni

the general is my lover

finctionary on the part of your.........

our general has sworn you out of reprieve

I mean thy general. My general cares
tor tlie woild nor your general

let your general do his worst

the wortliy fellow is our yeneral

against the general suit ot 1

be anght toward the general good.......

another general shout! I do believe.

to spurn at him, but for the general.

are to the world in general, as to Casar

and pity to the general wrong of Rome

the horse in general, are come witls..

let me go in to see the reneral

slame, you generals: what do you mean? -

Frepare you, generals: the enemy comes

the generals would liave some words
what says niy general? Mlessala, this

What says niy general? Mlessala, this is

in a genersl honest thought.

but this dots, te of our general

and whose generzil graces, speak that

pray you, hasten yeiu generals after
had our general been , wat he knew
general. Good-morrow, general!.... ii.
is

alike conversant in generas services

to see the general liunting in this. Tilus Andron.

blot and enemy to our general o.ame!

what says our general?

go tell their general, we attend

and p] ace of general wonder

express a gencral praise to he

as well in the general dependaut
GFNER $A I_{L}-$ left behind lim general! $\ldots .$. Lear, iv. 3
reneral, tuke thou my soldiers $\ldots \ldots \ldots \ldots-$ y. 3 our lresent business is general

somd tho general doom! ....... Komeo of Juliat, iii. 2

then will I be general of your woes

Hamlel, i. 4

shall in the general censure take.........

twreclaimed blood, of general

in general synod, take away her power

the kint sigh, but with a general groan.

great love thie general gender bear lim.

the duke does greet your, general .........

to incur a general mock, run trom her

nor doth the general carc take hold on

good lientenant, is your general wived?.

tis one Iago, ancient to the general.

of Cylnus, and our noble gen

to the henlth of our general................

the general were put in mind ot it

hold, lold! the general speaks to you ...

there are ways to recover the general aga

ant bid-gool-morrow, general...

and the general so likes your music.

the general does not greatly care .........

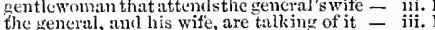

general will forget my love and service..

if the reneral camp, pioneers and all

I do attend here on the general .........

save you, worthy general! ...............
trom hence; I'll feteh the general's surgeo

with such general warranty of heave

clear general, I never gave you eause ..... v v.

best call them gencraliy, man by man.Mid. $N . D r$ i.2

hath generally taxed their whole. As you Like it, iii.
that so generally is at all times good... All's If ell, i. I

as to be-generally thankful ........

$\mathrm{king}$ stands generally eondemned... Richard $I 1$.
are generally fools and cowards...2 $\mathrm{Henry} I V$. are generally fools and cowards...2 Henry $I V$. iv. 3
and, generally, to the crown and seat.. Henry $V$. j. generally whoever the king favours. Henry VIII. ii. 1
fill, all over, gencrally? .... Troil «s of Cressido, ii. 1 and, generaliy, in all shapes .. Thinon of Alhens, it.

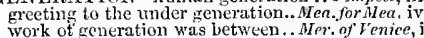

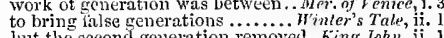
to bring the second generation removed... King . Tohn, it. beget. a generation of still-breeding..2 Henry ${ }^{\prime}$. iv. is this the generation of love?.

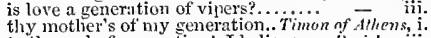
to the end of generation! I ber.

and rundo a whole generation ........... . Len

GENEROSITY-the licart of generosity. Coriolan nes, $i$.

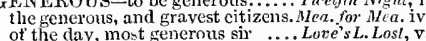

of the day, most generous sir

footing in your generous bosoms? Troilus $\delta$ - Cress. ii. 2

my mind as generous, and my shaj

most select and generous, chief in that.. Hamlet, i.

nost generous, and free from all contrivi
so far in your most geuerous thought

the generous islanders by you invited.. Öhello, iii. 3

GENITIVe-horum, harum, horum.

GENIUS-our worker genims can ….Tempest, jv.

his very genins hath taken...... Tuelfh Night, iii.
one of these men is Genius to..Comedy of Ery ors

one of these men is Genius to... Comedy of Errors, 1

under bim, my genias is rebuked .... Hacbelt,

the genins, and the mortal.

GENNET-and gennets tor germans .... Ohello, $\mathrm{i}$.

Antonio, as I heard in Genoa.

in Genoa, where we were lodgers. Taming of Sh, iv. 4

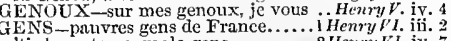

'tis bona terra, mala gens ..........2 Henry Fl. iv. 7

GENTILE-a G n n

le gentilhomme de bonne qualite ..... Henry $\gamma$. iv. 4 GENTILITY-law against gentility !. Love's L. L. I. 1 GEN'TLE-tor he's gentle, and not ..... Tempest, i. 2 she is ten time: more gentle .

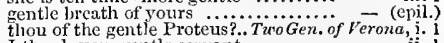

I thank you, gentle servant

O gentle Protens, love's.

gentle girl, assist me

with gentle murmur glides..........

as patient as a gentle stream

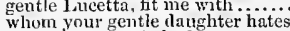

I gave him gentle looks

sit Proteus, gentle lady, and your
GNTLLE-gentle lady .... Thro Gen. of Ferona, iv. 3 thou gentle nymph, cheris

nay, if the rentle spirit of moving....

come, gentle master Slender, come..Mrrry Wri

she is pretty, and honest, and gentle

gentle master Fenton,

good gentle one mistress ........... - iii. 4

I eome to whet your gentle thoughts -

I pr'ythee, gentle friend, let tlughts

by whose gentle help I was preserver

gentle Isabella, turn you the key., Heas.for.Meas. $\mathrm{j}$.

gentle and fair, your brother ........ - i.

entle my lord, turn back ......... = ii. 2

nor, gentle daughter, feur you not $\because 01$ - iv.

or reprieve, tor the most gentle Claltio - iv.

greet 18 here anon, my gentle Varrins - iv.

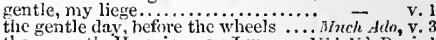

there, gentle Hermia, may I marry. Mid. N.'sDr. i.

my gcitle I'uck, come hither........ - ii.

I pray thee, gentle mortal, sing again - iii.

you wonid not use a gentle laly so.. - iii.

answers fiom my gentle tongue?

I'll apply, to your eye, gent]c lover.

thy fair larde ears, my gentle joy....
gentle Puck, take this transformed..

how eomes this gentle concord in ...

woy, gentle fricnds! joy, and frosh....

gentic's, perehance, you wouder ...

whose gentle hearts do fear the swalie

gentlcs, do not reprehend; if you ..... - (epii.)

no so, rentle beast: my lips are no.

but, gentles, agree: the civil war of.

it her train there is a gentle lady

and gentle gentles are at their game.

lend me the flourish of all gentle tongues -

fiir gentie sweet, your wit make

this is not generous, not gentle

touching but my gentle vesscl's side...I

- i.

tell gentle Jessiea, I will nut... queen - ii. 1

for lis gentle daughter's sake..........

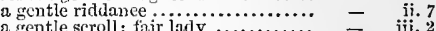

that her gentle spirit comnits itselit.. - iii.

gentlie lady, when I did tirst impart - iti.

we all expect a gentle answer, Jew

and pardon me, ny gentle Gratiano

in the gentie eondition of blood ...As you

yet he's gentle; never schooled

your fair eyes, and gentle wishes

displeasure 'gainst his gentle niece

and wheretore are yout gentle........

your virtues, gentle master, are sametified -

most gentle Jupiter!

an sorry for thee, gentie silvius

woman's gentle brain could not droj

he led me to the gentle duke

patience, gentle Audrey

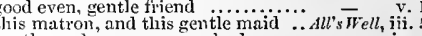

gentle madam, you never had ...... - iv.

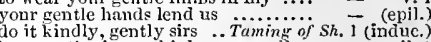

I find you passing gentle ............ -

entles, methinks, you frown......

-

hen you are gentle, you shall ...... - iv.

good-morrow, gentle mistress ....... - iv.

gentle my lord, jou searce can riglt - ii.

from the access of gentle visitors?.... - $\quad$ ii. 2

limagine me, gentle spectators $\ldots . .$. - iv. (chortus)

wherefore, gentle maiden, do you negleet - iv. 3

wild, and yet too, gentle ............... Fedy of Errors, iii. 1

then, gentle brother, get you in ...... - iii.

possessed with sueh a gentle sovereign $\quad$ - iii.

they are such a gentle nation ..........

itself untle mistress. And are not you..

, gentle lady, tis not for you $\because \ldots . . . \quad$ ii. 3

statute pur'ged the gentle weal ...... - iii. 4

my ever gentle cousin, welcome...... - iv. 3

say briefly, gentle lord, we eoldly ....Kins Jolin, ii. I

make a riot on the gentle hrow...... - iif. 


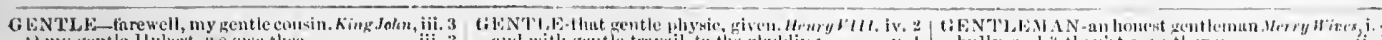

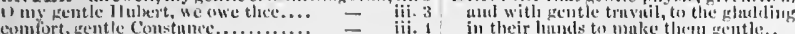

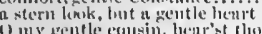
in their hiunds to make tlaru gentle.

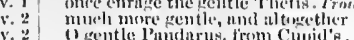

gentle killsmum, go, luet lirust

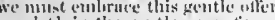
gimarleth in the gentle eye's of peace

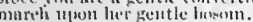
and their kentle lesarts to tieree.

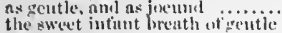

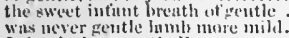
all youstiem of the gentle truce this is the most despitefiul gentle ghe

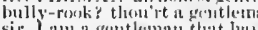
sire, an a gentleman that buse sinent

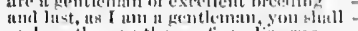

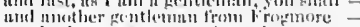
yomiler is a mosel revertinl gent lewan the fortientill is of mo having

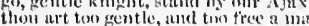
most gentle, man nost valiant liestew

there is a gentlemsens

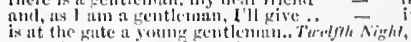
" pentleman. A rentlemus? (mp). . Hentle A peinantes. 'Till 1 be gentle. thinhs, gentle uncle; rome, iurlis. ung gentle carth, nor with thy lit's flitht with went le woris comblacter to a gousle buth

gentle Northumberlanel, if thy o s.lich with such gentle sorrow hear me, gentlo liced Rise up

we thauk thee, gentle l'ere

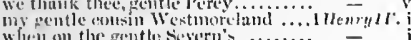
whell sin the gentle keverry

gentle llarry ]'erend und kind cous.... trest ine aente Kite

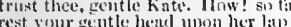

rest your gentle hent mon her lal

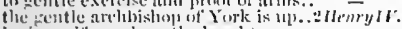
furing wife, and gentle datughter sleep, sentle sleer, mature's solft

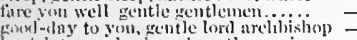
my gentle Marcins, worthy Cains. to take in a town with gentle word

be not jentle woumled....... izr.......

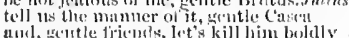

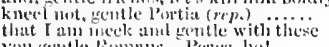

You genfle limmans, - fente, la

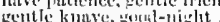

gentle knuve, poubl-niglit ...........

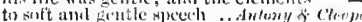

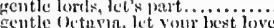

nay, yentle maxlitin, to linin.

gentle aclieus, and grectiniss

I am a gentleman. I

suve your, gentlemn

the led laviontr of the young Henthmat

fentleman, lind fave thee

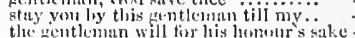

ns he is a gentleman and a soldier

it this yoming gentlenas lave dome

the count gentemun, bue cesario.

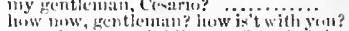

a frentleman, and tiollower of iny laily's

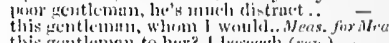

heres a gentlinan, and a friend of inine -

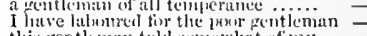

this rentleman told somewhat of iny -

gentle, henr me: mule alknt Chesar

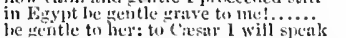

gentle madam, no. Yom lie ..........

(Which towath yout are most genth

gentle linly, big of this gentema
you gentle goin, give me but this

my gentle cheen, where is our tanghiter?

they are as gentle as zedryyrs

these gentle prineses (fir) sinel

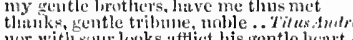

nor with sum lonks aftlict his gentle le
muler your patienes, gentle empress

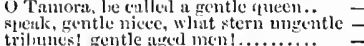

speak, gentle sister, who hath martyrud =

gentle Lavinia, let me kiss thy ips..
o gentie Auron! dirl ever raven sing

and, gentle girl, eat this; luere is no..

o, gentle Aaron, we are ail zinconen:

go, gentle Mlarens, to thy nephew Lusius -

bind them. wentle Publius .......... -

but, gentle people, give mo aim awhile -

iniet and gontle thy conditions.

thitlicr, gentle nariner, alter thy emire
gentle neighbonrs; lentl ne your liands

gentle neighbonrs; lent we your liand

toreflow you have a gentle hent
assured she eame of gentle kind

assured she eame of gentle kind

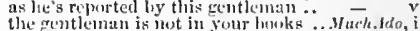

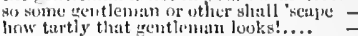

low tarty that acutloman look
whe+1 1 kjow the gentleman

whell 1 know the Eentleman ........

clothi wet the gentlemmen deserse as full -

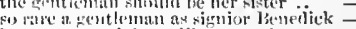

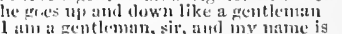

wi itc down, master gentleman Conrade

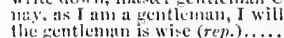

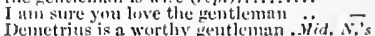

your name. houest fontleman?

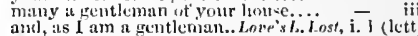

you are a reutlemun, and a famester

sil, the king is a milile gent lemun

mysetf", ur this sallant gentleman

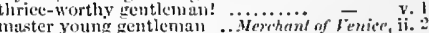

for the young gentlematn (uccording - ii. 2

the follower of so poor a gent lman...

ran in my veins, I was a rentleman

how true a gentleman you seud relices
unto the fentleman that lately stole his

Antonio, gratify this gentleman $\ldots$....

most worthy gent man, and my triend $\vec{F}$ iv.

excreises as may becime a feintieman

young gentleman, your spirits are tou

ay: fure you well, thir gentleman....

for all the old gentieman's sayting ....

her voice was cver soft, gentle, and low .. - v.

gentle snn Erlwiurd, thum wilt stay.
duke of Nortiolk, gentle Warwick

dik lions east their gentle luoks?

in pity of the gentle king ............

smile, fentle heuven! or strike (rep).

gintle Warwick, let me emilsace

1) pity, fity, gentle heaven, pity

then, gentle Clarence, welemine.......

gieak gentle words, und humbly bend

see sur tentle queen how weil slie fires

but, geritle laily Anine, to leave this..

there's many a pentle person

chorit me for my gentle cirunsel?

1 pray thes. gentle kecper, stay
thit the gentle duke is dend?

shusulal steal such gentle shapes.

wnw hath seized the gentle lifind

I thunk you, gentle wnele 0 my lind

conie hither, gentle ('utesliy

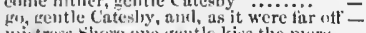

I westume, he'll tuke in untle purt

thauls sente citizens, and triends.

and gentle, kind, officininate rennesic

pesal eonsin; furewell. gentle triends

to gratulate the gimite princes there.

luy the gentle liabes; thes, thing.
and buried, gentle Tyrril?

if set your gentle senits Hy in thie.....

und lap their gentle bloxk.

w.lere is the fentle kivers, Vaushin.

I will le inifil and pentle in my korils

that love, so gentie in his view...

well met, honest gentleman...........

this is the motley-minded gentleman $-\quad \therefore$.

content thee, gentle eoz, let him alone

the sentle fine is this, - my lips....

I'If warrant liim, as tentle as a lamb

gentle Alercutio, put thy rapier ul .o.
ittcret witl gentle breath, ealm look

conne, gentle niglit; cume, luving ....

goof gentle youth, teniyt not a desier.

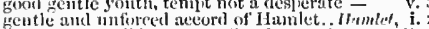

and gentle Guildenstern. Thanks (rep.

$O$ gentle son, unn the lieat and flume

but that I love the gentle Desicmonn othello, $\mathrm{i}$.

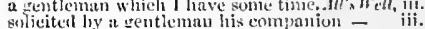

is a tentlement thut serves the cenut

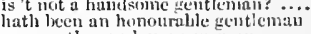

as a gentleman iovis a wernan

betike, some nuble gentlemun. Fo.....

an atluble and worteous gentleman

here is a rent lemun, whom by wance

this fentleman is luppily arrived.

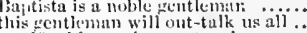

Eratify this genticonum, to whom ve

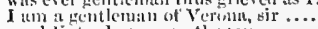

good kats, 1 mu a gentleman

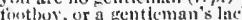

one ar leaves a gentlentan, and inakes

ir, tlus is the gentlemnn I told you of

the spouse of any whle gentlenme

why, low now, ge'tutlemant.

n surer aneient gentlemtu ..........

this kernel, this sinush, this gentlentu -

as you are certainly a fentfentan...

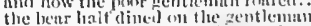

it the best be gone tirm tiac gentlemen

thin gentleme to is come to me...

here comes the rentleman your.

the fentleman is thill of virtue

as thoul art a fentlentan of blow

un ill oflice for a reutlemen

auxl sue the gentlenuu thut you asject

clenge craments with this gentleman

the gentemint

my brotluer (gemel gentlemun!)

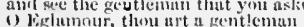

fromi a [entleman to a fion

"Where is the gentleman that was wit

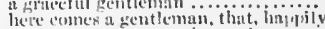

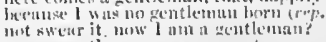

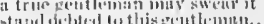

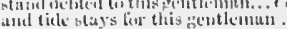




\section{GEN}

GENTLEMAN-that gentleman. Comedy of Err. $\mathrm{r}$. valiant cousin! worthy gentle he

hour fathent subjeet whilt your faithful subjeet,, a gentleman... Kimg
when this same lusty genteman was got that smooth-faced rentleman.

like a spriteful noble gentlems.

a loyal gentleman even in the ....... Richard 11 iv.

loyal, just, and upright gentlemain

that young and princely genileman

a gentleman of mine 1 have despatehed

sud, as I am a gentleman, I credit him - ini - iith he is a worthy gentleman..I Henry IF. iii.

a braver gentleman, more active-valiant

bears not alive so stout a gentlewan..

a gentlem:n nlmost forspent with speel -

to bear a gentlemin in band

as $I$ am a gentleman (rep.) ...........

a tall gentleman, by heaven

in England the most valiant gentleman -

honest gentleman, I know not your..

a very valiant gentleman

the most active gentleman of franee

a valiant and most expert gentleman

I am a gentleman of a company ...

as good a gentleman as the em

art thou a gentleman? what is thy...

signieur Dew should be a gentlemai
he is a gentleman of a gool hnuse...

his enemy is a gentleman of great.

as goot a gentleman as the tevil is

him, that is a true bort gentleman..1 Henry

poor gentleman! his wrong doth equal

so should we save a valiant de

bear him like a noble gentleman....

I am a gentleman; rute me at, what.

not leave one lord, one gentleman.....
noble gentleman gave up the ghost..3 Henry rz. i.
the worthy gentleman did lose his life

a sweeter and a lovelier gentlentun...R
since every Jack beeane a gentleman

slew to-day a riotous gentleman

and finds the testy gentleman so hot

me out some mean-born gentleman...

called betore us that gentleman .... Henry $\bar{\nu}$ iv. i.

(this was his gentleman in trust)

that noble lady, or gentleman.....

a bold brave gentleman

a gentleman, sent from the king

you are a gentleman of mine own....

depend upon a noble gentleman. Troilu

poor gentleman! a plague upon Antenor $\overline{\text { I }}$ do

this gentleman of mine hath served...
honourable gentleman, lord Lucullu

honourable gentleman, lord Luculli

a nohle gentleman 'tis, if he would not

thy lord's a bountiful gentleman

and an honourable gentleman

honourable gentleman

a gentleman. A marvellois poor (rep.)

a poor, hut worthy gentleman...

besides this gentleman in question.

here eomes the gentleman, the queen

be better known to this gentleman.

this gentleman at that time vouehing

or this gentleman's opinion, by this

thou wroung'st a of Rome.

when a gentleman is disposed to swea

who's there, that knoeks? A gentleman

that this gentleman may render

noble

where with't I may appear a gentlemus Aivdron.

sure he's a gallant gentleman (rep.). .

a gentleman of Tyre; who ouly.

a stranger and distressed gentleman

dn you know this noble gentleman...
my gentleman for chiding of his fool

to have her gentleman abused

I am a gentleman of blood and breeding

the prince of darkness is a fine gentleman

a gentleman to his son (rep.)........

a gentleman to his son (rep.) .........

good gentleman, go your rait. ...

good you love the gentleman?...............

he bears him like a portly gentleman

but, trust me, gentleman

a gentleman of the very first house...

a gentleman, nurse. that loves to hear

says like an honest gentleman (rep.)

this gentleman, the prince's near ally
honest gentleman! that ever I should

young, and noble gentleman

a gentleman to be her bridegroom?

a gentleman of prineely

hes a lovely gentleman! ............

I knnw the gentleman:

receive you well? Iost like a gentleman
like a good elild, and a true gentleman
GENTLEMAN-here was a gentleman. Ilamlet, iv.

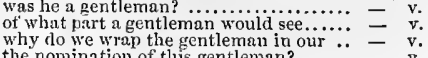

the gentleman willing, and the king holj - v. but pardon me, as youl are a gentleman.. - v. 2 why, thon silly gentlemnn! $\dddot{2} \ldots \ldots$

alas, what does this gentleman eoneeive? - - iv. alas, good gentleman; alas, good Cassio!

man-like dogs .......... Tw'o Gen of Verona, iv. 4 a most lovely, gentleman-like man. Sid. N. Dr. i. 2 all gentleman-fike qualities....... As you Like il, i. I
was the first gentleman-like tears. Winter's Tale, , y.

is a gentleman-like offer .......Romco \& Juliet, 11.

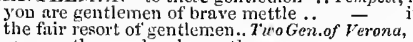

censure thus on lovely gentlemen

other gentlemen of good esteem.....

no more, gentlemen, no more $11 . .$.

to sort some gentlein

some of us are gentemen

now gentlemen, let's tune............

despateh, sweet gentlemen ...........
thest matters denied, gentlemen ...

bid these gentlemen, weleome

for swearing to gentlemen my friends

de lords, de gentlemen, my patien...

gentlemen, I have dreamed to $\mathrm{njght}$

gentlemen; you shall see sport anon $($ rep. $)$ -

let's go in, gentleme

good gentlemen, let him not strike

a little further: eome, gentlemen
let me spenk with the gentlemen

fare you well, gentlemen ........ Tüelfth $\mathbf{N i g h t , ~ i . ~}$

bore many gentlemen...... Mlegsure for $\overrightarrow{\text { ta }}$ i.

bore many gentlemen...... Measure for Measure, i. 5
how many gentlemen liave you lost... Much Ado, i.

gentlemen both, we will not wake your

yon mock me, gentlemen........Mid. N. Dream, iii. 2

gentlemen, will you prepare for. Mler.
on, gentlemen, away: our masking

gentlemen, my master Antonio is at

many young gentlemen floek to ...As you Like il, i. I

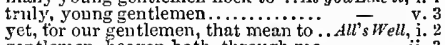

gentlemen, heaven hath, through me...

brought you tlus letter, gentlemen

二 iii. 2

hath had in him, such as gentiemen have

gentlemen, importune me no further. Tum. of $\mathrm{Sh}$. $\mathrm{i}$.

gentlemen, that I may soon make good
gentlemen, content ye; I am resolved.

gentlemen, God save you!.

if you be gentlemen, do me this right

God save you, gentlemen! And you

he patient, gentlemen; I ehoose her....

and wife, and gentlemen, adien...

faith, gentlemen, now I play .........

well, gentlemen, I am thus resolved
why, gentlemen, you do me double wron

gentlemen and firiends, I thank you

come, gentlemen, let's go...

will be all gentlemen

5 we must be gentle, now we are gentiemen

When gentlemen are tired......

kind gentlemen, your pains are...

where are these gentlemen? eome.

young gentlemen would be as sad as. King John
wrath-kindled gentlemen, be ruled ... Richtrd 1

come, gentlemen, let's all go visit him

and well met, gentlemen: Y hope ...

all your southern gentlemen in arm

we'll eali up the gentlemen

there are two gentlemen have in ....

lieutenants, gentlemen of companie

gallant warriors, noble gentiemen

arm, gentlemen, to arms! $\ldots$ gentlemen, the time of life is short

goodmorrow, honest gentlemen....2 Henry I

five you well, gentle gentlemen.

the worst of these three gentlemen!.

why gentlemen will not (rep.).....

gentlemen both, yon will mistake eaei

and gentlemen in England, now a-bed

ii. 4 esquires, snd gallant gentlenen, eight
ii. 5 and gentlemen of blood and quality..

great lords and gentlemen

dare not take up arms like gentiemen

and divers gentlemen beside ........

captaius, gentlemen, and soldiers ....

in England, sirce gentlemen came up

lawyers, courtiers, gentlemen, they cull
knights and gentiemen to come with.3 $H$
GENTLEMEN-knights, and gentlemen.3 Hen. $V r$. gentlemen, see, see! dead Flenry's.. Richard I come, noble gentlemen, let us survey good-night, linglords and gentlene watehful gentlemen, that yon have ta'en truly, gentlemen, a blondy tyrant.... gentlemen, every man unto his charge
inglit, gentlemen of England, figlit, bold gentlemen, the penance lies on you.Henry $\nu I I I$ gentlemen, whose finlt is this?

by all your good leaves, gentlemen..

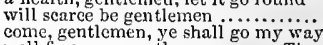

well fare you, gentlemen........ Timo
please your, gentlemen, the time is....

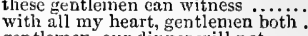
tor our gentlemen, the common file... Coriolanus ii. 6 gentlemen, look fresh and merrily.Julius Casar, ii. gentlemen all, alas! what shall I say?

were parted by gentlemen at hand ... Cymbeline,
suits, with gentlemen of your knowing -

let us leave here, gentlenien ........

gentlemen, enolgh of this............

in Cambria arc we born, and gentlemen - v. 5

these two young gentlemen, that eali $\overline{-}$ v. 5
for we are gentlemen, that neither..... Periclcs, 1 i. 3

cor we are gentlemen, that neither .....Periclcs, ij. 3

thanks, gentlemen, to all .............

gentlemen, why do you stir so early? ....

and taste gentlemen of all fashions......
well have no more gentlemen driven away - iv. 3
iv. 6

call up some gentlemen. Ho gentlemenl 二 v.

gentlenen, there is some of worth would $\overline{\text { on }}$, visty gentlemen. Strike, drum. Romeos-Juliet,

gentlemen, welcomel ladies, that liave -

you are weleorne, gentlemen! (rep.).

nay, gentlemen, prepare not to be gone -

God ye good-morrow, gentlemen..... -

gentlemen, good-den: a word with one

gentlemen, for shame forbear this outrage -

these gentlemen, Marcellus and Bernardo -

come hither, gentlemen, and lay your -

gentlemen, with all my love I do $\ldots$... -

bring these gentlemen where Hamlet is -

well be witl you, yentlemen!.........

good gentlemen, give him a further edge - iii.

no ancient gentlemen but gardeners - v. 1

gentlemen, let's look to our (rep.)...... othello, ii. 3

alas, gentlemen, help, ho! lieutenant.... - ii. 3

this fortifieation, gentlemen

light, gentlemen; I'll bind it with ny...... shirt - v. gentlemen all, 1 do suspect this trash....

stay you, good gentlemen; look you pale

do you see, gentlemen? nay, guiltiness will -

gonot gemed: O murderons coxeomit

GENTLENESS-so of his gentleness .. Tempest,, . the gentleness of all the gods go.. Twilfth Nighl, no way but gentleness; gently, gently - iii. your gentleness was guilty of it .. Love's L. Lost, v. with Jilman gentleness and love. Mer. of Velice, iv. 1 rour gentleness shall force (rep.). As you Like it, ij. 7 therefore sit you down in gentleness .. - ii. sweet gentleness, thy meekuess .....Henry $r$ rII. ii. learning, gentleness, virtue .. Troilus \& Cressida, i. not from your eyes that gentleness.Julius Cosar, $\mathrm{i}$. witls deeds requite thy gentleness.. Titus Andron. this milky gentleness, and course ot yours. L'ar, we marry a gentler scion to the..Winier's 7 ale, the gentier gamester is the somest.... Henry $V$. jii.

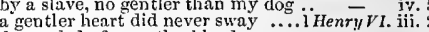
descended of a gentler blood $\ldots . . . \ldots$.

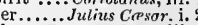

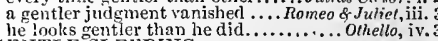

GENTLE-SI ELPING -

awake Ged's gentle sleeping peace... Richarl It I. i. 3 resort unto this gentlewoman?. Two Gen. of Ver. iv. 2 against a gentlewoman's farthingale? - iv. gentlewoman, good day! ........... - iv. a virtuous gentlewoman, mild ....... $\overline{\text { knory }} \overline{\text { rines, }}$ i. to desire this honest gentlewoman ... will maintain vou like a gentlewoman $\overline{\text { call in my gentlewoman (rep.)... Trelfih vight. }}$ i. call in my gentlewoman (rep.).... Trelfih vight. i. . a gis befel to the poor gentiewoman here's a gentlewoman denies all that you -

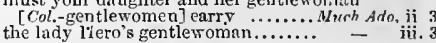


GENTLEWOMAN

princess' gentlewomnn, eonfesses ..ts you like it, fi. .

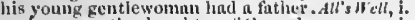
gentewomm the dnughter ot Gorard

"rht sny you of this gentlewontun?

you love your gentlewoman entirely

he hath perverted a young gentlewo

of the most virtuous geutlewoma

gnit, und action of a gentlewoman

gentlewomu, thy son by this lath

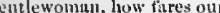

of Ér.

ir, with this gentlewoman?... Comedly of

gentlewoman, sir, and a kinswoman.

virtuous gentlewoman to elose with

gentlewoman, - what say's your grace?

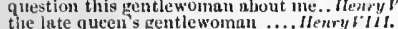
tive late queens gentlewomn

yes, nud a bentlewoman's son

ymbetine, i

your name, fair gentlewoma

jomen of Jutiet, $\mathrm{ij}$

one. gentlewoman, that ciod hath made

for the gentlewoman is young

if this had not been a gentlewoman.

Hamlet

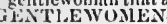

Col. daughter and her gentlewomen. Iruch Ado, ii. und you gentiewomen alt, withdraw

and gentlewomen wear such eups. "laraing of Sh. iv the gentlewomen here lave (rep.) 2 Henryst. (cpil.) A dozen or fourteen gent lewomen

uhlwed them gentlewome

ihichard $\mathrm{Ml}$.

her gentl : wonen, like the Nereides.Ant. \& Cleo, ii.

we must deal gently with him.. Tuelfih Night, ii

no way but gentleness: gently, gently - '

stion

the swcet wind did gently kiss ...Mer. nf

spesk you so gently? pardon me...As you Like i, yi.

cake lim up gently, and to bed with of sh. I (ind.

something gently considered..... W'inter's Tale, iv.

the enstles gently rendered ............Macbeth

may lie gently at the toot of peace... King John.

whicli gently laid my knighthood

tolil him gently of our grievance

Ilenryll. $y$.

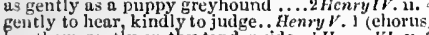
gently to hear, kind yenty on thy tender side.. I Henry VI. y. looked full gently on his warlike

let lim be gently used

must gently be preserved............. Kichard $11 I$. ii.

I were gently put out of office... Timon of VIII.

march gently un to meet him .....utius Carsar, iv.

what's umiss, may it be gently heard.Ant.\& Cleo. ii.

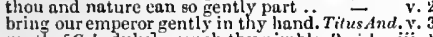

gently [Col.-duly] queneh thy nimble. I'ricles, iij.
but use all gently: tor in the very .... Hamlet, iii.

but use all gently: tor in the very .... Hamlet, iit
GENTRY - the article of thy gentry. Merry Wives,

serve a nursery to our gent

I have a file of all the gentry.

inter's Tiulc,

to grace the gentry of a land

Muebeth,

makes up the file of all the gentry... Heury 1 .

but by the suit o' the gentry to limm. Coriolames

Where gentry, title, wiglom, canuot.. ${ }_{\text {ineite the rentry to this business .. Cymbeline, iii. }}$

brought hither among the Italian gentry

if that thy gentry, Britain, go before

to sliow us so much gentry .............

W

whither go you, George? ........

you'ti come tis dimer, Geor

Hluglt Uateake, sir, or George Seacoaj.u.uch dilo, iii. 3

suint George's lialf elseek ......... Lore'sL. Lost, y.

by saint George, I am too young.. Taming of Sh. ii.
and if his name be George, I'll eall ... King Jokn, i.

saint George, that swinged the dragon $\overrightarrow{\text { ii. }}-$ ii.

and saint George to thrivel........... Richard
black Greorge Bare, and F rancis....21leury $V^{2}$

hlack Greorge Bare, and Francis '...21lenry I $r$. iii. 2

IIarry! Eugland! and saint Georgel Ilenry $V$. iii.

to keep our great saint Greorge's feast.

God and saint Georgel Tulbot, and.

saint George and victory! tight, sold

of the nolife order of saint Georye....

look on my george, I am a gentleman

Filward, and the lusty George? .....3 Henry VI. i.

lord George your brother, Nortolk

Goxl and agint George from Burgundy.

goot father; ery, saint George

of Clarence; (ienge of Gloster

of Clarence; (ienge of Gloster .......

and lo, where Genge of Clarence....

to the neld sictory

and thou. perjured ireorte ............

for my name of George tergins with.

till George be packed with postlurse

my george, my garter, and my

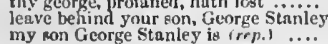

GI:ORGE-lest his son Geurge full .. I

thy brother tender George be exeeuted

shint George! Riehmond, and vietory

witli his son Genrge's hesd!

after the buttle let George stanley die

is youns George stualey living

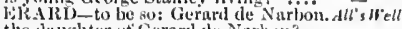
liter of Gerarl de Nirbos

likM AN-tlie Germuns desire to.iierry Fires like threc dierman devil

there it three consin German ...

u German from the waist dow uxard.Much Ado

that is like a German eloek

Lore's L. Lost, iii. I

it' there be here Germmn, or Dane.... All's N'ell,

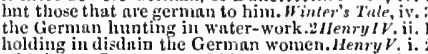

With husty Germans, and blunt....3 Henry I l.

tull-acoriled boar, a Girman

he more german to the matter........... Ilamle

your Dnne, your Gerinn

nn embussy to Germany in Germany. Mer. of 'en. i.

the land salique lies in Germany ......... Henry $V$.

is at this day in Gernany called, Meisen
the upper Germany, ean dearly.... Heury $\overline{V I I}$.

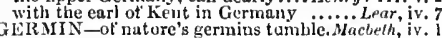

GLRTIUDE-teils me, my dear Gertrude. Haralch, ij.

sweet Gertrude, leave us too ..............
what, Gertrude? how does Iiamlet?

Gertride, come away! the sun no soone

o Gertrude, Gertrude, when sorrows come -

let lim go, Gertrude; do not ten ${ }_{0}$ rep.

let's follow, Gertrude; how much I had.

good Gertrude, set some wateh over....

GEST-behind the gest prefixed ..... W'inter's T
GESTURE-such shapes, sueh gesture.Tempers

near the heart as your gesture cries. As you Lilie

nand their gesture sad, investing. Heary $V$. iv. (chorus)

and nods, and gestures yicld them ....Hamlet, iv. 5

poor Cassio's smiles, gesture...

ps it were, his gesture import

GET-and get to Naples with bim

- iv.

and get thee, wood enough...

has a new master, get a new man..... - ji. 2 (son

'tis well that I get it so...

I'll get you such a ladd

go, get thee hence, and find...

I'll get me such a eoloured periwig.. $\quad-\quad$ iv. 4

they could never get an eye-wink of her -

they could never get her so much.

go, get you some propertics

and I ll do what 1 ean to get you

onee more. Cesario, get thee to yon

get ye all three into the bo

get lim to say his prayers (rep.).

get themselves a good report aft

get him to bed, and let lis liurt..

alas, he gets nothing by thut

than I will get again with drinking.

get you to heaven, Beatriee, get you

I pray thee, get us some excellent.

that are drnuk, get thein to bed......

get you some of this distilled

go, get you to Franeis Seacoul

thou art sad; get thee a wife, get the

but if I had wit enough to get out. Nid.

good monsieur, get your weapons in

get your apparel together.

tien will sle get the upshot by......... 'soves L. Lost

that you get the sun of them

pity you should get your living

how to get elear of all the gebts........

play the knave, and get tlice

shall get as mueh as he deserves.

so thou can'st get a wife ....

I'll ste if 1 eun get my husband

get you with him, you old dog

and get you from our eourt

let's axity, and get our jewels...

that I eat, get that I wear.........

to otter to get your living hy ithe

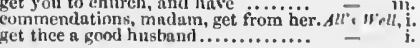

ET-thou eanst get the ring.. Al's Well, iil. z (letter)

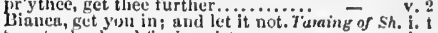

to get a hushand tior her sister.

rons filstest, get the ring .............

to get her cuning sehorimastirs....

You will get you heuce.

it' I get your clanghter's 1

tathers, commonety, for ger their childiren

disguised thus to get your

I am to get a man, - whate'er.

sirrah, get you hence, and bid my

or else yon get no beef of Grumio

not uncusy to get the eause of ... Hinler's Tale, iv. I

get you hence, for I must go....... - iv. 3 (sung)

stiff and weary; get thee awry.........

commends me to the thing I eannot get - i. 2

I must get a sconce for my heal ....

go, get you trom the door........

that we cannot get in ..............

gentle hrother, get you in agrai

therefore awhy, to get our stuiff

some get within him, take his.

go, get him surgeons ..................

get thee to bed; is this a dagger.
go, get some water, and wash

more knocking; get on your vightgown

vith what I get, I menn $\mathrm{i}$

but get thee baek, my soul.
why, exeept to get the lund.

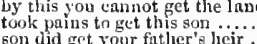

Gon did get your fatler's lieir
than was his will to get me

conld he get me? sir Rolvert ............

now by the me? sir light, were I to get again

sirral, get thee to Plashy.......... Richard 11. ii.

the strongest and surest way to get... - ii. 3

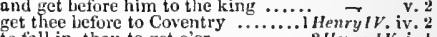

to tall in, than to get o'er ...........2Uenryl $V . i$.

get posts, and letters, and make friends

an' I could get me but a wife in....

I ean get no remedy against

any vantage of ground to get up

to thet a pottlepot's maidenhead.

Whe, tet you down stairs ...........

get on thy bouts, we'll ride all...

think'st thou my spouse to get

get you therefore lienee, poor
vacunt nind, gets him to rest

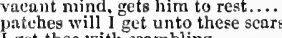

I get thee with scambling

With desire to get a grave .........
should ever get the privilege of me

let's get us trom the walls

we lose, they daily get $\ldots . . . .$.

go, get you to my house.............

this get $\boldsymbol{l}$ by his denth; ah ine
now, get thee heme: the king.

come, and get thec a sword

and get what you lave lost

and get a thousand erov

then get your hushen get .............

think st thou, I sue so much to get?

enn do how to get the erown ....... - iii. 2

two years ere $\mathbf{I}$ eould get a tooth ...Richard III. ii.

nnd look you get a prayer-book......̈. $\bar{F}_{\text {tis }}$ it.

go, get the from me, Cromwel

how gets the tide in.

you i the camlet, get un o. the raii.

I ll gro ret a fire.......... Troilus o chet

if my lord get a boy of you $\mathrm{x}$.

pr'ythee, get thee in; 'would thoo".

hipon the love you bear me, get you in

get on your cloak, and haste youl..

get the away, and take thy biagles

or Wrath, or eratt, may get him

to laclp to get thee n wife ............

gray, get you yut. Away! Away? Get

to get myself into more work......... Juliu

so get the start of the majestic world

get me a taper in my study.

get you to bed again, it is not.

ven, get the hetter of them $\ldots . . . .$. .

get thee apart and weep ............
het you hence, sirrah; sanes fellow. iii. i

iii. 2

v.
i. 1
i. 2

ii. 1

v. 7

i. 1
i. 1
i. 1
i. 3
i. 2
. 2
i. 2
i. 1
i. 2

i. il $_{2}$

ii. 3

- iv. 3

- ii. 2

ii. 5

二 $\quad$ iii. 2

ry $\boldsymbol{n}$ I. iit.

$=\quad$ iii. 2

v. 5
v. 8
.10

= iii. 


\section{GET}

GET-go, Pindarus, get higher on ...Julius Cresar, v

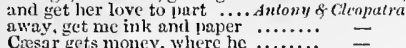

go, get thee henee; halst thou

get thee henee the mcrehantlize

ind can gut goal for goal of youth

get thee hence; farewell ................

bid you do, get them despatehed .... cymbeline, $\mathrm{i}$.

should got ground of your fair mistres

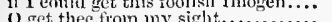

go, get thee from niy sisht ... Tilus....nedronicus, iii

ur get some little knife hetw

I will go get a leaf of bruss....

my lord, if I ean get lim once. .

gets more witls begging, than we .......

hy no means can I get (repeafed) .....

with what haste you ein, get jon to bed
get tire and ment for these poor meu

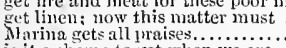

get this done as $I$ command you.

we must either get hor ravished

nay, ret thce in. Ill pray.

nat it doth hate what gets $i$

get horses for your mistress.

and get the Bedlan to lead him....

got thee glass eyes

nay, an' you get it, you shall get

(10, get thee to thy ]ove, as was deerced

get thee to chimreh o' T'hin srlay

you cot-ruean, go, get you to bed

nor get a messenger to hrimer it thee.

nor get a messenger to hrilg it thee.
get. me an irom crow, and bring it...

yo, get thee hence, for I will not awa

tis now struek twelve; get thee to loed

get thee to a nummery (rep.)......

how the murderer gets the love

get ine a fellowship in a cry of players

iny lord, we cannot get from him....

go, get thee to Yaughan, and lictch me
now get you to my lady's chanber...

now get yon to my lady's chanber.

if you please to get good guar

get weapons, ho! and raise some special

let me see now; to get his place........

get me some poison, Iago; this inght...

to get some office, have not devised

get yout to bed on the instant

bit every puny whinster gets iny sword

GFTrER-a getter of more bastard. Corio
GisTTING-getting madam Jnlietta. Mea.

fiur the gretting a himdred bastar

fur getting a wench with ehild
jave one of your thatlicr's gettin

getting up of the negro's belly. Merch. of lenice, iii.

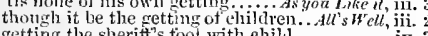

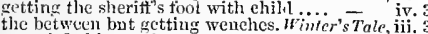

unsatisficd in getting...

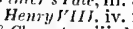

Getting of a law ful race ... inionis \& Cleopnt

if thom pet'st any leave of me........ Hen

GHASTLY-this ghastly looking?

1 ghastly, like a strangled man..2 $\mathrm{Hem}^{2} \mathrm{y} / \mathrm{l}$

gliastly looks are at ny servic

FITASTNT SS- the rhastness of je...

Gllus'T

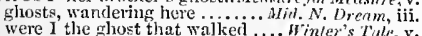

walked your first 'pueen's yho

art thou not? or else his ghost?

his design moves like a ghost ......... Whicb

some hanted by the ghosts they ... lichard Wh. Hii.

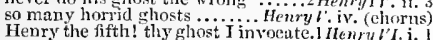

cause him once more vield the ghost

like pale ghosts, faintly hesiege........

this unstart is old Tallint's glost.

and ghosts break up their graves.....

oft have I seen a timely-parter ghost

as it duke Humplarey's ghost were

nohle gentleman gave un the ghost...3 Hen ry 1 ili. ii. 3

lastinl that I inyoute thy ghost ..Richard III. i. 2

my uncle Clarence' angry aliost.

poor mortal living gliost

why all these rliding ghosts .........Jutius $\overline{C_{0}}$ iv.

and ghosts clid shriek, and squeal abont

ready to give up the rhost

spritely port make the ghusts gaze to me - - viteo. iv. 5

fliost unlaid forbear thee! .. Cymbeline, iv. 2 (song) or we poor ghosts will ery to the

kow dare you ghosts, aceuse the.

vex not his ghost: O let him pass! ....... Lear, v.

I'll make a ghost of him that lets me .. Il tmlet, i.
GIIOST-alas, poor ghast! Pity me not... Hamlet, i. thon porr ghost, while memory
there needs no ghost, niy lord

there needs no ghost, nyy lord .....
it is un lronest ghost, that let une

it is a dimner ghost that we have seen..

Good In'mitio, Fil take the ghost's word - iif. 2

GIIOSTI.Y_- Your mhostly father. Meas. for Meus. iv. 3

the ghostly fatler now hath done...3 Henry rr. iii.

I to my thinstly tather's cell ..... Bomeo of Juliet, ii.

with Rosaline, my ghostly tiather?

a divine, a whostly confessor

GIANT-mollitication for your giant. Twelfh Night, i.

a giant's strenglly (rep.) ...YPownrefor Hensure, ni.

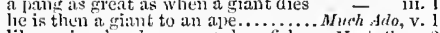

like a giant's robe uphal a dwarfish..... Miacterlh, v.

that never saw the mant world curam

sirrah, you giant, what says ......2 2lemuly $I V$ i.

Whiant siath into one giant arm ${ }_{\text {Henry }}$ 'III:

tine of the giant mass ...... Troilus \& Cressida,

before a slceping vinut ...............

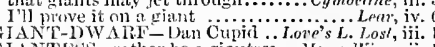

GLANTEA-rather he a giantess... Merry yires, ij.

that thy rehellion looks so giant-like?. Hamlet, iv.

finth such giant-rute invention... As you Like it, iv. 3

GIB_I am as melancholy as a gib cat. I Henry $1 I^{\prime}$. j.

GIBBET-i am no gibbet for youl.. Jlerry IFes, ii. 2

sweaten trom the murderer's gil
I had unloaried all the gibbets..

swifter than he that giblets
higla pyramids be my gibbet

. Antony s-Cleo. v.

GiBBET-MAK ER-tlie gibbet-maker? Titus $A$ and, v.

YIBE- to have his gibes, and ........Nerry Wives,

aml full of gibes and vlon

ready in sibes, quick :unswered .... Cymbeline, iii. 4

the gibes, and nutable seorns ............. Othello,

GIBER-understood to be a perfect giber. Coriol. ii. I

to langh at gibing boys ...
GIBING],Y - which yibingly
GIDDHI,Y - as giddily as for

GIDDII,Y - as giddily as fortune... Fuelfifh Nizht, ii.

GIDDINESS-call the giddiness of it..As you Like, v. 2

but art net thon thyseli" giddy with. . Nifh Night, it.

for man is a giddy thims............

many giddy offences as he hath...s you Like il, iii.

more giddy in my desires than

tor meat, shedy for lack of steep...Tuming of Sh, iv. 3

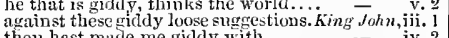

thou hast made me giddy with $\ldots . . .3$ - - iv.

a habitation gidly and unsure.

my sight fails, and my brain is giddy

still a giddy neighbour to us ............

and gain, giddy, shallow, humorture's furious fickle.

have their gidrly brains knoukc
see, how the girldy multitnde

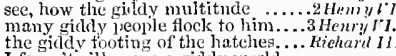

I fear, 'twill prove a giddy world .....

and givdy censure will then ery out. Coriotamns,

may'st thou the giddly men of Rome. Tilus $A n d$. i
and disperse the girdly Goths ........

turn pidely, and he hoiln ly .......Romen s.Juliet, i.

then as nuy rift, and thine own ....... Tempess, iv.

win her with gifts.

therefore the gitt the greater

the rift liath male me haypy

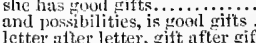

ctter after letter, gift after gift
to a dog for a ncw-vear's sift.
hath all the good gifts of nature.

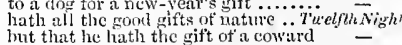

quickly have the gitti of a grave..... -

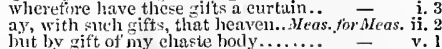

only his gift is in devising imossible. Much .Adn, it.

mant is the gift of tortun

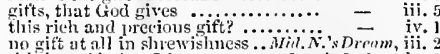

this is o cilt thit I heve

but the gift is good in those....

gave Hector a gift....................

that he do record a gift

scrves many nen to save $\ldots . . . . . . . .$.

so sly ally with your wife's first rift

a special deed of gift ................

most mist:ake in her gifts to
GIFT-they have the rift to know . As you like il, ii. 7 thint she these gifts should have - iii. 2 (verse
on the gift of any man

my dear fintlier's gift stands clifef....

a confirnation of my juromised gift.

nuwworthy this good gift

boy have not a wolnan's gift.. The $\ldots . .$.

Your gifts are so good, here is nove

this is a gift very gratefinl...... the meets sueh golden gifts............ nceording to the gil't which bounteous. Macheth, iii. he hath a heavenly gift of propl:eey. - iv. 3 of nature's rilts thon maly'st with ... King John, iii. I all the ot well the gift of tongne....... that, by gift of heaven, lis law ........ If my $F$. ii.

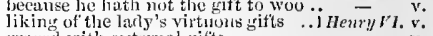

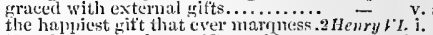
tears have moved me, gifts conld never - iv. a dukedom, six, a goodly gitt? .......3 Henry FI. v. I if' but by Warwick's gil't

Warwick takes lis gif't again

a greater gift than that (rep.) ........ichard 111 . iii.

iny lord, I claim the gift, my due....

which gitts (saving your mineing) .... - ij

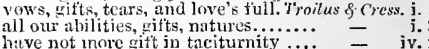

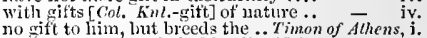

列

I am so fur already in your yifts....

to provide, and give great gifts $\ldots . . .7$.

for your own gifts, make yoursclves - iii. 6 (grace) in the great shower of your gifts

great show of your

the purchase, or merit for the gift. .. Cymbrline,

her pretty action did outsell lier gift

to make my gift the more delayed ...

proud $\mathbf{I}$ am of thee, and of thy gifts... Tilues And, $\ddot{\mathbf{i}}$.

a goodly gift in horning ............ with his gifts yresent your lordsips -

I have here my father's gift by will ... Perich take women's gitts lior' impudence cvoke thy iritt: or, whilst I can vent ..... $\overline{\text { sear }}$ i. traitorous gifts (1) wieked wit, and gifts... Hamlet, i. . Whose natural gifts were poor............
rich gifts wax poor, when givers $\ldots . . .$. such a one; 'twas my first gift .......... öhello, iit.

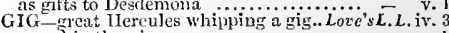
a go, whip of a evekold som!...............

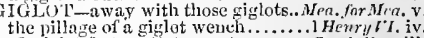

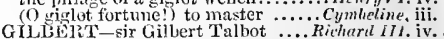
one Gilbert Peek, his ehaneellor..... Henıy /111. i. Gir Gilhert Puck, his chaneul] or ....... of Jerona, $\mathrm{v}$. gild mysclf with some more. Merchant of $\boldsymbol{V}$ enice, ii. Y'll gild the faces of the sleepy .......... Macbeth, ii. 2
slial! gild her briual bed $\ldots . . . \ldots \ldots \ldots$ KingJohn, ii. 2 to gild refined gold, to paint the lily - iv. 2 on me, anil gild my buishment ..... Richurd 1 . I. sluall double trild his treble ..........2Henry/l iv. the sun doth ofild our armour..........Hrinyl. iv. 2 with cunning gild their copper.. Troilus of Cress. iv.

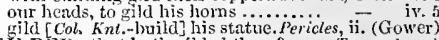
fild [ $\mathrm{Col}_{2} \mathrm{Knt}$.-1huild] his statue. Pericles, ii. (Gower)
GILDED-that hath gilded them?..... Tempest, v. her view gilded my toot.............. Arerry Wizes, i. a green and gilded snake had.... ds you Like il iv. men are but gilded loum ............. Richard il . hath a little gilded over your..........2 Henry $1 \%$ i. 2 the filded newt, and eyeless...Timon of .stkens, iv. 3 saw him rum after a gilded butterfly.Coriolanus, i. 3 the gilded puddle which beasts ...Antony of Cleo. i. 4

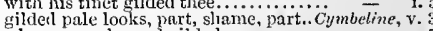
Whose rags shamed gilded amms ....... Andron. iii. 2 ling his slender gilded wings ..Tilus Andron. iii. 2 an at glded frterflies........... - v. offence's gilited hand may shove by ..Hamtel, iii. 3

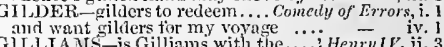
G1LLIAMS-is Gilliams with the ..... HenryIV. ii. 3 GILI,YIIOWERS [Knl.-GILLY'VORS]

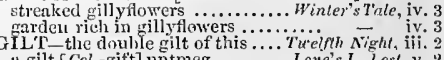

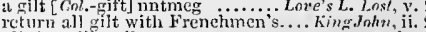

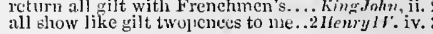




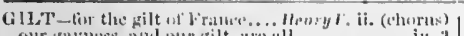
our gaymes, and ond gilt, are all ..... - is -

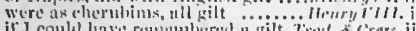

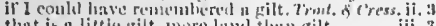
when thou

weeoues a whens, iv

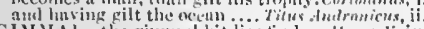

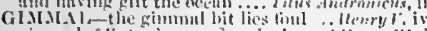

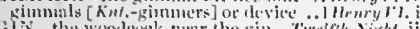
nor lime, the pit-titl, nor the gis
now be it by fins, by smare

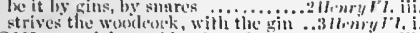
G1.N-new "uins to hite the spirits .... I'm/s'st, iii. as whence the sun 'gins his.....

1 'rin to le aweary of

(a) bom

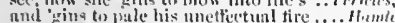

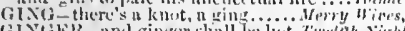

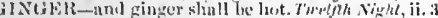

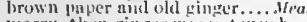

marry, then ginger was not much

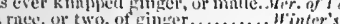

and two ruzes of singer

and of the linent of th

have it to thuy gingerbreal ..... Love's L. Lost

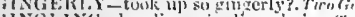

civivis

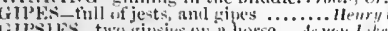

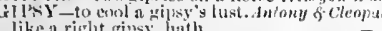

like a right gijsy, hiath

Clesputra, a fipsy; Jlelen, and .. Rimen f Juling

take a prick to rirel pt me.

lie bishop hatli a kinclly gird........

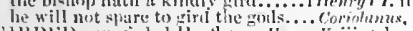

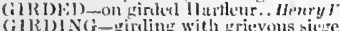

(illi) No-sirling with grievous siege

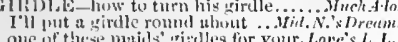

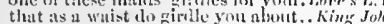

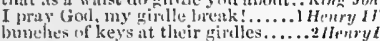

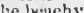

withiu the pirulle of these walls $\cdots \cdots \bar{H}$

cleave me to the girille........ Timon of Athens,

find us in our silit-water girlle .... Cymbelime, ii

but to the girdle to the gimls inherit .... Lewe,

GIIDl, E)-are all gird!ed witl milien. Ilenry

Whu row is giriled with a waist.... Hinn? Il.

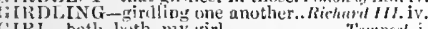

Gikl $\mathrm{L}_{\text {- hoth, loth, my girl .............. Trempr }}$

make the girl forget the love

for it girl that lover him gir

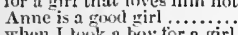

Murny Irines,

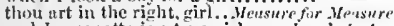

and Jaquenetta is a true gir

I do love that country pis

to woo these girls of France...

we are wise girls, to moek on

Iessica, my girl, look to my.Merchane of Tenice,

is

lill

there a pirl grocs befure the pre

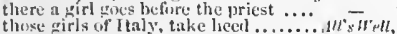

love thee ne'er the less, my nirl. Timing of sibe (m)

achiseve not this young minfest girl ..

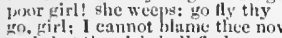

and that the girl sha!l find

witledeet disys wns my wifi an girl

tow green and idle for girls of nime
fullow une, girls. And you shall pus.

jrotent me the batly" of a girl.....

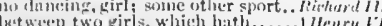

unl take my blessing fos ma mirl.

why" bere"s a "irl! I think

"tiz a girl, promises bows hereafter....

sail i fur this the oirl in like to him?

all tlie fireckinl girls shall. Wrailus crotsida, ii

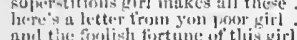

thel the fonlish fertune of this sir

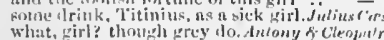

Youm, buy and girls, are le

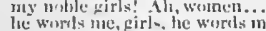

mull luse a fiallinu tirl at lo..... - y.

goldeu lucts anul girls all must...... iv.

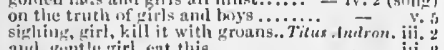

alkl, fentle wirl, ent this

thus surjorised, sweet girl, ravished

give sighs, sweet girl. fir here are...

and 1 hove sutfierd like a girl..

ol licarens blese iny yirl!

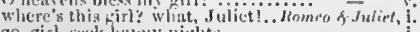

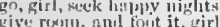

well, girl, thuu woepst not 50 muchi

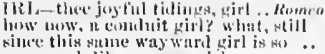

you spenk like a green girl.....

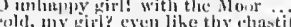

1 girt tisee with the valint

antl girt tlace with the sworl

I Hermytr. iij.

like to his isluml, girt in ............ 3hemryl I. jv.

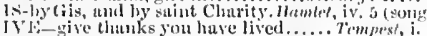

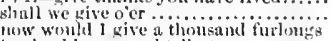

to give lim numul tribute

and give it wo

ance thou dost give me juling.

voulhst gise me water with berries

the visitor will not give him or

not alveliday fisol there but wo

When they will not give a deit

I will give him some reitef.

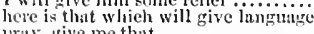

wrag, rive me thit

give him blows ........................

I did not give the lie ...............

that give delight, and hurt the

ger whom I give thee power
do nust rive clalliane ton nuel

gerel my lort, give me thy tavour stiii

give us partichlars of thy preservation

ay give me not the busts.
ive lier no tolen but stomes

aty, give it me, it's mine.

to rive your tillowers........

never give her o'er ..........

will wive the time to lea
to give the onset to thy.

i give eonisent to go illong.....

go, give your master thi

I give thee this tor thy

that was mine in silvia. I give thee.

ant Julia herself dirl give it me.....

they may give the clozen white.........

give, when she is ahle to
give ear to his mutions......

rive ler this letter

she gives the lecr of invitation

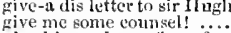

give him a show of comfort...

I'l giva your a pottle of burit seakn $y$,

and she gives you to notify .............

give tire: she is ny prize.

if you will give me the hearing
nitgerchly give me sight of her

many presents to give her

only give me so much of

pray you, give me my gow

he fives me the potions.....

he sives her tolly motion.

the elock gives me my eu

would give an exeel lent motio

to give him such cause of suspiejon!

I give leasen proi

give my sweet Nan this rin

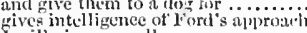

I'fill give over all ..................

to give our heart whited when I give the wateh-ord

seese is sot gnod to give putter

heaven ajve thee joy?

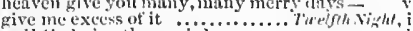

well bist give them wistlon

for give the dry fosolitrink.

give me thith, say 1.

gund gentle one, give me morlest

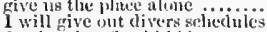

do give thee fivefishl bluzon

ir the knirlit give

you would not give means for

ive me some music............

iet all the rest give plate

as love doth give my heart

give her thin jewel; suy (rop.).......
give me this urerogative of siveed

I will not give my purt of this

thy reasoli, dear venom, give thy renson -

his legs emunt: I'll give $t$ thim

gives manhoot more approbation

of the young gentlenn! fives him

give thing a

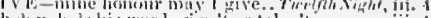

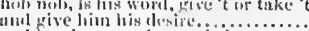

nnd he pives me the stark-in

cive grount, if you bee hiu

inhall give worse jaynent

take, and pive lack, alhitirs.

that in, to give a loge

(), you give we ill com

sliake aft these mames youl give one

misice my strength tetul wive you.

the heavens give safety to
ti1 give me secret hurlus

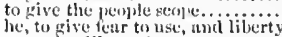

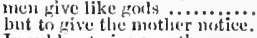

I could met give you threencee
youll be glad to give out a conmonission

or give up your place

rive t not o'er so; to him a sitin.

that gives this sentenee.

or toredecm him, give up you

Isulel, it you give me love

mul new i give my kensual r....

wes, he would give it thue.

the image of it gives ne content

give lin promise of satisfuetion

five hen give your sprits eomforti...

give hin liberty to eseape lienes

give your cause to henven ..........

lis eonfessur, gives une this instance

there to give mis their gower
this letter then to friar l'eter give.

give notice to such men if sort . .

here the like notire, to Vulentinus . .
here is lori Angelo shult give you justec -

give us some seats of justice............

(), give ne purion, that $\mathrm{I}$....

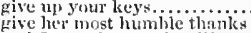

laving obtaincil her, give her to conist

nut Gond give the joy 1

cousins, Givd give yon joy......
as I shall yive you direction.

God give ine putience

ratber die than give any sign of her..

antl never gives to truth and virtne..

why give God thanks.

God grive me joy to

to give your shumbter to her hinsbiu

give me this maic, your ilaughter?

rive not this rutten ore (mo

which nan season give to lue........

give nut me counsel...................

theretore give me no eoumsel .......

my, then, give him anuther staft

give her the right $y^{\text {on }}$ shumbit.......

I give thee the bueklets. Give us...
gives her tame whrib never dies

and give her to young

I give him eurses, ret he girce me love = i. ?

if it be, yive it me, tirn I nm slow ....

to give their bed jos and brosperity
give me that boy, and I will go...

loray thee, give it me ....

Wha would give a bird the lie.........

wilt then tive lim me? I hacl (rep.)

are llermians; will you give her ow

five me your neif monsicur II

that Ilermin should fire answer of her

and gives to airy nothing a lora

tis give them thanks fist nothing

through this honse give glimmering

that give a name to every tixel star

and every godfictlore etr give n name

give the style shand give ne reanse

fair, I rive you lnek atain ............

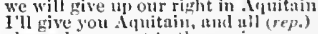

give enlargement to tlic swain

I give thee thy liburty, siot thee.

no, I'll give you a remunerution.

and every one give ear .................

Gol give youl gook-morrow, master

tlok give him grace to Eronan?...

the golicen stus gises not tin thiose

mel pores the erutels the eratles

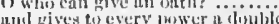

my street, nuil give me thine

iij. 4

iv 3

v. 1

i. 1

i. 5

ii.. 2

ii: $\frac{2}{2}$

ii. 4

iii. 1

iii.

iii. !

iv. 2

‥ 3

v. 3

iv.

v.

v. 1

ii. 1

ii.

ii. 1

iii. 1

iii. 3

iii. 3

v.

iv.

v.

roili

ii. $\frac{2}{2}$

iii. 3

iii. 1

iii. 2 
GIVE-pretty mistresses, give ear.. Love's L. Lost, v. 2 GIVE-that gives not half so great.. Taming of Sh. i. 2 GIVE-sworn to give lim aid........ Richard II. ii. 3 in courtesy, gives undeserving praise God five thee jou of him

and this the princess I $\ldots \ldots \ldots . . . . . .$.

for the ass to the Jnde; give it him..

I must rather give it the rein

mueh love, ril give you some

laughing hearers give to tools.......... of $\overline{\text { venic }}$
give him direetion for this merry.
the fiend gives the more friendly....

give me your blessing (rep) $\ldots$......
give him a present! give him a halter

give me your present to one (rep.)

give him this letter; do it seeretly.

must give and hazard all he hath

must give-for what? for lead? ......

look fairer ere I give, or hazard.....

I will assume desert; give me a key

I give them with this ring

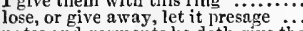

to give ten thousand dueats to

so can I give no reason, nor I wili not

go give him courteons eonduet to....

must needs give sentence 'gainst the

beseech the court to give the judgmen

your wife would give you hut little

awis bond doth give thee here no jot of 二

give me my principal, and let me go

give me your gloves, I'll wear them.

not shame myself to give you this ...
dearest ring in Veniee will I give you

nor give nor lose

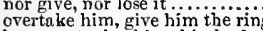

overtake him, give him the rive him this deed

house out, give him this deed ...........

Nerissa, give order to my servant

let me give light. but let me .........

a paltry ring that she did give me...

Woun rive your wife too unkind

of me to give the worthy doetor

give him this, and bid him keep it

thl give them him without a fee ( $r P$.

in his will to give me good education

or cive me the poor allottery my father

I'll give him his payment

and give over this attempt .............

I will give thee mine: I charge the

all this I give you: let me be your

if he for gold will give us any food.

I'll give you a verse to this note
to find my tawn, and give it food

to find my fawn, and give it food
give us some music, and good

give us some music, and good ......
give me audience, good madam....

1 vould give him some good eounsel

still girc the lie to their con

none here to give the woman?

proeeed, proceed, I'll give her

made him gire gattle to this

and to give this napkin, dyed in

had I kingdoms to give with her

you'll give yourseit to this most faithiful

nor lie durst not give me

to $\mathrm{J}$ ou $\mathbf{I}$ give myself, for I $\ldots \ldots \ldots \ldots$.

to give some gives us free scope

sir, give him head; I know ..........

I'll give her thanks, as though ......

will you give thanks, sweet Käte?...

God give him joy

and give assurance to Baptista..........

the bill, give me thy mete-yard..
give me Bianea for my patrimony

nay, I will give thee a $\mathrm{kis}$

we will give you sleepy drinks......... Winter's Tale

perceive not how I give line.

to give mine enemy a lasting

give scandal to the blood o' the .....

and give ' $t$ me in mine ear $\ldots . . . . .$.

that vulgars give bold titles

yet shall the oraele give rest .........

give her the bastard: tho

besecch your highness, give us better

your favour, I do give lo

then iny aceount I well growing...

to each part of you do give a life

give me those flowers
so give alms; pray so

do plainly give you out .............

vill lads to their dears.

I give my daughter to him

to greet him, and to give him eomforts

and they often give us soldiers the lie

elose with him, give him gold

I will give you as much as this old ma

give me the office to ehoose yon a queen

that gives ont himself prince Florizel

thy grave give way to what's seen

give me the lie, do an

and to give me your good report

therefore, give out, you are.... Comedy of $\vec{E}$ rrors

whiat bargain do you give it me?

I pray you, sir, give me the chain.

Why, give it to my wife.
till I give thee bail ......

hie thee straight; give her this key

some other give me thanks for

and gives 'em suits of duranee

give me the ring of mine

in' if you give it her

who give their eyes the libert

and munehed; give me, quoth I

to give thee, from our royal master

give him tending, he brings....

iii. 2 give him to eome give soiely sovereign

that nature gives way to in repose! give -

which gives the sternest good-night

give me the daggers....

you do not give the eheer

give me some wine, fill ful ...

all canses shall give way

we may again give to our........
charm the air to give a sound

seize upon Fife; give to the edge

none that Christendom gives out ...

your brows; give sorrow words

0 then give pity to her, whose state...

nay, to give great Charlemain a pen

I cannot give thee less to be ealled

and such thanks I give, as one nea.

to my endeavours, give eonsent...

give me some help here, ho!

give Helen this, and urge her.........

I'd give bay Curtal, and his furniture

but $I$ give me, and my service...

you give me most egregious...........

eornmon speech gives him a worthy.

if you give him not John Drum

first, give me trust, the count.

and great ones I dare not give
but give thyself unto my siek.

forsake ourselves; give me that ring

no power to give it from me....

no power to give it from me.............................

and $I$ would give his wife $m y$ bauble

give thee not this to suggest thee

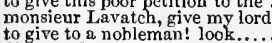

to give to a nobleman! loo

ỏigested, give a favour from you

you give away this hand (rep.)

and give me mine again....

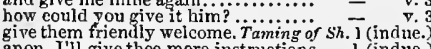

anon, I'll give thee more instructions - I (indue.

why, give him gold enough, and marr

why, give him gold enough, and marr
to give you over at this first.......... give me my armour.

than terms ean give thee out!........

ii. i I'd give it every foot to have ................

i. 2 love him, give him welcome

I'l give thee more than e'er

give grandam kingdom (rep.)........
or shall we give the signal to our...

ii. 5 open your gates, and give the vietors

in favour she shall give the day

wide ope, and give you entranee ....

then do I give Volquessen, Touraine

that give you cause to prove

of gawds, to give me audienee

give me the iron, I say

may give life to yours.

a) though my will to give is living

and can give audienee to any

my crown I should give off?

to give us warrant from the hand...

my arm shall give thee help .........

kind sonl, that would give you thanks

gives but the greater feeling
yet my letters patent give me.. mine armour on: give me my staff ...

that you give his offspring life

king, that thou canst give
GIVE-sworn to give him aid
strength, gives, in your weak
I'll give thee scope to bent

I'll give thee scope to bent ...........

will his majesty give Riehard leave

give some supportance to the bending

terms to give him chastisement?
what subjeet ean give sentence on hi

give me the crown; here, cousin

cares you give me with your crown...

the eares I give, I have .............

give me that gls ss, and therein $\ldots \ldots .$.

divide the realm, and give thee half..
thus give I mine (rep.) ..............

five me my boots, I say; saddi

tili thou give joy; until thou........

fellow, give place; here is no longer

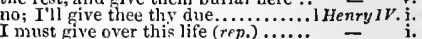

he will give the this life (rep.)

good eousin, give me audience

and give it him, to keep his anger

clerks, I'll give thee this neek $\ldots . .$. .

give me my horse, you rognes, give m

I will give thee for it a thousand....

give my roan horse a drench, says he

give me a elp of sack, boy ...........

give me them that will face me: give

give you a reason on compulsion?

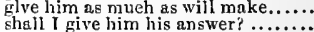

give me a eup of saek, to make..

yet doth he give us bold advertisement

will you give me money, eaptain?

did give him that same royalty....

give me life; which if 1 ean save .... - $\quad v$

give then sueh instanees of loss?

if yoll give o'er to stormy passion...

an old man, you should give me rest

who, half through, gives o'er .........

and gentle daughter, give even way

is that all the eontort you give me?

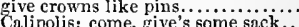

no, let the fiend give fire

give me my rapier, boy .....

thy fatler is to give me thanks for $\dddot{\text { it }}$

give me my sword, and cloak....

give me the spirit, master Shallow

gladow, - give me this man

$O$ give me the spare men, and spare

Burdolph, give the soldiers coat

that he will give you audience

to give admittance to a thought...

if heaven doth give suecessful end

being moody, give him line and scope

stand from him, give him air...

Eivgiand shall give him office

give cntertainment to the .............

give me pardon, sir, if sir, rou

the countenance that he will give me

and qualities, give you advaneement

unless you give me your doublet

to give a greater sum than ever.

whose wrongs give edge unto

did give ourself to barbarous

that may give furtlierance to

give me thy fist, thy forefoot to me give

give me your thoughts

if you give him life, after the

of his merey, give you patienee to....

my love, give me thy lips............

doth order give to sounds eonfused -

the work ish give over $\ldots . . . . \ldots \ldots . . . .$.

to our best merey give yourselves...

and give our vineyards to a barbarou

what willing ransom he will give....

and we give express charge, that ....

give the devil his due................

give dreadfui note of preparation

liberal eye doth give to every one

here's my glove? give me.another....

and bid thy eeremony give thee crere

will it give plaee to flexure and low..

give their fasting horses provender ...

o give to me egregious ransom.......

unless thou give me erowns..........

he will give you two hundred erowns

prisoners; give the word through .....
I will give his treason payment.....

\section{$\bar{z}$
$=$
$=$
$=$
$=$
$=$
$=$
$=$
$=$
$=$
$\bar{z}$
$=$
$\bar{z}$
$\bar{z}$
$\bar{z}$
$\bar{z}$ zry}

- 1.

iis

$$
\text { - ii. } 2
$$


GIV-glve me, in your conscleuce (rep.)2Hen, $l \mathrm{~V}$. iv. and give it to this fellow

vilose want gives growti to..

give me yon ner...................

give me my stecled cont ............ Ihenry $I$.

.

straightway give ling soul

of these rare.

kindly give one fuinting kiss...

only, give orter tior my funerat.

ronclisale to give ne hearim

all the wlole inheritance $i$ give.

I'll by a sign give uotice to

and give him chastisement .........

and give it ou that

and menus to give you battle

a member ot, ant give it you

(and for thy honour, give consent) ... -

give thee her hand, for sign ....

I give thee kingly thanks

king Jleury gives consent........

so should I give eonsent to flatter sin

sooner will receive, than give

our king Jlenry gives away his own...2Henry $r$ r. i.

friends, and give to eourtezans

and give no words but-mum

dame Elennor gives gold

give his censure: these are no women's -

give me my fun: what, minion!......

give her as a proy, to law, and shame

ere thou go, give up thy staff .......

give up your staff, sir, and the king.

when cvery one will give

what counsel give you in thi

and you will give them me ..........

give thee thy hire, and seod thy soul

I'll give thee England's treasure

give me some drink; and bid the

this prisoner freely give $I$ thee.

and so much shall you give, or off goe

I'll give it, sir; and therefore

and give me but the ten meals

I cunnot give clue action to $\mathrm{my}$

wo give thee for reward a thousand ...

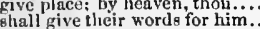

to give the enemy way

and them onr fort une give .............

peace thou! and give king Henry

I give thee this to dry thy eheeks.

to pierce it, or to give thee min

I ory'thee, give no limits to my tongue

what counsel give you? whether

give swect passage to my sintul souli

gives not the liaw thorn bush ...

Wrarwick, to give: slie, on his left.

he'll rather give her two

service wilt thou do me, if I give them?

lunds freely give thee..............

let me give hum

delay not, give thy hand to W arwick

ny vow, Live my han

pive the heir and daughter of lord Scales -

give me assurance with some $\ldots \ldots . . . .$.

Warwick, and Clarence, give me both

for a poor earl to give ................

give signal to the fight (rep.)

the loving kiss I give the fruit ....

to give them thanks, that were
to take is not to give

why, then give winy, duil cloud

that now give c vidence agains
God give your grace good rest

opens his purse, to give us our reward

opens his purse, to give us our re
keeper? give me a cup of wine

the duke give order for his hurial...

and ghalt that tongue give pardon

give me no help in lamentntion.

to give your censures in this

give you good-morrow, si

will give; and, being but a toy (rep.)

than that I'll give niy consis.

and give us notice of his inclination

for joy of thin good news give mistreso

but, that I'll give my voice on

we give thee up our guiltless hlond...

in the dukc's behalj I'll give my

and, to give notiec, that no manner..

I give a sparing limit to my tongue

Gid pive your grases hoth a hajipy

give me some lireath, some little

give nine the beneflit of seniory

after-hours give leisure to rey

we mut bot is give and take.
GiVk-gives token of a goolly day... Richerd 111. Y. give ino nome ink nind proper (rpp.)

God give you quiet rest to-night
give ure a wath : sadde white.

give ale a bowl of wine; 1 have not

give me another horte, binl ui

give me anotice horte,
time to arm, and give direetion

tell the elock there; give me a calenitins

as give their money out of hope. Jentry $r \bar{T} \bar{T}$, (prot.)

he gives us note, the force of his ow

pray, give me favour, sir; this cuining

nnd give tlinnks to you that clioked it

'tis time to give them phisuic...

go, give them welcome, yout enn s.peak

and give your hearts to, when they once -

yet I ean give you inkling ot .........

your grive her the araunt I ................

and so give me up to the sliarp
thus it came; give heed to't...

we shall give you the full cause....

to give up willingly that nolle.

thrit may give me remembrance of my

(thougla now the time gives way to us)

must give my tendaue to

give lim a líttle earth for charity

than man could give him, he died...

give your friend some touch of your

no more prevail than we give your

give her a hundred mark

and give it to a most noble judge

pluck it out, and give it him.. Troilus o-Cressida, i.

will he give you the nod?

or give, would give an eye to boot

or give me ribs of stecll........

iii. 1 give pardon to my specch.

and I will give a taste of it

and give him lial

come, give me an instrument........

gives is more pulm in benuty

and give me swift transportance

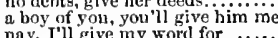

nay, I'll give my word for ....

and they will almost give us

if you give way, or hedge aside

can give expressure to ..........

and give him note of our approach

and must give up to Diomedes; hand

aliayment could I give my grief

to give thee nightly visitation.
lord, I'll give her to thy hand...

give with thy trumpet a lowd note

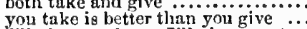

I'll give you boot; I'll give You (rep.)
for Venus' sake, give me a kiss ......

for Venus sake, give me a kiss

that give a coasting welcome ........

that I may give the local wound

give me some token for the .

O false wench! give't me again.....

and gives momorial dainty kisses.

I'll give you sonething else...

do not give ndvantage to ................

for we would give much, to use

yet give some groans, though ...

give him thy dangliter......
even such as they give out

as those, which sell, would give.

give them guidc to us.......

he gives, if he receive

too proud to give thanks to the gods

to provide, mul give great gifts

thou wilt give away thyselt.

not to give regard to you . $3 \ldots \ldots . . . .$.

why, give my horse to Timon (rep.)

give inc hreath; I do besceeh you

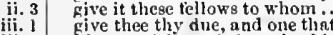

iii. 1 give thee thy due, and one that......

iii. 3

more than the man that gives

give them title, knee, and apjurobation

by wanting light to give ...............

give them diseases, leaving with thee.

kive us arme gold, good Timo
give it the heasts, to he rid of

fear to catch it, and give way...

steml not less, or this I give you

and give over my trade

give to dogs what thou deny'st to men

ill give yon gold (rep.)

to pive tliy rages balm $\ldots \ldots \ldots . . . . . .$.

he that will give good words to thei
Gilv E-give out eonjectural marriuges. Cor źolants, i. give me excuse, good mulnin
io, I'll iut

may give you thankful suerifec!

fruteful to us thut give you truly

I request $y$ ou to give my pror

give your disposition tlic reins

gives me an cetute of seven years; health -

wherein he gives my son the whole.

give wuy there, and go on.......
which that he'll give them....

than the relsuke you give it....

than misery itselt would give........
for my wounds' sakc, to give their

should be in them to give............

it' we give you any thing.

an 'twere, to give again ..................

therefure rive you our yoices heartily

the gods give you joy, sir, heartily ...

Tritusucs, give way; he shall to the.
the gods give him joy and make him

to give forth the eorn o'the....

why shall the people give one $\ldots . .$.
I'll give my reasoln, more worthier.

and give way the while to unstable

when we shall hap to give't them.

When we shall hap to give't them.....
check my cournge for what they can give

all despite: give hiin teserved vexation that he gives entrance to such

are mapt to give or to forgive...

yet give us our despatch
they $l l$ give him deuth by inclies

we have all great cause to give

and give away the benefit of our levies

nust give this cur the lie

alas! it cricd, give me some drink....

whes men stomach to digest...

five guess how near to day

for I can give his humour the truc

to give, this day, a crown to might

security gives way to conspiracy.

as a suitor will I give him this

sirrah, give place. What, urge

then follow me, and give me audience

then follow me, and give me audience
give him n statue with his anecstors

to every Roman citizen he gives...

in this mood will give us anythin

nd I will give rou audience.

I that denied thee gold, will give....

if you give place to accidental evils

give me a bowl of wine $\ldots \ldots \ldots \ldots . . . .$.
must, of toree, give place to better...

give me the gown .....................

Mark Antony, shall we give sign

back strokes, Brutus, you give good words -

the death which he did give himscif

and give these bills unto the legions

and nid me give't thee? didst thou

thy Britus bid me give it thee $\ldots . .$.

good sir, give me good fortune. Antony \& Cleopalv

and rive him a worse ..............

in each thing give him way.....

I am sorry to give breathing........
from folly could not give me frecdiom

as you shall give the advice.

and give true evidcnce to his love...

to give a kingdom tor a mirth

ha, ha! give me to drink mandragora

hy lin, 1 in give thee bod tceth

small to greater matters must give way

give mc some music; music, moody ..

give me mine angle......
the gold 1 give thee, will il.

with the healtl that Pompey gives him

the man will give thee all the worli

of the stars give light to thy finir way.

and gives his potent regiment to...
and give up yourself merely to chin

give me a kiss; even this repays me.

partly hege to be desired to give.....

to give them this discomfort?

to give them this discomfort?
Jet's see how it will give off

come, give me that: this winy

I. pive it you. Mack me not........
I'll give thec, friend, an armour...

fortines give him hope ...........

anish, or I shafl give thee thy..... .

give me some wine, and let

give her what comforts the quality...

to give me conquered Egy pe for my son

very goosl: give it nothing, I pruy you

give ine my robe, pint on iny .......

whieh the gods give men to exeuse

my cuther eluments I give to bnser life
leat I give cause to be susperted....... Cymbeline, i. 
GIVE-rive me hut this I lume fiel you must sive way ............... and give me directly to nuderstiml. I was going, sir, to give hin welesum

give me your parton. Thave spoke. Col. Knt.] dog! I give him satisfaction? -

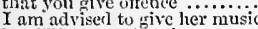
the thanks I give, is telling you the thanks I give, is telfing you shall give thee opport

avel a weleome as I'd give to him.

Cadwal now to give it motion....

give colour to my pale elieek .......

pence? I'll give no wound to thee

ave me the penitent instrument

aud thy state, I'll give it

give answer to this boy, and do it..

give me cord, or knife

I give him your; the noblest.

give me a statf of honour for

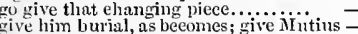

give yeu joy, sir, of yomr gald
inc your trace to know

we'll give your grace bon-jour ......

give me thy poniard; you shall know

thereby may give a likely guess.

hieh gives my soul the greatest spur

and I will sweet tidings

good Aaron, give his majesty my hiand

give me thy knife, I will insult...

give signs, sweet girl, for her:
well, God give her good rest!

nurse, give it me; my sword

in Virgo's lan, give it Pa!lia

but give them to his master for (rep.)

fet the emperor give his pleilges.....

now ting a liand to give it action?

now give some 'surance that

that gives our proy, our Rive me aim a while

give sentence on this execrable wretch

and give him burial in his fatlicr's

every virtue gives renown to me

that give heaven countless eyes

my lords, and give experionee tomguc

that lireath gives heat and st

strength left to give them burial

give them life, who are hunger

w give uny benison) .... -

to give ny tongue that heat

though caimed, they give't again...

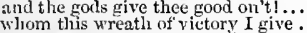

and rives them what he will

who freely give to every one .........

their hand should give them

or dead, gives cause to mourn .......

we, here below, reenll not what we gi

to give thee hallowel to thy grave
give this to the 'rothecary, and tell in

which to the rothecary, and tel

here I give to understand.

who tinks her, give her burying.. - iit. 2 (scroll)

I pray you, give her air: gentlemen

to give lier prineely training ........

cone, eome, give me your wreath....

hic that will give most, shall

would but give way to customers.....

no less than it gives a good report.

ther gain she gives the cursed baw

givere best I did give o'er.

give me frush garments

give me my robes $\ldots \ldots \ldots \ldots \ldots \ldots \ldots . . . . .$.
not good to eross him; give him way

and give them repetition to the life.

and give you gold for such provision

give me the map there: know, th
as here I give her father's heart.

royal Lear, give but that portion.

give me the letter, sir. I shall offend $($ rep. $)-$ i.

to give away thy land ......................

give me an egg, nuncle, and i'll

not to give it away to his daughters

seeking to give losses their remedies

tive country gives me proof ...............

follow it, sinee a fool gives it .............

give me my servant forth..................

give ear, sir, to my sister .....

you heavens, give me that patienee....... -
[Kut. $]$ didst thou give all to thy daugliters? -
GIVE-who gives anything to poor Tom?..Len thou give them ull?

the grives the web anci the pin way to loyalty.................. to some jrovision give thiee trive me some help: $O$ crnel!

give me thy sword: a peasant

antl give the distafl into my liushand.....

find him, pray you, give him this.

hewgh! give the word. Sweet Marjoram

give me an once of eivet...............

sliall give them instant way

take ny sword, give it the eapt

give me my long sword, ho! .... Inomeo \& Juliet, $\mathrm{i}$.

Would as willingly give cure, as know
than your consent gives strength to.

give me a torch; I am not tor........
give me a ease to put my visage in

give room, and foot it, girls....

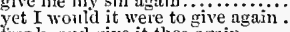

rink, and give it thee again

some speeitil good dotll give..........

what counterfit did I give you? ......

one sliort minute gives me in hor

which thou, prinee, must give

night, give me my Romeo

give me some aqua vitre
give this ring to my true knight

I'll give thee armonr to keep of

a rol. Kut.] shall give him suel an

she will none, she gives yon thanks.

doth she not give us thank

that she doth give her sorrow

in thy wisdom eanst give no hel

give me some present counsel?

if thou darest, I'll give thee remedy.

wive me 0 give me! tell marry Paris

love, give me strength! and strength

dotli it give me such a sight as this?

give it you soundly. What will you give -
give you the minstrel. Then will I give

mind be writ, give nze his letter.

give me thy torch, boy; henee
give me those flowers: do us I bid

the boy gives warning, something....

give me that mattock, and the

five me the light: upon thy life

give me the letter, I will look on it ..

give these inourning duties to....

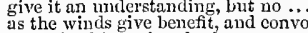

may give his stying deed

give thy thougints no tongue, nor any...

give every man thine ear, but few

$[K n t$.$] the soul gives the tongue vows...$

as to give words or talk wit

as a stranerer por request.....

as a him this mones, and these notes ...

here give up ourselves, in the full bent

give first admittanee to the embe assay of arms against

gives him tluee thousand crowns...
please you to give quict pass throu

please you to give quict pass throug
give twenty, forty, fifty, a hundred

come, give us a taste of your quality

gives me the lie i' the throat, as deep

that speeeh dotli give ny eonscience.

must give ns pause: there's the respeet

but now the time gives it proof...

Imagination to give then shape..........

a. teinperance, that may give it smooth

give him lieedful note: for I mine eyes

nor earth to me give food......................

give o'er the play. Give me some light

give them reals, never, my soul,
of our fanlts, to give in evidence

to give the world assurance of a man....

the eompulsive arfour gives the char....

he likewise gives a froek

power thercof may give thee sense...

give her good watch, I pray you $\ldots \ldots \ldots . .$. $O$, thou vile king, give me my father both the worlds I give to negligenee

I would give you some violets

wour soul to give it due content
give these fellows some means.

come, I will give you way for these.

Ehepherds give a grosser name

give me your pardon, sir

give them the foils, young osriek

if Iramlet give the first or second hit

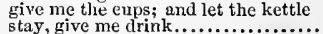

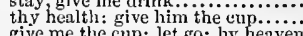

give me the cup; let go: hy heaven...

senseless, thu.t should give us hearing

give order, that these bodies, luigh ou

give order, that these bodies, ligh ou ...
give me a taper; call up all my people
, iii. 4 GIVE-enforce it on), will give him cable. Otwello, i. in these news, that gives them eredit .... - i. 3 there do give thee that with all my heart give us tiutl willo 'tis that is arrived give renewed fire to onr extinct spirits they give their greeting to the citadel that gives me this bold slow of courtes it rives me wonder great as my content and to give satiety a fresh appetite fit to stand by Casur and give direction a light brawler? give me answer to it

give me to know how this foul rout beyan to give plaee to the devil, wrath $\ldots . . . .$. - ii. 3 give me advantage of some brief discourse these letters give, lago, to the pilot..... - iii. 4 rather die, than give thy eanse awa...... . 5 and give thy worst of thenghts the worst - iii. i. 2 the work ta'en out, and give it Iago ..... - iii. a good wench, give it me. What will.... - iii. 3 1 be sure of it; give me the ucular joroof... give you satistaction, you may liave $($ rep. $)$ - jii. 3 fate would have me wive, to give it hier to ose or give t away were such perlition - iii. 4 of her honour tool may she give that?

that you give me the addition $\ldots . . . \ldots \ldots . .$.
she gives it out, that you shall marry her

there, give it your hobby-horse ...........
her iniquity, give her patent to oftend.. I will give over my suit, and repent $m y-$ give me my nightly wearing, and adieu
give me some help. ome, iveutenart! 3 I cannot give it vital growth again...... $=v_{2}$ fomel by fortune, and ditl give my lusibuid $=\quad \mathrm{v}$ GNVEN-What a blow was there given!. Tempext, it. 1 fike poison given to work $\ldots \ldots \ldots \ldots . .$. - iii. 3 rattling thunder have $I$ given fire ....

sinee you have given me ugain........

she hath given you a letter .............

she is given too mueh to alliciolily ... - i.

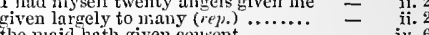

the niaid hath given eonsent $\ldots . . . . . . \quad-\quad \begin{gathered}\text { iv. } 6 \\ \text { and have given ourselves without.... }\end{gathered}$

and given to fornieations .............

have given us bloody argument.......
that whichl I have given to you?.... iii. 4

and has given sir Toby .............. - v v.

and given hove given me such clear ..

why you have given me such clear ...

at woman carlinally given .........

he has given him warning $\ldots . . . . . . .5=$ iii.

the better, given me by so lroly ....... - iv.

given way mo to this eourse of fortune...... rigltt you slionld have given her cousin $-\overline{\text { v. }}$ thou hast given her rhynes.....Mid.N.'s Dream, an tlie duke had not given him....... $\overline{-}$ jv. it will be given to A jax ............... false; we have given thee fices........ I would not have given it for........ - iit. 1 this ring was given me by my wife... I am given, sir, secretly to ......... As you Like il, i. I should have given lim tears unto.. metlinks, I have given him a peuny

truly, sle must be given ............. - iii. 3 lint, thanks be given, she's very..........All's W' wh, ij. ity treasure, given order for our.... $\quad$ - iii. 5 you liave not giventhim his...........
he hath given lier his monumental ..

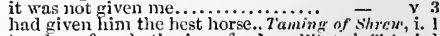
too dear, for what's given freely ... Winte' 's 'Tale, i. I grone, given to the fire, a moietv...... $\quad$ - ii. 3
they are given to men of middle age $\quad$ iv. 3 wilich like to have given us one......... $=$ iv. 3

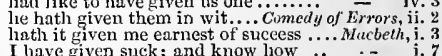
quenched them, hath given me fire and mine eturnal jewel given to the.. $\quad$ - iii. 1 a making, 'tis given with welcome.... $\quad$ - iii. 4 where there is ndvantage to be given
have given him time to land......... King John, ii. 4 have given him time to land........ King John, ii. I
as they have given these hairs their..
given away to nustart unthrifts? .. iichard II. ii. 3 given away to npstart unthrifts? ... Richard 11 . ii. 3 not that name was riven me at ...

if the rascal have not given me....... i Henry $I V$. ii. . 2 and given my treasures, and my rights - ii. if thit man should be lewdly given...
was as virtuously given as a gentlemar 


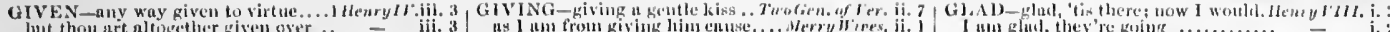
1 linec pisen than uway to buker's toulin trom giving lime es.

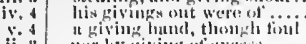

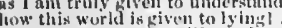
Jiar lenh Night,

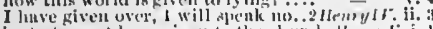

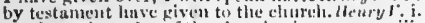
to whom the orler of the giene is piret hure the pioneces firion oce.

but lixeter bath given the cleom......

tine

as worbltiugs don, giving the

and fiving her them anatin ...........

thou linst givil me must bitter tureus

the joy thut ciod luatl given $u$ s.......
thyself hath given her woeful breast!

I have a while given truee unto

amb, giving hin tlue be, lenves him

by giving it the worship of reveng

from giving reins and spurs to ny

or thint a stroke was given thi.........

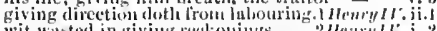

lusth given the duchics of Anjou

wit wasted in giving welkoniugs ....2 lirwy

both given unto the 1

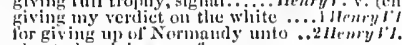

nud too well givell, to dream one.....

anil given me notice of their sillamis

wisulit never lave gaven unt these urms

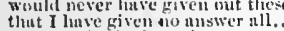

thus war linth given the peace.

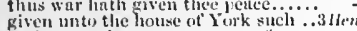

or lortme given me messure of

ubout the

iii. I by givine the house of laneaster.

... - ii.

released rom tivis. 3

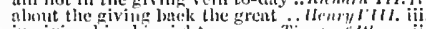

lie huth given for fence impregre

in wiving ham holy virgins to the.........

that, giving itselt the lie............
in giving him our own voices witli

tlironts tenr, with fiving hin glory
giving myself u voluntery wasud

Frent pronimtions are ditily given

I coufl hayc given my mele's grae

und given in earaest what l legect.

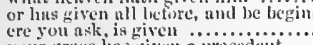

will be strons witlt us for giving on

as my giving ont her heat

take sme ocetsion witheut giving

gaughter, giving more light than lieat

your grue has given a preedent .....
my beduviusur given to your displeasure

there's orler given for her coronativa

fleased to have given ne lonser li

whin hath so liur given car to .........
l lisoked you woukl lave given ine your

gash that love huth given me. Troilus \& Cro

fuhulding as they have often given
she hath not given so many good

she hath not given so mayy goorl.

worth the sums that are gi
not ignobly, have I given...

nist ignobly, have I given...............

what hast thou given?

given to Lartius and to Marcius batic
when corn was given them gratis......

which they have given to begrar

have you th:s given IIydra

as now at last given lrostile stroke....

an' he had been cannibally given...

given your enemy your slid not lave given a disit

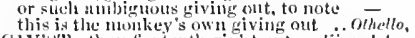

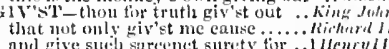

nud give sued surenet surety fir... Henryll:

thon giv'st so long. 'Timon .... Thimon of thens, i.

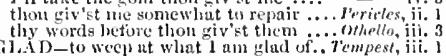

so giad of this ats they.

I am right glad thint lie's so.

will be glid of you ........

licld we oflnd of such a doom ......... is $e^{\prime}$ ry $\bar{w}_{i}$

I am glaul to see your worsh

I am glad to see you, good

I am glad I am so acrult of this
I am glad lie went nut in himself.

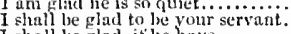

I shall be glad to be your servant....

why, I am glud of it ..............

I an, glad, the fiat knight is .............

I shall make my master ylud with

I am glad, though you hive ta'en

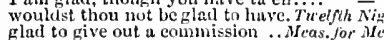

glad to give out a commission ...Meas.

which he is most glad to recive
the glad to receive some instruetion

we are glad to see you $\ldots$.

I am glad to liear it.

vo fur am I glas it so dil sort sort. . -

1 wonld he glad to see it ......... Lore's l.e Losi, if.

I am glat this pureel of wooers.
I sliouled be glad of his approach

father, I sme glad you are come.

1 am glad 'tis niglit, you to not...
I am glad on't; I lesire no

I km glad of it. I'll plague him (rep.)

I am heartily gltud $\mathbf{I}$ eame
glad of other men's good

I am glad of your departiore

I tam very glud to see you.

sorry, that he'll be glat ot this

glar ilat sou thus continue

I'll make him glatel to seem

I am glad, Youl did not nurse

ain glad to see you iu this. Cone

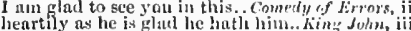
I am not glat that such n sore of

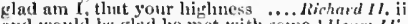

I am ghad you huve the money

raarry, and I'm plud of it wit

an glad to see your lor ilship ubroal..2 $11 \mathrm{~cm}-\mathrm{r}$ J

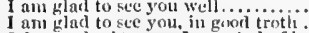

I do ant doubt you. I atn ghad

we are glail, the foutupin is

as we ure now glad to belould ..

I al1 $p$ lnd thou canst sirak no luet

ant ylud we trenped so well

are glad and fain liy llight to

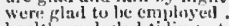

healifi, mind glad tielings, to your

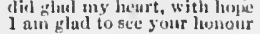

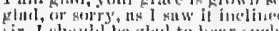

hir, 1 shombl be glad to licur such

and un glum to fave yout therein

and an riplit phal tocuteh this

I 1 min plarl, I cain

I am plat yon are well 1 a....

I unt glut on't; then we shath.

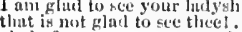

glad of your comprany (orp
that wonkd be gletd to luse

I an glal, thou liast set thy .....

the common lieri was glud he refused

I slumlit he glad to learm of nol

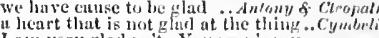

I num very glasl on't. I

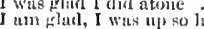

$1 \mathrm{mu}$ most glul you think of other

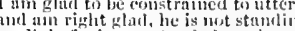

corthit of mine age tog ghul my lient? . Ti/us Ant.

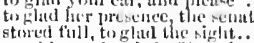

Would now be glat of brend.......... - ii. (ciswer

yeur presenee glais our disys ....... - ii. :

iftenee at that would make me glat ?

am glat to sec your honour

It th grlad to sece your highne:

right mlad 1 um, he was not.

why, I an glud ot't this is weil ....

1 am very glarl to see your; good cere

I $\mathrm{am}$ glan of it: a knuvish specel........ - iv.

1 am glat on t: tis a wortlyy buvernor .. - ij. 1

am glad of this: for now 1 shall lave

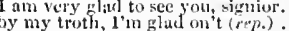

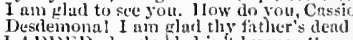

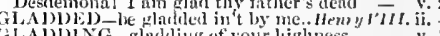
(iL, $\perp D D N G$ - Gladiling of your higliness

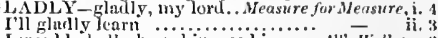

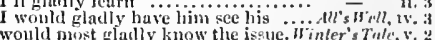

would most glatly know the ispue. Ininler's Tulc

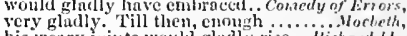

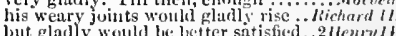

not the maun that be better satisfied..21/ewry/t. i. 3

ancd, fladly quaked, hear more

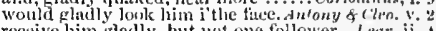

receive him giadly, but not one follower.. leter, ii.

gludly shumed wilo ghadly flet. Romen f Inliet, i.

is couched in :ceming gladness... Troilus of cre'ss. i.

with most gladness ......... Inteny of Cleoputra, ii.

I know, I am thane of Glamis........ - i. 3

Glamis, and thane of Cawchrs.

thoud'st lave, great Glumis

Great Glamis! worthy Cawdor

king, Cawdor, Glanis, all.

Tiro fien of leri.

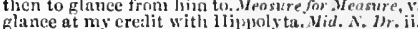

doth glanee from licasen to carth .... - v.

squandering flanees of the fool ... As you $\mathrm{s}$.

as the jest dif glanee uway.... Trming of shritu,

wuchsufe one glanke unto the

thid hut glanee a fiur-uth look ........

yet giance full wanteringy on lis .... Pericles, iti.

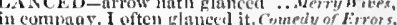

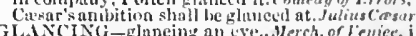

GIA NDLits-witl the glunlers. Praning of sh. ifi.

Gi.AR

look, how he stumb and glare?
look yout, how pale lie gla res!

GIARE1)-who glard wron me

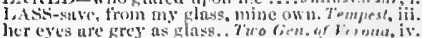

yet living in my glass ........... Turelfh, . .ight, iii.

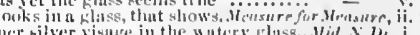

what wieked and diencenbling plas ...

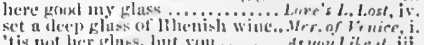

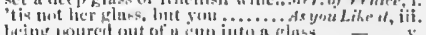

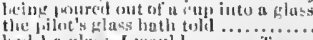

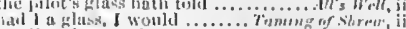

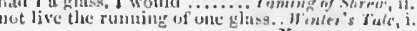


GLASS-I turn my glass .. Winter's Tule, iv. (chorus) not a riblond, glass, pomander

metlinks, you are my glass .. Comed $y$ of Errors, v, i who bears a glass, which shows me ..Macbeth,
this paper, while the glass doth .... Fichurd 11. give me that glass, and the:cin wili.

O) flattering glass, like to my follow

he whs indect, the glass wherein....2Henry $I V$. ii. 3

that never looks in his glass for love... Henry $r . \mathrm{v}$.

for ere the glass, that now ............ Henry $F_{1}$. iv.

like the sun 'gainst glass ...........2Henry $v$ I. iii. 2

till I have borght a glass

my kinglom stands on britile glass... - iv. 2

like a glass did break $i^{t}$ the rinsing.. Henry VIII. i.

tricle is his own of Pandar's.. Troitus cy Cressida, i. 2

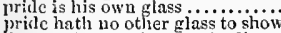

iii. 3

I, your glass, will modestly discover. Julius Ces sar, i.

for a man and his glass to confer...... Cymbetine, iv.

fair glass of light, I loved you.....

seems like diamond to glass.....

crack the glass of her virginity $\ldots . . . \ldots . .$.
woman, but slic made months in $\mathrm{a}$ glass.. Lear, iii. 6 get thce glass eyes

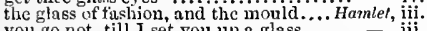

you go not, till I set you up a glass.

\section{GL.ASSES-at least two glasses.
wlich, but three glasses sinee}

w) aich, but three giasses sinee ........

ay, as the glasses where they view. Mlea, for Mea. ij. 4
my tears for glasses....... Love'sL.Los', iv. 3 (verses)

not pay for the glasses... Taming of Shrew, 1 (indue.)

even in the glasses of thine eyes .... Richard $I I . \mathrm{i} .3$
glasses, glasses, is the only drinking.2Henry $Y \%$.i. 1

take up the glasses of my sight! ... Coriolanus, iii.

and benrs with glasses .............Julize Cesnr, ii. I

ILASS-GAZING, superserviceable ....... Lear, ii. 2
ILASSY - his glassy essence.Measure fo.Measure, ii. 2

LASSY - his glassy essence. Measure for.Measure, ii. 2
the sun upon the glassy streans .... Herry VI. v. 3
his hoar leaves in the glassy stream ... Hamlel, iv.

his hoar leaves in the glassy stream .. Hamlet, iv. 7

GLEAN-to glean the broken ears, As you Like il, iii.

eouspectuities glean ont of this....

Hamlet, ii. 2

GLEANED-wonld then be gleaned...... Harer, of Ven.ii. 9

that may be thercat gleaned ....W'inter's Tale, iv. 3

galling the gleaned land with hot...... Henry iv. 2
when he necds what you have gleaned. Hamlet, iv. 2
gi.EANING-goodness of gleaning. Henry VIII. ifi. 2

iLlEFUL-make a gleeful boast?. Titus Andron. ii. 3

LEEK-nay, I ean gleek

and Charlcs his gleeks? ............ Henry VI. il. 2

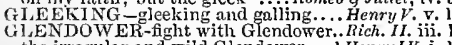

the irregular and wild Glendower ..I HenryI $I V$.

haruiment witl great Glendower....

as Owen Glendower for an enemy

steal to Glendower, and lord IIortimer =

$o$ crlendower. Owen, Owen, the same

spirit Percy, and that devil Glendower?

cousin Glendower, will you sit down?

within that bound to Owen Glendower

$\mathrm{my}$ father Glendower is not read

0 that Glendower were eome I $\ldots . . .$.
father and Glendower being both

what with Owen Glendower's absence

to fight with Glendower, and the ear

ert in inse the $1 V$. i. 3

but for Owen Glendower............2 Henry VI. ii. 2

encounterers, so glib of tongue.. Troilus \& Cress. iv. 5

of glib and slippery creatures ... Timon of Alhens, i. 1

for I want that glib and oily art ........... Lear, i. I in the clureh-way paths to glide... Nid. N.'s Dr. v. 2
with indented glides did slip away. As you Like,jy. 3 may not I glide thither in a day? .. Cymbeline, iii. ten times faster glide than the .. Romeo \& Jaliel, ii. 5
GLIDED-that slily glided towards..2 Henry VI. iii. 2 GLIDET1I-more water glideth. Tilus Andranicus, ii. I GIIDING-all these gliding ghosts..Jutivis Casar, i. 3
GLLIMER-some fading glimmer:.Comedy of Err. v. I
the west yet flimmers with some..... Machelh, iii. 3 the west yet glimmers with some ..... Macheih,
tliat it will glimmer thro' a blind ..i Henry VI.

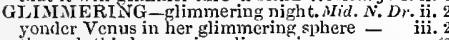
yonker Venus in her glimmering spher

GLIMIPSE-the fault and glimpse. Mens. for Meas. i that lie hath not a glimpse.... Troilus \& Cressida, i. 2 how he $\mathrm{glisters}$ that glisters.. Mer. of Ien. ii. 7 (scroil) GIISTER ING the god of war .......King. .ohn, v.

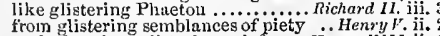
perked up in a glistering grief

the zodiac in his glistering conch.. Titus Andron.ii.
GLITTELING-ghittering streams.Mid.N.'s Lr. 7 . cloddy enth to glittering gold....... King John, iii.
glittering arms he will commend... Richard $I$ ii. over the glittering helmet of my foe! - iv.

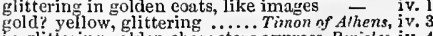
in glittering golden clarracters express. Pericles, iv, 4
Ol3E-the great globe itsclf

slie is spherical, like a globe..Comedy of Erean, is hid belind the globe $\ldots . . . \ldots \ldots$. Richard $[l$. iif. hou art in this of sinful $\ldots \ldots \ldots \ldots$.2 Henry IV . ii. make a sop of all this solid globe. Troilus \& Cress. $\mathrm{i}$. thon beacon to this under

ids a seat in this distracted globe ..... Hamele' $i$. that the affirighted globe should yawn .. Othello, v. LOOM X - and the gloom s shade..... Henry $V I$ Y ruthless, vast, and gloomy woods?. Tilus Anirou, jv. lay apnt the borrowed glories $\ldots \ldots \ldots$... Henry $r$.i. tis love I bear thy glories........... his image, and rencw his glories
but their titles for their glories all my glories in that one woman...... Henry $\bar{v} I I I$. iit. are all tlyy conquests, g]ories ....JutiusCcesar, iii. his speech tending to Cesar's glories to part the glories of this happy day ${ }_{\text {GIOR IFIED - so mueh be glorified .. King John, v. }}$ GLORIFY-do glority the banks.
with our stately presence glorify

1Heñrylli. we for the may glorify tlie Lord...

GLORIOUS - is the glorions sun.. Twelfth Night, iv 3
lives in death with glorious... Much Ado, v, 3 (scroll) in the arts, glorious in arms .......... ine s L. Lost i. I in that glorious supposition ........... Conedy of Err. iii. 2 the glorions sum stays in his course.. - iii. the most glorious [Col. Knt.-gracious] in glorious christian field streaming

in the closing of some glorions day...

to your, as us, florious deeds

in this glorious and well-foughter fieid far more glorions star thy soul ....1 Henry $F^{\prime}$ iv. trimmph in thy glorious prophet

altho' in glorious titles he exeel

reach at the glorious gold.............

ike to the glorious sun's transparent

aith, lords, 'twas a glorious day

her farewell of the glorious sun!

three glorions suns, each one a perfeet

mpaled with a glorious crown

made glorious summer by this sun...Richnrel $7 I I . \mathrm{i}$. 1 therefore is the glorions planet... Froilus \& Cress. i. whose glorious deeds, but in these. by the flame of yonder glorious heaven glorious gods sit in hourly synod .. Coriolanus, v. a better head her glorious body fits. Titus And on. i. 2 purpose to make men glorions .. Pericle

Were not this glorious cask
in the day's glorious walk

souglit the purehase of a glorious beauty

gild his statue glorious ........... thon art as glorions to this night. Rameo \& Juhet, ii. 2
in action glorious I had lost these legs. Othells, ii. 3 pomp, and eircumstance of glorious war! $\bar{D}$. iii. GLORY-the uncertain glory of an. Two Gen. of $T$. i.
herself the glory of a creditor.... Meas. far Miers. i. hath all the glory of my overthrow ... Aluch Ado, $\mathrm{i}$. lis glory shall be ours, for we are.

in glory of my kinsman Hercules... Aid . N. 's Dr. y. glory grows guilty of detested crimes

glory grows gutily of detested crimes iv. $\overline{3}$ (verses so doth the greater glory dim... Merch. of Fenice, $\mathbf{v}$
or show the glory of our art?............ Mncbeth, iii

low ligh thy glory towers ...........
all days of glory, joy, and happiness
till I have set a glory to this hand .

state and glory of the land!............

I see thy glory, like

strikes at thy great glory .............

and threat the glory of my precions..

a brittle glory shineth in this facc (.
shall render every glory up .......
to share with me in glory any more

may heaventy glory brightcn it!....2Ienry $I Y$ ii. 3

praise and glory on his head! .....$\overline{\text { iv. (chorus) }}$

in complete glory she revealed.

glory is like a circle in the water

before whose glory I was great

have glory for this vietory 1 ...........
ascribes the glory of his conquest...

this is the latest glory of thy

whose lil'e wis England's glory.......

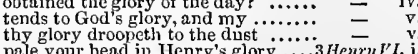

pale your head in Ienry's glory ....3 Henry $N I$. i.

lo, now my glory smeared in dust....
outlive thy glory, like my wretelied.Richard $I I I . \dot{\mathrm{i}}$.
GLORY-glory of your royal house. Richurd III. iii. 7 I envy not thy glory; to feed my .... thon woful welcumer of glory! .......

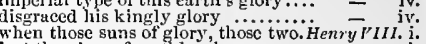
look they glory not in mischief

from that full meridian of my glory

many summers in a sea of glory $\ldots \ldots$

onee trod the ways of glory....

may glory in such an honvur.....

what glory our Achilles shares... Trroilus s. $\bar{C}_{r}$ ess. $\mathrm{i}$. 2

arlvantage of a promised glory ....... $\quad$ - ii.

if to my sword his fate be not the glory - iv. 1

stains the glory in that happy. . Timon of Athens, $\overline{1}$. 1

like madness is the glory of this life
wretchedness that glory brings us!

who'd be so mocked with glory? .....

for no less spoil, thau glory ......... Coriolunus, iv.

his glory not exteruated .........Julius Corsnr, iii.

I shall have glory by this losing day

partake in the glory of the action...Ant. \& Cleo. iii.

played my glory unto an enemy's

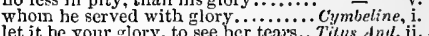

let it be your glory, to see her teais... Titus Aml.i.

a countless glory, which desert must guin -

no glory's got to overcome ............

in that glory once he was...

many's and pride of all his glory ...... \& $\overline{-}$ ii.

GLOSS-new gloss of your marriage... Much ddo, jij.

a commodity will lose the gloss witb...All's Well, $i$.

e worn now in their newest gloss .....Narbrth, $\mathrm{j}$.

hath suflied all his gloss

for all this flattering gloss

Fourr painted gloss discover

2 Heñyll. i.

d..... Troilus \& Cressida, ii.

content to slubber the gloss of your new. Olhetto, $i$.

GLOSTER-in the county of Gloster.Mer?y Wives, $\dot{i}$.

plot the duke of Gloster's deatl $\ldots . .$. Itichard II. $\mathrm{i}$.

my dear lord, my life, my Gloster

my brother Gloster, plain weli-meaning -

to Plasliy, to my sister Gloster ...... -

dost know of noble Gloster's death ..

when Gloster's death was plotted....

Humphrey, my son of Gloster $\ldots . .2$ Henry $I V$. iv.

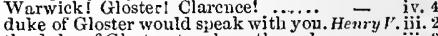

the duke of Gloster, to whom the order -

Gloster, 'tis true, that we are in great -

my brother Gloster's voice? ..........

my dear Sord Gloster, and my good.

and my brother Gloster, follow Fluellen - iv. 7

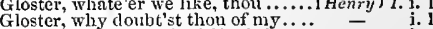

it is Gloster that calls. Who is it

it is the nolle duke of Gloster

Gloster, thou'lt answer this before

Gloster, we'll meet; to thy dcar eost

Gloster, we'll meet; to thy dear eost
abominablc Glistcr! guard thy head

for the truce of Wincliester and Gloster -

stuôiously devised Humphrey of Gloster -

Gloster, I do defy thee; lords ........

nncles of Glostcr, and of Winchester
bishop and the duke of Gloster's men

pray, uncle of Gloster, mitigate......

kind duke of Gloster, how joyful am I

when Gloster says the word, king Henry -

is this the lord 'Talbot, uncle Gloster

Gumphrcy of Gloster, thou shalt we.
my lord of Gloster, now you grow

Humphrey the good duke of Gloster

if Gloster be displaced, he'll be .......

duke of Gloster did bear him .........

brcaks a stick of Gloster's gro
while Gloster bears this base

believe me, cousin Gloster, had not.

why, how now, uncle Grloster?

Gloster, see herc the tainture of.....

disho of Gloster, William of Windsor

Eleanor Coblam, Gloster's wife
stay, Humphrey duke of Gloster

and Humphrey duke of Gloster...

ah, Gloster, teach me to forget

my lord of Gloster is not come

our kinsman Gloster is as innocent.

may, Glostcr, know, that thou $\ldots$ i....

so myself bewails good Gloster's case

who's a traitor, Gloster he is none!

this Gloster should he quickly rid

no straighter 'a ainst quickele Gloste 


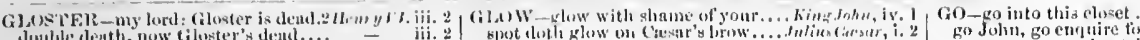

all, wo is me tor Gloster $\ldots$..........

I will ereuti: the duke of (iloster

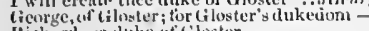

Itichiter $x$ duke of Gloster.

bruther of thluster, at suint Aiban?....

bro:lier of Gloster, lord llustings ...

by lichnrd duke of Gloster
groul (ildater, und good devil

Givorl (ilaster, and good devi] ........

untes the trust of ltichard Gloster .. ${ }^{k}$

the duke of ciloster and your broth

bruther of Gluster, you mistnke.... W. ster -
we know your meaning, brotluer Giloster

we know your meaning, hrother Gloster

my lord of ciloster, in those busy dny

in iny compung, ny brother Gloster

I'tl buek ti the duke of Gloste

in the duke of Gloster's purse.........

I will send you to my brother Gloster -

deceived, yulur brother

wanteth now our brother iloster here

[Col. hint.] Giloster, we have done deed

for my good uncle Gloster told me .

aviglity dukes, Gloster and Buckingliam -

wiste chloster, it our brother eome

inuriler me, and nyy rood lord ot Gloster?

the lerit of her kiud nunt of Giloster?

lorils of Erane sud Burgumly Gloster

go you betore to Gloster with these

oucusions, noble (iloster; of some puise

why, Gloster, Gloster, I d speak with..

or thase, it hath made thee earl of Gloster

seck wit the villuin Gloster.

furewell, my lord of Gloster .....
niy lord of Gloster liatly conveyed

go, seek the traitor Gloster, pinion.

of Gluster's trenelhery. nnd of the logal

iny most dear Gloster! O the difference

lut, $O$ proor Gloster! lost he his otlier e?

being widow, and my Gloster with her

great ignurance, Gloster's eyes being on

for Ciloster's hastard eon wus kinter.....

thy name is Giloster: thou must be jat.

thou art armed, Giloster.

strposel earl of Gloster....................... this is mere practice
GLOSTEItSIIliE-

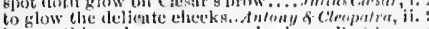

is something glow's ujom

llamlet, $\mathrm{iji}$.

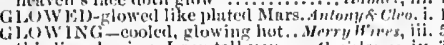
this lies glowing, I can tell you..... Coriolanus, iv. gives hent and stronger gloning

Gl,

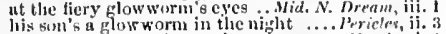
glowwsem shows the matin to be near... Mrmite

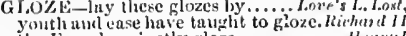

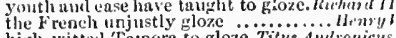
high-witted Tatnom to gloze. Tilus Antronicus, iv. but I will gloze with hin ............... Perieles, i. 1

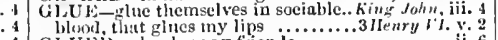
4 GLUED-glned many friends

i. lave your lath glued within your. Titus Andron. ii. 1

- GLU'TTONOUS-gluttonous maws. Timon of Ath iii 4

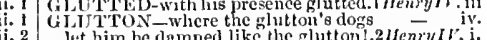

Get him he clamned like the glutton!.21

GLUTrithon disgorge thy glution bosom

if the cook help to make the gluttony - ii. 4

ii. 4 if the cook help to make the gluttony $\bar{F}_{\text {ii. }}$ it. 1

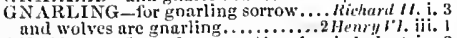

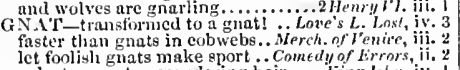

let foolisli gnats make sport .. Comedly of Errors, il,

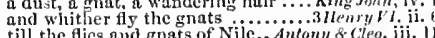

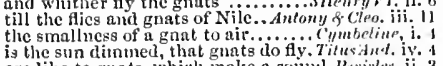

are like to guats, which inake a somml. Pryicles, ii. 3

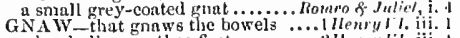

who shall gnaw thee first

that he could gnaw a erust at two... Hicharel $1 i l$. ii. 4
see, he gnaws lis lip. I will converse

sec, he gnaws lis lip. I will converse - ive 2

rats thither, to gnaw their garners .. Coriolanns, i. 1

pardon him! and hell gnaw his boncs!

alas, why gnaw you so your nether lip?..

GNAIVING-gmawing with my teeth Comedy of

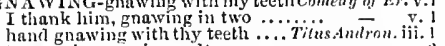

to ence the gnawing vilture...........

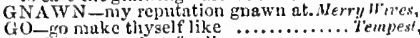

and then gn is bat-fowlin

go sleep, and hen us .............
so, king, go safely on to scek

so, king, go safely on to scek .......... ii.
would ery to a sailor, go hang $($ rep.) - ii. 2 (song)

I'll make the hut in (ilostershire..... Wich -

ain a stranger here in Glostershire... Kichnt - v. 6

it is in Gilostershire; 'twas where.... ileneny $t r^{\prime}$. i. 3

yoth shall inurein through Glostershire -

Ine leave to go through

it will go near to remo
wilt thou go with me?

nor go neither ill.....

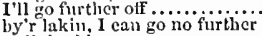

GLOVE-Sir, your klove ..... Tu. Gen. of Veronn, it. 1

not mine, my gloves are on ............

ot Yend siller, by these gloves

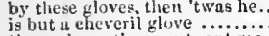

before you ean say, come and go

go with me to bless this twain

1 go, I go ..................

go to, earry this..

gliall mike it go quick away ......... of verona

I must gu scind

will't please you go..................

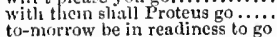

to-morrow thou must go
therefore, I pray you, go

therefore, I pray you,
go to, sir; tell me.

go to, sir; tel
wilt thou go?
well. I will go

conne, sir Thurio, go with me

good I'roteus, go with me.

go on before; ? sliall ...

if thou wilt go with me.

wilt thou go? ............

as soon go kindle fire ........
then let me go, and hinde

then let me go, and hinde

never dream on infininy, but go

presently go with me

come and go as lightly.

him we go to find?.

where it cunnot to

go to tliy lady"s grave...
host, will you go?...

arid go with ine

go presently and take

go on; good Filanour

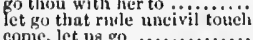

cone, let wa go .....................

yourkelf gluill go first.

truly, I will not to hrst.

firay thee, go to the easemeit....... - frra you, go mul vituh nit

go to, thien, there's sympritiy...

if I would but go to hell

or go tlus, like nir Aetacon.

whither go you, George?

go in with us, and see.

will you go with us to bichici ii?

may cone and go between you both

go thy ways; I n muke more ........

if money go before

you go against the liair of

you must go with me .......
go you throught the tiwn

go before you like a man .............

that Falstaft is there. I will gi

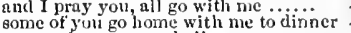

master doctor, you shall go...

go home, Juln Higgby

I'll go lide me...

go tell thy master, i ani.............

go take up these clathes.

let's go in, gentlemenl...

pray you go master Page...........

she mist nects go in fi..............

in brew ine a puttle of sack
let the proverly go with me

g) your way's and play, go

may I not go out ere lie comc

unl go out then. If you go ont

unless you go out disguised.

go ul; I'll hring linen for him

you are not to go loose uny
but let our plot go forward

I'll gor buy them rijzards

that silk will I go buty $\ldots \ldots \ldots \ldots . . . . .$.

you shall liear how things go

and bid her go, she eliall go with
given eonsent to go with him...

given eonsent to go with him ........
go before into the park; we two must go

go you, and where you find

let us crery one gu home

will you go hunt, my lord?

go you, Malvol

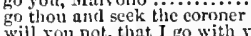

will you not, that I go with you?

shall seens sport. and I will go

to go to bed after mirluight, is to go to bed -

birl him go? What an' if you do (rep.) -

go slake your eas's ..... 'ti.

go to; thut art matie.....

shall we go sec the reliques of this

go call him hitler $\ldots \ldots \ldots \ldots . . . . . .$.

go to: thou art mule ............

go off; I discard you; let me enjoy (rep.)

go to, go to: peace, peace

that would rather go with sir jriest

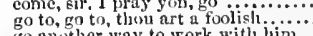

fo another way to work with him

go witls me to my house.......

thou shal t not choose but $g$

now go with me, and with

and go wir; but You wouli it....

diul not go forth of us........iveasure....

let's go learn the truth of it..

go to lord $\mathrm{Anzelo}$.

go tn: what quality are they of?

gond go throngh with all..

go to; let that the mine

go to your bosom

go to; it is well; away

and to we know not whe

go to your knees, anl make realy

go you to Angelo; answer his

your applointment, go in your place...

he were as goot gi) a mile on

go to kennicl, I'ompey, go.....

grace to stanl, alu] virtie.

go to, sir; you wcigh equally will you go on, hearts.

go about the flelels witl....

go to them; we'll use this

why dost thou not go to eluurch in

go to, joll're a dry fool

elter

to fetelis her tull, her gloves, her mask... Otheth, Giviv-wasted brands do gluw the red glow of secru and proud. As you Like it, jii. 1
the 
GO-I will go further than I meant.Mer. for Mea. iv. 2 | GO-I will go before, sir ....... Merchant of renice, ii. 5 GO-I have known to go about ... Winter's Tale, iv. 2 go in to him, nnd tetuli him out....... rook forwarcl on the journey you shall go by my trotl, I'll go with thee to the thus wronged, hence unbelieved go I will go durkly to work with her. go take her hence, and

go with him, provost

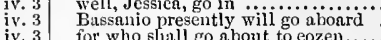

for who sliall go about to eozen...

let fortune go to hell for $\mathrm{it}$

jour good leave to go away

madnin, I go with all convenient ...

go in, sirrale; bid them

first, let us go to diuner.

take you, to go in the song?................

go to, $i^{\prime}$ fatith: an' thou wit need

go one, and call the Jew

go you, and tell her of it

go you with me, and I will ase......
shall we go prove what's to be done?

go to, num, sou are lie.

my principal, and let me go...

give me leave to go from hence

why should we go in? my friend

go to, num, you are he ....

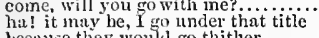

becunse thes would go thither

when mesn you to go to elurrch?

the time sliall not go dully by
go in with me, and I will tell.

go in with me, nnd I will tell........
go you to the prince your brother...

go then, find me a meet hour to...

inill wresently go learn their day

shall we go seek Benedick

and suffered liim to go displeased

let suffered him to go displeased away

which ho, I say..............

and gentle wishes, go with me

shall we go, coz? Ay: fare you
will you go, coz? Have with you

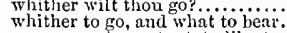

now go we in content, to liberty

Adam, wouldst thou have me go?

liave me go and beg my food?....

master, go on; and I wili follow the

$I$ cannot go no fint the

is to be sold; go with me; if you like

I can go no further ....................

no, rather I will go to Bcnedick

and then go I toward Arragon

go but with me to-nipht .............

let us go sit here upon the church-beneh -

let us obey yout to go with us

come let us go: these things, come thins

come me go. Be: thice, - in faith, I will go

but God slould go before such villain

and it will go near to be thoug
but I will go about with him....

I will go before and show him their.

go to; and a rich fellow enough, go to

it you go on thus, you will k
let me go no further to mine

and yet ere $I$ go, let me go with

will you go hear this news, signior?.

I will go with thee to thy uncle's...
round about her tomb they go $\ldots .$.
and then to Leonato's we will go....

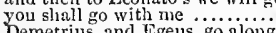

Demetrius, and Hermia, ere I go

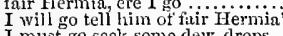

I must go seek some dew-drops....

and I will go with thee

well, go thy way thou shail not

let me go: or, if

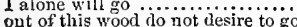

therefore, go with me; I'll give the

thou shalt like an airy spirit go

where shall we go? ...............

$\mathrm{I}$ fo, I go, look liow I go .
whom love dotl press to go?

you are a tame nan, go!

so you will let me quíet go

let me,go: you see how simple $\dddot{\text { jole }}$.

nay, go not back

now, go thy way ................

nought sliall go ill ..................

thus wall away doth go.

would go ncar to make a man look $_{\text {sad }}$

well, sit you out: go home, Biron.. Love's L. Lo

and go we, lords, to put in ..........

and go well satisfied to France agai

but 1 go, the way is but short...

to pray for her! go to: it is a plague

trip and go, my sweet.......

this same shall go....

good lover, let ine go

and you, go in pence away togetlie

go to; thon hast it ad dunghil

ns he is an ass, let him go.....

I go woolward for penance ..........

shonld I go to chureh......... Merchart of $\overline{5}$

go, presentity enquire ...................
I shall make shift to go without

sirrah, go before:- whiles we

you necd my help; go to them $\ldots . . . . .$.

will I slow: go with me to a notary
and I will go and purse the dueats.

go, father, with thy son................
go to, here's a simple line of $\ldots \ldots \ldots .$.
best-esteemed acquaintance; hie thee, go

I must go with you to Belmont.....

speak it privately, go..............

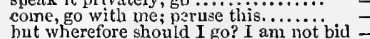

but yet rll go in haste

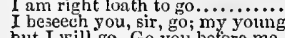

go to my eave and tell me.

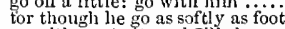

go with me to it, and I'll show

shall we go witi you to your chapel?

go thou with me

so he laughed, and let me go

without a eandle may go darl

will you go, sister?

go with mill you, Orlando

good sir, go with us ...........
counterfeiting to him; wil

counterfeiting to him; will you go?.

from hence $I$ go to make

I durst go no further

there commendatious go with pity.......Al's ${ }^{\top}$ Well,

of this, Helena, go to, no mo
good will to go to the world....

and he must needs go, that the devii

go not about; my love hath
speak truly, to go to Paris?

Iam glad; let the rest

go to, sir; youl were beaten

go with ine to my chainber

go to, thou art a witty fool

my lord will go away to-night

let that go: my haste is very......

are not the things they go

magnanimous in the enterprize, and go

ii. 6 good brother, or go about to thinik

iv $\overline{3}$ iv.

(vive 3 (somg)

you have let him go, and nothing.... - iv. 3

a plaee, whereto you'll go? ............

to go about to make me the king's

the sea-side: go on the right hand

-

and go indeed, having so good. Comedly of Errors, $\mathrm{i}$.

in this mist at all adventures go.......

this kuave would go sore.

while I go to the goldsmith's house, go

will you go witl ine?..

when I go from home.

masters, let lim go let him go, the debt

i. 3
i. 3
come, I go; I will fail

i. 3 to go in perion with me.........

ii. 3 go to a gossip's feast, gnd go with..... - v v.

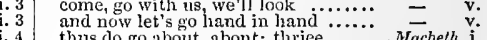

thus do go about, about; thriee ........... Macbeth, $\mathbf{i}$.

I ho, and it is done more: I am afraid ............ = ii.

that go the prinirose way to...

God's benison go with you

go not $m y$ horse the better $. \ldots \ldots \ldots \ldots . . . .$.
Col. Knt.J go to the door, and stay there

in thou ca............

so, pr'y thee, go with ne $\ldots \ldots \ldots \ldots \ldots . . . .$.

二

of your going, but go at once.......... - iii. ${ }^{4}$

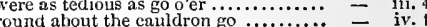

cone, go we to the wing

go to; go to; you have known......... -

some must go off; and yet.................

would have you go before

should go in quest of beaut

love should go in search of virtue....

go we, as well as haste will
i may not go withont you

let deatll and honesty go with your ..

\begin{tabular}{l|l} 
i. 3 & let go the hand of that ............. \\
i. 3 & I beg, go not to arms against \\
i. 3 & the side that I must ro withal
\end{tabular}

i. 3 but let it go; the sun is in

my blessings go with thee! ............

I pr'vthee, laidy, go away with mo well -

I pry hee, latis, go awh with me...

ii. 4 your promise? go to, hold your.

the colour of tire king doth come and go =

Ill go with thee, and find the.........

go after him; for he, perhaps ........

go I to make the French lay ..........

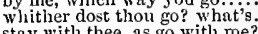

$\mathrm{I}$ did go between them .............. $\mathrm{Tain}$. $\mathrm{l}$ (induc.

go you to Bartholomew... Taming of Sh. 1 (induc.)
go by, says Jeronimy; go to thy .... 1 (induc.)

I am resolved: go in, Bianca

you may go to the devil's dam

'Tranio, let's go; one thing ....

let him go while the humour.....

than perfume itself, to whon they go

sir, a word ere you go.......

too blunt, go to it orderly...............

go witls me, and be not so discomfited

will you go with us; or shall

you may go walk, and give me leave

go to my elianber

better ere he go to churcli .............

nay, let them go, a couple

then go with me, to make...

go with me, sir, to clothe you

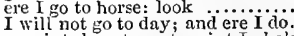

appointed me to go to srint Luke.

choose but drink before you go

not go to prison. Talk not (rep.).

stay with thee, as go
do not so quickly go

as to jest, go I to fight...

hanish him, and lie shall

and with him go these thought

why, so! go all which way it willi..

to go with us to Bristol castle....

i. 2 it nay be, I will go with you .........

noble lord, go to the rude ribs....

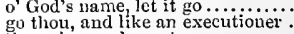

then give me leave to go

he goes, thither let me go ..............

go thou, and fill another room in hell

that take purses, go by the will go ... Henry $r \boldsymbol{r}$. i.

if you will go, I will stuff.............

ir. I tarry at ho I will stue.......

this adventure, that he shall go.......

no fur ther go in this .........

and o merrily to London

divide myself, and go to buffets.........

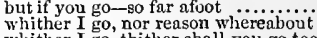

whither I go, thither shall you go too

as hot lord $\mathrm{I}^{\mathrm{P}} \mathrm{ercy}$ is on fire to go $\ldots . .$.
sliould go so general current through

slould go so general current through

go to the king; and let there

thonsands more that go bef

i. 3 say so then, and let him go ...........

Ine: go to, go to!

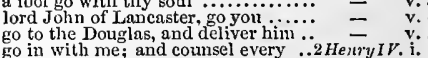

ii. 2 this action I now go on ....

ii. 4 prevail not, go and see ......

ii. 5 and go not too fir i' the land

I eannot go, I cannot tell

will I live? Go, with her ..............
to take soldiers up in counties as you go

go to: I stand the push of ............

for God's sake, go not to these wars!

come, come, go in with ine ..........

let my sheep ;

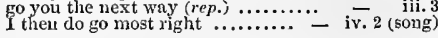


GO-I would not have you go off ...22lienry IF. ii. 4 | GO-nwhile, I'll go with you, ...... Hickard 111. iii. 4 GO-liray, go to the door proy thee. go down, gond uneient which cannot go but thirty inill see you usguin ere I gio. I will see you uguin ere I gu (........

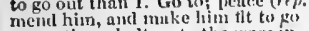

memt him, all mike him tit to por.: 二

go in with me to dinner. Come, I will go-

I hal ns liet he hungel, sir, ns go

and nwey ngait would n' go, and again -

will not go ot until they hest

our news slull fo lefore ux to.........

the great body of our state may go in

an' the elild "1 now go with.......
I churge you both go with me..
fear no colours; go with me tn

fear no eolours; go with we go in, to know his cmbas

go, ny dreal lork, to your great

no; to the spital ga; und trom the .

ay, or go to death; nul rile pay.......

go you and enter Ilarfleup

go down upon him let man go free, nul let not............

who will go to hinzard with me...

go with my brothers to my lords of

you may as well go about to tmin....

I know tlyy errand, I will go with the -

ant good luek go witl thee!

Crispin Crispinn shull ne'er go by.....

let lim go henee, nnd with

go sou with ine, uncle of i.xeter

come, go we in procession to ........

at their heels, go forth, ant fetch..

fair sister, gin with the prinees.

I will go witls them; haply ....

to go ajoni my prepination.

I go to certify her, ralhot's here.

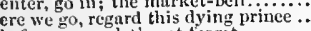

before we go, Jet's not forget .........

go cheerfully together.........
go to the gates of Bourdeaux

eome, goi I will despateh ...

blessing I eommand thee go
star, go, do what you will

well, go to; we will have no........

I go: come, Nefor,

I pray you, go in God's name...

thither go these news, as fast as....

gou go about to torkure me in

ere thou go, give up thy staff

and go in peaee, Humphrey

lords, let lim go; please it

all comfurt go with theel...

and go we to attire you for our

run, go, help, help! O Heury.....

presenee thou darest go with $\mathrm{me} . . . .$.

come, good Warwick, go with me

$O$, go nut yet! even thus two

$\mathrm{I}$ go. And take my heart ............

come you with us, and let him go...

think seorn to go in leather aprous

shall my palfrey go to grass .........
go to. sirrah, tell the king trom me..

go to, sirrah, tell the kin
und tain to go with a staff

go to then, $F$ ask but thi

but such as go in elouted shoon.

now go some num pull down the a...ibiet

my lord, when shull we go to Cliealside

you'll go with him? .......

go some, nud follow him
we twain will go into hig highes.....

ere they will have me go to ward

nay. Ho not from me

hrother, I go; I'll win thicm.....

thine inase le

go wherc yun will, the king slial

to wo with so

and go we, brothers, to the man.

yet, ere thim mo, lnt answer.

but, ere l fo, linstings aike.

go, trumpet, to the walls

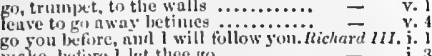

make, heture 1 let thee go.....

lords, will yough with inc?

let it go; there fiew,

go vou to hin from ine ....................

and yet go current from suspicism

and go we to deterinine

will you go ta give your.

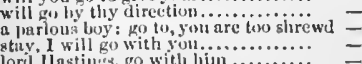

will yon go with me? I ("o, ny lori...

what, will you go unto the rower.

I'll $\mathrm{go}$, my lord, anil tell him what .

the boar, and $y 0$ so unprovi

go on betore, Fll talk witl

what, gur you timurd the Towe go thon to Richumud (rep.

to her gis $I$, a jolly thriving wox

go with me, and in the hreath of bitter

go then, my mother, to thy danghter
would'st thon do there, liciore i goo?.

I go, my lork. Stir with the lirk

what tis you gis nhout............. II n ry III. $\mathrm{i}$.

that virtue mist go through..........

a health, gentlemen, let it go round.

go with me, like got angels....
you are too bold; go to; I'll make

therefore, go on: tor no dislike

that hat not linlf a week to gis

so rude behavienr: no to, kneel

go to, go to: you tuke a preei

might go one way, nnd safely

than Ilelen's, (well, go to,

why, go to then; but to jrove.

go ihy way, Troilus, go thy wity

set go we under our opinion still
yet

go we to him struight

well, go to, go to. I serve here

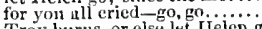

Troy burns, or else let lieten go

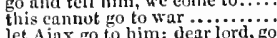

let Ajax go to him; dear ford
when they go from Achilles.

go to him! Jupiter forbid (vep.)
it I go to him, with my armed

o no, you shall not go

his pride: let me go to him ...........

go to, sweet queen, go to

i' the river: ho to, go to
our head shinll go bare

let me go and try ......

it will go one way or other

how go maidenlicads? here..

go hang yourself, you naughty ........

Uyou immortal gods!

I will not go from Troy............

truers of Greece, go to my tent.

honour, or go, or stay

we go wron:, we go wron

now, my good lord, go off

at something; will you go?

by all the everiasting gods, I'll go

unarm thee, go; and doubt thou not.

eome, Hector, eome, go baek

go in, and clieer the town

go, my lord. Renew, renew

go in to Troy, and say there...........

from me anon: go, not away...

mo, l'll not go; you hear, whint he ï don

vay

come, let us go: this fellow hith

go you down thint way tiwn neds ...

click 1 go through a tempest irapphin

let us ofo, tir it is after midniglit

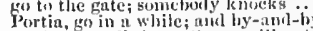

Decias, go tell them, Cissstr will not.

go in, and taste sone winc with me (rep) -

I must go in: ah me! ...............

go to the pulpit, Bratus

Cassius, go you into the other stree

will follow Cassius, go with him

they would go and kiss dead Cwsar's

why friends, you go to do you
but, Lepidus, go nou to Casar's liouse

go to; you're not, Cissius.

then, with your will go on .....

go on, and eee whe'r Brintus lee alive

let hiul marry a woman that connot

i 2 Newill not look upon hin: gow with us? -

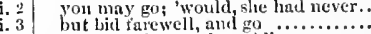

I go from henee, thy soldier...

ii. 3 and all the gods go with youl.............

men might go to wars ..............

go to then; your eonsiderate

go to the teilow, good $\mathrm{Al}$ exas...............

et him for eres go: let hels not

till the workl fo round (rep*).

say, - Casar; go no further .........

holf afeard to come. Gu to,

and the Pliceneians, go n dueking

go to him, madam

go on: retht royal

go we to him. Awake, awake, sir

word straight, how tis like to go ..

bruised pieces go; you have been ....

iv. 13

go to him, Dolabella, bid him yield..

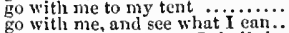

peathe, go hence: or I shnll show....

you'll go with us? I'll attend (vep.)

rather shunned to go even

and $I$ must go up and down

who lets go by no vantage

could go there, and do't

to dlifuril go, and fiud not her whiom

go you to lun ting, I'tl abicie.

for this time; or in, and rest

I go, sir. I go, sir: take the bonds...
no aecount how things go from him.

go to my steward. Plense it

go to my steward. I will go with you to..............

go away merry; but they enter
go to; pereliance, some single

go youl, sir; to the senators ............

go to Ventidius: $\mathrm{m}^{3}$ y thec, be nut sad
as I understand how all things go...

what, dost thou go? soft ............
thou'lt go, atrong thief, when gouty.

go on, here's gola, go on.........

go on, here's gold, go on.....

let it go naked, men may sce"t

let sour words go by, and langunge ..
where go you with buts and efuhs?

hesides, if things go well, opinitm

he let lt go again; and atter it a

you must go visit the good liuty
my prayere, but I eannot go thitie

come, you shall go witl $\mathrm{u}$

in truth, la, go with me........

go yon to the eity; learn
will not you go? I an atteni

will not you go? I an attemed love of Jumo, let's go.

good lindies, let's goi yes. yes, yes.

give way there, and go on

and the honour go to one that wonid

and ennmot go without any honest

let thein go on; this mutiny....

give me leuve, l'll go to him

ict go. You night huve lreel

I nr'y thee, now, my son, go to them.

and go alshtit. Nost

go ilinout it. l'nt him to .....

whither witt then go?

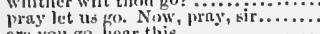

ere you go, hear this........

cone, let's go: leave thi
well, let us go together by heavens, I'll go: it you will

go before this lout, as he cxceeds $1 .$.

Romans, let us go: ransomless. Tifus,

fo to; have your lath gl

eome, let us go, and make

my" hinnd shall go. By henven (rep.)

come, boy, and go with me..........

would she huve thee go

come, to with me in to mine armotiry.

come, lit us go; and pray to nll......

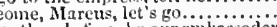

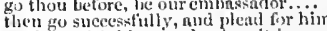

(a) thou with him; and, when it is ..

go thom with them; and in the emperor's

$1 \mathrm{go}, \mathrm{my}$ lord. Weleome is peace ...... Periels, $\mathrm{i}$.

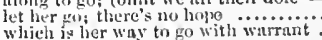

pruy you, will yoll go with us?

Oge to: we wh.

ii. 3 did you to to it en youm?".................

go to the Hins, would you?

go mot till he sireak ..............

go: tixcre's my kcy: it you dlo sti........ - v. 3

go you before to filoster with t
thy wit slall nut

to go out of my diuleet ............

l'll go with thees thy tifty ............

if mily ts go w:orin wer

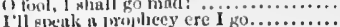

i.

iii. 2

iii. 3

iii. 7

ii. 10

119
19
13

พ.?

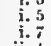

ii. 3

iii. 2

iv. 2

iv. 2

$\mathrm{v}$

ii. 3

iii. i

iii. :

iv.

iv. 3

V. 1

i. $t$

iv. 3 
GO-go in thyself; seek thine own... but I'll go in; in, boy; go in first.
go in with me; my duty cannot go in with me; my duty cannot
tuke his offer; go into the house importune him once more to go witl me to the duchess ............... then shall you go no further ........... let ro iny hand: here, friend

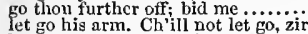

let go his arm. Ch'ill not let go, zir...
let go, slave, or thou diest (repeated).... let go, slave, or thou diest (repeated)
all my reports go with the modest desire him to go in ........... sister, you ll go with us? ...................

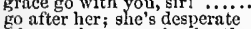

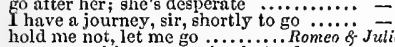
come, go with me; go, sirral, trudge go thither; and, with unattainted this mask; but 'tis no wit to go ...... you are a prineox, go ............... not a penily. Go to; I say, you shail take my fan, and go before............ have you got leave to go to or both, must go with hin up, sir, go with me; I cliarge thee and to they go like lightning. will yonl go to them? I will bring. go before, nurse; commend me
more care to stay, than will to to go with Paris to saint Peter's cliurcl or bid me go into a new-made grave nurse, will you go with me.

bride ready to go to church? Ready to go sir, go you in, and, madam ( $r$

Friar John, go lience; get me....

brother, I'll go and bring't thee

obey, and go with me

go with me to the vali.
stay then, I'll go alone

too desperate, would not go with me

go hence, to have more talk ............

stay with us, go not to Wittenberg

fashion you may eall it, go to, go to.

it beckons you to go away with it

go on, I'll follow thee (rep)

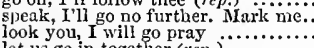

you may go so far. My lord, that would

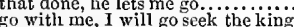
co witli me, I will go seek

go to your rest; at night we'll feast...

hied go...........

why do you go about to recove

without thoughts, never to heaven go....

you go not, till I set you up a glass.

and go with us to the king

how a king nay so a progress.

as you go up the stairs in to the lobby. go softly on. Good sir, whose powers

we go to gain a little pateh

go, my lord? I will be with

which bewept to the grave did go........

let him go, Gertrude: do not tear (rep.).

go to thy death-bed, he never

to a public count I miglit not go........

it the man go to this water

to the purpose, confess thyself-go to

rantz go to't

and his triends: you were best go in ........ othello,

here in the liouse, and go with you...... dear absence; let me go with him...

than to be drowned, and go without be

go to; farewell: put moncy enough,....

good Iago, go to the bay, and disembark

let me go, sir, or I'll knock you o'er

away, 1 say' I go out, and cry - a mutiny

go where thou art billeted

why, go to, then; she that, so young.

come, r'll go in with you

honesty and love. I will go on ..............

woman, go tol throw your. vile guesses.

to tell it o'er: go to, well said, well said

will $70 u$ ?

she can turn, and turn, and yet go on

do but go after, and mark how he..

you are a fool; go to

go in, and weep not............................
go to; very well. Very welli go to $($ rep.) and thither will I go to him ............ song to-night will not go from my mind
o did he so? I charge you, go with me.
Lear, iii. $4 \mid \begin{gathered}\text { Go-with Cnssio, mistress? go to } \\ \text { outlive honesty? let it go all .... }\end{gathered}$

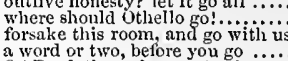

2 word or two, before you go $\ldots \ldots \ldots \ldots \ldots=$ - v.2

is goads, thorns, nettles

GOADED_-goaded with most sharp .... Wll's Well, $\mathrm{y}$.

which we have goaded ouward ..... Coriolamus, ii,
GOAL-but to the goal ............. Winter'stale,

can get goal for goal of youth ....... Antony \& Cleo. 1y. 8

then hollour be but a goal

of muttons, beefs, or goats ..Merchant af Venice, $\mathrm{i}$.

I will feteh up your goats, Audrey. As you Like, iii.

with thee and thy goats........

socbeth, iv.

the goats ran from the monntains..IIlenry $l V$. iii. wanton as youtliful goats...

and luxurious mountain goat .........Henry $V$. iv.

all his goats. There is one goat tor you - v. 1

hares, hot goats, and venison?....... Cymbeline,

and suck the gont............ Titus Andronicus, iv. 2

were tley as prime as goats...

GOBBET - gobbets of thy nother's. 2II ... Lear, i. 2 ii. 4 into as many gobbets will I cut it.... v. it. 5 GOBBO-Gobbo, Iaunelot (rep.).Mer. of Venice, ii. 2

iii. 1 honest Gobbo, or, as aforesaid (rep.)

GO-BETWEEN-or go-between ... Merry Wives, ii.

figured goblets, for a dish of wood... Richard I 1 . ili. 3 to me upon a parcel-gilt goblet ...2 HcnrylV. ii. I goblin, lead them up and down. Mid. N. D,eam, I have one of sprites and goblins. Winter's Tale, ii. I we talk with goblins, ow sif. Comed y of Errors, spirit of health, or goblin damned ....... Hamlet, i. 4 such bugs and goblin

slibstituterl tor this word, more especially in the historical plays.]
had I been any god of power had I been any god of power $\ldots \ldots \ldots . . .$.
Would controul my dam's god setebos
it waits upou some god of the island

look down, you god

to take this drunkard for a god ....... love were not a blinded god ...Tu. Gen. of Ver. iv.
those that have the fear of God..... Merry Wives, $\mathrm{i}$. an old abusing of God's patience ....

how, near the god drew to the

when gods have hot backs..

Well, God give them

God send you, sir, a speedy infir.

gentlencss of all the gods go witl thees

the nelancholy god protect thee!

pray God, he be not bewitch

gentleman, God save the

pray God, defend mel.

pray God he keep his oath! ...

how vile an idol proves this god
God b' wi' your, good sir 'Topas

for the love of God, a surgeon

for the love of God, your help.........

I thank God, and my coll hlood

God keep your ladyship still in .......

God forbid it should be so $(r e p$.$) ......$
to the tuition of God: from my house

God's sending that way (rep.).........

being too eurst, God will send you no

not till God make men of some other

God match me with a good dancerl
and God keep hisn out of my sight

I would to God, some scholar would

ani God, sir, here's a dise thee joy

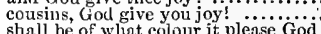

ghall be of whint colour it please God

O God! counterfeit! there never was

sweet Benedick! God give me patience
'fore God, and in my mind very wise

if he do tear God, he must

o God of love! I know, lie dotli........

my lord and brother, God save you .

give God thanks, and make no.........

and thank God you are rid of a knave

Gol give me joy to wear it ..........

but God send every one their heart's

as, God help, 1 would desire they

God help us! it is a world to see

well, God's a good man......

gifts that God gives ........

true, God defend mei how am $\mathrm{I}$ heset!

why then, God torgive me

masters, do yon gerve Gorl:
GOD-serve God: and write God (rep.).Much Ado, iv. 2 'fore God, they are both in a tale.

have writ the style of gods

content yourself: God knows I loved

and moreover God saw him when he

which, God be thanked, hurt not

and will lend notling for God's salke

and I prisise God for you

Got keep your worship.

may be wished, God prohibit it....... - $\quad$ v.

serve God, love me, and mend.........

God speed fajr Helena! ............... - j.

to bring in, God shield us! \& lion .... - $\begin{aligned} & \text { iii. } \\ & \text { like two artificial gods, have with.... }\end{aligned}$

God's my life! stolen hence $\ldots \ldots \ldots \ldots . \cdots=$ - iv.

a paramour is, God bless us! $\ldots . . . . .$. .

God grant us patiencel words .....Love'sL. Los!, i.

and God defend the righit 1 .............

I thank God, I have as little patience - i. (letter)

assist me, some extemporal god of ahy me -

now, God save thy life!.............

I thank your worship. God be with you! -

God dig-you-den all! Pray you...... -

God give you good-morrow, master... -

sir, you have done this in the tear of God -

God amend us, God amend:

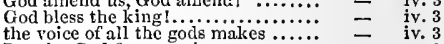

they will, they will, God knows ..... $=$ - $v$

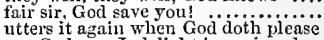

nor God, nor $I$, delight in perjured

(how white the liand, God knows!)..
so God help me, la! my love .........

so God help me, la! my love

doth this man serve God?..............

not like a man of God's making .... $-\quad y^{\mathrm{r} .2}$

he's a god, or a painter

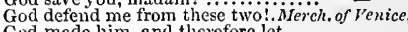

and I pray God, and therefore let.

who, (God save the mark!) is..........

by God's sonties, 'twill be $\ldots$ ï.......

marry, God torbid! the boy was the

is my boy (God rest his soul!) alive

God bless your worship!

you have the grace of God, sir

some god direct my judgment! $\ldots \ldots . .$.

pray God, Bassanio come to..........

to God limself; and earthly (rep.).

nothing else, for God's sake..........

[Col.] no, God's my judge, the clerk...

and so, God keep your worship! …..

is he of God's making?

God be rith sou. let's meet

and $I$ thank God $I$ am not a woman

would the gods had made thee....

I pray the gods make me lonestl.

the gods I am foull Well, praised (rep.) -

well, the gods give us joy! ..........

nay then, God be wi' you, an' you ...

and so God mend me, and by all pretty

God ye good even, William.

God ye good even, wir.

God rest you merry, sir

God save you, brotier

ii. 3 God he with you; God mend your ...

God send him well! the court's $\ldots . . .$. All's Well, ${ }^{4}$.

Iii. 2
iii. 3 'would Gever have the blessing of God

love, no trod, that would not extend

God's mercy, maiden, does it curd

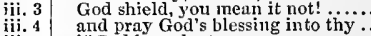

it' God have lent a man any

iii. 5 imperial Love, that god nost high.

Tho, God? Ay, sir. The devil it is

whither God send her quickly! (rep.)

thrice beaten: God save you, captain

the gods forbid else! So, now

now God delay our rebellion ..........

God bless you, captain Parolles. God

God save you, sir. And you

the office of God and the devii?....

praise God for you .................. ii. 1

iv.

v. 2

3

v. 2
v. 2

v.

v.

2
ช. 2

i. 2

ii. 2

ii. 2
ii. 2
ii. 2

ii. 2
ii. 2
ii. 2

iii. 1

ii. 5

viv. 1

i.

iii.

iii.

iii. 3

iii. 3

iii. ?

v.

v. 1

i. i. 1

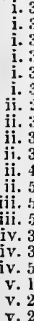


GOD-for Givl's sake, a pot of .. T'uming of sh. 2 (incl.) / GOD_gols me, my horke! What would to Gerl, I bad well knorkel .. God at we you, gignior Gremio! a stomach, to't, o tiod's nume gentlemen, Gol gave you! neighlour tiremio: (inl saye you

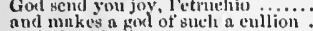
and minkes a fant ot

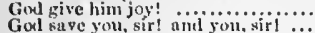
Gol suye you, sir! anel you,

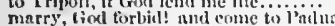
O merey God! whint musking stuff . the goils she may, with all ny $(r, p$.

come on, o' (ritcl's name, once more.

then, Goll be blesser, it is the.

Goll send 'em good shipring!

O immortal gods! o nne vilinin!

no, sir; God forbisl; lint aslumed.
proy Goul, sir, your wife send you

a winner, Goil give you gevel-higlit!

the gods themselves, wotting ....

serve you as I would do the got

a meetlng of the petty gods, and you

the gods themsel res, humbling tlicir

and the fire-robeil gowl, golden Apollo

as they vere gods or goddesse

sure the gods do this year connive at

the blesset gods wurge all infection.

yoll gorls, lnok down, and from

O had the gols tlone so......... C
for God's sake, hold your hands

for God's snke, send some other.

hold sir, for God's suke: now your jest

pray Gol, our eheer may answer

are you a gool? would you erente

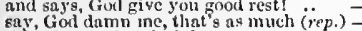

O husband, Gok doth know .......

God and the fope-maker, bear me

God help, poor souns

hold. hurt him not, for God sake

for God's sake, take a house
which, God he knows, I saw not

God save the king?

pray fiot, you have not murdered

2 a fiult, fiot help the wiekeil

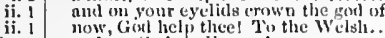

iv. 2 and, as fool ehall mend me.

v, Gocl parlon thee! yet let mo

iv. and $\mathrm{g}$

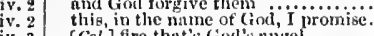

iv. 3 [Col'] fire that's Gol's nnigel.

[Col.] I dufy thec: Croul's Tight:..........

I pray God, my girelle brenk ........
well, God be thanked for these rebels

pray God, my ucws be worth

to God, you were of our detcrmination

ancl God defend, but still

and vow to God, he came but.....

why, thou owest God a death.....

did you beg any? God forlid

God keep lend ont of me!.........

for God's sake, come. By heaven

and woull to God, thy name in arms

he that rewards me, God reward him!

God may thish it when lie will ....

I woukl to God, my name were n

and Gol knows, whether those that..

from a god to a bull? $a$ heavy

from a god to a bull? a heary it....

for God's sake, be quict..........

'tore God, a fikely fellow! cone ....

we owc God a death; I'll ne'er bcar

God keep you, master Silence .......
your grace of Y' York, in God's name

you were within the books of God?

under the counterfeited zeal of God.

let God for cver keep it from my liead

by the crown, $O$ God, torgive!

land be to God! cveu thiere my........

but yet, God forbid, sir, but a knave

"fure God, you have here a goodly

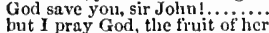

but I pray God, the firuit of her ...

God save thy grace, king $1 \mathrm{Ial}$ ?

God save thee, my sweet boy!

and God forbid, my dear and faithfui

for God doth know, how man

and, by God's heln; and yours

in Franec, by God's grnee, p]ay a set

iies all within the will of God.

for, God betore, we'll chide this

fore God, his grace is bold

and God acquit them of their practices!

our purposes God justly liatli discover

and glister like the god of war.

$O$, God defend my soul from

to Gol, my king, and my succeeding

by the gracc of God, and this mine arm -

a traitor to my God, my king, and me! -

thy lance; and Gool defend the rigitit =

bid God speed him well

pray God, we may make haste ......... -

but w'lat, o' God's jame, disth

God save your majerty! und weil...

God fur his merey! what a tid

I would is God, (so my untruth

if he serve God, we'll serve hin

they break thieir faith to God....

show us the hani of God that.

$O$ Grorl! $O$ God! that e'er this.

$0^{\prime}$ Grol's name, let it go ..............
in Gorl's name, I'tl ascenil the (rep.)

woula Gom, that nny in this

sha]! the figure of God's inajesty

Gorlid it, forl, that in a christian..

Gor pardon all outh, that are (rep.)

cod save king llenry unkinged $: .$.

no man eried, Givl yave him

that liad not God, for some strong

if Goul prevent it not. I purjose so

God for his mercy! Wiot treneliery

I would to God, my lords, he might

for God's kake, let me in 1 pa............

I pardon him, as god sha]l pardon me

I tray Gial make thee new

as, Cind save thy prace, (majcsty...... inenry W $^{2}$

Goll forgive thee firs it?

and wounds, (fisd save the mark!).

(whose wrungs in us (iod pardon!).

as loth of you, (joil yardon it!

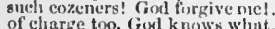

1. 4 should not think of God; I hoped

ii. I in the name of Goi Alniclity

God's vassals drop and die; and sword

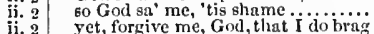

ii. 2 yet, forgive me, God, that I do brag
ii. 2 yet, God before, tell him we will come

God Almighty! there is some

no rings to fly from God ................

what kind of God art thou

God's arm strike with us (rep.)....

God's will! I pray thec wisl not

your places: God be with you all...

food God! why should they mock

(as, if God please, they sliall)

Alexamler (God know's, and you day!

and you know) -

praised be God, so lone as your majesty -

Got keep me sol our heralds go

O God, thy arm was here .............

v. 3 or take that praise from Gon ..... for

quite from hiunself, to Gonl.

God be wi' you, and keep youl ......
but, before God, I cannot look greenly

Gixi save your majesty! my royal

Gorl, the beet maker of all murringes

i. 2 ench other! God sjeak this amen?

i. 3 rod's mother ilcigned to apurear

i. 3 then eome ${ }^{\prime}$ Genl's name, I fear 10.

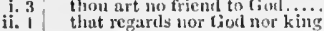

yet, God before, tell him we win God's hand, brother

Goll's peace! I would not lose so grent

take it, Gor, for it is only thing.
.1 HenryIV. ii. 3 , GOD-against God's peace .... Henry VI. i. 3 (procl.) ii. I the joy that Gos hath given us.....

ii. 4 God is on furtress; in whose eompucing -

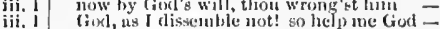

fiod syeet the parliament!

Gind be wi' you, my lord! we came.

Gokl save king lifenry

for help your riglisteons (joxl!

fod comfort him in this necessity i.

then God take merey (n) brave

for Grod's bake, let him liave 'em

tends to God's glory...
Gorl knows, thou art

Gorl knows, thou art is collop....
with-Goxl ineserve the grod riuj

so God helip Wurwiek, as lie loves.
what it deith buic, God kuows

ly the graet of Gool, and IIume;

but Gos in merry so denl with my soul

pray cod, the duke of $X$ ork excuse.
Gool is my witness, I nm falscily

for God's rake, tity my casc! ...

by the eternal God, whose name

to see how rod in and he creaturce...

now, God he praised! that to believing

God's goodness hath hecin great to thec

ay, God Alnighty help me?

ii. 2 I thank God and saint llhan

ii. 2 OGod, secet thou this, and bear'st

i. 3

in fight of God, and us, your guilt .
such as by God? book are adjudged.

and God shall be my hope ............

o' God's mame, sce the lists (rep.) .....
I pray God! for I ann never.........
fellow, thank God, and the good wine

and God, in justice, hath revealed....

but God's will be done.

so lielp me God, as I have watclici

more than truth, so help me God! $\because \because 3$

pray God, he may acquit ............

O heavenly God! IIow tares
but how he died, God knows

but how he died, God knows

forgive me, God; for judgment .......

it' God's good pletsure be!............

mathes i were a god, to sloot
save to the God of lieaven...

save to

sir, I thank God, I have been so weil

for, God forbid, so many simple souls

come, Nargaret; God our hope

he speaks not o' God's name

God should be soolklurate

God save his minesty! .............. -

Gol's curse light upon you

I pray God, I may never eat

great God, how just ust thous.

no, God forbid, your griec should....3 Henry $r$. i.

my sons, God knows, what hat

open thy gate of mervy gracious God

fuil'st (as (rod forbid tire hour!).

God and St. George fior us?

for liod"s suke, hords, yive signal

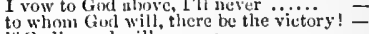

il Gorl's grood will were so.............
o) God! methiuks it were a balpy

0 God! it is my tiather's face

O lity, God, this miseruble age

in Golls ninc, leal (rep.)

God forbil that! for lie ll take

and, by God's mother, I, lueing $\ldots . .$. .

let us he hekerl with Gorl

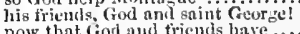

after Gorl, thou set'st me free (rep.)

till God please to send the rest $\ldots . . .$.

if any such be here, as Got forbil.

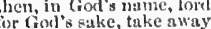

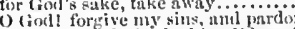

which dune, Gorl take king likward. Hichard int. i. 1

foul devil, fur God's sake, hene

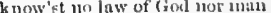

then, God grant me too..............

therefore, for Goll's sake, entertain..

frol make your mnjesty joyft

whon (forl preserve better

(Fol grant we never may have (rep.)

which Gint revenge! ................

i.
ii.
ii.
iii.
iii.
ii.
iv.
iv.
iv.
iv.
iv.
iv.
iv.
v.
y.
i.
i.
i.
i.
i.
i.
i.
i.
i.
ii.

ii.

ii. 
GOD-God, not we, hath plagued (rep.) Richard III.1. 3 God, I pray him, that none of youl ". and there awake God's gentle-sleeping he to yours, and oll ot you to God's. by God's holy mother...

Grod pardon them that aro the..............

that Grod bids us do good ti

God give your grace good rest!

like a traitor to the name of God

low eanst thou urge God's direadfiil

it' God will be avenged firr the.

make peace with God, for $y$

war with God by murdering me?

God punish me with hate..................

I thank my God for my limmility......

God grant, that some, less noble ...

G God! I fear thy justice ............

fod is anch disple

for God's sake, let not us two.

neighbours, God speed! Give you.........

too true: God help, the wlile?

no, mo; by God's good grace

all too nestr, if God prevent not

be well ; if God sort it so...........

which God lie knows, seldom, or neve.

God keep you from them (rep.).

liod bless your grace with health

on whint oecesion, God he knows

God knows, I will not do it (rep.)...

pray God, I say, I prove a needless

God lieep the prince from all .

0 remenber, God, to hear her

be sntisfied, dear God, with onr

we more limnt for than grace of God!

God and our innoeenee defend and guard -

cry, God save Richard, England

marry, Grod detend his graee slouid say

earnest in the service of my God

but, God be thanked, there is no

tor God he knotr, and you may

God bless your grace! we see it ...

God give your graces both a happy

ere men can say, God save the queen.

wilt thou, O God, ily from such .......

O upright, just, and true-disposing God

God witness with me, I have wept .

rear God, I pray, that I may live to say

Ithank God, my tather, and yourself

by God's just ordinance, cre from

why then, by God. God's wrong is

in God's name, cheerly on, conrngeou

kings it makes gods, and mean

God give you guiet rest to-night

God give us leisure for these.

yet remember this, God, and our good

then, in the name of God, and all these

God, and saint George! Richmond

Great God of heaven, say, amen

iy God's fitir ordinance conjoin (rep.)

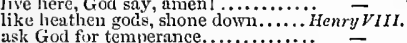

ask God for tempernce.

God mend all! There's something

lead on, $0^{\prime}$ God's name.

God's peace be with him? $\ldots . . . \cdots \ldots . . . .$.

I have done; and God forgive mel
pray God, he do! he'll never know

pray God, he be not angry. Who's there -

him that does best; God torbid else!

0 God's will! much better, she ne'e
in God's name, turn me away .....

in God's name, tiurn me away .....

nav, betiore, or God will punish me

but with thanks to God for

(pray God, ye prove so!)

now, God incense him, aud let him ery

ever God bless your highness!

thy God's, and truth's; then if

had I but served my God with

Gud save you, sir! where have .....

God safely quit her of her burden...

Gorl, and your majesty, protect mine

God's blest mother: Iswear ........

God turn their lieart! I never........
I woult not for a eow, God save her..

God protect thee! into whose

God siall be truly known ..............

O gods, how do you plague me.
well, the gods are above............

by god's lid, it does one's beari ....... i. 3 make the service greater than the god

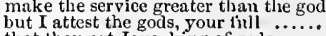

that thou art Jove, king of gods........

the gods grant! O my lord!

missions 'mongst the gods themseives

and almost, like the gods .............

$O$ the gods! what's the matter?

O you immortal gods! I will not go

that the blest gods, as angry......

have the gods envy?.......

it would discredit the blessed god

o all ye gods! o pretty pretty pledge!

if sanctimony be the gods' delight...

by all the everlasting gods, I'll go.....

for the love of all the gods.

farewell: the gods with safety.

Hector? the gods forbid!. .

it, gods upon your thrones .............

I call the gods to witness ...... Timon of $\bar{A}$ then

the gods preserve you! ..............

Plutus, the god of gold ...............

O you gods! what a number

too proild to give thanks to the gods

imnortal gods, I crave no pelf'

the gods themselves have provided
O you gods, think I, what need we

so the gods bless me, when all....

o you gods, I feel my master s........

now, before the gods, I am ashaned on't -

Servilius, now before the gods, I an not -

now all are fled, save the gods only..

a elear way to the gods. Good gods 1

and the gods fall on you! ............

now the gods kcep you old enough..
slould brook as little wrongs, as gods

the gods require our thanks..........

religion to the gods, peace, justice ....

gods confound, (hear me, you good gods

for bounty, that makes gods...........

no, gods, I am no idle votarist.

ha; you gods! why this? what this (rep.) -

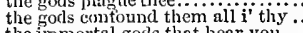

the immortal gods that hear you .....

o you gods! is yon despised.

the gods are witness.

the gods out of my misery

what a god's grold, that he is........

for the gods know, I speak .

who, under the gods, keep you in aw

that the gods sent not corn fur

he will not spare to gird the god

the erom an sod he stamp of a

and the rods duom him after

we thank the gods, our Rome latl ...

the gods begrin to mock we ................

the rods grant them true? True?

God save your good worships .......

petitioncd all the gods for my prosperity -

such a pother, as if that whatsoever god -

o me, the gods! you must not

the gods give you joy, sir, heartily...

God save thee, noble consul!

we pray the gods, he may deser

as it you were a god to punish

now the good gods torbid

the lonoured gods keep Rome in.....

as fiee as I do pray tlie gods

the gods preserve our noble tribunes!

O the gods! In follow thee........

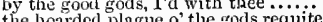

I wonld the gods had notining else to do

you bless me, gods! ............

now the gods keep you ....

if! he is their god; he leads.....

the gods be good to us! ............
the glorions gods sit in hourly

the glorions gods sit in hourly

you tods! I prate, and the most ioble

the rod of soldiers, with the consent

thou barr'st us our prayers to the gods

to imitate the graces of the gods

and the gods will plagne thee........

the gods look down, and this unnatural $=$
he wints nothing of a god, but eternity

the gods be good unto us! (rep.)......

praise the gods, and make triumphan

naise the che god, thit be

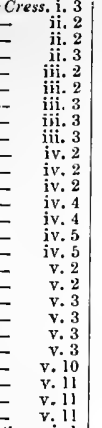

i. i

\section{i.. 2 i. 2 in}

iii. 1 and the high gods, to do you justiee...

iii. 2 gods, and yoddesses, all the whole synod

iii. 2 he is a god, and knows what is ......

iii. 4
iii. 4 the wise gods seel our eyes ...........

and say, God quit youl be familiar..
tlie gods forbid! Well, my good.....

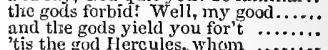

the gods maike this a bapry day

the gods make this a happy day .....

that the gods detest my baseness ....

my sceptre at the injurious gods ....

but you, gods, will give us some

so the gods prescrve thee!........

up to the hearing of tlie gods
sir, the gods will have it thus

the gods! it smites me beneath
the gods forbid! Nay, tis most

the gods forbid! Nay, 'tis most ......

n woman is a dish for the gods ......

same whoreson devils do the gods great =

whicb the gods give men to excuse .. - v.

you gentle gods, give me but ........... cymbeline, $\mathrm{i}$.

Othe gods, when slanll we sce again? -

of the gods. Which the gods lave given -

by the gods, it is one: it I bring $\ldots . .$.
it is an office of the gods to venge $\mathrm{jt}$.

sits 'mongst men, like a descended god

but the gods made you, unlike
protection I conmend ine gods

you good gods, let what is liere ........

the gods will diet me with $\ldots \ldots \ldots . . . . .$.

may the gods direct you to the best!
but of those who worship dirty

what pain it cost, what danger! Gods!

pardon me, gods! I'd ehange my sex

where, thimk the gods! they grow....

let ordinance come as the gods forsay
$O$ gods and goddesses! these flowers

feared crods, a part of it! .............

though the gods hear, I hope

god l if you please the gods ......... -

gods, put the strength o' the Leonat

searce are men, and you are gods....
youl goor! gods, give me the peniterit

youl goorl gods, give me the penitent

gods are more full of mercy .............
then, Jupiter, thou king of gods

as when his god is pleased.

but since the gods will have it thus.

the gods do mean to strike me .....

lady, the gods throw stones of sulph

marry, the gods forfend! I wonld no

draw near the nature of the gods? Tit

the self-same gods, that armed

I swear by ant the Romau gods ......

the rods of Rome fortend I sauld

by the gods that warlike Goths ndore

mless the gods delight in tragedies!

What God will have diseovered......

and pray to all the gods for our......

the gods have given us o'er

Al piles nave the

and move the gods, to send down

God rive your lorctsip jos

God give your lordship joy

God forbill I loould be so bol
God be with you, sir; I will

i

Cosar, i. 2 


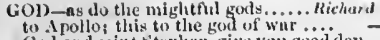
ford and suint Steplien, give you good den thou believest no God; thint pronted for a god, and keeps the outh (rep.) ye genls thint male me min and nll the gonds whenrken....... the gods of Greece protect youl now gods firbidt 1 liuve n gow the gouts give tluee roud oun't lincest tie ouds nor now lis: the gots, he could not jilense. now lig the fods, 1 pity hị misfortune the most high gods not mincling by the gols, I have not, sir ..... mox, fry the gohls, 1 to npylnum thou Ged of this great vast "l you gotls! why do you make us now the toul guils trow their hest what eutrage, sir? Goul suse you the former, making a man a goll...

the gods ret) nite lis charity.....

the forls make up the rest ............ the gods revenge it upon me and mine the liter then the geds slould huve lier for the rody a gre gick of ear

sure terins we stand upon with the got come, the gaxls have done their part... the gools detend me! 11 it please the gods the gous do like this the worst

she is nble to freeze the god I'riapos

now, the gorls to bless your honour.

that the good gods wonld set ne

the goils strengthen thee The god

hark, hark you goxls! she conjure.

0 that the ginls would safely trom

strived god Neptune's annual feast

the gods preserve you! (r'p.

and the giols

and the gris lo her pros..

this, this: no more, you godls! your....

besides the gods, for this greut

thruegla wiom the gous have show.

the geds ean have no mortal ofticer $(r e p$

the gouls for murcler seem so content -

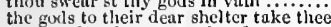

gods, gods, 'tis strange that from

now goxls, stand up hor hards?

now, gods, that we adore, whereof ....

here, you gods, n poor old innn.

let the yrent gods, that keep this .

the gods rew' ard your kindness!

0 eriael! O ye tods! ...........

kind gols, furgive ne tha

O gods! who is t ean say ...............

fairies, and rods,

Oyon nnigbty gods! this worl

think to the girdle do the gods inie.............

you ever-gentle gods, take my lireath...

5ou ever-gentle gods, take my lirenth.

ns it' we were Got's spies

the gods themselves throw iocense......

fulse tol thy gods, thy brother, and thy.

the gods ure just, and of our pleasant

tion fi' gool e'en: I pray, sir.... Romeo of Jutiet

Gixl rest all christian souls! (rep.)....

timl be with his stul! a was a nurry

likd shall mend my soul-you'tl

which is the Gud of my idolatry

tiol parlon sind wast thon with ....

trox ye foot-morrow, gentlemen. G

now, alore Gind, 1 an so vexet!

now, fiod in hetven bless thee!...
i) Guel, ahe comes! O honey nurse

gii thy way, wench, perve Gud

OGol's lnily dear! are you si hois..

Gorl scrid me no neet of thace!

ing sare the mark! hare on his

Gexl's will what williuluess is this?

is trol! I liave un ill-divining soul.

tiinl giardion laim! I do, with al

that ! ienl had sent us bit this...

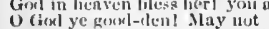

Gool's lirend! it makes ne mai

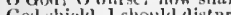

Gorlion

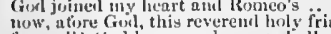

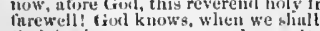

Gol torkive me (marrv, and ament)

letiore my (int, I miglit not th.

thruat a a wake the god of day ...........

for fiesl's lewc, let me licur. 'Two nights

Goxl willing, shall not luek...

Gind he w' $\mathrm{i}^{\circ}$ you; tare you reli ..............

hoth th my roxl, and to my graciuns kin

a gond [Col. Kint.-gord] kissing carrion
Gud save you, sir! My lonoured lord! \begin{tabular}{l|l} 
lv. 4 & in apprelension, how like a gotl! \\
iv. 4 & as by lot
\end{tabular}

as by lot, tiod wot, und tlien, $y_{111}$ kiow

fray tion, your voice like a fiece.

all you gode, in general sy nod

eyes of heaves and pustion in the.....

[Col.] God's bulikin, man, mucls better.

God be wi' [Col,-goor]-lye's you,

anil nick muxe diod's eren tures, andi.....

God bless yot, sir! My lord, the guech

God be wi' 'yon, sir. Will't plense you

well, God 'ichd youl

God he at your tulste...

I pray God. Gind be wi youl (rep.).

one thut would ct.

one thint wonls cirenment

0 Goll lloratio, what a wonnded name

and 1 (God bless the mark!)...

Will hot serve God, if the devil.
God's will, lieutenunt? houne

as ler whetite shall play the you witl

God be wi you; take mine office........

GOD-A-MLIRY, Grumio!. . Taming of

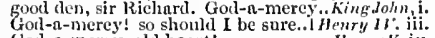

God-n-merey, old heart! ........... Henry $V$. iv.

well, gotl-n-merey. Do you know me... namlet, ii.

GoDD

GODDESS-the goddess on whom these. Fempesi, i.

but, like a tlarifty goddess... Mersure for. ireasure,

pardon, gorldess of the night...Much Aclo, v. 3 (song)
OIleten, goddess, nymph (rep.) ....Mid. N. Dr. iii.

thou being a godless.... Love's L. Lost, iv. 3 (verses)

a green goose, a goddess; pure phre.

a guide, a goddess, and a sovereign

titled goddess; and worth it ......... - inder Tale, ii.

and your fair brincess, foddess!...

that goddess blind, that stands ....... Henry r ij. 6

or a duughter a she be...... Troilus \&

the fuir goddess, fort une, tall deep. Cos

dear goddess, hear that prayer ..Anlo
in the hahiliments of the goddess Isis

Othou goddess, thou divine nature. Cymbeline, iv. 2

this goduless, this Semi ramis.. Titus.Indronicus, ii.

celestial Dian, goddess argentixe
who, O goddess, wears yet thy

thou, nature, art my goddess $\ldots . \ldots \ldots \ldots$....ear, i. 2

GOD-DEN-god-den to Jour worship..Henry ${ }^{r}$, iii. 2

as they were gods and goddesses.. Hinter's Tite it, iv. 3

gods and goddesses, all the. Anlony f. Cleopat?

GODDESS-LIKE-most goddess-like. Wimler's T. iv. 3

more goddess-like than wile-like ..Cymbeline, iii.
and sle dances as goddess-like..Pericles, v. (Gower)

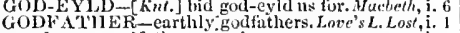

and every godfather can give a name

thou shait have two godfathers. Herch, of tenice, iv.
for that, commit your godfathers.. Richur

you must be gothinther, and answer. IIenry FIII.v. 9

GOD-IIEAD-make his god-head wax. Lore's L. L. v.

thy god-hend lad apart.. As you Like it, iv. 3 (letter)

low-laid son our gorl-head will uphift. Cymbeline, $v$.

GOD-L1k E-gol-like recompense... Love's L.I.ost, i. 1
n true conceit of god-like anity. Mer. of ínice, it. 4

observance of thy got-like scat.. T'poilus \& Cress. $\mathrm{i}$.

caparility and god-tike reason to tist... Hamlet, iv.

ii. 4 GODLY - eivil, Lodly company ............ H'in's, i.

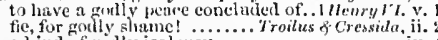

a kind of gindly jealonsy

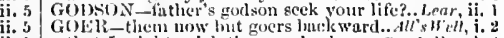

iii. 1 thut $x$ nipht prick the goer back .... Cymbeline, 1 .

vitifial goers-lwetwecn be ealled.. Troilus f. Cress. iii.

iii. 5 Silver! there it goes, silser! ......... - iv.

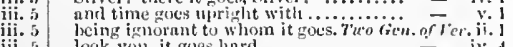

look you, it goes himrd....

loginour that goes with her

now, the repore goes ................

her hubland goes this morning

and goes to them by his nute.

the tinc gones by; away

....̈icelfh Night, iii.

goes as fuirly, th to say

as the rest gineseven.

Weasuri. for Meusure,

thut goes not out to prey ...........

rec how he goes nbont to nluse ni

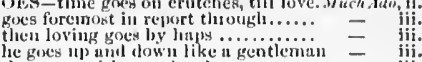

lie gares uf) and clown like u gentleman - iii. 3

your wit anbles well; it grees ensily

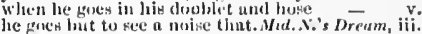

ay, thint wny goes the gane......... -

it goces mot firward, whth it? ........ - iv. 2

my lady gocs to kill lourus

$O$ vilel then as she gocs.

and erjed, all gots well ................

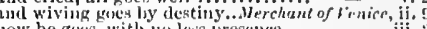

now he goes, with no less presence ä you Like it, ii.

it goes muel, against my stomach.... there a girl goes betore the priest .... $^{-}$iv.

then dny dial geses not true.....

the report that goes uxen your

she goes off anfion at pletsure

who goes there lat .......... Taming of slirew i.

jet oftentimes he fores but mean

how foes the world? $A$ cold world

who is this world goes, to pass for lionest

howe er the husiness focs.......

ave 2 (song)

and goes to the touc of two mats wooing - iv.

he that goes in the etalls-klin. Comeriy of Errors, iv. 3

and when yocs hence? To-norrow .... Wacbeth, $i$.

and she goes down at twel

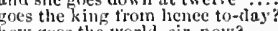

goes fleare with you? ...

this gocs it? When I came

look where three furthings goes!...... King John, i.

the hare of wham the proverb goes ... - ii. ?

how goes the day witlı us?

off goes his bonnet to an ..............

nll goes worse than I have power

yet all goes well, yet all our joints... i Itenry $I F$. iv. I

wow goes the field? The noble scot

what's he that goes there?

I hone your tordshin goes abroasi

the soit of the achievement roes witi me - i.

and down goes all betore them. Henryl, iii, (ehoris)

their villany goes against my

for tortb he goes, nud visits all.. - iv. (churas)

ask goes there? A triend

says the word, king fienry goes. ....

there goes the Talbot, with his

so, there goes our protector

shall you give, or off goes

all hitherto goes well; the common
who goes there? stay, or thou diest

how goes the world with thee?

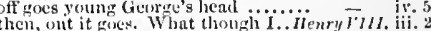

dowager? how goes her businc.
welt, the voiec gocs, naulam

the fruit she goes with, I pray for..... $=$ iv.

the noise goes, this ................

hisw he looks, and how he goes?
by a pace goes back warl .......

ny, sir, when lie gnes betore me

where one lut goes abreast ....

and farewell goes ont sighing.:.

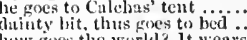

how goes the world? the werld, that I am thus

in all shapes, that man goes up....

lie pixes away in a clowil.

report that goes of his having.

lie goes upon this present artion

firth he goes, like to a harve t-man
bring me word thither low the workl goes

bit when goes this timward?

bhish, that the world goes wi

as far, as who gives turthest .........Julins cir

the world, vint the sworil goes up agatin? -

goes to, anil bask, lackeying gatony i cleopatro, $i$.

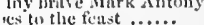

he geses torth pillnntly. ...

he gos lienee frownilug ........

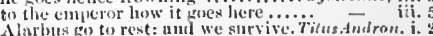

uhy, there it goes: link give ........, iv. 3

but poes thin with tlyy lieart?

i.ror, i. 1

but the great one that goes up the bili .. - i.

the wrenges to' t. anl the small

gos to' with a more riotons apentite. 
GOES_how this world goes, with no eyes.. Lear, iv. 6 GOLNG-men must endure their going .... Lear, v. 2 love roes toward love, as sehoolhoys eannot liek his fingers, goes not with ime- iv. 2 at least the whisper goes so

goes slow and stately by them ........... then goes he to tle length of all his arm it this world goes, is to be one man.....

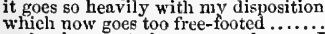

nd so he goes to heaven: and so am $I$

look, where he goes, even now

goes it against the main of Poland........

it is, will he, nill he, he go

preferment goes by letter, and affection... o no; he goes into Mauritania

\section{how roes it now? lo looks gentler.}

GOEST-goest about to apply a morai. WIuch Ado, i. 3 whither goest thou? marry

peruse this as thou goest ............

thou goest to the grange... Winter's Tale, iv. 3 (song.
thon goest to Coventry............. Richard II. $\mathrm{i}$.

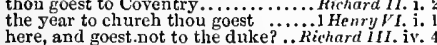

thou goest foremost: thou rascal ..... Coriolanus, i.

What, goest thon baek? .... Antony \& Cleopatra, v.
still in that clear way thou goest....... Periclps, iv.

ride more than thot goest . .............. Lear, i.

Gollow, where goest? Is it a beggar-man? - iv. 1 GOING-the sound is going away .... Tempest, iii.

and am going with sir Proteus ......

and I am going to deliver them....

that going will scarce serve

I was going to your house ............Miferry $\bar{W}_{\text {ives, }}$ ii. 1

and now she's going to my wife ..... - iii. 2

and they are roing to meet him...

waylay thee going home. Twefth $\mathrm{Night}$, jii. 4 (eliali.)

for

I am now going to resolve him.....

art going to prison, Pompey?....

I am going to visit the prisoner........, $\overline{\text {, }}$ iii. 2

is bad, going o'er it erewhile............

expediently, and turn him going. As you Like it, ivi.

your wife's wit going to your neighbour's $\bar{y}_{\text {and }}$ iv in going, madam, weep o'er.....All's

and I in going, madam, weep o'er

to Rousillon; whither I am going.

trat I knew of their going to bed.

should yet say, sir, no going?.Taming of shrew, i.

unto whom $I$ was going

when you are going to bed

if his going I eould frame...$\ldots \ldots \ldots$ - iv. 3

a man always going to hed...Cornedy of Errors, iv. 3

me the way that I was going........... Macheth, ii. I

stand not upon the order of your going $=$ iii. 4
and others more, going to seek......
are pilgrims going to Canterbury.... 1 Hewy $r \%$. i. 2

and go not, I'll hang you for going... - is

is now going with some cliarge...

what's he, that now is going out of door?

with deatl, going in the vault

your intent in going back to school ..... Iamlet, i. 2

either for her stay, or going ........... othello, i.

and I was going to your lodging, Ca......

GOING-OUT-this French going-out. II

and the rocks of pure gold .. Tuo Gen.of Verona, ii. 4

of monies, and gold, and silver .......ierry lives, i. 1

all gold and bounty

I warrant you in silk............... - i.

h hundred pound in goid

for saying so, there's gold ............ Tikelfi $\bar{N}$ ight, i. 2

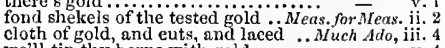

cloth of gold, and euts, and laced ...Much Ado, iii. 4

turns into yellow gold his salt-green

one, her hairs were gold ......... Love's L. Lost, iv.

your gold and silver, ewes and rams

the first, of gold, who this inscription

this saying graved in gold

was set in worse than gold

the figure of ar angel stamped in gold

gold, sil ver, and base lead

I shall never see my gold agrin.........

you shall hare gold to pay

with patines of bright gold

about a hoop of gold, a paltry ring....

here is the gold; all this I give you.. - ii. 3

if he for gold will give us any.

buy it with your gold right suddenily $\overline{\text { take this purse of gold, and let........All'sell, iii. } 7}$

with well-weighing sums of gold - ... Anl's iv. 3 (note)

the count's a tool, and full of gold
bid him drop gold, and take it.

if gold will corrupt him to a revolt.-
stndded all with gold and pearl. Taming of $\overline{S h} .2$ (ind.)

give him gold enough, and marry

of gold. Hortensio, peace (rep.)......
richly furnished with plate and gold

valanee of Venice gold in needlework

goldt all goldt This is fairy gold. Winter.

close with him, give him gold
oft led by the nose witl gold

here is that gold I have.

gold, and a menns to do the prinee.... - iv.

a thousand marks in gold

my gold quoth he; your meat (rcp.)

you received no gold? your mistress.

with a thousand marks in gold...

the fineness of the gold, the elargefui

what gold is this? What Adam.

deny the bag of gold? ................

I am undone by his going

and, but my going, nothing

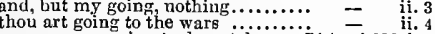

are you now going to despatch $\ldots \ldots$....ickard $11 I$. i. 3

I am glad they're prisone

give us gold; methinks, they a

by the merit of vile gold, dross

whither were you going

'tis not well: she's going a.........

as his queen, going to ehapel.

ahe is going, wench! pray, pray......

by going to Achille

belolds itself, not going from itself...
whither art going? To

thou art going to lord Timon' $\because$ feast

I am going to the market-place

coing ahout their funetions friendly

are going all to the senate-house

same pulpit whereto I am roing

whither are you going? Where do ..
am I going? where do I dwell? ${ }_{\text {directly, I I am going to Cxsar's funeral }}=$ iil. 3
iii. 3
out of his heart, and turn him going

out of his heart, and turn him going $\begin{aligned} & - \\ & \text { whose quality, going on ..... Antony \&. Cleopatru, i. } 3\end{aligned}$

seek no colour tor your going.....

no going then; eternity was in ......
most with you should safe my going

provide your going; choose your ow

in parting, than greatness going off..
now, my spirit is going; I can no more iv. 11
I was going, sir, to give him weleome. Cymleline, i. 7

to whom being going, almost spent.

to the king's party there's no going
still going? this is a lord!

to direet them the way I am going ...

going with thy honey breatl...Titus.Andronicus, ii.

why, I am going with my pigeons

for going on death's net, whom none .. Pericles, $\mathbf{i}$.

since my young lady's going into France.. Lear, i. 4

thut gomg ghall be used with feet ...... - iii. 2

going to put out the otlier eye of Gloster

and let me hear thee going ............. $=$ iv.
GOLD-every grain of Plutus' gold. Troil. \&. Cress. iii. 3 if I want the god of gold, is but.. Timon of Ath bawds between gold and wait!...... whilst I have gold, I'll be his steward gold? yellow, glittering, preeious gold
have but little gold of late ......... here's some gold for thee ............. there's gold to pay thy soldiers ....... give us some gold, good 'Timon ...... there's more gold; do you damn others have gold: look, so I liave (rep.) $\ldots$.... where should he have this gold?

the mere want of gold, and

there's more gold; eut throats and gold confound you howsoever

the do so; I have gold for tliee

you have heard that I have gold

Inl give you gold, rid me these viliains there's old, ye eame tor ............... = an alehemist, make gold of thit ..... and the gold that's in them ......... Coriolanus, ii. 1 as the ass bears gold, to groan .......... mart your offices for gold, to undeserver for gold to pay my legion

than Plutus' mine, richer than gold

the poop was beaten gold .. Antony \& Cleopat (eloth of gold, of tissue,), o'er-pieturing why, there's more gold! but, sirrah. the gold I give thee, will I melt......

there is gold for thee ................

in ehairs of gold were publiely..... . turpitude thoul dost so erown with gold! iv this your jewel, and my gold are yours play with all infirmities for gold whieh tis gold whieh burs admittanee and tis gold which makes the true.. there's gold for you! sell me
lost the worth of it in gold

though I had found gold strewed..... all gold and silver rather turn to dirt! wagered with him pieces of gold ...̈. I would not for a nillion of gold

to bury so muel gold under $a$ tree ...

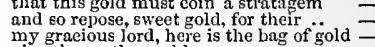
give the mother gold $\ldots \ldots \ldots \ldots \ldots$ a $\ldots$ holding out gold, that's by the touchstone sea's stomach be o'ereharged with gold = to part their fringes of bright gold... . he will line your apron with gold....... that for our gold we may provision have - Y. usurers tell their fold $i^{\prime}$ the field ......... Lear, î̈. 2 plate sin with gold, and the strong linee $\overline{\text { ive }}$ iv. 6 that in gold elasps loeks in .......Romeo \& Juliet, $\mathrm{i}$. there is thy gold; worse poison to men's

I will raise her statue in pure gold ...

never facked gold, and yet went never..... there's a. poor piece of gold for thee...... - iii. GOLD-BOU ND-gold-bound brow.... Nacketh, iv. GOLDEN-to exeel the golden age ..... Tempest, ii.
whose golden touch could.. Tuo Gen. if Veroma, ii. to these golden shores............... Nierry Wives, i. wow might do me golden service. and golden time eonverts...... iv. eut with her golden oars ..............vuch Ado, jii. for by thy gracious, golden, gtittering, and golden cadence of pocsy $\ldots .$. Love's $L$. L.nst, iv. 2 the golden sun gives not to those - iv. 3 (verses) her temples like a golden fleece. Herch. of $\overline{\text { Eenice, }}, \mathrm{i}$. 1 a golden mind stoops not to shows ...

an angel in a golden bed lies

those crisped snaky golden lock ...As you Like il $\mathrm{i}$. $\mathrm{I}$ the fire-robed god, golden A pollo. Winter's Tate, iv. 3 golden quoifs, and stomachers .... - iv. 3 (song) silver waves thy golden hairs. Conedy of Ervors, iii. impedes thee from the golden round ... Macbelh, i. 5 liave with his golden blood

hancing a rolden stamp about

with lier golden liand hath plueked..King John. iv. 3 that it in golden letters should he set - iii. and embrace his golden uncontrolled, Richard II. i. s 
(iOI.I)FN-against our golden erown. Richurd 11. iii. 2 now is this golilen erown like a deep pleasure, anl thy gohlen sleep? ....1 Hewry $t$. ji.

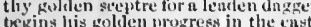
topins his golden jrogress in the enst at the lieals, git golden inultiendes. perturbation! goleten eare!

from this golden rigol hath ilivoreed

golken times and hapyy news of price

s speak of Atrien, and gildtets joys.

recived the golden enrnest of

after this goldell day ot' victory.

to put a golden secptre in thy hand.

sate in golden pataces.

uutil the golden eireuit on my hen

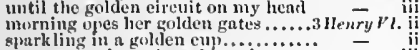

to eross me froin the golden time

to neeomplish twent $y$ golden

theen ill former golden durs ........ kicherd III. il.

as if the golden tee, for which I plend

the inclusive verici of golden metill.

did I enjoy the golden dew of sleep

that forehead witl a golden erown

asyiring tlame of golden sovereiznty

the wenry stun hath made a golden set

as lief, Irelen's goliten tongue. 7 roilus of Cresside

pnte dupks to the golden fingl. Timon of $t$ the $n x_{4}$

to ope their golden eyes ....... Cymbeline, ii. 3 (song

with golden theruhims is fretted .

put his lirows within a folden
golden lads and girls all must

golten lads and girls an muat .... - iv. 2 (song)

as nth , that have this golden elanee - y.

anstines dons posess a roliten sinmluer - ii.

fill his aged ear with golkicu promises.

with golden truit, but innerous $\ldots . .$.
shake otl the goldien slumber of rejose

in glittering goliden eharacter

when thou gavest thy golicn one away ... Lear, i.

locks in the golden story
there golden slecp doth rei

eut'st my head olf witls a golden axe

mnjestical roof iretted with golden fire

all his golden words nre spent

GOLDESLY-

acquninted with goldsmiths' wires. As you Like, iii. 2 gequninted with goldsmiths wires. As you Like, iii. 2
I go to the goldsmith's houtse..Comedy of Errors, iv. I
but soft, I see the goldsmith......... ncither ehain, nor goldsnith, came.....

you linve found the goldsmith now

suborned the goldstnith

one Angelo, an goldsinith ............

bring ine where the goldsmith is ....

there did this perjured goldsmith swear

the golnismith here denies that saying _ v v

field of Golgotha and dead men's ... Kichard 11. iv. i GOLI ANSES-Sampsons, and Goliassea, llenry rl.i.

GOLLATI-I fear not Goliath ..... Merry "ires, y. I Gou have swam in a gondola .....As you Lite it, iv.

GONE

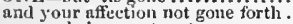

no. no. lie's gone (rep.)

i. 2

when that's gone, he shail....

with a heaviness that's gone

particular aceidents, gone by ......... of Ferune, v.

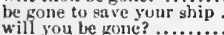

go, gut gou gone?

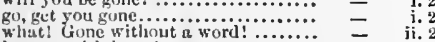

is gone with her along

when you arions

the youthtul lover now is gone

tis nut to have you gone gone .......

for get you gone ............

aceorling to our proclaination, gone?

gone, my good lord

gone to reek his do

therefore, be gone, solieit me no.......

his suecessors, gene before him ...... Ierm

I pray yun, be gunc

yould have gone to the truth

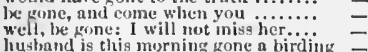

a fitt woman. gone up iito his.

evell now with me: but she's gone...

they nre gone but to meet the duke...

sinec I mut nects be kone

Iudesiry, be gone! I pr'ythec........ - iv. I

I am gone sir, unt anon, sir......... iv. 2 (soug) they had kone down too......Mressure for Merisure, i. : that ninetern zodiucks linse gene roind very strungely gone from heise

get you gone, and lat me heur

pray you, be gone...................
GON -1 know you'd fuin be gonc. Mens. for Jeas. v but 'Inesday nily lat lust gone

duke gone? then is your eanse gone too

for trouble being gone

I nm cone, the aluht to link

thy slancler hath gone through

thou lot of spirits, I il ine gone.......... $N$.

get thee gone, and follow ime no no...

thronght the forest linve I gone ......

so aw ake, when I am gone ..........
whint, out of hearing? gine? no sound

all that love is gone .................

get youl gone, you slwarf

to their wormy hed ure gone

Where he ealle, then he is gone .......
fairies, he gone, and he nll ways away

Was, to be gone from Atliens

how eliance mooushine is gone

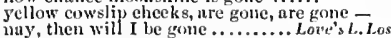

ay onr way to be gone

gone.

so be gone. She snys, you bou rogue

gone to her tent: please it your ......

martain tums, gone tis heaven. Mereh. of ten

I'll le gone about it straight

under suil, and gone to-night.....

must be gone from hence immediately

to leave you and he gone

a diamond gone, cost me two thoursand

despatel all business, and be gone

but get thee gone; I sliall be there

well, you are gone both ways ...

get thee gone, but do it ...........

more virtuous, when she is gone......

Wherever they are gone, that y
he is but even now gone hence

would have gone near to fill in $\%$ luve.

and is gone forth,-to sleep iö.........

get you gone, sirrnly; the compluints

vou'll be gone, sir knave, and do as i

be gone to-morrow: and be sure of this

is she gome to the king? She is

madam, he's gone to serve the duke

I will be gone; my being here it is

thither gone: ambitious love

they have gone a contrary way

mis graee, you are gone about it?

whither is he gone?

crying, that's good that's gon.

firrah, be yone, or talk

I must be gone. Faiti, mistress

go, get thee tone thuu fialse deluding

be gone; and say no m.ore.

列

tis far gone, when I shall gust .......

suy, that she were gone, given to the
do not pusl: me; I'll be gone

firewell; we are gone. Thou, traitur

for I do teel it gone, but know not ..

what's gone, and what's prst help

the ehace; I nm gone for eve

and see if the bear be gone $\ldots . . . . . .$. .

wilt please you, sir, be gone? .........

nor my sister; we ure gone else......

respecting her that's sone.

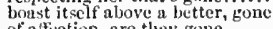

of affection, are they gone.............

he's somewhere gone to dinner...

go, get thee gone, feteh me an ir
to trulge, prek and be gone

fet thee gone; liny thou a rope

be gone; on, officer, to prison
lost is wailed when it is gone

tis time tlat I were gone...........
forth to-night? niay we be gone?

to lenve ine, nnd be gone .........
and I'll be ene, sir, and not trouble

fly, he gone. Come, stund by me..

have 1 fot gone in travail of you

whose care is gome betore to bid $u$.

he is alresuly named; and gone to sion

is Bungug gone from court?
get thee tone; tomorrow we'll.

get thee gone; to-norrow we'l
feing gont I am a man again

get you pence and at the pit

whicte are tlacy? andey

lewitimation,

gone to be married! gume to swear

or get thee sishe, and lente those

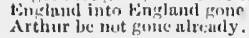

GONE-which you demund is gone ...

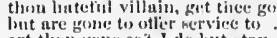

nrt theou pene 80 ? 1 do but stay

six winters? they are duirckly gome.

York is tes fin gone with grief.

your husbant he is gone to save
your son wats gone before I eame

he, my lorll, is gone to Itavensiunte.

our countrymen are gone and flet

are gone to Bolingloke, dispersed

Salishury is gone to mect the king ...
then be gone, and tronble you no more

mine own again, be gone, that 1 may

pardoned thee: nway, be gone
Worcester, get thee gone, for 1

this heat up, after I was gone?

is Gilliams with the packet gon

still? nay, pr'ythce, be gone

8o, be gone; w'e will not now be.

time's guhjects, and time bids lie gone

when she was gone dow

be cuict; the ruseal is cone

thou'lt torget me, when I am gone. .

I wout ten yeurs gnite, since kichard

do any thing about her, when I an gone

of the days but newly gone ...........

I think, he's gone to hunt, my lord ..

then get thee gone, and dig ............

my fither is gone wild

the king will be gone from Southampton

thic French is gone otr, look you....

often weleomed when they are gone

not to be gone from lience

come, dally not, be goise

my other life? mine own is gon
now he is gone, my lord.................
be gone, I say; for till you do.

say, when I am rone, I prophesied ..2 nc ury VI. $\mathrm{i}$. old Joan had not gone out

when I am dead and gone

what, gone, my lord

art thou gune too? all eomfort

all our unele

so, get thee gone; that 1 may know.

therelore get ye gone

my hope is gone, now suftiolk...

too much already; get thee gone....

now thou art gone, we have no etrif

are gone to France tor aid $\ldots . . . .$.

there's thy reward, be gon

both gone to War

and be gone to keep them back .....

and $t$

when they are gone, then must

therctore be gone, swcet sain

the branelies, when the root is gone?

but Edward, and he's gone (rep.)......

but they, and they are gone.

get thee gone; death and destruction

and be gone to Brecknock ...............

thou wouldst be gone to join with

ii. 3 then wouldst be gone to join with ....

I have no farther gone in this.........
Lovell's hends sliould lave gone off.:

gone slightly o'er low steps have uncontemned gone by him

the king has gone beyond me

are ye all gone? and leave me

get $y$ ou gone, and do as $\mathbf{I}$ have biil yo

gone between and between.

Was Ilector armed, and gone
IIfector was gonc; but Ifelen

condition, I had gone barefon

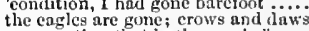

every action that hath gone belore

I wotld be gone: where is iny wit?.

where's my lord gone? tell me
thou must be gone, wench (rep.)

thou must be gone, wench (re

be gone, I say; the gols have

lieetor is gone? Hino shall tell .......

get you

nnswer nut, I am pone.....

how quickly were it gone?

are gone thint buy this prnise (rep, $)$.

get you gone, sirrah, draw nearer....

bent thy drum, and get thee gone...

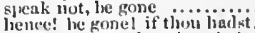

get thee sone: thint the whole lite.....

till now you have pone on

lanee! to your homes, be gone

Cominius the general is gone

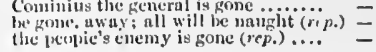

ng, Jwhn, iv. 2

-

ii.

ii. 


\section{GON}

GONE_will you be gone? You shall.Coriolanus, iv. 2 GONE- he is far gone, far gone; and,.... Hamlet, ii. 2 get you golve: you have done a brave
if he had gone forth consul therefore forth consul

therefore, be gone: nislodged, and Mareius gone...

are dislodged, and Mareius gone

my rage is gone, and I am struck .....ंilus $\overline{C a}$ sar

be gone; run to your houses.

he's gone to seek you at your house.

not to answer me, but get thee gone.

ay, Cresar; bint not yet goue

away, away, be gone

are they fled away, and gone

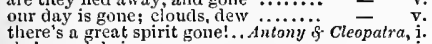

she's good, being gone ..............

had gone to gaze on Cleopatra

get thee gone: say to Ventidius ....

when Antony is goue tlurougly whom

done already, and the messenger gone -
he knew himself, it had gone welf
friends, be gone; I have myself resolved -

be gone; my treasture's in the harbour -

be gone; my treasure's in the har

not many moons gone by. $\dddot{3} \ldots \ldots$

is he gune? most eertain

bid them all fly; be gone $\ldots . . . . . . . .$.

'tis well thou'rt gone, it it be well .

O quick, or I am gone. Here's sport

our strength is all gone into heavines
the odds is gone, and there is notling

well, get thee gone; farewell

you must be gone; and I shali here...

so, get you gone; if this penetrate ..

I hope it be not gone, to tell my lord

Why hast thou gone so far.

gone she is to death, or to gone? ......

now I think on thee, my humger's gone

home art gone, and ta'en thy wages - iv.

this gone. Pisanio, all curses madded

the great part of my comfort, gone

why

but ( $O$ scorn!) gone! they went hence

had it gone with us, we should not...

but her son is gone, we know not-how

discovered not which way she was gone
groaning shadows that are gone .. Tilus Andron.

trouble me no more, but get you gon

Aaron is gone; and my compassionate

get thee gone; I see, thou art

get thee gone; I see, thou art ......
for love of her that's gone, perh

go, get ynu gone; and pray be carefiul

the breath is gone, and the sore eyes

suffieiently, he's gone to travel (rep.)

but sinee he's gone, the king

I must needs be gone: my twelve...

master, I have gone thorougl for.....

his daughter hoine, who frst is gone -

plaee as this, she being once gone .......

therefore he gone, without our grace.

and the king gone to-ni

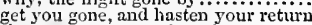

thy asses are gone about em ...................

ask for me, I am ill, and gone to bed

but trouble him not, his wits are gone

are gone with him towards Dover ......

king of France is so suddenly gone back

gone, sir? farewell. -And yet 1 know not $\mathrm{O}$ she is grone for ever them a measure, and be gone............. Jumes Juliet, i. would please 'tis gone, 'tis gone, tis gone prepare not to be gone

let's away; the strangers ail are gone

almost morning, I would liave thee gone

is he gone, and hath nothing?...

Romeo, away, he gone! (rep.) ...

if those two are gone? Tybalt is gone

either be gone betore the wateh be set
well, get you gone: o"Thursday be it

wilt thou be gone? it is not yet.

I must be golie and live, or stay and die -

stay yet, thou need'st not to be gone

o now be gone; more light and light

art thou gone so? my love!

get you gone, be strong and prosperous

he gone: we shall be mucl unfurnished

is my dalighter gone to Friar Yaurence?

we may put up our lipes, and be gon

therefore, hence, be gone; but if thou

therefore, hence, be gone; but if thou -
I will be gone, sir, and not trouble you -

think upon these gone o be gone! by heaven, i.........

stay not, be gone; live, and hereafter say -

knows not; but I am gone hence .....

'tis gone, and will not answer $\ldots$.........

tis here! 'tis here! 'tis gone! we dn it

he good old lord Gonzalo

and oar'd himself with his good arms.

other gentlemen of good esteem.

currish thanks is good enough

do a good offlee between............ hath Phobus' cart gone round Neptune's - iti. 2
where is he gone? Tu draw apart........
he is dead and gone, lady (rep.)..... iv. 1
next, your son gone; and lie most violent - iv. 5

when these are gone, the woman ........

it is too true an evil: gone she is

there's one gone to the harbour?

you see this fellow, that is gone before...

slie is gone; I am abused; aud my relief
sond the the

avaunt! be gone! thou hast set me on

'tis gone: arise, black vengeance.........

is't gone? speak, is it out of the way? ...

so, get thee gone; good-night. Nine eyes

sle's like a liar, gone to burning hell

he's gone, but his wife's killed $\ldots . .$.
GONERIL-Goneril, our eldest-born

than that confirmed on Goneril.

I cannot be so partial, Goneril, to the
panting fortl from Goneril his nistress

panting fortli from Goneril his nistress

arraign lier first, 'tis Goneril

hither, mistress, is your name Goneril

o Goneril! you are not worth the dust

your affeetionate servant, Goneril

Hungarian] wight! .................. Nerry Wives, i. 3

GONZAGO - the murder of Gonzago..... Hamlet, ii. 2
Gonzago is the duke's name (rep.)..... - iii.

monrterer gets the love of Gonzago's wife

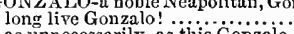

as unnecessarily, as tjis Gonzal

to fall it on Gonzalo

holy Gonzalo, honourable man....

O my good Gonzalo, my true preserver

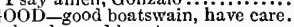

clieerly good hearts.
stand fast, good fate

should the good ship so have swallowe

like good sir lo...

good wombs have borne bad son

that in't which good natures could not

you will some good instruction give

good things will strive to dweli with $\dddot{t}$

then wisely, good sir, weigh our sorrow

for a good wager, first begins

why, in good time

content tender your own good fortune?

thy good friend Trinculo

by this good light, this is ....................

than you, good friend .........

jf thou beest a good moon-calf $\ldots \ldots \ldots . .$.

my good friends, hark? ........

you did supplant good Prospero .......

so with good life, and observation strange

good my lord, give me thy

the good old lord Gonzalo

I will requite you with as good it thing

our royal, good, and gallant ship
with the help of your good hands...

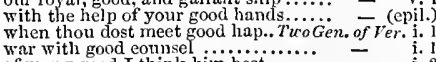

of many good I think lim best

be calm, good wind, blow not....

and in good time .......................

your father's in good health

of much good news?

but, if he make this good....

tell me some good m

no worldly good slionid d...............

and cannot hear good news...........

she brews good ale (rep.)

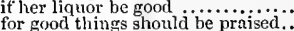

the good conceit I loold of thee......

where your good word cannot

ravel, and be good to none
the onset to thy good advice

and so, good rest

witness guod hringing up....

OOD-will you, upon good dowry...Merry Wives, i. his meaning is good

the good humour is, to steal

the humour rises; it is good

gave me good eyes too

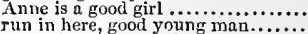

to speak a good word to.............

I'll do your master what good $Y$ can

it pleases your good worship to.......

good faitl, it is such another Nan...

twas a good sensible feilow.............

how does ood mistress 4 nne.........

hath good skill in his rapier.

grated upon nyy good friends ............

why, sir, she's a good crenture.......

the attraction of my good parts aside

for 'tis not good that children..........

money is a good soldier sir

though I had never so good means

I shall proeure-a you de good guest.

wh gar, tis good; vell said.

and a good student from his book

we are come to you, to do a good office

use your patience: in good time.......

such a league between may good man

good plots! they are laid $\ldots$ knot.........

thuu'rt a good boy; this secreey.....

dat is good: by gar, vit all

my uncle can tell you good jests.....

now heaven send thee good fortune..

and rood luek wood as my wo word have it

as good luek would have it .............

to be compassed like a good bilbo ....
in good sadness, sir, I am sorry ......

that is good, William

he is a good sprag memory

ay, in good sadness, is he ..............

the witness of a good cons

I hope, good luck lies in odd numbers

that's good too; but what needs.....

able to woo her in good English......

seese is not good to give putter $\ldots . .$.
clothes are good enough to-drink in.T

and hath all the good gifts of nature

art thou good at these kick-shaws...

make that good...

as good as a hanging to you (rep.).....

apt, in good faith: very aptl ...........

put me into good fooling!.............

she made good view of $m$

'twas very good, i' fait
or a song of good life?

I care 1 ot for ood life.

excellent good, i' faith! Good, good...

'twere as good a deed, as to drink ....

but I have reason good enough ...

before me, she's a good weneh........

this, and my good wishes .............

a cheveril glove to a good wit........

love sought is good, but given ........

a good note: that keeps you...........

to be of good capaeity and breeding .

I'll be as good as my word.

done goon feature shame

ii. 4 to be thought a good student .............

au honest man, and a good housekeeper

\begin{tabular}{l|l} 
ii. 4 & cmnnterfeits well; a good knave ........ \\
ii. 4 & Yll follow this good man .............
\end{tabular}

primo, secundo, tertio, is a good play

as to your soul seems good.. Measure for Meas?

thou art good velvet $\ldots . . . \ldots . . . . .$.

if they'll do you any good.............

your do blaspleme the good

in me to do him good?
make us lose the good we oft

if these be good people ........

that yod good hoour two........

od ehristians oug

unless they kept very good diet....

an open room, and good for winter

cause to whip ........

worst thing about him; good then.....
thank your worship for your good counsel =

uncler your good eorrection....

for those things that make lier good?

is like a gond thing, being often......

mueh good do it your good heart!

'tis a good dog (rep.)

good worts. Good worts? good eabbage - it were as gnod to pardon him.

or seem so, craftily; and that's not.... good - i.

i. $\mathrm{i}$.

i. 3

i. 5
i. 5
i. 5

i. 5

ii.

ii. 


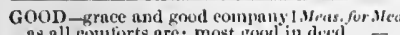
in all coonltior

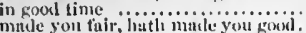

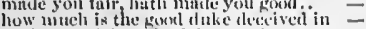
to the love I lave in sloine seror. and good workls wont with frer nume -

he were a goxd go $n$ mile on

Mhy. is kiknd it is the riklit of

I hope sir. your goud wership wili lie

yes, in good roeth, the vier is

tis good: thomgh misic ott hith

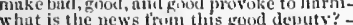

clie comes to do you gourl ............ -

rour good favour (tor sits.

Iowe you a good thrin....

more tlinn thanks and goorl fortine.

I will keep her ignorant of her gone

in that good patt that I would wisle

and yood supporters vout are...

this a goud friur, lelike!

jii very groul time: spetak not

he liath dene pood service, lucly.

and a gool soldier too, lady

and so good a continuer ..............

to tell cols a is a ent

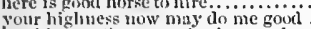

haril lesen that may do thee good...

are they gool? (rep.) ...............

with a good leg, nud a good foot, unele

if ron be not woved in good time...

brother, make good room

Gother, make good room $\ldots$ me........

that I had my good wit out of the

in every good thiug................

none, but to desire your good eompany

and his gondwill obtained

to liel p my cousin to a good lusband.

ten mile nfoot, to tee a good armon

of graot discourse, utl excell

it were good, that Benediek $\mathrm{knew}$

Were it good, think you?.................

let her wear it out with good counsel

how much he is unwortliy so good a lady -

it were not good she knew his love..

the word is too good to paint ont her.

are you gool mes and true?

a punisliment too good for them ......

by my troth, it's not so gnod.

for I hear as good exclamation on

a good old man, sir

well, God's a good man $\ldots \ldots . . . . . . .$.

lie praved upon thee by good witnes

on I may have good eheer

soy, said $I, a$ good wit.....

to eatisfy this gond old $\mathrm{men}$.......

gond purt to intermingle with them (rep.) -

that lived in the time of good neighibours

a good persunsion.................id. N.

a verv goow piece of work

will do any ninn's heart good to hear me -

and they shall have good luek

if $5 \mathrm{mu}$ think it goorl, und tarry .........
goos troth, you do me wrong, good sooth

Ilave a reasonable good ear in music

a buttle of hay; good hay, sweet lasy

good strings to y unr beards, new

a giand moral, my lord:

the mon ehines with a good grace.

thy mantle gord, what, stained with

illl lay my head to any'good ma.....

let them be men of gorsl repute

he was a man of gewal enrriage.

and lie had a very gom wit.

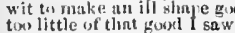

your own geoul thoughts exerise me.

Katharine, by it goorl?

Katharine, by food linp
gors] wits will fec jnog

a gond l'envoy, ending in tle goose.

sir, your jeniy worth is good.

a good friend of inise: stand isitie, good a good innster of mine, to a lad

thou can'st not bit it, my goud man.

in the testimony of $n$ gund eonseienc

a go the gift is gond in these in whom

a geod lustre of conceit in a ture

a fingmel old Mantuan!..............

is net that a goxd word?

twere goul, yours did

I lo assire you, very pooil frichi.

are goosl ut such eruptions ...........
benutculs as ink; a good eodelision (20)1)-weeping-ri

ves, in goul lintls...................

he to a tice to

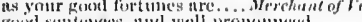

to know what vere poos lo tlo
it is a good divine that follows

What were gond to lie dine
the meshes........

at their rleath, have foral inspiration

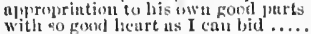

Antolius is a pool maus

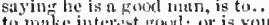

tis n rood rouncl simin:

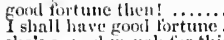

she's a goonl wench for this

We have not male good preparation.

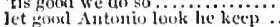

thet the wood Antomio, the liones

a title good enough to keen his ......

good new, prod news...............

to ery, gosel joy; goud joy, my lord . -

tell me bow my gowel triend dottl.

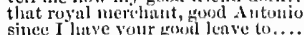

I never disl repurt fir. doing good.

therefore, he ot guod visecr ..........
hope in it that can do you niny good

you are no good menlice of

nud now, goud sweet, say thy opinion

food cheer. Antonio! what man?....

thy bands nizil goods are, by the law's of

thy hall thy roods are contisente.

why then the devil give him good

sinth seize me hing his goorls

with his lornt full of good news.

so shines a good heer mo a

hatlo gome good, 1 see, with

to give me goot edneation

than becones me for my good ......

good monsieur Charles! what's the news

therefore he gives them goot leave to

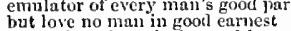

let us sit and moek the good bousewife

by his honour they were good pancake

you have lost nuech good sport

Y would have tuld you of good wrestling -

pity lier for her good father's sake ".

let us talk in good earnest

in stones, and good in esery thing

in goot old man; how well in the

for a eoumter, would $I$ do, but goo

a rude despiser of good manners

if ever sat at any good man's

and be blessed for your good eomfort?

round belly', with good capon lined .

if that you were the good sir l.
good old mun, thou art right ......

of itself, it is a good life.........

that good past ure makes fat slice

may compla in of good breeding.

saw'st gond manners; it thon ( $r c p$.

that are gool manners at the cour

glad of other mea's good ............

good ruy complexion! clust this

relish it with a good obser'unce $\ldots$...

nor a muus frood wit sevouder .

were to put good meat into ai

of hits gools: right; many a man (rep.

an would be a good excuse to len

as gond eause as one would tesire.

I told him, of as good as he

fasting, for a gond man's lore.

tis good to be sad and say nothing (rrp.)
very good oratars, when they are out

for, good $y^{\prime}$ enth, he went bat

not food? I hope so. Why then (rep.)

\section{he of toud eluer joth}

take a good henrt, aud counterfeit

fuilh, the priest was good ewough

a good unswer: art rich? (rep.)

of gand eonelt: I sueak wot this (rep.

to do youraelf good, ank not to

as you have books for good manner.

he's as gowl at any thing, and yet a fool

good wine neerls no bush (rep.) ......

to grod withe they do nse rood (rep.

a good epilogne, nor eaminot (rep.......

that is so generally at nil times gowil.. All's will,

I have those hopes of her groul, thint lier -

is a virtie of a gorkl wing, nud I like
get thee a goom husband............. v. 2 lis gorel rememintance, sir, lies...

- 1.

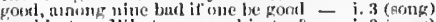

good in ten. What, anc geses in the

one gom wosman in ten, mathin

that his good receipt shall.

good spmeks and liktrmes, a woril, good -

wo happy, and toes gond, to make

unworthy this good gist ...............

our will which travals in thy gond $\mathrm{k}$ -

yet art then, good for nothing but.... -

lie is iny grod lord: willan I

goonl very good; it is so then (rep.

a gork knave, i'taith, and welt feil

is a goo' now your ow'n goud procecelling

a good trmeller is tomething at.....

hit we must do good against cril

the finvolirs of so good a king

notlying here, that is too roud for lim

he is too root and fiar

a right towes erenture

ly the goot aitl that $\mathrm{Y}$ of you

giblise curnght, and good enough ....

minglet yarn, groot and ili tugether..

in grod sadness, I do not know .....

'twas a good lady, 'twas a good lady

since I heard of the good lady's death

is a gootl livery ot honour.

with what gool speed our neat

crying that's good that's gone..

how silver made it gond ... Tuming of shrer, 1 (ind.)

Belman is as gond as he, my lorl... - 1 (ind.

I,ord be thanked for my good amends $\quad-2$ (ind.)

.

here is some gnod pastime toward...

soon make good what inge said..

not displease thec, gond Bianco

vour gifts are so good, here is no...

my reascins tre both good and weiglit

a good mutter, surely; comes there..

nul goods at lome, and so am eome.

scolding would do little good upon him

otlier books, good ones, I warrant you

news indifferent good for either

I do hope good days, and long, to see

I were as sure of a good dinmer $\ldots . .$. .

the motions good indeed, and

and he, for your good sake

heir to all his lands and goods

prove a grod musician? I thin

three or four as good, witlin

in my head to do ray master food.....

twere goot, methiuks, to ste

she is my goads, my eliattcls $\ldots . . . .$.

tis passing good; I pr'ythee let .......

good do it unto thy gentle

stand good father to me now

for the good report I hear of you

she is of gond esteem, lier llowry...

God send 'em good slippling!

I thank my goad father I nm ablo

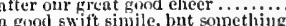

a good swift simile, but something

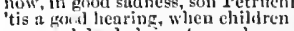

one gorl decd, dying longueless...

no, in govel carlicst: how sometimes.

at the goon queen's entreaty ('ep.)

I must be the poisoner of good Irolixenes -

gord be the loisoner of good

coud time encounter her!

if the good tratlight it good

Eurne is too good

not he doubted I whall do goon

he took good rest to-night.

ynir woud queen. Good queen? (rep.

the good incen, for slie is gand

and, thou, gonl gokless nature

will never do linin good ...............

'tis gonl speed; foretills, the great

hut that the gond mind of camillo.

have poisoned good Camillo's honour

gerol lnek, an't be thy will

thut's and werd deet............... 
GOOD-my good falcon made her.. Winter's Tale, iv. 3 GOOD-manhood, nor good fellowship.1 HenryIl'. i. 2 GOOD -matched witl as few good deeds. Heury $l$. jii. as your good flock shall prosper since these good men are pleased cast your good counsels upon to my good use, $I$ remembered $九$ good nose is requisite also............ to do the prince my master good took something good, to make $\dddot{\text { and for future good, to bless the bed }}$ and for future good, to blcss by your good father's speed ........... and to give me your good report .... ay, an, it like your good worship

we'll be thy good masters........

his goods confiscate to the duke's. Comedy of Err. grcat care of goods a t random left. lest that your goods too soon be....
go indeed, having so good a mean in good time, sir, what's that? learn to jest in good time $\ldots . . . . . .$.
good will, and your good welcome good

good meat, sir, is common

as good to wink, sweet love

is't good to soothe him in these $. \ldots . .$. .

I shall have leisure to inake good....

your goods, that lay at host, sir.....

cannot be good; if ill, why ...

you have good leave to leave us.

circumstance considered, good my iord = into the good thonghts of the world.. an twere not as good a deed as drin.

and a good jest for ever............. -

shall command all the good lads

till $I$ am so good a proficient

there live not three rood men unhanged Z

all the titles of good fellowship come

wcll, that rascal hath good mettle....

a good [Col. goodly] portly man
wherein is he good, bot to taste.

wherein is he good, but to taste......

for a true face, and good conscience.

no persuasion can do good upon

your majesty's good thoughts

lived well, and in good eompas

would have bought me lights as ...

darest thou be as good as thy word now? -

I must still be good angel to thee.

I am good friends with my father

I press me none but good ho

tut, tut, good enough to toss .........

your great deservings, and good name

any way, your good deserts forgot.....

what good tidings come with you?

we will all put fortli; body, and goods

done good service at Shrewsbury

to the hearing of anjthing good ....

give your lordship good tin

good my lord, be good to me! I beseech

tie! what man of good temper

she had a good dish of prawn

to pawn my plate, in cood earnest

upon my good lord here

how many good young princes

let it be an excellent good thing ....

a erown's worth of good interpretation

delivered witl good respect.........

in an excellent good temperality ...

sick of a oalm

you are both, in good troth

am in good name and fame with

drink no more than will do me good

these be good humours, indeed 1 .

a good shallow young fellow (rep.)

and swears witl a good grace.......

$O$ the Lord preserve thy good grace

there is a good angel about him

that stirs good thought in any breast

there's a good mother, boy, that blot

to say what good respect I have

shall come, for me to do thee good

fortune means to men most good

the rich advantage of good exercise..

which for our goods we do no further

as good to die, and go, as die ........

whate'er you think, good words,

away then, with good courage

will not let me velcome this good new

good quarter, and good eare to-night

be of good eomfort, prince...............
here to make good the boisterous... Richard II. i.
worthily, as a good subject should ...

my body shall make good up....

too good to be so, and too bad to live

will I make good agaiust the

God, and good men, liutc so foul .....

as much good stay with thee.

heaven in thy good eause mak

is banished upon good advice

the apprehension of the good

a precedent and witness good.......

their events can never fall ont good

to hear of good towards him (rep.)

than your good words

a soul rememhering my good friends

keens good old York there ..........

and crossly to thy good all fortune.

the news is very fair and good ......

dear friend of the good duke of York

to the bosoin of good not greatly good)
sit by the (and yet no with good old follks...

'twere no good part, to take on .....

thy overflow of good eonverts to bad

but neither my good word, nor princel

g. eommodity of good names wcre...... ifi. 3 good speed. How many of my thousand William is become a good scholar.... how 2 good yoke of bullocks at Stamford done a man's lieart good to see done a man's lieart good to see ....

what is your good pleasure with me?

knew lim a good backsword man (rep.)

is good; yea, indeed, is it; good ph

a word of exceeding good command.

good limbed fellow; young, strong (rep.) -

no man's too good to serve his prince

go to; very good; exceeding good.....

whose learning and good letters peace

onr hearts should be as good ........

heaviness foreruns the good event.

gome good thing comes to-morr

as good a man as he; sir, whoe'er $\mathrm{I}$ an

in your good report

a good sherris-saek hath a twofold

ii. 1 drinking good, and good store of fertile

and wherefore should these good news

heard he the good news yet?...

\begin{tabular}{l|l} 
ii. 3 & marry, good air; spread, \\
ii. 3 & serves you for good uses
\end{tabular}

i1. 3 a good varlet, a good varlet, a very good

hut eat, and make good cheer...... - v. 3 (song)

wind which blows no man to good

jii. 3 and shall good news be baffled?

iit. 4 devise somcthing to do thyself good...

if $\mathrm{I}$ will be as good as my wor

v. J but a good conscience will make

v. 1 and two hundred good esquires............

v. 5 advised hy good intelligence of...

a little, in good terms, as 1 ming is a good king ........

what, man! be of goot ehecr. look, here comcs good sir John (rep.) i. 3 it is not so good to come to tlie mines

i. 3 in good truth, the poet is make.........

$$
\text { the fig of Spain! Very good }
$$

ii. 2 of a good and particy!ar mistress

ii. 3 have good jut rment in horsemanship he wiil keep that good name still...
botil healthful and good husbandry

ii. 4 a good soft pillow for that good white

ii. 4 'tis good for men to love their present

ii. 4 as good a gentleman as the emperor.

ii. 4 a good old commander, and a most

bnt if the cause be not good .............
this story shall the good man teach

(good argument, I lope, we shall not fly)

might have a good of good house

$I$ am Welsl, you know, good countryman -

and is good knowledge and literature

what prisoners of good sort arc taken

as in good time he may $\ldots \ldots \ldots . . . . . .$.

teach you a good English condition...

of this good day, and of this gracions.

may do some good, when articles .....

a good leg will fall; a straight back

but a good heart, Katc, is the sun ....

must needs prove a good soldier-breeder

love her, and that is good English . H Hen $-V_{V I}$

except thou sorrow for my good........

I am as good, - As good? thou bastard

sweet virgin, for our good...........
and for these good deserts, we herc ..

as rood a man is York

your purpose is both good and

ii. 1 good wishes, praise, and prayer

burn her; hanging is too good ...... - v. v.

excepting none but good duke Himphi.... -

together, for the public good
silly owner of the goods weep

ii. 2 silly owner of the goods weeps .....

$X$ have good witness of this .........

well guerdoned for these good deserts

were it not good, your grace could fly
so good a quarrel, and so bad a peer

in my sleep by gcod saint Alban ....

that virtuous prince, the good duke..

here's a pot of good donble beer......
thank God and the good wine in thy

in studying good for England! ......

for good ling Henry, thy decry ....

bewails good Glostcr's case ...........

I judge mine own wit good...

'tis my good lord. A way, be gonei...

true evidence, of good esteem ...........

by the good duke to kecp ...........

if God's good pleasure be! …........

king's council are no good workmen

with a man as good as himself

and good reason; tor thereby is.......

if we mean to thrive and do good.... -

for watehing for your good ...........

continue still in this so good a mind

sallet was born to do me good...

lands, goods. horse, armoric.

created knight for his good service.....

T'll warrant, they'll make it good
the heavens? good Miargaret, stay

my title's good, and better far

thou art as opposite to cvery good.....

the happy tidings of his good escape

if God's good will were so

good fortune bids us panise

ay, good leave have you

to do them good, I would sustain.......

and yet too good to be your concubine

appear by Edward's good success...

he liath good usage and great..........

lands and goods be confiscate

the good old man would fid

stand we in good array

as gnod to chide the waves .............

good was littlc better: good Gilostcr (yep.) -

and that good man of worship...... Richaril

good time of day unto my gracious lord -

which renders good for bad blcsings

which renders good for bad, cheer

good time of day unto your ...........

to your good prajer will searce

good counsel, marry; learn it.

that God bids us do good for evil ....

\section{iii. 2}

iii. 6
-

iii.

iii. 7

iii. 7
iv. 1
iv. 1

iv. 1

- iv. 1 
GOOD-talkers are no good doer Grod give your grace good rest! ........ Rich why, so; now I have done a goorl day's and desire all good men's love ...... for my good uncle Goster told

make me die a good old man!

me scemeth good, that, with some .

no, no; by God s good grace, his so

year your treasure and your goods

and in goud time, herc comes (rep.)..

for joy of this good news $\because . . . . \cdots \cdots$.

he sends yon this good news, that.

hold it, to your honour's good content

[Col. Kint.] hope in air of your good looks -

and your good araces both have well

and

here's a good wordd the while! ....

that did love their country's good

less importing thian our general good

iny lord, you mean no good to hm ...

all good men of this ungoverned is

be of good cheer: Mother, how fares

Richmond, and good fortine guicle thee? -

good angels tend thee! Go thiou (rep.)

cold were os good as twenty...

but think how I may do thee good..

good news or bad, that theu comest.

and brief, good mother; for I am...

births good stars were opposite .......

what good is covered with the face (rep.) -

quick conveyance with her good aunt

all planets of good luck to my

tempit thee to do good.

neither good nor bad! what need'st.

bring I......

prays continually for Richmond's good

good angels guard (rep.) , .............

for any good, that $I$ myself ...........

God, and our good canse, fight xpon

a good direction, warlike sovereign

ordered by the good disuretion of ...

take good heed, you charge not

all the good our Euglish have got....

good compant, good wine, good (rep.)

and to you all good health

by all your good leaves, genticmen

go with me, like good angels

all good people, pray for me!

ont of malice to the good queen.

thint angels love good men with.......

this good man, this just and learued

and soe so good a lady

nay, good troth, - - ves, troth

nds his good opinion to you...

and take your good grace from

arainst the person oft

they should berson

that honour every good tongue biesses

like a good man, your late censure
both for your good wills, ye speak

you turn the good we offer into envy

you wander from the good we aim at

'tis a kind of good deed, to say w wh.

to the good of your most sacred.......

as you respect the common goo

to forfeit all your goods, lands ....
my little good lord cardinal (rep.)

my little good lord cardinal (rep.) ..

must I needs forego so good

hear me speak his good now? yes, good

scholar, and a ripe, and a good

to ontlive the good that did it $\ldots . . .$.
such good dreams possess your fancy

take good comfort ...................
his highness? Madam, iu good health

his highness? Mudam, iu good healt

a right good hussband ............

that it may find good time ........... -

my conscience says slxe's a

glad to catch this good occasion........

the good I stand on is my truth.......

look, good cheer....

now, good angels fly o'er thy roya!

amoug them (at least good manners)

you are always my good friend.

by your good favour, too sharp....

not only good and $\mathrm{w}$ ise, but most

you were ever good at sudden........
this good man, few of you cleserve...

I made good my place ...................

and the good queen, my nobie ........

good grows with her $\ldots . . . . \ldots \ldots$.

merciful construction of good women

now good, or bad, 'tis lyut... Troilus \&

hark, what good sport is ont of tow

and he's a man good enongh ........
is a' not? It does a man's lieart good \begin{tabular}{l|c} 
I. i. 3 & GOOD $\rightarrow$ it does me's heart good .. Troil \\
i. 4 & this will do Ielen's heart good now
\end{tabular}

rood [ Col. Kut.-god] Achilles stili cries a seantling of good or bad

cood words, Thersites.

a' were as good crack a fusty nut...

a good ridrlance. Miarry, this, sit....

a good cuarrel, to draw..

good now, love, love, nothing but (rep.)

it may do good: pride hath no

iii. 2 ay, and good next day too $\ldots . . . . . . . .$.

those scraps are good deeds past.......
had I so good ocension to lie long....

not givea so many good words

you'll ne'er be good, nor suffer other

good, good, my lord; the secrets of ..

he was a soldier good

embrace thee, good nid chronicle

Work done; I'll take good breath

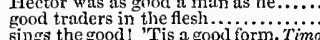

tis a good piece. So tis

here is a tonch; is't good? ...........

good for their meat, and safer for.

no power to make his wishes good

you gave good words the other hay

as good a trick as ever hangman

a fool in good clothes ...............

very boun tiful good lord and master

if he would not keep so good a house

well; good parts in thee..
he is my very good friend...

see, by good hap, yonder's my iord

disfurnish myself against such a good

bountifully to his good lordship

1 will look you out a good turn.

as you are great, be pitifully good

my honour to yont upon his good return

hear me, you good gods all

good fellows all

sin is, he does too miuch goodi...

good as the best. Promising is

and thy good name live with a

and thencerit

to give him good report for'

the senators of Rome are this good belly -

such a nature, tickled with good snecess -

then his good report should have been
dear than thine and my good Marcins

a fine spot, ine and my

you must go visit the good lady.

6o, the good horse is mine.

numhers to make good the city

make good this ostentation ........

we have ta'en good, and good store

more cruel to your good report

for their own good, and ours ......

delivered back on good condition

what good condition can a treat

news to-night? good, or bad...........

an interior survey of your good selves!

wear out a good wholesome forenoon

the good patricians must be visited .

doing them neither good; nor harm

that's thonsand to one good one...

your good voice. Eir; what say you?

shall! $\mathrm{O}$ good, but most unwise......

the power to do the good it widst

a good demand. If it be honour.

in asking their good loves

take good Cominius with thee $\ldots \ldots . . .$. wint -

his good sword in his hand

good man, the wounds that he

all tending to the good of their

a good memory, and witness of the

we stood to $t$ in good time............

may wish good Narcius home again

if they should say, be good to Rome

shows good husbandry for the vöiscian -

good work; a pair of trlbunes that...

and hum a.t good Comini

the good gods assuage tliy wratli.....

good unto usl No, jn such a case (rep.)

strike at him admits a good construction

therefore my good triends be grieved. Julius $C$

aught toward the general g

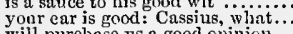

but in the subirbs of your goud plensurs? -
GOOD-take good note, what Cæsar.Julius Casar, to be so good to Cxsar ..............

Publius, good cheer; there is no harm

kind love, good thoughts, and reverence
our rcasons are so full of gond regard

but speak all good you can devise....

the good is oft interred with .........

'tis good you know not that you .....

gond reasons must, of force, give

good words are better than bad (rep.)

and, with this good sword that ran
mistrust of good success hath done

thou art a fellow of a gond respect...
killed not thec with half so good a will

and common good to all, made one...

take but good rote, aud you shall. Anitony \& Cleo.

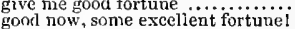

she's good, being gone................. =

good now, play one sccne of excellent

wise powers deny us for our good ....
be it so, to make this good?

be it so, to make this good?............

to trumpet such good tidings?.

does allay the good preced

for what good turn? For the best

at Plilipi tle good Bratus best...

in thee, it had been good service

I could do more to do $\Lambda$ tonius good

good fortune, worthy soldier

the fellow has good judgment.

and the good gods will mock me $\ldots$

a good rebuke, which might have well

when my good stars, that were

never anger made good guard.

married to your good service

and tenfold for thy good valou

what, what? good cheer! why, how now

be of good checr; you have fallen.....

bercave yourself of my good purposes
truly, she makes a very good report ..

very good: give a very good re

and 'twere good, you leaned unto his..Cymbeline

bless the good remainders of the court!

as fuir, and as good .................

an earnest of a further good that $I$

but when to my good lord I prove....

their tenor good, I trust................ -

be our good deed, though Rome.

good gods, let what is here contained

good wax, thy leave: blest be .........

methinks, thy favour's good enough

all good seeming, by thy revolt

can make good use of either....

such a foe, good heavens

goor troth, I have stolen initig

I yoke me in my good brother's faij

my brother make good time with him

then on gnod ground we fear

by good Furiphile, our mother.....

hath altercd that good picture? ......

many, all good, serve truly ...........

O Pisanio! every good servant does not -

madc good the passage .............

sunce, Jupiter, our son is good......... -

thou bring"st good news; I am called

of one mina, and one mind good

that their good souls may be appease

the rood Posthinnus, what shonld (rep.)

of all amongst the rarest of gnod one

how of descent as good as we?

two of us are as good as I have given

good and great deserts to Rome. Titus

the good Andronicus, patron of virtue

of the good that noble-minded.

to gratify the good Andronicus....

'tis good, sir: Fou are very short

take up this good old man, and cheer

must advise the emperor for his good

ay, and as good as Saturninus

madam, to you as many and as good

good king! to be 50 mightily abused!

strength to do thee so much good ....
shall thy good uncle, and thy brotlic

let fools do good, and fair men call.

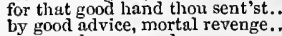

cin you hear a rocd man

it did me good, before the palace-gate

but me more good to see 80 great .....
well, God give her good rest? ........

iii.

v.

ii.

iii.

iii.. 2

iv. 3

v. 5

. i. 1

i. 2 


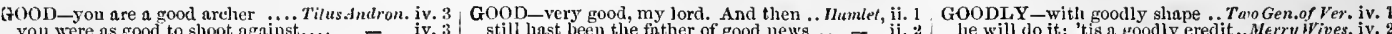

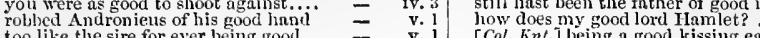

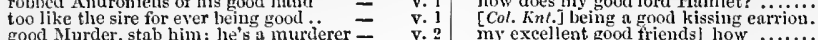

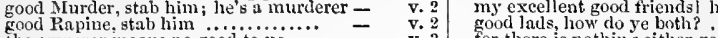

the emperor meaus no good to us...... $=$ v. 3 for there is nothing either good or bid

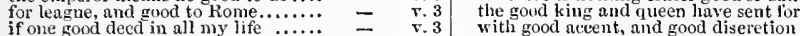

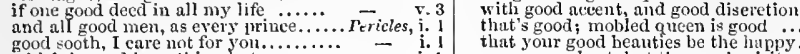

good sooth, I care not for youl.

no revenue hast, but thy good spi

who seemed my good protcetor $7 . . . . .$. .

(Gower)

and was accounted a good nctor.

you are as good as a chorus, my lor

goud llelicane hath staid at home.....

nse of actions tair and good he

and he, good prince, having all lost =

kills the unseen good old man

but if the good king Simonides were.
the good simonides. 'The good king :

peneenble reign, and good government

he gains the nnme of good

the make some goou, but other

to make some goou, hit others $1 . . . .$.

good-morrow to the gool Simonides

now the good gods throw their best

go thy ways, good mariner ..........

by good appliance was recovered

does preptre for good Marina .......

are even ns good as rotten

she has a good fice, speaks well $(\mathrm{rep}$.

for England? Ay, Hamlet. Good.

'twere goorl, she were spoken witl .......

give her good watch, I pray you ..........

to his good friends thrus wide I'll ope....

now you speak like a good ehild
they say, he made a good end.

I am to do a good turn for them........... iv. 6 (letter)
these good icllows will bring thee - iv. 6 (letter)

the water, good: here stands (rep.) ...... - v.
no medicine in the worlil can do thee rood - v.

he, in good time, must his lientevant be. othello, i. 1

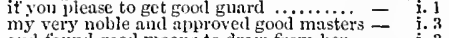

and found good means to draw from lie

and heaven defend your good souls i.....

very good; well kissed! an excellent.

or his gond nature prizes the virtue that
than to deceive so frood a commander...

good wive is a good tamiliar ereatur..........

parallel course, directly to his good? ...

not for your quict, nor your good

he that filches from me my good name.

a good wench; give it me........

founded his good fortune on your love...

tis very good; I must be eirenmstance

that's not so good, now. What, if I had .
and laid good 'sense nopon your eestasy

good, good; the justice of it pleases (

o pardon me; twill do me good to waik

good father! how foolish are our minds

good troth, I think thou wouldst not.

wear thy good rapier bare, and put it

are you of good, or evil? As you shall

alas, good gentleman! alas, good Cassiol

sueh a fool do with so good a wite? .

GOOD-BYE-[Col.] so, good-bye you.... Hamlet,

excellent good-eoneeited thing ....Cymbeline, ii. 3 GOOD-DA $Y$-good-day! I pray. TaioGer.of I cr. iv.

good-day to both of you. Hear youl.. Much
good-day, my lord. Weicome, signior
good-day and happiness, dear.....As you Lit

onee more good-day to thee.. Taming of Shrew, iv.

not speak? good-day, Camillo .... Winter's Tale, i. 2 good-day, my lordi what, at your..3 Henry VI. v. 6 good-day to both your graces...... Henry r' 111. ii. 2
good-dar, good-day. How do you? Troil. Cress. iji. $3^{2}$ good-day sit. I am glad you are.. Timon of Ath.

good-day at once. Weleome, good... - ii.

GOOD-DEED-good-deed, Leontes. Winter's Tale, i.

GOOD DEN-good den, brother...

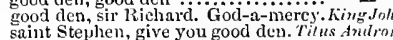

saint Stephen, give you good den. Tilus Anutron
God ye good den $($ rep. $) .. . . . . .$. Romeo of Jul

i. 2 gentlemen, good den: a word with one

GOOD-E'EN, our neiglibours (rep.)... Coriolan?

I must to the learned: in good time

slie was too good for me

making them wrumen of good earria....

when good manucrs slatil lie all in

some speeial good doth give (rep.)...

that's my good son: bit where hast
a very good blade! a very tall (rep.)

madam, good-even to your ladyship

i. 5 good-even, and twenty............... Her

good-even, good tather....... Measure, for
good-even! Friar, where is the provost?

good-even! Friar, where is the provost
good-even to you friend .......... As you
good-even, good master wliat ye call't

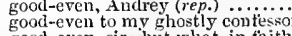

if I see occasion in a good quarrel ...

good heart! and i'faith, I will tell lier

that it would do you good to hear it

if good, thou shamest the
good, good nurse, speak

good-even, sir; but what, in faith ....... Hamlet, $\mathrm{i}$.

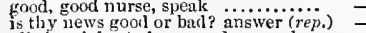

all the night, to henr good eounsel ... -

shall never do thee good: trust to't..

chance to do some good on her

letter doth make good the firiar's words

grod now, sit down, and tell me $\ldots . . . .$.

GOOD-FACED-no, good-fnced sir, Winter's Tale, 1.

\begin{tabular}{r|c} 
ji. 5 & GOOD-FELLOW SHIP- \\
ii. 5 & soul of sound good-fellowslip.. Troilus \& Cress. \\
iti. 3 & GOOD-F RIDA Y-upon Good-Friday. Kinu Joht \\
iii. 3 & sold'st him on Good-Friday last .... H H'm
\end{tabular}

iii. 3 sold'st him on Good-Friday last .... Hem H'yl I

Iii. 5
iii. 5
iv. 2 GOODLLER-to see a goodlier man .... Thenpest

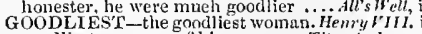
Gondliest weapons of his armonry. Titus Audrom. iv
gono slonld express her goodliest........ Lear, iv
Goon

nor it eamnot eome to good .........
sir, my good triend; I'll ehange

sir, my good triend; [ Ill ehang

this good lesson keep as watch $\ldots \ldots \ldots \ldots . . .$.
good sir, or so; or friends, or gentlemn.

with goodly burden bowing $\ldots . . . .$. iv. 1 (son.

how mally goodly ere

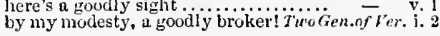

like of it: tis a goodly eredit...Merry Wives, iv. there's goodly catching of cold

a goodly count-eonfect

a goodly apple rotten (rep.)............. inerchant of $\vec{V}_{e}$ ice, i.

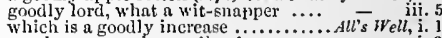
you have wound a goodly clne
sold a goodly manor for a soly

but a goodly manor for a song.....

- iiv: 5

by my fay, a troodly map. Taming of Shrew, 2 (indue. did you study all this goodly speech?

wherefore gaze this roodly company - iii.

you have some goodly jest in hand

spread of late into a goodly bulk... Irinter's Tale, ii.

about to say, she is a goodly lady .... -

have said, she's goodly, comke letween
a goodly babe, lusty, and like to live
such goodly things as you? ..........

joyfly goodly things as you? ..........

ofter of goodly thousaids $\ldots \ldots \ldots \ldots . .$. Macheth,
Eliall show more goodly, and attraet..i Jenry 1 .

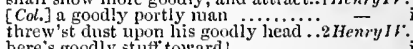

here's goodly stuff toward! $\ldots . . . . . .$.
here's a goodly tumult! I li forswear
in goodly form comes on the enemy.

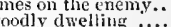

a goodly prize, fit for the devil's ..... i Ilenry $V T$.

pit $y$, that this goodly lioy should lose - ii. 2

and Somerset another woolly mast?...

the fruit of such a good $\mathrm{y}$ tree.........

we have many gnodly days to see
token of a goodly day to-norrow

nor goodly lition stund ....... Troilus \& cressida, ii.

O heart, as the goodly saying is........
goodiy transformation of Jupiter there

thou art a goodly mark; No? .........

thy goodly armour thus liath cost.:

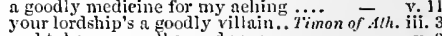

and take our goodly aged men ....... - - y. 2

a goodly eity is this Antium...

you are goodly things, jou voices!

those his goodly eyes......... Antory og Cleopatra, i.

pyramises are very goodly things ....

a goodly lady, trust me ...... Titus Andronicus, i.

you liave a goodly gift in horning $\ldots$
your smow-white goodly steed $\ldots . .$.

a goodly humour, is it not, my iord?

thike goodly buildings left without..... rericles, ii.

make us love your goodly gifts.....
but yet she is a goodly creature.....

seeing this goolly vessel rid

is't not a goodly presene till the disaster $=\mathrm{v}$.

here's goodly gear! $\Lambda$ sail, a sail. Bomeo \& Jutiel, ii.

aroodly one, in which there are many.

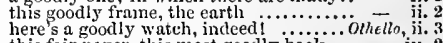
this fair paper, this most goodly book. . $\overline{2}$ iv. 2 come hither, goodman baldpate...Meas. for lleas. y. goodman Verges, sir, speaks a little...Much Ado, iii. 5 via, goodman Dull! thou hast ....... $\overline{\text {. }} \overline{2}$ (induc. ord, I am your goodman ...Tameng of Sh. 2 (induc. but goodman P puff of Barson.........2 Henry IV.v. 3 goodman death! goodman bones! ..... - v. arainst John Goodman, my lord ....2 Henry $/ I_{1}$. i. with you, goodman boy, if you please.... Lear, ii. 2 nay, but hear you, goodman delver.... Hamlet, v. when you have given good-morning. Cymbeline, ii. 3

a thousand good-morrows!. Two Gen. of terona, ii.

and so good-morrow, servant.

good-morrow, gentle lady..........

二 iv.

give your worship good-norrow ...Aifery $\bar{W}$ ires, iv. 3

give you good-morrow, sir

good-morrow, good sir Hugh .........

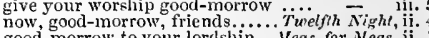
good-morrow; for as I take it.......... for good-morrow, eoz. Good-morrow.... Mrueh Ado, iii. good-morrow, masters; put your torehes - v. good-morrow, masters; eaeli lis several - v. good-morrow, Benedick .............ं.ं.'s Dream good-morrow, triends .............. Lne's 's L. Lost, iv good-morrow, my good lords. Merehum, of Vemice,

good-morrow, fool, quoth I

good-morrow, fair ones: pray you ... $\overline{-}_{\text {en }}$ iv good-morrow, noble captain $\ldots \ldots \ldots$. All's well, iv good-morrow, Kate; for that's your - if. should bid good-morlow to my bride

good-morrow, gentle mistress....

good-morrow, noble sir! (rep.) 


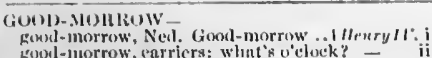
rook-1110row, carricers: whint'a

I tlink, it is goxal-morrow; is it not?

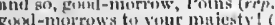

why thith, $g^{\prime}(x)$ d -1 morrow to you in

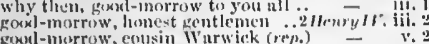

gead-inimrow, emising

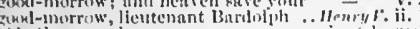

bids the'm gecel-morron

rither licitiond

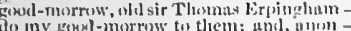

政

goonl-morrow to mily sosereign king. Richa

give you genl-murrow, sir

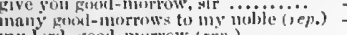

iny lort, tood- morrow (rep.)

nivl eansink, all, good-murrow

when he disth hid gent-murruw with

gond-11worrow, Rithmond.

goxhl-morrow, ladies. What were'.

gond-mosrow, uncle (rep.).... Troilus of

Isain, good-morrow, Ajax

gonk-morrow, lord Anens ..........

gond-morrow then. I'r'y the now, tolied

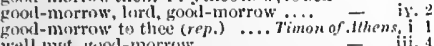

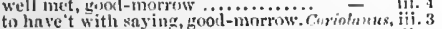

gexhl-inurrow to yoll every one

rolletente gout-morrow trom a ficibi

goul-morrow, worthy ('tear ....... Wiblius -

good-morow, Casca: Caius Ligurius

gond-murrow, Antony, so to innst mold
goul-morrow tis you: here the strect

good-morrow to thee; welermne...hiton

gonl-morrow, general. Groml-

good-morrow to your majes
gensl-morrow, firirest sister.

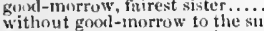

good-morrows, loris: (1 tall me, fitus lis

good-morrow to the goni Simsnid

goorl-morrow, sir. Good
gise you zool-morruw

good-morrow to yon bothi

good-norrow, enusin. Is the ilny. goot-morrow, father! Benetieite! .. - ii. 3

so soon to bid gnot-mornw to thy bed

God ye gon-morrow, gontlemen ..... - ii. 4

gonl he gont

and bid good-morrow, genernl

othello, iij.

gool-morrow, good lientenant ........ Tempst i.

goodness that is cheap in (rep.). Meas. for Meas. iii.

and good ness never fearful

bliss and goodness on you!

there is so great a fever on goodiness.

we liear such goodness of your justice

friend Esealus, for thy much gonduess - v.

her honesty, and achieves her goodness...All's Well, i. I

thy goolness share with thy birt

6o great as the first in goodness .......

the report that goes upon your goolness - Tulu v.

anil your groulness, is so evident..

thine own gooklness hath made

with you, worthy his gookluess

and the ess clares not eheek thee!

thy alundant good ness ahail excuse. Rimart $11 . \mathrm{v}$.

there is some soul of gondness in.

fur Tubot means no goodness.

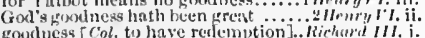

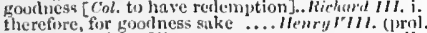

gortness and he fill up one munument! -
if they have any goodness.............

for gorrlnesy" sake, ennsider wiint you do -

to erntirm his gorbluess, tied it

whilst your great gocklnces, ont if holy -

gondness is poisun to tly stomneh ( $r p$.) -

your gindurss, since youm provoke ane
comnenderl to his gondoess the model

from thy endless woulncess ...........

the gormlness of a suarrel.... Truilus f Cressida, recanting fondness, forry' ere 'tis shown

unelone by gondness: strange

enougl to darken all his gorulne..... Antony $\overline{\text { f }}$ Cleo

hut there's no gooshess in thy liu

there inistress exteceds in goolness the... Cymbelin

thy most perfect kionlness lice ansured

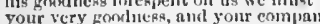

Your very thomlue as, alid your compling

that robs thee of thy gooriness!

wimlom and gnodness to the vile si.......... vile. Lear, iv.

and work, to mateh thy fondmens......... - iv, 7

at a like goxiness still; tor goolness .. Hizmiet,

gomelness of the night upon $\mathrm{yrm}$, friends!. O/hello

die lsolds it a vice in her gord nees......... -

and ont of her own gom noess make the net - it.
(1)1)-NIGIIT : this deet unshapes, Mru. for Mru.iv.3 Foni-night to your reilress

and your own, mul goos-night

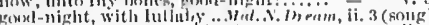

tud gohl-night, swect triemt

so, foost-niplit infor you a!

Giol give youl goul-night!

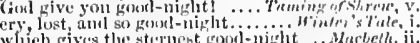

at onece, good-night; of unil not nigen

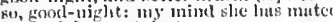

good-nipht, good doctim

cre thimu biul goosl-night

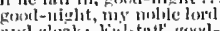

\section{King John,}

unl clonk: lint-tint, wond-

will birl you gons-might ..........

hath bid the worlel sond my gowd-night to hio

goosl-night, pookl euptenin blunt

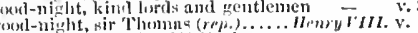

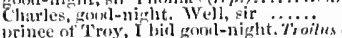

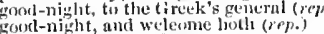

koosl-night, great Ilector ............

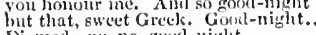

Diumer--130, ro, gond-niglist ........

goml-night. I presthee, fomle........

no more: gonsd-night ; early to-morrow

gonl-nighit, Titinius: mol.

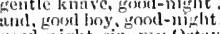

good-night, sir: my Octuvit

Fonumey, gom-night

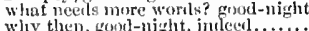

goor - nigght: to morrow is the

froor-night to youl. Well sir (mp.).

to bid my king and master aye good-n

goou-night; I'll to my truekle-bed.

sweet, fousl-night! this but of

gond-night, trood-nigrlit! (rep.

thousand times good-night! ......

goorl-niglit; ani hicre stands all your

tis late; turewe?l, gooul-night ......

madam, good-night, commend ine

gonl-night! get thee to bed, and rest

woll, goot-night: if you do meet (rep.).
gond-niglit; but go not to my umele's bu

once more, gonol-pirlat: and, when you.

mother, goul-night. Indeed (rep.)

ruod-niglit, sweet; good

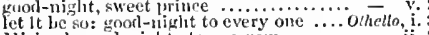

Michael, food-night: to-morrow ....

good-niglit, lieutenant i I must (rep.)
madam, food-night; I humbly thaik.

so, get thee gone; good-night

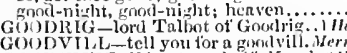

-tell youl tor a gow

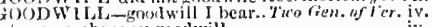

to rentember my goodwil
for my gool will is to it

for my gool will is to it .............. Tempes'

I hope, I lave your goodwill

let me hinve your good
he hath my goudwill

it he coulli gat her gonoliwiii...

had got the gendwifl of this young

with our good will. Tliat you....

may huve your latyolip"s goodwiil.

do beg your goodwill in this eas

1 have your goot will to have mine own

wir gowlwill effects Bianea's grid

cleer may answer ny gonlwili.......... Coredy of Err. ii

my sister, to get her goodwill.

that nfhe, of thine own gorll
I will do my good will, sir

pretend some alteration in gool wili?. Henry $1 \%$. iv.

dwiil

Michard IT. iv.

your good will mitst have that thanks $-\bar{y}$ v. I

yet my good will is great ................. P'erirles, iii. 4

so innch tentry, anl good will........... Iramlet, ij. 2

three nights agro on tioor win sands.. King Jokn, v. 3

minl sunk, on the liondwin sands

GOUD-YEAR-[Cnl.] the good-year! iverry Hires, i. I

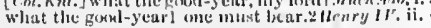

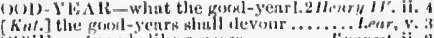

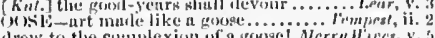

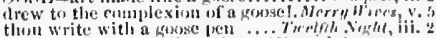

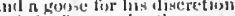

nor the fox earries the gurse for

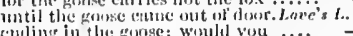

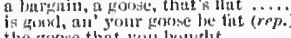

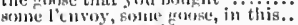

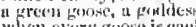

When every goose is a

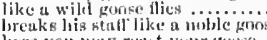

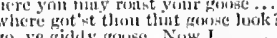

Macketh, ii.

iiirurulr. iii.

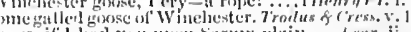

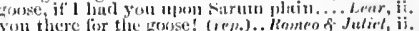

iny, goos Lentere, bitc bint

Well served in to a swect wons
to the goose, proves thee for

are alruill of goose quills, and clure .... Humbet, ii.

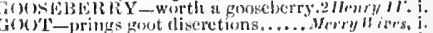

to your worship, goot eaptain

wring as goot a man as yourstif.

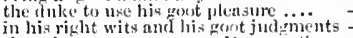

there is gows nen porm at Mrmmoutl

thomgh he be as gint a penticinan.

tlacere is more gost tow wous you

it is with a gont will; I can tell your

will you be so goot, seald knave

imuefingt do yoll, seuld kwave

the skin is goot ior your proken

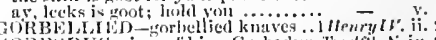

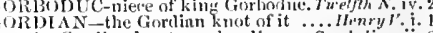
Hs the Gordian knot was lard! ....Cymbetine, ii.

where in gore he lay instecued

Mucteth, ii. 3
Henry 2 .iv. 6

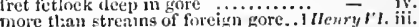

the war recive't in valiant gore.. Timon of $A / \mathrm{h}$.

and this o'ersized with coagruiate gure.. Hamist, $\mathrm{ii}$.

(inED-round haunches gured ...As you Like it, ii.

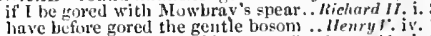

is gored with Menelaus' horn. Troilus of Cressides, $\mathrm{i}$. 1

my fume is shrewdy gored ............ -

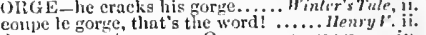

de coulper yostre gorge. Ony, enuljer gorge -

messes to gorge lis apretite ................. Litur, $i$.

my gurge rises at it: here hung ...........Wamlet, v.

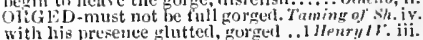

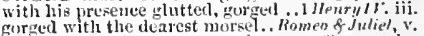
opis lious-tle gorteous pul thees.... Tempest, iv.

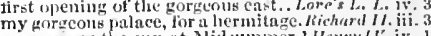
gorfeotis as the sun at Midsummer.! Menry I I iv. I all these, thrice gorto garment .... . lfenryl: iv.

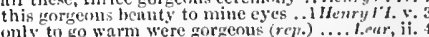

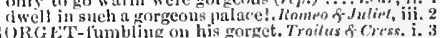

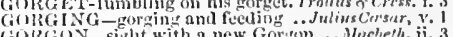
bilinted one way like a Gorgon... An ony $f$ c\%,o. ii.

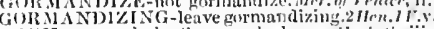

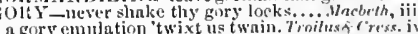

marry, whige thee, gosling: I think.

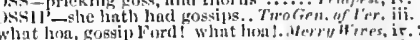

the babbling gossiz of the uir ....7 Therth . Vight,

if my gossip repurt he an lomest. Mer. of Jenice, lii.

na lying a possp in that, ns ever.

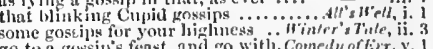

co to a gossip" fenst, and oo with. Comedy of thr v.

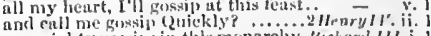

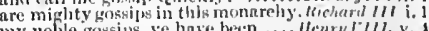

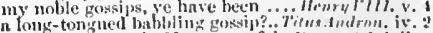

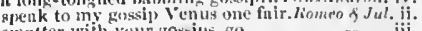

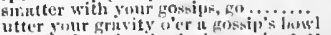

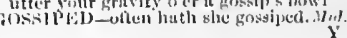

culling in the gange; woulal y'o

it were a geot motion

pour shoce is not so

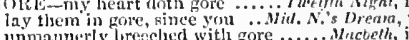

thesc mastcrless and gory sworls. Romen of Juliet,

G(1SPELED-are you an gospeled 
GOSSIPING-to see their gossiping. Comedy of Err. v. 1
of bluod, of nirth, of gosiping..... King Johth, v. of bluod, of nirth, of gossiping....... King John, GOSSOMER-been aught but gossomer ... Lear, GOT $\mathrm{T}$-got by the devil himself ........... Tempes

who hath got, as I take it
by sorcery he got this isle...

fyom sot this isle...

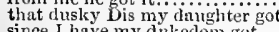

since I have my dukedom

our youth got me to 1 lat

erona, iv.

desire to hear the fiar of Got.

Merry Hives, i. 1

Got deliver to a joytul resire

here is Got's plessing

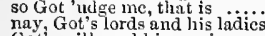

Got's will, and his passion ...........
serve Got, and leave your desires....
who hath got the right Anne?

I got possession of Julietta's bed...Meas. for Meas. i.

he hath got his friend with clit.

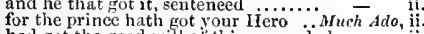

hat got the good will of this young lady

your fatlier got excellent livshun

what a beard hast thou got! (rep.).

You have got me one ...................

that your father got you not
since he hath got the jewel

there was never virgin got

the F rench ne'er got them............

when your sweet self was got

a scar nobly got, on a noble scar

by what rough enforcement you got it
she got the rimg; and I had that ....

he got his wife with child

till Katharine the eurst have got.. Taming of Sh.

so like to him that got it....

before I have got strength of limit

the one ne'er got me credit ..

what have you got the picture
where our desire is got without
Gweltered venom sleeping got.

irinter's Tale,

your face hath got five liundred....

for thou wast got i' the way of

didst not well when I was got....

got with sweariug, lay

got with mucli case ...............

I have got, in exchange for

my appetite was not princely got.. $.2 \mathrm{Heniry} I$

all the riches I got in his service..................

Got's plood! up to the preaches....

ay, I praise Got; and I have merited

Got pless your majesty

trod upon Got's ground and

an' please Got ot his grace ............
Got's will and his pleasure, captain.

here is (praised be Got for it!) .........

I pray you to serve Got, and keep you

when G: t's will is: I will desire

and swear, I got them in the gallia ...

glory of his conquest got $\ldots \ldots \ldots \ldots$..... Henry $V I$, iii.

eities, that I got with wounds...........

had Henty got an empire.

thus got the house of Lameaster

二 i.i

we hove not hot that which got...

by conquest got the crown .......... 3 Heñry VI. i.

the army of the queen hath got the field

and grandsire got, my careless .....

Who air hath got into my deadiy.....
thow these layds are to be got .....

the fox hath once got in his nose

my meei hath got me fame

got my lord chamberlain his..........

he got this Ed ward, whom our

our English have got by the late

that they got in France, with all

have got a speeding trick to lay....

by what means got, I leave to your...

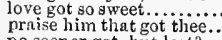

no sooner got, but lost?.....

I may eonfer what I have got.

you have got a humour there

have sooner got another service.
you were got in fear ..............
together, but Aufidius got off

thau hear say, how I got them

I got them in my country's se

the spoil, got on the Antiates ..........
plebeians have got your fellow-tribun

got upon me a nobleness ........Anlony \& Cleo. jv.

what got he by that?

nur voiees have got the mannish crae
only affected greatness got by you....

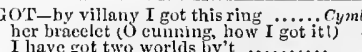

Thave got two worlds by

Tilus Andrant iy. here's nothing to be got now-a-days ..... Pericles got "tween asleep and wake

got iraises of the king for him

daughters got 'tween the lawful sheets...

vieions place where thee he got.......... the tears have got small victory by that

they got clcar of our ship.

v. 6 (lctter)

o heaven! how got she out?

$\overline{0}$ hello, $\mathrm{i} . \mathrm{l}$

GO'TH Wyid, was among the Goths. As you Like. iit.

the proudest prisoner of the Goth
whou yon Goths beheld alive

whon yon Goths beheld alive ......

greater than the queen of Goths (rep.)

by the gods, that warlike Goths adore

hic to the Goths, and raise an army

revenge mpon these traitrous Gotlis..

now to the Goths, as swift as

join with the Goths; and with

is warlike Lucius general ot the Goths?

led by a lusty Got

I must bear thee to a trusty Goth

and you princes of the Goths

and disperse the giddy Goths

enquirc him out among the Got

the cliefest princes of the Goths

Welcome, ye warlike Goths ........
GOT'ST-as thou got'st Mílan...

where got'st thou that goose look? ... Tempest, ii.

by what means got'st thou to be ..... Herry VI. i.

at length have gotten leave

which Henry the fifth had gotten?..3 Henry VI.

once gotten, doubt not of large pay.
GOUGH-send you Matthew Gough.

UJERE- what the goujere [Col.Knt.--good-yea

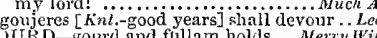

GOUT-do curse the gout, serpigo. Mi as. fir MIeas.

GoU man that hath not the gout... As you Like
rich mand
and dudgeon, gouts of blood .......... Macte
but the gout ga!ls the one........... Henry

a pox on this gout! or a gout on
than one that's sick o' the gout.

2 GOU'TY-he is a gouty Bria:eus ... Troilus \& Crcs

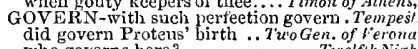

who governs here?

governs lord Angelo ....... Mcasure for Measure

if such a one be fit to govern, speak .. Macbeth. iv.

govern the motion of a kingly eye .. Kints John,
and for mine, sir; I will govern it ..2 Herny $L V$.

of age to govern of himself?.......... Henry ${ }^{\prime}$

king Henry govern England's helm

not fit to govern and ruie multitudes - v. 1

how should you govern any kingdom $-\bar{l}$ them, and till then, govern well... Richard 11 .

then, and till then, goverll weil..... Richard 11 .

high powers, that govern us below. Jutius Casar,

is all atiaid to govern thee near him
Venus govern your desires .. Tihus Andronicus,

but yet let reason govern thy lament
thyself should govern Rorne and ine

may 1 govern so, to heal Rome's harms

high estate, is left to govern

abcve us, govern our conditions

she's desperate: govern her.......

GOVERNED-ever governed fren

due sineerity governed his deeds. Meas. for Meas.

and now governed by stops.

being governed as the sea is

are altogetler governed by hum

Henry 1 i $\mathrm{i}$.

rotspur, governed by a spleen

$I$, being governed by the watery ..2 Henry IV IV . . that land, that's governed by a child! - ii. governed with our mothers' spirit

a father by thy step-dame governed.Cymbeline, ii. i governed our determined jestr. Tilus Andronicus, $\mathrm{v}$.

GOVERNESS-governess of floods. irit. $\ldots$. Dear, iv,

of government the povernment I cast .. Tempest,
or ies to...Meas. for Meas.

or diseover his government.

now in the government of lord Angelo

a sound, but not in government. Hid.N. Dream,

must be even in our government ... Richard $I I$.
be men of good government ........ Henry $i$

want of goverument, pride, haughtiness -
under whose government come they
GOVERNMENT-yoke of government. 2 Hen.IV.iv. 4 for government, though high, and low. IIenry $V$. i. 2 whereof I had the government...... Henry VI. ii. resign my government to thee ....... - iv. that no dissension hinder government = iv. in bearing weight of government ......
there is a hope of government
IVI. kingly government of this your land $\bar{v}$ iifi. ii. 7 wife-like government, obeying....Henry VIII. ii. Tharsus, o'er which I have government. Perieles, $i$. peaccable reign, and good government

peaceable reign, and good government

deprived of supple government...Romeo \& Juliel, jy demuting Cassio in his government

OVERNOR-governor doth ride. Meas. for Blea but this new governor awakes me

thy lord, thy king thy gove...ner. York lord governor of England. Taming of sh.

how yet resolves the governor.........Henry $V$. iii. being ordained his special governor. now, governor of Paris, take yonr

Picardy hath slain their governors..2 Henry VI. iv.

Rome's gracious governor! .... Titus Andronicus, v.
where's the lord governor? Iicre ...... Pericles, i. lord governor, for so we hear you are.

and are the governor of this place.....

and in it is lovsimachns the governor...

1 am governor of this place $y$

I am glad on't; 'tis a worthy governor out

my hopes do shape him for the governor -

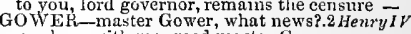

go along witi me, good master Gower

will you sup with me, master Gowcr?

master Gower, if they become me not

was porn at Monmontl, captain Gower.

under captain Gower, my liege (rep.)

know'st thou Gower? He is my dear
stand away, captain Gower ...........

as my friend, captain $\mathrm{G}$ owe

(Gow ) OWN-put off that gown, Trinculo .. Tempest, iv.

in madam Julia's gown ...... Two Gen. of veror

pray you, give me my gown.......Merry Wives, iii. there is no woman's gown big enough - iv. 2

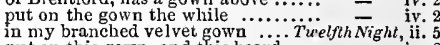
put on this gown, and this beard ..... = that ever dissembled in such a gown
without thy beard and gown ........ without thy beard and gown ......... Mea furred gown to keep him warm .... and your gown's a most rare

and one that hath two gowns

over the black gown of a big hieart .....All'sWell , i. 2 lay forth the gown: what new's.. Taming of Sh. iv. like to have neither cap nor gown $(\ddot{r} \rho$. $)$

apparel, for an almsman's gown ...Richard 1

like an old lady's loose gown ...... HerryIV iii. 3 thou shalt go to the wars in a gown.. what colour is my gown of?...........

our bodies, in black mourning gowns., 3 Henry $I^{\prime} I$. I have lost my gown ........... T'imon of Alhens, iii. for I cannot put on the gown............. Coriolan $\overline{\text { iins, }}$ ii. I have here the customary gown .... I have here the customary gown $\ldots . .$.
wolvish gown [Col.-toge] should I stand Lucius, my gown: farewell, good...Julias Ces ar,

1 put it in the pocket of my gown.... -

I have a gown here; come, pat it on ...

robes, and furred gowns, hide all ......... Lear, iv for shame, put on your gown ............ Othello, $i$. RACE-the noblest grace she owed ... Tempe save our graces!

a grace it had, devouring

and with her sovereign grace

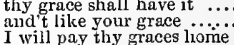

of whose sott grace...............

that swear'st grace

and seek for grace $\ldots \ldots \ldots \ldots \ldots \ldots \ldots .$.

with all good grace to grace a gentleman -

eannot your grace win her .......... -

what would your grace have

the grace that with such grace hinti

than I prove loyal to your grace

not live to look upon your graee

the heavens such grace did lend her.

your grace is welcome to

to make your grace to snitil

the boy hatl grace in him.

7 2
2
2
2
2
4 1)

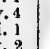

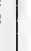




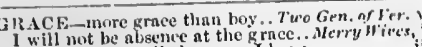
they have not so little grace, I houe .. if you will leut these grnces grace, and good disposition 'teic. put vour grace in your pocket......... $-\bar{y}$ y. thou ne'ver wast where graee was snid why not? grace is grute, desprite of all may yoll grnee sjerak of it:.......... unless you linve the graee liy you henven gise thee moving grues with one lralf so gond a grate. grnee go with rou? Bencet but graee freing tlie soul of your grace to stand, nna virtue go

Gluen onue our grnee we linve forgut

har return lo your ruynl grnce

that's $I$, nn't like your grace ........

heayen shield your grace from woe.. agninst vour grace in your ret

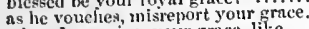

when I perecive, your grace, like.

in the likenes of your grace.

jhense it your gruec lenim on to...

now that is your graces yart.

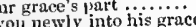

graces will appear, and ticere a that your grace had got the good will will your grace commend me niny therefore your grace ma well s. his grice hath minde the mateh (re

hath your coee neer a brother your grace is two contly

till all graces come in one woman (rep) as huslied on purpose to grace harmony if half thy out warrl grnee hiad been

that all the grace she hath left ..... I do critreat your grace to pardon m but I besecel your grace, that 1

0 , then, what graees in my iore do.. more my prayer, the so in grace as you if you have any pity, grace, or manier came here in grace of uur solemnity so plense your grace, the prolugue is I am thy lover's grace; nnd like .... truly thic monn shines with a good grare hand in hand, with fairy grnee, will we then grace us in the disgrace of.... a maid of grace, and complete majesty by might mastered but by special grad by for I nm his grace's tharbor

of all dear grace, ns nature was (rep.) of to win grace though he had no wit. I hear, your grace hath sworn-out .. so ylease your grace, the packet is no and fair desires consort your grace to gratify the table with a grnce God give him grace to groant. thy grace being gaiaed, cures all good heart, what grace hast thou ... your grace needs not fear it ........... though few have the grace to do it .0 wit's own grace to grace a learned fool where s her grace? Thy news, Boyet?
shall have the grace, despite of suit. render we no grace; but, while 'tis... I do adore thy sweet grace ' 8 slipper.. purifies itself and turns to grace

your grace is perjured much ........

of that loose grace, which shallow ... while grace is saying, hood mine ..... wear my dagger with the braver grnee the best grace of wit will slior

ready, so please your grace $\ldots \ldots \ldots . . .$. I hnve heard. your grace hath titen.
I have possesed your grace of what Bellario greets your grure........... 5our grace sluall understand. that.. to fill up your grace's request in my mightily grace himeelf on thee.... d* no, I warrnnt your grace; I am not
yes. I theacech your graec; I am not yet I do besecell your grace, let me .... they are as ionncent as grace ittelf
linpy is your grace, that can trunglnte rour grace was wont to lnugh

resiler thint = their graces gerre them but as enemies? the enemy of all your praces lives with all graces witle enlargerl but yet have the grace to comsisior yourself gond, and not to grace me tears graee his rementirance more by grace itself, I swear: you know and find your grace in health.....

\section{shall continue our grnecs towards}

ii. 1 renown, and grace is dead

ii. to grace us with your royal.....

ii. with such grace, that the malevolence

ii. 1 what's your grace's will? .............

ii. 1 wear the brows of grace, yet

\section{by the arace of Grace, we will perform}

out of your grace, devise, orlain ... Kin

so shall it be; your grace shill stay.

to graee the gentry of a land remote

to graee the gentry of a land
your grace shall pardon me.

yourgrnee shall pardon me............ and, by the grace of God ....................... did grace our hollow parting with here comes his grace in person grace me no grace, nor uncle me
beseech your grace, look on my it beseech your grace, look

but we must win your grace

how brooks your graee the air

why looks your grace so

your grace mistakes me $\ldots . . . . . . . .$.

should grace the triumph of great ...

of rue, sour herb of grace ............

Eave your grace: I do beseech ( $r e p$.

ii. 1 thrive, if thou grant any grace! $\ldots$ mourng

save thy grace, majesty (rep.) ......

well, an' the fire of grace be not

violently carried away from grace...

Four grace would take me with (rep.)

that's the nenrest grace it renders you
the archlishop's grace of York, Douglas

I heard your grace eay so.............

I would, you would accept of grace.

to grace this latter nge with noble

chid his truant youth with such n grace -

how tares your grace? si

if a we not send grace, pardon .......
I beseeh your grace, I may dispose
and dic grace the shame of those....2 Henvy

he may keep his owa grace

please your grnec, I am a poor widow
this is the riglit fencing grace, my lord gave your gruee! And yours

be henrd of your grace s coming

O the Lorl preserve thy tood graeci

what snys your grace? His grnce say.

plense it your grare, to go to

then, my lord, unto your grinee to

that bears such grace, into the liarsh

to tell you from his grace, that he

to meet his grace just distance $\ldots . .$.
before, and greet his grace: my lord

before, and greet his grace: my lord

the grace, and sanctities of heoven

I sent your grive the purcels

pleaseth your gricl:, to askwer .......

ii. 3 I plenpe your grace; and, if you kncw

I beseech your grace, let it be bookel

nor lose thie good advantage of

your son, cluth kiss your graee's hand

will't please your grnec to go along..

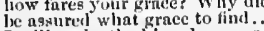

I will make the king do yon graee.

God gnve thy grace, king Inl! .......

the king is full of grnce, and fa
low his grace slonld glem it.
GRACE-opened to his gruce at large

Hiturys: i.

your grice luatli cause, and menn

minto whose grace onr passion is.

hy this arace, piny a set.

ture Gool his gruec is belel, to trust

do your gruee inesssunt services

the cool nour teminerate wiod of $\ldots$ rrae

pur in gruce de Dieu

snyive, our crnee is only in our hecl

gayiul, our grnee is only in ourelect

as lung as it pleases his grace $37 . . . .$.

look your grace, thant he kecp hounur
your yrace does me as grent honour

nin' please Got of his grnee, thint I

plenseth your grace, to al suint

to win the Dauphin's grace

to look to heuven for grnee? ........

we grace the yeoman, by conversing

is not his, we know your graee to be.

your grace may starve, nerhaps......

tis my God, nnd next unto your grace

whit neans his grace, that he...

we institute your grace to he ............

how doth your arace afiect

to your grace in marriage......

prize, fit for the devil's grace?...

sour grace shall well and quietly conjoy

mad, natural grnees that extinguish

because you want the grace

priness M I argaret for

so it please your grace, herc are....

we here dischure your grace from

but grace. But by the grace of Gorl (vep.) -

as by your grace shall be propound ted

work your grace's full content

whether your grace be worthy, yea, or no -

whit needs your grace to he protector
we make your grnec lord regent o'er

your grace shali give me lenve

your grace could fiy to heaven?.....

in the north, an't like your grace...

yes, my lord, if it please your grace.

go plense your grace, we'll take her.

I summos your grace to his.

an't please your grace, here my......

I should have told your grace's tale

cool in zeal unto your grnee.

we intend to try his grace to-

and ealls your grace, usurper, openiy

so might your grace's person be......

please it your grace to be advertised

seditious to his grace, and to the stnte

I present your grace a traitor's hen

and not to grace in awrul princely for grnce. Wouldst hnve me kneel?

do repute his grace the rightfni.

and kneel for grace and merey

about that which conecrns your grie.

forbid, your grnce shonld be fursworn

what would your grace have done.

wilt thou kncel for grace ..........

ask will do wher, and your grace command

twill griere your grace, my som

jour grace hath ntill heen famed

one thing let me blame your grace

by the grrae of God, king of..

that waits upon your grnce?..........

and eheer his grace with quick

of day unto onir royal prnec

his grace sneaks cheerfully

speaks your grnce? To thee (rep.)

his royal grate, whom God prescrve.

we will tend upour your grnee......

why looks your grace fo henvil your grnee good rest!

turn his liate upon your grace .......

take our brother Claresec to your grnce -

we wait upon your grnce

I did not see your fraec..............

that her grace did leave it ont.

virtuous uneles to protect his ernce.

small herbs lave grace

I could have given my unele's grace

.

God bless yum grace with heulth

come with me tu mect your graee...

will your grace personde the queen

two weighty fur yrur grace to wear oin - 


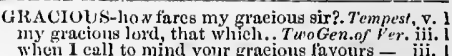
thank his grace, he loves me weil

his graee looks cheerfully and smootly

myself secure in grace ant fivvour....

miunentary graec of mortal men (rep.

at any time, to grace my stratangms
good grices looth have well procecdell

your graec's word shall serve

doth entreat your graec, iny nobie loird

to have some conficence with his yrnce

[Col. Knt.] frate the sovereignty thereof
Grid defend his grace slould sny no nay

what suys his grace? Ile wonder

thencl thereot

see where lis grace stands tween...

[Col.Knt.] your graee to pardon nie.

what is your grace's pleasure?...........
would it might please your grice

this argues eonseience in your graee

God bless your graee! we see it

then we will attend your grace......
God give your graces both a happy

motlier, how fares your grace!

your grace may do your pleasure $\ldots .$.

- you hercin prescntly]............ -

to put your grace in mind of wlint you
that called your grace to breakfast onice $=$

true, when avoitled graee makes destiny

if grace had blessed thee with

and mees your grace, where and what

to grace tlyy brows withal ....

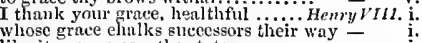

like it your grace, the state ..........
ay, please your grace. Well, we shail

of the king's grace and parton....

put the grnees that once were his ......

Jis graee is entering: nay....

your graee is noble .....................

thus they prayed to tell your grace

they have done my poor house errace
my lord,- your grace! Pray, tell them

my lord, - your grace! Pray, tell the

your graee is grown so plensant......
an't please your grace sir Thoma

an't plense yourr grace, sir Thomas
your gruee, I fear, with daneing
I do beseech your wrace, for charit.

commend me to lis grane

water side I mnst conduet your........ grace

good-dlay to both your graces.........

your grace bas given a preeedent
your graec must needs deserve all

your graec must needs deserve all ...

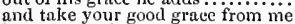

his grace hath spoken well, and justly

pray their graces to come nea

your graces find me here purt of

obedience he still bore your grace.

your grace would leave your grief

your grace could but be brought t
of your best graces in your mind

of your best graces in your mind ....

your royal graces, showered on me dnily
for your great graces heaped upon me

let his grace go forwarl $\ldots \ldots . . . . . . . .$.

cured me, I humbly thank his grace
I am glad, your grace has made.....
while her grace sat down ...........

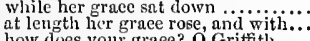

at length her graee rose, and with....
how does your graee? O Gritfith $\ldots . .$.
but, I think, your grace, out of the pain
you note how mucl, lier grace is altered

mine own service to your frace .......
that lis noble grace would have some

of his great grace and princely care.

your graee must wait, till you .......

your yrace may enter now

may it please your rraee, $-\ldots$ no,

may it like your graee to let my ....

und to your royal grace, and the good =

had I a sister were a graee.... Troilus \& Cressid

you are in the state of grace." Grace!

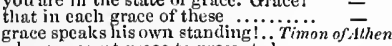

ghose prescnt grace to present ilaves
our pleasures mueh grace, tiuir ladies

even so thou outrun'st grace ...........

and be denied sueh common grace.
use him as the grace fore meat ....

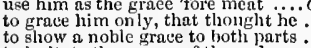

to imitate the graces of the gods

dost thou think I'll grace the

to grace in eaptive bonds lis ...... Jultins $\bar{C}$ cos

we will grace his heels with the most
do grace to Cxesar's eorse, and grace his

and whose general graees ... Antony \& Cleopat

further this act of grace.

now hazarded to thy graee

give me grace to lay my duty ..........
grace grow where those drops fali .

to grace it with your sory
who is so full of grace.

where he for grace is kneeled to......

in her strong toil of grace...............

past rrace? past obedicnee?
whep....
whieh, by their graces, I will keep

but tis your graecs that, froni niy

to criticnt your graec but in a smial

and on promise to sce your gruee
all joy befal your grace, and you

meal, and bran; contempt and grace

if our grace enin monke due

by our hreatness, nuld the truce of

liighly honoured of your grice. Titus

thus much 1 give your graec to know
and bet for fritee in vain: eome, eorne

and his nephews kncel for gruec

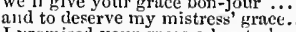

I promised your grace a hunter's peal

no grace? no womanshood? $\Lambda \mathrm{k}$, lecastly

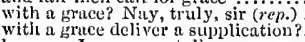

how can 1 grace my talk.
you could not ber for grace

You could not beg for grace.............

graces her suljects, and her thounglits
your grace is welcumte to our towit...

your grace is weicome the our tow

he thauks your gruce; names himself

I um at your graee's pleasure..........

your gruee, that fied my country
we'll bring your grace even to the

mistress, on whose grace you may

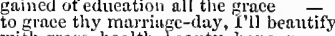

may fitly like your grnce, she's there

mey tity like your graee, she's there...

without our graee, our love, our benison
stood I within his grivee, I would prefer

fools had ne'er less grace in a yc

for him I thank your graee

your graees arc right weleome
against the grace and person of my waster

let me bescech your grace not to do so

hail to your graee! I am glad to

what means your grace? Who stoclied

marry, here's grace, and a cod-piece ...
and cry these dreadful summoners grace

low fares your grace? What's he?

I do besecch your gritee, $-\mathrm{O}$ cry you
y

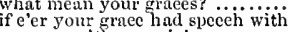

graee go with you, sirt

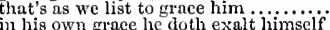

God mark thec to his grace! ..... Romeo of

o mickle is the powertul graec.....iij

doth grace for graee, and Jove for love

to thee do case, and grace to me...

in grace whereof, no jocund hearth

(be they as pure as grace, as infinite.

angels and ministers of grace defend us

so grace and mercy at your most need.
thy self do graee to them, and bring them

that your grace hatll screened and stood

what a grace was seated on this brow

mother, tor love of grace, lay not that

eonseicnce, and grace to the profoundest

convert his gyves to grnees $\ldots \ldots \ldots \ldots . . . . . .$.

your grace hath lnid the odds o' the
good your orraee, pardon me; neitler

himbly I thank your grace; here is thic

please it your grace, on to the state affair

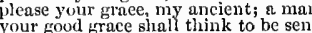

the grace of heaven, before, belind thee

and denotement of her parts and graces

if I have any grace, or power to move you
O graeel o heaven defend mel ...........

untin me, - have graee and favour in the
some rrace, yet have we some revenge

some grace, yet have we some revenge
unreconciled as yet to heaven and grace

RACED-was never graced before.... Tempest,
daily graeed by the cmperor. Two Gen. of Verond

daily graeed by the emperor. Two Gen. of Verona, i.

were the graced person of our $\ldots . . . .$. . Macbeth, iii. 4

antl blessed, and graed indeed $\ldots . .2 \mathrm{Henryl}$

Knt.-dulled and cloyed with gracivus $H$ Henry $r$, ii. 2

her virtues, graced with external ..1 Henry $V /$
and grneed thy poor sire with his ..3 Henry $V$.

and we are graced with wreaths.

ever graced me in thy company?.. Richard $11 \%$. iv.

in whom already he is well graced... Coriolanus, i. 1

nind gracell the thankings of a king... Cymbeline, y.
to intrude where I am graeed.. Tillass Andronicus,

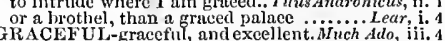

a holy fither, a graccful gentleman. Winter's $T$.

and gnve him graceful posture.
not with graceful eyes attend..

Coriolanus, ii.

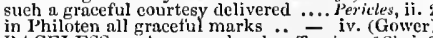

in Philoten all gracetui marks ... - iv. (Gower)

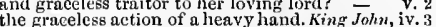

graceless! wilt thou deny ..........1 Hemry $\mathrm{r}^{\prime}$. v.

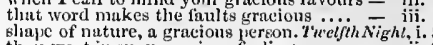

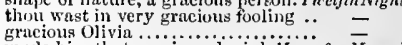

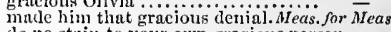
I am a brother of gracious order $\ldots .$. .

to you, fair and gracions dungliter

O gracious duke, harp not on that
to try her fracious fortune with

to try most graciocious lord, I lope you

iiv. 3

and, my graeious dulke, this hatly... Mid, N.'s Dr.

ard, my procious duke, be it so......
to make it the more grncious, I slaii

for, by tlyy gracious, golden, glittering
in such apt and gracious words .. Love's L.L

lier mistress is a gracions moon......
the way to make mun offenee gracious

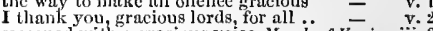

seaconed with a gracious voice. Merch.of Venice,

shamcd that was never gracious ... As ymo like ii, i. ?

the paper to tais aracious luind........

my gracious sovertign, howe'er it

gracious sovereign, whetlier I have

my gracious lord, I may be negligent

and comlort the graeious queen .....

how fures our gracious lady? As weil

a gracious innoeent soul; more free..
and gracious be tlie issue! ..........

and graeious be the issue!

their issue not being graeious, thian.

sir, my grneiout lord, to chide at ....

the gracious mark o' the land ......

graeious my lord, you know your...
vearest to him, which is your gracious

thicreture, most graeions duke...Comedy of Errors, v.

justice, most gracious duke, on, grant

for them the gracious Duncan have I. Macijeth, j.

the gracious Buncan was piticd of

and here, from graeious Englaind

gracious England hath lent us good...

what is your gracions pleasure?

my grucious liege, when that my....... King Joln, i.

there was vot sich a gracions creature

my grneious sovereign, my most .... Richard $\mathrm{l} h$. $\mathrm{i}$.

but eoneeit, my gracious lady $\ldots \ldots . .$.

$[C o t . K n t$.$] the most gracious regent$

my graeious unele! Tut! tut! grace

my graeious unele, let me know

springs from one most graeious head

with all the gracious utteranee.

my greious lord, $\bar{I}$ cone but for mine

my graciuns lord; for more unev
is well known, my gracious lord

shall herenfter, my thrice gracious lord

for lie is gracious, if he be observed...ZHenry $I$.

my gracious lord, you look beyond.

my gracious lord! my futher

my gracious lotd of Canterbury?

then hear me, gracious sovereign.....
gracious lorl, stind for your own...

ot those marches, gracious sovereign $=$ i.

the general of our gracious enpress - v. (chorus)

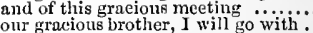

my graeieus lords, to add to........... Henry VI.

heaven, and our lady gracions....

be thon gracious to none alive ......
my gracous prince, and honournble

my gracious suvercign, as I rode from
grant ine the combat, gracious sovereign!

grant me the combat, graeions sovereign! -
as deputy unto that gracious king....

to vour inost graeious hands ..........

of England, and my gracions iord....

all health, unto my graeious sovereign!

gracious lord, these days are dangerous! =

how fares my gracious lord? (rep.)

my gracious lord, entreat lim........

my gracious lord, retire to Kenel worth

(n)

open thy gate of merey, graeious Good!

my graeious liege, this too much jenity

my gracious fatler, by your kingly leave =

right graeious lord, I eannot brook ..

three, my most graeious jord .... ' do it better said than done, my gracious lord

gracious lord, flenry your foe is taken
those gracious worls revive my.....

Fraeious madain, in our king s belial

gracious sovereign; they are so linked

yet, gracious madam, bear it as ......

time of day unto my gracious lord...
bey one favour at thy gracious hand. 


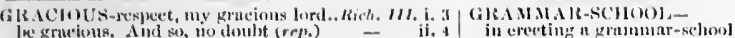
Ine gru'iour. And so, io doubt (rrp.)
unkiown to me, my gracious laty iny grueious lauly gu: und thither beur

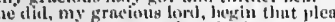

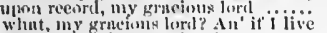

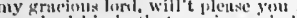

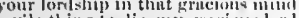
are thina to die, imy grneisis lord his graciotus plensure my way therein

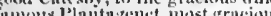
gracisus sovereign. tive me thy luid prose me, my grielous loral

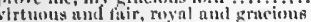

grneious sovereign, nin in pevonshir

here, most aricious linge. Noriblk

traitury, gracious lord, that wonla reduce

a gracints king, that purdons ail ...

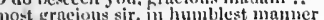

he's living, mul most grueitus

jov, in this nost grnejous laly

gomd and gracious nat ure hanging. Timnn nf.Ath

my gracinas silemee, hail

so his gracions nat tare woubl think upon -

either his gracions promise

by your most aracious parion.......

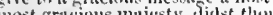

most gracious mikjesty, (ficst thot

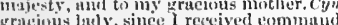

tranious sir, lere are your suns agnin

(1) sce this graciuns siason

grnegens in the eyes of royal kome. Fitus Anu

rateints havinin, kome's rich orn

he ns just and griteions unto me....

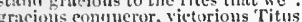

rat ious triunpher in the cyes of liomel

nuke's me less gracisus, theo more

lear soverefin, nild here

my urueious lord, no tribume hears

tor! $O$ antle Anron!

my uracious lorl, my lovely saturnine

weleothe, my graeions lord

Rome s gracisus governor!.............

calls my gratcious lord? Thou art n gr

alack, bircheaded graeists my lor.

and a tracious aged mun, whose reverence

so hulliwed and so gracious is the tim

to your gracions leave and prialen

ti) my god, all to my gractons king
what wous, so plense ynt, we will bestow
what would your grations figure?

thy state is the more gracious
the Ottomans, reverend und

yet, by your grncions patience, I wiil ....

graeisus duke, to my unlolding lend

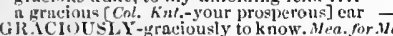

sinee Ciod so uraciously hath brought.. Henry $l^{\prime}$. it. lid zracionsly pleud for

lowk gracionsty on him

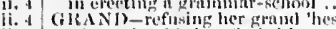

Thesest, is

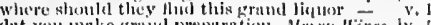

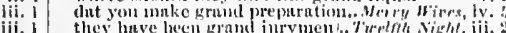

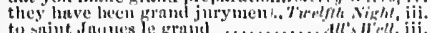

bilgrimuge to raint daques le grand

the grami complirutor, ulbbot of

suivex-vous le grnud eapita
that execllent grund ty rant

produre the graud sum of his silis...14mry III, iii,

the norte lent to his grund

of your grand [ kinl, wreat] ispeet

to mincent their griml eommission ....... ihuthet,

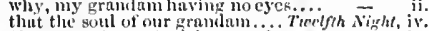

dispostess the soul of thy gramiam

might luye been a grandam ere .. lare's L.lost y.

to plense lis grandium ...........

authisized hy her grandam

Mecheth, $\mathrm{jii}$

there's a food grandam, boy $\because \ldots . . . \%$
thy gramlam, ehild. Do, child (rep.)

his grantlum's wrongs.............ii! ?...

grandatn, I will not wish thy........

thy grundim loves thee; and thy uncle

gramiam, a will proy (itever I reinember - - ii. 3

at your birth, our grandam earth ... I/fenry/I'. iii. I

your grundam had a worser ........ Richarth /W. i. 3

good grandan, tell us, is our fither.

grabrian, we ein; for my good uncle

my unele dict dissemble, grandun

grandam, this would hove becin n biting

my grandam tolul me, he wa...........

ludy was fitirer than hiegrandam. Troilus \& Cress. i. 3

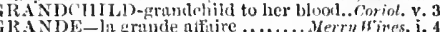

IRA NDEUR-yostre grandeur.

Vienryt:. i. 2

\section{GRANDFATHER-}

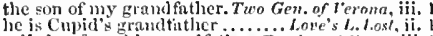

called so from his grand father. Taming of Strere, jii. 1

Joln of Gaunt, your gramelfit

a seal-ring of my grandiather's..... n- iii. 3

my grent grandfither, never went

his grandfather was Limel hluke..

IJenry the tiurth, grnulf father to

thou bnstard of my grandfatlier!..... - in ii. I

my father, and my grandather,

message from his mad grnudfather... Timues Ane, iv. 2

GRAND-JUROR-are graud-jurors..1 Henry!W, ij.

the son of thy grandmother . Tuo fren. of ler. iti. I
child of our grandmother Eve. Lore's L. L. i. I (let.)

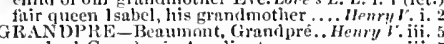
my lord Grandipre. A valiant

of lusty earls, Grandpré, and Roussi her grantsire leave her seven hundred - i. I do, good old grandsire ...... Taming of Siren. my grandsire was an Englighman, .. King John, stands upou thy royal grandsire's bones - iii. 3 thut our great grandsire, Edward ...3Henery I iv.

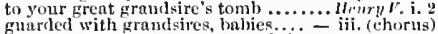
wherein my granclsire, and my father.3 IIemy $I^{\prime} T$ i. 1 great-grandfintler and grandsire got

was monldy ere your granklsires had

I knew thy grandsire, ant onee fonght -

good grandsire, lenve these bitter. Tilus Andro

to gee his graudsire's heaviness ....... -
hell, grandsire, help! my aunt Lavinia -

heard my trandsire say full oft. ...

gramlsire, 'tis (Ovid's Netamorphosis

dagger in their bosoms, gran
my grandsire, well-anlvised

tliy grandsire lovel thee weil

6randire. gramdsirel even with all

proverbet with a grandsire phrase.. Women

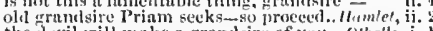

the dhevil will make a grandsire of $y^{\prime}$ oul.. othello, i. 1

thoul goest to the grange... Winter's Tule', iv. 3 (song)

GRANT-how to grant suit

will you grant, with me that

crona, ii. i

to grant one boun thint i

I grant it, for thine own
grant me another request.

well, crant it tlien

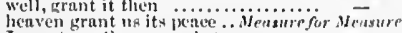

the fuirest grunt is the necessity ............ Murefs.sido,

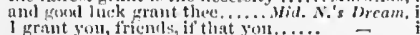

Gol grnit us patience?....

so you prout pasture for me.

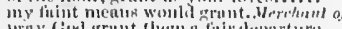

the duke shall grant anc justice.

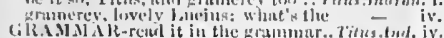

iRANT-Will never grunt this. Merrhe of lenice, iil. 3

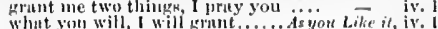
mul, worling, fhe shumld gront? ....... wiph receive, which greut Iove grant! - ii. ancl kres to grant, reprieve hin from - iii.

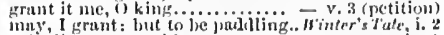
a death, to grant this

wil grant preseoss things …........

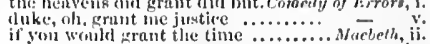

I grunt him blooty, lixuriou

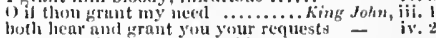

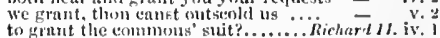

thrive, if thou ginat any grace........ I grant you, I was down , ............ grinit, that sur hrues, set lekely ii.. -

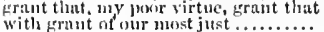

aud grant it may witis the

I hruit your worship, thut lie

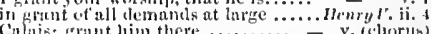

to wite funt him there ...

grant anc loe combat (rop.)

ilsenryltiv.

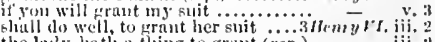

the ladly hath a thing to grunt (rep.) - ii :

which virtte begs, and virtue grants

it thou volichsafe to grant tlat virthous

your grant, or your denial.

it was my will, and grant....

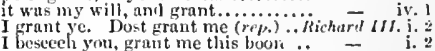

God grant him healthe this boos

God grant we never may jiave (r

unjutty too, must grant it youl.......

the gails grant! Omy lord! (rep.) Trroilus of Cres. iii. 2

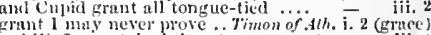

to kill, I grant, is sin's extremest guit o iii.

and grant, as 'Timon grows, his hinte

Which the forls grant thee to attuin to?
grant, I nay ever love, and rather woo

he porls grant them true! ........... Cortolunes, if.

entresty and grast of the whole tuble

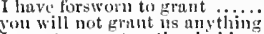

I frant, we put a sting in him

ghant, 1 am al waman (, ep.)

grant that, anis then is deat

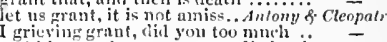

und his sword, grants searee distinetion

thon meanest to lanve him arniut thee

I grant we were to question further.
grant, heavens, that, which i fear...

thy words, I grant, are bigger...

by whom, I grant, she lives...

little space for prayer, I grait

grant thou, lest tiith turn

before your lanlyslipip, I grant, she puts... Othe?

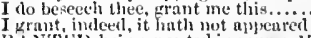

GRAN'THD-beine granted in eourse.Mea. for.Mea. iii.

come on, theu art granted sjiare........All's $\|_{\text {ell, }}$

thust be granted. I am dnke of..... /ichard ) i

restored ngaill, be freely granted

on thy royal party grtuitcd one

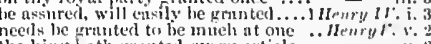

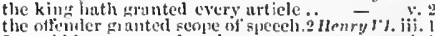

I would have granter ti that act $\ldots . .3$ Henryl.

is always granted to those wluse.. Richard III

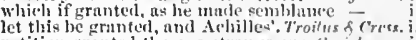

what is granterl them? live trilmats

when we grunterl that, here was.

which som le grinsed ......

not grmutel. he lessens lis requests .. _ - iii.

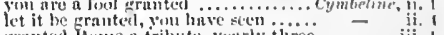

captives which omerelf linve orentel

grunted, luw ennst thou believe .. Fitus tum ron,

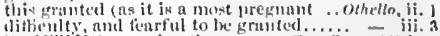

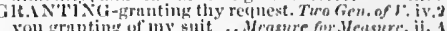

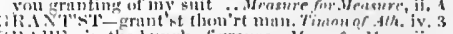

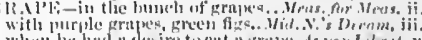

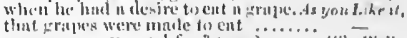

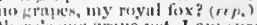
$d I^{\prime}{ }^{\prime}$ 'rit, if 
GRAPE-subtle blood of the grape. Timnn of Ath.iv. 3 tartness of his face sours ripe grapes. Curialanus, v. 4 the juice of Egypt's grape shatl

the wine she drinks is miade of griples .. Othello, ii. I was as willing to did he make.. Twety Night, grapples yon to the heart and love..... Mracbeth, iti. and grapple with him, ere he eome

and grapple thee unto a pagan

trapple your minds to srernare... He.... Hry $r$ ii. (chior.

grapple your minds to sternate

grapple them to thy sonl with jooks of . Hamlet, i, 3 and in the grapple I boarded them - iv. 6 (letter) GRASP-that's ia the tyrant's grasp ... Nacbeth, iv. 3 is made to grasp a palmer's staff ...2 Henry VI. . . would fly, grasps in the eomer.. Troilus o Cress. iii. 3
but flies the grasps of love............ GRASPED-grasped and tugged for life.2 Henry steel grasped in their ireful hands

trash, as may be grasped thus? ..Julius Cesar, iv. 3
that grasped the heaviest clnb.. Antony \& Cleo. iv. 10

GRASS-lusla and lusty the grass look s.. Tempest, ii. I liquid pearl the bladed grass.....Alil. N.'s Dream, i. tread a measure with you on this yrass $\vec{r}$ v. 2 plucking the grass, to know ... Werchant of Yenice, i. J and I long for grass: 'tis so . Comedy of Errors, ii.

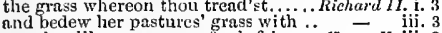
mowing like grass your tresh fair ..... Inenry $V$. iil. 3 cold wonld never let grass grow ......2 Henry $V I$. iii. 2 Cheapside shall my palfrey go to grass

to see if I ean eat grasi

I na.y never eat grass more...

we cannot live on grass, on berries. Timan of $A$ th. iv. 3 grass beat down with storms.. Titus Andronicus, iv. WRASS-GREEN - a grass-green turf - iv. 5 (song) GRASSHOPPERS-of grasshoppers.. Romeo \& Jul. i. GRATE-looked through the grate. Nermy Wimes, ii. or a dry wheel grate on the $\ldots \ldots . . .1$ Henry $I V$. iii. 1

Henryili.

grates me: the sum........... Antony \& Cleopat grated to dusty nothing
GRATEFUL this is a gift very grateful .... Taming of Shrew, grateful to us that give yon truly.M.Corialanus, i.
GRATIANO-kiaman, Gratiano.Mer, of Fenice, i. but as the world, Gratiano; a stage for Gratiano never lets me speak and desire Gratiano to come anon... Gratianol I have a suit to you methe thon art too meet me, and Gratiano, at Gratiano' with him is Gratiano gone along and do yon, Gratiano, mean good faith? now in faith, Gratiano, you give your and pardon me, my gentle Gratiano Gratiano? I cry you gentle pardon ....... Antonio, -gratify the table with. Love s L. Lost, iv. as we do, gratify this gentleman.. Taming of Sh. i. to gratify his noble servi to gratity the good Andronicus........ Titus Andron. $\mathrm{i}$. the which when any shall not gratify .. Pericles, i. and she did gratify his amorons works..Othello, $v$. GRATILLITY-thy gratillity ...Twelfth Nighi, ii. grating so harshly all his days of quiet. Hamlet, iii. I e lends out money gratis ...Merchant of Venice that lent out money gratis

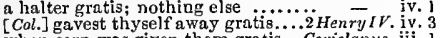
when eorn was given them gratis

the corn o the storehouse gratis....

the lover shall not sigh gratis...
GRATITUDE-which gratitude

等 canst not in the course of gratitude. Cymbeline, iii. of courtesy, dnes of gratitude

GRATULATE-more gratulate.. Meas.f. for Meas. $\mathrm{v}$.

to gratnlate thy plen teous bosom. Timon af Athens, i.

gratulate his safe return to Rome.. Titus Andron.

graves at my command have ..........

in his grave, assure thyself. Tú Gen. of Verana go to thy lady's grave.

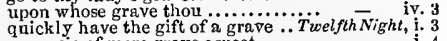
a nuncio of more grave aspect........

if you will lead these graces to the grave $\overline{\text { ii. } 4} 4$ (song)

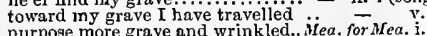
there my father's grave did otter forth may seem as shy, as grave, as just ... Much $A d o$, ii.
till he sink into his grave.... graves, yawn, and yleld your dead.. - v. 3 (song)
GR.AVE-the graves, all gaping wille.. Mitl. N. Dr. . . 2
eerecloth in the obseure grave .. Mer. of fenice, ii. 7 should lie with you in your grave.... of tenice, it. and theasure out my grave ......As you Like il, $\mathrm{il}$ 'tis dead, and I am the grave of renowned for grave ditizens ............ Pion return unexperienced to thy grave -

issue will hiss me to my grave ..... Vivinler's Tale

ue need no grave to bury honesty.....

ery, fie apon my grave!.........

for some other reasons, my grave

break his grave, and come agriu to...

so mast tliy grave give way to what's

come; I'll flll your grave up ...........
many a prayer upon her grave $\ldots \ldots \ldots$.
and dwell upon your grave.. Comedy of Errors, iii.

as tirom your graves rise up .......... Macbelh, ii

hath been both grave and prosperous

Dunean is in his trave

and our graves, nust send those.

bit our grave; where nothing.

brape dnke came early to his grave... King John,

that I were low laid in my grave

my lord? A grave.

a grave unto a soul ................

going to seek the grave of Artluir.

to a grave, found it too precious (rep.) $\overline{-}_{\text {death, that lives }}$ iv.

seemed bnried in my sorrow's grave

gaunt am I for the grave (rep.)

to my bed, then to my grave

let's talk of graves, of worms.

a pair of graves within the earth

yieep with thee in the grave.....

become enamoured on his grave
lave talked of Monmouth's grave

turning your books to graves

and dig my grave thyself .............

the grave doth gape for thee thrice

or else our grave, like Turkish
the grave doth gape, and doting

seem they grave and learned
break up their drowsy grave
labours, to his grave .............

二 i. i.

hall, no doubt, find native grave

Talbot mount, or make his grave

wither with me to the grave

why grave admonishments prevail

young son welcome to the grave?...

and ghosts break up their graves

sell my title for a glorious grave
to see how deep my grave is made.

clip dead men's graves, and from

thy grave is digged already $\ldots . . . . . . .$.

go dig a grave to find ont war.

either victory, or else a grave

Wichard hairs into a quiet grave

Richard marked him for
but I could dig his grave?

turn yon fellow in his grave

with politic graye counsel.

sage, grave men, since you wili buekle

gage, grave men, since you will buek le

would'st as soon afford a grave

to chase us to our graves ............

dead, poor infants, in their graves.

on the graves of great men

envy shall make my grave $\ldots . . . . . .$.

almost, no grave allowed me......

and she, sleep in the my grave

as of grave and austere guality... Timon of $\overline{A t h}$

bears not one spurn to their graves
pluck the gra ve wrinkled senate

robbers your grave masters are

companion, thrown into his grave

presently prepare thy grave...

graves only be men's works......

on thy low grave, our faults forgiven

your most grave belly was deliberate.

that eay, you are reverend grave me

deserve not so hononrable a grave

every gash was an enemy's grave.
most reverend and grave elders.

you grave, but reckless senators

which show like graves i' the hol

must hear my benting to his grave.

find ourselvesdishonourable graves. . Wulius opens graves, and roars as doth the lio

and graves have rawned, and yielded
GRAVE-this grave charm. Antony \& Cleopatru, iv. 10 in Egypt be gentle grave to mel

every day do honour to her grave .. $\dot{C}_{y m b}$ eline

icli make his grave a bed

Fidele, l'll sweeten thy sad grave

and renowned be thy gravel.

are strewings fittest for graves

with onr pikes and partizans a grave - iv.

deep pit, poor Bassianus' grave....... it. it. hear me, grave fathers! noble tribnnes - iii. grave tribunes, once more I entreat.. were they but attired in mrave weed

grave witnesses of trne experience

commit him to the orave grave ......

give lin burial in his fither's grave

their parent, and he is their grave

if in his grave he rest...............

a chaplet, hang upon thy grave.......

like Patienee, gazing on lings' graves

so be my grave my peace............
follow us disquietily to our graves!

why, thoul were better in thy grave.

wrong, to take me out o' the grave $\ldots . . . .$. 二 - iv.

my grave is like to be my wedding hed -

not in a grave, to lay one in ..........

and you shall find me a grave man.

wash him from his grave with tears?

the fuol were married to her grave!..

or bid me go into a new-made grave

[Col. Knt.] burial in thy kindred's grave
to follow $t$ lus fair corse unto her grave go with me to Jnliet's rrave, for there

with digging up of graves..............
$[\mathrm{Col}$. Knt.] to strew thy grave and weep

in a triumphant grave, a grave?

my old feet ftnmbled at graves?

to take her trom her borrowed grave

to strew his lady's grave

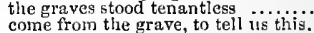

into my grave? indeed, that is out

most secret, and most grave

go to their graves like beds $1 . . . . .$.

which beweet to the grave did go ... - iv. 5 (song)

whose grave's this, sirrah? mine, sir

and not have strewed thy grave.........

this grave shall have a living monument

grave Brabantio, in simple and pure .....
most potent, grave, and reverend signiors

so justly to your grave ears I'll present.

iii. 2 no more moving? still as the grave .......

v. 10 graved in the hollow ground ...... Richard I1. jii. 2 we see each grain of gravel ........ Henry VIII. i. I GRAVEL-BLIND-

sand-blind, high gravel-blind...Merch. of Venice, ii. GRAVELESS-lie graveless, Antony \&. Cleopa'ra, jii. 1 GRAVELY - dost it half so gravely..1 Henry $1 \%$. ii. gardeners, ditchers, and grave-makers.. Hamlet, v. 1 this question next, say, a grave-maker $\ddot{0}$ 二 v. RAVE-MAKING

v. 4 this business, he sings at grave-making. Homlet, $v$. I GRAVEN ESS -health and graveness..... T T iv. ? let some graver eye pierce into that. Henry VIII. agrinst a graver business frowns at thi... Anfony \& Cleo.ii. 7 and to the graver, a child that guioed.Cymbeline, i. 1 youl bear a graver purpose, I hope..... f. $\bar{M}_{\text {Mes. iv. } 6}$ may beat thy gravestone daily. Timon of Athens, iv. 3 let my gravestone be your oracle

G AVITES-our oaths and gravities. Love's $L$. GRA VTY -gravity and patience. Merry Wives, for gravity to play at cherry-pit. Tuelfih my gravity, wherein let no man. Meas. for Meas. ii. as gravity's revolt to wantminess.. Love's L. Lost, v. wisdon, gravity, prononnd conceit. Wed of Rrrors, what doth gravity out of his bed....I Henry I Y'. should have his effect of gravity ....2 Henry $/ 1$. but all be buried in his gravity ..Julius Cresar, i

your gravity o'er a gossip's bowl. Romeo \& Juliel,

the gravity and stillness of your youth... Othello,
GRA V Y -effect of gravy, gravy, gravy. 2 Henry $I V$.

GRAYMALKIN I I come, Graymalkin. Macbeth, $\mathrm{i}$.

GRAZE-beasts most Gray's-inll..2 Henryl iti. not sheer the fleeces that I graze.. As you Like it, to see my ewes graze ................. so graze, as you find nasture 


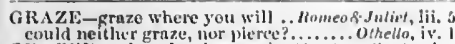
conla neither graze, nor pieres.

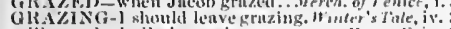
like to the bullet's grusing

these fretted in their own that fretted in their ow'n grems

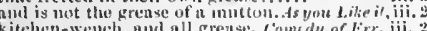

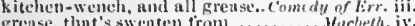

greases his pure niml ........ Timon of thens, iv. 3

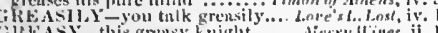

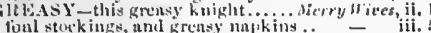
greasy Jom dotlt keet .... lowe's L.. l.nst, v. 2 (song) you fint and greasy citizens ........Asyou Like ",ii. their fells, you know, nre grensy obsene, grensy tallow-keech $\ldots . . .1$ llenry 1 r. ii. you the getink

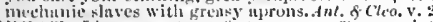

Gle $\mathrm{AT}$ - I have greitt contiort.......... Jempest

in its contrary as great

and his great person perish

thank yourself tor this grcat loss...

whint great hoyk have you! .

their great gint like pisison .......

$=$
$\bar{z}$

greut Junn eounes.

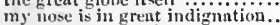

my nose is jin

tis great to me, us late...............

wonld be great impealument

in a grent perplexity

commenchution fron gient potentates =

of so grent a fiwour growing froud

some grent matter she'd employ.

and fit for great employment ...........

mine own great elamber ugain

does he not wenr a grent round bea....

'tis a great elinre, to come ..........

You shat find it n great char

to thy greut comfort in this.

of grent admittance, nuthentic $\ldots . . . . .$.

I have a grent dispositions to ery ....

he doth object, I am too great of birth
when a coman has a great peard ( $r_{e p}$.)

w ith great ragged horns.......................

ue two in great amazedness will fly.

fat Falstatt' hath a grent scene.

and she's a great lubberly boy $. . . . . \quad-\quad$ v. 3

what great ooes do, the less ......... Trelfh Nigh, i.

takes great exeeptions to your ili jours

a fool, he"s a great quarreller
but I an a great eater of beef

1 have taken great pains to eon it...

I took great pains to stady

to find mine eye too great a fillti.....

and utters it by great swarths...

huth for your love as great a pang ..
and thus makes she her great P'g

हome are born great

the matter, I lioje, is nit great, si

in his visage no great presage of cruelty

snul take ' $t$ for a great favour .........
you slew great number of his people

some are boru great.

that word ol' soine grent man

a earefal man, and a reat scholn....

and then thon art as great as that...

at sir Toby's great importance.

why, some are born great.

a great while ago the wordd......... $-\vec{v}$. 1 (snig)

I lave great hope in that

sir, she came in great with chilid.

alas! ic hath leen

alas! it hath tren preat pains to you

cuald great inen thumder as...........

grtat min may jest witl knints

a pang as great as whell a giant dieg

of Frederiek, the grent solrlier.

the vice is of a great kindreel ...........

the struke and line of his great justice

$O$ denth's a yreat disgnifer

brave ma-ter Shoe-tye the great traveller -

and that by

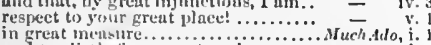

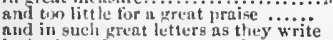

he hath male great preparation.....

I eame yomkler from a great sujper.

let us to the griat yiplper: their cheer
that I was duller thun n great thaw

that was duller thun ne great thaw
a hair from the grent Cliam s bearu..

a hair from the grent Cham s bearul..
he avoids them witls great discretion

nor nn grent uskumerst of her folly.

nav, that wonla be as grent a soil in

tirere is a great enil to-nigh

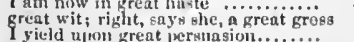

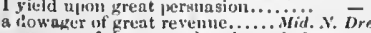

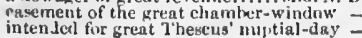

GIS DAT-I have a proat desire to ... Houl
we'll buld a feast in great solemity

grows to nomething of preat eomstumey
where i hove come, great clerks lanve

frent deputy, the welkin's. Lorre's L.tost

a creat sign sir, tlat he will look sud

of goid enrriage, of greste carrinere

and that's great marvel, Joving al light

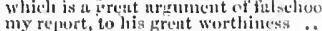

anili grent generitl of trotting puritor

to see grent llerenles whipping

and of great impurt inteesl, to

great reason; for, pust eure is stili.....

my finvour were as great; be witness

when great thing hishouring perish

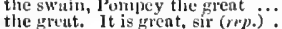

grent thanks, great l'ompey.
inude a little fualt in, great

Pompey the great, - your servant

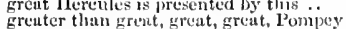

a wiml too grent might do at sea...Mer. of $P^{\prime}$

from the great debts, wherein...

and he mukes it a great apuropriation

he hath a great intection, sir ........

your grace hath ta'en great pains....

the grent heap of your knowledge? As you $\bar{L}$

that wise men have, makes a great stow -

and that a great easse of the ligint .
'tis a word too areat for stny moith.

tis a word tou great for nny mo

there is ton greut testimony in your.

theugh there was no grent mintter in

weilling is grent Juns's crown .......

men of great worth resorted to this... - v. 4 (song

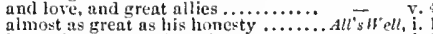

these great tears grace his remeinbrance

think lim a great way fool.

great frictas; for the

dissever so our great self and our eredit

great floods have flown from (rep.)

wish receive, which great love grant

where great additions swell, and viltue

when I eonsider, what greut creation

a ressel of too great a burden.

the grent prerogative nud rite of love

he is very great in knowledge.

my great fortune. Let that go (rep.)
whose grent decision hatl much blood

that the great figure of a couneil

this very day oreat JI

the worth of the great eouni himself

four or five, to greut saint J aques...

at some great aud trusty business

well approves you are great ia fortu.

and great ones $I$ dare not give

three great oaths would scaree make

should swear by Jove' great attribut
so should 1 be a great deal of his act

the rreat dignity, that his valour

so great as the first in goodness (rep.)

if my heart were grent, 'twould.....'

I ean serve as great a prince

that always loved a great fire......

the broad gate, and the great fire.....

the nature of his great offence is dead

to the great sender turns a sour offence

or sent it us upon her great disaster.

great king, I am no strum
for the great desire I lud

garden of grest Italy.

a merchant of great traftic

ii. i their lose is not so great, Ilortensio...

that male great Jove to himmble

pot half so great a blow to the car..

leave that labonr to grent hercules..

aceept them, then their worth is great

bo less than three great argosie

prepared great store of wedding eheer

too little payment for so grent a dibit

nyy heart as ireat: my reason.

as liave suid, great difference...

this great sir will yet stay longe

as she's rare, must it he great .........

in the which tluree greut ones sutre

as well as onc so great, and fo forlorn

so meet for this grest errand ........

foretels the great Apnlo sudelenly will =

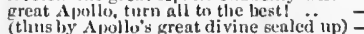

(to our great grief, we pronomne)

a great king's daughter, the mother

delivered of grent Apolio's pricst

now bli'ssed be the great A pollo!
GiREAT_come to a great matier.

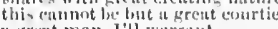

if grent man, lin wirrant

le sears to lue of preat anthority

greut $\Delta$ lexamder left his to

hac hat some great matter theris in hami -

grent comfort that I luve hou of thee! -

fent a charse from thine own custody? =

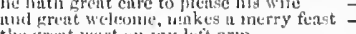

they thew on him great pails of

deeps slinnes und great indignitio.

poum $\mathrm{r}$ ife, grent king, where ...........

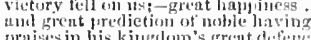

monise's in his kingilom's grcut deferme

thum'dat lanve, great Giamia

great (xlamis, worthy C'twedrr.

this night's great lawiness intu.

so clear in lisis grent untiec ........

scht fortly greut latrese to your allices

hurt mines, grent Netnres secenind

is a grest provoker of thee things

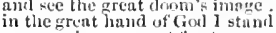

as a gaj in our great tiast............

that grent bond whieh keeps me pale
lis person, ant our grent bideling? ..

until grent Birmam wool to hirh

that this arcat king may kinuly

the preat assuy of art ........................

merlicines of our great revenge

great Dunsinanc he strongly

so great a day as this is elicapily...

arise more great, arice sir Richard ... Kinr John

whom hast thou this great eommission

as great Aleides' shoes upon ut uss .

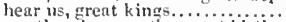

nar thou become thy grent birth

joined to muke thee grent..............

thou little valiant, great in villany!
that grent supremary, where we do

(having so grent a title to be nuore...

from the graat, grow great by your....

and grent affections, Wrestling in thy

the great metropolis and see of Rome

for the great snpply that was

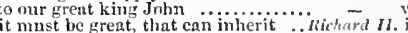

with too rreat a court, and liberal

not lirother name, grent king, to fluter

for these rrent affairs do nsk some

my lieart is great; but it must .

grows strong and great, in substance

strikes at thy great glory

O that I were as grent as in my

done so to ircat and growing ince....
in the halminee of great Bolinglore.

grace the trilumpli of great lBolingbroke?

good king. grent king, (and ret not

for thy grent bounty, that not only ..

heing so grent, I have no nced to beg

and thine aunt, grent king: 't is I ...

and that it was great pity.

against the great marician ilumi........

lurdiment witlo great Glendower.

imacination of some great exploit...

for they have freat charge

counterpoist of s igreat nn nilyosition

on some great sululen haste

had his grent yume protine

incursins, uml sreat nome in o......

great upinim, a larger dare (rel)

powers of no may serve sas grut a
being men of such grent lending

some envy ynur great destrvings

feeding to gogrent a bulk.
the odds of his great name

fire the well, grent henrt! .........

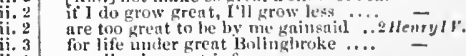

yory liye in great infumy . ...........

Imin the fellow with the grent belly

plays the rogue with my gretat toe oni

and sn, with grent imngination, proper
. 
GREAT-thou art a great fool! „....2HenryIV. ii. I GREAT-the great commanding ....3 Henry $V$ as thou hast not done a great while.. - ii. 2 was, I must confess, great Albion's queen in the pert uned chambers of the great that great Northumberlanel $\ldots \ldots \ldots . . .$. and spare me the great ones $\ldots . . . .$. who, rreat, and puffed up with this.. with is great power of English......

iii. I good usage, and great liberty .......... oppressed them with great subsidies... to Atins for so great a weight........ great lords, wise men ne'er sit..... while great promotions are daily ....Richard $\overline{\text { RII. }}$. than agreat queen, with this il diep deneanour in great sorrow.... a prince of my great hopes forget so great that shall make you great ........... - v. cyphers to this great aceount ....... - i. (chorus) from Edward, his great grandfather where Charles the great, lurvin snisdned I.ew is the son of Charles the sreat ... to your great grandsires tomb and your great und encer of your great predecessor, king Eiward sir, you slow great mercy, if you. wedges of gold, great ancher nut til the great judrmentuday the great King of kings hath grent weeds do grow apace ........... [Col. Knt] I be guilty of so great a sin! my alsence doth neglect no great design
were't not, that loy great preservation
in matter of treat moment to high promotions and great dignity England's king, but great York's heir? = my lord, the army of great Buckingham what, from myself? great reason: why? a thousand hearts ale great within great God of heaven, say, amen to aiii $\bar{i}$
think, you see them great ....... Henry $I^{\prime} I I I$. (prol. be mercitul. great duke, to men abate tlyy rage, great duke!.......... and ot great expedition, anil knowledse not yet rendy to raise so great a siese
great princes, barons, lords, and (rep.) perfect in rreat commanders' name very great, very reasonable great...

then give then great meals of beef

examine the wars of Poinpey the great -

$O$ be siek, great greatness, and bicl

I would not lose so great an honowr.

with the

no, great ling; I come to thee for....

and your great uncle Eelward the plack -

your grace does me as great honour...

ever known so great and little los

eonscience, he did us great soot.

by whom this great assembly is.....

nice custoins conrt'sy to great kings.. -

or the loss of those great towns...... Hent
to keep our great saint George's feast

the mother of treat Constantine

is eome witl a great power to raise.

by me entriats, great lord, thou .... =

great is the rumour of this dreadf

great lords, and gentlemen, what means -

(before whose gliry I was great in arms) -

in this haughty great attempt

malice was a great and grievous sin

great Coenr-de-Lion's heart swas buried =

then judge, great lords, if I have .... =

great York might bear the name

your loss is great, so your regard

where is the rreat Alcides of the fieid

great earl of Washford, Waterford

reat mareshal to

a man of great autbority in France....

our great progenitors had conqueren

of that great shadow I did represent..2I

great king of England, and my

and no great friend, I fear me.

why doth the great duke Humphrey

as the suspect is great, would make thee -

great is lis comfort in this earthly

God's goodness hatll been great to thee

and us, your suilt is rreat.......

but great men tremble

levy great sums of money through the
that these yreat lords, and Margaret

my lord is cold in great affairs

there is great liope of help......

I have great matters to impart

policy art thou grown great...............

savage islanders, Pompey the great

great men have reaching hands $;. . .$. -

swallow wy sword like a great pin

shouldst raise so great a power withoat

iny choler is so great

great God, how just art thou

it is great sin, to swear unto a sin .....

to our heart's great sorrow ..........

though great Plantagenct is erowned

unload my heart's grcat burden......

promise of high pay, and great rewards

methinks, $C$ hear great Worwick speak

whom as great a charge as littie
manors or

manors on them for this great journey

your subjects are in great grievance.

furnish and instruct grcat teachers

n supper, and a great one, to many lords -

but few now give so great ones ...... -

tlie great duke came to the bar
evils on the graves of great men

the quieen's great nephew, he dives into =

the two great cardinals wait in.

for your sreat graves heaped unon rive

to render up the great seal presently

whilst your great goodness ..........

so little of his great self...............

wonder, a great inan should decline?

is lield no great good lover .........

great child of honour, cardinal Wolsey

they say, in great extremity ........

of lis great grace and prineel

prayed ne to make great haste ........

and one as great as you are

with the great tool come to court
we shall have great store of room

fou great fellow, stand close up....

as great in admiration as herse.

as great in fame as she was

the protractive trials of great Jove.

godlike seat, great Aganemnon (rep.)

thou great,-and wise, - to hear Ulysses

and the great Hector's sword had

the great Achilles, whom opinion.

will physic the great Alyrmidon

Hector shall have a great catch...

bear the great sway of his affa

disgrace to your great worths.

and that great minds, of partial

their great general slept .............
0 thou great thunder-darter of.....

be thine in great revenue!

with entertaining great Hyperion

please it our great general to call...

the island kings, disarn great Hector

let him le sent, great princes

and great Troy shrinking

thou great and complete man....

and crave great Mars to faction.......

great Hector's sister did Achilles (rep.)

to see yreat Hector in his weed

Jove bless great Ajax. Iumph!

it is great morning; and the hour

though the great bulk Achilles ...

and great deal misprizing.

the extremity of great and little

did in great Ilion thus translate $\ldots \ldots$.

a great addition earned in ..........
and great Acliolles doth long to see..

great A gamemnon comes to .........
of very heart, great Hector, welcome

but, by great Mreat Hector, the captain.....

whereont Ilector's great spirit flew

from my great purpose in to-morrow

good-night, great Ilcctor. Give me

great Achilles is armiug, weeping....

great flector was as good a man as he \begin{tabular}{l|l} 
GREAT-great Troy is ours. Troilus \& Cressida, v. 10 \\
some dedication to the greatiord. Timon of Athents,
\end{tabular}

this great flood of visitors.

iv. 8 to provide, and give great gifts, and all =

and your sreat flow of debts occasion.

and your great flow of debts ........

great Timon, noble, worthy, royal ...

who, having great and instant oecasion

anch may rail against great buildings

as you are great, be pitifully good.

i. 4
i. 4 you great benefactors, sprinkle ...

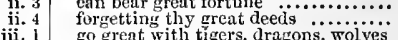

iii. 1 go great with tigngers, dragons, wolves

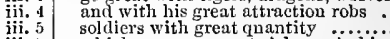

iii. 7 which argnes a great sickness in his

iv. 4 in the great shower of your gifts ..... -

iv. 4 pant in your great chairs of ease .... -

iv. 4 that these great towers, trophies

v. 5 the great toe of this assembly?(rep.)...Coriolun zs, i.

dearth is great; the people mutinous - i. 2 (letter)

to keep your great pretences veiled

great charms misguide thy opposer's

where great patricians shall attend ..

why, 'tis no great matter (rep.)......

many great men that have fittered

censor twice, was his great ancestor.

and sack great Rome with Romans.:

i. 3 those whose great power must try $\mathrm{him}$

i. 3 say, their great enemy is gone ........

i. 1 all the Volsces, greaf hurt and mischief but peace is a great maker of cnckolds which great nature cries, deny not .... like a great sea-mark

have all great cause to give great thanks we'll deliver you of your great danger and labour of our great action......... made my heart too great for what the great danger which this man's life from Aufidins a great part of blame
when they are jn great danger ....Ju to see great Pompey pass the streets

as . Eneas, our great ancestor..........

an age, since the great flood...

he is a great observer ................

and our great need of him $\ldots \ldots \ldots \ldots$.

that great vow which did incorporate

from yon great Rome shall suck (rep.)
speak to great Caesar as he comes...

speak to great Casar as he comes....
real it, great Cresar ................

more sweetly in great Ciesar's ear

Cresar has had great wrons

ran blood, great casar fell ............

and now, Octavius, listen great things -

so great men great losses should endure defend him from so great a sliaine ! .

they dick in envy of great Cassar...

comes too short of that great propertony \& $\mathrm{Cl}$

a great spirit grone

between them and a great cause ....

begin to throw Pompey the great....

so great weight in his lightness.........

sleep out this great gap of time.

and great Pompey would stand...

the firm Roman to great Egypt......

if the great gods he just..............

great Nark Antony is now a widower

and sway our great designs...........

power by land? great, and inereasing...

royal wench! She made great Cesar

the senators alone of tlis great worid

yon have been a great thief by land..

have a name in great men's tellowslip

may make too great an act

tulke from me a great part of myself

our great navy's rigged...............

fred from that great face of war......

say to great Casar this

determine this great war ...............

disl persuade great Herod to incline

to this great fary I connend thy acts

had our great palace the capacity...

he windowcd in great Rome .........

must be as great as that which makes it

bmrn the great sphere thou movest inl

tire breaking of so great a thing should

and it is great to do that thing that end

ii.

ii..

iii.

iii. 5

\section{iv. 3}

iv.

v.

v. 1
v. 2
v. 5

ii. 2
ii. 4
iii. 1

iii. 1
iii. 1
jii. 2
iii. 2
iv. 1

iv. 3

v. 1

i.

i.

i. 4
i. 4
i. 5

ii.

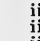

ii.

ii.

ii. 6

iii. ?

iii. 5

iii. 6

iii. iI

iv. 4 


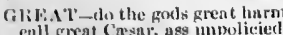
enll great (arsar, ass unpolicied! a frent elenl from the matter a grent de areat then ubused. youre a great thent our greut king himiolit yon art then as grent as is thy muster reesil from your grent stoke. yeul grent julkment in the slection their values grent; and I um something thy hunishey lort, and this grent land! one of your great knowing sho

und perjured, from tlyy sriat fiil.

in a preat pukl, a swail great

in a great lykel, a swun's nest .........

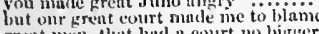
grent men, that luel in eourt no bigger

grant griets, I see, nediene the less

fenr no more the frow'n o' the great

the grent part of my comfort Lone

grent the slanghter is here

gereat the answer be Britons........

grent a upiter he prused l lucius ....
ant so, great powers, if you will talie

great nuture, like his uncestry

with eare nerform his great belust

hnit, great king! to sour your...

thou luwlst, great king, n subject ....

in the temple of grent Jugiter....

for many goorl and great deserts .

thun great defender of this caphitol ..

no more, great c'mpress, 13assian

mi.htit not guin so ereat a hapjiness.

in Rome's great quarrel

to see so great a loril basel phsininte

nur ereat Aleides, nor the god of war

wretilh, that holp'st to muke me gre

receivel letters from great rome

sprung from the great Introniens

Antioch the great bnilt up....... ${ }^{2}$ 'rictict

thint whinlit be soin to great

great kin: fatw love to hear.........

since he's so great, enn make ......

ans prisle so great, the nume of help

the great ones eat ups the hithe ones.

envy the orent, nor do the low despise

though this king were great

mas be as grent in blood as

my pood swill is greut, though the gift

the breadth of his grent voynge

serve the great pirate Yaldes....

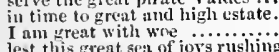

lest this great seat of joys rushing

great sir, they shall be brought

the gots, for this great miracle .ighe.

as my ereat patron thought on ........

muke a great yap in your own lonou

there's a great ubatement of kintues

lords and grout men will not let me

tu the great love 1 bear you

$[k n t$.$] the nllowanee of your great uspe$

when $n$ great wheel runs dow a
but the great one that goes up

sijeak , fainst so preat a mumicer

let the grent fords, that keep this ...

his sworil to his great naster

it was grent inmorance, Gloster's eyc

shake pationely my great aflliction off

quarrel with your great opposeless wils

belobll the gre'at imnge of nuthority

we are esme tu this great st:age of fool
eure this ereat loremeht in his abused...

the great rage, you see, is eured.

parks und seets of great onts.............

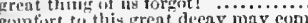

emaster is the preat rich Capulet...Honeo of Jutic

ton grent oppression for a tender thing

and songht fir, in the great elianber

the ouly sinn of your great enemy......

ilriveling love is tike a great naturnl

we"ll kees n' grent axlo ..............

a preat sllspicion; stay the friar tong.

the grent ranmon to the clouds shall.

that we tice fruit to that freat

enteririses of yiveat pith and moment....

in great ones inust not un watelied fo.

a. great man's mingry" may outlive.....

the sreit man disw'n, yon mark

in sust great atilietion of syjirit...

aq my great power thereot may give

seemy proligue to some gritat uniss

where the offence is, let the great axe fil

the kreat beve the peneral gender bear hil

that great folk a should have en

in's time a $b$ reat buyer of land ............

if he do not. 'tis no grent matter there

that he will keep out water a great whil
but that great command o'ersways .....

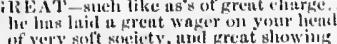

of very sollt seseicty and gre

to be a 8 on of trent artile

three great ones on the dity

und litie of this grent world ean $i$ apenk

your serions und great bisiness gen

preat dere, othellon gunrel, aud swe] li li

the gr'ut eontention of the sea and skies

will I ensmare as grent a fly' as ('assiot.

it given me womster prent as my content.

I linve fomend grent love mmongst them

stand uevemntunt firr us wreat a sin

and tis grent pity, thet the moble sic.

great fume in Cyprus, and great uflinity

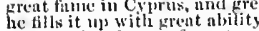

yet, 'tin the pingue of great onces.

thongh grent ones are their object 73 woul

and the great messengers of Venice it tily

I thave ne great devotion to the elece

great revente hul stomaeh for them

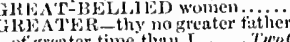

the swenter hirles the less

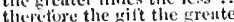

I will do a rreater thing than that......

greater tile of the subjest.. Neasur

is no grenter for thit tis the my hention.

their eheer is the ereater, that i am...

on this travail lock tor great
ean you do me greater liarm.

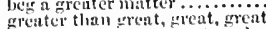

the greater throw inay turn by.

no greater heart int the

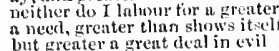

but greater a grent dealin erif

with no greater a rum but my hend

5et, for a greater eontirmation ... Hi
never tender lady latl borne grenter

of something greater than hersell...

lesser than Nueluth, and grea

greater than both, hy the all-hail...

n sreater power than we denies

as we? greater he shall not be

why, I am rreal cre than a king
l'li malke it greater, ere l part

l'll make it greater, ere l part
I would my me:ms were greate

grow ton greater filsencs
revives two greater in the heir

to give a greater smm than ever...........

greater therefore should our
the greater flatre of honour

but to make my sorlow greater?

resolved to bear in greater storm...

eommanded always by the greater .3H $\mathrm{cm} ! \%$. iii.

a greater gift than that (rep.) ..... Michur

nore miseries, und greater fir

never greater, nor, I'll assure.

the service ereater than the rod. Troitas of

in self-assumption preater .....

the creater seorns the lesser .. Tim

and throw forth greater themes for ...

the greater lout clublit tor

we are the preater will .................

but a greater seldier than he ........

1 take him to be the greater solelier.

liche greater jart, the horke in general

miakes mine freater than
they are greater storns.

may give way to greater ...........

lut small to prenter maters and he are pienter frient

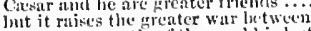

the greater enntie of the world is losit

glomk mutke a greater cruck

y't tis grente't kill in a true luite.

which uttench in place of erester state -

were endowmente frenter thain

where the freiter malady is fixed

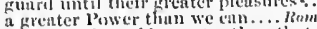

to clammation add, greater tlum that

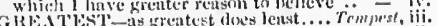

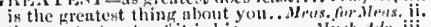

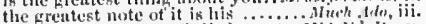

is thic erentest error of all the

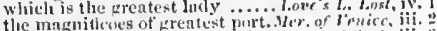

and the grentest of my prifle is ... is you inke it, iii.

was the Lrentezt of his protengis...

have by the greatest been denicel

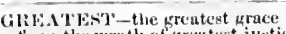

Al's'ell, ii.

(a)

he has taken their prentest commander

the frentest ollowing i the world

one of the greatest in the ehristian

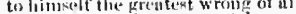

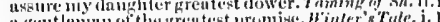

a fent leman of the greatest yromibe, min

the oreatest is behind: thanks for

one of preatest note Reenns bruited

mightient if thy greatent encmices

Kingr Johy

it is the ereatest admiration in the.... Ineryory.

empty vensel makes the preatest sumind

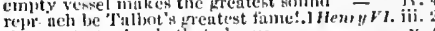

the grentet miracle that e'er ye .......

the grente-t favour of the con

the herestest

thy trentest help is ifuict, gentio viuil $=$ ii.

disl suldlue the greatest part of syain - 11 iii.

when the greatert atroke of fortune. Henry Vili. ii.

her thunks in thic greatest lambleness

the grestest numarele now alive......

1 count it one of my greatest afllictions

your rrentest want is you want

the griatest tuste most palates their... Coriolanns

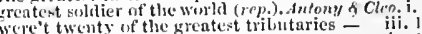

like the grentest spot of all thy sex.. - iv. 10

the greatest prince o the wrorlo.....

make the greatsst king double ...... Cymbelin" i. 7

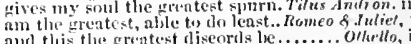

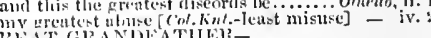

what my grent-fretudlatlier and ....3HenryVl, ji.

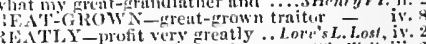

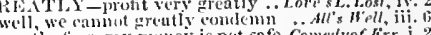
greatly fitar, my numey is not snfe. Comerlyof firr. i. nor I grently tore nut: Gud knows . He $\overline{2}$ (elorus)

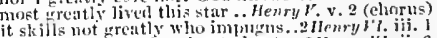
they ennnot grestily sting to hurt...3Heny li ii. 6 wonder greatly that man's tace.. Tilus indron. ii.

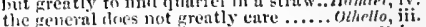
R T-MASTEI of France ........ Henryl l. iv. I do heseceli thy greatness ............. iii. be not afrainl of greutness. Fredfhs Night, ii. 5 (letter) be nut afraic of great ness..........; - iii. some have greutncss thrust (rep. v. 1) , $\overline{M e a s . ~}$ iii. 2 o plate and greatness ................ iv. phenseth his greatness to impart ... i.ove's L. Lost, vo greatuess whereof I cannot. Yer. of len. iv. I (letter)

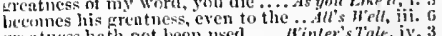
greaturess hath not been need..... Hinter's Tale, iv. iny d ient ise the in norment of whet greatness is promised as will to greatness dedicate themselves
jeriured too, and sonth'st up greatness. thist grentuess should ko grossly' ofler it

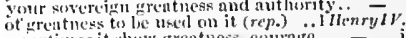

acempun the treathess of tity biood

which oft the car of grentness newls = iii. 2

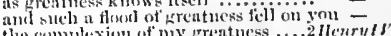

the cimplexion of ny greatness .....2ne'nry

that 1 inil greatuess were compllled

in slundow and sted grentmess! $\ldots . . .$.

thoil seck'st the reatness that will.

deliver mp his greatnes.

and show gly knil of greatness

moricl to thy inwatrl greatness.......

outlive that day to ree his greaticess

Obe sick, freat grent nese .............

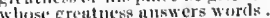

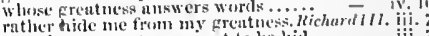

than in my grentuess civet to be hicl $-\bar{T}$.

the list tit of my greatme

point of ull my freatnes ..............

finl surely hin prentness is at ripenit

elsin their greatiness. not by how

and the greatness of his mane +hall he $\overline{-}-\bar{r}$

sceming he acts lly great tues

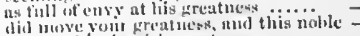

pessessed lie is with preatuens. .... 


\section{GREATNESS-who deserves greatness. Coriolanus, i, 1 | GREEK-of this leg all Greek .. Troilus \& Cress. iv. 5 GREEN-SICKNESS-}

for keeping your greatness back?

the abuse of greatness is

shall not make poor my greatness Antony more in does confess thy greatness

more in parting, than greatuess going off -

I send him the greatness he has got..

my greatness i' the posture of a whore

thit depend on greatiess' tavour.

only affected greatuess got by you

suffice the greatness of your lowers.

g greatness was no guard to bar...'

his greatness weighed, his will is not ... Hamlet, $\mathrm{i}$.

GR by your safety, greattues, wisdom ..... $-\bar{C}$. iv. 7

GRECIAN-townrd the Grecian tents.... Mer. of

dashed

why the Greeians sacked 'Troy?.All's Well, i. 3 (song)

how many Grecian tents do stand. Troil. \& Cress. i.

to rouse a Grecian that is true ......

not in our Greeian host one noble

he bronght a Greeian queen

the Grecians keep our aulut.

captain general of the Grecian army

the Greeian Diomed, and our Antenor

I'll bring her to the Greeian presently

I must tien to the Greeians?

I will corrupt the Greeian sentinels

the Greeian youths are full of quality
bring the Greeians are most prompt
bring $\mathbb{A n e a s ,}$ and the Greeian, with you

Grueian, thou dost not
this hand is Grecian all

my famous eousin to our Greeiau tents

cost a drop of Grecian blood

you wisest Grecians, pardon me $\ldots . .$.
sinee you refused the Greeians' eause

many times the eaptive Grecians fall

the Greeians begin to proelaim

hold thy whore, Greelanl.............

blood at Grecian swords' contending. Coriolanus, i.

'GREE_how' 'yree you now... Merchant of Vewice, ii.

old John Naps of Greeee .. Taining of' Shrete, 2 (ind.)

have I spent in furthest Greece. Comed yof Errors, i.

from isles of Greece the princes. Troil. \& Cress. (proi.)

than Agamemnon and all Greeee

among the fairest of Greece......

the plague of G Greee upon thee .......

make thee the loathsomest scab in
rather Troy were borne to Greeee

I tell thee, lord of Greee, she is.

all you peers of Greece, go to my tent

than ever frow ned in Greece!

there's many a Greek and Trojan dead

fall, Greeks; fail, finme; honour.......

and good-pight to the Greeks' general

any thing but that, sweet Greek.......
guardian! why Greek! pho, phol....

guardian! why Greek! pho, pho!...

hark, Greek; as nueh as I do Cres

stand engaged to many Greeks

and there the strawy Greeks, ripe for his -

stand, stand, thou Greek

forego this vantage, Greek
ay, he spoke Greek. To wl

it was Greek to me: I could tell

madded Hecuba gave the Greeks … Cymbeline, iv

when subtle Greeks sur|rrised king ... H- vinter.

GREEKISlf

Greekish [Knt. (Greek's] ears to his. Troilus\& Cress.

fore all the Greekish heads.

ii. 2 all the Greekish girls shall tipping sing -

nnt bear from me a G reekish member

in Ilion, on your Greekish embassy.

iii. 3 in llion, on your Greekish ent

send that Greekish whoremasterly
GREEN-how green!

with an eye of green int $\mathrm{i}$.

to this short-grass'd green?
and on this green laud

iv. 4
iv. 4 'twixt the green sea and the azure vault

to the tune of Green Sleeves

and fairies, green aud white

tliunder to the tune of G $\mathrm{G}$ reen

blaek, wrey, green, and whit

turned $m y$ daughter into

did you take her in green? .........

a green and yeliow melaneh
but with one green leaf on

when wheat is green

to dew her orbs upon the green

in grove or green, by fountain

the quaint mazes in the wanton green

purple grapes, green figs, aud mulberries -

his eyes were green as leeks............ - Tove's L. Lost

when green geese are a-bre

green, indeed, is the eolour of iovere.

a green goose, a goddess...............

ho! unto the greun holly........... you Like it, ii. 7

and like green timber, warp

about his neck a green aud gilded snake

o'er the green corn-field did pass .. - v. 3 (song)

While your boots are green ... Taming of Shrew, ii1.

in my green velvet coat $\ldots \ldots \ldots \ldots$ Winter

the green Neptune a ram

to look so green and pale.

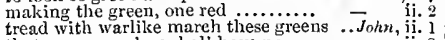

that yon green boy shall have no....

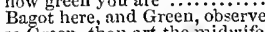

so Green, thou art the midw

Bushy, Green, I will not vex.......

Where is Green? that they have let...
is Bushy, Green, and the earl $\ldots . .$.
the fresh green lap of fair king, $\ldots . .$.
the earl of Wiltshire, Bushy, Green

strew the green lap of the new-eome ne $-\begin{array}{r}\text { y. } 2 \\ \text {. }\end{array}$

knaves, in Kendal green.............

they were ill for a green wound.

Peter Bull-ealf of the green at Mile-end green

sinee griefs are green ................

it is goot for your green woun

burnet, and yreen elover ...........

how much the estate is green......
yet, since it is but green, it should

an't had been a green hair ${ }^{\prime}$ Tro

were your days as green as Ajax .....
thous green sareenet flap for a sore eye.

when I was green in judgment

and o'er green Neptune's baek .......

the green leaves quiver ................
branels, that's only rreen at top

ay, Greek, that is my name.

in view of Trojans and of Greeks

than ever Greek did compass ........

no man lesser fears the Greeks than i =

shonld do some vengeanee on the Greeks -
whom the Greeks held cantive

whom the Greeks held cantive

that all the Greeks Gee

a valiant Greek, Eneas: take his hand -

to bring this Greek to Calchas' honse -

as for her Greeks and Trojans suffered 二

Cressid 'mongst the merry Greeks!

by my soul, fair Greek, if e'er thou

half Trojan, and half Greek

thy commixion Greek and Trojan so into a kind ot male green-sickness..2 Henry $I V$. iv. 2
troubled with the green-sickness. Antony \& Cleo.iii, 2 pox upon her green-siekness for me!.. Pericles, iv. GRE green-sickness carrion I....Romeo of fuliet, iii. 5 G GRE GRELT-greet my poor eorpse.. Fou Likf il $N$. ii. 5 (song) your brother kindly greets you... Meas. for Meas. i 5 will greet us here anon ..................$\overline{\text { ream }}$ iv. 5 to talk, and greet................... Love's L. Los!, v. 2 when we greet with eyes best seeing
Bellario greets your graee... Merchant of Venice, iv. 1$]$ and rever stays to sorcet him .....As you Lilie it, ii. . my mother greets me kindly ........All's $W$ ell, ii. 4 to greet a man, not worth her pnins

witls his former title greet Macbeth ... Macbelh, $\mathrm{j} .2$

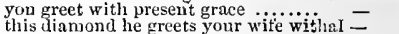
in all duty greets your highness .... Richard II i. 3 greets me well, sir; I knew him.....2Henry $1 \gamma$. Hii. 2 before, and greet his grace; my lord - iv. I and thns he greets your majesty $\ldots . .$. . Henry $\nu^{\prime}$ ii. friends greet in the hour of death ...iHenry $V I$. iv. 3

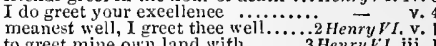
to greet mine own land with ......3 Henry $V$ l. ii. of London comes to greet you........ - iii. 1

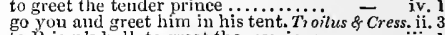
to Prian's hall, to greet the warriors greet him from me ............ Timon of Athens, ii. 2 of Aliens, greet thee, Timon

day did never yet greet Rome ........... Coriolinus, v. 4 he greets me well: your master..Julius Cosar, iv.
Antony shall well greet together. Antony \& Cleo.ii. such dignity as w'e greet modern friends - v.
and greets your highness dearly .... Cymbetine, i. ? if you please to greet your lord...

there greet in silenee, as the dead. Titus Andron. $\mathrm{i}$. and seeretly to greet the empress .... - iv. it greets me, as an enterprize of ...... Pericles, iv. I pray you to greet them fairly ........

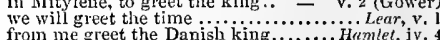
from me greet the Danish king.................. I greet thy love, not with vain thanks ... - iji. and senators of Veniee, greet you ....... GREETING-his journal greeting. Meas for Meas.iv. 3
salutation and greeting to you all!. As you Like il, y. 4 my loving greetings to those of miue...All's Well, i. 3 and thus mueh for greeting ... Taming of Sirew, iv. 1 with suel prophetie greeting? ...........Mocbeth, i. 3 thus, after greeting, speaks the king . King John, i. return'st no greeting to thy friends?

prince of Wales, greeting ...2 ISemry ir. ii. 2 (letter) health and fair greeting from our.... - iv. 1 expressly I bring greeting too...

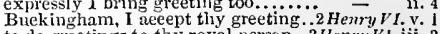
to do greetings to thy royal person..3 Henry ${ }^{\prime}$. iii. 3 most despitetul gentle greeting. Troilus o Cress. IV. I pray you, do my greeting.... T'imosi of Athens, iv. 5 I have reeeived not only greetings.. Coriolanus, ii. my greeting to the senators ...... Julizi. Cresar, ij. every stage with an augmented greeting - iii. sends greeting to the queen of F..... tremhle in their different grecting..Romeo \&. Jul. i. the appertaining rage to stich a greeting bearers of this greeting to old Norway.. Harnlet most fair retrurn of greetings ........ .. $\overline{\text { othello, ii }}$, they give their greeting to the eitadel .. Othello, ii. Nathaniel, Gregory, Philip?.. Taming of Shrew, but Adam, Ralph, and Gregory ..... commission to Gregory de Cassalis. Henry " IIT. iii.

Gregory, o my word ............. Romeo

so will I signior Gremio; but a word

tpeh, Gremio! though it pass your..

how say you, signior Gremio?
God save, you, signior Gremio!

Gremio, 'tis now no time to vent.....

you will have Gremin to keep you fir

neighbour Gremio: God save you ..

signior Gremio; give me leave

o pardon me, signior Gremio.........

a the signior Gremio, sinat Gau

old signior Gremio has in I'adua ....

have f pinehed yon, signior Gremio?

Gremio, tis known, my father hat

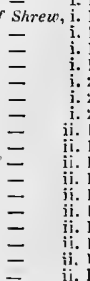




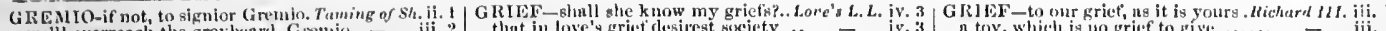
we'll overreach the greyheart, Grenio - iii. 2 thint in love s grict desirest seciety

Gremio, eame you from the churels...l

talk not, signier (iremitu; I s:t)

my griets are doulole $\ldots . . . .$.

bent picree the enr of grief.
go: these griefs anul loses

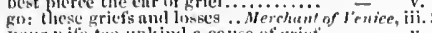

GiEW-to ny state grew stranker .... Tesupest, i.

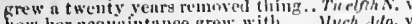

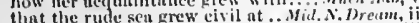

so we grew tong ther.

to leour your gricfiz yourself

my sorrow and your grief were...

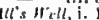

so many quirks of joy, unl griet.....

if thou engrossest nil the griets

reasonable mail grew so in love with - $y$, ivi.

grew by our feediun to so grent...

grief would liave teurs, and sorrow....

gool-will eflects Binnea's grief . Thming uf $S h$

not for your turn, the more nyy grief ${ }^{\prime}$.

on her frights, and griets

(to nur grent griet, we pronounee)
ss I wejoll grict, which I would syase

no doubt, grew like the sumn

some words there grew 'twixt Somerset - ii

they sny.-my unele grew so fast

past help should be past grief. siare

whely entive to his lurity

emore

sick sudhlenly, and grew so ill .... $\dddot{\&}$ cleopatra, ii.

tlint grew the more by renpiag

absenee, grew shameless desperate...

which fear so grew in me, I hither fled.

the name of lielp grew odious to repent
whereupon slie grew round-womlied.....

whereupon slie grew round-womlied...

heak,

he grew unto his fent.

to speak my griefs unspeaknble... Comedy nf Rrr. i.

oh, grief hatli clungerl me

as we slall make our griefs.

What is the newest griet:

the grief, thut dhes not speak

let grief convert to unger

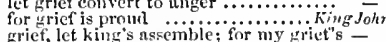

W... Hacleth

will make niy mother die witls gricf

what grief sliould I forget !

but sensible of grief, my reasontible.
do plue themselves in sociable grief.

too heinous a respect of grief . . .ill...

Whe tire is deat with grief

our griefs, and not our mang

little reason in your griet.

liath becu heforchand with our griet

word more; grief boundeth where

hit grief makes one hour ten.

that I was a journeyman to gricf?

within me grief lath kept a tedious fast

York is too far gone with grief

weleome such a gries hath twenty shadows

ands glapes of rrief, madows (rep.).

forefather grief; mine is not (rep.)...

nothing lives, but erosses, care, and

ns great as is my rief, or lesser

smrow and grief ot henrt makes hin

no measure keeps in grief...........

(nilst you mount

but still my griefs are mine.

very true, my grief lies nll within

should hard-favoured grief be lotged

join not with grief, fair woman.......

there is such lengtl in grief.

the badges of his grief and patienee...........

out of my grief and my impatience... Henry

a plague of all sighing and grief:

to know the nature of your

or take away the grief of a wound?
swoln with some olher grief $\ldots . .2 H$

swoln with sorse

this present arief had wiped it

it hath its original from much grief.

find our griefs heavier than our offences -

the summary of all our griefs......... -

to huild a grief on: were you not

to know your gricis; to tell youn....

these griefs shalle with speed.....

ere you with grief had spolke

firm enough, since friefs are green ... L-

suffer'st more of mortal griefs.

sluall change all griefs, and quarr

verborne with hurlening grief
Rouen hangs lier heal for grief.

a foresee with grief the utter .

and ruminate my griet. Ay, grief
unload lis grief, your grief (rep.)

greatness of his fince be grief to ns.

full of tears, nny lieart of grice

gentle Nell; forget this grief

my heart is drowned with grief...

goine, that I may know ny grief
fot limve I lieard, that grief sotten

I remember it to my grief

and $I$, with grief alid sorrow

is to nuke less the depth of grict.

in this world, but grief and woe?

and break o'ereliared with grie

for grief ean sienk no more.

queen. Margnret, and tell tly grie

1 must eonfess, are full of grief .

liath allayed their swelling grief.
many lengthened hours of grief

a moiety of my griel' [ $\mathrm{Cnl}$. Knt

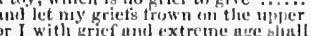

or with grief und extreme
of prict makes will grief tam

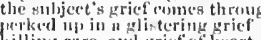

killimp care, and yrief of lieart.

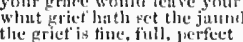

allatyent (o) ald I give my

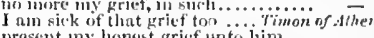

poor steward wenr a truer griet.

to neeyt my grief', and, whilst this poor
twas time, and grict's, thint frumed him

that, to ease them of their grict

you hove reecised were bul

thot alfhorredst in us our human ericts

(r grieft where hust thou lel in
for redress of all these griet's

aermainted with your eunse of grit:t..
wlyat private grictis they hase

speak your griefs keftly.

enlarge yout griefs, ard I will give.

I am sick of many griefts

and gries, that young Oetavius with

nolsle vessel full of wricf, that it.......
grief is erownel with $\bar{f}$ Cleo.

no further the grict's between ye
being dried with gricf, will break

a grief that shonts my very heart ....
my sup come crown of griet?

remembrance is yet tresh in the grie....

let that grieve hím, (some grieft' are

Ido note, that grief and putience....

jollity for nyes, and grief for hoy's.

great griefs, I see, medicine the l
to my grief, I am the heir of his

to my grief, I am the heir of his ....in $\overline{-}$

rissemble all your griefs and diccontents -

my gricf was at the lieight...........
for, at your grief, see, how my wreteicd -

now no more will $I$ entrol thy griefo

in olslivion, and hateful griet's .....

gricf las so wrought on lim .

extremity of griefs would make

utter all our hittur grief, but floods.

should associate riends in grict and woe

bear such griefs as you do lay

relnting tales of other $\$$

know, that our gricts are risen

your griefs, for whint? wrong not

sustenance hut to prorogue lis grief.

hut the main grict of all springs from

thy griefs might equal mine ......

as full of grief as nge .............

When grief hath mates ..............................

started to deal with gricf alone ..........
my thouglits be scvered frum nix griefs.

passion, joy and grief, burst smilingly

his grief grew puissant ........

griefs of mine own lie heary ................ o Jutiet, $\mathrm{i}$.

one desprernte grief eures witl nnotlier's

al realy sick and pale with griet

thy stit, and leave me to my grief

it were a grieft, so lirief to pnrt

some grief shows mineli of love (rw.)

griping grief tlic lienrt doth woind

grief of my grief, it is allpperile l....

to remove that siege of grief from lyc

it us befitted to lear our hearts in grief. Mam

impious stubbornuess, "tis unmmuly grici

more grief to lide, than hate to utter lowe

the violeme of cither grief or joy

grief' doth most laner grief or joy

it youldeny your grief: to your ir
Ot this is the poison of decperict.

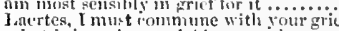

what is he. whose griet leats stich on

my particulur grief is of so flont- me im

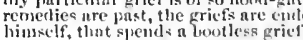

to pny gline. must of pon pntielue borro

now begin with grief and shame..Weas, far.Mpar. v.

being that $I \mathrm{fl} / \mathrm{W}$ in grief.

and uyon the grief of this, andelenly

nnd sueh a grief for swin, in every

poteh grlef with proverbs............

$m y$ griefsery loutler than alvertis ment - v. 


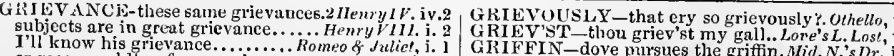

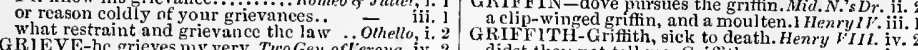
GRIEVE-he grieves ny very. Tu'o Gen.oficrona,

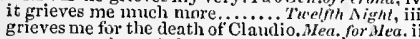
nor man, grieve at the mercy......... - ii. would it not grieve a worman .......... Much ddo, ii.
not suddenly, for it mas gricve him.Mer.ofl'en. grieve not that I am fallen to this

sir, grieve not you; you are welcome the melancholy Jaques grieves at that a moonisls youth, grieve, be effeminate

how it grieves me to sce thice wear.

host canse to grieve it shoul

he shall not need to grieve at knowing

no unkind mate to grieve thee. Comedly of Erro
how it did grieve Ilacbeth! .......... Mucbeth

show his eyes, and grieve his heart

$O$ it gricves my soul

at solnething it nrieves more than...........

hath the nothing that I grieve

who, Douglas, grieves at heart

do not you grieve at thi didst thou not tell me, Grifitl? .......

pr'y thee, good Griftith, tell me how

yes, good Griffith; I were malicious else such and honest chronicler as Griffith good Griffith, causc the musicians

Griffitl farewell garlands, Griffit

RIM-look, so dead, so grim...Hid. N.'s $\overline{-}$

for her father is but irim......... Love's $L$. Losi,

grim death, how foul and... Tarning of Sh. I (indue.) and the grim alarm, excite the....... Macbeth

wcrt grim, ugly, and slanderous...

King John, ij

brother, swect, to grim necessity...

for his grim aspect, and large .......

sits, in grim majesty, to fright

that grim [Col. Knt.-sour] ferryman. Richard $I H L$. in

thou hast a grim appearance

as yon grim looks do testify ....

ay, there, look grim as hell! this act shows horrible and grim

nor grieve that IRouen is so recovered
glound grieve thee morc than streams
it

wherefore grieve I at an hour?

GRI act shows horrible and grim .......

it grieves my soul to leave the

pry thee grieve, to make me m
how it doth grieve me that thy

'twill grieve your grace, my sons.

eontent, to that whieh grieves my jeart

that grieves me when I sce ......... Richard 1 . iti.

it grieves many: the gentleman.... Henry ${ }^{\prime}$ III. i. the cause he may a little grieve

who grieves much for your wealiness

I grieve at what I speak, and am right

doth that grieve thee? 0 withered

and grieve his spirit that dares not

it grieves me, to see so many dip. Timon of $A$ the

we liave. And grieve to liear it

shali it not grieve thee, dearer

and I grieve mysclf, to think .........

which more may grieve thee, as it doth

unless thou wouldst grieve quick
and nothing grieves me heartily

princely cliarity to grieve them.......... Periet

it shall no longer grieve, wi thont reproo

like he doth grieve my heart .. Romeo \& Jutiet, iii. 5

joy grieves, on slender accident..........

1 know it gricves my husband

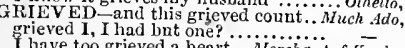

be not thou grieved a beart ... Merchart of frenice,

be not thou more grieved than I am. As you Lilke, $\mathrm{f}$.

nor be not grieved; she is of good.

arc not you grieved, that Arthur.

that doth vex iny grieved soul

1 see thy grieved heart

notling have, with nothing..............
king, so gricved for subjects ' woe?

grieved commons hardly conceive... Henry VIII.

I have heard, and grieved, how cursed

acquainted my grieved ear withal. Ant. \& Cleo.

alis, poor souls, it grieved iny heart . Perion.

GRIEVING-a women so his sickncss.. Homlet, ii

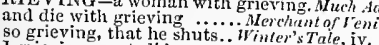

so grieving, that he shuts...Winter's Tale, iv. (chror.)

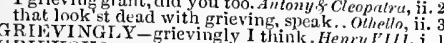

GRIEVOUS-a grievous labour.. T't

stand under grievous imposition. Meas. for Meas. i.

ald John of Gaunt

the commons hatl he pilierl with grievo

my lort, he's grievous sick ........1 Henry

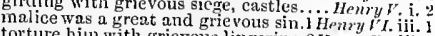

suddenly a wrievons sickness took f. 2 Henry $V I$. iii. 2

very grievous to he thought upon ..Richard III. $\mathrm{i}$. I

hloy unto the grievous charge of
hlood shed for our grievous sins....

this most gric vous guil ty murder rone! -

Anne my wife is very grievous sick
a grievons burden was thy birth to me

many grierous, I do say (rep.) ...

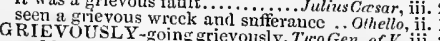

and has been grievously peaten...Merry H"ives, iv.

he beat me grievously, in the shape ...

grievously hath Casar answered it.Julum Cocsar, in: paugs of deatl do make him grin.

when a eur doth grin, for one........
to grin like lions npon the pikes

to grim like lions upon the pikes ..... Cymbeline, v. they to dinst should grind it......... Coriolanes, ivii. I will grind your boues to dust... Titus Andron. v. let me go grind their bones to powder

not to stay the grinding of the axe $\ldots$... Hamle
GRINDSTONE - Susan Grindstone

I like not such grinning at his

your own griming? [Knt.-jeering]
GRIPE-let vultures gripe thy guts..

doth gripe the hearer's wrist....

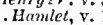

and gripe into your hands'...

ean gripe the sacred haudle...

with a feeble gripe, says ...............

how inly sorrow gripes his son
out of the gripes of eruel men

can gripe as hard as Cassibelan....

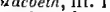

King John, iv. 2

Hesry $V$ iv.

gripe not at earthly joys..............

trould he gripe, and wring my hand .... Othello, iii.

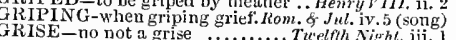

every grise of fortune

which, as a grise, or step
RISLY - this grisly betast.

Timon of Al

my grisly countenauee made.............

RISSEL L prove a second Grissel. Taming of $S h, \mathrm{ii}$.

GRIZZLE-hath sowed a grizzle.. Tw'elf h Nighi, v. 1

the grizzled north disgorges such. Pericles, jii. (Gow.)
his beard was grizzled?

thy groans did make wolves howl ...

with penitential groans
sad sighs, deep groans.

with groans that thuniler love...........

sovereign of sighs and groan....... Love's L. Lost, ii. I

God give him grace to groav!

v. 3
iv. 3
iv. 3
v.
3

the clamours of their own dear groans

heaved firth snch groans .........As you Like il, $\mathrm{ii}$.

mande a groan of her last breath

where sighs, and grouns, and shrieks...Mactel

Int mire ages groan for this foul act ...

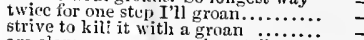

are clamorous groans, that strike ujon -

blows, and groans appland our sport. I Henry $I V$. i. 3 how dying Salisbury denth groan...... Henry $V^{\prime}$ it. 4 and hear my decp-tet groans........2 Henry $r i . j i .4$ or heart-offending groans............ - iii. 1 sick with groans, Look palc as primrose
kill, as dotll the mandrakc's groa!n .. groan like life und death's departing. 3 Henry $_{\text {migh }}$. ii. 6 save for a night ot groans endined. Richard 111 . iv. $\mathbf{2}$
GROANS-yet give some groans. Troilus\& Cress. v. 1] religion groans at it ......... Timon of Athens, iii. 2 with the easy groans of old woimen. I did hear him groan......

to groan and sweat under the busine.

iv. 1 where I did hear him groan rather rroan so in perpetuity........ - v, 4 can you hear a groans ...... Titus Andronicus. iii, 2 but he made a groan at it............ $\div$ iv. 3 such groans of roaring wind and rain..... Lear, iii. 2 thy old groan, and tell thee? Groan?komeo \& Jul. i. unless the breath of heart-siek groans - ii. 3 have not art to reckon my groans. Hamlet, ii. 2 (let.) two or three groans [ Col. Knt.-groan] .. Othello, v. 1 two or three groans [Col. Knt.-groan] .. Othello, v. I ROANED-under, iny burden groaned.. Tempest, i. 2 fair, which groaned for him, as I ...Richard II. v. ROANING-the groaning J Jiliet. Reos ful. i. 5 (cho. converse with groaning wretches., Love's L. Lost, $\mathrm{V}$. gave to me many a groaning throe. Henry VIII. ii. groaning underneath this age's yoke.Jul.Cosar, i. to appcase their groaning shadows. Tilus Androu. i.

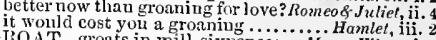
GIOAT - groats in mill-sixpences....... Herry Hivives, as fit as ten groats..................... All s W Well, ii. 2 is ten groats too dear ................ Riehard II., v. seven groats and twopence ........

Henry $V . \mathrm{v}$. or any groat I hoarded to my use..2Henry $V I$. iii.

to buy and sell with groats

.2 Henry VI. iii. 1
Corrolanus, iij. 2
$\ldots 2$ Henry $Y$.ii. 4

you'll prove a jolly surly groom ..... -

loggerheaded and unpolished grooms ${ }_{\text {and the surfeited grooms do mock ..... Maebeth, iv. } 1}$ smear the sleepy grooms with blood … a poor groom of thy stable ...........Riehar dII, v. to thee, or to the uneanest groom....2 2 Henry $V I$. ii. 1

uneovered to the vulgar groom .......

groom is for such payment ........ Henry $\bar{V}$ IIX.

counscllor to try him, not as a groom

thon wert too base to be his groom.. Cymbelin

and rou are gallant bro your groom

prostitute me to the brsest groom

slave and sumpter to this detested groom. Lear,

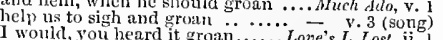

of sighs, of groans, of sorrow $\ldots \ldots \ldots \ldots$
or groan for Joan?

there for welcome, but my groaus? . Richeth, iv. 3

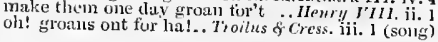

GROPED-in tlie dark groped o to find ... Othello, ii.

ROSS-this grose watery pum trouts .. Meas. for Meas.

never saw him so gross in his jealousy - iii.

to prevent so gross o'er-reaching $\ldots .$.
I will washoff gross acquaintane.

with character too gross ...Mreasure for Mea sure, $\mathrm{i}$.

I'1l speak more gross: your brotier..

pight, says she, a great gross one......Mruch $A d l o, v$

upon this gross world's baser....... Love's L. Losi,

proves dainty Bacchus gross in taste -

and we that sell by gross, the Lord doth =

raise up the gross of full three...Merch. of $\overline{V e n}$
it were too gross to rib ber cerecloth

which to term in gross, is au unlessoned -

he sce, gross fools as he.....As you Like it, $\overline{i i}$. 5 (song

now to all sense tis gross, you love... All's Well, i. 3

pronounce thee a gross lout ......Winter's Tale, i.

a gross hag! and, lozel, thou art

a gross and foolisli stre, blemished

to my cartly eome to him by the gross - iv. 3

gross rebellion, and detested treason. Richard II. ii.

gross as a mountain, open, palpabie. I Henry IV. ii. 4

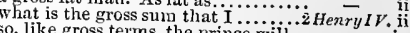

so, like gross terms, the prince wiil...

free from gross passion, or ot mirtli.. Henry $V$. ii.

of those gross taunts I often have... Riehard 11 . i. 3

cannot make gross sins look... Timon of athen s, iii. 6

forgetfulness, too general, gross...... - v.

he flashes rank of gross diet .. Antony $\&$-Cleopatra, v. 2

show scarce so gross as beetles ............... Lear, i. 3
very gross kind of beliaviour ... Romeo 8 iv. 6

n the gross and scope ot mine opinion.

thiugs rank, and gross in nature ....

I say again, hath made a gross revolt

fools as gross as imnorance made drunk

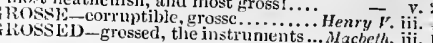

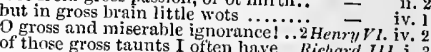

abuse their husbinds in such gross kind 


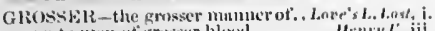

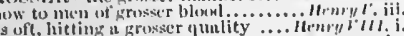
us of, hittimg a grosser quitity llemente iv. to strain byy speceh ti) gressect issmes

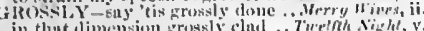

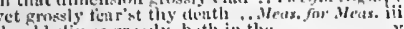
should stip so gresssly, buth in the.... -

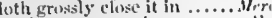
Aprenk not so grussly: you are ul

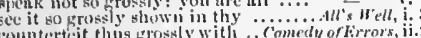

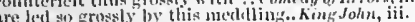
and could an erosisy ofter it

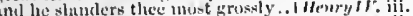

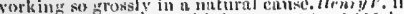
grossly grew (anptive to his homey . Kirkatri $/ 7 \%$. is. most enes, by his ow

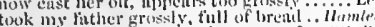

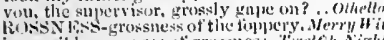

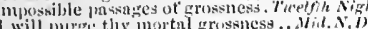
N.Dr. iii. 1

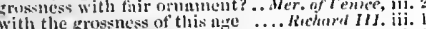
whose frossness little chanracters. Troilus f Cress. i.

the groman. indeed, is tawny

cannot muke him give ranum

beat the ground for kissing

built upou another man's ground.........ry 1

that it is lis gromend of faich

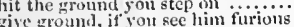

on hase and ground enough

know the crotunds and authors of it..

havine waste grount enough

the wirkedest exitill on the ground

on the dark and dirty ground............. N. Dreum, if. 3 fulluw grome the dead? or ascep?

on the rround sletp sount

rock the ground whereon these sibejer

with these mortals on the gruand...

between her fother's gromind and mine

I do aftect the very ground

kisses the base ground with obedient

have found the ground of stmly

the fairest gorldess on the oround

tiumble on the ground, with such ..

till I have run some ground.

as far ths Goil lias any ground ..........

it well beeomes the oround, ....... As you Litie

head on ground, with eat-like watch ${ }^{\prime} \overrightarrow{W^{\prime}}, l$,

ill my uncertain grounds to tail .....

I slall lose the grounds I work upon - iii.

the ground of all accord........

my grount to do 't is the obedienee. W' 'Tinter's Tule, i. ?

than I, my lord, upon this ground

shall liel i, to pot him i' the ground

her fight aeross thy father's ground -

the gromud of iny defestures . . Comety of Errors, ji.

kiss the gromind before young Nialeoin's -

senttereif on the bleeding tround.... King

dished thent to the gronmi...

to run even, ilyon even gromill...

=

good groudd, he pitiful, ind hurt me not.

measuret back ward their own ground -

or any nther yroumd inbalitable

then, Fingland's gromul, finrewell....

to touch a dust of Englind's gromnd?

ed is the hullow aroum

sin ve our deposed botics to the ground?

of Evglish shnll manure the ground

will I rise un from the ground

as if he divlnined tley grownd

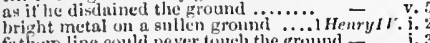
fathom line eould never touch the ground -

eight yards of uneven thine ear elose to the ground
lay the

began to give me ground

rise froin the ground like featlierei...

and bleeding upon the grome $\ldots . . . .3$.

by this heavenaly ground 1 tread on..

get jomant and vantage of the king

toncl

and, hy the ground they liade, I judige

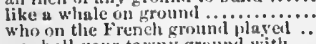

we shall your tawny ground with

who hath measured the gromul? ...

pitchell in the groum comfusedly

digesed stones out of the grouml......
on any plot of gromend in Christendion.

his sapless branclies to the ground

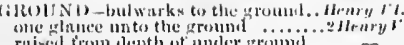

ruised from dlepth of ander aboum

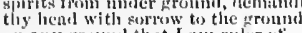

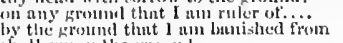

to come to rob ny groums, elimibin.

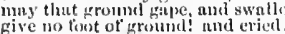

unifht in the gromud be closed up.

listumour lnid me on the eroumul...

root was fixed in virtue's ground

blowl of laneaster sink in the grounile?

gather the gromb of your ill-wili. Mi
for on that gromd I'll make a holy

let us survey the vantage of the gromal
these dewy tears were trom the grominl

these dewy tear's were from the gromind

iosks upon the grount, then, la
lily shinll she pass to the ground

blood mint the urouml, getes. Timon of

they hute mpon nio lietter a grommi.
on fair grouml, 1 eould bent forty.

while I remain alove the groundi....

the to a bowl upon a subtle ground..

stands on sueh slippery ground

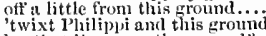

he, that lies upon the ground?

round. Antony of Cleo.

gave you some ground ..............

should get ground of your fuir mistress -

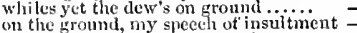

have male the ground my hed

then on good ground we fear

sing him to the ground, as onee our..

we huve the advantace of the ground

what fairies haunt this ground?

neer thised twixt, sky and groumd....

full well I wot the ground of all.. Titus sndro

know this diseord'g grouml, the inusie
hepe to jluek a dainty doe to ground

make a chequered shadow on the ground -

the ground's the lowest, and we are....

or kmuw what ground's male liappy.

upon wlant oromb is his distemperature? - iv.

methinks, the ground is even............ Lenr, iv.

mistempered weapons to the ground....... Re \& Jul. i.

stakes me to the fround, I cannot move

and fall upon the ground, as I do now
there on the ground, with his own tears

lifts me above the ground with eleerfu

thine ear close to the lollow ground

the groumd whereon these woes (rep.)

friends to this ground. And liegemen.

it waves you to a more removed ground
hic et ubinue? then well slitit our ground

I'll have groumls more relative tlinn this

we go to gnin a little patch of ground...

they slould lay him the eold ground

how the knave jowls it to the ground
what ground? Why, here in Demuna

she should in ground unsanetified have.

on other grounds Christian and heatien.

hnt that $Y$ did proeeed upon just grounds -

GROUNDED upou no other argument..As you Like
sickness, and no grounded malice... Richard II

Epeak on: how groundel he his title. Henry I'II

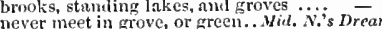

thou shalt not fiom this grove

ere he do leave this tro

and seek through this grove ........

like a torester, the groves may tread

for, besides the groves, the skies ....
ever Dian so become a grove.. Taming of Shret

ever it eoming; I say, a moving grove... Whecteth.

amongst a grove, the very straiglitest.1 Henry W'.

on the enst side of the gro

a grove of cypress tree.

Fon grove..Coriolamus, j. 10

but like to groves, being topped

Iinderneath the grove of syeanore.. Rome of $u$ u. i.

\section{prostrate, and grovel on the earth}

GROVELL NG-husbnnd groveling lies. King John,

to make this eontract grove

his body uglier grow

二 iv.

if matters grow to your likings.... Merry I'ive's,

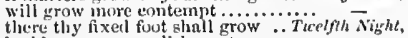

besikles, your grow dighonest.

even when they to perfection grow.....

I would not have it grow on my ehin

the man grow's mal; a was...

so quickly frow, that thine own

and. I trust, jt wifi grow to 4 most.

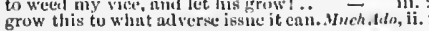

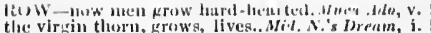

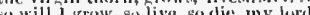

and sogrow to n print $\ldots \ldots \ldots \ldots$.

and grow big-hellict, with the wanton

mid tho nokiling violct krows........

thase kisting cherries, temuting grow

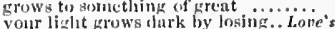

and still lets grow the weeding

a mun of great spirits growo melanciol y? -

my spirit frows heavy in love

glory prows guilty of detested erime.

your lips grow toul ..................

inctore your liorns do grow

it grows dark, he miny stumble .......

I'll grow a talker for this gear

will turn eloristian; le prows kind

sometiring sumack, something grow to
that Dobbin's tail frows back ward ..

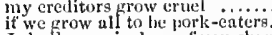

I sliall grow jealous of you shortly

and discourse grow commendable in $\bar{L}$ ike iij.

begin you to frow upon me? ......... -

and mine; but it grows sometling staic

if he, eompact of jars, grow musican.

to grow there, and to benr

I grow to you, mal our par

vou do so grow in niy requitii

he grows impaticnt .... Tuming of Shireu, $\bar{j}$ (ipduc.

otherwise would grow into extremes - I (indue.

no profit grows, where no pheasure is

whenee trows this insoleoce? Bianea =

you grow too forward, sir.............

bids the other grow, faster than thought

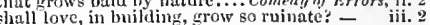

knowing how the dielit grow so ruinate

say, how grows it due?

there if I grow, the harvest is...

he grows worse nnd worse ...........
with this, there grows, in my no

stieks deeper; grows withmore pernicious - iv.

this day grows wondrous hot

grow great by your example

our security, grows strong and great

that hath some hope to grow .....

where kings grow base, to eome...... =

my knees grow to the carth.

sprinkle ground they grow

one ot them is fut, and grows old ...i illenry $1 \%$, ij.

the finster it grows, yet youtli...

if I do grow great, I'll grow less $\ldots . .$. .

to me! - -

our present musters grow upon the file
that it may grow and sprout as high

this will grow to a brawl anon

what rank diseases grow, nind witi what -

of that seed, grow to a grcater falseness -

grow till you eome unto it $\ldots$..........

the strawbery grow's underneath
itt you grow foul with me, I'istol

that grows not in a fisir conseut

in a garden where lceks did grow.

but grow, like savages, as soldiers.

the natter grows to compromise

now yoll grow the hot

befbre the wonnd to grow ineurabie

wonll never let grass grow

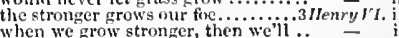

why grow the hranches, when the.. Biehart $1 / 1$. ii.

young eonsin? it is gow to grow ..... -

grow apraee; and sinee, methinks (rep.) -

Bingham grows eireumspeet

for it grows again fresher than èer. IIenry $_{\text {r }}$

my soul grows sad with troubles

they that my trust minst grow to
felt the flatierics that grow unom it

grow from the king's ac'plunintan

and grow as terrible as storms

so) I grow strunger, you more....

good grows with her .......

diansters rrow in the veins... Troolins of cressida

grows to min envisus fover.

trows dainty of his werth $\ldots . . . .$.

and 


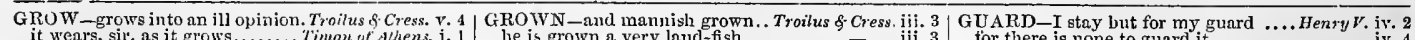
it wears, sir, as it grows....... Timon of athens, i. as Timon grows, his hate may grow is grown too proud to be so valiant... Coriolanus $\mathrm{i}$. for there is rone to guard it............ $O$, he is grown most kind of late

Gloster! guard thy head ............ which grows here in this Marcius is grown from man ..... - v. actions would grow wondrous single what a blunt fellow is this grown to be? purposed thing, and grows by plot yct prodigious grown, and fearful... Joan was his defensive guard......... the duke, and guard hin sure......... Heary $\boldsymbol{V} I$. to guard the chicken from a hungry - iii. 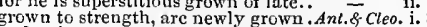 and quietness, yrown sick of rest... wounds where it should guard ...... $=$ v. as his kind, grow mischievor

Lepidus was grown too crue

When IIarcus Brutus grows so covetor are you so desperate grown .. Titus Antronicus, ii. for wise men are grown foppish .....Lear, i. 4 (song) nor curstness grow to the matter wash my brain, and it grows fo
but his whole action grows not.

the room is grown too hot......... Rameo b.Juliet, i. 5 my true love is grown to such excess - ii. 6 had grown by whown bold

grace grow where those drops fall! .

grow patience! and let the stinking

valour, that wildly grows in them

stock, and freshly grow (rep. $\mathrm{v} .5$ )

ay, boy, grow ye so brave?

what being more known wrow ware

grows elder now, and cares it be not

but grow faster than their years

shall your thoughts grow on..... - iv.

here comes that which grows

his kitights grow riotous

what grows of it, no matter
but now grow fearful, by whet

fortune may grow out at hecls......

all the idle weeds that grow in our

your other senses grow impertect.

from whence his sorrows grow ...R
nay, bigger; women grow by men
uake laste, for it grows very late

uake laste, for it grows very la

unweeded garden, that grows to seed

does not grow alone in thews, and bulk

my sinews, grow not instant old

low comes it, do they grow rusty?...............

fears grow grow themselves to eommon

spirits grow dutl, and fain I would beguil

ay, sir, but, while the grass grows ...

there is a willow grows ascaunt the

does by their own insinnation grow.

even as our days do grow! ......................
shall grow stronger than it was before

other things grow fair against the sun

and the night grows to waste: about it

almost to the sense, and he grows angry

GROWETH-fine musician growe

GROWING-his ambition growing

with clustering bunches growing
great a favour growing proud.. Tu, $z^{\prime}$ iven. 1 (song)
growing ruinous, the building forl

things growing are not ripe until ... Mid. $\bar{N}$. Dr. ii. 3

my scene such growing ... W'inter's Tale, iv. (chorus)

yet your maideuheads growing .......
growing to me by Antipholus... Comedy of Err. iv.
labour to make thee full of growing ... Nacbeth.

done so to great and growing men.. Nichard 1I. 1ii.

to ripe his growing fortunes........2 Henryl $V$. iv.
si kness growing upon our soldiers .. Henry $V$. iii.

sic kness growing upon our soldiers .. Henry

bathed thy growing with our heated.3 Henry Vi. ii. 2

contend with growing light

Henry VIII ii.

the mind growing on ce corrupt

- ii. 3

still growing in a majesty and pomp

growing feathersplucked from Casa

shakes all our buds trom growing

now is growing upon thy shoulders.

for goodness, growing to a plirisy

Cymbeline i. 1

and words are grown so false.... Tuelfith itght $\mathrm{i} i$. grown feared and tedious... Measure forkMeasure, ii. and are you grown so high in his.... master is grown quarrelsome... Taming of Shrew, of Perdita, now grown in grace

grown in to an unspeakable estate
is not your father grown incapable

there the grown serpent lies

are grown somewhat light

but that the world's grown honest

the age is grown so picked, that the toe.. - v. 1

gain nothing under him but growth. As you Like il, i.

let me stay the orowtl prese

leave the grow th untried .. Winter's Tale, $\bar{i}$. (chor.) whose want gives growth to overta'en him in lis growth

to touch his growth, nearer thian

whose growth may damage me $\ldots . .$.

I cannot give it vital growtl again GRUB $-a$ grub, and a butterfy........... Coriolanello, v. 2 the joiner squirrel, or old grub... Romeo \&-Juliet, i. GRUBBED-wish it grubbed up now. Henry $\bar{\nu} I I I$. v. GRUDGE-served without or grudge .. Tempest, i. 2 feed fat the ancient grudge... Merchant of Venice, i. that grudge one thought again

your private grudge, my lord

3 Henry $V l$ iii. 3 it ever any grudse were lodged..... Richard III here grow no damned grudges. Tilus Andranicus to grudge my pleasures, to cut off...

Lear, $\mathrm{ii} .4$ GRUDGED-grudged us contribution.Jul.Ccesar, iv. 3 GRUDGING-meat without grudging. Nhuch Ado, iii.
how will their grudging stomachs..1 Henry $V I$ iv. soul is purged from grudging liate.. Richord III. ji. GRUEL-make the gruel thick and slab. Mocbeth, iv. that dost grumble there i' the straw? ... Lear, iit. a grumbling groom, and that ......... Taing of Sh. ifi.2 that, with his grumbling voice ......3 Henry VI. i. 4 my old friend Grumiol and my good
rise, Grumio, rise; we will compound

patience; I am Grumio's pledge ....

pleasant servant Grumio: and tell me

peace, sirrah. Grumio rival.

Grumio, my horses. Ay, sir, they

master and his wife coming, Grumio?

I prythee, good Grumio, tell me, how

let's ha't, good Grumio. Lend thine ear

good Grumio, fetch' it me

Grumio gave order how it should be done

God-a-mercy, Grumio! then he shall

may beat dy a simple guard .........3 henvy

wherefore else guard we his royal.... - iv.

and see, where stand his guar talseliood of his

but attended with weak guard

what means this armed guard........ Richard III

and our innocence defend and guard us -

good angels guard thy battle!

good angels guard thee from the boar's $\overline{-}$

to $A$ chilles be thy guard, I'l cuit .......

commands the guard to tend on you

and all offences, a guard of patience,

Ajax, your guard, stays to conduct...

- iv. 4

upon my brother's guard, even there Coriolanus, i. 2

let a guard attend us through the city $=$ iii. 3

you guard like men; 'tis well ........

anger made good guard for itself. Antony \& Cleo. iv.

the messenger came on my guard....

We must rcturn to the court of guard
the guard! ho! O despatch me

call my guard, I pr'y thee (rep.).......

guard her till Casar come

Y'll take her to my guard ................
destruction whicl 1l] guard them from of the night, guard me, beseech ye!.. Cymbelir

where is the emperor's guard?.... Tilus Andron

his greatness was no guard to bar......

no place, tliat guard, and most unusual

good guard until their greater pleasures

to some retention and appoin ted guard.

with your wings, you heaveniy guards!

had neither motion, guard, nor eye

Fith no worse nor better guard
if you please to get good guard

quencl the guarls of the ever-fixed pole

great Jove, othello guard, and
watches on the court of guard

look you to the guard to-night

and on the court and guard of

GUARDAGE-rmo from her guar........ - .2

UARDAN'T-angry guardant stood.1 Henry $\nu T$. iv. 7 GUARDED-guarded with fragments. Mruch Ado, $\mathrm{i}$.

so strongly guarded: cousin .........King John, iii.

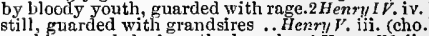
still, guarded with grandsires ...Henry/ ${ }^{\prime}$. ifi. (cho.

iii. 2 see them guarded, and safely brought $\overline{\text { iii. } 2}$ motley coat, guarded with yellow Henry $v$. vol. so, let the ports be cuarded.......... Corioh so slackly guarded? and the sesrch... Cymbcline, i. the lane is guarded; nothing roots us $-\overline{\text { valet, }}$ v. guaricd, to know your pleasure ...... Hamlet, iv. 3 the guardian of their bones my sweet guardian! Hark!.. Troilus \&-Cressida, v. 2 guardian! why Greek! Pho, phol..... made you my guardians, my depositaries. Lear, ii.
GUD-it sall be very gud, gud feith (rep.) Henry ${ }^{\prime}$. iii. aile do gud service, or alle ligge i'the - jii. GUDGEON-this fool's gudgeon. Merch. of Venice, $i$ GUERDON-death in guerdon. Much Ado, $\mathrm{v} .3$ (seroll guerdon [Knt.-gardon] (rep.) $\ldots$.. Love's L. Lost, iji.
sweet guerdon!] [Knt.-gardon] (rcp.) GUERDONED-you well gucrdoned..2 Enenry $^{V J}$. i. $\mathrm{EE}-$ 'tis Gual tree forest UARD-will guard your person whose wraths to guard you from he's ont of his guard already ..... Tuelfth Nigh best have guard about you

stands at a guard with envy

and cover in princely envy, ........eas, for Meas. the guards are but slightly basted..... Much Ado, i.

left in the fearful guard of ..... Merch. of Ventice
and keeps ber guard in bonestest ...... Alt's Well, and keeps her guard in honestest....All's Well, iii. from those that had the guard of. Comg; guard with halberds

heaven guard my mother's honour ... King Joh

to gilard a title that was rich before... ${ }_{\text {pichard }} I I$. for heaven still guards the right

to velvet guards, and Sunday ....... i Henry $I V$.
thou art a guard to wanton for......2 Herry $I$ some guard these traitors to

and see you guard him sure...........
here it sits, which heaven shall guard
immortally, long guard it yours! ....

that guards the peace and safety

guard your sacred throne...........
GUERRA-to fortuna della guerra. Love's L. Lost,

I guess not.................. Heasure for Mensure, $\mathrm{i}$

we may guess by this what you .............

the near guess of my memory. Merchane of Venice, $\mathrm{i}$.

partly guess: for I have loved (rep.). As you Like, ii.

but, as I guess, by the stern brow....

that square our guess by shows .......All's $W$ ell, i or your thoughts can guess . Taming of Shrew, ii. which I do guess, you do not purpose - Iv. humph! I guess at it

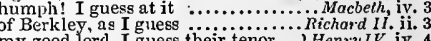
my good lord, I guess their tenn ...1 Henry $1 \mathrm{~V}$. iv might create a perfect guess $\ldots \ldots \ldots . .2$ Henry $1 V$. iii. better far, I guess, that we do ...... Henry $V I$. ii. as near as thou canst guess them ...3 Henry $V I$. iv. guess thou the rest, king. Edward's.. - iv. and, by thy guess, how nigh is Clarence -
and, as I guess, to make a bloody....
you cannot guess who caused your. nichard
IIII. ii.
Ajax is grown self-willed .... Troilus \& Cressida, i.

truce is rusty grown .....................
clilddren, growu too headstrong for
จ. 2 v. 3
ii. 4
v. 5 dissension, grown betwixt the peers

your priesthood grown peremptory?.2 Henry VI. ii. is the man grown mad?.

1
1
2
2
2
2
3
3
4
5
1
5
3
3
3
2
2
4
5
1
2
2
3
2
10
3
2
2
1
6
9
2

2 i. 2 ii. 1 
GUFAs gues that he dnth aim ., Richurd tIt. iij. 2

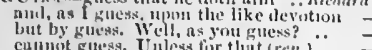
grcat sport tagetleer, ns you gu now, ly thy lowks I guess thy imessuge we might guess, they relieved us . . . Coriotom guess, hut by myys, their lumbs i' the give guess liow near to duy ........Julins Copsor.

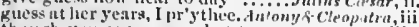
now

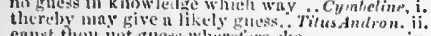
eanst thut not guess wherefire slo

liere is the guess of their true streugin

liere is the giress of their trie strength .. Lear, alerehance, um vicious in nyy guess to fuil ts often as I guesscd.

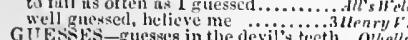
GubsingIT-lettergnessingly set down. Le

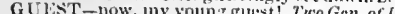

hurdom guest justice

I shatl prosure-a you de good guest...

Thue turned away nay other guents

thot y'ield to be your house's guest.. l.ot'e s L. Lost

a forwarl gnest within your louse. Teming of

and bid the guests; I will be sure.

or my guest? by your dread verily. Winter's Tale, i. ?

my kingly gnest unclasped ny practic

your guests nre eoming: lift

sce, your guests approach...........

n guest that hest beemes the table.

weleome to their shipwrecked guests. Com. of iv.

gtuest of summer, the fenple liawiting . Macbeth,

here's our clice guest. It he hini

jos'ial 'mong your grnests to-night ... - iii.

trimmph is become an alehouse....... Richard 1 . il.

look to the guests within........... i Henry $/ \mathrm{r}$. ii.

fits a dull fighter, and a keen guest

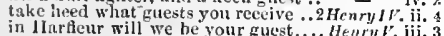
in lintieur will we be your guest...

your lordship is a guest tao

and there ge shall be my guests

but I appenr not like a guest

better, he became her guest..

milk yet the queen know of our guests

you are my giest, Lavinia .... Titus

by me so used $\mathfrak{n}$ guest is,
you nre my guezts (rep.)

you nre my guezts (rep.) ...

what guest s were in lier eses.

I have invited many a guest

it fits, when sueh a villain is a guest

make a mutiny nunong my guests!

somany girests invite as here are writ

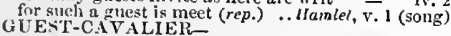
my knight, my gnest-eavalier? ... Merry Wives, ii. 1 GIIA $A-a$ region, in Guiuna ..... Merry Wives, i. 3

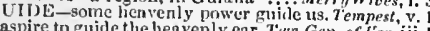
aspire to guide the heavenly ear. T'w Gen. of I'cr. jii.

guide him to thy husband's eudigul

and the devil guide his curlgel

to guide aur measure rounid.

henvens themselves to guide the state

if my instruetions ingy he most. Afe

youth mounts, and folly givides. As you $\vec{i}$.

th gitidc, a gorldess, and a sovereign.....A $l^{\prime}, W^{\prime}$

discumfort suides my tongue

in stov, iny guidour gujue .

a rill good fortune guide thee!.

who did guile, I mean, who set

till julur mensure, fnirly guide then!

till judgement guide his bounty

if oruls guid

give them guiste to us

Tienonnfthens,

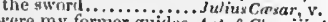
heaven gujle thy pen to print

yon'd guide me to your sovereign ....... Pericles, ii.

beentine lis guide, led him ..........

come, unsavoury guide! ..................... therenes, $v$, i Uil)F,

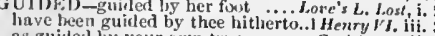
as guirjerl by your own true

to be guiled by nthere' experience...

GIDER_nur guider, emne.......... Corintanus i. WIDERIUS-father ealled Guilierius . . Cymb. iii. 3 as yours, is true Guiderius $\ldots \ldots \ldots \ldots$
Guiderius had upon his neck a mole send her a bettur guiding spirit!.. Wiwler's Tale, ii. 3

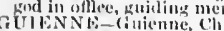

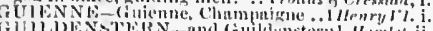

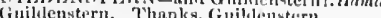

how dost thou, Guildenstern?

hark $y^{\prime}(0 t 1$, Ginildenstern; and

lo, Guildensternt liring in my his

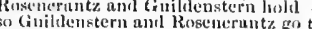

liosenerunt: and Guildenstern are dear

for the news that the Guililanly atford

treatherous, and tull of guile

G Un

GUIlis U L-by guileful fair words

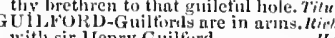

with sir I Ienry Guilford..............
vou are young, sir IIarry Guilioril.
GUILT-is so possegsed with guilt...

GUI $T$-is so possessed with guilt

shnue and guilt contounds me. Tr....... Gen. nf ter.

a murdernus guilt shows not.... Turethih Nirht, iii.

who bear the guilt of our great quell?... Macheth, i. 7

for it nust seen their guilt............

my guitt be on my licul

double gilul his treble guil

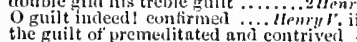

your guit is ireme

dentl, we do peres............

store of treasons to nument my ......i

his guilt should be but idly posted nver

that laid their murder bucklers

his appnrent openg guilt onitited

speak a word, the grilt is pluin . Tritus Audron. ii.

the old man hath found their guilt..

elose pent $=11$ guilt

elose pent-1up guilts, rive your ........... Len

$\mathrm{m} \mathrm{y}^{*}$ stronger guilt defeats my strong

so ful] of artless jealousy is gui
GUIITIAN-Guiltian, Cosmo

Ailis " $\overline{\text { ell, }}$

f should he guiltier than my giviliness . .

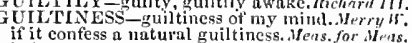

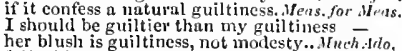

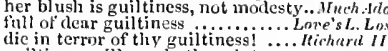

dic in terror of thy guiltiness! .... Mirhard III,
guiltiness will speak, though tongues ... Olhello,

fear, sinee guiltiness I know not....

ns guilt less labour when it lies... ifeas. for Mpies.

lie not guiltless here under some..... Mach duld

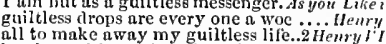

by shameful murder of a guiltless king

are free from guiltless blood-sltedding

o spare my guiltless wife, and iny poor

beeuse I will be guiltess of the meauing

our guiltless bloou to drink.

then my guiltless blood must ery

my lord, I nm guiltess, tis full...... -

I an guiltless of your father's denth ... Hunlet

even thus all guiltless meet reproach ......

a puiltless death I die. $O$, who hath done

wot gulilty of Lysander's blood. Mid. N. Drea

glnry grows guilty of detestel crimes

I heard your guilty rhymes..........
guilty, my lord, guilty; I confess.

your gentleness was gailty of it...... $=$ iv. 3

no bed shall e'er he gutilty.. Merehani of renice, iii. 2

Whercin I eonfess ne mueh guilty. As ynu Like it,
e'er thine own tongue was guilty of.. All's $I^{\prime} e l l$, iv.

e'er thine own tongue was guilty of ., All's li'ell,
because he's guilty, and he is not guilty -

boluly not guilty; the imposition.
spenk for lier, is afur off ruilty

mor guilty of, if any he, the trespass

he is not guilty ar

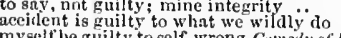

myselt be guilty to self-wrong. Comedy of Er

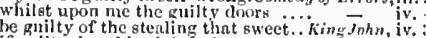

if guilty dread liath left thee so...... Richard $J$. . i.

the eloging burden of a guilty soul
his liands were guitly of no

his hunds were gutitly of no...........

this blonel of from of my true appea

or misprision, is guilty of this fauti... I /leury $/ \mathrm{r}$.

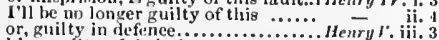

king guilty of their damnation (r....... Men - iv.

and shall my youth be guilty of sueh - ivenry th. it.

aecuse me? Wherein am I puilty?..2 Ilenry VI. iii. !

as guilty of duke Ifumphrey's timeless
UIl'TY-unless I find him guilty. 2NenryVI. i off witli bis guilty licul..........
nlwoys launts the guilty minil

$\because$ itichard II

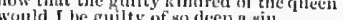

within the cuilty elosure of thy wails

thint ever yet this land was

mod, with guilty fear. let fall tiö länes -

crying nli, guilty! guilty! 1 slakl despair -

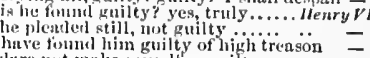

hlure not make myselt so grilty

is guilty of a severul basturily

guilty enves. Jilus Cosar,

we make guilty of guilty blow $\ldots \ldots$.

damnel guilty deeds to sinners' dfomeo fo Jutiel, iit.

hour is guilty ut this lamentable cluneel - v. 3

birth, wherein the upon a fenrful

mon brent the of, guilty, be assured .........

hili. 2

he, thint is not guilty of his own denth $:-v$.

GUINEA-IIEN-the dove of a guinen-hen

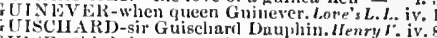

GUISE-this is hervery guise.............. Macoeth, $v$ i

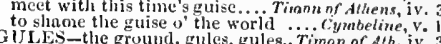

is he totul gules; Jorridly tricked .... If Ath. iv.

GULF-water in the hrenking gult. Comedy of lirr. ii. 2

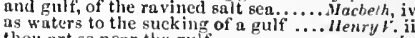

thou urt so near the gulf ............

shouldererl in the swullowing oulf. Kichory 1 . . y.

that only like a gulf it did remain .. Coriolanus, $i$.

like a gult, doth traw what's gueur it . . Mamlet, iii. 3

me in steep-down gulls of liquill tire... Othello, y.

yon guil i ulvolio is turned henthen

a thin-faeed knuve, a gull?

most notorious geck, and guil...........

ungentle gull, the enckoo's bird ....... i henry Ir. y. I

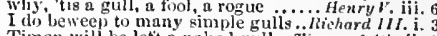

Timon will be let't a naked gull.. Timon of $\mathrm{A}$,h. ii.

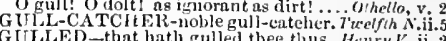

GUN-from his bomeless guns............ Wracbeth, i. ?

the gum down-roping from their........ Hem $V$.

our poesy is as a gum .......... Timon of Athens,
thiek anber, and 1 lum-tree gum ....... Hambet,

Arnbian trees their medicina gum ........ Hathele, ii. 2

GUMIEN-like a gumned velvet .iilien,yル.ij. 2

cawing nt a gun's report........Mid.N.'s Dreain, iij.

slow which is fired from a gun?.. Love's L. Lost, iii. 1

and, but for these vile guns...........

perilous shot out of an elder-gun ...... Henry $r$. iv. 1
or like an overeharged gun, recoil...2 Henry $r T$. iii. 2

GUNo the deadly level of a gun.. Romeo \& Juliet, iii. 3

nimble gunner with linstock.. Hem ${ }^{2}$ l. iii. (chorus)

GUNPOWDER-gunpowder Percy..1 Heury $1 \%$ v.

with choler, hot as gunjowder......... Henry $r$.

GUNSTONE-his balls to gunstines .... ${ }_{\text {G }}-$ i.

GURNEX-James Gurney, wilt thou. King John, i. I

fretted with the gusts of henven. Jr.r. of 'tnice, iv.

extreme gusts will blow out .. Taming of Shret, ii.

as rigour of tempestuous gusts ....IIllenry $1 \%$. v

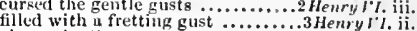

alway by the greater gust

grant, is sin's extremest gust... Timon of Amens, iil.

windsand ligh tempestuous gusts. Filurindianus,

USTY-upon a raw and gusty day.Julius Corar,

as -let vultures grifie thy guts!... Werry H'ives,

that sheep's guts should hale souls ....Mrachdetn,

why, thoil elay-brained guts] ...... i Henry $W$, ij.

you cnrried your guts away
that stuffid eloak hag of guts

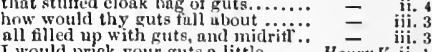

and his guts in his head a little ......... Hewry $V$. ii.

lug the guts into the neighbour room.. Hondes, iii.

GUTr-GIRIPINt, ruptures .. Troilus of Cressida, v.

GIY Sampson. nur sir Guy, nor . jienry blll.

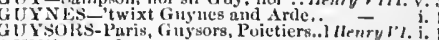

GYV L - you from your gyves ... Meas. fnr Meas. jv.

ns if they had gy ves on ............ Ilienry $l \mathrm{l}$. iv.

prisoner in his twinted gyves... . Hoineo of Juliet, it.

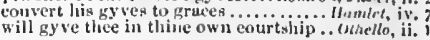$$
\begin{array}{r}
1 \\
3 \\
3 \\
2 \\
3 \\
3 \\
3 \\
1 \\
1 \\
1 \\
1 \\
2 \\
1 \\
2 \\
2 \\
3 \\
4 \\
2 \\
3 \\
3 \\
3 \\
3
\end{array}
$$ 
IIABERDASIIER'S wife of small ..FenryVIHI. v. 3 IABILANEN T-pour habiliments. T'wo Gen of $V$. iv. these honest ne:m habiliments .. Taming of Sh. iv. 3 liabiliments of the groddess Isis.. Antony \& Cleo.

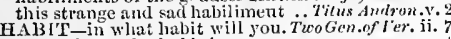
use doth breed a hitbit in a inan

and in that habit, when slender....... to these halsits of her liking ........ in the liabit of some sir of note
one habit, and two persons

supply me with the habit... Measure for Meas

often dost thm with thy ease, thy lit

my mind promises with my hat

al pureled in more precious hal,it

never more in Rnssian hahit wit.

these tour will cliange habits

ot labits, and of forns, varying

if I do not put on a

under that habit play the knave........

fie! doft' this habit, shame to.. 2'aminar of s'hrew', iii. 2

sober ancient gentleman by your habit

the celestial habits ..............menter's Tale, iii. and not alone in liabit and deviee... Kimg John, i. by our habits, and by every other.

you know me by my habit

Henryl $r$.iil.

hath into monstrous habits $132 \mathrm{t} . .$. Henry VII . i.
any thing but clurchmen's habits .: any thing but clunrchmen's habits is her habit only that is houest. Timon of

this slave-like habit? .........

valour in me th:m my habits show
a fourtl man, in a silly habit......

makes us scan the outward habit.

and in this habit met I my father
costly thy labit as thy purse can

costly thy habit as thy purse can
or by some habit, that too much

my father, in his habit as he live

all sense duth eat of liabit's devil

these thin habits, and poor likelihoods .. Othello

a loeal habitation, and a name.. Mid. N.'s Dream,

habitation which your prophet $\ldots$ Mer. of Venice, i. 3

Jabitation giddy and unsure hath
II ABITED-she shall be habited.

or is it Dian, habited like her. Titus Andromicus, ii.

FACK-these knights will hack.... ${ }^{M}$.
limbs whole, and hack our Englisli.

he teaches him to hick and to hack

to hack thy' sword as thou ....

i Henryll. ii.

look you what haeks are on..........ilus \&

incre be haeks! Be those with sworils?
and then haek the limbs......... Jul
HACKED-bones my flesl be hacked ..

is hacked down; and his summer.... . Richareth, my sword hacked like a hand-saw... i Henry $1 \%$. ii. sword so hacked? Why, he haeked it

here was hacked to death ........Richard III. iii. haeked, the air will drink the sap.. Henry $V I I I$. handless, hacked and chipped

when your vile daggers hack

bear our haeked targets like ....Anto

HACKLT-ask Marian Haeket. Taming of Sh. 2 (ind.
you would call out for Cieely Hacket -2 (ind.)

HACKNEY - perlaps, a liaekney.. Love's L. Lost, iii. 1
HACKNEY ED-hackneyed in the eyes.1 Hen. 1 '

HCC

HAEC-nominativo, hic, hec, hoc.. Nerry W'ives,

$\mathrm{HAG}$ - this blue.eyed hag was hither.... Tempes

nominativo, hig, hag, ho

yon witch, you hag youn.......

youss har and, fozel, thou ....Winter's Tale,

filthy liags! why do you show

and hag of all despite .............

wedded be thou to the hags of heii...2Henry $r$

thou hateful withered hag.......... Richard III

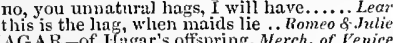

AAGAR-Of litugar's offspring. Merch. of Venice,
HAG-BORN-freckled whelp, hag-born. Tempest,

HAGGARD-and, like the haggard. Terelfth Night, iit.

and wild as haggards of the rock ... Much Ado,
I have to man my haggard .. Taming of Shrew.

loved this prond disdainful haggard

if I do prove her haggard, though that. Oinello,

11 AGGISIT-on us both did haggish age. All's Ie
11 AGGLED-York, all haggled over... Henry $\mathrm{V}$.

IIAG-SEFD-hag-seed, hencel

hail, many-coloured meser! (rep.)

hail kissing-comfits, and snow..........ry wives,

lail, virgin, if you be...... Measure for Mcasur

liail to you, provost! ................

hail, mortall Hail! Haill Haill.....

hail, sweet madam, and fiir time (rep.)

a sunshine and a hail in me ........All's $\bar{W}_{\text {ell }}$, v.

hail, brave friend! say to the.............Macbeth, i. I

all hail, Macbetli! liail to thee (rep.).. i. $\overline{5}$ (letter)

hail, king! for so thou art

hail, king of Scotiand ! (rep.) ............ $\overline{\text { hong }} \overline{J o h n}$, iii.
IIAIL-sometime ery, all haill....... Hichurd $H$. iv. ericel all hail! when as he ineant ...3Henry

hail, all the state of Grecel. Troilus $f^{2}$ Cressida,

hail, worthy Timon! our late.

hail, noble Marcius! Thianks ......... Cariola

my gracious silence, hail! wouldst thon -

hail, Jurds! I am returned your soldier

Cesar, all hail! good-morrow...

crying, long live! hail, Cxsar?

and hail rich pearls upon thee

laail, Cwsar, and my lord! hail...

liail, tlou fair heaven! we house

hail, heaven! IIail, heaven!

hail, great king!

Lucius, all hail; Rome's royal (2

all hail! the gods preserve pout (rep)

hail, sir! nyy lord, lend ear .......

hail, madlam, and my queen!

hail to your graee! 1 am glad

hail, gentle sir. Sir, spced you
hail to your lordship! I an glad
hail to thee, lady! and the grace

the he halled down oat

HAIISTONE-vanish like hails

HAIR-not so much perdition as a juir. Tempes

then like reeds, not hair

not a hair perished

yolt are like to lose your liai.

lady ghip must cut your hair.

there's not a hair on's head.
she hatly more hair than wit

and more toults than laairs

her hair is anbur'n

you go arainst the liair....................

an exeellent head of hair

would that have mended uny.

tetch you a hair of the great Cham?.

and her hair shall be of wh

if the heil were a thought browner...

and, with grey hairs, and bruise

French erowns have no hair at all

pard, or boar with bristled hai

desire lime and hair to speal better?

with lime and hair knit up in thee.

amber hairs for foul have amber.
one, her hairs were gold ............

that painting, and usurping hai

cutting a smaller hair than may.

hant of te

more hair on thy chin, than

here in lier hairs the painter plays.

do turn but in the estimation of a hai

will ne'er wear hair on his face

his very hair is of the dissembling. As you $\bar{L} i$ is hair is of a good colour

your black silk hair, your bugle ....

man, orrown witl hair

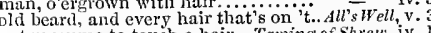

not presume to touch a hair.. Taming of Shrew, iv.

so tliat there be not too mueh hair. Wi

hiave made themselves all men of hair $\overline{\text { his }}$

thy golden hairs, and as a bed ......
war against her hair [ Col. Knt.-Keir]

a rusl, a hair, a drop of blood

mire to quench the hair............

and thy hair, thou gold-bound brow

had I as many sons as I have hairs

this hair I tear, is mine ............ King John

multitude of those her hairs! I........

as they liave given these hairs their.

a walsdering hair, any annoyanee.

never wear hair on my faee more .... Hen Hentr.

his white hairs do witness it $\ldots . .$.

the tithe of a hair was never lost

was sluvel and lost many a hair

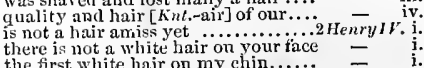

the first white hair on my chin.....

how ill white hairs become a fool ....

with one appearing hair....... Herry $V$. iij. (chorus)

as if his entrails were hairs .......... $\quad$ iii. 7

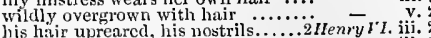

his liair, you see, is stieking.......$\div=$ iij.

conb down his hair; look $i$
HAll-shame to thy silver hair.....2Henry VI. y.
would bring white hairs unto ......3 wound about thy coal-black liair..... with bright liair dabbled in.

with bright liair dilbbled in............ her hair, her cheek, her gait

three or four hairs on his chi

to spy a white hair on his chin .........

at the hair, as at his pretty answer -

hairs, quoth he, and one white (rep.)

whiel of these hairs is Par

your brother's excuse? To

tear' my briglit hair, and serateh

pluek Kundus down by the laair...

his silver hairs will purchase us.

yea, beg at hair of him for memory ..

like the euurser's hair ....... Anloury \& Cleopatra, i.

with thy grapes our hairs be crowned - ii. 7 (son

her hair, what eolour? Brown, madam

my very hairs do mutiny....

thy flece of woolly hair.... Titus

rent off thy silver hair ...............

shalt this hair of mine remain..... Pericles, iv

the colour of her hair, emmplexion .. - iv.

to wash his face, nor cut lis hairs $\ddot{-}$ iv. $\overline{4}$ (Gower)

tears by hair in k

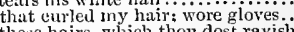

these hairs, which thon dost ravish.....

作

to stop in wy tale actoinst the hair

a hair more, or a hair less in his beard - iii.

each particular hair to stand on end ...... Humlet, $\mathrm{i}$.

your bedled hair, like life in exerements $=$ iii.

IIAIR-BRAIIED-hair-brained slaves. I Hen. $\boldsymbol{V}$. i.

IAIR-BRE A DTI- hair-breadth 'scapes. Othello, i.
II AIRIESS-thin and hairless scalns. Richard II. iii.

IIAIPY - I am marvellous hairy. Mic.

tor she his hairy temples then had ...
th us the hairy fool, much malked...
ive, ii.

you are rough and hairy ........Winier's 'Tate, iv.

conelude hairy men plain dealers. Comedy of Er:

indeed, you eone near me now, Hal

but, Hal, I pr'y thee, trouble me .
Hal, God forgive thee for it: (rep, $)$

good-morrow, sweet Hal

where's Poins, Hal? He is walked

Poinsl Hall a plague upon you both!

where hast been, Hal? ivith three.

tell thee what, Hal, if I tell thee a lie

four, II I al, I told thee four

dost thou hear me, I Hal

ah, no more of that, Hai

when I was about thy sears, Hial...

but, tell me, Hal, art thou not horribly

wilt thou believe me, Hal? ............

why, Hal, thou know'st, as thou...

dost thou hear, Hal? thou know'st..

now, Ilal, to the news at court ...
what, Ilal? how now, mad wag?

mine, Hal, mine. I did never see.

Hal, if thou see me down in the

nay, before God, Hal, if Percy be alive

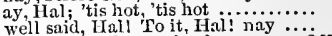

no abuse, Hal, on mine lion

king Hal! my royal Hall ............

unless our halberds did shut up....3Hemy $l i$ iv.

advanee thy lialiberd higher than .. Kichard lih.
HALCYON-8ummer halcyon days... Henry $F I$.

their halcyon beaks with every gale....... Lear, ii.
HALE-eannot hale them together. Twelfih Night, iii.

sheep's guts should hale souls out ... Huch Atlo, i.

altho' ye hale me to a violent.

hale luin away and let him ...........

and hale him hither........ Troilus \& Cressid.

and hale him up and down.......... Coriolanus,

to hale thy vengeful waggon... Tilus dndronicus,

so hales [ $K$ nnt. shakes] and pulls me..... Othello,

IALED_strangers may be haled.. Taming of ' Sh

a man new haled from the rack .... Hen'y $V$ i
$H A \mathrm{LF}$ - farewell, 'till half an hour.... Tempest,

but half a fish, and half a monster... - iti. 2

within this half hour will he be asieep $\overline{\text { Merry }}$ -

with half Windsor at his heels

I am half afraid he will ....

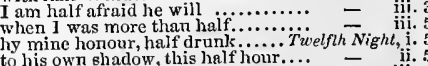

for the halt of my dowry 
HII

$[3: 37]$

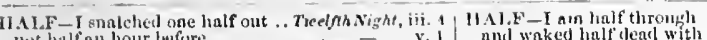

v. nnd waked half deasl with nothing

and $n$ hialt, sir .......................

leeenne them with one half so good.

the'n half signior lkeneliek's tongue... Murh ddo,

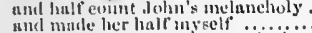

noll lulf tly nutward graee lial ...

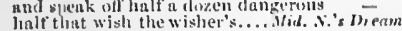

null halt his titee mast be seen .......

a dark sighlit tor of hatf the day. Love's L. Lost,

the one hulf of an entire sum.........
but that one halt which is unsatistied

one halt so briglit through the ..

he 'elepeth a cilf, eute
is too lons by lialf' a mite

close mine cyes some half ain hour

to your vizar, and half once to you .

afturil my speechless visor half

no, I Il not be your half

no,

I an half ufeard, thou wilt ...Merehum

and hindered me of halt' a million .

I am lialf yourself, and I must ( $r$ p

bear halt the keenness of thy sharp..
one halt lis goods: the otluer half comes -

one halt' lis goods: the other half comes -
for half thy wealth, it is Antonio's (rpp.) -

for half thy wealth, it is Antonio
the fine for one halt of his goods

the otler half in use to render it

or hall her worthinesa that gave

or hat her worthinesa that gave ....

linlf of the which dlaye not slak

a cheek of two pile and a half.

not half way to her heart ....
eall him half a seure knaves

that gives not half so great a blow

one lialt of my lands: and, in possession -

to wish me wet? to one half lumat

three quarters, hatf yurd, quart
son, I will be your liule, Bianea.

hast the one half of my hear

there is not half a kiss to ehoose.

tweive foot nnd a lialt by the squire.
the gentleman is lialf flinyed alrendy

not half au lionr since........ Conedy of

gave it you half an hour sinea

now o"er the one halt' worli $\ldots . . . . . . .$.
to lialf a soul, and to a notion crazed

we have lost best half ot our

he is the half part of a blessed man..

the sear enraged is of half so dea

in mortal my power this niglit.

who halt an hour sinee eame.........

divide the realm, and give thee hiolf. Richnrd

old sir Jolu, with half a dozen more.1 lenery

if thou dost it lialf so gravely.......
or duath's hand for this one hair year

blitrt and a halt' in all my complany (rep.) -

not a horse is lialf the half himse

half his Troy was burned

xho, half tlirough, gives
IIarry had but huif thuir

Inarry had but hisf their ............

provided me here half a dozen sutficien

not so sounch, and half so deeply swe
to stah at half an hour of my life.

we lose the better half of our

with haif their forees the full...

one half is eut awas

rum not lialf so timorous from

taunt with cowardice a man half ienil?

with more than half the Gallian

Iot hali" so bad ns thine to England's

within this half hour, hath received

Woved him half so well as 1 .

ctand pensive, as half malcontent?
my joy of liberty is half eelipsed

anil half nur sailors swallowed.

gearee lialf made up, and that so

hears lialf my burdent yoke....

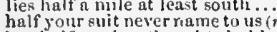

but half my lay-thoughts in him....

you met nim linif in lieaven

you met him half in lieaven .........

some half huur, or so, in a rich

that lad not half a week to go .......

and has done half an liour, to kn
would you were half so honest!

an 'twould, you'd enrry half.. Troilus \& cressidn

In twain, unil give him half ........

I would not tior hals Tros have
this $A$ jax is lialf inacie of (rep.)

being kin, halt stints their strife.

my propheey it but latif lis journey get
may worthy Troilus be lialf attaclied

your eyes, half out, weep ont at ...

laeks a half to pay your present ilebts

I should aot urese it half so faitlifully

end the beat half should have return
who then lures to be half so kind....

whin then lares to be half ro kind.
half to laif the world by the ears

half all Cominiug'

h' Wedneorlay half an leur togetier

I will, for half a iundret

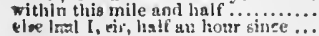

to me, yourself, your half, why you. one lialf of what lie was yenterday

went I let forth your lialt pint ot blook

lest I let forth your jalt gint ot biow

I killet not thee with hall so gont a will

whiere now halt tules be
lialit the lienrt of cresar

so half my Egyjt were sulmerged

who with halt the bulk o' the worls

when half to half the world oppos

never be suved by half that they

half all ment's hearts are his

for one not lunli' so whil as that...

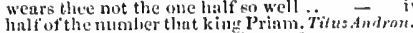

was ever Seythia half so burlbarous

as lialf thy love? .........

ere half an hour ean pas

lowest, and we are hilf way there.

they arey, they are hials fish, hait flesi

tharry, sir, halt a day's journcy.

walk halti an huur, Leonite.

shall earry halt ouy love with hiin, iuil

slonla erijor hialf his revente (rep.)

abated me of half my train

dismissing half your train

and hait, tathom and hulf! Poir rom!.

laalf why town hames one that ...

not linlf so big as a round little ... Jimeon of Juliel $i$.

in lutif an henes sle promised to

I eamot sum up half my sum ......

we'll have some lalf' a dozen frich
full half an hour. Go with me

memary may outlive his life hnif a year. Haniet, iii.

lialt $n$ slare. $A$ whole one, I
the purer with the other lialf

that earry but lialf sense

there is not halt an hour's life ...........

you have lost half your soul i even now. O

fuitl, half asleen. Good inaltam

would half have eorrupted n vota
but hali an hour. Being done.

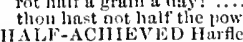

IIAI, -BLOODED-half-blooded tellow .. I.car, v

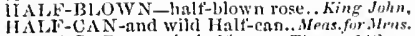

IHAIF-CAP-eertain half-ems.. Thimon of - Aht

IIALF-CONQUERED, must I back..king John,

HALE-FACE, like my father (rep.)
HALF-FACED-a half-faced groat

out upon this half-faced fellowshipl. Wenryl i. .

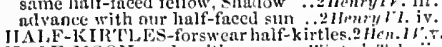

IIA LF-AIOON made with a pen . . W'inter's T
a pint of hastard in the half-moon...1Hen'y

a pint of hastard in the half-moon...1/

IIA LF T IRT-lialf-part, mates (rep.). Perieles, iy. I

like one anther, as halfipence are...ts you Like, jii.

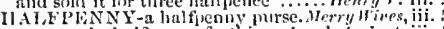

marry, sir, lualf penny furthinc.. Love's L. Lust, iii.

thou hinlfyenny pure of wit

py hat to a halfpenny, Pompey nroves - - Y.

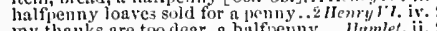

my thanks are too dear, a halfipe
JIAI.PENNYY

I1 A LF-SUPPED-half-sumed sword. T', oil. $\delta$ ('ress.y.

IIALF-WORKEIS-be lalf-workers. Cymbeline,

II.IJ,L-logs into the lrall .. Lor'e's $L$. Lit

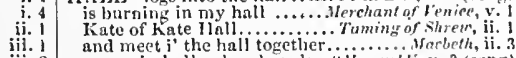

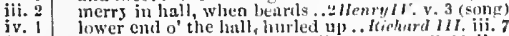

to the hall, to hear what slall .... Hewyly lili.

lct us to I'riam's hall, to greet. Frailus o cres.
rreep in skittislı fortune's lall ......

ns many as be here of ' $I^{2}$ ander's irail

a hall, a hall! give roonl........
sir, I will walk here in the hiai

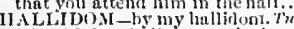

Y. 2 II SLLOO-halloo me fike a hare stir

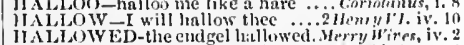

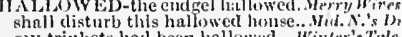

my trinkets haul been liallowed.. Winter's Tule,
make fast witlin a hallowetl verge ..2llenry

make fust witlin a hallowel ver
nre not words duly hallowed...

to give thee liallowed to thy grave..... lericles. ili.

so hallowed and so graeinus is the time. Hamlel, i.

4 It:litow IIAs-

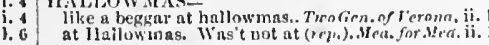

$\mathrm{II} \Lambda \mathrm{M}$

IIALAOW NAS-back like Mallowma s. RichardII. .

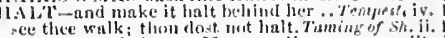
und y'et you lialt not. Not

cloge hark at me, as I halt by thein. Ruchad 31 . i.

on me, that lialt and am nik-shagnen

ony liee trift halts not particularly. Timon of $A^{\prime \prime}, \mathrm{i}$.

come the on. I'll hitit nfter iming 8

or the blank verse shall hat
that their desizument hult

1Al'TliR-give him a halter.
a halter grutis; nothing el

no, if rightly tuken, a hialter..........
ns somo he strangled witl a haiter

n halter, soldiers; hang him on

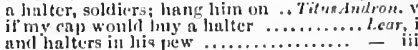

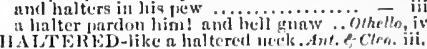

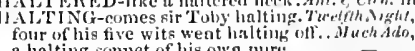

a halting fomet of his own purc

mot trusting to this halting legrte
js to eome halting oft, youl know

nof further lialting: aatisfy me lome. Cymbeline, iit. 5

IIAI-kniglit that eowers it the hans? Pericles iv.

a man to bow in the hams...... knme of Juliet, ii.

together with most weak hams

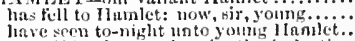

yet of I Iumlet our dear brother's deuth.

but mow, my eonsin Iamlet, and my son
food Ilamlet, cast thy nighted eolonr off

commendable in your nature, Iamlet .
not thy mother lose her proyers, Ilamlet

not thy mother lose her prayers, Ilamet -
gentle and unforcel accord of flamlet sits -

tor Ilamlet, and the trifling " if his favour -

fur lord If amlet, lolieve ro much in him -

Words or talk with the lord llamlet

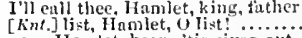

now, Inamlet, hear: tis piven out .....

[Col. Ku'.] adieu, adieu, Ilamlet!.

what so poor a man as llamlet is way do

something liave you heard of IIamlet's..

bring these gentlemen where IIamlet is

the very cause of Hamlet's lunacy

Whilst this machine is to hin, I Iamiet - it

low IJamlet is a prince mut of thy sphere

you go to seek the lord In numlet.

closely sent for Wlamlet hither ..........

we the liappy eause of IInnlet's wildness

low fares our cousin Ilamlet? Execllent
I have nothing with this answer, Ilamlet

eome hither, my dear IJamlet, sit by

how now, Ilamlet? What's the matter.

O Ilamlet, speak no more: thou turn's

no more, sweet mamlet. A murderer.
speak to her, Hamlet. Inw is it witl?
OHamlet! thou hast cleft my lieart

how does I Immlet? Mal as the sua .0...

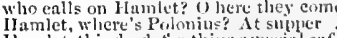

Ilamlet, this deed, tior thine esperiul sufity
for England? Ay, Hanlet. (rod........

thy !rvine father, Jamilet.

the prescuit death if llanlet ..................

he that thou knowest thine, Ilumlet

letters, my loril, from tamlet .......

and more strange return.

and that in IIamlet's horrin.

diit llamlet sn envenom witli his env.

thulet, returued sirall know you are

our last king llamlet overeame lortinbr

that very doy young IImmlet was born
slouldst have been my Hamlet'y wite

this is I, Hamlet the Dane .....

come, I ianlet, eome, and t:lie this liand

wast llamlet wromgen lantertes? (oep).

Ilanulet is of the thetion that is (rep.).

if Inamlet give the first or second hit

shall drink to Ilamiet's better breath

Inumlei, this peurl is thine....

here, llamlet, take my napkin
carouses to thy fortulic, llumlet

O my clear I tumlet! the drink, the ilriok

it is laro llamles: IJamlet, thou art slain

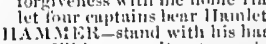

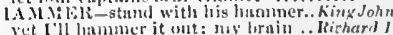

yet ill limmer it ont: ny lirnin .. Nichard 11 .

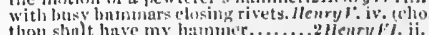

thou shint hinve my hammer.......2henryl. ii.

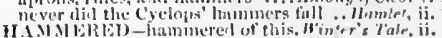




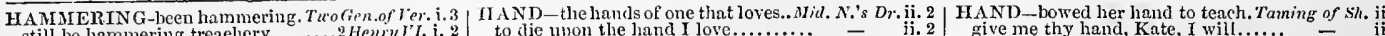
still be hammering treaeliery........2 Henrylti. i. revenge are hammering in my head.. Titus And. il. to die upon the land I love.......... when, at your hands, did I descrve... IAMPTON-kill us here in Hampton. Henryt. ii. 2 at IIanpton pier embark his royalty - iil. (cho.
HAMSTLING-in his hamstring. Troilus $\&$ Cress. HAND-we will not hand a rope note.. Tempest, lend thy liand ...........

and when 1 rear my hand

with mine own hands

here's my hand. .

by this liand, I will supplant....

i. 2 (song)

as if our lands, our sides, voices ....

your hands, than mine, are quied...
get your weapons in your hand...

get your weapons in your have

man's hand is not able to taste

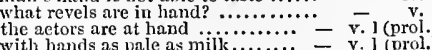

hand in hand, with fairy grace ......

- v. 2

and the blots of nature's hand shall

ive nie thy liand; I am

that his own hand may strike his. Love's L. Lost, i.
reeeive sueh welcome at my hand ...
or vour hands in your pocket........
to her white hand see thou do $\ldots \ldots \ldots$

give une the again t teuder to thy hand

give me your liands

a giving hand, though foul ........

the bow hand I I'faith your hand is..

O hateful p of your good hands..... of .

liere is her liand

to see him kiss his hand! ............

into the royal liand of the king......

but aluek, iny liand is sworn $\ldots,-{ }_{-}$iv. $\overrightarrow{3}$ (verses)

our eat wringing her hands....

wringing her hauds,

a maid with clean hands

when one's rishit hand is

of all hands must we be forsworn...

or I would these hands might never part -

as tall a man of his hiands

the gallants are at hand $\ldots$............

that kissed away his hand in eourtes

all is in his hands above ..............

let our lands part.

my hand, bully....................

no promise of satisfaction at her hands? -

with any deteetion in my hand....

the sudden hand of death close ....... of $\bar{V}$

ii. 3 but give me your hands; God send.

to lave her dainty hands............

to give my hand, opposed against
whose hand (she being now at hand)

whill they kiss

till they kiss their hands

she bears me fair in hand..........

here is my hand, and here I firmiy...

lay hands on the villain; I believe.

no other tribute at tlyy hands, hut love

and place your lands below your...

shook hands, as over a vast ...........inter's Tu

make thee open thy white hand ....

trifles of his eyes, first hand me.....

for ever unvenerable be thy hands

what need these hands! you, that are

with these ny proper hands shall I..

by the hand delivered of great Apolio's

heavens with what we have in hand
tlyy hand, I'll help thee; come (rep.)

your hand, my Perdita: so turtles...

five justiees' liands at it; and witnesses =

I take thy hand, this liand, as soft as
to wash the hand, was fair before...

take hands, a bargain; and friends .

come, your hand; and danghter, yours -

and a nimble hand, is necessary ....

to the outside of lis hand............ -

of the right hand; I will but look upon -

some great matter there in hand ....
took me by the hand, and called me

give me thy hand; I will swear ...

turn up of your right hand..........

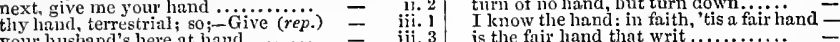

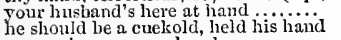

eome, give me your liand.

with rattles in their hand her hy the liand...

to pinch her by the hand.....

his wife into your ha

pray you, lock hand in hand

a tail fellow of thy hands (rep.).

weigh thy value with an even hand

lie witung Bassanio's hand

he wilyng Bummer was at hand

give me that hand of yours, to kiss...

eostly summer was at hand

your hand, Salerio; what's the news

render this into my cousin's hands.

I have work in hand, that you .......

wy this liand, they are seoundrels. Tiretfih Night, i

do sou think you have tools in hand?

sir, Ihase not you by there's my hand.

on forfeit of my hands, my head ....

I pray jou bring your hiand to

but I can kcep iny hand dry

I hold the olive in my hand ...........

she slatl know of it, by this liand

jine sllat make distinction of our hands

I extend my hand to him thus

by my life this is my lady's hani.....

it is, in eoc tempt of question, her hand - in
if this fall into thy hand, revolve
tly fates open their hands........ - ii. 5 (letter)

with a willow in her hand upon

your mistress is at hand

now, by this hand, $T$ gave it to

to cut my left hand off; and swear....

thout lay hands on me, villnin? .......As you Like $i t$, $\mathrm{i}$.

I would not take this hand from

a. boar-spear in my hand ...............

give me your hand, and let me

do we seize into our hands

do not your courtiers' hands sweat?

besides, our hands are hard...........

by the white hand of Rosalind....

even a toy in hand, here, sir .......

go, write it in a martial hand........

we do know the sweet Roman hand

and kiss thy liand so oft?

to have rich eyes and poor hands
by this hand, it will not kill a fly....

give me your hand, Orlando .......

her hands; she has a housewife's land

a man's invention, and his liand

by this hand, I $\mathrm{nm}$......................

give me thy hand; and let me.

here is my hand; you shall from $\dddot{2}$

but, ont of question, 'tis Maria's haid

give me your hand ..........

by this hand, sir, his wife is .

the hand that hath made you fair

for putting the hand in the pocket

lere is the hand and seal of the duke

give me your hand, and let ...........
must walk by us on our other hand.

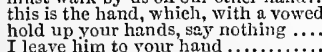

for yout lovely sake give me your han

your hand, Leonato; we will go ......

marry, it is your brother's right hand

here's his dry hand up and down....

taming my wild heart to thy lovi.

take not away thy heavy hand
with charitable hand, took up

these hands sliall tear her.

in hand until they eome to trike hands

loy this hand, I love thee .

never lay thy hand upon thy sword

marry, beshrew my hand ..............

a third is fled, that had a hand in $\dddot{\text { jt }}$.

deserve well at my hands, by helping

give me your hand before this holy..

a paper, written in his hand........

writ in my cousin's hand, stolen ....

give me your hand: art thou ........

they shook hands, and swore brothers

here's eight that must take hands.

a pen in his lind, and write to be

give me with thy kiugly hand

here is my hand; the premises

kiss his land, and say nothing ( $r \cdot p$.

very hand of heaven. $\Delta y$, so I say.

and with this healthfial hand, whinse

liere, take her hand, prond seornfui

take her by the hand, and tell her

give me thy hand. Ny lord.

you have or will deserve at my hand

after some lespatch in liand at eourt

nay, precent your havd..

hold your hands; nay .................

now at hand? Nay, he is at two bands -

never toueh well-weleome to thy hand

iii. 4 from iny false hand cut the.

\begin{tabular}{l|l} 
iii. 4 & I have your liand to show \\
iii. 4 & if by strong hand sou offer
\end{tabular}

give me thy hand. O, soft, sit

rather persuade him to hold his hands

hand, and let me feel your pulse (rep.)

with Time's deformed hand have...

now let's go hand in hand, not one...

and ne'er shook hands, nor bade

the weird sisters hand in hand

in your eye, your hand, your tongue

ii. 4 give me your hand; conduct me .....

what hards are liere?

my hand? No; this my hand will rather-

their hands and faces were ali badged

in the great hand of God I stand....

how you were borne in hand .....

bloody and invisible land, eancel

I have in head, that will to hand

shull be the firstlings of my hand.

here would be hands uplifted

look how she rubs her lrands

to seem thus washing her hand

Arahia will not sweeten this little hand

wash your hands, put on your ...... =

come, come, give me your hand.......

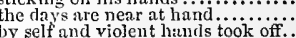

the same into young Arthur's hand... King.Jo

give me your land; my father gave

give you welcome witl a powerless hand -

till your strong hand shall help ....

3 they are at hand, to parley $\ldots . . . . . . . .$.

2 than e'er the coward hand of France

let him fetel off his drum in any lian

by the hand of a soldier, I will ...

hold your hands; though 1 kno

give me your hand; how does...

you give away your hund...

your gentle hands lend us..............

1 have some sport in hand, wherein -1 (indue.)

your mightiness to wasil your hands?

v. J Jove to humble himself to her hand

$\begin{array}{ll}\text { v. } 1 & \text { till the father rid his hands of her } \\ \text { v. } 2 \text { master, for my hand, both our.... }\end{array}$

v. 4 see that at any hand; and see you ...

v. 4 at any hand, I pray ............

may be kept on either hand

who are at hand triumphantly .......

in those same hands that did ........

all with purpled hands, dyed in .....

holds hand with any prinees...

thy son and danghter to join hands

the power to elutch my hand........

but for my hand, as unattempted...

what means that hand upon

assistanee of a mortal hand............

let go the hand of that areh-heretie (rep.) -

by disjoining hands, hell lose a sonl

i. 2
i. 2 than hand and mine are newly knit
ii. 1 and shall these liands, so lately purged
ii. 1 that hand whieh thou dost hold (rep.)

each army hath a liand............. 
IIAND_I kiss your hnd, linrewell. King Joh give me thy hami: l liad a thing.... snutelesed with su unruly lutucl ...

and with my hand at milnithit...

and with my hand at mind nipht....... =

shears ams measure in his lumel...... -

thy hand hath murdered him...

here is your hamd and sent

thy rude liand to set the deed

this innd of mine is yet a maiden $(r e p$.$) -$

a henvy hand, if that it lie (rep.)..... -

the shamelul work of ltahert's ham

a thousund busincsits to brictin line -

yielded uy into your lutud tlse eircle

by some damucd hund was robled

but with the very land of stern.

Glialt thrust thy hund as deep.......

wurnnt trom the hand of heaven.
like a lion fostered up ut hand

thant hand, wheh had the strength

nnd even nt hand a drum is ready

for at lund not trustin

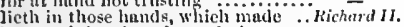

by envy siand, and murders

let me kiss my sovereigi's hant

deserved st your highness' lan

pur royal sword your banished hand.

O who ean hold a fire in his hand

furnish us for our affing in hand ...

infection, and the liand of wor.

his triumphant father's lumd (rep.)..

gripe into your hands, the royaltic.

thrust disorderly into

to wash your blood from off nir himi.

to excention and the hand of death..

Eark loughly custle call vou this at liand? -

I lo salute thee with mir hand $(r e p$.

with lecads, and not with hantis

show us the hand of God...

no hand of blood and bone

lift yonr vassal hands again

and by the lu kiss thy hand.

uncle, give me your hand

may my hands rot off, and never

the possession of thy royal hand

loweel for at yonr helping hand

linwieldy sceptre from my hand

with nine own hands I give a wry

wash your hands showing.

ay, hand from hand iny love

but heaven hath a hand in these...

interchangeably set down their hands

stay thy revengeful hand.............

with my hand. "Twas, villain (vep.).

is all the suit $\mathrm{I}$ have in hand (.......

cat bread from my royal hand (rep.)

hand shall barn in never-quenching fire -

thy fierce land hath with the king'

with thy fatal hand, upon my
wasl this blood off from my guilty hand

the rumle hands of that Welshminn ..1 Henry

in sincle opnosition hand to

in single opposition, hand to hand ..

at liand, quoth pick-purse

give me thy hand, thou shait hiave...

business hath my lord in linud

elapped even now into ing hand

washes his hants, and says to his wife

in foot and hand; and, with a thought

but be near at haud, for we....

promises be kept on every hand

onr luads nre full ol business.........
and do it witl unwashed linnds too..

or death's land, for this one lialf year

and kiss your hand, when yet you

the general sway into your hand...

the earthy and enld hend of deatis

killed by the land of Dougrias .....

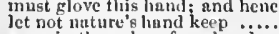

let not nuture's linnd keep......
grow in the palin of my land.

to bear a genticusat in liund

a dry lianel? a yellow cheek?

I cannot rid my hands of him .......

are near at hand; the rest.

by this hand, thou think st me.

that $I$ an a froper fellow of my iianils

these in ward wars once out of hand

your gnod hand, pive me your (rep.)

put ne a caliver me warts

the silver

and unerpat hand upon our lionours?

and a liand ouen as day.

doth kiss your grace's hand....

never eome witi buth hands fuit....

and tavourabie hand wjll whispor music

[Col.] friend sickness' hands determined -

give me your hand, master Iardoiji.
so into the hands of justice ..........
AN l)-commit inty your hund...

my hank, you slant be as a futior

most neelianicul and elirty lutul

ith regard of eauses now in
the urmed lamed doth tight

my rightful hand in a well-jitilowe

by tleir lutunds this graee of kings

now, by this hand l swear, l scorn .
protits will acerte; give ne tliy lanid

forget the oflice of our hand...

I jut my hand into the bed.....

in liherty of bloody liand, Blatl range

fall into the hand of hot ind for

appellée, de hant. De hand: et les duirts -

merited some love nt his linnds

we the in Gitd a hama, hrotiar

biv this lumul, I will tuke thee a box..

not work enough for all our liminds

into the hauds of (as le thinks).

with his eap in hant?

ranglt me his hand...............

enseheduled briefly, in your hands ...

and so clap hands, and a bargain

take me that I will kiss your had

ne'ur lift up his hand....
for suecour is nt hand

for kuecour is at hand..
atay, stay thy hands

and hands thou hast at once subdued

recursed fatal hand, that hatl

wants merey at thy lands

hy this maiden blusson in my jinnd

to hold your slaughtering hands

and hand for hand I give................

gather we our forees out of hand

when septres are in ehildren's hinnds

on either liand thee there are

by bloody hands, in sleeping .........

my hand nould free her .............

give thee her hand, for sign
and here at ham the Dnuplin

to your most gracious hands

elapping their hands, and eryin.

put forth tby haud, reach at the

the matter that we have in hantl ....

fits the work we have in hind

lay hands upon these traitors.

elased hence by rancour's hand

here is my land; the deed is

Eharp weapons in a madman's ling.

and all the peers arc herc at hand

some violent hends were laij

my fingers feel his hand unfecling...

that violent hands were laid

give me thy land, that I may dew...

could this kiss be printed in thy hand

hast thon not kissed thy hand

this hand of mine hath writ in

Brutus' bastard hand stabled.

barnt $i^{\prime}$ the hand for stealing of shcep

aught exneted at your hand

great men have reaching hands....

thy liand is but $n$ finger $t 6 m y$ fist..

has was made to fander nonght hint

liere is $\mathrm{a}$ hand to hold a seeptre np

lierc is a hand to hold a seeptre np . . Ju

how the king escaped our hands ...3 Henr

to thrust his hand between his teetli

parted but the shadow with his han

king llenry had shook hands witi...

1 reap at thy too crucl hand.

for, hand to land, he would inve....

whose hand is that, the forest

darraign your battle for they are at liand -

and throw my lunds, nine eycs

give ine thy liand; and, gentle

the liand, thit stalbbet thy father (rep.)

and cheers these hande, that slew...

who at lis liands reecived my life ( $(\mathrm{cp}$.) -

blondy steel grasped in their ireful lands -

for this right hand, would buy two....

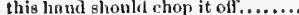

jet us lay hands uuon lim

unless in y hamd and strength conid equal =

linmbly to kiss your hand . .........
sladl you have all kindness at my hand -

give thy hand to warwick (rep.) ...
to pled ise my vow, I give nyy linnd..

seck for hatred at my hand

at whose hands be hath good usage.

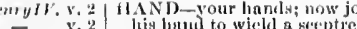

we will proslinim you ont of hianit...

truth, I kiss your hiphness' land

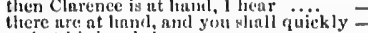

and at his hames beg merey, ....

this linud, fout wound obout thy

to deserve well at my brither's linidg

take my linnd, and with

will take the present at our hands...Richard JI

by the self-same hand that made.

be the lastr that mate these

this hand, which, for thy lowe, did kill

one favour at thy gracius linud

I kiss tloy hand, in sign ol learic.

we go to use our hamets, and not our

noml lny no linuds ost ne ............

he holds vengeance in his hand......

and Ilast ings, take each other's hand

with my hand I senl my true lionts

let him kiss jour hand

two erutches from ny feebile lianilis.

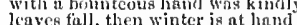

that proinge then winter is at hand

hath no shriving work in lind...

never looked for lecter at lyis hands

the phe in a set loud fairl

get a praver-book in hand .

a look of prayer in his hand...

led in the hond of her kind sunt .....

give me thy hand: thins hirh .........
my griefs frown on the unper hiazd..

but at luad, at hand, ensues his ....

wither hands, which the king's King

put in their hands thy bin

then hand in hand to hell.

a hand as fruitful as tlic lind

the tairest liand I erer tumelicil!

to your higliness' hand I tender

your grace, whose hand has raised ine

under your lands and seals.

canse into his hands that hates mie?
to his own hand, in his bedehamber

as $y$ lond los

so your hand, and heart, your brain

the grcat seal presently into our liands

into your ow hands, Cardinal...

still in the right hand carry gentle.

contains, that paper in your fiand?.

her two hands, and she, sleep in

give me sour hand and tongne....

give me thy hand. stand up.

ve have made a fune hand, fillows.

inth whose hand 1 give thy life ......

she lias the mends in her own hands

piany hands, nind no 1100

her white hand to his eloven elin

and the hand of Greece should liold

of hand: the still mal mental parts (

let me touch your hand.

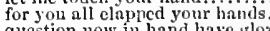

what exploit's in hand? where

shuls your hand; here. my coisin'

tuke his ling

by Venus' haud I swear

give uy to Diomedes' hand...

they are at hand and reacls

I'll give her to thy hand

lally, give me your hand

his heart and hand bo eomes

this hand is Greeian all, and this..

give me tly hand, my cousin.......
sos long walked hand in hand witli tine -

ii. 2 thy hand upon that mated . H.......

ii. 2 nor the hand of Mnrs beekoning

ii. 3 her wory hand wafts to her

ii. 4 my haud to thee: mine hon

give ne your liand: we must.........
the eape plays in the right liamil, this
to hold vour hand more elose.......

nay, put all your lumbs

but 1 shumld infeet my hinnts.

ii. 6 with his timer lima, sftering .....

iii. I work's, my eonntrymen, in liand? ... Corisian

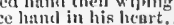

your hnul, und yours; cre in our own

iii. 3 aget sir, hunds otr. llenee, rotten thing -

iii. 3 lay hands npon lum. and hear (rep.)

the 'Tarpeian rock with rigorous hands
people's inouths, and we their hand

people's mouths, and we their hand
to them, with this bonnet in tlyy hand

. 
HAND-thy liands clutehed as many.Coriolanus, iii. 3 HAND-mother's hand sliall right. Titus Andron, give me thy haud: come

take our friendly senators by the hands your hand! most welcome! .. sanctities hinisclf with's hand you have made fair hands .......

and in her hand the grandchild

too strunge a hand over your

come on my riglt hand, for this ear

and clapped their chopped hands...

in several hands, in at his windows.

in his own hand bears the power .....

like the work we have in hand .......

thy full petition at the hand of Brutusl -

give me your hands all over

with an angry wafture of your liand

if Brntus have in hand any exploit..

such an exploit bave I in hand

the first that rears your hand...

Y kiss thy hand, but not in flattery

let us hatle our hands in Cæsar's blood

by

by our hancls, and this our present (rep.) -

next, Caius Cassius, do I take your han

therefore, I took your hands; but was
else shall you not have any hand at all

woe to the hand that shed this

quartered with the hands of war..... -

though he had no hand in his death

he is at liand; and Pindarus is come
$i^{\prime}$ he be at hand, I shall be satisfict .

like horses hot at hand, make..

give me your hand. And my heart too

canst not die by traitors' (rep.).

give me thy hand, Iessala: be thou

give me your hand first...

show lim your hand.................... \& cleopat

lo, now! if it lay in their liands
the hand could pluck her back

let me have thy hand: further this.

there is my hand: a sister I bequeath
the touches of those flower-soft hands

a hand, that kings have lipped

these hands do lack nobility....

let me have your hand: I did not....

let me shake thy hand; I never

whatsoe'er their hands are

eome, iet us all take hands ............

your hand. I'll try you o' the shore

and shall, sir: give's your hand

to lay my duty on your hand

so sancy with the hand of she here
with my playfellow, your hand

with my playfellow, your hand...
the white haud of a lady fever thee.

give me thy hand, thou hast .........

unto his lips thy favouring hand ....

give mo thy hand; through Alexand
the laand of death hath ranght him..

even here do we shake hands

and with those hands, that grasped.

on flowers, we'll haud in hand

my resolution, and my handis 1 ili trus

youl have fallen into a princely hand

quick, quick, good hands! ...........

they were parted by gentlemen it hand -

to hold the hand fast to her lord

this hand, whose touch, whose every

join gripes with hands made hard ..

your sweet band. Good-morrow, sir
not say, I am one; but I have a hand
the place was near at hand ..........

nyy husband's hand! that dri.........

let thine own hands take away

if I do not by thy hand........

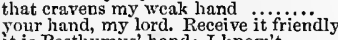

it is Posthumus' hand; I know't....
give me thy hand, here's my purse .

fivc me thy hand, here's my purse

slain thee with my proper hand

this is his hand; his foot Meremial.

lay hands on him; a dog!.............

whom she bore in hand to love .......
there's other work in hand ........
hy the hand of his queen mother....

have laid most heavy hand

ere bloody hands were washed..........

I hegged the empire at thy hands...

with his own hand did slay his bunting is in hand

a solemn bunting is in hand ........

wash their hands in Bassianus' ..... with thine own hands kill me

reacli me thy hand, that I may.

thy hath

if thon hadst hands to help thee ....

seen those lily liands tremble....

what accursed hand hath made

I'il chop off my hands too

i. 2 that thou hast no hands; for hands.

i. 2 thou hast no hands, to wipe away

or shall we cut away our hands.....

for that noble hand of thine

i. 3

which of your hands hath not defended

my hand hath been but idl

my hand shall go. By heaven

I will spare mp hond

lend me thy liand, and $\mathrm{I}$ will give

give his majesty my hand (rep.)
and for thy hand, look by and by

I litt this one hand np to heaven

and here's thy hand, in scorn to thee

Warlike hand; thy mangled daughter

thy other hand gnawing with thy ....

bear thou my hand, sweet wench

this poor right hand of mine is ........

violent hauds upon her tender

hands can she lay on her life? (rep.)

no hands, if Inreus did not (rep.)

this prey ont of his tather's hands

iv. 2 shalt luve justice at his hands....

iv. 2 robbed $\Delta$ ndronicus of $3 i$ g good hand $^{2}$

played the cheater for thy father's hiand -

for his hand, he had his two sons' hauds

thy coming for my other land?

some culning practice out of hand

my hand cut off, and made a merry

her swect hands, her tongue (rep.)

this one hand yet is left to cut . 3 ....

trumpets show, the emperor is ath...

bring our emperor gently in thy hand

on whion

ii. 5 on whom plenty helr full hand 0 ö

ii. 6 scorn now their hand should give ..

and we'll clasp hands; when peers

or my hand subscribe to any your hands and lips must seal it too

lend me your hands

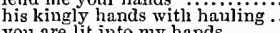

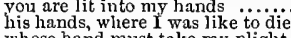

whose hand must take my plight ......

I tad he a hand to write this?

it is his hand, my lord

wilt thou take her by the hand? (rep.)

tear this hand, for lifting food to

give me thy hand: wilo's there
light of ear, hloody of hand...

thy hand out of plackets $\ldots \ldots \ldots . . . .$.

with robbers' hands, my hospitable fa.....

to whose hands have you sent $\ldots . . \ldots \ldots$.

distafr in to my hushand's hands

to let these hands obey my blood

more convenient is he for $\mathrm{my}$ haid

hold thy bloody hand; why dost

$O$ here he is, lay hand upon him

give me your hand; 1 'll lead thy friendly hand put

give me your hand; far off, methink

and hold your hands in henediction

give me tly hand; away (rep.)......

from those bloody hands throw

iii. 4 all in one or two men's lands $\ldots$ doth enriels the hand ot yonder kniglit? make happy my rude hand.

if I profane with my unwortiy liand -

saints liave hands that pilgrims' hainds -

let lips do what hands do ............

it is nol hind, nor foot, nor arm

hop a little from her hand

and for a hand, and a foot, and a body

whom Romeo's hand did słay.......

why dost thou wring thy hands?

did Romeo's hand shed Tybalt's blood? -

the white wonder of dear Juliet's hand - give me your hand ..............

give me your hand; you are now ........

but elose our hands with holy words
11AND-thy desperate hand... Romeo \& Julicl, iii. 3

\begin{tabular}{l|l} 
ii. 3 & give me tly hand; 'tis late: farewell \\
ii. 4 & frum the reach of these my hands ...
\end{tabular}

ii. 4 sce how he will take it at your liands
ii. 4 lay liand on heart, advise

thon our hands; and ere this hand...

you have your hands full a

at my hands [Col. Knews thee will keep

O give me thy hand, one writ with me -

a cup, closed in my true love's hand?

give me thy hand; this is my daughter's -

iii. 5

iv. 1

v. 1

v. 3

thesc hands are not more like............ -

by a brother's liand, of life, of crown ....

lay your hands again upon my sword....

with his other hand thus o'er his brow ...

deserved at tlie hands of fortune ......................
your hands: come then, the anpurtenanee

not saw the air too much with your hand -

and Hymen did our hands unite $\ldots . .$. .

what if this cursed hind were thicker ... - iii. 3

ears without honds or hands...

caps, hands, and tongies, applaud it ....

by collateral hand they find us touched.

iv. 7

the hand of lites, are hands, are accidents - iv.

with desperate hand fordo its own life ... - v.

and take this hand from me $\ldots . . . . . . . .=v=v_{2}$

no, by this hand. Give them the foils.....

the treacherous instrument is in thy hand - v.
hold your hands, hoth you.............. Othello, ${ }^{2}, 2$

rather use, than their bare hands.......... -

and on every hand, enwheel thee roundi

paddle with the palm of his hand? .......

hard at hand comes the master

hard at hand comes the master .........

if my heart were in your hand

the my hand, cry-O sweet creature.

give me your hand: this hand is (rep

this hand of yours requires a sequester..

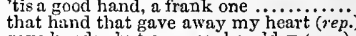

gave hands: but our new heraldry (rep.)

by this hand; and to see how he prizes..

I strike it, and it hurts my hand

and $\rho$ ut in every honest hand a whip....

give me thy hand, Roderigo; thou hast.

her hand on her bosom, her head on $-i v . \overline{3}$ (song)

at hand; I may miscarry in't (rep.)

indeed, these hands have newly stopped

v. 1

of one, whose hand, like the base Judean $\overline{-}$
HANDED-and handed love

as poisonous tongued, as handed..... (ymbeline, iii. 2

HANDFUL-rather have bandfni Nid N

' t'other side, that handful of wit!. Love's $L$. L. iv. 1
HAND-IN-HAND comparison ...... Cymbeline, i. 5

will, hand-in-hnnd, all headlong. Titus Andron. $v .3$ lo, hand-in-hand, litcius and I will fall - venlet, 3
that it went hand-in-hand even with ... Hamle HAND-KERCHER [Kn $]_{\text {] about your .....John, iv. } 1}$ When he showed me your landkerchief? - vell, v. 3 but a handkerchief, and rings....Winter's 7'ale, v. 2 my handkerchief [ Knll-hald-kercher ]..John, jv. in Rutland's blood, a liand kerchiet. Richard $I I I$. iy. 4 their scarfs and handkerchiefs...... Coriolanus, ii. 1 with glove, or hat, or handkerchief .. for that same liandkerchief? (rep.) ...othelto, iii. 3 you not sometimes secn a handkerchief - iii. 3 fen she

that handich or did an

fetch me that handkerchief (rep)

there's some wonder in this handkerchief

but if I give my wife a handkerchief...

he had iny handkerchief. Ay, what of .:

is it possible? confess? Handkerchief"

did you mcan by that same handkerchief

that should he my handkerchief !

that handkerchiet, which I so loved

I saw my handkerchiet in his hand......

it was a handkerchief, an antigue token

ii. 2 that handkerchief thou speak'st of

ii. 2 by that handkerchief that was ny vife?

HANDLE-the handle of her fun ..Merry Wives, chall see how I'll handle her.... Meas, for Meos. y. 1 the handle toward my hand?........... Macbeth, ii. the sacred handle of our sceptre......... Riehard Il, iij. then I know how to handle you ...2 Henry $I V$. ii. 4 could not therefore handle an English not to wear, handle, or use $\ldots 1$ HenryVI. i. 3 (procl.)
hand was made to handle nought. .2 Henry $V I$. v. 1 


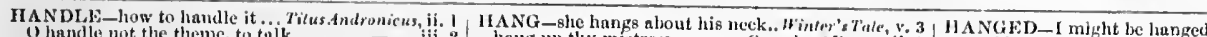

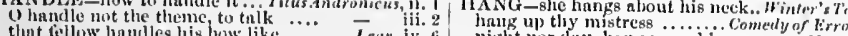

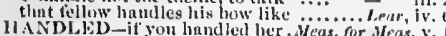
jus" wert thou hundled beins.

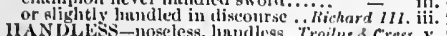

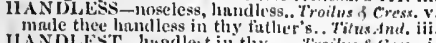

IIN NDLEST-landlest in thy

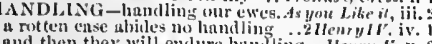

ald wilt not hold the handlind

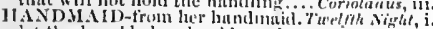

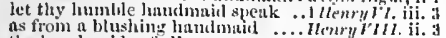

thic handunaids of inll womes

Cymbeline, iiî.

a handlunill be to his desire

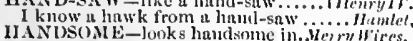

HANOSOME-Jooks handsome in. V V $e^{\prime}$ ry Hires, iij

let him be a hundsome fellow

and every thing handsome about lim

is't not a hardsone enteman?

myself hundsome till thy retion

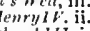

becher, a hame some stripling too.. Kictharl III. $\mathrm{i} .3$

see a handsome man loose-wived. dn hny it. Cle

now, afore ine, $n$ hnndsome fellow!.... Pericles, ii. i

and a kind, and a handsome .. Komeo f Julie

very nueh more handsome than the ... Mamtet, ii.
lesides, the knave is handsome, young.. Othello, ii.

n woper mank. A very liandsome man

1.NDDSONELY - trim it hamlsomely. Tempest,

th meet him hindsomely. Titus.indronicus, ii.4 (let.)
II ANDSOMENESS-

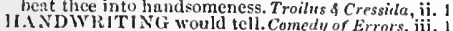

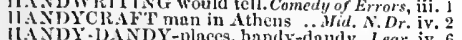
IIADY-1) ANDY-plnees, handy-dandy.. Lear, iv, 6
IIANDYCRAFTSAEN-

11 is not regrarled in handyeraftsmen 2 Henry $f^{\prime}$. iv. 2 IIANDY WOlk k-his handywork .... King John , i. I have gone upon ny handy work ...Julins Ciesur, IIANG-hang, eur, hang!

would ery to a sailor, go hang (rep.) $-\overline{\mathrm{ii}}_{2} 2$ (song 2 men hang and drown their proper selves - iii. 3 come, lung thein on this live.

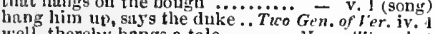
well, thereby hangs a tale

niglit nor day, hang upoij lib............

who must hang them.................

nnel liang nap them

blesimgs linng nout his throne.....

lum those that tulk of tear.

himng out our bumners on the

mow the mext tree shalt thou liang alive

hang a eait's skin on those recrestit (rep.)

eaches me to kill or hang myselt'

beam to hang thee on.

pestilence hamgs in our air.....

any plague hang over us, 'tis he

anil go not, Inl hang you tor going.

if 1 hang I'll make a fat pair.

hang ye, gorbellied knaves...........

hang himl let him tell the king ....

play to you, hang in the air

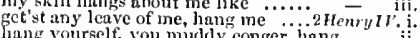

hang him, swaggering rasieal!

ie a good wit? hanc himes upon

fud hangs resolved correction in the

let us not humg like roping icicles.

in my gallery thy picture hangs...

Runta hangs her head for grief

hreak your necks, or liang yourselves!

alus, my lord, hang me, if ever ........
this lotty pinc, and hangs his sprays

axe of death hang over thee

no, it will hang upon my riehest robics

hmg lim with his pen and ink loorn

and hang thee o'er my tomb .......

政,

fow well the sequel hangs together $\vec{r}^{\prime}$ iii. 6

that hangs on princes' fnvours!

that ling their heads with sorrow our quarrel. Troilus \& Cressita, ii. 4

he liangs the lip at something

go hang yours

lang him, lie'll abuse us..............

Timon of Athens, iv. 2

hang "em, slaves! I do not

hang no more about me

hang him, pour cuckoldly $\mathrm{knavel...}$.

it shall hang like a meteor $0^{\circ}$

there's the tool linngs on your back

eity hang his poison in the sick.....

I'd give thce leave to hang it.....

hang them, or stab them, arown
felt the axe, and hang himself

hang ye! Trust ye? with every

they are dissolyed: hang 'em!

as they would hang them.

than pieture-like to liang by the wail

think upon ne? hang 'em! I would

let them hang. $A y$, and burn
ind hangs on Dian's temple

and hangs on Dian's temple .........

your diver did hang a salt-fil $\ldots . . . . .$.

your diver did hang a salt-flsh. . Ant

whip, or hang, or torture

and hang me un iner on me

sluall hang in what place you please

hangs both thicf and true man.......

liang there like truit, my sous.

my ense, I should go hang myseif. Tituss.A
low would he hang his slender gilded

away, and hang him presently

hiang hin on this tree.

first hang the elijld.

here's a fish hangs in the net.

as a cliaplet liang upon thy g

marry, hang her up for ever 1 .......

thick slimber hangs on mine eyelids -

humf him instantly..................................

hialf way down hangs one that gat

restoration, hang thy medieine on

to hang Cordelin in the prison
benuty hangs upon the cheek.......

benuty hangs upon the check... komeo of J

hang thee, young baggnge .............

an' you be not, liang, hreg, starve......

liangs raggetl [Cot. Knt.-liang upon].

poison yet loth hang on them

that the clouds still hang on you?...
flie would hang oul himn as it inerease...

ler eoroncet weeds clambering to han

tyranny, to liang elogs on them themsed

liangs a tail. Wficeby hangs a tale, sir?

nor loop, to hang a doubt on ...............

Fo hangs, and lolls, and weeps illon

hut to go hang my head all at one

IN N
he'll be linnged yet

till he be hanged

he hal been liauged for
ANGFD_I might be hanged
would I were linnged, lin, clse

yet you will be hanged, for leim

I'll be hanged thest: thou art

it 1 sloulal be henged 1 eannot iming....

and is langed betimes in the murning

and be hangel an hourt...

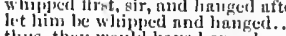

thius, they would hine langed ...

l, lnying Pyrumus, I'll be lianged. Mirl.

Julas was langet on an cicler ....jore
und linnged, firr Ponpey that is dead

langed for juman slaugliter... Mrret

theretore, throu innet he lianged at $t$

langed on Sunday tirst (rop.). Tanin you like it, iij,

thou art worthy to be langed :... Winter's Tale, ii.

linesed. And must they all he hanked

hanged in the frowning wrink le ..... A

my erown, let him be langed.

tarry at home, and be haigged .........
be not four by the day, I'll be hanged

eome away, and he lianged, come awn

Poins! Poins, and be langed! Poins!

to make me love lim, I'll be langed

give me my horse, and be hanged.

ftrike him, if $i$ should be hanged.

leave, thou wert better be lianged....2. $H_{e}$ nry $1 \mathrm{~V}$.

do not make lim he hnoged ninong you - ii.

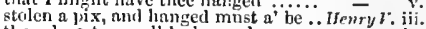

thon darest as well be hanged.

most fight, or else be hanged

conll not real, thou hast haupd doors

will you needs be hanged with your..

better do so, than tarry to be hanged.3 Henry Vl. iv.

bciong to the gallows, and be hanged. Hewry liti.v.

how got they in, and be hanged? ....
sce yon hanged, like clotpoles.. Troilus \& Cressidn, ii.

haviged it, have you not? ...... T'mon of Athens, i.

some that were hanged, no matier

would I were hanged, but I thought. Coriotanus,

I ens ns well be hanged.............Jutius Caso

sound, and be lianted, sonnd on

it was hanged witl tapestry of silk...Cymbeline, ij.

not be langed till the next weck. Tilus Andron. iv

sirrul, , you must be hanged. Ilanged!

I am sure to be hanged at home..........

and my poor frol is hanged t............... Lear, $y$. :

rather to be hanged in comprassing...... Ohello

hanged for his labonr. First, to be hanged

deviscel this slander; I'll be hanged else - iv.

the carriages, girdle, hangers, and so ..Hamlet, v

I would, it nirht be hangers till then.... - v.

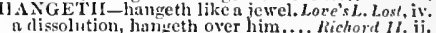

IINGGING-to his hanging! .......

hand hanging at them wallets of fesli?... - iii. 3 thut is lianging in your chamber .... Th many a rood hanging prevents ........ but that you liave a lannging look
mystery there should be in hanging

this may prove worse than hanging.

pressing todeath, whipping, and hanging -

my

hinging and wiving goes by destiny

like ner medal, hanging alout.... H'inter's Tule.

beating, and langing, are terrors to me -

hy hanging thee, I can but shorten

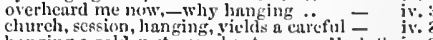

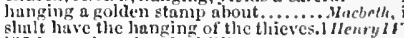
glthit have the hanging of the
if 1 'scape hanging for $k$ illing

and a frolish lianging of thy netler lip - ii

minht I, lianging on IIotspur's neck.2nenry 17 . ii.

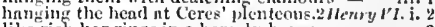

like rich hangings in a homely house - . Y 3 hanging at his brotler's leg.. Froilis \& (iessida, v. tir froth, and so 'scape hanging

stund'st not i' the slate of hanging... Coriotanus.

we count not worth the hanging .... (ymbeline i.
shook down my mellow hangings ...

lannging is tlewewrel, sir; if you be ready - v.

nelpath. as hanging preeently. Titus Androniens,

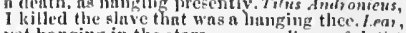

vet hanging in the stars ......... Humeo $\delta$ Jutict

cuntent to he a law ful hangman Merus. for Heas.
your hangman is a more penitent trade 
UANGMAN-sir; the hangman. Mleas. for Mleas. iv. 3 , the little hangman dare not shoot... Much Ado, jii. no, not the liangman's axe...Merchant of ' 'enice, and so become a rare hame 1 HenryIt the hongman hath no lean wardrobe the ladder, or the hangman either?. keep that for the haugman (hen served thef. Timon of athens, it. which does the hangman thank. Anttony \& Cleo. and a hangman to help him to bed.. Cymbeli the common hangman shall execute it

I rather would have been his haugman. . Othello, IANGMEN-hangmen would bury.. Coriolanus, best of them were hereditary han

\section{IIANNIB AI - wieked Hamnibal!.}

prove this, thou wicked Hannibal

as. formeas,

by fear, not torce, like Hannibal

Henry Vi. i.

good hap.. TwoGen

what else may hap, to time ....... Tuelfth Night, $\mathrm{i}$.

Katharine, hy good hap .........

whose hap sliall be to liave her.

lap what hap may, I'll roundly ....

wom it wos tileir hap to sc

envying earth's good hap.

Richard II.

ur low haps it, I seels ne

try your hap against the Irishmen? 2 Henry $F I$. iii.

what hap? what hope of good? (rep.).3 Henry

more direful hap betide that ...... Richard III. i. .

from that contented hap which.......

see, hy good hap, yonder's my. Titron of Athens, fij. 2

when we shall hap to give t then...Coriolanes, ini.

and when it is thy hap, to find. Tilus Andronicus, v. 2

word of all that haps in Tyre

Lear, iii.

what will hap more to night .............. Lear, ini.

from time to time every good hap to you - iil. 3

howc'er my haps, my joys will ne'cr begin - iv.

HAwLESS-perhaps a hapless gain. T $w$
O my dear Silvia! hapless Valentiue!

hapless Acgeon, whom the fates. Comedy of may finish ere that hapless time

and wrings his hapless hands.

I, the hapless male to one sweet $: \ldots$ Gen. of Ver. $\mathrm{i}$.

haply, I do

haply, when they have juciged ........

haply, your eye shalt, shall

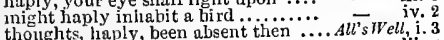

but the boldness of his hand, haply

when, haply, he sliall hear that $\because \ldots .$.

to counsel them: haply. Taming of Shrew, $\overline{1}$ (indue.)

[Col.] haply institute a cour

iny reason, haply, more, to bandy

haply, in private $\ldots . . . \ldots . .$. comed

speak, a word; haply, $I$ see $a$ friend...

speak a word; haply, I see a friend ...

inay, haply, purchase him............ Henry $F$. iv

the commons haply rise to save ....2Henry $V I$. iii. 1

but if we haply seape...............

and I, that liaply take them from ..3 Henry VI. 1i.

haply, may misconstrue us in him

you might liaply think, to in

fame unparalleled, lnaply, amplificd. Coriolanus

haply are they friends to Antony. Ant. \& Cleo, iii. il

haply, you shall not see me mo

yea, yaply, near tlie residence

huply, despair hath seized her

who may, haply, be a little angry

though haply well for you $\ldots \ldots$....

haply, some poison yet doth hang.. Romeo Lear,

I I comlet ii.

haply, the seas, and countries different

so, haply, slander, whose whisper o'er

haply, with his truncheon may strike

i1, haply. you my father do suspect.......

H.APPED-lord and lady what has happed $\overline{-}-$

HAPPEN-if this should ever happen. . Wuch Ado,

whatever I shall happen to devise... Richard II.

against the worst can happen....... Henry VIII. iii. what ean happen to me, abov

on plots, and errors, happen ........... Hamlet, v. happened all as I would have had it. All's Well, iii. 2 tell what hath happened..... Taming of Shrew, iv. 4 what ruin happened in revenge ..... Henry

how unlnckily it happened..... Fimon of

H.APPIER - the happier woman Merry Wives, ii.
[Col.Knt.] happier is tlie rose distilied.Mid.N. Nr. i. I

hapuier the man, oluom fuvourable. Tum of Sh. iv. 5
APPIER-the happier for thy son. Taming of Sh. iv. 5
wiluat lis happier affairs may be.. Winter's Tale, iv. I what lis happier affairs may be.. Winter's Tate, iv.

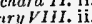

makes me a little happier than

happier is he that has no friend .. Timon of Alth. 1 .

this is a liappier and more eom

Cymbeline, $\mathrm{i}$

are means the happier to arise ......

I am wretehed, makes thee the liappier.. Lear, iv. 1

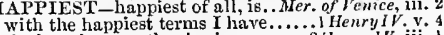

the happiest youth, viewing....

the happiest gitt that ever

2Henry $I_{1}, \mathrm{i}$.

HAPPILY - how happily he lives. Two Gen.of Ver. i. 3

happily, you something know ... Meas. for Meas. iv.
parts, that become thee happily. Mer. of Venice, ii.

and I wish it happily effected..........Al's Well, iv. 5

and happily [Col.-haply] institute. Ta

this gentleman is happily arrived....

signor Baptista, you are happily met

happily, we might he interrupted....
happily met; the laappier for thy son

and happily I have arrived at last

the king hath happily received .......

eonsummate this business happily ....... King John,

and happily may your swcet self put -

fashion it, shall happily meet $\ldots \ldots$. I Henry $I V$. i

stepped before me, happily...

I am happlily come hither.............

happily, amen! I did not think.. Anlony \& Cleo.

a Roman now adopted happily..

our ships yon happily may think

shall happily make thee there... Romeo \& Jutiet, iil.

Perictes, $\mathrm{i}$. 4

her country forms, and happily, repent. Othello, iii.

APPINESS-in thy happincs

geal our happiness with their consents

bring you baek in happiness!.... Meas. for Meas.

hath, indeed, a good outward hinpininess

(saith the text) is the happiness of.. Love's L.L. iv.

t is no mean happiness therefore. Mer, of Venice, 1 .

good-day, and happiness, dear Rosalind

nto happiness through another inan

tuned his bounty to sing happiness

treats of happiness hy virtue .. Taming of Sherew, i. 1 of glory, joy, and happiness

King John, iil.

still better others happiness betic

wish I all happines

sick of happiness; and purge

and happiness, to my royal fatherl (

envy of eaeh other's happiness......... Henry $v . v$ v.

and happiness to his aceomplices! ... inrmry $V I$. v.

queen Margaret, England's happinessl 2 hen - iii. I

thou dost eonfirm his happines.

beget your happiness, be happy then

compare dead happiness with living woe

consists my happiness and thine

hcaped liappiness upon him ........ H

they promised me eternal happiness

to the happiness of England...........

all happiness to your honour! ....

of happiness, honour, and fortuncs

Casar will unstate his happiness. Anlony \& Cleu. iii. I

wishes youl all happiness ..Cymbeline,

to sour your happiness, I must reprojt - -

not gain so great a happiness .......... - ii. 5

save that, I wish thee happiness!.......

erown you king of this day's happiness

happincss courts thee in her best array - iii.

a liupplness that often madness hits on. Hamlet, ii. 2

well. happiness to their sheets?........ Othello, ii. 3

in my sense, 'tis happiness to die ...... $\overline{\text { Ier }}$. ii. 4

and happy being at your court

therein made me happy

lady, a liappy eveningl

to make this happy close

the gift hath made me happy

ghall yet belie thy happy year

I thank my stars, I am happy .......
to make us happy hoth............
share in this most happy wreek......

Herry Wives, iii

happy thou art not ......... Aleasure for measure, $\mathrm{v}$.

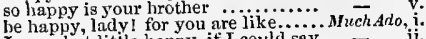

be happy, lady! for you are like...... M
HAPPY - happy are they that hear ...Much Ado, ii. happy days bring in another moon. Mid. N.'s $s$. i. hapuy be Theseus, our renowned dukel happy fair! your eyes are ........ lappy some, o'er other some, ean bei happy is Hermia, wheresoe'er she ..

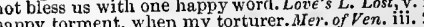
happy in this, slie is not yet so old .. - iii. fair thoughts, and happy hours...... and pra ${ }^{-s}$ for lappy wedlock hours.. our mistress shall be happy .....Asyou Like it, i. I sluall think my brother lappy .... every ot this haplyy number............ All's $\mathbf{W}$ ell, ii. in happy time, this man may......... $\overline{\bar{s}}$. vi and bc happy rivals in Bianea's love what luappy gale hlows you to Padua woo, and happy be thy speed! $\ldots \ldots$. . happy the parcents of so fair a child ... hort, what not, that's sweet and happy why happy man he his dole........ W.. a care of happy holding her........ - iv.

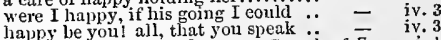
a woman, happy but for me .. Comedy of Errors, $i$. and happy were I in my timeiy death $-\frac{1}{i}$. are told as happy prologues to the ... - i. emptying of the happy tlurolle ....... King John, ii. out of one side her happy minion ....... and I lave made a happy peace with when we were happy, we liad other.

many years of happy days befal ..... Fichard II. i. .

my mouth the wish of happy years... -

his hopy bred of men

how happy then were my ensuing ... -

count in myself notling el se so happy

a happy gentleman in blood .........

our former state a happy drean

been still a happy king of men .....

rob me of a happy mother day that the happy sees....

$O$ happy vantage of a kneeling kneel - v.

disgraeed me in my happy vietories - iv. 3

wish me health in very happy season - iv.

should rejoice now at this happy news - iv.

he happy, he will trouble you no more - iv.

happy am I that have a man so ......

times, and news of happy price ........

happy are they who have bicen my friends -

omit no happy hour, that may

thou art less happy being feared....

we few, we happy few, we band......

from Franee arrived more happy men

this happy night the Frenehmen .... i Henry

St. Dennis bless this happy stratagem!

this is the happy wedding torcl......

if happy England's royal

Reignier, happy for so sweet a ehilid

yourself shall steer the happy helm - v. 3 count them happy, that enjoy the sun? - ii. 4 might make this island happy $i$ shook $=$ this happy day is not itself $\ldots \ldots \ldots \ldots . \cdots$ Henry $V T . \mathrm{i}$.

should have heard the liappy tidings

and happy always was it for that son

methinks, it werc a happy life ......

why, 'tis a happy thing to be

my mind presageth happy gain........ -

hist made the happy earth thy hell. Richard

to buy a world of happy days.

and make me happy in your unity...

a happy time of day! Happy, indeed your grace with health aud liappy days! -

to-morrow then I judge a happy day

in happy time, here comes the duke

happy were England, would this ....

nake, no doubt, us happy by his reig

a liappy and a joyful time of day! ...

am happy in thy news?....

for happy wife, a nost distressed

and fortune, bar me happy hours

and be a happy mother by the deed..

live, and beget a happy raee of kings!

dream of success and lappy vietory $\ddot{H e}$

so much I am happy above a number

may you he happy, in your wish

never so truly happy, my good......

those men are happy; and so are all

those men are happy that shall have ii. 2

iii. 2

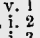

i. 4

iii. 1

iii. 4
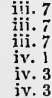

$$
\begin{aligned}
& \text { iv. } 3 \\
& \text { iv. } 4 \\
& \text { iv. } 4
\end{aligned}
$$

$$
\text { iv. } 4
$$

iii.

iv. 2 
HAPPY - to make parents happly

never, before this hapuy clili ...... be happy, thut my nrms ure.. Troilus 8 Cressiln, y. senutors of Athens: hapmy men!

he is gone hinpyy, and hus left me rich

rieh nnd haply: hut thus cond itioned

\section{iii.}

ever taints the happy mun $\ldots . . . . .$. .

you nre come in very happy time..
never eomest unto a happy birtl

to part the glories of this hinply diey

deetls to-morrow: rest you lininy:

alieu, le happy! let all the number

gods make this n happy day to $\Lambda$ utony?

ns my two brothers, hapsyy.

tell me how wales was niade so hajpy

tell him wherein you are happy ....

he shall he huppry that ean find him

wheu witli a happy sturm....? Titus 1 in
o hapjy man! they have befiended

how huply art thon then, from these

was't nut a haply star led us

so I bequeath a happy peace to you
he is a happy kinn, sinee from his.....

nnd weleome: linppy day, ny lords

mole happy by his breath

haplyy what follows! thou hast as elidi

do't, and be hapy, by my silver bois...

nad, by the happy hollow of a tree .....

those hapyy smiles, that played on lier.

therefore, thou happy tather, thi
most huppy? that ereles liend .

most huppy? that ereless liend ............

about it, and write happy, when thou hast
thou wert so laappy by thy stay. Romeo o. Jutiet

these happy masks, that kiss tuir hadics

seck haply nithts to happy mothers

seck haplyy nights to happy days ...... -

this alliance may so happy prove....

marym, in liapoy time, what day

I think you are happy in this second

O haplyy dngger! this is thy shenth.

haply, in thut we are not over happy

all are eoming down. In happy tim

maid-so tender, fair, and happy ...... Olhello, i.

twere now to be most happy; for, I fear - ii. 1

in happy time, Iago. You have not been

I had been happy, if the general camp.

chaste, and true, there's no man happy ... - iii.

viee like virtue's harbinger.. Comedy of Errors, iil. Ill be mysclf the harbinger............. Maebeith, i. those elainorous harbingers of blood

as harbingers preeding still the fates.. Hamlet, $i$.

1ARBOUR-in harbour is the king's ship. Tempesi, $\mathrm{j}$

my thoughts do harbour with my

that they should harbour where

he harbours you as her kinsman. Tirelfih Nighe, ii. 3 to give me seeret harbour.. Neasure for Meosure, i. 4 come to harbour suddenly ... Merchant of Fenice, any place that harbours men... Comedy of Errors, i. I

where slame doth harbour............ nieharel it.

simple show he harbours treason...2Henry $V^{\prime} l$. iti.

and find no harbour in a royal.....

where shall it find a harbour in....

to harbour sueh a thought!

let's harbour here in york.

make their harbnur in our .... Timnn of lthess, y.

crare might ensilicst harbour in? .. Cymbeline, iv.

in this pilaiuness harbour more craft ..... lear, ii.
there's one gone to the harbour? ...... Oliello,

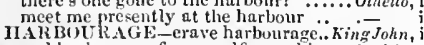

ant harbourate for oursclf, our ships... Fevicles, i. I

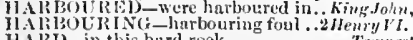

IIA 1 b-in this hard rock.

pray yon, work not so hard...
miltither is haril at study

steril, and roek $y$ hard

it shul? go hard, but I'll.
and lecing go liard to me

and lecing so liard to me

she'll prove as liard to you
for she's as hurel as steci

you are harel beset

to bear a liard opinion

be ready liere hard by in the ..........

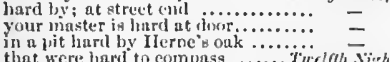

that were hard to compass ........ Juclas . Nioht, j. 2

it is too hard a knot fis me to untic

noder your harl ematrurtion

tlint I lud uot a liand heart

any liarl lesson that mar (li) thee..... Mood -

for scorn hors, a hard rhyme

but there is two harl thing w. Will. N.'s Dram, iii.

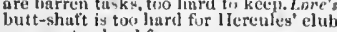

you are too harel for me

spurred his horse so hard against ..
ble's too hard for you at prieks, sir.

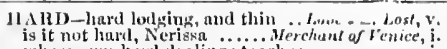
is it not laurd, Neriska .......Merchun twill be a hard way to thit

twill be a hard way to hit .

thou gnudy gold, hurd food rur sliuas

it will go hard with poor Antonio

he standeth here hari by, to know.....

ko stogkish, hard, and till ot rage ...

punish me not with your hard thoughts -

I have by hard adventure found

hesides, our lands are hard ...........
it is a hurd matter for friends to

marry, he trots hard with a yougr

time's flace is so haral that it

necustomed sight of death makes hard

here hurd by : will you go, sister? ( $r e p$ )

tis hard; a young man, married...

'tis a hard hominge, to become tlic

something hard of hearing .. Thming

it shall go hard, if Cambio go

against the hard hearts of maids

ay, or else twere hard luck

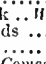

master, knuck the door liard

by the barrenness; hard, in the....

shnil his day's hard journey ...

at onec, 't is hard to reeoneile.

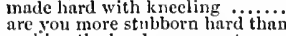

making the hard way sweet .....

it is as hard to come, as for

they will be too hard for us.....

who bears hard his brother

here, hard by ; stand elose

their eourage with hard labour.....

eame, spurring hard, a gentlema
ntter you have laboured so hard.

lie be killed with your hard opinions

hold hard the breath $\ldots$ and hard of heart, in liberty

castle enlled, that stands hard by?

a hard condition for a maid....

in pity of my hard distress... $\ldots \ldots . . . .$.

'twill go hurd with you. Let me

and his brother are hard by...

and eannot brook hard langunge

were thy heart as bard as stcel....

the world goes hard, when Ctifford

whint at your book so hard?

hard [Col. Fint.-mueh] to drow.

spur your proud horses hard
suffer too hurd an exelamatio

hearts of most hard temper melt

strikes his breast hard: and anon

not on't, you are too hard for me...

the hard und soft, scem all affined

blunt wedges rive hard knots

my Cressid then so hard to win? Hiard

hard fute! he might have died...

time liath made thee har

too lard for him, I have heard (rep)

$O$ you hard hearts, you eruel men

hug them hard, and after seandnl them
under these hard conditions as tlis time
Caesar doth hear me hard ...........

Caius I jgarius doth benr Co.... hä hitid

low hard it is for wome

if you bear me hard, now, whilst
from the luard hatuds of peasants

take to you no hard thousht

but make hard your henrt ...............

as the Gordian knot was hard:

can gripe ns liarl as Cassibelno.

ans lurd to leave, as kecp ..............

and he's at some hurd point

finds the down pillow hard.

the certuinty of this hard life.

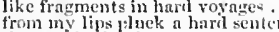

thomph thy hard heart say no. Titus dndron

tribunes more hart than stones
dragons here aflriarit the hard

I have watehed and travelied liaril
they have travelled liaril to-nisht?

Periols's i.

'tis hard: alsost imgossible $0 . . . .$.

hard by here is a hovel ......................

while to this hard house, (more tiard

nature, thut makes these hard hearts.

hard in has extes traitor:

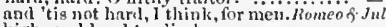

and tis and lurd to elimb .............
who knocks so hard? whence come you?
I1 Alid-I sealed my hard eonfent

ineled, my lord, it fillowed hard tipon.

given him any hurd werds of late

iii. I I I dir full hard firbear him.

he not too lard for my wits..

jard nt hand comes the master anil min

let gne but bincl it hard, within this hos

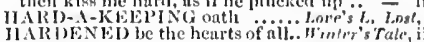

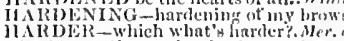

itrelf a pastime to huriler bo
anul hearts liarder than steel

the hariler mateleel, the grenter.

thinking it harder for our miat

pull of my loot: liarder, lask

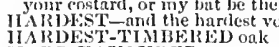

IIDD-FAVOURED

is she not hard-fuvoured, sir?

liard-favoured grief be lorlged

fir nature with hard-fivomi
beenme hard-favoured death

IARD-IIANDED men,

II R D-IIE ARTED_so harl-heur

that how ment grow hard-hearted adamatit

believe not this hard-heartet man,

same pale lard-hearted wench from.3 Henry $V$. i.

HARDIEST warriors dil\} retire
IA RISILY [Col.-hardly] attain

IARDLMENT-ehranging harilim

allenry

popped Paris in his lordiment..

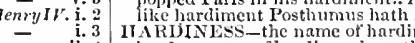

cymbing

hardness ever of hardiness is mother. Cymbertine, iii.

I ean hardly think you my master

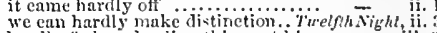

hardly torbear hurling thines at him

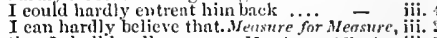

that I shall hardly spare..... Merchont of tenice, iij.

which I ean hardly remember .. As gou tike
say I was stripperl. IIarlly serve..... At's Well, iv. I

that I may hardly tarry so. Tamine

leave yoursel' hardly one subject. W'inter's Tole, ii.

ns liardly will he endure your sight - iv. 3

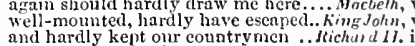

and hardly kept olur countrymen ... Aichurd

very hardly, upon sueh a subjeet ..2llenry
pistol-proof, sir; you shall harlly offend

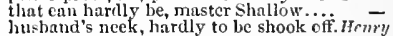

and liardly keeps his men

that hardly we escaped the pride

for more I lardly can endure.

2 Henry ri. i.

knowing how hardly I eau brook abuse? -

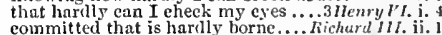

grieved commons hardly eoneeive...Ienry rlii. $\mathrm{j}$.

will hardly stop the mouth of.. Timon of -dthens, it.

once denicd will hardly specd . . . coriolan us, iii.

hardly gave audience ....... tuton's \& cleopera y.

how hardy I was drawn into.

in the law; "twill hartly eome out

of his lands will hardly lie in this

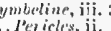

flint and hardness of iny faul

is so from sense in hardness, that $I$ cat

alarity, I find in hardness................

IARD-RULED-hard-ruled king Ilenry l/st. ii

jike a goot and hardy soltiver.

fur hardy and untoubted el

how now, my hardy, stout, resulved.

ns harly as the Nemenn liom's ne

such a hatre is madneas the
lice love is not the hare that.

cagles: ur the hare, the lien

what say"st thea to a har

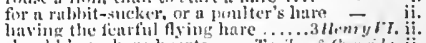

shumld hate hare hetarts .... Troifus of Ciessidu, ii.

lisus, fiuls you bes,

if 11 ly, Mnreius, hallo
as we tuke haren, betion

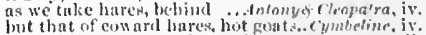

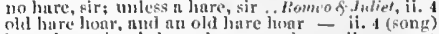

a mole $=$ ii. 1 (son

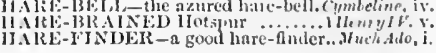


ILA RE-LIP-never mole, hare-lip. Mid. N. Lream, y. squints the eye, and nakes the hare-lip.. Lear, iii.
HARFLEUR-eourse to Harfleur. Henry ${ }^{\prime}$, iii. (elio.) gaping on girded Harfeur............ therefore, you men of Harfleur...... go you and enter Harfleur. iii. (cho.) painted in the blood of Harfleur .....

We eould have rebuked him at Harfenr HARLOCK-harlocks [Col,-hoar-docks].. Lear, iv. HARLOT-for the larlot king ..... Minter's Tsle, i. 3 skin off my harlot's brow .... Con

dissembling harlot, thoul art false
while she with liarlots feasted .....
consorted with that harlot .......

or a harlot for her veeping. $T$.

Richard III. iii. 4 held with a brace of harlots.

possess me some harlot's spirit!.... Coriolanus, iii. 2

aud Hero, hildings and harlots.. Romeo \& Julie

harlot's elieek, heautied witls plastering, Hainles
brands the harlot even liere, hetween....

with a harlot [Col. Kul.-harlotry]

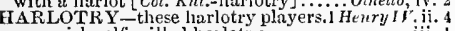
a peevish self-willed harlotiy

peevish self-willed harloty it is. lomo o Jutiet,
[Col. Knt.] sups to-night with a harlotry. Othello

ARNI-there's no harin flone (rep.).... Tempesi, i.

that does harm to my wit....... Tuelfhh Nigh

do tle eonstable's wifice? harm?

would do no harm in him

but, iscleet, I ean do you little harm

and good provoke to harm ..........

is there any harm in, the heavier ...Much Ado, iii. 4 yet bend not all the harm upon.......

laughing at their harm? .......Mid.N.'s Dream, ii. never harm, nor spell nor charm.... - ii. 3 (song)
we will do no harm with our swords - iii.

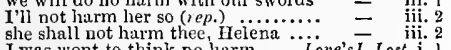
I was wont to think no liarm ..... Love's $\bar{L}$. Lost, i. most power to do most harm ......... content witl ny harm..........As you Like it, iii. 2 in his sleep he does little harm

bars a thousand harms.. Taming of Shrew, $\overline{2}$ (induc.) all, masters, I liear no harm thou dost guess of harm is ereeping.... - i. 2

any tragie instince ot our harm.

they will surely do ots no harm...... -

the win elo

none of woman born shall harm $\mathrm{i}$ iaeheth -

I have done no larm. But I remernbe

where, to do hirm, is often laudable

harm have I, good lady, done $(r e p.) . K i$

praetises more harm ta me

is cold, and would not harm me.

thy words again, to do thee harim

thut ang larm should stain so fizir .. - iii. 3

thou hast done much harm npon

to say, I know more harm

no harm: what more?

he never did harm, that $\mathrm{I}$ heard of .... Ilenry $V$. iii.

see there be no harm betwcell thei

can no longer bear these harms

most bloody nurser of his harms.

intend no ham to us...

good, I wonld sustain

good, I wonld sustain some harm

seek how to redress their harms........
when as he meant all harm $\ldots . . . . .$.
no other harm, but loss of (rep.)

aud think no harm

lest, to thy liarm, thou inove ...........

none can cure their harins by wailing
the fear of harm, as harm apparent.

Henry VI. iv.

wish thyself no harm ................ Henry $v I I t$
peeped harms that menaced him
an enemy intends you liarm.. Troilus \& Cressida,

reason flies the objeot of all harm.

naming of him does him harm

harm. Yes, thou spokest (rep.)..

3 Henry VI.

iii.

it sleeps, and does no hired harm ..... $\rightarrow$.

one that means his proper harm harm ean your bisson eonspectuiti

doing them neither good, nor harm

no further harm, than so much loss.

the harm of unseamed swiftncss

no harm iutended to your person

ten thousand harms .........

do the gods great hirm

harm not yourself with your vexation. Cymbeline, $i$.

hal no harm, I trust, is done?

good masters, harm me not.

no exoreiser harm thee!

do no liarm hy it, though the gods .. - iv. 2 (song)

he hath clone no Briton harm

too well to do thee harm ................. Andronicus, iv.

nature is so far from doing harms ......... Lear, i. 2

never inore be feared of doing liarm
IARMI-sheep shall take no barm. Lear, iii. 6 (song) let this $\mathrm{kiss}$ repair those violent harms

of my thought; no further harm ...... Olhello, iii. but then I saw no harm

hast not halt the power to do me harm . $v \overline{v I}$. v. HARMED_yet he never harmed...

IIenry $V$. i.

you or yours by me were harmed!. Richard III. iv.

it harmed not me $\ldots \ldots \ldots \ldots \ldots \ldots \ldots \ldots \ldots$ othello, iij.

no further harmful than in show

suffered in that harmful slumber...

too mueh lenity and harmful pity ..2 Henry $V I$. iii.

mild, but yet more harmful pity .3Hen'y $I^{\prime}$. it.

than praised for harmful mildness

Lear, i.

BARt not without that harmful stroke

which you say, is a harmless fairy

why be, a harmless necessary eat. Mer, of

the bowels of the harmless earth .... I Henry 17.

is the sucking lamb, or harmles

looking the way her harmless you

steeped in the harmless blood of
poor harmless lambs abide their

so first the harmless sheep doth.

and she, like harmless lightning .... Cymbelin

poor harmless fly! that with his, Titus Andron. iii.

duleet and harmonious breath.......... Tempest, N.Dream, iv

HAMIONY-harmony
what harmony is this?

hushed on purpose to grace harmony 1 Much $A d o$, ii. 3 ravish, hike euchanting liarmony.. Love's L. Losl, i. 1
makes lieaven drossy with the harmory - iv. 3 the touches of sweet harmony ...Mer.

patrouess of hegenly harmony. Taming $\vec{s}$.

while I pause, serve in your harmo

while 1 pause, serve in your harm
no touch to tune the harmony .......
like deep hiarmony; where words.

jar, what hope of harmony?........

that celestial harmony I go to

Henry $r$ ii.

heaven of this peace .... Cymbeline

with her sweet harmony and other choice
eommant to anv utterance of harmony. Hamlet,

HARNESS-we'li die with harness on. Macbeth

their hitrness stindded all with. Taming of Sh. 2
fill fields with harness in the realm.I Henry IV
lo

doff thy harness, youth ....... Troilus \& Cressida
should drink with harness on .. Timon nf Athe

througl proof of harmess to my. Antony \& Cleo.
IARNESSED - this harnessed mask. King John,

he was harnessed light ...... Troilus \& Cressida,
HARP-more than tlie miraeulous harp. Tempest,

graoions duke, harp not on that... Meas, for Mea.

an unstringed viol, or a harp

I framed to the harp many

i) HewryI $I$.

yol ne'er had done't, (harp on that. Cor iolanus,
II AlPED-hast harped my fear aright. Macbeth,

IIARPEL-a blind harper's song.. Love's L. Lost

Harper cries: 'tis time, 'tis time ...... Nacbelh,
IIARPING-harping on what I. Anlony \&-Cleo.

still harpiug on my daughter.....
HARPY - the figure of this harpy

words' eonference with this harpy ... Much dido, ji.

HARRIED-so Pharried him .. Antony \& Cleo. iii. 3

it harrows me witly fear, and wonder ... Hamlet,

liglitest word would larrow up thy soul
HARR - when, Harry? when?...... Richard $I I$.

is Harry Hereford armed? Yea

holds you dear as Harry duke of ...

just? and is not Harry true? $\ldots . . . . .$.

my son, young Harry Percy, sent from -

Harry Bolingbroke on both his knees

thrice nohle eousin, Harry Bolingbroke - ii

brow of my young Harry.

Harry Perey here at Holmedon took

whatever Harry Percy then had said

banished woman from my Harry's bed? -

no furtherwise, than Harry Perey's

Harr sure

there is a thing, Harry, whiel thou

for Harry, now I do not speak to the

for Harry, I see virtue in his looks ..

now, Harry? Whence come you?....

yet let me wonder, Iarry, at thy ${ }^{2}$.

why, Harry, do I tell thee of my

on Wednesdiny next, Harry

and, Harry, you shall march ........

I sarry to Harry shall, hot horse to horse-

meets with lord Harry; and I fear... -

let not Harry know, in any case
HARRY-I, and Harry Monmouth!..1 Henry I $l^{\prime}$. v. for, instead of thee, king Harry...... my name is Harry Percy............ Harry Percy, and the prine

and you, son Harry, will towards.... to noise abroad that Harry Monmouth - (indue.) prinee Harry sluin ontright.

young Harry Percy's spur was eold

and out-b:eath'd to Harry Monmouth

Welsl, himself, and IIarry Monmou

my lord, and Harry prince of Wales

Harry prince of Wales, greeting.. - ii. 2 (letter)

when my sweet Harry had but half

and here is four Harry ten shillings in

when IIarry Bolingbroke, and

conc hither to me, Harry: depart

Harry the fifth is erowned ${ }_{\text {for }}$ the fifth Harry from eurhed......

for the fifth Harry from enrhed......

therefore, my Harry, be it thy eours

dend Ilarry; O that the living Ilariy
but Harry, Harry: yet be sad........

that IIarry's dead; and so will $\mathrm{I}$ (

Shorten Harry's hamy life one day.;
king Harry. Harry the fourtlo (rep.)

then should the warlike Harry.ile.... $r$. i. (ehorus) to Harry, and his followers ...... - ii. whoias tells Harry that the king ........... bar Harry England, that sweeps

say thou to Harry of England

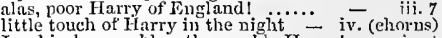

Lord in heaven bless thee, noble Harry! -

what's thy name? Harry le Roy ....

king Harry: and so fare thee veli

Harry of Monmouth's life is eome
Harry Monmouth, being in his right

more cause, did they this Harry.. - - (ov.

till Harry's back-return again ..... - v. (chorus)

sooner persuade Hasry of England . H - v. 2

gervant in arms to liarry king ....1 Henry ${ }^{\prime}$ L. iy. 2

holy Harry died, and my swe

Harry the sixth hids thee despair.....

Harry, that prophesied thou shouldst

or ary young, sir Harly Guilford.. Henry i. HARSH-too harsil a desent. Tü..... Geri.of Verona, for they are harsh, untunable........ $\overline{\text { they will digest this harsh indignity. Loves } L . L . v .2}$ but on thy soul, harsh Jew... Merchant of Venice, iv. I harsh one, and not to be nuderstood...Al's '"'ell, ii. 3 but a harsh hearing, when women . how dares thy harsh rnde tongne .. Richard III. iii. 4 it doth present harsh rage........... I HenryI $V$, iii. as harsh, and horrible to hear ......2 Henry VI. iii.
tlat Clarenee, is so harsh, so binint ..3 Henry VI. v. that Clarenee, is so harsh, so blunt ..3 Henry VI. not honest, is too harsh a style ...... they are harsh and heavy to me ..MenryVIII, iv, and harsh in sound to thine......... Coriolanus, the time with conference harsh

wo more ado with that haish

thy harsh and potent injuries...... Cymbeline, iii.

ony danceth at so harsh a ehime........ Pericles, $i$. straining harsh discords.................... \& Juliet, $_{\text {, ii. }}$ bells jangled, out of tnne and harsh ..Hamlet, iii. and sweet revenge grows harsh ......... Othello, v. ARSHLX-harshly in her ears.. Comedy of Err. iv. 4 grating so harshly all his doys ARSHNESS-Composed of harshness. Tempest, iii. due to me, to stubborn harshness. Min.N. s Dream, IIARSH-RFSOUNDING trumpets'.. Richard II. i. IARSI-SOUNDING rhymes ....... Kin solm, iv. 2 that instant was I turned into a hart
if a hart do lack a hind...As you Like it, iii. 2 (verses) if a hart do lack a hind...As you Like it, iii. 2 (verses)
leave me at the White Hart ......2 Henry Vl. iv. 8 leave me at the White Hart .....2 Henry VI. iv. 8
the hart Aehilles keops thicket.. Troilus \& Cress. ii. 3 here wast thou bayed, brave hart.Julius Casar, iii. 1 thou wast the forest to this hart .... cymbelize, $_{\text {ii. }}$ our Britain's harts die flying ......... go weep, the hart ungalled play ....... Iamlet, iii. HARTAI-horum, hiarum, horum... Aler, $y$ Wives, iv. wit and youth is come to harvest. Twelfh Nighi, iii frame the season for yonr own harvest. Much ddo, $i$. man that the main liarvest reaps. ds you Like it, iii. 5 if I grow, the harvest is your own ....Mocbeth, i. reap the harvest which that rascai..2 Henry Vi. iil. 1 


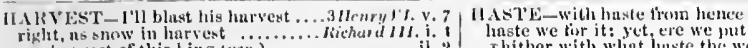
right, ns snow in harcest

to reay the harvest of jerpetuil jeace

and shortly eomes to harvest..lulony of eteopalru, il. 7 In his sprimg beenme a harvest...

whither with wlint huste the veriglit

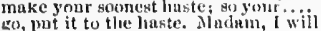
Lo, pot it to the haste. Mndrm,
imine haste; who has the note must not in huste aluuse

eonl yourselt, telling your haste. sorrows which thom hring'st in
then, with whont luste you

the mutiny there lie lovistes t'un........

1) lo my work will inick hate

resolve me, with all wudest haste.

A reeking jost, stewed in his hinste

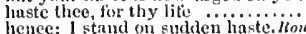

henee: 1 stand on sudden liaste. Hor

make huste, lest mine be about your cars

let Romeo heree in liaste.

make haste, for it grows very late .

do youl like this haste? we'll keep no

notling slow, to slatek his haste....

in his wisdom, hastes our minrriage.

do you know the reason of this huste

of my wateh, hil them make haste

this sweaty huste doth make the night

and let your haste commend your duty

while one with moderate haste might tel

laste me to know it; that $I$,

too free-footed. We will haste us....

I pray you, haste in this

pray yon, make haste. And, Fngland

to me with as much haste as tho

and he reculires your haste post-inaste

ever as she could with haste lespatch.
the attinir eries - haste, and specd nust

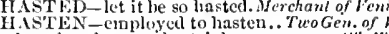

lest thou hasten thy trin

hasten your generals after................

get you gone, and hasten your return

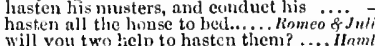

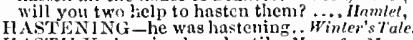

IIASTLY - henting how hastily. ieas. for Mens. comes the prince and Clavdio hastily. Wuch filu, v.

brings you here to court so liastily?.. King John, $i$.

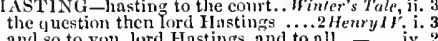
and so to you, lord Hastings, and to all -

yon are too shillow, Hastiugs $\ldots . .$. .

good tidings, my lord Ilastings......
the bishop Scroop. Hastings, and ail

lord IInstings well deferves to have, $3 H$.

hut, ere I go, IInstings, and Montague
Ilastings, as he favours Edward's causel

Richard and Ilastings; let them go

Richard and Ilastings; fet them go in -

of Glostcr, lord IIastings, and the rest

the lord liastings who attended him

lord Hastings, and the rest.......... Richard 11

lord Ilastings was to her for $h$

the new-delivered Hnstings? ..........

and su wast thou, lord Hastings.......

to Stanley, Ilastings, Backingham...
Kivers and Ilastings, take ench other'

as I love Jiastings witl my leart

there, Hustings; I will never more..

embrace hion, Hasting ...

crme, Hastings, help ne to ny....

fie, what a slug is llastiugs?

lord llastings will you go with me?

willitin lord instirgs of your mind

sound thou lord llastines, how he doth

if we pereeive lord Hastings will not

Ihestings, $y^{\circ}$ ou and he are near in tore

than my lortl J lastimgs, no man nuight

Cateshy linth sounded Itastings in our

lighted on yoor Irastings' wrettehed head

dangerous and unsispected ll:astings

within these five hours Ilastings lived

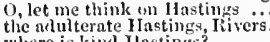

where is kind Jlastings?

think on lorel lIastings: and despair

IASTY - first snit is hot and hasty ...
are rou so hasty now? well, all is onc

ankindness of his hasty words. $T$.

or temeh thy lusty spleen to do

lieing upon hasty employment.

is he so hasty, that lie lloth

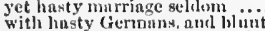

with hasty Gernmns, and hl unt...

art thum so hasty? I have staicl.
lie not so hasty to contound my.

le not so liasty to conto

in eloler, ill, and hast y.............

as histy to expel him theme.

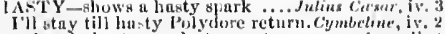
to limuly husty words, t's seant my ....... i im, ii.

ciil provoke onr hasty sending ......... Hambt, ii.

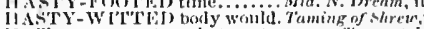

i1 $\mathrm{A}$ - vour rye struw hats put on .... Y'enpese,

fetelh ine the hat and rapier.

this hat is Nun, our mad.. Turogen, of J'erno, it

liy this liat, then loe in

anel there sler thrummed hat...

jic hirnshes his hat $0^{\circ}$ merning

the bishion of a donllet, or a lint

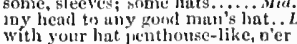

my lint to a hulfuciny, Pompey

with my hat, and sinh.

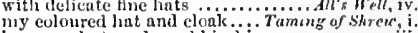

in a new hat, and anold jerkin.

an old lat, and the humour
no link to colour I'ter's hat

no link to colour I'eter's hat ....

a colntain hat! O, I an nindo
take your sweetheart's hat

nav, you slinll live no bat

ne'er pull your hat upon your hrows.......

and putting off his hat, said, I will..2 llenryI $v$. ii.

my fect I stamp thy eardinal s lint... - i. 3

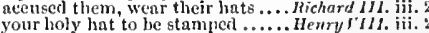

hats, eloaks, (doublets, I think, . ....
he lias beat it out of my lat .. Timon of Aluens, iii.

. Coriolanus, ii.

and witl his liat thas waving it ..... $\overline{\text { hats }}$ are plueked nbont their ears...fulius ii.

with glove, or hat, or handkerclief.. Cymbeine,

no hat inon his liead; his stockings .. IIomele, ii.

by his cockle hat ant staff........ iv. 5 (somg) window, or else o'er the linteh ....... King John, and make you take the hateh

become the hatels and brood of time.2. Henry $1 \%$ : iii. my illeness doth hateh .... Anlony o Cleopalra, i. raven dotli not lateh a lark...Tilus Andromicus, ji. I do doubt, the hateh, and the disclose. Hamlel, iii.

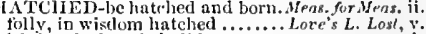
'tis hatehed, nnd shall he so..... Taming of Shrern, i. new hatched to the woefol time ......Macteth, ii. Nestor, hatched in silver .... T'roilus \& Cressida,

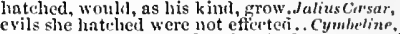

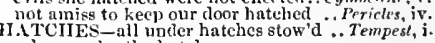
aslepr under the hatches

it he conce under my hatehes .........erry $\overrightarrow{\text { Vives, }}$ ii.

stood upon the hatches in the storm.2 Henry l. iii.

to walk upon the hatehes
the giddy footing of the lia te...........

we liave a chest bencath the hatehe

IIITCIIET - the pap of a hatcliet

IATCIING, it secnied, appeared...

IATE-clide thee, if not hate thee .... Tempesh

they all do hate him, as rootedly

huit harren hate, sour-eyed

descrves more fee than hate. $T$ ing Ge...

whom your gentle daughter hates

not hate un to my friend

that women highty hold in hate

that it is spoke in hate.

than hate of

thm hate for silvia ..................

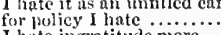

I hute ingratitude nore

I hate a drur:ken rogue.......
to exense the thing i hate..

do exense the thing Thate...Measure for.Metsure, ij

an' if she did not hate him deadïy....

the more I hute, the more he ... Yid. ...'s Dre

cau you not hate ne, as I know

yesu hate me witli your heart

the: hate I bear thee made me........ -

wherefore spleaks he this to her he hates? -

greater harm, than hate? II ate me....

to sleep lyy hate, and fear no erimity?

so unech i liate a breaking oumse

1 hate lim for he is a christian. Mach of lenice

he lintes onr sucred nution

bon know yourself, hate pounceis not

moan to me; therefore he lates me..

hates any mun the thing lie.........

"wery offenete is not a hate at first.... - jv.

I plinuthl hate him, for ny tither..... -

grte no man hatc, envy no man's (rep. hute him not; nut yet I have (rep.).

pim! ering, none of you hate them ...

iienrytrti.

. All's'll, i. 3 
HATE-both my revenge and hate.... All's Well, ii. 3 | HATE-than hate to utter love

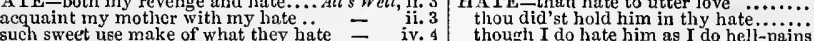
such sweet use make of what they hate -
while shameful hate sleeps out ......

thou didst hate her deadly $\ldots . . . . . . . . \quad$. v. 3 and hearted throne, to tyrannous hate!.

thou liest Camillo, and I liate thee. Winter's Tale, i. 2
shall, Autiploolus, hate ....... Comedy of Errors, iit. 2 HATEht I did in hate, but all in honour.

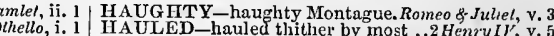
and my heresy, of all be hated .......

HAULING- - with hauling of the ropes..Pericies, iv. I your favours, nor your liate.............. Nacbeth

others, that lesser hate him.

and from thy lated presence part I so

thou hate and terror to posterity ..... - iii. 4 my father hated his tather dearly. As you

how God, and good men, hate so foul Richard II. i.

o sir, I shall be hated the greatest.

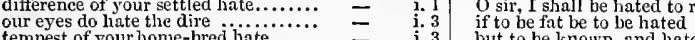

tempest of your home-bred hate....... - i. 3 but to be known, and hated.....

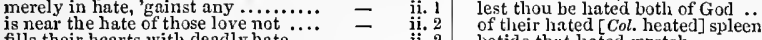

fills their hearts with deadly hate....

to the sourest and most deadly hate

iii. 2 whom I most hated living

.1 Henry IV. ii.

that fear, to hate: aud hite twrns....

I hate the murderer..........

henceforth hated be of Timon. Timon of Alhens, iii.

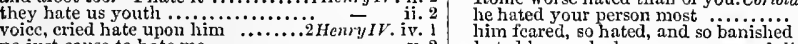

liated by one he loves.... so bansilied

no just cause to hate me

iHenry YI. ii.

hateth thee, and hates us all

the hated, grown to strength. Anlouy \& Cleopatra,

es many signs of deadly hate...

hater for being preferred so well

lord Say, the traitors hate the.

pitied, or hated, to the face of peril

liave turned my late to love

turn thy hated back upon our kingdiom ... Lear,

never hadst deserved our hat

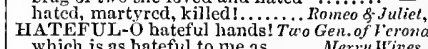

in deadly hate the one against

in har heart's extremest hate

which is as hateful to me as...... Merry I'ives,

against his honour, in hatcful practice

Jive each of you the subjects to his hate -

do love my brother, hate not me .... -

this decd, will hatc you for the deed

my soul is purged from grudging hate

doth turn lis hate upon your grace.

God punish me with hate in those

I hate it, and desire all good men's

[Col. Knt.] your high-swoln hates

can lesser hide his love, or hate...

he hates me for my father Warwick

sweet savours for this hatelui fool

I will undo this hateful imperfection

a little more hateful to mine

any secret course thy hateful life.......... Kacbeln John,

a passion hateful to my purposes

avaunt, thou hateful villain $\ldots \ldots . .$. Richard 1 iv. ii. 3

arms this hateful name in us ......1 Henryl IV

and in thy hateful lungs, yea

2 Henry $1 V$.i. 1

alas, I rather hate myself

nothing teems, but hatefin docks

disposed as the hateful raven.......

I. ii.

into his liands that hates me?

and glory of this world, I hate $\ddot{y e}$

of purpose laid, by some that hate me

but left that hateful office unto

charm, thou hateful withered lag....3ichard III. $\mathrm{i}$.

urge lis hateful luxury, and bestial

for hateful deeds committed by myself
the noblest hateful love. .... Troilus of

a hateful truth. What, and from

do hate a proud man, as I hate. Troilus \&-Cress. ii. 3

by weight hate $I$ her Diomed

hate a lord with my lheart.

I hate not to be banished.

hef thee..... Timon of Athens, iv

record bear hateful menoory. Antony so Cleopatra,

a wooer, more hat eful than the foul. Cymbeline, if.

his hate may grow to the whole......

who all thy human sons doth liate

why should'st thou hate

on what 1 hate, I feed not. Dost liate

from men; hate all, curse all ........

deserves greatness, deserves your hate.

is the man of my soul's liate, Aufidius

for I do hate thee worse than (rep.)...

the fusty plebeians, hate thin

'gainst my hate to Marcius .........

care whether they love or hate him..

but he seeks thcir hate with

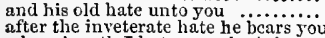

whose breatl I hate as reek o' the "

my birth-place hate I, and

ay, and it makes men hate one another

then you should hatc Rome as lie does

when I tell him, be hates flatterers.Julius $\overline{C c}$ s

when thou didst hate him worst ....

to hate one wreat competitor

I cannot liate thee worser than $\mathrm{I}$ ido.

as if a god, in hate of mankind

(to accuse myself) I hate you.......

I will conclude to hate her

hate they bear their emperor

.. Titusandro

wehate the prince of Tyre ............Pericles, $i$.

new-adopted to our hate

to mateh you where I hate

thou call'st on him that hates tilee..........

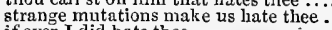

if ever I did hate thee...................

I hate the word, as I hate hell ... Romeo of Jutiet

to part your cankered hate

my only love sprung from my only late -

my life were better ended by their hate -

an interest in your hate's proceeding

by doing damned hate upon thyself?

you know I hate, rather than Paris..
what I hate, but thankful even for hate -

in oblivinder of our hateful days

with this hateful liquor temper it....
pluck upon my hateful life ...........

dear saint, is liateful to myself.... Romeo...

unlappy, wretched, hateful day! ...

HAUNCH-bribe-buck, each a haunch. Meri'y $W$. y.

IMAUNCHES-round haunches gorcd.As you Like, ii. I in idle price to haunt assembles... Mrerry. Fromes, iit, and I will spare your haunts.. Mid. N.'s Dream, ii.

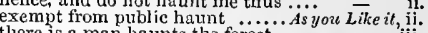
launts wakes, fairs, and bear-baitings $w$ inter's $T$. iv. onc that haunts me.......... Comedy of Errors, iii. 2 wherc they most breed and haunt........Macbelh, i. 6 there is a devil haunts the ......... Henry $\bar{I} V$. ji. 4 his open hammts and popularity ........Henry $V$. . . I suspicion always haunts the guilty..3 Henvy HI, v. 6 did haunt you in the field ...Troilus \& Cressida, iv. did haunt you in the field . Troilus \& Cressida, iv. and all the haunt be ours.. Anlony \& Cleopat $r a$, iv. 12 the foul fiend haunts poor Torn............. Lear, iit. 6 in the public haunt of men ................ Leareo \& intit. and out of haunt, this mad young man. llamlet, ir. ] charged thee, not to haunt about my doors. Othello, i. 1

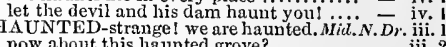

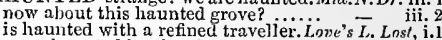
some haunted by the ghosts they ... Richard Il. iii. 2 that haunted us in our familiar $\ldots \ldots$ Henry $V$. ii. 4 fairies will his tomb be haunted .... Cymbetine, iv. 2 do you mean by this haunting of me?.. Othello, iv. to a wise man ports and happy havens $R$ ich of Sh. from Ravenspurg haven before ...3 Henry VI. iv. 7 to bring him to the haven.............. Cymbeline unto the shores o' the haven in Cambria, at Milford Haven $\ldots . .$. iii. 2 (letter) he is at Milford Haven ............ - iii. opportunities at Milford Haven - iii. 4 (letter) comes to Milford IIaven to-morrow..
over land, to Miltord Haven ........ meet thee at MIilford Haven $\ldots \ldots \ldots . .$. 二 iii. Milford Haven, sir. What is your name? - $\quad$ iii. 6 yes sir, to Milford Haven .......... - iv. 2 what lading's in our haven .............Pericles, i. with the same 'haviour that your. Tuelflh Nighl, iii. in the lusty 'laviour of his son ....... Richari II. i. 3 put thysclf into a 'haviour of less .. Cymbeline, iii. 4 $\mathrm{HAV}$ OCK -havock with them?.... Tuelfih $N_{i g h l}$, v. I made such havock of my meari...... Much dio, iv. 1 wide havock made for bloody power.. King John, ii. of pell-meli havock and confusion ...1Henry $I V$. v. 1 to spoil and havock more than she ..... Henr? $r$. i. 2 havock, and let slip the dogs of war.Julizes Casar, iii.

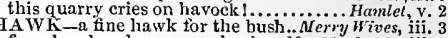
for a hawk, a horse, or a husband?... Much Ado, iii. I'll venture so much on my hawk .. - v. I soar, I am a hawk.................. Henry $V_{\text {. }}$. .ii. 7 and queen do mcan to hawk .......2 Henry $I V$. 1.2 my lord protector's hawks do tower.. HAWKED-hawked at, and killed ........ Macbeth, ii. 4 A W ING-hawking or spitting.. As you Like it, v. 3
his hawking eye, his curls .............All's $W_{e}$, i. I dost thou love hawking. Taming of Shrew, 2 (induc.) talking of hawking; nothing else 2 Henry $V I$. ii.
H WTIORN-Jisping lawthorn buds. Merry $W$. iii. when haw thorn buds appear. . . Nill. N.'s Dream, $\mathrm{i}$. hangs odes upon haw thorns........As you Like $i$, iij. 2 the haw thorn busly a sweeter.........3 Henry VI.ji. 5 $\mathrm{HAY}$-bottle of hay, good hay (rep.) (rep.).. Lear, iii. 4 and let them dance the hay ..... Love's L. Lost, v. 1 $I$ will drain him dry as hay...............Macbeth, $\mathrm{i}, 3$ winter mars oul hoped-for hay......... Ifenry VI. iv. 8
kindness to his horse, buttered his hay .. Lear, ii. 4 the punto reverso! the hay! ..... Romeo \& Juliel, ii. HAY-STACKS in the night.... Titus Andronicus, v. I will inyself in hazard .............. your latter hazard back again... Merch of Venice, i. 1 your hazard shall be made $\ldots \ldots \ldots$...... hazard for lead? this caskct (r'p.)

cor give, nor hazaid, aught for lead..

comes to hazard for my worthless self

pause a day or two before you hazard

to the extreme edre of hoz must.

ccrtain hazard of all incertainties. Winter's $\bar{T}$ ale, $\mathrm{iii}$

lies on the hazards of all husbunds .. King voln, i.

I will, upon all hazards, well believ

be with hazard of my head .......... Henry 11, i. 3 


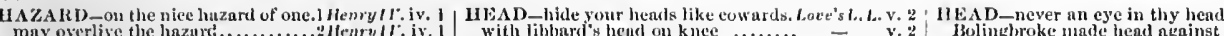
may overlive the hazard............. Jenry 11, iy. who will go to hazard with me fur : to haznral all our lives in one .......illenry 7 t. iv.

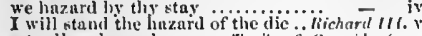
gets all on hazarrl... Troilus \& Cressidu, (prol.) to hazard life for ili? ........ Timm or Athens, tii.

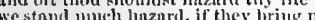
we stand nimuch hazard, if they brimg an

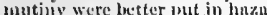
break his neek, or hazard nime. the hazards of this untrod stnte...Julius Corsar, $\mathrm{ii}$. and ull is on the huzarc.

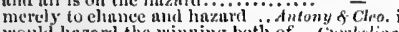
Would hazard the winning both muy not endure huzard so near vi.

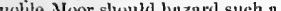

II.AZ.1RDED-I hazarded the loss. Comedy of

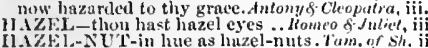

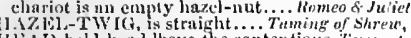

IIlisi)-bold heal bove the contentione. Fempest,

sces a crown dropling npou thy head

thy eycs are alsuost set in thy heal..

keep a good tongue in your hend

kecp a roul tongue in thy hend

whose heads stood in their breasts?

clse falls upon your heads ..........

which I wear miny head ..............

heap on your head a paek

there's not a hair on's head..............
Sleuder, I broke your head .........
I have mut ter in my head against ..

1 have operations in my head.

as any is lwetween this and his

shall turn your head out of my door

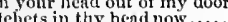

let it lit on my head

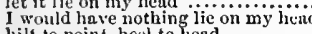

hilt to point, heel to head.

hold up your head (rep.) ...............
will look some linen for your head

with huge horns on his head ........

of waxen tajers on the
flaring 'bout her head.

hold up your head, and minee

by the head and shonlder

no sea-cap on your head

has broke my hend across

you broke my head for
still had dranken head

neittern hemi. The hend of a bodkiu

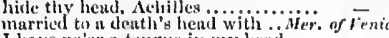

I lave ne'er a fongue in my herd

whose authitious hencl suits in publie

no more thun a foul's head

- ii. $\overline{9}$ (se

I will crer be your had ..... - ii. 9

dare searce show his licad and

the rlowry of a secounl lsent

to shake the heas, relent, and sigh... - iji.

of my hunds, ny heju, my hear

a precious jewel in his hend
with forked lieads have their

As vou Like

is his heal wortli a laat

carries his liouse on his hend

and hose plucked over your heail..

to set the deer's horns upon his head

tall on thy head! farewell, my lord .. All's $W^{-}$

and find your salt teare $\ldots . .$.

whilst I linve a tooth in my liend....

to pluek his indigmation on thy hend

which bow the head, and not...

baln his foul liead with. Faming of Shrew, 1 (indue.)

and with deelining liead...........

young folks lay their heads together!

slie struek me on the head

tis in my head to do my niaster good

let their heads be sleekly eombed...

head and butt: a hasty-witted body

your head and battwere healant

thy keeper, thy head, thy sovereign.

sometimes her hẻal on one side.

what maids lnck from head to licel - iv. 3 (song)

ii. 1 how she longed to eat adders' heads.. - iv.

preferment drop on my head $\ldots . . .$.
upon my daughter's head! teli me
I shall have a holy head...... Com

I had rather have it a licad ...

sor my head, and enseouee.

no longer from head to foot.

coned his that his head is light .......

the spring, the head, the fountain....

gashes on his head; the least

strange things I have in head.

do slope their heads to their fonndations -

rebellious head, rise never........

and thy head stands so tiekle.

give out a eommission for more heads

hind he twenty heads to teuder

to suve a head, to cleas
nips youth i'the head.

the usurver's enrsed hend...

still I lay upon my mother's head ... King Joh

take heal from all indifferency

mean by shaking of thy head?

under heaven are supreme head

the yower of France upon his head ..

keep this form upon my head...

at midnight held your head.

to stutt my head with more

hadst thoo but shook thy head.

drew this gallant head of war.

by cutting of your heads...

hot vengeanee on ofienders head

reach at victory above my hend.

eompass is no bigger thun thy head.

a thousand daingers on your head..

their heurls shill pay for it.....

with hearls, and not with hands..........

at Bristol lost their heads.

eover your hutals, and mock not.

from henee, hath lid his head.

taking so the liear your

the henvens are o'cr your hend ...

hands against my head, and threat..

spring from one most gracions heatl.

buried once, why not upon my hend?

eut oft the heads of too tast-yrowing

as Calais to my uncle's head?

heavy weight from oft my lie
ere foul sin, futhering hend

my g(iilt twe on my heal, and there

dust and rubbish on king Richarel's head -

dust was thrown upon his sacred head

upon my head, mad all this fumous

and never show thy head by lay

hid his erisp head in the hollow

be with hazard of my head

upon the head of this forgetful man.

save our heads by raising of " thead.

when the suspicious head of theft....
firr thon art not so long by the liead.. and the hazard of much blood

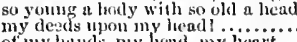

lay eoutehing, head on cround

upon my head they plaeed

Austria's head lie there.

when your head did but ach
at miduight held your liead.
Bolmghroke made head against $\ldots . .$.

and rest yoor gentle heal upon her lop

wouldst two have thy head brokeli?

turns hetul ahamkt the lion's ...

aul on my hent iny sliames redonbled

many u man doth of a death's hend.

no bigger than pins' he'arls

cuit sne off the liends of all. .

the special head of all the land:

fortune showering on your

enterprise set ofl his head .......

his offences live ujom my head
quarrel lay upon our hearls

lonenur dost thon seek upron iny heid?

to make a garland for my hetil

bear the sin npon their own head

stooped his anointed hend as low

he gave his nhle horse the heat $10 .$.

with a white head, and Eomething
aetion ean peep out his head

aetion ean peep out his head ........

are in thirce heads; one pow

to the Lublur's head in Lumbert Sirect

cut me off the villan's hend

when the prince hroke thy heat
do not speak like a death's head

drop upon our bare unarmed heads.

corling their moustrons heads

nueasy lies the hood that wenrs.

and betted mueh money on his head

which show like pins' heads to

I put it on my head; to try witli it.

let God for ever keep it from my

lay thy head in Furies' lnp

the advised head detend

turm head, and stop pursuit..........
of what a monarelyy you are the head

of what a monarely you are the liead

througli the portage of the head
any man'y head but his own.

roverend heads dashed to tlie walis.

for if their heads had any intellectnal

and have their heads crushed

pillow for that good white head.

the ill upon his own head.

job down their heads, dropiping

o'er the French soldiers' hends

the Freneh have gathered liea

earl of Cambridge, lost his head

louen hangs her head for grief.

set the crown upon lis hend.

and let her head fall into Engtand

wear the diadem upon his head.

hantiling the liead be circled witi......

lift our heads to benven.

were flaced the heads of
shall lose his head tor hi

and on my hend did set

the triple erown ipon his head ......

the ringleader and head of ait this rou

on their own heads thereby

have laid disgraces on my heal.

all of you have luid your heads together

the golden cirenit on my liesd
or else lay down your lead.

happy when I shook mr herat?

there let his head and lifeless body lie

no; and therefore we't have his hemd

here may lis head lie on my
juth sworn to lative thy heas

get you to smithtield, and ganther hem

政

slall not wear a head on his.

take your houses aver your heads...

that brings his head unto the king

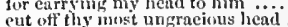

fron tochle llenry' head.

your grace a traitor's heal, the hend

he shall not hide his head, but boliliy

that heal of thine doth not heome:

hope to shake king Ilenry's liced.....3

iii.

i

iii. 22

iv.

iv.

r.

- (indine.)

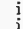

i.

i.

i

iii.

iv.

- $u v y$.

ii.

iii.

iii. 3

erus)

iv.

iv. 1

I. i. 3

ii.

i

I. i. a mighty ancl a fearfin hent.

to seck ont this heach of safety

tro wanton fur the head...................

for which we have in head assenbled

set a preeions erown upon thy head.

nod thejr heads, and throw the

lomg-boat's side strike oft his head

iii. 2

I du beseech thee apparel thy head... 
HEAD-the usurper's head (rep.) unto the house of York such head,
will you pale your head in Henry' and, with the crown, his head my blood upen your headsl........... whe th they took his head, and on the gat the diadem from faint Henry's head the fault make forfeit of his head .. yonder's the head of that areh-enemy thy diadem upon my head the head, your fatluer's head off with the traitor's head.. in my heart, not on my head trunk that bears this head al tho' my head still wear the crown his head by nature framed ...... off with his guilty head

off $a$ thing eomes in his head

if a thing eomes in his head

if your head were laid. $\mathrm{m}$. $\ldots . . . .$. and shake your head, and call us ... chop off his hend, man ............. might better wear their heads curse is fallen upon our heads that he will lose his head...

off with his head: now, by saint $P a u l$ on poor Hastings' wretched head.... short shrift, he longs to see your head to the block; bear him my head

Breeknock, while my fearful heed is even here I slip my wearied head. thy head, all indireetly, gave cireling now thy head, had graeed cireling now thy head, had graeed relse he turned my feigned prayer on my head vengeanee on the head of Richard.. that ever entered in a drowsy head

off instantly arrows to the head $\cdots . .$.

Thomas Lovell's heads should have. Henry $r I$ who first raised head against ... too many curses on their heads hung their heads, and then lay by the heads of all thy brother cardinals
I'd rather want those, than my head I'd rather want those, than my head I'll serateh your heads

spared any, that had a head to hit.... her pinked porringer fell off her head and on your heads clap round fines. elose up, or I'll make your head aclie

well as you love an idle head. Troilu and bears his head in such a rein fore all the Greekish heads $(r e$.
didst iteh from head to foot... and his guts in his head.

hut, by my hend, tis pride.

our melaneholy upon your begdi

our head shall go bare your

our head shall go bare $\ldots . . \ldots \ldots \ldots . . . . . .$.

would he were knocked o' the head!

oft make thee to hide thy head

may pierce the head of the great

you fillip me o' the head

and wear a castle on thy head!

onward Troilus, show thy head!

bowing his head against the steepy. Timon of

I have shook my head, and wept

what heart, head, sword, force

but they do shake their heads........

set quarreling upon the head of valour let's shake our heads, and say

pillows from below their heads

he'll beat Aufidius' head below .......

in our own house I do sliade my bean

made a head for Rome, he fought...

not that our heads are some brown.

to show bare heads in congregations

waving thy head, whieh often, thus

the beast with many heads butts

not a hair upon a soldier's head...

one another and shook their heads.

to cut the head off, and then hack

when Cresar's head is off ........

waving sur red weapous head $\ldots$.....

we must straight make head

doth therefore hide his head $\ldots . . . \cdots$.

fly o'er our heads, and doy
O yet hold up your heads!

Antony look over Cæsar's head....Antony s. Cleo. $\mathrm{v}$.

and put garlands on thy head

that Herod's head I'll have.

ner hend's declined, and deat $\ldots$ iji.

send this grizzled head death will.
HWAD-that head, my lord? Antony \& Cleopatra, iii. 11 HEADED-hoary headed frosts fall in. Mid.N.Dr. ii. I let our best heads know, that

embossed sores, and headed evils..As you Like it, ii.7 now from head to foot $I$ am

audacity, from head to foot! ......... Cymbeline will soon be drawn to hend

HEADING - it is but heading . Meas. for Meas.
HEADI.AND-we sow the headiand.2 Henry $1 V$. my a up my way upon their headless necks..2 Henry VI. i. 2 that headless man I thought had been thy liead, which now is growing gates of Lud's town set your heads., 0 to set a head on headless Rome .. Tiius Andron. HEADLONG-throw the rider headlong.. Rich. II. 2

to plick him headlong from ........ Henry $V I$. i. I may make some stronger head more perilous than the head .... violet, not wagging his sweet head we must lay his head to the east ... alas, where is thy head? where's that! your death has eyes in's head then those which I heaved to head! $\ldots \ldots$ fall on their heads like dew! ......... a bead ou headless Rome (rep.) ... Titus $A n$. with thee: their heads, I mean ....... here are the heads of th for these two heads do seem to speai come, brother, take a head .. the Goths have gathered head as true a dog as ever fought at head thy car is laden with their lieads two pasties of your shameful heads to love my hearl. Heaven, that $($ rep.)... $P$ heart ean lend no suecour to my head

iv. 2 whose towers bore heads so high too harsh for ladies' heads.......... all headlong east us down ....Tilus Andronicus, $\mathrm{Y}$. 3 the defieient sight topple down headlong. Lear, iv. 6 EADLY $-[$ Knt.] of headly murther..Henry $\bar{v}$. iii. of head-piece extraordinary? .... Winter's Tale, $\mathrm{i}$. of head-piece extraordinary? ....Winter's Tale, i. 2 HEAD-SIIA KE - or this head -shake..... Hamlet, $\mathrm{j}$. 5 HEAD-STAI, $L$ of sheep's leather. Taming of Sh.. ini. 2 HEADSTRONG - headstrong steeds. Mea. for. Mea. i. tell these headstrong humo

headstrong liberty is lasherl. . Comedy of Errors, ii. I for when his headstrong riot hath..2 2 HenryI $V$. iv. Heuryt'I. i. too headstrong for their mother. Troilus \& Cress. iii. how now, my headstrong? ...... Romeo \& Juliet, iy.
HEADY-currents of a heady fight ... Henry $r$ ii. with such a heady current ............ Henry $V$. $\mathrm{i}$. HEADX-RASH-nor heady-rash. Comedy of Err. v. 1 rupture that you may easily heai.Mea. For Mea, his eye did heal it up ............. As you Like it, iii. 5
we will lieal up all: for we'll ereate.King John, $\mathrm{ji}$. we will heal up all: for we'll ereate. King John, ii. and keep you, and heal your pate...... Henry $\nu . v$. halm to heal their wounds........... those wounds heal ill........Troilus \& Cressida, iii. 3 to heal Rome's harms ........ Tilus Andronicus, v: 3 HEALED-thoroughly healed. ?uo Gen. of Verona, i. 2 healed by the same means... Merehan of Venice, iii. 1 murder in healing wounds.. Antony \& Cleopaira, ii. 2 doth but signify my heaiti

with drinking healths to my nicce. Tuelfih $N i g h t, i, 3$ learn to begin thy health ... Neasure for Mtasure, i. 2 God restore you to health .............. Much Ado, v. but, as in health, eome to my...Mid. N.'s Dream, iv. a beard, fair health, and honesty ..... heal th your grace in health!.........All's Well, i1. health, shall live free, and sickness... noble lord restored to health...Taming of Sh. 1 (ind.) quaff carouses to our mistress heal tin

therefore, a heal th to all that shot it argues a distempered head ....... thy head is as full of quarreis as yet thy head hath been beaten ...... but my head, here come the Capule thou cut'st off my head with a golden axe vaulty heaven so high above our heads heap not auother sin upon my head. their spring, their head, their true descent and the chief head of this post-haste.... Haml it lifted up its head, and did address my lord, trom head to foot ........... with all my imperfeetions on my head no hat upon his head; his stockings thrice his head thus waving up and do the head and source of all your son' head to foot now is he total gules ....... a elout upon that head ................... at his head a grass-green turf .... and wager a'er your heads ............ a flagon of Rhenish on my hear onee ... or the skyish head of blue Olympus. my head should be struek off ............. he has laid a great wager on your head fallen on the inventors' heads. the very head and front of my offending and meu whose heads do grow beneath destruction on nyy head, if my bad blame ehange the cod's head for the salmon's tail on horror's head horrors accumulate ..... liave you not hurt your head? .......... if any wreteh hath put this in your head kinds of sores, and shames, on my bare head - iv. on her bosom, her head on her knee - iv. 3 (song) his health, and ampler strength... come, love and health on both

and better heal th attend his majestyi

purge it to a solis a in the instant of repair and health.. King $\bar{J}_{0} h_{n}$, iii. that for the health and physie ....... to have learned his health of you.... hore health was never better worth ... i Henry $I V$. iv. to have a reverend eare of your heaith - i. in bodily health, sir................ health and fair greeting from our general 二
health to my lord, and gentle (rep.).. health to my sovereign $! \ldots \ldots \ldots . . . . .$.
such are the poor, iu heaith..........

health, peaee, and happiness $\ldots . .$.

I'll give you a liealth for that anon..

health and long life to you, master... when they were in healtin, I tell thee - iii. 6 to our sister, health and fair time of day and peers, health to you all1 ......... health unto my gracious sovereign!.2 Henry VI. iii. heal th, and glad tidings, to your...

health, and all happiness to my lord reeover his aeeustomed health.Richard III. $\mathrm{i}$. God grant him healthl ............. - i. your madae with health and $\ldots . . . . . .$. for your best health and recreation.. = iii. all health, my sovereigu lord! ....... Henry $_{\text {vil }}$ iv. a health, gentlemen, let it go round..

I have half a dozen healths to drink disturb him: luealth to your lordships madam, in , ad health your health and your digestion.......... Troilus \& - ress. ii. 3 health to you, valiant sir

and let the health go round ..... Timon of $\overline{\text { Athens, }}$ i. 


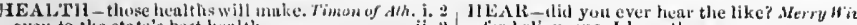
evell to the state's best heulth..... his health is well sir $(r e p$.

he is mueh out of lieul thi......... if te so far beyond his lieatth.... my tong sickness of henlth, and living

lor believe ine, I hear the parsom.

I had rather lien them seold.

winrmet the, nohely hear.

sir, year youre a selolar.

hear mine host of the ciarter. a nun may lieur this slower sir, will you hear 11

murvel, I heur not of maste. you shall heur. As good luek. lay, you shall hear, master Brook have mind unou rour health

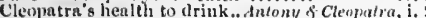
will you aboard? I lave a heniti fir you an! some wine: a healthi to 1 cepiclus with the health that Ponpey grves him this hemith to Lejidus.

gon shall henr how things go ....

yet hear me spen.

Yill hear yon, master lenton...

do vou not hear, fellow......

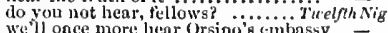
rather to womler at you than to hear

We will henr this

to stay and hear by the nose, it is dilicet.....

I lind rather hear you to solicit....

so let me hear you sjeak ....

he will not hear of godliness

but hear me this: sinee you.

good mulch more

und, as I liear, the provost ifeasure for he

do you hear how he inisplaces?

please but your honour hear me

that I desire to henr her speak again

your partner, as 1 hear, must die .....
wherein (let no man hear ne,) I take

nay, but hear me; your sense

I may be eoneealed, yet hear them...

nay, hear me, Isubel (rep.)

you shall hear more ere morniu

pray you, let's hear ................

ny \&leo. ii.

is both heulthful, aud good hu

a healthful ear to hear of it.....

and makes as healthful musi

it indues our other healthful members.. Othello, iii. 4 II ALTH SOME air breathes.. Romeo of Juliet, iv. 3 was a goot hicalthy wuter.............2 Henry $I V$

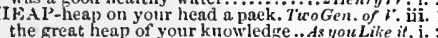

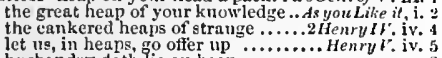

husbandry doth lie on heans

great anchors, heaps of pearl......

among this princely heap, if any

alas, why would you heap those eares

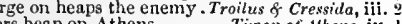

I hare laid proud Athens on o. Timan of Athens, iv. 1

even such heaps and sums of love...

in heaps and piles of ruin ........... Coriolanus, iii. 1 drawn upon a heap a hundred ...... Vulius Cesar, all on a heap, like to.......... Titus Andronicus,

all thy whole hean must die .............Pericles, i.

EAPED-measure heaped in joy.As you Like it, v. 4 the late dignities heaped up to them ...Micbeth, i. 6 your great graees heaped upon me...Henry VIJI. iii. 2 his overthrow heaped happiness upon too highly lieaped tor truth

honours that are heaped on cæ....... Coriolanus, ii. 3

thy joy be heaped like mine ..... Romeo \& Juliet, ii. 6

HEAPEST-heapest a year's age on met. Cyinbeline, i. 2

heaping confusion on their own ....2nlenry rit.it.

EA $\mathrm{K} \rightarrow$ do you not hear him?

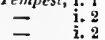

hear a little further............

I hear the strain of strutting ........ $-\vec{i} .2$ (song)

hark! now I hear them............ - i. 2 (song)

I hear it now ahove me

- i. 2 (solng)

to hear thee speak of Naples

will hear none.

I hear his str

hear me 0 , hear ; for that whieh I

good friar, let's hear it

whom it eoneerus to hear this natter

I had rather hear nyy dou bark at ......

you hear, eount Claudi

you should liear reaso

but liear the 1lero, wooing, wedding

she cannot endure to hear tell of

hear me eall Margaret, Hero; hear

come, shali we hear this musie?

we'll heur that song again

and hear what he will say

well, we'll hear further of

are they that hear their detractions

tell her of it, hear what she will say.

I hear what they say of him.

these hobby-horses here muat not hear

if you hear a child ery in the night

for the ewe that will not hear

well, masters, we hear our eharg

tidst hear as hood something

I am glad to hear it

am sorry you must hear...

at that hour....

hear me a littie; for I have only

he proutlest of the labal we

hear me, Beatrice ....................

as you hear of me, so think of $\mathrm{me}$.....

hear you, my lords

do you not hear me speak

I hear it sing i' the wind

hear my soul speak...

the blind mole may not liear 8 foot foll

Bu) is mine. Do you hear, mouster? ..

I long to hear the story of your life...

put dost thnu hear?................

utt have wish'd to hear from

I will not hear thy vain exense........

ard cannot hear good new's

where you shall hear music....

but shall I hear him speak?

ay, but peace, let's hear'em....

where, I hear, he makes abode

to hear me speak the message.

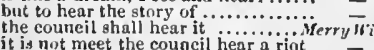

it is not meet the council hear a riot

we three to hear it, and end

he hears with ears (rep.) .............
you hear all these matters denicd (rep.) =
hear the truth of it ................... det me hear from you $\ldots \ldots \ldots . . . . . . .$.

and either I must shortly hear from him -

will you go hear this news, signior?

therefore hear me, Ilermia ...........

to hear the sca-maid's musie

speak, an' if you hear, speak

that they shall hear I am not afraid.

stay, gentle Ilelema, hear my exuse

I do hear the morning lark

my love shall hear thie music of $\mathrm{my}$.

never did I hear sueh gallant chisling

jud ge when you heur: but, soft .......
of this diseourse we more will hear anon

let us lear, oweet Botton

I do not doubt but to hear thiem say

and we will hear it

to spy an' I ean hear my 'Thishy's face

go wilful to hear without warnin

or to hear a bergomask dance

to hear, or forbear hearing? To hegr

you hear this letter witl attentiun ( $r e p$.

1 an less proud to hear you tell hear me, dear lady; I lave sworn.

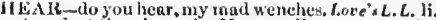

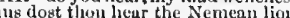

did you ever hear better? .............

let me lear a stinf, a stanz

when that he slaal hear a linith

and therefore let's hear it

you hear his learning

the butcher hears

but will you lars you cry.

in the ear of line that hears it

will heur your idle seorns.

licars merry tades, and oniles not........ or of $\vec{F}$ enice, $\mathrm{i}$.

but, hear you, hethougrit............

nnd you'll not liear me: this is kind

but hear thee, (iratiano.

hear you me, Jessiea (rep,)

la you licur, whether hear

often eame where I lid hear of lier.

but let me hear the letter
hear me yet, good sliyloek

hear me speuk. I'll have my boid (ïp.) -

the eourt shall hear Bellario's letter..

you hear the learned Bullario.

I lieur the footing of a man

elose it in, we eannot hear it

never merry, when I hear sweet music

at hand; I hear Jis trumpet.

for, as I hear, he was muel bound

thou shalt hear how he will shake.. As you like

you shall hear me: my father

I cannot hear of any that did see her

when I did hear the motley fool ....

didst thou hear, without wondering

I had rather hear you ehide

pleases those that hear

did you ever hear sucli railing?

nor doth not liear....

but time lost to hear suel.....

I will now hear; what say you..........

I must not hear thee; fare thee well

do you hear hor my sict

my sword, or hear the drum

you shall hear, I am run away

for my part, I only hear, your son

when, haply, he shall hear that she is

by the ear that hears most nolly...

look to hear further from me......

you shall hear one auon
till we do hear from them

my motler shall from them

iii. 2

what hear you of these wars? I hear

you numst have the patience to hear $i$

we shall hear of your lordship auon

to hear me one single word ...........

I long to hear him eall

I see, I hear, I speak; I smeil.................

thought it good you hear a play
thou mayst heur Minerva speak

masters, I hear no harm $\ldots . . . . . . .$.

[Col. Knt.] go great a blow
do me this right, hear me

no, sir: but hear I do, that lie...

for that's your name, I hear

nay, hear $y$ ou, Kate $\ldots \ldots \ldots \ldots . . . . .$.

take heed he hear us not ................

yet we hear not of our son-in-law
to hear of Petruehio's eoming? .......

to tell, and larsh to hear

hark! I hear the minstrels play

do you hear, ho? you must meet

silence! I hear my master..........

for the good report I hear of you .....
signior Baptista, of whom I hear so wel]

signior Baptista, of whom Ihear so wel] -
do you hear, sir? to leave frivolous (rep.)

to hear my sovereign nistre

yon eriekets shinl] not hear it...

lo you now; you hear!

and, I beseech you, hear me

who please to come and hear

luit yet hear this; mistake me

if yoll did bint hear the pedlar.

thou shalt hear, 'tis in three parts
O hear me breathe my life before

let me hear what you profess

ean he speak? hear?

I ll hear you by-and-by...............

nay, but hear me. Nay, but hear me

do you hear, an t like you, sir?

your ears ghould rift to hear me....

whieh you hear, you hll bwenr you see

as, you hear, my spell is iaw fuil......

iv.

jv. 3

i

v.

iii. 4 

HEAl:-for thou shalt henr, that .. Winter's Tale,
be quiet, when we hear it cry ... Coonedy of Err.

thou but hear I were licentious?

and think I hear all this?.

do you hear, you minion? .....

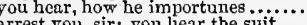

do you not hear it ring?................

that did I never hear .............

thoul knowest, did hear thee .....

if this be not a dream, $\mathrm{I}$ see, and hear

and hear at large discoursed

hear not my steps, which way

didst thou not hear a noise?

Thear a knocking at the ......

we hear, our bloody cousins

we hear, our bloody cousins ..........
hark! I hear horses ...............
to-morrow, we'll hear, ourselves again

I hear it hy the way

to hear the men deny it ......

at the tyrant's feast, I hear :...

hear his speech, but say thou

I did hear the galloping ot hor

preparation makes ns liear something

cooled to hear a night-sluriek.

thou'lt be afraid to hear it $\ldots \ldots \ldots \ldots$.......

but heaven, and you, and I, shall hear

peace! Hear the crier...............

therefore, hear us first $\ldots \ldots$..........

hear us, great kings

not, hut hear me, miglity kings........
hear me, 0 , hear mel Lady Constance

o husband, hear me!

hear me without thine ears ............

wow heal' me speak with's feeble

0 sir, when he shall hear of your....

nay, hear me, Hubert!

hoth hear and grant you your.........

in France, and she not hear of it?

if you be afeard to hear the wors...

whilst lie, that liears, makes

do but hear me, sir $\ldots$ nobles will not hear you

now hear our English king

curselves will hear the acer

[Col.] what hear there for welcome....

my life's counsel would not hear ....

to hear of good towards him

and yet we hear no tidings from

but they are by to hear ............

be patient; hear me, gentle liege ....

I never longed to hear a word till now

to hear my true time broke

the latest news we hear, is ......

be ta'en, or slain, we hear not..........

hear me, Yedward; if I tarry at home

and what he hears may be believed.

ns we hear, the earl of March

or you shall hear in such a kind

he did; myself did hear

hear you cousin; a word $\ldots$.

eye in thy head? canst not hear?

if thou canst hear the tread

stand close, I hear the

you, my lord ...............

dost thou not hear them

comparisons, hear me speak hut this

eome, let's hear, Jack.

why, hear ye, my masters................

complaints I hear of thee are grievou

as often as he hears $O$ we

as often as he hears Owen...

I had rather hear a braze

and hear the lady sing in Welsh (rep.)

ear of greatness needs must he

dost thou hear, Hal? thou know'st...

to liear this rich reprisal is so nigh

that's the worst tidings that I hear of

tut, I came not to hear this ...........

and so, I hear, he dotll account me too

doth he hear it? No. Is it insensible

never did $I$ hear of any prince ......

and, as $I$ liear, is now going with some

I hear, his majesty is returned

I hear moreover, his highness is failen

for you hear not what I say to you .:

I hear, you are going with lord John

would fain hear some music

yon would bless you to hear .

didst thou hear me? Yes ...........

hear me more plainly; I have in equ
to hear, and absolutely to determine
HEAR-to hear with reverence.......2Hen
until they hear you speak
I hear the king my father is so........ sick
I never thought to hear you spealk

and hear, I think, the very latest

when thou dost hear I so much profaned -

as we hear you do reform .............

I will hear you soon; take them awny

gently to hear, kindly to judge.. Henry $V$. $\overline{\text {. }}$ (chorus)

hear him but reason in divinity

and you slabll hear a fearfiul battle

and you shall hear a fearful bat the

I'll wait upon you; and I long to hear it -

before we hear him, of some things

and we will hear, note, and believe

for hear her but exampled

for, we hear, your greeting

that you claim, hear no more of you

hear me, hear me what I say ..........

hear the shrill wlristle, which doth - iii. (chorus)

the duke will hear thy voice

your majesty hear now any more...

I will be glad to hear you confess it.. $\overline{-}_{\text {is }} \mathrm{v}$

is it you whose voice I hear?

hear, hear, how dying Salisbury dotti

hear him, noble prince! $\ldots . . . . . . . .$.

hear ye, cnptain? Are you not...

from me, and let me hear no mo

sorry $I$ am to hear what $\ldots \ldots . . .$.
my lord, I long to hear it at full

and hear my deep-fet groans

didst ever hear a man so penitent?

harsh, and horrible to hear

let me bear from thee; for wheresoe.

hear me but speak, and bear me

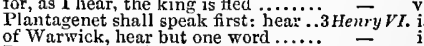

I cannot stay to hear these articles

I shame to hear thee speak ...........

hear me speak before I die spea

nay, stay; let's hear the orisons........

Richard, dost thou hear...............

I hear great Warwick speak ........

for as $I$ hear, you, that are king...

my lords, and hear me speak

What we say

and, as 1 hear, the great commanding

to hear, and see, her plaints

and lady Bona, hear me speal

let us hear your firm resolve

fled, as he hears since...

to hear what thou command 'st

Clarence is at hand, I hear his drum

the drum your honour hears

that well might hear delivered with...

as we lien', march on to fight

I will not hear them speak ...

let us hear him speak: What
be sure to hear some news.....

didst thou not hear me swear...

I'll hear no more: die, proph

if you will hear me name

Richard III. i.

to hear the piteous moan

hear me, you wrangling pirates.

stand on end to hear her curses

do not hear him plead

methinks, to liear you tell it

unless your highness hear m

when they did hear of Clarence deat

hear you the news abroad.............

iii. 1
iii. I

to hear lier prayers for them.

jii. 2 yet wituess what you hear we did

iii. 3 I hear the news, my lord

iv. 1 and hear your mother's lamentationi...

hear his drum [Col. Knl.-trumpet sounds] -

let not the heavens hear these........

then patiently hear my impatience...

hear me speak. You speak (rep.).....

but, hear you, leave behind your son

to hear, if any mean to slirink.........

hark, I hear their drum. Fight .....

that eome to hear a merry says not...... Henry $P \overline{I I}$. (proi.

I am sorry to hear this of him .......

i. 2 in person I'll hear him his confessions
i. 2 you shall hear (this was his gentleman youl too little, hear too much $\ldots . . . .$. .

ii. 4 to hear from him a matter of some $\ldots$ -

ii. 4 to hear what shall become of the ....

ii. 4 to hear his knell rung out

hear what $I$ say, and then go home... HEAR -of late days hear a buzzing. Henry VIII. ii. I
pray, hear me. 'Would I had never..
glad to hear such news as this once..

so I hear. "Tis so. The cardinal......

may be, he hears the king does........

hear the king's pleasure, cardinal...

can ye endure to hear this arrogancel

and thus tar hear me, Cromwell

to bear me speak his good now?.....
but, sir, sir, hear me, sir 'Tliomas .....

close: we shall hear more anon.

comes to hear the cause betwixt...

do youl hear, master Porter?...........

others, to lear the city abused extremely -

good we are like to hear for this..... \& do you not hear the people cry. Troilus \& cre $^{-}$.

hear what Ulysses speaks.

and wise to hear Ulysses speak...... -

we shall hear music, wit .............

he hears nought privately $\ldots \ldots . . . . . .$. .

thourht unfit to hear moral philosoping -

hear you, Patroclus; we are too......

we'll hear you sing, certninly.........

I long to hear how they sped to-day

hear me, Paris, for every false drop.

hear why I speak it, love ............

anon shalt hear of me agnin...........

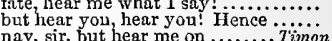

nay, sir, but hear me on...

you shall hear from me anou

till you hear further from me

so; thou'lt not hear me now

you would not hear me

though you hear now, (too läe

which $I$ hear from common rumours

do you hear, sir? By y our leave ....

Alcibiades is banished: hear you of $\mathrm{i}$

(hear me, you good gods all) ........

the immortal gods that hear you

ay, and you hear lim cog...........

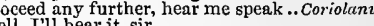

did see, and hear, devise, instrue......

you'll hear the belly's answer........

hear me profess sincerely ............

methinks, I hear hither your luusband's -

then shall we hear their "larum...

and, gladly quaked, hear more .......

before our army, hear me ............

and the blind to hear him speak?... please you to hear Cominius speak?.

never shame to hear what you have

than hear say how I got them

to hear my nothings inonstered......

than one of his ears to hear it? .....

hear me one word. Beseech you (rep.

hear me spenk: as I do know the

accusations, as I hear, more strong...

hear me, my masters, and my...........

you sliall hear from me still...

worthily as any ear can hear .......

re you go, lear this: as far as dotl.

joytul to hear of their readiness.....

hear you? Nay, I liear nothing (rep.)

'faith, we hear taithful news

nay, if he coyed to hear Comininis speak

do you hear? Yet one time he did call
I think, he'll hear me; yet to bite his lip -

who, as I hear, mean to solicit ......

I will not liear thce speak.

do you hear how we are shent.

wourll hear naught from kome

and grieve to lear it: what faults......

peace, both, and hear me speak

my noble masters, hear me speak

hear the replication of your sounds. Julins $C$ a

Cæsar is turned to hear.............

be prepared to hear: and, since you.

patience hear: and find a time (rep.)

had you a heaithful ear to hear of it

I hear none, madam. Pr'y thee ......

to Cæsar, as to hear me.......

those that will hear me speak...........

hear me for myeak. I will hear (rep.)

and let us hear Mark Antony........

iii. 2
iii. 2
iii. 2
iii. 2
iii. 2
iii. 2
iii. 2
iii. 2
iv. 2
v. 1
v. 2
v. 2
v. 2
v. 3
(epil.)
(elil.)
(da, i. 2
i. 3

i. 3
i. 3
i. 3

ii. 1

iii. 3

iii. 1

iv. 1

iv. 4

v. 11

, 


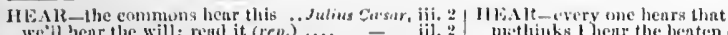

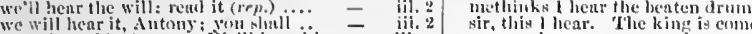
heur the noble Antury. We'll heur him vet henr me, comimtrymin: yet hewr (rep.) let's stay, and hear the will..... .i. herar me with patience. l'ace, li

hear you anght of her in yours?

hear them Antony: Fulvia.

therefire, hear it, Antony

luear the enulnsstiors.

genil late, hear ne this prayer.

ilear gonless, hear thit juty

hear me, yucen: the strong neessity

not now to hear the sing . . . . .......

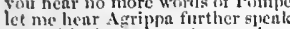

not till he hears how Antony is

forl mulam, licur me. Well, go to...

will 't please you, lienr me

so pour, henr me one work ...........

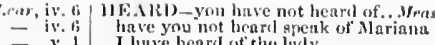

I huve heard ot the lad $y$ or . ...........

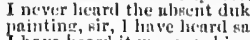

Ihave hearri it was cver lits nanier

stay yet; heur re'uson

wifl they not hear? whit hint...............

till you have hearil me my tr

to hear trike shrift... i. o...............

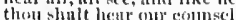

and I have hiral ventr myal ear
saw her, nor heral from hier

if lhe lasur thee, thou witt anger himi

shall I hear more, or shall I speak

Thent some noise within

saw her, nor heard from her.......
rely upon it till my tale be henerl

theit loves to hear himsclf talk

it would do you wood to hear it

as I have hearl him swear himself

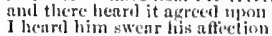

look to hear nothing but diseori

all the night, to henr good comsel

I must he:tr from thee cvery day....

hear me with patience but to spusk

J hear thou must, and nothing may

things that, to hear them tolle, have.

hut ar him near; nurse

I hear sume noise

let Neptune hear we bid a loul farewell -

sweet letavia, you shall hear from me
hear her spenk? is she shrill-toneruel

who s his lieutenant, hear you?

hear it aphrt. None hut fitends...
to hear from me thant you had left

to hear from me thent yom

dost thmu hear, lady?

watehmen tlo hear wliat we do .....

for our repose, shall hear a storm...

he slunl not hear thee................

hear you, sir?' Thic liand of deatly...

gentle, hear me: notre abuut Cresar
hear me, gond friencls; but 1 will...

will hear him what he says..........

hear me, gond madam; your los

I hear him moek the luek of Ciesar.

that I might hear thee call great

and lenr lima mock the Frenchiran

let me licar no more

did you hen of a stranger, that's eome and you shall hear the legions

whill you hear more? Spare your $\dddot{\text { wind }}$

gool madam, hear me .............

hear but my name, and tremble

though the gods hear, I hope

no less than what you hear of

nor hear I from my mistress .......... -

heavens, hear patiently my purposc

to wonder at the things you hear

wilt thou hear more, my lord?

peace, my lord; hear. hear

peace, my lord; hear, hear

hear me speak inelifterently .. Tiitus

that ever ear did hener to such effect.

hear me. grave fathers l noble tribunes

the Iribunes hear you not.....

no tribune hears you speak..........

for heaven sliall hear our prayers...

ean 5 ou hear a good man groan......

vex thy soul tio hear whut I...

which thes shalt hear of me anon....

but let them hear what fearful

and weep to hear him spcak...........

tow love to hear the silus they love

let their cars hear their faults hid

where inliear from thee

superfluous riots, hear the $\ldots$ tears!

tor so we hear you are .........

liear, therefore, mistress; frame (rep.)

nid make us weep to hear your fate

did you ever hear the like? . ...........

I hear say, you are of honourable.

I'll liear you more, to the buttom

musie? Jy inril, I liear lione ........
do ye not hear? Musie? My lord, I he

I long to liear how you were found.

to hear thie rest untold

I think, I hear them: stand, ho $1 \ldots . . . . . .$.

searcely hears of this his neplew's

I womlil not hear your enemy say so

but let me hear from $y$ cau

and hears it ron beneath.

I am lomul to hear. So art thou

now, IIanlet, liear: 'tis given out

o speak of that, that do I long to hear

bo you hear, let them be weil used

licar $n$ play to-morrow - dost thou he:

lear a play to-morrow,-do
a kind of joy to hear of it.

to hear and sce the matt

v. 2 I lear lim eoming; let's withdraw............

to hear $\left[\mathrm{K}_{\mathrm{m}} \mathrm{-sec}\right]$ a robustious periwi

will the king hear this piece of work

dist thou hear? since my dear soul......

withdraw, I hear him coming.

ii. 1 did ron nothing hear? No nothing...

she hears, there s trieks l' the world
and they slaall heur and judge 'twixt

iii. 3 you shortly sha!l hear more.

iii. 4 nay, but hear you, goodman delver.

hay, huthear you, goodman what is the reason

iv. 2 wilt thon hear now how I did proceed?...

iv. 3 eannot live to hear the news from England

iv. 3 so shall you hear of earnal, bloody

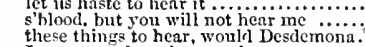

I pray you, hear her speak ..............

I never yet did hear, that the bruised.

do you hear, Roderigo? What say you?..

no more of drowning, do you hea

will you hear it again? No; for $\mathrm{I}$ hold

as they say, to hear music ..............

hear, my honest fricnd? No,
why, stay, and hear me speak

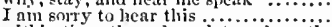

Within these thrce days, let me hear the
dost thou hear, Iagu? I will be found...

but (dnst thou hear?) most bloorly

when he hears of her, esmot retruin ...

you shall hear more by inidnight

mine of earth, and will not he
will you henr ane, Iioderigo?

will will hear further retason tor tijis....

but, so, I hear him coming

where you shall hear us confer.

hring you to lienr ny lord spen

he's enming, malam, I hear him

hear, nature, hear; dear gnddese, hear!.

when she sliall licar this of

did you not hear a ery? .....................

hark, ennst then henr me? ..............

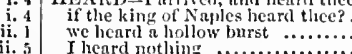

heard you this, Gomzalo

eo often I have henril renown

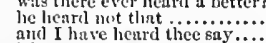

and I have heard thee say.

I heard say, he was.

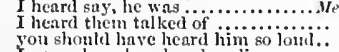

Inever hearil such a drawlin

you lieard what this knave
yes; and you hearl what.

Yes: and yout leard what ..........

for 1 huve heard my duupliter say

I hal as lict have heart the night-riven -

scen more, and hearil more, jouced.

what liearil you him say else?
brother, away, I will be heard

wateh heard them talk of one Deformed

uljon the error that you heard debated

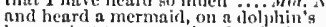

he goes but to sec a noise that lie lieurd

the eye of man hath not heard

lic eannot he hearil of:. Out of douht

I have hearel it over, and it is nothing

that ever Theard diseourse, my loril

the silliest stuff that ever I licard .....
hut the best that ever I heard .... Love's $\overline{\text { L. Los }}$

so I heard you say .............

if I have heard a truth, Biron.....

I do protest, I never heard ot it..

her mother's, I have heard

I heard your guilty rliymes.............

fin have Theard of yol, my lord Biron - iv,

oft have sou hearl that told ...... - ji. 7 (scril

I never liearth a passion so eoufused..

as I heard, one night, fourseore duents

was with him, I liave heard him swear

whs with him, I lave heard him swear
I have heard, your graee hath ta'en

nor we liave not heard front him

liath heard your praisce.

O yes, I heard them all......

I have heard him read nany ...........

yon have heard him swear downright
for I never heard it yet; yet heard too

for I never heard it yet; yet heard too
I have heard him speak of that......

if I heart you

much matter to be lieard and learned =

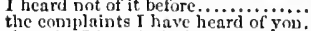

that e'er I heard virgin exclaini in.

should be once heard, nut thrice beaten

now have you heard the fundamental

sinee I heard of the good lady's death

never heard a play .... Taming or shreen, $\overline{1}$ (indue.)

have I not licard great ordnanot heard

in a pitched battle heard loud

report which I so oft have heard
well have you heard, but somethin

sueh news as you never heard of!..

shouldst have heard how her hore fell

have hearl, in how niry a place
I have iften hearrl of your entire

you might have heard it else proelaimed -

fiv.

, to a vision so apparent. Himters rale, $\mathrm{i}$.

shall I be heart?

I ne'er heard yet, that any of........ - iii.

hlise heard, sir of sueh a mon

for I have heard it sail there is an... art

you have hearil of my pour serviecs..

I hearl the shepherd sny, he foumd...

I never heard of such another enenuiter

told him, 1 heard them talk of a fartel

have you not hearil men 5 la

who liend me to deny it $\ldots . . . \ldots \ldots . . .$.
these ears of mine heard you confess

I have not heard the eloe

I heard the owl serenm.....

somentings heard is the air .........

have you heard lier sny?

of my cennon shall be heur

no I liave henrd my futher speak

who liath read, or henrel, of any

I never heard a man of his place.

indeed, we heard how near

you have hearl of such a spirit......

tistgue I idly henral; if true heard my lady talk of it yesterelay

I heard you were saucy

whon I know you have hearil of

nutique sond we heard last night

I have heard of some kind of ine...

than you hare lienril him brag

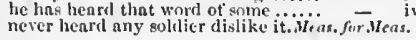

hark, do you hear the sea?

and let me liear thee going

to lear of pleasure"s name

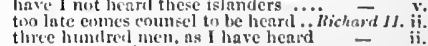

was plotted, I hearil von say heard

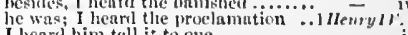

I hears him tell it to oue

as ever I hesed hull-enlf

Whieh thon hast often henrd of ......
Jesu! I have heard the prinee teli 
HEARD-I heard your grace say so..1 Henry I $V$. iii. 3 and, when he heard him swcar

the strangest tale that e'er I heard

I heard say, yourlordship was siek. "2neñy IV.

thus have you heard our caus

I have heard better news .............

he heard of your grace's coming ....

we have heard the chimes at midnight

who hath not hoard it spoken

and I had heard the course .

this that you heard, was but

than if we heard that England

great state he heard their emluas

I have heard a sonnet, begin so.

never did harm, that I heard

myselt heard the king say, he would not

the king hath heard them.

ne'er heard I of a warlike enterprise. i Henvy $\%$. ii. 1

and $I$ have heard it said-unbidden.

I have heard you preach that malice

jest, and never heard before..........2 Henry $V I$. $i .1$

have heard her reported to be a........ wom

to hear what $I$ have heard ...........

for offenders, never heard of

oft have I heard, that grief softens

champion that ever $I$ heard

who since $I$ heard to be discomfited -

heard the news; or, had he $($ rep. $) .. .3$ Henry $v I$. ij.

the like yet never heard of

in the Marches here, we heard, you were -

oft have I heard his praises in

dismal clangour heard from far.....

have often heard him say, and swear

for I have heard, that she wa

even now we heard the news
if a coward heard her speak

rest be true which I have heard....

often heurd my mother say

mereiless, that e'cr was heard of

last nighit, I heard, they lay at

we would have had you heard the traitor -

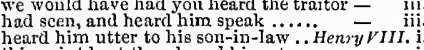

this point hast thou heard him at any

having heard by fame of this

you heard it? Come, you are pleasant

what here you have heard, to

be now produced, and heard

every thing that heard him play...

no mention of me more must be heard

to have heard you without endurance

somcbody had heard her talk.. Tro

hateful love, that e'er I heard of

the gods have heard me swear.........
have heard in some sort of thy..Timon of
I have heard, and grieved, how eursed

you have heard that I have go

it may be, you have heard it ............

four days gone, since I hea

we have heard the charges of our friends -

we have heard the charges of

reluke from every ear that heard $\mathrm{it} .$. .

that ever he heard the name of death

I may be heard, I'd erave a word or two -

seen him do, and heard him spea

have I heard groan, and drop

punish him, where he heard this

punsh him, where he heard this heard your gencral talk.

would you have heard a mother less.

have heard, where many of the best.

the things that wc have heard and see

of all the wonders that I yet hare heard -

when you have heard what

sure, the boy heard me .............

I heard him say, Brutus and Cassius

ne'er the word of no woman heard spea

I have heard it, Pompey (rep.) .......

I have hcard, that Julius Cæsar (rep.)

certainly, I have heard, the Ptolemies

I have heard that too $\ldots . . .$.

madym, I heard her speak

heard you of nothing strange about

noble empress, you liave heard of me?

what I have heard, or known

Ihunned to go even with what I heard. Cymbeline

hath heard of great Augustus........

this you might have heard of he

I have heard of riding wagers.

I have heard, I am a strumpe

I have heard you say, Love's reason;

gorls, what lies I have heard! .........

iv. 1
HEARD-I have heard of such

perhaps, it may be heard at eourt...

heard you all this, her women?

mine ears, that heard her fattery....

(yveline, iv. 2

I have heard ( $O$ could I find it now I)

some never heard of torturing pain

had he heard the heavenly liarmony

Theard a child cry underneath (rep.)

now you have heard the truth.......

such whales I have heard on a' the laid

and I have often heard, you knights

Thave heard of an Egyptian

you have heard me say, when $I$ ilid fiy

ut I have often lieard him maintain

have told you what I have seen and heard

you have heard of the news aluroad

have you heard of no likely wars toward

I have heard strange news

I never remember to have heard

and Cornwall's powers you heard not?

eannot be seen or hear

tell me not, for I have heard it all. Romeo

heard, the cock, that is the trumpet ..... IFamlet, $\mathrm{i}$. 1

so have I heard, and do in part bclieve i

indeed? I heard it not; it then draws..

something liave you heard of Hamlet's

I have heard, that guilty creatures

I have heard ot your paintings too

iii. 3 what lord Hamlet said; we heard it ail

have you heard the argumeut?

you have heard, and with a knowing ear

and you nust needs have heard

thou hast heard me say, my daughter

by parcels she had something heard

that $I$ heard the clink and fall of sword

have any music

in sleep I heard him say, - sweet .......

nor ever heard; nor ever did suspect

ii. 1 and then I heard each syllable ........

I have heard it said so. O these men

you heard her say herself, it was not I
HEARD'ST-which thou heard'st ory.

BEARER-tire the hearer with a book...MIuch Ado the better; the hearers may cry, ame

pitied and excused, of every hearer ...

wearying thy hearer in $\ldots \ldots \ldots . .$. . As you Like

filling their hearers with strange ..... Macbeth, jii.
doth gripe the hearer's wrist ........ King.John, iv.
and eend the hearers weeping ...... Richurd II. v.

the hearers will shed tears

3 Henryl I. i.

first and happiest hearers of the town.. - (prol

who play they to? To the hearers. Troil. sons. ili.

doth move the hearers to collection.

stand like wonder-wounded hearers?

3 HEARING-to enter liuman hearing

she is not within heariog, sir. Tuo Gen.ofverona, ii.

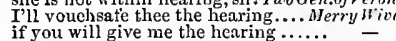

and leave me to my hearing ..... Tuelfh $\mathrm{Night}$, iij. i
you to the hearing of the cause... Meas. for Meas. ii. I

my invention, hearing not my to......

to have hearing of this business.......

and take her hearing prisoner.........Much $A$ do iv.

what, out of hearing? gone? ...Mid. N.'s Dreaw , ii,

it pays the hearing double recompence

to hear? or forbear herring?....... Love's L. Lo

and younger hearings are quite ravisicd -

make passionate my sense of hearin

which hearing them, would call.. Mer. of

hearing applause, and nniversal shout
in the lrearing of these many friends

merry, learing of a song ...........As ynu Like it,

ii. 6 merly, learing of a song ...........As ynu Like it, ii,

and, hearing your high majesty is .... d d 's $W c l l$, ii. 1

honour's players, hearing, .. Taining of sh. $\overline{2}$ (induc.)

but hearing of her bcauty...

hearing thy mildne praising

a good hearing, when children are (rep.)

no hearing, no feeling............Winter'

ing of her mother's - $v$,

where hearing should not lateh them

all the Welshimen, hearing thou....Richard II. jii. 2

his gentle hearing kind eommends.

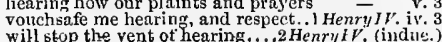

HEA RING hearing of any thing good.2 HenryIV i.

did not think thou wast within hearing

is come, to give him hearing ........... Henry $r$ iv.

for, hearing, this, I nust perforce.... i Her - iv.

to give me hearing what I shall

give me hearing in a couse....

to please you with the hearing ...... Rishard III. jv. most pestilent to the hearing ....... Henry VIII.

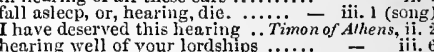

hearing the surges threat

hearing you were retired ............. coriolanus, i.

in hearing a cause between

when you are hearing a matter......

the more entangled by your hearing

Aufirlius, who hearing of our Marcius' - $\quad$ iv. 6

shall have judicious hearing .......... $-\overline{\text { vulus }}$ Cresar, iii. 2

Mark Antony, hearing that yoil. Antony \& Cleo. iii. 6

you lie, up to the hearing of the gods - if this worth your hearing ........ cymblize,

than story him in his own hearing ... - i.

prevailed on thy too ready hearing? $=$ = iii.

should fill the lores of herring $\ldots . .$. 二

of region low, offend our hearing .... - iv.

if you please to give me hearing $\ldots . . . \quad$ - $\quad$ v. 5

an y mortal body, hearing it... Tilus Andronicus, ii. 3

who, hearing of your melancholy statc. lerecics, $^{2} .1$

ready to dissolve, hearing of this.......... Lear, v. 3

living mortals, hearing them ... Romeo \& Juliet, iv, 3

but lend thy serious hearing............ Hamlet, i. 5

we beg your hearing patiently .......... iii. 2 (prol.)

and that it Hamlet's hearing .......... - iv.

that should give us hearing, to tell him.. $-\mathrm{v}$.
HEARKEN hearkens my brother's suit. Tempest, $\mathrm{i}$.

be pleased to hearlien once again $\ldots . .$. . verona, ii.

hearken after their offence, my lord $\$$. Much Ado, $v$

daughter, whom you hearken for... Tanning of Sh. i. 2

well, hearken the end ............2Henry IV. ii.

and all the gods to hearken $\ldots . . . \ldots \ldots \ldots$. Pericles, i. 1

hearkencd to their father's testament.. Pericles, iv. 3
HEARKENING-is hearkening still. Tam. of Sh. iv. 3 HEARSAY - only wounds by hearsay. Nuch ddn, iti. 1 bedew king Henry's hearse ......... Henry HI. i. stand from the Jearse, stand ....Julius Cassr, iii. 2 We wept after her hearse ............. Pericles, iv. 4 thy canonized bones, hearsed in death.. Hamlet, $\mathbf{j} .4$ HEAR'ST-hear'st thou, Biondello? Taming of Sh. iv. 4 English henee? hear'st thou of them?... Macbelh, v. 3 hear'st thou the news abroad ...... King John, iv. thou hear'st thy doom................. I Henry r'l. iv. hear'st thou, Pissnio? ................ Cymbeline, iii. if thou hear'st from me, it shall ...... Pericles, iv. 6 as signal that thou hear'st something - v. HEART-heigh, my hearts $\ldots \ldots \ldots \ldots \ldots$ Tempes, i. $\mathrm{i}$ 二 i. 1 tell your piteous heart.

set all liearts to what tune

awake, dear heart, awake!............. $=$ i.

I could find in my heart to bent him..... - ii. 2

ay, with a heart as willing.........

is nothing, but leart's sorrow

white cold virgin snow upon my heart $=$ iiv. 1

still embrace his heart, that doth ...... ve - vona,

enforced my heart to smile!...........

my heart accords thereto

of mine own heart's sorrow.

hls heart as far from fraud

blessing of your heart.

I stablicd unt to the hear

makes me have a slow heart

if you knew lis pure heart's trith...

did cver eome so near your heart

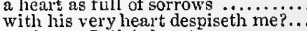

read over Julia's heart ..............

much good do it your good heart!...Me

love you always with iny heart (rep.)

tis tize heart, master Page ....

bave won any woman's lieart .........

blessilig on your heart for't!

here is the heart of my purp

my heart is ready to erack $\ldots . \ldots \ldots . . . . \%$ i. 2
i. 3
i. 3
i. 4

ii: 4

iii: 1

iv. 1

iv. 2

iv.

ivis

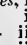

ii.
ii.
ii.
ii.
ii.
ii. 
IIE.IR'-my heart of eller? tund his pastion of my heart

Your luents are mirlity .......ii......

nirewell, my heart:

a klum heart lie lusth ...............

fire ami water fom such a ker fiult

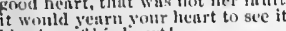

blessing it' lis lieurt?

garl hearts, devise anum thine

ollow the immointious of your ow $n$ heart -

if they ean flut in their heart

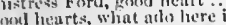

to give our lutarts united corcmonn.

fiel in lient.

.

$O$, I um vexed at heart

nyy heart miszives me...............

whe'ul liver, hruin, und heart

Tumrus? that's sides and

no, my profonind heart ..............

show you the heart ot

in the first or lis lieart $\ldots$. ..............

in women's waxen hearts to set tilieir

hom now, my hearts?

arewell, mast....

as preat a pany of heart as you

dotl give my fieart: no woman's henrt

they are as true if lieart as we

liules iny poor heart

I have une heart, one boson ........

mny"st move that henrt, wh

it at heart?

til tor stone.

he started one poor hea

had the heart to dolt within.....

tr spite a raven's heart within..........
live in thy toungue and heart ....

tongue far from heart

the valiunt hearts not whipt ou

it so your heert were touehed..

und in my heart the strong and sweliling -

we to mo ble

(1) elcave a heart in twain.........

revenges to your heart, and general.

frim your eyes with a light

I un ple at mine heart.............

not ehanging heart 'vith liabi

I know, sits at you heart.

so dleep stieks it in my penitent heart

my heart that I had not a hard heart ... Huch

in her boson I'll unelasp my heart

in her boson all hearts in love use their

therefore, all hearts in love use their
limve lost the heart of signior Benediek

a donble heart for his single one......

that he is in her heart

beats her heart, tears lier hinir...

she may wear her heart out first .....

taming my wild heart to thy loving hand -

for what his henrt thinks. Fis tongue

antl in dearness of henrt hath he

fis iny heart is excecting heavy

and lus it to your heart .............

in despite of his henrt, he eats his.

and counsels of thy hent?.....

With all thy heart. I love you (rep.)
I would eat his heurt in the market-place

gene through and througli her lieart

my" heart is sorry for your danght
plinek up, my heart, and be sal!

plinek up, my heurt, ant be

in thy lajp

here's our own hands nguinat our heart

that we may lighten our own henrt.

sis the motion ol 3 )emetrius' heart

any man's heart goxl to hear me...

et your heart at real

ficrec a lismetred thomand hearts....

the wildest hnth not such in li..........

one heart, one bed, two hosnms.

thy heart unto yotir is knit (rep.)

a serient eat ay heart awu

pierceil through the heart with your

you hate me with your hearts........

my heart with he

wo seemin: horlies, bint one lieart

stolen my love' lreart from him

a toolish lieart, thint l lenve here

nor his henrt to revort

are theac lats? where are these hear

dnys of love, necomplny your heart

whose gentle hearts dis fine the simulle

hishrew my heart, lut I pity the man

decm yoursclf lislyos in my heart. $i$,

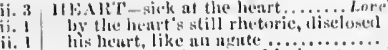

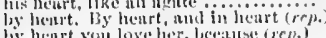

ii heart you bove her, Inecuse your luen

anil ont of licetrt you

to that the working of his inear

thut my heart me:tns 110 ill ........

persusle my heurt to this tilse.....

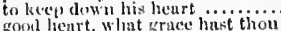

foot sweet henrt, let tlunt pass.

but, sweet henrt, tho impol

swest henrts, we slanll be rick

dost thon not wish in heart..

thut well by hurt luth conned his

witl kill the ficinker's hest.

entres sweet henrts ........

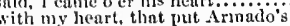

in their lieurts it lies ...........

a heary heart hears not a hunbie........

ather intited in the other's jeart

my heart is in thy breast

the window of my heart, mine eye ... $\bar{F}$

with so gowl heart as I can ...........

out-brave the hart most dariur an

hanging about the neek of my hear

I have tuo grieved a heart to take

fortune now to my heart's hope! ....

or in the heart, or in the head?

to entrap the hearts of men...

witls all my heart, so thou ean

mintam, with all oiy heart

and rinugh hears of lint

his Jewish heart: therefore

with all my henrt: some three $\ldots . . .$.

of my lands, my head, my heart.

eut off nearest the merehant's heart.

I'll pay it instantly with all my heart

take it love, so much at leart.........

so void is your false heart of buth

so mueh io the heart of the world... $\ddot{s}$ you Like $i t, \dot{\mathrm{i}}$.

envious disposition stieks ine at hear.

these burs are in my hear

and, in my heart lie there what.....

no arcater heart in thee?

that your highness knew my heart.

Helen's check, but not her heart ..

faees, eyes, and hearts, to have .....
the westler's heels, and your heart.

he comes to kill my heart

as elenn as a sound sheep"s liear

with all my heart, good yout

if he were of a feartul hent, stagger

whose heart, the neenstomed sight

frown on thee with all my heart

Plocke, with all my heart.....

in iny head, and in my heart ........ - iii.

iii. 4 that a matclen's heart hath burnetl? - iv. 3 (letter

being strong at heart, he sent me....

take a goorl heart, and eominterfeil

thy lienrt in a earf (rep.)

so neur the lienrt as your gesture

whose hetre within her bosom i

you and? you are heart in heart

never approaches her heart.............

in our hen rt's tuble; heart, too eapable
howsoe'er their hearts are severed in

a man may draw his heart out ......

over the hiack gown of a big hesr.

and set my hesurt will not eomfers.

ay, with all my heart; nud thus art.

which his heart was not eonsentime to

my heart is heavy, and mine age

with all my heart, ny lord

but iny heurt hntli the fear of iiars.

as if she sut in his lient.

if my heart were great. 'twouldi bists

Whose dear perteetion hearts that
ere my hen't durst muke too....

and tike our hearts

raming of sis

with all iny heart ..... Faming of.
is it not half way to her heart......

atleetion is not rated from the heart

not aet lim for my heart to do it ....

my leart in my belly .....

mrove mistress of my heart ............

the anger of my heart, or else my hear

she nuy, with ull iny heart

this huth fust ine in heurt ...........

and our hents ghonld well agree

as one of yisurs, my he

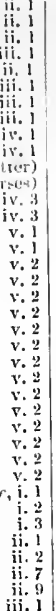

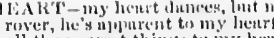

all the nearest thing to my heort

"whrew my heart, yom never spoke.

I raw his herert in his fate............

and the justire of your lis.

my lenrt will be a burden to me

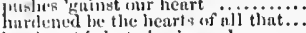

ler heart is hut ocehehrgell.........

cleft the heart that eoulal conceive

lie is toubled to the nohle hesirt...

I num glat at lacart to loc so rik ......

I fray you; that kills my heart.

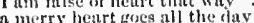

aguinst the liurd hearts of muit

are parkect an! locked wip in my ieast

are py heart? ['ll have thy heat $y . .$.

bosom there, and spenk his rery hear

the back of man, the lienrt of monster

as if she would pin her to her hear

I am sure, my leart went hlo:

though your heart be tninted
my dear lieart's dearer heart

and my heart of sted.

of his heart's meteors tilting

thy lont

whose hard heart is buttoned iaj

eneart and geod-wili.

I confll fisd in my heart to stay

with all my heart, I'll gossip...

our free hearts each to other

and hold the to iny heart .............

what fulse heart dintli know...

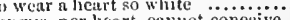

lud a heart to love, and in that leart

grapliles fou to the heart and love..

for my heart sjeaks, they are.

encounter thee with their luearts thank

twould have angered any lieart alive

how his eyes and grieve his heart

wie very firstlings of my heurt shall be

whint

the licart is sorely eharged (rep.)

inil the Jeart I bear shall never sagg

which the poor hent would tial de...

which weighs upon the heart?

whose henrts are absent ton.......

nor keep his princely heart from

with all my heart I thank thee.

that rolbed the lion of his heart

thousand hearts of England's breed.

and quartered in her liear.

and then the hearts of all lis people

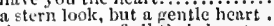

the purposes of all their hearts

with all my heart, my liege.

my heart hath melted at a laidy's....

and wirl a great hent heave nway
thrust this entermise inte my lieart.

und their gentle learts to fieree.....

beslinger thy rery

the tarkle of ny heart is eracked

as low as to thy heart.

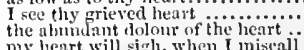

avid for my heart disdained

did seem to dive inte their hearts...

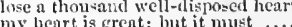

grievous taxes, and lost their hearts...

fills their hearts with deadly late...

if henrt's presages he not vain.

my heart this covemant make

is siẹn, ant iny heart prepar

ation

warmed, that sting my

und his lseart to fuith ful servie........

swetl'st thou, proud heart?

corrow and rief of heart mikes liin

my heart mierlat fod your love

your lent is uj, I know

when my pour hentt un mensite.

turn thy fulsehum to thy heart...

vour heths of sorrow, mat your ey

micecthe wity out with a henvy heart

to keme smel kill thy lucart

iny heart is not eonferlerate.

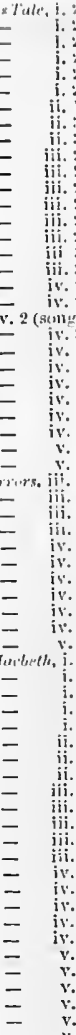

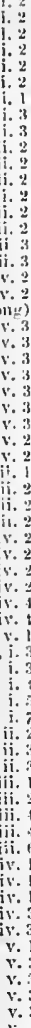

King John, i.

$\equiv$
$\equiv$
$\equiv$
$\equiv$
$\equiv$
$\equiv$
$\equiv$

.

i. 
HEART-will sting thee to the heart. Richard II. $\mathrm{v}$ pray with heart and soul and all beside with all my heart, I parclon him with all my heart, I pardon him . $\dddot{\text { wourt }}$ groans, that strike upon my heart.... blessing oul his leart thot gives..... O low it yearned my heart...

dnres not, that my heurt shall say

for I will ease my heart................

I eould find in my heart-Francis!.

larls, buys, hearts of gold ...........
I'm glad of 't with all my heart.

loseth men's hearts; and leaves...

'heart, you swear like a eomfit-maker'

im!nediately. With all my heart.

an alien to the hearts of all ...

pluck al legianee from all men's hearts

tear the reekoning from his he

but a braver place in my heart's $\cdots$ love

with hearts in their bellies no bigge

speak it out of fear, and cold heart

in kind heart, and pity moved

grieves at heart, so many of his

with all my heart. 'Then, brother John

as good as heart ean wish........

that buildeth on the vulgar heart.

but I tell thee, my heart bleeds.

my heart's dear [Col.-heart-dear] Ḧ...

it angered him to the heart

as extraordinarily as heart would desire -

a good heart's wortl gold...

I kiss thee with a most constant he....

blessing $0^{+}$your good heart!

if my heart be not

danger, near the heart of it .......... -

our hearts shonld be as good

the blood weeps from my lieart

whetted on thy stony heart, to stab...

I thank thee with all my heart

fashion on, and wear it in my heart.

there's a merry heart! good maste

and a merry heart lives long-a ....

and wilt not eall, beshrew thy heart
my Jove! I speak to thee my heart

note, and helieve in heart..............

little body with a mighty heart

the king hath killed his heart
ah, poor heart! he is so shaked

ah, poor heart! he is so shake

that sits in heart grief and uneasiness

no: for my menly heart and of zeal

no; for my manly heart doth yearn.

rough and hard of heart, in libert
lie'll clrop his heart into

and my heart, and iny duty, and $\mathrm{my}$ life -

firm and sound of heart, of buxom

God-a-merey, old heart! thou speak'st

steel my soldiers' hearts! .............

ts from them! =

our hearts are in the trim....

desired in the hearts of his subjeets.

from the heart; never eame any.....

plead his loverry eheerer of the heart

love me soundly with your Freneh heart -

but a good heart, Kate, is the sun

that you love with your heart.........

neither the voiee nor the heart of flattery -

heart and hands tho hast at

heart and hands thour hast at onee...1 Henry

to shoot me to the heart.

it irks his lieurt, he cannot he...

your hearts I'll stamp out with .......
with all my leart; and think me....

for his eraven heart, say thus

to join your hearts in love and ainity

I would see his heart ont, ere the priest -

Cour-de-lion's heart was buried

Burgundy eng rines thee in his heart

his hear

with submissive loyalty of heart

in heart desiring still, you may....

passions of thy heart burst out

who in proud heart doth stop

thy father's heart with proud desire

fury, and great rage of heart

a pure unspotted heart, never yet.....

kills thy father's heart outright!

turn your unrelenting hearts? ......

lend me a heart replete with ........

the fulness of my heart's content

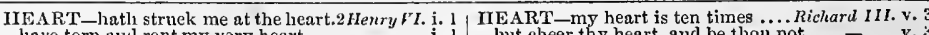
have torn and rent my very

exploits done in the heart of France unto the prince's heart of Calydon

in her lieart she seorns our poverty

the treasure of thy heart

low irksome is this music to $m$. such as my heart doth tremble .......

leave to aftict my heart! .............

my heart assures me, that the ear

sort thy heart to patienee..............
hatl he won the commons hearts

hath he won the commons' hearts

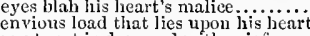

my heart is drowned witl grief......

find no harbour in a royal heart

in your breasts, will sting your heart

a heart it was, bound in with....

I wished, thy body might my heart..

mine eyes be paeking with my heart

with whieh the henrt there eools $\ldots .$.
shall be seoured in his rancorous heart

breastplate than a heart untainted!

heart's diseontent, and sour afflic

and take my lieart with thee.

hath given them heart and courng....

as free as lieart can wish .............

tongue be equal with thy heart

my leart is turned to stone...

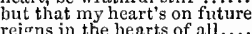

my heart tior ancer barns..

thought of this from Inenry's heart

a heurt is very jocur

and take it from a heart that wishes. Henry VIII. i.

the heart of heart of it, thanks you.. -

and cold hearts freeze allies...

ever any maliee in yrour heart were.

and every true heart weeps for't .....

hearts in most liat to deny .....

have too a woman's heart; which ever

kilting eare, and grief of loart.

and hollow hearts, I fear ye

but heaven knows your henrts .......

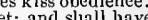

the string, the master-cord of his heart! -

my heart dropped love, my power....

so your hand and heart, your brain..

I feel my heart new opened....

I feel my heart new opened......

cherisl those hearts that hate

God turn their heart! I never...

may never find a heart with les...

with a true heart, and brother-love

joyful tears show thy true lieart .... \& - -

when my heart, as wedged witl

the open uleer of my heart her eyes.

it does a man's heart good ..........

this will do Helen's heart good now

then though my heart's eontent ....
heart ot our numbers, soul and only

nothing so full of heart ...............

what heart reeises from hence.......
slould have hare hearts...............

my heart beats thieker thian

nay, you shall fight your hearts out

eomes to me now, and brings me lieart

to stick the heart or falsehood.

these thiee lords torment my heart

slake mine ire, nor ease my heart...

thy fiery heart so parched thine

$O$ tiger's heart, wrapped in

my finrnace-burning heart (rep.)

were thy heart as hard as steel

olject eheer your lieart, my lord?

steel thy melting heart, to hold......

detect thy base-born heart?...........

mine eyes, my heart to thee

and here's the heart, that triumphs .

and let our hearts, and eyes, like ....

my heart, sweet boy, shall be thy (rep.)

will pieree into a marble heart

my leart o'erweans too mueh

content, to that which grieves my heart -

while heart is drowned in cares.

my beart with unhoped joys (rep.)

where a molle heart hath pawned

glad iny lieart, with hope of this ( $r e p$.

this eheers my heart

me heart will burst (rep.) ............

fonler than heart ean think thee

my proud heart sues, and prompts

If wonld, I knew thy heart

thy breast eneloseth my poor heart.

win all my heart; and much it joys

my heart were flint, like Edward's .

split thy very heart with sorrow

may move your hearts to pity.

I seal my true heart's love

as I love Hastings with my hearti

thy vow unto my sickly heart........

truly, the hearts of men are full

I long with all my lieart to see

looked not on the poison of their hearts =

with all my heart. A beggar ........

and, with a heavy heart, thinkin

our hearts, he knows no more of mine and will, my lord, with all my heart his raging eye, or savage heart

on pure heart's love, to greet

my woman's heart grossly grew...

poor heart, adien; I pity thy

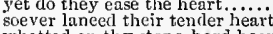

whetted on thy stone-hard heart ....

anil from my heart's love, I do thank

madam, with all my heart

put in her tender heart the aspiring.

with pure heart's love, immaeulate.

look your heart be firm, or else...
Cod he when, with all my heart ..

as leart ean think, or conrage

come, come, bcshrew your heart! ....

there offering to it his own heart .....

O heart, as the goodly saying is (rep.)

or my heart will be blown

no maeulation in thy

his heart and hand both open.....

from heart of very heart, great Hector

must take my heart withal (rep.)

there is a eredence in my heart $\ldots . .$.

mere words; no matter from the heart

here lies thy heart, thy sinews.........

and tendanee all sorts of heart

out goes the very heart of kindness...

I am bound to your free hear

my lord, in heart; and let the health thy good heart, Apemantus! (rep.)...
that you would onee nse our hearts.. chiefly belong to my heart!........... your several visitations so kind to lie false hearts slionld never have sound what heart, head, sword, force, means bounty liath yet passed my heart ....
seeure tliy heart; if I would broach. try the argument of hearts by ....

it is against my heart

show me an iron heart?

ne'er preter his injuries to his heart

troops, and lay for hearts...........

vet do our hearts wear Timon's livery

brought low by his own heart........

the eyes, and hearts of men at duty

lend me a fool's heart, and a woman's

in excess hath broke their hearts ...

the eounsellor heart the arm.....

even to the eourt, the heart

to break the heart of generosity......

their very heart of hope.

shall say, against their hearts........

wash my fieree hand in his heart

it does offend my heart: pray now

for the time, but hearts for the event

and his aetions in their hearts........

and have hearts inelinable to honour

rather to have my hat than my heart

had your bodies no heart among you?

I have a heart as little apt as yours

which your heart prompts you to.... such a faint and milky heart.

methinks, 'tis warm at his heart (rep.) 
11F:Al:T-all their hearts were yours, cot iolanus, five 1 my neble lieurt a lic

With as high hart as theoll

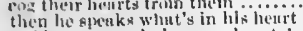

fecble rumour shake your heart 1 ...

invineible the he'nrt that ennmed the

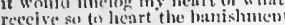

sech to wear whe luenre

weolet foreth in thee, that will

weelcil from iny hemte n mot.

whin with a rrached heart

hesul mets of luart loubed wonderime.

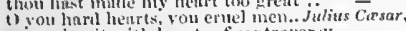

stemming it with luart of eont roversy

such me'th as he he never at hent'
tirgave him with ull their leurt

sits high in ull the peoples heurts ..

and let our liearts, ns sulitle masters do -

the ruidy drofs the vist my hatd hear

nnd with a heart new-firel, l fisl] ow

!lok you -

they alould be a henst without a loeurt -

heart of Brutus yearns to think tum?

my heart laneuts, that virtue

momintain tween my hent and tonguc!

weak a thing the lies rt ot womant

buldest anci best hearts of liome

and our hearts, of brothers temp.

indeed, $O$ world, the heurt of thee.

thy heart is bis: yet thce apart.

hetrrt is in the entim there witl Carsar

then birst his mighty henrt.

fluck lut his name out ot his heart.

hine in their lienrts, $l$ tear.

fret. till your lroud heart hreak $\ldots . .$.

3rutus ly

within, a hesert denree than Plutus' mine -

denical the gold, will give my henrt

rour lumd. And my heart, too

inw leart is thirsty tor that nohle....

the thle you mude in Ciesar's heart.

emr heart! Is not that he?

entme rymen, my heart dotli joy.......

there were a lieart in Egypt

bit my full henrt remains in use...

ato near he heart as Clepatra thi ...

fo near the heart as Cleopatra this ...
his speeeh stieks in my heart.......
Crequr gets mones, where he loses hearts -

to knit your hearts with an unslippin

nur kinguloms, and our hearts

half the heart of Casa

she pursed up his henrt, npon the river

pays his heart, for what his eye

can settle the heart of Antony

no slunder; they steal heart

hol hearts, tonyues, figures, seribes

and make the liearts of Romans serve

not ohey her heart, nor ean her heart

What eost your heart has mind to

clwer your heart: he you not troubled

cash heart in kome does love.

my henrt was to thy rudfler tied ...

anil plighter of hish hearts!

from my cold heurt let heaven

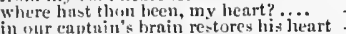

kntow, my hearts, I hope well nf ....

thon art the armolirer of iny heart

through pirnof of harness to niy hieart

throw : hy heart against the flint

nuil iny hart makes only wars.....

hepuiled me to the very heart of loss

whose heart, I thought, I had.

dividerl between, her luart and lipa..

lieart, onee le gtronger than thy ....

gnot sirs. take heurt: we'll hury him
cournge wisieh the heart didl lend it (rep.)

as sovereign as the hlotel of hearts

and lise lave whe minc

that slusots my very heart at roint.....

huth on heart that is not glin! ........

take it. luent; lout keep it till you

air, with ull my hear

this practise but make litril your lieart

the very millile of my heart is warmed

n $T$ have smeli a heart, that both

hulf all inen's hearts are his

two from twenty for hia lieart

which know ing leeart, do liere pronoune

to allure lube hearts, and he fulse

against himself With all my heart

mansion of my love, my lieurt .......

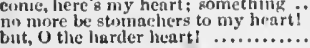

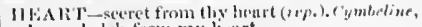

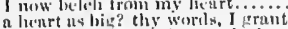

might liave killed thee at the henet..

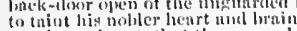

woe is my hent, that the poor soldice

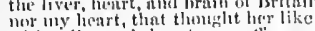

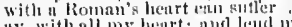

the with ald wheart; ant hath my

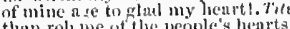

$\because 3$ than rol, me of the people's hearts

mistress of my heut, und in the saced

nee razors to my wounder heart

wud

leert, look laek

mon thy liesert, and tit thy thoughts

but he your henrt to them

thomph thy hasel lieurt say no.

neer let my heart know merry cheer

with sight, numle heart lam

iny emminssiona te heart

doth burn the heart to einders

thy nolle heurt to break

with all my heart, I'll send...

do then, dear heart; fur heaven

and te wy lieart an cver-burning hejl!

alns, porr heart, that $\mathrm{kiss}$ is eonfortle
when my heart, all mad with misery

when thy ponr lieart beats with.

just arainst tliy heart make

enrsed lie thiat heart, that fored

more sears of scrrow in lis hear

enaets and eounsels of the heart . W...

that were his heart almost insuregualule

botlu ear and lieart ohey my tongue.

almost broke my heart with ext

maliee of iny swelling heart

my heirt is sut compuct of

yomr hearts will throbet of .........

with nll my heart would I were dead

my heart enu lend no suceuur to
it grieved ny heart to hear what

that neither in our hearts............

thou bast a heart that even crack

take from my lieart all thank fulncssi

the heart and place of general won

with more than foreign heart........

with all ny heart, sir; and when you.

my heart leaps to be gone..............
in my true heart I find, she names

in my true heart I find, she names .........

but gnes this with thy heart?

a stranger to $m y$ heart and me

invade the region of my heart

a henrt and biain to breed it in?

in pieees tlie heart of his obedience.

I know his heart; what he hati.

O marlam, my old heart is eracked.....

0 me, my henrt, my rising heart:

serpent-like, upon the very heart........

but this heart shali break into ..........

what he his lieart should make...

I have one part in my heart ....
will break nyy heart? I'd ratlier

made lim proul of lieart, to ril

fet not thy swcet heart on
proud in heart and mind

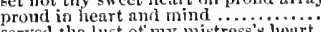

false of leart, light of ear

betray thy poor heart to women
were fike an old lecher's heart

that in the fury of lis heart.

proclain what store her henrt is ma...... of

see what breeds about her heart
in nature, that makes these hard jo...

one that's of a neutral heart

yet, pour old heart, he holp the .........

with all my heart. Why I do trific........

it is and my heart breaks at it ......

I'll prove it on thy heart .............

if my speceh oftend a noble heart

to prove upin thy heart, whereto $\mathrm{I}$ sicenk

lic o'erwhelm thy leart.

let sorrow split iny heart .......

but his flwed heart, (alack, too weak

it came even from the heart of

break, heart; J pr'y thee, brenk ...........
gorsl heart, at what?
get her heart: my will to ber consent

let wantoms, light of heart, tickle...

dis iny heart love till now.

well kan, my henrts; you are a prine

furward, when my heart is here?

if my heartien my heart is here?

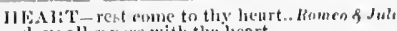

my heart's dear love is set on...

not truly in their lieurts 0 ii.....ii

the very jin of his luart eleit u'ili

t) break, iny heart! ponr bunkruj,

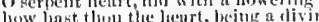

with all my leart: aul yet luon

my por lieart so fir a kinsman vexed

onc's hesut combl [Col.-tlusught would]

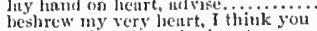

speakest thom from thy lutart......

or my true lienrt with trencherous

ny heart itself jray - n:y heart is full

gryping yriet the henrt floth wound - i

to hene our learts in grief................

a heart unfortified, or nind impatient

ill our peevisli opposition take it to heart? -

but break, iny heart; for I tuust hold....

nr lose your heart, or yonr eliaste treasure

ns watchman to my heart.........
bold, hold, my lacart; and soi

wonld heart of man one think

or given my heart a working

with all ny leart; and it doth mich..................

this something-settletl matter in his heart

since love our hearts, and II ymen disl.

would pluek out the heart of my mystery

Oheart, lose nrit thy nature

and, hedart, with st rimes of stcer.

thou hast eleft my heart in train...

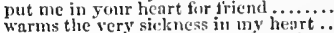

ot a sorrow, a tree without a heart?.....

in my henrt tlice was a kind of

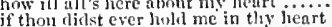

now

yet their hearts attending on themselves

firure of my heart in eompliment extern -

wear my heart upon my siceve . $3 . .7 \%$.

to draw trom her a praver of earnest heart -

whe lruised beart was piereed throngl

my heart's subdued even to the very .....

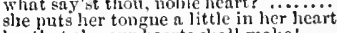

lic, that eer our hearts stall make?.

let not thy disereet heart think it
the people's hearts brimful of fear

working from the heart........................

ennnot, if my heart were in tour hands, lieart, to wronged othello's

fruittinness, and liberal hear

that hand that gave away my heart

the hearts of old gave lrands (rep.) ..........

the skilful conserved of maiklen
with all the duty of iny heart

no, my heart is turned to stone

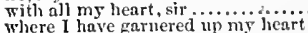

where I have garnered un my heart.
upon her, as true hearts tunnot lear

nuen, with all my heart

helies to the heart. sle was too fond

speak, for my heart is tull .............

no werpon; for he was great of heart .... -

this heavy aet with heary heart relate . iimles, iii.

EAR'A-BLoOn which breatled this, Jichard Il. $\mathrm{i}$

iil my heart-blood warmed

in thy heart-hlond, thougl locing ail

within a monarcli's heart-blond ..2Henry It: ir. a

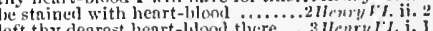

Funs the heart-blood of leauty. Troil. $f$ Cres iit.

JIFART-BREAK-denl of heart-break. Merry W. Y.

HEAliT-BU RNED an hour after.... Wreh Als, ii. 1

IIEAR'T-BURNING heat.. Loce's L. Los!, i. I (letter)

IIE.ART-DE.AR-

EAlRTED-hearted, hreathed Antony fore Cliti. II

olove. thy erown, and henrted throne . - iii. 3

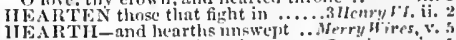

I will not hurt your hearth ......... Coriolems, iv.

Gath brought ine to tliy hear
he enime unto my henrth

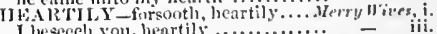

pray henrtily, pardon ne................ $=$ a iii. 3

for the whis she, wept heartily............

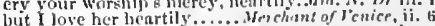

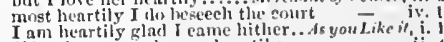
didst then nerer lore so henrtily"

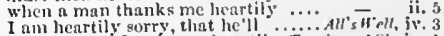

and wash, and wuleome henrtily. Taming of sh. iv. I

pray heartily he be at palace $\ldots . .$. Winter s Tale, iv. 8
as henrtily, ws lie is glad he hath... King John, iit. 4 


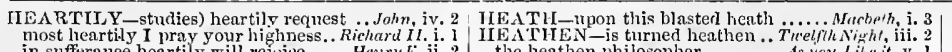
in: sufferance heartily will rejoice .....He peseech you heartily, seurvy lousy kuave much gant do you, scald knave, lieartily - y. heartily solieit your gracims selt.Richard 11 . jii. the queen hath heartily beseech yo

Yes, ieartily besecth yo

IIE ATHEN-is turned heathen .. Treelfih Night, ii.
the heathen philosopher......... ds you Lithe it, v.
all in gold, like heathen gods. all in gold, like heathen gods when most heathen, and most gross!

HEATING-heating of the

prity, and heartily, for our deliverance

fruit, she goes with, I pray for heartily

Your' highuess most heartily to pra

give you our voiees heartil

the gods give you joy, si
so, sil', heartily well net

two ereatures, heartily. Am I one

nothing grieves me heartily indeed

nothing grieves me heartily indeed . il - $\overline{\text { wat }}$ v.

otrend you, heartily; yes, 'faith heartil

I coulif heartily wish this had not...... Orhello, i.

HEARTINESS from heartiness

FEARTLINGS od's heartlings.. Merry Wives, iji. 4 IIEAPT-OFEENDING groans.

heart's-ease, heart's-ease (rep.). Romeo \& Jalie

HEART-HARDENING speetacles., Coriolam,

the breath of heart-siek groans. Romeo \& Juliet, jii. HEART-SORE sighs (rep. ii. 4). Turo Gen. or Ver. i. 1 HEART-STRINGS

grieves my very heart-strings. Tu'o Gen, of trpr. iv. 2 and from my heart-strings i love ....Henry $r$ iv.
shall I, till heart-strings break .... Kichard III. iv. lier jesses were my dear heart-strings.. Othello, iii. 3 HEART-WHOLE--.him heart-whole. As you Like, iv. I if hearty -I borrow be ........ Tu'o.Gen.or Vernna, $\mathrm{v}$.

hath her hearty commendations... .Merry irives, ii.

and heart $y$ thankings to you both. Meas. for Meas.

and last, the hearty welcome .........Macbeth

and eoncludes in hearty prayers....2. Henv?

my hearty friends ........ Antony \& . Cleop w

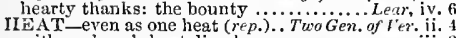

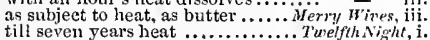

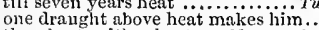

thou hast neither heat Neasure for

both in the heat of blood

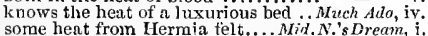

heart-burning heai of duty. Lave's L. Lost, i. l (letter)

ofter made in heat of blood ...........

then, farewell, heat; ani, welcome

of eolour, weight, and heat, poured ...All's Well, ij.

ere with spur we heat an aere ....
ler eye, heat outwardly, or breath

when I am eold, he heats me... Camedy of Errors, iv.

from the heat-oppressed brain
words to the heat of deeds

Iacbelh, il. 1

whose heat hath this co

though heat red-hot, approaehin

I ean heat it, boy. No, in good ..... - iv.

in the very heat and pride of ........ I Henry $1 V$.

who struek this heat up after

exeuse of youth, and heat of blood ...

measure the heat of our livers inerrinent, if you take not the heat.

HEAT'ST-thou heat'st my blood.. Troilus \& Cress. i. with a wreat heart heave away ....... King John, v.
wive

there seen, heave him away. Herry $I^{\prime}$. v. (chorus) to heave the traitor Somerset from..2 idemyl I'I. v.

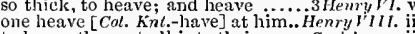
to heave them at all into their...

a partizan I could not heave.

I eannot heave my heart into my begin to heave the gorge, disrelish

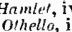

which the sailors heaved overboard

the wreteled animal heaved forth. As you Like it, ii.

if mine arm be heaved in the air......2 Henry iv. 10

one heaved a high, to be hurled ...Richard /II. iv. 4

those which I heaved to head! ...... Cymbetine, v. 5
she heaved the name of father pantingly. learr,iv. 3

HEA VEN $-O$ the heavens! ( $r p$.) .......
infused with a fortitude from heaven..

heavens thank you for't

heavens keep him from these beasts

O heaven, $O$ earth, bear witness

heavens rain graee on that ....

Give us lind keepers, heavens!

hall the heavens let fall to make this

witness heaven, that

pray heaven he prove

by lieaven, my wrath.

the heavens sneh graee did

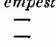

i. 2

as heaven, it knows......

is nor of heaven, nor earth

$O$ henven! were man but constant

benr witness, heaven, I have ....
0 heaven! this is mistress Anne

yet heaven may deerease it up

I praise beaven for it

heaven

leaving the fear of heaven on tilie ieft

are they so? hearen bless them ......

weaven be praised for my jealou.......

heaven prosper the right!...........

pray heaven it be not so fi..........

heaven forgive my sins at the day

no, heaven so speed me in $\ldots \ldots \ldots \ldots . . .$.

a. sickly ereature, I give heaven praise
now heaven send thee good fortunel

beaven guide him to thy husband's ...

pray heaven it be not full of $\dddot{3}$ hen be my witness, you do if

does not serve heaven well

heaven torgive our sins! .....

heavens detend me from that id

Fenton, heaven give thee joy!

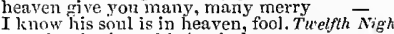

if the heavens had been yleased......

too old, hy heaven; let still......

heaven restore thee!

O heivens themselves! ..............

and heavens so shine, that they

now heaven walks on earth..........

and whom, by heaven I swear I tender $\overline{-}$

heavens give safety to your purposes!

the words of heaven; - on whom it will

well, heaven forgive him! ...........
I detest before heaven and your houou
whom, I thank heaven, is ...........

heaven give thee moving graees

and neither heaven, nor man

shall we serve heaven with less

use his heaven for thunder (rep.). .

pray heaven she win him

that heaven shall share with you.....

that shall be up at heaven.

heaven keen your honour sate! ......

heaven hath my empty word

heaven in iny mouth, as if I liil biit

heaven keep your honour!

tis set down so in heaven, but not...

heaven, let me hear it!

women! help heaven! inen their
Tampers,
With deneing is a little lreated...
II EA VEN_heaven 1 it eamnot be.Mens. for Meas. iii. 1 what should I think? heaven shield have paid the heavens your function he who the sword of heaven will bear heaven give your spirits eomfort! $\ldots$.

give your enufe to heaven............

pray heaven, you then be perfeet .... by heaven, fond wreteh, thou know's

heaven shield your grace from woe .0.

as there eomes light from heaven ..... Much Ado away to St. Peter for the heavens...

a. silver bow new bent in heaven..... ifirl. $\bar{N}$.'s $D r$.

turned a henven nnto a hell.

and make a heaven of hell

- iii.......

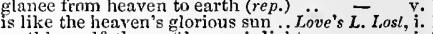

eartlily godfathers ot heaven's lights

by heaver, that thou art tair....... iv. 1 (letter)

ah heavens, it is a most pathetieal hit 1 -

that sings heaven's praise...

by heaven, I do love

o heavens, I have my wish

by heaven, the my wish ........

wished himself the heaven's breath

look upon the heaven of her brow....

by heaven, thy love is biack as

erest beeomes the heavens well

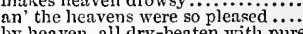

but seeing heaven's fiery eye ........

by heaveu. Jou did, and to confirm...

fashioned, by the hand of heaven. Nerer. of Ten

for the hearens; rouse up a lirave....
O heavens; this is my true begotten

in plain terms, gone to heave

heaven, and thy thoughts, are witness

spits in the face of heaven

toward heaven breathed a seeret ....

he finds the joys of heaven here

lie slould never eome to heaven

from heaven upon the place beneath

I have an oath in heaven....

I would she were in heaven.

look, how the floor of heaven is thick

pray heaven, I be deceived in youi!ds you Like it, $\mathrm{i}$. to find the way to heaven by doing ..

I give heaven thanks ................

heaven would in little se fortune $\cdots$ ii.

henven would that she these gifts.. - iif. 2 (ver.)

and thank heaven, fisting $. . . . . . . . \quad-\quad$ iii. 5

Hymen from heaven brought her.. - ${ }^{\mathrm{v}} \mathrm{q}$ (ver.)

whiat heaven more will . . .............

whieh we aseribe to heaven ...........

whan $\mathrm{I}$ do for heaven, so I were not..

as heaven shall work in me ........... by the luckiest stars in heaven

the help of heaven we eount the act

of heaven, not me, make an.......... -

vert hand of heaven. Ay, so I say ....

and thank heaven for you

one, that she's not in heaven

a heaven on earth I have won

to thank both heaven and mel
and now she sings in heaven

where, henven aiding, and by the leave

than the first o dear heaven

the heavens have thought well on...

you give aw ay heaven's vows.

hou give aw ay heaven's vows... .....

and heaven's artillery thunder

do spangle heaven with sunder ......

the heavens continue their loves! II

as heaven sees eartl, and earth ('ep.)

by each partienlar star in heaven...

till the heavens look with an aspect

i' the eyes of heaven, and to you

the heavens with that we have in hand

I lever saw the heavens so dim by, day

the earth the heavens, and all

as heavens forefend! your ruin

should to the heavens be eontrary.

that 'twixt heaven and earth .........

Whieh the heavens, taking angry note
blessed (as he from heaven merits it)

the heaven sets spies upon us .........

light the heavens did grant .. Comed

nothing, situate undler heaven's eye
in eartl, in heaven, or in hell? ...... 


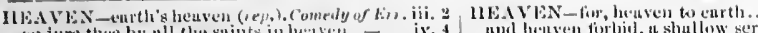

entijure the by ull the suints in lie:tven

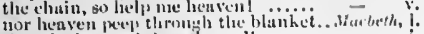
that the heavien's bieath smells.....

or heuven's etherubius.

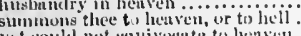

yit tould mot equivocute to henvell.

thou see'st the heavens, as troubled.
if it fint heaven, nust find it......

as, un't please heaven, lue shutl no

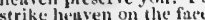

sueli sanetity hath lienven aiven

how he sulieits heaven, himself.

mercitul heaven! - whint, man! ....

lut, gentle heaveu, ent siu

if the "seupe, heaven torgi

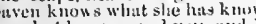

none, but heaven, and you, and I...

I put you o er to heaven, and to my

rive leuven thatnks, I was not (rep.)

hearen lay not my transgrcssion

the peace of henven is theirs

that beat his peace to husten ...........

erystal beals heaven shntl te bribed

the invalmerubte elonds of henven

work unow ourselves, for heaver, or leell -

by heaven, ludy, you shall have

arm, arm, you heavens, ugainst .... -

as we under heaven are stipreme lest

heaven knows, they were besmeared

so jest with lieaven, make such ...

male to heaven, first be to heave

the doum forethouglit by hea ren

by heaven, Ilubert,

to my uet, ly, heusen, $i$ cl ilu

I would to heasen, I were? ...

and know our friends in heaven

tonutes of heuven, plainly denoumeing

and I would to heaven. I were your sui

if heuven lie pleased that you niust...

for heaven's sake, IIubert, let nle

in lieaven, that there were liut....

the breath of heuren hath blawn

to seck the beunteous eye of learen

the last nceount 't wixt heaven and carth -

heaven take my soul, and England.

by lieaven, I think, my swords as

is fied to heaven; and England now is

but, heaven be thanked, it is ........

geen the vaulty top ot heaven figured

warrunt from the hand of heaven.11..

sur ol heaven, methought, was loti:
indiggurtion, mighty jeaven, aud tempt

where heaven lie knows, how we ....

my soul shall wait on thice to heaven

tirst. licaven be the record to my

goul answer it in heaven.

quarte to the will of heaven

let heaven revenge; for I may wever

complain myself: To leaven.........

which, heaven detend, a knight slourd

as I truly fight, defind me licaveus
by heaven's grace, and nyy body's

meaven in thy good eause make.

however heuien, or fortme cast......
the duty that you owe to heuven ...

so heip you truth and heave

all places that the eye of heaven yisits

now, phit it, heaven, in his physieian's
whoin fair beful in heaven 'mongst..

now, afore heuven, 'tis slume

now, gore heuven, 'is in heuven forbid ............

for heaven's sake, speak eomfortible
fright the fixed stars of heaven $\ldots . .$.

my comfort is, that lieaven $w$ ill take
for lieaven's sake, fuirly let luer......

heaven yields must be emlirneed ( $(r e p)$.

whon the seareling eye of heaven is his

for hea ven still guturds the right

for heaven y bake, let us sit upon .....

the heavens are o'er your liead

the eloudy cheeks of heaven

the king of heaven forlint, our lori...

by heuven, l "Il throw ut all..........

as false, by heaven, as heaven itselt.
stirred up by heaven thus buldly for

if' heaveli do think lim me

dammed in the bork of heaven...

like the meteors of a troubled heave

by heaven, methinks, it were an ....

by heaven, le shall mit hince us seot.
slanll the blessell sun of heuve's prove

he wisheth you in hensen.

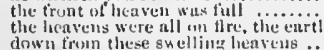

vengeasec and the $r(x)$ if heaven.

1 stole all courtesy from heasen ....

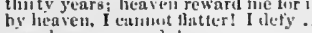

yray licarcu, jou du!................ by luewen, thou hist dereived me...

tike thy pruise with thee to leetven!

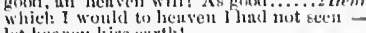

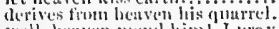

wetl, hemsen mend him! I pray

dielst thon beat has aven with blensing

us the surs is the grey' vitul of heave

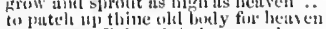

ly heaven, Poins, I teel me muth.

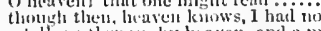

a tall gentleman, bs heaven, and $n$ mo

the sanetities of herven, and our diul

the pountentance ant grace of leenven

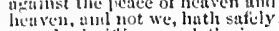

now, Jiris, it ireaven sloth gixe sueces-ful -

from enemics henven keep your manjesty -

hore it sits, which heowen shall guard

omy sent? henven put it in thy mind

hencen knows, my sou, by what

and heaven save your miajesty?

Jenven shorten Ilarry's haplyy life

lie heavens thee guard and keep

for heaven doth know. so shall the

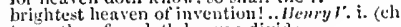

true: therefore doth heaven divide

by tift of heaven, by law of nat

withered hands hold up toward lieave

till we neet in henven, then, joyfully
their honums reeking up to heaven ..

thine keep eompany to heaven
humg be the hear ens with black

with alverse planets in the heave

with advorse lianets in the heave

a vision sent to her from lieav

heaven, and our ladly graeious,

heaven, be thon gracuns to none....

what tumult's in the heavens?

the heuvens, sure, favour him

heavens keep old Bedford safei....

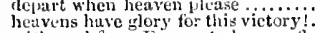

with soul frem France to heaven tly

ut the gates of heaven..............

together lift onr lwads to heaven

your grace eould fyy to heaven?......

to heaven I do aly,eal, how 1 .

blow ten thousund sonis to heuren

0 thou eternal mover of the heavens

if thou think st on heave

wing wherewith we fly to lieaven

and hestens and honlonr be witness.

wrong'st me, heaven be iny judge

2 by lienven, thou shalt rule no (rep.).

if nut in heaven, you'll stuely sup in hell -

pance with his soul, heaven

knit eurth and heaven together

chit earth and heaven together

3 I vow by lieaven, these eyes shail....3 3 uenry

3 if I be not, heavens, he revenged on me!
I throw mine eves to heaven, seornint

my son] to heaven, my blood upon

in this the heaven figures some trent

smile, yentle heaven! or strike.

i. 1 thy bruzen gates of heaven may ope

pity, gentle heaven, pityl...........

ii. 1 I'll make my heaven in a latly's lap
iii. I I'll make my heaven to dicum upon

iii. 1 yet heavens are just. and time …..

iii. 2
iii. 2 heavens grant that Warwick's words

to whum the heavens, in thy nativity

furewell, to meet again in licasen.

iii. 2 which, hy the heavens' ussistutec..

heaven, I will not do the so vuucic..

iii. 3 sinte the heavens lave stuped my body

ly lieaven, I think, there is mumm. Mich
thy sonl to heaven, it'lueven will tnk

le pucked with posthorse up to liearen

either, heaven, with lightning strik
king of heaven that hath him (rep.)

the henvens hitye ble

eurse frevial so nuel

fieree the elouts, ant enter henven!

if heareu have nuy grievous plingue.

thruland to the juys of heuven

in geace uy soul shall part tu henven

by lieasen, my solnt is purbed from.

alt-resing lieaven, whint a worli

tol he thos opgessite with heavell

until we mect aguis in heaves.......
11..AV liN-heaven, we conte to... Richurd HI. iii. 7

nt. lang as hrovecti, unl nature.

lienven, nind hortute, bar me haphy.

it' not to heaven, then hand in hand

grent (ind of henve'll, fay umen to all

suie lieaven upon this fair eonjunction

it gilt that beaven givey for hin .... II.nory rhll

the will of leaven be dome (rep.) ....

whase hromer heaven slield from scili!
where this lieaven of heanty shall gline

by leaven, she is a dinty vic

vuli lite un seal to luess

you sucet fim half in heaver.

heav(') has un chet in all

heaven kecrs me from such enumsell

bensen's preace he with him!

mo, not for all the riclice mour heaven

Istrod mot in the smile of heaven

heuven if ahove ali yet ...............

joved him next heaven? obeyed him?

it's heaven's will; some spirit put

henven furgive me! ever God bles
my payers to heaven for you..........

licavy for a man that hojes tor hicar

and ny integrity to heaven, is all

heaven bless thee! thou hast

east her fair eyes to heaven ...........
his blessed part to heaven, ami slept

yray, pray. Ileaven comfort lic

loved him, heaven linow's how ilearly

it heaven had pleased to bave.

by heaven, will; or tet me nae ....

pruy leuven, he somnd not my disgrace!

tis the right rimg, hy heaven .......

how much are we bound to heaven

and let learen wituess, how dear...

hearen, from thy enthess gendiess...

let me speak, sir, for henven now bids

when heaven shalt eall her from

Wherever the bright gut of heaven
chilclren shall see this, and bless hearen

when I am in heaven, I shall desire.

axletree on which lieaven rides... Trod

now lienvens forbid such scarcity ....

lieuven bless thee from at tutor

ay; the heavens hear me! $\ldots$........

Oheavens! what have I done?

(.) lienvens, what some men lo

farewells as be sturs in heuve

o heavens! be true, again? (

tell me, you heavens, in whicli part

allswer me, heavens! It would discrud

for the heavens, sweet lirother

funl's play, hy heaven, Ilector.......

the flume of yonder glorions hen

heavens, that I were a Inral .... Tho or thens,

I'll loek thy heaven from thee
heavens, hive I euid, the bount

roots, you clear heavens! .............

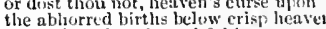

in all the suite of wreak ful heuven ..

not all the whips ot heaven are lure

many as well strike at the heaven ifilius! Coralo
henvens thless iny lord from fell Aufilius!

by the tires of heaven, I'll leave the the -

O heavens! 0 heareus: Nay, I pry thee

heaven will not have eartla to know

by the jealous queers of heaven

behold. the heavens to ope

there is a eivil strife in heave.

to open the hreast of heaven, I lich

did you so nruch tempt the heavells?

the stranse impatience of the hearens
that heaven hath intused then with

nor henven, wor eurth, have been.

the heavens themselses bluze torti

hy heaven, 1 had rather coin my heur

heeds find out wew lieaven ...fnitony

hist was a race of lienven

seem 12, the spots of helven.

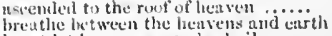

heait let beaven engender hail

his face wus as the luebliens

that $k$ las, wlich is my heaven to have

no more olxy the henvens .......... rymbelin

tormes, air: henren resture me!.....

but jet, heascu's bonnty towards hail

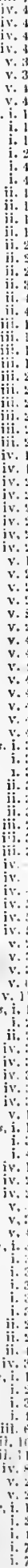


FEAVEN-the heavens hold firm ...Cymbeline, ,i. 1 HEAVEN-heaven finds menns.. Romeo \& Juliet, v. with blue of heaven's own tiue

ustructs you how to adore the lienvens

hail, thou fair heaven, we honse i' the

hail, heaven! Hail, heaven! .....

paid more pious debts to heaven $\ldots$.... -

grant, heavens, that which I fear

get left in heaven as small a drop........

murder in heaven? how? 'tis gone

heavens, how deeply you at

by heavens, I'll go: if you wili biless

therefore, good heavens, hear patiently

all was lost, but that the heav

heavens, how they wound...........

in thy feeling. Heaven mend allt.

these covering heavens fill ou

to inlay heaven vith stars

in sight of heaven, to Rome I swear.. Tit us

sent by the heavens for prinee Saturni

by deviee, or no, the heavens enn tell

and the rigliteous heavens be my judge -

and vow to heaven, and to his high

hy heaver, it shall not go

hy heavea, it shall not go............

for heaven shall hear our prayers

when heaven dotll weep, doth not

nor hold thy stumps to heavens reveal the damned

or else to heaven she heaves them

heaven guide thy pen to print thy

$O$ lieavens, can you hear a good man -

which I would hide from heaven's ey

with Jove in heaven, or somewhere.

we will solicit heaven...............

eome fiom heaven? From heaven

to press heaven in my young day

he writes to heaven for lis redress $P$

her faee, like heaven, entice

sce heaven, but fecling woe.............

that give heaven countless eyes to ...
draw heaven down, and all the gods

casts eopped liills towards lie

heaven that I had thy liead ..........

how dare the plants look up to kings

if heaven slumber, while their ereatur

the curse of heaven and men succed.

ye angry stars of heaven!.

wich heaven makes like to itself $f .$.

a fire from lieaven eame, and shrive

which wash both lieaven and hell

the heavens, sir, through you, inereas

and the rentlest winds of heaven ...

of all the faults beneath the heavens

lieavens forgive it! and as for Periele

birthchild on the heavens

heavens make a star of him!

led on by heaven, and crowned ....

heaven and earth! Edmund, seek lin

not mad, sweet heaven! keep me

stored vengeances of heaven fall ...

you heavens, give me that patience.

and slow the heavens more just

broke them in the sweet face of heaven...

$O$ heavens! that this treason were not

he holp the heavens to rain

now, heaven help him!,$\ldots \ldots \ldots . . .$.

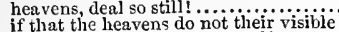

if that the heavens do not their veaven

the bounty and the benison of heav

and bellowed out as he'd burst heaven

this judgment of the heavens .............

Y'd use thein so that heaven's vaut.......
that make dark heaven light ..... Romeo

fairest stars in all the heaven

her eye in heaven would through....

a winged messenger of heaven

now, God in lieaven bless thee!

smile the heavens upon this holy act

away to heaven respective lenity...

can heaven be so envious? (rep.)

live here in heaven, and may look on

the heaven, and earth? sinee birth (rep.)

whose notes do beat the $y$ a

on earth, $\mathrm{my}$ faith in heaven..........

send it me trom heaven by leaving earth -

alack, that heaven should practise

to move the heavens to smile npon

heaven and yourself had part (rep.)

'twas y'our heaven, she

the heavens do lower upon you.......

by heaven, I love thee better

O heavensi $O$ wifel look how our
bear this work of heaven with patience - to illume that part of heaven

have heaven and earth together...

a will most incorrect to lis

the heaven slanll bruit again, re-speaking

the winds of heaven visit her (rep.).....

in heaven or ever I had seen that day

the steep and thorny way to heaven

almost all the holy vows of heaven ...

loring with thee airs from heaven ......

heaven will direct it. Nay, let's follow

o heaven! Revenge his foul and most.

leave her to heaven, and to those thorn

0 all you host of heaven! $O$ earth!
with baser matter: yes, by heaven

with baser matter: yes, by hat

not I, my lord, by heave

more things in heaven and earth

with what in the name of heaven?

as oft as any passion under lieaven....

$[\mathrm{Col}$.] heaven, it is as proper to our of

your ladyship is nearer to heaven

a silenee in the henvens, the raek...

made mileh the burning eyes of heaven

to my revenge hy hearen and heli

o, help him, you sweet heavens?

Oheavens! die two months ago.

to me give food, nor heaven light? ...

rain enough in the siveet heavens.

he goes to heaven: and so am I revenged

do this same villain send to heaven...

without thoughts, never to heaven go
heaven's face doth glow; yea, this solidity

eonfess yourself to heaven; repent

but heaven hath pleased it so.

by heaven thy madness shall be paid

O heavens! is 't possible, a young maid'

as 'twere from heaven to earth.

the easnons to the heavens, the beaven

heaven make thee free of it!

by heaven, I rather would have been his. Othell heaven is my judge, not I for

heaven I do confess the viees of $\mathrm{my}$ biood

and she wished that lieaven had made

voucl with me, heaven..........................

and heaven defend your good souls...

pray heaven, he be, for I have served him

O let the heavens give him defence....

the graee of heaven, before, behind thee

duck again as low as hell's from heave

the isle of Cyprus

fore heaven, they have given me a rouse

heaven's above all; and there be sonis

by heaven, my blood begins my sufer.:

past all surgery. Marry, heaven

by heaven, I'l] know thy thought

in Venice they do let heaven see

false, $O$ then heaven moeks itsel
heaven knows, not $I$; $I$ nothing

do deeds to make heaven weep

fond love thus do $I$ blow to heaven

now, hy yond' marble heaven

would to heaven, that $I$ had never seen it

heaven bless us! Say you? It is not lost

virtue tempts, and they tempt heaven

by lieaven, $f$ would most gladly bave forgo

jeaven, that should be my haudi..........

he is not: I would to heaven he were

lest, being like one of heaven, the devils

heaven doth truly know it. Heaven trul

pleased heaven to try me with afflietion

heaven stops the nose at it, and the moon

by heaven, you do me wrong. Are not

O heaven forgive us! I cry you merey

if any such there be, heaven pardon him!

for, by this light of heaven, I know not

heaven me such usage send, not to pick

leg is cut in two. Marry, heaven forbid

yes, sure: O heaven! Roderigo .........

unreeonciled as yet to heaven and graee

then heaven have merey on me! $\ldots . .$. .

by heaven. I saw my handkerchiet ..

deed of thine is no more worthy hea re

O heavens forefend! And your

O henven! O heavenly powers! ........

by heaven, I do not; I do not, gentlemen that his heels may kiek at heaven

good leaven, the souls of all my tribe

pray heaven, it be state matters o....

o heaven, that sucl, companions ...... IIEAVEN-are there no stones in heaven. Othello, $\mathrm{v} .2$
of thine will hurl my soul from lieaven -
HE

HEAVEN-BRED poesy ....TwoGen. of Verona, ii.
HEAVEN-KISSING hill.............. Hamtet, ii. HEAVENLY - tell me, heaveniy bow... Tempest, iv. some beavenly power guide

O heavenly Julia!........... Tuo Gen. of Veron

is she not a heavenly saint?
aspire to guide the heavenly ear

the promise for her heavenly pictnre $\overline{\text { iv }}$ ives

to make her lieavenly eonforts...Meus. for Meas. iv. 3 [Knt.] uttered heavenly (rep.). Wuch Aith, v. 3 (song) was earthly, thou a lieavenily love - iv. 3 (verses) who sees the heavenly Rosaline .... - iv. 3 out of your favous - v. 2 if, in your heavenly eyes .......... - v. those heavenly eyes, that look into... - v. 2 contains her heavenly pieture. Herch. of Fenice, ii. 7 shoukl play some heavenly matel ...
but heavenly Rosalind! ............ by heavenly synod was devised -.... All's $\mathrm{s}$ Wetl, ii. 3 patroness of heavenly harmony......... Aing of Sh. iii. lie liatli a heavenly gift of propliecy...Nacbeth, jv. 3 in heavenly pay a gloxions angel ... Richard $H$. iii. may heavenly glory brighten it! .... - if 3 O heavenly God! low fares my.....2 Henry VI. iii. so Snftolk had thy heavenly company - iii. 2 but 'twas thy heavenly faee that set. Richard HII. i. 2 mind, and heavenly blessings.

and heavenly thoughts still eounsel lier

nothing but heavenly business. Troilus \& $\overline{C r}$ res

shudde but to hearenly agues . Timor of $A$ ch.

. though this a heavenly angel ......Cymlelme, ii. flow! you heavenly blessings, on her! - iii. heard the heavenly harmony.. Tilus Andronicus, ii. most heavenly musie; it nips me... Lear, $\mathrm{i}$. the holy water from her heavenly eyes .. \& $\overline{j u l}$. iil. name, speaks heavenly eloquence. Komeo \& J J let iii. with your wings, you heavenly guards! - $-\overrightarrow{\text { if }}$ heavenly light! nor I neither (rep.)

this sorrow's heavenly heavenly true!

o heaven! O heavenly powers!

O heaven! O heaveniy powers!.......... $-v$.

from the possession of this heavenly sight! $\bar{I}$. vii.
HEAVFNLY-HARNESSED team.1 Henry .

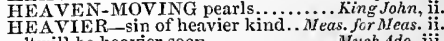

twill be heavier soon ....

doth heavier grow for debt ...Mici. $\dddot{N}$.'s Dream, iji. are heavier than all thy woes.... Winter's Fale, ii for thee remains a heavier doom .... Richard $I I$. tongne hath but a heavier tale......... griefs heavier than our offenees $\ldots . .2$ Henryy $I V$. iv. peaee be with us, lest we be heavier! $-\bar{R}$ lightly, were it heavier.......... Richard III. iii

the leavier for a whore.............. Rroilus \& Cressida, iv.

brain the heavier for being too light. Cymbeline,
HEAVIEST-the most heaviest. Tuo Gen.of 'Ver.

possess them with the lieaviest sound. Macbell,

laws, at heaviest answer ........ Timon of Athens, v.

or endure your heaviest censure .... Coriolanus, v. 5

that frrsped the heaviest club..Antony \& Cleo. iv. 10
HEAVILY-how heavily this befel. Mea. forMea. ii. sigh and groan, heavily, heavily. Much Ado,v. 3 (song) heavily, heavily [Knt.-heavenly (rep.)]- - v.3(song) tidings, which I have heavily borne... Naebeth, iv. with a man that looks not heavily

it goes so heavily with my disposition.. Hamlet, ii. 2
HEAVINESS-put heaviness in me .... Tempest, i. 2

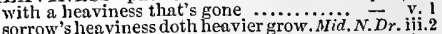
quicken his embraced heaviness.. Mer. of $V^{\prime} \in$ nice, ii. 8 at the height of heart heaviness ... As you Like it, v, 2 to lay aside life-harming heaviness. Richard $1 I$. ii. 2 your blood with pleasing heaviness. I Henry $I V$. iis. I am here, brother, full of heaviness - iv. 4 heaviness and guilt within my bosom. Cymbeline, v. 2 too light, being drawn of heaviness ..
weep to see his grandsire's beaviness. Titus $A$ nd. iii. 4 in the heaviness of his sleep.............. Lear, iv. 7 to put thee fram thy heaviness ........

HEAVING - heaving of my lungs. Love's L. Lost, ii. performanee of our heaving spleens. Troit.\& Cres. ii. 2
TEY - asleep, for I am very heavy?.. T empest, ii. I do not omit the heavy offer of $i$

thank you: wondrolls heavy .............

is it too heavy for so light a tune. Tuo Gen. of Ver. $\mathrm{i}$. heavy? belike it hath some

........ $\overrightarrow{\text { Herry }} \overrightarrow{\text { Wives, }}$ iv. under whose heavy sense... Measure for Measure, i. 5 thou hear'st thy beary riehes....... - $\quad$ iv. of dumps so dull and heavy,..MIuch.4do, ii. 3 (song)
indeed that tells a heavy tale for him 


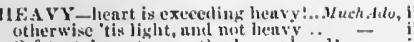
0 fate, tuke not away tlay henvy lumil! her dentlis slall full heny on you.

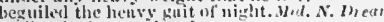

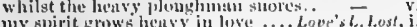

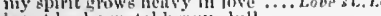

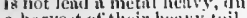

a harvest thetr heary inl

and, and heery: Mnd soshe dict......

a lemey heart bew

loth make a licavy hustonil

burden of luenvy

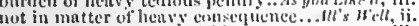

youder is henvy news within ..........

a clarge too heavy for my strength.

my heart is fenvy, and nime aye

she ecased, in leavy sutisfintion
lenvy ehume twixt him and you.

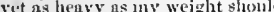

heary mutters] heavy mutters?..

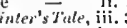

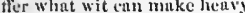

this week he hath been henvy.

even now was heavy on me...

a hear summons lies like lemil...

a havy curse from Rome.

and male it henvy, thick.

anon eleered un the beury time.

the graceless aution of a hicury hand

so long, lies heavy on me

sins so heavy in his bosom..........

so heary sul, as, thungh in thinking

makes me with heavy nothing faint

with the eves of heavy mind...

by my dull and hetry eye .......

drive awny the heavy though

ghall lie so heary on my sword

alack, the lieavy day, that I have.

the heavy acceit of thy moving..

the way out with a heavy heart...

some heavy business hatl my lord

lie too henvy on the commonweal

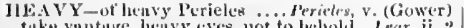
take

jour just und he:av y enuses uuk

steals home my liedry son ...........

griets of mine own lie henvy in nyy.

boing but heavy, I will hen the lipht

towarid shemil with heary hol

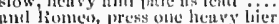

Which heavy kerrow makes them ant

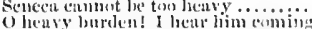

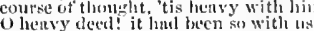

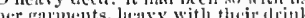

this is too heary, let me see another
and I a lieuy interim shall nupour

obeavy ignoment thou protiost the

alas, the henvy day! why do you ween

it is a heavy night: these muy be.......

this heavy aet witls liong, heart ruln

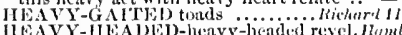

I1 EAVY-IIEADIE)-heavy-headed revel. I
IIEBENON-with juice of cursel hebenon

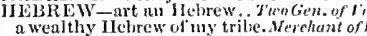

this Hebrew will turn Christiun

ECAT'E-triple Hecate's team..
celebrates pale IIcente's oflerings

why, how now, llecate? you look

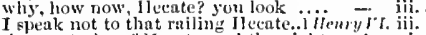

the mysteries of lifecte, and the night ...Lfrar, i. I

IIECTIC-like the heetie in iny blood....

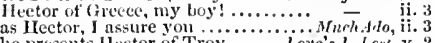

he presents flector of Troy $\ldots . .$. Lore's L. Lost, v. 2

Hector was lut a Trojan in ..........

his ler is too big for Hector

this cannot be fiector

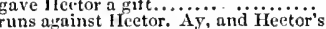

feak, brave liector; we are mut

then shall Jieetor be whipped.

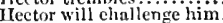

was not that Hector? as iliector.

a second Mector, for his grim

farewell, my llector, and in $\mathrm{T}$. 1 Hewry $\mathrm{J}^{\prime}$

lest Ilector or my father should. Troilus \& Cress.

Hector, whose patience is, as a virtue
weep what it foresnw in IIector's wrath -

of Trojan blond; nepliew to Hector..

makes me smile, make Ilector angly?

yesterday copled flector in the ba

Jlector's a gallant man

was lleetor armed, and gone

what? not between Troilus and ilector?

he is not Hector. No, nor Heetor is not -

Jift ns mich as his lorother Jiector year $=$

and Hector lauthed. At what was all

that's llector, that, that, look you :

Hector; there's a brave man (rep.).

and the great I lector's sword had.....

a prince called Hector, (Priam

Ifeet or in view of Trojans ..........
if any come, Hector shall honour...

that one mects llector

when liector's grandsire sucked.

this challenge that the gallant Jlecto

tinds llector bring those honours off

he, that meets II eetor, issues ........

'tis meet, Achilles mect met II eetor.

shoulil he 'seape llector fair

the sort to fight with Hector

Ileetor shall have a gireat eate
that llector, by the first hour

ilcetor, what say you to't? ${ }_{\text {knows }}$ what follows?

why, brother Jlector, we may not....

Ileetor's opinion is this, in way .

but, wortliy lleetor, she is a theme.

brave IJector would not lase so.......

lector, jeiphobrs, Helenis

to help unarm our llector 1 iecto....

if llector will to-morrow be answered

foot were on hrave llector's breast.

great Heetir's si,ter did Achilles wi

to see great lifector in his weeds of .

fight singly te-moriow with jleetor.

tirr if Jeetor brenk not his neck.
to invite the most vislormis Jlector.

to invite llector tu his tent .....
when llector lus knowets out

blom

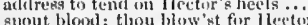

Hector hade ask. Whifel way (rrp,

and pride excel themselves in II icto

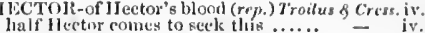

manly as llector, but unore (rep)

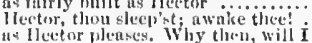

un Ilector wheares. Why then, will I

1 thunk thee, lleetor: llom art too.

tio sce nuarmes the valinut llector...

of very lenrt. grent Ilcetor, weleme

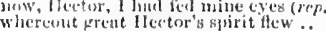

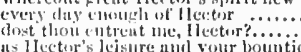

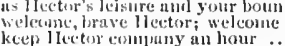

keen lector esminguy an hour

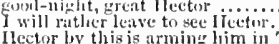

vylure is my brutlice Jloctor? Il The

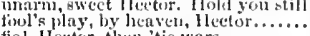

fie! IIector, then 'tis wars......

come, llutur, come, go back
o fincwell, dear llector

all cry-1 lector: llector's dend?

yet, suft: lluetor, I take my leave
urt tliou fior Ilector's mateli?

art thou for Ilector's mateli? .........

come to him, rrying on ficetor...

Ilectur! where's llector! I will ( $r$ p $\ddot{p}$.

when $J$ lave the bloody jicetor foind

decreterlinector the grent must dic.

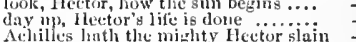

Ilectm"s slan! Aeliniles! (rep.)....

$v$
v.

Hector is gone: who shall tull Prim - v. II

and suy there-j]ector's dead.

suckled llector, looked not (rep.)..... Coriolanu

wert thou the Hector, that was the whip - i. 8

the Poman llector's hope.... Thitus Androniens, iv.

queen Jlecuba launhed, that her eys oressidu, i. 2

here is a letter from queen Ileenba.. - $\quad$ v. 1

lot Prianus, und fecula on knees ..

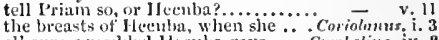

all eurnes makded llecuba gave .... Cymbelime, iv.

say on: cume to 1leculu.............. Hamlet, ii.

IIEDGE-to hedise, and to lurch..... verpy wives, ii. 2

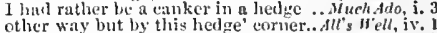
good at the hedge' eorner.. Taming of $\mathrm{sh}$. 1 (indue.) bleaching on the hedge anger's Tale, iv, 2 (song) her hedges ruined, her knots ........ liehard $l l$. iit. they'll find linen enough on every hedge her hedges eveu-pheaclicd "............ plueked out of hedres, they pitched...1 Ienry $/$ I. i. 1 there was he born, under a bedge ..2Henryl'l. iv. I and hedges, his own way............ henry Th. ini. this shat not herlge us otit...Troilis actersida, ini.

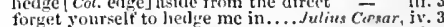
berry on the ruclest hicdge ...Antony f Cleopats $a, \mathrm{i}$.

such divinity doth hedge a king ..... Lamlet, iv HEDGEDORN-a hedge-born swain.1 Hen-yIT. iv. 3 Jngland, ledged in with the main.. Kirs Joln

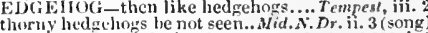
dost Krant me. hedtehog? ........... Richard III. i.

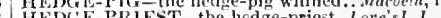
3 ITED - 3 . therefo tnke heal, as Ilymen's m... - iv. take heed; lave olen eye .....

for yourself: take heed to it. Mensure for Wonsure $y$ take heed. the queen come not. Mitl. .'.'s Irenm, $i$

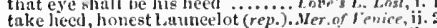
take heel of them; they say
take hced of this French earl

to take heel of the allurement

take heed he lu'ur us not

to listen with more hect .... comedy of hrorn, iv.

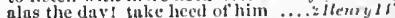

therefore tike heed whit guests.

.

take heed, be wary how you pluce.. illenry/ $I$. iii. 2

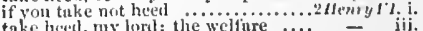

take leed, le it ly your laeat........... Bichar

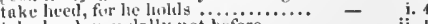

takk heed, yom dally not

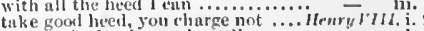
say, take hest; yes, heartily
thus it eame; give heed to $t$

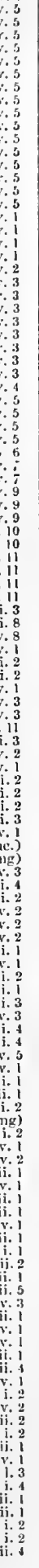




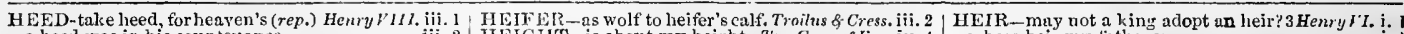

het tivem take heed of Troilus. Truilus \& Cressilu, ii. take lieed, the quarrel's most oninous

I take no heel of thee.......... Trinon of A'hens, i. 2

huve you with heed perused

but there's no heed to be taken....

Coriolnmus, vil. 5

take lieed of Cassins.

take leed you fill not ...............

take heed, sirrah; the whip

Lear,i. 4

take heed, take lieed, for sueh... Rompo \&. Juliet, i

take heed of that; but, sir, sue

with better heed, and jui

of $t$........... Othello, iii.

BWEet soul, take heed, take heed of perjury - $-\mathrm{v}$

IIEEDF UL-heedful of the other. Compuly

be heedful: hence, and wateh

late entering at his heedfy
give lim heedful note

Hewall.

HELDFULLY - sir, most heedfiily

All's Weil,

may lreedtinlly be broke

f leroust, 1 .

II EEDLESS-heedless joltheads... Tuming of Sh. iv. I

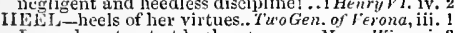

I am almost ont at heels .Merry Hives, $\mathrm{i}$

follow my lieels, Rugby.

with Ring wood at thy heels........

or eye your master's heels?....
witl half Windsor at his heels

and at his heels a rabble

see to point, detraction at your heels. Tüelft $\bar{N}$ igh

heels [Col.Knt.-wheels] of CæEar? MIea. for $\bar{M}$ ea. iii. 2 Yea, light o' love, with you
I scorn that with my heels

our own hearts, and our wives' heels of sern runniug with thy heels. Merch. 4

my heels are-at your commandment

tripped up the wrestler's heels ... As you

I think it was made of Atalanta's licels $-\overline{\text { iii. }}$ on

on the eatastrophe and heel
dog the heels of

Ail's Well, i. 2

from my shoulder to my heel. T'aming of shreu, iv.

lack from head to heel ....Winter's ' 1'ale, iv. 3 (song)

wir, I'll take my heels

Coinedy of Error

kcep from my heels, and beware

skipping Kernes to trust their heels ... Mucbeth, $\mathrm{j}$.

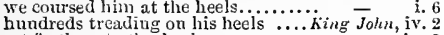

set feathers to thy heels.

the Daullhin rages at our very heels - - at

show it a fair pair of heels
hang me pp hy the heels

hang me np hy the heels $\ldots . . . . . . .$.

eren at the heels, in golden.........

than to wait at my heels.

baying him at the heels.

after the admired heels of Bolingbrok

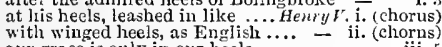

our' grace is only in our heels

follow Fluellen closely at the heels.

Mlebeiaus swarming at their heels $\overrightarrow{-}$ v. (chorus)

shall be dragged at my horse' heels.2 IIenary $V 1$. 1 . 4

makes me betake me to my heels

destruction dog the at the heeis. . Richord

destruction dog thee at the heels ... hichord 11.

wings of reason to his lieels

nor lieel the ligh lavolt.

to tend on Hector's heels..

the heels of my preseutment..... imon of $\overline{\text { Athens, }}, \bar{i}$.

like a dog, the hacels ot the ass........

pare thy heels, and skip when thou.. - iv. 3 or at wild horses' heeis ................

we will grace his heels with.......... - iit.

at lieel of that, defy him $\ldots \ldots \ldots . . . . .$.

would have still tollowed thy heels

hearts that spanieled me at heels...
ne'er wore rowel nor iron on his hee!
took heel to do 't, and yet died too?

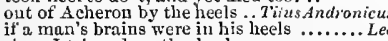

sivee I tripped an thy heels...

good man's fortuue may grow ont at jieels $=$ ii. 2

the lieel of limping winter treads. Rnmeo \& Jutiet, i. 2

the senseless rushes with their heels

by my heel, I care not there no sequel at the heels....... Hamlet, iii. 2

that his heels mat kick at heaven

at his heels a stone................

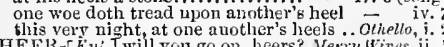

HEFT-Kis sides, with violent hefts. Hinter's 'Tale, ii. 1

IIEIFle -the heifer, and the calf.

who tiuds the heifer dead....

2 Henrylt iii. and in the heiglt of this bath.... Af orry irives, iii. not your heisht of pleasure....Mreas, for Meas. v. she lath urged her height ....Mid.X.'s Dream, iij. her height, forsooth, she hath prevailed main flood bate his usual height. Mir of $t^{2} \in$ ice iiv. at the height ot heart hea viness ...As you Lilie it, $\mathrm{y} .2$ now put you to the hejght of your ...All's Well, ii. 2 the height, the crest ................ KingJohn, iv. sweench ny lieight before

Kichard 11 . i. 1 to his full height! ...................Menry $/$. iii. 1 fear, our happiness is at the heldht. Richurd 11i.. . raised me to this careful height..... - i. 3 pitch and height of all his thought

falls dignity and lieiglit of fortune... - iv.

he's traitor to the height $\ldots \ldots \ldots \ldots$ Henry $r$ H11. i. 2

let us fiast hin to the height

on height of our displeasture...7imon of Athens, iii. 5

we, at the lieight, are ready .......JuliusCresar, iv.
they know, by the height ...Antony \& cleopatra, ii.

leaving the fight in leight, flies......

my grief was at the height

to be advanced to this height?

even in the height and pride of

Pericles, ii. 4

look up a height

thougl performed at height $\ldots \ldots \ldots \ldots \ldots$. Hamer, iv.

HE INOLS -

withiu itself so heinous is .......... King John, iii. 1

you hold too heinous a respect

exampled by this beinous spectucle... - ip.

so heinous, blaek, obscene a deed!. . Richard II. iv.

shouldst thou find one heinous article

if but the first, how heinous ere it be

to view thy heinous deeds.......... Iichard 11I. i. 2

Rome reputes to be a heinouts sin... TitusAndron. i. 2

performers of this heinous. bloody deed?

sorry for tliese heinous deeds?

as fur that loinous tiger 'T

due to this heinous capit offenc....

thy heinous, manifest, and mauy treasons. Lecr, y. 3

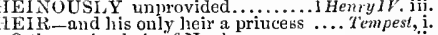

O thon mine heir of Naples...

so is she heir of Naples.

she's his only heir ........................

and she alone is heir to both of $\mathrm{x}$

and make us heirs of all eternity... Love's $\overline{L .}$ Lo

the hear of Alencon, Rosaline

she is an heir of Faul conbridge $\ldots . .$. - ii.

gave Hector a gift, the heir of Ilion.. ve v. 2

thon shalt be his heir .............. As you Like it,

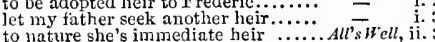

to nature she's immediate heir .........Alls's $W^{r}$ ell, ii.

I am my father's heir, and only son

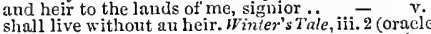

thon a sceptre's heir ...........

Leontes shall not have an lieir

the erown will find an heir

sour contracted heirs of your kingdoms - v. 3

the son and heir to that same........ Kin' John, i. .

get your tather's heir; your father's heir

nay, ny kingdom's heir ............... Richard Il. i. 1

to have an heir? is not his leir.

Bolingbroke my sorrow's heir

old enough to be my lieir $\ldots \ldots$.

adopts thee heir; and his high ....... He- iv.

iny brother Edmund Nortimer heir to - i. 3

gave him their heirs; as pages

and heir from heir shall hold this....

unfithered heirs, and loathly birth
the immediate heir of England...

did, as heir general, being descended.

as heir to the lady Lingare...

sole heir to the usurper Capet....

you are their heir, you sit upon...

and the lawful heir of Edward king.i Henry $r^{\prime}$

leaving no heir begoten of his body

thou art my heir, the rest...........

sou and heir of John of Gannt .......
the first son's heir, being dead $\ldots . .$.
William of Hattield died withmut an heir-

my mother, being heir mito the crown

as next the king, he was successive heir -

rightful heir unto the crown ........

and not ling Hen'y's licirs. whose heir my tather wus............

to me, and to mine heirs

and his heirs unto the heir.....

now you are heir, therefore enjoy....

this is he was lis adopted heir

I was adopted heir by his con

to have the heir of the lord Ir uingerford -

give the heir and dauthter of lord Scaies -
bestowed the heir of the lord Bonvilie

true heir to tle English erown ......

t' Edward's heirs the murderer.... Richard iv.

and that be heir to lis unhappiness!

to bar my master's heirs in trne $\ldots .$. - iii.

what heir of Yo his soln heir to the ero

$\begin{array}{lll}\text { left them the heirs of sliame } \ldots . . . . . & \overrightarrow{ } & \text { v. } \\ \text { le } & \text { v. }\end{array}$

and let their heirs \& God, if they will be $\overline{-}$ v.

well worthy the best heir o' the worke gladding of your higlmess with an heir! -

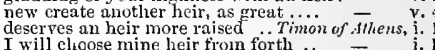

many an heir of these fair ....... Coriolanus, iv.

as if he were son and heir to Miars

makes the survivor heir of all........

kuow not that you are his heirs.. Jutius Cosur, iii.

of the $P$ tolemies for lier heirs... Antony s $\overline{C l e o}$. iii. 10 and the heir of his kingdom ........ Cymbeline, i. I sore-shaming those riel1-left lieirs... $=$ iv.

I the world, as great Sicilin

this my first-born son and heir!......... An . Andran. iv.

he received for the emperor's heir....
died and left a female heir....... Pericles, i. (Gower) never comes, but brings an heir........ the heir of kingdoms, and another $\ldots . .$.
and the son and heir of a mongrel biteh.. Lear, ii. the son and heir of old Tiberio .. Romen of Juliel, $\mathrm{i}$. yickng aftection gapes to lie lis hieir her purblind son and heir $-\mathbf{5}$ (chiv.) death is my heir; my danghter he ..
to see thy son and lieir nore early down natural shocks that flesh is leir to .... Hamiel, iii. eael second strod heir to the first ........ Othello, $\mathrm{i}$.

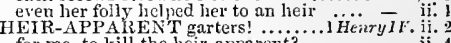
for me, to kill the heir-apparent

heir-apparent to the English erown..2 Henry $r . . \mathrm{i}$. our hejr-apparent is a king.... Sericles, iii. (Gower)
HEIRLESS-heirless it hatl made. Hinley"s Tule, v. HELD-I fear, a madness held me .... Tempesi, v my brother held you in .... T'u'o Gen. of t'erona, and held me glad of such ............... isery wives, ii. there was no proportion hela in inve - v. ......Measure jor Meus

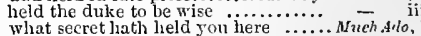
the other must be held the worthier.. Mid. N. Dr. i. held precious in the world's $\because$. Lme's $L$. Lost, ii.
the thing held as a ceremony?.Merch. of $i$ exice, $v$. eveu he that had held up the very....

I have held familiarity with............ make possible, things not so hejd..... you look, as if you hreld a brow of ...

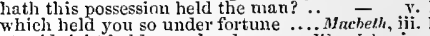
at midnight leld your head. ..... Kinucholn, iv. onr tongues held vile to nam they say, is held by Bushy...........

these triumplis held at Oxford.......

his thumb he held a pouncet-box ... i Henry $1 r^{.}$i. that held the king so lon

of dignity is lield from falling.......2 Henry $I V$. iv. 4 indirectly held from him 1 think he held the right $\ldots . . . \ldots . .$. . Henry $r$. thy hand, and held my stirrup?....z Henry $F I$. iv. the queen, that living held him dear
Plantagenet, which held thee dearly.3 Henvy 1 , all the rest is held at such a rate ..... and the nobility held in contempt ... - i. two councils held [Col. Knt.-kept]..$\quad$ - iii. 2 ever since hath held mine eyes from = iv. by'r lady, held current music too ...Henry $v$ HII. i. yes, but it held not? for when .....

was he not held a learued man?

held a late court at Durstable .......

to York-place, where the feast is held - id 1 might still haye beld off

is now, held with a brace of ... Timon of Alhens, iv. 3 better he held, nor more ..... Coriolanus, i. spies of the Volsces held me in chase $=$ i. in what hatred lie still hath held them = ii. ealled you up, have lield him to .....

\section{,}


II El,D-many never be held iy yon hedd ug his lett hand, which did
lie licld nome of fantasy, ot drean. liat I held Eiveurus otrong

I held the sword, and he diel riun oil it -

I have ever held iny ene otl' tul ony it -

thic loyity, well helil to fools.

y lamel hatlu nobly lreli

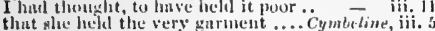
that slic held the very garmest

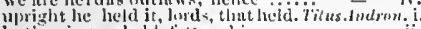
Jath prisolier leth, fetlerex in

Irayer have they been hillt up

I heldi it ever, virtue und cumnin

and lielal a malkin, not wortl

my life tuever lield but as...

beimg lield a fire thong...... Homen

wherein the spirit held his wont

Hamlet, i.

liekl then sixpenee all too tenr...jihitio, ii, $\overline{3}$ (song)

HEI.EN-Ilelen, to you our minds. Vid.... L

to honour llelen, and to be

and now to lleten, it is lione (r.......

Ifelen, I love thee; by my lite

bes Ileten's benuty ju a brow of

aur I like Itelen, till the fates ....

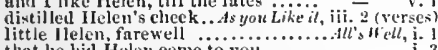

would sireak with her; If lelen, I mean

the business is for Helen to come luther -

you know, Ifelen, I am a mother to you -

but think you, Irelen, if you should

why, IIclen, thou shalt have my leave

five lleten this, and urge her to...
mort du vimuigre? is unt this IIelei?

you must not imirvel, Ilelen

be this sweet Ilelen's knell ............

and, when I gave it Irelen, I bad

't was mine, 'twas Helen's

1 am afeard the life of IIelen $\ldots . .$.
thy Doll, and Helen of thy noble

II elen, the mother of great

IIelen of Greee was fairer far...... 3 Henry J'. ii.
the ravished Helen....... Troilus \& Cressidit, (prol.)

as Helen: an' she were not kin (rep.)

IIelen must needs be fair.

queen Heeuba, and IIelen

Ilelen was not up, was slie? (rep.)
llelen herselt' swore the other luy

I had ns lief, IIelen's golden tongue

I think, Helen loves lim better than

white hair that Helen spied....

nnd Ifelen so blushed.

this will do Helen's henrt govol now

and, I warrant, Helen, to change.

deliver ifelen, and all damage else

let IIc]en go; since the first

n Helen, and a woe; cry, ery (rep.)

when Helen is defended,

where Helen is the sub
if Helen then be wife

if Helen then be wife to...............

in resolution to keep 1 Ielen still
no, sir, IIelen; eould you not find

sweet Ililen, i must

merits fitir Ifelen best ...

who's there? my woman IIelen?..... Cymbeline, ii.

Helen and Hero, hildings ....... Kmmen \& J uliel, ii.

I did mpet thee onee witl Ilelena .

his folly, llelena, is no tault of nine

I will, my Hermia. Jfiena, adieu

transpurent Ifelena! nature
nut Ifermia, but Helena I love

Hent liermia of Atiens look thou find

Ilelena is here at hand ........

both rivals, to mock llelena ........

woulis not let him biste, fair Ilelena.

gentle I Ielcna, hear iny exense (rep)
I Io hate thee, and love 11elena

olre shall not harm thee, Ilelena

sjeak ust of IIelena

thine, or inine, is most inilielen

this Ilelena, old Nerlar's I lelenu

pleasure of mine cye, is only IIelenn

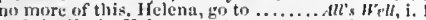

and the lively Helena .... lomen of Juliet, i. 2 (note)

II lelenns. Can IIelenus fight, uncle $(r e p)-$.

Ilelenus is a priet

when IIelenus hololds a Greeian .....

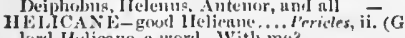

wrong nut yourvelf then, nuble IIelicane -

live, noble Helieane! 'I ry honnur"

IIEIICANUS, thou liast moved us.

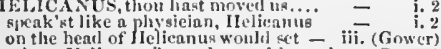

whom Helieanuslate advarnewl in - iv. i (Gower) where's the loris Ilelieng beh

ho. Helicanus! Calle my grai.ionis inöd?

Uilclicamus, strike me, houourcil sir
115LICANIS, down on thy knees

owil i Ielicumus, my Marina, tell him

llelieanus! Sir. Ny purpose was

twas Ilclieunus then, still entirmation

in Meliemus may yon well resery - v. 3 (Fower)

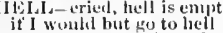

Herry Hires, ii.

1 am daumet in leelt, far swearitig.

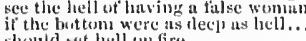

hould ret hell on fire

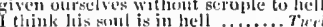

it all the tlevils in hell ine.

as ficll, sir t'vias

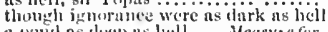

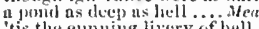

'tis the euming livery of hel.

(rep.)..........huch.Idw, ii

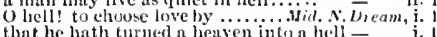

and nake a henven of hell, to dic a hel

and nite! 0 hell! I see you all.

more rlevils thnn vast hell can holil.

black is the badge of hell ....... Lorets L. l.ost

o hell! what liave we here:

let fortume go to hell for

for this fiend of lell ...................
so very a fonl to be married to hell?.

jove to her, lead apes in hel

in heuven, ir in licll?

carries pour souls to hel

pall thee in the dunnest sinoke of

this place is too cold for hel

not in the legims of horrid hell

swect milk of eoneord into hell

a hotter mume than ary

Fork sent houl to hefl................ king J

clamours of hell, he measures

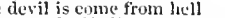

not yet so ugly a fiend of hell.

let hell want jains enougla to

injustice with the pains of heil .......... kich $\bar{u}$

terrible holl intke war upon...

thou art damned to liell for tiig

torment'st me ere I eone to hell

and fill another room in hell $7 . . .$.
that this deed is chronicled in

what hole in hell were hot

and you in hell, as often

if hell and treason liold....... Heny $I V$ ii.

voice in hell for exeellenee

with conseience wide as hell (rep.)..

horrid niglit, the ehild of hell
al] hell shall stir for this

huntreds he sent to bell

heavens, can you sutfier hell so to.
with witches, and the help of hell

a fiend of hicll. If not of thell

and hell too strong for me....

thou fint aceursed minister of liciii.

but a hell, an nge of diseord.

my pomp, shall be ruy hell.............

thy hire, and send thy soul to hell

the fonl terrors in dark-seated hell

Wedded he thon to the hags of hel

you'il surely sup in hell.

Owar, thoi son of hell

not one alive, I live in hell

to neeount this world but hell...

down to hell; and say, I sent ......

let hell make cronked my mind........

male the hinpy carth thy liell

Jie thee to heil for shame.

atlights thee with a liell of uigly

slave of unture, and the son of hell
sin, death, und hell, have set thei

believe but that $I$ was in hell.

with Richmond, from the reaeh of hell

yet lives, hel]'s black intelligeneer

to make the errth unv heil

as long as hell, and lichur

not heaven, then hand in has
if uot trom liell, the devil is

begins a new hell in himselt"

aq biuck as if hesmeared

with such a hell ol pain
slse stinys, as tellinusly ns heil

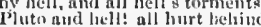

the thres i' the lowest hell tols

I would I might gat to hell an

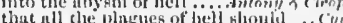

a henverly nugel, bell is liere

a henvernly angel, hell is here.
and all the ficuds of hell divide. thow

suy heart un cver-burnitur heli!

it you will have revenge from lici

minht liave your company iii heji...

cunit! not all hell nilliort youl such

which $w$ ass beth heaven and heif

the puned'st feme of hell woujd not

there's hell, there's durkncs
as I hate hell, all Nomtange

should be ruared in dismal hel
what hat ot thou to do irn leell.

purgattory, turture, licll it.se:1t?

thomgh luell it celf slould gape.

or blast from hell, le thy intents

and shall I eunple hell? ofies hrid

as if he had been loosed out of hill

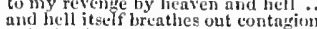

as hell, wheretu it aes

rebellious hell, if thou canst mutine

to hicll, allegiance! vows, to the blacke

to find out practiees of euning heil

hell and night must bring this

divinity of hell! when devils will their.

[Kut.] venreunce, from the hollow

truly knows, that thou art false as iieil

and keep the gute of hell; you

pardon him! and hell gnaw his buties

IELL-BLACK-liell-b]aek nipht endurel. Lerr, iii. 7

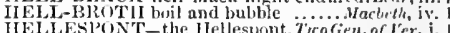

yet yom never swam the llellespont.
to wasl him in the IIellespont

to the Propontick and the Ilellespont .. Othello, jii.
IELL-FIRE-I think on hell-fire... Henryl\%.

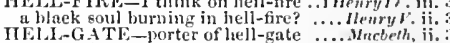

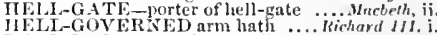

IIEIL-IIATED-witl the hell-hated lic .. Lear,

hath erent a hell-hound .......... Kiehurd III.iv.

A jair of eursed hell-hounds... Tilus Awdromicess. v. 2

only sin and hellish obstinaey tie ..... Hll's "Ieth, i. 3

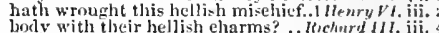

had they told this hellish tale. Tilus.tndronicus, ii

and therein, hellikh $\operatorname{dog} . .$.

seeks the hellish Pyrthus ............. Hamed, ii.

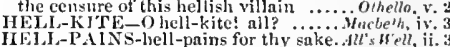

thoum I hate him as I do hell-pains.... Othello, i. I

IIELII-upon thy prosperous helm ...Ails $w_{\text {'vll }}$, iif. 3

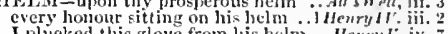

yourself this glove from his helm .. Henry iv. 7

govern England's helm [Col:-renlm]

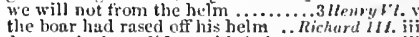

drcam, the boar did rase lis $h$

and vietory sit on thy lielm

helm more haeked than II our lie in

that stitlyy'd Mars his helt

mine, that he'll bear on his helim.

of Troy there, in his helm
you slander the helms o. the state.....

unbuekling lielms, fisting each .....Coriolanus, i.

would have donned his helm ..........
at the helm $\bar{\delta}$ Clco. ii.

with plumed helm thy shyer............ tenr, iv.

make a skillet of my helm

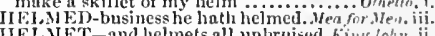

ELAIET-and lielmets all unbruised. Kims Jehn, ii.

the glittering helnet of my to

from helmet to the spur, all

his bruised lielmet, and his benied $-\bar{v}$ - teloris

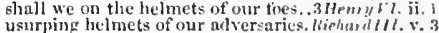

what hineks are on his helmet!.. Tratilus of cress i.

put of my helnet ......... Antony \& Clenpinto, iv. 13

I will help lije arue more potent

I will help his ague

and help to conteract.

you have not fourbt her big

with the frelp of your good lumb.

I will helg the to prefer .. Two (ien. ofieron

and stully help tor that.

and that I enumet licly?

to help him of his blimbess
if you witl lotp we to betr it...

hejp me away: let me...

help to search iny liowse

help me to n eandle.

gond foul, help me to

for the love of coll, your lielp.

will you help an ass-heait...

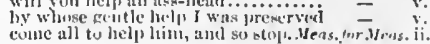


HELP - help heaven! men their. Neus. for Meas ii. 4 will help you to-morrow in your. what! resists he? help him, Iucio ... . . to help my cousin to a good liusband

and $I$, with your two helps ............

0 God hel 1 me! Goxl help me

help to dress me, good coz.......

God help us! it is a. world to see!

二

dead I thisk; help uncle..

help us to sigh and groni ...........

help me, I ysancler, help me?...Mial. N.'s Drcam, ii. 3

pray, masters! fly, masters, help!

but to help eavilero Cobwel to scratch - iii. 2

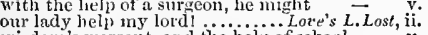

wisdom's warrant, and the heli of school

help, hold his brows! he'll swo

so God help me, la! my love to $1 .$.

I wonld have him help to waste...

upon eommand whint help we

I will help you, if I can .........
by the helpof roor epilogies.
they cammot help him (r'p.).

a senseless help, when help past sense

thou thousht'st to help me ..........

when the hiclp of heaven we
but, if I help, what do you

give me sonve help liere, ho

let me buy y'our friencily help thius fiu

we eannot liclp it; but, since

this man may help me to his ......

lielp, nasters, hely! my master $\because$ Taming of $S h$
I ean. Petruehio, halp thee to a wife

pronised me to lielp me to another

help to dress your sister's chamber up

help, sou! help signior Baptista!

Camillo was his help in this ....Winter's Tale

what's past help, should be past grief
how he cried to me for help, and said

and you shall help to put him i' the

no lope to help yon; but, as you shai

to seck thy help by leneficial help. Comedy of Err. i. ${ }^{3}$

so, come, help; well struck

God help, poor souls, how idiy

let's call more help, to have

ant borne hence for help ..........

never silw the chain, so help me.

with hidden help and vantage

by the help of these (with Him.

now, God help thee, poor

hand shall lielp to give him

and, by whose help, I mean to

when it first did help to wound....

so help you truth and heaven!

to help him to his grave inmediately!

good unele, help to order several
weary of it. Help, help, helpl .....

weary of it. Help, help, help
prince IIal, help me to iny ho

God help the while! a bad .....

God shall we need his help these......

now Gorl help thee! To the Wels
that did help ne to the crown

if we, without his help, ean make
what with our help; wliat with......

I clo not need your help................

ii. 4

and helps to end me: see; sons ....... iven -4

rise, and help Hyperion to his horse

without more help, niglit fight this

Christ's mother halps me............ II

I will help to bury it ..............

witches, and the help of hel

so help me God, as dissemble (rep.)

so help you righteous Gedi....

and cunnot help the noble..

the help of one stands ne.......

now help, ye charming spelis.......
help me this onee, that France

condescend to help me now.....

wonfters, but by lielp of devils .....

at my slirine, and I will help thee :.

ay, God Almighty help $\mathrm{m}$

so help me God, as I have watched.

no more than truth, so help me Godi

there is great hope of hel

my lord? help, lords! the king ........

run, go, hel l, help! ( Henry
[Col.] and the help of hatchet

so let it help me now against

if the help of Norfolk, and myseif $\ldots 3$

how can thelp them, and not myself
Scotland hath will to help (rep.) .... with-thy help to this distressed ..3lle

so God help Nontague, as he

Bustrundy will yield him hel

desired help from Burgundy

to help king Edward in his time

for we want, before we need his help

did it to help thee to a better
she may help you to many fair.

to help thee eurse this poison

give me no help in lamentation......

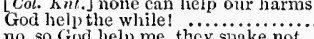

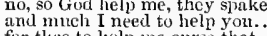

for tliee to lielp me curse that

do impart help nothing els

and help to arm ine; leave me, I say
that were the means to help him

my lord, I'll help you to a horse

it will help me nothing, to plead

now the Lord help, they vex me

but yet I eaunot help you. Why?

there is no help; the bitter

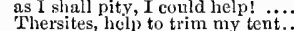

'tis not enough to help the feeble up

from whose help I derived liberty

that I shall have much help from you

what he cannot help in his nature .. Coriolunus, $\mathrm{i}$.

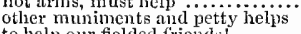

will haste to help Cominius

for your helps are maliy a little help will serve; for once.

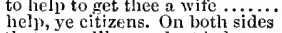

that seem like prudent helps

help, help, Marcius! help, you (rep.

I cannot help it now

in this so never-heeded help w......

take him up: help an

Caesar cried, help ne, Cassius

help, ho! they murder cæasar.

but say, I could not help it

nay, I'l help too; what's this for?

help me, my women! .................

help, help, Iris; help, friends below

and had no help of anger.

but that my resolution belps

help! or we poor ghosts will cry

help, Jupiter: or ve appeal...

help, help nine, and your mistres

help to set a head on headless Rome.

brothers, help to convey her henee

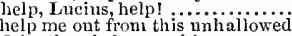

o brother, help me witl

that I may help thee out .............

hands to help thee knit the cord

the one wili help to eut the other

help, gran isire, help

help her: what would she find?

without the help of any hand at ali.

now help, or woe betide thee

be iny helps as I am son and servant

awake their lielps

the name of help grew odiou

to help them, when, well-a-day $(r . \ldots$.

that heat, to ask your help .............

she dies! help, gentlemen!

father! father! stop, stop! no help?

here's a spirit; help me, help me

eome, help to bear thy master.

give me some help heaven help him.

he, that helps him, take all my..........

where's Potpan, that he hel sind of not. Remeo \& Jutiet v.

his help to crave, and my dear hip.

help me into some house, Benvolio..

past hope, past cure, past help $\ldots . . . . .$. .

thou canst give no help ...

and strength slatl lielp afford

to help me sort such neelful

to Juliet, help to deek up her

do you need my help! No, madam

help! help! call help $\ldots \ldots \ldots \ldots \ldots . . . . . .$.

with speedy help doth lend redress
no friendly drop, to help me after?

to help to take her from her borrowed

never, so help you mercy

merey at your most need help you

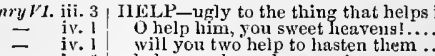

lielp, angels, make assay! ..............

help, help, ho! What, ho! help

is ready, and the wind at holp......... - iit. 4

vour counsel and your help .. Othello, i.

may help these lovers in to your fayour - 1.

a fellow, crying out for help...

sle'll help to put you in your place again

this may help to thicken other proots.

help! [ Col.-light] ho! murder! (rep.)

help! lielp! ho, help! O lady, speak ... - v.

HELPED-being helped.Two Gen.of V'er. iv. $\overline{2}$ (song)

not to be helped, -right .................. All's Well, ji. 3

by the ship's side, to have lielped her -
that helped thee to the erown...... Richard III. $\mathrm{v} .3$

even her folly helped her to an lieir ..... Othelto, ii.

and helper to a liusband ..............All's W'ell, iv.

you speedy helpers, that are ........... Iren'y vi. v. 3

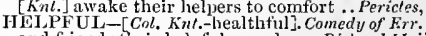

and friends their helpful swords.... Richard $I I$. iii.

practices, pleasant and helpful to him!. Iramlei, ii. 2

IELING -helping me to the speech...Much Ado

I an helping you to mar that ....As you Like il, $\mathrm{i}$.

till by helping Baptista's eldest. Taming of Shew, i.
looked for at your helping hands .. Richard II. iv.

too little helping him to all....... Richard 11 . iv.

too little, helping him to all..........
HELPLESS -

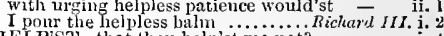

HELP'ST-that thou help' 3 me not? - i. 4

HEMLER-SKELTER have I rode ..2Henry IV. v.

hern them away. I would (rep.) .. As you like it, i. 3

upon the very hem of the sea .. Timon of Athens, v. 5

and cry hem, if anybody come ......... othello, iv.

durnel, hemlock, and rank fumitory...Henry $r$. $\mathrm{v}$

with harlocks, hemlock; nettles ......... Lerr, iv.
HEM] IED-hemmed about witl grim.i Henry

Gill

Greeks have hemmed thee in. Troiluse Cressida, iv.
HEMP - let not hemp his wind-pipe . Henry $V$. iii. 6

upon the hempen tackle....... Menry $V$. iii. (cliorus)

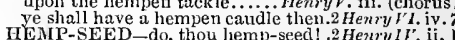

HEN-cock-pigeon over his hen .. As you Like il, iv.

Lork hate will be my hen ...... Taming of Shrew, ii. I
I have no pheasant, cock nor hen. Winter's'Tale, iv. 3

Thave no pheasant, cock nor hen. Winter's Tale, iv. 3
how now, dame Partlet the hen? ... Henry IV.iil. 3

not swarger with a Barbary hen....2 Henry $I V$. ii. 4

(poor lien!) font of no second brood... Coriolanus, v. 3

HENCEFORTII earry your letter's. TwoGen, of $t$. i.

meaning henceforth to trotble jou.... $\overline{\text { in }}$ ii.

henceforth, do what thon wilt .... Aferry Hives, iv. dispose for liencefortl of poor Claudio. Much ddo, $\mathbf{v}$. henceforth be never numbered., Hil. N.'s Dream, iii. from henceforth, I will, coz ....... As youlike il, $\mathrm{i}$. that her gifts may liencetortl be .... i. lenceforth I vow it sholl be Taming of show, lienceforth I vow it shall be ...Taining of shrew, iv. 5 and kinsmen, henceforth be earls .....Nacbeth, v. 7 from henceforth bear his name $\ldots . .$. King John, i.

but, sirral, henceforth let me not henr -
must not have you henceforth question ungracious boy? heneeforth ne'er look - ii. flow heuceforth in formal majesty . 2 Henry $I V . \nabla .2$ and herefor henceforth, I charge you, as you love - iv. heneeforth, he shall trouble us ...22 Henry $V I$. iii. I and be heneeforth a burying-place to all - iv. 10 henceforth, I will not have to do with $-\overline{-}$ VI. never hencefortl shall I joy again..3 Henry VI. ii. and henceforth $I$ am thy true servitor - iii. will heneeforth be no more unconstant $-\overline{\text { v. }}$. henceforth be no feast...... Timon of Alhens, iii. henceforth hated be of Timon ...... - iii. yes, Cassius; and heneeforth ......Julius Cresar, iv. 3 henceforth, the white hand of........ $\frac{-1}{\text { ini. il }}$ and reas, be heneeforth treacherous! Cymbeline, iy. heneeforth I'll bear affliction ............. Lear, iv. 6 henceforth I never will be Romeo, Romeo $\delta-J u l$.ii.
my bosom heneeforth shall be twain HENCE FORW ARD, upon pain.1 Hen. VI. i. 3 (proci.) henceforward, it shall be treason .2Henry VI. iv. 6 and henceforward all things shall be - iv

henceforward do your messages. Romeo \& Juliat it.

hencelorwari I am ever ruled by you - iv.

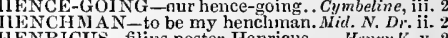
IENRICUS_filius noster Henricus.... Henry $V_{\text {. v. }}{ }^{2}$
HENRY-Henry Pimpermell. T'aming of Sh. 2 (ivdue.) prince Henry in their company ...... King Jolun, v. hither Henry Hereford thy bold son. Richurd 11 . i. I his young gon Henry Percy.........
and long live Henry, of that name .. 


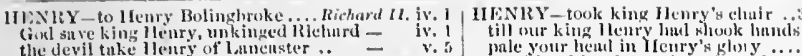
the devil take llemry of lancenster ... - three thes luth line ry perey .. $-v$.

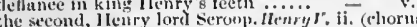
by the uane of te enbussalurs from l lenry king

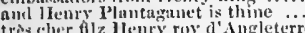
triss cher filz llengy ron d'Angleterre $\because$ (elooms)

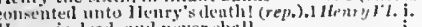
Jenry is dean, alu herer shing avat mot, haf

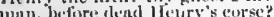
if Ilenry were recallecl to life aguin. berlew king I Ienry's he" or

your ouths to llenry sworn. Gi........ king = Heury"s deuth, the English eirele ent whon llenry, our late soverei

fior the right of English Ifenry

sinee le'try shmonth

Ienry the fourth, grandfither

when llury the tilth, sueceeding

and virtuous fichry, wity the eit

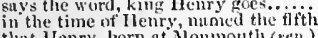

that IJenry, born at Mlommoutis (rep.)

as sure ne Eughish IJenry lives $\because$ young llenry, with his nobles,

were no place for Henry's warriors

God salve king llenry of the
princely llunry, and the rest

princely llenry, and the rest

king llenry s peers, and chief.

man if memory, IJenry the fifth.

grent unrenchal to llumry the sixth..

let lienry fret, and all the world repine

Ilenry is youthitul, and will q
to muke thee flenry's queen,

I um un wortlyy, to be llenry"s wile.

shill he Ilenry"s, if he please .......

in Henry's royal name, as denuty
king l len ry, were he here .........

solieit Henry witlt her wondro

in restril king Heliry gives consent.

honour Henry as her lord (rep.)

Itenry is able to enrich lis queen.

with Henry, heing a king.............
king Henry's fuithful and anointei

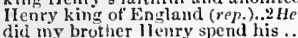

did ny brother llenry spend his ....

shmll Ilenry's ennquest, Bedford

and nur king Ileury gives a

and IJenry was well pleased, to eliange -

till II enry, sur

king Ulury's dialem, encliased

iny kily and neghew, virtuous lienry

where Ilenry, and dame Margaret

yet lives, that llenry shall depose (rop.) -

demanding of kimg llenry's life and

hy the nane of Ifury the fourth...

lilury doth elaim the erown

lenry will to-himself protector be.

God and king Ifenry govern F

here, noble Henry, is thy stintt

why, now is lfenry king, and hare.

why tits to be, in lTenry's hand.

ah, thus king Henry throws lis eriuteh

fisr, groud king Ilenry, thy deen

and Henry put apart, the next for me

(1) IIcney, (spe thine cyes! ............

nyy soveremgn! gracious Henry, eointort

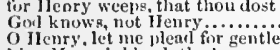

king Ifenry"s blood, the honourabie

for his futlier's suke, llenry the flith

his father, Jenry the fitt

is Cutle the son of Henry the fifth....

IJenry hath money vou are stron

and I lury, thom he he infortunate

a messenger from Itenry, our alread.

my coveruign virturnus llenry

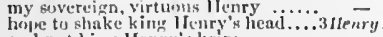

and not king l lenry"s heirs.

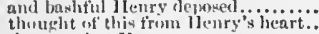

the war that llemry ineuns to use...

in following this usurbing Il, lury

I am the om of llenry the fifth......

aud give king llenry teave to sis.nk
Ifenry, and thou whalt he kint. Ienr

Ifenry and thou whalt he kink. Ilenr
resignet the erown to llenry the fourt

that llenry shall lee 80 deprized

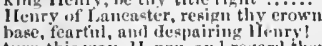

turn this way, llenry and regarel the

from thy table. Ilenry, and tliy letel

not till king llenry be deal.

Ifenry' had mone, hut did msurp...
linkewarm blood if llenry's heart.

likewarm blood of llenry's lieart

yos forwturs, Ilenry's liope is done...

t..l means this, liernit?............ pale your hem in Inemry
tomeling king llenry's onth

from fiulit Ilenry's licas

what suy'st thom, Jenry; wilt thou

ony, llenry, shat I have my risht

impuiring lienry, strengthening

und, llenry, hatlst thou swayed.

reveing aid for ileviry

and suys, her lleny is a jeponed

sus wotila yen be agein to Irenry

is Clurence, llenry, nut his son.

that llenry, sule josseseor of my love

Nenry liveth still: hint were he (rmp.

John of Giunt, Ifenry the tourth
thut wise prince, IIenry the fifth

ii. 1 thom thesc our Henry lineally des

low llenry the sixth hath lost all

the more, that lenry was uotortum

coming, Iewis was IIenry"s fretr.

llenry now lives in seotland

renounce him, and return to Henry

becomest king Ilenry's friend

how shall poor IJenry live, unles
not that I pity Henry's misery.....

not that I pity Henry's misery
belike, he thinks me Ilenry

but what said Henry's queed?

bijl Ifenry now shall wetr the

to frec kiog IJenry fyom im

once more on llenry's head..........
to If nenr's body, and supply his plite

my liege it is young Alcnry, carl of

is Itenry's late presaging propheeg.
waned state firr Henry's regal erow.

ullewiance unto Henry (rep)
ne are king Jlenry"s filend

ne are king lenry stiend......

that Ilenry is no soldlier ............

seize on the slume-faced I Ienry

and Henry is my king, warwick

you lift poor Henry at the ............

'tis true, that Ilenry told me of.....

king Ilenry, and the prince his
triumph: Henry, in thy day of

whiles I lament king Ifenry's corse. kichrord 111.

see, seel dead IJenry's wounds open
these Plantarenets. Ilenry, and Erlward

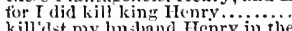

kill'dst my hu band Henry in the
that Henry's death, my lovely ....

that Henry's leath, my lovely ......
when IIenry the sixth was crowned

as I followed IIenry's corse ..........
I do remember me, Ilenry the sixth

loly king lienry, and thy tinir son

king llenry's issue. Richmond, enmforts -

my noble father, Ilenry of Buckinghum

Henry the seventh sneeeding

say, Ilenry king of England, eom

ENT-live hent the gates. Measure for Measure, iv.

and know thon a more liorrid hent. ilume (smy)

ii. 3 HERALD-my herula thoughts. " "woGen.

silence is the perfuctest

their herald is a pretty knivi

too bolel a herald of my tongue ........ A

a herald, Kate? O put me in.. Taming of sherem,

to herald thee into his sight ...

heralds, from off our towers we miglit. King Jolu

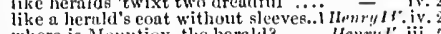

where is Momitioy, the he rale?

herald, save then thy labour

never shalt hear herald any nore...

take a trumpet, heralu

iere comes the herate of the

onr leeralds go with lim; lring ine

heralis, watit ons.us; insteal of gold.

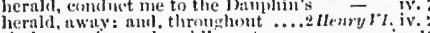
shult wear it as a heralil's eoat ...... - iv. in bight-walking heralds that trudye.. $R$ i

by their herulids challenyed

may one, that is a herali

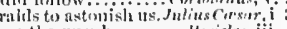

to herald the from the woml

but the hernlal ery and l'll ajpear a

come hither, herulil; let the trumpet

love's heralis slusuld he tho

a gtation like the heralel Mereury ....... Ilameles,

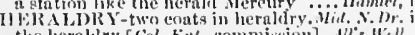
the lieralelry [Col. Knt.-eommission]. . Alt' Hell, ii.

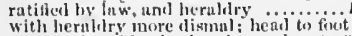

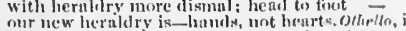

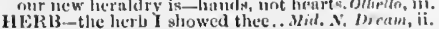

HERH-feteh me this herb ......Wid. N.'s Dream, ii. ? as $I$ con take it with another herb.

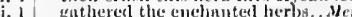

light on sach another herb

2 und her whulesome herbs swarning. Riehurd 11 .

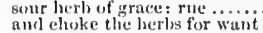

amall herbs have graec
the lierbs, that have on the

itlenery $V I$, tij.

the lierhs, thut have on the in ........ ('ymbetine

that lies in iterbs, plants, stones. Kume's of Julel, ii.

in man as well as herbs, grace ...... -

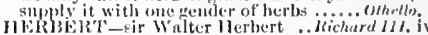

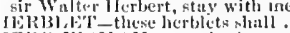

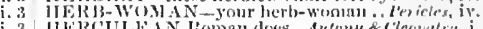

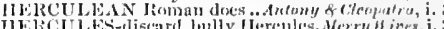

she wemla hove made II erenles have. Much fdo, ii.

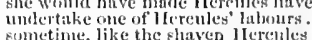

bemetime, like the shaven lerent

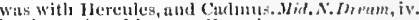

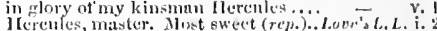

is too hurt for Iferenles' eluls........

in not love a llereules, still climinis

Ponuey the great; the page, Herenles

well done, Hereules! now thou ......

Amato's page, I Iereules; the pelant

Hercules, and lichas, play at diec...Mer. of $V_{c}$

go, llerenles! Live thou, I live .......
the betrds of Hereules, and frowning

II recules by thy spect, young man!. Is yon bitie

ceave that labenur to great Hereules. Thaming of sho i.

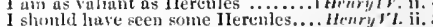

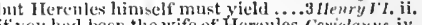
as IIerenles did slake down nudlow

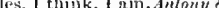
not liereules eonld liave knocked .. Cymbetine, iv. the brawns of ferentes ................ my lord; 1 Iercules and his lowl too.

let Hereules himself do what he may .... - v.

IER D-the roar of a whole herd of lions. Temprst, ti.

anon, a eareless herd, fuli of.

like any deer i' the lierd

thew the rest of the herd to me... Ininler's Thte, iv.

a lit tle herd of England's

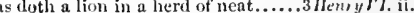

will seare the herd, and so my shoot - iii.

the hext hath more annoyance... Troilus $\delta$ Cress. i.

are these your heri? ................

when he pereeived the convoun herd. Irllius consm $\mathrm{i}$.

to out war the horned herd! Antony f Cleopatra, iii.il

11EIDSIEN - fuur threes of herdsmen - iv.

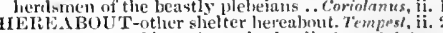

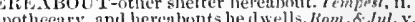

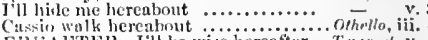

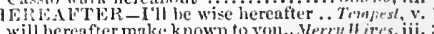

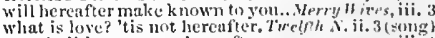

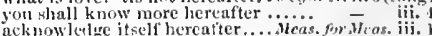
todeliver us lrom devieus hereafter ... iv more of this hereafter ................... sir, fare you well; leereafter....... As you Like it, $\mathrm{i}$. for me hereafter to leave my wife.... - $\overline{\text {. }}$. iii.

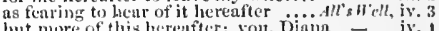

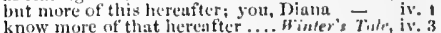

whon we name hereafter, the prince... Whetheth, $\mathrm{i}$. than lotll, by the all-hail hereuft

yorls hereater thy tomenter be!...Richaral II. ii. show it celf more openly hereafter ..2 llenry 11 i iv.

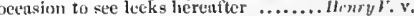

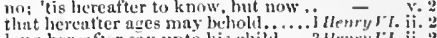

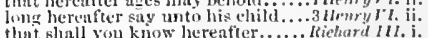
that shall you know hereafter. dhall ery wo for this hercafter ...... = whose memory herenfer mure... Timon of dethens, $v$. obey yoll in every thing lacreatter .. Coriohmus j.

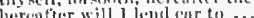

times I shall recenmt herenfer.

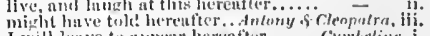

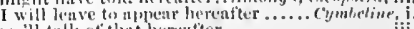
shalt hicernfter tine it is no aet ........

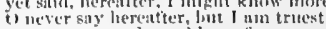

grace your mus depend herenfter ....... Fesisles, i as you shall use me luerenfer .. Romeo of Juliet, iti. 


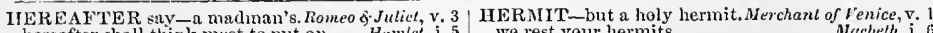
hercufter shall think meet to put au ..... Humlet, i. 5 thon shalt know more hereafter.... Tempest, ii.

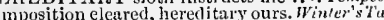
ingratitude in them hereditary. Timon of dithens, ii. senator shall bear contempt licreditary

compounded thee poor rosue hereditary of them were hereditary hangmen.. Corintamus, i1. to thee, and ther the, hereditary ever....... Lear, $\mathrm{i}$. cousin of Hereford, what dost thou our eousin Hereford and fell Mowbray recreant to my eousin Hereford. arainst the duke of Hereford against the duke of Hereford Inarry of Hereford, Laneaster
Hereford, as thy eause is right

rou, eousin fiereford is upon pain of.. bronght you high Hereford on his way? death, nor Hereford's banishunent Hereford? is not Gaunt dead? (rep.) wrongtully seize on Hereford's

Harry Ilereford, Reignold lord Cobiam I fenr, revolt on Hereford's side ..... to offer serviee to the duke of Herefor

my lord of Aereford, my message is..

Hereford here, whom you call king (rep.) the earl of Hereford was reputed ..2 Hen', $1 \mathrm{r}$. iv. and love, were set on llereford

the earldom of Hereford, and all...

and earl of Hereford, stafford ....... Henry $r$ rII. HEREFORDSHIRE to figh

HERESIES-or, as the heresies..

ure heresies, and, not reformed .... Henry VIII. v. my surfeit, and my heresy .....Nlid.N.Dream, ii. heresy in fair, fit for these day.

and strange without heresy ......... Merchant of venice, ii. 9 all turned to heresy? Away. $\ldots \ldots \ldots$. Cymbeline, iii.
HERETIC-was of late a lieretic ... Merry H'ines, iv. thou wast ever an obstinate heretie ... Nuch Ado, i. from his allegiance to a heretic .... King Joh a heretic, an areh one, Cranmer ..Henry VIII. iii. a most arch heretie, a pestilenee that $-\bar{v}$ v. transparent hereties, be burnt.... Romeo \&.Juliet, i. HERETOFORE-heretofore sounded you.. Lea HEREUX-je m' estime liereux

gorgeous palace, for a heritage ..... Richard mine heritage, which my dead father.. Pericles, $\mathrm{Hi}$.

HERMES-than the pipe of Hermes..Henry ${ }^{\prime}$. what say you, Hermia? be advised

therefore, fair Hermia, question your
relent, sweet Hermia; and, Lysander

let me have Hernia's; do you marry

for you fair Heateor

therefore hear me, Hermia ...........

there, gentie Hermia, may I marry.

I will, my Hern 1

doting on Hermia's eyes, so $\mathrm{I}$.........

ere Dernia.s eyne

I will go tell him of fair Hermia's flight -

where is Lysander, and fair Hermia?

because I eannot meet with Hermi

for Jying so, Hermia, I do not lie

if Herma meant to say, Lysander lied -

happy is Hermia, wheresoe'er she lies

your Ifermia? lord, what though? (rep.)

content with Hermia? no.......

she sees not Hermia: Hermia, sleep thou -

en away from siceping Hermia? -

these vows are Hermia's ..........

for you lnve Hermia; this you know

in Hermia's love I yield you up my

injurious Hermial nost ungratefui."

we, Hermia, like two artifieial gods.

not I Hermia? are not you lysan

that Hermia shonld give answe

my love to Hermia, melted

betrothed ere I saw Hermia............
HERNIIONE-well said, Hermione.

Hermione, my dearest; thou never

so foreing faults upon IIermion

Hermione. queen to the worthy - - iii. 2 (inilict.

Hermione is chaste, Polixenes

Hermione hath snffered death

the memory of Hermione, I know

O Hermione, as every present time doth -

near to Hermione hatl done Hermione

ever sinee the death of Hermione.

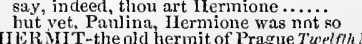

we rest your hermits, ........

and like a lermit overpassed thy

Hemplts.

政

HERIITAGE-aud naket hermitare

HER NE-thet Herme the humter ......

this tale of Herne the hunter

disguised like Herne, with hnge......

in a pit hard by Herne's oak

round about the oak of llerne the hunter

will none but Herne the liunter......

if Hero would be my wife tow

with Hero, Leonato's short daughter
no ehild but Itro, she's his only heir
prompting me how fair young Hero is

if thon dost lnve fair Hero ............

and tell fair Ifero I am Claudio
marry on Hero, the dantiter and

marry on Hero, the dangliter and heir
the prinee should woo Hero for aimself

t'or hear me, Hero; wooing, wedding
sure, my brother is annorous on Huro

he is enamoured on HEero

for the prinee liath got your Hero.....

and fail Hero is won; i have broke.

the waiting-gentle woman to Hero Hero

to undo Hcro, and kill Leonato......

hear me cull Margaret, Her

that fero shall be ausent ..............

such sceming truth in Hero's disloyalty

Hero thinks surely, she winl die $\ldots$...

'tis even so: Hero and Margaret have

Hero? Even she. Leonato's Hero (rep.)

the lady Hero's gentlewoman ....... Ḧ.

good-morrow, sweet Yere.

is this fuce Hero's? are our eyes our own?

is it not Hero? who ean blot that .....
can Hero; Hero itself can blot out Hero's

O Hero! what a Hero hadst thou bee

how now, enusin Hero! .............

sweet Hero! she is wronged

the count Clatudio hath wronged Hero?

to disgraee Hern before the whole

Hero was in this manner accused

incensed me to slander the Jady Hero

court Margaret in Hero's garments

sweet Hero! now thy image do
to-night I'll mourn witis Hero

to-night I'll mourn with Hero $3 . . .$.

Hero? Nothing certainer: one Hero

I'll tell you largely of fair Hero's death

thougl Hero harl turned unn ..... As you Like

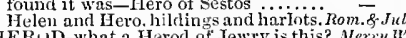

HERUD-what a Herod ot Jewry is this?. Merry $W$
IIernd's bloody-hunting slanghtermen. Henry $V$.

to whom Herod of Jewry may...... Antony \& Cle

good majesty, Herod of Jew

king of Pont; Herod of Jewry

it out-herods Herod: pray you, avoid it. Hamle, iif.

being but fourth of that heroie line ... Ilenry

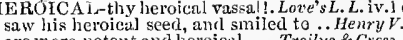

HERR ING - de herring is no dead...̈Lerry Wiv

as pilchards are to herrings

of stealing a culde of lierring

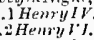

or a herring without a roe ... Troilus \& Cressida

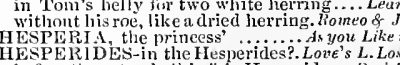

before thee stands this fitir Hesperides. . P

HEST-refusing her grand 'hests

spongy $A$ pril at thy 'hest betrims...

[Col.] some great sudden 'hest ...

HenryIV. ii.

hew them to pieces, hack thei

hew down and fell the hardest.

or hew my way out with a bloody axe

than hew to't with thy sw'ord.. Timnn of athens,

ance mure to hew thy target from.

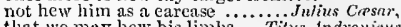

that we may hew his limbs .. Tilus Andronicus,

JEWED-have Jolped, and hewed... $=$

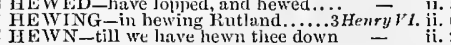

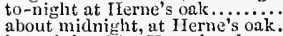

onr monarehs, and outstretched heroes. Hamlel, ii.
HEX-DAY-hey-day, a riddlel... Richarn III. iv. 4 hey-day! what a sweep of vanity.. Timon of $A: h, i_{2}$ HIBOCRATES-in Hiboerates......... Herry lyivet, iij. HIC-nominativo, hic, hæe, hoe ....... - iv. that drum or another, or hie jaeet... Alt's H'el, iii.

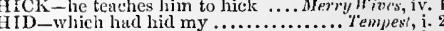

I lid me under the dead

where ny wine is hid....

wherefore are these things hid?.... Tivelfth Nisht, i. 3 lie hid more thousand deaths ... Miers. for $\bar{M}$ eas. iii. $t$ appear, where it seems hid .......... Much -ido, ii. 3 when he was hid in the gardeu ........ - - Lost, mistiesses from tommon sense are hid - i. all hid, all hid, an old infunt play

that hid the worse, and showed....... of $\overline{\text { Venice, }} \mathrm{i}$. murder eannot be hid long.

the day is when the sun is hid ...... be hid in sap-eon suming winter's. Comedy of Err.v. be hid in sap-eonsuming winter's. Comedy of Err. v. .
our fate, hid within an auger-hole.... Nacbeth, ii. 3 we have our naked frail ties lid.......... - ii. 3 firom hence, hath hid his head ....... - iij. 3 there's nothing hid from me ......... Henry $r i$ i. have I hid me in these woods . ...2 Henry $l^{\prime} l$. iv 10 irm of Naples, hid with English ..3Henry $/ 1$. ii. in my greatness covet to be hid ... Richard III. jii. in your heart were hid against me. Henry VIII. in.
bears it not about him, 'tis hid .. Timon of dth. iv. bears it not about him, 'tis hid ... Timon of Ath. iv. and hid the gold within the letter. Titus Andron. v. let their ears hear their fanlts hidt .... Pericies, $\mathrm{i}$. is given where you are hid $\ldots \ldots \ldots \ldots \ldots$ tear, ii. o lady, lady, sliame wonld have it hidi... be hath hid himself among .....Romeo o Jutiet, heart, hid with a flowering face! .... - if I will find where truth is bid (rep.)..... Hamlet, ii. poisoms sight; let $j \mathrm{t}$ be hid............... Othello,
HIDDEN - of my hidden power ... Meas. for Hets what hidden woman's fear...........As you Like with hidden help and yantage

it is no hidden virtue in him ........Henry ${ }^{\prime}$. will turn your hidden worthiuess...Julius Casar, his sult and most hidden loose affection. Othello,

of the salt hides the salt .. T'woGen. of Verona, for the greater hides the less ......

ti) hide what I have said to thee .....

in the house you eannot hide him

is it a world to hide virtues in? .. Twelfth Ni

nor reason, can my passion licle

thought it meet to hide our lovè. ileas. for $\overline{M e a}$

what may man withiu him hide
and hide the false, seems true

I camnot hide what $I$ an

ean virtue hide itself? ........

to listen

an' I may hide my face, let me.....Mid.N.'s $D_{r}$. i. and hide me in the brakes, and leave

where dost thou hide thy head? iij.

hour heads like cowards.

safest way to hide us .............As you Like it,

ere they ean hide their levity $\ldots . . . . .$. A Al's $W e l$

his court, hides not his visage ...Winter's Tal,

or the profound seas hide in ........
when he hides his beams .... Comedy of Erors

seek to hide themselves in drops of ..... Nacbeth,

stars, hide your fires!............... -

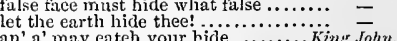

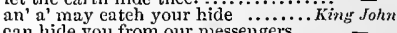

can hide you from our messengers

thon wear a lion's hide! $\ldots . . . . . .$.

wive off hole to hide this deed..... ivichard

sacred king should hide his head! .. - iii.

to hidle thee from this open

go, hicle thee behind the arras.

...iнerryIr. ji.

and therefore I'll hide me ..........

by the ground the y hide, I judge. $.2 \mathrm{Henry} W$ iv.

ather choose to hide them in.

with ordure hide those roots

- ii. (cliorus)

make ineision in their hides.

droplying the hirles and hips.

al. Gloster, hide thee from their ....

$2 \mathrm{Hen}: 4 \mathrm{VI}$, ii.

hide not thy poison with such....... - iii.

hitle her hide him quiekly from (rep.)

and if flom dost not hide thee from

.

withered hermit, fivescorc wimters 


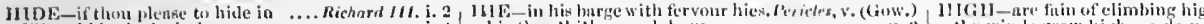
i. hice the thither, ard dir upun .......... - v.

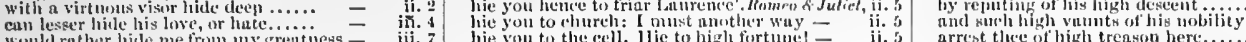
wonlil rather hide me from ung greitiess - iii. 7 hie you to the ecli. llie to higlt fortunel -

then would r hite iny hones $\ldots$........ stream, thut must fin eser hille me. Itenry / III, iii. 2 t'll hide usy silver beatrd...... Troilus f Cresvida, i. 3 will hide okr joys no lomger. sill hunt thee for the hisle bouk of revenge shntl hicle suin, hide thy bents Tino.....

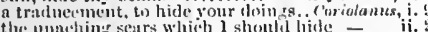

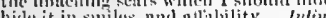
hitce it ins simles, num allability who did hith their tives cren from if Ciesur hide fiimselt, sluall they mot this suber form of yiurs hides w rongs and hide tley sulus in him lie you, make haste, for it grow's very it is, it is, hie hance, be gonc, away E iii. lies dend, mol your fate hies njate.

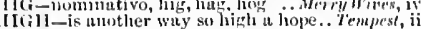
my high chinrms wirk, and these.
thoush with their ligh wromgs.

a most high miracle:

I enmot rench so high.........?

whose hing imperions thomght

avil mine's as hivit

and high und low beguije.

both ligh and low, both r

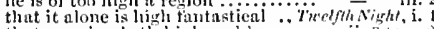

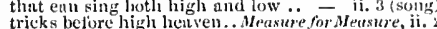

if Casiar wan hitle the sum from 11.

Plt hitce my naster from the flie.

tricks beliore high hemven...Mrasure for hetrsize, iv.

ton low for a ligh praise

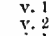

in so hish a style, Nargaret..........

and yet a place of high respect with

cotugenled white, high Tuurus' snow

are you grown so high in his estcem

humble-visared suitors, his high will

hath not such need to hide itscll

the beast no hide, the sheep no wor.

robes, und furred gow'ts, hile nil.........

but us in mind they hide the ti

higt gravel-blind ............ Merchant of Fenice,

to stand high in your aeeount.........
to wag their high tops, and to make

have desersed ligh commendation, As you like it i.

jukt as hich as my heart .............

higit wedlock then he honoured (rep.) $-\bar{y} \cdot 4$ (song)

which nount my love so high?

beture high heaven and you (rep.) $\ldots . .$. .

if thon proced is high as word...

imperial Love, that jod most high
the bound and hight curvet of Alars

though my revenges were high bent

that set him in high fine.

whose high respect, and rich valiality.....

high esteem, should be iufused. Tam, nf sh. 2 (ind in

and arraigned of high tresson.

thoughts high for one so tender.

your high sell', the gracious mark....

derires aecess to your hish and low's alike.

therefore 'tis high time .................. Comedy of Frrors, iii.
nothing takes from his high respeet... Whecbeth, iii.

wool to high Dunsinane hil

to treat of figh affairs touehing.........

- iv.

how high thy glory to

and that high royaity was ne.er $\ldots$

appeal eaeh other of high treason.....
setting aside his high blood's royalty

how high a piteh his resolution soars?

bleedintr, in his high disgrace...
hirh Hereford on his way? (rep.)

and make high majesty look.

are ve not high? high be our thonglits?

are ve not high? high be our th

thus lijgh at least, althong

whilst you mount up on high..........

thy seat is up on lingh ...............

ever been, high sparks of lon

by and by, in as high a flow .......
my love and your high majesty

as high $i$ 'the air as this....
he thut rides at high speed

he thut rides at high speed lie holds your temper in a high.

he holds your temper in a high realeet
whose high deeds, whose hot incursions

Perey stands on high: and either they

a preathent of your high desecut
the graejous dluke, in high despite.

with promise of hi gh pay ..............

alsd ehilitren of so ligh u eouruget

: lanll luve a high rewirl

thome homums on your ligh desert.

but I wns horn so high $\ldots \ldots . . . .$.

ummeritalsle, slnums your high rece...

matel not the lifyle perfection

one heaved a high, to be hurled...

eall home to hiah promotions

say, she shall be a ligh and mighty..

thint hith All-peer whieh I dallicel with

for high feats done to the erown
what his high hatred would effcet.

I arrest thee of high treason .......

to your hiph person his will is most.
have tound him guilty of high treason

was lord high eonst

and high note's ta'en of your many.

empluyed you where high protits....

'tis the same; high steward.

there, my lorrl: the high promotion.

their hish bloos ehafed ...Troilus $\dddot{\&}$ Cressida, (proi.

should liold up ligh in brass.

is the high and mighty Agamemnon

beanty, wit, high birth, vigour of bone

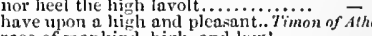

raee of mankiad, high, and
the other, at high wish

till the hight fever sceth your

as high as I eould piek my lane.

dhe honour .... Coriokan

to be set high in place $\ldots \ldots \ldots \ldots \ldots \ldots$.

he sits high in all the people's hearts

most hi gh most mighty, and most

aplear as huge as high olympus?...

higli in name and power.... Antony \& Cleop

moble, courareous, high, namatehable

it is just so high as it is

nequire too high a fame............
he his high anthority abused

ard the high gods, to do you justice

and let me rail so figh

after the high Roman fashio

nuy eomintry g high pyramids

see higl order in this great solemnity

gates of monarels are arehed so high. Cynted
distinction of plaee 'tween ligh and low

fur this high good turn so far?. Titus d nu

high emperor, ypon my fe

whose high expleits, and honourable

his till my honour must keep high

and hiph licaven forbid. that king

towers hore heads so high

never aimed so him to bove your.

horse, and s:il, and high expence - iii. (Gower

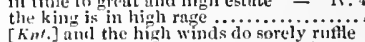

their great stars throned and set ligh?.

Tinn, nway: mark the high noise

and henting heal.

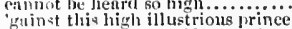

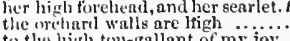

to the high toll-gallant of my joy

lic to high furt une honest nurst.

\$n high abowe our heads.

as him ase hench itselr?

iil the inost high and palmy state.

the dew of yon high eastern hill

(1) i.

surte, with high and monstrous main ... Uhicello, ii.

temiests thenselves, high seas

he was a wight of high renown.... - ii. 3 (sung)

of so higl and plenteous wit and invention = iv.

the noise was hiph: lat no more niving -

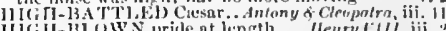

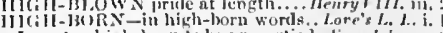

I in too high. horn to be propertied.. king John, $\mathrm{V}$.

IApiclun is hiph-coloured .. Antony s. Clenpatra, ii.

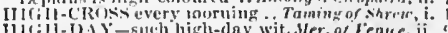


IIIGH-ENGENDERED batties

HIGIIER-higher and highler. Mfrry in ives, v. 5 (song)

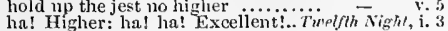
no higlier than thyself ............. let higher Italy (those hated

will he travel higher, or return ...

ne'er been higher reared

the higher powers forbid! ............

higher to the plan ; where well sct...

steps me a little higher thank........

Mentyllit: it: 3

lead on to higher fields...................

whicls tlies the higher piteh

no higher than a bird can soar......

ilenryri. ii.

advance tlyy halberd higher ...........

Richard III.

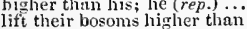

holds lis honour higher than
up higher toward the north

get higher on that hill .......

higher than both in blood
but let 115 rear the higlier.

bnit let 115 rear the higher..............
whose fortunes shall rise liggier

the higher Nilus swells, $t$

then we'll hicher to the now........

one mountain to cast up a ligher.....

being topped, they higher rise .......

HIGHIEST-lighest queen of siate

misprision in the highest degree!. T

is the greatest lndy, the highesi? $L$
the highest compulsion of base fear.

but take tlie Highest to witness....

Eubstance valued at the highest.
let's to the highest of the tield .....

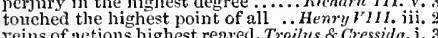

and flourish with the highest

thin those she placeth highest! ....

in the lighest degree he lat ath abused

cimb the highest promontory. Tilus A ndronicus, it. 2
on the summit of the highest mount .. Hamlel, iii.

HIGII EST-PEERING hills .. Tites Andronicus, ii.

IIIGII-JUDGING - to high-judging J

IIG
her wit values itself so highty
I will show moself highly

eredit infinite, highlyy beloved.Comedy of Error

what thon wong thichly

we love him highly, and shall continue $\bar{n}$ as sweet as ditties highly penned i Henry

thyself shalt highly be employed... Richard II

errer be too highly heaped.

Thidd me highly honoured....

it highly us enncerns, by day and night

lighly may arlvantage thee to hear...
learl others praise, and that highly.

HIGH-MI

HIGHMO T the highmost hill Pomeo \& y ich

IIG IIN ESS-well believe your highness. Tempesi, iit.

pluck his highness' frown upon you

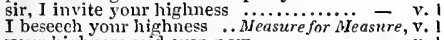

your highuess said even now ...........Much $A d d_{0}, \mathrm{v}$ i.

your highness will sec first.... Mid. . N.'s Dream,

did I offend your lighness ...........As you L Like il i , i. 3

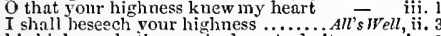

his highness hath promised me to do it - All's $W$ ell iv. 3

hath reference to your hi glyness....

it did concern your highness

let your highness lay a mor

your highness wilin take again

please your highness to take ........

beseeh your highness, my women ...

about some gossips for your highness
besecech your highness, give us better

please your highness, posts, from thos
plom

it is lis highness' pseasure $\ldots \ldots \ldots . .$.
till the firy of his higluness settle

as shall hecome your lighnes.

by his linghness "fail of issue...

for visiting your highness....
your highuness simple truth

your highuness simple truth ...C

highness' part is to receive our duties.

andit at your higliness' pleasure

it was, so please your highness

may it please your highness sit?

may it please your highness sit? ....
please it tour highress to grace us
what is't that moves your highness?

rise; lis highnes is not well $\ldots . . . .$.
passionate at your highness' tent....

her highuess is in safety, fear you not

I leave your highness: grandam
but that your highness pleased ....

but it pleased your highness to
but

a stand at what your highness wiil

your highness slourld deliver up

aimed at your highness.

reverence of your highness cirbs in

lendings for your highness' soldicrs
IIGUNESS-to his highness' soldier's.
your hightuess to assign onr trial-day
in all duty frets your highess

in all dutty greets your highness

deserved at your híghness' hend mouth -

their advantage, aud your highness' joss

that your highness is so armed

in your highness' name demanded 1 I Hrury IF'.

your highness knows, comes to

at more leisure, may your lighliness $r$

are with his highness very ordinary

agninst yourr highluness' claim to Frane

so hatly your highlness: never king

will raise your liighness such $\ldots . . .$.

may your lighlness, and yet punisi.

sulnnit me to your lifighness' mercy

which 1 beseech your lighness to orgive -

nud, if your father's highness do not

thanks to your liginess. I hope ....

I beseech your highness, partion me

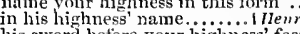

lis sword before your lighimess' feet

it grieves his liggliness; good my lords

informed his highmess so at large

and hath his highness in his in

'tis his highness' pleasure.

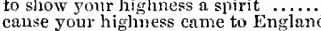

to present your higlmess witl the man

lis highness' pleasure is to talk with
other of your highness' privy couneil

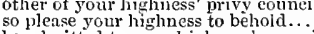

be admitted to your highness' eounci

well hath your highness seen int

his highness hath lost Franee
I do arrest you in his highness' name

exiled your highness' land

will your highness leave the partiament?

in him they fear your highness' death

but 1 hope, your highness shall have bis

we twain will go into his highness' tent =

your higlness would depart the field. 3

your highness shall do well, to grint

bind it plense your highness to reso

what I perceive your lighness aims at -

your highmess wrongs both them and
of truth, I kiss your highness' hand

have moved his highness to commit. Richard

I do beseech your higluness to
unless your highness hear me

what says your higlness to my just

tell me your lighness' pleasure .......

good comfort bring I to your highness

tis his highness' pleasure .......... Henry $V^{\prime}$

please your higlnness, note this danger

before your lighness sped to France

now, madam, may his highness live in

Rochford, one of her lighness' women =

once more, I present unto your bigh
to your higlmess' hand I tender my

his highness having lived so long...

a blushing handmaid, to his highness
which before his bighness shall speak

and his highness' favours, gone slightly 二

I require your highness that it shall
did broach this business to your highness -

so please your highness, the question

so please your highness, the queen

peace to your highness! your graces find

gairst his lighness' pleasure

ever may your highness yoke together -

for your lighness' good I ever laboured

a leasue between his highness and ...

long in his highness' favour, and do

highness to hear me -

do entreat your bighmess' pardon
how does his highness? IIadam

in all humility unto bis highness

desired your ligighness most heartily.

gladding of your highness with an
I wish your highness a quiet night

he attends your highnness' pleasure
to attend your highness' pleasure.

I lummlly thank your highness.

iii. . your highess saw this many a day

what's your highness' pleasure?... Anitony $\bar{\xi}$ Clco

I crave your highness' pardon

will not be denied your highness

please your highness, I will from

I humbly thank your highness.

pleaseth your highnness, ay: here they

your highness shall from this practise

and greets your highness dearly

beseech your highness, hold we
we did, so please your highness....

we did, so please your highness......

I lumbly thank your highness.....
II ICIIN ESS-than I to your highness. Cymbeline, v, 5 to heaven, and to his lighness...... Titus Antron. why doth your highness look so pale st your highuess' will an' if your hirhness knew my lieart

will't please your highness feed? .

so farewell to your hiqhness

in your dear highness' loye

more than hath your highness offered

when I think your highness is wronged

displayed so savicily arainst your hichno

I an giad to see your himliness highne

i. 2 yill't please your highress walk?

ive ..Macbcth, iv.

ii. 2 HIGH-REACHING Buckingham. Richard 11 . iv.

ii. 4 HIGII-REARED-high-reared bulwarks - vil

HIGH-R HSOLVED men....... Titus....Ardronicus, iv.

IGII-SIGIITED tyranny range ou.Jul. Ceesar,

HIGH-SOARING oer thy praises. Troil. \& Cress. iv
HIGH-STOMACHED are they both.. Rich

ii. 4 HIGH-SWOLLEN hearts .......... lichard 111. ii. 2 HGHT-by name lion hight WNid. N.'s Dream, v.

as I remember, hight Costard .....
this maid hight Philoten .......Ppicles, iv. (Gower) HIGH-TOP-her high-top iower. Merch. of fienice, $\mathrm{i}$. i. 2 HIGH-VICED-high-viced city. Timnt of Aihens, iv.
i. 2 HIGHWAY-highwry ol talk.. Alcrch. of Venice, iii. and should be buried in highways....

All's Irell, i.

and should be buried in highwnys..... All's sell,

but to the next highway, and there.. Richard $11 . j$.

I'll be buried in the king's highway for a highway to my bed ...... Bomeo \&. Juliet, iii. 2

for a highway to my bed ...... Romeo \& Juliet, iii.
HIGH-WIT'IED Tamora to gloze.Titus Andron. iv.

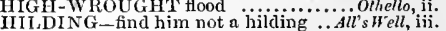

thou hilding of a devilish spirit.. Taming of Sh. ii.

he was some hilding fellow.........2 HenryIV $\mathrm{H}$ i.

a hilding for a livery ................ Cymbeline, ii

out on her, hilding! God in heaven..

your name to the reverberate hilis. Tirelfithpest,

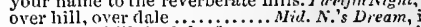

met we on hill, in dale, forest....ï.

or, mons, the hill .....................

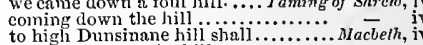

my watch upon the hill.

and at the other hill command..........King Jnhn, ii.

he is walked up to the top of the hiil. I Henryl $r$. ii.

money ot the king's coming down the hill -

this huge hill of flesh ...............

o' horseback up a hill perpendiculä

and, falling from a hill, he wras ......

against Clement Perkes of the hill..2 Herry IV

oll a hill stood smiling, to behold..
when down the hill he holds

to sit upon a lill, as I do now ...

I'll stay above the hill .............. climb steep hills, requires slow pace. Henry $V I I l .1$.
upon a high and pleasant hill ... Timon of and this hill, methinks, with one.... ten hills on the Tarpeian rock ..... Coriolanus, ili. this hill is far enough

get higher on that hill...
his bondman, on this hill

squadrons on yon side o' the hill. Aniony \& Cleo. $_{\text {iii. } 8}$ upon the hill of Basan ............ - iii. i upon the hills adjoining to the city...
up to yon hill, your legs are young $\overline{\text { iy }}$. 10 ovcrlooks the highest-peering hills. Tilus Andron. ii. casts copped hilis towards heaven .........'tericles, $\mathbf{i}$. for who dig hills because they $\ldots \ldots \ldots . . . .-$ i.

when a great wheel runs down a hill ....

Pillicock sat on pillicock's hill

to the top of that same hill?
back sladows over lowering hili...........

the dew of yon lis

round nave down the hill of heaven

new-lighted on a heaven-kissing hil

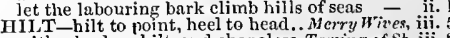
with a broken hilt, and chaneless. Taming of Sh. iii. weven, by these hilts, or I am........ I HenryIV. ii.
hiles a sword, from hilts unto the. Henry ${ }^{\prime}$. ii. (cho.) I'll run him up to the hilts

painted to the hili in blood

with the hilts of thy sword
here, take thou the hilts

3Heñy $\mathrm{FI}$.

very responsive to the hil

liusCasar, v.

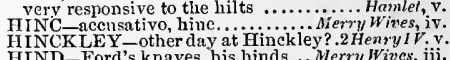

the mild hind makes speed.......Mid.N.Dives,

with the rational hind Costard ..... Love's L. Lost, i.

if a hart do lack a hind.......... üi. 2 (verses)

the hind, that would be mated by ....AAl $l^{2}$ Well, i.
out uuon thee, hind!. ........ Comedy of Errors, ii. 


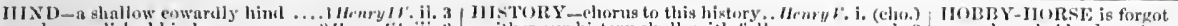

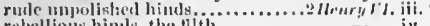

ragred multitule of hinds ani peasants - iv. hath seizerl the gentle linit..

parr] to the himl, ur step-dame... Troilue of ('ress. iii

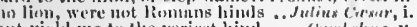
hat yield me for the veriest hind

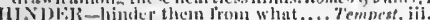

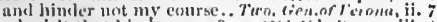

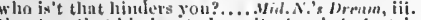

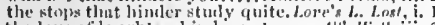
the fore of laughter, himler nol........All's rectl, iii. to hinder, were, in your love i...Nichard 11. ii. must hinder lite \& steray 3iltenryllitiv. 2 fhat ne dissension hinder goverment - iv.

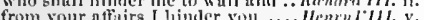
from your affirs I himler you .... Mrenry ThI. v. let me not hinder, Chssius .........Juliust'arser, i, 2 thou so sought'st to lignder. Antrny of Clesputra. Y.

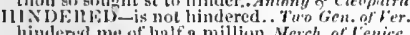

himlered me of half a million. . Merch. of fie

surry, sir, that thave himderci you

lijs sleeps were hindered by thy ruiling
his sports were hindered by thy brawls

his sports were himlered
if we he hindered, we sh

bint oft hise hindered.

IIINi)EING knot-grass made. Hiil. N. Dream, jii. rush by, and heave you hindmost. Trail, k 'ress. iii. 3

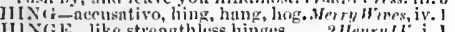
IIXGi-like etrengthless hinges hlimge thy knee, and let his very.. Fimon of $A t h$, iv. 3 thint the prohation bear no hinge.

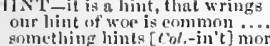

Othello, iij.

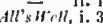

trons. anul rendy for this hint.

when the hest hint was given

toxk his hint: and, not disuraisin

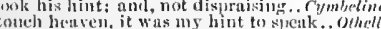

III)

from the lip sipward, no doublet

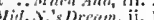

catch him once unon the hij...Merchant of le enic', $i$.

now, inflilel, I have thee on the hip.

mensure her from hip to hip.. Camedly of lerrars, iii.

too wicle fir Nepture's hips.

dropping the hides nnd hips...

dic liriers searlet hips ........ Timon of Alhess, iv. 3

I'll have mir Mliclutel Cassio on the lifip. o/hello, it

IIIPly, - his liorse lipped with.. Tomaing of sh. it

Ifiplyoly in I wowel thee with my sword

come, my Il iplolyta; what cheer.

come, Ilipholy ta. These things seem

IXea; and wy father. Aml llipjolyta - iv. should fall as Jacob's hire ...Merchant nf fenice, i. you sent me to, to hire waftage... Com dy of Err. iv. 1 that firceign hire could ont of thee.....Ifenry

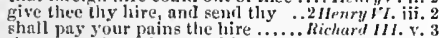
thrcepence bowel] would hire ime... Ilevry r III.

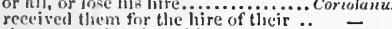

than erave the hire which first we

there, take thy lire; and all.

go hire me twenty ento................

ink and paper, and hire post-horses

ami hire those horses; 1 ll be witl thee -

III I F.D-hired to it by your hrother... . Iuch to that end riclers dearly hired...... As you Like il, liave hired me to undermine. it it sleeps, and does no hired harm. Timon of dh. iv. (if juntiee, nor liy a hired knife. Antany of Clco.

hired with that self exlibition

IIIRE.V-lint IIiren here? (rep.)

IIISs-do hiss me into madness

if I do not nit it, liss me ...

Cymbeline, i.

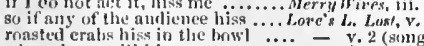
these

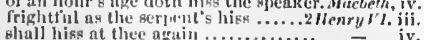

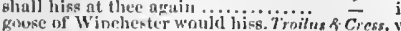

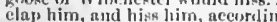

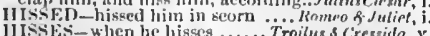

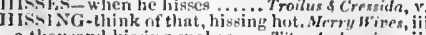
a tlousanel hissing snakes.... Tituss Andronicus, ii.

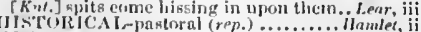

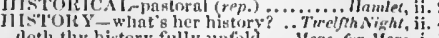
loth thy history fully unfold . Wheas, fur Heas. t'is strange eventfinl history....... ds you like it, ii. it is a kind of history....... Tainaing of sh. 2 (induc.) more than history can nattern ... Winter's Tale, iii. repeat, and history lis loss to new

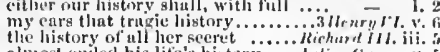
almont ellued his hite ghistory. Whe kn history, report......... ('ynbetine, $\mathrm{i}$. hloul to

shoull I tell my history, "twould :

oten leaves the history uim

nul pirtance in my travel "s liktor

to the history of lust and foul thought

as surely as your feet hit tige grimel

and lie that hits me, let him be

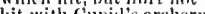
is lit lower, have I hit lier now?........

a little boy, as tomehing the hit it? ..

fire they both dicl hit it ....

or he'll ne'er hit the elout!

what, not one hit? from Tripelis.... -

thit a fool doth very wisely lit...As ynu like il, ii.

thou last hit it, come, sit on me.. Tuming of Sh. ii.

gimed nt, thinghy you hit her not.

conless; liath lie not lit you lier

the winger, though you hit the white

by what wonder you do lit on.

lave but hit your thouglit

you luave hit it. Su did he neter.
fleslicd with eonesuest, nim to hit.

the golden mark 1 seek to hit....
thou liast hit it: for there is

lath stmething lit oursel

I think, you have hit the mark.... nirkarel WH. iv.

giared any, that had a how

once, and hit that womun.

What would not have hit
lnit, hit or mise, our project.

why, this hits right me deat? 7 ..... of sthens, iv. 5

thou mightst lave lit ipon it here . . - iv. 3

upon an uy-cast, to be hit away?.... Cymbeline,

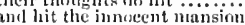

Auron, thou hust hit it (rep.).. Tilus Andranicus, ii. 1

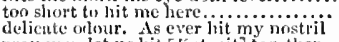

pray wom, let is hit [ Kri?.-sit] together

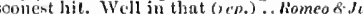

love tamme hit the mark

thou hast most kindly hit it...........

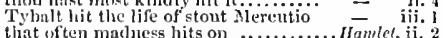

and jit the woundless air

he sli:ll] nut exeecd you three hit

mive the first or second hit the ordi hit

a hit a very palpable hit.

another hit; what say you

my lori, l'll hit him now

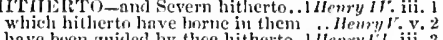

have been guiled by the hitherto.. lienry hii. 3

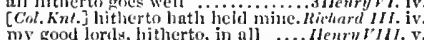

if you have hitherto coneealed this........Wamiet, $\mathrm{i}$.

and hitherto doth love on fortune tend - ii. 2
I un hitherto your daughter $2 \ldots \ldots \ldots \ldots$ othello, i. 3

is mureling hitherwarils .......... I Henrylt. jv. !

or hitherwarrle intended speedily..

marehing hitherwards in proud...2 2lenery I'T iv.

forth already, and only hitherward.. Coniolaurs.

sail of ships inake hitherward ........... I'eriels, i. 4

II TTING-hitting a grosser quality. IIewry $J^{\prime}$

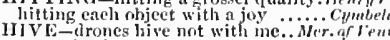

were disal ved from my hive

from their hives, and houses.

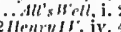

like an angry hive of bees.

Henryll.

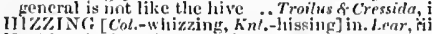

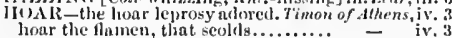

stale and hon ere it be sivent...........

hoar, and an old hare hour

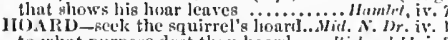

to whit purpose dost thes hoard

II)A 13 DED-any groat I huariciel

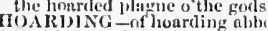

for lik horeling went to hell? .......3 Henry! i, ii.

10 ARSE-Raying we are loarse ... ds yon like it, $v$.

Waren himself is linarse .............. Mncheth,

bondage is hoarse, and may not. Romen f. Juliel,

tongue more hoarse than mise

IOARY - hoary lieaded frosts

Mitl.v. Drenm, ii.

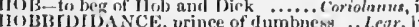

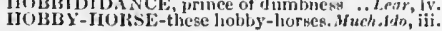

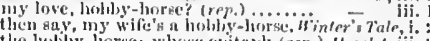

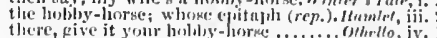

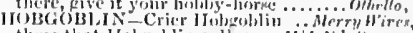

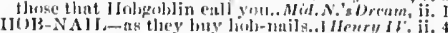

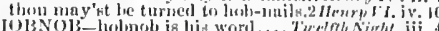

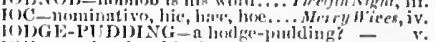
aceukativo, hing, hang, liog.

hang long is Jatin firs laceo

at bors, a leadless bo

ill raise he pricte, at every

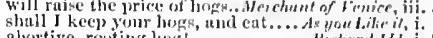

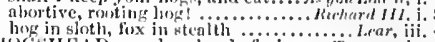

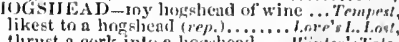

thirust a cork into a lingshen.

liear sucli a luge-full hoghtiead?

II(1)

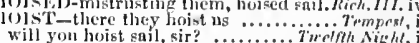

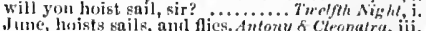

and hoist thee uy to the shontiug

the the hoist me up, and show ....

IolsteD -

IOIBORN-I was last in Ilolborn./2uchor III

D-hold, notwithstanding

did hwil his eyes jocked.......
she holds them prisoners still.

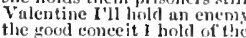

the food conceit I hold of t!ce
that women highly hold in thit

that women highly hold in tith
llint they may bold excused.

when you hold your pence..........

I hold him bit a lool.

for divers philosophers liold. ...

for govrer, antl follam holds...

his gold will hold

dees be not hold up his hiead

hold, there's money for thee

prothec, hold thy peace ...........

on, I'll hold: this is the third time

fiold up your head, nud m

you yet sliall hold your word

if one break, the other will holit.

who of my people hold him in delay?

nor hoild him up witli hones

hold thy peare, thou kna

is begins, hold thy peace ............

I boli as rieldily as tortune.

so lijis, to hold sn mueh!.

hind, there's expenees for thice

pr'ythee, hold thy poace.

Therefore, if you hold

o good sir Toby, holi..........

holk, sir, or I'll thror

hold, Toby on thy il...................

thou slaut hold the npinion.

he lolus Belzebub at the staves

hiold therefore, Angelo ..... Measure for verasure, $i$

I hold you as a thing ensky'd.

linld you there: farewell

put thum in seeret holds .........

nor wished theld my pene.

and hinld no longer

no longer session holal upon my finme

hold uy your hands, sny nothilut....

nn, no; we will hold it as a drem.

rnther thun Juld tharee worls semserence -

estination do you mightily hold up

he hath ta'en the intection; hold it us

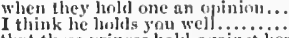

that these princes lobld against lie

lyal you content; what, man

the whle ruire hold their hips...

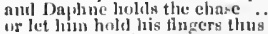

holet then hold his fingers thus.

I pereeive, a weak hoit liwlel........

mow she holds me not...............

a fortuiglit hold we this snlemnity.

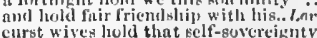

Verana,

二 ini.

- jiv.

Merry Trires, i.

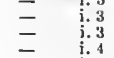

\section{$=\quad$ iv: 1}

$$
\text { 三 }
$$$$
\text { Tisht, }
$$

$$
\text { 三 }
$$


HOLD-holds in the exchange (rep.). Lore's L. L. iv. 2 11OLD-what thy soul holds dear ah, never faicli conlil hold.

the world cannot hold argiment

1, that hold it sin to break the vo

I never knew man hold vile strft....

hold, Rnsaline, this fa vour thou.....

hoid, take thou this,

this field shall holl me............. sold.

help, hnld his brows! he'll swoon!...

face of brass hold longer o

that he dicl hold me dear noili.............

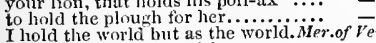

to hold a rival place with one.

hold here, take this: tell gentle......
that ever holds: who riseth from.

what! must I holel a candlc

iv. 3 (verses)

hold out my horse 707 .

hold thy peace; he that hath suffered

in eating him to hold him np......

he is in the miglsty hold of Bolingbro

our council we will hold at Windsore.

never hold that man for the fortur.

which now we hold at much uncertanty

it holds enrrent, that I told....
such as tan hold in: such as

will she hold out water in toul.:

and this civit butfeting hold

or hold me pace in decp experin

he holds your temper in a high.....

and hold their level with thy princely

in arms, holds froun all soldiers

In lold as little counsel with weak fear

I saw him hold lord Percy

I'll hold thee any wager ...................

that lonlds this present question .....

the law hath yet another hold on you
slee would not hold out enemy tor ever

rie should hold day with the Antipodes

yout that witl not, hold your tongines

foll death awhile at the ar
be flouting; we camnot hold

be flouting; we caminot hold

if truth holds true eontents ...........
must of necessity hold his virtue to you. $A l{ }^{\prime}$ s

you must hold the credit of your

I lave a desire to hold my acquanintance

which holds not colour with the time

[Knt] hold a goodly manor for a song

Which holds him much to have......
the eaitifl' that do hold him to it

the eaitiff'; that do hold him
it is, that holds thee hence

it is, that holds thee hence
not a hilcing, hold me no mor

this ring he holds in most rich ehoice

by your leave, hold your han
hold thee, there's my purse.

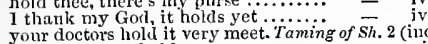

Four doctors loold it very me

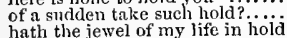

iron niay hold with her....

by saint Jamy, I hold you a penny. Taming of Sh. ii

to hnld my stirrup, nor to take

a tall fellow; hold thee that.

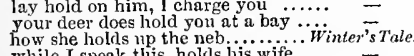

While I speak this, holds his wife.
much ado to make his anchor lnol

hold your peaces

and so forlorn, may hold together.

if the springe hold, the cock's
your resolution cannot hold.

more than my pack will hold ....

should hold some eounsel in such

not hold thee of our blood....

whom here I cannot hold on
what course I mean to hold

visitation shall I hold up before him?

ret hold thee, there's some boot......

r hold it the more knavery to..........
for God's salke, Jold your hands

hold, take thou that, and that. Hiold, sir -

I hold your dain ties cheap,

nor I will not hold me stili

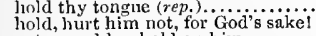

enter, and lay hold on him

hold up thy head, vile Scot (rep.) ......

hold up head without Northumberland

good master Fang, lobld him sure...

to hold your honour more

thousand reasons hold me back

a hullk better stuffed in the hold

hold hook and line, say $\mathbf{I}$
doth she hold her own weil?

holcl, Wart, traverse; thus

ii. 3 as might holld sortance witli hiis.........

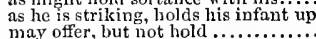

may offer, but not hold....

to hold our safety up ................

from hirir shall hold this quarrel up

can this eockpit hold the vasty. Henry

to hold in riglst and title of the female

and hold out mine iron

I have, I will hold, the quondam.....

ean hold licentious wickedness (rep.).

and hold their manhoorls cheap.

pander, hold the chamber-door .....
hold, there is twelvepence for you

lhold you, there is a groat to hcal

I see, must hold his tongue ..............

to hnld your slanghtering hand.........

yet, Pucelle, hold thy peace
o hold me not with silence

nor hold the sccptre in his childisii...2 IIenry ${ }^{\prime} I . \dot{\mathrm{i}}$.

which now they hold by force.

hold, Peter, hold! I confess....

in the conflict that it holds witil death

on heaven's bliss, hold up thy hand

but that my puissance holds it u

men shall hold of me in capite.

here is a land to hold a sceptre

sworl, hold thy temper

here holds her parliament

and therefore fortify your boid, $\mathrm{my}$ lord

hold. valiant Clifford $\ldots$ you his $i$

to hold thine own, and leave ..........

or else, hold clnse thy lips

or else, hold clnse thy lips
denth doth hold us in pursuit.

nor strength to hold out flight

to cry, hold, hold! great Glam

why do we hold our tongies

to-night we hold a a solemn supper....

from whom this tyrant holds

to hold what clistance his....
wlyen we hold rumour from

when we hold rumour from
let us hold tast tlie mortal

that first cries, hold, enonght!....

that holds in chase mine hon...
of him it holds, stands young

in his right, we hold this town

for the worthiest, hold the right.

that here hold up his right

blood, holds hand witl? any princess

why holds thine eye that lamentable
but the huge firm earth can bold it up

for he, that holds the kingdom, hold

thou may'st hold a serpent by
that hand which thou dost liold.....

I hoing hold of both.

you hold too heinous a respeet

no vile hold to stay him up..

go to, hold your tongue ........
let me not hold my tongue

in right you hold, why then

we cannot hold mortality's strong

three toot of it doth hold

nothing there lsolds ont but Dover..

we hold our time too precious........

and press to that last hold, confound
which holds but till thy news........

I hold it cowardice, to rest

the third, if this sword hold........
that they do hold their eourse

hold Richard, hold, for we have .....

for he holds vengeance in his hand..

aud he holds me dear .....................

will take hold on me; and you

doth the news hold of good ling

the saying did not hold in him .......

to-mnrrow hold divided councils.....
my lord, I hold iny life as dear as yours -

God hold it, to your honour's good

no cause to hold my friendship
franked up in hold: if I revolt

for when they hold them …….... Henry $r$ ril

such a bowl may hold my thanks....

you hold a fair assembly
1 hold my most malicious foe........

who holds his state at door ................

shall hold you play these two mont
if they hold. when their ladies bid

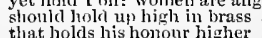

that 1 must hold you ...........

I will hold my peace when

it holds his estimate and dignity.....

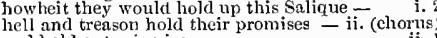

enchantress, hold thy tongrie

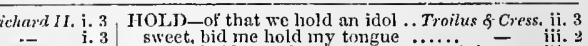

sweet. bid me hold iny tongue .......
here I hold your land; here, my cousin's -

Trny holds him very dear $\ldots . . . \ldots . .$.
we in eilence hold this virtue weil ...

now, Ajax, hold thine own! ........

Enod-night. Jold, patiencel .........

nothing elsc holds tashion......

lite every man holds dear (rep.).......

lay hold upon him, Priam, hold him

hold thy whore, Grecian! now for ${ }^{\text {in }}$ in the course I hold ............ Timon of Athen

mine eyes cannot liold out water .....

ubt me -

it cannot hold; it will not (rep.) ....

to hold your hand more close.........
will't hold? will't hold? It does ....

bankrupts, hold fast; rather than....

hold up, you sluts, your aprons

than liave lim hold that purpose e... Cor

neaee, peace, pcace; stay, hold, peaee!
therefore lay hold of limin

that it shall hold companionship.....

that will not hold the handling ......

hold, hold, holli, hold. My noble masters =

the rout, then hold me dangerous..Julius $\bar{C}$ e

wherefore do you hold me here so long?

and your mind hold, and your dinner

loold $\mathrm{my}$ hand; be fictious for redress

may hodl him from the Capitol to-day

but one in all doth hold his place....

I will not hold thee long

1 would hold more talk with thee....

but holld thee, take this ga:

I pray thee, hold thou my sword-hilits

hold then my sword, and turn away

what hoop slould hold us stauneh.

to hold yon in perpetual amity .......
dost thou hoid there still?

to destiny hold unbewniled their......

lecions thou shalt hold by land.......
and hold our best advantage

yet eannot hold this visible shane.....

she holds her virtue still ............Cymbeline v. 2

ny ring I hold dear as my finger....

to hold the hand fast to her. lord......

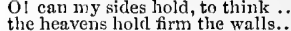

anotleer stain, as big as hell can hiold

by the power we hold, be our good deed = the sliarded beetle in a safer hold....

thighness, hold me your loyal servant

so we'll hold thee ever.

.. Titus Andronicus

nor hold thy stumps to heaven ......

will hold thee dearly for thy mother's

at a banquet hold him sure .........

'tween her stumps doth hold the bason
this jewel holds his biding on my arm

in your innagination hold this stage...

for the babe eannot hold out to Tyrus

hold, villain! A prize, a prize.
hold, here's gold for thee ( $r e p$.

the jewel you hold so dear

hold thee, from this, for ever

denr to us, we did hold
to hold my very courso

yes, forsooth, 1 will hold my tongue

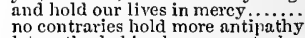

let go thy hold, when a great wheel ...

too tought will you yet hold? ...........

this tyrannous night take hold upon you

fellows, hold the chair

than now to bil you hold..

beadle, hoid thy oloody hand...

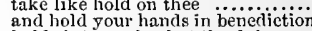

loolds it true, sir, that the duke....

appear where you shall hold your...............

inpear where you shand col but a subiect of this war......

hold, sir; thou worse than any name

more woeful, hnld it in

this night I hold an old accusiomed

lead I hold it not a sin ................

he, that can lay hold of her............

limits cannot hold love out .......

hold friends! friends part! and, swifter

old thy desperate hand

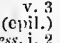

hold, daughter: I do spy a kind of hope

hold, then; go home, be merry

worth loolds in his blood
tis said, he loolds you well .............. $\begin{array}{ll}\text { i. } 3 & \text { hold, get you gone, be strong .......... } \\ \text { ii. } 1 & \text { hold, take these keys, and fetch more }\end{array}$

ii. 1 hold, there is forty ducats.............

ii. 2 hold, take this letter; early in the....

\begin{tabular}{l|l} 
ii. 3 & hnld him in safety, till the prince.... \\
ii. 3 & will not let belief take hold of lim
\end{tabular} 


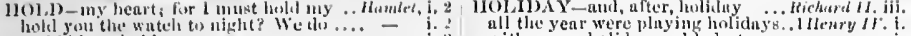

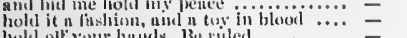

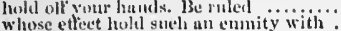

whose etlect hold soleh an emmity with

hold, hull, my lieart; unkl you, my sinewis -

while memori holds a seat in this

I hold my dints, as I hold my soni

yet I holit it nit honesty to have it.

truly, and 1 holit anthition of so uiry

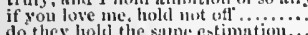

do they lwald the same estimintion...

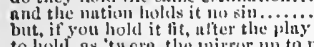

to holil, as 'tw cre, the mirror up) to nature

women's fear mul love hold ylumetty .

holi their eosurse for Es: Inum.... - iv.

might holit. if this should bl

our purphise mus hold the

they hold un ddum's protission

will senree hold the luying in

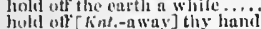

I onee did hold it, as our statis
and the king hold his purpose

it sour pletsure huld to pliny with i.......

if thou lialst ever loold me in thy
thou diclst liold him in thy hute

vec do 1 hold it very stuft o the conseiene

yec do 1 hold it yery stuft o the cons
lay hold upon him; if he to resist

hold your lands, bith you of $\mathrm{my}$

the ofliee 1 do hold of you, not uniy take

he holds me well. the better slinll in

meit on them, can hulk the mortise?

no; tor l holu him to be unwortiy

G pray you, sir, hold your hasid...........

linhl, fur your lives. Ilokd, lubld, lientenant

hold, holit! the general sicenks toyou (iep.)

fur his own rage, libls lijs sounlight

if yon plense to hold lim oft a while

anit liokl her free, 1 do bescech your

hold your peace. "Twill out $\{r p$.$) .......$

IOIDP-1)OOR - hold-door tradc.. Trail s.

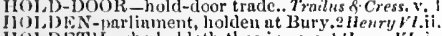

IIOL.DETI - she holleth thee in awe. Ilenry VI. i.

IIOIDF AsT-loldast is the only dog.. Henry ${ }^{\prime}$

base and vile, holling no quantity. Mits. N.'s Dr, $\mathrm{i}$.

that, one man holding troth

this has no looldine, to grear by ly . Lore's L.

make a cure of hapy holding her. II'tinler's Tale, iv.

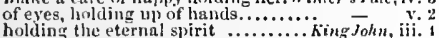

as hollino of the pope, your sovereign

who holding in disdain the Germun ...Henry r, i. a

holding the course to Hartleur .. - - iii. (thirus)

the ho!rling anchor lost...............3 lieury ir I.

holling Corioli in the name of Rome. Coriolunus, i. 6

will serve for a short holding.

holkling them in luman action .........

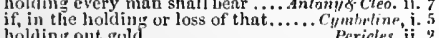

holding out gold $\ldots \ldots \ldots \ldots \ldots \ldots \ldots \ldots$.

holding thine ear close..........Raineo \& Julict,

HOI, D'S $\mathrm{C}$-hold'st up thy hand.. Mid. N. "si) rean,

and hold st it fear, or sin, to speak ...2 Henry $I J$ i. i

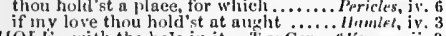

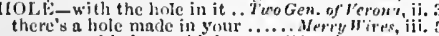

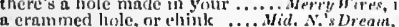

C...... Luves L. Last,

the little hole of diseretion ..... Lave's s. Last

spit in the hole, man, and tune.. Taming of sh. iii.

had not a lole to hide this deed.

throush every guilly bole.

Ilirhmorlt Il. iii. 2

lue lial made two hules in t

1 IIrury, I i i. 2

wilt thou make os many hol

Henry viij.

the hand that mate these holes!. . Richurd III. i.

and, in thos: holes where eyes did.

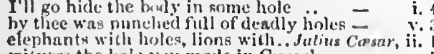

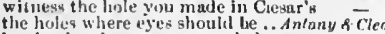

her husband to sume seeret holc... Fitus Andron. ji.

this is the hole where Aaron lid ..... -

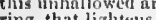

r'ti see what lole is here, and what..

make thou a hisle, that all ..........

thy hrethren to that guilefis iole.

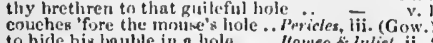

to hide his bauble in a liole .... llomes of Juliel, ii.

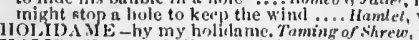

IIOLID. $\mathrm{X}$-not a holiday fool there... Tempert, il.

make holilny: your rye straw liats .. in the holiday time of my lweauty...Merry wives,
in the

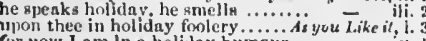

for now 1 am in a holingy humoir... with many holidhy and lady terms...

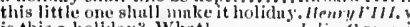

we this a holliny? What!...

and do ynu now eull out a lisliding?

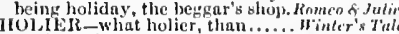

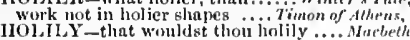

who have died hotily in their bed

how holily he works in all his

it dottl hesecm your holiness.

shall give a holiness, a purity

and from his holiness use all your power -

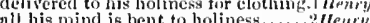

a state fit for his holiness.

with euch holiness can yoil do it?

iny whole cause fore his holiness.. ienry thl

did entrent his holiness to stay.

all the business I writ to his holines

rinil thee into wit and holiness. Troilus of Cress OLI,A-holla your name ........ I'welfth Ni

\section{presently: holla witlin!}

raming of sherew,

in his ear 1 'll holla, Hortimer! ..... I ilew.

holla, holla! that eye, thint told you s.

lie lsollaed but even now

as may be hollacd in thy.

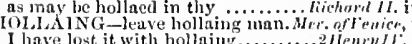

IIULI.AND of cight shilling

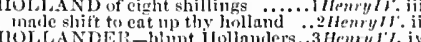

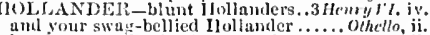

he gives your Hillander a vomit..........

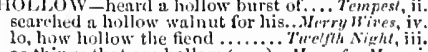

as things that are hollow $(r e p)$. ... Meess. for Meas.

to view with hollow eye.... Merchat of tenice, iv.
and the most hollow lover.......As you Like it, iv.

echoes from the hollower enth. Jaming of sh. 2 (init.

he will look as hollow as a ghost......

cren through the hollow ey

With hollow poverty and emptiness.,2 Herryll. $\mathrm{i}$.

and hollow pampered jacles of Asin.. - ii.

a nest of hollow bosoms ....... Henry l. ij. (chorus)

a full eye will wax hollow

the hollow passnge of my poisoned

comfort from a hollow breast

we were but hollow friend
foes, than hollow friends

dcep, hollow, trcacherous...........Richard III. ii.

purely from all hollow bias-drawing $q$ Cressidti, $i$.

on faint deeds, hollow welcomes. I thon of $\bar{A}$ thens,

but hollow men, like horses....... Julius Cresar, iv.

this gaping hollow of the

beats in this hollow prison of iny fices $=$ iij.

hath stuffed these hollow vessels .......... Lenr, i. 1

pierced the fentul hollow of thine ear -

pline car close to the hollow ground

Who in want a hollow friend ioth try.; Hamtet, iii.

husled within the hollow nine of earth

IOIJOW-IIE ARTLD frientls.... Richard III

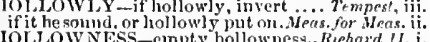

whose low sound reverbs no hollowness .. lear.
we

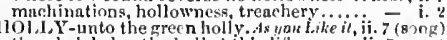

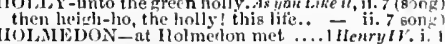

bet wixt that lolmedon and this sent

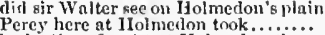

harist thou fought at Holmedion this - y.

OLIOFER NES-matter II tolofernes. Love's L. Los/, iv.

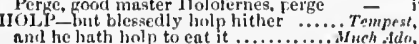

nnt he hath holp to eat it ...............

n man is well holp up........ Comedy of Errors, it.

hath holp him to his home ..............3/acberth.

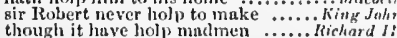

though it have holp madmen ......Richard $1:$.

to dav I holp him to his horse ....... 2 llewry l'l y.

houl to make.

art my warrior; I holp, to frame thee whose hollow womb juherits na.......

his within the hollow erown in the hollow baik

our cheeks and hollow eycs do witness.. P'ericles, be halp the heavens to ruin.

und be hol, by back ward thrnimi......... Lear, iil. 7

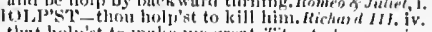

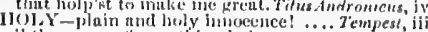

i' the wune of kumetling lioly.

may with full und holy rite........

thy grievnnec to my loly prayers, Tro Gen.of Ver.i.

ceal the burgaiu with a holy kis...

too fair, too true, too holy

where 1 intend huly contession.
the oflence fis holy that she hat

and with this loily man.

Iv. 2 (somg)

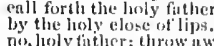

inetry Night, iv

most lioly sir, I tiınk you

most hily sir, I think you

ic doth with holy alstincince suldue

trust not iny holy order................

advertising, and holy to your the holy

to binel our loves up in a holy band...Much $\mathrm{A} d o$, iii.

a ludy garcel of the fuirest ........... tove's L., Lost,

and reet the holy edlifice of stone.......

and holy men, at their rlenth liave good

problucing holy witnest. is like

sle deth struy about lis holy erosec

mone, but a huly hermit, and lice maid

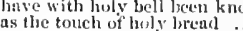

so holy, nurl so perteret is my low..... - it.

oo 1 bly. Writ in balkes hath judkment....

acly seems the quared upon your

What is nut holy, that we swear not.

which holy molertiking $\ldots . . . \ldots \ldots . . .$.
not dared to break the holy seal

What were more liwly than to rejoice
rou have a holy futher, a gracetul...

lier actions sliall be lor a

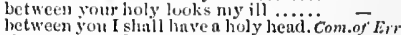

the earriage of a lioly saint $\ldots$...........

yield possession to my holy pruyers.

is gone to pray the lioly $\mathrm{king}$

Macúeth, iii.

some holy angel fly to the court...... - iti.

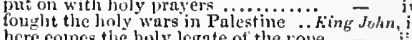

here comes the holy legate of the polve -
to thee, king John, my holy errand (rep.) -

$O$ lioly sir, my reverend tither.

if ever 1 remember to be holy

the ineense of a you, a holy you.

now keep your holy wort.

look, where the holy legate comes apaee
set the name of riglit, with holy breuth

so stond out narainst the holy efiurch

a elerirtman of Mila

you haly alergrmen

our holy lives must win a new

I'll make a voynge to the lloty iand

these pagus, in those holy tields ..... I nenryl\%.

our boly purpose to Joly Land

simcere and linly in his tlusught

your exposition on the holy text

vainly I supposed the Ifoly tand

cio we all holy rites

a holy maid hither witli ni...............

a holy propluetese, new
tut? holy Joan was his

lis holy state is touched so near (rep.)

if holy ehurclimen take delight.
tlyy statue in forme holy jloce.

rittuous: and holy; chosen from

his weapons, holy saws of sacred ......2 Hensy

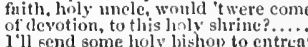

his life, against your boly oath?

forthwith in holy wedlock band

pool key-essd figure of a holy king!. Richard III.

by holy Puni, they love his grace ..... -

stolen forth if lloly writ.............

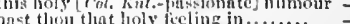

mitringe the holy jrivilege of lylessed

whe by the hinly ruorl, I do not

now by tha holy mother of our Isord

ou that grund ill make a boly tlescant -

to draw him from his holy exercise..

trite ornaments to know a holy man

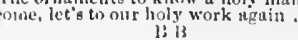


HOLY - when holy Harry died .... Richard III. Iv. 4 HOME-I'll home to-morrow ...... Twelfh $N_{\text {irght, i. } 3}$ no, by the holy rood, thou know'st...
lost his holy. [Col. Kni.-lordly] honour immaculate devotion, holy thoughts! virtuous and lioly, be thou conquetor

the prayers of holy saints $\ldots$ thi.........

certain words spoke by a holy monk

and thank the holy conclave for ....

sir, for holy uffices I have a time

caused your holy hat to be stamped

as holy oil, El ward Confessor's.......
by holy Mary, Butts, there's knavery

and to strengthen that holy duty...

by all that's holy, he had better

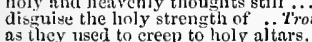

do not count it holy to hurt by.

priests in loly vestments blced

like g'aves i' the holy churchyard...Cor

more holy, and proiound

burn his body in the holy place.......

Octavia is of a holy, cold

carmmeled tike holy Phohns car

such a holy witch, that he enchants

and bows you to morning's holy oflice

and, donbling that, most holy

to look 1]jou the holy sun

prove holy water on thee!

priest and holy water are so nea.

hermits ia their holy prayers.

by the holy gods, I cannot righti...... Pericles, ifi. 4

gpoken holy words to the lord Lysin

oft bite the holy cords in twain

do protanc this holy shritie.

Rameo \&ुJuliet

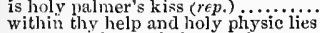

just combine by holy marriage

holy saint Francis. What a change
so smile the heavens mpon this holy act

but close our hands with holy words

o holy friar, o tell me, holy fitar

by my holy order, 1 thought thy

are you at leistre, holy tather,

am enjoined by holy Laurence ......

he liath still been tried a holy man.

holy Franciscan friar! brother, ho!.
it doth so, holy sil; and there's my.

amony a sisterhood of holy nuns ....

we still liave known thee for a holy man -

most holy and roligious fear it is .........

stwong as proofs of Holy Writ .............. Othello, ij. 3
HOL $Y$. ALE-and holy-ales...... Pericles, i. (Gower)

HOJ,Y-CR ITEL-be not so holy-cruel. All's Well, iv. 2
IIOL, X-DAIIE-by my holy-dame.. Henry III. Y. by my holv-(ame, the pretty.... Romeo \& Juliet, i. 3

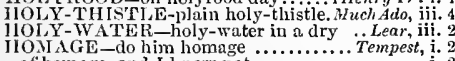

of homage, and 1 know not

we'll do thee homage....

uraGen. of Verona, iv.

when they do homage to this. Taining of Sh. 1 (ind.)

I know his eye doth homage.. Comeely of Errors, ii. I

and deny lifis offered homage ........Richord I I $I$. ii.

and his countenance enforces homage. Henry $V$.

and do him homage as obedient....I Henry $V I$. iv. 2

sfter all this fearfal homage done..2 2 Henry $V I$. in.

thy free awe pays homage to us ....... Hamlet, iv.

thy free awe pays homage to us ...... Hamlet,

HONLAG LR-is Cresar's homager.. Antony \& Cleo. i.
HONE-bonnd sadly home for Naples.. Tempest, i.

will carry this island home in his pocket

thongh fools at home condemn them

dully say thy graces home............ $\overrightarrow{\text { Twerana }}$

as much to you at home!...

to spend his youth at home......

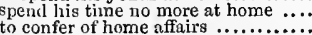

then stay at hon

thes stly at honie you home to bed...
presently you hie you
hie home unto my chamber.......... iv.

get you home, go .......................

that her husband is seldom from home -

I am come to fetch you home...

to sce your wife: is she at ho wife at home, indeed

some good cheer at home ............

go home, Jolin Rugby

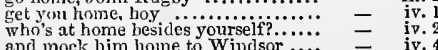

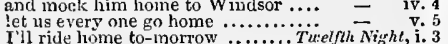

and come home in a coranto

I will waylay thee going home...... iii. 4 (chai.)

rather than forty pound, I were at home - v

I pray you home to dinner with me

shall witness to him, I am near at home

aceuse him home, and home

had been at home, he had lived...

that broirght you home the head

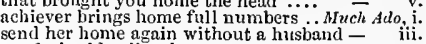

to Helen it is home returned.

Mid, N's Dream, iii. 2

tronp home to churchyards...

go home, Biron; adieu! ................. Love's L. Lost, i.

comes frozen home in pail .......... $-\overline{\mathrm{v}}$. 2 (song)

to return to their home....... Merchant

sir, I entreat you lome with me

dear lady, welcome home.

you are wclcome home, my lord

he keeps me rustically at home...As you Like it

stays me here at home nnkept

when I was at home, I was in a better = ii. I

I would, I were at home. We'li lead

nor wax, nor honey, ean bring home.. All's Well, i.

stay at home, and pray God's blessing
here at home, spending his manly ...

you take your way for home

farewcll, hie home. Pray, sir

go thou torard home, where I wili...

shall at home be enconntered
my husband hies him lome.

the sense to know her estimation home

wait on me home, I'll make...........
home thy ancient thoughts. Taming of Sh. $\overline{2}$ (induc.)

your love mist live a maid at home

and goods at home, and so an come.

who is at home? you are welcome, sir the bride and bridegroom coming home? -

slutill find. when he comes home

welcome home, Grumio..............

hie you home, and bid Bianca .....

while I play the good luusband at home

while thou liest warm at home.

no sneaping winds at lome .......Winter's Tale,

if at home, sir, he's all my ex.

see'st a game played home $\ldots . . . \ldots \ldots . .$.
kecp it closc; home, home, the next way

come, good boy, the next way home
let my prophecy come home to you!

let my prophecy come home to you!

departed'st from thy native home. Comedy of

motions for our home return .....

strike you home without a messenge

from the mart home to your house..

come home to dinner, and prays (rep.)

I pr'ythee, is he coming home?

and feeds from home; poor I am

sent me hence, home to the Centaü

to-morrow you will bring it home

get you home, and fetch the chaind

go home with it, and pleang it home to me

to hie home to lis house ....

doth know, you dined at home

see him safe conveyed home

and bear him home for his recovery.

let me him of trom home.....

bound, and sent him home ....

and sent my peasant home ..........

dined not at home, but was locked

that, trusted home, might yet enkindle. Macteth, i.

to feed, were best at hone before.

and beat them backward home

as calling home our exiled friends

not think of home, but follow arms...

sold their fortunes at their native homes -

we will benr home that lusty .........
sirrah, were I at horie, at your den..

from home, and discontents at home

and welcome home again discariled.

these her princes are come home agai

ready to direct these bome alarms...
witl welcome home from banishment snip, snap, quick aud home; it rejoiceth

a day before our husbands home

bless him at home in peace ......

and your son, here at hon

whilst I at home starve for a inerry.

bring thy master home immediately

when I go from home; welcomed home
IIOME-jewel of thy home return .... Richard II. i. 3 when time shall call him home..... for their deeds as far from home cone to make him lose at home get thee home, provide some carts come home with me to supper ..... at home, and be hanged (rep.) ...... HenryIV. i. 2 to redecm a traitor liome? to..........

found a time to pay us home ........ a rendezvous, a home to fly unto (.... unminded outlaw, sneaking home brought you home, and boldly did that kiss my tady peace at home.. .2 HenryIV. i.
eaten me out of house and home $\ldots . .$.
persumarted you to stay at home? Mouldy, stay at home still...

ach hur those tokens liome

c

the cat must stay at home..

head defends itself at home

ike magistrates, correct at home....

bring home to thic tent-royal
thrice that power left at home

merriest when they are from home...

good husband, come home presently

and comes sufe home, will stand

king of England's stay at home - v. (chorus)

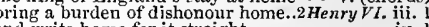
and write home for it straight........ -

sent the ragged soldiers wounded home -
she washes bucks here at home...... home to your cottages, forsake this..

and go home in peace. What say ye

aldition on his crown at place...... ...3HenryVI. ii. 2 can tyrants safely govern home...... $=$ - iii. 3 go home to bed, and, like the owl .... let not us two stay at home......... - ii. shall call home to higl promotions. bent down these rebels here at home

France as here at lome conquerors. $\overline{\text { van }}$ v. and then go home and lose me......... where higl profits might come bome - iii that Paris is returned home.. Troilus \& Cressida better at home, if would 1 might .....

who said he came hurt home

he brought home noble prize...........

grieve young Pyrrhins now at bome

desire them home: give me thy hand

never go home; here starve we.$\ldots \ldots$.

are more valiant, that stay at home of Athe

go, get you home, you frayments! .. Coriolan

mence! to your homes be gone $\ldots$.....

it at home, upon my brother's guard

ha! Marcius coming home (rep.)

he was wont to come home wounded

he cones the third time home with.

had I come coffined home, that wcep'st

have some old crab-trees here at home

let me say, I cannot speak him home

noble friend, home to thy house

go not home.

and come home beloved of all....

when point charge him hom

bid them all home; he's gone

bid them liome: say, their great enemy

you have told them home.

I will merrily accompany you home

may wish good Marcus home again

go, masters, get yon home............

come, masters, let's home ............

hear Comiuins spealk, I'll keep at hom

to the wars, and safely home, loaden

so we will home to Rome ....

and had no welcomes home

you are most welcome home

our spoils we have brought home......

what conquest briugs he (rep.)

I will come home to you ( $r e p$.

if he slould stay at home tomy are..

for thy humour, I will stay at home

my wife, stays me at home

begged, that I will stay at home to-day bronirlit nany captives home to Rome spenk to me home in Rome netition us at home
we had driven them home with clouts my wars, and called them home much loves a Gallian girl at home ... say, slie'll home to her father ........

nor know not what air's from home.

katisfy me home, what is become of he

i. 3

iv. 1

1 
HO.ME-spurn her home to her father . Cymbeline, iv. I IfONEST-honest neighlours.........Mufh Allo, iii. 3 |IIONEST-honest Ventilius .

is he at home? He wint lienee even nuw _ iv. 2 home art gone, and ta'en thy wases - iv. 2 (rong) that conll rus it home: this is 1 'isunio's lie by the aenate is aceiterl home .. Fir that 1 bring unto their

struek lume to show my strengti...

go home, call tor sweet water........

I am sure to lo linized at lonine

goxl llelienue luath at nitl at hoine

come, thou shult (a) home, and we'll have $\overline{\text { ii. }}$

conke mot, in twite six

() take her home, mistress, take her home - iv,

j'll bring home sume tornight...

take me lome nyuin

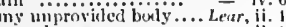

hit answer from our home ..............

thut the eare

I an now from hom

king now henrs will he re.......................

king now hears will be revenged home.

I must change arms nt home

away fiom light stenls home .... Romeo o. Juliet, i.

hath stolen fimm lome to bed

but, in faith, honest, as the ekin

I an ne honest as nny mun living....

as l um au honest man, he look s pilie

thank thee for thy cure anul bunest min

your nume, honest gentiemun?

and as I'in an lionest Puek.

1 , that am honest; 1 , that hold

J.one'st..tost (ciili.)

most dult, honest Jull

an homest man, look yoi

unless your play the lionest Trojin.

honest phin words best pierce........

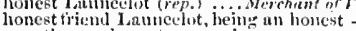

is an lumest exceeding poor man

be an howest woman of her word

the pood, the homest Antonio...

as I have ever found the honest...

she starce makes honest (rep.)......As you tike

is it hinest in deed, nud worl?

swear'st to me, thou art honest?

pray the gods make me hone

I thank you for your li mest care.

nyy friends were poor, but honest

what, have you ilined at home?

nt home, abroul [Col.Knt.-time, work] - iii. 5

go home, be merry, rive consent .... - - iv.

at home, my lord. let the rloors be..... =

look you lay liome to him

shali know you are conce

lie spenks home, madam.....

othello, ii. 1

what muke you fiom hume?

they clo command him home

I an eommunded home; get you nw.....

thy good rapier bore, and put

I charge you, get you hone ............

nyy friends were poor, but
tis pity, he is not honest

but, you say, slic's hond
she then wits homest.

was very lonest in the behinif of

ean serve the world for no honest use

y thy honest aid, thon kejt'st.....

and honest eompany, i thaink you ut

even in these honest menn habiliment

and wander we to see thy himest son

not obedient to his hone $t$ will

mine honest friend, will you take.. I'inter'

thou art not honest: or, if thou inelinest

'tis pity slue's not honest, honourable
ere you can say she's lionest ........

as truc; honest, as either

and no less honcest thin you are mad

as this world goes, to pass for honc

five or six honest wives that were present -

to lic close by lis honest bunes $\ldots . .$.

is no honest man ncither to his finthe
though I am not naturnaly honest.

if I hud a mind to be homet. I see

thou art as honest a true fellow.

nn honest suit might move .. Comediy of Errors,

where any honest men resort .........

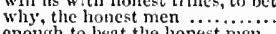

enough to beat the honest men

was ouce thought hone

some honest ehristian trust ne ..... Richard $/ I$. iv.

well, he is an honest man............JJenry $1 \%$. iii.

I am an honest man's wite $\ldots \ldots . . . . .$.

traetable to any honest reason

with them in lionest tnking up ......
did I sny you were nn honest nitil

did I say you were nn honest niall.
be honest, be lonest; nnd Got biess

marry, if thou wert an honest man

you are an honest woman, and well

I will bar no honest man my liouse.

in the world; honest Ned, none ......

or honest Burdolph, whose zenl birn

good-morrow, honest gentleman

bear ont a knaye ogainst an homest ioan

lonest Bardolph, welesnic

honest Bardolph, welenne

as your majesty is an honest man.

east $\pi$ way un honest man..............

and myself an louest man

he was an honest man, nud a gom

like an honest glnin-denling mum

for they are thrilty honest uen ....... - iv.

heree is thy lord, mine honest fetlow?

plain and not honest, is too harsh.

now an honest country lord, as I um

like free and honest men, our just

ye speak like lionest men, (pray God

our ends are lionest, you'd teel

of thy lonest trath to play the womin

but such an honest ehronficler us Grint th he's hemest, on mine honoin

would you were half so hunes

his honest man, wait like ..........

nn homest fellow enough

Thuilus f Crissidn loneat in nothing, hut in hils eluthes vuch vo

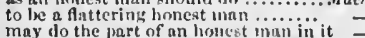

why, thut's sjoken like an hing, st drover -

like an honest man, and a suldier.....
I'll devise some honest slanders to stain - ding, and these knuves lionest

to knock ont nu honest. I thenisuin. too wenk to be a sinner, lonest wnter

thus honest fools lay out their wenlth

tlum art true, and bences, infenious

draminius, honeat frininins.

poor henest lori, brought low by jiso own -

I will preserst my honest erief uintoliom -

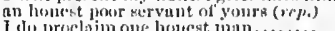

thes urt mure honest now, than wi

thun wingly honest man, lacre, tak

you, thut are bouest, hy leing

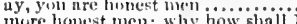

more honest men: Why how shat 1

honest men: yon have hen

nine humest neightour

mine honest neighiours shouted ... Gulie

honest Cusea, we have the tilling sicliues

a very pleasing nirht to loncst
urble, wive, valiant, and loonest.

in a generul honest thonght

thou're is honest to be dose. Antony/ \& Clenpal

though it le houl mant, it is never........

all-honoured, honest, Roman Bintus
hast been ridhtly honest; go hast thou

thon art homest too. I wish I ecmlla be

my tortunes have corrupted honest men -

a very honest honest sword ....... - iv.

where I have Jives] at honest frecdoin -

true honest men bejug hearil

come, fellow, be ther honest

but if I were as wise as lionest .......

disfonestly ufflicted, but yet honest

whicein I nm false, I an honest

Euldier, nu homest one, I wnrrant...

which must therove thee lonest

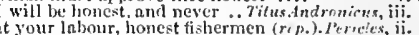

how well this honest mirth beeomes
an honest woman, or nut n woman

and for an linnest attribute, ery out

aut elianees into an honest hoise

I $\mathrm{am}$ no lionest man, if there be.

to lwe lim that is honest...........

an honcst mines and plain

where I could not be hintest, I never yet

my inveation is fair and lonest

says like un honest gentlemun (rip.)
to high fortunel honest nurse. fircuel

courteous 'Iylinlt! honest gentleman!

o farewell, honest soldicr; who hath

so lionest a nan. 1lonest, my lort? (rep.)

but that the world's grown lionest
to spenk to yon like un lionest man....

but enlled it, an homest ricthed......

ha, ha! are you honest? Ny lor
that if you be lonest, nud fuir

I am myselt indifferent honest

in homest plainness thou hast heard

honest Jago, my Desdemona must I leave

men honest, that but seem to

make this misic, as honest as I nm.......

it were an honest netion, to ERy so

as I am an h nest man. I thought y......

the sineerity of leve, not homest kindlue:
good-night, honest lato. And whut's...

nnd homest, protial to thinkin

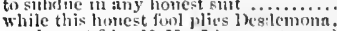

my honest friend? No, I hear nut ( 1 e $p_{\text {, }}$,

o that's an honest fellow: do not doubt

I lave an honest felfow: do not dombt - iii.

honest? Honest my lord $[C, k$,-hune

I think that Cussio is a! lionest man..
I do not think but Desdemrona's honent

this honest creature, foubtless, fices
to be direct and lionest, in not safe

nar, stay: thinu shonlist he homest.

I think my wife be lonest, nnd think

to wager she is honest, lay town iny soul

doilite dnnined, swear-thou nrt husiest

and pue in erery homest humbl a whip..

O brave Iago, houest, and just

but of life ins honest, as you thut thio.
honest Ingo lat th tin'en oriler fur't

thy liuband, honest, honest Ingo.

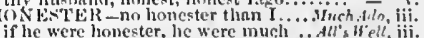

an honester, and trucr-hearted man.2Hroy $l^{\circ}$ ii.

when honester men than thon go ..21rnryly iv.

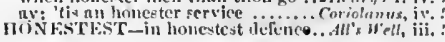


HONEST-HEARTED fellow, and as poor. Lear, i. 4 HONEY-honey like a drone .... Pericles, ii. (Gower) HONOUR-the very bent of honour.. Miuch Ado, ix HONESTLY -very honestly, a...Meas. F, Mlers. not honestly, my lord; hut so convertly Ado, ii. 2 you liave discharged this honestly .....All's $W$ ell, $\mathrm{i}$. it will slow honestly in us .... Timon of Alhens,

that rob the bee of her honey .... Pericles, ii. (Gower) O honey nurse, what news? .......... Romeo of Juliel, if. 5 death swetest honey is loathsome ....

sucked the honey of his musie vows ".. Hamlet, iii. honey, you shall he well desired. $\dddot{2} . \ldots$ Othello, ii.
HONFY-BAG-honey-bags steal. good monsieur, bring me the loney-bag

have your overtlown with a honey-bag
HONEYCUMB-thick as honeyeombs... Tempest, i.

HONESTY-by mine lonesty... Two Gen. of Ver. ii. to wrangle with mine own honesty. not sully the chariness of our honesty but in the way of honesty .......... siege to the lonesty of this Ford's wife $\overline{-}$ ii. no wit, unanners, nor honesty.... Twelfh Night, ii. by mine hollesty, if she be mad ....... valour, and confirmed honesty

a man who hath any lionesty in hï

a beard, fair health, and honesty.. Love's $\bar{L}$. Lo for honesty coupled to beauty, is to.

I blould think my lonesty ranker than

rich honesty dwells like a miser, sir =

whe derives her honesty, and achieves

though honesty be no puritan, yet it

a reserved honesty, and that 1 have

whin is lis honesty? IIe will steal

little more to say, sir, of lis honesty

for this description of thine houesty?

mine honesty pouts it to utteranee.. Hinter's Tal which hoxes honesty behind, restraining -

(a note infilible of hreaking honesty)

we need no grave to bury hodesty ..

to lock up homesty and honour

ia, lia! what a fool honesty is!

not a piece of honesty to acquaint ...

whose worth, and honesty, is richly..

mine honour and mine honesty.. Comedy of $E \mathrm{rr}$

thou wast got $i$ ' the way of honesty;... King John,

there's neither honesty, manhood

is no homesty in sueh dealing

why, then nine honcsty shall be ...3 Henry ${ }^{\prime} l$. iii. Finward's love, and Warwick's honesty - iit. 3 that hast nor lionesty, nor grace.... Richavd III.

you have as little honesty as honour

corruption wins not more than honesty

for honesty, and decent carriage

stand on is iny truth, and honesty.

parted so much honesty among them

to detend mine honesty ....... Troilus \& Cressid

you tound them in mine honesty

every man has his fault, and lonesty is -

thail honesty to honesty engaged..

mine honesty shall int make...

mine honesty, and I, begin to square

in honesty, I bid for you, as I'd buy. Cymbe

that nice-preserved lionesty of your. Cymbeline, iiti. 6

his offeuce honesty! strange! strauge! ....Lear, i.

on whose foolish honesty my practices

no faith no lionesty in men honest. ii. 2

yet I hold it not lonesty to have it .... Hamlel, ii.

col. Knl.] your honesty should admit no

howesty from what it is to a bawd (rep.)

I man he is of honesty, and trust........ Othello, i.

Ingo, thy honesty and love doth minee..
I know thou art full of love and honesty

my manhou, honesty, or wisdom .......

livest to make thine honesty a vice

honesty's a fool, and loses that it works for - iii. 3

pricked to it by foolish honesty and love - iii.

but why sliould honour outlive honesty?

honey, and milk, and sugar

my fair, sweet, honey mouareh

since I nor wax ar houey.

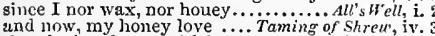

then 'nointed over with honey ... Winter's Tale, iv.

now my good sweet honey lord

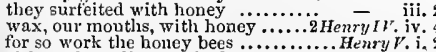

citizens kneading up the honey.......... -

have steeped their galls in honey

grew eaptive to his honey words ...Richard - iv.

grew eaptive to his honey words ... Richard III. iv.
mars the honey of his language ... Henry VIII. iii.

what honey is expected?...... Troilus \& Cressida, i.

you have the honey still

sweet honey Greel, tempt me.

sweet houcy and sweet notes together $=$ v. 11

the honey heavy dew of slumber...Julius Cresar, i.

you have the honey you desire .. Tilus Andron. ii.
coming and going with thy boney breath
as doth the honey dew upon a gathered -
iii.
HONEY'D-and honey'd sentences.... Henry
HONEY-DROP-diffusest honey-drops. Iempest,
HONEYING, and making love over ..Hamle,

HONEYING, and making love over ..Hamlel, iii. 4

HONEY-MOUTHED-

if I prove holley -mouthed $\ldots \ldots \ldots$ Winter's Tale, ii.
HONEY-SEED rogue! (rep.) $\ldots \ldots \ldots 2$ Henry $1 \mathrm{~V}$. ii.

HONEY-STALKS to sheep .Titus Andronicus, iv. 4

Pandarus; honey-sweet lord .... Troulus \& Cress. iji. 1

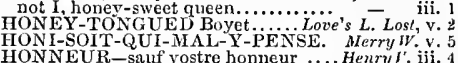

HONNEUR-sanf vostre honneur ..... Henry ${ }^{\prime}$. iij.

sauf vostre honneur, me understand well -

Sauf vostre honueur, le Frangois que - v.
HONORA'TO signior mio Petruchio. Taming of Sh. i. 2

HONORIFICABILITUDINITATIBUS-

HONOUR - witl all the honours........ T'empest, i.

seek to violate the honour of my child
upon mine lonour, sir, I heard .......

do love, prize, honour you

how does thy honour?

shall never melt mine honour into lust - ivi.

whour, riches, marriage blessing.

whose honour cannot be measured ...

her oath for love, her honour's pawn

dignified with this ligh lionour...

now, with my honour............

by the honour of my ancestry........

talke the honour: what is it?

I took ' $t$ upon mine honour.

you stand upon your honour?.........

hiding mine honour in my necessity
under the shelter of your honour!....
on the excellerey of her honour ...

now doth thy livnour stand ............

by maidliood, honour, trutl

and laid mine lonour too unchary oint -

how with milue honour may I give

in the modesty of liour on him

sueh ample grace and honour............eas. for $\vec{M}$

nor need you, on mine honour....

I'll wait upou your honour

let hut your hollour know

if it please your honour, I am...

if it please your honour, 1 know not

before heaven and your honour.......

saving your honour's reverence ....

your honour cannot come to that yet

eome to it by your honour's leave....

look upon lis honour.

dotl 1 your honour mark jis faee?

I would know that your hourm

I erave your honour's pardon...

save your honour! (rep.) ............. -

heaven keep your honour! (rep.)

little honour to be nuch believed....

in him such a mind of honour .......

more respect than a perpetual honour

your having the truth of

your honour is accounted a merciful man -

continuance, may it please your honour -

and general honour

remorse confutes mine honour

uborned against lis honour

upon my faith and honour $\ldots . . . \ldots . .$.

to the safeguard of your honour.......

upon mine honour, thou slialt..........

that he hatll wronged his honour

as in love of your brother's honour...

would better fit your honour to change

upon mine honour, myself, my brother

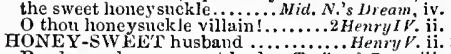

upon whose taith and honour I repo....

the gentleman will for his honour's sake - if they wrong her honour ........... - iv. on my honour, she was eharged witli $-\overline{\text { iv. }}$. honour Helen, and to be her kniglit!.Mid. $N$. Dr.ii. present hreath may buy that honour. Love's as honour, without breacls of honour for the best ward of mine lonour.... now, by my maiden howour.......... = within the eye of honour, be assured....... and that elear honour were purchased the true seed of honour? (rep.) ...... When your lionours mean to solemnize the ancient Roman honour more

wise young judge, how do I lonour thee! or your own honour to contain.

no, hy mine honour, madam ........

now, by nine honour, which is yet my

as I must, for my own

thou may'st in honour come off again

no by miue honour .................

swearing by his honour

my fatleer's love is enough to jomour him -

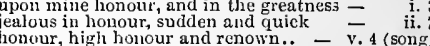

you to your former honour

and his honuur clock to itself.

uged honour cites a virtuous youth

would your honour but give me leave

not to wou honour, but to wed it .....

now by ny faith and honour.

wherein the honour of my dear.......

the honour, sir, thiat flames in your.

honour: that is lonour's scorn (rep.)

her own dower; honour, and wealtl

my lionour's at the stake ...........

and what dole of honour ............

by mine honour, if I were but two ..

he wears his honour in a box unscen

will lay. upon him all the lionour....

whence lionour but of danger wins...

the honour of a maid is her name...

[Col.] not the honour of his design

bring this instrument of honour again

it is an honour 'longing to our house

the clampion honour on my part....

mine house, mine honour, yea ......

in the spoil of her honour.............
he had the lionour to be the officer a

do the man what honour I can $\ldots$ is a good livery of honour: so belike

ech your honour, to liear me.

in that course of honour as she lad ..

and my honour's paid to him

whose age and honour both suffer....

nohle thought upon mine honour...

fairer prove your honour, than in...

an' it please your homour, players.

we thank soto that your lonour mean

for yet his houour never heard ....

what is 't your bonour will comm
will 't please your honowr taste ....

your hollour wear to-day (rep.) ....

your howour's players, hearing your

so honollr peeretli in the meancst habi

I'll give no blemish to her honour, non

whiel lionour does acknowledge

sinee I am charged in honour.

by mine honour, I'll geld them ail...

and one whom much I honour........

lock up houesty and lowour from.....

your honour, and your goodness....

durst not tempt a minister of honour

upon mine honour, I will stand.....

commit me, for committing honour

for life, and honour, 'fore who please

for honour, 'tis a derivative from ....

as in honour, he required

for mine honour, (which I would free)

your honours all, Apollo be my judge

commended, no richer than his hono

have poisoned good Camillo's honour

run not before mine honour..........

do him love and honour.............

on ruine hononr, I'll puint you where

I know, in honour, $O$, that ever I...

your honour not o'erthrow by your.

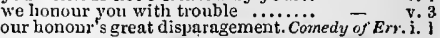




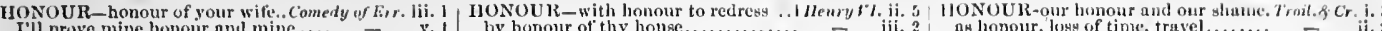

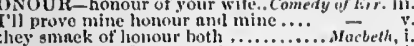

\section{Macbeth,}

arnest of a grenter bonoul

new honours come thon him like.

which honour inust not, unnecompninied

against those hounours deep ant lomnd

when 'tis, it slutl mnke homour firr you -

lave our honours in these flittering

and receive frec honours, all whish.

though in your strte of honour I am

to thy good trutli nuel honour.

ns hollour, love, nbed ienec, tromps.

a soldier, by the honour givilly lauld. King Joh

wound her honour with this cliffillence

my mother's honour, nut my landl..

miv futher gave me honour

a tout of honour better than I was

new-made honour doth forget men's
in chase mine honour up und down?

own gain shouldst defend mine him

in titles. honours, nnd promotion

his honour: Othine honour, Lewis ( $r$ ep. $)$ -

bestained cloak with our pure honours

by the honour of my marringe-bed

tuke up mine honour's pawn

mine honour is my life (

mine honour let me try ......

shall wound mine honour with ......
I sent thee forth to purchase honour

that love and honour lave ..........

homour and allegiance cannot thisk

the worth and honour of himself

or have mine honour soiled with

his honour is as true, in this

there is mine honour's pawn

may be repealed to try his honour

whose state and honour I for nye allow

now by mine honour, by my life ....
tukes on the point of honour, to support

tukes on the point of honour, to suppo
spend mine honour with his shame ..

mine honour lives when his dishonom

who is the theme of lionour's tongue.

who is the theme of lionour's tongue.
your banishetl honnours, nnd restore.
go honour eross it from the uorth...

to pluek briglit honour from

pluck up drowned honour by the locks

thou hast lost mueh honour.......

this same child of honour nnd renown

for every honour sitting on his helm

thou art the king of lionour..........

if well-respected honour bid me on

no matter, honour prieks m

there's honour for you: here's no vanity

I like not sueh grinning honour

if not, honnur eomes unlooked for

all the budiding honours on thy er
will do me any honour, so; if not

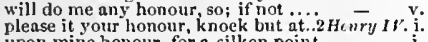

upon mine honour, for a silken point

divoree not wisdom from your honour

there were two honours iost

there sere two honours lost

thine lon

insurreetion with your fuir honours...

hand unon nur honours? $\mathrm{O}$ my good

what thing, in lionour, hud my father

by the honour of my blood, my father's
which, by mine honour, I will perform

wot foree this lineal honour from me

invest thee with mine honours before

give him office, honour, might ......

as your honour; and as your renow.

what $I$ ilid, $I$ did in honour...

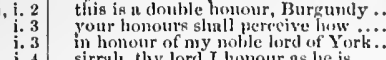

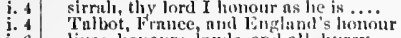

fives, lionours, lnums, and all, hurry

nil his gloss of former honour.
the trust of linirlanel's humbur

stuin the honour you hnve wor

uid for thy honour, wive eonsent

in Aljou whint your lunour please.

to love not houour Heury as lier

deftee your honour with

dims the honour of this wrilike

with all the honours of the world?

lut if she have forgot honour, and virtue

honour of lis birthingt to the crown
despoifed of your honour in your lite

this staft of housur raw:

the map of honour, truth, nuil loyalty

bat nll the honour sulisbury hati

a proper man, on mine homour.

ernves aid of your homour from:

have I affeeted wealth or ho

and homours not his father ...........

and heavens nnt honour he witn
to emblaze the honour that thy.

upon thine honour, is he

to honour me as thy king and sovereign -

do not honour him so mueh, to firick

to see these honours in possession

nawn my eredit and mine houour

my desert is honour (rep.)

more for wanton linst than honour

as this title honours me nnd mine

like it better than a dangerons honour

honour now, or never! but follnw me

the drum your honour henrs, marchel

lny those honours on your lijgl desert

thy honour, state, and seat, is due

thou rag of honour! thou cletested

ar: outward hour is scarce eturrent.

his honour, and myself, are at the one

hold it, to your honour's gond content!

your honour. Well met, my lord (rep.)

for which your honour and your faitl is

what dignity, what honour, eanst thou

the law, my honour, and lie

hath lost his holy honour.............

as ittle honour he meant to lay upon

towards you honour and plenteous..

and sell his honour as he pleases ...

not uneonsidered leave your honour

whose honour henven shield

things to strike honour sid.

life, honnur, name, and all that....

all men's honours lie in oul lum....

and does purpose honour to you no less

heauty and honour in her are so

agninst mine horour aurlyt ...

you tender more your person's honour

yen, upon mine honour, I free you

on my honour, I speak iny good .....

so near mine honour (more near my life

both for your honour better, and your

yet will I add an honour, - a grea
the honour of it does pay the net

my power rnined honour, more on you

with the place and honours, during

you have as itte hmesty ns homon

ton mueh henour: $O$ tis a burden

usher forth mine honours, or gild.

all the depths and shoals of howour..

that bear the cloth of lonour over lyer

the great child of honour, eardima...

was fushioned to muel honour

to keep mine honour from corruption

now in his nslies honour

het me be llsed with homnur

to queneh inine honnur

is this the honour they do gne another?
please your honours, the chief eause

$f$ ery your honour merey

the elief nim of his homotr

mny glory in snch an lionour

stronger, you more homour fa.

plense your hnnour, we are but men.

shall reak the perfert whys of homsur

his lionoureand the greutuess ott.

for the linnour of the fortorn French

how sliall i honnur thee fur this suecesa? -

will not your honours hear me eompany? -

mpon the holuer of his hirth ........

I have received mieh hounir.

in honour of a truc Plantagenct

ii. s holds his homour higher thum

Ifertor shall linnour hin iii. 2 nH lonour. lons of tine, travel.

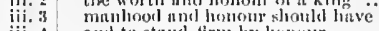

andi to stand firm hy henour

wheh hutle onr seevernl honours uil.

a theme of honour and renown.

homour noll lerdship are my titles

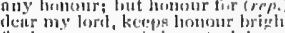

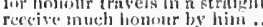

in mine cmukus lonosir ...........

in wyy spirit mol honour,

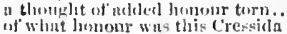

honour, or gn, or stay ; my mujor viow

mine honour keeps the weather of niy

art thou of his and, and honom

Timun of dthe ns,

flawil the to thia your lomour (rep.

may it please your lonom

las sent you homour two brate oif

of hapenes, honour, nmel fortunes

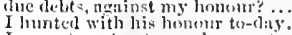

this slnve molo lis lommer

was very lit tle honour slowed in'

plense your honour, my lor!l huti

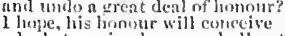

whobres mine lomour, shall not

an honoms in lim, which buys

'tis hesour, with most limbls

whut nis at teration of hom

besech your honotr, to make

half all Cominius' lionturs ne

to Marens slinll he honours

and kecp your bour

that alssence wherein he won homnur

this is true would become such.

inte thine, hnnours

hitll not thit honour int.................

by decennehieving honour newly named -

hit with them cliange of honours... -

transport his honours
these his new honours

so planterl his honours in their ey.

to remember with lionours

your honours' parclon.

venture all his limbs for honour

rour honour with your form

joy and hounur. To Coriolnmis (rep.)

every one of us hns a single honour.
let the high offiee nond the honnur go

heard you sny, howour and botie

in pence with honour, ns in wri

I should do so in honnur.

I will answer in mine honour

could not carry his honours ever

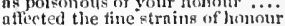

sufely home. Inalen with lumour....

I powned mine hovour firr lis trutl.

with no less honour to the Antinte

set bonour in nne eye. nnd denth ...Julius Cuss ur, i.

love the name of lienour more thais.

for some new homours thut ar

ant no man here hut honesurs you

nny cxplnit wortly the nnine if lionour

by my honour, depint untouchesl.

for mine honour: num hinve (refl.).....
for his fortude; honour, fir his valou

we lay these homonrs on this man.

the name of 'Essius homours this

mighty space of mir late honour

hath hat some suntel of himingir. in it

no man clse luth homour by his rleath

let it look like jerfert linnour

your homour enlls you hen

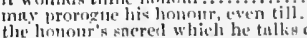

the hrome senered whe he tulis on

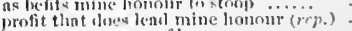

int lay me terins of hemontr .....

munluexl, lemour, lie er le fore did

mine lomeur was lowt yietded

hathe my droing hounis in the bilowe

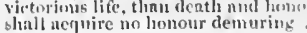

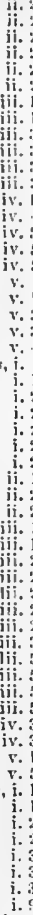

i. 10

ii. 1

ii.

ii. 2

ii.

iii. 2

iii.

iv.

i. 3 


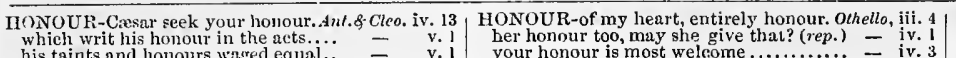
his taints and honours waged equal.
doing the honour of thy lordliness

but why slioudd honour outlive himesty?

who did join his honour ............

maught I did in hate, but a!l in honour ...
HONOURABLE-honourable man $\mathrm{v}$. $\mathrm{T}$.

I honour him even out of your report mine interest, and his honour

mateh were rich and honourable. Tiro
it is an honourable kind of thievery..

he bears an honourable mind

my chambers are honourable ..........erry $\overline{\text { wives, }}$ iv

the honourable lady of the house... Twe f fh Night,

bring from thence that honour of her

from thy report, as thou from honou

he hath a kind of honour sets him of

and pawn mine honour for their safe
firm the walls of thy dear honour...

and ta'en the treasure of her honour

according to the honour of his

opinion you had of her pure honour

or do your honour injury ............

this is her lonour! let it be granted

of him I gathered hovour.

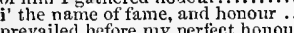

prevailed before nyy perfect honour

and every day do honour to her gra

the due of honour in no point omit

honour untaught; civility not seen

have civen their lonours to have saved

with fronour to maintuin

the grace of it, which is our honou

to violate my lady's honour

let my father's honours live

by honour of his name. whom, worthily

whom you pretend to honour and adore -

so I love and honour thce and th

in peace and honour, rest you here (rep.) -

in peace and honomr live lor

mine me at staff of honour for mine age

for your honour and your state.

proclaim our honours, lords .........

died in honour and Lavinia's cause.

in opinion, and in honour, wronged

but, on mine honour, darc I undertake
and let it be mine honour, good my lord

our' sister's honour, and our own (rep.) -

make your honour of his body's hme..

beciuse they dicd in honour's lofty bed

nor honour shall shape privilege

as doth befit our honour..................

buots me to say, I honour him

then honour be but a gonal to my will.

ese triumph

to preserve inime honcur, I'll perform

every one that comes to honour them

try lionour's cause; forbcar your.

try hen yirgin honour will not break it

bent all offices to honour her ..........

shiall prove, he's honour's enem

therein may vie honour with yourselve

to be thirsty after tottering honour

your honour lias through Ephesus

I helicve you; your homour and your.

bless your honour I I am glad (rep.)

I beseedl your lonour, give me lea
leave his honour and her together

if you were born to homour

with grace, lieal th, beauty, piece.....

love you and most honour you

to plainness honour's bound .............

make a great gap in your own honou

to feel my affection to your honour...

never spring a babe to honour her!
as I've life and honour, there shall

as I've life and honour, there shall

who inake them hon ours of me

no, by mine honour, madam ......................

it is the privilege of mine honours
such additious as your honours have

an honour that I dream not of (rep.).

where honour may be crowned sole...

to no issue of true honour bring.....

behoves my daughter, and your hono

upon my honour, then came each.

after your own honour and dignity

your linnour for this many a day ?.........

when honour's at the stake

your nature, honour, and exception

but in my terms of honour, I stand aloo
some elder masters, of known honour.

provoking terms against your honour

and to his honours, and his valiant parts

and to his hopours, and his valiant parts

wonld I might entreat your honour to scan stuffed with all honourable virtues ...Much Ado, i.

for you are like an houra be

marriage honourable in a boggar? ( $r$
here stand a pair of honourable men

ii. 3 in the state of honourable marriage.

how honourable ladies songht my love

esteemed thy father honourable..As you

let us make an honourable retreat

more lionourable than the bare brow

with lords, and hollourable personages

need but pletid your honourable privilege

hath been an honourable gentleman $\bar{s}$.

on. Tam. of Sh. l (ind.)

and by him that I think honourable

honourable thoughts (thoughts high
to find thee an honourable husband.

gn honourable conduct let him have. Kino Joln v.

from a resolved and honourable war

let me wipe off this houourable dew..

and by the honourable tomb he sivears

that honourable day shall ne'er

and is not this an honourable spoil?..1 Henry $/ r^{2}$.

and thy place shall be honourable

to you this honourable bounty sliall

imitate the honourable Ruman.

2 Henryl $V$. ii.

jut and his querrel homourable

an honourable padge of the service.

beguu upon an honourable respect

1 Henry $r L_{\text {. }} \mathrm{i}$.

prince, and honourable peers, hearing

confirm it so, mine honourable lord

and whiles the honourable eaptain th

disnonour not her honourable name $-\overrightarrow{-}$

am I of an lionourable house (

shame thine honourable age with blood

set down your honourable load

[Col.Knt.] honourable lords, may naine

with all their honourable points.... Henry rIII. $\mathrm{i}$.

in honourable keeping her .. Troilus \& Ch essida,

honourable gentleman, lord Lucullus

you are honourable, but yet they conild

denied that bonourable m

I might have shown myself honourable?

plensure such an honourable gentleman -

virtue, and honourable lord did but try us...

deserve not so honourable a grave... Cor

think'st thou it honourable for a noble

of hourourable dangerons consequence

you are my true and honourable
derived from honourable loins

Brutus is an honourable

than I will wrong such honourable me

that have done this deed, are honourable

wise, and honotirable, and will

thou couldst not die more honourable

which stands an honour

thollgh he be honourable.....

for he's honourable, and doubling that

thy name, and honourable family

and hovourable deerls ingrateful Ro

hath orlained to an honourable end

but how honourable he is in that ...

I hear say, you are of honourable parts

my oath before this honourable assembly

thy bent of love be honourable

a damned saint, an lonournble viliain

(as they say), with honourable parts

with love, in honourable fashion.........

as of a man faithful and honourable...... 'tis pity, she's not honest. honourable

the honourable blood of Lancaster

friend, and an hollourable gentleman

my most honourable lord, I am e'en sick -

attendants are all sworn, and honourable -

dirl not fiow from honourable cou
IONOUR ABLE-that honourable stop.. Othello, ii.
knows not yet of his honourable fortune

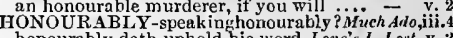
honourably doth uphold his word. Love's L. I.ost, y.
[CoL.] lords, use her howourably ..... Henry VI. Hii. Edward will use women honourably - iij. 2 like a soldier, ordered honourably.Julius Casar, v. how lonourably and how kindly. Antany \& Cleo. v. I do this message honourably.. Tilus Andronicus, iv.
HONOURED with a human shaye....... Tempest, i. and honoured in their issue......

glances of thy honoured love... Tüo Gen. of $\vec{V}$ er. i. the devil be sometime honoured.Meas. for Meas, v. wedlock then be ho from humble, he from honoured name. All's Well,i.3 the tomb of honoured bones indeed ..

my honoured lady, I bave forgiven... $=$ v. 3 assisted with your honoured friends - r. noble honoured lord, is feared and loved? - vacbeth, i. 6 I honoured him, I loved him

most fine, most hououred ........... Henryl IV, iv. 4 feared, and honoured of the people... Hen? y ${ }^{\prime 1}$. ii. my honoured lord. Why, this it is. Henry ${ }^{2}$ III. ii. six or seven times lionoured. Troilus \& Cressida, iii. most honoured Timon........... Timon of Athens, i. 2 pity not honoured age for his wlite... - iv. 3

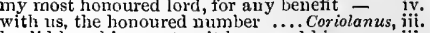
with us, the honoured number .... Coriolanus, jii.
he did love his country, it honoured him
iii. the honoured gods keep Rome $\ldots . . . . \quad-$ v. mayst be honoured being Cato's son - v. mall Brutus, and be honoured in his death - v. kiss the honoured gashes whole... Antony \& Cleo. iv. he wore upon his honoured finger.
help, help! mine honoured lady!.

lighly hunoured of your grace.... Thizs Andron. i. we are honoured much by good Simonides - ii. 3 strike me, honoured sir ................ strike me, honoured sir ................ 3 (Gower) ever honoured as my king ................. L eur, i.

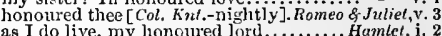
is a custom more honoured in the breach - i. my honoured lord, you know right well - iij. live in this fair world belind, honoured
HONoU R-FIA WED, iii. 2 HONOURING of Neptune's triuniphs..Pericles, $\nabla .1$
HONOUR-OWING wounds ........... Henry $V^{2}$. iv. 6 HONOUR'ST-lovest and honour'st ....3 Henry $F^{\prime} . i$. grace is saying, hood mine eyes... Her. of Venice, ij. now, by my hood, a Gentile, and no Jew - is. 6 the old Robin Hood of england ... As y J ouL Like it, i. hood my uumanned blood........ Romeo \& Juliet, iii. HOODED-you must be hooded ....Meas. forMleas. y. 1

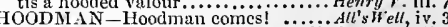
HOODMAN-BLIND-athoodinan-blind? IIamlet, iit.4
HOOD-WINK this mischance $\ldots \ldots$. Tempest, iv. I HOOD-WINK this mischance,$\ldots . .$. . Tempest, iv. I
we will bind and hood-wink him so..All's Well, iii. $t$ the time yoll may so hood-wink....... Macbelh, iv. 3
HOOD-WINKED as thou art .........All's Well, iv, such as war were hood-winked....... Cymbeline, v. 2 IOOF-trudge, plod, away o' the hoof. MIerry 'ives, $i$. with the armed hoofs of hostile......I Henry $I . \quad \mathrm{i}$. under the hoofs of vaunting enemies

printing their proud hoofs ....Henvy $F^{\prime}$ i. (chorus) HOOK - pair of anchoring hooks... TwoGen, of $V$. iii. bait the liook well; this fish wili ..... Iuch Ado, ii. but she 1 can hook to me ........ Winter's Tale, i.. upon the cross of a Welsh hook .....1 Henry $I V$. with her; hook on, hook on
hold hook and line, say I.....

bended hook shall pierce ... iniony \& cleopatra, besides, that hook of wiving, frirness. Cymbeline, $v .5$ bait from fearful hooks.. Romeo of Juliet, i. 5 (chorus)

WOOK ING botll right and wrong. Meas. for Heas. ii. HOOP-Nas or in of Rome...

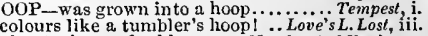
about a hoop of gold ........ Nerchant of or hoop his body more

pot shall have ten hoops.............2 Henry $I V I$.

hoop should hold us staunch........... Antony Cleopalra, ij. HOOPED-the three hooped pot ...2 Henry VI. iv. HOOT-nightly boots, and wonders...Mid. N. Dr. ii. 3 who did hoot him out o' the eity . Coriolanus, iv.
HOOTED - hooted at like an old tale. Winter's Tale,y. HOOTED_hooted at like an old tale. Winter's Tale,
rabblement hooted, and clapped .. Julius Casar, i. HOOTING-fall a hooting. Love's $L$. Lost, iv. 2 (epit.) hooting and Coriolanus' exile .... Coriolnnus, iv. 6

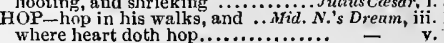


IloP-hop, ns light as bird from brier. Mid. N. Dr. v. hol no over orery kennel.... Tuming of shrew, Iv for you shall hop without............ sat lier once hop firty prees. Antony s cleopitra, ii. who lets it lop a little from ..... Romeo of Jmliet, jl. IOPE-no hope that he's unlrowned... Tempesi, ii. out of that no hope what grent hope

no hope, that wny, is another way (rep.) -

I hope now thoul nrt not drowned.

even here I will put off iny hope o.....

I am right glad that he

the fnir efleets of future hopes...Tico Gen. of

hope is a lover's staff
would quell a lover's liope

ay, but I hope sir

1 hope iny master's suit wili

thou hast beguiled my hopes

Ihope we shall drink

to cntertain him with hope $\ldots . . . . . .$.

I hope, is an unmeasurnble

huipe it be not so. Hone is

they have not so little grace, I hope.

I hope, I have sour

and give him another liope......

I hope not; I had as lief

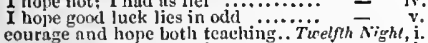

escape untoldeth to $\mathrm{m} y$ lione

I hope to see a housewife tak
nor hold him up with hopes

nor hold him up with ho $U$ shall end, I hope

the matter, I hope, is not greut ........

and the full prospeet of my hopes....

wreck past lope be was.

acting this in an olsedient liope.....

in hope it shall not

I have great hope in that .............

in haud, and hope of action.

all hope is gone, unless you have .....

I hope here be truths ............

so, then you hope of pardon.

luit only hope: I have hope to live....

with hopes that are finllible.

I hope, sir, your good worsh ip .......

and I hope, if you liave oceasion ....

I hope it is some pard

there's some in hope

I hope you will not moek me.............

but I hope, you have no intent $\ldots . . .$. . MIuch Ado, $\mathrm{j}$.

well niece, i hope to see you one day

we hope. Write down, that they hope

and 1 hope, here is a play fitted...Mid.

therefore, be ont of liope, of question Dream, i. 2

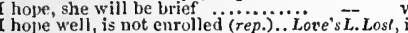

I hope in God for ligh words $($ rcp.)..

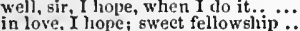

in love, I liope; swect fellowsing

hope sir, tliree times thrice.

but, I hope, I was perfect...............

he with my hopes abroad...Merchant of

bein' I hope, an old man

the place 1 go to and lose my hiopes...

do it in hope of fnir advantuges....

fortune now to my lieart's holel $\ldots .$.

there is lint one hope in it the

bastard lope neither. And what hope is -

you may partly hope that your..

low ehalt thou hope for merey .......

which speed, we hone, the better for

I hope, I sliall ree an end of him... As you Lik

that there is little hope of life in him

in the whieh hope. I blush, and hide

nay, I hope,-Truly thou art damned

hope not after it; 'tis not your

are you not good? I hope so $3 . . . . .$.

those that fear they hope, nnd know

what liope is there of his mijesty"s.

the losing of hope by time

the losing of hope by time ....

I hope to have friends for my wife's

atrive ngainst hope, yet, in this .....
it is our hope, sir, after well-entered

or eorrunt our hope, to prostitute....
of it lits, where fiope is eoldest......

ly my sceptre, and my hojes of hieaven -

hut never hope to know why I $\ldots$ it...

ut hope, your lordship thinks not

and we, great in our hope, lay our best -

and holve I may, that ghe. henring

I hope so; look, here eomes you (rep.)

men make hopes [Col, Knt.-ropes] ...

though there my hole be dim

and truly, as I hope to live (rep.)....

i hope, lhis reason stauds. Thaming
JOPF-and I do hope good days ... Ta
l'uris eame, in lope to speed alone ...

quietly enjoy your hope, nul murry

I hope, theu art not mud

out of hope of all, - hit mir.

I hope, better. Sirrah, Jiondells

ngree with you iu the hopen of lim.
I hope so, sir; for I have abont me.

no hupe to belp you; but, ns you

wherein. my line is, I shall so prevituil

that e'er man fired his liene's out of

from his hupes, and with a slieplierd

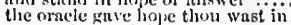

not retain mueh hope ........ Comedy of Error

for which, I hope, thou fult'st I was

nnd my sweet hop's aini...

I hope you have; or ele ......
she is too bis, I loope, fir me

I hope, you do not intiun to

and of royal hope, that he seems ........ Mescleth, i. 3

do you not hope your children shail.

nud set ine up in hope? but, liush

I hope, in no place so unsanetified

Thave lost my hopes

my breast, thy hope ends lierel.....

'tis his main hope; for where

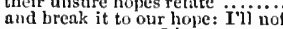

scme proper man, I hope . . .......... King John,

hope, your warrant will bear ......

as to my ample hope was promised

of the world, what liope. what stay .. - v.

by all my hopes, most falsely dofh ... Richard II. i.

grace's pardou, and I lowe, I had it..
strong as a tower in hope, I ery.....

our snibjects' next degree iu liope...

1 hope, the king is not $y$ th

and be at enmity with cozening hoje...

swectched with the hope to have ....

that huth some lioue to thaw

ghall i falsity men's hoves .......... Henry u. v.

induction full of prosperous hope....

the hope and expectation of thy time

bottom, aud the very soul of hope...
Epend upou the lope of what is to...

by my hopes,

never' owe so swcet a bone, so much.

I hope your lordship goes nbroul...

plainly your opiniong of our hopes.

in the hone of great Nortluumberland

who lined himselt with hope

lives so in hope, as in an early spring

our hopes, (yet likely of fair birth)

I hope, you'll eome to supper...........

thus do the hopes we have in him

we hove no other from your mie

a prinee of my grent hopes forgtt.

$I$ lope to see London once ere $I$ dic.

shall refresh itself with hope

some of them will frll to-morrow, i hope-

share from me, for the best hove ....

I hope. your majesty is near me

we fairly hoje, liave lost their

entrnnee, (ns I hope, we slini

where I hope ere long to be...

iii. 2 lis fulse hopes, the trust of

in you all liopes are lost

there is mo hope that ever I......
shall all thy nother's hopes

no hope to have redress?

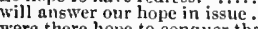

were there hope to eonquer
tor I had hope of Franee

post, in hope of lis reward

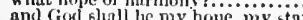

$=$
$=$
$=$
$=$
$=$
$=$

iii. !

v. 1 .

i. for I had hope of France ( $r, p$.) stay -

ii. 1 tis my spee inl hope, that you will ciear -

there is great hope of help ...........

and we, I lope, sir, are no

make signal of thy hope $\ldots . . . .$.

ii. A in time tu come, I hope to reign.....

ii. : ay, but I hope, your lighness shait.:

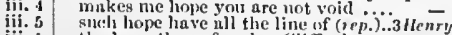

the liope there of inakes Clifford mourn -

and I, I hope, sliall reconcile them all

and in that lome, I throw mine eyes

nguinst them as the hoyre of Troy..

ino hiope to win the day

What anpe of gonel? bul lape is (I, p.
for yet is loope of life, and vietery...
IIOJ'E-that lsopea to rise ngain.

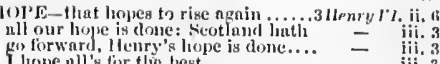

py the houe I have of lieavenly biliss

till tluen, fitir lowe inust libuer

my fenr to liope, my sorrows unto

with houe of this young.................

mot tiglit for such n hope ............

lets than a inother's lone .............

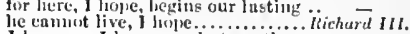

I hope so. I know so; hut fentle ....
shonl I live in hope? All nicn, I lioje

inulam, good hope his araed

ly you ny lopes are lititebercil.

ns you hope fir any toodness .......

in hin' there's a hole of govertine

I hope, he is much grown since.....
I hope, he is; but yet let mothers...

live, 1 hope. An' it they live, I louge

builds lis longe in nir of your fiur..

even that. I hope, whiel pleascth God

to stop nul lopes, whose growth
true liope is switt, and flies witl

I died tur lope, ere $I$ could lend fisee

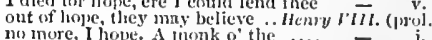

here, he boves, in all this nolle bery

in this world I ne'er linpe....

your lowes and friemds are infinite.

no frients, no hone: no kindred

falls like Ineiter, never to hoje a......

for a num that hopes for henve

imane of his $\mathrm{Naker}$, lope to win ligy

farewell, the hopes of eourt? my holes

I hope, I am not too lnte

let me wever liope to sce

hope of the strand

there ny hopes lie drowned .. Troilus \& Cresside

that hope makes in nll desioy

he hopes, it is no other, hut .............
I hope, I sliall know your houour better

on him ereet a seemend hope ...........

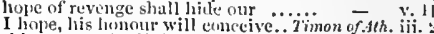

this was my lord's best hope ........ - iit.

I hope, it rematims not unkindly

if There well, ill never see

our hope in him is dend

Auficlius, their very lenrt of hope....

we hole to rain lyy you.............

and lope to cone ulion them in

not out of hope, mistalie me not

so, that all hope is vain ........

there is some hope the laclies of Rome

it trade, sir, that I hope. I may use.Juliu.

slinll give

now, Antony, nur lopes are minsere

I will hope of better deeds... Antony $\ddot{f}$ cteopatra,

and my anguring hope says, it will.

there is hope in it yet.

I have an absolute hope our landinen

part hone, gnd in despnir.

you bear a graver purpose, $I$ iope...

much to blame. Not he, I hoje.

I hope, it be not gone, to tell my ...
I hope so; go, and seareh.................

conective, I hope, lut the worst of ine
in these feared hopes, 1 barely......

I hope, the hrietiness of your answer

I hole, you know that we must not

and so llope, he came ly 't ............

this forwardnees mnkes our lomes fai

I home they'll pardon it ................

thus quenched of hope, not longing

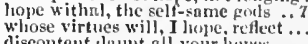

Lavinin is thine clder bruther's lioje

or not ut all, wland you in lione......

lmit liope to pluek a dainty doe

with blint painted lope lirnves

voutli, the livie of Rome.

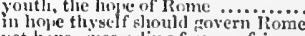

yct hope, sineecelling from so finir 30.

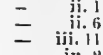

iii. ii

- ivi 3

Thole, shall neer be seen... - j.

I hope, sir, if you thrive, yom'll rememlier - ii.

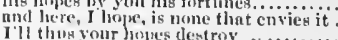

iii. 3

$y$.
$y$.
i.
i.
i.

i. 4

ii. 3

iii. 7

$v_{3}$

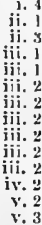

i. 1

i. 3

iii. 6
jv. 3
iv. 3
i. 32

i. 6

iv. 3

iv. 5

i. 1

not do th fur nll the worlil, i lific......... - it. is 
HOPE-there's no hope she'll return .. Pericles, iv. 2 , HORN-if we choose by the horns. Love's L. Lost, iv. J HORROR-these thoughts of horror. Ant \& Cleo. v.

\begin{tabular}{l|l} 
I hope, for my brother's justification...... Lear, i. & are the tender horns of cockled $1 . .$. \\
but, I hope, his heart is not in the $\ldots . . .$. & spelt back ward with a horn on his head -
\end{tabular}

I have hope you less know how

swallowed all my hopes but she. $\dddot{R} 0$ ineo \&... Julic? it.

for then, I lope, thon wilt not keep.

with a horn added. Ba, most silly (rep) -

what is the figure? Horns............

a gig of a euckold's horn ..........

I do spy a kind of hope, which craves

with his horn full of good news... Merer. of Fenice

as horus are odious

has good horns, and knows no......

by so much is a horn more

to set the deer's horns unon his head

leatlier skin, and horns to wear....

the horn, the horn, the lnsty hor.

they may joll horns together..........

the cuckold to his horn, as a scolding ..

your head and butt were head and loorn

that will take pains to sorn ....Winter's Tale, j.

for he hath tlie horn of abundance ..2Henry ${ }^{\prime}$, i.

the basest horn of his hoof.............Henry $V$.

our heads, to gild his horns...

your nail agrinst his horn

the bull has the game: 'ware horns, jo

lang them on the horns o' the moon. Corrola being but the horid and noise

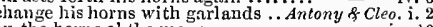

with horn and hound, we'll give...... Titus - indr. 10

shrilly to the well-tuned horns ... Tilus Andron. i. 2

whiles hounds, and horns, and sweet

hast slo ot off one of Taurus' horis...............

fell both the xam's horns in...........

and leave lis horns without a ca. Tom, thy horn is dry ..........

with horror, madly dying ..........Cymbeline, y.

nothing like the image and

loosed out of heli, to speak of horrors... Hamet i. on horror's head horrors accumulate ... Othello, iii. RS-a team of hor'se shall.. Two Gen. of Ver. iij. a horse can do no nore; nay, a horse $\overline{\text { Wives }}$ ii. esire to have three of your lorses ... - iv.

where be my horses?

of horses and money

his horses are arrested for

Tuelfth $\overline{\text { Night }}$ v. and I'll give him my horse.......... - iif.

have his liorse to take up as well...

a horse whereon the governor...........

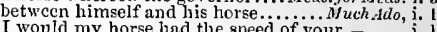
as they write, here is good horse to hire -

an' two men ride of $a$ horse.......... $=$ iii.

a fat and bean-fed horse beguile........id. $N .{ }^{\top}$ 's $D r$. ii.

sometime a jorse I'll be

like horse, hound, hoo, bear

the dancing horse will tell you $\ldots \ldots$... Love's $\overline{\text { L. Lost }}$ iii. I

to be embassador for an ..Love's L. Lost, i 2

send the ass upon the horse.

the tired horse his rider...........

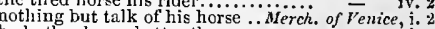

where is the horse, that doti untread $\overline{-}$ ii. 6

his horses are bred better .........ds you Like $i$, $\mathrm{i}$. 1

that spurs his horse but on one side - $\quad$ iii.

ere twice the horses of the sun shali...An's $W^{\prime}$ ell,

given order for our horses; and to-niglat -

the general of our horse thoul a

witl our horse upon our own wings $=$ ili.

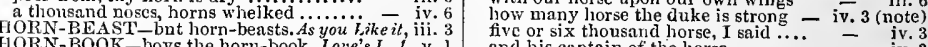

HORN-BOOK-boys the horn-book. Love's $L$. L.

Jet my horses be well looked to $\ldots . . . \cdots$ -

we must to horse again; go, go ........

thy horses shall be trapped

given him the best lorse in Präua

as many diseases as two and fifty horse

caparisoned like the horse .........

my horse. Ay, sir, they be ready $\dddot{r e p}$.

ny barn, my horse, my ox...

one horse! what's that to thee? (rep.)

her horse fell, and she under hier horse

how the horses ran away ...........

my stirrup, nor to take my horse!

seven, cre I go to horse

are less than horrible imagining

horrible siglit! ay, now, I see.....

fearful, comfortless, and horrible

as harsh, and horrible to hear.....

King John, iv.

is Horatio there? A piece of him $(r e p.) . .$. -

speak to it, Horatio. Looks it not $(\mathrm{rep}$.

Horatio, or I do forget tremself

make you from Wittenherg, Horatio? ...

or ever I had seen that day, Horatio!....

set them down horrible traitors. Timon of

with this horrible object, from low farms

why then let fall your horrible pleasure

horrible steep: hark, do you hear the sea? - iv.

there assuine some other horrible form.. Hamlel, $i$.

but there is, Horatio, and mucl. offenee... -

what ho, Horatio! Here sweet lord (rep.) - iii. 2

Horatio, when thou shalt have .... - iv. 6 (letter)

by the lord, Horatio, these three years...

pr'y thee, Horatio, tell me one thing .....

I pray thee, good Horatio, wait upon hiu

where I found, Horatio, a royal knavery

but I am very sorry, good Horatio

IIoratio, I am dead; thou livest

0, I die, Horatio; tre potent poiso.........

HORIZON-border of this horizon ... Henry $^{r} t . \mathrm{i}$

the horn I say; farewell .............Meryy Hives,
the

o'er the enckold's horns

mad

with hreat ragged horns horus on his head

in thy brain some lorrible conceit ..... Ökello, iii. 3
what horrible fancy's this?............ - iv. 2

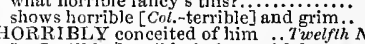

for I will be horribly in love with her. Much Acio, ii

Hal, art thou not horribly afeard? .. I Henry Ir:ii.

leek, I will most horribly revenge ..... Henry $V$.

my niece is horribly in love.... Troilus \& Cress.
horribly stuffed with epithets of war... Othello

whose horrid image doth unfix ......... Macbeth, i.

shail blow the horlid deed .

not in the legions of horrid hell....

so many horrid ghosts.

never sees horrid night ..............

and fresh our horses back again ...., $\bar{T}$ ix. 5

as you would lay to your horse... Comedy of $F r$, iii. I

therefore, to horse; and let us not ..... Macbeth, ii. 3

go not my horse the (a thing most ...

I wish your horses swift, and sure

hark! I hear horses

his horses go about $\ldots \ldots \ldots \ldots \ldots \ldots \ldots .$. = iii.

send out tnore horses, skirr the.... - iv.

to horse, to horse! urge doubts (rep.). Kichard 11 . ii.

wound thee with their horses joofs

saddle my horse. God for his mercy!

that horse, that thou so often $($ rep. $) ..$...

forgiveness, horsel why do I rail ....

did take horse, pucertain of the.......1 Henry $I$

new ']ighted from his horse....

you have horses for yourselves

tut! our horses they shall not see.....

and yet our horse not packed..........

give me my horse, you rogues ( $r e p$. .)

prince Hal, help me to my horse ....

the boy slaill lead our horses down...

now merrily to horse; the thieves....

than that horid aet of the divorce.. Cymbeline, ij.

to quit this horrid act.

not in the fiend so horrid, as in wonan

the general ear with hortid speech...

love set on thy horns.................

here are his horns, master Brook .... for $\bar{M}_{\text {eas. }}$ ii.

pluck oft the bull's lioms ...........nuch Ado, i.

God will send you no hol'us...........

列

those horses from the sheriff? (rep.).

my horse, my love, my horse .........

give my roan horse a drencli, says he

spit in my face, call ne horse........

as tedious as is a tired horse

and then to horse immediately $\ldots . . .$.

horridly tricked with blood of fathers..-11.

and take lzer hence in horror .........

take the present horror from the tine. Afacbeth. fi. I

to countenance this horroi

I have supped full with horrors

ontface tlie brow of bragging horror... King John

in the night to cateh my horse....

would it had been of horse $\ldots . . . .$. .

ome, let ne talie my horse...........

hot holke to horse meet, and ne'er part

not a horse is half the lalf luimself

like a horse full of highl feeding $\ldots .2$ Henry $I I^{\prime}$.

\begin{tabular}{l|l} 
changes, horrors, divert and crack. Trnilus \& Cress. i.3 & by me to hreathe his bloodied Piorse... \\
prosecution of disgrace and horror. Ant.f. Cleo.iv. is & he gave his able horse the head.......
\end{tabular}

the horns on his head (rep.)............ 
IOJRE-stolen the horse he role on..2Henry $11:$ i. 1 IIOLSE-On a bay trotting horse.

a horse. I bought him in l'nul's (rep.) - i. 2 horse to risle, and wenpon to wea

v. get horecs for your mistress

get hores for your mistress.

-

good mine host o' the Garter

my merry host hath had

awioy, Harilolph, eatille my hors.

to she a troop of horre with felt

mine lost ile Jarterre.

when we talk of horses, thut you...Ifeny/t. i. (ehw.)

aell the pasture now, to buy the horse - ii. (chis)

he judgment hy mine liost of the Garter

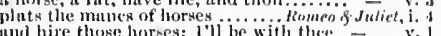

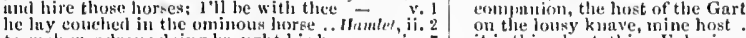

you talk of horse and nrmour

to such wondrous doing brought his horse

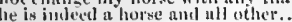

that prnised nyy lord such-it-one's hor

it is thine linst, thine Ephesian

a inost ulsolute and exccllent hores
and iny liorse is argumsent for them all

Burbary horses ngainst six Fremel sworis

for nyy horse is my mistress.

dumghter corvered with a burbary horse... omb

there was, mine host, an olil fat...

yet do I not use my horse for

ond whACK-sits on his horseback... King John,

uy thut there was, mine host
where is mine bonst?...............

that has cozened all the hosts....

even as your horse benrs your praise

niy hores! Valet! lacruey! hu! ...

weell our horses' blood?.

v' liorsebuek, ye euckoo! but, afoo

saw them salute on horkeback...... in, inry J t

to

II) RSE-BACK-BREAKER, this huge.l le

give their fastimg hurses provender.

IIOKSED-horsed wion the sightless..... Harktheth

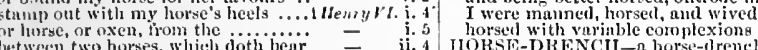

hetwecti tho hores, whicla doth bear

IIORSE-IIAIRS, nnd eats-guts

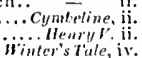

monnt on my swiftest horse..i…… die! =

for oxen, sherse that bears in

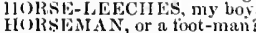

as fast as horse enn earry them.....
shall he dragged at my horee' heels.

nORSEMANSHIP-noble horsemanship.l H. $/ 1$.

away, take horse. Cone, Margaret.

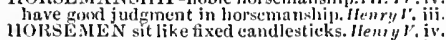

not to let thy horse wear a elonk

ride thou unto the horsemen

I holi hiots, hiorse, arm a

for yet a many of your horsene

your troojs of horsemen witl his....
out, some light horsemen and peruse

nuy promised supply of horsemen.

Ind kill iny horse, beeanse I...........

your horse stands realy at the

I will desputeh the horsemen straighi

where every horse beurs hiscomminding

presently you will take horse with lim

presently yon will take horse with him
my footeloth horse did stumble......
give me another horse; bind up my..

pursued the horsemen of the

vere is mine host de Jarterre?

hoth, my gool hon

where you slall host: of enjoined ... All's $\bar{n}$ rall, iji.

to the Centaur, where we host. Comedy of Frrors,

to a niggardly host, and more sparing - iii.

Macbeth, $\mathrm{i}$.

then, as his host, who should agaimst

the numbers of our liost.

tor mureh a bloody host

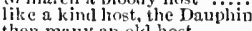

tolen from my host ut $\mathrm{s}_{t}$. Aibans

Henryll. ii.

eaparison my horse; call up lord stanley -

the ling expally of horse and foo

well winged with our chietest horse.

gpur your proud horses hard

a horse! a horse! my kingdom (rep.

anger is like a full-liot horse........... ilenry $r$.

the horses your lorelship sent for - - ii. 2 (letter

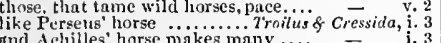

and A hilles' horse makes many.

I1ORSE-SHOE-like a horse-shoe... Merry Wires, iii.
IIORSE-STEALER-a hor'se-stealer..Asyou Like it, iit.

IIORSE-TAIL-master's horse-tail.. Tam. of Sh.

HORSEW A Y-horseway, and footpath .... Lear,
HORSING-horsing foot on foot? .. Winier's T'ale,

HORTENSIO-there Hortensio. Taining of Shrew, i.

is not so great. Hortensio

think'st thou, flortensio, thougl her

and approved triend, Hortensio......

food IIortensio, I bade the raseal knoek -

gignior Hortensio, thus it stands with me -
signior IIortensio, 'twixt sueh friends

Hortensio, pence; thou know'st not.

I will not sleep, II ortensio, till I see her -

what a man is there! a very horse

like a gallant hor ze fallen in....

take thou Troilus' horse; present the

he fights on Galathe his prose...

IIortensio, have you told him all her

Hortensio, hark this gentleman ...

IIortensio, to what end are all these

jost Pistol? Base tike (rep.) ............

mish on his host, as doth the mejted

- iv.

not at pieee of feather in our liost ....

of the Lord of Ilosts he fought

scud me packing with a host of men.2 Henry ${ }^{\prime} J$. iii.

and the forchand of our host. Troilus \& Cressilio,

Grecian host [ Kint.-monld] one noble man -

like a fashionable liost

you do disemfort all the host .......

applatse and elamour of the host. .. Coriolanus, i.

to-morrow set down nur hos

messnge a host of tongues ...Antory o creop

safed the bringer out of the host.

success to the Roman host ............. Cymbeline, iv.

am your host: with robbers' hands .... Lear, iii. ?

0 all you host of heaven! O carth!......... ilantet, $\mathrm{i}$.

IIOS'TAGE-now your hostages... Troilus \& Cress. iii.

your hostages I have, so have yon. An/ony \& Cleo. ii. $t$

tam on hes

willing you to demand your hostages - - v.

is't not Hortensio? If thou affeet'st..

to plead IIortensio's passion .........

ranging, Hortensio will be quit with
an eallei Hortensio. Signior Hortensio

lave forsworn you, with llortensio.

eat it up all, IIortensio, if thou lovest

Ilortensio, say tliou wilt sce ...........

thou, Hortensio, with thy loving widow

for ny life, Hortensio, fears his wiclow -

how likes Hortensio that? My willow

where is your sister and Hortensio's wife?

HOR UN-horum, ha Hortensius.. Timon of Ath. iii. 4

and to call horum: fie upon yon!....

IOSE-see to garter his hose. Yico Gen. of

a round hose

in round hose, madam donblet and hose.....

slaill make the a new donibiet and hose

mount thou my horse, and hide thy

drink the stale of horses ...... Antony
or is he on his hore? 0 liappy horsel

do bravely, horse! for wot'st thot....

so, this is to horse: arlieu, noble

worke for that, were he a horse ......

with horse und mares together (rep.)

would bear a sollier, and his lowrse

and our twelve thonsand herse
the legions anul the horse whole.

guards on wanton Cupid's hose. Love's L L L tosto, v.

his round hose in France...... Merchant of tente, i.

as doublet and hose ought to

I have a doublet and hose

shall I do witl my donblet and hose

then your hose should be ungartered
have your doublet and hose plincked

dost muke hose of tliv sleeves? ......

a velwet hose! a searlet chak!. Taming of Shro

four, tlirnugh the hose

down fell their hose

your Freneh hose off ...............Wenr?! $\mathrm{V}$. iji.

where horses have been nimilier..... - iii.

when we eame from

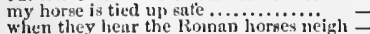

never bentride a horse, save one.......

and I have horse will follow

we hunt not, we, with horse nor hoilind

hore, and sail, and higl, exprence

knnw when the eart iraws the hor

saldle my horses; coll my train

pone eompany, ani] away to hor

be my horses rindy? 'Tly, asies ( $r$ p. $)$

Where may we set nur harses?

straight took horse; tommandeil ine

in pure kindness to his liorse, butterel.

Iosplet, hat, hose, all that answer.. ('ymbin

there ugainst the hospitable eanun... Coriolumws, io

I know your hostess as ample as .....All's ' H'll. iii.

rail npon the hostess of the house. Tam of Sh. ? (ind.

and not the hostess of the meeting ... iv.

upon nime hostess there .... Comedy of Errors,

fair and noble lostess, we are your

towards him: by your leave, hostess

our hostess keevs her state

on his horsebaek at mine hostess door. King John, ii

列

to do with $m y$ hostess of the tavern?

how how, iny lady the hostess?

you lie, hosters; Bardolph was

thou say'st true, hostess

hostess, my break fast; eome

eome hither, hostess.

dost thou hear, hostess?

so you do, hostess. Do I? yen?

is thine hostess here of the wicked?

farewell, hostess; farewell, Doll.

eome to my master, antl yon, hostess.. Henry

farewell, hostess. I camnot kiss ...... -

ruminates like a hostess.... Troilus \& Cressidn, ini.
IIOST uttemut of hostile arms!

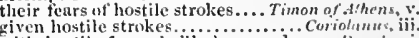

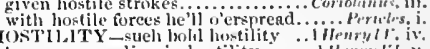
ly our proceed ing in hestility ... I Henryl't.

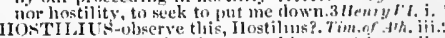
efter great Hostilius, here was kimg. Coriolanus, ii.
IIOT-SIars's lut minion is returned .. Temprst, iv.

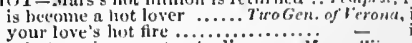
your love's lut fire .................. the sined ot hot meat
with liver hurning hor

mul ermblal, plewing hot

when hets iuve hot liat...

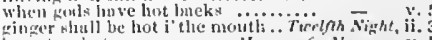

but, host dioth this sir l'roteus
host, will yon go?

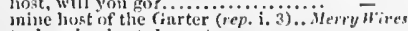

truly mine host, 1 must

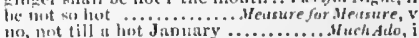

appointed nime linst of je Inrterr

lawned his harses to inine host......

the tiret suit is hot ume las

hot iee, and wondrous strange...Mili.i:'s Dream, $v$. 
IIOT-your wit's too hot, it speeds. Love's L. Lost, ii. but a hot temper leaps over.............. which is the hot condition of their ..

slie is not hot, but temperate... Taming of shere soon hot, my very lips might frecze.

for being slow inl thy hot office

the unnstard is too liot a little.

not so hot, good sir.

it hath seen very hot service

your purse is not hot enough $\ldots . . . . . .$.

here is more matter tor a hot brain.

or some othcr hot intusion ..........

but I felt it, hot in licr breath.

that hot rash haste so indirectly.........

commancler of this hot malicious day!

in this hot trial, more than

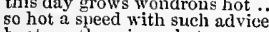

heat me tliese irons hot

must you with hot irons burm.

and with hot irons must I burn

lords, I am hot with haste.

the salt in them is hot

the blood is lot, that nust be cooled. Riehard

for young hot eolts, being raged.

now the lord of such hot youth...

mounted upon a hot and fiery steed

a fair hot wench in flame-coloured

what hole in bell were hot

if there come a hot June ...............

as hot lord Percy is on fire to go

wlose loot incursions, and great name

all hot, and blceding, will we offer

I am as lot as molten lead ...........

ay, IIaI; 'tis hot, 'tis hot

join not in a hot day

if it be $a$ hot day, an, $\because$ brandish

where they supped, is too hot...........

fie! this is hot weather; gentle
become very hot, and valiant.....

when rage and lot blood are
with liot essays; girding with

with lot essays; girding w
to so hot an answer for it ...

the knocks are too hot; and, for mine

the humonr of it is too liot, that is

that their hot blood may spin

touched with choler, hot as gunpowder

ties me over to time and a hot summ

and cease our liot pursnit

are you so hot, sir? Yet, Pucelie

my sword slionld slied hot bioo.

now yon grow too hot; it was..
churchmen so hot? good uncle...

melts with the sun's hoot beams.

seen a hot o'er-weening cur rum

our part hot coals of vengeance!

the sun shines hot, and, if we use ...3Henr

I was too hot to do somebody good.. Richard 1 . iv

finds the tcsty gentleman so liot

and now while it is ge yourself $\ldots$ Henry ${ }^{\prime} 111$. $\mathrm{i}$.

bot digestion of this cormorant it

or is your blood so madly hot

to the hot passion of distemper

gnch swoln and hot discourse........

hot blood, hot thoughts, and hot deeds? -

the gods are deaf to hot and pecvisi

under hot ardent zeal ........ Tim

une that loves a cup of loot wine

by his side, come hot from hell ...Jutius

like horses hot at land

many hot inroads they make........... $\overline{\text { Antony }}$ Cleo. i. 4

you are most hot, and furious ..... Cymbetine, i. 3

but that of coward hares, hot goats

as Dian had hot dreams, and she alone

now too hot; first pay me for

now let hot Atua cool in Sicily. Titus An

that these hot tears, which break

tell the hot duke, that

hot questrists after him, met

not so hot: in his own grace

the room is grow; to came even.......

the day is hot, the Capulet's abroad

thou art as hot a Jack in thy mood.

- iii. 1

of unimproved mettle hot and tull....... $\overline{H \alpha}$

now I had seen this hot love on ....

in your motion you are hot and dry

in your motion you are hot and dry

it is very sultry and hot ........... v. 2

HOT-as hot as monkeys, as salt a

HOT-BLOOT, and moist: this hand of yours why, the hot-blooded France ...Merry Wives, y. HOTHUUSE-professes a hothouse. Meas. for Mear, ii. HOTLY - this chase is hotly followed.. Herry $r$. ii. contest as lootly, and as nobly

thou hotly lust'st to usc her in
you have been hotly called for

M... Lear, iv.

HOTSPUR-gallant Hotspur there
of prisoners, Hotspur took Mordake

Percy's inind, the Hotspur of the uorth

sit, good cousin Hotspur ..........

this gallant Hotspur, this all-piraised

a harebrained the Hotspur bot

beaten down young Hotspur....2 HenryI $\bar{V}$. (induc.)
the wratl of noble Hotspur's sword...

of Iotspur, cold spur? that rebellion

young Hotspur's case at Shrewsbury

han sonn tak

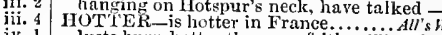

lusts burn hotter than my faith........ All's 's well,

a hotter name than any is in hell ....Mroebelh

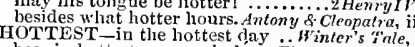

bces in hottest summer's day. Titues Andronices,
HOUND-fell and cruel hombls . Tw'elfh N'igh

sometime a hound, a hog.......

Iid.N.'s Dream, jii

like horse, hound, hog, bear .......

shall hear the music of my hounds.
of hounds and echo in conjunction.

bayed the bear with hounds of Sparta

iii. 2

so doth the hound his master ..........

tender well my hounds .. Taming of Slurew,

thy hounds shall make the welkin... - 1 (ind.

on my hask, or hound, but twenty.. -

as hounds, and greyhonnds, mongrels. Mucbeth, jii.

leashed in like houmds $\ldots$......Henry $V$. i. (chorus)

turn on the blood 5 hounds ......... Henry VI.

boy! false hound! if you have...... Coriolanus,

as a carcase fit for hounds..........Julius Casar,
like asses, and fawned like lounds
with horn and hound, we'll give.. Titus Andron

hunt not, we, with horse nor hound

the babbling echo mocks the hounds

whiles hounds, and horns, and sweet

your husband from his hounds to day

hound or spaniel, brach, or lym ........ Lear, iii. 6

not like a hound that hunts, but one .. Olhello, ii. 3
HOUR $\rightarrow$ for the mischance of the lions... Tempesi, i. 1

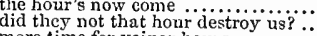

more time for vainer hours

any business that we say befits the hour

he's safe for thesc three hours

within this half hour will he be asieep

one phouix at this hour reigning there

on the sixth hour ...............

who three hours since were

when that hour o'erslips me

the next ensuing hour some

swill be this hour ere I.

our marriage hour, with ail ...

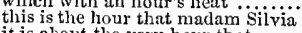

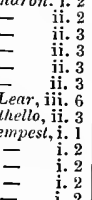

very hour that

we had an hour's talk of that wart...Merry $\bar{W}_{\text {i }}$

we have an hour's talk with
the first hour I was born.

the hour is fixed, the match

eleven o'clock the hour.......

'tis past the hour, sir.......

o this blessed hour

I was at her house the hour she.....

within a quarter of an hour

why, that hour of fairy revel

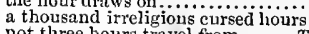

great exceptions to your ill hours.

and a sister, both born in an hour.

some hour before you took me.

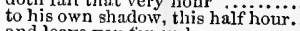

and leave you for an hour

not half an hour before ............

drunk, sir Toby, an hour agone.

the condition of this present hour

to mect me two hours since. Measure for Measure

si:e's very near her hour

at what hour to-morrow shall I......

the hour draws on prefixed 0 by Angelo

and be hanged au hour!... ii.
iii. 1
iii. 2
iii. 2
v. 1
v.
induc.
induc.
indnc.
i.

HOUR - at an unusual hour? .... Aleas. for Meas. v.
gou will temporize witl the hoirs .... Mluch Ado

7ou will temporize with the hours .....
but I am heart-burned an hour after

find we a meet hour to draw

I talked with no man at that hour...

at that hour last nigit ..

with me conversed at hours unmeet

you have stayed me in a happy hour

whys did she, an hour togeth
why in clamour

promised by this hour to visit me

our nuptial hour draws on apace. $M i i d . N . \overline{D r e}$

in her dull and sleeping hour....

the hours that we have spent

abate thy hours: shine, comforts....

o most happy honr! ...........

ease the anguish of a torturing hour....

sleep but three hours in the night ...

you may do it inour; when beasts - i. 1 (letter)

I never spent an hour's talk withai... dances, masks, and merry hours $3 . .$.

close mine eyes some half an hour

they stayed an hour and tallsed (rep.)

and return all in an hour ... Merehant

Gratiano's lodging some hour hence

outd wells his hour, for lovers...........

and happy hours, attend you! ........

and prays for happy wediock hours...

would wear it till your lour of death

- v.

from hour to loour, we ripe and ripe (rep.) -

and neglect the creeping hours of time =

slceping hours excepted...

and groaning every hour ................

two hours Rosalind, I will leave (rep.)

one minute behind your? honr............

at this hour the house doth keep itseif

this carol they began that hour....

to sce him every hour after.

by such a day, and hour

if I were but two hours younger

to beguile two hours in o'erflow....

to beguile two hours in a sleep $\ldots . .$. .

remain there but an hour ..............

for he is dicted to his hour $\ldots \ldots . . .$. .

had were to live this presen

thou diest within this hour

shall I be appointed hours ............
spent an hour, your lecture shall .....
Ill not be tied to hours..............

is at your command at ali hours......

clocks more swift? hours, minutes?

to take the urgent hour

are come an hour since

if I might die wour to plant...... - iv. (chorus)

shall know within this hour ...... - iv. 3

seen this hour, he had paired weil with -

any time these four hours............

very hour, and in the self-same. Comedy of Er

till a merrier hour than this ..........

a con here, not half an liour since

in Ephosus, I am but two hours oid

when that place, nome hour hence........

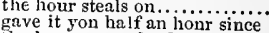

to turn back an hour in the day......................

from the hour of my hour sine

within this hour I was his ........

and careful lours, with Time'

time and the hour runs throngh

can entreat an hour to serve .....
I have almost slipped the hour
had but died an hour before.....

I lave seen hours dreadfni

war or twain ..............

the tate of that dark most, I will advise

ii. 4 let this pernicious hour stand

continle in this a quarter of an hour

now blessed be the hour, by ni $\ldots \ldots \ldots$.

shalt rue this hour within this hour

v. 1 entertain an hour, one minute

ii. 2 to see so sad an hince I left

ii. 2 an hour or two before the stumbling

iv. 3 when he sees the hours ripe

We fly-slow hours hours ripe on.

but gricf makes one hour ten

ii.
ii. 2
iv. 1
iv. 1
iv. 1
iv.
v.
v. 2
v.
i. 1
ii. 1
iii. 2
iii. 2
iii. 2
iv. 2
v. 1
v. 1
i. 1
i. 2
ii. 1
i.

iv. 3

v. 2
v. 2

ii. 4

ii. 6

iii. 4

ii. 7

iii.

iv. 1

iv. 3

Irswell, $\mathrm{i}$.

i. 3
ii. 3
ii. 4

iv. 1

iv. 2

iv. 3
iv. 3

v. 3

ii.

iv. 4

ii. 3

iv. 3
iv. 3
v. 1

v. 2

ors, $\mathrm{i} .1$

ii. 2

ij. 2

iii. 1

iv. $]$

iv. 2
iv. 2
iv. 3
iv. 4 


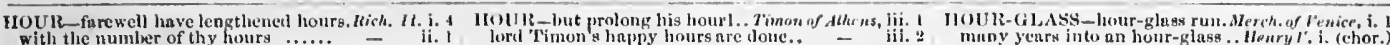

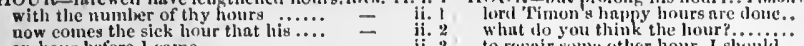

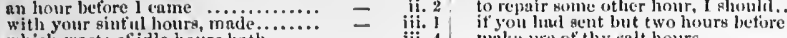

with your sint ill hours, made.
whicli waste of idle hours hat

make $116 \mathrm{se}$ of thy salt hours ...........

iii. I muny yenrs into an hour-glass... Henryl'i, (chor.)

I would it were this hour

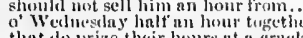

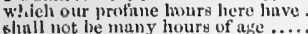

that do prize their hours on

above an hour, my lord...............

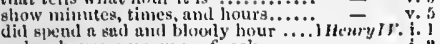

eouldst thou in a mile confouml ma hour
hulf an hour since brought my report

unless lours were eups of snek
o let tlie hours be sliort, till fleld

within these thre hours, Tiiliin

lenve you withine these two hours...

in one quarter of an hours

some fourteen, an lour after ........

the very hour you take it off agnin?

whose hours, whose bed, whose meal

a dozen of them two hours together.
ut lenst nine hours, in reckoning..

the lour betore the heavenly-larne.essed

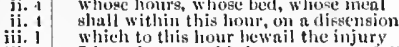

as thrm art to this hour, was lieliari

whe been up this lour.

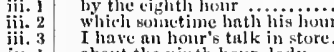

not ubove once in a quarter-of an hour
on the nice hazarl of one doubttul hour?

with quiet hours: for, I do protest

about tlee ninth hour, lat

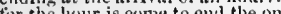

fonglit a long hour by shrewsbury eloek

I know, my hour is eome Not so .

have lut liboured to attain this hour

and crery lour, most noble Cassar

is every hour in Rome expeeted ....

when poisoned hours has hound me up -
from this hour, the heart of trothers

ere the ninth hiour, I trunk him ....

when nine hours were niee and lueky

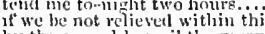

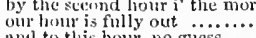

about some halt' hour hunc...

nt vertain hours, sueh thonghits........

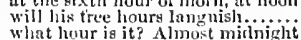

I have read three hours then

in an hour, was't not? - or less
ride 'twixt hour and hour?

dierourse the freezing hours
shall within this hour be off

the the minth hour o' the mor

broad awnke two hours and more. Tiluss.hut

brought hitiser in a most umlueky hour

tis not min hour since I lctt hi
one lour' $y$ storm will drow'n

ere hall mu hour can pass............

heard nie wish tor such an hour

not an hour, in the day's glorious .......
shonld at these early hours slanke off.

may usurphs on nat ure many hours....

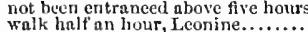

we have this hour a constant wili

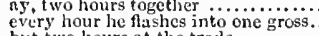

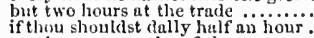

weeds are memorics of the wor ......

[Col. Knt.] not an hour more nor less.

until some hinlt hour past .................
is now the two lours traffic.. Rompo
an hour before the worshipyed sun..

al, ne? sald lanurs seen long ........

I can tell her age uuto sun hour anours? -

at the hour of nine. I will not fail

in half ant hour she pronised to retion

till twelve is three long hours
my life for an hour and in quarter....

that an hour hatl? been my kinsmail

when I, thy three humrs wite

Suliet thy love, an hour but married

he:ur from thee every day i' the hour

[Col. Knt.] deny, nightit, hour, ticle, time

glantt remain ful: two and forty hou

at some humrs in the night gipirits.

within this three hours will fair Julie

ah, what an unk inil hour is guilty

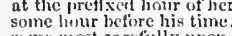

y noon your hour

ii. $A$ hourly jovs be still upong you ........ - iv. 1 (sollin

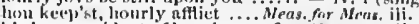

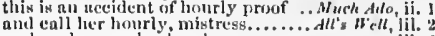

aul bourly urounise-breuk

she aclulterntes hourly, with thine., himk John, iii.

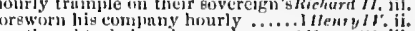

an hourly do hourly prophesy

2Henryllitii.

sit in hourty synod alwout

albide the loourly shot of anisry ery \& Clenpatru,

-

a mother hourly coining ptot

slankl render him hourly to your ear

where thourly trumble ........

main dexcry stands on the hourly thinifitit lear

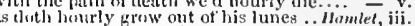

oU SE - hy any other house .......... Tempest,

if the ill silitit have ar fair a honse $\ldots .$.
lac liath raised the wall, and houkes too

the trimery in my horle

the trumpery in my honse ............

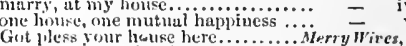

Gat 3 tess

and fint an burly in the hou

ouse withal.

come nuar the house i irray you.....

Was in his compuny nt P'age's lonfe
husbund will to atsent from hix louse

like a fitir house, brilt upon....

is lace now in the hone

if the houke, y'on eannot hide him

to my hersyymoly in the house

thus stili to haunt my louse .........

to search his house fur his wife's love

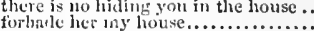

conveycal out of my house yesterdiny

laclp to searel my house this one time

have I not torbid her ny lowse?
they have had my house a week

his chamber, his housc, his castle ...

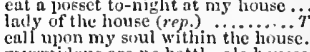

myrmillons are no bottle-ale houses

make an alchouse of my lady's house

he is alsout the house .................

atmy house, and ny houlse doth stand

will you cheominter the huse?

I will return again into tle laouse

back you shu!l rot to the liouse......

go with me to my house.....

she could not sway her house.

here at my houtse

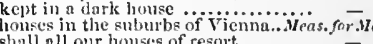

wse their nluses in cummon houses

Whose houte, sir, was as they say....

this house, if it be not a basd's lioule.

gir, we had but two in the house....

I'll rent the frirust house in it.

your worklip's houre, sir? "To my hou

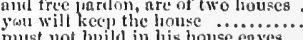

as I was in our house of yrofersion.

it were misfress Overdone's own house

I'll (all you at your lonus

never enne troully to my hou

from iny house (if I lad it).

thke thy fair hour, Lacrtes; time le thine

my hour is almo think, it laeks of tweclec

the this non hrour for temporal uffiizi...

when was the hour, $I$ ever enentraslicted =

guch news as this once every hour....

by the honr seems to flow trum hin
within there forty hourd Surrey

goune lialf hour, or soo in a rieh.

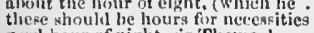

gixxl hour of night, sir Thomas!

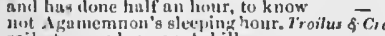

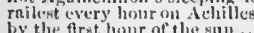

niter so many hours, livey, sliecelice.

and the honr preftixul of hier delivery

keep I feetor empluny an linur or two

Wectil seckin: you this hour, my" iord

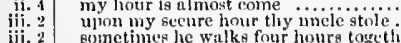

oumetimes he walks four hours together

an hum of quiet shortly shall we see

took onee a pliant hour; and fount youl.oltiello, i. 3

Thave hut an hour nf love, of worlthy

not this hour, lieutenant; 'tig not yet...

make the lours keem short

within this hour it will he weil

Bense had $I$ of her stolen hours of inist

aurt lovers absent laoters, nore tedients.

an lour, or more, not meaning any hurm

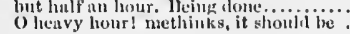

no: 'twas the vane in the house ....

frum Athens is her linse remote.......

steal forth thy futher's house to-morrow -

dunce in iluke Thesents' bovouse....

have yon gent to Buttom's house?

stiml disturb this hallowed house,...

throngh this house each fairy struy... - v.

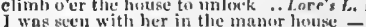

to let you cinter his unperpled hemse

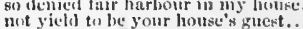

np ind a nourning house .............. 
HOUSE-our house is hell, and...Merch. of Venice, ii. 3 HOUSE-worse than a smoky house.1 Henry IV. iit. 1 , HOUSE-the secret louse of death..Ant. \& Cleo, iv. 13 take her from her father's honse $\ldots . .$. look to my house; I am right loath. bht stop my house's ears, I mean ..... my master Antonio is at his house the husbandiy and inana, and this same what if my husu be troobied with would make else an unquiet honse You take my louse, when (rep.).......
if thou can'st un to Antonio's house. enquire the Jew's house out.......... will you show me to this loonse weleome for the nistress ot the house within the honse, your mistress is at the musie, madam, of the house....... doetor e'er come near my house... descended from another house. make an extent upon his house and liands deserves as well a dark house and a whip worse than Jove in a thatclied house! if you will know my house carries his house on his head .... the owner of the house 1 did enquire for? my father's house, and all the revenue to the dark honse, and the detested wife -

\section{ii. 5 .} keep thieves in my house? ............ - iii. 3 never lost in my liouse before.......... $\quad$ - iii. 3 never called so in mine own house.

iii. I from myself, and all our house.... we see the figure of the honse.......
draws the model of a liouse beyond draws the model of a louse beyond
he stablued me in mine own heuse he stablved me in mine own heuse he hatheaten me out of house and home I' will bar no honest man my

I'll forswear keeping house.......... upon our lyouses' thatch.

he is a gentleman of a good house

even so our honses, and ourselves....

I trained thee to and house

so great a warrior in my house

that they object against your house.. Somerset hath offered to my house.. belong unto the honse of York .....

grapple with the house of Lancaster.2

lieart-blood of the honse of Laneaster

affect the house and claim of York...

go, get you to my house

therefore am $X$ of an honourabie house -

had never a honse but the cage

from the dnke of Clarenee' house

of paradise did fan the house......

Jacques bound; already at my house

now will I lead yon to the ho

an honour, 'longing to onr house......

my chastity's the jewel of
mine house, mine lionour.

fled from his house

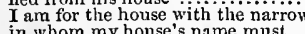

nothom my honse's name must .....

the citizens fy and forsake their houses =

take your houses over your heads

meet $Y$ an infant of the house of Yor

ii. 1

$\begin{array}{r}\text { ii. } 4 \\ \text { ii. } 4 \\ \text { ii. } 4 \\ \hline\end{array}$

ii. 4

v. 4
i. 5
.

ii. 3

ii. 4

nothin thatmy house arfords. Tam

and rail upon shun your house $\ldots . . . . \quad-2$ ind.

the house. Why, sir, you know no honse -2 (ind.)

will I keep within my house

keep house, and ply bis book

yet been seen in any house

keep honse, and port, and servar. I trow, this is his house

to the house of signior Baptista Minola?

within your house, to make mine eye

that belong to house, or housekeeping

she is ny house, my household stuff

the house trimmed, rnshes strewed.

we return nuto thy father's house...

we return muto thy father's house own house $\ldots . . . . .$.

and sport us in thy father's house...

not in my house, Lueentio

or ere I journey to your father's house

with the best, and welcome to my house

from the house of a most homely. Winter's 2

at your father's house, thes
tlie medicine of our house!

visited that removed hou

my poor house to visit $\dddot{2}$ to yonr house, the Phi........

no house, no wife, no mistres

my house was at the Phœnix? denied my honse for his, me for his wife -

did deny my wife and house. $\dddot{x}$ owe?

for there's the house; that chain

walk with me down to 1
to the goldsmith's house

take the stranger to my house

to hie home to his honse

and feast it at my house to-day.....

denied to enter in my house?

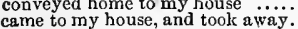

and bear them to my house

for Grod's sake, take a hous

not a ereature enters in my house.

with hariots feasted in my house

in person with me to
if here you house bim

a fat friend at your master's honse

yonr majesty loads our house...

yonr majesty loads our house.

the sleepers of the bouse?.......

woe, alas! what in our
bot in his house I keep

jewels, and this other's house......

within the bloody honse of life.

as a moat defensive to a ho

thou new ruin of old Clifford's house
iike rich hangings in a homely house

now the honse of Lancaster

let's stay witlin this house ..........

thon and thy house sliall rue it
fill the honse with armed men

fill the honse with armed men

unto the house of York sueh head

by giving the house of Laneaster

nor any of the house of Lancaster?.

make against the house of Lancaster

colours of our striving houses.......

that fatal seritch-ovil to our house

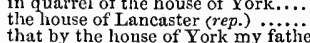

that by the honse of York my father
sold tilieir lives unto the house of York

I will not ruinate my father's house

that lowered npon our house ......R

pale ashes of the house of Lancaster

befal thee, and thy noble house! ....

in quarrel of the house of Lancaster

meaning, indeed, his house, which ...

the disgrace and downfal of your house

succeeders of each royal house ......

to make jour house onr Tow

at your own house; there be... Troilus \& Cressida, i. 2

to bring this Greek to Calehas' house

by night frequents my house ........ Timon of $\overline{\text { Athens }}$

if he would not keep so good a house

his wealth, mnst keep his honse

no house to put his head in ...........

burn, house; sink, A thens!.....
such a house broke! so noble

all broken implements of a rnined house -

in Corioli, at a poor man's house ..... Coriola

ere in our own house $\mathrm{X}$ do shade....... -

the noble holse o' the Mareians .....

go. get you to your houlse; be gone..

pursue him to his house, and pluek him -

at his house this night (rep.) house

a goodly house: the feast smells well

pray you, avoid the house.

\section{\begin{tabular}{l|l}
2 \\
1 \\
1
\end{tabular}}

2
2
2 \\ \begin{tabular}{l|l} 
v. 1 & m \\
v. 2 & h \\
v. 2 & to \\
v. 2 & this \\
v.
\end{tabular}}

to fo, in one house, should many people

this house is little; the old man

court holy-water in a dry house is better - iii.

he that has a house to pnt his head in
the cod-pieee that will house .... $\overline{2}$ iii. 2

while I to this hard house, (more hard.. - iij.

took from me the use of mine own house $=$ iin.

revenge, ere $I$ depart his house $\ldots . . . . . .$. - iii.

a dog of the house of Montague...Romeo \& Juliet, i. 1

a dog of that house shall move me to
here comes two of the house of

at my poor house, look to behold .....

my house and welcome on their pleasure -

if you be not of the house of Montagnes -

in my louse, do him disparagement

hatl sent a letter to his father's house

a gentleman of the very first house..

a plagne o' both the houses! (rep.).:
help me into some house, Benvolio..

bid her hasten all the house to bed.

Yon shall not house with me $\ldots \ldots . .$.

remember, this shonid be the house..

both were in a liouse where the infectious -

I saw him enter such a house of saje .. Hamlet, ii. I
play the fool nowhere but in's own house - iii. I play the fool nowhere but in's ow house
unpeg the basket on the house's top $\ldots .$.
the houses that he makes, last till $\ldots . . . .4=$

sliot my arrow o'er the honse, and linrt

look to your house, your ;

Othello, $\mathrm{i}$.

my honse is not a grange ................

at every house $\left.\Upsilon^{\prime}\right] l$ call, Inay eommand

I will but spend a word here in the house

but still the honse affairs would draw her

as doth the raven o'er tlie infected house

he supped at'my house; but I therefore - iv. I

Gratiano, keep the house, and seize upon $\overline{\text { rat }}$.
HOUSED-ever housed, where it. Coinedy of

even now wee, Satan, housed within... - iv.

IIOUSEHOID-household stuff? Toming of Sh. 2 (ind.)

conformable, as other bousehold Kates - ii. 1

fingere with thy household worms.. King $\bar{J}_{o h n}$, iii. 4

dispersed the houselold of the king
windows torn my household eoat...

under his household roof did keep ten $\bar{I} v$ iv. i

born an household cruelty, I make my - iv. 1

in their mouths as household words. Henry $V$. iv. 3

our household's nanie, my death's . 2 Henry VI. v. 1

by notes of household harmony....3 Hem

and ornaments of his household.. Henry ${ }^{\prime} I I I$. iii. 2

closed in our household's monument. Titus And. v. 3

shall undo a whole household ........Pericles, iv. 6

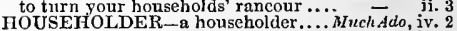

none but good householders........ i Henryly'
IOUSEKEEPER-good housekeeper. i wetfh

HOUSEKEEPER-good housekeeper . Twetfh $\mathrm{N}$. jv. 2
the subtle, the housekeeper ........... Macueth, iit. 1

run to your louses, till upon your.jutius $\bar{C} a s a$
to seek you at your house...

ere day, see Brutus at his house....

my fear, that keeps you in the house

at mine own house, good lady........

with triumph home nuto his house...

we'll bring him to his house......
we'll burn the house of Brutus

with the brands fire the traitors' houses -

he and Lepidus are at Caesar's house

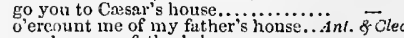

yon have my father's honse........... i. 3

HoU are manifest housekeepers ..... Coriolmurs, I.

belong to house, or housckeeping. Taming of Sh.
tliv plainness, and thy housekeeping.2 Henry VI.

HOUSELESS-you houseless poverty .... Lear, iii. 4
how shall rou houseless heads, and unfed IIOUSEWIFE-a housewife take.. Treinh Night, the breathless housewife ehurn.... Mid. N.'s Dr. ii. I doth fortune play the housewife ........ Henry V v. the bounteens honsewife, nature. Timon of Ath. iv.
have yolt play the idle housewife.... Coriolanus, i. flhe has a housewife's hand.

I piay the noble housewife with $2 . . . . .$. All's $W e l l$, ii. 2

and cau show it you here in the hou
foilowed certain men to this house

lut me entreat you leave the louse 


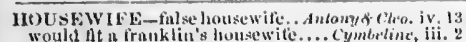

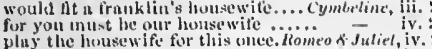

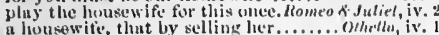

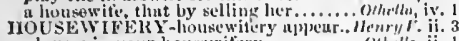
nolayera in vour houke wifery.............. (lthello, ii.

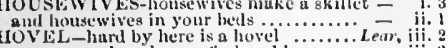
二 come, bring us to this hovel.

iin, fellow, there to the lave

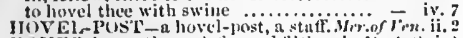
HOV'E R-hover tlirought fog and litthy uir. M/ratbe/h, $\mathrm{i}$.

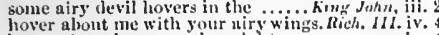
hover atout her; suy, that right

hover on the dreath bl store of styx?. Titus.tsd. i.

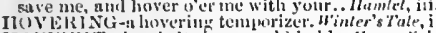
IIow Bl:1T-howbeit they would hold... Henery how weit I thank you ................ Coriolanus,

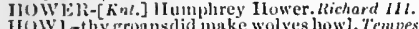

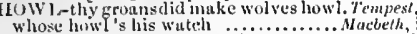
new widows howl, new

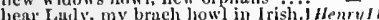
for the Whiel, I think, thou wilt howh.2 2Henry II and fiends for hood howl on! .
with their llowls cont ised do break

and handogs howl, and spirits wulk

howr. hwi. howl, howls o you are men ... Lear, a dog, thut should have hawled tluus. that would he hawled out in the desert. Macteth, iv.

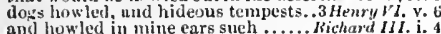
and howled in mine ears such

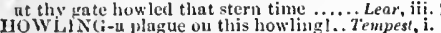

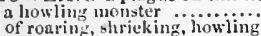

of roarin shrick as howling ufter musie.......... Tirpifh Night, thoughts 3 inagine howling!...Measure for Measure, jii. like the howling of Irish wolves... As you Like howlings attend it: how hast..... Komeo \& Juliet
my sister be, when thou liest howling... Ilomlel hish seas, and howling winds

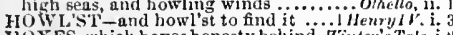
IIOY - to tarry for the hog .... Comedy of Errors, iv. 3

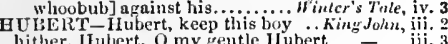
hy heaven, Hubert, I ain almost Hubert, Hubert, Hubert, throw thiue Irubert, I love thee .................. good-murrow, Hubert. Good-morrow so you would love me, Hubert are you sick, Hubert? you look pale too fairly Hubert, for so foul efte
llubert should put out mine eye O, save me, Hubert, save me Het ine not, Hubert! or, Hubert, if you will = with shanne of your proceedings, llubert
O now you look like Ilubert! . . . ....

that Hubert, for the wealth of ail...

Oheaven! I thank you llubert

the shameful work of Hubert shing.
deed of deatl, art thou damned, Huhert

deed of death art thould meed, idulert
that villain Hubert told me he tid live

$O$ tell me, Ilubert. Badly, I feur

commiend ine to one Huber.

1 'It tell thee, Hutert; half my power

1: UDDLING-huddling jest upon jest. inuch d.

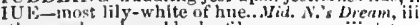
the ousci-eock, so black of '

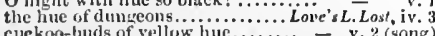

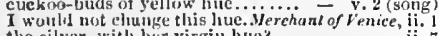
the silver, with her virgin lue? another lue unto the rninbow....... King Jnhn, iv. 2

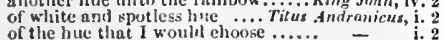
make your lemour of his bedy's liue is black so base a liue

ansther hue, in that it scorns (re......

did not thy hue bewray whose brut..

HUE ANI) CKY villain, so (rep.)....iverry Itiver,

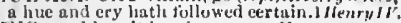
IItGi-and luy it in mine arms. Hews for $y$, that hugg lis kieksy'wicksy here ....All's ' Well, i embrace and hug witl anplest. Finion of .thens, $i$ hisg their slisenced perfiumes.............

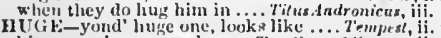

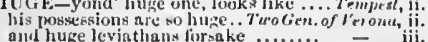

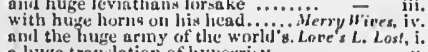
a liugo transiation of hy poreriny.......
thant to your huge store wise things

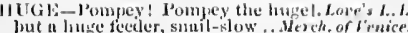

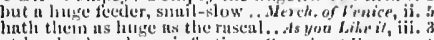

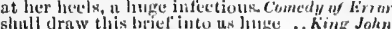
no supporter but the hoge jom eurih -

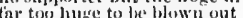

this lation fill of tests

that hoige hombard of suek

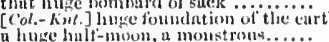

hear such a hate full heogshear

or the huge, or the magnaninous.

in their hote and proper lif

were a luge man, 1 should tear. Timon of whens,

wet a luge monntain theen my heart

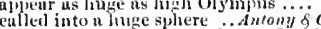

this euse of that huge spirit now is cold

will look so huge, umazentent
I never saw so huge ab billow.

ingenious feeling of my luge sorrow.

in that smaring makes huge waste. Fome o of Jutict, $i$.

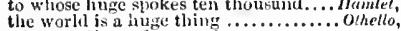

a hinge eclinse of sun and $\mathrm{m}$

IIIGS N ESS-in goodiess the lungencss of $C_{y m b}$.

UGGED-hugged and embraecd.r.ter. of lenich,

IIIGGER-MUGGER to inter him ... Ilamlet, iv

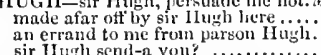

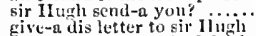

between sir Ilugh the Wels prie.t.

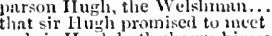

and sir Inghl hath shown himself
sir IIngh to there, is he?

he is eomints, this way, sir Iing

save you, good sir Ilugh!

anid you, sir Ilugh ..............

sir IIugh, my husband say's

adieu, gund sir Hugh ii weh

pell faid, fairy Hugh .
II ugh Oatcake, sir, and Gieorge

IIngh Oatcake, sir, and George
IIngh Canpet also, that usurped
title, and Inugh Capet's claim

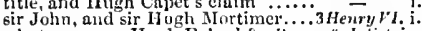

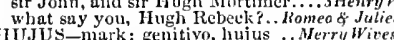

IIULK - the hulk sir John is prisoner.2 Ilesiry 11

you have not seen a hulk better
provokes the mischitiest luulk...

HULLL - laull here a little longer

i Henryrt.

there they hull, expecting.$\cdots 1$
HILLING-hulling in the wild

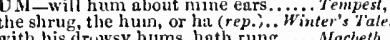

turns me lis baek, and hums

with his surly hum, delivering

to bite lis lip, and hum at good

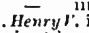

and his lium is a batter

HUMI $\Lambda N$ - to enter human hearing

not honoured with a human shape

than of our humnan generation

in humasi modesty sueh se parution. . . .

toueling now the point of human skill

hanged for husran slaughter ......... -

before your eyes, human as she is. As you Like it,

as monstrous ton our linumun rea.... Th

full o' the nilk of human kindeness..... Narteeth

ere human statute purged the gentl

his seuses huve but human eonditions. Ilenry

Talbot, above humbun thought

hat's the end of humall misery .... -

thon abluorr'dst ins our luuruan Griefy

crept into his luman pawers..
holding them in humban action

sworn by, both divine and humait.....
tle hanging (but none human)

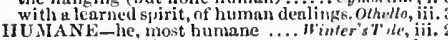
in humane gentlenes

is the humane way; the other course. Corinhaness,

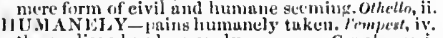
they relieved us humanely

Carroltmis

nencer debt in all humanity froitus of Cressida, ij. lac's opynosite to humninity ...... Timon of dthen

mildle of humanity thou never knewest -

never lid steer hummnity ......... Antany \& Cle

humanity ynast perforee prey on itself .. Leter, iv. mented

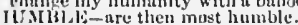

Teriello,

Tempest,

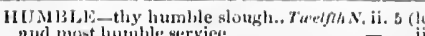

and most himblele serviee

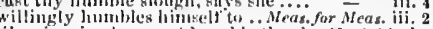

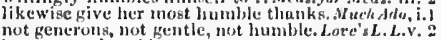

wears not u liumble tonyuc ..........

whut humble suit attends thiy.

lis lumblle umbition, proud humility. All's I'ell, i.

my low and humble mume to proprante - ii.

her that so wishes, and her humble fovel - ii.

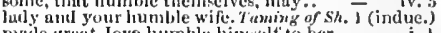

mithe great Jove hurnhle himselif to her -

humble swain, as I seem now ... Winter's Tale, iv, 3

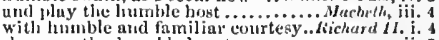

show me thy liumble licart ...........

my humble duty rementbered .......2 Henry $I V$. ii. I

I will stool and humble my intents.. =

our humble author will eontinue ........
your liumble patienee pruy (e.... (epil.)

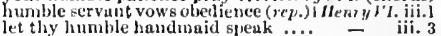

let thy humble handmaid spean ....

but with as humble lowliness i.......

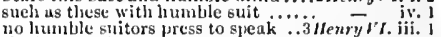

the king will grant her hunbles suit - iii. 2

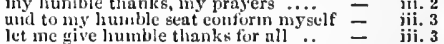

let me give lumble thanks for all $i^{\circ}=$ jii. 3

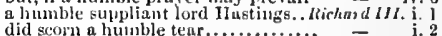

did scom a humble tear................
thunder, lut thy looks are humble...

with hauble livers in eontent .... Henry $\bar{v}$ III. ii. 3

to you a true and lamble wife ...... - ii.

cardisal, though from a humble stoek = is.

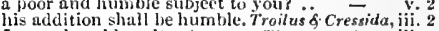

I am a lumble suitor to your. Timon of dihens, iii.

Jieart he wore lis liumble weeds.

coutempt he wore the humble weed

best loisure, as his hingthe suit

before thy stat a humble heart ....... - iii. 1

young humble thanks: I liarl al noost..... C.ymbetine, $\mathrm{i}$.

made it like a humble suppliant. Titus. . nutron. iv. 3 ne'er ebb to tumble love ................ (thellollo, ii:

and kill ne u red-hipped humble-bee $X^{-}$.

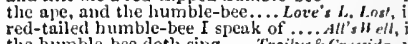

tle humble-bee doth sing.... Troilhis $\delta$ ('ressida,
HUNIBLED-all humbled ... Tro Gen. of ter ona.

and hath so humbled me

upon the humbled neek .................

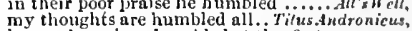

honour's ensigus humbled at thy feet

plugues have humbled to all strokes .... Lear, iv.

ay, sontl; so humbled ................ Ohellh in

HUIBLFNESS-whispering humbleness. Mer.off'i.
which hunbleness may drive unto a fine - iv. all humbleness, all patienee....... As you Like it, $y$.

thanks in the grentest humbleness.ienyy III.

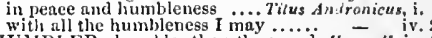
With nll the humbleness may m...... A H - iv.

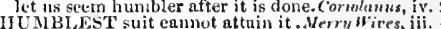
in humblest manner I require your. Menry '111. il.

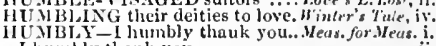
I humbly thank you

I humbly give you leane to depart........ Nuch $d d o, v$. humbly entreativg frour your roy'al.. Alt's I'elli, ii. 1 humbly thank you

to scric, humbly called mistress

your pleasture, himmbly 1 subseribe. Tanning ar $\leqslant$,. $\mathrm{i}$. humbly beseceh you, sir, to pardon. Ninier's ' Tale,

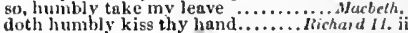

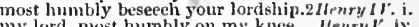

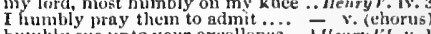
humbly now upon my bended knee... Alenry $r i$ i. 1 humbly thunk your royal majesty - i. and humbly thus with hinlters on.... and what lie will, I lambly yiteld linto = iifi. I and lumbly lxinl thy knee? lumbly beg the death upon my kinee I humbery tuk my leare aro

being sued to one that liumbiy......

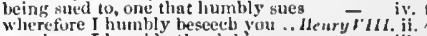
curcel me, I limbly thank his graee = iii. 
HUMBLY-most humbly pray you. Henry VIII. iv. 2

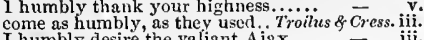
humbly desire the valiant $\mathrm{Ajax}$

Wumbly I thank your lorlship ...Timon of Athens, i

and humbly prays you, that with ..

he humbly praye your speedy payment -

I'll hurnbly signify what in his

I humbly thank your higliues

I lumbly set it at your wiil....

they bumbly at my feet reeeive. Tilus Andron iii

I humbly thank him ............... - Juliet, jii.

knees humbly bowed, eould not.

I will most humbly take my leave

I bumbly thank you; well.

baek to Demmark. I humbi

humbly I tlink your grace

most humbly therefore bending

most himbly therefore bending

I lunubly thank your ladyship.

HUDSE - of God, and llume's a

Hume must make merry with

but, how now, sir John Hum
Hume, if yout take not lieed

at last, Hume's knavery. ..............

master Hume, we are therefore provided -
convenient.

from the earth rotten luninidity. Timon of Athens i i i. 3

HUMILTY - mild lumility .... Love's L. Los', iv. 3

what is his humility ? rering eoncord... All's Well, $\mathbf{i}$.

proud of his humility, in their poor
it will wear the surpliee of lumility

fawn on rage with base humility .... Richard $I$
the very base striug of humility

the very base string of humility
dressed myself in sueh humility

modest stillhess and humility.

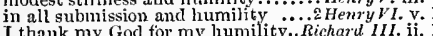

your hounty, virtue, fair humility

with meekne and humility unto his

the napless vesture of huminitity.... Corio

he eomes, and in the gown of humility -
IIUMIMING -I heard a humming

and humming water must o'erwhelm. Pericles, iii,

the duke is humorous; what he is. As you Like it, i. 2
the bony priser of the humorous duke?
iis a

is a most himmorous sadness...........
hut when her Joln, ivumorous ladyship ...

no marvel, he's so humorous ..... Hearyl H',

giddy, slallow, hummorous youth....... Henry $V$.

his himorous predominanee.. Troilus o Cressida, ii.

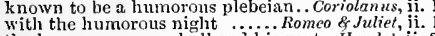

the humorous man slall end his part. Humlet, ii.
tIUNIOUR-sliee! that's my humour! Herry Wives, $\mathrm{i}$.

and pass good humours.

if you run the nuthook's humour on me

and there's the humour of it

the good humour is, to steal

will that humour pass? ...............
the humour rises; it is good; humour

I thank thee for that humour .......

run no base humour: here, take (rep.)
the humour [Knt.-honour] of this age

whieh be liumours of revenge.......
with both the humours. I: I wili (rep.)
my humour shall not cool ...........
that is my true hurnour...........

that is my true hurnour $1 \ldots . . .$.

I like not the humotur of lying .......

the humour of bread and eheese (rep.)
the humour of it quoth'a! ...........

firghts humour [Col.-Englishi] out of his -

see whiat humour he is in............

this is fery fantastical humnours ....

let's obey his humour a little further
you either fear his humpour ..... Twe
and then to have the humoor of state

and then to have the humour of state

and the spirit of humours intimate ...
I am of your humour for that..........
and elave

teaeh you how to humour your eousin

where is but a lumour, or a worm?

your gossip-like hurmour

Hlumphirey of Gloster, thou shat

UMOUR - while the humour lasts. Taming of Sh, i. 2

HUMPHREY-duke Mumphrey died.2 Henry VI. iii. 2 the liumour of torty faneies pricked

政

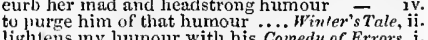

I am not in a sportive humour now.

saving your humbury humour, liere.

now you run this humour out of breath

the unsettled hnunours of the land...

that take their humours for a warrant
more upon humour than advised respee

in lisumours, like the people of ...... Richtivil 1 II.

the anyoled humour of your idieness
of all humours that liave showed (rep.)

witl that trunk of humours

are altogether goverued by humours = iit.

must not be in this liumour with me -

military rules, hrunours of blood....

sirrah, whiat humour is the prince of? $=\quad \begin{aligned} 11.4 \\ \text { ii. } 4\end{aligned}$

the humour of it [Col. Kut.-nn end] ...Henry $V$. ii. ]

as I may; and that's the humour of it =

the king hath run bad humours...

Temunt kiss, that's the humour of it

for humburs do abound.

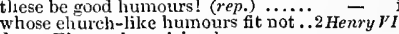

dame Eleanur's aspi ring hrumour.

in this humour wooed? (rep.) ........ Richard $111 . \overline{\mathrm{i}}$.

feed my humour, wish thyself no harm

nature hath so erowded humours. Troilus $\&$ - Cress.

youl have got a humour there. Timon of Alkens, i.

and nanght but humour sways lim

Cassius, he shonld not humour me.J
I can give his humour the true bent

hoping it was but an effect of humour
and suek up the humour's of the dank

for thy himnour, I will stay at home
and erouch under your testy humour?

when that rnsh humour, my mother

I'll know his humour, when he knows

though his humour was nothing but

a soodly humour, is it not, my lords?

pursued my humour ............. Romeo of Juliet,

portentous must this humour prove

Romeo! humours! madmaut passion

neighboured to his youth and humour.. Hamle

sueh humours from him

(1)

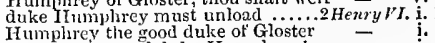

nreserve the gooud duke Humphrey!

hoise duke Ilumplirey from his sea

despite ditke Humphrey, or the eardinal

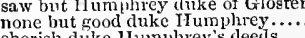

eherish duke liumplurey's deed

of love to proud duke IInmphrey....

Huke Humplurey knit lis brows....

to me my Humphrey, iny sweet duke
attainture will lue II umjhrey's fall.

empress, thass duke Humphrey's wife

bronght duke Inumplurey in disgraee

and listen after Humphrey $\ldots . . . . .$.

II umphrey has done a miraele to-day

prince, the good duke Jlumplurey

ah, Humphirey, this clishonour ...............

stay, Humphrey, fluke of Glost
and go in peaee, Humphrey

Ifumplrey, duke of Gloster, ecarce.

al2, llumphrey, ean I hear this

and dnke Humplirey's lady

in, unele Hlumplurey! in thy face I Ise

and yet, good Himmihrey, is the hour

as plaee duke liumphrey............

as Humphrey, proved by reasons.....

return we to the false duke Ilumphres

good duke lumpluey traitorously is

Fands were haid on Hinmzhrey's life

dinke Humphrey's timelcss death?
fult ty in duke JHumplirey's deatin :
service to duke Humplirey's ghost

as if duke Humphrey's ghost were
at good duke JTumplirey's death...

at good luke Ylumplires's death $\ldots .$.

sir Hlunphrey Stafford and lis brother's = iv. IIumplirey of Bnekinglam, l aecept
IIUNCCHBACK ED toad ............ Richarl III. i. that foul hunchbacked toad .........

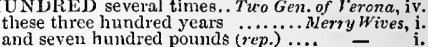
and seven hundred poun

in three hundred pounds a yea.......

will make you a hundred and fifty...

iii. 4

a hundred, if they'll do yout any.

ar the getting a hundred bastards...
wit out of the hundred merry tales.. Much Ado, ii. 1

pieree a humdred thousand liearts.. MHid. N. Nr. ji. remains unpaid a hundred thousand - it of one sore I a hundred make . . .
I have five luundred crowns. 2 (epit.)

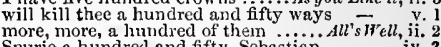
more, mo he, a linnd and of then ...... All's stell, iv. 3 and Gratii, two hundred and fifty eael - iv. 3 Thave a hundred mileh kine. Taming of Shrew, ii.

keep your humdred pounds to yourseif

a hundred marks, my Kate does put

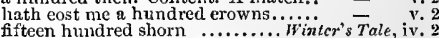

amount unto a hundred maiks. Comex'y of E'rors,

two lnundred dueats. Say, how ......

a half-faced groat five hundred pound

hath got five hundred pounds a year

with many hundreds treading on his $-\overline{\text { iv. }} 2$

the offer of a hundred thousand erowns - jv.

craeked in a hundred shivers..........
whieh, fourteen hundred years ago $I r .$.

hath brought three liundred marks
a hundred upon poor four of us $(r e$ i

as they buy hobuails, by the hundreds

I will die a hundred thousand deatilis

a hundred and fitty soldiers (rep.)

a hundred and fifty tattered prodigals $=$ iv.

a hundred marls is a long loan $\ldots{ }^{2}$ Henry
fifteen lundred foot, five liundred liorse

me have five laundred of my thousand

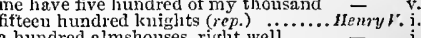

a hundred almshouses, right well....
four hundred one and twenty years.

four huudred twenty-six: and Charles

fifteen luundred paces of your tent

shall have eael a hundred Englislmen =

five hundred poor I have in yearly pay -

full fifteen liundred, besides eommo

one lundred twenty -six; added $\ldots$.
eight thousand and four' lundred
age

are but sixteeu hundred
hund reds lhe sent to hell

beside five hundreel prisoners..............

assault we lost twelve hundred men $=$ iv.

Ioather a hundred iimes to part tlian - iii.

lieenee to kill for a hundred laeking one - iv.

ay, with five hundled, father .........3 Henry $r$. i. 2

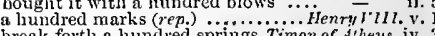

break fortl a hundred springs. Timon of . sthens, iv.

a hundred thousand weleomes

a hundred times hath that sound (rep.) - il. 3

a hundred ghastly women............... Iulizs Gaasar, $\mathrm{i} .3$

like a fountain, with a hundred spouts

I had a hundred pound ou't

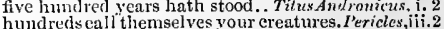

reservation of a linmelred knights.......... Lear, $i$. 1

a hundred knights: 'tis politie (rep.
sustain him aud his hundred lenigh

Eustain him aud his hundreel knights...

break into a hundred thonsand flaws ....

ii. 1 where, for these many humdred years

ii. 2 moderate laste might tell a hundred

ii. 3 a hundred and seven galleys (rep.)

ii. 3 a hundred times wooed me to steal it.

ii. 4 MUNDRED-POUND, filthy worstedses - iii.

HUNDRETH-the hundreth Psalm. Merry ivives, ii.

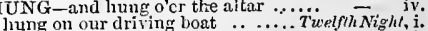

hung on our driving joat

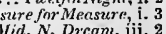

so hung upon with love .........Mid. N. Drcann, lii.

hung so tottering in the balunce ......AAl s s $F c l l, i$. .

she hung about my neek ....... Taming of 'is rew, iv.

and hung their eyelids down.... .1 Henry $I V$ iii. ?

his own life hung upon the

humg be the heavens with black

our bruised arms bung up for

a poor lhumour of mine, sir, to take..

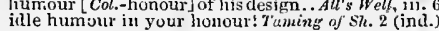


IIUNG-hung twenty yenrs about .. Ilenry 'Ill, ii. 2 hung their hends, nind then lay hy - iti. I (somg) iustruments luug up in enses. . Timon nf Aherns, $\mathrm{i}$. bo linum with Chesars tro

sign of battle is hung out ............ here lunge thuse lips, that l have kisedi. Hamlet,

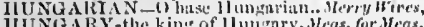

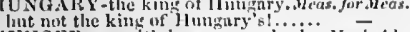
IIINGER - or with lumper, my loril.... Much Allo,

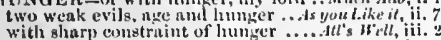
to mnke me lumger mor

so hunger for my empty elinir..........

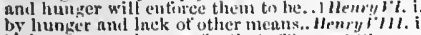

if thy resenges humger tor that.. l'imos of uhews,

if thy revenges humger tor that.
I speak this in hunger for laread

Ilat hutiger liroke stoue walls.....

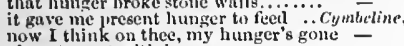

almost spent with liunger.

[Knl.] not used to hynger's savour

go sharp are hunger's teet

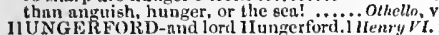
have the heir of the lord Ilungerford.3 lichry $/ \mathrm{l}$. IIUNGElRLY - thin and hungerly. Toming of Sh.

ther eat us hungerly
IIUNGER-STARVE

ivenrylit.

pursmed by humger-starved wolves ...3/enty b"

give them life, who the humger-starved.. Puricles,
IIUNG]ILY-feed most hungrily...Timon of Ath

HUNGliY-by a hungry lion ... Turo Gen, of Ver. is all as humgry ns the sea.

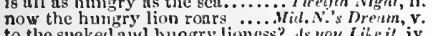
to the sueked and hungry lioness?.As you Liherit, iv. 3
but when they nre bumpry...... Hinter's Tule, iii. 3 but when they are buniry

must by the hungry, now he fel.... Kirg John, ii or cloy the hungty edge of alpsetite.

rush upon us as their hungry prey.

and, like a himgry lion, did con

the chicken from a huugry

and now an 1 so hungry .............

that the of his the humgry

I $\mathrm{nm}$ hungry for revenge.......... Richurd III.

unkindness should yet be luungry?. Tim of $\mathrm{A} t h$. i

Cnssius has a lean and hungry look. Julius Cersor

slie makes hungrs, where... Antony of Clenpatra, it.

makes them hungry, the more she gives. Pericles, $v$. strew this lumpry eliurelivard... Komeo \& Juliet, v
IUNT-he after honour hunts. Turo Ge will you go hunt, my lord? ..... Tuelfy' Night, comes to bunt here in the park not the hare that I do hunt........... you $L$ il to-morrow 1 intend to hunt . Taming of Sh. 1 (ind.) two and twenty, hunt this wenther? Minter's T. ini. 3 he's gone to hunt, my lord .......2Henry ir iv. 4 will hunt this wolf to death ........3 Henry $V I$. we more hunt for than the graee....3ichard III. iii. 4 that dot la hunt us all to death

nnd thon shalt hunt a linn .. Troilus \& Cressida, iv. to-morrow to hunt with him ...Timon of Athens, I'll hunt with him

a lion that I nm pronil to humt

where yoll should but hunt with
boys, we'll go dress our hunt

cave here, liunt here, are ontlaw

we'll hunt no more to-clay

to hunt the pantluer and the bart.

the liunt is un, the morn is hright...

as if a blouble liunt were heard

where he dirl hunt, 1 had we never

hollow of a tree, eserper the hunt.

Coriolanus, i.

not like a hounil that lumts...

his spirits glinull hunt after new fimeies

IIUNT-COU NTER-you hunt-entuter.2 IrnryI

well, sir, thizt you bunted .... Thming of Strew, y. he's hunted even to falling. Intony ficleopalra, iv.

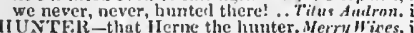
this tale of I r r rne the hunte

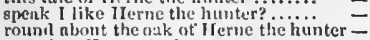

none but II ternc the lunnter aerve ..... from as the Hinter, nttents .. Tirelfh Wight, iij. he was furnished like a hunter ....... the housekeeper, the hunter $\ldots . . . . . .$. Mrebeth, iji. I

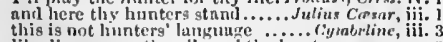
like lions upon the pikes $v^{\circ}$ the lunters and rinz a hunter's peal ....... Tilus frulron

IIIfromiked your grace a hunter's peal It tN'IN

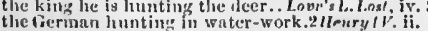
was killed with hunting him ........ llenry $b$. iv. eomes hunting this why to degport..3 lenry " for hunting was lis lníly exercise .. now he eumes frum lumiting... Timon of athens, ii.
we'll come to youl after hunting.... Cymbeline, iv.
IINTING-go you to buntin

a solemn humting is in lumbl. Tituss

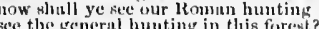

when he returns from funting, I will not.. l.

lumting thee henec witl luunts-np. Rom. Jul. iti. s

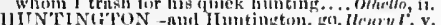

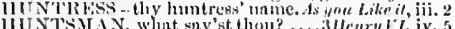

IUN TSII.N, whit say'st thom?

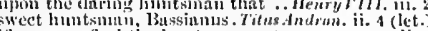

you're a youm finntsman, Marce.

IUNTSMISN - hid the huntemen.. Mis. N.'s Dr. iv.

like a jully troop of huntsinen

from tlue hisluy's huntsmen reseiei ${ }^{3}$

IIUN'TS-UJ'-hunts-up to the dny. Romeo of Julie

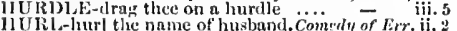

interehantenbly hurl down my...... lichard $I$. i. i

then lual dow their indignation..... Rishard III.j,

to hurl upon their heuds (rep.)

do often hurl from us........ Antony \& Cleopat

of thine will hurl my sonil from leaven. Ohello
nURLED-hurled up their eaps .. Richart $/ 1 /$

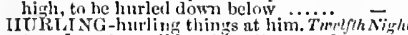

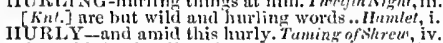

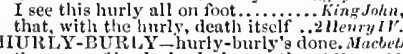

the news of hurly-burly innovation .I Henry Il
IIIJRRICANO-the huricano eall. Troilus \& Cres

IIURRICAN E. A-and hurrienoes, spout. Lear, it.

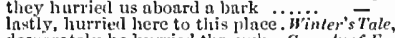

desperntely he lurried thromirl... Comedy of Rer.

IIURRIES-hurries up and down .... King Juhn

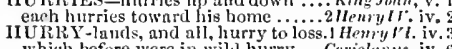

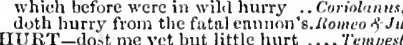

IURT-dost me yet but little hir

that give delight, and hurt not

hurt him in eleven phoes ..... Ta.
he protests he will pot laurt you ....
and a soldier, lie will not hurt you.

and hurt you not...................

he hins hurt me, and there's...

sorry, madam, I have hurt your ......

alas, poor hurt fowl! ..............

just. said she, it hurts nobody

which hit, but hurt not.

what, should I hurt her, strike her. Mid. $\bar{N}$. Dr.

hurt with the same weapons... Merch. of Venice

no force in cyes that can do hurt.....

no hurt donel (rep.)

enn do no hurt to try ; "................

perchance, he's hurt in the batt

balm of hurt mind

had be lis hurts before.

be pitiful and hurt me not...

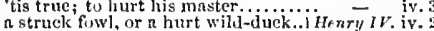

it never yet did hurt, to lay

linve hurt him, sir, in the sloulder.. =

any burt in the orld ............... Iteary $V$, iii.

strike those that hurt, and hurt not

where tortune eannot hurt me

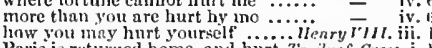

Henrythiti. 6

Paris is retulned home, and hurt. Troilus
caine hurt loome to-day? he's not laurt

I cloubt he lie hurt

nni Thons, dearly hurt.

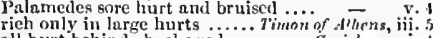

rich only in large hurts ...... Timon of Alichs, inj.

vou sootled not, therefore jiurt isot...

I will not lurt your hearth.............

I will not hurt him .......... Antouy \& cleopdra, if.

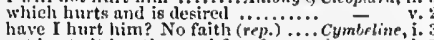

not hirt: it is a thoroughfare for (rep.)

some lurt done! 1 wish not 80 (

often hurts more than to he sure ....

linas men, lurt helind, mul eowarcls

[Col. Kuf.] with the dismal'st olyeet hurt -

hath hurt me more, than hasl he killed

but if you hurt these bear-whelps
to stop the air would hurt then..
IIIIT- they lunt you mortally

I never dinl her hurt in all my hite

recived this hurt you sa.e.............

to pouder wu things would hurt me

linave received a hurt: follow me

thee tlacy may liurt. Alack, sir........

who, nothing hurt withul......... Rimeo of Juliet

net thou hiort? Ay, ay, n seratel

eourace, nuni, the hurt eanut be jnuels -

lenth got his mortal hurt in iny bejialf

spendith rift sigh, that luarts lyy ensing.. Mrumbt,

oer the lomse, und hurt my hirothe
detend ine, friends, I am bint hurt

I bleet still, I an hurt to the death..... Othello, ii.

sir, for ythello, 1 m murt to danger.... - ii. 3

what, are you hurt, lieuterant?

by that small hurt, hast cashicred Cassio

bave you not liurt your heal?

to do me hinrm, as 1 lave to be la

Iago hurt him, rago set him on
IIIRT'T

Prisles, iv. (Gou er)

11 RTLESS-of justice hurtless brenks . Lear, iv, 6

IISBAND_my hushand then' ....... ternperl, iii, I

the Cluribel her hishand find at Tusis -

O that my hisband saw this letteri..

master Ford, her husband, will be ...
that her husbund is seldom from home

her husband has a marvellous infection 二

jealous rasenlly kuave, her husibngi

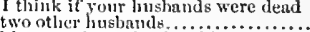

his nune is my husband had him of

having nn honcst man to your husband -

husbaul's coming with hale Windsor

your busband's here at hand.

that my husland is deceived.........

when rour hushand asked whin
I think, my husband has som

I seek you a letter husband ......... -

but the penking eormuto, her jusband

her husband is this morning gone

sir liugh, my husband says, my son

your hushand is in his old iunes again

he so takes on yonder with my husbund

I would my hushand would meet him

guide him to thy husband's euclycl .

hath the jealous fool to her hishanil =

nuy, good sweet husband............ -

shall we tell our liusbands how we.... -

the figures ont of your husinand s brains -

well, husband yotir devipe .........

that same knnve. Ford, her hushand

my horns I bequeath your husbands

see you these, liushand?................

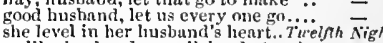

she level in her lousbund's leenrt.. Firel/nh Night, it.

Cesario, husband, stay. Ilusband? ( $e p$.$) -$

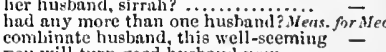

ye is your hushand on a yre-contract

until my hushund lid me

known my lusband; yet sny hübi...

un? you say your hushum charc

a husband! It is your how I will .....

to buy you a better husliand

so may my husband. O laal

inst, wilt never get the a liusliand ne no husbond

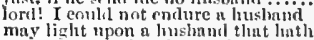

to see you one day fitted with a lusband -

nnd ery heigh-bol for a hushand.

eannot enelure to hear tell of a husliand -

th help my cousin to n good limslmu

send ler home aquin withont u husband -

sitring yom reycrenec, n liusbumi

the lieavier for a husband?

then if your lusbund luve stribies

for a hawk, a horse, or a hushand?

to give your daughter to her husbaud

I am your humband, if rou like......

you were nuy otluer hiutond

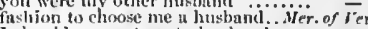
l shoull marry twenty hushnmis....

for the death of $n$ thire lushnnd ....

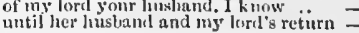




\section{HUS}

IAG

HUSBAND_see our husbands ..Mer. of Venice, iii. 4 HUSBAND_for her husband's lands.2 Ilenry Vl.iii. 2 HUSBANDED with modesty..Taming of Sh. I (ind.) I shall be saved by my lusband .... - iti. 5 wives for their husbands' fate ......3 Henry ri. $v$. I'll tell my husband, Launcelot $\ldots$ even sueli a husband hast thou of me - iii. 5 what tlo' I killed lier liusband ...... had been her husband, rather than a day before our husbands liome .... I'll see if I can get my lhusband's ring
been praying for our husbands' welfare your husband is at lyand ....... iv. I did not kill your husband...........

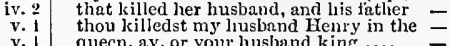
quecn, ay, or your husband king .... was not your lusband in Margaret's a husband, and a sul, thou owest to me in tly noble husband! (rep.) $\ldots . . . .$. . for him that had your husband's ring make lier fault her husbaud's occasion make her fault hor husband, if you I bury a second linsband..................... get thee a good hinsband, and use him
wint husband in thy power I will then call me husband................
shall bless this unworthy husband?. to this unworthy husbnit of
the count he is my lusband. the count he is my liusband and heljer to a lusband; but, ö strange you will lose a husband, send for your ring choose thou thy husband, and l'll pay - $\overline{1}$ v. 3 and will not call me-lusband?..... - 2 (iuduc. my husband and my lord (rep.) . i..... a husband for her sister (rep.)... to a husband, we sct lis youngest (rep.) Katharine the curst liave got a husband I am a husband for your turn I pray you, husband, be not so disquiet = while I play the good husband at home your husband, being troubled (rep.)...

them soundly forth unto their husband

they do owe their lords and husbands a woman oweth to lord, thy life your liands below your husbend's foot for ever earned a royal liusband ... Winter"s Tale, who late hath beat her husband. Jier child ren not her busband's! hang all the husbands, that can ah, for my husband, for my dear lord my husband lost his life to get .....

issued from my other angel husband

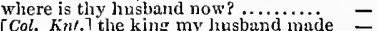
[Col. Knt.] the king my liusband made $\bar{T}$ iv. I deem you an ill husband these hajrs is Paris, my hushand?. Troilus \& Cress. than wife is to the husuand? $\ldots . . . \ldots$.... $\overline{\text { mated }}$ with an equal husband, if my son were niy liusband thear hitler your husband's drum... and saved your husband so nuch sweat =-
power to say so to my hiusband ......
lady's lusband herc, this, do you see when she's fallen ont with her husband -
my lord and husband! Thicse eyes arc not my lord and husband! These eyes are not
the son. the hushand, and the father

and not my husband's secrets?.... Julints Casar, not in my husband's nose ............ no worse a husband than the best of me $O$ bless nuy lord and husband?

lusband, I come: now to that nam she's wedkled: her husband banishied... Cymbeline, my dearest liusband, I sometling fear

lier hissband hanished; $U$ that husband! my luusband's hand! tliat drus-damned when I am dead to my husiand?

Jove shield your husband from his. Titus And bring thou her husband

shouldst a husband take by my consent
to find thce an honourable husband..

neither my husiband........... Cone

how if your husband start some.

how comes it now, my liusband.....

hurl tlie name of husband in my face

an elm, my husband, I a vine .....

quite forgot a liusband's office

thou liast no husband yet...........

Dowsabel did claim ine for her husband

is not your husband mad?

Idid not, gentle husband, lock tihee

wher a clian, your liusband had of him

feteh my poor distracted husband hence liave scared thy lusband from

let your servants briug my husband..

I will not hence, and leave my husband

to separate the husband and the wife
and take pertorce my husband .......
Antipholus, my hushand ............

long sinee, thy husband served me

I sec two husbands, or mine eyes deceive -

and gain a husband by his liberty

are not yuu my husband? No.....̈̈

her hushand's to Aleppo gone...........Macbeth,

for your husband, he is noble, wise.

wlierc is your husband? 1 hope ......

lies on the hazards of all hushauds ... King Jo make room for him in miny lusband's bed as thine was to thy husband ......... be liusbaud to me, heavens?.......... husband, I cannot pray that thou your husband he is gone to save far of
sweet husband, be not of that mind..

ah, my sour hinsband, my hard-hearted

so has my husband, man by man ... 1 Hen

where is your husband?
thy liushand he is dead

thy hushand he is dead ...................

ii. 2 it they did kill thy liusband

you killed her husband

he's father, son, and hiusband mild

pere she had a husband for her bed

why have my sisters liushands

post speedily to my lord your husband ..............

I marvel, our mild husband not met us.

your lady does not love her husband

a plot upon her virtuols husband
she, and the duke her husband ......

her husband being alive.

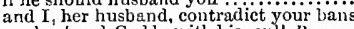

my husband, God be with his soul!. Ro
yea, quoth my husband, fall'st upon

there stays a husband to make you a wife -

[Col. Knt.] O prince, $O$ cousin, hushand -

my liusband lives, that 'Tybalt would

would haye slain my husband $\ldots . . .$. .

[Col. Knt.] lord! ay, husband, friend!
ere he, that should be husband, connes

my husband is on earth ............

unless that husband send it me from

there dead, was husbond to that Juliet -

with his sword her husband s lor husland slialt tliou

in second husband let me be accurst!

my husband dead, when second liusband

so you nistalke jour lusbands

the queen, your husband's brother's wife

this was yolur husband (rep.) ..........

but here's my husband; and so nuch .

prove to Desdemona a most dear husband

between you and her husband

pranks they dare not show their liusbands

wayward liusband hath a hundred times

look you! Cassio, and my husband.

abuse tlieir luushands in such gross kind?

would not make lier husband a cuckold

recordation to my noble musband ...2 Henry $17, \mathrm{ij}$.

good liusband, conc home pres

it is their husbands' faults, if wives do fall

for sweet and sour, as liusbands have .....

ask thy liusband else

thy husband knew it ail ( $r r p$.

our sons and husbands caiftivate .... i Henry $V^{\prime} I$. i

to tumble down tily husband.

my husband say, that she was false?...

although thy lusband may be Menejaus -

lany's husband, sir Joln Grey..

why then, thy hushand's lands i frecly =

iii. 2 my friend, thy husbend

by fortunc, and did give my husband...

mallured, liusbanded, and tilled....2 Henry $l V^{\prime}$ iv so fathered, and so lusbanded? ...Julius Casar, ii. HUSBANDNAN-vour lusbandman..2 Henry I $V . v$.
2 HUSBANDKY - tilth and husbandry the husbandry and manage of.. Ner. of Venice, ii . of all thy pains and husbandry ... As you Like it, ii. there's husbandry in lieaven

and all her husbandry dotli Mocbelh, ii. the herbs for want of husbandry......Henry $V . \mathrm{H}$. there were husbandry in war.... Troilus \& Cress. $i$.

if you suspect my husbandry ... Ti frothens, ii. tis not our husbandry................. Pericles, iti. duSH the edge of husbandry ........... Hamiet, i.

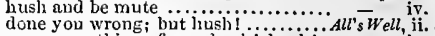
can say nothing of me; husli! hush hush, master! here is some goud... Taming of sh. iv. set me up in hope? but, hush ......... Macbeth, iii. hush! you shall be more leloving.Anlony \& Cleo. i.

hush, here come the lords of Tyre........ Pericles, i. hush, gentle neighbours $\ldots \ldots \ldots \ldots \ldots \ldots$. ${ }^{-}$iii. 2 IICSHED-all's hushed, as midnight... Tempest, jy. I hushed on purpose to grace harmony! Much Ado, ii. patience boast, as to be hushed ...... lichard 11 . i.

I am liushed until our city be ...... Coriolanus, v. 3

IIUSHES-my duty liushes me.... Tivelfth Night, v. your hogs, and eat husks with them? As you Like if, but the sliales and lusks of men........Henry $V$. iv. strewed with husks and formless, 7roilus \&

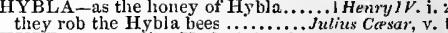
HYDRA-grow like Hydra's heads ... Inenry $1 V . \mathrm{v}$. whereon this Hydra son of war ....2 Henry $1 H^{\prime}$. iv.
given IIydra here to choose ........ Coriolanus, iii.

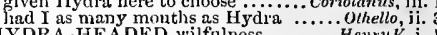
HYGM-on old Iryem's chin, and icy.Mid.N.Dr. ii.

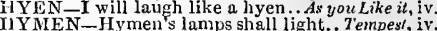
till Hymen's turcl he liglited ......... Hymen, now with luckicr issue....... Much Adio, v. 3
Hymen from heaven brought. As yuu Like, v. 4 (ver.) tis Hymen peoples every town..

to Hymen, god of every town!: $=$ v. 4 (song defiler of Hymeln's purest bed.. Timon or Athens, iv. and Hymen did our hands unite $\ldots \ldots$ Hainlet, iij.

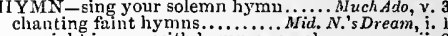
no night is now with hymn or carol
wake Diana with a hymn ... Merchant of Venice, $v$. who chants a dolcful lymm........... King John, v. 7 solenn hymns to sullen dirges.. Fomeo \& Juliet, iv. Wonld seem lyycrloles ...... Troilus \& Cressida, i. in acclamations hy perbolical........ Coriolanus, i. 9 with cutertaining great Hyperion. Troil. \& Cross. ii.
Hyperion's quickelning fire.... Timon of d/hens, iv. even from typerion's rising.. Thas Andronicus, v.

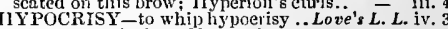
a huge translation of hypocrisy.......
prayers are full of false hypocrisy... all this spice of your hypocrisy .... Herry VIII. ii. 3 it is hypocrisy against the devil....... Othello, iv. I dare swear he is no hypocrite .........Muchsdo, i. a most princely liypocrite $\ldots \ldots \ldots . .2$ Henry $I F$. ii.

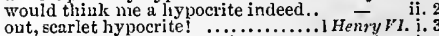

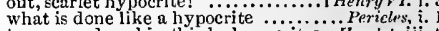
tongue and soul in this be hypocrites... Humlel, iii. calls virtue, hypocrite ................. HYRCANIA-tigers of Hyreania $\ldots . .3$ Henry $V l$. i. Pyrrhus, like the Hyrcanian beast ..... Hamlet, ii. HYSSOP-set hyssop, and weed up thyme. Othello, i.
HYSTERICA-hysterica passio! down ... Lear, ii. 4

ACHIMO-Iachimo will not from it.. Cymbeline, $\mathbf{i}$. 5 see! Iachimo! The swiftest harts.

Tachimo, thou didst aecuse him the conduct of bold Tachimo

suffer Iachimo sliglit thing of Italy.

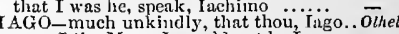
were I the Moor, I would not be Ingo... honest Iago, my Desdemona must I leave tis one lngo, ancient to the general left in the conduct of the bold Ingo...... let. it not gall your patience, good Iago. good lago, go to the bay, and Iago is most honest........................
wejcome, Iago: we must to the watcli

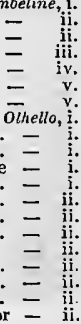

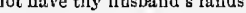


IAGO-honest Ingo, that lonk'st dend.... Othello, il. 3 Your ofllcer, lago,

Inso, who begun it?

hnow, Ingo, thy honesty nid love....... lage, look with care about the town

ny reputation, Ingo, my reputation

gexorl-niplit, hom

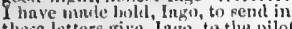

whint dost thull way, Inco?

dnst consjire against thy frlend, Ingo.

Ino, Inge; I'll sce, before I lwuht

lenve ulu Inuo, ily lord, I take my jeave

the work ta'en ont, and vive it lngin ...

0 blomel, Ingo, blood! Pntience, I say.

never lngo: like to the Pontick sen.

that here lngo doth give ul.

think ko, fugo? Whit, to kiss in private?

nnked abed. Iagn, and

lost thou henr, lago? .......................

how eliall I murier him. Ingo?

l.ughesl nt his riee? 0 lngo! .......

Ingo! O Iago, the pity of it, In 50 !. .
get ine some noison, Iaro, this niglit.

get me some poison, lage, this nis

alns, Ingo, my lord hath so bewliore

o. good Ingo, whint sliall I do to win

thiou doff'st me witl

Ingo keeprs his workl ...........

In yo? $^{0}$, I nm spoiled. undone hy vilinins!

O dainned Ingo! O inliuman do

friend, thy husband, lomest, honest Ia....

0 , nre you come,

perellanee. Iago, I will ne'er

belike, In:o in the lago knows...

how he upbrnids Iago, that he nude

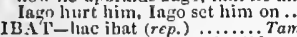

IBAT-lue ibat (rep.) $\ldots \ldots \ldots$ Taming
ICAR US thon learus; thy je.....
there died my Iearus, my blossom

there died my Iearus, my blossom

ICF-as a tigure treneli d in ice. Tirngen. nf

[Col. Knt.] from brakes [Col.-breaks] of ice

regions of thiek-ribbed ice

that is hot iee, nud wondrous....Mrit. N.'s Dreat

the very ice of enastity...

As you Like it, iil.

these boys are boys of ice.

Taming s... Wrll, ii.

anicee of ice if thon donbi it

to smooth the ice, or add annther ....King $\bar{J}$ ohn, iv

to turn the sun to ice, witli tanning...Henry $V$.

tut, tut. thou nut all iee

the cold brook candied with ice.. Timon of Alh. iv.

the eoal of fire upon the ice......... Corrnamus,

be thnu chaste as iee, as pure ns ........
ICE-BRello, ii.

ICEI,AND-lcelnnd dog! thou (rep.)...Henry V'ii.

jeicles hang by the wall .. Love's $L$. Los', v. 2 (song)

scarce thaws the icicles .... Merchant of Fenice, ii.

not hang like roping icicles bpon

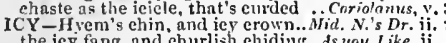

the icy fang, and churlish ehiding...As you Like, it.

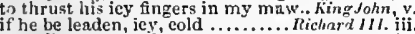

never learned the icy precepts. Timon of dhens, Iv. 3

the Pontick sea, whose icy current .... Othello, iii.

bjects, idens, apprehensions............ Mueh dido, iv

the riglat idea of your father........ Richnrd III. iii. 7

II EM- tis semper idem, for absque..2 Ieny IV. v.

rilen, farewell; and be proud of thy..

Alexnnder Iden, that's my nnme.

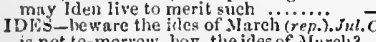

is not to-morrow, boy, the ic

remember Hrareh, the ides of jiarch

IDIOT-though well landed, is an idiot. Mer'y $w$.

will make a contemplative idiot.. Tecetfhight,

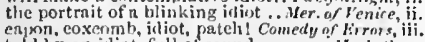

wold hy an idlint, full ol sound .......... Wracbeth

Muking that inl int, luughter, keep... King John, iii.

play the iclinta in her eves! ........... - iii.

an illint fiolds hia baulle..... Titus dndronicus, $v$

all. 1 idot

IDI. idnl of iliot-worshipuerf. Troilus \& Cressida, v. or clse for want of ille time...Tiro.... Gen. of Ver. ii. myself have been an idlc truant. Mö wives, iit. ns idle as she may hang logether.. Merry Wives, ji

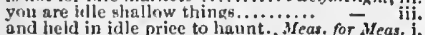
and heid in idle priec to haunt. Meas. for Meas. draw with idle spider's string.....

the father of their idle dream........ as the remembranee of an ldle gawd

and this weak and idle theme.........

will prove an irlle scorn ................e's L L. Lost, i.

will lear your ille at hie tnys

二 $1 v_{0}: 3$

no longer with idle tulking ............ di yon Like it,

prond. idle, made of
Dl, - yet, in his itle thre, t:

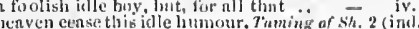

but very idle word

frifer, or idlle moss

a thoushnd ide primks

straint tieir aticelis

thou idte drenter, wherefor

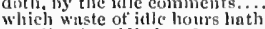

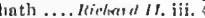

repent at idle times .........

seok, every inle, njee, and winton

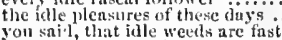

to entross his idle botl

ns well as you love an idle head.. Troilus 6 Cress.

laties, there is an idle banquet.. Timon of dthen $\varepsilon_{\text {, }}$

no, gods, I am no idle votarist

have you play the idle housewife.

every man henee to his idle bed

they pnss by me as the idle wind ..... -

and idle [Col.Knt.-servile] thoughts! Tilus.l

to find an idle and fond bondage.... Lear

nnd all the idle weeds that growy
on the unnumhered idle pebbles

the ehiklyen of an idle brain ....Roneo of Juliet, $i$.

looked upon this bove with idle sisht ... Humlet, ii. 2

I must be idle; get you a place

you nnswer with an idle tongue .........

of antres vast, and desarts idle

is nn idle and most falke imiosition............ ii. 3

for want of other illeness......... Tu elfih Night, $\mathrm{i}$.

brother of yours, witl idlencss ..... ds you Like il, i. I
found the effect of love in idleness. Taming of sl. i.

nur conversant with ease and idleness. King John, iy. 3

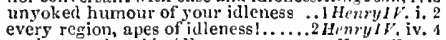

rank, coneeives big idleuess .......... Ienry $v$.

holds idleness your subject (rep.)...

bear sueh idleness so near the heart

either to have it steril with idleness .... $\overline{0}$ hello, $j$.

IDLY-idly I stood idly looking on. Taming af Sh. i.

poor souls. how irly

the air witl enlours idly spread...

$I$ talk but idly, and yon moek ..... Richard 11 . iii. 3

so hard, you should talk so idly? $\ldots .2 \mathrm{Hen}$ 'y $I V$. ii.

so iclly to profane the precions

king Pharnmond, idly supposed
she is so idly kinged, her seeptre

slay myself for living idly here.

nleury ii

should be but idly posted over ......2Henry $r t$. iii. I

when we sit idly in the sun. Troilus \& Cressida, iij.

a thing slipped idly from me .. Timonof a dhe

I am very loth to be your idol, sir.

but, $O$ how vile nn idol proves .. Firelfh $\bar{N}$ ight

what art thoul, thou idol ceremony? Ilenryl'. iv.

and iclol of idiot-worshippers.

the celestial, and my soul's idol II Inalet, ii. 2 (let
IDOLATROIS fancy must sanetify ...All's Hell, $\mathrm{i}$.

IDOLATRY - in his idolutry ... Tu

pure idolntry. God anend us .. Lore's 1. Ln'

tis mad itiolntry, to make. Troilus \& Cressida, ii.
which is the gond of my idolatry. Momen $\&$ Juliet, ii.

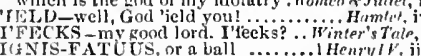

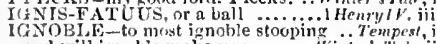

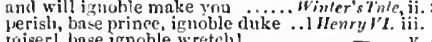

a base ignoble mind that mount no.2 Uen ry Fi. ii. I

blunt-witted lord, ignoble in demeanour! -

that I was not ignoble of deseent .3 Hen? $y$ \%

graft with ignoble plonts.

GNOBLY - thus ignobly used ......... Henry ${ }^{\prime}$ i. ji.

but that 'tis shown ignely ........2 Henry Wh. Y.

unwisely, not ionobly, hnve I... Timon of dihens, ii.

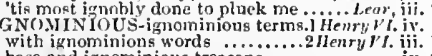

hase and ignominious trensons ......

GNO.II Y - ignomy in ransom.... Meos. for Mens. ii.

thy iknomy sleep with thee in ....... Henrylt. v.

Inon this ignomy [Knt,-ignominy]. Titur And. iv.

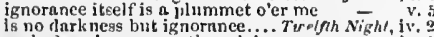

as dark as ignnranee, thinugh ignoranee -

his jenoranse were wlike (rep.).... Lote'sL. L

eharj, wit quite througli iny ignorapec
GNOLANCE-ignoraree makes thee. All's Well, i.

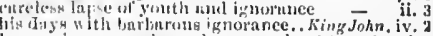
barsen igneranee is made my gunler. Whrtard II. i. 3

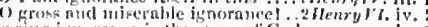

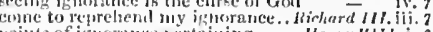
fonder thum ionnerasee; less vinlinit. Troil. \& C'ress. folly und jonurnoe, he thine jul grent in askep, than kuch a valiant ignorance - tii.

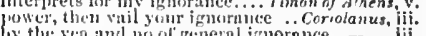
by thi: yea and no of perternl igmorance - iii. I only nocked for valimnt ignorance... is lost with very ignorate ..... Amony f rleo, jii. 9

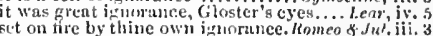
let me not burst in ignorume! ........... hamlet, i. 4 make ynur wnutmmess your ignrirance.. - ii. I Oheavy jonornace! thou jua est...... othello, it. I GNors ns ignormee made drunk ...... thon liest, most ignornnt monster ignorant how his compnnion ... Jiro Gen of $V^{\prime}$ er. for being ignorant to whom it goes.. - ii. I thou art not i norant, wlint dear..... $=$ iv. 3

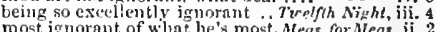
eitlier you are ignorknt, or seem so.. - ji. 4 a very superficial, ignorant, unweighing - iii. you are not ignorant, all-telling. Lore's L. Lost, ii. to hmour the ighorant, I have called - iv. All ignorant that sonl, that sees....... $\bar{y}_{\text {is }}$ iv. 2 not ignornnt of the impossibility.... Al's slell, iv. not in she is not ignorant .. Tuming of shrew, ii. either thou art most ignorant by age - ii. I am as ignorant in that, as you ....

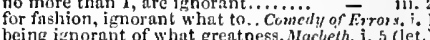
being iznorant of what greatness. Macbeth, $\mathrm{j}$. 5 (let.

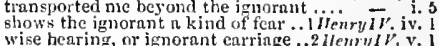
Wise hearing, or ignorant earriage ..2 llemylV. v. ignorant of his birth and parentuge.:Henry either, were you iguornnt to sect t?.. Cor iolamu, 11 . nll revolk your ignarant elcetion..... meen, the ignorant motive. do so far - if. poor ignorant baubles! ............ Cymberine

dost Eeem so ignorant, we'll enforce

tor I am uainly ignorunt wlat place.... -

confound the ignornnt; and aniaze.... Illamlet, ii.

yur ore are

what ignorarit sin have I committed?.. Othello, iv. \&

LBOW-de nails, de nrme, le illow . . Wenry - r

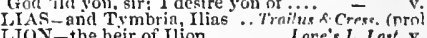

noN - the heir of Ilion............ Lore's L. Last, v. ?

as snte, as Priam is in Ilion..........

I saw yourself and Dinmed in Ilion - iv. 5

II.IUM - between our Ilinm, a... w where

when were you at nium?

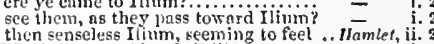

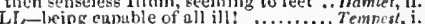

there's nothing ill of all ill:

if the ill spirit have so fair a house.....

ill, when you tnik of war. ......

thou friend of nn ill fashion!

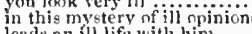

letds an fll life with hint...

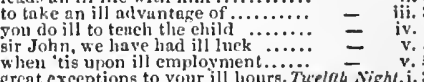

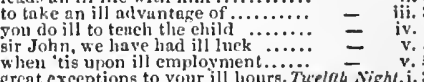

grcat exceptions to your ill hours. Tuelfts Night, i.

la you, an' ynu speak ill of

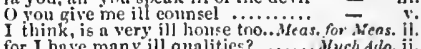

for Thn ye many ill qualities?

nay if they lear to any ill, I wili...
lut henr these 111 news with the

ant an ill singer, my lord.............

and his ill conditions; and in despite

suit ill spent, tha haliour ill bestowedl

very lil. Anl how co you? Very iil inn 
ILL -ill met by moonlight.......Mid. N.'s Dream, and the ill counsel of a descrt piace.

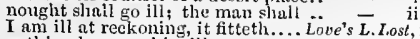

nothing becomes himill

knowing ill: for he hath wit (reps)

to teach a teacher ill beseemetl me.

shooting well is then aceount

that my heart means no ill .........

ill, to example ill, would from to

there is some ill a-brewing.. Mercthent of Venice,

yes, other men have ill luck to..........

yes, other men have ill luck too $\ldots . .$.
what, what, what? ill luck? ill luck?

O knowledge ill in habited!........ As you Like it, iti. 3

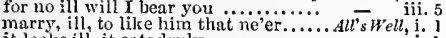

it looks ill, it eatsdryly.

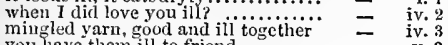

Jou have them ill to friend ..........
would derive me ill will to speak of..

there's some ill planet reigus .....Winter's $\bar{T} \alpha$ le,, $\mathrm{ii}$.

it to either thou dost ill $\ldots . \ldots \ldots \cdot-$ iv. 3 (song)

your holy looks my ill suspicion...... -

how ill agrees it with your

ill deeds are doubled with

unquiet worsc-bodied, shapeless

and ill it doth beseem your

this ill day a most outrageous..........

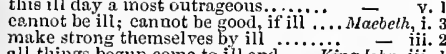

all things begun come to ill end ......... King Jo

where doing tends to ill

when we have run so ill? that you must use me ill, why

giudy with these ill tidings

my head with more ill news.............. =

even this ill night, your breathing .. -

as of a thonglat of ill in him ......... Richard I

or complot any ill 'gainst is

ard II. i.

is weak, and all ill left

shall ill become the tower.

shall ill becolnc the tower

would not this ill do well? camest thou by these ill tidings....

itl may'st thou thrive, if thou.........

that rehelliou had met ill luck?......

up and down, like hisill [Knt.-evil] angel

they irere ill for a green wound?

saith he, you are in an ill name..........

saith he, you are in an ill name...

good word before it was ill sorted....

wherefore do you so ill translate yourself -

on the sudden, something ill. A rainst

exceeding ill. Heard he the good

like a wet cloak ill laid up ...........

not the ill wiud which blows no man

how ill white hairs become a fool....

and trembled at the ill nei.

by Chrish, la, tish ill do

right ill disposed, in brawi.....

every man that dies ili, the ill upo....

old age, that ill layer up of

or make my ill the oflyantage ......... i Henry $v$

cowardly knight! ill fortune ..........

how ill we brook his treason

doth presagre some ill event

when I imagine ill against my........2 Henry

never meant him any ill himself

ill blows the wind, that profits....

with us; it ill befits thy state....

in that you brook it ill

alas! tor whose sake did $\mathrm{I}$ that ill deed?

ill news by'r lad

[Col. Knt,] when such ili dealing.......

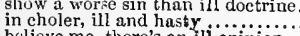

believe me, there's an iti opinion

I deem you an iil husband ..........

111, and gave the elergy ill example..

correets the ill aspects ot

whose life were ill be

policy grows in to an ill opinion

make thee, and thy state, look iil... Tim. of $\overline{\text { sthe }}$

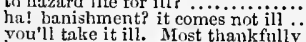

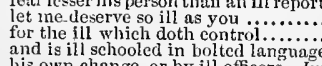

his own change, or by ill officers.. Tuliu
this was an ill beginning of the night
low ill this taper burns!

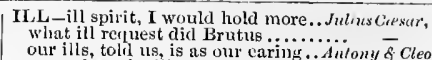

I am quickly ill, and well

lest my remembranee sutter ili report

but let ill tidings tell

mist not take my formg ili becomes th

I have done ill; of which 1 do aceuse

I have done my work ill, friend

since doubting things go ill ...........

doth ill deserve by doing well...

well or ill, I am bound to you

to second ills with ills, each elder.

too good, to be where ill men were

wherein I did not some notorious

who dares say, Jove doth ill?

this day I'll rise, or else add $\mathrm{i} i \mathrm{i}$ to $\mathrm{ill}$

nor did ill turn to any $\ldots \ldots \ldots \ldots \ldots \ldots \ldots$
that $I$ came with no ill intert............
no marvel then, though he were itl affected.

could not have made him so

to blame in this; 'twill be ill taken....

if he ask for me, 1 am in and tome.

or well, or ill, as this day's bat

word ill urged to one that is so ill!. Roineo of $J$

shall I speak ill of him that is

marry, sir, 'tis an ill cook that

yoll love your ehild so ill

ean be ill, if she be well (rep ill

0 pardon me, for brinfing these ill new

[Col.Knt.] ill doth all the noble substance. $\overline{\text { Iomlet }}$, i. 4

I am ill at these numbers

than their ill report while you live ....... - ii. 2

well to those that do ill; now thou dost ill - iii. I

how ill all's here about my heart

it were enough to put him to ili thinking ortho, iii. 3

the ills we do, their ills instruct us to....

ill-beseeming any eommon man...........

ill-beseeming semblance for a feast.

ILI-BODING-and ill-boding stars!.I Henry $V$,

and his ill-hoding tongue no more..3 Hem !
ILL-BREEDING-jli-breeding minds. II

ILL-COMPOSED affection...

ILL-DISPOSED, my lord misely!. Richard IJI.
ILL-Dilus \& Cressida,
ILDIVINING-ill-divining soul.

ILL-DOING-doctrine of ill-doing. Winter's Tile

in every thing illegitimate... Troilus \& C C ressida,

ILL-FARE-poisoned; ill-tare; dead. King, John, y. 7
ILL-FAVOURED children ....... As you Like it, iii. 5

an ill-favoured thing, sir,

are very ill-favoured rough things. Merry Wives,

a world of vile ill-favoured faults looks

'twas a black ill-favourel fly. Tim

LL-F A VOUREDLY, master Brook.. Merry $W$. ii

she makes very ill-favouredly $\ldots . .$. As you Like it, $\mathrm{i}$.
with reading them ill-favourediy.

of their bones, ill-favouredly beeome. Fenry $r$, iv.
ILL-GOT-things ill-got had ever ...3 Henry $I$ i

IIL-HEADED-a lance ill-headed... Much Ado, iii. I

ILLNESS-but without the illness...

ILL-NURTURED Eleanor! ........ Hertry VI. i.

ILL-ROASTED-ill-roasted egs.. As you Like it, iij. 2

ILL-SHAPED-ill-shaped fishes. Romeo \& Juliel,

ILL-SHEATHED-ill-sheathed knife. I Henry $I V$.

ILL-SPIRITED-ill-spirited Worcester! -

ILL-TA'EN-ill-ta'en suspicion! ... Winter'sTal

ILI-THIOUGHT on of her ( $(\mathrm{epp}$.). Troilus \& Cre
ILL-TUNED-ill-tuned repetitions.. King. Foh

ii. 2 ILL-TUNED-ill.-tuned repetitions.. King.Joht, ii.

iii. 2 ILLUAINATE so vile a thing

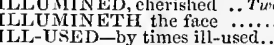

ILL-USED-by times ill-used
ILLUSION-by some illusion

of Verona,
Richard IV.
Ris.

here we wander in illusions. Comedy of Eream, iii. 2

by the strength of their illusion....... Muebeth, iiti. 5
by the devil's illusions this monk...Menry YII. i. 2
ULUSTRATE-illustratc king. Love'sL.L. iv. I (let.)

ILLUSTRATED-therein illustrated.Hen. $\bar{V}$ IIT. ii. .2
ILLUSTRIOUS-illustrious wight. Love's L. Lost, i.

ILLUSTRIOUS-illustriouls wight. Love's L. Lost, i. I
most illustrious, six or seven... Troilus \&. Cress. iii. 3

noble mind, illustrious virtue. Timor of Alheus, iii.

iii. 1 'gainst this high illustrions prince ...... Lear, v.
iii. 1 ILLUSTROUS-[Col.] and illustrous... Cymbeline, i.

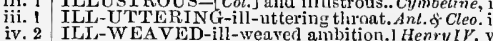

$\begin{array}{ll}\text { iv. } 2 & \text { ILI,-WEAVED-ill-weaved ambition. Henry IV. } \\ \text { iv. } 3 & \text { ILI-WELL-never do lim so ill-well. Much Ado, } \\ \text { iv. } 3 & \text { ILL-WILL-ground af your ill-will. Richard III. }\end{array}$
LLYRIA-Illyria, lady (rep.) .... T'welfth Night, i. 2

in tall a man as any's m illyria .....

as any man in Illyria, whatsoever

as stron' as any man in Illyri

found in any part of Illyria in Iilyri

$\overline{ }$
$=$

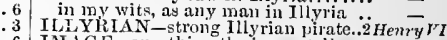
IM AGE-any thing the image tell me .. Tempest, i. it waxen image 'gainst a firc. Tus Gen. of Verona, ii. image of the jest I'll show you ...Merry Wives, iv. 6

that when the image creature. OTwelfh Night, ii.

from any image of offence leaves him

and to lis image, which, methought

image of it gives me content already for Meas.

the one is tomalion's images ........ - iii. now doth thy image appear in ...... Alth more witnesseth than tuncy's image... Mirl. $\bar{N} . D r$. with any branch or imace of thy ....All's Well, ii. father's image is so hit in you ..... H'inter's Tale, $v$.) the sight of my poor image would thus

did'st make, strange images of death ... Mac $\overline{-}$ the whose horrid image doth unfix

image of a wieked heinous tiult

in golden eoats, like images......... King John, iv. the noble innase pertect image of life the image of his power lay then

the image of the king whom I

to spurn at your most royal image .. - v.

image of pritle, why should 1 hold $\mathrm{my}$.

to survey his dead and earthy image $=$ i iii.

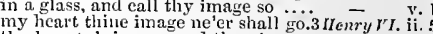

thy' benuty's image, and thy virtue.. - iii.

the precions innage of our dear ...... Riehard 111. ii. 1 the louking on his images .............. without some imaze of $\ldots \ldots \ldots$ Troilus \& Cressida, $\mathrm{ji} .2$ let no images be hung with Cæsar's
for pnlling seafs off Cresar's imacres even like a stony image...... Tilus Andronicus, iii.

the images of revolt and fiy in 5 off!................

Lear, i. 2

behold the great image of authority....... $=$ iv. 6

or image of that horror?

whose image even but now appeared ... Hamlet, i. 1

scorn her own itmage, and the very age... - ii. 2
this play is the image of a murder done - ii. 2

fur by the image of my cause, I see.

MAGINARY-imaginary wiles... Comedy of Em.

and foul imaginary eyes of blood ... King Johm, iv.

in forms imaginary the umusinaly. KichordII. ii.

on your imaginary forces work ... Henry $\boldsymbol{V}_{\text {. }}$ i. (cho

aud muke imaginary puissance

IMaginary relish is so swcet. Troilus \& Cressidn, iii.

nor can imagination form a shape ..... Hives, iii.

and not tollow the imaginations of your - iv.

to let imagination jade me ............

prove true, imagiuation, $O$ prove trie

.. Meas. for Meas. v.

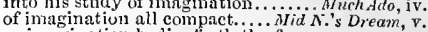

sucls tricks hath strong imaginations

if imagination amend them (rep.)

ny imarinntion carries no favour in it Al's $W$

magination of his neighlhours .. W'in/er's Tale, iv.

beyond imagination is the wrong. Comedy of Err. $v$.

imagination of some great exploit .... HenryIV.

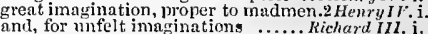

imagination moves in thís lip..... Timon of

your imagination hold this stage. Pericles, ivi. (Gow.)

(to take your imagination) ...... - iv. 4 (Gow. aud woes, by wrong imaginations, lose .. Lear, iv. 6 he waxes desperate with imagination ...Hamlel, $\mathrm{i}$. imagination to give them shape, or time - iii. my imaginations are as foul as Vulcan's - iii. 2 may not imagination traee the noble diust $=\mathrm{v}$. MAGINE-imagine howling ...Meas. for Meas. iii. if I should he hanged, $I$ cannot ima.

imagine no worse for them .... Nitl. $\Lambda$.'s Dream, v. he was to imagrine me lis love ... As you Like il, iit. imagine twere the right Vincentio.. Tam.ofsh. iv. imagine me, gentle spectators.. Winter's T. iv. (cho.) then imagine me taking your part ...2 flenry $1 \%$. v. imagine him upon Blackheath. Henry $Y^{\prime}$. v. (chorus) imarine him a Frenclsman and thy foe - iv.

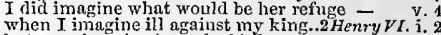
but may imagine how the bird was... iif. deep than you can imagine..... Richard 111. . imagine I have said farewell already $=$ i. as an $y$ man I can imagine........... Coriolanus, iv. 5 


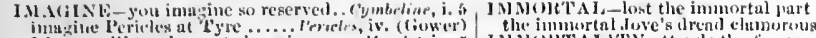
1 luge will temt you to imingine.

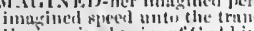
llac imneined bite of (in) with immgincd wing unt swift.I imagined wortil holds in his bil

as within me; lut imapilted,

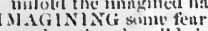

nre less than horrithe hits

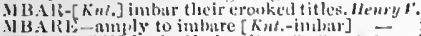

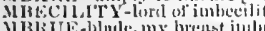

1.MBli Ure-blule, my bretst i

IMIT.1RI-imitnri is notling

imitate; nnd sal mos the

blatek, to imintute lice hrom

luerein will I imitnte the sun ........

then imitnte the action of the tiger ..

did they imitate thint which

me must not dare to imitnte

to imitate the grnees of the gerds

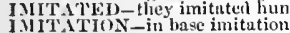

lie imitation calls) he pageunts us

nnd in the itmitation of these $t w$

with whint imitation you ean bors

MIAULATli white nud red.

immaculute, and silver fountain

in my pure, and immaculate valo
ehaste and inmmenlate in very.

heart's lore, immaculate devotion

I IN ASk-immask onr noted outwarl.I llen

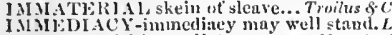

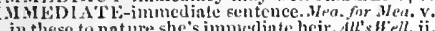

warrant of inmudiute death. . Comedy of Error.

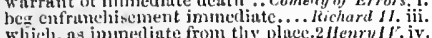

which, as immerlinte from thy

the immediate heir of En

Timon of

nil immediate freciom of repenl...Julins

asicmble wo immediate council ...A

shall prove the immediate author of

this immediate levy, he commands..

and it would eome to immediate trial

is theDICELY to marry

immediutely provided in that conse. $M$

dewth, or you, Ill find immediately..

I will return immediatcly ... Merchanl of
inust be gone from hence immediately

immediately to leave you and be gone

thy mister home immediately ... Comedy of Er

help him to his grave immediately 1 .. Fichord $/ 1$

nnd then to hurse immediately .... Hrnrylr. iii.

resolve your grace inmedialcly [ $\mathrm{Col}$. $\mathrm{F}$ int

resolve your grace imm

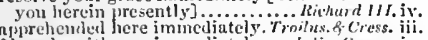

Ilessala with you immedintely Julius

sud something to he done immentiately

immeilintely we do exile........Ro
bring in elsudy niglat immediately

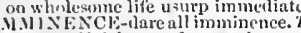

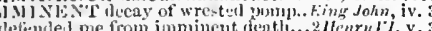

defendel me from imminent death

portents, anul evild inminent...

I see the inminent deatio of

'scapes $\mathrm{i}$ ' the imminent deally bry..... - iv.

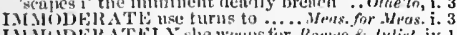

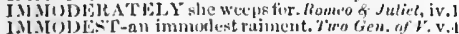

she slionld be so immolest to write .. Murh dan, ij.

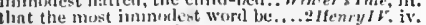

with this immodest elumerous ..... I lun

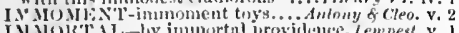

renonnemont, an immostal spirit. Mras. for Meus. i, o

to-murrow thou inust le made iminertal

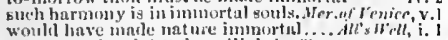

Uimorortal gots! t) the villan!. Thiming of sh. v

add an inmortal title to your crown!. Jieharel / . i.

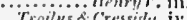

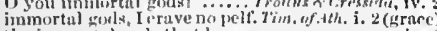

the immortal ferls thut liear you .....

if then best nost immortal...

1) $\mathrm{ge}$ inmortal

ii. 3 (1щн кеr)

for his bitino is iumbortai ..............

prumes the inmortal wimk..........

she sings like one immirtal ... Protes, v. (Guwer)

ah, the immortal pussarl

steal inumortul lilesting from lise lip. - iii.

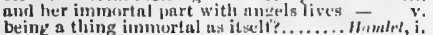

from lict his thatrest one, sweet

Antmy put ine to some impiatience.

will you teur impatient ans

he grows impatient .... Taming of Shr
wlen, with a most impatient devilisi

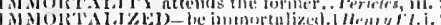

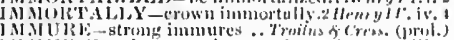

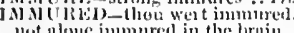

in silyer she's immured.....

JMex: $\mathrm{EN}$ - when lmogen is dend

if I could get this foulislt Inogen

o Imougen, sale mayst thou wancler

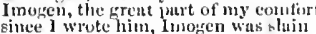

savel the noble limogen to rejent....

hut Imogen is your own; do your be

end it by some ments for Imogen

i) I mogen! l'ti speak to thee in siliene

truitful oljyect be in tye of Imogers ...

0 Imogen! my gueen, nyy lite (re

the tume of linegen? Lady

Inogen, thy mother's clear ...

$A P^{2}-$ self-same thing, dear

slivish yoke, imp out our il

a lad of life, nnd imp of fime

fame .........t

INPA lik-whereiu it doth impair. Micl. N. Dream, iij.

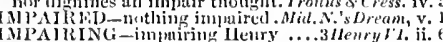

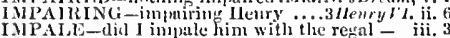

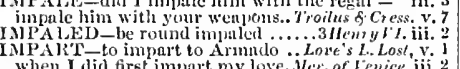

when I dich first impart my love. Me' of

great matters to impart to thee . Her s Tiate, ij. 1

to conceal what we impart.

though what they do impart help nothing

is it that you would impart to me? Julias Cersar, i.

his son, do 1 impart toward you

in drealful secreey impart they rlic

impart a thing to sou from his majesty.

IMPAlTAAL-I'll be impartial.

led by the impartial eonduct....

bold, just, and impartial spirit

IIPASTED-lraked and impustertment. Humlet,

IIPATIENCE-with impatience
but first, slieath thy impatience

but first, slicath thy impatie

impatience lowreth in your fuce.

... As you Like

out impatience hath his privilese .. King Jahn,

impatience waiteth on true sorrow...3 Henry 1 .

this sene of rude impatience

Kichard

own impaticuee takes from Aufudius, Coriolan

strange impaticnce of the heavens.Julius Cossu

fearing to strengthen that impation

impatienec does become n dog that 's mad

express impatience, lest you stir
his wits las given way to lis impan
IHPATIENT-J um impatient. T

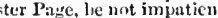

all impalient to spenk and not ser. Lore's L. Lustii.

more a shrew of thy impatient humour - iif.

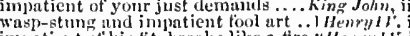

mpatient of his fit, breaks like a fire.z IIenryl

yoll are two impatient to bear erosst:

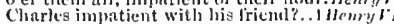

impatient of my alsecuce........

imperisms, tmol imputient

a henrt nufortificit, or mind imputient

to put nuy finther in impatient thoughts. (owe tho

impintiently stamperl with your firot.

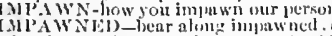

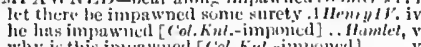

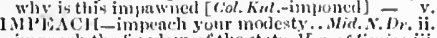

impewh the freedom of the state. Ir.r. of ience, iii.

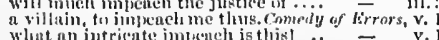

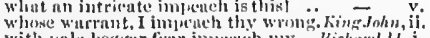

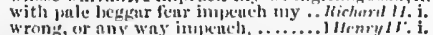

w rong, en any way impench.

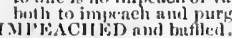

3Henryll. $\mathbf{i}$

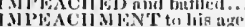

Rirlumilli.

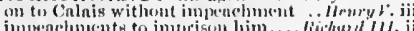

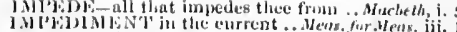

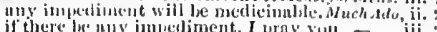

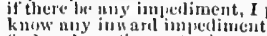

years loc no impelliment

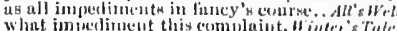

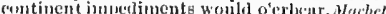

sexed witl thy imperliment

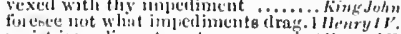

the impedinent that broke this of ..... Ilemy

what rits, or what impedine

marched on without impedimcrit... leichard $1 \mathrm{~J}$.

ean cver aplear in your impertiment.

shows, dream of imperliment ..... A utowy s cieo,

impedinent most profitubly re.....eved .. Ohello, ii.

IMPEN ETRABLE cur ......Merchant of tenice, iii.

INI'ERATOK, and great generul.. Lore's L.. Lost, iij.

said to LCT-You imperfect epcakerf... Varcheth, i.

something lie let't inpertect in

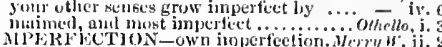

loutul

piete ont onr imperfuctions

gives growth to the inperfections...

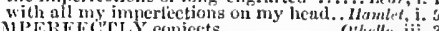

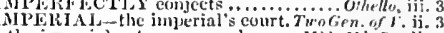

the immerial votaress passed on Mil. N.s D. ji.

the most impcrial monarch. ...... hinder's Thle, iv

nony recoil, to an imperint char:e.

from thee, is this imperial crown ...2iien, $\bar{l} W$ iv.

nnd services, to this imperial th
with crowns imperial.

our cue, and our voice is imperint.

the sword, the maee, the erown imperin

by your lifh imperial majesty ......2 liem, 2 (eho.)

the high imperial type of this

the imperial metal, eircling now

the imperial Cas:u, should ngaij $\ldots$... Cymbetio

that wore the imperial diade

to approaeh the imperial scat......... -

mount aloft with thy imperial nistress

no' your mistership be imperial..... - iv iv. 4

[Col. Knl.] injporial Casar, dead

the imperious flood hath left

"radle the rude imperious ain

imperious in another's thro

aufort, the imyerious

most im

not the imperious show ot the Troilus o C'ressido

the imperious stas breed monsters.. Cymbeline,

as your titles witness, imperions......

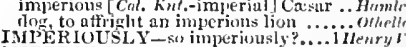

IMPERSEV EAAN'T thung loves..... Cymbryme,

IMPER'INENCY - impertinency nixed! Lenr,
MIPERTIN

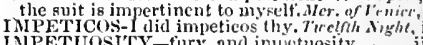

IAPETUOUS-the impetuous blasts … Leer, i

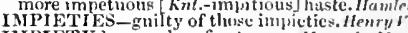

IIIPIETY has mude a feast ....... Meus, fnr.Mra

furewell, thou pure impicty
more impiety than Jephthal

to lie in anger, is impicty

Wuch filn

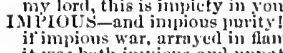

and York, and impious Bean

kec] their impious turliands

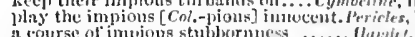

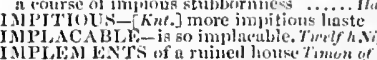

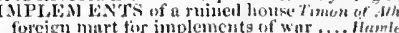

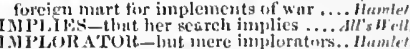

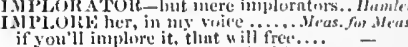

I lo implore secrey, that the king. Love's $L$.

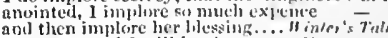

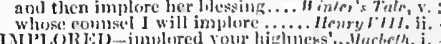

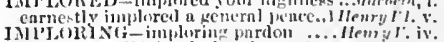

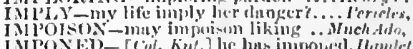

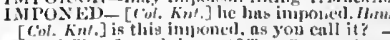

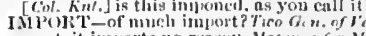

next, it imports no rasull. Messure for M/c

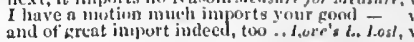


IMPORT-what the import is ........All's I'ell, ii. 3 what occasion of import hath all. Taming of Sh, iii. 2
should im port offending.......... Winter's Tale, i. 2

more general than these lines import. King John, iv.

if you knew how much they do import - iv.

some petty towns of no import ......1 Henry

which now import their dangers. Anlony \& cleo. ii. 2

thousands more of semblaule import

being Leonatus, doth import so much. Cymbel

which inports to the kinglom so much... Le

do import some mosad venture ... Romeo \& Jutiet, v. I

full of charge, of dear import ........

which imports at full, by letters conjuring - iv. 3

alns, sweet lady, what inports this song?

quali ty and respect, as doth import you

as it were; his gesture imports it

what dntli your speech import? ...................

in an act of this importance.......Winter's Tale, ii.

if the importance were joy, or sorrow

at our importance hither is he come. King Joh
upon importance of so slight and .... Cymbeline

Mpon importance of so slight and .... Cymbelinge,
IMPORTANCY -importancy of Cyprus.. Othello,
IMPOR'TANT-is important iu't.. Tuelfh Night

IMPOR'T ANT-is important iu't.. Tuelfh Nigh
if the prince be too important........ Much Ado,

now his important blood will nought. All s

sakc only, he makes importaint. Troilus \&

my mourning, and important tears....... Lear

by the important acting of your dread. Hamlel,
IMPOR'TANTSY-importantly as now Cymbelin,

IMPORTED his feliowsilip.... Timon of Athen

IMPORTETII-imoorteth none here.. Love's L. L
more serinus importeth thee to know. Ant.\& $C$.

INIPJRTING - an importing visage ...All's 'Well,

importing change of times and states.1 Henry

importing,-the several parcels. . Henry lriI. iil.

importing the surrender of those jands.. Hamler

weeds, importing health and graveness
reasons, importing Denmark's health

im lorting the mere perdition of .......... othello, ii.

IMPORTUNACY-importunacy?. Two Gen. of $I$. iv.

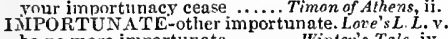

be no more importurate ....... Winter's Tale, iv. I

put on a milest importumate importunate business - ii.

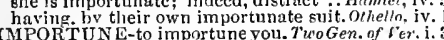

much importune you me to that

that thither them importunc.........

against all sense you do importume he

quick despateh, importunes personal. Lnve's $L . L . \mathrm{ii}$

and importunes access to you ....As you Like it, i. I

youl hear, how he importunes me. Comedy of Err. iv.

importune him for my munies. Timon of Athens, ii.

importune him for my monles. Timon of Athens, ii. 1

importune lier; she"ll help to put jou... Othello, ii. 3

now he importuncs him to tell it o'er... - iv.
IMPOR'TU

have you importuncd her to such. Nerry Wives,

importuned me, that his attendant. Com

since I have not much importuned you -

importuned him by any means?.. Romeo \& Juliet,

he hath importuned me with love ...... Hamlet, i.
IMPORTUNITY, to fill up... Mer.oflenice iv.l (Iet.)
to his unmastered importunity ......... Hamlet, i.

any strong or vehement importunity.. Othello, ii
IMPOSE-ladyslip's impose.... TwoGen. of Ver. iv

impose me to what penance your ..... Ifuch Ado,

a plague that Cupid will impose

impose some scrvice on me for .... Wirinter's Tale,
undergo, and nobleness impose ..

undergo, and nobleness impose .. Winter's Tale, ii.
ordain, impose some gentle order . . KingJnhn, iii.

What tates impose, that men must..3 Henry $l$ I. iv

you wor impose, this usage, coming from.. Lear, ii.
or thes
IIPOSE-imposed the office.... Neas for Meas,

task cnuld not have becn imposed. Comedy of Err.
slionld be imposed upon his father ... Henry $V$. j

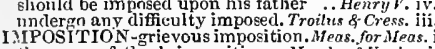

than your father's imposition ... Merch. of Venice,

not to deny this imposition ............ All's $W^{*} e l l$, $\mathrm{i}$

the imposition cleared ............. Winter's To

the equel of your imposition ....Riehard III. ji.

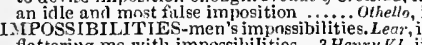

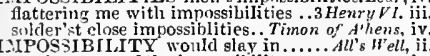

not ignorant of the impossibility

proof is called impossibility .... Troilus \& Cress.

murdering impossibility, to make ... Coriolanus, y
IMPOSSIBLE-imposible matter...... Tempest, i.

'tis as impossible that he's undrowned - it

as nothing is impossible.. Tre Gen of Ferona, iii.

he cannot 'scape me: 'tis impos
I will search impossible places

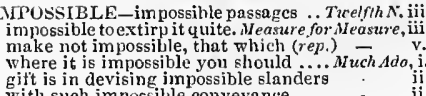

with such impossible conveyance...

nay, that's impossible; she may wear - il.
that were impossible; but I pray you
in an hour, sir. Impossible .......Love's L. Lost, i. I

it cannot be; it is impossible.

it is impossible I should live... Mercn.. of trenice, iii.

and it is not impossible to me ....As you Like it, v. 2

impossible be strange attempts ......

it were impossible I shnuld speed amiss - ii.
why, 'tis impossible. Why, he's a devil - ii.
to the encmy, is all impossible....... llichard $/ 1$. ii.

to the encmy, is all impossible.

Hewry $l^{\mathrm{iv}}$ iv.

traight a thing impossither.

2 Henryli.i.

to nominate tiem all's impossible

it is impossible, that I should die by $\overrightarrow{\text { iv }}$ iv.

no, 'tis impossible he should escape.

'tis as much impossible (unless we...

it is impossible, that ever Rome

Antony\& Cleo. ii

chamber, that it is impossible

amity? 'tis hard; almost imposibi

it is impossible they bear it out

there is no such man; it is impossible...$\overline{-}$
IMPOSTIIUME- full of imposthume. Troil.s. $\mathrm{Cr}$.

this is the imposthume of mucls weal th. Hamlet

I am not an impostor

and starts (impostors to true fear)

YNPO'TENCE-age, and impoten
INIPOTENT-impotent to smile.

MPOTENT-impotent to smile.. Love's L. Lost,

who impotent and bed-rid

O most lame and impotent conclusion!. Othello
IMPOUNDED-impounded as a stray.. Henry $P$ hath given for fence impregnable...3 Henry $V i$

were his heart almost impregnable.. Titus Am
IMIPKESS-weak impress of love. Two Gen. of $V$

who can impress the forest .......... Macbeth,
air with thy kcen sword impress .....
razed out my impress, leaving me... RichardI.

razed out my impress, leaving me.. RichardII.
and you as under an impress. Troilus \& Cressida,

people ingrossed by swift impress. Antany $\&$. Cleo.

why sucl impress of shipwrights ..... Hamlet,
IMPRESSED-print impressed .. Love's L. Lost, strong passion is impressed in fouth.. All's Well wears my stripes impressed on Jim..Coriolanus, v. IMPRESSION-no impression...Two Gen. of Ver. 1i. 4
the impression of keen whips...Mens. for Meas. ji. 4 and stoltn the impression of her...Mid. N. Oream, i. 1 that carries no impression like

such terrible impression made

Henry VI, jip.

whose soft impression interprets.. Timon of $A$ th. v.

more impression sbow than that.... Coriolamus, v.
gave't the impression; placed it safely. Homlet, v. 2
IIPRESSURE-tlie impressure.. Tuelfik Nighl, ii.

and capable impressure thy palm. As you Like

INIPRIMENDUM solum .... Taming of Shrew,
IMPRIMIS, she can fetch $(r e p$. $)$. Troo Gen. of Ver now I berin; imprimis, we came.
imprimis, a loose-bodied gow'n

imprimis, it is agreed between.2 Herry VI. i. 1 (ar

INIPRISON-then imprison him.. Neos. for Ness.

to be intormed, imprison it not in.. Winler's fal

impeachments to imlirison him.... Ricinard III.
IMIPRISONED-whicl rift imprisoned.. Tempest,

suffered me to be imprisoned .... Tu'elfth Night

jmprisoned in the viewIess winds. Meas. Jor ileas.iji.] inprisoned angels set thou at liberty. King Jnhn,
fair neohew, that imprisoned me ... Henry $\boldsymbol{V I}$. our brother is imprisoned by ........Richord $\mathrm{N}_{\mathrm{H}}$. i. imprisoned is be, say you?......

imprisoned; all is ont ward sorro

where you imprisoned were. . Tilus Andronicus,

and streked, punished, and imprisoned.. Lear,
IMPRISONING of unruly wind .... Herry IV.
IMPRISONAIENT shall not be long. Richord 1 .

your lordship brooked imprisonment?
my Iord Hastings' Iate imprisonment

as the mortality of imprisonment. Neas.

and imprisolmment can lay on nature

have your full time of imprisonment

the shame, imprisonment ....Cumedy of Errors, v.
minister the potion of imprisonment .2. HenryIVI.
my limbs with long imprisonment... IIenry VII. ii.

this her easy-held imprisonment hath
king Henry from inprisonment....3 He

made my imprisonment a pleasure .̈. ${ }^{-}$iv.

IMPROB A BLE fiction ............ Tirelfh Night, iii.
IMPROPER-service improper for a slave .. Lear, y. INPROVE-if he improve them ...Julius Cresar, ji.

IMP EDENCE-wit, or impudence........

of impudence, a strumpet's boldness.. All's 'Wel

less impudence to gainsay .....W'Wher's Talr, jij.
take women's gifts for inpudence......Pericles, ii.
IMPUDENCY - without impudency. Love's $L . L$. r. MPUDENT_an impude

why thou whoreson, impudent ....... i Henry $I V$. iij. 3 more than impudent sauciness .......2 Henry $I V$. ii. impudent with use of evil cleeds........3 Henry $V i$.i. 4 impudent and shameless Warwick .ius $-{ }_{\text {iii. }} 3$ What committed! Impudent strumpet!. Othello, iv. INPUDIQUE-grosse, et impudique...Henry $V$. iii. MP GN-cannot impugn you... Merch. of Venice, iv. IMPURE-impure blots and stains. Richard III. iii MPUTATION, for that le knew. Meas. for Mlens.v. with the imputation of being near..2 Henry $I V, \mathrm{v}$. the imputation of his wickedness ....Henry $\nu$. iv. but in the imputation laid on him Troilus\& Crrss. Yiet, I say, if imputation, and strong .... Othello, jii. your majesty, impute his words ....Richard II. ii. and not impite this y ielding.... Romeo \& Juliet, ii. in this desert inaccessible ..........As yax Lilie it NAITABLE her inaidahle estate....All's Well, ii. INA USPIClOUS stars ..........Romeo \& Juliet, v. to be iucaged [Col.Knt.-engaged] ...1 ItenryI V. iv.

INCANTATIONS are too weak $\ldots$. . Henry $V i$. v. $^{2}$ incapable of reasonable affairs?.. W'inter's Tale, iv incapable and shallow innocents .. Hichard 11 II. as was never so incapable of help ... Coriolonts, as one incapable of her own distress . Hamlst,
INCARDINATE-devil incardinate. . FrolfihN.

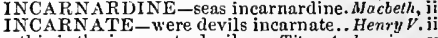
this is the incarnate devil .... Titas Andronicus, $\mathrm{y}$ INCENSE-I will incense Page .... Nerry 'Wives, $\mathrm{i}$. the incense of a vow, a holy vow .. King John,
$I$ jever did incense his majesty .... Richard III

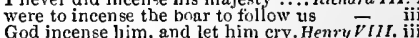
God incense lim, and let him cry. Henry VIIT, iij. the gods, incenses them to eend ..Julius Carsar, i. and what they may incense vim to ....... Lear, ii. incense her kinsmen, and though lie..... orkello, $\mathrm{i}$. CED-have incensed the seas .. Tempest, jii. 3 knight is incenscd g gainst you .. Tuelfh Night, iii, room for the incensed worthies.. Love's L. Lost, difference of incensed kings.............ing John, iii. report on their incensed rage ........2 ${ }_{\text {with an incensed fire of injuries } l v . .2 \text { iv. }}$ i.

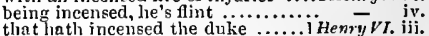
that hath incensed the duke ..... Herry VI. iij. not incensed by his subtle mother. Kichard IIJ. iii. I have incensed the lords o' the countil - v. if 'gainst yourself' you be incensed ... Coriolanus,, $\mathrm{j}$. the people are incensed against him

by some incensed the rabble........ Laertes, why thou art thus incensed ... Hantel, iv. and fell incensed points of miglity ....... $-v$ nart them; they are incensed ............
INCENSEMENT at this moment $\bar{N}$. $v$.
INCENSI INCENSING-incensing relics of it ...All's Well,
INCERTAI -incertain tlrougly ts. Aea. for Mrr. and devour incertain lookers-on. Winter's Tale, ontlives incertain pomp ..... Timnn of Athens, iv INCESSANT-yet the incessant. Conedy of Errers, i. to do your grace incessast services ...Hrn'y $v$. ii. plague thee with incessant wars.... I Henry VI. v. INCES:AN'TLY upon these jades...... King John, ii. and her to incest dia provcke ...Pericles, $i$. (Gower) black as incest; which by my knowiedge - i. Antiochus from incest lived lint free...... (Gower) a conch for luxury and damned incest.. Hamlet, i. such dexterity ay that incestuous. that adulterate beast -
or in the incestuous pleasures of his bed here, thou incestuous, murclerous........ - - v.
INCH-every fertile inch o' the island... from the farthest inch of Asia ....... Mhurh Atlo, ii. I'll not budge an inch, boy. Taming of sh. 1 (induc.) I'll queen it no incls further

at saint Colmes inch, ten thousand....... Narberh, i. 2 my inch of taper will be burnt ........ Richard $\mathrm{H} h, \mathrm{j}$. 3 an inch of any ground................ Henry $I V$ iv. with the very extremest inch... 2 Henry $r$. $\mathrm{i}$. an inch of fortume better (rep.). Antony \& Cleo. ay, every inch a king.................... Lenr, iv. stretches from an inch narrow............. \&utiet, ji. NCIARITABLE-incharitable $\mathrm{dog}$... Tempesi, INCHES-stceI, three inches of it......
how many inches is in ode mite... Love's L.Lost, v. 


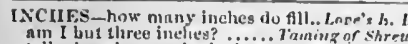
tell what thou art by inclies... Troilus of Cressida, Hith apnus and inclies so diminutive
knows the youtli even to his inches.

they'll give him death by inclies.

I would I liad thy inclies

as innny inclies as you liave oceans.. Combelene,

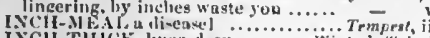

I. ClI-TIICK, knec-dec

I. CIDE \$CY thm dnat guess of him

CivaxT-most incident to muids.

plaguck, ineide ut to menl...... Thmon of Athens, iv.

IVCIIIOT int

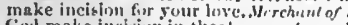

Goxl malie incisim in the

sliall we lane inge divith

ynu Like il iii.

and make incl-ion in their hijles...... Heryy $r^{*}$

fir she incites ine to that.

kimdness shnll incite flue to biid

gour reverence shatl ineite 11 to

no blown am fition doth our arms incite

INCIVII.ITY confing no less. Conedy of Er

inelinable to

have hearts inclinable to honour

his inclinatim, -after his und ressed to

to fieroe and blowdy inclination ..... King Jolth. ...

the state and inclination of the day. Richurd II. iit.

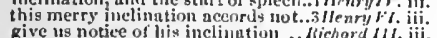

give us notice of lifs inclinution ... Aichard MII. iii.

her years, her imclination ...Antony t Cleopa'ra, ii.

thou find the inelination of the peop

though inclination be as sharp as will

from forage will iucline to iline... Sheas. for Mtros

doth his minjesty incline to it, ur no? Herry

I more incline t, somerset.

if he would incline to the people...

and neither way inelines

to incline limselt to Casas

we must incline to the kin.

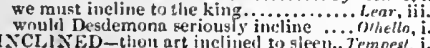

move my father to be inclined my way

I find they are inclined to do so

he was not inclinerl that way
till he were well inclined.

when thou art inclioed to 8 leep........

themselves, finding it so inclined.... Hoctell, iv. I

his blood inclined to mirth

he's inclined as are the ravenous

wrathful, and inclined so blood...
or sorry, as I saw it inelined ...

have been inclined to thrift
which men are best inelined.

.2llenryll. jii.

政,

not 1 , inclined to this intelligence............

Coriolanus,

eontent me to hear him so inclined.

inclining to them both

that way inclining

is it your own inclinitur

both you of my inclining, and the rest. Othello

for 'tis most ensy the inclining Desdemona
IXI.INES'T-inclinest that way.. Win'er's Tule

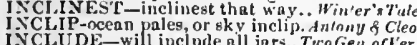

INCLUDE-will incl nde all jars.. Tero Geu.of'er.
loss of such a ford inclules all harms. Hicharilli.

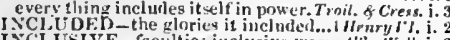

IXCLUSIVF, - feuities inclugive were. All's Wrlt, i.

that the inclusive verpe of golden.. Richard IIf.
INCOMPARA BI.E wealth. ... Taming or Shrew,

do show her wit inconpnrable......3 Henry J', iji.

a mori incomparahle man ...... Timon of Athers, i.

INCUNAIDERATE tuke sulve for, Lore's L.t.os', iif.

rash, inenn*iflcrafe, flery voluntaries. Kias John, ii.

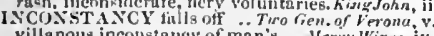

villanous incolnstancy of man's ...Verry Wive

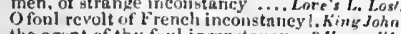

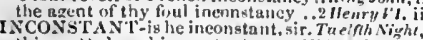

this spotted, and inconstant ma11., Wid. N. D, eam,

shallow, inconstant, full of teurs. As you Like it,

a city on thic inconstant billows. Henry $r$. iii. (c)

slic is turuing, and inconstant.

more inconstant thun the wind ... Homeo of $J$ wied

not by the miment the inconstant moon -

thou didst aceuce him of inementinency

that he in open to incontineney

will climh inemtinent (rp.).......ts you like it,

matrons, turn incontiuent.... Timon of dhens, iv.

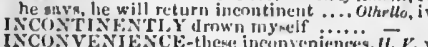

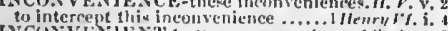

I.CUNVEAll.

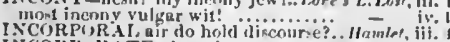

INCOKI'UR TTF.-been ineorpornte. Mid. N. Dr. iii.

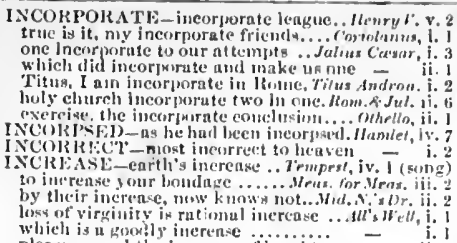

pleasure, nond the increrase of hing

vour hirnours miny increase, till $y$

but atil increane into my wernth
theirs for the earth's inerense", mize

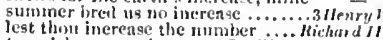

fo quicken your inerease, I wili

the I ors inerense this birsiness!

her wombs incrense, and treasure ...

drink thou; increase the recls ... Antony s

the earth, swallow hicr own increase..

dry uy in her the organs of inerease

as if increase of nupetite larl prown by... Hamle

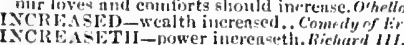

the enemv inerensetl every day. . Julius Casos.

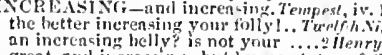

great, and incensing' but by sca.d

nerishing rort, witli the incrensmg vine! - i

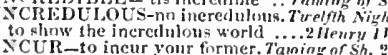

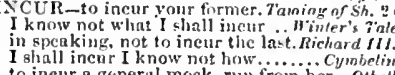

to ineur a generul mock, num from her.
to incur a private check: whicn shall

NCURABLE-gave him out incurable. Ait's $\overline{\text { Well, ii. }}$

but the disense is incurable

King John, v.

INCU IIRED-thou hast irieurred... Ner. of fienice, iv

he hath incurrel the everlasting ... Al's I'ell,
inearred a traitor's name. . Troilas \& Cressida,

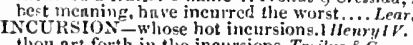

thou art forth in the incursions. Troilus $f$ Cress.
INDE- - with savages and men of Inde? ? Propes'.
a rude and savage man of

the enst to western Inde ..Asyou Like it, jij. 2 (
CNDEBTED-and stand indebted. Serof Fenice,

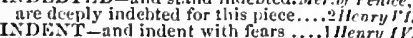

with sueh a deen indent, to rob me...

IDENTURE-indentnre of iny love. Kin
the cowari with thy indenture ....IHe

the eowari with thy indenture
our indentures tripartite are draw

are the indeutures drawn? shall we

serve by iulenture to the commont.

and breadth of a pair of indentures? .... I/amlet

INDE-as index to the story...... Richord $/ I t$.

so lourl, and thunders in the index? .. Hamles, iji.

MNDEXE. and ubseure brologuc.......... Othello, ii.

INDI A-my nettle of Indin? $\ldots$. Tuelsh Nigh', ii.

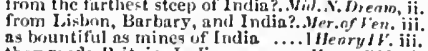

as bountiful as mines of India ..... I Henry/l. iii.

her bed is Indin: there she lie

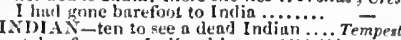

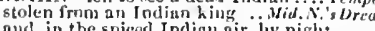

and, in the spied India

searf veiling an Indian lestuiy......... of benice.

diminonds, and Indian sto

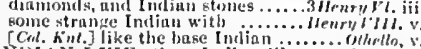

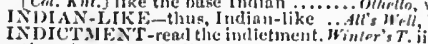

there is anntieer indietneent upon ..2Nenry $V$. .ii.

hare is the indietment of the ponsd. Richard $/ 1 r$.

WILS-my Eust and West I pllies.. Mrrry Nires.

another to the Indies.

where Amerien, the Indies?

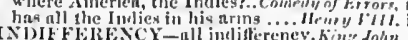

INDIF FEIREAC Y all indiflereney. King John,

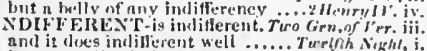

and it dues indlinterent well
item, two lips indifferent red

I'll tell you news inelifferent gomdi. Faming of st, i. .

their gurters of all indillierelt knit an

iny wrongy with sn inclifrerent eye.. Richurd II,

lite is eorne alfer it indiflerent we

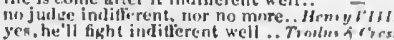

INDIFFERENT-Indlfferent. .. Timon of Athens, i. I

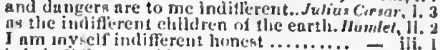

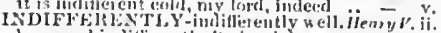

he waved inditlerently " w wixt doing. Coniolunus, ii,

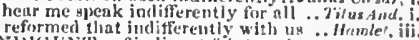

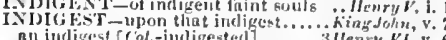

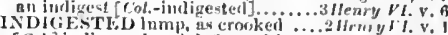

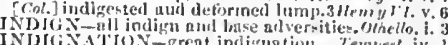

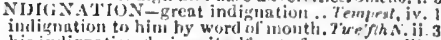

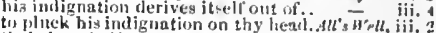

and quench his ficry indignation

ue indignation mighty lieaved

peace to scarlet ituliymtion........ Kichard $1 T$. iii.

hurl slown their indignation on llice. Nichardlil.i.

I volr indignation urgainst my brotlur....... Lear, i. 2

unnt to stir at these indignities. .... I Jenryly.

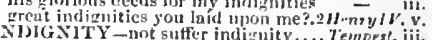

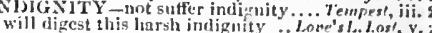

yoll give me most egregious indignity. Al', w'vll, ii.

mine age with this indignily. Jitus dudroureus, $\mathrm{i}$.

Fome strante indignity .................'sello, ii. 3

thyngh ind reet. yet indirection...... King John, i.

the which, we find too indireet....... Hensylv, ir.

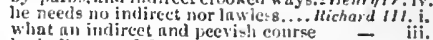

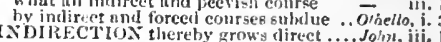

by indirection

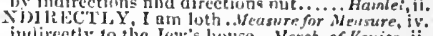

that, indirectly, and directly too .... . . - ing John, ii.

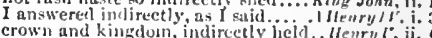
all indirectly, gave directict...... fliches a ill. is. sn drunken, and so indiscrect ain inficer . Uhello, ji. 3 INDI:PU.F.D and sickly fer us well ... ilmmlet, v.

INDISSTIUBLE put you lack. Tirnon of dthen, ii.

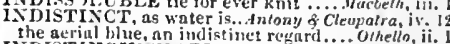

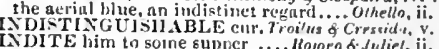

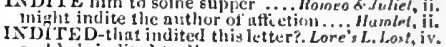
and he's indited to dinner.

the witness, and he's inditeil fillely

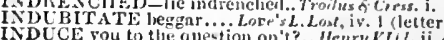
to induce their medicution on't?.. Ilenry VII. ii.

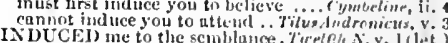

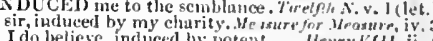

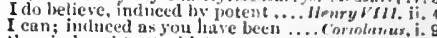
they indued to steal it! ............ ("ymbelise, ii. 4 inducement move her not to love llehord IIf.iv. 4

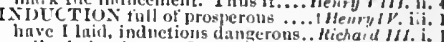
nordire induction am I witucs to .... I shall intue you with: meantime. King John, iy. it inlues our otluer lieatinful memiers. Othells, iii.

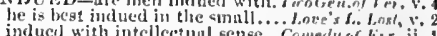
and hest indued, with sonse suspieion. Menry $r$. ii. 2 INI) U1 A E ECE set me fiee............. Trmpest, (epii.) of partial ind lulgence to their. Troilus forers ds, ii.

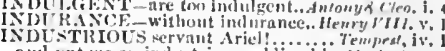

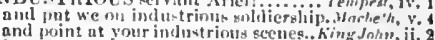

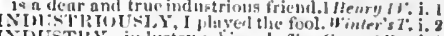

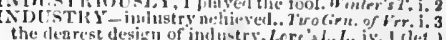

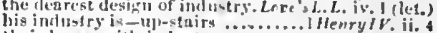

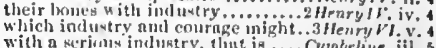
with a soriuns indukery. 1lut is .... Cyndefine, iil. s and with a dropping industry ........ Pericles, iv. I

JEREAITT - for inequality - yeas for Veas, is

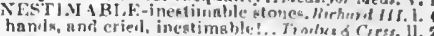




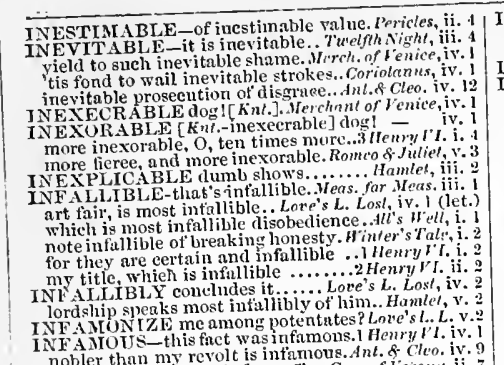

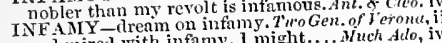
and mired with infamy, 1 might......
will quench the wonder of her infimy,

I will whip abont your iufamy ... Lovers L. Lost, v.

yon live in great intamy ....

what infuny will there arisc
life preserved with infamy.

queen, and erowned with infamy
I throw my infamy at thee

detaced with scars of infiamy th......

tlirow over her thet forth my infumy

live to trumpet forth my infamy ....... Perieles,
INFANCX-are in their infaney again.. Tempest,

tor, from our infaney, we have. Tuo fiem. of lert.

tor, from our infaress infaney.

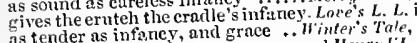

from ler tender infaney ...........

in his infaney been erowned

Richenryll.

skill-less as unpractised infancy.

soft infaney, that nothing eanst

simpler than the infancy of truth....ius Antron. v.

$N F A N T$-infants of the spring .....
define, define, well-educated infant.

define, define, well-educated hid, an old infint play ....

thou disputest like an infant

at first, the infant. mewling

from an infant, treely .......
did perish with the infint

doutreed infant state, and done a rane. Kin $\bar{g} J o h n$

plays in that infant's veins 1.

draws the sweet fortune comes

and iny infant fort une comes ........ Henry d

when his inarrior in lis enterprizes

holds lis infant up............................

and your flowering infatts $\ldots \ldots \ldots$ o........

in infant hands erowned...... Henry $V_{.}$v. 2 (choru

as very infants prattle of ...........

more than the infunt that is bo

hath dimined your infant morn

poor infants, in their graves

servants $\bar{J}$ III. v. 4

as infunts empty of all thoughti. Troilus \& Cress.

your infants in your arma.............

minds of in fants to exelaim ...

for the love of this poor infant ......... Pericles

and leave her the infant of your eare..... int ii. 3

infant rine infants of the spring ........... Hamte

INF AN'T-LIKE-are too infant-like.Corialnmes, ii.

NFEld - ven infect

would even infect mp mouth $\ldots \ldots \ldots \ldots \ldots$
she would infect to the north star.....

she would infect to the north star..... Wou Like it, iij.2

a fear which oft infects the wisest.. Winter's 7 .

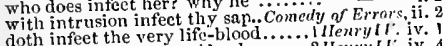

but if it did infect my blood....

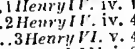

thon dost infect mine eyes............. Kichard III. i. 2

a pestilence that does infeet...

imperial voice, ) nany are infeet ..... - imon of Ath. i. 1

breath infeet hrenth..................

beat thee, but $I$ should infeet my honds

conversation would infect my brain. Coriola

nature of bad news infeets ...Aatony of Cleopatre, i.
infert her beauty, you fen-sueked fugs.... Lear, ii.

mining all within, infects unseen

wants not buzzers to infeet his ear .......
INFECTED - worm! thou art infeeted... it

Navarre is infeeted .............

they are infected, in their hearts . . . . witis the lampass, infected with.. Taming of Sh. iij. my wife's liver infeeted as her life,

infected be the air whereon in feeted minds to their deaf

infeeted minds to their deaf pillows. King.John

nerer to be infecter with being infeeted, died

2 Hewryl $\mathrm{l}^{\prime}$

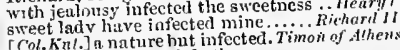

and cull the infected forth

infected witl my country's lore .... Cariolanns, v.
hoth been belehed on by iufected lunss. Ien icles, iv.
NFIRMITY-liseover thine infirmityl Henry Fl. v. not a man of their infirmity Julius Carsar, i. FECTED-infeeted with their man to think it was his infirmity .......Leari. tis the infirmity of his age; yet he ...... Lear. I am unfortumate in the infirmity on some odd time of lis infirmit

with one of an ingraft infirmity the.. Tutelfh Night, ini. he hath ta eu the infeetion ............Much dido, i. 3

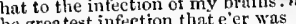

purge all infeetion from our air

such is the infeetion of the time infection [ $\mathrm{knt}$-infestion]

breathe infection in this air

Ri

1NF XING-of nine eye infixing

NELANE-will inflame thy noblc

King Jolin, it. 2 intlame [Col. Kul -inflaming] love (rep. ericles, ii. there should be-again to inllime it ..Olhellon, ii. his heat intlamed with Venus... Troilus of Cress. v. that have influmed desire in $m y$ brenst. Perictes, should kindle to infiamed respect

infection, being of eatching innture.

what a strunge infection is fahlen.

some new infetion to thy eye

so fearfil were they of infection...
INF

in

your potent and infeetions tevers. Timan of Ath. iv.

will be butli noisome and infectious.. Cymbetine, $\mathrm{i}$.

where the intectious pestilence... Rnmeo of Jaliet, vr.

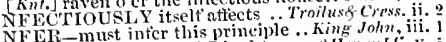
NFER-must inter this prineip
this doth infer the zeal I hat $t$

I this infer, that many things

infer the bastard lineaments....

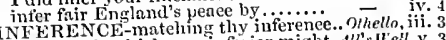

INFERIOR-w.hieh any inferior might. All's "N'ell, $\mathrm{x}, 3$

yet she is inferior to none. Tamin

by suhjeet and inferior breath

or be interior to the proudest peer....

may not prove iuferior to yourself..3 Henry $F I$. iv.

and small inferior veins, trom

Olhello, iit.

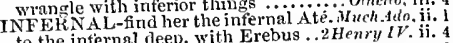

to the infernal deep, with Erebus. Titus Andros. v.

1NFERRED-the duke inferred

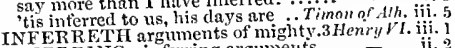

INEERR $1 N G$-inferring argume

INFEST-do not infest your mind
INFESTION-[Knt.] against infe
INFIDEL-Lorenzo, and his infic

INFIDEL-Lorenzo, and his infidel?.. Wer.of'en. iii.

now, infidel Thare the with Turks and infel

think you we are Tumks or infidels? Richury III. iii.

INFIN y T E- but an infinite loss

hit her favour infinite...... Trooken. of

instances as infinite of infinite rate. Merry wires,

it is past the infinite of thought ..... Much Ado, ii.

our dnty is so riel, so infinite .... Love's L. Losl, $v$.

speaks an infinite deal of nothing. Ate. Ail's Well, ii.

an infinite and endless liar ........... ${ }^{-}$- iii. $b^{3}$

amongst the infinite doings of the Comed $y$ of Er

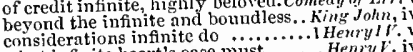

what infinite heart's case must ...... Heary $V$. iv.

for these fellows of infinite tongue....

the past proportion of his infinite. Troilus \& Cress. ii.2

to danger as infinite as imminent.

the one almost as infinite as all......

womb unmeasurealble, and infinite breast

liseovery of the infinite fiatteries.

in nature's infinite look of secrecy...

$O$ infinite virtue! eomest thou smiling

conclusions infinite of easy ways

whot an infinite mock is this

countless and infinite, Jet would. Tilus dnelrn

I have, for both are infinite ..... Romen of Utumlet

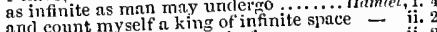

how infinite in facnltics! in form

a fellow of infinite jest, of most exeellent
INFINITEI,Y $\rightarrow$ so infinitely bnund. $M r r$ of $T$

I will swear I tove thee intinitely ... Henry IF. ii.

dehtors do, promise you infinitely.2 Henry $W$. (epil.

I am most infinitely tied .... Cymbeline, i. 7 (letter
INF IN ITIVE-an infinitive thing..2Henry Ir. ii.

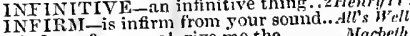
infirm of purposel give me the ...........

noor, infirm, weak, and despised old man- iii.

shonld bear his friend's infirmities. Julius Cecsar, iy
play with all infirmities for gold .... Cymbeline, $\mathrm{i}$

assuming man' 8 infirmities $\ldots$... Pericles,
these fishers tell the infirmities of men

with those infirmities she owes $\ldots . . . . . .$.

NFIRNIITY - with my infirmity .....Trinpest, iv

a speedy infirmity, for the better ..... $-\overline{\text { ineos for-leas. }}$

this in the infirmity of sense ..... Alos. ${ }^{\prime}$ s Woll, it.

wut infirmity. (which waits on . Winter's Tole, y.
[Cal. Kut.] infiuming love i' thy boson. l'ericles, iv.

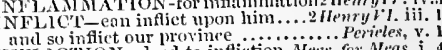

NLICTION - dead to infliction. Mets. for Meas.

by her fiir intuenee fostered.. Two (ien of J $\mathrm{er}$. 1il.

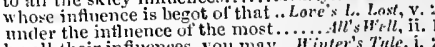

by all their infincences, yom may'. Winter's Tute, i.

bedience of planetary influcne.

whose infiuence, like the wroth of ........ inear it.

star upon whose infivence Ncpttune

let me infold thee, and hold thee...... Mactheth, $i$.

let me infold thee, and hold the ........ of Julirt, iii.

thou mayst intorm something

unt oo ourselves; inform 'em that

intorm yourselves, we need no...

which informs this to mine cyes....... Macbeth, ii.

what they will inform, merely hate. Sichard 11 . ii.

must inform yout ot a disnol

I must inform yout of a dismal

come, we'll inform them

how! I inform them

shall inform them ...................

to inform you riglitly hoth... Antony

your wisdom may inform you

$I$ will inform your tather............

young one, inform us of thy fortunes

who is't, that can in form me? ...........

all occasions do intorm against me - iv

INFORMATION aqainst me ....... - jii.

seeking tales, and informations.... Henry frit. v. ehance to whip your information ... Cortotanus, iv. many likelihoods informed me of this. Alls 1 etl, iv.

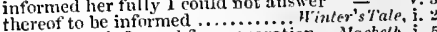
would have informed for preparation...Macbelh, i.

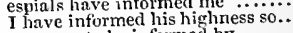

we come to be informed by ........... for so we are informed .............. Herry IIII. . have you informed them since?.... Coriolumus, iij. from my sister been well informed ....... Lear, ii. most fortunately been informed.......... are they intormed of this? ................

when he informed against him

INFORTUNATE in nothing but in. King John, ii. Henry, though he be infortunate $\mathrm{O}^{2 \mathrm{Henry}} \mathrm{Pl}$.

for your love, would infringe an oath. Love's L.L.iv.

not partial to infringe our laws, Comethy of Frrors, i.

inf rimge the hioly privilege.......

INIR1NGED-a taith int'inged... Love's L. Lose, iv.

INFUSE-infuse themselves...ilerch, of lenice, iv.

these looks infuse new life .... Titus Andronicus, $i$. INFUSED-infused with a fortitude.... Tempese, i. infused itself in thee ...... Merchan a clear rays which she infused on me .i Henry $F I$. INF USING-infusing him with .... Richard II. iii INF USION-other hot infusion ..Winter"s Tale, iv. hlest infusions that dwell in vegetives. Pericles, iii.
infusion of sueh dearth and rareness .. Hamlet, $v$. infusion of sueh dearth and rareness. . Hramel,
INGAGED-thought I stood ingaged.. All's Well, INGAGED-thought I stood ingaged...Al s inell, ii GENIOUS-an eel is ingenion

thy meaning, pretty ingenious?......

a poor, decayed, ingeniou, foolisb.... All's Well, $v$, learning, and ingenious st udies

haik, quick, ingentoument

and have ingenious feeling of my hige . Irar, iv. your nffieer, Iago, can inform you ....... Othello, if, 


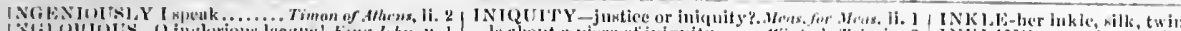

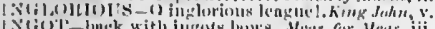

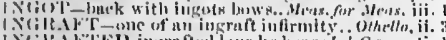

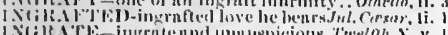

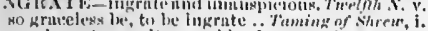
yon ingrate revolls yon blomidy .... hing John:

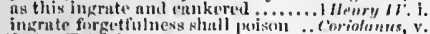

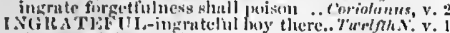

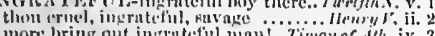

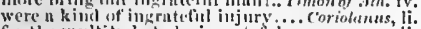
fur tlue multitinte to be intrruteful..... - - ii. 3

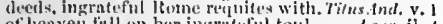

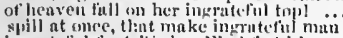

intratetiol firv! tis he. linil fint his.

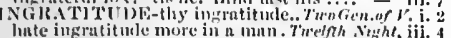

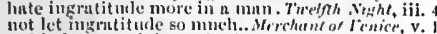

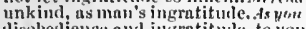

the monster of ingrutitudes.

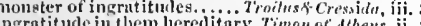

now ing nut if thle mankes its worse than
bulk of this ingratitule with any size

to wipe out sur ingrutitusle with

might they fester 'kninst ingrutituile. Corrottuns,

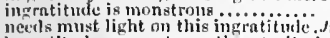

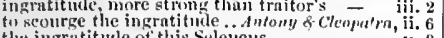

so supplant us for ingratitusle.

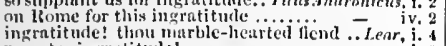

ingrntitude! ratitule!

filial ingratitude! is it no no ns this no......

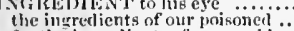

for the ingredients of our cantle ron

nullessed, and the ingredient is n deviloohello

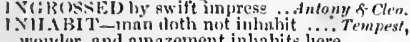
wouncer, nnd ninazement inlinbits here

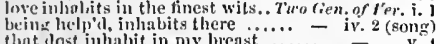

correption inluatiits our frail

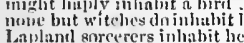

Laplanel emperers inliabit here Comedy of Err. ivi.

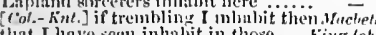
that I have secen inhalit in those ....

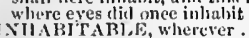

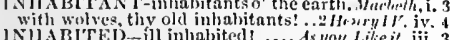
INIIEBENT bareness

all which it inherith inlerit here ....... T'rmpest, it. 2 dese

but let thing, will inherit her.. Ttrotien. ofs 'er. iii. 2 pain purehased, doth inherit pain. Lore's s.. Lost, i.

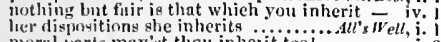
morul yarts may'st than inherit tool

that ran inlierit us ko much ns...... Richard $I t$ it. wermb inherits mauglit but bone

thy linen. sluntl inherit lis k ingdom.2 Henry $I V$. ii.

nut turnlly inherit of his father

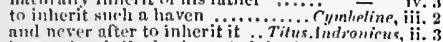

but to the girslle dn the gools inherit....... tern, iv, 6

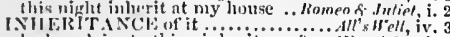

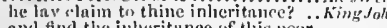

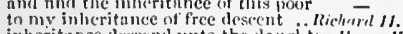

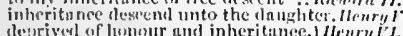

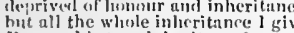

Franer, his trate inheritance?

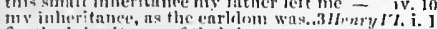

for the inheritanece of their loves .. Corrotumus, iii,

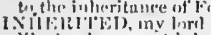

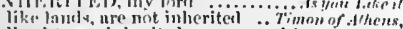

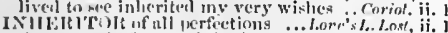

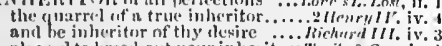

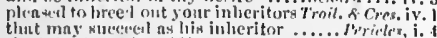

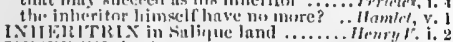

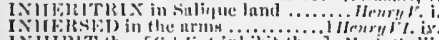

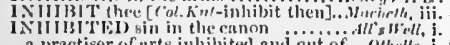

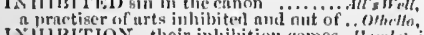

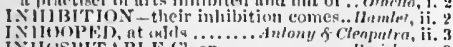

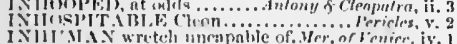

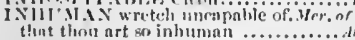

puraute. nut inhuman erestiur.

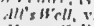

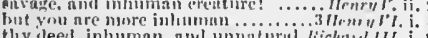

inhumpan trnitor

awav, inhuman dog! unlallowed wlave! -

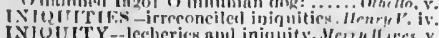

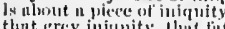

and Jaicuity's thent

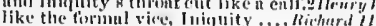

how now, wholeseme inticnity? ?........ lerietrs, iv

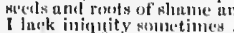

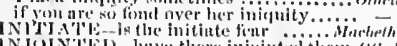

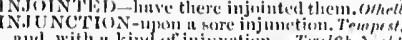

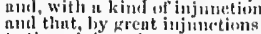

their injer innetions every one, im

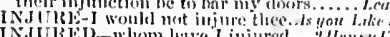

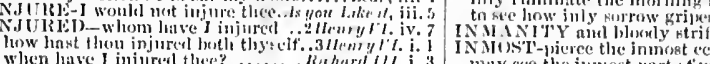

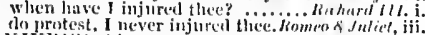

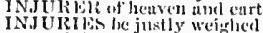

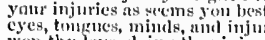

won thy lowe, doing the injuries.

stonpud my neck maler your injurles. Nich. II.

enrieled with nny other injuries
with the injuries of $a$ wantort tine

with an incensel fire of injuries

luft me onch to all injinies

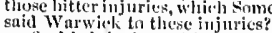

prefer lis injuries to his heurt. $t$

but he does buy niny injurieg

0 sir, to wiltul men, the injurite...

to outjest lisis leartst ruek inj uries

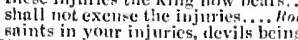

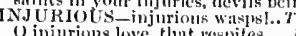

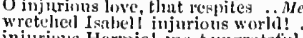

njurionts llermin!

a false traiter, num injurions

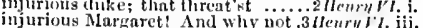

liy whose injurious doom

thiou injurions tribuic.

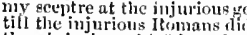

thom injurious thice; hear but my.....

and speak out of my injury ..........
till I torment thee for this injury.

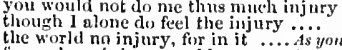

for suet an injury would in it..... As you Like is

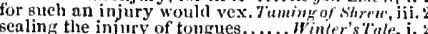

my comfort, and my injury...

his injury her injury, the beadle..

they did me too nueh injury ....... Illenry

thought toot good to bruise an injury. Ilenry ln $^{2}$

and quiekly will return an injury .. - iv.

you do me shameftul injury $\ldots \ldots . . .2$.

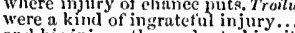

antl his injury the gaoler to his pity

or to your hewail the injur

hath done yom both this enrsed injury

putience her injury a nukekery makes

distinguish a l,ene fit and an injury

to he a larty in this injury
INJUSClCE-redress of inji

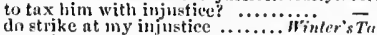

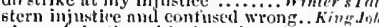

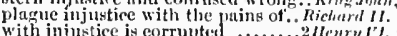

umderhnnd corrupted foul injustice. Richurd lit. $\mathrm{v}$.

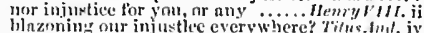

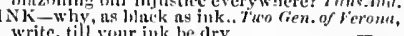

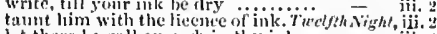

let there be gall enomels in thy ink

that never saw pen noll ink.

and pen, itik, and palke

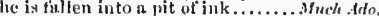

the lantll not drunk ink

until his ink were tempereel witi.....

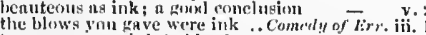

tofraves, your ink to bilo

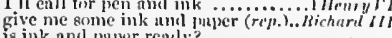

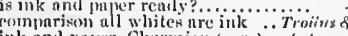

ink anel pnyere, Charmian (rrp.)....1n/ony s.

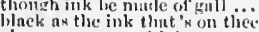

give me a pe't an!l ink

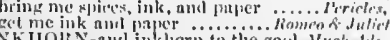

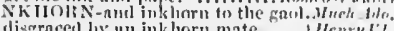

disgracen ly' un ink horn mate

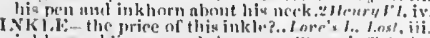

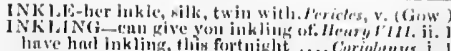

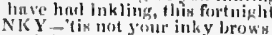

With ink blot N, metel roiten

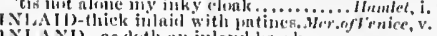

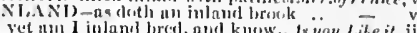

wat in bis youth and inland maw.

anr inlund fetty spirita.

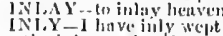

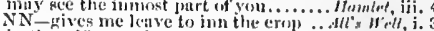

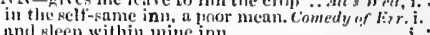

and then got to m inise inn.

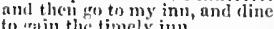

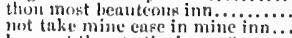

lic must then to the inus of court

others to the inns oll wom

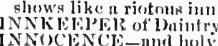

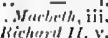

flallices with the inmorecire ont

the sense, sweet, of my, imo

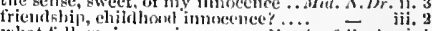

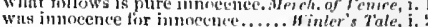

the silcnee often of pure innocence .. - ii.

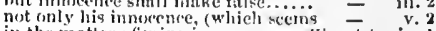

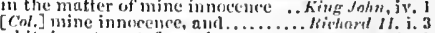

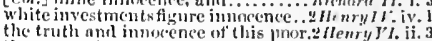

the trinst 1 have is in mine intorence - iv.

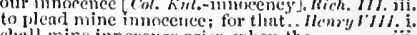

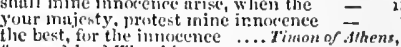

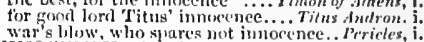

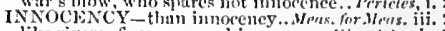

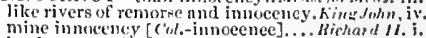

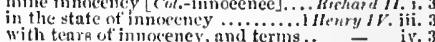

Mith tent of innoenes, and terms...

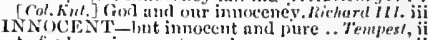

to fect me irnocent people

him and his innocent chile..............

so wromerel nuine innocent chitio aid me -

killed a sweet unrl innecent lut

in Mlessina here how junocent sle died

to lnily lout loaby, an inmocent rhyme
didl I not tell you slie was innocent?

they are ns innorent as grnce ....As
one aubther ciown his imorent nose

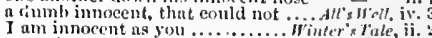

a gruevions innocent stuil; more free -

the imnocent milk, in its mo........... =

lis innocent balse truly hegotten - iii. 2 cornele

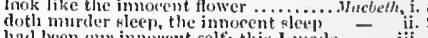

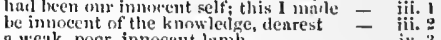

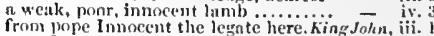

pone Inmerent. I do demmind of thee

withet $n$ muisent and an innerecent liani.

than to be butclier of an innoecent ehild

darre defench my innocent life against

Acsh his tomth in every soll........ Rirhard $11 . i$.

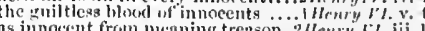

consricnee tells me, yon are innoe'ent

kill the immecelt yazer with thy singh

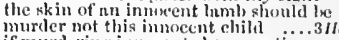

of murrlering innureents lie exceuting

just is Gerl, to risht the inmorent ... Micherd $1 / 4$

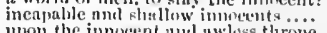

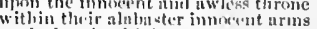

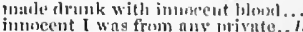

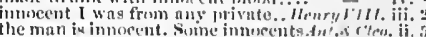

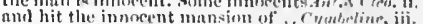

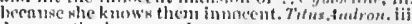

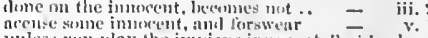

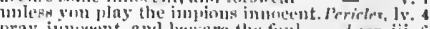

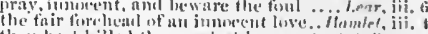

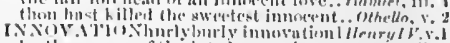

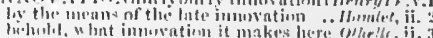

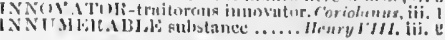




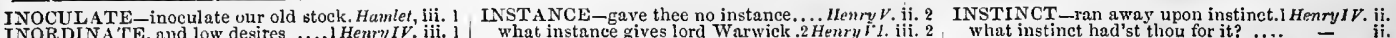

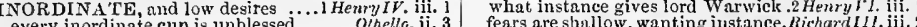
INQUU ISITION $-a$ bootless inquisition...Tempest i let not seareh and inquisition ausil.ts'youlike INQUISITIVE-became inquisitive. Comedy of Err. i.

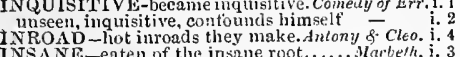

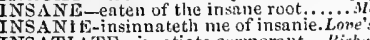

INSATLATE-insatiate curmorant . .
that insatiate Ed ward, noble York. ili

that insatiate Edward, noble York. Michurd IIl. iii. 5
the insatiate greediness of his clesires
iii. 7

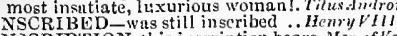

INSCRIBED-was still inscribed...Henry

survey the inseriptions lanck agnil
INSCROI,ED-not been inscroled

INSCRUTABLE, invisible.. T'roGen of Verna a ii. 1

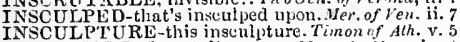

INSENSIBLE of mottality.......... Aleas. for Me

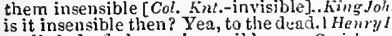

is it insensible then? Yea, to thed
mulled, deaf. sleepy, insersibib

INSEPAR ABLE - and insepara
jike.true, inseparable, faitliful 1

ut tor these instances....... Troilus \& Cressida, i.

instance, $O$ instancel strong as (rep.)

what instance for it? let me sec

upon instinet. I grant ye, upon instinct =

thou a natural coward, witliout instinet -

not with such familiar instances.. Julins Crrsar, iv.
instances, that second murriage move.. Hamlet, iii.

some lerecious instintee of itsel

hath, by instinct, knowledge from $.2 \mathrm{Henry}$

by a divine instinet, men's minds, thichard III $^{2}$.

INSTANT-very instant that I saw Youn. Pempes, iii.

both these letters at an instant

ansing to obey instinct ...Coriolanus, v.

Tempest, i.

that instant was I turned into.... True'ffu

but at this instant he is sick.

upon the instant that sine was accised

and without, upon the instant .. Love's $\overrightarrow{L . L}$ Lost, iii.

wealth of tlyy wit in an inst

but in the instant that you

rose at au instant, earned, played.As you Like it,

that ynu will take your instant leave..All's $W_{\text {ell, }}$,ii.

to this very instant disa

the sume instant of their master..... Finter's Tole v.

INSEPARATE-a thing insepurate. Troilus Cress,

get down, and insert in't? coukd you not? Hamle

IN-SET-CCol.] in-set youn neiller in gold.2.IIenry $l, i .2$

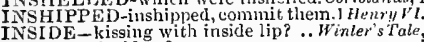

INSIDE-kissing with inside lit
show the inside of your purse

ontside or inside, $I$ will 1 not return

looked he o 'the inside of the paper? Heury, VIII

INSINU $\Delta$ TE with you in ............ you Like it, (epii. tlat I insinuate, or toze from thee. Win'er's ' lale, iv.
learned to insinuate, flatter, bow .. Hichard II, iv. he would insinuate witlt thee .......Richard III.
heselv insinuate, and send us gifts. Tilus dndron.

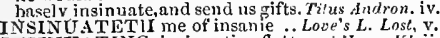

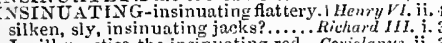

some busy and insinutating rogue....... Uthello, iv. 2

NSINUATION, as it were...... Love's L. Lost, iv.

does by their own insinuation grow.... Hamlet, y.

INSISTING on the old premogative. Coriolanus, iii. 3

INSOCIABLE and point-de-vice... Love's L.Lost, v. I

if this austere insociable life change

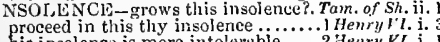

his insolence is more intolerable ...2. 2.enry VI. i. 1

England knows thine insolenec .......

wink at the duke of Suffolk's insolence $\overline{\text { in }}$ ii. 2

his insolence draws folly .... Trailus \& Cressida, iv. 5

and pursy insolence shall break. Timont of Alitheri

when his soaring insolence shall teach

the eockle of rebellion, insolence ......
queasy with his insolence already...jn.

the insolen

out, insolent! thy bastard shill

out, insolent? thy bastard slitll .... King John, ii.

aut he already is too ins

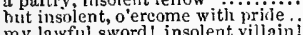

my lauful sword! insolent viliain

of heing taken by the insolent foe
ons
NSOMUCH - insomuch, I say ...

of my nativity to this instant

I teel now the future in the instanit.

for from this instant, there's
even in the instant of repair

to wage an instant trial with
bot we rose botly at an instant

indeed the instant action.....

upon that instant, craved audience $H_{e n r y} V^{\prime} \mathrm{i}$.

let us die instant [Col-in! $\mathrm{Kn}_{\text {. }}$-in hono

came to France, until this instant

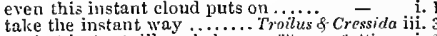

at that instant, like a baibe $\ldots$. Timon of
bid 'em send o' the instant $a$ thousand

to whom 'tis instant dae

having great and instant oceas
to stipply lis instant use with

to sipply his instant use with
convert o t the instant green $v$
even from this instant, banisl

more than the instant army

I'lil tell thee, on the instant.

or thy sileyce on the inst:
it was my instant deatla.....

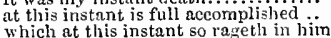

doth speak for instant reanedy

INSTINCTIVELY had quit
INSTITUTE a course of learn

INSTITUTION-city's institutions... Mea. far Mea. and instruct thee how to snare
and

instruct me how I may formally. Meas. for Mea

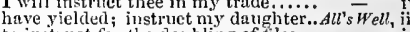

fit to instruct her youth …... Taming of $\overline{S h}$ rew,

cunning seloolmasters to instruct her?
well seen in music, to instruct Bianca

a fine musician tn instruct our mistress

to instruet lier fully in those ...........

as my understanding instructs ne. Winler's $T$

as your charities shall best instruct you

will instruct my sorrows to be prout. King John

instract ns, boy; what drean, boy p..2llenryIV.

able to instruct or teach

the occasion slanll instruct you

.

devise, instruct, walk, feel...........

Cinon of Alth.

his gate instructs you how ......... Cyinbeline, iii.

their tittor to instruct them. . Tilussindronicus, v.

if thou dost as this instructs thee ........... Lear, v.

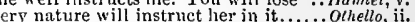

the ills We do, their ills instruct us to ..
INSTRUCTED-not yet instructed. Meas for

and that instrncted him to mercy . - iii.

bastard instrneted, bastard in mind

let thy sonl be instructed: mark me ... Ohello, ii.

INSTRUCTION-god instruction give. Tempest i.

am gning witli instruetion to him.s.Meas. for Meas.

correction and instruction must botl
by the instruction of his frailty......

receive some instruction from my fellow -

keep your instruction, and hold you

that $I$ see before me at this instant
shall give them instant way .................

shal three now marry in an instant

in the instant came the fiery Tybal

grow not instant old, but bear $m$

on the instant, they got clear.

appearance, even on tle instant - iv. 6 (letter)

and will upon the irstant put thee to't..

cet you to bed on the instant .......... - iv

take her hence, and marry her instantly

and instantly break with you of it...Much Adro

cand instantly unlock my fortunes

and it instantly witl all my heart
pad me instantly unto his cave ...

and see it instantly consumed
I'll follow instantly. I am glad

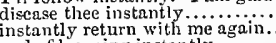

Sinter'sTale

instantly return with me again....
and of learning instantly

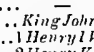

NSPRATION-good inspirations. Mer-of Venice, $\mathrm{i}$.

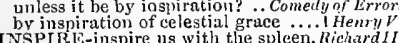

or Mercury, inspire me....... Titus And dronicus

inspired inerit so by breath is barred...All's $W^{\prime}$.

In an a prophet new inspired......... Richard ll

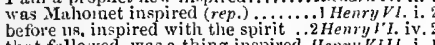

that followed, was a thing inspired. Henry $V_{1}$

as if you were inspired to do those

IXSTALLED-and have install od

thy lord of Winchester installed

any lord of Winchester instanted .... his Edward is installied ...3

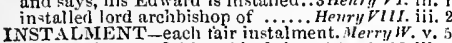

the intalment of this noble duke. Richard ill.
INSTANCE-and instanues as.. Tun Gen. of Ver. desires had instance and argument. Merry Wioes, ii. so far exceed all instance

off instantly with his son George

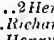

instantly will find employment ...Henry VIII.

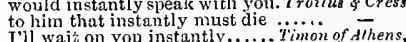

I'll waic on you instantly

get you hence instantly ........... Coriolanus,

Ieast noise of this dies instantly ...Anlory s Cleo.
therefore lustantly this prince must die.Pericles,

ghall the duke instantly know

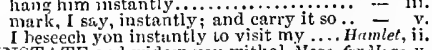

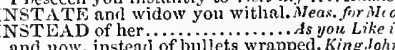

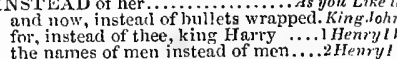

the names of men instead of me

thoun oft, instead of homage sweet
inztead of gold, we'll offer up our.

in

the regent there instead, of me.

borne before

lest that, instead of words ..........3 Llenry $v I$. $i$.

instead whereof, let this supply tlie ronm $-\overline{-}$ instead of mounting barbed steeds.. Richard
in

an old, an old instance, Beatrice .......
[Col.] till that instance .......... Lore's $\overline{L . L o s}$

[Col.] till that instance ............ Lore's L.Los',

instance, briefly; come instance

a better instance, I say, come.

menis the instance, shepherd.......
wherefore? what's the instance?

five have I slain to-day, instead ot him -

they shall want no instruction. Love'sL.Lost, iv.

that follows his own instructions. Mer. nf Venice,

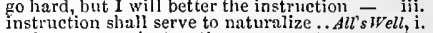

under my poor instructions yet must
give thee more instructions. Tamming of $S h$. T (induc.)

tis pity slee laeks instructions... Winter's Tale, iv.

and neigh bourhood, instruetion.. Timon of dlh.

their noise be our instruction

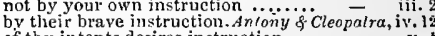

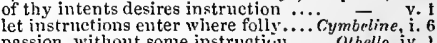

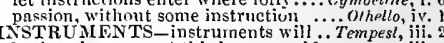

hath to instrument this lower world . $v$ V

partly know the instrument ... Twelfh Night, $v$.

to make thee an instrument $\ldots$.... ds yout Like it

can bring this instrument or hotr. $d l l$ 's $H$ ell, iii.

my books, and instruments .. Thming of Shrew,, $\mathrm{i}$.

in Inisic, instruments, and poetry

througl the instrument my pate made =

take you your instrument, play ....

before youl touch the instrument....

see withal the instruments that feel

so that all the instruments which ended -

and such an instrument I wos to use.

the instruments; who wrought with $:{ }_{\text {. }}=$ iii.

powers above put on their instruments
the instrument is cold, and would... King John, iv. 3
ing

and instrument, to nny screreign ......
like a eumming instrument cased up...

tongue is now a stringless instrument

ail the lofty instruments of war .... I Denry $I V . \mathrm{v}$. very instruments of chastisement... Henry $1 \%$. iy. fashioned thee that instrument of ii

the author, theu the instrument .3Henry $\nu 1$. iv.

the munisters and instruments. Troilus o Cress. (proi.)

liunbs are his instruments, in no less -

come, give me an instrument.........
instruments hung $\mathrm{np}$ in eases.. Timon of

where the other instruments did see. Corinlan

to make them instruments of fear. Juitizs Ce

the genius, and the mortal instruments -

nor no instrument of half that worth

where is thy instrument?
touch thy instrument a $a$ train or two?

iii. 1

and by their vehement instigation. Richari III. iii.

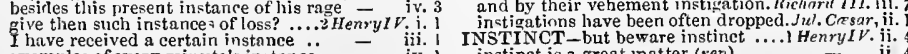
examples of every minute's instance

instinct is a great inatter (vep) 
INSTRUMENT-

thou break'st thine Instrument .. Jalius Corsar, lv,

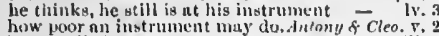
Jene, vile instrunsent! ............. Cymbelsne, jii. my ingenious instrument? hurk

glve me the pentent inscrument, to jiek

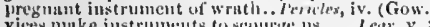
our instruments, to melaucholy. llomea of jutiet iv.

witls instrustents upen the

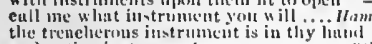

and active instruments

Inte your lustruments been at Nople

by muny a wind instrunsent thut I know

I kiss the instrument ol their plemsures
an instrument of this your enling lnek

an instrument of this your enlling
low these instruments summan to

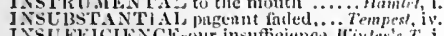

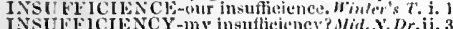

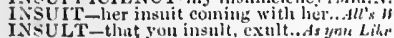

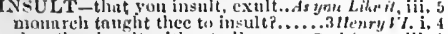

the other insult without al!

thy knife, I will insult on him. Tilus
INSU1,T

INSULTING-insulting man
the insulting hand of Donglas

the insulting hand of Donglas
like that prond insulting ship

from thy mstulting tyrumy

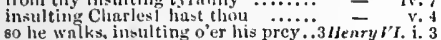

80 he wntks, insulting o'er
the proul insulting qucen

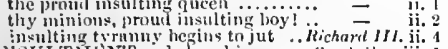

Insulting tymny hegins to jut

IXisUPJORTABIE rextion

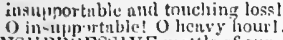

INSIIPPIESSIVE mettle of
INSURREC I'ION want such

turms insurrcetion to religinn ......
of base nnd bloody insuriection

Cilmhelim, iif. 5

themes for insurrections nrguing

.110enryll:

then the nnture of an insurreetion. Julius Cresar, ii.

INTEGR vita, scelerisque purus. Tilus.tndron iv.

I.NTLGRITY-such integrity... Texo Gen. of Ver. ii.

thnt neither my cont, integrity ....heras. for Meus. iv.

his integrity stands irithout bleni

my integrity ne'er knew the crafts ...Al's sien,

have bee:1 decelved in thy med

mine integrity' being counted fusehood $-\overline{\text { ini. }}$

of true zeal nul deep inteprity...... Wichard $1 . . v$.

of singular integrity and lear
my integrity should breed

my robe, and my interrity to heaven = iii.

thy integrity is rooted in us, thy friend

more out of malice than integrity.

my integrity and truth to $y$
with most divine integrity

with most divine integrity ......... _ _ iv,

bereaves the state of that integrity. Coriolanus, iij.

in liand to love with such integrity. Cymbeline, v.

LFTEI.I.ECT-train our intellects.. Love's $L_{*}$ Lost . i. I

his intellcet is not replenished

lonk again on the infelleet of the letter - iv.

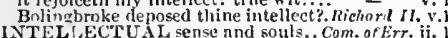

1NTELL.ECTUAL sense nnd souls.. Com. of Err. ii. 1

bearls had any intelectual armotir... Heiry $V$. ii. 7
INTEL1,IGENCE of Ford's approach.Merry $W$. 7 i. 5

lowsoever lie hnth had intellgence.

my intelliycnce is true ..............
give you intelligence of an intended...Much Ado, i. 3
this intelligence if I liave thanks. Vid. this intelligence if I have thank \&. Nid. N.'s Dr. i. I and deliver all the intelligence in his dil's il ett, iii. 6 hath the caunt all this intelligence?

in sucl intelligence hath aeldom fuiled

from whom 1 liave this intelligence. "Iinter's $T$. iv.

where hath our intellizence been ........ Wurhelh, i. 3

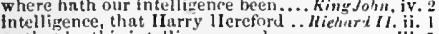

Bonght to entrap me by intelligenes.l nenry $l \%$ iv. 3

betwixt our armies true intelligence - v. 5

by fulse intellipence, or wrong .... Riehard $1 / l$. ii.

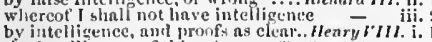

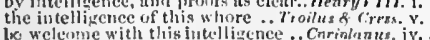

lo: welearse with this intelligence... Crrinlanus. iv. 3

not I, inclined (1) this intellizence

intelligence is given where you are hid ....enr, ii. I

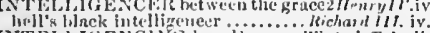

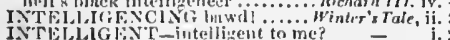

ansl speculations intelligent of nur state.. Lear, iji.

approves him un incellipecut jarty

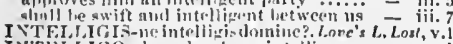

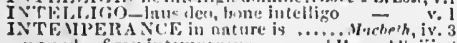

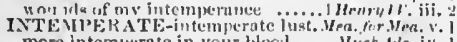

more intemperate in your blond ....... Iuch Alln, iv

this night intendy to steal ........... - iil.
INTLND-intend holy confession. Two Gen.afVer. Iv. 3 INTENT-intent, tenor and substance 2 Jenty $1 \%$ iv. 1

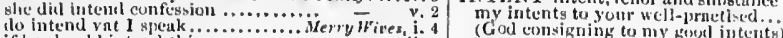

- ii. l lie hath intent, to my gouted interits

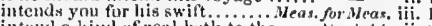

inculud a kind of zenl botl to the ....Murhado, ji.

for if thus dest intend

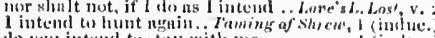

anid this lumly, I intend, that al

not suy what 1 intend fis the

a 1 intend to thive in this net.

whose temer 1 intend to stain.

king from dith all that they internd

for 1 intend whave it, ere long

les doth intend she shall be England

him first, that frst intends rlecit ...2

as ing soul intends to live with thite

conterpilars, and intend their death.
doth York intend no harm to us

doth York intend no harm to us

then what intend these forecs $\ldots . . . . .$.

intend here to besigge you in your.
to go whither the queen intends

no mipre thin what my soul inte

deeply to eflect whit we intend .....ich

witness what you hear we did intend

our tull intent buek to onr broticer.

nul their intent is this.

of virtubum charte intents,

from a stublom obintinate jute....

with a riull intent to due our our.

tinil not in my detep intent

another seeret ele e intent

..nenryb,ii.

sou cnme too lnte of pur intent...... - iit.

hime of ant intent that's coming. 7 imon of $\overline{\text { shens }}$ v. 3

may the'y perecive's intent! ......... Coviolsans,

to cutel at mine int (ent .... dutuny \& cleopatra, ii.

if you niply yourself to our intents

to conquer their most nlisurel intents

knowy to you my full intent.... Tilus Anlron. iv. 2

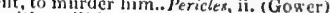

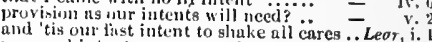

nood intent mny carry through cares... Leor, i.

when I dissuadel hin from his inten

shortens noble friends, know our intent.

nnd my intents ure savagc-wild. liomeo \&s Jutict

stay to louk cin hus interts

eontrarlict hath thwarted nur intents

be thy intents wicked, or elsaritable

be ndvised lie comes to bad intent...... omello, ii. 3

that wnly true we now inteid ...........

alpeal she intends mo his holiness - ii.

an encmy intends you burm.. T

this firtuights, what we intend to do. Corro

intenils to apinear before the people

gowtlenen, what you intent...... Julius Crrsur, iii.

fir we intend so to disponse yon

graentyh sy rin intends lis journe

acculint witl nll that we intend
that ! intend to eend them botlt

and to Tharsus intend my traic
since $x$ hat I well intend, I'll do

unsproke, thrat it intends to do?

you know the goodness 1 intend

is for the merey which he intends to

what I further shall intend to do.komeo s Jutien,

my lord, I did inteod it ................. Hrme sle

will you sup there? Faitl I intend
cail, what I intend to do. a murder

NTENDED-in his in tended

her mother hath intended ........ Mer.

intended gainst lord Angelo..... Tens. for

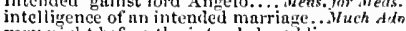

very night before the intended wedding - ii

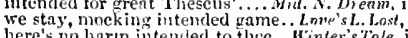

intented, or conminted, was this fanlt. Mich. I

or litherwards intended sicedily ..1 Hen y i i

is intended in the pentral's name $\left.2 H^{2} m y\right) \%$;

the measure as ym intended well

blow out the intended tire of your

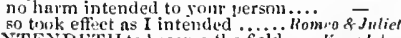

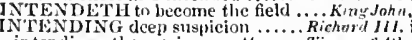

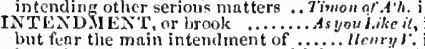

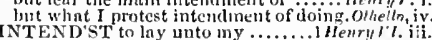

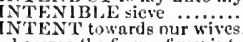

... All, Nell, i.

betome the furm of my inteo

knew ef intent every where....... - it

dill not o'ertake his lad intent .......

intents but aserely thought

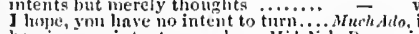

our intent was, to be gone from.

finl splorts in their intents

to content you, our true intent is..... - (proi.

null moek for moke is only iny inteut

cven to the opposed end of our intents

fur the intent aul enos

but my intents are tixed.

linl ymu not Inteiy un intent ............

trumpeters to our unlaw ful inte
ere I eus perfeet mine intents..

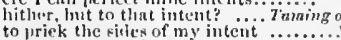

vile intent mant nects secm horrible

to bury mine intents, bit to effect. . Richard 13 .

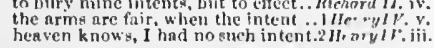

INTENTION-gredy an intention. Mierny Nires, i. 3

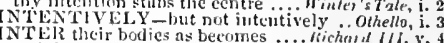

and daughter to a king, inter me....JPmy III. iv.

to interecpt this incenvenituee ....... I benry b'. i.

intercepts me in my expledition? . . Richurd 111. iv.

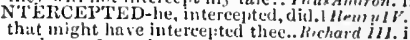

goudness of your intercejted pack ts. Men. WIII. iij.

INTERCLPTLR, full of despite.. Thethis Night, iii.

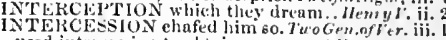

used interecssion to obtain

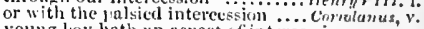

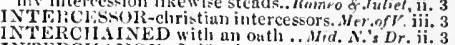

INTERCIIA INED witl an outh ...Mrd. N.'s Dr. ii.

once more I shall interchunge......3Henry/l. iv.

ample interchange of sweet discourse

and interchangenily set huri down.. lichasd $I l, j .1$

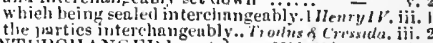

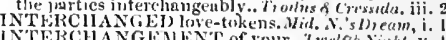

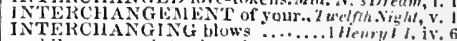

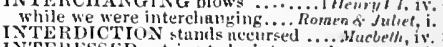

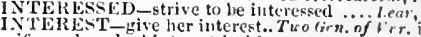

if ever love had interest in his....... Wher Allo, ir.

inserted to nuke interesi gervd $\ldots \ldots . .$. - i. 3

lie linth no interest in me ...........

shanll deceive our bosum interest .........Moetelt, i. 2

with interest to this land .............

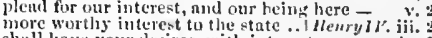

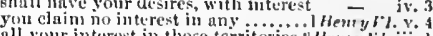

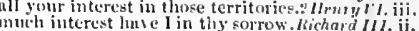

with interest oftentimes double......
he now poys interest firr't .... Timou of Athens

take down th' interest into their .... - i

should net betrny mine interest .... Cymbeline

my lord hinth interest in them

no more interest but to brenthe.. Timadndran.

interest of territory, lanres of statc ........ Lear, i.

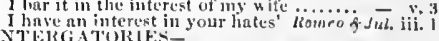

to the particulur of the intergatories. AIIs Well, iv. 3

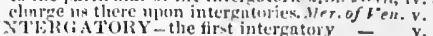

INTRin-no interim, nut a .... Tuinhsigh

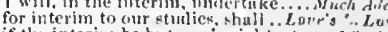

if the interim be hut a rénight...As you like st, ifi.

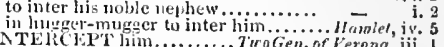

fowng hoy hath an aspect of in tercessiun - v. 3

Yom fuirly for this interchumge. Troilus \& Cress. iii. 3 


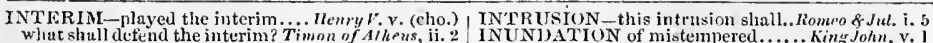
what shul di the interim is like a phantasma... Julius Cesar, ii.

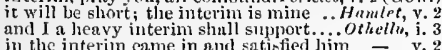
in the interim came in and satisfied lim

belike, at your interior hatred...

nutl make but in interior survey

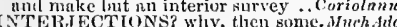

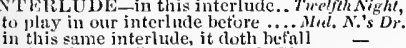

an interlule! 'Thou art armed, Gluster

INTERMINGLE with them ......... Muefh dero,

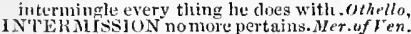

I did laugl, sans intermission....

eut short all intermission

delivered letters, spite of inte
INTERMISSIVE miseries.

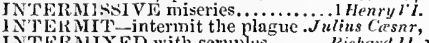

INTERPUSE, firir madarn

do interpose themselves betwixt...Julius Cissar, ii. 1
INTERPOSER 'twixt us ...Merchant of Feniee, iii.

NTERPRET-interpret to her. T'to Gen. of ' 'e?. i .

fiorbid me to interpret that you are ..... Macbeth, gesture one inight interpret .. Timon of Athens, i. 1 interpret ali her ignorance .......... A - if it be true that I interpret false .......Pericles, $i$. interpret between yon and your love. IIrmlet, iii. INTERPRE'TA TION should abuse. H'inter's $T$. iv. 3 interpretation will misquote........ HenryI by the interpretation of full time

1 N'TLRPRETED a thing perplexed.Cymbeline, Hii.

NTER PR ETER

thave a false interpreter.. Two Gen. of Veronn, i. 2 an interpreter. Good captain (rep.)...All's $W_{c}$ cll $l_{+}$iv. as for yon, interpreter, you must scem

interpreters of my behind-hand.......... my interpreter, what says she?......... Henry ${ }^{\prime}$,

an aged interpreter $\ldots \ldots . . . .$. Timon of d thens

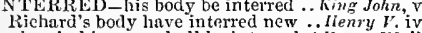

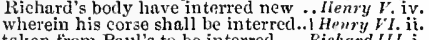
taken from Paul's to be interred....

solemuly interred, at Chertsey

he shall be interyed, os soldiers ..Jnlius Casar, iii. 2 ly a dead man interred ......... Homeo \& Julie

will serve our long interrogatories.. Cymbeline, $\nabla .5$
INTERRUPT the inonster one word.. Tempest, iii.

to interrupt my purposed rest... Lone's L. l.ost, . 2

for he, that interrupts lim, shall not.3IIenry VI. i. 1
I'll interrupt his reading .. Troilus \& Cressidu, iii. 3

vour story, and never interrupt you ..Perich's, v. 1

NTERRUPTED waters

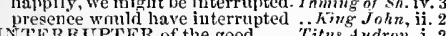

IXTERRUP'TER of the good ... Titns Andron. i. 2

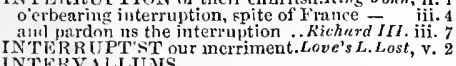

Iangh without iutervallnoms

NTERVIE WV-at which interview.Lue's L.Lns', i. 1

the jutervies, that swallowe

that the interview, betwixt Engiand.

siknify this oving interview r.oilus

INTEST 1TF,-nt intestate joys.... Richard III iv,

meet in the intestine shoek and ...1 Hemr? I $\mathrm{i}$.

here doth intimate the payment.

INI MAT intimate skillinfinite

INTITI

NTrTED-neither intitled in the

INTOLER ABI E frirht, to be .... . irerry Wives, iii. 5

withered, and of intolerable en

to this intolerable deal of sack!

his insalence is more intolcrable

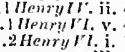

depiteful and intolerable wrongs! Tihus Andr

TouB-the face of earth intom

NTOXICATE-a little intoxicates
NTREASURED-lic intreasured

INTRENCHANT-the intrencliant

NTRICATE imperch is this

INTR INSICAT too intrinse t' unloose ... Lenr, ii.

IN'Tl UDE-to intrude where I ain. Titus

foul thing

IN'TRUDER-go base intruder! Tro

TrR

INTRUSION - unseasoned intrusion....Merry $w$. if.

with intrusion infeet thy aap... Comeriy of fir to stop the imundation of luer tears. Rnneo of Jul.iv. W - to imure thyself.... Tuelfh Nigh, if. 5 (let.)

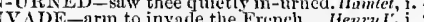
(

as France invades our land

IVVANIV E-to arms invasive?

IN VECTI VE-invectives 'yainst the. 3 Henr

INVENT-did invent this letter... Is you $L$ ike

to invent any thing that tends (rep.).2 lenryli 1 .

whell as hitter-seatehing terms

Ohello, $\mathrm{i}$

INVLN'TED-or is invented on

IJe lics, tor I invented it myself

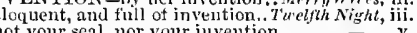

that e'er invention your nivention.

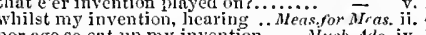

what penance ymur inveution can ing

of fancy the jorks in sad invention....

savouring of poetry, wit, nor invention

this is a man's invention, and his liaud

such giant-rtele invention, such Ethio]?

but return with an invention...

it must be a very plausive invention

olr inventions meet and jump in one. Tam.ofSh. $\mathrm{i}$.

retarn to plague the invention

the brightest heaven of invention! Henry $\bar{V}$.

do it without invention suddenly ..1 Henry

guch invention as $I$ can devise?

let them accuse me by invention .. Coriolan

this letter speed, and my invention th

my invention comes from my pate .... Othello, ii.

INVENTORIALLY-him inventorinliy

INVENTORIED-be in ventoried. Twelfh Night
INVENTOIR - the inventory of thy.2 Henry $\mathrm{IV}$.

forsooth an inventory ..............Ien

is as an inventory to particularize .. Coriolan

INVERT-invert what best is bodel... Tempest,

that doth invert the attest of $\ldots$ Troilus $\&$ - Cress
NVEST-you more invest it I $\ldots \ldots . .$. Tempest

to invest and cover in princely.......... Teas. for Meus. iii.

invest me in my motley ........... Is you Like it,

to invest their sons witl arts ....... HenryIV.

wilt needs invest thee with

would not invest herself in such ...... Oihello,

in absence well invested...

in the official marks invested ...... Coriolanus,

INVESTING lnnk-lean eheeks. Henry $V$. iv. (clorus

that dye whieh their investments show.. Humlet, i.
INVETERATE-to me inveterate....... Tempest, i.

heal the inveterate canker of one

Richard It

IN VINCIBI, t-been invinelble against. Mnch sdo, ii. 3 of an invincible unconquered spirit.1 Henryl

to he a woman of an invineible spirit.? Henry $I$. $l$.

Wond make invincible the heart . Corolimus, iv.

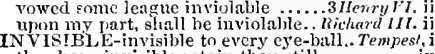
thy shape invisible retain thou still.

\section{to the king's ship, invisible as thou art $\overline{-}^{\prime}$ er.}

it would make yon invisible ...Tuelfh Nigh

I am invinible: and I wijl over-hear, Nid. N. Dr. ii. ancl his horns are in visible within.

keen as is the razor's edge invisible. Love's $\vec{L}$. Lost

shall you know the wounds invisible - iti.

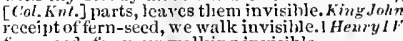

tern-sced, for your walking invisible - ii. 1
were invisible: [Col. Knt. invineible].2 Henry $I r^{r}$ ii.

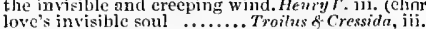

a strange invisible perfune... Antony o. Cleopntrr, ii.

makes moutlis at the invisible event .. Hamle,

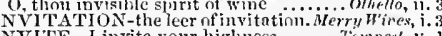

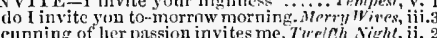

sir. I do invite yntr too.................ere's L. Los

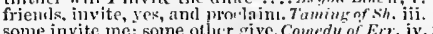

tentious storm invaces us to the sijn -

to delight the cleo. iii.

that he is borne about invisible. Comedy of Frrors,
INVITE-joumcy soundly invite him ... Macbeth, i. 7 tre bell invites ne; hear it not

Whom we ilvite to see us crowned .. - v. invite iny lords of Salishury and blessed truop invite me to a banquit. Hen.VIII. iv. invite the most valorous Hector to eume to invite Irector to his invite them withont knives ............ Timon of sthens and still invitcs all that pass by that mine own use invites me...

invite you to my sister's view ....... Antony \& Cleo. ii. to my house, whither 1 invite you....... Perictes, $v$. onests invite as here are writ ..Romeo \& Juliel, iv. to claim my vantage doth invite me $\ldots$. invited, sir, to vertain merehants. Comedy of Ern. invited by your nohle self'.......... Henry FII sent to her, invited her to supper. Antony \& Cleo, ii. that ne'er betore invited ey'es ........... I'ericles, v. oft invited me; still questioned me....

NVITING-an camest inviting. Timon of . Thens, jii. an inviting eye thee? ............ Cymbeline, iij.

IN ITIS-is writ, invitis nubibus ...2ilen'y I' INVOCATE-I invocate thy ghost.. Richard III. $\mathrm{i}$.
INYOCATION-invocation of a clild... Love's L.L. $\mathrm{i}$. 'tis a Gicck invocation to crell fools. As you Like it, ij. my invocation is fair and honest. Romeo \& Juliet, ii. IN YOKE-invoke lis warlike spirit .... Henry ${ }^{\prime}$. $\mathrm{i}$.
INVULNERABIL-like invulnerable. Tempest, the invwlnerable clonds of lieaven .. Kinglohn, ii.
air. invulnerable, and our vain blows ..Ilamlet, i. INWARD-inward pinches therefore..Tempest, v. 1 sir, I was an inward of his.......Meos. for Mleas. jii. for what is inward between us..... Love's L. Lost, y. but from the in ward motion........... King John, i. and my inward soul with nothing.... Richard II ii.

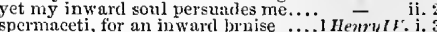
he writes me lace, that inward sickne were these inward wars once out ..2 Henry $1 T$. iv. makes it course from the inwards.

with an inward wisle you would rlesire. Henry $r^{\prime} . \mathrm{i}$. model to thy inward greatness.... - ii. (chorus) most inward with the noble duke.... Glall hide ous intward woe ..Troilus \& Cressida, v. Il draw the inward quality ...Antony \& Cleopntra, iij. 1] the outward liabit by the inward nan...Pericles, ij. the iuward service of the mind and sou

that inward breaks, and shows no euuse

poisonous inineral, gnaw my inwards .. Othello, ii. my heart bleeds inwardly that......2 Henry $1 \%$ I bleed inwardly for my lord .. Timon of Athens, $\mathbf{i}$. IO-We'll show thee Io...... Taming of Shrew, ? (ind.) IONIAN-crit the Ionian sea .....Antony \& Cleo. iii. IPSE-cunsent, that ilse is he (rep.). As you Like it, v.
IPSWICI-I pswien fellow's insolence. Hen'y III. i. he raised in you, Ipswich and Oxtord?

IR A - that ira furor brevis est .... Timon of Athens, I. 1R.A-tautæene animis colestibns ira?.2 Henry /'I. ii. Oras, Charmian, 'tis no ............ - ii. help, Iras; help, friends below ..... - iv. 13 nety, tis most certain, Iras $\ldots \ldots \ldots \ldots . . .$. - $\quad$ v. 2 vare, yare, good Iras ............... Ul E-provoked with raging ire.Comedy of Errors, v. and tull of irc, in rage deaf as........ Hichned 1. ret cense your ire, ye angry stars ........ Terirles, ii. IREFUL-each one with irctul lassion. Com,of Er.v. slanchefercd by the ireful ari...

grasped in their ireful hands ........
IFr.LAND-body stands Ireland.Comedy of Err. iij. in England, and in Ireland.......... _ _ i Irelancl, Poictiers, Anjon, Touraine., King
England, and Ireland, Anjou, Touraine

which stand ont in Ireland .......... Richard II. i. we will for Ireland; and 'tis time...

denarting ot the king for Ireland.

are there posts despatcherl for Irelaind?

sits tair for news to go to Ireland....
no; I'll to I reland to his majesty

like a kerne of Ircland, your French.. Henry $v$. iii. Englind is thine, Irelaud is thine..

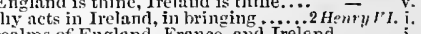

realms of England, France, and Irelna

uncivil kernes of Ireland are in.......

to Ireland will you lead at hend of men

J'l ship them all for Jreland

whiles $r$ in Ireland nourish a niglit 


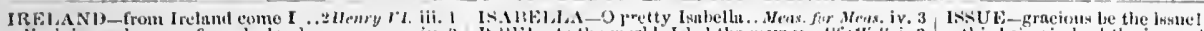
York is newiy eome frum lreland.... -

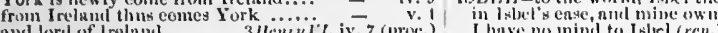

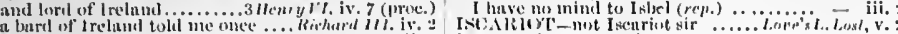

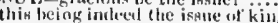
their ixente mut being gracions cire unt fint issue

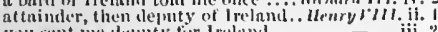

siivolilingt incirint

Iisis-eoloured I ris roments thine

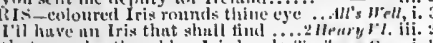
that promeler than blue lris bends. Trmitux a cress. $\mathrm{i}$. 121s/1-thut I was nu I tisth rut......ts you Like it, iii. the howling of lish wolves afation

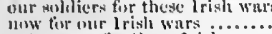

I. i. 4

tot money lisr these l rish wars

net forth youn his Irish expedition

when he was persemal in the lrish

sit ling in his mulueky Irish wars....

RISIIMAN-an lrishmun with.....Mrry Wires,

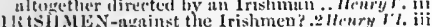

IItK-anul yet it irks me.

it irks his henrt, lue
it irks my vory soml

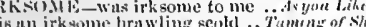

irksome is this music to my heart!..:Dlinenry 1 '

my $\rightarrow$ to wear iron ulout yon.... Tot

my yolug soldier, jut up yomr iram.
befire harred up with ribs of iront

runs not this speech like iron thrim

the irun tomgere of miduight hath

irom unat helle with he

fitch me min iron erow........ Cousedy

with his iron tompne and brazen montl

und yours tex, Isithore? It is ou

Finos of thit. ii.

fimm Isidere; le humbly pray

I would most glatijy kimw the issue of it -

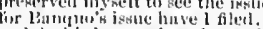

ant for lis issue, whe lowe hy...

good Isis, hear me this prayer (rep)
therefore, tenr Isis, kcep decorman

therefire, ilent Isis, kcep decormu

like her? O latis? 'tis inpossib

in the seen mitione

in the hithiliment sot the godetess Isi

shall Jhanguo's issuc ever reigrt

the trucit isslne of $\mathrm{tl}_{1 y}$ tlirume
but cortuin issace

witla ficarful blexply iskue

on this penosed intwe dear.

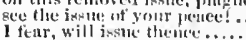

keeptrom me the lest of the island.

it witits unon some gon of the istame

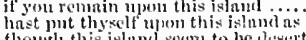

though this inland recm to be lesert . .

liring furth inore islatuls

every fertile ineh o'the islane.

the folly of this island

hath cliented me of this islinid.

firr, eertes, these are people ol the inguni

make this islancl thine own for ever

it thit prove a vision of the
dwell in this bare istand.

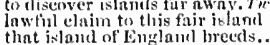

fon island earrions, desperate

might make this island happy

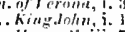

enough to purchave such anot

Henth

enough fy purehave sucla another is ant

realms and islauds wereas plates. fulutuly

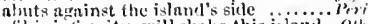
not I, for this tuir iwn nul: I do

give me the irou, I say

nor look upon the iron angeriy

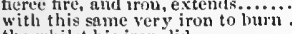

tle whilst his iron did .....

shock of wrathen iron arms ....
thee nuturmur tales of irom wars.

now bind my brews with iro

huld out mine iron; it is $n$ simple one.

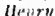
ISLANDER - no fish, but an islandler... Tempe

eoops frum other lunds he. isianders. King

sot hearl these is inders shomt ont

the generous ishuriers, by you invited. Invello, Si.E-dispersed them 'bout
in aut odt angle of the isle

Flicwed the thl the qualities "ilie isle

had 1 plantation of this isle, my lord

this is some monster of the isle.
there's but five upon this isle.

by surery he got this isle.

in this most ilesolate isle.

some subtilties o' the isle.

rou'd be king of the isle, sirriti

since I eame to this isle.

fertile the isle; the templ

owed the lrealth of all this isie

the sons and ehildren of this is

this seeptred isle, this earth in that nook-shot ten isle of Aibion

our isle be made a nourish

sir John Strnley, in the isle of

that is to the isle of $\mathrm{M}$. Mn

eivilest place of all this isle

the fent royal of this tamons isle

good men of this ungoserned isle ..
the notile iste doth want her proper.

even in the entre of this isle.......

$.2 H+m . M r$. ii. 4

IRRECOVERABLE

IIRlekGULA B-irregular eotrse....... King John, v.

the irregiliar and wild Gremlower.

from isles of Greece the princes. Thil. f Cress. (proi.)

the nuturnl hravery of your isle....
sue course toward the iste of Rhoile

thanks to the valiant of this warlike isio

how do our old aequaintanee of this isle?

heaven bless the isle of cyprus

the very elenents of this warlike isle
some action that inny offend the islo

some artion that mny offend the isile
it frighits the isle from ler propriety

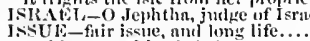

ant honsured in their iscue.

that his isse sbmint berome king

see the issue of his serurelt

it issuce frum the raneour of .........

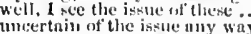

umsertnin of the issue
eome, what's the isso?

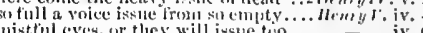

hupy be the issme, hrother Lngland

thou scest thut 1 mo issuc hin

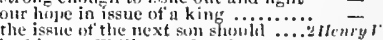

hat issue-Philiple a daughter.....

on, if the issue of the eliler son a.... - ii.

issue forth, and bicl them lattle ....3/lenry $\mathrm{rl}$

and ruise his issue, like a boy

all the unlook co for issue of their ludies - iii.

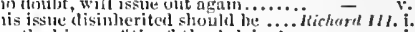

loathed issue of thy tather's leins! .. = ii.

well briog it to a huppy issue ...... - iij.

the issuc of your womb) (reps.).

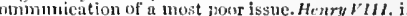

in their issuc are to be fielred

if the king should withent issue die.

for her mate issue or licd where

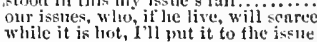

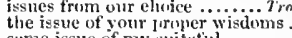

some issue of my sulfeful.........

we'll answer it; the issue is ........

I therein of a mangy dog! . Timon of Athens, is.

but issue forth their city ............ - i.

and interioin their issues :...........

the peoplle take the eruch issue...Julius Copsor, iii.

whose better issine in the war .........

nill the unlawful issue ....

then old and fond of issue ........... cymerlinf, i. t

they are the issue of your foins

how! my issue? As sure as you...

a joytul issue. A joyless (rep.)

a the issue of an irreligious $\mathrm{Aloor} . . . .$. .

Whenre an issue 1 might propagate ..... Terichs, i. 2

the issue of it being so proper

that finlt issue for which I razed

could not beget such ditferent issite.

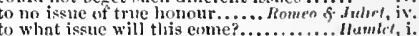

what is the issue of the busines. there.... . - v

to my hoses, if d depend on the issum?

not to strain my speech to grosser issue

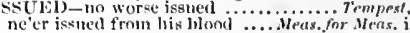

from it issued drops of fiureed ......... Hewry $i$. i

but issued from the progeny ......... Henryl i lo

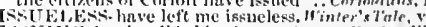

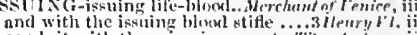

that none shall issue out

aec lut the issire of my jealousy........

look you for any other issue?.

grow this to what nolverse is
minl lote the igene show itself

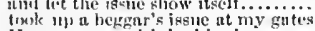

and the issue, there wreate

Mid. I. Drean,

she is tsalle to a faithluss lew .........

to view the issue of the expluit .....

till I have issue of my budy

M's milli,

call that and the mateh from laaire

come hither, I andel; your

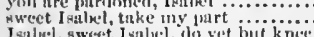

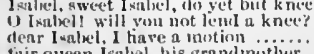

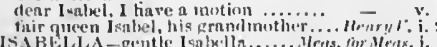

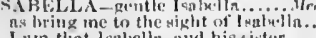

o hear me, Isabella....

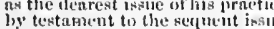

whose insue will hiss me to
where I the istle doubtul

where the isate doulteil

than they should not pronduce filir inste

it is the iosue on pinlixenste

in, I'll not rear anvelier ${ }^{*}$ insic

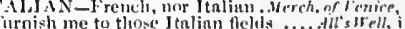

inw Dutch, Jtalian, or Freneh

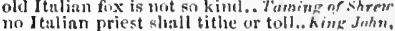

there's an Italian eme............... ('ymbelin

false Itainn (as poisnnous toneweil)

browght hither unweng the Italian gentry-

uine Italiun brain 'bun in vour thiller

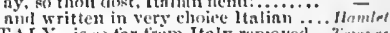

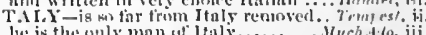

gives tiremost in rewort throngh jiaty

thou wnst the proyerest man in I tnl

it any unt in thely have in finirer

aly thint ir:aws hrent h in Ihaly

thuse virls of lisly, take lued 


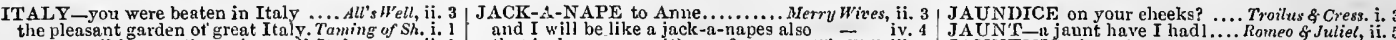

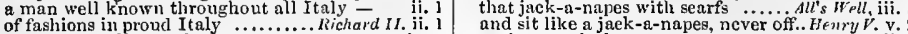

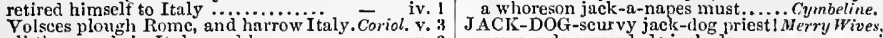
all the swords in Italy, and her..

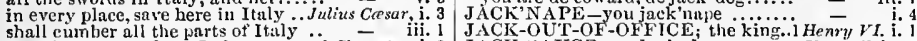

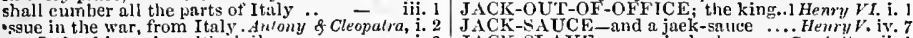

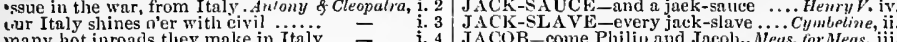
m! from Italy; ram thou tly ....... for Italy, and Casar: more, Domitius

the shes of Italy should not betray ...Cymbe $t$ ine,

not so far prefer her fore ours of taly
Italy contains none so accomplislıed

that drug-damned Jtaly liath.

some jay of Italy, whose mother

should fall as Jaeob's

and those were Jncob's; this was.......

a kinsman, who is bound for 1 thly

by Jaeob's staff, I swear T have .....

fear not wliat can from I taly annoy

iii. 4 JACULIS - non eget MI auri jaculis. Tilus Andron iv. 2 slight thing of Italy, to taint $\ldots \ldots$......

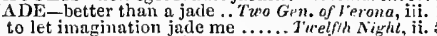
hearing us praise our loves of Italy
in thy inood as any in Italy....Rom

let earman whip his jacle. Measure for Mensure, ii.
you al ways end with a jade's triek ...Much $A d 0, \mathrm{i}$. we that dwell in't, jades

they shall be jades trieks.

no such jade, sir, as you
fie, fie on all tired jades

$\mathrm{my}$ fingers itch. I would $(r e p$.$) .. Troilus \& Cress. in.$

the itcl of his affection.... Antomy \& Clenpalra, iii. 1

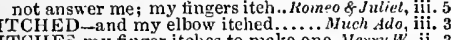

incessantly upon these jades

Taiming of Shrew, iv.

the manage of unruly jades.....

King John, ii.
Richard 11 . iji.

ITCHES-my finger itches to nake one. Merry $W$.

itehes, blains, so wo nl Athenian. Timon of. Athens,
ITCHING-an itehing palm (rep.). Julius Cresar, the poor jade is wrung in the

the panting sides of lis poor jade.....2 Henry IV.i. i. I

item, she brews good ale (rep.)

as item two lips indifferent red (rep.

item, that no woman shall come ...Lore's L Lost,

a drenely for sur-reined jades

all other jacles you may call beasts.

$=$ iii. 7

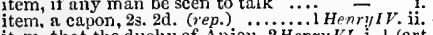

item, that the duely of Anjoi...........

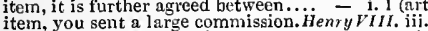

and 1 to peruse him by items

arouse the jades that drag the......2Hen ry VII. iv.

red murrain o' thy jade's tricks. T. Toilus \& Cress. ii. I

let the galled jade wince, our withers. Hamlet, iiit. 2
ADED - by sueh a jaded gron

TERATION-damnable iteration ... THerry $I$ H

[Col:] what needs this iteration, woman?. Othell be thus jaded by a jaded groo

We have jaded out o' the field . Anlony \& Cleo. iij.

AMES-James, wilt thou give us leave

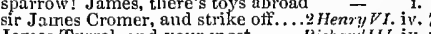

Jannes $T$ yrrel, and your nost........Richa

what say you, James Sound post? liomeo \&. Jul, iv.

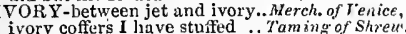

ivory coffers 1have stuifed
her ivory hand watts to her .
IVY - he was the ivy, which

iiid. N. Treanest

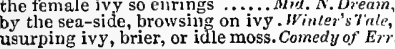

$\mathrm{J}$

captain Jamy with him (rep.).

to your worship, goot captai
JANE-anight to Jane Snile
and is Jarie Niglitwork alive

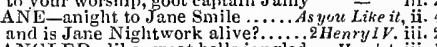
JANGLING I esteem a sport.....Nid. N. Dream, iii. 2

JACET-or another, or hie jacet .......All's $w^{\prime}$ ell, iii. 6
JACK-For Jack Rugby, Jaek Falstaff, Jack Cade, see Rugby, Falstaff, and Cade. 3 . little better than played the Jaek .... Tempest, iv say'st thou so, old Jack?

good wits will be janglings........ Love'sL.Lost, i. 1 vat is de clock, Jack?

take your rapier, Jaek
he is de coward Jaek prie

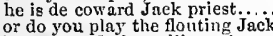

or do you play the flouting
braggarts, Jacks, milk $=$ ops!

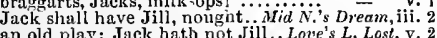
raw trieks of these bragging Jacks. Her. of Ven. iii. rawd tweks of these bragging Jack; with twenty. Taming of Sh. ii. and a swearing Jack, that thinks

be the jaeks fair within and the

fooling here, his Jack o the cloek...Pichard $1 I$. v.
take a purse to-morrow, Jaek? ......IHenry $I V . \mathrm{i}$.

Jack, how agrees the devil

girrah Jaek, thy horse stands.........

Ween? =

go thy ways, old Jack; die when

three and fitty upon pon old Jack

JANUARY - 1. o, not till a hot January. Much ado, i.
that blasts of Jnuary would .... Winler's Tale, iv.

come, your reason, Jack, your reason

mark, Jack. We two saw you four

come, let's hear, Jack w what triek ..
pr'ythee do. Jaek. Faith, and I'll send

hear comes lean Jaek, here comes.
how long is't ago, Jaek, since thou

how long is't ago. Jaek, since thou

yes, Jak, upon instinct. 1 grant ye
how 1 the prince is a Jak, a sneak-cnp =

what dielst thou lose, Jack?...........

I have proeured thee, Jaek; a eharge

daek, meet me to-morrow $i^{\prime}$ the

how now, blown Jaek? how now
but, tell me, Jaek; whose fellows

then an I a Jaek $\ldots \ldots \ldots \ldots \ldots \ldots$

ii. 3 J

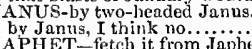

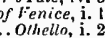

JAQUENETTA, the manner of it...Love's $L$ Losi, i.
for Jaqueuetta, so is the weaker .... $\mathrm{i}$. I (letter)

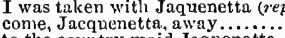

to the eountry maid Jaquenetta

for Jaquenet ta tliat is quick by him

none, but a dish-elout of Jaquenetta'
I have vowed to Jaquenetta to lold

JAQUES - heir of Jaques Fauleonbridge

brother Jaques he keeps at sehool.. As you Like
the melancholy Jaques grieves at than

much marked of the melancholy Jaques -

ay, quoth Jaques, sweep on ...........

what you will. monsieur Jrques ....

stay, Jaques, stay, To see no pastime ,

to saint Jaques le grand ....

a pirgrimage to saint Jaques le grand

AUNTING - jaunting up and down! - ii.

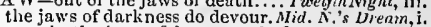
even in the jaws of danger and of... King John, v. hungry war opens lis vasty jaw

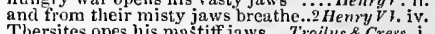
shall pierce their slinn jaws... Anlous \& Cless. enforee tly rotten jaws to open... Romen \& Juliet, v. and marble jaws, to cast thee up again!. Hamlet, i. in the corner of his jaw; first moutlyed.. - iv.

JAY - show thee a jay's nest............ Tempest, ii. to know turtles from jays................. W W Wires, iii. what, is the jay more precious. Taming of Shrew, iv.
the thrush and the jay .. Winter's Tale, iv. 2 (song) some jay of Italy, whose mother ... Cymbeline, iii.
JEALOU the jealous raseally knave.........Merry Wives, ij. the jealous wittolly knave lath $\ldots . .$.
trust his wife, he will not be jealous

it is not jealous in Frantee ..........

to be detected with a jealous, rotten

as jealous as Ford, that searched

my most jealous and too doubtful. Tinelfth $\overline{\text { Night iv }}$ iv 3 something of that jealous complexion. Much Ado, ii.
and jealous Oberon would have. Mid. N. Dream, ii. What, jcalous Oberon? fairy shöty...̈. jealous in lionour, sudden and ...As you Like it, ii. ? merriment lanth made theejealous. Toming of Sh.j. more free, than he is jealous...... Winter's 'Tale, ii. who would be jealous, then...... Comedy of Errors, iv. 2 clamours of a jealous wroman

your nobles, jealous of your absence.... Henry $V$. iv. the jealous o'er-worn widow
fair, and not jenlous: we say, thint ... Richard $11 T$. i. and from her jealous arms, pluek him $=$ iij. more vindicative than jealous love. Troil. \& Cres. iv. now by the jealous qucen of heaven. Corminlanus, y. you do love me, I am nothing jealous a blamed as mine own jealous euriosity .... L car, i. so loving jealous of his liberty.. Romeo of Juliet, ii. tis not to make me jealuous, to say ...... othello, iii. thus, not jealous, nor secure ........... - iii. 3 no sueh baseness as jealous creatures are
is he not jealous? Who, he? is not this man jealous? I ne'er saw .... = nor no jealous toy, enneerning you...... - iii. jealous for the eause, but jenlous ( rep.)...$=$ =

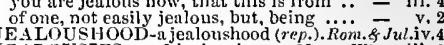
EALOUSIES-and jealousies..... Merry Wioes, iii. 3
tlis is jealousies

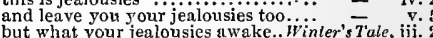
being transported by my jealousies.. the effects of his fond jealousies.. - iv. (chorua) my jealousies be your dishonours......Mapleth, iv. 3 all little jealousies, wlich now.... Anlony \& Cleo. ii. 2 JEALOTreak out in peevish jealousies.. Othello, iv. 3 give eternal food to his jealousy.. Merry Wives, it. he's a vary fom jealousy,

who says, this is improvident jealousy?

heaven be praised for ny jealousy!.
so gross in lis jealousy till now ....

in a continual 'larum of jealousy....

my jeulousy is reasonable.........

iv. 2

but jealousy what miglit befal .. Twelfth $N \overline{\text { gight }}$, iii. 3 a savage jealousy that sometimes .... these are the forgeries of jealousy. Mid.N.'s $D$ r. ii hatred is so far from jealousy, to sleep - iv

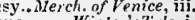
this jealousy is for a preeious ..... Winter's 7 ale fond fools serve mad jealonsy! .......
hast thou with jealousy infeeted....... or fell jealousy, whiela troubles oft .. a kind of godly jealousy .... Trritus \& Cressida, but our jealousy does yet depend ..Cymbeline, iv. but, heslirew my jealousy! it seenns.... Hamlet, ii. so fill of artless jerlousy is guilt ......... othello, iv. my jealousy slapes faults that arc......... souls of all my tribe defend from jealousy! = I'd make u life of jealcusy, to follow still - iii. 3

and join fors that you jartice resides. Thilus And I pray thee, Jack, be quiet; the ra.... well, sweet Jack, have a eare of thyself
by silken, sly, insinuating Jacks?. Richard every Jack beeame a gentleman (rep.) because that, like a Jack, thou keep'st take pereeive that a Jack guardant. Coriolnnus, y. this Jnik of Cæsar's shall ............ I kissed the jack upon an u......... Cymbeline, ii. he is, and twenty sueh Jaeks....Rom
thou art as hot a Jack in thy mood hang him, Jack! eome, we'll in here how wit may be made a Jaek-a-lest JARRING-lis jarring concord .......All's Well, $\mathrm{i}$. though long, our jarring notes agree. Tam. no Sh.
this jarring discord ot nobility...... Henry Hit. iv. the intuned and jarring senses............. Lestr, iv. J Jli.I. $\bar{Y}-t$ tun to an infeeted jelly

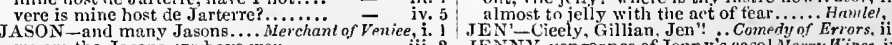
we are the Jasons, we have won ..... - iii. 2 JENNX-vengeance of Jenny's case! Merry Wires, iv

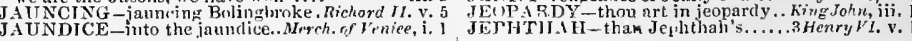


JEPfITIIA II-Jephthah, judge of Israel, Ilamiet, ii. 2 JEST-learn to jest in good time.. Co

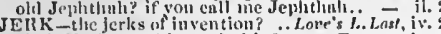
JFRKIN-is not tlis my jerk

now is the jerkin muler the line

now, jerkin, you are like

and prove a bald jerkin

my jerkin is a donblet $\ldots \ldots \ldots \ldots \ldots \ldots$........

in a new hat, and an old jerkin.. Tuming of $\mathrm{Sh}$. ii

and is not a butt jerkin n nost

liave I to do with a butt" jerk

put on two of our jerkins

poth sides, like a lentleer jerkilu. Troilus s cress. ii

JFliUNIIY-snys Jeroriniy. Taming of Sh. 1 (imlue.)

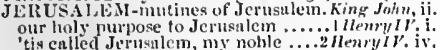

I shonlyl met die hut in Jerusalem

in that Jerusalem shall IIarry die ...

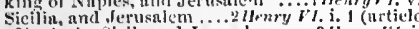

of both the sicils and Jerusalem

nect with joy in sweet lerusnlem

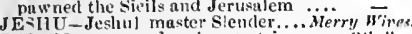

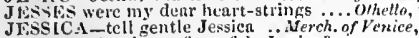

was not that letter from fiti jessiea?

Jessica! thon shalt not gormandize.

what Jessica? -and sleep and snor.

why, Jessica, I say! why, Jessica?

Jessica, my girl, look to my house

hear soul me, Jessica, lock uj.....

forenzo and his amorous Jessica....

will neknowlenge you and Jessica

fore you weer'st thon, Jessici?

did Jessica steal from the wealthy jew

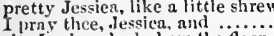

sit. Jessica: look, how the floor....

nol' you, Imrenzo Jessica, nor yon...

Jive to you, and Jessica, front the riok

do you not perceive the jest?

parted very fitirly in jest

my name is Brook; only

then let me be your jest

can tell you gond jests of him.
tell mistress Anne the jest

that's of prettr jest, indeed

there would be no periud to $t$ tie jest.

the image of the jest I'll show

while other jests ure something .......

hold up the jest no ligher.............
what's your jest? A dry iest...... Twelf

but such nnother jest

observe their mood on whom he jests

with some excellent jest, fir

great men may jest with saints

do we jest now, think you?

huddling jest uyon jest

I remember a pretty jest...............

never fleer nnd jest at me.........

you break jests as braggarts do their

I jost to Oheron, and im

do you not jest?

is $n$ ojest, that I do hate thee

then I swore in jest.................

but $a$ jest. Antl cvery jest but $a$ word

sliall that finish the jest?........

my troth. most sweet jests:.......

ton bitter is thy jest..............

tn mnke me proud that jests.

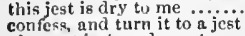

pleasant jeat, and emirtesy

n jest"s prosperity lies in

wwear the jest le laughahie............. of $\vec{V}_{e}$ ice, $i$.

turning these jests nit of service ...ds you Like il,

and manage well the jest.. Taming of Sh. I (indue.)

'tis not time to jest, and therefore

then you jest; and row I well pereeive -

hiding his bitter jests in blunt beliaviour -

Tranto, you jest; but have you both

to break a jest ujon

and, as the jest did glance away .... -

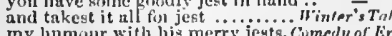

my humour with his merry jents. Comedy of $b^{\prime}$

I pray you, jest, sir, as youl sit

oo jest with me ngain.

what means this jest? I proy you.....

think'st thou, I jest?

now your jest is carnest...............
your sauciness will jest upoii my inve
If you will jest with me..............

close, in the name of jesting!

to run away from the Je

that the Jew having done me
to leave a rich Jew's service

the milnod, a Gentile, nnd no Jew

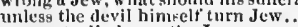

this jest shall eost me somie
thou didut but jest with my

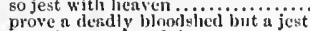

as to jest, go I to fight

I have a jest to excente...........

reproot of this lies the jest

hen a jest is so forwari

or a month, and a gond jest for ever

mude with this jent of the drawer

is't a time to jest ausl dally

not to me with ut teol-horn jest.............

his jest will savomr hit of shal
he was full of jests, and gipes

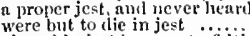

played in jest by cominterfeit

well, jest on, brothers.

none but I shall turn his jest

- iii.

this wourd have been a biting jest...nichard $I I I$. ii.

may jest on, hut hy the holy rood

brcaking scurril jests $\ldots \ldots . .$. ...

verily, I do not jest with you......... Cariolanrs,

ransom lives of me for jests. Antomy s Cleopatra, in.

here's no sound jest

have coverned our determined jests

my hand ent off, and made a merry jest $\overrightarrow{J_{u}}$

lie jests at sears that never felt

the jest may remain, after (rep.) $\ldots$ ite...

think on't, I do not use to jest

no, they do lnit jest, poison in jest ..... Hamtet, iii.

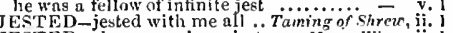

JESTER-the harson is no jester... Alerry Wives, i

why, he is the y, rince's jester

that I was the prince's jester ........ H Hen - $l \mathrm{~V}$. iii. I

become a fool, and jester!

jesters do oft prove prophets,............. Lear, v.

wESTING-liest thou jesting monkey... Tempest, jit.

Ninchl Arlo, $\mathrm{iii} .2$

a trencher, jesting merrily?

JESU -fought for Jesu Cirist.

suid at once, Jesu preser
stand. Jesu bless us!

o Jesu, my lord, my lord

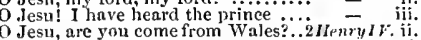

Jesu maintain your royal excellence!.2Iheriry

Jesu preserve your royal majesty!
for he's a good man! Jesu bless him

for he's a good man! Jesu bless him!

forswore limself, which Jeku pardon I. Rich. $J I I$.

have mercy, Jesu! Soft; I dil but.... -

Jesu Maria! what a deal of
by Jesu, a very gnod blade!

Jesu, what haste? ean you not stay...

JFT-how he jets under his advanced.. Twelfh $N$, ii.

than between jet and ivory. Werchant of renice, iij. 1

that giants may jet through........... Cymbeline, iji. 3

[Cal. - Knt.] to jet upon a prince's righit?

JETTED-dames so jetted and ndorned.. Perieles, $\mathbf{j}$. thou art a Hould hinve

if I do not love her, I am a Jew.........Much $A d o$, ii. 3 and eke most lovely Jew.........Mit.... Dr earo,

of man's flesh I my incony Jew!...Love's 7 . Lnst,
there is nuch kindness in the Jew... Her. of Ven.

hie thee, gontle Jew.

to run from this Jew my master ....
should stay with the Jew my master

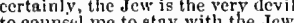

which is the way to master. Jew's?

but I am Iauncelot, the Jew's man..

my mater's a very Jew.....................

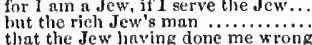

I'll take my leave of the Jew ...
most sweet Jew'? if $n$ Cliristian

ii. I myold master the Jew to sull.......

that she is issue to a faithless Jew

here dwells iny father Jew: ho!

as the dog Jew didl utter in tlie

and for the Jew's bond, which ha. hath

$n$ Jew. llath not a Jew cyes? (rep.)

if a Jew wrong a Cliristiun ...........

money to discharge tlie Jew

that ynu nre not the Jew's olnughter

becaupe I an a Jew's duughter.....
EW-ronverting Jewg to Clirlstians. Mer.ofVen. Ilt. B and rall the Jew into the eourt

think expect a gentle answer, Jew

have judgment, and the Jcw his wili

the lew ghall hitwe my flest

between the Jcw and Antonin.......

the merchunt here, and whieh the Jew

Jew, though justice be thy plen

by this the dew may claim a pound.

some pewer to ehanec this enrrirh Jei

murk, Jew; O learncd julge? (rep.)

$O$ Jew! an upright judge.

a Daniel, Jew! now, instel.

I thank thee. Jew, fur teaching

to he so taken at thy perit. Jew
tarry, Jew; the law hath yet

art thou contented, Jew?

duc unto the Jew, we freely...

steal from tie wealthy Jew .......

liver of blasplineming Jew

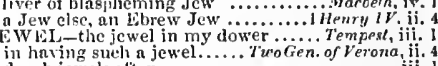

a Verona, ii

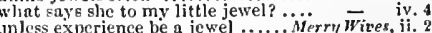

have I canglit thee, my heavenly jewel? - iii. 3

or play with some ricli jewe

the jewel that we find ................ Merure for Measure, ii. I

can the world buy socli a jewcl?....... Mreh Adn, $\mathrm{i}$.

I have found l)emetrius like a jewel Dew, iv.

as jewels in cry'stal for some....... Love's L. Lost, ii.

whis jow langeth like a jewel ...... - iv.

and jewclis two stones

and other precious, precions jewels... - iii.

at my foot, and the jewels in her ear - iii. I

since he hath got the jewel that I.....

wears yet a nrecious jewel in bis licad $\overline{2}$ ii. 1

my chastity's the jewel of our house. All's Well, $\mathrm{iv.} 2$

We lost a jewel of her ................ of shreur. i. 2

our prince, (jewel of ehildren)..... Winter's Tale, v. 1

see, the jewel, best enamelled.Comedy of Errors, ii.

rings, jewels, anything his rage ............

desire his jewels, and this other house - ivel iv, 3

where the jewel of life by some....... King John, vi

the precions jewel of thy home retirn - i.

I'll give iny jewels, for a set of ......

to your master, for a jewel .........2 ${ }^{2}$ cnry $I V$ ii. 4

bear her this jerrel, pledge of my ..1Henry VI. v. I a jewel locked in to the woefullest . Fichard iii. 2 unvalued jewels, all scnttered in ... Fichard III. i. 4 I have a jewel here. O pray.... Timon of Athens, i.

you nend the jewel by wearing

more jewels yet: there is no erossing

advance this jewel; areept, ant wea

plnte, jewels, and such like trifles ic

as if sour lordshould wear rich jewel

a jcwel the other day, and now (rep.) $\overrightarrow{ }$ iij. 6

till they hall stolen our jewel.. Antony \& Cleo. iv. 13

of money, plate and jewels ..........

slac your jewel, this your jewel ........

and jewels of rich and exquisite form

I beg hut leave to air this jewel.

'twas Ixonntus' jewcl: whom thour.

as jewcls purehased at an casy priee. Titus $\vec{A}$ d iii.

this jewel holds his biding of my arm.. Pericies, ij

as jewels lose their glory, if neglected

ii. 2 to those heavenly jewcls which Pericles

and some certain jewels, ay with you

to take from you the jewel youl holi
and found there rieh jewels; recovered

the jewels of our father; with washed

for your sake, jewel, I ant glad at soul. \&utet, i.

the inmediate jewel of their fonls

the jewels you have had from me.

if slic will return me my jewels.......... - jv. 2

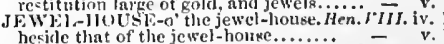

JEWELLER-the jeweller, that owes. $A l^{\prime}, \bar{w}$. $v, v$.

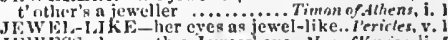

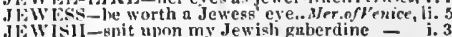

whit"s barder?) his Jewish heart ..... $\rightarrow$ lv. I

at the - what a Ilerod of Jewry. ..Merry Wires, ii.

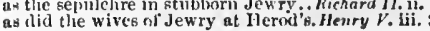


JEWRY - IIerod of Jewry may

Iferod of Jewry dare not look $\ldots$ inerod of Jewry; Mlitluriclates, king of

and went to Jewry, on affairs of Listony - iv. JiG - my very walk should be a ji. . . . etflh Night, ii. is as a scoteh jig, a measure (vep.)...... Huch $\bar{A}$ do, ii.

but to jig ott a tme at the .......

profoind solomon to tune a jig.

Ilamtet, iv. 3

you jig, you anble, and you lis

ï Cassur, iv.

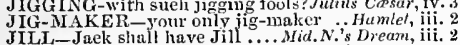

Jack hath not Jill: these lailies'. Love's L. Lost, v. 2 Jaeks fair within, and the Jills.. Taming of Sh. iv.
JoAN-love my lady, and some Jonn. Love's L.L. iii. or groan fur Joan? [Col.-love] or spend

while greasy Joan doth keel the pot - v. 2 (song)
Alice malain, or Joan madam? Taming of Sh. 2(ind.)

Alice malain, or Joan madam? Taming of Sh. 2 (ind.)

with ome Joan la Pucelle joined......

tis Joan, not we, by whom..........

holy Joan was his defensive guard ..

champion, virtnous Joan of Arc

thus doth 'Joan devise: by fuir

ah Joan! this kills thy father's

deny me not, I pr'y thee, gentle Joan

deny me not, I pr'y thee, gentle Joan

then, Joan, discover thine infirmity

JoB-and as poor as Job? not gone. 2Henry $r$ I. ii. I

I am as pool as Job, my lord .........2 HenryI $\mathrm{V}$. i 22

JOCUND-let us be jocund............. Tempest iii. 2

and I most jocund, apt ............. Twelfth Night, v. 1

and as jocund, as to jest $\ldots \ldots \ldots . . .$. Richard II. i. 3

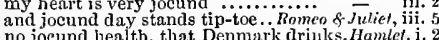

no joeund health, that Denmark drinks.Hamlet, i. 2

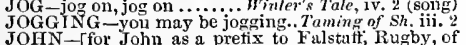

Gaunt, and of Laneaster, see those respective

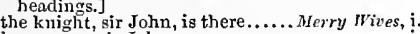

here coines sir Jolin

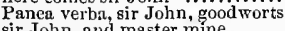

sir John, and master mine $\ldots \ldots . . . .$.

John, what, John I say!

go, John, go enquire for.
sir John affeets thy wife

sir Joln, there's one master Brook...

good sir John, I sue for your's ...... -

but, good sir $J_{\text {olm }}$, as you

now, sir John, here is the heart

what say you to't, sir John

want no money, sir Jolnn...

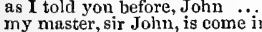

my master, sir John, is

I yonr lady, sir Jolnn!

what, John, Robert, John.

my husband is deceived, or sir Johin

that indeerl, sir John, is my business

your own semblance, you die, sir. John

run up sir Joln.11. Go, go, sweet sir Jolın

send quiekly to sir John .....
bully knight! Bully sir Joln

thou art elerkly, sir John

now, good sir John, how lik

sir John, we have had ill lnek

why, sir Jihn, do you think $\ldots . .$.
eountry fire; sir John and all......
sir Jolin, to master Brook you .

was not count, John here at supper?. Much $A d$

vou the length of Prester Jolin's foot

$I$ have earned of don John

possessed by my inaster don John

thot dohn had made

signior Benedick, don Joh

don John, the prinee's brother $($ rep. $)$

prince John is this morning secretly

how don John your brother ineensed

my lord, your brother John is tn'en

if you give him not John Drum's

unnatural unele, English John

than thou and Joln in manners

king John, this is the very sum of al

title they admit, Arthur's or John's
king John, your king and England'

hourly with thine unele John ...

and king John; that strumpet (rep.)

nark, Joln hath seized Arthur

the misplaced John should entertain

that John may stan

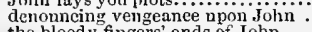

the bloody fingers' ends of Iohn

king John hath reconeiled himself.

to tell me, John hath made his peree

iii. 3
JOIHN-is warlike John, and in his .King Jokn, v, 2
king John, sore sick, hatll left tle field - vo geek out king John, and fall before...

Joln Kamston, sir Joln . Norbery.....Rirhard Il, ir tolu stends to lis word ...

sir. Iohn, I pr'y thee, leave the prinee what, a coware sir Jolu Paunch?

ny lord, old sir John, witl half

here was sir Jolin Braey.

why, you are so fat, sir John

why, sir John, my face does you no

no, sir John! what do you (rep.).

you owe monev here besides, sir Joln

an otter, sir John! why an otter.

hitherwards; with hin, prince Jolin

faith, sir John, 'tis more than time.

ay, but, sir John, methinks.........

I loved thee as a brother, Joln ......

the strangest fellow, brotler John

you son John, and niy eousin.......

the hulk sir. John is prisoner

vile turned

well, the trnth is, sir Joln, your

Joung? fie, fie, fie, sir John! .......
sir John, I arrest you at the suit of:

how now, sir Joln! what,

sir John, sir John, I am weli aequainted -

pray thee, sir Jolin, let it be but

taught you these manners, sir John?

olin, with my brothers (rep.)

there were five more sir Jolins

and sir John must not know of $\mathrm{it}$....

pray you, pacify yourself, sir John

save you, sir John! 'Weleome.........

now sir John, a boy; and page

this sir. John, consin, that comes ( $r e p$.

no, sir John, it is my eousin Sileince

what think you, sir John?

for the other, sir Jolin,-let me see,-

shall I priek him, sir John?

sir John, do you remember sinee we lay

ha, sir John, said I well?.

sir John, which four will you have?

sir John, sir Johm, do not yourself wrong -

ir John, lieaven bless you, and prosper -

taken sir Juhu Colevile of the dale..

prinee John, your son, doth kiss

sir John, you shall not be exeused

where are you, sir Joln? eome....

begars alt, sir John; marry, good air

a very good varlet, sir Jolu

Gor save you, sir John! ..........
kir Joln, I am thy Pistol and thy fiend -

Robin Hood, Scarlet, and John

O the Lord, that sir John were come!

ay, roarry, sir John; which I lesceeh

that you will die in, sir Jolin.........

the story, with sir John in it, and nake -

how now, sir John, quoth

brother John Bates, is not that

John duke of Bourbon, and lord

John duke of Alencon; Antony duke of -
if sir John Fastolfe had not played..1 Ilenry

whitlyer away sir John Fastolfe
English John Talbot, captains

and on his son young John ........... =

here is John Talbot? pause, and take

art not thou weary, Joh
where is valiant John?

young John Talbot's grave

gir John! nay, fenr not, ma
how now, sir Joln Hume?

against Joln Goodman, my jord

with sir John Stanley, in the isle

and sir John Stanley is appointed

must you, sir. John, protect

and so, sir John, farewell............

under the title of John Mortimer...

we, Jolin Cade, so termed.

nay, Joln, it will be stinking law

sir John, and sir Hugh Mortimer...

this is sir. Joh Montgomery

welcome, sir John! but why come

nay, stay, sir John, awhile

I thank thee, good sir John .........

iii. 4 John duke of Norfolk, Thomas.....

iii. 4 Jonfessor, John de la Court ..... IIenry ${ }^{\prime} I I I$. i.

v. 2 to permit John de la Court

v. 2 and John Court, confessor to him......

thon hadst been poor John....... Romeo \& Juliet, i. firiur Jolun, go hence; get une an irun crow -

JOH my leter, friar John, was staid

Jor

OIN - then meet, and joil

I will join with thee to disgraee her...Much dan, ifi.

but you must join, in souls.... Mitl. N.'s Drewn, iti.

i. 2 join you together as they join ........ . you Like it, iii. 3

to join in Hymen's bancls.

to join like likes, and kiss

when they join, do glorify the

Alr's Well, i. 1

in with the prester to join hands. Richard II. ii.

Richard II. ii.

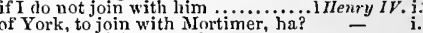

if once they join in trial

our armies join not ju a hot day

2 HemyIr.

shall join togcther at the jatter........ Henr $y$ v. iv.

to join with witches, and the help...iHenry $r$ i. it

to join your hearts in love and amity

on, my lorls, and join our powers....

join you with me.

we join with him, and with the oords

join with the traitor

notwithstanding, join our lights together -

post-haste, are eome to join with you

I'll join mine eldest daugliter.

now join your hands, and with

I'll join with blaek despair........ Richor $\overline{\text { iv }}$ iv. 8 wouldst be gone to join with Richinond - iv. 4

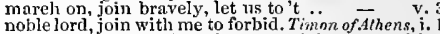

ii. 4 my deserts to his, and join them both

ii. 4 shall join to thrust the lie ........... Coriolanus, $y$. let witeheraft join with beanty...Anlony \& Cleo. ii. who did join his honour, against .... Cymbeline join gripes with hands made

and join for that you jar...... Titus $\ddot{A}$ ndronicus, ii.

when we all join in league

to join with him, and right his

ii. 2 which the worid together joins... Pericles, iji. (Gow. [Col.Knt.] two pernicious danghters join. Lesr, iii. go join you with some further aid...

JoINDER-joinder of your hands.. Twelfih Night, v. orise blood to false blood joined! .. King Johus
fals.

nature and fortune joined to make..

woe to woc, sorrow to sorrow joined..... Richarrl ii

our nucle York hath joined with ....

joined with no foot land-rakers ..... i Henry

v. 3 of Orleans with lim is joiner

with one Joan la Pueelle joined, a holy - i.

which joined with him, and inide.... - iv. 1 (letter)

feature, joined with her birtl ........

encountered as the battles joined ....3 Henry VI.
our battles joined, and both siles fiercely -

whon God hath joined together....

yet to have joined with France in....
splinted, knit, and joined together.. Richord $/ J$. ii.

are joined with me their servant . Henry VIIL ii.

Mlarcius, joined with Anfidius. ....Coriola

Toureins should be joined with Volseians - iv.

burn like twenty torches joined.....Jutius $\bar{C}$ Cosar, $\mathrm{i}$.

joined with a masker and a reveller.. Cleopatra, iv. io

revived, to the majestie cedar joined. Cymbeline, ..

and being joined, I'll thus your hopes.. Pericles, ii.

God joined my heart and Romeo's. Romen \& $J$. Jul. iv.l

tell them plainly, he is Snig the joiner . Dream, i. 9

one Snug the joiner, am a lion fell ... - .

JoINFTH-toreh that joineth Röinen.1 Henry' I'T. iii.

2 JOINING their force 'gainst Cxsar. Antony \& Cleo.i.

4 and join'st with them will be thy..... 3 - 3 - jii.

that they grind their joints ............
we'll touze you joint by joint....

beeause of his great limb or joint. Lore's L. Lost. v.

. clap their female joints in stiff .... Richard 11. iii.

this festered joint cut off

my true joints bended be........... = v.

yet all our joints are whole......... H $_{\text {nn }}$ ry $I V$ i

whose fever-weakened joints.

what's a joint of mintton or two

a joint of mutton; and any pretty.

than a joint burden laid upon

Irawn my shoulder ont of joint

cvery joint should seem to eurse..... Henr? $r$. iv. 3

the joints of every thing (rep.)

upon our joint and several dignitit 
JOINT-the elephant hath joint s. Trailus f l'ress. li. 3 with every jolut a woumul...

at erery joint by joint. Is this deliilies?

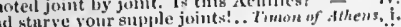

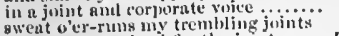

if I have harguinet for the joint

Ante

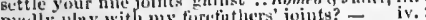

is setilect, nuth lher joints nete ot

I will tenr thee joint by jeint ..............

H.rmmel, i. i

this liroken joint, inetween you and her. Othelln, ii. 3

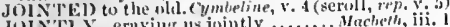

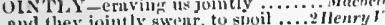
nnd they jointly swent to spoin
invest you jointly witl. my nower

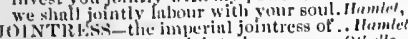

doN

JolNT-SERVANT with ne ......

thy state is taken tor a joint-stool

uni jumps nyon joint-stouls

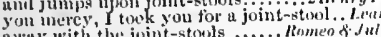

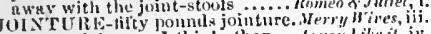

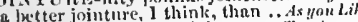
all which shall be lier jointure

toncling the jointure that your..

tol is alliet, JoLL OLILTT

in nightly revels, and new jollity

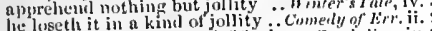
is jollity for anes, abd grief for boy. Cymbeline.

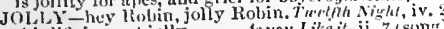
this life is nost jolly ......As you Like it, ji. 7 (sonin) You'll prove n jolly surly groon.

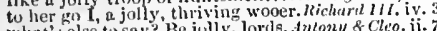
what's else to say? Be jully, lords.dntony \&
through Alexandria make a jolly matreh

through Alexand rin make a goh
whites the jolly Britum (your lor

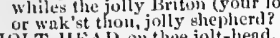

JOLT-1IEAD-ont the jolt-head. Trogen. of Yer ifi. JomDEN-allow us ne'er a jorden ... I Henry $W^{\prime}$ ii. I empty the jurden; and was ........2 llemy.

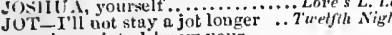
nu sir, no jot; 1 knuw your

his my pity, not a jot the other. Meas. for Meas. iv.

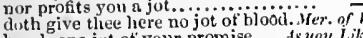

break one jot of your promise..As you Lited

if one jot heyond the bounc

列

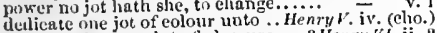

in possession any jot of plensure.....3 Henry fil ii.

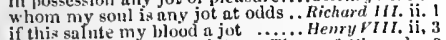

if this salnte my blood a jot

bate one jot of eeremony

... Coriulanus, ii.

hitain no jot, I ehurge thee........... Antongl \& Clio.

let me not stiay a jot for diuner

no, faith, not a jot; but to follow

Hiamel, $\mathrm{v}$.

not a jot. not a jot. Trust me.......... inhello, iii. 3 Jourk-0 seigneur! le jomr esi perd

mother J Jurlinill, be you prostrnte..... stirk t, your journal course
Joit REY

if l'roteus like your journey

upon my longing journey ............. thy heavy riches hut a journey. Meas for Meas. iii. lonk firward on the journey you slanli go - iv. 3 trave 1 journey to vour fatlier's lionec ince iv.

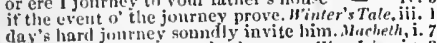
two lont datys journey, lords ...... King Johin, iv.

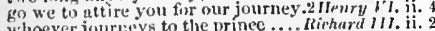
whoever journeys to the prinee
on thein for this great journey

eoneerning the lieneh journey ....... i.

is but halt his jomrney yet ... Troildus Cressitu in

I may fymr on my journey ........ Corinlanus, i. 10

have well savell ine und duy journey Cisar throurh Syria intends hio journey - y. 2

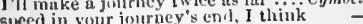

marry, sir, hulf a dny"s journey

1 laave a journey, sir, shortly to go ....... lear, y. 3

highnoset hill of this day's journey. Hamen s.

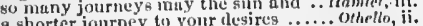

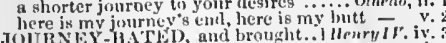
JoIrRNEYING to salute .. Tice Geno or l'remna, i. 3

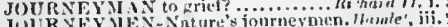
Jovk,-Jove's lighenings, the precurmerb.. Trmpest, i.

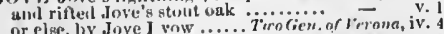

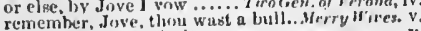
remember, Jeve, thiou wast a bull..... think on't. dove, a find fiuili

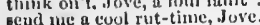

UV flove knows 1 lote fie............ love, I thusik the in. now dove, it his next emmenotity

well, dove nut $I$, is doer of this

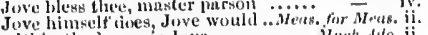
within the louke lit Jover.

as Eirropu ones did at lusty Jive

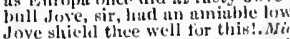

bly cre Joves liphtning bears... l.

anul cleny himselt tor Jove

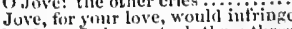

by Jove, I ul ways touk three threes.

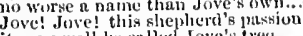

it may well he called Jove's tree.....

swear by dove's steat attributes

by Jove, it ever I knew mut

nade great Jove to humble him..... Pnming of sh

ove scind her a better guiding spirit! I'mter's $T$, ii. 3

kin to dove's thunder, so sil

it was Jove's ease: from a prinice....... 1 lenry $I S$. ii.

and in earthonake, like a dove

hy Jove, I nin not eovetous for

Jove sometime went disglised (rep).2 Henry I $t_{\text {iv }}$ iv 1

overieered Jore's spreadiny tree......

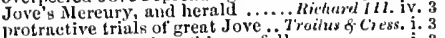

ind, Jove's aceord, nothing so full

fly like elididen Mereury from Jove
nud Jove forbid there should lee clone

forget that thou art Jove the king

Jove [Kut.-love] I have abandoncel Troy =

by Jove, I'l play the hiunter..........

Fe symputhise: Jove, let $X$.

by Jove, I will l,e patient ...............

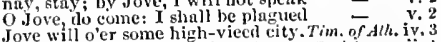

nobles bended as to Jove's stut

by Jove, "twonld be my mind ......... =

or Jove for his power to thunder

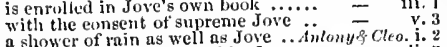

if thou lar'st be, the earthly
the Jove of wower make me

tinvoru's, by Jove that thunders

your cmperor eontinues still a Jove = iv. 6

Jove! onee more let me beloliti it..... Cymbeline, ii. 4

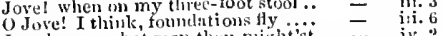

Jove knows what man thwu nuight'st
I saw Jove's bird, the Roman eagle.:

Jove shiclut your husband from . Tilus

Pallas, Juve, or Mlereury, inspire me

he thinks, with Jove in heaven

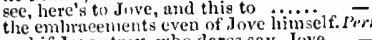

and if Iove struy, who dares sny, Jove
by Jove, I wonder, that is kinu........

tell tales of thee his high-juditing Jove ... Lear, ii. 4

perjuricg, they say, Jove laughis, Romeo \& suliet. ii. the front of Jove himself ................. Othello, iil. 4

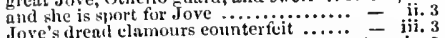

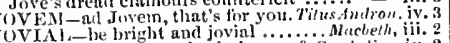
his Jovial fuce-nnurder in heavent. Cymbeline, iv. 2

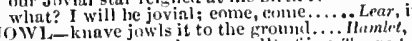

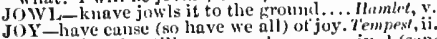
SoY-haye cunse (so have we all) of joy. Tempest,ii.
hourly joys he still upon yout...... - iv. I (song)

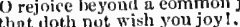

that doth not wish you joy!............... of $V$ er.

inwarl joy enfireed my henrt.

no such joy on earth1.........
what joy is joy, if Silvia

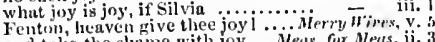
and take the slame with joy ...Neus. fur Meus. ii. 3

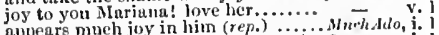
to weep at joy, than to joy at wceping? I wikh him joy of her

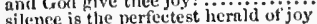

silensins, Gad give you joy!

Gisl pive me joy to wear it ............

anl mukes liin nll her joy ........ .

to give tlicir bed joy and pro.....erity

thy fair lurge ears, my gentle joy ....
some joy, it eompreliends some (icp.

filll of joy auml mirth (rep.) ..........

and leap for joy, thouglh they are lume

God give thee joy of himt.............. of

in measure rain thy joy ...........

of joy, expressed, and joy, my lord.

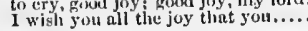

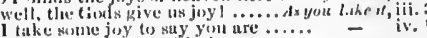

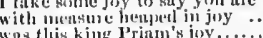

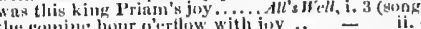

sul namy quirks of joy, and wrief.....

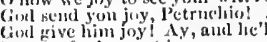

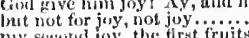

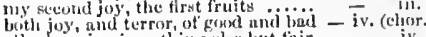

inyurtance were joy or sorrow ....... =

one joy erown another ......

for their joy waded int tears.............
'twixt joy and sorrow, was funglit

searec iny joy did ever so leng tive.

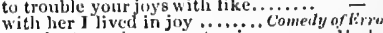

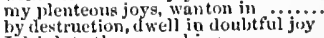

I drink to the genceral joy

nothing in this world ean make me joy

all days of mlory. joy, aml happiness

joy absent, grief is present

to joy, is little less $n$ joy, 0 than hope

nnd let him ne'er see joy .......
1 weep for joy, to stand upo

o'erthrowa thy joys, friencls, fortune

of sorrow, or of joy sof cither.
fior if of joy, being al together

mure sorrow to nin want of joy.

thoun give joy; until thou bid me joy

in Bolingbroke's prond joy

[col.] yea,joy; on cliains.....

intect my blood with joy...

do I bring, and lucky joys

I sleak of Afriea, anlut gulden joys

joy and good wishes to our most

to eelebrate the joy that God

will be repiete with niirth

and joy

ng, fill to weeping joys.2. nestry ri. $\mathrm{i}$.

surteiting in joys of love ..................
the treasury of everlasting joy!

eares and joys alound, a
my joy is-death; death

ot death I shall find joy

live thou to joy thy life; ni
poets feign of hliss and joy

poets feign of bliss and joy s.............

never heneeforth slabll 1 joy arain $(r \times p)$ -

curth aftords no joy to me

fill my leart with unloped ioys

mine cldest daughter, and my joy

do cloud ny joys with danger

to hope, ny sorrows unto joys
niy joy of liberty is half ecllysed

to meet with joy in sweet Jerusalem

and meh it joys me too, to see 1 in being Ensland's

as little joy, ny lord, as your (rep.)

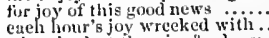

wherein dost ihwu joy? wh
succeders of intentate joys

sweet silent hours of mat riage joys.

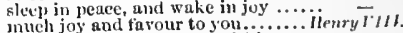

ne'er ureamed a joy bevond his...... - iii.

now all ny joy truee the empunction =

with the mere rankness of their joy...

sueh joy I never saw hefore ...........

some joy too fine, two subtle...

slall hose distinetion in 1 'y
will hite our joys no longer.

O joy, e'en made away ere it

I sprang not more in jos of first.

all joy ant honour. "To Coriolinus (vep.)

the gods give you joy, sir. lienrtily on =

ghould make our eyes flew with jus

lark, how they joy 1 First, the gots

we wil meet then, andis firtun
for lis love; joy, for lis
and hark? they shout for joy.....

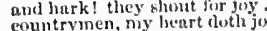

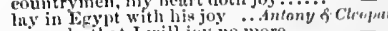

so sorely that I will juy no more ....
I wisl you all jou of the w'orm (rep.

joy whereof, the finmed cussilsclan..

with joy he will emlirace you...

mallim, all joy licfil your grace

bricen die tion jo

strike me to deuth with: uurtal joy

hitting each oljuet with a joy

tears of true joy fior lis return.. Titus drulronicus, i. all whose jey is notling else but fuir

thraldoun to the joys ot heaven .......

me to joy and weep, their gain and loss

joy's soul ties in the doing.... Trailus o 


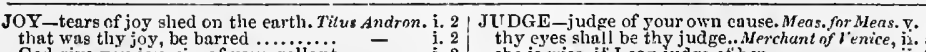

God give you joy, sir, of your gailant

God give your lordship joy .............

gripe net at earthly joys .............
shows, we'll joy in such $n$ son

$\begin{array}{rr}= & \text { i. } 2 \\ \overline{1} & \text { iv. } 2 \\ & \end{array}$

pleasure's art can joy my spirit

joy and all comfort in your sucred brea

make the gazer joy to see lim tread

further'grief,-God give you joy!....

and never more have joy. Maram
great sea of joys rushing upon me...
and crowned with joy at last

and crowned with joy at last ............ 3 (Gower)

joy wait on you! here our play.

then they for sudden joy did wcep - i. $\overline{4}$ (song)

two extremes of passion, joy and grief.... - y. -3

to the high top-gallant of my joy must

the exchange of joy that one short .

measure of thy joy be herped like mine
which you, mistaking, offer up to joy
stained the elilahood of our joy with

stained the elildhood of our joy with

thousand times more joy than.....

and joy eomes vell in sach a needfui

sorted out a sudden day of joy

hast thou not a word of joy?

but love's shadows are so rich in joy?

finds means to kill your joys with love

as 'twere with a defeated joy
old Norwav, overerme with joy

did seem in him a kind of joy to hear of it -

the violenee of either grief or joy ........
joy most revels, grief doth most (rep.).

that hilanks the faee of joy $\ldots \ldots \ldots \ldots \ldots$
howe'er my haps, my joys wiline er begin

howe'er my haps, my joys wilne er begin $\overline{5}$

thought that his joy be joy, yet throw. Oth

O my soul's joy! if after every tempest.

with joy, revel, pleasure, and applause...

'JoY-her joy her raven-coloured. Ti/ms Andrnn. ii. 3

ever king that ioyed an earthly ....2 Henry VI. iv. 9
joyed are we, that you are ........ Cymbeline,

JoYFUL,Got leliver to a joyfii .... Merry Wives,

what a joyful father wouldst.
right joyful of your reformation.

right joyful of your reformation.......

shall be joyful of thy company... Toming of sh.

make joyful the hearing of my wife ...Mucbeth

I know, this is a joytul trouble to you.

no joyful tongue gave him his....... Richard 11 .

o joyful day! I would not take $\ldots . .$.
of arts, plenties, and joyful births

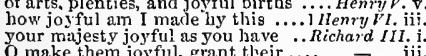

a happy and a joyful time of dsyi

for joyful mother, one that wails ....

good man, those joyful tears show

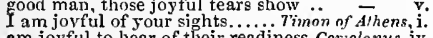

am joyftil to hear of their readiness. Corrolonus, jv.

let them be joyful too, for tliey......... Cymbeline, .

then be joyful, because the law hath. Titus And. iii.

slie will be a joyful woman $\ldots$..... Romeo \& Juliet

but now I'll tell thee joyful tidings
lappily make thee there a joyful bride $=$ iij.
ehall not make me tleere a joytul bride

Joresage some joyful news at hand .0. He- vry $V$. I

most joy fully, we take our leave.. Richard III. iii. 7 my goof lord, are joyfully returned.... Hnmlet. ii. 2 a joyless, dismal, blaek, and .... Titus Andron. iv. 2
JOYOUS-arrival be full joyous.. Taming of Sh. iv. 5 right joyous are we to behol

the pedant Judaceabreus

Love's L. Losi,

the pedant, Judas Maecal

Iudas I ain, yeleped Maccabæus (rep.)

proved Judas? Judas I am (rep.) $\ldots \ldots$.
to make Judas hang himself $\ldots \ldots \ldots$.
Judas was hanged on an elder $\ldots \ldots$.

二 $\quad$ v. 2

give it him:-Judns, away.

than one thrice worse than Judast.. Richard II. iii. so Judas did to Christ: but he

so Judas kissed his maste

L...3 Henryl VI. v. 7 JUDE--and so adieu, sweet "Jude!... Love's L. Lost, v. for the ass to the J ude $\ldots \ldots \ldots \ldots \ldots \ldots$. JUDGE you judge I wink.. Tu० Gen. of Verona, i. 2 you shall judge.

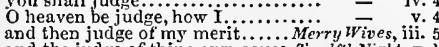
and the judge of thine own eause. Turelfth Night , $\mathrm{v}$. 1 to what. I pray? Judge .... Measure for Measure,
whieh if myself might be his judge... nor the judge's robe. become ......... should but judge rou as you are?

wlien judges steal themselves.

whose credit with the judge, or own

there is a devilish merey in the judge
no sinister measure from his judge..

\section{二}

i.. 5
ii. 2
ii. 2
i. 2

ii. 2 thy eyes shall be thy judge... Merchant of $l$ enice, i. 5 she is wise, it I can judge ot her
to offend, and judge, are distinct ....

if the devil may be her judge $\ldots . . .$. .

it woth young judge! how do I honour

O wise and upright judgel how mueh

doth it not, noble judge?

bid her be julge, whether Bassanio.

most riglitul judge! And you must

had I been judge, thou shouldst have

I gave it to the jndge's elerk

gave it a judge's clerkl ........
[Col.] no, God's my judge...
than thyself, the judge's. .

than thyself, the judge's clerk

or no, let the forest judge.

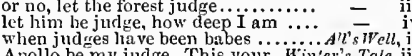

Apollo be my judge. This your.......... H's's Tale, iii.

from that surernal judge, that stirs.

that julge hath made me guardian be your judge

you urged me as a judge ........

noble to be upright judge of noble

and here I stand; judge, my masters

I jor

kindly to judge, our play ........Henry $V^{\prime}$. i. (chorns)

we jnilge no les

(as I judge by his biunt bearin

(if I were worthy to be judge)

you judge it straiglit a thing.

if I may judge. Let Somerset be ....2 Henvy $V^{\prime} I_{\text {. }}$. 3

forbear to judge, for we are sinners all $=$ iii. 3

I cannot judge: but, to eonelude $\because 3$ Henry Vr.ii. I

your young nohility could judge ... Richard 11I. i. 3

to-morrow then I judge a jiappy day $\overline{\text { lay }}$ ii. 4

I should fudge now unhappily.
having here no judge indifferent

you sliall not be my judge; for it is you -

iny soul refuse you for my judge (rep.) -

wiser than the judge, if wisdom. Timon $f$ Athens, iii.5 whieh way, do you judge, my wit .. Coriolanus, ii.

cats, that ean judge as fitly of ...... that $_{\text {thom }}-$ iv. 2

judge, O you gods, how dearly

play iudge, and exeeutioner.......... Cymbeline, the judge have pronouneed my.....

if your honour judge it meet................ear, it 2 we may of their enepunter frankiy judge $=$ iii.
they shall hear and judge 'twixt you and and you, the judges, bear a wary eye $\ldots . \cdots-$ iv. 5 now, sir, be judge yourself, whether I .. Ohello, i. JUDGED me fast asleep .... TwoGen. of Verona, ii. I it eould not be judged, sir............ Merry Wives, thieves are not judged, but they...

thou see'st hatl judged thee

holiness, and to be judged by him.. Üenry $V I I I$ iij. at least lye judged so.................. Pericles, $i$. O thou that judgest all things ....... Henry Hent. iii. JUDGMNT-his jndgment ripe.Tun Ger. of Ver. ii. she, in my judgmert, was as .

jydgment by mine lost of the Garter.Merry $w$. forgive my sins at the day of judgment $-\bar{T}$ the ouths of judgment and reason ... Twelf $h N$. the ouths of judgment and reason .. Twelf hN. iij. 2 exeeution, judgment hath repented.

if he, which is the top of judgment

lack of tempered judgment afterward

speals in sober judgment

go much without true judgment

yith his judgment look ...Mid.N.. .

love's mind of any judgment taste : 2 -

beauty is bought by judgment of.. Love'sL. Lost,

some god direct my judgment! .Mer. of Venice, ii. 7

young in limbs, in judgment old
seven times tried that judgment is $=$ ii. 7 (seroll)
ii. 9 (seroll)

me have judgment, and the Jew his will

I stand for judgment; answer

a Daniel eome to judgment I $\ldots \ldots$. $\dddot{I}$...

proeeed to judgment: by my sou
the eourt to give the judgment
yourself with your own judgment

yourself with your own judgment...As you Like

he disabled my judgment

whose jud gments are mere fathers......As $\bar{l}^{\bar{\prime}} \mathrm{s}$ W

stain our judgment, or corrupt our hope -
in babes hath judgment shown ...... judge you, ny lord of Warwick .....inenry VI. ii.

find your lordship judge and juror.
JUDGMENT-trust iny judgment ...All's Well. iii. 6 take a measure of his own judgments in your silent judgment tried it.. Winler's Tale, ii. ' one that, befure the judgment.. Comedy of Lrr. iv. 2
under heavy judgment bears that life.. Nacbeth, i. 3

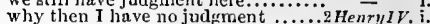

only old in judgment and understanding -

in uny very seat of judgment........ = but in purged judgnent, trusting ...... Hen $r y / v$. ii. right wits and hist in horsemanshlp - iii. 7 some shallow spirit of judgment ..... i Henry $r I$. ii. for judgment gm doth belung to thee! hath tempted judgment to desire ...3Henry $V I$. iii. 3 you showed your judgment.......... the urging of that word, judgment...Richard $I I I . j$. vodgment, he was stirred witl such.Henry $V$ III. ii. 1 Romed a traitor's judgment ........ - ii. nnmatched wit and judgnient....... \pm = ii. this was a judgment on me...........
to stay the judgment o' the divorce... in judgment comes to hear the eause $\overline{\text { Tress. }}$. one $o^{\prime}$ the soundest jud gments in Troy - i. will with great speed of judgment .. $=$ than in the note of judgment........ - ii. for a whore, be tempts judgment ..... nttend our weightier judgment ...... - iii. against the reetorship of judgment? Coriolanus, ii. 3 on a safer judgment, all revoke..... whether deteet of judgment, to fail.. = iv. your juilgments, my grave lords ..... a judgment, thou art fled to brutish $-\overrightarrow{\text { iii. }}$ by laying deteets of judgment to me $=$ - i. the fellow has good judgment....... - iij. Cæsar, thou hast subdued his judgment - iii. II
drop our elear judgments........... be it but to fortify her judgment ...... Cymbeline, i. 5 amplify my judgment in other ........ your grent judgment in the election slanders so her judgment ............. the effeet of judgment is of the eause to the judgment of your ere.... Pericles - iv. make the judgment gond that thought - (Gower) answer my life my judgment $\ldots \ldots \ldots \ldots . .$. Lear, i. to fear judgment; to fight when $I$...... thy folly in, and thy dear judgnent out! this judginent of the heavens, that makes - V. 3 \& Juliet, iii. 3 witl better heed, and judgment, I had not - ii. I whose judgments, in such matters ...... - ii. 2 we will hotly our judgments join ........ voon the jurlgment; and what judgment - $=$ iji. 4

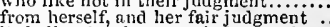
it shall as level to your judgment 'pear..
one. No. Jud gment. A hit............. one. No. Judgment. A tal judgments, casual slaughter.... nay, it is possible enough to judgment... so strong that judgment eannot eure ... having my best judgment eollied............. reeoiling to her better judgment

is not without wit and judgment $\ldots \ldots \ldots$. iv. 2 until the great judgment-day........ Richard III. i. 4 our common judgment-place.... Romeo \& Juliet, j. 1 he is noble, wise, judie ious, and best...Macbeth, iv. 2 shall have judicious hearing......... Coriolanus, v. 5 judicious punislment t 'twas this fiesh .. Lear, jii. 4 cannot but make the judieious grieve.. Hamlet, iii. 2
JUG-brought stone jugs .. Taming of Shrew, 2 (ind.) whoop, jugl I love thee.................... Lear, i. 4 JUGGLED-Il not be jnggled with .. Hamlet, iv. 5 as nimble jugglers, that deeeive...Comedy of Err.i. 2 a thread-bare juggler, and a fortune-teller $-\nabla$.

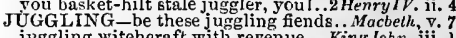
juggling witehcraft with revenue ...King John, iii. 7 and the Dauphin have been juggling.I Henry VI. .4 such juggling, and such knavery! Troilus \& Cress. UICE-seour with juiee of balm .. Merry Wives, v. the juice of it, on sleeping eye-lids.. Mid. N.Dr. ii. and $w i t h$ the juice of this I'll streak $=$ ii. no more the juiee of Egypt's grape... Ant. \& Clea. . JULE-wilt thou not, Jule? (rep.). Romeo \& Juliet, $j$ JULIA-thou Julia, thou hast $\because$ iwo Gen. of /er. i. gavest thou my letter to Julia?......

to Julia-say from whom? .......... 


\section{JUT،}

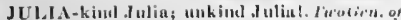
prasslunate Protects, to tlac swect Julin (1) heavenly Julius

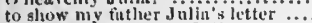

have patience, gente Jilith.....

for thy Julin's anke

wherein I sigh not. J ulin, lite tliy suke

Julia, farewch! What! Gone without

part witll mathlum Julin?

to eave my Julia, slanll I bo

Jur Julia, Silvia..................

shuws Julia but a swnrtliy

breaklng finith with Jutia whoui i invel =

one Jula, that his ehanging tlwughts

his Julia yave it to luiv.

Ghall un do his Julia so mieli.........

trisnmed in madam Jul

the ring I gave to Jnlin...

at my depart, I gave this unto Jilia

and Julin herseli elid give it me...

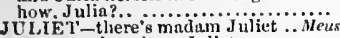

too gross, is writ on

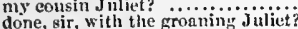

my brother clid love Julied

where's this girl? what, Julieti.......

tell me, danghter Juliei, how stands

with tender Juliet matelied

it is the east, ant Juliet is the sun.

als Juliet, if the measure of thy joy be

Tybalt, Romeo, Juliet, all sluin....

heaven is here, where Julict lives.....

the white wonnler of dear Jnliet \& liand

uuless philosoply can make

I conne from lady Juliet. Welconie.

for Juliet's sake, for her snke, rise

spakest thou of Juliet? how is it with

thy Juliet is alive, for whose dear
death, and welcome! Juliet wills it so

how now, Juliet? IIadan, I nim not well -

Julict, on Thursday carly will 1 rous

go thou to Juliet, help to deck up her

go, waken Juliet, go, and trim her up

wolint, mistress! Juliet! fust, I warram

fur shame, bring Juliet forth: her lord

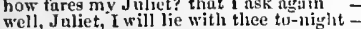

go with me to Juliet's grave

this three hours will fuir Juliet wake

Juliet, that [Col. Kint,-or wanting
the tomb, lay me with J Juliet

Paris slould have married

hearing him talk of Juliet, to think: it
for here lies Juliet, and her bealty"..

ah, dear Juliet, why art thou yet sof fiar?

ah, dear Jutiet, why art the thist suliet

and not tor Tybalt. Julict pined

ny master news or Juliet
to die, and lie with Juliet

as that of true and faitlsful Jiliet.

than this of Juliet and her Rome

I got possession of Julictta's bed

JULIO - i.

JULIUS - [For Julins Caesur, see Cassar.]

pardon me, Julius! here wast ..... Julusur Crrsar, iii.

lid not great Julius bled for justice' anke? - iv.

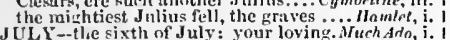

J ULY -tlie sixth of July : your loving. Afuch Adn, i.

as clear a a ionnts in July

Tirentith Night.

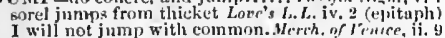

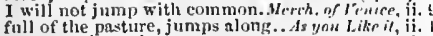

meet and justure, juny

jump her aut thump her........... "inter's Tale,

but jumys twelve foot and a half .

we d juinp the lite to eome

and jumps upon joint-stools.

Antrbeth, i.

and jumps upon joint-stools........2 2 Ilenryly

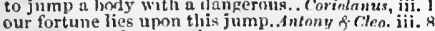

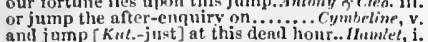

so jump upon tlis bloody yuertion

but, though they jump not on a just...... on otherlo, $\mathrm{i} .3$

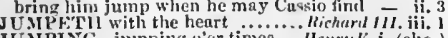

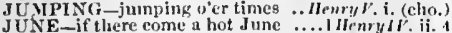

J UNE-if there come a hot June

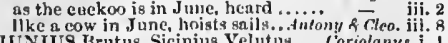

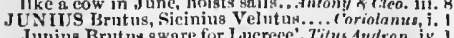

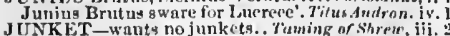

JTNO-great Juno comes............... Temprat, iv,

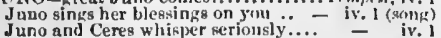

Juno and Ceres whisper serionsly...

swear, Juno but an Ethichen. Lore'sl. Lost, iv. 3 (ver.)

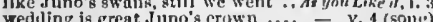

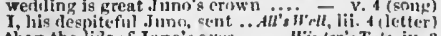

than the lits of Jugo"seyes....... Winitre's Tate, iv, 3

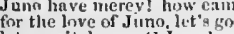

let me sit down: 0. Jumol. Antony of Clenpalra, iii. I

bad 1 great Jueo's power............. - iv. I3

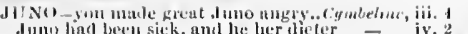

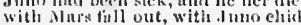

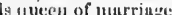

Jupiter, 1 , swear nut. By, jitalio. i sw

you were nlso, suyiter, a swan

Jupiter! how weary are my spiriti... Is you liks

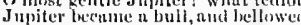

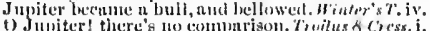

作

Jupiter forbitl; nad sny in thunder

transformation of Jupiter there.

linouly lrow: os Jupiter, no dil

lis nume? By. Jupiter, firpot .........

it dupiter hhosuld from yon clourl speak

政

we's the Jupiter at men (rep.).

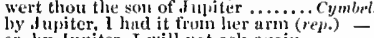

or, by Jupiter, I will not ask ayain.

by Jupiter, an angel! or, it not .......
Jutiter be praieded! Lueins is taken.

since, I lupiter, our son is goow

hell, Jnatiter; or we appeal aut from

great Jupiter upon his eafle backet
great

what says Jupiter?

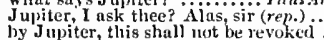

hy Jupiter, this shall not be revoked .... Lo dor

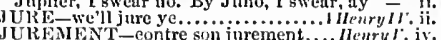

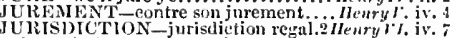

3 the jurisliction of all hishops ... Hen

kindred were jurors on thy life. Thinom of Antwens. iv.

his noble jury and foul eause...... Ifenry $r$.11. jii.

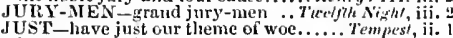

just as you left them, sir.

just 't wixt $t$ 'welve and one

just the eontrary; the better.

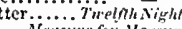

Ojust, but severe law! ...................
that the most just law now took

ay, just, perpetual duranee

and head, jutst of his culour

the grave, an just, as absolute.

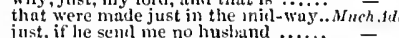

wliech is hence a just sevennight

just so many strange dislies.

yea, just so much in you may.

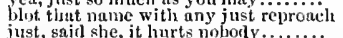

hut always hath been jonst and virtious

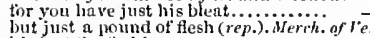

tis just the taslion.

Ax yout Liti

yes, just. I do not like lier nume...

twas just the dificrenee beiwixt.............

nat ure. stronger than his just oceasion

hut unsuitable; jnst like the hroor
would, in so just a business, shut his

my mother told me just how he

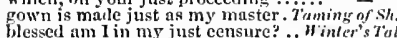

luve a just and olen trial.

your request is altogether just
such power, she hast just chuse

even just the sum, that $Y$ do
ant thou shalt find me just

todo, to the rlirection just....

You may be rightly just, whate

in such a just and eharitalle war ...King John, ii

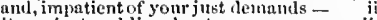

permit our sust and loynd, just, nnd upright geutleman. Richord $M$. i.

for he is just, and atways loved.

ns he is a prince, is just.

holut those justs and triusnitha

when the intent of ly aring the

is very just; lonk, here eonus ifor

the just proportion that we gave

to meet his grace just ilistance i.

grant eff our most just and fight desires
is this proceering just anul honouruble?

your majesty hath no just eause

nur peer, shill have just 'rintise to say

the things I speck, are just ....... i.
is not this just? for I shall sutjer hie

even just between twelve and once.

the linim-song is mont just ..........
just, just; and the men do symipntiz

his c'atuse hein y just, und his quarre

loring ine just nutise of the numblers..
witli full aceord to all our jukt demails

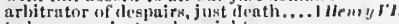

to be a Inan just nowel uprigli

answer of thy just leminti.........

arvied, thut liath his quarrel just.

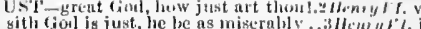
tlyy jumt nond lisk fild aid

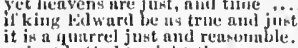

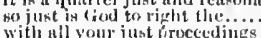

by inst [Col. Kut. trate coinputation.

silys your higliness to iny juet recine-t?

nsurn the just proportion of nyy sơrow?

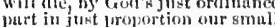

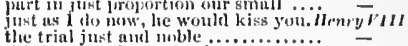

this just and learnel priest

our junt opinions, and coroforts to your
be just, and fenr not: let all the enids

'tis just to euch of them. ..... Trut

but the just gods gaiusay, that uny

just of the same piece is every. Timon
lyy nercy, tis nust just.

go trite, se just, und nuw so

just: tum it is very muchl lament

if the grent godls be jnst .... Antony $\ddot{f}$ Clengutru, it

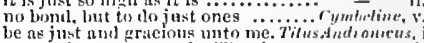

upon a just sirvey, tuke Titus' purt
sill preserse just so muchs strenyth.

anl just against thy heart make

ay, just! a veree in Horare .ii.......

thint my report is just, and full of

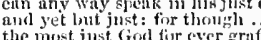

the most just God for evergrafit.

to perform thy $j$ just eoumand.

and slow the lieavens more just

in thy just prost, reperels...........

more just and heary

the gods are junt, and of our pleasant vieces $\overline{\text { just }}$, y.

$\left[k^{\prime} m.\right]$ betiore, aum just ant this deni Tiour. Inamlet

Horntio, then art e'ell as just a man

whether 1 in nny just term am nfined

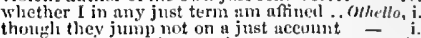

tis to his virtue u just cquinos

I think that thou art just, and think tiour = jii. 3

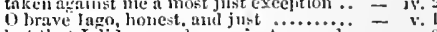

bit thint I did proseed upon just grounds

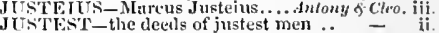

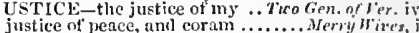

your friend, ant justice shallow

lie's a justice of peace in his country

thiouth we ure justices, and doctors..

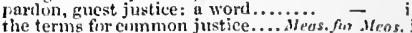

liherty plucks jnstice by the nose.... =
to unloose tlis tietl-up justice $\ldots . . .$.

what's solpen male to justice (rep).....

the wiscr here? jlatice or inigitity?

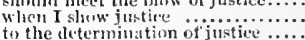

to the determination of justiec .......
but my lorother juttice lave I foud

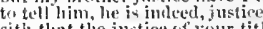

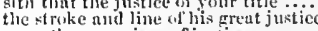

pit the iluke avouch the justice nf your

we henr such goolness of your justite

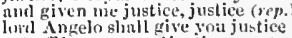

cut uff by cunrse of justice (rep.)

give me the scope of justice $\ldots . . . . . . . .$.
my hrother had but pustice, in that.

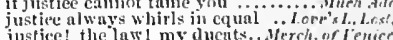

jnstice fint the girlt sle hati...

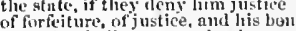

the luke slull trant me justice......

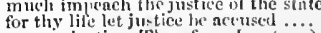

Eensoms justice. Therefure, Jew (rep.

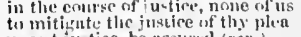

the dew shall have all justlee; solit?

he shall have merely justice, and his

then, the juatine, in fair rouml ...As you

time is the oli justice that cxannines
i knew when seren justices conld not

in the name nf justice, without all

from the wratih ol grentest justice

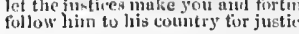

$\mathrm{D} \overline{\mathrm{D}}$ 
JUSTICE-now, justice on the docrs!...All's Well, y, 3 JUSTLE-justle jt from what it .. Love'sL.Lost, v. 2 KATE-shall Kate he my wife?

and the justice of your hearts.... Winter's T'ale, ii. I justles roughly ly all time ot...

$\mathbf{I}$ do in justice charge thee, on ti.....

proceed in justice; which shall have

so thon shalt feel our justice. . .

five justices' hands at it; and witnesse

iii. 2

USTI NG-in such a justling time?.i Henryest, lool 1 -be justly weighed...... Trelfth vight, and justly, as your soui should.... ald.......Much $A d o$, iv. , as you have exceeded... As you Like it, i. which he justly owes him $\ldots . . . .$. . Winter's T'ule, the madman justly chargeth them. Comedy of Er that I may justly say witl

and justly and religionsly unfold........ Henry God justly hatli discovered

hath spoken well, and justly Justly praise ...... Timon of thens, $\mathrm{i}$. 2 by him that justly may bear his.. Tilus Anuron. i. 2 Antiochus you fear, and justly too ..... Pericles, i. 2 if both were justly weighed.

keep thy word justly [Knt.-word's justice] - i ii. 4 let us deal justly ...................... - iii. 6 to what thou justly seem'st.... Romeo \& Juliet, iii. 2 am justly killed with mine own treachery - v. 2 justly to your it is a poison

so justly to your grave ears I'll pres
did justly put on the vouch of very
that thou deal'st justly with me

that thou deal'st justly with me ........ - iv. 2

UT-begins to jut npon the......... Fichard III. ii. 4

to jut [Col. Knl-jet] upon a prince's. T'ilus $A n d$, ii. 1
JUTTING-and jutting out of bums! Timon of $A / h, \mathrm{i} .2$
JUTTY-Do jutty frieze,

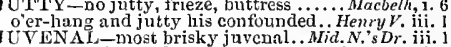
my tender juyenal? (rep.) …..... Love's $\mathrm{L}$. Lost, i. 2 a most acute juvenal; voluble and free - iti. I $\mathbf{K}$

$\mathrm{K} A \mathrm{E}-\mathrm{it}$ is $\mathrm{ki}, \mathrm{kr}, \mathrm{kod} \ldots$

KAM - this is clean kam ............ $\mathrm{K}$ ATE-none of us cared for Kate. Tempest, ii. 2 (song) mistress Kate Keep-down was.. Ncas. for MIeas, iii. 2
O most divine Kate! ............. Love's L. Lost, iv. O most divine Kate! .............. Love's L. Lost, send my daughter Kate to you?

called plain Kate, and bonny Kate (rep.) alas, good Kate! I will not

so Kate will be my lien (rep.)......

but where is Kate? (rep.) ...........

o Kate, content thee ............... they slall go forward, Kate,

nay, good sweet Kate, be merry

come, Kate, and wash, and welcome

will yon give thanks, sweet Kate?

I tell you, Kate, 'twas burnt

I am sure, sweet Kate, this kindness

come, mistress Kate, I'll bear you ..

well, come, my Kate; we will unto....

Ono, good Kate; neither art thon

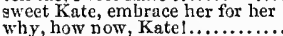

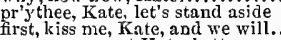

come, my sweet Kate, better .

to her, Kate! To her, widow! ( $\mathrm{rcp}$.)

come on, and kiss me, Kat

come, Kate, we'll to bed ....

I cnre not for thee, Kate

what say'st thou, Kate? ..........

lcave you, gentle Kate; I know ....

so far will I trust thee, gentle
will this content you, Kate?

come Kate, thou art perfect in ....

swear me, Kate, like a lady...

English tongue: do you like me, Kate? IIenry iii.

an angel is like you, Kate ...

or to dance for your salke, Kate

canst love a fellow of this temper, Kate

while thoul livest, clear Kate, take...

the enemy of France, Kate .............

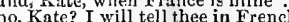

it is as easy for ine. Kate, to conquer

no, 'aith, is t not, Kate ...............

can any of yeur neighbours tell, $\dddot{K}$ atc?

hut, good Kate mock me mercifully

if ever thou be st mine, Kute .......

do but now promise, Kate................

but, in faith, Kate, the elder I wax...
wrell, Kate; it shall plense lim, Kate

moll, Kate; it shall please him
then I will kiss your lips, Kate

o Kate, nice customs conrtsey (rep.)

we are the makers ot manners, Kate slall I swear to Kate.......

go thy ways, Kate; that man ......... Henry $\bar{r}$ rII. ii. Katharing A-both love Katharing

that ever Kutlaarina will be wooed....

satharina, fair and virtuous? ( $r e p$.)

here comes Katharina! what is your

ATIARINE, by good hap ....... Love's $\overline{L . L o s t, ~ i i . ~}$

undertake to woo curst Katharine ...

but for my danghter.

mean, sweet Katharine, in.........

and will have Katharine to my wife

how now, daughter Katharine?.....

my Katharine shall be fine

my danghter Katharine is to be ....

that Katharine and Petruchio should

point at poor Katharine, and say ....

would Katharine had never seen him

if Katharine shonld be his wite......

Katharine, that cap of yours becomes

Katharine, I charge thee, tell these.. $-V_{\text {. }}$

With fair Katharine of France....2

fair and princely cousin Katharine..

fair Katharine, and most fair! (rep.)

I said so, denr. Katharine............

fair Katharine, will you liave me?
therefore, queen of all, Katharine.

therefore, queen of all, Katharine....

in St. Katharine's churchyard .......
between the king and Katharine .Hen
Katharine queen of England (rep.j...
with her, Katliarine our queen......

Katharine no more shall be called queen -

ii. 4

What's become of Katharine , $\ldots . .$.

Henry $V$. v.

that snch a keech can with ......... Henry $\nu^{\prime} I I$. . $_{\text {. }}$.

with keels of every kind ......... Antony \& Cleo. i.

halt the flood hath their keel cut. Perieles. iii. (Gow.)

to clog the guiltless keel............... Othello, ii.

the impression of keen $\pi$ hips........

whin she's angry, she's keen and slirewd _ iii.

some satire, keen, and critical ........

are as keen as is the tazor's edge..... - vo

to pieces with thy keen conceit.......

so keen and greedy to confound a man - iii.

thou makest thy knife keen ........

that love's keen arrows make........

cry thou, amen, to my keen curses... King John, iii.

fits a dull fighter, and a keen guest. 1 Hcury $I V$ iv.

with fortune fierce and keen..Pericles, v. 3 (Gower)

Fotl are keen, my lord, you are keen .. Hamlet, iji.

KEENNESS-half the keenness. Mler. of Venice, iv. 1

keep your cobins

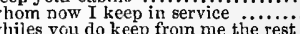

whiles you do keep from me the rest

to keep them living....

heaveos you keep a care ............

and keep hiun tame (rep.)

keep a good tongue in your hea

while thou livest, keep a good ......

and keep it wo longer for my flatterer

keep tane there still,........ Two Gen. of

for that I'll keep nhut.

to keep me from a most

yet I have much to do to keep them...

not I, sir; pray you, keep on .........

for I keep his house ..........

and keep place together.............

as much as I can do, to keep the terms

or else keep it in your arms........

keep a gamester from

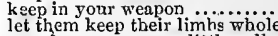

nay, keep your way little gallant

will, at the least, keep your counsel..

wll keep my sides to myself.

$=\quad$ i.

but I can keep my hand dry

ii:

keep you, keep it

what $I$ am willing to $\mathrm{keep}$ in

what a catterwauling do you keep up

we did kecp time, sir, in onr.........

she will keep no fool, sir, till she ....

that keeps you fron the blow........ 
KEF.' -you keep o' the windy side. Foelfis Night, iit. of priny Gokl, lie keep lis outh

kecp me imtion kes ne.................

and night did we kece coumung

you do not keep promise with nin

we intended to keep in larkness.

those swenrings keep ns true in soiil.. - v.

and wituess bruvery keeps

and let it kecp one sliape

henven keep your honour $($ (rep. $)$. ......

eren so? henven keep your hon

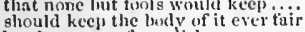

but keeps you from dishonou

but kceps you trim dishonour ......

rour will keep the house.

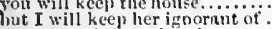

tire matter being ntoot, keep your...

favours tlant kecp witliu

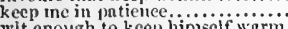

wit enough to keep hinself werm....

God keep your ladyship still in...
but kecp your way o' God's nume

and God keep him out of my sight

it keeps on the windy side of care.

keep your fellows' eounsels und your own

what paee is this thut thy tougne keens"?

God keep your worship.

shall I al wnys kcep below stair

keep promise, love: look, licre... Mili, N.'s Dream,

kecp word, Lysnnder: we mu

the king dot heep his revels.........

renson and love lieep little company

Lysantler, keep thy Jlermia

Demetrius, I will keep my wo

my leas can keep no pree with

keep those statutes thint are recorde

to your deep oath and keep it
barren tasks, too hard to kecp

eonfident f'li keep what I have swore

I am the last that will last

theep her as a vessel of th.

I must keep her at the park

dearlly sin to keep that oath, $m y$ lord

and keep not too long in one tume

that kecps here in court

then thou wilt keep my tears for -

to keep down his henrt

entirely keep the brain.

Fe lose ourselves to keep oir

keep some state in thy

ifell, keep me eomprny ........e.

if thou keep promise, I sliali end

to keep ohliged fuith unforfeited l...
let good Antonio look he keep his da

IIl keep my onth, patieotly to bear. -

good enough, to keep his nime corripa

which I did make him swear to keep
that whiel you did swear to keep for me
and bid him kcep it better than ....

swear to kcep this ring...

he keeps me rustically at home..... ds you Lik

shall I keep your hogs, and ent hiusks

and so, God keep your worship?

nay, if I keep not my rank.......

if you do keep your promises in

thy palm some moment keeps ......

nny. you might keep that eheck for

the house doth keep itself, there's no

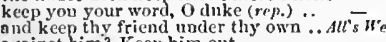

agranst him? Keep him out in eanon: keep it not.

this hovestly; keep it to yourself..

and to keep them on, have them stili

and will keep him mutlled

ever keeps n gool tire................

on your just proceedling, I'll keep oft

keep house, nnd ply his book..........

iil ony stead, keep house, and port

for in Baptista's keep my treasure

her father keeps from a

Gremio to keep you foir .............

tos; keep you warm. Neplin from stmmling, ho hat

I am come to keep my word

with the elamour keep her still awake
that I may surely keep mine oath .
keep your lumdred jounds to yoursel

keep your hundred pounds to yourself -

at feasts, keep with Bohemla

I'll kcep my stables where I lod fe.

creatures of prey, that keep upon't... -

these keep sceming, and savour, all the

to kecp niy pack from fasting.........
therefore I keep it Jonely, njart.......
your money that 1 liad to kecp.. Coind

your money that l had to
makes you tu keep unwed

kecp then fair league nurl truec wi....

Dromio, keep the gate; husband...

olirewish, when I keep not liour

you would keep from my heel

that keeps all this noise?

that Adlam, that keeps the
go, keep 1 s eompany, and
KEEl'-nor keep peace between thes a fic

sliall keep us both the sutior.

wc will keep ontrself till suljer-tinic.....

why do you keepolone.

that great bond which keepis nie jable

our lostess keeps her kitate.

pruy you, kcepseat; the tit is

and keep the natural ruby of your.

it it be mine, keep it not trom une.

and still keep eyes upon hc

tyrant keeps still in Dunsinnue...

that keep the work of promise

unless thou let his silver water keep

so peremptory, as we to kcep this eity

and fitith mounts up: keep my riced up

than keep in penee that hand

to keep what thom dost swenr.
llubert, keep this boy; Plilip

and I'll keep lim so. that he.

so I may kecp mine

my sonl, and Eugland keej ny bones?

keep the pence, I say .........

now keep your holy word.............

and keep our fiiths firm

well; keep good quarter, ant good eare

and I, to keep all this. Norfolk......
what stir kceps good old York there

wath power to keep you king............

of a king, keeps death his eourt...

my legs enn keep no mensure........

that I may loogest keep thy borrow

to kcep him safely till his day.

will keep a league till deuth

to take on me to keep, and kill

We'll keep him here; then whit

to his own use he keeps ....

I'll keep them all by heaven
I'll keep them, by this hand

those prisomers you slaall keep

what a brawling dost thon keep?

him keep with, the rest banis

whus did I keep my person tresi

do you think I keep thieves in

must kecp aloof from strict arbitrement

should keep his word in low

two stars keep not their motion in ..

ath las fitle life?

who kot nature's hand keep the

he moty leep it still as a face-royni..

since all is well, keep it so

what's the mntter? keep the neace

in the world keeps the road-way

and keep no tell-tale to his nemory

from eoemies heaven keep your

to keep prince Harry in eon tinual

the heavens thee guard and keep....

doth keep in one encent ...........

nor sinall my Nell keep lodgers.......

will be thouglat we keep a bawdy-lo
we keep knives to cut one another

let houscwifery appear, keep elose

but keeps the pridure most valiantly

he will the pridgte most raliantly

kecp thy worl: fure thee well

what watch the king keeps to maintain

yet keep the Freneh the lield......

God keep me so! our heralds.

is it fit this soldier keep his oatl??

that he keep his vow and his oat

blunt benring, he will keep his wor.

keep it, fellow; and wear it for

God be wi you, and keep yoi

keep it from eivil broils! ...........

to kecp the horsemen off troin

to keep our great St George
harrly keeps his men from
sinec he leeps no meall....

nun keep me on the side where.

but keep my wonted ealling?.

as an out law in a castle keeps .......

peasant footboys do they keep the wulls -

henvens keep old Bedford sate

diseord keep nwing the levied

to keep them here, tlicy would bist.

nnd kcep not back your no

I'll rather keep that which I hare.

and keep the Frenehmen in

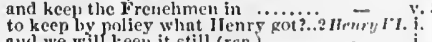

null we woll keep it still (rrp.)
l'll kecp my drenms unto ny seli.

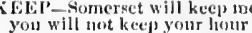

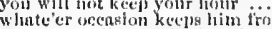

to kees, until your turtleer time of iriul =

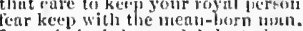

forkeoth, liat the grod duke to heep

be pray-fellows to kecp you com lanyl = iii.

to kecir the from the teringest

hat keces his lenves in spite.....

keces thou the najkin, ancl go bonst

bow true he keepa the wind!

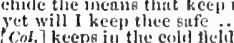

to keep them lnate tlat come

bones may keen thine company.

and with thy ligs kecp in iny roul

but keep our course, thougl l the

but I will not kecu her lon."...

$O$ let then keep it, till thy sins...

it beggars aby mant that kecps it.

keep you from them, and auth ( $(\mathrm{rpp}$.)

now, 1 tell the (kecp it to thyseif

God keep [Col,-bless] the prioce fiom all -

devised at first to keep ths strong regiment -

and keep it trom the earth

or Clutbarius, they keep stute sin....

gou are one will keep it from us:. ......

pray you, kecp your way.....

to keel mine bonour from colrujtion

kep comfort to you; num this murning

that keeps Troy on foot

k will keep where there is i.

why keep we her? the Grecians keep

stolen what we do fear ro keell?
in resolution to keep Ilelen still

the hart Aelialles kecps thinket.

to leep her constaney in plight.....

keep theo the path; for emulation.

keeps place with thought.

place of the field doth Calchas keep?

and keps the tent now? The gurgeon's

and garing me to keep au oath that

to Calehas' tent; I'li keep you eomisan

of the monn, when Diomed keeps his

here, Diomed, kecp this sleer

yet it is not; I will not keen my.....

mine honour keeps the weat her.

shall we in? I ll keep you company. Timon of Ath.i.

that keep their sounds to themselves

fortmes, keep with you, lord Timo

fond my lords, keep on; r'll wait .

who camnot kcep his weulth, nust keep -

nd keeps his chamber. Many do keep -

kect't I gods keep you old enough

beeayse thou dost not keep a dog ...

thoul hadst eome means to keep a dog

yet an arelı villain keels him company

deseend, and keep? your worls

to keep your grent protences veilai...

and keep your honours safe:

the field, we ennuot heep the town

nay, keep your place ................

I'll keep you eomyany

to kcep him here, our eertain clintli.

honoured gols keep Rome in safety

now the gods kecp you

speak, 1 'll keep at home

tenuper.....

kecp us all in servile fearfulnes ....

to keep his state in lome, as easily

to keep with you at nieals

call it my fear, that keeps you .....

coustant alo remain to keep him so

but keep the hills and ujperr regluns

eome now, kecp thine ontly

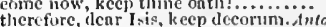

not say, 'tis I that keep you here....

keen his hroin fuming

llyy spirit whirlt keeps thece is nuble

goud madam, keep yourself within

keep off then, tor you sink

so, the gods kees you, and innk

vou kcep by lund the lections

bat we k(c) whise hy lated

ii.

iii.

iii.

-

ii.

iit.

iv.

$\because 2$
$\because 2$
$i 3$

i.

i.

iii. 2

v.

1. 1

ii.

iii. ?

, i. 3

i. 3

ii.

ii.

iii.

iv. 1

$v$

$\mathrm{v}$

i. 2

ii.

iii.

iii. 5

iv.

$r$. 


\begin{tabular}{|c|c|c|}
\hline & & \\
\hline & & but keeps due on to the Propontick.... - iii. 3 \\
\hline & & kecp thin monster from othelio's mind ! - iii. 4 \\
\hline love....... & - & 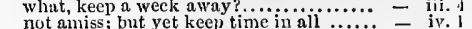 \\
\hline their graces, I will keep.... & $\begin{array}{l}\text { l. } \\
\text { i. } 5 \\
5\end{array}$ & 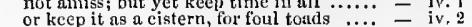 \\
\hline -chamber & - & and kcep the gate of hell $\ldots . \ldots \ldots \ldots \ldots \ldots$ - iv. 2 \\
\hline ber & ii. 3 & turn tlic key, and keep our counsel ...... - iv. \\
\hline goutl sir & ii. 4 & 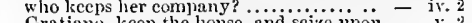 \\
\hline murried to that your iliamond; I'll kecp - & - & Gratians, kcep the house, and scize upon \\
\hline$\cdots \cdots \cdot=$ & ii. 4 & KEEP-DOWN-Kate Keep-down. Meas. for Meas.iil. 2 \\
\hline c......... & $\begin{array}{l}\text { iii. } 1 \\
\text { iii. } 3\end{array}$ & 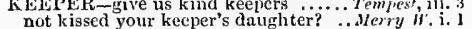 \\
\hline nd keep their impious - & iii. 3 & ndsor forest.... \\
\hline uncrossed .......... & iii. 3 & don Armado shall be your keejer ...Love's $L_{\text {. }} L_{\text {. }}$ i. i \\
\hline & iii. 3 & the apc his keeper, the tircd horse.... - iv. 2 \\
\hline ce still & iii. 4 & and know her keeper's eall ....... Taming of Sh. iv. I \\
\hline .... & v. 1 & 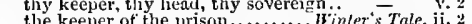 \\
\hline bicatli; which neithe & $\begin{array}{l}\text { v. } 3 \\
\text { v. } 4\end{array}$ & 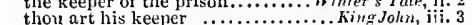 \\
\hline keep then this passage to the Capitol. Tilu & d. i. 1 & a parasite, a keeper lack of death... lichard II, it. \\
\hline & & fire out of his kceper's arms..........2Henry iv. i. i \\
\hline 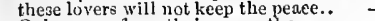 & ii. I & the temnis-court keeper know's ...... \\
\hline & ii. 3 & kecpers of my weak decaying $\ldots \ldots \ldots$ Henry $V I$. ij. 5 \\
\hline & iii. 1 & but tell me, keeper, will my.. \\
\hline eep? & 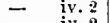 & kecpers, convey him hence $\ldots \ldots \ldots$ - \\
\hline & iv. 2 & then in London, keeper of the king...3 Henry $r$ I. ii. I \\
\hline $\mathrm{I} \mathrm{k}$ & iv. 2 & whose skin's a kceper's fee $\ldots . . . \cdots \cdots$. iip. \\
\hline re... & iv. 2 & I pray thee, gentle keeper, stay \\
\hline & iv. 2 & where art thou, kecper?... \\
\hline that god & $\begin{array}{ccc}\text { v. } 1 \\
0\end{array}$ & a kceper with my fieedom.. Timon of sth. i. 2 (grace) \\
\hline e keeps. & v. 2 & when gonty keepers of thee cannot.. - iv. 3 \\
\hline ep her still, and men & & 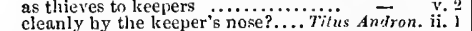 \\
\hline t. iagit & i. 1 & 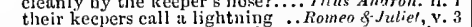 \\
\hline $\operatorname{light}$ & i. 1 & KEEPETII [Col.-keeps] in the ......3 Hewry II. jv. 3 \\
\hline clear keep high & - & ith moon-like.L \\
\hline u returu... & i. 2 & or keeping wlyat is \\
\hline & ii. (Gower) & keeping safe Nerissa's ring ........Mer \\
\hline & ii. 1 & itleman ...........As you Like if, i. 1 \\
\hline & ii. 1 & deam............Alls s ell, iv. 3 \\
\hline & & es not keeping of oaths .... \\
\hline & & is in the kecp \\
\hline & iv. & .......llemrylV i. 2 \\
\hline keep & - iv. 3 & and keeping such vile company $\ldots .2$ Henry $1 \mathrm{~F}$. ii. 2 \\
\hline s, which I'll keep from bonst... & - $\begin{array}{r}\text { iv. } 6 \\
\text { v. (Gower) }\end{array}$ & $\begin{array}{l}\text { I'll forswear keeping house.......... } \\
\text { keeping them prisoners undernenth.1 Henry } Y \text { I. }\end{array}$ \\
\hline ... Lear & 2 (Istter) & for kreping my house, and lands ....2 Ilenry VI. i. 3 \\
\hline ..... & i. 4 & take order for her keeping close \\
\hline & i. 4 & th keeping? \\
\hline $\bar{k}$ & 4 & in honourable keeping her. \\
\hline ster & - & Alheris, i. I \\
\hline & $1-$ & olanus, v. 2 \\
\hline & 1 & y. 2 \\
\hline pig & 4 & iii. 5 \\
\hline & & KEEP'ST-wl \\
\hline & & Taming of Shrew, ii. 1 \\
\hline t & ii. & , Cometly of Err. ifi. 1 \\
\hline & ii. 4 & ary $I V$. ii. 4 \\
\hline & ii. 4 & ii. 2 \\
\hline & & that ke \\
\hline an & & $r y$ VI. v. 6 \\
\hline & iii. 2 & d III. iv. 2 \\
\hline & iii. 4 & $\begin{array}{l}\text { elf } 1 \text {... Cymbeline, iii. } 6 \\
\text { ney ....... Olkello, iv. } 2\end{array}$ \\
\hline I will keep still with in philosopher... & 二 $\begin{array}{ll}\text { iij. } \\
\text { iii. } 4\end{array}$ & $\begin{array}{l}\text { keen'st from me all conveniency ........ Olhello, iv. } 2 \\
\text { KEISAR-Keisar, and Pheezar .... Merry Wives, i. } 3\end{array}$ \\
\hline Edmund, keep you our sister company... & $\therefore$ 二 iii. 7 & KEN - I ken the wight............... \\
\hline & iv. 6 & in a ken, our \\
\hline & & thy clialky..2nenry 1. ifi. 2 \\
\hline & 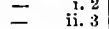 & er....Troilus \& Cressida, iv. 5 \\
\hline & 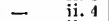 & eline, ii \\
\hline & & 1ry 15 \\
\hline & ii. 4 & TH] - \\
\hline & & VI. iv. 4 \\
\hline & & iv. 4 \\
\hline 7010 & & . Meas.for Meas. ifi, 2 \\
\hline & & of Sh. iv. 3 \\
\hline & - & Herry YI iv. 2 \\
\hline & & 1 \\
\hline & & lII. iv. 4 \\
\hline & & hat must to kennel \\
\hline & iv. & Kent \\
\hline & & alt Kent hath yielde \\
\hline & & 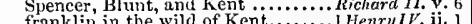 \\
\hline & v. 3 & 1 \\
\hline earc & & nind seum of Kent \\
\hline
\end{tabular}

micaning to keep her closely at my cell
kecp you in the rear of your nffection lesson keep as wateclunan to my heart . and you yoursclf shall keen the key of it
leeeps wrassail, and the swamgering... aull where they keen, what company but keep a tarm, and carters ....... with a crafty madness, kceps aloof the rest shail kcep as they ere the players eannot keep couns to keep those many many bodies safe to keep itself from noyance
doth templerately keep time

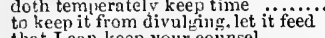

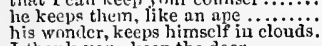
I thank yout: keep the door wonlld you do this, kcep close within he will kcen mint water a great while
ston a linle to teeep the wind away

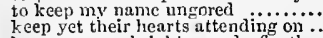
keep up your brights sworlds, for the dew

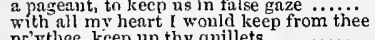
pr'y thee, keep up thy quillets ...................
on nourishing dishes. or keep your warm apprehcnsions keep leets, and Yaw-days.

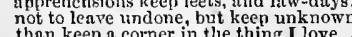
not to leave undone, but keep unknown
lie eonjured her she shonld ever keep it. you men of Kent (rep.)......

\section{Kent to mnintain, the kin}

ii. 1 Alcxander Iden, an esquire of Kent

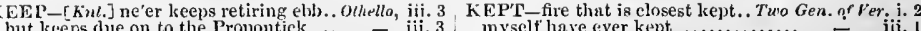
and kept severely from

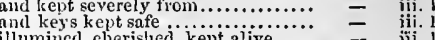
illuminch, cherished, kept alive he kept not time ........................ Merry $\bar{W}$

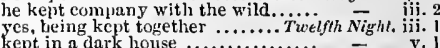
umless they kept very good diet. Mleas. for Meas. ji. 1 let her awhile be seerctly kept in..... MuchAdo, iv. I cur, that cver kept with men ...Mer. of Venice, iii. 3 have been respective, and have kept it
no face be kept in mincl. As you Like il, iii. $\overrightarrow{2}$ (verses)

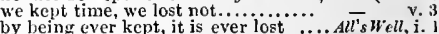
the longer kept, thic less worth ....

the wars have so kept you under.....

I have kcpt of them tame, and know = ii. may be kept on eitlier hand.. Taming of Shrew, ii. the sactdler had it, sir, $\mathbf{Y}$ kept it.. Comedy of Err. i. 2 not that Adam, that kept the paradise - iv. 3 fittlicr might have kept this calf ..... King John, i. 1 that droth make vows kept ............ = iii. shall our fcast be kept with $\ldots \ldots \ldots \ldots$ - iti. ont of prison, and kept sheen, $\mathrm{I}$ should
grief hath keyt a tedious fast ...... Richard II. iv. and hardly kept our countrymen..... - ii. is troke, and no proportion kept!.... had still kent loyal to possession..... proceedings, kept the earl from hence 二 iv. conld be kept trom cankers!........2Henry $I V$. ii. 2 a mere hoard of gold kept hy a devil - iv. those that kept me company ......... $=\mathrm{v}$. ever kcpt together, as two ............ Henry $r_{\text {. ii. }}$ maids, well-summered and warm kikept -

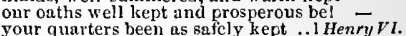
your quarters been as safcly kept ...1 Henry VI. ii. and would huve kept, so long as breath

who kcpt him in captivity

would have kept my word he inight have kept that glory.......3 Henry $/$ ' 1. if. and kent low shrubs fiom winter's.:. Uhe hath kept an evil diet long.... Richard III. a holiday shall this be kept hereafter = preserved, chertshed, and kept that might have kept that title....... long kept in Bretagne at our ......... I have kept you next my heart....... - iii. 2 as if we kept a fair here .............. - . shouldst have kept one to thyself. Timon of $A t h$. i. ard kept his credit with his purse .. $=$ iii. 2 all that 1 kept were knaves........... - iv.

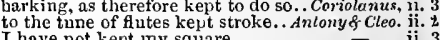
I have kept me from the cup.......... he, at Philippi, icpt his sword even what linve I kept hack? Enough to = v. it shall safe be tort Livia.......... Cymbeline, $\mathrm{i}$. have I kept it to a worthy end ... Titus Andron. iii. I would lave kept such a jangling of.. Pericles, ii. it kept where I kept, I so dearly ...... \& suliet, $\overline{\text { i. . }}$. kept witlout my food, whipped.. Romeo o Julet, being kept close might move more $\ldots \ldots . .$.
whose providence should lave kept short $=$ ii. I
iv. I that earth, which kept the world in awe $=\mathrm{v}$. KEPT'ST-thou kept'st a wife herself. All's W Well. $\mathrm{Y}$.

KERCHIEF-a plain kerclief ..... Iterry Wives, iii.

a hat, a muffler, and a kerchief........ iv. - iv KERNE-of kernes and Gallowglasses...Macheth, i. compelled these skipping kernes to trust -

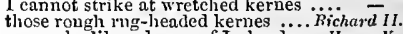
you rode, like a kerne of Ireland.... Henry $V$. iii. himself against a troop of kernes.... - ii. in - iv. 9

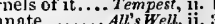
there ean be nn kernel in this.

and sweetcr than the kernels.. Taming of Shrem, ii. I I then was to this kernel. ......... Winier's Talc, i. KERSE Y - of an English kersey ... Meas. for Meas. a kersey bont-linse on the other.. Taming of Sh. KFTT KETCIE-DRUM and trumpet thus bray $\mathrm{KEY}$ - having bnth the key of .......... Tempes

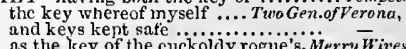

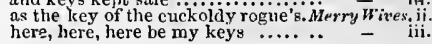


KEY-turn you the key, nnd know..Meas. for Meas. i. his npening with this bigger key

give up your kcys....................... they say he wears a key in his ear . Oifil. $\bar{N} . D r$. one sonn, botls in one key ........... trke that key, give enlargement. l. and in a boulman's key ......... H there nre my keys:-hut wherefore.. give me n key for this, and instaintiy सilis ii. to cominul the key of nil . irinkers I would have filed kers off, that liumg give her this key, and tell her.. Comedy nf firm, iv.

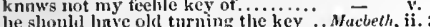
he slould have old turning the key ....Aacbeth, ij. Dunean's sous under lis key...

and bunches ot keys at their giolies. 2 Inenry

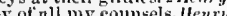
done so, bring the keys to me were the keys of Normandy but y Illenryts illenry I' nn aceent tuned in selt-snme key. Troilus \&. Cro the keys thmt lock up your restraint. Cymbetin who is the key to unbar these locks.
there's my key: if you do stir nbroad

neer turns the key to the poor

knid, gond porter turn the key........ vou, yourself shall keep the key of it.... Ilumlet lock nnd key of villanous secrets ....... Oll KEY-IIOl, E-out at the key-holc. As you l, ike KI - it is ki, ka, kod: if you foryet..Merry wines, iv. why then, let kibes ensue.......

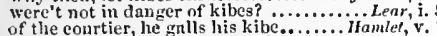
KiCk-she feels her young one kick..... All's $\|^{\prime} p l l, \mathrm{v}$. I should kick, being kieked.. Comrdy nf Errors, iii. I KICKED-kick, being kicked. Comediy of Error,

our spoils he kicked at

she kickel the poor king her fither....... Lear, iij. pretty little tiny kick-slaws.......2 Henry I $\mathrm{r}$. $\mathrm{v}$.

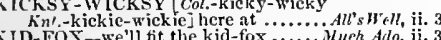
KIDNEY - a man of my kidney ... Merry Wives, ii. KIIDARE-Kildarc's attrinder.... Henry $\bar{V}_{\text {fII }}$. ii.

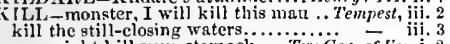

yall might kill your stomacl.. Tüo Gen. of rer. i. 2

and kill the bees, that yield it...

I vill kill de Jaek Priest................

he knew your worship would kill him

herring is no dead, so as I vill tell you hou I vill kill him....

by gar, me vill kill de pricst .......

that is, kill him whom you ...... Toelfh Night, ii.

if it be thy chance to kill me - iii. 4 (challenge)

that they will kill one another

nnd fear to kill a woodcock............

we kill the fowt of season. Mensure for Mens

kills for laults of his own liking

some Cupid kills with arrows

kill Cupia

you kill me to deny it

you ges on thus, you will kili yourseif -

et him kill one first.

hast mettle enough in the to kili care

a liver, that kills himself most. $\because$ irit. $N$,

some, to kill cankers in the musk-rose

stay, though thot kill me, sweet

plunge in the deep, anil kill me tno.

- 'lien trith kills truth,

spurn me, nay, to kill me io

apurn me, nay, to kifl me too........

fi) Pyramus thercin doth kill himele

like Irelen, till the fates me kill

now mercy gues to kill. than purpuse. mennt to kili..............

my lasly goes to kill harns

will kill the speaker's leart.

do all men kill the things............. of $\overline{\text { Venice, iv. }}$.

the thing he wonld not kili? ........

the animals, and to kill them up....

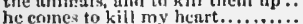

now let them kill thee

might kill me. By this hand (rip.)

that dirl on oft contrive to kill him?

I will kill thee $n$ liundred and fifty...

though I kill lim not. I am ..........At's $\bar{b} \cdot$ ell, iii.

the first view shall kill all repetition $-\bar{v}$.

this is a way to kill a wife

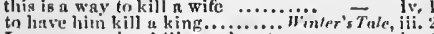

I pray you; that kills my heart

for then you kill her lonble .........

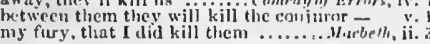

KIl.I-to kill their graeious futher? find what 'twere to kill a father

but thou hadst none to kifi hion.

if thon didst kill this child

dost seck to kill my name $\ldots . . .$.
be fenred, and kill with looks......

to keep, mind kill thy heart
strive to $k$ ill it witl n $\mathrm{n}$ ror

to kill the king at Oxforl

le that kills me some six or seven ... Ineury $H$. ii.

was it for me to kill the heir apparent?
with his pistol kills $n$ sparrow tlying
I will kill all his coats ...............

he it indeed; nnd living to kill the

wilt thou kill God's afticers.

first thrust, I'll kill him ....

to kill us here in llampton.......

then every soldier kill his prisoners.

kill the poys and the luggage.
kill his pest friend, Clyttis.

as Alexunder is kill his friend

mnny wounds, when one will kili...i Itenry $/$ \% ii.

nh Joant this kills thy father's...... -

and kill the innocent gazer

would enrses kill, ns doth

jiccnec ta kill for a hundred

kill and knock down! throw
when I command them kill?

with the chnne to kill nud
for enemies, but princes kill

for enemies but princes kill .........

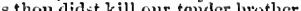

I'll kill my horse, because

murdered where I should not kil

$O$ kill me too! Marry, and shall

nh, kill me with thy wenpon

I did not kill your husbaud.

for now they kill me with a living.

then bid me kill myself, nnd $y_{\text {will }}$

did kill thy love, shall for thy (rep.)
thou whet st a knite to kill thyself.

not to kill him, having

persuading me not to kiti the duke.

to kill a friend of mine? (rep.) $\ldots . .$.

thou didst kill hims; I had (rep.)

till death, that winter, kill it ...... Henry $\bar{F}$ II iv. seems the wound to kill. Troilas 6 -Cress. iii. I (song) the thing lie means to kill

sleep kill those pretty eyes

for I'll not kill thee there, nor there

I'll kill thee everywhere $\ldots \ldots \ldots \ldots . . .$. iv.

that then thou might'st kill 'em

to kill, I grant, is sin's extremest... - iii. 5

if Alcibiades kill my...

let us kill him, and we'll

kill, kill, kill, kill, kill lhim

and kill him in the slell..............utines Cops

burn

wilt kill me straight; kili Brutus

I'll rather kill myse

to kill kill all our womien.

women ..... Aniony \& Cleop

since my beemings kill me

that kills and pains not?

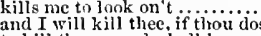

to kill the marvel, slall be so ever

bringing me here to kill me $\ldots . . .$.

first, kill him, nnd in her eye

if you kill me for my fail
for friends kill friends

with thine nwn hands kili

nh me! this abjcet kills me!
if they dirl kill thy lusband

girl, kill it with groans.....

we can kill a fly, that comes

as kill a man, or else devise....

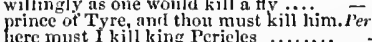

here must I kill king Perieles

ean as well influme ns it can kill
why will yom kill me? To satisfy...

that winter kills the flie

do, kill thy physician, and the fee.

prevent the fiend, and to kill vermin.

they kill us for their sport

these sons-in-law, then, kill, kill (rep.).

I shonll kill thec with mueli elierishing -

for one wonll kill the other

twenty eould hut kill one life $\ldots \ldots \ldots \ldots$.

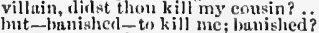

Tybalt would kill thee.............

in my eell there would she kili jierself -

flnds menns to kill your joys with love! -

to kill an mapital a eair there ............ Ilume , iii.

as kill a kinc, and marry wili liag (ifp.)
KILI,-kills the unseen good old mnn ... Humlet, iv. I fle aldition, whose want even kills me. Othello, iv. kill men i'the tark

and I will kill thee, and love thiee nfter.

if you say so, I hope you will not kill mi

initurat kills for loving

Il hill myselt for erive

et liin not pass, but kill hio..........

if that thnu he'st $n$ devil, I cannot kili thee--

this lack-love, kill-courtesy......Mid. N. Wrenm,

would liere lave killed your bin.

J killed a mon, whose death .. Two 6 o

for geese he liath killed.

killew my deer, anil broke........

I think you have killed
hatl killed the flock of

that killed lusty Pudd
killed and cnten in tlie

thou hast killed ny child..

you have killed a sweet louly (rep

that Pyramus is not kilicol incied.

the deer the prinecss killed, a pricket

whose elub killied Cerjeru

if killed, hut mic dead that

which is he that killed the deer

lie have that killed the deer?

I killed a man and forought (rp.). . All's Well, iii.

by my regard, but killed none so.. Winterstale, $i$.

killed! slic I killed? I clisl so

but killed itself' mueh sooner

thrt was killed for the prodigai . Comedy of $F$ r

scotelied the snake, not killed it
l.leance killed, for Fleance fled

he has killed me, motlier

my wife killed too? I have suid...

wilied to-night on your

tome sleeping mince?

how many linst thou killed

why, Pcrey I killed myscif

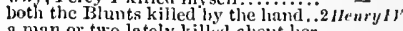

a man or two lately killed about lic

the king hath killed lis heart ......... llenry

own caunsel is suppressed and kilied

heast lived, was killed liunting him

you that killed young Rutland

conflict I mawares liave killed...

was lined, was eanght, and killed

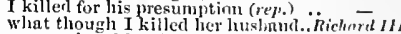

revenged on him that killed my hiviliand-

my brother killed no man, his fauit

till a Riehard killed lim (rep.)....
lic is dead, that killed my Eilwril

if I have killed tlic issue of your womb
wouldst be killed by the borse.

killed $\mathrm{my}$ son

cven with the swrod that killed thee. Jul. Co sos

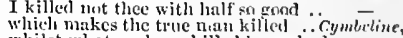

Whilst what we have kilicd le cook

I have killed thy mistress: peace!

im Postlumus, that killeri thy danghter -

than hind he killed ne dead.. Titus.dudronic

beenuse they killed her liusband.

at that that I have killed, iny lord.
nlas, my lord, I have but killed a fly

merry; nud thou hast killed him ..

empress' Moor; therefore I killed liim

You killel her husband.

killel her, for whom my tears

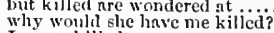

never killed a monse

I kilied theat rage yoll sec, is killed Lel

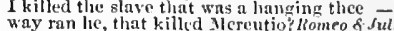

Fonco, thit killed him, he is bnnished -

well of him that killed your eousin?

distressed, lated, mortyred, kiliedi.

dend befrie, Warm and new killed

wed the seemsl, lsat wha killed thie tir

tis draw apret the holy he linth killed

lie that hath killed my kin

I um juatly killed with mine own

my lord, lus killed nyung Venetinn.... othelto

billedl and Cassio killerl? (1ep.)...

the Moor lins killed my mistress

test innocent

he's gnne; but lis wite's killed 
KISSED-I kissed thee, ere I killed thee.. Othello, v. 2 ,
KIILEN-strive to killen bad .. Pericles, ii. (Gower) KILLEST-thou killest me ..T Tuely? $N$. iii. 4 (ehal.) if thou killest me, boy, thou shalt..... Mruch Ado, $\mathrm{v}$. 1 villain, thou killest thy nistress. Antony \& Cleo. 1i. 5 Kf t. ETH - that killeth me......... Henry $5 T$. i. we must leave the killing out...Mid. N. Lream, ii. 1

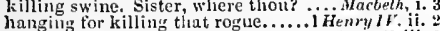
haguth a killion tongue................ Henry $t . \mathrm{iii}$. killiug their tiut with frowns?

ivi. 5 at their masters, killing them twice - iv. 7 killing all those tliat withstand ....2 Henry $/$ I. iv. but to be damned tor killing him .. Rirhard III. i. 4 comes a frost., a killigg frost ........ Thon of Athens, iv. 2 that, by killiug villains „.... Timon of Ahens, 1v. killing our enemies? the blood he.. Coriolanus, iii. or butehers killing flies............... only in killing ereatures vile......... Cymbeline, v. 5 though grieved with killing griet.... killing that love whieh thou .. Romeo \& Juliet, iii. 3 I would have him nine years
talk you of killing?. Ay, $\mathbf{l}$ do

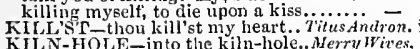
KILN-HOLF-in to the kiln-hole.. Merry Wive Gning to bed, or kiln-hole....

KIN he comes, one of thy kin ..... Tuelfih Night, $\mathrm{i}$. what kin are yout to me?............... my sword and yours are kin...........All's Irell, the oraele, kin to Jove's thunder. Win

no not our kin, far than I will show thee to ny kin .............. King John, wars slath kin with kin, and kind.. or any of my kin, und y'et I love him
those that are kin to the king ......2Her: ${ }^{2} I r$. ii. nay, they will be kin to ns even sueh kin as the parish heifers

so little kin to the purpose
slaugliterman to all my kin

kin to me, theretore slie's

Hemry $r$ iii.

seem all affin'd and kin

nokin, no love, no bloor

the eombitants being kin, hai

daughter have 1, no kin else... Tim

nis those kin, whieh, in the bluster.

is lic thy kin? thy friend? (*cp.).... Cymbeline

what lim thon and thy daugliters

the stock and honour of my kin.. Romeo \& Juliel,

more than kin and less than kind....... Hamlet, $\mathrm{f}$.

compounded it with dust, whereto 'tis kin -

Words and performances, are no kin ... Othello,

for nokind of traffie would I admit

- ii.

who, in this kind of merry tooling

a kind of, not of the newest...

some kinds of baseness are nobly .......
erown what I protess with kind crent

erown what I profess with kind crent
give us kind keepers, heavens! ......

a kind of exeral kinds have done...

one of their kind, that relish

and here is writ-kind Julia.

he is a kind of cameleon

even in kind love, I do.......

my master is a kind of knave............

we dare trust 5 ou in this kind

is she kind, as slie is fuir?

good-morrow, kind sir Eglamou.

an honest. willing, kind reilow.......

or any kind of light........

not have your distemper in this kind

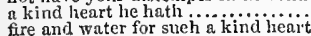

I have a kind of alaerity in sinkin

she will admit no kind of sut..... Fecelfth $\mathrm{N} / \mathrm{g} / \mathrm{t}$

at these set kind of fonls ........

sometimes lie is a kind of puritan

and, witl a kind of injunetion.

craves a kind of wit .....................

I have heard of some kincl of men

tempests are kind, and kalt waves ..

there is a kind of eliaracter...

hath yet a kind of medieine

your sin of heavier kind thian his....
is't not a kind of incest, to take life.

and still forfeit in the same kind?

to be aged in any kind of course

nay friar, I am a kind of burr $\ldots \ldots . .$.

$O$ most kind maid, it was the.

a kisd overflow of kindness ............

do solicit you in that kind, you know

intend a kind of zeal both to the

what kind of catechizing call you this?
EIND-awaked in such a kind, both...Much Ado, iv but, in this kind, wantin be kind and courteous to this gentleman are bred out of the Spartan kind ....

they ean do nothing in this kind..

the best in this kind are but shadows a kind of insinuation, as it were.. Love's L. I.ost, iv in the doing of the deed of kind.. Mer. of Venice, $i$. will turn Cliristian; he grows kind. is a kind a kind of taste

the pateh is kind enongh; but o hinge a kind of luastard loope (rep.) ......... more kind than is her custom to a youth, a kind of boy ............. and with a kind of umber smireli... and in that kind, swears you do more the profit, and this kind of life.....

of what kiod should this coek come of

if the eat will after kind ........ - iii. 2 (verses) thy youth and kiod will the $\ldots .$. - iv. 3 (letter your cuckoo sings by kind ... All's $W^{\circ}$ ell, i. 3 (song) fare thee well, kind maid; thy pains

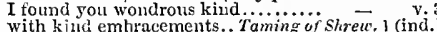
with kind emhracements.. Taming of shrew. 1 (ind.)
it is a kind ot history .............. -2 (ind.) I will be very kind, and liberai.............. discreetly in ali kind of companies. affords notling but what is kit........ wath such a kind of love, as might . Inter's Tale, i. of that kind our rustie garden's barren = iv. so rarely kind are as interpreters. drew me from rind embraenents... Comedy of $\mathrm{Err}$ i.

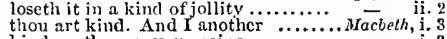
kind gentlemen, your pains.

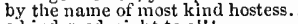

akind good-night to ail $\ldots . . . . . .$.

this seizure, and this kind regreet? ${ }^{\text {. King }}$.

we had a kind of light, what would. - iii.

I have a kind soul, that would give... - v. 1 but in this kind to eome
do abet him in this kind

do abet him in this kind ............

I send to her my kind commends....
to his gentle liearing kind eommends

and kind witl kind confound...

they find a kind of ense, bearing
kind unele York, the latest new

shall hear in sueh a kind from me... 1 Henry $I V$. i. 3

and, kind cousin, - O the devil tak.

but for sweet Jaek Falstaft, kint Jaek

breed a kind of question in our

shows the ignorant a kind of fear...

my father. in kind heart and pity

as I take it, a kind of lethargy

a kind of sleeping in the blood

but thou, like a kind fullow.

they form into a kind of male

all my heart, kind master Bardolph

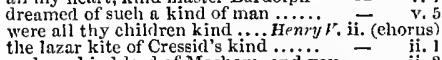

and $m y$ kind lord of Masham, and you

liath loft a kind of biot, to mark

still be kind, and eke out our ..... -

what kind of god art thou............

lord Exeter, and my lind kinsnian.

untrained in any kind of art...

kind keepers of my weak $\ldots . . . . .$. ....

just death, kind umpire of men's...

$O$ loving unele, kind duke of Gloster

this argues what lier kind of life

than this kind kiss. O lord, that

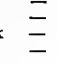

ii. 4
iii. 1
iv. 1

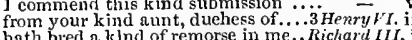

hath hred a klnd of remorse in me..

of my kind uncle, that I know will

gentle, kind, effeminate remorse ....

led in the hand of ber kind a unt

kind sister, thanks; we'll enter all ...
kind Tyrrel, am I liappy in thy......

where is kind Hastings?

v. 1
v. 7
ii. 3
ii. 3

iij. 3

shall see their maves lew

borne against the old kind king $\ldots \ldots . . . .$.
your old kind father, whose frank heart

by the kind gods, 'tis most ignobly done

kind gods, forgive me that wi...........

O jou kind gods, cure this great

what kind of help? Speak, man

were that kind of fruit........... Romeo \& $-\mathbf{v}$ v.

(kind -

and a eourteous, and a kind

the kind prinee, taking thy part ...

in him a kind of joy to hear of it ......

gliall lend a kind of easiness to the next $\quad$ - iii. 4

I must be cruel, only to be kind........

like the kind life-rendering peliean ....
dear maid, kind sister, sweet Ophelia

dear maid, lind sister, sweet Ophelia .

a kind of figliting, that would not let..

but it is such a kind of gain-giving

for mere suspieion in that kind..........

slie is of so free, so kind, so apt, so blessed
I never knew a Florentine more kind..

there are a kind of men so loose ........

if my offenee be of such mortai kind....

had he rained all kinds of sores $\ldots \ldots \ldots$

abnse their husbauds in sueli gross kind
kind gentlemen, let's go see poor Cassio

a kinder centleman treads not . Ner of $V$ enis no kinder slgn of love $\ldots \ldots \ldots \ldots \ldots . \ldots$ Henry $V I$. i. 1

more kinder than mankind .. Timon of Athens, iv.

if he remenber a kinder value .... Coriolanus, ii.
Gloster's bastard son was kinder to....... Leor, iv. 6

O DEST-the kindest man... Merch. of $/$ enice, i11. at your kindest leisure. If you shall... Macbeth,

we do request your kindest ears .... Coriolnnus, hut that I kindle the boy thither.. As you Like it, i Hewryllil. ji. fire to kindle their dry stubble....... Coriolanus, ii. fire enough to kindle eowards.... Julius Cresar, ii. mine his thoughts dirl kindle.......Anteny \& Cleo v.
and yet the fire of life kindle again ... Pericles, iii. my love should kindle to inflamed.......... Lear, i. KINDLED with unehaste .. Merry Wines, v, 5 (song)
dwell where slie is kindled......As you Like it, iii. dwell where she is kindled ........As you Like it, iii. you equal potents, fiery kindied spirits! -

goun kindled, and soon burned .... H Henry $I V$. iii. 2 
KINDLIER movel than thou art?

KINDLING-is kindling conels

.......Tempest, r. 1

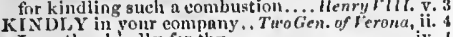

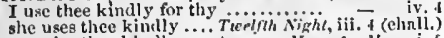

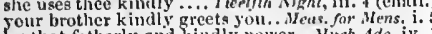
by that fatherly nud kindly power...Mueh Ado, iv. frosty, but kindly; let me go wititi you

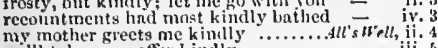
we'll take your offer kindly .......... and do it kindly, gentle sirs...... -1 (induc) that have been more kinilly beholden this great king may kindly sny .......Mrtcbeth, iv.

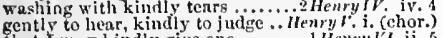
the bishop hnth a kindly gird ........ - iii, I take it kindly.................... Henry $r T$. i ii. I and kindly kissed my eheek......... Richar'd HI. ii. bounteous hand was kindly lent .

shall see, the horr will use us kindly

why, this is kindly done.... T, oilus \& Cressida, iii. mast use expostulation kindly ..... Servilius! you are kindly met, eir . he used me kindly; he cried to me ...coriolanus, i. . to ask it kindly. Kindi ? $^{2}$

kindly erentures turn all . An'ony \& Cleopatra, ii. 5
how honourably and how kintly... good sir, you are kindly welcome..... cymbeline, i. 7

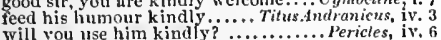
why other dnumhter will use thiec kindly .. Lear, i. s

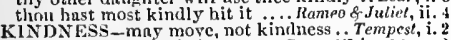

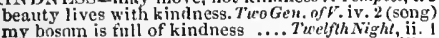
my bosnm is tull of kindness for the fair kindness you have

he did me kindness, sir ................

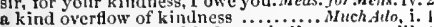
if thou dost love, my kindness shall

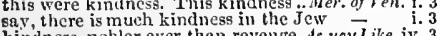
kindness, nobler ever than revenge. As you Like, iv. 3 a way to kill a wife with kindness

kindness in women, not their...........

I with self-same kindness w'elcome

Padua affords this kindness.

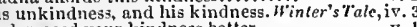
and grneen your kindness better

too full ' the milk of human kinedy of Errors, i as full of valour, as of kindness ...... Henry r. hatl' a woman's kindness overruled i i Henry $r /$. ii. 2 and I nay live to do you kindness. 2 Henry $r^{\prime} l$. ii. 4 in kindness, and unfeigned love.....3 Henry $/{ }^{\prime} I$. iii. 3 a!l kindness at my hand, that

serve me. Inl requite this kindness....

to have it yielded with all kindness. Richard $I I$. iti. 7 the kindness freezes................

therefore aceept aucl kindness as 1 can $-\overline{\text { iv. }}$ yet is the thy kindness subtle, covetous ........ - iv. 3

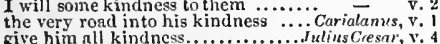

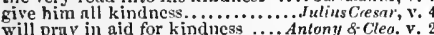
sir, you o'errate my poor kindness .. C.ymbeline, equal discourtesy to your best kindness do him thut kindness ....... Titus Andronicus, vi 3 it had becn a kindness becoming .... - iv. 4 as an enterprize of kindness, performed

do me the kindness of our profission

since your kind iness must relieve me
for such kinut

your present kindness makes my past

a great ahatement of kindness a ppears
in pure kindness to lis horse, lhuttered

sincerity of love, aud honest kindincss.... othello, ii. 3 KINDNESSES-those kindnesses. Turelfth Night, iii. 4 give me thrnks for kindnesses... Comedy of Err. iv. 3
some stual kinduesses from him. Timon of Ath. iti. 2 to whose kindnesses I am most. Cymbeline. i. 7 (let.) a sin to match in iny kindred.

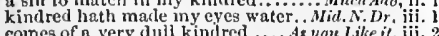

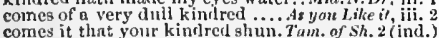

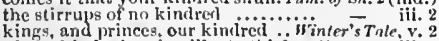
of any kindred aetion like to this? .. King John, iii.
disclaiming liere the kindred of ... Richerd $I T$. i. disclaiming here the kindled of ..... Richurd
wade even in our kindred's blood.... were guilty of no kindred's btond....

and my kindred bils to ripht

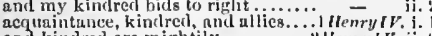
and kindred are mightily .............

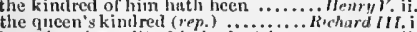
how that the guilty kinkred of the gucenaid you with our kindred tears?.......
quecen's pronel kindred from the prince your enemies, the kinslrul nf the queen
we hive noted in you to your kiutred kinglom, kiutrest, freedom, lifie. no kinul es we for oll: kindred, though they be long. $l^{\prime}$, oil. \& Cress iii. 2
KINDRED-of mine own kindred .... Cymbetine, v. s I KING-the king's not hare [Col. Knt.] in thy kindred's grilve. Romeo \&. Jut. Iv. 1 like to see the king betore me.

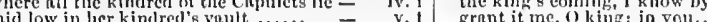

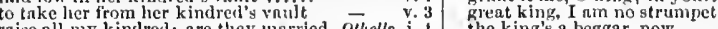
raise all my kindred: nre they married... Othello, i. 1 the king's a beggar, now

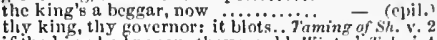

KING-roarers for the nnme of king..... T'empest, $\mathrm{i}$, if the king line no son, they would. Winter's Tale, $i$. the king nod prince nt prnyers?.. I boarted the king's ship

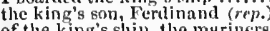

of the king's sliplp, the muriners

that they saw the king's slip wrecked

whielh first wre mine own ki
the king my lather's wreek

he marringe of the king's fair daughter

and yet le would be king on

the king, his son's alive..............

now good ungels preserve the king!

so, king, go salely on ................

I do think, $n$ king; I would not so!

daughter and $\mathbf{I}$ will be king and quecen

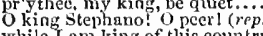

kine am king of this countrs

the king, his brothicr, and yours

to the king's slipip, invisible..........................

behold, sir king, the wronged duke.

the ling and queen there! .............

we have safely found our king
you'd be king of the isle, sirrah

you d be king of the isle, sirrah?
while 1 , thir king....... Twa
were a king for our wild liketinn

as our eonmander, and our king

you'll complain of me to the king? Merry Wives and the king's English......

with one self king

the king lies by a beggar

said to a niece of king Gorboduc

ali the dukes fall npon the ki
not the king's erown
subject to a well-wished king..............

suljeet to a well-wished king..................

what king so strong, can tie
if $I$ were as tedious as a kine.

the king doth keep lis rerel........ Bncth Aln,

lorely boy, stolen from an Indian king

believe me, king of shadows
fiiry king, attend, nnd mark

the French king's daughter ............

ballad, boy, of the king and the
who the king your father sends.

if then the king your father will ....

sou do the king my tatlier too mieh

was that the king that spurred his.

Who came? the king? (rep.)....

into the royal hand of the king

would the king, Biron, and Lo.

the king your mote did see

God bless the lingt $\ldots . . . . . . .$.

sir, it is the king's most swcet.......

sir, the king is a noble gentleman

that the king would have me presc

what I have from the loving king

addrest the king nnd his companifin

for, quoth the king, an angel shalt
and then the king will court tlice..

the king was weeping-ripe

the king is my love sworn
than the king's nud his con

the king your father-Dead

by these badges understand the king

her lord, her governor, her king. Mer. of tenie, the dreal and fear of kints
enthroned in the hearts of kings.

brightly as a king, until a king lie hy

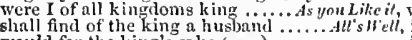

pould for the king's sake (rep.)........
the king very lntely spoke of him....

good lord, the king languishes of

the king's disease-my project.

whereof the king is rendered lost ....

stay; the king,-Use a more

than alone the recovery of the king.

restned the king to healiti

is now the praised of the kin:

the king has done your wrong.

your instant lenve o' the kin ?
is she gone to the king? Slie i

spoke witls the king, nut have procuirel

she luth recovered the king

the tivours of so good a king

everlusting displcasure of the king

letters of eommendation to the king
he tno sweet for the king's tartness

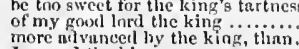

more nut vancell lyy the king, thinn....
I movel the ling my master.........

give this poor petition to the kin. hat struck anointed kings

by the king. For whint? Ile tlitinks

and so the king's will be performell

these dnngernus vilng fe lunes o' the king:

not a party to tlye nilger of the king

the douphter of $n$ ling: our weyte...

our sovcreign lord the king ....

a grent king's daugliter, thic motl

to have him kill a king.

I mentioned a son o' the king's

and reconciled king, my brother

of ale is a dish tor a kin

that unlapppr king, my master

please to think fove the king

against lis dangliter and the king's son -

to tell the king of this cscape

but to tell the king glie's a cliangeliing

and blood hiss not oflended the king

to make me the king's brother-in-ta

which none must know but the king

the king is not at the palace

in man, besides the king, to effect.

we must to the king, and slow onr .:
the complaint they have to the king

that a king, a friend, can send

I perceire dnughter of $\mathrm{a}$ king?

the king's daughter is found

the king tound his heir?

our king, heing ready to leap out of..

conduit of many kings' reigns

worth the audience of kings and princes -

and then the two kings called

hark! the kings and prinees $\ldots . .$.
by us, a pair of kings; let's from

say to the king the knowledge of ...

from Fife, great king, where ...

Sweno. the Norway's king, eraves

thou shalt get kings, though thou

to be king, stands not within.......

your ehildren shall be kings (rrp.

if ehanec will have me king, why

let us toward the king

witl, hail king that shalt to

the king eomes here to-niglit.

is the king stirring, worthy thane?

goes the king from hence to-day?..........

thou hast it now, king, Cawdor

and father of many king

first they put the name of king unnn..
liailed him father to a line of kings

them kings, the seed of Banquo kings

aay to the king, I would netcris

lath

like the issue of a king

were I king, I should enit off

the sword of our slain kings ......

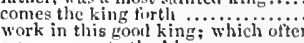

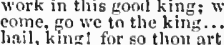

then trke my king's lefinnec trom........ King John,

advantage of his nbsence took tlie kis.g -

a bastarkl of the king deecised

[ku, ] king shtil be king.

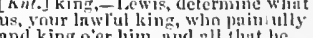

and king ger him, and all thut he

the erown of Englumel prove tle king?

England's hing, and yours

conplet to the nume of kings

bloul of kings is set on fire! 7 . o......

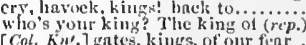

[Cnl. Ku'] gntes, king's, of our ficar

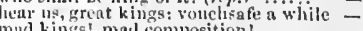

and the king slanll live withou

by the power a' the king: one of

he's with the king your tather

and son unto the king let's from .....

his lawtul king, ent of the sequence

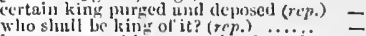

ii.

iii.:

iii.$$
=2 \text { (son: }
$$$$
\text { iv. }
$$$$
\text { iv. }
$$

jv. 3

iv. 3

iv 3

iv. 3

$v$.
$\mathrm{v}$.
$\mathrm{v}$.
$\mathrm{v}$.
$\mathrm{v}$.
$\mathrm{v}$

$\mathrm{v}, 2$
$\mathrm{v}, 2$
$\mathrm{v}, 2$
$\mathrm{v}, \mathrm{2}$

v.

eth,

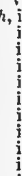

-5
5 (letter)
5 (letter)

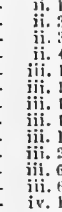$$
\text { iv. }
$$$$
\text { iv. }
$$$$
\text { iv. } 3
$$$$
\text { iv. }
$$ 
KING -of kings, of beggars, old men.. King John, ij. 2 KING-and thine aunt, great king ..Richard II. v. 3 KING-doth the king eall?

since kings break faith upon .........

not go without you to the king's....

great grief, let kings assem

discord twixt these perjured kings!

the free breatl of a saered king?

the king is moved, and answers not

difference of ineensed kin

go witl whe to the king

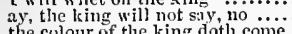

the culour of the king dotll come.....

it is the eutse of kings, to
to be endeared to a king

the king, by me, requests (rep.) ......

the king hatl sent for you ............

there, tell the king, he may enquire
I'll to the king: a thousand businesses

from the king I come, to learn

now hear our English king ..............

I did not think the king so stored

to one Hubert, with your king

the king, I fear, is poisoned by .......

contuet me to the king; I doubt

but now a king, - now thins...........

was now a king, and now is clay!
lere the kindred of the king ...........

and the king's, say who thon art ....

to his God, his king, and him ...

the king hath thrown his....

I fear, tlie king shall rue...

sieh is the breath of kings

the king did hanish thee (rep.)

nill not, the king exiled thee.....

wilt the king coine? that $I$ may ..... -

the kint is come; deal mildly

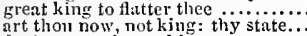

for liow art thon a kin

the king is not himself ...............

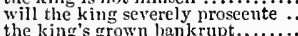

most degenerate king? but, lords.............

first departing of the king for.....
when you parted witl the king...

to please the kind, I did I hone, the king is not yet slipped

the king had cut off my hearl..
whom the king hath wronged

to the king in love, is near (rep.).

dispersed the linuselinld of the kin

the anointed king is hence? (rep.)

the sovereiern merey of the kill

the king reposeth all his confilienc

forernn the deatly or fall of kings.

a royal king, a happy gentleman...

near to the king in blood..............

hath power to keep you king

wash the balm from an anointed king

am I not king? awake, shiggard

ye favourites of a king; are we not.

rounds the mortal temples of a king

how ean yout say to me-I am a king?

is gone to meet the king ...............

a saered king should hide his headi.

contains no king? Yes, ny gnod (

we thonght ourself thy lawful king

the king of heaven forbid (rep.)

sar, thus the kinf returns
what must the king do now? (rep.).....

base court, where kings grow base

hath seized the wasteful king...

meet at London, London's king

can give sentence on his king? .....

why am I sent for to $a$ king

God save the king! will no man say

my griefs; still am I king of those

containing the deposing of a king

undeck the pompois body of a knis

good king, great king, (and yet not.

mark, sicht king, the moral of.....

greater than a king; for when (ep.)

greater than a king; for when ( $\mathrm{ep}$.
I have a king here to iny flatterer.

rise thus nimbly hy a true king's fail

this thay the king will eome

nny resting for her true king.s.......

and a king of beasts? A king of beas

tor plant un riglitful kings, wilt

and send the king witli ne

lasting fealty to the new-made king

my hoots: I will tin to the kin

and get hefore him to the king

where is the king? What m,ean
from the traitor's bosom, king

\section{iii.
iii.
iij.
iii.
iii.
iii.
iii.
iii.
iii.
iii.
iv.
iv.
iv.
iv.
iv.
iv.
iv.
iv.
v.
v.
v.
v.
v.
v.
v.
v.
v.
v.
v.}

the king hath sent to know the nature

if that the king have any way ......

that the absent king in deputation.

were well ploeed in: soon after that

shall I return this answer to the king? -

to wage an instant trial with the king

ere the king dismiss lis powe

what with the absent king

that lield the king so ling in his

ii. 2 it cannot be the

in any ease, the offer of the kin

there is no seeming merey in the king

we live to tread on kings

the king comes on apace

and thom shalt find a king that will.".

here breatlliess lies the king

wert a king? The king hath many.

pieee by piece, until I meet tlie king

another king! they grow like.........

iii. 2 person of a king? The king limseif

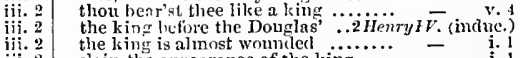

slain the appearance of the king

is,-that the king liath won............

power and puissance of the king

with the king. What! is the king but -

so is the unfirm king in three........ -

give us that king again, and take.

hasty employment in the king's affiairs -

the king, my lord, and Harry prince of -

where lay the king last night?
comes the king back from wales....

comes the king back from Wales.... -

there is some of the king's blood spilt

knight to the son of the king....

ii. 2 (letter)

ground and vantage of the king

rather damn them with; king, Cerberus -

ha! a bastard son of the king's?

and means to boot, deny it to a king?
one of the king's justices of the peare
with ringing in the king's affairs....

our late king, Richard, being infeeted

ere this, we offered to the king ......
have you been galled by the king?

and not the king, that doth you injuries -

either from the king, or in the presen

the king, thut loved him as the

graeed indeed, more than the king....

shall, to the king, taste of this action

note this, the king is weary of
hesides the king hath wasted all

the countenance of the king, alack

lower, princes; for the king reeovers

how dotll the king? Ixeceding ill .
the king your father is disnosed to sleen will sit and wateh here by the king.

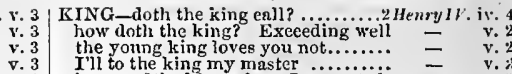

image of the king whom I preseuted

and, as you are a king, speak... ...

why, there spoke a king

under the king, in some $(r e p$, ..........

thy tender lambkin now ig

the young king is sick for me

I will make the king do you grace...

my king! my Jove! I speak to thee

the king hath called his narliament

. Herry $r$. chor.

year o' the last king's reign.......

to the king's honour, full fitteen ....
and to the coffers of the king

the king is tiull of grace................

and all at once, as in this king ......

your brother kings and monarclis of

tame with prisoner kings............

from lim, not from the king

no tyrant, but a Clristian king.

the mirror of all Christian kings

this grace of kings must die....

the ling hath killed his heart .....

the king liath run bad humours on..

the king hath note of all that............

would have sold your ling to slaughiter =

much mistaken in this king ........... =

thus says my king: and, if your father's

the well-appointed king

- iii. (chnris)

that the kmig doth offer him $\ddot{\text { a }}-$ iii. (chorns)

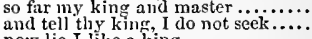

now lie I like a king ................

a hetter than the king. The king's... the king is but a man, as I am

$I$ will speak my eonscience of the king as in the king's eompany

the king himeelf hath a hea

for the king that led them to

the king is not bound to answer ....

breach of the king's laws (rep.).....

every subject's duty is the king's.

I myself, lieard the king say .......

the king himself will be (rep.) ......

with a king's repose: $I$ am a king....

the fore-hand and vantage of' a king

what wateh the king keeps to maintain

Warry the king, Bedford, and Exeter

is this the king we sent to $\ldots \ldots \ldots .$.

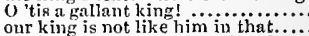

no, areat kins, I come to thee for....

great king, to view the field in safety

sndier, you must come to the king.

of Orleans, nephew to the king......

now we bear the king toward...

great kings of Franee and England!

the king hath heard them .........

to with the king; and take with you
tloo wouldst fird me such a plain kin take a soldier, take a king .........

the word of a king and a bachelor

nice eustoms curt'sy to great kings.

the king lyath granted every article.

a king of so mucl worth $\left(\mathrm{rep}, \mathrm{y}_{\text {. }} . . . .\right.$.

Clinarles is erowned king in Rheims!

the Dauphin erowned king! .........

young flenry king. To thing ( the king from Fltham $I$ intend.....

not yroteetor of the king or realm...

that regards nor fod nor king .....

to erown himself king, and suppress

in our late king's days?

of Fiward king, the thir

the king, thy sovereign, is not quite

bilt he should be about the king ....

his grace protector to the king?.......

sweet king! the bishop hath

the presenee of a king engenders love

to Paris, to the kin:; for there youn

but kings, and mighitiest potentates

elect no other king but him

iii. $f$

iii. 6

iv. 1
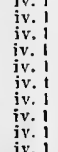

iv. 1

iv. 1

jv. 1

iv. 1

iv. 1

iv. 1

iv. 3

iv. 7

iv. 7

iv. 7

iv. 8

v. (chorne)

. (chorus)
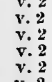

v. 2
v. 2
v. 2

v. 2

ciarjes, the right u! king.

thisturb the king and us? ...........

the king prettity, methought, did...

\section{-}

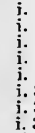

3 (proel.)

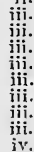

ive

(letter)

iv. ? 


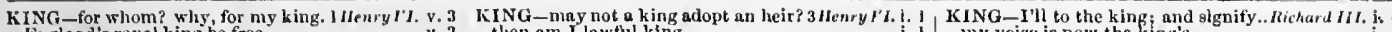

Lingland's royal king be free
aliall be wedded to my kling.

to be made comprnion witl a king...

deputy unto that gracious king...

this ls in traffic of a king ................

such peevish tokens to a king.....

lelters of eoumisaion from the kin.

proceeling from our king:............

disg rnee not so your king ..........

tit tior none, hut for a kin

our linpe in issue of

rule the king; but I will rule (rep.)...

quecn that ever king received

delivered to the king her finther

Fingland's kings lave had large

against my king und nepliew

where kings and queens are erowned

whereas the king and rueen $3 . . .$.

neenlise the king, forsunth ( $r e p$.)

wert king (and who is king, but thou?)

food kitro nook to t in time?

first, of the king; what sliall..........

the king and eommonweal are deeply

so hild as thine to Lnylands king

so witl king and commonweal: ...

come to the king, and teil him whint

bring him near the king, his lightuess'

how I hate lored ny kin

death, reigned as king ......

but for Owen Glendower, had heen king -

sueeed hetore the younger, I am king

England's king! We thank rou (rep.)

reatest man in lingland, but the king =

to thy king. I see no reason, why a king

why, now is Henry king, and Mrargaret

nor the king, nor the queen..

her penance exeed the king's ......

as next the king, he was suecessive.

that e'er I wrested from the king....

dilke kinmphrey for the king's protect

help, lords! the king is dead

with that drend King, that took

an answer from the king, or we'll

once by the king, and three times

sometime, he calis the king........

the king, thou know'st, is coming

the daughter of a worthless king ....

erept into the palace ot our king

God of heaven, and to my king.

the king's couneil are no good ......

of putting down kings and prinees
and when $I \mathrm{am}$ king, (as king I wili be

are hard by, with the king's forces

true; therefore he shall be king

tell the king from me, that

fellow kings, I tell you, that ihat.....

assail them with the army of the

tight for your king, your eountry...

and, entrary to the king, his erown

the king, the realm, and you? .....
my hook preferred me to the king

parleyed in to foreign kings

from the king unto the commons...

who loves the king, and will embrace -

Goll save the king: God save (rep.
we'll follow the king, and Cliftord

he, that brings his hearl unto the king

to reconcile you all unto the king....

was c ver king that joyed an eart

never subject longed to be a king..

get a thonsand erowns of the king

bear in triumph to the king ............

the king hath sent him, sure

better born than is the king $\left(r_{e p}\right.$. $)$...

renove prond Somerset trom the king
the king hath yieldert unto thy demand

into the presence of a king, la........

exquire of Kent, that loves his king.

false king! why hast thon hroken .

trenson 'gainst the king and erown.. -

this is my king, York, I lo not......

oppose hlowself ayainst his king.......

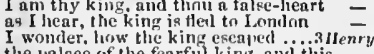

the palace of the fearfill king. ant this

and, when lie king eones, wher him

neitler the king, nor he lliat ioves..

the crown, aukl reign as king
follow, but his natural king

let him le king. Jle is hoth king.

and trumpets, and the king will fly

lrove it, Ifenry, and tlwu shalt he king - then am I lawtul king $\ldots$

tor this niy lifetime, reigu as $\mathrm{king}$

fitinthearted and degenerale king

honour me as thy king and sovereign

nri thou king, and wilt be foreed

mnd yet the king not juivy to my drift -

v. Jeft proteeters of the king

v. that wonld he England's

v. 5 now should not be king, till our $\mathrm{k}$ ing

kecper of the king, mustercd my...

bearint the king in my behalf along
whether 'twas the eoldness of the kin the king ime eoldness

wrought the easy-melting kivg...

would have his son a king $\ldots$ with......

proelaims him king, and many fy

yon- lint ure kinga tho'

am a king. and privileged to speak

bears the titile of a king, (as if

finlse woman, as this king by thee....

in pity of the gentle king.............
deny'st the gentle king to speak

and wheker town of kings!............

from Londonl hy the king was I.......

wis cverking so rued for subjects' woe?

here sits a king more woeful than ..

swayed as kings should do .......

be erowned Englaud's royal king...

to crave the Freneh king 's sister

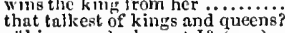

of' kings, and wliy not I? (rep.)

kings enjoy. Well, if you be a kin

You are the king, king Edward hath
king at nime months old (rep.)......

subjects, but while you were a $\mathrm{king}$

you kings; command, and I'll (rep.)

ii. 4 and in the king's, to go with us....

iii. your king's name be obeyed ('ep.)...

iii. 1 'tis but to love a king ...............

is of a king, become a banished man

\begin{tabular}{c|c} 
iii. 2 & true-anointed lnwful king .......... \\
iii. 2 & to England's king in lawful marriage
\end{tabular}

madam, in our king's behalf ........

is Ed ward your true king?

is Edward your true king?...........

iii. 2 jointure that your king must make

iv. 1 wife to the English king (rep.).....

setter up and puller down of kings!
these from our king unto your majesty

iv. 1 what, has your king married.........
iv. 2 nn more my king, for he dishonours me

iv. 2 Eaward thy supposed king (rep. iv. i) -

go fear thy king withal.

forbcar this talk; here eomes the king -
I am Edward, your king and Warwiek's -

your will, because our king..........

Edward will be king, and not be tied

the king, by this, is set him $\ldots \ldots . .$. .

why commands the king, that h

dcaraded you trom being king

always benr himself as king

nind, be Edward England's king

ynu know, our king, my brother

you know, our king, my brother ....

I eame to serve a king, and not a duke

here proelaim yourselt our kin

eall Edwarl king, and at his $\ldots \ldots \ldots . .$.

and Henry is my king (rep.)

the king was slily fingered from ï…

against his brnther, and his law

exeuse me to the king my hrother

weeps for the poor king's death 1

and the king in deadly hate...

hetwixt the king and mistress siore

if we will keep in favour with the king

We say, the king is wise, and virtnous

the king is sjekly, weak, and melancholy-

poor key-eold figure of a haly kingt

sivalow up this gfiod king d block

ficter for tle $K$ iug of heaven

at Clertacy monastery this nobie $i$ ing so it must he, if the king misearry

that comulnin unto the king, that $i$

the king, of lis own royal disposition

marry with a king, a liachelor ...... -

nvoueli in presence of the king

or Jour Jushand king, I was.

were roun this country's kin

your king, as nurs by muriler (rep.) my voire is now the king's .............

is our king. Jirronenus vassal! (rep.)
your king: lett he, that is (rep.) ....

your king: levt he, that is (rep.)
to my fovereign king, and queen

dear brotler, live, and he a kin

did urge it atill unto the king
1 do lament the siekness of the king

the king iny unele is to blume

the king doth love yon well ..........

the king, provoked to't by the quicen

thy son, our king, is dend

spent our harvest of this king .......

I hope, the king male peace

i. 1 yes, the king's den!. Ill news

then the king hat virtuons uneles.

when I an king, elain thou of me.

the king my brother was possessed

Riehard, Fingladd's royal king

son shall never reign our king

Richard, England s worthy king!...
the ling hath strictly eharged (rep.)

I would be king. Why, so you are (rep.) -

the king is angry, see, lie gnawe his lip
should be king, when Riefimond (rep.)

made I lim king for thi

bear this tidings to the bloody

Mercury, and herald tor a king I ....

who dost thon mean shall be her kit

the king, that calls your beanteons.

again slatl yom be mother to a king

the king thy hrotler made

is the $\mathrm{king}$ dead?

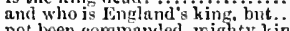

not bcen commanded, mighty king

kings it makes forls (rep.

besides, the king's name is a tower.
from the miglity power of the king.

that prophesied thou shouldst be kin

the king enacts more wonders than

the two kings, equal in lustre ....... Henry ${ }^{\prime}$ It

a plaee next to the king

Without the privity o' the king ......

I'll to the king; and trom a mouth.

suggests the king our ni..............

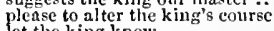

the name of our most sovere ign king

king is pleased, you shall to the Tow
and the king's plensure hy me obey'ed

here is a warrant from the king ....

yet the king s grace and pardon

of the king grace and pardon the king should without issue

prove perfirlious to the king's danger

neither the king, nor his leirs

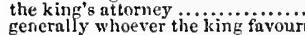

generally whoever the king favours

my vows and pray'ers yet are the king's

certain, the king will venture at it

how is the king entioy

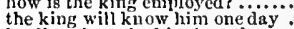

he dives into the king's soul ........

ont of all these to restore the king

the Fruneh king's sister (rep.)

so I'll stand, if the king please .......

the king hath sent me otherwhere

a graeious king, that pardons....

favour to yon; you are thic king.....

the kiner's majesty comme

the firir eonceit the king hath of you

that they have eaught the king...

please you, sir, the king, your fatlie

what is lunsettled in the king...

the king is present: if it be.

lie might the king lis lord ..........

madam, you wrong the king's love.

cause into the king's protection.

a judge, that no king can corrupt...

grow from the king's aequaintance.

the king loves you it you cannot bar his arecse to the king

Witeheraft over the king with his tong

the king hath foum matter ngainst lim

anl cume to the eye o' the king

has the king this? Believe it

the king iu this pereeives lim

the kinu nirendy hath marricd the

lunt, will the king dicest this letter.

the king eried, ha! at thi

have sutisflet the king tu.............

Cromwel, anve it yont the king

ot Alencon, the Feneh king's sister

he hears the king doth whet $30 . . . .$.

criwled into the finvour of the king.

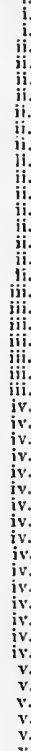

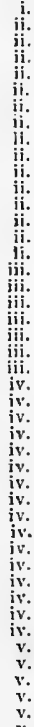

i.

i.

ii. 1

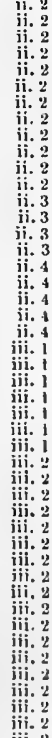

ii. 3

ii. 3

ii. 4

ii. 1

iii. 1$$
\text { i.i. }
$$

iii. 2

iii. 2

iii. 2

iii. 2

iii. 2

iii. 2

iii. ? 
KING-the king, the king.......... HenryVIII. iii. 2 KING -hadst, great king, a subject... Cymbeline, v. in the packet 'sent the king? 政 the king, (mine, and your master, who'll take it? The king, that gave toward the king, my ever royal master = Fon writ to the, pope, against the king without the king's assent, or knowledge n which you brouglit the king to be = either of king or coune

hat to he stamped on the king's coin out of the lcing's protection the king shall know it

our displeasure with t............. your displeasure with the king $\ldots . . .$. the king has gone beyond me. eeek the king; that sun, I pray.... the king shall have my serrice ....... 'tis the king's; my robe. $\ldots \ldots \ldots . . . .$. and the king's late scruple.

our king, has all the Indies.

the king s, and called-Whitehall with the king, and truly (rep.)...

ent from the king, to see yo

to deliver this to ing lord the king and urge the king to do me this las and daughter to a king .............

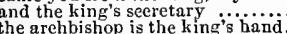
have broken with the king

the kng shall understand it (rep.).

the ling may never find a heart ...

till the king's further pleasure

is the king's

the king will suffer but the little...

as I live, if the king blame me ....... kings, princes, lords!

the worth and honour of a king......

be wife to Sparta's king...

fresh kings are come to Troy

fresh kings are come to Troy ........

han all the island kings

for a day of kings' entreaties

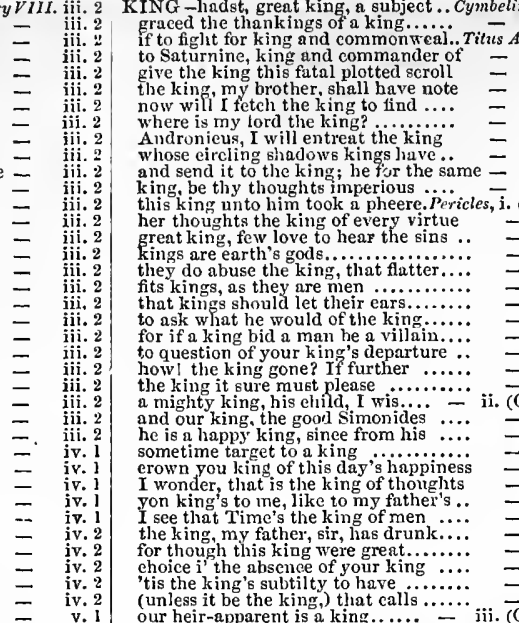

(unless it be the king, that calls.

slie was the daughter of a $\mathrm{king}$.

I love the king your father, and you
have brought this king to 'Tharsus

of Tyrus, the king's daughter....

bir, king, all hail! the gods preserve

the eause of your king s sorrow........

and a king. How! a king's daughter?

my mother was the daughter of a king

in IIitylene, to greet the ling ..

our king, and all his eompany ...
the king, my father, gave you sueh...
I thought, the king had more affected

the king is coming

name, and all the additions to a king

now, by Apollo, king, thou swear's

fare thee well, king; since thus....

for you, grent king, I would not from

thnt.] roya! king, give but that portion

and the king gone to-rilglit?

the king lalls from his bias of nature..

maledictions, against king and nobles

that sueh a king should play bo-peep

and beat thee, before the king?

messengers from our sister and the kin

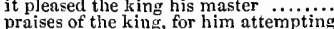

I serve the king; on whose employment

and the good king his mast

good king, that must approve $\ldots . . . . . .$.

the clanee the king comes with so sma.

the $k$ ing is in high rage

I know you; where's the king?.
borne against the old kind king

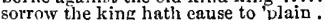

I will go seek the kin

when we have found the king

these in juries the king now bears will

we must incline to the king $\ldots \ldots \ldots \ldots . . . .$.

thou sayest the king grows mad....

or a yeoman? A king, a king!

she kicked the poorking her father

where is the king my master? Here,

how now where's the king? My lord of

where hast thou sent the king?

for the love thou showedst the king

rebel-like, sought to be king o'er h

was this before the king returned?

is t not the king? Ay, every inch a king past a king, my masters,

past speaking of in a king! ......

how does the king? Madam, sleeps stili. that we may wake the king

the king is come to his daughter

the king $1 \ldots . . . . . .$.

to send the old and miserable king to

followed his enemy king, and did him

to bid my king and master aye ............

[Col. Knt.] two sueh opposed kings. Romeo o.Jul. ii. 3 good king of cats, nothing, but one of $\overline{\text { Hamlet, }}$ i. I like the king that's dead

looks it not like the king? (rcp.) ........ moiety competent was gaged by our kin.
KING-like the king that was, and is ... Hamlet, $\mathrm{j}$. power to business with the king .........

i. 2 so excellent a king; that was, to this.... the king your father. The kingmy father? ii. 4 the king doth wake to-night, and takes ii. 4 call tliee, Hamlet, king, father, royal Dane

ii. 4 I will go seek the king: this is the very

ii. come, go we to the king: this

to my God, and to my gracions $\mathrm{king}$

count myrelf a king of infinite space...

and your eccreey to the king and queen

he that plays the king shall be welcome

no, not tor a king, upon whose property

will the king hear this piece of work?

there is a play to-night before the king

this is one Lucianus, nephew to the kin

for if the king like not the comedy

the voice of the king himself for your

never alone did the king sigh

nay, I lnow not; is it the lking? $\ldots . . . . . .$.
as kill a king and marry with his (rep.)

a king of shreds and patches: save me

should be made by the son of a king?.

that sonks up the king's countenance?

to the king. The body is with (rep.

the king is a thing, - A thing, my lord?

your fat king; and your lean beggar.

how a king may ao a progress throug

from me greet the Danish king; tell him

choose we; Laertes shall be king (rep.)

Wh thou vile king, give me my father....

these fellows some means to the king ... - iv.

let the king have the letters, ...... - iv. 6 (let.

here comes the king, the queen.

an earnest conjuration from the king.... $-v_{\text {. }}$

he that hath killed my king, and whored $=v_{\text {. }}$

his crib shall stand at the king's mess

the king, sir, hath wasered with him....

and the king hold his purpose

the ring and queen pell a.........

the king shall drink to Hamlet's (rep.).
the

KING-BECONIING graces, as justice.. Macbelh, iv. KINGDO I'll turn you out of my kingdom

yes, for a seore of kingdoms........... not for thy kingdom; fairies, a way ...Mid. N. Dr. it. watery kingdom, whose ambitious. Mer of i ien. ii. had I kingdoms to give with her.. As you Like il, $\mathrm{v}$. were $I$ of all kingdoms king ........... in eourts and kingdoms known ... Winter's $T$ ale, may drop upon his kingdom, and devour= heirs of your kingdoms, my poor house ever reign in this kingdom? ..........
thee compassed with thy kingdom; pearl
the manage of two kingdom's must... King the manage of two kingdom s sulst .. King J
give grandam kingdom, and it' grandam give grandam kingdom, and it' grandam -
dreadful trial of our kingdom's king! his kingdom here, for he, that holds (rep.) our kingdons, and our royal selves
his little kingdom of a forcerl grave..

this lcingdom this confine of blaod. this chastised kingdom and myself ..

nor et my kingdom's heir ............. Richard 11. our kingdom's earth should not be.
thy kingdom cannot buy my breath

to stand upon my kingdom once again = say, is my kingdom lost? ..... Titte grave = do not beat thee ont of thy kingdom.
all the kingdoms that aeknowledge - iv. a kinglon for it was too small a hound of thy linen, shall inherit lis kingdom
the body of our kincdom, how foul it is to all the rest of this little kingdom. kingdom for a stage ...........Henry $r$. $\overline{\text { i. (chorus) }}$ on his unfurnished kingdom came ...

of order to a peopled kingdom .......
and this whole kingdom into desolation but we our kingrom's safety must .. peace itself should not so dill a kingdom = then resign your crown and kingdom = lenity and cruelty play for a kingdom to conquer the lingdom, as to speak
that the contending kingdoms of France that the contending kingdoms of France -
'twixt your kingdoms such a spousal hetween the paction of these kingdoms that two and fitty kingdoms hath ... Henry $Y$. iv. 7 all the wealthy kingdoms of the west.2Henry VI. i. by her I claim the kingdom $\ldots \ldots \ldots . .$.
cujoy the kingdom after my decease.3Hensy r. ii. $\mathrm{i}$ 


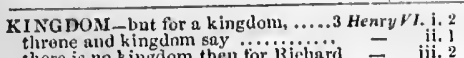

there is no kingdom then for izieliard = iii.

preseription for a kingdom's worth...

how should ynu govern iny kingdom

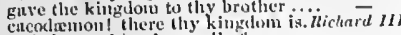

and thou, a kingdom; all of you

their kingrom's loss, my woetul .....

to his new kingdom of perietual rest

or else my kingdom stands on brittle

if I dicl take the kingtom fram your

a horsel my kinglom for a horsel (rrp.) - in

the benuty of this king lom a

in Christinn kingdoms, huve their tree -

that my kingdom, well worthy the best -

slipwreeked upon a kingdnun to the mere undoing of nill the kingdom -

pawer legatine within this kingdom

all the elinicest music of the kingdom

by sugtestion tied all the kingdom...

the nost remarked i' the kingtlom...

and a soul nome better in my kinglom

a could deal kingdouns to my ... Timon of Athens,

like to a little kingdom, sutters ...Julins Casur,

take is my spoce; kingdoms ore

to give a kingdom for a mirth ......

piece her opulent throne with kinghion

to join our kingunins, and our heart

as the president of my kingdom

we have kissed away kingdoms ...

math minsed of taking kingdoms in.

heir of his kingdom, whom he ......

the under-hangman of his kingdom

to tiglit against $\mathrm{my}$ lad $\mathrm{y}^{\text {'s }}$ kingdon

thou hast lost by this a kingdom..

sent from the infernal kingdom.. T
whom mighty kingdoms court'sy to...

and knowing this kingdom......

thus knit, a kingdom ever stands.

will in that kingdom spend on

will in that kingdom spend onr $\ldots \ldots .$.

we have divided in three, our kingdon.

this ample third of our fair kingtlom...

that all the kingdom may have due

a power into this seat tered kingdom....

1 never gave you kingdom,
late footed in the kingdom?

late footed in the kingdiom?

imports to the kinglom so much fear

in your own kingdom, sir. Do not a

the powers o' the kingdom approaeh

a promise' 1 march over lis kingdom

we will our kingdom give, our erown...

some rights of nemory in this kingdom
KINCD

KINGED [Col. Knt - -kings] of our fenrs. King.John,

a king, $t$ len am i kingel again.

KING-KLLLER, and dear .... Timon of Alhens,

KINGIY-'gainst the kingly state. Love's l.. Lost, i

give me with thy kingiy hand.........All's Well, ji. 1
to my kingly guest unelasped ..Winler's Tale, iii. 2

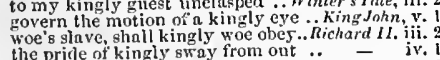

to abide thy kingly doom.

and leavest the kingly eonch.......... Henry $I V$. iii. 1 and all her almost kingly dukedous.. Henery. $i .2$ I give thee kingly thanks.

more kingly in my thoughts........2 Herry l'l. that 1 will leave my kingly throne..3Hen.y $F l$. i. by your kingly lea ve, I'll draw it

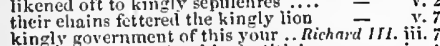

proteet him from that kingly title!.

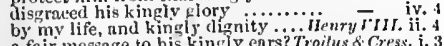
a fair message to his kingly enrs? Troilus foress. i. presented him a kingly erewn.... galling his kingly liands with

Weg leave tn see your kingly eyes. Jizmiet, iv. 7 (let.)

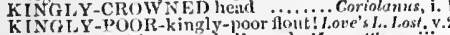

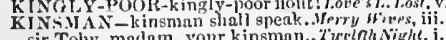
sir Tolyy, madam, your kinsman.

she harbours you as her kinst

opposite with a kinsman (rep. iii. 4) - ii. 5 (letter)

madam, I have inurt your kinsman.. - veas.

were he my hinsman, hrother ...Meus. for Meas. ii. 2
thou art like to be iny kinaman....... Much sito, v. 4

in glory of my kinsman Ilereules. Mirl. N.'s Dr. y. 1

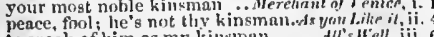

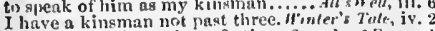

kinsman to grim and emufortless. Comed y of Err. y.

it is a peerless kinsman ................

come hither, little kinsman........ King John, iii.

gentle kinsman, go, and thrust thysel

your valiant kinsman, Fanleonloridu

whet he no kinsmun to my liege.

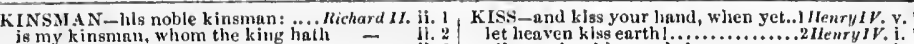

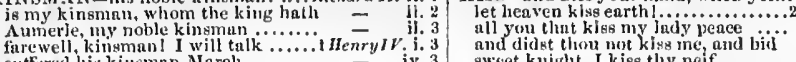

aweet knight. I kiss thy neif .........

kisy me. Doll. saturn and Venus...

I and greatness were compel!ed to kiss

his friencl? Anl his kinsman too

your sou, dotli kiss your graee's liant

nud my kinkl kinsmun, warriurs

I eannot kiss, thist's the lumour of tt...neary

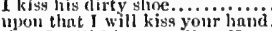

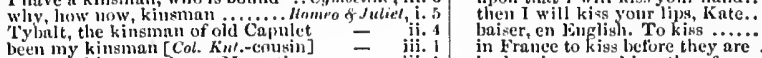

been my kinsman [Col. Knt.-cousin]

slew thy kinsman, brave AItreutio

is spilled of my dear kilssman!.......

enrsed hand murdered her kinsman

being our kinsman, it we revel much

my poor heart so for a kinsman vexed

in denying me a kiss; therefore......

may kindly give one fuinting kiss... Henry $V I$. i

of love, than thers for eternal .........

eould this kiss be printed in thy laind

and kiss, and take ton thonsand

let them kiss one another.

at every eorner, have them kiss; away - i

join, cmbrace, and seem to kits ....3 henry VI. ij.

humbly to kiss your hancl, and with

in sign of truth, I kiss your highness"

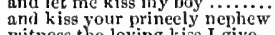

witness the loving kiss I give...........

my thanes and kinsmen, heneerorth richord st

there lies two kinsmen, digged ........

thy kinsmen, and thy friends..............

whose kinsmen have made suit

Henyllit. i. i

and, kinsmen, then we may go pfpe.

kinsmen, his sorrows are pust remedy

kinsmen, shoot all your shafts into.

one of my master's kinsment ....Kameo of Juliet, $\mathrm{i}$.

if any ol my kinsmen find thee here

therefore tiy kinsmen are no

let him kiss your hand; and whit...

one gentle kiss the more .......

he would kiss you twenty with ...... Henry ${ }^{\prime}$ III

to take you mit, and nnt to kiss you

the hearts of 1 ininces kis obedie
with this kiss take my blessing.

my purpe the to lope lis

wive = iv.

enme, kiss, and let us part . .

the first was Menelaus' kis............

the kiss you take is hetter than (rep.) -

sweet lady, beg a kiss of you?.

never's my day, and then a kiss of you -

kisses to it, as l kiss thee

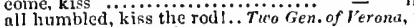

I'll kiss each several pnper

I scareh it with a sovereign
now kiss, emhrace contend

seal the hargatin with a loly

now should 1 kiss my father

chanec to stenl a kiss.

giving a gentle kiss to ever.

(song)

and kiss thy hand so oft?............ $-\overrightarrow{\text { iii. }}$

stop his mouth with a

and thereupon I will kiss the

o let me kiss this princess
and kiss thy fair large ears...

and kiss thy fair large ears.............'s Dieam, jii. 2

for my take but one lovin

to see him kiss lis hand t............

so sweet a kiss the golden
as he treads on them, kiss $h$.
I will kiss thy roval finger

I will kiss thy royal finger ........... of of $\bar{r}$ en

to kiss this shrine, this mortal

ii. 7

and elaim her with a loving kiss - ii. 2 (seroll)

dicl gently kiss the trees .............

out you kiss your hands ..........

ynu might take oceasion to kiss.

I would kiss as many of you as hai... $\overline{\text { - }}$ (epili.)

and kiss like native things

put of 's edp, do sunder, and not $\mathrm{kiss}$

boys are but to kiss $\ldots \ldots \ldots \ldots$.

and kiss on kiss she vied $\ldots$... Taming of Shew, i.

seal the title with a lovely kiss?

one, Kate, that you must kiss

firat kiss me, Kate, and we will

but ashamed to kiss $\ldots \ldots \ldots$.........

nay, I will give thee a kiss....

come on, and kiss me, Kate

with one soft kiss, a thmisand ..... rin/er's 7 ale,

there is not half a kiss to clinnse.

they kneel, they kiss the earth....... -

give ne thint liand of $3^{*}$ ours, to

you'll mar it, if yau kiss it

living light shoild kiss it .......

to kiss the ground hefore youm
lay I this zealous kiss, as seal

ankl kiss him with a glorious

so I kiss your hnud. Farewell

and kiss the lips of unnequaintei

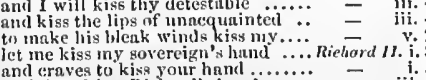

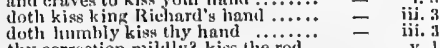

thy eorreetion nildlly? kis

one kiss shall stop our months
see Titan kiss a dish of butter? impossibilities, and makest them kiss 1 thens, iv.

that kiss I earried from thee, dear...... - v. 3

stream do kiss the most exalted

would go and kiss dead Casar's wounds -

Will e'en but kiss Octaria.. Autony \& Clenpalra, ii.

give me a kiss; even this repays me =

return his conquering liand .............

this is a soldier's kisis thebs

and kiss the honoureo gashes whole

the favoung hand; kiss it. my warrior -

I eould give him that parting kiss ... Cymbeline, $\mathrm{i}$.

might tnueh! but kiss; one kiss?

that kiss is comtortless, as frozen....

let's kiss and jart, for we...........

and loving kiss fnr kiss, thy brother = $\quad$ v. 3

when tyrants seem to kiss..............Pericles, j.

if he should clieapen a kiss of her....... - iv.

ant let this kiss repair those..............

masks, that kiss far ladies ..... Komeo of Juliet, $i$.

palm to palm is holy palmer's kiss...

whieh, as they kiss, eonsume........ = ii.

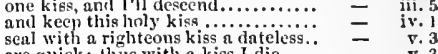

are quick; thus with a kiss I die $\ldots . .5=\quad$ v. 3

sweet crenturel and then kiss me hari...

to kiss in private? An unathorized kiss - iv, i

I kiss the instrument of their pleasures..

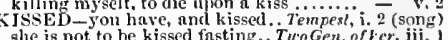

she is not to be kissed fasting.. Two Gen. of her. iii.
thou sluat be worshipped, kissed ....

but not kissed your keeper's

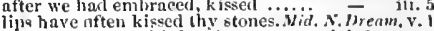

that kissed away his liand......... S.ore's 2 . I.ost, v. 2

and kissed lier lijs with sneh.

thy lips, that kissed lie quee

Ilevery riv.

kinfly kissed my cheek.

Riehardill. ii. 7

Thet summer henuty, kissed eael nther were kissed in genernl. Trnil. \& Cress. iv

he kissel, the last nf many doulyed.. Ant. of Cleo. i.

when I kissed the jack upmn an up-east -

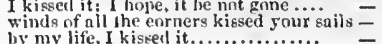

my lord that I kiss aught bnt he .... Til- ii.

and kissed his lips; ank so
hast thnu nat kisked thy hand.

his handkerchiet. Ant kissed it ...... rymbeline, ii. 
KISSED-80 high, they kissed the clouds. Pericles, i. that I have kissed 1 know not lrow oft... Hamlet, well kissed! an excellent courtesyl. and sished, and kissed; and then cried... - iii. I kissed thec, ere I killed thee ......... but my kisses bring again. Meas. for Hieas. iv. 1 (song) strucken blind, kisses the base... Love's $L$. Lost, iv.
marry his ki 6 ses are Judns's own. As you Like it, iji. sister hood kisses not more religiously
lie that kisses my wife, is my friend kisses, and with declining. Taming of Shrew, l (ind.) kisses the hands of your tresh.... Winter's Trle, iv. 3 .... Henry $1 V$. iii. । by the beard; kisses the gashes ...... Henry $V$. and consigned kisses to them. Troilts \& Crossida, iv. this, mine: Patroclus kisses you

gpoil of Phobus' burning kisses the last of many doublea kisses ...A

of many thousand kisses the poor last

gave me twenty kises

who straight on kisses dream........

as thinking their own kisses sim ....

when second husband kisses me in bed. Ilam

for a pair of reechy kisses ................

as i1 he plucked up kisses by the roots.

KISSING-for kissing of their feet .... Tempest, thy lips, those kissing cherries.. Mid. N. Dream, iii. 2
a kissing traitor:-how art thou ... Love's L. Lost, v. virgin palm, now kissing thine ...... v - 2 and his kissing is as full of sanctity. noses? kissing with inside lip? ..... Winter's Tale, i. 2 make the base earth proud kissing it. Richard II. iii. 3 Colevile kissing my foot $\ldots \ldots \ldots \ldots \ldots$. Henry $I Y$. iv. 3 lay kissing in your arms ...........Henry VIII. iii. for kissing once (rep.)
in kissing, do you render Troilus \& Cressida, iv. 5 like bondmen, kissing Caesar's feet.JuliusCessar, v. have lipped, and trembled kissing. Antony \& Cleo.ii. quieken with kissing ................... Hamlet. $\mathrm{ii}$.

being a god kissing carrion ............ Hamlet,
KISSING-CoNIFI's, and snow eringoes. Merry $W$. KITCHEN-for our kitchens we kill. Mea. for Mca the kitchen malkin pins her richest. Coriolamus, il. brags were cracked of kitchen trulls, Cymbelin, wild cats in your kitchens ............... Othello, it. KITCHEN-MAID rail

KITCHEN-VESTAL scorned you...
KITCHEN-WENCH, and all grease

to his lady, was but a kitchen-wench. Rom. \& Jul, ii. KITE-as we watel these kites ... Taming of Sh. iv. I

instruct the kites and ravens ....

shall be the maws of kites ............

the chicken from a liungry kit

Macbeth, jii.

is Beaufort termed a kite?

a prey for carrion kites and crows .. - v. While kites and buzzards prey .... Richard $I M$, i. ravens, crows, and kites, fly o'er ...Julizscresar, v. detested kitel thou liest...................... Lear, i. 4 finted all the region kites with this....... Hamlet, ii.
KITTEN-be a kitten, and cry mew. KITTENED-cat had but kittened

NACK-conceits, knacks, trifles. Mid. N. Dream, i. a knack, a toy, a trick ......

no more shalt see this knack ........ iv. 3 KNAPPED-ever knapped ginger. Mer. of Veniec, iii.
$\mathrm{KNAVE}-$ all idle; whores, and knaves. $T$ empest, $\mathrm{ii}$. thy master is a kind of knave. Two Gen. of ver. iii.

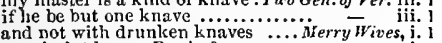
vere is dat knave Rugby?................ the jealous rascally knave, her husband hang him, ponr cuckoldi knave

Ford's a knave, and I will

shalt know him for a knave and cuckold knog his urinals about his knave costard.he is a knave besides; a cowardly knavemav be the knave bragged of...

on the lousy knave, mine host ...

a lousy knave; to have his gibes

met the jealous knave their moster.

lest the lunatic knave would

the knave constable had set me......

strange things of this knave, Ford

Falstaff's a knave, a cuckoldly knave:

thou knave, knight! (rep.) $\ldots . . . . . . . .$.
I have constrained one to cail me knave

knave counterfeits well; a good knave
a knave? A thill-faced knave, a gull?

a knave? A thill-faced knave, a gull? - v

grinst knave and thief men shut... - v. I (song)

show your knave's visage
KNAVF-you are rid of a knave little better than false knaves....... it is thought you are false knaves.... and to conclude they are unjust knaves O my good knave Costard! ....... Love's L. $\bar{L}$ ost, $\mathrm{iii}$. good my knave, do one thing for me - iii.

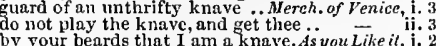

play the knave with him............. -

ne'er a fantastical knave of them..... ali
what does this knave here?

for the knaves come to do that for me

a foul-moutlied and calumnious kna

a scolding quean to a wrangling knave

O my knavel how does my old lady?

a knave. You should have said (rep.)

all night, poor gallont knave...

all night, poor gallant knave........
you knave, they are nose-lierbs (rep.)

a shrewd knave, and an unhappy

ingenious, foolish, rascally knave.

played the knave with fortune .......

a fool and a knave, you shall eat

as thou art a knave, and no knave

lyingest knave in Christendom. Taming of $\overline{S h} .2$ (ind.)

call him half a score knaves, or so

tis the base knave that jars

the knave dot li court my love

where is the foolish knave I sent

bring along tliese rascal knaves.

carry this mad knave to the gaol

take you that, sir knave. What mean of Err. i.

sir knave! go, get you from (rep.)

what is it, knave? An hour before... Richard $1 I$. ii.

mintanght knaves, unmannerly

farewel, you muddy knave.....

bacon-ted knaves! they hate
hang ye, gorbellied knaves.

what, ye knaves? young men

three visbegotten knaves, in Kendä

thou art a knave to call me so ....

a rascally yea-forsooth knave! .........

to bear every knave's wrong

that arrant Malmsey-nose knave...

is a knave, sir; but yet, God forbid (rep) -

the knave will stick by thee, I can $\because .3$ -

no, thou arrant knave; I wonld I might - - r. $\mathrm{r}$.

beggarly, lousy knave it is; $i$ hope.

lousy pragging knave, Pistol

you seurvy lousy knave (rep.) (.....

a counterfeit cowardly kuave.

a crafty knave does need no broker..2 Henry $r$ T

both-a pair of erafty knaves.......
a subtle knave! but yet it shall not

the lyingest knave in Christendom.

fo prove him a knave, and myself an

to prove him a knave, and nyself an

her lusband, knave, wouldst ....... Richard III.

these porters, these lazy knaves?

you are lazy knaves; and here
a most unjust knave; I will no..
y oung knave's sleeve of Troy there

a scurvy ruiling knave, a very........

small love 'mongst these sweet knave

ay, to see meat fill knaves, and wine

so base as you, for you serve knaves

let in the tide of knaves once more
to knaves, and all approachers

what! a knave too? If thou...

thou hadst been a knave, and fiatterer

trust a knave, that inightily

for poor knaves' caps and legs

the smiles of knaves tent in my eheeks

will bear tlie knave by the volume ...
thou knave? thou naughty knave..Julius

poor knave, I blame thee not; thou art

a foul knave uncuckolded ...Antony \& cleopatre

with knaves that smell of sweat $\ldots .$.
his fault should make a knave of thee

my good kn tue, Eros, now thy captain

cannot hold this visible slape, my kn
he's but fortune's knave, a ninister.

a sly and constant knave

there are verier knaves desire to live.

though this knave came somewhat saucily. Lear,

knaves, thieves, and treachers
where's my knave? my fool?

my lord's knave: you whoreson dog 1 . .

now, my friendly knave, J thank thee

how now, my pretty knave? how dost

a kliave; a rascal, an eater of broken.......

notling but the composition of a knave
KNAVE. knave, know you no reverence? Lear, ji. 2
and such a knave. Why dost thou (rep.) tliese kind of knaves I know thon (rep.)

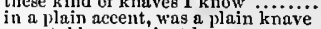
you stubborn ancient knave
sir, being lis knave, I will .... nore liglit, ye knaves; and turn. Romeo \& Jutiet. i. 5 seurvy knavel 1 am none of his (rep.) - ii. and suffer every knave to nse me.... but he pestilent kne is the sane? we are arrant knaves, all; believe ....... - iii. in life a foolish prating knave .......... - iii. suffer this rude knav'e now to knock .... $=\mathrm{v}$ a duteous and knee-crooking knave...... othello, i. whip me such honest knaves.
with a knave of common hire.

a knave very voluble; 10 further....

a slippery and subtle knave

a devish knave! besides the $\mathrm{knave} i \mathrm{i}$

a pestilent complete knave

such things, in a false dislopal (rep.).

as knaves be sucl abroad, who having

Villanous knave, some base (rep.)........ - iv. commit'st thy knaveries wilfully...Mid. N.'s Dr. iii. to make such knaveries yours ..........All's Well, i. NAVER Y -rid of this knavery. Trelfh Nighi, iv. this is a canavery of them ....Mid. N.'s Dream, jii.

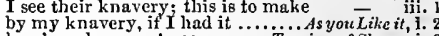
here's no knavery 1 see ......... Taming of Shrew, $\mathrm{i}$.

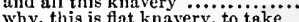

to sound the depth of this knavery ${ }^{\prime}$...

the more knavery to conceal it.. Winter's Tale, iv. 'tis as arrant a piece of knavery.......Henry $r$ '. iv. 7

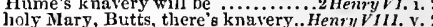
juggling, and such knavery! Troilus \& Cressida, ii. 3 iny way, and marslal me to knavery. Hamlet, iii. [Knt.] upon malicions knavery........... olsello, i. 1 a double knavery-how? how?........ ${ }^{\text {knavery's plain fuce is never seen } \ldots \ldots .3}$ Cupid is a knavish lad ............... ii. 2 over many knavish professions.. IF'inter's Tale, iv. the knavish crows fly o'er them all ... Henry $V$. iv. 2 thavish speech of work........... Hamlet, iit. KNEAD-I'll knead hin .... Troilus \& Cressida, ii. NEADING-kneading up the honey... Herry $r$. i. the kneading, the making of....Troitus \& Cress, i. lair knighthood's bending lue ... Merry Wives, go to your knees, and make.....ieas. for Heas. iii.

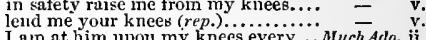
I ain at him upon my knees every........uch Alo, ii. I with libbard's head on knee ....... Love's L.I.ost, v. 2 down on your knees, and thank. As you Like it, iij. 5 when pitli his knees lie kissed...

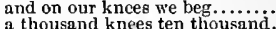
T'inter's Thale, ii. 3 oftener upon her knees than............ Macbeth, iv. 3 on my knee $\mathrm{I}$ give heaven thanks ..... King Jolin, $\mathrm{i}$. my knee, made hard with (rep.) .... bow my knee before his majesty ..... nichard II. i. had the tribute of his supplle knee .. an both lis knees, whoth kiss is..... the fearful bending of thy knee

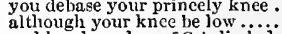
and bend my knee [ Col.-limbs]........ for ever may my knees grow to...... mother's prayer I upon my knees our knees slall kneel tiill............

Ohappy vantage of a kneeling knee! - v. Wa'st thrst bowed my knee unto ... Henry thy guts fall about tlyy kneesl .......

came in with cap and knee ........... - iv. I felt to his knees, and so upward...... Henry $V$.ii. 3 command'st the beggar's knee ...... - iv. - most humbly on my knee I beg .... - iv. 3 and set your knee against my foot.i Henry $\bar{V}$. iii. almost yield npon my knees ........ - ifi. and on my knee, his bloody sword... - iv. how did yow unon his knees

immedintely he was upon his knee...

witli stiff mubowed knee ............

than these knees bow to any .........

I besecell God on my knees...

bath thy knce forgot to bow?

in duty bend thy knee to me...

here on my knce $I$ vow to Grod

I do bend my knee with thine

三

i.
ii.

= ivi.

iv. 10 ;

3Henry YI. ii. ere my knee rise from the eart

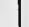
. 
KNEF-no bending knee will eall ...3Hewy $\%$. iii. I | KNEELED down at the board. and liumbly lend thy knee? ......... kicherd 111 . i. !

Foustraiglit are on your knce

but on his knees nt meilitntio

the knees of knottenl oaks

f beseech you on my kness

pursue we him on knees .................

Prianus, and lleenbu on knees......

even on their knees and hunds

eap and knee sluves, vopours .........

five them title, knee, minl approlntion

hinge thy knee, and lot his very

Anficlius' lient below his kne
nnd struek him on his knce

nnd strick

and my nrmed kitees, who howed........

and elijldren, on our knees, nre bound -

col. Kn'. knee the way into

sink, my knee, i the earth ...........

sour knee, sirrah. That's my brat.e boy -

let us shame him with our knees.... .ulius $\overline{\text { Cepsar }}$.

let me, upon my knee, prevail you....

let me, upon my knee, prevail.

on her knee lat th begged, that $1 . . . . . . \quad \bar{c}$ ii. 2

bow your knees; arise, my kuights

here's my knee; ere I nrise ..........

all humbled on your knees.... T'itus

upon my feeble knee I beg this boon

many a time he daneed thee on his knee

mnster-reason, her prayers, her knees

down on thy knces, thank the

be brought to knee his throne.

on eourtier knees, that dream ........... \& Jutiet it.

calm look, knees humbly bowed

I beseceh you on my knees, hear

his knees knocking eneli other $\ldots . . . .$.

let her have your knees: hail to thee .. orhello, ji. 1

upon my knees, what doth your speeeh. iv. -3 (song)

KNEE-CROOKING knave, that .......Winter's T i. 1

KNEEL-I will $k$ neel to him ........... Ttmpest, ji. but when they weep and kneei.......... fors. $\overline{\text { Neas. }}$ i. 5 kneel down before him ............. - ii. 2 should she kneel down, in mercy of this -

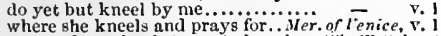
can perfeet mine intents, to kneel ..All's Well,

they ghould kncel for peace .. Taining of Shrer, v.

to see this bastard kneel and caii.... - inter's Tale, ij. 3

they kneel, they kiss the earth .....

that I kneel, and then implore her.

kneel to the duke, before ne pass. Coinedy of $\overline{E r}$

kneel thou down Philip .............. King john, $\mathbf{j}$

will I kneel [Col. Kni.-Walk] upon.. Richard II. v. 3

witls a we and terror kneel to it:

and so kneel down before you...

when thou eomest to kneel at ........ i fenry r. v. 3

lorl Marquess, kneel down........

IJenryl. $\mathrm{i}$.

father Salisbury, kneel we both

kneel for urace. Wouldat have me kite

thy sovern, Clifford, kneel aguined? - v. I

and kneel for grace and mercy

kneel down. Ed ward Plantagenet

wilt thon kneel tor gruce, and set thy

take the time, knecl down, kneel down

where I stand, kneel thou, whilst I

nay, we must longer kneel.

IIJ.iv,

ant kneel [Cut. Kut,-knee] the way...Coriolanus, iv.

than the nlint, I kneel betore the

but kneels, anil holds up hands

kneel not, gentle Portia .............. Jüus Cessar

doth not brutus hootless kneel

did my master lid me kneel ........

and there to kneel: twll him ..........

as I will kneel to him with thanks..

You shall not kneel: I pray yoll, rise
kncel not to me; the power.......... Cymbeline,

kncel $n$ int to me; the power........... Cymbeline, $v .5$

to let a queen kneel in the streets.

and his nephews kneel for grnee

what, wilt thou kneel with me? $\ldots . .$.

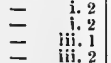

kneel down with me; Lavinia (rep.) - iv. 1

firt approa'ls you must kneel .......

when thou shalt kneel, and justify ....Perirles, v.

na, sir, you must not kneel ............. Lear, iv.

and yet ahe $1 t$ kneel, and pray $\ldots \ldots \ldots \ldots$ oihello, iv. 2

and yet she lt kneel, nnd pray i...... Othello, iv.

KNEEI.FD_you were kneelet to...... Tempesl, ii. I how I prayed, and kneeled ....Meas. for Mens. y.
you had kneeled my lord, tu ask me...All's Well, ji. I

no sooner knew thould prove

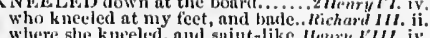

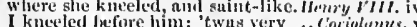
that kneeled unto the burls dusong

where he for graee is kneeted to

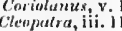

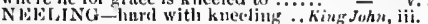

kneeling betore this ruin of sweet life -

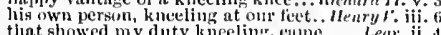

ENEI, liourly ring his knell., ? Tem

let 11 all ring faney's knell. $a$

and elnmonr will be my knel

the it a knell, that summon

and so his knell is knolied

to hear his knell rung out ...............

as twere a knell unto our .... Timon nf thens, iv.

KNEW - if you but knew, how you .....Tempest,

I would I knew lis mind .. Tu'o Ger. of feront,

I knew him, as myself .

if you knew his pure henrt's truth.

him he knew well...

I never knew a woman so do

he knew your worship would kili...

I knew of your murpose...

I knew 'twas I; for many...

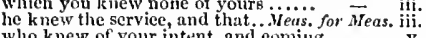

who knew of your intent, and coming

that ever he knew me

in his gnrden-house, he knew me....

you knew that friar Lodowick to: $\mathrm{be}$. .

I thouglit it wns a fault, but knew it not

you sirrah, that knew me for a fool

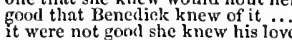

I knew it would be your answer

nor knew not what she did, when sh

were eivil, and knew courtesy. Mhid, N.'s Drean, ii.

I never knew nan hold vile stuff. l.
I would, you knew; an' if my face

Inew her hy this jewel on her.

fou knew, none so well, none so.

for my part, knew the tailor that....

but, if you knew to whom yout show

the doetor, and I knew you nor?

knew yourself with your judgnient. . As you $\bar{L}_{i k}$

one that knew eourtship too well...

I knew when seven justiees eould not

to itself, knew the true minute ...... A

I wore fit you knew him .............

ne'er knew the erafts, that youn.

she kriew her distanee, and did anitic

that I knew of their going to bed

if ever 1 kmew man, twas you ....... - v. 3

in the

as though, belike, I knew not whint.

and he knew my deceased father weil

an she knew him as well as $I$ do $\ldots$.

if you knew my business, you would

I who never knew how to entreat

I knew a weneh married in

knew not the doctrine of ili-doing..... inter's Tale, $\overline{\mathrm{i}}$.

would I knew the villain, I would ... -

you knew of his departure, as you...

his fortunes here, whieh you knew great-

and that he knew, I warrant hin..

knew, "twould be a hald eonclusion... ${ }^{2}$ - y.

I knew, he was not in his pertect wits of v.

he did, for aught he

he did, for aught he knew $\ldots \ldots . . . . .$.
I would to God, thou and I knew.... IrenryIV.
before I knew thee, llal, I knew nothing -
by the Lord, I knew ye as well

if you knew how mueh they dlo im init

knew that we venture

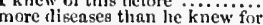

you knew me, as you did when (rep.)

we knew where the bona-robas were

and if you knew what jnins I ......

I never knew yet, but rebuke.

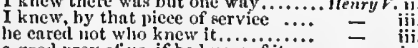

a good prey of us, if he knew of it..... - iv. 4

I knew not what I did! ( rep.) .......3 llenry $b$ l. ii.

I would, I knew thy henrt! ......... hirkard III.i.
KNEW-tll now I never knew thee.Henry III. i.

to whom, if I but knew hiul..........
that never knew what truth meant.

she never knew in know lim

although I knew he were nine cinimy?

ance first you knew me.

anw hin before, and $\mathrm{k}$ new him.. Firoilus

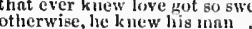

by my troth, 1 knew you not

knew, thon wouldst be lis deatl

I knew thy grantsire, and once.

the devil knew not what he did

were oledient. on but better

nay, I knew by his lace.

irrah, if thy eaptain knew I were here -

of Rome, knew you not Pompey?... Julins

who ever knew the heavens menace so? -

0 that I knew this husluand. Antony of Clcopatra, $\mathrm{i}$.

I knew it for my hond

yet, if I knew what hoop should hoid

you were half blastetl ere I knew you

you were half blastell ere I knew you
what I am, not what he knew I was

loath to telis say, they knew not ... - iv,

that astrononer that knew the stars.

she alone knew this.

knew she and all the world ............ Titusindronicus, ii.

that I knew tliy henrt; and knew

an' if your lighness knew my heart

0 that she knew she were!...... Homeo \& Suliet, ii.

I knew not why it should be slowed

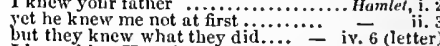

Hamlet, i.

I knew him, IIoratio

iv. 6 (letter

knew, you must be edified by the : -

I never knew a Florentive more kind - iij. 1

I knew, that stroke would jrove the worst - iv.

this extremity, thy hushand knew it all
KNEW'ST how I do love her? .... As you Like it, it.

wreteh! that knew'st this was... Winter's Tale, iv.

of humanity thou never knew'st. Timon of dth. ji:

of humanity thou never knew'st. Tinon of Ath. iv.

and knew'st the royal oecupationt

so is it, if thou knew'st our purposes ... Hanlel, iv.

or eut his weaznnd with thy knife.....

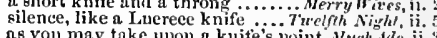

as you may take unon a knite's point. Wuch Ado, ii.

say, my knife's naught

po point, with my knife.................

whet thy knife soearnestly?.MPrchan of

must prepare your bosom for liis knife

like eutler's poetry upon a knife

that my keen knife see not

like an ill-sheathed knife

I'll thrust my knife in your

carved upon it with a knife....
have washed his knife with ge

1 Henryll: $\mathrm{i}$

from treason's secret knife........2unenry $\%$ iv.

I wear no knife, to slaughiter................

set his murdering knife to the root...3 Iemy $_{\mathrm{r}} \mathrm{r}$. ii.

thout whet'st « knife to kill thyself.. Richard $I I I$. i. is

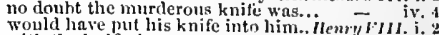

with the knife, he stretelsed him

to shenth his knife in us

given me the knife tlint male it.. Troilus \&-Cress, i.

if knife, drugs, seryents ...Anlony \& Clenpatra, iv. I

Where's thy knife? thou art ton slow. cynteline, iii. I

$O$ give me eord, or knife, or poison
he would have dropped his knife.. Tïns sndran

get some little knife between thy teeth
strike at, Narens, with thy knife? .

give me thy knife, I will insult.

have with my knife eife?.......

witness iny knife's sharp point

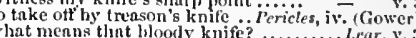

would fnin lny knife ahoard ....Rrmien is Julict, ii.

and with this knife I'll help it presently -

hut dipa knife in it lilny

Inomlet, iv.

kniglit, you have henten my men.....

thine own true knjeht.

amainst this

our messenger to this paltry knight
I do not think the kniglit woulif ofter it

hast thou no suit a gainst my knight?

ret there has bcen kniglits, and lo.....

de enrl, de knight, de forrls
what io you call your knigh

I will to my linnest knighit Falstaft.
are these your letters, knight?

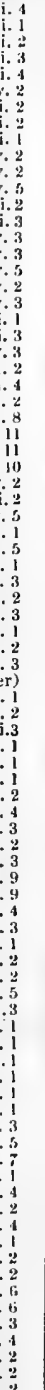




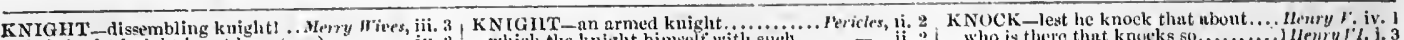

glad the fat knight is not liere (rep.) an undone! The knisht is leere

it be not full of the knight ayain

the poor unvirthous tit knight

to burn the knight with niy tiber

the knight may be robbed

assist me, knight ; l an unclone

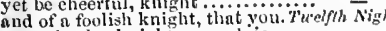

and of atnke, knight: neest, is

8 knight, thoul lack'st a eup

pourquoy, my denr knight? ..........

thy excellence in a galliurd, knight?

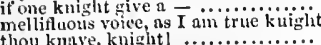

thou knuve, knight I ......

to eall thee knave, knight föling.....

knight : 1 'll write thee $n$ challenge

thy exquisite renson,

send for nouey, knight....................

your time ; with a foolish knight

knight, dubbed with unlaneked rapier

as to know of the knight what my

go with sir Priest, than sir linight.

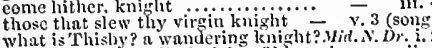

what is Thishy? a wandering knight?

to honour 1Ielen, and to be her knight! - ii. 3

poor knight, what drendful dole is here?

the worth of nany a knight ....... Lorp
of fire-new words, fishion's own knight
in this, most tender-smelling knight

the worthy kniglit of Troy

of $n$ certain knight, that swore by...is you $\bar{L}$ ik

and yet was not the knight forsworn

no more was this knitht, swearing,
stretched along like a wounded knight

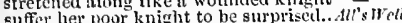

a landless knight makes thee.

knight, knight, gool mother...
henven defend, a knight should

ask yonder knight in arms...............

speak like a true knight, so defend
two-and-twenty knights, balked

he, tlut wnudering knight so fuir

this all-prnised knight, and your...

but stay the knights aro coming.

knights, to suy you are weleont
but you, my knight and guest

but you, my kmight and guest

no more thus other knights have done.

what, are you merry, kniyhts?

yon knighit, methinks dotlis sit too

you kniglnts ot Tyre are excellent...

concluet these knghts nnto their severil

knights, trom my anughter this
she't wet the strunger knight

the Freuch knight that cower
ly many a lord and knight

- ii. 2 who is there that knueks 50 . $3 . . . . .$.

thenryl'ti.

knek him town there ........... 2nsnry r. iv.

kill and lonock downl throw them into - lv. who knocks? One from lord staniey. Kich. $11 \%$. li.

the lord Nluy'or knocks; welcome.

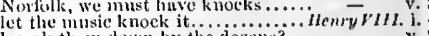
knock them ctown by the dozens? knoek out either of your brnins. Troints gerrs. iv.

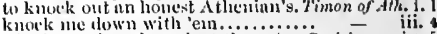
whether to knoek agninst the gotes. Coriolansss, iy. 5 go to the gute: somebody knocks.. Julins Carsar, ii. IAkins, who's that kuneks?........... who's there, that knoeks? answering aluve without at klock.. - iv. 2

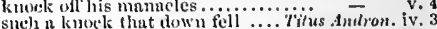
knock at my door, nnd tell me..... - iv. 3 a morlous knoek, und it eried.... Llomeo \&. Juliet, i. 3 come, knock, and entcr

suffer this rude knave now to knowek ...Itamlet iii. or l'll knock you o'cr the mazzurd ..... Othello, ii.

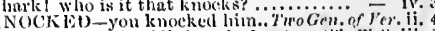
lnitus of my Cupid's knocked out ... All's $W_{c}$ 'll, iii. of' late knocked too often at my door - iv. their gidely brains knocked out .... Re hery VI. jii. has knocked out his brains. '7'roiltes s' C'rrssida, iil. if Brutus so unkindly knocket .. Julius Cressar, iii. coukl linve knocked ont his hrains. Cyubline, iv. KNoCkiNG abont tho mngzard witli... Hamket, v. whence is that linoeking? 110 w is't ... Macbeth,

I heur a knocking at the south cutry

Wake Duncan with thy knockingl

hure snocking has awaked him

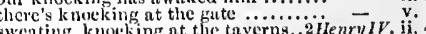
more knocking at the door? how now? - il. 4 will not show without knocking. Truilus of Cress, iil. 3 Othello's place; knocking out his........ othelle, iv. 2 KNOG-knog his urinnls $(r+p$.$) ..... Merry \boldsymbol{H}^{2}$ ives, iii. I

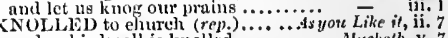
and so his knell is knolled ............... Mucbeth, v. No'T-his arms in this sad lnot ......... Tempest i. 2 break her virgin knut before ........... of ver. ii. 7

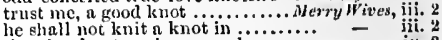

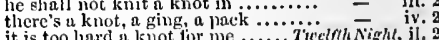
of war in the knot of his scarf.......... A $u^{\prime}$ s $W$ 'tl, iv. 3 that has a knot on't yet............... - iving of sh. iii. notives, those strong knots of love ...Marbeth, iv. by this knot thom shalt so surely.... King Johth, ii. this elum lish knot of all abliorred ...1 Henry $1 i^{\prime}$.

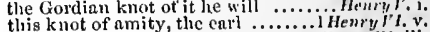
this knot of amity, the earl ........ Henry H He. his aneient knot of and and, by that knot, looks yroudly .... - iv, 3 as knots, by the confux of .. Troilizs \&-Cressida, i. 3 will their knots be strong $\ldots . \cdots \cdots \ldots$..... you knot of mouth-firiends! ... Timon of Athens, iii. so often sliall the knot of us be ...Julius Carsar, iji. heurts with an unslipping knot...Antony s. Cleo. ii. this knot intrinsiente of ffe $\ldots \ldots \ldots . . .$. cymbeline, ii. 2 brats and beggary) in self-figured lonot $\overline{\text { ii. }}$
unknit that sorrow-wreathen knot.. Titus $\bar{A}$ nd. iii. 2 I still my virgin knot will keep ........ Perieles, iv. 3 eif all my hair in knots ................. Lear, ii. 3

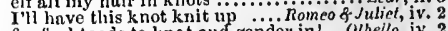
for foul toads to knot and gender in $\because$ Othell, iv. KNOTTED-knces of knotted onks. Troil. \& Cress. $\mathrm{i}$. thy knotted and eombined locks......... Wamlet,
KNOTTED-PATED fool, thou..... KNOT'TY - thee in his knotty entrails.. Tempest, Winds have rived the knotty oaks..Julius Carsar,
KNOW - more to know.................. thou must now know firrtier..............

and I know not how muels...

know thus fiur forth..............

I know thou canst not elioose.........

savage, know thine own meaning ...

I know how to eurse ...................

my lord shall know what 1 have dos

I know not where to hicle my

I slonld know that voice.

I do not know one of my

as thou dost know, do now

we know what belongs to $a$ frippery

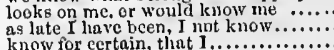

honour, knoek but at the gat
who knocks so loud at door?

hol who knoeks? Why now

- ii.

the knocks nre too hot (rep.) .......
I'll knock his leck about his pate.. 


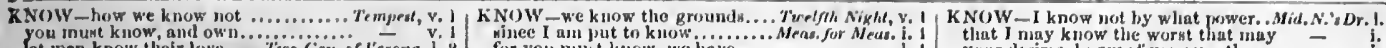
let men koow their love that knowe I am a trald

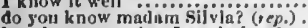
how know you that I am in love?

wir, 1 know that well enougli (rep.).

I know it well, slr (rep.

know you don Antonio (rep.).......

I know, you joy not in a live.

know, worthy prinee (rep.)....

he aball never know that.....

I know it well, iny lorrl.

doth Silvia know that I am.

that knows ine to le in

becaune we know, on valentine's rejort -

then know, that I have $\ldots$.........
know then, that entne of iis

for you know, that love will

learin to know lim hy his volice.

me to enll, and know lier mind

early come to know what Bervice

therefore know thou, for this i

as lica ven, it knows..............................

dost thou know her' ("rp.)

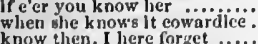

I know the young gentlewoman

the counell thall know this.

to know that of your mouth

more ocearion to know one another..

I know ynne's

nay, I know not nay, I know not .......................
unless he know some straii in ine (rep.) -
and I know not what...............

what they marle there, I know not.

sir. I know not how I may deserve.

sir. kaow not how I in

tn know what ahe would have given

believe it, for you know it ..........

you shall know how I epeed

do you know Ford, sir?

too higli a region, and knows too mueh -

my master knows not of your.

well, heaven knows, how I love joil

if you know yoursell clear...

and you may know by my size...

you come to know wliat pussed.

and you thall know how I speed

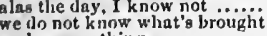

we know nothing.

and well you know the superstitious

to sir John to know his mind...

to know, sir, whether one N

to know if it were my master's foriun

dat de court is know to come.

because I know also, life is

how to know one another (rep.)......

I know yat I have to do..............

the best in Glocestershixe know on't.

how you should know my thaurinter.

an, you know, what greal ones do.. Twelgh Night, I. 2

I know, thy constellation ls right...

your lord does know my mind..................

I suppose him virtuous, know him....

yon must know of me then...........

by my troth, I know not: but I know

by my troth,
every wise man's son doth know...
she shall know of it, by this liand...

I know, I can do it....................

ay, but I know-what dost tliou know? -

and yet I know not..................

you know he brought me out of ....

for I know this letter will make
telling them, I know my place.
Jove knows I love : but who? ..

no man minkt know (rep.)...............

thou canet not choone hut know....

re do know the sweet looman baind

do you know what you say?

yoil shall know mnre liereafter.......

ns I know his youth will apty

thou liast done him, I know not....

as to know of the knight what
knos of this matter? I know

know of this matter? I know

I care not who knows mo mucl .......

I know of none; nor know f you by

no, do not knnw you

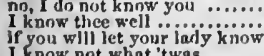

I know not whint 'twas

and that I partly know...

what thou dont know, hath newly..................

and the dont know, hath newly.

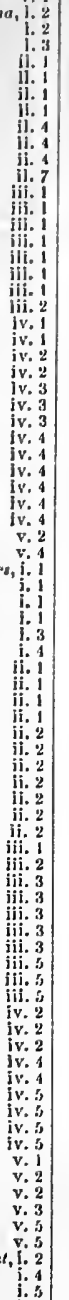

minee I an put to know

I coine to know your pleasure

and do losek to know what doth

bendes, you know, it draws.

you know the lady

that it may know he cail eomna.......

and know his business of litm

for I now must make you know

and let limat know the very nerves.

what knuw the laws, that thicie....

I know no law, bring themn........

how know you that? (rep.).......

for as you know, master Froth

I'll know his pleasur

then I pity those I do not know

anit know that's like ....

to know your pleasore (rep.)........

I know, your virtise hath a licence.

let me know the point ...

and 59 we know not wher

I kirow nonc; can you tel

that I know to be true ................

air, I kuow him, and I love him

erime, fir, I know what I know.

since yem know not what yous speak

he shall know you better, sir.......... =

pattern in himself' to know

for I have made him know

you something know; yet i icjicke...

you know the eliaracter

at $A$ ngejo knows not

the provest know if yet her.

to make them know that out ward

who knows that lodowick's rep.

whow him for a inan divine 3 ij....

yet my hustand knows not.

he knows, that he reer knew (rep.).

know you this woman? (rep.).........
your provost knows the place wiere

how 1 know you where you are?

goodman baldjate; do you know me?

brother's death, I know, gits at your heart -

confessed her, and I know her virtue

I know none of that name, laly $\ldots . .$. ... fuch $\mathrm{Ado}$

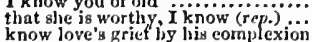

know love's grief hy his eornplexion! -

cousing, you know what you liave to do -

you know your an swer

I am sure you know lim well enoug

when I know the gentleman, I'll tell

Claudio, I know lim by his bearing

you know me well; I am lie

Glould know me, and not know me!

the unhojefulest husinand that I know

know that; but I would have tice henee -

for the man, as you know all

and never to let Beatrice know of

- ii. I and never to let Beatrice know of

one doth not know how mueh an ili
nay, but I know who loves him (rep.)

one that knows him not ............

eonfegs not that you know

ii. 3 it'we know him to be a thief ..........

with any man that knowa the statues
therefore know, I have earned .......

I know that Deformed ................

I know him, he wears a loek $3 \ldots . . . . .$.

wow you may he converted, I now not

if either of you know any inward.

know you any, Hero? None (rep.) .001
she knows the heat of a luxurious lied

I know what yout would say

in wonder, 1 know not whint to any

they know, that do aecuse

though, you know, my inwardness.'.

as strange as the thing I know not

and one that knows the law, go to

and that shall Claudio know

God knows, I loved my nicec.

If he me, lie knows low to turn his girlle

fare you well, boy; you know my mind -

if know not how to pray your gratlence

in nnything that I do know by lier.

and knows inc, and knows me your deeires, know of your youtl l..... -
will not know what all but lie do kuow -

but I know when thon hast stolen...

knowing I know thy love to Thereus?

I know a bank wiliereon the wili

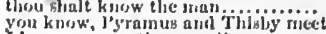

yon know', J's'ramus and Thisloy rined

can you not liak ne, as I know you do

the fuitls theou demst not kiow

conld not this make tlice know, thic liate-

I uni antazed, and know not wliat to kay -

I know, you two nare rivul colmies.

you blaill know all (rep.).

pould know; this beanteous (rep.)

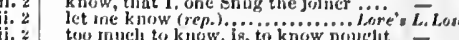

well you know, liere comes in erulnasy

onr conrt, you know, is lasunted ....

if. 4 delight, niy lords, I know not

yo know how mach the gro

to know wlice it is situate

know you the man? 1 know lian, inadam -

kro most, that nost his humours know -

a touguc which I know wili not lie...

I know not; but, I tlink, it was not he -

thou shalt know her, fellow, by the rest -

the decer, was us you know, in sanguis

to kuew thee shall suffiee......................

not by twn, that I know..............

I would not have him know $50 \mathrm{much}$

which they'll know lyy fuvours several
know whut they would ..............

I know the reason, lauly why you....

and so will she, I know, my Jard...

my ford doth know, lave not the...

and knows the trick to make my...

they wowld know, wlyether the the

we know what we know $31 . . . . . . . .$.

I know not the degree of the worthy

where fits the wind.

I know, Alitonin is aad to

fo know of these, that therefore only -

let me know it; and if it stand...

you know me well; and herein

in truth, I know it is a sin to be

you know, I say nothing to hin

slall I know your ansker?........

ho gravel-hind, knows me not.

it i甘 a wise father father? (rep.).....

I know not what $I$ ghall think of...

as your wordigy shall know by .......

1 knnw the hand: in faith, 'tin

and now who knows, but you, Iorenzo

and who know s, birt you,

and $I$ know not what's spent in ......

you know yourself, hate counsels not

never dicl I know a creature

his reason well $Y$ know; I on delivered

I know you would be prouder of

that you yet know not of : weili....

I know my dity ....................

to know your ansecer, whether you'

you know the lnw, your exposition.

and know how well I have deserved

he know's me, as the llind man know

dirl know to wliorn I gnve the riug (

know him I sliall, I am well sure (rep.) -

You sliall not know by what strange
know you where you nre, sir? (rop.)As you $I_{\text {sik }}$

yet I know nnt why, hates nothing.

my own people, who best know limn
vou know my father linth no cliild.

hut now I know her; if she be .....

know you not, master, to soine kind
must do. or know not what to do...

I know I eannot jlease you

inland bred, ant know some niurture

and know what 'tis to pilty, nnd be.

hut their fells, thou know, are .......

to know the quintessenee of every - III.

do you not know I am a woman?....
nguinst whom I know most faults ..

lie taught we low to knnw a man ...
I do not know wluat joctical is ......

ii.

y. 1

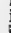

(1) 
KNOW-knows no end (rep.) ..... As yun like it, iii. 3 KNOW-to know the cause.... Taming of Shrew, then shall you know the Hou

if you will know my house...

if you will know my house........

I know not the contents (rep.)

little knows this love in me.

pray you, if vou know wh

pray You, if yon know whes'c.......

if you will know of me what

the wise man knows himselt' to be $i$ foul -

I know where you are: nay, 'tis true -

innow of me then, (for now I spenk (rep.) -

I know into what straits of fortune.

they hope, and know they fe:

r'll stay to know at your abandoned

and yet I know him a notorions liar.

I fill a place, I know 't: how long

for I know, you lack not folly

I know, madam, you love your.

concerns you something to know it.

but knows of him no more............

you know, my father left me some...

her demand) and know her business?

but, what at full I know

with him that all things knows ......

whom I know is free for me to ask

though, more to know, could not

but never hope to know why I should

I know her well; she had her

that wilt not know

what the import is, I know not yet.

to do nothing, to know nothiug

and know their natures; farewel

and know their natures; farewell $\ddot{\text { not }}$

to you that know them not

you know your places well .........

run away; know it, before the report

Fou may know by their trumpet

I know she will lie at my house

the count Rousilloo; know yon such

his fuee I know not ... lï lady

whom, I am sure. he knows not from

I know not what the suecess will be

which thou art valiant; and to the

you do not know him, my lord....

I know not how I slail assure you...

knows he not thy voice?
not to know what we speak

seem to know, is to know straiglit.

he should know what he is

I will confess what I know

do youk know this captain (rep.

though I know, his brains are...

the duke knows him for no other
in uood sadness, I do not know

I do not know, if it be it, or no

but hliey know his conditions...

more of his soldiership I know not

the general, and know his pleasure

look about you; know you any liere?

who knows himself a braggart .....

the velvet hnows; but 'tis a goodly

the king's coming, I know ............

until we know their grave

and yet I know not-thou didst hate

to blume, nr no, I know not.
who, by this, I know, is here

you know, and therefore know how.

do yon know these women? (rep.)..

know you this ring?..................

know he promiscd me marriage? (rep.)

of furies, and I know not what

will not speak what I know.

or hers, for aught I know......

can make me know this cleariy....

I know my remed I I must. Taming of sh. $\overline{1}$ (induc.)

if she know me not well asurp...

you know no house, nor no such

I firmly am resolved you know.

because I know you well ...........

kou, know any such, prefer..........

for [ know, thou canst: assist me (rep.)

and then I know after who comes

than a cat: you know him not, sir.

I know, she is an irksome brawling.

if you'll know, that she's the choice..

I know, he'll prove a jade ......

whereof, I know, she is not ignorant

this I know, she is not for your...... who knows not where a wasp doth...

flrst, as you know, my

so far to know th, my lion

I know you not; hic est sigeia telli...

you know, to-morrow is the

after ine, I lruow, the ront is.

first, know, my horse is tired

who knows not that? Thou.

she, poor soul, knows not which way

and know her liceper's call

know, sir, that 1 an ealled...

or a pedant, I know not whit...........

to Padua? know you not the cruse

in place where thou shouldst know it

where tilen do you know best....

I now, it is the sun (rep.) ...............

and now you know my meaning

I know not what to say $\ldots \ldots \ldots \ldots$

Winter's Tale

let me know my trespass

I dare not know, my lord $($ rep. $) .. .$.

I know not: but,

knows what she should sliame to know

whom you know of stuffed sufficiency

you know me, do you not?

I know not what I shall iny

if she did know me one

fou, my lord, best know, (who least

as you know what you have underta'en -

when shail know not how it wert

I know this man well: he thath

you must know, 'tis my oceupation.

I know, sir, we weary you

o father, you'll know more of

old sir, I know she prizes not....

but what of lim? Knows he of this?

must know the royal fool tho

you know your father's temper

besides, you know, prosperity's the very

that you may know you shall not want -

know ye well enough ...

I know not, what impediment this

I know, by the picking on's this

none must know but the king $(r \in p$.

who knows low that may turn back
of Jermione, I know, in honour ....

gladly know the issue of it ..........

rings, of his, that Paulina knows

I know, you are now, sir, a gentleman

but I know, thow art no tall.

for him, I partly know his mind .... $\overline{\text { we }}$

know, he is the bridle of your will

v. 3 I know his eye doth homage

you know no Centaur?.........

jest with me, know my aspect

I know thou ean'st; and therefore, see =

to me, fair dame? I know you not

but I know what I know: that you beat -

I know a wench of excellent discourise

the chain; by this, I koow, 'tis made

thell, well I know, your weeping.

and I know not what use to

if cvery one know us, and we know

you know, since Pentecost the sum.

you know, I gave it (rep.).

the percock; mistress, that you know

I know it, by their pale and deadiy

God he knows, I saw not

strange on me? you know me well.

dost thou know my voice?

my only son knows not my feeble

$\begin{array}{ll}\text { i. } 2 & \text { the duke, and all that know me in ... } \\ \text { ii. I know not which is which....... } & \text { all the gurters that they know } \mathrm{i} \text { the } \\ \text { ii. } & \text { all the }\end{array}$

all sinel's death, I know, I am thane. you know, there wants no wit...

Where, it fits you not to kno

he must know, 'tis none ot your

v. I know, quoth he, no house, no wife

should know her uncertainty .........

do you know him? I know the man
KNOW-places are the nearest, know .... Macbelh i. 4

asked for me? know you not, he has?.

hide what the false heart doth know....

to know my deed; 'twere best not know

you are, and do not know it ..............

to know it further know it

know, that it was he, in the times

you know your own degrees

notling, to those that know me.

for now I am bent to know.

and you all know, sccurity is

(howe'er you come to know it)

my heart throbs to know one thing..... seek to know no mor .

yoll know not, whether it was

not know ourselves fits o the $\ldots . . . . . .$. .

what know, helieve: and, what I eno

in whom I know all the...............

countryman: but yet I know him not

almost afraid to know itselfl ...........

heaven knows what she has known....

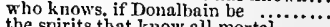

the spirits that know all mortal..........

which I say $I$ saw, but know not how.

know not why, except to get the ... King $\bar{J}$ y. 5

we know lis lows what

let me know my father

when we know the king. Know him

I know, she is not; for this mateli

heaven knows, they were hesmeared

hut, if not, then know, the peril

do not I know, thou wouldst?.

see and know our friends in ........

your uncle must not know but .......

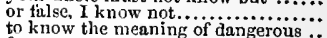

few, or none, do know me...
and tell him so....

and tell him so; we know the worst
yet, I know, our party may well...

may know wherefore we took........

You tanght me how to know the face
I do know the seope and warrant ...

no; know, the gallant monareh...

why, know you not? the lords .......

it seems, you know not then so......

and knows not how to do it....

herven, thon, and I do know

what presence must not know

when they shall know what men.....
mude me, knows I see thee ill

yet I know no cause why I ............

I know, or which way, to order....

lear'n to know him now

to know, whint pricks

I know, iny uncle York hati power

for wew it, uncle; and oppose not....

yet know, my master, God

your heart is up. $Y$ know ..............

more than every one doth know ....

and am I last that knows it?....

my lord Anmerle

wilt know agnin, being ne'er so little

his aspiring rider seemed to know

aught I' know, my lord, they do (rep.)

but now l know thy mind ..........

and thou shalt know the treason

liave them, if 1 onee know where...

Which thou wouldst truly know

I know them to be as true-bred.....

but what I know is ruminated ...... -

I know a trick worth two of that.

I know, thou worshippest St. Nicholas =

and tied him I know not where.

tis our know it well enough....

and I must know it, else he loves...

11 know your business, Harry

utter what thou dost not know

all? I know not what ye call, ali...

how couldst thon know these men ...

ny lord, the man I know. I know ..

I know not whether God will.....

know you well enongh (rep.)

I would thou shouidst $\mathrm{know}$ it

a man knows not where to have her

there shalt thon know thy eharge ..

by some that know not why he is away

for poretty, I know not where

hath sent to know the nature ..........
und well we know, the king knows .. 
KNoW-as greatness knows itself i Henry $W^{\prime}$. iv. 3 KNOW-the king shall know vir, sir licherd - $\quad$ v. 2 that 1 may know my grict......

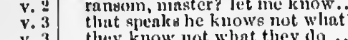

now then this tice full weill.

nor knows he how to live, but hy.....

fears the thing he woslil not
you know wilhere to thed me.

know our own estate

not know me? Come, eome, I know.

or to know thy fnet to-morrow ......

God knows, whether those that baw

every innu inust know that

and eir John must not know of it...

is to eone haltinit ott, you know ....

I know you, inistress Dorothy

know we not Gullowing nags?........

brend-climer, and I know not what

danned for that, I know not $\ldots \ldots . .$.
though then, heaven knows, I liad..

I know not the plirase
know you where you are?

.

lord Mowbray, now you know not wh

who knows on whom fortune would

fiom our princely teneral, to know

I k now it will well please them...

they know their duties

I know not; here he is $\dddot{2}$ kno..........

and how aceompanied? I do not kno

your highness knows, eomes to no...

1 myself know well, how troublesome

I know, king Copletua know the truti.

gentleman, I know not your breeding

I know the young king ins

Jeave gormandizing: know, the grave

for heaven doth know...............

then we go in, to know his embassy

loth know, how many, now in heal

to know the pleasure of our fnir

and know, I know your worthine

let them know of what a monarehy.

that you may know, 'tis no sinister..

to-morrow shlall youk know our man...

we send to know wh at willing ransom

I know him not. Do you not know.

if your mujesty know the man

you know me by my habit (rep.) ....it =

What is thy name? I know thy qualits
I know him to be valiant (rep.)......

that's more than we know

know enough, it' we know we are....

how shall I know thee again?...

and I know 'tis not the halm now thy errand, I will go withe

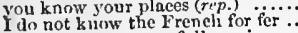

I did never $\mathrm{knnw}$ so full a voice.

God knows, and you know ..........

I know not if the day be ours, or no

which, your majesty know

I eare not who know it.............
for I do kirow Fluellen valiant

sir, know you this glove? (rep.)........

sir, know you this glove? (rap.).....

that I may know the let

I know no ways to minee it....

come, I know thou lovest me .........

and, I know, kate, you

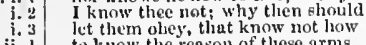

ti) know the reason of these arms
I know ere they will have me go

might I but know the

dien knows how long it is inge

I know our saftety is to tollow then

I know not what to say.................

but God he knows thy share...

for thou shalt know, this stron

ii. 4 would thy beet friends did know

iii. ye know thou, since we have

lost thou know who epeak
I know by that, he's dend.

you know not what you swear

he knows the game; how true

other time, to know our mind.........

and yet I know not how to get the not

alus you know, "tis far from henee

iv. 3 why, knows not Montague that of

iv. 4 Fou know, our king, my brother

and you shall quickly know

iv. 4 know you what this means?

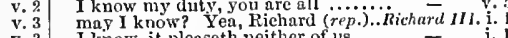

\begin{tabular}{l|l} 
v. 3 & I know, it pleaseth neither of us, $\ddot{v}$. \\
$v .3$ & lady, you know no rules of ehnrity
\end{tabular}

but knows some touch of pity $($ rep.).

1 hope so. I know so: but rent

come, come, we know your mening

0 , know you, that he doth it ........

who knows not, that the gentle duke

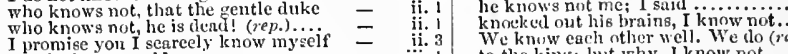

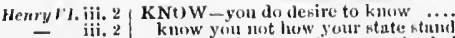

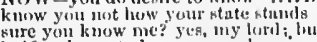

half an hour, to kmow yomi picusure

fo nut I know you for a fiusol.

alns, I know not

I know, within a while nil the best.

true, he was so; I know the rauke. Tro

do you know a man, if you fee him?

why, you know, 'tis dimplet

do you know what a man is? $\ldots$... i i

one knows not ut what ward youl ie
that she bolowed knows nalught $(r, p$. $)$

and know, by neasiare of their otservant -

thou blualt know, Trojian, he is awake

let himi know, what. Troy metns ....

and knows not his fear though, $A$ pollo knowe,

I know that, fool (rep.)..............

I know not, it is put to lutt

who knows what follows? ..........

know, an enemy intend you harm (jep.) -

whom, we know well, the world's....

tselt knows it so abundant searee

or know not what we are

know the whole wride

youl know me, do you not? (rep.)

but partly know, sir; it is musie (rep.)

yout know all, lord Pandarua....

you know uow your hostages.......

I lnow is sueh a wrest in their...

you know my mind, thl fight no

the benrer knows not, but eommends

a very horse; that has he knows not

We knuw each atler well. We do $(r e p$.
to the kinr; liut why, I know not...

do not you knew of lim, yet go....

God he knows, not I, the queen....
of my kind unele, thit I know wili give -

to know youl lordship's pleasure
God knows, I will not do it, to the death -

I know, they do; and I have well

knows the lord protector's mind ( $(r e p$.)

his lordship knows me well, and loves

hy his face straight shall you know h
my loril, you know my mother lives

true ornaments to know a holy man

know, then, it is your fin ult, that....

yet know, whe'r you aceept our suit

for God he knows, and you may partly -

1 know a discontented gen ticman

to say the truth, I do not know ......

for I know the Bretagne Riehmond.

God knows, in torment, and inl, I love

I know not, mighty sovereign, but by

alone, no man knows whither $\dddot{2}$.....

gentle hearers, know to rank.... Henry $v \bar{l}$. (prol.)

fo know kinsmen of mine....

you know his uature, that (rep.)

know you not the fire

1 do know, to be eorrupt and treasono

I know but of a single part...........

to those which would not know them

in what kind, let's know, is this ....

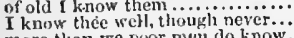

more thass we poor neth do know.

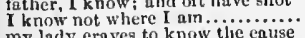

my lady eraves to know the ea.
and know us by these eolours..

but he shall know, I nm as good ....

know the office that belongs

let me know, and then 111 answer yo

yet know, my lord, I was provoked

to know who hath obtinined.

I came to know whint priso

begut her, all the parish knowi.....

Gud knows, thon art a eollow

for know, my lords, the states

for know, my lords, the stntes ......

I know it wifl cxense this .....

neither know my faculties, nor
if I know you well, you were

ii. 3 will know hin one day (rep.)

I'll make you know your times o

I know your majerty has alway6...

I do not know what kind of my

who knows yet, but from this lady

if he know that $1 \mathrm{am}$ free of your (rep.

with thy appronch, I know, comfor

I know my life so even: if your -

ns not to know the language lave

in truth, I know not; I was se

but heaven kpows your heart

coukl but be brought to know ...

you know, I am a woman........

wizarils know tlieir times...

they know, their master loves

God knows, of pure devotion

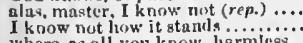

where, as all you know, liarn

we know the time, sines he was.

nily, Gloster, know, that thou ar

I know, no pain, they ean inflict

let liim know, we liave despatelied

Gol,at know I, how the world may

what though I know her virtuous (rep.)
I know 'twill stir him etrnugly (rep.)

know officions lores, I dare

the king shall know it, and, no doubt

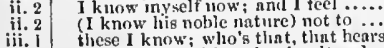

I know it, but 'tis so lutely altered

all the land know's that

iii.

I know what 'tis to love; and would

thic know you, lorel, I'll nothing do

for, you know, 'tis truc, that you....

one that knows the youth even.....

great soldier may his weleume know
you know me dutifinl; thercfose

know what it is to meet Achilles

.. Timon of sth

but you well know, things of like...

you know me, Apemnnt us .............

nor will he know his purse; or yield

I know, no man ean justly pratse....

if you did know, my lord.

you are, and lo not know yourketyes

they know not, - but sumething

one that knows what helongs to reaso

we know him for no less, though
I know his lordship is but merry.

mine homour; sliall not know my eoin

l know, my lord hatli spent of

now we shall know some answer

fnow, your reverend ages

what does his loriship mean? I $\mathrm{k}$ now

know you the runlity of lord Timon'

ever know unthirift, that was (rep.).

lre; I know him. Sure thee, Timon.

I beg of you to know me, goud miy iord -

heaven linows, is mercly love.......

nowe them, my lowl, let's know then

let $\Lambda$ leiliades know this of Timom
then. let him know, and, tell him

you know, Csins Miareius is (rep.)

for, the gods know, I spenk thiss in .

presilne to know what's dome i' the

where, I know, our preatest frieuds.

and know how we proeced ..........

where they ghall know our mind ....

know you on whieh side they hatre.

Jome must know the value of her

I know, you can do very little alone

there's nine that I know ...........

know, Rome, that milne Marcius

I know not where to turn ..........

know, goot mother. I had ratlier

I know you wise, religioua.............

you know the cause, sir, of my stanting -

(ri il.) 
KNOW-we let the people know 't .. Coriolanus, iii. I KNOW_knows what is most ....Anlony \& Cleo. iny soul aches, to know, when two. he shall well know, the noble. as I do know the consul's worthines although, I know, thou hadst rather I talk of that, that know it ............. we know your drift: speak what? heaven will not lave earth to know
I know you well, sir, and you know me then know me not; lest that thy know thou first, I luved

tell not me: I know, this cannot be........ (how probable, I do not know) $\ldots \ldots$.... he knows not what I can urge

he would not seem to know nie come, my captain knows you not.... you shall know now, that $I$ am in... you know the way home again thow this lady? The noble. as know it; and my pretext to strike. you are to know, that prosperously what! know you not, being ........... you know, it is the feast of Lilpercal since you know you cannot (rep.)
if you know that I do fawn (rep.)

I know that virtue to be in you (rep.) I do not know the man I should avoid

you know him well by sight . .......

fnow where $I$ will wear this dagger

I know he would not be a wolf

now know you, Casea, I have moved

tis Cinna, I do know him by his gait

I know no personal canse to spurn ..

know I these men, that come...

and, yon know, lis means............

1 sliould not know you,

then should I know this secret

danger knows full well, that Cæsar...

because I love you, I will let you know what I can say: and know it now...
to know my errand, madam ........

none that I know will he

know, Casar doth not wron

know but one that unassailable

e will know your pleasures (rep.)

I know not. gentlemen, what you in tend -

jou know not what you do ...........

I know not what may fal

who, you all know, are honourabie...

it is not meet you know how Casar.

ron all do know this that

for Brutus, as you know, was Cæasar.e griefs they have, alas, $I$ know not..

deserved your loves? alas, you know not you know, that you are Brutus

for, I know, when thou didst hate ... I know young bloods look for

I know not how, but I do find

whether we shall meet again. I knownot 0 that a man might know the end now me for Brutus

know, my hour is come is't vou, sir, that know things?

we know all our fortun

more than the ills I know...

I know, by that same eye, there's some -

the gods best know $\ldots \ldots \ldots \ldots \ldots \ldots$ but there's not it; that you know well and henceforth know, it is not Cæsar' know, worthy Pompey, that what.

I know not, Menas, how lesser

petty difference, we yct not kno

1 do not know, Mecænas; ask Agrippa not so; I know you could not lack

I do not know, wherefore my father

you must know, when Cæsar and you

you must know, when Cæasar and you

I know thee now; how far'st thou ...

they know by the height, the lowpess

geen some majesty, and should know

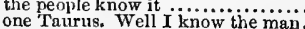

one Taurus. Well I know the man.

Fou did know, how much you were.

know you him? Cæsar, 'tis his

for ns, you know, whose he is, we a

for $n s$, you know, whose he is, we are
he knows, that you embrace not Anton

\begin{tabular}{|c|c|c|}
\hline$i$ & & \\
\hline & 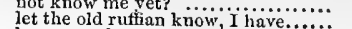 & - \\
\hline iii. 1 & know. my hearts, I hope well of....... & \\
\hline iii. 1 & like lim that know a warlike charge & \\
\hline iii. 2 & and let the queen know of our gucsts & \\
\hline iii. 3 & she soon shall know of us, by some... & \\
\hline iii. 3 & for, I know, your plight is pitied .. & \\
\hline iii. 3 & know, sir, that I will not wait pinioned & \\
\hline iv, 2 & thy master Cæsar knows, and he hath & \\
\hline iv. 3 & assuredly, you know me ............ & \\
\hline & know you what Casar means to do ... & \\
\hline $\begin{array}{l}\text { iv. } \\
\text { iv. }\end{array}$ & in triumph? Madam, he will; I know & \\
\hline iv. & Cleopatra, know, we will extenuate.. & \\
\hline $\begin{array}{l}\text { iv. } 5 \\
\text { iv. } 6\end{array}$ & know the devil himself will not eat (rep & \\
\hline $\begin{array}{ll}\text { iv. } \\
\text { iv. } 6\end{array}$ & $\begin{array}{l}\text { you know the peril ............ } \\
\text { I shall incur I know not how }\end{array}$ & \\
\hline iv. 7 & but, you know, strange towl light..... & 二 \\
\hline iv. 7 & I do know her spirit, and will not.... & \\
\hline v. 1 & I do not know what is more cordial.. & \\
\hline v. 1 & but, henvens know, some men.......... & \\
\hline v. & you do seem to know sumetling ...... & \\
\hline 8 & to know if your affiance were deeply & \\
\hline v. 2 & wlich you know, cannot err ......... & \\
\hline v. 2 & no, I know that: but it is fit .. & \\
\hline v. 3 & not know on'tl he's a strange (rep.)... & \\
\hline v. 4 & I know her women are about lier...... & \\
\hline & that $I$, which know my heart......... & - \\
\hline v. 5 & I hope, you know that we must not.. & $\longrightarrow$ \\
\hline v. & or who knows if one of her women ... & \\
\hline$r, \mathrm{i}$. & I know not wherc when I was stamped & - \\
\hline i. & nay, that hell knows, why liers...... & \\
\hline & you must know, till the injurious.... & - \\
\hline i. & I know your master's pleasure & \\
\hline i. & Dor know not what air's from home & - \\
\hline & did you but know the city's usuries.. & \\
\hline i. & these boys know little, they are sons & - \\
\hline $\begin{array}{l}\text { 1. } 3 \\
\text { i. } 3\end{array}$ & heaven, and my, conscience, knows .. & \\
\hline i. 3 & $\begin{array}{l}\text { it is Posthumus' hand, } 1 \text { know't } \ldots . . \\
\text { know, it you kill me for my fault.... }\end{array}$ & - \\
\hline i. 3 & I know not why I love this youth.... & - \\
\hline & hereafter I might know more......... & \\
\hline & I partly know fim (rep.) ............ & \\
\hline i. 3 & thou shalt know I'm son to the queen & \\
\hline ji. & Jove knows what man thou mighitst & - \\
\hline & I know the shape of his leg ........... & \\
\hline & Who needs must know of her departire & - \\
\hline & I nothing know where she remains... & \\
\hline ii. 1 & beither know I what is betid to Cloten & \\
\hline & to know from whence we are & \\
\hline & lour & \\
\hline & 'll quickly fly & \\
\hline & more cle & - \\
\hline ii. 2 & whose bolt you know, sky-planted .. & \\
\hline ii. & Irs; whom best I love & \\
\hline & is golden chanc & \\
\hline & & \\
\hline & wl & \\
\hline & and yet I know thou wilt. & \\
\hline & tho & \\
\hline & & \\
\hline & & \\
\hline & & \\
\hline
\end{tabular}
sir, as your highness knows.

I know not how to wish a pair

know, that the people of Rome.... Titus Andron. I know not, Narcus ; hut I know it is and make I give your grace to know till you know better how to handle it should the empress know this discord's

iii. 2 you shall know, my boys........

iv. 2 ne'er let my heart know merry cheer

iv. 3 how dost thou know 'tis he?

iv. 3 we know not where you left $\mathrm{him} . .$. ...

iv. 3 learn to know thy meaning....

v. 1 every where, I know not why...

v. I my lord, I know not, I, nor can I guess

that we may know the traitors.

my lords, you : rnow, as do the...

i. 2 but he and his shall know that justice

3 when he knows thou art the empress'

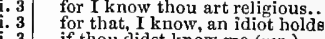

\begin{tabular}{l|l} 
i. 3 & if thou didst know me (rep \\
i. 4 & know thou, sad
\end{tabular}

ii. 1 well mou, sad man, 1 am not Tamora I know them all, though they suppose I know thou dost; and sweet Revenge

ii. I what's your will? Know you these..

alas I you know I am no vau

taught my fow the common ......... $-\quad$ v. 3

as sick men do, who know the world

\begin{tabular}{l|l} 
ii. 6 & it is enough you know; and it is fit.... \\
ii. 6 & one sin, I know, another doth provolk
\end{tabular}

ii. 6
ii. 6 one sin, I know, another doth provoke
desired he might know none of his secrets

(on what cause I know not)

I have forgot to know; but what $\mathbf{I}$ ain

hark you, sir, do you know where ....

and further he desires to know of you

that's the mark I know you level at

no, no, my Escanes; know this of me

or know what grounds made happ that knows to court it with words

although, I know, there is enough

ii. 2 you know your mother means

we desire to know of \begin{tabular}{c|c} 
i. Il & KNOW-who, for a ught I know ......... Pericles, il. 5 \\
iv. I & command. Know you the character? \\
come, cone, I know tis good for you
\end{tabular} come, come, I know' tis good for you mistress, do you know the Frencli.........
I know, he will come in our sliadow none does know, but you (rep.).............
but yet I know you'll do as $I$ advise your jonour know's what 't tis to say.

v. 2 do you know this house to be ...........

v. 2 I made to it, to know of wlience you are entreat to know at large the cause .... I know not; but here is the Regent.... now I know you better: when we do you know this noble gentlcman.

. 5 know, that we have divided....

i. 6 I know no onsw...

i. 7 I know you what you a............

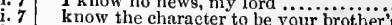

I do not well know, $m y$ lord.................

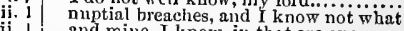

ii. 3 dost thou know me, fellow? No, sir

ii. 3 my lord, I know not what the matter in.

ii. 4 dost thou know the difference, my boy

wisdom whereot I know youl to wear may not an ass know when the cart ... does any liere know me?

nevcr affict yourself to know the cause.

I know his heart; what he hath uttered.

iii. 3 nay, I know not: you have heard..................

I know not, madan: it is too bad

you know not wly we came to visit you

v. 2 neither known of thee, nor knows thee?

v. 2 beastly knave, know you no reverence?

v. 2 I know, sir, I am no fl know

iv. 3 all the world well knows, will not be.....

my dear lord, you know the fiery quality

you less know how to value her desert

I know't, my sister's ................... what they are, yet I know not

to horse, but will I know not whither

sir, I do know zou; and dare?

your fcllow is that yet you do not $\ldots . . .$.

forbid thee, shall the duke instantly know

be simple-answered, for we know the truth -

dost thou know Dover? Ay, master...

suddenly gone back, know you the reason? seemed not to know what guests

letters to him? I know not, lady $\ldots \ldots \ldots . . . .$.

something-I know not what-I'll love... I know you are ol her bosom

in understanding, you are, I know it.....

and yet I know not how conceit may...

dost thou know me? I remember thine...

ii. 3 I am a king, my masters, know you that?

to know our enemies' minds

my boon I make it, that you know me not

ii. 4 sir, do you know me? (rep

I should know you, and know this man

nor I know not where I did lodge last

I know, you do not love me..............

you know the goodness I intend upon $y$

kno, know the riddle...

know, my name is lost; by treason;

no tearing, ]ady; I perceive you know

worthy prince, I know it wejl

he knows not what he says.

know our intent: what comfort..........

you know not what you do....... Rameo \& Juliet,

do you know the cause? I neither $\mathrm{know}$ -

I'll know lis grievance, or be much..

ay, if I know the letters.............

I know what: you mist contrary mel =

a name I know not how to tell thee...

utterance, yet I know the sound ...

plainly know, ny heart's dear love...

you know not how to choose a man..

but all this did I know before........

at my hand, that I yet know not......

fou shall know my errand ...........

and know her mind early to-morrow

Romeo, whom you know I hate ....

you do not kuow the ladp's mind...

you know the

I already know thy grief

by my letters know our drift $\ldots . . . . . .$. .

God knows when we shall meet aggin
for the cook, gir; but I know not what

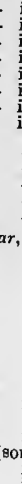

.

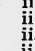

ii.

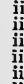




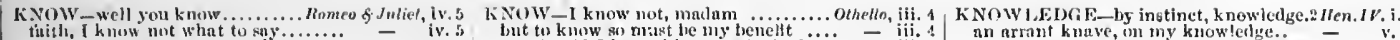
mith me thint know's yon wath my mister knows not, hut I ami...... know their, Anring, their hens. then say nt ouse what thon clost know thmeligh to work, Inow not............... was, ns you know, by Fortinhras

che

may, it is:

nay, it is:

for whint, we know, inust be, atud is

$1 \mathrm{know}$ you are no trum

in our dity, to let you know of $i t$

I do know, when the blood burns

laste me to know i

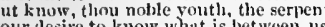

that they do know my son.............

ny, niy ford, I wonlel know that

I knew the gentlemnn, I saw him

(I'd fain know thnt) that $\mathrm{I}$ jinve positively

not that 1 know. Take this fiom this

do you know me, ny lord? Excellent w

I know, the good king and queen have

I hnve of late (but, whicrefore, 1

you know, it eame to pass

than fly to others thow my eourse...

you know riglit well, you did .

we shall know by this fellow.

my love is, proot hath made you know

I know nin touch of it, my lord........

and tell you whit $1 \mathrm{know}$

who knows, saye heaven? ............
uj) sword, und know thon a more horrid

nay, I know nut; is it the king?.

I must to England; you know thint?

guarded, to know your pleasure till I know 'tis done, howe'er my hajs.

you know the rendez-vous....

in his eye, and let him know so ....

we know what we nre, but know not.....

my brother shall know of $i$

if you desire to know the eertainty

I do not know from what part

Horatio, as I ain let to know it is

high and mighty, you slyall know
know you the hand? 'Tis IInmlet's

I know him well, he is the brooeh

but that I know, love is begum by .......

do you think it was? Nay, I know not.

that I have kissed I know not how oft..

let us know, our indiscretion sometime

[Col. Knl.] and know of these eontents.

dest know this water-fly?

for 'tis a vice to know him.......

I know, you are not ignorant ..........

he sends to know, if your pleusure......

since no man of anght he leaves, know
this presence knows, and you must

cousin Ilamlet, you know the wayter

I know my price, I $\mathrm{nm}$ wor th .............

ner the division of a battle knows more

reverend signior, de ye

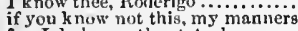

for, I do know, the state, howeve

do you know where we may apprehend

'tis yet to know (which, when $1 \mathrm{know}$.

for know, Iago, but that I love the genti

conduct them; you best

nor know I aught but that ie's weil....

the Moor, - I know his trumpet

I do not know; friends aii buit now

of all that I de knuw; nor know I aught

give the to know how this foul rout began

what harl lie done to you? I know dot.

thou shalt know more hereafter $\ldots . . .$. .

many a wind instrument that I know

[Knl.] I know't, I thank you ............

nothing, my lord; or if - I lnow no...... wh

wowed iny lauly, know of your love?
my lord, tor anght I know (rep.).

I know thou art full of love and honest

to let you know my thoughts ..........

hy heaven, I'll know thy thought

if more thou dost perceive, let me know

doubtless, Bees and knows more

knows alj qualities, with a learned
what he'll do with t

than hut to know't a little..............

let him not know it, and he's not robbed
I know not that; but such a hand kerel

uor should I know him were he in farour - iii. 4

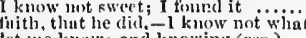

tet me know; nnd knowing $(r, p)$

and nit know who left it there?

wy did he so? I do not know.

nuy, heaven loth know ....

kinws not yet of his honvurable fortune

I know a lndy in Veniee, whe

I know his grit, "tis

we do not know. Did you not bear n er.

krow we this hinee, or no! alas, my
did yout know him? Know him, ay

nor do I know the man ...............

know of Cassio, where he supped to-night - v.

I know not, since guiltiness I know not

I know, thou didst not...

I know, this act ghows horribe

yet, Iago knows, that she witl Cassio

whint you know, you know ...........

the state some service, and they know it
KNOWLR - thy knower (rep.) .. Troilus of

KNOW I NG-nought knowing of Troilus of Cress. ii.

nowing I loved my books.

knowing that tender youth. . Turo Gen. of Fer. iii.

not knowing what they do! ........Much Ado, iv. 1

with knowing what hath pos

withowing I know thy love to ..Mid. N.'s Dream, ii. 2

knowing aforehand of our merriment - v.

the other knowing noburden of... As you Lilie it, iit.

praises towards him; knowing him...All's I' ell, ii. I

I knowing all my peril, thou ne art

not knowing them, until we know

to rieve at knowing of thy eloiec. Hro of Shrer, ii. 1

that I, knowing by Panlina, that the

knowing whom it was their hap.. Comedy of Err. i. 1

and, knowing how the debt grow

not knowing what they feur

Marbe/h, ii. 4

knowing dame Eleanor's aspiring ...2 Henr

knowing, that thou wouldst have me

broken tith with me, knowing how - v.

not knowing how to find the open....

youl are to hlame, knowing she

knowing myselt again, repair to.... Cnrioltunus, ii. 3

he's very knowing, I do pereeive't...Ant. \& Cleo. iti. 3

gentlemen of your knowing

and ofttimes not knowing why

one of your great knowing should learo

knowing 'tis a punishment, or trial?

nowing, that with the shadow.. Tilus Andron. iv.

that knowing sin within, will toueh..... Pericles, i. I

and knowing this kingdom,

have lseard, and with a knowing ear....... Hamlet, iv.

and knowing [Col.Knt.-know] of these.... - v.

knowing what I am, I know what she..Othello, iv.
KNow INGLY-madam, knowingly...Alt's Well,

and felt them knowingly: the art.. Cymbeline, iii. 3

he has no more knowledge in..... Alerry Wires, jii.

and feed your knowledge with ...Tuelfh Night, iii. 3
I profit in the knowledge of myself ..

or if your knowledge be mere... Weas. for

with better knowledge, and knowled ge

being come to knowledge that there was

for that angel knowledge you ean. Lav

if knowledge he the nark, ta know.

your knowlerlge may by me be done.

defire more love and knowledge of you

let me the knowledge ot ny fault.. As you Like it

delay me not the knowlerlge of lis
O knowledge ill inhalited! worse than

a good npinion of my knowledge....

ourselves into secming knowletse

or rather, my knewledge; that $I$ may

he is very grent in knowledge. .......

upon my knowledge lie is, and lousy

in the freelom of $\mathrm{my}$ knowlelge.. W'inter's $\mathrm{T}^{\prime}$ ale, $\mathrm{i}$.

does belove my knowledge thereof.

for his knowledge is not infeeted

rou shall come to elearer knowledge

let him have knowledge who I am

hall fore, ant knowledge, mnre than

nothing benefit your knowledge

makes us unthrifty th our knowled ge

in your knowledge, and your...Comedy of Err. iii.

more in them than inortal knowlesge - i. 5 (let.)

the certain knowledge of that truth.. King John, i.

bear thee fron the knowledge of thyself
to my krowledge, I neer in my.... Michard II. ii. of grent expedition, min knowlethe... In

to mone so tir ont of his knowledge

than is in your knowlerl oe to drenm

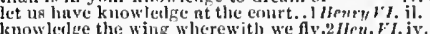

never did har any to why knowledge. Wichard III. i.

the king's assent ar knowlcelge.... Henry J'II. iii.

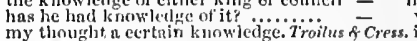

manifest the truc knowledge ...... Coriblanus, ji. 2

I shnll ere lang have kmowledge of my - it.

who being mature in knowled cte... Antony \& Cleo.i.

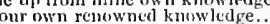

and lare not speak their knowledge.

no guess in knowletlge which way . Cymbeline,

partieulars inust justify my knuwledge

which by my knuwled pc found........

and justify in knowlectge, she is thy ...

marks of soverei futy, knowledge, nind
from some knowledge anrl assurnnee

lose the knowledge of thenselves.

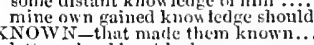

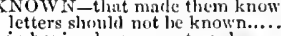

n having known no travel........ Tirn Gen of ler.

the execution of it shall muke known
if it were known in coun:el..........Mcry ${ }^{\prime}$ ives

a man long known to ine.

the truth being known, we'll all

the matter will be known to night

nor no railing in a known dircrect
when that is k nown, and golden

rell known to the duke

I bave not yet made known to Mlaiala - iv. I

are but easy when they are known .. - iv.

I have known my husinand............

I have known, when there was no..... - Hi. 3

hath sle made her aftection known... =

ever was known in tlie eommonwealth - iif. 3

and our deviees known..................

and the country proverb known

as brief as I have known a play........

as well known as disguised ............. of Fenice
but where thou art not known

often known to be the dlowry of ...... - iii.

be it known unto all virtue of

had I before known this by.........As

have known thee al ready.......

ay, that would be known: to the wars

and uses a known truth to pass

which I have some time know

I would, I had not known tim

whel is known inine; for $\mathrm{i}$ by vow. - v. 3

a man well known througheut all

Gremo tis known, my father liath.

kingdoms known and allied to .... Winter's Ta

make kmown how he hath drank.

if the good truth were known

let 'Time's news be known, when 'ti. - iv. (chorug

that I have known to go about with

make us better friends, more known.

fitting to be known, discover...

they were to be known hy garment

nor must he known no less to have. Cornedy of Err. ii.

to make his love known?

is t knewn who did this mere thinn bloody

you male it known to us .............

I am not to you knewn, though in

you have known whit you should no

yet I have known those which

that is well known than if you had at leisure known of this

政

that is not yet known..............

be it known to you, I do remain

if then the tree may be known by

this oily rascal is known a

our eause, and knowll our m

but to be known and hated ....

be it known to youl, (ns it is very w....ii) $=$ (cpil.)

wos ever known eo grent and little.... Henty $r$. ii.

wh this dny is not known
no loss is known in me

"tis known already that $\mathrm{I}$ am ........... 


\section{$\mathrm{KNO}$}

$[420]$

I. AC

IENOWN-if they were known

.21lenryt. i. 3 na well have known our mumes.......
why, "tis well known, thut whiles I..
for it is known we were but hollow"..

KNOW'ST-thou know'st .... Yerch of trenire, iv be it known unto thee hy these presence - iv. 7 he it kurisn to

for these known evils, hut to give . Rishard III. i .

are known the first and han

better, she ne"er hall known pomp

be a know triend, 'rutinst his high

frad not known those customs...

God shall be truly known

would I had kuow no more
ns it is known she is

let it be known to him, that we.....

known, Achilles, that rou tre in love(vep.) -

purpese, a vietor shall be known?
ny, thnt's well known ..........
that might have known iny place

that miglat have known my place
le has been known to eommit.

make them hest seen, and knowi

but it is not known whetler...Coriolions, i. 2 (letter.)

be it known, as to us, to all the world

my nolle steed, known to the eamp.
Menerrins, you are known well $\{$ rep.

that I am known well enons

it I he known not known the worthiest men

never klown before but to be rongh

I haye not known when his aftections

and I knowa wherefore they do it

and then the end is known

I shoult have known no less. Antori... \& Cleoput

you und I have known, sir ...........

make it so known. Casar.

purchinse whint you have made know

I.will be known your nlvoeate......

kun'st thou the youth that spoke...

at full I know, then know'st

know'st thou not, liertrum .......
thou know'st she has raisel me...

thou know'st net gold's effect.

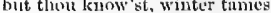

thou kunw'st he dies to me again.

witls him? know'st thou his mind? Com. of Er.

in srrnews, dor thour know"

thou know'st, that Bumeto, und his......ucheth, iii.

my friend, thint know'st my tongue. King John, y.

which know'st the way to plant...

thou know'st, he's no starveling .... HenryIJ. ii.

thou know'st my old ward; here ling
why, thou know'st, 1 wun as valiant..

iii. 3

thou know'st, sir Jolu eamnot......2nenry J

a Welshman. Know'st thou Fliellen? Henry r.iv.

whut means this, heralel? know'st thou

know'st thon Gewer? He is my dear

sirruh, thon know'st how orleans....
villuin, thou know'st, the law -
thou know'st what eolour jet is of?...2 Henry ${ }^{\prime}$

ol"?

villain, thou know'st no law of Goil.Richard n1. $\mathrm{i}$.

thou know'st our reasons urged.

althougln thou know'st it not.

as thou know'st, umjustly must be....

know st thon not any, whom eorrupting - iv.

how know'st thou this? ............ isen $\bar{y} / 111 . j$.

thou may'st tell, that know'st.. Troitus \& Cress. ii.
knaves? Thon know'st them not? Timon of flhens, $\mathrm{i}$.

and thou know'st well enough

in thy rags thou linow'st nome

to frown: know'st thou me yet?

thou know'st thy country's strength

thou know'st, freat som, the end
why, know'st thou any harm's...

thou takest up thou know'st not Antony \& Cleo.

we have kuowa together in Orleass

that have a sharper known ....

she wished me to make known.....

$1 \mathrm{~nm}$ known of many in the army

I nad my brother tre not known
vision which I made known to Lieiu

the cause were known to them.....

be it known to you my hill intent....

be it known to you, that have preserved

in being known, he fll stop the coirse (iep

reason to herself is only known.

'tis known, I ever have studied physic

made knowu to you who I am?

made known herself mp daughter. .

that you make known it is no vieious

that is neither known of thee, nor know

better thus, and known to be contemned
when I an knowu aright, you shall not

tis known before; our preparation

by the art of known and feeling sorrow

yet to be known, shortens my made
pleasures first be known that are to.

pleasures first be known that are to

how have you known the miseries ....
and 'tis known, I am a pretty..... Ro?
seen unknown, and known too late!

seen unknown, and known too late!
still have known thee for a holy man

still have known thee for a holy man
this side of our known world esteemed.. Hamlet

never make known what you have seen.

this must be known; which, being kept.

custom not known, the ratitiers........

safely, the changeling never known.

some elder masters, of known honuur.............

if this be known to you, and your .......

should have known it withont a prompter
fortitude of the place is best known to you

if thou hast no name to be known by

you have known him long; and be

her sweet body, so I had nothing known

felt no age, nor kuown no sorrow...........

to speak what I have seen and known
will make myself known to Destemona

I'll make thee known, thougl I lost...

nf your fault be known to the Venetian
KNOW' $\mathrm{W}$-from Argier, thou know'st.

thou best know'st what torment I did
and yet know'st her not? . . Tu' Gen. of

for love. thou know'st, is fuil of jealousy

o know'st thon not, his looks.

thou know'st, being stopperl

thou know'st, how willingly
ns thou know'st their deserts

know'st thou this colntry?

and dilueulo surgere, thou know'st.

Tirelfh $\overline{\text { Night }}$

thoul know'st not me 1 .................

till thou know'st what they are. Ni.... for $\bar{M}_{e \alpha s .}$ ii

friar, thou know'st not the duke, $;]^{-} \quad-$

thou know'st, that the fashion of.... NurhAdo, iii.

1) thou knuw'st not whint it is.... Linve's $L$. Lost, iii.
know'st, that all my fortunes.. Mrerch. of i'enice, thou villuin base, kinnw'st me not by my -

thou know'st our meaning........ - ii. 4 (letter)

where, as thou know'st, against the face

that best know'st how to rule .........

speak less than thou know'st ........... Le

thon better know'st the offices of nature -

know'st thou the wry to Dover?
that not know'st, fools clo those.

that not know'st, fools do those.
tell me wlat more thou know'st

thou know'st, the first time that we....

thou know'st, the mask of night is on
farewell, I see, thou know'st me not

which, well thou know'st, is eross ...
thou know'st my louging: get me in

thou know'st my lougiog: get me ink - v.

he that thou know'st thine............... iv. 6 (letter)

to this was sequent thou know'st already $-\bar{l}$.

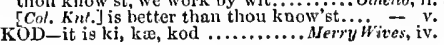

\section{I.}

IABAN-his umele I, aban's sheep... Mer.

I ABEL- lahel to another deel... Romeo o Juliet, iv.

LABEO-Iabeo, nnd Flavius, set .. Julius Crsar, v.
I.ABIENUS (this is stiff news).... Antony \& Cleo. $\mathrm{i}$.

LABOUR-you mar our labour

join's to their suffered labour............
but their labour delight in thein sets off

and makes my labours pleasures

o'er ears for my labour ...............

then a grievnus labour won.. Turo

take it for your labour

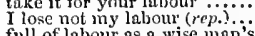

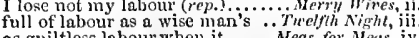

you do but lose your lubour.

and labour ill bestowed. ...........

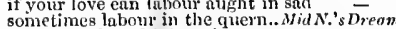

cold incled, and labour lost. Merchant of lenice, ii. saves my lnbour by his own approach

neither do I laheur for a greater, ......

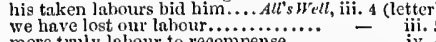

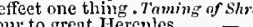

to painful labour, both by sea nnd laind

age, thou hast lost thy labour.........
pure truth why lalour you .... Comedy of $E$

that labour mny you save..............
or lose my labour in assaying it...... for nught thou know'st, aflected be... Trius Amm. ii.

know'st thou this paper? Ask mo not

undertake one of Hercula

more truly nibour to recompense.

her face o' fire with labour ....... Winter's Tale,
L.ABOUli-lubour to make the fitl .....Macbeth, i. sure inbour's batl, "hulu is ol

the labour we delight in

thom losest labour $\ldots \ldots \ldots \ldots \ldots \ldots \ldots \ldots$ - $\quad$ v. 7 Jring this latour to a himpy and ... King John, iii. 2 surmounts our labour to attrin it.....

fi) a mnn to labour in his vorntion.. . I lenry

an if it do, take it for thy labour... =

their cinrage with hard labour tume

the incessant eare and labour son ...ं

ubour shull refresh itsuit' with hope... Hewry $r$. ii.

there's fur thy labour, Nontjoy.....
with profitalile labours, to lis

heruld, save thou thy labour

linll these labours, und these homours.2 - iven iv.

hour for their nwn preferment (rep.)

my thoughts, that labour to persuaie

it is suicl, labour in thy voention

and of our labours thou slaglt reap

the woulu habour my delivery. . Richard III. $\mathrm{i}$.

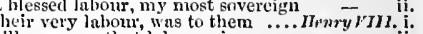

the queen's in labour (rep.).............

but small thanks for my labour.......

a nabour sured! A wonderl.......... - i.

labome on the bosmin of this ..... Timon
vonehsufe my labour, aud long live..

and to for thy thee for thy iabour.........

neser beuring like labour............... Coriolanus

tis not to save lubour................

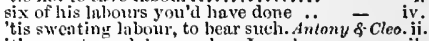

it's monstrots libour, when 1 wasli..

does pay thy labour richly

all lubur mars what it does

but take it for thy labour.

nur horses labour?

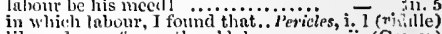
like a clrone, from others' lahours - ji. (Gower)

peace he at your hirthour, hecomes their labour

who labours to outjest his lieart-struck

and sulply the plaee tor your lubour

lahour of his pilgrimage! ...... Romee \& Juliet (let.

thank yout for your well-trok lahour . Hamiel, ii. 2

but $m y$ muse labours, and thus sle is.. Othello, iv.

and he hanged for his labour........... - iv. ant having the world for your lnbour.. - iv. 3 for you, mistress, save you your labour - v. 1
LAOURED-I have liboured.. Meas. for Meas. iii. 2 never laboured in their minds. Mid. N.'s Dream, v.

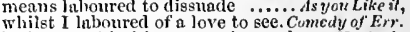

he labourel in his country's wreck.... Naebeth, i.

whose labourerl spirits, forwearied .. King John, ii.

after you have laboured so hard ....2Henry $I$. ji.

that have laboured with all my.... Henry $V$. y.

I ever laboured more than nine...Heney VIII. iii.

which laboured after him to the. Timon of $\overline{A t h e n}$

if they laboured to bring mansluugliter

that we laboured. (no impediment.. Coriolanus, ii.

and rou've her laboured scholar . Dines Casar,

and lonboured mueh how to forget....... Hamest,

ABOURER-a true labourer............. Hou Like il, it

to give some lalourers room ......... All's well, i.

when great things labouring perish. Love's $L . L$. v.

that iabouring art ean never ransom. All's Well, ii.

direction doth from labouring ....... Henry I $V$

all descended to the luboning benrt

let the ningistrates be labouring men

our own a nouring breath. Troilus \& Cressida,

labouring fir destiny, make cruel .

the lonl? Jabouring tor nine. Fimon of sthens, mi.

not walk, upon a labouring day...Julius Crsar, 1 .
there saw you labouring for limin. Antony \& Clco. ii.

there's no labouring in the winter ....... Lear, ii.

LABOURSOME and dainty ........ Cymbeline, iii. my glow leave, by laboursome petition.. Hamiel, i. 2
$\mathrm{M}$ BOU

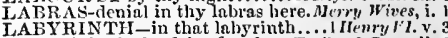

in tho labyrinth of thy fury? .. Troilus \& Cress. ii. 3 LACE-O ent my lace; lest my ... Winter's Tale, iif. yoll promised me a tawdry lace...... - iv. 3 (song) daughter, and sold many laces .....2 2 Henry $r$ l. iv. ah, cut ny lace nsunder ........... Richard Cl hat iv,

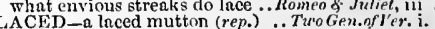
and cuts, and laeel with silver ..... Much dilo, iii. one buckled, nnother laced.. Traming of shrer, iii his silver skin laeed with ............. Mocheth, ii. white and azure, laced with biue o. Cymbeline, ii. hip service done nt I aecdamon........ 


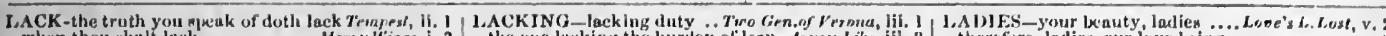
when thon whult law.k................Mrry Wires, i.

they thek no ditrection

the onc lacking the barilen ol lens. As you like, isi. and for lovers, lacking (Giol waru us!) - iv. ain a womun, lacking wit to unake, ilenrylll, iij. and l, that an sure Plack liee..... Tireigh Night, mastur, not my melf, Jacks recumpenso they lack

ACK-l,iVl' kill-courtery .....Mid...'s Dienm, il. iii. 4 IACK-I,ISTRV;-a lack-lustre eye..As you like, ii. goorl counsellors lack no clients...Meus. fur Heas. h. 2 we do the denunelation lack

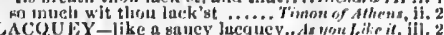

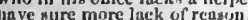

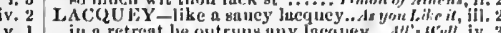
liave sure more lack of reazys.......

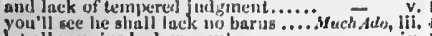

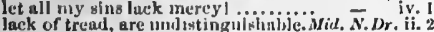
nor doth this Workl lack worlds of .

stubborn lines lack priwer tu move. I.ove's $L$. Lont if.

beauty doth beanty luek

oul shall I lark the thos .............. of $\bar{V}$ enic

let his lack of years le $n n(r e j)$.) … iv - I (letter)

but that her hand lacks means.....As you

thou slault not dic for lack of a dinner

if a hart to lack a hiiid

- iii.

in a retreat lie outruns any lacque

firotboy, or a f'entleman's lace pucy..... -

lever anylow y saw it, but his lio......

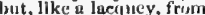

unr mujerflaoss lu'f[ucys, and

and base lacquey peasants, whom.... fichnerd

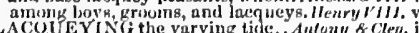

- iii. 2 (verkes)

graveled firr lack of inn I.

I ain not fack thee fur two haurs

you lack u man's heart

LA I - nome few odd lads

Merry Wivez, i.

should have play for laek of work..... All's Well, $\mathrm{i}$.

after my flame lacks oil ..............
lend it you, shanl luck you first......
I know, you lack not folly to eoinit

and lack not to lose still

you did never lack alvice to teny :-

riej validity did luck a parnllel

giliay lor luck of kleep; with ontlas Tuning of Sh. jv.

drat lack any moucy? I liave.

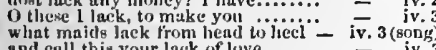

"tis pity slie lacks instruction.

we will thrive, luds, we

therefore, ladiem, our love being.

these lud lieg' eourtesy miphit weli

Alrr. of tenice, iii.

fair ladies, youl drop namnn in ........

3ou unaze inc, ladies: I would have

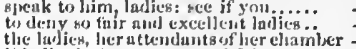

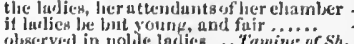

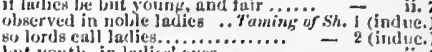

with Jadic's' fuces, and fierce dragons' $k^{*} i$

your ow'h ladien, anil pale-vikayel muids - vo

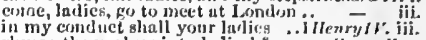

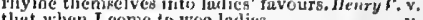

the when I enme to won lndies.

whice ladics erave to lee eneonstered.ine

tiromgh tle court with truols of larlies -

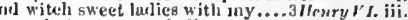

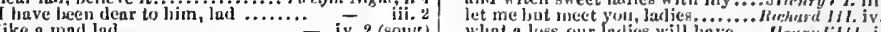

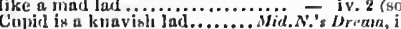

where are these lads?

how now, old lad?

to thee, lauls. IIow likes Gremio.......

a nieeding trick to lay down ladiek...

a great one, to many lorids and ladic

these ladies, By my faitl (rop.) ....
these foir larlies pass away trowning

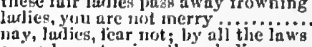

erive leave to view lliese ladies.

lead in your ladiek, every one.

youmg lail, conte firth ............. King, John, iv.

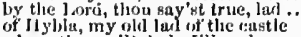

where thou wilt, lud; r'll make...
but my lads, ny lads, to-morrow

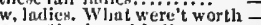

left for the ladies, when they lass back =

all the good lads in linsteheap

as merry as crickets, wy lad , i...

thou'dst ander ladies thein ciap...... - (epii.)

galla ints, lads, hoys, hearts of .......

Jaljes most desirous of a.dmittance. Iadies? - i.

you lack the senson of ail

liow now, lad? is the wind in...

ladies, there is an idle bang uet .......

usty lads roan, lud, low is that $\ldots$...

a lad of lifie, und imp of fume........ Henry $V$ iv.

this prety lad will prove our
nnd, ike a tearful lad, with...

I lack same of thy iustinct............ illenry $l^{\prime}$, ii.

doth not the king lauk sulpijects?
things that are mouldy lack use

ike youd acly tho art to malert

lack nothing, lie merry; look whio's

their swords for lack of ur siment.

and sleathe for lack of sport

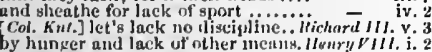

then will Ajax lack matter

and there lacks work; nnon ...........

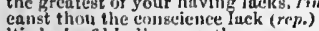

mend inine own, by the luck of ihine

a lack of 'Tlown's aid

abundantly tliey luck dizcretioi.......

I shall lack voiec: the deeds of.

who lack nut yirtne, nu, nor power.

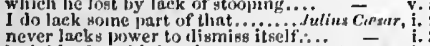

lack blood to think on't ..... Antong 8 Cleopat

I know you could not lack

these hands to lack nolitity........

to lack the enurage of a woman

anil am so near the lask of
smiled at their lack ot skill

that I slonili] secm to lack liuinanity

thou sliali not lack the flower that pupils lacks she nolte.......'Pricles, $v$ ( (Fower) of nature is repose, the which he lacks .
to't luxury, pell-mell, for I lack soldicition

to't. luxury, pell-mell, for I lack solulicrs

to beautlfy him, only lncks a cover. Romen \& J $u l$. $\mathrm{i}$.

God willinacks in twelve

for the yourger sort, to lack discretion...

二 ii.

and lack, have a plentilul lack of wit

not need w, shall never laek a friend.

sir. I lack ad vaneement

men and larls, if you have writ....... Corivlasum, v.

golden lads asut girls all inust, Cymbeline, iv. 2 (sing)

lads inore like to run a cotuntry bas

I.tlo not hid thee beg my lifte, good lad
that sweet rosy lad. who died ........

here's a young lad framed of

my ladies both, gord-duy to you .... Coriolanus, j.
where lndies gliall be friglited........ -

good ladies, let's go: yes, yes, yes.... = ii.

down, ladies; let us shame lini.......

ladies, you deserve to have a termile $=$

if the Juman ladies lying not ......

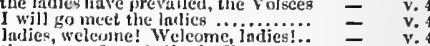

the rarest of our lulies in France.... Cymbeline, i. 5

tht worn, a lait for ladies .......... = iif.

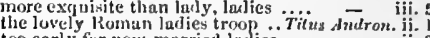

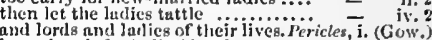

no, lad; teach me $\ldots \ldots \ldots \ldots \ldots \ldots \ldots \ldots$. Whar, i.

[Col. Kul.] news lads! our wars are done. Orhetlo, ii.

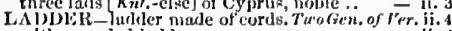

und with a corded lardier feteli........

a ladder, quaintly made witl cords.

shall I hest convey the liculder thither?

and here's the ladder for the pur
Northumberland, thou ladler

iii. I

execllent in making lalies trip...... - ii. 3

part un't, und laulies [Col.- - oullg] too ....... Lear, i. 4

that kiss fuir ladies brows....... Romeo \& Juliel, i, I

here in reronn, lanies of esteem .... - i. 3

o'er ladies lips, who straight ......... - i.

I, of laslies most deject and wreteleel., Mumtet, iii. I

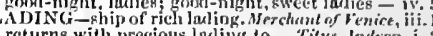

the cords, the Jadeler, or the hangman

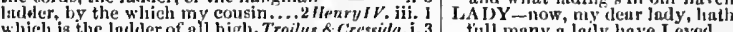

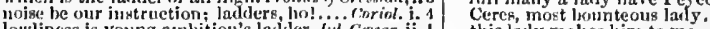

lowliness is young aunbition's ladker. Jul. Corsar, ii.

tet nie a ladder

this lady makes him to me

how does your laly?

anl from the ladier tackle washed off. Perieles, $\mathrm{i}$.....

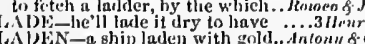

A ) N - a ship laden with gold. Antory
l have heen laden with like frailtie

AI ILS-beauteous laulies" eyes.." "20

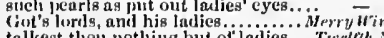

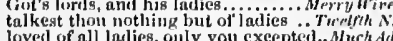

loved of all ladies, only you exeepted.
the ladies follow her. and but one

sigh mo more, ladies, sigh no more ${ }^{2}-\bar{i}, 3$ (song)

slunlal triglit the larlieg out ol their wit

will not the latics be nlearl if

a linn among lalies, is a most

ladics, or fair luties, I would wish $y_{0}$

to lear my lad y's train ..................
O but I love this lady too, too much

there is n lady, sir, in Nilan .........

practining to stenl awity a lady .......

too to thy lasly a lasy

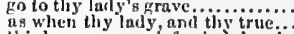

think unon my grief, "I lady's grief

tell my laty, l claim the ........... -

yes, py'r larly: iflie has and left! ............ Werry

() that $]$ serven that liwy ........ Firelsh Nighr,

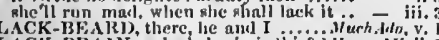

LACK-BRAIN-a lack-l,rain is thï?:iHenrylV. ii.

you three forls lacked ine linsl.... I.ore's I.. l.ont, iv.

that lacked sight only, nauglat fist. irinter.

your charity would liave laikeul foting -

Jeetor's aword lial lacked a nauter, Trnil. A Cress, I.

ere they laekerl mower to erosa vou.. Corinlantes, ifi.

comertenr, lay being lacked... Antony of Cleopatrn

though it laeked form n little........... Inomet, jit.

we lacketl your counael and your helip... Orhelio, i.
never lacked gold, and yet went never gay - ii.

or tluree lorly and laslics mure married

and tuke your filnces, lus ica...........

not to ree lindies, stuly y, fust, not slcep.
fiml blese my lailieg!

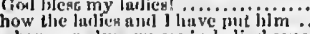

when ourselves we see in lalien' eyes

for, laclies, we will every one le.....
fnir laulies, masket, are roses in their

ladies, withingw: the gallants are at

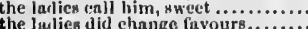

I lenrd my laly talk of it yeaterelay

my lady will hang thee for

take away the lauly .....................

gentlewomul, my lady catls ........ -

a larly, rir, though it was said ...

poor lady, she were better jove.

my lnily lins a white liand .....

if inv laily huve not eallerf wp.

'ílly-valley, ladyl There d weli $($ rrp.

muke an ale:house of my lad y' 


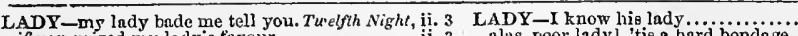
if you prized my lady's fivour ...... was to-day with my lindy say that rome lady, as perliaps ...... the lady of the strachy married...... by my life, this is my'lady's hand bis my lndy; to whom should this bo I serve her. she is my lady ........... that my lady' lov'es me mark his first approach before my lädy my lind is withine sir.

most excellent accomplished lady

into the north of my ady's opinion.

I know rny lady will gtrike hin

eir Toby, my lndy prays

not lose him to........

now in ome commerce with my lady

nor I am not sent to Jou by my lady

this will i tell my lady straight

good sir Topas, go to my lady...

tell me liow thy lady does.

wliat I will set down to ny lady

or else the lady's mad....

but here comes the lady ...........

bou uneivil lady, to whose ......

and follower of my lady

ii. 4 writ to iny lady mother, $I$ am

'twas a good lady, 'twas a good ïidy

heard of the good 'lady's a good lady

ii. 5 who of herself is a good lady .........

my honoured lady, I have $f$

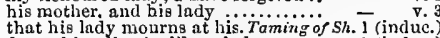
dressed in all suits like a lady ..... - 1 (induc.

wherein your lady, and your humbi

thou hast a lady far more

bring our lady hither to our sight... - 2 (induc.)

piece of work, madan lady ......... irinter's Tale, i..

a lady's verily is as potent as a lord's

O my most sacred lady, temptations
o miserable lad p! but, for me ......

Ihe is a goodly lady, and the justice.

good lady! no court in Europe

for a worthy lady, and one whor

never tender lady hath borne greater

there is no lady living so meet

away with tbat andacious lady

arraign our most disloyal lady

o lady Fortune, stand you ausicious perfume for a lady's chambe

6.......... do a poor wronged lady a merited

I have heard ot the lady, and good... a virtuous and a reverend lady... Comedy

look to the lady ................... Macbeth, ii

now can I make any Joan
look in the lady's face
can you love this lady?

truty, the lady fathers herself (rep.

bow may we entent this widow lä.....

ghe is the sweetest lady that ever $\mathbf{I} .$.

too like my lady's eldest son .........

by my troth, a pleasant-spirited lady

look out of her lady's chamber-window -
never think that lady would have loved

and torment the poor lady wor

ohe's an excellent sweet lady

much he is unworthy so good a lady

they seem to pity the lad

by this day, she's a fair lady ...........

nay, by'r lady, that, I think, $\dddot{\text { he cannot }}$ -

nay, by'r lady, I ann not guch.

my lord, to marry this lady?

by noting of the lod

if this sweet lady lie not guitiogs..............

列

you have killed a swcet

the lady is dead upon mine and in

can find ont no rhyme to lady, but baby -

Which is the lady I in ust seize npon?

it is the lndy that Pyramus must love

then I must be thy lady

a sweet Athenian lady is in love......

come our lovely lady nigli.........

O that a lady, of one mau refused...

zon would not use a gentle lady so.

this beanteous lady Thisby is, certain

lady help my lordi he'll be forsworn. Love's L. L.

what lady is that same?

a gallant lady! Monsienr, fare

slie is a most sweet lady in her train there is a gentle..........

oome men muet love my lady

pray you, which is the head lady?

my lady goes to kill borns

to see him walk before a lady

and the lady hath it (rep.)

first learned in a lady's eyes ........

to see a lady's face

to see a lady ace $\ldots \ldots \ldots \ldots \ldots \ldots$

tair lady, - Say you so? (rep. the......

whlsper in your lady's ear?..........

to make my lady langh, when $\ldots$.....

the king doth to my lady come

stndies my lady? mistress, look.......

in Belmont is a lady richly left

my lady his motber played false

never to speak to lady afterward

extend so far as to the lady.............

why, that's the lady; I do in birth.
why, that's the lady; all the world

where is my lady? Here $\ldots . . . . . . .$.

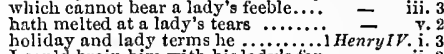

i. I I conld brain him with his lady's fän - ii. 3

ii. 1 and for secrecy, no lady cloger .......

how now, my lady the hostess?

by'r lady you fought fair (rep.)......

to the Weloh lady's bed

lilke an old lady's loose gown

all you that kiss my lady peace

thave belinst my lady a kingdom.

help. help! mine honoured lady!...

why did you throw your wedded lady
lord cloten, upon my lady's missing

to violate my lad y's honour ........

a goodly lady, trust me........ Titus Andronicus, $\mathrm{i}$.

he and his lady both are at the lodge

there stauds a lord, and there a lad $\ddot{y}$...Pericles, i.

wilt thou tourney for the lady? $k$.......

here is a lady that wants breathing too
the lady ghricks, and well-a-near!

the lady shricks, and well-n-near! - lii. (Gower)

your lady seeks life...

$O$ here is the lady that $I$ sent for ......

a gallant lady. She's such that were

wide-skirted meads, we make thee iady

what suy you to the lady?
since my young lady's going into France

my lady's father. My lady's father?

then Lady, the brach, may stand

thou art a lady; if only to go warm

naughty lady, these hair, whicb thou

come with nyy lady hither

my lady charged my duty in ..................

for my hand than for your lady's.

your love to me, my lady, is besnolke...........

your lady, sir, your lady, and her sister.

your lady'a love against some other.

tale in a fair lady's ear, snch as would

by'r lady, thirty years. What, man!

what lady's that, who doth enrich ...

the lady of the loouse, and a good lady

to his lady, was but a kitehen-wench

farewcll, ancient lady (rep.) $\ldots . . . .$. .

my young lady bade me enquire ....

my mistress is the eweetest lady .....

here comes the lady ..................

my concenled lady to our cancelled..

slay thy lady too that lives in thee...

commend me toll my lady you will come......

and why, my lady wisdom?

I'll make my hath a thing to grant

capers nimbly in a lady's chanber.. Richard III. $\mathrm{i}$.

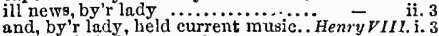

that noble lady, or gentleman

crept too near another..........

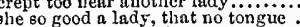

alas, poor lady! she's a stranger

there was a lady once ('tis an old story) -

thanks to God for such a royal lady

bring a wretehed lady? (rep.) ......

aicler, when he strains that lady...

richer, when he strains that lady.

alas, good lady! God eafely quit

in this most gracions lady

bath a lady, wiser, fairer, truer... Troilus of Cre

that my lady was fairer than.

and to make a sw eet lady sad.

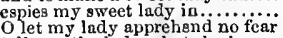

tell yon the lady what she

my lore is the lady, which for Aivtenor.

on this sopcreign lady fixed.... Timon of Athens,

visit the good lady that lies in

noble lady ? come go with 2.

this lady's husband here
do you know this lady?.

do you know this lady?.............

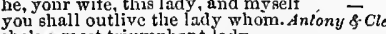

ohe's a most triumpliant lady...

a more nnhappy lady, if tlis ........

O thy vile lady' ahe has robbed ... - iii.

nor the lad will suddenly..... As you Like it,

but with the eyes of a lad

oome lady trifles have rcserved .......

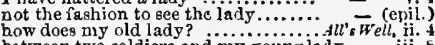

gentle lady, big of thig genteman ... Cymbeline, i. I
peace, dear lady daughter, peace .... you do not know the lady's mind.....

my lady cane and found me dead

how doth my lady? is my father weli?

partly, to behold my lady's face ....

with flowers, to strew his lad 's's grave

as rich shall Romeo by his lady lie.. - v. 3

thiue evermore, most dear lad $y$. Hamlet, ii. 2 (letter) 2ny young lady and mistress? (rep.)

now get you to my lady's chamber..

gend for the lady to the Sagittary
how I did thrive in this fair lady's love.

here comes the lady, lct her witness it

when you woocd my lady ....................

poor lady! she'll run mad, when slie.

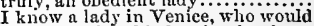

tell my lord and lady what has happed

and alas! that was my lady's voice.....

but for my duty to your ladyship...

what means your ladyship?..........

from your ladyship's looks .............

my fellow-servant to your lady $6 \mathrm{hjp}$

why then your ladyship mis

that attends your ladyship, ............

uccording to your ladyship 8 impose
I will not fail your ladyship.......
this is the letter to your ladyship.... the lo.dy doth protest too much ......

LADY-BIRD - what ludy-birdl...Romeo 8 . Juliet, $i$.

we'll both attend upon your ladyship 


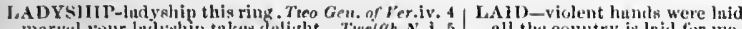

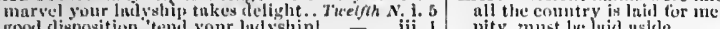

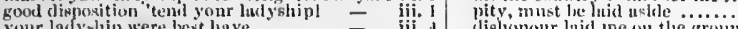

dialsonour luid tne on the prounis

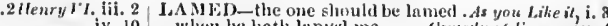
your ladyslatio were best bave....... = an' your hadyship will hinve it ......

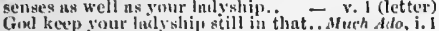

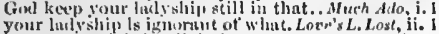
your luds'ship's in all deviret...

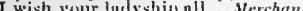

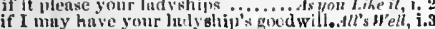

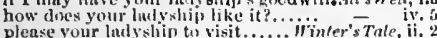

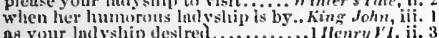

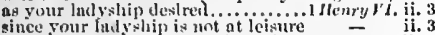
since vour ludyelip is not at leisure

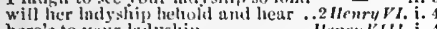

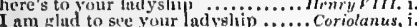
$1 \mathrm{am}$ glud to see your

harvest, if your teds are haid glside

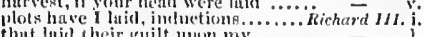

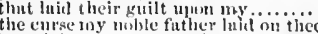

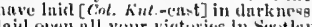

nutd all my armonr laidl into my tent?

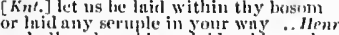

and nll snehe embleme ineid nobly on lio

our re'tsons latill lecfire him....

this is of purpene laid

heaven ever laidl up to make

in my

when I lave lniel proud Atlens

be hatls lub stee pinin way

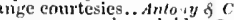

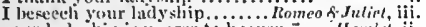

marry, betore yourr ladyship, I grant ... Oohello, ii.

I humbly thaik your ludyship?.

SADY Inlyship. Your honour is most ,....

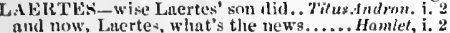

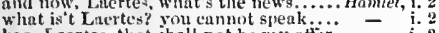

beg. Laer tes, that shall not be my ofter

take thy filir lour I areteg

nothily saves the wager you have laid ..Cymb. ii.

hath laid knives under lis pijiliow........... L prat, ifi. .

here stanel till she land laid it it.......

how if, when I am laid into tlie tomb

I saw her laid low in her kindred's..
whut a seouroce is laid upon your late

it will be laisl to us, whose providence.

that he has luis a grent wegere on

the killg, sir, Intls laid, that in

he hath laid, on twelve for nine

yet here, Lacrtes! abonrd, nhourd........

then laid his leg over my thigh. and laid good 'seuse upon your ecitosy

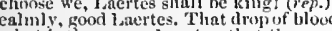
whint is the enuse, lasertes, that thy tell me, Laertes, why thou art thus

good Laertes, if you desire to know .....

Lacrtes, you shall henr them 1 if le so, Laertes, as how should it

if it be so, Laertes, as how should it

but, gond l lacrtes, will you do the

your sister's drowned. Laertes ............

that to Lacrtes I torgot myself

here is newily eome to court, I,aertes.
of Laertes? II Is murse is empty ulreaiy

of Laertes? his purse is empty al ready to Laertes befinre you finl to play

wrong Laertes, then ilamlet does it not I'll be your foil, Lacertes...

how is't, Laentes? iv ber os .............

LAFEU-now, good Latipu, bring in ...All's $\bar{F}$ ell, was tiret smoked by the old lort Lafen

greeting will you to my lord Lafe

give my lord Lateu this letter
have thought well on thee, Lafi...

LAG-in favour, makes him lag ..... Henry $\boldsymbol{V}^{\prime}$. iji. 3

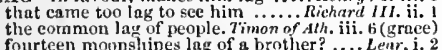

1.AG-END-the lag-end of my life ... Henry!

Wcar away the lag-end of their
IAGGNGG-four lagging winters

Hichard $\| H_{\mathrm{i}} \mathrm{i}$.

LAlD $\rightarrow$ good plot: t they are laic

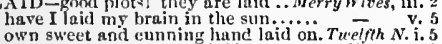

in sad eypress let me be laid ...... - - ii. 4 (song)

and laid mine henour too.

they have laid me lhere in hideous.... on sleeping evelids laid ........Mid. N.'s Dream, ji. 2

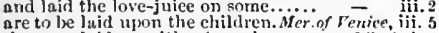

that was laid on with a trowel. ...As ynu Like il, i.

who laid him down and basked him

that he laid to the chnrge of

mueh wortly hlame laid unpon himu-... dil's Well, iv. 3 the earpets luill, and everything.Taming of Sh, iv. I
eireumstances partly laid ojen. Winter'sT. iit.2(ind.) nor is't directly lnifl to thee.

this is not, now laiel to thy answer....

condd not have laid such terms upon

I.AID'ST-in that thou laid'st a trap. III.

dog that hath lain asleep ..... Romeo \& Jutiet, jii.

lath death lain with thy bride
berc hath lain these two days buried

a senll now lath lain you $i$ the earth. Homlet,

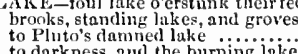

to darkness, and the burning lake ..2 Henryl
dive into the burning lake below. Titus. Antroun an nngler in the lake of darkwess

AKIN-by'r lakin, I ean go no furthicr. Tempesi,
by'r lakin, a parlous fear ...... Mid. N.'s Dream,

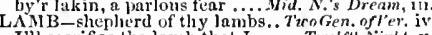

Tll sacrifice the lamb thint I.....

doing, in the figure of a lamb

no slieep, swcet lamb, unless we fied. Lo

gainst thee, thou lamb, that stantest

male the ewe bleat for the lamib
mant

ewes graze, and my lnmbs
tut! she's n lamb, a dove
we were as twinned lambs

poor, innocent lamb, to appe

I will sit as quiet as a tininb

ras never gentle lamb more.

whist 1 waited on my tender lamili.... Henery $V I$. i.

not, when he would steal the lamb...2Henry $r I$. iii.

is lie a lamb? hing lamb, or harmless.

of the skin of ant innorent lamb sliould

finds the trembling lamb, environed

poor harmless lambs unitio their

fawns upon the lamb, the lamb wili

to worry lambs, and lay, their.......

to revel in the entrails of my lambs.

as fox to lamb, as woll to . Froilus
how now lambs? Cressil, i jove thce

if thon wert the lamb, the thx. Timon of gthens,

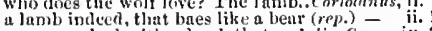

you are yoked with a launb that. Juthescerrsur, iv. 3

your sorrow way two sore laill on

or sivinter, laid cluim to me.

and laid in sume dark room...........

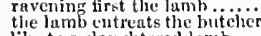

like to a slaughtered lamb.

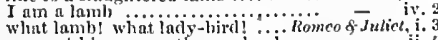

the taints nnd blames I laid upon.....

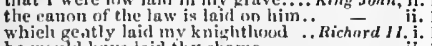

he would hinve laid thy shame
that laid the sentemere of Ireat

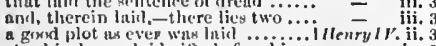

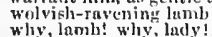

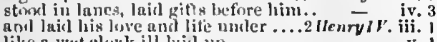
like a wete clonk ill tuil up

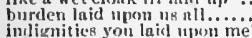

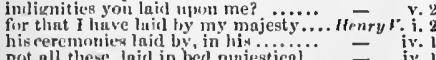

nort all these, laill in bed numjestical.

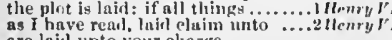

gre lain unto your eliarge..........

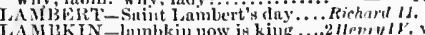

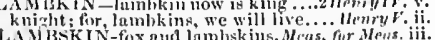
LAMU-to relieve a lame heggar.......... Femperst, ii. 2

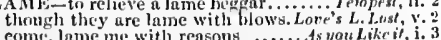
eomen lame me with reasns
ghould in my old limbs lie lame ay, but the feet were lame . .

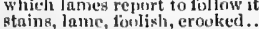

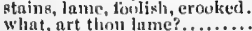

nnele thy lume to leup

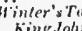

al) new legs, and lane ones

all of you have laid your heads together -

have you laid tair the hed?...... lifei
naads were laid on Ifumphrey's lo

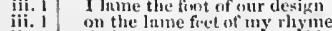

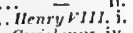

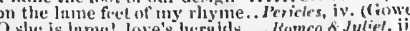

Oot dest lame and impotent camelusion.

When he hath laneal me .... Cometly of liriors, iv

and therefore stoor lamely in.... As snon Laks in, iii.

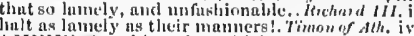

LAMLN LSS-taking airs, with lumeness.. Leur,

well, she laments, sir, tor it .........Merry Hirrs, $\mathrm{i}$

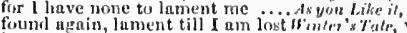

lament we may, but not revesuge..... ltichard $1 \mathrm{i} . \mathrm{j}$.

how tolanent the catuse. I'll herg one

why ther lauent therefore

to achl to your laments, wherewith.. I//6rury is a

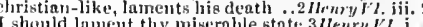

weakness to lanent, merable state.3henry

obsequiousiy lament the untimely. Wichard $M I$.

Whiles I lament king llenry's eorse

fir you will live, lament; if die $\ldots . . .7$ -

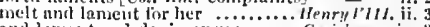

and lament as 1 do, in anfer

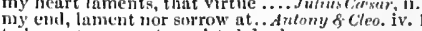

to lument our most persisted deceds

with sight, made heart litment

futher, you lament in vin $\ldots$.........

why lament you, pretty one?

joy mast revels 118 all lament...Romeo

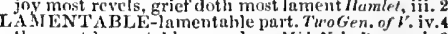

the most lamentable comedy ...Mid. N.'s Dreom, i.

thine eye that lamentahile rlieum ... King John, iii.

that it is most lamentable to belsold . Henry

is not this a lamentalle thing.....2Herry $r$. iv.

lamentuble! what! to hide me from... - i.

is not this a lament: hle thing .. Romeo o Juliel, ii.

is fuily of this lamentable eliance !.: $\quad$ - v.

and sinks most lamentahly ... dulony 2 Cleo. iii.

LAMENTATION is the right ...........All's Well, $\mathrm{i}$. I

on her own lumentation..........Mers. for Meos. iii.

as yet the lameutation of the... Henry t'. v. (chorus)

give me no help in lument:ttion....... -

and lear your mutlier lamentution! - iv,

modern lamentation nighit .... Romen \& Juliet, ivi.

than thou went'st fintly in lamentation - iit.

even now to he afresh lumented... Winter's Tate, jv.

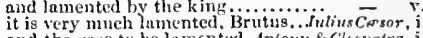

and the case to he lamented.Antony f-Cleopatra, $\mathrm{i}$.

Which brought them to be lamentet..

they any, samentings hearl i' the air.. Mhche'h, ii. 3

new lamenting ancient oversights ..2 flewy l.

then return lameutiug to my love. Itichtard III $i$

and lamenting toys, is jollity for.. Cymbeline, iv.

and buz lamenting doings in the air? - iti.

LAMEN'T'STthou lament'st. Tro Gen, or Fer. iit.

LAMING the shrine of cnus......... Cymblirline,

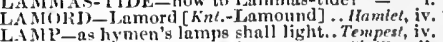

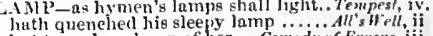

but to make a lamp of her .. Comedy nf Errors, it.

strangles the travelling lamp .............. Macbeth, ii.

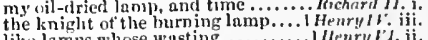

like lamps whose wasting ........... I Henry f'd. ii.

her lim mond tlumes of love.. Troilis o. Cressida, iii.

and wantes the lampls of night.... dutony of Clco. i.

and aye-remainime lampls ............ P'erictes, in.

as daylifht doth a lampi lier eye .....

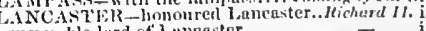

my noble lord of ' laneaster.

luw fares our molle uncle. haneaster? -

veli loris, the duke ot laneaster is dead -

my answer is - tw ].anchster ........

must be granted, lam cluke ot I ancuster -

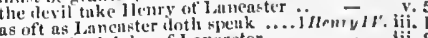

my sell, lord Jolin of laneaste

this letter to Juhn of Janeaster.

lard Johm of Janneaster. the nohle ..

loril Joln uf Lancaster, go you with him -

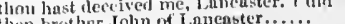




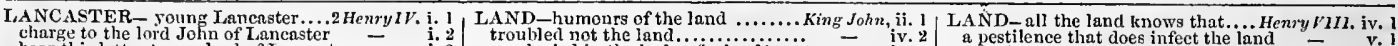
bear this letter to my lord of Lancaster are marched up to iny lord of Lancaster good my lord of Lincaster, I ann no strong-fixed is the house of Lancast

i. 3 traveledicd in the body of a landi.....

ii. 1 in the body of this fleshly laud.... heaven itself doth frown npon the iand fair' weather in your blustering land the gentry of a of our land... witl interest to this lond, yes... clain this land for mine....... prond Lancaster usurp my right ....2 Hexpy grafuple with the house ot Lancasicr. duke of Lancaster, the eldest son got the house ot Lancaster the crown

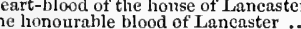
the house of Lancuster usurps ....... 3 uenry $F$ ic that holds up Lancast

I Lenry of J Lances him be king (rep.). .

now York and Lancaster are reconciled house of Lancaster leave to breathe

make against the house of Laneaster

O Lancaster! I fear tlyy overthrow..
upholds the honse of Lancaster......

Oxterd, Oxford, for Lancaster! (rep.)

the stoncs together, to set up Laneate
stolen the breech from Lancaster....

blood of Lancaster sink in the grourid? - v.

pale ashes of the house of Lancaster!

pale ashes of the honse of Lancaster
factions for the house of Laneaster.

during the wars of York and Lancest

in quarrcl of the house of Lamcaster

this divided York and Lancaster.... -

TANC:E-if tall, a lance ill-headed ...Much Add, iij. I
the armipotent Mars, of lances .. Love's L. Lost, v. 2 the armipotent Mars, of lances .. Love's L. Lost. v.
I gee our ances are but straws .. Taming of Sh. v, their neelds to lances, and their ..... King John, v thy blessings steel my lance's point

receive thy lance, and God defend...

go bcar this lance to Thomas.

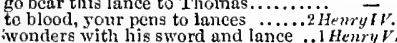

break a lance, and run a tilt ........

a braver soldier never couched lan

with guilty fear let foll thy lance...3HenryVI.

not worth the splinter of a lance. Troilus \& Cress. $j_{\text {. }}$

as I conld pick my lance

turned a distaff to ases.

Antony \& Cleopatra,

more the whipstock, than the iance..... . Pyericles

and the stroug lance of justice ........... Lear, iv. 6

ANCED-lanced their tender hearts. Riehard III.iv. 4

body, lanced [Knt.-launched] mine arm.. Lear, it. I

LANCETH-but lanceth not the sore. Richard I
LAND-he came alive to land.......... Tempest,

bound of land, tilth, vineyard,

and on this green land

if a galto

my thou no mouth by land?

money buys lands, and wives ......Merrywives, prizes not quantity of dirty lands. Twelfih Night, ii. stolen away from fairy land ... Mid. N.'s Dream, ii. 2 the fairy land buys not the child ....

and sail upon the land, to fetel 1 .

to my bower in fairy land
the soil, the land, the earth

as roes run over ined

thy lands and goods are by the....Wer. of tenice.

thy lands, all things that thou

an extent upon his house and lands.

soll their lands restored to them

his lands with restd; and to the (rep.)

you, to your land, and love........... Anl's

heir to all his londs and geods. Taming of $S h$.... i. in all my lands and leases whatsoever

by the year, of land! my land amounts

and heir to the lands of me............

by sea, and by land, but I am not...

and contrived in this land

our stinte, our subjects, or onr jaind

our ftesh is banished from this land..

the envy of less happier land..........

this land of such dear souls (rep.)

no lesser than thy land....

his money and his land...

in this declining land....

strengly hath set footing in this land

here am I left to underprop his land.

rushing on this weeful land at onecl

covering your fearfül land with...

our lands, our lives, and all are....

and lands restored ant some

green lap of fair king Richard's $3 . .$. every stride he makes npon my land make a dearth iu this revolting laud the whole land is full of weeds..... not so trimmed and dressed his land. how blest this land would be.. to all his land and signories........ the state and profit of this iand.... as 'tis current in our land.

stained the king's own land .......

make a voyage to the Holy Land...

like a stubble land at harvest home...

yon may buy land now as cheap...

and all the fertile land within that..

from the best of all my land...

the fand is burning; Percy stands.....

the special head of all the land

rebellon in this jand shanl lo

dear lords, nnto the Holy Land,.

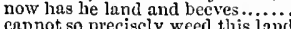

cannot so preciscly weed this land

steril, and bare land, manured

vainly I supposerl, the Holy Land.

vainly I supposer, the Holy Land

for all the temporal lands .............. galling the gleaved land with hot
for he is footed in this land already.

for honour of our land, let ..........

- iv. 2 a pestilence that does infect the land

v. 2 ficher than sea and land? .. Troilus \& Cressida, ii.

his and's put out of office...... Timon of Alhens,

iv. 3 and all the lands theu hast lie in....

ay, defilert land, my lord

- $\quad$ v. 2 to Lacedæmon did my land extend...

- v. 2 with most lands to be at odds........

Richard II. i. 1

such as you, a sea and land full

...Coriolanus,

sea and land I can be place.....Julins Crsar, i.

what's his strength by land?

1. 3 at land, indeed, thou dest o ercount
i. I by land. Therc I deny my land

ii. I should have met you by sea, and iand

ii. 1 being prepared for land...........

ii. fail, we then can do't at land .........

ii. 2 stirike not by land, kcep whole (rep.)

ii. 2 hark, the land bids me tread no.....

ii. 2 our force by land hatli nobly held ...

ii. 3 by sea and land I'll fight

iii. 2 to make me fight at land!

iii. 2
iii. 2 we whease them not by la

you have land eneugh of your own ... Cymbeline, $\mathrm{j}$.

iii. 3
iji. 3 banished lord, and this great land:...

iii. 3 bantshed lord, and this great land:..

iit. 4 as thou reft'st me of my land

or stomach-qualmed at land $\ldots \ldots . . .$.

iii. 5

as at land.... TilusAndromiens, iv. 3

lie'll fill this land with arms

$\begin{array}{ll}\text { v. } 3 & \text { he 'seaped the land, to perish on ........ } \\ \text { v. } 5 & \text { such whales have I heard on a' the land }\end{array}$

we would purge the land of these drenes

Edgar, I nust have yonr laud

if not by birth, have lands by wit.........
so mnch the rent of his land comes to

i. 3
ii. 4
ii. 4
in.

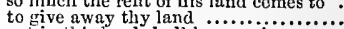

iii. 1 and of my land, loyal aud naturai bey...

spreads his bampers in our noiseless land

ightly toils the subject of the land ...... Hamlet, $\mathrm{i}$.

with lis life, all those his lands....

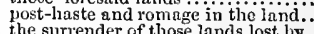

the surrender of those lands lost

iii. 2 in's time a great buyer of land.

the very converanecs of his land

-

ii.

to let him land; and solemnly....

fives, honours, lands, and all.....

all the princes in the land bes.

tend the profit of the land

as he loves the land, and common....
while his own lands are bargained for

while his own lands are bargained for
and lands, and wife, and all, from me

worth than all my father's lauds.

did ncver traitor in the land commit

a prince, and ruler of the land....

exiled your highness' land....

and threw it towards thy land...

tis net the land I care for...

lands, goods, horse, armonr

sinew hoth these lands together.......3

mine own land with my wishful (rep.)
his lands then seized on by (rep.).... all your lands, an' if what pleases $\mathrm{him}$ lose thicir father's land .............

then get your husband's lands

how these lands are to he got .........

the people of this blessed land may not

all his lands and goods be confisci...

of all my lands, is nothing left me

Woe to that land, that's governed.
for then this land was famously

this sickly land might solace $\ldots . . . . .$.
not for all this land would $I$ he gilty

breathe $I$ in a christian land

government of this your land.........

deny them, all the land will rue it

ever yet this land was guilty of.......

into the bowels of the land ha.......

have in their own land beaten.......

shall these enjoy our lands?
this land's increase, that would (rep.).

as fruitful as the land that feeds us. Henry - .

yea, the clect of the land $\ldots \ldots . . . .$.

the reverend fathers of the land

robbed this hewailing lard of notble

gleaning all the land's weal th

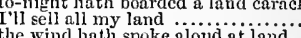

the wind hath spoke aloud at land....... -

LAND-DAMN -land-dnmm him.. Winter's Tale, ii.

are both landed though well landed. MIerry Wives, iv.

fear we have landed in ill time.......

givest out, are landed here?...........

who latcly landed, with gome....... Riehard II. iii. 3
or quickly will be landed .......... 3 IIenry VI. iv. a mighty power landed at ïilford. Riehard III. iv.

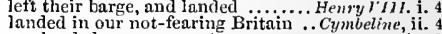

1 arc landed on your const ...........

i. 3 I told him of the army that was landed Lear, iji.

LAND-FISH-a very land-fish.. Troilus \& Cress. iii. 3 LANDING-upon her landing ...Anlony \& Clco, ii. 2 LANDLESS-a landless knight makes. King John, i. LANDLORD of England art thou . Richard $I l$. ii. the universal landlord.... Anlony \& cleopatra, iij, is

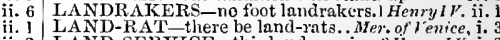

iii. 2 our horses unto long lane end.... Taming of Sh. iv. 3 every lane's end, every shor, chirch. $W_{\text {'in/er's }} T$. iv. front them in the narrow lane...... Henryl $I$. stood in lanes, laid gifts $\ldots \ldots \ldots \ldots \ldots . . .3$ - - iv. 3 the lane is guarded; pothing roots us. Cymbeline, v. 2 all flying throngh a straight lane.... narrow lanel an old man, and two boysl = $\quad$ v. 3

ii. 7 LANGL.EY-famous Edmund Tangley .1 Hen. $v l$. i. 5

iii. 7 was Edunund Langley, duke of York. 2 Henry $r$. ii. 2

iv. 1 LANGTON - keep Stcphen Langton..... King, $\bar{J}$ ohn, iii. for learning -you taught me language. Tempest, i. a

and sluely, it is a sleepy language ...

should he learn our language?

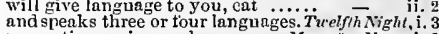
proportion, or in any languagc ...Meas. for Meas. i. 2 yout speak the former language ........ Mush nd $_{\text {not }}$ iv hecn at a great feast of langmages. Tove's L. Lost, $v$.

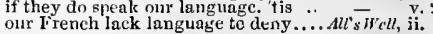

was landed, to bc the lord on't......... - y.

iii. 2 LAND-SERVICE-this land-service .2 Henry $1{ }^{\prime}$.

ii. 2 LANE-Tith thes; I mean,... Merehant of $v^{\prime} e$ n

athwart the lane, he, with two stripilings - v v. for learning me your language 


\section{LAN}

LANGUAGE-is it not a language .... All's We't, ii. 3 encak what terrible lubgunge you will -
a sinack of all neighbouring languages chough's languuge, gubble ctwough ..

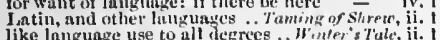
like language use to alt deprees.. Wuter sule, ii. t you spenk an their very gesture ....... the langunse I have fearned these.... niehart II. i. 3 in his own lunguage doring my .... I Itenry $/ \mathrm{F}$. ii. till I have learued thy langunge .... ${ }^{2}-\bar{y}-$ iii. wherein, to gain the lungrage et tu parles bien le langunge

or hlosect in disthintul himge.... ...2Itenryly liv.

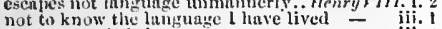
the lioney of his innguage...$\ldots \ldots$. has strangled lis language in his tears I shall remember this bold language

there's lnnguage in her eye.. Troilus \& Cressidh worls go by, nutl lunguage ent. Jimon of athens, y. is ill selooleft in boted langta. cymbeliac, iii. he is not hunters langrang

to use one lungutuge. in eachi.. Periclss, iv. 4 (Gower)

know the letters, and the iangerach

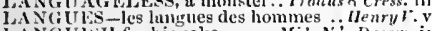

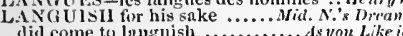

that ricls our dogs of languish? .... An intany \& C Cten. nav let her languish a drop of bloxt. Cym
wili his freo hemrs languisli for assured

and sou] to langnish, and punish that.. Perictes,

eures with nusther's languish ... Romeo of Juliet, it. 2
LANGU ISII ED. Leave me ...... Minter's Tole, ii. 3

LANGUISII ED. Leave me ..... Hinter's Tale, ii.

thint mingishes in your displeasure.... Othrino, iti.

the movers of a Innguishing deatlo...Cynbeline,

IANGUISIIENT must we pursue.

lANk-are lank numl lean with thy

her lank and all o'er-teemed loins ..... Homlet, ii, 3

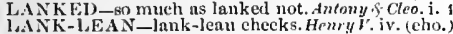

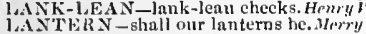

ilicrefore bear you the lantern.

this man, with lantern, dog, and bush

his lnntern doth the horned moon

the circumterenta

the man should be put into the lanter
thut the lantern is the moon..........

why all these sliould be in the lantern

1 pry thee, lend me thy lantern .... 1 Henry ${ }^{\prime}$

have his own lantern to lishit jiin...2 IJenry iny inuide, and lantern to my feot...2 Ha
"laitern, slau hitered youth .... Romen

L. $\mathrm{l}^{2} \rightarrow$ as a cat lips milk

lie in thy lap, and be thried

wife hul chestmuts in licr lä

the fresh green lap of fair....

...... Trmpest, ii.

vour gentle head ulon lice

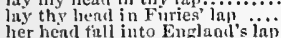

like a plensant slumber ia thy lap?.2 Itrnery l

nake my heaven in a laty's la

to worry lambs, and lap their geitle

unenver, dings, ancl lan

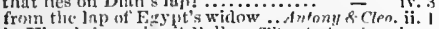

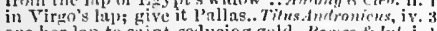

ope her lnp to suint-sedneiog guld.. Komeo ful. i.

I mean, my heal upon your lap?

pour our treasures in to foreign laps..... om on

no, it is lapis; I pray you ............. - iv. I

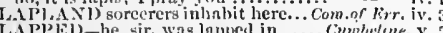

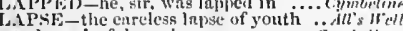

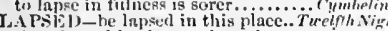

that, lupsed in time and mssion ...... Untemlet,

LAPSING-witlont lajsing suffer

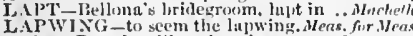

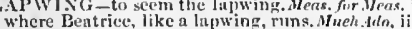

from her pest the lnjwing cries. Comedy of $\mathrm{krr}$.

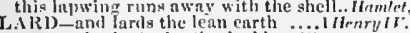

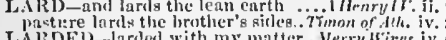

LARDED-larded with my mafter.. Herry Wirps, iv,

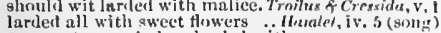
nn exact commission, lariled with many

LAR RER-I belong to the larler .. Ifenry ITII. v. 3 LARDING-he lie, lariling the plain. Hraryl. iv. 6 ,

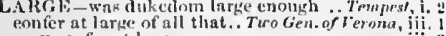

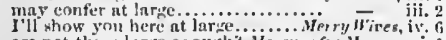
are not these hirge enough? Meakurefor Merusure, i. never templed her with word two larke - iv. at hurge diseoure, while here ......... and the worlil's large tomgue procitims

an Inrge a charter as the wind ...... te you t.ike it, ii.

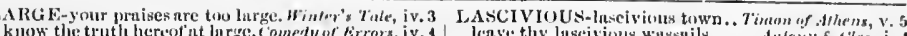

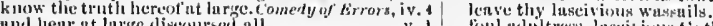
be lares in mirth. unon

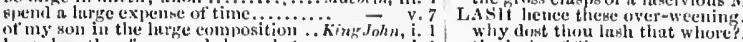

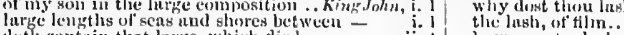

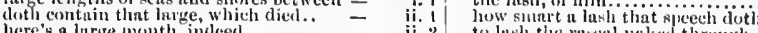

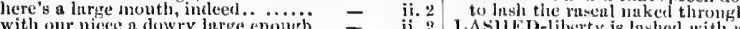
in some large measure to thy ........ Richard JI. i. 2 LAs. is it no brave a lnss?

subseribe liem for large sums of gold

mil my large kingaloni for a littic.

may npleur at larige diseonrsed in

plense it you, emtains ut large .......

ruling, in lurge and ample enjery

in prant of afl demands at large.

Irif tell you nore nt larige.

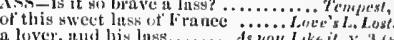

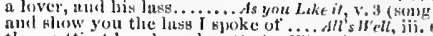

the prettiest low-burn lass that.. Winter's Tale

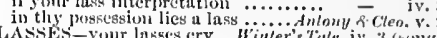

ASCES-your lakes cry .. H'inter's Tiale, iv. 3 (konng)

LAST-and hear the last ot our sea-sorrow

and feed, altinouel my last...

nod break our minis at large........ - $\quad$ i. 3 your last kervice did worthijy jerfo....

a ad large proportion of his strong-knit

with a larife and sumptuous dowr....

informed his higlness so at

at last I left themi i

since I saw youl lust...

set 1 was last chicldeir for................

Jave had lajge sums of gold

last night, slee enjoined ne iv

till the last step liave bronglit

upun All-liallownas last

large gifts have I bestowed on lcarned -

once gotten, loubt not of large jay. 3 Henry VI. iv.

large Achilles, on his pressed bed. Trailus 6 - Cress. i. 3

fiir leave, and large security

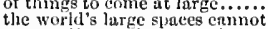

so roundly to a large confession

hy his large nend portly size.......... $=$ ivi.

their coin upon iarge interest (rep.).. - iii. 5

make large confusion; and, thy fury

will be large cicutriecs to show

mighty space of our large honours.Jutins Casar, iv. 3

most large in his abominations... Intony fo Cleo. iij. 6

to know at large the cause of ...........

and ull the large ellects that troop.

and your large spceches may your deeds.

male us with such larote discourse....

I restitution large of rolk, and jewels .. Othello, v.

LARGELY - have given largely ... Nerry Hives, ii.

I'll tell you lartely of tair IIero's..... Much Ado, v. 4

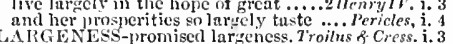

A RGER-a laryer dare to onr grcat.. I Henryll. iv.

to try a larger furtune....... Anfony \& Cleopalia, ii. 6

witl a larger tether may he wall ....... Hamlel, i. 3

LARGESS-mentl it with a largess.. Taming of Sh. i. 2

sent forth great largess to your offices.. Hacbelh, ii. I

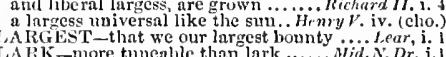

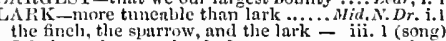

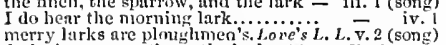

loth sink as swectly as the lark... Ner. of Venice, y.

I took this lark for a luntiler......... All's Whll, ii. 5
above the morming lark.. Taming of sh. 2 (induetion)

is the jay more precions than the lark

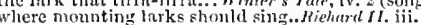

from the rising of the lark to .........thenryt. ini.

stir with the lark to-morrow ....... Hichard III. y. 3

the busy rlay, wakerl hy the lark. Ornilus \&-Cress.iv.

the lark at henven's gate .... Cymbeline, ii. 3 (song)

the raven doth not lateh a lark... Triks Anitron. ji. 3

ever raven sing so like a lark ............ Lear, iv. i

nightinute, nnd not the lark ...Momeo of Juliel, iii.

it was tle lark. the herals of the morn

is the lark thit silus so out of tume

the lark and loathel toad wange eyes - iii.

IARTIU.-T'itus Lartius, thou slinit. Coriolanus, i. i

T'itus lartius, n most valiunt...... - i. 2 (lelter)

your loril, and Titus I,artiuz are set..
to Iartius, and to Mareius hitle ....

hww is't witl' 'Titus Jartius?

ritus Lartins, must to Corioli ing.....

nni to send for Titus lartius, it reimsing $=$

liearel loud 'larmms, neighing stecels. Trmming of sh.

then shatl we lear their lo..........

with Inm Iarums welcome them.. Tiinsdudron. i

ASCIVIOUs-of laseivious men. Two Gen of Ser. ii.
find you twenty laseivious turtles... Merry W'ives,

to be a dangerous and laseivious bey...Ali's Well, jv. 3

that laseivitus young lwy the count..

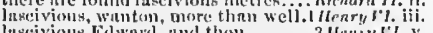

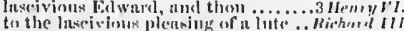

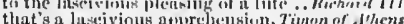

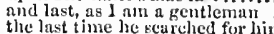

as they did last time

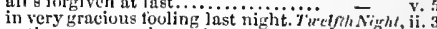

antique song we heard last nigit

come, the sung we had last night.

yet when I saw it last

this will last out a night in............... fors. for . ve

is't not drownel i't the iast rio....

in our last contlict, fuur ut his tive wits ... vuch ddo v. arst of Mny doth the lnst of December -

were you her belfellow Just niglit? $($ rep. $)$ -

yet, at last, she conelnded with a sigh

last that will last keep his oath $\ldots$ Lore's $L . L a s, i$.

bear this triat, and last love

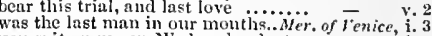

you spit (1) me on Wethesday last.. - i.

on black-Nonlay lust, at six

at last, if promise last, I got

In lieu of this, last night did lie........

last scene ol all, that ends

Ge

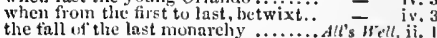

made a groan of her last breati........ - iv. 3

he lience removed last night.

I lad talk of you last nifht

the last that e'er 1 took her leave.....

where left we last? Ilere, madam .. -

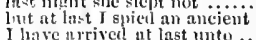

at last, thengli long, our jarrin

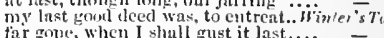

but the last, $O$ lords, when I have.

thy motlier appeared to me lust night

at the last, do as the heavens have don
which never my life may last to answer

it I last is this service, you must....

none of these, except it he the last

I dreamt last night of the three weird. Nurbelh

gave thee the lic list uight

masle goud to you in our last confe....

when wis it she last walked

to the lnst syllahie of recorded time.

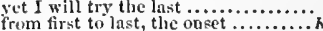

in the list repeating, troublesome.

last in the flelel, and almost

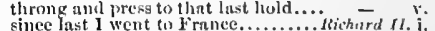

cre I last received the sacranient

the last leave of thee trakes

breathe iny last in wholesome..........

as the linst taste of sweets $\left(r r^{\prime},\right)$
fieree blaze of riot cummot last...

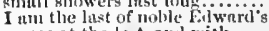

eomes at the lint, null with.

and am I last that knows it? .............

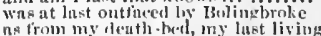

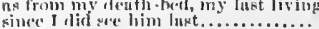

. 
LAST-On Good-Friday last .............

.1 HenryIV.i. 2 LAST-that held it last

...Titus d

he held med since thou drunk'st last

fallen away vilely sinee this last action? - iii.

on Tuesday last to list

the last true duties of thy noble soni

sharp physic is the last

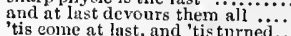

'tis eome at last, and 'tis turne

for your sweet music this last night.

where lay the king last night?

at last, I spied his ercs; and methought

to try our fortunes to the last man

we will eat a last year's pippiu

my court'sy, last my speech........... - $v^{v}$ (epi. $^{3}{ }^{3}$

eleventh year o' the last king's reign... Henry $V_{i}$ i. i

the tenth of August last

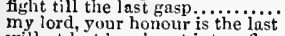

wy lord, your honour is the last

shall we at last conelude

both at first and last .......

be my last breathing in this

for your sweet music this last night...
at last, from 'Tyre, Fame answermg - iit. (Gower)
while summer days do last ..........

this, as my last boon, give nie

and crowned with joy at last

al thongh the last, not least.

this last surrender of his wili

W' hen saw you my father last?

know not where I did lodge Iast $\ldots . . . . .$. - iv. I

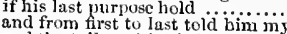

and from first to last told bin my .......

since last yourself and I werc in a mask? -

we'll weed them all at last

last time. I danced attendanee on....

gave us the counterfeit finirly last night =

wall be the last of the nes

was the seventh and last......

bid him come to take his last fareweil

eycs, look your last! arms, take your last--
last niglt of all, when yon same star .. Hut
our last king, whose image eren but now

to the pound, the last subsidy

and at last, upon his will I sealed.....

and, to the last, bended their light $\ldots \ldots \ldots$

face is vilanced since I saw thee last...

saw you last, by the altitude of......

Jast, and as much containing as all thcse

houses that he makes, last till doomsday

he will last you some eight year (rep

patience in our last nights's speech

patience in our last niglit's speech

he did, from first to last..

onc more, and this the last.....

which while it lasted, gave kin both...All's $\bar{W}$ ell, i.

LASTING-with gold on lasting piliars. TempI. ii.

keep tresh and lasting

to give mine enemy a lasting wink... Winter's $T$, $\mathrm{i}$. .

and body to their lasting rest ..........ing John, iii. 4 and lasting fealty to the new-made..Richard 1I. $v .7$ hope, begins onr lasting joy.

Richard ILI v. 7

to this last costly treaty ............ -

the last hour of my long weary life.

tor I feel the last fit of my greatness =

love thyself last: cherish those ....... -

at our last encounter, the duke of....

at last, with easy roads, he came $\ldots . .$.

the last is, for my men

the king to do me this last right

and, last, eat up himself....... T

I will come last .................

look in thy last work, wher
he last asked the question

must I be his last refng

bear himselt in the last conflict.............

this is Timon's last; who stuck.

whilst this poor wealth lasts

there came-news from him last $\mathrm{night}$. Coriolan

and last general in our weil -found

for this last. before and in Corioli

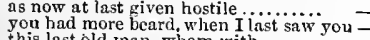

this last old Inan, whom with.

this is the last; so we will hom

till at the last, 1 seemed his.

what fanlts te made before the last

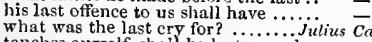

touches ourself, shall be last served..

be patient till the last

this speech were else your iät

purchase with still lasting war .... Richard

us thy lasting friends... Titus dndronicus, ji. 4 (letter) lasting labour of his pilgrimage? Romeo \& J J

sweet, not lasting, the perfume.......... Hamlet, i. 3

and hence, pursue me lasting strife.... - in

sixth and lastly, they have bolled (rop.) Much $A d o$, , i.

lastly, hurried here to this place. Winter's Tale, ini.

and, lastly, to con firm that ........3Henry $r^{-} I$. iif. 3

lastly, myself nokindly banished.. Tilus Andro

LATCHES-latches to his catrance... Hinter's
LATE-be not too late ............... T'empes

as late I have been

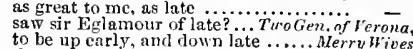

than a minute tou late ................

in him that was of late a heretic $\ldots$.

to be up late, is to be up late
'tis too late to go to her now

commend my yellow stockings of late

I saw thce late at the eount .......

wis tro late. You are toocold(rep.) Meas. for

you secmed of lnte to make.

who called here of late?

yon have of late stood ont against.........ure $A d$

for meeting her of late, behind .....Mid. $N$. Dr. iv

our late ediet shall strongly stand ${ }^{. .}$Love's L. L. i.

to sturly now it is too late, elinb

Rutssians left us hut of late

he came too late, the ship was.Merch. of Venice, ii.

the pardon, that I late pronounced ....

come, my queen; last night you....̈n̈iony \& $\mathrm{Cle}$

at the last, best; see, when, and where

sinee I saw you last, there is

to-morrow the last of many $\mathrm{Eg} g \mathrm{ptian}$

this last day was a shrewd one to us

say, that the last I spoke was, Antony
the last she spake was, Antony! ....
tis the last service that I shall ......

the poor last I lay upon thy lips

bravest at the last; she leveled......

whot was the last that he spake

an argument that fell ont last ni
winning both of first and last.........

and his name is at last gasp...........

my lord, when last I went to visit he

whilst suminer lasts, and I live bere

last night the very gods shewed......

that was the last that wore $\dddot{2}$. Tilus $A$
and now at last, laden with honour's at tomrscore, it is too late a week .....

i. 5
ii. 6
ii. 6

disgraees have of late knoeked

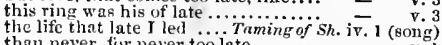

than never, fur never too late ........ v. I

and privy to this their late escape.... - ii. I

who late hath beat her husband

he is of late muel retircd...

but they come not too late now

rather aphe of ate sprung from. Comedy of Err. i.

come, Antipholus, we dine too ia te...

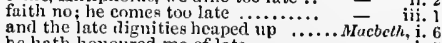

he hath homoured me of late ........... i. which Iate wate more near her ..........All's Well, $\mathbf{i}$. 3

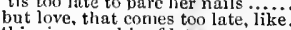

LATE-Banquo walked too late

men must not walk too late.............. Macbcth, iij. 6 make good the boisterous late appcal. Kichurd II. $\mathrm{i}$.

sentenee, plaining eomes too lite....
make haste, and come too late!.....

the all too late comes counsel

that late broke from the dnlie of

after late tossing on the breaking....

bubbles in a late disturbep.

it is very late, $i$ ' faith

.i Henry 1 ii. 2

of which disease, our late king, Richard -

where is the life that late $I$ led

who are the late commissioners?.......

that was quick in us but late

your grace the late embassadors

late, did he shine upon the Englisli... Henry VI. ji. 4

whom Henry, our late sorereign

cxecutcd, in our late king's days?

sour ot late thion wert despised?......

forbilden late to carry any weapon

this late dissension, grown hetwixt

they that of late, were daring ton'n

noble duke of Bedford, late deceased

it is too late; I cammot send them ...

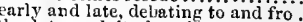

thy late exploits done in and ..2Henry VI. i.

how insolent of late he is hecome......

whom yon late vanquished .......... - iv.

bereft thee of thy life too late .......3 3 Henry VI. ii. 5

where fame, late entering at $\ldots . . . .$. - iii. 3

what late misfort une is befallen $\ldots . .$. = iv.

lord Hastings' late imprisonment ...Richard $111 . \mathrm{i}$.

too late he died that might have.... $=$ i ii. 2

the late demand that you did...

have got by the late voyage ........... Henry $\bar{V}$ inI. $\mathrm{i}$.

did you not of late days hea.......... - i.

betwixt too early and too late....

the late queen's bentlewoman of his truth

you have done of late by your power

and the king's late scruple

and the late marriage made of .......

whither so late? Came you from

some touch of your late business ....

of late heard many grievous, I do say

as, of late days, our neighibours.

what, am 1 poor of Iate? .... Troilus \& Cressida
but in these fields of late

for my own part, I eame in late...... = iii. 3

were his fellows but ot'lote Timon nf $\bar{A}$ hens.

and late, five thousand to Yarro

I have but little gold of late

and snspect, alas, are placed too lote

our late noble naster. 1lave I

and bring thy news so late .............

and, of late, when corn was given....

will, too late, tie leaden pounds...

- do observe you now of late .......... Julius $\overline{\text { Cas sar, }}$ iv

he is stuerstitious grown of late......

and great. ot late upon me: I must....

those that served Mlark An tony ho. late -

I dread, too late. Tuo late, good Diomed $\overline{-}$

a widlow, that late he married........ Cymbeline, i.

I am glad, I was up so late

hast any of thy late master's tarnicits

of late, of this war's purpose?

then all too late I bring this fatal. Tituss $\overline{n d}$ iven. if

Wrom but of late, earth, sea, and air ..Pericles, $\mathrm{j}$

whom Hlelicanus late advanced - - jv. 4 (Gower)

these late eclipses in the sun ............. Lear, $i$.

too mueh of late faint negleet of late .....

which of late transform you

woe, that too late repents.

very lute, to strike at me

the very fellow that of late displayed..... -

what letters had you late from France?..

the traitors late footed in the kingdom ..

done, and we shall come too iate. Romeo of Jul

seen vnknown, and known too jatei

back again, that late thou gavest me

make haste, for it grows very late.....

Tybery late, she'l] not come down ...

atore me, it is so very late.............

is slic not down so late. or up so carly? 


\section{I.AT}

LATE-whom late I noted...

that consurts, 80 late, the dead?...... - vo voliet, v. I brother's deentl he hath very oft of lite given private..

given hum any hard words of lnte?

given lim of $_{\text {lute, }}$ (but, wherefore, 1 know.

comes lyy the means of the lin

ynu are so sick of late, no fur from checer - iii. 2

it is the poisonel eup; it is tho hite.

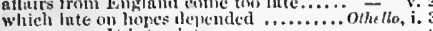

one praver. It is too late.
LATH-BELOVED, all his

7imon o....

L.ATED-now spurs the latiol travelier. linbeth, iii.

I am so lated in the world...Antony \& Cleopul ra, iii. ?

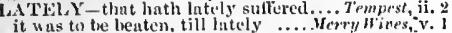

thougl lately we intendeal to ..... Twrolfh Nigh, y. 1

the gentleman thit lately stole...Herchoof rinice, iv. I

the dicl but lately toil the sinewy.As you t,ke il, ii. 2

had you not lately an intent

ynu were lately whipled, sir
for lately we were bound..

these limes, so lately purged of ..... Kinty John, iii. .

wholintely landed, with some.

Richard II. iit. 3

did lately meet in the intestirs

Henty It. i. :

the enrl of Aarch hath lately married

bated like cagles hnving late

a man or two lately killed about lier.2 Henry $1 \%$. v.

I was lately here in the end of .....

gentleman, fately attendant on........

Campeius is arrived, nnd lately.... Henry $\bar{v}$ ii.

but tis so lately altered, that ........ - iv. !

true that you liave lately tolil us.... Corintunus :

by thee lately is left untendered.

that lately didst deseend into.. Tilus Andromirus, ii.

I saw you latel y, when you caught....Pericles, iv. I

he sought my life, but lately, very late.. Lear, ifi. 4

I lay with Cassio lately; and, being ...Othello, jii. 3

1.ATKR-I take't, 'tis later, sir ...........Wacbeth, ii. 1

the latest breath, that gave $\ldots \ldots \ldots$... King John, iii. 1

the latest news we hear, is, that

II. $Y .6$

the very latest enumsel the latest parle we wili...

iHenrylitio. 3

father breatied his latest gasp.....

and, to his latest gasp, cried out .

3 Henry ri ji.

shall apply thy latest words.. Troilus \& Cressic

the latest of my wealth $I$ 'H share. Timon of $d i h$.

their latest refuge was to senter. Julins Corsar,

that I bring unto their latest home. Tit us Andron. $\mathrm{i}$.

make this his latest turewel

latest favour [Col. Kint.-obsequics]...Rom. \& Juliet, y.

LATE-WALKING

Othello, i. 3

decay of lust and late-walking .... Nerry Irives, v. 5
LATH - with dagger of latl.. Tu'elfithigh, iv. 2 (song) thy kingdom with a dagger of lath..I Heary $I V$. ii. 4 a sword. though made of a lnth

your lath glued within your shenth...Titus And. ii.

a Tartar's painted how of lath .. Romeo \& Juliet, $\dot{i}$.

LATIN-you spake in Latin then ... Merry wives, i.

that's the Latin word for

he hath neither latin, French....... Fer. v. 1

with a priest that lacks Latin.....As you Like il, iij. 2

what he leges in Latin ......... Taming of shr

in Greek, Latin, and other langunges

thus in Lat in, Praclarissimus filius...Henry r. v.

away with himl he speaks Iatin ..2 Henry liviv. 7

Omy good lord, no Latin.

Henry VIII. iij.

L.ATTEl end of his eommon wealth Merry Weropese, ii. I

sing it in the latter end of a play. Aid. N. Dream, iv. 1

sing it in the latter end of a play. Arid. N. Dream, iv.

bring your latter liazarit bnek .... Mer, of leevice, i. I

sainething at the latter end of a dimer

therefore, thy latter vows...

farewell, thou latter spring $!$
well, to the latter cull of a fray

toigrace this latter aye with ...........

I Hevryl I i. i.

join together at the latter layy.

bosom spenel my latter gasp

nenry $v$, iv. 1

express thee in thy latter sjirits.. Timon of $d i h$ v. 5

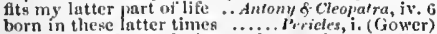

mav the two latter darken anil expend

1.ATCFR-BORN, hal fintenet.Comedy of Errors, $i$. I

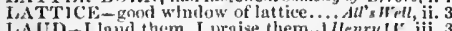

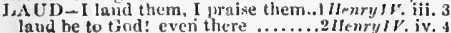

laud be to tind: even there ........2llenrylW.
more land than gilt o'erlustei. Troilus \& Cress.

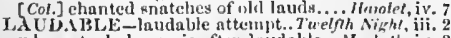

where, to do harm, is a ften luudalsle. Shorbeth, iv.

I.AUDis-laudis numma it .........3lirnery r.

will you laugh me anleen

I shall laugh my alf to death.

I mall never langh hut in............. ieery Wire

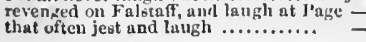

LAUG Il-to laugh at my witi (rep.) Merry Wites, v.

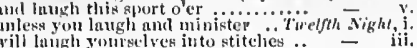
lly luy h you at suels

all thenselves laugh mortid

laugli wlien I nom merry.

diil lic never make youl langh?

then they langh at him, and bent him

o lawels moderatele ont of myself

and critie 'rimm langh at idle toysi

to nuke my huly lungh

and at her eye

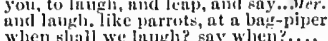

div we not lutul? if you pois

oft your grace was wont to laugh...A

they most nunst laugh; and why, sir

I will lavgh like a hyen

that done, laugh well at weora - iv. 2 (sing

my naster wink and laugh ajom täning of sh, it.

they should not laugh, if I cotili reach

otrgl my woes to seor

there's oue did laugh in his slece

lameh to seurn the power of man

reapons langli to scorn, brandislieil.

thy hand to laugh a little ........

hor a man ennurt make him layph.2

more than did latgh at it.

unless it he to laugh at $m$

ship so....... iseury It ii.

the cnvinus people laugh, and bia me.

shall laugh at this a twe vemonth. Richord $I I I$, ii

no more to make you lnugh .... Hewry ${ }^{+} / H$. (p)

femnint ehnose but laugh....

I wnild laigh at that misat

at others" lives nuy laugh.... Timan of Athens, iv

strok as tis to I could lough

this unatural seene at them......

I durst nest langh, for fear of ....... Julizes Cessa

and langh at this hereafter ..........

this day langh away his tortune

mugh at us, while we strut ...........

you laugh, when loys, or women

laughs from 's tree lumgs, eries

why dost thou laugh! it fits not... Titus a wron. iji.

to make the world laugh at me

and laughs at my departure.....

and laugb at gilded hutterflies

dost thou not langh! No, eoz.

call medlars, wlyen they laugh aione

at lovers' perjuries, they say, Jove laughs -

the clown shail make those laugh

though it make the unskiftut lungh

nake her laugh at that

to make fools laum i' the alehouse

look, how he laughs alrcaly i.........

so, so; they langh, that win $\ldots \ldots \ldots \ldots$........

AUGHED_t $\mathrm{w}$ as you we lauglied at.. Temprest,

when you laughed, to

not markerl, or nut laughed at

after he hinth laughed at such.

with that all layslect and elainel.

so he laughed, and let me go .... As you Like,

waugher in his fuce: and, when ....3 Henry?

of their lewhess, and be langhed at

laughed, that her eyes ran (rip.) Troilus \&-Cress.
and llector latughed. At whint.......

I should linve linghed ton (r'p.)

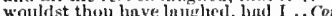

lest I be laughed at, when 1 ....... Julins Corar,

I must be langhed at .........utomy of Clcopatra,

more laurherl at, that I should in

Ilaughed him ont of potienee (a)

negigenee may well be laughed at .. Cymbelin

ohe lamphed, and told the Morr.

and laughed so heartily, that both

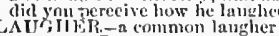

othello, iv.

LAUGHIES thou, wreteh?.......... H heury it. ii.

thou antie cleath, which laughest us

some be of lutughing, as, hu! ha! hic

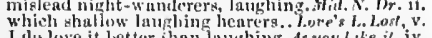

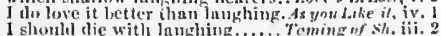

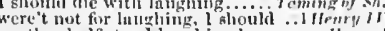

unother half stund laugh ling by ........
1. $\Delta U G$ IING-lonks still laughing ..2 flerry IT, il. there was suth laughing! (rep.)
at what was all this lang hing?

time, thut wece with langhing... Fimon of ath. iv. 3

follow him lawelsing to his grave. Antuny f cloo. $\mathrm{f}$.

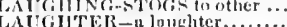

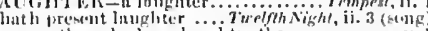

may iather pluek om laughter than.

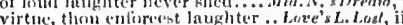

ol an stubled with langlit

such at zealents lumgliter, ko profoum

with mirth and laneluter let old... $\mathrm{Mer}$.

and the incrence of langhter.

stay tlemedves trom langliter. Tuming of $\overline{\$} / \mathrm{l}$. (ind.)

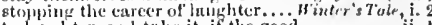

making that illiot, laughter, keep.. King John. iii.

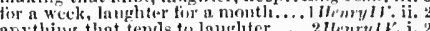

any thing that tends to laughter ....

an areument of laughter to .. Timon of Athens, iii.

but themerla lust, nul laughter...

yea, for my langhter, wher you...Jalias Corsar, iv.

his eyes in flood with laugliter ...... Cymbeline, $\mathrm{i}$.

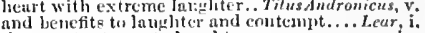

the worst returns to langhter............

AUNCE-lind of the Launee. Tuo Gen. of $V * \%$. ii.

Launce, away, away, aboard.

but, Laumee, how say'st thou......

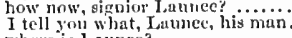

WAUNCEIOT Goblo.................

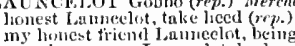

conscience says, Lanneclot, hindere not

talk you nt young master Lanncelot?

master Launcelot. Your warkhip's

mister Laumeelnt; talk not of (re

Inm launcelet, your boy that was.

but I ani Launcelot, the Jew's man

if thou be Lamecint, thou art nime

farewell, good $\mathrm{I}$ a uncelot.............

my hauncelot, what's the news?..

of you shortly Launcelnt, if you thu

Launcelot and 1 are out; he tells nic

LAUNCHED-liath launehed abov

[ hil.] body, launched mine arm ........ Lear, ii.

LAUNDRESS - to the launtress (rep.) Merry $W$. iii.

LA UNDRY -or his cook, or his laundry -. $\bar{J}_{\text {uliet, ij. }}$

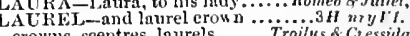

crowns, eceptres, laurels ....... Troilus o cressida,
hound with laurel bmughs .... Tituss andronicus,

it lanrelesl vietory? Anfony \& Cleo, i,

L U R ENCE-friar Laurence met. Ttro Gen. of $T$ ir.

hie you henee to friar Jaurence' cell

displeased my fat her, to Jairrence...... cell

is nyy denghter gonc to friar Laurenee?

met the youtliful hird at laurenee' eell
LAIS-laus Deo, bone intelligo.... Lore's L. Lost,

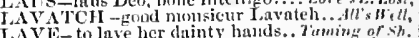

A lo lave her danty hands..

althomgh slie lave then hourly... Titus stritrow.

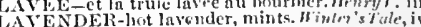

AVINI A-graeinus Lavinia .. Tiassductronicus i. I

Lavinin, live: "ittive thy tather

Lavinia, you are nnt dis lileased.

treason, swet lorl: lovinia is surpirise

re-tore lavinin to the emperor

in the resene sif lavinia, with lis...

and fiear not, lorks, nurl you, Lavinia

you are my guest, havinia, nnd your

pleat my bassints tor Lavinia

I love Lavinia more thas all the woind -

Lavinin is thine elder brother's holve -

Gle is lavinia, thercere

and resel in lavinia's treasury

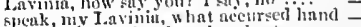

tie well, Javiniy, that thus hast not

gentic lavinia, let me kiss thy lips...

Javinia, thou shat be empleyed in.

farewell, lavinia, my noble sister...

Jasinia, wo with me: I'l to thy cleset -

ny nine Lavintio hy these sijns?.... -

how now, lasinin? Jarens, whatmeane - ii. 3
ii. 5
ii. 5

iii. 1

ii. 2

ii. 2

ii. 2

ii. 2

ii. 2

ii. 3

iii. 4 ii. 4

ii. 5

iv. 2 
LAVINIA-Invinia, wert thou. Titus,Andratic look here, Lavinia; this sandy plot.

iavinia, come: Marcus, look to my..

come, come, Iavinia; look, thy toes

Whilst that Lavinia 'tween her stumps

Lavinia, come, receive the blood

die, die, Lavinin, and thy shame .... -

LAVISH-but not lavish, curbing his lavish spirit .......

when means and lavish manners ...2 Henry

he used his tavish tongue .......... 1 Henry Yri. ii.

LAVISHLY - too lavishly wrested ..2 Henry

LAVOrT-heel the high lavolt.. Troilus \& Cress. iv. 4

LAW-the law of tricndship. T'o Gen. of Jerona, iit.

make their wills their law.

Tieielfth $N$ ig $h t$, iii. 4

' the windy side of the law.

Meas. for Mexs. i.

if there be any law in Inyria

and most or qualify

run by the hideous law.......

make a scarecrow of the law
what know the laws, that thi
I know no law; bring them.

if the law would allow it, sir (rep.)

if this law hold out in Vieun

your brother is the forfeit of the law

it is the law, not I, condemns ......

that the most just law now took

now the yoice of the recorded law

account to the law unon that point
tle manacles of the all-binding law

to make the law a tyrant

bidding the law make court'sy to.....

bite the law by the nose............

bour brother from the angry law $\ldots$ o...

he hath offended the law ............

is no greater forfeit to the law than

that enforced the law against it!

the very mercy of the law cries out..

and one that knows the law, go to ...Much Ado, iv.

or else the law of Athens yields

the sharp

withont the peril of the Athenian law

I beg the law, the law, upon

a dangerous law agninst gentility

a vessel of thy law's fury.....

these oaths and laws will prove.

may devise laws for the blood... ilerch. of $\overline{v e n}$

justice! the law! my ducats

in law, what plea so tainted $\ldots . . . . .$.

the duke cannot deny the course of law

if you deny me, fie u

that the Venetian law cannot.

I crave the law, the penalty

wrest onee the law to your authority

zou know the law, your exposition.

I charge you by the law, whereof....
purpose of the law hath full relation

awards it, and the law doth give it

are by the laws of Venice, confiscate

is that the law? thyself shait see...

the law hath yet another hold

what law does vouch mine own $\ldots$.....

T'll answer him by law.. Taming of Shreun, $\bar{T}$ (induc.)

since this bar in law makes.
do as adversaries do in law

now by law, as welt as reverend a....

by law and process of great nature..

to o'erthrow law, and

iv. chorius)

let the law go whistle.

to infringe our laws; the enmity. Come

were it not against our laws.....

sir, I shall have law in Ephesu.

the canon of the law is laid on

law and warrant, lady (rep.)

to understand a law; to know...

must I rob the law? your sword $\ldots . .$. Richard II. i. 3

thy state of law is bond slave to the

I am a subject, and challenge law ....

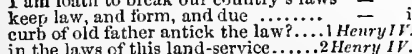

in the laws of this land-service......

I see no reason, in the law of nature.

to the correction of your law

and power of law and justice $\ldots i . . .$. .

most dreadful laws so loosely

the laws of England are at my ........

the founder of this law and female bar

establislied there this law, to wit

the Salique law was not devised....

idly supposed the tounder of this law
they would hold up this Salique law

to the answer of the law

that to ber laws we do deliver you............
$\mathrm{J}, \Lambda \mathrm{W}$-by law of nature, and of nations.. Henry $r$ ii. 4 prerogatifes and laws of the wars have defeated the law, and outrun
for before breacli of the king's laws

this expressiy against the law of arm

there is any martial iaw in the 'orld

been a truant in the law.

frame the law unto my wili.
nice sharp quillets of the law

nice sharp quillets of the law

I certain question in the benefit of law of arms.....

by law to be thy privilege.

and I lie open to left the

let him have all the riguur of the $\mathrm{la}$ w

what shall we say to this in law....
this is the law, and this duke.......

as a prey, to law, and : 3 hame

receive the sentence of the law
the law thou see'st, hath julger

the law thou see'st, hath julge
in danger for the breach of law

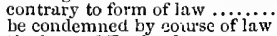

be condemmed by soiu'se of law ......
the laws of England may come $(r e p$.

it will be a stinking law..............

with the same to act controlling laws -
should not deal in her soft laws ....3 Henry $r z$

my will shail stand for law..........

before I be conviet by course of law.

in the table of his law commanded.

urge God's dreadf'ul law to us...

against the form of law, proceed

that God, the law, my honour...

onr conscience, swords our Iaw

not rend our subjects from onr

by all the laws of war you are

sharp reasons to defeat the law

of less place might ask by law, schoiars

trial of the law o'ertake you ........
the duke by law found his deserta

his faults lie open to the laws

his own opinion was his law

if this laws, in filling the whole

there is a law in each well-ordered.

these moral iaws of naturc

if doing nothing be death by the law.

for pity is the virtue of the law.......

hath stcpped into the law.......
he owes the law his life, why.

law is striet, and war is nothing (rep.)

masters are, and pill by law!

civil luws are cruel; then what

the laws, your curb and whip....

to your public laws at heaviest

was law, then were they chosen..... Coriolanus,

he hath resisted law, and thescfore lav

into the law of children.

which we will answer as a law....Jullius $\mathrm{C}$

stronger than ever law conld miake..

[Col. Knt.] MIulmutius made omr laws

the law protects not us

he stayed, attending Nature's law

and must endurc our law

lat the laws of Rome cletermine all

becnuse the law hath ta'en re
but even with law, against ....
that died hy law for nurder

he made al law, (to kcep her still
within our law, as dangerous

inke a poor man's right in the law

a son by order of law........................

by the law of arms, thou wast not $\ldots$..........

say if $I$ lo, the laws are mine, not thine
let us take the law of our sides .. lianseo

is the law on our side, if I say-ay?

what the law should end

hath rushed aside the law

ut Jantua's low is death to ang lom

nor the world's law (rep.).......

unto the rigour of severest law
well ratified by iaw, and iseraldr

with all bands of law, to our most

the law's delay, the insolenee of office.

biys out the law; but'tis not

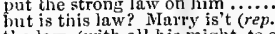

the law, (with all his might, to enforee.. othello,

time of law, and conrse of direct session

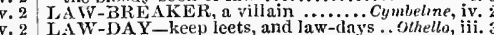

$\begin{array}{ll}\text { v. } 2 & \text { LAW-DAY-keep leets, and law-diny' . Othello, } \\ \text { v. } 3 & \text { LAWFU -lawful name of marrying. Merry } W \\ \end{array}$

is it a lawful trade? ...... M

I will be content to be a lawful hangman -

now prove our loving lawful .... Love's L. Lost, iv.

and that no lawe not lawful. Merch. of l'nice, iv.

yout sec it lawful then $\ldots i . . . . . . . .$. .tll's Well, iij.
LAWF UL - a lawful deed (rep., ....... All's Vell, iii.
if this be not a law ful case for nie..Taming of sh. i.
is it law ful, pray you, to see...... Winler's Tale, ii.

is it lawful, pray you, to see.....Winter

let it be an art lawful as eating .......

his lawful king, cut off the sequence

on the sight of us, your lawful king

lawtul let it be that I have room.

we thought ourself thy law ful king. Richard II. iii. 3

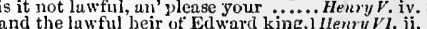

doubting thy birth and lawful progeny - iii.

reverenced for their lawful king $\ldots . . .2$ Hen $-v V t$

then am I lawful king ..............3 Henry $V I . i$.

before a true and lawful magistrate.

crave thy just and law ful aid.........

him that were not lawful chosen......

against his brother, and his lawiul king? - - v.

our lawful [Col. Knt.-sovereign] king - i. 3

what law ful quest have given their..

joy ful, grant their lawfit suit ..... $=$ intest on England's lawful earth

prove but onr marriage law ful .......

is as law ful, for we would give.. Troilus \& Cress. y.
shall answer by a lawful form .... Cariolanus,

to suffer lawful censure

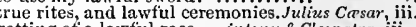
getting of a lawful race... Antony \& Cleopatra, iii. things set down by lawful counsel ... Cymbeline, is another's law ful promised love... ritus $_{\text {Andron. }} \mathrm{i}$. to make man his lawful music............ Pericles, got 'tweer the law ful sheets cast away ... Lear, i.

their papers, is more lawful.............. iv. it prove law ful prizc, he's made for ever. Hamlet, ii. in session sit with meditations lawful? $\because$ - iif. may law 'ull - lawfully by this...Ner.of Verice, iv. may lawfnlly deal for his wife's soul... Pericles, ii. may lawfully deal for his wife's soul... Pericles, ii. lawless and incertain thoughts.. Meas. for Meas. iii
seal this lawless and bloody book ..2Henry $1 V$. iv. needs no indirect nor lawless course. Richard $I I I$. [Col.] list of lawless resolutes............. Hamlet, i. in his liwless fit, behind the arras hearing - iv. lawn as white as driven snow......... - iv. 3 (song) nor for measures of lawn; nor gowns .. Othello, iv.
AWRENCE-Lawrence Poultney.. Henry VIII. i. AW YER-lawyers in the vacation. As you Like it, iii. nor the lawyer's, which is political ... Tht $T$, iv. thain all the lawyers in Bohemia. Winter's Tale, iv. all scholars, lawyers, courtiers ...... and crack the lawycr's voice $\ldots . . . . .6$. onc of lier women law yer to me ..... Cymbeline,
like the breath of an unfeed lawyer ...... Lear, i. may not that be the skull of a lawyer?.. Hamtet, $v$. I, IY lay her a-hold.................... Tempest, i. a torment to iay upon the dammed... they will hay out ten to see............ I could see this taborer; he lays it on $=$ iii. 2 you must lay lime ................... of torona, ii. you should lay my countenance ... ierry Wives, ii. 2 I must very muel lay open milie.... = i.

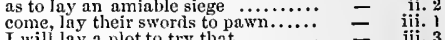
I will lay a plot to try that............ and how long lay you there? ............ to lay any of them on you........ Taelfth $\mathrm{xight,ii.1}$ lay me, $O$ where sad ............. - ii. 4 (sonx) you must lay down the treasures. Meas. for Meas. ii.4 lay by all nicety, and prolixious.... - ii. 4 I will lay myself in hazard.......... lay bolts enough upon him

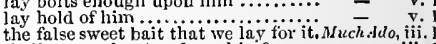
shall we not lay hands on him?..... - ini. 3 and lay it to your heart.i............

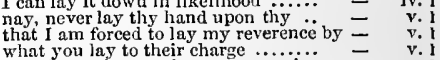

your mention can lay upon my sin

lay breath so bitter on your

lay them in gorc. since you............. nor never lay his w reathed arms ..... - iv. 3

lay these glozes by ...............

some necessity, now lays on you. Mer. of J'en

therefore Iny bare your bosom $\ldots . . .$.
where Cressid lay that nisht...... thy sovereign, and thy lawtul king? 


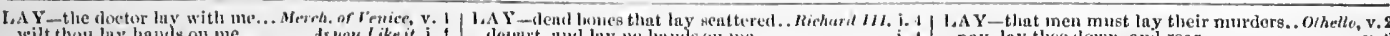

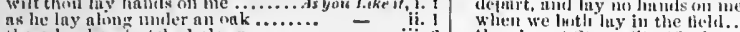

there lay he, itreteluet along.

o'eryrown with luir, hy sleeping....
with ulders nll draw -

with ulders nll drawn dry, lay enching -
a youth here in the forest luys clutu to

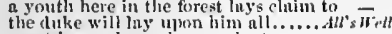

grent in our hoye liy isur bes.

iii. 2 they lay at stony-strat finrl.

on him I lay what you would lny on me -

quotly Diphton, lny the pentle biines

a bonk of grayers on their pillow lay
little boner he meant to lay umo.

a spering triek to lay down lanjes

theng lays his finger on lis tey by

talking lord can luy upon my eredit

when the brown wencli lny kissing.. -

Anpthill, where the primeess lay ....
goodliest woman thut ever lay by man -

is come to lay his wetury bones
embnim me, then lay me fortly

let your lighness lay a more noble...

for though you lny here .. Taning of Sh. 2 (indue.)
how the young tislks luy their ......

'twas a coinnolity lay tretting

shame, lay it on me..........
lay hands on the viliain

lay ull the weight ye can upon

lay hands on the villain
lay liold on lim, I char

I'll lay ye all by the heels..

I dare my life lny down........... Hinter's 7

lay thy finger on thy lipsi ....
if she, that lays thee ont, says

and, might we lay the old proverb
your dreams, which I'll lay down

my eabin where l lay; tlirice bowed

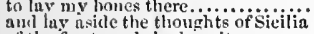

of the feast, aml slue kny it on

more rugs to lay on thee $\ldots \ldots \ldots \ldots . . . .$.

and we lay by our appertainmente

and layrme where no priest

lay't so, to lis charge.

and lay my life, with ny ............

rain, to lay this winl, or my

lay hold upon him, Priam

troops, and lay for hearts......
to whim all sores lay siege

Apemantus, if it lay in thy

the nobility lay aside tleir

nay, lay thee llown, and ron

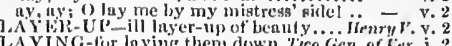
AYING-for lnying them down. Fien Gien. of Rer. i.
fixol you, for laying on my duty. . Thming of sh. v. at once her ehopgy tinger laying unwn... Whetseth,

\section{there's laying on; take't wfl}

lisury rllil i.

scaled them (laying l,y that nothing.. Cymbetine, ili. ay, and for laying gutumn's dust .......... Lear, iv.

that will wcarce hold the laying in.

thYs-whilst thou lay'kt in tliy. Mler. of fenice, iv. for all the claim thou lay'

thou lay'st in every gash that. Frolius of Crenry I'?

lay'at thom thy leacen mace
A Y

what elaim lays she to thee?

enter, and lny hold on himi.

lis it to thy henrt, and fureweil........

where we lay, ont chimneys

liere lay Duncan, his silver........

frent ty ranny, lay thou.......

lay on, Machluft: and damn
lays most lawtinl ciam to.......

to

doth he lay claim to thi
that still Ilay upon my

between ny fitlier nud my moti..... lay =

heaven lny not iny transgression

upon thy check lay int this zealous $\mathrm{kiss}$

we'll lay before this town..........

resigy them, and lay down thy arms?

hetore we will lay down our just-borne

and lny this Angiers even with

John lays you plnts; the time
doth lay it open, to urge on.....

to make the Freneln lay down

he'll not lay down his arms,

whint doth our cousin lay to
once did I lay an ambush

let them lny by their helmet

lay on our ropal sword $\ldots \ldots . . . . . . .$.

personally I lay my elnim

to lay my arms and power

I will lay a plot, shall show
our children where they lay

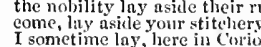

Iny' a fuult an us, your tribunes

lay the finlt on is. Ay spare us not

that is the way to lay the eity flat

therefore lay liold of tim $\ldots \ldots \ldots \ldots . . .$.
lay liands tipon him, and bear (rep.)

masters, lny lown your weapons

LAZAR-to relicf of lazare, and weak .. Henryl

is like to lay upon us.............

never shrouled any but lazars .. Troil

for 1 care not to be the louse of a lazar -

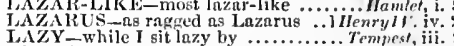

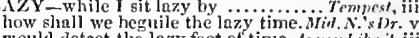

would detect the lazy foot of tinse. As you l, ike il, iii. 2
pale the lazy yauning drone

pale the lazy yauning drone ........... Hrnyy ${ }^{\prime}$.

are these porters, these luzy knaves? Henry III. v. 3

Patroclus, inpon a lazy hed..... Troilus \& Cresside, i.

from the lazy finger of a maid ...........

he was very loath to lny lis.............
and look you lay it in the prator's clin

and though we lay these honours on

lo, now! if it lay in their hands...Antony \& $\overline{C l}$

male great Caesar lay lis sword to bed

to luy his gny comparisons apart

to lay my duty on your hand.......

on Nilus' mud lay me stark nnked

else nn easy battery might iny flat

I will have it no lay ....................

he'd lay the future open
wilt lay the leaven on all

say, where shall's lny him?

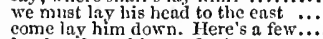

lay hands on him; $a$ dog!.........

this tahlet lay upon his breast.........

by night lay bathed in maiden blood
teach her not thus to lay such violent

hands ean ghe lay on lier life?

got with swearing-lay hy ............

these words, and lay it by

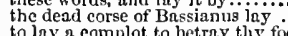

and Valentine, lay hands on them

her fallow leas the darnel...

Temprst, iv.

lie down; lay thine ear close ........

and lay open all our proceedings .... -

here I lny, and thus I hore my point
upon the wanton rushes lay you down

that I may lay my head in ..........

sueh griefs as you do lny upon your

on thee I lay, whose wisclom's
lay the babe upon the pillow

money, caistain? Tny out, lay out.....

rebellimil lay in his way, and he found it -

I lay nside that whiels grows to me!..2HenryIV. i. 2

to lay down likelihoods, and form

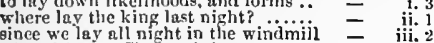

when I lay at Clement's in

to lay a heavy ant unegual hand:........

the imnge of his power lny then in m

I uill lay odls, that, ere this year....

or lay these bones in an unworthy

so, $a^{\gamma}$ bade me lny more elothes......

to lay apart their particular

indeed, the French may lay trenty.

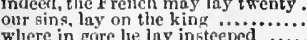

W eould lay on like o butteher

jewcls, lay with youl in your coff
that lay with the little baggnge.

ns godelcss-like to her admired lay

to fay his gontish dispositlon to......

if thy llight lay toward the raging sen.

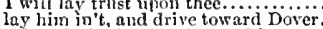

Ohere he is: lay hand upon him .........
and to lay the blame ipon lier own.....
Verona, where we lay our scene. Romeo o Jut. (proi.)

I'll liny fourteen of my teetl

LEAD-lear of this ground

nor lead me, like a firehrand
I pr'ythee now, learl the way

that lends townds

noy, pray you, lead tl

the sweet woman lends an iji

ghe leads a very frampold

whether lad you rather, lead mine eye
I had ns licf bear so mueh lead .......

it you will lead these graees to

then lead the wry....................

lead forth, and bring you back..., ileas.

please it your grace lead on?

and lead his apes into hell

nay, if they lcad to any ill, I will.

didst thou not lead him through...irit. N.Dream, ii.

and leads me to your eyes

come, wait upon him, lend him to.....

and lead these testy rivals so astray...

look thou lead them thus ...

Is say, lead is slow...................

purpose now to lead you

of gold, silver, ancl lend, whereof........

I pray you, lead me to the caskets...

for lead? hazard for lend? (rep.)......

is't like that lead contains

but thou, thou meagre lead

we

though the devil lead the mosure.... All's Weli,

why, he's alle to lead her....

my prayers to lead them on $\ldots \ldots . . .$.
knave, that leads him to these ulnees

now will I lead you to the house

will lead thee mi to gather
tliat lends to the brond gate

fortunes nt thy foot I'll lay....

not in a grave, to lay one in.........

lay hand on heart, advise; an' you

then will I lay the serving-crenture"

open the tomb, lay me with lluliet.

here untimely lay tize noble Paris...

and lay your hands again upon ny
to lay our service freely at your feet

and lay new platforms to endamage

interid st to lay unto

come come, and luy hin in

when he lay coutehed in the ominous

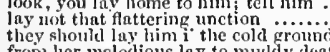

from lier $i^{+}$the earth; and from her fair

methought, I lay worse than the niut

lay a sentenee, which, as a grise, or step
lay thy flnger-tlus, and let thy soul be

for the command, I'll lay't upon you.

fortunes ngainst any lay worth namiog.

I lny with Cassio lately; and, being

lioncst, lay down my soul at stuke

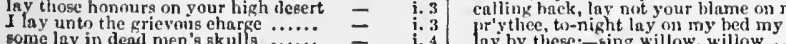

sirraly. lead these gentlement to my

must lend on to sone foul issue i... -

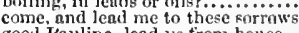

goon I'aulina, lead us trom henee...

till then, lead thou first....

lies like leat npon me

leail thy foot to Englanil

leal nie to the revolts of Englani...

lidst lead me forth of that sweet

the hoy shall learl our horse
birl Pitier lend him forth

ere I leal this life long.

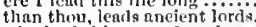

who leuls his power? under whose

I am ns bot as molten lead

God keep leal ont of me

like dull und heavy lead

should icad his forees hit
what a life doet thou leal ?

on. Bardolplip lead the

we will our youtl lead on to higher

Macleth, ii.

v.

ineharil II. ii.

let lis lay hands upon him $\ldots \ldots \ldots . .$. . 


\section{LEA}

[430]

LEA

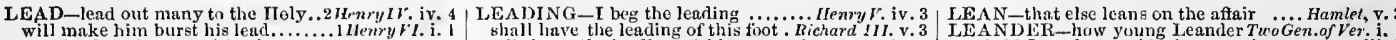
then lead me hence; with whom ..... - y

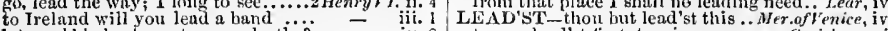
let a rabble lead you to your dentlis? - iv. 8 to run lead'st first, to win some.

in God's name, lead; your king's ...3Ifenry 1 I. jii. I Edward dares, and leads the way Eome lead me to tlue hluck. Bichard $I I I$. jii, 1 go, go, up to the leads

$\mathrm{EAF}-$ but witl one green leaf on it...MIuch duo, ii. writ on botll sides the leaf'......... Love's L. Lost, $\mathrm{v}$. fillen into the sear, the yellow leaf an' "twere au aspen leaf

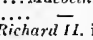




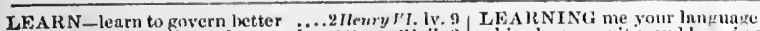

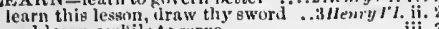
and learn awhile to ecrve....

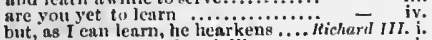
these, as I leurn, and such like toys.

my tongute conlth never lenru swect

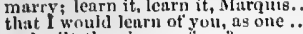

i.

and wilt thou learm at me?

nenr to the town ot Teieester as we learn -

lens'n this, brother, we live not ....I/cnry r III, i.

than thou learn a prnyer without. Troil. of 0

Y lude the vile owl go

I'll learu to conjure and raise

men must learn mow with pity $\ldots . .$. .

to the city; learm low 'tis held ..... Coriolnnus, i.

for learn this, Silius; better leave.... - iii. 1

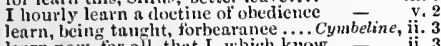

learn now, for all, that I, which know - ii. 3

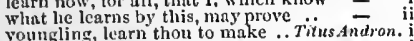

youngling, learn thou to

I witl learn thy thought

learn to know thy meaning........... $=$ iii.

and learn of us to melt in showers .. $\overline{\text { v. }}$.

to learn of me, who stand i' the gaps ... Pericles, iv. 4
learn more than thou trowest ............ Lear, i. 4

I wonld thin learn to lie

Lear's shadow ? I wond learn that.......
sir, I am too old to learn.............
neitlaer know it, nor can learn ... Romeo \& Juliet,

could we but learn from whence ......

learn me how to lose a winning miteh $\overline{-}$ iii. 2

do not learm of him, Enilia .........

lase learned ne how to brook

and learned preparations.

than ever I learned before ...........

free, learned, and valiant

I un sorry, one so learned ........Mens. for Mcas. v

only get the learned writer to set....Much Ado, iii.

ay sir, and very learned

well learned is that tongue .........

but love, first learned in a lady's .....
learned without opinion, and strange

illustrate, and learned gentleman....

rit's own grace to grace a learned fool
that the two learned men have eompiled

that the two learned men... Merchant of Ven

B youn and learued doctor.

you hear the learned Bellario...

most learned judgel a sentenec (rep.j)

never sehooled, and yet learned
where learned you that oath, fool?

rose at an instaut, learned, ployed

that hath learned no wit by nature.

art thou learned? No, sir............

when our most learned doctors leave.

if the learned and autlientic fellows

all the learned and anthentic fellows - ii

I learned it out of women's faces? Winter's Tale, it.

of your speed is learned by them..... King John, iv. 2

to have learned his health of you....

hard I yave learned thy language

and further, I have learned, the king

I am sure they never learned that of me

than they have learnet of me

learued lord, we pray rou to proceed - iv.

seen they grave and learned?.........

with all the learned council ...........2 Henry VI. i. 1

learned, that fearful colnmenting. Richard III. iv.

but by learned approbation

my learned lord eardinal, deliver ail

i

most learned reverend sir............

clerks, I mean, the learned
this just and learned priest

was lie not helrl a learned man?....

my learned and weli-heloved servant

sudden, but he's a learsed man......

assent of all these learned men.
the learned jate dueks to $\ldots . .$.

and never learnel the icy preeepts

it you are learned, be not as

more learned than the cars
set in a note-book, learned

set in a note-book, learned ......... Jutius Crpsar,

to do thus I learned of thee.... Sntony \& Cleo.

hast thou not learned me how ....... Cymbeline, i. 6

they learned of me, as true a dog. Titus Andron. v. I

the worth that learned charity. P'ericles, $v$. 3 (Gow.)

as I learned, the night before

where learned you this, fool? ..............
word with this same learned Theban

wit with this same learned Theban.

I must to the learned.............. Nompo s... Jutiet, i. 6

a rhyme I learned even nnw ........
where I have learned me to repent

where I have learned me

all qualities, with a learned opirit

Othello, ii.

in Bohemia caul learnerlly handie....... Tempest, ii much he spoke, and learnedly.... Henry rili. ii. his place, gravity, and leariting

for the deutlo of learning

were there a foteh set on learuin.

learning is but ma aljunet $(r+\mu)$.

you hear his lenrining................

not learninu more than the fond

fond .... -

of leun anu wasteful learning .... As you like il, iii. 2

Insticute a eourse of learning.. Taming of shrew, i.
0 this learningl what a thing it is!

for learning, and behaviour.

whose learning and good fetters.....2Henry $W$. iv.

for such receipt of learning ........ Ilenry ${ }^{\prime} /$ II. ii.

of singular integrity and learning

such men of gravity, and lcarning

manhood, learning, gentleness . Troilus f Cress. i.

theve will little learning die ... Timon of Athens, ii. 2

puts to him all the learnings that.... Cymbetine, i.

$O$ what lenrning is! ............... Romeo \& Juliet, jii. 3

how to formet that learnin
LEARNING-PLACE-

Hamiel, v.

LLARN'T-thus mucli I have learnt.......Aove's L.L. ii. 1 he hath learnt so much fence already..2 Henry J I. ii. 3 LEASE-they are ont by lease... Two Gen. of $r^{\prime} \mathrm{cr}$. V. shall live the lease of nature.

to let this land by lease

have a lense of my life for

Richard II. s.ASH - not following my leaki...Winter's Tale, iv.

a fawning greyhound in the leash ... Coriolarus, $i$.

LEASING-indne thee witl Measing. Tuelfth Night, i. 5 LEAST - at least two glasses.........

where she, at least, is banished

a. greatest does least

二 iii. i

1 they love least, that let men ..............

that is the least, Lucetta .........

the lenst whereot would quell

or the lenst, if the love of................ ives, ii. l (ivetter)

and I will, at the least, keep ........ - iv. 6

anen to the least sinister usage

that upon the least oecasion more.

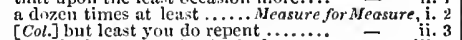

when it is least

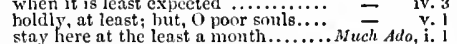

[Col.] at least a patient sufferance.........

in least, speak most, to my eapracity.Mid. N, Dr.
that breaks them in the least degree..Love's L. $L$.

and shall, at the least of thy sweet - i. 1 (letter)

most harm, lenst knowing ill

that doth least know how

they, that least lend it you....

or not removes, at least, affection's. Trming of Sh. i. 2

and so long am $I$, at the least

seening to be most, which we least nre $=$ whereof the least is not this suit... M'inter's Tale, i. 2

at least, thus much; I'll paw

who least will seem to do so ....... - iii. 2

usage (nt least, ungentle $)$ of the dreadful - v. 1

at least we'll dlie with harmess on...........

let it at least be said, they saw

Richard II. iii. 3

thirty, at least, he fought with

sixteen, at least, my lord

at least nine hours, in reckonin........

二 ii.

the least of which, haunting a nobleman - iij. I
or at least desist to build at all? $\ldots . .2$ HenryIV. i. 3

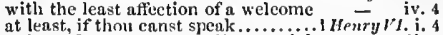

at least five Frenchmen died tönight

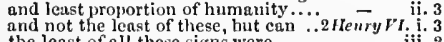

at lenst, for less I slouuld not be.....3 I lenry 1 r. iii. I

ten clny's' wonder, nt the least.

at the least, is iluke of $y^{\prime}$ r

at tho least, is dinke of York $\ldots . . . .$. - iv. 7

half a mile at least sonth from ..... Kicharl III. v. 3

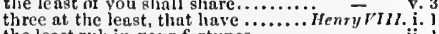

the least rul, in your fortunes....

spake one the least word ............
to meet the least occasion, thint may

or nt lenst strangely neglected

二 ii. $\quad$ ii. 2

at least goor mamers ............ v. v. 2

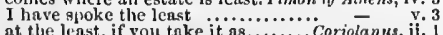

at the least, if you take it as......... Coriolanns, ii. 1
forget, with the least cause ........ - ii. I

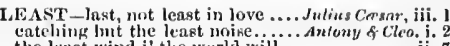

Antony \& Cleo. j.

you shall, at least, go sec my lord ... Cymbelize, i.

se nigh, ut benst, that though ........ - iii.

the lenst of these unspeukable deserts. Titus And $i$

or, at the least, make them............

that's the least fear

half an hour, Eemine, at the least

danghter does nut love thee least.....

what, in the least, will you rejuil.

in the least would fuil her obligation...........

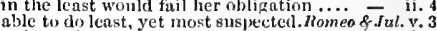

at least the whisper goess so $\ldots . . . \ldots \ldots$..... Hamlet, $i$.

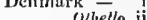

put the Moor at least into a jealousy

[Col. Kut.] lepint) so prove it .................

suppy iest me with the lcast advantage ... - iv.

his leather skin, and horns.. As you Litip, iv. 2 (song)

a headstall of sheep's leather ... Taming of sh. iii.

you must case me in leather.. Comedy of Errors, ii.

put on two lenther jerking

llenrylly.

po in leather alron

drink out of his leather bottle .......3 Henry $\mathrm{FI}$.ii.

where is thy leather apron

Julius Carsar,

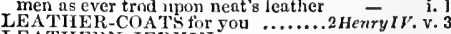

wilt thon rob this leathern-jerkin ... HenryI $V$. ii. 4

did stretch his leathern coat..........ss you Like it, ii.

I A VE-let's take leave of him.

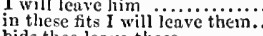

Tempest, i. l

bids thee leave these.....

leave not a rack belind................
where clidst thou benve these varlet

now let us take our leave.... T'uoGen.

give him leave, madain....................

I'll leave you to confer of.

I cannot fave to love (rep.).

give us leave, I pray awhile

to leave our royal court.

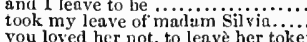

you loved her not, to leave her triken

and leave no memory of $w j_{1}$.

and leave her on such slight condition

did her grandsire leave her

by your leave, good mistress

we must give folks leave to prate....

give us leave, drawer

she ealls you, enz; i i li leave you

by your leave; I cry your mercy.

let the boys leave to play....

we'll leave a proof, by that ............
serve Got, and leave your desires

if sir Toby would leave drinking.. Tirelfh Night, i. 5

give me leave to prove you a foo.
and leave the world no copy ......
I shali crave of you ynur leave.

it would please you to take leave of ther

by your leave, wax le.........................

and leave image of it leaves him

and leave me to my hearing
Oby your leave, I pray you

give me leave, I beseech you

till he take leave, and presently

and leave thy vain libhle babble

I leave my duty a little........... v- ver 1 (letter)

exeention do I leave you of your

yet give leave, my lord, that we

I take my leave of you.

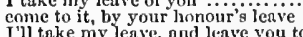

I'll take my leave, and leave you to

leave me a while witl the

did Angelo so leave her?

but leave we him to his events

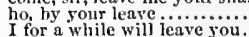

give me leave to question

gir, by your leave .................

and happiness takes his leave

and so I leave you ..................

If it will not he, l'll leave you...........

and leave 11 alone

I must leave you
二 iii. 3

iv.

ii. 4

ii. 6

iii. 1

iv. 4

v.

i. 1

iii. 2

iii.

iii.

v. 5

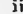




\section{LEA}

[ $4: 32]$

LEA

LEAVE-father, by your leave ........Wuch All
I will kiss your hand, and so lenve you I will kiss your hand, and so lenve you and leaves off his wit!

to-night I take my leave

I leave an arrant knave with your....

there will Ilve you leave to de yourt too, for here

thanks to you all, and leave u

in his power to leave the figure.

only give me leave, unworthy as i $i$

to leave the city, and commit yourself

ere be do leave this groved

0 wilt thou darkling leave me?..................

that men do leave, are hated most...

I believe we must leave the killing out

why, then you may leave a casement

Why nnkindly didst tho

a foolish heart, that 1 leave here behind -

pray, you, leave your eourtesy

not till it leave the rider in the .. Love's $L$. Lo

study his bias leaves, and

througl the velvet leaves the wind

then leave this chat; and good Biron

I'll leave it by dearees

and so I take my leave

kiss thy royal finger, and take leave $\quad$ - v. 2

we $t$ wo will neave of ren

we two will leave you...............

to take their leave: and there is .....

to leave a rich Jew's service, to beeome

I'll take my leave of the Jew in

I am sorry, thou wilt leave my father so -

by $y$ our leave, sir $\ldots \ldots \ldots \ldots \ldots \ldots \ldots$
to take a tedious leave $\ldots \ldots \ldots \ldots \ldots$
immediately to leave you and be gone

of them all to leave the dam

steal both his, and lenve itself ...
fair lady, by your leave, I come

fair lady, by your leave, I come ....

since I have your good leave to go

may'st have leave to han th $\ldots .$.

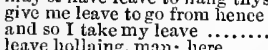

leave lollaing, man; liere.

love me, and leave me not...................

how you do leave me to mine own
of your will: I pray you, leave me.

of your will: I pray you, leave me. As you Like

and never leave thee till he hath ta'en

co please you give us leave.....

your griefs yourself, and leave me ou

leave me alone to woo him

did yon leave him in this contemplation? -

give me leave to speak my mind

for me hereafter to leave my wife $\ldots . . .$.

Rosalind, I will leave thee

did he leave him there, food to

which is in the vulgar, leave....

freely have they leave to stand on

and gives me leave to inn the crops

pray you, leave me: stall this in

thou shalt have my leave, and love

that dare leave two together

when onr most learned doctors leave us =

grant! and so I take my leave!

in whe leave to use the help of......

alse I'd call you knave; I leave you..

take your instant leave o' the king.

procured his leave for present parting

so I leave you to vour wisdom
your lordship; I'll leave you

you barely leave our thoins to $\ldots . .$.

of whom he hath taken a solemn leave

nay, by your leave, hold your........

and take your leave of all your frien

briars shall have leaves as well...

and leave him to your lordship

that eer I took her leave at court...

leave me and her alone.... Taming of shreu

by my father's love and leave........

leave shall yon have to court

to take, and what to leave? ha!.

for a while I take my leave, to see

have leave and leisure to make iove

yea, leave that labour to great ...

and so I take my leave, and thank

then give me leave to have prerogative

then give me leave to read philosophy
you leave his leeture when $I$..........

you leave his leeture when $I \ldots \ldots \ldots . .$.

hour father prays you leave your ....

for such a one as leaves a gentleman

and so I take my leave, in resolution
$I$ trust $I$ may have leave to speak....

\begin{tabular}{|c|c|c|c|}
\hline & .. Taming of & f $S h_{3}$ & \\
\hline & $\begin{array}{l}\text { herefore leave us } \\
\text { ir. You shall }\end{array}$ & $8-$ & \\
\hline & I be tamed so.. & & \\
\hline & $i i$ & & \\
\hline & slument leave & - & \\
\hline & $\begin{array}{l}\text { en corne; you have leave } \\
\text { entwe }\end{array}$ & 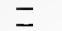 & \\
\hline & $\operatorname{ling}_{0}$ & & \\
\hline & $\begin{array}{l}\text { you llleave you } \\
\text { and that there }\end{array}$ & $\bar{Z}$ & \\
\hline & $\begin{array}{l}\text { and think } \\
\text { and }\end{array}$ & 三 & ii. 3 \\
\hline & rying & & \\
\hline & $\begin{array}{l}\text { and leave the growth untried of ..... } \\
\text { if tinkers nay have leave to live.... }\end{array}$ & & \\
\hline i. & & & \\
\hline i. 5 & f your & $z$ & \\
\hline & le & - & \\
\hline & emony.. & - & \\
\hline & $\begin{array}{l}\text { and le } \\
\text { never }\end{array}$ & - & \\
\hline & $\begin{array}{l}\text { leave? } \\
\text { …... }\end{array}$ & $=$ & \\
\hline & lo not say... & & \\
\hline & Comed & & \\
\hline & 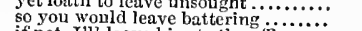 & $\overline{-}$ & iii: \\
\hline & officer... & & \\
\hline iv. 3 & a.......... & & \\
\hline & le $(r e p.) . . .$. & & iv \\
\hline & roil as thou di & & \\
\hline & …........... & & \\
\hline & e............ & - & \\
\hline & $\begin{array}{l}\text { by your leave, hostess ... } \\
\text { him }\end{array}$ & - & iit. 3 \\
\hline & bes............... & - & \\
\hline & $\begin{array}{l}\text { this. of full of ......... } \\
\text { e, to leave his babes.... }\end{array}$ & - & ivi \\
\hline ii & . & $=$ & \\
\hline & on....... & & \\
\hline & at peace, when $\mathrm{I}$ did leave them ...... & - & \\
\hline & aed is no & & \\
\hline & $\begin{array}{l}\text { lor } \\
\text { nd you }\end{array}$ & & \\
\hline & & - & \\
\hline & de & - & \\
\hline & $\begin{array}{l}\text { him } \mathrm{I} \\
\mathrm{m} \text {.... }\end{array}$ & - & iii \\
\hline & $\cdots$ & - & \\
\hline & & - & \\
\hline & f blood where'er & - & iv \\
\hline & e the field & - & \\
\hline & & & \\
\hline & irts, lcaves them insensible & $=$ & \\
\hline
\end{tabular}

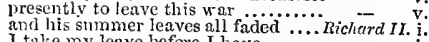

I talke my leave hefore I have
the list leatre of thee takes my

then let us take a ceremonions leave

but you gave leave to my unwilling

too few to take my leave of you

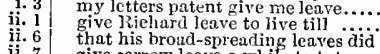

iii. 7 give sorrow leave a while to tutor...

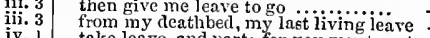

take leave, and part: for you must part 二

where did $Y$ leare?
well-graced tliat sad or leaves the stage.....

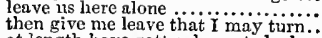

then give me leave that $\mathrm{I}$ may turn..

\begin{tabular}{l|l} 
i. 3 & leave the prinee and me alone \\
i. 3 & after we leave them; and, sirrab..... \\
i. 3 & you have good leave to leave us
\end{tabular}

i Henry $I V$.

ii. 1 and to leave thesc rogues, $I$ am

ii. 3 hew now, Kate? I must leave you.

ii. 3 this evening must I leave you
ii. 3

ii. 3 do thou never leave calling...........

ii. 3 give me leave to tell you once again

\begin{tabular}{l|l} 
ii. & mnst steal, and take no leave........ \\
ii. & and leaves behind a stain upon.....
\end{tabular}

iii. 6 and let us take our leave..........

\begin{tabular}{l|l} 
iv. & lords, give ns leave $\ldots \ldots \ldots \ldots \ldots \ldots$ \\
iv. 3 & by his lollow whistling in the ieaves
\end{tabular}

\begin{tabular}{l|l} 
iv. 3 & gyve me leave to breathe a while \\
iv. 3 & I'll
\end{tabular}

iv. 4 for pive you leave to powder me

$\begin{array}{ll}\text { v. } & \text { let ns not leave till all our own...... } \\ \text { v. } 2 \\ \text { v. } 3 & \text { and give me leave to tell you } \\ \text { it thou get'st any leave of me........... }\end{array}$

but, by your leave, it never yet....

and leaves his part-ereated cot...

I commend thee, and I leave thee

$=$
$=$
$=$
$=$
$=$
$=$
$=$

v. I take my leave, with many thousand

witl your le to speak ......

with your leave and favour............

v. 2 the leaves and fruit maintained .... and leave your brothers to go speced.

you shall give me leave to play ...... leave off to wonder why $\mathrm{I}$ drew you.. fair lords, take leave, and stand not.

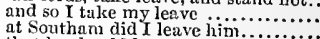
that he should leave the helm........... he should have leave to go aw.......... and leave the world for me to......... Richard $I 1$ known evils leave, by circumstance to leave this keen tneounter ......... may please youn leave these sad......
for shame, and leave this world ......

and leave ont thee? stay dog ..........
why wither not the leaves, that want that her grace did leave it out ...... when great leaves fall, then winter.. in this resolution, here we ica........ most joyfully, we take our leave .... no, I may not leave it so how.................. poor soul, that takest thy leave of it: Thumbly take my leave $\ldots \ldots \ldots \ldots . . .$. to give me leave, I'll muster up.......
but, hear you, leave behind your son but, hear you, leave behind your son leave ns never an understanding. Herny not unconsidered laave your hon
though we leave it with a root

leave these remnants of tool and feather by your leave, sweet ladies

by all your good leaves, gentlemen

whom to leave is only bitter to lim...
so I leave him to him, that made...

to leave so sweet a bedtellow? (rep.)...

the which to leare is a thousand-fold your particnlar fancy, and leave me out
and got your leave to make this present and leave your England, as ciead ${ }^{-. .}$iii. (chorns) I will not leave the half-achieved.... and those that leave their valiant

o give us leave, great king, to view...
Hrnry V. v. 2

Ienry

三 ii:

$=$ iii.

$=$ iv.

- v.

ii.

ii. 2

ii. 3
ii. 3
ii. 4

iii.

\section{ii.}

ii

iii. 2
iii. 2
iii. 2
iv. 1
iv.

iv. 2

iv. 8
iv. 8
v. 10

10
$\mathrm{v} .1$

v. 2

i.

i. 1

i. 2

ii. 1

ii. 2

ii. 2

ii. 3
ii. 3

ii. 6

iii. 2

- iii. 3

二

= iv

二 iv.

= iv. 7

二 $\quad$ iv. 8

$=\begin{aligned} & \mathrm{v} .4 \\ & \mathrm{v} .4 \\ & \mathrm{v} .\end{aligned}$

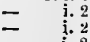

$\bar{\Sigma}$

$=$ ii.

$=\quad i 1$

三 i.

$=$ iii.

$\overline{\text { ivv }}$ iv.

iv. 4

II. (prol.)

(prol.
i. 2
i. 2
i. 3

=

$=$

ii. 2

iij. 3
ij. 3

ii.. 4
iii.
iii. 1 


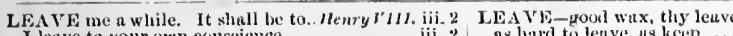
I lenve to your orn conscicice and so we the the ter lenves of lione... must 1 then lenve you? must 1 . gorrow Crumiell leuves his lord willing to leave their laurde give ne leove to spenk him

and leave me liere in wretehetiness..... hid the music leave, they are larsils. putience, you must not lenve me yet leave une alone; for I muit think of.. you'lt leave your noise anm ....... ye rude shites, leare your gaping
go shull she lenve her hlessulies. go shull she lenve her hilessed ness .... fair leave, und large secturity and lenve tle thetion of fisols my leave, my lord. Your leave $(r e p$. thit itself will lenve, to be if ever she leave Truilus!
my kiss, sir: lady, by your leave. my kiss, sir: lady, by your leave let's leave the hermit pity with. but give me leave to take that eourse Ilector, I take uny lenve; thou dost that I ghall lenve you one $Q^{\prime}$ these day aml every where, he leaves, and takes I had leave of means? nor more willingly letwes winter... as leives do on the oak 1 dive thee leave to ling it ..... so I leave yout to the lrotection
but leave without thy rage

and leave me hut the brain

I leave your honours: if we......... that you might leave pricking it for pity I'll leave the foe, and make........... and behind him he leaves tears ....... and leaves nothing mothing out for lensth

you'll mar all; I'll leave you

leave ns to eure this eanse.............

give me leave, I'll go to lim

eome, leave your tears; a brie

well, well, we'll leave youk............ tuking their leaves of me.

and leave his passage polled........

to leave unburnt, and still to nose
but, by your leave, I am an officer

but, by your lcave, I am a

mother of the world leave unsaluted

a dreamer; let us leave lim ${ }_{\text {Cassins, }}$ your desires; I'll lea...

for this time I will leave you.........

then leave him out. Indeed, 7 ie is not

my sad brows; ?eaye me with haste.

and leave us, Publius; lest that .......

here, under leave of Brutus...

and will you give me leave?

and will you give me lenve?

gou shall have leave. A ring ........

your mother ehides, and leure you 80
Irybln becs, asd leave them honeyless

where did you leave him?

by your leave, gods: this is a Roman' never giren you leave to comel...A
I'll lenve you, lady. Courteous lord

Antony, lenve thy laseivions wassails
give ne leave, Casur,-Speak, Agrippa

now Antony mnst leave her utterly.

better leave untlone, than by

leave unexecuted your own remosned

leave ne, I pray, a little

and lenve his navy gnzing

I will seek same was to leave him

on you, as one that tukes his leave.

whom Antony loved, now leaves him

give thee leave to plny till doomsdiny

avoid, and leave him: hast thou

guch as the aspick leaves upon the

should we be taking leave as long....
awcet sovereign. leave us to onrselics

for this time, leave nue ..............

let us lenve here, gentlemen..........

my man's abode where I diil leave jui

for his lieart, and leuve cigliteen the taper, leave it burning $\ldots . . . . . .$.
by your leave, hisl $1 \mathrm{know}$ her women -
by your leave. Who's there, thut knucks? to leave you in your mudness... oo I leave you, sir, to the worst .... upon whose lanves ure drops all leave us ale this tempest will not give
leave him to iny displeasure and leave me to my grief where did I leave? At elose

I must leave thee, love (rep.)

as will not leave their timet. and leave you hindmost go to hill rather leave to sec Yiector

by your leave, sir, - What do you ask

set an, and leave no ceremeny out...J

wave leave you, Brutus; and, friend

r'll leave tliee now, like a ma

I did not take my leave of him

and leave her in sueh lonour as you or masterless leaves both tu who
youll give me leave to spare.

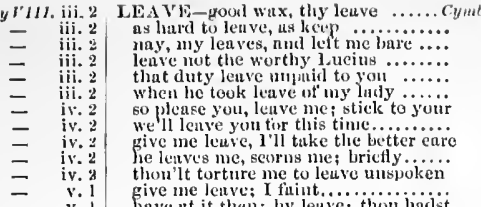

Cyinte:

$=$
$=$
$=$
$=$
$=$

iii. 2 IEAVE-1 lave ube for it: ger, lenve mo. Ohello, iii. 3

leave procreants alone, and shut the door LEA me have leave to firak .............. lay the lenven on all proper.

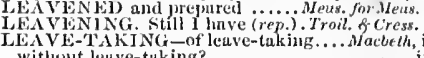
withut leuve-tuking? ................ \& cressida, it is not worth leave-tuking.Anforyg Cleopatra,
of letwe-taking between Frunce aud linm...Lear, have given me lenve to slienthe.
by your lenve, this maid is mine bo less: nnd so I tuke my lenve. prince Bassianus, liave to plead the green leaves quiver.............. and lenve me to this misernble ...... and so let's leave her to her silent... tremble, like aspen leuves.............
give me leave; for losers will hitve leave give me leave; for losers will have
he leaves his pledges dearer than good grandsire, leave these bitte note, how she quotes the leaves

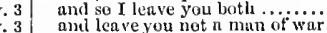
depart at pleasure, lenve us here that kindness, and tnke leave of hin since you have given me leave to speak who uever leave gaping, till they and leaves us to our tree election. and lave her the inturt of yrsing so I take my leave; good madnm... his woetul queen leave at Epluess I'll leave sou, my sweet lady........ there's for you; leave us (rep.) come, we will leave his honour

ii. 1 come, let us leave her, and the gods...

ii. 1 yet give me leave: how came you

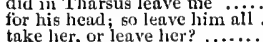

iij. 3 then lenve her, sir; for, $\mathrm{by}$ the power. which often leaves the history unspoke with washed eves Cordelia leaves you leave thy drink and thy whore.... and leave his horns without a case

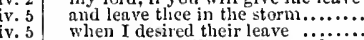

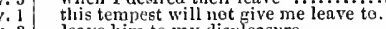

\section{v. 3 leave, gentle wax; and, mauner} ere he cau sprend bis sweet leaves. an' if you leave me so, you do...

nurse, give lcave awhile, we inust talk to think it should leave erying
wilt thou leave me so nnsatistied? I am aweary, give ne leave awhile. ii. 1 have you got leave to go to slirift to-day? ii. I by your leaves, you sliall not stay alone I will die, and leave him all ........

$\begin{array}{ll}\text { iii. } 2 & \text { dream I that gires a dead man leave } \\ \text { iii. } 2 & \text { since yon did leave it for my offiec ... } \\ \text { iii. o } & \text { not leave you [Col. Knt, sir, liare putienec] }\end{array}$

iii. 2 not leave you Col. Knt. sir, liaye putienec]

iii. 2
iv. 3
v. drink all and leave no friendiy dro your leave and thyour to retrin
gracious leave and pardon (rep.) wrung from me my slow leave.

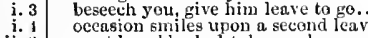
most humbly do 1 take my leave $\ldots . .$. ..

Wii.
iij.
iii. 7
Iwe me leave: haw does my good......... most humbly take my leave of you.

sweet Gertrude, leave us too....

sweet, leave me here awhile............
leave thy dumnable faces, and begin

eusily said; leave me, friends...........

leave wringing of your hands: peace.

and woo, for leave to do lim good $\ldots$

I pray you, give me leave. We will

you shall hear thens: leave us .....

his hoar leaves in the glusey stren
give me leave: here lies the water

give me leave: here lies the wate
of anght he leaves, knows what
if you huye not given lier lcave

if you have not given her lay
furewell; for I muat leave you

furewell; for must leave you .......... - i. Othello, lcave some officer behind....

ii. 1 my Desdemona must I leave to thee

ii. 2 [Cnl. when I liave leave to sleep ......

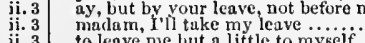

\begin{tabular}{l|l} 
ii. 3 & to leave me but a little to myseif........... \\
ii. 3 & not to leave undune, but kcep unknowi
\end{tabular} not to leave undone, but kcep unknowu
leave me, Inge. Ny lord, I tuke my leave I beg but leave to air this jewel
I ouce more take my leuve
LË

AVING the feur of henven........Merry Wives, enving her in the protection of .. Tuebh Night, i.

leaving lis wcalth und case. As you Like it, $\overline{i i}$. 5 (son.

1.contes leaving the cficets of. $U$
of thy serviees, by leaving me

Macbelh,

my impress, leaving me no siglar...King John

leaving their wits with their

Henry $r$

leaving their carthly parts to choke. - iv.

leaving this, what is your grace s. Richard 11 . i
forth on, leaving no traet betind.. Timon of sth.

give them disenses, lenving with ..." $\overline{-}-$ it

leaving so his scrvice, follow you ... Cymbetine, iv.

from lieaven by leaving eurti .. Rnmeo of Julec,

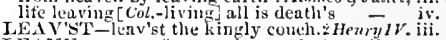

LEA V Y -summer first was leavy. $/ u c h A d e$, ii. 3 (soll: your leavy sercens throw down...........Macterth like a lecher, out of whorish..... Troilus \& Cress. were like un old leetrer's heart

the fost minsanctified of murierous lechers -

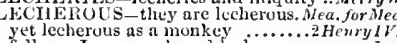
yet lecherous as a monkey $\ldots . . . .2$ Henry $1 V^{\prime}$. ii

treacherous, lecherons, kindless villimi i Humle
LECHERY-nud their lechery lechery! I dety lechery ........... Tuelsh Nivht, i. lechery? Cail it so ... a little more lenity to lechery would the most dangerons piece of lechery Much Ado, iii. lechery, sir, it provokes, and mprovukes. Nacbeth, ii said to be an equivocator with lechery - ii. war, and lechery, confound all l.. Troilus of Cress. nothing but lechery 1 all incontinent fry, leehery, try 1 But will you theu?
lechery, lechery l still, wurs and lechery

yet, in a sort, lechery eats itself...... -

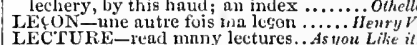
your lecture slanll have leisure

a troop, to xend n lecture of them?... Richard 1 . iv -Claulio, led by the provost.Meas. for Meas. i. I led them ou in this distracted. igid. $s$. Dream I am not solely led by nice..... Merch. of Íenice, ii. I foot again, led hither by pure.........Al', Well, iii. the life that late I led ....Taming of Sh. iv. 1 (song) you said, led fou to Dunean............. Mucteth, iij. jower is near, led on by Malceln ..... to dismiss the powers led by the Dauphin - v. but bascly led by flatterers............ Kichard 11 . ii. I linve led my rng-a-muttins......... Henry $1 \%$. v.

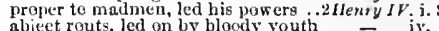
but as my betters ary bloody youth in honour, led by the impartial ....... - -

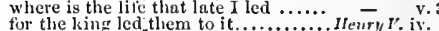
from the ufficers that led me

troops thats that the Douphin led.... - iv. fhould not thus lie led along.....

that led ealm llenry, tho he............. armed in proot, and led by slallew .. antl will be led, at your request ....... be led with manneles thorough

with blondy pas age, led your war.

Oprief! where hast thou led me?.. Julius Casar you are contented to be led in triumi...

suw her led between lier brother. Antony $\delta$. Cle both how you were wrong led

o whither last thou led me Egypt?.

take me ul); I have led you oft ..... - iv.

and led my connt led by tlicir master to the beeame him like the leaving it

leaving thy trunk tor crows ......2henry II. iv. 10 you read no other leetures to her.. Taming of $\$$. 3 .

leave his lecture when I ann. say, we read lectures to you ........ Coriolmas, ii. my niece Plantagenet lell in the...... Richard 111. iv. 

LED-led by a lusty Goth? ....Titus Andronicus, v. 1
led on by heaven, and erowned..
their noses are led by their eyes......... 3 (Gour, ii. and led by some discretiou. hath led through fire and through fiame.... my tather, poorly led? worl

and fortune led you well

and fortune led you well

became his guide, led him, begged $\ldots . . .3-$ v. 3

and will as tenterly be led by the nose... Othello,

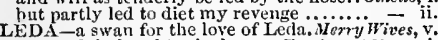

fair Ieda's daughter lad ..... Taming of Shrew'

LED'ST-Griffith, as thou led'st me. Henry VIII. iv.
LEECH-as each other's leech .. Timon of Athens, v.

LEEK-his eyes were green as leeks ...Mil.N.Dr. v. 1

ril knok

where leeks did grow, wearing leeks
to wear the leek upou Saint 'Tavy's day
but why wear you your leek to-day?

iv. 7

and bid me eat my leek ..............

to eat, look you, this leek

moek a leek, you can eat a leek (rep.) - v.

LEER - rives the leer of invitation...Merry Wines, i. 3 a Rosalind ot a better leer...........As you Like it, iv. I
I will leer upon him, as a comes by.2Henry $1 \%$. v. 5

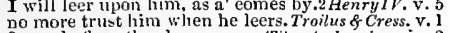
framed of another leer....... Th this dindronicus, iv. drink up the lees and dregs of.. Troilus \& Cress. iv 1 keep leets, and law-days .............. Othello, iii.

whom I left cooling of the air......

and here was left $\mathrm{by}$ the sailors.......

and left thee there they la.......................

at last I left then i' the.

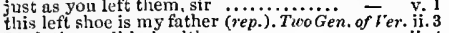
I left them

if left alone poor lady ${ }_{\text {alasolate and lefti } \ldots} . . \quad$ - $\quad$ iv. 4

thou hast no taith left now .........

he left this ring behind lim ....... Twetfih Night, i.

he left behind him, myself.

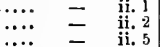

where I left Olivia sleeping

left her in her tears, and dried...Meas. for Meas. iii.

$i t$ is all the weal th he hath left.

war-thoughts have left their places.

all that Adam had left him belore

ever sinee you left it: doth not
all the grace that she hath left.

your danghter liere the princes left

that none is left to protest.

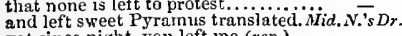

yet since night, you left me (rep.)....
stolen hence, and left me asleep!

ay, that left pap, where heart dotil ...

and lion are left to bury the dead....

of Russians left us hut of late $\ldots \ldots \ldots$.... $\overline{\text { Venice }}$

is a lady rielaty left. and she

see to ny house. left iu the .........

next turning of all, on your left

I were best eut my left hand off........

and how unwillingly I left the ring..

allottery my father left me by ........

murmuring stream, left on your

he left a promise to return again

my father left me some preseriptions...Alls $\mathrm{Well}$, i. 3

have left off the danger to itself?

for I have Pisa left, and am to. Taming of

me, left solely heir to all his lands

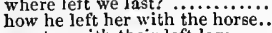

conrtsy with their left legs

gioee we have left our throne........... Winter's Tale, $i$.

be left her to perform................

and, why he lett your eourt.

if there be any of him left.................

the garments he hath left with the

is there no manners left among 1 had not left $a$ purse alive in the

great Alexander left his to the wrorthiest

and left them more $r$

have left me issueless ...............

and left the ship, then sinking-ripe

where have you left the money

patience in thee will be left....

the great wart on my left arm

it was two ere I left him

there left me and my man
some fading giimmer left.

and me they left with those...

only I have left to say..............

your eonstaney hath left you
is left this vault to brag of

when there's no merty left.
whet
LEFT-why in that rawness left you ...Macleth, iv.
left to be finished by such a she ..... King John, ii. not an hour sinee I left him well

and England now is left to tio

John, sore sick, hath left the field.....

more patient than when you left him

whiel he hath left so shapeless.... .

here an I left to underprop.

every thing is left at six and seven ...

the king is left behind

to be brief, left I his title oit.

left me in reputeless hanishment

in deputation left behind him...........

hath left a witnessed usurpation

now left him; never, 0 ne

which, before eoid and settled, left .

to mine leave, as 'tis left to me.....

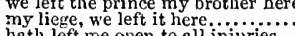

hath left me open to all injurie.........

there left behind and settled certain....

thy fall hath left a kind of blot...

late examples left by the fatal

upon their eliidren rawly left

there's not a boy left alive..........

and nime but women left to wail .... v. $\overline{2}$ (ehorvs)

$1 \mathrm{am}$ left out; for me pothing remains

so bold to take what they have left

this maliee, Somerset, be left?........

he left me proudly, as unworthy

and left thee to the merey of tie law.2Henry rI. i. .

left I the court, to see this quarrel ..

inheritanee, my father left $\ddot{m}$

stole away, and left his men.

.3Henry iv. i.

whom we have left proteetors.

hath left with thee; his dukedom (rep.)

my father had left ine no more

had left no mourning widows.

slie on his left side, craving aid...

you left poor Hepry at the bishop

eomfort of thy ehildren left

indeed, left nothing, fitting for your

and so I left them both, to bear..

and left thee but a very prey to

they have left their barge ...........................

I left him private.......................

has left the enuse o' the king ........

now has left me, weary, and old

and left him at primero with

no doubt, left for the ladies.

we left them all at home

Troilus \& Cressida, $\mathrm{i}$.

happy, and has left me rich ........... Timon of $\overline{\text { Althens, }}$ i.

which ne'er left min i' the mire

there wonld be none left to rail....

$=$ ii.

there is not so mueh left ............

what other mean is left unto us... - iv. 3

eonsume you wicked caitiffs left $1-\cdots$ v. 5 (epitaph)

i' the sloulder, and i' the left arm

now you have left your voiees
what is left, to lose it by lis.........

what is left, to lose it hy his..........

moreover, he hath lett you all.... Jutizs Ceeser,

moreover, he hath left you all.... Jutius Cee

turned down, where I left reading?

upon the left hand

you had then left unseen................

left unshown is often left unloved.

on what I have left belind .........

to hear from me you liad left Antony
my pillow left un pressed in Rome.

have empty left their orbs .........

that has this morning left thee

and there is nothing left remarkable $\quad$ - iv. 12

lefs these notes of what commands

fold down the leaf where $I$ have left

too casually hath left mine arm..........

motion and breath left out .........

which by thee lately is left untendered

I would lave left it on the board.......

in this place we left them....

at the lieart, and left this head on...

O godsl I left out one thing whieh
though you left me like a churl .. slime left on tliem by a flood?

is left to tyranuize upon my breast..

that left the camp to sin $0 . . . . . . .$.

who died and left a female heir...Pericles, i. (Gower)

scaree strength left to give them hiörial

othing to think or

buildings lett without a roo

here's all that is left living.

and tigh estate, is left to govern -...

. - v. (Gower)

I left behind an apcient substitute ... - and left nothing in the middle ........... Lear, i. 2

out went the candle, and we were left..... -

yet have I left a daughter (rep.) .........

you have one eye lett to see.

imperfeet.............. - iv.

and there left him tranced general?... - iv.

the pretty wreteh left erying .............. \& suliet $^{2}$ i

departed not, and left lim there...... - v. v.

had left the flushing in lier galled eyes.. Hamlet, $i$.

a Dane, here's yet some liquor left........ - $-\mathrm{y}$.

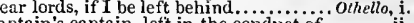

my right hand, and this is my left hand

that he hath left part of his grief

when Cassio left my wite............... - iii. 3

and not know who left it therel......... - iv.

four legs, and two voices $\ldots . . . . . . .$. .

I'll pull thee by the lesser legs

if any be Trineulo's legs

heave up my leg $\ldots \ldots \ldots . . .$.
wlat, that my leg is too lon

is too long?........ v. v

pineh them, arms, legs, backs....... Alerry Wives, v. 5 by the exeellent her legs......... Tuelfinight, 1. no sir, it is legs and thighs ..........

the did praise my leg being..............

taste your legs, sir ..............

my legs do better understand

by bidding me taste my legs

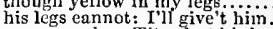

young neplew Titus lost his leg

with a good leg, and a good foot .......uruch $A d o$, ii. i

Beatrice his bad legs, falls into...... - ij. 1

my legs are longer though....Miil. N.s D ream, iii 2

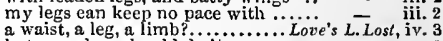

but your legs should do it.............

before the legs of this sweet lass.......
his les is toobig for Heeter $\ldots . . . .$.

use your legs, take the start. Merchant of Venice, ij.

if my legs were not weary the leg... ds you Likeit, i. 2

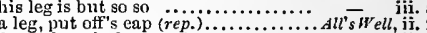

I am there before my legs ..............

no more stockings than legs ..............
seratehing of $5 h .2$ (ind.)

with a linen stoek on one leg

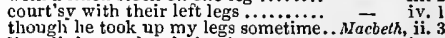

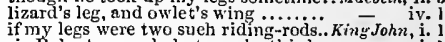

sir Robert never holp to make this leg

and forbidden legs dared onee to touch $\overline{-}$ make a leg, and Bolingbroke... Richard $I I$. i

my legs ean keep no measure........

afoot awhile, and ease our legs ...... - ï. 2

well, here is my leg ..............

mareh wide betwixt the leg

a deereasing leg? au increasing.......2 HenryIV

hecause their legs are both of

like unto the sign of the leg.

will you eommand me to use my legs? =

is weary; when my legs are too...... - (epil.)

when all those legs, and arms.

that has but two legs, that shall...

I will chain these legs and arms..... i Henry $V I$. ii. the garter from thy craven's leg.......

we must have you find your legs .....

thy leg a stiek, eompared with....... - iv.

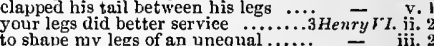

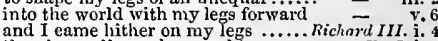

they have all new legs, and lame ....Henry VIII. $\mathrm{j} .8$

my legs, like loaden branehes......... - iv. 2

his legs are legs for necessity $\ldots . . . .$.
the sinews of this leg all Greek......

hanging at his hrother's leg ...........

(1.

our steed the leg, the tongue .......... Coriolanus, i.

for poor knaves eaps and legs ...... - ii. 1 
LEG-walk muter his linge legy ....Julius Carsar, i.

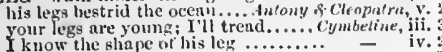
a leg of Kome shall not return - v. 3 turn a swan's black legs to white.Titus.fnetron. iv. tand upon sound legs .............. Pericle's, iv. serve seven years tor the loss of a jeg.... - iv. 6 put in his legs: come, my good lord .......ear, hi. feel you your lege? Xom stand ............ - iv. 6 every man betake him to lis made of long spinners' legs straight leg, and quivering

yet his leg excels all mens ........... - i. these leas, that brought me to a part.... Othello ii. these legs, that brought me to a part.

$m y$ leg is cut in

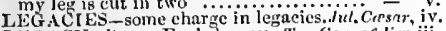
LEGACY - it was Eve's legaey. Two Gen. of 'rriii. shnil, for my legiey, he sunctined

as a rieh legacy, unto their issue.

from pope Innotent, the legate

the legate of the pope hath been

where the holy lezate comes apace.

the thusting to this halting lequte here

stay. my lord lerate; you slall....... Henry $\boldsymbol{r}^{\prime} \mathbf{y}$ you wrote to be a legate ..........henry/l11. iii. 2 LEGE - verse; lege, domine .....Lore's L.L.ns, iv. 2 what he leges in latin ........ Taming of shrew, i. 2 LEGERITY_and tresh legerity .......

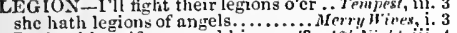
Legion himself possessed him.... Twelfh Night, iii. 4

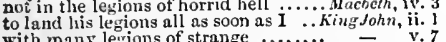

and tell the logions, strange

death trom his weak legions...

Henry Yi. 2

methonght, a legion of tunl fieuds.. Richard $I I I$. i. 4

for gold to pay my legions

these bills unto the legions on the other

as Cassius' legions are by Antony.

our nineteen legions thou shalt... Aniony \& $\bar{C}$ C

will $I$ render my legions, and my hor'se

his eoin, ships, legions, may be

and you shall hear the legions

with those legions which I have spoke of -

with those legions whicrisoned in Gallia -

the Roman legions, all from Gallia . $\overline{-}$ iv. 3

your hrother is legitimate............ King.lohn,

whether our daughter were legitimate lien. I T

well then, legitimate Edgar, I must

as to the legitimate: fine word

LEGITIMATION, name, and all .....King John, i. 1 and safe in Leicester town ............ v. v. 3 he came to Leieester, lodged in....... Henry $\overline{V I} l 1$. iv. 2 LEIGER-everlasting leiger..... Micas. for Meas. iii. I LEISURE-at picked leisure, which ... .. Tempest, v. to me at your convenient leisure... Micrry Wives, iii. 5
at our more ieisure shall I ....... Meas. for Meas. i. 4 might you dispense with your leisure

I have no superfluons leisure

which I, by my good leisure

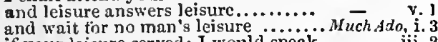
if your leisure served: I would speak of iij. 2 I am sorry, that your leisure setves..

when than hast leisure, say $\ldots$.

and sickness debate it at their

nore leisure shall express .......... va vanin shall lave leisure for as much

he shall stay my leisure

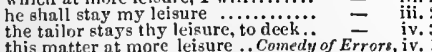

I shall have leisure to make good....

we stay upon your leisure

Nacbcth, i. 3

at

winds, whose leisure I have stayed.. King John, ii. then if you had at leisure known.... si hard II. $i$ ere further leisure vield them.....

liwhard Il. i. 1

we'll stay your leisure $\ldots . . . . . .$.

zounds! how has he the leisurc....... ${ }_{\text {at mon }} I V$. iv. I no leisure had he to enrank $\ldots . . .$. . Henty H. i. i since your ladyship is not at leisure.

attend ujon your hordish's leistire

come patient leisure to excise.......... Richard $\pi 11 . \mathrm{i}$. which after-hours give leisure to repent God give us leisure for these rites.... the leisure and enforcement of the time to steal from spiritual leisure ....llenry $\bar{V} / l$. iii. 2 krarce have leisure to salinte you Troins o Cress. iv. Ileetor's leisure and your bountics... at many leisures I proposed ... Timnn nf dthens, ii.
LISURE-at thy Bnvereign leisure. Antony o clen.i. 3 ant attend the leisure of their answer.... Lew. ii. are thou canst; lie better, at thy leisure -

my leisure serves me, pensive dauglite:

go slander any moment's leisure.

read it at more leisure

if your lordsliny were at leisur

so leisurely, that, if his rule were. Michort $11 \%$. it. LENAN - for his wife's leman..... Merry Hives, iv. drink unto the leman mine..2Lenry I V. v. 3 (song LENION-[Col.] for thy lemon .... Twerfih Night, ii. LEN A-what said Popilius Lena?... Julius Casur, iii. Leñ speaks not of our purposes

LEND-lend thy hand.................... Trempest, $i$

lend me wings to niak

such graee did lend her

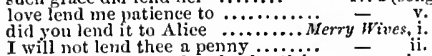

I will not lend thee a penny ........

I'll lend you something .........Twelfth Night, ii .

nor nature never lends ......Meas

lend me your knees, and (rep.).....

and will lend nothing for God's sake. Much Ado, $y$

lend me the flourish of all........ Love's L.Lost, iv.

lend me your horn to make one ..... nf Fenice, i. 3

albeit I neither lend nor borrow

a cur ean lend three thousand

it thou wilt lend this money, lend it

but lend it rather to thine

he was wont to lend money for...........

that least lend it you shall laek

lend me an arm: the rest

his senrnful perspeetive did lend me
Tom Drum, lend me a handkerehief

Tom Drum, lend me a handkerehief

lend thine ear. Here. There.Taming of Shrew, iv. $t$ if God lend me life ......

Winter's' Tale, iv. 2

but not lend a morrow.....................

lend no ear unto my purposes......

I $\mathrm{pr}^{+} \mathrm{y}$ thee, lend me thy lantern.

and lenc. me thy hand to laugh.

it lends a lustre, and more great

o this boy lends mettle to us aji!

Itotspur's loss, lend to this weight ...
let him lend me the money

will your lordship lend me thousand

lend me thy cloak, sir Thomas

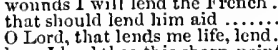

Lord, that lends me life, lend.....2 Henry Ir. i.

rise, and lend an ear

as I will lend you canse

ery, Trojans, ery! lend me ten... Troilus o Cress. ii. 2

this is no time to lend money.. Timon of Athens, iii.

I will lend thee money, borrow none,

lend me a fool's heart, and a woman's - - rorion

hereatter will I lend ear to

countrymen, lend me your ears..... Julius Carsar, iii.

to lend me arms, and aid .. Antony \& Cleopd

I shall bit lend my diamond.........

which rottenness can lend
it' savage, take, nr lend

it savage, take, nr lend .......

lend me thy hond.

my heart ean lend no succour

stars that frown, lend us a mile

hiril, sirl My lord, lend ear...

jend less than thou owest.

lend me a lnoking-glass; if that he

how one another lends entent.. Romeo \& sutiel, i.

but passion lends them power..
with speedy help doth lend redress

that vainly lends his light to grubs - v.

lends [ Knt.-gives] the tongue

pity me not, but lend thy serious......

and that shall lend a kind of easiness....

to lend your patienee to us

to my unfolding lend a gracious ear.
offerds me; lend me thy handkerehief.

oftends me; lend me thy handkerelice

enme, eome; lend me a light

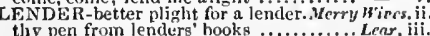

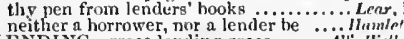

LENDING-graee lending grace ........As s r'ell, ii.

lame of lemilugs for your highness. Wichard h. i.

lending your kind eommiscration. Titus dul, on, y.

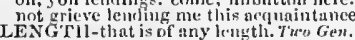

one of such another length
for this was of much lengtli

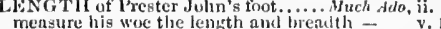
to measure out my length .....Mid.. .'sDrean, iji.

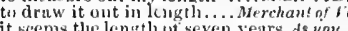

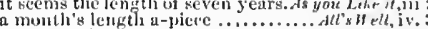
at length the sun, gazing ynon ...
at length, arother ship had seizesl

within my swords lengtlosect him

. Kacbrih, iv.

yur whole head's length

there is such lengtl in grice.

at length have gotten leave to look . - v left ine, but my body's leristh! ....3 3 henryVI. v. 2 shall be druwn out ill in length..... Richand IIt. $\gamma .3$ at lenutl her broke ruser me

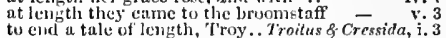
at lingth hew goes our reekoning?. Thon of dth, ii. till, at lenetli, vour iength....

in Sicyon: her lengtil of sickness.. Aniony ofleo

for now al! lengtl is torture

onee within iny pistol's length

measure your lubber's length again

then goes he to the lengtl of all his arm

than the length a

these foils have all a lenth? Ay......

lengthen out the worst that must. of Sh. 2 (induce.

I'll lengthen it with mine ..........2 Hemry ${ }^{\prime}$. $\mathrm{i}$.

as henven and nature lengthens it.. Kichard Whi.
who first shall dic to lengthen life .... P'erictex,

WE. What salness lengthens Roneo's. Romeo f Julie,

after many lengthened hours of grief. Nichard III.

my dream was lengthened aft

LEN ITY-lenity to lcchery would.....

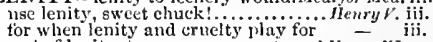

and of lenity, to ease your eomitry..1 Henry $r z$. $v$.

bold, but too much lenity?

awake your dangerous lenity ....... Coriolnnus, iii.

away to heaven respective lenity. Nomeo \& Jutiet, ii

lent him our terror, drest him. ...Meas.for.iveas,

my lord, he lent it me a while.......Afuch Ado, ii.

the money by our father lent $\ldots .$. Lne's L.Lost, ii.

if God have lent a man any ............ All's Well, ii.

whu lent it you? It was not lent me

gracious Englond hath lent is

what a mad-eap hath heaven lent ws.... Kincterth, iv

to you here lent, sliall point on me...Kichard 11 . $\mathrm{i}, 3$

money lent you, four-and-twenty... Henry $1 \%$. iii.

whose spirit lent a fire even

his skin is surely lent lim

a bountcous hand was kindly lent Hichard 111 . ii.

most narrow measure lent me..........

he lent me some slipping.............

Lucina lent not me her aid............. Cymbeline, v.

as heaven had lent her ail ....... Pericles, i. (Gower)

is very good meat in Lent ....... - ii. 4 (song)

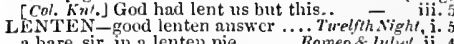

a hare, sir, in a lenten pie ....... Romeo \& Juhet, ii.

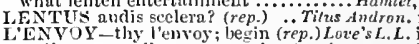

nol'enroy, no l'ellvy, no salve (epp) - iii.

LEONATI-strength o' the Leninati... Cymbelue, $v$,

LEONA TO, yom are come $\ldots . . . . . . .$. Much Ado,

if signior leonato he her father.

your hand lwonato: we will go tri....

note the rlaughter of signior Leonato?

with Ilern, Ieonato's short daugh

repair to Leonato's: commend me

hath Iconato any son, my lord?

the daughter and heir of Leonato...

to unclo Hera, and kill I weona to

come hither, lemato: what was $\mathrm{it}$

even she. Lconate's Ilero, your llero
watch about sirnior Leonato's deor

there Leonato, take her back again.

no, Iconato, I neser tempted her...

leonnto, stand I here? is this the prince
Ieonato, I am sorry you must liear.

signior leonnto, let the friar adrise.

we have some haste, Lennato

Leonato and his hrotlier ........

signiur Lcomato, ant the scxton to.

and then to leonnto's we will go.

signior l,esmato, truth it is ..........

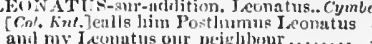


1.EON ATUS is in satety ............ Cymbetine, $i .7$ LESS-no less in truth, than life as you value your truest Leonatus - i. 7 (letter) both more and less have given.

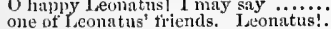
Lenur tus! 0 master! what a strange.... thist is iny lord? Leonatus?............. the scriptures of the loyal leonatus. with them, sinee Leonatus talse 'twas Leonatus' jewel ..............

Eu colled Posthumus Leonatus .

Leunine, take her by the ir

wack half an hour, Leunine.............

0 villain Leonine, whom thou hast.

none ean know, Leonine being gone

mistouk, my ladr, Polixeues for Leontes

queen to the worthy Leontes.

Leontes a jeatous tyrant ....

- iii. 2 (indict.)

fore Leontes; she shail be habited

methinks, I see Leontes, opeuing ....

king leontes shall not have an heir.
LEOPARD-make leoparls tame.

or oxen, firnm the leopard.......

seized by the leopard (rep.) .. Timon of $A$ thy $\nu^{\prime} I_{\mathrm{j}} \mathrm{i}$.

ilment Henryll Iiii.

LEPIDUS are at Ciesar's house ...Jultizs

Iepidus, go you to Casar's honse.

in some taste, is fepidus hut so.......

you may see, Lepidus ........A utony $\delta$ Clenpatra

Cesar and Lepidus are in the field

let us, Lepidns, vot lack Four eom

be at mount hefore you, Lepidus ....

Lepidus is high-eoloured $\ldots \ldots \ldots \ldots$.

some wine: a health to Lepidus.

this wine for Lepidus, What manner

this health to Iepirns. Bear him ashore

this health to lepidns. Bear him ashor

'tis a moble I.epidus. A very fine one

Casar and I epiclus bave mude way

that Lepidu of the triumvirate

told $\lim _{\text {, lepidus was grow' }}$...

make the hoar leprosy adored
there is no leprosy, but what thou

Egypt, whmm leprosy o'ertake! Anlony \& Cleo. iil.

and how the less, that burn

less than a pound sh

the grenter hides the less

and less thian this.......

thou knowest no less bit ali

二 iii. 2

二 iii. 6

the envy of less happier lands

tis nothing less; eonceit is still....

to jny, is little less in joy

with no less terror than

speak more or less than truth

I hope no less, yet needful ;

grow great, I'li grow les

and less, do flock to follow him.....

less noise, less noise. Who saw

other, less tine in carat .................

make less thy ludy, hence ..........

we judge no less; uncle of
no less tor bounty bound

in motion of uo less eelerity

Wherein tlioul art less happy

thou art no less than fame.

was nothing less than blood
much less, to take oeeasion

little duty, and less love..............

no less beloved, than when thing
thou deservest no less: this m.
is to make less the depth of...

is to make less the depth of...

for less $I$ shonld not be; and

it were no less; but yet I'll $\ldots . .$.
she could say little less; she hod

I know you for no less .................

brought forth less than a mother's

that some, less noble, and less loyal.

yet mueh less spirit to curse

a grandam's name is little less in love

a woman of less plaee miglit ask

....Macbeth, iv, a LESS_set less than thou throwest.

fools had ne'er less grace in a yea

deserved much less advancement....

servants, who seem no less

tor it, as noless is threatened me.

Whieh my father loses; no less than all.

Col. Knl.] not an hour mnre nor less

I am no less in blood than

making yourself no less. No jess? Romen s Suliet,,$i$.

her means much less to meet..

a hair more, or a hair less, in his head.

more than kin, and less than kind

and with no less nobility of love

wore matter, with less art .............

the less they deserve, the more.

for youth no less beeomes the light .....

with the oecurrents, more and less put..

thine hath no less reason...........

prerngatived are they less than the base

Buckingham shall lessen this big .....MTh he lessens his requests this bigenry $\boldsymbol{L}^{\prime} 11 \mathrm{i}$. $\mathrm{i}$. he lessens his requests .......Antony \& Cleo. iii. 10 and lessened be that small............ Richard $r$. iii. 6

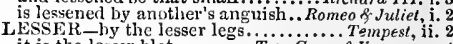
it is the lesser blot ..................... Gen. of Verona, $\mathrm{v}$ my prayer, the lesser is my graee. .Mid. N. Dr. ii. alaek, for lesser knowledgel...... Winter's Tale, ii. lesser weirht, but not with lesser. Comedy of $\mathrm{Err}$. i. others, that lesser hate him. more strong when lesser is my fear....... King John, iv. thy death-bed is no lesser than ..... Richard $I I$. or lesser than my name............ can lesser lide his love or liate...... Rickard IiI. ii. 4 doth lesser blench at sufferanee.. Troilus \& Cress. i. I the greater scorns the lesser ... Timon of Athens, iv. 3 that's lesser tlian a lit tle ............. Coriolanus, if any fear lesser his person.....

how lesser en mities may give ....... Antony \& $\overline{C l e o}$. ther honour confident.... Cymbcline, that caused a lesser villain $\ldots . . . . . .$. . Pericles, ij. 3 the lesser is scaree felt .................. Lear, iii. 4 all vight for lesser eause..................... but, lesser a gulf, doth draw .......... Hamlet, iii. 3 any hard lesson that thay do thee ... Nherona, but learn my lessons as I please.. Taming of $\mathrm{Sh}$. my lessons make no musie in ........ learn this lesson, draw thy sword ..3 Henry $F I$. ii. the effect of this good lesson keep as $\ldots$ Hamtel,
LESSUN

did elaim no less than what lie.

and they are no less, when, both

you that will be less fearful...

with striving less to be
how is it less, or worse

they then less need une another.....

and is no less apparent

proclaim you are no less! ...............
I think no less: good-morrow.......

serve heaven with less respeet th
but, in the less, foul profanation

more nor less to others paying

to pardon when it was

texpect.

heard a mother less? or granted less?

we looked tor no less spoil

they would have done no less........

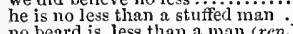

no beard is, Jess than a man (rep.)

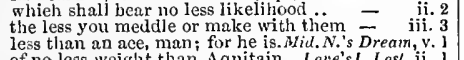

I am less proud to liear you tell...

I think no less; dost $t$.

I eannot give you less...................

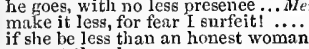

if she be less than an hone

or less, than a just pound

or doth the greater glory dim the less

and no less beloved of her uncle ...As you $\bar{L}$ ike

and I thought no less; that flatt

even danghter, wejeome in no ]ess degree -

the longer kept, the less worth....

all the progress more and less........

he is no less than what we say. Taming of

my father liath no less than three

which is for me less easy to eommit..

whieh no less adorns our gentry....

hath no less prevailed than so

yet that dare lese appear so ...........

and no less honest than you are mad

look for no less than death

kings are no less unhappy $\ldots . . . . . . .$.
and is less frequent to his prineejy.
mueh less the adventure of her person?

Jess, in your knowledge....... Comedy of $E$

his ineivility confirms no less ......... Errors, iii.

promised no less to them?................ Macbelh, $\mathbf{i}$.

present tears are less than horribie............

whose absence is no less material..... a prize no less in worth ...............

I should have known no less..............

twas a shame no less than was.....

less noble mind than sh

and their story is no les ingity...

as little as a erow, or less............ C

[Col. Kn'] taking a was les without lesed

bound fur no less than my life

and less attemptible than an

was't not? or less, at fir'st.

no whit less than in his feats........
put thyself into a 'haviour of less fear

to show less sovereignty than

then had my prize been less $\ldots . . . .$.

no less young, more strong

I will begin the fashion, less without

and hy villany less than 'twas

I say no more, nor wish no less ... Tilu

makes me less gracious.....
more or less. or ne'er a whit

mueh less in blood than virtue

no less than it gives a good....

and you, our no less loving so

no less in space, $v$ alidity

to my bond; nor more,

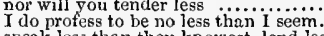

speak less than thou knowest, lend less... great griefs, $Y$ see, mediene the less.

movest no less with thy eomplaiuing

but, be snre, no less beloved as you were lessoned, when he...... Corialanus,
well hast thon lessoned us .... Titus Atudronicus,

LESTRALE-Foix, Testrale.............Henry $V$. jii. 5 and IIarle, Vaudemont, and Lestrale Herry iv. if nothing lets to make us hapipy. T'welfh Night, $v$
at the heart. Alaek, let it blood ... Love's L. Lost, hath much bloud let forth, and more. All's W' $W_{\text {ell, }} \mathrm{i}$ what lets it but he would be here?Comedy of Err. $\mathrm{i}$ to let this land by lease

that I may know the let ................ Henry $V$. v. and let ont their coin upon large.. Timon of $A t h$. iii.

go lest I let for th your half pint..... Coriolam

let a parish of steh Cloten's biood ... Cymbeline, are no let [Knt.-stop] to me......Romeo \& Julies, it.

LET-ALONE - the let-alone lies not ....... Lear,

LETIIARGIED-discernings are lethargied -

LETHARGY - by this lethargy? .. Tuelfh Tight, $\mathrm{i}^{2}$

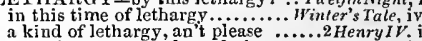

peace is a very apoplexy, ]ethargy... Coriolanus,

the lethargy must have his quiet ..... Othello, i
LETIE-my sense in Lethe steep. Tweif: hNight,

so in the Lethe of thy angry soul.. Richard $I I I$. sense in soft and delicate Lethe.. Antony \& Cleo.

rots itself in ease on Lethe wharf......... Hanlet
LETH $\mathrm{C}^{\prime} \mathrm{D}-\mathrm{a}$ Lethe'd dullness.... Aniony \& Cleo.

LET'ST-thou let'st thy fortune sleep. Tempest,

game's a-foot, thou still let'st sijp ..1 Henry $1 V$.
LETTER-letters should not be known. $7_{\text {cmpest }}$

let me hear from thee by letters. TwoGen. of $V_{e r}$.

for ealrying your letter (rep.)........

I would I had o'erlooked the letter.

force the letter to my view?.........

till $I$ have found each letter in the letter -

what letter are you reading there? .. -

I have writ your letter $\ldots \ldots \ldots \ldots . . . .$. may this be washed in Iethe...

gavest thou iny letter to Julia? (rep.)

to show my father Julia's jetter

\section{.}




\section{LET}

L EV

I.ETTElR-by a letter ...... Two Gen. of Veronu, ii. I IETTER-here's your letter

Alt's Well, y, 3 |

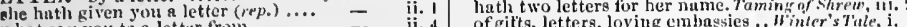
to henr my letters to my friends of gifts, letters, loving embassies ... himer's inte i. thy leters inny he here.

nay but my letters hy this means hein at your important letters....... Comedy of Erors, v. 1 that it in golden letters flronld lie.... who bromgint that letter from Richurd Il, ii. for reming my therewith this letice and the rout

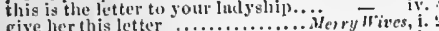
and the letter is, to desire. and yet iny letters jutent give with letters of your love to her

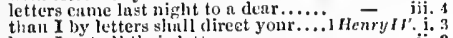
huve I not all their letters.......... - ii. 2 what lettis letter to John of Lancus his letters henr his mind, not l, my lord here's allesther let tel to her bear thou this letter to mistress $I^{3}$ itge bear you these letters tightly give-n dis letter to sir lugh... here's the twin brother of thy letier.. a thousund of these letters O that my lusbancl saw this letter. you'll not bear a letter for me. coach after conel, letter after letter. will carry a litter twenty niles... are these your letters, kiliglit? both these letters at an instant?. here is a letter will say somewh

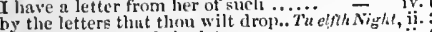
Wye the thatl find the letter

my lord, here are letters for youl...... bear this letter to my lord of laneaster you shanll have Jetters of me presently from Japhet; but the lette my lord, I will steep this letter in snck the terters that these new-dnted letters from Northimberland learning and good letters peace lath

fuir words still in fonlest Jetters. a letter was delivered to.....

view the letter sent from our

have you perused the letters from.

in his locket with red letters in

to write it on the top of letters

these letters are tor you '............ . every one of these letters are in my name lie do's obey every loint of the letter she ineites me to that in the letter... if this letter move him not .......... - iii. 4 then erer the hearing of letter did....

makes king Iewis unto our letters?

from the cross-row piucks the letter you shall have letters from me..... if she convey letters to Rielimond send her a letter of thy noble deeds. and his own letter the honourabl
send our letters, with free pardon let there be letters writ to every shire cardinal's letter to the pope miscarried the letter, as I live, with all the business tied it by letters patent............... patience, is that hetter, here's a letter for the .................. here's a letter from yon' poor girl ... your honourable letter he desires.. Timon of Ath. $\mathrm{i}$. read me the superscription of these letters mith letters of entreaty....

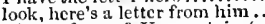

a letter for me? Yes, certain (rep.) ..

the senate has letters from the general my letters, praying on his side ....... myself have letters of the self-same.

therein our letters do not well agree

letters from your wife, my iord? (rep.)

of this, my letters before did satisfy you you did pocket up my lette

accuses him of letters he had formerly

letters did withold our breaking

you shall have letters from

to me known but by letter $\ldots \ldots . .$.

here are letters for you

the letter that I lave sent her

madum, here is a letter from my lor

she hanth my letter for the purpose -

sirrah, is this letter trte? ............ the Roman emperor's letters, seint

I heard no letter from my master...

see'st thon this letter? take it up.
who found this letter? Tamora.

who found this letter? Tamora.
your letter is with Jupiter by thi

have you any letters?

I have brought you a letter....

the letter that thy father found ( $r$.

by whose letters I'll dispose

what's lore! o fetter, that she ioves....

of king Simonides are letters bruupli

this letter, and some certain jewels.

trainerl in musie, letters

ifric Cerimon liath letters of gool credit

seck you to put up that letter?

five me the letter, sir..............

have you writ that letter to my sister?

to Gloster with these letters......

till I have delivered your

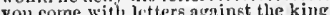

whoreson zed! Thou unnecessary letter

beams I may jeruse this letter! .......

commend your highness' letters to them

this appirove, lier letter, that she .......

iii. 3

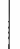

$\begin{array}{lll}1 & I \\ 2 & I\end{array}$

I

TTING-as letting her pass so .... Lill's I L.ll, v

letting I dare not wait upon ...........Macbel h, i. 7

not letting it decline on...... Troilus \& Cressida, iv. 5

letting them thrive again on ......... Cymbrline, y.

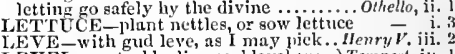
LEVEL-we steal by line and level (rep.) Tempest, iv.
so sways she level in her......... Twetgh Night, ii. description, level at my affection... Mer. of rewire.

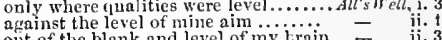
out of the blank and level of ny train $\bar{T}_{a l e} \mathrm{ii} . \overline{3}$ and hold their level with thy $\ldots . . .1$. Hemy 11. iji. 2 thrust me from a level

with as great aim level at the edge.....

and every thing lies level to our wish - iv. 4

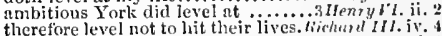

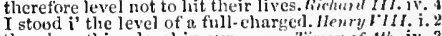
there's nothing level in our ....... Timon of th. iv. 3
girls, are level now with men ...Antony $\delta$ clen. iv. 13 gits the mark his ere dot' level at....... I'ericles, i. 1 that's the mark I know you level at ...
from the deadly level of a gun ... Nomeo of Iits, iii. 3 as level as the canvon to lis.............Hamle', iv. it shall as level to your judlement pear $-\overline{-}$ iv. 5 LEVEIIED-but this he levelled lalse. Wuch ddo, iv. she levelled at our purposes. Antom? \&. Cle opatra, v. 'LEVER-have you any levers to lift..1 Heny $1 \%$. ii. a LEV the leviathun can swim.....Mid.N.'s Dream, ii.

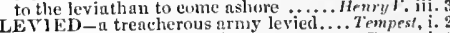
a thousand marks be levica.... Comedy of Eirurs, i.

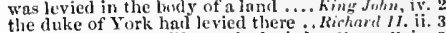
my ransom then will soon be levied . Hemy l. iv. 3 that were levied fur this siege!

the levied suecours that shmid.

these foldiers sliall he levied.
to he levied withmit delay

3isenryrr.iii. 3

thy soldiers all levied in my name ......... lenr, y. 3

LFV] Ws the lnencit of our levies.... Corrolmms, y.

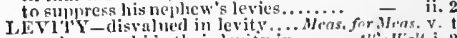

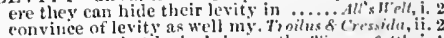

instruct us what levicy's in youth..
business frowns at this levity.....Antony of Ath. i. I

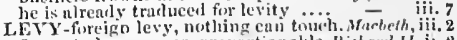

for us to levy jower, proport onable. Mishari $I, i_{1}, 2$

the whieh he canld not levy

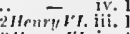

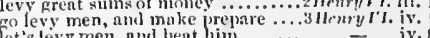
bid him levy straight................ Richard IIr. iv. $_{\text {iv }}$

Thave letters, that my son will
give my lord Lafen this let ter

ihave letters sent me, that act

列..... 


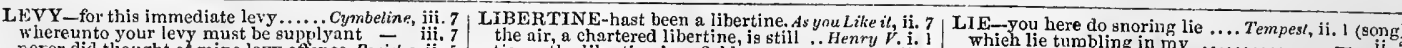

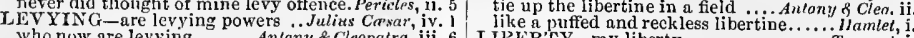

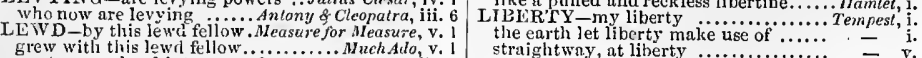

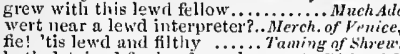
but you'll lie like dogs

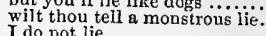

give me the lie another time straightway, at libert

trom too much liberty (ro liberty. Merry Wives, hath detinimed for lewd employments. Richard such lewd, sueh mean attempts

and liberty plucks justiee by tic and liberty, which haye, for long .

lewl, pestiferous, and dissentious ...2 Henry bim with lewd complaints...

he is not lolling on a lewd day-bet

IEWDLY-should be lam NED. I'll bring..... Peritles, jy. thot ${ }^{2}$ lewdness eourt it in a shape of'. Homlot, TIVDSTER - against such lewdsters... Norry $W . \mathrm{W}$. LETY IS-Lewis, determine what we .. King Jo/n, ii. uon the years of Lewis the Dauphin shinll Lewis have Blaneh? (rep.)

thine honour, Lewis, thine honour....

of rich prosperity, as Lewis liimself."

to Lewis the emperor, nud . ........

the liberty of the prison (rep.)

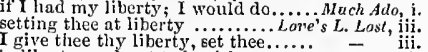

I must lave liberty withal, as large

thy liberty into bondage.

the potron of my life and liberty .. Taming of Sh. ii. I berty $\ldots \ddot{W}_{\text {inters }}{ }^{-}$iv. 2

a man is master of his liberty . . Comedy of $E_{r}$.

why, headstrong liberty is lashed

and bid you forsake your liberty.

gain a husband by lis liberty......

set thou at liberty; the fat ribs........ King $\bar{J}$.

you lrave bid now ask his liberty

an wrinee, so wild, at liberty

in liberty of bloody hand

also king Lewis the tenth, wh.

and Lewis a prinee soon won witli... 3 Henry $\bar{v}_{L}$ iij.

shouldst stand, while Lewis doth sit
be it known to noble Lewis, tlat Il enry

king Lewis, and lady Bora, hear

in liberty of bloody hand ............. Henry $V$.
and the liberty that follows oir ....
lost my liberty, and tliey their lives.1 Henry $V x$

from the liberty of to venge this

if they can gain your liber

grined thy daughter prineely liberty

show yourselves men, tis for liberty.2 Henry $V I$. iv. nuy, mark how rewis stamps........

if king Lewis vouclisate to furnish us

as well is Lewis of France, or the earl

they are but Lewis and Warwiek

tiiut king Lewis beenmes your enemy

hath good usage and great liberty...3 Henry $V I$. jv.

my captive state unto liberty.....
quite torget their loss of liberty

got my lord ehamberlain his liberty. Riehard - iv.

answer makes king Lewis unto our

is Lew is so brave? belike, he

LIABLE - is liable, eongruent ............ Love's $\overline{L .}$. Lo

find

apt, jiable, to be employed in

yet if ny name were liable to fear..... Julius $\overline{C c e s a r,}, \mathrm{i}$.

nnd reason to my love is liable.........

LIAR-I do despise a liar, as I do........ Perry Wives, i. 1

I know him a notorious liar .............. Al's Well, $\mathrm{i}$. 1

an infinite and endless liar, an hourly o $\overline{\text { nili. }} 6$

your are liars all. Beseeeh your ...Winler's Tale, ii. 3
than that or there be liars ..........

then the liars and swearers (rep.) .......Macbeth, iv. 2

good men hate so foul a liar...

Richard LI. i.

or else there be liars .........Troilus f Cressida,

measureless liar, thou hast marle

that he approves the eommon liar. $\dddot{\text { Antony }} \overrightarrow{\&} \mathrm{Clco} . \overrightarrow{\mathrm{i}}$

art turned the greatest liar.........

hereties, be burnt for liars!

che's like a liar, gone to burning liell ... Othello, v.

I.IBBARD-with Yibhard's heat.... Lone'sL. Lost, v.

LIBEL - libels, and dreams........

LIBERAL-for the liberal arts...
she is too lilueral .............

n. of Veron

all liberal reason I will yield ......... Love's L..Lost, ii. the liberal opposition of our spirits . v. 2 they show something too liheral...

I will become as liberal as you.

and liberal to mine own elíldren...

the liberal kind offer of the king .....i iden $\bar{y} I V . \mathrm{v}$

she hath been liberal and f.... Henry $V$. iv. (ehorus)

wealth dotla warrant liberal dower.

courtcous, liberal, full of spit it

a liberal rewarder of his friends.

of

this is all a liberal eourse allows.. Timon or $\bar{A} / \mathrm{h}$. ii Well studied for a liberal tlanks.. Antony \& Cleo. it.
that liberal shepherds give a grosser.... Humlet, iv. and of very liberal coneeit...

a most protane and liberal eounsellor?.. Othella, ii Jiheral hand: the hearts, of old

a will speak as liberal as the air.

LIBERALITY-Baptista's liberality $\ldots . .$. Hamlet, $v$ worrds, fair looks, and liberality?... Troilus \& \& Cress. LIBERTE - de vous donner la liberte... Henvy $V$. iv. ever spake against your liberties.... Coriolan

at point to lose your libertios.

upon one battle all our liberties....Julins $\bar{C} \pi s \alpha r$. fur their liberties, are now in alms... Cymbeline, iii .

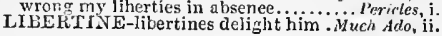

kot my and buzzards prey at liberty .. -

I muse, why she's at liberty

being pent from liberty, as $\mathrm{I}$ am $\ldots . .$.

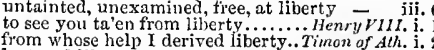

but if' it were at liberty, 'twould...

the men that gave our eountry iiherty Cesar, iif.

the men that gave our eountry liberty - iii. 1

a way, I think, to liberty........... Cymbeline, v.

by giving liberty to thine eyes ............. L

to prison, eyes! ne'er look on liberty! $\quad$ - ii. 2

most known to youth and liberty

and the liberty, these are the only men

bar the door upon your own liberty

and there is full liberty of feastin

IIBRARY was dukedom large enou take ehoiee of all my library.. Titus Andronicus, iv. ?

your virtue hatli a licence in' $t$...Meas for Meas.

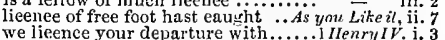

we lieence your departure with......1 Henry IV i. 3

did give ourselft to barbarous lieence ...Henry $r$ i. 2

thou shalt liave a lieence to kill....2 Henry $V I$. iv. 3
with such full lieenee, as botll.... Anlomy \& Cleo i. 2
by his licenee, Fortinbras eraves....... Hamlet, iv. 4

by his licenee, Fortinbras eraves ...... Hamlet, iv. 4
LICENTIOUS-I were lieentious? Comedy of Err.ji. 2
can hold licentious wickedness ....... Henry $F$ iii.

LICHAS-Hereules, and Liclias.. Mer. of I I enice, ii. I

lodge Lichas on the horns ..... Antony \& Cleo. i
LICIO_. his name is Licio...... Tameng of Shrew

now, Iicio, to you; good masters....

is't possible, friend Licio, that Bianca -

Iieio, this is wonderful (

LICK - let me llek thy shoe............. Tempest, ivi. 2

may diseases lick up their .... Timon of Athens, iv. 3

the them not liek the sweet $\dddot{1}$......Coriolanus, ii. I

they ean liek their fingers (vep.) Romeo of Juliet, iv. 2
the eandied tongue lick absurd pomp.. Hamlet, iii. 2

LICKED-dogs licked his sores....... Heriryl I'. iv. 2

LICTORS will eateh at us.... Anlony \& Clespatra, y. 2
LID-two grey eyes, with Iids .... Taelfh Night, $\mathrm{i}$. 5
than the lids of Juno's eyes

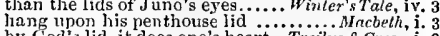

by God's lid, it does one's heart...Troilus \& Cress. j.

with thy vailed lids seek for thy noble.. Hamlel, $\mathrm{i}$.

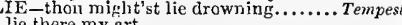

to credit his own in.

full fatloon tive thy father lies......... i. $\overline{2}$ (song)

would it not say, he lies?
ay, sir; where lies that?

ay, sir; where lies that?

no better than the earth he iies upon. for charitable lieenee, that we may .. - iv. 7

with all lieentious measure.... Timon of fithens, v. 5
to $\mathrm{m} y$ sense bend no lieentious ear .... Pericles,
I did not give the lie.

and with him there lie mudded

at this hour lie at my mercy
that now lie foul and muddy....

in a cowslip's bell I lie

- v. $\bar{l}$ (song)

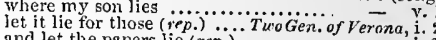

and let the papers lie $(r e p.) . . . . . . . . \quad$ i. 2

nay, then the wanton lies..............
shall $I$ tell you a lie? $\bar{W}_{i v}$

and lie under Mount Pelion.............

does lie lie at the Garter?............ =

I would have nothing lie on my head

and thou shalt lie with $\dddot{\text { his }}$ wife.........

master Brook, I will not lie to you..
good iuck lies in odd numbers ......

love-thoughts lie rich .............. Twetfi $\overline{h N}$ ight, i. 1

where lies your way

there it lies in your eye.................

in delay there lies no plenty......... - ii. 3 (song)

wit enoud to lie straight in my bed = ii.

the king lies by a beggar ............ $=$ ii.

there lies your way, due west $\ldots . . . \quad$ - iii.

where lie my maillen weeds .........

to lie in eold obstruetion ............ -

to-night shall lie his lold betrothed... - iij.

I had rather lie in tlie woollen ........ iI uch $A d o$, ii.

in my ehamber window lies a book... $\quad$ -

now will he lie ten night $a$ a a ke...

would the two princes lie? $(r \in p$.$) ....$

and yet I lie not, I confess nothing...

that only tells a lie, and swears it

and she lies buried with her aneestors

that lie, and cog, and fout, deprave..

were wont to lie, emptying our.Mid. $N$.' 3 s Dream, 3 (ecroll

amend it then, it lies in you $\ldots . . . . .$.

the durst so, Hermia, I do not lie...

happy is Hermia, wheresoe'er slie lies

who would give a bird the lie.........

puts the wreteh, that

find where light in darkness lies... Lo
she must lle liere on mere necessity.

I love to hear him lie...
which very seldom lies

a tongue whieh 1 know wiil not ije...

rothing in the world but lie, and lie in

where lies thy grief, $O$ tell me

what upward lies the street...........

in their hearts it lies

that lie within the mercy of $\ldots . . . . .$.

¿ jest's prosperity lies in .............. in a golden bed lies all within

and if my form lie there, then $i \ldots . .$.

in the cradle where it lies ............

and tell quaint lies, low honourable

twenty of these puny lies 1 'll tell...

and the offender's life lies in ......

if I could add a lie unto a fault.

lie not a night from home

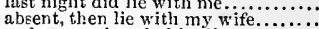

and, as much as in him lies ...........

yonder they lie; the poor old man .

and, lie there what hidden woman's

the lodging where you nse to lie...

who loves to lie with me ...........

still give tlie lie to their eonsciences

but tliese are all lies say mine........

these pretty eountry foli........ would iie

he would say, I lin

the lie eireumstantial $(r e p) . \ldots \ldots \ldots$.

the lie with cireumstenee the lie?.

our remedies oft in ourselves do lie...

reme that lies thire lies ricl

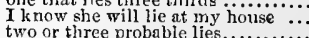

to return and swear the lies he forges

he will lie, sir, with suel volubility

in 
IIE-than in my thought it lies! .......st's Well, v. 3 LIE-in his tomb lie my affections ..2lleury $1 V$. v. 2 LIE-uow on Pompey's basis lies ...Julius Casar. iij. mook, nuthook, you lie; eome on youl lie, in laith; for you are. open, sir, there lies your way.......

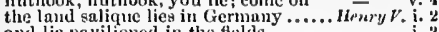
o mighty Casnrl dost thou lie so jow? by many princes, dost thou here lie? there doth my linther lie

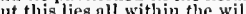

nuy, then yon lic .......

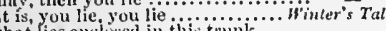
the clupel where they tic gillen dalline in the wardrobe

till in her ashes she lic buried...

may say, now lic I like a king

the chupel where they lie.............

the gimmal bit lies foul with

whilo we lle tumbling in the hay

their poor bodies must lie and fester

doth he lie, larding the plain.....

that's a lie in thy throut

where my land aud living

why should I enrry lies nbroad?

to lie elose by his lionest bones ......

my fortunes do nll lie there

that in the field lie slain

a lie; you are rough and hatiry

of those their nobles that lie dead.....

litsbundry doth lic on lieaps ....

at pleasure here we lie

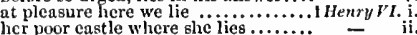

Young Henry, with his noble

give me the lie, do

Comedy of Evr

shall nll thy mother's hopes lie

fil the thee, and there lie............. Atacteth, i.

their dreoehed nat ures lie, as in

a huavy suminuns lies likc lead
whu lies i' the second chamber?

they must lie there....

the lie, leaves him (rep.)

of the mind to lie in restless e........

there the urown serpent lies .........

tell pale-henrted fear, it lies.

one that swears and lies .............

here let them lie, till famine

the fiend, thut lics like truth .....

whieh fult lies on the hazurds ........ King John, i.

who says it was, he lies ...........

whose sons lie senttered on the blecding -

groveling lies, culky embracing whin

with me thy fortume lies

Austria's head lie there.

he lies befisre me .............

my mercy, which lies dead

and, where lies your grief?

who speaks not truly, lies......

it may lie gently at the foot of
to lie, like pawns, locked up in

o long, lies heavy on me

and fly-blown, lies here at our fect....

now lies he there, and none so puor.

sirs, lie in my tent, and sleep

under which our army lics

that lies upon the ground? ile licsuot

where, Messala, duth his borly lic?

though in his tale lie death. Antony of Cleopatra, i.

when our quick winds

ghe did lie in her pavilion............. $=$

i the east my pleasure lies............ =

lie they upon thy haid

spurns the rush that lies before him

our fortune lics upon this jump......

pelleted storm, lie graveless ...

liver of the whole world lies.. - iv. 12

but something riven to for the gods

dost thou lie still? if thus thou.

in thy possession lies a lass unparalieled - ve

lie $[\mathrm{Col}$. Krt.-by] pecping in an eye.. - i. ?

on elaliced flowers that lies ........ - ii. 3 (song)

if not. let herlie still, and drean .... - ii. 3

(worthy the pressing) lies a mole.... - ii. 4

Bwear you have not done ' $t$, you lie ... - iii. 4 (liet.)

will poor folks lic, that have....... $=$ iii. 6

cods, what lies I have lieardi........ - iv.

hat let their fathers lie without..... = iv.

forth Ill priests $=$ iv.

that liere by mountaineers lies siain $\quad$ is I do lie, and do no harm by it....

so, lie thou there; die thou ...........

with lies well steeled with $\ldots . . . . . . . .$. michard - j. 1 that liere by mountaineers lies siain

[Col Knt] there lies the duke aslcep

my bed, too, lads, and there I'll lie..

iv. 4

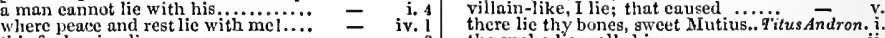

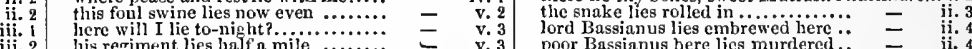

poor Bassianus here lics murdered...

yet I lie, I am not; fool................

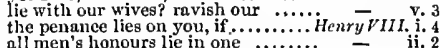

and will not lie till the slip be cleared - iii.
most wretched queen! Here slielies

as doth the sea she lies in ............ $\overline{-}$ iii. 3

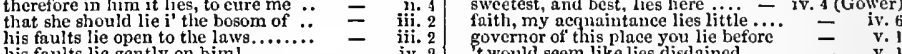

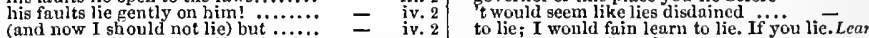

o that way madness lies $\ldots \ldots \ldots \ldots \ldots \ldots$.

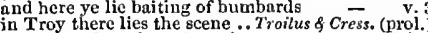

lie drowned, reply not (rep.)

tis a lie, I down and rest (rep.

the let-alone lies not in your

now swalluw down that lie

imagine it to lic that way.....

for their love lies in their purses .....

knows not at whent ward you $\mathrm{ie}$

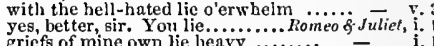

if judgment lic in them ..............

joy's soul lies in the doing

of ehance lies the true proof of men.

choice lies my eonsent and fair

and heavy-gaited toads, lie in their.

and lie full low, graved in

where lies our uncle with his ........

there lies two kinsmen, digged .......

with full as many lies as

that lie shall lie so heavy (rep.).......
whilst I say, he lies, he lies, he lieg

and soon lie Richard in

my grier lies all within..............

in his tent lies mocking..............

obscured in this fair yolume lies ....

that dreamers often lie .............

of your wit too lies in your sinews

in faith, tliss report

when maids lie on their backs .....

desire doth in lis death-bed lie in one - i.

but it lies 2.8 coldly in $\ldots$ im

go it ies ocession to lie long...

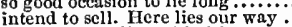

the demesnes that there adjacent lie

alack there lies more peril in thine
would I tear the eave where echo lies

that lies in herbs, plants, stones ....

thy help and holy physic lies.

my major vow lies here...............

thy master now lies think lic in publishing

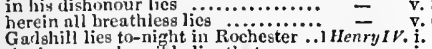

the incomprehensible lies that

reproof of this, lies the jest $\ldots \ldots . . .$.
when he lics asleep, and in his enr

Set I lic; for they pray continually

peace, yc fat-gutsl lie down $\ldots$...'.
you lic, you rogne; 'tis gning to.

cowardly hind and yon lie..........

if 1 tell thee a lie, spit in my face.

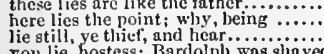

you lie, hostess; Bardol ph was shaved
or we, must lower lie. Rare words!

that lie too heavy on the $\ldots . . . . .$.
witlout ransom to lie forfeited ......

here breathless lies the king...

many a noblernan liesstark...........

our duty this way lies................

our duty this way lies................

in blood by noble Perey lie ...........

here lies thy heart, thy sinews

young men's love then lies not truly

for your rude brawls doth lie a bleeding -

lands thou hast lic in a pitehed......

for thou rilt lie upon the wings

so lies she, blubbering and weeping;
that dim monument where Ty balt lies

lic nlone, let not thy nurse lie with..

this shall forbid it: lie thou there...

death lies on her, like

lie where the light foum of

vacant lic for thy best use

v. 5 (epitanh)

ii. 4 lere lie I Timon............. v. 5 (epitaph)

see, there she lies, flower as she was.

Juliet, I will lie with the to-night

death, lie thou there, by a dead nian

to lie discoloured by this place.....

iii. 3 how far off lie these armies? .....

how lies their battle? know you

yet they lie deadly, that teli

in's nervy arm doth lie..........

$\begin{array}{ll}\text { v. } 3 & \text { that. giving itsclf the lie, would ... } \\ \text { v. } 4 & \text { nn antique time would lie unswept }\end{array}$

beeause that now it lies you on to

v. 4 as much as in him lies

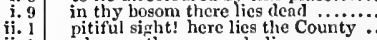

whereon these woes do lie $\ldots . . . .$.
here lies the county Paris slain...

here lies the county Juliet
to die, and lie with Ju.......
as rich slall Rumeo by his lady iie..

as rich slall Remeo by his lady lic..

that, opened, lies within our remedy...
rehellions to his arm, lies where it full.

my heart of what lies heavy to't ....

where great $A$ ufidius lics...

Northumberland lies erafty-sick....iilenry $\bar{l} \mathbf{V}$.

his divination lies; and I will take...

youl lie in your throut, if you ......

then, happy low, lie down! (rep.)....

and weak heginnings, ye intreasures

and every third word a lie, duer paid
for lo! within a ken, our army lies..

lords, we shall lie to-night together..

and every thing lies level to our wis

why doth the crown lic there upon.

t" that ehamber; there I'll lic ......

destroy what lies before them

so our virtuce lie in the interyretstion many lies in his behalf.

lic as to live cinastely

which are as cliear as lies lac bold

when he lies aloug after your

gives me the lie i' the throat, as deep.

that's a lair thought to lie between.

there the action lies in his true nature

or here lies the point.

of his lands will hardly lie in this box

vou lie sut on't, sir, and therefure (rep.)

'tis a quick lice, sir: 'twill away agrain

how long will a man lic i' the en

authority of this lies in our wills ......

ghall join to thrust the lie unto him

licutenant Cnssio lies. I dare say (rrp.)

here lies the east; doth not ...........
sliall Ciesar send a lie? ............

for me to say a soldier lles, is stabbing. 
LIE-is to tell you where I lie .......... othello, iii. 4 LIEGE-my good liege, she is go idly...Henry $V$. ii. 4 | LIEUTENANT-musi his lieutenant be... Cilkelu, i. I he lies here, or he lies there, were to lie.. - iil. that nightly lie in those unproper

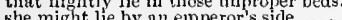
minion your dear lies dead.

he that lies slain here, Cassio was my a lie; an odious damned lie; upon (rep.) not so, my liege, 1 s not so vile a sin servants of the duke, and my lieutenant we shall, my liege, shall at tend the lierald of the friven - iv, 3 not this hour, lieutenant; 'tis not yet te so I will, my liege, as I live...... - iv.7 I am for it, lieutenant; a ad I'll do wou.

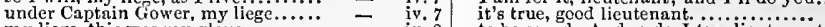
my liege, this was my glove $\ldots . . .$. . - iv. 8 to be saved. And so do I too, lientenant

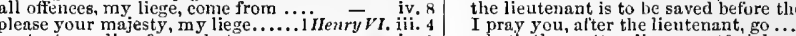

content, my liege? yes; hut............ pardon, my liege, that I have staid

proved hy reasons, to my liege.....

provel hy reasons, to my liegre.....

that I slanll do my liege: stay ......

from Ilenry, our dreud liere, to know

and never live but true unto his liegel

for shame, my liegr, make them

I mean, my loving liege ...........

speak arainst thy liege, whom

my sovereign liege, no letters .......

most sovereign liege [Col Knt-lord] Richarl

so you are, my thrice-renowned liege

my liege, I cannot guess (rep.) $\ldots$ io...

in Kent, ny liege, the Guiltords ...

tis said, my liege, in Yorkshire are

my liege, the Duke of Buckingliam
here, most graeious liege, Norfolk

it is, my liege; and all things are.... $\overline{\text { I }}$ - v.

very well, my liege. I have spoke long - ii. 4

most dread liege, the good I stand...

ay, ay, my liege, and of a lovely boy

you are amazed, my liege, at her. Troilus \& Cress. v.

good, my liege, the day that she .... - iv. 3

good, my liepre, your preparation ean

my liege, and bleod of your begetting

they are, my liege; and stay your . Hericles, ii.

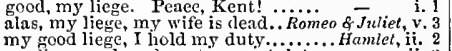

my rood liege, I hold my duty.......... Hamlet, ii. 2

I shall, ny liege. What says...

admiringly, my liege: at

if she, my liege, ean make me.

I wish, my liege, you had only ... in

we can; my royal liege, he is not ....

now, good my liege, sir, royal sir....
sir, my liege, your eye hath too mueh

sir, my liege, your eye hath too m

my liege, I am adviscd what I say. Comeay of Err. v. I

'tis true, my liege, this ring

my liege, they are not yet eome haek ... vacbeth,

we are men, my liege

as well becot, my liege, (fair fall.

my graeious liege, when that my

Philip, my liege; so is my name
but on, my liege; for very little.

myt on, my liege, for very is stopped......

with all mp heart, my liege

let us, my liege, to arms........

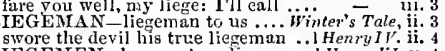

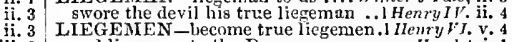
and liegemen to the Daue $\ldots \ldots \ldots \ldots \ldots$. Hamlet, i. 1
LIEN-had nine hours lien dead $\ldots \ldots$ Pericles, ii. 2
IIEST-thou liest, malignant thingi..... Tempest, i. 2 I.I EST-thou liest, malignant thing $1 . . .$. Tempest, i. 2
thou liest, most. iguorant monster (rep.) thou liest, l ean ............. Tu'o Gen. of Fer. iii. I what? thoul liest! sir Aliee Ford! ..... ii. thou liest in thy throat ... Twelfth Night, iii. 4 (ehall) yet thoul liest in the bleak...........As you Like it, ii. 6 minion, thou liest; is't not . Taming of

cut it to pieces: ergo, thou liest...

while thou liest warm at home...

I say, thou liest, Camillo............. ininter's Tale, i. 2 villain, thou liest; for even her.. Comedy of Err. ii. 2 thou liest, abhorred tyrant

of thy throat, thou liest! .

wherein thou liest in reputation ...... Richard 11 . i. 1

I say thou liest, and will maintain ( $(\mathrm{epp}$.)

thou liest, thou art not colted.....

inenrylV. ji.

no kinsman to my liege, I do

then, dear my liege, mine............

my most sovereign liege, and all

I thank my liege, that in

manage must be made my liege...................

my liege, old Gaunt eommends him

not be by, the while: my liege, farewell

eornfort, my liege why looks your graee
and happiness betide my liege, than ean

my liege. one word.

my liege, beware; look to thi.....

what ho, my liegel for God's sak

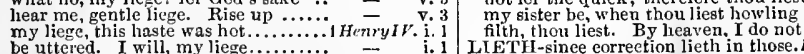

why liest thou with the vile

Bichard IIl. i.

in my soul's throat, thou liest .i.....

proud lord, thou liest, within these. Henry rill iit.

where liest o' nights, Timon? $\ldots . . .$. Coriolun - iv. 3

I would say, thou liest, unto
traitor, tliou liest. Traitorl

Perieles, ii. 5

detested kite! thou liest

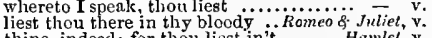

thine, indeed; for thou liest in t........ Hamlet, v.

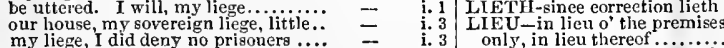

my sovereign liege, but by the

only, in lieu thereof............. Tu. Gen of ter. ii.
in lieu thereof, impose on thee .. Love's L' Lost, iit.
in lieu whereof, three thonsand Mer. of Venice, iv.

in lieu of this, last night did lie ....... v.

the prince my brother liere, my liege

o pardon me, my liege! but for my.

and dead almost, my liege, to think

my graeious liege, you won it.........

my person, or my liege's sovereignty

and $\mathrm{my}$ thrice puissant liege is in...

let their bodies follow, my dear liege

more feared than harmed, my liege...

therefore to Franee, my liege

so doubt, my liege, if eaeli man

so did you me, my liege. And me
Four lieutenant, if you list

bil my lieutenant Peto neet ine

illenry $I V$, iv.

for what, lieutenant? for well using
liere the lieutenant comes (rep.) ... Richarl $I I I$. iv

lieutenant, for quiek aceumulation. Ant.o Cleo. jii. I
who's his lieutenant, hear you?
suit to make me his lieutenant........... Othello, i. 1 lieutenant, is it you whose voice $\ldots . .1$ Henry $V I$. i. 3
I pray you, alter the lieutenant, go .....

nay, good lieutenant; I pray you (rep.)

and, good lieutenant, I think, you thini

good-nirht, lieutenant; I must to the.

good-morrow, good lieutenant

now art thou my lieutenant. I am your

LIEUTENANTRY, and no praetiee.Ari.\&. Cleo. iit.

LIF E-they would not take lier life ..... Tempest, $\mathrm{ii}$. ?

re is every thing advantageous to iife ${ }^{\text {Tempest, }}$

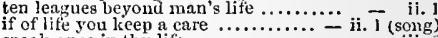

speak once in thy life...

so witl good life, and observation...... $=$ iii.

a thread of mine own life............ - iv.

quiet days, fair issue, and long life...

our little life is rounded with a sleep..

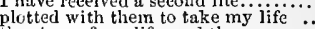

the story of my life, and the............

sweet lines : sweet life...... Turo Gen. of verona,

without apparent hazard of his life...

as thom lovest thy life $\ldots \ldots \ldots \ldots \ldots . .$.

some malisnant powei upon my life

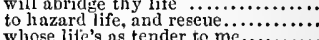

whose lite's as tender to me..............

it is a life that I have desired........... - i. 3

she leads a very frampold life with..

or bid furewell to your good life....

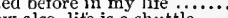

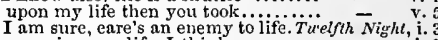

never in your life, I thinl

sueh a suffering, sueh a deadiy life...

or a song of good life? ..... life

by my life, this is my lady's hand....

II, $O$, A, I, doth sway my life (rep.)...

if you hold your life at any prive....

his life I gave him...................

more than my life, more by all mores

nor are sou therein, by my life, deeeived $\overline{-}$

a kind of eharacter in thy life..... Meas. for $M$

how I have ever loved the life remove

your brother's life falls into lorfeit ...

sometime in your life erred in.........

it is pity of her life, for it

that respites me a life, whose

now took vour brotler's life (rep.)....

that I do beg his life, if it be sin $3 . . .$.

the austereness of my life $\dddot{2} \ldots \ldots \ldots . .$.

reason thus with life

that bears the name of life?

that will free your life li.................

a feverous life shouldst entertain ....

were it but my life, I'd throw........

and most loathed worldly life...

to save a brother's life, Nature ......

to take life from thine own sis

what enrruption in this life, thin $i t$.

eanst thou believe thy living is a life

to take away the life of a man? ......

the very stream of his life... li..........

his lite is paralleled even with the

I will plead against it with my life

by so receiving a dishonoured life.....

that life is better life, past fearing.....

might reproneh your lite, an

all my life to come I'll lend you (rep.) -

and squarest thy life aceording to make an aecount of her life to ....... $u$ uch $A D_{0}$

ms very visor began to assume life ..
what life is in that, to be the death

came so near the life of passion ......

for my life, to break with him about

i. 3

i. 5 


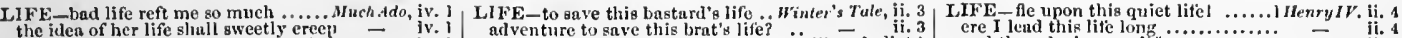
orcan of her life shall come appareled and full of lite, into the eye and prospect ine recluse and religions life....

to take away the litio

my porst life hath been as continient

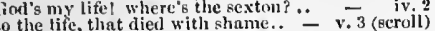
and partly, to anve your life, for I was

my lite stumds in the level

ean life be no enmmodity $(r(r)$,

out of thy single lite, to innke thee $\because x^{-}$v. 4 to live a barren sister all your lite... Mril. $N$
for aye, austerity, and single lite (rep.) for aye, austerity, and single lite

not life, 1 prize it not a

either fir life, or dentl, uinon the enth

for the life to eome, I sleep out

and then end lite, wlien I end.

not to tremble: my lite for yours

prig, for my lite, prig: he haunts

clange this purpose, or ny life.

ny love, my life, my soul...........

o hear me breathe niy lite before...

God's my life! stolen henee

I can but shorten thy lite one

who, on my life, did perish witl

sixpence a day during his life tide......

this place, 'twere pity ou my life

dash of my former life in me......

thou wilt amend thy life? ..........

which never my life may last to answer -

prepare to see the life as lively moeked -
such life of mnjesty (warm life .......

the very life seems warm...

(saitl the text,) is the happiness of life

if she pertnin to life, let her

by misfortunes was my life ......... of $\bar{E}$.

must end the story of my life...

upon my life, by some device or other
never spake with her in all my life.

never spake with her in all my life..

a man would rmu for life, so fiy

distemperatures, and focs to lite

deep sears to save thy life i see a friend will save my

I never saw you in ny life, till now

my night of life some memory ......

as well be amity and life 'tween snow

then yarts life from hence.............

live an upright lite; for, having....

and for thy lo me as life itself; but life.

not with me esteemed nlove thy life
he scek the life of any citizen ........

and the offender's life lies in the........

agninst the very life of the defendant
I pardon thee thy life before thou....

nay, take my life, and all

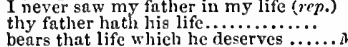

bears that life which he deserves

and thee, during my life .....

you take my life, when you do

you have riven me lite, and living

thou esteemest the ornament of life.

the death nf each tay's life.

chief nourisher in lite's fenst .......
the life o' the building. How (rep.)

the wine of life is drawn ..............

that there is little hope of life in him

and on my life, his maliee gain

and this our life. exempt from pubiie

yea, and of this our life: swearing....
and this kind of life, I will your very

whint a life is this, that your poor...

never loved $\mathrm{ms}$ brother in my life

ravin up thine own life's means.

otr bealth but sickly in his life

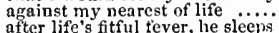

no lesg in truth ther, he slec....

unon my life, fast asleep

that my full life doth sway,......
how like you this shepherd's life

a good lite; but in respeet (rep.)

od's my little life! I think

my way of life is finllen into

and stir as life were in ' $t$....................

give his offspring life, shadowing

and all the eourses of my life do show

if not, the end of life cancels olt thanels

ament $b ! y$ fire, and I'lt amend my life

deprived him of his life, and, in the...

the lag-end] of my life with quiet

I never in ny life ditl hear

to beg during life. Bot who come

give me life: whieh if 1 ean save ...

brook the loss of brittle life

but thouglit's the slnve of life, and life

seep in a little life

the true nud perfeet ima of

have saved my life "Zounds. I am -

upon my life, spoke at a venture ....2 Henry $1 \%$.

buekle under life, impatient

if we wrought out lite. "twns

gasping for lite under great..

never shall have length nf life enough

what a life dost thou lead!

aid his love and life under my foot...

upon my life, [Col.-soui] my lord.............

to stop our very veins of life $1 .$.

the word to sword, and life to deatli.

will, on my life, one time or......

thy life did manifest

to stab at halt an hour of my life

preserving life in medicine potable
pre

even there my life must end ....................

hy my life, she will do as I do..

translnte thy life into denth.........
by my life, I do; which I tender

by $m$ y hife, $a$ life wns but a flower...

hath put on a religious life

my lite as soon: I do defy the

darest not say so, villaiv, for thy ijife

by any secret course thy hatef tul lite

under thy own life's key...

now by my life, this day

my life. my joy, my food ........................

that doth my life besiege ..................

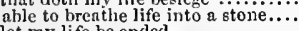

let my life be ended...............

I ne'er hnd worse luek in $\mathrm{my}$

than throw ames-ace for my life

than throw ames-ace for my lil beat him, by my life, if I

on my life, my lord, a bubble

and I shall lose my life for want

thea, my life he thine...........................

the web of our life is of a ming
upon my life, amount s not to

upon my life, amounts not to

if your life be saved, will you .........

gon. on my life, I have seen

ghe reckonerl it at her life's rnte.......

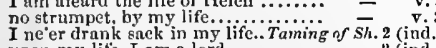

upon my lite, I am a lord..........

to save my life puts my apparel (rep.)

oir, such a lifo, with such a

now, for my life, the knave doth

upon my lífe, Petruchin means ......

whiles warm life plays in...........

and lose it, life and all, as Arthur

may give life to yours

commandment on the pulse of life?.

no certain life achieved by other's'
brenk within the bloody house of life

before this ruin of sweet life

not for my life; and yet I lare (rep.)

the life, the riglat, and trutl of

where the jewel of life, by some

retaining but a quantity of life...
the life of all his blood is touched

wherewith my life should sail

my hife shall prove it true

shall do it, or this life be splent .........

once did I lay an ambush for

my life; both grow in one ( $r e p$. $)$. . .

agninst the butchers of his life.

my life, my Gloster, one phial.

was the model of thy fnther's life....

to safeguard thine own life the best.

compnnion grief must end her life...

[Col.] Ilereford, upon pain of li

be blotted from the book of life.

the sentence my own life destrnyed

vnnieh with my life, how happy

he loves you, on my life, and holds
words, life, and all, old taneast $r$.

I spy life peering; but $I$ lare not...

to save jour life in this extremity

I dare not, for my life ............

saw you before in all my.life

and love, and guiet life, and a s fii...

thy lord, thy life tliy keeper

I never in my life did look

by Ilim that gave me life.

hy iny lite, my troth, I will appeach

had we pursued that life.............. -

if thou hear'st my life of henee

than my poor life must nuswer (rep)

and with it joy thy life

I must give nver this life $\ldots \ldots \ldots \ldots \ldots$

no, by my life, privy to none

more, alas, than the queen's life?.....

I see anod amendment of life in thee

in his own language during my life..

shorten Ilarry's liappy life one day

where is the life that late I led...

for competence of life, I will allow

the art nnd praetick part of life must

to sell his sovereigu's life to death...

nnd my life, and my livings, and my

for his life, and I will thee requite.

they have borne life of tame

the life of sueh a battle in iife so

he prays you to saye his life.

Alexander's life well, Itarry of $\quad$ irep.

in their huge and proper life be here

his thread of life had not so ...........

fighteth as one weary of his life...

Garerave, hast thin joy ...............

and prosperons be thy life, in peaee.

laid'st a trap to take my life

thy spiritual funetion not thy life

in the world, to save my

sell every man his lite a

to England shall he bear his ilife.

ather than life nreserved with .....

born to eelinse thy life this afternoon

the life thou gavest me first

hortening nf $\mathrm{my}$ life one day

thy life pright

where is my other life?

whose life was Fugland"

enuld but enll the se dead to life $i$

what her kind of life hath.

Lord, that lends me life. ...

but that in all my life, wlien I

with danger of my life.....

king IJenry's life and death.

2 your honour in your life, shall

2 their eomplet is to have dcrilish

doth level nt my life ....................

3 to make away my guilitless life

i. 3 his life the eommons linply rice (rep.

i. 3 rould have lost my life

in life, but doulle denth.....

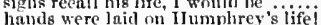

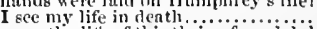

ii. upen the litio of this tlirice-fumed ciuke

ii. 2 and tugged for life, nntl was ly......

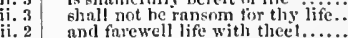

$v .2$ live them to joy thy life..................

ah, what a sign it is of evil life ......

nnd therefore spare my life

to recnifer them, woudd lnse my life...

but for plencling so well for liis life..

doont, of lific or deatli 
LIFE-my life for a thousand ......2 Henry VI. ir. 10 LIFE-sir, if yon'd gave your life, fly.. Coriolanus, v. 4 | LIFE-answer my life my judgment ...... Lcar, i.

thou preterr'st thy life before ............. Henenry VI. i. liy nepends not on his life, or denth thy griesthood saves thy life.

life; here must I stay, and here my life

prolong a while the traitor's life

now in his life againgt your holy.

for yet is hope of litc, and victory....

methinks, it were a liuppy life ......

yield both my life and them to ......

my life, have by niy han

gave thee life too soon (rep.)

like life and deatl's departing

o'ershades his beams of life
would hut two hours' life

gentleman did lose his life

fair hope must hinder life's decay

nyyself will lead a private life...

high reward, and he his life?

dost thou come? is't for my life?

if any spark of life be yet remaining

windows, that let forth thy life .....
my life. Black night o'ershade (rep.)

my life. Black night o

is outrage, life my shame.

my dream was lengthened after life

reward you better for my life.

would not entreat for

of my sovereign's life $\ldots$.............

my husband lost his life to get

in fame though not in life ..........

ay, on my life; and hopes

never in my life [Col. Knt..................

now, for my life, she's wandering

more miserable by the life of thee

dcad life, blis sight, poor mo

grave's due by life nsurped ........

shame serves thy life, and doth thy... -

gave her life, Thith a tairer life

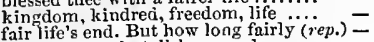

thy life hath that dislionoured

upon my life, my lord........

I have set my life upon a cast..........

lose some life, which action

my life is spanned already $\ldots . . . . .$.

unfit for other life, compelled

by my life, this is (rep. i. 4),$\ldots \ldots \ldots$....

for further life in this world 1 ...

Henry the eighth. life, honour, nane

of my long weary life is come.

by my life, she ncver knew ('ep.) $\because \because$.

by my life, and kingly dignity

mow my life y

prayers, while I sliall lave my life

the place and honours, during nyy life

the articles collected from his

to have given me longer li

how much more is his life in

send prosperons life, long $\ldots$ into whose hand I give thy

for thy stretched-out life ....

our project's life this slinpe

you tonched the life of our design

and, by my life, you shall

I'll play the hunter for tliy life............

now, by Anchises' life, welcome...

a Grecian's life hath snnk

and thy life shall be as sate

is yonder, dcali

to catch my life, so pleasanti........

life every man holds dear (rep.)

and pay thy life thou owest me ......

armour, thus hath cost thy life ......

close the day up. nd live a ye with....

pursue thy life, and live aye with....

these touches, livelier than life ......

I never tasted Timnn in my life.

to hazficient briber for jiis life

a sufficient briber for his
he owes the law his life...

he owes the law his life
with him to supply his life

with him to supply his life ..........

oft thou shonldst hazard thy life for

of thy kindred were jurors on thy iife

still serve him with my life...

gave life and influence to their

brave death outweighs barl life .......

I do owe them stitl my life

prefer a noble life before a long ........

than mine own life, my dear

mistake me not, to save my life.....

thou hast nevel in thy life ......... i: 3 which this man's life did owe you ${ }_{3}$ and other men think of this life..... $\bar{j}_{\text {utius }}$ Cesar,

and those sparks of life that

but life being weary of these . $\ldots \ldots . .$.

for your life, you durst not ..........

i. 3

ii. 5 my life is run lis compass

ii. 5 saving of thy life, that whatsoever

in all my life, $\mathbf{Y}$ fonnd no man

ii. 5 almost ended lis life's history

ii. 5
ii. 5
ii. 6 his life wath gentle; and all the........

I love long life better than figs $\ldots . .$.

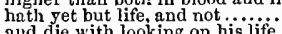

and die with looking on his life

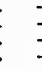

iv. 3 alrows a body rather

or dissolve my lifel

I'll expect victorious life, than

best fits my latter part of life.

v. 6 she rendered Jife, thy name so.....

and I wore my life, to spend upon

I yield thee up my life....

befin to make a better life ...........

other elements I give to baser life
knot intrinsicate of life at once untie

bound fur no less than my life

ii.
ii.
ii. 4 by my life, I lissed it wa..

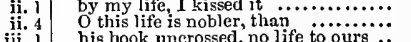

iii. 2 haply this life is best, if quiet life be

let thise iii

let thise own han'li 4 (let.)

or in my life what comfort $\ldots . .$.

I see, a man's life is a tedious one...

of which her life's in dang

sir, my life is yours, 1 humbly set...

what pleasure, sir, find we in li

the certainty of this lard life.
even for whom my life is, ev

dear life, take mine; and though (rep.

the action of my life is like it..

by medicine life may be prolonged...

madly dying. like lier lite

whose lite, bnt that her flight $\ldots$

i. 2 sliould by the minute feed on life.....

ii. 1 your life, good master, must shuffle.

my quecn, my life, my wife:

ii. 1

would cease the present power of life

Titus, riather of my lifel

and shall do with my life...

these looks infuse new life in $\mathrm{me}$.....

Moor, sweeter to me than life!

as you love your mother's life .

for 'tis not life that $I$ have begged

bereft my brother of his life.

not then have touched them for his life

nursed this woe, in feeding life

life not shrink thereat ( $r e p$.) his pledges dearer than his life

violent hands upon her tender life (rep.) -

will quickly melt thy life away

that first gave life to you ...............

never say grace in all my lite.....
lord of my life, commander of $y y$

as he regards his aged father's life

if one good deed in all my life I did

ber life was bcast-like, and devoid

his riddle told not, lost his life...

who tells us life's but breath

touch not, upon thy life, for that's

lest my life be cropped to kepp you..

makes war upon your life.

v. 9

power to take thy life.........

destinies do cut his thread of lite

each minute threatens life or deati..

who first shall die to lengthen life ..

and have no more of life, than may.

that holds his life of you

so mucli blood unto yonr

undertake a married life ...............

the king's subtlety, to have my life..

as a duck for life that dives...

now, mild may be thy life $\ldots \ldots . . . . . .$.

and yct the fire of life, kindle again..

Marina's life seeks to take off.

Mrina

never did hor hurt in all my life ....
or my life imply her danger?

your lady seeks my life.

daughter all his life's delight $\ldots-. . .$. iv. $\overline{4}$ (Gower)

another life [Col. Knt.-like] to Pericles - v.

give them repetition to the life $\ldots \ldots \ldots . .$.
no less than life, with grace $\ldots . . . \ldots \ldots \ldots$, Lear,
Kent, ou thy life, no more. Fiy life

I dare pawn down my life for him .......
now, hy my life, old fools are babes again

I'll tell thee; life and deatl

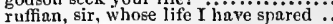

as I've life and honour, there shall he

to keep base life afoot...........

he sought my life, but lately.

his life, with thine, and all that offer.....

we may not pass upon his life ..........

pluck uon nicld to age

dissolve the life that wants....

to despateh his nighted life.

of life, when life itself yields

thy life's a miracle; speak yet again .... - iv. 6

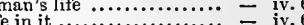

ch'ud ha' been zwaggered out of my life = iv.

a plot upon her virtuous husband's life.. - iv. 6

that thy life and wits at once.............

and the strings of life beran to crack.... - v. 3

I pant for litc; some good of

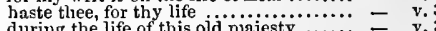

no, no, no life; why should a dog.........

a horse, a rat, have life,

lovers take their life .................... juliet, (proi.) term of a despised life

on my life, hath stolen him home.....

my life were bettcr ended by their hate
a challenge on niy life ...............

of my life for an hour and a quarter

those twenty conld but kill one jife

should end the life of Tybalt........

[Knt.] thy lady, that in thy life lives

when he shuts up the day of life......

aimost freezes up the lieat of life ....

life and these lips have long been

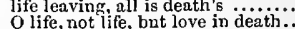

and breathed suct life with kisses....

upon thy life I cliarge thee

ed, some hou

if thou hast uphoarded in those his...

upon my life, this spirit dumb to us.

I do not set my lite at a pin's fee

of life of erown of queen at.....

except my life, except my life (rep.)

upon whose property, and most dcar life

to grunt and sweat under a weary life...

on wliolesome life usurp inmedia te $y$

the single and peculiar life is bound

i. 2 like life in excremcnts, starts up ........

who was in life a foolish prating knave.

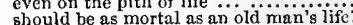

our crown, our life, and all that we call

father slain, pursued my life

upon my life to my life and soul.........

death, shortens not his own life ..........

with desperate hand fordo its own life.

for my proper life, and with such cozen

alld a man's life's no more than to sny

in thee there is not half an hour's life.

for nccessity of present life. I must show. Othello,

totch mence and being from me

still questioned me the story of my life...

my life upon her faith. Honest $\mathrm{rag}_{\mathrm{g}} \mathrm{...}$.

a life's but a span: why then

'tis the soldier's life, to lave their balmy - ii.

think'st tlou, I'd make a life of jealousy

hang a doubt on: or, woe

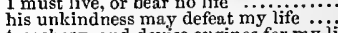

treachery, and devise engines for my lite

but of life as honest, as you that thus......

no, by my life and sonl; send for

I never did offend you in my life
LIFE-BLOOD-issuing life-blood.

infect the very life-blood of our

of Venice, iii.

draw life-blood from my heart...... HenryVI iv.

how couldst thou drain the life-blood.3 Henry ${ }^{\prime} I$. i. 4

5 to the quick, thy life-blood out.. Tilus Antron. iv.

IF ELESS_a mere lifeless block...As you Like it,

to procrastinate his lifeless end . Comedly of Err. i.

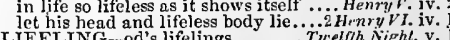

LIFE-PRESERVING rest ...... Comerly of Errors, v.

LIFE-RENDERING pelicain $\ldots \ldots \ldots \ldots$ Hamlel, iv.

IIFE-WEARY taker may fall ..Romeo \& Juliet, v.

lift up your countenaoce ................ Ter's Tale, iv.
lift up thy looks: from my succession - iv. 
LIFT-that lift their awords in such .. King John, li. I ITGHT-Doricles do light upm her. W'integ's Tale, iv. lift up thy brow, renowned Salisbury vigour litt me up to reach

vigour lift mewd steel acainst

that lift your vassal hinds

but I will litt the down-trod

any levers to lift me up ngai
ean litt your blool uj with.

he ne'er lift up his hase

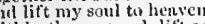

"ullil. ii. I

within threc pound, lift as much.
should lift their bosoms higher

in aspirntion lifts lim from

as lift them against the Romau...

hence! wilt thou lift up Olymprs? Julitu Crrsar, iii. I

why lifts she up her arms.

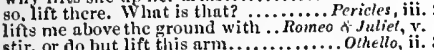

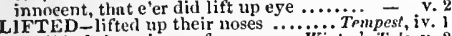
she litted the princess from ............... Thinter's Tale, $v$ it lifter up its head, and dic a. Troilus f. Cressida, LIFTING - the lifting up of day $\ldots . .21$ enry Ir. iv. tear this hand, for lifting

exploit have I in hand, Ligarius...Julius Cresar, ii. some to Ligarius! awny; go

IJGGE-or aile ligge i' the grund jo... Menry $V$. ii
IIGIIT-how to name the bigger liglit .. T'mpest, toads, beetles, bats, liglit on you! .......

lest tao light wiming mialit i but........

by this lood lirlit, this is (rep.).

of and on, hy this light.............

as Hymen's lamps slull iight you......

to the tune of light o' love...7u

or your own had the fights they

hath dinzzled my renson's light

that I had any light from
it will be light, my lord

what light is light, if Silvia.......... iii.

or any kind of light f........

till we see the

hard by Herne's nak, with obseured lights -

more than light airs.............. Tu'elfik Nigh

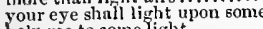

help nie to some light

some ink, paper, and light (rep.)

given me such clear lights of favour -

not light them for themselves iigheas. fnr Meas. i.

lights that do mislead the marn ... - iv. I (song)

rrom your eyes wish from heaven

for women are light at midnight

for womell are light at midlight

otherwise 'tis light, and not heavy

elap us into liglit o love ..................

yese things, come thus to light.

by this light, he changes nore and more -

these shallow fools lave bronght to light =

and light them at the fiery..

and both as lisht as tales........

yon riery oes and eyes of light........
wilfully exile themsel ves tron light

thou stiow me thy grev light, I'll find

by his small light of discretion.....

tongue, lose thy lirhth! moon take

this house give glinumering light .....

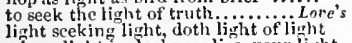

where liglit in darkness lies, your liy
give him liglat that was it blinded by

give him light that was it blinded by

that's great marvel, loving a light weneh -

Baw her in the light (rep.)

by this light, but for licr ese

through tears of mine give light

resembling spirits of light ...........

no eandles now, for lark is light

light wenches may prove plagtes
had she hecu light like you, of sueh

for a light heart lives long

iglit condition

light to find your meaning out (rep.)

a light wench. Indeed. I weigh not

fiery light for momsicur Judas ...........

good sooth, are too too light $\ldots . . .$. ..

let the danger light umon your charter -

as makes it light, or leavy

that light we sec is burning in $\ldots \ldots . .$.
give light, but let me not lie light ( $r e p$.

give light, but let me nat he light ( rem.) - - ik
we'll light upon some scttled low..As you Lik

bright radinnee aul collateral light ...All's $\|_{e} l^{\prime}$

in this my light cletiveranee

that he does weigh too light

of youth light not your mind:.

ere we light on such anather herb.
by any means light on a fit man... Taming of

an a man eould light on them

but young and light, - Too light for

for, by this light, whereby I sec... by the beneflt of his wished light

and run from her by her own light..

ergo, light wenches will hurn.

let not liglst see my bluek ........

light thickeng light slould kiss it?....

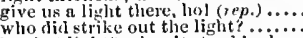

by that light? why, it stood by her(rep.) -

of our curses light on thee
we had a kind of light

we had a kind of light if $i$

turn me from my country's light

mock, and time-bewasted light

mocks at it, and sets it ligh

are grown somewhat light ............

the globe, and lights the lower world

darts his light through every...
vanities that make him light...

thou art so light of foot.......

then they light on us o.............. Henry $I$ H' ii.

shall be the dny, whene'er it lights .. - iii.

bought me lights us good cheap.......

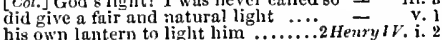

your ill angel is light $\ldots \ldots \ldots \ldots \ldots . . . . . .$.
by this light, I am weli spoken of $\ldots .$.

by this light, did all the chivalry.... - ii. 3

I am passing light in spirit ........... -

yet that were but light paymen

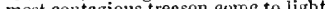

and this light, the fellow has mettle.

out, some light horsemen....

a plaguing mischief light on $\ldots \ldots \ldots \ldots$.

gives light in darkness, comfort in . $=$ ii. 1

bring to light in smooth duke Humphrey -

one lamp, one light, one sun .........3 4 Hemry
notwitlistanding, join our lights together

contend with growing light....

gave king Henry light

and untimely brought to light........ Richard $I I I$. i.

were it light enough (rep.)

yieid me not thy liglti ; nor niglit....

the lights burn blue, it is now dead ... Henry - VIII. i.

how came his practices to light?

by this light I ll have more...........

he was harnessed light, and to the field - i. 2

there, where we see the light

there, where we see the light ts ....... Thinon of $A t h . .4$

hath blazed with lights.

the plague of company light upon thee -

lie where the light foam of the sea...
by free and offered light: come.

contagion of the south welcome.......

that needs must light on this

sliall linht upor. the limbs of

nome more lis :

and made the night lighit with drinkiug -

give light to thy fair way! .......... - ii

as the smoky light that's fed

to see the enelosed lights $\ldots$ will par......

for being too light, the purse too ighit

and welcome me to this world's light

no course to keep thein from the light

day serves not light more fai

but like lesser lights, did vail...

pages and lights, conoluct tiese innights

to view nor duy nor light.............
no light, na fire; the untriendi.

light; ho, here: fly, brother...

he that first lights on him. holla .....

how light and portable my nain seem

in a heavy case, your purse in a liglit

stars, that make dark lianen iight

to soar with his light feathers.

let wantons, light of leart ..........

our liglits in vain [ $k n t_{0}-$ lights, lights] angels of light; light is nu effict of

by this light, were I to get a
or the light loss of England

shall beem as light as chaff

hath brouglit to light this dangerous

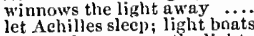

though light, take pieces for .........

fair glass of light, I loved you.

false of heart, ight of ear, bloody...

the this good light ...... Tale, ii a
LIGIIT-soft! what light through. Nomeo of Juliel, ii. 2 with love's light wings did I o erperch

not inmute this yieding to light love

the worke, to want thy light

$O$ so linht a foot will neier wear out

yet not lall, so light is vanity ........

light to iny eliamber, liol ufure me.

yon liglit is not daylight, 1 know it

more liglit and light it grows (rep.)

my heart is wondrous light, since.
give ine the light: upon thy life

a feasting presence full of light...

thint vainly lends his light to grubs

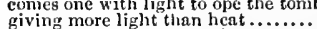

to the last, bended their light on me

of so airy and light a quality, that

a tyrannous and a damned light

to mc give food, nor heaven light!
give me same light: away! (rep.)

yet are they much too light

light and careless livery that it wear

the election lights on Fortinbras .

but, look! what lights come yonder

if my bad blame light on the mant.

for his own rage, holds his soul light

this matter, making it light to Cassio

trifles, light as air, are, to and 50 .

witness, you ever-burnling lights above

is lie nestures, and light beiaviour

for, by this light of heaven, I know not
heavenly light! Nor I neither (rep.)

heavenly light! Nor I neith

in his shit, with light and weepons

marry, heaven forbid! light, gentlemen

put out the fight, and then (rep.)....

again thy former light restore.

[Col. Kni.] but once put out thy light

IGILTED-Hymen's torch be lighted.. Tempest, iv.

Thave lighted well on this young Taming of $S h$. i.
shot, liath not yet lighted ............ Macbeth, ii.

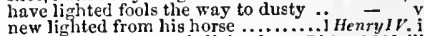

now thy heavy curse is lighted on... Richard III. iij.
when they lighted, how they elung.. Henry VIII. i.

when they lighted, how they elung.. Henry VIII. i.
when it is lighted, come and call..Julius Cassar, ji.

lighted the little 0 , the earth.....Antony \& Cleo. v, 2
LIGHTEN-lighten our own liearts ... Much Ado, v

lightens my humnur with lis... Comedy of Errors, $\mathrm{i}$.

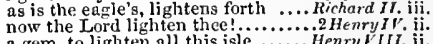

a gem, to lighten all this isle ....... Henry VIr. ii.

ring, that lightens all the hole. Tilus Andronicus,

LIGHTER-and the lighter people. Ticelfin Nighi,

my heart is ten times lighter than.. Richtord III.
LIGHTER-HEELED, than I.. Mid. N.'s Dream, it

LIGTEST-making them lightest. Mer. of Fence,
whose lightest word would harrow up ... Hamiet

whose lightest word would harrow up ..Hamiet

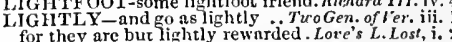

for they are but tightly rewrided. Lore's L. Lost,

a few light crowns, lightly conspired... Nenry

they love his grace but lightly........ Richard Iil.

short summers lightly have a forward

and. believe't not liphtly

punish it seeming to bear it lighio... Coriolanus, iv.

with tears not lightly shed.... Tilusdudronicus, ii.

sits lightly in his throne ........ Romeo of Juliet,

eyes are witness of her lightness.. Taming of $\$ h$.
stich light

the lightness of his wife shines through it -1

such is the Jightness of you common.3Henry $I$ ' 1 . iii.

go great weight in his lightness. Antony f Cleo,

thence ta a lightness; and, by this
LIGH'TNING-Jove's lightnings.

I would the lightning had burnt up .. - ii

as the lightning in the collied night. Mid.N.'s $D r$. i.

thy ese Jove's lightuing bears .... Lore's L. l.ost. iv.

in thunder, lightning, or in rain? .......... Karbeth

be swift like light ning in the ...........Richnrd 11 . 1 .

their weapons like to lightning...

with lightning strike the murde...

3 Hewry $\mathrm{Hi}$

the cross blue hightning sccmed..... Julins C'sily

yow nimble lightnings, dart yurr .......

nimber. Rameo of Jutiel, ii.

and to't they go like lighining

a lightning before denth (rep.) .......

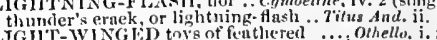

1k the of fentleered

tew in millions can sjeak like us.

when I rear my hame, do you the tike.

such baseness had neer like executor.

it the of lice two be brained like us ....

as you like this, give me
dost thou like the plot 


\section{LIK}

LIK

LIKE-even with such like valour .... Tempest, iii. 3 LIKE-I like him well. 'Tis pit

all men have the like onths pity

you are like to lose your hair ......... - iv. I I like lim well; 'tis not amiss

and t like your grace...

how does your lad yship like it?.

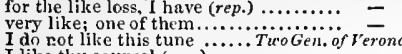

I do nou are like to see the king

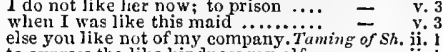

like exhibition thon slialt jiave..........

you have learned, like sir Proteus.

I be not like your mistress ..........

to express the like kindness myself..

if Protens like your journey

and $\mathbf{I}$, tor such like petty

the music likes you not....

the musician like thee well

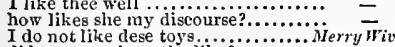

did you ever lear the like?

... All's Well, iii. 5 ,

LIKE-I like this fair proceeding...2 Henry $I V$. v.

I like not the humonr of lying ................

I like it nis money well ...............

Ilike not when a 'oman has..............

and I was like to be apprehended

how like you Windsor wives? ..........

are they like to take dust, like mistress

you are like to be much advanced.

what's a drunken man like, fool?
it is the more like to be feigned.

I ean write very like my lady....

ii. i call you this gamut? tut I I like it not

shalj be and had indeed against us

'tis like, you'll prove a jolly surly....

didst ever see the like? ................

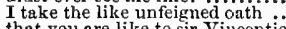

I like it well; good Grumio, fetch it

or love me not, I Jike the eap...........

if you please to like no worse........

you're like to liave a thin and (rep.)

one mess is like to be your cheer

hy me! how likes Hortensio that?

on the like oceasion whereon my. W'
my bosom likes not, nor my brows.

full like me: yet, they say (rep.)

how like, methought, I then was

I am Jike you, they say ..................

how dost thou like this turte?

a goodly habe lusty, and like to live

so like you, 'tis the worse.

have done like offices of pity

and fools are as like husbands.........

a fiend, like thee, might bear

been cast out; like to itzelf.

as you are like to find him ..........

'tis like to be lourd wenther...

I never saw a vessel of jike sorrow...

thou art bike to have a lullaby
say you the like to lim?

palace, an it like your worship

your worslip had like to have giren

much like the character................ $-\overline{\text { ueas. for Meas. }}$ but do not like to stage me to

for the encouragement of the like.... - i.

here, if it like your honour ........
frst, an it like you, the house...
I do desire the like

his successor was like to be the best.

comes not like to his father's greatnes

the visage of Ragozine, more like to..

five the like notice, to Valentinus

0 that it were as like as it is truei....

I do not like the man

like doth quit like, and measure stili

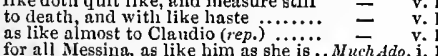

for all Messinn, as like him as she is ... NuchAddo,

but as she is, I do not like her.

watli y our grace ne'er a brother

who is thus like to be eozened with you? -

raith, like enough

show some sparks that are like wit.

I like the new tire within excellently

I do not like thy look, I promise thee
when he shall endure the like himself

we had like to have had our two noses

that when I note another man like him

nor are we like to be

is so like an old tale (rep.)

is so like an old tale (rep.) .........

I like your silence, it the more .......
to trouble your joys with like relation

the one so like the other ...... Comedy of Error

whilst I had been like heedful of

many such like liberties of sin .....

burdened with like weight
live to see like right bereft

or, if you like elsew here, do

these two so like, and these two ....

look like tlie time (rep.)

thanks, sir; the like to youi ...........

that did the like for Fleance

too like the spirit of Banquo $\ldots \ldots . . .$.

like the first; a third is like the former
and yelled out like syllable of dolour

and show like those you are

our father, and this son like him

I like thee well; wilt thou forsake

being as like, as rain to water

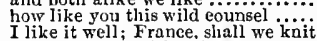

that makes him like, that any

it likes us well; young princes .....

like to Lysander sometime frame...Mil.N.'sDr. iij.

rat rou like Demetrius

Love's L. Lost, i. i

then was Venus like her mother .... - ii.

is but minstrels like of sonneting

We like not this; thou dost forget..

to look like her, are ehimney-sweepers

high majesty look like itself..

which show like grief itself.

yet looks he like a king

I take the earth to the like...

is be not like thee? (rep.)......

i.....ichard iv.

how like you the young German. Mer. of Fenice, $\mathrm{i}$.

I am as like to call thee so again

is't like, that lead contains her?

if we are like you in the rest

must needs be like my lord ...........

vor none is like to have.

have before end ured the like $\ldots \ldots \ldots . .1$ Henry $I V$. $\mathrm{i}$.

ay, but, 'tis like, that they will know us -

these lies are like the father $\ldots \ldots$.
o for breatl to utter what is like theel

and persuaded us to do the

the like do you; so shall we pass ....
I Jike this place, and willingly could
if you like, upon report, the soil ....
and how like you this shepherd's life

solitary, I like it very well

they were all like one another

would now like him, now loat $\mathrm{ne} . .$.

and like enough to eonsent............. -

little acquaintance you should jike her? -

like this fellow. I like him very well

I desire you of the like ...............

to like as much of this play as ........

ill, to like him that ne'er it likes.....

to join like likes, and kiss like native

like to prove most sinewy swordsmen

if thou canst like this creature........

of man, an it like your majesty?

runs me up with like advanta?

thon, that art like enongh.

I do not like that paying back

I like not sueh grinning honour

but one that is like to be executed..

this lodging likes me better

which likes me better, than to wish

tis so like as my fingers is to my

your majesty came not like yourself

like me. An angel is iske you (rep.)

none do you like but an effeminate $1-\bar{v}$ v.

whate'er we like, thou art protector

who ever saw the like? what men
saint Pliliv's daurliter, werelike thee

[Col, Knt.] like thee, Nero, play on ..

the substance shall endure the like.

Nestor, like aged, in an age of care..

of darnel; do you like the taste?

e are like to have the overthrow again -

what you will, the like do I........... = iv.

and like me to the peasant boys...... - iv.

to find the like event in love........$\quad$ v. 4

an' it like your majesty (rep.) $\ldots \ldots \ldots$. Henry VI. ii. 1

tis jike, my lord, you will not keep

as, tis great like he will

'ti like or thou not false like him? -

then we are like to have biting statutes - iv. 7

that being which was like to be? .....2 Henry $r v$ i. 1

caying her should jegd his .........

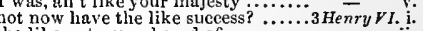

the like yet never lieard of $\ldots \ldots \ldots$ ije $\quad$ - ii.

to execute the like upon thyself $\ldots . .$.

where I must take like seat.

be thou still like thyself, and sit $\ldots$....

beseem a monarch like himself......

how like you our choice $\ldots . . . . . . . .$.

I like it better than a dangerous $\ldots$

tis like of this fight of edward's.

brother, I like not this .............

my sovereign speaketh like litmself

not like the fruit of such a goodly .

resident in men like one another.... - v. 6

and such like toys as these

I like you, lads: abont your business

so thrive I, as I truly swear the like
I do not like the Tower, of any place

I do not like the Tower, of any place

nay, like enough; for I stay dinner.

false traitors from the like attempts

being not like the duke.............

my queen is sick, and like to die ....

for whom you bid like sorrow.......

like it your grace, the state ........... Hen $\bar{y}{ }^{\prime} I I I . \mathrm{i}$.

eal advise me like you $\ldots \ldots \ldots \ldots \ldots$ -

do not like their coming

an't like your grace,-you are $\ldots . .$. .

for this, the girl is like to him?......

may it like your grace to let .........

the expected good we are like to hear

ike, or find fault; do as your........ - (vrol

like as there were husbandry in war
Iiberality, and such like [ $K$ nt.-so forth]

s like as Vtrean and his wife .......

'tis like, he'll question m.

the like allayment could I give.......

- iv. 5

that that likes not you, pleases me.. -

Trumpets sound the like, my lord....

I like your work (rep.) ........ 2 imon of Athens, $\mathrm{i}$.

as that I am not like Timou

there's no meat like them

joy had the like conception $($ rep. $) ..$.

and something like thee: 'tis a spirit

like a lord; sometime, like (rep.)....

he is very often like a knight........

plate, jewels, and such like trifles...

in like manner was I in debt....

were I like thee, I'd throw away (rep.)

more things like men? eat, Timon...

but himself, which looks like man

never bearing like labour with agin

that like nor peace, nor war?

who's like to rise, who thrives.

where he was like to find fame

to abuse, to seem like him

thy mother's a cold soldier $\ldots . . . . .$.

do you hike him, sir John? ...........

mark me, and do the like.

I never saw the like

you are like to do such business
express what's like to be their words

with the like, bold, just, and impartial - 
LIKE-und so are like to do to both it stands in like reques and he's as like to do't, 11 s niny min three examples of the like lave I do not like this new. may slow like all youself .......... which we, on like eontlitions, will. tis very like; lie hanth the kepever with their likes. that every like is not the sume
what may finll: I like it not. what may finll: I like it nest.......... was that done like Cussius? I lo mot like your fintits will be futud like Brutus, like himself $\bar{s}$ mo enforee the like from lim I do not like but yet

and well un like to do

it is shuperl, sir, like itself yo.......

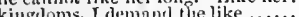
you eone not like Caesnr's sister .....
yes, like enongh, high-lattled Cassar
as he shill like, to yuit me .......... thou look'st like him that knows straight, how "tis like to go

the like is on her arm i...
of the enrtl for one his like.

I do not like her: slie dotl think so like you, sir, embassalors though 1 nin nowe, nor like to be tis very like. Was Caius Lueins but not like me: yet like (rep.) in ns like a foure, strikes lere $\ldots$ kili ine
most like; lringing ne here
first, make yourself but like one ..... she looks as like $n$ thing more. he henring, (as it is like him) the fower, that's like thy titce...

use like note, and words.........

that hud a rider like mysclf........... like hardiment Posthumus hat

most like I dicl, for I was dend was ever heurd the like?

affird no tribune like to these...

for this ungrateful country don

too like the sire for ever being good.......

how like the empress (rep.)

find st a man that's like thy

most wretehed, to perform the

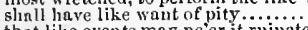

that like events may ne'er it ruinate

give ins tongue like leave to love...
in like necessity, whieh gods protect

which heaven makes like to itself

I like that well; nay, how as I am like to do .......
it you like her so; it' not, I have.

where you are like to live ............

come, roung one, I like the manner

the gods do like this worst

did you ever hear the like? .........

never came her like in IIityl

you are like something that ........

my dearest wife was like this maid..
for thon look'st like one I loved indeed

like a girl: yet thou dost look like

this maid is, or what is like to be

like him you sjeak, like him you are

more like n god than you

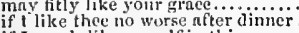

if I speak like mysclf in thi

as like this as $n$ crnb is like on apple

ghe will taste as like this.

his countenanec likes me not

only, I do not like the fashion of .....

preparntion; we are bound to the like

pleasint to his

one way I like this well

take like bold on thee.........................

and like her must, whose merit.. Rrmeo

can you like of Paris' lore? (rep.)....

be heaped like mine, and tliat thy skil

doting like me, and like me banisi....

do you like this haste? we'll keep no

and yet no man, like he, soth grieve

unesen is the contre, I like it not....
is it not very like, the loorrible (rep.)

aame fizure, like tlie king $(r e p$.$) ........$

but no more like mo fit ther

olanll not luok upon his like again.......

to motion, like ns it would speak

very like, very like: stayed it long?

it likes us well; and. at our more

as it is most like, if their means ...

play sumething like the murder of

malum, hou lîke yout this play?

If the king likes not the comedy

who like not in their judgment
Cormonus. iij. I L I KE-nothing is nt a like goodne

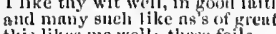

(tive with like timurens uevent

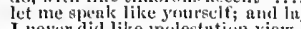

never didike molestation vicw.....

und the general so likes your music...

what didst not like? antl, when I tol say?

I do not like the oflice

lest, heing like one of heaven, the devilis

cven like tluy chastity ..... of co....

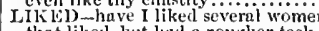

that likel, lut liud a rougher task...

suying, I liked her ere I went to wars
that loved, that liked, thit looked.

certain it is, I liked her

he liked not the seeurity.............

(ent Like it. (epil.)

= iii. 3

בii.i. 11

IIK ED'ST - thoun liked'st not that.

IJKELIEST-they are your likcliest.

but what likelihood is in theot? THo Gene. or Wer. v. 2

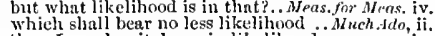

than I can lay it down in likelihood

whereon the likelihood depends
many likelihoods informed me

many likelihoods informed me of this . All'sl'ell,

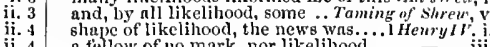

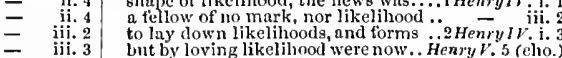

- iij: 4 what likelilood of his amendment... Richard HI. $\mathrm{i}$. 3

- iii. 4 to no apparent likelihood of hreach...

iii. 4

iv. 2 modesty enough, and likelihood to lead. Hamlet, $\mathrm{Y}$.

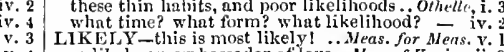

so likely an embassador of love... Mer. of Veatice ii. 9
never thought it possible, or likely Taming of Sli. 1 . 1

never tholight it possible, or likely Taming of sh. i. i
an edgc, more likely to fall in ......2Henry $W$. i. i

the respect of likely peril feared
our hoyes (yet likely of frir birth

orir hoyes (yet likely of fair birth)
'fore God a likely fellowl come, prick

fore God a likely fellowl come, prick
not seeing what is likely to ensue... Hen $r y$

is likely to beget more eonquerors
nor likely to be slain; for they

he's very likely now to fall from ...3Henry rI. iii. 3

and himself likely, in peace

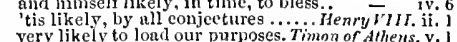

very likely to load our purposes. Timnn of Athens, v.
most likely, tis tor you...... Corriolanus, i. 2 (letter)

this is most likely! Raised only

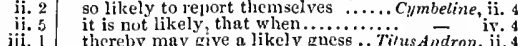

iv. 3 likely, sil. Nay, eertainly to-night... Pericles, iii.

did warrant me iras likely ............. v. y. 1

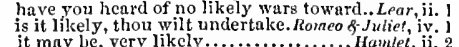

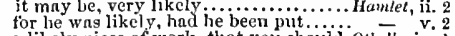

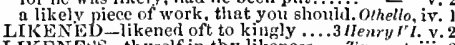

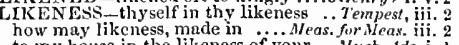

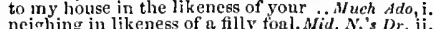

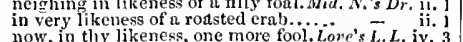
now, in thy likeness, one more fool. Love's L.L. iv. 3
he comes in the likeness of a Jew. Mrr. of Venice, iii. 1 so her dead likeness, I do well . Mid"inter's Tale, v. 3

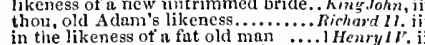
in tie likeness of a fut old man .....
dear to-day hath hought thy likeness

love in her in his true likenes.

the likeness of this railer here ....... Hitenry VI. v.
do not assume my likeness

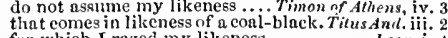

for which I razed my likeness ............ Lear, $\mathrm{i}$.

that in thy likeness thou appear to us
can translate bcauty into his likeness.. Hamlet,

can tranklate beanty into his tikeness.. Hamlet, ini.
LIKER - the liker you, few thller. Lore's L. Lost,
this boy liker in feature to his fnther. King John, ii

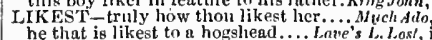
he that is likest to a hogglead.... Lane's l... Losh

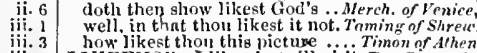

iii. 3 how likest thon this pieture ... Timon of Athens, i.

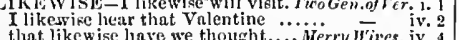

that likewise have we thought.
shall likewise ghuffle her away

iikevise lath la made promise to

is likewise your own henefit..........ens. for Meas.

where we are. our learning likewisc. Love's $L . L$. i

the error tluat love makes is likewi....

that's likewise part of my......... Winler's Tale, iv.

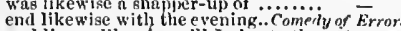

and liquor likew ise will I give to the. Henry $\mathrm{r}$.

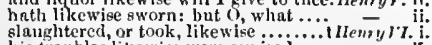

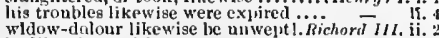

he likerise enriched por ....... Timonof athens. .1. 1
might from relation tikewise reup .. Cymbelne, 11.4
LIKLW ISE-likewise variable ... Romeo of Jullict, if 2
my intercession likewire stendls my foe

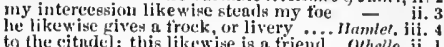

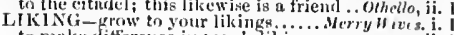
to make rifferenee in men'siking....

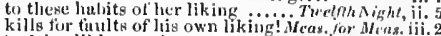

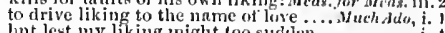
but lest my liking might too sudilen

mielt an ill ward niny impioson fiking - iii. I

a liking with old sir lowlung in.

to lose it to her owil liking?

in so true a flume of liking lad marricel laim against his

- iij

to add her futler's liking ..............

and bring him up to liking .............̈nter's Tale, jv. 3

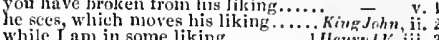

while 1 am in some liking........... I I Wenry 1 , iij.

the r.

thought to contrndiet your liking..2 Henry fr. jii. 2

such as stand not in their liking ...... Coriolanus, i. I

with whom the father liking took. Perieles, i. (Gow.)

to a vert your liking a more worthier....... Lear, i. l

[Col.] as liking not his voyage ........... Hamlet, iv. 7

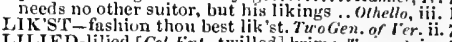

LILIED-liljed [Col. Knt.-twilled] brims. Temper, jv.

thou mayst with lilies boast ............ King John, iii the - she is as white as a lily..Tu'o Gen. of rer. ii. these lily brows, this cherry nose.Miil. $N$. Dream, $v$. as the unsullied lil 5 , I protest.... Love's L. Lest, v. to paint the lily, to throw ........... King John, iv. a most unspotterl lily shall she pass .. - v. may wallow in the lily beds.. Troilus \& Cressida, iij. $O$ sweetest, fairest lily!

the monster seeu thuse lily hands. Tiuss Andron. if.

LILY-IIVERED-lily-livered boyl ... Nacbeth, v.

a lily-livered, action-taking knave .....Lear, ii.

LINANDER-like Limander am I trusty - v. thy face, thy linbs, aetions ....... Twelfy Night iii.

affection, limb, nor beauty. Neasure for Measure, iii.

strength of limb and noliey of mind. Much Ado, iv. a waist, a leg, a limb? ................eve's L. Lost, iv. young in limb, in judgment. Mer. of Ven. ii. $\overline{7}$ (scroil

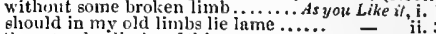
those tender limbs of thine to............All's $\bar{W}_{e l l}$, iii. whom am I belsolden for these limbi... King John, ealf's skin on those recreant limbs (rep.) - ii. 1
and do not break my limbs, I'll tind
learn to make a body of a limb learn to make a body of a limb .....Richarel $n$. iit. a perilous gash, a very limb lopped... Henry $1 \mathrm{H}$. iv. even so my limbs, weakened with.....2 Hensy $f r$.

he enn part young limbs and lechery

care 1 fur the limb, the thew

let us ehoose sueh limbs of noble.

whose limbs were made in Englani..

dreneh their peasant limbs in blond... - iv. ?

proportion ory limbs honour is eudgeled - v. 1

so fure my limbs with lon

swent from his war-wearied limbs.....
nnd weak unable limbs, slould brin

and a limb lopped off; this stuff ....2 Irnry . iv.

set limb to limb, and thou art tinr ... $\begin{gathered}- \\ \text { to rend his limbs asunder } \ldots \ldots \ldots \ldots \ldots\end{gathered}$

isle doth want lier proper limbs ...Richard III. iit.
who set the hody nud the limbs ..... Henryllil.

these are the limbs of the plot.

linve you limbs to bear that load

which entertained, limbs are his. Troilus of Cress. i. 3

nnd bows directive by the limbs...

view thee limb by limb

venture all his limbs for honour . Timon of Athens, jy.

o he's a limb, that has bnt

have thewcs and limbs like to their.julius $\bar{c}$ assar. i.

and then lack the limbs: like wrath
Antony is but a limb of Cxsar ......

hall light upon the limbs of men...

that we may hew his limbs .... Tirus, Andronitus, $\mathrm{i}$.

let's hew hís limbs, till t
Alarbus' limbs are lom

clrive upn thy new-trnusformed limbs

lirain duth eonel his limbs............. Fo suliet, i.

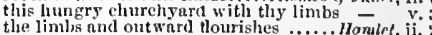

with his sword her luusband's limb.

IniBFCK-of renson a limbeck on

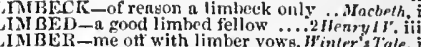

LIMR-NIEAI-tear her limb-menll... Cymbeline,

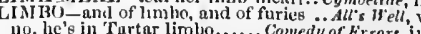

as far from licelp as limbo is from. Titus Fudrors,

Lisfor from licin as limbo is from. Tinusudron. iii, 


\title{
LIM
}

LIME-some lime upon your fingers ... Tempest, iv. I TrNE-line ove of their hands?

sou must lay lime $\ldots \ldots \ldots$. Twa Gen. af l'erana, iii. with lime and rongli-crst ... [Cal.] this lime, this rongh-cast ...... with lime and hair knit up in thee. from their fixcd beds of lime had. here's lime in this sack too

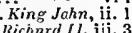
Ricinned Il. iii. worse than a cup of sack with 1 HenryI $V$. ii. 4

LINIDD-I hav'e limed her Tuelfh Night, iil. she's limed, [ Knt,-ta'en] I warrant.. . Much Add, iji. myself liave limed a bush for her have alt limed bushes to betray the bird that hath bcen limed in ....3 3 Henry $V I$. v. 6 limed soul, that, strigg in to bec.. Mamlet,

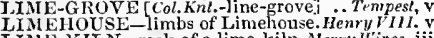
lime-kilns i' the palm, incurable. Troilus \& Cress. $v$. IME-TW TG-like lime-twigs set..2 Henry Yl. iii. 3 beyond all limit of what else .......... - iii. 1 and limit of the solemuity the sadness is without limit ..............

ont of all sanctified limit...............All's Well', i. g'll limit thee this day, to seek.Comedy af E)rurs, i. 1 the furthest limit of my embassy ....King John, i. 1 the dateless limit of tily dear exile

within the limits of yon lime

and many limits of the charge

solong, as out of limit, and true

- iv.

despatcli the limit of your lives ....Richard III. iii.

I give a sparing limit to my tongue

and the act a slave to limit.. T

ares to stride a limit. then into limits could I bind stony limits cannot hold love out

no end, no limit. measure, bound.... $-\begin{array}{r}\text { iii. } 2 \\ \text { LIITATION-stood your limitation Carialnnus, }\end{array}$ as it were, in sort, or limitation ..Julius Casar, ii. 1
LIMITED-the hour limited ..... Mleas. far Meas, iv. 2 to call, for 'tis my limited service.......Macbeth, ii. 3 warrant limited unto my tongue..... King Jahn, v.
theft in limited professions.... Timon of dihens, iv. theft in limited professions...
LIMNED - most truly limned.
LIMP behind the substance.

report, that Kate doth limp?... Taming of shrew, apish nation limps after, in base....Richard II. ii. a wenry ... iv. (chorns) LrMIPING -thy old limping sire... Timan of $A$ th on the heel of limping winter.... Ramea \& Juliet, i. 2
LINCOL $N$ Washes have devoured ... King John, v. 6 with you, my lord of Lincoln....... Henry VIII.
LINCOLNSHIRE bagpipe ......... HenryI

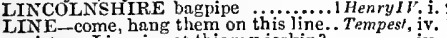
mistress Line, is not this my jerkin?

now is the jerkin under the line

we steal by line and level (rep.) $\dddot{G}$ wo

presume to harhour wanton

sweet love! sweet lines! sweet life !

to write some lines to one she loves.

the lines are very quaintly writ
and trame some feeling line

upon your master's lines ............. smile his face into more lines ... Tu'elfh Night, iii. the stroke and line of his great ........ what, clid these rent lines show

then his lines would ravish

here's a simple line of life... Merchani of Venice, ii. and write to her a love line......... - ii. looking on the lines of my boy's.. Winter's Tale, i.
yon perceive me not how I give live
or did line the rebel with hidden ........ Macbeth, i.

hailed him father to a line of kings

will the line stretch out to

now doth death line lis degn his line ...

more general than these lines import

at home, meet in one line.............

show the line, and the predicamen
sent for you, to line hisenterprize

and in that very line, Harry

hold hook and line, eay

give him line and scope.................

as many lines close in the dials...

to line, and new repair, our towns

sends you this most memorable line - ii.

with deep premeditated lines....... Henry ${ }^{\prime} I_{\text {. }}$ iii. $I$

make a volnme of enticing lines

from whose line I claim the erown..2 Henry $V I$. ii. 2

have all the line of Joln of Gaunt..3 Henry $Y I$, i. 1

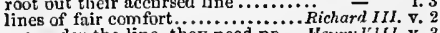

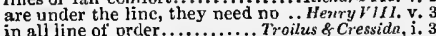

[Knt.] his pettish lines, his ebbs........ the lines of my body are as well .....

weapons wrapped about with lines.. Tilus $\bar{A}$ nd

wretched stump, these erimson lines

lie will linc your apron with gold

even from this line to this ........

Lericles, iv, i.

begin at this line; let, to make

Hamlet, ii. ?

a speech of some dozcn or sixteen jines....

二 iii. 2

as lief the town erier spoke my lines...

LINEAL entrance to our own! ..................
put on the lineal state and glory
than tor lis lineal royalties......

not force this lineal honour from

whence you spring by lineal descent. I Henry $V I$, iii.

unto a lineal true-der

LINEAMENT, branch, sliape...

Henrylyl. iii. 3

a

than any of her lineaments can show

well appeared in his lineaments. Richard 11. iii.

well appeared in his lineaments..

every married lineament

INED-with good capon lined

Ranea \& Juliet, i. 3

all the pictures, fairest lined .... - iii. 2 (verses)

who lined himself with hove...

Henry $1 \mathbf{r}^{\prime}$ i. 3

pluck the lined crutcl from ... Then they have lined their coat

LINEN - with rich garments, lincn

and throw foul linen upon him ...Mer.

Tempest,

will look some linen for your head.
I'll bring linen for him straiglit ....

pluck me out all the linen

him in home for want of linen.... Love's L. Los

him in home finen, Tnrkey cushions bossed. Taming of Sh. ii. I

with a linen stock on one leg

kite builds, look to lesser line.

those linend fineeks of thine

for it is a low ebb of linen with thee.2Herr $y I V$. ii

that bawl out the ruins of thy linen

senscless linen! lappier therein than $I ! . . \bar{C} y n n$ ), $\mathrm{i}$.

get linen: now this matter must...... Pericles, iii.

LINGARE-as heir to the lady Lingare. Henry $V$.
LINGER-but it thou linger. Two Gen. of Jerann,

she lingers my desire

by the time I linger here ...Merchant af lenice, i1.

false hope lingers in extremity .... Richard $I I .11$.

linger your patience on ......... Henry $V$. ii. (chorus)

away; we may not linger thus ......3 $3 H$
why do we linger thus? I can not rest

why linger we? lct us lay hand

linger not our sure destructions. Truilus \& $\bar{C}$ ress. v. i1

pent to linger but with a grain .... Corialanus, iti.

Would not have thee linger in thy pain. Othella, v. 2

say, that I lingered with yon. Comedy of Errars, iti. I

nnless his a bode be lingcred here ....... Tempest, iii.

draw ont to lingering sufferance. Meas. for Meas. ii.
from which lingering penance. Merch. af Venice, iv.

but with a lingering dram, that... Wirler's Tale,
feed contention in a lingering act....2

one would have lingering wars'.

and, in advantage lingering, looks ... - iv.

him with grievous lingering deatl...2 Henry $V 1$. iil.

she has strange lingering poisons...

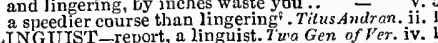

the marifold linguist, the armipotent. Al's $\|^{2}$ erl, iv.

LINING-as lining to the time .... Love'sL. Last, v.

LINK - to link my dear friend

there was no link to colour. Taming of shrew,

thousand marksin links and torehes.1 HenryIV.

to link with lim that were not

Henry VI. $\mathrm{iii}$

nor strong links of iron, can be

Culius Cresar

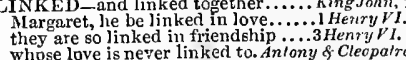

Whose love is never linked to. $A n$
though to a radiant angel linked

Ail'swell,

LINSTOCK now the devilish...Henry $V$. iii. (eliorus

of a while herd of lions

to walk like one of the lions. Tü $\mathrm{Gen}$. of Verona, ii.

heen seized by a liungry lion ......... $\overline{\text { hight }}$, iii. 4

like an o'ergrown lion............

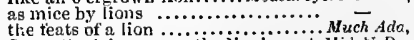

Suug, the joiner, you, the iron's part. Mid.N. Dr.

let me play the lion too.

it lion, bear. or wolt, or buil

lil not the ladies be ateard of the lion? -

more tearful wild-tow] than your ion =

must tell he is not a linn .............

must be seen through the lion's neck
if you think I am come hither as a lion
ION-that plays the liou, pare

Mid.N.Dr. iv.

shall hang out for the lion's claws

whicli lion vile with bloody mouti...

if the lion be to speak (rep.)..........

wo noble beasts in, a moon and a lion

a lion fell, nor else no lion's dam ( $ə e p$.

this lion is a very fox for his valour..

well moused lion. And so comes ....

[Col. Knt.] and so the lion vanished

didst thou lions frame? since lion vile
moonshine and lion are left to bury

moonshine and lion are left to bury

Love's L. $\bar{L}$ cst, iv.

your lion that holds his poll-ax ....

mock the lion when he roars.. Mereh of $\bar{V}$ enice,

and saw the lion's shadow erc himself - v.

that would be the claws of a lion. As you Like it, v.

I met the ravin lion when he roared

in my time heard lions roar?.. Taming of $\overrightarrow{S h}$ rew, $\mathrm{i}$.

the awless lion could not wage ........ KingJohn, i.

he, that perforce robs lions ot

plucks dead lions by the beard

hat lion's robe, that did disrobe thic lion -

'd set an ox-head to your lion's hide

not half so deaf, lions more confident

talks as faniliarly of roaring lions ..

thon wear a lion's hide!

shall they seek the lion in his den?.

hichurd IL. $\mathbf{j}$.

whe never lion raged more.....

whion, dying, thrusteth forth ...... - v.

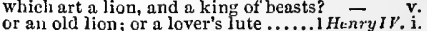

to ronse a lion, than to start

I for a valiant lion, and tho

you are lions too, you ran away ....

valiant as a lion, and wondrous ...

against the lion's al'med jaws.........

hon's whelp. And why not as the lion $\overline{-}$

like to a fangless lion, may offer .....

to behold his lion's whelp fora

the former lions of your blood

eat his breakfast on the lip of a lion $\quad$ - iii. 7

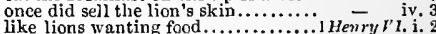

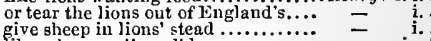

like a hungry lion, did $\ldots \ldots \ldots \ldots \ldots$.

that winter lion, who, in rage, forgets - v.

the pent-up lion o'er the wretch ....3 Henry $V I$. i.

to whom do lions cast their.......... - ii.

and when the lion fawne vpon ...... - iv.

under whose shade the ramping lion chans fettered the kingly lion $=\quad v$.

so looks the chafed lion npon........ Henry $\bar{Y} I I I$. iij.

yes, lion sick, sick of proud heart ....

they that have the voice of lions ....

which better fits a lion, than a man...

th' ass, more captain than the lion. Timon

if theu wert the lion, the fox

thou wert german to the lion.

where he should find you lions .......

he is a lion that $I$ ain proud to liunt ... Corialanus,

met a lion who glared upon me...Julius Caser,

he were no lion, were not komans ....

elephants with hal litered in on

playing with a lion's whelp ..... Antany \& $\overline{\text { Cleo. iii. }}$ il sometime, like a bear, or lion ........ - iv. and to grin like lions upon ............ Cymbeline, v.

when as a lion's whelps (rep.v. 5) - v. 4 (scroll) the lion, moved with pity ...iin i... Titus andron. il. the lion and the belly-pinched wolf....... Lear, iii. dog in madness, lion in prey ............. as hardy as the Nemean lion's nerve.... Hnmlet, i.
dog, to affright an impcrious lion ..... Othella, $\mathrm{ji} .3$ LTONEL [st' Clarence]-

till Linnel's issue fails $\ldots \ldots \ldots \ldots \ldots .2$ Hevry $r I .1 \mathrm{i}$. food to the sucked and hungry lioness? - iv. 3 the lioness had torn some flesh away - $\quad$ iv. with your lioness, l'd set an ox-head. King John, ii. I the mountain lioness, the ocean. Tilus Andrnn. iv.

$\mathrm{II}_{\mathrm{L} T}$ II'-or of your lips $\ldots \ldots \ldots \ldots \ldots \ldots$ that the lips is parrel of the mouth ... or I will not open ny lips............

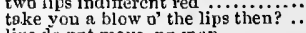

lips do not move, no man $i \dddot{0} \ldots \ldots .$.

attested by the holy close of lips......

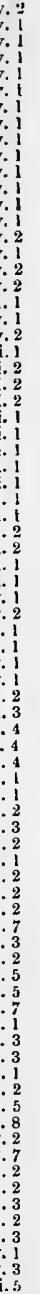
3
3
1 
LIP-hreathe withiu your lips I will open my lips in vain $\ldots \ldots . . . .$. take, uts take those lips awn

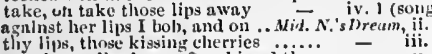
thy eherry lips have often kissed thy $[\mathrm{Col}$. Knt.] these lily lips, this eherry nose my lips are no common

I profune my lips on thy

when.I ope my ligs, let no do........ Mer of rence, i. 1

then open not thy lips

bought a pair of enst lips of Diana

a pretty redness in his lip i............

mude to eat, and lips to open

lins neither leg, hands, lip, nor eal..... $A l^{\prime}$ 's $w e l l$, ii.

as the nun's lip to the friar's moun lips to move.....

nor bite the lip, as angry wenehes..

my very lips might treeze to .........

kissing with inside lip? stopping .....

and talling a lip of mueh contempt.

eye, nose, lip, the triek of

have taken treasure from her lips....

the very lile seems warm upon her li

the ruddiness upon her lip is wet

finger laying upon her skinny lins ....

nose of Turk, and Tartar's lips

and your lips too; for I am well....

the murmuring lips of diseontent.

bleak wints kiss my parehed lips
with $\mathrm{my}$ teeth, and lips; ard dull

the attainder of his slanderous lips

shall daub her lips with her own...

and to tilt with lips; we must have.
0 villain! thy lips are searee niped.

foolish hanging of thy nether lip...

ny love, give me thy lips

and his lips plows at his nose.........

wounded arm, and kissed his lips...

then I will kiss your lips, Kate..

you have witeheraft in your lips, Kate

when my lips do toueh his eheeks

with mother's dug between its lips

with mother's dug between its
to have thee with thy lips to
thy lips that kissed the queen

thy lips that kissed the queen
or else hold elose thy lips .....

or else hold elose thy lips .......

and with thy lips keep in my.....

upon the lips of this sweet babe.

a eherry lip, a bonny eye .......

never pass the lips of those that....

see, he gnaws his lip. I will con

their lips were four red roses on....

divide thy lips

lay thy finger on thy lips!

truant vows to her own lips he loves

hites his lip with a politic.

which enld lips blow to their deities

rudely heguiles our lips of all.....

that winter from your lips, fair ....

her eleek, her lip, nay, her foot .......

imagination moves in this lip.... Timnn of

treads upon his lip, and yet..........

as he would to the lip of his mist
thy lips rot off? I will not kiss

returns to thine ow

lips, let sour words go by

marked you liis lip, and eres?

I will make a the hristled lips before him

make motion through my lips.

excented ere they wipe their lips
yet to bite lis lip, and hum at

my true lin, hath virgined it e'er since

coward lips did from their cold
for fear of opening my lips

for fear of opening my lips.
do ope their ruby lipa, to beg

Antony \& Cleopatra, i.

mestowed his lips on that unworthy...

once more to kiss these lips............
enmmend unto his lips thy favouring

enmmend unto his lips thy favourin
divided hetween her heart and lips..

the poor last I lay upon thy lips

had my lips that power.............

of Egypt's grape shall moist this lip

take the last warmth of my lip

have I the aspick in my lips?.

slaver witls lips as eommon............

let me my service tender on your lips -

should from my lips piuek a hard

rise and full between thy rosed lips, Tilus An

let me kiss thy lips.

this warm kiss an thy pale cold lips

fill to tenters on thy lip

fill to your mistress' lips ............

your hands and lips must seal it too...
on the touching of her lips I may ....

ii.

I.IP-smiles, that played on her ripe lip ..Lew, iv. 3 I.IST-liat a brief tale

frower to seal the acenser's lips

look on her, lonk, - her lips

o'er ladies' ips, who struight .....,
have not saints lips, and holy (rep.

dear saint, let lips dn what hands do

thus from my lips, by yours, my sin
my lips the sin that they have (rep.)

her searlet lip, by her foe tont

judgment vanished from his lips $\dddot{2} . .$.

and these lips have long been sepurated -

ensign yet is erimson in thy lips....

and lips, $O$ you the doors of breath

1 will kiss thy lips; haply some poison -

thy lips are warm ........................

here hullg those lips, that I have kissed - y.

yet again your fiugers to your lips?

they met so near with their lips

I found not Cassio's kisses on her lip.

by the roots, that grew upon my lips
pish! noses, ears, and lips; is it possihl

to lip a wanton in a seeure eonch

i.. 3

why gnaw sou so your nether lip?

torments will ope your lips.

Y. 3 LIPSBURY-in Lipsbury pinfold ........ Cleo. ii. LIQUID-deeking with liquid peari...Mid.N. In i , the liquid drops of tears

the liquid drops of tears ........... Kicliard III. iv. whose liquid surge resolves.... Timon of Alhens, iv. in the morn and liquid dew of youth .. Hamlet, $\mathrm{i}$. in steep-down gulfs of liquid fire!....... Othello, and bears eelestial liquor.

this grand liquor that hath gilded them?

ther liquor Tuogen. of Fer. iji.

that o'erflow such liquor ........

drop the licuor of it in her cyes.

whose liquor hath this virtuous

hot and rebellious liquors.......

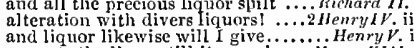

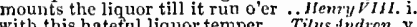

and this distilled liquor drink.

and feteh me a stoun of liquor ........ Hamlet $\mathrm{v}$

here's yet some liquor left

Hanlet, v.

IISBON, Barbary, and India? ... Mer. of Venice, iti.

LISP -he can carve too, and lisp ... Love's L. Lost, v. 2

you lisp, and wear strange .......As you Like it, iv.

Le not lisning thorn buds

sueh antic, lisping, affecting ...... Romeo \& Jutiet, ii.
LIST_your licutenant, if you list ..... Tempest, iif.

if thou beest a devil, take't as thou list - iii.

go to hed when slie list (rep.) ........erry Wives, ii. 2

she is the list of my voyage...........

between the lists and the velvet (rep.)

I had as lief be a list of ............. i. 2

think what I list; nor I list not......... All's $W^{\prime}$ ell, ii. 4 list to me, I am my father' $8 .$. Taming of Shrew, it.

seize thee, that list; if once............

take him up, quoth he, if any list

I list not propheer

Winier's Tale, iv. (ehorus)

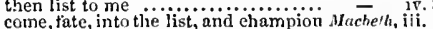

son, list to this conjunction............ King John, ii. 2

in his royal lists? against.

in lists, on Thomas MIowbray

daring hardy, as to tomeh the list

draw near, and list, what with ......

[ $k$ inl.] for a while, and list

the very list, the very ut

and eonquers as she list

forsaketh yet the lists by reason

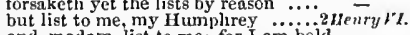

to enter the lists, so please your

see the lists and all thiugs fit

of fortune, turns what he list .....iirnry $\bar{r} M I$. ii

sliould she remember? List 1 .. Troitus \& Cress,

list, what work he makes

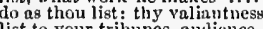

list to your tribunes, audience

olumnins, list a worl ........Julius Cepsar.

a more larger list of sceptres..... Antony \& $\$$ Ctco. iii.

stand elose, and list to him ..........
will she do what she list...... Titusdrandrons, iv. 9

I assume the lists, nor ask ............... I'ericle's,

of the spheres,; list, my Marin

within the lists of the ormy

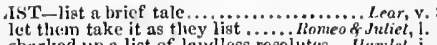
sharked up a list of landless resolutes.. Humicl, j. the lists, and full proportions...

list, list, [Knt.-llamlet] () list! if eve

or, it we list to speak

whe ocean nverpeering of his list, cats nnt list to me. The licutenan:t to-niglit.

do what she list, even as lier appetite.

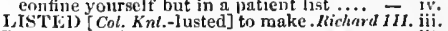

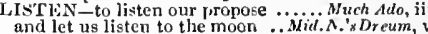

and readingt listen, ear.............nre's $L$. Lort,

listen to me, and if you speak me... Taming of $\mathrm{sh}$. $\mathrm{i}$.

teach your ears to listen with ...Comedyof frr.
listen, but speak not ................. Marberth,

king Philip, listen to the eardinal ........ing John,

on Tueslay last to listen after news...2 Henry $1 \%$.

lads, vonelsafe to listen what I say...1 Mrnry 1 '.

she will light to listen to the lays ....2 Lenry $V i$.

and listen after Humphrey, how
pr'y thee, listen well; I heard ....

now Octavius, listen great things

listen, fair madam; let it be .Tilus..indronicus, ii.

faith, they listcued to me, as they

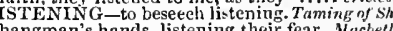

do so, for it is worth the listening to.. . Hacbeth, ii.

it is the discase of not listening ......2Ilenry $I V$.

almost with ravished listening....... Ienry $V$ KII.

it nips me unto listeniog, and thick...

IITERATURE in the wars.............. Henry $V$. LITIGIOUS-in a litigious peace . . .... Pericles,
LITTER-the son that she did litter here. Tempes ITTER-the son that she did litter here. Tempes/, i.
blind puppies, fifteen $i^{\prime}$ the litter.. Merry IVives, iii.

to crouel in litter of your stable ..... King John, $\checkmark$.

to my litter straight; weakness .......

Pendragon, in his litter, siek ...... i Henry Y. iii.

there is a lit ter ready; lay him in't ...... Lear, jii.
LITTERED under Nercury ....... Winler's Tale, iv,

were two liough in Rome littered ...Coriolanus, iii.

IT'CIE-Our own doth little advantage. Tempesl,

hear a little further ...............
of that there's none, or little

who shall be of as little memory

alter a little time ..............

has doue little better than played.............

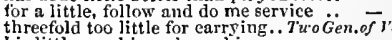

his little speaking, shows his

the reason I love lim so little.

a little time will melt her (rep.)....

I have little wealth to lose $\ldots$...........

what says she to my little jewel?

a little wee face, with a ilitt

tarry you a little-a while .............

not so little graee, I hope

to send her your little page $($ rep.).

to press with so little preparation.

you little Jaek-a-lent, have you

I would little or nothing with youl ...

with as little remmrse as they ........

my daughter, and my little son....

hetter a little chiding, than a great ...

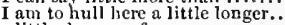

a little, by your favour

here eomes the little viliain.

yet, to erush this a little, it wouldi....

all the devis in hell be irawn in litile

let me speak a little.............

hold little faith, thrugh thou ........

leave my duty a little unthought of $-v$. 1 (letter

and rather cut a little, than fall.. Meas. for.Meas. ii.

stay a ittle while...................

ha! little honour to be mueh....... =

a little mnre lentity to lecliers would do -

but indeed, I can do you little liarm

this other doth enmmand a little door

il'it be too little for ynir thief.

your thief thinks it little ennugli ....

offenil you, we'll have very litcle of it

the better for being a little bad ......

and too little for a great praise ......

thore's little of the melanelinly ......
of this matter is little Cupid's erafig

and the little lianzman dare not....

speaks a little off the matter ........

and salt ton little, which may reason

that you are little better than false.. i. 


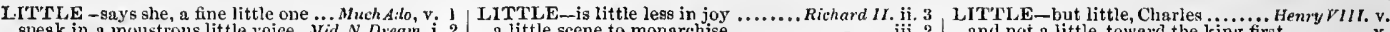
no but beg a little changeling

the wren with little quill ...........

iii. 1 (song)

reason and love keep little company

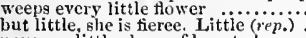

never so little show of love to her....

o'er the house to unlock the little gate

but little ut the marking of it

thou pretty, beeasse little (rep.).

and mueh too little of that good 1 saw

it seems, he little purposetli...

his almiginty dreadful little might

king Pepin of France was a littie boy
Gunnever of Bitain was a little weneh

Priseian a little seratelied; $t$ ' $w$ 'ill serve

you see low 'tis; a little o'er-parted.

through the little hole of diseretion.

my little body is aweary of this ...Mer. of Fenice,

how little is the cost I have bestowed

to do a great right, do a little wrong

your wife; would give but little thank.

tarry a little; there is something else
like a little shrew, slander her love

how far that little candle throws ....

it looks a little pulet

little serubbed boy, wo higher.........

that there is little hope of $\mathrm{l}$ ife in $\mathrm{inm}$

you will take little delight in it.......

little recks to find the way to heaven

a little, comfort a little (rep.).

forbear your fuod a little while.

heaven would in little sh
shepherd, go off a little...

let's meet as little as we can

than a great reckoning in a little room

go hence a little, and $I$ shall

a little riper and more lusty red

my pretty little coz, that tho

that on so little acquaintanee

than may in some little measure...

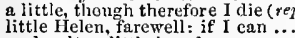

and writ as little beard

is within a very little of nothing

though little he do feel it .......

in his sleep he does liftle harm

I have but little more to say

to be toolittle for pomp to enter ....

my fears of little vanity, having (rep.)
thouddst thank me but a little.... Taming
scolding would do little good upon him

an' she stand him but a hittle.......

think you a little din ean da
walk a little in the orchard

walk a little in the orchard $\ldots . . . . .$.
little fire grows great with little wind

were not $f$ a little pot, and soon hot.

thongh tiiy little finger be armed....

a lias a little galled me, 1 confess

ton little payment for so grea

cannot praise us, as little aecuse... Win

dares trust me with her little bahe

a!thongh the print be little.........

upon liermione I little li

to be or none, or little.............

that know lit tle but bowling

eonsider little, what dangers

after a little amazedness, we were...

and himself little better, extremity

mark a little while; please yon...

holy sport to he a little vain.. Comedy of Errors, iii. 2

a little water elears us of this deed...... Macbeth, my little spirit, sec, sits in

as little is the wisdom, where.

hence, with rour little ones....

pardon me, mad thing than earth .

pardon me, madam; little joy have

it is too little, helping him to ali...

being ne'er so little urged.

thoughts people this little world .....

as thus; eome, little one

my

anld 'tis nulittle reason bids

1'll break thy little finger, IIarry

iii. 1 pray you, ftay a little, ny lord

where of a little more than a littie

swore little; diced not above seven

steps me a little higher than his vow

keep in a little life; poor Jaek

virtue is of so little regard

of their puissanee made a littie taste

you whoreson little valiant villain.

al, you sweet little rogue, you l......

good advice, and little medicine

little John Doit of Stafurdshire
give me always a little, lean .

to all the rest of this little kingdom

we want a little persenal strengtli

stny but a little; for my cloud

any pretty little tiny kiekshaw

I have but a very little eredit.......

and my little soldier tleere be merry

may attest, in little place ......

I say little but when time shall

I would priek pour guts a little ....

f little faults, proceeding on distemper

small breath, and little pause

for pix of little price ......

a little touch of Ilariy in the

though it appenr a little out of

but in gross brain little wot
a very little little let us do

shall yield them little...............

also being a little in toxicates .......

\begin{tabular}{l|l} 
ii. 3 & ever known so great and little loss.. \\
ii. 4 & tell him a little pieee of my desires
\end{tabular}

in little room eonfining ..............

lingering wars, with little cost.......

partakers of a little gain

a owe him little duty, and iess love...

my death the French ean little boast

of stands me in int tle stead...

harl been a little ratshane for

as little shall the Frenehmen
make but little for his benefit

some renson, of no little force

but little thinks, we shall be of...

though with a little axe .........

down a little wlile to breathe .......
we'll hear a little more. My queeil

she could say little less ................

a little gale will soon disperse .......
good was little better: pood $\ldots \ldots$ -
maintain it with some little cost ...
Richard III.
i.

as little joy, my lord, as you (rep.)...

nay, I pr'y thee, stay a little $\ldots . . .$. ...

with some little train (rep.).

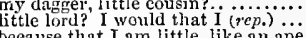

this little prating York was not......

cradle for sueh little pretty

some little pause, dear lord ...........

and little Ned Plantar

a grandam's name is little less ......

great a cliarge as little honour...

..Henry $\overline{V I I I}$

We cimnot feel too little, hear too much

for iny lit tle cure, let me alone

with daneing is a little heated

the eause he may a little grieve at

which makes me a little happier.

pluck off a little: I would not be.
in faith, for little England you'd.

in faith, for little England you d....

in England, but little for my profit..

she now begs, that little thought....

you have as little honesty as nonour

you'll ghow a little honesty..........

my little good lord eardinal (rep.)

like little wanton boys that swin

now, methinks, I feel a little ease

give him a little earth for charity!
found the blessedness of being little

found the blessedness of being little iii. 2 and not a little,toward the king first and with no little study, that my ..

I make as littie deubt, as you ......

iii. 4 you are a little, by your good favour

I have a little yet to say ............

this little one shall make it holiday

whose grossness little elaraeters. Tro

at your request, a little fion himself

to give me now a little benefit ......

to dust, that is a little gilt

a little proully, and the war

axtremity of great and little.... .

and too little brain, these two may..

stay a little while. How the devii ${ }^{\circ}$

I will strain a little, for t'is ....Timon of $\bar{A}$ the

as this pomp shows to a little oil:....

there will little learning die then...

there was very little honour showed

deep enough, and yet find little

sliould hrook as little wrongs, as ....

needs say, you have a little fauit....

to scale $t$ a little more $\ldots \ldots \ldots . . . . . . .$.

how does your little son? I thank...

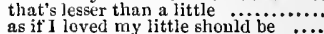

as if I loved my little should be $\ldots$.

I know you can do very little alon

to report a little of that wortliy work

a little help will serve.

with these that have but little .........

I liave a heart as little apt as yours..

as free as words to little purpose.

afire, and then I'll speak a little ....

and, sir, it is no little thing, to make

like to a little kingdom

let me a little show it, even in

lead their charges off a little from thi

Whieh we will niggard with a little rest

of 'secresy, a little 1 ean read. Anlony \& Cleop atrc
or a little, I sliould say myself offended

little jealousies, which now seem great

jittle thought, you would have followed sleep a little. No, my chuck: Eros.

yet come a little, wishers were $\ldots \ldots$

nay stay a little 0 , the earth ........

as little as a erow, or less .............

these boys know little they are sons

who may, haply be a little an ........

than themselves for wrying but a little

with the little skill I have .... Titus And

or get some little knife between......

the eagle sufters little birds to sing

and finding little eomfort to relieve.

were all too lit tle to content and please

t $\theta$ eat those little darlings whon,......

of your queen, $-a$ little daughter........

if you require a iittie spaee for prayer

that lay witl the little boggage........

thou little know'st how thou dost ....

O stop there a littlel ..................

mend your speeeh a little

it is not $a$ little thave to say

we have made of it hath not been little.

till some littie time hath qualified
him that is wise, and says little

thou hadst little wit in thy bald crown. this house is $i$ t the; the old man

O I have ta'en too little eare of this

thus little merey on their fesh?

now a little fire in a wild field were

Cordelia, Cordelia, stay a little ............

with a team of little atomies...... Romeo

stay but a little, I will eome again ..

who lets it hop a little from her hand

when 'twas a little prating thing....

eut him out in little.sters.

and little mouse, every un worthy thing

[Knt.] hear me a little speak ........

in one llttle body thon eounterfeit'st

therefore have I little talked of love

nis rest, that you shall rest but little

a little more than kin, and less than $\mathrm{kind}$

a little month; or ere those shoes

as twere a thing a little solled ......

here in our court some little time...

an ajery of children, little eyases.
二 iv. iv. 13

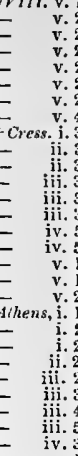

iolanus, i.

i.
i.
i.
i.
i.
ii.
v.
.
i.
i.
.
.
.
.
.

iii. 3

iv. 1

-


ITTTLE-a-piece, for his pictnre in little. numlet, ii. though it lacked form a little.

excellent voice, in this little orign

bestow this pluce on us a little while.

we go tn gain a litlle paleh ot groum

they shull go far with litle.................

with the little golliness I have

little blessed with the set phrase of perie

and little of this grent world enn 1 , peuk

she puts lier tongue a fitle in her lieart

you have little eanse to say so.
with as little a web as this, will

with as iiftle a web as this, will I.........

mul a lit tle more wit, return to Veniec.

entreats her a little favour of speec

sce, this hath a little dashed your spirits

your napkin is too Jithle; let it atons

the raek: than but to know't a little

bring ine on the way a little

tis but a little way, that I ean bring you

with this little arm, and this good sword

LITTLEST - the littlest doubts are fenr. Hamlet, iii.

IVE-merely ehented of our lives ......

Tempest, i. 1

this lives in thy mind?

sir, lie may live; I saw him...

long live Gonzalol $1 . . .$.

lreing most unfit to live.

where live nibbling slieep

let me live here ever. $\because \dddot{i}$ live now...... - iv.

merrily, merrily, shall I live now... - v. I (song)
how happily lie lives ........ Tico Gen. of lerona, i.

sourcet-1natored dous the

than live in your air

they live by your bare word

command me while

let me vot live to $100 \mathrm{k}$

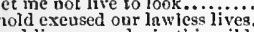

and live as we do, in this wilderness?

thou shalt not live to brag what......

and will live with you.........

gure as I live, he had .....

if shome thine she lives

whilst I live agnin...

centleman born.. - i. 1

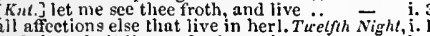

and thou ghalt live as freely as thy ...

an' we do not, it is pity of our lives...

shall this fellow live?.

dost thou live by thy tabor?.............

I live by the ehureh (rep.).....

I will live to be thankfu]

too doubtful soul may live at peace...
live rou the marble-breasted ........

live in thy tongue and heart ...........

but, whilst Ilive, forget to
that would live. How would you live

if you live to see this eome to

but, when they live. to end

lives not to act another

your brother cunnot live

tien Isabel, live ehnste, and brother $^{\circ}$

I have hope to live, and am prepared

tw sue to live, I find, I seek

yes, brother, you may live

that it will let this man livel

that is thy means to live $\ldots .$.

if 1 may live to report you

unfit to live or die: 0 gravel hearti...

the best is, he lives not in them

than will live a bach lives to fe

and there live we as merry as the day

a nan may live as quiet in hell 1 .....

no glory lives behind the back

do not live, Hero; do not ope

the practice of it live

bit my danghter live, that were...........

he shall tive no longer in morre....

lives in death with glorious fame

but I do live, and, surely, as I live

to live a barren sister all your ...Mid.N.'s $\overline{\text { Dream }}$

grows, lives, and dies,
no live, so die, my lor

in those frekkles live their savours....

upon the next live ereature that .....

all hunt after in their lives, $\dddot{i} \mathrm{i}$ e....... Love's $\bar{L}$. Los

for three years' term to live with me

to live and study here three years.

to have his title live in $A$

where all those pleasures live, thal art

for a light heart lives lon

for a light licart lives long........... - iv.

if I live to be as old as sihylla ......

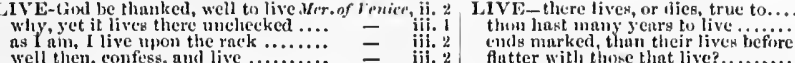

well then, confess, and live

will live as ninids and widows.

fivter with those that live?..

love they to live, that love

it is impostible I should live to live in prayer and entenplition..

whieh live like vonom, where

e'en as many as conld well live ......

than to live still, and write mine
take the means whereby I live

'yainst us, our lives, our ehildren..

where nothing lives, but crosses ....

our lives, and ull are Bolingbroke's.

if lie live to le a man (rep.)

well, while I live, I'll tear no.............
where will the nld duke live?

and there they live like the oli roobiu

the enemy of all your graees lives...

but now live here no more.

ere the crown lie lool fur live in pens....

they trearl, now whilit I live

that benring bouglıs may live.

or drink, or breatle, or live....

live a little, comfort a jitlle.

and long live llemry, of that name...

long may'st thou live in Richard's

it there live any thing in this desert.

and I to live and die her sin

our holy lives mast win a new

mine honour lives when his dishonour

the traitor lives, the true man's......

and to live in a nook merely

or we must live in bawdry

he that dies and lives by bloody

and here live and dic a sheplierd.

I cau live no longer by tlinking

so in nproof fives not $\mathrm{hi}$.

let me rot live, - thus his good $\ldots \ldots$.

ridtlle-like, lives sweetly where....

Whetleer I live or dic, be you ...
sny to him, I live; and observe

to those that wish him live

health shall live tree, and siekness...

ever whilst I live, into your guiding

with eamping foes to live .........

for which live long te thank both

Thlive and die a maid

if I were to live this present hour

let me live, sir, in a dungeon (rep.)

the thing I nm shall make me live.

your love must live a maid at . Taming of shrerr, iv.

my fortune lives for me.

if whilst $I$ live, she will be only mine

one that seorn to live in this disguise

need none, so long as I live

to iive. If the king liad no $($ rep.)....... Winter

she would not live the running of one

a goodly babe, lusty, and like to live
sliall I live on, to see this bastard....

but be it; let it live; it shall not.

while she lives my heart will........

pou're well to live; gold! all gold! .. - ivi.

and only live by gazing

we may live, son, to shed many more

he'll think anon, it lives

but it appears, alie lives, tiongh yet...

to redeem their lives, have scaled.Com

to make up the sum, and live .........

if thou live to see like right bereft....

thy sap, and live on thy confusion

to none that iives here in the eity.....

he ehall live a man forbid ..........

二

prison, where I live, unto the

to make misfort une live? $\ldots \ldots \ldots \ldots . .$.

wide mouth we live senndulized

young men must live..............

O, while you live, tell truth

and, as true as I live cheese...

so fretful, you eannot live long....................

yon, my lord, or any Seot that lives

[Col. Knt.] all our lives shall be stuek

all his offences live upon my head

if we live, we live to trend on king

nnd leave snck, and live eleanly

you live in great infamy

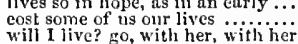

Will I live? go, with her, with her
I must live aunong my neiglabours

he lives upon mouldy stewed prune

there is a history in all nientow.

all their lives, that, by indietment

live, by which his grace must (rep.).

and never live to show the incrednio

to our purposes, he lives no more

till you do live to see a son of mine

so shall I live to speak my father's

and a merry heart lives long-a....

your lives, your faith, and services
will live so long as I may (rep.).

thint live honestly by the prick of their

for lambkins, we will live............

I have not a case of lives; the humou

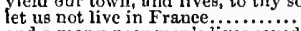

and a many poor men's lives saver

a quarrel hel ween us, if you live...

let us onr lives, our souls

and if to live, the fewer men...........

ghnll wituess live in brass of this

fo offer up our lives unto these

who, if a live, and ever dure to

so I will, my liege, as I ive ...........

toe famous to live longt............................

why live we idly here? Tallot

and live a eoward in thine ow

whiles I threat, he lives
whetler they live, or die

though our lives-Your spirits

I hear, Mlueduff lives in disgraee

dne of birth, lives in the Englis

thou slanit not live; that I

shall live the lease of nature

now not to live;

and good men's lives expire before

and live to be the show and gaze...

who lives and dares but say..................

there to live in pence! ...................

rescue those breatling liven to die in

which only lives but by the death..

there wliere my fortune lives.

he shall not live. Enough

well, see to live; I will not

fault lives in his eyc $\ldots \ldots \ldots \ldots \ldots . . . .$.

Arthur doth live: the king hath

told me, lie dill live. So, on my soui

a treacherous fine of all your lives.

and too had to live... your lives...

despite of death, that lives upon....... Richard

in that I live, and for that will.

be ready as your lives slinll answer it
thy youthful blood, be valiant and live -

and while I live, I ll ne er fly ........

his trespass yet lites guilty..........

my liberty, and they their lives.
as sure as English Ifenry lives.

meet where botli tlicir lives are done

meet where botli ticir lives nte done

for live I will not if my futher die
side by side tourether live nut die

side by sile togetler live and dic
all our lives in one smail hont...
we will have no bastards live

we will have no bastards live
an' if it had a thousand lives

Warwick may live to he the hest of ail

the duke yet lives, that Ienry (rep.)

Riehard sliall live to make the ....

done, live in your country here ......

and I may live to do you kinuness

weeps, that thou dost live sn long.

intends to live with that dreal king...

from thee, I cannot live...

so thou wilt lel me llve. nind fees ....

en I make men live, whe'r they ....
the lives of those whirdh we have lost

take runsom, and let him live....

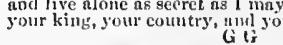

ichard H. i.

ii.

ii.

iii.

iii. $\frac{2}{2}$

iii. 3

iii. 3

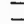

二

三

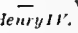
二
= iii
- iii. 3

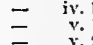

an' if it hind a thousund lives .......... =

long live queen Marguret, England's..2Henry $\%$ I.
shall 1 not live to be nvenget ...

your lives =

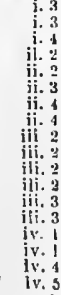


1.1 E- - berm mast worthy to

Olet me lived l feel retherse

nor kinews he hew to live, lout by

whilst you live at inr ............

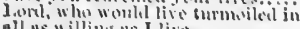

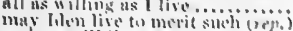

and we will live tose their the

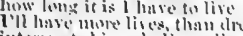

interrupts him, shanll mos liv

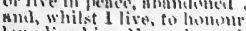

long live kitg llenry! trept the as

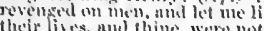

ous nlive, l lisw in bed

let me live in prisom nal iny digy.

Alteniyl I in

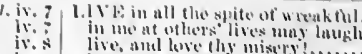

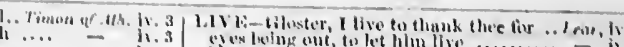

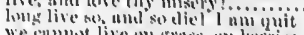

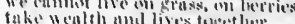

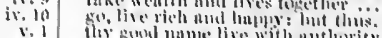

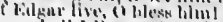

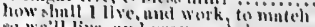

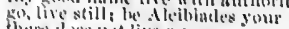

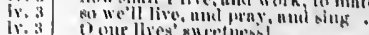

the be ches bist live a man ...........

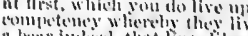

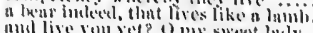

mols lise you yet? () my sweet lady

nt . Nutiun lives lat? nt Antium

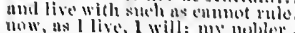

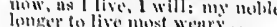

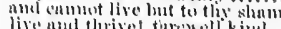

ne'er may lie lise to sev a sminhino

their ont lives in this some's cleferice

gears a motetal man may live

a thousand lives must withe

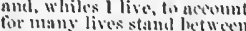

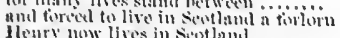

henry mow lives in s'otland

lowg live bilwnel the tourth

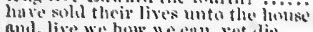

and, live we haw "sesme, yet die.

ret lives ceur pilot still

why shomld she live, to fill the worlet

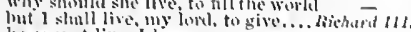

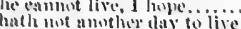

hath mot anothere day to live
Eitwand still lives, and reigns

eresping venomed thing that live

he lises that loves yom better.

cambst a plain mun lise, und think.

long may' st thom live to wail thy

that mone of you nay live your....

that means to live well (irej, ................

dear lowther, live, and be a king?

if you will live, lament

the truth shombl live from age to ng...

they say, so wese live lon

withent clumeters, fatne lives long....

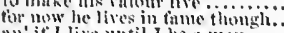

not it lire mentil I be a mat

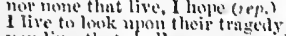

vou lire, that sluth ery woe (reg.).

lives like a drumken sailor on al mast

by great preservation, wo live to telt

you kum, my mother lives..... How

minl live with lichmonel

still live they, and tor erer let.

youm Elwarl lives: think now (rep.)

that bilunrd still shonlil lire.

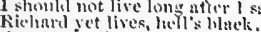

that I muy live to suy, the elog is cleat!

Olet her live andirlives.

so she ming live unsenred of

no, to their llies hat fitiends were

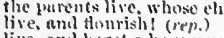

live. and beget a hnuly race ot kings.

hergars, weary of tleeir li

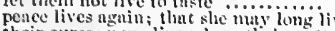

their eurses now, live where their .
nay his litghness live in frectum ....

may lie live lunger than I have time

we live mit to he gripet by

to be homest, null live a snliject? ....

the letter, ns 1 five, with nil the...

if we live thins tamely, to be the....

your meditntions how to live lictier..

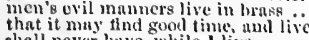

shall never have, while 1 live

as Ire and die i' the eyes of 'Treilus. Finilus

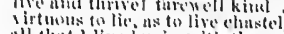

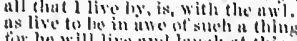

tow he will lixe mul hugh at this

that virlue emmat live wht of the

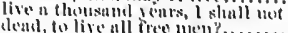

sead, folive gll free nen?

the avil that men do liros atter them

met liv' why is your sisters som (opp.)

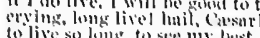

to live sol hing, forese my hest ..........

the tears live in 411 oniton

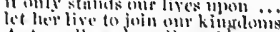

Alltony lives, is well, or triculs with

and reguires to lise in wayght

i. men did pansm lives of me for jests

or l will live or lothe my lyomg $(r+p)$

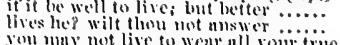

voum not live to wear nll your trie

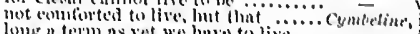

shomal he make ne live like Diund

when one is tiond, un

stmin the ktens, why, then slie tive live.

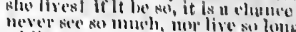

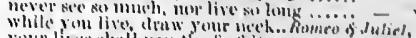

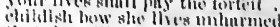

that she will still hive chaste

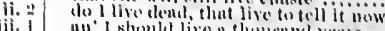

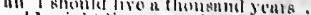

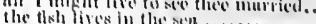

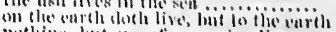

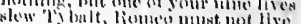

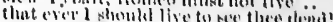

my lusband lives, that ryoule wesula

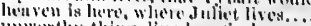

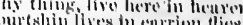

tlyo lady tow thent lives in theo

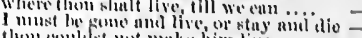

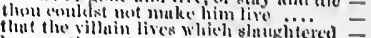

beanse the traitor mureser liven

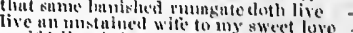

or, if live, is it mot very like......

contusim sore liges net in these...

m' you will luve me live...........

lere humbertul purt with angols lives.

take them that: Hive, und be proseserens

live, and herenfler shy-n muelmums

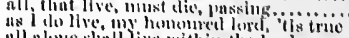

thll nlente slinll hire within the losok.....

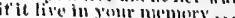

than their ifl refent why o.....

mortiect alremely, all lint one, slinll tive.

thou shate live in this tair worle belinel

denente, mad tevel, "nom your mujesty.

may, lont to live in the rank swent of

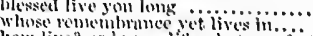

how live? or in my lite what eonfort

hy this male place we live in

thine live Casar! is Lneins generni .

summer lasts, and I live here, Fiidelo

sinee shy your live's you fet so sliglat.

there are verlerksanves sesire to live...

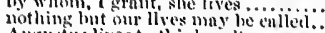

Augustus lives to think on t..........

to sty live boy: ne'er thmk thy (rop)

1 hud rather then shonkst inve while

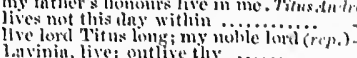

lavinin, live ontlive thy ...........

mul say, lang live our eth1

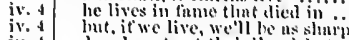

hut, it we live, we'll be us slury ....
drencls not yet theirlives" thestruetion

mower their susperisn with their lives

mene shnll save my brothers' live's

ner lavina lives, lint in ohitiviom

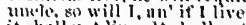

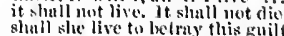

shull slue live to ledruy this guilt .....

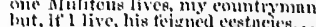

thut justiec lives in suturnimus hienith
the promest conspluntor that lives ..

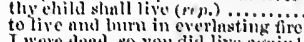

why yet live to way, thls thing's to tlo"

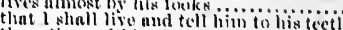

there lives within the rery tlume

thus unknown, shinld live behinel nie?....

onnent hive to heme the news

.

if the malmee of une lives lum not one ...

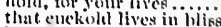

long live slie so!! and long livo.......... - iii.

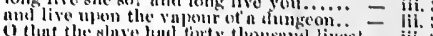

but, let leer live. 1 bum lice

fer she sluall nut live

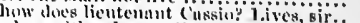

where either 1 must live, or heres,

live liselerlgo, Jie enlls me to n restituition

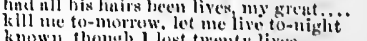

dicl le live now, this sight would make.

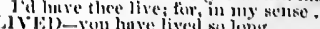

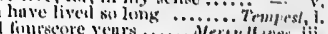

tor 1 hove livet long cinugh .............

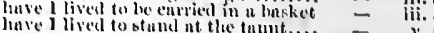

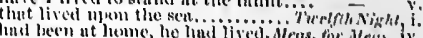

ie shomaliave lived, enso the his ... - iv.

wemlel yet he hul lived

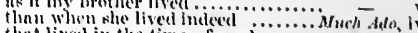

that livel in the time of good .......... - v

lorels and and so you diel live ngain! . - Y

as you will live, resolvo it you.... - -1 , i (ridelle)

as thim noilt live to trimpet forth....

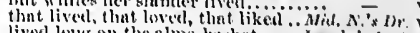

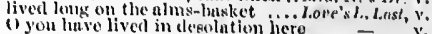

i. 1 when in the werlit 1 lived, 1 was.

I maryel huy the thates live in the sen

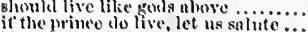

it in the workl lac live, we'll secele hiin

live nutle in

so dyning lowe lives stilfecties........

weep fens, live in flre, ent roiks.....

you say, live to eome in my lielial

for we may live to have need

gentlenten, this queen witi iive.

is pretty a prepertion to live allietly

ay, and you shull live in plensture.

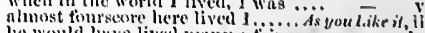

Fon biu then rise, ant live.

and live nye with thy name

to weep that you live as your clo.

the onos unvo lived nany a thir year

skilful enomght to liave fived still......

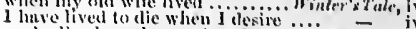

us slu lived pecrless, so her dend likeness -

muke't manitest where aln law livel =

where lived" low fomet thy thither's

with her 1 lived in joy......... (emedy of krors.

Thad lived a blexsed time

where slo yom live? ..................

freelom lises henee, niü banisho......

linterery ding she lived.

he only livel but till he was.

when thut my father ivest, your.

lived ued, not in good compus...

to hold on lives in merey

long may lie live in firtunes

who lives, that's not clepraved
that you may live only in hou

that you may live only in hone........

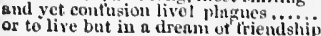

kep lenee, minem your live

nud 1)ires tlut fived in purple

When Rielured lived, wonld hus
inve net lived all this w hile

Kinntunlan

if wle live long, nne, in the end

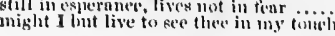

most greatly liverl this ster

Arnyll, iij.

Alemylt:i. 


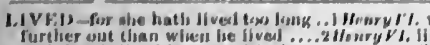

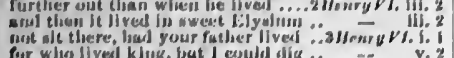
for whos llved kling, fout J esulind dig

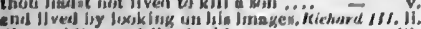

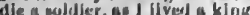

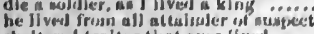

ahe luerod traikar that ever fivesl.......

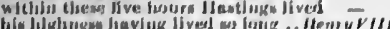

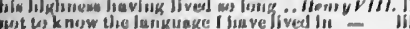

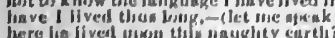

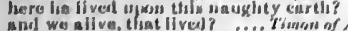

and we alive that livew?

have I abre lived to mee twr lusucut iness?

thinge liver to meve inheritud

wheni Civenar liveri, he darut nont .

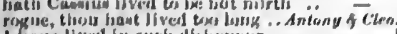

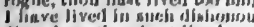

die, where thou hast IIverl.

wlitrein f IIved, the krenteat yringe

alnove the eilentent tisey lived in .......

(1) Coesur, thin Cliarinjun llved bist now

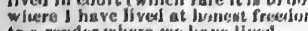

in a render where we lanve lived.

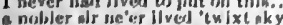

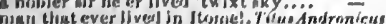

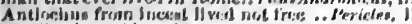

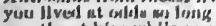

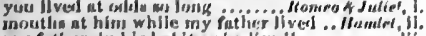

my fatlier, In hilo lisbit as lue li vest! .... - isi.

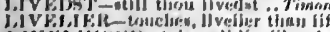

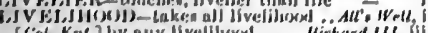

If fol. Knt.] by any livelils'sul,

the livelonk dey lorieak o w:urril

tivere liave mat the liveliong d,

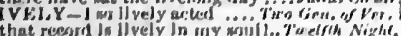

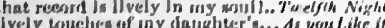

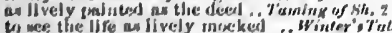

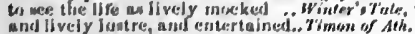

thou counterfelt it inim! IIvely

jow I lephisit thy lively budy

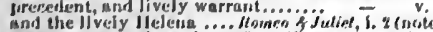

LIV Fill alsatee the ardour of my liver. 'Trmpenst. iv.

vith liver burnlug bet.............. strisy

when Jiver, loruln anil licart

Fuelfh Niuht, I. I

llise winn him, liver and ail

arid briming in in your ll ver

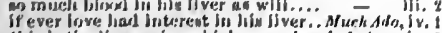
thin in tive liver veín, whisith.....

and let iny liver rallice hica.

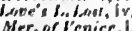

have livere white an milk?

were my wife' liver liffected

liver of olanjlicting $\mathrm{Jew}$

Ae you sithe in

Winter's Tisle, lot liverw, anis rold gurser.

lefictioe liver white and valce.

iiinemell,

I will inflame thy nolsle liver.

with humble Jivers in content .........jenry v 111.11 . \&

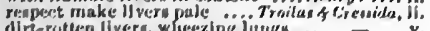

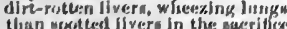

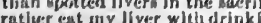

not

tisink, there wivers out of J Isitain

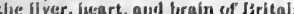

and the foncer ijver take all .... Homen o Jutiet is

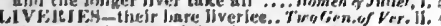

chauge their wonted ilverles...Mid. S.'s i)reum, ji. 2 glves rape new liverion......
just the Jiverlen

cime ts have made new liveriẹ......

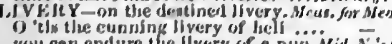

you can end ure the fvery of a nist. Mid. N. "o dir. i.

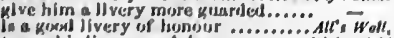

to mue his livery, and deny.

Michord 13. Ii.

denied to ane iny livery here.

ajuarel them afl in one livery

the wiliver livery of al vimed age.

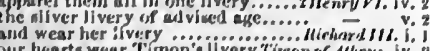

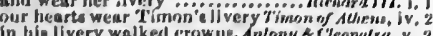

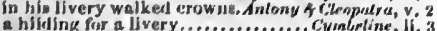

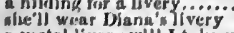

d'erictes, if.

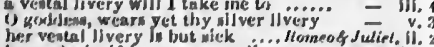
lianged, wir, if he wear your Ifivery... nature' livery, or fi,rtune' ntur.

glvea a frock, or IJ very, tlout apt

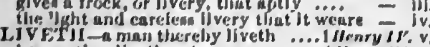

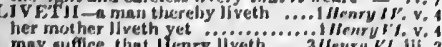

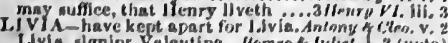

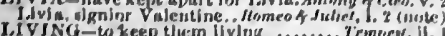

and art thon llviog, suephus

eliving droilery

thint a fiving urince joe..............

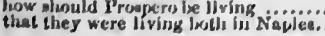

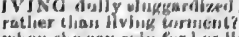

whell atie enon whin fir liee living

等

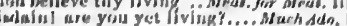

there were mo livlng sueur fin

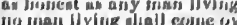

thas) youtr llous dliviou

witli all theme llvlug in phi

and youra frum lespe livinges

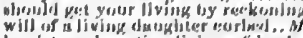

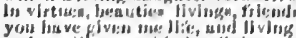

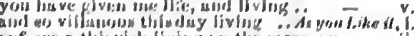

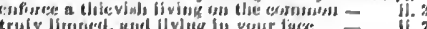

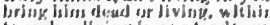

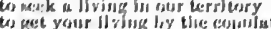

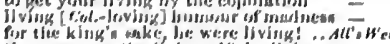

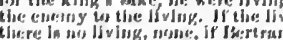

if lie were living, I woujed try lian

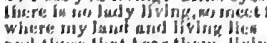

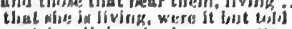

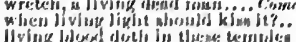

astheuplo ing will en glve lu diving

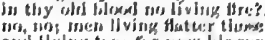

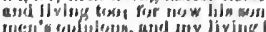

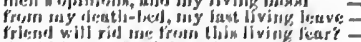

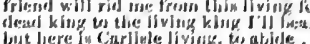

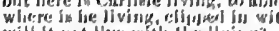

and livisu to tolit thes

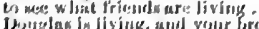

in old Jignisle of your vown living

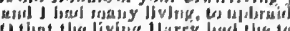

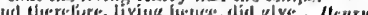

and my lite, , wd my living in .......

for living fifly hiere, in somin

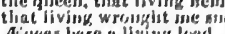

Aineas hase alliving lesud.

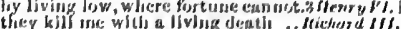

your froys lil fiving talwaril"w tirong

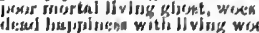

in young stasley li visng?

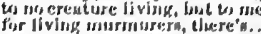

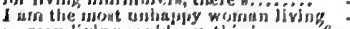

it, man living could way, thin in my wifs -

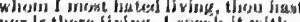

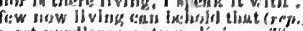

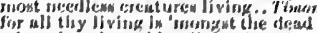

whe(t) there in nothing Jlving

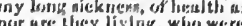

ure licey living, who were...

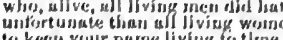

C. kecp your nume living wo tlme

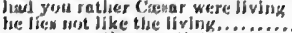

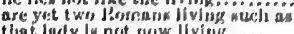

that liwly In noft newW Jiving

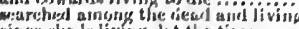

政

than any living inen could lear.. filus Audron.

III turn to any living ereatior

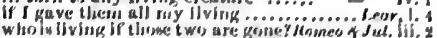

as living liere, and you no ume of his

that Jiving mortale jocuring theen

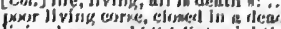

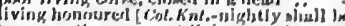

two inen there are not livink, $t$, whonn. II

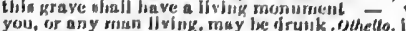

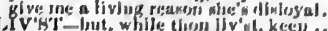

thlnk on pruting whilint liow liv'st, Fam, of sho

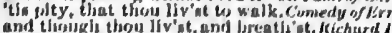

on thes liv'nt in weace.

Whlle thion livint, fitar Kate
yet livint thiou, Raliubury?

yet livent then, saliobury?

Jcury V. v.

in ujuliet whilie tjosj liv' ot.

illenty vi.

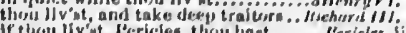

or thisil filve in wot

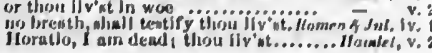

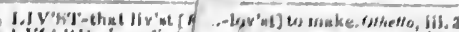

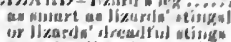

a low! e llzard, un cwl

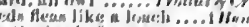

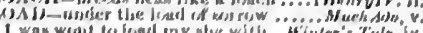

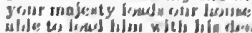

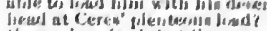

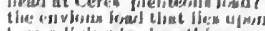

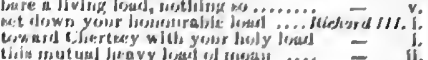

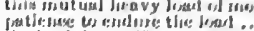

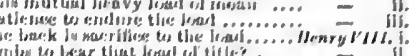

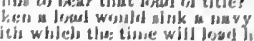

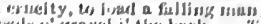

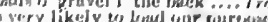

if divery nisuderesun logal

the:ll take xe down hin lewel

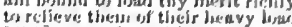

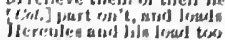

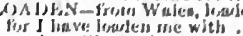

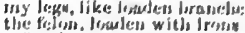

illienrylli, li,

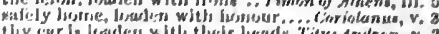

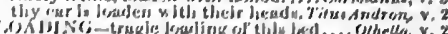

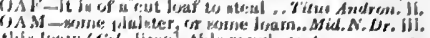

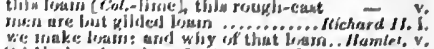

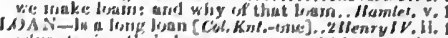

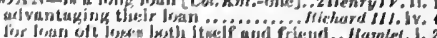

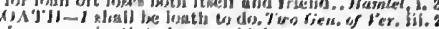

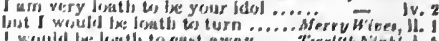

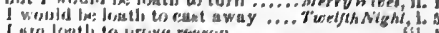

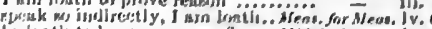

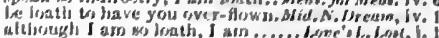

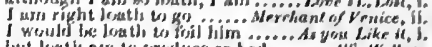

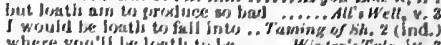

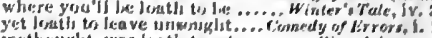

incthisisglit, was finathis tis net .......... King Jahn, v,

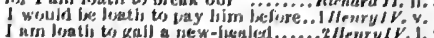

I im lonts to gail an new-iusled...

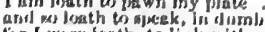

for I were frath, to link with

illeny, vI, fi.

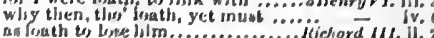

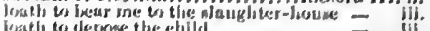

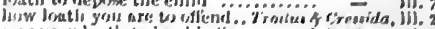

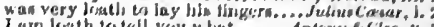

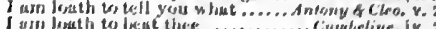

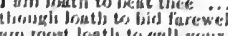

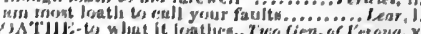

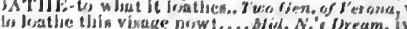

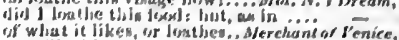

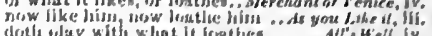

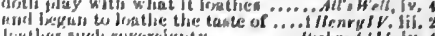

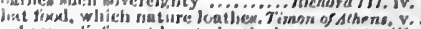

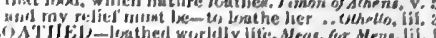

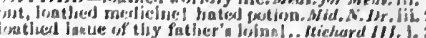

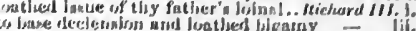

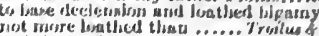

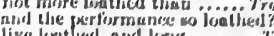

live Jentlied and lingy ........ Tionnn of Athens, lii.

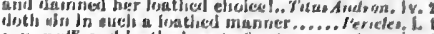

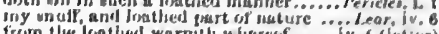

from the Jrathed warnith witereof - iv, G (letler)

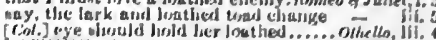

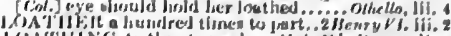

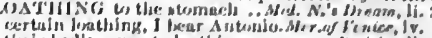

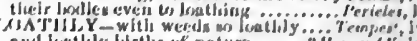

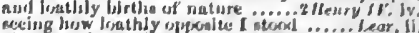

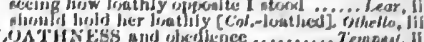

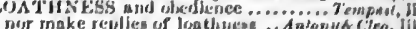

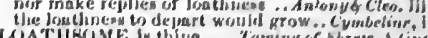

thun a pros end losuthame Leager..

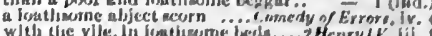

tlifi loat liasurie merguentration

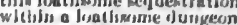

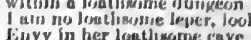

Illenry Vi.

inrurvvI. Iji. 


\section{LOA}

[452]

LON

LOATIISOME-lonthsme pit. Tilus an
will I bring son tot he lonthsome pit

as loathingene as a toal mions m.

here within this lonthsome sty

what with loathsone smells.

more murlers in this loathson
with vile and loathsume crust
cotTlisoul ENESS of them

LOATISOALENES of them .......... Hamlet, $i$. LOATHSOMES' stab in Greec. Troilus a Cre LOB-f:urewell, thou lob of spirits.

Lind their poor judes lol down........ Henry

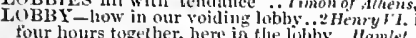

as you po un stairs into the bobly.

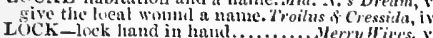

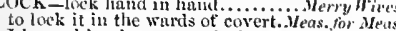

to know him, le wear's of lock.......... Much.du, iii. 3

for thee 1 'll lock up all the gutes

and a lock lianging by it .............

her sumy lirks hang on her .......Mer. of tenice, i.

Jessicu; lock up my doors

snaky gollen loeks, which mak

nul so loeks loer in embracing

wherefore didst thou lock me ..Comedy of Err. iv.

open locks, whoever knocks

we do lock our furmer seruple
drowined honour by the loeks

since we have locks to safeguard

the locks of your shrill-shrieking

I will loek his counsel

I'll loek thy heaven from thee...

Iacbelh, iit.

to tock sueh raseal counters from. . Juliolanns, ii

that loek up your restraint ............ Symbeline.

force him think I have pieked the ioek
that make these locks of eounsel! ..

to lock it from action and adventure?

who is the key to unbar the ioeks.

lueks fair dayliglat out the........ Romeo s-Juliet,, i.

in gold elaspss locks in the golden story suliet,

thy knot tei und combined locks to part. Hom
that she should loek herself

slort and repose lock from mie

a closet lock and key of villanous ..... ohello, iv. 2

but the doors be locked ................ of ' rer.ii.

a secret must be locked within........... fors. $\bar{M}$ eas. iii.

as fast locked np in sleep $\ldots \ldots \ldots \ldots \ldots$..... - ir.

I am locked in one of them. Ar rchant of r'enice, iii.

are paeked and loeked up in my.. W'inter's Tale, iv. 3

my door is locked; go bid them. Comedy of "tr

confess, sir, that we were locked out.

this womm loeked me ont $\ldots$ o.........

like pawns, locked up in ches

though loeked ny in steel

a jewel locked into the woefinlest

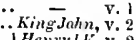

prevents our loeked embrisures.

locket in her monnment... Antony. \& Cleopatra, iv.

her ehambers are all locked of late... Cymbeline, jii. 5

I have lneked the letter in my eloset ..... L Lar, iii. 3

hol let the door be locked.

are your doors loeked? Why? .......... othello, i. Inore than the locking up the spirits.. Cymbeline

LOCUST -is as luseious as loeusts........... Ohrllo, i. 3

LODGE-a bed, shall lodge thee..Tico Gen. Drean,

I nightly lodge her mah

himself wonld lodge..........

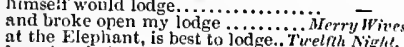

at the Elephant, is best to oodge...Tirelfh $N$ ighth, ii

I will visit thee at the lodge $\ldots$ a.... Love's L. Lost,

means to lodge yon in the field

ul's $\bar{w}_{\text {ell }}$

my stables where I lodge iny

I well might lodge a fear

we eaniot lodge and board $\ldots \ldots \ldots$. Menry $1 \mathrm{~T}$.

so often lodge in open field

and lodge by me this night ........

mors lon towns aboit....

prepare to lod reilus todgee there. Troilus \& $\bar{C}$ ress

let ine lodge Lichas on the. An/ony \& Cleopatra,

and his lady both are at the lodge. Ti/us dnd

and his lad y both are at the lodge.Ti/us dndron. it. 4

know not where I did lorlge lust night..... Pearicles, iv. 3

and where eare ledges, sleep will. Romeo of Juliet

anatomy doth my name lod

those thorns that in her bosom lodge..... Hamlet, i. s

where lodges he? To tell you (rep.)..... olhello, iii.

LDGED-lodged thee in mine own eell, Tempest,
as you shall deen yourself lodged.Love's L. L.ost,

a lodged hate, and a certain..Merchanl of Venice,

Where you shall be lodged

fil's Irell, ,i

50!1 shall be friendly lodged... Taming of Shem,
LODG FD-two lodged togcther ......... siacbith, ii. 2 summer's corn by tempest lodged ...2nenry $J$. iii. any grndge were lodged lretween us. Michurd Iil. ii. lave lodged till ged in the nbbey

LODGER-we were lodgers at.. T
nor shall ny Nell kech loilsers.

LODGi

to combering and thin weeds

and enquire iny lodging ont

at Cirntiano's lodging song and return

to burn the lodsing wone lou

to make the tor iug sout ...4s you Like it, ii

and take a lodining tit to entertuin

then at my lod ning, an' it like...

empty lorigings, nnd unturnislied .....Richard $11 . \mathrm{i} .2$ of the lark to the lodying of the lomb.

this lodgint likes me better

I have, my loril, at iny loding...

kniglits uin to their severni lod .....

sir, our lodgings, stunding bleuk upou

retire with me to my loding.............

nut to behold this shameful lodging

Suliet, iii.

being not at your lodging to be found .. othello, $\mathrm{v}$.

at my lolging. I'll be with thee betimes

and for me to devise a lodring, and say

and I was going to your ludging, Cassio.

what's the news, good cousin Lodovico?

this Ledovico is a proper man

signior Lodovieo? He, sir. I ery yon ......

yon knew that friar Ledowick to.....

Como, Lodowick, and Gratit.........Alls $\bar{F}$ ell

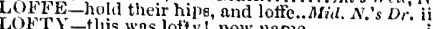

his humour is lofty, his diseourse... Love's L. Lnst, i. 1

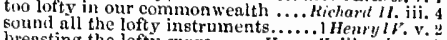

breasting the lofty surge........Henry $r$. ii. (chorus)

such a spacious lotty pitch .......... Hewry

France must vail her lofty plumed.....

and lofty proud encroaching tyrany - iv.

lofty, and sour, to them that ...... Henry J'HI. iv. 2

died in lonour's lofty bed.... Titus Andronicu, ii
doth with his lofty and shrili-sourding.. Humet,

$L O G \rightarrow$ sone thonsands of these logs..... Fernpest, fii.

I'll hear your logse logs.

or with a log batter lis skull

and Tom bears logs into..Love's $\begin{aligned} & \text { L. Los } \\ & \text { and }\end{aligned}$

sirra], teteh drier logs ............ Romeo \& Julicl, iv.

thot will find ont logs, and never.....

with three or four loggerheads. . Love's L. Lost

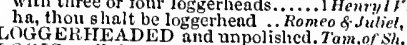

LOGIC-talk logie with acquaintance

JOG-MAN-am I this patient log-mun Tempest,
LOINS-ot thy proper loins. Measure for Measure,

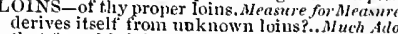

that fiom his loins ne bown loin

loathed issue of thy faoper.

ont of whorish loins are pleased. Troilus o Cress. iy.

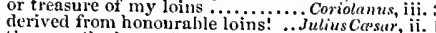

they are the igsue of your loins ...... Cymbetine,

monkeys by the loins, all my hair.

the fatal loins of these two foes............

LolTER-you loiter here too long ...2Henry IV' it.

LOITERERS and malcontents .. Love's L.Lost, ii

LOITERING-two days loiteriag?

Othello, iv

on his pressed ied lolling .... Troilus \& Cressitia, $\mathrm{i}$.

that rums lolling up and down.. Romeo \& Suliel, vi. 3

LOMBARDY - t'uitulul Lombardy. Taming of sh. i. 1

set on towards London $\ldots$............ Richard II. hij. 3

post you to London, and sou'li.......

our two eousios eening in to Lundon

when I beheld, in Londous

have to London sent the heads (rep.) -

house in all London road for fleas

a you mean to eome to London?

I eolild 'seape shot-free at London

is your master liere in Lo came

way hetween St. Alban's and I.....

not there to-day, we dines iul Ion....

about bondon. 1 hope to see London

I were in an alehonse in Londen!....

see him set on to $I$ ondondon.

how Landon doth pour out $\mathrm{jier}=$ v. (chorus)

Harry: now in London place him - v. (wortis)

as well at London bridge, as at ....I Henry rI. iij.

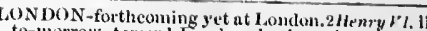
timlllorrow, toward Lindon, buck agmin -

evme, let's march townd Loindoi...

Jack Center hath gotten London bridge

thorefore broke through London grites

I sec them lording it in London sircets

the king is fled to london, to eail

trums nind trumpets; und to Loudoi

1ll keep Lemlon with my soldiers.. 3 Henry $F$ I.

gluil yust to Lomilon

I then in London, keeper of .............

why, viat to London will we........

and now to Lundor: (repg.)

mareh to $\mathrm{L}$ molos with (rep.) .........

that he cones towards London .....

dotly marel mmuin to London.

shull rest in Yondon, till we come....

hence fo Londin on a serions multer

let's away to lousdous and see our.....

hither to Londun, to be crowned.. Richard 11

to London, to your chamber .........

when they rode from Lumdon, were.

rendy to set out for Loudond their. $\bar{V} \bar{i}$ iv.

the king's secretary, the other, London ii. 2 (let.

I.ONDON

IONDONSTON E-upon Londunstone.2 Henry $V T$. 1

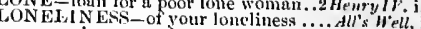

an exereise muy colour your lonclincss. Hamlet, $\mathrm{vi}$.

like to a lonely dragon

ONG - you hime lived so $\%$ long

Tempest,

un' it lud not fullen ilint iong.....

Thave no long spoon ................

if 1 then had waked after long sleep

quiet duys, thir issue, tud long lite

thom slinit cre long lie fiee

I long to hear the story of yom liate...

the why is wearisune and long......

for long atone $I$ have for.....

and longs fir every thing....

ncloak as long as thine...

she shall not loug eontin

have you long sojourned there.

leave not the mansion so long tenaritess

twe such friends sliowld be long foes

1 tarry toe long...

as long as I have an eye to ....

with my long sword, I weuld.........

this is the short and the long of it

and you have been a man long known

for I have fived long, enough I .........

and liow long lay you there?

come, we stay tou long

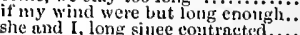

I'll drink to her as long o... there; Treelfth $\bar{N}_{i g h t}, \mathrm{i}$.

tor being so long absent............... =

I am not weary, and 'tis long to nient -

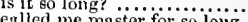

hung by the wall so long ling ieasure for Meas

how long have youglieen in this....... -

and it may be, as long as you, or I .

your stay with him may not be long.

they will then, cre't be long $\dddot{\text { the.......... }}$.

shake the head at so long a breatling

the lath been tou gong a talking of

long lave you professed aplurcliension?

only been sitent so lon

and which he hath used so long

or a downger', long withering ...Mid.N.'s Dr

$O$ long and tedions night, alate.....

for the short and the for it

to wear awny this long age of $7 \mathrm{three}$.

my lord, some ten words long the...

my lord, it is too lonk.................
nethinks, she should not use a long one

we will make amends, ere long.......

and keeps not tou long in one tiui

have lived long on the alms-busket

thou art not so long by the liead ....

the letter is too loug by haif

quick ly, sir, I long..................

that's two long for a pilay .................

murder eannot be hid font............. of terenic

$$
\begin{gathered}
\text { I. } \\
\text { i. } \\
\text { ij. } \\
\text { ii. } \\
\text { ii. } \\
\text { ii. } \\
\text { ii. } \\
\text { iv. } \\
\text { iv. } \\
\text { iv. } \\
\text { iv. } \\
\text { v. } \\
\text { v. }
\end{gathered}
$$


IONG-patlence for iny long alwole.. Mer.of b'en. il. A too watelis on long forr you

too long a pa use for thiat ........

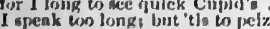

Ii.. 0

not long lee troulsed witls you ....... A ynu t.tke it, tell me, liow lonk you woulil liave her - Iv. I to a long and well-deserved lxed $\ldots$... A he lanker ing wi but on us how long le' $t$, count, slnce

inay werve fong, lint not werve ever in usurping his apturs mo Jong

1 long to talk with tlie younk........

would not have knuves thrive loug . $-\mathrm{v}_{0} 2$

I may liardly turry ob jong ........ - 2 (iull.)

that hatli been long studylng at

now in the day we long have looked

pastiny gamul long agi?

hath all no long detained you.

and

which hath as long loverl me

tricks eleven and twenty long

I liave watclud solong thint P........

to sta him not too liong

son of mine, which long I have not seet.

need none, solong as 1

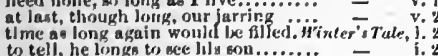

nay, let me have ' $t$; $I$ long

nay, let me have t; fill bear

Thil not he liature will lear ip (rep.)

and -a vour, all the winter long

and avour, alf the winter long $1 . .$. .

scarce any long could I atand by.....

there nlie had not heten ling............... Comeriy of Ërors.

for with long travel I asn stifi.

an' you use these blows long

ridea ine, and I Inng for $\mathrm{grams} . . . . . .$. .

you thinglit our love would Jast tor jong -

have held him ltere too long.

long apson. Whiy Dromics (rrp.)

You may prove it by iny

i jong, that we were nafe and souidi..

how long hath this possession........

Inng since, thy liuslrand $13 \ldots . .$.

aner wo long grief, auch nativity

hall not be lang hut I will...

the nlght is long, that never.

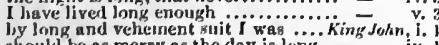

whould he as merry as the day is long

pur sorrows, and ere long, 1 doubt

ano long dag 'journey, lorda, or

fever that hath troubled me so lon

you have wialieal an long, are cast

that vow a lnng and weary

how long a time lies in one............

mall nhowers last jong, hut sudiden...

for aleeping England fong time have I

at once a tom long witheresl flower...

low long thall $f$ the patient? (rep.)....

a i a long parted mother wit

thus long have we ntwol to
whome colnurs he hal fough

and Jong live Jenry, of that name

Jong mayst thou live in Richard'y
of woeful agea long ago betid .....

I'll not be low long ago

no long staff, Hixpenny siriker.......... inerry $I V$

by'r ladly, a long lease for

ere I lead tlin life long

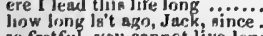

of fretfui, you cannot live long........

I fear we whall stay too lo

ow ing an, out of formit....................

liclil the king oo long In his...
shortneas lasely, were too lon

shortneas lascly, were too long ......
we hreathe tors long; come, cousin.

we hreathe tor long; come, cousin ...

fought a long hour by Shrewsbury clock -

ere ling they ahould call me madarn?

ir John you loiter liere too long

but he dld long in valn ..............

no no; he cannot long hold cut

will not tay so long tili h.

immortally, long gward it youri............

and a merry heart lives long-a.....

heal th and long life to you mader

I have long dreame

and make you long become iti.

no, hy my troth, not long; for wo.

no, hy my troth, not long; for

what a lorg night is thic.

longs for morning. Ile longs to......

he longo not for the dawning as we ilo

elee, uhame will he ton long lorils.
LONG; - as long as it pleasen lily gruge.

bo lony as your inajerty is an lioncut

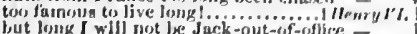

miy lord, metlinks, lin very long in tulk

interd to have it, ere long...

bon tine tliy shadow liatli.

my linalos wits long isolrikgnnent

long after this, when IJenry

I trunt ifse long to glowe thee.

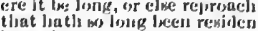

long wince we were rezs)lved

wherc I linpe ere long to lee

long live ousen Margaret.

France will lee jont ere long

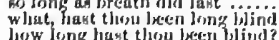

this, and bear'st so long?

rong live our a dovereign Itichari

Bo long as I am loyaf, tr

I lonk ts see my prison

iny licee that I las beartere long...

would have staycd in France sol losig

and figuelst sos lone, tilf that his...

weepen, that thou dont live so long

long nitting to determine porr.

as do Jong and wisli to be a silject

long live king IJ Jong

and long liereafter say unto his alijia

uncrown him, cre't belong (rep), iv. I)

8ro long as Elwart is thy conntalt...

thall lave more wars, before't lis: long

long ina Ed ward the fourth

innprisominent shall wet be long...... ilichard $111 . \mathrm{j}$.

kept an evil diet long . $70 . . .$.

I have ton long lorne your blusit

long die thy hapuy dayg betiore.

I long with all my heart to tee

solong a growing, and so leisurely.

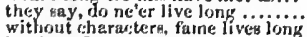

but long I eannot stay there

lie longa to see your hear

the precelent was full as long a droing

long live king kichard, England

I thould not live long after I saw

but how long whall that itle, ever

long fairly sliall her nweet life

which ws long kundered friend should

long kept in Pretagne at our

England hath long been mas

that whe muy longlive here.

a fellow in a long motley coat ...ilienry

not long before your be said, it reaclica

a long time out of play, inay bring .

as the long divorce of steel iall s on $m$

the last hisur of my long weary life.

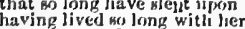

and we forgetful in our long absetuce

a fueen, (or long lsave dreaned so)

his love tron long ago: I am oidi...

have I lived thus long, - llet me

hy my goul, your long coat, pri

hath in acrecy long marricd

how long her fuce la drawn?

that solong, have followed

say, hin lone trouble now is passing.

from your affairs I hinder you too lon

prosicrous life, long, and ejer haupy

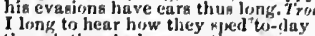

though they lec long ere tlicy are wored

in calm: and, so long, health you....

we do, and long to know cach other

doth long to sce unarmed

that hant no long walked

I have not seen you Jong...

and lonk live your fordulipi

long may he five in fortune

and eall lim to long peace

thou giveat so long, Timon, I fear mie

the dets

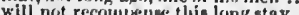

live loatlied, aisd long, mowt smilfirie

a madman so long, now a fool.

long live os, and so dle! I am quit?...

my long ajckneme, of hoal tl, and living

you are lnong ahout it

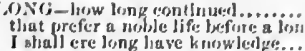

I shall ere long liave knowledyes.....

for you, Je tliat you are, long

I liave nat tro long. Nay, uro not

A retoly thet reveln long o' nights.

crying. long llve! liail. Cis:ar!

I love loug lite leetter tlias fige

that Joug time have fecen larres

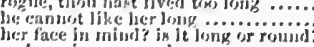

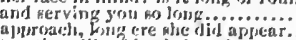

toggether, like irisenda long lon

kind Charmian; Iras, Jong fäc..... eji.

us Joug as torn a $\mathrm{yet}$ we liave.

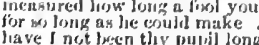

longs after fior the garboge

that lave nes long at toinderl thee.
blessed dive you long: a lady' to

liew jong is?

absalute cesmmistion: long live Cackar

Jo'f not is it einec I raw firm

did nake my way long forti

remajniug os lonu a from

the tine becing long; tlicir bluorl

aver-rosisted ratlier; realy long ago.

and kay long live our emusererl (r+p.)

have marde him noted long ..........

they liant ntayed us licere tow long.

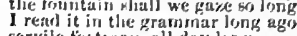

long have i lecen lorlorion

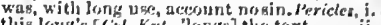

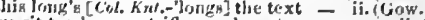

we sit $t(s)$ lenges trifles, and waske .... _ - ii. 3

hould ecrve after a long voyace.

how long have you been at this

how long bave

the herlge sparrow fed the cuckow so jong -

blall not lee a majed Jong, unlews......... - i.

I will pert be long from you.............. - iii, f

ko ling as we eand in thi

wake the king! lie hath glept long ...... - iv.

the winder is, lie hath endured to long... - v.

ah me! aad lours seem loog

you lived atcolds bo long ..............

wagrinamokes rnade of longmpinners" lege

till tw'elve is three long hours

moderately; long love doth 60

Ihepe, thisu wilt not keep him long

and these lijs liave long been sevarated

not well married, that lives married long -

how leng liath he lecen there?.

jong live the king! Bernardo?

Jird of dawning singetli all nighit lö....

very like, very like; ptayed it long? .....
I atay towloug; but here my fatlier coince

long atayed lic po: at last a little

that we much dil long to see you......

this is tu, long. It aliall to the burloci:

tlat I have longed long to redeliver

go long? Nay, then let the devil wear

pettlos

hut long it could oot

how lemg hast thou been a grave-mako

long's that since? Caunot you tell that

'tis not long after but I will wear

We lope it not, so long as we can amile

the one as leng as the other

that policy may eitlier latt po loriz

long lise slie so! and Jang live you

but now lie apake, after lonk secoing..... = iv. I

and hold him long, it dlall be lis ... all thin coll is 'fang of you.....Mid. N." Dreaun, il. 2

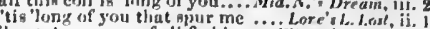
and of nationen, of all faslifon .... if inter's tate, fii. 
LONG-gll 'long of this vile traitnr.. 1 Henry FI. iv. 3 LONGER-a twelvemonth longer ...... Pericles, ji. 4 'long all of Somerset, and his delay 3 Henry $V J$, iv: surnall this is 'long of $y$ out and all the of her it was, that we ...... cymbeline, $v$. Conl. Kn'. this 'Iongs the text ... P'eridl's, ii. (Gow'er)

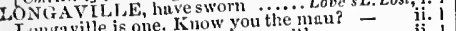
Lungaville is one. Know you the nite what, I,ongaville: and readlit would the king, Biron, and l, fngaville Longaville did never somet tor her sake = to ve sent Longnville $\ldots \ldots \ldots \ldots$.... his lord Longaville said, or my service loorn = and Longavill long wong ville, reign thy tongue -

LONG-BOAT-Our long-boat's side. 2 ftenry $r$. LONG-BONTINU ED truee is. Troilus \& Cressida, i.

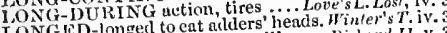
LONG ED-longer to eat anders till now. Richard II, v. never longed to hear a ward till now.2Hing although there longed no more to... Cymbetine, iii. neer I have longed long to redeliver ..Hamlet, iii. that I huve longed loned-tor change. King John, iv.
r. LONGER-hold it no longer $\ldots \ldots . . . .$. Tempest, ii. 2 and keepr it no me Jonger.... T'u'o Gen. of Verona, ii. 2 if you tarry any longer............... longer than I prove loyal..........

and longer might have stayer ........ $\overline{\text { Wives, iv. }}$ iy. voll are not to go loose any longer. Thelfh Nighl, i. if he mend, he is no longer dislionest

will you stay no longer? Ir wou tarry longer no longer staying but to give .... Meas. for Meas. i. 5 in his reprieve, longer or short

and hold no longer out upon

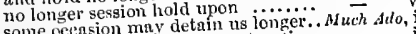

homve solved it with a longer trentise

Cupid is no longer an archer.........

yea, and I will weep awhile longer.

he shnll live no longer in montnient

clide downright, if l longer stny... Many

my legs are longer though, to rtun away

the ehain were fonger........... Love

but cunpeteney lives longer

if I serve the Jew any longer.

I'll stay no longer question...........

nn longer Celia, but Aliena...

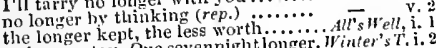

nolinger stay. One sevennight longer. Winter's $T$. i.

this great sir will yet stay longer.

no longer shall you gaze on't.

no longer slall did not retain... Comeily of Eror

eome, no longer will I be a fou

she'll burn a wrom bead ti foot............... aracbeth, iv.

I dare abide no longer ................ iv. iv.

no longer than we well could wash. Richard li. y. 5

hight longer tlian he sces renson.......

I til be no longer guilty of this sin.

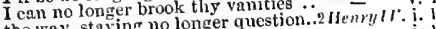

the way, staying world no longer be a stage

no longer ago thnn Wednesday ......

and when I cannot live any longer.

for we no longer are defer.

no longer m saint Dennis..........

mr spirit cau no longer benx.

if 1 longer stny, we shall begin.......

I eould stay no longer $\ldots \ldots \ldots$. . .......

stny we no longer dreamin

not willing any longer

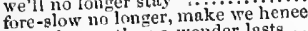

a day longer than a wouder lasts.

ean ino longer liold me patient....

longer tello must longer kneel.

may, we must live longer than $I$ have.

honour's train is longer than his

that longer youl desire the court

to have given me longer life..........

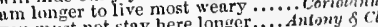

Iou must not stay hehold no longer

may hang no longer on ine ...........

one of them no longer than yester.
a clay, or two, longer: if you seck.

a clas, or two, longer: if exerese, npon.... -

see that you take no longer dars. Titus Andron. iv.

forty days longer we do respite you .... Tericles, i.

was not hest longer for him to muke

not minding longer to we longer grieve and will no longer have it be delaed .... Lear, iv.

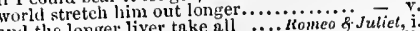

and I'll no longer be a Capulet

to occupy the argument no longer...

longer than thie tale thou doet... -

$I$ dare stay no longer. Go, get thee hence - $\bar{\alpha}$ mbet,

tell a hundred. Longer, longer

no longer than they can sing?........

I will indeed, no lonter end ure it $\cdots$

ONGEST-the longest night .. Two Gen.of I'er. when nights are longest there........eas. for meas. iii.

that $I$ may longest keep thy ......... Kichard - v.
go longest way shall have the longest..

and longest lengues th to a lover's. Tuming of sh. iv.

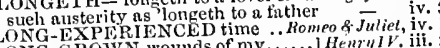

ONG-GROWN wounds of ny ........2 Henry VI.

Is toogen. of Ver.

upon my longing journey

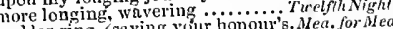

and longing, (saving yor prunes

that longing I have been sick for.......

changeable, longing, mnd longing... Wimler's Tale

no further than vainly longing...... Henry $V 1 I I . \mathrm{i}$.

I have a woman's longing . Troiluts \& Cresseela,

sir, you have saved my longiug... Antmy \& Cleo. iii. 6

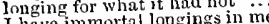

nice longings, simenders o.............

we do our longing stny, to hear
LONGING-honour 'longing to

the many to them 'longing.

Cymbeline

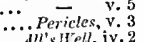

(song)

yet long'st, but in a fainter kind ... Taming of Sh. i. 1

LONG-TAIL-cut and long-tail ... Nerry Wives, iii. 4

a long-tongued babbling gossip?.. Tiks Andron. iv.

LONG-USURPED royalty

Richand II

LONG-WINDED-thee long-winded.i Herry Il. iii. s

LOOFED_onee beiug loofed

Lord, how it looks about!.

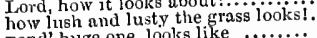

yond' huge one, looks like

you look wearily ....................

you do look my son.

that yet looks on me..

I pray you, look in ................

o look sir,look sir; here are more.

as look sir, look sir; my pardon

eoy looks, with lieart-sore

from your ladyship's looks

locked in her erytal loo

we look to hear from you ......

when I look on her perfections

his looks are my soul's fo
I gave him gentle looks....

unless I look on Silvia ......

no day for me to look upon

not live to look on your grat again

I will not look upon your master's line

I had rather wink than look on them

for my meed, but one tair look

look to the boy

look up; speak

when he looks so merrily

well, I will look furth looks.

Foll ent-a-mountaln ret look nfter thee?

er-de-claw

rou will also look thak hand soive

luok on, master Fenton: this is ......

as ever I did look upon ............

and the fool slanll look to the ........

what a deal of scorn looks beautiful.

than sir Toby to look to me..........

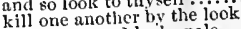

and pants, and looks pale.

to look into the bottom ..................

look into master Froth ber in this gentlemau's face.....

look upon his honour...............

merey is not itself, that ol glass ......

will proelaim thee $\Delta$ ngelo; look

look, liere's the warrant, Claudio....

lokefore, I beseech you, look forward

most bounteous sir, loo

till he did look on me

look that you love your wite......... have immortal longing

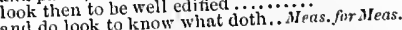

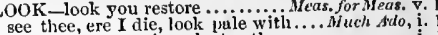

I look tor an earthquake too then.

how tartly that gentleman looks!

so yon walk snftiy, and look sweetly

appoint her to look out of her lady's

look you for any other isstie?

for look where Beatrice, like

misprising what they luok on ........

methinks, you look with your eyes.

this looks not like a muptial ........

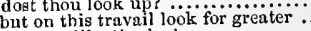

I do not like thy look..............

as I am an lionest man, lie looks pale

we look for you to-morrow ...........

must with his judgment look ... Mid

fair Hermia, look you arm yourself

O teach me how you look.

love looks not with the eyes ........
let the audience look to their eyes

then she waking looks upon

look on thee. And I am sick (rep.)

and look thou meet me ere the first.

a sweet look from Demetrius' eje...

and we ought to look to it .............

the moon, methinks, looks with ...

a murderer look, so dead, so grim (

yet ynu, the murderer, look as bright

I go, I go, look how I go ...........

from each other look thou lead .......

nor look me in the face..............
by day's approach look to be visited

eve'y man look o'er his part .........

seen them shiver and look pale.......

blind the eyesight of his look..... Love's

sirn, sir, that he will look sad .........

but what they look hipon ..............
now will I look to his remuneration

how deformed dost thou look ? .......

lie a claw, look how he claws him

I will look again on the intellect....

dares look tyon the heaven of her

she learll not of her eye to look.......

and pore, and thereon look?

why looks your highness sact

why look you pale?............

so did our looks...

mistress, look on me, behoid

Mariana's nosclooks red and raw - v. 2 (song)

look not well, signior Antonio ... Werch.

why look you, how you storm l.....

out-stare the sternest eyes that look
do I look like a cudgel, or a hovel-post

in my pocket, look demurely........

Jessica, my girl, look to my...

mistress, look out at window

you do not look on me, for 1 an his day

you shall look faires, ere I give......

let lim look to lis bond (rep.) ........

look on beauty, and you shall see....

yet look, how sift as yours....

rooler, look to him $r$

look, what nntes and garments .....

res, truly: tor look you, the sins.....

more elder art thou than thy look

it looks a little paler $\ldots \ldots \ldots \ldots \ldots$.

and thou must look pale and wonder

too young: yet therefore, look your eall mie.....

wherefore do you look upon that poor

though $Y$ look old, 5 et $[$ am strong and

been all this day to look you ...........

what ! you to it; find out thy brother...

eye, which in this forest looks.

for look here whint 1 found as

in the brook; look but in

why do you look on me? $\ldots \ldots \ldots \ldots . .$.
frow ning looks, Illl sance her $($ rep. $) ..$

shepherdess, look on him better.......

lout do not look for furtlier ..........

come, you look paler and paler .......

it is to lonk into hnpliness throu.

virtue's steely bones look

ii. 1
ii. 2 he did look fur into the seriee ..........
ii. 1 for, look thy cheeks eonfess it $\ldots . .$.

for, look thy cheeks eonfess looks upou his worshipper

a traitor you do look like ............

need not onen, for upon his boot ......

look on his letter, madam .............

and, by miclnight, look to hear......
I must go look my twigs: lie sliali .

\section{ii. \\ ii. 2 \\ ii. 2
ii. 2
i.. 3
ii. 1$$
\text { iii. } 1
$$ \\ iii. 12




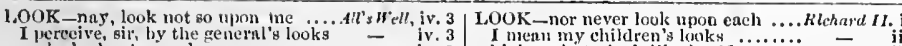
8n, lowk about you; kuw you
for he looks like a poor leciared...

he lnoks well on't. I am not......

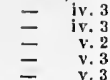

her busiress lnoks in her with .......

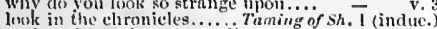

well, and look into them ail .....

toes luok throush the over-lenther
on them to look, and practise........

master, master, louk about you ......

'll say, she lonks as eleur ns

you mist not look 80 solr $($ rep. $)$.....

methinks he looks as though $7 . . . . .$.

by degrees we mean to lusk into

nay, look not big, nor stump $\ldots \ldots$.....

for then she never looks upon her...

in wonen, not their heuuteons looks

thy gpirits look cheerlully mon me
if this be not that you look fir........

every thing I luok on secmeth green

see where he lonks ont of the window

but love, fnir looks; und true ...........

eome, sir phrce, look on me

you look, as if you held ..............

till the heavens look with.

I'll be gone; link to your babe........

passage, look for no less than deatli... to look that aee what deat

the sties linok grimly, and threate....

get a boarl; look to thy bark ........

which look upon his removedress

when the kite builds look to lesser

how wonld he look, to see his work

he looks like sooth: he say's.

the gifts, she looks from me .......

but lisks on alike: wilt please
why look you so upon ne?

Iift will but louk upon the hedge

once more to look upon...

measureal, to look uipon yoir.....

measured, to look lipon yoll....

look on now. I thought of her $($ rep. $)$

whieh my daughter came to lonk ulo

make her do, mm content to look on
strike all that look upon with marvel

you gods, look down, and from your

look upon my brother.................

pity from our tlureatning looks. Comedy of $\bar{E}$,

a sunny look of his would soon repair

fashion your demennour to my look

ay, ay, Antipholus, look strange

look suteet, speak fair, hecome

sweet love, as look on night

how fiery and how sharp he looks

how pale and wan he look

ne'er may I look on day
why look yon strnoge on

why look yon strange on
wellil look to that anon.

th.....................

that look not like the inhab

if you can look into the seeds of time

if you can look into the seeds of time
look like the time ................
look like the innocent flower........

only look up elear...............

to look so green and pale at.

look on 't arain, I dare not ...............

look to the lady

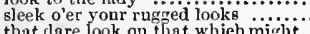

that lare look on that whieh might.

you look hut on a stool (rep.)........
how now, Heente? you look augerly

yet grace must still look so .........

lonk how she rubs her hands

put on your nightgown; look not so pale-

where got'st thou that goose look? ".

I must not look to liave.......

Pembroke, lonk to't; fareweil..........
lest men should say, look, where three
look here upon thy brother Gefirey's

look here upon thy brother Gefriey'
to look into the blots and stains ....

to look into the blots and stains
sirrah, look to $t$; $i$ ' faith, I will

look upon the years of lewis........

what say'st thou, boy, look in

why dost thou look so sadly on.......

look to that, rlevil! lest that Franee
look to thyself, thon art in jeopardy

cousin, lowk not sad

and he will look as hollow.............

puts on lis pretty looks, repeats ....

and, look thou stand within the arras

fear not you; look to t

Hubert? you luok pale to-diny

nor wijtis the fierce looks of

ne hath a atern louk, but a gentie..

but still to look nn yon!
o now you look like [nuberti.

you look but on the outsile.

ii. 3
I men my children's laks

of enrefinl business are his lonks.

looker in my life did look on him ...

monn louks bloody on the earth.
rich men look snd, and ruffians

why looks your grace so pol

have I not reason to lonk pale and dead? -

look not to the yround, ye tavourites
nnd kill with looks, intusing ........

and mark king Rieharl how he looks

yet looks he like a king

to look so pourly, and to spenk

that look too lofty iu our..........

stand forth and look upoin that..

that stand and look upon me

so many greedy looks of young and old =

that he stares and looks so wildly....

in earnest? lock upen his face.

aftighted with their bloody looks...

strangers to his looks of love ......

look to the guests within ...

to make mine eye lonk red..........

I see virtue in his a pleasiog

heneeforth ne'cr look ou me

his cheek lonks pale $\ldots \ldots \ldots \ldots \ldots . . . . .$.

thy looks are full of syeed

how! Poor? look upon his fice........

and mischanee look big thy

I ean tell you, look big upo

why say you so? looks he not for supply

the diny looks pale at his distempera ture -

look how we can, or sad

than I did look for of snch an....

iv. 3 I look to be either earl or duke.

so dead in look, so woe-begone

he that looks upon me will take
but look you pray, all you that $k$

v. 1 to look with forehead bold and big

v. 3 threw many a northward look ......

therefore captains had need look to it

and look whether the fiery Trigon

hy my troth, you look [Col.-like] well

for you, rebels, look to taste...

my gracious lord, you look beyond...

cheer up yourself; look up!

co thin, that life looks through

might make them look too near

look ahout, Davy; where are you

whieh eannot look more hideously upon -

you all look strangely on me.

look who's at door there; hol.........
if you look for a good speeeh now.....
look baek unto your miglity ..........

strike the Dauphin blind to look on us -

for, look you, the mines is not (rep.)
in a moment look to see the blind....

i. 5 as in despite, the sun looks pale...... $\quad$ - iii. 5

but freshly looks, and overbear.

plueks eomfort from his looks ....

if you look in the maps of the orid

it is necessary, look your grace

the venom of sueh looks......

Itern looks, diffused attire............

that never looks in his glass fo

whose very shores look

presume to look mee in the face ...... I Henry $r \%$. i. 1

they will look like drowned mice

methinks, your looks are sud
let thy looks be stern

meantime, look gracions on thy

one eye thou hast to look to heaven...

unto Tallot: nay took up to him

dirl look no better to that weiglity...

fir palc they look with fear ...........

why look you still so otern and traigieal? -

meuns no goodness, by his looks.

look on thy country, look on fertile.

as looks the mother on her lowl

lingering, looks for resene, you

look to it, lords; let not his.........
haste nway, and look unto the main

good king, look to $t$ in time

and look, thy self be fanlt tess ........

with envious looks still laugluing

hitle thee from their hateful looks...

that e'er I'Jl look npon the wor

with dimmed eyes look after $\mathrm{him}$

iv. I look not upon me, for thiue eye

look pale as primrose ...............

I am no loathsume leper, look on me ii. LOK-a thousant pound to look ....

1.2 to weep, and lenk on this" 2 .........

ii. 3 look on me well: I have eat no

ii. 4 fright us with nn angry look.....

iii. 2 Inok in a plass, and cull thy image

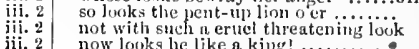

now louks he like a king! ........

ii. 3 to whom do lions eust their gentie looks?

and look upon, as is the tragenly.......

yet louk to have them buz.........

her looks als argue her replete.

likes it not, for she looks suth .

swect ladies with iny words and looks

look there:ore, Lewis, that by .........
lis lovks are full of peaceful majesty

look here, I throw my infamy nt thee

plain devil, and dissembling looks... Richurd

[Knt.] I cannot flitter, and look fiar

Why look 8 your grace so heavily

why look you pale? who sent

I spy some pity in thy look
look behind you, my lord.

look I so pale, lord Dorset, as tie......

then, masters, look to see a troul
who doth not look for night?

Who doth not look for night?

let me slic, to louk on deatlı no morei

and look to have it yielded

unprepareil, and look not for it

his grace looks elieerfully and smooth

look how I an bewitched

and Catesby, look that it be done

spenk, and look back, and pry on every

ghastly looks are at my service

look buck, defend thec, here are.......
look for the news that the Guildhial

look for the news that the Guildial
and look you get a prayer-hook in

ii. 3 stay yet; look hack, with me ........

your wife's son: well, look to it..

by that knot, looks proudly on

never lonk upon [Kwt.-nore behold] iliy -

why look ye so sad? my heart is $(, \mathrm{cp}$.

look that my staves be sound

look on my forees with a graeious eye

shall lessen this big look

I read in his looks matter against me

to look on the business present .....
pray, look to't; I put it to your care

look out there, sume of you

let them look they glory not in ......

how sad he looks! sure, he is looks upon the ground, then,

so looks the chated lion upoo

how pale she looks, and of an eurthy

now, by thy looks I guess............

do you look for ale and eakes here

fairer than ever 1 saw her look .. Troilus $\$$ Cress

look, how he looks ! there's $\ldots \ldots . .$. .

look well upon him, nieee; look you
and how he looks, and low he goes!

ne'er look, ne'er lonk, the eagles are gone -

nay , look upon him. So I do.........

he there; that he; look youn the

.

neither gave to ne good word, nor look

wer wanton spirits look out at.....

that same that looks so heary?

who neither looks upon the heaven

you look upon that sleeve.

I'll go look on: that disseriblin.

my prize; I will not liok upon

make thee, and thy state, look ill

after distasteful looks, and the

I will look you out a goud tirn........

to make an ugly deed look tuir ......

you cannot make gross sins look elcar
that none may look on you! ........

let me look bick mon thee,

for all her chernbim loo

ay, though it look like thee.

but himself, which looks like man

look out, and speak to friends...

and make bold power look pale.

and make my wurs on you; look to

but, with thy grim looks, and the.

which looks with us to break his neck

iii. 3

t. i.

ii.

ii. 3

iii.

iii. 2

iv.

i.

ii.

ii. 3

iii. !

iii.

iii. 1

iii. 5

iii. 5

iii. $?$

iv. 2

iv. 3

iv. 4

v. 3
v. 3

IJ. i.

i. 1

i. 4

iii.

iv, 
Look-and yon'll look pale before... Corio the gods look down, and this unnatural $-\bar{C}$ if 1 have veiled my look ................ and I will look on both indifferentes. and all the rest look the a chich ferret. and Cicero looks willind hungry luok... he looks quite throngh I'll pe'er look youl i' the faee again.. you look palé, and gaze, and put un tienr = and look you laty it in the protor's chair = look s in the clouds, scorning ......... liok fresh and merrity; let not our looks stared upon me withe whins is come... not immortal, look about you $\ddot{3}$ if then thy spirit look npon us now young bloods look for a tirne und downward look on us .......... we will not lonk upon him ...dnlats und let it look like perfect lion
which some did d lie to look on that make their looks by his ........ let Antony look over cassand's house sir, look well to my husbund s louse
Herod of Jewry dure not look upon I Herod of Jewry dirle not look upon pray you, look not snd, nor make abake thion to look on

I look on you, ae one that.

and look on their endenvolir

they cannot tell, look grim
look out o' the other side

look you sad, friends? $\ldots \ldots \ldots \ldots . .$.

declining day, or look on thine.....

wonld gladly look limim i' the face...

but she looks like sleep, as slie
to the bent of the king's looks

took here. love; this diamond . 3 i....

cracked them, you look on me

is it fit, I went to look upon him?...

or look upon our Romans ............

kills me to look on't ...................

look for frury 110 to be resisted

a fog in them that I cunnot look tiloogh

to me, with a look untender

she looks us like a thing more ......

go, look after; Pisanio look on't.

bid the captains look to't

scarce ever lowk on olo upon the holy sun

but to look back in frown............

gilded pale looks, part, shame, part.
gan to look the way that they did ..

look out; no longer exereise upon

naught but beggary and poor

you look hike Romanns, and look...... Ti.

at my suit, look graciously on witly sour looks aftlict his......

these looks infuse new life in me $3 \ldots$.

not be denied: sweet heart, look
words, fair looks, and liberality?

your lighness look so pale (rep.).

Aarun and thou look down

louk for thy reward amions

yet do thy cheeks look red...

arise, and look upon her $\ldots . . . . . .$.

look here; look here. Lavinia...

Mareus, look to my house

and then look for your reward

lent thee but thy mother's look.......

as yon grim looks do testify

what see'st thou in our looks? ......

how dare the plants look up to

Tyre, I now look from thee

louk how thou stirreet now! ........

and nohody will look after it

whieh looks for other revels $\ldots \ldots \ldots$
your schnlar be; therefore look to it

set't down, let's look on it

for look how rresh she look

look to your little mistress ................

and your looks foreshow you hast...

uone else, look friendly upon thee.....

yet thou dost look like Patience

look to the lady; O she's but .........

this ornament that makes me look

let his knights have colder looks...

I will look further into 't.......

do you handy looks with me ...............

art not ashamed to look upout thie bear

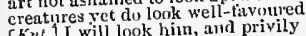

whose warped looks proelain.

how is't my lord? how lonk yon!.
louks fearfully in the coufined dee
LOOK-spenking looks to noble Elmund
I'll look no more; lest my brain turu..

look up a lieight (rep.)

look with thine ears 7 ..................

look upou me, sir, and

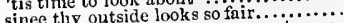

sinee tiy outside lookething more to say

look on her,-look,-ber lips (rep.) ....

look up, my lord. Vex not his ghost ....

Benvolio, look upon thy death . Romeo

at my poor house, look to look to like, il looking $\ldots \ldots . . .$.

I'll be a cnnde..hold

look to the plate ......... o jooks....

look thuu but sweet, and 1 am p

toward sthool witli heavy looks

she looks as pale as any clout........

look to hear nothing but dook

calm look, knees humbly bowed...

to prison, eyes! ne'er look on liber

may look on her, but Romeo may not

be wary, look about .................

or never after look 't, think on't, I do not use.....

from sluit' with merry look.......... -

look to the baked meats, good Angelica
look! look! O heavy day! ...........

revive, louk up, or 1 will die

meagre were his looks, sharp misery

his looks I fear, and his intents I doubt

eves, look your last! arms, take your

$O$ wife, lcok how our daughter bleeds!

lonk, and thou shalt see...............
with wild looks, bid me devise some

give me the letter, wing it not like the king?

you tremble, and look pale ................

and let thine eye nom his like again.。

in thy memory look thou character

look to't, I eharge you .............

and with a look so piteous in purport

may eoneeive,-friend, look tooks

a kind of eonfession in your looks.".

how eheerfully my mother looks ...

day would quake to lonk on.......

then l'll look up; my fault is past . . this -

look here, upon took? On him! (rep.)

do not look upon me; lest, with this

look you there, look haw and red....

alas, look here, my lord

that thy rebellion lnoks so giant-like?

lives almost by his looks ............

look to the queen there, ho!.............

you that look pale and your danghter ....... othetho

look to your house, your dang wh to 3 on?

look to her, Moor; have a quick eye ....

fooks sading, and not look behind.

shall she have to look on the devil?

that folly yand green minds look after.

Niehael, look you to the guard to-n

gentlemen, let's look to our business

looks not on his evils; is not this true?

Iago, look with care about the town

look to your wife; observe her wispos

to shake, and fear your ne'er ebb to

therefore look to't well....................

nor of them look for such observances

let mo see your eyes; look inl

lie looks gentler than he did

I pray you, look upon her s.............

louk in upon me the look now? ...............

this look of mine will hurl my soul.

look on the tragic loading of this bed

LOOK'Ds'T on majesty .... Antony \& Cleopara

thou then look'dst like a villain.... Cymbeline, it,

when you looked sadly.... Two Gen. of Irrona. .i. I

you had looked through the grate. Me

she is too bright to be looked against

which way have you looked for
this was looked for at your hand. $T$
let this fellow be looked to $(r e p$.$) .$

and let his hurt be looked to

and let his jurt be looked to .........

hath looked upon my passes ......... Much $\overline{\text { I }}$ do,, i.

gweetest lady that ever I looked on

I looked upon her with a soldier's eye

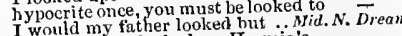

ere Demetrins looked on Hernin's.

durst thoa have looked upon him

that liked, that looked, with clieer :

this is not so welt as 1 looked ...... Ver. of Venice,

my foolish eyes l lavis looked on yet.. - ii. I

ever you have lnokedon better hing.
LOOKED; no sooner looked $\ldots . .$. As you like il, v. 2
let my horses be well looked to...... All'a $H$ ell, iv. 5 youl looked so longly on the maid. Ta

my father is here looked for

and that you looked for him this day

I have looked on thousatids a......

if you had but looked big, and quji:

I might have looked upon my queen's

have looked on, such good heard......

exeels whatever yet you looked upon

unless I spake, looked, toueh

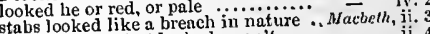

of mine eyes, that looked upon't

I looked toward Birnam, and anon $. \ldots . . \bar{K}$. v.

looked upon, I hope, with cheerful.. King John, iv.

alas, llooked, when some of you ...

which, looked on as it is, is naught...

he wistly looked on me...

then his cheek looked pale .........

I looked he slould have sent me

1

be looked upon, and learned

not looked on in the world....

but louked for no reply

...2nenrylli. i.

kindred of the queen looked pale....

but looked not on the poison .........

ever wretehed age hath looked upon

I never looked for better at his hands

ard $111 . \mathrm{i}$.

when I say, I looked on Richard's faee - iii.

列

sweetest face $I$ ever looked on

she looked yesternight fairer. Troilus \& Cressida, i

than if not looked on................ Coriolanus, $\mathrm{i}$.

looked not lovelier than him .... - i.

'tis time it should be looked to...... = i.

and looked upon things precious....

a strange one as ever fon less spoil

and men of lieart looked wondering -

ne'er looked but on my back ..... Jutony \& Cleo. ii.

in Rome I looked her in the faee.... - iii. 3

[Knt.] he not looked, or did it from..

the fairest that I have looked union.

but what he looked for should oppose

but must be looked hast looked thy self in to my grace

thou hast looked thy self into my grace $-\mathbf{v}$.

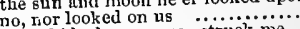

looked black upon me; struek me......... Lear

I looked not for you yet, nor am ........ v.

you are looked for, and looked not for $\quad$ iti.

what, looked he frowningly?

but, better looked this love with idle sight

Alexander looked o' this fushion

O vilanous! here in Vienna .... Mears. for Meas. $\mathrm{v}$.

long eould 1 stand by a looker-on. W'inter's Tale,

al, one that was a woful looker-on... Richurd $M I$. iv.

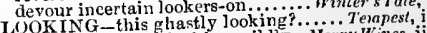

and blowing, and looking wildly .olerry Wives, iit.

and blowing, and looking wildy . ifrerry wor Meas. y.

to feel only yooklooking in her eye

now for not looking on a waman's.... - iv.

looking on it with a lack-lustre ..As you l,ike it, ii. idly I stood idly looking on.... Faning of She on a pillory, looking through the lute

and here looking out at the window ${ }^{-}{ }^{\top}$ Tale, $\mathbf{j}$.

the sun looking with a southward eye - iv.

your sweet majesty, looking awry...Richard 11. if.

whilst I, looking on the praise......... Henry ${ }^{2}$. . . 2

looking the way her harmless .....2Henry VI. iii. I

and lived by looking on his images. Riehard 1T. il.

God knows, looking either for .....Henry VIII. iii.

he had so; looking, as it were ....... . Corrolanus, iii.

by looking down on Casar... ïf..... Antony \& Cleo. i.

in Rome together, looking for Antong

by looking back on what I have left - iil.

looking all downwards, to behold world.... Pericles, ii.

to like, if looking liking move ...Romeo \& Juliet, i.

lnkking before, and after, gave us not.. Hamlet, iv.

and fetch a looking-glass ........... Richard $\mathrm{yl}$. iv.

to court an amorous oo lin at elarges for a looking-glass

-. Lear, $\mathrm{y}$

lend me a looking-glass wil not.irid. A. Diveam,
LOOK'ST for wars, and wil

well sajd, thou look'st eheerly ... As you Like it,

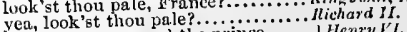

yea, look'st thou pale?............... Henry $V^{\prime} I$. i. how now? why look'st tliou pale? .2 Henry rt. iii. look'st like him that knows. ....Antouy s cleo. Iv. 
LOOK'ST - him thou look'st on? .... Cymbeline, y. 5 LoRD-now for the Lord's sake ...Meas. Sor.Meas. iv. foi thou look'st modest as justice .......

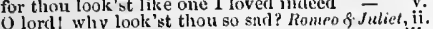
my eyesight fails, or thou look'st pate $-\bar{c}$ iij. that look'st dead with grieving ......... olinello, it. LoON-thon eream-fneed loon! .........Macbeth, $v$ WOP-every loup, trom whene. Iacbeth, iii. 3 (r) WOOSE-do now let loose my opinion ... Tempest, ii. 2

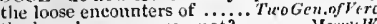
the bear loose, are you not?......... i. whe turn her loose to him.

- iv. 6 he will seem to break loose.....Mid.N.'s Dream, iii. vile thing, let loose; or 1 will ......... Love's $\bar{L}_{\text {. Lost }} \mathrm{i}$. is as eunning as fast and loose ....... - iii. 1 and let me loose.

at his very loose, decides that........

party-eoated presence of loosc

is thegt of that loose gruce ….....

loose now and then a scattered..... ds $y$ u u $i$ ike it,

are loose again... Comedy of Er.

and hi they are both broke loose

I will loose his bonds.

liang loose about him, like $\ldots \ldots . . . \ldots \ldots$.... Jacbeth, v.

against these giddy loose surgestions - iit.

with unrestrained lonse eompanions. Richard 1 ,

like an old lady's loose gown

madly hath hroke loose and bears ..2 Henry $I V . j$.

poorly are let loose, and our ai

..Hewry

he sure you be not to che

Henry VIIS î.

had their faces been loose, this day.

a file of boys hehind them loose slint

negligent and loose regard upon

hath, at fust and loose, beruiled. An/any \& Cleo. iv. 10

is Lavinin then become so loose ... Tttus Andron. ii. I

I will not loose again, till th

being loose, unfirm, with digging...... Romeo \& Juliet, v. 3

at such a time I'll loose my doughter... Hamlet, ii.

dangerous is it, that this man goes loose... $-\overline{\text { inello, }} \mathrm{i}$. 3

of his salt and most hidden loose affeetion? -

a kind of men so loose of sou

LOOSE-BODIED gown. Trming of Shrew, iv. 3 (note)
LOOSED-and loosed his love-shaft. Mid. N.'s Dr. ii. many arrows, loosed several wass...... Herry $r$. . and he that loosed. them from their.2 Henry ${ }^{2}$. ili. 2 are slipped, dissolved, and loosed. Trailus \& Cress. LOOSELY - not be so loosely studied..2 HenryIV. ii. dreadiul laws so loosely slighted.....

LOOSEN-should loosen hiln and me...... Lear, v. I LOOSE-WIVED-man loose-wived Antonty s Clea. $\mathrm{i}$. LoOSING-loosing upon thee ........All's Well, ii. 3 LOP-branehes we lop away Richard II. ili. 4

f'll lop a member off $\ldots \ldots \ldots \ldots \ldots \ldots$. Henry $V I$. v. 3

to lop that doubt, he'll fill............... Pericles, i. LOPPED-a very limb lopped off.... 1 Henry IV. iv.
banished, and a limb lopped off.....2 Henry $V I$. ii. 3
that he lopped the branelt in.......3 Henry $V I$. ii. 6 shall be lopped branehes (rep. v. 5).. Cymbeline, $\mathrm{v}$. Alarbus limbs are lopped.........

IOQUITUR-qui pauea loquitur. Love's L. Lost, iv. I,ORAIN-duke of Lorain (rep.)
LORD-Lord, how it looks about!

yes, faitl. and all his lords

to win it from me, the lord on't.....

good lord, how you take it.........

lords, that ean prate as amply

Prospero my lord shall

thou shalt be lord of $i$

the good old lord Gonzalo

but you, my brace of lords ............

was landed, to be the lord on't ...

Iord, Lord! to see the folly. Twa Gen. of Veron love's a mighty lord....

where their lord shoudd be ............ $\bar{y}_{\text {wer. }}$ ii

I,nrd, Lord! your worship's a wanton

ret there has been knights, and lords

de knight, de lords, de gentlemen....

by the Lord, a buck-basket

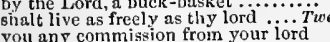

my lord and master loves you.

your lord does know

get fon to your nord.................

that you shoulil put your lord into

to report your lord's taking of this

none of my lord's ringl ............

o lord! Pr'ythee, hold thy peace ....

his employment between his lord and

what would my lord, but that he

even what it please my lord.....

by the inrd, madrm, you wrone me - vi 1 (lelter)
my lord hath sent you this note. Neas. for ileas. iv. 2
Lord! I could not enduie a liusband

rood lord, for alliancel

the prince and my new-trothed lord

is my lord well, that he doth spicak

rish wanton; am not I thy lord?

Lord, what fools these mortals be!

my fairy lord, this must be done

no, no; o Lord, sir, no

Lord, how wise you are! solne merry mecking lord, beli

Biron, the merry mad-cap lord

strive to be loris o'er their lords?

to any linly that subdues a lord

Lord, Lord! how the ladies and $I$ have

one of the strange queen's lords...

by the Lord, this love is as

no, a fair lord cilf? .............

write, Lord have mercy on us...

the noble lord most honourably...

how sny you by the Frenel lork......

the having any of these lords

Lord worshipped might he be

to signify the approaching of his jord

this fore-spurrer comes before his lord

Bassanio, lord love, if thy will

as from her lord, her fovernor, her king -

but now I was the lord of this.......

lover of my lord your husband $\ldots . . . \%$ -

until my lord's return $\because \ldots \ldots \ldots$

goodly lord, what a wit-snapper

that your lord will never more break
three or four loving lords have ...As you Like

three or four loving lords have ...As you Like

your featuresi Lord warrant $u$

fhave a woman to your lord.

than to see the lord the prologue ....

observe to-day in our young lords...

my master, my dear lord he is...

eall before me all the lords in court.

your lord and master did well

which if-Lord have mercy on thee .
old, filthy, scurvy lordit well, I must

an' he were double and double a lord

sirrah, your lord and master's married

you are more saney with lords

you are more saney with lords
madam, my lord will go away

my lord and you, monsieur (rep.).

madam, my lord is gone, for ever....

poor lord! is't I, that ehase thee

do not toueh my lord l.

O lord, sir; let me live ....

leave of my good lord the king...

and that my lord your son was upon

yonder's my lord your son w

Lord how we lose our pains!

zou remember the daughter of this iord? -

but for this lord, who hath abused

there is a lord will hear you

in noble ladies unto their lords

a lord, and nothing but a lord....

am I a lerd? and have I sueh

ord he thanked for my good

how fares my noble lord?

and my lord. my lord and husband

so lords call ladies

good Lord, deliver us:

good Lord how bright and goodly

they do owe their lords and husbands

to wound thy lord, tlly king

and graceless traitor to her loving lord? - -

hehind what lady she her lord

a lady's verily is as potent as a inrd's

was not my lord the verier wag.

was not my lord the verier wag.......

these lords, my nohle fellows....

my lord the king, the kingl

of mine own lord, wlio is lost......

lord should to the heavens be contraiy

yet if my lord will marry ...........

he har paired well with this lord ...
the noble honoured lord, is feared . the Lord doth know, have not.

so thint my lord, your son, were
my lord your son made me to.....

eeremony to the noble lords....

Lord let me never have a eause to sigh

thy husband is thy lord, thy life ....
LORD_my lord's almost so far.... Hinter's Tul , v.

tords of the wide world fimales, and their lords

whom I minde lord of me and all

the Lord's anominted temple.

my lord is often thus.

lord of thy presence, and no land ..... king Joh

shall your city call us lord .............

this rich fail town we make him lord of -

gain, be my lord; for I will.

bring the angry lords, with ali expedient the count Melun, a nolle lord of

would not my lords returu to me ....

my holy lord of Nlilan

in the field, and almost this louk

the English lords, by his persuasion

the lords are all come back...

myself, and other lords, if you

parting from my lord the king...

awry upon your lord's departure ...

than your lord's departure wis the weary lords shall

in it are the lords of York, Berkley...

were I but now the lord of such
my lords of England, let me tell

the deputy elected by the Lord.

our lord the king should so with civil

n your lord's scale is nothing.

princes and noble lords, what answ

my lord,-No lord of thine, thou

my liard-nearted lord, that set'st

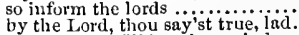

by the Lord, I'll be a brave judge.

an old lord of the eouneil ruted me

by the Lord, I'll be a traitor then

eame therc: a certain lord, neat

but I tell you, my lord fool...

by the lood, our plot is a good ......

by the Lord, so they call me

by the Lord, I knew ye as well 1 .

leads ancient lords, and reverend...

now, when the lords and barons of

didst thou? Lord, jord, how this worid

in the fortune of my lord your son ..2 fHenry $I$

for my lord your son,-Why lord your son had only bit

sir, my lord would speak with you

now the Lord lighten thee!..........

$O$ the Lord preserve thy good gracel

lord, lord, how subject we old men are

or, by the lord, I will have it in .......

in the bowels of the Lord, deliver.

eall them in their native lords... ....

the Lotd in heaven bless thee

not to-day, O Lord, o not to-day.....

of other lords, and barons, knights

where that his lords desire him ...

by the Lord, no; and yet I

ist so. my lords of England? $\ldots$ ?.......

the battles of the Lord of hosts

four of their lords I'll change

the other lords, like lions ................

contrivedst to murder our dead lord

at the north gate; for there stand

Lord have mercy on us (rep.)

moved these warlike lords to this .....

bold verdict enter talk wiih lords?

in friendship, as your lords have done

and we be lords and rulers over Roue

return, thou wandering lord .......

birrah, thy lerd I hotour as he is

defence of my lord's wortli

good Lord! what madness............

and for the proffer of my lorl your

$O$ Lord, that lends me life..............

it was the pleasure of iny lord the
and proud, as he were lord of all
still revelling, like lords, till all..

why droops my lord, like

what dreaned my ford?.

marry, the lork protect him......

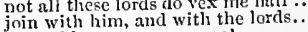

O lord have mercy on ne!...

for thee mayglorify the Lord $\ldots . . . .$.

O Lord bless me, I pray Gnd ........

that these great lords, and Martaret

the lords, cold snow melts $\left(e^{\prime} p\right.$.)

ii. 2

iv. 3

ichard $I I$.

iv.

v.

ii

ii. 4

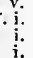

ii.

iii.

iv. 3
V. 1

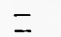

-

iv. 3

(chorus)

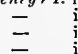

i.

i. 


\section{LOR}

[ 458 ]

LOR

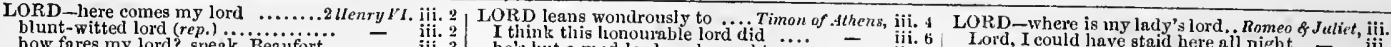

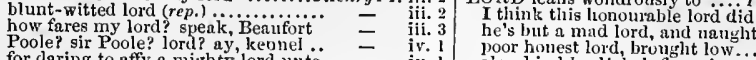
for daring to affy a mighty lord unt disdain to call us lord..... and worship me their lord. we will not leave one lord, ope
now is Nortimer lord of this eit now is Mortimer lord of this eity
nay, thou buekram lord! now nay, thou buckram lord! now $7 .$. here's the lord of the soil eome ........... and happiness to my lord the ling northera lords, that have forsworn... all the of those three lords torment and lords, bow low to him

father, and my loring lord $\ldots \ldots \ldots . .$.
cheer these noble lords, and bearteu so it please my lord............

my

convcyunce, and thy lord's false love

how far hence is thy lord, mine......

preposterous: therefore, not good lord $\overline{\text { of }}$ ay unto iny gracious lord! ...... kichard III. $\mathrm{i}$.

by my young lord, and the

Edward, her lord, whom I, some thi...

for his meed, poor lord, he is newed

we followed then our lord, our lawful

0 Lord! methought, what pain

dukes, earls, lords, gentlemen; indeed

here comes the sweating lord (rep.)....

go, return unto thy lord, bid him

many good-morrows to my noble iord.

now by the holy mother of our Lord

what says your lord to my request?..

by my dear lord's death.

alas, kinel lord! he's flung in ra

\begin{tabular}{l|l} 
iv. & denide that lord; the senutor $\ldots . . . . .$. \\
iv. 2 & despised and ruinous mau my lord?. \\
iv. 2 & aud as my lord, still serve him....
\end{tabular}

a truer grief for his mudone
upon tlieir first lord's neck

till my lord return from the wars.

your lord, and Tilus Lartius, are set

standing your friendly?

but for disturbing the lords within

which he was lord of; or whether.

i. 4 my lord and liusband Thesc lord

ii. 1 go, tell the lords of the city, I am her

ii. 6 you lords and heads of the state....

iii. 2 boy, if thy lord look well.............ulius Cesar, ii.

iii. 3 and commend me to niy lord ........

v. 6 saw you my lord? No, lady... Aniony \& Cleopat at your service: my lord approaches
lord of all tlie world? What say'st (rep.) 0 bless my lord and husbend!

i. 3 thanks to my lord: the Jove of

hail, Casar, and my lord! hail, mo....

lord of his fortunes, lie anlutes tie.

ii. 1 lord of his fortunes, he salutes thee...

to follow with allegiance a fallen lord

but since my lord is A n tony again

call all his noble captains to my lord

why is my lord eoraged against his lov

what would my lord? Since Cleopatra

how heavy weighs my lord:

full reference freely to my lord

lier father's brother wonld be her lord?
well, hie thee to thy lord; commend

an honest country lord, as I am.....

my master and my lord (rep.)

my lort gour son drew on my.

to hold the hand fast to her lord.

this coal betwixt my lord and me.....

but when to my good lord I prove.
comes from my lord with letters

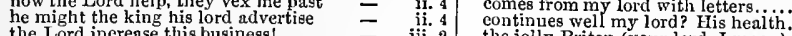

the Lord inerease this business!.

un worthy now to be thy lord and master -

a sorrow Cromwell leaves lis lord...

the rich stream of lords, and ladies.
a lord of Trojan blood, nephew ... Tro
strength should be lord of imbecility

kings, princes, lords! if there be one

so shall each lord of Greece ...........

ay, do, do; thou sodden-witted lord.

you scurvy lord! You eur! ............

thy lord, Thersites; then tell me ...

Achilles is my lord; I am Patroclus

thrice-worthy and right-valiant lord

this lord go to himl Jupiter forbid

sir; I do depend upon the Lord

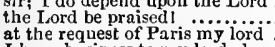

I have business to my lord, dear queen

if my lord get a boy of you

so do each lord; and either greet

no man is the lord of anything

to invite the Trojan lords after

so profourdly? where's my lord gone?

my well-famed lord of Troy

when was my lord so much ungentiy

$O$ 'tis a worthy lordi Nay ....... Timon of $\overline{\text { Ath }}$

some dedication to the gr

I eat not lords. An' thou shouldä (rep.) -

heavens, that I were a lord

hate a lord with my heart ......

that I had no angry wit to be a lord.

here comes the lord. So soon as din.

sometime, it appears like

I have told $m y$ lord of you, he is

here's my lord: one of lord' Timon's

thy very bountiful good lord and master -

whieh, in my lord's behalf, I come alas, good lord! a noble gentleman 'ti

that part of nature which my lord paid

yonder's my lord: I have sweat to se my ford hath sent-Hal what has he

endeared to that lord; he's always

Timon has bcen this lord's father.

and I amongst the lords be thought...

this was my lord's best ho

is not my lord seen yet?............

as if your lord should wear rieh

my lord hath spent of Timon's ......

my lord and $I$ have made an end ....

will jolly Briton (your lord, I mean).

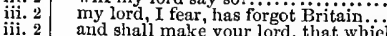

and shall make your lord, that which

and your lord, (the best feather of our

sinee my lord hath interest in them.

to greet your lord with writing

to tell my lord that I kiss auglit but he

from my lord. Who? Thy lord? (rep.)

who long'st, like me, to see thy lord

$\begin{array}{ll}\text { ii. } 1 & \text { shall be the lord o' the feast........... } \\ \text { ii. } 1 \text { no more of worthy lord, speak, or thy }\end{array}$

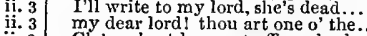

ii. 3 Cloten, hast here cut off my lord

as he exceeds our lords, the odd
this is a lord! $\mathrm{O}$ noble inisery 1

he shall be lord of lady Imogen

I thought had been in lor

iii. 2 see, lord and father, how we have... Titu

my noble lord and father, live in fame

where is my lord the king? ...........

what Roman iord it was du

to see so great a lord basely

hush, here come the lords of Tyre

peace to the lords of Tyrel............

my distressed lord, even such our griefs -

doth my lord eall?

where's my lord? what world is this

it is my lord's. That I was shipped..

blume both my lord and me ........

attendcd on by many a lord $0 . .1-$

ho,gentlemen! my lord calls.....

calis my graciou

to content your lord; who take...........

bring you to hear ny lord speak ...........

that lord, that counseled thee

lords and great men will not let $\mathrm{me}$

in the natures of their lords rebels ......

lord Edmund spake not with your lord.

my lord is dead..........

how does my royal lord? . . . .................

lord and you were then at Mantua. Romeo \& J

and, lord, she will be a joyful woman

lord, lord! when 'twas a little prating

O lord: why look'st thou sad?

dear-loved cousin, and my dearer lord?

ny love! my lord! my friend! I must =

ter to dispraise my lord with that.....

iv. 3 met the youthtu! lord at Laurence...' cell -

bring Juliet torth; her lord is come...

deliver it to my lord and father.......

lord! they figlat: I will go call

their lord's murder Knt................ that lord; and look you mock lim not. thy thoughts, wheu thy first lord is dead

the tithe of your precedent lord.

ho, Guildenstern I bring in my iord

Lord, we know what we are but kno... - iv.

the rabble call him lord...

but shows of service on their iords......... othello

you are the lord of duty, I am hitherto...

what tidings can you tell me of $m y$ iord

do love my lord; you have known lim

do love my lord; you ha

tell him, I have moved my lord in his

is my lord is not my

ny lord is fahen into an epilepsy

I hope, my noble lord and Cassio?

if to preserve this vessel for my lord

with my lord, madam. Who is thy lord?

alas, Iago, my lord hath so bewhored her

8uch as, sle says, my lord did say I was
what shall I do to wiu my lord agaio?

tell my lord and lady what has happed..

commend me to my kind lord

Cymbeline, i. 2 LORDED-being thus lorded, not only.... Tempest, i. 2

6 LORDIn lording it in London street

7 LORDLY

with a lordly nation that will wat... Henry $N$.

under the lordly monarch of

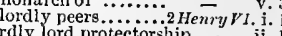

[Col. Knt.] lost his lordly honour ..... Richard $\overline{1} l$ I. iv.

your lordship is not ignorant how.... -

may 't please your him thither

relyiug on your lordship's will.

not here so please your lordship...T.̈elfh $\bar{N}_{i g h t}$

good morrow to your lordship ...MLeas. for Meas.

this is his lordsbip's man

we'll wait upon your lordship $\ldots . . . \ldots . .$. Much $A d$

I think I told your lordship, a year sinee -

his lordship, whose uuwished...Nid. N.'s Dream

I thank your lordship; you have. Ner of $v^{\prime}$ nice iii.

bescech your lordship) to make.

if your lordship find him not

worthy your lordship's entertainment

iii. 6

he is you lor your ..

as't please your lordship; I'll leave you -

his lordship will next morning for ... -

it requires hostop now; how now

I have told your of your lordship .... - iv. 3

if your lordship be in't, as, I believe... $\quad$ - iv. 3

we shall hear of your lordship anon...

and leave him to your lordshill

fly them, as you swear them lordship

please your lordship to accept our - (induc.)

lease your lordship drink a cup 二 2 (induc.)

I had torgot to tell your lordship.... Richaril 2 (ind ii.

because your lordship was proclaimed - ii.

Falstaff, an't please your lordship (rep.) -

God give your lordslip good time (rep.) -

will your lordship lend me thousand

pleaseth your lordship, to meet.....

Henry $P I$, iii.

- iii.

your supplications to his lordship? . 2 Henry $I^{\prime} I . \mathrm{i}$.

unto your lordslip. Be it a lordship - iv.

how hath your lordstip brooked..... kichary 111 . iv

to your noble lordship [Col, Knl,-seir] -

$[\mathrm{Col}$. Knt. $]$ then eertities your lordship
sends to know your lordship's pleasure

keep your lordship in that gracious

return before your lordship thenc....

IIl wait upon your lordship ....... - iii.

until your lordship came to see his end - ii. 4

to that end we wished your lordship
your tordship is a guest too........

ah, poor my lord, what tongue... 
I.ORDSHIP-I am your loodship's ... Henry ITHI i. 3 your lordship were but now eolfessor

by my fnith, I thank your lordship.

thealth to your lordships. Thanks

- ii.

I do beseceh your loriships. that

I ghull both find your lordship surige ze Y.

houonr and lordship are my ...Troilus \& Cress. iii.
your lordship ever hinds him ... Timon of Athens, i.

here at your hordship's service

labour, and long live your lordshipi

beseech your lordship to accent...
we will bear, with your lordship.

we will bear, with your lordship....
please it your lordship, he hath put

please it your lordsip, your lordslifip

Inay make his lordship to furnish

please your lordship, here is the wiue

your lordship speaks your plensure.

your lordship to supply his (rep.

your loriship's a goodly villain ....

we attend his lordship; pray, signify
hearing weell of your lordship.........

more willing, than we yourdorip
not unkindly with your lordship...
when your lordship this other day.

when your lordslip this oth

I was sure, your lurdship did not.Julines $\overrightarrow{C a s a r}$,

I'll attend your lordship .......

ay, it is fit for your lordship only

one of your lordship's pages .........
I'll at tend your lordship: that sizch

your lordship is the most patient man

after the noble temper of your

whith his gifts present your lordsio... Tilus and. iv.

God give your lordship joy.

good-morrow to your lordship .......

but I nule marvel that yourdship eall? Gentlemen.

$\mathrm{mr}$ services to your lordship....

pe please your lordship, none me to the murder of your lordship - i.

hail to your lordship: I am glarl to see... Hamlet, i.

what means your lordship? That if

Your lordship is right welcome buek
if your lordship [ $\mathrm{kn}, \cdot$-f friendship] we

I thank your lordship, 'tis very hot

your lordship speaks most infallibly

Ir commend my duty to your lordship

we'll wait upon your lordship .........

CORENZO: fare you well (rep.) Mereh.

and I must to Loreuzo, and the rest

shalt thou see Lorenzo, who is thy ...

the penthouse under which Lorenzo

here comes Lorenzo, more of this

Lorenzo, and thy love. Lorenz

who knows, but you, Lor

were seen together Lorenzo and his.

were seen together Loren

who eomes here? Lorenzo ..........

Lorenzo, and commit into your hands

nay, you need not fear us, Lorenzo.

his son Lorenzo, and his daught

will be well welcome to lorenzo swear he loved her

master Lorenzo, and mistress l,orenzo

nor you, Lorenzo; Jessica, nor you.

how now, Lorenzo? my elerk hath..

how now, Lorenzo? my a erk hath..

ay, but to lose our bottles.

you are like to lose your

w'e shall jose our time
when did you lese y our daughte...

when did y ou lose your taugh

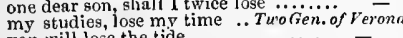

you will lose the tide $\ldots \ldots$.........

losing the flood, lose thy voyage $(r e p$.$) -$

fear thou slould'st lose thy tongue (rep.) -

Julia I lose, and Valentin

I needs must lose my
if $I$ luse them, thus.....

and doth lose his form ..............

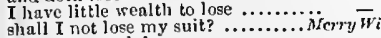

I loke not my labour.

shall t lose my doetor?

if lie lose, he makes a awan-like cnd

when yon lart from, lose, or give....

[Col.Kut.] not only lose the torfeiture

ere thon silialt lose for me one drop.

repe all, ay, sacrifice them all

nor give, nor lose it ...................

you lose your city ............

will lose the gloss by lyin

will lose the gloss by lyin
and lack not to lose still

and give where she is sure to lose...

when I lose thee again, I care not...

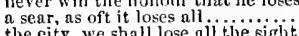

the city, we shall lose all the sight

lose our drum! well ................

shall lose my life fur want

lord, how we lose our pain

I will lose a husband) send for your

I would not lose the dog

to may you lose your arms

thou shat lose nuthing here .....Winter

will lose his beauty ; and though goli

l)ath the wit to lose his liaix.....
forty duents is too muels to los

or lose my labour in assaying
life which he deserves to lose.

mirylitst not lose the dues.

no extcin

by disjoining hands, hell jose $a$ soul

must iray that thou mayst lose $\dddot{7}$.
whorver wins, on that side shall

and lose it, life and all, as Arthur.

none, but to lose your eyes .........
and lose my way among the thorns..

since I must lose the use of all.....

and that breath wilt thou lnse......
you lose a thousand well-disposed ..

to make him lose at hom

infear to lose what they

what didst thou lose, Jack?...

nor lose the good advantage.

and you, my gentle creditors, lose

lose the better half of our

so soon did lose his reat

that you lose so mueh complexion?

I would not lose so great an honlon

he dies, we lose; I break

re lose, they daily get

shall lose his head for his...

I lose indeed; bealyrew the winners

no, not to lose it all, as thou ........

iii. 2 to lose thy youth in peace

iii. 2
iii. 4 to lose his birthright thus?

should lose his birthright

gentleman did lose his life .........

twere pity, they should lose their
having nothing, nothing he can lose

and lose no hour, till we meet

Warwick, may lose, that now liath... - iv.

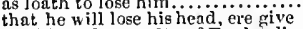

shall lose the royalty of England's :.

come seaffold, tliere to lose the

gond discourser lose some life

and lose by over-runting ...........

loves you, beware, you lose it not....
she will not lose her wonted greatnes

she will not lose her wonted greatn
ot let me lose the fashion of a man!.

should lose their names .......T
woulk not lose so rich advantage

would not lose so rich advantage ....

begin to lose their thloss

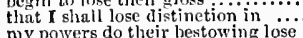

ny powers do their bestowi
for which we lose our heads

now if thou lose thy stay

I eome to lose my arm, or win.

I shall lose a stone by
but thieves do lose it

or all, or lose hi- hire

if I lose a ecruple of this sport ...T Tüelfh $\bar{\Lambda}$ igh my lady would not lose him .......... make us lose the good we of t.... Meas. for HFeas. i. 5
if I do lose thee, I du lose a thing.... - iii. 1

to lose his head.

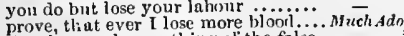

prove, that ever tose more bloof .....

my mind did lose it............... Hia.

by that which $I$ will lose for thee

tongue, lose thy light! .................
to lose an oath to win.
onee lose our oatha, to find (rep.)....

by light we lose light................
you will lose your reputation.

they lose it that do buy it with ...M

wisdom by their wit to lose...........
chunsing wrong, I lose your company

\section{cold}

to lose itself in a fing ..................

our authority. or let us lose it...

to lose it by his eonntry...........

but this single plot to lose.............
and lose advantage, which doth ever

and lose advantage, which doth ever

or lose mine arm for't .................
his kinduess, and cannot lose your way

alnek! or we must lose the country . Julius $\bar{C}$

when it serves, or lose our ventures.... Jin Casar, $\mathbf{j} .2$

if we do lose this luttle (rep.) .........

like a fool: the way to lose him.............

gets money, where he loses liearts...
at any game, thou art sure to lose... virtues which our tivines Jose bi them
you are nt point to lose your liberties \begin{tabular}{r|c} 
iii. 2 & Lose the praise of it by telling ...Anlony \& Cleo. ii. \\
:ii. 2 & if I lose nine honour, I loge myself..
\end{tabular}

iii. 2 would make any man cold tu lore ... Cymbeline, ii.

gains, or lopes, your sword, or mine
inm sure, she would not lose it

to $w$ in time to lose so bad eniployment =

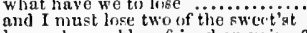

whe

his Philomel must lose lier tongue

as jewels lose their glory

at sea didist lose thy wite ........

a father, that you nust luse $a$ husband

it Ehall lose thee nothing $\ldots . .$.

with the waters that you luse ............

must draw me that which my finther loses

I had rather lose the battle

who loses and who wins.................. Jutive, iii. 2

which theu at once wonldst lose ....

reason to the Dane, and lose your voicc.. Hanilel, i. 2

let not thy mother lose her prayers

loan oft loses both itself and triend.

doth the purpose lose, the vivience

you will lose not this wager, my lord

二 iij. 2

as it may lose some colour .........

othello, j. 1

列

I will in Cassio's lodging lose this napkin - iii. 3

where should I lose that handkerehief... - ili. 3

to lose or give't away, were such perdition - iii. 4

with the losers let it sympathise.... I Henry IV. v. 1

suhducd, and neither party losers.

but I can give the loser leave

and well such losers may have ....... -

for losers will have leave to ease.. Titus Andron, iii.

unless you repute yourself such a locer... O'hello, ii.

thou losest lubour: as easy .............. Macbeth, v. ?

thou losest here, a hetter where to find .... Lear, $i$.
cosexll-yet lie loseth it in .. Comedy of $E$ r.w.

a nubleman, loseth men's hearts....IHenry I $\mathrm{V}$. iii.

played the sheep, in losing him

in losing the flood....

in losing thy voyage

ind, in losing thy service.

grows dark by losing of your eyes... Love's $\vec{L}$. Lost, $i$. on pow thus a losing suit against.

but only the losing of hope by time...All's "I'fll

than they are in ling them

ho more be in danger of losing ....
have you Inst by losing this day?

news hath but a losing office

$\therefore-1$

burs, hasing both beauty and utility ...Hetry $\%$.

by losing of our prayers. I shall...Antony \& Clen. ii.

'osing a mite, a mountain gain.

oss-my father's loss, the wenkness....
for our eseape is much beyond our loss

thank yourseif for this great loss

so is the dearest of the los

but an infinite loss

for tharale is the los

portable to make the dear los................

considered well his loss of time.. Two Gen. of Ter. i.

thus find I by their loss ................ morry Wives, iv.

and the tongue of loss, cried fame. Tueljh Night, y.

but in the loss of question ........Meos. for Meus. ii.

not proclaim against her maiden loss

hyve had nny loss at sea or no........... of I'enice, iii.

why, thou loss upon loss! the thicf.. $\overline{\text { Iii. }}$.

sithence, in the loss that mav hapjen - i.

that's the loss of men, thomgl it be .. - iii. ?

at the merest loss, and twice.. Taming of $\overline{s h} 1$ (ind.)

poor thing, condes, the gain

art thus exposed to loss, and what...

declined for the loss of her luspues

hazarded the loss of whom I loved. Cumedy of $E$,

tells of this war's loss, with slaurchter

or the light loss of Enyland for......

had you such a loss as $\mathrm{I}$.

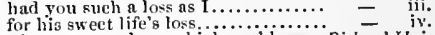

the worst is worliur highess

and what loss is it, to he rid of

my eare is-loss of eare hy old ......

ef loss?

henvy in Ilotspur's lusk

knew................

repeat and history his loss to ncw.... Henry $r$. iv.

ever known so ereat and little joss ... - iv.

or the lose of thoke grent towns

that now our lose night he 


\section{LOS}

LOSS-lands, and all, hurry to loss ... I HenryVl. iv. 3 LOST-we have lost our labour

your loss is great, so your regard (rep.)

but wail her darling's loss ............ Hen

grieve I at an hour's poor loss...

the loss of those three lords....

our hap is loss, our liope but sad

sad for the loss of thee, having....

what, loss of some pitched battle (rep.)

what, loss of some pitched battle

recover all our loss again I.

but loss of such a lord. The loss of...ंichard IIT.

their kingdom's loss, my woeful.......

had so dear a loss! (rep.) ....

and weep, their gain and loss...........

match not the high perfectio
bettering thy loss makes the

the loss, you have, is but a son (rep.)

what a loss our ladies will have

a loss of her, that, like a jewel

guecess, or loss, what is, or is not. Troilus \& $\vec{c}$ ii. 2

with such a costly loss of wealth

my grief, in such a precious loss.

and loss assume all reason ............
that seest not thy loss in ..... Timons of iv.
harm, than so much loss of time..... Coriolenus, iii.
but the loss of

but the loss of what is past ...........

insupportable and touching loss I...Julius Cresar, iv. 3

no less than was his loss

to the very heart of loss ..........

to your so infinite loss.

in the holding or loss of that

Cymbeline

the most patient man in loss

thou bidi'st me to my loss: for true ..

though with the loss of many a bold one all this loss of blood

whose loss hath pierced him

Pericles, iii. (Gower)

by the loss of maidenhead.

serve seven years for the loss of $3 \ldots \ldots . .$.
all springs from the loss of a beloved..

stand in assured loss ...................... Lear, iii. 6

feeling so the loss, but not the friend

then weigh what loss your honour ....... Hamlet, $\mathrm{i}$. 3

I a m most unhappy in the loss of it

LOSSES - a fellow that hath had losses...inuch $\overline{\text { ddo }}$, iv. 2

might prove the end of his losses1 Mer. of Ienice,

laughed at my losses, mocked at my
these griefs and losses have so 'bated me

iii. 1

an eye of pity on his losses..............

unto their losses twenty thousand. Taming of All iv. 3

read in your own losses, if he stay...

for our losses, his exchequer is too.

wailing our losses, whiles the foe

3 iif. 6

their aches, losses, their pangs . Timon of Alhens, $\nabla .9$

great men great losses should endure /ul. Cesar, iv. 3

LOST-all lost, to prayers, to prayers (rep.). Tempest, i. 1

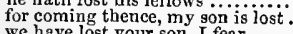

we have lost your son, I fear

thou wert but a lost monster

where I have lost, how shar

firr I have lost my daught

if lost, why then a grievous... Tüo Gen. of Verona, $\mathrm{i}$. 1

I, a lost mutton (rep.)

no matter if the tied were lost $\ldots \ldots . . . .$.

so that I have lost my edifice ..........

sooner lost and worn $\ldots . . . \ldots \ldots . . .$.

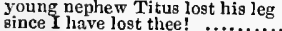

thus foolishly lost at a game of .......eas. for Meas. $\mathrm{i} .1$

there she lost a noble and renowned

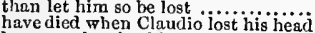

have you lost in this action? ...........Much Ado, i.

vour grace may well say I have lost

but being lacked and lost, why, then - iv, 1

the ploughman lost his sweat.. Mid.N.'s Dream, ii. 2

thus hath he lost sixpence a day

T.Lost, i. $\begin{array}{r}\text { iv. } \\ \text { Liti. }\end{array}$

with fire; so won, so lost........... Love's

from tawny Spain, lost in the world's
since, to wail friends lost, is .........
when I had lost one shaft........

that which $I$ owe is lost

a father, you a daughter lost

the end is, he hath lost a ship

the fleece that he lost a ship ......

and swear, I lost the ring defending it

most true, I have lost my teeth ...As you Like v. I

which you have lost good sport

monsieur, that the ladies have lost?

we lost not our time (rep.)

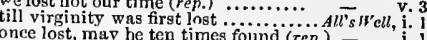

once lost, may he ten times foimd (rep.)
whercof the king is rendered lost
LOST_we have lost our labour
the modesty which is so lost

I wam so lostl there was

we lost a jewel of her; and our

praising what is lost, makes $I$ have lost,

how I lost my crupper ...... Taining of shretr, v.

as he had lost sone province........ Winiter's Tule,

cry, lost, and so good-uight.

your favour, I do give lost; for $\mathrm{I}$.

Which is lost, be not found

and, for the babe is eounted lost.

cozened by the ray, and lost all $\mathrm{my}$

age, thou hast lost thy labour

tiil his lost child be found?

and then I lost (all my own folly)

then have you lost a sight $\ldots . . . \ldots . .$.

were even then lost, when it wäs found

and recover the lost hajr (rep.) .. Comedy of

no evil lost is wailed when.

how hast thou lost thy breath?

blood that then I lost for thee

when the battle's lost and won

though his bark cannot be lost

be not lost so poorly in your tloinght

we have lost best half of our affa

rather, lost more; and by this hand... Kin

is my son, and he is iost

what have you lost by losing

gricrous taxes and lost their hearts. nichard iii.

at Bristol lost their heads

but that is lost, for being Ricliari... = iii. 2

therefore lost that title of respect...1 Henry $I V$. i. 3

why hast thou lost the fresh

in this robbery lost three luun $\ldots \ldots . .$. .

place in council thou hast rudel..

for thou hast lost thy princely

Was never lost in my house before

hast redeemed thy lost opinion

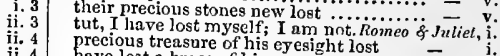

lands so by his father lost

Hamlel, $\mathrm{i}$.

your father lost a father $(r e$........... - i.

lost all my mirth, forgone all custom..... $=$ ii.

and so have $I$ a noble father lost .........

have lost it with hollaing $\ldots . . . .2$ HenryIV

had my father lost, that need

\begin{tabular}{r|r} 
ii. 3 \\
iv. \\
v. 1
\end{tabular}

my lord, you have lost a friend, indeed

hath lost never a man, but one ... Henry $V$.

the subjects we man, but on

the time was blessedly lost, wherein

in these ten thousand they have lost

have lost their quality...

that they lost France, and made $-\cdots$ v. $\overline{2}$ (chorus)

Poictiers, are all quite lost

is Paris lost? is Rouen yiclded uph...

how were they lost?..................

earl of Cambridge lost his head.......

lost, and recovered in a day againl.

we lost $t$ welve hundred men.

in you all hopes are lost

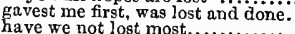

France will be lost ere lon

Paris is lost; the state of Normandy

was besieged, famished, and lost ....

whereof, his highness hath lost France

I rather would have lost my life .....

I lost fair England's view

lives of those which we have lost in fight -

I lost not Normandy

to France, and get what you have iost

the ten meals I have lost ...

you have lost half your; but

othello. $\mathrm{j}$.

what, have you lost gour wits?

how lave lost him on 4 sangerous sen!

how lost you company 6 The great

lost my reputation! I have lost.........

I had rather have lost my purse fnll of..

is't lost? is't gone? speak it it out of

not lost; but what an' if it it out of ...

if you have lost him, why I have lost him

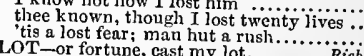

had paid me scot and lot too............

Richard II. $\mathrm{i}$.

it is lots to blanks, my name

Henry/IF. v. 4

. Antony \& Cleopatra, .i. 2

that man and nife draw lots............... Pericles, i. 6

why, as by lot, God wot, and then........ Hamlet, ii. 2
LOTTERY - the lottery that he ... Mer. of Venice, i.

besides, the lottery of my destiny ....

no, make a lottery; and, byderice. Troilus of Cress. i.

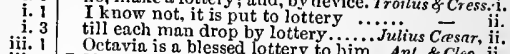

iii. 1 Octavin is a blessed lottery to 1 im.... Julius Cresar, ii.

iii. you should have heard him so winds.. Tempest. iii. 3

iii. t sing them loud even in the dead.. Tuelfih Night, i.

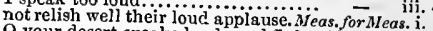

o your desert speaks loud; and I should - v.

speak loud, and kneel before him $\ldots$ assion of loud laughter.....Mid.N. $=$

whilst the scritcli-owl, scritching loud sDream, v.

thy lungs to speak so loud ... Merchant of Venice, iv.

bellowing, and neighing loud, which is ${ }_{\text {that fame may cry you loud... }} \bar{W}_{o l l}$ ii.

to endure her loud alarums ............All's Woll, ii.

though she chide as lond as thinnder..

in a pitched battle heard loud 'larums

'tis like to be loud weather amazed...

trumpets, and loud churlisj đrums...... King John, ii.

the holding anchour lost to him ............

won in blood, lost be it soi ............ Richard III. i. 3 were lost sorrow, to wail one that's lost -
$\mathrm{my}$ husband lost his life ...........

his death liath lost much majesty...

hath lost his holy honour.

my lord, or else the day is lost

then you lost the view of earthly.... Henry $\bar{V} I I I . \quad \mathrm{i}$.

a woman lost her lustre

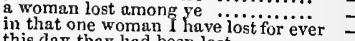

this day they laad been lost . 3 ince......

if we have lost so many...... Troilus \& Cressi roaring lench be lords of this loud day

when loud Rumour speaks? $\ldots . .2$ Henry $\bar{V} \bar{V}$. (induc.)

with what loud applause did

your tongue divine to door?

and the loud trumpet blowing

fills the world with loud repor

i Henryy

Temple hall we were too loud

and erying with lond voice ............ loud s loud, on the unsteadfast $\ldots .$. Hen $v_{y} I V$. i. 3 
I,OUD, and to as many tunes ...... Henry FlII. jv. aptak not soloun

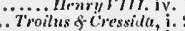
laughs out a loud applause...... trimpet, blow lond, send thy. who bimils in lourl applausc went toud the tambourino consort with me in loud and dear. peace, peace; be not so loud. (1) Cleo. i. as lond as Mar to our our trivinl difficrence loud as boud as his strong sides ean . we bid a loud farewcll to these....

by crying out as loud, $O$ bless my

$[\mathrm{Col}$.$] to the loud noise we make....$

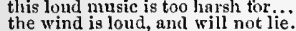

os loud as thunder thrcatens us....

with loud and coward crie

the calls so loud? Come hither.. Romeo \&. Jukiel, v. what act, that roars so loud, and thunders iii too slightly timbered for so lond a wind.. - iv. such loud reason to the Cyprus' wars tongue at will, and yet was never loud

either by speaking too loud, or tainting OUDER-are louder than the weather. Tempest, i. I no certrinly:-Speak louder

ten times louder than benuty............ fors. for $\vec{M}$ eas, ii. griefs cry louder than advertisement. Much Ato, you were best knock louder. . Taming of shrew, v. 1 you must speak londer, my master..2 Henry $I \gamma$. i. 2 and let him ery ha, londer !......Henry VIII. iii. breath that nay proclaim them iouder. Pericles, $\mathrm{i}$. 4 draw near; louder the music there ...... Lear, iv. 7 Fame with her loudest 0 yes cries. Troil. \& Cress. iv.

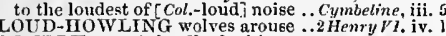
LOUD-HO WLING wolves arouse ...2 Henry Vl, iv. I
I.OUDLY - speak loudly for him........ Hamlet, ₹. 2 LOUSE-the dozen white louses..... MIerry Wives, $\mathrm{i}$. 1 r.OUSY - on the lousy knave (rep.). Nerry Wires, iii. 3 upon my knowledge, he is, and lousy. All's Well, iv. 3 rascally, beggarly, lousy knave it is.. Henry $V$. iv. 8 lousy, pragging knave (rep.)

LOUT-to yon foolislt lnut... Two Gen.... Vo Verona, iv. 4 pronounce tliee a gross lout $\ldots \ldots$... Winter's Tale, i.
in such a love, so vile a lout as he ... Kiny John, ii. 2 in such a love, so vile a lout as he ... King Inhn, ii. but a calf's skin, most sweet lout...

rather sliow our general louts...... Coriolinnus, iii. 2
go before this lont, as he exceeds.... Cymbeline, v. 2

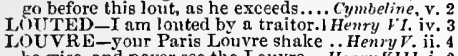

be wise, and never see the Louvre... Henry $111 . \mathrm{i}$.
LOVE $\rightarrow$ none that $\mathrm{I}$ love more than .... Tempest, i.

go dear the love my peopl

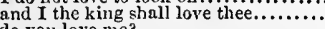

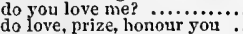

were but my trials of thy love

with such love as 'tis now

do you love me, master? ........... Joves -

a contract of true love to celebrate (rep.)

a contract of true love

no, my dearest love.................... $r$.

lut since thou hovest, love stitl ...

when $I$ to love begin

upon some book I love $\ldots \ldots \ldots \ldots \ldots$

a deep story ot a deeper love

more than over shoes in love

for you arc over boots in love.........

tis love you cavil at; I am not Love

love is your master, for he masters you even so love inliabit

of thy success in love........................

my friends, and all for love.............

which is worthiest love?

have me cast my love on him?

I think, best loves ye...

howe hin love be

do not love, that do not show their love

to plead for love deserves more .......

how uayward is this toolish love

some love of yours hath writ

to the tune of light o' love

sweet love! sweet lines

herc is her onth for love $\ldots . . . . . . . . .$.

our fathers would applaud our loves

take exceptions to my love....

exceptcd most agninst my love.........

she, that your worship loyes?.........

how know you that I am in love?...

because love is bliud

for he, being in love $(\ddot{r e p}$.

then you are in love .....

I was in love with my hed

you swinged me for my love ...........

to write sume lines to one she loves..

tbougli the eameleon Love can fced
I, OV E-my love's forgctín ay boy, it's for loye.

as wortly for an empress' love.

they say, that love hath not

upon a homely object love can wink. how thrives your love?

my tales of love, were wont

in revenge of iny contempt of love...

love hath chascd slcep from.

love's a mighty lord.

upon the very naked name of love.

for love delights in praises $\ldots \ldots . . . .$.

seest me dote nipon my lov

but she loves you? .....................

the remembrance of my former iove

I did love, tor now my love is thawed

$O$ but $I$ love this lady

the reason I love him so little.............

without advice begin to love her?...

if can check my erring love.........

to love fair Silvia.................

O sweet-suggesting love

cannot leave to love

where I should love............

for love is still more precious...

love, lend me ring

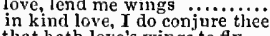

that hath love's wings to fly

quench the fire of love with words.

your love's hot fire

instauces as infinite of love

his love sincere............

this love of their's myself have.

bath drawn my love from her.

to beget more love in you

for love is like a child.....................

thou canst not see thy love .............

that knows me to be in love

yet I am in love.

nor who 'tis $Y$ love

nt that slye will love you

列

not long continue love sir Thurio?

this weed her love from Valentine

it follows not that she will love...

already Love's firm votary $10 . . . .$.

ghows thou hast been in love

love thee as our commander

my own love to prefer $\ldots \ldots$

love will creep in service.

that you love not here?
love doth to her eyes repai

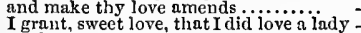

Iny love is buried, that I did love a lady -

your picture for my love $\ldots \ldots \ldots \ldots . . . . .$.

and thy true love died ............. Sivin

as well as you do love your lady Silvin -

that en that has forgot her love...

tis pity. love should be so contrary.

because he loves her

love him, I must

iny master's true confirmed love

reapects my mistress' love so m

ho have can trife with itself!

if this fond love were not a blinded god! -

to make my master out of love with thce -

but love will not be spurred

when $I$ discourse of love and peace?.

more tor Silvia's love

for silvia, that is gone for love

forced your honour.

love, lend me patience

$O$ 'tis the curse in love.

when women cannot love

thy first best love

descended into perjury, to love me

in love who respects friends?

maith or love

that my love may sppear plain.......

I dare thee but to breathe upon my love -

for a girl that loves him not

the story nf your loves discovered......

and gignifies-love ................ Alerry
I love [Cot, Knt,-thank] you always
can you love her?
LOVF-ean you love the maid

I love the syort well

to mukc love to Ford's wife.

of this love to Page ny master himself is in iove with

gir, the maid loves you

ii. 4 I'll be sworn on a book, slie loves you

ask me no reason, why I love you... - ii. ( (letter)

you love sack, and 80 do I $1 . . . \cdots \ldots \ldots$ - ii. I (letter)

ii. 4 you love sack, and so do $1 \ldots \ldots \ldots \ldots$ - ii. . ( ) (letter

ii. 4 he loves thy gally-mawfry.......... - ii.

ii. 4 love my wife?...

ii. 4 Falstaft loves your wife $($ rep. $)$

each other how they love me?

your little page, of all lov

\begin{tabular}{l|} 
ii. 4 \\
ii. 4 \\
ii. 4
\end{tabular}

shadow flies, when (rep.)

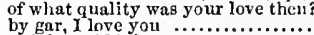

and de maid is love-a. me

ii. 4 what made me love thee?

ii. 4 I fear, you love mistress Page

ii. 6 well, heaven knows how $I$ love you

I love thee; and none but thee

a thing impossible I should love the

yet scek my father's love ............

\begin{tabular}{l|l} 
ii. 6 & mistress Anne, my cousin \\
ii. 6 & as well as I love any woman
\end{tabular}

ii. 6 for that I love your daughter....

acivance the colours of my love.

ii. 7 winl I question how she loves you ...

you are obscquious in your
in the simple office of love

the dear jove I bear to fair Aune

love set on thy horns $($ rep. $) \ldots . . . . . .$.
a swan for the love of Leda $(r e p.) . .$.
I will never take you for my love again -

there was no proportion held in love

in love, the heavens themselves.....

play on. Tuelfh Night, i.

to spirit of love, how quick........

this debt of love but to a brother (rep.)

did seek the love of fair Olivis

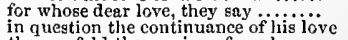

then unfold the passion of my love.

niy lord and master loves you (rep.)

with groans that thunder jove

cannot love him (rep.)

write loyal cantons of contemned love

love make his heart of fint (rep.)

if you will not murder me for my iove

she loves me, sure

ohe were better love a drean

is desperate for my master's love

your true love's coming, that can

an' you love me, let's do't.

ail that look on him, love him

in his way some obscure episties of love

and that sle is in love with him

if ever thou shalt love $\ldots$ to...........

upon some favour that it loves .......

and dallies with the innocence of love

tell her, my love, more noble than

hath for your love as great a pang

as love doth give my lieart

their love may be called appotite

too well what love women to m......

the never told her love, but let .......

was not this love, indeed

died thy sister of her love, my boy?

say, my love can give no place ......

obeerve him, for the love of mockery

she manifeets liersclf to $\mathrm{my}$ lo.........

if thnu entertainest my love

than love that would seem hidi: love

love thec so, that maugre all thy

love sought is good, but given.........

a great argument of love in her....

and not all love to see $y$ ou

ny willing love, the rather by

one ir that tor hy master.

eved hin with such sanctity of love

and galt waves fresh in love

and did thereto add $\mathrm{my}$ love.

pure for his love, into...

whom, I know, you love .............

ancrifice the lamb that I do love......

aftcr $\lim I$ love, more than $I$ love .
tluu e'er $I$ shall love wife............

ii.

i. 


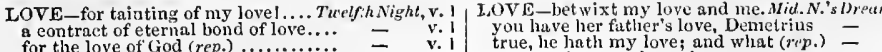

drest him with our love..... Measure for Measure,

I love the people, but do not

we thought it meet to hide our love.

if she he in love, may sigh it off......

the dribbling durt of love can pieree

love you the man that wronged (rep.)

o injurious love, that respites.

where their untaught love must need

for his alvantare that I dearly love..

if you give nue tove

I am s.) ont of lore witl life.......

to the love 1 have in doing good......

in his love toward her ever ned her love

and I love liin. Love talks with.

and knowledge with dearer love

seals of love, but sealed in

true, he hath my love; and what (rip.)

my love is orore thao his ............. what cheer, ny love? Demetriu coirse of trie love never did run snootl -
$O$ hell! to elioose love by another's eyel as due to love, as thoughts, and dreams and prospers loves; and by that fire keep promise, love; look, her

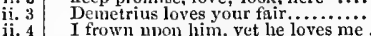

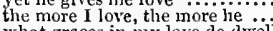

what graees in my love do dwell .... nor hith love's mind of any

so the boy Love is periured every....

tis the larly that I'yramus must love and versing love to amorous Phillida and your warrior love, to Theseus .. knowing I know thy love to $T$ now purple with love's wound $\ldots . .$.
she shall pursue it with the soul of love I love thee not, therefore pursue .... eannot love you? And even for (rep.) ean I beg your love, (and yet a plaee.. we eannot fight for love, as men may do to die upon the hand 1 love so well. a sweet $\Lambda$ thenian lady is in love with fond on her, than she upon her love do it for thy true love take; love... fair love, you faint with wandering love takes the meaning. in love's ..... for love and eourtesy thy love ne'er alter, till.............. this flower's foree in stirring love... he love your Hernia? (rep.) ..... love's stories, written in love's richest address your love and might ........ speak, of all loves: I swoon a to say, to swear, I love thee. reason and love keep little company and $I$ do love thee: therefore, go with to have my love to bed, and to arise
tre up my love's [ $\mathrm{Col}$.-lover's] tongue tre up my love's [Col.-lover's] tongue why rebuke you him that loves you so? some true love turned, and not when his love he dotl espy, let her. Demetrius loves her, and he loves not to what, my love, shall I comnare you both are rivals, and love Hermia in Hermia's love I yield you up .... whom I do love, and all that love is gone

whom love doth press to go? what love Lysander's love, that would not let. will you rent our aneient love asunder and made your other love, Demetriu deny your love so riel within...

my love, my life, my soul

Helen, I love thee; by my life ....... is this, sweet love? Thy love.

that I do hate thee, and love Heleng stolen my love's lieart from him I evermore did love you save thant, in love unto Demetrius for love, followed him ............... $I$ with the morning's love have of some inusic, my sweet love? $\ldots$......... o how I love theel how I dote ....... my love shall hear the music of $m y$. my love to Hermia, melted as doth now do I wish it, love it, long for it." joy, and fresh days of love, aceompany that have I told my love, in glorv of of young Pyramus, and his love Thisbe = my lovet thou art my love, I think. asleep, my love? what dead,.......... to love, to weal th, to yomp, I pine Love's $L$, I protest, I love to hear him lie.

in love; and as it is base for (rep.)

like a porter; and he was in love.... but to have a love of that eolou

my love is most immaculate
boy, I do love that eountry girl better love than my master......

if $I$ love: and how ean that he true love love is a faniliar; love is a devil (rep)

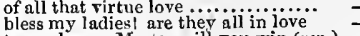
to my lope. Master will you win (rep.)

what is your will? Do not you love me?

swore you did. Do not you love me?

then you do not love me? No, truly..
love the gentleman. And I'll be (rep.)

live unbruised, and love my cousin .iid. $N$.'s $D r$. i. I

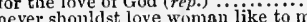
how now, my love? why is your cheek love can transpose to form and (rep.) with sighs of love, that cost the fresl you thief of love! what have you.... love, therefore, and tongu-tied.

what great men have been in love? of all that virtue love

LOVE with ginging love call'st thou my love, hubby-horse? your love, perhaps, a hackney (rep.) by heart you love ler becuase. in heart you love her, beeause......... 政 vell I will love,

some men must love niy

thy love? I may: shall I enforce $(\mathbf{r e p}$.) $-\overline{i v}$. understandeth thee not, loves thee not if love make me foresworn (rep.

oh pardon, love, this wrong ....
by the lord, this love is as mad

by the lord, this love is as mad .......

I will not love; if I do, liang me $\ldots . .$.
but for her eye, I wonld not love $h e r$

by heaven, I do love: and it..........

but do not love thyself; then

in love, $I$ hope; sweet tellowship ....

ii. 2 the shape of love's Tyburn that...... - iv. 3

empress of ny love ............... iv. $\overline{3}$ iv. 3

I'll mark how love ean vary wit $\ldots .$.
love, whose nonth is ever Mlay $\overline{3}$ (verses)

turbing mortal for thy love.... _ - iv. 3 (verses)

thy love is far from charity (rep.)...

you do not love Maria................

for loving, that art most in love?

[ $\mathrm{Col}_{2}$ ] or grosn for love? $\ldots \ldots \ldots \ldots \ldots \ldots$

are piek-purses in love; and we......

rent lines show some love of thine?.

my love, her mistress, is a graeious..

by heaven, thy love is black.

look, here's thy love: my foot $\ldots \ldots . . . . .$.

but love, first learned in

love's tongue proves daint $\ddot{\text { Bacehü }}$

is not love a Herenles, still

and when love speaks, the voice........

were tempered with love's sighs.......

all men love; or for love's sake (rep.)
and who can sever love from eharity?

forerun fail Love, strewing her......

yes, as mueh love in rhyme, as would

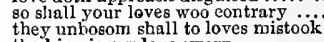

the king is my love sworn

my love to thee is sound....

the smiling the foot $\ldots . .$.

yet, since love's argument was ........

as love is full of unbefitting strains...
presence of loose love put on by us
our love being yours, the error tbat love

fill of love; your favours (rep.)......

srant us your loves...................

grant us your loves..................

your love, but that it bear this trial (rep.) -

what to me, my love? (rep.)............. -

if I have much love, I'll give you some some serviee on me for thy love.

for her sweet love three years ..........

o money, and in love (rep)

wind about my love witl eireumstance -

fit one who you shall rightly love..

and have your love, forget the slinmes

make ineision for your love...........
by my love, I swear, the best-regarded
I am not bid for love; they fatter....

am not bid for love; they flatter.

and thy love. Lorenzn, eertain (rep.)

but love is blind, and lovers cannot.

beshrew me, but I love lier heartily

more than these, in love $I$ do deserve

let it not enter in your mind of love

I think, he only loves the world ...

so likely an embassador of love.

Bassanio, lord love, if thy will it be!

something tells me (but it is not love) makes me fear the enjoying of my love snow and fire, as treason and my love

enfess, and love, had been the very

if you do love me, you will find

o love, he moderate, allay thy

presage the ruin of your love.

to have her love, provided that.....
when I did first impart my love

dear bought. I will love you dear.....

i. 2 dear bought. I will love you dear...

do bear an equal yoke of lore.

the which my love, and some necessity

sought my love, which I denying....

i. 2

human gentleness and love ..... ii. 1 kill the things they do not love? $\ldots$

whether Bassanio had not onee a love

in love and serviee to you evermore. 


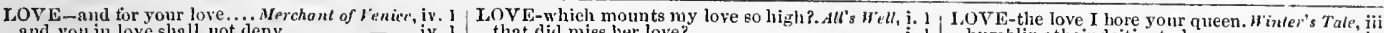

and you in love sliall not deny .... his descrvings, and my love withal $\ldots=$ and with un unthritt love, did run lirom -
slander her love, nud he forgave it tier slander her love, wnd he forgave it ther = since you do take it, love

I gave my love a ring, and made r. and for your love, I woitd be lnat therefore, out of my love to you .... not with the fuIl weight that I love thee I could have taught my love to take if the trutll of thy love to me were but love no man in tow in love? your father, loves. Ifly fither's love is if you do keep your promises in love true applause, and love...

Those lnves are dearer than $\ldots . . . . . . .1$ that you sliould love his sou dearly? love him for tlut: and do you loye him Rosalind lacks then the love which... I love to cope lim in these sullen fits Why do people love you? and wherefore
that thou knew'st how I do love her? love were ever like mine (rep.)
didst thou ne'er love so heartily that ever love did so hearti.

I remember, when I was in loye

80 is all nature in love mortal who loves to lie with me, and tune - ii. 5 (song)
and lores to live $i$ ' the slin ........ many a weary step limped in pure love must find of my love...............

what tedious homily of lore have you Rosalind is your love's name?

is to be in love. 'Tis a fault...
farewell, good sigoior Love.....

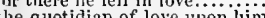

the quotidian of love upon lim

I eould make thee bolieve I love.

her that you love believe it...

are you so mucli in love

that the whippers are in love too...

from lis nad humour of love

not be one spot of love in 't..............

now by the faitl of my love, I

not true in love? Yes, when he .....

the shepherd that complained of love

feedeth those in love

say, that you love me not

that love's keen arrows make

asting, for a grood man's lnve

n love with her foulness, and (

my grief in love, by giving love.....

bear thee love: but sinee thou (rep.)

and so perfect is $\mathrm{my}$

think not I love him ..................

to hate him, than to love him

I do love it better than laughing

be out of love with your nativity

part ot a minute in the aftairs of love

he is one of the patterns of love
but not for love, I would not

then love me, Rosalind

he judge, low deep I am in love!

with pure love, and troubled brain

and that slie could not love me.....

her love is not tlie hare that I do hun

to raise such love in mine of....

whiles you chid me, I did loye

by him my love deoy ............

I see, love hath made a tame $\ldots$ me, I charge her to love

committing me unto my brother's love

you do love this maid? I do, sir

I love Aliena; say with her, that (rep.) -

they are in the very wrath of love..

if you do love Rosalind so near

tell this youth what 'tis to love..........

if this be so why hlame you me to love

I would love you, if I could .........
love Rosalind, meet; as youl love (rep.)

sweet lovers love the spring.......

why then, my love artieu?

why then, my love artieu.

a love, that your true faith doth (rep.)

a love, that your true faith doth (rep.)
for the love you bear to men, to like

love all, trust a few, do wrong to...... ne. Ali's well, $\mathrm{i}$.

the hest that shall attend his love 0.

the amhition in my love thus plagues

by the linn, must die for love...

chall your master have a thousand ioves - lis love nnd wistom appoved so to loves my flesh and blood, he that loves to as mich love as she finds love, no goll, that would not exterid... 'tis gross, you love my son

pardon mel do you love my gon?.... I love your son: my friends were (rep.) I know I love in vain

pour in the waters of my love

and love dearly, that your Dian (rep.) -

my leave, and ove, means

a poor friend of yours, that 1

a please! …

and to imperial Love, that god

and her humble lovel No bet

ny wish receive, which great love grant

cannot love her, nor will strive ....

lovest her, thy love's to me religious

prerogative and rite of love, which.

lay our best love and credence.....

an the

delighits to hear, and loves to grant.

led hitlier by pure love.

or the love of laughter, let him

in your fine frome hat . No more $(r e p$.$) -$

but I love thee by love's own sweet.. -

so holy-eruel; love is holy

and ever my love, as it heging

I begin to love him for this..........

truly labour to recompense your love

love her, strikes some scores away (rep.)

our own love waking eries to see

did he love this woman? Faith (rep.) -

Iill love her, sir, as a gentleman loves

as he will win my lover, ever dearly

and make known her love?

dost thou love hawking?

and, by my father's love and leave

both love katharina, beeause (rep.)

for I will love thee ne'er the less ....

yet, for the love I bear my sweet

be happy rivals in Bianca's love

that love should of a sudden take.

I foind the effect of love in idlene

if you love the maid, bend

your love must live a maid .

Tove fucentio. Tranio, be so (rep.)

and rivals in my love: supposing....

'tis the rival of $\mathrm{my}$ love ...............

'tis now no time to vent our love

I love no chiders, sir ..............

if I' get your daughter's love

this is, -her love; for that is ali.

Iove her ten times more than e'er

in a twink she won me to her love

I am one, that love Bianea more.

not love so dear as I (rep.)

disguised thus to get your love..........

the knave doth court my love

that loves with all affection

to looks as though he were in love concerneth us to add

now, if you love me, stay....

that I profess, the art to love.

O despitefurl love! uneonstant .......

forswear Bianea and her love for eve

ta'en you napping, gentle love

take in your love, and then let me

he does it under name of perfect love

love to feed upon.

and now, my honey love, will we...

a weighty cause of love between

and for the love he beareth to your

doth love my daughter ..................

now, pray thee, love, stay.............

but love, fair looks, and true obedience

are bound to serve, love, and obey

we will be justified in our loves .. $H^{\prime}$

were, in

love thee not a jar o' the clock ...

and clap thyself my love ..............

region loved as he loves himself

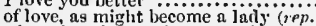

whose love had spoke, even since...

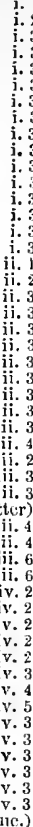

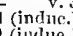

(indue.

i. 1

i. 1

i. 1

i. 1 i.

2

i. 2
i. 2
i. 2
i. 2

i. 2

ii. I

$$
\text { i. }
$$$$
\text { ing }
$$

iv. 3 he loves your, on my Jife and honour

iv. 4 as Hereford's love, so his

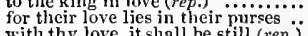

with thy lore, it shall he still (rep.)

shall be your love and labour'

and near in love, till you did....

with letters of your love to her
sweet love, I see, changing his

my heart might feel your love

service shall deserve your love
tears show their love, but want.....

are we beholden to your lov

the love of wicked friends.............
hand, my love, and heart finm lieart

that were some love. but little .....

ehall $I$, for love, speak trcason .....

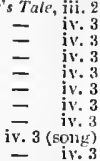

(song)

ii. 2

iii. 2

iii. 2

iii. 2

iv. 2

v. 1

, i.

i. 6
I. 6

1. 6
i. 6
i. 7

i. 7
i.. 3
ii. 3

jii.

iii. 1

iii. 5

iv. 3

v. 3

ii. 1

ii. 1

ii. 2
ii. 2
ii. 2

ii. 2

iii. 2

iii. !

iii. ?

iii. 3

iii. 3

iii. 4

iii. 4

iv. 1

iv. 1

iv. 3

v. 4
v. 4
v. 4

I. 7

i..
ii. 1
ii.
ii. !
ji. 2
ii. 2
ii. 3
ii. 3
ji. 3
ii.
ii.
i. 2
ii. 3
ji. 3
ii. 3
iv. 1
v. 1
v.
v.
v. 2
v. 3
v. 3 
LOVE, loving not itself, none otler ..RicharlII. v. 3 LOVE-his loves are brazen images ...2 Henvy VI. i. 3 tis a sign of love, and love to Richard they love not poison that

จ.

hate the murierer, love him murdered think his fove and your loves lim not

strangers to lins looks of love.......

- i. 3

respect of the love I benr your house ii. 3 (letter)

loves his own barn better than he loves

know it, else he loves me not

my horse, my love, my horse .......

you triflerl Love? I love thee not ..

Inill swear I love thee infinitely...

if thou love me, practise ...............

I will never be a truant, love.....

thy love is worth a million (rep.)....

love thy husband, look to thy servant

ome of us love you well

you would accept of grace and love...

we love our people well, even tiose (rep.) -

I were much in love with vanity..

and terms of love to all of you?.......

make me out of love with my greatness
but, for all our loves, first let them..

but I do not love swaggering

why does the prince love him so then? =

I love thee better than I love e'

wicked might not fall in love with him -

and laid his love and life under my foot -

proceeds from policy, not love ......

were our royal faiths martyrs in love

of our restored love, and amit

ober-blooded boy doth not love me.

he lores thee, and thou dost neglect

blunt not his love; nor lose the good

shall observe him with all care and love -

which nature, love, and filial te

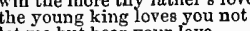

assured, I love you not ............. Hen to much love and $V$.

my love, give me thy lips....

a man that I love and honour .......

merited some love at his hands....

tis good for men to love their

I love the lovely bully

testament of noble-ending love........

apprehend him, an' thou dost love me

you do not love it, nor your affections,

on equal love, great kings of .

if you will love me soundly with .....

if $\mathrm{Imight}$ buffet for $\mathrm{my}$ love

if thou canst Iove a fellow of

in his glass for love of anything ....

for thy love, by the Lord, no; set I love What say'st thou then to my love?.$\ddot{r e p}_{\text {. }}$ )

love the friend of France; for $I$ love

canst thou love me? I cannot tel

that you love with your heart

in true English, I love thee, Kate....

how perfectly I love her ...........

as love is blind, and enforces ........

as love is, my lord, before it

I pray you then, in love and dear....

being two, are one in love...

I love no colours; and, without

in signal of my love to thee,..........

join your bearts in love and amity :

love for thy love, and hand for han

presence of a king engenders love....

as you love our favour, quite to......

my kinsmen, and $I$ love them both.

if you forsake the offer of their love.

little duty, and less love

O if you love my mother, dishonour not -

before thou make a trial of her love?

never yet taint with love ..............

do breed love's settled pasions

where I may have fruition of her love

to love and honour Henry as her lor

for wealth, and not for perfect

any passion of inflaming love.

to tind the like effect in love

..2Henry $V I$.

if sympathy of love unite our........

cheerful voice welcome my love

and make a show of love to proud ...

surfeiting in joys of love

and as you that love to be protected their master loves to be aloft....

to tell iny love un to lis dumb

mere instinet of love, aud loyalty

I tear, my love, if that I had

no, my love, I should not mourn ....

how well you love your prince

pledges of my fealty and love.

bearing should I be in love

nor he, that loves himself.

how love to me, and to her son

-

iii. $\frac{1}{2}$

VE-you are liheral of your loves. Hen

I love him not, nor fear him (rep.)

thank the holy conclave for their loves =

must needs deserve all strangers loves -

to wedlock, or my love and duty....

truth loves open dealing .............

his love too, long ago: I am old ....

the king loves you, beware ...........

my heart dropped love, my power....

as twere in love's particulie

love thyself last

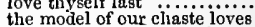

and a little to love her for her

by that you love the dearest ......

love, and meekness, iord, become......

I am, for his love and service
embrace, and love this man

embrace, and love this man.....

pam mad in Cressid's love... Troilüs \& Cressida v.

tell'st me, when I say, I love her .... -

in every gash that love hath given

for thy Daphne's love, what Cressid is

prove to you that Helen loves him (rep.) -

tears, and love's full sacrifice.........

love got so sweet (rep.) $\ldots \ldots \ldots \ldots \ldots . . . . .$.

my heart's content frim love doth bear -

loves his mistress more than his (rep.)

a Grecian that is true in love

one spark of fire to answer for his love

and yet lie loves himself ............ -

of beauty love invisible soul .......

my niece is horribly in love........... -

love! ay that it shall, $i$ ' faith (rep.)..

love, love, nothing but love (rep.).. = iii. । in

nothing but doves, love.

hot deeds is love (rep.)

is love a generation of vipers?........ -

8weet, above thought I love thee ....

in the fountain of our love? ........
this is the monstrosity in love, Iady

I love you now; but not, till now....

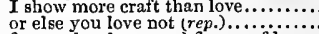

for aye her lamp and flames of love.

true swains in love shall

$[$ Knt. $]$ the sight $I$ bear in things to love

the love that leaned on them .........

desert in service, love, friends

that you are in love with one.......

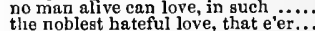

but flies the gresps of love.............

no kin, no love, no blood ..............

strong base and building of my love

my love admits no qualifying.............

Cressid, I love thee in so

hear me, my love

liear why I speak it, love.

in love whereof holf Hector stays

more vindicative than jealous love

sweet love is food for fortune's tooth

from her aanghter, my falr love ...

and one that loves quals ...............

as much as I do Cressid love.

or the love of all the gods

unon the love you bear me

the terder love $I$ bear your grace....

them, that did love their country's good

your wisdom, and your love to Richard

we come to him in perfect love......

your love deserves my thanks

mighty lord, this proffered love......

an pure heart's love, to greet....

v. 1 on pure heart's love, to greet

iv. 1 bunt I am in lav, in love their mothe

I will love thee, and prefer thee for it

from $\mathrm{my}$ soul

love my daughter, from thy soul's

this inducement move her not to love

gas, that I did all this for love of her?

a grandam's name is little less in love

the law, my honour, and her Inve....

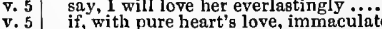

if, with pure heart's love, immacula

bear her my true love's kiss

give us leisure for these rites of $i$ lovel

what? myself on myself? I love myself

there is no creature loves me $\ldots . . . . . . .30$

to gain the love of the commonalty

exceeding mad, in love too ….......
my love and dut I w would surrender it 二
tlus duke as much they love aud dote on - iij. 7

I love bastards: I am a bastard begot

to his love and tendance all sorts.. Tim

does she love him?

he, that loves to be fiattcred..............

You mistake my love; I gave it ......

here, $m y$ Iord; a trifle of our love....

I love and honour him, but must not

to broach the vessels of my love ....

so much I love his heart

it shows but little love or judgment

of such a nature is his politic love ..

wert a dog, that might love thee

I love thee better now than e'er......

$\nabla .3$ and will love naught but even .......

live, and love thy misery 1 .

love not yourselves; away $\ldots \ldots \ldots \ldots$.

heaven knows, is merely love........

we tender our loves to him

look you, I love you well............ my love with words and errors .......

man of thine attempts her love .......

there should be small love 'mongst

wert a dog, that I might love the

then I love thee, because thou art.... ii.

ii.

ii. 4

ii. 
LOVE-sums of love and wenl th .. Timon of sth. $y$. in thee the flgures of their love. but I do prize it at my love. but yet I love my country .... their pangs of love, with other ...... our ingratitude with loves above .... Timon to our eity's love and there's all thie love they bear us. Coriotants where he would show most love .... each in my love alike............... to snve labour, nor that I want love that love this painting wherein....... for they love not Anarcius? $\because \ldots . .$. one that loves a cup of hot wine for the love of Juno, let's go .......... proud, and loves not the common peopleif they love they know not why .... whether they love, or hate him. to flatter thein for their love he loves your people; but tie him not your people, I love them as they weigh I have not been common in my love
he may deserve your loves ..........
his malice towalds you into love.....

when he did need your loves.

but your loves, thinking uno

that love the fundamental ...

when he did love his country........... in asking their good loves........

I'll mountebank their

I do love my country"s good

Whase loves 1 prize as the dead.....

plague o' the gods requite your love! and my love's upon this enemy town and as nobly with thy love, as ever and patricians, love him too....

what your love can do for Rome......

for whose old love, I have,

infected with my country's love ..... over your friend that loves you...

forgets the sliows of love to other men
with ordinary oaths my love to every with ordinary oaths my love to every
yet I love him well: but wherefore.. as I love the name of lonour. that you do love me, I am nothing so with love I might en treat you he loves no plays, as thou dost

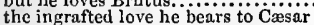
if' he love Cxasar, all that he can for he loves to hear, that unicorns.. he loves me well, and I have given. by all your vows of love $\ldots . .$. for my dear, dear love to your..... and reason to my love is liable..... say, I love Brutus, and I honour him shall not love Casar dead so well.... with all kind love, good thoughts... why I, that did love Cæesar when.... wot least in love, yours, good Trebonius = with you all, and love you ali that Brutus' love to Casar was....... there is tears, for lis love..... you all did love him once ............ when love begins to sicken and decas should perceive nothing but love... not presume too much upon my love you love me not. I do not like your

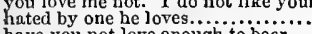
have you not love enough to bear..... love, and be friends, as two such men not that we love words better.

even for that our love of old

if it be love indeed (rep.). . Aniony \& Cleop how, my love! Perchance, nay..... now for the love of Love, and her the finest part of pure love.

and get her love to part..............

if you did love him dearly

are newly grown to love

so Antony loves. Ay precious ( $($ e.p. $)$.

ne'er loved, till ne'er wortl love ....
did I, Charmian, ever love Casar so

people love me, and the sea is mine

but all cliarms of love, salt Cleopatrn borrow one another's love $\ldots \ldots \ldots$..... govern in our loves, and sway ..... no brother did ever love so dearl $y . .$. ... and never fly off our loves again 1 .... moody food of us that trade in love than the he loves Cresar I

loves Casar best, yet lie lo............ Ant sing, number, ho, his love to Antony They are his shards

as is cement of our love, to kcen. it is love's spring, and these the showers -
wrestle with you in my strength of love -
let your best love draw to that ....... in Rorne does love and pity you

v. 2 love. I am full of lead: some wine

v. 3 as you did love, but as you teared him O love, that thou conidst see my the business that we love why is my lord enraged against his iove? let him that loves me, strike

j. 3 which my love makes religion to..... ob

i. 6 it is a mauacle of love...

and that she should love this fellow..... bring me word, she loves my son... the love I bear him gade at home..

i. 2 still, I swear, I love you

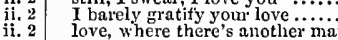

ii. 2 upon the love, and truth, and yows.

ii. '2 relish of love, of my lord's liealth...

ii. 2 what your own love will out of this

ii. 3 and your increasing in love.....

ii. 3 the innocent mansion of my love.

ii. 3 winged with fervour of her love

iii. 1 I love, and hate her; for she's fair ...

iii. 2 this love him as my brother..........

iii. 2 I love thee; I have spoke it..........

iii. 3 I know not why I love this youtl

iii. 3 love's reason's without reason...

iv. 2 shall find I love my country

iv. 4 deserved my service, nor your loves

iv. 5 whom best I love, I cross

\section{iv. 7 to love with such integrity}

v. 2 hearing us praise our loves of $\mathrm{I}$ taly....

v. 5 qualities that man loves womn for..

though you did love this youth

I. 2 love and honour thee and thine
i. 2 and to the love and favour of my

i. 2 Tet Rome reward with love ..............

2 plead my passions tor Lavinia.' lo....

i. 2 that for her love such quarrels

i. 2 and cannot brook com petitors in love?

than this Lavinia, Bassianus' love....
let her 'joy her raven-eoloured love
as yon love your mother's life.........

as yon love your mother's life.

that, if thou love thy son

she loves thee, boy, too well to do...

my noble aunt loves me as dear......

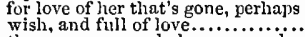

iii. i the common people love so much....

iii. 1 this do thou for my love; and so.....

iii. 1 made me man, and sway in love .......
iii. 2 few love to hear the sins they love to ac

iii. 2 all love the womb that their first .....

iii. 2 of whica love to all (of which thyself art

iii. 2 unlicensed of your loves, he would depurt

iv. 2 to just and tourney for her love

iv. 3 honour we love, for who hates honour

iv. 3 as you do love, fill to your mistress' lips

iv. 3 sinee they love men in arms

iv. 3 wrong not the prince you love..............

if thut you love prince Pericles.

then yon love us, we you ...............

never aimed so high, to love you

i. 2 any syllable that made love to you?

bestow your love and your affections..

mes, if you love me, sir ..............

i. 3 mat, for the love of this poor intarit.....

3 Inflame love in thy bosom
3 I love the king your father

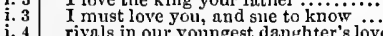
rivals in our youngest danghter
slial] we say, doth love us most?

i. 5 shall we say, doth love us most? ........

ii. I a love that nakes breath poor $\ldots \ldots \ldots \ldots$.

i.. 2 in your dear higlmess' of love

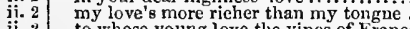

ii. 2 to whose young love the vines of Frane

ii. 5 obey your majesty according to......... obey you, love you, and most hono
if they say, they love you, all?
shall carry half my love with him like my sisters, to love my father all

\section{iii. 2 may spring from words of love}

$\begin{array}{ll}\text { iii. } 2 & \text { or cease your quest of love?............... } \\ \text { iii. } 2 & \text { I would not from your love make } \\ \text { iii. } 2 & \text { love is not love, when it is mingled }\end{array}$

respects of fortune are his love .......... \begin{tabular}{c|c} 
iii. 6 & without our love, orur krace, our benison \\
iii. 6 & [Col. Knt.]
\end{tabular}

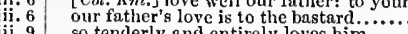

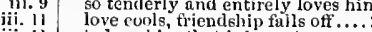

iii. 11 to love him that is honest......

not so young, sir, to love a woman

thou servest me, and I'll love thee

whoop, jug! I love thee fo..........

to the great love I bear you................

if thou love me, tell me. I love

and thou art twice her love............

i. 7 a boy's love, or a whore's oath.

ii. 3 for the love thon show'dst the $k i$

but love, dear love, and our aged tather's - iv

iii. 2 your lady does not love her husband.... - iv. 5

I'll not love; do thy worst $\ldots . . . .$. -

blind Cupirl; I know, you do not love me - iv. 7 love my sister? in honoured love

to both these sisters have I sworn my love $=$ v. will marry, make your love to me

a period to such as love not sorrow ...... - v.

in love? Out -of love? Out of Romeo \& Juliet, (prol.)

where $I$ am in love. Alas, that Iove

alas, that love, whose view is muffled

this love I feel, that feel no love in this -

why, such is love's transgression ....

love a that thou hast shown. ...

who she is

cousin, I do love a woman

and she's fair I love. A righit.

she hath forsworn to love.....

many a guest, such as I lo

Four lady's love against some otlier.
Paris seeks you for his love.........

can you love the gentleman?

this precious book of love...

under love's heavy burden $(r e p$.

is love a tender thing? if love be rough with you (rep.)

i. 2 if love be rough with you (rep.) $\ldots . .$.

brains, and then they dream of love
diad my heart love till now? ..........

prodi fious birth of love it is to me (rep.) -

is beloved, and loves again ........

-

i. 1

and she steal love's sweet bait from - i. 5(cho.)

couplc but-love and dove; speak to -

it is ny love; O that she knew ...... -

call me but love, and $I$ 'll be new ....

with love's light wings did I o'er-reech =

and, but thon love me, let them find

prorogued, wanting of thy love...

dost thou love me? I know thou wilit say -

if thou dost love, pronounce it ....... -

not impute this yielding to jight love $_{\text {love }}$ -

lest that thy love prove likewise variable -

this bud of love. by summer'............ =

the exchange of thy love's faitlitil vow =

as the sea, my love as deep ...........

some noise within; dear love, adieu!
if that thy bent of love be honourable

love goes toward love (rep.)...........

my heart's dear love is set on the fair

love so dear, so soon forsaken? (rep.)

and bad'st me hury love doth not

grace for grace, love for love ailiow...

your households' rancour to pure iöe

better' now than groaning for love?.

this drivelling love is like a great .

love's heralds should be thonglits

nimble-pinioned doves draw fove

would bandy her to my sweet love.

what says my love? Your love (rep.)
by the which your love nust climb.

therefore love moderately; long love

my trize love is grown to such excess
$[K u t$.] Romeo, the love I bear thee.

the reason that I have to love thee.
but love thee better than thou canst

know the reason of my love.

stran e love brown boli, think true

all the world will be in love with night -

Thave bought the mansion of a love.

encealed lady to our cancelled love?

fliamest thy shape, thy love, thy wit

lear love, sworn. but hollow perjury (rep.) -
that ornament to shape and love

pout'st upon thy fortune and thy love

get thee to thy love, as was decreed..
desperate tender of my child's love.. 
I,OVE-my son Paris' love....... Romeo \& Julit, believe me, love, it was the nigh look, love, what envious streaks a..j; convey my greetings, love, to thee

trust me, love, in my eye so do you... soine grief slows milcli ot' love ...... to werk the love I bore my eols I cannot love, I am too young therefore liave $Y$ little talked of lov must be, love, on Thursday next that you love me, I will confess ( $r i j$.) an unstained wife to my sweet love. gave him what becumed love I might why, love, 1 say! madam! $\ldots . . .$. ... o live ! O life ! not life, but love .... is love itself possessed, when but love' my obsequies, and true love's rites? I love thee, better than myself... O my love! my wife ! death that.....
here's to my love! o true apotheciry $\mathrm{my}$ master, one that you love ........ a cup, closed in my true love's hand? their eourse of love, the tidings of as neediful in our loves, fitting.... for Urod's love, let me hear I will requite jour loves

your loves, as mine to you : farewell perhaps he loves you now

he hath imys hoves you, it fits ... it thou clidst ever thy dear father lov.

whose luve was of that dignity

with all my love I do commend

express his love and friending to jou

this is the very ecstacy of love.

but never doubt I love..

but that I love thee best
but low hath she received his love?

had seen this hot love on the wing

looked upon this love with idle sigh

it he love her not, and be not from

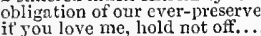

ithat I love passing well..........

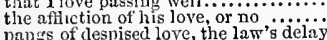

pands of despised love, the law's delay

loye! his affeetions do not that way...

grief sprung from neglected love ......

tis trief, my lord. As woman's love
sinee love our hearts, and Hymen did

as they love; and women's fear and love

love is, proof hath made you know ( $r$.

great love grows there! (rtp.)........

sueh love must needs be treason

respeets of thrift. but none of love .... love lead fortune, or else fortune love. and hitherto doth love on fortune ten. interpret betweeu you and your love..; my lord, you onee did love me.

the fair forehead of an inmocent lov

you cannot eall it, love ..................

and making love over the nasty sti...

was our love, we would not unders
if iny love thou hold'st at anglit.
how should $\mathrm{Y}$ your true love know

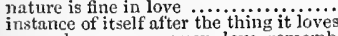
remembrance; pray you, love, remember noul love your father (rep.) within the very flame of love a kind of quantity of love make up my sum as love between them like the paim they did make love to this employment am attined to love the Noor

1 for love and duty, but seeming so. I must show out a flag and sign of loye. of my whole course of love; what drugs she feared that $l$ did love the $\mathrm{Al}$ loor to live with... the rites, for whieh I love him .........
I have but an hour of love, of worldiy a shall never love thee atter it $\ldots . . . . .$. a man that knew how to love himself whereof I take this, that you eall-love love's quick pants in Desdemona's arms our loves and comforts should increase.. Thave found great love amongst them base men, being in love, have then $\ldots . .$. and will she love him still for prating?.. that Cassio loves her (rep.)

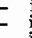

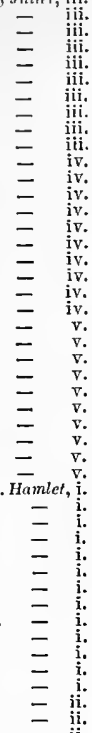

ii. 2 (letter)

2 (letter
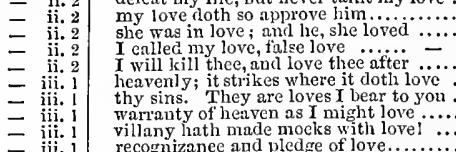

二 iii. 1

二 iii. 2

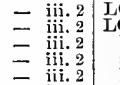

二 iii. 2
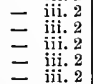

二 iii. 4 it seems, you loved her not

my master loved her well

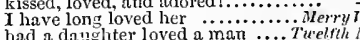
had a danghter loved a man...... Tuelth Night,

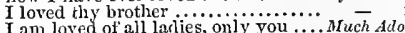
I neither feel how she should be loved that lie loved iny niece your danghter that lady would have loved any inan if they loved Benedick, to wish him who loved her so, that, speaking I love nothing so well as you .........
I was about to protest, I loved you.. that so loved his child ............... God knows, I loved my niee........ and when yon loved, you were ....... $\overline{\text {. }}$. and straightway loved an ass. if e'er $I$ loved lier, all tliat love is. since night you loved me $\ldots$............ that virtue love, tor virtue loved .. Love's that virtue love, tor virtue loved .. Love's L.I.
of our clime have loved it too ... Mer. of Fen you loved, I loved; for intermission say how I loved you soung Lorenzo swear he loved her well since he hath got the jewel that I loved $\overrightarrow{\bar{L}}$
never two ladies lover as they do.. As you my father loved sir Rowland as his soul the duke my father loved his father.. for I have loved ere now $17 . . . . . . .$. not loved; or if trou hast not broke. thou hast not loved: $O$ Phebe, Pheb the duke, that loved your father $\ldots$. who ever loved, that loved not at first
LOVED; no sooner loved...........As you Like il, v. 2
you are luved, sir; they that $\mathrm{j}$ east .....Al's Irell, i. 2 you are loved, sir; they that least it liurts not lim, that he is loved of ine would, he loved lis wi loved you dearly, would you....... since I hive lost, lave loverl ........ = iv. he loved her, sir, and loved her not...

more than that, he loved her ......... hath as long loved me, as I lave loved - iv. I have loved thee-inake't thy ....W Winte

a region loved as lie loves himself...

I loved him, as in honour he $\ldots . . . . .$. .

hath sometime loved; I take ........ honoured lord, is feared and lovedi... by his loved mansioury ................ Macbeth, you have loved him well i he hath ... ${ }_{\text {d }} \overline{-}_{o h n, \text { ii. }}$ iv. just, and always loved us well ........ RiehñrdII. ii. just, and al ways loved us before, $Y$ loved thee as a brother .... the king that loved him

better feared, and loved, than is ..........Henry y. ii. 2 for they loved well, ling ..... where

hadst thou but loved him half .......3 nenry $r I_{\text {. }}$. so dear I loved the man, that Y.... Richard III. iii.
you tew that loved me, and dare .. Henry VIII. ii. by those men we loved most has always loved her so dear ......... my fither loved you: he sald, he did if I loved many words, lord.......... for her mother's sake that loved him she shall be loved, and feared ......... but though l loved you well. she was beloved, she loved

't was one's that loved me better thai... why should our endenvour be so loved shouldst have loved thyself . Timon of Athens, iv. that hath al ways loved the people .. Coriolanus, i. as if I lored my little should be dieted
ne'er loved them; and there be (rep.) not, indeed, loved the common I sliall be loved, when I am lacked.. Coriolanus had loved you as we did.. who loved him in like beasts.

yet for $x$ loved thce, take this along...

loved we above the measure of a father honoured him, and loved him............ Juius as Casar loved me, I weep for him ... you know how Casar loved you 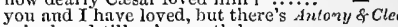 ne'er loved, till ne'er worth lo
sir, I never' loved you much.

mir, Inevel loved you much...........

Iicreules, whom An tony loved, now m, Antony; my mistress loved thee most praised, most loved ........... Cymbeline, $i$. Cymbeline loved me; and when......
dotl miracle itself, loved before me.. she confessed she never lored you....

Ihave loved and honoured Saturnine. Titus dud i Lavinia, therefore must be loved .... thy grandsire loved thee well ........ those little darlings whom they loved kept, I so dearly loved it ..............
he loved me dearly, and for his sake thou look'st like one Y loved indeed..
will I, my loved Marina, elip to form as mueh as child e'er loved..................... have begot me, bred me, loved me............. as iny king, loved as my father......

he always loved our sister most

wine loved I dceply; dice dearly.

if fortune brag of tro sle loved and hated near, when I supposed you loved Romeo \& Jut she loved lier kinsman Tybalt dearly the which he loved passiug well......... Hamber, oue speenh in it I ehiefly loved ..... shall relish of it: 1 loved you not ..... $X$ loved your father, and we love ourself loved Ophelia; forty thousand brothers her father loved me, oft invited me ...... if $I$ laad a friend that loved lier $\ldots \ldots \ldots . . .$.
she loved me for the dangers I had $($ rep.) violence she first loved the Moor

would never have loved the Moor.........

and he she loved proved false $\ldots . . . . . .$. never loved Cassio, but with such general $=v$. slie loved thee, eruel Mloor: so eome ....
of one, that loved not wisely, but too well 
LOVE-DAY- $\mathrm{R}$ love-dnv, Tamora.. Tilus Andron. i. 2 LOVER-Eend you many lovers!... Love's L. Lost, ii. 1 I.OVING-did us but loving wron

I,OVE-DEVOURING death do... Ilomeo of Jutiel, ii. is LOVE.-DISCOURSE-

You joy not in a love-discourse. Tuo Gen. of F'r. ii.
LOVED'ST-thou loved'st me not ...2 Henry IV iv. 'mass, thou loved'st plums well ....2 2tenryl $r 7$ ii. loved'st lim better than ever (rep.). Julius Cirsar, iv.
LOVE-LEAT will advance ...... Love's L. Lost, v. IOV E-GOD-are the only love-gods.. Mrech Ado, ii. LOVE-IN-IDTENESS-

maidens eall it love-in-jilleness. Mrid. N. Dream, ii. 2

LOVEL - Iovel, and Catesby, look.Ric

tho Lovel, with all giveed to doctor shaw

go Lomas Lovcl, and lord marquis Dorset what news, sir Thomas Lovel?

sir Thomas Lovel (rep.)...............

not yet, sir Thomas Lovel (rep.)

now Lovel, from the queen what

Lovel,-Sir. Give her a hundred marks
LOVE-LETTERS in the holyday... Merry $\bar{W}$ i

gox of your love-letters!... Turo Gen. of Terona, iii. looked not lovelier than Heetor's.... Coriolanus, i. 3 r.OVELINESS-loveliness in favour..... Olhello, ii. I full as lovely as is this of hers ....... $\bar{M}_{\text {iveas. }}$ iv. 4 for your lovely sake, give me ...M.eas. for Meas. v. and every lovely organ of her life. .

a most lovely, gentleman-like man...Mid. $\bar{N}$. $D$

hath a lovely boy, stolen from
come our lovely lndy nigla

two lovely herries moulded on one stem = iii. 2

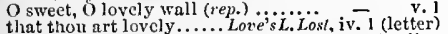

even in the lovely garnisiliof. of. Merch of Vencice, ii. 6

o'erran her lovely nce...

seal the title with a lovely ikiss?.......

fair lovely maid, onee more good day

the Dauphin, and that lovely maid. King $\vec{J}$

$O$ amiable, lovely deatl

Richard, that sweet lovely rose....... HewryIr.i. 3

I love the iovely bully

Franee, put up her lovely visage?

the hushand of this lovely lady.

hath this lovely face ruled

how sweet! how lovely

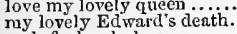

and of a lovely bo

Menry $V$.iv.

therefore, lovely Trmora (rep.).T.... Hentus Andronititis,

noble emperor, and his lovely bride
there will the lovely Roman ladies

wake the emperor and his lorely bride

my lovely Aaron, wherefore look'st..

hence to seek my lovely Mroo

gramerev, lovely Lucins ....................

2 HenryVI i. 4

and his lovely nieces...... Romeo \& Juliet, $\overline{\mathrm{i}} .2$ (note)

O he's a lovely gentleman! . $\ldots \ldots \ldots$.

TOVE-AIONGER-Old love-monger. Love's L. Lost. i. 1

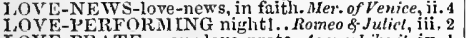

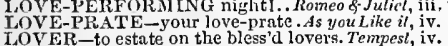

carrying a letter to your lover.. Two Gen.of $V$ er

parting strikes poor lovers dümb

to see such lovers, Thurio, as yourseif

is become a notable lo

is becone a hot lover....................

hope is a lover's staffe............

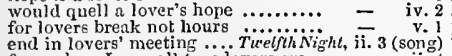

for such as $\mathrm{I}$ am, all true lovers are.

your brother and his lover have...i iseas. for Meas. i.

thou wilt be like a lover presently ... Minch Ado, i. 1 if then true lovers have been ever

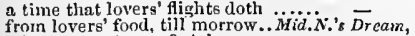

a lover, or a tyrant? A love

a lover is more eondoling..

al, Pyramus, my lover dear
[Cal.? tie up my lover's tongue

[Cal.] tie up my lover's to

these lovers seek a place to fight.......

back to Athens shall the lovers wend

back to Athens shall the lovers wend
I'll apply, to your eye, gentle lover..
the pairs of faitlitul lovers be wedded

fair lovers, you are fortunately .......

that these lovers speak of ? .

lovers, and inadmen, have such.......
the lunatic, the lover, and the poct.

the lover, all as frantic, sees Helen's

here come the lovers, full of joy
whieh did these lovers sunder...

Whieh did these lovers sunder.......
did these lovers think no seorn.

wall, and lovers twain, at large.

the fearful lovers are to whisper

1 am thy lover's graee $\ldots . . . . . . . . . .$.
Thishe comes back and finds her lover? =

lovers, make moan! his eyes were....
lovern, to bed; 'tis almost fairy time

lovera, to bed; 'tis almost fairy time with that which we lovers intitle....
that the lover, siek to death $\overline{\text { ii. I }}$ (verses)
and Longavile, were lovers tool

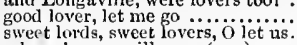

a lover's eyes will gaze (rep.) ............
thousand verses of a faithful lover

wise ginls, to mock our lovers so.....

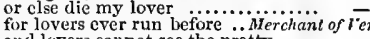

and lovers camnot see the pret
how dear $\mathrm{a}$ lover of iny lord

being the bosom lover of my loid....

ns true a lover as ever sighed...... As you tik

we that are are true lovers, run into
and then the lover, sichling like...

to resolve the propositions of a lover

then seeming the lover of any other

and lovers are given to poetry
nay be said, as lovers, they do

besides, the oath of a lover is $n$

athwart the heart of his lover

nor the lover's, which is all these

you a lover? an' you serve me

and for lovers, lneking (God warn us!)

if you be a true lover, hence

a lover of mine, and a lover of $h e r s$.

it was a lover and his lass...

sweet lovers love the spring.........
a lover of thy drum, hater of love....

to a lover's blessed casel or

th old lion; or a lover's lute.
they are drops of thy lovers..

and a true lover of the holy chiurch

and betrothed lovers, that shall....... - ii.

is held no great good lover

Henry VIII. iv.

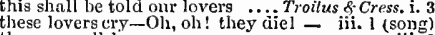

they say, all lovers strear more........

had she no lover there, that wails.....
I do not al ways follow lover ... Thinon of Ahens, 5 ii. 2

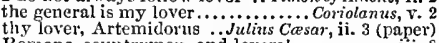

Romans, eurntryment, and lovers!
slew my best lover for the good of Rome =

that we may, lovers, in peace......... $\overline{\text { v. }}$ v. 1

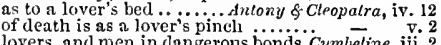

lovers, and men in dangerous bonds. Cymbeline, iii. 2

and one that had a royal lover

lovers will not keep the peace ...Tiius Andron. ii. I

makes pity in your lovers ............. Pericles, iv. 3

sparkling in lovers' eyes ............ tears -

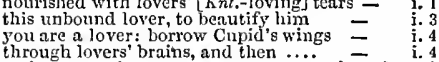

such vows as lovers use to swear $\cdots$, i. $\overline{5}$ (chorus)

at lovers' perjuries, thes say, Jove lauglys -5 (chorus)

silver sweet sound lovers' tongues

lovers en see to do their amorous rites $\overrightarrow{\text { them }}$ iite.

may help these lovers into your favour... O'llello, i. 3

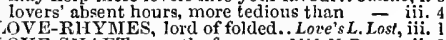

LOVE-SHAFT sinartly from ..... Mid.N.D. Dream, ii.

LOVE-SICK with them -...Antony \& Cleopatra, ii. 2
to love-siek Dido's sad-attending. Tilus Andron, .3 to love-sick Dido's sad-attending. Tilus Andron, v.
LOVE-SONG, like a robin.. Two Gen. of Verona, 1 .

would you have a love-song....... Twelfih Nighl, ii.
a love-song, a love-song ..........
whth writing love-songs ......... As you Like it, iii.

Asyou Like it, iii. 2
Winter's Tale, iv.
.

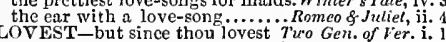

Lucetta, as thou lovest me (rep.) .....

as thou lovest Silvin ........

as thou lovest silvin

now as thou lovest me let me..... Tuetm

tis once, thou lovest; and I will fit .....Mruch Ado $\mathrm{i}$.

by my sword, Beatrice, thou lovest me $\overline{\text { if }}$ if thou lovest me then

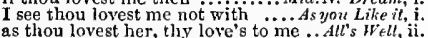

as thou lovest her, thy love'
tell whom thou lovest best

nay then, thou lovest it not.
IIortensio if thou lovest me

IIortensio, if thou lovest me
how thou lovest us, show in

as thou lovest me, Camillo

I think thou loyest me well
of that. IIal, an' thou lovest

of that, II al, an' thou lovest me
eome, i know, thou lovest me

King Joln iv.

I dare not swear-thou lovest un

1 Henryll $V^{\prime}$ it

est thie flesh

as thon lovest and honour'st arm

i Heñry $Y I$ i.

Titimius, if thou lovest me, mo

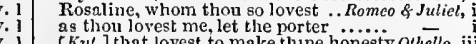

LOVE-SUIT-plead lis love suit to ler . Herpry

v. 1 Vy to me as Ciniseline

V. ${ }^{2}$ and she loveth him

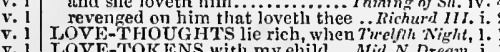

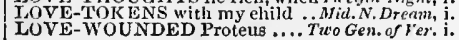

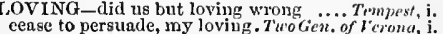
to tear such loving words!

a journey to my loving Proteis

goad us on to sin in loving virtue. $\dddot{3}$ eas. far $\overline{\text { Ifeas. }}$ i.

in every thing, but in loving Bcicdick - Much Ado, i.

and wise, but for loving me

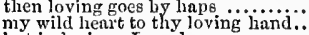

but in loving-teande

my loving lord, Dumain

Mid. N.'s

loving a light wench ...................

for my sake but one loving kiss

ath wart his loving bosom $\ldots \ldots . .$.
these worms for loving, thint art

now prove our loving la wful $\mathrm{i}$....

what I have from the loving king.....

elaim her with a loving kiss...

in loving visitation

most loving mere folly .............. As you ii. 7 (song)

as loving yourself, than seeming .... - iii. 2

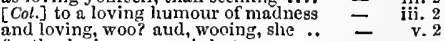

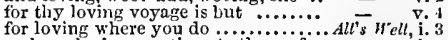

and my loving greetings to thoo........... i. 3

entitle thee, my loving father Taming of Shrew, iv.

and gracelcss traitor to her loving lord?

gifts, letters loving embassies...... Winter's Tale, $\mathfrak{\mathrm { j }}$.

my loving subjects-You loving men -

and ne'er have spoken a loving word.. . michard $I J .^{\text {i. }}$

leave, and loving farewell, of our...

my loving lord. I take my leave ........

love, loving not titslf $f$ none other can
should keep his word in loving us.. 1 Her

lives of all your loving compliees ...2 Henry 11 .

pray thee, loving wife, and gentle

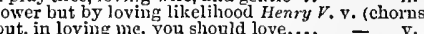
pair of loving turtle-doves......... i Henry $v 1$. ii.

my friends, and loving eountrymen.

$O$ loving unele, kind duke of floster

therefore, $\mathrm{my}$ loving lords, our pleasure for their tender loving eare ............

amongst the loving Welchmen

like a loving sire, thou, being a king

the brother of your loving bride......

With the loving citizens, like to......

what says my loving son?

we are alvertised by our loving friends =

witness the loving kiss I give. $\ldots \ldots \ldots$. Rich

which now the loving haste of these
very worshipful and loving friends.

say on, my loving lord . ..............

know, my loving lord, the marquis..

and my most loving friends, bruised

than I heur loving mothert........

beloved, and loving, may his rule.. Henry $\bar{r} z 11$. ii. he's loving, and most gracious ...... Tru $\bar{c}$ i iii. signify this loving interview ......... me to my loving countrymen... Timon of Athens,

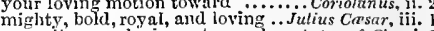
commits some loving act upon her. Antony \& Clen. i. I will here dismiss my loving friends

a loving nurse, a mother to his youth

lis loving breast thy pillow ........

like a loving child, shed yet some

some loving friends eonvey the emperor

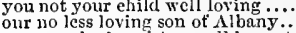

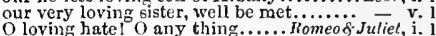

$[K n t$.$] a sea nourished with ioving tears -$

so loving jealous of his liberly $\cdots . . .$. ,

come, loving, blaek-browed night .. =

one poor and loving elild, but one thing -

hy, tis a loving and a frir reply .......

thy loving father, Inmlet ................. iv. is of a constant, loving, noble nature $\ldots . .=$ ii.

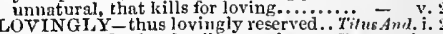
LOW-with foreheads villanons low ... Timplest, iv. too low a mistress for ...... Tu'o fien. of rerona, ii.

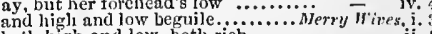
both high and low, both rich ........... that ean sing both high and low .. - ii. 3 (sollg) out of my lean and low nbility........

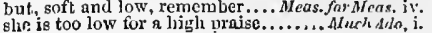




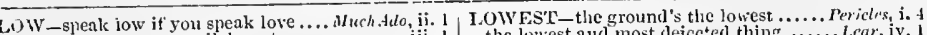
i: low, an agate very vilely eut...... - iii. 1 the lowest and most dejceted thi

sonill of ts wotk low

bill Jove, sir, lian an aniable low

and so low? low low am I, thou

now low and low and little?

how low soever the matter.

a high noge for now havi:s
for that, in low simplicity
or shall I bend low, and in

low numb low peasantry would then be

my estatc is very low, my bous to - iit. 2 (letter)

upon some setted low col:tent....

but the woman fow, and brown.

his err.nent top to their low rame proparate

or Dauc, Low Dutely, I talian

a low submissive reverence. Taming of $\$$ h. $\overline{1}$ (induc.) with soft lus tongue, and lowly.. for liyll and low's alike............ Hinter's Tale, y. $O$ sit, 1 lid not look so low... Comedy of Errors, iii. come. high, or low; thyscle

thint I were low laid in my giv

stoop low within those bounds........ inch $^{-}$. v.

Boisugbroke, as low as to thy hart...

although your kince be low

now, in as low an ebb as the

firm my lowest note to the top....

Hamlel, iii. 2

the dam rums low int up and dow
IOW-LAII-your low-laid son

LOWIINESS- thy lowliness. Love s... Lost, iv, I (let.)

mercy, lowlincss, devotion, paticnee... Alacbelh, iv.

with as hnmble lowliness of mind .... Hemry $r$ i. v.

that lowliness is yount ambition's. Julin

Low IY feigning was called

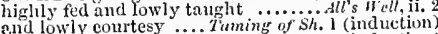

hence these albject lowiy dreams -2 (induction)

and me, joor lowly maid.

Richard II ii.

the mother on her lowly babe.

anil lowly words were ransom.

obscure and lowly swain

by stich a lowly vassal as thysclf

or lowly factor for another
tis better to be lowly born

I Henryll. iij.

and these lowly courtesies

Henry IIII. ii. 3

LOWN-both lord and low

Julius Casar, iii. 1

LoW NESs low or the mean. Othello, ii. 3 (song)

and palter in the shitts of lowness.

have subdued nature to such a lowness . Lear, iii.

LOWV-RATED English play at. Henry $V$. iv. (chorus)

LOW-SPIRITED swain............ Cove's L. Losi, i. I (letter)

LOW-VOICED-she is low-voiced. Antonys Cleo. iii.
I.OYAL sir to him thou followest ....... Teinpest, v.

journey-bated, and brought low

jotrme yat in aw

liead as low as elcath

for it is a low ebb of linell...........

a iow transformation! ...............

swcet prince, speak low; the king
and low, and lower, put into parts

whose low vassal se: t...................

place to Hexure and low bending?.

more abase our sight so low

with loyal blazon, evermore...

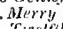

write loyal cantons of contemned. Tuet

and fiurions, loyal and neutral

Nlacbeth, ii.

against the good, and loya
to lim will we prove loyal

Richard II. $\mathrm{i}$.

to prove myfelf a loyal gent

a bold spirit in a loyal breast ........

in my loyal bosom lics his power...

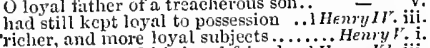

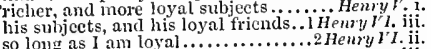

wert more loyal than thou art

nor you, as we are, loyal

less moble, and less loyul ............ $\bar{v}$ ii.

take notice, lords, he has a loyal breast - iii. 2

deliver inyself your loyal servant .. Coriolanus, v.

that remains loyal to lis vow. Cymber

and of the loyal service of his son.

your true and loyal wite $\ldots$ his.......

Lear, ii. 1

as low as to tliy foot doth.

is she shrili-tongued, or low?

and her forehead is as low as slie.
thy mind to her is now as low....

u-leose roof"s as low as oum

in simple and low things ..........

distinction of place 'tween high and low -

son perty spirits of region low .......

.

the the dospise.

hose low sound reverbs no hollowness

rum low farms, poor pelting village

to cast one's eyes so low! ...........

[Col. Kni.] now thou art so low..Rp
$\mathrm{I}$ saw her lajt low in her kindrerl's

LOYALTIES-of all their loyalties... Henry $r I I I$

OYAITY - true loyalty to her. Tu'o Gen of Ter. iv.

the service and the loyalty $I$ owe........ Nacbel

the service and this defend my loyalty ............... Richard 11 .

let th to defend my loyalty and tiviti
both to
wiscom, loyalty, and mere dislike... Henry $I$

wistom, loyalty, and mere dislike...... Herry $r$, ii

with submissive loyalty of heart ..1 Henry ${ }^{2}$.

mere instinet of love, and loyalty

$O$ where is loyalty? if it be banished - v.

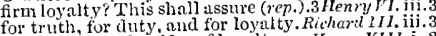

for truth, for duty, and for loyal ty. Richart 171.111 .3

which breaks the sides of loyalty

my loyalty, which ever has...........
in the way of loyalty and truti.
the loyalty, well held to tools...

soul to the oath of loyalty......

ber ton for loyalty excitcd me........

of faith, of loyalty .............. Pericles, v. 3 (Gow.
that nature thus gives way to loyalty ... Lear, iii.

IUBBAR- to the Lubbar's head....2 Herry

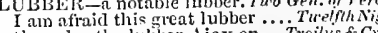

if you will measure your lubbcr's length...

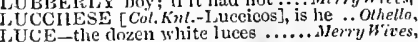

the luce is the tiresh fish .......

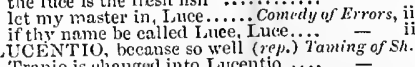

po she shall; Lucentio shall make one

Lucentio is you name?...............
supposed I jicentio must get $a$ father

I am lucentio; hic cst, son unto.

and that Iucentio that somes a wooing

signior Lueentio, this is the 'pointed

a)l for my master's sake, Lueertio

I'll tell you, sir I cucentio.

lucentio, fou shall sipply ...........
she sliall, Lucentio: come, geitlenien

fancy any otlier but IAccitio? ......

in the world so well as lucentio ....
signior Iucentio, here is my hand..

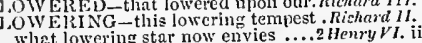

shyulows over lowering iiilis ..... Romeo of Jnliet, ii.

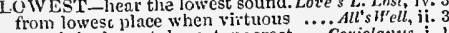

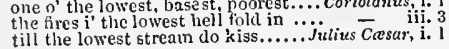
.UCENTIO-signior Lucentio .. Taming of Sh. iv. 2

your son Lucentio here dot

Lucentio's fittler is arrived (rep.)

what is his name? Iucentio, gentle sir

is sirnior Lucentio witlin, sir....

tell signiol Iucentio, that his father

his name is Luentiolio; and he is mine

where is my son Lueentio?

not Lucentio. Yes I know thee (rep.)

Cambio is changed into Lueentio....

since the vutiotial of Luccritio......... Romeo of Jul ve

UCETTA, now we are alone ... Two Gen. of Ver. $\mathrm{i}$.

how chunlishly I chid Lucetta .......

what ho! Incettal

counscl Lucetta; gentle giri..........

fashion thou best likest, Lucetta....

out, out, Lucetta! ..............

the least, Lucetta, of my fear...........
LUCIANA, it is two o'clock... Cometly of Errors

LUCIANUS, nephew to the king ........ Hamlel, iii. 2

deep damued than prince Zuci......... Merry Wives, i. 3

and made Lneifer, cuckold.......... I Herry IV. ij.

his face is Lucifer's privy-kitchen...

as Luciter and Belzebub himself....... Henry $Y$.

UCILIUS-named Lucilius.... Timon of sthens, i.

what now, Lucilius? is Cassius ....... intiuscersar,

a word, Lucilius; how he received you -

ever note, Lucilius, whan love begins

Ineilius; hark, a word with you......

even so, Lucilius. Now, most noble

hast proved Lucilius' saying true...

(till I not ne her aid ......... Cymbeline,

Lueina, $O$ divinest patroness............ Pericles

Ineio, a word wilh you $\ldots \ldots \ldots . . .$.
I pr'ythec, Iucio, do me this kind .

I thank you, good friend Lncio......

sir, my name is lucio ..............

one Lucio as then the messenger ....

you vouch against him, signior Iucio?

what! resists he? help him, Lucio .̈. Juliet, $\overline{\mathrm{i}}$. 2 (note)

LUCIUS, ont of his frce love .... Timon of diters i.

you, to lord Lncius.................
lord Lucius, and lord Lucuilius?

he miglit have tried lord Lucius ....

Lueins, Lueullus, and Sempronius.

what, Lucius! ho! I cannot....... Jutius

get me a taper in my study, Licius.

let Imcius and Titinius guard .......

Incitus, a bowl of wine ..............

fill, Lucius, till the wine o'erswell

Jucius, my gown: farewell..........

boy! Lucius! Varro! Claudius $\ldots$...

sleep again, Lulius ..................

the one is Cains Iucius .............
Caius Lucius will do his commission the embassador, Lucius the Roman.

'forc noble Lucius present yourself.
so, farewe 1 , noble Lucius ..........

so, farewe the noble Lucius

is lueius general of the forces?.......
Isucius is taken : 'tis thought.......

conc, Lucius, come; stay not........

why, foolish Iucius, dost thou not

ah, son I ucitis, look on her! ........

tly brother lueius, and thou, and I

nor Lncius, nor Iavinia liyes

stand by me, Lucius; do not fear.....

Incius, I will. Ilow now, Iavinia?...

Licius, what bonk is that she tossetli so? -

Lucius and $I^{\prime} l l$ go brave it at tie court

here's the son of Lucius............

O well said, Lucins! good boy.

under conduct of lincius n.............

Arilike Ijcius general of the Goths? -

reruests a parley of warlike Lueints.
proud Luejus from the warlike Gotlis

renowned Isucius, from our troops

Lucins, save the child $\ldots \ldots \ldots \ldots$.
why, assure thec, Lucius,

iv. 2

3

1

ii. 2

iii. 3

ii. 1

ii. 1

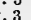

(3)

beline, ii. 3

iii. 4

iii.

bron. i. 2$$
\begin{aligned}
& \text { jii. } \\
& \text { iii. } \\
& \text { iii. } \\
& \text { iij. } \\
& \text { iii. } \\
& \text { iii. } \\
& \text { iii } \\
& \text { iv } \\
& \text { iv. } \\
& \text { iv. } \\
& \text { lv. } \\
& \text { jv. } \\
& \text { iv. }
\end{aligned}
$$ \\ jii
iii
iii
iij
iii.
iii
iii
iv
iv
iv
iv
jv
iv
iv}

then, happy low, tie down!...............

hold me your loyal servant.............

as low as to the th in lis

thill persevere in my course of loyalty - iij. 5

they clap the luther Ajax on ...Troilus of Cress. iii.

Tranio is uhanged into Incentio

that lacentio indeed haces Baplista's

Iueilius and Titinius, bid

Lucius, who's that knocks?

Iucius hath wrote already

he crcates Lueits procousul

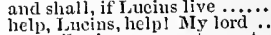

if Lucius live, he will requite........

ay, but the citizens favour Lucius ..

iv. 2

v. 1

ii. 2

iv. 3 


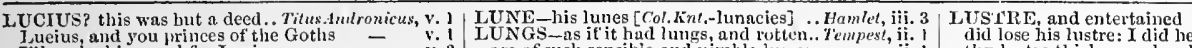

I'll make him send for Lucius

to send for Inteius, thy thriee

Mlarcus, to thy nephew Lincius....

cleave to no revelnge but Lincius aij

welcunde, lutius, and welcome, all

Lue hard, Lucilis

Ifueius, all hail; Rome...............

ns good luck would have it........... - iii.

I holve, good luck lies in odd numbers

strew good luck, ou

sir Joln, we have had ill luck ......

aud they shall have gool luck

if we have uuearned luck now

nor no ill luck stirrint ..... Nerchant of Venice, iii.

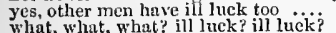

what, what, what? ill luck? ill luck?

I ne'er had worse luck in myck, an't be thy will?....... Wirinter's Tate, iii. 3

have but lean luek in tlie mateli. Comedy of Err. iii. 2

that rebellion had bad luek

and good luek go with thee!.......... Henry $/$. iv.

ween you of better luck, I mean.... Hen'y PllI. v.

and,of that motural luek $\ldots$ intony \&

I hear lim mock the luck of Caes

Wrs there ever man had such luck!... Cymbeline,
I. TCKKER-with luckier issue speeds. Much Ato,

1.UCKIEST - by the luckiest stars .....All's $W^{\prime}$ ell,

1.ICKLLY-fall'st on me so luckily... Henry $I V$.

1.UCKLESS-in this luck less

1. CH. CKY -we are lucky, boy

tis a lucky day, boy

1 bring, and lucky joys, and golden...2 Heñy

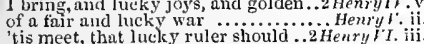

mine hours were nite and lueky..Antony \& Cleo. iii.

maliee and lucre in them have

IUCRECE-impressure
like a Lucrece knif

ke a lacrece kni...............

roman lacrece fur her chastity..Tam

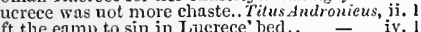

I.UCRETIA's modesty .. As you like it, iii. 2 (

to lord Lucullus you ................

was with the lord Lucullus, to borrow

have tried lord Lucius or Iuenllus. :
has Ventidius and I ucullus denied him? -

I.ucius, Lucullus, and Sempronius.
I.

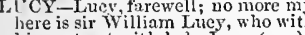

lis contract witli lady lucy (rep.). Richned lI

LUD-made Lud's town with rejoicing. Cymbeline, iii.

on the gates of Lud's town set (rep.) - iv.

that straight sliall post to Ludluw

L

lig the guts into the neighbour room.. Hinmet,

LUGGAGE-thus on such luggage? . Tempest,

hestow your luggrage where you found it -

with the luggage of our camp.

kill the poys and the luggage! $3 \ldots \ldots$....
LUGGED-a gib cat, or a lugted hear.1 Henry

LUKE-presently to saint Lul

old priest at saint Luke's clumeh. Taming of Sh.

I.U KEW AR II-lukewarm blood of... 3 Henry

suLoke and lukewarm water .. Timon of Athens, iij. 6

lulls $\lim$ whilst she playeth.. Titus Andronicn

LULLABY-lullaby to your bounty. Tuelfh Nighl, $\mathrm{v} .1$
our sweet lullaby (rep.).Mid. N.S Dream, ii. 3 (song)

like to have a lullaby too rough. Winler's Tnle, iii.

as is a nurse's song of lullaby.. Titus Andr'mnicus, ii. 3

and lulled with sounds of sweetest..2 Henry I $F^{\prime}$. iii. I

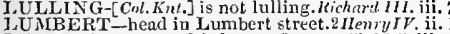

I.UNP - this counterfeit lump of ore.. All's $W$ ell,

unable to support this lump of clay.i Henry $r$.

an indigest deformed lump.....

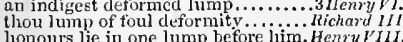

lonours lie in one lump before him. Henry $Y I Y$. ii. 2

1.UNPISH-fur she is lumpish. T'uro Gen. of Ver. iti.
IUNA-a title to Phobe, to Lima. Love's L. Lost, iv.

].UNAClES-[Col. Knt.] of his lunacies. Hamlel, iii. 3
LUNACY-that the lunacy is so...As you Like it, iii. 2

lience by your strange lunacy. Taming of $\$ \$ 2.2$ (ind.)

elosing with him fits his lunaey.. Titus Androm. y. 2

with turludent and dangerous linacy?.
wU

oman, art thou lunatic

to visit Malvolio the lunatic..............elfh $\overline{\text { Nigh }}$, iv. the lunatic, the lover, and the poet. Mid. N. s Dr. v. that he hath been a lunatic ... Tuming uf $\rightarrow h .1$ (ind.) wed to one half lunatic; a mad-cap...
that, being luatic, he rushed ... Comenly of $\bar{E}_{r}$. a lumatic lean-witted fool ...........Mirhard $\mathrm{l} i$. ii. clispute not with licr, she is jimntic. Richard $11 \%$. i. sometime with lunntic bans.............. Leur, ii. ?

I.UNE-old lunes [ $K$ vt.-lines] again. Nerry wives, iv.

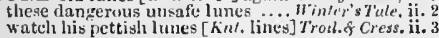

LUNE-his lunes [Col,knt,-lunacies]
LUNGS - as if it had lungs, and totte
are of such sensible and nimble luin.

are of such sensible and lirom thy lungs military

liea ving of my lungs provukes me. Lo
but offendst thy lungs to speak..AEt.

my lungs begain to

gare wasted so

God viltures vile seize on his lungs

and in thy hateful lung

now eraek tlyy lungs, and split. $T_{7}$

wheezing lungs, bladders fnll ot.

which ne'er came from the lun

laughs from's free lungs, cries

lunis [ $[\mathrm{Col}$. Knt, -tongues] fetch breath ...

whose lumgs are tickled o' the sere

LUPERCAL-the feast of Lupereal.

LURCH-to liedge, and to lurch .. Alerry $\bar{W}_{\text {ives, }}$ ii.

LURCHED-he lurched all swords.. Coriolants, ii. 2

to lure this tassel-gentle back .. Romeo of Juliet, ij. 2

and ugly treasous, lurk

there lurks a still and dumb.

here lurks no treason, here no envy. Tilus sud

safe 'scape the king! Lurk, lurk ......... Lear,

where have you lurked, that you

LURKETH-hurketh in men's ear

treason, lurking in our way ........

who 'scapes the lurking serpent's

LURKING-PI,ACG, no vast...

to him now is as luecious as locusts

Mlan'y

LUS1-1-how lush and lusty the gras

LUsh $[$ Col. Knt.- meit mine lionour in to ]ust
till the wicked fire of lust have .

fie on lust and luxury
fust in

lust is but a bloody fire............ v. 5 (song)

concupiseible intemperate lust...Meas. for $\bar{M}$. v.

an lust dotll play with of lust

nor my lusts burn hotter than ...........

is mingled with the erime of lust ....

not fill up the cistern of my lust.

bodies to the lust of English youth

matcling poliuted with your lists....i Hemry $V$

bestial appetite in ehange of lust... Rich

lust and liberty creep in lust. Troilus \& Cressid

in different beds of lust.............

to cool a gipsy's lust ......... Antony o. Cleopa

join witli beauty, lust with both

an obstruct 'tw'een lis lust and $\mathrm{him}$

lust and rank thouglits, hers.

there serve your lust, shadowed

make his dead trunk pillow to our lust

from their worse than killing lust

hy turn to serve our lust..............

nurder's as near to lust, as flame

of monstrous lust the due and just

epicurism and lust make it more li

of lust, as Obidicut; IIobbididance.

won to his shameful lust the will

our carnal stings, our unbitted

it is merely a lust of the blood

not out of absolute inst foul thous

she repeals him for her body's lust

sense had I of her stolen hours of lust?

LIST-DIETED man that slaves ........... Lear
LUSTED [Col. Knt.] to nake a prey, kiehard III

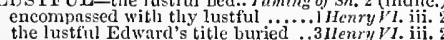

the lustifil Edward's title buxed . 3Henry VI. iii.

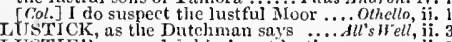

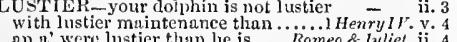

nn a were histier thun he is ....Romeo \& Juliet, it. 4

livers pale, and lustihood dejeet. Troilus \& \& Cress.

livers pale, and lustihood dejeet. Troilus of Cress. it.
I.USTILY - to it lustily awhile Tu' Gen.af I'er. iv.

determine to figlt lustily for him .... Henry $r$. iv.

and rou have rung it lutily..'T'tus.melronieus, ii. 2

tineture, or listre, in her lip .... Winter's Tule, i
it lends a lustre, and more great.... I Hemy $1 V$. i

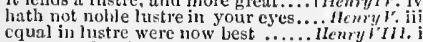

yet never lost lier linstre

the lustre of the better shail... Troili. \& cressida $\mathrm{i}$.

the lustre in your eye, heavein did lose his lustre: I did ...... Timon of Athens,

thy lustre thickens, when lie shines. Aut. f Cleo. ii.

vile jelly! where is thy lustre now

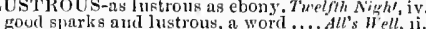

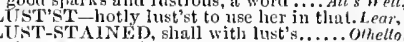

IUST-WVEARIED Antony...An'on! \& clomatro,

his good arms in lasty stroke to the shore - ii

as once Europa did at listy Jove..... M/nch Ado,

as once Europa did at listy Jove..... Buch Ado,

riler and more lusty red than winte...

the horn, the loorn, the lusty loorn...

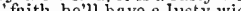

a goodly babe, lusty, and like....W Winlur's Tale, ii.

when this same Iusty gentlemai ..... KingJohn,

come our lusty Englisl, all with

begot this lusty blood

whath lusty tympet this.........

but lusty, young, and cheerly

is it a lusty ycoman? will a' stand..2 2 enry $1 \%$. ii.

you were called lusty Slinllow, then

of lusty earls, Grandpré, and Roussi.. Hrm y $v$ (song)

Ed ward, and the lusty George?.......3 Heney ris, $\mathrm{i}$

we did buftet it with justy sinew's.

many lusty Romans cume smiling

who, in the lusty stealth Goth?. Titus Andron.

as do lusty young men fecl when. Romeo \&... Juliet.

lo suspect the lusty [Col.-lustfu]. iloor. Otheils

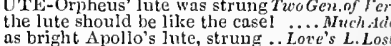

take you the lute and strung ...Love's L.Lost,

may holl with her, but never lutes..

looking througli the linte: while she..

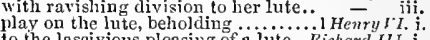

play on the lute, beholding . ......... Henry I I.

take thy lute, wench: my soul.... Herry!lh. iii.

upon a lute, and make the silken. Titus And
or when to the lute she sung ...Pericles, iv. (Gower)
UTE-CASE-stole a lute case........ Henry

LUTE-CASE-stole a lute case......... Herryy ${ }^{\prime}$. jii.

LUX lux tua vit: mihi .................. Jericles, ji.

bloody, luxurnous, avaricious .......... Mncticth, iv.

damned and luxurious mountain .......Henry $V$. iv.

most insatiate, Juxurious woman . Titus Andron, v.

UXUPY-lust and luxury!.Merry Fires, v. 5 (song)

one all of luxuly ........... Neasure for Heosure, $\mathrm{v} .1$

urge his hateful luxury ............. Richard III. iit.

how the devil luxury ......... Troilus \& Cressida, v.

a couch for luxury and damned incest . Hamlet, $\mathrm{i}$.

not only my success in Iybia .......... - vinter's Tale, v.

Bocchus the king of Lyia

LTCHORIDA, her nurse......... Pericles, iti. (Cower)

O how, Lychorida, how does my queen? - jii.

now Lychorida-here is a thing too young -

Lychorida, bid Nestor bring me spices

te lo

I. FCURGUSES, if the drink ........ Coriolanus, it.

ria to Lydia.......Antony \& Cleo. i.

Cyprus, Ly'dia, nbsolute queen
LYING-thou most lying slave

where senseless they are lying. Tu. Gen of fert. iji.

than lying, vainness, babbling... Tuelfin Nives, ii. 1

that lying by the violet.... Neasure for Measure, ii.

why, you bald-pated, lying rascal! ..

for, lying so, Hermia ............ Mid. $\dddot{N}$.'s Drsum, it. 3

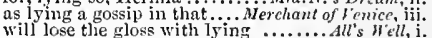

on every grave, a lying truphy .........

let ne have no lying ............ Hinter's inte, iv.

thou art perfect iu lyin down

how this world is given to lying! $\ldots$...

in thy lying tongue both numbers...... Corrolonus, ivi.

lying etill, are full of rest.......... Sulius (insor, iv. 3
thus in a clialel lying! ............. Cymbeline, ii. 2

be it lying, note it, the woman.......... ii.

thou'lt have me whiped for lying

tis as casy as lying..........................

ilimed, liij.

the lyingest knave in Christendom..2IJemry Vl. ii.

1. Mloges-o lymote, o Austria! . King John, fii.

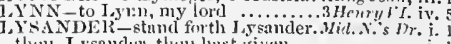

then, Lysander, thum laset given 


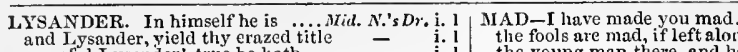

scornful Lysander! true he hath....

I,ysander and myself will fly this (rep.) -

there my Iysander and myself

kep word, Lysander: we wnust starv

we it so, Iysander: find you out a bed

nity, good Lysander; for my sake...

Lysander ridales very prettily

meant to say I,ysander lied............

J.ysander, it' you live, good sir, awalie

do not say so, Lysander, say not so ..

heler may'st thou come hy help mel

Iysander, look, how I do quake.....

Iy sander! what removed? Iysander

if thou hast slain Lysander in

what's this to my Ly'sander? .......

Lysander keep thy Hermia......

by mine eye, Lysander, fonnd ......

l.ysander from my side? Lysander's

wherefore doth Lysander deny your love -

are not you Lysander?

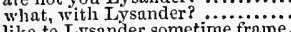

like to Lysander sometime frame...

crush this herb into Lysander's eye..

hysander shield $L y s a n d e r$, if tiley me

and this Lysander; this Demetrius .

holy words to the lord Lysimachus.

from whence Lysimach it is Lysimachus the governor..

MAB_Mab lath been with you ... Romeo \&-Juliet, i. 4 Which oft the angry arab yot

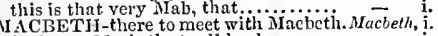

for brave Macbeth, (well he deserves

former title greet MI acbeth

former title greet Macbeth......

a drum

all hail, Iracbeth! (rep.)

lesser than Macbeth, and greater........

happily received, Nacbeth, the news.

wrorthy Macbeth, we stay upon.

Macbeth shall sleep no more!

the sovereignty will fall upon Macbetis

as upon thee, Macbeth, their speeches

join with us? AIacbeth. He lieeds not

gracious Duncan was pitied

how it did grieve NIacbeth!...........

none of woman born shall harm Macbe

IIacbeth shall never vanquished be

and our high-placed Nlacbeth shall live
why stands Alacbeti thus amazenly?

$\mathrm{I}$ ain not treacherous. But BIacbeth is

black ILacbeth will seem as ...

better Macbetls tlan such $\&$ one

devilisl Macbetl by many of........

Dlacbeth is ripe for shaking

fear not, Macbetli; no man ...........

my name's MIacbeth. The devil...........
either thou, MIacbeth, or else my......
MACCABAUS-[see Judas] alas, ponr Maccabras

MACDONWALD, (wortiry to be............. Ma

that Macduff denies his person...

I hear, Macduft lives in disgrace.

thither Mneduff is gone to pray
gent he to Macduff? He did

beware tacduff beware the thane.....

then live Macduff; what need $\mathbf{I}$....

the cavtle of Macduff I will surprise

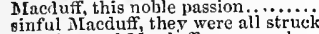

and the good MIacdiff, revenges bur

wortlyy II Iacduft, and we, shall take

tell thee, Macdnff was from liis.....

lay on, Macduff; and damned be he ..
NLacduff is missing, and your noble son

IACE-the warden pies; mace ..Winter's Tale,

more exploits with his mace. Camedy of Errars

the sword, the mace, the crown
instead of maces, will we ride.

thy leaden mace npon my hoy
MACEDON_in Macedon (rep.)

2Henryll

between Macedon ard Monmouth ...

a prince of Iacedon, niy royal father.. Pericles,

IACHIAVEL-am I a Nachiavel? Merry wives, ii. 1

Alencon! that notorious Machiavel!.1 Henryly . v.

IACHINATION, hollowness, treachery

MACIINE-this macline is to him. Hanlet, ii. 2 (let.)

AACK.IREI, $\rightarrow$ as stinking mackarel.I Henry IV

how now, captain Macnorris? (rep.)

captain Mracmorris, I think (rep.)....

MACULATION in thy hent. Troilus \& Cressida, iv.

the is but mad yet, madonna.....

fou be not mad, be gone

ii. 3
ii. 3 I'm in mast run mad.

first told me, thou wast mad

how now mad spirit?.

farewell, mad wenclies

that wench is stark mad

will make the man mad.

away, nway, mad ass

wast thou mad, that thus.

that I gatlier he is mad.

he is mad; some get with

thou'rt mad to say it ......

some say, he's mad...

it will make wise men mad......

mad ire, and wratliful fury....

thy wife, (it any be so mad) \begin{tabular}{c|c} 
MAD -1 have made you mad.......... Tempest, iii. 3 & MAD, sir? O very mad (rep.) \\
the fools are mad, if left alone.Tia Gen. of $V$ er. iii. 1 & that he ran mad, and died
\end{tabular}

.. Henry VIII. i. 4 the young man there, and be mad. Alerry trives,

if I have horus to make one mad....

ii. I 'tis mad idolatry, to make

....... Trailus \& Cressida, i. i

lie is very eourageous mad, about

this is mad as a mad dog! ........
the fincst mand devil of jealousy

Cussandra's mad

the young prince will go mad.

hatli done to-day mad and fantastie

they are mad women

$\mathrm{r} m$ as mad as he ..................

why, we shall make him mad, indeed

tbe man grows mad; away with him

are all the people unad?

i. 2 good sir Topas, do not think I I........

I am not mad (rep.) $\ldots \ldots \ldots . . . . .$.

like a mad lad .................... iv. 2 (song)

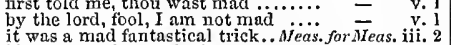

if she be mad, (as I believe no other)

many that are not mad, have sure

you will never ruu mad, niece.

thus to make poor females mad. Mid.N. Drearn, iii. 2

do you hear, my mad wenches?., Love's L. Last, ii. I

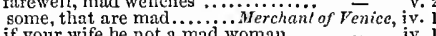

if your wife be not a mad woman
fetching mad bounds, bellowing

an 'twere to me, I should be mad at it $\overline{\text { v }}$ v. 1

the other mad without any .......As you Like it, i. 3

but your son, as mad in folly

would you make me mad?. Taming of $S h . \overline{2}$ (induc $)$

masters, help! my master is mad....

some meaning in his mad attire.

such a mad marriage never was.
be mad and merry, $\rightarrow$ or go han

of all mad matehes, never was.

on all mad masters ! and all foul

earry this mad lnave to the ga........

no less honest than you are mad..

then run mad, indeed; stark mad!. . - iii.

but, sure he's stark mad....... Com

or waking? mad, or well-advised?

it wonld make a man mad as a buck

Antipholus is mad, else would he...

is a mad tale, he told ......

I am not mad. O that thou wert not

dost thou mad me? will you (rep.)

that the man was mad ...............

would nad or man or beast.....

his bondman, all as mad as he .......

might make one wiser mad..........

you are all mated, or stark mad ....

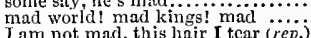

I am not mad, this lair I tear (rep.) KingJahn, ii.

thou fond mad woman, wilt thou ... Richarel II. v.

how uow, how now, mad wag? ........ III n $r y I V$. i.

tor he made me mad, to see..........

nong of these mad, mustachio

what, art thou mad? art thou mad?

that same mad fellow of the nort

cousin Percy, you will make him mad

ny dauthter will run mad (rep.)

what, Ial? how now, mad wag?

my lord, this is a poor mad sou
thou whoreson mad compound.

they will talk of mad Shallow yet

I an worse than mad.

he's but a mad lord, and naught but

they say, she's mad................ Cariolnurs, iii.

it will make you mad; 'tis good .....

though I am mad, I will not........ Antony \&.Cleo. ii. 5

'twas I, that the mad Brutus ended..

O he is more mad than Telamon $\ldots . .$. iv. II

what! art thou mad? Almost, sir.... Cymbeline is

are men mad? hath nature

as I anm mad, I do (rep.)

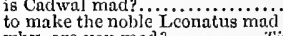

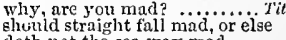

doth not the sea wax mad

no han shnuld be mad but $I$.

of griefs would make men mad..

ay, some nad message from his mad

I am not mad. I know thee well ....

meing credulous in this mad thoight

thongh they suppose me mad ( $r+p$.)

mal, not mad, sweet heaven! (rep.).

What, art tlou mad, old fellow? ........

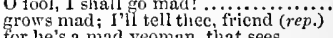

he's mad that trusts in the tameness

alack, sir, he's mad. "Tis the times'

as mad as the vexed sea...................

the king is mad....................

nakes mad her sister Goneril...............

Romeo, art thou mad? Not mad. Romeo os Jutiel, i.

hot days, is the mad blood stirring...

thou fond mad man, here me but...

it makes me mad.

mortals, hearing them, run mad

that you run mad, seeing that

that hath made him mad.

your noble son is mad (rep.) ....

make mad tlie guilty and appal

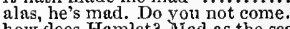

he that is med, and sent into man ......

why, because he was mad.............

a whoreson mad fellow's it was.......

a pestilence on him for a mad roguel....

poor lady! she'll run mad

a......

二

iii. 3

iiv. 3

os le all mad [Col. Knt.-o'erwhelmed] .-

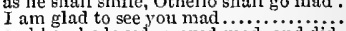

than slie was wont; and makes men mad

Humlet, iv.

Othe mad days that I have spent!

rather moody mad, and desperate....i Henry $V t$ iif.

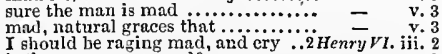

is the man grown marl?..............

thou mad misleader of thy brainsick

wert distraught, and mad with terror?
MAD-BRA YN rudesby, fuli of. Taming of Shrew, iii. 2

MAD-BRAINED bridegroom took him - ii. 2

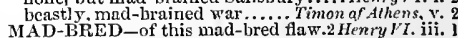

MAD-CAP rutian, and a swearing. Taming of Sh. if.

the merry mad-cap lord

what a mad-eap hath heaven lent ... King John, i.

once in my days I'll be a mad-cap

nimble-footed mad-cap prince of Wales

IADDED-madded Hccuba gave ..Cymbeline,

most dereneratcl have you madded .... Lear, iv.

he to madding Dido, would unfold. $2 \mathrm{H} \rho \mathrm{Am} Y \mathrm{Vl}$. iii.

to the madding of lier lord ......... Cymbeline, ii
MADE-made such a sinner of his ...... Tempest,

made thee more profit than .............. -

that made gape the pine....

of his bones are cornl made......

What strange fish hath made his meal

the suit I made thee?

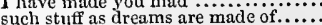

made me neglect my studie.

when she hoth made weak

made use and fair advantage... witi words that made them known $\ldots . .$. -

if you be nade [Col. $\mathrm{Kn} /$-maid] or no?.. -

thou art made like a goose a 
MADE them watchers of........Two Gen. of ter. the ladder made of cords (rep. iii. 1). that made her fuirl.

when the flight is made to one...........

one made privy to the plot.......

therein made me liapıy ..............

as it the gurment lad beeu, made for ine

I made lier weep n-good

the gift hath y

and mude me druuk (rep.) ............ Herry $\bar{W}_{i v e s}$

made afar off by sir Hur]

as sure as his gnts are made of puidilings

would have made yon four tall fellow

shrewd consticuction made of lier............

the hour is fixed, the match is made...
he has made us lis vlonting-stog......

what made me love thee?

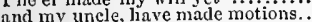

there's a hole made in your best coat..

likewise hath made promise to.......

that I am made an ass.

how wit may be made a Jack-a-lent

could have made you our delight? $\dddot{\text { Tivelfh }} \overline{\text { Night }}$, i.

she made good view of me $\ldots . . . . . . . .$.

thou art made (rep.iii. 4)

last made thine enemies?

who hath made this havock ..........

how have you made division of yourself?

that day that mnde my sister

shall be innde of our dear souls.......

impiety has marle a feast of thee...

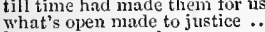

like man new male $\ldots . . . . . . .$.

gtolen a man already made

we are made to be no stronger than fault

only he hath made an assay of her.

hath hede lim that mracious deniai...

hath made you fair, hatl made you good -

that Angelo hath made to you...

lie macle trial of you only ..........

made it more violent and unruly ....

what offence hath this man n

they say this Angelo was not made by

low should he be made then

I am made to understand ............

there have I rade my promise to cail

have not ret made known to Mariana

thou must be inade immorta

you will think you have made no offenee

of which he made five marks.

ere twiee the sun hath made bi

we have made enouiry of you

we have made ellquiry of you $\ldots . . . .$. .

that e'er made a duke ( $(\cdot e p$. $)$

he hath made great preparation.......

not been amiss, the rod had been made

slie would have made Hereules have..

his grace liath made the mat

who hath made this matel ...........

hath she made her affeetion known...

other respeets, and made her half myself

like favourites made proud by princes

is little Cupid's crafty arrow made....

any slander that don John had made.

5ou'll be made bring Deformed forth..

$O$ that is stronger made......

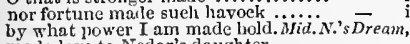

made love to Nedar's daughter ........

have every nelting river made so pro not made to woo..........

your kindred hath made my eyes water -

made senseless things begin to do...

the hate I bear thee made me leave...

and made your other love ..........

of hindering knot-grass made ....... -

the morning's love have oft made sport = iii.

I must eonfess, made mine eyes water $\overline{-}$ iv.

this article is masle in vain........ Love'sL.Lost, i. 1

Navarre hatl made a vow ........

I only have made a mouth of $\ldots \ldots \ldots$ iv. - ii.

O we hinve marle a vow to study ...

he made her melancholy, sad, and heavy -

and ever and ann they mate a doubt

I made a little fault in, wreat

I made a little fault in, great......

not your ofier made in lieat of blood..

well have made our sport a comedy...

than if you had made waste of ail.....

God made him, and therefore let hin.
AIADE good preparation.....

to seal love's bonds new made

my atlairs, hrye mitde you wait......

that made the wings she flew withal

having made one, methinks, it sliould

at times made moan to me

why he lat made the ewe bleat for

let their beds be made as sof't as yours

she made me vow, that I should ncit
and made lim swear never to part

you to mar that which Gud made.. $i$ s you Lik

when nature hath made a fair ereature
were you made tlie messenger?......

supplied when I have nade it empty

that will be made after my flight....

that I made yesterday in despite of.

with a woeful ballad mude to his ...

the better part made merey.......;

gods had made thee poetical (rep.)

the wonnd mine eye liath made...
falser than vows made in wine

love hath made thee a tame.

made him give battle to the ioness..

have they made a pair of stairs...

to be made of sighs and tears (rep)

when earthly things made even

with tne breach yourselves made

that, you were made of, is inetal

meerish, proud, idle, made of self-love

a further use to be made, than alone

love made your fortumes twenty,

thinks himself made in the unchaste

in fine made a groan of her

saffron would have made al

my lord that's gone, made himself ..

of that $I$ have made a bold charter

since you have made the days

our esteem was made mueh poorer

how Silver made it good. Taming of Shrew, $\mathrm{J}$ (induc.)

that made great Jove to humble ....

are made to bear, and so are yon (rep.

I see, a woman may be made a fool

how did you desire it shonld be made?

my son Lucentio made me accuainted

our first merriment hath made thee

that have by marriare made

Bianca's love made me exchange...

the offeness we have made you do

made his basiness more material

or half-moon made with a pen

Polixenes has made thee swell thus..

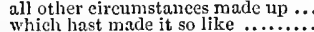

Yon have made fault i' the boldness.

hath made thy person for $\ldots$ made old nan; if the sins...

thine own goodness lat in made

thou, having made me businesses

made me four-and-twenty nosegays

yet nature is made better by no

fairest youth that ever made eye swerve

and made more homely than thy state

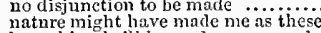

hanr lim, he'l be made an example

that heirless it hath made my kingdom

even in these looks I made...

and male between's by vows.......... $\vec{E}$

had made provision for lier

marle daily motions for our hone.

my mistress made it one upon my

the doors are made against you.....

eomment will be made on it
by this, I know, 'tis made

had not heen made of taith...

hath almost mude me traitor.

I lave made it for $y$ ou. Made it for $m$

whom I made jord of ine and all I liad

but this bird lanth male his...................

that made you break this enterprize

mine cyes are made the fools.

hatl made them drunk, hatli made ine

yet I made a shift to east him

by the verities on thee made good

this I made good to you

are made, not marked; where violent

been prevented, and made whole ..... King $J$

not worth this coil, that's made for me -

but Gorl hatli made her sin will.......

and wide latyock male for lifoorly
this day liath made mueh work

this day liath made mueh w'or

to two sueh streams niade one $\ldots . .$.
that anity which you have made
Venice, ii. 4 MADE-for this match, made up .... King John, ii. 2

ii. 6 niade to run even, upon mad

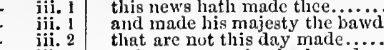

iii. 3 and our oppression liatl made up this

iii. 5 O, upon my knee, made haril...

iv. and made it heavy, thick

iv. 1 to be made, then shall this hand

to a king, made it no conscience

shook thy head, or made a pause ....
struck me dumb, made me break ofí

comment that my passion made upon

$O$ death, made prond with pure

John hath made his jeace witl Rome?

but stayed, and marle the western

so sad to-night as this hath made

manage must be made, my liege

hath made a sliameful eonquest

hast thour made me gaunt........

have ever made me solu my the siek hour that his surfeit made.

base men by his endowments are mide

sinful hours, made a divoree ......
that Power that made you king

thave made peace with Bolingbroke...

their peace is made with heads....

tliat are made [Col.-swear] to

for with a kiss 'twas made.....

when weeping made you break.

time male me his numbering elock.

this hand hath made him proud $\dddot{i}$ iee

I was not made a horse; and yet I bear -
for he made me mad, to see him ....। Henry IV

the king hatl made your nephew

an' I lave not ballacls made on .......

what eunning match have you made

knew ye as well as he that

hath Henry Bolingbroke made head

enlarged him, and made a friend of him -

what the inside of a churreh is made of
and they have made bolters of then

hath already made thee butter

his vow made to my father

he made a blusluing cital of himsel peace -

Percy, I have made hin sure ........

pregnaney is made a tapster $\ldots$ m....... -

and made her serve your uses both ..

have made a shift to eat up.....

he had made two holes in the...

of their puissauce made a little.......
methought, he made a slirewd tlirust

metliouglit, he made a slirewd tlirust
he would have made a good pantler.

like a man made after supper.....

ii. 3 let there be no noise mode

iii. 2 be with lim that hatl made us heavy

iii. 3 time to have made new liveries .......

the king were made a prelate.

I have made an offer to lis majesty...

he liath made a matcl with suel. ....

a made a finer end, and went a way

had twenty years been made ........

whose limbs were made in England
the fault my fatlyer made in eomjassing

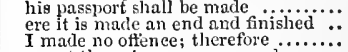

as yet there is no answer made

as yet there is no answer made .......

fort France, and made his England $-v .2$ v. (chl

our isle be made a nourisl of

ny grisly eountenanee made ot liers

guarded, where the breach was made

and made me almost yield upon....

made their mareh for Bourdeaux....

suddenly made him from no......

liappy, to be made a queen? To be made -

fit to be made companion with ......

made thee feared, and hownured .....2 $\mathrm{He}^{\prime} \mathrm{n}$

and must be nuade a subject to a duk
point, ny lord, your falcon made....

and made me clind, with danger.

it made me langh to see

true; made the lame to leap

thy thither Ilenry made it nine.

made me colleet these dangers

but mine is made the prologne

be jud red, I made the duke away....

to see how decl my grave is made ...
beard made rough and rugged ......

suspect 'twas he that made the slangliter?-

a sword, though made of a lath.

an innocent linnly should be made...

sir, he made a ehimney in

ancl mide it an enuuch ...............

he that made us pay one and twenty
made me full of sickness and diseases

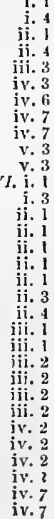

i. 4
ii. 1
ii. 4
iii. 3
iv. 3
iv. 6
iv. 7
iv. 7
v. 3
y. 3
I. 1
i. 3
ii. 1
ii. 1
ii.
ii. 1
ii. 1
ii. 3
ii. 4
iii. 1
iii.
iii. 2
iii. 2
iii. 2
iii. 2
iv. 2
iv. 2
iv. 2
iv.
iv.
iv. 7 
MADE all France to quake.........2 Henry ${ }^{\prime} I$. iv. 8 MADE-this praise is made .... Timon of Alhens, ii. 2 MADE those clothes, which ... Cymbeline, iv.

but I was ma

this hand was made to handie (.ep.).

and made a prey for carrion $k$ itea

\begin{tabular}{lr}
\hline & v. \\
$=\quad$ v. 2 \\
$=\quad$ v. 2 \\
v. 2 \\
v. 2
\end{tabular}

what are you made of? you'll nor fight

this breach, now in our fortunes mad

made us hy-words to our enew

he made thee duke of York.......... -

mide him to resign his erown perforee

rather than made that savage

the duke is made protector of the....

'twas he that made yon to depose..

and made an evening at the noontide

and made a preachiment of your

muchanging. made impudent with

py him that made us all

and made tre Dauphin stoop...

our sunshine made thy spring

the match is made; she seals

when he was made a shriver choice?

stay till Warwick made return?

he hatl made a solemn vow ........

the gates made fast! Brother....

so sorry for my trespa

is prociamation made.........

and male our footstool of security

nor made to court an amorous

searce half made up, and that

that made him send lord $\ldots 0 .$.
kindred are made gentlefolks.

Jand that made these (rep.).

thon hast made the happy earti ....

and twenty times made pause .....

for it was made for kissing, lady

say then, my peace is made........

miny a gentle person made a Jack.

impression made my dream .....

it made me once restore a pur.
who made thee then a bloody.

since I liave unade my friends .......

I hope, the king made peace

I hath made you melancholy.

have made it tedious, wearisome

made him my book, wherein my

I am not made of stone

than thou hast made me by my.....

unade I him king for this?

your danghter is made queen

the king thy brother made

hath made a prey for worms ........

and made his course again for Bretagne

the weary sun hath made a golden

one that inade means to come.........

foul stone, made precious by the foil

the last made former wonder

they made Britain, India ...........

but when the way was made

made suit to come in his presence (rep.)

Hopkins, that made this mischief

and all that made me happy

as 1 am made without hin

then you are weakly made

or made it not mine ton? .......

and made to tremble the region

or died where they were made ......

an earnest motion made

there had made a lasting spring

have I not made you the prim

you made bold to carry in to Flander

I am glad, your grace has made that

the late marriage marle of non

the ling has made him master.

my haste hatl made me unmannerly

he's mude inaster o' the rolls .......

to have this young one made (rep.)...

I made no spare, sil. Yood my place..

they fell on, I made good m.

ye have made a fine hand..........
thou hast made me now a nian

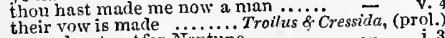

or made a toast for Neptune.
hand that made the engine

ere you be made tame...

go to, a bargain made; seaj it...........

made tame as they are made..................

though they are made and moulded

made emulons missions 'mong

impressure made of our rank fend...

i. 1
i.
i. 1

i. 1 i.

i. 2 . 2 an

if renown made it not stir $\ldots \ldots . . . . . . .$.

and made what work I pleased ......

and eities he made all of false-faced.

ii. 1 let him be made an overture 3 he................

ii. 2 and the commons made a shower.

iii. 2 when Tarquin made a head for Rome

by his rare example, made the coward

made you against the rrain

made you against the grain ........

often made arginst the senate

my praises made thee first a soldier.

promise that you made your mother?

'tis I that made thy widows

his clothes made a false report 3 why he is so made on here within

why, he is so made on here witjin
o you have made good work I (rep.)

like a tling made by some

you are they that made the ai

i. 1 made him fearea, so hated, so banished

i. 2

Why, so; yon have made good work..
in the same time tis made?..........

as a thing made for Alexander

made him joint-servant with me ...
what faults he made before the last.

we have made peace, with no less.

thou hast made my heart too......

2 sounds, made in her concave shores...

there's a bargain made ................

I have made strong proof of my
same ague which hath made you lea
your swords, made rich with

i. 4 your swords, made rich with ........

ii. I know not, that made them do it ...
ii. 2 best friends made, and our best means

lave made themselves so strong....

witness the hole you made in Casar"s

this parting was well made (re

iii. 7 good to all, mude one of them.........

iii. 7 state made friends of them...Aito passions are made of nothing

Cresar, made out of her impatience...

out of Egypt, made wars here.........

and made the water, which they beat

and made tleir bends adornings ...

royal wench? she made great č......

no; I made no such report

the news, made not the

and made a cistern for sealed snakes

and what made the all-honoured....

hath made me rig my navy

you have made me offer of Sicily....

purpose made more in the marriage

they have made him drink alms-drink

made his will, and read it to public ea

ii. 3 Cesar, having made use of him......

ii. 4 made her of lower Syria, Cyprus ....

my sword, made weak by my affection

repent thou wast not made lis daughter

never anger made good guard for ....

like $a$, $T$, and now 'tis made an $H . .$. .

with ships made cities

purchase what you have made known

though ink be made of gall.......

hath made you reek as a sacrifiee...

thou shouldst have made him as littie

assanlt you have made to her chastity

it is a thing 1 made........

my father shall be made acquainted

made me to fan you thus (rep.).

v. if 'tw'ere made comparative for

v. 3 were they all made such men ......

of your answer made the

to where they are made..............

with his tools made me a counterfeit

Cxsar made here, but made not here

iii. 2 made Lud's town with rejoicing ....

iif. 3 which I have made to thy command?

iji. 3 tell me how Wales was made so happy

wherein you made great Juno angry

iii. 3 hath made us forward

iv. 5 a thing more made of majice...

court made me to blame in memory

have made the ground ny bed

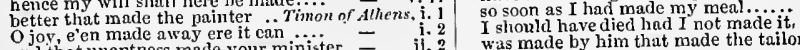

\begin{tabular}{l|l} 
iii. 2 & my taijor made them not.......... \\
iii. 3 & being scarce made up, I mean...
\end{tabular}

iii. 4 dead, that we have made so muci, on

iij. 5 what man thou mightst have made.

\begin{tabular}{l|l} 
iii. 6 & from whore they made the stand?.... \\
iv. 2 & made good the passage; eried to.......
\end{tabular}

shaves, the strides they victurs made.

you are made ratler to wonder .........

he'll do, as he is made to do..........

slaugliter is here made hy the Roman
happier mueh by his affiction made

I am ealled to be made free ............
whom the gods have marle preservers

i. 2 whose kinsment have made suit......

for beauty that made barren.

which by his tongue heing made..

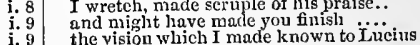

ii. 1 the vist not to be molca

ii. 2 till all the Androniei le nade away -

with sight, made leart ament ......

ii. 3 if fear hath made thee faint...........

iii. 1 and made thy body bare of her

iii. 2 hath made thee handless in thy......

iii. 3 and made a brine-pit with our bitter

iv. 2
iv. 4 was sorrow made thee dote already? and he made miserable?..

iv. 5 thou art made of tears, and tears

that made me to fear; al though

iv. 6 by nature made for murders

iv. 6 well made away, then let the .......

iv. 7 I made unto the noise: when soon

$v$ these trenches, made by grief and care

. cut off, and made a merry jest ....

my tears have made

which to prevent he made a law - i. (Gower)

ye gods that made me man.............

hath inade the ball for them to $\ldots . . . \cdots$ - ii.

what ground's made happy by his ....... iii. (Gower)

is made, with all due diligence - iii. (Gower)

and fear made me to quit the house

slie made more sound by hurting

and made the night-bird mute = iv. (Civiver)

iii. 2 she made him roast-meat for worms ....

death hath made this slaughter 3 iv. 4 (Gower)

why, hath your principal made known

goodly vessel ride before us, made to it - v.

the regent made in Mitylene - v. 2 (Gower)

she made known herself my daughter..

Leor, i.

I am made of that self metal as

ii. 2 potency made good, take thy reward

by the power that made me o... it.......

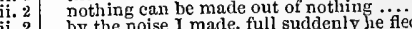

ii. 2 a tailor made thee $\ldots \ldots \ldots . . . . . . .$.

made you no more offence than

made you no my guardians, my depositarie

but she made mouth in a glass ...........

made him proud of heart $\ldots \ldots \ldots \ldots$. 3 ...

irne or false, it hath made thee earl ....

it

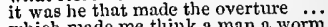

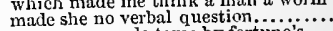

poor man, made tame by fort

shortens my made intent ...........

sisters have in thy reverence madel

made Verona's ancient citizens.. Romeo o $\mathrm{s} J$ utiet, $\mathrm{i}$.

your son: towards him I made .....

than slie, are happy nothers made...

marred are those so early made...

esteem, are madc already mothers ...

made by the joiner squirrel ...........

and made exchange of vow..........

else have madle thy tale large (rep.)..

bring thee cords made like a tackled st

well, you have made a simple choice

men's eyes were made to look........

thy beauty latl made me effeminate

he made you for a high was to my bed

wear them told, have made me trembi...

what made your master in this place?

this present object made probat
are all made out of his subjeet

each word made true and good

iii. ? but answer made it none $\ldots \ldots \ldots$. 3.

even with the vol I made to her..

no reckoning made, but sent to $\mathrm{my}$....

that hath made him mad: I am sorry

a damned defeat was made

as made the things more rieh

indeed, my lord, you made me believe

no more of ' $t$; it hath made me mad.......
journeymen had made men, and not $(r e p)=$. iii. 2

and that unaptness made your minister 


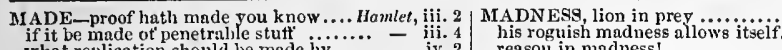

that made us with such large discourse.

they say he made a good end .............

he unade confession of you

iv.

a pit of clny for to be macle (rep.)... -1 (song)

is not parchnent made of sheep-skius?

I say again, hath made a gross revolt.... Othello, i.

lawiful prize, he's made for ever ........

made tlie flinty and steel eonch of war....

when the blood is male dull with .......

the purehase made, tlie fruits are to ensie

not yet made wanton the night............

as gross as ignoratee made drun

and made of no such baseness as jealous

but if she lost it, or made a gift of it

made demonstrable here in Cyprus

that breath made up between then.....

goodly book, made to write whore upon
made you to suspect me with the nloor

made you to suspect me with the Nloo

I have made my way through more.......

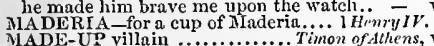
YAD-HEADED ape 1 of atthens, $\mathrm{v}$.

that's gomewlrat madly spoken... Meas. for.Heas. $\mathrm{y}$.

shot madly from their spheres...M.N.
or man or woman madly dote upon.

sever themselves, and madly sweep.

venture madly on a desperate...

mad herself, she's mady thou didst ans

or madly think, a babe of clout.......... $\overline{\text { ing }} \overline{J_{0}}$. Y.

madly liath broke loose, and bears ..2 HenryI $V^{\circ}$.

or is your blood so madly hot.... Troilus

with horror, madly dying, like...... Cymbeline, v.

MADNi.AN-nothing but madman.. Twelfth $N$ ight, i. 5

a fool, and a madman ..................
the fool shall look to the madman

madman, thou errest .................

nay, I'll ne'er believe a madman ....

when the fool delivers

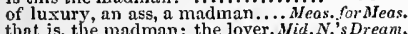

that is, the madman: the lover. Nid. N.'s Drean,

but your words show you a madman

how now! a madman!

in this the madman justly chargeth.

sharp wea pons in a madman's hands 2 Henry $v$ I. iii.

for a madman owes 'em ....... Timon of' Athens, iii. 4

a madman so long, now a fool

frighted, when a madman stares? JaliusCasar, iv. 3
witether a madman be a gentleman .... Lear, iii. 6

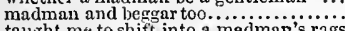

taught me to shift into a madman's rags
bound more than a madman is.. Romeo

Romeo! humours! madman! passion!

a miadman's mercy bade thee run away

crown thee for a finder of madimen 7 wetf $h$

lovers, and madmen, have such Mid. N.'s Dream, v. have holp madmen to their wits.....Kichard $I$. v. 5
great imagination proper to madmen 2 Henry $I \%$. i. 3

I'll be a curer of madmen ....... Troilus \& Cress.

else such stuff as madmen tongue ... Cymbeline.

will turn us all to fools and madmen.

plague, when madmen lead the blind....

IADNESS - do hiss me into madness... Tempest, ii. 2

any madness, I ever yet beheld ........ Mry nives,

if sad and merry madness equal be. Twelfh

yet 'tis not madness........

fellow, thy words are madnes

no madam, I do but read madness

show mneh like to madness ..........

her madness hath the oddest frame

as e'er I heard in madness

fetter strong madness in a silken .........u

such a hare is madness the youth.Mer. of $I e n$, v.

for if he love me to madness, I shall

love is merely a madness....

born of inadiess; that blind .......... - iv. I

can matel the pleasure of that madness

can matels the pleasture of that madnees -

his flight was madnes................ Mlacbelh, iv. of thy ${ }_{1}$ you niter nesed good Lord! what madness rules..... Uenry VI. were't not madness then, to make...2 Henry $V I$ iii. o plague and madness! ..... Troilus \& Cressida, v. 2 negation hath no taste of madness

O madness of discourse, that eause .

all the madness is, he eheers $\ddot{\text { Time }}$ Tike of Athens,

riotous madness, to be entangled.. Antony $\&$ Cleo.

to leave you in your madness ...... Cymber

maduess, of which her li
$\mathrm{O}$ that way madness lies

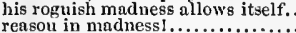

madness rnost discreet.

mand draw you into t, a ehoking. Romeo \& Juliet, $\mathrm{i}$. to define true madness, wiliat is't ...

into the madness wherein now he raves

though this be madness, yet therc's method

with a crafty madness, keeps aloo

lacked form a little was not like madness

madness in great ones must not

to let his madness range

for madness would not err; nor sense.

o'er whom his very madness, like some ore
IIamlet in madness hath Polonius slain

thy madness shall be paid with weight.

a document in madness; thoughts

I here proelaim was madness.

his madness is poor Hamlet's enemy

now, in maduess, being full of supper

by-and-by breaks out to savage madness

TADONNA, that drink and...... Tuelfth $N$

good Madonna, give me leave (rep.)

I think his soul is in liell, M Madonna

thou hast spoke for us, Madonna.....

he is but mad yet, Madonna

MADRIGALS; there (rep.). Merry

what observation mad'st thou... Comedy of Evest, iv.

thou mad'st awav her uncle Clarenee

for her sake, mad'st quick conveyanee

thou mad'st thine enemies shake..... Corio

IAGGOT otentation

if the sun breed maggots in a dead dog.

MAGGOT-PIES, and chonghs....

MAGIC-pluck ny magie garment

Tempest, $\mathrm{i}$.

there's magic in thy majesty .... Winter's Tale, v. 3

distilled by magie slights $\ldots \ldots \ldots \ldots$. Naebeth, iii. 5

by magic verses have eontrived....... Henry $V_{1.1}$ i. 1

the noble ruin of her magic. Antony \& Cleopatra, iif.

if she in ehains of magic were not bound

there's magie in the web of it $\ldots . . . . .$. - iii. 4

MAGICAL word of war ....Antony \& Cleopatra, iii. 1

a great magician, olsseured in tlie circle

great magician, damned Glendower.1 Henry $I{ }^{\prime}$.
what blaek magieian eonjures up... Richard $I I I$,

MAGISTRATE-name of magistrate.. 'Tempest, ii.

like magistrates, eorrect at home

magistrates be labouring men (rep.)2 Henry $V I$.

before a true and law ful magistrate..3 Henry VI. i.

they choose their masistrate

established the people's magistrates
MAGNANINITY, and make him, iii. 1
.3Herry vI. v. 4

MAGNANIMIOUS, and most. Love's L. Lost, iv. 1 (let.)

be magnanimons in the enterprize. .All's W'ell, iii. 6
dove, or most magnanimous mouse. 2 Henry I T. iii. 2

is as magnanimous as Agamemnon

valiant and magnanimous deeds. Troil. \& Cress. ii. 2

of the magnanimous, and most

MAGNE-magne Dominator poli... Tilus Andron.iv. 1
MAGNIFICENCE, in so rare..... Winter's Tate, i. 1
MAGNIFICENT Armado

than whom no mortal so magnificent! $\bar{O}_{\text {hello }}$ ii. 2

MAGN IFICOES of greatest port. Mler. of I enice, iti. 2

MAGN US-saint Nagnos' eorner! ..2Henry VI. iv. 8

MAHU-Modo lie's ealled, and Mahu .....Lear, iii. 4

IALD-[Col.Knt.] if you be maider

but, certainly a maid........

if not. I'li die your maid ...............

that knows I am a maid.... Tuo Gen. of Verona, $\mathrm{i} .2$

since maids in modesty, say no...... - i.

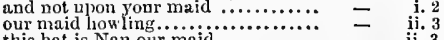

this hat is Nan our maid................
yet 'tis not a maid ..............

a maid, tor she is lier master's maid $\quad$ 二

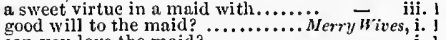

can you love the maid?.............

as honest a maid as ever broke bread

never langh but in that maid's eompany -

good maid, then ......................

my maid's aunt (rep.)

bring you the maid, you sliall

there pinel the maids as blue..........

went you not with master doctor, maid? - v. 5

a virtuous maid, the daughter....T'Telfh Night, .
MAID-a fair eruel maid ..Twelfih Night, ii. 4 (song) would have bcen contracted to a maid
betrothed both to a maid and man..

hath my maid's garments ..........

a woman with maid lyy him ......... - i.

with maids to seem the lapwing

be you content, fuir naid.

from fasting maids, wliose minds.

how now, fair naid?

leave me a while with the maid

to take this poor maid from the worldl

we shall advise this wronged maid.

be aequainted with this maid.

a deflowered maidl and by

are you a maid? No, my lord

neither maid, widow, nor wife
eonfess, besides, I am no maid

and now, dear maid, be you as free.

here's no place for you maids

aid

a maid, and stuffed! there's goodly..

give me this maid, your daughter?

that she vere a maid hy these

now if you are a maid, answer to this

they are dangerous weapons for $m$

be advised, fair maid: to you...Mlde. N.'s $^{-} \overline{\text { Dre }}$

despised the Athenian maid .........

reason say's you are the worthier maid =

to conjure tears up in a poor maid's ey

a maid of graee, and eomplete .....Love's $\bar{L}$.Lost,

with a majd. This maid shall not (rep.)

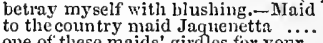

ove of these maids' girdles for

and a maid not vendible.... Merchant of $\bar{V}$ enice

to woo a maid in way of narriage.....

my maid Nerissa; and myself (rey,

none, but a holy hermit and lser maid

to us, maids as we are, to travel ...As you $\mathrm{L}$

speak sad brow, and true maid....

trots hard with a young maid

maids are Nlay when they are maids

fare thee well, kind maid .....................

fair maid, send forth thine eye
simple maid; and therein (rep.)

simple maid; and therein (rep.).......

the misprizing of a maid too virtoous

many a maid hatli been sedueed

many a maid hatl been sedue
this young maid might do her

corrupt the tender honour of a maid

and this gentle maid, to ent with $u_{B}$

to a proper maid in Florence

a the behalf of the maid

a poor maid is undone $\ldots \ldots \ldots . . .$.

I an eitber maid, or else tl
when I was like this maid
a. wife herself, thyself a ma

as she was a maid; and how.. Taining of

maid of the louse, Why sir.. Taming of Sh. 2 (ine

mates, maid I how mean you ...

you looked so longly on the maid

if you love the maid, bend thonghts

yourtertake the teaching of the maid

a slave to aclieve that maid whose.

a title for a maid, of all titles....

why then the maid is mine trom

fair lovely maid, once more good

and me, poor lowly maid...........

Fou see, sweet maid, we marry....

the prett iest love-gongs for maids.

he makes the maid to answer.......

is there no manners left among maids?

ballad against the hard hearts of maids

beaten the wooing a man (rep.).......

and your maids, eould not fill up...... Macbeth, iv. 3

as maids of thirteen lovely maid. King John, ii.

but the word maid, eheats the poor maid

to the fire-eved maid of smoky

for the maids in Framee to kiss....... Henry

a lrard condition for a naid to consign

for maids, well-summered and warm

for one fair French maid that....
the cities tumed into a maid

a holy maid hither with me...........1 Heñry Vy, i.

a maid, they say. $\Lambda$ maid! $\ldots \ldots \ldots$......

onth, be vanguished by a maid iit: 2

iii. 1

iiv.

v.
v. 1
v. 1

ii. 1

i. 4
v. 1
v. 1
v. 1
v. 1
v. 2
y. 4
i. 1
i. 3
i. 3
i. 3
i. 2
$i .2$
i. 2
$i .1$
i. ?

i. 1
v. 1
i. 1
i.

ii. 9
ii. 2
ii. 2

ii. 4
iii. 2
iii. 2
iv. 1

ii. 3

ii. 3
ii. 3
iii. 2

iii. 5

ii. 5

v.
v. 3
v.

3
$\vee$

ad.)

i.

i. 1

ii.

v. 5

iv. 3 
Af AID-beeause she is a maid.

..l HenryVI, v. 4 MAIDENHEAD for't

low now? how go maidenlieads? Troilus \& Cress. iv.

by the loss of maidenhead .....' I'ericles, iii. (Gower)

there shall not a maid be married..2 Henry $r I$. iv

play the had a

or their maidenheads; take it ..... Rome \& J Juliet, i. 1

now, by nyy maidenhead, at tweive..
death, not Romeo, take my maidenliead

fair yound maid that yet wants...

among false maids in love... Troilus

MAIDENHOOD of thy first figh

when Niobes of the maids and wives....

and maid is fair, the youngest. Timon of Athens, 11

love you the maid?

a pair of stainless maidenhoods. Komeo

MAIDENLY man at alm

maid, to thy master's bed...............

ladies and maids their seart's.

not friendly, 'tis not maidenly. Mial. N.'s Dream, jii.

MAIDEN-TVIDOWED. Cime.. Romro of Juliet, iii.

I loved the maid I married.

your maids, manage this war...Antouy \&-Cleo. jii.

by your leave, this maid is mine... Titus Andron ii.

ravish a maid, or plot the way .......

ah me! poor maid, born in a tempest

for me, that am a maid

Iir, we have a maid in Mitylene...

my dearest wife was like this maid ....

what this maid is, or what is like to be
fortunes bronght the maid aboard us

to their dear shelter take thee, maid......

buy this unprized preeious maid of me.

any man or maid of MLon tagne's.. Ro

I will be cruel with the maids

the heads of the maids? (rep.) ......

these years that you are now a maid

pricked from the lazy finger of a maid

when maids call medlars, when th

as maids call medlars, when they .

the property of youth and maidhood.... Oinello,

MAIL in monumental

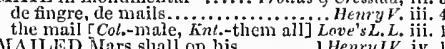

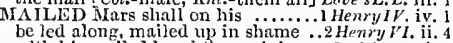

with his malled hand then wiping

MAM as to be enst fort

that bears so shrewd a maim

and stop those maims of sham

thereby is England maincel.

i.Richard $I$

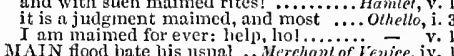

but I, a maid, die naiden-widowed.

this fair maid; how heaven hath (rep.)

a fair thought to lie between maids' legs

and I a maid at your window

let in the maid, that ont a maid
dear maid, kind sister, sweet Ophelia!

a young maid's wits should be as mortai

cold maids do dead men's fneers eall...

a naid-so tender, fair, and happy......

and poison this young maid's afteetions?

MAID-CHILD ealled Marina ...........Pericles, v.

where lie my maiden weeds..........

when maidens sue needs.

majden, no remedy ...................

will not proclaim against her maiden loss - iv.

why, then are you no maiclen

than that whieh maiden modesty doth

such maiden pilgrimage..........Mid.N.'s $D$ r

in maiden meditation, faney-free....

and here the mniden, sleeving soum

past the bounds of 'maiden's patienee

have you no modesty, no maiden shame - iii.

and, in our miclen eouncil ...

maidens bleach their summer sisoeks - v. 2 (song)

rection of a maiden's eyes ...Merch. of

yet a maiden hath no tongue but.....

thie best brine a maiden ean season

in's. 3 (let.)

we thank you, maiden

my maiden's name seared otherwise

you are no maiden, but a monument
you have eonquered my yet maiden bed

not a maiden, as thon say'st. T'aming of Shrew", iv. 5

wheretore, gentle maiden, do you. Winter's Tale, iv. 3

is yet a maiden and an innoeent hand - iv. 2

the pining maidens' groons ........... Heriry

if your pure maidens fall into...

put off your maideu bluslies ...

are all girdled with maiden wall

this pale and maiden blossom (rep.)

whose maiden blood, thus rigorously

strew main on

grant all tongue-tied maidens. Troilus

brook into the main waters

in a main danger, fail you

the main consents are had

though the main part pertain

As you Like it, iti.

'tis his main hope: for wh

hedged in with the main .................

of the main ehanee of things

but fear the main intendment
la main, en Anglois? La main?

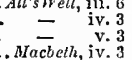

entre les mains d'um chevalie

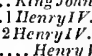

look unto the main. Unto the ma

whieh by main force Warwick.

charged our main bat toe's tron

tumbling billows of the main .........Richard III. i. $\mathrm{i}$.

commission and main power. Ifenry VIII. ii. 2 (let.)

see this main end, the french

put your main cause into the king's

by the main assent of all these

with all our main of power.

it remains, as the main point
the main blaze of it is past

quite trom the main opinioin....

if of my freedon 'tis the main part.. Cymbeline,

the main descry stands on the hourly

is the main motive of our preparations.

goes it against the main of Poland

'twixt the heaven and the main, descry

and monstrous main [Col. Knt.-mane]

comes the master and main exercis

MAIN-CUUlist-try with nain-eourse. Tempe

Touraine, Maine, in riglit of Arthur

Maine, Blois, Poictiers, and Tonrs..1 Henry Vl, iv,

duke of Anjou and Mlaine (rep.).......
and the eounty of Naine (rep.).2Henry VI. 1 (art.)

O fatier, Maine is lost; that Maine.

but I meant MIaine (rep.)............

for selling the dukedom of Ml aine.

I sold not Maine, I lost not Normandy -
MAINLY-and mainly thrust at me..

so maiuly as my merit ...... Troilus \& Cressida,

else, you mainly were stirred up ........... ijamelet, iv. 7

M $A$ INT $\Lambda$ IN no words with him.. Tweljth Night, iv. 2
he will maintain you like .........Merry Wives, iii. 4

you have courage to maintain it. Mleas. for Meas.

and neyer could maintain lis part.

fiather, I am ahle to maintain it.

this business, and maintain this war. King John.

to maintain I would allow him...... Richard $1 i$.

and further will maintain upon hi

and will maintain, what thou hast.

I dare well maintain it with my life. I Henry IV.iv.

but

when my maiden priests are met together -

would a maiden blush bepraint... Romeo \& Jutiet, ii.

somewliat seanter of your maiden....... Ham
her maiden strewments, and the bringing

a maiden never bold; of spirit so still .. othello, i. 3

AI AIDENHEAD, of Colebrook.... Merry Wives, iv.

are as seeret as maidenhead ....Tuelfh Night, i.

yet your maidenheads growing. Winter's Tale, iv. 3

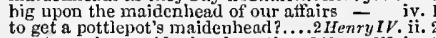
by to me her maidenliead ere they.2 Henry I'I. iv. 7

as mueh as wonld maintai

ce

the king keeps to maintain the peace

but dare naintain the party of

and piercing, to maintain his truth...

I'll maintain my words on alyy plot

will not yon maintain the thing .....

Jesu maintain your royal excelleneed 2
M A I NTAINS my state ...........2 Henry $V I$. iv. 10

a father able to maintain yon......... - iii: 3

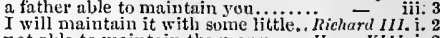
not able to maintain the nany ....HenryVIII. i. to fight for and maintain! .......... none, but to maintain my opinion .. $\frac{-}{-}$ iv. 3 naintain sueh a quarrel openly?... Tinsandron. uphold and maintain in your speeches - - vear, i. go yon, and maintain talk with the duke - iii. 3 will maintain upon Edmund....

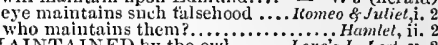
WAINTAINED by the owi............... Hames L Lost, v. 2 as it must be so maintained............

maintained so politie a state of evil.

be for forth friendly maintained. Taming of $S h, \mathbf{i}$. I have maintained that salamander.I HenryI $V^{2}$.ii. 3 by a eivi peace mint saliander. Menry 1 . is gone, that maintained that fire......Jenry $V$. ji. yery gallantly asuintained the pridge $=$ iii. 6 fruit maintained with beanty's sun.3 Henry fll. iii. 3 for thee, and tor thy maintenance. Taming of Sh. v. MAN-T()P-struck the main-top 1. . Cymbeline, iv. MI AJESTAS-ah, saneta majestas!

A

this is a most majestie vision Henry $V_{\text {. }} \mathrm{v}$.

get the start of the majestic

Tempest, iv.

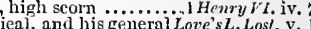

presence majestical would put him out . ${ }^{-}$vo ${ }^{2}$

in bed majestical, can sleep so soundly - iv.

we do it wrong, being so majestical...... Hamlet, i.

this majestical roof fretted with golden fire - ii. 2

IAJESTIES might, by the sovereign..... Hamle $l$, ii.

besecehed me to entreat your majesties - iii.

if your majesties is remembered of it.. Henny $I^{\prime}$. iv.

bring your most imperial majesties ... Tempes

maid of graee, and complete majesty.Love'sL.L.i.

hold fair fiendship with his majesty

please it your majesty, eommand me

the attribute to awe and majesty. ifer.of $F_{t}^{-}$ice, iv. 1

Cleopatra's majesty....... As you Like it, iii, 2 (verses)

what hope is there of his majesty's

approved so to yuur majesty, may...

thank your majesty..................;

this is his majesty, say your...........

hearing your high majesty is touehed

please it your majesty, I have.......

may help me to his majesty's ear....

chivi to his majcsty, his mother ....

so please your majesty (rep.)........

bless the bed of majesty again with. Wirinter's Tale $v$

even with such life of majesty .......

there's magie in thy majesty .........

mean you his majesty? .................

better health attend his majesty!....

the majesty, the borrowed majesty.. King John, i. I

majesty! low high thy glory towers - ii. 2

pawned to you uny majesty? ....... - ii.

a counterfeit, resembling majesty....

I am muel. bounden to your majesty

he sliall not offend your majesty

know the neaning of dangerous majesty -

low fares your majesty? ............. =

desires your majesty to leave the field

and they are all abont his majesty

how tares your majesty? Poisoned

spleen of spced to see your majesty...
nothing but his majesty's ajpproneh.. Richard and bow my knee before his majesty

my seat's right royal majesty........

bescech your majesty, impute his....

and make high majesty look like...

niadam, your majesty is too mueh sad

Go your sweet majesty, looking ......

no; I'll to Ireland to his majesty...

awake, thou sluggard majesty!...... 
MAJESTY_eontrolling majesty .... Richard II. iii. 3
faithful service of your majesty ....

will his majesty give Richard leave

what snos lis mojcsty?

and show fair duty to his majesty.....

which tired majesty did make thce.

all pomp and inajesty I do forswear

proud majesty, a subject; state.....

jour inajesty, to have some conference -

gruce, (majesty, I should say ..........

as is delivered to your majesty.

my prisoners, in your mujesty's behalf

of man, an' it like your majesty?....

so please your majesty, I wonld I could -

swayed your nujesty's good thoughts

I do beseech your majesty, may gulve

you stand agninst anointed majesty!

it pleased your majesty to turn .......

I do beseech your majesty, make up

I hear his majesty is returned with..
whoreson mad compound of majesty

many good-morrows to your majesty! =

tainely to the foot of majesty...

sliall go before us to his majesty

but your majesty shali soon enjoy $;$.

from enemies heaven keep your ma

o majesty! when thou dost pinch ...

no course of breath within your majest

save your majesty!

gorgeous garment, majesty ............
we hope no other from your in ajesty

your majesty hath no just cause

the majesty and potwer of law.........
flow henceforth in formal majesty

doth his majesty incline to it, or no?

with good acceptance of his majesty

who, busied in his majesty, surveys..

may it plense your majesty, to give.

that I have laid by my majesty.

and loved, than is your majesty

and thus he greets your miajesty.....

the bitter moek you sent his majest
not so, I do beseech your majesty...

not so, I do beseech your majesty...

ay, so plcase your majesty; the duke

I can tell your majesty, the duke is

if your majesty know tie ma

iii. 3
iji. 3

iii. 3

iv. 1

iv. 1

v. 3

i. 3

i. 3

ii. 4 .

I $\mathrm{nm}$ unfit tor state and majesty... .

iii. 2 what time your majesty ghall please

the news I have to tell your majesty
iii. 2
iv. 3 thunk your majesty: that you .....

I know, your majesty has always....

still growing in a majesty and pomp
the king's majesty commends his good

service to his majesty and you (rep.)

God and your majesty, protect mine $\overline{\text { encountering the eye of majesty. Troilus \& }}$.

encountering the eye of majesty. Troilus \& Cress. iil.3

what majesty is in her gait? (rep.)...

some majesty, and should know (rep.)

good-morrow to your majesty

- veline,

his majesty bids you weleone .....

so plense your majesty, the Roman.

I thank your majesty . ........Tilus Andronien.

you shall ask pardon of his majesty

many good morrows to your

yes, please your majesty. It plenseth.. Pericles,

large effects that troop with majesty

when majesty stoops to folly

so please your majesty, that we may wake -

how fares your majesty? you do m
d uring the life of this old majesty....

whicli the majesty of buried Deumark... Ha

the assay of arms against your majesty
what majesty should be, what duty is

what majesty should be, what duty

your majesty, and we that have free soul

that live, and feed, upon your majesty

the cease of majesty dies not al

if that his majesty would aught withi...

is the beanteous majesty of Denmark?

impart a thing to you from his majesty..

if it please his majesty, it is the breathing $-v$.

here comes his majesty. I was not

an't please your majesty, and your great -

your majesty says very true: if your
which, your majesty knows, to this heur

your majesty takes no scorn to wear

as it pleases his grace, and his majesty

I am your majesty's countryman

ashamed of your majesty (rep.)......

I charge you in his nijesty's na
here is his majesty. How now!

the glove which your majesty is

your majesty is hear now (rep.)......

that your majesty is give me....

an' please your majesty (rep.)

your mi

your majesty entendre bettre que moy

God save your majesty! my royal cousin

in a vision full of majesty

juferior to none but his majesty

we do exhibit to your majesty .......

at Eltham Place I told your majest

best avail your majesty, to cross ....

yes, if it please your majesty, my lie

princely majesty is such ...............

swear allegiance to his majesty

imperial majesty I had in charge....

words yclad with wisdom's riajesty...

royal majesty! What say'st (rep.).

please it your majesty (rep.) ........

and that your majesty was an usurpe

I humbly thank your royal majesty

an' it like your majesty, my lord....

your grace to his majesty's parliament

with what a majesty he bears himsel
I will, my lord, so plcase his majesty

in grim majesty, to fright the world

flided towards your majesty, it were

by his majesty I swear, whose far

sent to tell his majesty, that even now

what canst thou answer to my majesty

God save his majesty! who liateth him

and glad tidings, to your majesty!..

I came unto your majesty ...........

from our king unto your majesty....

I told your majesty as much before..
it pleased his majesty to raise my....
more incensed against your majesty my major vow lies here....... Troilus \& Cressida,

in compound with the major part. .. Coriolanus, ii. 1

MAJORITY, and military ................ Try $\mathrm{IV}$. iii. 2

thy groaus did make wolves howl

go make thyself like to a nymph

took pains to make thee speak

make thee roar, that beast
and make a vassal of him

I'll make you the queen of Naples

this swift business 1 must uneasy make

make not too rash a trial of him

and make thy weapon drop............

the earth let liberty make use of .......

you make me study of that...

impossible matter will he make easy ...

I myselt could make a ch

and let's make further search

and make him by incli-meal

this monster make a man (rep.)

to make a wonder of a poor drunkard

and makes iny labours pleasures.....

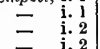

2

to mak

will make me sleep again .............

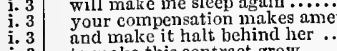

i. 3 and make it halt behind

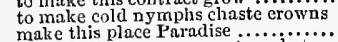

make holiday: your rye straw hats...
which may make this island thine...

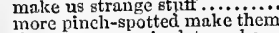

the green-sour ringlets make

and portable to make the dear loss .....

this larly makes him

make fows and ebbs $\ldots \ldots \ldots \ldots \ldots \ldots \ldots \ldots \ldots \ldots \ldots$

will make me cry baa ....... Tu. Go.... of verona, i.

she makes it strang

shall make known $\ldots \ldots \ldots \ldots \ldots . . . . . . . .$.

so printed to make her fair.

why, then we'll make exch

marks the moan she makes ........... make the rope of his desting...

whose pastime is to make midnighi.... makes other worthies nothing
will you make haste

that makes me reasoniess

to make my yurpose swif

he makes sweet music with

what fashion, madan, shall I make your -

it will make me scandalized ......... -

scorn at first makes nfter-love the more -

wake speed trolu hence me surfeit

bid him make haste

that word makes the fautts gracious

makes me the better to confer

to make the girl for
make tigers tame.

we'll make you sit.

it makes me lave a slow heart

and make thy love amends.....

I will make true love ...............

where, I hear, he makes abod

he makes me no more ado

thinking on it makes me cry alasi.....

but I can make respective in myself

to make it molew out of love

O sir, she makes no doubt of that

let this habit make thee blusb

makes lim run through all....

to make this happy close ......

to make such means for her....

to make your grace to smile............

to make atonements and compromises

I will make a prict of it

$I$ will make an end of my dinner.

an old cloak inakes a new jerkin ....

make the beds, and do

priest to meddle or make ; 7 liking

it makes me almost rendy to wrangle

and make them his servants! $\ldots . . .$. .

I make bold $(r e p$.) ................

thint is, he will make thee amends..

there will we make our peds ot.....
one way or other make yon amends

have you make-a de sotor us?.........

and shall make thee a new doublet..

thou wouldst make an absolute courtier -

why then make sport at me...........

I will hereafter make known to you

I shall make two (rep.) ......

he will make you a hundred

I wonld not, shall not make me tame

if I have horms to make one mad...

to mother experime

but I'll make them pay

to make us public sport.....

dat you make grand preparatiou

a present recompence.

elind of eonseienee; he malses restitution -

make the fairy 0 -res ................

let that go to make amends..........

would not so mucl as make water. Tzelfih $N$

make tliat good.....................

make your excuse wisely, you were best -
make your proof ...................

doth ever make the better fool $\ldots . .$.

one draught above heat makes him...

make me a willow eabin at your gate

and make the babbling gossip of .....

but shall we make the welk in dance
do ye make an alehonse of my ........

and make a fool of hinn..............

and make him a common recreation $=$

your horse now would make him an ass -

and let the fool make a third ........ -

that always makes a good voyage...

make no compare between that love.. -

contemplation mukes a rare turkey-cock -

witl an obedient start, make alt for him -

if I could nuke that resemble

O ay! make up that

I'll make one too........................

slight! will you make an ass o' me?

but since you make your pleasure

I ean no answrer muke, but thanks
this does make some obstruction ...

i.. 4

ii. 4

iii. 1

iii. 2

ii.

iv. 1

iv. 2

iv. 3

iv. 4

iv. 4

iv.
iv. 4
v.
v. 2

v. 2
v. 4
v. 4

vis

v. 4
v. 4
v. 4

i. 1

iii. 3 
MAK

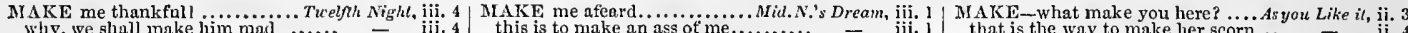

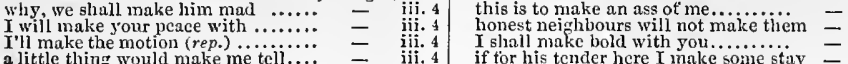

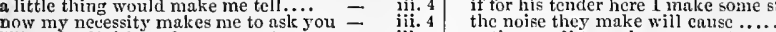
I'll make division of my present.... lest that it make me so unsound .... - iii. 4 more quick of apprehension makes. will you make me believe ....

make him believe tholl art sis
make the trial of it in any

and make an ass of me

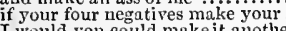
could nint this make thee know..... I would you could makeit another. such scathful grapple did he make to make us haypy hoth. make us pay down for our offence......eas. for Meas. $\mathrm{i}$. that she make friends $\ldots . . . \ldots$.... sir, make me not your story

cul make us lose the good we oft..... we nust not make a searecrow. till custom make it, their perch

as make the angels weep $\ldots \ldots \ldots \ldots \ldots$...... counterfeit sud looks, make mows upon you would not make me such

notwith tanding laste; with wonted two of both kinds makes up four telay thus to make pour females mad.

make choice of which your higlines

which makes it tedious: for in all... make periods in the midst of sent...
till truth make all things plain.....

go near to make u man look sad...

for tliuse things that make her good?

trip away; make no stay

we will make amends, ere long

and dainty bits make rich the ribs

and make a dark night too of half

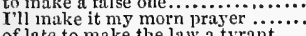

for he hath wit to make an ill shape

if you make me stay ..................

as easy brole as they make forms

may make tender of to thy true

bidding the law make court'sy to...

his bchaviours did make their retire

warble, child; make passionate my.

your best appointment make with speed -

go to your knees, and make ready

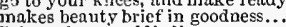

and make fir for his attempt.

that when he makes water

let me desire you to make your answer

to make societies secure

to make fellowships accursed.......

which professed to make him rejoice

to inake bad good, and good provoke

but make haste; the vaporous night

thmusand 'scapes of wit make thee

when vice makes inercy, mercy's so.:.

to make you understand this

I may make my case as Claudio's

who makes that noise there?

make a swift return

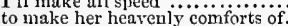

me quite, makes me unpregnant

you make my bonds still greater

make not impossible, that which

as words conld make up yows..

ere you make that my report.

and would not rather make rash ....

that will make a voyage with him

scratching coula not make it wor

not make the full show of this .......

can you make no use of your (rep.).

cousin's duty to make court'sy (rep.)
not till God make men of some other

to make an account of her life to a clod

brother, make good room ......

either to make him a garland.

wilt thon make a trust a transgression?

what proof shall I make of that? ....

he shall never make me such a fool..

he would but make a sport of it.....

if she sinould make teader of her love

ly some large jests he will make...

I'll make her come, I warrant yoit..

lest she make sport at it

you shall also make no noisc...

the less jou meddle or make with them poor ones may make what pric

to make vou answer truly to your

to make you answer truly to your ...

make misfortune drunk with .........

make a pish at chaace and sufferance

Inake those, that do offend sou ....

to make thee a double-dealer $\ldots$ i........

and make and mar the foolish fates.

I will roar that I will make the duke

and bootless make the breathless.....

and sometime make the drink to...

and make him smile, when I.

and make him break his faitl

will make or man or woman .........

the mild hind makes speed to.

and make a heaven of hell, to die.....

and make her full of hateful fant

so that but one heart we can make of it -

thrnngh thy bosom makes me see

and make them men of note

to make plain some obscure precedenc

and one that makcs sport to the prince

$\mathrm{L}$ to sore nakes fifty sores (rep.)

and make me forsworn

and still make me weep eyes.......

which makes flesh a deity; a green

that ever love did make thee run into

as my passion now makes me.........

and make no boast of them

iii. 2 of such a naturc make an extent...

that good pasture makes fat sheep

iii. 2 let us make an lonourable retreat ...

could make thee believe I love (r.... .).

iii. 2 I pray the gods make me honest!.....

iii. 2 accustomed sight of death makes Jiard

that love's keen arrows make.........
that make the world full of........

he'll make a proper man .....

makes you sad. I had rather $(r e . \ldots)$. .

than you can make a woman $;. . . . .$.

and all that I can make; or else $\cdots-$ iv. 3 (letter)

I kill thee, make thee away, transiate $\quad$ - v.

I have promised to make all this.... - v. 4

to make these doubts all even.........

when I make court'sy, bid me farewell $\overline{-}$ (epii.)

the excess makes it soon mortal 3 ....

your mistress, and make mucl of her
is netal to makc virgins .............

within ten ycars it will make itself

that your valour and fear makes....

that ma

seem to have us make denial........ -

ability enough to make such knaveries -

may lawfully make title to as

of heaven, not me, make an experiment -

make thy demand. But will you make it -

what makes treasen here? (rep.)......

where several worthics make one diguity -

of all the ods makes heaven drowsy

to make fiantic, lunatic..............

lend me your horn to make one......

joyful father wouldst thou nake ne.

I'll make one in a dance, or so

that was the way to makc his........

and make him proud to make me prond

to make theirs ours, and ours none but

your wit makes wise things foolish..

to make us thing uintin

confounded makes most fur

do make Judas liang himself

or a painter; for he makes faces

the error that love makes is.....

the tongne of him whout-end bargain

sechess makes of me, that I have...MPer.of $\bar{v}$

out of doubt would make me sad ....

ould make me sad

ii. nor do 1 now make moan to be...

and I no question make, to have it,

and he makes it a great appropriation

ii. 2 inserted tio make interest good

i. 3 and let us make incision for your.......

to make nie blest, or cursed'st ......

$\begin{array}{ll}\text { ii. } 3 & \text { Lorenzodesircd us to make stand } \\ \text { ii. } 3 & \text { I will make fast the doors, and gild }\end{array}$

iii. I noble prince: now make your ehoiee -

I can make what merchandize I will

you'll make me wish a sin, that I....

which makes me tear the enjoying of

which make such wanton gambols

too mill make tiaste; but, till I .........

makes me think, that this Anton.

make room, and let him stam

and to make no noise, when they .....

none that thou last wit cnough to make -

to hear you make the offer ...........

be it but so mueh as makes it light

which I did make him swear to keep

away, make haste; thou knowst

and they did make no noise; in such

you shall perceive them make a mutu

light wife doth make a heavy husbund
that is to make me cuckold?

what make you here? (rep.) ............ ss you Like

those that she makes fair (rep.)

that she inakes honest, she makes

when fortune makes nature's natural

that wise men have, makes a great slow
we will make it our suit to the duke

no, makc it two more..................

y'll make lim find him; do this .....

what place make you special, when

to make moderu and familiar things $(\dot{r e p}$.$) -$

thy frank election make (rep.) ....... -

to make yourself a son out of my.... -

thou didst make tolerable vent of thy -

make some reservation of your wrongs

to makc the coming hour o'erfow.....

and make this liaste as your own...

I pray you, make ns friend

and sworn to make the not eternai... iii. 2

lne will make no deed at all of this .

we'll makc you snme sport with the

many oaths, that make the truth...

I see that men make hopes ..........

sometimes, we make us comforts of

the thing I am shall make me live.

but rather make you thank your

our means will make us meaus ......

to make it natural rebellion. for tume

pruising what is lost, makes

our rash fanlt tmake trivial price....

can make me know this clearly......

to make the even truth in ...

to make the lodging sweet.. Taming of Sh. I (induc.

and make known her love?

would you make me mad? am not I $=2$ (indue.)

that makes your lady mourn (rep.) - 2 (indue.) the hounds shall make the welkin ... that 1 a stale of me amongst

and make her bear the penance...........

thile I make way from thencends....

to make one among these wooers......

leave and leisure to mnke love to her

Lncentio shall make one, though Paris

to make a bondmaid and a slave

do make myself a suitor to your.

never make denial, I must ....

wretch can make the eurstest shrew

let your father make her

you make this assurance

point the day of morriare ...........

and make assurance here in Padua..

make it no wonder; if you knew
sent beforc to make a firc (rep.)

to make her come and know her...

and makes a goul of such a callion ...

to make the matter good $7 \ldots . . . . . . . . . .1$

yon bict me make it orderly and well

belike, you mean to make a puppet..

hid Bianea make her ready...

and withel, man mad, to make...

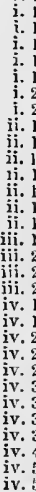




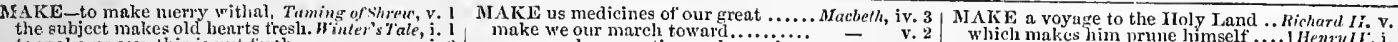
to make us say, this is put forth

flus make no conchusion thin...

ere $I$ could make thec opren thy........

and make itself n pastime to harder

lie mukes a July's day short as ....

you hal much alo to make his......

make me not sirhted like...

to his eye, make known how he

such ado to make no stain a stain

laugh at me; make their pastime..

that makes but triftes of his ey'es...

that makes the firc, not she

aud will ignoble make you, yca ....

piety docs iny deeds make

all fuults I make, whe

make your best haste ....................

that make, and unfold crror

aud make stale tlie glistering

if I make not this cheat bring

a way to make us better friend

but nature makes that mean

is all art that nature makes.........

then make your garden ric

$O$ these I lack, to make you gariands

he tells her something that makes her he makes the maid to answe

and will nake her portion equal hi is

yea, him too, that makes limself ...

make for Sicilia; and there present.

we must make an exchange.

to make me the king's brother-in-law

what wit can make heavy

I'll maise it as much more

no fault could you make which.......

make proselytes of who she but bid.

follow me, and mark what way I make

I make a broken delivery of

our absence makes us unthrifty

what was he that did make it?

what
Osweet Paulina, make me to think
I'll make the statue move indeed ....

what you can make her do

easy to make her speak, as more

ay, and make't marifest where

of whom I hope to make much. .

servitude makes you to keep unwed

make a-common of my serious hour

let foolish gnats make sport
I'll make you amends next.

I'll make you amends next

stronger state, makes me with thy...

of welcome makes scarce one dainty

and great welcome, makes a

good sir, make hoste

poor women! make us but believe...

to make it wander in an u

therefore make present satisfaction..

God make me a light wench

to make a loat hsome abject scorn....

suffer them to make a rescue?.

to make of him a formal man.

when thou didst make him.

fear of death doth make me

age and dangers make thee dote

I thall have lessure to make good....

and we shall make full satisfaction

afeard of what thyself didst make

and make my seated heart knock.

than would make up his message.

make thick my blood...

to make their audit at your.....

and yet you would make both .......

as we shall make our griefs

it makes him, and it mars him......

makes him stand to, and

courage, to make his love known....

as they would make war with

that would make good of bad..........

to make socicty the sweeter welcome
to make them kings, the sced........

to make them kings, the sced...

and make our faces vizards to

hegun, make strong themselves......

gate make it their walk

why do you make such faces?...........

you make me strange eren

but make amends now $\ldots . .$.
let's make haste; slie' 1$]$ soon

make the gruel thick and slab .......

but yet, I'll make assurance

what had he done, to make him $\mathrm{fy}$.

our fears do make us traitors...

a sallce to make me hunger more...

crcate soldiers, make our woinen your royal preparation makes us hear

and mnke discovery err in report....

make all our trompets spea

and make us even with yol..

a landless Is night makes thee

never lolp to make this leg

i. 2 to make room for him in mat

ii. 2 to make a hazard of new fortunes here

let me unake auswer

shall make your sloulders crack ....

\begin{tabular}{l|l} 
ii. 3 & to make a shaking fever in .......... \\
ii. 3 & when l have said, make answer to
\end{tabular}

ii. 3 hirle, and make a monster of you
iii. 2 and, pell-nell, make work upon

to this conjumetion make this match

and make her rich in titles......

and makes your sou a shadow

this rich fair town we make lin

sorrow to make ime die

joined to make thee great.

proud, and makes his owner stout

good reverend father, make my person

jest with heared, make such unconstant
iv. 3

iv. 3 conquest never canst thon make

onlip, make un; my mother

iv. 3 and make reply without $\mathrm{a}$ tongue...

iv. 3

政

may then make all the elain that

strong rensons make strong aetions.

you will but make it blush, and glow

doth make the fault the worse

doth make a stand at what

O make a leagne with

wlile he, that hears, makes fearful .

makes deeds ill done!................

long traded in it, makes it secm like

and malke fitir weather in your......

go I to make the French lay.

and make compromise, insinuation.

the cardinal cannot make your peace

do make an earthquake of

and makes me more amazed

should make me now deceive...

by the idle comments that it

ii. 1 to malke his bleak winds kiss .........

nought shall mak our love

ii. 2 my body shall make good upon (iep....

ii. nnt re rerence, makes thee to except.

deep malice makes too deep.

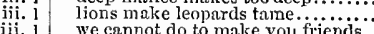

iii. 1 we cannot do to make you friends...

in tly the eud most sweet.

iii. 2

and make us wade even in our.

but grief makes one hour ten away

every tedious stride I make wili

iv. 4 we will make for Ireland...

pray God, we may make haste

nisery makes sport to mock itseif

v. I admonition, make pale our cheek....

duty make me suffer wrong?

and make high majesty look like......

to make him lose at lome

v. 1 our miles, and make them wenrisome

shall make their way seem short

my heart this covenant makes

your presence makes us rich

i. 5 and make you stooly unto the sovereign

till you did make him misinterpret...

make dust our paper, and with rainy

i. 7 and learn to inake a body of a limb..

ii. 3 make foul weatlicr of despised (rep.).

ii. 3 of heart makcs him speak tondly...

ii. 3 to make the hase earth proud

'twill make me think the world is...

to make a second fall of cursed man?

ii. 4 to make a second fall of cursed man

glall I make to this base man?

iii. 1 tired majesty did make thee offer...

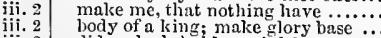

iii. 2 did make beholders wink?

iii. 3 to make my end too sudden

iii. 4 we make woe wanton witl

iii. 5 make way, unruly woman

villain, $r$ 'll make thee safe .....

suppliant makes this eager cry?

iv. 2 but makes one pardon strong

iv. 2 I pray God make thee new

to make misfise men m

slould sprinkle me, to make me grow

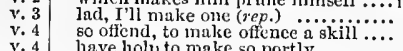

and make the Douglas' son your only

to make us strangers to his looks of'..

I'll make a fat pair of gallow

and make hake all whol

medicincs to make me love him

give himough to make us all....

fut he would make you helieve.

with spear-grass, to malsc them $\mathrm{ijced}$

to make mine eyes look red..........

ii. consin Percy; you will make him mad

ii. 1 thy passages of life, make me believe

ii. 2 make blind itself with foolish

ii. 2 a bawdy song; malie me merry....

ii. 2 I make us good use of it as many a man

ii. 2 sngar-candy to make thee long-winded =

of his absence make this use ........

can make a head to push against

but sirral make haste; Percy is.....

import, you would imake liasts...

iii. 1 wisdom to make strong against $\mathrm{him}$

iij. 1
iii. 2
infinite do make against it
inge a carbonado.

iii. 3

beseech your majesty, make un $(r e p$.

iii. 4 to make a garland for my head

iij. 4 I should not make sodear a sinow of zeal -

iv. 1 I would make him eat a liece of my

only $\mathbf{I}$, make fearful nusters 2 Henry $I \vec{r}$. (induc.

and make thee rich for doin

and make friends with sjeed

of rebellion can tell how to make it.

the wise may make some dram

good thing, to make it too common.

to marry me, and make me my lady.

if a man will make court'sy

these lumble considerations malie mc out -

you do not make him be hanged ....

to make strength stronge

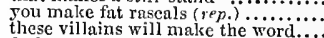

doth not make thee wrong this .....

consider of them; make good speed

will thou make as mantains level

mend lim, and make lim fit to go...

I will make him a philosolther's two.

I muse, you makc so slight a question

if we do now make our atonement well

nor a man cannot make him langh

makes it apprehensive, quick .........
warms it, and makes it course from

should these good news make me sick?

and make me as the poorest vassal

miglit make them look too nenr

my worldly business makes a pcriod
I should make four dozen sucl

royal thoughits, make the case yours

nothing but eat, and make good eliee

I will make the king do you grace...

make less thy body, hence ..........

the man yet, that shall make you grent

good conscience will make any possibl
make you nerry with fail Katharine

and make imaginary puissance .. Hen

and make you long become it
that make such waste in brief

there is no bar to make against...

with chm and title to the crown

who wifht and conscience, make this

and make your chronicle as rich

armed in their stings, make boot ipon

we hope to make the sender biush....

to make you friends (rep)

he that makes the first thrust

and of Orleans, shall make torti

his approatlies malies as ficree

makes much against my manlood.

would glatly make slow to the orid

$x$ could nake as true a boast as that

our bad neighhour makes us carly

hath a heavy reckoning to make ....

said so, to make us fight cheerfully.

mount them, and nake incision in.....

v. 3 may make a pencetill and a swcet :

thic cmpty yessel makcs the greatest

and make them skir away, as swift..

I will make you to-day a squire ....

I say, I will make hint eat some ....

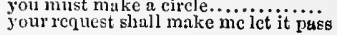

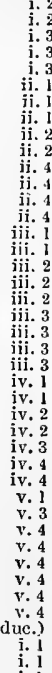

j.
i.
i.
i. 3
ii. 1
ii.
ii.
ii. 2
ii. 2
ii. 4
ij. 4
ii. 4
ii. 4
iii. 1
iii.
iii. 2
iii. 2
iii. 2
iii. 3
iij. 3
iii. 3
iii. 3
iv.
iv.

iv. 1

iv. 3

v. 3

v. 4
v. 4

4
$r .4$
$3 c$. 


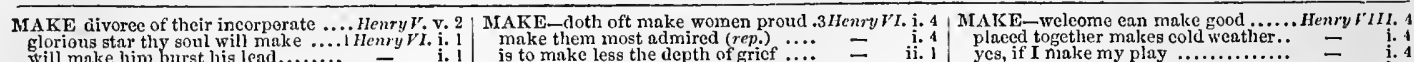
in make him burst his lead........ in ranee forthwith am to make nor money, hath he to make war proof I'll of thy valour make ... but to make open proelamation
best place to make our battery and make a quagmire of your ...... hereof will make me lide my head. conmand the citizens make bonfires that we do make our entrance mount, or make his grave $\ldots$ it! make us partakers of a little gain... in a monent makes them desola
or mule my ill the advantage or muke my ill the advanta
and makes him roar these

and makes him roar these ....... our policy must mike a breach... and we will make thce famous .... in fuvour, makes him lag. or nature mukes me siddenly what makes you thus exclaim and wrathful fury, makes me weep. to muke a bastard and a slave.... that shall make all Franee afeard.... I'll either make thee stoop, and bend the tongne, and makes the senses rong I'll undertake to make thee Henry's what answer makes your grace ......
make this marriage to be solemnized comntry where you make abole! to scek a queen to make him rich... makes me the bolder to salut makes me, from mondering
then let's inake haste away..... pirates may make cheap

and make a show of love to proud this night dotil nake me sad....

that shall inake answer to sueh...

St. Albans we do make retu
make mery, man (rop.

will make hut little for his....

would make thee quickly lop
bcfore we make eleetion, give

we make your graee lord regent

blessed for the penee I make

ghall np no mo the duke of Yor

shatl live to make the earl of Wartic

When he please to make commotion

and all to make away my guiltless life

to make the fox surveyor of the fold?

to nalke commotion, as full

will make him say, I moved ........

but to make my sorrow grenter?

my sovereign's presenee make

makes them thus forward in

might makc the s.

two of you; the devil make a thirdi

two of you; the devil make a third

that makes him casp, and stare

can I make men live, whe'r they

pangs of deith do make him grin....

make sirmal of thy hope; he dies (rep.
here shall they make their ransom

his mate, make boot of this.

not this make thee be bloody-minde

amall thiners make bisc men proud ...

to make dog's leather of

nay, he ean make ohligations...........

and makes it fearful and degenerate

what answer makes your grace...

which makes me hope you are not
and that will make 'em red again.

and that will make em red again

I will

and all marl.

and makes them leave me desolate.

my sword make way for ne

treasons, malkes me betalse me.

but retired, to nake lim strong?

but I'll make thee eat iron like......
I'll warrant, they'll make it good...

makes him oppose himself

heavens do make their minister.....

to make a shambles of the parliament

whicls makes thee thus presumptuous

that seeks to make them foes! .......

but to make thy sepulehre .......

do makes him ch

did Riehard make a lane to me.........

are numbered that make up my life.

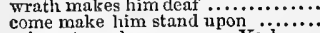

grieve, to make me merry, york....

grieve, to make me merry,

I see, to make me sport

let's hear the orisons he makes .....

is to make less the depth of gricf ...

short tale to make, we at St.
tliy glories, makes me speak

may make against the house

2 shath tor the 2

i. 4 my liere, make them yon precerent

i. 4 soft eourage makes your followers fain

1. 5 that durst make you stay...

i. 6 to make this shameless callat $\mathrm{know}$.

ii. J no longer, make we henee nmai

ii. i stay not to expostulate, make speed..

ii. 1

ii. 5 thise ot blood doth make me fitint

iii. 1 her sighs will moke a battery.

iii. 2 entreaty shall not make you guilty.

but yet I'll make a pause

iii. 3

iii. 3 the joint ture that your king must make

by this alliance to make void my suit

I make king Lewis behold

iv. 2 had he none else to make a stale ....

what answer makes king

whant makes you in this sudden change? =

\begin{tabular}{c|c} 
iv. & this is it that makes me bridle.. \\
$\nabla .1$ & this lour, he make his way
\end{tabular}

v. 3 I make you both protectors.

v. 3 find means to make the body follow

v. 3 then we'll make our elaim ...........

fellow-soldier, make thou

that makes smalt brooks ............

and make him, naked, foil

and make him of like spirit to

the wolf, that makes this spoil
satisfaetion ennst thou make

to make a bloody supper in the

reason, think ye, to make haste
let hell make crooked my mind....

the readiest way to make the wench Richarl
that makes us wretehed by the.

I'll make a corse of him that disobeys

thou canst make no excuse

3 God make your majesty joyfnl is

4 and myself makes him to send

ii. 1 [Col. Kut.] wrens make prey where cagles -

ii. 2 olet me make the perion to

makes the night morning.

insinuate with thee, but to make the

device! and make a sop of lim ......

make peace with Ged (rep.)

iii,

and make me happy in your unity

to make an act of tragic violenee

and make me die a good old man

untimely storms make men expect.

conquerors, make war upon themselves -

good lords, make all the speedy haste

an easy matter to make William lord

which may make you and him to rue
and make pursuit, where he did mean

and make pursuit, where he did mean

make haste, the hour of death is expiate

makes me most forward in this.....

make a short shrift, he longs . $\ldots . .$. .

listed to make his prey .............. -

on that gronnd r'll make a holy

$O$ make them joyful, prant thei

make me die the thrall of Margaret's

and makes her pew-fellow with othe

bettering thy loss makes the bad-caus

thy woes will make them

when avoided grace makes destiny

use of grief malses wild grief tane

to make her queen of England (rep.)

make bold her basliful years

can make seem pleasing to

greatest strength nnd power he ean make

tell me, what makes he upon the seas?

makes his trough in your embowelch

eke no delay

make some good means to speak
make us thy ministers of

enjoy it, and make mnch of it.

and make poor England weep in .....

to make that only true we now intend

be sad, as we would make ye....

he makes up the file of all...

i. 4 and make iny youch as strong

i. 4 here makes visitation: his fears.......

which makes my whitc

to make the seeptre his .......
this night he makes a supper and hither make as great embassadors here I'll make my royal choice. make of your prayers one sweet nake of your prayers one sweet .... will make them ene dany groan ...... for tho I'll make you know your times... good lady, make yourself mirtl $1 . .$. my appearanec make in any of their to make this pressent summons.
but all hoods nake not monks

a strange tongue makes my cause.... but how to niake ye suddenly

your studics make me a eurse like this

I dare not make myself so guilty ....

to make a seemly answer to such persons -

as thick as thought could make them

then makes him nothing $\ldots \ldots \ldots \ldots$.

make use now, and provide for .......

as the shrouds make at sea $\ldots \ldots \ldots \ldots$.

to make your house our tower

will make my boldness manner

prayed me to make great haste

they would shame to make me wait.

in their hands to make them gentle
men that make envy, and erooked

I make as little doubt................

makes the chureh the chief .........

make me no more ado .................

make way there for the princess .....

or I'll make your head ache......

shall be to make parents happy

this little one slanl make it holiday.

I'll not meddle nor make (rep.).. Troilus \& Cre

that's true; make no question.........

that hope makes in all designs

and make a sop of all this solid globe

for these two to make paradoxes .....

makes factious feasts; rails on ......

shall make it good, or do ..............

in the publieation, make to strain

no, make a lottery; and, by device...

and make him fall his erest...........

and make you plougl up the wars.

reason and respeet make livers pale...
to make the service greater ............

and makes pale the morning

than to make up a tree determingtion

but makes it mue more heavy .....

make that demand of the prover

requests sake only, he makes important

the step, that Ajax makes when ....

I will make a conpllimental

you shail make it whole again

you will make lis excuse (rep.) $\cdots . .$. .

after falling out, may make them three -

what makes this pretty abruption?..

fears make devils of cherubims.......

cannot make benst to have that.......

makes the whole world kin $\ldots \ldots . . .$. .

$\Lambda$ pollo get his sinews to make entlings

gods divine! make Cressid's name $\ddot{ }$

shall oft make thee to lide thy head

let us make ready straighit

make eruel way through rank.

and make distinet the very breach...

to make a recordation to my ..........

girl makes all these bodements........

make wells and Niobes of...

make sacred even his stirrop.... jimon

make thy requests to thy friend

no, you shall not make me welcome

let my meat make thee silent

thou weep'st to make tliem drink.....

musie, make their welcome .........

we make ourselves fools, to disport..

which makes it five and twenty......

that I may make his lordship......

you make me narvel: wherefore

nud make a elear' way to the go

to make an ugly deed look fair.

y ou cannot make gross sins look elear

what make we abroad?.............

make not a eity teast of it ..........

make yourselves praised (rep.)...

let's make no stay. Lord Timon's
f'or bounty that makes gods ....

$$
\begin{aligned}
& \text { i. }
\end{aligned}
$$

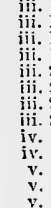

$$
\begin{aligned}
& \text { v. } \\
& \mathrm{v} . \\
& \text { v. }
\end{aligned}
$$

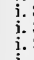

i.

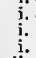

ii. 1

ii. 2

ii.

ii.:

iii. 3
ii. 3
iii. 1

iii. । 
MAKE-that makes him lean.. Timon of Alhens, iv. 3 MAKE-strives to make itself .... Antony f Cleo. j. I M M KE not, sir, your loss your sport .. Cymbeline, ii. 1

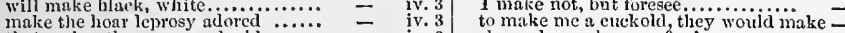
that makes the wrosyened wilow........ I will make thee do thy riglit nat ure make nse of thy salt hours .......... let not the rirgin's cheek inake soft make large confusion................... makc a whore forswear her (rade (rep.) = make curled-pate ruffians bald....... and nake thine own sclf the eongic let us muke the assay upon him tis je then best seen, and known.... to make it known to us. an alcliemist, make gold of that to nake their sorrow finl rendee..... all thy powers siall make their... to mukc vast Neptune weep for aye make war breed peace; make (rep.) make edicts for usury, to support.... I may make the belly smile

yet $I$ can make my audit up
but make yon ready your stiff bats.... your opinion, make yourselves scabs? the other makes you prond virtue is, to make him worthy ..... and make bold power look pale... to make only my wars with him and to make it brief wars. $\ldots \ldots \ldots . . . .$. list, what work he makes amongs which makes me sweat with wrath and make my wars on you fetch hin of, or make remain alike what noise the general makes!
numbers to make good the city make good this ostentation. but caunt make my heart...

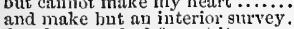
I make a erooked face at it

you make faces like munmers...... I will make my very house reel I will make a lip at the physician make I us little question as
make way, they are coming make way, they are comirg $\ldots . .$.
make us think, rather our state's. are well pleased to make thee consul and to make ns no better tliougrit of he's to make his requests by .......

I will make much of sour voices.... make lim good friend to the pcople to make road upon's ngain

what makes this chang

and make me your fellow tribune and make your channel hi it makes the consuls base............ that you have holp to make this.... 'tis fit you make strong party......... a beggar's tongue make motion througls that would make invincible the heart that his fen makes feared...

he'd make an end of thy posterity.... a small thing would make it flame.. aur meneral himself makes $a$ mistres ay, and it makes men hate here do we make his friends blush that Rome can make against them to make coals cheap: a noble

the instant army we ean malke.... which ean make golls forsworn? thus changed, makes you think so... to make what eannot be, slight work ghould make our eyes flow witl joy that you make doubt of it?

Romans, make the sun dance.........
praise the gods, and make triumphant fall of cither makes the survivor heir let's make the best of it... holida....... will make lum fly an ordinary pitch to make them instruments of fear with haste will make a mighty fire.. O Rome! I make thee promise fre. this shall make our purpose

dear my lord, make me acquainted.. did ineorporate and make us one... that will make sick men whole (rep.) look, how he makes to Cæesar by our permission is allowed to mak inflame youl, it will make you mad. we must straight make head...

make gallant show and promise of.. whler than youreolf to make condition and make your bondmen tremble....

make your vaunting true.

mother gave me, makes me forgetfui of your plitosophy you make no use make forth, the generals would have if arguing make us sweat...

that make to him on the spur........ can but make a fire of lim ..........

iv. 3 there are members to make new

iv. 3 Sextus Pompeilus makes lis approaches nuke the sca scrve then miny hot inroads they make in Italy and make his eyes grow in my brow

iv. 3 and will make no wars without door and nake the wars alike agains. you have not to make it with.......
shall not make poor my greatres. siall not make poor my greatnes Agrippa, be it so, to make this good? she did make defect, perfection.. but she makes liungry, where most.
Enobarbus, make yoursclf iny guest therefore nake space enough between and though 1 make this marriage for make thee a fortune from me.

and make thy fortunes jroud (rep.). to punish me for what you make me do to make my heart her vassal possess it, I'll make answer

i. I of Mareus Crassus' death make me. of Marcus Crissus' death m as mer makes choice of loss .......... make me not oftended in your distrust and make thy spirits all of comfort I cannot make better note $\ldots \ldots . . . .$. . make your soonest haste.

to do you justice, make them minister fly, and make your peace with Casar your confort makes the rescue. make thine own edict foreue.... Antony only, that would make his will loes make our faith mere folly... sliould make a staff to lean upon

ii. 1 he makes me angry with hini (rep.)

ii. 1 but now make boot of his distraction

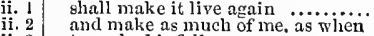

ii. 2 to make his followers wcep .................

ii. 3 be took alive; make it so known

ii. 3 make her thanks bless thee...........

ii. 3 make mingle with our rattling

ii. 3 my heart mukes onl y wars ...........

iii. I with our spritcly port make

iij. I make an end of what $I$ have begun..

iii. 1 as great as that whicl makes it......

iii. 1 make death proud to take us

iii. 2 by the pauses that he makes

iii. 3 does begin to make a better life...........

iv. 1 malke gour full reference freely......

iv. 2 make way there,-Casar

iv. 5 does even make me wild

iv. 5 make prize with you of things

iv. 5 make not your thoughits your....

iv. 6 make your best use of this

v. I she makes a very good report.

v. I hevery ten that they make demand of her

\begin{tabular}{l|l}
$\mathbf{v} .3$ & strike those that make them ......... \\
$\mathbf{v} .3$ & and makes him of his bed-chainber... Cymbline
\end{tabular}

v. 3 make him the reiver of

$\nabla .3$ and make yourself some comfort

v. 4 a sin to make a true election
$\nabla .4$ for so long as lie could make

v. 4 make him swrear the slics of Italy

v. 5 with that which makes him both...

\section{but I make my wager rather}

gather those flowers; make haste ....
learned me how to make perfumes?. but make liard your heart.

\begin{tabular}{l|l} 
ii. & in what show of death it makes \\
ii. & ean we not partition make with \\
ii. & what makes your admiration?
\end{tabular}

ii. $\begin{aligned} & \text { ean we not partition make with .... } \\ & \text { ii. } \\ & \text { should makes your admiration? }\end{aligned}$

ii. 1 with pity, that doth make me sick

iii. 2 should he make me live like Diana's

iii. 2 and shall make your lord that ......

iii. 2 Fou make amends. He sits 'mo

iv. 2
iv. 3 of the divorce, he'd make! $3 \ldots \ldots . . .$.

iv. 3 it would malie any man cold to lose

iv. 3 malke denials increase your...............

iv. 3 which makes the true man killed...

iv. 3 had rather you felt, than make $\because \ldots$ my

v. 1 if you will make ' $t$ an action

v. 1 whiat means do you make to limi.....

\begin{tabular}{l|l} 
v. 5 & to make your vessel nimble ........... \\
v. 5 & I'll make a journes twice as far.....
\end{tabular} if you cun make 't apparent ........

make pastime witl us a dny or two
you bees, that muke these locks ....

that we should make in time

our cage we make a quire.......

二 $\quad$ iii.

to malke thee stare thins.....

and make me put into is done.

you'll make him know, if that......

this she wished me to we make....

\begin{tabular}{l|l} 
ii. 2 & my end can make good use of either \\
ii.. 2 & nature, makes it voliant.
\end{tabular}

ii. 2 nnake what's homely, savoury........

ii. 2 I'll make 't my eonfort, he is a man

ii. 3 I wish my brother make good time...

\begin{tabular}{l|l} 
ii. 3 & may make some stronger lea \\
ii. 5 & did makc my way long forth
\end{tabular}

\begin{tabular}{l|l} 
ii. 5 & make him stoop to the vale \\
ii. 5 & hell make his grave a bed
\end{tabular}

\begin{tabular}{l|l} 
ii. 5 & make distinction of place.................... \\
ii. 6 & which the brain makes of fiumes
\end{tabular}

\begin{tabular}{l|l} 
ii. 7 & forwardness malkes our hoyes fair..... \\
ii. 7 & nature doth abhor to make his bed
\end{tabular}

and make him with our pikes

and make me blessed to oley! ......

let me make men know more valour

to make my gift, the more delayed ..

if our grace can make him so .........
which, l'll make bold, your highness

make thy demand aloud .............

language that would make me spurs

$\begin{array}{ll}\text { that } I \text { can make no collection of it .. } & \text { v. } 5 \\ \text { v. } 5\end{array}$

away with him? and make a fire straight-

and this suit I make, that you create

Lavinia will I make my empress ....

can make you greater than ...........

and make them know, what 'tis to..

youngling, learn thou to malie some....

uncouple here, and let us make a bay

every thing doth make a gleeful boast? =

and make a chequered shadow an $\ddot{0}$ thy sons make pillage of her chastity
the

doth make your honour of his

would make such fearful and coofuised
and make his dead trunk pillow

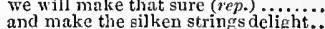

let us go, and make thy father blind

the sorrow that their sister nuakes ..

or make some sign how I may

sight slould make so deep a wound.

make proud Saturninus, and lis emnre

t strike it thus to make it still

nor make a sign, but I, of these.......

make my aunt merry (rep.)...

of grieff would make men ma

make no more ado, but give your

that holp'st to make me great........
let him make treble satisfaction

make poor men's cattle break

to make me ope the coor ..................
which makes the foul offenders riake

at the least, make tlicm lis enemies

make too pasties of your shameful heads -

offieious to make this banquet ...... -

purpose to make men glorions ....Pericies, $\bar{i}$. (Gower)

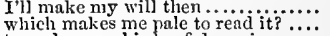

to make nan his lawfut minsie........
my pistol's length, I'll malke llim sure

can make his will his act ............

makes both my body pine

you, makes war upon your life $\ldots \ldots .$.

sail of ships make littlerward ......

who makes the fairest show

corn, to make your needy brend

[Cal.Knt.] statne to makc him glotious - $\overline{\mathrm{ii}}$. (Gon.)

make such umguiet, that the ship..... -

Id wish to make one there .........
shall make the gazcr joy to see liim

my best gown to muke thee a nair

which heaven mukes like to itself

make some good, hut others to excee

therefore to makce's entrance more sw

offence at that nould make me glad?

his qucen with child, mankes her

make swift the pangs of :ny queen's
why do you make us love your goodly

water earth, and heaven can make..
O make for Tliarsus .................

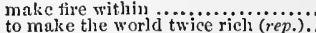

to make the world twice ricli (rep.).
the gools nake up the rest upon youi

eloould thercin make ne vile ........ 


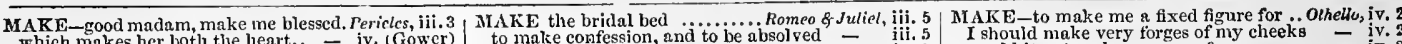

which makes her both the heart.: - iv. (Gower)

makes pity in your lovers.

and longest lengucs make short $\cdots-$ iv. $\overline{4}$ (Gower)

make raging battery upon shores - iv. 4 (Gower)

and make all our swearers priests.

upon you, make the judgment good

she makes our profession as it

and make the rest malleable ..........

make a battery throngh his deafened

and the gods make her prospcrous
she feeds, and makes them liungry

which you make more rich to owe?.

make my senses eredit thy relation

makes my past miseries sport..........
this ornament that makes me look

heavens make a star of him 1

can make choice of either's moiety...

we make thee lad hat nakes his generation

or he that makes his generation .......

onr abode make with you by due turn

election makes not up on such

from your love make sucl a stray

makes the world bitter ..............

we make guilty of our disasters.

can you make no use of nothing

what makes that frontlet on?.............

which they will make an obedient fathe

make it more like a tavern

make servants of their betters......jii!

shonld make thee worth them.

how an oyster makes hood fool

in thee make thy words faithed

and thou must make a dullard.

potential spurs to make thee seek

make your own purpose ...............

I wonld make thee care for me...

a tailor make a man?

a tailor make a man?... hilind..........

to our sister yon do make return

make your yourse daugliter, do not make me ma......

in their fury, and make nothing of

at once, that make ingrateful man!

makes his toe what he his heart $(r c p)-. .-$

and make them keep their caves

that can make vile things precious.
make content with his fortunes fit

this prophecy Merlin shall make.

gquints the ere, and makes the hair-lip

that makes these hard hearts?

make no noise, make no noise ...........
makes me lend, makes the king bo

thy strange mutations make us hate the that $I$ an wretclied, makes the
at each make not the altitude...

at each make not the altitude....

and the wind to make me cliatter

this would make a man, a man of sait

my bon I make it, that you ...

to make him even o'er the time $\ldots . . . .$.
most just and heavy causes make oppose

exasperates, makes mad her sister .......
flesh and fell, ere they shall make us weep

thou dost make thy way to noble

if you will marry, make your love to me

$[K n t$.$] I"ll make it on thy heart..........$
of our pleasant vices make instruments.

too much, would make much more

the hearens, that makes ns tremble...... viliet,

makes eivil hands unclean . Romeo \&

not laying that, which, having, makes
bid a sick man in sadness make his will

bid a sick man in sadness make haring makes huge waste

most welcome. makes my number more -

that make dark heaven light

and $I$ will make thee think thy swan

she, that makes dainty she, I'll swear
touching hers, make happy my rude hand -

you'll make a mutiny among my....
I'll make you quiet; wlint ! cheerly

makes my flesh tremble in their .....

and make her airy tongue more hoa
that thou dost make in this delay.

stays a husband to make you a wife

we will make short work.

make it a worl and a blow ..........
make us minstrels? an' thou make.

make us minstrels? an' thou make
here's that shall make you dance...

that I mean to make bold withal

make haste, lest mine he

he will make the face of heaven so fin

that make the answer, $I$; if he be slain

these sorrows make me old ..........

heavy sorrow makes them apt unto.

make haste, for it grows very late...
gir Paris, I will make a desperate..

air Paris, I will make a desperat
the lark makes sweet division

thou conldst not make him live

make thee there a joytul bride (rep.) come you to make confession make haste, make haste: sirrah (rep.) hatll tn'en her hence to make me wai no law to make thee rich

her beauty makes this vauit.............

to make me die with a rest

doth make against me, of this $\ldots . .$. ;

my watel, bid them make haste...

doth make the night joint lahourer

what make you from Wittenberg (rep.

makes us tradnced, and taxed of other

and makes each petty artery in this body
by heaven I'll make a ghost of him that

make thy two eyes, like stars, start from

never make known what you have seen.

to make enquiry of his behaviour .......

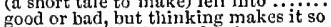

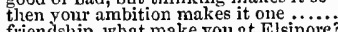

the clown shall make those langl

to make them exelaim against

to make the matter savoury ......

saw Pyrrhus make malicious sport
make mad the guilty, and appal

make mad the guilty, and appal „oit...

that makes calamity of so long life...
his quietus make with a bare bodkin?

makes us rather bear those ills we have

what monsters you make of them

one face, and you make yourselves....

make your wantonness your ignorance

go, make you ready:- low now my lord?

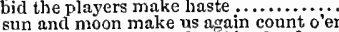

the poor advanced makes firiends of.

to nake me a wholesome answer (rep.)

silch answer as I can make

yet cannot you make it speak...

since nature makes them partial ........

makes marriage vows as false as dicers'

to stones, would make them capable

on the affair: pray you, make haste
makes mouths at the invisible event

makes mouths at the invisible
indeed would make one think

without an oath, I'll make an end on

go but apart, make choice of whom

we'll make a solemn wager on your.....

as make your bouts more violent to that

therefore, make ber grave straight

she must come make her laugh at that

of earth we make loam: and why of that

of love make up my sum

zone, make Ossa like a wart $\ldots$.............

they did make love to this employment

to make true diction of him, his sembla

heaven make thee free of $i$

to make me his lieutenant $\ldots \ldots \ldots \ldots \ldots . . . .$.

or else the devil will make a grandsire

to make this bitter to thee

ancient, what makes he here?............

if we make thought of this, we must not

patience her injury a mockery makes.

mighty preparation makes for cyprus

make head against my estimation!

make all the money thou canst (rep.).
thus do I ever make my fool my purse

framed to make women false.

even till we make the main ...............

to make fools langh i' the olehouse....

that e'er our hearts shall make

make the Noor thank me, love $m$

some to make bonfires, each man to

behold. what innovation it makes here.

to make me frankly despise myself......

that she may make, unmake, do what

and action, make the hours seem short..

the wars must make examples out of

- iii. $\quad[\mathrm{Cn} /$.$] doth make the meat it feeds on.$

- iij. 1 tis not to make me jealous to say ......

the big wars, tlat make ambition virtuc:

make me to see it; or (at the least) so....

to make thine honesty a vice

that is, make questions, and hy them.....

make it a darling like your precious eye

the sun to make [ Col. Knt.-course]

for I will make him tell the tale anew

but you shall make all well. Are you sure

make her amends, she weeps $\ldots . . . . . .$.
wish, that I would make her turn... iv. i would it not make one weep? .................

world's mass of vanity could make me

who would not make her husband (rep.)

and you might quickly make it right...

every way makes my gain: jive Roderig.

that makes me ugiy; and, besides

I will make proof of thine $\ldots \ldots \ldots . . .$.

that either makes me, or fordoes me quite

than she was wont; and makes men mad

I'll make thee known, though I lost

this sight wonld make him do a desperate - v.

NAKEPEACE - to be a makepeace .. Richard III. i. God, the best maker of all marriages - Henty $V$ v. 2

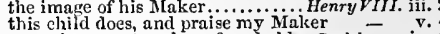
meace is a great maker of cuckolds.. Coriolanus, iv. far fortune maketl us amends $\ldots . .3 H \rho n \cdot y / V I$. iv. 7 IAKING -of this business' making .. Tempest, ii. making practice on the times........ in making me a cuckold ............. mistake your shape and making quite as nature was in making graces...Love'sL. Lost, ii. I not like a man of God's making....... making question of ny uttermost. Mier. of Venic put the liveries to making; and desire

making them lightest that wear

their father, making such pitiful...... As you Like it, i.

is he of Gnd's making? ............. -

their low ranks, making them prond. Alls in her ehamber, making a sermon . Tam. of Sh. lest barbarism, making me the precedent

to sce the making of her carkanet....

stigmatical in making, worse in mind sorriest fancies your companions making? - iii. while tis a making, tis given ......... John, iii. of one wound, by making many ....... as sugar, naking the bard way ...... - ii. heaviness; making such difer ........ v. making the wind my post-hors

is of mine ow $n$ making; and what ... - cpil. making defeat on the full power .......Henry $\nu . \mathrm{i}$. some making the wars their lufl
that ruaking God so free an offer

making another head to fight again.3 IIenry $r I$. for making me, so young, so old .. Rickard HIl. the making of the eake ...... Troilus \& Cressida, making their way with those of......
she's making her ready, she'll come..

not making any scruple of her soilure making your wills the scnpe of justice
makirg parties strung, and feebling.. makiug not reservation of yourselves
making the mother, wife, and child...

making a treaty where there was. making peace, or war, as thou.... Anlony \& Cleo. you not making it appear otherwise... Cymbetin exeellent in making ladies trip ........ Pericles, ij. the former, making a manl a god .... iv. $\overline{4}$ (Gower) there was good sport at his making ....... Lear, i. by making this well known unt to you.... - iii. 1 bliss lyy making me despair ....... Rome making them wonen of good carriage min in the moou making nigl t hicleous....... of the making love over the nasty stye..... - i. making so bold, nyy fears fogetting.

now making the beast with two bac
for making him egregiously an ass

this matter, making it lighit to Cassio.... - ii. IAK'ST -mak'st a show, but dar'st not. Tempest, i. thou mak'st me merry ................ - ili. thou mak'st the triumsiry ....... Lore's L. Lost, iv thuu mak'st thy knife keen........... - iv. thoul almost make st me waver in ..... you Like it, ii. and mak'st conjecturnl fears to come All's Well, so nuak'st thou fuith an enemy to ... King John, jii. and mak'st an oath the surety ....... thou mak'st some tender of my life ... Henry $r$. thou mak'st use of any thing $\ldots . . .$. . Henry
what nii. ii. and mak'st them kiss ........ Timon of Alhens, that mak'st my blood cold .......Julius Cresar, iv. what, mak'st thou me a dullard......... - v. 5 why mak'st thou it so strange? ... Titus Andron. ii.
thy wisdom mak'st a prince............. Pericles, i. 
IAK'ST thou this shame thy pa

mak'st his ear a stranger to thy..........hihele, iii. 3 and mak'st me eall, whit I intend to do.. $\bar{r}$, v. IALADIES-engenders maladies Love's L. Low, i IALADY - on your malady. Two Gen. of 'rerona, ii.
he owes the maindy that doth iny ...Al's W'oll, i.

our past-cure nacrad malady.. Taming of $s h . \overline{2}$ (indne.) a malady most incident to imaids. Winter's 7 ale, iv. 3 their malndy convinees the great Henrylliti. ' the spital of malaly of France the pining malady of France ..........̈ienry i' $t$. iii. the infinite malndy crust you. Timon of sthens, iii. 6 hut where the greater malady is fixed.... Lear,

MALAPERT-this malnert blond. Faelfh Nigh master marquis; you are malapert.. Richard III. L ALCHUS of Arabia; king of..... Antony \& ALCOLAI $\rightarrow$ our eldest,

Malcolm! awake (rep.) .................. it was for Maleolm, and tor Donalbain..

led on by Mraleolm, his mincle .

the rround befure young $\mathrm{M}$ alcolm's feet.

IALCONTENT-a makontent. TwoGen. of

thou art the Mlars of malcontents... Merryl lives, $i$. stand pensive, as half nalcontents? 3 Hen

for a wife, that thou art malcontent

IALE-my deer? my male deer?.. Merry W

[Col.] no salve in the male, sir.. Love's L. Last,
of such a burden, male twins.. Comedy of Er

are their males' subjeet, and at their. .

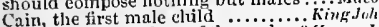

Cain, the first male cluld $\ldots$.........

into a kind of male greea-sickness ... Hen

sole heir male of the true line.

love the breeder better than the male. 3 Herry VI. ii.

the hapless male to one sweet bird

if it eonceived n male child by me..Ilenry $\mathbf{F} I 1$. ii.

for her male issue or die

than there is milk in a male tiger. Coriolanus,

MALEDICTIONS against king and nobles. Jee

MALEFACTOR-not malefictors? Meas. for Meas

whieh be the malefaetors?

for th some monstrous malefactor. Antory \& Cieo. ii.

MLALEVOLENCE of fortune..........Macteth, II ALICE-shrug'st thou, maliec? ...... Trmpest, i. 2
yet, by the very fangs of malice ..Tuelfh Night, i. 5 how with a sportul nour malice........ fors. for Meas. $\mathrm{iii}, 2$ this fashion of thy malice ..... Merch. of Verice, iv. ! it must appear that malice bear's ..... you Like il, i. 2 his malice 'gainst the lade $\ldots . . . \ldots \ldots$. without any malice, but to speak.....All's ' W'll, iii. 6 either malice, or matter, to alter........ Iacbeth, ii. 3 fit of treason malicenting

whilst our poor malice

poison, malt' dolice vaini y sliali be.King John, ii. sharpest deeds of malice on this town

there is no malice in this burnin

the blood of maliee in a vein of.....

appeal the dnke on ancient maliee.. Richard II. i. 1 at your highness, no inveterate

as the malice of this age shapes.......2 HenryI $r . i .2$ from envious malice of thy ...........Henry $V I$. iii. begnn through malice of the bishop

that malice was a great and grievous

will not this maliee, somerset, waliee..

such malice; with such holiness ( $r e p$. )

eyes blab his heart's malice............

iii.

and avoiding, fortune's malice

and avoiding, fortune shated maliee.... Richard III

the new-healed wound of malice

the cardinal's malice and his

I bear no malice for my death .....

if ever any malice in your heart
out of maliee to the good queen...

all offences malice ne'er meant........

(I mean, your malice), know, offieiou

your envious courses, men ht malice

from any private malice in with a malice of as great size

and with a malice of as

I never songht their malice............

make envy, and erooked maliee.

more out of malice than integrity....

purgation to the world, than malce $\overline{-}$. Troilus $\&$ res

no leveled malice infeets one .. Timon of Alher

tis in the malice of mank ind

gnend $\mathrm{my}$ malice in my breath ..... Coriotan

unon their aneient malice, will forget

to affect the malice and displeasure.

to report otherwise, were a malice .

and translate his malice towards you

witness of the maliee and
and to thy ancient malice

and to thy ancient malice

in strength of maliee ..........

both truth and maliee have
will not trust one of her malice.

will not trust one of her malic

a thing monre made of malice.

the malice towaris you to forgive

malice of tow swelling heart......

slow too bold malice agninst
MIALICE-vouch of very malice itself?.. Othello, ji. more in policy than in malice
what malice was between you?

nor set dow $n$ aught in malice.

M $\Lambda$ LICIOUS, smacking of every $\sin \ldots \ldots \ldots a r b e t h$, iv, 3

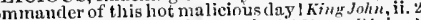
retend malicious practiees against.1 henry I l iv. I to cope malicious ccnsurers

good Griffith; I were malicious else.

contess yourselves wondrous maliciou

rougher aceents for malicious sound

and our vain blows malicious mock

make malle

mpou malieious hravery, dost thou eome. Othello

nay, but speak not malieiously..

may, but speak not ma
and fight maliciously

Aurtune did malign my state ...............

NALLIGNANT-liest, maliguant thing:.

some malignant jower npon $T u^{\circ}$ Gen. of ${ }^{2}$ 'mpest,

with that malignant canse wherein ... All's Well,

maliguant and ill-boding star's!

in vieces by malignant deat

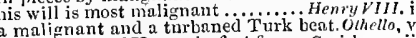

a malignant and a turbaned Turk beat.

MALK IN pins her riehest Ioetrain

blurted at, and held a m
MALL, Nieg and MJarian
like nistress Mall's pict

Pericles, iv. 1

MALLARD-a doting innllard . Antony \& Cleo.

MALLECHO-this is micling mallecho. Hamle

IALLET - than is in a mallet $\ldots . .2$. Herry $I V$

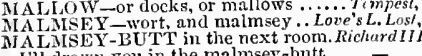

II'll drown you in the malmsey-butt

MALT-mar their malt with water $\ldots . .$. Lear,

malthorse, capon, coxcomb .. Comedy of Errors,
MALT-WORAS; but with nobility... HerryI

nothing but roast malt-worms......2 Hemry $1 \mathrm{~F}$.

IALVOLIO-of this fonl, Malvo

how say you to that self-iove, Malvolio

what bo, Maivolio

hie thee, Malvolio ......................

have not ealled up her steward, MLalvolio -

Malvolio's a Peg-n-Ramsey ..........

Malvolio's coming down this walk

if this should be thee, Mialrolio...

Inalvolio, why that begins $\ldots \ldots \ldots . . .$.

where is Mlalvotio? he is sad (rep.).

how now, Malvolio? Alilvolio?

how do you Malvolio? (rep.)

what meanest thou by that, Malvolio?

not Malvolio, nor after my degree

who eomes to visit

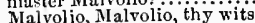

at Malvolio's suit, a gentleman...

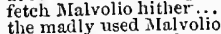

the mady now, Malvolio?

have 1 Malvolio? No ..................

set this device against Nlalvolio here

Mamillius, art thou my boy?

go nlay, Mamillius; thou rt an hone

MANIMERING - so mammering on .... Ohello

M A winin - o play with mom

MAMNOCKED it!

would I might ever see that man

was the first man that leaped...

this is the third man that e'er I saw.....

no, as 1 am a man $\ldots \ldots \ldots$....................

ii. 2 no ambition to see a

none, man, all idle .................

ten leagues beyond man's ile...

what lave we here; a man or a fish?

there would this monster make a man

any strange beast

misery acquaints a man with

misery acquaints a man with ...........

as proper a man as ever went.

the whole bitt man

I was the man in the moon (rep.)

but follow thee, thou wondrous man

has a new master, get a new ma

was there ever man a eoward....

monster, I will kill this man...

if thou beest a man, show.

charm upon this man and maid....

holy Gonzalo, honourable man ..

when no man was his ow

let no man take eare for $\mathrm{him}$ imelf

lie cannot be a perfect man...T'wo

as a nose on a man's faec...
AN-why weep'st thou,
thet erer any himt tied.

tit, man, I mean thon'lt lose...

come, con

why, man, she is mine own...

that a man is never umdlone...

that man that hath a tomaue

that man that hath a tongue (rep.)..

why man how black......

whayed for a hetter man tlian the

fur he's a proper man.

a man I am, crossed witl adversity

lkilled a man, whose dea

a man of such perfecinon ..............

Lannee, his man, told me.....

subtle, perjured, false, disioyal mant

how use doth brecd a habit in a man.

treacherous man!..........

your grace is welcome to $a$ inun diegraced

it is a fimiliar heast to mad...

go sirrah, for all you are my man......

beholden to his friend for a man

as any man in Eugland.

a softly-sprighited man, is he not?

it lie liad found the young man.....

he'll find the young man there ........

dere is no honest man shall. . $\ldots$.....

ere one clisste mar

aud nyy good man too..

commended lim for a true man

what wouldst thou more of

he's a very jealousy man

linew a woman so dote ppon a mai...

master Page is an honest man

built upon another man's ground

if any man may, you may as soon

he is the wiser man............

I never heard a man of his place....

go before you like a man.

a man may hear this shower

a man may hear this shower .........

that you have such a han here....

for the water swells a man.

bid her tlink, what a man is

a man of iny kidney, think

brine my young man here to school

and he's but a dead man

Why, man, why,-Master Page (rep.)

if you find a man there (rep.) iled...

as yon see, like a poor old man $\ldots \ldots .$.

for in the sliape of man, master

makes a beast a man; in some

no man their viorks must eje.

a puffied man? ....................

tut, there's life in't, man....

as any man in Illyria (rep.).......

that say, thou art a man

may pass for a wise man ... Đi........

no railing in a known disereet min

'tis a fair young man, and well.

what's a drumken man like, fool?....

kind of man is he? Why, of man kind

what manmer of man is he?....

between boy and man

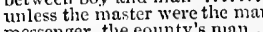

messenger, the

as I am man, my state is

every wise man's son doth know.

there dwelt a man in Babylou .......

a daughter loved a man

I would exuit, man....

no man must know (rep.)............

wliy man? (rep.)

as a wise man 8 art $\ldots \ldots \ldots \ldots \ldots \ldots$.............

prevail in man's commendatiun with

for sure, the mant is tainted.

what, man! defy the devil (rep.)....

taken the infection of the device,

of oftence done to unv man...

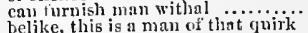

what manner of mul is he?

why mueh I lack of a man....
how is the nian; do thy oflice
thio

ii. 1

ii. 1

ii. $\frac{2}{2}$

ii. $\frac{2}{3}$

ii. 3

iii. 2

iii. 2

iii. 4

iii. 5

iv.

iv.

v. 1
v. 2
Y. . 5
v.
.

$h, \mathrm{i}$.

i. 3

j. 5 
MAN-so unsonnd a man ........Tuelfh Night, iii. 4 MrAN-as honest as any man (rep.) ... Much Alo, iij. 5 . MAN-a man of God's making.... Love's L. Lost, v. 2 I hate ingratitnde more in a man.... he man grows mad

of some great man, and now well, God's a good man

a careful man, and a good what man was le talked with you.... a careful man, and a great I talk with no man at that honr....

there was never man thus abused (rep.) = iil my wits, as any man iu Illyria.

and witl this loly man... han's dagaer here a point

I'll follow this good man

bere comes the man, sir.............

lady, what man is he yon are ocensed of?

if I know inore of any man alive (rep.) -

may a man do it? It is a man's office

talk with a nian out at a window?

that $I$ were a man for his sake (rep.)

wor do came to man's estate ....... - v. I (song)

youder man is eirried to prison.

this man said, sir, that don John ....

but no man's virtue, nor sufficieney

do not quarrel with us, good olil man

whan of strieture, and tirm...

do

it is a man's voice...............

you say not right, old man

that dare as well answer a main, indeed

What, nan! I know them, yea $\ldots . . .$.

master Froth here, this very man....

a man of fourscore pound a year

that she was ever respected with $\ldots$ man

here is the sister of the man condemned

and neither heaven, nor man

as I am an honest man, he looks pale

thou wast the properest man in Italy

what a pretty thing man is

ke man new made

if the first man that did..

a youns man more fit to do another...

wherein (let no man liear me)

from nature stolen a man already made -

aloud, what man thou art $\ldots$.........

whit offence hath this man made you

is the world as it was, man?...........

to take away the life of a man?

ere he wonld have hanged a man....

is aceounted a merciful man $\ldots$ i.......

here comes a man of comfort

can you cut off a man's head? If the man -

every true man's anparel fits (rep.).

yonr true man thinks it bis

a man that appreliends death no more

the rapier and dagger man ..........

a man of Claudio's years.

given me by so holy a man

I do not like the man: had he

a man that never yet did, as he.

to aecuse this worthy man
is this the man, that you did teil

is this the man, that you did tell .....
for this new-married man, approachin

I crave no other, nor no better man.

a fiar told ine of this man

a man to a man: stuffed (rep.)............

by this what you are, being a man

than a man swear he loves me

in what key shall a man take you.....

hath not the world one man, but he..

I can be secret as a dumb man ......̈

thus much overheard by a man of mine

smile at, no man's jests (rep.) .........
be said to be a flattering honest $\mathrm{man}$

be said to be a fattering honest man

sucli a man will win any woman...

no beard, is less than a man (rep.)

unless yon were the very man.

you strike like the blind man...

that I stood llke a man at a mark.

while she is here, a man may live...

that one man, seeing how much (...

like an honest man, and a soldier...

for the man, as you know all ........

he is a very proper man...

a man loves the meat in his...

awe a man from the career of.

as much as may be yielded to a man

I never yet saw man, how wise ......
so turns she every man the wrong

so turns she every man the
he is the only man of I taly

hath any man seen him at .....

the barber's man hath been seen ...

man to be constäle? =

to be a well-favoured man

senseless and fit man for the constabile

you are to bid any man stand
to be no true man; and, for such $\mathrm{kind}$

always called a mereiful man, partne

much more a man who hath any ....

with any man that knows $\ldots . .$.

here, man, I am at thy elbow...

or a cloak, is nothiog to a man........

by the weight of a man ...............

and old man, sir, and his wits are .....

Iuch Ado, i.

e

when r note another man like him

to satisfy this goorl old man, I would

no man living shall come over (rep.)

there's not one wise man among twenty

if a man do not erect in this age
tnsh, fear not, man, we'll tip tlyy

no: if a man will be beaten .................

a young man's revenue ............hid.

[Col.Knt.] this man hath bewitched.

upon this spotted and ineonstant man

and ere a man hath power to say

here is the seroll of every man's name

a sweet-faced man, a proper man...

thon shalt know the man by

th'

o that a lady, of one man rcfused....

I am a man as other men are ........

Ninus' tomb, man: why you ...

note full many a man doth marik -...

that, one man holding troth

you are a tame man, go

I should know the man by the Atheuian -

that every man should take his own

past the wit of man to mare

man is but a. patched foo

eye of man hath not heard (rep.)

of any landyeraft man in A thens...

every man look o'er his part

his man wiramus, if you would know -

at the which let no man worder (rep.)

the man i' the moon (rep.) $\ldots . . . . . .$. .

make a man look sad

I pity the man

item, if any man be seen to talk ... Love's $\bar{L}$.Lost,

for every man with his affects is born

a man of complements, whom right..

a man of fire-new words, fasbion's

it is the manner of a man to spea

a man of good repute, carriage....

my head to any good man's hat.....

the varnish of a complete man

he was a man of good earriage
maid. Man. I will visit thee

maid. Man. I will visit thee ......... -

of all perfections that a man may owe

a man of sovereign parts he is.....

bnt a merrier man, within the ......

a man, if $I$ live; and this .......

nay a man buy for a remnneration?

that was a man when king Pepin...

thou canst not hit it, my good man.

O a most dainty mant...........

a true man, or as thief, that gailops so.

that, like a rude and savare man of.

I never knew inan hold vile stnff

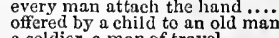

a soldier, a man of travel $70 \ldots . . . .$.

that some plain man recount .........

still she is the inoon, and $I$ the man

till this man showed thee? $\ldots \ldots \ldots \ldots$.....
to parfect one man, e'en one poor mun
doth this man serve God?........... iii. 5 a man so breathed, that certain......

iv. 1 ay, if he have no more man $\mathrm{s}$ biood...

iv. 1 for a man replete with mocks..............

iv. 1 every man must play a part...........

more than any man in all Venice...

therefore let him pass for a man ....

lie is a proper man's picture...

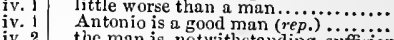

the man is, notwithstauding, sufficient

why fear not, man; I will not

of man's flesh; taken from a man....

play at dice which is the better man

young man, youl, I pray you.

but a poor man's son ...............

ergo, old man, ergo (rep.)

I am lounid long, a man's son......

here comes the the Jew's man (rep.)

being $I$ liope, an old mav (rep $)$

if any man in $r$ old mav (rep.)......

a simple coming-in for one man

why, man, $I$ saw Bassanio

drudge 'tween man and man .........

the constitution of any constant man

the kindest $\mathrm{so}$ keen and greedy (rep.)

use thon all the endeavour of a man

a plain man in his plain meaning

a plain man in his plain meaning ..

hates any man the thing he would not

What man? courage yet! the Jew...
in the tongne of man to alter me ....

Oxcellent youno man!

to let the wretched man outlive........

Thear the footing of a man

the man that man; here. ....

let no such man be trusted

as the blind man knows the cuckoo.

a man. Ay, if a woman live to $\ldots . .$. .

what man is there so much unreasonable -

unless he live until he be a man.

of every man's good parts

but love no mau in good earnest

there com

[Col. Knt.] there is such od o.ds in the inan -

young unan, have you challenged.... -

Hercules be thy speed, young man! (jop.) -

what is thy name, young

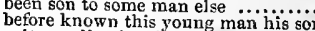

suit me all points like o man?

call thee, when thou art a man?... .

possible, that no man saw them? ....

the service of a younger man in all."

to disgrace my man's

a young man and an old, in solemn.

one of you question never man love 8

I am shepherd to another man, if he

if ever I thank any man (rep.) ........

can nowhere find him like a man...

the wise mun's folly is anatornized..

unclained of any man

art thou thus boldened, $\ldots . . . . . . . .$.

ever sat at any good man's feast ....

and one man in his time plays .......

so unkind, as man's iogratitude

good old man, thou art right $\ldots \ldots . . .$.

most shallow man (rep.) .............

the life of man runs his erring .....

is it a man? And o chain

thongh I am caparisoned like a man

pour this concealed man out of .......

so you may pat a man in....

if the man will be thankfni

in this forest, and in man's appareli?

and a rich man that hath not.........

the

but you are no such man

am I the man pet?

it strikes a man more dead ...

a man may if he were of a fearfii...

a man knows no end of his goods (rep.)

the forehead of a married man mare

the man more

so man hath his de.......

being a man of your breedin

to not become a man ............

a thousand times a properer man (rep.

fasting for a good man's love ........

jou chide, than this man woo.

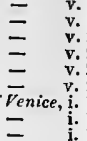

i.

i. 2

i. 3

i. 3

ii. 2

ii. 2

i.i. 2

ii. 2

ii. 2

ii. 2

croll

iii. 


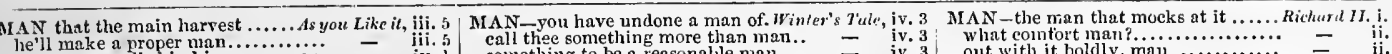

not any man died in his own person

aman that liad a wife with.

were man as rare as phcenix $\quad . . . . . .$.

this is a man's invention

what mar $I$ am, and low, and why..

a wretched ragged man, o'ergrown.

when that the sleeping man shoutd..

you a man? you lack a man's heart

eounterfeit to be a man..............

here eomes the man you mean ......

if ever I satisfied man, and you.

if any man doubt tllat,

that no man else will ..............

meeting with an old religious mail .

welconie young man; thou offer
called you the man you speak

men is eneny to virginity

there is none; man, sitting down

being a man might be a copy

such a man might be a copy $\ldots$ ina.....

man shoulc be at woman's command

liere's a man stands, that has....

if God have lent a man any.

as 'twere, a man assured of ...........

this is the man. Whan? what is count's ma

I write man; to which title, age ...
in tle default, he is a man $I$ know

every man should beat th

a young man married, is $a$ man

a young nian married, is a man

the soul of this man is his elothes ..

like a common and an ontward man

to be a very melaneholy man i know a man that had this trick.

as an old man loves money

steal himself into a mar.'s fa vour....

every one be a man of his own fancy

he changed almost into another man
an honest man should not have (rep.)
I would do the man what honour ..

and means, for every man to live

at a man's. Your distinction (rep.).

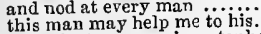

or against any man's metapho

I against any man's metaphor ....

I saw the man to-day, if man hoor man, and at your.

if ever I knew man, 'twas you.

or else this old man's wife ............

$O$ that a mighty man, of such ....

nor no man ever saw

light on a fit man, to teach

any man is so very a fool to .........

why man, there be good fellows (rep.)

or mean man of Pisa ................

I killed a man, and fear I was ......

lighted well on this young man ....

will not promise her to any man.

the man must stead ns all ..........

a man well known throughout.

a mighty man of Pisa; by report....

be married to no man but me.

to refresh the mind of man

Priami, is my man Tranio.........

spit in the hole, man, and tune ....

a horse, and a man is more than ore

I am to get a man, whate'er he be ..

rescue thy mistress if thou be a man

was ever man so beaten? (rep.) $1 . . .$. .

winter tames man, woman

what, no man at door, to hold....

another way I have to man

a' will make the man mad ...........

happier the man, whom favourable..

this is a man, old, wrinkled, faded..

what if a man bring him a hundred.:

what, is the man lunatic?

their life, to see him a man.............

why, happy man be his dole!

and many a man there is, even ......

thot'rt an hollest man: Camillo $\ldots$....

for cogitation resiles not in that man

do this? could man so blench?

by all the parts of man, which honou

dishonoured by a man whicls ever...

there was a man;-llay, come...

as cold as is a dead man's no
so were I a nun, the worst
Camillo

whom I proclaim a man of truth.....

whom I, proclaim a man st thou, man? I have seen .

to have helped the old $\mathrm{m}$

you're a made old man $\ldots \ldots \ldots \ldots . . .$. .

a man, they say, that from very ....

alas, poor man! a million

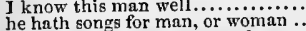

whoop, do me no harm, good man

fear not thou, man, thou

two maids wooing a man ..............
knowledge, more than was ever mant
know man from man? dispute his .. something to be a reasonable man

and had not the old man come

time that the unjust man doth thrive

yields a enreful unan work ( $r e p$.) ....

a great man, I'll warrant

will break the back of man

jv. 3 has the old man e'er a son, sir

iv. 3 in man, besilles the king (rep.) .....

as much as this old inan does..

that e'er man bred his hopes ont of .

more worth than any nan ...........

I brouglit the old man and his son..

or liand of man hath dove.

forward, old man, do not break. Comedy of Ëror

many a man wonld take you at .

i. - a man is master of his liberty.

i. 3 so no man, that hath a name

i. 3 was there ever any man thus beaten

whilst a man to recover his hair (rep.) -

ii. 3 it would make a man viad as.

ii. 3
ii. 3
an I your man? am I myself? (rep.)

ii. 3 as a man may not speak of

ii. 3 a man may go over sboes ...................

ii. 3 you are a merry man, sir

\begin{tabular}{l|l} 
ii. 4 & there's no man is so vain ..... \\
ii. 5 & I sec, a man here needs not...
\end{tabular}

iii. 1 a man is well holp up...

iii. 2 there's not a man I meet

iii. 2 the man, sir, that when geintlemer.....

iii. 6 he that brings any man to answer

iv. 3 your man and you are marvellous

iv. 3 fear me not, man, I will not

iv. 3 here comes my man; 1

both man and master is possessed.

ah me, poor man, how pale

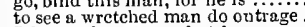

$\mathrm{v} .2$ I know the man; what is

v. 3 hory is the man estecmed $\ldots \ldots \ldots \ldots \ldots$

hath this possession held the man?
much different from the man he was

much different from the man he was

came it, that the man was m

make of him a formal man again.....

my master and bis man (rep.

a living dead man...

there left me and my man

Dromio, and his man, unbound.

and whatsoever a man denies.

which is the natural man, and which

if thou be'st the man that.

what hloody man is that?

he shall live a man forbid .......
or are you aught that man mas

shakes so my single state of man

I dare do all that may become a man..

durst do it, then you were a man

if a man were porter of life was to be trusted ....

no man: the expedition of $m y$

as troubled with man's act

let every man be master of his ........
given to the common enemy of mail

to pray for this good man

are you a man? Ay ..........

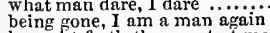

being gone, I am a man again

laugh to seorn the power of man ......

the dead inan's knell is there

what, man! ne'er pull your' hat

dispute it like a man (rep.) ............

exeite the mortified man

no man, that's born of woman

by man that's of a woman born ...

only lived but till he was a man

but like a man he died

ii. 1 in the large composition of this man

my piced mon of

my picked man of conntries
that same mighty man?

iii. 2 some proper man, I hope............

the half part of a blessed man

iii. 3 common man; believe me (rep.)

iii. 3 made thee a most ngly man

ivi 1 corrupted pardon of a man

$\begin{array}{ll}\text { iv. } 2 & \text { Hubert shall be your man .... } \\ \text { iv, } 2 \text { the dull ear of a drowsy man }\end{array}$

jv. 3
iv, 3 thany a poor man's son wo
this the man should do

to hurt his master, no man [Knt.-man's] -

made him a man

against what man thon comest

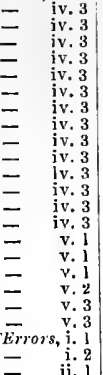

ii. 2

ii. 2

iii. I

iii. 2

iii. 2

iii. 2

iv.

iv. 2
iv. 3
iv. 3

iv. 3

iv. 3

\section{(19.}

out with it boldly, man ............

for every mant that Bolingbroke...

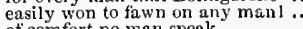

of comfort no man swectly

let no man speak again to aiter.

banisliment on jon proud man .....

make a second fall of cursed man?

look upon that man...

shall I make to this base man

thon haught, insulting man (

he is as like thee as a man may be...

can 10 man tell of my unthrifty

can no man tell of my unthrile man enter till ny tale

the true man's put to death ..........
believe not this hard-hearted man

I would thou wert the man that...

breal the neck of that proud main....

ercated to be awed by man

in the atreets, and no man regards it.

for a man to labour in bis vocation

that ever cried, Stand, to a true nan

never hold that man my friend....

truly as a man of falsehood may ....

purchase, as I am a true man....

to turn true man, and to leave.......

roguery to be found in villanous man

what a hurdred, man? I am a rogue

dealt better since $I$ was a man

bound, every man of them ..........

manner of man is lie? An old man..

it blows a man up like a bladder

what manner of man, an' it like (rep.)

if that man should be lewdly given

fat old man; a tun of man

become a cart as well as another man

a gross fat man. As fat as

I think, there is no man spealis.

why, so can $I$; or so ean any man...

the soul of every man prophcticaijy...

so has my husband, man by man, boy

he is an honest man. Good my lord

like a foul-mouthed man as he is....

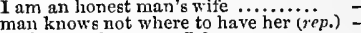

as thon art but man, $I$ dare..........

heart's love, hath no man (rep.) ...

yea, every man shall be my friend.

and that no man might draw sloort.

he gave you all the duties of a man

have better spared a better man

of a man, who hath not the life of $a$ man

tell me, this fat man was dead? .....

if the man were alive, and would deriy it

and not a man of them brings..2IIenvy $I \bar{r}$. (indue.)

yea. this man's brow, like to

he is a man who with a dortile

and counsel every mnn the aptest....

this foolish compounded clay, mau

as if he had writ man ever since

did I say you were an ilonest man?.

all the other gifts appertinent to man

a man can no more separate

neither woman, man, nor ehild ....

what man of good tenper would ...

if thou wert in honest man, thyseif

if a man will make court's

let the end try the man................

what a maidenly man at arms

every unan must know that...........

than will do me good, for no man's

the fiery Trigon, his man, be not ...

when the man of an is called

and truer-hearted man,-well, fare.

a man may proplecy, with a near.

Will Squele, a Cotswold man .......
it would have done a man's heart good

I wnew him a good backsword man.

when a man is, as they say (rep.) ....

but if he had heen a man's tailor (rep.

a mann's too good to serve his prinee

a man? care 1 for the limb (rep.)...

give me this man; he presents no.

to see you here an iron man, cheering

that man, that sits within...

try our fortunes to the last man.....

as good a man as he, jir, whoe'er...

nor a man cannot make him laugh.

an houcst mun, sir, is able (rep.) ....

ii. 3

iii.

iv.

vis

v. 3

v.

i. 
MAIF-no man could better eommand.2 Henry $I V . \mathrm{v} .1$
though no man be assured what......

that have a man so bold, that dares..

had been a man of this mett

then say an old man can do somewhit =

deliver them like a mitu of this woild

Harry the fitth:'s the man

lut us take uny man's lorses....

for the man is dead, tliat yon and $\mathrm{Pi}$ istol =

thou thin man in a censer.

spetak to that vain man...

dreamed of sucl, a kiud of man

and this is not the man that shall...

thudsand parts divide one man.. Henry

[Col.Knl.] w lien the man dies, let the
the state of wa in divers funetions

plodded like a man for working-days

lin every man now task his...

v. 2 fear keep with the mean-horn mai.....

how ean man then, the image

endure cold as anotlier man's sword

v. 3 Woe is me for Gloster, wretched t?

v. 3 fnil ghastly like a strangled man...

iii. 2 no man living eould say

v. that no man slion:ld disturb yon..

a emning man did ealculate ........

an honest man, and a good briekiay

and I was never nine own a man?

tike man is a proper man honest plain-dealing man........

shall be enconntered with a man as good

why dost thou quiver, man?

$\begin{aligned} & \text { v. } 5 \text { not amiss to eool a man's stomach.... } \\ & \text { (e)ii.) } \text { to combat a poor famished man..... iv. } 70 \\ & \text { iv. } 10\end{aligned}$

art thou the man that slew him?

enn brook I bow a knee to man.

is the man grown niad?

ah wretelied manl wonld I had

slow the valour of a man, and put up

hated both of God and man

iii. 2 as a man sorely tainted....

alas, poor man! at last....

he was a man of an unboinded...........

greater lonours to his age than man

or let me lose the fashion of a man!..

what than I myself, poor man

look, the good man weeps!

to suffer a man of his place.............

childish pity to one man's honour.....

no man dare are detests.

no man dare aceuse you ............

'tis $\mathrm{n}$ eruelty to load a falling man...

of this man to he vexed!

against this man, (whose honesty....

good man, sit down (rep.)

every man shall eat in safety..........

i.
i. 4 thou liast made me now a man mo man think he has
ii. 2

jt' exeh mun do his best

ii. 1 he is a man, and Clifford, eope with hin

enlurge the man eommitted $(r e p.) . . . \quad$ - ii. 2 years a mortal man may live

to mark the tull-fror a few light..$\quad$ - ii. 2 this man, whom hand to hand I

is like another fall of man

if ever man went to Arthur $7 \ldots \ldots$ bosom

What, man! be of good elieer..........

eould not be a man to me.

nilticks do not annount to a man
never broke nny man's liead but

ne ver broke any man's head but as any military man in

and a man that I love and hononr

and he is $a$ man of no estimation

here eomes tlie man. Captain .....

let man go free, and let not hemp.

the duke is a prave man ..........

if your majesty know the man

the king is but a man (rep.)

no man shonld possess him with

as every sick man in his bed...

to some man else, as this dead man.

wisl not one man more (rep.).

we would not die in that man's eompany -

perish the man, whose mind .....

the man, that onee did sell the

not so mueh of man in me .........

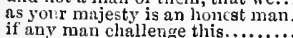

if any man challenge this.

I met this man with my glove

weep, wretched man .................

here eomes for the loss of the

not a man comes for redres

do $I$ not breathe a man?

to the man that took him .......
am I then a nan to be beloved?

beeome a banished man.

each man take his stamd

iii. 6 nay, this way, man ...........

the good old man would fain
surly Warwiek mans the wal

naked, foil a man at arms

snspeet a feartia

and many an old man's sigh

and that good man of worship.....

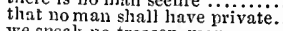

we speak no treason, man

vouchsafe, diffused inteetion of a mai

myself to be a marvellous proper man

$\Omega$ man that loves not. me

eannot a plain man live ............

as I am a ehristian faithful me.....

a man a eoward; a man cannot ( $r$ ep. $)$.

spnrn at his ediet, and fnlfil a man's?

bot he, poor man, by your first

my brother killed no man.

as man and wife, being two ..........

a thind man thinks, withont

$a$ baser man of a a inan by fi...

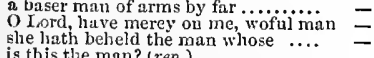

dare no man answer in $a$ ca.

it will glimmer thro' a blind
even like a man new haled

more tlian well beseems a man

to be a man jnst and npright ..........

as good a man as York ...............

ni) simple man that sees this

a breathing valiant man ..........

the eause I cannot aid the man

a man of great anthority in

Charles the Danphin is a proper man

you have suborned this man

a murried man! that's most

hut privilege of a private man

were I a man, a dnke, and next.

nas, fear not, man, we are alone.

what say'st thou, man? hast

for he's a good man! Jesu

York is meetest man to be yonr....

is most nnmeet of any man...

beeause here is a man acensed of .....

this is the man that doth accuse his.

doy, mat east away an honest man for

the spite of man prevaileth against me

yea, man and birds, are fain

had not your inan pat up.............

the greatest man in England.

the armourer and his man ...

drink, and fear not your man .......

and myself an honest man ..........

not his wont to be the hindinos.......

Gloster is a man unsounded yet $\ldots . .$.
tle cuting short that fraudful $\mathrm{man}$

and not a man of you had

i. 2
i. 4

not a man would speak.

reason almost with a man old man!

more can yon distinguish of a man..

nn' if I live until I be a man.

chop off his head, man ...............

where is your boar-spear, man? $\ldots$...

when I met this holy man, the men
than my lord Hastings, no man might

there's ne'er a man in Christendom

that witl? no man here he is offiended

so dear I loved the man, that I......

I partly know the man

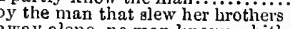

away plone, no man knows whither

ever man unto his chare

enaets more wonders than a man.....

no man's pie is freed from his

every man a is freed from he

not a man in England ean advise....

free pardon to eaeh man that...

there's mischief in this man

i. 2 in treedom, and this man ont of prison?

i. 3 the noble ruined man you speak of

a man of my lord eardinal's....

slept vpon this bold bad man

this good man, this just and learned

3 sueh a man I would hove wislied for

3 in this man's place before him (rep.)

kept him a foreign man still

thate an able man, to leave so......

ii. l like a good man, yonr late censure.

the prime man of the state?

ii. 3 Went beyond all man's endeavours.

and no man see me more...

ii. 3 I could despise this man, but tiait $\mathbf{I}$

iii. 3 press not a falling man too fa

iii. I wonder, a great man should deeline

too heavy for a man should deeline?

but he's a learned man hopes......
Heetor's a gallant man

Troilns is the better man (rep.)........

better than any man in all Phrygia

an 'twere a man born in April

Aneas; is not that a brave man?.

brave man? O good enough (reps.)

do you know what a man is?........

one that was a inan when Hector's (rep)

a man distilled out of onr virtues....

wlat's of our best man $(r \in p.) \quad \ldots . .$. -

no man is beaten voluntary ............

propugnation there is in one mau's.. he is a privileged man; proeeed ....

if you will favonr the man

why should a man be proud? (rep.)...

here is a man,-but 'tis before.

wise, and love, exeeds man's miglit and are the proud man's fees .........

that no man is the lord of anything

lieavens, what a man is there!

how one man eats into another's ....

tlian an effeminate man in

the mall's undone fur ever.

what think you of this ter

a man may wear it on botl sides.....

a maughty man, let it sleep?

yon're an odd man; give even (rep.)

gentle, and too free a man

prond man to embraee thee...

any man nt first sight. And any man

never did young man funcy ..........

lietter fits a lion, than a manl

that, unless a man were eursed

much more a fresher man, had $i$.....

great Heetor was as good a man as he

most ineomparable man....... Timo

with one man beekoned from

call the man before thee

this man of thine attempt

most the natural man; for sine.

which will not eost a nuan a doit

the strain of man's bred ont into ....

a hnmour there does not beeome a man

dip their meat in one man's blood.....

is the readiest man to $\mathrm{kill}$ him $\ldots \ldots$.

Which ne'er left man i' the mire ....'

that man might ne'er be wretehed.

that man goes up and down in

nor thon al together a wise man.

i pr'y thee, man, look eheerly $\ldots . . . . .$.

denied that hononrable man?.

I see the monstrousness of man.......

whe the first mant that e er received

the villanies of man politic

ii. 2 he is a man, setting his fate aside.....

ii. 2 the worst that man ean breathe

ii. 2 bnt who is uran, that is not angry?

iii. 1 every man here's so. What wonld ..

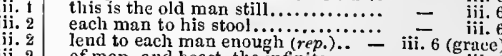

(grace)

whem mon, and all humanity

when man's worst sin is, he does

showing me again the eyes of man?

is nan so hatefnl to eyes of man?.

with man's blood paint tlie ground
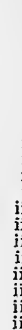

ii.

iii.

iii. 3

iji.

iii.$$
\text { iv }
$$
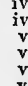

\section{(in}
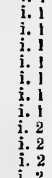

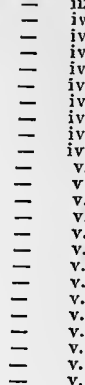

of Cress. i.

iii. 3
iii. 3

iii. 3
iii. 3
iv. 1 
MAN-in hollow boncs of man.. Timon of .thens, beingt sick of man's unkindness....... arrogant man, is pufted, engenders $(\ddot{r}$.
no more bring out ingrateful mant what man didst thou ever know think, thy slave man rebels. co miserable, but a man may be trie despised and rninous man my lord?. when man was wished to love. if thou grant'st thou'rt maj.......... I ne'er frad honest man about mie..... surely, this man was born of woman I do proclaim one honest man ( rep. $^{\text {. }}$ ne'er see thou man, and let me ncer
not paint a man so bad us thy'scif... eacli mun a part, all single

Whicli looks like man, is fricndiy with this man was riding from Alcibiades there does not live a man ............. not a man shall pass his quarter. the cranks and offices of man. a sick man's appetite, who desires..... ever man so proud as is this Marci.

perform to the utmost of a man....... it more becomes a man, than gilt no, nor a man that fears youl less there is the man of my soul's hate tongue from every meancr nan in with a man busied about i.......... no more of lim; lie is a worthy man no more of lim; lit be, the man is seak of cannot he proved best man ' $i^{\prime}$ the field wortly man! He cannot but so soon ont as another man's will. there was never a worthier man...... go witlout any honest man's voice.. my masters? have you chose this man no: no man saw eni. He said

not a man of their infirmity ......

the cit $y^{+}$, nd be every man himself

I play the me every man

thy tears are salter than a younger man's

to seek a single man

was not a man iny father!

good man, the wonnds that he.........

and am the man, I think, that shall

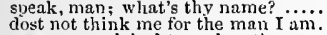

never man sighed truer breath

he is simply the rarest man i' the....
I had as lief be a condenined man...

I had as lief be a condenine

as any man $I$ can imagine...........

than nature, that shapes man better..

ever taints the happy man

this man, Aufidius, was my beloved..

this last old man, whom with .........

ean alter the conditlon of a man?

is grown from man to dragon....

as with a man by lis own alms

the man is noble, and his fame

which this man's life did owe yon
what man is that? A sootlsayer...

what man is that? A soothsayer...
and this man is now become a god

a man of such a teeble temper

there is in it but one only man

I do not know the man I should avoid

I am no true man. What said he..

an' I liad been a man of any
name to thee a man most lit

a man no mightier than thyself........

poor manl I know, he would not be... and to such a man, there is no fleerin

shall Rome stand under one man's ar and the state of yes, every man of them; and no man till each man drop by lot tery....

......

sometime hath his lour with every man

here is a sick man, that

will crowd a feeble man aimost

do so; and let no man abide.

ay, every man away: Brutus

let each man render me his bloody hand the ruins of the noblest man

not a man depart, save 1 alone $\ldots . . . .$.

Brutus is an honournble mani (rep.).

a plain blunt man, that love

he gives, to every several man...

a married man, or a bachelor $(r e p$.$) .$

this is a sliglit unineritable man......

lay these honours on this man.......

and let no man come to our tent

because I knew the $\operatorname{man}$. .............

away, slight man! Is't possible?.....

no man lears sorrow hetter

young man, thou couldst not $\mathrm{die}$...

more a man might know.....

more tears to this dead man

I found no man, but he was trie.....

what man is that? My master's man

and no man else hath honour by

say to all the world, this was a mani \begin{tabular}{l|l} 
Mi & MN-is this the man? Is't you, sir. Ant \\
v. 3 & to sce a linndsome man loose-wived ..
\end{tabular}

the mall from sicyon

slie is cunning past man's thoughit

you shall find there a mow who is...

and the ebbed man, ne'er loved ......

so the man; but note hin

paracon nguin my mall of men

with snakes, not like a formen ......

thou'rt an honest man

they would lunocent .................

a man prepared to take this offer

I will proise any man that will traise

I am the man will give thee $o^{\prime}$ thei.......

the third part of the the man

the holding every man shall bear.....

so is he, being a inan

a proper man. Indecd, he is so

the man hath scen some majesty...

will appear tlere for a

well I know the inan.................

a private man in Athens ........

leave thee now, like a man of steel

behold this man; commend unto

what man is this? stand close..

best force is forth to man his galleys

wilt thou not answer, mant...

the business of this man look

might see but such another man 2 man as this I dreamed of?

wert thou a man, thon wouldst

this is the man. Avoid, and leave

you do not meet a man but frowns : Cy/mbelis
alack, good man! and therefore banisherl

alack, good man! and therefore ban

truly read, what kind of man lie is

tenderness than doth become a mani

he is a man, worth any woman
desire my man's abode where I

that inan, - who knows by listory

was there ever man had such lnck!.

and man's o'erlaboured sense repair

gold which matient man in loss (rep.) ...

love, where there's a nother man
that most venerable man, which $I$

that tends to vice in man.

one that rode to his execution, man.....

I see before me, man, nor here ......

speak, man! thy tongue

wretched man, a thing the most........

and am almost a man already

I would think thee an honest man

I see, a man's life is a tedions one

for a man and his glass to confer

so man and man should be

the man that gave tleen the

I mean, to man, he had not...........

that I never did see man die?.

ait old man, and two boys.

an old man twice a boy

the old man and his sons were (rep.)

tween man and man, they wcigh no

but a mee he was mature for

that a man should have the best ise

inless a man would marry a gallows

. man, and speak

qualities that man loves woman for..............

that headless man I thought had

the man lie slew

no man sherl tears for noble Mutiusi...

beholden to the man that brought

take up this good old man

what, man! more water glideth by.

where never man's eye may behold.

that man's tace can fold .................

no man is by, and you recoun

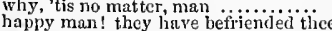

happy man! they liave befriended thice stands my other son, a banished man for thou, poor man, hast drow

no man sliould be mad but

alas, poor man!........

can you hear a grood man groan.

then let no man, but $I$, do execition

and leave you not a man of war

for the man must not be hanged

as you think needful of the man

as kill a man, or else devise...

find'st a man that's like thysel

or more than any living man coildi."

come, come, thou reverend man of Ro

no funeral rite, nor man in mouruful

assuming man's infirmitie

to hear an old man sing....

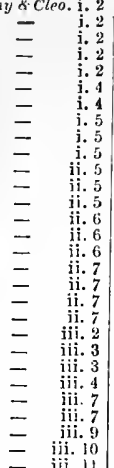

iv. 8
iv. 8
iv. 9

10
$v, 12$
$v, 1$

\begin{tabular}{r|r}
$r$ & 2 \\
$v$ & 2 \\
& 2
\end{tabular}

a good man's fortune, may grow out

whentempt of man, brought near

having more man than wit

when a wise man gives thee...

dost thou understand me, man?

who put my man i' the stocks?

man's life is cheap as benst's

ii. 2 a poor old man, as full of grief as age

water-drops, stain my man's cheeks

followed the old man forth

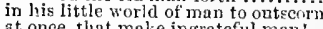

weak, and despised oid man

the man that makes his toe

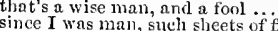

man's nature cannot earry thic afficiction.

and thou simular man of virtuc...

I ain a man, more sinned agains

unaccommodated mans is no more.

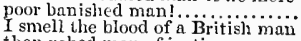

thou rohed man of justice.
if this man come to good

which made me think a man a..............

good man [Cnl. Knt.-good man's son] ...

undo exeess, and each man have enough

v. 3 O the difference of man, and vian

v. 4 a man, a prince, by him so bevefited?

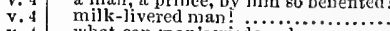

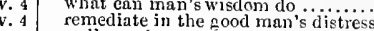

v. 4 well wortl a poor man's taking.......

I took it for a man , y....

a man may see how this world goes......................

this wonld make a man, $a$ man of salt

nay, come not near the old man

I am a very foolisly fond old man

I should know you, and know this juan

onr sister's man is eertainly miscarried.

iii. a a ny, old man, give me thy liand

if it be man's work, I will do it....

if any man of quality, or cleqree

came there n man, "ho having seen

3 (herald)

iii. 1
iii. 2
iii. 2

I am the very man. I'll see that

any man or maid of Montague's. liomeo. of sutict, $\mathrm{i}$.

bid a sick man in sadues mak

tut, man, one fre lumns ont authothis

a was a merry man, took up.......

wery man betake him to lis legs

mont be the man! Why uncle.

any other part belongring to a man..

in man as well as lierbs, gruce

I bear no in trecl, blessed man

with his man

any man, that ean write, may

is he a man to encounter Tybait?...

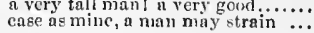

s. Pericles, i.

ii. (fiower)
ii. (Gower)

\author{
=
}

iii. :

\author{
$\overline{\mathrm{l}}$
}

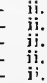

i. 1

6
6
6

i. 1

i. 2
i. 3
i. 4
i. 4

ii. 2 
MAN-constrains a man to bow.. Rom out upon youl what a

I dare draw as soon as inother......

withiu this hour $m y$ mun sliall be

is four man secret? did you ne'er

my man's as true as steel ......

that Paris is the properer man.........

you know not how to choose a man

face be better than any man's

quarrel with a man should buy the fee-simple

bullye for no man's pleasure

here eomes iny man (rep.) ..............

and you shall find me a grave man

a eat, to serateh a man to deatho...

ah, where's my man? give me some

cone forth, thou tearful man.

thou fonl mind man, hear

art thou a man? thy form (rep.)...

yet 110 man, like te. dotli grieve.

as one's heart could wish it man

hide math with been tried a looly man..

unfortunate old inan!

that gives a dead man leave to think

an' if a man did need a poison now

come hither, man: I see, thit thou.

temit not a desperate man...

what said my man, when my

there, hy a dead man interr
here's Romeo's man (rep.)

known thee for a holy man.

they are actions that a man might pla

give every man thine ear

the apparel oft proclaims the man

canst not then be false to any man.

as infinite as man may undergo ...........

buch an enmity with the blood of man.

for every man hath business .......

what so poor a man as Hamlet is........

nor the in ward man resembles that

as of a man faithtul and honourable...

one man pieked out of ten thousand

to speak to you like an honest
what a piece of work is a man

zoan delights not me (rep.)

if you delight not in man .............

an old man is twiee a ehild.

bodikin, man, mueh better: use every ma

the proud man's contumely, the pants

as just a man as e'er my conversation

a just a man as e'er my conversation

that man that is not passion's slave
what should a man do, but be merry?

a great man's memory may out

the great man down, you mark .............

to give the world assurance of a man

kilis the unseen good old man .......

that this man may fish with the worm

no man mayse without why the man dies.

what is a man, If his ehief good...

speak man. Where is my father?.

should be es mortal as an old man's
stands the man, good: if the man go

what inan dost thou dig it for? For no ma
sexton here, man and boy, thirty years.

sexton here, man and boy, thirty year

why, man, they did make love $\ldots . . . .$.

and a man's life's bo more than

but, to know a man well, were to.

as thou'rt a man, give me the cup

by the faith of man, I know my price ...

liere is the man, this Noor ..............

tliat heaven had made her sueh a mas

if my had blame light on the man

a man he is of honesty, and trutl

cone, be a man: drown thyself? .........

Cassio's a proper man: let me see now

every man put himself into (rep.)

a man, a [Knt.-O man's] iffe's hut

a man, a to the genai, nor any man of qu
as I am an honest man, I thought

what, man! there are ways to reeover.

to be now a sensible man, by and by a fool
or any man living. may be drunk ( $r \in p$.

a man that ianguishes in your disp

in a man that s just, they are elose.....

good name, in man and woman

are you a man? have you a sort

are your a man? have you a soln .........

this is within the compass of man's wit.

you'll never meet a more sufficient man

is not this man jealous? I ne'er saw

\section{- ii. 4 a horned man's a monster, and a beast good sir, be a man; think, every \\ a passion most unstiting sueh a man.... I never \\ ehaste, and true, there's no man happy... \\ fye, there is no such man; it is impossibie \\ a proper man. A very handsome ma \\ 'tis but a man gnne: forth, my sword. \\ some good man hear him earefuly $\ldots . . .$. . \\ send for the man, and ask him \\ an honest man he is, and hates the slime \\ disprove this villain, if thou be'st a man}

man but a rush against Othello's breast.

MANACLE-I'll manacle thy neek and. Tenpest, $\mathrm{i}$ manacles of the all-binding law.. Mea.s. for Meas.

and manacle the bear-ward

it is a manacle of love.

knoek off his manacles.

Coriolanus, i. ANAGE-the manage

ath this brave manage...

iny state..........

Tempest

thello, iv. 1 MANIFEST-that I now will manifest. Much Ado, iij. 2

they are taught their manage ..... As you Like it, i.

can sufficiently manage, must

now the manage of two kingdom

expedient manage must be made

wanting the manage of unruly jades - iil.

v. 3 speak terms of manage to thy bounding -

come, manage me your caliver ....2 Henry I $\%$. iii. 2

and a' would manage you hi

till they obey the manage

slaek, wanting his manage...Troilus \& Cressida. v.

your maids, manage this war ...Antony \& Clen. Hit.

pains to work her to your manage .... Pericles, iv.

and the son manage his revenue

that still would manage those authorities

or manage it to part these men . Romeo of

to manage private and domestic quarrel. Othello, ii.

HANAGED-well managed .. Comedy of Errors, iif.

IANAGER - manager of mirth? Afid. N.'s Dream

MANAGIN'G - managing of quarrels.. Much Ado, $\mathrm{ji}$.

so many lad the managing .Herry $\boldsymbol{V}$. v. 2 (chorus)

MANAKIN-a dear masiakin to. Twelfih Nighe,

MANDATE-powerful mandate to. Anlon

special mandate, for the state affairs .....
sir, I obey the mandate, and will return

MANDRAGORA-d rink mandragora. Ant \& \&
not poppy, nor mandragora, nor all .... Oihello

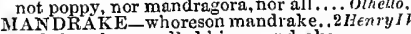

and the whores called him mandrak

as doth the mandrake's groan......2Henry $V$

and shrieks like mandrakes'.... Romeo \& Juliet, iv ad mane fratrum sacrifice his.. Titus And'onic per Styga, per manes vehor ............. [Col. Knt.] high and monstrous mane .. Othello, it
MAN-ENTERED thus, he waxed.. Curiolanus, MANFULLY in fight ..... Two Gen. of Verona, do see him mangle.. Honry $r$ dishonour mangles truejudgment. Coriolanus, MANGLED-in mangled forms.... As you Like it, is. 7 my favours hide tlyy mangled faee .. I Herry $I V$.v. poor, and mangled peace, dear nurse. ${ }_{m y}-\overline{-}$. with nis mangled myrmidons .. Troilus \& Cress, or if, a mangled shadow .... Antony \& Clempotra, thy mangled danghter here... Titurs Andronicus, wife, hath mang the mangled Tybait from

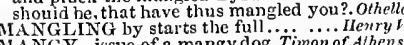
MANCY - issue of a mangy dog. Timon of Alhens,
MANIIOOD more approbation. Twelfih $N$ ight, manhood is meited into eourtesies. Nuch.Act, we'll trv no manhnod here..... Mid.N.'s Dream, iii. 2
not in the worst rank of maniood .... Macbeth, iii. 1 even now protest their first of man

there's neither honesty, manhood..... Henry (saving your manhoods) ............2HenryI makes much against my manhood and liold their manhoods cheap.

rsaving your majesty's mar

now is it manhood, wisdom, and ....2 Henry no, nor your manhood, that durst ...3 Jen

with sleiglit and manhood stole...

thy prime of manhood, daring ......... Richara $I I I$. iv. 4

manhood, learning, gentieness...

purity of manhood stand upriglit. Tïnon of $A$.

aud manhood is ealled foolery.

and fit yon to your manhond ....... Cymbeline, iii.

my bosom takes off my manhood

marry, your manhood now! what news? - jv.

for my inanliood, honesty, or wisdom.. O/hello, jii.

tnderstand this in $a$ inanifest effect. in this she munifests herself.... Twelfh Night, ii. 5 appears by manifest proceeding ". Mer. of Venice, iv. manifest where slie has lived thy life did manifest, tliou ........

\section{Winter's 7 ate,}

back, thou manifest conspirator

you are inan ifest housekeepers

manifest treason. This a consul?

thy heinous, manifest, and many

foul, shall mantest me rightly .......... o: hello, $\mathrm{i}$.

find your sn fety manifested ....Meas. for Meus, iv.

thy fault's thus manifested

I ANIFOLD-for misehiefs manifold.... Tempest, i

which he confessetl to be manifold. 1 Henry $I V$. iv

mow manifold and strong a bond ......... Leor,

he is a manifold traitor $\ldots . .$. - v. 3 (licrald

MANK IND-howbeauteous mankind is!.Tempest, $\mathrm{y}$ rails aguinst all married mankind. Merry Hives, iy the tentl of mankind would hang.. Winler's Tale, $\mathrm{i}$. out! a mankind witch! hence ............. Jacbeth, i the common curse of mankind .. Troilus $\&$ Cress. ii. beast more kinder than mankind....

tn the whole race of mankind, high

thou eommon whore of mankind

I am misanthropos, and hate mankind

tis in the maliee of mankind, that he

and disclaim would I liave liated all mankind

in hate of nankind, had destroyed... Coriolanus, iv.

a trim exploit, a manly enterprize.Mid.N. N.'s Dr. somewhat drown my manly spirit.Mler.of ienice, ii mineing steps into a manly stride . . spending his manly marrow in her ...All's $W_{\text {ell, }}$ ii. 3 let's briefiy put on maniy readiness ...Aacbeth, ii. 3 this effusion of such manly drope..... King , $\overline{\text { olin }}$ iv. no; for my manly heart dotli yearn ... Henry ${ }^{\prime}$. ii. you are strong and manly ...........2 Hen ry $V^{\prime} I$. iv. 8 so bear I thee upon my manly shoulders - y. my manly eyes did scorn ............ Richard III. $\mathrm{i}$. be manly aud take comfort ............ Perirles, iji. I MEre on his mauly breast ....... Romeo \& Juliet, iii. MANNA-drop manna in the way. Mier. of Terice, vi 1 the eastle is royally manned ........ $\mathrm{I}-\mathrm{iij}$.

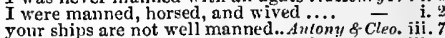
your ships are not well manned.. Antony \& Cleo. iii. 7
MANNERS-manners nre more gentle. 7 empest, ii. 3 as disproportioned in his manners $\ldots$. here's a million of manners.... Tuo

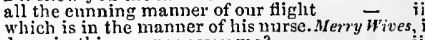

dares in this manner assay me?

all ehecks, rebukes, and manners.... - iii.

what manner of man? (rep.) ...... Tuelfth Night, i.

tlierefore it charges me in manners .. $=$

have you no wit, manners, nor honesty -

the manner of his gait.

but in strange manner
fets down the manner how

what manner of man is he? .

what manner of man is he?........ - iii.

in most uneven and distracted manner

in tlis

now manner aceused (rep.) ....... Afuch Ado, iv.

in

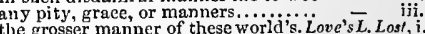

the manner ot it is, I was taken (rep.)

my lady, (to the manner of the days)

to his blood, I am not to his manner

of lineaments, of manners, and of spirit $\overline{\bar{L}}$

if we judge by manners; but yet......

or else a rude despiser of good manners
good manners; and if thou never (rep.)

good manners; and if thou never (rep
that are good manners at the court ..

what mauner of man? Is hi

ves, one; and in this manner.

as you have books for good manners.

suceed thy father in manners

which lay nice manners by, I put..

and mark the manner of his teacling

thot elanges thus his manners $\ldots . . W$
what manner of fellow was he that ..

What manner of fellow was he that

is there no manners left among maids?

the manver of four bearing towards.
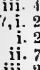$$
\text { iii. }
$$

iv.

iv. 2
iv. 3
iv. 3
iv. MANL1K E-more manlike than Cleopatra -
MANLY-a most manly wit ......... manly as Hector, but more... Troilus \& Cressida, iv. 5

where manners ne'er were preached!
heard it was ever his manner......Meas. for $\bar{M}$ eas. iv.

have lent a man any manners........ 


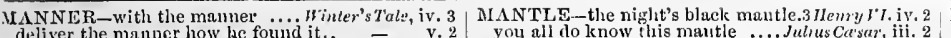
deljver the manner how he fouind it.

with the manner liow she came to it.

with the manner low she cune to it..

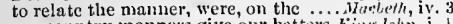

our country manners give our betters. King John, i.

than thou and John in mumers...

not our manners, reason now (rep.)

nny, it is in a manner done alrealy, pichard II. i.
whose inanners still our tardy apisll.

you have, in manner, with your sintul $=$ ii.

these external manners of lument.

the manner of their taking may....

what manner of man is lic? (rep.) ... Henry $\mathrm{H}$. it.

and wert taken with the manner .... -

good manners be your speed $1 \ldots \ldots . . .2-$ iij. 1

your manner of wrenching the true..2

and tavish minners mect togeticr.

aud hash min how this action (rep.).....
the manner
the seasons change their manuers...

some dishonest manners of their lite ... Henry $f_{\text {iv }}$ i. 3

the pretty and sweet manner of it....

we are the makers of manners, Kate..
all manner of men ...........

the treacherous manner of hi

it is more than manners will ......

as crooked in thy manners as thy...2 2 Henry III. $\mathrm{y}$.

to scorn us in this manner? .......3 Hemy VI. iii.

the manner and the purpose of

that no manner of person have $\ldots . .$.

whom our manners call-the prince.. -

in despera te nanner daring......... Henry $\bar{V} I I$

to see a nobleman want manners

men's evil manners live in brass

what manner of man are you? iny lord

will make my boldness manuers

among them, (at least, good manners)

in fellest manner execute your arms.

'gainst the authority of mann

instruction, nanners, mysteries

as lamely as their manners!

thon dost affect my manners.......

I pray you, in wholesome manuer

manner of it, gentle Casca (rep.)...
she is dead, and by strange manuer

but the manuer of his speech..... Antony \& Cleo. iv.

what manner o' thing is your crocodile?

in Alexandria, heres the manncr of

can we, with malners, ask what

you all do know this mantt

put my tires and mantles on him......

the green mantle of the standing poul

witl thy black mantle

look, the morn, in russct mantie elad

MANTLED pool beyond your cell

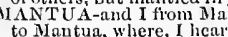

to Mantua, where, I hear....

is Licin, born in Mantua

of Mantua. Of Mantua, sir?

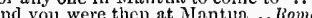

for then thou canst not pass to iintua

light thee on thy way to ijantia...

Romeo bear thee hence to Miantu.........

Fale sencl a triat with speed to Mantua

from Hant ua: what says Ronco ....

my speed to Mantua there was stayed

in post he came from Mantus.

IANTUAN-old Mant uan! (rep.)....... Lores L.

IIANURE-shall manure the ground

with idleness, or manured with industry. Olhello,

MANUS-serpents in his manus
IANY-COLOURED messenger

MANY-HEADED multitude.

IAP-than are in the new map... Treely/h Night, iii.

peering in maps, for ports..... Mercizant of $i$

thou map of honour; thou king .... Fichard
upon it! 1 have forgot the map .... I Menry I

look in the maps ot the orld

I see the map of honour, truth

if you see this in the map of ny

Henryl. iv. 7

Michard III. i.

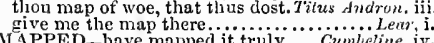

MAPPEDY, closet war......... Troilus \& Cressidet
MAR-yon mar our lahour............ Tenepest,

and mar the concord with ...Two Gen.... of Irerona, $\mathrm{i}$.

men their crcation mar... Neasurefor. Measure, ii.

you'll mar the light, by taking it....

what mar you then, sir? $($ rep.)....As you Like

what mar you then, sir? (rep.)
I pray you, mar no more trces

I did not bid you mar it.....

and mar the seeds within!

Taming of Shrew, iv. 3

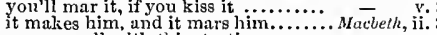

yout mar all with this starting

winter mars our hoped-for ha

that for ever mars the honey ....Henvy III. iii. 2
makes gods, does still mar men. Timon of sthens, iv.

and mar men's spurring

you'll mar all; I'll leave you

the devils mar five

ere the sea mar it ................

ride, run, mar a curious tale

when brewers mar their malt.

to mar. By my troth (rep)

it makes us, or it mars us ...........

ARBLE-a marble to her teal's.Meas. for Meas. iji.

who was most marble there monument!

liun ts it, more than marble hard. Comedy of

whole as the marble, founded as.

and much rain wears the marble.... $\overrightarrow{\text { and }} \overrightarrow{\text { iii. }}$

peep through thy marble mansion ... Cymbeline, $\mathrm{v}$.

did turn to marble......................... Tndronicus, i
oped his ponderons and marble jaws.... Homlet

by yond'marble heaven, in the due... Ohello,
MARBLE-BREASTED ty rant ... Tuetf

MARBLE-CONSTANT; now..... Antony of Cleo.
MARBLED-the marbled mansion. Timon of $A t h$.

MARBLED-IIEARTED fiend

if you do meet Horatio and Marcellus.. Hamlet

now it burns, Marcellus, and myself

stay and speak; stop it, A
Marcellus? my good lord

gentlemen, Marcellus and Bermardo

MARCH-take the winds of M

with much expedicnt march

in warlike march these greens

we step after a stranger march upon

dared to march so many mile
while here we mareli apon the.

while here we marels upon the

marcli on, and mark king Richard...

marcll sadly at'ter: pracc my

well-besecming ranks, march

the earl of March hath lately ........ Henry 1

on Thursday, we ourselves will murch

inust we all march? yea, two and two

worse than the sum in March ........
our soldiers shall marels tliroigli ...
HARCIl-I'll not madel throwgh
the villains narch wide betwix

suffered his kinsman 1 lawel $\ldots$......

let our trains march by us......

they wh her sot't month, and mi

mort de ma vie! if th

and famished in tlicir marel.

be willing to march on to calais
Linglisile

march to the brichge; it now draws

now soldiers, march away .......

and march vuto liim straight

rojal Chartc

etrl of Mareh (rep.

earl of March, naryed the duke of

come, let's march towards Londo

brave earl of IInerch (rep.)...........

to London will wc masch amai

towns as they do mareh along ........

but mareh to Lonclon with ..........

march amain to London (

as we march, our strength.

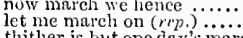

thitlier is but one day's marc

marel God's name mareh $\ldots . .$.

march patiently along, l..... Thoilus \& Cressida, v. 10

but, march, away: llector is dead.... - v. II

strike a frce march to Troy! ........
march, noble lord, into onr city. Timon of $\overline{d t h e n s,}$

swords may mareh from hence....... Cor iolanks, i.

beware the ides of MIarch (rep.)....Julius Casar, i.

sir, March is wasted fourteen days ...

march gently on to meet him

the ides of March, the i begun

Alexandria make a jolly march.......

so through Lud's town march ...... Cymbetine,

we will come: march away.

come, marcli to wakes and fairs

$\overrightarrow{\text { I.ear, }}$ iij. 6

with solemn nareh, goes slow and sta
the conveyance of a promised march

MARCH-CHICK! how came...........

when we first marched forth

marched up to my hord of Lancaster. Henry $I V$. ii.

as he in is marched to Bourdeaux

with colours spread marched th.

we marched on without impediment. Ric - ii.

MARCHES-his marches are expedient. Kino John, ii.

they of those marches

in our marches throu.

in our marches through the country
tor in the lies lere, we heard

dreadful marches to delight ful.

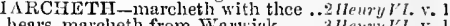

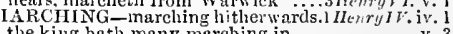

the king hath many marching in

with rainy marching in the .......

Charles? for $\mathrm{I} \mathrm{am}$ marching hence

chareng hence...

and bravely marehing, it hath served

at Dunsmore, marching litherward.3 Henry Vl. v. 1

the enemy, marching along by them - iv. 3

British powcrs are marching hitherward. Lear. iv.

MARCIANS_honse o' the Mrarcians. Coriolunus, ii. 3

hail, noble Mrarcius! Thanks...

IIarcius, 'tis true that you have iatei $=$

was ever mau so proud as this Jiareius!

will then cry out of Marcius

lionours are to Mlarcius, thoush Haru

to Marcius shall be honours, though

dear than thine and $m y$ good Alareiu

thou art left, Marcius; a carbunuld

'tis Marcius: let's feteh him oft'......

thou worthicest Marcius! go, sound.

given to Lartius and to Marcius battle
Ogods! he has the stamp of Marcius

I know the sound of Marcius' tungue
MIarcius, we iave at disadvantage .

Marcius, we inve at disadvantage
as I guess. MIareius, their bands...

if I fy, Mareius, halloo me like ....

Marcius, his name? By Jupiter, forgot

five times, Mareius, I have fought ..

the people, for thicy love not Murcius

plebeians would the muble Marcius.

you blame Marcins for heing prond?
gou must be saying Marcius is proud

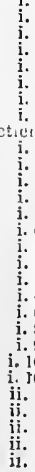


MIARCIUS-boy Mareius appronelacs, Coriolanus, ha! Marcius coming home? ( $/ \mathrm{ep}$.) these are the ushers of MLarcius. tis thoulut that did fight within ... fiom whenee enme that Anens Mincius Marcius wonld have all trom you ( $(2)$ help, help Mareius! help, you that. where, if you bring not hineius. this mould of Mareius, they to dist o Mareius. Mareins, each word thuu all noble itarcius, ó let me twine worthy Marcius, liad we no quarrel. enemy; yet, Mareins, that was men hearing of our IIrcius' banishment come what talk you of Mareius?... that Marcius, joined with Alfitius.
may wish good Mareius home again if Itarcins should be joined with.... this Mareius is grown from man the dislodged, and Mareius gone

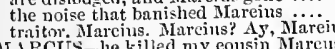
M.ARCtS-lie kilied my eousin Marey when MIarens Brutus grows so covetous son of Marcus Cato, ho! (rep.)

fortune does of Mareps Crassus' death Mrodes, pays this for Mrareus Crassus Mareus Andronieus, so I do aff'y .. Titu gentle tribune, noble brother Ma reus suffer thy brother MIareus to inter rise, Mureus, rise; the dismal'st I know not, Narcus; but, I know. eoines with our brother Alareus here? why, Mareus, so she is

lik, look. Minter mark, Mareus, mark! I under Marcus, unknit that sorrow-wreathen why, Marcus, no man should be mad hark. Marcns, what sle says. what dost thon strike at. Mareus. good unele Marens, see how swift... Mareus, what means this? ia....... hourcus, look to my house ......... Marens, attend him in his eestasy be you remembered, Mareus, she's gone Mireus, we are but aliruls
bint metal, Marcus, steel to

vou are a good archer, Mar

Miareus, the post is

here, MIarcus, fold it in the oration........ come, Mareus, let's go; Publius minto my father, and iny uncle Mreus, my brother! tis sad (rep.

unele IIareus, sinee 'tis my father's thy brother Mareus tenders on ....

Mrareus lacelese, bes DIAN - tholl eun witl

to the monument; Mardian, go tell him hence, Mardian, and bring me low he

MAliE-shall have his niare aga

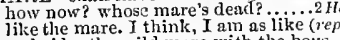
and rides the wild mare with the boys

and inares together, the (rep.). . Antomy
MARESHAI,- to the lord mareshal .. I Hen

IARESHAI - to the lord mareshal.. I Henr! I $V$. iv.

the mareshal of France. Mousieur le Fer.. L"ar,

MARRARELON hath Doreus ... Troilus \& Cress. hear me eall MIargaret, Hero (rep.).

Hero and Iargaret have by this played that I have to-night wooed Maryare and tholight they, Mhargar IIaryaret.. mav me court Iarqaret in Hero' shall faee to face te bronglit to Margaret we'll talk with Margaret, how her in so high a style, IIargaret, that no man a most manly wit, Margaret, it will not if youl use them, Margaret, you must then my eousin, Margaret and Ursell Mingaret, my name, and daughter..I Henry $I^{\prime}$ t'll win this lady Margaret; for whom? fair MIargaret knows, that Suffolk shall Suffolk ever have of Margaret. of beanteous Marearet hath astonished that Margaret may be England's... but MIargaret, that is danghter to. as is fair Margaret, he be linked . .

that Jaly Margaret do vouchsafe ..... to marry primeess IIargaret, for .......
MARGARET--the lady Margaret and dame Margaret, kneeled to me .. ay, Nargaret; my heart is drowned. a thank thee, Margaret [Col.-Meg. then dame Jargaret was ne'er thy. in thy palace perish Margaret die, Inargaret! tor Ienry weeps .....

eome, Margaret, God, our hope ontrun the heavens? good Margaret pardon me, Margaret; pardon me .... stay, gentle Aargaret, and hear me where's eaptain Mlargaret, to tenee you them, O Margaret, thus 'twill be; and thou of England, worthy MIargaret, sit... now Margaret must strike her sail $\ddot{0}$ be plain, queen Miargaret, and tell thy injurious Margaretl And why not queen queen Margaret, prince Edward, and draw near, queen Margaret; and be.
still is tiriend to him and Margaret hers, and thine, and Margaret'a... is Wrwick triends with inargaret? your grace have done with Margaret

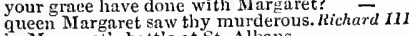
in Margaret's battle at St. Albans.... by me; and ends in-Margare and say, poor Margaret was a prophetess now Margaret's eurse is fallen upon die the thirall of Margaret's eurse as sometine Alargaret dicl to thy father thus Margaret's curse falls heavy

remember Mlargaret was a prophetess

iji. MARGEN on both sides the leaf, margent and all

you must be edified by the margent.... Hainlrl, v. Margery, your wife, is (rep.)....Nerch. of Venice, ii officions with Lady Margery

2 Henry $r i$

Miargery Jourdain, the cunning. ...meo \& Jul IAR IA-a stoop of wine, Mar
Haria onee told me, slhe did good Miria, let this fellow be

out of question, 'tis Maria's hand

Naria writ the letter, at sir Toly's...
sweet Nraria, empress of my love! Love's $\bar{L}, \mathrm{l}$ you do not love Mar

what says Muria?................. Jesu Muria! what a deal of brine. Romeo \& Juliet, ii. Marian, I sayl a stoop of winel... Tuelfih $\mathrm{Ni}$ Marian'a nose looks red.... Love's L. Lost, Marian Haeket, the fat.. Taming of shrew, (induc.) maid Marian may be the deputy's..1 Henry I $V$.

M ARIANA-speak of Mariana.. Meas. for Meas. resides this dejeeted Mariana not yet made known to Mariana... his eompany at Miariana's house .... you must pardon for Mariana's sake MARIGOLD, that goes to bed.....Winter's Tale, iv.

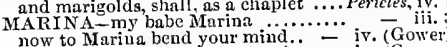
now to Mariua bend your mind..

Marina's life seeks to take (rep.) .. -

and they have seized Marina: let leer go

east their gazes on Marina's face ....

Marina was she called........

my name, sir, is Marina (rep.)

this is Marina: what was thy mother's
tell Helieanus, my Marina, tell himu..

of the spheres: list, my Marina

lend your arm. Come, my Marina..

a maid-child eallerl Marina (rep.) ...

MARINER-Epeak to the

all, but mariners plunged .......

the mariners all under hatches.....

shalt thou find the mariners asleep.
your mariners are inuleteers.....

mariner, say, what eoast (rep.
MARITINI,-borders maritin..

MARJORAN; the marigold...... Winter's Tale, iv. 3
give the word. Sweet marjoram. Pass..Lear, iv. 6 give the word. Swcet

no drowning mark upon him

I pray thee, mark me (rep.)

nor set a mark so bloody

and do you mark me, sir? $\ldots . . . .$.

mark but the badges of these men .... verona, $^{\prime}$ ii.
by these special nuarks ....T Tuo Gen.

mark the moan she makes..........

but mark the gequel master.

政,

pray you mark: genitivo, hujus .....

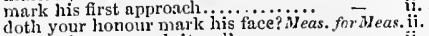
I besech you, mark it well.......... - ii. 1
M $\triangle$ RK me; to be rceeived plain. Meas. for M*as. ii. of which he made five marke.... mark what $I$ say; whieh you shaii. as much in mock as mark signior Benedick; nobody marks you. Mruehtado, $\mathrm{i}$. mark you this, on my allegiance

that I stood like a man at a mark...

I do spy some marks of love in her.. - ii. many a man doth mark Mid. N's $D r$. iii. 1 (song fairy king, attend, and mark...

but mark: poor knight, what dreadful nor mark prodigious, such as are.

a mark marvellous well shot (rep.

if knowledge be the mark, to know thee -

once more I'll mark how love can vary

they do not mark me, and that ...... mark what, Jacob did: when Laban Mer
mark you this, Bassanio, the devil ... mark you this, Bassanio, the devil
who (God bless the mark!) is a kind

mark me now; now will I raise ....

0 upright judge! Mark, Jew (rep.).

be trusted: mark the music

nork of my uncle's marks (rep......

none of my uncle's marks (rep.) As you Like il, iii.

mark how the tyrant writes

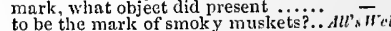

to be the mank of smoky miskets?.. a linndred marks, my Kate does.....

mark, and perform it well...

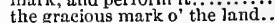

mark ou eon tract. Mark your divore mark thou my words................

Id bid you mark her eye....

and mark what way I make .........

a thonsand marks be levied .... Comedy of marks thou hadst of me? ( $(e p$.).......

asked me for a thousand marks (rep.)

with a thousand marks in gold ......

mark! how he trembles....

...... Macbeth, i.

mark, how they whisper ................ King John, ii.

thirty thousand marks of English coin -

therefore, mark, Solin hath...

and mark my greeting well

mark king Riehard how he

mark me how I will undo

didst thou not mark the king....

Richard 1 ...

God save the mark

three hundred marks with him.

mark now, how a plain tale shall....

yea, but mark, how he bears

of hargain, mark ye me... iikelilo....

a fellow of no mark, nor likelihood

thou hast saved me a thousand marks

eaper with me for a thousand marks.2 HenryI $V$. i

a hundred mark is a long loan

he was the mark and glass......... - ii.

he presents no mark to the enemy .. $\quad$ - iii. 2

fly to one mark .................... Hen ry $r . j$.

to mark the full-fraught man $\ldots . . . . \quad$ ii. 2

mark then, a bounding vajour in.... $=$ iv.

piece of knavery, mark you now (rep.) 二 iv.

bit mark; as, in this haughty .......i Henry ${ }^{\prime} 1$. ii.

if your grace mark every cireumstance - $\quad$ iij. 1
eall we to mind, and mark but this..

that's the folden mark I seek to hit. 2 Ilenry $r I .1 .1$

or hast thou a mark to thy self ...... - iv.

for reward a thousand marks........

nay, mark, how Lewis stamps ....... to pity, if you mark him ....

mark low well the sequel .......... then mark the inducement ............ - ii. mark you her eyes?................ hark you her eyes?................ but mark Troilus (rep.) ...... Troilus \& Cressid mark him, note him art a goodly mark

mark what I say; attend me.......... - v $v$ to mark me for his friend .... Timon of Athens, iii. whose tall the mark of his ambition is $=$ mark me, and do the like ............ he fought beyond the mark of others wlyere it did mark, it took .......... from the people. Mark you the gown himility; mark his.. in the official marks invested........ mark you his absolute slall? ........ mark you this, people? To the roek A.ufidius, and you Volsces mark

$$
\begin{aligned}
& \text {. } \\
& \text { i. } 3 \\
& \begin{array}{l}
2 \\
.1 \\
6
\end{array} \\
& 4
\end{aligned}
$$


MARK-did nark how lie did sinake.Julintsa'sar, i. 2 MARKET-PLACE-the market-place Coriola I did not mark it ....

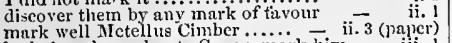
look, how he makes to Cresur; mark him look, how he makes to cresur' m

now mark him, he hegins again $\ldots \ldots$ med
mark how the blood of Casar followed

mark sirrah,

bcyond the mark of thought

this be worth your hearing, mark it. Cymbeline, $i$.

nay, soine marks of secret on

star; it was a mark of wonder $\dddot{\ldots}$ a..... indronicus,

not mark me; or if the did inark.

who marks the waxing tide.

mark, MIarcus, mark I I nnderstand

tlyan foemen's marks upon lis

hits the nuark his eye

I know it by this mark .....................

all graceful marks, that Cleon's wife

mark me; you mist seem to

mark it, nuncle; have more than

for by the marks of sovereignty

do you mark that, my lord? .........

Toin, away; mark tlie high noises

mark but the penning of it .......

I will preath to thee; mark me 07.

a right fuir mark, fair coz

blind, love eannot hit the mark.

thou dost not mark me.

bid her, mark you me, on we winesday

like the king? mark it. Horatio

mark me. I will. MIy hour is
do you mark this. Reynaldo?

mark you, your party in converse

in her duty and ober

mark it:- - you say, right,

you are naught; I'll murk the play.

you are naurk his favourite flics

say you? Nay, pray you, mark (rep.)

will he, nill he, he goes: mark you that

that is Laertes, a very noble $y$

and I (God bless the mark!) .......

you sliall mark many a duteous ........

palm of this hand? didst not mark that

contempiation, mark and denotement of

mark the fleers, the gibes, and notable

I aay. but mark his gestire..............

M A RKED - not marked, or not .........1urh $\overline{d d}$

I have marked a thousand blushing.. -

yet marked I where the bolt ...Mid. N.'s Dream, ii. 2

and marked you both............ Love's $\mathrm{I}$

mach marked of the melancholy

perhaps you marked not ...... Tami

the fates have marked to bear.... Comedy of Er
when we have marked with hlood....... Macbet

are made, not marked; where violent

by the hand of nature marked....... King John, i甘. 2

more are men's ends marked

of an oatl, marked with
but 1 marked him not

i Heñyll

signs have marked me extraordinar

go to, but marked him not a word

that thou art only marked for

if we are marked to die $\ldots$..................

Henr!n

or Kent, matked for thies to be.....3 Henry Fi. ii. 2

Richard marked lim for the grave *... kichard 111 . ii. 1

their witchcraft thus have marked me

marked you his lip, and eyes? ....... Coriolun

marked ye his words?. $\ldots \ldots . . . . . .$. ultus Capsar, iii.

to this your son is marked......... Titus Andron.

for villains marked with rap.

marked he your music?.

MARKET not for idle marketa. Tuelfith Night, iii. 3 and he ended the market

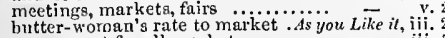

you are not for all markets...

I can buy me twenty at any market.....Mocbeth, iv. 2

win before my horse to market ..... Richavd III.

search the market narrowly (rep.) .....?'er

hast thou cried her through the mark.

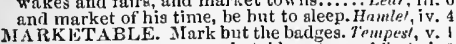

we shall be the more marketable... As you tike it,

MARKET-CROSSES, read in........ lllenryl

MARKET-BELI is rung $\ldots \ldots \ldots \ldots$. He

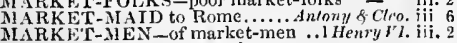
A $A$ K $T$ -

as market-men for oxen, sheep ...... of
MIARKET-PLACE; and then.. Two Gren. of

eat his heart in the market-place ... Much . Adn,

more toward the market-place ... Tuming of sh.

in open market-place produced ...... II Inery $\mathrm{F} i$.

advance it in the market-pince.

thy trumpet in the market-place..... Coriolan

would he appear i' the markct-place

give way; he shall to the market-place ineet on the market-place: we'll attend -
I luave been i' the market-place $\ldots . .$.

to the market-place; you have put me -

mother, I am going to the market-place -
bid them repair to the market-place
he fell down in the market-place..
vulius
Casar,
i. 2

upon the market-place, hooting ....

produce lhis body to the market-place

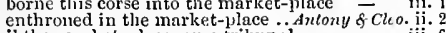

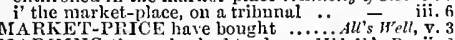

IIARKING the embarked traders... Hid.N. N's $D r$. Hi.

but little of the marking of it .... Love's L. Lost, i.

the malady of not marking..........2 Henry 1. i.

MARL to a clod of way ward marl?... Irueh Ado, ii.

MARMOZET - the nimble marmozet... Trmpesi,

IARQUESS-ever marquess gave.

lord marquess, kncel down ...........

Hastin; lcarn it, lcarn it, marquess

MARRED-or else our spell is marred. Tempest, it.

you had marred all else ...Measure for 'Mearure, 11.
then the play is marred ......Mid.N.'s Drean, iv.

married, is a man that's marred........Al's cell, ii.

that thou hast marred her gown. Taming of Sh. iv.

there all is marred.................. I Hemry I'

repetition of what thou hast marred

there is himself.red his fortune ..Joriohnus, il.

soon marred are those so early made. Rnmeo of Jul. $\mathrm{i}$.

af, that's spolie, is marred.

twas a sweet marriage ..............

otur marriage hour, with all ..Tu $\bar{T}$ Gen. of $/$ er. ii.

and desire a marriage between ..... Merry Wives, $i$.

question is concerning your marriage

her norriage vow, and a thousand

prevents a bad marriage.

he promised her marriage.

some speech of marriage betw

intelligence of an intended marria..... Nuc $\bar{h}$ ddo v.

nowe the day of marriage .............

how canst thou cross this marriage?

presently go learn their day of mairiage -

thave railed so long against marriage

in the new glose of your narriage

holp to effect your ensing marriag

only to the plain form of marriage

in the state of honourable marriage...

afteruard in way of marriage... Hereh. of $\mathrm{T}$ e

and summon him to marriage

the contract of her marriage......... you Lik

or the niarriage is not law ful.

can tell you what marriage is ....

according as marriage binds

marriage, sooner than thy wickedness. All's $H_{c} l l, \mathrm{i}$.

there were no fcar in murriage.

do you know he promised me marriage?

as promising ber marriag

ger........

'point the day of marringe ............
good, methinks, to steal our marriage

issurance of a dower in marriage 'twixt

that have by marriage made thy

fat marriage. How dost (rep.). Comedy of Error's, ini.

rites of marriage slall be solemnized. Fin $\bar{y} J_{o} h n, \mathrm{ii} .2$

ye violate a twofold marria

by the which marriage, the line

the best makcr of all marringea ........
troubles oft the bed of blessed marriage

prepare we for our marriage

marriage, uncle? alas! my years....

marriage is a matter of more...

got an empire by his marriage

to effect this marriage ....

king in lawful marriage .......
by this league and marriage

matter of marriage was the charge

hasty marriage seldom proveth well

about the marriage of the lady Bon

than any home-bred marriage

what said lady Bona to my marringe?

yet in marriage I may not prove

yet in mariage ina motched in narriage

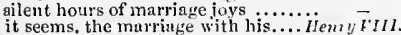

and all these for his marriage........

whin decmed our marriage

respecting tlis our marriage to woo a maid in way of marriage

such a mad marriage never was

for mocking marriage with a dame..

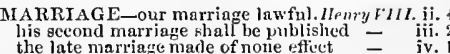

in her marriuge iny consent be.. Timon of d/hens,

and give out conjectural marriages.. Coriolams, i.

within the bond of marriage....... Jutius Casur though I make tlis marriage for my

more in the marriage, than the love

with marriagre thercfore was he...... Cymbeline, $\mathrm{v}$. by Juno, that is queen of marriage this most pompoue marriage feast $=$ iii. (Gower) well, think of marriage now ..... Romeo \& Juliet, i. thy purpose marriage, send ne word

must conbine by holy marriage

what says he of our marriage?

delay thia marriage for a mon
hastes our marriage, to stop

lest in this marriage he should be...

and to the marriage her nurse is priv. and with dirge inge her nurse

coldly furnish forth the narriage tabi

the vow I niade to her in marriage.
futher's death, and ouro'erhasty marring

I say, wc will have no more marriages.

the instances, that second marringe moy
makes marriage vows as false as dicen

so opposite to marriage, that she shunned oupello.

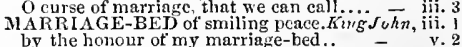

troubles of the marriage-bed.. Comedy

MARRIAGE-DAY, I'll beautify

y of Errors, ii.

their stolen marriage-day was.. Romeo \&. Juliet, v.

IARRIED-marriel Ty

when we are married, and have.....Mern y wives, $j$. I

so rails agrainst all married mankind

master Slender hath married.

at the deanery, and there marricd

have married her most shamefuli

of the strachy married the yeoman

having been three months marrierl.

before lo married with her (rep yeacd - v.

her should this Angclo have married - jii.

but if lie be a married man $. . \ldots \ldots . .$. - iv. 2

what, are you married?............ - v. 1

Benedick the married (rep. $v$. $1 \& \ddot{4}\rangle$... much $A d$, , i. i

not tlink I should live till I were married -

when are you marricd, madam? ....

to be married to her, friar.....

not to be married, not knit my soul.

let's have a dance ere we are married

lords and ladies more married.Mid. N.'s Dream, iv,

unpleasing to a married ear!....

rather be married to a dcath's ...Mer. of lenice, i.

at that time I may be married to

Antonio, I am married to a wife

the forehead of a married man ....As you Litie it, iij.

be narried under

better to be married of him than....

we must be married, or we ...

to-morrow will we be marrice (iep.) -

your lord and master's married......... All's Well, ii. 3

they have marricd nie

the king lad maried him arainst.

unless thon canst say they are marricd - v. 3

when be married; but here she comes

thon must be married to no man....

Kate, we will be married o' Sunday

and Petruchio should be married...

Iwill be married to a wealthy widow

I knew a wench married in...

have you married my danghter.

we thrce are married, but you

have married a shejlerd's

whose weakness, married to... Com ...

w's I married to her in my dream?

gone to be married! gone to swear..
our inward souls marricd in league.

against the blood that thou last nuarried

betwixt me and my married wife.... Richnd $1 I$.

their spirits are so marlied in $\ldots \ldots 2$ Henry $1 \mathrm{~V}$

to kiss hefure they are married

a marricd man! that's most $\ldots . . .$.
who narried Edmut

iHenry $l^{\prime} l$

heir unto the erown, marricer hieliard -

whilst I think I am thy married wife

whilst I think I am thy married wife 
MARRIED-not a maid be married..2 Hewry $I^{*}$. iv. your king married the lady Grey?..3 Henry VT. i1. must be married to ny brother s.. Richam Henr. iv but now married to one above ......

the king hath in secresy long waried

the king hath in secresy long narried

and is morried tlee where it may see

I loved the maid I married

a married man, or a bachelor? (rep.).Jul. Ceester, ii .

to three kings.. Aniony \& Cleo. i.

what says the married woman?.......

madam, he's married to Octavia (rep.)

pray you, is he married to Cleopatra?

a master married to your good service

a widow that late he marricd.

I mean, that married her, a alack ..... Cy

it must be married to that your diamond -

you married ones, if cach ol you would
and in our temple was he married.

married your royaity, - was wife to

till she be married, madam, by

live to see thee married once ...Rome
stands your disposition to be married?

every married $[K n t$. several] liname

if he be married, my grave is like to
Laurence cell be shrived, and marrie

an hour but married, Tybalt murder

she shall be marricd to this noble

I would, the fool were marricd to

Think it best you married with .....

married to the [Col. Knt.-to-morrow]

because he married me before to Romeo? -

best married, that dies married young

Paris should have married Juliet

I married them; and their stolen .....

married with my uncle, my father'

she marricd: O most wicked speed .......

those that are married already, all but one
are they married think you? 'Tinly .... Olnetho

but, I pray, sir, are you fast married

true, I have married her; the very hea

true, I have married her; the very head $=$ i. 3

Whore of Venice, that malried with othello
MARRIES-your brother marries.. As you Lihe

that she, which marries you, must....A All's Well, v. 3

IARRING-it is marring indeed .. Merry

I doubt, prove mine own marring. 2 Henry $1 \%$. (epil.)
making, and marring fortunes... Anton!s 8 Cleo. iil. 9

he were manly marrow in

the minds and marrows of

dry up thy marrows, vines............

when crouching marrow, in the bearer

MARROWLESS, thy blood is cold.... Miacbeth, iit.

shall she marry him? (rep.) . Tuo Ge

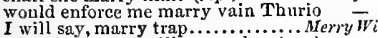

why if it be so I will marry her (rep.)

youn tood dowry, marry her?....

do not marry me to yond' fool

and marry her nt Eton ....

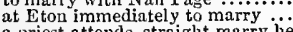

a priest attends, straight marry her..

I could marry this wencli for this. Tuelf: Nis

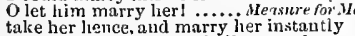

take her lience, and marry her instantiy
fet her appear, and he shall marry her

do not marry ine to a whore!

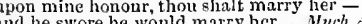

I would not marry her, though she.

Claudio shall marry thic damoliter

I did never think to marry ...........

he swore he would never marry

tou come to marry her

the whule assembly, and not marry her

disgraced her, when you should marry

and swear to marry her.

and swear to marry her...................

hatl my consent to marry her (rep.). . Nid. $\bar{N}$. D

do you marry lim ..................

there, gentle Hermia, may I marry thee $-\overline{\text { orry me to one Frances }}$.... Love's L. Los',

if thou marry, hang me hy the nee

if 1 should nirry him (rep.). Nerchant of tenic

as it may be, 1 will marry thee.......

be the priest, and marry us (rep.)....

that must marry this woman........

marries Aliena, you shall marry her

you'll marry me, if 1 be willing? ...

if you refuse to marry ne

word, Phobe, that you'll mariy me
Silvius, that yon'll marry her.........
the reason why thou wilt marry ...... All's $w^{\prime} e l l$,

I do marry, that I may repent

to know why I should marry her....
after this, to marry her, I'll add three

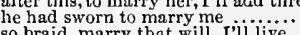

go braid, marry that will, I'll live
his many protestations to marry n
IIARRY - yet you desire to marry

slee, which marries you, must marry me

ald marry him to a puppet. Taming of Shr

will you, nill you, I will marry you

plcase him come and murry her

and marry sweet Bianca with consent

did he marry me to fanish me?

sweet maid, we marry a gentler.. Winter's Tole,

marry her; ind, with my best en

we sharry, it' you will, sir, no remedy

well, I will marry, till the din

of all husbands that nuarry wives.... $k$ is

these two princes, if you marry them

whom I have weckly sworn to marry.
to marry me, and make me my lady

to marry me, and make me my lady
thou art to ninrry lis sister Nell

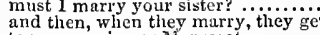

to marry princess Mitrraret..........2 Herm

I'll marry Warwick's youngest..... Richurd IiI.

mariy may slie? marry with a king?

whond 1 will marry strajght to Clarence
murder her brothers, and then marry her

king's sister: lie shall marry her.. Henry $V I I L$

to say, they are fools that marry. Jutius Ceesar, iii.

to marry me with Octavius Caesar

unless a man would marry a gallows. Cymbeline,

I shall never marry like wy sisters

so beggars marry many .............

marry, that marry is the very ...Romeo \& Jutiet, $i$. 3

I will not marry yet ....................

give consent to marry Paris ........ -

wilt needs marry, marry a fool

kill a king, and marry with his brother
why did 1 marry?

gives it out, that you shali marry her (rep.) - iv.

ARRYING 'mong his subjects?....... Tempest, ii.

you may, by marrying ..................
in the law full name of marrying.....
at the doctor's marrying my daugiter

marrying a punk, my lord....... Weas. for Meas.

in murying the renowned Claudio...Much ddo,

duke of York, marrying my sister... I Herry '?

marrying her, which I must reach . Richord WI. i.

did deceive her father marrying you ... Othello, iii. 3
IARS'S hot minion is returned........ Tempest, iv. 1

thou art the Mars of malcontcuts .... Nerry Wives, $\mathrm{i}$.

the armipotent MIars, of lanccs... . Love's L. Lost,
Hercules, and frowning Mars ... Mer. of Venice, ii

Mars dote on you for $\mathrm{h}$

liigh curvet of Mars's fiery steed

- ii. 1

this very day, great Mlars, I put

the seat of Mars, this other Ëden ....Richard II. ii.

the Black Prince, that young Mars.. ${ }_{\text {then }}-1 \%$. iii. 3

the mailed Mars shall on his altar! . . $v$. i. (chorus)

big Mars seems bankrupt.

Mars, lis true moving ........

Henry VI. i.

and drave great Mars to fnction................

by Mrars his gauntlet, thanks!

the forge that stitly'd Mars his helin

as red as Mars his healt................

thou valiaut Mars!..............

as if he were son and heir to Mars

hear'st thou, Mars? Name not

and think, what Venus did with

and speak as loud as Mars ..........

with Mars tall out, with Juno chide.C

hammers fall on Niars's armour.

an eve like Mars, to threaten .....

ARSEILLES-is at Marscilles........All's $\overrightarrow{\text { Well }}$

his niajesty comes post from Marseilics -

MARSH-the enemy is past the marsh. Richard HI. 1.3

becomes the marshal to my will ... Hid.N. N's Dr. 11. 3

marshia, command our officer's ....... Richard II. i. I

v. 2 except the marshal, and such officers

lord marshal, let me kiss my

order the trial, marshal, and begin

the marshal, and the archbishop.....

be assured, my good lord marstial
Norfotk, he to be earl mnrshal.

marslial the rest as they deserve

thcse mutualities so marslial the way... Othello, ii.

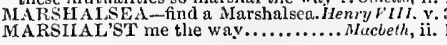

MIART-so smug upon the mart... Mer. of Venice, iii. at any Syracusan malts and fairs. Comedy of $\mathrm{Err}$. $i$. I'll meet with you upon the mart

to fetch you from the mart home...

at first I sent lim from the mart ....

deliver to me on the mart

on the natu

come to the mart,

In to the mart, and there for Dromio

to sell and mart youre mart

to mart as in a Romish ste

we lost too much moncy this mart... Cymbeline, i.

eirn mart for implements of war...... Hamlet,

MARTEM - ad martem, that's for. Titus tudrom

AR-TEXT, the vicar (rep.).... As you Like at, jii. 3

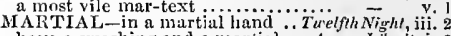
have a swashing and a martial ... As you Litie it, i. 3

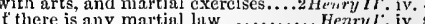
it there is any martial law .......... Henry $l^{\prime}$ iv. 8
thou, mirror of all martial nen?.... Henry $r x . \mathrm{i} .4$ a maridi and be so martial I.

warlike and martial Tulbot ........ - iii. his martial thigh: the brawns of .... Cymbetine, iv. with martial stalk hat li he gone by .... Hamlet, $\mathrm{j}$. MARTIN - Saint Martin's summer $\because$ Henry $\%$. $i$. MARTLEMAS, your master? …2. Henry $1 \%$. ii. MAPTLET-like the martlct.. Merch. of Yenice, ii. 9 temple haunting martlet, does approve. Macbe'h, i.
MARTYR-faitl's maityrs in love..2 Ifenry IV for Oldcastle died a martyr............ how I mean to martyr you.... Tilus Andronicus, v.

MARTYRED-martyred thee? (rep.)..... Titus And. iii.

hated. martyred, killed!.......... Romeo \& Juliet, i

MARULLUS and Flavius for pulling. Jul. Casar, i.

I marvel your ]adyship takes .... Ticelfh Night,

may maryel, why I obscured .. Neas, for Mleas.

and that's great marvel

I marvel, thy master hath not

I marvel, why I answered not ...As you Like is,

you must not marvel, Helen, at my .. All's Well,

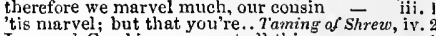

I marvel, Cambio comes not all this - v.

my marvel, and my message .... Winter's Tale, v.

no marvel though she pause..Comedy of Errors, ii. I

and 'tis no marvel, he's so lummorous - iii.

Charles; I marvel, how he sped ..... Hevry $V$ i. ii.

no marvel, an' it like your majesty..2 Hemy $V I$.

no marvel, lord, though it affiriglited. Richard 111 . i. 4

marvel, where Troilus is! (rep.). Troilus \& Cress . i.

who marvels then, when Ilelenus

you make me marvel great ............. Timon of $\bar{x}_{\text {thens }}$ iii. 3 and, to kill the marvel, shaili be.... Cymbetine, master, I marvel how the fishes ...... Pericles, ii. marvel, mark marvel that your lordship - iii. no marvel then, though he were ill...... no marvel, you have so bestiried....

of these gentlemen, this marvel to you.. Hamlet, $\mathrm{i}$.

MARVELLED-army marvelled at it. Coriolamus, v. 5
MARVELLOUS sweet music! $\ldots \ldots \ldots$ Tempest, iii. 3

husband has a marvellous iffetion.

a marvellous witty fellow, I assure.. Much ito,

a marvellous convenient place. Hid. N.'s Dream

I am marvellous hairy about the fice

a mark marvellous well shot
marvellous well for the pen

he is a marvellous good neighinou

the rogues are marvellous poor

you are marvellous torward... Toning of shrew,

that's a marvellous scarchin wine...

for they have marvellous foul linen.

solns in thy most marvcllons fice

is a marvellous falorous gent leman. to $_{\text {ichurd }}$ ir

she has a marvellous white hand. Troilus \& Cress.

a marvellous poor one............. Coriolanus, jy.

retirement, marvellous distempered ... Himle', it

you may be marveliously mistook

Ilenry $V$ iii.

AARVELL'ST-marvell'st at my words. Macbeth, iii.2

where, good mistress 11 ary?
mistress Mary, if you prized

二 ii.

for at Saint Mary's clapel ............. King John, ii. of Orleans and our daugh ter Mary. Henry VIII. ii. by IIoly NIary, Butts, there's knuvery - v. MARY-BUDS begin to opc.... Cymbeline, ii. 3 (song) pray God! she prove not masciline.s ir'mry VI. ii.

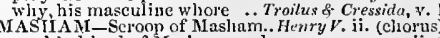
my kind lord of MIasham, and you...
lord Suroop of Mlasliant (rep.)........ 


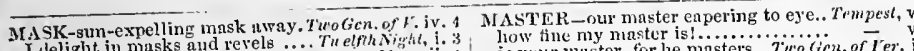
I delight in masks and rele ....ilents. for Mens. ii. as slanll play it in u mask.....Mid. N.'s Dreant,

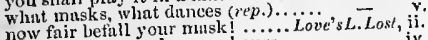
dances, masks, and merry hours ....

within your mask, and would aftori

prepare for this mask to-nighit? .Mer.
I will not say you shall see a runs.

whatl are there masks?...

no mask to-night

masks for faces, and for noses. harnessed miask, and unacivise

my favours in a bloody mask
death put on his ugliest nutsk

my mask, to defend my benuty..... Troilus \&.Cress.

slrows as fairly in the mask.

to mask thy monstrous visage?....... Jiklius $\overline{C r}$ sar,

with faees tit for masks $\ldots \ldots . . . . . .$. . Cymbeline,

these laappy masks, that kiss fair. Romeo \& Jul

we mean well, in going to this mask

since last yourself
thon know st the mask of night

her gloves, her mask, nor nuthing?.... oh hello,

MIASKLD, he was not sure...

mist lither mosked

come hither masked wo.................

we will every one be masked ...

be musked, the maskers come...

fair ladies, masked, are roses in their

wherein thou see'st me masked....... Corrornanks

give you up to the masked Neptu

and then we masked .............. Romeo ov's L. L.st, v.

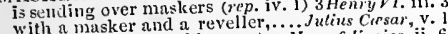

with $\mathrm{n}$ masker and asking mates. Her. of tenice, ii. 6

what masking stuff is here? ... Tamng of shchelh

masking tinging masons building roofs. H'try $l^{\prime} \cdot$ i. 2

builds stronger than the mason (rep.). . Hommete,

MIASONRY-on the plain masonry ....All'sell,

mass, and my elbow itched............Much Ado, iii. 3

mass, and mass, that it is

by the mass, there is ne'er a king.... Henry $I V$. ii. 1

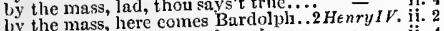

mass, thou say'tet true; the prince

by the mass, here will be old utis

by the mass, I was called
by the mass, I have drunk

mass, you'll pay him thenl
by thie mass, our hearts are

have cost a mass of public treasury...2Henry $r_{I}$ i. i. 3

mass, 'twill be sore law then

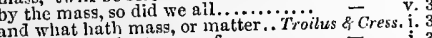

figure of the giant mass of ....

a moiety of that mass of moan.......

constringed in mass by the almighty - v. 2

noised, he hath a mass of treasure Timon of Ath. ive
come to you at evening mass?.. Romeo of Jutiet, iv. 1 i

by the mass, I was about to say........

by the mass, and 'tis like a eamel

this solidity and compound mass.... $=\begin{gathered}\text { iiii. } \\ \text { iv. } 4\end{gathered}$

of such mass, and charge, led
to't. Alass, I cannot tell. Cudgei...

I remember a mass of thin

by the mass, 'tis morning $\ldots \ldots \ldots \ldots$.... $=$ iv.

MASSACRE-triumpl in massacres! 1 HenryI I: v.

the general wreck and massacre .....
in all our bloody massacre, I muse..

your subjects from such massac

arch deed of piteous massacre........ find a days to masces, aets ot black niglit..... v v.

and massacres, aets ot black nighit. $\dddot{M}$.

MASSY - too massy tor your strength. Much Ado, iii

seems as massy as his club.......... Cressido, (proi.)

without drawing their massy irons

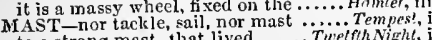
to a strong mast, that lived .......Tuelfor figror, i. ourselves at either end the nast.......

upon the high and giddy mas

3 Henry $v$ iti. 1

Somerset anotleer goodly mast?

like a drunken sailor on a mast ...Richard $\bar{T} I I$. iii. 4

the oaks bear mast, the briers. Timnn nf Athens, iv.

ten masts at each make not............... Lethre, iv. 6
MASTER-here, master, what cheer? ... Tempest, $\mathrm{i}$.

'tend to the master's whistle ..........

Prospero, master of a full poor eell ...

then appointed master of this design..

all hail, great master

close by, my master.
I thank thee, master

pardon, master: I wili be.

the masters of some merchant...

the masters of some mercliant...........

the master, the swablber .......... -

farewell, master, fitrewell, farewell =

$m y$ valiant master would destroy thee

this will I tell my master.

what would my potent master?

du you love me, master? no
seak masters though ye be

the master and the boatswain liow tine my naster is!..................

hant my master is a sliepherd (rep)

followest thy master, thy master for

Inll conmmesid youn to my master

I can hardly think you my ma.
my master sues to ler..............

that my master, being scribe.

lose thy master, and in losing (rep.)

and the master, and the service?

how dill thy master part with......

that my master is beeon

I neant thy master......................

conld their master eome and go.

master, shall I strike? ..........

firr she is her master's maid......

with my master's shin?

master, be one of them

by' his inaster's command...

hrow my master ..................

ennnot be true servant to $m y$
from nay master, sir Protens

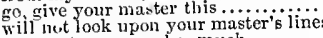

my master wronge her mine

my master loved ler wit wiil ì

make my master out of love witio thee

O good sir, my master charged me $\ddot{M}_{\text {crry }} \overline{\text { Wives, }}$,

sir John, and master mine

to solicit your master's desires

and see if you can see my naster...

Slender's your master?.................
I will do what I cast tor your master

here comes nny master

go enquire for my master.

tor my master, in the way of marriage

I'll do your master whiat good I can

master, - I may call him my mast

now, good master doetor! (rep.)

but first, master guest ....
comes my master, master Sirailow

how now, master parson? (rep
so do y'ou, good master doctor

but my wife, master doetor (r

my master, sir John, is come.......

go tell thy master, I am alone

that's my master, master doctor

unt yet, I would my master had

met the jealous knave their ma.
look, where his master comes.

your master is hard at door.......

if it were my master's fortune

master doetor, my daughter is in...

my lord and master loves youn.... Tre

if I did love you in my master

let your fervour, like my master

unless the master were the man

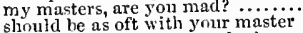

my master's tears to you deplore.

go on $m y$ master's griefs

your true love for my liaster.........

sits ernowned in his master's spite...

yolr master quits you .................
called me master tor so long
from this time be your master's mistress

from this time be your master's mistress
to me master tayster (rep.)

coine hither, master constable

wetl, every one can master a grief....Much _Ado

both which, master eonstahle
well, masters, good niglit (rep.).

some treason, masters; yet stand

the prince, Claudio, and my master.

posscesed by my master don Jolin
but the devil my master knew she

call up the right master constable

mat them come before master coustalii

master gentleman Conrnde. Mlasters

masters, it is proved already that...

master constable, you go not (rep.)

masters, I charge you, in the ........

but nasters, remenulier, that 1
whon lavo you offended, master

whin havo you offended, masters.....
mine and my master's frlse aecusation

and masters, do not furget to specify

good-niorrow, masters (rep.) .....i.i.
that master so their blond.

by the serull: masters, spread yoursely

this is he, my master said

this is he, my master said
masters, you onght to consider with

pray, masters! fly, nusters! help! . lan niy master's true eonfirmed love

or eye your master's heels?

answer your master, be not afraid

I shall make my master glad........

is desperate for my master'
MASTERS the duke is coming... Mid.N.'s Dream, iv. 2 you this in my prnise, master?.... Love's $\bar{L}$. I ost,, i. ilercules, master (rep.)

most muculate thoughts, master...

a dangerous rhyme, master, igains

master, will you win your love witi

no, iny compllete master (rep.)
and ont of heart, master: all those.

lonest master; of rather, muster, no

a gond master of mine, to a lady of..

good-morrow, master pirsoln. Master

marry, master school master, he that

so dotll the loound his master.

I marvel, thy naster hath not eaten

remuneration I lad of thy master

master, let me take youl all be...Merch,

-

master, young man, you ( $r \in p$.)

no master, sir, but a poor man's......
how dost thou and thy master agrce?

his master and lie. (saving your

Slislock, thy master (rep.)
take leave of thy old master

where is your master? ............

who is thy new master's guest $\ldots . .$.
my old master' the Jew to sup $(r e p)$.

my young master doth expect your..

master of my Eervants, queen o er .

is my master yet returned?..............
from my master, witll his liorn fuli (rep.)

from my master, witle his lorn masters

neitlier man, nor master, would talie
zonder comes my master............ss you Like

sweet masters, he patient; for your.

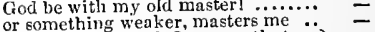

my young inaster? O my gentle (rep.)

your virtues, gentle master, are $\ldots \ldots$

die well, and not my master's debtor

my master is of ehnilish disposition

farewell, kind master...................

right welcome as thy master is.......
mistress, and master, you have oft

the old carlot once was master of

our master and mistress seek you.

your master have a thousand loves .. All's W'ell, i

my master, my clearl lord he is .......

my master. Are yol companion

count's mastex is of another sty
your lord and master's marricd.

ny master? Who? God? Ay, sir
sliakes out his master's undioing

sliakes out his master's undoing ....

how now, where's your master?.

to suggest thee from thy master ....

and the master I speak of, ever to speal

the displeasure of your master $\ldots . .$. ij

gentle master mine, I am in all ... T'uning of

only, good master, while we do....

master, some show, to welcome......

well said, master, mum! $\ldots . . .$.

master, it is no time to chide .............

master, you looked so longly on ....

I have it, Tranio. Ninster, for my linmi

or naster; then it follows thus (rep.)

sake, but your master's, I advise...

my master is grown quarrel sone.....

tn use his master so? being perhaps

niaster, master, look about you.

softly, my masters! if you be.........

I must believe my master

good masters, take it not .........
firewell, sweet masters, both....

master, master! news, old news

all for my master"s sake, Lucentio.

on all mad masters! on all toul.

is my master and his wife coming

it hath tamed my old master

my mester and mistress are (rep.).

my master riding behind my........

you must meet my master...

low near is our master?

what, master, read you? first

prove, sir, master of your ar

$O$ master, master, I liave watched

master, a mereatante, or a pedant

I bid my master cut out the gown

master, it up unto thy naster's use

Isay, commend me tin thy master..

you saw my master wink and langh
my master hath appointed me to

back to my naster as soon as I can..

mine old master, Vincentio? now we
thy muster's tather, Vincention? (rep.)

thy misth murdered his master! ....

i. 2
ii. 3
i.i. 3
i. 3

ii. 3

ii. 6

ii. 3

ii. 3

iv.

v. 5

v. 3

i. 1

i.

i.

i.

i.

iiti: 


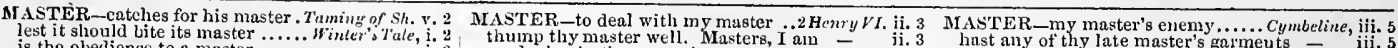

wolf will sooner find, than the master

the penitent king, my master, hath seut -

O master, if you did but he:

good wine in thy master's way $\ldots . .$.
master, this prisoner treely give $\mathrm{I} . .$.

ii. 3 hust any of thy late master's gar'meuts

he the ransom, master? let me.

my master, a very valiant Briton.....

that nuhappy king, my master, whom

may be to the fliglit of my

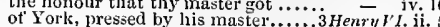

come on, my masters (rep.)

thiere are no more such masters....

never find sueh another-mast

the same instant of their master......

by that rare Italian master, Julio.... -

report to the prince my master

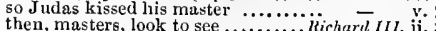

than thy master in bleeding $\ldots . .$.

thy inaster [Col. Knt.-lord Stanley] sleep -

go bid thy master rise and come to me -

we'll be thy good masters.............
haste I scrit to seek lis master!.. Cumedy of Er.

is master of his liberty; time is (rep.)

more divine, the masters ot all these

are masters to their females .......... -

quoth my master: I know, quoth he

fetel thy master home

lie's muster of my state.....

I pray youl, master, tell me...........

whilst man, and master, laugh my.

if any ask you for your master, say...

master, shall 1 be porter at the gate?

my master in, Luce. Faitl no (rep
if you went in pain, master, this..

if you went in pain, master, th

would say so, master, it' your garments

their owner, master, ond , mean

servants must their masters minds finfil -

Where is thy master, Dromio? ........
bring thy

master, here's tlie gold you sent

master, is this mistress Satan? ......
master, if you do expect spoon meat

but, surely, master, not a rag of

both man and master is possessed
and, gentle master $I$ received no

ma, gentle master I rec.....
master, I am here entered

master, I am here entered

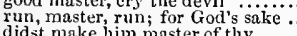

didst make him master of thy.

my master preaches patience

master, shall I feteh your stuff

I am your master, Dronio

ere give consent, his muster's elitil.

iii 2 I lieard no letter from my master

points on tlieir

iii. 2 ne'er thank tliy master, live .........

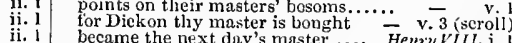

ii. i suggests the kingrour master ...

Your life, good master, must sliuffie...
I'll be thy master; walk with me....

of my master's then in my pocket...

suggests the king our master to thi

in my inaster's garments.

yet the king our master, whose lionour

my good master, I will yet do you

how now, my nasters? $\begin{aligned} & \text { now... Titus } \\ & \text { now, masters, draw : } 0 \text { weell said }\end{aligned}$

give them to his master for a present

ii. 2 the king (mine, and your master, with

my ever royal mastex.................

iii. 2 -

ii. 2 so noble, and so true a master?

what say, you our master, not to us..... l'erich

nay, master, said I not (rep.)

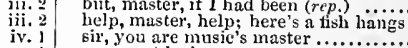

the ling lias made lim master

he's made master o' the rolls

than your master, whose minister.

Trojan that is master of his heart. 7 roil. \&

how now? where's thy master?

so much but I might master it

but I'll be master of $i$

yet are we masters of the field

are prized by their unasters

my master is awaked by great ...
know, ny lord, my mister's waint

know, ny lord, my mister's wants..

very bountiful good lord and master?

I feel my master's passion?

to guard sure their master.

when your false masters

faitlt, I perceive, our masters may

maid, to thy master's bed...

where's our master? are we tindone?

so noble a master fallen! $7 . \ldots . . . . .$.

my dearest master. Away! ..........

stay, and comfort you, my master

why, masters, my good friends

you must be her master...

the inaster calls, and trebles you......

my masters, you say she is a virgin?...

well, follow me, my masters ..........

to be my master, or rather my mistre

as my father, as my master followed......

which I would fain call master.

more knave than fool, after your maste.

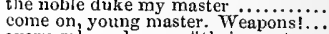

every gale and vary of their masters...
it pleased the king lis master

arrinst the grace and person of my maste

a fat friend at your master's house..
to Aleppo gone, master o' the Tiger

from our royal master, thank

is thy master stirring? our knoeking

let every man be master of his time

from our mouths, or from our masters'
snatch at his master that doth tarre. King

to hurt lis master, no man else...

my master; God omnipotent

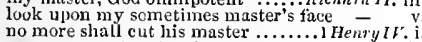

now, my masters (rep.)......

buund them, and were masters of their

why, hear ye, my masters............

back a gain to your master

speak louder, my master is deaf....

what foolish master taught you.......

is your master here in London

and a kinswoman of my master.

no word to your master, that I ......

feel, masters, how I shake; look you
rogue, a way I I am meat for your master -
lisping to his master's old tables .....

mistress Tearsheet come to my master

of being near their master; if to his me

I'll to the king my master that is dead

the prince our inaster says, that you
Pistol, yon must come to my master

as dogs npon their masters, worryin

and these he masters now; now he

shall I know of thee? my master's mind -

so far my king and master; so mucl

tell thy master here I am; my ransom

the business of the inaster the authio

son, nor the master of his servant...

the master of the cross-bows

furewell, my masters; to my task...... $u_{u}-$

away, my masters! trouble us no....

did represent my master's blusling

the proffer of my lord your master

against my inaster, Thomas Horner

my master was! No, forsooth: (rep.)

and send for his master with

most master wear no breeeles $\ldots . . .$.

coine, ny masters; the duehess...

well said, my masters; and welcome all -

their master loves to be aloft $\ldots \ldots .$.
stand by, my masters, bring him

a plum-tree, master. How long ( $(r e p)$

yes, master, as clear as day

alas, master, I know not (rep.)

and fear not thy master; fight for

mow now, my masters? lave you chose

masters, lay down your weapons ....

pr'y thee, call my master to him.....

tell my master what a strange
not thy master. How, sir (rep.)

who? my master? nay, it's no

go, masters, get you home (rep.)
my nohle masters, hear me speals

masters all, be quiet; put np your

as subtle masters do, stir up.

Brutus, did my master bia me kneel

my master Antony. Thy master is..

the choice and master spirits

is thy master coming? he lies to.n. night

O masters! if I were disposed to

salutation from his master (rep.)

my noble master will appear
my master's man: Strato (rep.

how died my master, Strato

did the latest service to my master

that did his master conquer.........

to-morrow, you'll serve another maste

master married to your good service

do you hear, masters? do you hear?.

find morc cause to change a

my dear master, my captain.........

he was my master; and 1 wore

if your master wonld have a quee.

do not abuse my master's bounty ...

wait pinioned at your' master's conit

my master and my lord I must (rep.)

your son drew on my muster ......

why came you from your master?

he's for his master, and enemy to...

as great as is thy master

the agent for his master

to master Casar's swor.

I know your master's pleasure......

O masterl what a strauge (rep.)

thou art no servant of thy master.

too slow to do thy master s biclding

iii. 3

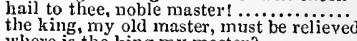

where is the king my master

bless thee, master! is that (rep.).

dost thou know Dover? Ay, master...

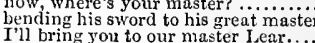

will ne'er accomodate his master thi...

my masters, know you that?

create thee here my lord and master

o my good master! pr'ythee, a way....

my master calls, and I must not say, no

comes one of my master's kinsmen...

my master is the great ricli Cayulet

am I the master here, or you? ......

there's my master, one that you love

my master knows not, bitt I am gone

I dreamt my master and anothere (rep.)

what made your master in this place?

you are welcome, masters! (rep.)...

you are welcome, masters (rep.).

till stole his master's daughter.....

cannot all be masters, nor all masters

my very his master's ass, for naught

bring thou the master to the citadel

comes the master and main exercise ....

to the plattorm, masters; come, let's set

what is the uatter, masters? honest Iago

masters, play here, I will content your.

but, masters, here's money for you .......

nay, stare not, masters; it is true, indeed $\overline{\bar{c}}$. v.

IIASTERDOM-sway and masterdom... Mncbelh, i. 5

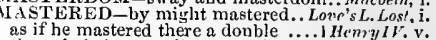

thou shalt be so well mastered ..... Cymbeline, iv.

MASTER-LEAVER, and a fugitive.Ant. \& Cleo. jy.

what mean these masterless .... Romeo of Juliet, y. 3

Night, ii.

masterly done; the very life seems. Winter's Tale, v.

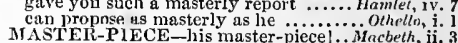

MASTER-PIECE-his master-piecel.. Macbeth, ii.

IASTERSH IP-your mastership? Two Gen of $F$.

an't please your mastership, Merchant of lenice, ii. 2
alike showed masterslip in floating. Corinianus, iv. 1

MLSTICK - [Knt.] mastick jaws.. Troilus \& Cress. i.

MAS'IIFS are of nnmatchable ......Hemy $V$. iii.

this mastiff $[K n t$-mastick] jaws. mastiffs - iii. 7

mast tarre the mastifi on $\ldots$............ i. 3

M.ATCH - a mateh ..................... Tempesi, ji. will't be a match?........................ of remona, ij. the mafeh were rich and honouribie $\quad$ - iii. 
MLATCH hetween sir Thurio. TwoGen.of Verona, iii. 2 MATE-one self mate and mate could not. Leur, iv. 3 MA'T'TER-was no great matter .. As you Like at, v. 3

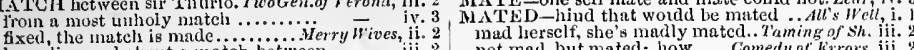
have lingered about a match between mad liersclf, she s maldy mated..Taining of sh. ii. not mad, but nated; how .... Com even strong ugainst that matel ..... she'll not match above lier degree. Twetfih Nighis. that took aw wh the meter irom. my mind she has muted; and amazed... Macbeth, $v_{\text {. }}$ if slie be mated with an equnl.. Timon of Athens, $i$. makle his busincss tnore material.. Winter's ' whose absence is no less material which is inaterial to the tender of ...Cymbeline, i. 7 God match me witli a good dil I would taiu have it a match MATHEMATIC-the mathematics. Tamingof sh. i. I A'TIN-glow worm shows the natin..... Hamkt, i. M ATRON-please it this matron Macbeth, iv. 3

should play some hea venly match . could mateh this beginnin your daughiters, your matron

fellow theasonable inatch.

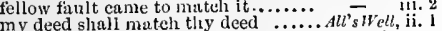
is mutch well mude; matel. ....... iv. 3 (lecter.) then shall we hinse a mateh: I have strike me the counterfeit matro the matrons flung their gloves...... Coriolan can'st mutine in a matron's bones to make all this natter eve ${ }^{2} . . . . .$.
thire is much matter to be heard....
lier matter was, she loved your son..... All's Well, what is the matter' sweetheart! trast lrim not in matter of lieavy... what is the matter? ................ no matter; his heels have deserved .. there is no fitter nıatter

we'll sift this matter farther a good matter, surely. Tuming of Shirew, i. how now? what's the matter?........

to make the matter good

how now! what's the matter?...

citlier malice, or matter, to alter it Winier's Tale, i. my mirth, my matter.............. to beur the natters the gain.

the wholc matter and copy of the father

heavy matters! heavy matters!

rochaim a matter from thee.

the match is fully made, and all is.. - $\mathrm{v}$. cun match the pleasure of that ... W'inter's Tale, this is a match, and made between's.. - $-\mathrm{V}$. have but leanl luck in the match. Comedy of Err. iii. soughlit a match of birth

and most poor matters point to ricil ends

no matter, since they (rep.)

open the matter in brief ..... . Tuo Gen. of Veron

what's the matter?

without

conjunction, make this match.....$\quad$ - ii. 2

for this match, made up

how stands the matter with them?

no matter who's displeased.

nay, then no matter

to wint this easy match played for $\because \overrightarrow{\text { inc }}$

and make some pretty match with. Richard 11 . ji.

have set a match

there's some great matter she'd.

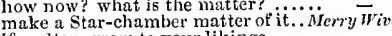

if matters grow to your liking

if it be doleful mait ter, merrily

breals a funl gap into the matter ...

here is more inatter for a hot brain.

which will have matter to rehearse.

will debate this matter at more. Comedy of $\overline{E r}$. iv.

what is the matter" (rep.)............. - Mocbelh, it. 3

what's the matter?...................

and pick strong matter of revolt ............ king $J_{o h n}$, iii. 4

what better matter breeds for.

brought in matter that should feed...

what matter lave you (rep.)

why uncie, what's the matter? .....Richard 1 . ji. 1

nobility will scorn the match $\ldots . .$. . Henry $F I$, v. 3

whom should we mateh with lenry - V. 5

oppose yourselves to mateh lord Wirwick - v. 1

but match to match I have encountered $\bar{V}$. vii. 2

grandain had a worser mateh....... Richard III. $\mathrm{i}$. 3

whose humble means match not

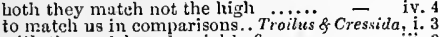

with the matcli and weight of ...... - $1 \mathrm{ij}$ - 2

I'll make my match to live

you hear all these matters denied

I will description the matter to youl.

it is no matter-a for dat....

o it be fairly done, no matter...

What's the matter? (rep.)
what is the matter, sir?

so larded with my matter

the matter witer known to night

that it wants matter to prevent

you have sume hideous matter to... Twelf $\overline{\text { h }}$

words are as full of pcace as of matter

no such matter, sir'; I do live hy

the mutter, I hope, is not great

my matter hath no voice, lady $\ldots$ it is no matter how witty, so it be....

thou write with a goose pen, no matter -

why, what's the mutter? (rep.)

more matter for a liay molning

do you know of this matter?

set it's no matter for that.

what's the matter? (rep.)

leaves unquestioned math

no matter for the dish, sir........

few of any wit in such matters

now what's the mat
well; the matter?

yet as the matter stands, he wili .....

to this tune, watter, and method?

the matter being a-foot, keep your

the phrase is to the matter ..........

to hear this matter forth, do with your $\overline{-}$

and 1 see no such matter ............

born to spenk all mirth, and no matter
I will so faslion the matter...........

of another's dotage, and no sucli...... matte

of this matter is little Cupid's crafty

that to her all matter else
what's the matter? (rep.)

what's the matter? (rep.) $\ldots \ldots \ldots . . . . .$.

speaks a little off the matter

but that's no matter (rep.) r.........

why, what's the matter, that you...

tis no such matter

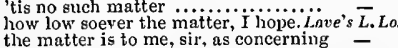

no more of this matter (rep.)

is the very defect of the matter......... of $\overline{v e n}$

so did mine too, as the matter falls...

I speak my agitation of the matter.

and yet no matter; why should we go

ho, already? what's the ma

to acquaint you with a matter ....... As you Like $i,, \mathrm{i}$.

for then he's full of matter

why, what's the matter? ........... = ii. 3

I think of as many matters as he....

that's no matter, the feet might bear

it is a hard matter for friends to nieet

the matter's in my head

gravelled for lack of matter........

lacksing (Ged warn us!) matte

'tis no matter how it be in tune...

but that's no matter

it is a matten who sees it

what is the matter (rep. v. 3) .......... - v.

if natters shonld be looked into

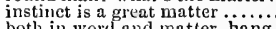

both in word and matter, hang....

a trifle, some eightpenny matter

war, and no such matter?.......

when there were matters against

it is no matter, if I do halt ...........

how now? what's the matter? (rep.)

we think it so, it is no matter............ Hen $y$

- ii. 4

take the matter otherwisc than......

hid be a black matter for

tis no matter for his swellings .......

to write for matter of grant......

to confer about some matter

.iHenry $r$ I

now the matter grows to compromise

marriuge is a matter of more worth..
more of your matter before the king .2

but, to the matter that we have in

said nor thought any such matter

'tis no matter how, so he be dead...

I have great matters to import to the

before tinem about matters they were

mater of marriage was the charge.- 3

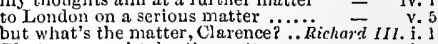
Gloster, you mistake the matter

is it not an easy matter to make..........

in deep designs, in matter of great... $=$ iif.

the king hatl found matter against..

what's the matter? it seems you are

in charging you with matters....

nor male no more in the matter. Troilus \& Cress

no matter. Nor his beauty

is it matter new to us.......

what hath mass, or matter ...........

then would come some matter from him -

what's the matter, man? (rep.)...... -

but it is no matter ..............

then will Ajax lack matter.....................

never suffers matter of the world

what's the matter? will you beat (rep.)

my matter is so rash

no matter, now I have't (rep.)
mere words, no matter from the lieart

intending other serions matters... Timon of $A$

no matter what i lie's poor ..........

the matter? speak (rep.)

why, 'tis no great matter............. Coriolan

have delivered the matter

what's the mutter? You are seut for

the matter? II atl he not passed

nor by the matter which gour heart 
MATTER - what is the matter.. we necd not put new matter to hi 'tis no matter: if lie could burn...

matter?

no tradesmen's matters (rep.)........juliz

Casca will teli us what the matter is

for the base matter to illum

fast asleep? it is no matter ..........

consider rightiy of the matter

that matter is answered directly

how covert matters may be best disciosed -

what's the matter? (rep.)

thou deny me a matter of more.........

what s the matter? I know, by that

the matter that is then born in it $(r$

nor curstness grow to the mat

i do not much dislike the matter

that matters are so weli digested....

pour out the pack of matter....

tis no matter: go to the fellow......

but 'tis no matter; thou shalt bring

no nutter, sir, what $I$ have heard

but whut's the matter? this matter of marrying his king's....

a great deal from the matter
what is the natter, trow?...

what's the matter? why tenderest

what's the matter, sir? By Jupiter.

the matter? triumphs for not hing

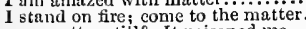

new matter still? It poisoned me

to take up a matter of braw

mow this matter must be looked

how now? what's the matter? ........

more than words can wield the matte
if the matter were good, my lord

what grows of it, no matter...

I know not what the matter is $\ldots . .$.
what's the matter, sir? Illl tell thee.

how now? what's tile matter? (rep.)

priests are more in word than mat

if the matter of this paper be certain

posted hence on serious unatter ............

matter and impertinency mixed

come, no matter vor your foins.

conceit, more rich in matter

containing sucll vile matter............

and never trouble Peter for the

what is the matter? Look, look! .

no matter; get thee gone, a

......... $\overline{\text { Hamle }}$

how now, Ophelia? what's the matter?..

more matter with less alt ................

no such matter: I will not sort you......

make the matter savoury, nor no matte

like a neutral to lis will and matter

to hear and see tive matter .............

do you think, I meant country matter

therefore no inore, but to the matter
now, mother, what's the matter? (rep.)

now, mother, what's the matte

there's matter in these sighs ..........

what is the matter? Save yourse

two light for the bore of the matte

'tis no great matter there (rep.).

we'll put the matter to the present pus

would be more german to the matter...

about my heart; but it is no matter

what is the matter there (rep. i. 2$)$......

take up this mingled matter at the best

take up this mingled matirection...

what's the matter, lieutenant? (rep.)

more of this matter can I not report ....

there's matter in't indeed, if he be angry

pray heaven, it be state matters .......
what is the matter? My lord is talien

what's the matter with my lord? (rep.)

what's the matter? This is (rep.)

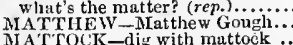

IA'TOCK-dig with mattoek .. Tiius Andron. iv. give me that mattuck ......... Romeo \&. Juliet, v. 3
we took this mattock and this spade AI TTRESS-Cresar in a mattress. Antony \& Cleo. it.

not yet mature, yet matchless. Troilus \& Cress. is almost mature for the violent.... Coriolanus, i who, being mature in knowledge. Antony \& Cleo to the more mature, a glass that

in the mature time, with this nngracious. Lear, iv. MIAURI'CY-maturity blown up. Troilus \& Cress. i. MIUD, Bridget, Marian, Cicely.Comedy of Err. iit. II A UGRE-maugre all thy pride. Tueish Night, iii. I I protest, mangre thy strength .......... Lear, v.
MLALL-I'll so inaul you and your.. Kirg $J o h n, \mathrm{iv}$
MIAUL-to maul a rumner... Antony \& Cleopata a, iv. MI AURI-non eget Mlanri ...T'TusAndronicus, MA UVA Is, corruptible, grosse........ Henry $l$. methinks, your maw, like mine .Comedy of Lir i. 2 shall be the maw's of kites..............

his icy fingers in iny maw ........... King.Joh

Yea, in thy maw, perdy. ..tlemyl detestable maw, thou womb of... Romeo of Juliet, MIXIAI-this maxim unt of love. Troilus of Cress. MA Y-lie smells April and Hay....Merry Wive

as the first of May doth the last of his Mray of youth, and bioom of.

do olservance to a morn of Mlay

to observe the rite of Alay

ii. 2 love, whose montll is ever Miay

maids are Miny when they are

Mil. N.'s

of spirit as the montly of Diay.

- iv. 3 (verses)

thirtieth of Dia next .....

Richard II

[Col.] were like a better Alay ............ Lear, iv. 3

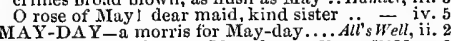

to make them sleep on May-day

MAY-AIORN of lis youth . ........... Henry $i$. $\mathrm{i}$. 2

Alls

peace, mayor; thou know'st farewell: thou dost but what

iii. 4 we will have the mayor's sword ....2 Henry $V I$.

the lord mayor craves aid............
but, master mayor, if Henry ${ }^{r} 1$.

the mayor of London comes to.

lord mayor, look to the (rep.)....

lord mayor, look to the
the mayor towards Guildhall hie
asked the mayor, what meant thi

asked the mayor, what meant this ... -

the lord mayor knocks. Welcom

myself, the mayor and aldermen

to you, my good lord mayor.

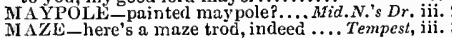
as strange a maze as e'er men trod ......... vest, v.

and the quaint raazes in the .Mid.N.'s Dream, ii. 2 MAZED-many mazed considerings. Henry lill. $\mathrm{ii}$.

and the mazed world, by their...Mid. N. Dream,

Iimorous deer, mazed with ........ Henry ${ }^{\prime} I$. iv. or I'll knock you o'er the mazzard ..... Othello, ii.
MIEACOCK -a meacock wretch can. Taining of Sh. ii. II EAD-flat meads thatch'd witli stover. 7empest, iv. forest, or mead, by paved fountain.Mid.N.

as frosts bite the meads

fallows, meads, aud hedges

will drown the fragrant meads. Titus.indronicus it.

plenteous rivers, and wide-skirted meads.. Lear, 3 .

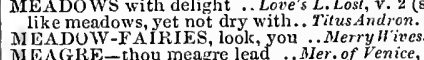

meagre cloddy eartl to glittering ... King John as dim and meagre as an ague's fit

of ashy semblance, meagre, pale.....2Henry $V I$. iii.

meagre were his looks, sharp ....Romeo \& Juliet,
MEAL-hath made his meal of theel...Tempest,

and but one meal on every day beside.Love's $L . L$.

unquiet meals make ill digestions. Comedy of E r

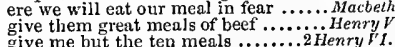

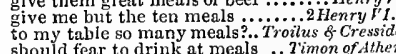

should fear to drink at meals ... 2imon of $A$ then

meal and bran together he throwe neal, and exercise, are.....

to keep with you at meals ............ Julius Casar,
be bounteous at our meal ...Antony \& cleopalra, be bounteous at our meal ...Anlony ocleopalra, iv.

nature hath meal, and bran

I EA LED - were he nealed with. Meas. for Neas. MIEALY - show not their mealy, Troilus \& Cress.

true; save means to live

this ny mean task would be

since they did plot the mean

have I means much weaker....

I mean the pound, a pinfold... Tro Gen. of íerona,

what means this passion at his

there wanteth but a mean to fill
the mean is drowned with your

I mean, that her beauty is

what means your ladyslip?

he means to spend lis time

but too mean a servant

and all the means plotted...

tliey have devised a mean...

but doth not mean, away....

you mean to whip the dog

to make such means tor her.

what mean you by that saying?

though I had never so good means
M E $\triangle N$-in my mind, or in my means. Memy W"ives, ii. I nuean, master Slender...

yes, by all means; if it be but........... her tather means she shall

which means she to deceive? .............

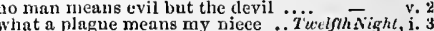
what dost thou mear?

you would not give means for this....

whean, she is the list of my .........

1 mean, to go sir, to enter $\ldots . . . \ldots .$.

tlant meins to be saved by believing

if you mean well, now go............

no sir, nor I mean it not ........... -

needful, but nut iavish, means .......

that there were no earthly mean to save -

we speak not what we mean
thou art by no neans valiant.....

that is thy means to live $\ldots . . . \ldots . .$.

oby no means; she nocks all

when mean you to go to church?...

I mean, the fashion to be married................

what means the fuol, trow?.......

made such havock of my means......

ability in means, and ehoice of triends =

I mean in singing...................

by no means we may extenuate...Mid.. . Dream,

I mean, that my heart unto

I understand not what you mean.

shield Lysander, if they mean a fray

thil. 2

which I mean, 1 walked upon (rep.) - - i. I (letter)

how mean you, sir? ..............

he rather means to lodge you in .... -

that my heart means no ill............

nay, he can sing a nean most meanly
what inean you madam? (rep.) .......

it you my favour mean to get...........

my extremest means, fie all
had I but the means to hold

no mean happiness theretore (rep.).

yet his means are in supposition .... -

who wins me by that means i toid you =

bealed by the sam mean,

when your honours mean to solemnize

do you, Gratiano, mean good faith
to feed my means. Here is a letter

if on earth he do not mean it........

that no lawtul means

when you do take the means whereby

that never means to do it... ia..........

by some indirect means or other

you mean to mock me after.....

I'll put myself in poor and mean attire -

and this night he means to burn ....

woo the means of weakness and debility -

that the very very means do ebb? ... -

my cost, (thinking that I mean hini....

that wants money, means, and content

why, what means this?

she means to tangle my eyes to

that mean to see the Tuscan service... Alt's $W_{\text {ell, }}, \mathrm{i}$.

speals with her; Helen I mean

and love, means, and attendant

and when he means to come ........

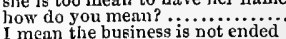

I mean the business is not ended

and means, for every man to

our means will make us means.......

treas Soto that your lonour means

how mean you that

by any nreans light on a fit man

or mean man of Pisa.

is't he you mean? Even he?

Fou mean not her to-Perhaps

if me you mean ............

what, you mean my face $\ldots . . . . . .$.

and so mean, sweet Katharine.

yet never means to wed where.

oftentimes lue

here I mean to take my leave

belike, you mean to make a puppet..

this poor furniture, and mean array

1 believe $\Omega$ ' means to cozen sumebody

1 mean, Hor tensio is afeard of you

I mistress, how mean you that?

ii.
ii.
iii.
iv.
v.
v.
v.
i.
i.

i.

ii.

iii. !

iii. 2
iii. 2
iii. 5

iv. 1

v.

i

ii.

ij.

ii.

iii.

ii.

v. 1
i. 2
i. 3

i.

iiii.

iv.

in. $v$ (ind.)

$=$

i

$$
=
$$

\section{iii.}




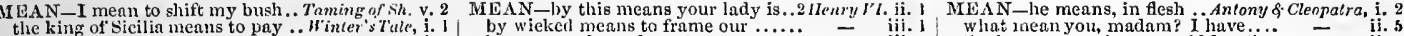

whol lowed, as I mean to utter it ..........

1 mean, in this whiels you aceuse lier

mo nean but nature makes that mein

so turtles puir, that never mean to part

would, as it were, menn mischief....

as never I mean thou shait

as, in fiith, I mean not to sce him

by whiclu menes, I siw whose purse

letters by this means, being there

gold, and a means to clo the prince.

but few, and those but mean $1 . . .$.

a noor mean woinan was...... Comedy of $\bar{E}$ rroo

for other means was none...............

what mean you, sir? for God's sake.

1 mean not euckold-m

what didst thou mean by this?.

but though my eates be nean....

despite of misth mean to be merry

that hath such means to die .......

how dost thou luean, a tat ma

What Adam dost thou mean?........

used the approved means I liave
whit do you mean? still it eried.

mean you his majesty? ..........
rnvin up thy own life's ineans!

rnvin up thy own life s mears
lyy the worst means, the worst

it is myselts 1 to mer.

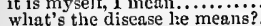

the means that make us strangers...

remove trom her the means of all ...

I mean to learn; for it

by whuse help, I mean to chastise it

what dost thou mean by shaking.

with advantsag means to pay thy lov

when fortune means to men most good

brenth of what I mean to speak......
the sight of means to do ill deeds.

i. 2
ii. 1
and thea a shape, that means deecit?

$\begin{array}{ll}\text { iv. } 2 & \text { in vain are these mean ubsequies.... } \\ \text { iv. } 3 & \text { unto my state by Suftolk's means. }\end{array}$

\begin{tabular}{l|l} 
iv. 3 & the elotinier means to dress ............... \\
iv. 3 & nay, that I mean to do. Is not this
\end{tabular}

it we mean to thrive and do good...

it we mean to thrive and do good....
we'll devise a mean to reconeile you

I mean to take possession of iny

he means, barked by the power of

that lleury means to use.............

I an too mean a subjeet for thy wrath

I mean, our princely father

I think, he means to beg a ehil

eanst do what $I$ mean to ask

that whieh in mean men we entitle.Richard II. i. . 2

leisure yield them further mean

- eousuming means, soon preys

and shortly mean to toneh.

the menns that heaven yields.........

I mean the earl of Wiltshire, Bnshy

for some reasons, sir, I mean to see..

what means our eousin, that he
how now 1 what means deatl......

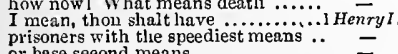

you only mean for powers in Scotland

What time do you mean to comp
what a plagne mean ye, to colt...

What a plagne mean ye, to colt.

whom means your grace?.............

sueh mean attempts

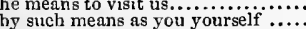

did not ine finits of love I mean

I am too mean to be your queen

elide the means thot

bethink a means to lireak it off.:

advertised him by secret mean

by tair or foul means wh of

lie'll soon find means to make

by what safe means the crow
know you what this means?

I mean, my lords, those power.

use means for her reeovery.

is imprisoned by your means..........
$[$ Col, Knt.] tlat you were not the mean

[

what means this scene of rude ......

youn mean, to bear me, not to
where he oid mean no clase

the garland? dost thou mean the crown?

I mean, your voice, for erowning....
I mean, his eonversation with Shore's

my lord, you mean no good to him..

whlose humble means naatel not liis

[Col. Knt.] inquire me out some nean

1 meant those bastards in

open means to eome to them
I mean, that with my soul I Iove.

I mean, that with my soul I love...
well then, who dost thou mean shail be

make solne good means to speak

made means to eome by (rep.)

never promiseth, but he means to pay
but what meall
1 , to speak so. .2 Henry $I \bar{V}$. (induc.)

your means are very slender

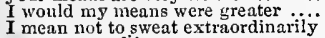

our canse, and known our means....

when we mean to build, we first ....

he sure means brevity in breath

when means and lavish manners

and sir, do you mean to stop any....

I did mean, indeed, to pay you...

admit the means, how things.............
hath cause, and means, and might

we do not mean the coursing.

of courage, and with means defendan

by the means whereof $a^{\prime}$ fase '.

by the means whereof, $\mathfrak{a}^{\prime}$ faces $\ldots . . . .$.
then, mean and gentle all, behold

for want of means, poor rats

lunger and laek of other mean

all the clerks, I mean, the learned ones =

he (I mean, the bishop, ) did require
what should this mean? (rep.) ......

(I mean, your maliee) $\ldots \ldots$

by what means got, I leave
longer life, and able means.

I mean, in perjured witness.

all fast? what means this?

to the utmost, hand ye mean...........

that means not

1 mean of ours; if we lave ve los.

cause that hath no mean dependance

command, I inean, friend

what mean these fellows?

the thing he means to kil

his means most short .............

for 1 mean to give thee none $\ldots$ by no means, honest Ventidius

what means that trump? How now?

as $I$ had leave of means.

means, but is lord Timon's $(r e p.) \ldots$.

his means? who without those mean

thlou ladst some means to keep a dog

message, and by nromised means....

then we shall have means to vent....

Iike one that means his proper barm

I mean of us o' the right-hand file?

seeking means to pluck away......

In wish, sy , (I mean, for your partieular)

how, now! what means this, herald?

sinee he keeps no mean? He may mean -

I mean to tug it, and to enff you

or by what means got'st thou to be...

1 mean to prove this lady's courtesy

I do, my lord, and mean accordingly

gentlemen, what means this silence?

exeept you mean, with obstinate.

our saes thall be a mean to sack
for Talbot means no goodness

what means his noce

what means his grace................

warriors wot not what it means.......

Warriors wot not what it means......
and as the only meens to stop effusion
we mean shall be transported

we mean shall be transported

means to give you battle presently...
hast thou by seeret means used.....

command, I mean, of virtuous ....... $=$

nephew, what means this passionate.2 Henry VI.

and queen do mean to ha
what means this noise?

if you mean to save yourself
I mean, thy general. My general cares

what means this shouting? I do fear

tis crow not what you mean

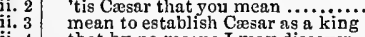

that by no means I may diseover

\begin{tabular}{l|l} 
no, by no means. O lol us have him \\
ii. 2 his means, if he improve them .......
\end{tabular}

Portia, what mean you? wherefore.

he wonld embrace the means to eorn

no mean of deatlt, as here by Cosar

what eornpact mean you to..........

and our best means stretched out.

they mean this night in Sardis to be

I can raise no mone g by vile means
what do you mean? love, and be friends -

they mean to warn us at Philippi..... as 1 hear, mean to solieit him for...

whlat mean you, Casarar? think you. iii. 1 Whe lowness, or the mean, if dave....

ii. 7

iii. 2 last of many battles we mean to 0 ig

what means tisis? Trs one or.......

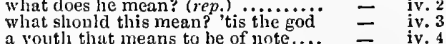

a swifter mean shall ontstrike though $1 \mathrm{t}=$ iv. 6

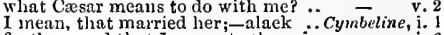

further good that 1 mean to thee, $:$ -

yet who, than he, nore nean?....... $=\begin{array}{r}\text { i. } 7 \\ \text { i. } 3\end{array}$

wilint meens do you make to him?.. - ii. 4

if one of mean aftairs may plod......

your means abroad you have me ...

I mean, where they should be relieved =

in lis own ela mber, I mean .......

those runagatesl means le not us?... = iv. 2

what does lie mean? since deatl] .... $=$ iv. 2

some talls are means tle happier to arise $=\quad$ iv. ${ }^{2}$

end it by some means for Imogen.... $=v .3$

as youd did mean indeed to be our.....

I know not what it means .......... $\mathrm{ii}-4$ ii. 3

Bassianus 'tis, we mean...

sone with thee: their leads, $\mathbf{I}$ nican

I know not what you mean $\ldots \ldots \ldots . . .$.

what means this? some bo

I think, she means, that the

have, by my means been bate ........

iii. 2 have, by

for wliat I mean to

how I mean to martyr you

your mother means to feast............

year no good to us....

the

what mean you, sir? To heg of you....

by no means ean I get (rep.).........

what man y lis you require

二 iii. 5

as I shall find means, and aequaint you $-\bar{L}$.

I mean, the whispered ones.

Whien by no means he could (rep.)

what means your grace?

what do you mean? My villain! ......... =

our mean [ Knt.-means] secures us ....... $=$ = iv. 1

to see his daughter -

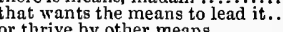

or thrive by other means
mean you to enjoy him?

what means that bloody knife?

I mean an we be in eholer we'll.. Romeo o suliet,

you importuned him by any means?

and we megn welay we waste our.

her means mueh less to meet (e....)

bid her devise some means tocome.

tlat I mean to make bold withal....

inean of death, though ne'er 80 mean

let's see for means: 0 mishief

what mean these masterless and gor

bid me devise some means to rid her

that heaven finds means to kill your

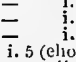

amiliar, but by no means vulgar ...

this mean, that thou, dead eorse...

but do not go with it. No, by no means.

and who, what means, and where they...

by time, by means, and place, all given...

I mean, the matter that you read.........

by the means of the late innovation

f their means are no better....

what cause he will by no means speak

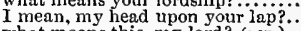

what means this, my lord? (rep.)......

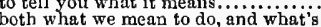

what dost thou mean by this?

and strength, and means, to do't $\mathrm{t}$ ask you, what it means, say you thi

for my means, I'll husband them so we

his means of death, his obseure

ive these fellows some means to - - iv. 6 (letter)

that le means no more to undertnke it..

con penience both of time and means....

I mean, sir, tor his weapon ...............

mean, my lord, the opposition of your

hy the means I shall then bave to prefer

and 's' devise a mean to draw the Moor

Who is't wou mean? Why, your lieutenant

thou dost mean something: $I$ heard .....

whiat dost thou mean? Good name .......

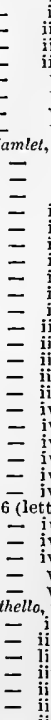


MEAN-with some swift means by your virtuous means, I may again. not mean harm? it is hypoerisy (rep.)

what do you mean by this hauting

do it witl gentle means, and easy tasiks I have wasted inyself out of my mean I mean, purpose, conrage, and valour.

how do you mean-removing of him?

my lork, what may you mean by that?.. - v, mean-born [Cal, Knt.-meall, poor].Richard III. iv. MEANDERS-and meanders! ........ T

thou and thy meaner fellows your last

whom I from meaner form have... Winter's Tale, i. 2

with ambition of the meaner sort .1 Henry I' 1 . ii.

and meaner than myself liave had .3 Henry $F I$.

gods, and meaner creatures kings.

tongue from every meaner man's.

that they strike a meaner than.

to make some meaner ehoiee. Tilusties -

to make some meaner ehoiee..Tilusandron

how meanest thou? (rep. v. 2) ... Lore's L. Lost, iii. I
m'y thee, who is't that thou meanest?. As you Like, i. 2

wonour peereth in the meanest hahit. Tam. of Sh. iv. 3

what! thou meanest an offieer. Comedy of
what meanest thon, Suffolk? ......... He He

and nake the meanest of you earls.

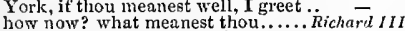

there's not the meanest spirit on. Troilus \& Cress. i.

what meanest thou to enrse thus?

what meanest thou to enrse

exceed the meanest house in Rome Coriolanu

what meanest thou by that? .......JuliusCresar.

does the meanest chares... Antony \&-C

his meanest garment (rep.)

prosecute the meanest, or the best....

change me the meanest bird ......Pericles.

what meanest by this? .............. Lew, ii. 2

if thou meanest not well I do .. Rameo \& Jutie

IIEANING-know thine own meaning. Tempes

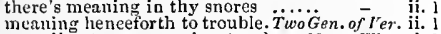

aceording to our meaning $(r \varepsilon p$.$) .... Merry Wives, i. 1$

not meaning to partake with me .....

there's a double meaning in that

there's one meaning well suited

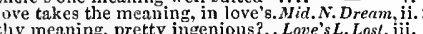

what's your dark meaning, mouse

more light to find your meaning ou

chooses his meaning, elhooses you.

a plain man in his plain measing

meaning me a beast.................
into his mouth: meaning thereby.

speak'st thou in sober meanings?

my meaning in't, I protest, wa.

he hatls some meaning in his mad. Taming of Sh $\mathrm{V}$ ii. 3

to expound the meaniog or moral

my meaning. A very mean meaning - ver

foldied meaning of your word's deeeit - iit ${ }^{2}$

'tis not my meaning to raze one...... Richard II. ii. 3

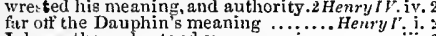

I do partly understand your meaning

shows, that her meaning is, no way.l Henry VI. iij. 2

from meaning treason to

'tis wisdom to eoneeal our meaning.....

know your meaning, brother Gloster. Richard III. i. 7

be guilt tless of the meaning.

I moralize two meaniogs in one word

meaning, indeed, his house, whiel

so hasty to eonfound my meaning 3 iv. 4

III. iv.

mith my more noble meaning. Troilus \& Cress. ii. 1

1 have fair meaaings, sir ...4ntony \& Cleopatra, ii. 6
read, and declare the meaniug...... Cymbeline, v. 5

thou know'st our meaning. TitusAndron. ii. 4 (let.)

learn to know thy meaning

he has found the meaning $($ rep. $) \ldots \ldots \ldots$....... Pericles, i. 1

if there be any good meaning ............ Lear, i. 2

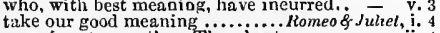
meaning, to eourt'sy. Thou hast...... -

that's not my meaniog: but breathe ... Hamlet, ii. hour or more, not meaning any harm .Othello, iv.
IEANLY-a mean most meanly . Love'sL. Los', not meanly proud of two such ... Comedy of Err. meanly have I matched $; i \ldots \ldots$.... Richard 111 . trained up thus meanly $\mathrm{i}$ ' the eave. Cymbeline, iii.
$\mathrm{IEANT}-\mathrm{than}$ I meant you should .. Tempest, ii. I meant not thee: I meant thy. Tuo Gen. of $F^{\prime}$ er. ii. think my eousin meant.well .....Merry Wives. I will go further than I meant .......
IEANT to take the present time

my hand meant nothing to my sword $=$ vii. if IIermia meant to say ..........Mid. N. Dream, is, meant by the tool multitude ............ of renice, ii. 9 if the viear meant to eozen

tell me what you meant by that ..... he meant, he did me none ... Comedy of $E$. Irore

exeept they meant to bathe in .........Macheth i.

the matter otherwise than is neant... Hewry $r$. iii.

you meant; but I meant Mi

far truer sjoke than meant.

when, as he meant, all harm.....

what is meant hereby.

what mennt this wilful silence.....

thy fat never knewt to act upon .......

that's to say, I meant to reetify

where all faith was meant

meant for his trial, and fair purgation

as if I meant nanghtily ....Trailus \& Cressida,

take me, if I meant it thus!.........

she meant thee a good tur'n....

and meant, indeed, but meant?....... s s -

even for hate, that is meant love ...... Hamlet, ii.

do rou think, I meant eountry matters? - ifi.

horse, tell us what this show meant?

Roderigo meant to lave to beg it

IE ANTIME, sweet sister, we .... Tueifh Night,

meantime, let me be that I am

in the meantime, I will so fashion

Much Ado, i.

io the meantime, I will draw ....Mid.

mean time, receive such weleome. Love's.'s $D$ r

meantime, the court shall liear, Mer. of Venice, iv.

in the meantime what hear you ..... All's ' Well,

meantime, but ask what you would meantime, let this defend............. Richard $I I$
desire yout to live in the meantime.... Henry $V$.
meantime, look gracious on thy .... Henry $V I$.

meantime, your cheeks do eounterfeit

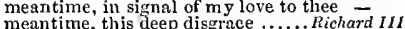

or else Jie for you: meantime...

meantime, God grants that we have
meantime, but think how I may

in the meantime he wants less .. Timon of Ath. iij.

what you shall know meantime...

mean time, laugh at his ehallenge.

mean time we shall express our darker..... I.ear

meantime forbear, and Jet misehanee

meantime, we thank you for your

thongh in the meantime, some necessary

IEANT'ST-that thou meant'st....2Henry I'I. $^{\prime}$.

meanwhile I am possessed .... Tilus dndronic

mean while, gir, witl the little skill.

mean while, here's money for thy eharges -
MEASURABLE for the afternoon. Love's L. Lo

IEASURE us back to Naples?
to"measure kingdoms with. T?

Tempest,

.

de Jarterre to measure our weapon... Merry $\overline{\text { Wives, }} \mathbf{i} .4$

to guide our mensure round about .. - $\mathrm{v}$.

is a good trippling mensure....... Twelfth Night, v.

no sioister measure from his ...Meas. for Meas. iii.

in great measure.................

Nuch Ado, i.

there is a measure in every thing....

a measure full of state and ancientry

measure his woe the length and breadth

which now in some slight measure

to measure out my length on this.

always whirls in equal measure... Love

the measure then of one is easily toid

then in our measure do but vouehsafe

and so the measure ends (rep.)

in measure rain thy joy, seant .......

and measure out my grave .......As you $\overline{\text { Like }}$ il, ii.

than may in some little measure draw

according to the measure of their states

with measure heaped in joy (rep.)

for other than for danein

and undeserved measure, my lord

co meylit take a measure of his...

soll measure to her maidenthend .....
slurew, measures my husband's sorrow
MEASURE-measure me ........Winter's Tale, ii. 1 not mensure her from hip to hip. Comedy of Err. iii. 2 took measure of my body ............ $\overline{\text { atachel }}$ iv. we will perform in measure. fill up the measure of her will (rep.).King Jokn, be measures to our pomp? ...........

large neasure to thy futher's ........ Richard iv

let the dangerous enemy measure...

no meusure in delight (rep.) .........

you measure the heat of our liver.

mor measure: and for the other (rep.) nenry $r$. given me measure of revenge De must be answered

measure of his love unto our

to delirlitful measures ....Richar. III

measire to lead them once ..Henry VIII.

fiir desires, in all fair measure

with all lieentious measure...... Timon of Athens, fter the mente oved me above the measure of a father

'erflows the measure

then, to send measures of wheat ....

most narrow measure lent me

knowing all mensures, the full ....... $-\overline{\text { iii. }} 1$

$O$ above measure false! Have patience -

their measures are as excellent.......... Pericles, iil. 3 if you will measure your lubber' iength.. Lear, i. 4 jet them measure us by (rep.) $\ldots . . . \ldots$ Romeo \& suliet, $\mathrm{i}$. if the measure of thy joy be heaped.

hat word's deatl

aking the measure of an unmade grave - iii. 3 empest, v. have measured many miles (rep.). Love's L.Lost, v. 2 your throne and his measured...... Winter's F'ale, $v$. must not be measured by his worth...Macbeth, v. 7 if I be measured rightly ............ Henry $1 \%$ '. who hath measured tlie ground? measureless liar, thou hast miade.... Maebelh, ii. measureless liar, thou hast made..... Coriolanus, 8 . tot measuring what use we made........ Henry $\nu . i$. I, measuring his aftections by . Rnmeo \& Juliet,
IEAT-stomacl on your meat.. T'ero Gen. of Ver. and would fain have meat

that's meat and drink, to me

Merry Wrives,

dress meat and rining

in the thanksgiving before ment......... feas. for Meas.

a man loves the meat in his youth

he eats his meat without grudging

for the meat, sir, it sliall be....

were to put good meat into............ $\bar{s}$ sou $\overline{L i k e}$ it, iii.

it is mett and drink to me to see .....

and so is all the nuent: what dogs. Taming of Sh. iv.

she eat no meat to-day

as with the meat, some $\ldots . \ldots . . . . . .$. .

it is too eholerie a meat: how say....

to dress thy meat myself, and bring...

so shall mine before you toueh the meat

the meat is eold; the meat is cold.. Comedy of $E_{r}$.

your meat doth burn, quoth I

that never meat sweet-savoured in ...

good meat, sir, is eommon

if you do expect spoon meat........
thou say'st his meat was sauce

the sauee to meat is eeremony.

to our tobles meat, sleep to

and who abstains from meat, that $\ldots$...

away! I am meat for your master ..24enry $I V$. ii.

what you want in meat, we'll ....... - (epil.)

I have eat no meat these five $\ldots \ldots . .2$ Henry $\bar{Y} r$. iv 10

ay, to see neat fill knaves...... Timon of Alhens, $i$.

let my meat make thee silent (rep.)..

to see so many dip their meat in one

good for their meat, and saf

has my lord's meat in him

to let the meat cool ere

make the meat be beloved.....

where my stomach finds

that, meat was made for mouthi.....

anger's my meat; I sup upon..... Coriolanus, $\mathrm{i}$.

ise him as the grace fore meat........

upon what meat doth this our ....Julius Casar, i. there is cold meat i' the cave ....... Cymbeline here's money for my meat

you come in faint for want of meat.. 
SIEAT_and ment for these poor men ..Pericles, iii. 2 and eat up the meat, the tir.

Lear, i. 4 very good meat in Ient... Mnmeo \&.juliet, ii. $\overline{4}$ (song) quarrels as an egg is full of meat.... the funeral baked nerts did coldiy .... Iramlet, i. 2 which doth moek the meat it fecds on.. Othello, fii. 3 [Col. Krt.] of Venice stay the meat

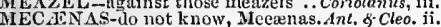

worthily spoke, Mecanas ........... AECIIAN $1 C_{-}$poor mechanie porters ... Men $r y \boldsymbol{V}$.i. ou more ineeltanic compliment...Antony of Clco. iv. meclanic slaves with greasy aprons.

rude meelanieals, that work for.. Mid. N.'s Dr. iii. by most meehanical and dirty hand.2 Henry $V^{\prime}, \mathrm{v} .5$ dunghill villain, and meelianieal...2 Herry $V I$. $i$. know you not, being mechanieal...julius Cesar,
IED ILDDCINA BLE eye correets.. Trailus \& Cressida, Thave derision med'einable, io use.. $\overline{\text { Cymbline, iii. } 2}$

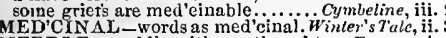
MED'CXNAL-words as med thoughts... Tempest, i. 2 priest to meddle or make. for meddle you must, that's ..... Tweelfth Night, iii. 4 and they are to meddle with none...Muck Ado, iij. 3 do not you meddle, let me deal........ All's $w^{2}$ ell, iv. 1 go ply thy needle; meddle not ... Taming of sh. ii. I'll not meddle nor make (rep.)... Troilus of Cress. 'faith, I'll not meddle in'

whom relation durst never meddie... $\quad$ - iii. 3 medile with my master (rep.) ...... Coriolan I meddle with no tradesman's .......... should meddle with his yard .... Romeo fouliel, $\mathrm{i}$.
MEDDLER-a temporary meddler. Meas. for Mleas. monev's a meddler .......Winler's Tale, iv. 3 (song) hadst lated medd lers sooner... Timon of Athens, iv. 3 on meddling monkey, or on busy ape. Wid. N. Dr.ii. 2 so grossly by this meddling priest.. King John, iii. 1 beat away the busy meddling fiend.2Henry $V^{\prime}$ i.ili. 3 IEIDE-Mredea gathered the... Merch. of lenice, v. 1 as wild Medea young Absyrtus did..2Htenry VI. y. 2
AIEDIA - spur through Media..., Aniony \& Clco. iii. 1 great MIedia, Parthia, and Armenia -
MEDIATION-effeet of mediation...2 Henry $I V$. iv. 4

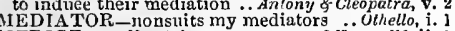
MIEDICE -mediee teipsum ..........2 Henry I'I. i. i MIEDICINA.L-their medicinal gum ..... Othello, v. 2 yet a kind of mcdieine in itself...Mreas. for Mleas. ii. 2 have no other medieine, but only hope $-\overline{i i}$ i. 1 would give preceptial medieine to rage out loathed medicinel hated potion. Nid.N.Dr. iii. 2 patiently receive my medieine ...As you Like $i$, ii. 7 I have seen a inedieine that's able to - ii. 1 the tinet and multiplying medieine

the medicine of our house! ........Winter's Tale, iv. 3 let's make us medicines of our great... Macbeth, iv. 3 meet we the medieine of the sickly

that present medicine must be ....... King John , y. medicines to make me love him ....... Henry $I V$. ii. 2 I have drunk medieines; Poins! ...̈Henry $-\mathrm{V}$, iji. $\mathbf{2}$ preserving life in medieine potable ... - iv. 4 medicine tor my aehing bones 1. Truilus \&-Cress. v. 11 great griefs, I see, medicine the less.

bung thy medieine on my lips

[Kni.] if not, I'll ne'er trust medieine .... - y. 3 rosidcnee, and medicine power... Rome of Juliet, ii. 3 and medicines bouglit of mountebunk 8 .. Othello, $\mathrm{i} .3$ shall ever medicine thee to that sweet

WIEDITA TE the while, work nothing do but meditate on blood ....Henry i. $^{\prime}$ v. 2 Clitus: look. he meditates ......... Julius Carsar 1 EDITATING or virginity? All's "ell, $\mathbf{i}$. meditating that, shall die your .... Henry rl. ii. 4 whilst I sit meditating on that .. Hewry III. iv. meditatlug that she must die ....Jultus Cossar, iv. and let us all to neditation ........2 2ilenry 1 , iij. divinely bent to meditation but on his knees at meditation .......... - iii. ? bet wixt thy begging and ony meditation $\overline{-}$ iv. $\frac{2}{2}$
into my private meditations?...... Henry ${ }^{\prime}$ 'II, ii. to your meditations low to live better - iii. 2 eontinual meditations, tzare, and sorrows - iv. 2 in sessions as with meelitations law fui?. Olhello, iij. 3 salt ware of the Mecliterranean. .. Lore's L.l.ost, v. 1 Malt wrare of the Mecliterraneal ... Lor' 's L. L.ost, v. traft it with a medlar ............ ds you tetke st, jii. a medlar for thee, cat it (rep.). Timon or Allens, iv. 3 will he sit under a medlar tree.. Kooneo \& Juliet, ii. that kind of fruit, as rniticls cali medlars
MEE, -yet did want his meed.. Te'o Gen. of for my meed, but oue fair iook ......
MEED, I am sure, I have received none, Merry W. $W$ i. 2
the meed of punishment ..Love's L. Lost, $\mathrm{i}$. I (letter)

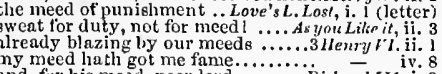
and, fur his meed, poor lord Nichard III. i. 3 and whien I lave my meed, I will away - i. 4 no meed, but he repays sevenfold. Timon of $A / h$. i. I with slownessed was brow-bound i. Coriolan zs, i1. 2 noble minds, is honourable meed.. ititus.Audron. $\mathrm{i}$. there's meed for meed, deatin fo

in his meed he's unfellowed............. Hamlet, v. 2
MEEk-ean be meek, that have no.Comedy of Err. ii. 1 hath horne his facnltics so me are meek, and humblc-mouther affible wolves, meek hears... Timonenry YIII. ii. I am meek and gentle with thiese.Julius Casar, lordliness to one so meek ..Antony \& Cleopatra, , 2 W EEKNESS-meekness in thy breast. Iichard III. ii. 2 thy meekness saint-likc, wife-like .

meekness, lord, beeome a eh

when thou dost meet good hap.. Two $G$

as meet to be an enperor's eounseilor

what thou think'st meet $\ldots . . . .$.

and meet me at tlie north gate.

where shall 1 meet you $\ldots \ldots \ldots \ldots \ldots \ldots \ldots$

and meet with me upon

it is not meet the eonneil .................

that sir Hugh promised to meet

y would my husband would meet him

to meet liim at the door with it ....

and they are going to meet him

they are gone but to meet the duke.

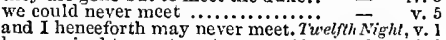

he promised to meet me two .... Neas. for Migas.

from whom we thouglit it meet to
should meet the blow of justice..

'tis meet so, daughter .............

if you think it meet, eompound with

him I'll desire to meet me at
who do prepare to meet hin....

who do prepare to meet him........

of sort and suit, as are to meet him

but he'll be meet with you

Tempest, i. 2

Dever meet, but there i.

while she hath such meet food to feed it $=$

and there will the dcvil meet me

not bite one another, when they meet

if you meet a thief, you may ..........

he would meet her as lie was appointed

nd meet me at the gao

well, I will meet you wit in ....

he and I sliall meet; and tili then

I did meet thee once with $\mathrm{H}$

my Lysander and myself shall meet

and meet me in the palace wood

for if we meet in the eity ...........

at the duke's oak wc neet

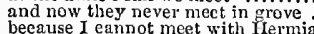

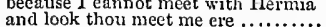

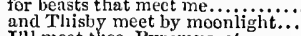

I'll meet thee, I'yramus, at.....

meet presently at the palace

wilt thou at Ninny's tomb meet me

meet me all by break of day

where to meet some mistress $\ldots .$.

do meet, as at a fair, in her

upon the next oecusion that we meet

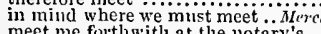

meet me furth w'ith at the notary's.

Tubal, and neet me ab our synasogue

fare you well, till we shall meet again

and it is meet, I presently set forth."

know me, when we incet arain

let's meet as little as we ean ........

if i could meet that faney-mo

you neet in some fresh elieek

meet: as youl love I'lixbe, meet ( $\left.(r e)^{2}\right)$

ean meet lum with any eonvenienee.

an' if 1 could but meet him agai
with me till they meet together

or, ere they n:ect, in me, $O$ nature

and, if it end so meet, the bitter past

ins hold it very meet.... Tamin.

two rogin

you must mect my master ...........
IEEr-did I not bid thee meet me. Taming of sh. iv. I

and in no scnee is meet, or amiable..

so meet for this grent errand....

8hould I now meet my father.......
fair eouple) meets he on the way

ere the ships conld meet by twice. Comedy of $E$ r

In meet with you upon the mart.

he mects such golden gifts

if any hour meet a sergeant.

did 1 neet him with a ehain

when shall meet each other's man

there to meet with IIacbeth

let us meet, and question this

at the pit of Acheron meet me $i$ the

and tis most meet you should

meet we tlie medieine of the

when I slanll meet him in

journey, lords, or e'er we meet

go meet the Freneh; and from

and run to meet displeasure

our party may well meet a prouder foe

and meet him, were I tied to ..........Richard $I I . \dot{\mathrm{i}}$.

never by advised purpose meet.....

here part, that ne'er shall meet agai

well, we may meet again. I fear me
Salisbury is gone to meet the king .

and myself shonld meet with no less

to meet at London London's .........

for kings' months so meet..............

did lately meet in the intestine.....................

when we meet at supper

and meet me to-morrow night

shall happily meet to bear.:
sirral, if they meet not with

dare not meet each other ............

to mect me in arms by the ninth

unthought of Harry, chance to meet

Jaek, meet me to morrow i' the

hot horse to horse, meet, and ne'er par

power, meets witl lord Harry...

that you and $\mathrm{I}$ should meet upon (rep.)

and night to meet you on the way .

until I meet the king $\ldots$...............

dearest specd, to meet Northumberland -

it is not meet that I should be

must go, and meet with danger there
fain would I go to mect the arehbishop

you two never meet, but you .........

of both our battles we inay meet ....

to meet his graee just distanee

means and lavish manners meet together -

we meet like men that had forgot.

[Col. Knt.] streams meet in one sait sea

it is most meet we arm us............
'tis meet we all go forth, to vjew ....
is it meet, think you, that we

no, nor it is not mect he should....

if we no more meet, till we meet in

farewell, until I meet thee next......

I'll meet thee to thy cost .............

nfter, mcet you sooner than....

wale did meet thee next

now they meet where hoth their lives

but meet him now, and, be it in ....2 IIIen

'tis meet, that luck $y$ ruled by

crying, Villageois I urito all they meet

meet me to-morrow in St. Gicorge's...

meet I an infant of the house of York

take leave, until we meet again .....

we'll meet both thee and Warwick..

let's meet at Coventry

you'll meet him in the Tower ..........

wheresoe'er I meet thee (as I wili mcet

is't meet, that he should leave. (rep.)

to meet with joy in sweet Jerusalem

come with me to mect your grace....

met'st me last where now we meet...

until we meet again in hearen .......

who meets us here? my niece.

let me but meet you, ladies.

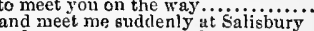

and meet your grace, where aud whet

this mightineas mects misery! .. Henry VITI. (prol.)

there ye shall meet about this

I am joyful to meet the least oceasion

thing meets in mere oppughaney. Trniius

近 ii. 3

i.

i. 2

i. 1

iii. $\frac{1}{3}$

iv. 2

1

3

ii. 2

ii. 3

ii. 1

iv. 1

i. 2

ii. 4

iv.

ii. 4

iji. 4
iji. 4
jv. 1

iv. 2

iii. 1

iv. 9

ii. 2

iv. 7

vis

i. 5

iii. I

iii. 3

iv.

v 4

ii. 2

i. 3
i. 3 


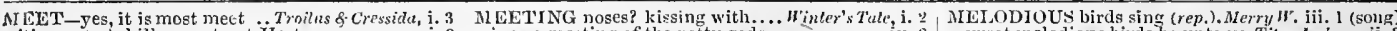

tis mect, Achilles meet not Hector..

it was thouglit incet, Paris should

but when I neet you armed $\ldots . . . .$. his purpose nects you

Ag:amemnon comes to meet

A morrow, do 1 meet thee ......

would I could meet that ro-morrow

one onother meet, and alla

I would fin see them meet.

what, do we meet together? .. Timon of dithen

wherever we shall meet

all that you meet are thieves........

when we may profit meet...

fil meet you at the

Caius Marcius chance to meet

if e'er aginin I mect him ...........

you anon do meet the senate .........

what's not meet, but what must be.

let what is meet be said (rep.

let's not meet her.

conld I meet therp but once $a$ day

wil! go meet the ladie

(rip the joy

therefore 'tis meet that noble minds

prodigies do so conjointly meet......

when Casar's wife shall meet with..

it is not meet you know how

meet to be sent on errands.......

it is not meet that every nicc...

tis not meet they be alone

and meet them at Philippi .............

whether we shall meet again...

whilst I go to'meet the noble Birutus

whilst I go to'meet the noble Brutus

for Cydnus, to meet Mark Antony

if she first meet the curled Anton

you do not meet a man..................

he never can incet more mischanee.

I'll meet you in the valleys

the plaec where they should meet

that possible strength might mect
and meet the time, as it secks us

that we meet here so strangely .......

if we miss to meet him.. Firus dndron

mect, and agreeing with thiue infanc

be it ns you think meet $\ldots$........

\section{等,}

is as a meeting of the petty gods

and not the hostess o' the meeting ...

our point of sccond meetiog

mecting were bare without it.........

broke the good meeting, with most..

shock at meeting tears the cloudy

meeting the check of such another

fearful meeting of their opposite.

peace to this meeting ................

KingJohn, iii.

that bred tlis meting here

changed to merry meeting

by thic confux of meeting sap....

. IenryIt:

and, meeting him, will tell him.

Richary III. i.

and meting andron, iy.

witly wilful eholer meeting. ...... Komeo \&-Jutiet,

ii. 2 and for this time of meeting ............ Hamlet, i.

MEETING-PLACE, and the fellow. Cymbeline, iv. 1

MEET'ST-thou meet'st the fellow.... Henry $V$. iv. 7

how now, Meg? and Marian

good Meg, I'll wear this (rep.
[Col.] I thank thee, Meg............
MEHERCI, if their sons be

MEDERCI, $\mathrm{E}$, if their sons be .... Love's L. Lost, iv.

MEINY-they summoned up their meiuy

MEISEN-in Germany called, Meisen ..Henry/ i. 2

MELANCHOLLY I am! …... Nerry protect thec! Tuelfth Night, ii.

be boiled to death with melancholy

being atdicted to a molancholy as she is -

lumpish, heavy, melancholy. Two Gen. of $V_{e r}$.

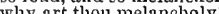

Why art thoul melancholy? (rep.)

half count John's melancholy in signior -

strikes him into melaneluoly

I found him here as melancholy as.

the greatest note of it is his melancholy -

or we are high-proof melancholy ..

turn melanclioly torth to funerals. . ATid. N.'s $\mathrm{Dr}$. i.

of great spirits grows melancholy?

thou part sadness and melancholy a the -

and to he melaneholy; and here (rep.) -
lie made her melancholy, sad, and heavy

not, with this melaneholy bait ...Mer. of $\overline{V e}$

the melancholy Jaques (rep.)

I can snck melancholy ont of a...... -

under the sliade of melancholy boughs -

adicu, good signior melancholy follow =

neither the scholar's melancholy

a melancholy of mine own ... $\dddot{2}$ thus his good melancholy oft begain.

lord to be a very melancholy man ...

why is he melancholy? Perchance... - iii. 5

melanchply is the nurse of .. Taming of Sh. 2 (ind.)

a new ship to purge melaneholy...Winter's Tale, iv.

dut with care and melancholy.

comes this way to the melancholy vale
or if that surly spirit, melancholy.. Ki

of conseience, and sour melancholy... Richard Il.

or the melancholy of MIoor-ditc

musing, and enrsed melancholy? ...

was troubled with deep melancholy ...
is siekly, weak. and melancholy.. Richard $1 I I$.
methcught the melancholy flood ....

i. 4
iii.
iv. 4

eanst yield a melanchoy seat .......

the melancholy lord Northumberlan

you may call it melancholy; if you.

ummanly melaneholy sprung. Timon of Athens, iv.

hatcful error, melaneloly's chr

mistress of true melancholy

a most rare boy, of melancholy

silence, and my cloudy melaneloly? Tilus An

doth sit too melancholy, as if the.

hill awake him from his melanch

my ene is villanous melanclioly

to melancholy bells ......................... Keareor, i. o'er which his melanelioly sits on brood - iii. MIELIUS-quo antiquits, eo melius.Perictes, i. (Gow.) MELLIFLU aUS voice, as I an... Twelfh Night, ii. 3 prosperity berins to mellow mellow $\bar{T} \overline{1}$ ich iv. did shake down mellow fruit ........ Coriolanus, iv. 6
shook down my mellow hangings.. Cymbeline, iii, 3 shook down my mellow hangings... Cymbeline, iil.
fall, unshaken, when they nellow be...Hamlet, iii.

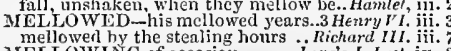
mellowed hy the stealing hours ..Richard III. iif. 7
MELLOWING of occasiou ....... Tove's L. Lust, iv.
MELODIOUS-melodious were it. TwoGen. of Ver. i. sweet inelodious birds be unto us. Titus Anclron. ii.
where, like a sweet melodious bird.. from hicr melodious lay to muddy .... Iramlet, iv. 7 IELOD Y-tongue's sweet melody. M Fid. N.'s Dreum, i.

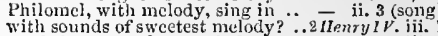
not bob us out of our melody.. Troilus f Cress. iii. with his pretty buzzing melody

at pleasure stint their melody $\ldots . .$. . Te mpest, ij. 1 sliall never melt mine lonour ........ iv. they would melt me out of ny fat.Merry Hives, iv. 5

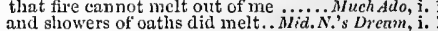
to melt myselt away in water-drops: Richard II. iv. doth begin to melt, and drop........2 Henry $1 V^{\prime}$

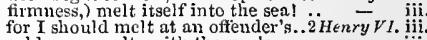
for I should melt at an offender's...2 Henry $V I$. ii.
cold snow melts with the sun's.....

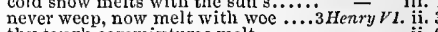
thy tough commixtures melt...

most hard temper melt and lament. Henry $V I I I$ ii. 3 and to melt the city leads upon.... Corrolanus, iv. 6 let Rome is Tiber melt $! . . .$. Antony $\&$ Cleopatra, $\mathrm{i}$.

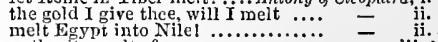
anthority melts from me...

melt their sweets on blossoming..... - - jv. 10 the crown o' the earth doth melt.... Tius $\overline{\text { w }}$ iv. with warm tears I'll melt the snow. learn of us to melt in showers ...... perisles, iv. touching of her lips I may melt........... this too too solid flesh would meit........ Hamlel, $\mathrm{i}$.

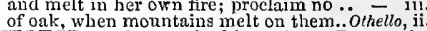
MELTED-and are melted in to air.... Tempest, iv. have melted him in his own grease. Merry Wives, ii. my love to Hermia, melted as doth. Mid. N.'sDr. iv.1 counterfeit lump ot ore will be melted. All's 'Well, iii. 6 with slurieks, she melted in to air. Winter's Tale, iii. 3 what seemed corporal, melted as breath. Mucbeth, i. lest zeal, now melted, by the windy.

they must perforee have meited ..... Richard $I 1$. v. Titan, that melted at the swcet ..... 1 Henry $I V$. ji. 4 as doth the melted snow upon........ Henry $r$. iii. 5 three parts melted a way with rotten. Coriolanus, ij. till he lod melted fron the ........ Cymbeline, i. 4 With that which melteth fools..... Julins Casar, iii.

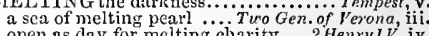
open as day for melting charity...2 Henry 1 V. steel thy melting heart, to hold......
melting with tenderness and mild.Richard $I I I$. iv. 3 the melting spirits of women .....Julius Casar, ii. albeit unused to the melting mood....... Othello, v. my lord Melun, let this be copied out

the count Mrelun is slain.

MENBER of the commonweaith........ a good member of the commonwenlth Meas. iv. member of the commonwealth. Mier. of veniee, vo

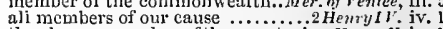
the slave, a member of tbo eountry's... Henry $V$. iv. as festered members rot............ Henry VI, iii. I'll lop a member off, and give it you - v. 3 not bear from me a Greekish inember - iv. all the body's members rebelled ..... Coriolanus, i. 1 replied to the discontented member

being members, should bring (rep.).

therc are members to makc new. Anlony \& $\overline{C l}$ MENENTO MOLI: I never see ..... Henry $\overline{I V}$. iii. 3 he sends yout this most memorable line - Hewry $V$ ii. wear it for a memorable honour...

MENIORANDUMS of bawdy-liouses. I Henry $1 \mathrm{~V}$. iii. 3 IEAIORIAL-with the melnorials . Tuelfth.i.iii. 3 oblique memorial of enckolds .. Truilus or Cress. v. IEMORIES-unbreathed memories. MLid. $\overline{N .}{ }^{2} s \mathrm{~s} r$. v. thcse weeds are memories of those worser. Lear, iv. MIENORIZED-in it be molnurise. Henry VIII. ii. who shall be of as little memory ........ i. no memory of what it was.. Tuo Gen. of rerona, v. 4 he is a good sprag memory......... Merry Wives, iv. else your memory is bad, gaing... Love's L. Lost, iv. are begot in the ventricle of memory

by the near guess of my memory...Mer. of $\overline{\text { Venice, }}$ i. planted in his memory an army of .. - iii. you memory of old sir Rowland. As you Like il, ii. many things of worthy memory.. Taming of Sh. iv. of life some meinory, my wasting. Comedy of Err. v. that memory, the warder of the brain...Macbeth, i. 
MEMORY-pluck from the memory ...Nucbelh, v. ? whose memory is written on. keep no tell-tale to his memory...... may waste the menury ot the... may waste the meniory of the........ Four grand father of famous memory.. Henryl: iv. 7
in memory of her, when she is dead..i Henry $T$. i. 6 note you in my book of memoty note you in my book of memoty your namies from books of moryory.... iv. 3 I thank ny memory, I yet......... liekry Vili. iii. some little memory of me will stir liim - $\bar{C}$ iii. 2 yet let memory, from false to .. Thoilus o Cress. iii. 2 of whose memory hercafter more.. Timon of Alh, y. 5 aen, my memory is tired ........... coals cheap: a noble memoryl ret he shall have a noble memory....... $-\mathrm{v}$. beg hair of him for memoryto... \& Cleopatra, iii. upon record bear hateful memory .. - iv. 9 upon record bear hateful memory

how thy memory will then be panged

made me to blame in memory

it presses to my memory like ....... \&omen \& Juliet, iii. brother's death the memory be green 'tis in my memory locked, and you while memory holds a seat in this...
from the table of my memory...

from the table of my memory....
if it live in your memory, begin

a great man's memory may outlive his

wonld dizzy the arithmetic of memory

it enmes o'er my memory, as doth .... Othe

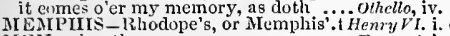

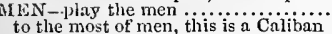

than we bring men to comfort them...

all men idle, all...........................

now they are my men

and men of Inde?..............

or that there were sueh men

you are three meu of $\sin$....

men hang and drown their proper selves - iii. 3

as strange a maze as e'er men trod

that let men know their love ...Two Gen. of $\bar{V}$ er.

while other men, of slender...

eneounters of lascivious men

base men, that use them ...........

kept severely from resort of men.....

by all men's judgment....

black men are pearls

sliapes than wen their minds $($ rep.)...

these hanished men, that $I$....

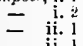

are men endned with.......

jou have beaten my men................Merry wives

fir the putting down of men

of fat men, as long as $X$ have (rep.) ...
a yoke of his disearded men........

were they his men?.

laughing-stogs to other men's humo..... -

iike women in men's apparei

send him by your two inen to...

eall your men, mistress Ford ....

she does so take on with her men....

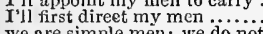

we are simple men; we do

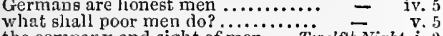

the eompany and sight of men...... Twelfth Night, i. 2

1 take these wise men that crow so..
and three merry men we be

and three merry men we be $\ldots . . . . .$.

what love women to men may owe.

we men may say more, swear more...

Thave heard of some kind of men

'grainst knave and thief men shit $\cdots$...

rou must not speak with men

when maidens sue, men give like.....

are there not men in your ward......

great inen may jest with saints

ever, till now, when men were ford...

men their ereation mar..............

the steeled gaoler is the friend of men

give notice to such men of sort

they say, best men are moulded

not till God make men of some $\ldots$.

for hic both pleaseth men, and angers

men were deeeivers ever........

$=\overline{\mathrm{ij.}} 3(\operatorname{son} \mathrm{s})$

are you good men and true?

you shall comprehend all vagrom men

they are not the men you took them
and for such kind of men, the less ...

being taken up of these men's bills.".

an' two men ride of a horse.

we are now to examination these ne....

what men dare do? what meil (rep.)

and men are only turned into tongue

in the prinee's name, accuse tliese me

for brother, men can counsel......
MEN-all men's office to spenk patience. Mach Ado, $v$ therein do men from ehildre

two of us, and men indeed $\ldots . .$.
witl two old men without teetl

what offence have these men done?..

a pair of lonourable men.............

with armed men back to Messina.

abjure for ever the society of men.....iria. $\bar{N}$.'s $D$

for love, as men may do

the heresies, that men do leave

I am a man as other men are......

if you were men, as men you are in.

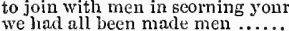

lard-handed men, that work in

they may pass for exeellent men

men sit down to th, I beseech you. Love's L. Lost,

what great men liave heen in love?

let thein be ment of good repute

and make them men of note (rep.).

some men must love my lady .........
with moon [ Col.Knt,-men] like men

affeetion's men at arms

a word that all men love $\ldots \ldots . . . . . .$.

by whom we men are men

prove plagnes to men forsworn

where will you find men worthy

nor I, deliglit in perjured
never breaks men's troth

the two learned men have compiled...

mocks married men, for thus sings he

these same dumb wise nen

and poor men's eottages ................

of all the men that ever my....

is blessing, if men steal it not.....

or cursed st anong men

men, that hazard all, do it in hope

yes, otlier men have ill luck too

to entrap the liearts of men, faster

that ever kept with men .............

that men siall swear, I have

why, shall we turn to men?.

do all men kill the things they

themselves in to the trunks of men....

serves many men to save their....
did give the rings away to men....

a many merry men with hir

...... As you Like

what wise men do foolishly...........
the little foolery, that wise men have

three proper young men, of excellent

be it known unto all men by these..

such odds in the men [ Col. $K m t$.-main]

to some kind of men their graces....

and sat at good men's feasts

glad of other men's good

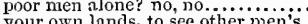

men have died from time to time.

men are April when they woo

unnatural that lived 'morgst men

every day men of great wort

I eharge you, O men, for the love.

how virgins might blow up men?

which men full true shall find

of heaven we count the act of men..
I have an answer will serve all men

created for men to breathe themselves

Where are my other men, monsieur?
that's the loss of men, thourgh it be..

that you do eharge men with.

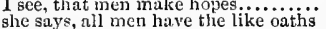

men are to mell with, boys......

but, O strange men! that can
that she, whom all men praised...

that she, whom an men praised.....
men will stay themsel yes. Taming of shere, 1 (ind.)
nor no sueh men as you liare....

my men should eall me, lord ...

for to cunning men I will be very

as seat ters young men through
of all the men alive, I never yet

when men and women are alone

and may not young men die....

thou hast braved nany men

whilcs other men have gates..

saw I men scour so on thi

the miven to men of iniddie..........

and all men's ears grew to his tunes

the dis ut a

made themelves all men wear-a.

since these good men are hleased

pleased

that are not simple men.

seem to be honest plain men men, that slue is the rurest of all women -
-

men, that slue is the rurest of all women -
has these poor men iu question......
MEN-as seafaring men provide
or any piace tlat harbours men

men more divine, the masters of

lairy men plain denlers without wit

have you not heard men say

they appear to men like angel

where any honest men resort......

prevailing much in youthful men

by men of Epidannim...

deign him burial of his men

where men may read strauge.....

attend those men our pleasure?...

and so of men

so all men do from jience...........

to liear the men denp it late...

why, the honest men

and like good men, bestride.............

ten thousand warilike men (rep.

of all men else $I$ have avoided

I doubt, as all men's childiren may.........

lest men should say, look, where.

have is have, however men do eateh

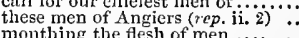

old men, young men, maids

the fury of two desperate men

be kept with slaughtered men?...

laugl ter, keep men's eyes, and strain

when fortune menns to men most good

thive these men away, and I will (rep.)
drive

the faiths of men ne'er stained

my lord; men's mouths are fuld

old men, and heldams in the .........
what men provided, what munition

and cood men, hate so foul a liar.... Ricluerd $\mathrm{v}$.

that which in mean men we entitle..

are like two men that vow ...........

to men in joy; but grief ...........

the tongues of dying men enforee...

more are men's ends marked.

this happy breed of men, this little.

dying inen flatter with those that (rep.) three thousand men of war.

will you go muster men? .............

manned with three hurdred men...

that Foung Mars of men

rich men look sad, and ruffians...

bring forth these men; Busluy

here, in the view of men .............
the breath of worldly men eannot.

weak men must fall: for herven

have twelve thousand fighting men!

wise men ne'er'wail their present

to great and growing men $\ldots \ldots \ldots \ldots . . .$.

of Golgotha, and dead men's skulls.

the favour of these men; were they not
the souls of ner may cleem that you

roof did keep ten thousand men?...

been still a liappy king of men

the eyes of men, after a well-graced.

nore contempt, men's eyes did seowi

it will make wise men nad

learling the men of Ilerefordshire....

and let men say, we be men of good

$\mathrm{O}$ if men were to be saved by

shall roh those men that we have.... -

when men think leost I will s hopes -

that men of your nohility ............

young men must live...............

such as we see when men restrain

there live not three good men $\ldots . .$. .

eleven buekram men grown out of ...

know these men in Kendal gicen...

followed certain men to this house (rep.) -

if he have robbed these men

$I$ am not in the roll of common men

a nobleman, loseth men's hearts..... -

that men would tell their children..

did pluek allegiance from men's hearts -

as eloudy men use to their adversuries

tecds him tat, while men delast tlink, if wre

tusl man, mortal men, mortal men

being men of such grent leading ....

and dear men of estimntion....

and all his men upon the foot of ....

so disl our men, heavy in rIotspur's - (induc.) 
MLN-as men drink potions. men of all sorts take a pride ........

the cause that wit is in other men . using the names of nien instead of men $O$ thoughts of men accurst .......... die, men, like dors; give crowns ... die, men, like dogs; give crowns ... there is a history in all men's lives. two of sir Joln Falstaff's men laklf a dozen sufficient men? there are other men fitter to go out.... come, sir, which men shall 0 give me the sparc men, and spare o give me the spard the men away lord, lord how subject we old men are for crowding among the marshal's men in the throngs of military men. our men more perfect in the use against ill chances, men are ever $\ldots . .$. thint we may peruse the men we slould colierence of his men's spirits and hi I would humour his men with the if to his men, I would curr.

as men take diseases, one of ............

we meet like men that had forgot...

thrice wider than for other men whicl men devout by testament lurketh in men's ears, to steal men may sleep, and they may have sweet men, come to him ....

show men dutiful? why,

with men of courage, and with mean the dead men's blood, the pining

copy now to men of grosser blood....id that men of few words are the best men the men would carry coals

as familiar with men's pockets .......

like to men proud of destruction

what men have you lost, Fluellen?..

just, just; and the men do sympathize

would men observingly dist

'tis good for men to love their........

'tis a mans poor men's

now if these men do not die well ....

if these men have defeated the ...

outstrip men, they have no wis.

kings neglect, that private men enjoy?

creating awe and fear in other men?

of fighting men they have full .......

the fewer men, the greater share

if men my garments wear.

old men forget: yet all shall

unwished five tbousand men ...........

have reinforced their scattered men

there is goot men porn at Monmouth

fifteen hundred, besides common men

of all other men, but five and twenty

pales in the flood with men .......

confining mighty men $\ldots \ldots \ldots . . . . . . .1$

bnt bont of weu and morey

no leisare had he to enrank his men

keeps lis men from mutiny

nor men, nor money, liat

mean more than we poor men do kno

draw, men; for all this privileged place

all manner of men, assembled ......

mirror of all martial starved men.

hear how we have played the men

amongst the troops of armed men....
when $a$ world of men could not prevail

prove on better men than Son

through malice of the bishop's men..

and my power of men are yours

we lost twelve hundred men .........

what madness rules in brain-sick

men's flesh preserved so whole

will you lead a band of men

twas men I lacked, and you .............

no knife, to slaughter sleeping men... with the men of Bury ...............

blasphening God, and cursing

clip dead men's graves ...............

great men oft die by vile ............

let the magistrates be labouring men

for they are thrifty honest me

that thou hast men about the

when honester men than thon

you men of Kent, - what say

great men have reachiog hand
Cade driven back, his men dispersed

come thon and thy five men

3 dead men's cries do fill .....

二 iv. 10

WhN-for 'tis a bond in men .... Timon of Athe

whint a number of men eat Timon $($ wender, men dare trust themselves (rep.)

great men should drink with harness

five set our men in order....

be thou reveuged on men....

like mell born to renown $\ldots \ldots \ldots . .$.

a band of thirty thousand men

iii. 2 a thousand men have broke...

iii. 2 sad-hcarted men, much overgrown

iii. 2 and men man say, it is the wise

iv. i al, simple men, you know not....

iv. the lightness of you common men

iv. 2 go levy men, and make prepare for war =

iv. 2 so near as men report.

that men must needs abid

for few men rightly temper...

let's levy men, and

shalt find men well inclined

wise.men ne'er sit and wail

born to be a plague to men .....

and men ne'er spend their fory

men for their sons, wives for .........

two braver men ne'er spurre

this it is, when men are ruled........ Richard III. i.

all men, I hope, live

smile in men's faces $\ldots \ldots \ldots . . . \ldots . . .$.

iii. 4 some lay in dead men's skulls

iii. 2 from out a world of inen, to slay

iii. 2 and desire all good men's love

iii. 3 storms make men expect a deart

iii 3 men's minds mistrust en suing

iii. 6 oft have I heard of sanctuar

when men are unprepared ..........

and so 'twill do with some meu else

momentary grace of mortal men...

when holy and devout religious men

(y)

ere men can say-God save the queen!

go, muster men shall deal unad visedly

what men of name resort to him?

force the swords of wicked men to.....

call for some men of sound direction

let men conquer us, and not

what men of name are slain $\ldots \ldots \ldots$. Henry $\bar{V}_{I I I}$.

men might say, till this time .........

should juggle men into such strange

abusing better men than they can be

understand again like honest menl ..

men of his way should be most liberal
their evils on the graves of great men

by those men we loved most.

that angels love good men with......

all men sonours lie in one lump.

two equal men; the queen shall....

they should be good men; their affair

like free and honest men, our just.

ae speak like honest men .............

either for such men, or such business

my amen to't $t$ All men's. Tivere's.

your envious courses, men of maliee
main assent of all these learned men

those men are happy; and so are all

i. 5 men's evil manners live in brass

ii. 2 those men are happy that shall (rep.)

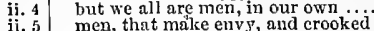

to men that understand you....

iii. 3 men's prayers then would seek you..

out of the gripes of crucl men.........

I had had men of some

please your honour, we are bit men...

so do all men; unless they are. Troilus

men prize the thing ungaine

persistive constancy in men? $\mathrm{f}$.......

or the men of Troy are

iii. 2 that we have better men .....

an' all men were o' iny min

iv. 1 at whose request do these men play?

must fall out with nien too ....

iv. 4 for men, like butterflies

iv. 7 save thege men's look

iv. 7 some men do, while some men $($ rep. $)$

that men do give themselves

you men will never tarry ...........

that gods and men, address their .... to drink those inen, upon whose.

men shut their doors against

where be our men? Here, my lord.....

when men come to borrow.....

men, and men's fortunes ............

\section{i. 4}

one of lord Timon's men ?............

has paid his men their wan

what charitable men afford to

but, I perceive, men must learn.........
one of lord Timon's men. Flaminis

why do fond men expose themselves

to borrow of men, men would....

plagues, incident to men, your potent

sociesties mar men ...........

pluck stout men's pillows from ........

borc at men's eyes, are not

and mar men's spurring
men daily find it such.

men report, thou dost affect..........

the escs, and hearts of men at ditity

not been born the worst of me

the the melves -

fall in the confusion of men, and remain =

not thieves, but men tlat much do want =

you must eat men: yet thanks ...... -

Ihave forgot all men; then..........

thou shalt build from men

give to dogs what thou deny'st to men

thine ine blasted woods

thine own faults in other men? ?........

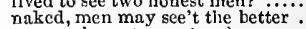

you are honest men (rep.)

goodly ager men ly, the beards

ii. 2 all living men did hate .............. v. 5 (epitaph)

corn for the rlch men only .........

rou men are best inclined

you two are old men ....................

yet, by the faith of men, we have som

many great men that have flattered

so men obeyed, and fell below his stem =

run reeking o'er the lives of men...

supplied with worthy men $1 . \ldots . . . . .$.

of all the men i' the world.

than war's a destroyer of men......

ii. 1

the econd name of men, obey

ii. 2 whence men have read his fa

ii. 2 my best and freshest men.............

and men of heart looked wondering
men and lads, if you have writ.......

you cruel men of Rome, knew you..

assemble all the poor men of your sort

else wrould soar above the view of men

the shows of love to other men ......

if you know that $I$ do fawn on men
what you and other men think of ..

and we petty men walk under

men at some time are masters .......

have men about me, that are fat (rep.)

too much: such the deeds of ment......

they saw men, all in fire $7 \ldots \ldots . . . . . . .$.

let not men say, thcse are their.......

but men may construe things.........
it is the nart of men to fear and tremb

old men fools, and cliildren calcnlate

if not the face of men, the sufferance

cowards, and men cautelons ...

such creatures as men doubt .........

any thing that other men begin ....

in the spirit of men there is no blood

with toils, and men with fiatterers..

care draws in the hrains of me

that will mike sick men whole.

and dying men did groan......

iii. 2 most that

bat one mind in all these men ... -

\begin{tabular}{l|l} 
iii. 3 & might fire the blood of ordinary men \\
iii. 3 & furnished well with men, and men are
\end{tabular}$$
=\text { i. }
$$$$
\text { ii. }
$$

ii. 2

ii. 3
iii. 3
iii. 3

iiv. 1

iv:

iv. 6

v. 2

v. 5

,

i.

ii.

the men that gave our country liberty

sliall light upon the limbs of men ... have placed their men ot trust?......

advanced, declines; and then men die

chances common men could bear ....

men and lads, if ever trod upon ......
lead these men abnut the streets?....

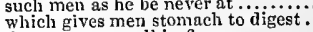

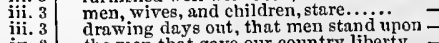




\section{MEN}

[501]

MER

IFEN-issue of these bloody meu..Julizs Cersur, iii. 1 MEN--which men may, blame, but not.... Lear, iij dead, and live all free men? $\ldots \ldots \ldots$.... nll honourable men (rep.)............. and men have lost their reason......... you are not stones, but men (rep.) and staled by other men, begin his... but hollow men, like horse I shall be glad to learn of noble men he firiends, as two such men should be even so great men great losses

Clandins, and some other of my men since the nftairs of men rest still

show to the apt thoughts of men .... 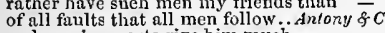 and men's reports give him much

the arm and burgonet of men.....

paragon again my man of men ......

that the men might go to wars with

a husband than the best of men

all men's faces are true...

to have a name in great men'

and that slain men should solder up

by the way should have borne men.

have well becomed the best of men.

And we are women's men.

iii. 2 they are not men of their words....

iii. 2 men must endure their going

iii. 2 howll o you are men of stones

...

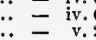

iv. 2 our masters, and us their men

iv. 3 draw, if you be men. Gregory

iv. 3 to part these men with me

iv. 3 what ho! you men, you beasts

iv. 3 men so old as we to keep the pence

as do lusty young men feel.......

nay, bigger; women grow by men.....

athwart men's noses as they lie asleep

all in one or two men's hands

young men's love then lies not .........

yet his led excels all men'

ii. 1 in the publie haunt of men....

ii. 2 men's eyes were made to look

ii. 6 they are free men, but I am banished

when that wise men liave no eyes?

covered quite witl dead men's rattling

the thonglits of desperate men!

the strength of twenty men.

worse poison to men's souls..............

fit to open these dead men's tombs

o'erwhelm them, to men's eyes

that the se men, carrying, I say, the stamp

sure I am, two men there are not
that old men have grey beards

that old men have grey beards $\ldots 1 . . . . . .$.

and the liberty, the se are the or
for wise men know well enough

nature's journeymen liad made men

could of men distinguish her election...

young men will do't, it' they come - iv

dead nen's fingers call them

even while men's minds are wild

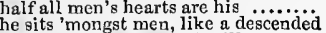

attended by my men; I will ...

were they all made such men.

our countrymen are men more ordered

remembrance $y$ et lives in men's eyes

men's vows are women's trait

true honest men being heard .......

great men, that lad a eourt

the common men are now in action

we scaree are men, and you are gods

we scaree are men, and you are god
pass was dammed with dead men

pass was dammed with deal

you are more clement than vile men

as men report, thou orphans' father art =

in despite of heaven and $m$

to be where ill men were to men of noble minds, is honourahie. Titus $A$

remit these young men's heinous fault

gentle aged menl unbind my sons..
with their tongues doom men to death

whilst I live, deeeive men so

and fair men call for grace......

of griefs would make men mad...

mo big-boned men, framed of the $\ldots$...

a power of high-resolved men...

thou the gidayen of Rome

digged up dead men from their graves

take vengeance of sueh kind of men
but we worldly men have miserable

you sad-faced mea, people...

are by, men praise themselves .........

every virtue gives renown to men!....

all good men, as every prince should do

eonntless eyes to view men's acts
those men blush not in actions...

those men blush not in action
our men be vanquished...

our men be vanquished......

whose men and dames so jetted and....

ships and number of our men..........

liarbourage for ourself. our ships, and

be quiet then, as men should buccer

where when men been, there's seldorn -

thinking of the poor men that were..

why, as men do aland: the great ......

all that may men approve, or men detect

since men take tromen's of men......

since men take women's gift
reft of ships and men (rep.).
since they love men in arms

gince they love men in arms meat for these poor men...

if men were as they bave been men......

by men, then men must comfort $(\mathrm{rep}$.

tords and great men will not let me
lord

for wise men are grown foppish...

to be such men as may besort.

by train are men of choiee......

are led by their eyes, but blind men.

if you do love old men, if your .......

and fifty men dismissed? ....................

pities neither wise men nor fools
hing fated o'er men's faults ....
MEND...Eo I shall mend mine own. Timon of Ath. iv. 3 you take much pains to mend
now begins to mend.

plague and infeetion

mend, and cliarge liome.

you must return, and mend

our worend you (rep.)............. Julius Casar, $\mathrm{i}$

to mend the petty present.

such that mend upon tlie world

mend your speech a little

2 mend, when thou canst

our toil shall strive to mend................. Ro

i. 4 dull ass will not mend his paee

i. 3 bad from bad; but, by bad, mend

Hamlet, y. !

MENDED again; the matter. Measure for Miteasure, $v$

would that have mended my hair?. Tuelfih Night, i. 3

but this (and all is mended). Mid. $\%$;' 3 Dream, (evil.)

to-morrow it shall be mended .. Taming of Sh. iv.

show now your mended faiths ........... King John, v. 7

whieh he mended thus...

'tis not well mended so ......... Timon of \& Crens, iv.

my mended judgment (rep.) $\ldots . . . \ldots$. cymbelime, $\mathrm{i}$.
MENDER of bad soles

MENDING of highways in summer. Mer. of Ven. $v$.

and ean put them to mending.........Much Ado, ii.

MENECRATES and Menas .......Triony \& Cleopalra, i. 4

MENELAUS' queen ....... Troilus \& Cressida, (prol.)

fair Helen best, myself, or Menelaus?

the first was Menelaus' kiss...

answer? the noble Henelaus ........ - iv.

but to be ius' tent, most princely Troilus - iv. 5

of a lazar, so I were not Menelaus.... - $\quad$ v. I

thy husband may be Menelaus........3 Henry $F^{\prime} 1$. ii. 2 MENENIUS-Menenius Agrippa ...... Coriolanus, $\hat{i}$. honourable Menenius, my boy Marcius -

ay, worthy Menenins.
on's brows, Menenius.

ever right. Menenius, ever, ever

noble Menenius, be yon then as.......

with old Menenius, and those senators

is this Menenius? 'Tis lie, 'tis he .....

touched your ears: it is Meneniu

than thy old father Menenius doest.

another word, Nenenius, I will not hear -

MENON-hatli beat down Menon. Troilus \& $\bar{C}$ res

MENTAL - the still and mental parts

what a mental power this eye.. Tineon of Athens, ii. 3

MEN'TEITH-Angus, and Menteitl... Henry I $\mathrm{V}$. $\mathrm{i}$.

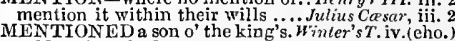
gold witbin the letter mentioned. Titus Andron. MIENTIS-tanta est ergà te mentis.. Henry $/ 11$. îi. MENTON-et le menton? de chin .... Henry ${ }^{\text {MEP iil. }}$ MERCADE-Welcome, Mercade .. Love's L.Lost, v. MERCATANTE, or a pedant. Taming of shrew, iv. MERCENARIES; the rest are ........Henry $l$. iv. and soaked in mercenary blood ....... Hen'y $r_{\text {. }}$. H

MERCER. Three-pile the ineree...... Coris. for Meas,

MERCHANDIZE-witl merchandize. Nid. N. Dr. ii.

my merchandize makes me not sad.

I can make what merchandize I will - - i

merchandize, whieh thou hast ...Antuny \& Cleo. ii.

adventure for such merehandize. Romeo \& Jutiel, ii.
MERCIIANT - of some merchant......

and the merchant, have just ..........

merchants most do congregate,.. Merch, of renice, $\mathrm{i}, 3$

what news among the mereliants? .

twenty merehants, the dike himself

to press a royal merchant down......

the Jew and Antonio the merch is the merchant here.
which

give sentence 'gainst the merehant ...

cut of nenrest the merchant's heart..

a poind of that same mercliant samin

now I play a merchant's part.........

merchunt of Syracuea, plead no..Comedy of Er.

merchants, our well-dealing eountrymen -

therefore, merchant, I'll limit thee ..

to certain merchants, of whom I
some merclinnt hatl invited him

some merchinnt liatl invited him .....

iii. 2

there's a whole merehant's venture. $2 H_{\text {an }}$ ij.

like merehants, venture trade abroad.. Henry $;. \mathrm{i}$.

this is a ridaning merehant .......... Henry . il.

ourself the merchant ........ Troilus \& Ciessida, i.

like merchants, slow our fonlest wares -

turucd crow ned kings to merchants."

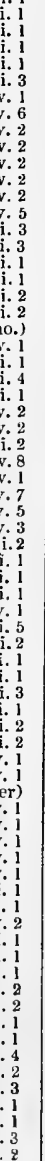

ii. 2 
MERCHAN'I-I know the merchant. Timon of Alh. i. I

art not thou a merchant? ............ what sauey merchant was this... Romeo \& Juliet, ii. 4 MERCHANT-MARRING rocks. Mer. of lenice, iii. commit my body to your mereies.2 Henry IV (epil.) althourly the king had mereies ..... Uenry ViII. it. MERCHF UL-they are mereitul......... Tumpest, v.
mereiful heaven! thou rather ...Meas. for Meas. ii. your honour is accounted a merciful mun - iii. 2 then must the Jew be inerciful...Mer. of

be merciful; take thrice thy money.

you are a merciful general $\ldots . . . . . . . . . A t^{\prime} s \bar{w} e l l$, iv. death had bcen niore merciful ... Winter's Tale, ii. mereiful powers! restrain in me.
merciful henven! what, man!

o let us $y$ et be mereiful. So may ........ Henry $l^{r}$.i. be mercitul, great duke, to men of mould! - iii. the king is merciful if you revolt ..2 Hewry I. iv.
you are so merciful: 1 see your... Henry VIII. v.
the mereiful eoustruetion of good.

mear them then in being mereiful. Titus Andron. i. if thou be mereiful, open the tomb

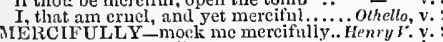
MIERCIFULLY-mock me mercifuliy..Henry I: y. the merciless Maedonwald (worthy to.. Macketh, i. mereiless proeeding by thesc Frencl. King $\mathrm{John}_{\text {, ii. }}$ the peasants, rude and merciless the $^{2}$ Henry $V I$. iv. 4

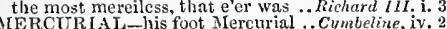
MIERCURIAL-his foot Mercurial COymbeline, iv. Mereury endne thee with leasing.. Twelfhh Nigh', the words of Mereury are barsh... Love's L. Lost,
littered under Alercury.......... Winter's Tale, be Mercury set feathers to thy ....King John, iv. the ground like featlered did bear . Richas iII
that a winged Mercury
Jove's Iercury, and herald for a king like ehidden Mereury from Jove. T'ooitu and, Mereury, lose all the serpentine the strong-winged Mercury.... Antony \& Cleo. i here to Mercury: to Sattirn, Caius

to Jove, and this to Mercury ........
a station like the herald IIercury MERCUTIO, and his brother. Romeo \& Jul. i. 2 (vot peace, peace, Merctitio, pcace ........ pardon, good Mercntio, my business Mray thee, good Mlereutio, let's retire rentle Irercutio, put thy rapier up ... liold Tybalt:-trood ALereutio......... in triumph! and MIerchtio slain!.... which way ran he, that killed Mereitic
slew thy kinsman, brave Mercutio.. slew thy kinsman, brave Mercutio
steel at bold Mercutio's breast

hit the life of slout Mcrentio

Romeo slew him, he slew Mercution

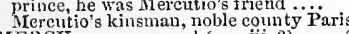
MERCY -merey on us! (rep. iii. 2)...... Tempest, alick, for merey!........................

I'll tum my merey out of doors

lie at my mercy all mine ene

o cry you mercy, sir.................... Ge ve ver merey ou me! his merey sake.......
pless you trom hour merey; give your worship prompt us to have merey on him. Tuelfth God have mercy upon one of (rep.) - iii. 4 (chal.) mortality and mercy in Vicnna...Meas.
merey is not itselt, that ott looks so.. nor man, grieve at the mercy..

and mercy then will brcathe within lawful merey is wothing akin to there is a devilish merey in the.

aul that instructed him to mercy

this would make mercy swcar ....

when vicc nakes merey, mercy's so $=$ kneel down, in mercy of this taut. crave death more willingly than mercy
take this merey to provifle tor.........

Oery you mercy (rep. ii. 1)

let all imy sius lack merey!
leave thce to themercy of wild beact.
I cry your worship's mercy, heartily

I cry your worship's mercy, heartily

Lurd have mercy on us, on those

that lie within the merey of your ......

there is no merey for me in.......

empty from any dram of merey .....

how shalt thou hope for mercy......

thic quality of merey is not strained.. =

we do pray for mercy; and that same -

all to render the deeds of merey ....

and beg mercy of the duke

what merey can you render hiin
MERCY - better part made merey. As you Like it, iii. I
cry the man mercy; love him ...... God's merey, maiden! does it eurd..... All's Well, i. to ask me merey (rep. $\ldots$ fo..........

O merey, God! what stuff is.. Taming of Shrer, iv. 3 that mercy does; for calumny.... Winter's Tale, it. without more merey, to its

mercy on's, a barne! a very pretty... - iii. 3

name of merey, when was this, boy?
God, for thy mereyl they are... Comedy of $E r r$. iv.

when there's no mercy left .....

perseverance, merer, lowliness.....

merey ou me! methinks, nobody ...
he will awake my merey, whicli lies

that merey, whieh fierce fire, anc iron

infinite and boundless reach of mercy - iv.

unto the sovereign merey of the king

then let them have that mercy

let my soul want mercy ......

and roared for mercy, and still ran...

there you no seeming mercy in ........

this offer eomes from mercy.........2 Henry $I V$.

and do observanee to my mercy $\ldots . .$. . . iv. 3

sir, you show great mercy, if youl....

to your highness mercy talk of merey

God quit you in his mercy! .........

and to take mercy on the poor souls

the gates of mercy shall be all shut up

and lives, to thy soft mercy: enter...

besides, in mercy, the Constable

I will some mcrey show ............
shall take, shall taste our merey....

have mercy on us $(r \in p$.$) ..........$

then, God take mercy on brave

I ery you mercy, 'tis but quid ......

I ery you mercy, madam, was it you? - i. 3

but God in mercy so deal with my ..

yield to mercy, whilst 'tis offered you

stoop nuto a Frenchman's merc

for grace and mercy at my fect .......3

open thy gatc of merey, gracious God!

Clifford, ask mercy, and obtain no..... graee -

my mercy dried their water-flowing..

and at his hands beg mercy.

no hoped-for mercy with the brothers

I ery thee merey then; for I did think

I do ery you merey (rep. iv. 4) $\ldots$....

mercy, lords, and watehful gentlemen $\overline{\text { in }}-\bar{v}$.

列

to the mercy of a rude stream.........

is there no other way of mercy

merey o' me, what a multitude ......

stand at merey of my sword ............

brief plague be mercy, and linger not

emboldens sin so muchi as mercy. Timon of $A t h$.

in defence, by merey, tis most just.. - iii. 5

i' the part that is at mercy?.......... Coriolanus, i. 10

I would not buy their mercy at....... - iti, 3

unless the noble man lave mercy.... - $\begin{array}{r}\text { iv. } 6 \\ \text { v. }\end{array}$

mean to solicit him for mercy ..........

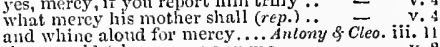

thou wouldst have mercy on me .....

Gods are more full of mercy .........

merey is nobility's true badge..... Titus Andron. v.

this merey shows, we'll joy

and hold our lives in mere $\ldots \ldots \ldots \ldots$...... Lear,

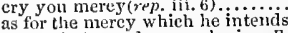

mercy but murders, pardoning. Ro

merey, and thou sec'st it not! (rep.)

a madman's mercy bade thee run away

never, so help youl mercy ..................

God a' merey on liis soul! ..........
dealt with me, like thicves of mercy

I cry you mercy (rep. v. 1) $\ldots . .$.
heavch lave inercy on me! $(r \in p$.

and have youmerey too
IERCY-IACKING uses

cozenag!

.....................

the merc effusion of thy proper.... nyon his mere request, being eome ...ve' $\bar{L}$.Lost, i. he spcaks the mere contwiry .......... a mere lituless bluck................ sts you Like

that we are mere usurpers, tyrants
second childishincss, and mere oblivion
MER E-judgments are mere fathers of.. Al's Irell, i. 2 the merc word's a slave

the mattcr thus; inere wenkness... Winter's Tale, ii. 3 shall procecd; this is mere falsehood - iii. 2 your son, with mere conceit and fear - iii. 2 and tize anatomy, a mountebank . Comedy of trr. v. your will, of your nere own loyalty, and mere dislilse of our...... Henry $I V$. iv. 1 but this is mere digrcssion from.....2 Henry $I V$. iv.

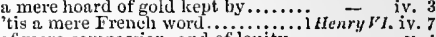
of mere compassion, and of lenity... mere instinct of love, and oyalty. madam, this is a mere distraction. Henry VIII. jii. that, ont of mere ambition ........... - iii. 2

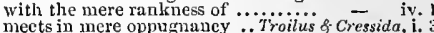
mects in mere oppugnancy ...Troilus \& Cressida, i. 3

a mere recreant prove $\ldots \ldots \ldots \ldots \ldots$.

words, words, mere words, no matter

answer mere nature, bid them flatter

even the mere neccssities upon it.....

but in mere suite to be mere foolery, 1 did not mark it .... Julinsciesur, $\mathrm{i}$. nay, to thy mere confinsion ........ Cymbeline, iv, your pleasure was my mere offenee...

and that opinion a mere profit......... Pericles, iv. and our mere defects grove our....... and our mere defects 1 rove our.

but mere implorators of mnboly suits... Hamlet, $\mathrm{i}$. 3 we are pictures, or mere beasts mere prattle, without practice is all his.olnello, $\mathrm{i}$. but $I$, for mere suspicion in that kind than in putting on the mere form of civil - i. 1 the mere perdition of the Turkish ......

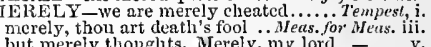
which will be merely a dumb show... Huch sdo, ii. 3 men and women mercly players... ss you tice it love is merely a madness............ - iii. to live in a nook merely monastie... are we! Alerely our iii. will inform, merely in hate......... Richard Ii. ii. are merely shadows to the unseen ... and merely to revenge ............... may be merely poison!........ Timon of Athens, iv. I heavell kuows, is merely love.......... $\overrightarrow{\text { coriolunus, iti. } 1}$ of my countenance merely upon ...Julius Ca'sar, i. 2 give up yourself merely to chance some falling merely through fear.... Cymbeline, $\mathrm{v} .3$ gross in nature, possess it inerely ....... Hamlet, i. it is merely a lust of the blood $\ldots \ldots \ldots \ldots$ othello, i. 3 MEREST-the merest loss ... Taming of Sh. I (induc.) ERIT-uurivalled merit .. Two Gent. of Verond, v.

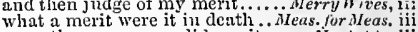
more than ever man did merit....... Huch $A d o$, iji. takes simpleness and merit purchaseth - iii. my beanty will be saved by merit... Love's $L . L$. iv. by the merit of the wearer!............. inspired merit so by breath.........

but that the merit of ervice is.

this kinduess merits thanks.. Taming of sfiren, iii. as he from heaven merits it ....... Hinter's Tale, v. 1 by the merit of vile golid...

a clearer morit, not so deep. If men were to be saved by merit..... Henry $I r$. i. 等

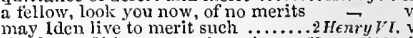
may lden live to merit such .......2 Henryly y. makes merit her election .....Troilus f-Cressida, $\mathrm{i}$. what merit's in that reason........... -

some image of the affected merit .....

assubjugate his merit, as amply

prizes of aecident, as of as inerit.....

in your thoughts, merits fair Helen.

both merits poised, each weighs

too mueli of your own merits.

Timon of sthens, intecd, in atught he merit net ....... Coriolanus, i. lalsely i' the plain way of his merit

but he has a merit, to ehoke it

if for the sake of merit thou wilt..... Antony \& Cleo. ii.

we answer others' merits .............. cymbelin

to load thy merit richly $\ldots \ldots \ldots \ldots \ldots$
the graces for his merits die ......... 
MER [503]

Merch. of finice, i. $3 \mid \begin{gathered}\text { MESSAGE-your message done. Two Gen. } \\ \text { many wonien would do sueh a niessage? }\end{gathered}$

and thou a merry devil, didst rob $\mathrm{it}$ of

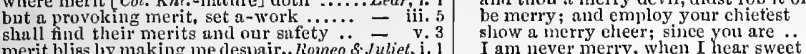

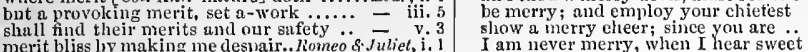

ii. 8 slow you the heart of my message......

som pothe hight, i.

many merry men with him......... As you Like it, i. 1

it was loy private rogure

alce preate merst.......

whose merit must shall be ........... Hamlet, it.

the more merit is in your bounty ....... Hamlat, it.

the spurns that patient merit ............ $\overline{\text { nello, }}$,

oft got without merit, and lost without.

nor purposed merit in futurity

[Knt.] Jujiter] how merry are niy spirits

a message well sympatlised .... Love's $l$. Lost, iii.

and tuve his merry note unto .... -

have a fool to make me merry .......

tlian would make up his niessage.

unfold his messare ere he conie.

when you are disposed to be merry .. - i - iv. 1 of Hereford, my message

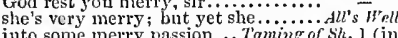

IERITED bene fit .........Measure for Measure, iti.

but, whatsoever I have merited.... Merry Wives, ii.

your grace. how merited to be so. Wminrs Tale, iil.

more of thee merited thrn a band... Cymbeline, v. 5

more hath it merited, that let. Titus Andronicus, iji.

to be noted for a merry man ......
though be be merry, yet withal

be mad and merry, or go hang

good sweet Kate, be merry (res.

by message craved, so is lord Talbot.j Itenry VI.

on what submissive message art $\ldots \ldots$ - - iv. ?

go, tell this heavy message to the king

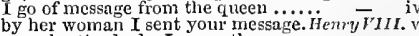

now, by thy looks I guess thy message - v.

do a fair message to his kingly ... Troilus \& Cress, i. 3

merty, or sad, shall't be? As merry. Winter's $T$. ii.
a merry heart goes all the day ... - iv. 2 (song)

a merry heart goes all the day .... - iv. 2 (song)
be merry, gentie; strangle such though ts - iv. 3

a merry ballad; but a very pretty (rep.) $=$ iv. 3

slall break that merry sconce

sliah break that merry sconce 1 ane starve for a merry look

to see you in this merry vein ..........

by bumble message, aud by ...Timon of A/hrns,

MERIIAID, on a dolphin's baek. Mid. N's Dream, ii.

mine ears against the mermaid's song - mis.

so many mermaids, tended ber ...Antony \& Cleo. ii.

at the helm a seeming mermaid steers - - it

MEROP - thou art Merop's son.. Two Gen of Ver. iii. I

MER a merrier man within the limit.. Love's $L . L$. .i. 1

would you yet I were merrier?.... As you Like it, i. 2

reserve them till a merrier hour.. Comedy of Err.
indeed I have been merrier........... King John, iv.

indeed I have been merrier...........

a merrier day did never yet gre
I am merrier to die, than thou

that men are merriest when they

girls which hath the merriest eye ....ïHerry VI. ii, 4

girls which hath the merriest eye .MHeary

after summer, merrily (rep.).... $\because$ empes', $\nabla .1$ (song)

what! youl look merrily.................

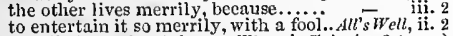

merrily lient the style-a.. Winler's Tale, iv. 2 (song)

doleful matter, merrily set dow

or sad, or nerrily? .......... Comedy of Errors, iv. 2

now merrily to horse; the thieves.... - ii. 2

is near; die all, die merrily ........

so merril and ever (rep.) ... Henryi IV. v. 3 (song)

so merrily, and ever merrily the humblebee...Troilus \& Cressidt, v. i]

enter my nistress' house meirily.. Timon of $A$ th. ii. 2

I will merrily accompany you

look fresh and merrily; let not....JuliusCcesar, il.

MERRIMAN, the poor eur is. Taming of Sh. I (induc.)

AERRIMIENT than a vice. Measure for Mersure, ii.

to set a nouth to merr...

do it but in mocking joerriment... Love

L.Lost, v. 2

nowing aforeband of our merriment

despite of mirth, mean to be merry.

you are a merry man, sir.

saving your merry humour .........
the netry wind blows fair from

your man and you are marvellous merry

I should be as meriy os the day

be merry, for our time of stay

shall we be merry? As merry

if to be old and merry be a sin ......
make me merry. I was as virtuousi

a merry song, come; it grows la
ha, it was a merry night ...........
ill chances, men are ever merry.

ill chances, men are ever merry.......

and bid the merry bells ring .........

there's a merry heart: good naster..

be merry, be merry, my wife's (rep.) $-\bar{v} .3$ (song

I have been merry twice and once.

and a merry heart lives longa.....

they with merry march bring....... Henry $r . i$.

this was a merry message.......

make me, the merry

some message to deliver to us (rep.).
AEmilius, do this message honourably

with message unto princely Pericles

Hume nust make merry $\ldots \ldots \ldots \ldots .2$ Henry $V I$. i. 2

be merry, Peter, and fear not

never merry world in England, since
grieve, to make me merry. York $\ldots . . .3$ Henry $v 1 . i .4$

this merry inclination accords not .. _ - ili.

changed to merry meetings

to hear a merry, bawdy play ..........

not freely merry, is not my friend....

ladies, you are niot merry

you are $n$ merry ganester

and deliver a plain message bluntly

own fashion, like a merriment ....... of Veniee, ii. 2 .

to mirth and merriment...Tamimg of sh. 2 (induc.)

their cheeks to idle merriment........ King John, iii. 3

turn all to a merriment .............2

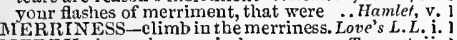

AIERRY - beseech you, sir, be merry .. Tempest, ii. I

thou

thou makest me merry ..........

from the furrow, and be merry ..........

because I eannot be merry.

let's be merry; good my lord cardina

and sing the merry songs of peace $\ddot{\text { and }}$ - - ressid

then she's a merry Greek, indeed

Cressid 'mongst the merr'y Greek

saảly, and go away merry

in heart as merry, as when

Tim

fortune is merry, and in this mood

was he sad, or nerry? (rep.) .......

so merry and so gamesome

do sour messages yourself ...... liomeo \& juliet, it.

you are merry, so am I.... Merry Wives, ii. 1 (letter)

my merry host hath had

wives may be merry, and yet

heaven give you many, many merry days! $\overline{-}$ iv. $\quad$ y. 5

three merry men we be ........... Tuelfh Night

twas never merry world, since lowly

if sad and merry madness equal be ... $\bar{n}$ iij.

to see another merry, than merry at - iii.

there is a kind of merry war betwixt

there live we as merry as the day is long -

there iive we as merry as the day

under that title, beeause $I$ am merry

nor siek, nor merry, nor well ........

and to be merry best becomes you

yon were born in a merry hour.......

I assure you, and a merry........ Mid. N.'s Drea

merry and tragieal? tedious and brief

but more merry tears the passion....
if ever I do see the merry clays.... Love

if ever $I$ do see the merry cays.

Biron, the merry mad-eap lord.

dances, masks, and merry hours.

of sucb a merry, nimble, stirrin

and Ill be merry in my revenge

my heart know merry cheer.....

came here to make us merry
cut off, and made a merry jest

what, are you merry, knights?

then I pr'ythee, be mer

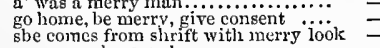

Romeo \& Juliet, i. 2

a merry whoreson! ..............

UESSAL, a with you immediately. Jutins
welcome, good Hiessala; now sit we close

no more, I pray you:

we must die, Messala: with meditating -

farewell, good Messala; good-night -

give ine thy hand, Messala; be thou
ride, ride, Messala (rep.) .............

no, this was be, Messala, but Cassius

hie you, Messala, and I will seek....
where, where, Mressala, do th his body
from the bondage you are in, Messala

from the bondage you are in, Messala

MESSALINE, whom I know .... Tüelfth $\bar{N} \mathrm{~g} h l$, ii.

MESSENGER-and messenger, am I... Tempest, iv.

hail, many-colour'd messenger........ $\overline{\text { Gen of }}$ iv

or fearing else some messenger ...... - ii. I

any happy messenger from thence.

pure messengers sent from .....

now am I (unbappy messenger) $\ldots . .$. - iv.

I have another messenger to your....

I am a messenger ................ Tivelfh $\bar{N}$ igh

invites nie in this churlish messenger
one Lucio as then the messenger. Dleos.

$\bar{N}_{\text {eas. }} \mathrm{v} . \mathrm{i}$

here stays without a messeng

instant that your messenger came
but there is come a messenger before

(- v. 1

am but as a guiltless messenge.....

o you leaden messengers, that ride

despateh the most convenient mes

you lome without a nessenger.. Conedy of Er.

seud some other messenger

not lightly trust the messenger.......

our messenger Chatillon is arrived.

hide you from our messengers of $\mathrm{War}$.

messenger betwixt me and the peers

eall in the messengers sent from ...... Henry

a messenger, or come of pleasure? (rep.) - v r

cousin, you shall be the messenger .

here comes a messenger: what news? hichard III. ii.4

he shent our messengers ....Thoilus o Cressidu, ii.

beat the mossenger who bids ...... Coriolumins iv.

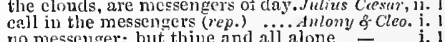

point of death have they been merry? $\quad$ an $\quad \nabla .3$

you are merry, my lord. Who, I ?...... Hamlel, iil. I

I am not merry: but I do beguile ....... olhelln ii. I

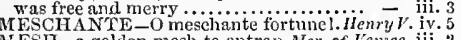

MESII-a golden mesh to entrap. Mer. of Vemce, iii. 2

MESOPOTANI $A$, and the slelters... Ant. f Cleo. iii.

MESS - tell of a ness of porridge ... Merry Hives, iii. 1

me fool to make up the mess....

one mess is like to be your eheer. Taming
in every mess have tolly ........ Winter

at my worship's mess...

to borrow a mess of vinegar

King John, i. 1

merry larks are ploughimen's...... - $\overrightarrow{\text { v. } 2}$ (song)

tu-whit, tu-who, a merry note.....
because you are not merry (rep.). 2 (song)

till i had made ynu merry ..........

where are your mess of son

lays licer fuil mess hetore you... Timon of $A$ thens, iv.

n:artam, twenty several nessengers..

had superfluous kings for mescengers

a viessenger from Cassar ............

my messenger he hath whipped with

too slow a messenger. 0 conic; aprac

there is a messenger from Pime.. Th
the several messengers from hence

the messengers from our sister and......

of my master, stocking his messenter.
he's so slightly valued in his messenger

and not seid hack my messenger.

meeting here the other messenger $\ldots$ winged messenger of lieaven. Nomeo of Juliel,

admit no messengers. recive no tolsens. Humlet, ii. 2

if your messenger find him not there.... - iv.

live sent a dozen sequent messengers. . Olieko, i.

a messenger from tlie gallcys. Nuw? .... 
MESSENGERS of Venice stay

IIESSES - lower messes, perehance... ininter's 'trale, makes his geucratiou messes.

MESSINA-tlis night to MIessina

he hath an mucle here in Messina
he set up his bills here in Messina

he set up his bills here in Messina

as arrant knaves as any in Mlessina.

a piece of flesl as any is in Messina.
is fled from Messina; you have......

possess the people in II Iessina here
with armed men baek to Messina...

MET-they all lave met again.............
the surges most swoln that met him

the surges most swoln that met him
I met her deity entting the clouds

how thou hast met as here

friar Laurence met them both...Tino Gen. of $\overline{\text { Verer. }}$
you are very well met .............. Merry Wives

well met, mistress Page (rep.............

met the jealous knave their

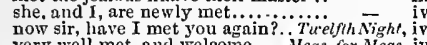

very well met, and welcome.......Mea

my very worthy eousin, tairly met ...

ill met by moonlight, pro
met we on lill, in dale
are we all met? Pat, pat

are we all met? Pat, pat......................
were met together to rehearse......
fair lovers, sou are fortunately met

exreedingly well met.............. Love'sL. Lost, iii

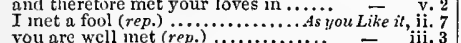

you are wcll met (rep.).....
r met the duke yesterday

二 iii. 4

bat I lave met him oft.

till sou met your wife's wit $\ldots .$.

well met, honest gentleman (rep.)...

faith, we met, and found the quarrel
when the parties were met themselves

when the parties were met themselve
how thus we met, and these things.

we met him thitherward

better 'twere, I met tlie ravin lioi.

and ynu're well met, signior.

apd I have met $n$ gentleman

you are happily met; sir, this is .....

happily met; the happier.
even now I inet him with

was he met there? (rep.)
you are well met, sir......

you are well met, sir.

he met me on the mart .................. of Errors, iii.
the instant that I met with you.......

well met, well met; master Antiphol us

with drawn swords, met us a
by the way we met my wife

by the way we met my wife.........

they met me in the day of ......MI
we might lave met them dareful.

we might liave met them dareful.

before Angiers well met ....

besides, I met lord Bigot
once more to-day well met

nor met with fortune other....
well met gentlemen: I hope

well met gentlemen; I hope.
now himself met with the fall

at Holmedon met

as well have met the devil alone

as well have met the met with some mischanee

and, the English rebels, met

a mad fellow met me on the w

met him in boroughs, eities...........

that rebellion had met ill luek? ?.....2
I met, and overtook a dozen eaptains
erooked ways, I met this erown.......

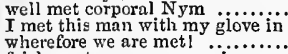

fairly met: so are yon, princes
that met them in their

met not with the Dauphin's grace.... i Henry $r$. . ii.

before we met, or that a stroke ...... - iv.

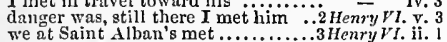

when you and I met at Saint Aiban's

would ong ere this have met us ..Richard III. iiii.

wall when I met this holy man

the eause' why we are
daughter, well met

dall met; how have you done

iii. 2

of $\mathrm{men}$, met in the vale of Arde...

Henry $\bar{r}$ in. i.

well met, my good lord chamberlain

affections still met the king?

you are well met onee again

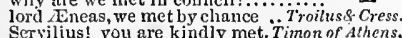

well met; good-morrow, Titus

shall be met witin thank

I met a courier, one mine aneient....

has our, general met the enemy

iv. 1
v. 2
v. 3
$\nabla .4$

v. 3
v. 4
v. 4
$\nabla .4$

$\nabla .4$
v. 4
$\nabla .4$
iii. 2

iii. 2

2 here's metal more attractive ..........

among a mineral of metals bas..
METAIIORP HOSED me...T

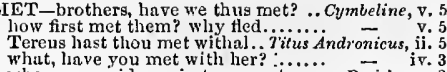

when my maiden priests are met .......Pericles, v. 2
he met the nightmare, and her.... Lear, iii. 4 (Bong)

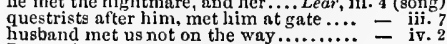

I met him back again

二 iv. 2

why, he was met even now

our very loving sister, well be met .......
in this habit met I my father ...........

we met, we wooed, and made.

haupily met, my lady, and my wife..

I met the youthiful lord .................... Fanlet, $i$,

raised, and met, are at the dnk
once more, well inet at Cyporus

they met so near with their lip
METAL, eorn, or wine

$[$ Col. $-\kappa$ Kit. $]$ my metal of India?
more test made of my metal

Tu.elfihnsiyht, ii. 5

make men of some other meto.....Neas.for Mleas. i.

is not lead a metal heary, dull .. Love's L. I.ost, iii.

but no metal ean, no, not the

Al's $W^{\top} e l l, i$

a word good metals: you shail

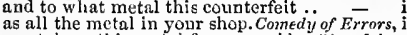

must draw this metal from my side. . King John,

for from lis metal was his .....

inclusive verge of folden metal......

2 HenryII

of what coarse metal ye are
of which metal is not found

Henry $\overline{V I 11}$ iv. iit. 2

toucled, and found base metal ... Timono of Ath. iii.. 3

whe' $r$ their basest metal be not......Juling
yet, I sec, thy honourable netal inay

but metal, Niareus, steel to the .. Tite

now you are metamorphosed.

METAMIORPHOSIS; my ... Tilus Andronicus, iv.
METAPHOR - where's thy metaphor.. T'rel'th $N$. i.
a metaphor. Indeed, sir, if (rep.)...

a metaphor. Indeed, sir, if (rep.) ....All's Well, v. 2

METAPHYSICS, fall to them......... of $\overline{\text { Shr rew }}$, i. 1

METE-to mete at, if it may be ... Oove'sL. Lost, iv. 1
by whieh his grace must mete......2HenrylV. iv. 4
METELLUS-[see CIMIBER]

now, good Metellus, go along...... Jullius Casar, ii.

now, Metellins, what Trebonius!

now yours, Mletellus; yours, Cinna..

of his heart's meteors tilting. Comedy of Errors, iv.

quite o'er with burning meteors

and meteors fright the fixed stars .... Richard $1 I$ i Heury

my lord, do you see these meter.

I missed the meteor once, and hit..Henry $\bar{v}_{I I I}$.

it is some meteor that the sun... Romen of Juliet,

MIETE-YARD, and spare not..Taming of Shrew, iv.

metheglin, wort, and malmsey .. Lov'' L. Lost, v.
METHIN KS, he has no drowning mark. Tempest, $\mathrm{i}$.

and yet methinks, I see it in thy face

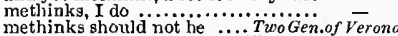

and yet, methinks, I do not like

methinks, my zeal to Valentive
methinks, you're allycholly

beenuse, methinks, that she loved.....
methinks, you prescribe to.......... Ferry Wives

methinks, there would be no period..

methinks lis flesh is punished .......

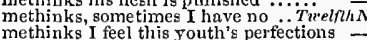

why, then, metllinks, 'tis time to.
methinks, his words do from suel

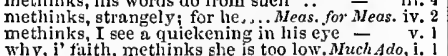

so say $I_{;}$methinks, you are sadder

iii. 4

but nethinks, you look witly rour eyes
oh, methinks, how slow this old, Mild.N.

metlinks, mistress, you should have

for methinks, I am marvellous liair

methinks, I have a great clesire to

methinks, I see these things with parted =

the wall, methinks, being sensible

methinks, slie should not nse a long one
methinks. I should outswear Cupil... Love's $L$.

of that colour, methinks, Samson had

a time, methinks, too short to make
having made one. methinks. Hlerch. of Venice, ii. 2

now, methinks, I have a mind to it.

Troilus, methinks, monnted ........

methinks, it sounds much sweeter
this night, methinks, is but the dayight

thanks me heartily, methinks.....As you Like it
methinks, I hear him now............All's Wreh

metlinks. in thee some blessed spirit

methinks, thou art a seneral offenee

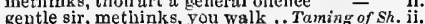

we should have met you by sea ......
Cleopatra, when she met her Romaline, ii. 4
4
METIINKS, lhe looks as though.. Taming of Sh. iii. I

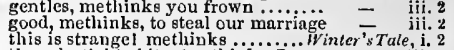
this is strangel metllinks $. \ldots \ldots \ldots .$. Winter's Tate, i.
the eelestial habits, (methinks, I so.. the eelestial habits, (methinks, I so...
methiuks, I play as I have seen them

methinks, a father is, at the nuptial methinks, I see Leontes, opening lis

still methinks the already

methinks, your maw, like mine.Comedy of Errors. v. 3 methinks, they are such methinks, you are my glass............. Araēeth v. ends of John, methinks, I see this ... King John, iii. merey on me! methinks, nobody should - jiv. !

even there, metlinks, an angel spake = v.

methinks, I am a prophet .......... Richard II. ii.

for, nethinks, in you I see old Gaunt $=$ ii. 3

Bolingbroke (for yond', methinks, he is) $=$ iii.

by heaven, metbinks, it w'ere an easy. I Henry IV. $\mathrm{i}$. 3

metlinins, my moiety, north from

sweetheart, methinks, now you $\ldots .2_{\text {Hen }}$ I I V. ii. 4

this revolt of thine methinks, is like .. Henry $r$ ii.

as one man more, methinks, would share - iv.

my lord, metlinks, is very long in....

yet, methinks, my tather s execution
methinks, my lord should be religious

methinks, his lordship should be .0.

you, my lords, methinks, you do not

yet, methinks, I could be weil eo.....

methinks, the realnıs of England....2Henry VI. $\dot{\mathrm{i}}$.

Buekingham, methinks, you watched

but, methinks, he should stand in fea

methinks aiready, in this civil broil - iv. 8

yet methinks, you lose ..............3 HenryVI. $\mathrm{j}$.

or, had he scaped, methinks, we should
methinks, 'tis prize enough to be hig son

now methinks, I hear great Warwick
O Godl methinks, it were a happy life

his pale cheeks, methinks, present ...

methinks, these peers of France sloould =

methinks, the power the

methinks, a woman of this valiant spirit and since, methink o would not rrow -

not registered, methinks, the truth.. $\overline{-}$ ii.

I and able now, methinks...........

methinks, I could cry the amen
for thint, methinks, is the curse.. Troilus \& $\overline{C r}_{\text {ress. }}$ i.

who do, methinks, find out something

aud this hitl, methnks, with ole... Timon of $A$
methinks, they should invite them..

cannot hold out water, metlinkks...

methinks, conld deal kingdoms to

methinks, talse hear ts should never
methinks, he should the sooner pray
methinks, thou art more honest nuw

metlinks, I hear hither your....... Coriolanus, iv.

methinks, 1 see him stamp thus......

by his looks, methlinks, 'tis warm at his $\overline{\text { in. }}$. that, methinks, is strange............. methinks, if you did love him..........nitony \& Cleo. i. methinks, I hear Antony call ...... $=$ methinks, thy favour's good........ Cymbeline, iii. wethinks I'do digress too muel.. Titus Andron. v. methinks, doth sit too melancholy .... Pericles, ji. methinks, you are too much of late ....... Lear, $\mathrm{i}$.

methinks, thy voice is altered ...

methinks, you are better spoken ..............

methinks, he seems no bigger than lis ...
far off, methinks, I hear the beaten drum

methinks, I slonld know you, and know

metlinks, our pleasure might have been

and yet, metlinks, it should not

Olook! nethinks, $I$ see my eot

my father,--methinks, I see my fatlier.. Hamies

methinks. I seent the morning air $\ldots \ldots . .$.
the lady doth protest too mnch methiniks

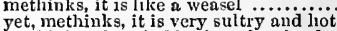

methinks, the wind hath spoke aloud.

metlinks, it sounds a parley of (rep.).. Ohello, ii

IETHOD- mater by the methode eclipse -

the tune, matter, and method?...Meas. for Meas.

beat this method in your sconce... Comedy of Brr.

rehearse the method of my pen.... Herrery

you do not lhold the method to

be madness, yct there's method in it

most unpitifully, methought .............

that sure, methought, her eyes liad..

methought, it did relieve my passion

wleich

methought, a gerpent eat my lieart. Mid, $\bar{N}$.'s $s$ rii. ii. ${ }^{4}$

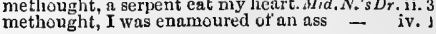


METHOUGHT I was there (rep.). Mrid. $N$.'s $D r$ iv. methought, all his senses were... Love's I. Losice, i. hear you; methought, you said... . As you Like it, v. a mother, methought you snw .........All's methought, you said, yon saw one....̈rter's Tale, i. of my boy s tace, muld i then

how like, methough, I heard

only this, methought, f heard ....... Macbelh, methoug, 1 hood began

and sun of henven, methought ....... King Joh the mo ...2 Henrylv. ii. methourht he made a shrewd thrust a foil the other day, methought ..Henry $V$, iij. prettily, metlought, did play........ methought, I sat in seat of najesty..2Henry VI. ii. methought, he hore him (rep.) .......... kichard III. methought, I had; and orten did I.. methought, the melancholy flood (rep.) - v. methought, the souls of all that in .... Henry VIII. ii. 4 a kind of free, methought... as I slept, methought, great .......... Cymbeline, v. methought, thy very gait did prophesy

yet once, methought, it lifted apeet (rep.)

methought. I lay worke than the

HE - What? in metre?... Aleasure forkasure, i. there are found AS-MONGERS ..I HenryI $V$. iii. I IETR King John, v. 2 IET'ST-thou met'st with things

met'st thou my posts? ......... nekt

IET TIE - gentlemen of brave mettle.. Tempest, ij. who knows so much of my mettle.

against the mettle of your sex...

why, your mettle is the more.

thou hast mettle enough in thee........ aluch Ado, y. I folly to the mettle of my speecli?...As you Like it, 1i. thy undaunted mettle should composc. Mactorn, ii.

HenryIV.

bad of mette

that rascal hath good mettle in him

now their pride and mettle is asl

had been a man of this mettle .......2 Henry I

the mettle of your pasture..........

where have they this

our mettle is bred out................

the fellow has mettle enough in ..... $-\overline{i v}$ iv 8

every Grek of mettle, let him...Troilus \& Cress. i. 3

whose elf-same mettle ....... Timon of Athens, iv.

was quick mettle, when he went ...

show and promise of their mettle..... $\overline{\text { s }}$ Clea. i. 2

do thimk, there mettle hot and full...... Hamlet, $\mathrm{i}$ why, now I see there's mettle in thee.. Othel

WEW-why will you mew her up..

to mew up your tender kinsman

to mew up your ten and cry mew

the cat will mew, the dog will........... Hamlel, $v$. has he closely mewed her up .. Taming of Shrew, i thrice the brinded cat hath mewed.. Richard III. i. should Clarence closely be mewed.

that the eagle should be mewed

poor lord, he is mewed up ................ \& o Jutiet, iii. 4

MEWLING - the infant, mewling.. As you Like it, ii. IIEXICO-a third at Mexico

trom Tripolis, by lions, ) hath..........

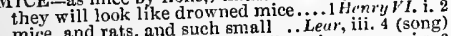
walk upon the beach appear,

MICHAEI, - see CASSIO]

good sir Michael (rep.) to prevent the worst, sir iichael, speed
friends; and so farewell, sir Michael

worthy St.Michael, and the golden.1 Henry $V_{L}$ iv. $[K n$.] O Michael IInpkins? He .... Hemry I'III. i.

good Michael, look you to the guard

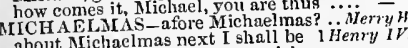

MICHER of henven prove a micher

MICHNG-marry, this is miching .... Hantet, iii. an oath of mickle might; and fury Henry $V$.ii. I shall die with mickle age $\ldots . . . \ldots$ Henry VI. iv. unto the grave with mickle age ...2 Heary $V I$. v. O mickle is the power my microcosm Coriolanus, ii. I IIID-past the mid season

MIID-past the mid season ............. Temperstil. ahout the mid of night, come MIDAGE-midare and Wrias. Merchant of Vinice, iii. as piercing as the mid-day sun ......3 Henry $/ 1 . \mathrm{v}$ MIDDLE-2 man of middle earth .MHerry Wives, v. 5 the heavy middle of the night ...Meas. for Mers. iv.
since the middle summer's spring. Mid. N.'s Dr. . we are tor you; sit i' the niddle...As you Like il, v. now, $\mathrm{i}^{+}$the middle $\ldots \ldots \ldots \ldots \ldots \ldots$.........

flowers of middle centre of this ........... i Henry? $V I$. ii. thy breath in middle of a word .... Richard HII. iii. 'ginning in the middle .... Troilus \& Cressith, (prol.)

the middle of humanity $\dddot{0}$ our general is cut $i$.... Coriolanus, iv.
IIDDLE-very middle of my heart ... Cymbeline, i. 7 $\mid$ MIGHTIYX-fear him mightily when thou clovest thy crown i' the mididie and left nothing in the midalt

nose stands i' the middle of his facc? .......

the dead waist and middle of the

or in the middic of her favours?

all's liush'd as mionight yet

to make midnight mushrooms

all the winter time, at still midnight

bet to be a-bed after midnight (rep.). Twelfh $N$. ii. 3

'tis now dcad midnight ... Measure for Measure, iv.

for women are liglit at midnight $\ldots \ldots$...Muchstdo, iii.

midnight, assist onr monn...

till morrow deep midnight ........ Mid. $\overline{\text { N. }}$ 's Drean, i.

and will, to-morrow midnight, solemnl

sighed upon a midnight pillow...As you, Like il, ii. 4

by midnigit, look to hear further ...All's Well, ili. 6

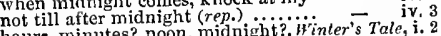

hours, minutes? noon, midnight?. Finter's Tale, i.

the midnight bell did, with his iron. Kir

present twelve o'clock at midnight

gravity ont of his bed at midnighit?.

England, as dead midnight still...Henry $V$. iii. (cho.)

tis midnight, I'Ll go arm myself .....

it is now dead miduight, have in them a wilder. Henry VII $i, \mathrm{v} .1$

'tis midnight, Charles, pr'y thee, to bed.

as patient as the midnight sleep..... Coriolanus, iii.

let us go, for it is after midnell .. Antony \& Clea. ifi. il

at midnight, to encounter

almost midnight, madam ....̈.

of miduight weeds collected .......

you shall hear more by midniglit........ Othello, iv.

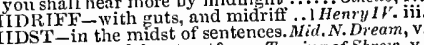

in the midst of the street? .... Taming of Shrew, v.

here $I^{\prime \prime l l}$ sit i' the midst .............. Nacbeth, iil. 4

they left me midst my encmie.

throngla the very midst of you
in the midst of this bright-shinin

cleave in the midst, and perish .... Coriolantes, iii. 2

then in the midst a tearing groan ... Cleopatra, ili. 12

MIDSUMMER madness........... Twelfh Night

gorgeous as the sun at midsummer ، I Henry I $V$. iy.

midway -just in the midway

mo midway'twixt the extremes Antony \& Cleo. iii. 4

which now are midway stopped...

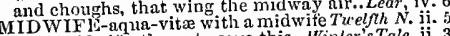

your midwite, there, to save this Winler's Tale, ii. 3

hore's the midwife's name to't ....... Richard II, ii. 2

knew her well, she was a midwife..2 2flenry $Y I$ iv.

midwife wondered, and the women..3

the midwife presently to me (rep.)... - Pericles, iii. 1

patroness, and midwife, gentle to ....Pericles,

MIDW IVES-but the midwives say. 2 HenryIV. ii. 2

[Knt.] her mien or Valentinus'. TwoGen. of Ver. ii. 4

no might nor greatness in........ Neas. for Meas. iii. 2

address your love and might .. make

takes it in might, not merit

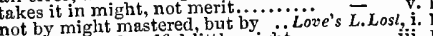

his almighty dreadful little might

I spread my conquering might ........

now would not extend his might .....Alls s $W^{\prime}$ ell, i.

give entertainment to the might of

right should thus overcome might

hath cause, and means, and might

and love, exceeds man's might... Troilus \& Cress. iii.

man's mind, but a woman's might,

not urge thy duty past thy mignt.. Antony \& cleopatre, iii. 10

with all his might, to enforce it on....... Othello, i. 2

MIGHTIER-mightier member .... Mleas. for Meas. v. 1

stir them up adainst a mightier task. Kins John,

two mightice troops than that....... H Henry $r$. iii. 1

a man no migh tier than thyself.....

the mightiest in the mightiest.. Mer. Of of thy greatest enemies. Richard II. $\mathrm{y}$. 6

but kings, and mightiest potentates. 1 Herry $r$ l. iii.

provokes the mightiest hulk again tht ... Humlet, i.

AIGHTILY--youmightily hold up...Much Ado

the prince and Claudio mightily abused $\bar{L}$ ike

if he do not miglitily gracc himself.As bencfits are mightily misplaced..

that have so mightily persualcd him at $\bar{T}^{\prime}$ ell,

how mightily, sometimes (rep.)...... All's Well, i

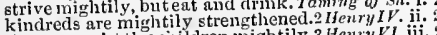

kindreds are mightily strengthentily. knave, that mightily deceives ... Timon of $A$ th. v.

queen 80 mightily betrayed..Antory tair, tay be so ming I an mightily abused .... Lear, iv. THTINESS to wash ....Taming of Sh. 2 (induc. your mightiness on both parts ....... hope braves your mightiness ....Titus sndron. ii. 3 love's a mighty lord ........ Two Gen.of J'erona, ii. your hearts are mighty ..............erry here, mighty Theseus ............... Love's L.Losl, i. addressed a mighty power.........

and his lady, offence of mighty note.. othing but a mighty lord.. Taming of Sh. 1 (induc.) a mighty man of Pisa; by report ..... and as his person's mighty ......... Winter's $T$ ale,, 1. which are mirhty ones, and millions $\overline{\text { iv. }}$ iv. nost mighty duke (rep.) rock ... Comedy of Err. v. that sane mighty man? is it sir ..... King per mighty kings that promiseth a mighty truit...

thine indignation, most mighty liege, and my........... Richard $I I$. i. most mighty prince, my lord ......... - iii. he is in the mighty hold of Bolinghroke - iit. mighty, and to be feared, than my ...

with strong and mighty preparation

the king, with mighty and quick-raised $\bar{Z}$ iv.

confined two mighty michty ancestors

whiles his most mighty father $\ldots . . .$. .

raise your highness such a mighty sum - i.

- ii. (chorus)

not misbecome the mighty sender....

or the nighty, or the huge ......... iv. 7

like a mighty whiffer 'fore the .... $-\mathrm{v}$. (chorus)

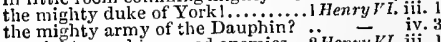

so mighty are his vowed enemies ..2 Henry VI. iii. 1

it is reported, mighty sovereign (rep.) - iii.

a puissant and a mighty power........ - ivenry $V I$. ii. 9

this way, like a mighty sea.......... - ii.

arguments of mighty strength $\ldots \ldots . .$. .

no, inighty king of France ...........

did forsake the mighty Warwick

the mighty dukes, Gloster and

solse with, but by mighty suit......

bark to brook no mighty sea

refuse not, mighty lord, this

mighty liege [Col.Knt.-my good lordj

have not been commanded, mighty king -

is with a mighty power landed

bearing a state of mighty moment... Henry $\bar{V} I I I$. ii. as he then was, mighty ..............

mould up such a mighty piece $\ldots$.... most mighty for thy place and ...Troil es cress. i. mighty states characterless ........

unto his steward a mighty sum. Timon of

with haste will make a miglity fire...

end is purposed by the mighty gods?

most mighty Caesar $(r e p$. . ............

most high, most mighty, and most ...

O mighty Cassarl dost thou lie

then burst his mighty heart

down upon as with a nighty power

two miglity eagles fell

a inighty strength they carry

be not angry, most mighty princess

mighty sir, these two young gentlemen -

proud empress, miglity Tamora...TilusAndron.

your rcason, mighty lord!............ = v. $\quad$ v.

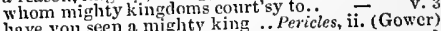

stood equivalent with mighty lings...... ve ver 1

you hou mighty gods!......................... - iv. 6

points of mighty opnosites ..............

the Turk with a most mighty prepartition - - i.

he needs will he absolute Milan.......... -

alas, poor A[llan! \#........

open the gates of Mlilan
the duke of Milav, and his (rep 
MILAN-of Naples and of Milan (rep.).Tempest, ii. ] MILFORD-[see IIAVEN]

that stand 'twixt me and Milan ....... - ii. from Millan did supplant good Prospero = ii. 3

as 1 was sored duke of dilian.......

was thrust forth of Milnu

was thrust forth of Milan $\ldots \ldots \ldots \ldots \ldots . . . . .$. - v.

at Milan, iet me to my Milun.............

all happiness bechance to thee in MLilanl

to embark for: Milan

there is a lady, sir, in Yilian

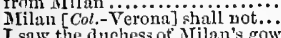

I saw the duchess of Nilan's gown
of fuir Mrilm catherlal, and rom it is to this same blessed Milford ... Cymbeline, iii.

IILITARIST, (that was his

is there no military policy

as well as any military man.........Henry $V$. iii.

my holy lord of Ailan, from the .....
IIILCI- - have nade mileh the burning. Hrmlet, ii.

MILCH-KINE yield blood ...........Aerry Winc

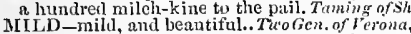

mild, or come not near me

a wench that had shed lier milk ....All's W'ell, iv. 3

wondrous qualities, and mild behaviour - ii.

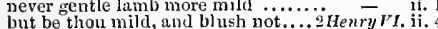

since he was mild and affible...

my sovereign's presence makes me inild -

as mild and gentle as the cradte-babe

women are soft, mild, pitiful...

my mild entreaty slaall not.

AILKLNG-TIME, when you are...Winter'sTale, iv. 3

if she be obdurate to milld entreaties

with tenderuess and mild compassion

more mild, but yet inote harmf

will be more mild and tractable ... Titus

could never be her mild companion .....Pericles, $i$.

son, and husband mild, I mot

I marvel, our mild husb:und.

IILDER-milder than she was. Two Gen. of Ver. y.

clange you to a milder form
of geutler, milder mould ....

of geutler, milder mould ....... Taming of

why did you wish me milder?...... Coriolanus, iii.
MILDEST-in her mildest words! ...All's Well, iii.

a mutinv in the mildest thoughts. 'itus. Ane

MILDEW $\rightarrow$ mildews the white wheat ...... Lear, iii.

MLLDLY -him but mildig

take thy correction mildly?

yourself to answer mildly (rep.)..... Coriolan $u$, iii.

what we did, was mildly ........ Tirus Andronicus, i. 2
MILDNESS-thy mildness praised. Taming of sh. ii. 1

thou with mildness entertain

for mildness, peace, and prayer.

my mildness hath allayed their.

than praised for harmful milanes
MILE-carry a letter twenty miles.

as good go a mile on his errand...12e
he would have walked ten mile afio

a mile without the town..........Mid.... s D ream, i.

too long by half a mile

measured many miles (rep.). .....

do fill up one mile

of many weary miles yon have

in the travel of one mile? ....

is a monastery two miles off.....

our public conrt as twenty mil

within a mile where my land..

your sad tires in a mile-a
almost a mile: but he does

within this three mile may you.....

draw out our miles, and

threeseore and ten miles a foot

and $I$, have thirty miles to ride yet.

i must go but thirty miles a day...

I'll pledge you a mile to the bottoin

come near our person by ten mill trot to-morrow a mile....

some six miles off the duk

run so many miles about
lies half a mile at least

six miles off from Ampthiil

within this mile break fort

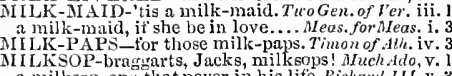

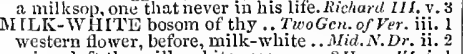

IILKY-faint and milky heart. Timon of Athens, iij. I

this milky gentleness, and course of yours. Lear, i.
on the milky head of reverend Priam.. Hemlet, ii.

MILI-mole sacks to the mill! .. Love's L. Lost, iv. 3
goest to the grange, or mill. Winter's Tale, iv. 3 (song)

MILLE-vous donne nille remerimens. Hew $V$, iy.4
MILLER-a-pleee of Yead Miller...Merry Wives, i. 1

by the mill than wots the miller of. T'tus And. ii. 1

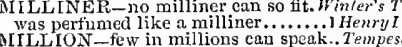

MILL-SIXPENCES-in mill-sixpenes. Mer'ry H

ay, millstones; as he lessoned us to weep -
eyes ran o'er. With millstones.. Troilus o Cres

eyes ran o'er. With millstones.. Troilus \& Cres.
MILLWHEEL-as millwheels strike .. Tempest
MILO-bull-bearing Milo ..... Trnilus \& Cressida

MILO-bull-bearing Milo ..... Trmats sid comes. Mid. N. Dr, iii. 2

and love doth minee this matter
MINCING-two mincing steps...

infect another against the wind a mile?

tis not a mile; briefly we heard

in a mile confound an hour...

a mile before his tent fall down...............

i. 6

abused so many of miles, with a pretence?

can it be six miles yet? ...............

I aim a mile beyond the moon ... Tilts $A$ nd, on. iv. 3

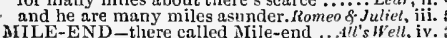

I remember at MLile-end grven ....2Heny $L V$. iii. landed at Milford, is colder news.. Richard III. iv. give thee opportunities at MIilford $\because$ iii. 4 (letter)

my revenge is now at Mrilford...........
to Mil forl go, and find not her
Alilford,

he embarked at Anilford....................

MILITARY - thy lungs military ... Aierriy $W^{\prime}$

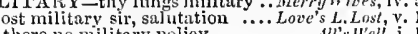

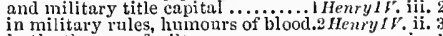

in the throngs of miltary men.

item, slee can milk (rep.) .. Two Gen. of t'trona, iti. I

think his mother's milk were ..... T'u'elfh Night, i. 5
skin milk; and sometimes labour...Nid. N. Wr. ii. 1

with hands as pale as milk

honey, and milk, and sugar............ Leve's $L$. Lost, v. 2

and millk comes frozen home livers white as milk!. Merciant of venice, iii. 2

but milk my ewes, and weep

it is too full o' the nilk

to love the babe that milks me

pour the swect milk of coneord

a dish of skimmed milk with
I would, the milk thy mother
than there is milk in a male ti

- i. 5

as the maid that milks.... Aniony 8 . Cleopatra,

the milk, thou sulk white as milk. l'erictes, iv. (Gow.)

vines of France, and milk of Burgundy . Lear $i$. 1

dike eager droppings into milk........... Hamiet, i. 5

western flower, before, milk-white ... Mid.N.Dr. ii. 2
ruise aloft the milk-wlite rose $\ldots \ldots 2$ Henry $Y$. i. 1

to you fuur milk-white horses. Timon of Alhen,
bull and cow are both nilk-white. Tilus dnderos

('tis soutl the city mills, ) bring ..... Coriolanus, $\mathrm{i}$. 10

villages, sheepcotes, and mill
MILLE-vons donne

here's a million of manners.... Two Gen of rer. ii.

a million fail, confounding oatl. Wid. N.'s Dr. iit.

hiuclered me of galf a milition ...Mer.or

buckler thee against a million ...Taming of Sh. iii. 2

a million: thy love is worth $\left(r e p_{0}\right)$..1 Henrylt. iij. 3

in little place, a million.

I fear, millions of mischief

and fertile every wish, a million.

a million more, now lost at a million a drom

count the turns; once, and a million! Cymbetine, i. 5

I would not for a million of gold. Tilus Anctron. ii. 1

I remember, pleased not the milliou .. Hamlet,

there's millions now alive, that nightly. Othello,
the

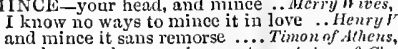

speak to me home, mince not..... Antony \& Clen. i. 2

that ininces virtue, and does shale.

nothing so muel as mincing poetry.i $H_{e}$

your mincing

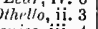

to sink?....

this lives in your mind?

for still 't is beating in my mind

$O$ that you bore the mind that I doi

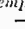

MIND-miglit her mind discover. Tu.oGen. of Ver. ii.

when le in feature and in mind.....

do move a woman's mind...

revolt and clange your mind

he bears an hunourable mind

shapes, than men tluir mixds (rep.)

his mind is mous mind............. Merry $\bar{W}^{\prime}$

know is not heroic...........

faith, but you do, in my mind ......

sou may know one another's mind..

of eloolers 1 am, and trempling of mind

keep in that mind, I'll deserve it...

knowing my mind, you wrong me..

to sir Juhn, to know hie mind

ther sports are tasking of the.......

and yet the guiltiness of my mind...

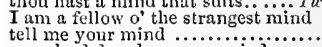

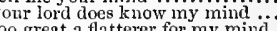

slie bore a mind that envy could not

for thy mind is a very opalt .........

not admire not in thy mind..........

with profits of the mind, study.......eas. for Meas. $\mathrm{i}$.

whose minds are dedieate to ........

my nind promises with my liabit...

an unlaw ful bawd, time out of mind

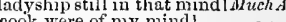

to have all things answer my mind.

'fore God, and in my mind, very wise
fit your honour to ehange you' mind

policy of mind, ability in means

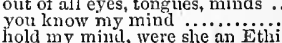

hold my mind, were she an Ethiop $N, \bar{D}$ re

not with the ejes, but with the mind

nor liath love's mind of any

nor none, in my mind, now you ....

and all their minds trausfigured so..

which never laboured in their minds

he showed a mounting mind

being of an old fatlier's nind.

know their minds, Boyet .......................

I wish you the peace of mind, most.

will syeak their mind in some

have in mind where we must meet

I have a mind presages me such

rouse up a brave mind, says the

and better, in ny mind, not undertook

I have no mind of feasting forth $\ldots .$. .

a golden mind stoops not to show's...

unless it be in mind; nor well ( $r e p$.

my people do already know my mind

for in my mind you are mucls

my mind was never yet more mercenary

world was of my father's mind ... As you $\overline{L i}$

give me leave to speak my mind ....

I am not in the mind but I were.

my right Rosalind of this mind

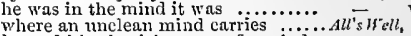

he and his physicians are of a mind

an' thy rnind stand to it, boy $\ldots . . . .$. .

I have no mind to Isbel, sinee I... .

of youth light not thy mind .........
frame your mind to mirth. Taning of shew, 2 (ivi.

tell me thy mind: for I have Pisa $\because \ldots$ i. $\bar{l}$ (indi:.

he telis you flatly what his mind is

nyy mind presunies, fur his own goud

have endured me say my mind

for tis the mind that makes .........

my mind hath been as big as ..........

five rest to the minds of others ...Winte
hint the ordering of the mind too....
but that the good mind of Camillo..

themselves are o' the minds ........

but not take in the mind

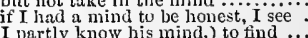

convey unto our fearful minds .. Com

that change the mind, soul-killing...

his mind? ay, ay,

must their master's minds fulfil $\ldots .$. .

in making, worse in mind fo............

as hard to you in telling jer mind..

I'll slow my mind according

you have a month's miad to thein.

but a dagser of the inind; a false.... 
MrND-balm of hurt minds, great ..... Macbeth, il. 2
to that dauntless temper of his mind have I filed my mind; for them full of scorpions is my mind, dear wife! = ii. no mind, that's honest ............ my mind she has mated $\ldots . . . \ldots . .$. the mind I sway by, and the beart speak my salntation in tlicir mind your mind is all as youth

the cover of a fairer mind than . in his physician's mind, to help ..... Richard II. $\mathrm{i}$. nay, speak thy mind; and let with the eyes of heavy mind ......... now Bagot, freely speak thy mind (rep.) both in shape and mind transformed my lord, the mind of Bolingloroke but now I know thy mind $\ldots . . . . . .$. I am not yet of Percy's mind his letters bear his mind, not I both with hody and with mind...... grief had wiped it from my mind.... if captaing were of my mind

show a weak miud and an able body

to diet rank ninds, sick of happine.... care and lalyour of his mind hatl.. heaven put it in thy nind, to take to busy giday minds with

shall you know our mind at full grapplc your minds to sternage

of my mind, as touching the direction

or will tell him my mind

my master's mind. Unfold it........

and when the mind is quick

to feel other men's minds..........

$I$ do thee wrong to mind thee of $i t$

if our minds be so. Perish the (rep.)

break thy mind to me in hroken ...

meet, and break our minds at large...

meet, and break our ming

yeu perceive my mind $\ldots$.

call we to mind, and mark but this

pen and ink, and write my mind.

as humble lowliness of mind

Wincheserer, that my mind hath had

bears this base and humble mind ...

base ignoble mind that mounts no

we know your mind at full.

ill can thy noble mind abrook............

respecting what a rancorous mind he

first been put to speak my min mind, that

shall perceive the commons mind...

shatl perceive the commons ming shall know your mind

no better sign of a brave min

that grief softens the mind $\ldots \ldots \ldots \ldots$....

my mind was troubled with deep....

other time, to know our mind ......

but let thy dauntless mind still ride

I mind to tell him plainly what

belike, she minds to play the.

but if you mind to hoid your trine...

my mind exceeds the compass (rep.)

and fearless minds climb soonest unto

my mind presageth happy gain

let hell make crookcd my mind....

provoked by thy bloody mind........ Richard 11

take the devil in thy mind

grace to put it in my mind

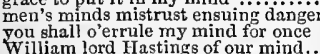

your lordship in that gracious mind:

the men you talk of came into my mind =

knows the lord protector's mind

should soonest know his mind

in your form and nobleness of mind

I have considered in my mind the late

to put your grace in mind of what ... -

quoth Forrest, almost changed my mind -

my mind is changed; Stanley ....... =

nor cheer of mind, that I was wont..
his mind and place infecting......... - ifenry $V I L$

bears a bounteous mind indeed

you bear a gentle mind, and heavenly

sir, call to mind that I have been...

and complete in mind and teature

your best graces in your mind

shown at full their royal minds.......

to spesk my mind of him......

my mind's not on't, you are too.......

my mind gave me, in seeking........ an' all men were o' my mind....

v. 1 appear it to your mind, that

appear it to your mind, that

my mind is troubled, like .........

that's my mind too: good-morrow...

and let your mind be coupled

0 then conclude, minds swayed.

my mind is now turned whore ....

how all minds, (as well of glib.. Timon of $\bar{A}$ the

ne'er be wretched for liis mind

iii. 3 ne'er be wretched for his mind ........

v. 1 for his right nolle mind, ilinstrioü

but for my mind's sake.

reep in the minds and marrows of

greases his pure mind, that from

noblest minds to basest ends

duty and zeal to your unmatched mind

every minute you do change a mind. Cor

your minds pre-occupied with .......

teach my mind a most inlierent

iv. 1 yet my mind gave me, his clot

will you be put in mind of his :......
your nind hold, and your dinner...J
tis meet that noble minds keep ever

tis meet that noble minds keep ever
some sick offence witlin your mind

not come, their minds may change..

I lave o man's mind but...

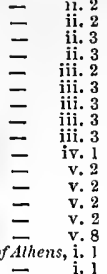

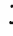

- $\quad$ iii. 2

ii. 2

iv. 1

but yet have $I$ a mind, that fears. ...

your hearts and minds to mutiny...

have mind upon your health ........

he hears too great a mind....

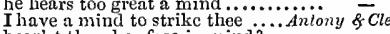

what cost your heart in mind?

which sorrow shoots hut of the nind

less nolle mind than she .............
as the fits and stirs of his mind eould,
holds her virtue still, and I my mind

furmished with a mind so rare .......

and to expound his beastly mind $\dddot{0}$ to

thy mind to her is now as low

what is in thy mind, that makes

if you could wear a mind dark as....

I had no mind to hunt this day......

and then a nind put in

to men of noble minds ..................

rail at him to ease my mindl.......

iii. in a tedious sampler sewed her mind

and arm the minds of infants

iii. 2 that bloody mind, I think ........

v. 2 the gnawing vulture of thy mind

and our mind partakes her private

the passions of the mind, that have

musings into my mind, a thousand....

good king Simonides were of my

bear you it in mind

hrought hither a corrupted mind

iv. 1 my mind as generous, and my shape.

an honest mind and plain ....

commands the mind to suffer.........

proud in heart and mind....

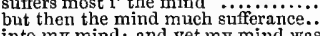

into my mind; and yet my mind was ....

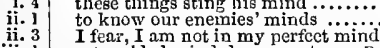

iii. 1
iii. 1
iii. 2 pnt us in mind they lijle tlic fair.....

for my mind misgives, some

iii. 4 guilty deeds to sinners' ninds

iii. 4 and know her mind early to-morrow

you do not know the lady's nind

iv. 2 if his mind be writ, give me his letter.

iv. 2 a mote it is, to trouble the mind's eye ..

a heart unfortified, or mind in

in my mind's eye, Horatio inward service of the mind and so....

but to nly mind, - though $I$ am native

taint not thy mind, nor let thy...........

'tis too narrow for your mind............

whether 'tis nobler in the mind, to suffer

\begin{tabular}{r|r} 
ii. 4 & for, to the noble mind, rich gifts ......... \\
iii. 2 & o what a noble mind is here o'erthrowni
\end{tabular}

iii. 2 the strength and iarmour of the mind...

iv. 1 if your mind dislike anything ...

even while men's minds are wild.

trust not your daughters' minds

I saw Othcllo" visage in his mind
to be free and bounteous to her mind the general were put in mind of it

your mind, perinaps, may

but my noble Moor is true of mind.

that liandkerclief: my mind misgives...

beap that monster from othello's

good father l how foolish are our minds

AINDED-were I so minded ..........

I minded him, how royal 'twas...

one minded like the weather
too much minded by herself.

IINDING to content you...Mid. N.'s Dr. $\mathrm{v}$. I (uivi

most high gods not minding longer $V$. iv. (chorus)

oot minding whether I dislike or no...... ii.

mindless of thy worth ............. Timon of Alhens, iv. IINE-mines my gentility with my. As you Like it, $\mathrm{i}$.

not wed her for a mine of gold. Taming of Shrev, i. 2

as bountiful as mines of India

come presently to the mines (rep.).... Hemry V. vil. 2

the mines is not according to

howe you quit the mines like

showed like a mine ...............Henry VIII. $\mathrm{i}$.

0 Artony, thou mine of bounty. Antony \& Cleo. iv.

burn like the mines of sulphur ........ Othello, iii.

MINERAL-a mortal mineral of earth

with a mineral of metals basc.

With arugs, or minerals, that waken ...... Othello i.

like a poisonous mineral, gnaw my inwards - ii.

of Venus, or straight-pight Minerva. Cymbeline, v.

to mingle 1aith with him ............

mingle, mingle, mingle, soll (rep.) - iv. 1 (song)

and mingle with the English epicures.... $\vec{r}$. v.

where senators shall mingle tears....Coriolanus, i.

O heavenly mingle! be'st thou ... Antony \& Cleo. i.

do something mingle with our brown

make mingle witli our rattling

both, mingle their spurs together ... Cymbeline, iv

those that mingle reason with Jour...

MINGLED with your love ... Merehan

red, and mingled damask........ As you Like it, iii. 5

blood is mingled with the crime.. Comedy of Err. ii.

part your mingled colours ........... King John, ii.

mingled his royalty with ........ IIenry I $V$. iij.

a quagmire of your mingled brains .1 Henryl VI. i. 4

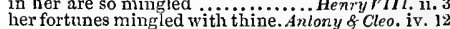

bave mingled sums, to huy a present. Cymbeline, $\mathrm{i}$

(now miugled with their courages)

when it

take up this mingled natter at the best... Othello, i.

by mingling them with us ........ Coriolnnus, iii.

MININI-his minim rest, one, two. Romeo \& Jutiel, ii.

MINI ML-Minimé, honest master.. Lave's L.. Lost, iii. 1

MINIMUS, of hindering knot-grass.. Nhid. N.Dr. iii. 2 MINION, thou liest............ Taming of Shrew, iii.
Mars' hot minion is returned again .. Tempes', iv.

bow now, minion! $\ldots \ldots \ldots \ldots$. TreoGen. of t'erona,

you, minion, are too sa

must do his minions grace

do you hear, you minion?
yon'll cry for this, minion

you minion, you, minion

the miniours of thion, car

out of one side her happy minio

who is sweet fortune's minion......

what, minion! can you not?

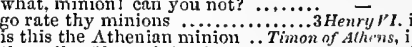

is the the Athentan ninion ...Thon

minion stood upon her chastity . Ti/us Androu.

mistress minion, you, thank me. Komeo \& Juliet, iii.

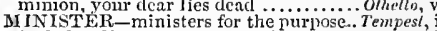

by lielp of her more potent ministers

$I$ and my fellows are ministers of fate

my tellow ministers are like invuluerable -

my meaner ministers their several ........-

we two will still be the ministers.. Alerry Wives, jv.

and minister occasion to him

the minister is here .................. for $\bar{D}$ teas.

that I may ministcr to them accordingly - ii. 3

as eause doth minister ........

how sweetly do you ninistcr to love... Much $A d n$,

if you them by the weakcst minister....Al's $W_{e} l l$, ii.

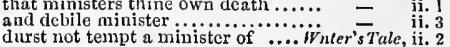




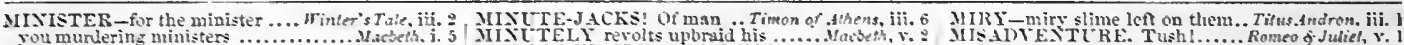

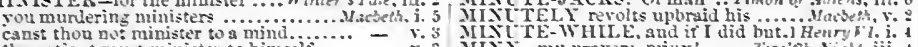

cruet ministers oi this desul buteles

an sust arm assinst his minisior

IIXX-ny prayers, nii

londship may minister the potion.

mustee Dutwb, our miuister.

this is some miux's toke

What misdventure is ov encly ul ... - r. s.t. Thom of Alhers, ly.

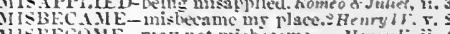
II AClLE-but for the miracle........ Tempes', ii.

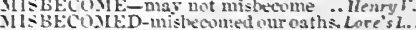

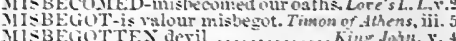
overjos of heart doth minist

1 Heary I. Y.

heavens do make their minister........ kiekand II . i.

their ministers attedd on him.

a miracle. to scape suffication ... Nerry Wires,

a miracle! here's nur ow h hani.

then niracles have by

hey say, niracles sis

make tis thy ministers of ehastioment but minister comumunicativa of .....

wants not a minisier in his power....
your .Ister. whose minister you are

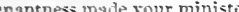

and minister in their steads.

did minister muto the sppeti

make them ministers of us.dnlonyo- Cieopatra, iij.

whose ministers would prevail ynder - iii. 11

not by a nublic minister of justice
fortune

fortune snare, a minister of her will -

or hath mure ministers than we .... Titus And. $\mathrm{r}$.

take my ministers along with ne... - i a

but set I tall sou servile numisters .... Lear. uii.

tine shall more farourably minister...

if I quench thee, thon timing minister.

with full and holy rite be mimistered.. Temp

hantig may be ministered........As you Like it, ii.

there" n nothing can be ministered to . Pricles,
MIXISTER IXiG angel shall nyy sister be. Humbet.

MINISTERST a pution un to me .......

IIXSOW of thr mirth .... Lote's L. Lost. i. 1 (letter)

this Triton of the ninuow

MLCOLA-[see BAPTIST. I] Taming of sh

the narrow-prying father, Iinola...

present Herules in minority...... Lore's L. Losi, $r$.

quoniam. he seemeth in his minoriry -
his minority is put nuto the trust.. Richard Ill. $\mathrm{i}$.
III

MINOS-father, Indos, that denied ..3 Henry inl. $\mathrm{T}$.

tush, none but minstrels ........ Late's L. hust, ir. 3

make ns minstrels? (rep.) ...... Romeo of Jutiet, iii.

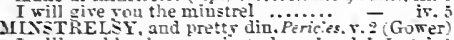

I will use hin for ny minstrelsy... Lere"s L. Last, i. I

and brased with minstrels .. Timon of timen

that hath a mint o' phrases in.... Loce's L.. Lest, i.
that mint. That columbine .........

hot larender, mints. savory .... Hinler's Tale, ir.

Mall enins s]anders like a mint .. Troilus o Cress. $\mathrm{i}_{\text {. }}$.

minute of their plot is almost come. ${ }_{\text {to }} \bar{T}_{\text {teal at a }}$ is. 1

to steal at a minute's rest.........

hours two soon than

eren in a minute?

no interim, not a minute. s raeaner...Ttelfh Night, i. 1

about the earth in torts ninures... via

for the third part of a minnte, hence - ii. 3

or spend a vinute's time in $\ldots .$. Lore's $L$. Lost, iv.

now, at the latest minute of the .....

else sighing erery minute diride a minute into a thousand

thousandth part of a minute in the

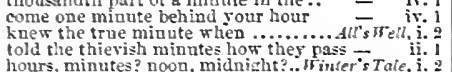

every minute of his being thrusts..... Sracbeth, iti. i

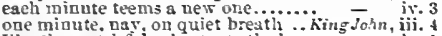

Iike the watehful ninutes to the hour
but not a minute, king, that thou ... Richard II. i. 3

my thoughts are minut

show minutes, times, and hou

of saek, and minutes capons

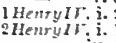

examples of every minute s instance - iv.

and think it but a minute spent....2

so many minutes, hours, dass, weeks - ii.
his hour of speeeh a minute........ Henry $111 . \mathrm{i}$. .

fed him evers minnte with words

fith every minute you do ehange .. Coriolanus, i. i

there's not a minute of our lives..-A
whieh he gehieved by the minute

throes forth, eaen minnte, some

ore wrught these miraeles

think, rou are come by mirach

I have scapel by miracle.

for miracles are cessed................. Henry i. i.

nirzea dust thoule that e er.......... Henry J. ii.

St. Alban here hath done a niraele..
Humphrey has done a miracie to-das

Fou have ilone more mir:icles than 1

doth mirade itself................ Cymitin

neason without mirncle could never plant.

thr lite s most sees miracles, but miser

a most miraculous work in this gnod. Wacbeth,
MIR.

swelve yess since. Miranda

ret from other mislegroten hat

three misbegutten knaves in Kendai.1 Henry $F^{\circ}$. ij.

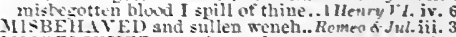

MISBELIEYER, eut-throst dog...Mer. of Fenice, i. 3

MISC.ALL, when I miseill it so....... Riehard II. i. 3

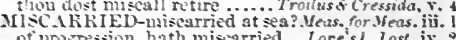

of progresion, hath mistarried ... Loce s L. Lnst, iv. I

my ships have all miscarried..... it. - (letter)

since nistarried under bolingbrike. Henry $1 \%$. iv.

have misearried by underhand ..... Richurd III. Y. 1 our sister's man is certainly miscarried... Lur, v. 1 in this miscarried by wr tisult .. Fomeo duliet, y. 3 MIS.LRIY -have him misearry. Trelnh Night iii. t they miscarry we miscoir. it the ning John, v. an' the ehild I now go with, do niscarry the fruit of her womb misearrs? ....... Henry 5 . is. if he miscorry, farewell wars ....... Henry Henry. iv.

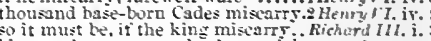

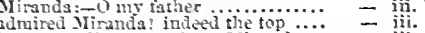

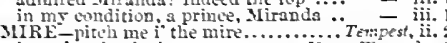

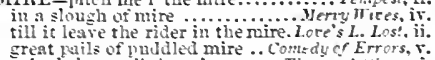
great puils of puldled mire .. Comedy of Errors, $\mathrm{c}$.

east mine upon me. set the dogs ...... cynibeline. ..

IIE draw thee from the mire... Romeo of Jutiet it.

IIRROR - to me a mirror........... Winter's Tale, i. \$
commant a mirnor hither strighit...Richard II. iv.

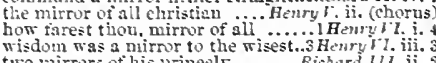

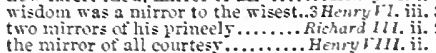
the mirror of all courtes.......... Hen y i lll. ii. such a spacions mirror's set. Antony a Cleopulra, s.
shotid be like a nirror, who tells us .. Perries. i. as 'trere, the mirror up to nature ..... Hmile', iii.

IIR 'IH-moment's mirth

triumphs, mirth, and rare

she enlaut trugal of my mirth .......erry Fies, ii.

the mirtli nhereot so larded with.... = iv.

mirth hath present laughter. Ttret?h .y. ii. 3 (song

I ras born to speak an nirth

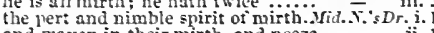

and waxen in their mirth. and neez

where is our usual manager of mirth

tragical mirth. Merry and trasical..

within the limit of becoming mirth

and sudden brenking out

makes most form in mirth

mirth eamnot more s soul in agons
with mirth and langhter let old...ifer.or Fenice, $i$. 1

your boldest suit of mirth $\ldots \ldots . .$. ...

then is there mirth in heaven...
trame your mind to mirth. Taning of sh. 2 (indue.

my exereise, wu nirth........... Winter's Tale, $i$.

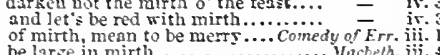

you have displaeed the mirth..............

of biood, of nirth, of gossiping
his blood inelined to mirth...

if yon miscarry, your business of the

IISCARRYIXG, what heart .... Troilus 6 -cress. shail houd-wink this niseliance........ Tempest it.

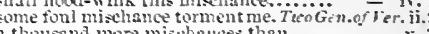
unkimdness. than pity tor vischance!..Yacbetr, iü. nimble mischanee, that art so ..... hichard H. iii. glad he net with some mischance.... heny ${ }^{2}$ i. 3 full of bad nischance, France is ..... Henry r 7 i. i. sevrn. and subject of mischance?

mischance unto my state by ........ entenry ri. iii. ? nisehance, and sorrow, go aloug with - iii. in triumph over all mischance ......

Eurard fall wars mischance - iij, 3

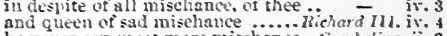
he never ean miet more miscliance.. Cymbeline, $\mathrm{ii} .3$ never come mischanee bet is mone mischance, on plots, and errors mischance; the ery is yers .... Othello, $v$. best is boded me, to mischief?.......... Tempest i. il. do that good mischict, which mas..... my thoughts are ripe in mischief. Tuelnh Nisht, $\nabla$. i nuy model to build misehief on? ...... - i. 3 his had roice bedle no misehief! but I shall do thee inischiet....viri...'s Dream, ii. mischief, and brenk a fonl gap ....WHinter's Tale, ir. 3 son wait on nature's mischief .......... Vacbeth, i. the skr, and pours down mischief ... King John, iii. of brosched nisehief to the unborn..1 Henry I 1 . I 1 alack, what misehiefs might be set...

sueeess of mischief shall be born

nto a second eonrse of misehitf...... Henry $\mathrm{J}$. iv. this sudden mischicf never could..... Henry $r$ iv. sce whst nischier, and what murder - iii. wrought this hellish mischief mawares $=$ jii. till miselhef, and despair, drive yon.. mischiefs work the wieked mes..... Henry $V^{\circ} 7$ ii. my heart's on tuture mischief set.... and, as pone to mischiet, as able .. Hen y rill. i. Honkins, that made this miselief.... = look they glory not in misluef....

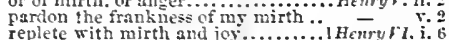
replete with mirth and joy............

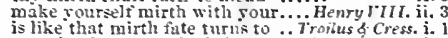
must be the seene of mirth: to congh..
rill but disease onr better mirth..... Coriolanus, i. 3
3 Till but disease our bett
I wish you mueh nirth
I'l use you for my nirth

to be but mirth and langhter to his.. - - iv. 3 to be but mirt and langhter to his.. - . if in mirth, report that I aim suden d... - $=$ i. 3 is he disposed to mirth: I hope, he is. Cymbeline as the procuring of mirth $\ldots \ldots . . . .$.
how well this honest mirth becones

for mirth, for mirth beemes a teast...

with mirth in funeral, and with dirge
lnst all my mirth, forgone nll eustom

MIRTHFUI, mirthful eomie shows.3

IIIRT-in how mirs a place........ Lore's l. Lost . fhose that would mischiet me... Timon of thens. iv. 3 Folsess, great hurt and miselhief. Corinlanus. iv. Il ischief, thour art afoot, take thou .. - iii. I fear, millions of mischict .......... complnts of misehief, treason

[Col.hint. ] and seen with mischiet' that with the mischief of your persou ..... Lear $\mathrm{j}$. to see sonle misclief on him $\ldots . . . . . . .$. - iii. ? miching nulleeho; it means mischief.. Hamlet, iti.

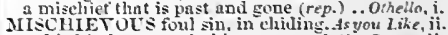
as lis kind, grow njechievous ....Jutius Casar, ii. Miscoxs Th CTIONsisc ANSTKUE-misconstrues all. As you Like it i. ? mischief! thou art switt to enter. Romeo o Jntiet, $v$ 


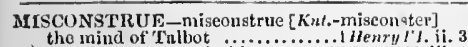

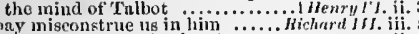
MISCONSTRUED in the place... Ner. of t"enice, it. linen

ISCREAN'T-and a misereant

Nichurd 1 i. $\mathrm{i}$ well, misereant, I'll be the

O vassal I miscriant I [ Col -recreant

MISCREATE-opening titley niscreate... Lear,

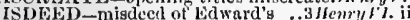

he avenged on my misleedls

IISDEMFANOULS, you ar

..fichardlll. i.

I do not misdoubt my wife.

our paraon mistlonbls it

I could neitlier belicve, nor misdoub

if you misdoubt me that I am not
as his misdoubts present ocension

change misdoubt to resolution.

stab of rancour I misdoulst.

IISDR EAD-conception by misdread

IISER-dwells like a miser, sir ... As you Like it, doth, like a miser, spoit his cont

decrepit miser! base ignoble.

as misers do by beggars .... Troil

IISERABLE-our case is miserab

else I often had been miserabic. Tu'

the miserable have no other........

miserable most, to love unloved?..

from miserable slumber fowak
o miserable lady I but, for me
O nation miserable ..............

hence, poor miserable wretches........................

hence, poor miserable wretches..........Henry $V$. ii.
what's more miserable than ........ Henry VI. iii.
O miserable age! Virtue is not regarded - iv.

$O$ gross and miserable ignorance

should lament thy miscrable stat

Oet liscrable thought! ........ maje more iniserable

to lose it, and be miserable!...

O bloody Richard! miserable En

desirc to die, being miserable

there is no time so miserable ........ - iv.

but most miserable is the desire

leave me to this miserable death... Titus Andron, $\mathrm{ii}$.

was hurnt, aud he made

I made thee miserable miserable?

have miserable, mad, mistaking eyes

to send the old and mised, for such die miserable.

most miserable hour, that e'er time saw - iv

MISERABLY - miserably slain as I

MISERICORDE! ayez pitić de moy . Henry

MISERIES-if your miseries were...Mer oflenice i. 2

most certain, to miscries enough.

whose miserics are to be smiled at

to weep their intermiscive miseries

eyes to see her miseries

so many miseries have crazed

not wish ye half my miserie

a tcar in all my miseries...

in sorne sort of thy miseries

ollr son is good, take off his misericg

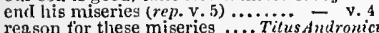

reason for these miseries.....

we have heard your miseries as fhr

makes my past miseries suort

scarcely think our miseries our foes................

known the miseries of your father
MISERY - misery acquaints a man

do not tempt my misery

. vor.

my misery ........ Tuelfh Night, iii. 4

thus misery doth part the flux.... As you Like it ii

the world, and all our misery

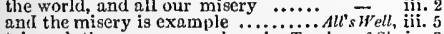

triumph thus upon my misery 1.. Taming of Sh. iv.

but see the flatness of my misery.

though beuring misery, $\mathrm{X}$ desire.

to acknowlcdge me in misery.
misery's love, $\mathrm{O}$ come to mel

no, misery makes sport to mock

Errors, y.

my body round engirt witli misery.

Richarel $1 \mathrm{i}$.

not that I pity Henry's misery

2 Henry

O ill-dispersed wind of misery! ... Richary $\mathrm{HI}$. ii

soon mightiness meets misery! .Henry VIII. (prol.)

timon of Athens, jv. 2

Wive. and love thy miscry

the gods out of my misery liave....... $\rightarrow$ iv. 3

the object of our misery, is ............... Coriolnnus, i. i

he covets less than misery itself would -

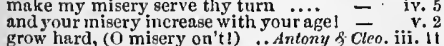

exchange one misery with another... Cymbeline,

() noble nisery 1 to be i' the field ...

conId our mourning case thy misery.Tilus And. ii.

plot some device of further misery..- iit.

taking arlvantagc of our misery........ Pericles, i.
nothing almost sces mirncles but misers... Lear, ii. 2
MISERY-repuir the nisery thon dost bear.Leur, iv. 1 in pity of lisis miscry, to despatch.

mine conte hecilite the tyrant s rage.

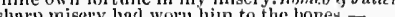

ragged nisery [Col.-kint. upon thy back]

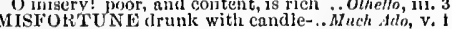
make mo fear misfortune ....... Mrreh. of l'enice

never clare mislortune cross her foot

if misfortme miss the first carcer.. Kiehord $1 J$, i.

brings me fool to make misfortune ilive?

with mildness rry misforture's cross

what, amazed at iny misfortuncs?.Henry $\bar{r} I J l$ i

Who only by misfortunc of the seas... Pericles

untangled, much misfort une bodes. Romeo \& Jul. i. A

MISGIVE-my heart misgives me...Merry Wives, v. 5

so doth my heart misgive me .......3 llenry l'1. iv. 6
tor my mind misgives, some .... Romeo \& Jutiet, i. 4

that handkerchief nly mind misgives. Othello, iii. 4
MISGIV ING still talls shrewdly ...Julius Casor, iii. I

MISGOVERNED hands, from ....... fichard th. v. 2 MISGRAFFED, in respect of years.
MISGUIDE thy opposers' swords!...

MISHAP - of my own mishaps.
the extremity of dire mishap!

the extremity of dire mishap
curse the planets of mishap.

curse the planets of mishap........... Henry $V I$. i. i

from worldly chances and mishaps. Titus A nilron. i. 2
MISHEARD - misspoke, misheard . King John, ii. 2

MISINTERPRETING, we might ....... Pericles, $\mathrm{i}$.

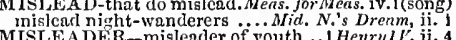

MISLEADER - misleader of jouth ... H Herry $1 \%$ ii. 4

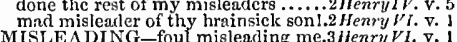

MISLE $\triangle D I N G-f o u l$ misleading me.3Henry VI. v. 1
MISLED-wisdoms be misled in this.. NuehAdo, iv. 1

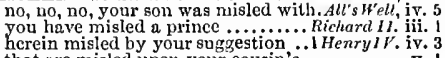

hcrein misled by your suggestion

misted the youthful prince (rep.)....2 Henrylt. i. 2

and our peers are both misled .......3 Henry $/ 21$. iii. 3

MISLIKE-mislike me not ... Merchant of Venice, ii. i

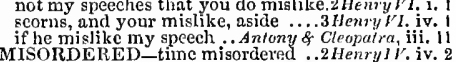

MISORDERED-time misordered ..2 Henry J. iv. 2
MISPLACE-how he misplaces?. Meas. for Neas. ii.

MISPLACE-how he misplaces?. Meas. for Meas. ii. I
MISPLACED-mightily misplaced. As you Lite it, i. 2

misplaced John should entertain

see the crown so foul misplaced . Richard III. jii. 2
MISPR ISED-a misprised mood. Mid.N.Drenm, iii. 2

that $I$ an altogether misprised.

MISPRISING what they look on

misprising of a matid too virtuous $\ldots$... Al's $\|^{\prime} e l l$, iii. 2

MISPRISION in the higlest degree! Twelfth Night

there is some strange misprision. 1. . Ml uch Ado

out in sancers; sweet misprision!. Love's L. Lost, iv. 3

dost in vile misprision shackle up....All's $W^{\prime} e l l, i i .3$

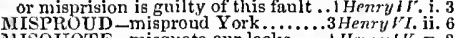

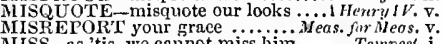

ISS-as 'tis, we cannot miss him

I shall miss thee

that will not miss you morning .........rery Wives, ii. 2

and so miss the accent ..................

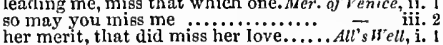

her merit, that did miss her Iove.

sensible, and yet you miss

when he shall miss nie

daggers ready, he could not miss them...Mrabelh, ji.

friend Banquo, whom we miss

or it misfortune miss the first

I should have a heavy miss of tiee... Riclmel $\mathrm{Il}$. $\mathrm{i}$.

hit or miss. our project's life ..... Troilus \& Cress. i. 3

would miss it, rather than carry it.. Cosiolumes, ii.

an' if we miss to meet him. Fitus Andron, ii. A (letter)
what here shall miss, our toil. Komeo \& Julie', (prol.)

well, in that hit, you miss

MISSED-all that shot and mised. Taming of Sh. v.

though thy master missed it.......jenry/lis. iii, 2

I missed the meteor once, and hit.... - v. 3

is not much missed $\ldots \ldots . . . . . . . . .$.

you shall bo missed at eourt ........

when was she missed? he is in Rom
MISSES-he misscs not mueh

MISSHAPED-ny inisshajed truik.

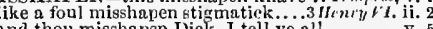

and thou misshapen Jick, I tell ye a!

that halt, and am misshapen thus?. Richarel $11 \%$ i. 2

misenen in the eond uct of them

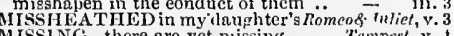

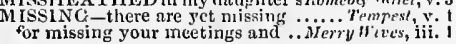

MISSING-to laugh, is also missing. As you Like it, ii. 2 Maedutl is unisuing, and your noble ... Macbeth, $v$. marriage my consent be missing. Timon of Ahens, 1 . upon my lndy's missing.................

ISSION_cmulous missions . Troilus \& Cress. iii. as from the king .......Maciselh, i. 5 (letter IIST-this mist at all g........... through the foul and ugly mists

MIS'TA'EN his colours.

MISTAKE the truth totally

nichard 1 II

mistake the word.................

you mistake, sir (rep.)

either I mistake yonr shape and ...Mid.N.'s Dr. ii.

to take what they mistake

doth most mistake in her gifts .....As you Like it, i.

mistake me not, I speak but as... Taming of $S h$. ii.

mistake no more; I am not Licio.

you mir

you, my lord, do but mistake

mistake . No, no (rep.)

is, to mistake aroin

mistake me not, my lord

King John, iii.

your grace mistakes me ....
mistake not, uncle, further

Richard 11. ii.

lest you mistake; the hea vens

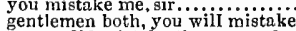

as you did mistake the ontward.

I do not mistake ............

brother of Gloster, you mistake...............

cousins, you mistake me both.....

your rage mistakes u

...

yow you mistake my fortunes..............

not out of hope, mistake me not..

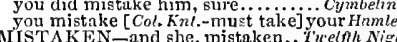

thou hast mistaken quite, and laid. Niu'. N's Dr. iii.

you have mistaken him. my lord

too much mistaken in this king

he were something mistaken in't ...Henry VII. ${ }^{\prime}$.

you are mistaken: the one may be ...Cymbeline,

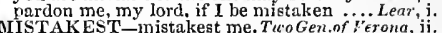

still thou mistakest, or else ..Mid.N, s Dream, iii.

Mut thou mistakest me much .......2 Henry f' $v$.

by mistaklng the place where I ...Merry Wives, ii.

by mistaklng the place where I .. Merry Wizes, ii.
envy in you, folly, or mistaking, .jeas. for Mens. iii.

yet sinned in thot, but in mistaking ...Much Ado, v.
old father, my mistaking eyes. Taining of Sh. iv.

I pray thee, for my mad mistaking ..2 - - iv
for thy mistaking so, we pardon ....2 Henry $I$.
miserable, mad, mistaking eyes... Titus And ron.

miserable, mad, mistaking ejes ... Titus And ron. v.

mistaking, offer up to joy ...... Romeo \& Juliet, ji
MISTERMED -is death mistermed ..

your mistcmpered weapons to........... Rineo \& Juliel, i

MISTF UL - with mistful eyes ........ Hewry $V$. jy.

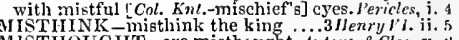

MIST-LIKE-groans, mist-Iike...Romeo \& Juliet, iii.

or else $I$ mistook . . . . . . .............

O cry you mercy, sir, I have mistonk
how an I mistook in fou I ........ Ner

they mistook their crection

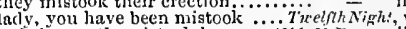

and the youth, mistook by me... Alid. N. Dream, iij.

this letter is mistook, it importeth. Love's L.Lost, iv.

you lave mistook, my lady ....... Ininter 's ' rale, ji.

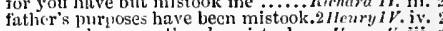

you may be marvellously mistook .. Hemry $F$. jii. 6

yet, had he mistook him ...... Timnn of Alhens, ii.

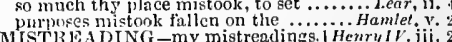

MISTJESS-ny mistress showed ne .. Tempesi, ii.

but the mistress which I serve $\ldots \ldots . .$. .

my swect mistress weeps when

no, noble mistress: tis fresh morning

inistress line, is not this my jerk in?

mctanorphosed with a mistress. Two

o bic not like your inistress.

Scrvant. Mistress? Master.....

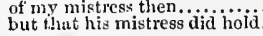

IISTAKEN-and she, mistaken.. 'uelfh Night, ji.

the nistook her frets, and bowed. Teming of $S b$. ii.

3
3
3
3 
MISTRESS, I beseech you .. T'iro Gen. of t'von mistress, it is ......................

a louk of such a worthy mistress

wolcome to a worthless unistress

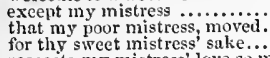

respects my mistress' love so mueh ..

kindly for my mistress' sake..... .3 .
by youry leave, good mistress

farewell, gentle mistress; farci...ii

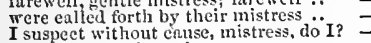

now mistress? how ehance you .......

on yout part so, mistress, I woula... Thelnh.tight,

with your master, as with my mistress

nor nerer none shall mistress be of it
how now, nistress?...................

from this time be your ina...............

Orsino's mistress, and his timey's queen -
t) the grombl, mistress ..... Je'asure for $\mathrm{Hea}$

t) the gromnd, mistress ..... I e'asure for

Your mistress's name? $\ldots$. . . th..........

come on, mistress; here's a gentlewoman -
at her mistress's chamlier-window ... Much.

here my inistress: would that he .. Mid. $N_{\text {.' }}$ 's Dr.

your buskined mistress, and your....

methinks, mistress, you should have
my mistress with a monster is in love

you, mistress, all this coil is 'Iong of you -

an' your wrist, mistress, were as slender

my love, her mistress, is a gracious

will advance unto his sereral mistress

white-handed mistress, one sweet....

studies iny lady? mistress, look on me
mistress, look out at window ...... Mer. of

farewell, mistress; notlying else

you saw the mistress, I beheld ......
your fortune achieved her mist ress.

mistress [Col.-masters $K$ n $n$ l. - master] of
my mistress wi]l before tlie break of das

my mistress will before the break of day
weleome for the mistress of the louse

welcome for the mistress
your mistress is at band

touches pierce jour mistress' ear .....
more mirth than I am mistress of...ts you Like it

nistress, you must come away to.

your mistress shall be happy .........

mistress, despatch you with your safest

thy hearer in thy mistress' praise....

male to his mistress'eyebrow.
iny new mistress's brother....

iny new mistress's brother
will rail against our mistress

to imnyine me his love, his mistress.

mistress, and master, you have ot

no, taith, proud mist ress ........

but, mistress, know yourself $\ldots . . . .$.
heloved mistress? unary that $(\mathrm{rep})$.

our master and mistress seek

a mother, and a mistress, and a triend

mine honourable mistress. .

your pardon, noble mistress...........

you have a new mistress

and ent her honrly mistre

nor you, mistress, ever a

humbly called mistress .............

musieian to instruet our mistress ...

quaff carouses to our mistress' lealtin

mistress, your father prays you leave
faith, uistress, then I have no cause

rescue thy inistress if thou be a man

mistress, what's your opinion

my new mistress, and myself ......

for my master and mistress are alinost

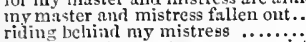

my mister, to countenance my mistre

now mistress, profit you in what

sweet dear, prove mistress of my heart
mistress, we have. Then we are rid.

mistress, and Petruchio is the master

i' the rigit, sir; 'tis for my nistress

take np iny mistress' gown for

and you my merry mistress.

mistress, how mean you that?............

ny, mistress bride, hath that awak
Biondello, bid your mistress coune.

sir, my mistress sends you wor

Grumio, go to your mistrc
gracious mistress (rep.)...

to hear my sovereign mistress clonded

this erack to be in my dread mistre

your mistresa lias deserved prison...

mistress of the feast (rep. iv. 3)

wopsa inust be your mistress ........

where you may enjoy your mistress.

fortumatc mistress, let my propheey.

I'd beg your preeious mistress.........
my mistress made it one upon... Cimed

the sadaler for iny mistress' erupper

I from my mistress eome to sou......
my mistress, and lier sister, stay for.

some of mv mistress' marks (rep.)

my mistress, sir, q ioth $\mathbf{I}$; hang ( $(\mathrm{rep}$.)
MISTRESS_no wife, no mistress. Comedy of Eir. your mistress sent to have me bome. of a mistress and a dimer ........... some other mistress huth thy sweet..
sweet mistress, (what your wame is else Will you send him, mistress .........
says tlue peacoek: mistress, that jou mistress, respice fncm, respeet your end mistress both man anil master is

Omistress, mistress, shift and saye..

I, gentle mistress. And are not....

go, bid thy mistrcss, when my .....

and I, the mistress of your eliarms

by our noble and chenste mistress

... Macbeth

that this is from some mistress, some.
or volunt ary lotage of some mistress.

some of your finction, mistress...........

you, mistress, thint have the office opposite

for you, mistrese, save you your labour..

eome, mitale, mistress? do you perceive

O swect mistress, speak! A guiltless death

O mistress, villany bath made mocks .
the Moor has kitled my mistress ........

the Moor has killed my mistress....

were it the mistress court of might

my inistress here lies mirdercd in.

a sonnet heitin so to one's mistress
my horse is my mistress (rep.)...

Henryl

my horse is my mistress (rep.) ......

to my mistress. I had as lief have

if I had a sow to ny mistress

I do not use my horse tor my mistress

until the queen his mistress bury it.2 Henry VI. iv.

that our fair queen and mistress ..3 Henry Ir. iii. 3

for their poor mistress sake.........

lily, that once was mistress of the field
to be her mistress' nistress! the queen's

my good mistress will remember...... $\overline{\text { roilus }}$ \& Cres

rub on, and kiss the mistress

jarder tor our mistress to deyse..

you shall be mistress, and eominand $\overline{\text { ind }}$ iv.

look you, here comes my mistress' page

my mistress is one, and 1 am her fool

as he would to the lip of his mistress

than to medule witl tly mis

first my rredded mistres

eompanion ine with my mistress. Antony \& Cleo.

say thou, slall call her mistr

thou killest thy mistress ..............

sovereign mistress of trit.

my mistress loved the .............

the queen my mistress, confined in
the diadem on her dead mistress ....

to his mistress, for whom he is now.. Cymbeth

my queen! my mistress! O lady

eit!er your unparngoned mistress is

get gronnd of $y$ ou: fitir mistress

my mistress exceeds in goodness ....

tell thy mistress how the cuse...

think thou hast thy mistress still....

and you his mistress .................

bronght the knowledge of your mistress

thy mistress, Pisanio, hat pula poy

discover where thy mistress is ......

why should his mistres a

thy mistress enforced; thy garments

nor hear I trom my mistress...

I have killed thy inistress $\ldots$ is.....

it is my mistress: since she is

help mine, and your mistress.......
wake, my mistress! if this be so

how fares my mistress?..................

given his mistress that eonfection

aloft with thy imperial mistress

and to cleserve my mistress' grace

come, mistress, now perforce we
thy nohle inistress thus? (rep.).....

love, fill to your mistress' lips ..........
mistress, 'tis well, your choice agrees.

yea, mistress, are you so peremptory?

look to your little mistress

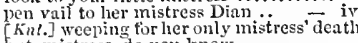

take her home, mistress, take her ....

but, mistress, if I ture hargamed......

worse and worse, mistress.................
to be my master, or ratler, nistress

sinee my master and mistress ha

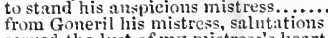

served the lust of my nistress's henrt
hither, mistress; is your anme Goneril?

get horses for your mistress.

when your mistress hears thins multeh.

as duteous to the vices of thy mistres

ISTRESSES -my two mistresses. Mierry irites, iii.

mistresses from common sense.... Love'sL. Lost, i.

your mistresses dare never come in.

in praise of our eountry nistresses... Cymbeline

ah ha, my mistresses! ........... Romeo of Juliet, i,

not to do them the wrong to mistrust. Mhuch Ato $\mathrm{i}$.

ugly treasen of mistrust ... Merchant of l'enice, iij.

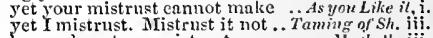

he reeds not our mistrust.

more than mistrust, that sliow

whieh now mistrust no pareel .......

ilenryl. ili. i

minds nistrust ensuing danger.

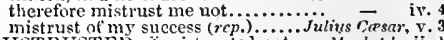

all's true, that is mistrusted....... Win/er's Tale, i.

vicious, to have mistrusted her........ Cymbeline, v. 5

MISTR USTING them, hoised sail.Riehard $J$. lateful as Cocstus' misty mouth, Titus dndron. ii. obscurity, or misty vale .............

on tlie misty mountain teps..... Romeo \& Juliet, iii. 5 proof enough to misuse the prince ...Much Mdo, ii. had studied to misuse me so . Taming of shrex, ii.
there was such misuse, such beastly.i Henryll. $\mathrm{i}$.

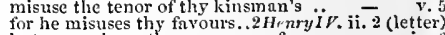
but you misuse the reverence of

[ $\mathrm{Col} . \mathrm{Knt}$.] on my least misuse?........ Othello, iy. you have simply misused our sex. As you Like il, iv myself is self misused. TVhy then. Richard $I I I$. iv

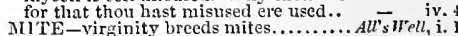
losing a mite, a mountain gain. Pericles, ii. (Gower) AITIRIDATES, king of Anlony \& Clcopntra, iii. nncle Gloster, mitigate this strite..1 Henry II. iii.
to mitigate the scorn he gives .... Richard III. iii. MITIG ITION or remorse of voice? . Trelfil $N$. ii. how now for mitigation of this bill ....llenry ti. think you now are alf in Mitylene - - iv. 4 (Gow.) there never came lier like in Sitylene

there's a barge put off from Mitylene
sir, we have a maid in Mitylene

hrought me to Mitylene; but now

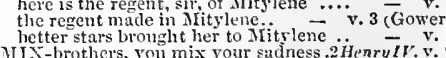

IIXED-that mixed in his elicek. As $2 H_{\text {enry }} \mathbf{V} \mathrm{V}$. v. mixed with sugared words. .........1Henvy $/ \%$. iii. the elements so inixed in him ...JuliusCresar, v. impertinency mixed! reason in madness 1. Lear, iv. 6 hast thou no poison mixed ..... Romeo \&- Juliet, iii. 3 hast thou no poison mixed .... Tomeo \& Juhet, ii. thou mixture rank, of midniglat....... Hamlet, iij.

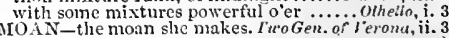
midnight, assist our moan..... Mhuch ddo, $v .3$ (song)

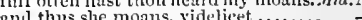
lovers make mon!

now make moan to be abridged........

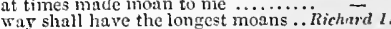

thy mirtl shall turn to moan ....... Heary $r$.

Thiles, in his moan, the ship ......3 Henry II. y

[Col. Knf.] but a noiety of my moan - ii. pew-fellow with $y$ load of moan

of that mass of moners to come. Troilus \& Cressida, it. hast finislied joy and moan.. Cymbeline, ix. 2 (song) that still records with moan...Perieles, iv. (Gower) is gone, and we east away moan. Hamlet, iv. 5 (song) is gone, and we east a marinured her mas....... Olhello, iv. 2 (song)

or as a moat defensive to a lionse .. Richard II. ii. in lis mistress' name, I conjure $\ldots$ and wish his mistress were that kind to thy laciy and mistress (rep.). .

my nistress is the sweetest lndy

MIOATED - at the moated grange. Meas. for Meas. iii. loCK-Whiles thus you nock it!........ Teinpest, lo, how he noeks me

and the sea moeks our frustrate ....... but trust ine. we'll moek him .... Merry Wires, ii. 3 that it but moeks reproof......... Tirelfh Nig."'t, iii not mock me with a husband ........... for nay, mock not, mock not: the bodly.. iluch Ado,
she mocks all her woots ou: 
IOCK_she'd mock me into air...

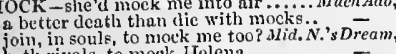

hoth rivals, to mock Helena .......

though you moek me, gentlemen.......

wise girls, to mock onr lovers so... Love's

in tlicse sliarp mocks! ...............

let's nock them still, as well know

they"ll moek us now downright

for a man replete with moeks

on every trec, moeks marricd men - v. 2 (song)

mock the lion when he roars.. Merch of $F^{\circ}$ nnice, ii.

sit and mock the good hous

you mean to mock me after...

nfllict me with thy mocks, pity.......

and mock us witli our burencss .......All's lre

nay, that's a mock; I have seen.. I'inter's Tale, ii.

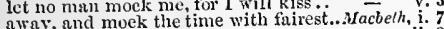

do nock their cliarge with snores

moek the deepl-mouther thunder..... King John, v.

the man that nocks at it.........

I mock my narne, great king .........

mock not my suscless conjuration.

ii. 1

talk but idly, sind you moek at me

sit in the elouds, and moek us.......

is come to mock at form

and nock yonr workings

to mock the expectation of the

this mock of his hath turned his

his ninck mock ont of their dear (rep.)

sweeten the bitter monk you sent

and return your nock in

should they mock poor feliows thins?

anci cipes, and knaveries, and mocks

if you crn mocz: a leek ..............

will you mock ut an ancient tradition

your majesty shall mock at me......

make thee mad, do mock thee thus.

deformity to mock my body .....

Yo. mock me, madnm; this is not

eren for revenge moek my destruction

my state now will but mock me ..Henry $r$ II. ii.

you smile, and mock me, as if I. Troilus

$m$, ok : sot, tlat I afiect the

sl.ow their scars, a mock is due.

thou never shat moek min morls begin to moek me.........
kind of speeeh, he did not mock us.

did not ask, but mock

for I moek at death with as big ..... - iji. 2 gods will moek me presently $\ldots$ Antomy 8 C $C$

moek me not, Euobarbus

and mock our eyes with oir

he mocks us by the panses ...........

Thenr him mock the luck of

whot an infinite moek

by leisure. him that mocks me on

Whilst the babbling ccho moeks.

did mock sarl fools witlal...

one side will moek another.....

i pray thee, do not mock me.

and look you mock lim not.

to mock your o

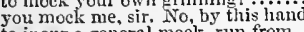

to ineur a reneral mock, run fron

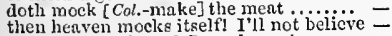

then heaven mocks itself! I not
dost thou mock me? I mock you!

villany hath made mocks with love.....-

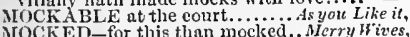

not amazed, he will be mocked...

he will every way be mocked.

the rod becomes more moeked...Meas. for Mreos. $\mathrm{i}$.

and so be mocked withal, upon ... Love's L.Lost. v.

and they, well mocked, depart away

my losses. mocked at my gains. Brer. af T'enice, iti.

should not have mocked me before. As you Like it.

roared, and the sea mocked thcm. Hinter's Tale,

and the bear mocked him, both roarin
as lively mocked. as ever still (rep.)

as we are moeked with art ...

be mocked and wondered at $\ldots \ldots \ldots .3$. 3 Henry $V I$.

a mother only mocked with two.....

our motion will be mocked .........Henry $/ 111$. i

who'd be so mocked with glory ?.. Timon af $A$

he mocked us, when he begged our.. Coriolan ns, ii.

the people ery, you mocked them

a sort, as if he mocked himselfi.....Julius Casar, that villain hatl mocked me ....... Cymbeline, iv. With marriage therefore was he mocked $-\overline{\text { nnol. }}$. $\mathrm{ii}$.

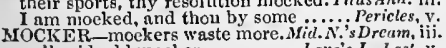
well saill, old mocker............. Lave's $\boldsymbol{l}$. Last, it is a sin to be a mocker ........Mcreh. of le enice, very priests mnst become mockers.. Coriolamus, ii.
mocker! that's the dog's name... Romeo of Juliet, ii.
MOCKEREES and his mockcries l Merry Wives, iii. 3 MOCKERY for the love of mockery Twelfh $N$ ight, ii. was I to this kecen moekery born? [Col.] they do it hut in moekery .. Lave's L. Lost, v. what mockcry will it be .... Taming of shrew, jil.
horrille shadow! unreal mockery.... Hacbeth, iii. a mockery should it be to swear? .. King John, iii. seck revenge on Edward's mockery.3 Henry I'I. ii. to trust the mockery of unfuict .. Richard 11 . mail in monumcntal moc

and rent it for acry?

onr vain blows malicions mockery

patience her injury a mockery makcs

some merry mocking lord, belikc. Love's L. Lost,

in mock ing [ Col,-mockery] nerriment

shall we stay, mocking intended gam

the tongues of mockin! wenches arc
nay, but the devil take mocking. $A s$ you
ike it, iii.

come, cone, you'xe moeking.. Taming of Shrew, v.

mocking the air with colours idly ... King Jolm, v.

sits mocking in our plumcs $\ldots \ldots . . . .$. Henry $V I$ iv.

for mocking him about the marriage

lies mocking our desicns.

yourselt, you nanghty moeking uncle?

it is a pretty mocking of the life...Timon nf Ath. i. I
MOCK'ST-then thou mock'st me..Mid. N.'sDr. iii. 2
MIODE-my death elanges the mode.2Henr? IV.iv. 4

MODEL - for any roodel to build..........ueh Ado, j.

that was model of thy father's $\ldots$ Riehard 1 . i.

as in a model, our firm estate? $\ldots \ldots . .$.

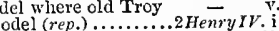

the plot of situntion, and the model $\bar{v}$ ii. (chio.

I'll draw the folm and model ..... Fichard III. V

for princes are $a$ model

Which was the model of that Danish ...Hamlet,

IODEN A - beaten trom Hodena.. Antony \& Clco. i.

be moderate, allay thy ecstacy. Miferch. of Penice,

moderate lamentation is the riglit

be moderate, be moder

furnisis out a moderate table............ of of Ahens, iil.

while one with moderate haste might ...Hamlet,
AODERATELY - laugh moderately .. Love's L.L.

therefore love moderately ...... Rameo

IODERN instances ............... As you Litie it, ii.

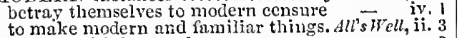

coming with her modern grace

a modern [Knt.-mother's] invocation. $k$ in

as we rreet modern friends.. Antony \& Cleopatra, y.
modern lamentation might have Romea \& Juliet, iii. 2

poor likclihoods of modern seeming .... Othello, i. 3
IODEST $-\mathrm{n}$ civil modest wife .... Mlerry Wives, ti. 2

the modest wife, the virtuous creature $\overline{\text { iv }}$ ivithin the modest limits of order.. Tuelfh
witht, 3

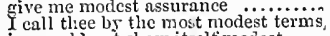

joy could not sliow itselt modest.

I will do any modest office...

as modest evikence to wituess.........

hath in it a more modest working. As you Like it,

eallcd the quip modest $(r+p.) \ldots \ldots \ldots$. ${ }^{\prime}$ ' ${ }^{\prime}$ ell

a mot this yonng modest rirl.

not froward, but molest as the dove
and modest wisdom plucks me ...... Macbeth

more wise and modest to the world... nenry IV

and decked in modest compler

how modest in exccption ...............

good-morrow with a modest sm

or modest Dian, circled wallest paces came.

young and of a noble modest nature

modest as morning when slie...

bemodest donbt is called.

praiscs vouched, would seem buit i... Coriolatan

too modest are you; more cruel.

ghould but hunt with modest warrint

Octavia, with her modest eyes.. Antony \&-Clea.

were neither true nor nod

for thou look'st modest as justice................

resolve me, with all modest haste........ Lear, ii.

and yet, methinks, right modest ....... Olhello, ii.

MODESTIES have not eraft enongh.... Hamlet, ii.

donhtrill of your modestics. Taming of Shet , Much Ado ii.

a challenge urged more modestly ...1 Henry I br. v. 2

modestly I think, tbe fall of every. Troil.\& Cress. iv. 5

will molestly discover to yourself.Julizs Corsur, i. 2
HODESTY - by my modesty .......... Tempest, iii.

by my modesty a goodly brokeri Tüa Gen.of i er.

since maids, in modesty, say no

and she, in modesty, or else

praised women's modesty ............ Merry $\bar{H}^{*}$ ives, ii. 1
MODESTY_-veil of modesty....... Nerry Wince, iii. 2
so excellent a touch of modesty.. Twelfh $N$ igni, ii. I tell me, in the modesty of honour .. $\overline{-}_{\text {Meas. }}$. I can it be that mollesty maly ....Meas, for Meas. ii. 2 her blush is guiltiness, not modesty. Much Ado, iv. 1 how it may concern my modesty... BIid.N. $\overline{\text { 's }} \mathrm{Dr}$. $\mathrm{i}$. you do impencli your modesty too much in huma modesty such scparation..

have you no modesty, no nuiden...

and in the modesty of fearful duty.. - v.

some cold drops of modesty ...Merch. of Venice, ii. 2

wad Luerctia's modesty... As you Lilie it, iii. $\overline{2}$ (verses)

for then we wound our modesty.
but the modesty which is so lost

of $S h .1$ (ivd.)

$\begin{array}{ll}\text { as is the other for beauteons modesty } & \text { i. } 2 \\ \text { bashful modesty, her wondrous qualities } & \text { ii. } ~\end{array}$

and modesty, plead on her part. Comedly of Err. iij. I

the modesty of it, to be otherwise ...... Henry $r$. iv. I

with modesty admiring thy renow'n.1 Henry 1 . v. 2

argue her replete with modesty ....3 Henry H. iii. 2

with thy religious truth, and modesty - iv.

you can with modesty speak... Timon of $\vec{A}$ thens.

in a friend, it is cold modesty..... Julius Cersar, jii. I

gift beside thy modesty can beg.......

true fove acted, simple modesty. Rameo \& Juliet, iii. 2

${ }^{\prime}$ 'cr the bounds of modesty............ $=$ ivamlet ii.

as mueh modesty as cumning .......... Hamlet, ii. 2

the grace and blush of modesty ......

that would to cinders burn up modesty. Ohlello, iv. 2
yoDICUAl - what modienms of wit Troil. \&-Cress. ii.

IODO.. Modo he's called, and Milhu .... Lear, iii. 4

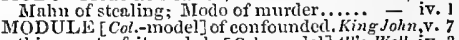

IoL-that moe and chatter at me .... Tempest, ii. 2

MOIECY of the prineipal ... Alerchant of renice, iv. ]

a moiety of my rest might come... Hinter's Taie, it. 3

which owe a moiety of the throne ... $=$ ive me the puoiety 3

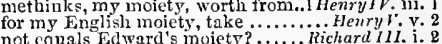

not equals Edward's moiety? ....... Richard III. i. 9

otluer moiety, ere you ask is given... ilenry $V I I 1 . \bar{i}$. 2

let us pay betines a moiety ....T'Troilus \& Cress. ii. 2

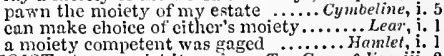

a moiety competent was gaged ........ Hamlet, i. 1

occidental damp moist Hesperus .....All's Well, ii. I

my tears, the moist impediments... - iv.

mothers' moist [ $\pi$ nt.-moistened] eves. 1 Henry $r$ I. i. 1

Egypt's grape sluall moist this... Antany \& Cleo.

the noist star, upon whose influence ..Hamlet, i. I
this hand is moist, my lady............ Othello, iij.

hot, hot, and moist: this hand of yours... - iii. 3 [Kn'] their mothers' moistened eyes.1 Henry Vl. $_{1}$.

MIOLDWRE searce serves $\ldots . . . \ldots .3$ Henry $V 1$. my father had a mole nuon not hear... Tempes', iv. never mole, hare-lip, nor scar... Vid.N.'s Dream, v. 2
I will bring these two moles .... W'inter's Tale, iv. 3 the mole in my neek ......... Comedy of Errors, iii. 2 breast a molc cincue-spotted............ Cymbeline, ii. a Gies a mole, right proul of that..... = v. the bind mole casts copped hills ....... Pericles, i. some vicious mole of nature in them ... Hamict, i. here on this molchill will I sit........ as if Olympns to a molehill should.. Coriolanus, y. 3 (loth molest my contemplation . Titus Andron. v.
MOLESTATION view on th enchafed .. Othello, ii. I AIOLLIF ICATION for your giant. Tuelfh Night, i. IIOI.TEN-as hot as nolten lead ...... HenryIV. v. 3 let moltew eoin le thy damnation!.. Tim. of Ath. iit.
tcars do scald like nolten lead .......... Lear, iv. IONENT-momcint's mirth.. Tu. Tuen.ofierana, i. I his incensement at this moment... Trelyh Night, iii. 4 Wharles in a moment threw him ... As you Like it, i. 2 thy palm some moment kecps ....... o' the time, the moment on't ........ then, in a moment fortune shall.... King John, ii. in a moment, look to see tire blind ... H- iii. what towns of any moment...........1 Henry $r i$. i. in a moment, cren with the...

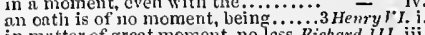
then, ill a monsent, sec low soon. Hetury $F I h$. (jrol.) 


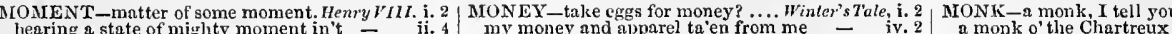
bearing a state of miglity moment in't - ii. 4 my money and apparel ta'en from me

business of more moment............. hut in this extant moment.. Trailus \& Cressida, iv. 5 upon far poorer moment ...... Antony \& Cleopatra, i. small jequest, and yet of moment the moment is thy death: anay enter...... to the very moment thot lie bale me teli ochello is angry? something of monent, then Knl. momentary] as a sound......Mit. N.'s Dr. $\mathrm{i}$. tht out-running. Tempest, the fit is momentary; upon a thought. Mracbeth, iii. 4

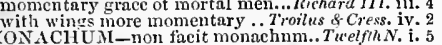
MONACHUMI-non faeit monachnm.. Taelfin. cuenlius non faeit monachnm ...Meas.for, Meas. v. 1 buw to a new-crowned monarch. Mer.of l'enice,

and gou, monareh. No............

that sits within a monareh's heart..2 H $V$, i. (eliorus) kings and monarchs of the earth do all

never was monarch better feared .....

displeasure can do against a monareh

than a general petition of monarchs - v. 2

the lordy monarch of the north ..... beseem a monarch like himself .... - iii. 3 the greatest monaich now nlive Henry $V I I I$. v. 2 I was a morsel for a monarch. Aniany \& Cleopatra, i. 5 come, thou monarch of the vine $\overline{\text { ii. } 7 \text { (song) }}$ a book of all that monarchs do monarch of the universal earth. Romeo of Jnliet, ini. 2 monarchs, and outstretched heroes

lack any money? (rep.) .............

faster than you'll tell money

by the way, and lost all mey of me.

mone's a merdler, that dotli utter

your money that I had to keep'. Comedy of Err.

where have you left the money

place you have bestowed ni.......... money?

is o'er-raught of all my money

grcatly fear, my money is not safe.

receive my money for the chain

the money now, for fear (rep.) ......

not furnished with the present moncy

return without your money

to my wifc, and fetch yonr money

redemption, the money in the desk?

there's the money, bear it straight

some tender money to me

so much money to warrant the

I think, he brings the money

alas, I sent you money

surely, master, not 2 rag of money

I sent you money, sir, to be your bail

his goods, his money, and his lands
he hath not money for these Irish.

he hath not money for thes

there's money of the kin

Your money. Villains I .......

the money shall be paid back

paid money that I borrowed .........

you owe me money, sir John (rep.)...

the moncy is paid back agrin........

and there receive money, and order.
will you give me money, captain?

let hin lend me the money

what money is in my purse?

MONA

MIONARCHO; and one that ....... Lave's L. Lost, iv.

of what a monarchy you are the head. Henry $V$ ii. 4 and is worth a monarchy ........2 Reriery iII. i. 1

can this dark monarchy afford false - i. 4

is a monastery two miles oft... NMer. of Ienice, iif.

Chertsey moniastery this nolle king. RichardIII.

to gaze upon a rninous monastery. Iilus Audron. $y .1$
MONASTIC-nook merely monastic.. As you Like, iii. 2

MOND AY - not till Monday............Much Ada, ii.
swore a thing to me on Monday night - v.

swore a thing to me on Monday night -
snatched on MIonday night ........... HenryIV i. 2
MLonday, my lord. NIonday?.... kamea \& Juliet, ii. 4

you say right, sir; o'Nonday morning.. Hamlet, ii. 2

la plus belle Katharine du monde ... Tempest, $v_{0} .1$

that the money, and the matter. TuaGen. of 'er. $\mathrm{i}$.

it was for want of money ..............

or money in his purse....

for they say if money much money

money is a good soldier, sir.

I have a bag of money here troulies me -

there is money, spend

one you may do with sterling money

I owe her money ....................

transporting a sum of money

I will none of your money

nor money, hath he to make war....
eome to gather money for their corn

come to gather money for their corn
the sum of money, which 1 promised

discharge, money, or furniture

great sums of money thro' the realim

there shall be no money $\ldots . . . . . .$.

Henry hath money, you are strong... - iv.

give their money out of hope.... Herry VIIl. (prol.)

toward a supply of money

that this is no time to lend money

be cannot want for money a money, plate, jewels, and sucili

vay, Timon's money has paid his

for mine is money...

your lord scnds now for money

send for money for 'em

for ccrtail money here, irir (rep.)

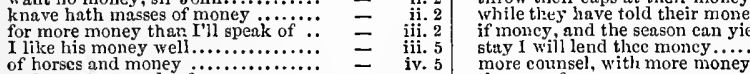

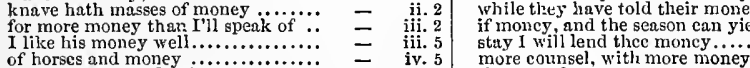

of horses and money

and twenty pounds of money.

that you have cozened of mo

money buys lands, but wives ..........

send for mond

send for money, knight..............
gome of that nomey. Whit money..
I dare lay any money, 'twill be......

there's money for thee

carr tool no more money out of nie

1 do it for some piece of money...Meas. far $\bar{M}$

for fire marks, ready money

a horn fur my money, when all's done

if he be sad, he wants money

and borrows money in God s name..

have the mouey by our father lent ...

nor have $I$ money, nor commodity

inquire, and so will $\mathrm{I}$, where money is
he lends out money gratis ...........

hath a dog money? ? .............

he was wont to lend money $\ldots \ldots \ldots . . . . . .$.

the fool that lent out money gratis.

a rasher on the coals for money.......

is he not able to discliarge the money?

here is the money

have no money in your purse............

he that wants money, means .......... Als's and $^{-}$iit.

and $f$ her money $\ldots \ldots \ldots \ldots \ldots \ldots \ldots$. $\ldots l$ 's $w e l$, ii.

with all fanlts, and money enough. Taming of Sh.i.

for I have bills for money by exchange the wars, for my money ........

raise no money by vile menns ..... JuliusCrsar,

this is the brief of money

moncy, youth? all gold and silver.

empty purse, there was no money in't antran.

how innch money must I lave

and have not money enough in the end

-

go money, on my faith.......... Rameo \& Juliel, iv. 5

no money bid for argument

put money in thy purse (rep.)

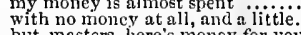

but, masters, here's money for you

Othello, i. 3

NONEY-BAGS to-night ...................

thou mongrel, beef-witted lord!.. Troiluse-Cress. ii.

in policy, that mongrel cur, Aj乞x

the son and heir of a mongrel hitch

Lear, i. 4

Mastiff, greyhound, mongrel grim ....... Tives, 6

MONIES-rated nie about my monics.Mer. af I'en. i.
Shylock, we wowld have monies..... over your threshold; money is your suit 'll lend you thus mucl monies...

take no doit of usance for my monies $\overline{\text { seren hundred pounds of monies... Merry wives, i. }}$ jmportune him for my monies.. Timon of sthens, ii. we lost too much money this mart...

there's money for the

twenty money-bags at a burden.. Winter's Tale, iv.
King John, v.

this monk might be deceived..........

MONKEY - thou jesting monk

on meddling monkey, or on $\ldots$. $\ldots . \ldots$ T'empest, jii. 2 your daughter for a monkey ... Aler. of Verice, iii. in my desires than a monkey yct as lecherous as a monkey ........ Arenryl mey..Timon of Ath. $i$. for apes and monkeys, contemn....... Cymbeline, i.

2 as prime as goats, as hot as monkeys ... othello, iii. goats and monkeys! Is this the noble Moor - iv. MONNIOUTH-[see-HARRY]

have talked of Mlonmouth's grave ..2 HenryIV.ii.
ay, he was porn at Monmouth....... Herry $V$.iv. ay, he was porn at Monmouth........ Henry $V$ iv. there is goot men porn at Monmouth - iv. since ,Henry Monmouth first began.i Henry VI. ii. born at Mlonmouth, should win all. Lear, i. MONS - or, mons, the bill........... Love; 2 .Lost, . . MONSIEUR_monsieur monster....... Tempesl, iii. a word, monsieur Muck-water ...... Merry
for monsieur Malvolio, let me.... Tuelfih Night, ii.

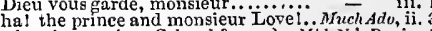
where's monsieur Cobweb? (rep.)...Mid.N.'s Dr. good nonsienr bring me the

where's monsieur Mustard-seed? (rep.)

nothing good monsieur, but to heln..

a gallant ladyl Monsieur......... Lave's L. Lost, î.

ape oi form, monsieur the nice...... -

but what is the sport, monsieur ...As you Like it,

why, how now, monsieuri

do you hear, monsieur . .............All's Well, ii.

between my lord and you, monsieur -
farewell monsieur; I have spoken better -

where are my other men, monsieur?

if you linve a stomach to't monsieur

what says monsieur Remorse ...... I HenryIV

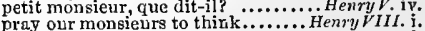

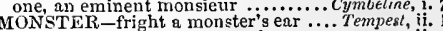

there would tlis monster make $\mathrm{n}$ man

thest delicate mon stert ...............

this is a devil, and no monster

a very weak mon

a very weak monster .................

well drawn, monster, in good sooth.....

a most perfidious and drunken monster

a most seurvy monster!.....................

an abominable monster $t$

a most ridiculous monster!............

he were a brave monster indeed .......

shalt be my lieutenant, monster ......

we'll not run, monsieur monster

being but half a fish, and half a monster

that a monster should be such a uatural

the poor monster's my suhject $\ldots$ inter.

a murrain on your monster..............

at thy request, nionster, I will do reason

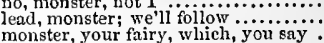

monster, I do smell all horse-piss ....

do you liear, monster?

disgrace ond dishononr in that, monste

this is your harmless fairy, monster.

ho, monster; we know what

monster, come put some lime

monster, lay to your fingers.

have with you, to see this monster Wives, iii. $\mathrm{I}$, yoor monster, fond as much .. Tüelmh Night, ii. as a monster, fly my presence... Mid.N.'sDream, ii. my mistress with a monster is in love

charmed monster ignorance ....... Love's L. I.ast, iv. let me turn monster..............As you Like il, i. a monster, a very monster .. Taming of shrew, iii. back of man, the heart of monster... Winter s $T$ iv. as our xarer monsters are

King John, ii.

and be a carrion monster like thyself , iii. these English monsters!.............. Hen ry $t^{\prime}$ i i. 2 it is a pity would move a monster....... Hry $V$ lil. ii. 3 there is presented no monster.. Trailus of Cress. iii. 2 a great-sized monster of ingratitude.

a very ind-fish, langungeless, a monsterhang thee, monsterl....

teem with new monsters .............

make a monster of the multitude ...
the horn and noise $0^{+}$the monsters.. 
MONSTER-monster's her accuser?. Cymbeline, iii. 2 the imperiouts seas breed monsters

leing an ugly

but alack! the mouster evvy.. l'ericles, iv. (Gower) but atural degree that monsters it

he cannot be such a ruonster ........... women will all turn monsters

like monsters of the deep.

abliorred monster keeps thee................ Juties iv. . 3 what unonsters you make of them .... Hamlel, iii. as if there were some monster

it is the green-eyed monster

tis a monster, beg upon itself (rep).

a horned man's a monster and a beust

noNSTH Ci, and many a civil monster - iv. MIONSTER-LIKE, be shown .Anlony \& Cleo. iv. 10 MONSTROSITY in love.......Troilus $\$$ Cressida, iii. 2 though they are of monstrous shape - iii. 3 $O$ it is monstrous! monstrous! $\ldots$.... that's monstrous .......... Tuo Ger. of Verana, ili. 0 monstrous! O strange! we are haunted - iit. I sinallest monstrous mouse that creeps

one fault sceming monstrous ....As you Like il, iii. skill infinite, or monstrous desperate. All's W'ell, ji. I 0 monstrous beast! .....Taming of shrew, $\vec{l}$ (induc.) O monstrous arrogance

O monstrous arrogance

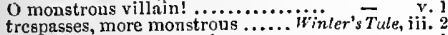

low monstrous it was for Malcolm ...Macbeth, iji. 6

thou manstrous slanderer (rep.) ....King John, ii.

blushed to hear his monstrous devices

slieriff with a most monstrous watch

half monstrons! but one halfpenny

curling their monstrous heads 20 Henry

and crush us, to this mmnstrons form

0 monstrous treachery!...

and cast account O monstrous "

Henry $Y$ s. iv.

and cast account. $O$

have slain, that monstious traitor?... - iv. 7

gavainst that monstrous rebel, Cade .. - $\quad$ v.

O moustrous traitor! I arrest thee $\ddot{H}_{\text {Henry }}$ VI.

O monstrous fault, to harbour such.3 Henry $Y I$. iii. 2

O monstrous, monstrous! ........ Pichard 11 . iil.

lath into monstrous habits put ....Henry $/ 7 / I . \mathrm{i} .2$

nor nothing monstrous neitler?. Troilus \& Cress. iii. 2

seat of moustrous fiends...... Timon. of Athens, iv.

cannot cover the monstrous buik...

marly, 'tis not monstrons

bring ourselves to be monstrous ....... -

faculties, to monstrous quali

to mask thy monstrous visage?

that shes this monstroige?..... 1

monstrons matter of feast ... Anlony \& Cleopatra, ii. 2

bring forth sone monstrous malefaetor

it's monstrous labour, when I wash

O monstrons! what reproachful.. Tilus Andron. i. 2

sliall I endure this monstrous villany?

of monstrous lust the due ....

why, what a monstrous fellow art thou...

monstrous? know'st thou this paper?

is it not monstrous, that this player

surge, with high and monstrous main

tis monstrous. Iago, who began it?

O monstious world! take note

tis a strange truth. O monstrous act! ..

NIONSTROLSLY, to have .... Camedy of Errors, $\mathrm{v}$. 1 NONTACUTE-lord Montacite.... Heury $/ I l$. i. therefore eomes my brother Montague valiant Richard, Montague

rom your brother, marquis ilontague and you too, Somerset, and Mrontague and Montague, resolve my doubt

and Montague, resolve

so God help Montague ...............

Oxford, and my loving Montague

our brother Montague? (rep.)........

now, liontague, sit fast

ah, Mrontague, if thou be there...........

quickly, Montague, or I am dead(rep.) 二

and Montague our top-mast

a dog of the louse of MIontague... Rameo $\& \bar{j}$

of any man or maid of Montague's.

two of the house of the Mon tagues

as I hate hell, all MIoritagues, and the

Capulets! dnwn with the Montrgues

old Montarue is come, and flourishe

Montague, come sou this afternoon.

you be not of the hollse of Montagues

by his voice, sliould be a Montague.

uncle, this is a Montague, our foe

his name is Romeo, and a Montague

not a Montague: what's Mnntaguc?

art thou not Romeo, and a Montague?

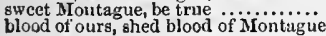

MONTAGUE-to the Montague. Romen $\delta$ Juli
this is that hanished luaglity Mlontagne stop thy unhallowed toil, vile Moutague raise up the Montagnes minti........ come, Nontigne; for thou art early up o hrother ifontaguc, give me tiy hiand IONTANO, your trusty and valiant ..... othe sir,-Montano,-sir; help (rep.)...

Mantano and myself being in speech ..... i.
MoN'T A NT-distance, thy montant Mervy ION'TAN'TO-is signior Montanto ... Nuch dis, i. IONTEZ-montez d cheval ............ He

MON'T GONIER Y-Joln Miontgomery.3 Henry V l.iv. thanks, good Montgomery (rep.)

have' a month's inind to them. 7
whereon this month 1 have been

some sixteen months .......

for but a month ago I wedt ....... Tueljth Night,

having been thrce molitis married...

and for three montlis betore

he hatlievery montis a new siroru....

stay here at the least a month ........

the moon was a month old (rep.)

slie is two montlis on ber way.....

how many months do you desire?

three montis from twetve

within these two months (rep.)....

ships come home a month before .....

is but for two months victualled...1s yon ithe in

some six months since my lor

a montli's length a-pieee $\ldots \ldots . . .$.

three crabbed months had sotred

very true: and but a month old

there was not full a month between.

my absence was not six months.. Co

laughter for anonth.

by the ninth of the next mointh?

where hast thou been this month?

full of spirit as the month of $\mathrm{M}$ ay

had found soine months asleep.

for eimhtecn months concluded t

ep.).2 Henry l'l. i.

at Bury the first of this next month

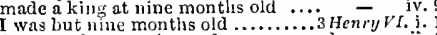

days, weeks, months, ond yeirs, nassed -

king at nine months old; my fatlier $-\overline{\text { iin. }}$.

whom 1, some three moinths since.

hold you play these two months ... $\ddot{H}_{\text {enry }} \overline{v^{\prime} J I J}$. v.

for many weary months .... Trailus

succession of new day's this month. Timon of Alh. ii.

Yet may your pains, six
I'll follow thee a month

some two thee a month....

what will whole months of tears.

Calius Cosar, it.

for this three months hath not spoken

and with you; next month with us

than he will stand to in a month. Rninea \& Jutiet, ii.

delay this marriage for a month

and yet within a month (rep

and yithin a month (rep.) ........... -

nay, 'tis twiee two months, my lord

two months ago, and not forgotten yet?

two months since. here was a gentleman

monthe o... Romeo o Juliel ii.

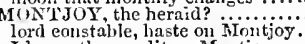

I know tlyy quality. Montjoy

and so, Mnntjoy, fare you well

like patients shall be the maws of... Macbe'h, iii. 4

here, a marble monumeat!... Heasure for $/$.

on your fanilly's old monument .....Much Ade, iv.

he ghall live no longer in monut

is this the monument of leonat

saw some wondrou, mo a s

joble deeds, as valour's monur ent.1 Henry, 'l. iii. 2

detacing monuments of conquered.

to wash a way my woeful monuments
this monument of the victory will I bear

and he fill up one monument!........ Hem? I I II. ii. 1

to the monument (rep.)..... Anlany \& Cleupalra, iv. il

out o' the other side your noniment

cont the other side your bioni.....nt

confed in all she lias, her monument

her sense but as a monument...

likenument five liundred years.
MUNUMEN'T-household's monument. T'ílus And, y. 3 for a monument upon tlyy bones.

dim monument where Tybalt lies. Komeo \& Jul. iii. 5 her body sleeps in Capel' monument

now mist I to the monument alone.

open outery, toward our monument.

IONU IENTAL ring.

mail in moumental mo...............

and smooth as monumental alabaster o Cress

OD-whom, in iny mood. Tu' Gen. of Pranu, iv.

your passion on a misprized mood. Hid. N.'s $D$ r. jii.

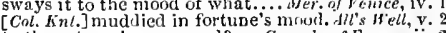

to thwart me in my nood?

does show the mood of a mueh....

to break in to this woman's mood
jis moods, and his displeasures

stabled in my angry mood at ....

one of his father's moods

int this inuod will give ns ......... Julius Cresar, fii. 2

in tiat mood, the dove.....Anlony/ \& Cleopalra, iii.

snow to their colder moods

(Gower:)

when the rash mood's on

as lot a Jack in thy mood as any... Romea s. Jul. iii. [Col. Knt.] together with all form

but now cast in lis mood ....

alkeit unused to the melting mood ..............

Othello, ii. the nor moody beggars, starving

hath banished moody discontented... Heery VI jii. but rather moody mad

after many moody thonghts .........3 Hernry $I I$. iv.

observe, obscrve, he's moody

music, moody food of us that .... Aniony s-Cleo. ii. 5

m OON - lift the moon out of her spliere. ?'empesi, ii.

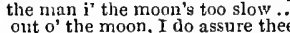

I was the man in the moon (rep.)

'tis not that time of moon with me. Tuelfh Nighl. $\mathrm{i}$.

happy days bring in another moon... Kid.N. Dr. i.

and then the moon, like to a silver

hymns to the cold fruitless moon.

by the next new moon (the seali
the moon, the governess of floods

between the eold moon and the eartii

the chaste beams of the watery moon
doth the moon shine, that night .....

and the moon may sline in at

the mon methinks, looks with.............

swifter than the wandering noon

two mole heasts in a moon and a lin

to the moon. This lantern doth (rep.)
moon present; myself the man (rep.)

r am aweary of this moon

that the lantern is the moon (rep.j

for they are in the moon $\ldots \ldots \ldots \ldots . . .$.

moon vanishes [Col. Kui. lijon vanisilied] -

moon, take thy flight! ..................

andl the wolf behowls the moon...........

tu the moon. The moon was ......... Lore's L. Lost

nor shines tlie silver moon one hal

ber mistress, is a gracious moon $\ldots . .$.
$m y$ fitee is hut a moon, and clouded too

vouclisate, oright moon, and 'these

thus change I like the moon the moon at full

yet still she is the moon, and $\mathrm{I}$

the moon shines briglit: in such...

peace, hoa! the moon sleeps with

of Irish wolves agginst the moon...... you you $L \overline{i k}$

I say, it is the moon that

it shall be moon, or star

and be it moon, or sun. or what

and the moon clianges even as .....

now the ship boring the moon with

the pale moon shimes by night..

for never gazed the moon upon is down; I have not.....

upon the corner of the monn ther
slivered in the moon's eclijse.

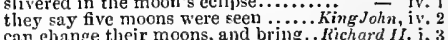

can ehange their moons, and bring.. Richard 11 . i. 3

go by the moon and seven stars....... Henry 17. i. 2

ininions of the moon; and let men say

onr noble and chaste mistress the moon -

briglit honour from the pale-faced inoon -

as much as the full moon doth ....2 Henry $I V$. iv. 3

and moon; or rather, the sun (repe) 
MOON-that reaclies at the mon ..2 Ifrury $F$ I. foverned by the watery moon.... Rictarid lil lis thinkings are below the non ns plantage to the moon

as the moon does (rep.).......

the moon's an arrant thiet .....

resolves the moon into salt tears.

hemock the molest moon.

and the moon, were she eartlity.

Yon are smelt ahove the moon

tine mom of Rome; ehaste as

rather be a dog, and bay the

nion and stars! whip him ...........

O) thon blessed moon, when men

remarkable beneatls the visiting mon

therein stuek a sun, and moon

or lut the moon in his lineket.

so pale did shine the moon on.

one twelve moons more sho'll wear.

and elondy billow kiss the mon

the siln and moon ne'er looked upon!

the sum, the moon, and the stars

theugh it the nicht the uno

for ati heneath the ne moon ellines

his eyes were two tiull moons ............

that cbb num flow by the moon

ladv, by yonder blessed nroon........

unmask her beauty to the mon

revisit'st thus the glimpses of the mo....

the sun ant moon make ns again cout.

till now some nine inoons woon

$t$ to follow still the changes of the mos

stons the nose at it, and the moon wink

now a huge eclipse of sum and
it is the very crror of the moon

Mito N - BE.MIs trom his sleeping.. Nid. $N$.'

mnder the dead moon-calt's gaberdine

moon-ealf, speak onee in thy life

if thon heest a good moon-ealf" ........
Ino

MONISII-bat a moonish you

vil met by moonlight, proud Titania

and see our moonlight revels.......

to brimg moonlight into a eham

how sweet the moonlight sleeps.......

it is not monnlight now..... Taming

IIOONSUINE do the grcen-sour

monnshine revellers, and shade...

find out moonshime, find out (rep.).

or present, the person of mo

presenteth moonshine (rep.) lion, moonshine, wall, and lovers

how elinee moonshine is gone......

mononshine and lion are left to bury
request'st hut mooushine........ Love's L. Los

reguest st hut mooushine..........

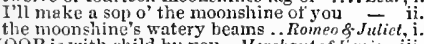

MoOR is with child by you... Merchant of te
that the Mloor should be more thanl..

my sweet Mloor, sweeter to ne.. Tiins

wecoinpanied with a barbarous Moor

like to the cmpress Moor.

cumes in likeness of a coal-ijiak $3 i$.

dill rou see Aaron the Moor?........

and told the Mnor, he should not ch.

fitted, had you but a Moor ......

in her eompany there is a MIoor.

take you in this barbarous BIoo

thither hale that misbelteving MIoor.

done to Aaron, that damned MLoor.

to feel, and batten on this mor

were I the $\lambda$ I oor, 1 wonld not be Iago

your danghter and the Moor are now.

to the gross clasps of a lascivious Mon
os, it I stay, I shall), against the Mloo:
unhaypy girl! with the MIoor.

we may apprehend her and the $\mathrm{AI}$ oor?

Eignior, it is the Moor. Down with him
eomes Brabantio, and the valiant גioov.

hrofess dne man, this Moor $\ldots$ iö.

come hither Moor; 1 here do give thee.

long continue her love to the $\mathrm{MI}$ ion........

these Moors are ehangeable in their wili

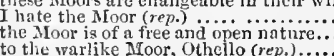

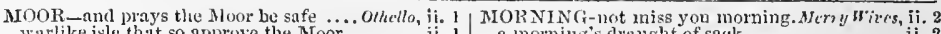
warkike isle that so approve the Mioor... with what violenee she first loved the Miour ali which the Aloor is defective she would never lrave loved the Mionr

the Moor-howbeit that I endure hin

suspect the linsty Moor Jath leaped.

abuse him to the roor in thealousy.

make the Nons thank me, love ine.

that the noble Mnor should hazard sueh

the eomrse to win the Hoor again?

phat then for her to win the Moor.......
tirr lim pleads strongly to the MLoor

myself", the while, to draw the MIoo

to draw the Moor out of the way.

her first remembrance from the $M$

the Moor already clianges with my noi

cursed fate: that gave thee to the MI

is this the noble lloor, whom our fitil

Mnor's abused by some most villanous
inacle you to suspeet me with the Moor.

the Moor may untold me to him

the Moor lias killed my mistress........

v.

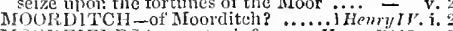

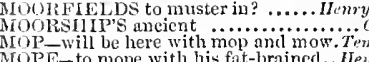

MOPE- to mope with his fat-brained...Henny

part of one true sense conld not so mope Hum
IOPING-W'ere bronght moping hither? Temp

IOPPING-Fliblertigibbet, of molping... LFar, iv. 1

if I were not in love with Hopsa...

IORA L-to apply a moral medicine Much Ado, i. 3

moral in this Benedietus. Moral?.. =

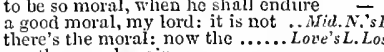

say the mural again ...............

thes moral on the time ............

virtue, and this moral discipline.

silent king the mornl of this spor.

look you, is an excelient moral.

this moral ties me orer to time

unit to hear moral philosophy

Troilus \& Cress. ii. 2

the moral of my wit is plain and tiue

a thousand moral paintings.... Timon of

whilt thou, a moral fool, sit'st stiii

MORALER -are too severe a moraler

MORALITY of imprisonnent ... Med
MORALIZE-did he not moralize. As $y$
I pray thee, moralize them...... Fomation

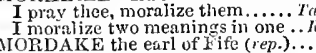

MIordake, and a thousand blue-caps

MUPE-that sir' Thomas More

Henry $V I I I$. ivi.

Belarins, that am Morgan ealled

MOld Morgan, am that Eelarius

IORN - in the morn 1 II bring you Henry VI. iii. I

for exeeution in the morn.... Tou Gen. of pest, v. 1

lights that do mislead the morn

betimes $i^{\prime}$ the morn, I'll call
but the next norn betimes

to do observance to a morn of Miay.Mid. N.'s Dr.i. i

shall out-sleep the eoming morn .....

bea, trom morn temperate as the mom;... Tan

each new morn, new witiow

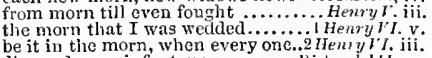

twice done salutation to the morn

ouble not yourself; the morn. Troilits of Cress. iv.

the moru is fair: good-morrow

by the sceond hour i' the morn

at the sixth hour of morn ..........

- iv. $\quad$ iv.

and morn to the lark, less wel

the golden sun salutes the morn.. Titus Andion ii.

the hunt is up, the morn is brig! !

earis, one blusteriog morn, this lady... Pericles, v.

was the lark, the herald of the morn

early next Thursday morn, the gallant - iij.
eock, that is the trumpet to the norn .. Humle $l, j$.

lock the morn in russet muntle olad ...

in the norn and liguid dew of yonth.

Tuesday morn, or Tuesday noon ....... Ollello, iii.
IORN-DEW on the myrtle leaf. Anitony \& Cleo, ii io

IORNING - tis fresh morning ...... Tempest, iii.

as the morning steals upon the nigiti. $\bar{v}$ er.

send to me in the mornin

angets given me this morning........... a morning's druught of sack

to-morrow morning to my house....
lier husband goes this morning $(r, p$.

were set at cicht i' the morning

have given it you to-day morming

政

Barnartine be this morning executed

and is hanget betimes in the morning

good morning to you, fitir and gracions

my knees every merning and evening. Much.

next morning at the temple, and there

prince Jolin is this morning seeretly

which he forswore on Tuesday morning -

to-nurrow morning come you to my

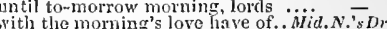

I do hear the moning lark.

ears that swcel away the morning dew

and for the morning now is sornething,

to those frest tomorrow morning. Love's L. Los, iii.

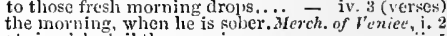

he plies the dulke at mornin.

and in tlic morning early wíli we both

my master will be here ere morning

in the molning eariy they found.. As you Like

and shiming morning face, crecping.

his lordship will next morning.......All's

ant this morning your cleparture henee - iv.

at the high-cross every morning
as morning roses newly washed.

the morning wens, "tis time we were
begins lis morning story right.. Comedy of $\mathrm{Er} r$.

meet me $\mathrm{j}^{\prime}$ the morning; thithicr.......... Macbeth, iip.

to-morrow morning let us meet .........ing.rohn, iv. 3

to-morrow morning by four o clock... -

you must to the court in the morning

be with me betimes in the morning..

lut I would it were morning.....
the Dauphin Jongs for morning

inly ruminate the morning's danger - iv.

is not that the moining which breaks

rehearsal of my morning's dream .

how the morning opes her golden ...3 Henry $I$ l. ii.

fires like to the morning's war....

makes the night morning........... Richard 1I.

eincerfully and smooth this morning

prepare thy battle carly in the morning -

how far into the moming is it, lords?

this fomd I on my tent this morning $\bar{v}$ at

to-morrow morning to the couneil-board -

you shall this morning come betore

make them sleep on Diay-day morning

modest as morning when she eoldly

to-montow morniog call some knight

take leave till to-morrow morning..

it is great morning; and the bour

how have we spent this molning?

iv.

caudle thy morning taste, to eure .. - iv.

with the furehead of the morning... Coriolanus, ii.

and then we pout pon the morning

the morning comes upon us ........Jutus

the lumours of the dank morning?.

this morning are they fled away ....

this morning, like the spirit of i youth -

this morning left thee (rep.)

advised to give her musie o' mornings -

I do think, I saw't this morning ..... =

and bows you to morning's holy oflice -

it is great morning; come ...……그

many a morning hath he (rep.)... Romeo \&
tis almost morning, I would have thee

yon grey is not the morning's cye ..

in the morning comes to rouse thee...

this lnot knit up to-morrow morning -

thought lone to see this morning's face -

alls our person from our morning's rest? -

a glooming penee this morning witl it -

and I this morning know whe

methinks I seent the morning air

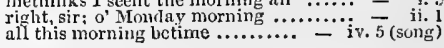

you shall hear more ere morning...

will it never he mornimg?............. nenry

this morning papers of state

we'll go to supper i' the morning ........ Le $e^{2}$ 


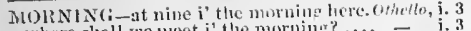
where shall we meet i' the mor

by the mass, "tis morning............... rentere. i. ? panse there,

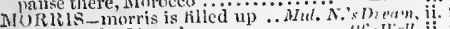

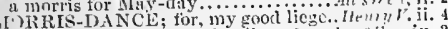
IORR IS-PIK E-a morris-pike . Comerly uf lirr, iv. 3

MORROW-morrow deep midnight . Mrd. $N$.s D\%. i. never shall sum that morrow see?

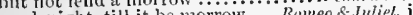

goot-night, till it be morrow......

MORSEL-put this ancient morsel..... Tempes ii.

forth this morsel of dead royalty .. King John, iv.

the sweetest morsel of the night ....2 lienryl $I$.

icin

I wos a morsel for a monareh

I was a morsel for a mong

inay'st cut a yorsel off' the spit.

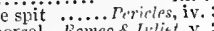

gorted with the dearest morsel... Komeo onl's rell, ii. 3 as 'twere the mort o' the deer .... Winler's Tale, mort de ma vie! (rep. iv. 5)

peaceful words? no mortal business .. Tennest, $\mathrm{i}$.

\section{sil, she's mortal; but by}

excels each mortal thing. ThoGen.oficr. iv. 2 (song)

even to a mortal abitrement...

With such a mortal motion..........

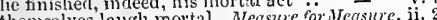

and desperately mortal...

ruch ado, $\mathrm{i}$.

weli, we are all mortal...

-

the human mortals want........

I pray thee, gentie mortal, sing agrin

I will purge thy mortal grossness so

loil, mortal! hail! hail w.........

lord, what yools these the ground...

with these mortals, on the ground..... $\bar{L}_{\text {no }}$ iv.

$r$ tongue of mortal tell ......... - iv. 3 (verses)

by heavens, the wonder of a mortal cjel - iv. 3

their bucks to mortal views! (rop.) -..

ortal in mature $(r e p)$.

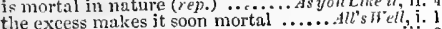

the excess makes jt soon mor

into my mortal yreparation .........

mortal ears in thit hiard the queen. irimes's rite, iti. 2

the mortal and intestine jars.. Comedy of Errors, i. I

that tend on mortal thoughts.

with twenty mortal murders on .....

to time, and mortal custom

hold fiast the mortal sword ..........

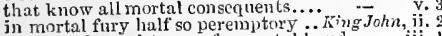

without the assistance of a mortal hand -

a cased lion by the mortal paw ....... ${ }_{\text {nichard } 11}$ ii..

the purest treasure mortal tim

be poor, it ends a mortal woe...

nounds a me unortal temples of

the extremest point of mortal breation - iti.

mortal men, mortal men .......... Henryl $\mathrm{H}^{\mathrm{V}}$,

last breathing in this mortal w

the mortal worm night make .......

tide tise mortal fortune of the field?

years a mortal man may live.

proclaim myself thy mortal foe.

proclaim myself thy mortal foe.......

wonld it were mortal poison ...

momentary grace of mort

noor murtal living ghost .............

when I was mortal, my anointed borty

to wear our mortal state to com

amongst my brethren mortal.........
from eyes oi other mortals? . Troilus
the mortal Venus, the heart-blood..

by my mortal sword be drained!

alone he eutered the mortal gate.
mortal, tn eut it off; to cure it

mortal, tn eut it off; to eure it ........ - iii.

see how mortal an unkindness... Anlony \& Cleo. i. .

see how mortal ant unkindness de.Anlony

by some mortal stroke she

marta! wreteh, witli thy sharp teeth

together with so mortal a purpose.... Cymb

to read would be eren mortal to me

are grown the mortal bugs o' tlie field

show thy spite on mortal flics .......

she had tor you a mortal nineris

to strike me to death with mortal joy -

is any mortal body, hearing it ...

losked to, fur her relupse is mortal .. Perieles, iii. 2

which his mortal vessel tears

one mortal night, drove him to this

wondering eyes of mortals ...... Romieo \& $\bar{J}$

got his mortal hurt in my behalf....

mortal paradise of soch mad.

such mortal drugs I have.

unless things mortal move them not .. Hamte

when we have shufflet off this mortal coll

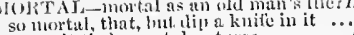

do omit their unortal untures

() you mortal engines, whose ruble....

if my oflence be of sucli mortal kiml

thy mitch was mortal to him

greatness in mortality

could be set up agninst niwortali

nothing serious in mortality.

at mortality' s strong

make such waste in brief nortality...

killing in relapse of mortalit

1 beg mortality, rather than life .. I IIenry $l$

what nortality is! ....................

ocribar the slores of my mortality
wipe it firs, it smells of mortality

tiongh they hurt you mortally

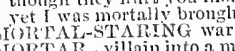

IOR'PAR-PIECE, to bluw us.

HORTIFIED-Dumain is mortified.. Lore's L.L. $\mathrm{i}$.

alam, excite tlie mortified nian.

conjured up my mortificd spirit.

Henty i.

numbed and mortified bare
IORTIFY ING mischief.

cool with mortify ing groans
IORTIMER-

that the nohle MIortimer, learling .... Inemy $1 \%$.

home revolted Ifortimer (rep.)

never could the noble Hortimer receive -

not hear you epeak of Mortim

speak of Mortimcr? Zounds, will ${ }_{\text {lift }}$ -

trembling even at the name of Mortimer -

ansom Mrortimer; firbartiner

tantht to speak nothing but Nortimer -

and of York, to join with MIntimer..

I fear, my brother jlortimer doth stir

and his son-in-law, Mortimer.

lord Murtimer, and cousin Glendowe

so m:uch slie doteth on her Hortimer

grace of York, Donglas, MIortime

Donglas, and Miortiner (rep.).

thus the Mortimers, in whom the titl

here dies the dust y tereb of Alortinn

under the title of Johm Miortimer...2 2 er

my father was a Mortime

preclaims himself lord Mortimer........

now is Mortimer lord of this eity

cals me other flard Mortimer..

thy grandfather, Roger Mortime

sir John, and sir High Mortimer
MIUT ISE-ean hold the mortise?

MURTiSED-things are mortised and

ORTUN, didst thou come from......
yet speak, Mlorton; tell thinu thy enj

Met speak, Alorton; tell thinu thich to fich

by Dorset, Buekinglsam, and Mlorton

AI! isE-like to mose in the chine.. Tumng of $\mathrm{Sh}$. iii.

yea, and furred moss besides.

o'ercome with moss, and haleful ... Tilus Andron. ji.

AOsSED-boughs were mossed....As you Lite it, iv.

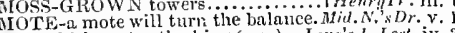

found his mote: the king (rep.)... Love's l. Lost, iv.

that there were but anote

wash every mote ont of his ......... Henry $V$. iv.
like motes and shadows see..Pericles, iv. 1 (Gower)

a mote it is, to tronble ................. Ham Hot, i. I

Samson's love, my dent Moth?.... Lot

nay, nothing, master Moth

my dependants. Alot 1 , tollow..

the candle singed the moth............ of the on ii.

if 1 be left behind, a moth of peace

MIOTHER was a piece of virtuc ........
mother brushed with raven's feather

i'empest,

by syeorax my mother

my

this lett shoe is my mother (rep.) .... -

here's my mother's breath up and down -

tili my mother be dead ................ Merry

as my mother was, the first mother, do not marry ........

come, mother Prat, come...........

to this her mother's plot si

lier mother lath intended.............

good my mother, purdow ............

so near the manners of my mother ... i - i

but to give the mother notice of ... Mcas. - i it.

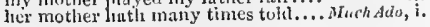

Notidele-prove the mother of fool

no sure, my lord, suy motlere (rickt

Wonk hang us every mother's son ${ }^{2}$.

hown, every mother's son, and rehutarse

to mistress Scluasli, your mother monger

her mother's, Ihive heard .......

uny lady his mother hlayed false.

Margers, your wife, is my nother"
so the sins of my mother should li,

damned both by fiatlice and moth

to lie with his mother eartls?

we comfortable to my mother

is to accuse your mothers...

a mothets, and a mistess, and a

a mother; why not a mother?

acquaint my mother wit.

my mother greets me 'iwill be to.......

my mother dirl but duty ............

take my mother shall not hear.

not given him his mother........
writ to my had mother......
the denrest grouns of a mother

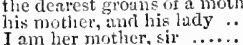

good mother, fetch ing hiail

0 my rear mother, do 1 s

now by my mother's son

thy mother plays, and I play too... IFin.

the dishonour of lijs nisother

the mother to a holeful mince 3 might

thy mother appeared to me last night

your mother was most true to werloc

cries, 0 thy mother, thy mother!

to look nom, the statue of her mo

to look npon, the statne of her mother -

to tind a mother, and a brother........

mother

was ny father a traitm, nother

he has kitled me, mother ...........

was from his mother's womb

silence, goud mother

of one nuther, then, it secms (rep)

thou dost shame thy mother

heaven guad my mother's homoni...

still I liny unon my nother's

hetween my father and my moliter lay

that this, my mother's son....

this conchides; my mother's
brother by the nother's side

o me, it is me mother

thereture, sood mother .........................

o tike lis mother's thinks......

wert his mother (rep.)

good my mother, peace?

for' tears in mañy an Englisi mother

and slanderons to thy muther's wumb

our mother, breathe her curse (rip.)

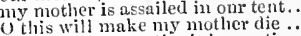

[Kinl.] scorns a mother's invoeation ..

Where is my mother's care that ......

what! mother dead? (rep.)

of your alcar mother England

my mother, and my nurse .........

as a long parted nother with her child

of mothers' sons shall ill become

rob me of a happy mother's uame?

let your mother min .................

your mither well hath prajed

send him baek afain to my mother..

I have partly thy mother's word....

ny mother's son, sir (rep.) ......2 $H^{\prime} n \bar{y} I r$. iii.

mock muthers from their son

dishomour not your mothers

but all my mother came into ........

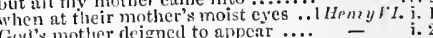

God's mother dejgncel to appeas

llelen, the mother of grent Constantine -

the mothers still their babes?

my sister, that thy mother wa.........

0 , if yout love my mother.

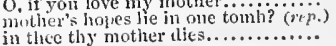

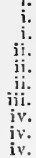

i. 2
i. 2
ii. 3
ii. 5
ii. 5
iji. 3
iv. 5
iv. 5
iv. 6 
MOTHER-her mother liveth yet....I Henry VI. v. 4 , MOTHER_son, let your mother.... Cymbeline, iii. I MOTION-no motion of the liver. Tuelfi Night, ii. that I was wedded to lier mother.... - v. 1 they took thee for their mother

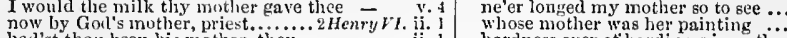
ii.

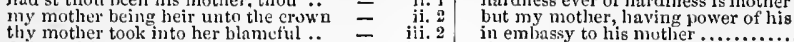

dring with mother's dug hetween . since death of my dearest mother...................... by gond Euriphile, our mother

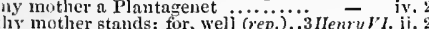
liow will my mother, for a father's when my daughters call thee mother and, by God's mother, I, heing but.

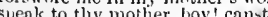

nuther felt more than a mother's (repo)

linve often hearl my mother say

fright the liopeful mother at the ... Wich

die neither mother, wife, nor Englan

blame her, by God's loly motler

yet thon art a mother, and hast.

comfort, dear motlier; God is nueh

like a earefui mother, of the young.

madam. my mother, 1 do cry you

and you ny mother [Col. Knt,-sister]

ay, mother, hut I would not have it

my inutlier, and my brother $\dddot{Y}_{\text {ork }}$.

what, will our mother come?

the queen your mother, and your
by lis mother was perforce witlheli

will to your mother: to entreat of

not incensed by his subtle nother

all the mother's, from the top to toe

my lord, you know, my mother live

now by the holy mother of our Lord

a care-crazed mother to a many son

their mother, who slall bar me (rep.)

in love their mother; theu bring ne

mother, how tares your grace?

thy mother's name is ominons to....

hear your mother's lomentation

preys on the issue of his mother's body

for ioyful mother, one that wails...

and brief, good mother; for $I$ am

my daughter's mother thinks it

arain shall you be motlier to a $\mathrm{king}$

go then, my mother, to t.,y danghter.

dear mother, (I must call you so)

and be a lappy mother by the

our loving mother? $(r / p.) \ldots \ldots \ldots \ldots . .$.

kept in Bretagne at oul' mother's cost?
to love her for her mother's sake.. Henry $\bar{T}^{\prime} I I I$. iv.

Gorl's blest mother! I swear, he is

my mother's blood runs on the

boj'row'st from thy mother, my sacred

think, we had mothers; do not give.

that can soil our mothers? .............

the lermit pity witl oll mother
thy motier lath had visions

thy mother's of my generation. Timo

nor yells of mothers, muids, nor bal

he did it to please his mother.

a mother slould not seli him ......

look, sir, your notlier, -O you have

and motliers that lack sons.........

know, good mother, I had ra ther...

I muse, my mother does not approve
let tlzy mother rather feel thy pride

pray, be content; mother, I am going

mother, where is your ancient courage

nay, mother, resume that spirit....

nay, inother, resume that spi
furewell, my wife, my mother

my mother, you wot well

my dearest mother, and my friends

here comes his mother, Let's not...

his mother, wife, his child, and this

unless his noble mother, and his wif

wife, mother, child, I know not...
my motlier bows; as if Olympus

my motlier bows; as if Olympus

making the mother, wife, and child

esecialty his mother, may prevail.

no more remembers his mother now

no more remembers his mother.....
mercy his mother shall bring...
with the welcome of his mother

With the welcome of his mother .....
(! say, your city.) to his wife and mother-
if C'esar had stabbed their mothers.

that mothers shall but smile

rash mumour, which my mother gave

he'll think your mother chides

kill'st the mother that engendered thee

your mother came to Sicily.......

because of the was mother's.

because of the queen my moth.
crafty devil as is his mother......
a mother hourly coining plots

majesty, and to my gracious moti...

your mother too: she's my rood lady
yet my mother seemed the bian to the ground, as once our mother

thou hust created a mother, and two

by the hum of his queen mother.....

in mother to the birth of three? (rep.)

a mother's tears in passion

altho" our mother wingavised

nor would your noble mother....

dear sovereign, and onr gracious mother

as you love your mother's life $\ldots . .$.

yet every mother breels not sons.

ous father's sake, and mother's care

fly had a futher and mother?

as dear as e'er my moth

my mother gave't me................

here lacks but your motlier should not

for our beloved nother in her pains.

our mother. Villain, I have done (rep.)

by this our mother is for ever shamed

and give the muther cold

ient thee but thy mother's look . ....

spirit had they from their mother.

your mother means to feast with me

yet I feed on mother's flesh.

an eater of her mother's flesh.. - i. 1 (riddle)

mothers, who to nousle up their babes

when my mother died, this worjd overboard thrown me, to seek my mother -

thy mother? $\mathrm{My}$ mother was.

what was thy mother's name?

to be gone into my mother's busom.

sir, this young fellow's mother could....... Leur, i.

my father conjounded with ny...........

daughters thy mother [ $\mathrm{Col}$. Knt.-mothers]

turn all her muther's pains............

divorce me fiom thy motlier's tomb

than she are happy mothers .....Romeo is.Juliet, i.

hre now, who calls? Your motlier.

madam, your mother eraves a word

the earti, that's nature's motior

where is your mother? (rep.).

thy father, or thy mother, nay, or

where is my futher, and my mother

your lady mother's conning (rep.)....

not alone my inl:y cloak, good mother.. Hamlel, $\mathrm{i}$.

let not thy mother lose her prayer

so loving to my motlier, that he m

contrive acainst thy mother aughit

with blood of father's, mother's, daughters

better, my mother had not borne me
let his quieen mother all alone entrent

no, good noother, here's mutal more

the queen, your mother, in most great

my mother: therefore no more (

so astonish a motherl but is there (
ovey, were she ten times our mother

then will I come to my mother.

now to iny mother; - O heart, los

more andience, than a mother, sinee

my motlier stays: this physic ...........

now, mother, what's the matter?

mother, you have my father mucli...

it were not so:-you are my mother

amazement on thy mother sits

and from his mother's closet hath her

farevell, dear mother (rep.)...............

a father killed, a mother strined

unsmirched brow of my true moth

the queen, bis mother, lives almost...

killed ny mother shall uncharge

thy mother's poisoned; I can no more

duty as my mother showed to you...

did an Egyptian to my mother give

my mother had a maid, called Barbar

MOTHER-QUEEN, an Ate............... Joh $\overline{\text { hin }}$, y.

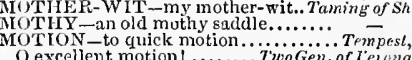

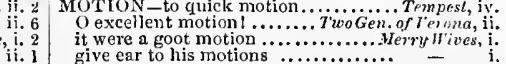

Merry

ii. i he gives her folly motion

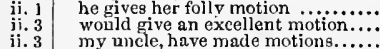

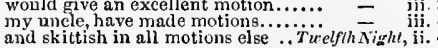

pTlON-no motion of the
put them to motion ...............

I'll make the motion

and motions of the sense....iveasure for Measure

this secome

I have a motion nuch imports

the motion of Demetrius' heart $\dddot{M}$ i.d., $\bar{D}$.

apyrehensions, motions........... Love's L. Lost, iv.

as mution, aril long-during action..

but with the motion of all elements..

to the motion of ation to it.

sem they in motion?

but in his motion like an angel sings

ii. 1 with spriaht] y fire and motion.......

in wlat motion age will give me ieo...Al's ${ }^{2}$ ell

(")

excellent motion! fellows (rep.) .. $\ddot{\text { Taming }}$ o f

then he compaesed a motion ....Winter's Tale, iv.

the fixture of her eye has motion in't - $t$. y.

we in your motion turn, and you ......

more free from motion $\ldots$.............

the dreadful motion of a mirderous..

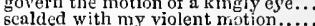

to keep his anger still in motio

keep not their motion in one sphere...

in niy poor and of a pewterer

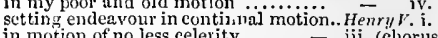

in motion of no less celerity $\ldots \ldots \ldots,-$ iii. (chorus)

your grace affect their motion?

Henry $r$ l. ii.

but from sincere motions

an earnest motion made to the queen - ii.

still in motion souner catch ...Troilus \& Cress. iil.

what, all in motion? .............. Coriv $\overline{l a}$.

your loving motion toward the common -

whose every mution was timed

a beggar's tongue make motion through -

holds on his rank, unshaked of motion

his corporal notion governed

to rot itself with mot

her motion and her station are as one

the wild motion of mine eye ........

motion and breath lel't out

for there's no motion that tends to $=$ i ii.

but to 1 , t those nowers in motion... $\quad$ iv. 2

doth this notion please tnee? .... Tilus Andron. $\mathrm{i}$.

in fell motion, with his pre ared .............ener, ii.

to earth resign; end motion here....

it did address itself to motion ......

lach neither motion, guard, nor eye ........

or minerals, that waken motion and dis

that her notion blushed at herself ........ -

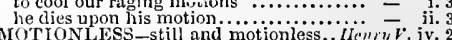

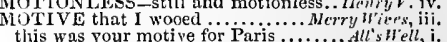

to be my motive and helper to

are motives of more fancy........

whose precious motives $\ldots . . . .$.

the slavish motive of recantin

Anceleth, iv:

every joint and motive of her body Troil. \& Cress. iv.

if the were the motives that you. Timon of Aliens,

ignorant motive, do so far ask ...Anlowy \& Cleo. ii.

you had a motive for't

thy safety being the motive $\ldots . . . . . . .$. Lear, $\mathbf{j}$.

is the main motive of our preparations. Hamlet, $i$.

without more motive, into every brain .. -
had he the motive and the cue for passion -

the other motive, why to a public.

[Knt.] am I the motive of these tears . Öhello, iv.

in my brain ............. Tueplfh Night,

motley's the only wear $1 . \ldots . . . . . . . . . . . .$. -

invest me in my motley ........... -

will you be married, motley? ........
in a long motley coat ...... Henry iii. 3

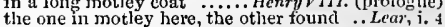
MO'TLEY-MINDED gentleman ...As yau Like it, $v$ la repetix mots d'Anglois....

vous prononcez les mots aussi droict

ces sont mots de son mauvais...

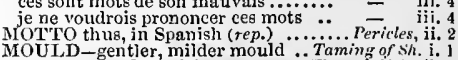
the very mould and frame
cleave not to their mould.

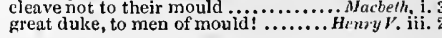


MOELD_mould up such a mights.. Henry rIIT. v. [Knt.] not in nur Grecian mould. Tratins ? Cress. i. this mould of Anreius, they to dust crnck nature's moulds, all germins spill. Lear, iii. 2 of finslion, and the mould of torm .... Hamlet, iii. lovely berries monlded on one stem. Hid. $N$. D. lovely berries monlded on one stem.. Mid. $N$. this was moulded on

ont of his, KinurJohm, whose arms were moulded in ........ HemryII
what coarse metal ye are moulded. Hemry IIII.

mide and moulded of things past. Truilus se Cress.iii. like his ancestry, moulded the stuff . Cymbeline, v. 4 a babe is moulded ............ pericles, iii. (Gower) IOULDY-in your mouldy ehaps ..2Henry $\mathrm{V} V$.

he lives upon mouldy stewed pru

is thy name Nonldy? yea ant please you things that are nouldy lack use ö̈̈ to free Mouldy, and Bull-ca marry then, Mlouldy, Bul

mouldy ere ...Troitus or

MOULr - and queen moult no feather.. Haml

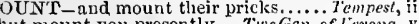
and lie under mount Pelion ........Aerry 17 that youth mounts and foll As you Lik it. which mounts my love so high?

there will we mount, and thither. Taming of sh iv. amen. amen! Mount, elievaliers! .. King John, it. let rance and England mount their

when I mount, alive may I not...... Richard II. whilst you mount up on high.....

after, $\Lambda$ umerle; mount thee upon....

while his rider mounts him ............. mount them, and make incision in

here will Talbot mount, or nake

dear boy, mount on my swiftest

never mount to trouble you again

fall, he is the next will mount...

mount you, my lord, towards .......3 Henny $V_{1}$ ii.

when I should mount with wings.. Richard 11I. .
that mounts the liquor till it ...... Hewry riII.

the base o' the mount is ranked. 7imon of dithes, i. against the steepy mount to elimb.

mount thou my horse, and hide... Julins Cresar,

about the mount Misenum

be at mount before yoll, Lepidus

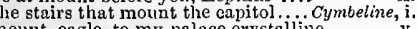

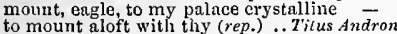

will I mount myself upon a eourser...Pericles,

on the summit of the livghest mount.. Hanlet, iii. 3

on mnint of all the age for her perfections - iv. 7

thy turfy mountains, where live nihbling -

hey, mountain, hey!. slould liave been a mountain of mummy fit for the mountains, and the

in to the mountain's top, and mark lip to the mountain's top, and mark.Mid.N. Dr. on the top of the minntain ..... clove's

well forbid the mountain pines. $1 . \ldots$ of $v$ onie but mountains may be removed. As you Like it, iii. as mountains are for winds .. Taming of shrew, ji. uponl a barren mountain ........ Winter's Tale, iii. 2 mountains and rocks more (rep.) ... King John, ii. 2

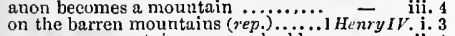
gross as a mountain, open, palpable the goats ran from the mountains ${ }_{\text {make mountains level, aud the...2 }}$ - iii. 1 mand as firm as roeky mountains..... whiles that his moun tain sire (rep.)... Henry $V$. ii. 4 upon this mountain's basis by ...... - iv. damned and luxurious motritain goat - iv. standing naked ou a mountain top.2 Henry $/ 1$. iii. 2 as on a mountain top the cedar show's - v. 1 that raught at mountains with......3 Henry VI, i. 4 to make an ellvious mountain on....in. $\overline{\text { iii. } 1 \text { (song) }}$

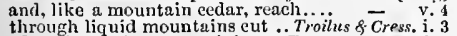
after tim to the mountain's top. Timon of Athens, $\dot{i}$. set a huge mountain 'tween my..Julius Casar, ii. 4
a forked mountain, or blue..... Anlouy \&.Cleo. iv, 12 a forked mountain, or blue.

now, for our mountain sport ..... Cymbeline, iii. 3 when from the mountain top Pisanio

doth take the mountain pine .........

sons, we'll higher to the molntains

on the mountains near to Milfurd

the mountain lioness, the ocean... Titus Andron. iv. losing a mite, a mountain gain . ${ }^{-}-$ii. (Gower) on the misty mountain tops.... Romeo \& Julint, jii.
on this fair mountain leave to feed ... Hemlet, iii. no sooner shall the mountains touch,

his shroud as the mountain snow - iv. $\overline{5}$ (sung) till of this flat a mountain you have made -

of on pre of mountains, let them

of oak, when mountains melt them. .Olkello, it. some villain un yield, rustic mountuincer
MOUNTAINEER-traitor, mountaineer.

MOUNTAIN-FOOT that leads.. Teo Gen of Ver.. .
MOUNA INOUS error be too highly. Coriotonus, ii. OUNTANT-a MUUNTEB $\Lambda$ NKS, and many sueli. Comedy of'Err. a monntebank, a threadbare

I bourlat an unetion of a mount thank. Itamlet, iv.

and medicines bout re mountebank...

motuted the Trojan walls

ready mounted are they, to spit

great Bolinbroke, mounted upon

his affections ale higher mounted

where eastles mounted stand beggars, mounted, run their

I thought, it would have mounted

anl now are monuted, where...... Hemy $\overline{V I}$

MOUNTETH with oceasion $\ldots . . .$.

he showerl a mounting mind.... Love's $L$. Lo L

where mountinu larks should sing...King $J_{\text {oh }}, \mathrm{i}$.

the mounting Bolingbroke ascends

mounting his eyes, he did diseh

then shall he moutn. (if' cver love.. Much ddo, iv.

it nourns, that painting $\ldots . .$. .

Tamine of Sh. I ind

that makes your lady mourn $\ldots . . \%$
shall I go mourn for that.. Winier's $T$ a

come mour with me for what ...

I slitli have time enough to mourn..2 $\mathrm{Hrmry}_{\mathrm{I}} \mathrm{i}$. 1

mourn not, except thou sorrow.

c molin, France smiles.

(thee......2 Henry $/$ I. iii. 2

nakes Clifford mourn in steel......3Henry VI. i. I

with ne mild, while she doth mourn 1 mourn for yours.. Richard 1 III. iv. I

who hath any causc to mourn; but we? $\bar{V}_{\text {iv. }}$ i
all the world shall mourn her .... Henry

and mourn you tor lim ............. Coriolanes, v. 5

you then to mourn for him?......Julius Casar, iji. 2
tor we wiil mourn with thee.. Titasdndronicus, ii. 5

gives cause to molurn his funeral

to mourn thy crosses, with thy

and all we mourn [ $\mathrm{Col}$. Knt wai ${ }^{\circ}$ for....

to mourn a mischief that is past .......... Olhello, i. 3

that mourned for fashion ..... Comedy of Er

not have mourned so much
mourned by Mark Antony

of reason, would have mourned longer. Humlet, i. 2
MOURNER-eause to be a mourner. Richarl IIt i. 2

I am no mourner for that news...... - i $-\overline{\text { iii. }} 2$

MUURNFUI,-mournful epitapls ... Much Ado, iv. 1
munner of his mournful death......1 Heury $v 7$. ii. 2

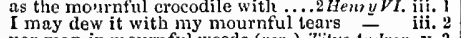

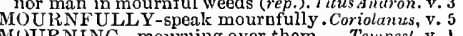

IOURNING-mourning over them Tempesl, v. I

maintain a mourning ostentation ...Much Allo, iv.

the moulning brow of progeny ". Love's L. Lost, v. 2

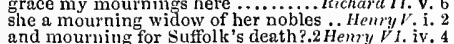

bodies in black mourning gowns....3 Henyy Vi. ii.

had left no mourning widows for

my mourning weeds are

here is a mourning Rome .........Juli

could our mourning ease thy misery

my mourning, and important tears

IOUE mourning duties to your father... Hreml

IOURN'ST. - why mourn'st thou?. Tuelfih Night,

the smallest monstrous mouse.Mid N.'s Dream, v.

not a mouse shall disturb this........

or most magnanimous mouse......2 Henry $\mathrm{I} V$. iii. 2

phouse, in absenee ..........Henry

couches 'fore the mouse's lole. Pericles, iii. (Gower)
I never killed a mouse, nor hurt ...... - iv.

look look, a mouse, nor hirt....

dun's the mouse, the constable's. Koraeo of Jul

a rat, a mouse, a eat, to seratch a man

not a mouse, every unworthy thing

MIOUSED-well moused, liou ...Mil. N.'s Dreum,

MOUSE-TRA P-the mouse-trap ...... Hrmlel,

IOUSING ow ha wour at ............. Macdeth,

[Col. Knt.] mousing the flesh of men... King Joth,
IOUTH-must our mouths be cold?.... T Tempesi,

open your mouth (rep.)................

doth thy other mouth eall me?......

silfer the flesh-fly blow my mouth

wnuld even infeet me

hast thou no niunth by land?
MOUTH-thou stop my mouth?. Two Gen off I'er. ji. 3

sine hath a sweet musth.

that the lips is parcel of the moutli..
ginger shall be hot i' the month.. Thelfh Night, i. 3

milignation to him by word of nont

deliver his elullenge by word of mouth

heaven in my muatl........ ileasure for Mcasur

() perilous mouths that hear in

to speak, as fiom his molth $\ldots . .$. .

put your trial in the villain's mouth

if foul mouth, and in the witness.

Muchtdo

列

as quick as the greyhounl's mouth.

Col.] make mouth upon ne...Mid. N.'s Dreen iii

but matelied in moutli like

ha ve made a moutl of his eye..... Love st

he last man in our mouths.

cven in the cornon' of new

quit thee by thy brother's moith

this concealed man out of thy mouth

take the cork out of thy moith ....

approached the opening of his mouth

as the nun's lip to the friar's moutli... All's Well,

my mouth no more were broken .....

i jot of Tranio in your montl. Taming of $S h . i .1$

my tungue to the root of my mouth... Hinter's 7 ale i. 2

she drojs booties in mny moutl ......

my king's defiance from my mouth... King John, i.

battering cannon, charged to the(mouthsi-

shoot in the mouth of thy artillery

the moutl of passage shall we fling... -

here's a large mouth, indeed ........ - ii. 2

alf's-skin stop that mouth of thine $=$ iii.

low new is husband in my mouth!.. -

tongue were in the thunder's moutlı!

s common in their mouths.

take from my mouth the wish......... Richard

nlooked for from your higliness' moutl - i.

within my mouth you lave engaoled - i. 3

in an ungracious mouth ............

one kiss shall stop our months ......

his words come from his mouth...

from your own mouth, ny lord

and salutations from their mouthis

to fill the mouth of deep defiance, up

with wax, our moutlis witli honey

with full mouth, speak freely

worse, within thy nasty mouth!

coward dogs most spend their mouths

with fatal moutlis gaping on .... -

and in their pale-dull mouths

in their moutlis [Knt. - his mouth] as
to take the tales out of my mouth

stops the moutlis of all find-fault

provender tied to their mouths ...

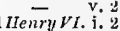

whieh hath the deeper mouth .......

from their mouths to raise sucking babe -

thy lips to stop my mouth .........2Henry $v$ I. iii.

dam up this thy yawning mout

may come out of your nusuth...

montl shall be the parliament of England -

that I am now my tather's mouth ...3Hemry I I

opon their congealed mouths ........ Richare

drop into the rotten mouth of death -

from a month of honour quite ....... Henry hill. i.

this makes bold mout lis

which stopped our mouthis, sir....... - ii. 2 (letter)

have your nouth filled nip

will not toint my mouth with

but stop their montlis with stubborn

he will spend his mouth, ancl promise

would I had a rod in my month...Timon

will hardys stop the mouth of present -

the mouths, the tongtes, the cyes.... - iv.

the tongues o' the common mouth ...

hou being their mouths....

tribunes are the people's mouths

spoke freely out of many mouths...

thice dumb montlis (sep. iii. 2) ......

I wear not my dagger in my montlt. Cymbeline, iv 2 
MoU'CII-I'll stop your mouth ... Titus.Antron. ii. 3 IIOVE-or move the people with .....Coriolunzs, y. 5 hose mouth is covercel with.

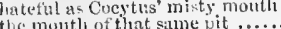
sirs, stour hits moutl tuif their mouths.

will choke me, if 1 ope ny linutl

these mouthe, whom but of late".

crickets sine int th' oven's month

was a Spaniatrd's montly so watered...

but she mate nonths in a glass.

thoul'st nwet the bear i' the mouth

as this mouth should tear this hand

shut your mouth, dame. or with this paner

seal mp the mouth of outrage tor....... . nt

numke months [Col.Knt.-mowes] at him

but if you monith it, as many of our...

inakes mutlss at the inyisible eve

nuy an' thoul't mouth, f'll rant as

and from his m: nuth whose voice will.

your name is great in mouths of

bonid put an enemy in their montlis...

had I as many mouths as Hydra...

if not, he tivalis at moutl

no, ins month is stopped; honcst Iago.

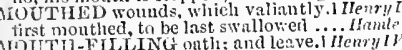

MI.)UTH-FRIENDS! smoke, ant
Mi.) UTHEUI,

3. UTH-11ONUUk, breath

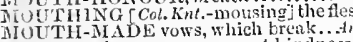

MLUVE-stripes may move, not kind

pity move uny father to be
do move a woman's nind.

perliaps, may'st move that hear.

if this letter move him

susli as noves men .............

let me but move one
coutd stult afiection

I will move storms

virtue's furce perfirce doti move me

it did move him to

we will not move a foot

mirth camnot move a soul

thy plainness mores me nore

gee if you ean move him .........

more than your force move no

how then might your prayer
the Floreutive will move us

eit, sisesk, and move under.

move the gtill-piecing air
what the devil should move

scem to :ncve and wathon
I suw her voral lips to mo

slie moves ma not, or not $r$

custd not move the gorls, to look

custhing lut that; move still

tl:e bagpipe coulli not move so

miny think anon, it moves $\ldots \ldots . . .$.

to make lier slucak, as move ..........

titrn, aud you may move us.

in an honest suit might move .........

sives hinve hecn kuov's to mo

those twe commands, move only

methodist, the wood beymu to
what doth move you to thain

any thing he sces, which more

slould move you to mew un yo

liat move in youl right splieres.

pity may inove thee pardon to
what thus speak'st nuxy move

what thus speak'st niay move
move iil that obedient orb again.....

of Einglaud move to do bratve aicts....

weightiless down perforce must

newly nove with easter slongh
$I$ siall never move thee in lench

thy nords move rage aukl not

that moves both wind amil tide

to thy harm, thou move our patic

if this indusement move her not to love - iv. it is a pity would move a monstcr.. Henry $V^{\prime} I I$. ii.

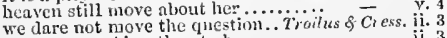

what noves Ajax thus to bay

what moves Ajax thus to
did move your great ness
liow novelty may move.

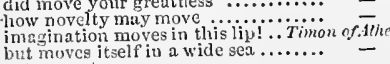

yet, more to move you .........
gears to move langhtcr only

none but mygelf conld tnove thee

when lie walls, le more like an sione - if 1 could pray to move (rep.)

if Casur move him, let $\mathrm{A}$ ntony

and moves with its own orgnus .......
your heve can equally move with the

I'll move hime the wing to any siaje.

as truly as he moves ................
whence he moves his war for Eritain

spicler, 'twould move me sooncr....

in motion, that long to move

move the gods, to send down. Tilus
when it should nove you to attend

dirst thy tongue move anger to

bid you, or you'll move me els
shadows see tliem movetawliile.

he moves all hearts against us

of Montarue inoves me. To move. Ram

a dog or tlint house sha

not had time to move our ciniti.........

to move the heavens to sinile upont

doubt, that the sun doth move .......... ii. ${ }^{2}$

unless things mortal nove them not at al

dotli move the hearers to collectio

revenge, it could not move thus.

as the star moves not but in his spincre... - iy. 7

I'li move your suit, and seek to effect it - iii. 4

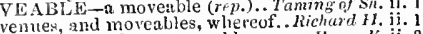

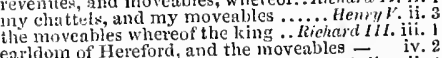
earldom of Hereford, and the moveables - meline, ii. TUVED-louk my son, in a moved sort.. Tempest, i. be kindlier moved th

be moved, be moved ............... if he had been thoroughly moved.. Merry Wires, i. 4 it hath not moved lim at all ... Aleas. for Mens. iv. 2
why, a block moved with none ....inuch Ado, iii. I

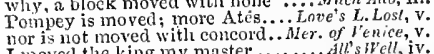
I moved the king my master..........All's well, iv. a woman moved, is like a fountain . Winler's Talc, i. 2 are yon moved, my lord?..........Winler's Talc, 1.2 this presence, that hath moved me. Richterd 1 .

now slalt thou be moved ...

in kind heart and pity moved

moved with compassion of .emorse malse him say, I moved him .....2IIen'y VI. iii. I have moved his higlness to commit. Richardlll. i. upon yout you have nll moved milue $\overline{-}$ iii. now, what moved me to t $\ldots \ldots$........

moved you, my lord of Can terbury...

lave moved us and our council.

fixed, to-day was moved...... Troilus \& Cressidn

you are moved, prince; let us depart

in part tor his salie moved

beng noved he will not spare

I was bardly moved to come to

entreat you, be any further moved.

are not you moved, when all the sway

I eoula be well moved, if I were as you

how innch the penple nay be moved
the beople, how I had moved them

I think, not muved by $\Lambda$ utons .... - in

like egg-shells moved non thei

and highly moved to wrath...... Titus.sud

and high moved with pity, did clidn
the lion, moved moved witl her sigls ....
iny sea be movion moved, doth veep to see.

inelinanus, thou host moved us .

[Kul.] firtume noved, varies again

o then it moved lier. Nut to :

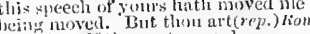

thear the sentence of your mover prince -

is soun inoved to be mood

lamentation might have 1 in

but, I do sce yon are moved

moved. No, not mueh moved ................

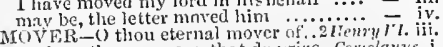
see here these movers, that do irize. Corolanis, $\mathrm{i}$

the movers of a laurnishing deatir ... Cymbline, i.

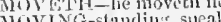

if the gcutle spirit of movino speaks in every power that moves.

move them no more, by erussi iny grace, or power to move your
MOVING -give tnee moving graces! MFa.for.Mea, ii. 2

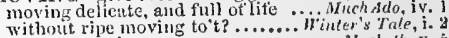
I say, i moving grove ...................Mucbelh, v. I say, a moving grove ................. Mucbell, v. fur moving such a dish of skimmed.. 1 Henry $1 \mathrm{~V}$. ji. Dars his true moving, even as ...... Henryl' i. yot move soon won with moving words. peace, for moving me to rage.......... Antony \& Cles. ii. 5 moving, how express and aunirable ... Numel,, i. 3 $[\mathrm{Kn} t$.$] lis slow ant moving finger at .$

政. MiviNGLY $\rightarrow$ more movilis as the grave. or burn the great sphere thou mov'st in! - iv. is thow mov st no less with thy .......... Tempest, iv. mows [Col.-mouths] upoul me............ Nid. N.'s $D$ r. iii. 2 to mow down thorus that would ..2Henry $V I$. jii. ] to mow then down before ne....... he will mow down all belore him.

contemis with mows the other

cymbeline, $\mathrm{i} .7$

MUW BRAY - Thomas Mlowbras?......Richard Il. $\mathrm{i}$.

now, Thomas BLowbray, do I turtz

lay to Nowbray's charge? it n
that Mowbray hath received

fetch trem tulse Nowbray their first

Mlowbray, impartial are ot:

he is our subject, Now bray ............

cousin Hereford and fell Mowbiay fimht! =

may enter butcher Mowbray's breist.
be Mowbray's sins so heavy in his ...

my name is 'Thomas Nowbray

in lists, on Thomas Nowbray .......

if I be gored with Mowbray's spear.

co I with Mowbray fight

bray's waxen coat

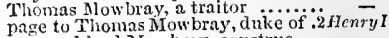
my good lord Mlowbray,

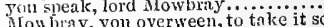

encountered here, my cousin MIuwbray

my loid, and gentle cousin, Mowbray

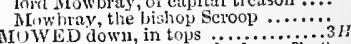

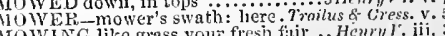
Io W ING like grass your fresin ftir .. Hemry $\mathrm{r}$. iii.

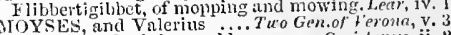

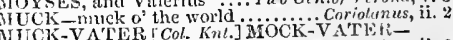
Muck-vaterl vat is dat? .............Merrylyives, ji. 3 I have as much muck-vater as de -WATER-
ii. 3 a work, monsieur MIuck-water ...... = MUD-filled up with mud....... Ak $d . N$.'s Drean, ii. spring is not so fiee from mud ...2Hem $y$ lli ii. she not, for all the mud in EgJpt... him 's Cl'o. ii. ratler' on Nilus' mad lay me etark

you have stajned witl mud
MUDDED-tliere lie mudded

nyyself were mudded in that oozy bed.. I am now, sir, mudded in fortune's...All's $F_{c} c l l, v$. and, ns he says, is mudded withal.

MUDDY-lie foul and mudily

IIamlet,

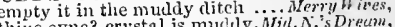

thine eyne? erystal is mudely.

like a foum tain troubled, mudy. . Trming of sht.

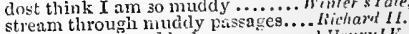

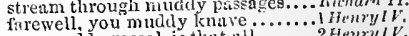

liang yourselt, you muddy conger

her melodious tay to mudily death.... Hamlet, MUDUY-METTLED rascal, peak ......; nuffle your false love................. Comety of Errors, mufle me, night, awnile.......... kome of Jnliet, and will keep him nuther, till we ...All's W'll,

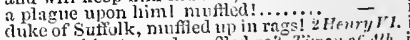
not that his steward muflecl so? Timan nf Ath. ii

MUF $L E R$, and a kerclief.......... Merry Hives, iv her thrumned hat, and lier muficit..

witl a numlther befise her eyes..........Henry $l^{2}$. iii.

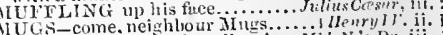
MULBER RI ES- ind mulberies... Wid.N. No Dr.

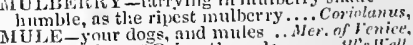
buy auther of Bajazt's mule........All's Wfell,

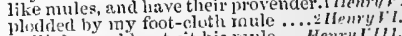

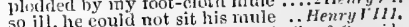
to be a dos, a mule, a eat.... Troilus \& (ressida, he would have made them mintes 3 -Clenpalra,

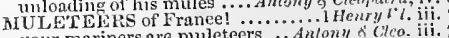
MUli El: whieh mulier, I divine ... MULILPES ne suecedant

IIILAED deaf, slcepr, insensible corinitums, ix.

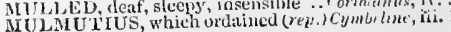




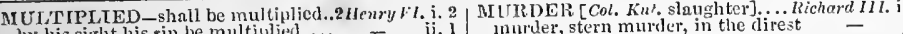
by hisight his sin be multiplied

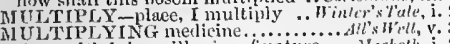
with multiplying banns

..... Timon of the thes, iv.

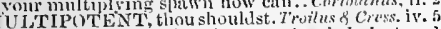
MULTTTUDE call, the atternoun. Loze's h. Lost, by the fool multitude ....... Herchme of fen
rank me with the harbarous intl titudes the buzzing plensed multitude....

finir multitude of those lier

at the hecls, ind golden mintiti

wayering multifude can play

so tew, wateh girdy multitude

with the rude multitude

multitude of hinds and peasants

blown to and fro, as this im

to guvern and rule multitu!

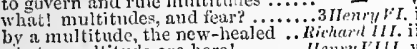

What a multitude are here

the multitnde to be ingrateful (rep.) Cor

call us, - the many-header multitnde

have appensed the multitude

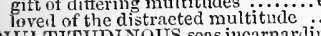

Titricted multitide .... Intmiet, iv.

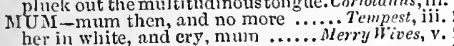

what needs either your mum........

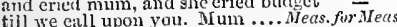

go to, mum, you are he...

well said, master, mum? no words but mimi...

eitizens are mum, say not a word. $R$

mum, mum, he that keeps nor clust...

IIUABLING of wieked eharms

nenee, you munbling fool. .....

MUUM MY -a mount tain of mummy. Mierry

witehes' mummy; naw, and guif..... Mretosth, iv. I

dyed in mummy, which the skilful... Ollnello, ii

i] UNCHED, and munehed, and munulied Mactelh,

MUNDANE cost ............. Pericles, iit. 2 (seroli) MUUNITION sent, to underprop........ King John, $v$. view the artillery and munition

MURA, now is the mural down....irid. N.'s Dr. v.

$1 \mathrm{CRDER}$ - and do the inurder first .. Tempest, iv. better shame than murler.

it you will not murder me.
what is it, murder?

he

murder cannot be hid long ... Merch of beruce if.

there is murder in thime eye ....As yon Like ii, iii.

virginity murders itself

here's a madman will murder me. Toming of sh. v,

haled ont to murder

to murder her I married

what, will you murder me?..........

whose murder yet is but fantastical

an.l withered murder, alarumed by

and one cried, murde

Mi:cleth does murder sleep...........

the alarum-bell: murder! and treason

a wolnan's ear, would murder as it fell

with twenty mortal murders.

gtronge than sueh a murler is ..........

his secret murders aticking

this murder had not eome........... kingr $J_{0}$

murder, as hating what himsel

- iv.

hand, and nurder's bloody axe ..... Richard II. i.

teaching stern murier how to

in murders, and in outrages, bloody -

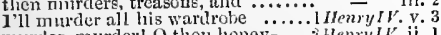

murder, murder! o thou honey-..

murder, I wartant now

rob, murder, and eommit...

wilful adultery and nurder .......... Iferry

treasun and murder, ever kept ti:

of deadly murder, spoil, and villany

premeditated and contrived umurler -

contrived'st to mirder our leud lord.
what miselief, and what murder too

murder not then the fruit

murder, indeed, that bloody sin......

slanders me with murder's crimson

the guilt of murder bucklers thee ..
sliameful murder of a guiltless king

you camnot but forbear to murler ine

cliftorrl! murder not this inmocent..

murler is thy almsdeed; letitioner'

to, to, to, - to murder ne? ay, ay

forewearing, and for murcler ton

he sends you not to murder me...

most grievous guilty murrer done 1 ..

mincler thy breath in middle of $n$ word -

murder ler brothers, and theu mal':y

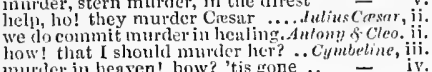

must murder wives much beter

how casily murder is discovered.
mule for murders, and for rapes

tur I must talk of muther.

of murder and of death .............

where bloody mmreler, or detested ral

Wapine and Murder there (rep

Muriler, stab him, he's a murderer

let Rape and Murder stay will me..

nurder's as ncar to lust, as flan

did seck to murder me

at fourteen years he songhit to murder

the gods tor num blot, numder, or foulness

nive ta the murker of your lorklship

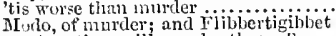

merey but murders, pardoning those

to murder murder our solemnity?

doing more murders in this loathsome

most unmatural murder. Murder?

ean you play the murder of Gonzago

like the muiver of my tather..

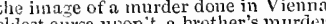

forgive me my fioul nurder!

effects for which I did the murder.

thinu wilt not murder me? help

indeed, should mirder sanetuarize ...

how shall I murder him, Iago?

help, ho! mirler! murder! (rep,

whose noise is this, that cries on minrce

O good iny lord, yonder's foul murder

then murder's out of tune, and sweet
killet my mistress; murder! murder

most lay their nurders on your neel

your renorts have set the murder on $\ldots . ., \bar{n}$

so shouli the murdered look

he hath inurdered his niaster

our royal master's murdered!

your royal father's nurdered.............

on the quarry of these murdered deer.

all murdered; for within ..................

the murderer, love him murdered.

pray dosed, and, shortly, murdered..i Hen $y / r$. i.

are murdered for our pains .........

Jichard was murdered traitorously.2

Hounphrey traitorously is murdered

it eannot be, but be was nurdered

told me, he was murdered there... Kich

sonls, whose bodies Rieliard mudered

officer, that murdered Pompey... Artory
poor Bassianus here lies murdered ... T

shonld have murdered Bassinn

sume bring the murdered body ........

were they that murdered our emperor'

rybalt murdered, doting like me....

enrsed hand murdered her kinsman

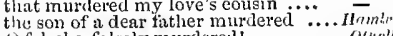

O falsely, falsely murclered!............. Othello,
why, how should she be murdered?......

my nistress here lies nurdered in her bed -

heing a murderer, though he ... MIeas. for Mfras. iv.

that Angelo's a murderer, is't not.

so should a murderer look

yet you, the murderer, 10ok as bright - iij. 2

stand and play the murderer in? Love's L. Lost, i..

to say inine eyes are muderers...... - iii. 5

arainst his murderer slut the door..... Macbelh, i. 7

sweaten from the murderer's gibljet... - iv. 1

till I slienth it in a murderer's skin. King John, iv. 3

thou art a murderer. Do not prove

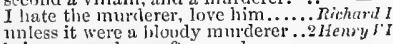

being aecuscd a erafty murderer ....
yet Folus wonld not be a murderer

we. 1 linpe, sir. are no murterers

heirs the murderer shall be ........ Rirhard $111 . \mathrm{i}$.

if two such wing strike the murterer deal - see thee, they wili murder thee... Romeo

and know how this foul murder eon
of this direful murder; and here I

ay, to be murdered by his enemies ...
MUR1)ERER-a murderer here? . . knthard III. v. 3

at the murderer's liorse's tail..

they were villains, murderc

and be a eharitable underer. T'itus aniro

the murilered bolly, some the innrderers

ant rind out murterers in

show me a murderer, I ll deal

a jresent murderer does prepnre.

apletr, with lentine, a jurderer

Tybalt that murderer........... Rom

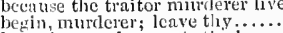

low the murder

the

prospect, murdering basilisks! ...2 llmryl'

if murdering inmocents be

Murcting impossibitity, to

this murderous sliat't that's sho

motion of a murderous thought.:

thy eycballs murderons tyrann

to do a murderous deed, to rob a

murderons Machiavel to school....

snw thy murderous faulchion.

whose muavoidel eye is murderous! - iv. 1

Onurderous slumber! lay'st thou. Jutizs

fomd it inurderous to the senses?.. Cymbeline, iy.

miles such murderous tyranny...Thus andron. ii.

stay, murteroms ving ins the murderous eoward to
bring....
the post unsanetified of murderots iecher

incestuous, murderous, dammed Dane..H

o murderons slave! O villain! $\ldots \ldots \ldots$...

IUPE-hath wrought the mure $\ldots .2$ Henry $[V$. iv.

MURKK-ere twice in murk and......... dil's Well, ii.

IURKY-liell is murky! fie, my lord...Harbelh,.

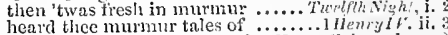

when creeping murnur, and .. Hemry $f^{r}$. iv. (chorus)

MURMUURER, there's ploces....... Hewy r III. ii.

doth move the mumbring lips of .. Aing. John, iv.

or murnuring, where's my serpent. Antong ifore iv.

IURRAIN on your monster.

fathed with the murain flock... Bhid. N.'s Dream, ii.
red murrain o' thy jade's trieks. Troilus \& Cress. ti. 1

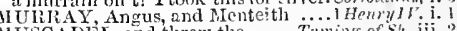

IUSCADES-the fresli-brook museles... T m nes' i.

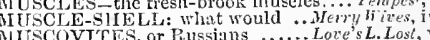

twenty adiens, my frozen Muscovites
disgrised like Muscovites, in slapeless

MUSCOVY-coming from Museovy ... Tempest, iii.

mise not, that I thus suddenly..T Trogen. of fer. j. 3

well, I will muse no further........... If erry wines, s. 5

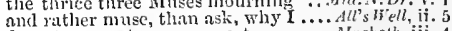

do not muse at me, my most.

I muse, your majesty doth so slight

for a muse of fire, that hontd ..Henry . . (ehorns)

I muse, my lord of GJuster is not ...2Henry Vl. iii. 1

brothers, you muse what chat.

I muse, why she's at liberty

hut my muse labours.................. Ohello, ii. I

IUSIrROOMI-midnight mushroonis Temper, li

this music erept by me ..................

I shall have my musie fio
marvellous sweet music 1

as they smelt music.

required some heavenly music ......

there is no nusic in the

some evening music to her ear.

that will be musie.

the numsic likes you not

what time change is in the music ......

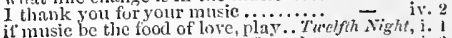

peak to him in many sorts of musie - i. 2

alve thee, friemd, and thy imusic

as low ling after musie

music of hath suel a eharm ....ifeas. for heas.

the fault will he in the music, cousin 1 uch $A d$ 
MUSIC-when there was no music.. cone, shall we hear this musi

to slander music any more tlian once

get us some excellent music

thereture, play, musie.

to hear the sea-maid's music...

gome music, my swe
Titania, music call

music, ho! music

sound, music; come, my queen.

my love slall lier the music....

what mask, wlint nusic?

one, whom the music ot
is music, and sweet fire

play, music, then.

the music plays.

let music sound, while be doth......... of ster

a swan-like end, fading in music

what is music then? (rep.)

bring your music forth in to the air.

music. I am never merry (rep.)

or alyy air of music touch

by the sweet power of music ........

the man that hatl no music

mark the music hark: it is your music, inadam

longs to see this brolicn musi

play, music; and you brides

with musics of all sorts.

procure me music....... Taming of Shrcu,

music and poesy use, to ciuicken you

well seen in music. to instruet Bianca

music and the mathematics (rep.).

when in music we have spent an hou

make no music in three parts

it is my father's music.

music; a wake her; strik

never words were music
and musie at the close

this music mads me................

by' that nusic let us all emba

......... Winter's Tale, iv. 3

the inusic is come, sir

whisper music to my weary spirit (rep.) - ii.

whose music, to my thinking, pleased - v. 5

a tull and aaturial close, like .

in broken music; for tlyy voice is mi

sings heavy music to thy timorous.. Henry J'liv.

how irksome is this music

s - iii. 2

thou sing'st sweet music........... Richard III.

e.t the music kliock

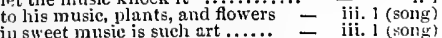

all the choicest music of the kingdom

bid the music leave ...

what music is this? (rep.)

and theirs that love music

albeit sweet music issues thence

what music will be in him

furewell, and come with better musio

feast your ears with the music a while

tongue, shriller than

that play's thee music?

give me some rnusic; music.

the music, hol Let it alone......

to our ears with the loud music...

hark! Music i' the air $\ldots . . . . . .$.
would this nusic would come

would this nusic would come (rep.). Cymbel

I have assailed her with music

the music would not please

to make man his lawfil music ........

lond music is too harsh for ladies' head

for you sweet inusic this last

thic rough and woeful music that we

by Cleon trained in nimsic.

marked lie your music?.

what musie? my, lord, I hear none (rep.) - v.

londer the music there ......................

thou shamest the music of swcet new

let rich music's tongue unfold

the County will he here with music

and let him ply his music............

some music; come, the recorders (rep.).

some misic; come, the recorders (rep.

there is much misic, excelient voicc...

the soldier's music, and the rit

the geveral so likes your music............

to hear music, the gencral does not...

I will play the swan, and gie in music
MUSICAL-here so nusical ...... Ieas. fo

USICAL-here so musical ....... Meas, for Meas

I never heard so musical a discord

and musical, as bright Apollo"s... Lore's L. Lost, iv.
MU UICAL-be nothing but musical. 1 Henry IV. iii. I more musical than the pipc of........ Henry $V$. iii.
MUSICIAN likes me not.... TuoGen.of Verona, iv. an excellent musieian ................Much A musician's, which is fantastical . As you Like it, iv. a fine musician to instruet.... Faming of Shrew, $\mathbf{i}$. will my daughter prove a good inusicia

the quaint musician, amorous Licio

the quaint musician, amorous licio - iii.

suppose the singing birds, musicians. RichntrdI i. 3 by'l' lady he's a good musician...... - iii. pay the musicians, sirral, farcweli, 2 Hew $/ \mathrm{IJ}$. ii. cause the musicians play me that. Henry III. iv. come, musicians, play: a halll .. Romeo of Juliet, i. musicians, $O$ musicians $(r e p)$.

[Col.] musicians have seldom gold ...

IUSING-with musing weak. Two Gen. of Verona,

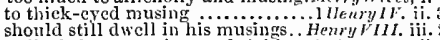

shomld still dwell in his musings.

musings into my wind, a tho
MUUS-sosweetly, (all musk)

MIUSK-CA'T-but not a musk-cat

MIUSlios-the MLuskos' reriment

II USK-ROSES, and witl eglantine .Mid.N.'s D

kill cankcrs in the musk-rose buds.
stick musk-roses in thy sleek smootl

NUSS-boys unto a muss...Antony \& Cleopatra, ii

these mad, mustachio, purple-hued .1 HenryI' and the mustard was good

saw those pancakes or that mustard...

a piece of beef, and mustard?. Taming of Shrew,

as thick as Tewkesbury nustard...2 Henry $I V$. ij.

IUS'TARD-SEED! Reudy ... Mill. N.'s Drea
Mlustard-seed. Good master Miustard-seed

Mustard-seed. Good master Mustard-seed? (rep.)
whicre's monsieur MI

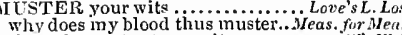

there do muster true gait ...............

the muster file, rotten and
will you go muster men?

let us take a muster speedily

our present nusters grow upon

nur pres me all to their captain

defences, musters, preparntions........

those will I muster up: (rep.).........3 Henry $r$

go, muster men.............

well, go, muster me

in the.... Henry $\bar{V} I I I$.

$o^{+} \mathrm{er}$ the files and musters of the war.

hasten his musters, and conduct.
MUSTERED in my thouglits

mustered my soldiers, gathered.

our present numbers be mustered

nichard II.

1 Henry Il:

II'TERING in his clouds

ISTY-you had musty victual
as I was smoking a musty room
to vent our musty superfluity......

to vent our musty superfltity

noisome, musty chaff $(r e p$.$) .............. Tear$

the proverb is sometling musty
MUTABIIITIES; and her foot

MUTABIIITIES; and her
IUTABILT, all faults.
IUTABLE rank-scented n

MUTABLE rank-scented many ....... Corinbeline,

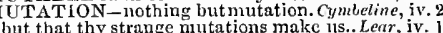
but that thy strange mutation and be mute

and your mute I'll be ..................

all the rast is mute ..................... All's Well, ii.

say, she be mute, and will not. Taming of Shrew, ii. I rumour cannot be mute $\ldots \ldots . . .$. Winler's $T$ ale, $\mathrm{i}$.

and the mute wonder lurketh........... Henry

woe-wearied tongue is still and mute
thou wilt be a voluntary mute iv...Cymieline, iij.

why should wrath be mute.... Tilus dudronicus, v. 3

made the night-bird mute...... Ptricles, 1v. (Gower)

that arc but mutes or audience.

IUTCEST-ny mutest conscience

worse than the mutines in the bilboe
IIU'TINEER-if you prove a mutineer

worshinful mutineers, your valour

to cheer his dad in mutinies?

in cities, mutinies; in countries, discord ... Lear, i. 2

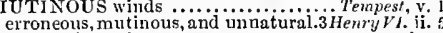

not mutinous in peace

the mutinous parts that envied li..... Coriolanus, i. I

you the mutinous mem

then let the mutinous winds strike

to mutiny anpire of their mutiny. I.ove's $L . \bar{L}$ sost, $\mathrm{j}$.

where will doth mutiny wit $]_{1}$ wit's.. Richard 1 .

herror, fear, and mutiny, slaall here - iv.

to raikc a mutiny betwixt

sack this country with a mutiny
MUTINY-their splendid mutiny ..2Henry $F I$ iji. 2 what mutiny? what raging.. Troilus \&.Cressida, i. this nutiny were better put in .... Coriolanus, ii. confounded with this mutiny.... Julius Ciasur, iti. and minds to mutiny and rage.

to such a sudicn flood of mutiuy .....

my very hairs do mutiny... Ancony \& (leopatra, jii. 9 to stir a mutiny in the mildest...'2itus sundrou. iv. srudge break to new nutiny.. Romeo of Juliet, ( cause these of Cyprus to mutiny guests go out, and cry-a mutiny .............. my nephew Mutius' deeds do plead .. not 1 , till II utius' hones be buried.... let not young Nlutius then, that was.

no man shed tears for noble Mutius TER - what mutter you? ....... Hemry $1 \%$. ji.

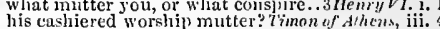
in their slceps will mutter their ...... Ohello, iii. 3 I UTTON-I a lost mutton (rep.). Tü Gen. of Fer. or such a store of muttop.

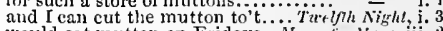
would cat mutton on Fridays...Meoss. fivr.lie'as. iii.
with mutton and porridge......... Lore's $L$, l.ost, as flesli of muttons, becto

Trease of a mintton as wholesome . Tam you what is this? MIutton? $\Delta y$... Taming af sher, jy. a joint of mutton, and any pretty.... $-\bar{v}$ v. confirmed by mutral joinder of.. Tuetshis sight, scemed all one mitual ely ..Mid.N.'s Dn Dams them make a mutual staid. Merchant of renice, the mutual conference thit this mutual heavy load of moan ....Rithent $/ 11$. $\mathrm{it}$. being muthal act of all our solls. Troilns \& Cress. i. 3
when such a mutual pair.. Antony \& cleopuret, i. corn into one mutual sheaf' .. Titus andronicus, v. make a mutual closure of our honse.

it be covered witl mutual cumning ...... Lear,iii. MU'TUALLY, hath answered my..Nervy Hivers, iv.

pinch him fairics, mutually ....... v- v 5 (soug mutually participate, did minister..C Cnrolanus, i.
IUZZLE-trusted with a muzzle .... Much.4do, i plucks the muzzle of restraint......2 Hevry! ${ }^{2}$ iv. 1 Save not the power to muzzle him..Herty rIII. i.
AIUZZLED-my dacter muzzled... Winter's Tale, like to a muzzled bear, save in....... King soln, ii. will physic the great myrmidon. Troilus \& Cress. i. 3 will physic the great myrmidon. Troilus \& Cress. i. 3
together with bis mangled myrmidons - v. come here about me, jou my myrmidons

MYRTLE-than the soft niyrtle.. Meas. for $\overline{\text { Mreas. }}$ ii.

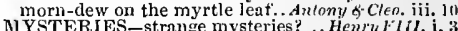
manners, mysteries, and trades. Timon of dith. iv. the mysteries of Hecate, and the night.... Lear, $i$ IYSTERY of ill opinions............ Mtry Wines, ii he will discredit our mystery ...Meas. for Meas, iv, prove my occupation a mystery (rep.)

Gir, it is a mystery. Proof $\ldots . . . \ldots . . . .$. . All's $w e l l, i$. if you think your mystery in........ - iii. hath not in nature's mystery more... there is a mystery (with whom. Troitus \& Cress. iii. have us thrive in our mystery. Timon of . Athens, iv, pluck out the heart of my mystery.... Humlet, iii. your mystery, your mystery ........... Olhtllo, iv, 2

\section{$\mathrm{N}$}

$\mathrm{NAG}-$ gait of a shtuffling nag........ Henry $I V$. iii. I NAIADS-you nymphs, called nainds.. T'empest, iv. ! A Ir_with my long nails will dig na one nail by strength .... Truo Ger.. of veronta, ii.

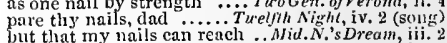
pare his nails, for they shall hang

the shepherd btows his nail. Love's L. Lost, v. (song) too late to pare her nails now ........... half yard, quarter, nail; thou flea of hand, nain, fingere's and thou... but with these nails, $I$ 'll pluc:

as nail it door: the things.......

de nails. De nails. Escoutez...............

and with my nails digged stones

the very parings of our nails shial

lichard Il, v.

Henry II'. iii.

blowing of his nails, can neither ..3 Hemry $\mathrm{Vl}$. ii. till that my nails were anclured .... your nail against lis horn .......... iv. up with her prepared nails.... Antony \& Clro. iv. io 
NAIL $\rightarrow$ my nails are stronger than. An'ony \& Cleo. v. 2 with her nails she'll fluy thy.

nails, sprigs of rosemary ..............

NAII.D

NAKED-naked name of love.. T wo Gen. of ter. ii. 4

or strip your sword stark naked. Twelfh Nirhl, iii. 4

and leave you naked .... Measure for Mreasure, ing

to some forlorn and naked hermitnge $\overline{\text { tole }}$,

years together, naked, fusting ... Winter's Tale, iii.

and come with naked sword-Comedy of Krors, iv.

like a naked new-born habe
when we hnve our naked fraities jhid.

leave them as naked as the vulgar.. King John,

stand bare and naked, trembling.... - i - iii. 2

the naked sliore at Ravenspurs ....

when he was naked, he was, for ail.:.

your naked infints spitted upon .... Hen $\bar{r}_{y} v^{\prime}$

to give eael naked curtle-nx........... -

why that the naked, poor, and n

of a naked blind boy in her naked $\ldots$ - v. 3

the truth apsears so naked .......i Irnnry rr. ii.

standing riaked on a mountnin top

anci make him, naked, foil a nimn ...3 [lemy! II.

I ling it naked to the my naked villany with

all thin and naked, to the numb-cold

left me naked to mine enemies ..Henry IrTI. iii. 2

whose naked natures live in all

let it ro naked, men may see't

nor sanctuary, being naked, sick

and here my naked brenst $\ldots$..... Julius $C_{\ell}$

whose naked breast stepped ......... Cymmotine, .5

poor naked wreteles, wheresoe' er ynu.. Lear, iit.

is that the naked fellow? (rep.)
bring some covering for this naki....

$\mathrm{my}$ uaked weapon is out ......... Bomeo \& Juli, $t, \mathrm{i}$.

I am set naked on your kingdom. Hamlet, iv. 7 (let.)

'tis I Iamlet's character. Naked

makla the rnoal naked through this world

$\mathrm{nr}$, naked, as I am, I will assault tliee..

AKEDNESS-in proper nakedness? Much A in his nakedness he appears but...... Henry $v$. iv. I but nakedness, thou detestable.. Timon of $A$

NAME-for the name of king........... Tempest, i. I

teaeh me how to name the bigger light
dost here usurp a name thou ow'st not

no name of magistrate

wh the name of something hoig, sir

pronouneed the name of Prosper.......

what means this passion at his name?

did in your name receive it.

d throw thy name against the ........

poor wounded name!

except mine oxn name.

in one line is his name twice writ.....

he couples it to his complaining naries

and yet I will not name it ...

sir Proteus, for that's his name...

not worth the name of a ehristian............

not worth the mame of a ehrist.

Sebastian is thy name?...

do not name Silvia tlin

pieked (with the devil's name) out of

with blank spaee for different nanes

odious is the name. What name sir

my name is Brook (rep.

Broo's, is his name (reg.)..........

her husband's name is ford ..........

terms! Names! Amaimon sounds well

the devil limself, huth not such a name

and friend simple by your name...

what do you call your knight's name

what do you call your knigh

in the name of foul cloti:es

never name her, ehild, if she $\ldots \ldots \ldots . . .$.

I'll to lim agrin in name of Brook

elyes, list your names ....................

in his name. What is inis name?. Ti

I have heard my fath

my name is Mary, sir................

holla your name to the reverberate.

close, in the name of jestinct

why, that begins my nnme.........

my sister load had no nome in ny name -

why sir, her name's is word

what is your nane? ( $r$ p.

way is he, in the name oi sanetity?..

your name is not master

what name? what parentage? ........

and, for a name, now puts ........ IIeas. for .lleas.

'tis surely, for a name

in the ambush of my name.........

as school-maids change their names

and my name is Elbow (rep.)
YAME-your mistress's nam

bour nmme, master tapster?.........

as if $I$ did but only eliew his name.

my unsoiled name, the austere
thut bears the name of life?

should do what I abhor to name.....

and good words went with her
I prity you, your name? (rep.)

had I more name for baduess

his name is Barnardine $\ldots . . . . .$.

I know none of that name, lady

to drive liking to the name of love

answer $I$ in the name of Benedick

name the day of my name

when I do name him, let it be thy

God hatl blessed you with a good in

any man stand, in the prince s name

by the name of Her.

we eharge you in the prince's name

truly to your name (rep.) $\mathrm{d}$.

and my name is Conrade.

in the prince's nane, aecuse these me

whose names yet run smoothly in

I answer to tliat name; what is

the seroll of every man's name...

then read the names of the actors
ready: name what part I am for

now name tlie rest of the players.....

you must name his name (rep.)

I beseech, your worship's name?

which by name lion hight

one Snout by name, present a waj]

hat give a name to every fixed star

and every god father can give a name

which we may name $(m p$.

more authority, dear boy, name more

the reputation of your name .........

I desire lier name. She hath but une

what's her name, in the cap? .........

then they name her name

loves another of the name........

he was fain to seal on Cupid's name

to change a word? name it.

her name is Portia....................

her llame is Margery, indeed .........

good enough to keep

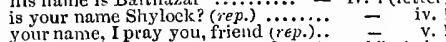

what is thy name, young man? ... is you like il, $\mathrm{i}$.

she robs thee of thy name.............

I eare not for their names..........

thy huntress' name, that my full.

low thy name should be hanged

your love's name? yes, just (

is thy name William? (rep.)

I will name you the degrees $\ldots . . . .$. . Alt ${ }^{-} W_{c l l}, \mathrm{i}$.

my maiden's name seared otherwise

can rate worth name of life.

dislikest of virtue tor the name.............

is good, wi thout a name; vileness.

I do wash his name out of my blood

his name with zealous fervour.

far.leas. ii. I $\begin{gathered}\text { NAME-my name be yoked with his. Winter's Tale, i. } 2 \\ \text { comes to nue in name of fanlt......... }\end{gathered}$

in Apolln's namc, his nracle
sairl, lis name was Antigonus.

name of merey, when was this, hoy?

which lilorizel i now name to you.

i' the name af ine, -0 help me

here's the inidwite's name to't

your names, your ages, of what .....

be distingruislied but by names. Cioned'y nf

no man, that hath a name ......

certain ones then. Nane them . ....

call us by our names

my name is Dromio ......

iii. 3 for o ofice and my name.............

for a name, or thy name for an ass.
if thy name be enlled luee.........

what your name is else, I lonow not

ay, that's ny name. I know it ....

doth eall me by iny name........

is not your name, sir, calleo

well he deserves that nanie.

i' the name of truth, are

by the name of most kind hostess.....

who's there, i' the name of Bckzebib?

who's there, i the other devil's

when first they put the name of king

all by the name of dogts.

w'hose sole name blisters our

every sin that has a name

what is thy name? $\ldots \ldots \ldots \ldots \ldots \ldots$. $\ldots$.

what is thy name? (rep.) . . i i........

made honour doth forget men's name

learitimation, name, and all is gone.

coupled to the name of kings.

wants notluing, to name want ......

what earthly name to interrogutories

What earthly name to interrogatories
devise a nane so slight, unwortliy

even for thut name..................
stronger with thee thair the name of

my name is Construce $\ldots . . . . . . . . .$.

both our tom Coun

on our actions set the name of right

we were happy we had other names.

with a foul traitor's name stuff I.... Richurd Il.

in name of lendings for your

but my fair name
ask him his name

in Grod's name, and the joing's, say

is thy nume? and wherefore eomest

traitor, my name be blotted

O how that name befits my..............
play so nicely with their names?

play so nicely with their names?.
my name in me, I moek my name

but what, o' God's name .............

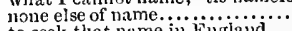

to seek that name in Eingland .....

griet or lesser than my nane

tile name of king? o' God's name
live Henry of that name the fourtli $($ rep. $)$

I have no name, no title (rep.)

[Col.] name be sterling yet in England

name it, fair eousin....................

read not iny une there

of good names were to he boinghit.....

in your highness' name demand
even at the rame of Mortimer.
lomo is a common name to all.

eall them by their ehristian na:

to sweeten which name of $\mathrm{Ned} . .$. ...

in our land by the ntme of pitch....

I remember me, his name is laistaf

for by that name as oft as Lumsaster

thes severaldevilst names.......

name profaned with their scoins $(r . \ldots$.

and great name in arms, $\ldots$............

preat deservings, and good name...

he bids you name your griefs $\ldots . . .$.

and an adopted name of privilege

this hateful name in $n 15 . \ldots \ldots \ldots . . . . .$.

know then, my name is Douglas ....

as if I would deny my name (rep.).

a very valiant rehel of the name ...

well-brel, and of good name

worse than the name of rebellion...

I would to God, my name were not so

using the names of men instead

to me, $t$ ) rememler thy name? $\ldots$......

but the snund of Hotspur's name

I au in goon name alul fame .........

deserves a nane as rank as any...

than our parent' noble uanies

what is his onum

take upon you another man's naisie. 


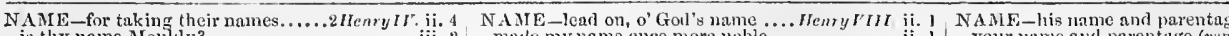

is thy name Alotilly?

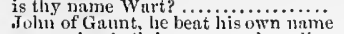

concurring both in name and quality

more full of names than yours

intended in the generial's name.

in God's mame then set forwari.......

prince's name, in deet

my name is coleville of the dale (rip.

doth any name partieular belong....

We ehare you in the liane of God .....
lose the iname of hardimess ..........

and in whose nume, tell the Dauphin
Dull Tearshect, she by name.........

dub thee with the name of traito

treason, by the name of lichard
of that biack name, Edward

in the name of God Almiglity

a narne, that in my thourghts

nerfect in great con
what is thy riane?

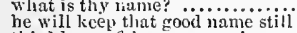

third hour of lrowsy morning name
ridieulons, - the name ot $A$ sincourt

ridieulous, - the nnme ot A Afincourt
what's thy name? Harry le lioy' $(r \cdot p$.

my nume is Pistol called ...

rouse him at the name of Crispian...

ther shall our names, famil
what is tlyy name, discuss?

in Freneh, what is his name.

he says lis vame is, master Fer
what eall you the town's name

the name of the other river...........

I elarge $y^{\circ}$ on in his majesty's name.

the unmes of tho

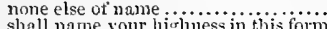

shall vame your highness in this form

then eome o' God's name, I fear no
exeellent I'ueelle, if' thy name be so

in his highness' name, to repair to.

so great fear of my name 'mongst

shall France be only in my name.

in whose conquering name, let us....

with his name the mothers still.

usurp the suererl name of knigh

great York might bear the nume
that T'albot's name miglit be in

that Talbot's name miglit be in.....
is my name Talbot: and am I your

dishonour not her honourable name.

yes, your renowned name

our household's name, my death's ..

if thy name be so, what ransom

in Henry's royal name, as deputy

blot ting your names from books
go in God's mame, and leave us

go in God's name, and leave us .....
name and power thou trenblest at

tell me, sirral, what's my name?

as well have known olr names (rep.)
dishonnured G loster's honest name

crowned by the name of Ilenry the

'. God's uame, see the lists and all ...
sirrah, what's thy name: Peter, forso

at whose name I of hiave been,......

I do arrest yon in his higlumes

bear the nume and port of gentlemen?

my name is, Walter Whitmore
thy name affrights me, in whose

thy name is, Gualtier, being riglitly

dirl base dishonour blur our nat

what is thy name? Em to write thy name.

that I can write my name

the umme of Ilenry the fifth hales them

Alexander Iden, that's my name $*$.

hilt by eireumstalee, the name of
Kichard, I bear tliy name
lis name that valiant duke hath

in Gorl's name, and in theking's (rep.)

applanil the name of Ilenry

two of thy name. both duk
then, in God's name, lords

then, in God's name, lords............

because my name is - George.

niv name of George begins........
furer than tongue ean name thee

farer than tongue ean name the...

it yout will hear me name it.........

botween their tities, and low name...

in Grod's name, what art thou?
a traitor to the name of God

in Goul's name, speak .....................
you. my wolye lord, may name the tim

5ou. my liolde lord, may is ominous to $\ldots . .$.

What is his name? His name, my lor

at which name, I started

mother, one that wails the natme

confortabie lour eanst thou name
should to thy ears not name my boys

a grandam's name is little less

What mell of name resort to him?....

in God's name, eheerly on ( $r e p$.)

besides, the king's name is a towe
what men of name are slain on

from the flow of gall 1 name not...... iten

half your suit never name to $113 . . .$. .

by Clat name must die ...............

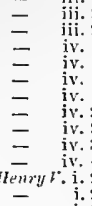

ii.

ii. 2 to the not name clesert ...

to the world's end after my name

make Cressill s nime the very erown

it mery of my sword, name Cressid

tell me name by name ................

may give the local wound a name.

vntruths stantl by thy staned manie
and live aye with thy name! .........
I called thee by thy name .... Timon

to use your signet and your name...

what is thy name? is man so hateful
if I name thee. I'll beat thee........

uane them, my lord, let's know the

seek not my name ..........

DLareius, his name? By Jupiter

gives my son the whole name of the was
with fane, a name to Cajue Iarcius in whose name, myself attach thee. that ever he heard the name of deatl
so can I name lris fual ts

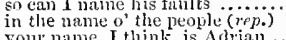

your name, I think, is Arrian $\ldots . .$. .

coimmands me name myself (rep.)

only that nane remains

the Eeeond name of men

he did calt me by my name $3 \ldots \ldots . . . \%$

rorbate all names; he was a kind of

a name i' the fire of hurning Rome.
my name liatl toueled your ears ..
the virtue of your pane is not ......

remember, my name is Menenius ( $r$ ep.)

to kcep your name living to tinxe.

is sithl a lame, whose repetition ....
anrl his name remains to the ensum

tlyy stolen name Coriolanus in Coriu

Iname not the god, thou bny of tears

why should that name be sounded (rep.)

yet if my name were liable to fear

that Rome holds ol his name.........
could 1 , Casea, name to thee a man

O name him not; let us not break
exploit worthy the name of honour

whint is your name? Whither (rep.)

pluek but his name out of lis lieart

their names are prieked

the mame of Cassius bonours....

I wili proclam my name about .....

name Cleopatra as she's enlled

for Pompey's name strikes more

once name yon derogatcly (rep.) .....

this it is to have a name in great ....
his name, that magical word of war
and in our name, what she requires

and in our name, What she reque
what's your name? My name
what's her name sines slie wa

groun did break the name of Antony

thy name so buried in her ...........

in the name lay a moiet y of the worl

other's nerits in our name

to that name my courawe pro

lie hath been allowel tlut name of

and his name is at last gasp ........

how! my good name? or to report
she hatli bought the name of whore.

in Casar's name promomice

my name was not firr ofi

the event is yet to name the in iner

What is your name? Filele, sir......
liear but my name, and trem!le (rep.

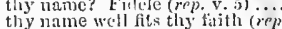

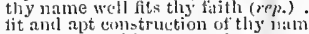

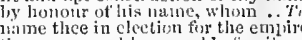

thy mane, and honomiable family

for no nane tits tloy nature lint

blet and enemy to our general name

death should let lifie bcur his name.

wherefore dost thou urge the name.

when I lave witit my name without

thy thonghts imperiuns, like thy name

whose nane was once our terror ....

Raye is the uther's name.........

he gains ble namic of onod ii. 1 your nume ant parentage (rwp.) ....... Icricles, ii. 3

nanjeg himfelt Perieles, a gentleman...
what I cannot jame but I shall offend

iv, 1 would ow to name it.................

onnit that be:urs

tliy name, my most kind vircin? (

we nane Marina, was given me ......

my drowned queen's name, theu art ..

did you not name a temprest .............

and $h_{1}$ no tred name of Porieles.

only ve still rutain the name.

iii. 2 your ratne, fair gentlewoman?....

lie says his morstip or their

your names? Toor Tom; that eats..........

[Knl.] I mistress; is younge names at home

to hear of pletsire's name; the fiteliew.

thy name is Gloster; thou must be 1 antic
solntiers, all Jevied in my name (rep.)

what are you? your name? your quality
know, my name is lost ....................

in wisdom, I shonld ask thy name................

thon worse than any name, read .........

whose names are written (rep.). . Rom
go, ask his name; if he be married...

this name is Roneo, and a Montagrie

lonest, and in his mistress' yame....

desy thy father, and refuse thy name
tis but thy nanie, that is my (rep.).

by a name, I know not liow (ocp.)...

have forgot that name, and that names -

I am the youngest of that name

Whicl mame I tencier as dearly as nine -

I charge thee, in the prinee's name..

what seaks but Romeo's name......

what tongue sliall smooth thy nane

as that name's cursel] hand murdered

while Verona by thit name is known

. Hanlet, i.

with whe in the mame theaven?...... -

and lose the name of aution

Gouzago is the duke's name (rep.)

may miss our name, and hit the ........
that hath in it mo profit but the name

shepherds give a rotio, as I am let to.. - iv.

tokeep my name ungorel: but till..... - v.

whatio, what a wounded name, things.. - y.

your name is great in montlis of wisest.

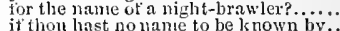

if thon hast no mane to be
I pray thee, name the time

gootl name, in man and women

tilclies from me my good name, robs

her name, that was as fresh as Dian's....
am I that name, Iago? Wlint name

thIED-he named Sehastian .. T'relfih Nighl, jii.

they are not to be named, my lord.. Much ddo, iv.

my father named me, Autolycus. I'inter's Tale, iv.

he is alrearly named, and gone to .....Mlacbeth, ii.

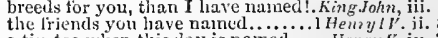

a tip-toe when this day is named .... Henry $V$ iv.

and the pretenee for this is named... Henry plil $\mathrm{i}$.

that sad note I named my knell ..... - iv.

hast a servant, named Lueilitus.... Tmomof $\mathrm{mh}$. i.
newly named, what is it?

anm nobly named so, being censor tu ice - ij.

whom late you jave named tor consul - iii. 1

than eome to be but named ot thee.. Cymbeline, ii.
all fiults that may be named .........

burm at sea, 1 have named so ............ Pericles, iii.

called the man? I have named him oft $-\overline{\text { Lear, }} \mathrm{i}$.

your fanlts, as they are named............. Lear, i.

to hear him named ............ Romeo $s$. Juliet, iti.

she hath many trameless virtues....

tis nameless woe, I wot............ Richard. H, ij.
NAHELY - and did, sir; namely.Comedy of Err. ii. except it be the list; nanely, some ... King $\bar{J} h_{n}$, ii. cause you come; namely, to apleul. Richard $I . \mathrm{i}$. and to his heirs; namely, the erown..Hem $y l$. ii. simple gulls; namely, to stanley ..Wichar: MII. i. AIING-but attends thy naming ...All's 'Fell, ii.

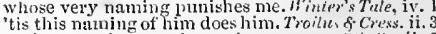

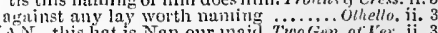
an-this hat is Nan our maid. Tuoge... of of Eer. ii. 3 it is sucli another Nan ..............Mcry Hives, $\mathrm{i}$. no more tuln me to him, sweet Nan $=$ give my sweet Nan this ring .........
tud thus: Nan Pago my dangliter ..

and thus: Nall lase my dainghte...

sliall master Slender steal my Nan away -

to marry with wat Nage

must my sweet Nan present .......
wliere is Nun now, aud her troop.

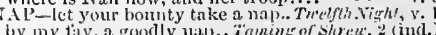


NAP-John Naps of Creece .. Taming of Sh. 2 (ind].) ank set n new nap upon it........... Henry 'll.

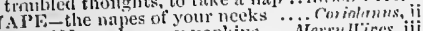
AP'kiN-and mreusy tunkina. he scrat this blody inplin? aud to give this unpkin, dyeed in this

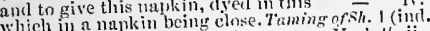

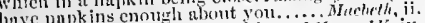

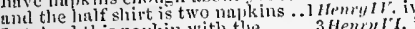
I stained this napkin with the ke(e) thon the napkin, nut go bonst. a napkiu stceped in the larmic tlyy napkin camot trink a trar. lis mapkin, with his true thy brows your napkin is too little: let it alone.. an glat, thaye fomd this mankin

N A I l.ES - the king of Nuples (rep.)

bouml sadly home for Naples

it the king of Naples thes speak of Naples

myselt am Naples .....................

huit of Naples and of Milan (rep.) ....

who's the next heir or Naples
slie that from Naples ean have

measure us back to Nayles?

there be, that ean rule Naples .........

as thou got'st Mlilan, I'll com

and in Naples I shonl treport this now.

they were living both in Naple

shonld beeome kings of Nap

and so to Naples,

or sent to Naples..................

tho' her father be the king of Nailes

the king of Naples, that prevailed.

the king of Naples, and

king of Naples, Sicilia....... biloody.

car's the type of king of Naples.

iron of Naples, hid with English

Nollr instruments been ut Naples...

N.APPING-and taken nupping so Love's L. Last,

nay I lave ta'en yol nappin
N.ikBON-Gerard de Narbon

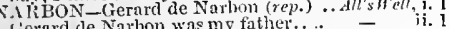

N.IlicisSUS in thy tace ..... Anlowy o Cleopatr

N.1RINES-qui a les narines de fen... of Jen

wrecked on the narrow sea

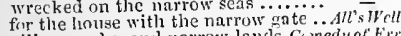

silies, creeks, and narrow lands. Cin

they say, as stand in marrow lan

fint them in the narrow lane

burdens at his nurrow gate

chaming d the narrow seas.

'the rarrow seas

travels in a straight so narrow. Troilus s. Cress, in

licre the street is narrow

a narrow lane! an old man, anil.... C.ymbet

an inch narrow to an ell broadl. Romeo folntied

N.lis toow narrow for you the

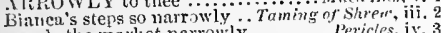

searel the market narrow ............ Pertikes, iii.

NARROWPRY ING father ....... Taming no Sh. iii. 2

NASTY - within thy nasty month!.... Hen' $\mathrm{t}$. ij.

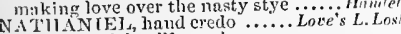

Eir Tathaniel, will you hear

sir Nathaniel, this Biron is one of

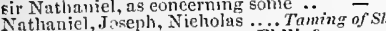

where is Nathaniei, Gregory, Philip?

Nuthaniel's coat; sir, was not tully

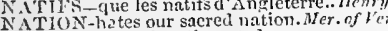

fcorned my nation, thwarted my....

the curse never fell upon our mation

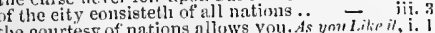

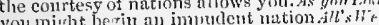

youth of a mution in his colour.

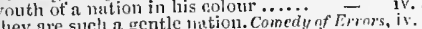

Onation iniserable, with $\ldots \ldots \ldots \ldots \ldots$ Wheth $h$, ix. 3

at the crying of your ration's erow

still our tardy apish nit mu limps .. Richard $/ 1$. ii. ?

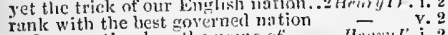

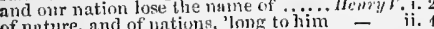

of nutare, and of nations inn?

that nation boast it so with nis ....

anmongt ufekle waveriner natiom . 0 - iv. I

betwixt our nation and the..........

aud nake new natirns ............. Ienry

laws of nature, and of nations

among the rout of ustions ... Tizum of sthens,

to some nation that won you

I would no tbe a loman of all nations -

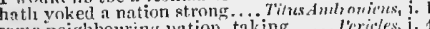

natiou o traveller, we shoutd lod".
NATTON-curiosity of nations to de

and the nintiou holds it no sin to tur

brooel imeed, and gem of all the nution

wealthy curled darlings of our nation.

ITIVi-which pative sledoth

for native hlood is counted paintius

puts tirom her native bay ...Aerchant of

in their assifned and native dweiling

are youn native of this place?

and choicc breeds a native sip

again into his native quarter.

departedst from thy native home. Comedy nt ter

their fortunes at their native

chase the native beanty from.

native English, now I metst for

from his native residence...............

ere her native king shall fulter.

his true, nitive, and most proper.

native eolours

let us fear the native mightiness $\ldots$....

we may eall them in their native lords

and outrun native pumishment..

no doult, find native graves

not speak English in the native garb

hack again unto ny rative elime?

England, for it is your native eoast .. Hemry $r$. iii.

to warrant in our native place! Trailes f (ress. ii.

the beggar native honnur of never be the native of our

your native town you entered like

back to your native spring ....Romen $f^{-}$

[Col. Knt.] shall keep his native progrese - iv.

the heat is not niore nat

and thus the native hne of resolution

the native act and figure of my lieat

in their natures more than is

in their nativity all truth appear. $M i d . N$.

sueh as are desisised in nativity.......

from the lowe of my natiyi

long grief, snel mativ.

and notivity, the front of

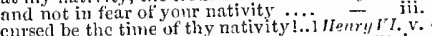

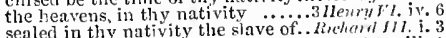

thom hast as ehiding a nativity .......

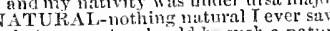

that a monster should be such
their words are netural breath

these are not natural event

he hath incled,-almost natural.. Tivelfh Nigh

a natural perspective..

wers. forlteas

if it eonfess a natural guiltín
ever most kind and naturai

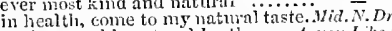

against me his natural brother .. $A_{s} y /$
makes nature's natiral the eutter of

our natural wits too dull (rep.)........

smel a one is a natural philosopher

to make it natural rebellion...........

her natural post

which is the natural man ....Comedy of Evrors, v. 1

keep the matural ruby of your

he wants the matural toncl...........

will pluck away his matural cause

and thou a liatural coward

did give $a$ finir and natmal $\mathrm{li}$

in a full and natural elose r........

so grossly in a natural cause.

shall we then hehold their natu
natural graces that extingutish

follow but his natural king?

3lenrylt $\mathrm{i}$.

lie and take his vatural rest ........ - iv. 3

is almost the natural man

thixt natural son and even naturil in thine ort

receive that natural eorupeten

it is not Casar's natural yoice.

of that natural link, he beats thee

together with the natural bravery..

they take for natural fathe

than my nohle and natural person

upon him still that natural stam

her art sisters the matural roses. $f^{3}$ eriet
loyal and natural boy, I'll work

am even the natural fool of fortume...

drivelling love is like a great natural

his natural [Col. Knt.-native] yrogress - -

the natural wates and alleys of the lu

something in this more than matmil.

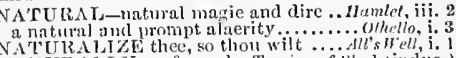

A'TURA 1.I.Y performed... T

1 an not naturally houest $\ldots . .$. Winler s sale, iv.

naturally inherit of his father.

wTick-awiked at? evil matire

my tither's of a better nature, sir......

in common nature should jroduce...

but natrire sliould bring forth .........

cxpellet remorse and nature

more than mature was ever eouduct of

nature is thy friend...

a noble dinke in noture

and hath all the groor gifts of native

thon see'st, it will not cull by mature

nature's own sweet and ctuming him

that nature pranks her in.

not of such a blondy nature.

in mature there's no blemish.

but be that deity in my unture....

the nature of our people ..............

nor nature never lenrls the stuallest.

our naturcs do pursue, like rats

all her clouble vigour, art, and nature

know the nature of their erines ....

but in what nature?

and imprisomment ea fay on native

nature dispenses with the deed so far

with the clisposition of natures.......

why nature, drawing of an antick
to write and read comes hy natme

ehid I for that at frugal nature's frame?

Ifelena! nature here shows art ...Mrid. N. $\vec{s}$ Dr. ii. 3

the blots of nature's hand shall not... - v. 2

nature was making graces dear ... Love's L.Lost, ii. I

your eapacity is of that nature ....... Ner.of ten i

offiees, and of opposed natures ...... - ii. 9

works a miracle in nature $\ldots \ldots \ldots \ldots . \cdots=$ iit. 2

or the time doth change his nature... $-\overline{\text { Like }}$ it, $\mathrm{i}$. 1

something that nature gave me ...As you L
from fortunc's ofice to nature's......

not in the lineaments of nature (rep.)

tou hartl for nature (rrp.)............. -

not fortune's work neither, but nature's -

let my officers of sueh a nature make

therefore lieaven mature

nature presently distilled

mature, stronger than his just..

would have made nature immortal..... All's

tis against the rnle of nat:ire........ -

as a desperate offendress arainst nature

frank nature, rather cirious ........

if we are nature's, these are ours ....
the show nid scal of nuture's truth..

atloption strives with nature $\ldots . . . .$.

in these to nature she is immedinte heir -

theor tame, and know their natures... -

corripts a well-derived nature with his -

all the miseries, which nature owes..

the tenderncss of her nat

in the nature he delivers it ..........

that ever nature had praife for $\ldots \ldots \ldots$

right, by the law of nature ..........

in me, 0 nature, cease! ................

whose nature sickens, but to sueak...

though the nature of our quarel. Tam

noted, is't, but of the finer natures?.

and than, gond gnd?ess nature

and thoul, gond gnadess nature

which some eall nature's bastards ...

shares with great ereating natnre (rep.)

ment nat ure, change it rutlice (repp.)

and then let might have made me as .

uature slows above her breelling....

$\overline{0}$

that grow s bald by

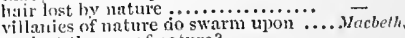

against the nse of nature?
yet alo I fear thy nature

visitings ot nature shake my tell ....

you wnit on nature's miseli

that nature rives way to in reposel.

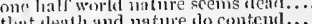


NATURE-great nature'ssecond course.,Wacbeth, ii. 2 | NATURE-his nuture in that's no.. Coriohmm, looked like a breach in nature .......

turned wild in nature.

and in his royalty of nature reigus...

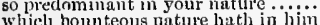

but in them nature's enpy's not etern

the least a death to enature

hatl nature that in time will......... -

you lack the season of all natures, sleep -

shall live the lease ot nature

a good and virtuous nature may recoil -

intemuerancc in maturc is a

for strangers to my nature ...........

a great perturbation in mature?.........

nature and tortune joined to make (rep.

by the hand of mature marked

slandered nature in my form

seven are dried by nature's
built by nature for herself

ail of one nature, of une substanc

sent to know the nature of your griefs
the nature of a tragic volume........2 hemy 11

now let not nature's liand keep...

gentle slcep, nature's sof't nurse

figuring the nature of the time

a peace is of the nature of a conquest

and loathly birtlis of niture ......... -

how quickiv nature falls into revolt

by a rule in nature, teach the act....

mangle the work of nature

by law of nature, and of nations $\ldots$....

and began thins: Wonder of niture..

defective in their natures .........

to their firm proposed

to their firm proposed natures .......
froward by nature ...............
ol nature makes me suddenly releut

be not offended, nature's miracle ....

heing opplosites of such repairing nature - a

nature brought him to the door.

head by nature framed to wear a erown

more than the nature of a brother's love - - Y. 1

of feature by dissembling natire. Hutche

tramed in the prodigality of nature

slave of nature, and the son of hel
replenished sweet work ol nature

as heaven, and nature lengthens

you know his nature, that he's
still exaction the nature of it?

to nature none more bonnd...

lord of York, ont of his noble inature

and nature does require her times of

(I know his noble nature, not to let

to repair our nature with comforting

men, in our own natnres fit:

thow hast a cruel natnre ..............

thic nature of the sickness found

gifts, natures, shapes, severnls . .

mature craves, all dues be rendered
if this law of nature be corrupted

these moral laws of nature

and thy parts of nature thricc-faned

and most familiar to my natur

one touch of nature makes the

with gifts of nature fluwing

thon erusty batch of nature

a fight of this strange nature

I'll say of it, it tutors nature .. Fimn

good and gracious nature hanging ..

dishunour traffics with man's niture

and nature, as it grows again toward

and nature, ns it grows again toward

of such a nature is his politic love

nut natnre, to whom all so

nuthing level in our curscd natires

I will make thee do thy right natur
this is in thee a nature bnt affected.

this is in thee a nature bit affected.

naked natures live in all the splte ...

thy natnre did coumence in sufferanee

almost teous hy dangerous natur...

almost tnrus my danger

throes that rature's fragile vessel

are nnremoveably compled to nature

that food which nature loathes
which from niggard nature tial

what he cannot lielp in his natu

such a nature tickled with good 0.

so his gracions nature would think.

would have galled his surly nature.

if, as his nature is, he fall in a rage

we debase the nature of our scats...

of catching natnre, spreal further

you have me false to my nature?...

coue other deity than nature .... or whether nature, not to be other.

whicl great nature cries, deny not.

he bowed his nature, never known.

how that might change lis naturc

then the nature of an insurrection

but yct my nature could not bear

and nature must obey neces

in nature's infinite book.... Anlony of Cleopat

the nature of bad news infects.

we see, the fancy outwork nature ..

and made a gap in nature $\ldots \ldots$

that nature must compel us to.
nature wants stuff to vie strange

Antouy, were nature's piece 'gai

of so slight and trivial a nature.

hath naturc given them eyes to sec.

was as another nature dumb

and nature prompts them, in simpie

if slecp chirge nature, to brea

erc clan it o er throw nature $\ldots$ worthiness of nature! breed of.....

thon divine nature, how thysel
for nuture doth abhor to make

otherwise tlatn nuble naturc did

a very drudge of nature's,

great mature, like his ancestry

shouldst live while nature will

postnres beyoud brief nature.........

it was wise nature's end in the donation -
near the nature of the gods? .. Titus dndroni

doth nature plead. Father $(r e p$.

for no name fits thy nature.........

for nature puts me to a heavy task

nature this dowry gave, to glad

like beauty's child, whom nature gat...

nothing can be ininistered to nature

the disturbances that nature works.

death may usurp on natnre............

it that my nature need a spur

when nature framed this piece

composes nature's own shape ....̈-

nor our nature nor our place ............

a wretch whom nature is ashained in nature, which often leaves.

thou, nature, art my goddess

in the lusty stealth of nature

in the lusty stealth or nature $\ldots . . . . .$.

falls from his bias of nature

whose nature is so far firom doing

hear, nature, hear! dear goddess, he

I will forget iny nature................

natures of such deep trust we shait.

that in the natures of their lords $r$

quite from his nature; he camnot

when nature, being oppressed, comn:and

nature, in you, stands on the very verg

thou better know'st the offices of nature

nature more than natnre yceds (rep.).

nature's moulds, all germins spill .......

tou ron.ly for nature to endure

nothing could have subdued nature

censured that nature thus gi
is therc any causc in nature

oppressed nature sleeps: this rest.

that nature, which contemns its origin.

our foster-nurse of nature is repose....

my snuff, and loathed part of nature

O ruined piece of nature! lhis creat

redeums natme from the gencral ctrrse

despite of minc own naturc..............

of some strange nature ...........

by art as well as by nature

do in hell

lath diseretion fouglit with nat ture

passing through nature to eternity

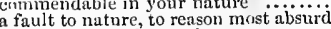

things rank, and gross in nature

a violet in the youth of primy nature

for nature, crescent, foes not grow al

sine mature cannot cloose his origi ...

ii. 3 being nature's livery, or fortune's star

de fools of nature, so hurritily to sliak.

iii. 1 if thou hast nature in thec, bear it not...

that does afflict our nature

iii. 1 o'crstep not the modesty of nature

iii. as 'twere the mirror up to nature.

thought some of nati:re's journeymen nature hath meal, and bran

hiad nature lent thec but thy ........

nature's above art in thiat respect. v. 7 NATURE-nature makes them partial. Hamlel, iii. 3

there the action lies in lis true nature.. - iil.

can ehange the stamp of uature.........

nature is fine in love: and where 'tis fine

so crimeful and so capital in mature....

when the baser nature comes between

to let this canker of our naturc cume

after what flourinh your nature will

I um satisfied in nature, whose motive

so floodgate and u'erbearing nature
for natue so preposterously to err

i. 3
ii. 2 in spitc of nature, of years, of countr

baschess of uni natures would conduct $u$ s

the Mloor is of a tree and open nature...

v. 2 do omit their mortal natrircs

v. 2 very nature will instruct her in it ...

or his cood nature pries the viltue that

it is my nature's placue to spy into abuses

your free and noble nat ure, ont of .....

we see, in all things nature tends.....

are, in their natures, poisons . $\ldots . . . . . . .$.

this the noble nature whom passion ....

of your fuilt be

NAUGHT-raught knowing of ......... T 1 empest,

set the world at nanght .... Tu. Gen. of rerona,

maught but mine eye could.

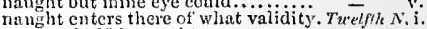

say, ny knife's naught .............. Aruh dilo, y.

Gaugh bless us! a thing of nauglit!.... soream, il.

is, to know naught but fume.......... Lone's L. Lost, $\mathrm{i}$.

since naught so stockish, hard. Yerch. of V'enice,

be better employed, and be nauglit. As you $\bar{L}_{i k}$

was laughlit; now, ril stand to it (rep.)

amportant blood will naught deny ...An's $w$ well, iii. ? touched you, naught remains. Taming of' Shrem, i. nanght for alprobation ............ Winter's Tale, ii. they stay for naught at all ... Comedy of Errors, iv. naught's had, all's spent ..............Macueth, iit.

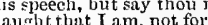

that it yjelds nauglit, but sliame .......... $J_{0.2 n}$, iii. naught shall make us rue, if England and naught at all to say: first ....... Richurd II. saught but shadows of what it is . ${ }_{2}-$ ji. Pistol speaks naught but tiuth........ truth, it was corrupt and naught........ Heñy $V$. i. 2 there's nanght in France, that ean.... - - i. 2 naught rests for me in this tumultuous - i. can do naught but wail her ........2Heury $\nu^{\prime} l$. iii. myself no joy in naught, but thiat... = iii. was made to handle naught but goid nanght to do. Naught to do (rep.). Richasd Iri. and ajl will come to nauglat, when ... - isposing of it naught rebelled..Henry let him in naught be trusted ........ - ii. which are, indeed, nanght else........ - i. he hears naught privately, that comes $\overline{\text { i. }} 3$ naught but humour sways him. Timon of Athens, iv. away, all will he nanght else ...... Coriolonus, iii. when it is all to nanght.... Antoney \& Cleopalra, $^{\mathrm{ii}} .3$ twill be naught; but let it be $\ldots . . .$. - iii. nallght, naught, all naught is can nalight; patience is sottish $=$ iv. 13 good troth, I have stolen naught ... Cymbeline, iii. o she was naught; and long of her $-\overline{-}$ remaineth naught, but to inter .. Tilus Andron. I will discover naught to thee ......... thought naught too curious............... Pericles, i. as knowing naught, like dogs ............ Lear, ii. shall so wear ont to naught.............. - iv. nanght conld remove ........................ Julie!, (proil. for naught so vile that on the carth all torsworn, all maught, all disscmblers you are naught, you are naught ...... IIanlet, iij. despised time, is naught but bitterness... - i. I uijustly. With nanght but truth ...... - iv. tor nanght I did in hate, but all in honour- v. A UGIITY - is a nangh ty house. Neas. for Meas. ii. thou naughty varlet! $\ldots \ldots . . . \ldots . . . .$. Mach Ado, iv. these naughty times put bars... Mer. of Venice, iii. I do nanghty times put bars ... Mer. gond ded in a mangly

my lord, but a naugity orator ........At's 1 eell,.. sort of nanghty persons, lewdly bent. $\mathrm{Henry}_{\mathrm{I}} \mathrm{r}$, ii. he lived upon this nauglity earth?... Ienry $/ 11, v$. you nauglity moeking unele't Troihts of Cisessta, jv. would be not, a naughty man, let it thou naughty knave, what trade?...Julius Cossar
this is a nanghty night tu swim in ...... Lear,

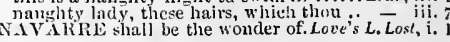


NATARRE-ct Navarre ... Love's L. Lost, i. I (letter) n man may owe, mutehless Nuvorre Navarre hath made a vow, till painful Navarre had notice of your fair.........

deceive me not now, Navarte is intected AVE-unseamed him from the nave.. Mtict NVIGATION-swallow navigation. Macbeth, iv. 1 minds to sternage of this navy? .Hemy ${ }^{\prime}$. iii. (cho.)

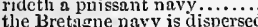

enry $\bar{V} I I$, iii. hath made me rig my novy......... Henry \&leop

our great navy's rigged...

and leave his navy gazing one $\ldots \ldots \ldots$.....

if to-morrow our navy thrive.

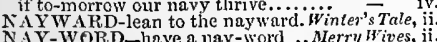
and we have a nay-word how to know

gull him into a nay-word. T'welflh

NEANT-MOINS-decon, nent-moins Heury $V$ iij neant-moins, pour les es

eapolitan ...Tempest, two Neapolitans'sesped:

a horse better tlian the Neapolitals.

some Neapolitan, or mean man .. Taming of $S h$. i.

O blood-bespotted Neapolitan ......2 Herry VI.

[Col.] the Neapolitan hone-ache. 2 roilus \& Cress.

besides, our nearness to the king

NEA'T-as ever trod on nent's leatlier.. T Tmpest, i well spoken, neat and fine.. T'us Gen. of lerona, in a neat's tollgue dried .... Arerchant of Shrew, What say you to a neat's foot?

we must be neat; not neat.........Win

heifer and the calf, nue all cailed neat

lord, neat, and trimly dressed

as doth a lion in a herd of neat

as ever trod upon neat's leather

but his neat cookery! he cut our

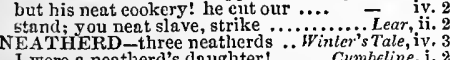
I.

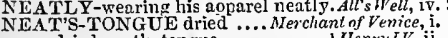

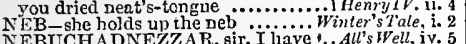
NEBUCHADNEZZAR, sir, I have '.. All's some neessaries that I needs ... T'wo Gen of Ver. ii. 4 we have culled such necessaries........... Homeo of Jutiet, iv. my necessaries are embarked, farewell... Hamlet,

I must fetch his necessaries ashore...... Othello,
NECESSARIL NECESSARY fitness?..................... for . Heas. ii. he, a harmless necessary cat ...Merch of Vcnice, iv. 1 nimble hand, is necessary for ......Winter's Tale, iv 3 be great pity, yet it is necessary

provide us alj things necessary

by the necessary form of this.
it is necessary, look your grace. . must not stint our necessary actions. Hemry $V I I I$ i. omission to do wliat is necessary Troilus \& Ciess. 'tis necessary he should die .. Timon of Alhens, jii. than a riecessary bencher in the ..... Corinlanus, seeing that death, a necessary end..... $\overline{\text { s. Cleo. }}$ i. 2 return was most required, and necessarv. Lear, iv. some necessary question of the play ... Hamlet, jii.

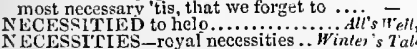
one of these two must be necessities all your business and necessities.. As you Lilie it, ii. 3 then necessities? then let us $(r e p.) \ldots 2$ Henry IV. construe the times to their necessities $-\bar{V}$ the mere necessities npon it.. Timon of Alhens, it must omit real necessities......... Coriolumus call in question our necessities....... Julius Crssar, your content these strong necessities. Ant. \& Cleo. iii.

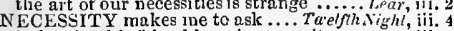
in leaving his friend here in necessity - jii. to make a virtue of necessity ... Tu'o Gel of Fer. iv. it shall bite upon my necessity...... Aerry

the fairest grant is the necessity ....... Much Ado, i. I am forsworn on mere necessity ..... $-\bar{V}$. I'll rather dwell in my necessity...Mer. of $\bar{V}$ enice, some necessity, now hays upon you .. must of necessity hold his virtue...... All's " Well, 1 . were there necessity in your request.. Winter's $T$. i. thy necessity to reason thus (rep.).... Richard II. i. sworn brother, sweet, to grim necessity ne - v. that is but a cursce neessity .......... Hernry deceit, bred by necessity ............3 Henry FI. iii. his legs are legs for necessity. Troilus \& Cressida, ii. sliowed what'necessity belonged to't on Alh
ECESSITY nade use of me ... Thimon of thens, iii.
necessity commands me name....... Corrolanus, iv. nature must obey necessity the strong neccssity of time. Antony \& Cleapalra, i. till he hath passed neccsity .....Pericles, ii. (Gower) in like necessity, which gods protect...

there's no furtlier necessity of qualities - iv.

ecessity will call discreet procecding.....

wherein necessity, ot matter be

Hamter, iv.

.......... Otkello, i. 1

N I.CK-I'll manacle thy neck and feet.. I' empest, i. 2

item, one neck, one chin.........Twetfh Nighl, i. 5

his neck will come to your waist. Meas for Meas. iii.

needs thrust thy neck into a yolse ......Much Ado,

he seen through the lion's neck .. Wiul.N.'s Dr, iii.

break the neck of the wax ....... Love's L.I.ost, iv.

hang me by the neck, if horns..........

thou didst brenk his neck

with bills on their vecks

about his neck a green and gilded...

she hung about my neck.......

he took the bride about the neck

no greater $a$ run but my head and neck

hanging about his neck ........... Winter's Tale,

her jewel about the neck of

she hangs about his neck ............ of Er rors, iii. 2

that self chain about his neck ( rep.)... $\overline{\text { macbeth }}$, iv.

a golden stamp about their necks ......Macbelh,

and stooped my neck under your.

lower than his proud steed's neck.

clerks, I'll give thee this neck

in the neck of thet, tasked.

le neck. madame. De neck.

in the Thames up to the neck

let his neek answer for it .......

he yoketh vour rebellious necks

I may embrace his neck nouk

my way upon their headless necks ...2 Henry VI. $\mathrm{i}$.

I tock a costly jewel from my ueck

his pen and inkhorn about his neck..

with your pardons about your necks?

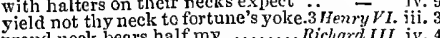

Richardilit. iv.

cirsc falls heavy on my neck ......... ${ }_{\text {hung }} \bar{r}$ twenty years about his neck... ii. 2

shall from your neck unloose. Troilus \& Cressida, iii.

If weetor break not his neck i' the

but a plagne break thy neck ......... $-\overline{T i m o n}$ of Alhens, iv.

and tread uron lis neck

eyes towards the napes of your neeks

one in the neck, and two in the thigh

richest lockrmm 'bout her reechy neck

shall break his neck, or hazard mine

and, he returning to break our nceks ..........

were like a haltop in my neck.

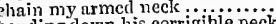

bending down his corrigible neck .... ${ }_{\text {mmbelize }}$ iv. 12

your neck, sir, is pen, book, and...

poor men's cattle break their meeks.

dogs, and bears, by the neck..........

he fastened on my neck, and hellowed .. - v. 3

draw your neck out of the collar Romeas Juliet, i.

or paddling in your neck with his ...... Hamlet, iii. 4

break your own neck down

men must lay their murders on your neck - v. 2

NECTAR - the water Nectar Two Gen of

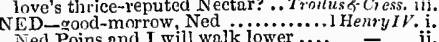

Ned Poins and I trill walk lower.

away, good Ned; Falstaff sweats....

Ned, jr'y thee, come out

but Ned, to drive away.............

but do you use me thus, Ned?.....2HenryI ${ }^{\prime}$ ii. 2

with the folly; follow me, Ned

no ahuse, Ned, in the world (rep.) ..3 - ii. 4

Ned, sweet Ned! speak to thy:... - v. 5

young Ned, for thee, thine uncles Birhar - III. iv. 4

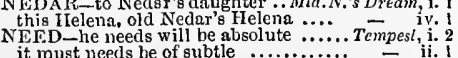

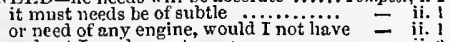

and yet I needs must curse.

needs must rest me

faith, sir, you need not fear..............

I need not 'cite lim to it
NELD-that I nceds must usc... TinoGen. of Fer. ii. you must necd hove them

ot what $I$ stand in need of

What need $n$ man care for

for then she need not be...........

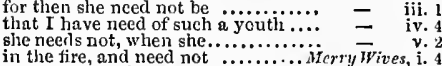

ever need understand any thing....itcrry $\bar{W}$ i

and would needs spenk with you .....

clie must needs go in .................

needs to fear no colours

thou hadst need send for more money

and his must needs be yours ..........

you must needs yield

nor need you, on mine honcur.....................

you need not to fear the bawds

if you should need

must needs appear offence....

but that you will needs buy and seil

must upon a warranted need .........

this needs nust be a jractice?

what need the bridge much broader

when there is no need of sucl vauity

therefore you must needs play...Nid.N.'s Dreat

that must needs be sport alone

for your play needs no excuse

but mean, needs not the painted......

your grace needs not fear it

dark needs no candles

0 'tis more thisn need! .............

I must needs be friends with thee.... $\quad$ - $\quad$ v. 2

you need not fear, lady...... Merchant of

I must needs teli thee all ..............

needs a like proportion iord.....

nay, you need not fear us.

must needs give sentence 'gainst .....
so had you need ................... As you Lite it, ii. 7

good wine needs no busi, tis true $($ rep.) - (epii.)

wilt thou needs be a begar?

and he must needs go.............

thou this to hazard, needs must

may make it probable need...

I hope, I need not to advise you

you shall not need to fear me...

I need not ask you, if gold wiil

vou need but plead your honournbie

nay, you need not to stop you

so had you need.

chance to need thee at home

he shall need none solong as I

nay, then she needs must cons

why, what need we commune

we need no more of your advice...

satisfied, and need no more.

yon veed not fear it, sir.
what need these hands?

the need I have of thec...

thon hast need of more rags to lay

I needs nust think it honesty

most opportune to our need..........
for ad vice, or stronger for your need

forced by need, and accident

of the one, it must needs be...........

what need she be acquainted?

it shall not need, thy father

I had most need of blessin

what need I fear of thee?

what need we fear who know

or, so much as it needs, to dew.

for it is more than need

needs must you lay

thou slialt not need...............
uncle, I needs mist pray that

then Arthur needs nist

your vile intent must needs seem......

sust needs want plcadio.

so ripe it needs nust bred sone messenger betwixt.

used rather for sport than need.......

shail not need transport

needs must I like it well

I need not to repeat

80 great, I have no need to beg.......

love not poison that do

nor shall we need his lielp

you must needs learn, lord

二

ii. 4

ii. 5

v. 3

i. 1

v.

ii. 1

ii. 2

v. 2

v. 3

Y. 3

v. 2

iii. 2

ii. 2

.

v. 2

i.

ii. !

iii. 4

v. 1

v. 2

ii. 3

ii. 2

iii.

i. 3

iii. : 


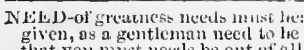

that you mast neetls be out of all.

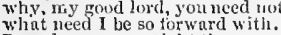

Ineed no more weiglht tham

I do not needl your help; masd heave...

known. $2 H^{2}$

do nut tire rebels need soldi more need

jf you will necds say, I Inu nu olil inan

yuissanee, need not be dracted .......

therefore equtains ball need look

you need nut to have pricked mie....
there is no nced of any such redress

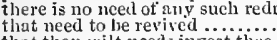

that thou wilt needs invest thee ....

a new link to the bucket must n

he needs not, it is no lindderi.

the gulf, thou nceds muet be c.........

I need not be ashanned of you

you must needs be friends

must therefore needs prove a go

so you had need; fir Orlean
my lord, you neel not fear

my lord, you need not fear

and then 1 need not crave his.
a erafty knave does necd no br
whint needs your graee to be

What needs your grace to be
her fume can peed no spurs

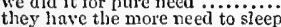

they have the mor'e need to sleep.
so he had need, for 'tis threndbare

a must neets; for lisggary is valiant

wili yon needs be hanged with your.

a sulitic traitor needs no sophister
slie shall not need, we'll noet

five hundred, tather, for a need....

and, in thy need, such com

spite of spite, needs must I.
that Edward needs must flow.

that men must needs abide.

I need not add we necd his

never may have peed o...........

when I have most need tol

my lord protector needs will have it so

they do need the priest; your hionour

[Col. Knt.] now I need the priest that

nay, tur a need, thus fiar eome ......

there is no need of me (rep.)

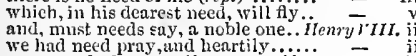

must needs deserve all strangers' luves -

whint's the need? it hath al'eady....

wilat need you note it? pray you.... -

must I needs forego so good you...... $=$ i iii.

they need no other penance....... $.5 \quad$ v.

[Kin.] needs tary the grinding... Troilus of Cress. i. I

he shall not need it, if' he have........

white hand, I must needs confess

nust needs, for youall cied

come, come, what need yoii biush?

for we may live to have need of such

and wliat need thesc tricks?

my friend when he must need me. Tinon of . Alh

we must needs dine together (rep.)

true friendship, there needs none...

or my triends, if I should need 'em- $-\overline{\mathbf{i}} 2$ (grace)

what need these feasts pomps (rep.)

immediate are my needs ....

$I$ must niceds eonfess, I

I need not tell him that

beyond them, and I must needs appear - iii. 6

must thou needs stann for

Imust needs say, you lave

till when the barren of atcusations... Coriotanus

thin when they needs must slow

we need not need your lores.

because they then less need one another -

neither need we tear him.

that needs must light un this......... $\ddot{j}_{\text {ullius }} \overline{\mathrm{C}} \boldsymbol{}$

his worth, and our great nced of him

wliat need we any spur, but our own
or our perlormance. did need an oath

or our perlormance, did need an oath
I should nut need, if you were gentle
please my eountry to need my deuth

plian must thou needs tind ont ... Antor
the present need spcaks to atone you

whot needs more w'ords?

vour presence needs must juizzie....

in eonrse, which has no need of you...

he needs as many, sir, as
he needs must see himse!

fluws over on all that need

we shall have need to employ......... cymbetin

when you shall find you need it not
what shall 1 need to draw my nword? -

mant needs appear unking-
is sorer, than to lie for nee

who needs nust know of her depinture

theeame the lite o' the need

the emperor needs lier not.......... in

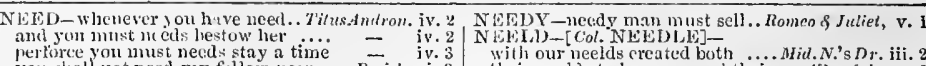
you shall not need ny fellow pecrs
what they will, wliat need we fear? what seed speak I?

he had need mean better tia.... his

Willy our neelds created bot

Mid.N.'s $D+$ r. iii. 2

heir neeldes to launces, anel their.... Ning Jolin, $\mathrm{v}$.

with her neeld eomposes nature's - v. (Gourer)

if' to that my nature need a spur

provision as our intents will need?

thun nunst necds wear my euxeomb.

When thou hindst no need to ense.

Whlieh I must nects call mine

Whit should you need of more?
whiat need you five and t wenty

need one? O reason not the need

more than nature nceds (rep.)

and must need staste lis foll

I must needs atter him madamg need."

God send nee no need of thee!

when, indeed, there is no need

for liere we need it not....

F. WR-TOUCHED vestal

Antony \& Clen. iii.

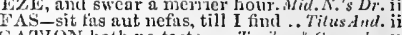

GATION haih no taste... Troilus o d Crossthe v,

ureise be impudentiy negative .. Winter'stale, $i$.

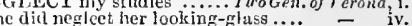

out of pyy unetlect, was .............

that thou neglect me not... iseasure... for Mensure, v. 1

strike me, negleet me, lose me .... Mid. N.'s br. ii.
for my neslect of his ilmimhty ... Love's L.Lost, iii. I

lose and neglect the creejisg ......As ynu Like il, ii.

maiden, do you neglect thin?

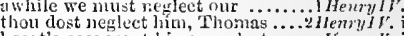

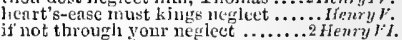

my absence doth neglect no great. Riehard 111 . iii.

gevd Cromwcll, neglect lim not.. Henry $r \bar{M} T$. iii.

clap round fines, tor neglect .........

do you neet my help? No, mad

to bed, and rest; for thou hast need.:
my dismal seenc I needs must act nione

my dismal seenc I needs must act nion

an' if a man did need a puison now
thonglt d did but forerum my need

need and oppression starveth in th:y eyes-
there needs no gliost, my lord, cone.... IJamlet,

the need, we have to use you, did prov

you conld, for a need, study a speech....
or, if thou wilt needs marry
you need not tell us what lord irämië..

you need not tell us what lord ira
such love must needs be treason.

fur who not needs, shall never lack.......
wheu he needs what rou have gleaned..

Jer mood will needs be pitied

but thou must needs be sure, my spirit...

if thou wilt needs dann thyself..........

growth again, it needs must wither

I must needs report the trutis.....

What needs this iterance, woman? $\ldots \ldots \ldots-$ v.

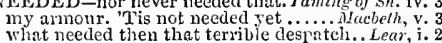
EEDER-the absenee of the needer. Coriolazus,

the needful bits and curbs.

it is but needtul; merey neeilut. but not lavishi...

do more than that, if more were needful - ${ }^{2}$ i. 3

to us seemeth it a needtul course . Love's $L$. Lost, ii. I

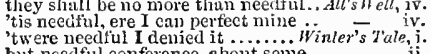

buit needful conference, about some

this, and what needful clse
the time bit needtul woe ........

King

yet needful "tis to fear.....

never so needfil the the earti

HenrylV iv.

or soldiers to this needful war.

now then itis more than needful

from me this most needful note.... Richard 1 III. $\mathrm{Y} .3$

'tis a needlul fitness ..............Hen'y VIII. ii.

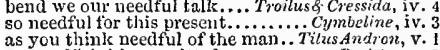

as you think needful of the man.. Tillus Andron, v. bestow your neeuful eounsel to o.......... Lear, ii. 1

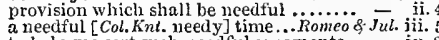
to belp me sort such needful ornaments - in iv.

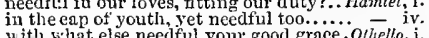
with what else needful yomr good grace. Ohe

marry, sir, with needle and thread

thread the postern of a needle's eye. Richard 11. $\mathrm{v}$.

by the prick of their needies.......... Henryt.

myself by with a needle

pointed him as sharp as my ne....... .

NEEDLESS-needless process iby. Mileas. for Mollons. iv. how need less was it then to ask.. Love's L. Lost, ii.

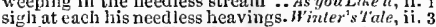
a volley of our needless shot ......... King Jolm, y. . that matter needless........... Troilus $\delta$ Cressidn, i. 3 their needless vouehes? and brain with needless jea............ Cymbeline, v. NEEDLEWORK, pewter ...Toming of Sirear, ii.

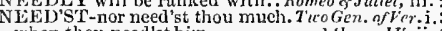
when thou need'st him 1 Henry IV. ii.

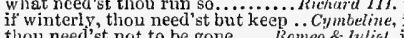
thou need'st not to be gone .... Romeo of Julich, not tax the needy commons........2 Hemy. $Y^{\prime}$.

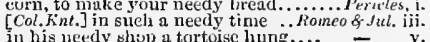

in his needy ship a tortoise hung... pereeived a most faint negleet of late..... - i.

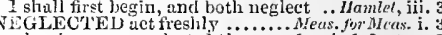
sakes have we negleeted time....... Love's L.Lost, i. 13 a beard neglected; which you ...As yun Like it, iit. and not neglected; else, if heaven .. H- inti. if ance it be neglected, ten to one. MHenry $1, v$. of rule hath becu neglected .... Troilus of Cress. i. neglected, rather; aild then .....Anlony \& cleo in.
their glory, if negleeted, so princes....Pericles, ii. of his grief sprung from negleeted love ... - iii. excuse my manners, that so neglected.. Ohello, v. legleeting it may do much danger......Temeo o Jul. $\mathrm{J}$. NHGLECT NGLY, I know not what.j HenryIV, N1EGLECT'ST-if thou neglect'st ....... Tempesh, i. it is something of my negligenee.... this is thy negtigence,$\ldots \ldots$ Mid.N.'s Drerm, iit. it was my negligenee nut w cigling w ell - i. my rest ond ne or tliat the negligence may wcll be coilus \& cress. $Y$. put on what weary negligence you picase.. Lear, i. buth the worlds I give to nerligence ... Hometet iv. l,y night and negligence, the fire is spied.Othello, $\mathrm{i}$.

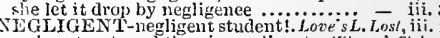
I may be negligent trein neglifent.... if may be negligent, foolish, and fearful

negligent and lieedless disejpline!.... Henry $V I$.iv. as negligent and we in negligent danger. Antony o Cleopatra, iii. more admired, than by the negligent - iij.
mEGOCIATE with my fave........ Tuelf $h N i g h t, i .5$

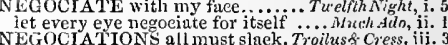
NEGRO--up of the negro's beliy. Mer. of ' 'eness, iii. NEIF-give me your neif, monsieur. Nia. N.'s Dr, iy.
sweet kniglit, 1 kiss thy neif sweet knight, 1 kiss thy neif ........2 Henry $1 V$. ii.
NLIG II-neigh, and barik, and grunt.Mid. $N$. Dr. ii. nebour; neigh, abbrevinted, ne ... Love's L. Lost, v. lis neigh is hike the bidding of ....... Hemry $l$. iii.
in high and bat low our steeds for present service neigh - iv. hurses did neigh, and dying nen..Julius Casar, ji. 2 and the neighs of horse to tell .. Antony \& Cleo. ini.

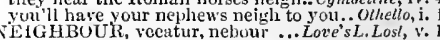
I stule into a neighibour thicket.
he is a nuarvellous rood neighto

my nuboling

give them their charge, neighbour ... Much ddo, iii.

cone hither, neighbour Sea-enal ...

and gond night: come, nejghbour

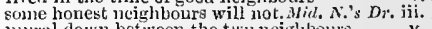
the Seottish lurd, his neighbour...ver.of Venice, $\mathrm{i}$. to whom I am a neighbour ........... wit going to your neighbour's bed .. - iv. 1 1 liave told my neiglibour ............Alls $\bar{W}_{e l l}$, ii. 5 neigilinur Baptista (rep.) ....Taming of Mtreze, ii. lieighwour, this is a gift very gratefin

I an your neighbonr, and was suitur

by his next neighbour (rep.) ....... Hinter's Tule, $i$. FGLECTION doth betray ......... Hemry $\nu_{I}$ i this neglection of degree it is.. Troilhs f. Crrssida, i.

would you with me, honest neigl boin? neightibour Verges. Neiglybours (sep.) eme nejuhbour

livef in the time of good nejghibours

or made her neighbours belicye...... 


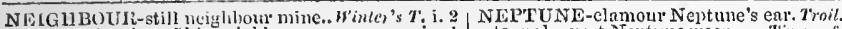
the imncimntion of his neighbours

and this my neighbomr too?....

to make vast Noptune weep..... o'er' green Neptunc's back...An/mig s Clupatru, iv. 12
which stands as Neptune's park .... Cymteline, iti. 1 sliakes on Neptune's billow

gou Neptune's annunI teust to kcep

come, neiglibour, the boy sliall lend

whose influence Neptune's empire siands.
Neptune's salt wash, and 'tellus' orbed

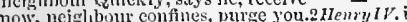

a giduly neighbour to 11 .

and sich another neighes us

N

[knt.] on the vigil feast lis neiglaboir

is it not hard, Nerissa, that I........

can any of vour neighlyours tell me..

neighbour lforner, I drink to $(r \cdot y$.$) ... II$

is will do any thiug, Nerissa, ere I $\mathrm{I}$ will

eome, Nerissa: sirrah, go before

come, come, Nerissa, for I lonis to see

Nerissa, an! the rest, stand all aloot

Nerissa, cheer your stranger

my maid Nerissa, and my all ......

come on, Nerissa; I have work in hand -

go in, Nerissa, give order to my servants -

Nerissa teaches me what to believe
Nerissa there, her clerk.

that my Nerissa shall be swom on.............

and die and neighborth

mine houest ncighbour's shouted

our neighbour shepherd's son 1 ........

my neighbour's onl the appr

hush, gentle neighbours $\ldots$............ pericls, jii.

With thy greath this neighbour air. Romen s. Jut

NEIGIIBOURED by fruit of baser
be as well neighboured, pitied, and

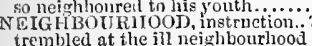

ncighbnurhoorl and christian-like aecord $-\tilde{W}^{\prime} \mathrm{v}$.

NEIG IBOUR ING languages
and neighbouring gentlenen

light mon neighbouring ponds

descried unon our neighbouring shor

moluve; is not that neigh bourly?. As you L Like it,

NEIfIIED-who neighed so high... Anilony \& Cleo.

LIGH NG in likeness of a filly foal. Hid. $N$.

lout 'larums, neighing steeds.. T
their neighing coursers daring of

their neighing eoursers daring of ..2Henry $I V$. iv, 1

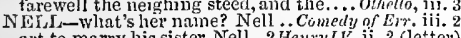

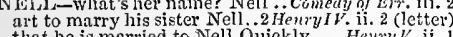

nor shall my Nell keep lodgers.

nor shall my Nell keep lodgers

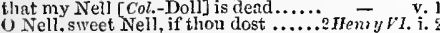

come, Nell, thou wilt ride......

sweet Nell, ill can thy noble ..........

be patient, gentle Nell

greatest help is quiet, gentie Nëli....

my Nell, I take my leave ... .............

let in Susan Grindstone and Nell. Roineo s. iii.

NEMIEAN lion roar............... Love's $i$. Lost, iv. 1 Nap hardy as the Nemean lion's nerve... Hamlet, i. when your young nephew Titus.. Twelfh Night, he yet my nephew: my brother ....... Nuch Adn, v. nephew, and right royal sovereign ... King Johm, i. I tell your nepliew, the prince

O no, my nephew must not know

my nephew's trespass may be well

of Orleans, nephew to the king

keeper, will my nephew come...

your nephew, late despised Richard...

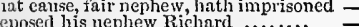

u ith silence, nephew, be thou politic

nephew, what means this passionate..2 $\mathrm{Henry}_{\mathrm{FI}}$ ij.

ngainst my king and nephe

kiss your princely nephew ..........3 Hrnry/rI. v. 7 the queen's great nephew ......... He Hry VIII. ii.

my royal nepliew, and your name.............

Trojan blood, nephew to Ilector.. Troilus \& Cress. i.

welcome, nephews, from successful ... Tilus And.

to inter his noble nepliew here iu...

the tribume and his nephews kneel .

to ransom my two nephews trom thei

E

hears of this his ncphew's purpose.
to suppress his nephew's levieg

one lucianus, nephew to the king........

the nephew to old Norway. Fortivbra

Yop'll have your nephews neigh to you... othelln, i. do chose the bing sempest, i. sat with me on Neptune's yellow ... 3 iti.....'s $\bar{D}$ r. ii. opening on Neptuue with 1air blessed, - Tii. of the dreadful Neptune, to greet a man - v. will all great Neptune's coean wash.. Macbeth, ii.

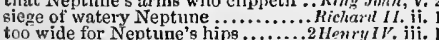
or made a toast for Neptune ... Troilus \& Cressida, $\mathrm{i}$. 3

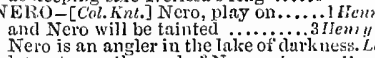

let not ever the sonl of Nero enter.... Hom/el, iii. 2

NIR i-LIKE [Col. Kut.-like thee, Nero]I Hen
AERVE-nerves are in their infancy .. Ten

know the very nerves of state... Metrs for Meas.
my firm nerves shall never tremble.. Afacbelh, ii

nerve and bone of Greece ....7 Troitus \& Cressida, i.

the strongest nerves, and small .... Coriolan

Nelivy as the Nemean hon's nerve...... Hamlet, i. 1

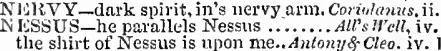

the shirt of Nessus is upon me..Antony \& Cleo. iv. 10
NES'T-show thee a jay's nest.......... Tempest, ii. 2

overjoyed with finding a bird's nest... Much ddo, ii. ]

bird hath done to her own nest ... As you Like it, iv. 1

a nest of traitors! same nest

Winler's Tale, ii. 3

et on the liead of a wasp's nest.

from her nest the lnpwing .. Comcily of $E$.

thin comes near his nest
the

did oppress our nest

Kinte Jollh, iv. 2

him that climbect unto their nest ...3Henry $y^{\prime}$. i.

in Cleopatra's sails theirnests...Antony s. Cleo. iv. io

in a greac pool a swan's rest.........

own birds famislt in their nests

must climb a bird's nest soon ... Romeo of Jutiet, ii. 5

lasly, come from that nest of death ..
N ISTOR play at push-pin .......... Love's $L$.

IVestor swear the jest be ............Ker. of renice, i. 1

the orator as well as Nestor........3 Menry 1. . iit

Nestor shall apply thy latest....

venerable Nestor, hatched in........
play me Nestor; hem, and stroke

'tis Nestor right! now play....

Nestor,-What says Ulysses?

old Nestor, whose wit was mouldy.

thus once again says Nestor from

he's Nestor, instrueted by the

tis the old Nestor. Let me ...........

most reverend Nestor, I am frlad...

old mouse-eaten dry cheese, Nestor.
bid Nestor bring me spices, ink and

NET-fear the net, nor lime

rather choose to hide them
doth the coney struggle in t
the net has fallen nion ime

for going on death's net, whin

I'll go daw un the inet

here's a fish hancs in the net.

and the painter with his nets....Romeo in ii.

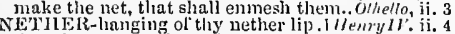

that these our nether crimes so specilily..Lear, iv. 2
Palestine, for a touch of his nether lip.. OLhello, iv. 3

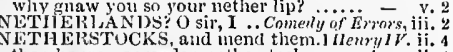

then he wears wooden netherstack

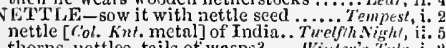

yield stinging nettles to mine....... Michurd 11 .

out of this nettle, danger .......... Henry 1.

grows underneath the nettie .......... f fenry strains lis young nerves ........... Cymbeline, iii. 3

to her unguarded nest the weasel...

seek not a scorpion's nest .........

so much for Nestor. I'll take

loof come, and bring away the nets
NETTI,E-call a nettle, but a nettle. Coriolanus, ii. I

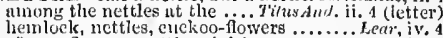

of erow flowers, nettes, daisics.

Hotmlet, iv.

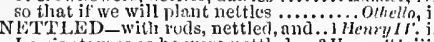

Leivis stamps as he were nettled ...
NELTRA, loyal and neutral, in.

like a neutral to his will and mat

NEUTRE-I do remain as neutre ...Richarl II.

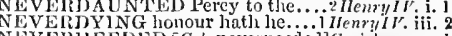

EVEROUENCII

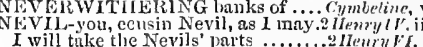

do more in lingland than the Nevils

the Nevils are thy subjects to command -
and, Nevil, this I do assule myself..

nnd never of ihe Nevils' nobl

my futher's badge, old Nevil's erest.

or else new formed then

being rather new dyed ................

has a new master, get a now man $\cdots$ ii. $\overline{2}$ ii.

Orave new world, that hins....

what is the news? The best new........

and what news else betideth ..Tü Gen. of Ver. $\mathrm{j}$. 1

what news. There is no news........ - i. 3

'tis nn unwelcome news to you...

once nore, new servant, welcom
cannot hear good news (rep.)..

hat news with your mastership? (rep.)

old cloak makes a new jerk

What news? how does prett

what news with yon?..............

to a door for a new year's gift

story of the prodigal, resh ani new

than are in the new map

what's the news with you?

nut the new deputy now for

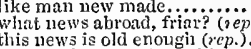

this news is old enougin (rep.)........

now, sir, what news (rep. iv. 3)...... iv. 2

I caur tell you strange news that you

but hear these ill news with the $\ldots .$.

as great a sul inion of a new doublet

as to show a child his new cont ........

now, signior! what news?

will you go hear this news, signior?

what's the news with thee? Full of..

to seek new friends and strainger.......

O me! what news, my love?

now thou and $I$ are new in amity

now ribbons to your pumps..................

nightly revels, and new jollity ......

the world's new rashion plan
for a new devised court'sy

and learns news of lim...

tlyy news, Boyet?............................

how now! what news?

What news on the Rialio? (rep. iii.
I will tell you news of your son

who is thy new master's guest ......

friend Launcelot, what's the new's?

to seal love's bouds new made.

the times, to be new varnished?

what news among the merchants.
what news trom deuna? laast.......

no news of them? - why, so.........

be content, and seek no new

if that the youtl of my new interest

what's the new's from Ven:ce? ......
from the doetor, new come firom Padua

with his horn full of good news.

and I have better news in store tor you

the new duke (rep .)..............
with lis moutli full of inews

monsieur le Leau: what's the news? =

Ganymede, my new mistrcss's brother - iii. 2

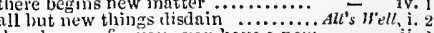

there's news for you; yon have a new
yonder is heavy news within ........

sone comfort in the news, sonie comfort - - iij. 2

pray, what's the news?

news, old news, and such news (rep.)

the old master, and my new mistress

the serving-men in their new fustion

I pray thee, ne.vs. First, know.....

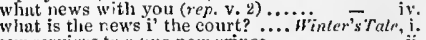

our services to a tine new prince ...... 


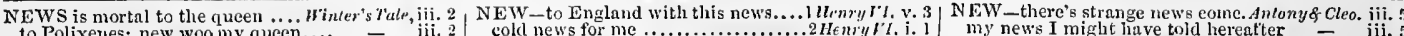

woo my queen.

he is gone aboard a new ship to purge

he is gone aboard

iv. (chorits)

this news, which is called truc

some new" graee will be bor

and be new beaten home?

picture of old Adam new applarejed

Macbeth, the news of thy sucecs

new honours eome upon him...

he brings great news; the rave

crents, new hatelied to the woefil time

destroy your sight with a new Goryon

old robes sit easier than our new?

eaeh new norn, new widuws (rep.)

what news more? All is confirmc....

a hazard of new fortunes here....

cold news for me .....................

thithur go these news, as first .........

what news fromk, hath

what news from France? $\ldots$............

what new's, lord Somerset (rep.)

and set a new nap npon it $\ldots \ldots \ldots .$.

how now! what news? ...

come, thou new ruin of old

let us tell the queen these new.

what news? why comest thou

what fure? what news abruad? (rep.)

If we should recount our baleful news

eaused him, by new act of parlitiment

and nistress smiles at her..............

with him and his new bride

of this new marriage (rep.) ..........
lord Bonville on your new wife's son

what letters, or what news

is new committed to the bishop.

these news, I nust confess, are tull ..

what news, my friend? .................

hear no news of his repair? ........

even now we heard the new

that you shall be new christened....

what news alsroad? no news $\ldots . . . .$.
by St. Iraul, this news is bad

hear'st thou the news abroad

this news was brought to Richard

not let me welcome this good news

here: what news? the count AI un

ah, foul shrewd news! beslrew......

news fitting to the night (rep.)

but till thy news be uttered.

you brentlue these dead new

Bushy, whint news? old John....

so it be new, there's no respect.

I am a propliet new inspired

the wind sits fair for news to go...

the news is very fair and good...

tongue sound this unplensing news...

for telling me this news of woe.

intend to thrive in this new world

gain of care, by new care won.

well in this new spring ot time

what news from Oxford? .....

I pray God make thee new ..........

new broils to be eommeneed

loaden witii heavy news .............

unwelcome news came from the

and his chin, new reaped, slowed.... =

what news? case ye, case yc

there's villanous news abroad ......

in a new channel, fair and evenly...

keep my person tresh, and new.

wherefore do I tell these news to thiee?

now, Ial, to the news at court.

there is more news; I learned...

at the news of hurly-burly imbovation

witls a new wound in ring will

brings other news than they

certain news from Shrewsbury? (rep.)

rendered me these news for true....

Tuesday last to listen after new

look here comes more new's.......

Westmoreland; this is the news at full =

now, master Gower; what news? (rep.)

two holes in the alewife's new petticoat -

liow now? what news? (rep. iv. ii)....

deliver to the army this new of peace

our news shall go before us...........

and new happiness added to that....

lookl lere's more news. From enemies -

Iherefore should these good new's make

heard lie the good news yet? $\ldots . . . . .$. .

this new ant gorgeous garment.

eume from the eutrt with new

happy news of priee (rep.)

what? I do bring good news

to line, and new repair, our towns..

the gay new coats o'er the French

news have I that my Nell is lead.

these news would eause him one

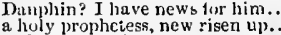

and lay new platiormis ...................

doth beget new eourage...............

these news, my lords, may eheer ... hear you the news abroud? (rep.)

what news? Such news

for joy of this good news

he scnds you this good news

I am no mourner tor that news.....

dead- 3 illing news that the Guildial

what's tile news? (rep.)

kind Tyrrel! am I Jappy in thy new.

hownow? what news? (rep.)

till thou bring better news. The news

is taken, that is the best new

and he begins a new hell in himself. Hen $\bar{y}$ VII

a vessel follow that is new trimmed

new enstoms, though they be never

they have an new legs $\ldots$ i............

but the new proclamation that

these news are every where ...........

Gardiner to me, my new se

sustain more new disgraees........

no new device to beat this from..

what news abroad?

that's news indeed

ii. 2 from the queen what is the news?...

I have news to tell you; come ......

rew opinions, divers, and da

her aslies new

shall be, and make new nations .....

What news,

become as new into tlie world

whith ne whe what's the wer

how now, what news?.......... T.

succession of new days this month.

how do yon? wha:'s the new

the news is, sir, the Volsces are..........

tell you excellent news of your hisi...

there came news from him last night

thy new's? the citizens of Corioli ......

angurer tells me, we

these his new honours $\ldots$...........?

we need not put new matter to his

what's the news in Rome?

I ean tell you news; news, you raseals

but, more of thy news?...

but the bottum of the news is.

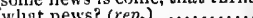

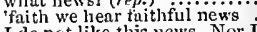

I do not like this news. Nor $\mathbf{I}$

what's the news? Good news (rep.).:
he watered his new plants with dew:

my love to every new protester..... Juliu

I eould tell you more news too.......

sirrah, what news? (rep.)

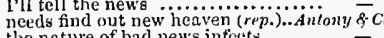
the nature of bad news infects ......

labienus, (this is stiff news) hat
trom Sieyon how the news?........

trom Sieyon how the news?.......

old smoek brings forth a new petticoat

there's some good news ................

I, that do bring the news....

never good to bring bad news........
he hath waged new wars 'gainst.... v. 3 to his new kingdom of perpetual

and bring thy news so late?..........

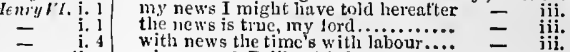

what news? Belike, 'tis but...

what news? My lord, your soin drew.Cymbeline, $i$.

your loril, that which he is, new......

the exile of lier minion is too new.

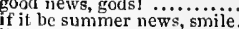

i' the field, and ask, what newg, of ine!

thou bring'st good news...............

new matter still? It joisoned me $\ldots . .$. . - v.

these looks, infuse new life in me....

the news? That you are both (rep.).

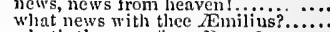

iv.

What,'s the news trom Rome?
this fresl new seafur, I.....

new joy wait on you! .............. v. 3 (Guwer)

Edmund! how now? what news ......... - i.

I know no news, my Jord

you have heard of the new.

I have heard strange new's abroad...... - ii.

what news? 0 , my good lord, the duke.

madars is not so tart

madam, news; the Britis

their precious stones new iost............

crudge brenk to new mutiuy . Romeo.....

this aneient quarrel new abroach? new struek nine

take thou some new infeetion

but love, and 1 'll be new baptized....

these new tuners of accents! ........

Ohoney nurse, what news

though news be sad, yet tell them ..

hou shamest the music of sweet news

is thy ny bones, and thy news....

in scarlet straight at any news......

wearing his new doublet before ( $(\mathrm{rep}$.

jmpatient clitd, that hath new robes

ny nurse, and she brings news .....

father, what news? what is the prince's

these are news indeed! .............

nome joyful news at

for bringing these ili new

dead before, warm, and new $\mathrm{kili}$ ed...

brought iny master news of Juliet's death

what news my lord? (rep. ii. 2) ..........

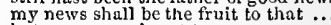

but your news is not true ......................

rengeance sets him new a-work ........

levised a new commission ..............

live to hear the news from England......
what is the news? The duke does greet.

there is no composition in these news
here is moxe news. 'The Ottomites.

to draw new $[$ Col.-more $]$ mischiet on..............

to slumber the gloss of your new fortune

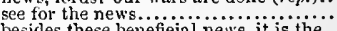

our new heraldy is-hands, not hearts

should hunt after new fancies ...........

what's the news with you? (rep. iv. j)

this is some token from a new friend

NEW-ADDED, and eneonraged ...Julias Corsar, iy. 3

NEW-ADOPTED to our hate..............eror, $\mathrm{i}$.

NEW-BEGOT - homours, new-begot il Hen?y $\nu_{1} . \mathrm{i}$.

3 NEW-BELOVED any where . Romen \& Jut. i, 5 (cho.
4 NEW-BORN chins be rough ........... Tempest, ii.

as it'new-born, and gives the crutch. Lote' sL. L. iv.

like a naked new-born bäbe.............. Nacbeth, i.

proise new-born gawds, though. Troilus \& Cress. iii. 3

be soft as sinews of the new-born babe. Homlet, iii.

NEW-BUILT virtue and....... Taming of Shere,

his new-come ehampion, virtuous.... I Henry VI. ji.
NFW-CONCEIVED, and so in . Meas. for Meos.

NEW-CREATE this fault? ............ Othetlo, iv.

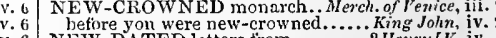

NEW-DELIVER ED inother.

the new delivered Hastings?

Richard II.

NEW-ENK INDLED fire............. King.John, iv.

what olc, or newer torture must. Winler's Tale, ii

here eomes newer comfort ............ Maebelh, y. 7

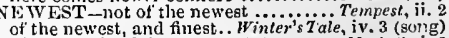

of the revolt of hie newest state...

worn now in their newest glose...

oldest sins the newest kind of ways.2 Henry $I V$ iv.

NEW-FALLEN dignity ...........As you Like it, v.

NEW.-FANGLED shows............ Love's L.Losi, i

, 3 more new-fangled than an ape ...As y mulike it, jy.

4
NEW-FIRED, I follow you ....... Julius Carsar, ii.

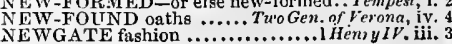




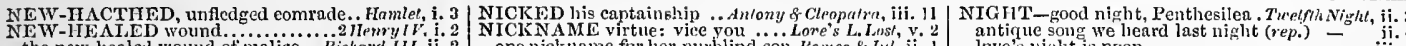
the new -healed wound of malice......... Bichard III. ii. 2

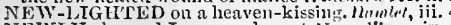
NEWLY-she, and I, are newly met Mcrry wives, iv. hinth newly passed between...... Turely'h Night, y. images, ncwly made woman............... lie liath ta'en you newly into his .........Mnch Alo, i. rejoice at friends but newly found ... roses newly washed witl dew... Taining of Sh. ii. but that you'tc but newly come ..... iv. the statue is but newly fixed ........... v. 3

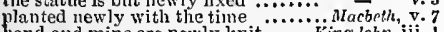
hand aud mine are new] $k$ nit... so newly joincd in love, so strong..... IIen? $\vec{l} l v$. iiv. stings and teetly mewly tacn out

newly move with casted slough...... newry $V$. iv. 1 of Winchester, (newly preferred ..Henry $I I I$. iv. of the senate newly alighted.... Timon

sects and factions were newly boru... iii. are newly grown to love....Antony \& Clenpatra, i. 3 you are but newly planted........... Tilus Andron.i. and newly dead, who here liath lain - v. 3 here is newly come to court, Laertes .. Hamlet, v. these hands have newly stopped ......... Othello, fenlty to the new-made king .......... Richard II $I$.
the new-made duke tlat rules....... Henry $V I$. too early for new-married ladies.. Titus A ndron. ii. 2 NEWNESS-glimpse of newness ..Mleas. for Heas. i. 3 bappy newness, that intends old right. Kunbeline,

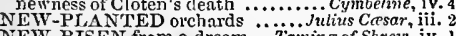
NEW-RISEN from a dream Taming of Shrew, iv. 1 NEWS-CRAMLMED. All the better.As yon Lile NEW-SHED-drops of new-shed blood. Titus And. ii. 4 NEW-STORE France with hastard .. Henry $V$. iii. eye of newt, and toe of frog.............. Macbelh, iv. 1 gilded newt, and eyeless venomed... Timon of $A$ th. iv. 3 NEW-TA'EN Spar'row ......T roilus \& Cressida, iii. 2 NEW-TR.OTHED lord $\ldots \ldots \ldots \ldots \ldots \ldots$. NIBBLING-wluere live nibbling sheep. Tempesl, iv. I so wedloek would be nibbling.... As you Like it, iii. 3
NICANDER bring me the satin coffer...Pericles, iit. I NICANOR-know you me yet? Nicanor?..Coriol. be welcome with this intelligence, Nicanor - iv. 3

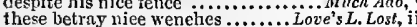
we'll not be nice.

of this measure be not nies.

and if you grow so nice $\ldots . . . . . . . . .$.
nonsieur the nicc, that when he....

by nice direction of $\Omega$ maiden's ... Mifer. of Venice, ii. 1

which lny nice manners by

......All's Well, v. 1

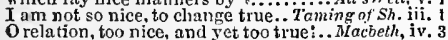
malses nice of no vile hold to stay ... King John, iit. 4
on the nice hazord of one .........INenryIV. iv. 1 on the mice hazard of one ............ hestce therefore, thou wice crutcli...
more precise and nice with others

every idle, nice, and wanton reason

O Kate, nice customs court'sy

the lice fishion of your country in these nice sharp quillets .......... Herny $\mathrm{VI}$. ii. 4 respects thand you on nice poin ts?.3 Henry Vl. iv. prenominate in nice conjecture. Troilus \& Cress. iv. every nice offence should bear .....Julius Casar. iv. when mire hours wcre nice

disclain, nice longings, slanders

bethink how nice the quarrel . Romeo \& Jnliet, iii. 1
the letter was not nice, but ful .......

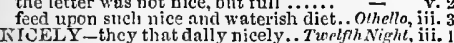
plas so nicely with their names

..Hemy $V$. i. one foot standing, nicely dejending... Cymbeline, ii. inflame ton nicely .................... P'ericles, iv. 1 what safe and nicely I might weil........... Lenr, v. YTICEY Y-GAWDWD cheeks

IVICENESS, (the jiandmaids of ........ Cymbeline, iit 4

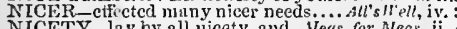
NICJOLAS he thy siced I. . Tuo Gen. of lerma, iii. 1 Nathaniel, Joseph, Nicholas., Taming orshren, iv. then worship'st saint Nicholas as truly - ii.

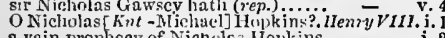
a vain prophecy of Nichola llopkins nav, sir Nichlolas, let it alone ..........
nicik-loved her ont of all nick. Tirocien. of Ver. iv. Nick Bottom, the wcaver ( $r$ ep.)... Mid N.'s Dream, $\mathrm{i}$. nicks him like a fucl.......... Cometly of Errors, v.

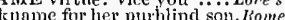
NI LCE-a plage menns my niepe. with drinking henlths to my niece

my niece's chaniher-maid.

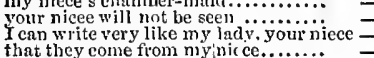

if I caunot recover your nic ce............ =

my niece is desirous you should enter

I am bound to your nicce, sir .........

marry, I saw your niece do more

between lis lord and my nicce confirms

liere he comes with your niece.

so far in oflence with ny niece ......

what is he that you ask for, niece? ....
faith, niece, you tax signior Benedick

you nust not, sir, mistake my nicec.

that he loved my nicee your daughter

by my troth, niece, thou wilt never.

niece, will you look to those things

your niece Beatrice was in love

Gell, I am sorry for your nie

your niece regards me with an eye of

displeasure 'griust his gentle niece. As you $\bar{L} i k e$

o my dear nieee, wclcome thinn a......

with her her niece, the lady Blanch...

what say yout, my niece? .............

pass the abuse done to ny niece? .3 Henry VI.

good niece, do; sweet niece Cressida..

look well upon him, niece...

my niece is horribly iu love.

who's tlis, my niece, thint flies ....... Tilus Andron. ii. 5

speak, gentle niece, wliat stern

patience, dear niece; good Titus

thy niece and $\mathrm{T}$, poor creatures, want
sit down, sweet niece...............

write thou, good niece; and heredisplay -

and his lovely nieces....... Romeo \& Juliet, i. 2 (note)

my far niece Rosaline ......... - i. 2 (note)

there lies yotri nieee; whose brenth .... Othello, y. 2
NIGGAPD of lnir, being .... Comedy of Eryors, ii. 2

be not a jiggard of your speech....... Macbelh, iv. 3
the devil is a niggard ............. Henry l'lll. $\mathrm{i} .1$

from niggard nature fail ........ Timon of Athens, v. 5
we will niggard with a little rest.Julizis Ceesor, iv. 3

niggard of question; but of our demands Hamtel, iii.
NIGGARDI Y give me sight ot.... Horvy Wines, ii. 2

niggardly rascally sheep-biter ... Tirelfih $N^{*}$

ay, to a ni ngardly host...... Comedy of Errors, iii. 1

NIGH - but was not this nigh shore? .... Tempest,

one that is well nigh woin .........Merry Wives, ii.

then I well perceive you are not nigh $\overline{\text { ii. }} 3$

that dost not bite so nigh... As you Like it, 11. 7 (song)

now is your lninsband nigh ... Comedy of $E$.

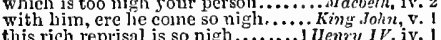

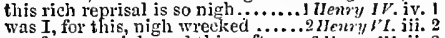

our foes are nigh, and this soft

how nigh is clarence now?.

ah, who is nigh? come to nre.

so nigh, at least, that thongl ...... Cymbetine, iit. 4

her revenge being nigh bade lier ....... Othello, ii.

that burn by day and niglit

Tempest, i.

when night kent chain'd below

or else goou night, your vow

as the morning steals upon the night.

wour rest for this one night:.......... of $\bar{v}_{e r}$

last night she enjoined ne to.

this night, lie meaneth with

I would resort to her by night,........

this very night, for love is ...........

this night $I$ will entranchise tliee....

by silvia in the night $\ldots$.............

the nirlit's dead silence will $\ldots$

thy advice this night I'll put in ....

as wretches have o'er night ..........

a posset for't soon at night .......... Merry $\bar{n}$ rives, i.

by day or night.................. - il. I (letter)

conse $y$ on to me at liight (rep.)...........

ferr in dcep of night to walk by ....

at once display to the nighit.

revel lers, and shades of night.........

loud even in the rlead of nigl

in very gracious fooling last night

for this night, to bec, and. and 'tis long to niglit.........

both clay and night did we

sonn at night I'll send hin ..............

this night's the time that $Y$ sliould do

if for this night he entreat you ......
upon the heavy midale ot the night

the vaporons light approaches $\ldots . . .$. .

I have heen drinking all night (rep.) -

he that drinks all night, and is lianged

but Tuesday night last gon

good night to your redress.

comes this night to Mlessina .............Much $A d_{o}, \mathrm{i}$.

for the fool will eat no supper that night -

though it cost me ten nights" watchings

very night hefore the intended wedding -

and now will he lie ten nights awake -

for sle'll be up twenty times a night =

even the night before her wedding-day -

a cilild ery iu the night you nust

if you neet the prince in the night..

bids me a thousand times good niglit

partly by the dark night

were you her bedfellow last nighit?

until last niglit, I have this twelvemonth -

swore a thing to me on Monday night
who, in the night, overheard me ....

pardon, Goddess of the night $\ldots . . .-\bar{v} \cdot 3$ (so

steep themselves in nights (vep.) Mid.N.'s Dream, $\overline{\mathrm{i}}$.

shall behold the night of our solemnities -

thy father's louse to-morrow night (rep.) -

to con them by to-morrow night ..... -

I am that merry wanderer of the rigint =

no niglit is now with liymn...........

by niglit, full often hath she gossiped

to trust the opportunity of night ....

I think I ain pot in the night........

so good night witl lullaby.

night and silence! who is liere?......

and for night tapers, crop their waxe

who more encilds the nirht than....

have night, you loved me (rop.)

overcast the night; the starry welk in
for niglat's switt dragnis coit the cloni

for aye consort with black-lrowed night

think no nore of tlis night's acejdents

trip we after the night's shade
tell me how it came tlis niglit

or, in the night, imagining some
but, all the story of the night told

coning first by niglit, did seare.

o grim-looked night! 0 night witi hine $=$

o night, which ever art (rep.)

well begniled the henvy gait of $n$ inglit

now it is the time of niglit, that the..

to think no harm all night (rep.)... Love's $\overline{l .}$ Lost $\mathrm{c} i$.

no more profit of their shinis

evio.

and would turn to night!

from morn till nirglit, out of ......... of $\overline{\text { venice }}$

for the cluse niglit dotll play the .... -

as I heard, ove night, fourseore......

must away this night toward Padua

comes so fast in silence of the $u$ itgit?

of lis spirit are dull as night, and his

his night, methinks, is but

y these blessed candles of the jight

last night did lie with me

whether till the $n$

and this niglit lie means to burn.. As you $L$

thrice-crownel queen of night

not been for a loot nidsummer $n$ iglit

endured slurewd dars and nights with

which you shinl see this very ni........

in the niwlit, I'll put another ring ..

he luas snt in the stocks all niglit.....

defiles the pitelly niglit! so lust......

day and night, must wear your.......

he hence removed last vight

yet for a $n$ iglit or two .... Taining of sh $\overline{2}$ (induc.)

nay then, gond night our. part!.

if it 
\begin{tabular}{l}
\hline NIGHT, we'll fast for conpany .. Taming of Sh. iv. 1 \\
last night slie slept not, nor to-iiglit
\end{tabular} in conclusion, she slall wateh all night = iv. and there, this night, we'll pass

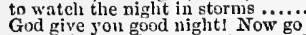
nor niglit, nor day, no rest ....... inin'er's Tale, ii. safety. to fly away by nimglt.... - iii. 2 (indict.)

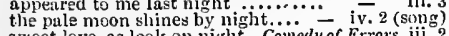
stealing on, by night ard day? ...... - iv. 2 tiith stay here this night

nor sleep on night, bnt she tells.

yet lath my night of life some $\ldots \ldots . . .$. ... $\overline{\text { nacbeth }}$, i. 3

come, thick night, and pall thee

how goes the night, boy?

I dreamt last night ot the three........

the night lias been unruly .............

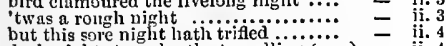

dark night strangles the travelling (rep.)

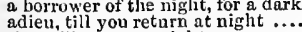

time till seven at nighth......................
hath rune night's yawning peal

come, seeling night, scarf up ....

what is the night? Almost at odds....

this night I'll spend unto
sleep to our ni nigls; $^{\prime}$ free from

kleep to our nights; fiee from
days and nigh ts last thirty-on

the night is long, that nev

blessed be the hour, by niglit, or day.King John $\mathrm{i}$.

one unto the drowsy race of night

from the eouch of lasting night.....

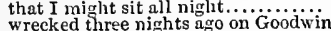

but even this night, wliose black

the stnmbling night did part our......

and eyeless nighth have done me slain

news fitting to the niglit, black......

half $m y$ power this night, passing.....
for, in $\Omega$ niglit, the best part ........

for, in \& night, the best part ..........

and pluck nights from me, but not.
there repose you for this niglt ...

the cloak of night being plucked.....

hath revelled in the night
from Richard's night to Bo.........

in winter's tedious nights, sit by $\ldots$.

go wander through the shade of night
that are squires of the night's body..1 Henry $I V$. $\mathrm{i}$.

on Monday night, and most dissolutely -

who studies, day and night, to answe
company, last night at snpper .......

more belolden to the niglit
a business that this night may

aun may away by night ma...........

difference betwixt day and night...

in the night to eatch my horse

walking with thee in the night:....
the other night I fell asleep lere.

we must away all night [Knt.-to-night] =

posted day and night to meet you.
vet once cre night $I$ will embrace.

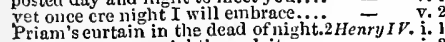

gilded over your night's exploit

or I'l ride thee o' nights, ighe.....
where lay the king last night?
fighting o days, and foining o

flghting o days, and foining o night

ealmest and most stillest nig
since we lay all night in the

ka, it was a merry night ..............
open wide to many a watcifuil night!

snores out the watch of nigh

drink, dance, revel the night...........

doth the man of war stay all nighit, sir
now comes in the sweet of the piight

we'll ride all night; O sweet Pistol.
as it were, to ride day and nightt...
I shall be sent for soon at njght....

fastest by night, unseen
a nighit is but small breath

it now draws toward night

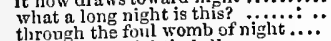

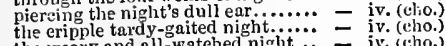

the wear' and all-watehed night

you heard him all night ....

as cold a niglit as tisht, the cliild.....
never sees horrid night

and all night sleeps in Elysium $\ldots \ldots$

yet ere night they'll be infresher...

that swaggered with me last nishts
wituess the night, your garments
and at night when you come into

and at night when you come into.

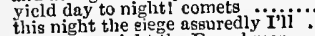

this happy night the Frenchmen...

shall this night appear how

most part of all this night ...........

and dosky vapours of the night .....

not live asunder day or niglit

souls to deatl and deadly night
by day by night; w aking, and in ...
this ni, lit doth moke ne sad...... to sup with me to-morrow night ...
let never day nor night umhallowed well, for this nightit, we will repose..

watelied the night, ay night by night conld I curse away a winter's night defer the spoil of the city until night
and lodge by me this night............ ere night yiel's covertnre, thy biother
bovered wight the night's black mantle but in the night, or in the time ....

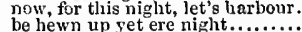

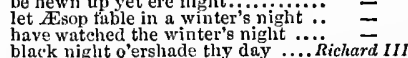
passed a miserable niglint, so fuli ....Richard makes the nigl perpetual nigh [Col, Knt.] of ne'er changing night ..
who dotl not last night, I heard, they lay at.
grandam, one nirht as we did grandam, one night as we did sit. [Col. Knt.] this night lie dreant the boar = forbear to sleep the night, and fast.. save for a niglit of groms endured..

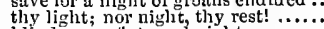
blind cave of eterual night......

confort that the dark night can …..

by day and night, he's traitor to
0 'tis true: this nighit he makes...

this niglit to be controllers ..........

this night he dedicates to fair content

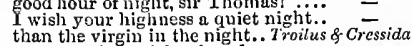

to answer in a nighlt alarm..............

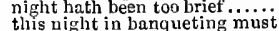

not meet witl you to-morrow niglit

and this whole night hath nothing.

and tell $y$ ou them at night.............

how ngly night comes breathing....
the dragon wing of night o ${ }^{\prime}$ erspreads

hy night frequents my house ...Timon of $\overline{\text { Athe }}$
band peasants, this night englutted!

it turns in less than two nights? ....

before black-cornered night, find that

cane news from him last nighit .....
more with the buttock of the night..

at his louse this night
as far as day does niglit

as far as day does night

and such as sleep o' nights

yesterday the bird of niglint did sit

submitting me unto the perilous nigh

a man most like this dreadful niglit

for now, this fearful nightt (rep.) $\ldots$
to show thy dangerous brow by night

awake, all night: know I these men

the unaceustomed terror of this night

dare the vile contagion of tlie night?:
Antony, that revels long o' nights...

\begin{tabular}{l|l} 
iiii. 2 & Antony, that revels long o' nights.. \\
iii, 2 & they mean this night in Sardis.....
\end{tabular}

iv. 4 the deep of night is crept upon .......

\begin{tabular}{l|l} 
iv. 4 & this was an ill beginning of the night \\
iv. 4 & yet ere night we shall try fortune....
\end{tabular}

\begin{tabular}{r|r} 
iv. & yet ere night we shall try fortune... \\
v. 1 by niglit; at Sardis, once $(r e p.) . . .$.
\end{tabular}

v. 3 nyight hangs upon my eyes ........

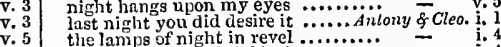

more fiery by uiglt'sblackncs............

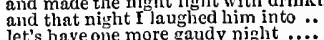

let's have one more gaudy niglit ....

to burn this night with torehes.....
the night is sliny; and, they say...

the poisonous damp of niglit cispunge

an argument that fellout last nightic

only for this night; I must aboard.

swift, swift! you dragons of the night

last night 'twas on mine arm ........"

but, in one night, a storm, or robbery

day, nighit, are they not but in Britain? -

may this night forestal him ..........

'tis almost night: you shall have....
the night to the owl, and morn to...

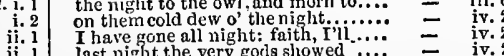

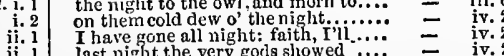

last night the very gods showed
been tronbled in my sleep this niglit. Tilus $A$ nd. ii.

at dead time of the night .i..........
for all the frosty nights thiat I.....

acts of black night, abominable $\ldots . .$.
barns aud haystacks in the niglit $\ldots . .$.
.

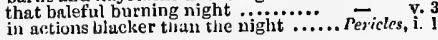
neither call it perfect day, nor night would not spend another such a night
the kinglom of perpetual night and naked, to the numb-cold night?

and, tliree nights after this, about

and dreaming night will lide our joys
NIGHT-glorious walk, or peaceful night. Perictes, i.2
under the covering of a careful night..

for your sweet music this last night....

a turbulent and stormy night (rep. $^{\circ}$...

she died hy niglst: I'll say so...
one mortal night drove him to....

will offer my nipht oblations to thee..

the mysteries of Hecate, and the night.... Lear,

why, the night gone by ..................

by day and night! he wrongs me $\ldots . . . .=4.3$

iv. 2 now i' the niglt, i' the haste

v. 7 for though it he niglt the moon shines..... till night, my lord; and all night ton... Tlearned the night before there was $\ldots . .$.
alack, the night comes on, and the bleak

this a wild night; my Regan counsels wel

here's a night pities neither wise men

things that love night (rep)

this is a brave night to eool a courtezan

the tyranny ot the open night's too roug.

in such a night to shut me ont (rep.)
this cold night will turn us all to fools

this is a naughty night to swim in ......

what a nisbt's this? 1 do bes

i' the last night's storm I sneli a fellow

what $i$ ' the storm? $i$ ' the night? ...........

have stood that night against my fire

himself an artificial night ....... Romed

behold this night earth-treading stars

come Lammas-eve at night ........

this night you shall beliold him .....

seek happy nights to happy days....
she gallops night by night through

plats the manes of horses in the night =

hangs upon the cheek of night iike...

I ne'er saw true beauty till this niglat

scorn at our solemnity this night....
consorted with the humorous night

as glorious to this night, being o'er..

I have niglt's cloak to hide me from

thou know'st the mask of night is on

Which the dark night hath so diseovered -

sweet sound lovers' tongues by nighit

morn smiles ou the frowning night ..
and night's dank dew to dry ........

you gave us the counterfeit last ni...jit =

must be my eonvoy in the secret night =

and bring in cloudy night inmediately =

love-performing nightt.....................

eome, niglitl come Roneo, come? (rep.) =

lie upon the wings of night whiter night; come, loving, black-browed night =

night; come, loving, black-browed night =

as is the night before some festival..

your Romeo will be here at night

night's candles are burnt out........

day, night, late, early, at lome

and that very night, shall Romeo bear

provision; 'tis now near night .......

the horrible coneeit of death and night

sick to-morrow for this night's watching =

all niglit for lesser cause ............

for the next night, I wariant $\ldots$ th......
son, the night before thy wedding-day $=$

muffle me, night, awhile ..............

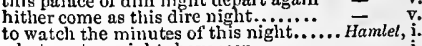

what we two nights have seen $\ldots . . . . . . .$.

usurp'st this time of night

doth make the night joint labourer......
bird of dawning singetl all night long..

the niglits are wholesme.................

the dead waist and middle of the night..

the third night, kept the wateh ...........

wonld the night were come

making niglit hideous $\ldots$ a certain term to wa....................

O day and nigltit, but this is wondrons

niglit, night, and time is time (rep.).....

the night resemble when he lay couehed

we'll have it to-morrow

this night to play betore him.............

'tis now the very witching time of night

your patienee in our last night's speech.

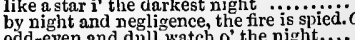

odd-even and dull watch o' the night....

rajse some speeial officers of night $\ldots \ldots . .$.
goodness of the night upon you, friends.

messengers this very night t..............

in eouncill in this time of the night! .....

not yet made wanton the night with her 
NIGHT-what, man! 'tis a night of revels. Othello, ii. that's said or done amiss this night.......

in night, and on the court and guard ..... $=$ ii.

seven days and nights? eight score

if $I$ shall see you soon at night

poison, Ingo, this night

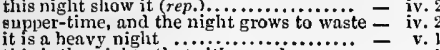

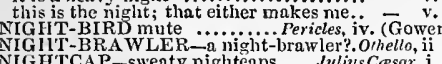
NIGHTCAP-sweaty nighteaps .... Julits Casar, i. NIGIIT-CROW-the night-crow cried.3 Henryll.v. IG IIT-DOG-night-dogs rnn ... Merry Wives, v.
IIGHED - to despatch his nighted life.. Lear, iv. Hamlet cast thy nighted eolour off $\ldots$. Hamlet, VIGHT-FLIES-buzzing night-flies. 2 Henry $I V$.
NLG HT-FOES-from night-foes $\ldots . .3$ Henry $V I$. NIG ITGOW N-it's but a nightgown. Much Ado, iii. 4 get on your niglitgown, lest oecasion... Macbeth, ii. throw her nightgown upon her, unloek

put on your nightgown; look not 60 pale

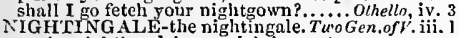
to the nightingale's complaining notes - v. 4 nightingales answer daw

an 'twerc any nightingale .....Mid. N.'s Dream, twenty caged nightingales. Taming of $\$$ h. 2 (induc.) sings as sweetly as a nightingale

my nightingale, we have beat. Antony \& $\&$ Cleo. iv. 8 poor Tom in the voice of a nightingale.. Lear, iit. IGIITLY - with nightly tears. Two Gen.of Ver. $\mathrm{i}$ I nightly lodge her in an upper

harbour with my Silvia nightly ...... $\bar{w}_{\text {ing }}$ iil. arunk nightly in your company.. Twelfh Night, 1 . in nightly revels, and new jollity.

nightly sizgs the staring owl. Love's $\bar{L} . L,-\bar{v}$ v. dreams, that shake us uightly

作 unless the nightly owl, or fatal Titus, indron. ii. or shut me nightly in a eliarnel-house

[Col.Knt.] with sweet water nightly.

[Col.Knt.] nightly shall be, to strew thy $=$

so nightly toils the subject of the land..Hamlet, i. give me my nightly wearing, and adieu

NIGHT-OWL in a cateh........... Twelf $h N$

for night-owls shriek, where $\ldots \ldots$. Richard III.
like the night-owl's lazy flight ....3 Henry VI.

NIGHT-RAVEN-the night-raven... Much Ado

NIGH'T-REST, and neighbourhood. Timon of $A$ th.i

NIGHT-RULE now abont this. Mid. N.'s Dream, iii. I

NIGHT-SHRIEK-a night-shriek ..... Nacielh
NIGHT-TRIPPING fairy had ...... IlenryI

NIGHT-WALKING heralds that ... Bichnrd II
NIGHT-WANDERERS, laughing. Mid.N.'s Dr.

NIGH'T-WATCH constable....... Love's L. Lost,

IGHT WORK alive? She lives ...2 IJenry IV

NIIII - for absque hoe nihil est .....
NILE-my serpent of old Nile? ...Antony $\bar{q}$ Cleo.
melt Egypt into Nile! .............

melt Egypt into Nile! . . Nï.

they take the flow o' the Nile ......

the aspick leaves upon the caves of Nile - y.

NILUS-a'erflowing Nilus presagetl.. Antony \& Cleo. i.

by the fire, that quickens Nilus' slime

rather on Nilus' mud lay me

hast thou the pretty worm of Nijus

Iike Nilus, it disdaỉneth bounds. Tilus Andron. 3ii. nor I my spirits are nimble

awake the pert and nimble spirit..... prisons up the nimble spirits .... Love's L. Lost, iv. 3 you have a nimble wit; I think. As you Like il, jii. 2
who with her head, nimble in threats

a quick eye, and a nimble hand.. Winter's Tale, iv. as nimble jugglers, that deceive... Comedy of Err. i. 2 nimble mischance, that art so .... Richard Il. iii. but with nimble wing we $\ldots \ldots \ldots \ldots$ Henryl $V$. v full of nimble, fiery, and delectable.2HenryI $V$. iv. 3 be with a nimble galliard won
the nimble gumner with linstoek to make your vessel nimble ......... Cymbeline, ii. gently qreneh thy nimble.............. Merictes, iij. in the most terrible and nimble stroke.... - iv. 7

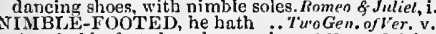
the nimble-footed mad-eap prinee.. Henry $1 \%$. iv. TMBLE-PI -and nimbleness.. Julius Cosar, IMIBLER-nimbler than the sands.. Cymbeline, iif. IMBLY and sweetly recommends .... Macbeth, i.
that rise thus nimbly by a true .... Krichard II. iv. that rise thus nimbly by a true .... Kichard $I_{\dot{*}}$ i

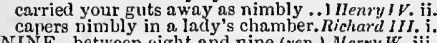
NINE-between eight and nine (rep.).Merry W. iii
the youngest wren of nine comes. Treelfh Nigh, iii. by nine to-morrow morning ......Me us fnr. Weas. ii. nine, sir; Over-done by the last. Ninel one that is a prisc

one that is a prisoner nine years old
studied eight or nine wise words .....Mrch $\overrightarrow{\text { dito }}$, iii. 2
the nine worthies (rep.)
NINE-thure times thrice is nine ... Love's L. Lost, I always took three tlection, si

eleven widows, and nine maids.. Mer. of renice, ii. 2 'tis nine o'clock; our triends

an hour ago, since it was nine..... ds you Like it ii. 7 was seven of the nine days ont .... $\overline{\text { iti. } 2}$ nine changes of the watery star...Winter's Tale, $\mathrm{j}$.? and the third, nine, and some five

eary screnuights, nine times niDe.

that hath eaten her nine farrow

these nine in buckram, that $I$......

better than the nine worthies.

made a king at nine months old?

I was but nine months ofd

in Paris but at nine months oid

supper-time, my lord; it's nine o'clock

sixty and nine, that wore.. Troil

I will buy nine sparrows for...... Cressida, (proi.)

to Isidore he owes nine thousa

there's nine that I know.

he hath been ont nine years

but new struck nine

the eloek struck nine, when I $i$ did....

and trom nine till twelve is tbree...

or nine year; a tanner will last (1e.p.). . Hamle

he hath laid, on twelve for mine $\ldots$....... till now some nine noons wasted.

at nine $i^{\prime}$ the mornlng here we'll

NINEFOLD_-and ber ninefold..... Lear, iii. A

I have for ${ }^{2}$ and seventeen .... Ners. for Heas.

INETEEN zodiacks have gone. Meas. for MIeas

Canidius, our nineteen legions... Antony \& Cleo. ii

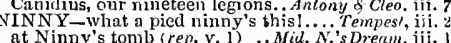

at Ninny's tomb (rep. v. I) .. Mid. N.'s drenm

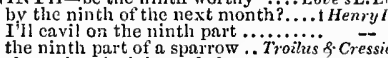

the ninth part of a sparrow ... Troilus \& Cressida
about the ninth hour, Iady . O.... Julius Cassar
ere the nintb hour, I drunk. Antany \& Cleopalra

'tis the nintl hour o' the morn ...C Cymbeline,
NINUS' tomb, man (rep. v. I)... Mid. N.'s Dream,
IOBE-make wells and Niobes. Troiluso-Cress.

like Niobe, all tears; why she, even she. Hamle

thin weeds, nip not the gaudy.... Love's L. Lost,

here's snip, and nip, and cut. Taming of Shrew,

these tidings nip me.

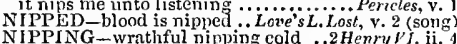

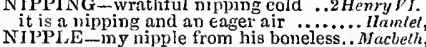

taste the worm wood on the nipple. Rnmeo \& Jaliet,

thou nit, thou winter

Taniting of Shrew, iv.

Noali's flood could not do it.. Comedy of 1 .

Noalr's flood could not do it.. Comedy of Errors, iii.
NoB-I would not be sir Nob in any... Kintr John, $\mathrm{i}$.

OBIIITY-against his own nobility. All's Well, iv. 3

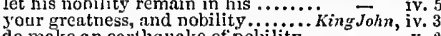

do make an earthquake of nolility ...

that men of your nobility and power
but witl nobility, and tranquillity..

stand aside, nobility. 'This is.

where stained nobility lies trodden on

.

peers, and cbief nobility, destroyed.. - iv. I

and our nobility will scorn the match $=$ iv.

as, like to pitch, defile nobility ....2 Henry $F t$ ij. 1

sueh high valunts of his nobility

the nobility think scorn to go in

anc the nobility held in contempt...Richard 111 . i.

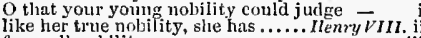

farewell nobility

the state of our tlespised nobitit

would the nobility ay aside the

the nobility are vexed, who, we see

the nobility of Rome nre his........... $\quad$ - $\quad$ iv. 7

to justice, continence, and nobility. Tilus Andron.

sweet mercy is nobility's true ladige..

sith trute nobility warrants these
with no less nobility of love ........

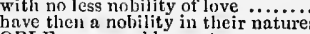

Hamle

BLE-8ome noble creatures .......... Tempest,

that a noble Neapolitan.

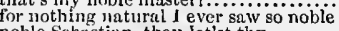

noble Sebastian, thou let'st thy

no, nolle mistress; 'tis fresh

first, noble friend, let me
NOBLE-know, noble lord, they. Tuo Gen, of Ver iii.
a noble duke jn nature ........... T'uetgh Night,

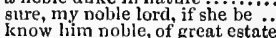

more noble than the world

liere comes my poble or

Orsino, noble sir, be pleased that I

to serve this noble count

betore so noble and so great..............eas. for $\mathrm{Ne}$

had a most noble father.

thou art not noble

thou art too noble to conserve $\ldots \ldots \ldots . .$.

how now, noble Pompey?

noble prince, as there comes light....

jardon me noble lord

jardon me noble lord ...............

in eompany of the right noble

he is of a noble strain .....

how noble, young, how rarely featured

you learn me noble thankfulness $\ddot{3}$, noble sir, your over-kindness

he would play the noble beast in love

got a calf in that same noble feat.... .

none, of noble sort, would so offend..

tragical, my noble lord (rep.)

here come two noble beasts in, a moon

sir, the king is a noble gentleman. Love's

the nolie lord most lionourably doth

your most noble kinsman, Gratiano. $M$

caskets to this noble prinee ..........

you have a noble and a true conceit.

i noble judgel (rep.) .................

breaks his staff like a noble goose.... -

upon my parents, his all noble ..........A. Al's $l_{V e l l}, \mathrm{i} .3$

your pardon, noble mistress! .........

we shall, moble captain ................

but you will, my noble grapes........

this youthful parcel of noble bacheiors

not one of those, but had a noble father
fields, where noble fellows strike ....

stuch is his noble purpose

God save you, noble caltain

or a noble scar, is a good livery $\ldots \ldots$.....

of her that threw it; noble she was ..

lay a more noble thought upou

some noble gentleman.. Tamizg of shrew

observed in noble Iadies unto their -

to sce her noble lord restored ... $=1$ (induc.)

thice noble lord, Iet me entreat $\quad-\quad 2$ (induc.)

the spouse of any noble gentleman

of your most noble offer...........

these lords, my noble fellows

he is touched to the noble heart.......
to see his work, so noble, vilely bound up?

too noble for this place ...............

he secms to be the more nobie in being =

most noble sir, that whieh I shall report -

but, $O$, the noble combat, that

my noble partner you greet ....

great prediction of noble having

fair and noble hostess, we are your
you do unbend your noble strength

good-morrow, noble sir! .................

your noble friends do lack you .......

I should ent off the nobles for their

yocdnff, this noble passion,
your right noble son, lead

the noble thanes do bravely

is missing, and your noble son . .......

died your noble mother.

spoke like a spriteful noble gentleman

my nobles Icave me; and my ........

your nobles will not hear you........

a noble temper dost thou show

so, nobles shall you all, that knit....

hail, nohle prince of France

y, noble English, you are .............

hath received eight thousand nobles.

for you, my noble lord of Laneaster.

let no noble eye profane .............

of youl, my noble cousin, lord Aumer

I am the last of' noble Edward's sons

his noble hand did win what he ...

the nobles hath he fined for

[Col.] his noble ancestors achieved.....

his noble kinsman: most degenerute

the nobles they sre fled ............... i.
ii.
ii.
ii.
ii.
ii. 2
ii. 3
ii. 3
ii.
ii.
iv. 3
v. 5
iv. 5
v. 3
v. 3
v. 3
ue.)
uc.
uc.)
ule.
ic.)
i. 2
v. 5
i.

iii. 3

iv. 3

v. 1

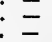

- ii. 3 


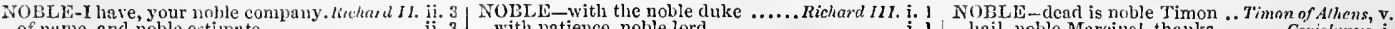
makes us rich, most noble lord my noble uncle! sliow me thy ton late, 1 fear, my nuble lord noble lord, go to the rude ribs his unble eutin is right

noble Giloster's death (, ep.)............. princes, and noble lords, what answer = in this noble presence were enough noble thanks, noble peer; the eheapest .... that the noble Miortimer

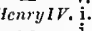

by our noble and chaste mistress...

nor never could the noble MLortimer.

those same noble Scots, that are.

cannot ehoose but be a nolle piot..... pleasing eve, and a most moble earriage = my noble lord, from Eastcheap (rep.) = wh the world with noble horsemanship galtant warrors, and noble gentlemen this litter age with noble deeds. a noble eail and many a ereature else the noble Stot, lord Douglas $3 . . . .$. . the noble Percy slain, and a noble earl, I bring you ecrtain new's from shrewsburv, my noble

so fonght the noble Douglas ......... my most noble friends.

et it be but twenty nobles.

baek from Wales, my noble lord?

wherein

till that the nobles, and the armed..

reverend to to my noble husband....

my most noble lord of Westmorelarn

to $y$ on, my noble lord of Westmoreland -

and noble offices thou may'st effect.

and he, the noble image of my youti

the noble ehange that I have purpuscd! -

tis ealled Jerisalem, my noble lold

such limbs of noble counsel...

and lielen of thy noble thouglits

noble English, that could en tertain

a mourning widow of her nobi

the noble sinews of our power........

a noble shalt thou have, and present have my noble? in casl.

my princes, and my nohle peers

coine they of noble family?....

tinat hath not moble lostre iu

Lord in heaven bless thee, noble Hiarry! -

joy fully, my noble lord of Bedfurd.

he noble carl of Suffolk also lies..

and nolles bearing banners.

the names of those their nobles....

that nobles should such stomachs bent -

ay, fill that noble earl, and was behcoted -

that two such noble peers as je...

see, noble Charles! the beseon of ...

the young IIenry, with his nobles. lies -

in lonour of $\mathrm{my}$ noble lord of York.

of the garter were of noble birth

hear him, noble prince! (rep.).........

rescue of the noble Talbot (rep.) .....
cries ont for noble York and Somerse

while he, renownct noble rentleman

basely thed, when noble Talbot etond

my uoble birtly. "Tis true, I gave a noble thinu, nor thy nobles, to the

rure deseliption, noble eark ...........

bear liim like a noble gentleman...

fur my part, noble lords, I carc not..

noble slie is ; but, if she have tiorgot.

here, noble lienry, is my sta

then, noble York, take thouk this task

well, nobles, well; 'tis politicly done

(tall him presently, my noble lord

and noble stock was graft with....

never of the Nevil's noble race.....

how now, my noble lord? what all .

but, noble as he is, look where lie eom

noble Warwiek, Cobham, and tbe rest.

when as the noble duke of York was
eheer these noble lords, and hearten

the noble gentleman gave up the ghost

my noble queen (rep.)

where a noble heart hath pawned...

thanks, noble Clarence; worthy .....

\section{ii. 3

(1)
at Cluertsey monastery this noble king

towards Chertsey, noble lord?

two days sinee were worth a noble...

befill thee, and thy noble house $i . .$. .

anc youn noble lords (rep.)

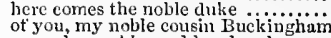

some, less noble, and less loyal ...

if that our noble father be ali

t say, with noble Buckinglian

I say, with noble Buckingham......
the nobles were committcd
[Col. Kut.] liow fures our noble brotlier?

eousio, noble lord of York?

comments lim to your noble lordship

good-morrows to my noble lord: ....

now, noble peers, the eause why we

noble lord [Col. Knt. lonourable lords]

my noble lords and eotsins, all......

this noble [Col. Knt. prineely] presence

I do nnt doubt, right noble princes.

noble York, my princely father.

being nothing like the noble duke

entreat your grace, my noble lord

the noble isledoth want her proper.

draw forth your noble aneestry.......

nend her a letter of thy noble deeds...

come, noble gentlemen, let us

sueb noble scenes as draw ...... Hcnry $V \overline{L I}$

the very persons of our noble story

cliallenged the noble spirits to arm

when these so noble benefits shall

not in your spleen a noble person...
no doubt, he's noble; he had a black

in all this noble beyy

that noble lady, or gentleman

your graec is noble: let me.
a noble troop of strangers.

a noble company! what n

rest show'ed a most noble patience..............

and see the noble ruined man

his noble friends, and fellows........

made my name once more noble ....

thist needs say, a noble one

the trial just and noble..

all strangers' loves, $y$ ou are so noble

she is noble born; and, hke her tr.

may it please you, noble madam....

ont of his noble nature, $z$ cal and....

that noble title your master wed me

you have a gentle, noble temper

a 110 bile spirit as yours was put ........

his noble jury and foul cause ......

as you are truly noble, as you

stir him, (I know his noble nature)

so"rood, so noble, and so true..........
is that old noble lady, duchess of...

noble madam, men's evil manners

noble lady, first, my own service

that his noble grace would have.

good husband, let lim be a noble.

men so noble, however fauty

to a most noble judge, the king

two noble partners (rep. v. 4).....

in noble eminence enthroned. Troilus \& Cressida,

find the welcome of a noble foe.

be brought home noble piize.

dull and factious nobles of the Greek

your greatuess, and this noble state

noble Ajax; you are as strong (rep.)

do depend upon a noble gentleman..

and tell me, noble Diomed ............

most nohle 'Timon, eall the man....

I pr'y thee, noble lord $(r \in p$.$) ............$

my lord, there are certain nobles

other noble parts you'll suit, in.

grent 'Timon, noble, worthy ........

a nolyle gentleman' tis, if le would not

for his right noble mind, ilitstrious

my noble lord, - ah, my good friendi

here's a noble feast towar

busc, noble; old, young; coward......

our late noble ninster.

80 it is said, my noble iord

speak to them, noble Timon $\ldots . . . . .$. .

noble, and young, when thy first

march, noble lord, in to our eity......

my noble general, Timon is dead... i. 2 and noll him Marcius! thanks

i. 2 youl ery against the noble senate....

i. 3 noble Lartius! Hence! to your homes

noble Auficlius, take your commission

o nohle fellow! who, sensible, ontdares =

i. 4 my noble steed, known to the eamp

ii. 1 plebeians would the noble Mareius..

. 9 and the nobles............

ii. 2 and, ont if lis noble carelesenesta.

ii. 2 to gratify his noble service ............

ii. 4 he's right noble; let him be called for

iii. I his noble deeds, we must also tell (rep.)

iii. 1 God save thee, noble consul! worthy

iii. 2 the noble house o' the MIarcians....

passed the nobles [Col.Knt.-noble] aud

\begin{tabular}{l|l} 
iii. 4 & or nerer be so noble as a consul....... \\
iii. & -4
\end{tabular}

iii.
iii. 4 prefer a noble life before a long......

I pr'y thee, noble friend, home to...

his nature is too noble for the world

the noble tribunes (rep.) $\ldots \ldots . . . . . .$.

iii. 5 well said, noble woman..............

iii. 5
iii. 7
therein you can never be toon noble..-

iii. 7 noble ladyl come, go with us .......

iii. 7 amen, nuen! a noble wish ............

\begin{tabular}{l|l} 
iv. 2 & the gods preserve our noble tribunes \\
iv. 4 & craves a noble cunning..................
\end{tabular}

craves a noble cunning.................

more noble blows than ever $\ldots$ m.....

against the senators, patricians, and nobles-

for the nobles receive so to heart .... -

feasts the noules of the state.

j. 2

permitted by our dastard nobles......

all noble Mareius, - let me $\ldots$ li....;

that I sce thee here, thou noble thing
the nobles, in great earnestness.....

unless the noble man have merey...

ii. 1 to make coals elieap: a noble memory

ii. to make coals cheap: a noble memoryl -

ii. 1 a noble fellow, I warrant him........ =

ii. 1 the noble sister of Publicola

ii. 1 to show a noble grace to both parts...

ii. 2 the man was noble, but with his last

honourable for a noble man still ....
most noble sir, if you do hold the

ii. 4 read it not, noble lords (rep.)...

the man is noble, and his fame $\ldots . . .$.

regarded as the most noble corse ...

h'et he shall have a noble memory wished that noble Brutus -

have wished that noble Brutus ...Julius Ca

till then, my noble friend, ebew......
he is a noble Roman, and well given

of any bold or noble enterprize.....

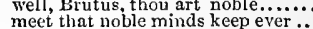

win the noble Brutus to our party

whieh every noble Roman bears of

render me wortly of this noble vife!

the fortunes and aftiairs of noble Brutus -

with the most noble blood of all .... -

most noble! in the presence of thy corse?

noble Antony, go up (rep.) ..........
for when the noble Cxsar saw (rep.)

but that my nobie master will ......

most nuble brother, you have done...

glad to learn of noble men ..........
my heart is thirsty for that uoble pledge

noble, noble Cassius (rep. v. 3) .......

by noble Brutus' power (rep.)..........

we must not: a noble prisoner!......

now is that noble vessel full of grief

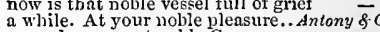

every hour, most noble Cresar ......

then, noble partners, (the ratlue

noble Antony, not sickness should cletain is noble, courageons, high, unmatchable -

Rome cast on my noble fither........

noble Ventidius, whilst yet with ....

most noble Antony let not the pieee

my noble brother! the April's in her

Onoble emperor, do not fight .......

the noble ruin of her magic, Antouy

most noble sir, arise; the queen ....

ay, noble lord. Snntetime, we see....

was Antony, most noble Antony!

from me then that $n$ ble countenance

my uoble girls! ah, women, women!
stained with his most noble blood

that I shu uld not be noble to myself

now, noble Charmian, we'll desuateh

house hior an instif to praise my noble act

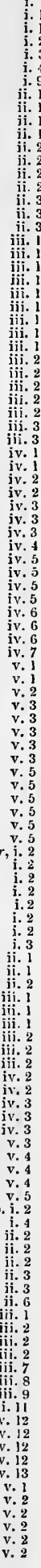




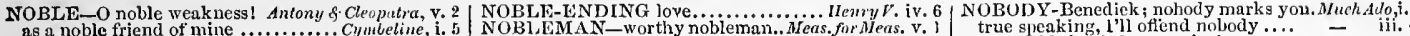

as a noble friend of mine ...............

more noble than that runagate

I had rather not be so noble as $\mathrm{I}$ am

after the noble temper of your lordship

fore noble Lucius present yourself.".

my noble mistress, leve is a box

s), furewell, noble Lncius

ty

o noble strain! o worthiness is't since

that promise noble service

otherwise than noble nature did.....

saved the noble Imogen to repent...

O noble misery! to be i' the fick

most like a noble lord in love....

to make the noble Leonatus mad....

noble patricians, patrons of my ...Tilus

my noble lord and father, live in farne gentle tribune, noble brother Marcus

and service of their noble country ."

and thanks, to men of noble mitus (rep.) ...........

aecompany your noble emperor......

no man shed tears for noble Mutius

this noble gentleman, lord Titus her

lose not so noble a friend

great reason that my noble loed

O noble father (rep.)

thy noble [Col.-aged] eyes to weep (rep.)

for that noble hand of thine

the heads of thy two noble sons......
farewell, Lavinia, my noble sister

farewell, Lavinia, my noble siste

wilt thou betray thy noble mistress.

to see thy noble uncle thus distrac
then, noble auditory, be it known

the last true duties of thy noble son!

yonrself then, moble Helieane (rep.)

my actions are as noble as my

when noble Perieles shall demand

to think of what a noble strain ...........

pupils lacks she none of noble race

of gentle, kind, and noble stock.....i.

thou art a grave and neble counselior
it seems you have been noble towards li

noble sir, if you have told Diana's...

do you know this noble gentleman

right noble Burgundy (rep.)

and the noble, and true-luearted Kent

maledictions ugainst king and nobles.

father, and a brother noble ...................

how now, my noble friend?..........

lail, to thee noble master! How

touch me with noble anger

when nobles are their tailors' tutor

noble philosopher, your eompany

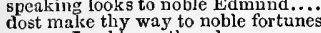

yet am I noble, as the adversary

if my speech offend a noble heart.....

if thou art noble, I do forgi noble Kent, your friend.

you lords, and noble friends

my noble uncle, do you know ...

o noble prince, I can discover ali....

thy noble shape is but a form of wax

she shall be married to this no

[Col. Knt.] a gentleman of noble

noble county Paris (rep.) ......................

seek for thy noble father my noble father's perso

doth all the noble substanee of ten

but know, thou noble youth ..............

your noble son is mad

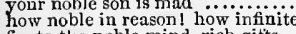

for to the noble mind, rich gitts

$O$ what a noble mind is here o'erthrown

now see that noble and most sovereigu

no noble rite, nor formal ostentation....

he, which hatl your noble father
and so have I a noble father lost

trace the noble dust of Alexander

that is Laertes, a very noble youth

forgiveness with me, noble Hiamle

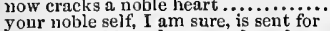

my very nobleand approved good master

do you perceive in alt this noble company

and, noble signior, it virtue no delighted

what say'st thon, noble heart

a noble ship of Venice hath seen ........

our noble and valiant general, that

our noble and valiant general, that
of Cy'prus, and our noble general

lads of Cyprus, noble swelling spirits...

lads of Cyprus, noble swe ling spirits...

my noble lord (rep.)

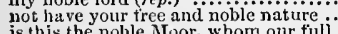

is this the noble Moor, whom our full

this the noble nature whom passion ....

I hope, my noble lord esteems ine hones

ling the forsook so many noble matches.
such noble sense of thy friend's wrong .

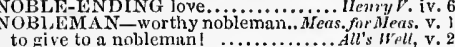
name was Antigonus, a noblena............ Winler's Tale, jii. dar'st thou brave a nobleman?
my lord, there is a nobleman of

Wiearts -

muny a noblcinan lies stark and stiff

live eleaniy, as a noblemun should d

fanltless may condemn a noblema

to see a nobleman want manners..Henry $\bar{F}_{H}$. iij.

O there's a nobleman in town .. Romeo \& Juliet, ij. 4

converse with noblemen „...Tun Ge

NOBLE-MINDED Talbot ................

NOBLEN ESS of birtl......

to see his nobleness! conceiving ...

may undergo, and nobleness impose

but signs of nobleness, like stars .......Macbeth

[Knt.] then true nobleness wonld.... Richard II. iv.

stamp and nobleness in any person Henry VIII. ii

whose stal-like nobleness gave. Timon of 'thens,
flitterers, foes to nobleness ........ Coriolanus, iij.

inform thy thoughts with nobieness....... $\overline{\text { cleo. }} \mathbf{\mathrm { v }}$.

got upon me a nobleness of recor

cliarming wi th their own nobleness... Cymbeline, y.
greater than nobleness and riches .... Perreles, iii.

iii. 1

gait dicl prophecy a royal nohleness

NOBLER-yet with my nobler reason... Tempes! v.
but kindness, nobler ever than ...As yon Like it, iv.

was in my nobler thoughts most........ All's Hell,

thy nobler parts against these ........King John, iil.

and spoil your nobler soul! $\ldots \ldots \ldots$..... Hemry VIII. i. 2

moon, were she earthly, no nobler.

you do the nobler. I muse, my mother..

there's not a nobler man in Rome.Julius Casar, iii. 2

thrice nobler than myself! .......

$\mathrm{O}$, this life is nobler, than attending. Cymbeline, iii.

a garment nobler than that it covers

a nobler man, a braver warrior

whether 'tis nobler in the mind........ Hannet,

NOB [.ESS [Knt.-nobleness] would ...Richard $H$.
$[$ Knt.] nobless English, whose blood.

OBLEST-the noblest grace she owed. Tempes!, iii. 1

so I do, the noblest that I have.... Tu elfh hi
the noblest deer hath them as.... As you Like

you noblest [Knt.-nobless] Englisl ... Henry V.

the noblest

who can bring noblest minds to.

art the ruins of the noblest man ...ju

now, most noblest Brutus, the gods

this was the noblest Roman of them ail

this was the noblest Roman of them all -
tis your noblest course.... Antony \& Cleopatro

prince o' the world, the noblest

he is one of the noblest note... Cymbel

demand a prisoner, the noblest ta'en - letter

the noblest that survives, the cl
call the noolest to the audience

NOBLY - sin to think bot nobly of my.

kinds of baseness are nobl

that sometimes savours nobly?

reports of men very nobly held

a scar nobly got, ol a nuble scas.

very nobly have you deserved

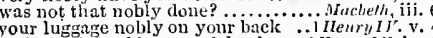

both parties nobly are subdted

for you are more nobly born...

and, pray, receive them nohly

'tis nobly spoken: take notice

so stale his paln, nobly acquired... Troil.\& Cress. ii.

I had rather had eleven die nobily for. Coriolanus,

bear the addition nobly for ever!

to hear what you have nobly done

he has done nobly, and camiot...

nobly named so, being censor...

every Roman bears, and nobly ... ulitius Creser.

'tis nobly spoken ............ Antony \& Cleopatra

our foree by land liatli nobly lield

you have been nobly borne ...

nobly doomed! will learn our.

will use you nobly, and your...Tiluss Andronicus, i.

yes, and will nobly him remuinerate

of Hitylene, speaks nobly ot her ....... rericles, $\mathrm{v}$.

sir, you speak nobly ........................ Letr, y. 1

NOBUDY, by the pieture of nobody . Tempest,

I aurra go glail you have nobody here just, said she, it luurts nolooty

nobociy will steal thent from thee

nobody sliould be sad but I
but eyes, and nobody sees m

or no es, and nobody sees me

klie has mobody to do any thin

wind, that profits nobo

who, I? why, lie'll answer nobody

nobody will look after it .............

touch not you, it comes near nobod

let nobody blame him, his scorn..
nobody come? then shall I bleed to den
nobody; I myself; farewell: commend

NOCES-baisees devant leur noces......
NOD-did she nod? (rop.).... Tu' Gen.

nod, I? why that's nodd

nod to him, elves, and do him...Nid.N. Dream,

my lord, you nod .... . . iming of Shreur, $\mathrm{i}$. 1 (incluc.)

if thoul canst nod, speak too

if thoul canst nod, speak too.
with nods, with rolling eyes.

nod their heads, and

duek with French nods and apisi... Rickerte 111, i. 3

ready with every nod, to tumble ..... iit.

you shall see him nod at me (rep.). Troil. dress.

half-caps, and cold-moving nods ....

to a molelinl should in smpplication nod - v. 3

if Cosar carelessly but nod on him.Julius Corsar, i. 2
if thou dost nod, thou break'st ....... iv - 3

that nod nnto the world... Antony \& Clcopatra, iv 1 .

as her winks, and nods, and gestures... Hamlet, iv. 5

Cleopatra hath nodded him to her ..
NODDING violet grows..........Mir.

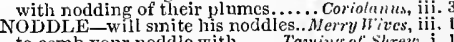

to comb your noddle with .... Taming of Shreer, i.
NODDY-why that's noddy (rep.) Tu.oGen. of Ier.

nothing but the word noddy ......... 'NOT' - i.

then 'nointed over with honey ...W'Hinter's Tale, iv.
NOISE-insolent noise maker .......... Tempest, i.

there was a noise, that's verit

no noise, and enter

with strange and several noises............

but hark, what noise? (rrp.)......Meas. for Meas. iv.

you shall also make no noise in ....... Much $A$ do, iii. 3

he goes but to see a noise .....Mid.N.'s Dream, iii. !

doth noise abroad, Navarre hath. Love's L. Lost, ii, 1

and to make no noise when

in tune, so it make noise enough. As you Like it, iv.

there's noise in it: 'tis hard ........... All's If'ell, ii. 3
what noise there, ho? no noise . Winter's Tate, ij. 3

that keep all this noise? .... Comedy of

didst thou not hear a noise?

and what noise is this? sliow 1

what is that noise? it is the ery

from forth the noise and rumour....

without the noise of threatening ..Richure II. iii. 3

to find out Snealk's noise

let there be no noise made

less noise; less noise. Who saw ..... - iv. 4

what noise is this? what traitors ....1 Hewry $b^{\prime} I .1 .3$

if any noise, or soldier, you perceive $-{ }^{2}$ ji. 1

what noise is this I hear? dare ans be - iv.

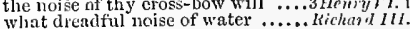

that, with the yery noise, 1

a noise ot urets; or to see

such a noise arose as the shrouds .....

you'll leave your noise anou..........

what noise? what shrick is this? .... - ii. -

their noise be our instruction $\ldots . . .$.
hink, what w

from the noise of our own drums....

being but the horm and noise o' thie..
unsliont the noise that hanished ....

bid every noise be still: peace yet..jutius Cirsar,

the noise of battle hurtled in the air = ii.

lark, boy, what noise is that?........ \& Clenpatro.

to a truh, that noises it against 1 s... $\quad$ - iii.

peace, that noise so far as we $\ldots . . . \cdots$
follow

whercfore's this noise? here is

to the luuldest of noise we make ..... Cymbeline, iii. 5

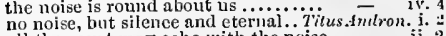

and mark their yelling noise........ $=$ ii. 3 
NOISE-ghasted by the noise I made make no noise, make no noise; dra mark the high noises; and thyself ...... - iii. I hear some noise within; dear love What noise is here? O lamentalle das yea, noise? then I'll be bricf ......... and then a noise dicl scare me from... thy tongue in noise so rude arainst but soft, what noise? who ealls on but, stay, what noise? how now what warlike noise is this? what noisc? the town is empty but, hark 1 what noise? you rogue who's there? whose noise is this what noise is this? not dead! noise was high. Ha! no more movingi it is noised, he hath a nass.... Timon of $A$ ither NOISELESS foot of time ................Al's $H^{\prime}$ ell. $\mathrm{v}$. sprearls his banners in our noiseless land. Leat
NOISOML-foul breath is noisome ... Much Ado root away the noisome weeds.... a pile of noisome, musty ehaf Will be both noisome and infeetious... Cymbeline, can you nominate in order now bat suddenly to nominate them ail..2 Henry VI. nominated for an equal pound is it so nominated in the bond?
NOMLNATION of the party

what imports the nomination of this ... Homlet, $\mathrm{v}$. NONAGE-tha, in hise (rep.) NONAGE-that, in his nonage a riddling merchant for the nonce... i Henry $V I$.

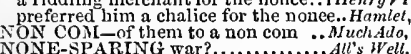
NONE-SPARING war?.....................'s Well, iii. 2 NoNNY-hey nonny, nonny .. Nuch Ado, ii. 3 (song) says suum, mun, ha no nonny no nonny, nomny hey nomy .. Hamlet, iv. 5 (son
NONPAREIL-calls her a nonpareil.. Tempest, iji erowned the nonpareil of beauty.. Twelfh Night, $\mathrm{i}$ thou art the nompareil doth my wife the nonpareil of this.. Cymbeline, ii.
NON-PERFORMANCE, 'twas.... Winter's Tate, $i .2$ NON-REGARDANCE cast my ... Twelfh Night, v. NON-SUITS my mediators
NoOK-in the deep nook

many winding nooks he strays... Fi..... Gemper $v e s$ and to live in a nook merely $\ldots$... As you Like
NoOK-SHOTTEN isle of Albion.... Henry

\section{NOOK-SHOTTEN isle of Albion .... Henry V.} business must be wrought ere noon ... Hacbeth, iti. Ascension-day at noon ( $1 \mathrm{cp}$. v. 1) ... King Joltn, Ascension-day at noon (icp. v. I) and on that day at noon, whereon . 3 Henry I shadow which he treads on at noon.. Coriolan $z$ to reel the streets at noon..... Antony \&-Cleopntra at noon, at miduight, to eneounter .. Cymbeline and I'll go to bed at noon.

is now upon the prick of noon ...............

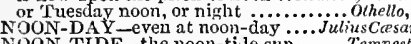
NOON-TIDE-the noon-tide sun. noon-tide with the Antipodes. Wid. N. s Dream, ii morning, and the noon-tide night... Richard II TORFOLK-against the duke of Forfolk Thomas of Norfolk, what say'st we'll calm the duke of Nortolk ....... = the doke of Norfolk (rep.) ...........
Norfolk, for thee remains a heavier Norfolk, so far as to mine ellemy.
I heard the banished Norfolk say with a gage, that Nortolk lies till Norfolk be repealed.

why bishop, is Norfolk dead?

Thomas Nowbray, duke of Norfolk. to all the duke of Norfolk's siguories $-\overline{-}$ and I to Norfolk, with my followers shalt unto the duke of Norfolk. your brother, Nortolk, and nyyself..
where is the duke of Norfolk, gente
now, if the help of Norfolk, and myself in Suffolk, Norfolk, and in Kent. attendant on the duke of Norfolk.... Richard $I I I$. friend post the duke of $N$

my lord of Norfolk (rep.) ........... = with the lark tn-morrow, gentle Norfolk --
John duke of Nortolk, Thomas earl of what thinkest thou, Norfolk? A good my ord of Norfolk, reseue, reseue!..

my lord of Norfolk, as you are....Henry $\overline{V I I I}$ next, the duke of Norfolk, he to be earl ard that my lord of Norfolk? Yes .. the old duehess of Norfolk, and lad $\dot{y}$
NORMAN-revolting Norman NoRMA NDY deep seurs in France and Normandy? eounties were the keys of Normandy

giving up of Normandp unto mo

here was a gentlemau of Normandy... Hamlet, iv. meet meat the north gate (rcp.). TuroGeu. of Ver. iit. welfih Nigh', iii. it stands north north east .. Love's L. Lost, i. I I (let.) $_{\text {. L }}$ hy the north pole, I do challerge.......

from east, west, north, aud south.. ivinter's Tale, i. I from the north ................. King John, ii. 2

from north to south; A A ustria

towards the north, where shivering. Richard II. V. eame from the north, and thus.

the Hotspur of the north

that same mad fellow of the north
my moiety, north from Burton.

and on this north side win

east, west, north, south; or, like

the Pereies of the north

at Berwick in the north

pursued the horsemen of the north ...3 Henry ${ }^{2}$. i. post with him toward the north

the best breed in the north. Henry fly east, west, north, south.

tyrannous breathings of the north ... Cymbetine, $\mathrm{i}$. the north side of this pleasa

the grizzled north disgorges such. Pericles, jii. (Gow.) Whe frozen bosom of the north ... Rnmeo \& Juliet

I am but mad north nort 1 west......... Hamlel, ii. NORTHAMPTON, and in..........3 Henry VI. Stafford and Northampton, I arrest. Henry VIII. i. NORTHAMPTONSHIRE; and eldest King Joln,
NORTH-EAST-north-east wind.... Richrord II, NOR'THERLY - the wind is northerly . Hamlet, $v$.
NORTHERN-like a northern man. Love's L. Lost, $\mathrm{v}$. bolted by the northern biast

to toueh our northern shore........

and all your northern castles yielded - iii.

proud northern lord, Clifford........2 Henry $V I$.

with all the northern earls and lords
with

I am constant as the northern star.Julius Cessar, iii.

angry northern wind will blow.. Tirus Andron,
NURTHU

eonfident to speak Northumberland.Richard II.

not proclaimed Northumberland...

beseem the lord Northumberland, to say -

North me berland, say, thus the king
slatl we call baek Northumberland

Northumberlaud eomes baek from..

my lord Northumberland, what says

it no more, my lord Northumberland
Northumberland, thou ladder where

Northumberland, thou ladd
part us, Northumberland...

part us, Northumberland.

my lord Northumberland, we lieensc
and old Northumberland; and that

pereeived Nortlmmberland did lean

the sickness of Northumberland ...

to meet Northumberland, and the ..
old Northumberland, lies $\ldots 2$ Henry

npon the enraged Northumberland!

and the earl of Northumberiand ...

up head without Northumberland

againsc Nortlumberland, and the -
my lord Northumberland will soon

my lord Northumberland will soon
sinee Rieliard, and Northumberland

and rated by Northumberland ...

that great Nortluminberland, then

the bishop and Northnmberland are

earl Northumberland, and the lord..

Grey of Northumberland (rep.)....

earl of Northumberland, he slew thy

rough Northumberland (rep.) ,

speak thou, Northumberland,

Clifford's and Northumberland's (rep.)

the son, and two Northumberiands

Nortlumberland, then present .... Rich

what said Northumberland, as ...... - v.

the remnant northward. iying off ... Henry $J V$

threw many a northward look......2 HenryI
NORW $A Y$ himself, witl terrible.... ... Iacbeth

Sweno, the Norway's king, erave

Macbeth,

by Fortinbras of Norway, theret

hath in the skirts of Norway, here and

wearers of this greeting to old Norway

the embassadors fiom Norway

what from our brother Norway?
receives rebuke from Norway
NORWAY-Norway, overeome with joy. Hamlel, ii. powers are tlese? they are of Norway nor wifl it yield to Norway, or the Pole - iv. NORWEYAN lord, surveying vantage... Mactelh, i. 2 in the stout Norweyan ranks..............
NosE-_ifted up their noses at which my nose is in great indignation - iv. as a nose on a man's face. . Tu'o Gien. of lerona, ii. to hear by the nose, it is duleet...... - ii. nor this is not my nose neither........ - i make liin bite the law by the nose.

did not I pluck thee by the nose

to have had our two noses snapped...Mucth Ado, v. this eherry nose, these yellow...Mid.N.'s Dream, v.
sometime through the nose .... Love's L. Lost, tii. your nose says, no (rep.) ............ that my nose fell a bleeding ... Merch. of Venice, ii. the bagpipe sings i' the nose .......... with spectaeles on nose, and pouch.. you need not to stop your nose (rep.)
I'll slit the villain's nose .... Traming of Shreu,
$\mathbf{v}$. what, hast smutehed thy nose? .. Winter's'Tale, i. I have seen a lady's nose that has

eye, nose, lip, the trick of his frown.

masks for faces, and for noses.

reeeives not thy nose eourt-odour
lic is oft led by the nose witl gold

hic is oft led by the nose with gold
$O$ sir, unon her nose, all o'er. Canned

to be billast at nose, all

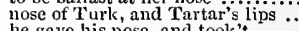

he gave his nose, and took't $\ldots . . .$.
bloody noses, and craeked crowns

yea, and to tickle our noses

let them the nose of thec

whose zeal burns in his nose.......... Henry

for his nose was as sharp as a pen.

and his lips plow's at his nose.

his nose is exeented, and his fire's out

wring him by the nose $\ldots \ldots \ldots \ldots .2$ Henry VI. iii. their very noses had been counsellors Henry VIII. i. more wasps that buz about his nose

of the dog-days now reign in's nose.
three times was lis nose discharred

Troilus for was his nose discharged - v. 3 in love, $i$ 'faith, to the very $\dddot{t}$ ip of the nose $\bar{A}$ iii. down with the nose, down with it. Timan of $\overline{A t h}$. iv. 3 see your wives dishonoured to your noses and still to nose the offeree............ not in ny husband's nose ... Antony \& Cleopatrn, i. for wearing our own noses........... Cymbeline, iii. cleanly by the keeper's nose? .... Tilus Andran. ii. ......Lear, i. all that follow their noses are led $\ldots \ldots \ldots$ - i. there's not a nose among twenty ........ th wart men's noses as they lie............. she gallops o'el' a eourtier's nose

tweaks me by the nose, gives me the lie. Hamlet, you shall nose him as you go up stairs ...
will as tenderly be led by the nose .......
at Naples, that they speak i' the nose... - ii. pish! noses, ears, and lips: is it possible? = iv. i see that nose of yours, but not that dor - jv.

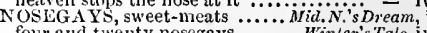
four and twenty nosegays........... Winler's Tale, iv.
NOSE-HERB - they are nose-herbs ...All's Hell, iv. NOSELES, handless, hacked . Troilus \& Cress. y. 5
NOSE-PAINTING, sleep, and urine ...Macbeth, ii. 3 NOSE-PAINTING, sleep, and urine .. Macbeth, ii. 3
NOSTRIL-Stephano breathes at nostril. Tempesi, ii. strike the dullest nostril where.... Winler's ' Inle, i. and streteh the nostril wide..........Henry $V$. iii. I
his nostrils stretehed witl struggling..2 Hen.. $\mathrm{I}$. iii. smokes elimb to their nostrils ....... Cymbeline, v. 5 as ever hit my nostrils................. Perictex, iit. 2
NOTABl,E-a notable lover.Tuv Gen. of Verona, ii. a notable lubber, as thou............. come by some notable shame?...... = turu him into a notable eontemp

notable piratel thou salt-water thiefs $-v$. thou wilt prove a notable argument.. Much Ado, i. i he's a most notable coward.............Al's Well, ii. 6 a notable passion of wonder....... Winter's Tnte, $v$. O notable strumpet!

No'TA RY - with me to a notary. Mlerch. of Venice, $\mathrm{i}$. NOTC11ED-and notehed him...... Cariolanus, iv. 5 yet note their manners............... T Tempest, ii. $^{-}$ii. a tune, give me a note ................. of $\overline{\text { Verona, i. }}$ to take a note of what that is the and goes to them by his note......... 
NOTE-habit of some sir ot note.. Twelfh Night, iii. 4 NOTE-service as if he were of note .. Cymbeline, v. 3 NOTHING of what is writ...... Meas. for Meas. iv. 2

a good note: that keeps you .......... - iii. 4

fairly note this act of minel

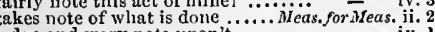

a due and wary note upon't...

my lord lath sent you this note.....

pray you, take note of it $\ldots$

do it in notes. Note this before $(r e p$.

iv. 2

why then, take no note of him.

- ii.

iii. 2

when I note another man like, $\dddot{2 . . .},-\overline{\text { v. }}$.

whose note full many a man .... - iii. 1 ( nong)

ear is much enamoured of tlyy note.

to each word a warbling note..........

men of note, (do you note, men?.....

my forehead wipe a perjured note...

bears not so strong a note.............

二 iv. 3

, 2 (song)

f come by note, to give, and to $\ldots . .$. .

for, do but note a wild and wanton

that they take no note at all ........

tune lis merry note unto...As you likike it, $\overline{\mathbf{i}} .5$ (solig)

I'll give you a verse to this note

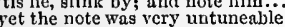

no note upon my parents.............

All's Well, i.

as notes, whose facultics inclusive (rep.) -

preepts on this virgin, worthy the note -

ii. 3

offence of mighty note

one cliff, two notes have $\mathrm{I}$..... Taming of Shew, i.

one cliff, two notes liave I......

though long, our jarring notes agrec $-\overline{-}$, v

the shepherd's note, since we have

didst note it? he would not stay at..

dates, none; that's out of my note...

taking angry note, have left $m$

were very notes of admiration

With thy note, to drown me in...Comedy of $\bar{E}_{r r}$. iii.

shall be done a deed of dreadful nö..... Macbelh,

rest that are within $t$

one of greatest note seems bruited .....

$O$ what love I note in .............King John, iii.

taking note of thy abhorred aspect

perusing o'er these notes, may know $\overrightarrow{-}$ the more to a $\mathrm{v}$

to take note low many pair .......2Hen.y $I V$. ii. 2

we will hear, note, and belicve.

Henry $V$. i. 2

the king hath note of all that ....

give dreadful note of preparation.

sonuanee, and the note to mount.

I'll note you in my book of memory.

first note that he is ner you....2Henry $V$.

now to sing a raven's note ............

from the this most needful note ..Rickard III. v. 3

he gives us note, the force of ........Henry $F I I 1$. i. I

please your higlmess, note this .......

and high notes taen of your many

play me that sad note I named...

do you note, how much her grace is
mark him; note lim; 0 brave.. Troil

mark him; note liln; $O$ brave.

and give him note of our approach

a loud note to Troy.................

no notes of sally, tor the beave

my lord, here is a note of certain dues

note me this, good friend.............. Cor
which, without note, here's many else

they have ta'en note of us

note but this fool : was not ..........

rather than pity note how much $\ldots . .$. .

and take good note, what Cesar doth

ever note, Lucilius, when love

you must note beside that we have...

never noman shall take note of him $-\overline{8}$ v. 3

and note the qualities of people.

note him, note him, good Charmian (rep.) -

three in Egypt cannot make better note -

the world should note something.

left these notes of what commands

he was then of a creseent note

he is one of the noblest note

but my design? to note the cliamber

ah, but some natural notes about.

be it lying, note it, the woman's

first with the best of note............

use like note, and words, save that

for notes of sorrow, out of tun

waste their time upon our note....... a verring notes of chamber-hanging... - y 5

it sung sweet varied notes

note, how she quntes the leave........ - iv. 1

note it not you, Thaisa?

that I may worthily note hi

may have due note of lim............... Lear, ii.

I do advise you, take this note

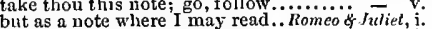

whose notes do bent the vaulty..... $\quad$ - iii. 5

for let the world take note.............. Hamlet, i. 2

to note that you know aught of me......

five him hecdf these notes, Reynaldo.

Idid very well note him

sound me from my lowest note to ........

note, it your lady strain his ......... Othello, iji.

take note, take note. O world, to be direct - ii. 3
NOTE-BOOK-in my note-book.... Merry Wives, $\mathrm{i}$.

old tables; his note-book

set in a note-bock, learned.
NOTED-I noted her not.

raven was well noted...................... Muche's L.Lost, iv, 3

from you, noted well your passion .. $-\overline{\text { iv. }} 3$

not noted, is't, but of the finer ..... Winler's Tale

and honesty, is richly noted

our noted out ward garments $\ldots \ldots \ldots . . .1$ Henry $I V$. i.

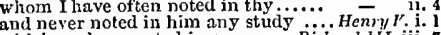

which we have noted in you....... Riehard III. jii. 7

can take her clifr'; slie's noted .... Troilus \& Cress. v. 2

I have noted thee always wise. Timon of Alliens, iii. I

than of duty; we have noted it .... Cymbeline, iii. 5

slips have made him noted long... Titus Andron. ii. 3

ro more of that: I have noted it well .... Lear, i. 4
late I noted in tattered weeds ...Romiso \& Juliet, v. I

as are companions noted and most .... Hamlel, ii. 1

the world
NOTEDLY-most notedly, sir... Meas. for Meas. v.
NO'E-WORTHY object in thy..Two Gen.of Ier. i.

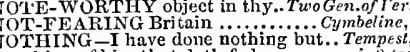

OTHING -I have done nothing but.. Tempest, $\mathrm{i} .2$
nothing of him that doth fade $\ldots \ldots-$ i. 2 (song)

for nothing natural I ever saw so noble

thou dost talk nothing to me...........

am nothing to you ........

I heard nothing $\ldots \ldots \ldots \ldots \ldots \ldots \ldots \ldots$

but my rejoieing at nothing can be more

and yet say notliing neit]

why I said nothing..................

where I shall have my music for notiling

is nothing, but heart s sorrow $\ldots$ instruetion hast thou nothing bated

iil.

nothing but the word noddy

nothing but the word noddy $\ldots . . . .$. her -

so gingerly? Nothing.................

my duty, will I bonst of, nothing else

all $I$ can, is nothing to Jier.....

and say nothing, it will

nothing. Can nothing speak?.........

as nothing is impossible

othing but my fortume.

' faith, I'll eat nothing (rep.)....... Merry

my brows become nothing else $\ldots \ldots . .$.

p would little ur nothing witli you ..

we know nothing. ..............

they were nothing but about $\mathrm{I}$ and nothing for it neithe

he hath enjoyed nothing of Ford' $\mathrm{s}$.

that nothing can dissolve us ...........

do nothing but reprove.............

he speaks nothing but madman ....

always makes a good voyage of nothing -

if that be to care for nothing, sir.....

you'll nothing, madam, to my lord

he does nothing but smile...

what can be said? Nothing....

nothing but this, your true..........

negligence, nothing of my purpose ..

twill be nothing yet ...

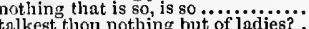

you broke my head for nothin

you set notling by a bloody coxcomb

if nothing lets to make us happ

and nothing come in partial.

that do nothing but use their........

for thunder, nothing but thunder

are dedicate to nothing temporal.

let me be ignorant, and in nothing good = if he be less, he's nothing; but he'...

why, you are nothing then: neither

say nothing, I'll speak all $\ldots . . . . . .$. nueh $A d o$

too like an image, and says nothing

sqy nothing, I am yours for the walk

that her ear lose nothing of the talse

or a cloak, is nothing to a man

nothing, unless you render her again

love nothing in the world so well (rep.)

confess nothing, nor I deny nothing my liand meant nothing to my sword I lesire notluing but the reward of..

will lend nothing for God's sake...

nothing certainer: one Hero died.

I will think nothing to any purpose

oath with oath, and you will nothing

bc certain, notling truer; 'tis no jest

what's your will? nothing

sixpence a day, in Pyramus, or nothing

and gives to airy nothing a local

it is nothing, nothing in the world ..

to give them thanks for nothing ....

for he is dead; he is nothing ..........

nay nothing, master Moth, but what

and tlierefore. I will say nothing....

shall break it, will, and nothing else

and yet nothing at all .............

mothing but fair is thot which you

imitari, is nothing: so doth the......

makes nothing sir. If it mar nothing =

where nothing wants, that want

came nothing else along with that? (rep.) -

in the letters; nothing in the praise -

nothing but peace, and gentle

we number nothing that we spend ... of $\bar{F}$

reputcd wise, for saying nothing ....

is Portia; nothing undervalued to

as they that starye with nothing

he doth nothing but frown.........

you know, I say nothing to him

alas, fifteen wives is nothing could do nothing without biding

it was not for nothing that my nose

farewell, mistress; nothing else..

[Col. Knt.] sum of me is sum of nothin

else nothing in the world could turn

rating myself at nothing (rep.) .......

he sliall have nothing but the penaity

shalt have nothing but the forfeiture

a halter gratis; nothing else $\ldots . .$.

notling is good, I see, without respect

gain nothing under him but ........As

know not why, hates nothing more

notling remains, but that I kindle..

for in it I have nothing ............

they owe me nothing; will you sing?

and we will nothing waste till you..

have seen much, and to have nothing

I will weep for nothing like Diana.

to prey on nothing that doth seem

kiss his hand, and say nothing...

art thou good for nothing but taking.... - ii. 2

why, I say nothing. Marry, you are

nothing, to do nothing (rep.)

to pass a thonsand nothings with....... - ii. 4

sir, I can nothing say, but that I am......

are nothing like your old ling and your - iii. 2

well born, nothing acquainted with these - iii. 7

it nothing steads us, to chide him ......

nothing, but let him lave thanks ........

honest man should have, he has nothing

as nothing can unroot you

which nothing but to you ............ - v. 1

is nothing but a mighty lord. Taming of $\mathrm{Sh}$. I (induc.)

let them want nothing $m y^{y}$ house

madam, and nothing.....

why, nothing comes amiss, so money

why, that's nothing (rep. ii. 1) ......

faitl nothing; but be has left........

notling but erost!

undone and brought to nothing ........

Padua afiurds nothing but what is.... 
NOTHING-and fellowest nothing.. Winter's Tale, i. 2 ( NOTHING-nothing do bnt meditate.. Henry $V$. is whispering nothing? is this nothing why........... ls this nothing? why, then (rep.)...... betrayed'st Polixenes. 'twas uothing betake thee to nothing but despair patience to you, I'll say nothing.... there is nothing in the between but.. requires nothing but seercey .........
that from very nothing, and beyond. apprelend nothing but jollity nothina she does, or seens, but smacks man, thou shall lose nothing liere.... let him go and nothing marted witl him acrain does nothing but what he did.. whose joy is nothing else but tair but nothing altered; what I was, I an shall nothing benefit your knowledge nothing so certain as your allchors soug, and admuing the nothing of it ounit nothing, may give os aid to the king concer'ns
nothing but bonfires notling so aged, as this seems ......... nothing, sir; but that I am beaten . that jou gave me for notling (rep.). for that's nothing but words $\ldots . .$. but her foce nothing like so cjean $\mathrm{kept}$ thou art sensible in nothing but blows sent for nothing hut a will jou be bound for nothing?................ nothing afeard of what thyself didst......Mucbeth, nothing is, but what is not

repentance; rothing in his life .......... there's compose noting but males to be thus, is nothing

foreign levy, nothing can touch which is nothing to those that know nothing is the love

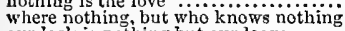
our Iack is nothing but our leave
ouly in command, nothing in love ue doubt it aothin

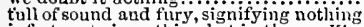
infortunate in nothing but in thee ...King Joh she again wants nothing, to name that nothing do I see in you

nothiog can allay, nothing but biood there's nothing in this world cau. nay, nothing is so black $\ldots \ldots \ldots \ldots \ldots . .$. shoula nothing privileçe him

stay for nothing but his majesty 's..
boast of nothing else, but that I... nay, nothing; all is said

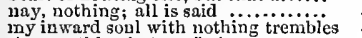
show nothing but confusion........... heavy nothing tiint and slrink (rep.) Where nothing lives, but crosses, care = speak of nothing but despair

nothing can we eall our own .........
lord's seale is notling but bimself no; ay; for I must notlung be... that nothing have, with nothing grieved 二 my lord. 'tis nothing

nothing but some bond

and straight am notning

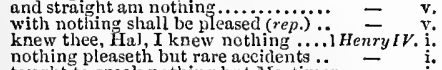

taught to speak nothing but Mortimer

there is nothing but roguery to be found -

wherein worthy, but in not

lord $\ldots \ldots \ldots=$

then should you be nothing but musical -

tor nothing ean seem foul to those that =

in account nothing so strong, and.... -

that you did nothing purjose 'gainst

nothing confutes me but eyes

than to be scoured to nothing iviti

and say nothing, he is virtuous......

where nothing but the sound...

and are etceteras nothing?

if he do nothing but speak ( $r \circ p$.)

where he doth nothing but roast

when there was nothing could have staid-

skill in the weapon is notlling .....
nothing but well to thee, Thoma

do notling but eat, and mak

lack nothing, be merry; look who's..

thinking of nothing eise (rep.)

good corporal, offer nothing here ..... IIen

there's nothing so becomes a man

there be notling compolled from

all that I can do, is nothing worth..

eternal shame, nothing but shamel.
and buv nothiug of me but eudgels.

and nothing teems, but hateful docks

do impart lolp nothing else.

by nothing; for this is no onth.
owls! nothing but songs of deat

it will help me nothing, to plead

more than my all is nothing.

ye turn me into nothing: woe upnin ye

can nothling render but allegiant thanks -

pelformance, as he is now, nothing....

1 fear nothing what ean be said against
you did nothing, sir. I am not Samson

You did nothing, sir. I am not Samso
nothing of that shati ........ Troilus 8
Jove's accord, nothing so fuil of heart

infaney, that nothing can'st but cry

he eats nothing but doves..........

are grated to dusty nothing

that he raves in saying bether ......

nothing but heavenly business should

let us cast away nothing

the other blank as nothing

were nothing; he is both an a.s. (rep.)

nothing but lechery! ail incontinent

nothing at all, unless that this were she

nothing else liolds fashion

if doing nothing be death by the lay

no, I will do nothing at thy bidding

ask nothing, give it him, it foals me

'faith nothing but an empty box....

like tritles, nothing eomparing to hi

strict, and war is nothing more...

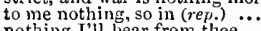

it wonld the gods had nothing else to do -

this peace is nothing, but to rust iron

and nothing else? (rep.)..............

sooth, madian, I hear nothing .....

nothing but death slali stay me ....

see any thing? Nothing, my lord (rep.)

pity to cast them away for nothing ..
her passions are made of nothing but
cross him in nothing ................

for I can do nothing buit what in .....

when you liave nothing else to do

dangers, would then be nnthing ....

there's nothing in ler yet...........

to Rome: nothing more dear to me.
heard you of nothing strange (rep.).

and there is nothing left rcmarkable

a princely haud, fear nutl in

that I have reserved to myself nothing

and Thave nothing of woman in me

but nothing, (always reser ved my....

I would nbate her nothing ..........

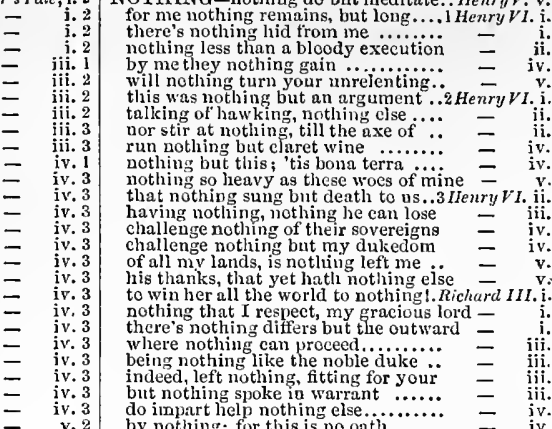

ii. 5

love, love, nothing bnt love (rep.)

of nothing so much, as tliat ..... Timon of Athens,

iii. 1

and nothing more, may fitly like your

reading? Nothing, my lord...............

ii.
iii. 1 there is notlzing done, if he return
thow art in nothing less than $I$ have

thou talkest of nothing...............

$O$, she says nothing, sir, but weeps.

and all for mothinter, did nothing......

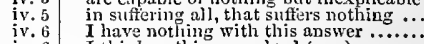

v. 4

ii. 4

ii. 6

iv. 6

for here's mothing to be got now-a-day

you'll losthing ean be ministered

yet nothing we'l] omit that bear.

nothing, my lord. Nothingt (rep.).......

ueh.....

ii. 3 it' it be nothling, lahath not need spectacles -

iii. 1 nothing like the image and horror of it... -

this is nothing, focl..................

nothing for't: can you malke no use (rep.) -

iii. 3 notling can be made out of nothing .... -

I am a fool, and thou art nothin...

ace bids me, though you say nothing

have you nothing said upon his party

away, I have nothing to do with thee.....

something yet; Edgar I nothing am

v. 2 in their fury, and make nothing of ......

$v .2$ pattern of ali patience, I will say nothin

go to; say you nothing; there is division

death, traitor I nothing could lave.....

in nothing am I clianged, but in $\mathrm{my}$

who, nothing hurt witlal, hissed ... Romeo of Jul. $\dot{i}$.

sle speaks, yet she says nothing

look to hear nothing but discords

nothing, but une of your nine lives

and $I$ am nothing slow, to slack his.

must, and nothing may prorogue it..

nothing can be ill if she be well (rep.)

I have seen nothilkg. Horatio says....... Hetrilet, $\bar{i}$.

vele

but to be nothing else but mad

ng either good or bad

and cals say nothing: no, not for a king

discomfort ynu, my lord, it nothing mu

see nothing there? Nothing at all (rep.)

what dost thou mean by this? Nothing.

my though ts be bloody, or be nothing

though nothing aure, yct much unhappil

song)

(n)

二 iii. 4 v.

Will nothing stick our person to arraign

that he conld nothing do, but wish.............

and nothing $i<$ at a like goodness still ...
methought, there was nothing meet -

trace him, his umbrage, notling more

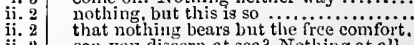

can you discern at sea? Nothing at all..

for $I$ an nothing, if not eritical .......

are nothing to your English

to speak the truth shall nothing wrong.....

a mass of things, but notling (rep.)......

nothing, my lord; or if -1 kuow

tis something, nothing; twas nine

, nothing, but to please his fantasy ....

yet we see nothing done; sle may he.
sueh perdition as notling clise could . for nothing eanst thou to damnation add 


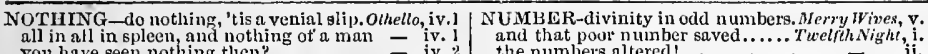

You have seen nothing then?...........

ay, and I liave sail nothing, bnt what

fear nothing; I'll be at thy elbow...........

nothing extenuatc, nor set down aught.".

Gen.uf ver. ii. 6

the inother notice of my attair...Mleas. for Meas. i. 5

give notice to such men of sort and suit

at the least of thy sweet notice.Love's $L . \overline{L .}$ i. I (let.)

Navarre had notice of your fair.

had mysclf notice of my brother's. As you Like it,

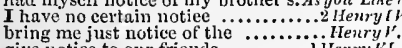

had notice of our friends ............

given me notice ot their villanies... - ini.

give us notice of his inelination ...Richard 111. 1il.

the state takes notice of the private. Henry

gave notice he was from thenec $\ldots . .$. -

to my poor unworthy notice........ Coriotanus, ii. 3

belike they had some notice....... Julius Ceesar,

who shall take notice of thee.

and echo, the numbers of the feared

for we liave a number of shadows

to know the numbers of our enemies

I judge their number upon, or near..

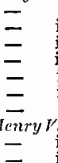

his numbers are so few, his soldiers sick -

too fuint a number; and for our disgrace
my numbers lessened; and those few

proud of their numbers...........
if the opposed numbers pluck their..
just notice of the numbers dead......

iv. (ehorus)

we must extend our notiee .........

I'll give but notice you are dead $\dddot{2} . .$.

to no more will I give plaee, or notice.

you'd take no notice; nor build.. Romeo \& Jutiet, v. 2

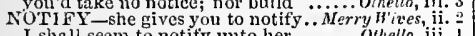

I shall seem to notify unto her......... Othello,

NOTING-that's worth the noting ..... Mue
notes, forsootl, and noting [ Col. -nothing]

by noting ot the lady

noting this penury, to myself I said. Romeo \& Jul. v. NoT ION erazed, say, thus did Banquo. Aracbeth, his own notion iwho wears my........

NOTORIOUS wrong ............... Ta elfih Night, v. and made the most notorious geck.... two notorions benefactors ........ neas.

I would it were not noturions ........A A $\imath^{\prime} \bar{s}$ Well,

yet I know him a notorious liar.

what, you notorious villain, didst. Taining of $S h$. v. to your notorious shame $\ldots$... Comedy of Errors, iv.
Alencon! that notorious Machiavel.. I Henry VI. v. shall be most notorious.............Henry VIII. ii .

wherein I did not some notorious ill.. Titus And.

some base notorious knave

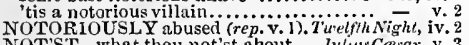

NOT'ST-what thou not'st about ...JuliusCasar, y. 3
NOT'T-PATED, agate-ring .......... Herry IV. ii. 4 NOTT-PATED, a gate-ring $\ldots . . . \ldots \ldots$ Herry $I$. . ii.
NoUN-many numbers is in nouns?.Mery Wives, iv.

because they say, od's nouns

usually talk of a noun, and a verb. 2 Henry $V t$. iv. 7
NoURISH all the world ............ Love'sL.Lost, iv. 3 such as you nourish the cause...... Winter's Tale, ii. 3 isle be made nourish of salt tears..... 1 Henry $V I$ whiles $I$ in Ireland nourish we nourish 'gainst our senate ........... Coriotanus, iii. j to nourish, and bring him up.. Titus Androniens, v. nourished in the womb of pia mater. Love's $L . L$. iv. 2 how begot, how nourished?. Mer. of Ven. iik. 2 (song) oozes from whence 'tis nourished. Timon of Athens, i. I say, they nourished disobedienee.. Coriolanzs, iji. .

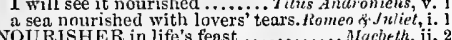

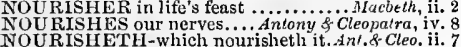
NOURISHETH-which nourishetly it..Ant. \& Cleo. ii. 7 NOURISIIING dishes, or $\mathrm{keep}$ you ..... Olhello, iii. 3 from whence they have their nourishiment? nourishment which is called.Love's L. L. 1. (letter) NOUSLE mp their babes ............... Pericles, i. 4 NOVELTX is only in request ...Aeas. for Meas. iii.

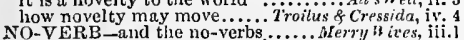
Novr hominem tanquam te $\ldots . .$. ... Love's L. Lost, v. Mars dote on you for his novices! .....All's Well, $\mathrm{ii}$, O you are novices! 'tis a world.... Taining of sth. ii.i last sold me to this novice. Antony s. Cleopatra, iv. 10 hast sold me to this novice. Antony ${ }^{2}$ Cleopatra, iv.
NovU A -abate a throw at novun. Love'sL.Lost, v. little company together now-a-days...iid.N. Nr. i i .

liere's nothing to be got now-a-days ..Perieles, ii. NOWL I fixed on lis head ..... Mid. N.' 's Dream, iii. 'NOYANCE-keep itself from 'noyance. Hamle', iii.

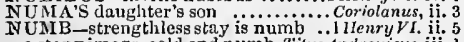
a stony image, cold and numb. Titus Androvieus, iii.
NUMB-COLD niglit? .............. Richard 111. ii. NUMBED-numbed and mortified........ Lear, ii. I thought there had been one number - iv. and the numbers of the genders! ....

here is the number of the slanglitered

is the number of our English dead?. make up no fuctious numbers for

people by number swarm to us ...3 Henry VI. iv. 2 descried the number of the traitors? so much I ain happy above a number
heart of our numbers ......... Troilus \& Cressida, i. 3 and sanetify the unmbers

dreadful Sagittary appals our numbers =

what $\Omega$ number of men eat Timon. Timon of $A t h$. i. 2

may thesc add to the number that

a certain number, though thanks to all -

with ns, the honoured number....

in thy Iying tongue both numbers...

among which number, Cassius ....Jut

yet in the number I do know but one
pricked in number of our friends....

the other street, and part the nurabers -

whose numbers threaten.... Antony \& cleopa

cast, write, sing, number, no, his love

we may the number of the slips .....

our present numbers be mustered.....

liot our slips and number of our men.

good report to a number to be chaste

speak 'gainst so great a number?

makes my number more $\ldots . . . . .$. lomeo
stand in numbel; though in reckoning

now is he tor the numbers .............

TUNBERED thirteen years...... Tueifih Night, iv.

be never numbered among men!... Mid.N.N's 'sr. iii. 2
are numbered in the travel of one, Love's L. Lost, v. 2

as when he numbered thirty

now lierald; are the deal numbered?. Henry $V$. iv. 8

stones 1 pon the numbered beach? ... Cymbeline, i. 7

NUMBERING too, I were the.

Richard Lt. $\mathrm{it}$.

numbering our Ave-1laries witl .3Henry $V I$. ii. 1
NUMBERLESS offences 'gainst. Henry VIII. ii. I

that numberless upon me stuck.. Timon of dih. iv.
NUMIBNESS-your numbness.... N'inter's Tale, v. 3
NUN-have you nums no further... Neas. for Meas. i.

NUN-have you nuns no further.. Neas. for Meas. i.
can endure the livery of a nun.. Mid. N.'s Dream, i. a nun of winter's sisterhood......... As you Litie it, iit. 4

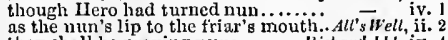
they shall be praying nuns ....... Richard /J1. iv. among a sisterhood of holy nuns. . liomeo 8 Jul.
NUNCIO of more grave aspect .... Twelfh Night, NCLis-how now, nuncle?

mark it, nuncle; have more than .......

five me an egg, nuncle, and I'll'give...
I have used it, numele, ever since thou

pr'y thee, nuncle, keep a schoolmaste

for you trow nuncle, the hedgesparrow

cry to it, nuncle, as the cockney did....

good nuucle, in, and ask thy daugliters

come not in licre, nuncle, here's a spirit

NE'y thee, muncle, tell me, whether ...... and that pour number saved........ Twetrit Nigh, i.

you slew great number of his people
more for number than accouut...Meas. for Mers, ii.

achiever brings home full numbers . .H. Hch dido, i.

in number more than ever ... Mid. N. s Drean, j.

thesc numbers will I tear, and write

now the number is even...............

numbers true; and, were the numbering -

we number nothing that we spend ...

sliadow the numbers of our host ..... King $\bar{J}_{\text {oln }}$, i.

or add a royal number to the dead... King Joln, il.
the little number of your doubtful ...
hath from the number of his...

hath from the number of his....... Richard 11. it.

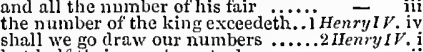

shall we go draw our numbers.
but lialf their numbers,

to number Ave-Maries on his beads .2 Henry VI. i. inerease the number of the dead .. Richard III. iv. I

is-numbering sands ................ to see fair Padua, nursery ot arts.. Taming of sh. $\mathrm{j}$. 4 from their nursery were stolen ....... Cymbeline, $\mathrm{i}$.

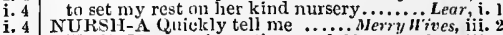
NURSING-nursing a thousand.Meas. for Meas. iii. the nursing of thy sons (rep.)......... ('ymbeline, y. 5
there I'll leave it at careful nursing ...'criclex, iii. I by nnrsing them, my lord................. Lear, v. 3 NU'T-and tetch the new nuts.Afid. N.'s Dreom, iv.
sweetest nut liath (rep.) ...As you Like il, iii.2 (ver.)

NUPTIAL-the nuptial of these our ... Iempest, v.
and the nuptial appointed ..... Meas. for'Meas. iii. the nuptial finished, let him.

hour draws on apace.....MLd.N.'sDr. i.

intended for great Theseus' nuptial day -

this same plas, against your nuptial - v.

strainht shall our muptial rites.. Mer. of lenice ii. 9

celebration of that nuptial ....... Winter's Tale, iv. 3

companion of his nuptial bed....... illenry FI. v. 5

that amity with nuptial knot......3 Hemy VI. iit.
as when our nuptial day was done.. Coriolames, i. 6
her clinstity, upon lier nuptial vow. Titus Aud, ii.

we'll eelebrate their nuptinls ........... 1'ericles, y. 3
dissipation of coliorts, nuptial breaches ...Lear, 1.2

since the nuptial of lueentio
of his nuptials [Kat.-nuptial]

URSE - will scratch the nurse. Fuo Gen. of V'er.

in the manner of his nurse (rep.)... Aferny $\vec{u}$ ires, $\mathrm{i}$. 2

is still the nurse of second woe .......

how if the nurse be asleep

and puking in the nurse's arms.. As
never let her nurse her child herselt

I am glad, you did not nurse lim. Winter's 'inte, ii.

where chance may nurse, or end it...

too old to fawn upon a nurse......... nichard I1. i. 3

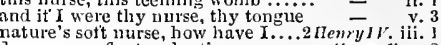

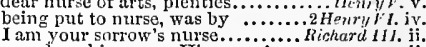

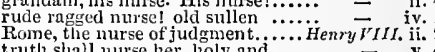

your prattling nurse in to a rapture. Coriolanus, ii.

the country, our dear nurse but at his nurse's tears he whe...

the beggar's nurse and Casar's...Aniony \& $\overline{\text { Cleo. v. } 2}$

Euriphile, thon wast their nurse...... Cymbeline, iii. 3

a loving nurse, a mother to his.... Titus and $\begin{gathered}\text { v. } 5 \\ \text { t. } 2\end{gathered}$

as is a nurse's song of lullaby...

and the nurse, well made away........

old nurse's [ Krit.-only mistress'] death

my father, as nurse said

nurses are not the fatc's.

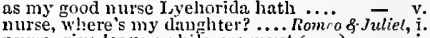

nurse, give teave awlile, we must (rep.)

the nurse cursed in the pantry

anome hither, nurse; what is yon

a gentleman,

what wilt thou tell her, nurse?.....

what say'st thou, belinc the abbey-wall

ay, nurse; whint of that? both with =

now, good sweet nurse (rep.)..........

my nutse, and she brings news (rep.)

come, nur'se; I'll to my wedding-bed
nurse! Al sir! ah sirl Well, deatl's

go before, nurse: eommend me to

Onurse! how shall this be prevented?

some comfort, nurse. 'Faith, here tis

nurse, will you go with me (rep.)...

and let the nurse this night sit up
nurse! what should she do here?

and fetch more spices, nurse ........

to the marriage her nurse is privy and they have nnrsed this woe. Titus Andronicus, iii. at Tharsus was nursed with Cleon .....'Pericles, v. 3 prettiest babe that e'er I uursed. Romeo \&. Juliet, i. 3 
NUT_goblet, or a worm-eaten nut.As you Like it, iii. 4 , OATH -would infringe an oath .. Love's. L. Lost, iv. 3, OATH-of oath, and big compare. Troilus\& Cress. iii.

can be no kernel in this light nut.... Alt's Well, ii. 5

with a fusty nut with no kernel. Troilus \& Cress

With a man for cracking nuts... Romeo of Juliet, iii.
NUTHOOK'S humour on me ........Merry W'ives, nuthook, nuthook, you lie .............. Henry IV. $\mathrm{v}$. nutmegs, seven; a race, or two.... W'inter's 'Tale, iv. 2 he's of the colour of the nutmeg....... Henry $f$. NUTSHELL_than a nutsliell........... Tempest, i. 1

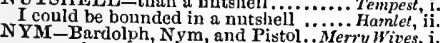
away, sir corporal Nym (rep.) ........
my name is $\mathrm{Nym}$................. you and your coach-fellow Nym...... $^{2}$ - ii. 2 well met, corporal Nym $(r \in p . \ldots \ldots \ldots$....... Henry $v$. ii. Nym, thou hast spoke the right live - i1. I Nym, rouse thy vauntin right

for Nym, he hath heard, that men

Nym and Bardolph (rep.iv, sea nymphs hourly ring his knell... - i. 2 (soug) you nje cold nymphs chaste crown . ollr oatlis, to find ourselves $(r e p . .$. of your eye must break my oath $\ldots . .$. your oath once broke, you force.... when I break this oatli of mine. never swore this lady such an oath ... played foul play with our oaths...... your oath I will oaths and gravitieg

hath ta'en his oath, and comes......... of $\overline{\text { ven }}$ I'll keep my oath, patiently to bear...

was dry with oatlis of love 7 worn an oath, that $\mathrm{I}$ will....

an oath, an oath, I have an with in.

yet for your velement oaths, you should and there's an oath of credit

never more will break an oath witli thee -

where learned you that oatly, fool? As you Like

full of strange onth

the oath of a lover is no stronger......

and by all pretty oatls that are not..

promises, enticements, oaths, tokens. $A l$ 's $W$

three great oaths wonld scarce make

tis not the many oaths, that make..

therefore your oaths are wordds.........

he professes not keeping of oathis.................

ask him upon his oath, if he does...

thinks with oaths to face ..... Taming of shrew,

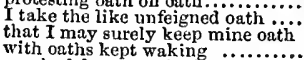

you had drawn oaths from him..........

or by oatherere the stars with onth

if word, nor oath, prevail not........

to be by oath enjoined to this.........

break my oath to this my fair

my crown, my oath, my dignity.........

with circumstance, and oaths....

I lave a king's oath to the contrary.

like a civil war, set'st oath to oath...

an oath the surety for thy truth (rep.) - iii.

thy voluntary oath lives in this .... $=$ iii. 3

according to thy oath and band...... Richard II.. . 1

come knighthood, and thy oath....

and take oned by oath

to keep the oath that we ..............

whom both my oath and duty bids..

all duteous oaths: [Col.-duties, rites]

the strong warrant of an oath

let me unkiss the oath 'twixt.........

a good mouth-filling oath

my oath should be, by thi

proffered him their oaths ..............

that oath at Doncaster (rep.)

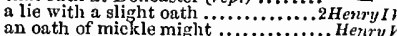

an oath of mickle might $\ldots \ldots . . . . . \ldots . . . H e$

for oaths are straws .................

trick up with new-tuned oaths

that she may tread out the oath

only downriglit oaths

we th take your oath.

our oaths well kept and prosperous be!

lords, your oaths to Henry ........... Henry

amity, and oaths, take your oath...

a ruler with unlawtul oatbs.

a dreadful oath, sworn with

against thy oath, and true allegiance

dispense with heaven for such an oath

sin, to keep a sinful oath .......

that here thou take an oath to cease..3Henry $V_{I}$.

this oath I willingly take...............

any oath may be broken (rcp.) .....

your oath my moment

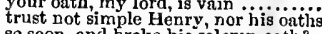

so soon, and broke his solemn oath?

ho soon, and broke his solemn oath

for my oath, here's for my father's..

his oath enrolled in the parliament.....

to frustrate both his oath, and what

since when, his oath is broke $\ldots . . . .$.

break an oath? No, never such an oath

but do not break your oaths

my holy oath; to keep that oath....

ii. I by notling, fur this is no oath ....... - iv.

to whom by oath he menaced ....... Henry $\bar{V}_{I I I . \mathrm{i} .}$ iv se did discharge a borrible oath....... - i.

\section{v. 3 that I affect the untracled oath}

I pr'y thee, do not hold me to mine oat

mour on his of thon of Ath. i. 2

brean

stale with ordinary onths my love...Julius $\bar{C}$ essar

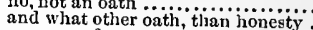

or our performance, did need an oath

the article of your oatl (rep.).......... Antony $\overline{8}$ Cleo

soul to the oath of loyalty ...........

as if I borrowed mine oaths of $\mathrm{him}$.

I will confirm with oath curtail his oaths -

whose false oaths prevailed before.... = ii. 4

with oath to violate my lady's honour
how canst thou believe an oath?.. Tilus Andron.

therefore I urge thy oath .............

thy word for faith, not ask thine oatl... Pericl hound by the

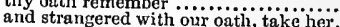

swore as many oaths as I spake words...

I loy's love, or a whore's oath

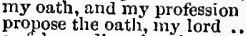
your wite in all obedience.. Taming of Sh. 2 (induc.) fair obedience, her new-built (rep.)

is the obedience to a master ..........Winter's Tale

contending 'gainst obedieuce, as they...Macbeth, ii.

to give obedierice where 'tis truly owed..

honour, love, obedience, troops of friends

from whose obedience I forbid my soul

our people quarrel with obedience ... - $\quad$ v.

obedience bids, I should not bid ....... Richard 11 v. and true obedience, of this madness.2 Henry $I V$. iv.

as an aim or thist obedience rise

our obedience to the king wipes

or bring him in obedience to your .... HenryVI. i.

to your obedience fifty fortresses... -

to hold your true obedience .....3 Henry $\boldsymbol{l}^{\prime} \boldsymbol{I}$. iv. obedience, and true duty!.Rich what kind of my obedience I should my thanks, and my obedience ....... zeal and obedience he still bore your with him is only iny obedience...... in all obedience makes the cluurch.

政 obedience fail in children l... Timon of Athens, iv. nut had a taste of his greater bench. Coriolanus, iii. learn a doctrine of obedienee..... Anitony \& Cleo. $v$. past grace? obedience? past hope..... Cymbeline, $\mathrm{i}$. a little witness obedience, which.... - ii. 3 you have obedience scanted, and weil .... Lear, i. in pieces the lieart of his obedience ...... whose virtue and obedience doth this $: .$. = i. if your sweet sway allow obedience...... where most you owe obedience? ............ Othello,

1 OBEDIENT-with this obedient steel.. Tempest, my people witl an obedient start. Tueth $h$ Night, ii. acting this in an obedient liope.

obedient to your graee's will ...... Meass, for Meas. ground witli obedient breast?.... Love's L. Lost,
own fortunes that obedient right .....All's Well, I am your most obedient servant..... $\mathrm{I}$ am tied to be obedient .. Taming of Shrew. that beat, and will not be obedient... - iv. and not obedient to hedient to com

Four most obedient counsellor ... Winter's Tale, ii. 3 will thereto be obedient, I Lave reason - iv. move in that obedient orb again ..... I Henry $1 F, \mathrm{v}$. do him homage as obedient subjeets. 1 Henry ${ }^{\prime} \mathrm{l}$ i or, like obedient subjects, follow ... Richard III. ii. a loyal and obedient subject is .... Henry $\bar{V} I I y$. ivi. 2 poison were obedient, and knew.. Timon of Ath. iv. he, obedient to their doom ............ iii. (Gower) 
OBEDIENT-make an ohedient faller .... Lenr $\mathrm{i} .4$ whate'er you be, I am obedicent......... Olkello, iii. 3
truly an obedient lady: I do beseech.... - iv.

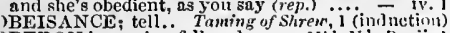
OBEISANCE; tell.. Taming of Shrem, 1 (ind net i.

I jest to Obernn, and make him smile

here comes Oberon. And here my...
wlyy should Titania cross lier Oberon?

for I must now to Obero

Oberon! what visions have I seeni... =

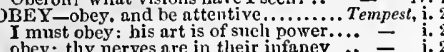

my spirits obey; and time

will senrce obey this medieine......ilerry ivives, iii.

if he bid you set it down, obey him.

he does obey every point of the...Tweifft Nights

I must obey: this comes with

let your flesh and blood obey

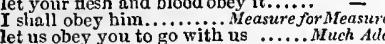

will not obey an old decree................

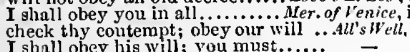

obey the bride, you that attend... Taining of $S h$, lii. 2

bound to scrve, love, and obey....

I willingly obey your command

Winter's Tale

learn love, I'll practise to obey..Com

in the duke's name, to obcy me.

I do obey thee, till I give thee

offend you, and obey you, as I did...2 Henry $l F$. v.

let them ohey, that know not

arrested, but will not obey

command, and I'll obey .............

whom they must obey? (rep.)
and will obey. We are (rep.)

I obey; 0 my lord Aberga ny........ He

shall more obey, than to the. Troilus

he cares not, he'll obey cond

vow lies here, this I'll obey.

plagues, that thee alone obey?.. Timon of Alicens, $v$.

will obey you in every thing......

the second name of men, obeys lis points -

such a gosling to obey instinet

and pature must obcy necessity .... Julius $\overline{C a s}$

the very dice obey him . . Antony \&

would obey it on all cause ..........

my master and my lord ligust obey

no more obey the heavens

that you in all obey ler, save

both ear and heart obey my to

as fits my nature, do ohey you

we cannot but obey the powers above

goddess argen tine, I will obey thec

obey you, love you, and honuur you.

to obey in all your daugliters' hard

you are a royal one, and we obey you

the weight of this sad time we must obe
obey, and go witl me; lor thou... Romeo \&

I shall in all my best obey you, madam.

tis not fit thus to obey him

but we both obey; and here give up.....

which he, in brief, obeys; receives rebu

we shall ohey, were she ten times..

if your mind dislike any thing, obey

what if I do obey? how may the duke... Olhello, to spend with thee: we must oley the

and to obey shall be in me remorse...... - iii.

sir, I obey the mandate, and will return - iv. 1 'tis proper I obey him, but not now .... your king's naine be obeyed .......3 Henry Vl. king's pleasure by me obeyed ...... Henry VII loved him next hicaven? obeyed him?

as cause will be obeyed .............. Co

80 men obeyed, and

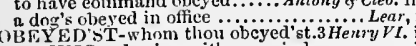

OBEY ING-obeying with my wind . obeying in communding ...........Henry $V I I I$. ii. dexterity so obeying appetite ... Troilus \& Cress. v.
from his all obeying breath...Anlony \& Cleo. iii. 1 . from his all obeying breath.....Anlony \& Cleo. iii. I B.J ECT-note-worthy object. TwoGen.of Verona is by a newer object quite .............. throwing it on any other object... Neas. Jor Meas. v the object, and the pleasure MMid.N.s. Dream, iv. for every object tliat the onde clotll. Love's L. Losl, ii. I
ghapes, objects, idens, apprehensions - iv. 2

to every varied objectint make ...Mer. of Veniee, every object, that might make ...As you Like it, liv. mark, what object did present itself1 1 - ${ }^{-}$iv. 3 never object pleasing in thine eye. Comedy of Err.ji.. without this objeet, form such...... King John, Woe thing entire to many objects .....
when gold becomes her object! ....2
Henry $I$
OBJECT-so great an object

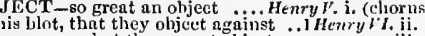
doth not the nbject clieer your henrt.3 Henry $v 1$.,ii. thou wilt oljject my holy oath......

the liat al object in mv eye .......

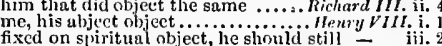

flies the object of all harm should still

eye praises the present ohjeet.
subseribes to teniler objects

swear against objects ....................
the oljiect of our nisery...

Timon of Althe

dreadful objects so familiar ........ Julinos Cosas i.

one that feeds on objects, arts, and

his object, which takes prisoner .....
or fruitful object be in eye of Imogen

hitting each object with a joy

ah mel this object kilis mel..................

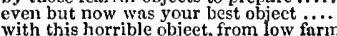

wee'st thou this object, Kent?

this present oljject made probation

witls variable objects, shall expel
thoumh great ones are their object

the object poisons sight $\ldots . . . . .$.
BJECTSD-it is well oljected

BJECTED - it is well oljected ........

as for your spiteful false oljections...2 Henry $V I$. i

I dare rour worst objections .......Henryl $V J I$. dii. 2

BLATION-night oblations to thee.... Perieles, v. 3
BLIGATION of our bleod .... Troilus \& Cress. iv, 5

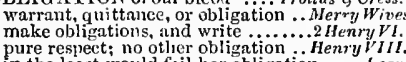

in the least would fail her obligation .... Lear;

the survivor bound in filial obligation...

BLIGED faith unforfeitedl... Nerehlant of Venice,

all is oblique .......... of o..... Timon nf Athens, iv

childishness, and mere oblivion ..As you Like it

deeper than ollivion we do bury.

which now shall die in oblivion.. Taming of $S h$.

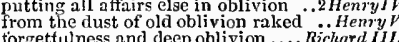

forgetfulness and deep oblivion .... Richard III
bilind oblivion swallowed cities. Troilus of Cress.

wherein he puts alms for oblivion....

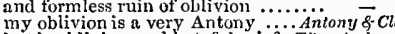

my oblivion is a very Antony ..... Antony

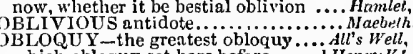

whiel obloquy set bars before......... Alenry $i$.

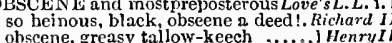

ohscene, greasy tallow-keech
BSCENELY, and

so obscenely, as it were...
OBSCURE epistles of love

Love'sL. Lost,
Tovelfh Night

some obscure precedence....

Tuelf hi Night, it,

cerecloth in the obscure grave .. M Mer. of Venice, ii.

obscure bird elamoured the livelong...Mactiell, it.

little grave, an obseure grave ...... Kiehard II. iii.

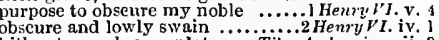

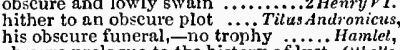

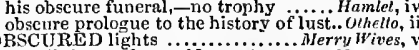

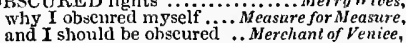
a great magician, obscured ... Merchant of vence As you Like

for what obscured lifht ....... Comedy of Errors,

the prince obseured his contemplation. Henry $V$. i.
then hath Rielard been obscured ... Henvy $V I$. ii. been informed of my obscured course .... Lear, ii. oBSCUred in this tair volume lies.. Romeo of Juliet, OBSCURECL Cxar's ambition.... Julite CCesar,

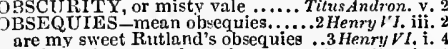

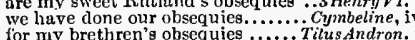
for my brethren's obsequies ......... Titus Andron. i.
$[$ Col. Krnt.] obsequies that I for..R Romeo \& Julict, $\mathrm{v}$.

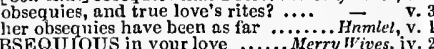
inSEQU IOUS in your love .............. Werry Wives, iv. to shed obsequious tears upon.... Titus Andron sime term to do obsequious sorrow ..... Hnmle

doting on his own obsequious bondage... Othello,
OBSE

OHSERVANCE-doting observance i Herry Wives, do observanee to a morn of May ...Mid.N.'s 's Dr. there are other strict observances. Love's s.. Lost, i.

relish it with a good observance...As you Like it, iit.

and observance.

with true observance seek to eke out. All's ${ }^{-}$rell

by what observance, I pray you?..... -

and do observance to my mercy ...2 Henry $I V$. iv.

observance of thy godlike seat...Troilus \& Cress. . 3

without observance or respect ........

or I have no observance .. Antony \& Cleopalra, iii.
OBSERVANCE-than in the observance. Hamlei, i. 4

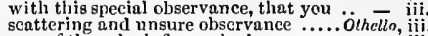

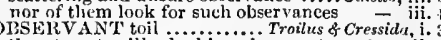
than twenty silly ducking observants ... Lear, ii. strict und most observant wateh $\ldots . .$. .IImantet, ny realing, nor my observation

if my observation, (which $v$
by my penny of obscrvation

what ober

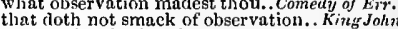

the observation we have made of it ...... Lear, i.

that youth and observation copied .... Hamlet, i.
OBSERVE his construetion of it .. Trueffic Nighl, ii.

observe him, for the love of mockery

to observe the riglt of May on...Mid. N.'s D $\overrightarrow{\text { ream }}$

the aenson, and observe the times. Love's L. Lost, v.

which I can well observe to-day .......All's $W e i l$,

her eye is sick on't; I observe her now
and observe bis reports for me ......

observe her; stand close ................Machelh, v

We did observe; cousin Aumerle .... Richard 1 .

will you not observe the strangeness.2 Henry VI. iti.

observe, observe, he's moudy...... Henryl Hat iii.

observe degree, priority, and place Troilus \& Cress. i.

do you observe this, Ilostilius?

how to observe a strange event
whom thou'lt observe, blow off

both observe and answer 1 .

I do observe you now of iate............
must I budge? must I observe you?

observe how Antony becomes. Aniony \& Cleo, iii.

observe his inclinatiou in yourself...

comment of thy soul obscre my uncle

observe her well with Cassio .............

VOn shall observe him; and his own courses - . iiv.

rhymes, observed your fashion o. . . Leve'sL. Lost, iv.

gnell as he hath observed ... Taming of Shl s $\mathrm{t}$ (indlic.

I lave observed, the air is delicate .... Macbeth, $\mathrm{j}$.

observed, a man mas prophecy ....2 Henryl $W$. iii.

gracinus, if he be observed; he hat

I have observed these tluree swashers. Henry $r$.

I have observed thee always ... Timon of sthens, iii.

all his faults observed, set in........ Jutius Cessar, iv. 3

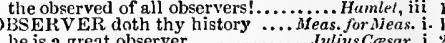

he is a great observer ................ Julius Cassor.
the observed of all observersi.......... Hamlel,

OBSERVING him, do bear............2 Henry $I V$.
we have stood here observing him. Henry

rite in

observing, took once a pliant hour.... Othelto,

BSTACLE - no obstacle ......

eiffh Night, i i

that thou will one full of obstacles.

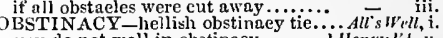

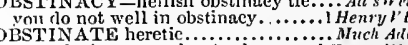

with obstinate repulse, to slay ....... i Henry 17. iii
the queen is obstinate, stubborn ... Henry inli. ii

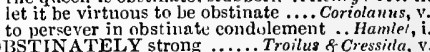

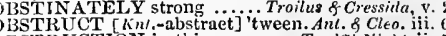

OBSTR UCTION in this .......... Ta'elfhNimh', ii. 5

ret complainest thou of obstruction

to lie in cold obstruction. Neasure, for Measure
nurge the obstructions, which begin.2 Henry $W$.

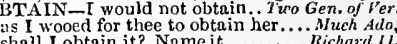

shall I obtain it? Name it............ Richard 11 .

intercession to obtain a league $\ldots . . .1$ Henry $V I$
ask mercy, and obtain no graee $\ldots . .3$ Henry ${ }^{\prime} I$.

Titus, thou shalt obtain and ask...Tilus Andron. i.

Yet, let me obtain my wish ........... Periclex, y.

lis good will obtained ..................

greless I be obtained by the manner. Mer. of Ver. $i . ~$
unle

thou hast obiained thy suit (rep.).....

having this obtained, you presently... All's Well, 1 ,
special thing is well obtained.. Taming of Shrew, ii.

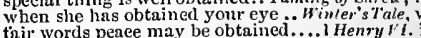

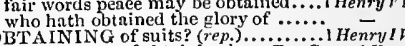

am desperate of obtaining her... Tioo Gen. of Ver.

the oceasion speaks thee ........................

feed every slight oceasion.

on the wing of all occasions ............

unless you langh and minister occasion -

I sent for thee upon a sad occasion...

you may have very fit occasion for

what occasion now reveals before $\ldots . .$.
if you have oceasion to use me... Neas. fur $\bar{M}_{\text {frns. }}$ i 
OCCASION may detain us longer ....Muchddo, i. no measure in the occasion that

may, I can gleek, upon the occasion. Mit. N. Dr. iii. delivered upon the mellowing of occusion

upon the next occasion tlant we .......

all unlocked to your ocensions

yet more quarreling with ocension!... $=$ i.

yon night take occasion to kiss...As you Like il, iv. i

inake her fault her lushand's occa

goaded with most sharp occasions

till I can flld occasion of revente. Taming of sh. ii. I

tell us what occasion of import hath... iii. 2

courted now with a double occasion.. - iv. 3

lest occasion call us, and show us........ Naclseth. ii.

for courage mounteth with occasion. King John, ii. 1
to grace nccasions, let it be our suit $\ldots \ldots . .$. - iv. 2
withold thy speed, dreadful occasion!... - iv. 2

of this most fair occasion, by the whic

of that occasion that sliall bring it on.] Henry $l$, i.

you took occasior to be quickly wooed - v.

I well allow the occasion of our arms.2 nenvy $1 \%$. i. 3

publish the occasion of our arms.

by the rough torrent of occasion

witl gud leve, as I may pick occasion. Iten

there is occasions and causes why and

whicn you take oceasiou to see lecks..

having any oceasion to write for matter - v. -2

to take ocesion from their month

whate'er occasion keeps him from.. 2 Henry $V$. ili.

repairs him with occasion? $\ldots \ldots \ldots . . .3$.

when I give occasion of offence

as occasion serves, this noble qu......

I'll sort occasion, as index to ....... Richard $I I I$. ii.

on what occasion, Grod he knows, not I $\bar{V}$ joyful to meet the lcast occasion.

the occasion shall instruct you

had I so good occasion to lie long. Troil. \& $\overline{C r}$ ress. iv. I

master is awaked by great occasion. Timon of $A l h$. ii. 2

that my occasions have fonnd time

having great and instant occasion denied lis occnsion so many talents

denied his occasion so many talents
has only sent his present occasion now

if his occasion were not virtuous ....

many my near occasions tlid urge me $\overline{-}$ iii. 6

he married but his ocension here. Antony \& Cleo, ii. 6

but what occasion hath Cadwal .... Cymbeline, iv. 2

Eo tender over his occasions

I would breed from hence occasions ........ Lear, i. 3

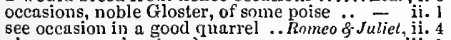

give me occasion (rep.

occasion smiles upon a double leave...... Hamlet, $\$ .3$

to visit you, my lord: no otluer oecasiou

政 4

a finder-out of occasions .......... Oihello, ii

do you find some occasion to.............

to take the safest occasion by the front

I would on great occasion speak with you - iv. 1

OCCIDENT-passage to the occident. Richard $\bar{I} \overline{1}$. iij.

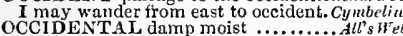

OCCULTED guilt do not itself ............ Hnmlet, iii, 2

OCCUPAT artus: 'tis thee I fear....2 Hen.y VI.
OCCUPATION - no oscupation ........ Tempest

your occupation a mystery? ........ea

prove my occupation a mystery .....

in Rome, and occupations perish!... Coriolanus,

so much upon the voice of occupation

had been a man of any occupation. Julius $\bar{C}$ crs

knew'st the royal occupation! ... Antony \& Cleo.
sir, 'tis my occupalion to be plain......... Lear,

farewell! Othello's occupation's gone!. Othello
OCCUPY-odious as the word occupy.2 Herry!

occupy the argument no longer.. Romeo \& Juliet,
OCCURRENCE of my fortune... Tu'elfin Night,

and omit all the occurrences... Henry $V$. v. (chorns)

OCEAN - to the wild ocean.. Tuo Gen. of Yerona, ii. 7

an ocean of his tears $\ldots$ ocean whelm them.............

your mind is tossing on the ocean...11er. of'l'terice, $\mathrm{i} .1$

that in the ocean seeks another.. Comedy of Err.

spurns back the ocean's roaring tides. King John, ii. I

a peaceful progrcss to the ocean.

even to our ocean, to our great king

and drinking oceans dry............ Riehard $I I$.

the beachy girdle of the ocean too..2 HenryIV. iti.

with the wild and wastelul occan.....

deep bosom of the ocean buried ...... Richard $\mathrm{rll}$ iv. $\mathrm{i}$.

seen the ambitious ocean swell ......Jutius Cors ir, i.

the angered ocean foam

his legs bestrid the oceall

as many inches as you have oceane... Cymbrline,

gilt the ocean witli lis beams ....Tiilus.tndro
for all the water in the otean can....
OCEAN-the ocean swells not so.. Titus Andron. iv. 2 ODD-I will lay odds, that, cre this...2Ienryl\%.y. 5 the ocean overpecring of his list ...... Hrmlet, iv. cleven o'clock the hour

it liath struck ten o'clock.............

but till 'tis one o'clock, our dance... - Y. Y. 5

tis almost five o'clock, cousin .............uch A to, iti. 4

nt six o'clock i' the morning ... Merchan

what is't o'clock? You should ........ you Like it,

y two o'clock I will be with thee (rep.)

ten o'clock: within these thirec hours. Alt's Well,

tis now some seren o'clock.. Thming of

soon, at five oclock, plense you.. Cömedy of Er

it is two o'clock. Perhaps, som

at five o'elock, I shall receive....... - iv. - iv

at two o'clock it the afternoon ........ - is Henry $I V$. ii

tis one o'clock, and past $\ldots \ldots \ldots \ldots 2$ HenryIV. iij. I

is't four o'clock? It is. Then we go in. Hestry
it is now two n'clock: hut let me see

sir's, what's o'clock? Ten, my lord..2 2 Henry $/$ TI. i
what is't o'clock? Upon the stroke. Richard 1 III. ii

towards three or four o'clock, look for

what's o'clock? I am this bold (rep.)

it's one o'clock, boy, is't not? ...... In lury

What is't o'clock? Cxsar .........Julius Cosar, ii.

'tis three o'clock; and, Romans ....... $\overline{\text { Juliet, }}$ ii.

'tis not yet ten oclock; our generai..... Othello, it.

take Antory Octavia to his wife .....

and his power unto Octavia

my Octavia, read not my blemishes

he's hound unto Octavia and we'll

madam, he's married unto öctavia (rep.) -

Casar's sister is called Octavia ......

Octavia is of a holy, cold, and still.
then shall the sighs of Octavia blow

Octavia weeps to part from Rome ..
what, Octavia? I'll tell you in your ea

no, sweet Octavia, youl shall hear from

nay, nay, Octavia, not only that ....

gentle Uctavia, let your best love draw

your wite Octaria with lier modest.

for Livia, and Octavia, to induce

CTAVIUS'serve Octavius Cassar.jüius Cassar, iii. no Rome of safety for Octavius yet.

sir, Octavius is already come to Rome -

Octavins, I have seen nore days than -

so is my horsc, Octavi us; and, for that -

and now, Octavius, listen great things

Octavius, Antony, and lepidus have put -

Octavius, lead your battle softly on...
are better than bad strokes, Octavius

cold demeanour in Octavius' wing.

having seme advantage on Octavius
for Octavins is overthrown by noble

bring us word mnto Octavitus tent ..
morc than Octavius, and Marl Autony

Octavius, then take him to follow thee

Marcus Octavius, Marcus Justeis.

OCULAR-give me the ocular proof.... othello. iii.

$O D \rightarrow$ od's plessed will! ...................erry Hives, i.

od's me! qu'ay j'oublié?

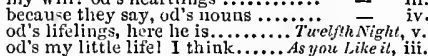

od's my will! ber love is not..........

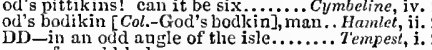

some few odd lads .................. -

is at most odds with his own ............... Wives, iii.

that makes these odds all even...Meas. for Meos. iti.

I may cliance have some odd quit

no: not to be so odd, and from all ...
and theretore too much odds for... Love's $\overline{L . L o s l}$,

were still at odds, being but .........

stayed the odds by adding four (rep.)
too odd, as it were, too peregrinate..
and such odd sayings, the sistcrs. ler.

and such odd sayings, the sisters. Mer. of Venice,

eyeing ot his odd belaviour.

true rules for odd inventions ..........

Grumio! thicn he shall have no odde

yields-pound and odd slilling... Winter's $\bar{T}_{a l e}$, iv.

amount to thrce odd ducats.. Comedy of Errors, iv.

almost at odds with morning ..........Mracbeth, iil.

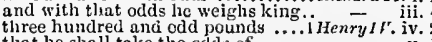

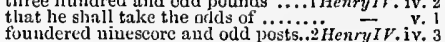

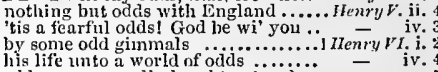

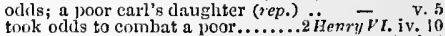

though the odds be great..............3Henry Vl. i. 2

twas odds, belike, when valiant....3 Memr? 2.1 .

with whom my sonl is any jot at odd

an odd man $(r, p$.$) ........... Troilus o cressida,$

that you are odd, and he is even $\ldots$

withdrew me from the odds of multitide -

are equals; there's no odds

that put'st odds among the rout

sct them into confounding odds....

bear of 'wounds two dozen odd .......

he beats thee 'gainst the odds.... Anlony $\bar{\xi}$ Cleo. ii.
ever beat mine, inhooped, at odds....
one of those odd tricks, which sorrow $=$ iv.

the odds is gone, and there is nothing - iv. 13

the odls is, thint we scarce ........... Cymbeline, v.

that sets 11 all at odds ..................... Lear, $\mathrm{i}$.

yoln lived at odds so long......... Romeo \&
a fortnight, and odd cinys. Even or odd
how strange or odd soe'cr 1 bear ......... Hante

nothing but my shame, and the odd lits

your grace hath laid the odds............

bettercd, we have therefore odds
on some odd tive of his infirmity

ODD-CONCEITED trie-love .. TwoGen of Fer. $\overline{\text { ii. }} 7$ ODDEST $\rightarrow$ hath the oddest frame. Neas. for Meas. v. shall be oddly poised in this.. Troilus \& Cressiela, $\mathrm{i}$. ii. 5 ODE-once more I'll read the o....... Love's L. Lost, iv. langs odes upon hawtliorns....... As you Like it, iii.
ODIUUS-heavy to me, as 'tis odious... Tempest, ${ }_{\text {iii }}$ $O$ odious is the name! ................rry rive flowers of odions savours sweet..Mid.N. Drenm, i horns are odious, they are necessary. As you Like, iii.
traduced by odious ballads ........... All's Well, ii. captain as odious as the word $\ldots . . . .2$ Henvy $I V$. ii. name of help grew odious to repeat .... Pericles, $\hat{\mathrm{f}}$. 4 ODORIFE ROUS flowcrs....................

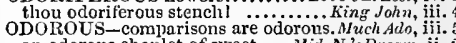
an odorous chaplet of sweet..... Nhid. N.'s Drean, ii. ODOUR-stealing, and giving odour. Tuelfth Nigh
the heavens rain odours on you! (rep.) the heavens rain odlours on you! (

odonrs, odours -odours savours ... Mid. N.'s Dr.
a delicate odour ..................... Pericles, a delicate odour $\ldots \ldots \ldots \ldots \ldots \ldots \ldots \ldots$ Pericles, iii. GILI A DS-[Col.] judicious œiliads. Merry Wives, i. 3

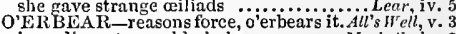
impediments would o'erbear .......... Aacbelh, i o erbear what they are used to bear. Coriolnnus, iii. I o'erbcar the shores of my mortality..... P'ericles, $\mathrm{v}$. O'LRBEA RING interruption ........ KingJohn, iii. 4 O'ERBEA'T-flood o'erbeat [Col,-o'erbear]. Coriol. iv. 5 O'LRBOARD - swear'st grace o'erboard. Tempest, v. 1 I threw her o'erboard with these very... Pericles, v. 3 'ERBORNE their way ............. Coriolanus, iv. 6
friends o'erborne $i$ ' the former wave..Cymbeline, v. 3

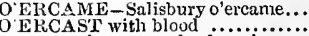

you see, how soon the day o'ercast. Riehard 111. iii. 2 sea's stomach be o'ercliarged with ...... P'erieles, iii. O'ERCHARGING your frec purses ... i Henry $\nu I . \mathrm{j}$. ERCOME with pride............... Coriolanus, iv. to o'ercome you with her show ....... Cymbeline, y. 5
o'ercome with moss, and balefui... Tilus sndron. ii. 3

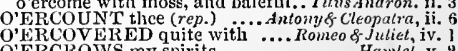
O'ERCROWS my spirits ................. Hamlet, y.

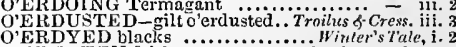
O'EREATEN faith ..................... O'ERFED breast of $\ldots . . . . . . . .$. Perich's. iit. (Gower')

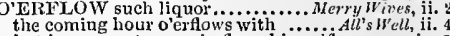
in lis proper stream o'erflows himseif if - iv. 3

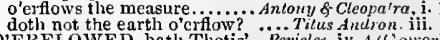
O'ERFLOWED, hath Thetis'... Pericles, iv. 4 (Gower)

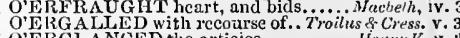

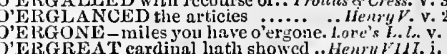
ODDLY - but O how oddly will it sound. Tempest,
how oddly he is suited the sight of me is odious...........2 Herry VI. iv. her heart is but o'crcharged...........Minter's.'s Tale, iii. 


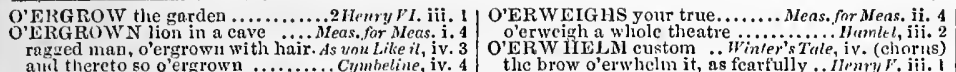

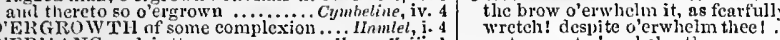
'ERHANG and jutty

Catesby, o'erlook the walls

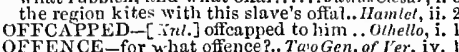
OFF ENCE-for what offence?.. Ta'o Gen. of I'er. iv. 1

o'erlook what shipping...l'erieles,

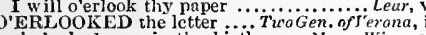

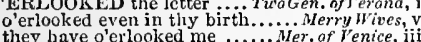
they have o'erlooked me .......Mer. af Yenice, iii. 2

O'ERMASTER it as you may ............ Hamlet,

O'ERMASTEREST? From whom hast. King John, iti. 1
O'ERMATCHED forces ............. Henry $l^{\prime} t$. iv.

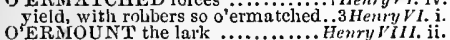
O'ER-NIGHTS surfeit? ...............man of Athens, iv. O'ER-OFFICES-[Knt.] ass o'er-offices...Hamiel, v. 1
O'ERPAID_madam, is o'erpaia.......... Lear, iv. 7 O'ERPAYS all I can do ................. Cymbeline , it. 4 O'ERPAST -in the time o'erpast ... Richarl lill. iv. O'RRPICTURING that Venus... Antany \& Cloo. it. O'ERPOSTING that action $\ldots \ldots . . . . .2$ Henry $I V$. i. 22 a Fear, as being o'erpowered..... Antony \& Clea, 'ERPRISED all popular rate

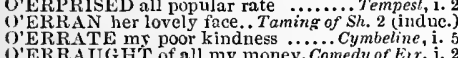
Cymbeline, i. players we o'erraught on the way ....Hamlet, iii. ('ERREACHES [Knt-o'er-offices] U'ERREAD these letters. doth desire you to o'erread that I have not all o'erread

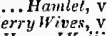
O'ERRULES; that, one man

let me o'errule you now.................. 2 Henry $I V$. iii. so you will not o'errule me
O'CRRULED by prophesies

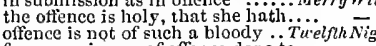

from any image of offence done to

what my offence to him is

gentlemian have done offence......... $=\begin{gathered}\text { iii. } \\ \text { ii } 4.4\end{gathered}$

but what's his offence? .............Mens. for Meas. iv. $\mathrm{i}$. 2

nay not so extenuate his offerice...

is it that hath died for this offence?

which a dismissed offence would ....
more fit to do another sucl offence.

must nceds a ppear offence

and his offence is so, as it appears

what offence haill tllis man made

hence hath ofrence his quick.........

the offence pardons itself............

without offence to utter them

what oftence, sweet Beatrice? $\ldots$......
offerice, my lord! officers, what ofiewce

I ask what's their offence (rep.) $\ldots \ldots . . \quad$ v.

nor snail, do no offence.. Mid. N.'s Dream, ii. 3 (song) thou shalt fast for thy offences.... Lave sL. Losl, i. 2

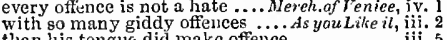
than his tongue did makc offence..... art a general offence, and every man... $A l^{-}{ }^{-} W_{\text {ell }}$, ii. 33 but that, my offences being many....

the nature of his great offence is dead I will o'errun thee witli policy..... As yous. far Like it. v. v.

thought o'errun my former time ....3 Henry v1. il a chilling sweat o'erruns,
O. ERSET-since we are o'

O'.REET-since we are o'erset ....
O'ERSHADE-fear o'ershades me.

cloudy death o'ershades his beams..3 Herry VI. ii. 6 O'ERSHIN you as much as

I have o'ershot myselt, to tell

O'ERSHOW ERED, leaves.... Pericles, iv. 4 (Gower) 'ERSkIP-sufferance doth o'erskip ...... Lear, iii. 6 G'ERSLIPS me in the day
O'ERSP'READ the land

Wing of uiglit o'erspreads.... Trailus \& Cressida, i'ERSTEP not the modesty of uature.. Hamlet, iii. 2 O'ERST NK their fee

so resolved. I cau o'ersway him... Juli hs Cessar, ii. I O'DRSWELL with course disturbed.. K̈ing Jahn, ii. 2 let floods o'erswell, and fiends.

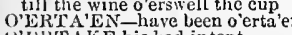
All'swell, iti. 4 'EH'TAKE his lad intent o'ertake me, if thou canst s. for Heus. v. ot Egypt, whom leprosy o'ertakei Ant. \& Clea. iii. 8

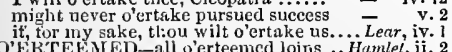
O'EKTHRUV law and in Winter's Tolo ive, (cho.) too late, o'erthrows thy joys ...... Riehard Lit iiio. 2 ere eiean it o'erthrow pature ...... Cymbeline, iii 6
O'ERTIIROW N-all o erthrown.... Tempest, (cil.) as sport by sport o oertirown... ve'sL.Last, v. your honour not o'erthrown. HenryVI, i. valour hath o'ert hrown Autony.......... 'El'TOOK - never is o'ertook ...........Maebelh', iv. there gertook in his rouse .............. Humlet, ii. to o'ertop old Pelion, or the skyish ....Hamlet, v. U'ElRTIR the dew .......... Merchant of Venice, v.

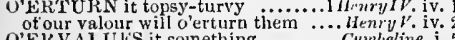
O'ElCVALULS it something...

O'LRWALK a current, roaring......... Hienry If' i. all weary and o'erwatched, take vantage. Lear, ii. my heart oerweens too much........ Henryl'T. iii.
O'ER WEENING cur run back.......2 Henry VI. v. 1 epentance of all your dear offencesi... Henry $V$. ii. ail offences, my liege, come from

take no offerse, that 1 would not. Anitany \& Clco iit. her wheel, provokel by my offence.. pays dear tor my offences............. Cymbeline, i. 2 without offence my conscience bid̈s am falien in this offence......... for the offencec has dies ......... Thtus Andrnnicus, v. punislied, that ne'er thouighit offence ...Pericles, i. my proffer take tor an offence w'reteln! despipte orwheim theef... Cnriolanns, iii.

pay down for our offence by weight
what's thy offence, Claudio?

due to this heinnus capital offence.....

who takes offerice at that would make

sure, her offence murst be of such............
lis oftence, holresty! strange! strangel..

do yout that offenee, which clse were

whiat's his offence? [Knt,-fault]
what was the offence you gave him?

madc you no more offence than what
all's not offence, that indiscretion finds..

cown to tame these vile offences ......... tutict iv.

for that ofrence, immediatcly... Romea a. Hamiel,

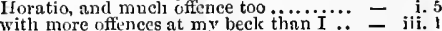

argument? is there no offence in t?
noison in jest; no offenec $i$ ' the world

O my offence is rank, it smells to heave

one bc parloned, and retain the offence?

offence's gilded hand may shove by justice $=$ iii. 3

is weighed, but never the offence .........

as full of quarrel and offenec. as my.

he that is approved in this offence $\ldots . .$. - ii. 3

there is morc offenee $[K n /$-sense] in that

if my offence be of such mortal kind ....

the business of the state does him offence $=$ iii. 4

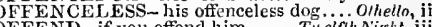
to speak of, would offend again ......Meas. far ineas. $\mathrm{i}$. 3

do so offend, let mine own .........

so to offend him still ..................

if bawdy talk offend you

your silence most offends me ........... Much $d$ da $a$,ii. 1 I cannot see how sleeping should offend -

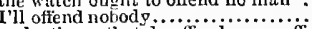

unake those. that do offend you, suffer, - vo 1 would so offend a virgin ....... Mid. N.'s Dream,
if we offend, it is with (rep.) to offend, and judge, are distinct. Mer. of Verice, ii. 9 as to offend, himself being offended .. - iv. 1 as will no further offend you .......As you $\bar{L} i k e, i l, i$. I did $\mathbf{I}$ offend your highness

merry passion, and so offend. Taining of Sh, I ind oc.) loathsomeness of them offends me. Winter's Tale, iy. 2 he shall not offend your majesty .........Macbing Jahn, iii. 3

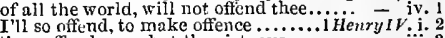
they offend none but the virtuous ..... the tongue offends not, that............. - ii. a son of mine offend you, and oliey you
we'll not offend one stomach ...Henry $r$. ii. (chorris) they do offend our sight.............. - iv. 7 that night offend your majesty........ if this servile usage once offerd.......... I must offend, thetore I be attainted...2 Henry $r$. it. 4 buz, to offend thine ears .............. Henry VI. ii. let me march on, and not offend .. Richard MT. iv. 4 might offend the weakest spleen. Troilus of Cress. ii. 2 What offends you,

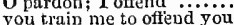

you train me to oftend you ............ v. v. 3 or ofiend the stream of regular ....... that I would not offend you.Aniony \& Cleapaira, ii. 5

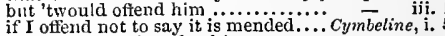

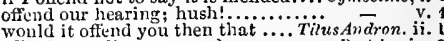
wfind as well as we (rep.)
of............. P'ericles, iv. 3
what I cannot name but I shall offeind 6 last surrender of his will but offend ......... L $6 a r, i .1$ I shall offend, cither to detain ......

nonc does ofiend, none, 1 say, none ........ I am sorry they offend you, heartily..... Hanlet, i. 5 O it offelids me to the soul, to hear .......
some action that may offend the isle.... speecl which something now offends me - ii. 3 a salt and sullen rheum offends me....... give her patcut to offiend

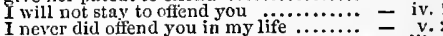
FF ENDED nostril .....................irizes, iii. be not offended, dear Cesario ..... Tutelfh Night, v, ath but as offended in a dream! Meas. for Meas. iit. if he had so offended, lie would lave $\overline{\text { mave }}$ v. who have you offended, masters...... Mueh Adn, v good sir, be not offended ............ Love's L.Lnst, ii. good sir, be nut offended himselt' being offended.... Her. of renice, iv. be not oftended love hath so in me offended.................. iii. 4 (letter blood has not offended the king . Winter's Thie, iv.
those vapours that offended us. Comedy of Errors, $\mathrm{i}$.

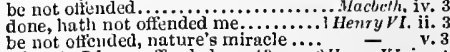

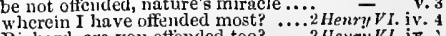
Wichard, are you oftended too? .....3 Henry VI. iv. : to cut off those that have offended lim - i. 
OFFENDED-liere he is oftended. . Richard III. iii. sir, in what have I offended you?.. Henry IIII. ii. all have not offended ........... Timon of for lim have I offended (rep.).... Julius Cassar, iii . then none have $I$ offended

this tongue had not offender

I should say myself offended ....Antony $\overline{\text { \& }}$ Cleo

make me not offended in

soon as I can win the offended $\mathrm{king}$. cymbeline

thou in per'son ne'er offended me Tilus Andron.

low have I nffended ..................

wherein you may lave offended him.

how have I offended? all's not offen.
it is offended. See! it stalks away

offendefl, playcrs in your house wifery... othello, it.

WFF FNDER - be sueh an offender... Mierry Wizes, ii.

love, is the oftender friended ...Mens. forMleas. iv.

this plaintifi here, the offender, did eall

offender's lite lies in the merey...Ner. of $V$

examines all sueh offenders........ As you like it, iv,

a strainger, no offender

where we oftenders now appear............. Winter's Tate, v. 1

hot vengeance on offenders heads ..i Richard II. i.

all his rods on late offenders........2 Henry $1 V$. iv,

would have all sucl offenders cut off. Henry $V$. iii.

chiet offender in the same? ........ Henry $V i$. iii.

upon offenders, luth exeeded la w ...2 Henry $V I$. i. 3

call these foul oflenders to the

should melt at an offeniler's te.......

and the coftender rranted scope of speech - iii.

betwixt her and this great ofiender. Henry $v i$. Richard

bind the offender, and take him .... Cymbeline, $\mathrm{v}, 5$

makes the foul ofienders quake... Tilus Andron. v. 2

the offender's scourge is weighed....... Hamlel, iv.

OFFENDING twiee as much .... Love's $L$. Lost,

should import oftending

the ehureh, offending eharity.......... Kinger's Tahn

whipped the offending $\Delta$ dam out

front of my offeriding hath this extent. . Othello,

UFFEND'S tlyg lungs to speak...ifer... of Venice,

pleasant to him, what like, offensive

pleasant to him, what like, offensive... Lear,

that dare not nffer what I desire ....... - iii. t didst thou offer her this from me? . the knight would offer it.............̈erry $\bar{W}$ ives, ii. 1

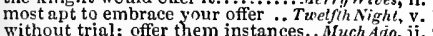
I do embraee your offer; and dispose

if he will offer to say what.....Mid. N.'s Dream,

ehange not your offer made in ... Love's L. Losl, v. this is kind $I$ offer

to offer to connsel me to stäy.........

which doth offer to swear upon ......

make no more offers, use no further

tis well you offer it behind her

I take this offer then ......................

and to offer to get your living....... As you Like

the faithful offer take of me

for my kind offer, when I make..

iv. 3 (letter)

we'll take your offer kindly

All's $\bar{w}_{\text {ell, }}$,ii.

of base fear, offer to betray you.......
that offer serviee to your ...Taming of $S h$. 1 (induc.)

and offer me, disguised in sober robe

sir, whint are yiu that off the best

to offer war where they should kneel

the queen of your most noble

you nffer him, if this be so, a wrong.

to offer to have his daughter eome

you offer to break in now... Comedy of Errors, ivi. 3

some offer me commodities to buy .. - iv. 3

to offer up a weak, poor, innoeent ......Macbeth, iv. 3
liave I otfer of goodly thousands ......

tondly pass our proffered nffer

to offer service to vour perilous

from him such offers of our peace..... - y. $\quad$ v. 7

to offer serviee to the duke.
an offer, unele, that we wili.

will not, heaven's offer we refuse

the offer of $a$ hundred thousand.

tired majesty did make thee offer

with graeions offers from the king

will they take the nffer of onr
we offer fritr, take it advisedly

kind uffer of the king (rep.).
wouldst thou turn our offers

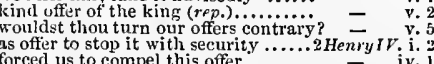

this offer eomes from merey, not from

enraged him on to offer strokes...

I have made an offer to his majes

how did this offer seem received

the offer likes not; and the nimble
OFFER-offer us his ransom .......... Itenry $r$. iij. $s$ we'll offer our lives un to these

I offer thee my hand. Fic, uncle

Heñy VI. i. 5

offer at my shrine, and I will

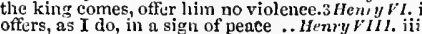

the good we offer into envy you omit the offer of this tim.

ny weak-hearted enemies dare $\ldots \ldots$ - iii. 2

he offers in another's enterprize... Troilus \& Cress. $\mathrm{i}$

come to offer you our service............

I saw Mark Antony offer him ....JulizusCossar, i. 2

take the offers we have sent you...Antony o Cleo. ii. 6
you have made me offer of Sicily....

you have made me offer of Sicily....

a man prepared to take this offer..... - ii. 6

scorn her most, when most she offers

rom thine invention, offers............

ince your offer

and will offer my night oblations....... - v. 3

offer this office to you my lord, take his offer.

and all that offer to defend him $\ldots \ldots \ldots \ldots$ -

is a gentlemanlike offer .......... Romeo \& Jutiel, ii. 4

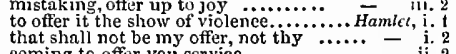

OFFERED-that's offered

he hath offered to the doom

and then I offered her mine own

and I offered him my company ........Much $A d n$, ii.

thriee thy money offered thee.Merch. of Venice, iv.

the duke hath offered him letters .... All's Well, i

nay, I have offered all, I have. Taming of shrew,

I'll entertain the offered failacy. Comedy of Err.ii. 2 refuse so fair an onered chain

we offered to the king, and mighit...2 Henry $I V$.

Richard II.

as ean be offered in the orld ......... Henry $V$ iv. 7

which Somerset hath nffered to my...iHenry $r i$.

to merey, whilst 'tis offered yon....2 Henry VI.
why, madam, have I olfered love..Richard III

but that time offered sorrow ...... Henry VIII.

I offered to a waken his regard .......
onee more offered the first ennditions

there was a crown offered him (rep.).Julius $\overline{C a}$ sar

then he ofered it to him again (rep.).

when onee 'tis offered ...... Antony \& Cleopatra $^{-}$i. 2

a paper lost as offered merey is ....... Cymbeline

ay, he offered to cut a caper.......... Pericles,

no more than hath your highness offered.. Lear, $i .1$

an ill thing to be offered to any..Romea \& Juliel,

OFFERING - faithfullest offerings. Twelfh Night,

uneartlly y it was i' the offeringl. Winter's Tale, iii.
eelebrates pale Hecate's offerings ....Macbeth, ii. 1

with rich offerings, and traders....... 1 Henry I

there offering to it his own heart. Troilus $\&$ Cress. iv.

offering the fortunes of his former. Timon of $A t h$.

the entrails of an offering forth ..Julius Casar, ii.

whate'er thou ofite'st next ... Taming of Sherex, it.

molntain goat, offer'st me hrass? ..... Henry $\nu^{\prime}$. iv. 4

the key of offieer and office.......

and serves in offiees that profit us.....

their eyes do, offices of truth

Two Gen. of Verono

therefore the offiee is indifferent $\ldots . . .$. - iii.

I would I eould do a good offiee ...Merry Wives, i. I

in the simple offiee of love

attend your offiee, and your

do me this eourteous offiee

thís is the man; do thy office...

on Angelo imposed the office

do you your offiee, or give ............

thinking me remiss in mine office.

that fail not to do your office.

clo you the offiee, friar

I do diseharge you of your office .... $\mathrm{Much}$ Ado

I will do any modest wfitiee to help..

by virtue of your offiee (rep.).........

it is a man's offiee, but not yours ....
tis all men's offiee to speak patience

yon know your office, brother.........

the your offees, and let me rest ......Mid.N. N.'s Dr. .i. for virtue's office never breaks ....... why, 'tis an office of diseovery ....izer. of venice, ii. th degrees, and offices, were not derived

to oficies of tender courtes

from fortune's office to nature's ..... As you Like

no more enforee mine office on your.

and required offiee on my partieular

I did him a desired office $\ldots . . . . . . . .$.
OFF ICF-truer office of mille eyes? . All's " ell, v. 3
and each one to his office. Taming of Shreu, 1 (induc.) eaeh in lis office ready at thy beck - 2 (indue.) heing slow in thy hot office.

that's my uffiee. Spoke like an offieer

Winter's Tale

you ha' done me a elharitable offiee...

who do their hest offiee, if they enn..

give me the offiee to ehonse you......

both nine oftice, and my 1 ame.. Coincdy of E $r$ r.

quite forgot a liusband's otriee?

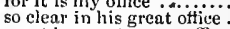

Macieth, $\mathrm{i}$.

grcat largess to your offices

sir offices, and what we liave to do.

deny their office ...................... King $\overline{d n h}$

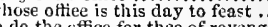

do the offiee for thee of revenge . Richard

serves in the offiee of a wall

for little office the hateful commons

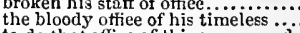

i Henry $I V$. v.

my offiee is to noise nbroad $\ldots \ldots \ddot{2} \ddot{H}$ enry $I \bar{r}$. (induc.)

the model in fewer offices.

offiees, do your offices, master i i......

and noble offiees thou may'st

a foutra for thine offiee!

do the office of a warmilig-pain....

shall forget the office of our hand..

and master; so mueh my office

since then my office hath so far.

and know the office that belongs...... sale of offices, and towns in France..2 2 Henry $v^{\prime} I$. i. it is my offiee (rep.).

that hateful office unto thee

is my office, for my father's sake ...3 3 Henry VI. $\mathrm{i}$.

both are ready in their offiees .... Richard $1 I 1$. iij. 5

take tliy office from thee on my perii - ini.

the offiee did distinetly his full ..... Henry $V I I I$. j.

your effiee, serjeant; exechte it .......
the dignity of your ofkee, is the point
lost your offiee on the eomplaint..... Henry VIII

as't please yourself pronounce your office -

sir, for holy offiees $I$ have a time

since I had my office, I have kept

that elaim their uftiees this day ......
of my life and office, I have laboured

season, torm, office, and custorn ... Troil
wlieh is that god in office, guiding ..

thou should'st have my office, ere that

gently put out of offiee, before I........
when all our offices have been oppressed

always a villain's oftice, or a fool's ...

then our oftice may, during his power

let the ligh office and the honour go

what are your offices? ................

cannot office me from my son Coriolanus

sell and mart yeur offiees for gold.Julius Cars iv.

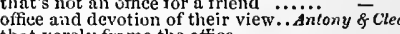

that yarely frame the offiee,.........

he it so; deelare thine offiee..........

but it is an offiee of the gnds..........

you are appointed for that effiee

Ill offiees of nature should again.

shown y our father a ehild-like office $\ldots . . .$. Lear, ij.

thou hetter know'st the oflices of natme

offer this efliee to 5 ou

a dog's obeyerl in of since you did leave it for my office ... - y. the trust, the affiee, I do hold of you ..... Othello, i. twixt ny sheets he has dowe my office...

all utfices are open or ieagned in oftiee, thou dost deliver......

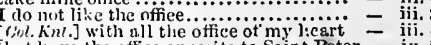
- iv.

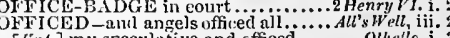
[Kat.] my speculutive and offieed......... Otheltr, i.

you an othiser fit tor the place... Tua Gen. of l'er with all the officers in Windsor ... Alerry Wives, iii. 3

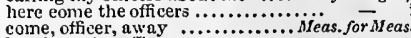

think me the poor duke's officer.......
truly, offieer, beeanse be hath....... 


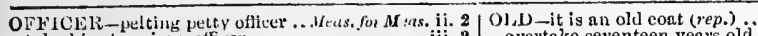
take him to prision, officer............ - iii. 2

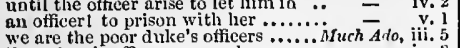

the prince's officer, coxco

oflicers, what offence have these.........

by thy sweet grace's officer.. Love's L. Lost, $_{\text {i. } 1 \text { (letter) }}$

from special officers of Cliartes ......

fet my officers of such a nature ....As you like il, iii.

a filthy officer he is in tho

but a poor officer of mine ..............

every officer his wedding-garment Taining of Sh, iv. call forth an officer: carry this mad

spoke like an officer ...............

Ill attach you by this officer

well, officer, arrest him at my suit

on, officer, to prison till it come...

what thou meanest an officer will thou do thou peevish officer

he did arrest me with an officer...

then fairly I bespoke the officer..

pommand onr officers at arms ..........

and such officers appointed to direct

takes his fellow for an officer $\ldots \ldots \ldots$.

but for these foolish officers........... - ii. I

do desire delivernnce from these officers

pluck down my officers, break
a king and officers of sorts

a king and officers of sorts $\ldots \ldots . . . \ldots$. Henry $V$. i. 2

come, office $x$, as loud as e'er thou ..... Heñry $v i$.

then broke $I$ from the officers that led

therein some expert officers

to go with us un to the officer

fear each bush an officer .... $[$ Col. $-K n t$.$] lead me, officers, to the... Richard I I t . \mathrm{v} .6$

to choose an officer, that with his......

to choose an officer, that with his.

allow their officers, and are content.:

here will be an old abusing of

hotls young and old, one with

old folks you know have discretion

say'st thou so, old Jack?

make more of thy old body than

old Windsor way, and every...

your husband is in his old lumes aguin

'tis old but true, still swine..

an old cozening quean! .................

grievonsly peaton, as an old 'oman..

there is an old woman (rep.).

as you see, like a poor old man

like a poor old woman $\ldots \ldots . . . . . .$.

will not compare with an old

not yet old enough for a man...

too old, by heaven; let still

it is old, and plai

like the old age................

for as the old hermit of Prague.......

like to the old vice.

if it be aught to the old tun

and when thou art old and rich

his elilild is a year and a quarter oid

shall lie his old betrotlied

and perform an old contracting ...j

one that is a prisoner nine years old

commodity of brown paper and old..

for the old women were all dead....

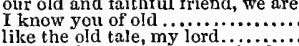

ere you flout old ends any further

beating your officers, cursing yourse

as if he were his officer; desperatio

his own change, or by ill officers. Sulizes Casar,

let our offieers have notice ... Antony \& Cleopalra, i. 2

more in their officer, than person....

the throat of that his officer $\ldots \ldots \ldots . . .6$.

than thyself domestic offeers .......

ean have no mortal officer

some officers take them away....

o'erbears your officers 1 the rauble..

I have al ready chose my officer

there is no believing old signs o......

the old ornament of his chcek hatb.

old signior, walk aside with

an old man, sir, and his wits (rep.).

and on your family's old momument

not quarrel with us, good old man
or what would do, were I not old

witl two old men without teeth...

the old man's daughter told.

an old, an old instance. Bcat

yonder's old coil at home.............

$O$ spite, too old to be engaged to young!

on old Hyem's ehin, and icy .........

that is an old deviee; and it was

this is old Ninny's tomb ............

your officer, Iago, cail intorm you

so drunken, and so indisereet an officer.

with mine officer I that's fouler......

OFF officious with lady MLargery........ Winter's Tale,

fur being so fur officions $\ldots$............. officious, and not valiant............. Coriolanus, i.

be every one officious to moke .... Tilus Andron.
OFFSPRING - Hagar's offspring .ifer. of Veutice,

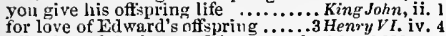
offspring of the liouse of Lancaster.. Richard III. $\mathrm{v} .3$ the offspring of so toul a fiendi. Titus Andronieus,

yet oftentimes he goes but inean Taming of $\mathrm{Sh}_{\mathrm{h}}$ iil. hatli of tentimes upbraided me.. Conedy of Err. iii. I and of tentimes, to win us to mur harm... Macbeth, i. 3 nature oftentimes breaks for ih in.. 1 Henry $I V$.

zet ottentimes it doth present harsh

OHTIMES not knowing why

Henry $V I$

appertinent title to your oid tune.Love's like a man after the old pain ling.... come upon thee with an old saying.

being of an old father's min

a month old at Cain's birtl (rep.)

the monn was a month old (rep.)

an old infant play: like

offered by a child to an old man

yet I liave a trick of the old rage ....

the face of an old Roman coin

let old wrinkles come .................

when he grows old, being oo ful

if I live to be as old as sibylla ......
but I pray you ergo, old man (rep.)

the old proverb is very well parted ...

my old master the Jew........

of old Shyloek and Bassanio

in judgnent old, your answer

she is not yet so old, but she may...

young a body witls so old a liead

came you from old Bellario? ........

Antonio and old Shylock, both stand
show my youtl old Shylock's house

show my youth old Shy lock's hou

that did renew old Ason ......

you old dog. Is old dug .............
God be with my old masterl
but the old news: that is, the old dive

but the old news: that is, the old duke -

wive like the old Robin Hood of Eingland -

thou losest thy old smell ................

an old man, with his three sons ( $(\mathrm{rep}$.

hath not old custom made this life...

o you memory of old sir Rowlandl..

should in my old limbs lie lame ....

O good old man (rep.)..................

young man, and au old, in solemn ta

there is an old poor man $\ldots \ldots \ldots . . .$. .

song

i. 1

iii.

an old I talian fux is not so kind ......

$\begin{array}{ll}\text { iii. } 2 & \text { beguile the old pan taloon } \\ \text { iii. } 2 & \text { old fashions please me best }\end{array}$

iv. 2 news, old news, and such news as ( $r e p$. $)$ -

iv. it hath tamed my old master

iv. 3 the rest were ragged, old, and beggarly

this is a man, old, wrinkled

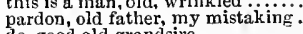

do, good old grandsire id vincentio

mine old master, Vincentio? ( $r e p$.

well, go thy ways, old lad

makes old hearts fresh

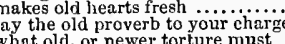

to have helped the old man!

you're a male old man

列

very true; and but a month old ....
old sir; I know she prizes not such

thou old traitor, I am sorry

thou old traitor, I am sorry $\ldots . . . . . .$.

an old sheep-whistling rogue $\ldots . . .$. .

heard the old shepherd deliver (rep.)

is so like an old tale (rep.)............
should be hooted at like all old tale .

I, an old turtle, will wing me .........

absence was not six months old. Comedy of $\bar{E} r$ r

in Epliesus 1 am but two hours old ...

the picture of old Adam new

all these old witnesses.

O my old master I who hath bound...

speak old Agreon, if thou be'st

he should have old turning the $\mathrm{key} \ldots . . .$. Nacbeth,

before thy here approach, old siward.....

yet who would have thought the old man $-\mathrm{v}$.

v.

v. 2

the rotten carcase of old denth....

of begrirs, old men, young men

fresli in this old world!

i. 2 of plain old form is much

ii. 2 the burning erest of the old .......

ii. 4 old John of Gaunt, time-honoured ...Richard II.

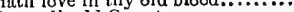

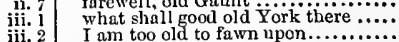

I $\mathrm{am}$ too old to fawn upon...................

old John of Gaunt (rep.ii. 1$)$........

what stir kceps good old Yor

in you I see old Gaunt alive $\ldots \ldots . .$. .

thou, old Adam's likeness, set to ....

of care by old care done ..............

sit by the fire with good old folks...

looks of young and old throug

shall thy old dugs onee more a traitor

come, my old son

our purpose is a twelvemonth old.......

witl drinking of old sack ..............

or a lover's lute

or an lord of the eouncil rated

ii. 3 if I liang, old sir John hangs witli me

how old art thou, Francis?...........

my lord, old Sir John, witli hirif.....

sisee the old days of goodman Adam
go thy ways, old Jack (rep.)...........

go thy ways, old Jack (rep.)..........
one of them is fat, and grows old ....

iv.

iv. 1
iv. 3
v. 1
.

v. 2

v.

i. 3

ii. 3

ii. 2

v.

i. 2 
OLD-thon know'st my old ward ...I HenryI $V$.ii. what manner of man is he? An ojd man in the likeness of a fat old man...... Falstaff, that old white-bearder saitan that lie is old, (the more the pity) it to be old and merry be $n$ sin (rep.) being as he is, old Jack Falstaft. shakes the old beldam earth ........ this advertisement is five anys old rake an old lady's loose gown? (rep.) to crush our old limbs in ungentle what! old acquaintancel could not. father, old Northumberland....2HenryI $\bar{V}$. (induc.) written down old with all the charaeters I am only old in judgment ........... if rou will needs say, I ain an doth the old boar fecd in the old frank? Eplesians, my lord: of the old church but old mistress Quickly, and mistre by the mass, here will be old utis... to patch up thine old body for heaven? lisping to his master's old tables

sce how many of mine old acquaintane is old Donble of your town (rep.) old, old, master Shallow (rep.)

a little, lean, old, ehapped ...........

hot our old aequaintance be renewed dnce be $a$ bait for the old pike $\ldots . .$. . and the old folk, time's doting ......

with wolves, thy old inhabitantsl..... what I is the old king dcad

I know thee not, old man.............

a saying, very old and true ................ rom the dist of old oblivion raked.. 0 then, belike, she was old and gentle old sir Thomas Erpingham ............ a good old commander, and a most good old knight, collect them all live this day, and see old age..... old men forget; yet all shall be....... enforced from the old Assyrian slings old I du wax; and from my weary my comfort is, that old age

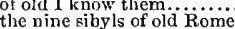
...l Henr ont of a deal of old iron I chose..... heavens keep old Burgundy safei... think, her old familiar is aslcep... (as yet I an not old,) I do rcmember now iny old arms are ronng this upstart is old 'Talbot's ghost... the king is old enough (rep.) .........2 at nine months old old Salisbury, - sliame to thy silver.. my fatiner's badge, old Nevil's crest.. York not our old men spares ......... his will in his old feeble body...

I was but nine months old (rep.)....3 Hen ay, and old York, and yet not satisfied anointed king at nine months old the good old man would fain many an old men's sigh nilkce villany with old odd ends .... Hich in Paris but at nine old man! couli gnaw a crust at two hours old nurse! ofd sulden playfellow for......

old barren plants, to wail it.....

a kind of puppy to the old dam

or pack to their old playfellows.....

would hire me, old as I am, to queen it -

a lady once, ("tis an old story)

and old with service, to the mercy.

is that old noble lady

that the old name is fresh about me

an old man, broken with the storms

either youness of Norfolk, and lady

young a man, and so old a lifter? Troilus $\bar{c}$ Cre

he is old unw; but, if there .......
I see them not with my old eyes
there's Ulysses, and old Nestor.......

the seas and winds, (old wranglers)..

and, for an old aunt, whom ..........

when time is old and hath forgot...

let an old man embrace

and that old eommon arbitrato.......

old Nestor tarries; and you too......
that stalc old mouse-eaten dry cheese

these old fellows have their.... Timon
now the gods keep you old enough ...
this is the old man still..............

erutch from thy old limping sire... \begin{tabular}{l|l} 
ii. 4 & OLD love made a particular ..... Timon of Athens, v. \\
ii. 4 & Marcins, your old eneny.... Coriolunus, i. 2 (letter
\end{tabular} you two are old men; tell me....... and his old hate unto you ............ lielp lim, young, and old! .......... I'll try whether ny old wit $\mathrm{b}$ insisti in thou old and true Mlenenius

from these old arms and legs

I the easy groans ocquantance.

no worse than thy old fatlice.

this last old man, whom with
for whose old love, I have.......

than an eiglit year old horse

surgeon to old shoes................ulins $\bar{C} a$ why old men fivols, and clildren

ii. 2 set this up with wax upon old Brutus

ii. 4 O Cassins still! come Antony ii. 4
ii. 4
shall paint when you of old $\ldots$ a......... that wlyen old robes are worn out.....
your old smock briugs fortl $\ldots . . . .$. where's my serpent of old Nile?

than with an old one dying... let the old ruffian know....

might well have warmcd old Saturn...

but of a minute old (rep.)

when we are old as you?

Pisanio, her old servant
an vid man, and two boys.

an old man twice a boy

the old man and his sons were angelg

why, old soldier, wilt thou undo

then, spare not the old father.... I, old Arorgan, am that Belarins ......
the np this good old man $\overline{-}$.......
the unhappy son of old Andronicus.. or thyself, old Titus, or any one of you revenge the heavcus for old Andronicusl the old man hath found the who should say, old lad, I am thine own it cumes from old Andronicus wilful sons ot old Andronicus (rep.)
his old ears deaf, yet slould both... tell us, old man, how shall we be ... go, go into old Titus' sorrowful house and that to hear an old man sing old nurse's [Knt.-onily mistress'] death clid steal the eyes of young and

shame to get when we are old? old Escanes, whom Helicanus la passion stands for true

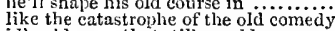
idle old man, that still would....

old fools are babes again

nor so old, to dote on her

as you are old and reverend, you sho..... uld foud eyes, beweep this cause ......... beaten for being old betore thy tim o madam, my old heart is cracked put him on the old man's death our good old friend, lay comfort
what, art thou mad, oid fellow? what, art thou mad, oid fellow
sir, I am too old to learn ...

I sir, you are old .....

$O$ heavens, if you do love old men

if yoursel yes are old, make it your cause

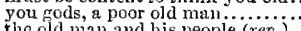

the old man and his people (rep.)...

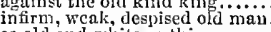

so old and white as this..................

your old kind father, whose frank

were like an old lecher"s heart

swallows the old rat and the dituli -do

cruel nails pluck ont his poor old eycs

yet, poor old lieart, he holp.......

meet the old contrse of denth

thou old unhappy traitor...

nay, come not near the old man

I an a very foolisli fond old man .....

awuy, old inan; give me thy liand

to send the old and miscrable king

I am old now, and these same crosses.

during tixe life of this old majesty ........ \& of by thee, old Capulct, and Montague
to wield old partizans, in hands as old to wield old partizans, in hands as old for men so old as we to keep the jeace = the rank poison of the old will die..
OrD-joiner squirrel, or old grub .. Romeo \& Jul, i. the son and heir of old Tiberio $\ldots$ lo... i. $\overline{5}$ (chorus) watel in every old man's cye.

thy old groans ring yet in my

Tybalt. ? the kinsman of old Capiilet cannot sit at ease on the old bench? but old folks, many fuign ol tying his new shoes with old ribband? these sorrows malke me old $\ldots \ldots . . . . .$.
doth she not tlink me an old murderer unfortunate old man!
packtliread, and old cakes of roses...

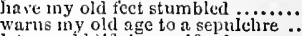
warus iny old age to a sep

this greeting to old Norway .............. rrow not instint old, but bear

well said, old mole! canst work ......... whereori old Norway, overcome with joy yoursclf, sir, shall be as old as $i_{\mathrm{i}} \mathrm{im}$.......

alons old frols?

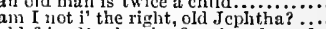

old friend: Why thy face is valanced.....
the hellish Pyrrhus old grandsire Priam dost thou hear me, old friend...

the nephew to old Norway, Fortin

should be as mortal as an old man's life?

cre we werc two days old at sea.

to o'ertop old Pelion or the skyisj.

not by the old gradation, where eaclı.... olnello, $\mathrm{i}$.

an old black ram is tupping

liave ta'en away this old man's daughter

these are old fond paradoxes, to make.
how do our old acquaintance of this isle?

an old thing 'twas, but it expressed...

pure grief eliore his old thread in twain $\overline{\text { vo }}$ v.2 OLDEN-i' the olden time, ere human. Nacbells tii. ere a fortuight make me older soldier $-\overline{\text { Richar }} I I I$ iv. 3 a soldicr, I, older in practice ......Julius Cresar, iy. Ronncu will be older when you... Romeo \& Julict, ii. betwecn the youngest and oldest ...Coriolanes, iv. 6 the oldest hat l. borne most ................ Lear, v.
oLD-FACED-yon old-faced walls..Kin . OLDNESS cannot relish them....... Lear, i. 2 (lettcr) 'tis at the tuft of olives.............. As you Like it, iii. puts forth her olive every where ....2Herry $W$. iv. use the olive with my sword ... Timon of Aihens, $v$. OLIVER-Oliver Mar-text (rep.).As you Like it, iii good master Oliverl (rep.) ......... - iii. 3 all Olivers and Row lands ......... Henry VI. i. 2 OLIVIA-eycs did see Olivia first.. Twelfh Night, i. gossip of the air cre out, Olivia!

sighs slant whe countess Olivia?

that the lady olivia's father took

a pang of heart as you have for olivia

where I left Olivia sleeping...............

art not thou the lady OIivia's fool?..

the lady Olivia lias no folly............. iii. belono to the lady Olivia, friends? - 4 (cliali.) wherein Olivia may seem serviceable?

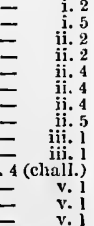

OLYMPIAN wrestling .................... \& \& Cressida, iv. as if Olympus to a mole-hill......... Coriolanus, y. 3 do appicar as huge as high Olympus - iv.
climbeth 'Tamora Olympus' top.. Titus Andron. ii. or the skyish head of blue Olympus.... Hamlet, v.

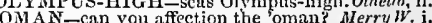
for it is a $o^{7}$ man that altogether's....

your wife is as honest a omans ....

Youve your prabbles, 'onan...........

'omall, forbear (rep.)

I think the 'oman is a witcli indeed

I like not when a .oman lias $\ldots \ldots . . .$.

grievous $y$ peaten as an old 'oman.

OMEN - prologue to the omen coninin on. Hamlet, $\mathrm{i}$. OMINOUS-very ominons endings.... Much Ado, v. 0 ominous: he comes to kill .... As you Like it, if

Gloster's dukcdom is too ominous...3 Henry $V I$.

thy and orpinous to noble pecrs! Richard III.

prove ominous to the day (rep.) Troilus \& Cress.

the quarrel's most ominous to us.... OMISSION to do what is neccssary Troil. Famess. iii. 3 ONI'T-if now I court not, but onit.... I empest, i. if we do omit this reprobate.... Meas.,for Meas. iv. omit nothing nuy give us aid ...Winter's \%ale, iv. 3 therefore, my lords, omit no happy.... Henry $V . \mathrm{i} .2$ 
OMIT the ofter of this time. Henry I'III. iii. 2 nust onit real necessities ......... Corinhmus, iij. omit we all their dole and woe.Pericles, iti. (Gower) vet nothing we'll omit that benrs

I will omit no opportunity ....Rnmeo of futiet, iii. 5 do om it their mortal natures, lettiug .. Oihello, ij.

OMITTA NCE is no quittance .....As you Like

OAI I ITE D-shall be omitted ...... Love's L. Losi, iv. his apparent open guilt onitted..Richard III. iii. omitted, all tlie voyage of

Pericles, $\mathbf{v} 3$ no needful thing omitted.
OMITTING the sweet henctit

Henry VI. ii. 2

nmitting Suffolk's exile.... Love's L. Lost, iv.

OALIPOTENT lovel how near ...Merry $\overline{\text { Wires }}$

is the most omnipoten

NE-my denr onel

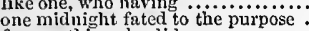

for one thing she d

one thing or other $\ldots \ldots \ldots \ldots . . . .$.
soft, sir; one word more $(r e p$.

$u_{s}$ if it had lungs, and rotten ones

if but one of his pockets could speak

one stroke shall free the

and that a strange one too

Yond' linge one, looks like

$I$ do not know one of my sex.........

nor hath not one spirit to command

do not, for one repulse, forego

there is one tree, the Phonix throne...

one Phonix at this hour reigning there

each putter-out on five for one

but one fiend at a time

eneh one tripping on his toe

encounter every one in eountry footing

shall not myself, one of their kind ....

not nne of them, that yet looks

nor thought $i$ had one

one of them is a plain fish

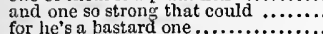

I should have been a sore one then

your rest for this one night

one fading moinent's mirth . TuoGen. of Verone

twenty to one then, he

fold them one upon another writ....

as one relying on your

like one that had the pestilence (rep.)

beeause the one is painted

I $a m$ one that an nourished

slsed one tear .......................

even as one heat another
or us one nail by strength

for one shot of tivepence

and understand is all one...

hut one may enter at.....

that one eannot climb it ..............

that's all one, if he be but one knave

spoken by one whom she esteemeth.

master, be one of them ...................

one, lady, if you knew hi

one that attends your ladyship's......

one that I broughit up...

ce that 1 saved from drowning.......

even as one would say (rep.)

one Julia, that his changing

glie says, it is a fair one.

mischanees than this one...........

for my meed, but one fair look (rep.)

which is too much by one...

I have one friend alive

when one's right hand is ......

that one error fills him ..............

one feast, one house, one mutual .....

as I do desyise one that is false (rep.)

as it shall become one that

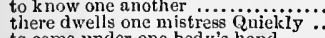

to come under one body's ha

and one that is your friend ...........

if it were not for one trifling respect

ere one chaste man .....................

one with annther Ford

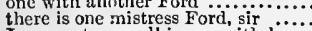

$\boldsymbol{I}$ warrant vou, all is one with her

anl one (I tell youl) that will not ...

that you may know one another's mind

this punk is one of Cupid's carriers.

there's one master Brook below

as yon have one eye upon my
vat be all you, one, two, tree

my finger itches to make ore...

and you shall one day find it...

it there is one, I shall (rep.)

eot'es in one mistress Page...........
ONE-thought there hal been

there was one conveyed out $\ldots . . . . . . .$.

tis one of the pest diseretions of . .

whether ane Nym, sir

from belind one of then

the devil take one party

sure, one of you does not serve.

just 'twixt twelve and one (rep.)

but till 'tis me o'elock

to strnd at the taunt of one that

and one that is as slanderous.

let us every one go home.

with one self kingt

whith great ones do, the less wili

that you brought in one night here.

that if one brcak, the otlyer me

for here he comes, one of thy kin...

there's one at the gate $\ldots \ldots$ give me faith, say. $\mathrm{x}$. Wiil...

one dranght abnve heat makes .......

gentle one, give me modest assuruure

to make one in so skipping a dialogue

Enel $a$ one as I was this present

item, one neck, one ehin, and so forth

so quiekly may one cateh the plagne

if one knight give a- $\ldots . . . \ldots . . . \ldots . . .$.

draw three souls out of one weaver

and one that adores me; what o' that?

come, but one verse.........

no one so true did slare it ...........

it should be one of my eomplexion...

than any one else that follows her.

ir Andiew

for every one of these letters are

I am almost sick for one

if one slrould be a prey.

one heart, one bosom, and nowe triti

if it pleave drawn one to a longer voyage -

please one, please all

have mercy upon ane of our soulsi...

I am one that would rather go with

have one bout witly you .......

I snatehed one half out of the

he started one poor lieart of

for I am one of those gentle ones.....

though it please you to be one of $\mathrm{my}$

whit you in mintl ; one

send one presently to sir Toly

that's all one; he has hiurt me

pardon me, sweet one, even for

ii. 5 one face, one voice, one habit........

$I$ uas one sir, in this interlude on

one sir Topas, sir, but that's all one.

all one, our play is done.

to one that can my part in him

iii. 2 nay, not as one would say.....

there's one yonder arrested...

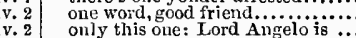

only this one: Lord Angelo is
some one with child by hin?

iv. 4 one who never teels the....

'tis one thing to he tempted

v. 4 one that serves a bad woman .....

she had any more than one husband?

that to great ones 'lon

v. 4 With one half so good a grace.

v. 4 look, here comes one; a wentlewo.....

repent you, fair one, of the sin you.

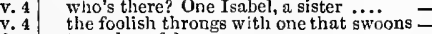

to make a false one.................

I have no tongue but one...........

young sister an (you eonsent)

clried not one of them with his cointort

this is one Lucio's information.

one has my pity, not a jot the

one that is a prisoner mine years old

one would think, it were mistress

ii. 2 one Ragozine, a most notorious pirate

one of our eonvent, and his contessor

you'll answer this one day

tis not impossible, but one

one the sister of one clandio

some one liath set you on.....

\section{as she from one uncot}

one that hath spoke most yillanous

in testimony wheleof, one in the prison

1 am sorry, one so learned and so wise -

one all of luxury, au ass, a muduan \begin{tabular}{l|l} 
iv. 1 & ONE whom he begot with ehild .. Mras. for Mras. v. \\
iv. 2 & is the whole man governed with one.. Much
\end{tabular}

iv. 2 is the whole man governed w
iv. 2 hath not the world one man

\begin{tabular}{l|l} 
iv. & tath not the world one man .......... \\
iv. & the one is too like an image. and says \\
iv. 5 & I hope to see you one day fittcd witld
\end{tabular}

and but one visor remains

you must wear it one way

$n$ double heart for his single on

thus goes every one to the world

I will get you one. I would (rep.)

of affection, the onc with the other

contamiuatea stale, such u one as Hero

that one man, sceing how much

eome in one woman, one woman

one foot in sea, and one on $($ rep.)
to write to one that she knew would

we have ten proofs to one.

rather than sle will "bate one breath

when they hold one an opinion of
one doth not know, how mucls.

one doth not know, how much i...

wo bears will not bite one another.

five shillings to one on't, with any

need of poor ones, poor ones may

send every one their heort's desirel.

send

ii. 3 one word, sir: our watch, sir

ji. 3 your wintow, betwixt twelve and oue?

grieved $I$, I had but one? $\ldots \ldots \ldots \ldots . . . .$.

in to tongue and trim ones too.

and one that knows the law, go to

but such a one whose wrongs do

if sueh a one will smile, and stroke.

are you so hasty now? well, all is one

true, says she, a fine little one

a great gross one ....................

there's one meaning well suited

heard them talk of one Deformed...

not one wise man among twenty

to bind me, or undo me, one of them

nothing certainer; one Hero died....

one that composed your (rep.)...Hid. N.'s $\bar{D}$ rea

as one shall see in a summer's

the one I'll slay, the other

into the hands of one that loves

one, aloof, stand sentinel

one turf sliall serve

one heart, one bed, two bosoms (rep.)

that a lady, of one man refused

so every one according to his cue...

liere o'er and o'er one falls

that one man holding troti........

then will two, at once, woo one......
lo, she is one of this confederacy

one flower, both on one sampler (rep.)

moulded on one stem (rep.............

here comes one. Where art thou....

come one more; two of botli

go, one of you, find out the

one sees more devils than vast jieli

not one word apt, one player fitted

that I, one Snout by name (rep.)

an ace for him; for he is but one

she shonld not use a long one

one day in a week to touch (rep.)... Love

one, whom the music of his own

afflietion may one day smile again

how many is one thrice told?.

amount to one more than two

Longaville is one

every object that the one doth eate.h

like one that eomes here to besiege

being but the one half (rep.) .........

one part Aquitain is bound to us...

for my sake but one loving kiss

keep not too long in one tun

do ane thing for me that I shaii

by heaven, one that will do the deed

one of these maids' girdles for your

monsieur Biron, to one lady Rositine

he came, one; saw, two; overeame
on both in one, or one in both...

and one that makes sport to the

so I may answer thee with one as old

of one sore I a hundred inake (rep.).

and if one should be pierced (rep.).

v. from one monsieur Biron, one of the

v. 1 this Biron is one of the votaries.
v. 1 well, slie hath one o' my sonnets

here eomes oue with a latper ........

silver moon one half so bright $\ldots . .$. ...

now in thy likeless, cne mist
one drunkurd loves anothe
N $\mathrm{N}$

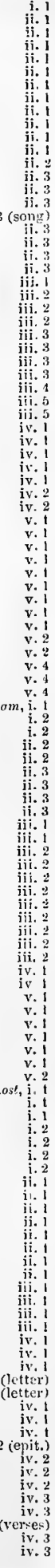




\section{ONE}

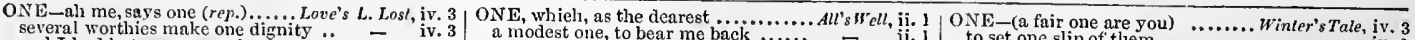
and $T$ had but one penny in the. I'll make one in a clance, or so we ruhbed his elbow, this

how many inches is in one nile (rep.) how many melies is mone

do but vouchsate one elange

one sweet word (rep.) .......

for every one pursents thrce.

bit to parfect one man, e'en onc poor

art thou one of the worthies?

that's all one, my fair, sweet, honey

the one maintuined by the ou.

not in one bottom trusted (rep.)....... or of $\overline{F_{e}}$ nice,

I must be one of these.................

than be ome of the twenty to foilow....

ll rightis iove.

for there is not one among

shut the gate upon one wooer......

can yout tell me whether one Launeelot -

your present to one master Bassanio

as one wolld sas, to serve

a simple fornt you?

a simple coming-in for one mau

and lart with him to one that I......

one of them contains my picture (rep.)

1 as one near death to those that..

but such a one, thy vassal, whoin I

to set one slip of them................

name to't, one mistress Tale-porter...

very pretty one. Let's have some (rep.) =

marry to each, but one! ............

fair one, I think not so. There's one

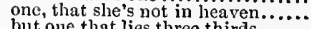

liang hin! one Parolles...............

thither they send one another

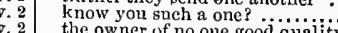

unless some one among us, whom

we minst every one be a man of ....

what we speak tu one another.
yet sliglit ones will not carry

yet sliglit ones will not carry it

and great ones I dare not

you should be such $a$ one as you are

all's one to him; what a past-savin
whether one captain Dumain be.

one Diana, to take heed of (rep.)

is reputed one of the best that is

wronged you, one of the greatest

ii. I to hear me one single word (rep.)

not one word more of the cousumed

a eommoner o' the camp, if I be one

young one kick (rep.)

i. 2 courtesies alone, they are senrvy ones

lere? one dead, or drunk ?. Taming of Sh. $\overline{1}$ (indnc.)

some one be ready, witl a eostly

every one doth swear, that comes...
with one tool's head I came to woo.

a young Venetian, one that comes

one of them showed me a ring

one half ot me is yours .....

having made one, methinks

jou have got me on

I got a promise of this fair one here....

and not one vessel 'seape (rep.)....

and one in whom the ancient.....

there is but one hope in it that .......

and Portia one, there must be

go one, and call the Jew into the...)

the twentieth part of one poor seruple

friendly welcome every one..
that one shall swear she bleed

and cffect one thing speeially...

inventions meet and jum

if thou know one rich enough to be.

books, good ones, I warrant you

more suitors have, and me for
then well one more may fair

make one, though Paris eame
the one as famous for.....................

the one half of my land

well aimed of such a young one

to wish me wed to one half lunatie

as any one old signior Gremio bas in

been re, ond cliff, two notes.

one girt six times pieced

with a linen stock on one leg.

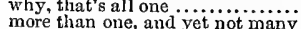

mauy vows of faith, and ne'er a true one -
there is not one so young and so... ds you Lit

one that old Frederie, your.......

there is but one shamed that $(r c p$.)

you shall try but one fall.....

one out of snits with fort

when the one slonld be lamed with

teachetl thee tliat thon and I am one

I pray you one of you question.......

and after one hour more, ' $t$ will

thou slalt have one.

when such a one as shie..

and one man in his time plays

the more one sickens, the tyorse .....
such a one is a natural philosopher..

ill-roasted erg, all on one side ....

one inch of delay more is ...

answer me in one word. .............
for the one sleeps easily. because

for the one sleeps easily, becau

one that knew eourtship too weli

like one :motlier, as halfpence are (rep.) let them go, a couple of quiet ones

one, Kate, that you must ki.............

and sits as one new-riser

as one unworthy all the former...

among them, know you one Vincentio?

as an apple doth an oyster, and all one

then both, or one, or any thing ....

gentle, you shall have one $\ldots . .$.
with one consent to have her

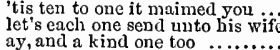

to sip, or touch one drop of it ...........

thy sovereign; one that cares for the

one that, indeed, physies the ......

with one we thank you, hany one..

and sevennight longer

one good deed, dying other

with one sof $t$ kiss, a thousand

that is one of the points in
yes, one: and in this manner.

yes, one: and in this manner.
slaall not be one spot of love

then one of you will prove

as good cause as one would desire.....

spurs his horre on one side

and lie is one of the patterns of love

why then, can one desire too much of

'tis but one cast away, and so

that abuses every one's eyes

by filling the one doth empty tile othe but they asked one another

her and death were both one thing...

met themselves, one of them thoughit

to one, his lands withheld.

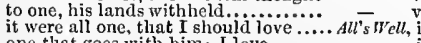

one that goes with him; I love
how might one do, sir, to lose it...

is like one of our Freneh withered pears -

and he is one-What one, i' faitli?

if one be good, among nine bad (rep.) - i

what, one good in ten? (rep.)

confess it, one to the other

no sword he worn, but one to dance with!

of the Spinii, one captain $S_{p}$

I have sioke with one, that, in her..
now, fair one, does your business...

hy one that fixes no bourn ......

in every one of these no man is

would not live the running of one gilass

thou hast the one lalf of my heart ..

a master; one, who, in rebelion

bears not one, let villany

a fine new prince, one of these days

I have one of sprites and goblins

a spider steeped, and one inay dring

one that knows what sh.

in the suffer

as well as one so great, and so forlo.....

nor any, but one, that's here ........

you'll leave yourself hardly one suijest

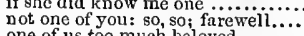

one of us too much beloved....

if one jot beyond the hound...........

thoughts high for one so tender.

one grave sliall be for both

a pretty one. a very pretty one

song-men all, and very good one................

which are mighty ones, and milious

to each onc sip) (rep.)

- 1 (induc.)

i. i

such store, when one is one too dainty

the one ne'er got me credit

one that elaims me, one that $(\mathrm{rep}$.$) ...$

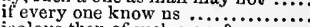

one, whose hard heart is buttoned.....

a shoulder-clapper, one that .........

every one doth call me by my.....

ask but the paring of al ways........

both one, and other, he denies......

one Angelo, a goldsmith

each one with ireful passion...

might make one wiser mad

they brought one Pinch ; a liungry....

these two Dromios, one in semblanee

by this sympathised one day's error.
hand in liand not one before another

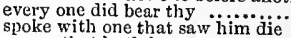

spoke with one that saw him dis

one of my fellows had the.....

therc's one did laugh in lis sleep, and on.

one cried, God bless us, and, amen ......

making the green-one red .........

every one according to the gift

I am one, my liege, whom the vile

ay, and a bold one, that dare

v. 2 there's not a one of them, but in

v. 2 and every one sliall share i' the...

v. 2 my heart throbs to know one thing

why, one that in her nest

every one that does so............

i. 2 lience, with your little ones.....

if such a one be fit to govern

each minute teems a new one

all my pretty ones? did you say

neither to you, nor any one

out, I sayl one; two ...............
sueli a one am I to fear, or none.

by this great clatter, one of great.....

must not yield to one of woman boru

youl came not of one mother, then ...........

one that will play the devil, si.

one must prove greatest

thon hast not saved one drop of........

out of one side her part eonfirm ....

two sueli streams made one

but thas these young ones?

sound one unto $[$ Co!. Knt.-on into $]$ tie

an hour, one minute, nay, one quiet

then I, as one that am ..............

whisper one another in the ear

at home, meet in one line ............

commend me to one Hnbert...........

I come one way of the Plantagenets...
one thread, one little hair (rep.).......

the one my duty owes....

botll grow in one

whereof thyself art one, were ..........

spriming from one root .................
onte phiul full of Wdward's saered (rep.) 


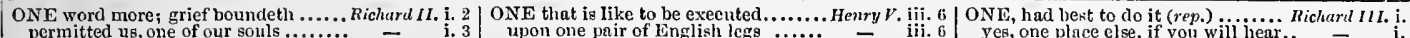

permitted us, one of our souls long a time lies in one litile.

Dut grief makes one hour ten ........

or bend one wrinkle on my ........

did not the one deserve to have....

divides one thing entire to many ....

where one on his side fights, thousand

to raze one title of your honour......

the one, in fear to lose w

one day too late, I fear ...............

each one thrice worse than Judas!

gnring from one most gracious head

to drop them still upon one place...

for every one doth so against ........

no more than every one doth know..
excepting one, I would he were the best =
a thousand spirits in one breast ....

found truth in all but one $\ldots$....

should'st thou fina one heinous articl

I'll heg one boon, and then be gone.

and hate turns one, or both, to worthy

togetlier weeping, make one

one kiss shall stop our mouths .......

from one side to the other turning

I had as lief be none, as one

come, little ones; and then again.....

come, little ones; and then again....

of one nature, of on

little better than one of the wicked...

I'll make one; an' $\boldsymbol{Y}$ do not, call ...

ask me fur one penny cost to ransom

needs no more but one tongue .......

him tell it to one of his company.....

one horse, my lord, he bronght......

proficient in one quarter of an hou

in England; and one of them is fait.

all's one for that; a plague of all ...

as like one of these harlotry ..........

monstrous! but one halfpenny-worth

equals not one of yours.

than one of these same metre........

one no persuasion can do good upon

one poor penny-worth of sugar-cand

at one cast? to set so rich (rep.)......

drop down a cors

death's hand, for this one half-year..

in one spbere; nor can one England

is come to end the one of us.

let one spirit of the first-born cain.

wrought out life, 'twas ten to one

overwhetmed all her litter but one
than he shall get one on his cheek

than he shall get one on his cheek

to be on any side but one.............

for the one, or the other, plays $\ldots .$.

like one, that draws the model of.....

[Col. Knt.] a hundred mark is a long one -

one you may do with sterling $\ldots \ldots$.

not have attached one of so high blood

one for superfluity, and one other

slall I tell thee one thing, Poin

to thec (as to one it pleases me

perfumes the blood ere one can say...

what the good-year! one must bear

I am the woodse, when one says ........

and asking every one for sir John...........

and asking every one for

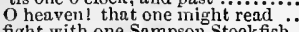

fight with one Sampson Stock fish ..

one of the king's justices of the peace

for one to do lier hushandry

to ena one doubt by deat

on my life, one time or other.........

whole strength into one giant arm

shorten Harry's happy life one di....

there's one Pistol come from the court

one word more, I beseech you...

one word more, I beseech you........

than ever at one time the clergy

are every one a woe, a sore...........

never did the clergy at one time....

doth keep in one concent $($ rep.).......

in one town; as many fresh (rep.)...

once afoot, end in one purpose......

we'll not offend one stomach..

it is a simple one; but what though

I will cut thy throat, one time or other the crow a pudding one of these days
knives to cut one another's throats?

knives to cut one another's thro

nor leave not one behind, that
I one, my lord; your highuess
extract one spark of evil .........

extract one spark of evil ............

even just between twelve and one ..

with one appearing hair ......... iii. (chorus) a sonnet hegin so to one's mistress .

by one that knows him bette

二 iv. (chortis)

twenty French crowns to one..........

there s five to one; besides, they all..
but one ten thousend of those

wish not one mun more (rep.)

likes me better, than to wisla us one

that every one may pa
are all one reckonings

but 'tis all one 'tis so like as my....

the the gage of one that $I$

on one part and on the other.

there is one goat for you

princes English, every on

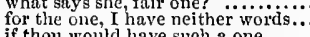

if thou would have sitch a one $\ldots . .$.

needs be granted to be much at one.

for one fair French maid that.

in one, your retlins in one! (rep. $)$.....

one would have lingering wars.... .1 Henry $V$

coat one half is cut away

I'll change for one of ours

besiege ns one hour in a month

he fighteth as one weary of ......

one to ten! lean raw-boned

one that still motions war $\ldots$ count every one, and view....

one of thy eyes, and thy cheek's side

with one Joan la Pucelle joinea...........

that one day bloomed, and firuitful..

that every one may read

kindly give one fainting kiss.

when one will kill; mourn not...

but one inperious in another's throne?

so fast at one another's pate

that grudge one thought against....

one drop of blood, drawn from

that any one should therefore

for vantage, every one will swear.

the help of one stands me in ......

all our lives in one small boat
shortening of my life one day.............

among professors of one faith

have their answer's every one

two parts, is now conjoined in one

teu to one, we shall not find

lords, with one cheerful voice

so, one by one, we'll weed them aili..

or York, all's one to me doth any one acense York for

in the gurret one night, as we

ten to one, old Joan had not gone...

mischiefs work the wicked one

shall one day make the duke of $\ddot{Y}$ ork

when every one will give the.

her harmless young one went...

were't not all one, an empty

show me one scar charactcred

as one end, as one distract

it is our pleasure, one of them depart

apparel them all in one livery ......

will not leave one lord, one gentleman

kill for a hundred lacking one

struck'st thou one blow in the field?

let them kiss one another

if one so rude, and of so mean condition

of one or both of us the time

nor liave we won one foot...

a thousand oaths, to reign one year...

and been ten to one

thou hast one son, for his.

blows, twice two for one ................

for one to thrust his hand between...

each one a perfect sum

but one lamp, one light, one sun .......

each one already biazing by his ....

protection of their tender ones

vow, one the better; then, another.

the one, bis purple blood right well..

wither one rose and let the other....

one way, or other, she is tor a king..

like one lost in a thorny wood

and this English queen's, are one...

but answer me one doub

nor how to be contented with one wif

yet in this one thing let me............

and, ten to one, you'll meet him ....

hapless male to one sweet...............

resident in men like one another ....

Richard ItI. i. I yes, one place else, if you will hear.
so I might live one hour in your

name, but one of better nature....

log one favour at thy' gracious .

nor no one here; tor curses never.
but while one would tell twenty

it fills one full of obstacles ...........

to wail one that's lost

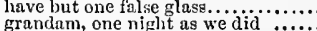

I moralize two meanings in one word

one trom lord Stanley

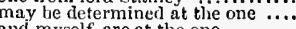

and myself, are at the one 7.17 .

for never yet one hour in his bed....

girdling or such little pretty ones ....

one heaved o' high, to be hurled

for one that scorned at me (rep.)

now fearing one; for one cominanding

as one being best acquaintce

of all one puin, save for a night.......

thitlier, is hut one day's march......

by this one bloody trial of sliarp war

wet one thing more, good captain...

and every one did threat to-morrow

one raised in blood, and one (rep.).

they would restrain the one, distain

a milksolp, one that never in his ...

what four throned ones could $(\mathrm{rp}$.)
but now married to one above itselt

twas said, they saw but one

one, certes, that promises no element

once weak ones, is not our's....

and, with ove hand on his dagger....

but they are shrewd ones; for when
lame ones; one would take it, that

a supper, and a great one to that..

but ter now give so great ones $\ldots . .$.
brought with her one care abroad

a sweet society of fair ones.....

confessor to one or two of these

there should be one amongst them

such a one, they alk amongst th

lend in

of state was a deep envious one...

of your prayers one sweet sacrifice .

goodness and he fill up one monume

at one stroke one day groan for't

must needs say, a noble one .........

the king will know him one day....

I'll ven will one day open the.

I mean, the learned ones....

hath sent one general tongue.

was not one doctor Pace in ..........

spake oae the least word ..............

one that ne'er dreamed a joy ........

all the land's wealth in to one ......

but, thus much, they are foul ones..

all my glories in that one woman

and. sometimes, falling ones

the one, of Winchester, (newiy.......

and one, already, of the privy-council

scholar, and a ripe, and good one....

of which there is not one, I dare avo

it's one o'clnck, boy, is't not?

the honour they do one another? (rep.)

clildish pity to one man's honour ...

might go one way, and safely.....

one that, in all obedience.

this young one male a Christian (rep)

a dozen crabtree staves, and strong ones -

this one christening wil gel

lenve her blessedness to one...

'tis ten to one, this play can

for such a one we showed them....... $-\overline{\text { (evil.) }}$

black-a-moor: "tis all one to me

one [Col. Knt,-two] and fifty lairs $($ rep. $)=$

he's one of the flowers of Troy ......

it's all one: by God's lid, it loes one's

say one of your watches $\ldots . . . . . . .$.

thy him too

ay thin onew

which with one voice eall $A . . . . . . .$.

if there be one among the firimest.on -

one is, or hath, or mcans to he, that one -

on when Ilector's.

one noble man, that hath one spurk
and such a one, that dare maintain.

this one again says Nestor.............
the value of oue ten..................

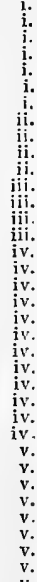

v. 3

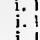

i.

i. 3

i. 4
i. 4
i. 4

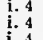$$
\text { . }
$$ 
ONE-is in one man's valour .... Troilus \& Cress. ii. 2 ONE-hear me one word; beseech you. Curtolunus, jii. 1 , ONE-your lady is one the tairest ..... Cymbeline, i1. Paris, less than the tenth part of one if ever you prove tialse one to nuotlie greatness, one fallen out wit do one pluck down another.......... how one man eats into a nother that one by one pursue......... with one consent, praise new-born in love with one of Pritm's it will go oue way or other the one and other Diomed embraces hark I there's one up .................. In give your three tor one the one almost as infinite.

as weleome as to one that would ..... time, will one day end it and one that loves quails. hark, one word in your ear. 'twas one's that loved me better... one camnot speak a word

frrewelll one eye jet looks on thee... like witless anticks, one another meet they ore thing, what another (rep.) think they have swallowed one another let one be sent to pray another (rep.) of gesture, one might interpret..... Timon of Ath. i. one do comma in the course with one man beckoned from.

not one aecompan ying lis

art one which holds a trencher (rep.) =

art not one? Yes. Then I lie not. sliouldst have kept one to thyself. commandling one another's fortunes! that bears not one spurn

Would one day stamp upon me.....

but rather one that smiles

one Varro's servant, my good lord .

the reason of this? I conld render one two stones more than his artificial one one elond of winter showers. one of lord Timon's men ( I ean tell you one thing, my lord...

one of his men was with lord Lnetili I count it one of my great sflliction
one business does cominand us all one may reach deep enongh

debt 3 may well be called desperate one one day he gives us diamonds and not one triend, to take his... not one word more: thus part we if one be, so are they all

let not thy sword skip one ........... thy plenteous boson one poor rooti have with one winter's brush..................... no prodignl. I, that I am one now ... way; rob one anoth

expecting in return tstake me not (rep.) I'd exchange for this one wish there's ne'er a one of you but trusts reside but where one villain is ...... and am not one that rejoices in

one word, good eitizens.......................

one that hath always loved (rep.)

for that being one o' the lowe

whieh else would feed on one another? a strange one, (to break ............. one's $J$ unius Brutus, Sieinius velutu I'll lean upon one eruteh....

than one voluptnously surfeit out of one of his father's moods.

witli one part of our Roman power.

and one infeet another against

tell me one thing that I shall ask yo e's poor in no one fault

and one that loves a eup of jot wine ye that converses more with

I think, there's one at home for you one in the neek, and two............. tis thought of every one, Coriolanu I had rather have one seratch my that's thousand to one good one neither will they bate one jot.

our wits were to jssue out of one skiul their consent of one direct way should by ones, by twos, and by threes .... every one of us has a single hon to one that would do thus (rep.). one thus descended, that hath beside and sich a one as he, who puts... why shall the people give one.........

\begin{tabular}{|c|c|c|c|}
\hline & & & \\
\hline & lience, were but one danger............. & $=$ & $\begin{array}{ll}\text { iii. } 1 \\
\text { iii. }\end{array}$ \\
\hline iiji. 2 & one word more, ons word ................... & - & iii. $\mathrm{i}$ \\
\hline $\begin{array}{l}\text { Iill. } \\
\text { iii. } 3\end{array}$ & $\begin{array}{l}\text { When one but of my ordinance ....... } \\
\text { at the price of one fair word ......... }\end{array}$ & $=$ & iii. 2 \\
\hline & to go rove with one tlat's yet........... & & $\begin{array}{l}\text { init. } 3 \\
\text { iv. } 1\end{array}$ \\
\hline & shake of but one seven years ........... & & $\begin{array}{l}\text { liv. } \\
\text { iv. i }\end{array}$ \\
\hline & baited with one that wants her wits? & & \\
\hline & a most royal one: the centurions .... & & iv. 3 \\
\hline & seem to wear one heart . & & \\
\hline & to take the one the other $\ldots \ldots \ldots \ldots . .$. & & \\
\hline $\begin{array}{l}3 \\
3\end{array}$ & $\begin{array}{l}\text { a strange one as ever I looked on ..... } \\
\text { a mavellous poor oue. True }\end{array}$ & - & \\
\hline .1 & $\begin{array}{l}\text { a mave the one poor one. True } \ldots \ldots . . . . . \\
\text { take thy commission.. }\end{array}$ & & $\begin{array}{l}\text { ivv. } 5 \\
\text { iv. } 5\end{array}$ \\
\hline & as one would sct th a top $\ldots \ldots \ldots \ldots$ & & \\
\hline .5 & than he, you wot oue. Who? .i...... & & \\
\hline & $\begin{array}{l}\text { anth, look you, one annot tell how } \\
\text { and bint one lanif of what he was .... }\end{array}$ & & \\
\hline & hate one, another. Reason (rep.) & 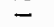 & \\
\hline & and affecting olle sole throne & & \\
\hline & not to be other than one thing .... & - & \\
\hline & $\begin{array}{l}\text { Din, one ot these, as he hath spices } \\
\text { one drives ont one fire, one nail, one }\end{array}$ & $=$ & $\begin{array}{l}\text { iv. } \\
\text { iv. } 7\end{array}$ \\
\hline v. & yet one time he did call me.............. & & \\
\hline & $\begin{array}{l}\text { to one whom they had punished } . . . \\
\text { for one poor }\end{array}$ & & \\
\hline 2 & $\begin{array}{l}\text { lor one poor grain or two (rep.).... } \\
\text { Inm one, that telling true ....... }\end{array}$ & $=$ & \\
\hline v. 3 & than seek the end of one ........ & $z$ & \\
\hline & prate, like one i' the stoeks $\ldots .$. & - & \\
\hline & o the elliefest soldiers; I'll be one & & \\
\hline 8 & 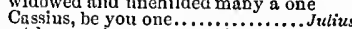 & & $\begin{array}{r}\text { r. } 5 \\
, \mathrm{i} .2\end{array}$ \\
\hline & set honour in one eye, and death ..... & - & \\
\hline & with more than with one man? (rep.) & - & \\
\hline & $\begin{array}{l}\text { twas one of these coronets } \\
\text { smiled at one another and shook....... }\end{array}$ & & \\
\hline & for here comes one in haste..... & & \\
\hline & no, it is Casca; one incorporate.... & & $\hat{i}$. \\
\hline & Shall Rome stand under one man's awe? & & \\
\hline & $\begin{array}{l}\text { give me your hands all over, one by one } \\
\text { good-morrow to you every one ......... }\end{array}$ & 一 & 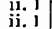 \\
\hline & which did incorporate and make us one & - & \\
\hline & rk, hark! one knocks: Portia .... & & \\
\hline & & & \\
\hline & to be rendered, & & \\
\hline & there is but one mind in all .... - & ii. 3 & \\
\hline
\end{tabular}
each on one toot standing......
believed of one persusdeal wel like a full-acorned bear, a German on one vice but of a minute old, for one are med'cinable; that's one of thiem. If one of mean affairs may plod it why, one that rode to his exeeution be in one niglit, a storm one, but painted thus, would ï be.... first, make yourself but like one I torgot to ask lim one thing............. I see, a man's life, is a terlious one ... When rich ones searce tell true ....... no eomf one o' the false ones

he is but one: you and my brother. crut off one Cloten's hlead

wears the nad the to worse ........ rot ting to nether one half so well.. young one, iuform us of thy fortine... reserve my eracked one to more eare no bond, but to do just one soldier; an honest one, I warrant.... ten, ehased by one, are now each oue yet am I better than one tlat's sick from lier his dearest one $\ldots \ldots \ldots \ldots \ldots$...... you'll never return to tell on

so should I, it I were one

one that promised naught but beggary though with the loss of many a bold onc

one sand another not more resembies

of all amongst the rarest of good ones

I left out one thing wlich the queen

buried one and twenty valiant ${ }^{2}$ sons.... one tit to bandy with thy lawless sons
my foes I do repute y'ou every one .. nor me, so I were one ou tiger s young ones teach the dam? and one thing more, that womanhood that the one will help to cut I stand as one upon a rock

or any one of you, ehop off

turn me to each one of you

more than one eonfiderate in......... liast shot off one of my eountryman my unele and one of the emperial's.". as willingly as one would kill a fly t!:e one is Murder, Rape is the other's this one hand yet is left to ent ....... come, be every nue officious to .......

corn into one mutual sheaf $(r \in p$.$) ....$ if one good deed in all my life

one sin, I know, another doth provoke. Feric of which thyself art one, whon

who shuns yot to break one.....................

throws down one mountain, to east up . one sorrow never eomes, but brings

the grent ones eat up the little ones.......

to every one that comes to honour thiem therefore each one betake him to........

let me ask one thin

every one with claps ".................. iii. (Gower in I have one myself, who shall not be - iv. (Gouler)
hath our Cleon one daughter....

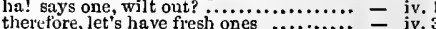
why lament you, pretty one? why lament you, pretty one?

yon are like one, that superstitiously y $\ldots$ - iv. now, pretty one, how lone (rep)

I besech your lonour, one piece for me... $=$ iv. 6 one thing first. Come, now, your one thing - iv. she sings like nue imn ortal ............ v. (Gower) hath not spoken to any one

weleome, fair one! (rep.)

for thou look'st like one I loved indeed.... was given me by one that had some...... I know, in that, ore mo

for taking one's part that is ont

gavest thy golden one aw ay ..........

here eomes one of the paring

ni.hy one's nose stands ' ' the midiile..

I mean, the whispered ones, for the

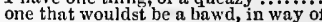

ii. 3 one whom 1 will beat in to clamorous

thisu to rail on one, that is neither.
but the great one that goes nu the hili

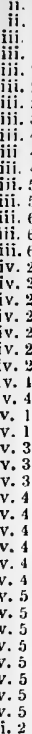

ii. 3

iii. 5

iii.

v.

iv. 4
$v, 1$
$v, 2$
$v, 2$

v. 2

v. 3
v. 3 i. 1

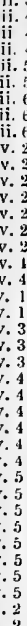
3 . 
ONE-no more see one another

how, in one house, should nany peopie....

what need one? 0 renson nut the need .:

one minded like the weatler

one minded like the weather

Thave one part in my heart .............
one, that slept in the eontriving
let me ask you one word in private........

for one blast of thy minikin month - - iii. $\overline{6}$ (solig)

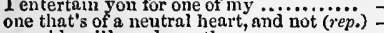

one side will mock another

my lord, you have one eye left ............

dizzy 'tis, to east one's eyes so lowl

ere the blaek ones were there

all the latters aus

thou hast one daughter, who redeems..... $=$ iv. 6

every one hears that, which ean distinguis

so poor, hcar me one word.................

paeks and seets of great ones

one step I lav ve advaneed tbe.

the one the other poisoned when one is dead, and when one

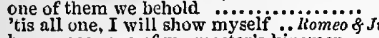

bere comes one of my master's kinsmen
stir one $[K n t,-a]$ font to seek a foe....

iill urged to one that is so illl ........

one more, most weleome, makes my

being one. may stand in number .....

one desperate grief cures with anotlier's =

one fairer than my lovel ............

why, may one ask?

lie all in one or two men's hands

learned even now of one I danced

but one rylume, and I am satisfied ....
Veuns one fair word, one niek-name

ere one ean say-it lightens..........

on a sudden, one hath wounded me..

a grave, to lay one in, another $\ldots . . .$.
in one respeet $I^{\prime \prime l}$ thy assistant be

one, two, and the third in your bosom
more of the wildgoose in one of thy wits

more gentlewoman, that God hath made --

a nobleman in town, one Paris

of joy that one short mioute gives $m$ e

holy church ineorporate two in one..

thou art like one of those fellows ....

for one would kill the other..

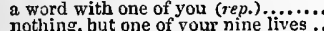

nothing, but one of your nine lives $\ddot{3}$

those tw'enty eould but kill one life..

and Romeo, press one heavy bie

that one word, banished, hath
arise, one knocks; good homeo
one kiss, and I'1l deseend .............

os one dead in the bottom of e.........

I'll send to one in Mantua

one, who, to put thee from thy heaviness =

in one little body thou eounterfeit'st

may not one speak? Peaee

proportioned as one's heart could wish

but one, poor one, one poor and (rep.)

one of our order, to assoeiate me.....

one writ with me in sour misfortune's
bere's one, $a$ friend, and one that know

my master one that you love ........

anon, comes one with light to ope the

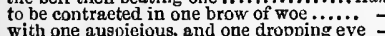
while one with moderate haste.

carrying, I say, the stamp of one defect.

that one may smile, and smile, and be

give me one poor request

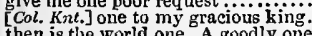

then is the world one. A goodly
Denmark being one of the worst

Denmark being one of the worst
then your ambition makes it one

why-one fair daughter, and no more

I remember, one said, there were n

one speech in it I eliefly loved ............

God hath given you one face, and you..

madness in greent ones must not

the ceusure of whieh one, must, in your

as one, in suffering all, that sufters

do not itself unkennel in one speeeh

one as kind for husband slaalt thou. $1 . .$.

a whole one, I. For thou dost know

0 the recorders: let me see one

may one be pardoned, and retain the......

when one ean not repent?

but a siekly part of one true sense.....

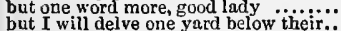

when in one line two crafts.
two dishes, but to one table...

man and wife is one flesh

hath but one part wisdom, and, ever

would make one think, there might

sueh envy frum him, as did that one

a siglit indecd, if one eould match $y$

one woe doth tread upon another 8

one that would eireumvent God

his purehases, and double ones too

oue, that was a woman, sir .......
ONE now, to mock your own grinning?.. Hamlel, v. I OPEN your chaps again

pr'ythee, Horatio, tell me one thing
life's no more than to say, one

come, one for me. I'll be your foil

the elouds, methonght, woulia open.....
opcis the matter in brief ..... Tu'ofien

open your pusse, that the

three great ones of the city

his thefts were too open

one Michiael Cassio, a Fiorentine
and such a one do $I$ profess inyself

take heed; have oppen eye...............
which I with sword will open

zounds, sir, youl are one of thuse
I am one, sir, that comes to tell yoi

all ways do lie oper

some one way, some anther $\ldots \ldots \ldots$
this very night, at one another's heels

(n)

goodnight to every one: and, noble signior $=\begin{gathered}\text { i. } 2 \\ \text { i. } 3\end{gathered}$ or f will not open my lips.

supply it with one gender of herbs ......

one that exeels the quirks of blazoning

tis orie lago, ane ient to the general
there's one gone to the harbour?

pranks sor use, the other useth it

one, that in the authority of her merit.

he is a good one, and his worthiness doce

good faith a little one; not past a pint

the one as long as the other.............
with one of an ingraft infirmity

and tilting one at other's breast

as one would beat his offeneeless dog. $_{\text {. }} .$.
diseourse fustian with one's own sladow

one unperfectness shows me another

thy fates open their liands..........

do not then walk too open

by my troth, tlsou hast an open hand

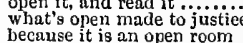

I will open my lips in vain

refused it in the open eourt

then open not thy lips

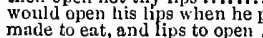

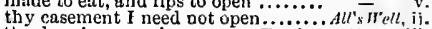

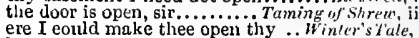

bow came tle posterns so easily open?
so shall she have a just and open trial

so shall she have a just and open trial
partly laid open, thou. Hermione

open air, hefore I have got strength.

open't: so, let's see (rep.) ..........
to his entranee open, or hoop

to have an open ear, a quiek eye

from one that so imperfeetly conjects.

i. 2 yet, tis the plague of great ones

I eommand thee to open thy affaic...

ho, open, the door .................eded
lay open to my earthy gross coneeit

one is too poor, too weak for my revenge! =

though great ones are their obje.

ii. 1 his second fit, he had one yesterday

ii. 1 to beguile many, and be beguiled by on

a most unhappy one: 1 would do much.

i. 3 lest, being like one of heaven, the devils

would it not make one weep?

ii. 4 all's one: good father! how foolish are.

slu'oud me in one of those same sheets.

to go hang my head all at one side $\ldots . . .$.

one of them is here about (
one more, one more (rep.).

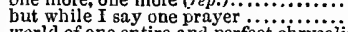

world of one entire and perfeet chirysolite

of one, that loved not wisely (rep. ). ......
of one, whose hand, like the base Judean

of one, whose subdued eves a abeit unuse
uNE-TRUNK-INHERITING slave ....

slanders, and this open slaume!

the doors are open; and the s
open, locks, whoever knocks

you see, her eyes are open

open wide your gates ( $r e p$.
with open mouth swallowin

doth lay it open, to urge on revenge

or, being open, put into his $h$ a

is open, and my heart is.... - $=$ iii.

open the door (rep.)................

and then open the door. Poins

from this open and apparent shame?

open your ears; for which $1 . . . . .2 H e n r y$
hand open as day for melting charity

keep'st the ports of slumber open...

hath left me open to all injuries

from open haunts and popularity
their faults are open, arrest them

this war opens his vasty jaws........

open your gates: eome, unele Exeter
open the gates (rep.) .................

but to make open prociamation

in open market-place produced

open your eity gates, be hich
often Yodge in open field

and I lie open to the law :....

wink now; now, open them..........
after three days' open penanee done

my lord, to see my open shamel

break open the gaots, and let out .....

I'll open them. So looks the...

my father's blood open it again.
opent thy gate of mercy, graeious.

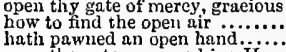

open the gates, we are king IIenry.:.

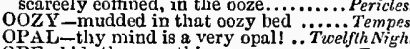

OPE-bids thee ope thine ear............. Tempest, $\mathrm{i}$. 2

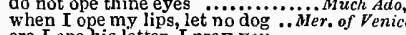

ere I ope his letter, I pray you .......

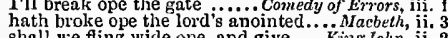

shall we fling wide ope, and give....King'Jo
now, eitizens of Angiers, ope your gates

he is eome to ope the purple ....... Richard $1 I$. iii. 3

set ope thy everlastiug gate

the morning opes her golden gates...3 Henry $V I$. ivi. 1

brazen gates of heaven may
wilt thou ope the eity gates

when rank Thersites opes his. Troilus \& Cressida,, $\mathbf{i} .3$

rampired gates, and they shall ope. Timon of $A t h$. v. 5

so, now the gates are ope $\ldots \ldots \ldots . .$. Coriola nus, i. 4
in time break ope the locks o the..

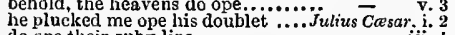

to ope their golden eye...................

thy erystal window ope.................

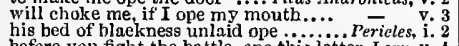

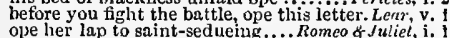

comes one with light to ope the tomb
thus wide I'll ope my arms

thus wide r'll ope my arns...

Hamert, iv. 5

OPED - oped, and let them forth......

Tempello, v. 2

and oped their arms to embrace.. Titus.sndron.

hath oped lis ponderous and marb

to be asleep with open the gates...

Tempest

open your mon th (rep.).

gates are open, let us enter too .

wead Frenry's wounds open their......
dearth, gape open wide, and eat him..
so, when lee opens his purse to give..

his apparent open guilt onititted .....

have open means to eome to them ...

'tis wotul; we are too open here ... H
will one day open the king's eyes...

mouth filled up, before you open it..

truth loves open dealing

his fanlts lie open to the laws

this day was viewed in open

what, are all the doors open here? ...

his heart and hand botl open........ $=$ iv.s

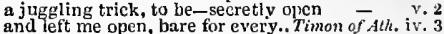

break open shops; nothing ean.

it opens the eyos of expectation.

descend, and open your uncharged ports -

they'll open of themselves.......... Cooriztumzs,

lightens, opens graves, and roars $\ldots . . .$.

he'd lay the future open.......... Cymbetine. iit. 2

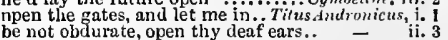

open them, boy: but thou art.........

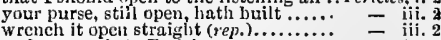

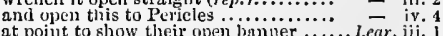

open this purse, and take what it contaius - iii. I 
OPEN-the tyranny of the open night's .. Lear, iij. 1 OPINION-in craving your opinion ..21lenry YI. ii. 2 OPPOSER Coriolanus being now .... Corinlanu, iv. 3 [Col.] an open etcetera.................... entorce thy rotten jaws to open......

if thou be merciful, open the tomb ...

and all run, with open outcry,

my nlinion, ought to be prevented. Rithurd II $I$. ij.

in mine opinion, camnot have it .......
the npiuion that we bring

theres an ill opinion spread then

fit to open dead mien's tombs $\ldots \ldots \ldots . . . \overline{H a m l e l}$. .3

that to

the Aroor is of a free and open natiure....

envy and bissood opinion to you $\ddot{3}$ -

our just opinions, and comtorts....

he is returael, in his opinion

new opinions. divers, and dangerous - - ive

if he were opened, and you find. Twelph Night, ini. 2

and those gates opened, as mine.. Mintry's Thite, i. 2

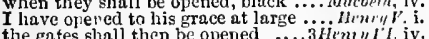

the gates shall then be opened

my hand as opened bounts' to

opened, in despite of lieaven

opened, nn despite of heaven $\ldots$ mine, if both were opened

that, opened, lies within our remedy.... Hantet, ii

OPENER-opener and intelligencer .2 Henry IV
IPEN-EYED conspiracy his.... Tempest, ii. ]

OPEN-EYED conspiracy his.... Tempest,

all fiery-red, opening on Neptune.Mid. N' 's Dr. iii. 2

the first opening of the gorse

theontes, opening his free arms .... Winler's'tale, iv. 3

I was by at the opening of the fardel

with opening titles misereate......... Henry $V . .1 .2$

for fear of opening iny lips...

opinion ero wins with an inperial vois trial much opinion divells

to steal a strong opinion to themselves

our we under our opinion stili

ifector's opinion is this, in way

a plagne of opinion! a man may
fish with craft tor great opinion.

and poliey grows into an ill opinion

the poor itch of your opinion .......

OIPOSIN( $\mathrm{f}$ freely the heauty of her Heiry $I^{\prime} I I I$. iv.

opposing laws with strokes ........ Coriolanus, iii. and, by oppusing, end them? to die ... IRamlel, iii.
OPPOSITE to humanity ........ Timon of d/hers i. and his opposite, the youth.ii..4) Tuelfhh $\boldsymbol{N}^{\prime}$.ii.5 (let.) for your opposite hath in him

skilful, blootly, and fatal opposite what is opposite to England's love... King John, iii. to weigh against his opposite.......2 Henry ${ }^{\prime} . \dot{\mathrm{i}} .3$ and feurful meeting of their ojposite $-\bar{v} \mathrm{Vt}$. being opposites of such repairing nature

hov apt as uposite to every good ..3 Henry $/ 1$. i. to be thus opposite to ever se

beopposite all planets of good

laring an olposite to every danger.

opinion, that so stieks on Marcius

so, your opinion is, Anfidius, that...

does become the opposite of itself. Antany/s Cleo. j. 2

you land liut that opinion of yourself

opposite to

quite from the main olvinim lie heid

each opposite, that blanks the tace.... Humlet, iii.

bring me their opinions of snecess

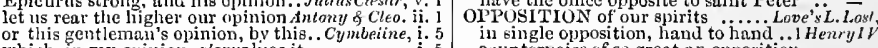

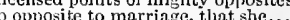

lave the the marriage, that she....... Olhello, i.

for your ill opinion, and the asstult

is in opinion, and in honour, wronged. Titus And. i. 2

since we so openly procecd in.
which now you wear so ovenly.

Which now you wear so openly... Cometly of tir.

and my case so openly known to

shall show itself more openls hereatier - iv. 2

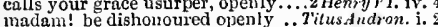

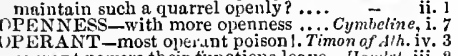

his very opinion in the let ter

when false opinion, whose wrong thouglit Lear, it.

to east beyond ourselves in our opinions

the most fond and winnowed opinions

spend your ricls opinion, for the name of

do build on thee a better opinion than

I'ERA'TE-operate another way. Trailus \& Crrss. v.

PERATIONS in my head

hath a twofold operation in it

Merry

by the operation of your sun ......Anlony \& Cleo. ii.?

edge, stiug, or operation. I am safe
hy all the operations of the orbs

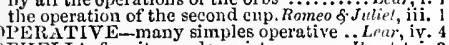

OPIELI A, fear it, ny dear sister.........
farewell, Ophelia; and remember weil...

what is 't, Uphelia, he hath said to you?

Oplielia, do not believe his vows .......

the most beautified Ophelic...... - ii .2 (letier)

O dear Ophelia, I am ill'at these.. -

may hour part, Ophelia, I do wish

OPINIONED-let them be opinioned. MIueh $\overline{A d} a$, iv.

OPPOR' UNE place, the strongest....'I"empest, iv. 1

PPORTUNITIES to meet her

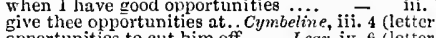

opportunities to cut him off....... Lear, iv. 6 (letter)
OPPORTUNITY and humblest ... Mery $W_{\text {, wes, }}$ iii. 4

double gilt of this opportunity..Tuelfih Night, iii.

more better opportunity to be....... Henry $V_{\text {. ifi. }}$

we shall not find like opportunity .. Henry $V I$. i. sluttish spoils of opportunity .. Troilus \& Cress. iv.

Uphelia, walk you here...... now the fair Oplia

admittance, and opportunity

i.

how now, Ophelia? (rep. iv, 5 )

nay, but Ophelia- Pray you, nark...

joor Ophelia divided trom lierself....

Ophelia, and therefore I forbid my te

the fair Ophelia! sweets to the sweet

in thy opinion, which is

that opportanity, which then they lad

shall give thee opportunity

I will omit no opportunity:..... Rameo \& Juliet, ii.

if I can bring it to any opportunity.... othello, ii.

I do oppose my patience to l. Tuo

oppose agaimst their wills

alone do me oppose arainst the po.........acbell iv.

and oppose not inyself against... Richard ll. ii.

oppose himself against a troop of..2 Henry VI. iii. I

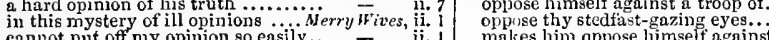

cannot put off ny opinion so easily..

into a most hideous opinion of his rage

what think'st thou of his opinion?

if you oppose yourselves to match ... $\overline{\text { Heo }}$ wreak to oppose your cunning.

whom may you else oppose .... Trailus \& Criss. i.

to oppose his hatred filly............ Cortiol

where I will oppose his fate.....Antony \& Clen. iii. il

to oppose the bolt against ny coming in..Lear, ii.

with that opinion that I am tonched ${ }_{\text {is the opinion that fire cannot melt .. Much } A d o, \text { i. I }}$

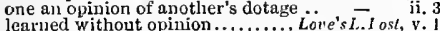

learlued without opinion .......... Love st

this fool's gudgeon, this opinion ij...
eay thy opinion, how dost thou ije

nay, but a,k my opinion too of that..

lie is furnished witl my opinion $\cdots$ iv. $\overline{-1}$ (letter)

opinion that grows rank in them. As you Like it, ii. ?

at least, in my opinion

what's your olvinion of your sister? Taining of sh. iii.

be cured of this diseased opinion... W'inter's Tule, $i$.

remove the root of his opinion

I have bought golden opinions

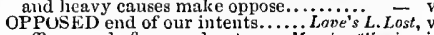

offices, and of opposed natures...Merch or'Y 'enice, i. 9

to give my hand, opposed arainst. Taming of 'shifi.

when 'tis opposed, as it must be.

thou opposed, licing of no womun born. Masbeth, v.

no.more opposed against acquaintance -

my lord, they shall be well opposed..

whereby we stand opposed by such

decay!..2Henryll $Y^{\prime}$. iv.

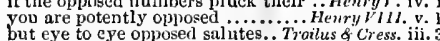

misprising the knight opposed

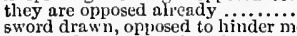

sword drawn, opposed to linder me..
are my doors opposed agaiust. Timon of dileens, iii.

mert sopinions, and my living blood. Richart $1 \mathrm{~h}$.

partly nuy own opinion $\dddot{3}$ ha.............

apinion, that did help me to thic crent and more great opinion

thou hast redeemed thy lost opinion = v.

better opinion, better confirmation

in gencral part we were opposed

to such neot excellence upposed Antony \& Cleon. iii. i

and to raze out rotten opinion

to such neat excellenet olposed .... Cymbelin

remorse, opposed ayainst the act ........
[Kut.] opposed against the jurring winds?
two such opposed toes

partly, to satisfy my opinion ......... Henry $r$. iti.

yield the other in the right opinion... - ii. 4

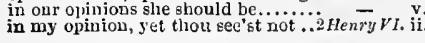

guard, nor eye, it you oppored them .. Hamlet, iv.

eounterpoise of so great an opposition $-\vec{c}$

more remarkahle in single oppositions -

in our peevish opposition .............. hamele 1.

one at other's breast, in opposition ..... o/hello, ii.

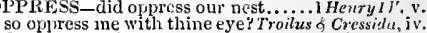

dumps the mind oppress. Lomeo \& Juliet, iv. 5 (s(m)g
OPPRESSED_oppressed with truvel. T Tempest, iij.

maid with travel much olpressed. As ynu Like it, ii.

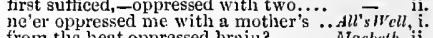

and rights of this oppressed boy ......... Karing Johth, ii.

in the relief of this oppressed child... King John, i

oppressed with wrongs, and therefore - iii.

all our offices have been oppressed. Timon of $A i h$. ii.

when nature, being oppressed............. Lear, ii.

for thee, oppressed king, an I cast dow

PPRESSES-it oppresses me already .... Othello, i. I

OPPRESSETH-oppresseth strellgth. Richurd 11 . iii. 2

our oppression hath made up this league - iii. I

steop' with opyression of their prodical subjects to oppression and eontenut..Henry $r$. ii. such as your oppression fecds.1 Henry $\%$ l. iv. I (let.) how under uny oppression I did.... Hen'zl $r \bar{I} 11$. ii. 4 our oppression exceeds what..... dutony o cleo. iv. 7
in the oppression of aged tyranoy ...Lear, i. 2 (lei.) at thy good heart's oppression ... Romeo \& Juliet, $\mathrm{i}$. too great oppression tor a tender thing - i. lack gall to make oppression bitter ..... Hamlet, ii. PPROBRIOUSLY? No doubt ... Richard $\overline{I I}$ l. iii. I PUGNANCX-mere oppugnancy. Troil. \& Cress. i. 3
PULENCY -youth and opulency. Timan of $\mathrm{Ath}$. $\mathrm{v}$. I a third more opulent than your sisters? .. Lear i. RACLE-agaiust an oracle .........Tenepest, iv.
sume oracle must rectify our kuowierlge sume oracle must rectify our knowlerlge - y.
his oaths are oraeles........ Two Ger. of Ferona, $\mathrm{it}$. as we would hear an oracle ...... Love's L. Lost, i. $\mathrm{I}$ am sir Oracle, nnd when 1 ope... Ner. of 'Venice, i.
from the oracle tliey will bring .. Winter's Tale, ii. yet slall the oracle give rest to....... - ii. I those you sent to the oracle, are come
the ear-deafeoing voice o' the oracle I do refer me to the oracle .......... $=$ iii. 2 in Apollo's name, lis oracle ........ there is no truth at all i' the oracle - $\quad$ iii. 2 profaneness 'gainst thine oracle!.... the oracle is fulfilled (rep.) ...........
that the oracle gave hope thou wast $\quad$ - $\quad$. 2
v. 3 may they not be my oracles as well. . Na.cbeth, iii. I these oracles are bardily attained ..2Henry $I .1 .4$

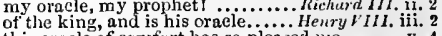
this oracle of comfurt has so pleased ne - v. 4 bold as au oracle: and sets Thersites - i. 3 wert thou an oracle to tell me so....
the oracle hath doubtfully ...Timon of Athens, jv. 3
. 35 let my gravestone be your oraele .... answering the letter of the oracle ...Cymuetine, v.

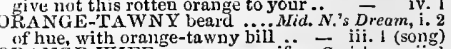
of hue, with orange-tawny bill $\ddot{\text { RANG }} \overline{\text { ini. I (song) }}$

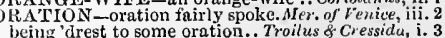

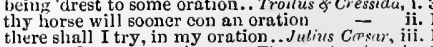
to serve for your oration .... Tirus sudiun ires, jv, OI'POSW'R-thy opposers' swords! ..... Cor ivle

deliver an oration to the emperur... 
(IRATION-fold it in the oration.. Tilus Androm. iv. 3 ORA'TOR-very good orators .....As yinu Like it,

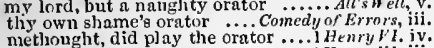
how quaint an orator you are.....2 Henry ${ }^{\prime}$ l. no, I cas better play the orator hath Clifford played the orator.... piay the orator as well as Nestor.... I'll play the orator, as if the ....Ri

gold were as good us twenty orators

poor breathing oratnrs of misersesi . I am no orator, as Brutus is........ Julintitasar. il. my teare no iv sweet poetry and Tully ortor ....i inenry $V_{I}$. ii. if my weak oratory can from his.. when my oratory grew to an end.. you seem to me as Dian in her orb Much.telo, iv. to dew her orbs upon the green ...Mid. N.'s Dr. ii. there's not the smallest orb. Nerchant of Venice, move is that olsedient or a folds in this orlo o' the earth. have empty lett their orbs $\ldots \ldots$ Ani meant to qunil as:d shak

after this fery orbs above ........... Cypmeline, but in our orbs we'll live so ............. Pericles, $i$. by all the operations of the orbs ......... Lear, i. and the orb below as hnsh as denth.... Hamlet ORBED-that orbed continent.... Tweifth Night, v. ORCHARD-I saw't i' the orchard. Tüeifh Night, me for him at the eorner of the orehard

attends thee at the orehard end....... bring it hither to me in the orchard

I and Ursula walk in the orehard.

saw afar off in the orchard this amiable

very well, here in your orehard ...Asyon Like walk a little in the ord let lim be brought into tlie orehard.. King John, sou shall see mine orehard

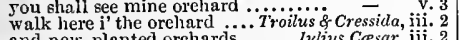
and new-planted orchards.......Julius Cresar, iii. 2 the orehard walls are higl, and hard to - ii. sleeping in my orehard (rep.)

ORD-as prave ords at the prige .....Henry $V$. iii. 6 ORDA INED-musie was ordained. Taming of $S h$. being ordained his speeial governor..1 Henry this order was ordained, my lords

wast thou ordained, dear father ....2 Henry $l^{\prime}$ amongst the rest, was I ordained.

this shoulder was ordained so thick.

Mulmutius, which ordained our laws ... Cymb. things, that we ordained festival. Romeo \& Juliel, iv. OlRDAINING he should be........Mer

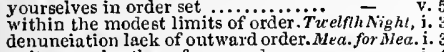
as 'twere a brother of your order ....

there are pretty orders beginning....

hiad st thou not order?

and my blessed order, I eome to visit

nllowed by order of law a furred gown

by the vow of mine order

trust not my boly order.

that sbould by private order eise have

was a votaress of my order..... Mid. N.'s Dream, ii.

give order to my servants .. Merchant of l'eniee, $\mathrm{v}$.
ean you nominate in order now .. As you Like it, $\mathrm{v}$.

given order for our horses.

this order bath Baptista ta'en... Taming of $\overline{S h}$.

to learn the order of my fingering ...

it was the friar of orders grey .... $\frac{-}{\text { iv. }} 1$ (song)

gave oreientest order was.. Winter's 'rule, iv. (ehorus)

eharitable duty of my order ... Comedy of Errors, $v$.

to take order tor the wrongs $\ldots . . . . .$.
not upon the order of your going... .

according to our order

inpose some gentle order ................ King Joh

all form is formiess, order orderless... - iii. sueh temperate order in so fieree

send fair-play orders, and make

having our fair order written down...
order the trial, marshal, and begiu. . Richard $11 . \mathrm{i}$.

which way, to order these affairs....

madam, there is order taen or youl
help to order several powers to Uxford -
aceording to our threetold order....I Henry $I$

now I live out of all order

and order for their furniture $\ldots \ldots \ldots . .$. - iii.

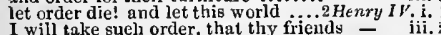
the manner and trne order of ........ - iv. the act of order to a peopled kingdom.. Henry $\nu$. $\mathbf{j}$ to whom the order of the siege is given - iii. toorder pcace between them ...... v. v. (chorns) that thinge are set in order here..... II I enry $V l$. ii. bive ordex for wy tuueral............ - ii.
Rl)ER-some order in the tow $1 . . .$. Hlenry VI. iii. 2
when first this order was ordined ..

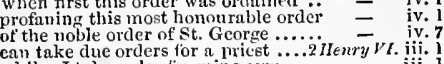
whiles I take order for mine own.... - iil they hear the order of his deati in order, and march toward us $(r e p$.$) \quad - iv. 2$ till that the duke give order for........ kichard $11 . \mathrm{i}$. the order was reversed (rep.) ........

[Col. Knt.] to give order, that no ö ö

order gave each thing view ......... He

there's order given for hier eoronation

in all line of order.............

any voiee or order of the ficlid?...........

will you go sce the order of .........

and by that orcler of

order for sea is given ....Antony \& Cleop
sec ligh order in this great solemnity

atterwards, to order well the state. Tilus Andron. v

we bave given order to be next. ...

a son by order of law by hol.................... Lear i. $\mathrm{i}$.

one of our order, to associate me $\ldots . .$. . $-\overline{\text { amlel, }}$, vii.

that great command o'ersways the order

give order, that these bochies high on .....

unless it may be quaintly ordered Aler.oflenice, ii.
my battle shall be ordered ........ Richard $M I$. v

my battle shall be ordered $\ldots . . . .$. Richard 1 .

like a soldier, ordercd hnnourably. Julinus Casar, y. 5

bear his courses to be ordered.. Pericles, iy . (Gow.)

if thou hast the ordering of the miud - ii. 3

have thou the ordering of this ....... King John, $\mathrm{y}$

RDERLY -very orderly ... Two Gen. of Veron

bought, and orderly bestowed ...Mer. of Ienice, ii. 2 you are too blunt, go to it orderly. Taming of $\mathrm{Sh}$. ii. 1 you bid me make it orderly and well and orderiy proceed to swear him .. Riehord II. i. 3 frame your'elf to orderly solicits.... Cymbeline, $\mathrm{il.}$. by God's just ordinanee $($ rep. v. 4$)$.Richard III one but of my ordinanee stood up.. Coriolanus, from their ordinance, their natures.Julius Casar, i. let ordinamee eorne as the gods

Inan, that slaves your ordinanee $\ldots . .$. . Lear,
ORDINAN'T-was heaven ordinant... Hamle,
RDINARIES, to be a pretty wise.... All's Well, ORDINARY - an ordinary man .. Tuelfth Nighl, i. 3

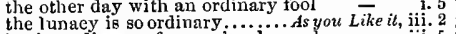
in the ordinarg of nature sale-work - iit. 5 being an ordinary inundation ....... hing John, v. 2 an ordinary groom is for sueh....... Henry hulius Casar to stale with ordinary oaths my love - i. 2 fire the blood of ordinary men ....... $\quad \begin{array}{r}\text { iii. I } \\ \text {. Cleo. ii. } 2\end{array}$ that whieh ordinary men are fit for ...... Lear, i. 4 the eompulsion of their ordnance ... King John, ii. second accent of his ordnanee $\ldots \ldots \ldots \ldots$ H H nry $V$. ii. 4
behold the ordnanee on their ..... a piece of ordnance 'gainst it ......... Henry VI. i. 4 all the battlements their ordnance fire. Hamlet, v.

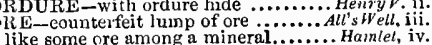
like some ore among a mineral.......... Ham Wives, v.
is as the maiden's organ, shrili..... Tuelfh Night, i. is as the maiden s organ, shrill.... Tueth the organs of our own power. Meas. for Heas. i. I and every lovely organ of her life... Mruch Ade, iv. I within an organ weak

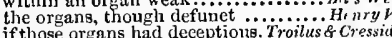
if those organs had deeptiolze. Troilus o cressida, $v$

dry up in her the organs of increase ........ Le

devise it 80, that I might be the organ..... - iv. ?

from the organ-pipc of frailty ...... King John, v 7

ORIENT pearls, stood ........Mrid N.'s Drtam, iv. 1

trom the orient to the drooping. 2 Henry 1 . (indue.)

agabled kisses, this orient pearl. Anlony ocleo. i.

ORIElCE-admits no orifee .... Troilus \& Cress. v. 2
ORIG IN-which eoutemns its origin...... Lear, iv. 2

natnre eannot cloose his origin the origin and commencement of his grief - iij. 1 RIGINAL-parents and original...Mid.N.'sDr. ii. it hath its original from much grief. 2Henryl 1 . it. let's hear the orisons he niakes.

I have need of many orisons........... nymph in thy orisons be all my sins.. Hamlet, iii. I
OKK-we will afterwards 'ork.....Mes ry Wives, i. । ghoud opportmities f'or the 'ork.......
OIRLANDO, my liege, the youngest. As you Like it, i. poor Orlandol thou art overthirown run, run, Orlando, earve, on every tree it is yonng Orlando; that tripped up.. when there is such a man as Orlando? hy, how now, Orjandol.

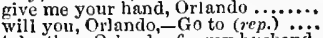

take thee, Orlando, for my hissbond

no, no, Orlando: men are April when

two o'clock? and here much Orlando

the young Orlando parted from

seeing Orlando, it unlinked itself

but to Orlando; did he leave him

dost thou believe, Orlando, that
will bestow her on OrJando herc?.

ORI, yours, Orlando, to receive verson for all the 'orli. i

he is an ass, as in the orld $\ldots \ldots \ldots . .$.
well as any military man in the orld

any hun of no estimation in the orid..

make show to the 'orld he is ........

in the universal 'orld (rep.iv. 8) ....

I will confess it to all the orla......

vourself, and all the orld know to he you dukes - and of Orleans, Bourbon my lord of Orleans, and my lord $\mathrm{bigh}$

Clariles duke of Orleans, licphew...

the bastard of Orleans with him ....

for Orleans is besiegred of Orleans....

here we lie, near Orleais.

shal] we give over Orleans or no?....

sirral, thou knowest how öleans $\mathrm{is}$

now it is sppper-time in Orleans ....

Pucelle is entered into Orleans......

rescued is Orleans from the English

engrayed tie sack of Orlcans...

Oras not the duke of Orleans thy foe?

beat down Alencon, Orleans

the ireful bastard, Orleans, that ..... - iv. 4

the sw' ord of Orleans hath not....... Henry $V I$. iv. 6

'twixt the duke of Orleans, and...... Heriry VIII. ii. I

ORNAAIENT that deeks.... Two Gen. of I trona, ii. 1

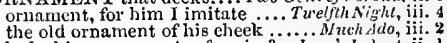

bedeeking ornaments of praise? ..Love's L. Lost, ii. I

hiding the grossness with fair olnament? - iii. 2

let us see these oruaments .. Taming of Shrew, iv. 3

so prove, as ornaments oft do $\because$.. Hinter's Tale, i. 2

the tongue a helpful ornament ..... Henryly' iii.

this ornament of knight

eluthing me in these grave ornaments $-j^{\prime} L$ iii.

true ornaments to know a holy ...Richard III. iii. 7

and ornaments of housebold..... Henry hIT. iii.

those sweet ornaments, whose eireling - ii.

this ornament that makes me louk .... l'ericles, v. 3

their grave beseeming ornaments... Romeo \& $J u l$. i. 1

wit, that ornament to sliape and love - iii. 3

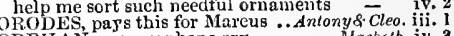

RPHAN-new orphans ery .......... Hacbeth, iy. 3

the widows the orphan of his patrimouy... 2 Henry Vi. v. I

many an orphan's water-standing...3 Henry VI. v. 6

and orphans for their parents'........ - . y. 6

were never orphans, had so dear a loss - ii. 2

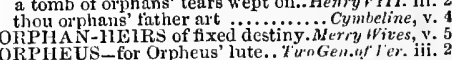

did leign that Orpheus drew trees. Mer of Venice, $Y 1$

Urpheus with his bute .... Henry... Tuelfhikight, i.

trom the eount Orsino, is it?, ........ -

in Orsino's bosom ................ - i. 5

I saw thee late at the count Orsino's = iii.

you are servant to the count Ursino $=$ iii.

young gentleman of the count Orsino's =

Orsino, this is that Antonio

Orsinu, nuble sir, be plenscd

Ground enough, Ursino's chemy, ....

ORT-her taith, orts of her love.. Trwilus \& Cress. v. 3

ORT - in the 'ort dissolutely (rep.)...Merry ines, i. 1

OR'IIUGRAl'HY, as to speak.......... Wue's L. Lost, v. 1

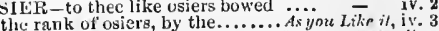

unifill this osier cage of ours........ Romen \& Juliet, ii. 3

OSLREY $\mathrm{Y}$-as is the osprey to the tish .Coriolanus, iv. 7 
OSRICK-the tols, young Usirck ........Iumlet, v. 2 OSSA-make Ossa like a wart:............ in sueh hisir ostents of love as

full trophy, signal, and ostent. It.m.... $F^{\prime}$. v. (ehorus)

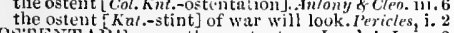
OSTENTARL - or rather, ostcutare.Lore's $L . L$. 1 1. with some delighttrul ostentution.: Lore's $L$. Lost, $v$. blown me full of muggot ostcitation
and ostentation of despiscd arms? taken from ine all ostentation......2 2 Heary $1 \%$ ii. make good this ostentation............. Coriolanus, i.

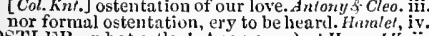
OSTLER-what ostler! Anon (rep.)...1 H bid the ostler bring nyy gelding ..... out, rogne! shall 1 he your ostler?

aE an ostler, that for the poorest .... Con iolanns, iiti. OSWALD-rhat. Os wald, lo! (rep.) ....... Lear, how now, Oswald? what, have you writ...
OTHELLO-valiant Othello, we mnst ... Oinello, $\mathrm{i}$. but, Othello, spenk: did you by indireet

othello, the fortitnde of the plaee is best

I saw Othello's visage in his mind
Othello, leave some ofticer bullind

to abuse Othello's ear', that he is to

throw out our eyes for brave othello...

great Jore, Othello guard, and swell his

iny dear Othellot It gives me wo

of Cyprus, and our noble general otheilo:
to the health of the black othello

the trust Othello puts him in..

worthy Othello, I am hurt to danger........

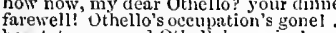

heart, to wruuged Othel ho's serviee! ....
keep that noonster from Othello's mind

I say! Othello! How how, Cassio? .....

how, sweet otlello? Devil! l hive not.

Cassio in Othello's

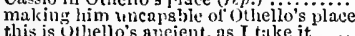

this is Uthello's ancient, as I take it ....
who's there? (thello? $A$, Deslcmona

against Othellu's l.renst (rep) $\ldots \ldots \ldots . .$.

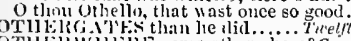

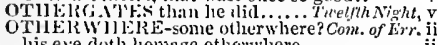

the king lyath seitt me otlerwlere. Henry $\bar{\gamma} I I I$. ii. OTHERWISE-importuned otler wise. Tempest, $\mathrm{it}$.

I never knew himp otherwise.. Tur Gen.
otherwise he had been executed......

otherwise he had sufficred tor't....

if she be otherwise, 'tis labour ..........

other'rise you might ship away er
otherwise, he might put on a hat

you'll find it otherwise, I assure. Tüetrh, $\overline{\text { inghth }}$, iti. 4

otherwise 'tis light, and not lieavy"

my maiden's name seared other' in you it best lies; otlerwise..- v. 3 (petition)

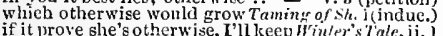
pousuades me, it is otherwise.
thou art a beast to say otherw

I would it were otherwise (rep. $\psi .2)$ take the matter otherwise.............. Henry l: iii. and the modesty of it, to be otherwis

yon fiud it otherwise; and, henceforth
otherwise, I renounce all confinene, 1 He

we do no otherwise than we are willed $\boldsymbol{l}$. $\dot{i}$.

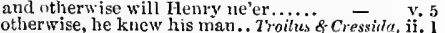

to refort otherwise, were a malice. Coriol anus, ii. 2

doth tune us otlierwise

snd le that otherwise aceounts of ni.....

take this from this, if this be intierwise.

how otherwise? will you be rnled by nie
the thing I am, by seening otherwise.

OTTER-an otter, an otter (rep.).....
OTTOMAN-general enemy Ottomun....
OTTOMITES, reverend and

OTTOMITES, reverend and gracious ....
these present wars against the Ottomit

Which heaven hath forbid the Ottomitus? - ii.. 3 Useigneur Dieul je m'en oublie
OUBLiE-od's me! qu'ar j'oubli

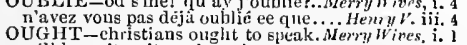

will have it as it ought to be...... T ' *et?

good ehristians ought to have
he ought to enter into a quarrei
the watel onght to offend no man

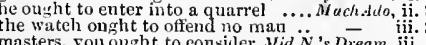

masters, you ought to consider. Mid $\ddot{N}_{\text {.'s }}$ Dream, iii.

asclonblet and hose ought to show..... which true prayers ought to have ., Micharal 1 , as in discretion you ought to use me.. Henry $r$. . iii. 2
tior disciptines ought to lie used....... 6uch cowards ought to wear $\ldots . . . . .$. i Henry $r r_{1}$ as every loyal subject ought to do...3 Henry VI iv. 7
opinion, onght to be prevented ..... Richari $1 / 1$. ji. ?

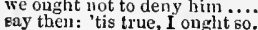

UGinT-meclunical, you ouglit
or iny pluee, I ought to know of

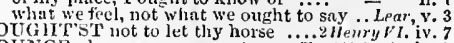

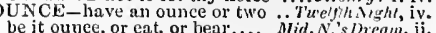
my sweet ounec of man's fiesilu!.. Love's sL.. Lost, iii. by I know how mich an ounce.. Himler

that he laath, by many an ounee ... Coriolonus, iii. I give me an ounce of
OOPPIIES, and tairies.

good luck, oullies, on exery sacred

OUSEL-COCK [Col.-0Osolsin .....2 Henry $I V$. iji. 2

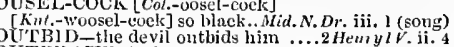

OUTBRA - the devil ont thids heart most

OUTBREAT of a fiery miud

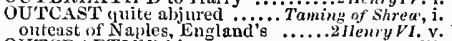
OUtcast of Naples, Er

UTCLICS raised the duke...ilerchanc of lenice, it. 8 OUTDARE the dingers.

sentible, outdares lis sen
OUTDARED dastard?

OUTDENE lis former deeds

OUTFACE then, and o

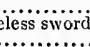

Cichard 11,

政, .. Mer. of Venice, iv. 2

outface the brow of bragging horron: Aing John, v. 1 seesinted nakedness outtince

outface me with leapping in her grave? . Humble $i$, v.
oUTWACED them all

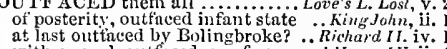

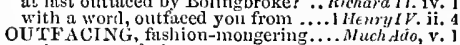

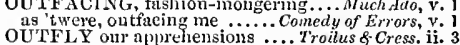

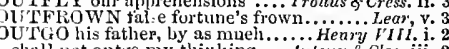

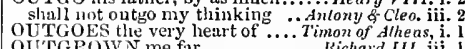

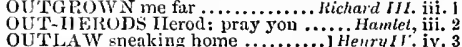
ge, as an outlaw in a castie........... Hemry $V I$. iij. 1
we are held as outlaws: hence...... Cymbrtiae, iv. 2

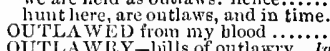

Lear, iii. 4

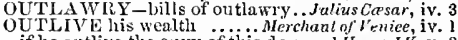
so many years outlive performance? 2 Henry $1 \mathrm{IV} V$. ii. 4 he that outlives this day, and cones

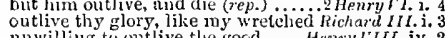

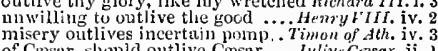

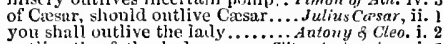
outlive thy father's day's........ Tithes Andronicus, i. 22
let not this wasp ontlive us both to stiug let not this waspontlive us both to stiug - ii. 3
to outlive the age $\mathrm{I}$ am, and die as $\mathbf{l}$...Pericles, $\mathrm{V} .1$ a great man's menory muy outlive ... Hamlet, iii. 2
that firane outlives a thousand tenants.. v. v OUTLIV ED the eagle ........ Timon of Athens, iv. 3
OUTLIV iNG beauty's outward. Troilus \& Cress. iii. 2 OUTLOOK conquest, and to win .... King John, y. 2

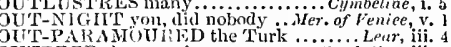
OUTPEER these twain........................ Colize, iii. 6

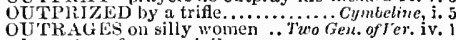

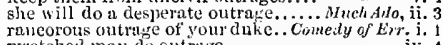

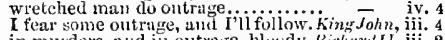

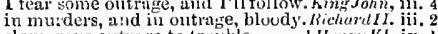
slall parton thee these outrages....3 Henry VI. v. I

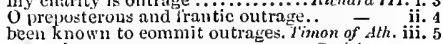

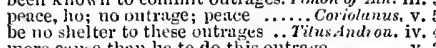

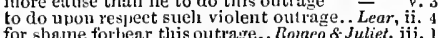
seal up the moutl of outrage

OUTKAGEOUS, and so variabie. most outrageous fit of madiness.. Comedy of Err.
of thy vile outrugeous erimes ...... 1 Heary $V I$. iii.

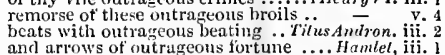

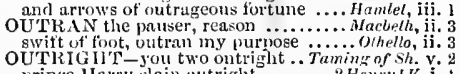
prince IIn ryy slain vot onight

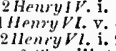

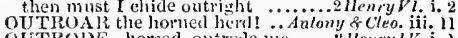
OUTRODE-horsed, outrode me ...... HenrylV. i. I

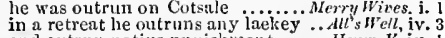
and outrun native pnusishment.

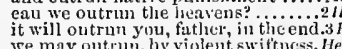
re mav outrun, by violent swiftnces Heury
OUTSCULD - thou canst outserld us. . King John, v. 2
UUTSCURN the to and fro conflieting wind Lar,ii..

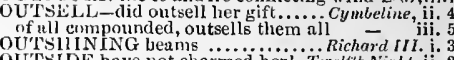

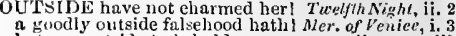
n yolodly outside falseliood hathl Mer. of Veniee, i.
but my outside to beliuld .... a swasling and a martial outside. As you Like il, i. 3 of your purse to the outside of his land - Tule, iv. 3 the outside of this work (rep.) ....... King John, v. 2 were but the outsile of a Roman

erented with a stubborli outsicle ..... and make lis wrongs bis outsides ... thy outsicle looks so fair and warlike $\ldots$..... Lear, ${ }^{2},{ }_{3}$

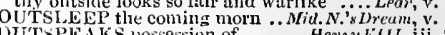
OUTSTART - not to outsiont discretion. Othella, ii. 3 Thl follow, and out tare linu ....... Henry VIII. i. OU'TS'TAY - you outstay the time..As you Lite z', i. 3 OUTSTUOD-I have ont totod ny time. Cymbeline, i.

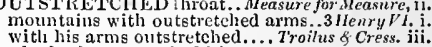
who hatls outstreteded his spun ... Timon of $A t h$. $\mathrm{v}$. our monarels, and outstreteled heroes. Hamlet, ii. OU'T'TlIP -will outstrip all praise... Tempest,

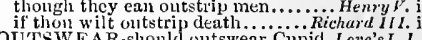
and outswear them toutswear Cupid. Love's $L$. L. i.

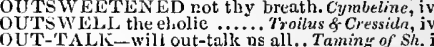
OUT-TONGUE lis eomplaints .......... Ohinello,
OUTVENOMS all the worms of Nile.Cymueline,

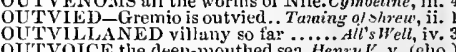

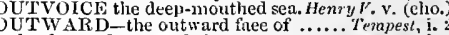
UTWARD-the outward faee of ....... Tempest,
thy fair and outward character.... Turelfh Night, the wrong side may he turned outward! $-\overline{\text { in }}$ in
the denunciation lack of outward. Meas. forMeas. though angel on the out ward side!
to make them know that outward.

a good eover, they show well out ward. Much d $d$ ar hath, indeed, a good ontward happiness = if lialt thy out ward graces had been..
slow out ward hideousness ..........

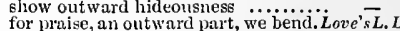
the weatlier on the outward wall.. Mer, of Fenice, ii. so may the outward slows be least .

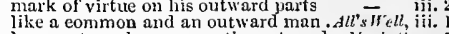
hang out our banners on the out ward...Maeletth, y. exterior form, ontward accoutrement. King John, i.

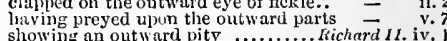
the outward wateh, whereto. my finger to immask our nteted outward ...... Henryg Hen he may show what outward courage
sulcli outward things dwell not in
thic outward composition of his body. in your outward aetion slows itself. Kriehard III. i. an sutward honour for an inward toil nothing differs but the outward fame

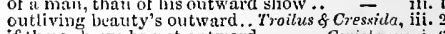
if these shows be not outward........ Coriolints s, $i$. ns I do know your outward fivour. Jutlius $\bar{C}$ Cas things oatward do draw the inward. Ani.\& Cleo. ii i all is outward sorrow $\ldots \ldots \ldots \ldots \ldots \ldots$. Cym
so tair an ontward, and such stiff witlun better than lis outward show can
that mikes us scan the outwart habit neitller in our hearts, nor outward eves..
lhelps him, tuke ii. tediousness the limbs and Uutward ..... Huntect, must show' fairly outward, should more.

for wlien my outward action doth almost the wrong side outward [Kni-onit] - ii. 3 that indeed which outwardly ye show... Maebeih, i. 3 and this will witness out wardly ...... Cymbeline, ii. OUTWARD-SAINTED deputy. Meas. for Meas. iii. sun is high and we outwear the day.. Henvy $V$. iv. 2

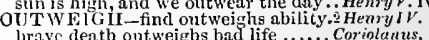
OUTWENT her, motion and breath... Cynabeline, ii.

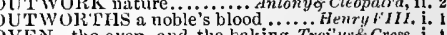
VEN-the oven, and the baking. Trotituss Cress. i. I
eoncealet, like an oven stopyed .. Tilus Andron. $\mathrm{ji} .5$ crickets silng at th'oven's mouth. Pericles, iii. (Gow.)

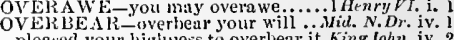
pleased your highness to overbear it. King John, iv. OVELBLLOWN-the storm overblown?. Tempest, ii.:

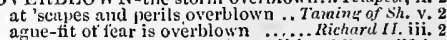
elor being overblow'n with walking.2 Henry $\nu t, \mathrm{i} .3$ oVIRBOARD-lieaved overboard ..... Terapest $\mathrm{i}$, that thou ht to stay him, overloard. KichordII, $\dot{i}$. your queen must overboard (rep.)..... Pericles, iii. 


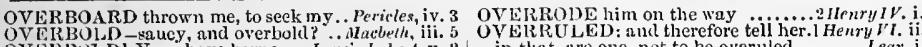

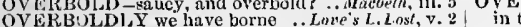

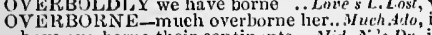

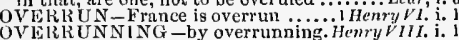

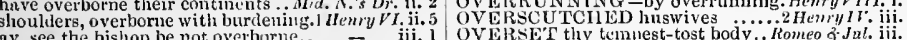
ay, see the bishop be not overborne
bislop will be overborne by thee.

emperor of Rome thus overborne. Tiitus.Andron. iv. OVERBULK-to overbulk us all. Troilus of Crest OYERBUYS me nlmost the sum he

OVERCANE: he came (rep.).L
who overcume he? the beggar

1 eame, saw, and overumin

I came, saw, and overcame ..........2llenrylv. iv.

that day he overeame the Nerii. Julinenryl. i.

Brtutus only overcame himself.

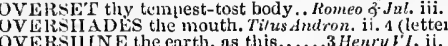

OVERSIINE the earth, as this....... 3 Herry

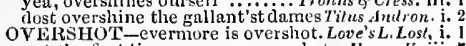

not the first time you were overshot.. Henry $V$. iii. 7

crutus only overcame himself ........

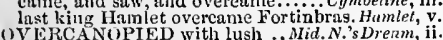

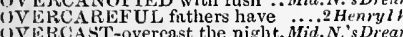

WVERCAST-overcast the pight. Mid. N.'sDream, iii. OVERCHARGED, you were best Two

as eannuns overcliarged with double
or like an overchnrged gun, reeoil.

VLiRCOMIE: to whom cane .. Love'sL.L. iv. 1 (let.) fond to overeome the bony priser. As you Like it, ii. right should thus overcome might!..2 Henry IV. $\mathrm{v}$. ware lovereome mine enemie

war may st thou be overeomel.......3 shenthens, iii.

whereas no glory's got to overcome

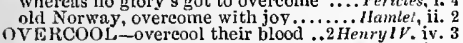

UVERCRLDULOUS haste $\ldots$.......... Mocbeth, iv

OVERD ARING Tailot hath sullied.I I Ienry Vl.
OVERDONE-Overdone's means. Meas. for.Heas.

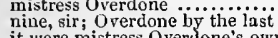

it were mistress Overdone's own house

for anything so overdone is from ...... Humlet, iii. .

OVERSPREAD witl them......... King Joh

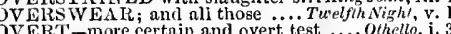

OVERTAEN him in his overt...... Richard III. ii.

OFDod-will, hath overta'en mine act..Coriolamus , your slow purse ... Two Gen.of Ver. i.

she is able to overtake seventeen ...Merry
run and overtake him....... Merchant of $V$

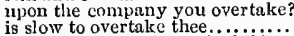

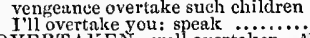

I'll overtake you: speak ................. ven

OVEM'TAKLTM in his pilgrimgge. Tur Gen.or $i$. ii. 7

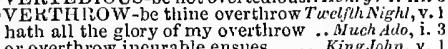

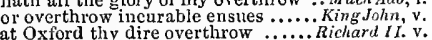

before thy nost assured overthrow ... HenryI I. iv.
plotted thus our glory's overthrow?... iHenry VI. i.

hath the late overthrow wrought

that seeks to overthrow religion

I have seen our enemies' overthrow = O Lancaster! I fear tl:y overtlurow.3 Henry VI. ii. 6 mis overtlưow hcaped happiness ... Henry $\overrightarrow{V I I I \text {. iv. } 2}$

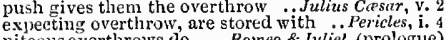

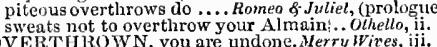
OVEREARNEST with your Brutus. Jul. Casar, OVERFAR-overfar believe that... Tw' lffhthight, ii.

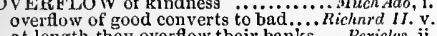

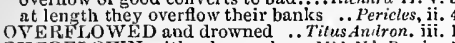
OVERFLOWN with a honey-bag.. Mid. $N$.'s 's Dr. iv. OVERFOND of the shepherd's ....... Win

OVERGLANCE the superscript... Love's $L$. Lost, OVERGO thy plaints, and drown...Richard lli. ii. OVERGORGED with gobbets of thy.2 2 enry $\mathrm{Vi}$. $\mathrm{V}$. OVERGRE WD with hair, put forth . Heiry $V$. v. 2 mucls overgrown with car

OVERHEAR their conference .... Mhid. N.'s Dr. ii. 2 overleard what you shall overhear Love's L. L. v. 2
OVERHE.ARD what hath past.. Meas. for Meas. iii. 1
thus muel overheard by a man....... Mruch Ado, i. 2 in the night, overheard me eonfessing
and overneard what you shall.... Love'

and overnenrd what you shall.... Love's $I_{\text {. L Lost, }} \mathrm{v} .2$ I overheard lim and his praetices. As you Like it, ii. 3
if they have overlineard me now.. Winter's Tale, iv 3

hath often overheard them say...
OVERHEARI' ST us; and bid...

thoul overleard'st, ere I was ...Rameo \& Juliet, ii. OVER

overioyed to see lier noble.. Taming of Sh. I (indue.)

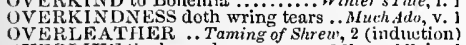

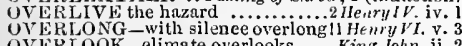

willing you, overlook this pedigre

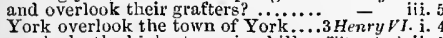
overlooks the highest-peering hills. T'itus A nd. ii. I UVERLOOKING-to my overiooking.. All's Well, i. I find it not fit for your overlooking..

nVhen a man is overlusty at legs ...........Lear, ii. . OVERAATCHING waves............... H Herry Vi i i.

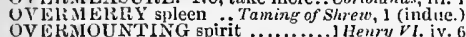

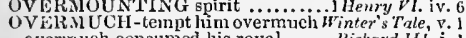
OVERNAME them ..................... had given you this at overoight.......AII's Well', iii. OVERPASSED thy days ............. I H H nry. $V$.

OVERP'AY - which I will overpay....... All's Well, iii. ? tower, to overyeer tle eity
heaped for truth to overpee

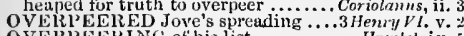
OVERPEERING of his list .............Hninlel, iv.

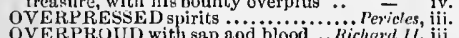
we think him overproud .... Trnilus \& Cressidu, ii. OVERREAD it at yourpleasure... Meas. firt Mras. iv. UVERRED-prick thy face, and overrda. Mhe beth, v.

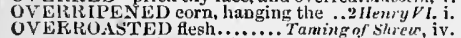
overroasted rather; ready long ago.. Cymbelinc, v.

and all the preperation overtlirown...M1uch Adlo,

overthrown more than your enemies As you Lik

O poor Orlandol thou art overthro
and proved, have overtlurown him

sleriff of Yorkshire overthrown....2Henry $I V$. IV. is overthrown by noble Brutus.... Julies Cerser, v. errucl thee quite overt thrown 1 ..... Ronzeo \& \&uliel, v. 5 OVERTOOK, a dozen eaptains......2HenryI $I$. Hit

OVERTCPPED them all . Antong 8 - Cleopatra, iv. I hear, there is an overture of peace.. Alt's
as she had rnade the overture, she ceased

tried it, withot more overture ... Winter

made an overture for the wars

OVERTURNED-will be ove

OVERVEILED the earth .......... I He
OVERVIEW to thy overviel. Love's
OVERWATCHED. This palpable. Mid.

OVERWEATHED. This palpable. Mid.N.'sDr. v.

OVER WEEN - you overween .....2 Henryl
thou dost overween in all ...Tilus Andronic
OVER WEENING Slavel. Turo Gen, of yeron

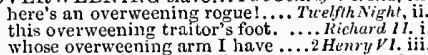

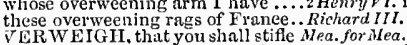

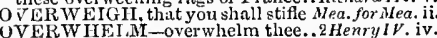

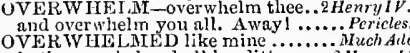

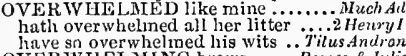

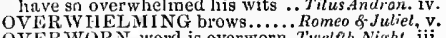

OVERWORN-word is overworn. T'welfh/ Night, iii.

ns Ovid be an outeast quite .. Taming of Shrew, i.

oVIDIUS Naso w'as the man

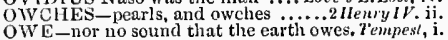

such an ass should owe them ... Tro Gen of Ver,
oursclves we do not owe .......... Tweifh Night

and that 1 a do not 0 is...

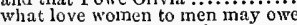

thenselves would owe them ......Meas. for NMeas.

but only he, owe, and

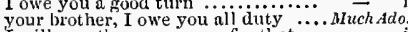

I will owe thee an answer for that

all the power this eliarm doth owe.3Iit. N.'s Dr.

thint binkrupt sleep doth owe..............

all perlections that a man may owe..

clear of ail the debts I o

1 ove you much; and like $(r \in p$.
of the sum that he did owe him

.....

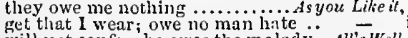

will not confess he owes the malndy.. All's $W^{\prime} e l l$,

which both thy duty owes, and our

the miseries, which nature owes

my lord, such as you owe your wifl
but not when he does owe it ....
OW E-the jeweller that owes the ring...All's Well, v. as the suljeet owes the prince...... in inter's Tale which owe a mniety of the tiinone i...

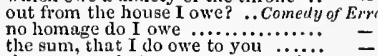

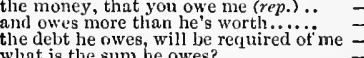

whence you owe this strange

to the disposition that I owe

say we have, and what we owe...
whicllowe the erown that thour

you truly owe, to
we owe thee mueh

the one my duty owes .................

the duty that you owe to heaven.....

all the debt he owes you

you owe me money (rep.)................

England did never owe so sweet

the gross sum that $I$ owe thee?

pay her the debt you owe her.....

we owe God a death; I'll ne'
I owe you a thousand pound

that owe your lives, your faith

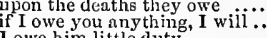

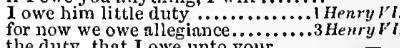

nor feels not what he owes.. Troiltes \& Cressitiln, iii.

. ........

all these three owe their estates

should pay more than he owes

desperate ones, for a madman owes "en -

I do owe them still my life

one time will owe nonother
but owe thy pride thyself

though I owe my revenge properi....

whieh this man's life did owe you

a liberal thanks, whiel I do owe you. Ant.\& $\mathrm{Cl}$

argets like the men that owe them.

but to owe sueh straight arms, none...

the tribute that I

by all the duties that I owe to Rone

which you make more rich to ow
with those infirmities she owes.

you owe me no subseription

dear perthing to thy blasta .......

the price of his dear blood doth owe?

a full fortune does the thick-lips owe.... ol hello, i. I

OWED - the noblest grace she owed..... Tempest, iii.

I could not have owed her a mod.

since you owed no more to ti.

the dearest thing he owed ............... Hizcusth $\mathrm{i}$.

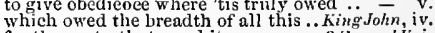

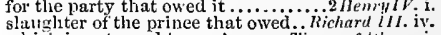

Which is not owed to yon! ...... Timon of thens, i. I
oW ED'ST-sleep which thou owed'st.... Ochelln, iii. 3

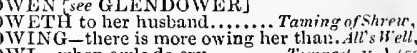

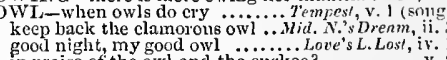

good night, my good owl $\ldots$........

maintained by the owl, the other $\ldots$ igh $-\bar{v} \cdot 2$ (solig)

goblins, owls, and elvish sprites.. Comedy of krr. ii.

it was the owl that shrieked ............1/acbeth, ii. 2

wheard the owl scream, and the crickets $=$

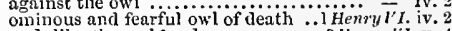
and, like the owl by day ..............3 llenry $; .1$. v. 4

out on ye, owls! nothing bnt songs. Richard $1 I$. iv.

I bade the vile owl go learn me... Troilus $\delta$ Cress. ii.

the night to the owl, and morn....... Cymbelinc, iij. 6
unless the nightly owl, or fatal raven. Fitus And. ii. 3

a comrade with the woif and owl .......... Lear, ii. 1

the nwh was a baker's daughter'............ Hamlet, iv.

not - you will not own it ......... Wiater's Tale, iii. 2

wolld own a nanie too dear
OWNER-worthy the owner

restore them th the owner.

the owner of it blest................Midi.N.'s Dream, v.

are not you the owner of the ..... As you Like i iv.

the owoer of no one gool quality....A $A l^{\prime}$ 's $W$ rll, iii. 6

proud, and makes his owner st sut ... King John, iii.

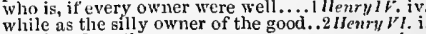

in spite of me the owner....................
dures be renderel to their owners.

differing in the owners.......... Timon of thens, i. 1

bid the owners quench them... Titus And rnnicns, v.
like the owner of a foul disease ........ Hamlet, iv. I 
OWNING-my father owning it .. W'muter's Yale, iii. 2 a million; thou ow'st me thy love ... Henry ir. iii. 3 why, thou ow'st God a death Richard $I 1$. i. 3 a son, thou ow' st to me................ kichard $I I$. i. 3
life thou ow'st me for my horect. Troilus \& Cress. . 6
lendl less than thou ow'st

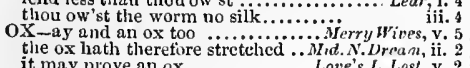
it may prove an ox $\ldots \ldots \ldots \ldots . . .$. . Love's L. J.ast,,$y$, as the ox hath his bow, sir

my horse, my ox, my ass .... Taming of shrew, iii. that roasted Manning-tree ox ...... Henry

ox: to an ox were nothing (rep.). Troilu: of Cress. v. 1 OXEN and waintopes ............ Tuelfh Night, iii. 2 six score fat oxen standing in. Taming of shrew, ii. we shatl feed like oxen at

or horse, or oxen, from the

foll betore thee like sheep and oxen...... Henry $r$. on sheep or oxen could I spend my fury !

yoke you like draught oxen ... Trailus fo Cressida, it
oxFoRD-what news from Oxford?... Richard 11 . to kill the king at Oxford............. hielp to order several powers to Oxford

I have from Oxford sent to Jondon..

the is at Oxford, still, is he not?........2 Henry Oxford. how haps it, that in ...

and Oxford, vouchsafe, at our request

and Oxford, with five thousand men

therefore lord oxford, to prevent

sweet Oxford, and my loving Montague =

bee, where Oxford comesi (rep.) .......

welcome, Oxford! for we want thy hel

is not Oxford here anforther auchor?

sweet Oxford, thank

away with oxtord to Hammes' castle

When Oxford had me down

my lord of Oxford, you, sir Wiliam....

Ipswich and $O$ xford $1 . \ldots \ldots \ldots \ldots \ldots$ Henry $\overline{V I}$

OXFORDSHIRE shall muster up.....3 Henry $F$ I. iv.

OXLEAD to your lion's hide

hold oxlips, and the crown

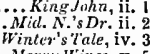

- Y ES - make the fairy o-yes ....... Merry Wives, v. 5

OYTER-the world's mine oyster..Merry I'i

till he have made an oyster of me

as your pearl, in your foul oyster....

as an apple doth an oyster.... Tumins of shirest, iv.

sends this treasure of an oyster ...Anlony \& Clea. i.

\section{$P$}

PABYLON-sat in Pabylon. Merry Wives, iii. I (song) if you can, pace your wisdom .... Neas. for Heas. iv. 3 what pace is this that thy tongue ...Much.talo, iii. 4 can keep no pace with my

travels divers them first? ...... Mer. of Venice,

time's divers paces with dive

he has no pace, but runs where ........All's ${ }^{-}$ell, iv.

speed so pace to speak.... Winter's Tale, iv. (chor us)

pace softly towards my kinsman

creeps in the petty pace from day to day - . - vacth, houfs of hostile pacty

or hold me pace in deep...............

but now, two paces of the vilest

fittcen hundred pnces of your tent.... Henry $\mathrm{V}$. iii. 7 so swift a pace hath thought ... - v. venry (chorus

requires slow pace at first .........

with modest paces came to the aitar

wid horses, pace them not in their.

by a pace goes backward
by the first pace that is sick

that to the pace of it I may spur.....

I cannot bring my tongue to such i pace - i.

with a snaffle you may pace easy. Antony \& $\overline{C l}$ eo. ii.

I saw her ouce hop forty

in pace anotier Juno

endeavour keeps in the wonted pace ... Ilamlet, ii. 2

your dull ass will not mend his pace

my bloody thoughts, with violent pace. Othello, iii. the same full state paced back ...... Henry 1 Hich. iv. I my lord, she's not paeed yet .......... Pericles, iv. 6

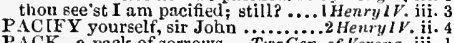
PACK-a pack of sorrows ...T. Tü Gen. of Vernona, iit

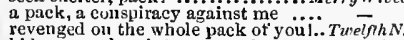
bids me pack; vial .... . . Merchant of Venice,
if slie do bid me pack, $\mathrm{I}$.i give... Taotiug $n f$ Sh. on thee, and all the pack of you ..... Taoting $n f$ Sh. ii. 1 bring a way thy pack after me......... - iv. 3 to keep my pack froin fasting.

to trudge, pack, and be gone ... Comedy of Err. iii.

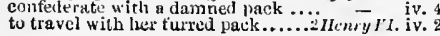

PACK-from all the pack of you! .. Richard 11I. iii. 3 PAGE-woming at master Page's.. Merry Wives, jii. 2

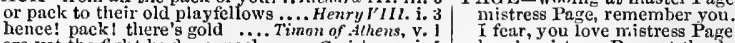

ere yet the fight be done, pack up... Corialanus, $\mathrm{i}$. pour out the pack of matter ...... Antony \& Cleo, ii. go pack with him ............ Titus Andronicus, iv. packs and sects of great ones...

a pack of blessings lights upon... Rameo \& J Juliet, iii. 3

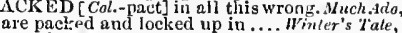

were he nor packert with her... Camedy af Error our thighs packed with wax........2 Henry $I V$. iv heorge be packed with posthorse

has packed eards with Casar ... Antony \& Cleo.

ACKET is not come, where........ Lover's $L$. Los', ii. is Gilliams with the packet gone?..I Henry $I V$. ii. 3 this packet, please it you .........2Henry $I V$.

put this paper in the packet, to bless

secret in the packet I sent the king?

goodness of your intercepted packets

fingered their packet; and, in fine

packhorses, and hollow pampered

faith, and I'll send him packing....
be packing thercfore, thou that ...

to send me packing witl a host

to send me packing with a host....2Henry $V$.

I'll send some packing, that yet.. Richard III. iii.

what1 are you packing, sirrah? .... Cymbeline, iii. 5

in snuffs and paekings of the dukes .... Lear, iii.

PACKTHREAD-with packthread Taming of Sh. iii. 2

Pemnants of pack thread ........Ranneo \& Jutiet, v.

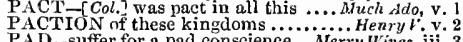

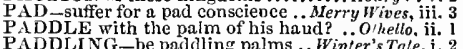

or paddling in your neck with his.... Hamet, iit.

would from a paddock, from $a$ bat

PADGE-an honourable padge........Henry $V_{\text {iv }}$.

a man, in speed to Padua.. Merchani of Ventice, iii.

a man, in speed to Padua... Merchant of

must away this night toward Padua

to see fair Padua (rep.)........ Taming of Shrew,

as time in Padua shall beget ........

and be in Padua here Vincentio's son? -

to see my friends in Padua; but, of all

in Padua, if wealthily (rep.).......

renowned in Padua for her scolding

old signior Gremio has in Padua....

that stops my way in Padua

and come to Padua (rep.)...............

having come to Padua to gather in."

father is arrived in Padua

and bound I am to Padua .....

Padua affords this kindness (rep.)

AGAN-most beautiful pagan. Mercii. of Verice, ii. 3

grapple thee unto a pagan shore .... King John, v. 2

to chase these pagans, in those holy..1 Henry $I V . i$.

what a pagan rascal is this?

What pagan may that be? ...........2Henry $I V$. ii. 2

por the gait of christian, pagan ........ Humlet, iit. 2

AGE-[s'e ANNE]

sir Valentine's page ......... Tro Gen. of
some well-reputted page ...........
what think you of this page, my lord?

I will peat the door for master Page

master Page, I am glad to see you ...

wronged me, master Page (rep.)

and here another to Page's wife ...

bear thou this letter to mistress Page

myself, and skirted page .............

let it suffice thee, mistress Page...

the name of Page and Ford difficr

believe it, Page; lie speaks sense
wifl you go, mistress Page?

good master Page! Itaster Page .....

though Page be a secure tool .....

mistress Pare hath her hearty (rep.)

has Ford's wife, and Page's wife

master Page is an homest man............

mistress Ford, and mistress Page.

revenged on Fulstatf, and laugh at Page -

is it not true, master Pnge (rep.)

master guest, and master
well met, mistress Page

has Page any braing?

the so seeming mistress Page $(r \mu p$.$) .$

I have your good wilt, father Page here's mistress Page at the door (rep.)

tis ny fitult, master Page..............

pray you go, master Page ............

nay, master' Page, be not impatient

comes in one mistress Page .............

farewell, mistresa Page

mistress Page and I will look.

if it p-ove truc, master Page

Nan Page my daughter, and

to marry with Nan Page...........

vere is mistress Page?

no, laue: it is on up hage... Mid.N.'s Drear,

and his page o' t'other side

the page, Hercules (rep. v. 2$)$...........

put Armado's page out (rep.)

so is Aleides beaten by his page. $\dddot{M e r}$ of $\overline{\text { Venice, }}$ ii.

what page's suit she hath in .........

come two of the banished duke's paces - v. come. sir page, look on me with .. Winter's'tale, i. 2 as pages followed him .............. Henvy $\mathrm{H} V$. iv. 3 master page, good master page, sit....ं ${ }_{\text {thenr }} \bar{t}^{\prime}$ U. $\mathrm{i}$. work us all from princes into pages - ii. here comes my mistress' page.. Timon of Athens, ii. here comes my mistress page.. Timon of Athens, ii.
outlived the cagle, page thy lieels ... prosperity be thy pagel

howl a pagel or dead, or sleeping .... Cymbetine, ii.

never master had a page so kind .... - $\quad$ iv.

thou art my good youth, my page... -

pages and lights, conduct these......... Tericles, ii. 3 where is my page? go, villain...Rnmeo \& Juliel, iii. where is the county's page, that raised - v. 3
PAGEANT-insubstantial pageant.... Tempest, iv. I all our pageants of delight. Tu'a Gen. of Fernat,iv. or show, or pagcant, or antic .... Lave's L. Lost, v. or shuw, or pagcant, or antic ....Lave so. Lost, v. more woeful pageants than to play my part in fortune's pageant.2 Henry $F I .1 .2$ pageants, and sights of honour...... Henry $V I I I$. iv. imitation calls, ) he pageants us.. Truilus \& Cress. in all Cupid's pageant there is.

they are black vesper's pageants. Antony \& $\bar{C}$ leo. iv.

'tis a pageant to keep us in false gaze .. Othello, $\mathrm{i}$.

PAID - so, you've paid.................... 7 impest, ii.

till some certain shot be paid. Two Gen.of Verona, ii. 5

then I am paid ......................

which must be paid to master Brook $\overrightarrow{\text { Night }}$,i. 5 pleasure will be paid, one time

would have paid for the nursing........ you have paid the heavens your ..... $-\bar{c}$ iti. 2 and never paid, that now men grow.. hath so faith fully been paid .... Love's L.Lost, i1. he is well paid, that is weil.

than is paid; and more shall be paia... All's $\|^{r} e l l, i$. not used, must by thyself be paid.... - ii. and thy hou wilt see the tailor paid. Taming of Sh. iv. paid you all he promised (rep.) all my services jou have paid home ${ }^{-}$二 v. he parted well, and paid his score ...... Macbeth, v. 7 seven of the eleven $I$ paid

the money shall be paid beck

paid money that I borrowed

the money is paid back again ........

a lie, cluer paid to the hearer than...2Henry/ $l V$. iji. let it be cast, and paid

in eash most justly paid Henry $V$. ii. (chorus) nothing taken lut paid for i Henry Vl. ii. 2

wow have I paid my vop.

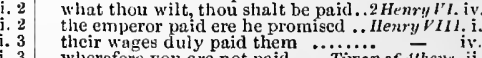
wherefore you are not paid ..... Timon of sthens, ii. of nature which iny lord paid for...
has paid this men their wages....

has paid his men their Cresar, iij. 1 I nm jaill for't now .......... Aniony s Cletpa/ra, ii. whoo, ho! hol father Pagel......

one of your lordship's him.... a woeful pageant have we here........Richard II. iv. I when it is paid, bring your true $\ldots .$. - iii. 


\section{PAI}

[555]

PAL

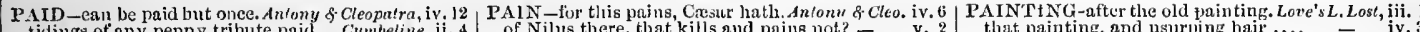

tidings of any penny tribute paid ... Cymbeline, ii. phid ino pious derte to be paid remcmber, he was paid for thet. sorry that you have paid too much (rep.) -

praises, which are paid as debts . l'erictes, iv. (Gow.)

marluess shall be paid with weitht....Hamict, iv. 5

a hundred milch-kine to the pail. Taming of $\$$ sh, ii. 1 great pails of puclded mire.... Comedy of Errors, y. t

PAIN-since thou dost give me pains

took pains to make the speak.....

pains to set it together (rep.) . Tw

here is for your pans (rep.)............

you think too much of so much pains $\overline{\text { Wing }}$ ii. 1

and turn him to no pain ............

it may be worth thy pains........Twelfh Nighl, i. 2

taken great pains to con it (rep.

you might have saved me my pains $\quad$ - ii. 2

there's for thy pains. No pains, sir
you make your pleasure of your' pains

it hath been great pains to youl. Heas. for Meas. ii. 1

accountant to the law upon that pain

th ank you for your paing (rep.).........

no more pains tor those thanks $(r e p$.$) -$

any pains that I take for you..........

there's for thy pains

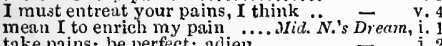

and conned with cruel pain.

pain purchased, doth inherit pain.....ove's $\overline{L . L o s l, i . j}$.

express my true love's fasting pain ...

where lies thy pain?

pray thee, take pain to allay.......... $\overline{\text { iver }}$ iv.

hath ta'en great pains to qualify.

cope your courteous pains withal....

of all thy pains and husbandry

because he feels no pain.

shall pay me for my pains

Al's ${ }^{\prime} \mathrm{Yell}, \mathrm{i}$.

thy pains, not used, must by

are sorry for our pains. I pr'y thee

make you thank your pains for $¥ 3$

lis studies, or his usual pain

I thank you for your pains...........
and all my pains is sorted to no proof
not worth her pains; much less ...Winter

burdened with tike weight of pain Comedy of $\mathrm{Em}$

it' you went in pain, master.......

thanks for your pains; do you not ..... Maceleth,

your pains are registered where every

we delight in, physics pain ...................
well donel I commend your pains

bones that took the pains for me ..... King Joh

took pains to get this son...

that will take pains to blow

for very little pains will bring .......

to recompense the pains you take.... $=$ iv

on pain of death (rep.) ............. Richarel II. i. 3

against thee upon pain of life.

that breathe their words in pain

injustice with the pains of hell .......

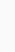

thank thee, gentle Percy, for thy pains

thy pains, Fitzwater, shall not the forgot -

are murdered for onr pains

of Nilus there, that kills and pains not?
the biting of it, what pain slie felt

I thank you for your pains

a pain that only seems to seek out

native blood is counted painting now

this is the own with oily painting. Finter's Trite, v.

pleasures here are past, so is their 1

for our beloved mother in lrel pains
sloould be so conversant with pain.....

and not your knowledge, personal pain

put me to present pain.....

in which your pain that way; 1 ij this

on pain of their perpetual displeasure.

how light and portable my pain

on pain of torture, from those ... Romeo \& Juliet, $\mathrm{i}$.

once more, on pain of death $\ldots . . . . .$. .

here is for tly pains. No, truly, si
be trusty, and 1'll quit thy pains.

harsh world draw thy breatlo in pain . - Fante

good Roderigo; I'll deserve your pains.. Othelio, $\mathrm{i}$.

Ghe gave me for my pains a world of

I have a pain upon my forehead here.

even to that sense of pain.

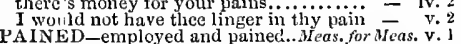

to enforce the pained impotent to. Love's L. Lost, v. 2
PAINED'ST-the pained'st fiend of hell P'ericles, iv. 6

PAINF U L-some sports are painful

with most painful teeling..

till pal been painful, I wonld not... Much Ado, ii. 3

commits lis body to painful ]

the painful service, the extre

many a dearn and painful..... Pericles, iii. (Gower)

a dozen years.....Tempest, i. 2

thou hast painfully discovered. Timon of Ahens, $\mathrm{v}$.

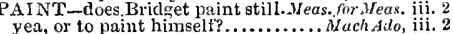

too good to paint out her wickedness

nay, never paint me now.

paints itself black, to imitate....... - jv. 3

do paint the meadows with delight - v. 2 (song)
and paint your face, and use.. Taming of shrew, i. I

where revenge did paint the fearful. King John, jii.

to paint the lily, to throw a perfume

with your blood you daily paint. Truilus of Cress. i. 1

with man's blood paint the ground. T'mon of Ath. iv.

paint till a borse may mire............

I paint him in the character

you shall paint when'you are old..... Antony $\overline{\text { \& }}$ Cleo. i.

PAIN'TED-with colours fairer painted. Tempest,

and had but this fish painted

because the one is painted (rep.jTuo Gen of $\vec{v}$ er. ii.

'tis painted about with the story...Mi.

winged Cupid painted blind ............Much Ado

pluck the wings from painted butterflie

how low am 1 , thou painted nay pole?

out of the painted cloth for this

sweet than that of painted pomp? As you Like it ii.

painted by a running brook.. Taming of $\overline{S h} .2$ (ind.)

as lively painted as the deed was

because his painted skin contents ...

childhood, that fears a painted devil. sale, iy.

monsters are, painted upon a pol

not painted with the crimsoln.....

not painted with the crimsoln.......

King John, iii.

banish thee on pain of death $\ldots . . . .$.
and your pains, we thank you for.....

will take the pains but to examine..

with painted imagery, had said

as Lazarns in the painted cloth ..... Herury $J V$. jy. 2

Fortune is painted plind ..............

falchion, painted to the hilt in blood.3Henry $V I$. i. 6

poor painted queen, vain flourish.. Richurd III. i.

poor shadow, painted queen

your painted gloss discovers........... Henry $\bar{V} r I T$, y.

pluck his painted wings ....Troilus \&. Cressida, iii. ${ }^{2}$

wrought he not well, that painted.. Timon of $A t h$.

but only painted, like his varnish
he painted wi th sluunless destiny

are painted with unnumbered...

though he be painted one way... Antony \& Cleo. ii. 5

with that painted hope braves.... Titus Anuron. ii. 3

ye alehouse painted signs

so, as a painted tyrant, Pyrrla .. Romen of Juliet,

my deed to my most painted word.

he's a god or a painter

the painter plays the spider........ L Lover. L L.Losi, y.

better, that made the painter ...... Timori of $A t h . i .1$

a stonecutter, or a painter, could not .... Lear.

aAIN'ING painter with his nets.... Romeo s s.Julie

painting, do ptove my occupation.... labour was to thein as a painting

a piece of pninting; which I do beseech

painting is welcome: the painting is

of your paintings [Knt.-prattlings] too. Hamlel, iii.

Orare you like the painting of a sorrow

pair of ane soling hooks............. - ili.

I can to get you a pair of horns .... Nerry 1 in

there went but a pair of sheers... Meas. for Heas. i. hall btand a pair of lionourable menl. whu hd to, $v$. lath bought a lair of east lips...As you Like il, iii. have they made a pair of stalirs....

a pair of stocks, you rogue. Taming of $s h . \overline{1}$ (induc.)

and a pair of sweet gloves..................

by us, a pair of'kings

wair of stocks in the town

I'll mialse a fat pair of grallows

slow it a fair pair of heels

canvas thee betwcen a pair of bi

apon one pair of English legs........

a pair of bleeding hearts ............. Richard IIl. iv.

you are a pair of strange ones ...... Coriolanus, i.

a pair of tribunes that have racked.

world, thou hast a pair of chap

like a pair of twins appeared .....

a pair of cursed hell-hounds.. Titus indronicus, v.

my best gown a pair of bases ...........Pericles,

pair of star-crossed luvers take.. Romeo \& $\overline{\text { Jul. }}$ (prol.)

for a pair of reechy kisses ........... Hamlet, iii.

PAIRED well with this lord ......Winler's Tale, v. $]$

paisans, pauvres gens de Frauce ...1 Herry $V I$, y. 5

PALABRAS, neighbour Verges.........MuchAdo, iii, 5

PALLABRIS-paucas pallabris. Taming of sh. I (ind.)

so, bring us to our palace ....... Meas. for Heas. v.

meet me in the palace wood

through this palace, with sweet peace $\overline{\text { Venice }} \mathrm{i}$.

pray heartily he be at palace ..... Win'er's Tale, iv,

to the palace, an' it like your worship - iv. 3

the king is not at the palace ......... iv. 3

something from the palace....

gorgeous palace, for a hermitage

in golden palaces, as it becom

tear him from your palace ..................

Richard II. ivi. 1

nto the palace of our king - iii. 2

my soul's palace is become a prison.

your prisoner to your palace gute...

poor Henry at the bishop's palace....

thoinghts do hit the root's of palaces. Cymbeline iii.

mount, eagle, to my palace crystalline .. - v.

or climb my palace, till trom ....'Iitus.Andron. $\mathrm{i}$.

so near the emperor's palace dare....

before the palace gate to brave the

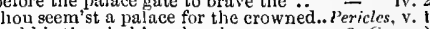

in paces - v. 3 (Gower)

or a brothel, than; and the bond

in such a gorgeous palace 1 ..... Romeo ö Jutiet, iii. a

as where's that palace of dim night... whereinto for

PAIAMIEDES sore hurt and .... Troilus $\&$ Cress. y. 5

ALATE-liver, but the palate .. T'welfh Night, ii.

let their palates be seasoned..... Mer. of Fenice, iv.
repute with their fincst palate. Troilus o Cressida, i.

when that the watery palate tastes.. - jii. a

to a weak and colder palate..........

the greatest taste most palates theirs.
thy palate then dirl deign ... Antony \& Cleopatra, i.

and never palates more the dung....

to please the palate of my appe tite....... Olhello, i. 3

PALATINE-county Pulatine...Merch. of renice, iv.

PArowning than the count Palatine $-\bar{C}^{-}$i. 2

PALE-tliey waxed pale.... Tiu Gen. of kerona, iii. t

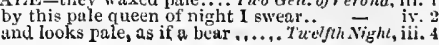

that love this painting wherein you .Coriolanus, $j .6$

pair of old breeches, tlurice turned (rep.) - iii.

tor a pair of carved saints

pair of crafty kmaves

how to wish a pair of w orthier son

from hence to the palace gate.

touch my palate adversely........... Coriolantus, ii.
I thank you for your pains........... Hinlins Cresin

mas: taut own edict for thy paims.. - iij. 


\section{PAL}

[ 556 ]

PAP

PALE at mine heart......... Heasure for Measure, iv.
ere I die, look pale with love ........ Much Aldo, $i$.

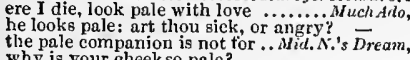
why is your cheekso pale?

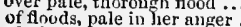
all fancy-sick slie is, and pale of clicer seen them slifer and look pale you may look pale, but I should. Lnve'sL.Losl, iv. thou pale and common drudge...Mrer.of len enice, iii. thou must look pale and wouder... As you Like it, i. i this heaven, now at our sorrows pale

from thy pale spliei'e above............
between the pale complexion of

what, pale again? my fear hath ......All's Well, $\mathrm{i}$. look not pale, Bianca; thy fatlier ... reigns in the winter's pale..Winter's $T$. iv. 2 (song
the pale moon slrines by night.... - iv. 2 (son! pale primroses, that die unmarried.. $\bar{b} \overline{-}$.

looked he red, or pale $\ldots \ldots \ldots \ldots . . .$.

how pale and wan he looks

troop of pale distemperutures.........

bond which keeps me pale $1 . .$.

look not so paie; 1 tell you yet...

look'st thou pale, Franee?

you look pale to-day

the cygnet to this pale faint swau . " - v.

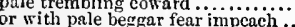

is pale cold cowardice in noble

make pale our cheek. ............

Why looks your grace so pale?
reason to look pale and dead?

in the compass of a pale ............

yea, look'st thou pale? let

PALE-DEAD eyes $\ldots . . \ldots \ldots \ldots . . . . . . .$.

PALE-FACED villages with war.
the pale-faced moon looks bloody honour from the pale-faced moon

Henry $V$. iv. i HenryIr. i. Al.ENESS of this flower............... Mactienry $V t$

PAL.ER - looks a little paler: 'tis a day

you look paler and paler .........As you Like il, iv. 3 PAI.E-VISAGED maids, like......... King John, v. PALFREY-the prince of palfreys.... Henry vary deserved praise on my palfre

provide tliee proper paltreys...T
PALISADOES, frontiers, parapet Henry 1 iiv. WALL, when our deep plots do pall ....... Iamlet, $\mathbf{v}$. here, boy, to Pallas: here to Mlercury in Virgo's lap, give it Pallas ........

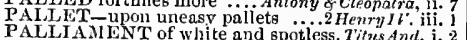
PALM and, by this virgin palm.. Love's L Lost, $\mathrm{F}$. but to be paddling palms ......... Winter's Tale, $\mathbf{i}$. still virginaling upon his palm?
hard, in the palm of the liand.

hard, in the palm of the hand.. Comedy of Frr. iii. 2
fair angels would salute my palm .. King John, ii. again to snatch our palm from palm

grow in the palm of my hand $\ldots \ldots .2 \mathrm{Henry} I \mathrm{~V}$
hard as the palm of ploughmani Troilus \& Cress must not so stale his polm

gives us more palm in beauty

slall see him a palm in Athens .. Timon of $A t h . v$.
the virginal palms of and bear the palm, for $\ldots \ldots \ldots$..... Coriolanus and bear the palm alon

an itching palm (rep.)

nay, if an oily palm be not...

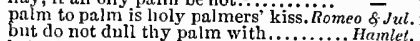 bctwcen them like the palm might fiourish - v. val hee her lier by the palm: ay, well said. Oth with pale policy seek to divert

pining and pale before, beholding $\ldots$ iv. (chorus) whose very shores look pale with $-\bar{v}$. (chorus) like pale ghosts, faintly besiege ..... i Henry VI. i. for pale they look with fear...

this pale and angry rose

withered, bloody, pale, and dead

parked, and bounded in a pale

why look'st thou pale?
look pale as primrose.

meagre, pale, and bloodiess.....

these cheeks are pale for watching... - iii.

and will you pale your head ........3 $3 \mathrm{Hen}_{\mathbf{r} y} \mathrm{VI}$ iv. $\mathrm{i}$.

but severed in a pale elcar-shining

pale ashes of the house

why look you pale? wbo sent

look I so pale, lord Dorset, as thie rest?

each other, and looked queen looked pale

pale she looks, and of an earthy ...Henry $\bar{V} t I t$. iiv.

of pale and bloodless emulation. Troilus \& make livers pale, and lustihood deject

and makes pale [Knl.-stale] the inorning -

a oale, a shore, confines thy spacious

and make bold power look pale. Timon of Athens, iv.

faces pals with flight and agued tear...

ay; and you'll look pale b

you look pale, and gaze, and put on fear

that moved pale Cassius to..An/ony \& Cleopa

whate'er the occall pales, or $\mathrm{k \textrm {k } y}$....

then, if you can, be pale .............

give colour to my pale chee

gilded pale looks, part, sliame, part...

look so pale aud wan? (rep.)

so pale did shine the moo
struck pale and bloodlos.

this warm kiss on thy pale colil lips

specchless tongues, and semblance
which makes me pale to read it?
already sick and pale with grief.

ah, that sanne pale hard-hearted weneh

she looks as pale as any
heavy aud pale as lead

pale, pale as ashes all bed aubed in blood -

tis but the pale reflex of Cynthia's brow-

jour looks are pale and wild ........

ard death's pale flag is not advancer

Romcol O pale! whint else? what

you tremble, and look pale

for a palmer's walking-staff'
made to grasp a palmer's stafi.

holy palmers' kiss (rep.)............2 Hemeo \& Juliet, i.

PALMY Y and palmy state of Rome....... Hamlet, $\mathrm{i}$. 2

in form as palpable as this gross play. Mid. N. Nr. v.

as a mountain, open, palpable.

a hit, a very palpable bit

"tis probable, and palpable to thinking... Hamlet, v.

PALSIED-alms of palsied eld...Meas. for.Meas, iii.

PALSIES-cold palsies, raw eyes. Troilus \& Cress. v.

PALSY - now prisoner to the palsy ...Richard II. ii.
the palsy, and not fear, provoketh..2 Henry $\mathrm{Vl}$. iv. 7
PAISY

PALSY-FUMBILING on his.. Troilus \& Cressida, i. 3

that shall palter thus with us... Troilus \& (ress. ii. 3
pho, pho! alieu; you palter..........

pho, pho! alieu; you palter.......... -
the word, and will not palter?.....utius Crsan
palter in the shifts of lowness ... Antony \& Cleo.
PAITERING becomes not Rome ... Corrolanu,

palter in the slifts of lowness ... Anlony \& Cleo. iii. 9
PALTERING becomes not Rome .. Crriolanu, iij. I

a very dishonest paltry boy.... Twelfh Nigh, iii.

it is a paltry enp ............ Taming of Shrew, iv. 3

your forces from this paitry siege ... King Joht, ii. 1

upon these paltry, servile, abject...2 Herry VI. iv. 6

underneath an alehouse' paltry sign
but a paltry fellon, long kept ..... Richard III. v. $\mathbf{3}$

a paltry, insolent fellow ... Troilus \& Cressida, ii. 3
tis paitry to be Casar; not being. Anlony \& Cloo. v. 2

wonld I go to chate his paly iips ..2 Henry (Chorus)

shall fade to paly ashes ......... Romeo of Jutiel, iv. 1

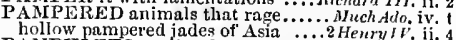

PANPHLETS studiously devised?..2 Henry I I iii. I

the pancak-were good pancak

before ever he saw those panrakes .......

as a pancake for Shrove-Tuesday.....All's $W_{e l l}$, ii.

this sailing Pandar, our doubtfiui hope

than in the flass of Pandar's praise..

eall them all-Pandars (rep.).........

PANDARUS-sir Pandarus of Troy. Merry ${ }^{*}$.

Hlay lord Pandarus of Plirygia.. Tuelfth Night, iii.

Pandarus! I tell thee (rep.)... Froilus \& Cressida, $\mathrm{i}$.

madam, your uncle Pandorus (rep.

know me better; I am the lord Pandarus -

you lord Pandarus; honey-sweet (rep.) -

no, Pandarus: I stalk about her door

PANDER-liave heen a pander

the fir'st employer of panders
his help in this, his pander

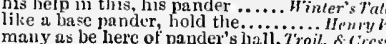

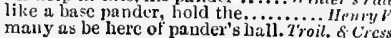

PANDE R to her dishonour .... Cymbeline, iii. 4 (let.)

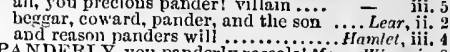
PANDERLY -you panderly rascals! 1 iferry Wives, iv. the cardinal Pandulph is eardinal. King John, ii. ANG-suffered the pangs of three.Merry till the pangs of death shake him. Twelfh Nighl. for your love as great a pang of heart

finds a pangs of deatli and sepulchre - iii. I do see the cruel pangs of death. Wher. Meas, iii. canoot long hold out the pange.... King Hown, v. see, how the pangs of death........2 Hrmry VI. iii. 3 and, in the very pangs of death .....3 Henry $V i$. ii. for that neither; here's the pang.. Henry VIII. made almost each pang a wars

losses, their pangs of love...... Timion of Athens, $v$. pitying the pangs of barred affections. Cymbeline, make swift the pangs of my queen's... Pericles, iii. the pangs of despised love, the law's .. Hamlel,
PANGED-then be panged by me ... Cymbeline, PANGING as soul and body's ....... Henry ryllin. ii

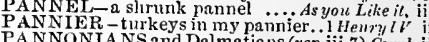
PANNONIANS and Dalmatians (rep.zii.7) Cymb. ifi. PANSIES, that's for thend Pansa. An/ony \& Gleo. $\mathrm{i}$. ANT_pants and lools s pale..... Twelfih $N^{*}$ irtht, for frighted peace to pant ........... IfIenryl ride on the pants triumpling ...Antony \& Cleo. iv. love's quick pants in Destlemona's arms o. the lean and slippered pantaloon. As you Like it, i. PAN'ED, that she did make defect.Aut. \& Cleo. ii. ascend, fair queen, Pantheon will rouse the proudest panther

where I espied the panther fast asleep - ii. 2 PANTHIN O-tell me Panthino.. Tu* Gen.of $V^{\prime}$ er. $\mathrm{i}$. PANTING sides of his poor jade......2Henry IV.
smothered it within my panting ...Richard $I I I$. to ease his breast with panting .... Richard III. i. breatliless, panting forth from Goneril ... Lear, ii. PAN'TLER, butler, cook........... Win'er's Tal. iv. he would have made a good pantler.2 Hemryl $r$. ii. pantler, and bread-chipper.

PANTRY-cursed in tlee pantry...Romeo \&-Jutiei, $\mathrm{i}$. PAP the pap of Pyramus (rep.).....Mill. N.'s Dr. v. 1

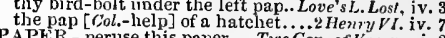
APER - peruse this paper .. Tuo Gen. of Verona, i. 2 to take a paper up that I let fall ..... - - i. 2 is that paper nothing?

aod let the papers lie.................

shall these papers lie like tell-tales..

try me in tlyy paper

delivered you a paper that

baillez me some paper.

as will lic in thy sheet of paper. Tuelfth Night,

some light, and some paper $($ rep. ......

commodity of browl paper ...Meas. for Meas. î. 3

and these paper bullets of the brain

for here's a paper, written in his ......

he hath not eat paper, as it were .....

aeliver this paper into the royal hand
here comes one with a paper ........

I'll drop the paper; sweet leaves ....

we crammed up in a sheet of paper..

contents in yon same paper (rep.).

the paper as the body of my friend.

core's a paper; shall I read it to you?

commend the paper to his graci
this paper. Foln, pr'ythee (rep.)

wrapped in a paper, which contained

take forth paper, too, and let.... Taming of Sh. i.

remain, let paper show................. Richard $1 \mathrm{i}$. $\mathrm{i}$. make dust our paper, and with rainy read o'er this paper, while the glass.. $=$ iv. 1 nothing but papers, my lord......... Henry IV. ii. 4 we fortify in paper, and in figures ...2 Henry $1 \mathrm{~V}$ i. 3 what see you in those papers ......... Henry $r$. ii. witl papers on my back............2 Henry $r$ t. ii. 4

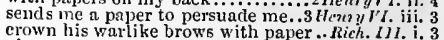
give me some ink and paper (rep.)...

must fetch lim in the papers ......... Henry ${ }^{\prime} J 11$. i. 1 lonked he o' the inside of the paper? put this paper in the paclset

must read liis paper (rep.) ........ - iii. 2

have been beholden to your paper

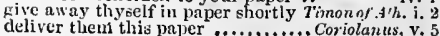




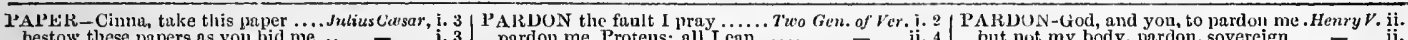
bestow these papers as you bid me

I found this paper, thus sealed up . 'twere a paper lost as offered......... Cymbeline. $O$ damned paper! black as the ink.

the paper hatli eut her throat already

then, sir, this paper is the history

ink and paper, my casket and my..... Pericles, iii. what paper were you rending?............. Lear, i. if the mntter of this paper be ccrtain.....
their papers, is more lawful............. 5 - iv. 6

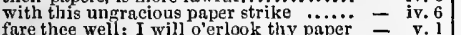
fare thee well; I will o'erlook thy paper
or with this paper shall I stop it ........

get me ink and paper, and hire.. Romeo of Juliet, v. this fair paper, this most goodly book...

PAPER-FACED villain.

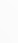

with thy lustful paramours 1 ......... I Henry $V I$.

than wanton dalliance with a paramour
how can NIargaret be thy paramour?.

here in dark to be his paramour?.Romeo \& Juliet, v. 3
PARAPETS, of basilisks ............. HenryI $V$. ii.

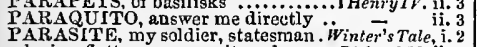

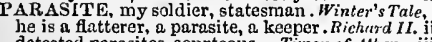

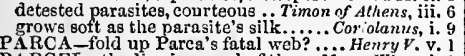
PARCA-fold up Parca's fatal web? ... Herry $V$. v. 1 a holy parcel of the fairest dames. Love's L. Los', v. 2 marked him in parcels as I did...As you Like it, iii. 5 this youthful parcel of noble

about me many parcels of charge. Winter's $\bar{T}$ ale, iv. 3 it is a branch and parcel of mine. Comedy of Err. that swoln parcel of dropsies

the smallest parcel of this vow $\ldots . . . .2$ thenry $I V$ iiv. 2 the parcels and particulars of our ..2 Henry I $V$. iv. 2

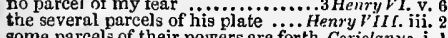
as it were, a parcel of their feast $\ldots$... Coriolanus, iv. 5 judgnents are a parcel of their.. Aniony \& Cleo. iit. 11 here comes a parcel of our hopetul Titus Andron. ii. 3 Whereof by pareels she had something ... Othello, i. 3
PARCEL-BAWD: one that serves SIea. for:Hea. ii. I PARCEL-GILT goblet ..............2 Henry $1 \mathrm{~V}$. ii. PA irCif in Afric sun .......... Troilus \& Cressida, $\mathrm{i}$. PARCHED_kiss my parched lips ..... King John, v. 7 PARCHING ho parched thine Henry VI.

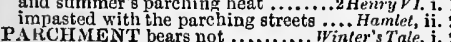
if the akin were parch ment... Comedy of Errors, ii. 1 drawn with a pen upon a parchment King John, v. 7 blots, and rotten parchment bonds.. Richard II. ii. I made parchment? that parchment.2 Henry VI. iv. is not parchment made of sheep-8kins?. Il Iamlet, $v$. or bear, pard, or boar with .............. Tempest, iv Dream, i. and bearded like the pard,..........As you Like it, ii. and ${ }^{2}$, master: I will be ............ Tempest, $\mathrm{T}$. and do entreat thou pardon me paruon, dear madam; tis.. Tu. Gen. of Veronu, $\mathrm{j}$.

sir, pardon me in what I bave to say - iv. 4

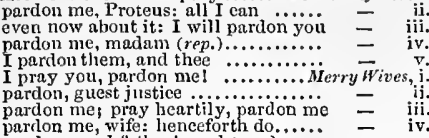

pardon me, wife: henceforth do....... $=$ iv.

pardon me, sir, your bad ......... Tiwetrth $\overrightarrow{N i g h t}_{\text {.ii. }}$

pardon me, sweet one, even for.........

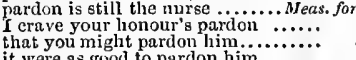

and tree pardon, are of two houses

o, pardon me, my lord ...............

you hope of pardon from lord Angelo?

let me ask my sister pardon

I hope it is some pardon, or reprieve

this is his pardon; purchased with...

pardon me, good father; it is against

her brother's pardon (rep.) ....

pardon $i t$, the phrase is to the matter

pardon, my lord (rep.) ..............

O give me pardon, that I, your vassal

you must pardon for Mlariana's sake

the offence pardons itself .

no, you shall pardon me

I beseecl your grace, pardon me $($ rep. $)$

pardon, my lord. I pray you all....

pardon me, I am too sudden-bolä. Love's L. Lost, ii.

pardon me, madam, for I meant nö

under pardon, sil, what are the contents?

good my liege, I pray thee. pardon nic -

pardon me, sir, this jew

pardon thee thy life before thou.......... of

take my life and all, pardon not
or else I do recant the pardon

do desire your grace of pardon

not to deny me, and to pardon me (rep.) =

pardon me, good lady; for, by these

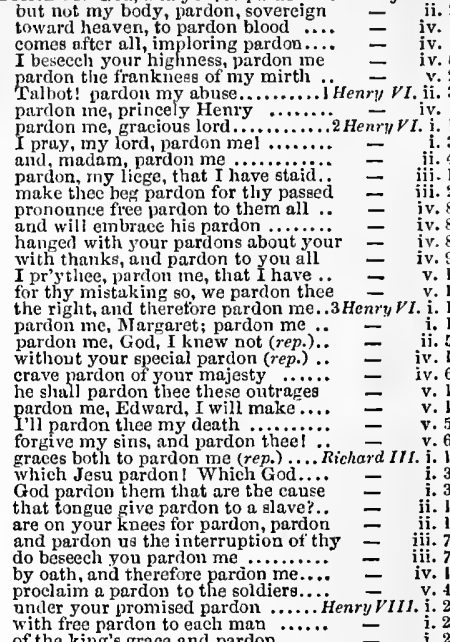

this revokement and pardon comes...

gracious king, that pardons all offences -

tis like a pordon ofter execution...

pardon me, pardon me ........... Troilus

give pardon to my speech

pardon me; if I confess (rep.)

pardon me this brag, his insolence ...

under favour, pardon me. if I .

0 , good madam, pardon me........ Coriolanus, i. 3

O my sweet lady, pardon ..............

for they lave pardons, being asked..

to pardon when it was less expected

sworn you out of reprieve and pardon

pardon me, lords, 'tis the first time...

pardon me, Cresar; for my dear dear

pardon, Casar; Casar, pardom $\ldots \ldots$....

pardon me, Cains Cassius .........

O pardon me, thou bleeding piece of

pardon, my lord, for me and for my

that has brought his pardon

pardon, my gracions lord

pardon me, madam, I had

but first I beg my pardon
let him not ask our pardon.

let him not ask our pardon.....

like a remorseful pardon slowly..... - $\quad \begin{aligned} & \text { v. } 3 \\ & \text { both } 3\end{aligned}$

both, both; O pardon! $0 \mathrm{my}$ good ... $\overline{\text { v. }}$,

to pardon me yet for a dight.. Taming of Sh. 2 (ind.)

pardon, old father, my mistaking eyes
pardon, I pray thee, for my mad....

pardon, sweet father (rep.) $\ldots . . . . . \ldots . .$.
whom, for this time, we pardon...

Apollo, pardon my great profaneness - iii. 2

O pardon, that I name them \%...... = iv. 2

your pardon, sir, for this; I'll blush -

pardon, madam: the one I have almost -

to pardon me all the faults I bave
both your pardons, thet e'er I put

may pity, though not pardon thee. Comedy of Err. i. 1

I crave your pardon; soon; at five..... . . Macbeth i. 2

implored your highness' pardon ....... Mache
but crave your pardon; that which....

pardon me, madan, I may not $\ldots \ldots$ King John, iji. 3

corrupted pardon of a man

your grace ehall pardon me $\ldots \ldots \ldots . . . \quad$ v. v. ${ }^{2}$

begged your grace's pardon........... RichardII. i. I
o my liege, pardon me, if you please - ii. I

pray, pardon me: go, fellow, get thee $=\begin{array}{r}\text { ii. } 2 \\ \text { pardon me, madam; little joy ...... }\end{array}$

God pardon all oaths that are broke

beseech your grace to pardon me $\ldots . .$.

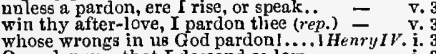

whose wrongs in us God pardon!....

as you, God pardon it! have done

first pardon me, my lord

fina pardon on my true submiseion (rep.) -

and pardon absolute for yourself.

ii. 4

pardon; a soldier is better (rep.) ... Hen ${ }_{\text {ry }} 1 V$. jii.

$O$ pardon me, my liege! but for my tears -

give me pardon, sir; if sir, you come

and my speech, I beg your pardon ... ${ }_{\text {but }}$ (epil.)

but, pardon gentles all (rep.) ...Henry $V$. i. (ehor'ts)
more advice, we pardon him ........
ii. 2 under your pardon: you must note.

by your most gracious pardon ... Anton

do so far ask pardon, as befits mine..

pardon what $I$ have spoke

I erave your highness' pardon

I begged his pardon for return

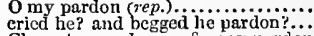

Cleopatra, and weep for my pardon

(dear my lord, pardon,) I dare vot...

give me your pardon: I have spoke this -

pray, your pardon. All's well, sir
pardou me, godel I'd change my....

pardon's the word to it

pardon's the word to all .................

to pardon Mutius, and to bury him

pardon me, sir; 'twas a blnck

then pardon me for repreliending thee

pardon me; for when no friends

shall be next, pardon old Gower

pardon us, sir; with us at sea

pardon me, royal sir; election makes
I beseech you, sir, pardon me (rep. i. 4$)$

yet, under pardon, you are much more.

I hear my father coming, pardon me...

pardon me, dcar madam; yet to be known - iv. 7

our power, shall never see his pardon $\ddot{\text { jo }} \overline{\text { vi. }}$

God pardou sin! wast thou with.... - ii. 3

Ge , pardon of the prince, and call thee

pardon me; but, an' you will not (rep.) -

pardon me for bringing these ill news

pour gracious leave and pardon....... Hamlet, i.

if not, your pardon, and my return $\ldots .$. 二 you shall ask pardon of his majesty

you hiall ask pardon of his majesty
they die before their pardon come

pardon, good Mercutio, my business 
PARDON-first asking your plardon. IIam'et, iv. 7 (let.)

give me your pardon, sir (rep.) ...........

good your grace, jardon me

good my lord, pardon ine; thongh $\mathrm{I}$ aim

do beseeeh yon of your pardon

but pardon me; I do not, in position...

pardon me, Bianea; Thave this while

O pardon me; 'twill do me good to walk

I do believe it, and I ask your pardon

PARDONED-pardoned the deceiver. T

as you from erimes would pardoned be - repil.

for his sake is lie pardoned; and, for your

thy offences, ere thou be pardoned. Love's L. Lost, i. 2

I pleased not to be pardoned

Richard HI. ii.

till Bolinglroke have pardoned thee

some shall be pardoned, and some. Pericles, iv. 4(Gower)

or partoned, being down? then I'll ... Hamlet, iii. 3

may one be pardoned, and retain $\ldots . . . .$.
PARDUNER himself is in ....... Meas. for Meas. iv.

PARDUNING Rntland..................Richard II. v. 3

mAliders, prardoning those that........ Reo \& Juliel, iii.

cle pardonner aucun prisonnier.

ARDUN NEZ moy

pardomez moi, I eannot tell vat is...
PARDUNiEZ-MIOIS-[Knt.-pardon-mes]

who stand so much on the new. Romeo

whe stand so much on the new. Romeo soliet, ii.

that plays the lion, pare his nails.Nid. Ni's Dr. iv.

may lare his nails with a wooden...... Henry $r$ iv. 4

to have his princely paws pared... Titus Andron. ii. 3
thou hast pared tlyy wit o' loth sides....... Lear, i. 4

thou hast pared thy wit o' hoth sides........ Lear, i.
P.MENT-like a good parent.......... Trmpert, $\mathrm{i}$.

we are their parents and original...Mid.N.'s Dr. ii. 2

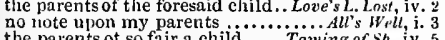

the parents ot so fair a child

by the hollow of my parents.........
their parents were exceeding poor. Comedy of Err.

these are the parents to these ehildre

of parents good, of fist most valiant ..Henry $V$. i

for their parents' timeless death ...3 Hemry VI. v.

tlie parents live, whose children

laid up to make parents happy ....̈̈ Henry $\vec{V} I I I . v$.

do't in your parents' eyes.....
between the child and pareut

our parents, and us twain $\ldots \ldots \ldots . . .$.

by the defiling of her parent's bed....... Perisles, $v$.

hetween the child and the parent $\ldots \ldots . . . .$.
Lear i. 2
obey thy parents; keep thy word justly...

bury their parents' strite .....Rnmeo \& J Juliet, (prol.)

the continuance of their parents' rage $\overline{\text { (prol.) }}$
PARENTAGE I was ............. Asyou Like il, iii. 4

what is your paren tage? $(r+p)$

upon knowledge of my parentage. Taming of sh. ii. 1

the next by birth and parenta

ignorant of his birth and parento

his name and parentage (rep.) .......
time hath rooted out my parentag..

my fortunes-parentage-good parentage =

report thy parentan pare

che would never tell her parentage
PARFECT one

'AKING-itself' to c............... Love's L. Lost, v.

ask but the paring of one's nail . Comedy of Eir. iv.

liere comes one o' the parings .............. Lear, i.

PARING-KNIFE? No, forsooth ...Merry Wives, i. 4
PAIIS-welcome to Paris............... All's Well, i. 2

speak truly, to go to Paris?

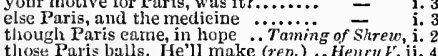

Url'sans, Paris, Guysors, Poictiers. .. H Henry Vi. i.

is Paris lost? is Rouen yielded up?

tluen depart to Paris, to the king

now to $P$ aris, in this conquering vein

then march to Paris

as did the youthful Paris once....... - v. 5

Paris is lost; the state of Normandy

crowned in Paris buc at nine........ Richarit 1 III. ii.

with wanton Paris sleeps..... Troilus \& Cress. (prol.)

let Paris bleed, 'tis but a sear (rep.)...

complexion above Paris. Why, Paris
Ileen loves him better than Paris ..

which of these hairs is Paris

yonder so blushed, and Paris so chäed =

Paris? I'aris is dirt to him.......... -

Puris should do some vengeance...... =

our firebrand brotlier, Paris, burns ...

Paris should ne'er retract what he

Paris, you speuk like oue besotted

do not you follow the young lord Paris? -

at the request of Paris, my lor

it it be not ny lord Paris.
PARIS- to be his servant, Paris Troilus
as you, prituee Paris, nothing but....

there is at liand Paris your brother.

for thus lopped Paris in his .......

no, Paris is not; fur, you know......

but woo her, gentle Paris..............

the valiant Paris seeks you.......

ean you like of Paris love?............

and tarl her that Paris is the propere

sir Paris, I will make a desperate...

aequant her here of my son Palis love

you know 1 hate, rather than Paris

to go with Paris to St. Peter's church

rather than to marry county Paris (rep.) -

give consent to marry Paris $\ldots$ will walk myself to county Paris..

I'll go and elant with Paris

the county Paris hatl set up his rest

and go, sir Puris: every one prepare

Paris should have married Juliet.

what, Puris too? and steeped in blood?

some-J uliet, and some-Puris

here lies the county Paris slain $\dddot{\text { marie. }}$

first what Danskers are in Paris ....... Hamlet, i.

PARISI-I-sufficient of your parish. Meas. for Meas, i. the parish eurate, Alexander .... Love's $L$. Lost, $\mathrm{v}$. plain as way to parish church

as the parish heiters are to .......
beget her, all the parish knows.

within the parish saint Lawrence

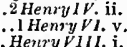

parish, ehureh, steeple (rep.) ...........Pericles, ii.

wearied your parishioners withal. As you Like it, iii.

PARIS-WARD-marching unto Paris-ward - iii. 3

ARK-I vill cut his trout in de park. Merry Wives, i. 4

come, come, walk in the park ...

be you in the park about
go before into the park

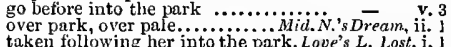

taken following her into the park. Love's L. Lost, i. 1
it is ycleped, thy park ............

that I took in the park with
I must keep her at the park.

I must keep her at the park......

first, from the park let us conduet...

stays for us at the park gate... Merch of venice, ifi. 4

bid thee meet me in the park. Ta
disparked my parks, and felled

Richard II. i

ehiefest thicket of the park

Henry ${ }^{2}$ ii.

stands ready at the park corner...

my parks, my walks, my manor

straying in the park, seeking.... Titus Andron. iii.

PAlK-WARD, every way

to parle, to court and tiance. TwoGen. of I'erona,

yet never brooked parle, know now. "íming of $s$,

the French, amazed, vouchsafe a parie -

or sound so base a parle.........

this is the latest parle we will admit... Henry $\nu$.

dites moi, si je parle bien ...

meilleur que l'Anglois lequel je parle - $v$

nephew, break the parle ....... Titus Ardronicus,

PARLER-que j'apprenne à parler ....

PARLER-que j'apprenne à parler ....

to paridy with the sole inheritor.. Love
to

calls to parley the sleepers of the house? Mucbeth

in signs again parley with sin........

insimiation, parley, and base truce
in such a parley would $I$ answ'er

we shall admit no parley
the town sounds a parle

summon a parley we will talk......... Henry

a parley with the duke of Burgundy (rep.) - iii, 3

will parley with Jack Cade.

bo bold to sound retreat

they stand, and would have paricy.

the craves a parley at your father's

higher rate, than a eommand to parley.

it sounds a parley of provocation $\ldots . .$. ... Othello, ii.

i. 2 PRLEZ - le Francois que vous parlez. Henyy $v$. v.

if. 2 I am in partiament pledge for bis ...Richord II. $\nabla .2$

ii. 2 the speaker in his parliament .....2 Henry $I V$. iv. 2

\begin{tabular}{l|l} 
ii. 2 & call we our high court of parliament \\
ii. 2 & the king hath called his parliament.
\end{tabular}

wiped out in the next parliament ...

therefore haste $I$ to the parliament..
God speed the parliament!..........

grace to his majesty's parliament.....

your highmess leave tlie parliament?
ghall be the parliament ol Euglaud.
P.IRLIANIENT-court of parliament .2Hrnry VI. v. 3 the bloody parliament shall this be.. here in the parliatient, let us assail until that act of parkiament be repealed = you thate deeree in parliament his oath enrolled in the parliament..

PARLOUR -into the parlour......... Much dilo ii. sit conferting by the parlour fire.. Taming of sh. v.

art in a parlous state, shepherd...As you Like it, ifi. a parlous boy (rep. iii. $\mathrm{J})$............ Richard III. i PAROLLES, my lord calli for you ........Al's Well, Parolies, you were born under

o my Parolles, they have married me

some time known. Parolles, was't not?

this is monsicur Parolles the gallant

to thee in thine ear, Parolles ..... -

God bless you, captain Parolles......

my name, my good lord, is Parolles

PARLICIDE-their eruel parricide ifear, iv.

'gainst parrieides did all their thunders.. Lear, ii.

in none only but parrots

more elamorous than a parrot..........

parrot, beware the rope's end ... Comedy of Err. iv.

his poll clawed like a parrot.

2 HenryIV.ii.

and speak parrot? and squabble?

PARROT-TEACHER. A bird of $\mathrm{my}$. MU uch Ado

ARSLEY to stuff a rabbit ... Tuming of Shrew, iv

tell master parson Evans......

I hear the parson is no jester

parson Hugh, the Welshman

you study them both, master parso....

to do a good office, master parson...

nay, good master parson

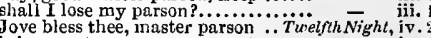

being master parson, am master par'son

master parson, be so good as read. Love's $L$. Los

our parson misdoubts it.

- v. 2 (song)

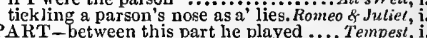

for my part, the sea eannot $\ldots . . .$. .

'gainst my fury do I take part.

how did thy master part with.. Two Gen. of Ver.

and ere $I$ part with the

the company parts ...................

for I did play a lamentable part .... - iv.

for my part, I say .....................

the attraetion of my good parts aside

truly, tor mine own part ...............

and remember your parts............

is semblative a woman's part .......... - i. 4

and that question's out of my part ... = i. $\quad$ i. 5

my part of death no one so true
the parts that fortune hath bestowed

I will not give my part of this sport.

have found in any part of Illyria.....

and part, being prompted by

we will not part from hence

can my part in him advertise .........

for mine own part, I never .......

dispossessing all my other parts .....

to accuse him so, that is your part ..

sweet Isabel, take my part

=

who? now that is your grace's part.

I will assume thy part in some disgui:e

you may do the part of an honest man

Thave played the part of lady fame

fear you not my part of the dialogue

played their parts with Beatriee....

for mine owp part (rep.iv. 1)........

come to part almost a fray $\mathrm{i} . . . . . . .$.

any good part to intermingle with (rep.) -

name what part I am for think Mid.N.'s $\overline{\text { Dre }}$

or a part to tear a cat in

the joiner, you the lion's part...........

you can play no part but Pyrau?...

but, masters, here are your parts ....

tor the third part of a minute, hence

you speak all your part at once.....

and trom thy bated presence part $\dddot{I}_{\text {so }}$

and superpraise my part

I yield you up my part .............
slie shall not, though you take her part
take not her part: for if thou........ 


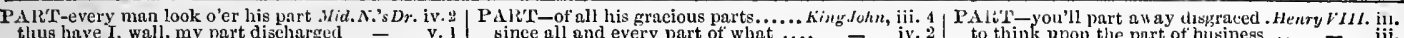

thus have I, wall, my part discharged part sadness and melancholy....... Love's Lost, i. part sadness and melancholy

one part of Aquitain is bound to ns. an outwnrd part, we bend to that....- iv. $\overrightarrow{1}$ (letter) only sensible in the duller parts .... - iv. that I sle parts that do fructify in.... and here is part of my rhyme.......... = or I would these hands might never part 二 only to part frie nds:

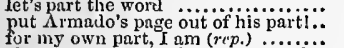
the extreme parts of tine extremely

do deny, let our hands part ........... of $\overline{\text { Venice }}$ the better part of my afteetions... every man must play a part

appropriation to his own good parts..

in what part of your body pleaseth ..

parts, that become thee happily enough =

a tedious leave: thus losers part ....

a tedious leave: thus losers part .....

I saw Bassanio and Antonio part...

for his own part, knew the bird was..

mark of virtue on his outward parts

which when you part from, lose, or g

for my part (rep. iii. 4 and $v$. l)......

in six parts; and every part a

the tweutieth part of one poor scruple

to part so sliglitly with your wife's it

made him swear never to part with it

for my part, he keeps me rustically As
you shall have some part of your will

of every man's good parts, a secret

thy better parts all part with weeping-

they take the part of a better .........

shall we part, sweet girl?

thus misery doth part the flux .........

for my part, I had rather (rep. iii. 5)

in his time plays many parts

were I not the better part made........

Atalanta's better part

of many parts by heavenly......

thousand parts, and break but (rep.).

clubs cannot nart them.

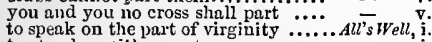

to stand on either part ..

at full I know, thou know'st no part

from your sound parts shall fly.....

set thy lower part where thy nose....
a great part of your title ...........
the quarrel upon your grace's part .

for my part, I only hear, your son

tlie champion honour on my part....

and yours our parts; your gentle...

we'll play our part ...T.Taming of Sh. I (incluction)

and that part of philosophy will $\mathrm{I}$..

for who shall bear your part

come you to part the fray?

nay, then, good night our part l......

now I play a merchant's part.

make no music in three parts.......

shall with either part's agreement

well agree with our external parts?

we'll part the time between's then .
but so disgraced a part, whose .....

by all the parts of man.

queen, part of his theme ..............

and the testimony oo my part ........

for tlye most part, been aired nbroad

to each part of you do give a life....

that never mean to part $\ldots$ a...........

I can bear my part ..................

that I must bear a part...
thor what dull part in't you

and answer to his part performed in

and answer to his part performed in

than thy dear self's bctter part ....... -

take them in good part...
we sliall part with neithe

mine own self's better part ...........

your lighness' part is to receive.........

was never called to bear my part...

though the main part pertains to you..... = iiv. 5

and would not take their part?

cowed my better part of man! ....

sir Robert miglit have eat his part

and part your mingled colours once

be is the half part of a blessed man.

willingly departed with a part

thy constant and thy nobler parts...

my reasouable part produces ........ since all and every part of what
to part by the teeth the unowed

and part this body and my soul

night did part our wenty powers?

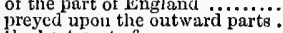

the best part of my power 1 ...........

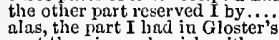

part therein we banish with yourselves

we three here part, that ne'

part of your cares you give me with

take leave, and part (rep.).

part us, Northumberland............

eall for thee to pay thy part?......... I HenvylV.

but how shall we part with them....

yea, on his part [Knt.-in his belialfj]

and east, is to iny part assig...

on the ninth part of a hair ............

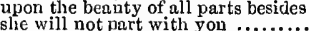

he had his part of it; let him pay

and ne er part, till one drop down....

for mine own part, I eould be (rep.)

misled ipon your cousin's part

better part of valour is diseretion (rep.)

for my part, if a lie may do thee graee -

and every part about you biasted.

than he can part young limbs

tap for tap, and so part fair..........

marry, the immortal part needs

yet, for mine own part, sir, I do (rep.)

and, for your part (rep. iv. 1).........

why not to him, in part.

inwarem have pay, and part

inwards to the parts extreme .........

imagine me taking your part.

narrow ocean parts asunder............ $v$. $\bar{i}$. (chorus)

a thousand parts divide one man - i. (chorus)

gwaying more upon our part

put into parts, doth kep in wal .

for my part (rep. iii. 6)

the sick and feeble parts of France

have, in these parts, from morn......

leaving their earthly parts to .........

on oue part and on the other?.......

on both parts best can witness......

dispraise those parts in me $\ldots . . .$.

your French part of suen a boy $\ldots \ldots \ldots$
most part of all this night $\ldots \ldots \ldots \ldots$

the smallest part and least proport

would some part of iny young years.

banding themselves in contrary parts

ravely played her part in this

part of thy father may be saved $($ rep. $)$

into two parts, is now conjoined......

I will take the Nevils' parts

to play my part in fortune's.

for my part, noble lords, I care not...

these rags are no part of the duke....

dare not) take our parts.............

now part them aga

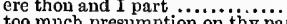

bosoms of our part hot coals part

the hearts of all our preseut parts...

disproportion me in every part.....

subdue the greatest part of Spain
Clarence shall not want his part

for my part, I'll not trouble...........

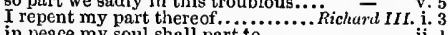

upon my part, shall be inviolable......

to part the queen's proud ...............

I see, you'll part but witli light gifts

I presume, he'll take in gentle part..

lord Hastings had pronounced your part -

play the maid's part, still....

part in just proportion our

shall share his part thereof $\ldots \ldots \ldots \ldots . . . .$.
peep through each part of him....... Henry $\bar{V} I I I$.
for the most part such too....

which makes my whitest part black...

I know but of a single part ...........

sixth part of eaeh?

bark, and yart o' the timber.

the nart my fother meant to.....

you, that have so fair parts of womar

thy parts sovereign and pious else ...
fiud me liere part of a huusewife .... to think upon the part of business ...

from all parts they are coming

for my purt (rpp.).............. Troilus \& Cressida, v. 3

receives from lience a conquering part

not worth the nintli part of

virtuously on his own part beheld

his menta! and his active parts

thy plarts of nature thrice-l'amed
thy spacious and dilated parts

it is musie in parts

fight your hearts out, ere $\mathrm{I}$ part $\mathrm{you}$

comnunicate his parts to otliers.

tor my ow u part, I came in late

may move, and parts w'ith person.....

come, kiss, and let us part.......

in which part of his body shall $x$

after we part for Agamemuon'

a retreat upon our Grecian part

now, parts bread with him...... Timon of $\overline{\text { Athe }}$

ii. 1 use thee well; good parts in thee..... -

purchase the day before for ä iittle part =

for mine own part, I never

we must all part into this sea of air...

thus part we rich in sorrow ...........

it is our part, and promise to the

though in general part we were

the mutinous parts that envied....

with one part of our Roman power
stand upon my conmon part with

stand upon my common part with

with the major part of your syllables

where being three parts melted away

the greater part carries it ...........

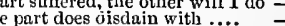

ve the fundental part of state.

you have put me now to such a part

perform a part thou hast not done before -

you take my part firom me, sir ......

tor mine own part (rep. v. 3) .........

to show a noble grace to both parts.

which to a mother's part belongs.

from Aufidius a great part of biame

lack some part of that quick spirit.Julius $\bar{C}$ cesa

and for mine own part (rep.) .........

that part of tyramny, that I do bear

three parts of him is ours al ready

for Jour part to But it is doubtful yet -

for your part, to you our swords have

the other street, and part the nurno

the greater part, the horse in geveral

this is a Roman's part

to part the slories of this happy day

the finest part of pure love.. Antony \& Cleopat

none our parts so poor, but was a race

to part with unhacked edges... not

we'll feast each other, ere we part

third part o' the world, man (rep.)

gentle lords, let's part; you see.....

you take from to part from Rome

you take from me a great part of
if on both parts this be not

your ends 1 we will here part.

for the most part too, they' are foolish

we had not rated him his part o' the isle -

conquered, I grant him part

fortune and Antony part here

if thou and nature con so gently part

dear as my fiuger, to draw upon .... Cymbelis

enjoyed the dearest bodily part of your -

I affirm it is the womann's part

why,

all courtly parts more exquisite ....

south to this part of the west .............

Imogen. the great part of my comfort

'll tight against the part I come wi

part, shame, part, spirit renewed..... in -

of my freedom 'tis the main part

scornful page, there lie tly part ....

thanks in part of thy deserts...... Titus Andron

take Titus' part, and so supplant...

let's kiss and part, for we have much
come trom all parts of the world...... l'ericlss,

mine own, part of mine heritage ${ }_{\text {bogin to part their fringes of briglit gold }}=$

, i. 1

ii. 1

ii.

ii.

ii.

iv. 2

v. 4
v. 4

v. 5

v. 9

i. 2

iii. 2

iii. 5

iv. 2

v. 3

i. 1

i. 9

ii. 1

ii. 3

ii. 3
ii. 3
jii. 1

iii. 1

iii. 2

iv. 3
iv. 5

v. 3

v. 3

i. 2
i. 2 


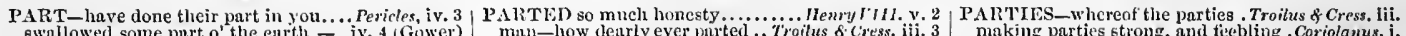
mun-low dearly ever purted.. Troilus of cre'ss. vit. you sre ot hogonrable parts $\ldots \ldots . . . . .$. the thousandth part uf my endurance how came you in these parts?.

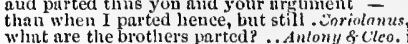
that have my heart purted betwixt. ns in part I understand thein... were parted by gentlemen at hand I will not ant from thee $y^{2}$ for taking one's part thint is out of how warted wour brother with tein parted Pentapolis... when we whe the purted yuu in chood termis?

ind gavest away both parts

new of choice and rarest prirts

nnd take vanity the puplet's part .....
how now? what's the matter? Prart.

which parted thence, ns pearls from

rhich, for my part, I will not le.

I have one part iu my leart

there is part of a power already footed

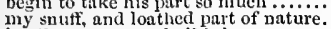
lie, that parts us, shall bring

part fools; put up your swords... Romeo o Juliet, i.

or manage it to part these men.

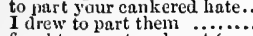

fought on part and part (rep.)

to her consent is but a part...........

that name, which is no part of thee

with that part cheers each part...

thant every part nbout me quivers....
hold friends, friends, part I and, swifter -

ere I could draw to part them ......

but the kind prince, taking thy part
in what vile part of this anatomy..

in what vile part of this

each part, deprived of supple..........

Four part in her you could not keep

her immortal part with angels live

to illume that part of heaven ..........

thy knotted and combined locks to part

that we shake hands, and part ..........

his friends, and in part, him (rep.) ....

what thing was that wlies purted trom

who parted either part ........... Rome of Juliet,

they were parted with fonl and violent.
of the sea and skies parted our fellowslip

was not that Cassio, parted trom my wife? - iii. 3

PARTHLA did I take thee prisoner Jutius Creser.

compose well here, to Purthin ... Antony

now, darting parthia, art thou strick
that neer yet beaten jorse of Parthia
great Media, Pnrtlia, and Arnentia

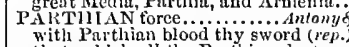

PARTIAL-come in partial

I am not partial, to infringe... Comedy of Errers, i. I

a partial slander sought I to avoid ... Richort 11. i. 3

of partial indulgence to their....

iii. 3
iii. 3
PAInce nature makes thicm partial
PAITE the unstooping

Lear, i. 4

PA RTIALLY affined, or leagned in .... Othello, ii.

from the womb I did participate.Tuelfh $\mathrm{Night}, \mathrm{v}$
PAl'TICIPATLN of society........

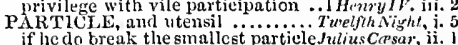

if he do break the smallcst particle.Julius Casar, ii.
PARTICULARS of thy preservation .. Tempest, and the particular accidents, gone by

swear down each particular saint

swall recount their particnlar duties. Mue/t Ado, iv.

trans-shape thy particular virtues .. $\overline{-}$ v. 1 ay, and no, to these particulars.. As you Like it, iil. 2 required office on my particular

I knew in what partienlar action...

let me arswer to the particular.....
their own particular thritts

by each particular star in lienven...

does receive particular addition........... Macbeth, ii. 1

examine ne upon the particuia...... i Henry $I V$. ii. 4

make my quarrel in particular .2 ${ }^{2}$ en'y IV. iv. 1

parcels and particulars of our grief.

with every course, in his particular.

doth any name particular belong to
upon my particular knowledre...... Henry

to lay apart their particular tumetions - iii. 7

the particular endings ot lis soldiers

whose tenors and particular effects.

here I am, thou particular fellow..2 Henry $V 1$. iv. 2 but by particular consent proceeded

as 'twerc in love's particular.

of their particular additions. . Troilus
soun bring his partieulars therein .

although particular, shall give.......

as tir as touchetly my particul

dwells not in particular will $\ldots . . .$. - ii. 2

PARTAKE-to partake with me.. Tuelfih Night, v. depart, and yet partake no venom. Winter's $T$ 'ale, ii. your cxultation partake to every one -1
may partake of any thing we say.. Richard what, what? let's partake.......... Coriolanus, iv. 5 by and by thy bosom shall partakeJulius Casar, ii. I
not let him partake in the glory. Antony \& Cleo. iii. 5

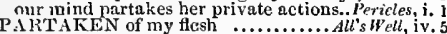

PARTAKEN of my flcsh ..............All's Well, iv.
I'ARTAKER in thy happiness...Tuo Gen. of Fer. . make us partakers of a little gain ... Henry VI. i. I. I

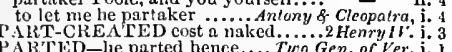
they parted very fairly.

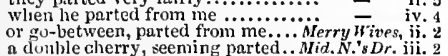
I sce ble elhery, seening parted...Mrd.N. sDr. 2

wall is down that parted their fithers

Bassanio's hand, and so they parted

hore are severed lips, parted with.

hou would not then have parted .....

how parted he with thee?.........

when his disguise and he is parted ....Alls $\bar{s}$ ell, iii. 6 who parted with me to go fetch. Comedy of Err. v. thou know'st, we parted $\ldots \ldots . . . . .$.
he parted well, and paid his score ..... Macbeth, v.
when you parted with him?

as a long parted mother with.

yet parted but the sliadow with $\ldots \ldots$. Henry $_{\text {. }}$. i. i. 3 when we parted last, thou $\ldots \ldots \ldots \ldots$...... $\overline{\text { HI }}$ ivi. he parted frowning from me....... Henry able means, we had not parted thus

that his particular to foresee..........

our old love made a particular force

to make his requests by particulars. Coritar
revenge thine own particular wrongs

I mean, for your particular...........
luved him in a most dear particular

about thy particular prosperity

give me particulars ........ Antony

world should note something particular - iii.

forgive me in thine own particula

more particulars must justify .....

inform lier full of my particular fear....

for lis particular, I'll receive him gladl

for these domestic and particular bront
in what particular thought to work
why seems it so particular with the?

why seems it so particular with the
particular act $[K n t$-peculiar sect $]$
oft it chances in particular men

corruption from that particular faili......

than your particular demands will....

let me question more in particular......

PARTICULARITIES. I do not know. Henry $V_{\text {. Hi. }}$

PARTICULARIZE their abundance. Coriol
PARTICULARLY, and to all the Volsces

drift halts not particnlarly .... Timon of $A$
PAlTIES-from the two parties... Merry $W$

PANTIES-from the two parties .. Merry Wives,
the parties themselves, the actors. Lnve's L. Lost,

the parties themselves, the actors. Lnve sL. Lost
bnt when the parties were met.... As you Lite it the partics sure, and our induction.1 Henry I $r^{r}$.
for then both parties nobly are ...2Henry $1 V$. lest prarties (as he is beloved) break out wherein you wished us parties.

than the love of parties ....Aniony \& Cleopatra, ij. firtl the partics of suspicion.... Rrméco o Juliet, v. PARTING strikes poor lovers. Tuco G'n.of $V_{\text {er. }}$ ii. wept to have secn our purting

hasty-fuoted time for perting us...Mid. $N \bar{r}_{s} \mathrm{D}$ r. iii. for parting uny fair Pyramus and me $-\overline{-}$. procured bis leave for present part

fither charged me at our parting. Taming of $S h$. lit the parting all the clurel did echo - iij. proclaimed his, parting with her..... Winter s Tole, 1. what store of parting tcal's were shed? Richard Il. i. more than the parting with

the parting of your wiyes and you...iHenry $/ Y$. ifi. aw ay! thougl parting be a tretful. 2 Henry VI. ii. a w a b! though parting be a tretful.2 Henry $F$ T. ii. 2
my body's parting with my soul....3 Heury $r$. ij. 6 his parting guest by the linnd.. Troilus \& Cress. iii. ricl in parting from us.............. this parting was well nade (rep.) Julius Cossar, v. ere I conld give him that parting kiss

whicl are often the sadness of parting

parting is such sweet sorrow... Romeo or Jutiet, ii. ARTITLN - a union in partition. Mid. $N$. Dr. iii. good from bal find no partition $\ldots .2$ HenryIV. iv. PARTIZAN I could not heave ...Aniony « Cleo. ii. 7 with our pikes and partizans $\ldots . .$. . Cymbeline, iv. to wield old partizans, in hands as old

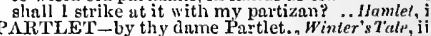
liow now, dame Partlet the hen? . I Henry $I \%$. PARTLY, seeing you are .... Two Gen.of Verona, partly, that I have need of sich.......
that 1 partly know the instrument. Tuelfhight,
your you are partly a bawd Pompey

1 partly think, a due sincerity ..........

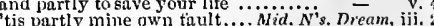
marry, you may partly hope that.Mer.eflenice, iii.s l,y circumstances partly. Winter's Tale, iii. 2 (indict.) for him, I partly' know his mind partly thy mother's word, partly ... H Henr? $I V$. partly to satisty my opinion (rep.)

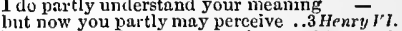

he knows, and you may partly see. Richard 111. iii. 7 I partly know the man ................ to be pa partly credit things that do presage. Julius $\bar{C}$ cesar, v. I but believe it partly ................ apace, despatch I partly feel thee..... I partly know him; 'tis Cloten .... Cymbeline, iv. 2 partly, to behold my lad 's face.. Rnm o \& Jutiel, v. but partly led to diet my revenge......... your partner, as I lear...............Meas. for Meas. ii. 3

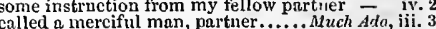
go, good paitner, go, get you to...... - iii. 5 marry, that am I and my partner..... $\bar{W}_{\text {in }}$ iv. as it becomes the partner of your bed - iv. my noble partner you, greet with

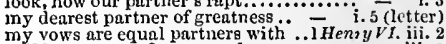
my vows are equal partners with ...1Henvy VI. iil. sweet partner, I must not yet forsake. Hen,$y$ VIII. my noble partners, and myself .......

my partner in this action ............. Coriolanus, $v$.

I seemed his follower, not partner.....
vouchsafed to think he liad partmers. .
. Cleo then, noble partners, (the rather

are partners in the business.

PARTRLDGE' wing anved ............. ifuch Ad

finds the partridge in the puttock's.2 Hem y $/ 2$. iii. PARTY-bring me to the party?...... Tempest, iii. 2 and the three party is...

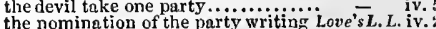
the party is gone, fellow Hector .... ve venice, iv. 1 therein tax any private party? ...As you Like it, ii. must be a party in this alteration. Winter's Tale, $\mathrm{i}$. not a party to the anger of the king..

are you tried, the daughter of...... - ii.

are you a party in this business? .... King John, i. I whose party do the townsmen yet .. - ii. 2 and swear upon my party 1 ...........

our party may wall meet a prouder.. in arms upon his party [Kni.-fnction $]=$ iif. 2
on llyy royal party grauted once .... 


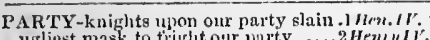

ugliest mask to frighit our party

but. for the party that owed it

subdued, and neitleer party lose

d...

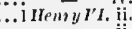

untar the party wear this rote...

Richard III. i.

o figlit un Edward's party

to fiud you torward upon his party...

caine from Buckinulam par lis party

the meanest spirit on our party. Troilus \& Cress.

and he upon my party, I'd revolt

I saw our party to their trenches....

hearing a matter betwcen party and

factionary on the party of your general -

Cersar, i. 3

I would not be the party

to the king's piarty there's no goilug. Cymbetine, iv.

for whom we stand a special party. $r$ '

have you mothing a upon his party .... I.eur, ii.

I would show what party I do tollow

1 would show what party I do tollo
scek him out upon the British party

party in converse, hin you

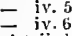

to be a party in this injury

PARTY-COLOURED lambs. .... Love's L. Los', v.

PASH, and the shoots...............

PASIll Dosh him over tlie face ... Trailus \& Cressida, ii. 3

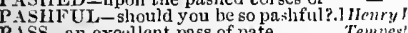

PASS-an excellent pass of pate ......Tem

I'll tell you as we pass alon.

nind pass good liuinours.

Herry Wioes, i. I

but let that pass

that I may pass with a reproof

to see thee mass thy punto.

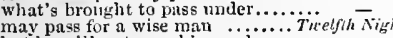

but lie will not pass his word

for it eomes to pass oft

have their permissive pass

that thieves do pass on thieves?.

if you live to see this come to pass

on the duke, he shall not pass
that moment (so it came to pass)..

how came these things to pass?

oath is passed to pass away from

let it pass: I do beseech (rep.).

therefore let him pass for a ma.

so shali we pass along, and ne

if it do come to pass, that any ....
o'er the green corn-field did pass.

the thievish minutes liow they pass... All's Vicll, i $^{v}$

it might pass; y yot the scarfa truth to pass a thousand nothings with

gives him a wortliy pass

for it will come to pass, that every

though it pass ynur patience... Ta

which to bring to pass, as I before....

a wealthy widow, ef a dower in .....

pass my danghter a suffieient

we'll pass the busioess private

brought to such a silly pass!

Whin I siall meur, to pass it .....Win!er's Tole, ii

let me pass the same $1 \mathrm{am} \ldots \ldots \ldots-$ iv. (chorus)

and, bet, should pass this way, as you

before he pass the abbey.

if you tondly pass our proffered........... King John, ii. i

joss them current too .............. Henry $1 l^{\prime}$ ii. 3

daffed the world aside, and bid it pass?

seas to give you gentle poss

if we may pass, we will...

suddenly, pass our accept $\ldots$

Thave no power to let lier pass....

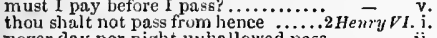

never day nor night ushallowed pass

for your lives; let her pass by .........
listurb him not; let lim pass peaceibly -

these silken-coated slaves, I pass not

may pass into the presence of $a \mathrm{king}$

iu every borough as we pass along ...3

lid I let pass the ajuse done to.

let former grudges pass, and henceforth

no delight to pass away the time.... Kichar LII $_{\text {. }}$.

stand liack, and let the cotfin pass....

for curses never pass the lips of

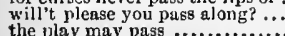

the play may pass ...............

it's come to pass, that tractable ........

pray you, pass on

the lady Anne pass from her eoront

when they pass back from the christening -

to let the troop pass fairly.......

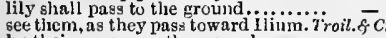

by their names, as they pass by $\ldots . .$. .

to pass strangely by him

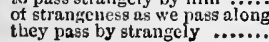

PASS-still invites all that prass.. T'imon of $A$ thens, ii. 1 hecome your lips as they jass tji.........

not a mun shall pass lis quarter $\ldots$...

lass by, aud curse thy fil;

all noble sullerance. Pass do further

you will pass to where you are bound -

you mily not bass, you nust retur'1...

ou love to pass

see great Pompey pass the streets ...Juliusficos

cimer; let us leave him;

I stand, till Cæesar pass aloug.

to see him pass on to the Capitol .... - ii.
they pass ly me as the iule wind $\ldots$ iv.
betore him: on, there; pass aiong..intony \& Cleo. iij.

shall pass on thy approof.

the straight pass was damned with... Cymbetine, $r .3$

my lord, you pass not here .... Titus indronic

in dumb shows pas the remait an hour can pass.

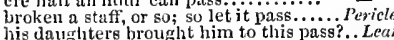

we may not pass upon his life ..........

thus inigfit he pass indeed

sweet marjoran. Pass. I know that voice -

Olet poor volk pass.

I will frown as i pass by

Romeo \& Jutie

give quiet pass throughiyour dominions. llaml

t came to pass, as most like it wa

I pray you, pass with your best viole

which patience could not pass........... oth

PASSABLE $\rightarrow$ not here passable

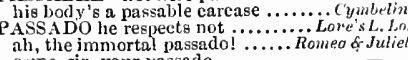

come, sir, your passad

such inpossible passages of grossness

all unseen, 'Gan passag fidn 'tist

in whose easiest passage, look....

or my swift passage, that I slide... - iv. (chorue)

one that countermands the passages of - iv.

carved out his passage, till he fueed ... Macbeth,

passage, vexed with thy impediment. King John, ii. 2

the mouth of passage thall we fling..

the sullen passage of thy weary

apprentieelood to toreign parsige

his biglit passage to the cecideit ...

may tear a passage through the flinty

in thy passages of life, make me ... Hemry $I V . \mathrm{iit}$.

is gallant and most prave pasas

redeen the passage of your aye!

is the hest and satest passage in?

hath stopped the passage where

give sweet passage to my sintul.......

oft the passages made toward it....Henry $\vec{F}_{H}$. ii.

passage and whole carriage of ..Troilus \& Cress. ii. 3

and leave his passage polled

with bloody passage, led your wars.

it is no act of common

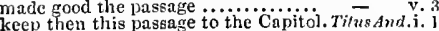

passage of their death-marked.. Romeo of Jul. (1)rol.

I see, in passages of proof, tine qualines

ind, for his passage, the soldiers musions may have passare free

no wateh? no passage? murder! murder! -

PASSANT-it aqrees well, passant.
PASSED-pussed tile careires

slirieked at it, so that it passed.
what hath passed between

hath newly pased between this.

with knowing what hath passed
the imperial votaress passed on

the imperial votaress passed on

to buy them, along as you pass

which I have passed upon her..... As you like it,
your gallery have we passed ..... Winter's Tale,

and passed sentence may not be.

and had indeed against us passed.

Comedy of Err. i.

he hath passed the river Some

and parn far thy pased spcech...2 Henry $r$ I. iii.

well have we passed, and now.

hath passed in sa fety the narrow

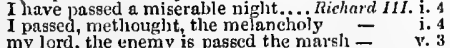

and that not passed me, but by .....Heury VIII. i. 3

but, pray, how passed it? the reat so laughed, that it passed.... Troil.s. $\bar{C}$ ress. i. 2

for they passed by me ............... Fimo of Athens.

upon him as he passed.......

and passed him unelected

hath he not passed the nolsles
that being passed for cousul
PASSED-that hath passed from him. Julius Cersar, ii. I
I have passed ny worl and promise.. Titus Anti, i. 2 there naught liath passed.......
till lie liath passed neees

till he hath pussed neeessity ...Pericles, ii. (Cower)

who passed that passing fiir?.... Ro
[Knt.] so far he passed my tlioiglit.

sieges, fortunes, that I have passed

SASSENGER-I see a jassen rer. Tao Genech of $\bar{F}$ i.

silly womcn, or poor passengers

our wateh, als rob our passengers... Richard It v. v.

will sorrow snares relenting passengers

PASSES-Your passes, stoccadocs... Nerry Hives, ii.

hat h looked upon my passes............. fors, for $\overline{3}$ eas.

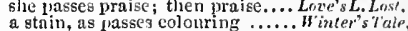

he passes some humours, and caireers... Nenty $t^{\prime}$.

continuate goodncss: he passes. Timnn of Athe

that in a dozen passes between yourself. Hant

I have that within which passeth show.. Ilamiet, i. 2

aud her passing deformity

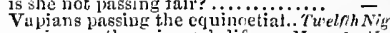

you apprehent passing shrewdity.... Much A

Oberon is passing fell and wrath ... Mid. N.'s

bitter With him, and jassing glhor t. As you Like i

you are passing weleome. and so I pray -

pleasant, gamesone, passing courteous

tis passing good; f pr'y tlice let......

this is a pas:ing nerry one ..........Wizter's Tate, i

am passing light in spirit ........... Keng Joh $I$.

was employed in passing to and fro. Hem? if

a passing trator, perjured, and

is passing out of tilis world.

vet are they passing cowardly ....... Coriolen

tits the purpose passing welt.. Titusd udroni

passing through nature to cternity.

twas strainge, 'twas passing strange ....

PASSIO-Hysterica passio? down, thon . Lerr, ii. 4

in some passion that works lim strongly

passion as they, be kindlier mored

means this passion at his name? Two Gen.of Ver i.

unfold the passion of my love.... T welfth Night, $\mathrm{i}$

the cunning of her passion invites me - ji. 2

it did relieve my passion much...... - ii. 4

the beating of so strong a passion.....

same 'haviour that jour passion bears

his words do from such passion fly $-:$

if my passion change not shortly in fuch $_{\text {sth }}$

counterfeit of passion came so near (rep.) -

counsel him to fight against his pnssion -

their counsel turns to passion $\ldots \ldots$....

the passion of loud langhter never slied

this passion, and the deatly of a dear
and her nassion ends the play

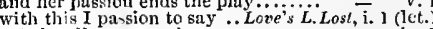

noted well your passion

it did move him to passion ...........

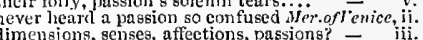

dimensions, senses, affections, passions? - iii. I

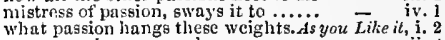

as my uassion now malies me........ - ii. 4

this sleplerd's passion is mueh upon
for every passion something (rep.)..

all made of passion, and all made....

the proclanation of thy passion

Cox' my passions give me your hand

into sone merry passion. Taming of shrew, $\bar{l}$ (induc.)

to plcad Hortensio's passion..... - iii. I (gamut)

you his ty runnous passion more. IIinter's 7 'ale, ii. 3
cast your good counsels upon his passion - iv. 3

a notatile passion of wonder his passion

his passion ne'er brake into... Comedy of Er, ors, $v .1$

offend him, and extend his passion.... . Aacteth, iii. 4

this noble i assion, child of integrity ..̈. - iv. 3

a jassion hateful to my purposes ...Kng -

Jis passion is so ripe, it needs........ - iv. 2

for I must speak in passion .......... - ii.

tlistemperature, in passion sliook.....

if you give o'er to stormy passion.....
till that his passions, like a whale...
unto whose grace our passion is....... Henry $p$. iv. 2

unto whose grace our passion is........ Henry $P$. j.

had the prassins of tly heart ...... i Henry $\mathrm{Vl}$. il. 1 
PAS8IUN-passions in my hent ...I HenyVI. v. 5 PAST-I an past more children .. Winter's Tale, v. 2 PASTURE-the mettle of your pasture. Henry V. iii. 1

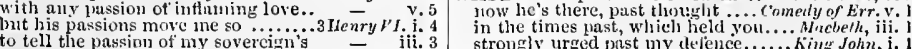
makes me bridle passion sovercign's - iti.

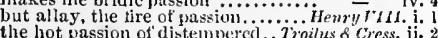
the hot passion of distemperce... Troilus of Cress. ii. 2 which here his passion doth express? your passion draws ears hither

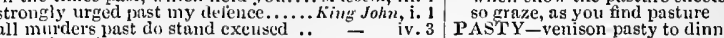
when gasture lards the brother's . Timon of Ath. iv Coymbeline, $\nabla$.

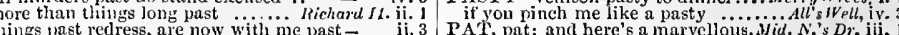
things past redress, are now with me past - ii. 3 PAT, pat; and here's a marvellous. Hid. N.'s Dr. it.

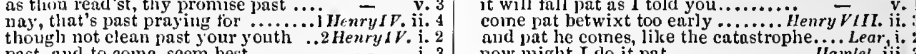
past, and to come, secm best ........ what perils past, what cross

such solier and unnotet passion.....

still; yoll are past service.

whose passions and whose pluts...... Coriotanus, iv. 4

ons of some difterence

turng is follow no further now

turning past evils to advantag
fiint souls, past corjoral toil

lassion, I sce, is catching............ - iii. 1

uhose every prassiont fully strives. $A$
alack, sir, no; dicr passions are nide

cither past, or not arriyed to

iii. (chorus)

your spcech is passion

by sucl poor passion as greater cantle - iii. 8

the quality of her passion shall require - iv. v.

pour soll. Tins and. i. 2

then be my passions bottomless.

in passion moved, doth weep to see..

borrowed passiun stands for true

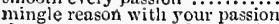

slie was a queen over her passion...

passion lends them power . liomen \& $y_{\text {uliet, }}$ i. $\overline{5}$ (clio.)

Romeo! humours! inadmanl passion!

my true love's

to-clay? St. Davy's day is past

gricf that they are past recovery

Henry Vi. let's stay till he be past..............

till stoms be yast of civil elmity.... $-\bar{j}$ iv.

PATAY - at the battle of Paizay Henryvi.jv.

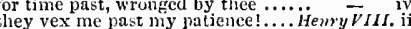
they vex me past my patience! ...Hen

but now I nin past all comiorts......

has not past three or four hairs... Troilus \& $C^{2}$

past hidug, and then it is pust watehing -

those serays are good aleeds past

patels grief witls proverls

were there a pateli set on learning. Love's L. Losk, iv. the patch is kind enough ... Nerchant of Venice, ii. capon, coxcomb, idiot, patel!!.Coinedy of Errors, iii. what soldiers, jateh? begin to patch up thine old body ..... Henry IV. if you'll patch a quarrel ..... Anlony \& Cieopatra, ii. should patch a wall to expel the winter..... V ATCIIBIREECH, I say! What say you. Perieles, ii.
ATCIIED-man is but a patelied. Miu. N.'s Dr. iv. is but patched with sin (rep.) .......... prodigious, patched with funl moles... King John, iii. this must be patched with cloth though less than yours in pust

but your patched up your excuses. Anlony \& Cleo. ii. made and moulded of things past..

eyes of loen licaven ..... Hamlet, ii. 1

in a dream ot passion, could torce

what's past, and what's to come

the motive and the cue for passion ...... - ji. 2

tear a rassiun to tatters, to very rags... - iii. 2

that man that is not passion's slave $\ldots . .$. - iif. 2

in passion we progrose, the passion ending - iii. 2

lapsed in time an:d passion, lets go by

did put me into a towering passion.

and passion having my best judgment...o'kello, $\mathrm{ji} .3$

from the heart, that passion cannot rule

lierself in such shadewing passion......

n passion nost musuiting such a man.

nature whom passion could not shake?

some bloody passion slakes your very

amazed at your passionate words. Mi $u$. $N$.'s $D_{r}$.

mate or... Love sL.Lost, iui.

what means this passionate discourse? 2 Hentry $\nu_{L}$, i.

$[C o l . K M]$ this passionate humour.. Kichard III. $\mathrm{j}$.

come, a passionate speech........... Iamtet, ii.

PASSIONING for Theseus' perjury Tu'o Gen.nf $V$. iv.4
PASSIVE drugs of it freely .... Timon of Alhens, iv. 3

his pissport shall he made.............. Hen's $V$,

a passport too! Apollo perfect me........ Herrictes, iii. 2

PASTY measure or a pavin........ Tuelfth Night, v. I

Whereot " wat's past is prologue.
till the diegs of the storm be past

二 iii. 3

since I f.cl the best is past.....

his days and times are past....

Timon's happy hours are done and past

the law, which is past depth to those -

know his gross patchery, love him. Trinon of Ath.
PATCHES-a crew of patches.. Mid. N.'s Dreann.

than stiy, past doint. for greater.

the main blaze of it is just

as patehes, set upon a Jittle.......... King John, iv. arms. Henry $V$. ii.

a king of shreds and patches ........... Haintet, iii. 4 there is either lichuor in his pate ....ierrempest, iv. tat paunches have lean pates ...... Love's L. Lost, $\mathrm{j}$

anbitions past all thinking....

Through the instrument my pate ming

by any understanding pate hut.... Winter's Tale, $\mathbf{i}$.

things thot urge tly duty nast...juliuts Casor, iv.

slic is cunning list mants thougitit...

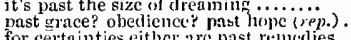

marks of yours uyon my jate......

enter, lest I break your pate

I'll break your knave's pate $1 \ldots \ldots \cdots$, ii. 2 to break the pate of thee ............. Henry $1 b^{\prime}$.ii. I

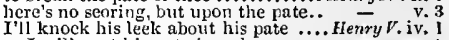
or I will peat his pate four days....... - v. there is a groat to heal your pate (rep.) - v. do pelt so fast at one another's pate.i Henry $r$ r. iii. chop a way that factious pate of his..2Heury VI. v. I the learned pate ducks to the.. 'Timon of Athens, iv. 3 melt the city leads upon your pates. Coriolanus, iv. is their pleasures here are prast, amel so is

of what's past, is, and to come

sweet, pardon for what is pist .... Titus $\bar{A} \overline{n d r o n}$. $\mathrm{j}$.

unspeakable, pist remcin

betiought ine what was past

creature's dagger on your yate... Romeo \& Juliel, iv.

makes my prast miscries s!lort

past speaking of in a king!

unti] some half hour past....................

yet they are past compare
but that a joy past joy ealls

past lioye, past cure, past lielp!

all pressures yast, that youth and

this might be the pate of a politician
to have his fine nate fill of tine dirt?

singeing his pate against the

my invention comes from my pate...... othelio, which he thinks is a patent for his ...All's Well, iv. call in the letters patents that he ...Richard 11 . ji. tied it by letters patents .............̈enry $\bar{Y} / \Omega$. ili.

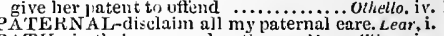
repent what's past; avoid what is to come $\overline{-}$ iij. 4 . Pour wisdom in that good path..... Meas.fur.heas. iv.

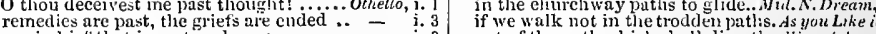

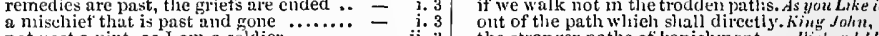
not past a pint, as 1 am a solclier

my riots past, ny wili

past question, for thou see

that have on botli sides past

Jurt, lientenant? Ay, past all surgery .

were past eure of the tling...

Meas. for $\overline{\mathrm{M}}$ eas

he's now past it, yet, and I sny........

life is better life, past fearing death.

she misused me past the endurance.. . Much $A d_{0}$,

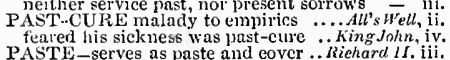

feared his sickness was past-cure ...King John, iv. 2 in that paste let their vile jieads

When she put them i' the paste
PASTERN - but on four pastern

thon drivest 2 ine past the bounds of.

saint Valentine is past

PASTIME is to make nidnight

the stranger paths of banishment.... Kithard II. i. haunted us in our familiar maths...

Richusd II

that iny path were even to the crown -

keep then the path .......... Troilus \& Cressidia,
for if thou path, thy native ...... Julins casm, what is this? licre is a patli to it..... Cymbeline, pursue, and I have tound the path. Fins Animon, ii. I PATHETICAL, break - momise ...A, you, Likt it, i $\%$,
most pretty, and patheticall ...... Love's L. d.ost i PATHW AY - naked jathway to thy... Richard 11 iv. make a pastime of each.... Tu. G.....Tempest, v make a pastime of each.... Tu'o Gen. of Verona, ii. forbear till tlis and now subscribe

for, past cure, is still past

did entrcat me, past all saying nay.

past all expressing: it is very........

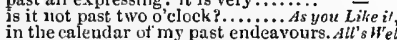

when help past sense we deem ...

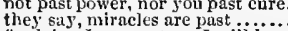

they say, miracles are past 1 nm past: as $I$ kili by

the troop is past; come, pilgrim

to what is past already

we have had pastime here

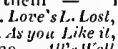

the catastrophe and heel of pastime... All's Well be pastime passing excellent.. Taming of $\$ h .1$ (ind.)
here is some good pastime toward....

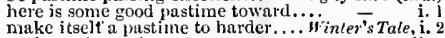
make their pastime at my sor

make pastime with us a day ...... Cymbeline, iii. I
our pastinnes done, possess a goiden.. Titns dud. ii. 3 makest thon this slame thy pastime?... Lear, ii. 4

tis past, my liege; and past deeds

the bitfer tast, inore welcom

ghoois witl danger, and think it pastime

why, 1 ain past my gamut ... Taining of Shre

as weak, our weakness pasi compare

he so troubles me, 'tis past enduring

dear serviees, 1 ast, and to eome.......
my past life hath been as continent..

were past all shame (rep.) ..........

PASTOR -as some ungracious pastors do
PASTORAL-Whitsun'pastorals. W'iule.

pastoral, pastoral-conical (rep.).........Humler, ii. 2

PASTRY-quinces in the pastry. Romeo of Juliet, iv. 4

PAST-SAVING slave is this? ........All's Well, iv.
PASTURE-too small a pasture.Tirogen of Ver.

$\mathrm{r}$ kinsinan not past three quarters

full of the pasture, jumps ajong.... As you Like it.

buy his flock and pasture? (rep.)

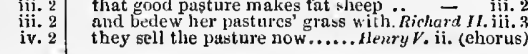

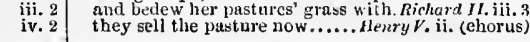

from fortl day's patliway [Col.Knt.-path] -

by your patience, I needs must........ -

and patience says, it is $\ldots . . . . \ldots \ldots$. my paticnce more than thy desert .

Jend me patience to forbear a while.. $=$

odds with his own gravity and patieuee -

pray you, use your patience ........

by your patience, no a......... Tucelnh $\overline{N i g h t, ~ i i . ~}$

she sat like patience on a monument

nay, patience, or we break the sinews

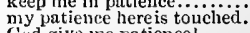

God give me patience! ........

and bid him speak of patience

to speak patience to those that wring

to speak patience to thase that wring
we will not wake your patie: ce......
I know not how to pray your patience

$\bar{c}$ Aduo,

二 $\quad$ v. 


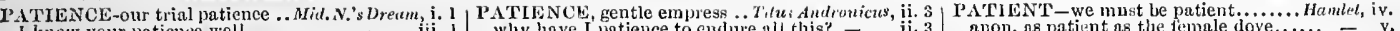

past the bounls ot maiden's patience - jii. 2 patience, rlenr niece: good Titus a poor soul's patience, all to muke.. - iii, 2

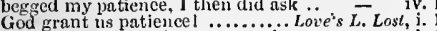

I have as little patience as another.
with what striet patience have $I$ sat

I'll stay with patience

your patience tor my long abode.

I do oppose my patience to his fury.. -

never cried, have patience, good peoplet -

Andrey; patience, rentle Audrey.

humblencss, alt patience, and impatience-

patience ouce more, whiles our compact -

sir, by your paticuce: if I heard you

your patience, and your virtue, well $\mathrm{All}^{\prime} \overline{\mathrm{W}}$.

think upon patience $\ldots . . . . . \ldots \ldots \ldots$......

yours be your paticnce the

though it pass your patience........ Taming of $s$

putience; I an Grumio's

for parience she will prove $a$ secoud

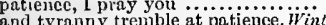

and tyranny tremble at pati

your patience this allowing, I turn.....

o patience; the sta tue is but newly.
patience, unmoved, no marvel .. Con

patience, nnmoved, no matience wonldst relieve me

this fool-begged patience in thce will

hepart in patience, and

with patience bear such griel's as you ..

I slinll with aged patien

patience then, and think you now -

paticnee. good sir, or here I'li cease

I pray you, sir, take patience; Ihave.

give me that patience, patience $I$ necd

where is the patience now, that you go of

sir, by your patience, I hold you but.

patience pertoree with willul ..Rom

[Col. Kint.] beseecls you, sir, have patience

Let mischance be slave to putience.
benr this work of heaven with patience

they stay upon your patience.........

content to lend your patience to us.....

your patience in our last night's

till then, in patience our proceeding be... - $\overline{\text { pallo }} \mathrm{v}$.

yet, by your gracious pa tience, I will

pay grief, must of poor patience bor row

let it not gall your patience, good lago..

tndignity, which putience could not pass

and talk him ont of patience.

patience, I say; your anind, perhaps

marry, pntience; or I shnll' say, you

in some part of my soul a drop of patience

patience, thou young and rose-lipped....

PATIENT-nay, good be patient

am I this patient log-man

I'll be as patient as

come, come, be patient...........

I will be patient; I wili find........
shown limself a wise and patient...
de lords, de gentlemen, my patients.

sir Tuby, be patient for to-night. Tw'el/hh $\overrightarrow{N i g h t,}, \mathrm{ii} .3$

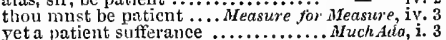

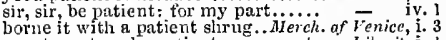

sweet masters, be patient ..........As you Like it, i. I

my preserver, by tlly patient's side .. - ji. 3

Well, I must be patient (rep. v. 3) .....

to this most patient, sweet, and virtuous -

be patient; to-morrow it shall be...ं.

if so, be patient, sister.......... Camedy of Er

be patient; for I will not.............

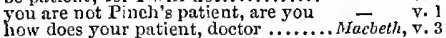

therein the paticnt must minister ..... $-\overline{k i n g}$ v.
he is more patient than when $\ldots$.
patient underbearing of his fortume... Nichurd $I I$. i.

how long shall I be patient? $\ldots . . . \ldots$.

sweet York, be patient; hear me .....

as Job, my lord; but not so patient...

rest showed a most noble patience...

they vex me past my patience!

adod sir, have patience. So I have

Patience, be near me still; and sct - .

we wake her; softly, gentle Patience

nay, Patience, you must not teave

good corporal, be patient here

anon, as patient as the female

PATIENTLY-this patiently. Tust .... - iv.

bear the shame most patiently....Yeos, for Meas. ii.

conla endure the toothach pitiertiy. Mnch Ado, v.

If you will patiently dance..... Mid. N.'s Dream, ii. 2

patiently receive nu medicine......As you Like it ii

you will not bear them patiently Cumedly of hir. i. 2

it patace this fortunc patiently .... Themy . (clo.)

therefore, patiently, aud yieldiug..... $-\bar{r}$. $I I I . \mathrm{i}$.

march patiently along ......Troibus \& Cressida, y, 10

rool heavens, hear patiently my purpose -

we bes sour henring patiently. Hamlel, iit. 2 (13rol.)

A Ns, good: what author

are have the patricians of you

the gods, not the patricians, make it

I am kilown to be a lumorous putriciar

the good patricians must be visited

but most unwise patricians, why.... -

senators, and patricians, love him too - iv. 3

patricians, patrons of my right Tiins Andran. Y. I

patricians draw your swords. and sheathe - i. 2

lest then the people, and the patricians $\overline{\text { ing }}$ i. 2

at Patrick's cell (rep. v. 2) ............ Hamlet,, . 1

bereft and gelded of lis patrimony... Lichard $I t$. ii. 1

reave the orphan of his patrimony... Hewry $V T$. v.

prisoners, patrimony; dispose of them.... Leur, v.

cnowgh, Patroclus; or give me ribs... - i.

there's fur you, Patroclus. I will see
then tell me, Patroclns, what's Achilles?-

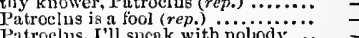

may easily untie: here comes Patroclus -

hear you, Putroclus; we are too well =

- iij. 3

let Patroclus make demands to me... - iii. 3

to him, Patroclus: tell him-I humbly - jii. 3

Patroclus, let us feast jim to the lieight - iv. 5

must all be spent: away, Patroelus.. $\quad$ - v.

Patroclus will give me anythiug for $\quad$ - v.

go, bear Patroclus' hody tö..̈hill... -

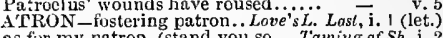

as fur my patron, (stand you so .. Taming of Sh.i.

been patron to Antipholus.... Comediy of Errors, v. 1

call Warwick patron, and be........3 Henry VI. v.

patricians, patrons of my right..... Tilus.Jnuron. i. I

as ny great patron thought on in my .... Lear,i. 1

mp worthy areh and patron, comes to night - ii.

as well as you dare patronage the.... - iii.

behold our patroness, the life of Rome Cariolanus, v. $A$

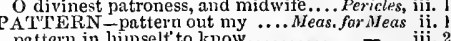

pattern in himselt to know ........... of of $\overline{\text { Veniee, v. } 1}$

he is one of the patterns of love.. As you Like it, iv.

by the pattern of mine own thoughts. - iv. 3

find some pattern of our shame .... King Jahn, iji. 4
shall as a pattern or a measure ....2Ilenry $\mathrm{V}$. iv. 4

shall as a pattern or a measure $\ldots . .2$ Ilenry $V_{\dot{v}}$ iv. 4

and deface the patterns that...........Henry $V$. ii.

this pattern of thy buteheries....... Richard III. $i$

a pattern, precedent, and lively ...Tilusdudron. v.

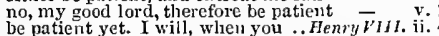

his physic after his patient's death.

sail upon her patient breast .. Troilus \& Cressida, i.

phy'sician, that should be the patient

the surgeon's box, or the patient'
by Jove, I wili be patieut (rep.)

were $I$ as patient as the miduigh t..C $^{\circ}$

nay, pray, be patient; if you

alli patient fuols, whose children...
with patient expectation ..........

only be patient, till we have appease

will you be patient? will you stay

and let patient Octavia ploughin. Antony \& $\&$ Cleo.

your lordship is the most patien

if yon'll be patient, I'll no more be mad -

sir, be patient: this is not strong enough -

patient yourseif, madam, and pardon. Titus And,

I'll be patient; thou little know'st

pray sir, be patient. Dutested kitel $\ldots \ldots \ldots$. $\overrightarrow{\text { car }}$, i. 4

hear free and patient thoughts

tliou must be patient; we came crying ... - iv.

if you with prtient ears attend . Romea $\& J_{u}$. (prol.)

the spurns that patient merit of ti... . . Hamlet, ii.

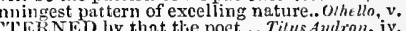

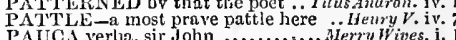

slice, I say! Pauca, pauca; slicel....... $-\overline{\text { Laves }}$ L. i. I

vir sapit, qui pauca loquitur..... Lave's L. Lash, iv. 2
you shall not say me nay: pauca verba
therefore, paucas pallabris .. T'aming af Sh. I (ini.)

therefore, paucas pallabris .: Taming af Sh. I (imi.)

PAUL-is known as well as Panl's ... H IImry $I$. ii.

I bought him in Paul's, and he'll....2Hemy H $V^{\prime}$. i.

taken from Pauk's to be interred .... - i.

or, by saint Paul, I'll make (rep.)....

ny holy Paut, they love his gruce...

may be to-day read o'er in Paul's

we may as well push against Paul's. Henry I'III. v.
PAULINA-see thy wite Paulina. Winter's 'rale, iii.

good Paulina, who hast the memoly

never, Panlina; so be blessed un spiritl

my true Paulina, we sliall not narry
here comes tlie lady Paulina's stcward 
PAULINA-that Paulina knows.. Winter's Tute, hat was funglit in Paulina!

Whicl is in the keepiug of Paulina.

grave and good Paulina $(r<p$.

O sweet Pauliua, make me to think

knowing by Pauliua that the oraele

Opeace, Paulina; thou shouldst (rep.)

AUNCH him with a stake............ Tempest what, a coward, sir John Pinneli

zounds, ye fat pamneh, an'
PAUNCIES have iean pate

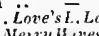

PAUSt, or staggering ............. Herry H wes, i pause awhile, and let my counsel Mid. Mueh tho, as he deserves? pause there .....Merch. too long a palse or that which you

why doth the Jew puuse?

while I pause, serve in your.. Tuming of shre

no marvel though she pause.. Comedy of Frm?
we coldly pause for thee ............. King $J_{0} / h$,

peree, lady; pause, or be

or made a pause, when I .......

then pause not; for the present......

stay, and pause awhile: here comes.. I Henry 1 i. i. 3

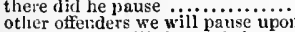

and pause us, till these rebels....

sinall breath, and little pause.

pause, and take thy breath $\ldots \ldots$. . . .

I'll never pause again, neve

good fortuine bids us pause

but yet $I$ 'll make a pause............

nay, du not pause, for I did $\mathbf{k}$

some little panse, dear lord....
roughly by all time of pause
I have seen thee pause, and taike

I have seen thee pause, and take
pause, it thou wilt. I do disduin

pause, it thou wit

I pause for a reply ..............Julius Cesar,

by the pauses that lie makes

yet pause a while: you kniglit.........Pericles,

so, atter Pyrrhus' pause, a roused....... Hamlet, ii.

this mortal coil, must give us panse .....

must seem deliberate pause.........

P.USER - love outran the pauser........... Hacbeth, i.

PAUSINGLY ensued..

HenryVIII, i.

PAVED_paved bed would break. Heas. for Meos. v.

paved fountain, or by rushy trook... Move's $L$. L

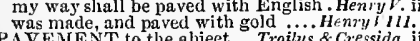

PAVEALNT to the abjeet

PAVILION -come, to our pavilion..... Lyen'sL.Lost, ii.

the princess at her pavilion, in
till night, out of his pavilion

desire them all to my pavilion.

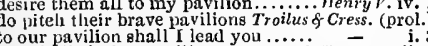

she did lie in her pavilion .Antony\& Cleapatra, ii.

PAVIN-passy measure or a pavin.. T welfth Nitrh

thrusteth forth his paw, and wounde.. Richard 11.

trembles under lis devouring paiss...3 Henry VI. i.

to have his princely paws pared...Tilus Andron.

PAWN-her honour's pawn

lay my countenance to pawn............

lay their awords to pawn

leave this young man in pawn

Winter's Tale, ii. 3

your pawh, till it be brought you.....

to lie, like pawns, locked up in

. King Jich ard 1i. i.

redeem frum broking pawin

therc is my honour's pawn $\ldots . .$.

'faith I am loath to pawn my

have it, though r pawn

ny honour is at pawn......................

2 Henry 1 viv.

thereon I pawn my eredit

Knost noble lord, pawn ne to this. Timon of Alhens. i. 3

I'll pawn my victorie:

pawn their experience to .... Anlony \& Cleopaira,

1 dare thereupon pawn the moiet

willingly; and pawn mine honour

as a pawn to wage against thine enemies .. Lear

1 dare pawn down my life for him

must be sumetling else pawned.Mer.of venice, iii. 5

I paw ned thee none.............

lath pawned an open hand

hath pawned the Sieils

honour and your faitl is pawned..... Richard $[1 /$. iv.

biemished, pawned his knightly virtue - iv. 4

PAY -shall pay for him that hath him.. Tempest, ii. I will pay thy graees hom

take all, pay all, go to hed ..............erry Wives, ii.

to pas this debt of love but to .... Tuelfih Nigh', i. I

I'll tay thy pleusure then....
I shall pay dear.... he pays you, as sirely as

make us pay down for our .........iveris. for.Meas. i.

pay wit! falsehood false exacting

in some slight measure it will pay. ifid. $N$.'s $D r$. iii.

it pays tlie hearing double recompence

swore he would pay him again... Her, of Vence, $\mathrm{i}$.

keep his day, or he shall pay for

to pay the petty debt twenty.....

to see me pay hill debt, and then

repents not that he pays your debt

I'll lay it instantly with all ny

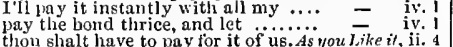

shall pay me for my pains ........... Al's

which I will overpay, and pay again ... iii.

he never pays the score (rep.).... - iv. 3 (letter)
who pays before, but not when.. iv. 3 (letter

nud pll pay thy dower.............

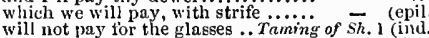

tailor, I'll pay thee for thy gown.....

you puy a great deal too dear....

and pay them when you part.

if this prove true, they'll pay for'

we pay them tor it with stamped coin

pay the saddler for my mistres

yes, to pay a fine for a peruke

I warrant you, will pay them ail...

how the debt grows, I will pay it..

frerald thee into his sight, not pay thee. $\overline{M a c b e t h}, \mathbf{i} .3$

more than all can pay

pay his breath to time

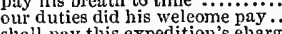

to pay that duty, which you truly owing John, i.

witl 1 advantage means to pay thy love

O let us pay the time but

hatl in heavenly pay a glorious.... Richard $J$. iii.

fearing dying, pays death

call for thee to pay thy part?

HeñyIV

and pay the debt I never promised..

sonl neer pays, but to the proud .

to fight against me under Perey's pay

I'll not pay a denier

what time to promise, when to pay.......................

many a soul shall pay full dearly

I would be lonth to pay him before.
the spring of all, shall pay for all...

never promiseth, but he means to pay - her the debt you owe her .....2

you'll pay me all together?.

pay the musicians, sirrah......

shall, $O$ dear fatlier, pay thee...

to pay you with this . $\ldots \ldots . . . . . . . .$.

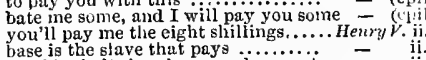

a noble slaglt thou have, and presenit pay -

although my body is, piteh and pay

pay it as valoronsly as I may.

poor I have in yearly pay

i will pay you in cudgels.......

my body shall pay recompense....

must I pay before I pass?
what ransom must I pay?

swear to pay lim tribnte.

for suldiers pay in France............ Henry $V I$. iti

never robbed the soldiers of their pay

much to pay two thousand crowus ..

he that made us pay one and twenty
unless he pay me tribute (rep.)

unless he pay me tribute (re
you shall have pay, and every

you shall have pay, and every

and pay for their presu

doubt not of large pay ...............

for Edward pays a dying debt ..... Ric

shall pay your pains the hire......... Henry $\bar{V} I$

let us pay betimes a moiety... Troilus \& Cressida

words pay no debts, give her

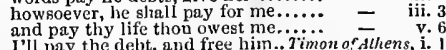

if I shoutd pay you tor't as 'tis.

and to pay thee for thy labour

that he now pays intcrest for't ........

lacks a half to pay your present de

fie should the sooner pay his deb.

the thonsand drops pays that

but that he pays himself' with

a bribe, to pay my sword.

to you for gold to pay my legions.Julius $\overline{C e s}$ ivar, iv. 3
PAY-than you slialt sec me pay....Julurs Carsar, v. for lis thy eleek pays shame ....Anlony of Cleo. i. pays this for Marcus Crassus.

pays this for Marcus Crassus......... aoes pay thy labour richly ....... $=$ iii. pays dear for my offences............ Cymbeline iv. overbuys me almost the sum he pays
will be ever to pay, and yet pay still we will nothing pay, for wearing...

why should we pay tribute?

the disl pays the sliot

first pay ine for the nursing of .......

pay eountless and infinite (rep... Tilus $A$ ndron.

or pay you with unthankfuiness ....... Pericles, i.

fresh ones, whate'er we pay for them.

shall pay the forfcit of the peace. Romeo \& $\overline{J u l i e t}$, i.

pay no worship to the garisl die....

1 pay [Kut.-pray] thy poverty ......

Hamlet, i.

seape ceteeting, 1 will pay the theft..... - iii.

and thy free a we pays homage to us

to pay five dncats, five, I would not .... - iv.

that, to pay grief, must of poor patience. Orhelio i.

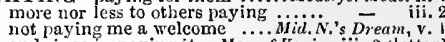
and since in paying it .. Ner. of Venice, iii. 2 (lettcr expire; paying the fine of rated...... King John, $v$. PAYMENT - thee wolse payment. Tuelfik $N_{i}$ ight, $\mathrm{i}$ fair pavment for foul words........... I'll give him lis payment $\ldots \ldots \ldots$. As you Like it, $\mathrm{i}$. both of thanks and payment might..... Macbeth, $i$. even with the bloody payment of... I Henry I $\mathrm{N}$. i. 1 will give treason his payment .......Henry $V$.Iv. 8 with downriglit payment, showed....3 Henry $V I$. prays your speedy payment .... Timon nf dthens, ii. done work for me, there's payment

be ealled to no more payments ...... Cymbeline, PiiA-barley, vetehes, oats, and peas.... - pest, iv peeks up wit, as pigeons peas ..... Love's L. Lost, y. 2 peas and beans are as dank here .... Illenry $1 V^{\prime}$ : ii

pr'ythee perce $(r e p$.$) ................$

we wisls your peace..................

peace, here she comes.

iii. 3

ay, but peace, iet's hear em.............. = iv.

perce! stand aside! ................

when you hold your peace $\ldots . . . \ldots . .$. .

peace; I pray you! (rip. i. 4) $\ldots . . .$.

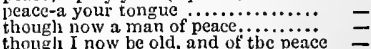

thougl I now be old. and of tbe peace

peace, I say (rep.)..........

ay, ay, peace: you use $m$

peace your tattlings

peace, you rogue, no more $o^{\prime}$ that. Tirelfih $\bar{N}_{i r}$ my words are as full of peace as matter -

never berin, if I bold my peace.......

for the love o' God, peace.............

drawn from us with ears, yet peace...

go to go to; peace, peace (rep. will make your peace with him...

and unjust extert against thy peace

doubiful soul may live at peace......

heaven grant us its peaee .............ea

bo! peree be in this placet $\ldots, \cdots \cdots . . .$.

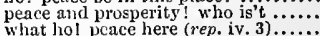

peaee be with yont ..............

nor wished to hold my peace.

but, peace be with him ${ }_{\text {keep peace; if lhe break the peaee }}$.......

peace, stir lot.................. lijke

I pray thee, peace; I will be flesh....

peace. $I$ will stop your moutli

and all things shall be peace... Mrid. $\%$.'s Drean, iii. 2

peace - the to me, and every man peace - v. 2

peace-be to me, and every man . Love's

men ot peace, well encountered........

peace, the peal begins..................

nothing but peace and gentle visitation

peace, for I will not (rep.)..............

peacel The armipotent Mars, of lances

well, penee be with you! ... Nerchant
peace, hoa! the moon slecps with .... 
PEACE, fool b he's not thy (rep.) .. As you Like it, ii. 4 PEACE-rest your minds in peacel pertec, you dull tool; I fotnd them.. - iii. 2 words peace may be ohtained.

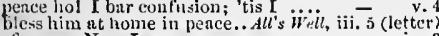
of peace. Niny, I assure yon, a peace.... - iv. ischaviour and sobricty peace.... peace. Grumio; "tis the rival (rep.). reace. Gr'umio; tis the rival (rep.)... war where thicy shonld kneel tor pence $\overline{\text { W }}$ Tale bold your my peace, until you peace, Panlina; thou shouldst a husband - v. pence, doting wizard, peace....... Comerly of Err. iv.

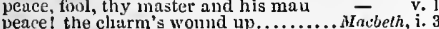
peace? the cliarm's wound up. vor keep peace bctw'chl the effect

pr'ytluce, peace; I dare do all......... place [Col.Knl.-pence] have sent to peace but peace! for from broad wor their peace? no; they were well at pence ticir peace? no; they were well at pence the peace of heaven is theirs .........

pence be to Fratuce; if France in peace contempt that beat his peace to heaven your children, wives, and you, in peace contirm the other's peace; till then... to a base and vile concluded peace gone to swear a peace! tulse blood wear out the day in peace

peace. War! war! nu peacc! peace is peace! peace is to clap this royal bargain up of peace of siniling peace to march .

than keep in peace that havi..........

now see the issue of your veace

fair aftliction, peace. No, no $\ldots . . . .$.

I'll make a piece between your.......

kecp the peace, I say

snarleth in the gentle eyes of peare..

liuve made a happy peace with him..

lie gently at the foot of peace........

peace with Rome? what is that peace

and turn thy fice in peace $\ldots \ldots \ldots . . . .$.

from him such offers of peace as we.

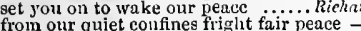

in peace was never gentle lan

more hath he spent in peace

and fright our nativc peace with....

made peace with Bolingbroke. Peace
would they make peace? terrible hell

would they make peace? terible

ere the crown he looks for live in peace

the complexion of her maid-pale peace

hold thy peace: he that hath.....

peace slall go sleep with Turks......

so, as thon livest in peace, die free

fur frighted peace to pant.

peace, cousin, suy no more $\ldots$ peace, ye fat-kidneyed rascal $($ rep.).

peace, ye fat-kidneyed rascal (rep.).

aud shake the peace and safety of our

a calin world, and a long peace.

from the breast of civil peace such ...

his livery, and beg his peace ........

niade us doff our easy rohes of peace

I speak of peace, while covert ... 2 Henry I

keep the peace here, ho! Good my loro

pr'y thee peace; pay her the debt

peace, good Doll! do not speak like

it well befits yon should be of the peace -

go to; peace, Mouldy, you shall go..

prosper your affairs, and send us peace

by a civil peace maintained (rep.).

Dor do $l$, as ar enemy to peace

not to break peace, or any branch (rep.) -

and either end in peace, which

of our peace call stand

our peace will, like a broken limb .

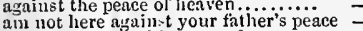

deliver to them this nows of peace

to breed this presellt peace...

a peace is of the nat ure ot a conques

but peace puts forth her olive.

woinuling supposed leace............

peace and happiness to my roval (rep.) -

well, peace be with him that hath (rep.) -

that war, or peace, or botly ut once

so, get you helice in peace; ank tell.

O peace, prince Dauphin! you are..

in peace there's notling so becomes

the gentle bosom of peace with....

a menber of the coluntry's peace .....

the king keeps to maintain the peace

to order peace betwcen them....

perce to this meeting, wherelore

wnur, and mangled peace, dear nurse

why gentle puace should not expel.

the peace whose wait gives growth.
must buy that puace with full accord till motions war, and never pcace.

against God's peace, and the kiug's -

enemy to peace; lascivious, wanton

who preferetl peace more than ........

who should study to prefer a pence.. -

Pucelle, hotd thy pence; if 'Tulbot

1 pray, and be at peace

your fighness shall command a jeace if you frown unon this proffered peace

to have a godly peace concluded ....

draw conditions of a frieudly peace.

pcace be amongst them, it the fingers for eternal peace.

and peice established between these

inplored a general peace betwixt...

conclude effeminate peace? (rep.)...

for here in tuitful peace...........

will confirm our peace $\ldots . . . \ldots . . . . . .$.

the articles of contracted peace......

peace, son;-and show some reason.

I pr'y thee, peace good queen

and be blessed for the peace I nilke -

作

peace to his soul, if God's good pleasure -

Jiast appointed justices of peace......

forsike thee, and go home in peace.

peace, for thou art still. Peace with.

sons, peace! Peace thou!

..3 HenryVI.

iii. 4 or live in peace, abandoned...

faned for mildness, peace, and pionyer -

peace, impudent and shameless $(r \cdots p$.

as likely to be blest in peace

perce wilful boy, or I will charin...

might'st repossess the crown in ....

myint'st repossess the crown in peace

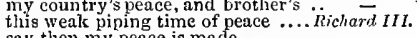

say then my peace is made

the troubler of thie poor world's peice

awake God's gentle-sleeping peace

make peace with God, for you must die -

in peace my soul shall part to (rep.)...

the blessed period of this peace

made peace of enmity, tair love...

entreat true peace of you ........

I pr'ythee, peace ......

the king made peace with all of us..

the peace of England, and our persons

wisdom in peace, your bounty.

where peace and rest lie with me

reap the harvest of perpetual peace

sleep in peace, and wake in joy

to come with smooth-faced peace

this tair land's peace $f(r e p$.$) ..........$

dashing the garment of this peace...

a proper title of a peace.

'gainst me, I can't take peace with

God's peace be with him! (rep.ii. 2)..

peace to your highness!..........

a peace above all eartily dignities

in thy right hand carry gentle peace

to heaven, and slept in peace

peace be with him:-Patience,

spirits of peace, where are $y e$ ?.........

as you wish ehristian peace to souls.

the merry soligs of peace to all

nor shall this peace slcep with her....

peace, plenty, love, truth

peace, you ungracious (rep.).... Troilus \& cressid

but peace

peace, fool I I would have peace...

peace. I will hold my peace

the wound of peace

peace, sister, peace ............

pee great 1 i ector in his weeds of peace

peace, drums. Achilles! Achilles!

returns in t)eace most rich in .. Thimon of the

call him to long peace................

let us first sce peace in. Ithens.......

peace and enntent be here! .......

dotls root up his comintry's peace ....

that like nor peace, nor war? ........ Coriole

peace, peace; st:ay, hirlu, jicare! (rep.)

Col. Kul. to brims lim in fleace ...

stood up to speak uf peace, or war...

grant tleat, inul tell me, in peace

grant t!at, anit tell ne, ill perce ....

large temples with the shows ot peace
PEACE, I say First, hear (rep.).... Coriolonns, iii. peace. peace; be not so loud (rep.)

it execeds pence. as lar as day.

peace is a very apoplexy. lethargy

tame i' the present peace and quietnes

but commandrng peace evell with the

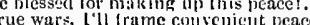

what lueace ynu 11 make, advise in

could not have made this peace.......

peace, botli, nnd licar me spreak (rep.)

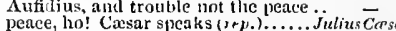

peace, comint the clock...

heaven, nor earth, have been at peace

to see thy Antory making his peace

peace; silence! Brutus speaks (rep.)

peace, peace; you clurst not so have

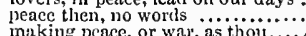

which fironted mine own peace

I make this marriage for my peace ...

and make your peace with Casar...
pr'y thee, peace. Is this lis answer?.

peace, what noise? (rep.)...............

peace, hark further. 3 sovereign ....

hence, saucy eunuch: peace

peace; not Casar's valour

peace, peace, Iras (rep. v. 2 )........

plenty, and peace, breeds cowards....

now, peace be here, poor house $\ldots . .$.

flourish in peace and plenty (rep. v. 5 ) =

peace, peacel see further (rep.) ......
promises Britain peace and plenty (rep.) -

do tune the harmony of this peace
publish we this peace to all our subjects $=$

our peace we'll ratify hands...............

plead your deserts in pence.... Tilus Ancironicu

and sleep in peace, slain in your $(. .$. peace and honour rest you here $($ rep.

these lovers will not keep the peace..
peace tender sapling; thou art made

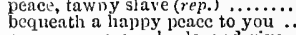

peace, pcace, my lords, and give .....

they bring us peace, and come to us.

welcome is pence, if he on peace
here to have death in peace, is all....

peace be at your labour, honest...

not to be a troubler of your peace.

peace, Kent! come not between....

so be ny grave my peace, as here.....
peace be with Burgundy! since that
l am whipped for holding my peace

keep whiped for holding my peace

peace, sirrah! yon beastly knave.............

peace, Smolkin, peace, thou fiend! .....

I do but keep the peace. ....... Ronte o iv.

what, drawn, and talk of peace?

enemies to peace, profaners of this
cankered with peace, to part your

cankered with peace, to part your

so old as we to keep the peace $\ldots . .$. ...

peace, peace, Mercutio, peace.........

well, pence be with you, sirl here comes -

peace, you mumbling , but...

ho, for shame! confusion's cu.

a gloura by this place of peace?

作

shonid gape, and bid me hold my peace..

peace; sit you down, and let me wring ..

imposthume of much wealth and peace.

me to a peace. To thine own peace ......

peaze; who comes here? your lordship
I have a voice and precedent of peace

lit:le blessed with the set phrase of pcaccothell if I be left behind, a moth of perce......
and practising upon his peace and quiet

to put up in peace what already $I$ have.

peace, and were best will so

PEACEABLE way for you

ifuch, $\overline{\text { sto }}$, iii 3

peaceable rejgn, and good government...Pericles, ii. let lim pass peaccably PACEF Ul, progress to the ocean.... King John, ii. our confines with such peaceful steps? - iii. 2 may make a peacetul and a swcet....Henry $V$. iv. how many would the peaceful city quit $-v$. (chon.) unto a peaceful comic spor

that peaceful truce shan be......... the frowns of war with peaceful lonks heaseful commerce from divilab!c Troith \& Cress. i. day's glorious walk, or peaceful night... l'ericles, i. 
PEACEMAKER; mueh virtue in it. As you Like, v 4 PECK-will peck the estridge ...Antony \& Cleo. iii. 11 PEERED forth the golden........ Romeo \& Juliet, i.

tor blessed are the peaceniakers ....2Henry Hi. ii. PRACE-PARTED souls

P'PACH-I'll peach for' this

iilenrulet, v. PE ACH-CUL,OUR ED satin

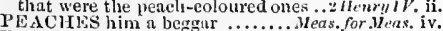
PEACOCK-her peacoeks $\mathrm{f} y$ amain ...Tempest, iv. thy pride, says the peucoek . Comedy of Error

like his tace with a pencuek's feat

up und down like a peacock . Truitus of

a very, very - peacoek $[\mathrm{K} n$ '. Paiocke].. Heunle, ii

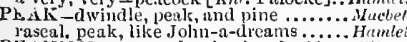
PEAkiNG cornute her husband...Mer.y H'ines, iti.

whether thise peals of begins ...Love's L. Lost, v hath rumg uight's yawning peal.......

$P L A R$-crest-fillen o d ried peer

'PEAR Jujesty is pear me testimony ... Hemry $\mathrm{T}$.

PEARD-a 'oman has a great peard. Merry Wives,

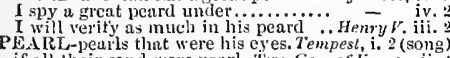

a sea of melting pearl

blitek men are peart

like sapphire, pearl, aud

set with pearls, down sleck

set with pearls, down sleeves..........uch . Ado, iii.

like round and orient pearl

pearl enough for a swine ..............eve's L. Lost, iv.

this. and these pearls, to me sent will you have me, or your pearl agin?
will

as your penrl, in your foul oyster . As you Like it $v$.

all with gold and pearl. Taming of She

I wear pearl and gold?

draw those heaven-moving pearls... Macbeth

your brouehes, pearls, and oweles ...2 Hearyl $I$

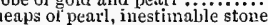

transformed to orient peur

there slue lies, a pear

doutled kisses, this orient pearl ........

and hail rich pearis ripon ti

this is the pearl that plcased

as pearls from diamonds dropped .......... Lear, iv. 3

threw a pearl a way, rieher tion $311 . .$. Hamlet, v.

P EASANT - whoreson peasant? T'o Gien. of

slie's fled unto that peasant Valen

predominate o'er tlic peasant ....Merry Wines, ii.

homage to this simple peasant. Toming of Sh. 1 (ind.)

you peasant swain! you whoreson . .
henee, prating peasunt; feteh .. Comedy of $E r r$ iv.

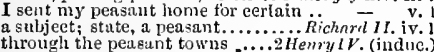

even to the dullest peasant in his camp
whose hours the peasant best ......... Hemry

uhose hours the peasant best .........
superfluous lacqueys, and our peasants

parma foy peasant, unless thou ....

like peasant footboys do they keep.l Henry $V I$.

to the peasant hoys of France........

so worthless peasants bargain for.

of hinds and peasants, rude and..... Henry $V I$. iv. 4

and you, hase peasants, do ye belie

and peasauts

and peasants, this night ...... Timon of Athens, ii. 2

from the lard hands of teasants..Julius Cesar

a peasant stand up thus!...............

wherefore, bold peasant, darest thou.......

that the toe of the peasant comes so near - v.

PEASANTRY would then .Mercliant of Venice, ii. 9

honest gentleman? Peas-blossom (rep

where's Peas-blossom? Ready (rep
PEASCOD-before 'tis a peuseod.
and to master Peascorl, your father

and to master Peascol, your father.Mid.N.Lr.

the wooing of a peascod ine peascod time

that's a shealed peaseod

a pretty pent! 'tis best put.... Taming of Shre

or I will peat his pate four days ....... Hemry $F$. v. PEBBI.E- a very pebble stone.. Tico Gen. of Ver. ii. 3 is a stone, WVilliam? A pebble.....Merry irives, such a s gower of pebbles

then let the pebbles on the hingry... Coriolanus, v. shards, flints, and pebhles, should he...Hameet, $\mathrm{H}$. PECK.-circumferenee of a peek ...Merry Wives, ruly, a peek of provender .....Mid.N. s Dream. iv this fellow pecks up uit.............. and doves will peck, in safeguard.

one Gilbert Peck, his chaneellor....

[Col.] peek you o'er the pales else. upon ny sleeve for daws to peck at .... Olhello,
WCKED-erows have pceked them.. Cymbeline,

C CAAR - in a peculiar river.. Meas. for Meas. i.

and so mach tor my peculiar care .. Cymbeline, v.

the single and peculiur life is bound

but seeming so, for my peeuliar end.... Othello, $\mathrm{i}$.

beds, whicliat profit to your own persor

Pus

PEDANT_like a pedant ......... Tirelfih Night, iii.?

the pedant, yudas Iaceabrus........

pedant, the briggrart, the hedge-priest

how fiery and firwaril our pedant is!

PTICAL; these summer-flies. Love's L.L. v.

watch you. Taming of Shrew, iii.

ol Gaunt dotl bring his peadigree ..iHenry HI. ii. 5

buekler falsehood with a pedigree?..

birth a pedler, by edueation...Taming of Sir. 2 (ind.)
but hear the pedler at the door.. Winter's Tule, iv.

but hear the pedler at the door.. Winter's Tule, iv. 3

pedler, let's have the first ehoice....

liave ransaeked the pedler's silken

pocket up my pedler's excrement.... $-{ }$ iv. 3

I hid rather be a pedler: far be it... Richard 11. i.
PEDRO-don Pedro of Arragon comes. Much Ado, j.

and equally remembered by don Pedro -

don Pedro is approaehed $\ldots \ldots \ldots . . . . . .$.

to draw dun Pedro and the eount....

[Knt.] peeled priest, dost thou.......... Henry YI. $\mathrm{i}$.

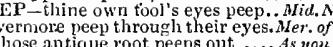

Whose anticlue root peeps out $\ldots .$. As you Like it, if.

Tartar's bosom would peep forth ..... All's 'I'ell, iv.
which fairly peeps through it.... Winter's Tale, iv.

peep through the blanket of the dark...Hacbeh, i.

thruugh a rusty beaver peeps

2Henry ${ }_{\text {Hi }}$ Hen.

and durst not peep out, for all.

peep out.............

no vessel ean peep forth

peep through thy marble mansion.. Cymbeline, v. 4 treason can hut peep to what it won

peened harms that menaced lim .... Henry $\boldsymbol{V}^{\prime} I I$ ii. theu

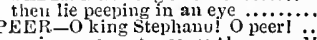

erying, peer out, peer out!......... . Mlerry Wives, iv. duffodils begin to peer .... Winler's Tale, iv. 2 (song)
think of this, good peers............... Hacbeth, iii. my discontented peers

o haste thee to the peers

and my companion peer

Richard 11. i. 3

the sim begins to peer above you

- iii. 4

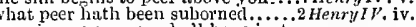

no prince, nor peer, shall have just.. Henry $V$. i. 2

my princes, and my noble peers

his princes and his peers tu servitude
are enbattled, you Fremelh pers....
meny of your horsemen peer.......

many of your horsemen peer...

and al the peers' for surety

that $t$ two such noble pecrs as ye.
dissension, grow betwixt tle pecis

Henry $V I$. iii.

gracions prince, and honourabl

inferior to the proudest pee

Slanghter of so many peers ....
England and her lordlly peers.

brave peers of Eugland (rep.).

IIumphrey with the peers be falle

and Warvick, are no simple peers ... -

dangerous peer, that smooth'st

quarrel, and so bad a peer ..........
whet not on these furious peers.

the king and all his peers are $h$

Warwick, that false peer, ) to aspi
our people ant our peers are bot

our people ant our peers are botly

and, princely peers, a happy time

these swelling wrong-incensed peers
and heart-sorrowing peers, that bear
fatal and ominous to noble per's! ..

now, noble pcers, the cause why

which of the peers lave uneontemne

first, all you peers of Greee. Troihus \& - iii.

not need, my fellow peers of Tyre

when peers thus knit, a kingdom.,......
king stephen was a worthy peer. Olieilio, ii. 3 (song

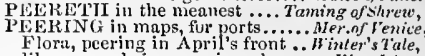

like a proud river peering o'er........ King John, ii PEEREESS-perteet, and so pecrless.. Tempesi, iii. the most peerless pieee of eartla ... Hinter's Tale, $v$. ns she liverl veerless, so her dead....

it is a peerless kinsman.

Alacbeth, $\mathrm{i}$.

stand peerless by this slaughter. I'cricles, iv. (Guw.)

PEVISH, sullen, froward.. Two Gen.of Verona,

why, this it is to be a peevisl girl....i

after that same peevish messenger. Fuelfh Night,

the jaundice by being peevish?... Mtr. of ence,

froward, pevish, sullen, sour. Taming of sherew,

why thou peevish sheep .... Comedy of Error

what wilt thou do, thon peevish officer?

a peevish self-willed harlotry........ Henryl $h^{2}$. ii.

what a wreteled and peevish feliow...Henry

leave this peevish broil

to send such peevish tokens to

why, what a peevislz fool was that..3 Henry $y I$. v

what an indireet and peevish eourse

when Richmond was a littlepeevisli boy

and be not peevish fonnd .............

a peevish schoolboy, worthless....... Iulius Cersar, v,

if the peevish bargage would but give. Pericles,

a peevish self-willed harlotry.. lomeo \& Juliet, iv.

should we, in our peevish opposition ... Jlamlel,

or else break out in peevish jealousies ...

PEG thee in his knotty entrails ......... Tempest,
but I'll set down the pegs that make.

PEG-A-RAMISEY, and three .... T'ueifin Night, ii.

PEGASUS-lodgers at the Pegasus. Taming of sh. iv.

to turn and wind a fiery Pegasus ..1 Henry $I V$. iv.

PEIZE-but tis to peize the time. Mer. of Verice, ifi. 2

PEIZED - lest lumber peize me down. Richard III. v. 3

PELF - I erave no pelf i Timon of Alhens, i. 2 (srace)

all perishen of man, of pelf $\ldots$... Pericles, ii. (Guw er)

flesh hegot tliose peliean daughters....... Leor, iii. PELION - to o'ertop old Pelion ............ PELLA_and noted Lueius Pella...IuliusCasar, iv. PELL-MELL, down with them!.. Lote's L.Lost, iv. 3 pell-mell, make work upon outselves, King Jnhn, ii,

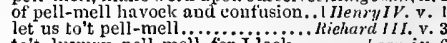
to't, lnxury, pell-mell, for $\mathrm{I}$ iack ........ Lear, iv.
PIELLY-your pelly is all putter ...Merry Wives, v. has mettle enongh in his pelly .... Henry $V$. iv.
PELLY-DOUBT,ET; he was full of jests - iv. PEIOPONNESUS are they fled.. Anlony \& Cleo. jii. PELT so fast at one another's pate ...1 Henry 17 . iii. 1
billow seems to pelt the clouds ........ othello, ii. I PELTING petty offieer ..... Measure for Measure, $\mathrm{ji} .2$ like every pelting river made so... Mid.N.'s Dr.ii. 2 we have liad pelting wars ...Troilus \& Cressida, iv. PFMBROKE, look to't................ King John, i. Pembroke, and Stafford, you ............. Kenry Vl. iv. when I linve fought with Pembroke - iv. earl of Pembroke keep his reginent $=$ v. nunchiomess of Pemhroke (oep.) ... Henry $\bar{V}$ IIr. ii.

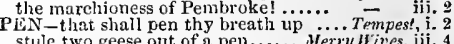
stule two geese out of a pell...... Herryires, ini. never saw pen and ink (rep.) ......... Much ado, i. 1

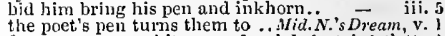
froni my snow-white pen.. Lov'e's L. Losl, i. I (letter) write pen; for I am whole volumes..
marvellous well for the pen..........

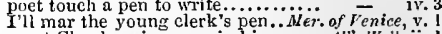
great Charleunin a pel in his .......dll's Well, ii. and I will presently pen down my.. - iii. 6 drav'n with in pen your pens to lances ...............2 HenryIV, iv. for his nose was as sharp as a peu ....Henry $V$. ii. 3 to rehearse the method of my pen..1 Heriny VI. iii.

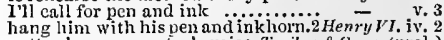
author's pen, or actor's voice. Troilus \& Cress. (prol.) than breath, or pen, can give........ your neek, sir, is pen, book........... - vy - v. give me a pen and ink .............. iv. 3 with rieh anà eonstant pen.............ereles, iv. (Gower) thy pen from lenders' books $\ldots . . \ldots \ldots \ldots$.... Lear, iii. 4 writ there with beauty's pen ...........
excels the quirks of blazoning pens ... 


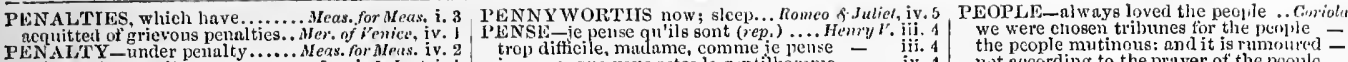

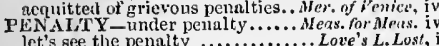
let's see the penalty .............. Love's L. Lost

with better tace exat the penalty Ner.of $\bar{v}$ enice, i. 3

where thou now exact'st the penalty

the penalty and forteit of my bond

hath full relation to the penalty .....

he sliall have nothing but the penalty $\vec{F}_{\text {feel }}$ we but the penalty of Adam...

to quit the penalty.

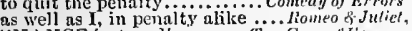

ENANCE is, to call

Thave in penauce

ns he in penance wandered....

tis your penance, but to hear .......

impose me to what penance your ......MucliAdo, v.

bide the penance of each three $y$ ca

take no delight, nor no pena

from whiell lingering penance.......... of tenice

bear the penance of her tongue?.. Taming of

now thou dost penanes to

let not her penance exeeed

madam, your penanee done ......... -

centlemen, the penanee lies on

they need no other penance

PENCE-One shot of five pene

two shillings and two pence a $\ldots$ ino

hadst thou not fiteen pence?

fourteen pence on the seore. Taming of $S h . \overline{2}$ (induc.)

seven groats and two pence

is it bitter? forty penee, no....

overstained with slaughter's pencil. Kin $L$. Lost, v. 2

the fisler with his pencil ....

round about the pendant worid. Meas. for Meas. iti.

his pendant bed, and proereant eradle.. Macbell, $\mathrm{i}$.

pendant roek, a forked mountain.Ant. Scteo. iv. 12

PENDRAGON, in lis litter, sick..... Henry HI, iii. 2

PENE-[Col. Knt.] pene gelidus timor $2 \ldots$ i...

PENELOPE-be anotiner Penelope .. Coriolanus, i. 3

PENELOPHON [Col.]; and he it was Love's $L . L$.

if it be made of pentetrable stinf ........ Hamlet, iii. 7

penetrate her uneompassionate.Two Gen. of Ver.

they say, it will penetrate $(r \in p$.$) ..... Cymbeline, ii. 3$

PENRTRATIVE shame . Anlony \& Cleopatra, iv 12 penitenee the Eternal's wrath's. Twoo Gen. of Ver. v. 4 more penitence, than done trespass. I'mer's Trate, v. I and not love, begets his penitenee.. Richart II. v. 3 that my penitenee comes after all .... Henry $V$.

PENITENT-they being penitent . ... Tompest $\mathrm{v}$. I
haugman is a more penitent trade. ilea.for Mea. iv.

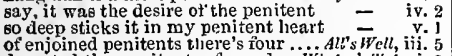
departed thy penitent reformed ...Winter's 'ale, $\mathrm{i}$. besides the penitent king, my master
with the rememibrance of that penitent

with the remembrance of that penitent - iv. 1
penitent for your default to-day.. Comedy of $E r r$ i. 2 penitent for your default to-day. Comedy of Err.i. 2 be penitent, and thon shalt remain.. 3 Henry VI, v. I to see you are become so penitent ...Richard I1I. i. a give me the penitent instrumeut ..... Cymbeline, v. 4

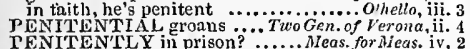
PENITENILY in prison? $3 . . .$. ... Meas. for Meas. iv. 2 PENKNIFE-edge of a penkuife...2Henry $1 V$, iit. 2 nor to their penned speech render. Love's L. Lost, v.
non nor to their pelle peched.

never will I trust to speeches penned - ve 2 oon of Clurelice have I penned up .Richard IIt. iv. 3 PENNING-mark bnt the penning of it .. Lear, iv. 6 PENNONS painted in the olood ...... Henryl. I will not lend thee a penny .....

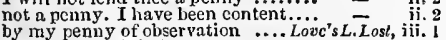
a penny: no, I'll give youl $\ldots \ldots . . . \ldots$ - $\quad$ iii.

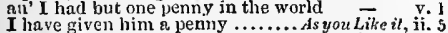
Yhave given him a penmy ............ s you Like il, you beg a single perty more............ An a penny, a horse and.. Taming of sh. iti. 2 What penny huth Rome borne ........ King Jnhin. ask me for one penny cost to.......1 Hen'yly.j. 3

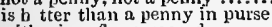
with edige of penny cord...............Henry ${ }^{\prime}$. iii. 6 seven halfpenny loaves sold for a penny $\overline{\text { of }}$ ill I liave to the last penny.... Henvy $V \bar{I} I$. iii. 2 buy nime sparrows for a penny. Troilus \& Cress. ii. I tidings of any penny tribute paid .. Cymbeline, ii. no, truly, sir; not a penny............. Romeo d Jutiet,

PENNY WORTH is good .......... Love's L. Lost, iii. I have a poor penuyworth ... Merchant of Venice, $\mathrm{i}$. the pennyworth on his side....... Winter's Tale, iv. give thee this pennyworth of sugar .1 Henry $I V$. ii. 4 iwas a pennyworth was't not?

cheap penny worths of their yillage..2 IIcñy VI. i. 1
$[507]$

be large cicatrices to show the people

his wounds to the people, beif their..

re must suggest the people, in what
shall teaeh the people (which time.

and loves not the eommon peopie...

flattered the people, who neer loved

been supple and colirteous to the people

masters o' the people (rep.)

lie loves your people (rep.)....

that you do sleak to the people.......

might well be taken from the peopl

you see how he intends to use the pen

I say, if he would incline to the pery

flatter my sworn brother the people
make him goon friend to the people

malue you with the people's voice.

the people do admit you

we stay here for the people.
will you dismiss the people?

Censorinus, darling of tlie people......

the peoule are incensed acainst him

the people cry. you mocked them

scaridaled the suppliants for the people

the people are abuzed; set on.

you speak o' thie people, as if you.....

twere well, we let the people know'
though there the people had more.

why shall the people give one

go, eall the penple; in whose these

hoar me, people; peace ..............

but the people? True, the people are

pronounce, upon the part o the people

tribumes are the people's mouths...
good people, I may be heard ........
be you then as the people's officer

be you then as the neople's officer
it lies you on to speak to the people

with his envy to the people..........

assemble presently the veople lither

submit you to the people's voices

hell fold in the people!.............

mark you this, people? To the rock

in the name of the people (rep.).

the people against the senators....

to take all power from the people..

peace and quietness o' the people...

the people deserve such pity of hin..

intends to appear before the people...

as we do find the people. The people
or move the people witl what he...

I do fear, the people choose Cosar.

and then the people fell a shouting.

it' the tao-rag people did not clap him
sits high in all the people's hearts

people, and senators! be not aftiggited -

know you how much the people may

they had some notice of the people.

the people, 'twixt Philippi and this

the people saw the ehain about

and fan our people cold................

but strangely visited people, all swo

the hearts of all his people (rep.)

I find the people strangely ...........

people this little world (rep.) ........

in one person, many people, and non

we love our people well

gond people, bring a rescue or two...2 2 Henry $1 \mathrm{~V}$.

familiarity with sueh poor people.

the perple fear me; for they do observe
and of your people, whiles yet my

whiles a more frosty peojle sweat

ampong tle people gather up

Henry $l$. ivi. 4

coin, and people in the wars?

the common people favour he

the abject people, gazing on thy face

I thank you, good people; there shall

it is to you, good people, that I spenk

the raseal people, thirsting after

the common people swarm like

our people and our peers are botl

to study tor the people's welfiur.

the people of this blessed land

and many giddy people floek to in

the people were not used to be.... Richard III

all good people, you that (rep.)...

the beauty of her person to the peopl

rose again, and bowed lier to the peopl

stand these poor people's triend.

do you not hear the penple ery.. Troilus fo Cress. i.

plainer and simjicr kind of people

is chiel enemy to the people.

our slippery people (whose love is

the people love me, and the sea.....

the city cast her people out ujon ...

people ingrossed by swift impress...

but in the keeping of wise people...

the people of Rome (rep. i. 2) ..... Cytumbeline, ii.

my tortunes, and the people's faivonr

I will restore to thee the people's liearts
the people will acept whom he admits

lest then the people, and patricians too

you heavy people, circle me about .

buz in the people's ears .................

the common people love

gentle people, sive me aim awhile

find the inclintion of the people.

strike my people; and your disordered.

many people, under two conmund

who is conductor of his people?.......... = iv 7

the people in the stre cry

the sea stand ranks of people...

the people's hearts brimtiul of tear ...... - ii.

EOPJ,ED-had peopled else this isle.. Tempest, i.

no. the rishing peopled towns. Tu'o Gen.or ter. v.

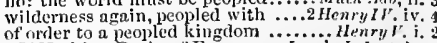

PFPIN-king Pepin of Frince..... Eove's L. L.ost, iv.

powerful to araise king Pepin............. Hes sell, ii.

king Pcyin's titlc, and 11 ugh Capei's 


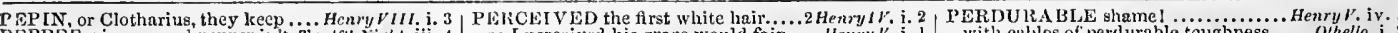

PEPPE, or Clotharius, they kep..... Herry

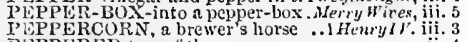
PEPPERED two of then

ragannffins where they are peppered

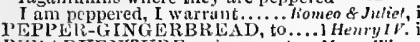

PLKADVENTURE, prings goot.... Merry Hives,

that, peradventures, shall tell you ...

it periulventure, he shall ever..Meas. for Meas. in
if perad venture he syeak against me

answer, if peradventure this be tr

perad

lerad veuture, this is not fortune's. As you Like it, $\mathrm{i}$.

and neral ven thre, may recover .... King Joln, v.
pernderenture, I will with you ...2 Heary $1 V$. iij.

captain Mlacmorris, peradventure.

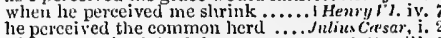

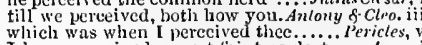

I have perceived a most faint neglect..... Lear, i.

welcome, $l$ nerceived, had poisoned mine
that my chnrity be not of lim perceived

as I perceived it, I must tell you thatt... Hainiel, ii.

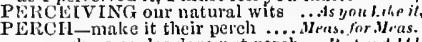

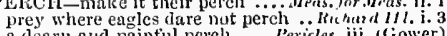

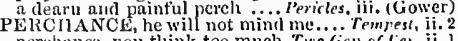

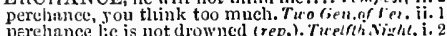

unless perelance, youl come to me.

and lerechance, wind up ny' watcls.

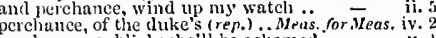

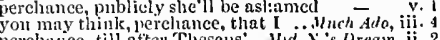

gentles, perchance, you wonder at this

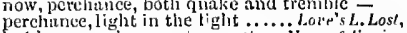

but hear percisance a trumbet...

lenice, y.

lower messes, perchance, are to this. Winter's rale, 1 .

worship those ayain, perchtulice. Cinmedy of Errors, $\mathrm{i}$.

perchance, I will be there as soon as you - ocelth, iv.

perchance, even there, where $i$ did tind

nay, it, perchance, will sparkle in ... King John, iv.

to arms: perchance, the cardinal cainnot

lest, perchlance, he think we dare not
percliance, my lorl, I show more ci ift

perchance, some single vartages.. Timon of

Fulvia, perelance, is angry irep. i...tntony of Cleo. $\mathrm{i}$.

perchance, to-miorrow you
which first perchance, she'll prove.

perehunce he spoke not

perchance, sle weeps becausc (rep.).
no more, perchance, does mine, or his

if, sir, percliance, she have restrutined...

perchance, these are but furrisising
slinlt, pcrcinance, do good, but specil

percliance, , she cannot meet limin. Ho

as 1 perchance, hereafter shall think .... Hainlei, $\mathrm{i}$.

perchance, I saw him enter
to sleep! perchance to dream

tcars, perehance, for blood
though $I$, perchance, aun $y$

perthance, Ingo I will neer go home in. Uthelln, iii.

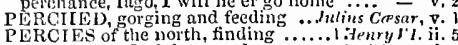

PERCUSSION of thy sound

PERCY [see HARRY and HENRY ] -

called mine-Percy, lis-Plantagenet! 1 Heury $I V$.

of this young Percy's pride?

I am not yet of Percy's mind ..........
I'll play Percy, and that dainved....
that same mad fellow of the nortli, Percy

that same mad fellow of the north, Percy -
Douglas, that spirit Percy, and that devil

sit, cousin Percy; sit (rep.).

as hot lord Perey is on fire to $g$

as $I$ was then, is Percy now

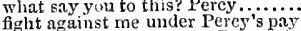

I will redeem all this on Percy's hend

Pcrey stands on higl

the power of Percy is too wea.

Esperance! Percy! and set on

I like paid Percy, I liave made

if Perey be alive (rep.) ..................

seck Pcrey, ancl thy'self, about the field =

no, Percy, thou art dust, and food $(r \cdot p$.
in blood hy noble Percy lie ...........

I am ufraid of this gunpowder Percy
there is Percy; if your fatler will

let him kill the next Percy himself.

why, Percy. I killed nyself
the noble Percy slain, and all $7 . . .$.

the noble Percy's deatll, ere thou .

for all this, say not that Percy's dead

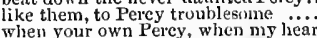

since this Percy was the man nearcst

PERDITA, I pr'ytliee, call't....... Winter's
to speak of Perdita, now rrown in - iv.
thou dcarcst Perilita, with these forced

your hand, my Perlita ..............

my prettiest Pcrdita: but, $O$, the thorn

o Pcrdita, what have
our Perdita is found

PEKDITLON-not so much perilition ... Tempest, pronounce by ne, ingering lerdition..... Thpest, iti.

or to their own perdition ......... Winter's Tale, iv:
the perdition of th'atliversary hath ... Henvy $V$. iii.

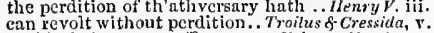
sir, his dehnement suffers no perdition.. Hamlet, $v$ the mere perdition of the Turkish flect... Othello, suel perdition, as nothing clse could match $=$ PERDONATE, gentle master mine. Taming of $S h$ PERDU, tout est perrlu! . $\ldots \ldots \ldots \ldots \ldots$ Heroy $V$.
With cubles of nerdurable toughness ..... Othello, i.

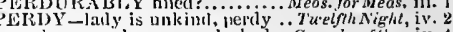
perdy, your doors were locked ..Comedy yentry $i$. ii. belike, he likes it not, lerdy

PEREGKINATR, as I may eall it...Love's L. Lost, $y$,

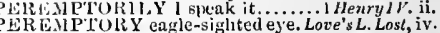
his discourse peremptory .............. of $\overline{\text { Verona, }} \mathrm{i}$. peremptory as she proud minded. Taming of $\mathbf{S h}$. ii. nut lalf' so peremptory as we ...... King John, ii. presence is too bola and peremptory. 1 Hemy your priesthood grown peremptory? $20 \mathrm{H}$

prond, peremptory, and unlike himself'? -

peremptory Warwick nuw remains.3Henry $V I$. iv.

briety then; for we are peremptory.. _ _ i

Pea, mistress, are you so peremptory?... Pericles, ii. 5

so perfect, and so peerless.

he calmot be a perfect man.. TuroGen, of V́erona, i.

mine is perfect yellow .................

man but constant, he were perfect. our perfect yellow .............Mid.N. 's Dream, i. goddess, nympll, pertect, divinei...... so holy, and so perfect is my love. As you Like it, I will return yerfect courtier...

ere I call perfect mince ilitents ........

thou art lictect then, our ship ... Winter'sTale, iii. 3

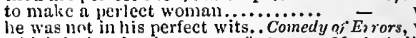

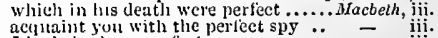

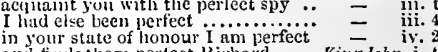
in Jour state of honour I am perfect
and tinds then nerlect lichard...... King John, i. i since law itself is perfect wrong ..... -

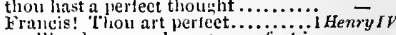

swelling hearens, $l$ am too jerfect in

but the true and pcrtect image of...... - v. 4

might create a perfect gliess.........2 Henry 12

sucl fcllwws are perfect in great...... Hen Henry

wealth. ant nut for perfect love..... Henty Hexy

neithere call it lertect day, no.......... nit we come to him un lerfect love ....... reat the perlect ways of hollour...... Henry PIIT. v. thinink ourselves for ever pertect... Timonof of Alitens, i.2

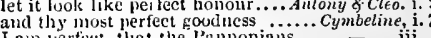

I am jerfect, that the Pannonians.
prevailed before my perfect houlour

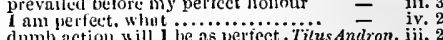
dumb action will 1 be as perfect. Titus Andron. jii. thou hast becn godlike perfeet ...... -

that sons at perfect age, and fathers

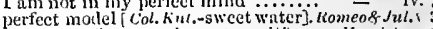

is't not perfict conscience to thitit?...... Hainlel, $\mathrm{v} .2$ $\mathrm{my}$ parts, iny title, and my perfect soul. Olhello, i. 2 PERFEC COED how to grant stils ........ Tempest, perfected by the swift course. Tu'o Gen. of Verona, 1 .

PENYECTER giber for the table .... Coriolanus,

PERFECTLS' lerald of joy ............Much Ado, ii. I learned by the perfectest report...Nacbelth, i. . (let.

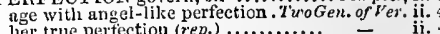

of such divine perfection ............
feed upon the shudow of perfection..

a man of such perfection ............ and tilled (her sweet perfections). Tuelfh Nighl, i. I feel this youth's perfectious ......

to a most prosperous perfection. Meas. for $\bar{M}$ reas. iii. a strange tice on his ow $n$ perfection. Mluch Atlo, i i. the sole inheritor of all perfection. Love's L. Losl, ii right praise, and true perectionhat or of venice, fulness of pertection lies in him ..... King John, ji. turn their own perfection to abuse...2 Henryl $\mathrm{V}$. perfection of a good and particular ...Henry $V$. iil. 7

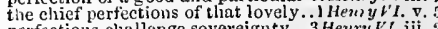

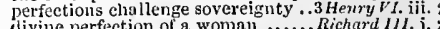
wivine perfection of a woman

more than the perfection of ten. Troilus \& C Cress. iii. no pertection in reversion shall....... she did make defect, pertection... Anlony of Cleo. ii. to knit in her their best perfections

no man on whom perfections wait ... $\bar{J}_{\text {retin }}$ i.

of all the age tor her perfections ...... Hun'sel, iv. of all the age tor her perrections so conld err agninst all rulek... Othello, $\mathrm{i}$.
perfection

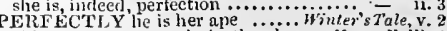
this they con perticctly in the phrawe. Heary $Y$. iii. consin how perfectly I love her...... 
TEREECTNESS? be gone ........ Lone's L. Los', v. 2 PERFORM LED-once performed.. Thming of Sh. iii. 2

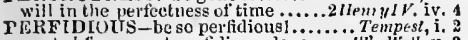
qunterl for a most perfidions slave....... ill's wett, v.

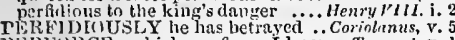
I'sRrolicE-which, perforce, I know.. Tempest, v. perforce agninst all checks $\ldots$. ...MArry Wives, perforce I must crintess..............

virtuc's foree perforec doth move me

of thy misprision must pertorce ensue -

gurl took perforce my ri!r away. Come:ly of Er.

and took perforce my ril: a

he, that perforce robs linns of their ...King John, i. I fure' perforce, keep Stephen Langton - iii. plucked for

pasion must perforce decay 2HenryIV.i.

perforce a third must take up us ....

was, force pelforce $(r c p$. iv. 4)......

weightless down perforce in ust mo

for he perforee must do thee right.

and must perforce endure it! .........

to resign, his crown perforce

Gin, bear her hence perforce

hy his mother was perforee withicld.

her jealons arms pluck him perforce

must perforee he their acquain

make parforce an universal prey... Troilus \&-Cress.

perturee he could not bnt pay

to scek of me again, perforce

Jou must perforce accomplish

Cymbetine, iti.

so that perforce wou enjoy th: at

tors, whicl break froin ime perfor...

to fake it again perforcet....................

perfor itself perturce into my busin.

perforce must wither and come to ...........

pertiorce with wilful choler...... Romeo $\ddot{\text { of Juliel }} \overline{\text { iv. }}$

would have married her perforce...

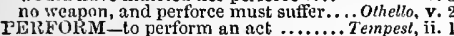

must I pertorm much business..

and perform an old contractiog. Meas. for Meas. iv. 2

to perform your father's will ... Merchi of Venice, i.

arc couning to perform it (rep.)..... As you Like

wilt perform my bidding. I wili (rep.)

what they did, than to perform it first
what cannot you and I perform.........

we shall my lord, perform what you

while you perform your antique round

we will pertorm in measure.....

good love may I pertorm for you?
commons will perform for $1 \mathrm{~s}$

King $\bar{J}$ hhn,

if lie be pleased I shall perform

1 Henry $1 \%$ iit

I will perform with a most ...........

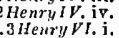

will perform it, to enfranchise you . Richard III. i.
they did perform beyond thought's. Henry VIII. i.
to misel ief as able to perform it ....

ability that they never perform $T r$

lut when he performs, astronomers .. - v.

me friendship, but perform none.. Timon of Ath. iv. 3

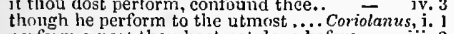

perform a part thou hast not doue before -1 ii. 2

perform't, or else we damn thee...
this if she perform, she shall not

one, that but performs the biddin

to perturm it, directly and tritly.

let us with care perfurm his great behest

wenpon notling darest perform .. Tizus And

mosi wretelied, to perform the like .....
wonld I perform, if I might liave iny will

to preserve mine honour ril perform. Po

shall for itself. itsclt" perform .... - iii. (Gower)

nerform my bidding, or thou livest ........

to perform thy just command, I here.... $-\overrightarrow{\text { viet, ii. } 2}$

it is, to act, to do, and to perform .......Hamlel. v. 1

I'll periorin it to the last article
PEREORMA

but it takes away the performance.......Muctell, ii.

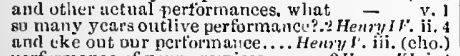

perfirmance of your promises.

but lifis pertormanee, as he is now

heaving Troilus \& $\overline{C r e s s}_{\text {ii. }} 2$

with a piece of 5 our performance

more performance than they are able

iii. 2

perfurnance is ever the duller. Timon of $\overline{A t h e s z s,} \mathrm{v}$. !

pertirmance is a kind of wil

or our performance, did need........Julius Cassar, ii. I
should my performance perish... Antory \& Cleo, iii. I

pertornanee shall follow................ Perietes, iv. 3

PER FOR.IED to point .........................

Olleello, iv. 2

which is not yetly is pertormed

of thia harpy, hast thou pertormed

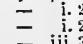

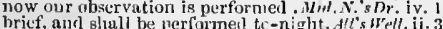

and naturally performed... Tuming of sh. I (induc.)

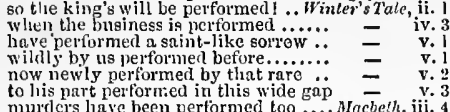

may not be performed by thyself ..........

swore him assitance, and performed.1 henry $I V$, iv. 3

gee performed the tenor oi our word... H, nryI

I lave performed iny task, and was..2 Henry VI. i. I

to see lier coronation be performed

that's not suddenly to be performed
lord Yerk, that I will sec performed

that's snon performed, becanse I am

woull have it sudrlenly performed. Richard $I I I$, iv

Wher performed, the chnir, with .. Henry VIII. iv.

Casur says do this, it is performed. Julizs Corsar,

I have performed your pleasure.

to see performed the dreaded act

halh to Cymbeline performed ........ Cymtiscline, v.

lave pertormed our Roman rites

well asked, twas so well pertormed.... Pericles, ii.

what have you performed?

let this same be presently pertormed

PRFORNER, I would liave that..... Ali'swell, jii.

performers of this heinous, bloody . . Tilus And. iv

ERF UME-are an excellent perfume. Much Ado,
with her breath she did perfime.. Taming of Sh,

she is sweeter than perinne itsel

perfime for a lady's chamber. Winter's $T$. iv. 3 (song)

to throw a pcrfume on the violet..... King John, iv.

hit their diseased perfumes....Timon of $A$ thens, iv. 3

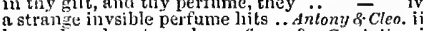

learned me how to make perfumes?... Cymbel

like incense, doth perfume the sky. Tilus

TERF PMED - nerfumed by a fen....... Tempest, ii.

hands are perfuned with eivet ... As you Like it, iti.
have them very well perfumed.... Taming of $S h$. $i . ~$

than in the perfumed chambers of..2 Henry $\mathrm{V}$. ii. I

so pcrfumed, that the winds were Antony \&.Cleo. ii. 2

PERFUNER for a perfunier................. Mrech Ado, i. 3

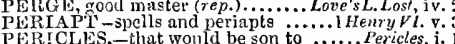

prince Pericles, touch not, noon thy life
my lord, prince Pericles is flet...........

say, priuce Puricles is dead (rep.)

message unto princely Pericles.
keep it, my Pericles, it liath been

my rame, Pericles írep.) ............. ii. 3

if king Pericles come not $\ldots . . . . .$. - iii. (Gower)

if thou liv'st. Pericles, thou hast a heart

heavenly jewels which Pericles hath lo

when noble Pericles shail demand

open this to Pericles w.................

Pericles is now again thwartine - iv. $\overline{4}$ (Crow.)

let Pericles believe his dallghter's
Pericles think this the bark...... iv. 4 (Gow.)
v. (Gower)

I am the daughter to king Pericies (rep.) - v.

another life to Pericles thy fatioer

you are-O royal Periclesi (rep.)

honotirel name of Perieles ......

PERIGORT and the beanteous .... Love's L. Lust, ii.

most provident in peril

as a peril to my soul (rep.).

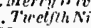

as you will answer it at your peril - iv 2 (notc)

lest, to thy perit, thou alyy it dear

without the peril of the Athenian ...

and to be in peril of my life with

this own peril on his forwardnes

inore free from peril tilan

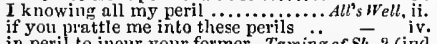

to peril to incur your former.. Taming of St. 2 (ind.)

on your displeasure's peril ......W'Wiuter's $\bar{T}$ 'ate, $\mathrm{it}$.

an peril of a curse (rep.) ............ King Jnhn,

he walked o'er perils, on an edge...
the respect of likely peril feared

what jerils past, what erosses

towards frunting peril and opposed.

nith peril I have answerch
that yet suspect no peril first be to lreaven performed

the sheep no wool, the cat no perfume .. Lear,

he was perfumed like a milliner ......1 llenry I ${ }^{2}$. i. 3

on thy soul's peril, and thy body's
L'LR LL_which peril heaven forfend .3 Henry $V t$. ii. I the extreme peril of the case ........̈. ichar 111 . iv. 1 if without peril it be possible ......... more tlan he fears his peril... Troilus \& Cressida, i. 3 own peril [Col.Knt.-apperil j.... Timon ff Athens, i. (in peace) to his utmost peril

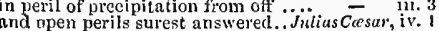
to meet all perils very constantiy which promises royal peril....... Antony \& $\overline{\text { Cleo }}$. iv. 8 than his peril, that I have reserved.. $\quad$ - v. 3 you know the peril: I'll fetch ....... Cymbeline, $\mathrm{i}$. to the tace of peril myself I'll dedicate - iii. 4 the after-enquiry on your own peril $\overline{-}$ v. wast thou not eharged at thy peril....... Lear, iil. 7 resist, subdue him at his peril ............. Othello, i.

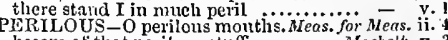

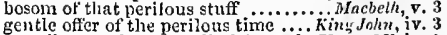
a periluus gash, a very limb lopped.i Henry IV'iv. I the perilous, narrow ocean parts...Henry $\overline{V . i}$. (cho:) a sword a perilous sliot out of an elder - iv. l a sword employed is perilous ...Troiters \& Cress. it. 2 more perilous than the head......... Cymbeline, iv. 2 pERsifted in such perilous circumstance.. Hamlet, i. 3 this is the period of ny ambition. Merry Wives, iii. there would be no period to the jest $-\bar{D}_{\text {man }}$ iv. 2 worldly business makes a period ..2 lienryI $\%$. iv. 4 the per tod of thy tyranny.......... Henry $V$. iv. 2 prove the period of their tyranny..2 Henry Vi, ivi. tet me make the period to my curse. Richard $[11, \mathrm{i}$. the blessed period of this peace ....... henry $\bar{v}^{\prime}$ III. i. it is the period of your duty..... Antony \& Cleo. iv. 2

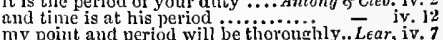
this would have seemed a period to ....... ERISH - and his great person perish ... T'empest, i. cannot perish having thee .. TwoGen. of leronn, i.
die! perish! might but my .....Meus. for.Meas. iti. I vile name, to perish on my sword! Mid. N's $D r$. ij. 3 labouring perish in their birth .. Love's L. Lost, v. 2 gain, or perish on the seas............. we strike not, but securely perish ...Richard II. ii. I perish the man, whose nind is ....... - iv. 3 so perish they that grudge one ....l Itenry $\nu^{\prime}$. iii. let Talbot perish with this shame... in thy palace perish HIargaret...... Henry $V 1$. iii. simple souls should perish by the sword! - iv. grief and extreme age shall perish. Richard III. iv.
I sliall perish under device and ..... Henry VIII. i. I'll hang my head, and perish

thy hopeful service perish too $\ldots . .$.
reinforcement, or we perish all... Troilus $\&$ Cress. v. 5 cleave in the midst, and perish ..... Coriolan us, iii. 2 trades in Rome, and occupations perish! - iv. 1 and perish constant fools ............ iv. that else must perish here...Anlony should my performance perisl

or this, or perish: she's far enough. Cymbeline, iii. 5 the land, to perish on the seas........... Pericles, $\mathrm{i}$.

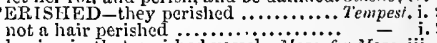
having in that perished vessel...Meas. for Meas. iii. 1

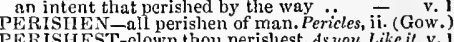

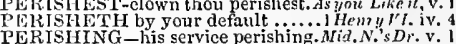
Erief, untwine his perishing root. . Cymbrline, iv.

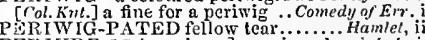
PER,I URE, [ Col.-perjurer'] wearing..Love's L.L. iv. 3 ER, perjure the ne'er-touched. Antony \& Cloo. iii. In I do detest false perjured Proteus...

hand is perjured to the bosom? .......

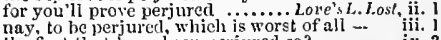
the first that have been perjured so? $\quad$ - iv. 3 from my forehcad wipe a perjured note
you'll not be perjured, 'tis a hateful
nor I, delight in perjured men ...... your grace is purjured much, fuil of $-\overline{\text { vof }}$ ver there did this perjured goldsmith ...... thou art perjured too, and sooti st up

if he berjured, see you now........ Henry $Y^{\prime}$ iy. now, perjured Henry! wilt thou.....3nenry

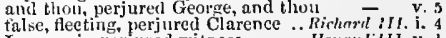
I mean, in perjurcd witness... Henryllil. v. 1 thou perjured, and thon simular man ... Lear, iij. all periurerl, all forsworn $\ldots . .$. Romeo \&. Jutiet,
O nerjured woman1 thou dosi stoue.... Othello, 


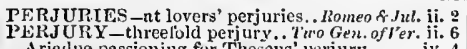
Ariadne passioning for Theseus' perjury - of er. iv. 4 ail those oaths descended into perjury with perjury cleft the roott............ why, this is flat perjury, to call....... my heart to this ful se perjury? Love's L.L.iv. pour the stars down plagues for perjury 二 now, to our perjury to add more terror shall I lay perjury upon my soul? II r. of tenice, iv.

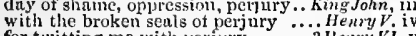
wor twitting me with of perjury.........3 Henry $V i$, $v$.

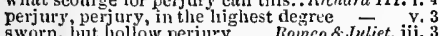
sworn, bet hollow perjury. .... Roineo \& Julliet, iii. .

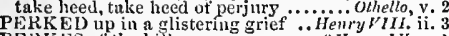
PERKES of the hill.................2HenryIV PLRMISSION-and by permission. Jut

by our permission is allowed to make

PEIRMIISSIVE pass Ccesar,

PLR if France in peace perınit our just ... King J John, it. but time will not permit.............
will you permit that I shall stand who dotli perminit the base contragious it that my fading breath permit.
to permit Joln de la Court ..........
will not so permit me it. 3 will not so permit me.......... you some permit to sceond iils....... Cymbeline, $y$, 1 nnd permit the curiosity of nations ....... Lear, i. 2

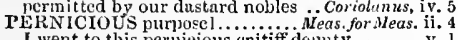
$I$ went to this pernicious caitiff deynty

and thou pernicious woman, compact
heen troubled witla a pernicions suitor. Much $A d o$, i.

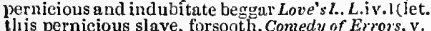
this pernicious slave, forsooth. Comedy of Errors, $v$.
let this peraicious hour stand aye.... Mactell, iv. grows with more pernicious root ......
of thy adverse pernicious enemy $\ldots$ iv.... too muteh urging your pernicious lives a most pernicious usurer ............. a mast perbicious usurer faction
forsaken your pernicious faction
perricious protector, dangerous...

perricious protector, dangerous
pernicions bloodsucker of slecpivg

that lave with two pernicious daughters. Lear, iii.

the fire of your pernicious rage ... Komeo \& S Jultipt, i. 1 man his pernicious soul rot half.......

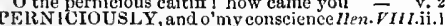
PERORATTON with such circumstane? 2 Hen. $Y$ I.i. therefore perpend, perpend.

therefore perpend, my princess ... 'iwelfth Night, $\mathrm{v}$. perpend my words, 0 seigneur Dew...Henry $V$. iv. perpend: I have a daugh ter ......... Hamlet, ii. PERPENDICULARLY fel
PERPETUA wink for aye

may stand till the perpetual doom....... Tempest. perpetual durance? Ay (rep.) ...Meas.for.Meas. iii,

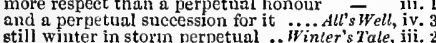
unto our shame perpetual ............ thou art a perpetual triumph

wly, t twere perpetual shame $\ldots . . .3$ Henry VI. v. perpetual rest [Col.Knt. ne'erchanging night] - ii. be not fixed in doom perpetual

reap the harvest of perpetual peace

to hold you in perpetunl amity........ Anlonis.s. Cloo. thine and Albany's issue be this perpetual. Lear, $i$.

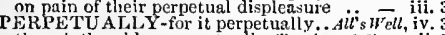
though they blow perpetually. Taming of Shrew,

CERP they not their sights perpetualiy. Pericles, 1 . PH.REIUITY, go hence in ......... Winter'sTal

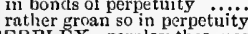

PERPLEX - perplex the more ..... KingJoh
PERPLEXED, thl know not what to say 1 rest perplexed with a thousand

put rexnain perplexed in

but reinain perplexed in all............

Wrought, perplexed in the extreme … Othello, v. 2 perplexity, and doubtfuld dilemma. Merry hines, iv.

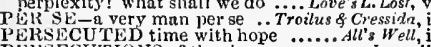
PERSECUTIONS of the sky................enr, it. 3 PELRE US - it is a beast for Perseus.... Henry V, in as hot as Perscus, ppur .................. PErseverance, dear my lord .... Troilus \& Cress. iii. 3 nersevere, comnterfeit sal looks. . Mill. N.'s br. iii.
will you persevere to enjuy her?.. As yout Like it, v.
PERSEVERE-she shall persev as it begins, shall so perseverc
as they say, and persc vere so.

Comedy of Errors persevere still in that me ........... King John, ii. $f$ will persevere in my course of loyality... Letr. iit. to persevere in obstinate condolement ... Haunlet, $\mathrm{i}$.
PERS1A-I amb bound to Persia.. Comedy of Err. ity. PERSIAN-and a Persian prince. Alere of l'enice, ii. PERSISTS, as if his tife lay on't $t . . . .$. Aill's Well, iii. 7 thins to persist in doing wrong ... Troiltes o cress, ii.
PERSISTS let the end PERSON and lis any other house,

thoor misht'st call lim

takes exceptions at your person. Fangen. of authentic in your place and person. Aferr

shiupe of nature, a gracious person. Twelfih Night no respect of place, persons, nor time
the quality of persons, and the time

one habit, aad two persons

pore reas. for. Meas. i. 4 finding yourself desired of sucli a person

do no stain to your own gracious person

to be a dislionest person?

cliange persons with me

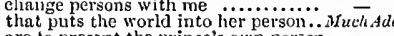
are to present the prince's own person
two aspicious persons, and we would

present, the person ot moonsliae.. $M$ Hid

yea, and the best person t

enfreedorming thy person?

good-morrow, master per

purse, my person, nyy extremest......

in her person, I say (rep.).

we have our philosophieal persoas....... All's 'well,

and, as his person's mighty .
from our free per'son slie should be

appear in person here in court

made thy person for the throv
as 'twere $i$ ' the fatlier's person

tender your persoas to his presence.

against whose person, so sacred us

his grace to come in person (rep.). Comedy of E

to go in person with me to $\mathrm{m}$

denies lis personl, at our great

phinished in thie person or this child . King $\overline{-}$ bear possession of our person here

no persou be so bold, or daring hardy, Richard III. $\mathrm{i}$.

here comes his grace in person.

committed by your person

in one person, many people.....

to such a person, in sueh a place ....1 Henry $I$

thus did I keep my person fre

che king himself in person is set forth

your uses both in purse and pings? 2 . $H e$ enry $I V$ here doth he wish his person, with

denied access unto his person even by
1 then did use the person of your fath

the peace and safety of your person..

my nlace, my person, or my

heed how you impawn our per.

that railed acainst our person.

preservation of our person, would have

conspired against our royal person .

his own person, kneeling at our feet

and an enemy to our person

a sort of naughty persons, lewdiy beat -

meaning treason to our royal person

meaning treason to our royal person.

in care of your most royal person.

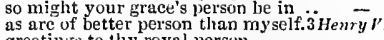

greetings to thy royal person

to defend llis person from niglit-foes?

loss of his own royal person.

over-much consumed his royal person

1do mistake my person all this while
there's many a gentle person made.

there's many a gentile person mate.

thus far cotne near my person .....

be to thy person, noble father-in-law:

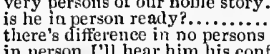

in person I'll hear him his confessio
my faculties, nor person, yet will..

to your high person his will is most

by his person, more worthy this prerson-

as suits the greatncss of his person.

not to be griped by meaner persons.

agaiust your :acred person, in God's

yon tencter more your persom's honou
or touch of her good person? ........
PERSON-I left nu reverend person... HenryVIII. ii. ngainst the person of the good queen
a seemly answer to sueli persons

and nobleness in any person

goud of your inost saered person .....

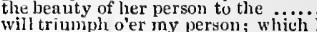

and shade thy person under their.

and a proper man of person. . Troilue

who is there in person: witl him...

safe condluet for his person

and parts with person, alas, a kind of

honour would become such a person

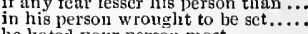

he liated your person most ...........
so tar as thou liast power and person

more proudlier even to my person

or clse thy persin, our comfort in....
his designneelts in mine o w'll person

no harm intencied to your person., fuliuscresar, ii. and but twelve persons therc Anlony of Cleopatra, ii. more in their officer thas

why should not we be there in person?

alle be there in person?

death of one person can be paid .... =

heady? ... Cymbelinc, ii. 3

your llace; ablorred your person
some marks of secret on lier person

myself, iny person, and the cause . Tilus Andron.

hadst thou in person ne'er offended me = ii.

the rnischief of your verson it woulda....... against the grace and person of my master - ii.

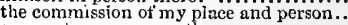

apjear to prove upon tliy person .........

find those persons out (rep)

that calls our person from our morning's - vo 3

if it assume my noble father's person ..Mamlet,

aur peric persons do, carve per.

do not fear our person; there's such

the opposition of your person in trial...

to do peculiar profit to your own perso..

ERSONAGE-of what personutge.. Tweeffh Night, $\mathrm{i} .5$ her persolinge, her tall personage. Mid. $N^{\prime}$ s. Shr i iij. 2

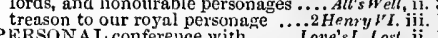
though not personai, have been ... Linter's Lost, in he reads thy personal venture in ........ Macbeth, $i$. he was persolnal in the Irish war ... HenryIV. thyself, or me, in personal aetion. Julins Cesar I know no personal cause to spurn at dares me to personal combat ....Antony \& $\bar{C}$ Cleo. iv. not your know ledge, personal pain . Pericles, iii.
his personal return was most required no further personal power to business ... Hamlet, i.

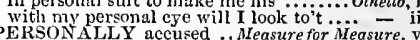

therefore personally I lay my elaim. Richard 11 . ii

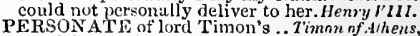
royal Cymheline, personntes thee ..Cymbelime,
PERSONATED-feelingly personated. Thelflih.

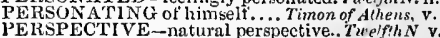

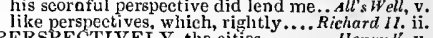
PERSPECTIVELY, the cities ........ Henry $r^{\circ}$ v PERSPICUOU even as substance. Trailus \& Cress. i. $[$ Col. Kut . ] only professes to persuade... Tempest, ii. eease to persunde, my loving. TwoGen of Verona, sir thath, persuade me not

that persuadecs me to any other...Tuelfth Night, iv. and well she can persunde ....... Meas. for Meas. i. do you persuade yourself that 1 . $\ldots=$ iv. love do not persuade you ... Mer.or $r$ en. iii. 2 (letter feelingly persuade me what I am. As you Like it, ii. we will persuade him, be it possible - iii. rather persunde him to loold. Comed $y$ of Errors, iv. it persundes him, and disleartens him.Macbelh, ii. yet my inward sotil persundes me .. Richard 11 . then crushing penury persuades me. sooner persuade Harry of England
let me persuade you to forbear $V . . .1$ Henry $V I$.

Bedford, let us nuw persuade you

discretions better can persuade

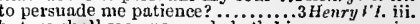
but we shall soon persuade both him - iv. I persuale me, from her will fall.. Henr'y $V^{\prime \prime l l}$ i iii. call my fanther to persuade ..Troilz $\begin{gathered}\text { \& Cressidn, } \\ \text { v. }\end{gathered}$ there did persuade great rather to..Corinlanis, v. persuade me to the murder of your....... Lear. ii. this act persuades me that this remotion - ii.

i. 4 thy wits, and didst persuade revenge $\ldots . .$. . $=$ iv.

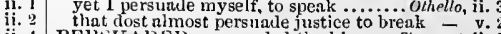
ii. 4 PEliSIUADED- persuaded the king ... Tempest, ii.

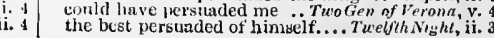



PERSUADED him, the youth's...Telyh Night, iit. 4 P'SSTILENT congregration..............

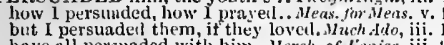
have all persuaded with him....Hereh. of renice, ii.

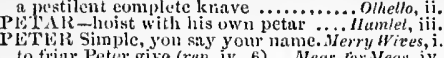
and persuaded us to do the like ..... Inenry IV. ii. who then persunded you to

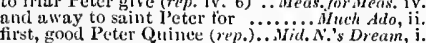

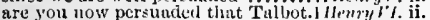
persund d hin from any turther..... Henry f $T_{\text {. v. }}$ be persunded: are ulmost thoroughty persualcd ..Coriolumus, i. l believed of one persuadert well of ... Cymbelme, ii. be false persuadel I harl daughters. nur an I yet persuarted, to fut up in peace - iv. 2
PERSUADING me not to kill ...... Richare $11 . \mathrm{i} .4$

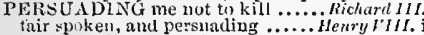

by per'sualling me to it......... Timon of 'thens, to you can lack persuasion? .... Tretfh Nigh, whose persuasion is, I come...... Alects. for Meas. my cort, integrity, nor my persua ion

not die to-day for any man's persuasion -

I yield upm great persinasion...........1nek $A d o, \mathrm{v}$. a good perstaion; therefore ...Mili. N. slicam, i. 1 what persuasion did he temp 0 t. Comedy of $\mathrm{K}$. Cor. by his persuusion, are again fallen.. King John,
the spirit of persuasion, and he ..... H Herryll onc uo persuasion call do good upon lift your blood up with persuasion

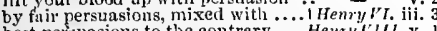
best persuasions to the contrary ....Hent? the persuasion of his new leusting. Timon

the persuasion of his augurers PERT-pert and nimble spirit ... Miti. N.'s Dream, i. this pert Biron was out of

if sle pertain to life, let her

the main part pertains to yoü.... Winler's Tale, $v$. and honours that pertain, by custom...Heney

in auglit pertains to the state .......Henry Vli. $\mathrm{i}$. more than pertains to fcats of broil Peter Ouince, - Wingt I will wet Peter Quinte to wite .... - iv. Peter Turf, and hlenry.... I amm, of Sh, $\overline{2}$ (indue. Peter, didst ever see tic lifert........ - iv.

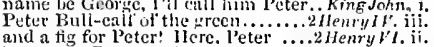
be merry, Peter, nim lear not.

Peter, fursooth. Teter I what mole?..
therefure, Peter, have at thee with therefure, Peter, have at the

O Peter, thou last prevatitel .......... Peter, stay at tlic sate

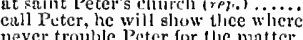

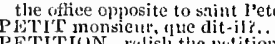

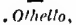

ETIT IUN-relisl the petition .ileas.
ali their petitions are is fiecly theirs

they shonld exhibit their lietitions..

would not stay at your petitions... Winler's Tale, $\mathrm{i}$.

not receive affliction at my jetstion
but your petition is yet unanswered

of solt yetitions, pity, aml remorsc.. Kins Jolu, ii. and my petitions, to eat. lonk you..... heury $v^{\prime} . v$.

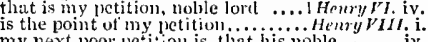
you would have given me your petition $\overline{-}$ iv. the zeal of my petition to thec.. Troilus \& $\bar{C}$ ress. iv. 4 and a pe in loml and dear petition.

it was a bare petition of a state.

reason our petition with more st
thon receivest thy full petition.
urge you your petitions in the st

- iii.

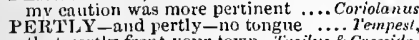

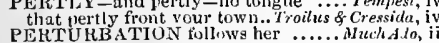

a great perturbation in nature!

o polished perturbation! golden care!

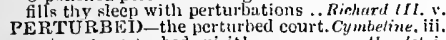

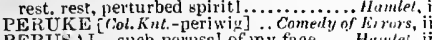

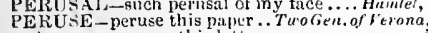
please you peruse this letter .......... priy you, peruse that letter ...... Tuelfh perusc them well; not one.............. Alt's ' W'ell,
of the town, jeruse the traders. Coinedy of Errors, peruse this writing here, and thou.

that we unay peruse the nen

some liyht horsemen and per
of state he sent me to peruse

and I to peruse him lly

peruse this writing else. W

let me peruse this tice.

Will not peruse the futls ............ Hamet.iv. 7 appointments may be well perised. Kichard Il. ii. have you perused the letters from .1 Heur! ri. v. I
I have perused her well ............ ilenry 111 ii. 3 with cxuet yiew perused thee...Troilus \& Cress. iv. 5
have you with heul perused what I.Corrolanus. v. 5 PERUSING o'er thees notes ................. Lear, i. 2 PERVELSE-covetous, antitions, or perverse 1 Henvy $V 1$. iii.

lil trown, anl pe perverse....... Romeo \& Juliet, ii. PERVERSEI, sle perseveres. Tuo Gen.of Ver. iii. PLRVERSENESS? You uncivil lady. Twelfh N. v.
PELVERT your course .........Heas. for Heos. iv. 3 and pervert the present wrath ....... Cymbeline, ii. 4 P pesech you how (reartily, iv. seurvy ........... Henry

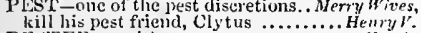
PEsTER us with message

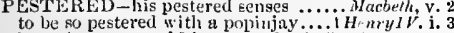
how the poor worlal is pestered.. Troilus \& Cress. v.
PESTERING streets............... Coriolonzs, iv. PESTIEEISOUS reports of men..........All's $H^{2} e l l$, iv. lewd, pestite eous, and dissentions...
PESTILENCE hangs in our air......

armies of pestilence; and they shall
one that har the pestilenue.. Two $G$.

one that had the pestilenue.. Two Gen. of Ver, ii.
she purged the air of 1 restilenec .. Tweelfih Night, i. is somer caught than the pestilence. Much Ado, a pestilence on lim int now will.. Troilus \& Cress. iv. the red pestilence strike all trades.. Coriolarıus, iv. I the most infections pestilence ... An/ony \& fleo. ii. infectiuus pestilence did reign ..........meo of Juliet, $\mathrm{v}$. a pestilence on him for a mad rogucl. Hlamlet, $v$. Iil pour this pestilence into his ear.... Ohello, ii.
PESTILENT to the licaring ........ Henry YMi. i. my slow leave, hy laboursome petition... Hanle in my slow leave, hy haboursome petition.. Hamlet, i.
PETITIONARY vehemence....... As you Like it, iii. PETITION LD all the gods for my PETITIONER-vain petition
let us, that are poor petitioners
I am but a poor petitioner. petitioners for bloor thou neer Poth put hy, a pardolph, Peto, and Gadshill. I Heary it.
Bardolph! Peto! I'll starve Bardolph! Peto! I'll starve ......̈h
so did you, Peto; so did you, Bardolph banish Peto, banish l3ardolph Peto, how now? what news?.......2 Henryly. ii. 4

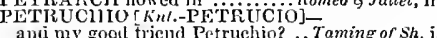
molti honorato signiol mio Petrichio Petruchio, shatil I then come roundly rich enougl to be Petruchio's wite..
Petruehio, since we have stepped this I can, Petruehio, help thee to a. wite
tarry, Petruchio. I mist ro with .... now shall my triend Petruchio do me Petruchio, stand by a while ........
be it so; Petruchio, I shall be your.. saving your tale. Petruchio, I pray
signior Petruehio, will yon go (rep.) ble comes; and now, Petruchio, speak
hark, Petruchio! she says, she'l] see God send you joy, Petruehio! ...... lo, there is mad Petruchio's wife.... to hear of Petruchio's coming $\ldots . . .$. . why, Petruchio is coming, in a new
that Petruchio came? Ay, that (rep.) I warrant him, Petruchio is Kated .
and Petruchio is the master........... Petruchio, ficl you are to biame well, Petruchio, this hath put me................. brother Petruchio, -sister Katharin o ho, Pctruchio, Tranio hits you no It link, be young Petruchio .... Rom
PET'TEl that friends is the swoid... her father is make her a petter jenn nay, it is petter yet

I warrant you, it is the petter for you. Henry $v$. iv.

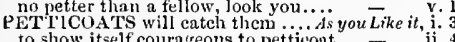
lo show itself courageous to petticont - inge upon a petticoat......... all my raiment, to my petticoat.. Taming of $S h$. holes in the alewifc's new petticoat. $2 \mathrm{H}$

still have worn the petticoat........3nenry $Y l$.
brings forth a new jetticoat. Ariony \& Cleopulro nor gowns, petticnats, nor caps ......... Ohello, PETTINESS would bow under ........ Henry $V$. iij.

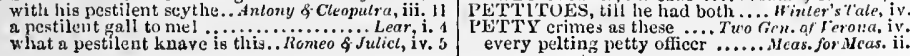

PETT'Y traffickers that eurt'sy... Merch. of Venice, $\mathbf{i}$. these pet ty lurauls, that culumi.......ंinter's Tule, ii. as a meeting of the petiy gods

ereeps in the petty pace trom däy......Macheth. v. and inland petty spirits...

some petty and unjrofitable

exeept some petty' towns
tut! thesc are pelty lanits.

counterpoised witl such a petty sum

iii. (ehrirus)

particnlarities and petty sounds .... $\bar{y} \mathrm{v}$

but was a petty servant to the rtate... -

to mend the walk miler his huge.Intins

his helm for sucli a petty war......

and bind up the petty (lifference

not petty thmits admitted.............

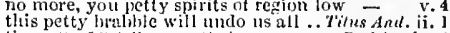
the petty [Col. Kut.-pretty] wrens.......Pericles, iv.
makes eachl petty urtery in this body... Howlet cach small antexment, petty consecuence - iit. 3 110\% caps. nor any petty exhibition...... Onello, iv. de Dieu; et en ncu de te........ PEW-halters in his new................. Lear, iit. 4 PEW'TER-iu necl!ework pewter. Iamms nfsh. ii. I

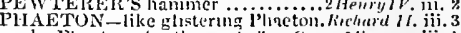
why Phaton, (hor thu art.. I wn fien. af lerona, iij. 1 that Phacton should clicek thy bery stecels - ii. 6

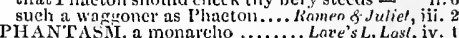
I abhor such fanatical phantasm ..... $\overline{\text { Put }}$ y. í PIIARANOND-from Plaramond .... Herry $V$. i. 2 Pharamond idly supposed the founder

PHARAOI'S soldiers $\ldots . . . \cdots \ldots \ldots \ldots \ldots$. Iuch Ado, iji. 3 PIAREALIA -battle at Pharsnlia...Ant.6. Cleo. iii. 7

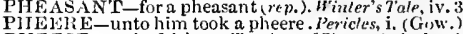
PIIEESE you in fith .. Taming of Shrew, I (induc.)

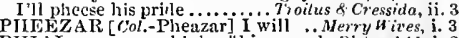
PHIAL-as seven phials of his sacred.. Richard 11 . i. a take thou this phial, being then. Romeo \& Jutiel, iv. 1 PHIBBUs' ear shall shine t'om far.. $\dddot{M}$ idd.N.'s $D r$ r. i. 2 PIIIL A DEIPIIOS, king of... A trimy $\hat{\sigma}$ cleopatra, iii. 6

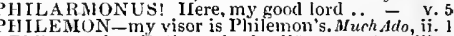
Plilemon, ho! Dotl my lord call? .... Perieles, iit. 2 Nicholas, Philip, Walter (rep.)...Taming of sh. iv. I Philip of France, in right and true ... King John, i. I Phitip, my liege; so is my name (rep.) good leave, goud Philip. Philip? .... Philip of rance (rep. iii. 1) ..... while Philip breathes (rep.)... nor yet St. Philip's daughter ........ Henry VI. i. 2

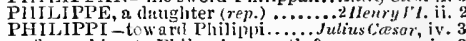
of marching to Philuppi presently if at Philippin we do face him there oursclves, and mett them at Plitippi thou slalt see me at Philippi (rep.)...

who to Philippi herc eonsorted us
last night, here in Philipui ficlus

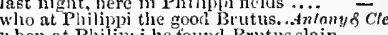 he, at Plnilippipi, kent his thined down, where Philomel gave... Cymuthetiue, ii. 2 could have betier sewed than I'lilomel - ii. 5 this is the tratic tale of Philomel .... PHII.OMEIAA. she but lost her .... Tilus Andron. it. 5 ravished, and wronged, as Philomela $\bar{p}_{\text {ive }}$ iv. for there was never yet philosolyer...Much Ado, $v$. prove the weeping philosopher.... Aler. ar emi.

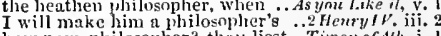
how now, philosopher? thou licst... Timon of Ah. i. and womni; sumetime the philosopher - ii. 2 noble philosopher, your company..... - iii. 1

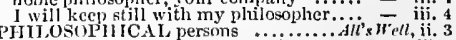

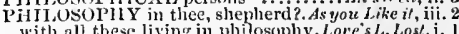
that part of pltilosolhy will I.. ? iaming of Shrew, to suek the sweet of swect plitosophy - i. I ireacll some philosophy to make ...King John, iii. even by the rule of that philosophy.. - v. 1 
PHILOSOPIYY-milk, philosoplyy.. Rorreo \& Jut. iii. 3 lang up philosoplyy! nuless pliilosophy - iti. 3 if philosophy conild find it out

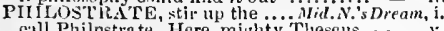
PIII Philnstrate. Here, mighty Theseus

this Philuten contends in skill. so darks in Pliloten all graceful . Pllluotus ton! Good-day ....Timon of dheres, iii PIISNUMY is more hot ter in France. All's Well, iv a title to Phobe, to Luna.......... Love's L. Lost, iv. Prowe, Pliøbe, Phœbe [.........As you Like it, ii. . Odear Phobe, if ever, (as that ever.

Phobe, witl all iny heart

my gentle Phol,e bid me give rou.

the contents; Phobe did write it ....
of Phobe's cruelty. She Prows s ne.

and 80 am 1 fir Plimbe (r

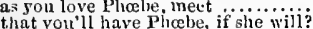

keep your word, Plucbe, that you'll.

like the stately Plicebe' 'nongst. ?

before the wheels of Pliobus.

where Phobus' fire scarce thaws. .iver.of Venice, ii.

not by Phobus, he, that waudcring... Henryl $V . i$.

the young Pliœbus fanning

o Phœbusi hadst thou never given..3 henry $v$. ii

coldly eyes the rmuthful Phobus. Troilns \&-Cress

that um with Phobus' amurous.. Antony \& Cleo

carbunelcd like holy Phobus' car

and golden Phobus never be belicld.:. $\overline{\text { iv. }}$ v.

n carbunitc of Phehtis' wheel......

$\bar{L}$ entr, ii.

steeds, towards Phobus' mansion Romeo \&...Ju'tel, iii. fill thirty times hath Phobus' cart

PIICENICIA-and Phoenicis.
PHIENICIANs, go a ducking

PIIE NIX-tree, the phonis throne... Ter

one phonix at this hour reigning there - iii. took the Phonix, and her fraught. Twelfih Night, v. a phouix, a captain, and an enemy ...Al's Well,

your house, the Phoenix (rep.

a phonix that shall malce.

my ashes, as the ploenix, may bring .3 Meury ${ }^{\prime}$ iv.

the maiden phonix, her asties....... Hevery illt

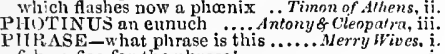

foli; a fico for the phrasel
for

foli; a fico for the poldier-like phrase.

your red-lattice phrase

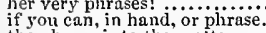

the phrase is to the matter
chit liath a mint of phrases

taffeta phrases, silken terms.

that was his own phrase

phrase, call you it? (rep.)

Ticelfth $\overline{\text { ight, }}$ ii. 5

these suns (for so they plurase them). Henry VIII.j.

there s a stewed phrase, intleed I roilus \&. Cress. iii. I

better phrase, and matter, than thou ..... Lear, iv. 6

proverbed with a grandsire plurase.. Romeo \& Jul. i.

with swinish plurase, soil our addition

pronouncing ot some doubt'ul phrase

acenrding to the phrase, or the add
nn ill phrase, a vile phrase (rep.)

nor no matter in the phrase........

whose phrase of sorrow conjures ......

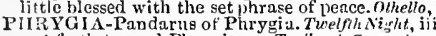

put forth toward Phrygia.... Troilus \& Cress. (proi.)

better thail any man in all Plirygia
PIIRYGIAN-spur thy Plaryoian steed

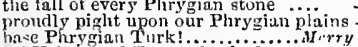

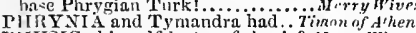

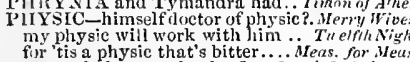

most wholesome physic of

my physic says, I ..................

int cast away my physic but on

thy plysic I will try $\ldots \ldots . . . . .$.

Alt'strell,

thitt, indeed, physics the subject.

physic for't there is none ........ Hinter's Tale, i.

$t$ ie labour we delight in pliysies pain... Macbeth, ii.

throw physic to the dogs

for the health and physic of our righit. King.lohn,
in poison there is physic

in poison there is physic $\ldots . . . .$.

I will see what plysic the taver.
'tis time to give them physic....
he brings his phy gic atter his.

Henry rl. iii.

Renry VIIL i.

that gentle physic, given in time $\ldots$...

will physic the great myrmidon. Troilus \& Cres

soft, take thy physic first...... Tinon of Alhens,

a body with a dangerons physic ..... Corio

one of them, for it roth physic love. C
learning, physic, must all follow this
PlIYSIC-I have glven her physie. Tilus $A$ mirom. iv.
sharp playsic is the last ................ Perictes, $\mathrm{i}$. crer have studied physic. the pliysic. thy sinered physic shall receive sucl pay

takc physic, pormp; expose tliyself ...... this physic but prolongs tlyy sickly.... Hamlet. is it plyysical to walk unbraced...Juhus Cesar, PIXSICIAN to comment.... TroGen. of Verona, silowed yourself a wise physician... Merry Wives, ii. 3

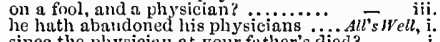
sice the physician at your father's 8 a poor physician's daughter (rep.)...

for your pliysiciaus have . Taming of Sh. 2 (induc.)
physician, your nost obedient ... Ir inter's Tale, ii. 3 needs she the divine, than the $p$ hys sician. Nacbeth, y. rie prescribe, thongh no plyysiciau
in his pliysician's mind, to

of tirose physiciuns tliat first wounded

inuch feared by his plysicians...... Henry $I V$. iv

the immortal part needs a plysician

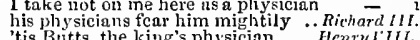

'tis Butts, the king's physician .... Henryl'I11.

he'll be physician, that should .. Troilus \& Cress. ii. 3
his triends like pliysicians, thrive. Fimon of Alh. iii.3

trust not the physician

r will make a lip at the physician .. Coriolamus, ii.
for her physician tells me ... dnfony \& Cleoputra, $v$.

than be cured by the sure phiysician.. Cymbelm

do; kill thy plyysician, and the fee

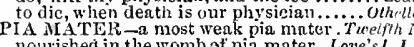

nourished in the womb of pia mater. Love's $L . L$.

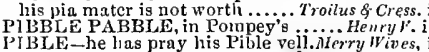

PIBLE- he has pray his Pible veli.Mierry Wives,
PICARDY - Watloon, and Picardy... Henry $\%$.

Picardy hath slain their governors. . 2 IIen
iCK-did you pick master' Siender's. Herry

pick out my eyes with a ballad-.

and sing; pick his teeth, and sing

we may piek a thousand salads.

the world pick thee out three

urned bawdy-house, they pick guile - iii.

as I may pick occasion ............... Henry $V$. iii.

or piek a salad another while .....2 ifenry $V 1$ iv. 10

as high as $I$ could pick my lance

to pick that solt to pick them in..... v.

we could pick up some pretty estate .. Pericles, iv. 3

ch'ill p:ck your teetir, zir............... Lear, iv. 6

a pickaxe, and a spade, a spade..Hamlet, v. 1 (song)

PICK ED-at picked leisure ............. Tempest, v.

ani af terwaras picked my pocket..

hath picked out an act ...... Measure for sreasure, $\mathbf{i}$.

yet, I picked a welcome

how much honour picked from..... Ler. of Venice, ii.

picked out the dullest scent... Taming of Sh. I (ind.)

my picked man of coun tries

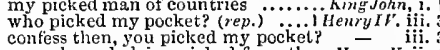

no a $\mathrm{k}$ ward claim, picked from the..llenry $\mathrm{V}$, ii.

lave luxuriously picked nut ...Antony \& Cleo. ii. il

think I have picked the lock ....... Cymbeline, ii.

one man picked out of ten thousand ... Hamlet, it. 2

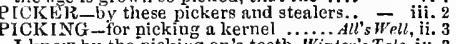

I knew by the picking on's tceth. Winter's Tale, iy. 3

no more from picking of purses ...1 Henryl $V$. ii. I

and such picking grievances $\ldots . .2 H e n r y$
$I V$ .iv. 1

I have been in such a pickle ...........

PICKLE-HERRINGS! How now, sot? Twelfth $N$. i. 5

PICK-PURSE- if it is a pick-purse. Mery Wives, i. I

and 1 , are pick-pnrses in love.... Love's L. L.ost, iv.

PICK-THA NKS and hase neirsmongers - iii.

PICTURE-by the picture of nobody.. Tempest, iii.
tis but her picture I have.. Tu'o Gen. of Jeronu, ii.

vouchsafe me yet your picture

the picture that is hanging in ......
the promise for her heavenly picture

he sencs you for a pietur

bring my picture there

you may come and see the picture.....

Tutetfin Night, i. 3

you never see the pieture of we thiree? - i. 3

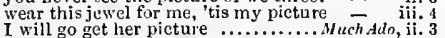

my eyes on thy picture ..Love? $s$ L.Losl, iv. I (song)

he hath drawn my picture in his .....

tite one of them contains my picture
PICTURES, fairest, lined....As you Like it, iii. 2 (ver.) with all my wanton pictures.. Taming of $\mathrm{SH}$. 1 (ini.) whose purse was best in pic will fetch (t) arthe aread, are but as pietures... aracth ii. and the dead, are but as pietires....... Marbeth, ii. in my gallery thy picture hangs.... I llewy $I^{\prime} \boldsymbol{i}$. ii. and let's picture left among .... iv.

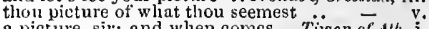
a picture, sir: and when comes .. THinon af

such, and such, the pictures ......... Cymbeline, it.

hath altered that good picture?

cliamber-hanging, pictures, this her

but seen thy picture in this. Titus andron, iti. jigour, and the picture of my youth - iv, his picture $I$ will send far and near ....... Lrur, ii. for his picture in little .................. Humtel, ii. we are picturon this pictersts on this - iit. you a re pictures out of doors .............

PICTURED-not seen him so pictured Cymbelin!,
PICTURE-LIKE to hang by ........ Coriolutes, PlD-do as I pid you ................... Corry Wives, in your pie and your porridge ..........Al's $w^{\prime} e t$ a bauble, a silken pie ......... Taming of Shrer", iv. 3 by cock and pie, sir, you shail .......2 Heary 1, . v. no man's pie is freed from.............Henry Hiti. baked with no date in the pie... Troilusf. Cressidu, i. a hare, sir, in, baked in tilat pie.. Tilus antron. v. PIECE-dashed ail to pieces.............. l'empesi, but would give a piece of silver......... lest he transform me to a piece of chcese - v. with witty a piece of Eve's flesh a....... Tü

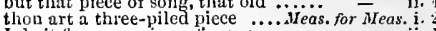
I do it for some piece of money ....... - ii. with a piece of valiant dust? $\ldots . . . . . .$. Muets dilo, the most clangerous piece of lechery a piece of flesh as ........... a very good piece of work ...Mid. N.'s Dream, i.
sir, is this stucl a piece of study?...Love's L.Lost, i.

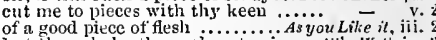
lest they shake themselves to pieces di's well, iv. 3 excelleut piece of work .. Taming of $S h$. i. I (induc. what say you to a piecc of beef.

never for a piece of beauty rarer. Winler's $\bar{T}$ ale, iv. 3 tresh piece of excellent witchcraft ...

is about a piece of iniquity .........

the wast peerless liece of earth......

a piece many years in doing....... .6 .

witl our company piece the rejoicing?

as he will piece up in himself ........ and tcar to pieces that grent bond ..... Hacbeth, ii. cul him to pieces. Keep the peace ...King John, iy. 3 and piece the way out with $\ldots . . . \cdots \ldots$.

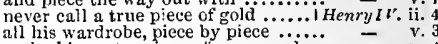
inake him eat a piece of my sword ...

would manage you his piece thus..2 2 Henry $I V$. iii. 2 and dash themselves to pieces ...... $v$. i. (chorus) or break it all to pieces; or there.... - 1 . i. 2 there's not a piece of feather in our... $\quad$ - iv. tis as arraut a piece of knavery $\ldots . . . \quad$ little piece of my desires $\ldots . \cdots \cdots \cdot$ iv. a piece of orduance 'gainst it........ Henry $/$ I. i.

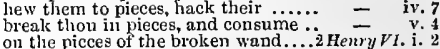
on the nicces of the broken wand....2 Henry and such a piece of service will you do

they dash themselyes to pieces .... lickard $11 \mathrm{I}$.

with a piece of scripture, tell them.

to do this viece of ruthless butchery

rush all to pieces ou thy racky bosoln $\bar{F}$ iv. woven so strangely in one piece...
this is a piece of malice; $\mathrm{I}$ am glad..

not being torn a pieces, we have done

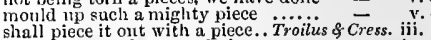
anti dregs of a flat tamed piece $\ldots . .$. .. a niece of painting; which $I$ do beseech and $y$ et he's but a filthy piece of wor

show me this piece: I am joyful

a thousand pieces. A thousand piecest

will promise him an excellent piece

that for the poorest piece wil

cut me to pieces, Volsces ................
teur him to pieces, do it presenily

thus must $I$ piece it out $\ldots . . . \ldots$....

pardlor me, thou bleeding piece of earth - 
PIECE-dash lim to pieces! .......Julius Crestar, iv. 3 PIGEON_going with my pigeons. Tilus Andron. iv. 3 PILOT-I am no pilot ............ Rumeo \&. Jullet, ii. 2 a wonderful piece of work ........ Aniony, I will piece her opulent thr.

let not the piece of virtue............

were nature's pisce ' guinst faver

a piece of work so bravely done ..... Cymbelin

to pieces with mel 0 meu's vows

thiy garments cut to pieces before thy

to let an arrogant piece of fles

a picee of tender air (rep. $v$. 5 )
wagced with lim pieces of gold

wagerce with limin pieces of gold
give that changing piece to him
a very excellent plece of villany
this piece of your dcad quten

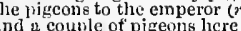

PIG aON-L1VERED, and lack gail .... Itanklel, ii. fomind him pight to do it...................ear,

this piece of your dead queen
a strong wind will blow it to to...........

Inave gone through for this piece
bated one doit of a thousaud pieces....

when nature framed this picee..ji...

PIGMIIES-embassage to the pigmies. Mruch Ado,
PIGMY arms, from out the circle .... KingJnhth,

o Dionyza, such a piece of slanghter

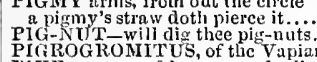

PlkE-treason, relong, sword, pike

Tuelfhn Ni. 3

with his pike bent bravel

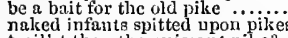

Menchtdo, y.

trail'st thou the puissant pike?

\begin{tabular}{l|l} 
iv. 3 & should have tossed me on their pik \\
iv. 3 & let us revenge this with our pikes
\end{tabular}

trail your steel pikes.

I beseecls your honour, one piece for me $=$ iv.

if she were a tly:rnier pieee of ground
and shake in pieces the heart of his

caitiff, to pieces slake, thant under

I will piece out the confort with.;

a ruined piece of naturel this gren

I am a pretty piece of flesh

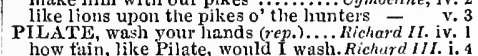

PILCH! Ho! come, and bring

PILCHER by the ear

PIL'D-ESTEEMLED C
PILE-tlice logs, and

beats as it would fall in twenty pieces
what, is Horatio there? a piece of him.. Hamlet, $\mathrm{i}$.

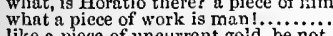

thint you are enjoined to

I'll carry it to the pile a.....................

What piles of wealth lath

All's $\overline{\text { Well }}$

like a piece of uncurrent goid, be not.
will the king hear this piece of work?

or pile teu hilts on the Tarpeian

tis a knavish piece of work ..............

I'jl tear ber all to picces ................... - iii. 3

likely piece of work, that you should find = iv.

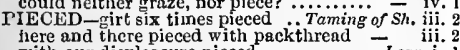

could not stay to piek them in a pile

upon a pile of wood, let's hew.........

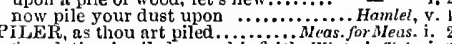

toundation is piled upon his faith. Winter's Tate
they have engrossed and piled up..2Henry $1 \%$.

PILIER ING borderers .................. Henry
fir pillerings and most common trespasses. Lear
PILG I IMS going to Canterbury....... Henry $I$.

I'IED-what a pied ninny's thisl.......'Tempest, iti.

when daisies pied............ Love's L..Lost,, 2 , (song)

PIhich were streaked and phares with great ...... Minter's Tale, iv.

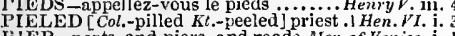

PlER-ports, and piers, and roads. Mrer. of Y'enice, i. 1

PIERCE a wink beyond

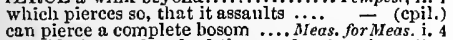

should pierce a liundred thousand. Mid. N.'s 's $D r$. ii.

best pierce the ear of grief ......... Love's L. Lost, $\mathrm{v}$,

can no prayers pierce thee? .. Nerch. of Venice, iv. I
with sweetest touches pierce .your....
our plaints and prayers do pierce ...Richard II. v. 3
sir Pierce of Ex ton who lately ......

if Percy be alive, I'll pieree him ....... i Henry IV. v.

I come to pierce it, or to give........

her tears will pierce into.....

Richard IJI. i. 3

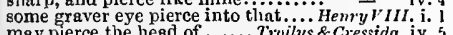

may pierce the head of $\ldots \ldots$. Trouilus \& Crersida, iv .5
bleeding, shall pierce a jot.... Tinon of Athens, iv.

'gan pierce liis ready sense...

he is able to pierce a corslet....

my bended look shall pierce.......... Antony \& $\overline{\text { Cleo }}$ it. 5 and pierce the inmost centre. Tit ths $A$ ndronicus, iv. 3 curse pierce every sense abont thee!

how far your eyes may pierce..........

a pigmy's straw doth pierce it

r Knint. ] as level to your judgment pierce..Hanlel, iv. 5 picreed and pricked a pretty.Love's L.L. one should be pierced, which is the one? - jv. 2 pierced to the soul with slander's.... Richard III. i. 1 it pierced me thorough................. Pericices, iv. 4 heart was pierced through the ear ...... Othello, $i$.

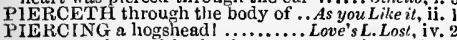
PIE RCING a logghead

a true devoted pilgrim is not. To. ToGen, of l'er. ii. 7

look, here conies a pilgrim
God save you, pilgriml

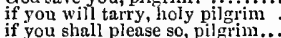

\begin{tabular}{l}
$=\quad$ iil. 5 \\
$=\quad$ iii. 5 \\
$=\quad$ iii. 5 \\
\hline
\end{tabular}

my lips, two blushing pilgrims ... Romeo \& $\overline{\text { J Juliel }}, \mathrm{i}, \mathrm{i} .5$

good pilgrim, you do wrong your ....

PILGRIMAGE to gaint Jnques ......All's Well, iv. 3
he overtaketh in his pilgrimage. TuroGen.of Ver. ii. 7

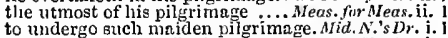

you swore a secret pilgrimage. Merchant of Y'enice, j.
his erring pilgrimage .... As you Like il, iii. 2 (ver'ses)

hliat vow a long and weary pilgrimage.RichardII. i 3

stop no wrinkle in his pilgrimage.....
which finds it an enforced pilgrimage
is spent, our pilgrimage must be

ie spent, our pilgrimage must be ....
grison linst thou spent a pilgrina

prison hast thou spent a pilgrinage..1 Henry $p t$. ii.
from first to last told him my nilgrimage.. Lear, $v$. lasting labour of his pilgrimagel. Homeo o. . Uliet, iv. 5
that I would all my pilgrimage dilate ... Othello, i. 3 PILL - you gave me bitter pills.. Two Ge. of of Ver. ii. 4
for pills to cool the reins.......... Merry Wives

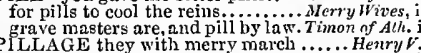

the gentle bosom of peace with yiliage
to be the pillage of a giglot wencla ...1 Henry

cheap pennyworths of their pillage...2Henry $V I$. 1 .

thy sons make pillage of her chastity. Titus And. if. 3
PILLAR - with gold on lasting pillars... Tempest, v. 1 you are a wcll-deserving pillar..Mer.of Venice,
of England, pillars of the state ......2 Henry $V$ call them pillars, that will ...........3 Henry VII. ii. 3 her base and pillar by us.... Troitus \& Cressida, triple pillar of the world transformed. Ant.s. Cleo. .
PILLED $[$ Knt. $]$ me certain wands... Ner. of Venice, i. the commons bath he pilled with ... Richard II. it.
tlint which you have pilled from me. Richard $I I I$ [Col.] pilled priest, dost thou she uttereth piercing eloquence.. Taming of $\mathrm{s} h$. $\mathrm{ii}$. as it is now piercing to my soul. . Winler's Tale, v.
piercing the night's dull ear ..Henry $V$. iv. (chorus as, sharp and piercing to maintain.. 1 Henry $V I$. ii. do peck the filcon's piercing talons..3 Hesry YI. i. 4
have been as piercing as the mid-day - y.

provide more piercing statutes daily. Coriolanus, i.
piercing steel, and darts envenomed.Jul. Casar, v. 3 the air is quick there, piercing ............ Pericles, iv . I

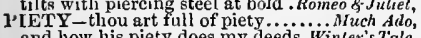
and how his piety does my deeds. Winter's Tale, iii.. from glistering semblances of piety $\ldots$.. Henry $\nu$. ii.
piety, aud fear, religion to the gods.Timon of $A t h$. iv. piety, and fear, religion to the gods. Timon af Ath. iv.
piety in thine, it is in these.... Thitus Andronicus, $\mathrm{i}$.

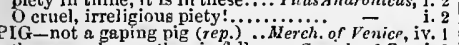
$P I G-$ not a gaping pig (rep.)...Merch. of Venice, iv. 1
the capon burns, the pig falls .... Conedy of Err. i. 2

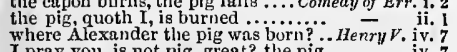
There Alexander the pig was born?.. Henry $V$. iv. 7 so cries a pig, prepared to ..... Titus Andronicus, iv.
PIGEON egg of discretion ........ Love'sL. Losl, v. pecks up wit, as pigeons pa.............
fister than Vents' pigeons fly ...Mer. of Venice, ii. as pigeons feed their young ........ As you Like it, $\mathrm{i}$. 2 are there no young pigcons? .........2 Henry $1 \% . \mathrm{v}$.
some pigeons, Davy $\ldots . . . . . . . . . . . . .$. some pigeons, Davy
ay, of my pigeons, sir................ Titus Andron. iv. 3

PILLORY - stood on the pillory. Tuo Gen. of Ver. iy. as on a pillory, looking through .. Taming of Sh. ii.
PIIAOW for us both.............Mid.N.'sDream, ii. sighed upon a midnight pillow .... As you Like il, ii. 4 we found upon their pillows............ Macbelh, ii. 3 to their deaf pillows will discharge ......... v $\bar{\nu}$, i set me the crown upon my pillow ...2 the crown? who took it from my pillow? - iv. 4
a good soft pillow for that good white.. Henry $r$. iv. 1 and whispers to his pillow as to him.2 Henry VI. a book of prayers on their pillow... Richard III fair thoughts be your fair pillow! Troilus \& Cress. iii. pluck stout tnen's pillows from. 7 imon of Athens, iv. 3 sloth finds the down pillow hard .. Cymbeline, his dead trunk pillow to our lust. Titus Andron. ii. 3 his loving breast thy pillow ................ a villow for his head

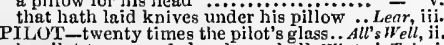
he pilot to ine, and thy places shall. Winler's Tale,
liere I have a pilot's thumb .............. Macbelh, yet Jives our pilot still $\ldots \ldots \ldots \ldots \ldots \ldots \ldots$ Herry $V I$. $v$.

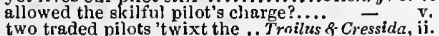
two traded pilots 'twixt the .. Trailus \&-Cressida, ii. 2
think his pilot thought ...... Pericles, jv. 4 (Gower)

thou desperate lillot, now at once .... . . o/hello, ii.

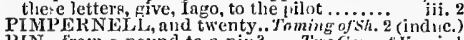
now's not worth a pin
tor

a cod-piece to stick pins on..............
tut, a jinl this shal be............

if you sliould necd a pin

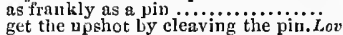

would not care a pin if the ofher.

scrnteh thee but with a pin.............

all eyes blind with the pin and web.

a drop of blood, $a$ piu .........

and with a little pin bores

yojerrors, iv. 3

my wretchedncss, unto a row oi pins - iif. 4

the whole frame stands upon pins

which show like pins' heads to her

pho,pho! come, tell a pin $\cdots$ Troilus \& Cressider iv. the kitchen malkin pins her richest. Coriolanus, numbed and mortified bare arms, pins.... Lear, ii.

let's see; I feel this pin prick

the very pin of his heart cleft ..Romeo \& Jatie', ii.

PIN-BUTTOCK, the quateh-buttock...A. Al'sWell, ii.

but they'll nor pinch, nor finght us..... Tempest, ii. 2

let the supposed fairies pinch
to pinch her by the liand

there pinch the maids as biine

still pinch him to your time

pinch him, fairies (rep.) ...........

or pinch us black and blue ..Comedy of shell, iy.

goorl doctor Pinch, you are no ...... - iv.

you are not Pinch's patient..........

when thou dost pincl thy bearer ..2 2 Henry $I V$. iv.

to fall down with a pinch ...........1 Henry $V I$. iv. 2

as they pinch one another.. Anlony \& Cleopalra, ii.
strokc of deatl is as a iover's pinch..

cannot be a pinch in deatl more ..... Cymbeline, i.

nccessity's sharp pinclit.................. Icar ii. 4

INCliED as thick as honcycombs ...... Tempest, $i$.

thou'rt pinched for't now, Sebastian

I sliall be pinched to death

pinched the lily tincture.. Two Gen. of Verona.

and $\mathrm{I}$ remain a pinched thing Winter's T'cle,

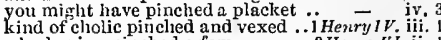

who having pinched a few........... 3 Hemy $r i$. ii.

chance to be pinched with the cholic. Coriolanus,
PINCHES-fill our skins with pinches. Tempest,

whose in ward pinches therefore

and the pox pinches the other ......2 HenryIV. i. 2

with Phobus' amorous pinches ... Anlmny \& Clen. i. 5

in this our pinching cave .......... Cymbrline, iti.

PINCH-SPOTTED make them ........ Tempest, iv.

Your master, Pindarus, in his own .

go, Pindarus, get higher on that hill

with Pindarus his bondman .........

what, Pindarns! where art thou (rep.)

INE - into a cloven pine ............... Tempest,

that made gape the pine

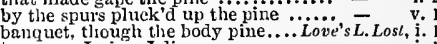

to pomp, I pine, I die................. I burn. I pine, I perisl, 'Tranio .. Taming of Sh. i. I
belind the tuft of pines, I met .. W'inter's i inle, ii. I

sliall he dwindle, peak, and pine........ Macielth i. 3
all which we pine for now ........... ii. 6

all which we pine for now $\ldots \ldots \ldots . . . .$. ichard $I I$. iii.

to Fint castle; there I'll pine away - iii. 2

cold and eickness pines the chine....

thus droops this lof ty pine........2 Henry $V I$. ii. 3

where yonder pine does stand...Antony of Cleo. iv. 10

and this pine is barked, that overtopped - iv. 10

makes both my body pine, and soul ..... Pericles, i. 2

dearth tliat 1 have pined in. Two Gen.of terona, ii. 7

the fool hath much pined away $\dddot{2 . . . . . . . . . ~ L e a r, ~} i .4$

IN FOLD-a pound, a pintold .. Two Gen.ofler. $\mathrm{i}$. I if I had thee in Lipsbury pinfold ......... Lear, ii. 2

wretch, pining and pale before ........ iv. (chorus) sec, tlye pining malady of France ..1 Henry $V I$. iii. 3
PINiON ol lis wing .......Antrny \& Cleopotra, iit, in pinion lim like a thicf, bring him ...... Lear, iii. 7 I will not wait pinioned at your. Antany \& Cleo. v. 2 PINK-Bacchus, with pink eyne ... - is. 7 (snng) PINKED porringer fell off ........... Iterry III. v.

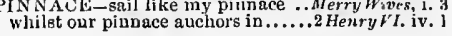




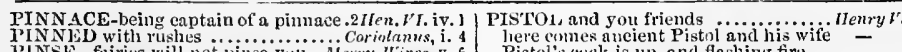

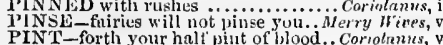
not past a pint, as I an a snldier

PINT-POT; pence, good tiekle-brain.i itemrit: ii. PIONELr-have the twioers giveno . Tempes, iv. a worthy pioneerl once moré remove...llam

if the general camp, pioneers and all ... othello,
PIOUS sir, you will deniand........ Ieas. for.Me in pious rage, the two delinquents..... Macbeth, iii. 6 is received ot the most pious Edward
and is not this course pious? ...... Henry $\bar{F}$ iii. and he whose pious breatlı seeks. Timan of $A$ paid more pious debts to heaven ... Cymbeline, iii. [Col.] plity the pious innocent the first row of the pious chanson devotion's visage, and pious aetion ........ - iii. I
PIP-two and thirty, - a pip out? . . Taming of Sh. i. 2
PIPE is as a maiden's organ ...... Tuelnh Nighl, i. 4 playing on pipes of eorn ........Mid.N.'sDream, shepherds pipe on oaten.......e's L. Last, v. 2 (song)
childish treble, pipes and whistles. As you Like it, ii. 7 dance again atter tabor and pipe. W'inler's T'ale, iv. 3 rumour is a pipe blown by ....2Henryl $V$. (induc.) and split thy brazen pipe ... Tro

when we have stuffed these pipes.

spouting blood in many pipes...

apr pipes tistice.. Tilus Andron. they are not a pipe for fortune's finger. Hamlet, ifi. 2

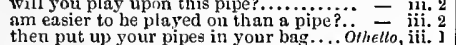

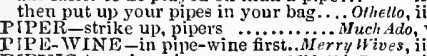

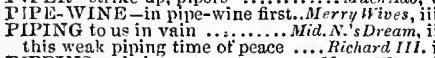
this weak piping time of peace .... Richard III. $\mathrm{i}$.

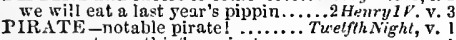
never yet was thief, or pirate......... fike the sanetimonious pirate.... one Ragozine, a most notorious pirate $\overline{\text { I mean pirates; and then, there... Mer.of } \bar{v} \text { enic }}$ pirates mav make eheap ............2Herry $\nu^{\prime} L_{i .1} .1$ Bargulus the strong Inyrian pirate. and boarded with a pirate.

you wrangling pirates, that fail out.ikichard $I I I$. famous pirates, make the sea rid all the sea of pirates or that these pirates, (not enoul...... Pericles, iv. a erew of pirates eane and resened m...

a pirate of very warlike ....... Hamlet, iv. 6 (letter) PISA, renowned for grave citizens.. Taming of $\$ h$, $i$. Neapoitan, or mean man of Pisa..... of Pisa, sir; son to Vincentio (rep.).

Vincentio of Pisa (rep, iii. 2$) \ldots . .$.
ever been at Pisa? Ay, sir (rep.)

ever been at Pisa? Ay, sir (rep.)

come, sir; we'll better it in Pisa ....

his fatlier is come from Pisa (rep.).

how WO, when shall we hear......... Cymbeline, $\mathrm{i}$.

fure thee well, Pisanio
what ho, Pisanio! (rep.)

how now, Pisanio? (rep. iii. 2 )

hear'st thou, Pisanio? he is at MLiliord

true Pisanio, (who long'st, like me.
Pisaniot man! where is Posthumus?

thy mistress, Pisanio, hath played

that part, thon, Pisanio, must aet
that man of hers, Pisanio, her old

Pisanio, thou that stand'st so for

rom the mountaiu top Pisanio s.
if Pisanio lave mapped it truly...
Pisanio, I'll now taste of thy dru

Pisanio, I'll now taste of thy drug

Pisanio hath with his forged letters

Pisanio might have killed the

this is Pisanio's deed, and Cloten:-

Of Pisanio! every good servant does

if Pisanio have, said she, given his ... ${ }_{\text {Puch }}$ Ado

TIS.M IRE-stung with pismires ....... HenryIV

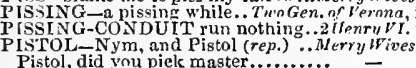

is this true, Pistol?

no quips now, Pistol $\ldots \ldots \ldots . . . .$.

nistol him, pistol him............. Tüelflh $\overline{\text { Nigh }}$ and with his pistol kills a sparrow... IJenry and take my pistol, if thou wilt.......
ancient Pistol's below (rep.)
Pistol. No, good captain Pisto........

Pistol, be quiet. Sweet knight

how sir John, I am thy Pistol and thy triendthen Pistol, lay thy head in Furies' lap when Pistol lies, do this; and fig me Pistol, I will double-charge thee with that : away, Bardolph: come, Plst cime here, Pistol, stand behind me. Pistol speaks nanght but truth B....̈̈lph -

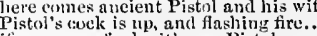
if you grow loul with me, Pistol
mine host Pistol, you must eome...
for Pistol, he hatli a killing tongue.
lee is ealled, ancient Pistol (rep.)...
my name is Pistul ealled. It sorts we
Got bless you, aneient Pistol, you seu.

PISTOI,PROOF, sir; you shall........ PenryIV. Pericles,

are all couehed in a pit hard by ... Merry wives, $\mathrm{v}$.

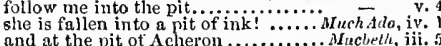

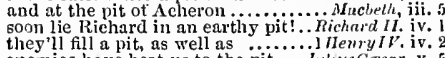
they'll fill a pit, as well as .......J Jemrytt. iv. slowed me this abhorred pit

gome loathsome pit (rep. ii. 4)
detested, dark, blood-drinking pit

show the ragged entrails of this pit

the swallowing womb of this deep pit

this is the pit, and this the elder tree

drag them trom the pit unto the prison -
what, are they in this pit? 0 wondrous

what, are they in this pit? $O$ wond
there is the sulphurous pit, burning

and grace to the profoundest pit!.
a pit of elay for to be made (rep.)

piteh me i' the mire

the savour of tar nor of piteh.....

of what validity and pitch soever. Tuelfin Night,
and piteh our evils there?

they that trueh piteh will be defiled. Huch delo.iii.

with two pitch balls stuck in .. Love

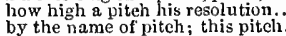

by the name of piteh; this pital

Richard ll.

such a spneious loft $y$ pitch...........
hawlss, which flies the higher piteh.

shall piteh a field, when we are dead

and what a pitch she fiew above....

as, like to piteh, defile nobility

here pirch our battle, henee...

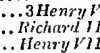

into what pitcli he please .....

Henry V711. ii

mistress, and mount her piteh ...TitusAudron, ii.

I eanuot bound a piteh above .. Romeo of Juliel, i. 4
so will I turn her virtue into piteh ..... Othello, ii. 3

PITCIIED-have pitched a toil ... Lave's L. Last, iv.
have I not in a pitehed battie .... Taming of Sh.

have I not in a pitehed batt

there are squiadrons pitched...

loss of some pitched battle.......... Inenry $I^{\prime} I$. jv. 4 PITCIIERS have ears ........ Taming of Shrew, iv. 4

with the child. Pitehers have ears . A All's $H^{\prime} e t l$, iv. 4

whose pitehy mantle over-veiled

PITE, I pray you; it is goot for .......
PITEOUS-tell Jour piteous heart.

Winter's Tale, ii.

the most piteous ery of the poor sonls! - iii. 3
piteous plainings of the pretty babes. Com. of Err. $\mathrm{i}$.

or piteous they will look lit was a piteous deed

l Heury Vi. i.

O pitenus spectacle! o bloody times! ${ }^{3 \text { Henry }}$ - ii.

hear the piteous moan that Kutland

O piteous spectacle! O noble Casar!.Jut.Crsar, iii.

told the most piteous tale of Lear ........Leur, v.

a piteous eorse, a bloody piteous eorse - iii. 2

true ground of all these piteous woes

with a look so piteous in purport .......

lest, with this piteous action, you ...... - iii. $)$

PTTEOUSI Y -pr'ythee, piteously.Aniany \& Cleo.iv.il

to hear, yet piteously performed.. Tilus Andron.
PITE PITF A LL, nor the gin ................... Mrcbeth,

marked not what's the pith of all. Taming of sh. i. I
or not arrived to, pith ......... Henry $V$. ili. (cliorus)

or not arrived to, pith ........ Henry

the pith and marrow of our attribute

Hamlel, $\mathrm{i}$.

let it feed even on the pith of life.

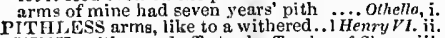

PITIIY - pithy, nnd effeetual.. Taming of Shrert.

PITIED ayez pitie de moy $\ldots \ldots \ldots$ ma
PITI

Tempest, $\mathrm{i}$.

know how far I may he pitied...

better than to be pitied of thee
Dunean was pitied ot Maebeth

barbarism itself have pitied him

All's Well, y.

a woman to be pitied much ..........3 Herry VI, iii.

Macbeth, iii.

v. 3 but all was either pitied in him ...Henry VIIt. ii.

freshly pitied in our memorien .......

your plight is pitied of him . Antony \& Cleapatra,

our name, are therefore to be pitied ...

neighboured, pitied, and relieved ........... Lear, i.

hath pitied, no blown ambition............. ivear, i. his innoeent nose in piteous ehase.

piteous plainings of the pretty babes.

his piteous and unpitied end

be lamented, pitied, and exeused
what 'tis to pity, and be pitied.
PITIED_her mood will needs be pitied. Humtet, 1 . 5 PlTILD'S-thou pitied'st Rutland.3Henry VI. ii.
PITIES-U, ay; and pities them. TwoGen. of Ver. $\mathrm{Y}$. perchance, shall dry your pities.. Winter's Tale, What beggar pities not? ............Richard 11 if any power pities wretehed tears...TitusAnc. iii. liere's a night pities neither wise men ... $\overrightarrow{\text { Lear, iij. }}$ PITIF UL-be a pitiful lady ........Merry Wives, iit. 3 how pitiful I deserve ............... Much Ado, v. 2 (song)

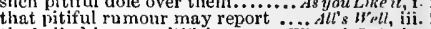
the ballad is very pititul .......... Winter's Tale, iv. though my case be a pitiful on

seart up the tender eye of pitiful day. Macbeth, iii. good ground, be pitiful, and hurt ... King John , iv. fur a pitiful bald erown! but now... Richari I. v. $\boldsymbol{X}$ did never see suel pitiful rascals "... $-{ }^{-}$iv. 2 with the pitiful complaints...... - iv. 1 (letter soft, mild, pitiful, and inflexible....3 Henry ${ }^{2}$. i. be pitiful, dread lord, ald graut .....
or Ed ward's soft and pitiful........ iii. $\mathrm{i}$. where he meant to ruin, pitiful . Henry I'III. T. you see not they are pitiful...... JulinesCesar, 11 i. you see not, they are pitiful......JulinesCasar, li. be pitiful to my condernned sons...

a sight most pitiful in the meanest...

roul lnow this is a pitiful ease. Rome.... Lear, iv. 6 yoll know, this is a pitiful case. Romea \& Juliet, iv. 5 and shows a most pitiful ambition.... Hamlet, iii. 'twas pitiful, 't was wondrous pitiful..... Othello, i.

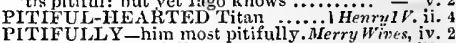
are great, be pitifully good.... Timon of Alhens, iii. pitifully disaster the cheeks ......Antony \& Cleo. ii. 7
they are so pitifullity sodden $\ldots . .$. ....Pcricles, iv. PITILESS-be prond and pitiless? As you Like $i$, iii. a fairy, pitiless, and rough .. Comedy of Errors, iv. bide the pelting ot this pitiless storm..... Lear, iii. 4 PITTANCE-and slender pittanee. Taming of Sh, iv. PITTIKINS-od's pittikins! ean it be.Cymbeline, iv. 2 to the wind, whose pity, sighing baik... pity more my father to be inclined...

sir, have pity ....................... $\overline{\text { no }} \overline{\text { in }}$ i. pity the deanth that I pity mitch your grievances...........

tis pity, love should be so contrary.

why do I pity him that..............

I will not say, pity me.....Merry ivives, ii. I (letter) but you should pity me........ Tuelfih Night an we do not, it is pity of our lives.

that very of $\ldots$ we pity enemies ..........

there will be pity taken on you... Meas. for Meas

yet show some pity

for then I pity those I do not know

tis pity of him .......................

one has my pity; not a jot the other -

tliey seem to pity the lady

or else it were pity but they should...

1 take thee for pity.................. - iii. 3 it were pity of my life (rep. v. I) .... the more the pity. that some lionest
this you should pity, rather than

if you have any pity, grace, or manners beshrew my heart, but I pity the min 然

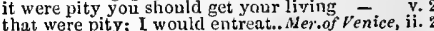
uncapable of pity, void and empty.. - iv. glancing an eye of pity on his $\ldots \ldots . .$. you $\overline{\text { ikke }}$ it, the more pity, that fools may not.. As you Lit and pity her for her good father's sake to the people, and they pity her $\ldots \ldots$ fair sir, I pity her, nltd wisl for lier drops that sacred pity hath engendered though it be pity to see sueh ........

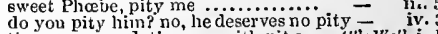
there commendations go with pity....A $A l l_{s}{ }^{2} \mathrm{Well}, \mathrm{i}$. otlien give pity to her, whose stats without all terms of pity: speak .... tis pity, he is not honest .............

I do pity his distress in my smiles ... ... $\quad \mathrm{v}$. tis pity, or I die .. Trming.of Shrew, iii. I gamnit have dnne like offices of pity ........ - ii. yet with eyes of pity, not reveugei... - iii. 2 tis pity slue laeks instrictious ........ though it be great pity, yet it is

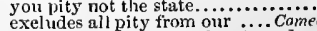

for we man pity, though not pardon

he, sir, that takes pity on decayed

tis pity, that thou livest .............. Macbeth, $\mathrm{i}$. 
IITY - than pity for mi schancel ........Mnrheth, iii. A IITY ING my father's loss.

of solt petitions, pity, and remorse... King $J_{0} / \mathrm{h}$, i

is't not pity, $O$ my gricverl friends!

is't not pity, $O$ my gricverl fricnds!..
to pity him, bereft and gelded of.... Riehard II. 1i.
O1 what pity is it, that he ..........

slowing an outward pity......

that you in pity may dissolve

sneak with me, pity me

let pity teach thee how...

pity may move thee pardon to........

lighing, I should pity him

old (the more the pity), his white...

in kind heart and pity

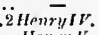

ake pity of your town .................

where (O for pityl) we shall much - iv. (chorus)

pity the eity of London, pity usi

too full of foolish pit

hope you are not void of pity.

Iweet clifford pity mel pit pity

harmful pity. mnst be laid aside.

were it not pity, that this goodly...

in pity to the gentle king,.............

not jity; for, at their hands (rep.)

twere pity, they should lose their

not that I pity Henry's misery.

my pity hath been balm to heal

more pity, that the eagle should...... Riehard III. i. i

but knows some touch of pity

may move your hearts to pity

adien; I pity thy complaining .......

pity, you ancient stones, those tender

tear-talling pity dwells not in
it I die, no soul will pity me.

find in myself no pity to myself ...

those, that can pity, here may ...Henry VIII. (prol.)

$U$ this is full of pity.

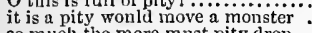

so much the more must pity drop

and to bestow your pity on me......

where no pity, nn friends.

out of holy pity (rep.)

would have soine pity upon my...

as I shall pity, I conld help! Troilus \& Cressida, iv. 3

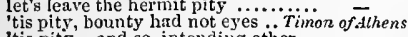

'tis pity, -and so, intending other

for pity is the virtue of the law

pity not honoured age for livis.

within the leaf of pity writ.....

pity sleeping: strange times........

sou might leave pricking it for pity. Coriolanus,

and wrath o'erwhelmed iny pity ....

banish him, I said, 'twas pity.

his injury the gaoler to his pity.....

rather than pity note how
than pity to our prayers

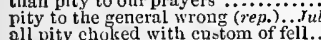

all pity choked with custom of fell.

I pereeive, you feel the dint of

it is pity of him.........................
pity me, Cliarmian, but do not

pity me, Cliarmian, but do not .......

he does pity, as constrained...........

our care and pity is so much

it haul been prty, youl shoutu iave.... Cynbeline,

bound to nity too. What do you pity

in the, deserves your pity? (rep.)....

took pity from most true.......

as snull a drop of pity as......

a thing of pity 1 Great nature..........

'tis pity, they shonld take him for.. Titus And. ii. 3

entreat her show a woman pity

the lion, moved with pity ..........

bootless to them, they'd not pity me

cavoid of pity. and, being so (rep.) ...

entreats you pity him,; he asks..........
now, by the gods, I pity his misfortune

nor let pity, which even women have cost

makes pity in your lovers (rep.)
their leave that I miglit pity him

their leave that I might pity him ......
O pityl sir, where is the patience now

who is too ginod to pity thee

fools do those villains pity
let pity not be belicved!

in pity of his misery, to despateh.

am pregnant to good pity...........

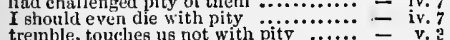

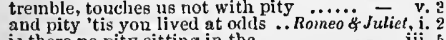

is there no pity sitting in the ............ Framlet,

tis pity, and pity 'tis, 'tis true...

and the more pity; that great fulks
I loved her, that she did pity them

二 ii. 2

and tis great pity, that the noble ilior - ii.

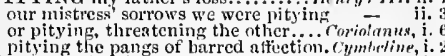

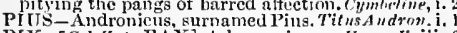

PIX $-[C o l . K n t .-\mathrm{PAX}]$ stolen a pix ..... Hewry $V$. iii.

PIZZLE-neat's tongue buil's pizzle.i $\|_{\text {enry }}$ rV. ii.

barren place, and fertile

or that we quit this place
the most opportune place

here, to this place (rep.).......

enforce them to this place

you an officer fit for the place... Tüo $\ddot{G} e n$ of $\bar{\nu}_{\text {rer. }}$ i. 2

never welcome to a place $\ldots$ it for her chief virtue

hangman's boys in the market-place $\overrightarrow{\text { nace }} \overrightarrow{\text { Wive }}$

appointed

by mistaking the place where I

yet, in other places, she enlargeth

I never lieard a man of his plaee....

at de place $I$ did appoint?

this is the place appointed ............

I will searcl impossible places......

for the remembrance of such places..
hours travel from this very place. Tuelfih $\mathbf{N i g h t}$ iv. $\mathrm{i} .2$

give us the place alone $\ldots$

let all tlie rest give place

say, my love can give no place.

jurt him in eleven ptaces

if I be lapsed in this place $\ldots \ldots \ldots \ldots . . . . . .$.

into the bottom of my place .......... Jeas. jir Mileas.

though you change your place .......
whether the tyranny be in his place

whether the tyranny be in his place
my absolute power and place here in

ho! peace be in this placel

a novice of this place, and the

time cohered with place, or place with

how long have you been in this place

or give up your place.

O place! o form! how often

or own great place, eould tetch your

and the place answer to converience

your appointment, go in your place

at that place call upon me

$O$ place and greatness, millions of

your provost knows the place where he

respect to your great place

here's one in place I cannot pardou

employ thee in a worthier place

here's no place for you maids

dost thou not suspect my place?

to that place the sliarp $($ rop.)......... Hid.

Lysander and myself will fly this place

what worser place can I beg (rep.).

a marvellous convenient place for
but $I$ will not stir from this place

but $I$ will not stir from this place
these lovers seek a place to fight

shifting every place, and dar'

and take your places, ladies ........

will we sing, and bless this place.

wit in his place and time........... Love's $\bar{L}$. Lost

then for the place where (rep.).....

melancholy, valonr gives thee place

trusted, nor to one place ..... Nerehanto

in such a place. surch sum, or sums....

misconstrued in the place I go to...

in place of call the place.

that stand in better place, garnished

give him conrteons conduct to this

you are welcome; take your place..

bars me the place of a brother $\ldots . . .1$ s you Like

I fill up a place, wlicil may be better -

counsel you to leave this place.....

to the which place a poor sequestered

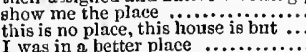

I was in a better place ...............

I like this place, and willingly conld

he hath strange places craminge
are you native of this place?

in this place of the forest....

west of this place, down in ..........

how I came into that desert place.

that they take place, wher virtures of another place

I fill a place, I know't .................

why, what place make you special ..

you know your places well

that time and place, with this decei

confirined by the rector ot the pluee.

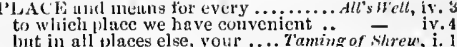

us $y$ murself were still in place....... - i.

shall supply the bridegroom's place..

in low miry a place

and I lad thee in pince where, thou.

and place your hands below your....

and thy places shall still neiglitour.

I'll not call a creature of thy ploce.

to some remote and desert place.... - ii. 3

urried here to this place........... - iii. 2

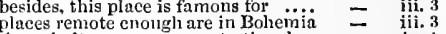

thou shalt accompany as to the place - iv. I

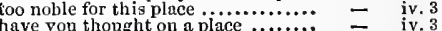

the place of your dwelling $\ldots . . . . . . .$.
let's from this place: what? look upon $=\quad$ iv. 3
v. 3

or any place that harbours men.. Cornedy of Err. i. 1

in whiat safe place you have bestowed

I'll meet you at that place ...........

the place of death and sorry

assembled in this place, that by....

where the place? Upon the heath...

and you whose places are the nearest

bring these daggers from the place?.

but this place is too cold for hell

to gain our place [Col. Knt.-peace]

here is a place reserved, sir .........

in a place from whence himself ....

in measure, time, and place...

stands upon a slippery place

all places that the eye of heaven

o drop them still upon one place...

hele in this place, I'll set.......... - iil. 4

i. 5 choose out some secret place …...... $\begin{aligned} & \text { - } \\ & \text { ii. }\end{aligned}$

2 and in such a place, at such a time.. -

what do you call the place?..........

and thy place shall be honourable

current in this place dammed up

thy place in council thon hast
but a braver place in my heart'

when yet you werc in place...

and he holds his place.....

or it will seek me in another place...........

or it will seek me in another place
or to the place of difference call......

misuse the reverence of your place.

the dungeon your place,--a place deep

thou hast a better place in his affeciion

immediate from thy place and blood

your highness pleased to forget my place

that misbecame my place, my person - v.

ii. 2 anglit else but place, degree, and form

will it give place to flexure and low.

now in London place him .........

it was in a place where I could not.
not the gift to woo in other places...

that follows our places, stops the ...

each lath his place and function .....

to earry thee ont of this place .......
draw, men, for all this privileged place

where is best place to make our......

sirs, take your places, and be vigilant
gome place bnt weakly guarded.....

gome place bnt weakly guarded......
he bears him on the place's privilege

long continuance in a settled place.

this place cnmmands my patience $\ddot{1}$

be wary how you place your words..

set thy statue in some hol pllace.

France were no place for Henry's

my cornets-were in Talbot's placei.

place barrels of pitch upon the ...

\begin{tabular}{l|l} 
i. 2 & greatness of his place be grief to us... \\
ii. 1 & it' Somerset be puworthy of the place
\end{tabular}

ii. 1 his pleasure, will resign my place ..

though in this place most mast

if I be appointed for the place.
combat, in convenient place

unto the place of exeeution...........

as place anke Humphrey for the king's -

rain of heaven wet this place $\ldots . . . . .$.

no home, no place to fly to

give place, by heaven, thou shalt....

rear it in the place vonr father's

thy place is filled, thy sceptre

i. 2 and support king Edward s place....
ii. 2 their rooms, ere I can place myseif.

ii. 3 heard, that she was there in place...

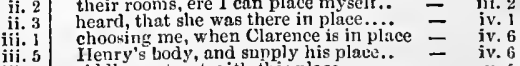

Henry's body, and supply his place.. - $\quad$ iv. 6

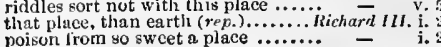




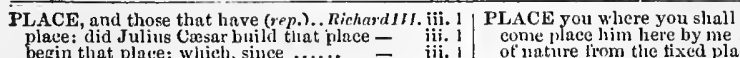

thou didst usurp iny pluce, and dust

his mind and place infecting one

arise, aud take place hy us

place you that side, I'li take

more worthy tlis place than myseif

not be so sick thongh, tor his place.

in this man's place before him?

murmurers, there's places of rebuke.

most couvenicnt place that I can think of -

jou sign your place and ealling.

alas! our places, the way ot 0
for if I did take place, I do.......

with the place and honours...........

chosen lord chancellor in your pl

suffer a man of his place, and so near

private conseience, and his place .....

once think his place becomes thee
is this a place to roar in?
I made good my place; at lengti.

here, here's an excellent place...
mighty for thy place and sway.

mighty for thy place and sway

priority, and place, insistu
stand in authentic place?

stand in autlentic place?

they place betore his hand

to warrant in our native placel.
move the question of our place

move the question of our place.

keeps place with thought..............

privileged by my plnce, and me

this place is dangerous; the time right

that might have known my place
the plice, which $I$ have feasted

your diet shall be in all places alike

ere we can agree upon the first place
place thieves, and give them title...

why this spade? this place?

took note of the place, it canuot...

by all description this should be the place -

in these several places of the city .... Coriolan

than by a place below the first

nay, keep your place

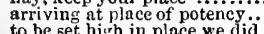

to be set hirh in place we did

all places yield to him ere he sits

in every place, save here in Italy ...Julius $\bar{C}$ c

by the right and virtue of my pl

but one in all doth hold his place

so please him come unto this

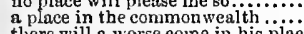

there will a worse come in his place..

Tre'll burn his boriy in the holy plate

if you give place to accident
ot force, give place to better

content to visit other places

to such whose place is under us......... $\overline{\text { intony }} \&$

the while, I'll place you .....

from which place, we may the number

earns a place $i^{\prime}$ the story ...............

his lips on that unwortiy place........................

shall hang in what place you please $-\bar{r}$

that it is place, which lessens ........

this place? mine action, and thine own?

glad you think of other place

I am near to the place where they

in this place re left them

distinction of place tween high and low -

he would change places witl his officer -

vias wife to your place $\ldots \ldots \ldots \ldots \ldots$.

to attain in suit the place of his bed.

nor the time, nor place, will serve....
he would have well becomed this place

till from forth this place I lead.... Titus
wonld voueh't in any place but liere

wonld voueb't in any place but liese
have'ticed me hither to this place

own hands kill me in this place.

a very fatal place it seems to me

ny, such a place there is, where we

draw nigh, and take your places

to place upon the volume of your deeds. Pericte

so your are, here take your place

gir, yond's your place ........................

heart and place of general wonder
in such a place as this, she being once gone

this house to be a place of such resort

and are the governor of this place.

bring me to some private place
free from this unhallowed place

thnn hold'st a place. for wlich

iv. 4

ot nature trom the tixed place

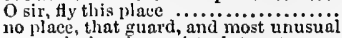

so much thy place nistook to set
cre I was risen trom the place thit

to no more will $\mathbf{I}$ give place, or notice...

here is the place, ny lord.

man of justice, take thy place.

ii. 2 corruption in the placel fialse justicer.....

come on, sir; here's the place.

ii. 2 change places; and handy-dandy

ii. 2 supply the platec for your hatout

I amply the platec for your labour - i

my brother's way to the torefended place?

her father, requires a fitter place

iii. 2 youth, place, and emineuce, despite...

the dark and vicious place where tlee...

and the place death, considering who

withlulraw into some privatc place...

to lie discoloured by this place ot peace?

this is the place, there, where the toreh
as the time and place doth make against

from Mantua, to this same place .....

aet and place [Knt.-sect and torce] may.. Hamlet, i. 3

the very place puts toys of desper
by time, by meaos, and place

ii. 3
ii. 3
iii 3 will but be idle; get you a place...............

\begin{tabular}{l|l} 
iii. 3 & will but skin and film the ulcerous \\
iii. 3 & bestow this place on us a little while
\end{tabular}

seek him i' the other place yourself

in many places gives me superfluous deatl - iv. 5

no place, indeed, should murde

and my place, have in them power

not meet, nor wholesome to my place...
neitiner my place, nor aught I heard of.

conduct them, you best know the place

due reference of place, and exhibition

to get his place, and to plume up my w

Moor should hazard such a place, as his

forgot all sense of place and duty

to give place to the devil, wrath

I will ask him for my place again

she'll help to pit you in your place again

I give thee warrant of thy place

though it be fit that Cassio have liis piace

she haunts me in every place.

[ Knt.] found in some place of my soul

what place? what time? what form? ...

\section{lace, the torture}

be placed in contempt

planted, and placed, and possessed... Much

had been placed about thy thoughts

she be placed in my constant ..Mer. of Fenice, ii. 6
upon my head they placed a fruitless. Mucbelh, iii.

if every owner were well placed.
well placed; there stands your

in the vaward, (placed behind

ordnance gainst it I have placed

words sweetly placed, and modestly.

were placed the heads of Wirliam

placed a quire of such enticing birds

archers shall be placed in the midst. Richard III. v.

two women placed together makes ...Herry $V I I$. i.

alas, are placed too late ...... Timon of Alhens, iv. 3

my resolution's placed....... Antony \& Cleopatra, v.

hath placed me here within this ...... Pericles, iv. 6

I'll be placed, so please you, in

on a stage he placed to the view

PLACEN TIO, and his lovely. Romeo \& Jul. i. 2 (note)

PLACING therein some expert

the placing of the British crown
PLACK prince of Wales

i Henry VI. iii.

as ever his plack shoe trod upon

Henry $V$. iv. 5

PLACKET-prince of plackets .. Zove's L. Lnst, ivi.

you might have pinched a placket

on those that war for a placket. Troilus \& Cress. ii. 3

PLAGUE-a plague upon this howling 1 Tempest, i. 1

a plague upon the tyra

I will plague them all ...

still reward with plagues ...Two Gen.... of Verona, iv. 3

a plasue o' these pickle-herrings! ... -

sa quickly may one cs tch the plagie

plarue on 't; an' I thourlt he ...... Much $\overline{\text { Ado, ii. } 3}$ ii.

plague right well prevented! ..........

may prove plagues to men forsworn

thus pour the stars down plagues for

they have the plague, and caught it - v.

in my love thus plagues itself .........All's Well,

'twas pretty, though a plague.

a plague of all drums! only to seem your place?

our nature nor our place can bear
I would prefer him to a better plue
PLAGUE-to plaguc the inventor ........Macbeth, i. 7

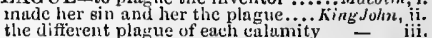
plague injustice with the pains.... Richard 11 . $\mathrm{iii}$ what a plague have I to do with ..... HenryIV. $\mathrm{j}$. a platrue upon't: it is in Glocestershirc -

Poins Ilal! a plague upon you both!

plague upon't, when the ves camnot
what a flugre mean ye, to colt methus? -

a plague of all cowards, I say.

a plague of sighing and griet $\mathrm{i} . \ldots . . .6$.

a plarue on ny bringing upl.

a plague upon it! I have forgot.

shail breed a plague in France ....... Henry $y^{\prime}$ iv.

or we will plague thee with .........

plague thee for thy foul misleading 3 Henry VI. $v$.

I'll plague you for that word (rep.). kichard 11 . i.

have any gricvous plague in store $\ddot{H e n r y} \bar{Y} I I I$, iii.

$O$ gods, how do you plague me! Trailus \& Cress i

what plagues? and what portents?.

the plague of Greece upon thee.....

a plague upon Antenor! (rep.).......

but a plague break thy neck ......... -

let your briet plagues be mercy.....

plingues, incident to men $\ldots . . . . . . .$.
the gods plague thee, for thou art...

be as a planetary plague, when Jove

plague ull; that your activity may.

plague of company light upon thee $i$

for aye be crowned with plagues

would send them baek tlie plague

amiss, plague and intectiou ment!
plague consume you wieked caitiffs

plague consume you wicked caitifs - v. 5 (e)

a plague! Tribunes for them $1 . . . .$.

the hus sir, - Plague upon't].

and the gods will plague the

intermit the plague that needs must.julius casar, $^{\mathrm{i}}$.

very devils cannot placruc them hetter

a plague on them, they ne'er come .... Pericles, ii.

stand in the plague of custom ............... Lear, i.

a playne upon your epilcptic visage! $\ldots .$. - ii.

now, all the plagues tinat in ...............

thou whom the heaven's plagues liave

[Col. $\mathrm{Kn}$ t.] make instruments to plague

a plague upon you, murderers, traitors

a playue o' both the houses! (rcp)

Ingive thee this plague for thy dow'y. Iamlet

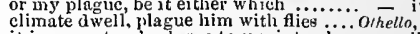

it is my nature's plague to spy into abuses -
yet, 'tis the plague of great ones .........

then this torked plague is fated to us.....

as 'tis the str'umpet's plague, to beguile.. - iv. hath plagued tlyy bloody deed.......... King Joh John, ii. do coine:-I shall be plagued. Troilus \& Cressinla, $y$ PLAGUE-SORE, an einbossed carbuncle.. Lear, ii.
PLAGUING mischief light on ......1 Herry PLAGUY - he is so plaguy proud. Troilus \& $\mathrm{c}$ ress. $\mathrm{i}$ one of them is a plain fish may appear plain and free.. TwoGen. of Verona, v.

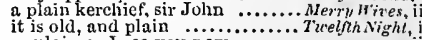
as plain as I see yor now.................. - iii.

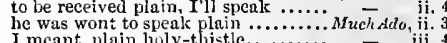
I mcant, plain looly-thistle.

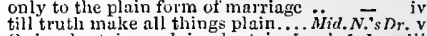
$O$ sir, plantain, a plain plantain. Love's L. Losl, to make plain some obscure

to tell you plain, l'll find.......

have worn plain statute-caps

and to confirm it pluin, you gave

my

Judas Naccabæus clipt, is plain jüdas

in plain terms, gone to hieaven

I was always plain with you

understand a plain man in his plain

with anl brief and plain conveniency

me why is plain as way to parish. As you Like it, it.

but the plain single vow ...............
if it appear not plain, and prove untrue

not these words vluill,-sirrah.... Taming of $S h$. i.

I'll tell her plain, she sings as

thus in plain te

and, to be plain, I think, there is. Winter's $T$.

we are but plain fellows, sir...

as plain as the plain bald pate

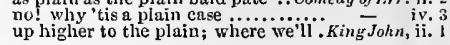


PL.AIN cannon, fire, ancl smoke...... King Jahn, ii. 2 PLANET-the planets, and this. Trailus \& Cress. i. 3 face of plain old torm is mueh

upon the grussy earpet of this ploing. Richard 11 . .ii.

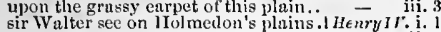

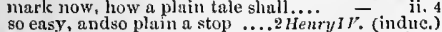
so easy, andso plan a stop

it is pluin pocketing up of wrongs..... Henry $r$. iv. larding the pluin: and by his bloody

but in plain shoek, aud even play of
thou wouldst find me such a plain king -

I spenk to thee plain soldier..........

take a fellow of plain and uneoined.. -

which is so plain, that Faxeter doth.1 Ilenry $I^{\prime} I$. ii

no more but, plain and bluntl

for, to be plain, thes, knowing ......2 Ht
glall he be upon the sandy plains $(r e p$.

what plain procecedings are more plain

be plain, queen Margaret, and tell.

simple, pluin Clarenee! I do love .. Richnrd HI.

but the plain rlevil, and dissembling

cannot a plain man live

ghall I be plain! I wish................

plain, and not honest, is too harsh

lead fortl? my soldiers to the plain ...

a sectary, that's the plain truth.... ilenry $1 \% 1, \mathrm{v}$.

his branehes to all the pleins about $\operatorname{lnim}-$. v.

lollow upon this plain, so many

ny, ay, ay; 'tis too plain a euse.
is, plain and true, there's all the

pight upon our Plirygian plains....$=$ = v. il

a ple plain way of his merit ...... Cariolanus, iij.

a plain blunt man, that love ....Julius Cesar, iit. 2

no trieks in plain and simple faith ${ }_{\text {run like swallows o'er the plain . Titus Antran. ii. } 2}^{2}$

this sandy plot is plain

thy pen to print thy sorrows plain $: .$.
dumb in show, I'll plain with... Pericles, iii. (Gow.)

dumb in show, I'll plain with... Pericles, iii. (Gow.)

and deliver a piain nessage bluntiy.

if I had you upon Sarum plain.

and plain,-lie must speak trutli (rep.

in a plain aceent, was a plain knave

sorrow, the king hath cause

Cheill be plain with you ...............

I would good son, and homely . Rameo s.tuliet, it.

knavery's plain face is never seen.....

PLAIN-DEALERS without wit.. Camedy af Err. ii. 2 now to plain-dealing .................... Ane's L. Los', iv. 3

like an honest plain-dealing man?.2 Henry $V$. iv.

PLALNER and simpler kind ...

tollow me then to plainer ground $\mathrm{Wid}$.

the plainer dealer, the sooner ... Comedly of Er

I took him for the plainest.

PLAININGS of the pretty babes... Comedy of Err. $i$.

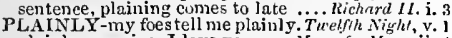

plainly coneeive, I love you .... Meas. for Meas. ii. 4

tell them plainly, he is Snug...Nid. N.'s Dream,

plainly give yon out an unstained. Wireler's 'Tale, iv.

nay, he struek so plainly, 1 eould. Comedy of Err. ii. 1

and tongues of heaven, plainly $\ldots$ King John, iii. 4

liear me more plainly, I lave in equal

and plainly say, our mettle is bred .Henry $y$. iii.

plainly signified. that $Y$ slinkuld snarl

[Col.Knt.] jeinly to her tell my joving

lets them plainly see't............. Cor

how plainly I have borme this busines
and, to deal plainly, I fear, I am not.

plaiuly know, my heart's dear .. Rnnea 8 . Lerr, iv. 7

PLA INNESS [Col. Knt.-paleness] Mer. of Fenice, iit. 2
and now in plainness do confess.. Taming of Sh. i. 1

your plainness, and your shortmess

rank and wet aneurbed plainness ... Henry $r . i$.

the truth and planness of the ease... Henry

plainness, and thy housekeeping ..2 Henry VI, i.
with truth and plainness I do.. Truilus ó Cress. iv.

enjoy thy plainaess, it nothing... Antouy \&-Cleo. ii.

which she ealls plaimness, marry her

to plainness lionour's bound, wlien majesty -
which in this plainness harbour more erutt

in honest plainness iliou hast hearl me. Othella, $i$.

PLAIN-SONG cuckoo grey...Mid.N.Dr. iii. I (song)

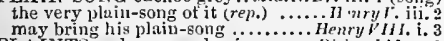

PLAINTS and prayers do pieree...... Richard II. v.

bootless are plaints, and enreless ...3Hchry 7 I. ii.

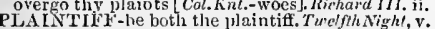

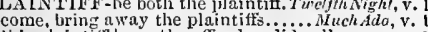

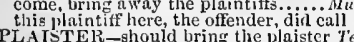

and let him lave some platse plaister 'T'empest, ii. 1 seek a plaister by contemned .......King John, v. PLAITS the manes of horses........Rame \& Juliei, i.

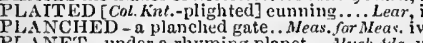
PIANE' $\Gamma$ - under a rlyming planet ...MuchAdo, $v$ there's some ill planet reigns ........... combat with adverse planets in the... - i. i. ruled, like a wandering planet ....2IIenry 1 I. iv. 4 therefore is the grlorions planet, Sol

strizek Corioli, like a plinet.

moon no planet is of millc

some planet strike me down. Tilus Andronicns,

then no planets strike, no fairy takes ...Ilamlet,

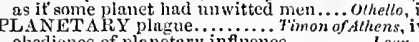

PLedience of planetary influenec......... Le

trust not to rotten planks... Antouny \& Cleopatra, iii

I will plant you two, and iet.

barren plants are set before us ....Lave's L. Lost,

and plant in tyrants mild humility .. $\overrightarrow{\text { iv. }}$

it is in us to plant thine honour.......All's Well, ii. 3

plant and o'erwlielm enstom.

advise you where to plant yourselves - i would the plants thon graft'st ... Richard $1 I$. iii.

I would the plants thon graft'st ... Kickard II. iii. 4

heart plant thou thine ear.

and plant this thorn, this eanker

conjunetion plant neigh bourlioo

I'll plant Plantagenet, root him

his may plant comrage in the

and plant your joys in living....... Richard III. ii.

stoek graft witli ignoble plants.

hut we will plant some other in

musie, plants, and flowers... Menry ïill. iii. 1 (song)

under his own vine, what he plants.. - y.

he watered his new plants with...... - y - y. 5

how dare the plants look np to heaven. Pericles, i. 2
conld never p!ant in me................... Lenr, i.

in herbs, plants, stones ..................... Lener, i. I

PLANTAGENE', lays most lawful... King Johi,

I come one way of the Pluntagenets

Perey, his-Plantagenet!........... Herery IV. i. 1

and Henry Plantagenet is thine ...... Henry V. v.

this white rose, with Plantagenet

ho, Plantagenet; tis not for tear .....
where not thy rose a thorn, Plantagenet?
where fantagenet dare not be seen

where false Plantagenet dare not be se
thy seorns this way, Plantagenet....

in honour of a true Plantazenet

Plantagenet, I see, must hold his.

in the right of Rieliard Plantagenet
rise. Richard, like a true Plautagenet

rise. Richard, like a true Plautagenet - iii.

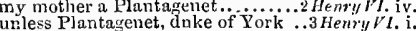

I'll plant Plaotagenet, ront him up.. -

Plantagenet shall speak first .........

Richard Plantagenet, enjoy the kingdom -

Plantagenet. embrace him. And lo

yield to our merey, proud Plantngenet

that great Plantagenet is erowned o -

that Plantagenet, which held thee

Edward Plantagenet, arise a kuight
deaths of these Plantagenets .......Richark 111.

name him. Planticreuct

brave Plantagenet, that prineely novice -

my niece Plantagenet led in the hand of -

Edward Plantagenct, why art (rep.)
and little Ned Plantagenet, his son

your plantain leat is exeellent ... Romeo \&. Juliet, i. 2

PLANTED-planted, and placed.......... Iuch Ado, iii. 3

world's new fashion planted........ Lave's L. Lost, i. 1
hath planted in his memory... Werch. of I'price, iij. 5

would be planted newly with the time. Mncbeth, v. 7

he hath, so planted his lonours ...... Corialanus, ii. 2
I saw the treasons planted... Aniony \& Cleopatra, i. 3

should be planted presently with horns - ii. s

PLASH -that leaves a shallow plash . Kichord II. i. I

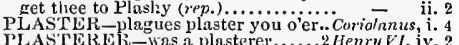

PLASTERE - was a plasterer......2 Hemry VI. iv. 2

PLATE - with plate and gold.. Taming af Shrew, ii.

we do seize to $\mathbf{n s}$, the plate, coin
his plate, his goods, his money

to pawn both my plate (rep.) …....2 Henry IJ. ii.

the several pareels of his plate ....Hewry V1HI. iii. 2

as money, plate, jewels ....... Timon of Alkens, iti.

were as plates dropped from his.. Antony of Cleo. v.
this is the brict of money, plate....... v.

tis plate, of rare device............. Cymbeline, $\mathrm{i}$. but, when the planets, in evil

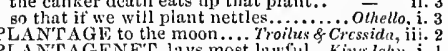

the very spirit of Plantagenet

PLAN little Ned Plantagenet, his son,- iv. 4

I saw the treasons planted... Aniony \& Cleapatra, i.

plate sin with gold, and the strong lance. Lear, iv. 6
PLATED-like plated Mars ... Antany \& Cleopatra, i.
PLATCORMS to endamage them .... Hemr? $I^{\prime}, \mathrm{ii}$.

upon the platform where we watelied .. Hamtel, i.

to the plattorm, masters ............... Ohello, ii.

PLAUSIVE words lie seatiered not.... All's Hell, i.

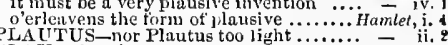

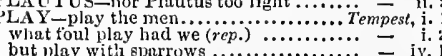

but play with sparruws .............

and I would call it fair play

v......

en of Terona, iv. 2

always play but one thing: (rep.) $\ldots$...

got me to play the woman's part

is let the boy's leave to play

go your ways, and play, go

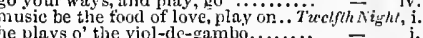

he plays o' the viol-de-gambo.

I swear, I am not that I play

or play with some rich jewel

I wonld play my frcedom at tray-trip

this fellow's wise enough to piay the fool =

tis not for gravity to

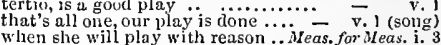

play with all virgins so.............. Jar -

like an angry ape, plays sueh fantastic $\quad$ - ii. 2

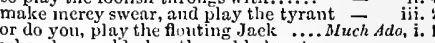

when he would play the noble beast - v... vuch ado,

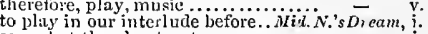

say what the llay treats on

I eould play Eicles rarely

nay, taith, let ine not vlay a woman...

let me play 'Ilis isy too

you must play Pyramus (rep.)............

yon must play There is a play fitted.....

what beard were I hest to play it in?

then you will play bal'efaced

that niglit we play our play? ..............

Grent clianiber-windo
what, a play toward?

to reliearse a play, intended for..........

if he come not, then the plity is marred

the long is, our play is prefurred

is there no piay to ease the

as brief as I lave knowa a p

for in all the play tliere is not...

what are they that do play it?

with this same play.

her passion ends the play

fir your play needs no exeuse...

ared ears play truant at his tales... Love'

must stand and play the murderer in?

from forate will ineline to play

Nestor play at pus $\ldots$ i......................

or I will play on the tabor...

play, music, then (rep.) .....

that when lie jays at tables

faith, unless you play the honest

doth not end like an old play

were every man must play a part.

let ine play the fool .......................

if a christian clo not play the knave...

the elose night doth play the run-a way -

the painter plays the spider..........

how every fool cun play upon the word! -

than the scene wherein we play in.....

one mun in his time plays many parts

so he plays his part ..................
under that hahit play the jinave....
I'll prove a busy uetor in their play.

I'll prove a busy netor in their play
startle at this letter, and play the...

play false strains upon theel

pliny, music; and you brides .........

good play's prove the hetter

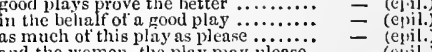

and the women, the play may please $=$ (eyil.)

play the noble housewife with........ Alt's $m$ ell, $\mathrm{i}$.

fortune play upou thy propering...

so lust dotli play with what it loatlies

a beggar, now the play is done......... $-\overline{\text { (epii.) }}$

we'll play our part ...... Taming of sheev" 1 (induc.)
a lord will hear you play to-night..
yet his honour never heard a p) (induy

liark! Apollo plays, and twenty enged -2 (induc.) 
PLAY-sedges play with wind. Taning of Sh. 2 (indue.) are eome to play a plensant comedy -2 (induc.) thought it goorl you hear a pluy .... - 2 (induc. you do not mind the play ............ - i.l (indue) now instrument, play you the whiles = iii. Your instrument, play you the whiles

while I play the good husband.....

a very trick for them to

for love to lie and play on.............

as if the scene you play, were mine...

I see the play so lies, that I...........

Dromio, play the porter well

and play $t$ he humble host $\ldots$ could play the woman with.

why should I play the Ronan fool

ond, it she did play false, the fau

doth play upon the daucing...........

his course, and p'ay's the alchemist .
play fast and loose with faith?

play fast and loose with fith?
whiles warm life plays in that

whles warm life plays in that..... - iii.

with her ehild plays fondly with .... - iii.

I play the torturer, by small and small

or shill we play the wautons

thus play $\mathbf{I}$, in one persun

no world, to play with mamizets .... i Henry $I V$. ii. 3

as to play the cusarit witli..................

shall we have a play extempure?

out, you roguel play out the plat....

列

the southeru wind doth play

you shall find no boy's play here

or is it fintasy that play's upon.

multitude, ean play upon it ....2 Henry $\bar{T}$, (indue.)

or the other, plays the rogue
well, thus we play the fools

na' you play the saney euttle.

let them play; play. sir's and he plays at quoits weil.........

in the end of a displeasing play $\ldots \ldots \ldots, \ldots$ - (epit.) $^{4}$

by God's grace. play a set.

distance, while we foree a play

not offend one stomach with our

fanning, play with your faneies

for when lenity and cruelty play for

do the low-rated English play at

even play of battle, was everk

and Nero-like, play on the lut

and Nero-fike, play on the lute
pretsily, methought, dirl play tise
as plays the sun upon the glassy

to play my part in furtune's

rade the prologue to their play

no, I can better play the orator....... 3 Henry VI. . . 2

Ill play the orator as well

belike, she minds to play tlie Amazon

and bite, and play the dog ...........

play the maid's part, still answer

play the maid's part, still answer nay

the beholders of this tragic piay

our tents I'll play the eaves-dropper

the play may pass .........IIenry VIII, (prologue)

to hear a merry, bawdy play

yeaten a long time out of play

yes, if I make my play .............

out of thy honest truth to play.....
simony was fair play

canse the musieians piäy me that

Charles, I will play no more t

Your play the spaniel, and think.

You play the spaniel, and think......
shall hold you play these two monitis

this play ean never please all.

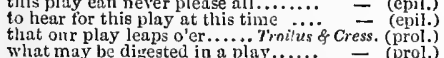

now play me Nestor (rep.)
who play they to? To the heare

at whose request do these men play $\ddot{\text { ? }}$

confess nuch, you will play the tyrant -

I'll play the hunter for thy life....

nor play at subtle games

fair plas. Fool's play, by heaven.....

and the enp plays in the right

seldom play the reeanter $\ldots \ldots \ldots$

Corioleme

I play the man I am .................

play one scene of excellent.. Antony \& Cleope

if tliou dost plav with him

best play with Mardian....

best play with Mardian..............

give thee leave to play till doomsdä =

that play with all infirmities

will play the cook, and servant...
PLAY_I must play tl:e workman.... Cymbeline you and Fidele play the eooks ...... sliall's nave a play of this? will let thee, play the seribe...Titus.Andronicus, plsys, and tumbles, driving the poor... Pericles, ij. for thein to play upon ................ funl playnoceint here our play has ending $\mathrm{K}$. sucl a king should play bo-peep do me nin fonl play, friends..............
bad is the trade must play the fool eome muscians, piay ............. Rom this bloody knife shall play the umpite

madly play with my forefather's' joints

my heart itself plays (rep.)
tis no time to play now...

are aetions tlat a man might play ........ he that plays the ling, slaili be weleome.... an excellent play; well digested gnilty creatnres, sitting at $a$ joläy have these players play sumething like.. the play's the thing, wherein that he may play the fool nowliere but.. after the play, let his queen mother... let those, that play your clowns some neessary question of the play ....
there is a play to-uight before the king the whilst this play is playiug

they are eoming to the play $\ldots \ldots . . . . . .$.

you are naught; I'll mark the play ....

miadam, how like you this

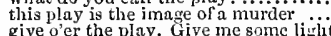

go weep, the hiart ungalled play

will you play upon this pipe?

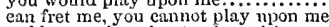

sudden coming o'er, to play with you

but to play at loggats with them

your pleasure hold to play with Laeite.

to Laertes betore you fall to play ...............

I Il play this bout first, set it by a while

you rise to play, and go to bed to work

you are most apt to play the sir
that says. I play the villain?

play here, I will eontent youl pains ....

sings, plays, and danees well.............

PLAYED and him he played it for ....

played by the picture of nobody ......

and Thave played the sheep.. Tuo Gon. of Ferona, $\mathrm{j}$. 1
all our pageants of delicht were played
since I plueked reese, played truant Herry Wives, v. 1

if this plueked geese, played truant Herry $_{\text {Wives, }}, \mathrm{v} .1$ that e'er invention played on?

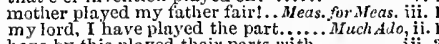

have by this played their parts with $\overline{\text { Pith }}$ iii.

Pyramus than e'er played here!

indeed, he hath played on this prologue $=\quad$ v. 1

a set of wit well played Pyramus ......... Love's L. Losl, v. 2

played foul play with our oaths ..... of $\overline{V e n i c e}$

learned, played, eat together ......As you $L$

see a pageant truly played. between
wherein have you played the knave.. Alls $W_{r l l}$, v. .2

wherein have you played the knave. Al's Well, v. 2
onee he played a farmer's. T'aming of Sh. 1 (indue.)

that see'st a game played home ${ }^{\prime}$ industriously, $I$ played the fool

if industrionsly, I played the fool and played, to take

before the mateh be played .......... King John, iii. 1

this easy mateh played for a crown?

wretehes that we played atdiee for?.

myself have played the interim...
Fastolfe had not played the coward .I nenry VI. i.

hear low we have played the mea.

winners, for they played nie false!...

hath Clifferd played the orator ...3Heny $T$. iit. 1

as if the tragedy were played in jest - ii. 3

woman with an eunuch played...Antony \& Cleo. ij. 5

played as I pleased, making, and

master rather played than fought
mistress, Pisauio, hath played

you have played your prive iii. 4 (letter)

but, beiug played upon hefore........... Pericles but, beiug played upois he

Lear, iv.

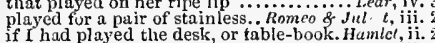

played onee in the university, you say? - iif. 2

would store the world they played for outhello, iv. 3
PLAYED'ST most foully tor't ........ Stacbetin, iii. I
PLAYER-the rest of the players ..Mid. $N$.'s Dr. i. 2 not one word apt, one player fitted..

men and women merely players ... As you $\overline{L i k}$ it, ii. 7 play'ers that offer service .. Taming of Sh. 1 (indue.)
your honour's players, hearing your -2 (induc.) a poor player, that struts and ficets ......Macleth, $\mathrm{v} .5$ one of these harlotry players......... Henry $1 \mathrm{~V}$. as they used to do the players........ JuliusCasor, i. you base tootball player ................... Lear. i. 4 what players are they? Even those you.

grow themselves to common players

there are the players, gentlemeu, you

lest my extent to the players .........

will you see the players well bestowed?

that this player here, but in a fietion.

that certain players we o'er-raught....

as many of our players do, I had as lies

bid the players make haste.............

the players eannot keep counsel

a

players in your housewifery $\ldots . . . \ldots \ldots$ othello, ii. I PLAYFELLOW-sweet playfellow...Mid.N.'s Dr. i. the eyes of my young play fellow... Winter's Tale, i. playfellows to keep you company!.2Henry $V t$. jii. 2 sullen play fellow for teuder princes. Richard 11 . iv. 1 or pack to their old playfellows .... Henry $V^{\prime \prime I I}$. i. 3 you bred him as my playfellow....... Cymbeline, i. iu marriage-pleasures play fellow. Pericles, 1 (Gow.)
PLAYHOUSE-there is the playliouse Hen.V.il.(cho.) that thunder at a playliouse ....... Henry PIII. v.

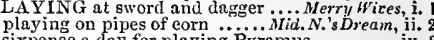
playing in the wanton .. Love's I.. Lost, iv. $\overline{3}$ (verses) if all the year were playing holidays i Herry $I V . i$. playing the mouse, in absenee ......... HenryV. i. 'tis better playing with a lion's whelp o t ii. il by playing it to me with so sour. Romeo \& Juliet, ii.

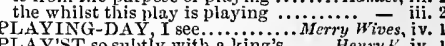
PLEA of no less weight than ....... Love's L. Lost, ii. plea so tainted and corrupt ......... Mer. of Venice, iii. 2 can drive him from the envious plea - iii. 2 to mitisate the justice of thy plea......
that is my brother's plea $\overline{\text { iv }}$ iv.
tha...... King PLEACHED-into the pleaehed bower. Mluch Ado, iii. I master thus with pleached srais. Antony \& Cleo. iv. 1 a
PLEAD-to plead for love.... Tuoogen. of Verona, $\mathrm{i}$. to plead for that whieh

pleat a new state................. he eamnot plead his estimation..... - iv. I will plead against it with my life.. may plead for amplest eredence........All's $W$ ell, $\mathrm{i}$. I'll plead tiv you, as for (rep. ii. 1) Taming of Sh. i. 2 to plead Hortensio's passion.. $-\overline{\text { iii. I (gamut) }}$ merchant of Syraeuse, plead no... Comedy of Err.i. and modesty, plead on lier part........

he would not plearl so eoldty

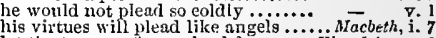
et the tongue of war plead for ....... King John, v. to plead his love-suit to her $\ldots . . . .$. .... Henry $V$. v. fitteth not a prelate so to plead..... i Henry $V I$. jii. let me plead for gentle Suffolk ....2Herry VI. jii. 2 un tamght to plead for favour.... our swords shill plead it in the field.3 Henry VI. i.

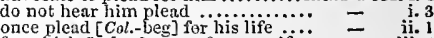
for which I plead, were for myself... and if you plead as well for them.... plead what I will be, not what ....... assembled to plead your eause ....̈. may never more false title plead. Thimon or Alh. iv. the actor may plead pardon. Antony \& Cleopatra, ii. plearl my suecessive title with your. Tilus did graeiously plead for his funerals leave to plead my deeds...............

fur thy brothers let me plead...

she for him pleads strongly to the iroor. othello, ii. 3 suppose that I lave pleaded truth ... Herrors, iv, 2 he pleaded still, not guilty ......... Henry $V^{\prime} I I$. ii. if you would be your eountry's pleader - y. must needs want pleading for ....... King Jnhn, iv. ove, pleadiug so wisely in exe use..2 Henry $1 \mathrm{~V}$. iv. I will be deaf to pleading ....... Romeo \& Juliet, iii. PLEASANT-th y riehes pleasant. Meas.for Meas. iii. 1
you are pleasant, sir; and פeak apace - iii. 2 


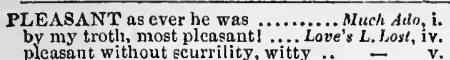

and pleasant game; a mess ot Russians

courtship, plcusant jest, and courtesy

to play a pleasant eomedy...Tunting of $\overline{S h} .2$ (ind.)

the pleasant garden of great Italy

trusty, pleasant servant Grumi

for thou art pleasant, gamesome $\ldots$

more pleasunt, pithy, and effeetuai.

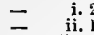

rare, pleusaut, and speedy ...... Winter's Tale, ivi.

or a very pleasant thing indeed...... $-\overrightarrow{\text { acheth }}$ iv. 3 this castle hath a pleasant seat............Macbelh, i. 6 to that pleasant country's earth ... Richart 1 . the Dauplin is so pleasant with us.... Hcrry $\mathrm{r}$. and tell the pleasant prince.

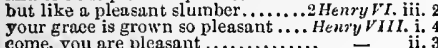

sweet queen, you are pleasant... Tho.... $\&$ Cress, iii. 3

upon a lighl and pleasant hill.. Timon of Alhcus,

exceeding pleasant; none a stranger Cymbeline, i. 7

north side of this pleasant eliase. inim.... Lear, iv. of our pleasant vices make instruments
awake as from a pleasant sleep Romeo \&. Julie practises, pleasant and helpful to him i Hamlct, ii. 2
PLEASANTEST angling is to see...Mruch Ado, iii. I PLEASANTLY-so pleasantly

PLEASE-please you further

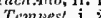

please you, sir, do not on it............ - ii. 1 on a trice, so please you

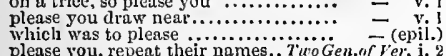

please you, repeat their names.

to-morrow, may it please you (rep.)

please you, delíberate a diny or two.
i will write, please you coinmand.

please you, I'll write you

and if it please you (rcp.)

please it your graee, ther

madam, please you peruse this letter

please you, I'll tell you as

\section{二}

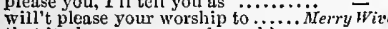

that it pleases your good worship...

I know not which pleases me bette

so please my lord, I might not.... Treelfth Night, ii.

if rot, an' it would please you to take
he is not here, so please your lordship

it' it please the eye of one

please one, and please all..............
put up your sword, if you please

though it please you to be one of...

think of me as you please.

my lord, so please you (rep.)

if it please your honour $(r e p.) . .$. Meas. for $_{\text {N I eas. }}$ it

yes, and 't please you, sir............
please but your honour hear me .....
wonld much better please me $\ldots$ -

please you to do't, I'll take it.

as many as you please ................

and much please the absent duke.....

continnance, may it please your honour
so please you, this friar hath been ...
will't please you walk aside? .........

look, if it please you, on this man.....

but I had ratiler it would please you
please it your grace lead on.............nuch $A d o$, i

and say, father, as it please you (jep.)

when I please. And when please you

shall be of what colour it please God

if it please you; yet count Claudio

and those thiugs do best please me.

so please your grace, the prologue is

so please your grace, the prologue is
will it please you to see the epilogue
my liege, an it youl please.........

my liege, an it you please........ Love

me an't shall please you; I am Antony

so please your grace, the packet is

did they please you to ahrogate.. .

it sliall please you to gratify the table

it will please lis grace (by the world)

please it youl, as much (rep.)

again when God doth please ........

there, an't shall please you (rep.)...

if you please to shoot another ...Mer. of $\overline{V e n}$

Launcelot, an't please your mastership

in a sad ostent to please his grandam

an' it shall please you to break up thi
you shall please to play the thieves.

so please your grace (rep.)

I am not bound to please thee witi...

I will not, till I please: you shall... As you Like so please you, he is here at the door

so please you give us leave

cente

a stuborn will, than to please myself

to blow on whom I pless

speaks them pleases those that hear

so please you, for I never heard it.....
if you please, that I can do strange.
PLEASE-pleases you eontents you. As you Like it, v. 2 PLEASE-if thou please to hide .....Richarn 111. i. 2 lie cut it to please himself as much of this play as please thein $=$ (epil.)
aud the women, the play may please
may it please you, madam, that he ...All's Well, i. 3 when love please 1 marry, to each please it your majesty, I have done
no better, if you please. MIy wish.... where we please to liave it yrow

if you shall please so, pirgrim ..... pa't please your lordship: I'll leave

that it will please you to give $\ldots . .$.
howe'er it pleases you to take it so..

so please your majesty (rep.)

with strife to please you $\ldots$ please your lordship ( $r c p$. .............

will't please your lordship driuk ...

and to marry her, if her dowry please
in sign whereof, please ye we imay

in sign whereof, please ye we may

old fashions please me best ...........
if it would please him come aud marry =
nor till I please myself (rep.)........

to the uttermost, as I please, in words

and if you please to like no worse

or what you plcase: and if yout please

if he please, my hand is ready ........
please your lighness to take the...Wi
will do't, sir, plense you to acept it

so please you, madam, to pnt apart.

please you, come sonething (rop.)

please your highness, posts (rep.).

if fortune please, both brced thee.

I, that please some, try a

will't please you, sir, be gone?

an't please you, sir, to underta
please you, great sir, Bohemin

please you to interpose, fair madion.

at five o'clock, please you .... Comedy of Errors

great care to please his wife

what please yourself, sir, I have.....
and please your wife withal
I will please you what you wil demand

may it please your grace, Antipholus

so please your highness ( $r e p$. itii. 4$)$

it it please yout, Fleance killed ..........

an' if thou please, thou me you

and wish, (so please my sovereigni).. Richurd II.

pardon me, if you please, if not.......
to please the king, $I$ did; to please

unless you please to enter in .........

thoy shouldst please me better

may't please you, lords, to grant $\ldots$

when he please again to be himself... IH

fo please your majesty, I would I could - ii.

please it your honour, knock but...2HcnryIV.

an't please your grace (rep. iili. $j$ )

where is Mouldy? Here, an t please you four, of which you please.

an't shall please yonr grace $\ldots \ldots . . . .3$.

it this may please you, disclinrge

and, good my lord, so please you

this paeket, please it you, contains.

an' it please your worsh ip, there's one -

may it please your majesty (rep. ili. 6). Hen

as long is it pleases lis grace.........

an't please your majesty (rep.)

an' please Got of his grace that $\mathbf{I}$

he is my dear friend, an' please you

please de your majesty (rep.)

depart wlen my wife? So please you $-\bar{v}$

yes if it plen heaven please

and, as you please, so let them liave

but bis can please your dainty eye..

in Anjou what your honour pleases

shall be Henry's, if he plense.

my lords, an' please you, 'tis not so

that your lordship please to ask
would it might please your graec

please yon to be erowned? (rep.)

I had rather kill

to please you with the hearing....

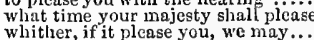

here, so please you (rep.) .............

and sell his honour as lie pleases

please you, sir, I know (rep.) .......

sweet ladies, will it please yon sit?

an't please your grace, sir Thomas
fashioned into what pitch he please.

so I'll stand, if the king please

if you might please to streteh it.......

as't please yourself pronounce their

that it shall please you to declare

an't please your grace, the two great

may it please you, noble madam

if you please to trust us in your......

please your honours, the elief cause

may it please your grace (rep.).

an't please your honour, we are brit men -

this play can never please all that - (epilogue

yet let it please both ......... Troilus \& Cressida, i. 3

or, if you please, laste there ........ - iv.

please you, walk in, my lords ...... - iv. 3

so please you. I am not warm yet (rep.) $=\quad$ iv. 5

likes not you, pleases me best..........

may it please your honour (rep.) $\ldots . . .=$ i. i.

please you, gentlemen, the time is .. = ii.

it pleases time, and fortune, to lie

dost please thyself in't? ............ - iv.

therefore, so please thee to rcturn.... $=$ v.

he did it to please lis mother.......... Coriolanus, i.

but, au't please you, deliver..........

therefore, please yon (rep.) $\ldots$ ii........

if you please to speak with me ....JuliusCasar, i.

soplease him come unto this place... $\quad$ - iii.

wo place will please me so $\ldots . . . . . .$. - iii.

vo please you, we will stand, and wateh - jv. 3

ay, my lord, an' it please you.........

will't please you, hear me?.......... = ii. 5

it much woukd please him $\ldots \ldots \ldots \ldots$.

please you, retire to your chamber?..

do not please slarp fate to grace it...

but please your thoughts, in feeding

$\begin{array}{lll}\text { iii. } 2 & \text { if thou please to take me to thee } \ldots & \text { v. } \\ \text { iii. } 2 & \text { if he please to give me conquered Egypt } & \text { v. }\end{array}$

I will speak what you slall please .. $\quad$ - $\quad$ v. 2

if it might please you,-His tace .... - $\begin{array}{r}\text { v.2 } \\ \text { shall hang in what place you please }\end{array}$

please your higliness, I will from ... Cymbeline, i. 2

if it.please you to greet your lord....;
please you, madim. What hour is it?
please you, read; and you shall.......
so please you, leave me (rep.).........

but first, an't plcase the gods

so please you entertain me ........... -

I will report, so please rou.

we did, so please your highness......

doth this motion please thee? ....Tilus Andron. i. 2

to-morrow, an' it please your majesty

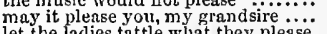

let the ladies tattle what they please

demand what pledge will please him

please me which thou poeak'st (rep.)

please you, therefore, draw nigh

please you eat of it (rep.).................

pardon me, or strike me, if you please

too little to content and please

they please us well; lord marquess

he conld not please me better.

yes, plense your majesty to please the fool and deati...

if you please, a niece of nine.............

Saunder Simpeox, an' if it please you -

bo please your grace (rep.

when he please to make commotion

if it please the goc

I will, my lord, so please his majesty

please it your grace (rep. v. 1) l.......

may it please your highness to resolve -

please you to name it............... - $\quad$ iv, 6

so please your lordship, none............. Lear, i.

if it shall please you to suspend

what weary negligence you please

with you, goodman boy, if you please.... - ij. 
PLEASE-again to die before you please! .. L trar, iv so please your majesty, that we .......... will't please your highness walk? please you, step aside (rep. iv. 3). Romeo \& Jutiet, i olense yon, something toucling. put on him what forgeries you please that it might please you to give quiet Hamlet, i. 3 to sound do as you please if it s!nall please you to make me........... vill't please you go, my lord

he shall sir, and $t$ plense him ............. if you please to get good guard.

please it your grace (rep.).......;

to please the palate of my appetite...

rse yon please.

yet, if you please to hold him off a
nothing, but to please his fantasy

the justice of it pleases, very good
PLEASED-what tune pleased his

wilt thou be pleased to hearken

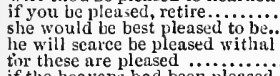

be pleased that I shake off

tied up justiee when orf

pieased you to do't at

were so pleased, that thon wert... Love's $L$. Lost,

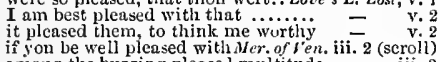

anong the buzzing pleased muititude -

it is, so you stand pleased withal

und I be pleased to give ten thousand

if you had pleased to have defended

shouldst have better pleased me... As you Like it, i. 2

and pleased with what he gets

a shrewd turn if she pleased

she and I be pleased, what's that. Taming of ell, iii.

fle will be pleased, theu wherefore

better pleased with madnes

cetter pleased with madness ..........

be pleased then to pay that duty..........

if heaveu be pleased that you must.

but that your highness pleased (rep.).

if not, I pleased not to be pardoned.. Rich

with all pleased, that hast all achic
with nothing shall be pleased...

the whieh if he be pleased I shall...

to my thinking, pleased the king.

hath it pleased to shine on
nngry, 1 am pleased again

angry, 1 am pleased again $\ldots \ldots \ldots . . . .$.

before it pleased his majesty ......3 Henry VI. v. as himself pleased; and they were... Henry IIII. $i$. the king is pleased, yon shall........ if heaven had pleased to have given of comfort has so pleased me al pleased to breed out your ... Troilus \& pleased with this dain ty bit.......... pleased to let him seek dusger are well pleased to make tiree coin.

as he pleased, and displeased them.Julius $\bar{C}$ as sar. you may be pleased to eateh at.. Anlony \& Cleo. be pleased to tell us (for this is trom and now pleased fortune does. as I pleased, making, aud marriag. when it pleased you to employ nie
as when lis god is pleased .......... be pleased a while; this gen fhen be pleased with this ....... Titus Andron i. what, are you both pleased?

fites had pleased pou had brought

never any: it pleased the king his maste

but heaven liath pleased it 80

it hath pleased the devil, drunkenness... Othello, ii. PIEd it pleased heaven to try me with.:.. - L iv. if thon pleasest not, I yield thee......iony \& cleo. $v$
PI,EASETH men, and angers them ... Much Ado, ii. it pleaseth his greatness to impart..... in the fields, jt pleaseth me well... As you Like it, iii. pleaseth you walk with me....... Comedy of trr. sing the song that please th you........ pleaseth your grace, to answer $\ldots . .2$ Henry $I F$. iv. I

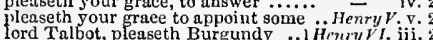
and undo, as him pleaseth best ....3 Horry $F_{i}$ ii.

I hope, which pleaseth Goll above ...
pleaseth yonr majesty to give me leave

pleaseth yonr majesty to give me leave
PLEASETH your highness, ay ...... Cymbeline, i.
it pleaseth you, my father, to express.. I'ericles, it. PLEASING prieket ....LLove's L. Losl, iv. 2 (epitaph) was no thonght of pleasing you... As you Lilie it, iit. more qnaint, more pleasing of shrew, 2 (indue.) more quaint, more pleasing

plear women. Comedy of Eir. i. of a eheerful look, a pleasing eye..... Henry $1 \%$. ii. 4 your blood with pleasing he

to whom I would be pleasing
to the laseivious pleasing of a lute... Richiard LII.

a pleasing coräial, princely 3 Buekingham

can nuke seem pleasing to her tender

very pleasing night to honest men...Julius Cessar

with such pleasing eloquence.... Tilus A

such delightful pleasing jarmouy .... Pericles, ii. 5

hath power to assume a pleasing shapc. Hamlet,

a ud makes my labours pleasures

1 am full of pleasure

what's tlig pleasnre? ..................

it is your ple thena, ii.4

what 1 do, is to pleasnre you, coz ...Merry $\bar{W}_{\text {ives, }}$ i. 1

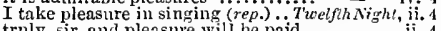

truly, sir, and pleasure will be paid.

you make your pleasule of youtr pai

for onr pleasure, and his penanee $\ldots$.

your worship's pleasure I should do

hat pleasure was he given to?

unto $y$ nur heiglit of pleasure ......

and see onr pleasure herein exeeuted - v. 1

do the minstrels; draw to pleasure us - v. 1

and the pleasure of mine eye, is only $\overline{\text { in }}$ iv. 1

to know his pleasure ...............

where all those pleasures live.

at your sweet pleasure (rep.)

will you pleasure me? ....... Merchant of Venice,

use your pleasure............... - iii. 2 (letter)

any extraordinary pleasure .......As you Like il, i. 2

so to your pleasures..................

your pleasure sirl to...................

and pleasure drown the brim .........

be it his pleasnre. Bnt I am sure ....

with the general, and know hi
she goes off and on at pleasure

the even truth in pleasure flow.

where is no pleasure ta'en

to your pleasure humbly I subscribe

sith it your pleasure is $\ldots \ldots \ldots . . . . . .$.

or is it else your pleasure.

the pleasure of that madness .......minter's Tate, iii.

their andit at your ligghness' pleasure... Macbeth,

attend those men our pleasure?.......

convey your pleasures in a spacions.

your pleasnre, and eontinue friends. King Jol

attended witli the pleasures of the world -

never to taste the pleasures of the world

travel that thou takest for pleasure.. Richard II.

pleasure, that some lathers feed upon
wherein it is at unr pleasure to fail ... Henry II

thy stomaeh, pleasure, and thy golden

sueh barren pleasures, rude society.

do me good, for no man's pleasure....

.2Henryl $\mathrm{V}$.

to know the plensure of our fair.......... Henry $V_{\text {ii. i. }}$.

to use his goot pleasure.

at pleasure here we hie .................

our pleasure is, that Richard be

break it when your pleasure serv
the pleasure of my lord the king
not worldiy pleasure at command

not worldy pleasure at command
'tis his highness' pleasure (rep. ii. 1)
at his pleasure, will resign my place

at your pleasure, my good lord...

every several pleasure in the

it is our pleasure, one of them depart

in possession any jot of pleasure?

what your pleasure is, sliall satisfy me

what pleases him, sliall pleasure you

surprise and take him at our pleasure?

a pleasure, ay, such a pleasure as incaged-

the idle pleasures of these days .... Richard all the pleasnres you nsurp, are mine

sends to know your lordship's pleasure his gracious pleasure any way therein
this, wlat is your grace's pleasure?..
PLEASURE-may do your plcasure . Richard III. iv. 2 'tis his higliness' pleasure ............. Henry ${ }^{\prime}$ III, ky g's pleasure by me obeyed.........

what are their pleasures? ............

your royal plensure

your plessure pleasure be fulfilled!

what are gour pleasures with me.....

'gainst his highuess' pleasure .........

my lords, you speak yout plcastures.. -

hear the king's pleasure, cardinal (rep.) but, I pray you, what is your pleasure
he attends your' highness' pleasure (rep.) -

but their pleasures must be fulfitled -

to know your pleasures

'tis his lighness' pleasure, and our

do as your pleasures are. Troilu; $\ddot{\text { c }}$ ressidu, vi

sweet niece Cressica. At your pleasure - i.

the pleasure my spleen .............

for pleasure, and revenge, liave more ears -

at whose pleas pleasure dia

you speak your fair pleasure.................

boun teons time in different pleasure. Timon of $\mathrm{s}$ ih. $\mathrm{i}$.

you have done our pleasnres much grace -

your lordship speaks your pleasure..

I eannot pleasure such an homourabie

at your pleasures (rep.) .......

I ean shake off at pleasure .......... Julius Cersar,

fates! we will of your good pleasure

reek and smoke, fulfil your pleasure

pleasures, to walk abroad.. $=\mathrm{jii}$

we will stand, and watch your pleasure $\overline{-}$ iv. 3
stretch without some pleasure now. Antony \&
at your noble pleasnre..............

the present pleasure, by revolution...

what's your pleasure, sir?............

experienee to their present pleasure..

i' the east my pleasure lies (rep.)...

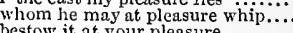

bestow it at your pleasure

I have performed your pleasure ......

myself to your sweet pleasure........
might not spend them at my pleisure

me of my lawful pleasure she restiained -

I know your master's pleasure ...... =

their pleasures here are past

what pleasure, sir, find we in life.

Werein

your pleasure was my mere offence... $=$ v. 5 now talk at pleasnre of your safety ..Titus $A$ nd. iv. 2 he can at pleasure stiot their melody to your' wishes pleasure bring ...Pericles, $\mathrm{i}$. (Gower) in marriage pleasures playfellow

which pleasure fits a husband.

here pleasures eourt mine eyes

I am at your grace's pleasure

it is your graee's pleasnre to commend

ay, and you shall live in pleastre....

in space, validity, and pleasure.............

'tis the duke's pleasure, whose disposition

why then let fall your horrible pleasure

bid thee or rather do thy pleasure ....

to he:r of pleasure's name

until their greater pleasures firstbe innown

methinks, our pleasure might have bee

to know our further pleusure

at his plessure?

at his pleasure? (rep.) .............

ii.

or in tle ineestuns plesures into..... - ii. 2

guarded, to know your pleasure.......... $=$ iv. 3

if your pleasure hold to play with Laertes - v.2

if't be your theasure sleasure ............

thou dost thyself a pleasure.

so Othelio s pleasure, our noble and...

with joy, revel, pleasure, and applause...

pleasure, and action, make the hours seei

vhat is Jour pleasure? (rep)

yon may take him at your plosure...

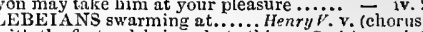

with the fusty plebeians, hate thise... Coriolasus, i.

the herdsmen of the beastly plebeians -

you are plebeians, if they be senators

up to

patrieians out plebeians, ...Anlony \& Cleo. iv.

PLEBEII - fast foe to the plebeii .... C Tilus And. i. PLEBS-pigeons to the tribunal plebs.. Tilus $A$ ind. iv. 3
PLEDGE-I am Grumio's pledge.. Taming of Sh. $\mathrm{i}$. . 1 am in parliament pledge for ........... Richard lil. v. 2 I pledge your grace; and, if you....2 Henry $I \boldsymbol{V}$. iv.
pledge you a mile to the bottom.. - v. 3 (song 
PLEDGE-there is iny pled" this jewel, pledge of my nffection. i'faith, and r'll plcdge you all.... as pledges ot my fealty and love. to pt plodgenave we of thy lirm .... to pledge my vow, I give ny and pledge it, madam, for 'tis...... Henry $F$ IIl, $i$,

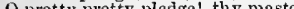
ond ly is thirsty for that noble pledge ... Julius Cersar, iv. I'll pledge it for him, Pumpey ...Antony \& \& Clea. ii. did him demand what pledge will

give his pledges unt to my father

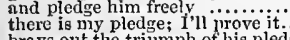

brays out the triumpl of his pledge

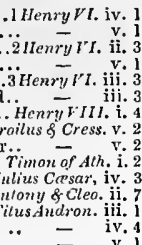

PLEINES-des hommes sont pleines .... Herryy PLENTEOUS joys, wanton in fulness.. Nacbel $\lambda$, think it a most plent teous erop ....As you Like it. iii. the head at Ceres' plenteous load? .2 Henry VI. i. 2 may send forth plenteous tears.... Richard III. ii. towards you taonour and plenteous.. Hen'y VIII. plenteous bosom (rep. iv. 3)

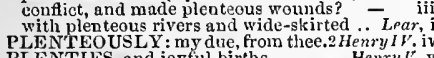
PLENTIES, and joyful births ........ Hemry $r$. V. more plentitul than tools to do't ${ }^{2}$. C. cymbeline, v. PLENTIFULLY gives me $\ldots$........As you Like it, i. if fairings come thus plentifully. Lnve's L. Lost,

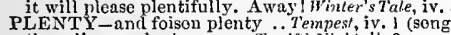
there lies no plenty ...... Tuelflih Night, ii. 3 (song) as there is no more plenty in it.. As you Like it, iii..
himself on the expectation of plenty... Macberh, ii. 3 your pleasures iu a spacious plenty.

... Henry $\bar{l} V$. ii. smiling plenty, and fair prosperous. Richard Ill. v.
peace, plenty, love, truth, terror .. Henry IIII. v.

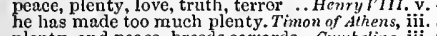
plenty, and peace, breeds cowar

promises Britain peace and plenty

prom whom plenty held full hand.

pless my soull (rep.)...

pless you from his mercy salke

Got pless it and pjeserve it, as long.

Got pless you, ancicnt Pist
PLESSED -od's plessed will

God be praised and plessed $1 . . . . . . . .$. Henry $Y$. iii.

PLIANT - took once a pliant hour. . Merry

PLIED-he plied them both with. Aniony \& 8 Cleo

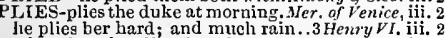

Wherefore she plies thee thus?
this honest fool plies Desdemon

PLIGHT - in better plight

plight me the full assurance
you see, my plight requires it .. Othello, ii.

as geemeth by his plight

see st, ourselves in heavy plighit ...3.

constancy in plight and youth. Troilus \& Cress, iii.

your plight is pitied of him....... Antony \& Cleo. $y$.

seen thy picture in this plight ....TitusAndron.

comfort his distressed plight

whose hand must take my plight.

bid her alight, and her troth plight $\ldots . .$. iti. Lear, i.

for sign of plighted faith............. Hesiry $V I . v .3$

[Ciol. Knt.] nafold what plighted cunning.. Lear, i.
PLIG HTER of high liearts! Antony \& Cleopntra, iit.

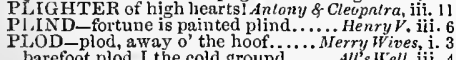

a tired mare, yet she will plod ....

M. Mery Wives, 1.3

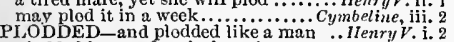

plodded by my footcloth mule …2 2 Henry ${ }^{\prime \prime I I}$. iv. 1

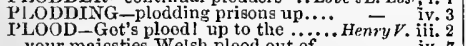

PLOODY mandies Welsh plood out of ..

PLOODY - and your ploody coxcomb
PLOT-rost thou like the plot ......... Tempest, iii. 2

since they did plot the means.

wit to plot this drift........ Two........

one nadde privy to the pot.............

good plots! they are laid......

will lay a plot to try that
but let our plot go forward

whint is your plot?
to this her mother's plot......................

break the sinews of our plot..... Tuelfih Nighl, ii. 5 this green plot shall be our staye...Mid.N.'sDr. iii. to unburthen all $\mathrm{my}$ plots ...Merchant of Veniee, $i$. let us assay our plot ................Al's $w e l l$, iii. ? who cannot be crushed with a plot? there is a plot against my life.... Winter's Tale, ij.
to cull the plots of best advantages.. Kiuy John, ii John lays you plots; the times.......
tiat he did plot the duke of ......... Richard 11 . i. tlat he did plot the duke of .......... Richard
to plet, contrive, or complot any iil. this blessed plot, this earth, this realm

is there no plot to rid the realin

tliey do plot unlikely wouders
PLOT-choose but be a noble plot
thuu lay'st the plot how

1IIenryI $\mathrm{r} \cdot \mathbf{\mathrm { j }} \cdot \mathbf{3}$

and your whole plot too light.....

my lord of York comunends the plot

We first survey the plot........
the plot is laid; if all thiug.

a protty plot, well cliosen $\dddot{t} 0$ boijia....

in this private plot, be we the first $\ldots$ ii.

conspire my death with devilish plots - iii.

these are the limbs of tlie plot........ Henry VIII. i. 1

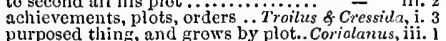

purposed thing, and grows by plot.. Co

were there but this single plot to oose
passions and whose plots have broke

passions and whose plots $\mathbf{I}$ full under this plot

二 iili. 2

a mother hourly coining plot.......... Cymbeline

the prettiest daisied plot we can .....

nany unfrequented plots there are..

plot some device of further nisery

this sandy plot is plain.

or plot the way to do it.........
strange plots of dire reven

suggestion, plot, and damned practice..... L $e a r$

Thave o'erheard a plot of death

fight for a plot whercon the numb

well, when our deep plots do pall.....

miscliance, on plots, and errours, happen
PLOT-PROOF - v. 2

PLOTTED-liad plotted with them.... Tempest, y.

and now eans plotted $7 \ldots .$. Two Gen. of lerona,

when Gloster's death was plutted... Richard II. iv.

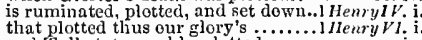

alloot, too rashly plotted.

not conelude their plot ted tragedy. 2Henry Vl. iii.
had plotted, in the council-house. Richard III. iij. 5

PLOTTER-plotter of these woes.. 'Titus, indron.
PLOUGH-to hold the plough for.. Lave's L. Losi.

make you plough up the wars

Octavia plongh thy visage. Anlany \& Cleapatra, iv. 10
sword shall plough thy bowcls up. Titus dnd ron iv

PLOUG HED up with neighbours' $\ldots$... Richard $I I . \mathrm{i}^{2} .3$ we ourselves have ploughed for..... Cariolamus, iii. 1 than she is, she shall be ploughed .... Perictes, iv.
PLOUGH-IRONS. Let it be cust ... Herry IV.V. whilst the heavy plouglmanan snores.

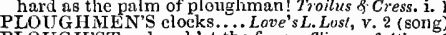
PLOUGH'ST - plough'st the foam.. T'iman of Ath. $v$. PLOW - think, a' will plow up all ... Henry $V$. iti. ${ }_{2}$
and his lips plows at his nose .....
iii. 6 and his lips plows at his nose $\ldots \ldots . .$.
give treason lis payment into plows PLUCK-and pluck my magic garment. Tempest, $\overrightarrow{\mathrm{i}}$. I here could pluck his highness' frown

shall not pluck that from me.. TuroGen.of $\overline{V_{e} e r}$, iii. pluck the borrowed veit.............Merry Wives, iii. 2

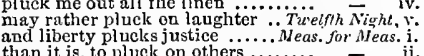

to plnck all fears out of you.

I will to him, and pluck ont his eye. $=$ iv. 2

pluck off the bull's horns, and set...

pluck up, my heart, and be sad

to pluck this cravling scrpent... Mid

ne'er to pluck thee from

youth so apt to pluck a sweet.

pluck tlie young sucking cubs..Yerch
pluck commiseration of his state....

nor pluck it from his finger.....

and my prayers pluck down.............

to pluck his indignation on thy head

my remedy is then, to pluck it. 'Tam
through the dirt to pluck him off' me

you roguet you pluck my foot awry

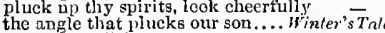

pluck but oft' these rags.

and pluck it o'er your brows .........
or pluck back thy business there

or pluck back thy business there...

hal they piuck out mine eyes!.......

pluck from the memory a rooted...

whose valour pincks dead lions.
but they will pluck away his.......

and pluck nights from me ...............

you pluck a thousand dangers.......
sworn to weed, and pluck a way

from thy bosom pluck a flower.

do not pluck my cares down

to pluck him herdlong from ......

creature pluck a glove, and wear it.

to pluck bright honour from....

and pluck up drown cd hon
we pluck this flower, safety.

that $I$ did pluck allegiance from

go, pluck lim by the elbow..............
almost, to pluck a kingdom down

pluck down my officers.

pluck down my ofticers...............
from eurbed licence plucks
PLUCK down justice from your......2 Henry $l V$. v. 2
beholding himp, numbers pluck their liearts from thent - iv.

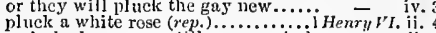
and pluck no mere, till you conclude

pluck this pale and maiden tlossum
prick not your finger as you jluck it

on my behalf would pluck a flower. let's pluek him down.................3llenry Vi.j.

can pluck the diadem from.

were it firther off; $I^{\prime} l l$ pluck it down
the crosi-row plucks the letter $G$... Richard $111 . \mathrm{i}$.

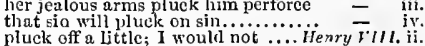

pluck off a little; I would not...... Henry $\mathrm{I}$. $h 1$. ii.

plucks down Achinles' phumes

shoulder pluck his painted wing
do one pluck down anotlier..........

pluck the grave wrinkled scrate... Timon of $A^{\prime h}$. iv.

son of sixteen, pluck the lined crutch $=$ ive iv s

sec him pluek Autidius down ........ Coriolanus, 1 .

pluck repreof and rebuke from every
at once pluck out the mnltitudinous

to his house, and pluck him thence

means to pluck away their power

pluck down benches. Pluck down forms -

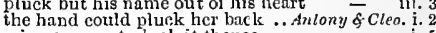

mine ear must pluck it thence ...... $=$ i.

off, pluck off; the seventuld shield .. $\overline{\bar{c}}$ iv. i2

hope to pluck a dainty doe Titus.Andronicus, ii. 2 to pluck proud Lucius from .............
this cause again, I'll pluck you out
in

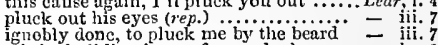
il the building in my fancy pluck unon = iv. with a silk thread plucks it back Romeo \& Juliel, $\mathrm{ii} .2$ pluck your sword out of his pilcher..

and pluck the mangled Tybalt from

plucks off my beard, and blow's it in ... Hamlet, ii. 2 would pluck out the heart of my mystery - iii. 2 did not together pluck such envy from...

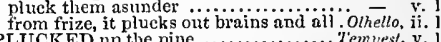
PLUCKED up the pine ...................'empes's, v. 1 of Vien ra must be plucked down. Meus. for Aleas.
plucked down in the suburbs....... hose plneked over your head ......... AsyouLike it, iv. I have plucked my nipple from his...... Hacleth. . .

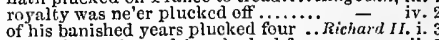
my rights and royalties plucked from
being plucked from off their backs ..

are plucked up root and all..........

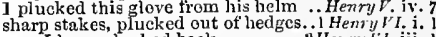
set thee up and plucked thee down? 3 Henry $V_{l}$. y. 1 betutish wrath sinfully plucked.... Richard III. ii. plucked two crutehes from my fee

with comeliness plucked all gaze...

from him plucked cither lis gracious

these growing feathers pluckcd .....Jul
he plucked me ope his doublet
their hats are plucked about their ea.

their hats are plucked about their ear
as he plucked his cursed stcel away..

may be, she plucked it off, to send ... c cymbeline, ii. 4 I may be plucked into the swallowing. Titus And. ii. never plucked yet, I can assure you ...Pericles, iv. 6
which since hathl plucked him atter....... Lear, iv. 2 as if he plucked up kisses by the roots... o ohello, iii now he tells, how she plucked him to nyy
when $I$ have plucked thy rese ...........

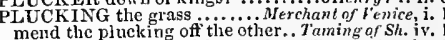
mend the plucking off the other.. Taming of Sh. jv. plucking to untix an enemy $\ldots . . . . .2$. HenryI $r$ '. iv. pre meet for plucking up, and .. Titus And?on, iii. I PLUE, and sonetimes red .......... Henry give it a plum, a cherry, and a fig.... King solh, ii. I PLUMlE-dowle that's in my plune... Tempest, iii. . 3 jets under his advanced plumes!. Fwelnh Night, ii. S what plume of feathers is

he; that with the plume $\ldots . . .$. sits mocking in our plumes

plucks down Achiiles' plumes .. Troilus $\delta$ C Cress it.

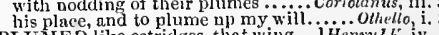

PLUMED like estrichces, that wing .... must vail her lofty plumed erest ....1 Hemry $r$ l. . v. 3 Farcwell the plumed troop, and the big. othello, iii.

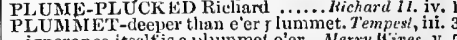
Pl.UMP - banikh plump Jack ......... I Henry I'. ii. PLUM-TUEE, inaster ..............2Heury I, iz. 
PLUM-TREE-and plum-tree gum ... Humlet, ii. 2 POINS-and master Poins unon......2 Henry IV. ii. 4 POINT-the sourest poiats with ....Antouy \& Clco. ii. 2 do not plunge thyself too far............All's do not plunge tliyself too far ........... All's Well, ii. without heed, do plunge into it... Timonnf dth. iii. 5

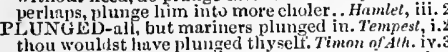
thou wouldst have plunged tliyseli. Timon of Ath. iy.

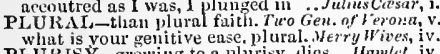

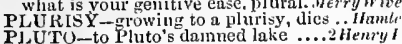
fo - to Pluto s damned lake ..... Henry in. ii. 4 nor I, hy Pluto

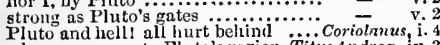
when you conse to Pluto's region. Titusandron. iv. 3
but Plinto sends you word if you ....

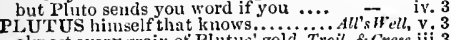
almost every grain of Plutus' gold. Troil. S Cress.iii. 3 a heart dearer thau Plutus' mine. Julius Casar, iv. 3 keep house, ply lier hard....... As you hike il, iil. 5 go ply thy needle; niedile not ....... - ii. and I must ply my theme.... Tïus.̈Andronicus, y. aly Desdemona well .....

and art thou Poins his brother?

by heaven, Poins, I feel me much

POLT - to point the tempest that...... Tempest, iv. exactly do all points of iny command most poor nuatters point to ay, there's the point, sir lilt to point, heel to head ........... he does obey every point of the let ter the Egyptian thief,', at point ot death

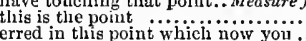
erred in this point which now you. let me know the point

gree with his demands to the point no man's dagger here a point for me? pray you, examine him

and toueling now the point of liuman no point, witl my knite (rep. v.2). Love did point you to buy them

all points like a man? ...

that is one of the points in the
that, from point to point (rep.

that, from point to point (rep. or very falsely pocket up his report.

will carry this island home in his poeket mette le au mon poeket ..............

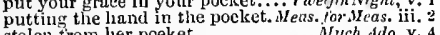
stolen trom her poeket ..............Much Ado, y. 4 wear prayer-books in my poeket. Mer.of i'enice, ii. 2 I have his letter in my poeket let me pocket up my pedhar's... search his pockets

anything in thy poeket but tavern.

confess then, you picked my pocket? - iii. 3

from another's pocket, to put in to

I have another leek in iny puck

h' as a book in lis poeket, with red.2 Henry Fi. iv. $^{2}$

brings a' victory in his pocket? .... Coriolanus, ii.

I put it in the pocket of my gown. ... Jlins Cersar, iv.

you did pocket up my letters....Antony \& Cieo. ii.

or put the mooun iu his pocke

of my master's then in mny pucke

iv - v. 5

let's see his puckets; these letters........ - Lear, iv. diadem stole, and put it in lis pock

POCKETING up of wrong

POCkY - we have many pocky corses

PODY-be any pody in the liouse. Othello, v.
Henry $\mathrm{V}$.

POEN_-or poem unlimited ....... Henry iv. 7 and golden cadenee of puesy .... Love sh. L.ost

our poesy is as a gum...

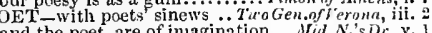
and the poet, are of in a fine freazy roliung

the poet's pen turns them into

never durst poet touch n pen to... Love's $L$. Loxt, iv. 3

therefure, the poet did feign that. Mer. of Venice, v. 1

as the most equrieious poet.

in good truth, the poet is make

all that poets feign of bliss and

ferryman which poets write of $\ldots .$. Richurd III. i.

art not a poet. Yes. Then thoul liest

I am Cimna the puet, I am (rep.).Julius Ceesar, iii. 3

figures, scribes, bards, poets .....Antony \& Cleo. iii.

parterned by thot the poet liere.

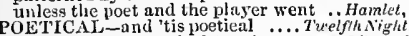
had mate thee poetienl (rep.)..... As you Like ot, iii. 3

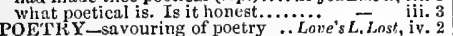

cutter's poetry upon a knife ... Mierch. of tenice,

fur the truest poetry is the most. As you L/ke it, iii. 3

and poetry, schoolinasters will I...Taining of Sh. i. I

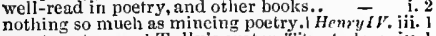

sweet yoetry, and Tully's orat
PôC'TiERS, Anjou, Touraine.

Maine, Puietiers, and all (rep.)

King John, i. 1
i henry VI, i. 1
iv 3

Mnine, Blois, Poictiers, and Tours..... iv. 3

PorNS-the wild prinee and Poins. Merry Wives, iii. 2

Poins: now shall we know if........ I Henry $I V$. i.

Ned Poins and I will walk lower

an the prinee and 'olins be not $t$.
no more valour in that Poins

noins! Anon, anon, sir. Sirrah

answer me to that; and Poins there

and so good-morrow, Poins .........

go, Poins, to horse, to horse; for thon
slrall I tell thee one thing, Poins?..2 Henry IV. ii.

be not too familiar with Poins .. - ii. 2 (letter) now must the world point at poor. Taming of $S /$

of any point in't shafl not only ... Vinter's Tale,

but that's not to the point .......... = iii.

i'the rainbow; points, more than all $=$ iv. 3

I think, the dial points at five. Comedy of Errors, v. I

point against point rebellious, arm ..... Macbelh, i.

point against point rebellious, arm

all ready at a point, was setting............

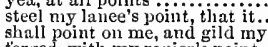

torced, with my rapier's point

talses on the point of honour

put a few floeks in tlie point....... i Henry $1 \%$.

thus I bore my point ..................
but took all their sevein points in ....
their points being broken - down feil

liere lies the point

tis a point of riendship..................

hold lord Percy at the point

J barony.2 Henryl $1 \%$. i

what, with two points ou your shoulcier?

loud trumpet, and a point of war? $\ldots$...

from hilts unto the paint ....... Henry $r$. ii. (chorus)

the milary discipline; thiat is the point

thou diest on point of fox

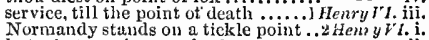

but what a point, my lord .............

Beaufurt is at puint of death

be wiped from thy point

the steely rapier's point, made issue

better brook tliy dagger's point......

'tis a point of' wisiom.................

tis a point of wisuom ................. - v.

paint hy point the treacons of his ...Henry VIII. i.

dangerous eonception in this point ...

all their honourable points of ignorance

but in this point all his tricks tounde

I do enjoy at ample point all ... I'roil

admits no orifice for a point.

sinee riclies point to misery... Timon of

as the main point of this our

whom with all praise I poin

you are at point to lose your libertie

in this point eharge him home

almost at point to enter

ere we eould arrive the puiut proposed

here, as I point my sword, the sun...

to you our swords have leaden points

swayed frum the point, hy look
or driven, as we point the way and points at them for his

and bloody point to point.............. Richard $-\mathrm{ii}$.

carve out dials quaintly, point by point = ii.

my good lord eardinal to this

in such a point of weight, so near mine

and swim to yonder point? .......... Ju let your best love draw to that point

at suel a point, when half and half.. - iii. 11

mingle eyes with one that ties his points? -

was onee at point, (O giglot fortune $\left.)^{2}\right)$

well then, here's the point

the due of honour in no point ornit.

and, in that point, I will conclude

when tenrful wars point at mod

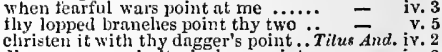

dies upon my scimitar's sharp point. Tilus And. iv.

witness my knite's sharp point ......

from lier bosom took tlie enemy's point - v.

tell him o'er, point by point.....

stand a loof from the entire point.......

Lear, $\mathrm{j}$.

are at point to show their open banner... - i.

my point and period will be thorougluly

beats down their fatal point

dideres a teartul point:

did spit his body upon a rapier's point

whe $=$ iv. 3

your business, and desire, shall point you - i. to this point l'll stand ............... - iv.

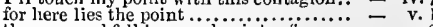
the pass and fell incensed points of........ $=v_{.2}$

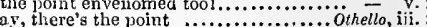
to point his slow unmoving finger at..... - iv. POINT' they do not point on me ........

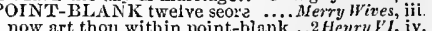
now art thou within point-blank ..2Henry $r$ I. iv. and point-de-vice companions ... Lave's L. Lost, y. 1 POIN'TED-art thou so pointed at?. I Henry had pointed hin as sharp as ny .... Cymbeline, $\mathbf{i}$. death: (and pointed to this brace) $\ldots . .$. ... Pericles,
POINTED 'TOINTED tines ........... Taming of Shere, iii. PolNTiNG on him ...........Troilus \& Cressida, $\mathrm{i} .3$ POINTING-STOCK, to every idle ..2Henry POISE of sin and chast........Meas. for Meas. ii. poise the cause in justice' equal ...2Herry $I_{T}$. ii. swing and rudeness of his poise.. Troihts \& Cress. it cecasions, noble Gloster, of some poise.... Leur. ii. it shall be full of poise and diffienty..... botl merits poiscd, eaeh weighs nor less - iv. herself poised witl herself .......Romeo of Juliet, i. POISON-like poison giveu to work .... T'empest, iii. 3 what a dislx of poison has slie........ Tuelfh Night, ii. 5 poison of that lies in you to temper... Much Ado, ii. if you poison us do we not die? . Ner.of lenice, iii. 1 praetise against thee by poison ...Asyou Like $i t, i$.

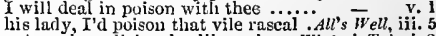
not work malicionsly, like poison. Winler's Tale, i. to poison my triend Polixenes $\mathrm{I}$ do..... elamours of a jealous woman poison more $-\bar{v}$. nor poison, malice domestic.............. Mocbeth, iii.
sweet poison for the age's tooth..... KingJoln, $\mathrm{i}$. and there the joison is, as a fiend.... they love not poison that do poison... - vet - v. 6 in poison there is plysie $\ldots . . . \ldots \ldots \ldots . .2$ Henty $I V . \mathrm{i}$. hide not thy poison with such ....2HenryVI. iii. pring the strong poison that i whose tongue more poisons than ....3 3 Henry $V l$. i. looked not on the poison of their...... goodness is poisun to thy stomaeli.Henry $\bar{V} I I I$. iii. may be merely poison!

with thy most operant poisoni....... = iv.

lang lis poison in the siek air .....

whose antidotes are poison, and he ... the sweet which is their poison....... - iii. in grateful furgetfulness shall poison - vo 2 feed myself with most delieious poison - i. poison it in the source; and the first - iii. il awry! thou art poison to my blool... Cymbeline, $i$. 2 think, she has strange lingering poisons we will fear no poison, whiel a $a \ldots \ldots$ tends or knife, or poison, some upright.....

thou gavest me poison: daugerous....

to temper poisons for lier............. yet they poison breed. Antioch ..........l'ericles, i.

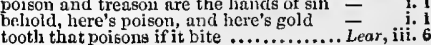


POISON-if you have poison for me ...... I'll ne'er trust poison $[K$ Knl.-medicine $]$

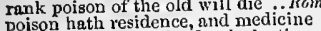
poison more than the deuth-durting no poison mixcd, no slutrp-ground. find out but a man to bear a poison. what if it be a poison, which the fria let me have a dram of poison ...

gold, worse poizon to men's souls .... cordial, and not poison: ro with me poison, Isee, hat doth hang on them did buy a poison of a poor 'potliecary no, no, they do but jest, poison in jest . Ham he poisons him i' the garden for his.. O1 this is the poison of deep grief. it is a poison tempered by himself ...... the potent poison quite ocrerows my.... make after him, poison maid's affections? with my poisou! dangerous conceits (rep.) or knives, poison, or tire, or sufpigt get me some poisou, Iago, this night

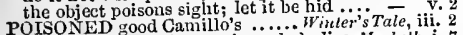
the ingredients of our poi soned ehalice, Macbelh, $\mathbf{i}$. in the poisoned entrails throw ......... King John, v, 6 how fares your majesty? Poisoned . $-\bar{c}$ v. some poisoned by their wives...... Ricleard II. iti. 2 homage sweet, but poisoned flattery? Henry $V$. passage of my poisoned voice...

my valour's poisoned, with only . Coriolanus, i. when poison basket. Poisoned then

would our viands had been poisonedicymbeline, v.

it poisoned me. $O$ gods! I Icit out

Leonine, whom thou hast poisoned

weleome, I perceived, had poisoned mine. Lear, ii.

and her sister by her is poisoned .........

the one the other poison shot

it is the poisoned cup; it is too Iate

the drink, the drink; I am poisoned!

thy mother's poisoned, I ean no more .., $\bar{T}$ Tale, 1.2

POISONER of good Pol the poisoning.... Hamlet, iii. 2 POISUNING-talk of the poisoning..... Tempest, $\bar{i}$. as all the poisonous potions in

poisonous too, and kill thy forlorn.2 Henry VI. iii. 2 with poisonous spite, and envy. Timon of thens, i. very poisonous where the dise

as poisonous of your honour ........ the poisonous damp of night..... Antomy s... Cy mbeline, i. 6 as poisonous tongued, as handed ..... . $\overline{\text { thellit. } 2}$ doth, like a poisonous mineral, gnaw .. Othello, ii.
POKE-drew a dial from his poke.As you Like it, ii. 7 POKING-STICKS of steel.. IVinter's Tale, iv. 3 (song) a preparation 'gainst the Polack (rep.)

a preparation gainst the Pill defend it

you from the Polack wars ............. v. PULAND winter............................ E supposes me travelled to Poland. Meas. for Meas, galnst some part of prond (rep.

PouD-be pold, I pray you ................. wives wives, v. 4 POLE, I do challenge thee (rep.) ...Wove's L. Lost, v. 2

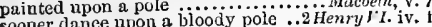
will stand steadier on a pole

both upon two poles hither

the soldier's pole is falle

the soldier's pole is fallen $\ldots \ldots$ Antony $\&$ Cleo. iv. $\mathrm{i}$

to Norway, or the Pole, a ranker rat

the guards of the ever-fixcd pole

you hargare, you polecat, you ronyon! POLE-CLIPT vineyard .............. Tempest, iv. 1 POLEAION and Amintas ..A A.... Tilus Androu, iv. POLICIES - wit for seeret polieies ...1 Henry Vi. iii. 3 for policy I hate policy of mind, ability in means.......... Auch $A d o$, iv tis some policy to have onc show. Love's L. Lost, $\mathrm{v}$ I will o'errun thee with polic it she be curst, it is for policy Taming of Sheu, ii. not something of the pulicy

some love, but littlc policy....
bare and rotten policy colour

Hentyl $F^{\circ}$ iv. to any eause of policy, the gordian.

with pale policy seek to divurt.. - ii. (chorus) throurh which our poliey must ....1 IIenry VI, iii. it is your policy, to save your........ it is no policy, respecting what .......
that he should die, is worthy policy

that wcre no policy; the king will

with all his tar-tet policy, had.....

with powertul policy strengthen $\ldots . .3$ Henry $r^{\prime} \boldsymbol{I}, \mathrm{i}$. it is but his policy to counterfeit

it is his polsey, to haste thus fast...̈nry $\bar{V}_{I I I}$. iii. plague of your policy, and call it. Troilus \& Cress. i. my foree, pursuit, and policy....... - iv. 1 the policy of those crafity swearing ...
POLICY grows into an ill opinion Troilus \& Cress, v. 4 and policy, like unsevcred fricnds.. Coriolanus, ifi. best ends, you udopt your policy.....

all the poliey, strength, and derence iv. I think the policy of that purpose policy and stratage

this policy, and reverence of agc.... Lear, i. 2 (]ctter)

hunts not the trail of poliey so sure.... II amich, ii.

that poliev may either last so iong

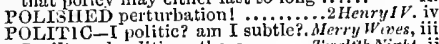
I will read politic authors

nor the lawycr's, which is politic....... you Like il, iv. it is not politic in the commonwcalth. All's $\mathrm{Well}$, i. 1

yeu must seem ver'y politic

with politic grave eounscl.

Richard III. ii.

when he made man politic .... T'imonof slhens, iil. 3

of such a natire is his politic love

'tis politic, and safe, to let him keep ....... Lear,

no further off than in a politie distance. Olhello, ii

a Cataian, we are politicians.......Twelf $h$ iefight, iil. 2

and, like a senrvy poltician, sitician ..Hamlet, v.

OLITICLY begun my reign .... Taming of Sh. iv.

nobles, well; 'tis politid done ..... Winter's Tale

for 'tis Polixenes has made ............
mistook, my lady, Polixenes for Leoites -

Camillo and Polixenes laxigh at me.

adultery with Polixenes, king $-\cdots$ iti...

i. $\overline{2}$ (indict.)

before Polixenes eame to jour court
Polixenes, (with whom $I$ am aceused)

you had a bastard by Polixenes

I'll reconcile me to Polixenes....

to poison my frien betrayed'st Polixenes...

OLL-not to fifteen thousana poll.... All's $W$ ell hath not his poll clawed like........2 HenryIV

we are the greater poll
set down by the poll?

Coriolanus, iii. 1

all flaxen was his poll.........Ha Hlet, iv. 5 (song)

OLLLD-leave his passage polled... Coriolanus,

POLLUSION holds in ............ Love s L.Lost,

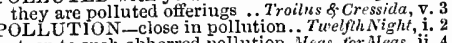

stoop to such abhorred pollution. . Ileas. Jor-Meas.
POLONIUS? He hath, ny lord, wrung... Hamlet,

Hamlet in madness hath Polonius slain - iv, 1

and whispers, for good Polonius' death...

POLYDAMUS hath beat down... Troilus \& Cre

you, Polydore, have proved bes

Pould Polydore, I love thee brotherly

hark, Polydore, it sounds! but what

Iet us, Polydore, though now our voices

this gentleman, whom I call Polydore

PONANDER-pomander, brooch. I
PONEGRANATE-of a pomegran

sings on yon pomegranate tree.. komeo \& Julie,

POMEWATER-as a pomewater.. Love'sL. Lost,
POMFRE'T-the streets of Ponfret..hingJohn,

you must to Pomtret, not un to

meaning the king at Pomfret

and him to Pomtret; where, as aii..2 Henry

and lord Grey, are sent to Ponf

of the queen, must die at Pomfiet .

0 Pomtret, Pointret! $O$ thou bioody

at Pomfret that died at Porafret!

POMP-is not for our ponap .... Mid.

with pomp, with triumph, and with .. - i.

sweet than that of painted pomp?.As you Like il, ii.

to be too little for pomp to enter ....All's Well, iv. 5

this unlooked-tor unprepared yomp. King Jo

be measures to our pomp? to be possessed with doulle poin

with dreadful pomp of stoui invasion! -

the imminent dceny of wrcsted pomp = iv. 3

and griuning at his pomp............ . ie

nor the tide of pomp that beats

in pomp and ease, whilst such

to think upon my pomp

why, what is pomp, rulc, reign

only to show his pomp as well in.....
still frowing in a majesty and pomp

much better, she ne'er had knowu pomp -

vain pomp, and glory of the world . Timon of

what need these feasts, jomps
POMP-his nomp, and all what. Timon of Athens, iv.

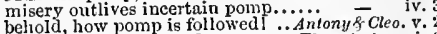
triumph is this funeral pomp..... Tilus Andron, i. take physic, pomp; cxpose thyself ....... Lear, iit. pride, pomp, and eircumstance of .... Othello, iil. POHP I-me pompe provexit apex.... Ptricles, in. Sextus Pompeius makes his approaches - i. in Sicily Sextus Pompeins spoiled ... for Meas. ii. Pompey the Great. Pompey (rep.) . how would you live, Ponpey? (rep.) Pompey told you so. Thank you (rep.) how now, noble Pompey?............ art going to prison, Pompey?

for delit, Ponney, or liow?

no indeed will I not, Pompcy ( $($ ep. $)$.)

go to kennel, Pompey, go..............

the swain, Pompey the great (rep.)..

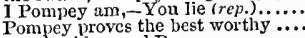

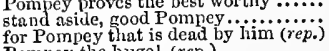

Pompey the hugel (rep.) .............

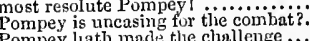

Pompey liath made the challenge...

the wars of Pompcy the great.........Henry $V$. iv

nor pibble pabble, in Ponpey's camp Pompey the great; and Suffolk ....2 Henry VI. iv.

to see great Pompey pass the strects

in Pompey's porch (rep.) .......... :

that done, repair to Pompey,s theatre

even at the base of Pompey's statue

ngainst my will, as Polypey was..... - - Cleo. i.

the condernned Pompey, rich in his

Pompey is strong at sea; and it appears =

Pompey thrives in our idleness..

and great Pompey would stand know, worthy Pompey that what they -

you hear no more words of Pompey

of us must Pompey presently be soüght -

thou eaust not fear us, Pompey....... =

that will I, Pompey. No, Antony ...

Pompey doth this day Iaugl away..

Pompey, a word. Say in mine ear $\because$ with =

no, Pompey, I have kept me from

Pompey, good-night; good brother.

they have despatched with Pompey

and Lepidus, since Pompey's fenst ...

Lepidus have made wars upon Pompey -

he had formerly wrote to Pompey

that his officer, that murdered Pompey -

were a fragment ot Cneius l'ompey's - iii. 1 i

POMIPION the great (rep.) ........ Love's L. Lost, v. madeck the pompous body of $n$ king. Kichard II. iv.

most pompous marriage feast.. Pericles, uii. (Gower)

and mantle, like a stauding pond. Mer. of yenice, i. 1

and his pond fished by his next ... Winter's Tale,

as fish are in a pond ................. Cymbeline, i. 5
light upon neighbouring ponds.....
PONDER - give me lcave to ponder on .. Lear, iii.

PONDEROUS and settled ......... Winter's Tale, iv. 3

oped his poudcrous and marble jaws.... Hamlel, i. 4
POND'RoUs and substantial......Meas. for Meas. iit. 2

PONIARD - she speaks poniards ..... Much Ado, ii.

stab poniards in our tlesh ..........3 Henry $V I$. ii. 1

six French rapiers and poniards ...... Hamlel, v. 2
PON'T-ling of Pont; 1Ierod of .. Aniony \& Cloo. iii. 6

PONTICK-like to the Pontick sea .... Uthello, iii. 3

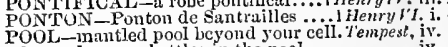

but to lose our bottles in the pool.

in a great pool, a swan's nest .............

away, away, goou twilliam De la Poolel - ii.
for your partaker Poole, and you....

have with the Poole. Farewell.

and Willian de la Poole........ Henry VI. $\mathrm{i} .1$ (art.)

and thee. Poole, when in the city.. - i.

yes, Poole Poole? Poole? Sir Poole? - iv. 1
POOP-the Iantern in the poop ...... Henry IV. iii. 3

the poop was beaten gold ..Antony \&.Cleopatra, ii. 2
POOPED_she quickly pooped him ....Pericles, iv. 3

PUOR - poor souls l..................... Tempest, i.

a full poor cell

alas, poor Hlitain

further search for $m y$ poor son

a nost poor credulous monster.............

to make a wondel of a poor druukard 

POOR matters point to rich ends ...... Tempest, iii. I POOR-how shall they eredit a poor....All's Well, i. 3 . POOR-such are the poor, in healtlh..2 IIenryI $V$. iv.

the poor monster's my subject.

his dukedom in a pour isle........

to my poor cell ..........

poor wounded name

this parting strikes poor iovers dumb

falsehnod, cowardice, and poor descent
my riches are these poor hubiliments

my riches are these poor hubilin
oilly women, or poor passengers.

ails, poor Prote

nlus, poor fool!

poor gentlewomaii.

sny poor mistress. moved therewithai

alas poor lady! desolate and left!....

the rich and poor (rep. ii. 1) .....

hang him, poor cuckoldiy knavel...

yot, I wrong him to call him poor...

the poor unvirtuous fat knight

as you see, like a poor old min .......
master Brook, like a poor old womail

what shull poor meı

and as poor as Job? ..................

if' it be so, (as 'tis) poor lady, s

and I, poor monster, fond as . .........

not a friend greet my poor corpse..

not a bosom. hides my poor heart

liow apt the poor are to be proud
one poor heart of mine in thee

they say, poor gentleman, he s

alas, poor tool! how have they ......
twixt you and your poor brother.Meas. for. Yea
the poor duke's coustable (rep.)......

a puor widow's tapster fi..........

truly sir, in my poor opin

but yet,-poor Claudiol ...........

ife soft and tender fork of a poor worm -

nnd the poor beetie, that we tread upon

a poor wronged lady a merited benefi

this befel to the poor gentlewoman.id =

the poor Mariana allvantaged

I have laboured for the poor geitleman

for my poor seif I am combined......

away with her: poor soul, slie speaks
for her poor brother's pardon (rep.)..

do perceive, these poor informal women

but, O poor souls, come you
alas, poor lurt fowl! now wili

a thank it, poor fool, it keeps on

and torment the poor lady worse ..

have need of poor ones, poor ones
but we are the poor duke's officers

and though I be but a poor man .....

turned over and over as my poor self

alas! poor heart! if $y$ ou spite it.......

conjure tears up in a poor maid's eyes

and extort a poor soul's patien

fiom these that my poor company detest -

thus to make poor females mad.

and what poor duty cannot do

and through wall's chinks, poor soulis

but mark, poor kniglit, what drealful

to spill the poor deer's blood

sometime to lean upon iny poor slioulder-

and rich things but pisor ......

e'en une poor man; Pompion........

the poor wench is cast away...........

poor men's cottages, princ

a poor inan's soun (rep.) $\ldots \ldots . . . \ldots$.

yct, poor man, my fatlier ..............

will go hard with poor Antonio

for the poor rude world hath not ....

a pound of this poor merchiant's flesh

but a poor thousand crowns ........ ds you Like

a poor uaworthy brother of your.

or give me the poor allottery

the poor old mun, their futher.........

o my poor Rosalind!

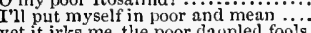

yet it irks me, the poor dappled fools
to the which place a poor sequestered stag 二

poor deer, quotl he, thou makest....

poor deer, quotl he, thou makest....

but poor old man, thou prunest...

alas, poor shepherd! searching of

that your poor friends mu

there is an old poor man

even so; poor men alone?..................

to have rich eves, and poor hands....

alas, poor shepherdt. il................

a poor humour of mine, sir, to tak

like a miser, sir, in a poor house

bless our poor virginity from....

in their poor praise he humbled

my poor body, madam, requires it

suffer her poor knight to be surprisci sir, I am a poor friend of yours $\ldots \ldots$.
a poor physician's daligliter $(r e p.) . .$.
my poor doing eternal $\ldots . . . \ldots \ldots \ldots$.

porr lord! is't $\mathrm{I}$, that ehase thee .....

the dark, poor thief', $l^{\prime} l l$ steal.
alas, poor larly! 'tis a liard.

are words, and poor condition

commanders very poor rogues $($ rep. $p$.)

the rogues are narvellous poor.

iv. 4 no other but a poor ofticer of mine...

under my poor instructions yet $\ldots . .$.

to give this poor petition to the $\mathrm{king}$

he looks like a poor detayed member
and speech of the poor sulupliant

and a poor maid is undone...

I am a poor man, and at your.........

no better than a poor and loatlisome -

let us, that are poor petitioners, speak

the world point at poor Katharine.

can change these poor accoutrement

that she, poor soul, knows not ...
sliall be proud, our

the worse for this poor furniture ....
my poor prisoner, I am innocent...

come on, poor babe, some powerful

poor trespasses, more monstrous

the thrower-out of iny poor bube

poor wretch, that for thy moth
than the poor thing is here

piteons cry of the poor souls! (rep.).

and me, poor lowly maid, no.............

a poor humble swain, as İ sectn now

you have heurd of my poor services.

now hath these poor men in question

my poor liouse to visit

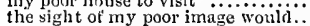

a poor mean woman was delivered. Come

parents were exceeding poor, I bouglit

part, poor soul!

froun home; poor I am but his

carries poor suuls to heii

wert not, poor distressed soul

ah me, poor man, how pale and wain

to fetch my poor distracted

so cracked and splitted my poor tong

wike the poor cat i the adage?

whilst our poor malice remain.

poor birl! thou'dst never (rep, $)$....

now, God help thee, poor monkey!

a weak, poor, innoeent lamb ....

the poor state esteem him as $\ldots . . . . . . .$.

which the poor heart would fain deny

his mother shames him so, poor boy. $\mathrm{kin}$

heaven-moving pearls from his poor ey
thy sins are visited in this poor child

cheats the poor maid of that

like a poor beggar, raileth
because niy pour child is

many a poor man's sun

find the inheritance of this...........

hath one poor string to stay it by...

thoing poor eraft

nor the prevention of poor Bolingbroke

thanks, the exehequer of the poor....

when my poor heart no measure

alas, poor lichard! where rides

no more thau my poor life must

strike him, Aumerle; pnor bov.....

for the poor abuses of the time

the poor jade is wrung in .............

poor fellow ! never joyed since

a hundred upon poor four of us......

Eucl poor, such bare, such lewd.

he is poor: he hath nathing (rep.)
onc poor pennyworth of suigr-caud

onc poor pennyworth of sugar-eandy
what should poor Jack Falstatf to ..

they are exceeding poor and bare.

a poor unminded outlaw

changelings, and poor discontents.

poor Jaek, farewell! I eunld lia ve

I am as poor as Job, my lord...

a long loan for a poor lone woman

poor widow of Eastcheap (rep.).

$\mathrm{my}$ lord, this is a poor mad soul

reputation, and satisfy the poor wom

I do now remember the poor creature

grant that, my poor virtue

you poor, base, raseally, cheating.......

for tearing a poor whore's ruff..

alas, poor ape, how thou sweat'st!

a poor esquire of this county ....... \begin{tabular}{l|l} 
ii. 2 & Ony poor kingdom, sick w \\
ii. 3 & this poor show doth better
\end{tabular}

the poor mechanic porters cruwding ... nenry $V$.

valued this poor seat of England
ah, poor lieart! he is so sliaked.....

orisons 'gninst this poor wretel........

therefore hence, poor miserable.

pour, we may call them, in their native

his exchequer is too poor......

alas, puor Harry of England $\ldots . . . .$. .

and a many poor men's lives saved..

their wives left poor behind thein .
that a poor and private displcasure.

poor I have in yearly pay behold yon poor and starved band...

and their poor jades lob down ......

their poor bodies must lie and fester
should they mock poor ficllows thus?

and my poor soldiers tell me ........

the poor and untemperiog ...........

more than we poor men do know......

thus are poor servitors (when otliers
to visit her poor castle where slie....

poor gentleman! his wrong.

poor market-folks, that come to seil

mean and right pror; for tlat $\ldots . .$. .

yet is he poor, and our nobility....

a poor earls daughter .................

unto the poor king Reignicr ........2 Henry

poor suul! God's goodness hath beed -

sent his poor queen to France........

that fieeced poor passengers............

so the poor chicken should be sure..

grieve 1 at an hour's poor loss?.......

poor men before them

and sends the poor well-pleased

to combat a poor famished inan

poor Ctiflord! how I seorn his .......3 3 Henty $r^{\prime} l$.

in vain thou speak'st, poor boy...

alns, poor York I but that I hate

graced thy poor sire with his bridai day -

poor liarmless lambs abide their

poor queen, and son, your lahour...

thou, poor soul, art then forsaken ..

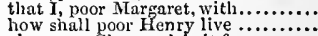

alas, poor Clarenec! is it for $\ldots . . . . . .$.

for a poor earl to give.......

you left poor Hemry at the ...........

where my poor young was limed....

I Diedalus; ny poor boy, Icarus ....

poor key-cold figure of a holy king! Richard III. the lamentations of poor Anne....

encloseth m y poor lieart ............

Edward, ny poor son, at Tewksbury

poor Clarence did forsalke his father

and for his meed, poor lord, he is.....

poor painted queen, vain fuurish...

my poor Margaret was a prophetess.;

bitter sentence of poor Clarence' deatll? -

how the noor soul did forsake.........

speak unto myself for him, poor soul

is lighted on poor Hastings' wretehed

thesc both put by, a poor petitioner..

go, go, poor sonl (rep.

[Col.knt.] some mean, poor gentlema....

blind siglte poor mortal living gliost

I ealled thee then, poor shadow ....

poor breatling orators ot miseries!...

a poor bark, of sails and tackling reft

too decp and dead, poor infants.....

for want of mea thy guile

and make poor England weep .........

communication of a most poor issue?

they have done my poor house

now, poor Edw'aru Bohun ..........

alas, poor lady! she's a strang

with me, a poor weak woman.

for their poor nistress' sake ........
alasI poor wenches, where are now.

upon me, poor undeserver ...........

I am a poor fallen

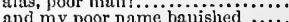

ame ballished ........

my next poor petition is $\ldots \ldots . . . .$.
stind these poor people's friend...

the estate of my poor queen...

tongues, than I myself, poor man....
that am a poor and humble subject. 
loOR - you see the poor remainder. Hrnry 'PII. v. 3 POOR Transilvanian is dead himselft Aias, poor Troilusl... Troilus to cressida, i. 2 a love that makes breatla poor alas, poor chinl many a wart is......

no, your poor disposer's sic
whiat, am I poor of late?

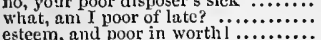

alus, poor wretcl 12 a poor capocecliäi i

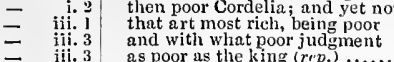

Pcricles, iv. 3

POPE-spite of pope, or dignitics of ... Henry $V 1$. i.

O poor gentleman 1 a plague .........

als, how the poor world is pestered..
ahi poor our sex! this fault in us...

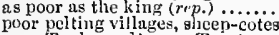

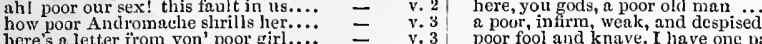

二 iv. 2 poor pelting villages, slacep-cote.

here's a letter from yon' poor girl.....
hus is the poor agent despised!.....

poor rogues, and usurers' men!. Timan of Athers, ,ii. .

he's poor, and that's revenge enough

poor naked wretelyes whereso'er you are

forthom and halt' poor Toml (rep.

but such a poor, bare, forked animai

and his poor self, a dedicated

and we, poor mates, stand ou....
rich in sorrow, parting poor...

rich in sorrow, parting poor......
poor honest lord, brought low

poor honest lord, brought low ......

thy pienteous bosom one poor

and hurrts the poor ereature of earth

poor Tom's a-cold (rep.iv. 1) i i...

the foul fiend haunts poor Tom in

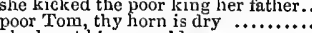

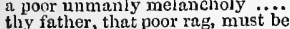

pluck out his poor old eyes $\mathrm{y}$.

compounded thee poor rogue hered

an houest poor servant of yours.......

ne'er did poor steward wear.

whilst this poor wealth lasts .........

interprets for my poor i gnorance

We are accounted poor citizens.......
they $s a 5$, poor suitors have strong

they say, poor suitors have stron
to chain up and restrain the poor

rubbing the poor itch of

yet, poor old heart, he holp the

poor Tom hath been seared (rep.)

well sir; the poor distressed Ciear
alnck, poor gentleman! of

well worth a poor man's taking.......

a poor unfortunate beggar.......

a most poor man, made

to watch, (poor perdul) with this thin....

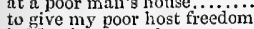

and wace had speechi with man so poo

s Marcius poor, that you two (rep.)

you are ambitious for poor knaves

to my poor unw orthy notice

a marvellous porr one (rep.)

one poor grain or two (rep.).......
tlis is a poor cpitome of yourg

this is a yoor epitome of yours .......

when she (poor hen), fond of no...

that shall our poor eity find

than that poor Brutus, with himself

poor man! I know, he would not be

when that the poor have cried, Cassar

puor soul! his eyes are red as are poor to do him reverence

wounds, poor, poor dumb moutlis...

poor knave, I blame thee not

hear poor rogues talk of court news.....

ii. 1 and my poor fool is hanged! .............

ii. 3 only poor, that, when she dies..........

at my poor house, look to behold .....
like a poor prisoner in his twisted gyves -

alas, poor Romeo, he is already

my heart! poor bankinupt, break at o
ah. poor my lord, what tongue shail

is my poor heart so for a kinsinin...

poor soul, thy face js much abused

but one, poor oulc, one poor and loving

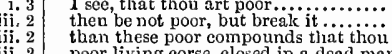

poor living corse, closed in a dead man'
buy a poison of a poor 'pothecary

poor sacrifices of pour enthity!

kle foilowed my poor father's body....

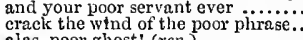

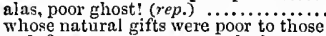

and, for my own poor part, look you

give me one poor recuest.

and what so poor a man as Humlet i....

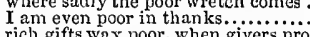

rich gifts wax poor, when givers p

of violent birth, but poor validity

the poor advanced makes friends

poor Ophelia (rep.iv. 7 . . .........

how poor an instrument may do.

poor venomous fool, be angry

usto a poor, but worlly, gentem.
as I my poor self did exchange...
sir, you o'errate my poor kindness

sir, you o'errate my poor kindness ...
alas, poor princess, thou divine Imog

alas, poor princess, thou divine Imogen
telling you that I am poor of thanks

alas, poor Yorick! 1 knew him, Horatio

his slipping (poor ignorant baubles!)

we, poor unfledged, have never $\ldots . .$.

poor l am stale, a garment out of.....
thus may poor fools believe.........
will poor tolks lie, that have affliction

poor house, that keep'st thyself!

for the disl, poor tribntary river

poor sick Fidele! I'll willingly .....
as deep as these poor piek axes can

remaining so long a poor unknown

hath my poor boy doone augh
or we poor ghosts will cry to

or we poor ghosts will ery to ..............
poor shadows of Elysium. hence

poor shadows of Elysium, henches that depend on greatness

poor wretches that die poor soldier, that so richly

guch noble fury in so poor a thing
but beggary and poor looks...

Thes three in poor beseeming..............
Tribunes! and me a poor competitor Tilus.Jn
bebold the poor remains, alive, and dead:-

bebold the poor remains, alive, and de:
poor I was slain, whlen Bassianus died

poor Bassianus (rep )

for thou, poor man, hast drowned.....

alas, ponr heart, that kiss is .........

thy nece, and I, pour creatures, want
this poor right hand of mine is......

when thy poor heart beats with
all thie tears that thy poor eves

poor harmless fly! that with hig

por horor man! grief has so wroughit
make poor men's cattle break ......

although the clieer be poor, 'tvitii fill

the poor remainder of Andronici

and the poor worm doth die for

alas, poor souls, it grieved any he.
driving the poor fry before him.

like a poor man's right in the law

up and down the poor shio drives

for the love of this poor infint

ah mel poor maid, born in . . .

and save poor me, the weaker.......
we have but pnor thrce, alyd tlie

we have but pnor thrce, alsd tley........
tis not the bringing up of poor bastard

ii. 1

thin habits, and poor likelihoods ....

must of poor patience borrow ..............
if this poor trash of Venice, whom 1 trasi

I have very poor and unhappy braing for

how poor are they that have not patience

there's a noor pieee of gold for thee.

not enriches him, and inakes me poor.....
poor, and content, is rich, and richn elloug

as poor as winter, to him that ever (rep.)

poor lady! she'll run mad, when slie ....
one is too poor, too weak for my reverige

alas, poor caitift! look, how he

at one side, and sing it like poor Barbura

the poor soul sat sighing by ...... - iv. $\overline{3}$ (solvg)

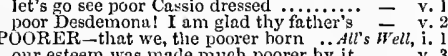

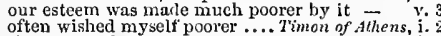

times upon far poorer moment ... Antony \& Cleo
POOREST service is repaid... Taming of Shrew,

thousand of my poorest subjects. .2 Henryl $1 r^{\prime}$.
the

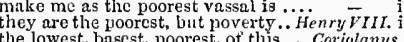

the lowest, basest, poorest, of th

Rome is thine, thou art poorest of ail

shown for poorest diminutives...Antony \&.Cleo. iv.

are in the poorest thing superfluous
ii. 2.2
ar.

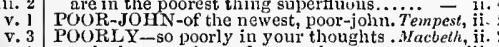
to look so poorly, and to speak so... Micharid $I$. curtains poorly are let loose

must poorly seli ourselves with. Troilus \& Cress. iv.

let me die, stealing so poorly ....... Cymbeline,
my father, poorly led? ................ Lear

POP -if he can prove, a pops me out... King inghin,

to an answer, as the pope.............

so tell the pope; all reverenice set....
against the pope, and count his

against the pope, and count his.......

as holding of the pope your sover
your stubborn usage of the pope

your stubborn usage of the pope
your oati of service to the pope answer this before the pope............
perused the letters tron the pope.

Would choose lim pope, and carry...2 Henry VI. i. 3

that made lim proud, the pope.... Herry VIII. ii.

letter to the pope miso bing iny

what's this - to the moaried, and can

You writ to the pope, against the king
POPEDOM-

POPILIUS [sce LENA] DOpe

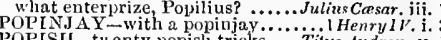

POPISI-tuenty popisli trieks...... Titus Andron. v. 1

popped in between the election ......... Ham/et, $\mathrm{y}$.

POPRIN PEAR - nol nor mandragora ... othello, iii.

POPULAR-o'erprised all popnlar rate. Tempest,

thou base, common, and popular?.... Ilenry $v^{2}$ iv.

the bewitchment of some popular ma

his shall, his popular shall, again.
in a violent popular ignorance .......

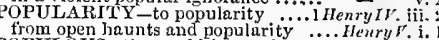

POPULOUS - the world is populous...Richerery $1 I$. . . . I

a wilderness is populous enough $\ldots 2$ Henr? $I^{\prime} I$. iii.
raised by your popnlous troops

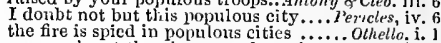

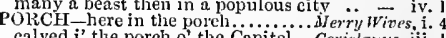

calved i' the porch o' the Capitol .. Cariolanus, iit.
for me in Pompey's porch (rep. ... Culins Cresar, i.

PORCUPINE- to the Porcupine.Comedy of Err. iiti.

to lave ta'cn you at the Porcupine..

breach of promise to the Porcupine.

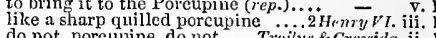

do not, porcupine, do not. ... Trivitus \& Cressida, ii.

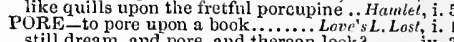

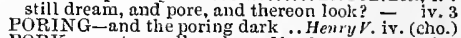

PORK - Yes, to smell pork.... Merchant of Venice, i. 3

PORK-EATERS, we slanll not......... - iit.

in Macedon, where Alexander is porin - iv. 7

PORRIDGE-confort like cold porrilge... Tericles, ii.

tell me of a mess of porridge p...Merry Wives, iit. I

month with mutton and porridge. Lore's $L$. Lost, i I

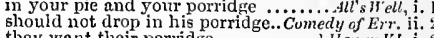
they want their porridge ............. Henry VI. i. 2 set ratsbane by his porridge ............. Lar, iii.

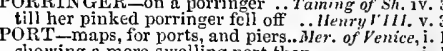
showing a more swelling port thian.

and the magnificoes of greatest port $\bar{t} \overline{-}$ iii.

saint Francis here, beside the port... All's Well, iii

keephouse, and port, and servant

and the very ports they blow........

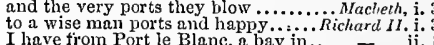

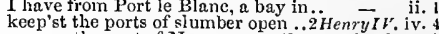

assume the port of Mars........ Henery $\nu^{\prime}$. i. (chojus

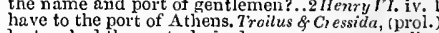

have to the port of Athens.
lie touched the ports desired

at the port, lord, I'll give her...

iv.

and open your unchanged ports. Timon of $\overline{\text { Athens, }}, v .5$

the city ports by this hath entered.... Coriolanus,

approacles to the port of Rome...Anitony s-Cleo. i. 3

and at the port expect you

and with our spritely port make...... $=$ iv.

all ports $\mathrm{X}^{\prime} \mathrm{s}$ bar; the viliain .............. Lear, ii.

secret feet in some of our best ports........ = iii.

PORTABLE to make the dear ioss ...... Tempest, $v$.

all these are portable, withl other ... Macbrth, iv. 3
like an engine not portable. . Troilus \& 8 Cressida, ii. 3

how light and portable my pain seems... Lear, iij.
POliTAGE of the head................ Henry

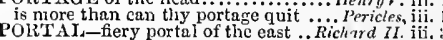

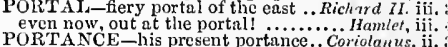

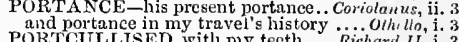

PORTEND no good to us

these eclipses do portend these divisionsi...

that alphnbetical position portend?. T'retfich $N$. ii. 5
what think you they portend?

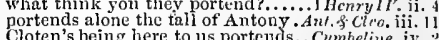

Wlich portends, (unless my sins abise -
whe, iv.

and a portent of broached are these? 1 HenryI $V$. ii. 3

and a portent of broached misclief.
plagues, and what portents?

portents, and evils imininent .... Julus Cararar, it. 2

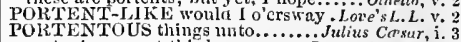

porteutous must this humour........ Romeo \& Jutiri, i.

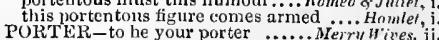

on his back, like a porter............ Love's l., Lost,
Dromio, play the porter weil...Comedy of Errors,

Dromio, play the porter wili......... Lovedy of Lrrors, ii
shall I be porter at the gite? ........ 
PORTER - made our porter?.. Comedy of Errors, iii. I the porter for this time, sir........... I pray you, remember the portc the poor mechanic porters crowding...Henry V. i. 2 good master porter (rep) Hen'y VIII. v. 3 are these porters, these lazy knaves? Achilles: a dray man, a porter no porter at his gate

the porter of Rume gesteg

good porter, turn the key...

PORTIA porter let in Susan

$\ldots \ldots \ldots \ldots$ Lear, iii. 7

to Belmont, to fair Portia

to come view fair Portia (rep.)......

how much unlike art thou to Portia

sweet Portia, welcome (rep.)

never shall you lie by Portia's side...

and Portia one, there must le something -

or I am much deceived, of Portia...

Gweet Portia, if you did know to wliom

yon shall find, thent Portia was........

why so I do: good Portia, go to bed.

kneel not, gentle Portia...............

Portia, go in a while ..........

Portia! art thou gone? No more

why, farewell Portia: we must die...

POK TION-with him the portion. Mleas. for $\bar{M}$ cos

prodigal portion have I spent .....As for

make her portion equal to

make her portion equal to his ... Winter's $T$ ate, iv.

accunulated to his own portion!.. Henry VIII. iit

that portion which yourself proposed .... Lear, i.

yonr argosies with portly sail ..MLtr. of Venice

a good portly man, i' faith .......... - ii.

a good portly man, i faith .............

like a portly gentleman............ Romeo \& Juliet, i.
PORTRA IT ot a blinking ..... Nerch. of I Ienice, ii.

PORTRAITURE-I see the portraiture. Hamlet, v.

PORTUGAL-bay of Portugal.... As you Like it, iv. 1
POSIES-fragrant posies (rep.) Merry Wives, iii.1 (song)

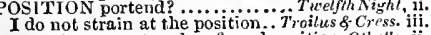

a do not strain at the position.. Troilus pregnant and unforced position. Othello, ii.

do not, in position, distinctly speak of her
POSITIVE as the earth is firm....

tis positive 'cainst all exceptions.... Henry $r$. iv.

Patroclus is a fool positive $\ldots$. Troilus \& Cressida, ii.
PoSITIVEL speak in this $\ldots \ldots$. Richard III. iv.

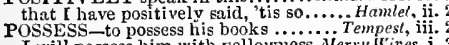

I will possess him with yellowness. Merry Wives, $i$.

possess us, possess us; tell us.... Tuelfh Nigh, ii. 3
youl both, possess the people ........ Much Ado, v.
still her cheeks possess the sime... Love's L.Lost, i. 2

still her cheeks possess the same.

spirit again possess her corpse...

why seek'st thou to possess ine

in reversion that I do possess

nor did the French possess the Salique. IIenry

no man should possess him with any
my soldiers' hearts! possess them not

possess it, York, for this is thine ....3 Henv? $\mathrm{Vl}$. i.

and good thoughts possess thee.

gou have promised I shall possess $: \ddot{H}$ gry $\bar{V}$ VIII

good drealns possess your taucy

by the way, possess thee whiat

and possess me some harlot's spirit! Coriolanus, iii. 2

I will possess you of that ship

done, possess a golden slumber
some fit or frenzy do possess lier

share all that he doth nossess. Ro... ive - iv.

and gross in nature, possess it merely .. Hamlet, i.

already hath possessed them. Tiro Gen. of Yer, ii. 1

he is sure possessed............. Twelfih Night,

and thaton himself possessed him ... flave possessed lim... Meas. for Meas. iv. 1

that spirit's possessed with liaste

an' she were not possessed with a fury.Mueh Ado, i. 1

and possessed by my master Don Joln

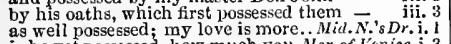

I have possessed your grace of what.

of all he dies possessed (rep. v. 1)....

possessed with the glanders. Taming of Shreu, ,iii. 2

possessed with an adnlterate blot. Co
her fair sister, possessed with such ..
both man and master is possessed...

cries out, I was possessed.............

thou possessed with a thousand ....... King John, iii. 3
to be possessed with donhle pomp....
iv. 2
I have possessed zou witl

I have possessed you with $\ldots \ldots \ldots$.......
possessed witl rumours, ful of idied..
wert possessed, which art possessed..

wert possessed, which art possessed.. Richard II. ii. 1

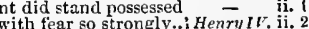

the king is certainly possessed of all

that we now possessed the utmost $2 \mathrm{Hemry}_{\mathrm{IV}}$. i. 3 you be possessed with devilish ...2HenryVI. iv.

possessed with some store of crowns.3 Ilenry VI, ii.
POSSESSED-brother was possessed. Richard III. iil. 1 possessed he is with grentness .. Troilus \& Cress. ii. is the and posessed conveniences.

and jewels, I am possessed of......... Anfony \& Cleo. $y$ I ac possessed of that is mine ..... Tilus - sutron. $\mathrm{i}$. 2 of a love, but not possessed it ... Romeo \& Juliet, iif. how sweet is love itself possersed .... POSSESSES-drowsiness possesses .... T'empest, ii.
enter, where folly now possesses? .... Cymbeline, i.
most precious square of sense possesses.... Leur, i.

most precious square of sense posse

POSSESSE'III me. and I am fuint

OSSESSIONS are so huge... Two (ien, of ferona, ii. 4

considers ali possessions she estecins not

$\mathrm{I}$ got possession of Julictta's bed.Meas. for Meas. $\mathrm{i}$. 3

his possessions, although by contiscation -

possession would not show us whiles. Whech Ado,
I should take possession of the bride. All's Well,

possessions, and so high esteem. Tam. of $\mathrm{Sh} .2$ (ind.)

possession, twenty thousand crown

where it once gets possession. Corneriy of

how loug hath this posession held

King John, i.

onr strong possession (rep.)
stalk in blood to our possession?

and bear possession of our person here

broke the possession of a royal bed. Richard 11 . iij.

to the possession of thy royal hand..i $-\overline{H e n r y} I V$. iii. 2

and right, must my possession be ..2Henry $v^{\prime}$. i

th' athversary was have possession ...

mean to take possession of ny right

outspaks possession of a subject. $\ddot{H e n}, \bar{V}_{11}$. ii. 6

now to deliver her possession up. Troilus 8 Cress. ii. 2

possession lies a lass unparalleled.Antony \& Cleo.v.2

master's garments in thy possession? Cymbeline, iii. 5
spacious in the possession of dirt ...... Hamlet, v.

the possession of this heavenly sighti 1 .. Othell,, $\mathrm{v}$.

sole possessor of my love

thou shalt eat a posset to-night at .. - v.

posset and curd, like easser droppings ..... Hamlet, $\mathrm{i}$. 5

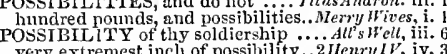

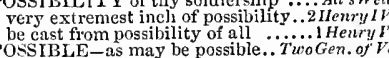

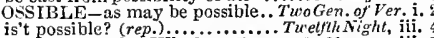

is it possible? Very easily possible ... Much Ado, i. 1

possible, disdain should die.................

tis very possible, he'll scorn it.

possible that any viliany slould ( $\mathrm{rep}$.

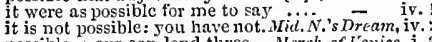

possible, a cur can lend three ... Merch. of Fenice, i.
is it possible, on such a sudden.....As you Like it, $\mathrm{i} .3$

can it be possible, that no man

possible, that on so little acquaintance $-\overline{\text { val }}$ is it possible he should know what.. 2 All's

thinks, it were not possible $\ldots . . .$. . - iv. 3 (note)

I never thought it possible, or ilikcly

not possiole, for who shall bear your

is't possible, friend Licio, that Biance

thou dost make possible, things ... W'inter'

any thing possible. It shall he possible it is not possible, it cannot be

make any possible satisfaction
is it possible dat $I$, should love (rep.

wliat possieste dat I should

if withont peril it be possible...... Richard III. v.

possible, the spells of France..........

possible, the world should so... Timon of Athens, iii. 1

not possiblc. The nobles, in great. . Corid
if it be possible for you to displace it

is't possihle, that so short a time

is't possible? Hear me, for 1 will...JutinesCrsar, iv. 3

is it possible? O there lass been much.. Hamlet, ii.

possible, a young maid's wits should

is't not possible to undcrstand in another -

with him! why, 'tis not possible

is it possible? 'remember rep. it.

possible? $U$ heaven forgive us!
POSSIBLY - when possibly I can.

zou conld possibly tove found. Tico Gen.of $F^{\prime}$ er. ii.

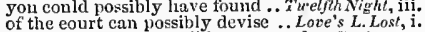

were found; how possibly prcserved .. Pericles, v.

from snch a worthless post.. Tur....... Teinpest, of Verora,

thon art to post after with oar

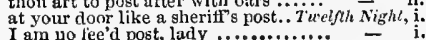

OST-and you'll beat the post .......Much Mdo, ii. I
I post from love; good lover .... Love's L.Lost, iv. 3 I post from love; good lover ..... Love's L.Lost, iv. there's a post come from my master.. 'tis good to be a post .............As you Like it, iv. I have despatched in post..........Winter's Tale, ii. please your lighwess, posts, trom....

hite thee presently, tost to the .. Coinedy of Err. iii. 2 thick as tale, came post with post........ Macbeth, i. will post to consummate ..............King John, v.
which else would post, until it.......Richard $11 . \mathrm{i}$. and hath sent post haste, to entreat away, with me, in post to Ravenspurg - ii. post you to Lopdon and you'll find - ii. spur, post; and get before him to the 二 v. the posts a post from Wales ......1 Henry $J V_{\text {. }}$, get posts, and letters, and make friends - (ind ue.) if $I$ be not sent away post............. $=$ = ii.

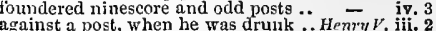

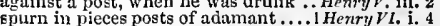
post, my lord, to France; agree....... v. 5 why comest thou in such post? Montague shall post to London...... - i. 2 as swiftly as the posts could run..... in haste, post haste, are come....... towarls Berwick post amain ..........
some post to us, or thee ........... messenger, return in post..............

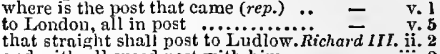
and with all spced post with him.... - iii. 2 towards Guildhall hies him in ali post $=$ iii. 5
some light-foot friend post to the.... told me, I should post before .......... $\quad$ iv. 4 like a post with packets ........... Henry VIII. v. 2 native town you entered like a post. Coriolanus, 5.5
post back witl. speed, and tell him.Julizescasar, jii. 1 met'st thou my posts? ....... Anlony \& Cleopatra, i. 5 away he posts with unchaste .......... v. post on the lame ftet of ......Pericles, iv. (Gower) post speedily to my lord your husband... Lear, ii. 4 our posts shall be swift, and intelligent - iii. 7 presently took post to tell it yon. Romeo o. Jutiel, v. 1 then in post he came from Mlantua ... Harmlet, j. $^{3}$ from $\mathrm{vs;}$ wish him post post haste........ Othello, i. 3 shonld be but idly posted over you...1 Henry I I $\%$. vii. nor posted off theil suits with......3 Henry 1. iv. 8 the swiftest harts have posted you... Cymbeline, i1. 4 POSTER-posters of the sea and land ...Macbeth, i. fair posterity await for wretclied ......Midenry Dr.iv. $^{2}$ should no else but tair posterity...Winter's Tale, iv. for amends to his posterity, at our ....King Johnt, ii. cut ofl the sequence of posterity .... he'd make an end of thy postcrity... Coriolanus, iv. 2
cuts beauty off from all posterity. Romeo \& Juliel, i. POSTERN by the abbey-walls TuroGen.or Verona, v. wounds the unsisting postern ... Meas. for Mleas. iv. the keys of all the posterns ............ - i. thread the postern of a needle's eye. Richard 11.
POST-IAS'E and romage in the land... Hamlet, requires your haste post-haste appearaneeolhello, POST-HORSE up to lieaven ........ Michard $\bar{l} l t$. $\mathrm{i}$. hire post-horses; I will hence.... Romeo \& Juliet, $v$. OST y ou Posth; brceds him ......... Cymbeline, so soon as I can win your fault that I have loved Posthumus - i. in love, Leonatus Postliumus .... ili. 2 (letter) so thou Posthumus, wilt iny (rep.).. near the residence of Posthumus....

since the exile of Postlumus, most retiredshe's flown to her desircd Postlumus throwing favours on the low Posthumus it is Posthumus' hand; i know't..... bare fortune of that beggar Posthumus
even there, thou villain Posthumus.. the very garment of Posthumus ....
nore equal ballasting to thce, Posthumus Posthumus, thy head, which now is..
the garments of Postliumus! I know

the garments of Postliumus! I know that from me was Postliumus ripped

then shall Posthumus end (rep. v. 5) - v. 4 (scroll) the good Posthumus (what should I say? - v. am Posthumus, that killed thy daughter = every villain be called Postiumus 0 Posthumus anchors upon Imogen
POSTING on in Bol

cxceeding posting, day and nighit

All'stl'ell, v. 


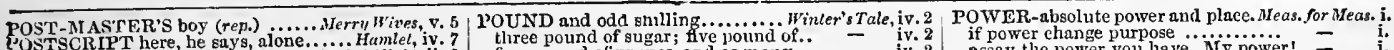

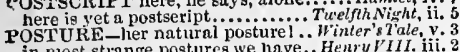

in most strange postures we have.. Henry VIII. iii. 2

Antony, the posture of your blows..julius Coesar, v.

greatiress $\mathrm{i}^{\prime}$ the posture of a whore. An/ony s Cleo. $y .2$

puts himself in posture that acts ... Cymb

Minerva, postures bisond
POSY [Col.Kw, -PUESY]-

whuse posy was for all the wrorld. Meraf Venice, $v$

what talk you of the posy.

is this a prologne, or the posy of a ring? Hamlel, iii.

greasy Joun dotl keel the pot. Lore's L.L. v, 2 (soug)
a pot of small ale (rep.). Taming of shrew, 2 (induc.)

were not I a little pot, and soon .......

have him poisoned with a pot of nle... i Henryl

my fune tor a pot ot ale, and safety. Henry $V$. iij. 2

and here's a pot of good doub

the three hooped pot shall ........... \& $-\overline{\text { Cressida, i. }}$ ive 2 fire under the pot of her eycs.

green eartliern pots, bladders ............. Theo \& fultit $t$, v. 1

POTATION - to forswear thin potutions - othello

curoused potations pottle deep ............

lis fiat rmmp, and potatue finger. T'roilus o Cress. v.

POTENCY - I had your poteney. Meas. for Meas. eardinal's malice and his poteney...1ren'y $/ / 1$ on their ehangeful potency.

arriving at place of potency $\ldots . .$. ... Coriotanus,

our poteney made good, take thy reward... Lear $\mathrm{i}$.

POTENT - of her more potent miuisters. Tempest, $\mathrm{i}$. 2

what would my potent master?

by my so potent art ...................... ivives, iv. 4 such a headstroug potent fault ...Twetfh Night, iii. at large, a potent dukedom ....... As you Like it, v. a lady's verily is as potent as a lor..... Macbeth, iv, you equal potents, fiery kindied ........King John, ji. 2 no man so potent breathes........... Henry IV. iv. too fine, too subtle potent .. Troilus \&-Cressida, iii. the reasons are more potent and heroical - iii. 3 your potent and infeetious fevers.. Timon of $A$ th. iv. 1 and gives his potent regiment to.Antony $\delta$-Cleo. iii, 6 thy harsil and potent injuries

o you most potent godsi ................. Pericles, iii. as he is very potent with such spirits ...Hamlel, il. the potent poison quite o'ercrows .......... othello, i. 3 most potent, grave, and in potting

POTENT ATE-great potentates. Ti......... of Ver. and mightiest potentates, must die. . Henry VI. iii. PoT roice potential as double as the duke's. othello, $\mathrm{i} .2$

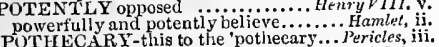
buy a poison of a poor 'pothecary ... Romeo \& Jul. v. 3
POTHER, as if that whatsoever god.. Coriolanus, ii. I keep this dreadful pother [Knt.-pudder]. Lear, iii.
POTION-he gives me the potions.Merry Wives, ii. loathed medieinel hated potion ...Nid.N.'s Dr. iii. tliat with no rash potion

as all the poisonous potims il ......1 Llenry 1. . v. constrained, as the potion of imprisonment

minister'st a potion unto me ........... Pericles, i. 2 by my art, a sleeping potion .....Romeo \& Juliet, v. 3 drink off this potion................... Iramlet, $\nabla^{2} 2$ Po'TPAN of where's Potpain irep................ \& \& Jnliel, i. 5 POTTER-like a potter's wheel ....... Henry

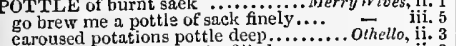
ere the next pottle ean be filled ............. $-{ }^{2}$, i. 3 yes, sir, in a pottlepot ................... on nose, and pouch on sicle .........As youl like it, ii. 7 POULTICE for my aching bones? liompo \& Juliet, ii.

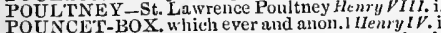
POUND-'twere best pound you.. T'woGent. of t'er. i. 1 less than a pound shall serve

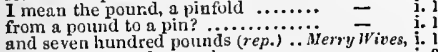

I sit at ten pounds a week............ - ii.

in three hundred pounds a year! ...

a hundred pound in gold

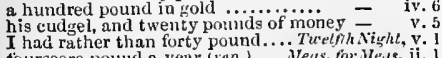
nineseore and seventuen pounds

it will eost him a thousand pounl ere. $M u c h$. $A d o, \mathrm{i}$. [Col.] an' 'twere a thousand pound more $\bar{V}$ enice, ii. 5 a pound of man's flesli, taken .........

ahall hardly spare a pound of flesi....

a pound of this puor inerehant's (rep.)

the pound of flesh (o ep.)...............

the dog for twenty pound... Taming of Sh. $\overline{1}$ (induc.) keep your bundred pounds to yourself
I buy a thousand pound a yearl. Comelly of Err. iv. 1 air five hundred pound a yeur (rep) King Joln $\mathrm{i}$. end me presently a thousind pound. Kichard 11. ii. tive thee for it a thousand pound $\ldots 1$ Henry $l V$. ii. taen a thousand pound this morning money lent you, four and twenty pound

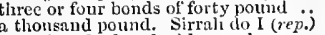

a thonsand pound, Sirrati

let it be leud me thousand poun

of good ewes may be worth ten poinds

I liave three pound to free Mouldy ...

I owe you a thousand pound

mousand pounds by the year..........Henry $V_{\text {. }}$ i.

many a pollild of nine own proper..2 Itenry 1. iil.

one shilling to the pound, the last...

a thousand pound a year $(r e p$.$) ..... Henry \bar{V}$ III. ii. 3

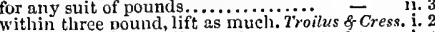

rather than they shall pound us

I had a hundred pound on't

a tribute, yearly three thousaind pounds

ghost's word for a thousand pound. Hamlet, iii. 2

I will pour some in thy other mouth.... Tempest, i. 2

let me pour in some saek ..........Merry Wives, iil. 5

thus pour the stars down plagues. Love's L. Lost, 8.2

as fast as you pour affection in $\ldots \ldots . . . . A l^{\bar{s}} W_{e l l}$, i. 3 from your saered vials pour your. Winter's Tale, v. 3

that I may pour my spirit ....

pour in sow's blood, that hath
I sliould pour the sweet milk

and with him pour we, in our ....... - v.

the sky, and puurs down misehief...King John, iii. 2

how London doth pour out her. Herry V. v. (chorus)

I pour the helpless balm of

pour all your tears, I am .............. pour in, pour in; it out; Plutus ........ Timon of Athens, i. 1 pour down thy ill-uttering throat.Antony $\overrightarrow{\&}$ Cleo. ii.s pour out the pack of matter........... pour on, I will endure $\ldots \ldots \ldots \ldots \ldots \ldots \ldots$. Lear, iij. 4 I'll pour this pestilence into his ear..... Othello, ii. 3 âd pour our treasures in to foreign laps $\overrightarrow{\text { and }} \overrightarrow{\text { ive }}$ it, $\mathrm{y}$. and heat, poured all together ............All's Well, ii. 3 liave poured it to her aceptance. inter's Tale, iv. $3^{-}$ and poured them down betore him .... Macoeth, ji. Ephesus poured forth your ehiarity ... Pericles,
he poured a flagon of Rhenisl on ...... Hamlet,
POURING, like the tide into .......... Henry $r$. pourin, war in to the bowels of....... Coriolanus,
POURQUOY, my dear knight? (rep.). Trelfth $N$ igh

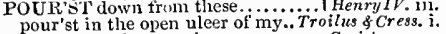

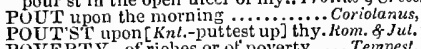
POUT'ST upon [Knl.-put test up] thy. Kom. \& Jul.
POVERTY -of riches or ot poverty .... Tempest, poverty in wit, kingly-poor flouti.Love'sL.Lost, $v$ an age of poverty ...................... of venice, iv. and $I$ in sueh a poverty in grace .....

poverty of her, the small acquaintanee

faith, for their noverty, I know not.1 Henry $I V$. iv.

to 1 ,e, in respect of poverty ..............

the truth is, poverty hatly distracted her

in her leart she scorns our poverty..2nenry $V I$ i.

so mueh is uny poverty of spirit ... hichard III. jii.

his disease of all-shunned

you houseless poverty, nay, get thee in... Lear, ii

poverty, but not my will (rep.)... Komeo o Juliel, $v$. steeped me in poverty to the very lips. Othello, iv.
POWDER; food tor powder ........ 1 HenryIV.iv. I'll give you leave to powder me ..... $\overline{\text { king }}$ ohn, ii. 2 wrind their bones to powder small.Titus A udron. $\mathrm{v}$ like fire and powder ............. komeo \& Jutiet, ii. 6 as hasty powsler fired doth hurry from $\overline{\bar{y}}$ v.

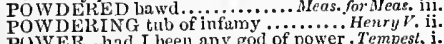

PUWER-had I been any go

what my power night else.

they are both in either's powers

the powers delaying, not forget ting...

they now are in my power
o'er whom I

some heavenly power guide us

and even that power, whicis

some malignant power upon

the staden stricrse of my powers .Merry Wives,

a power I have: but o what assay the power you have. Hi power! =

where to give up their power ........

your race like power divine

our grace, like pow divine ........

their pride against that power........Much Ado, ii.

withiu his power to leave. Mid. N.'s Drean, iv.

I know not by what power I am .̈.ji

your power to draw (rep. )..........

and all my powers, address your love

and all my powers, address your love

what power, (but by some power it is)

none spare that come within his power

most power to do most harm

in every power (rep. ...................

flatter up these powers of mine witli not in his power to bring to pass. Ml er.

there is such confusion in my powers
have power to bid you weleome ....

if' law, authority, and power deny not

upon my power, I may disiniss....

and earthly nower doth then show

no power in Veniee ean alter .........

the eould entreat some power to change

by the sweet power of musie ..........

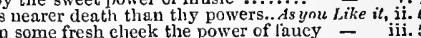

have power to raise sueh love.... - iv. 3 (letter)

addressed a mighty power.

what power is it, which mounts.

my art i

wy art is not past power, nor you.................

great power, great transcendence....
both sovereign power and a father's.

thou hast power to ehoose whil........

to defent, I riust produce my power

and our power elaims; or I will throw

but have no pewer to give it from me

nor shall she, within ny power.......inter's Tale,

powers clivine behold our.......... - iii.

ginee it is in my power. ............ iv. (chorus)

by the power o the king; one of these
had she sueh power, she liad just ....

power no jot hath she, to ehange our loves - v.

have power to take off so mueh..... grief $=$ v. 3

and to your power I'll yield. Comedy of Errors, iii. 2

ome blessed power deliver us .......

with barefaced power sweep him

with barefaced power sweep him

laugh to scorn the power of uxan

gought to win me into his power

I saw the tyrant's power a-foot.....
our power is ready; our lack ....

and the powers above put on their

when none can call our pow

slaall e'er have power on thee

find the tyrant's power to-night ..... Krng $\bar{J}$

power eonfronted nower: botli are alike -

a greater power than we, denies
slull we knit onr powers, and lay

not that I have the power to $\ldots .$.

no tongue liath power to curse.

send those powers oer to your

Dever such a power for any...

with ranks of foreign power

now powers from home, and diseontents

use all your power to stop their......

promised to dismiss tlie powers led by

our powerl I'll tell thee, II $\ldots$ hert $($ rep. $)$

the best part of my power, ns I .......

Where be your powers? show now.....

might have retired his power ..........

to diseover what power the duke....
in my loyal boson lies lis power...

beca use iny power is weak $\ldots . . . . . . .5$.

that power that nuade you king in power

hath power enough to serve our turi

the duke my father with jis power.

my fatlier hath a power; enquire...

that jower I have, discharge

to lay my arms and power ..........

help to orcler several powers to Oxford - torthwitl a vower of English shall ... Henry 
POWER-of your nobility and power.1 HenryIV. only mean for powers in Seotland.

if thou have puwer to raise lim.

made head agninst my power.....

who lends his puwer? under whose.

he cannot draw his power this

the powers of us may serve so grent..

but iny powers are there already ...

whose puver was in the first proportion
whor

the power of Perey is too weak

ere the king dismiss his pow

a speedy power, to eneounter you.................

is up, with well-applointed powers
the yower and puissance of the kin

with project of a power much smalle

beyond his nower to build it

one power against the French

you speak as having power to do wron

to sce his father hring up his pavers.
the powers that you already have...

with sucl powers as miglt hold...

and knit our powers to the arm.......
so that lis power, like to a fangless lion

discharge your powers unto their

call in the powers, good cousin

onr power collected, onlr substict

and by whose power I well migilit lodge

the image of his power lay then in me
majesty and power of law and justice

and in your power, soft silencing

on the full power of France...
thrice that power left at home

the nolhle sinews of our power...

that the powers we bear with is.......

thus eome the English with full power

Youl have power enough $\ldots . . . . . . .$.

take with you free power, to ratify

lad him bronght into my power.....
is come with a great power to raise.

at all times will you have my power

follow them with all the power
their powers are marching unto

my forees and my power of men
onl. my lords, and join our powers

marched to Bourdeaux with his power

keep not back your powers in da.
I have no power to let her pass.

name and power thou tremblest at...2

grief have vanquished all my
had twenty times their power.

time bereft my vital poivers.

until a nower be raised to put.
and all his powers do yield

with a puissant and a miglity power

so great a power without his leave

'tis not thy soutliern power, of Essex

their power, I think, is thirty thousand
meet Warwick with lis foreign power

if secret powers suggest but truth...

methinks, the power, that Edward...

France hath brought a puissant po.
to meet the queen's great powerl
those powrers, that tlie queen hath

those powers, that tlie queen hath
hadst but power over lis mortal

hadst but power over lis mortal ... Ric
you have power in me, as a kinsman

you have power in me, as $\Omega$ kin
and still his power inereaseth

the greatest strength and power

and their power grows strong.......

with a mighty power landed..........

[Col. Knl. S Jo they bend their power
seren thousand is their utmost power

part in just proportion our small por
trom the mirthty power of the king.

bid him bring his power before (rep.)

wants not a minister in his power...

I have not the power to muzzle hin

you have half our power: the other.
and main power, took 'em from me

of wisdom o'ertopping woman's po

wea, with a splitting power...

$\mathrm{my}$ power rained honour, more o

by which power you maimed.

I have no power to speak, sir....

I gave ye power as he was a counselior

poiver, power into will, will into. Troit

whereof all our power is sick

all our main power stand fast.

the capacity of my ruder powers
all my powers do their bestowing

all my powers do their bestowing

all these spirits thy power hatli. Tinon of $\bar{A}$ thens,

what a mental power this eye

I myself would liave no power
being of no power to make his

be of any power to expel sickness.....

bceause I have no power to be kind

in their rough power have unchecked

that you had power and weal
allowed with absolute power

within the shadow of your pow

ere thou hadst power, or we had
all thy powers shall makse tieir
POWER-make hold power look pale.. Coriolanus, i.

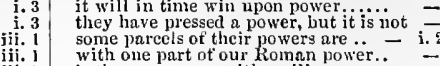

iii. both our powers, with siniling ......

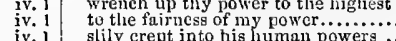

iv.r during his power, go sleep

iv. 4 to his power, he would lave made them 二

iv. 4 wheu he had no power, but was a peity =

iv. 4 when he hath power to eruslh.......

virtue, no, nor power, but that which
lave power, then vail your ignorance

the people had more absolute power
not having the power to do the coud

i. 3 not having the power to a the gou

$\begin{array}{ll}\text { i. } 3 & \text { take from you all your power } \\ \text { i. } & \text { in whose power we were elected thei }\end{array}$

$\begin{array}{ll}\text { i. } 3 & \text { or Jove fur his nower to thunder } \\ \text { ii. } & \text { the sererity of the puilic power }\end{array}$

\begin{tabular}{l|l} 
ii. 1 & the severity of the public power \\
ii. 3 & have had you put your power weil on \\
&
\end{tabular}

iii. $)$ ere they lacked power to cross you ..

so far as thou hast power and person
that he affects tyrannical power ...

the old prerogative and power $\mathrm{i}^{\prime}$ the

iv. 1 the old prerogative and power i the
iv. 2 wind yourself into a power tyrannical

those whose great power must try hin

to pluck a way their power; as now.
and in the power of us the tribunes

have the power still to banish your

now we have slown our power......

to take all power from the people...

I tell thee, we have a power on foot
the Volsces with two several powers

\begin{tabular}{r|r} 
i. 2 & leads a power 'gainst Rome........... \\
ii. 2 & power, unto itself most conımendaile \\
. &
\end{tabular}

\begin{tabular}{l|l} 
ii. & power, unto itself most conmmendable \\
iii. 4 & 'tis a spell, you see, of muach power.. \\
iii. & he lrath abused your powers
\end{tabular}

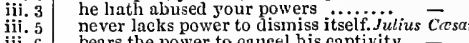

bears the power to canesl his captivity

when it disjoins remorse from power
utterance, nor the power of speech

Brutus, and Cassius, are levying powers down upon us with a mighty powe

\begin{tabular}{r|r} 
ii. 2 & bid him set on his powers betimes \\
iiii 3 & stay the providence of some high poivers-
\end{tabular}

rown by noble Brutus power -

high in name and power, higher.

I have no power upon you

the wise powers deny us for our good

my power's a crescent, and my auguring -

nor my power work without it ......

the power of Cresar, and his power
and breathless, power breathe forth.

and breathless, power breathe forth..
the Jove of power make me most $w$.

strange, that his power should be.

grows not in the power on't........

in every power that moves ..........

had I great Juno's power

had my lips that power, thus would I

take my power i the court
shall, by the power we hold

powers that he already lath in Gaili

my mother laving power of his testin
but to put those powers iu motion...

and so, great powers, if you will take

the power that $I$ have on you, is to.

Rome have law, or we have power

had I the power, that, some say, Dian

and raise a power, to be revenged on

and with a power of high-resolved $m$
but, $O$ you powers! that give heaven

but, 0 you powers! that give heaven
thou know'st I have power to take...
these hollow vessels with their power.

surfice the greatiness of your powers

sutfice the greatness of your will
beruty lath his power and will

Fe cannot but obey the power

given me by one that lad some power

whom the gods have shown their power

invest you jointly witl my powr

bet wixt our sentence and our poor

by the power that made me, I tell
subscribed his power! confined to

nat as it hath power, but as it

...............

i. 2 (letter)

may enguard lis dotage with their pow

from France there comes a power into

all the power of his wits has given way..

feel your power quickly

his musters, and conluct his powers ....
of Alhany's and Cornwall's powers you

whose power will close the eye ...
the British powers are marching

but are my brother's powers set forth?

who have the power to senl tle..........

the powers $o^{\prime}$ the kingdom approach

and they within our power. shail neever

he led our powcrs; bore tle commission

majesty to him our absolute gower
passion lends them power. Romeo \&

hatl residence, and medicine puwer

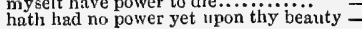

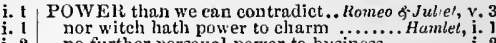
nor witch hath power to clrarm ......... Humlet, i. 1 no further persolal power to business....
that have the power so to seduce?
by the in general synod take away her power. and the devil liatl power to assume

i. 9 ny, truly; for the power of beanty will..

ii. 1 my operant powers their functions leav

ii. 1 as my great power thereof may give...

Gove in those powers are these ........

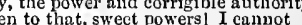

any grace, or power to move you ........

last not half the power to do me barm.

O heavent O heavenly powersl..................

POVERFUL and your command is taken $=\mathrm{v}$. 2 is powerfal to araise king Pepin........ All's Well, ii. his powerful sound, within an organ ${ }^{\prime}{ }^{-}{ }^{7}$, ii. you're power'tul at it. There was a nan -

are too powerful on the lightway....

for a charm of powerful trouble....... Nacketh, iv. with all their powerful friends ..... Richord 11 . ii. out of the powerful regions ........1 Herry frum winter's powerful wind

the quarrel from his powerful arm...Richnrd $11 I . \dot{\mathrm{i}}$. sent liis powerful mandate to vou. Anlony \& Cleo $\mathrm{i}$. drawn by the powerful sun, to fail ....... Lear. ii.

O miekle is the powerful grace.. Rlomeo \& Juliet, if.

lis sail witl thine own powerful breath - ii.

POWERLESS and potently believe. Hamlet, ii.

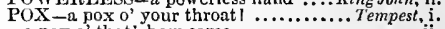

a pox o' thati how eame

ii.. 1 'pex of your love-letters!... T............. of veronn, pox on't, I'll not meddle......... Tuefifh $N$ ight, ifi. a pox $0^{\prime}$ ' your throats! ...... Heasurefor Mleasure, iv. a pox of that jest' and beslirew.. Love's L. Lost, $\mathrm{v}$. a pox upon him tor me (rep.)............ what a pox have ane the other $\ldots . . .2$ Henry $I V$. a pox of this gout! or a gout of this pox! - i. your face: a pox of wink i. a pox on't 1 had ratleer not be so Cymbeline, ii. ii. 2 now, the pox upon her green-sickness.Pericles, iv.

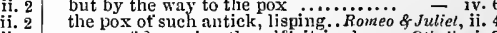

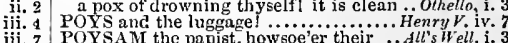

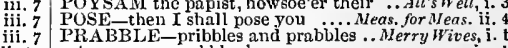
and starings, pribbles and präbiles?.

prawls, and prabbles, and quarrels . II PRAC'IISE tilts and tournaments. Tu'oGen.of Ver. $\mathrm{i}$. this night $I^{\prime \prime l l}$ put in practise.

such vile base praction

this is a practise, as fult of labour was this practise hath most shrewaly passed - v. as art and practise hath enriched..Meas. for Meas. i. to practise lis judgment with the.... - iii. making practise on the times........ $=$ iii. this needs must be a practise.........

to find this practise out ............... in practise let us put it presently ...... Much $A d a$, i. lis active practise, his May of youth

paid me richly for the proy o

to put in practise that which each. Love's $\overline{L . L o s}$

which $I$ will practise $\ldots \ldots$... Ilerchant of $V^{r}$ enice, iii.

lie will practise against thee .......As you Like il, j.

whose practises he hatls persecuted.....A Al's ${ }^{\top}$ Well,

the dearest issue of his practise ........
the practise in the chape of his dagger
I will practise on this drunken. Taming of $\overline{S h}$. I iv.
ind.
practise rlietoric in your common....

practise rhetoric in your common.
to look, and practise by myself

proced in practise with my sounger
sweet Bianca practise how to bride it?

unclasped my practise ........... Winter's $\bar{T}$ ale, iiji. learn love, I'll practise to obey.... Comedy of Err. ii.

this disense is beyond my practise ..... Macbeth, my uncles practise more harm to me

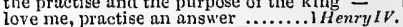

sworn uuto the practises of France.... Henry $V$.

God acquit thein of their practises!..
well, let them practise and converse. 1 Henry $V I$.

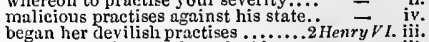

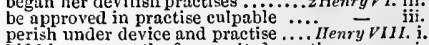

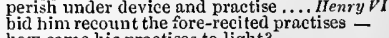

how came his practises to light?.

their practises must bear the same
practise your eyes with tears! ... Troilus \& $\bar{C}$ ress. ii.

practise your eyes with tears! ...Troilus \&-Cress. ii.
I will practise the insinuating nod.. Coriolunus, 


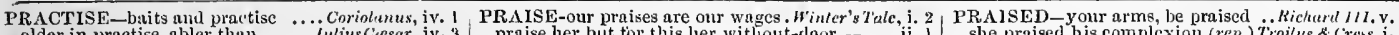
older in practise, abler than ....... Jntiuscirsar, iv.

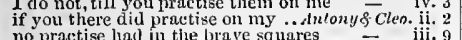

surpassing the eommon preise it bears gurpassing the eommon pritise it hears

iii. first, his did praises do montend

did bear thy praises in lis

shall from this practisc and, by still pratietise, learn to know.

Bome cunning practise out of hand
in those that praetise them, they are to these that praetise them.

quenched with some present practise

Jonesty iny praetises ride easy !.............

suggestioul, plot, and daum

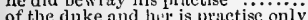

that England had this $\mathrm{p}$

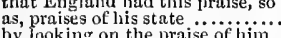

to praise him so for running

this praise cloth nourish agucs.......

trimmed up your praises wit

better than his praise, by still (rep.)

to blow away this praise, ending
praise heaven for the merry year..

your elroniele as rieh with praise
ay, I praise Got; and I lave merited

vary deserved praise on my paltirey

is the prescript praise and perfection

even as your horse bears your praises
cry, praise and glory on his headl

or take that praise from God

... Henry $_{\text {VI }}$ iv. 6

sing her cnd less praise ..............

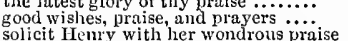

prefice of her wortly praise

annoy our foot, is wortlyy praise.
my vows of thanks and praisel

want praise and esteem, but tliat...

lheard lis praises in pursuit ........
sin's relbuke, and ny Crcator's

sin's rebuke, and my Creator's praise -1 iv. him in oye, stlll him in prise....... Henry VIII. $\mathrm{i}$. as they term it, praise her.... Troilus \&

too faining a praise tor a good .....
in the glass of Pandar's praise may be

of praise distains his worth (rep.).

seeks his praise more than he fears

so to be valiant is no praise at all
praises itself but in the deed (rep.)

praises itself but in the
furce hina witla praises

or covetous of pralse?

pr'll not praise thy wisdon.

I must needs praise him .

pritise us as we are tasted....
shall have a prnise in present.

one eonsent, praise new-born gawds

eye praises tle present object........
as tiur high-soaring o'er tly prais
do deed sorth praise, and tell

do deeds worth praise, and tell ..... no man can justly praise ............

praise his most vicious strain

wheo sle noes phis my work.

wh the spire and top of proiseses me - i.

in praiscs sauced with lies.

whom with all praise $I$ point at....

my praises made thee first a soldier (rep.)

praise the gods, and make trinmpliant

to bury Cxesar, not to praise him. Julius Carsar, iii.

you praise yourself by laying .... Antory \& cleo. ii.

will praise any mant that will preise me $=$ ii. 6

would you praise Casar, say, - Crsar
plied them both with excellent praises

rouse himself to praise my noble act

in praise of our country mistresses

tamous in Cæsar's praises, no whit ..

and praise myself for eharity deserved the praise o' the world....

hearing us praise our loves of 'taly
made suruple of his praise................

made suriple of his praise............

witl the glory of her praise

her tace, the book of praises, where is read

oft the wrack of earned praise........ iv. (Gow.) express a general praise to her

the argument of your praise ...............

got praises of the king for him attempting - ii.2

funeral praises do adorn thy tomb! Romeo \&. Jill. v. 3 seen play, and heard others praise .... Hamlet, iii, 2 if praises may go back again .........

thou slall not write my praise.

if thou should st proise me?

what miserable praise hast thou for...

but what pratse couldst thou hestow on - ii. nis thou shalt prove us, praise us........... heuven be praised for my jealousy
I slanl be ratler prai ed tor this...

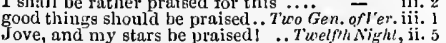

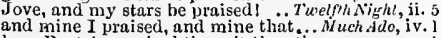
how Beatrice praised thy wit the other

well. praised be the gods for tlyy. As you Like it, iii. . whom the praised of the ping praised, and wio.......All's st'ell, ii. 3 Why mildness praised in every town Taming of Sh, ii. be the great Apollo! praised! .....Winter's s ale praised be God, and not our (rep.).... - iv. 7 here is (praised be Got for it ij ${ }^{\prime} \ldots . .$.
God be praised! that to bclieving ...

I praise.God for you ..................
thongh they cannot praise us .... Winter's Tale, i
cram us with praise, and make us .. she praised his complexion (rep.) Troilus \& (ress. i. 2

the lord be yraised! ................

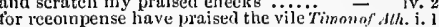

make yourselves praised: but reserve - iii. 6 (grucc)

the soothsayer that you praised

but I have praiscd you, when you

most praised, most loved ............. Cymbrtine,

in the elothes that she so praiscd

not dispraising whom we praised

than praisel for harmf'ul nilduess

which she hath praised him with Romeo \&.Juliet, iii.

rashly, and praised he rash ness for
well praised! how if she be bjack

Othello, $\mathrm{ii}$.

PRA [Col.-preyfni] Love's L. Lost, iv. 2 (eppit.

PRAISE WORTHY; and now teil me..... Auch At

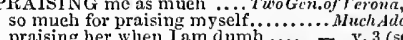

praising her

$\checkmark \cdot 3$ (seroil)

coigh-diny wit in praising him. Merrh,

yself - iii.

on the turf, praising the proud ..As you Like il, iii.

praising what is lost makes .............Ali'sWell, $v$.

blame you not for praising Casar. fulius Cossar, iii.

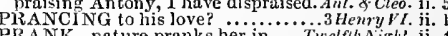

how many fruitless pranks this........

you of a thousand idle pranks. Comedly of Errors, ii.
pestiferous, and dissentious pranks.1 Henry $V_{I}$ i iij.

they do prank them in authority. .. Coriolanus, iii.

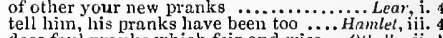

does foul pranks which fair and wise.... Othello, ii.

let heaven sce the pranks they dare not
PRANKED-roddess-like pranked up. Winter's $T$. iv.

PRAT_come, motler Prat, come... Merry Wives, iv. 2

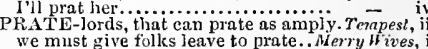

we must give follks leave to prate... Merry Wives, $\mathrm{i}$.

to prate and talk for life ........Winter's Tale, iii.

very stones prate of my whereabout .3lacbeth, ii.
with his innocent prate he will .... King John, iv.

done nothing but prate to me .......2 2lenryl 1 , iii.

we will not stand to prate.

what do you prate of scrvice?......... Coriciolanus, iii.

you godsl I prate, and the most noble - v.
yet here he lets me prate

yet her thon prate of mountains.......... Hamlel, v. 1

thou prate rogue? Nay, good licutenant. Othello, ii. 3
PRATED, and spoke such scurvy ...........

PRATER-a speaker is but a pratei..... Henry $r$. V.

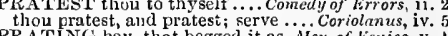

PRATING boy, that begged it as. Mirer. of venice, vv.

think on pration whilst thou livest! Tam, of Sh. iv. 3

cheater prating ......

hence, prating peasant; fetch thy master - ii.

a tool, and a prating coxcomb ....... Henryll: iv.
tlis little prating York was not ... Richard 1 il. jii.

why stay we prating here?

when'twas a little prating thing........... Roreo \& Juliet, ii.

and will she love him still for yrating? Othello,

RATCLE something
the less will prattle of

Tuetfh Night, i.

some cause to prattle for himself. Meas. for orleas.v. $^{2}$

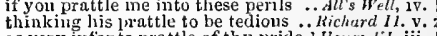

as very infants prattle of thy pride.1 Henry $/$ ' $T$. iji.

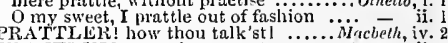

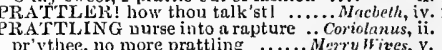

pr'ythee, no more prattling ...... Murry Wives, $v$.

there is gallant and most prave passarea - $V$.

the duke is a prave man . ......... - iii.

PRAWIS, and prabbles................ Henry

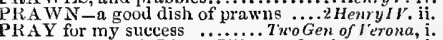

upon some book I love, $\mathrm{Y}$ ii pray for thee = i.

he has pray his Pible vell .......... Muerry rï̌ces, ii.

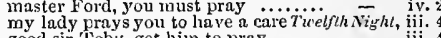

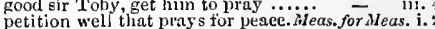

when 1 would pray and think (rep.)

I'll pray a thousand prayers fur thy

I will pray, Pompey to
I pr' the'e, pray tor me

comfort you, tund pray witil you.......

but prays froml lis heart some oecasion. Much Ado, $i$.

tears her hair, prays, curses............ $=$ ii. 3

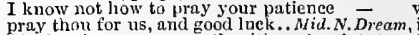

pray rather pray a month with ... Love'sL. Lost', i.

to watel for heri to pray for herl.

drink with you, nor pray with youl...̈er.of $\overline{V_{e}}$ iitee $\mathrm{i}$.

we do pray fur mercy; nnd that same of vente, i.

where she kneels and prays tur liaping

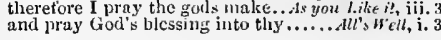




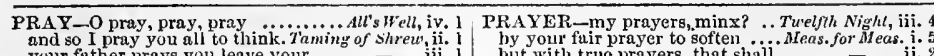
your father prays you.

I pray the gods she may

so give alms: pray so; and, for...Winter's Tale, iv.

pray heartily he be at palace.......

nnd pray your mother's blessing ....

and pray's that you will hie you

ny heart prays tor him.

is gone to pray the holy king................. Hacbeth,

let wives with child pray, that......... King John
do pray to thee, thon virtuots Daiphin

cannot pray that thou may'st win

I will pray, it ever I remember.......
most heartily I pray your highuess... Richard III.

visit hiun: pray God we may mnlse haste -

to pray tor your foul sin (rep.) (......

I pray God make thee new

pray: and yet I lic; for they pray

watch to-night, pray to-mor
but look you pray, all you

to pray your patience for it

your humble patience pray ..... Henry $\bar{r}$. $i$. (eliorus)

lie pray you to proceed; and justly ..

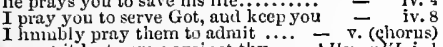

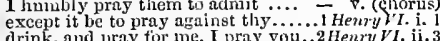

in that I pray you use her well ......

priests pray for enemies..............

and pray that I may repossess........ Richar ${ }_{\text {God, I pray lim, that none of..... }}$ iv.

to pray fur them that hath done scath

saiurs pray, to have him suddenly
who prays continually for lichmond's

the wronged heirs of York do pray fur:
thy adversary's wife doth pray for thee

thy ad wersary s wife dothould pray our monsieurs ...
and pray them take their pleasures..

and pray them take their pleasures.

we had need priy, and

now I prav God, amen! .............

pray their graces to come ncar
that sun, I pray, may never set!

she is going, wench! pray, pray

sir, I most humbly pray you to......

most heartily to pray for her (rep.)...

noble partwers, and myself, this pray

to pray Achilies see us at our. Troilus \& Cress. v. 10

aud humbly prays juu (rep.)
as free as I do pray thic gods

are bound to pray fur you botl

how can we for our country pray.....

pray to the gods to intermit........Juliug

if I could pray to nove, prayers would

prays, and destroys the prayer

by your fuir prayer to softer

prayers from preserved soul

going to temptation where prayers...

I'll pray a thousand prayers for thy.

as our prayers are he may

with a prayer they may prove prosperous
desire you to elap into your prayers

I say my prayers aloud ................ Much .A

that my prayers could such affec
anen, to thut finir prayer, say $I$.
the more my prayer, the lesser.

the more my prayer, the lcsser ....... -

lest the devil eross my prayer ... Der of Yen

follow him no more with bootless pruy
to live in prayer and contemplation

chn no prayers pierce thee?........

might your prayers move? As you

might your prayers move? As yout Like it, iv. 3 (lett

say thy prayers; when thou hast none
you bad my prayers to leud then ou

though I tuok him at his prayers .....
bosom against our borrowing prayers

muless her prayers, whom heaveu......

drugs, and holy prayers, to make

mut they did say their prayers

my prayers with him!

put on with holy prayers...

better part our prayers come in ............. Joh J w tii.

unto my mother's prayers, I bend...

no tears, his mayers are in jest $(r, p)$.
low our plain ts and prayers do pierce

low our plaints and prayers do pierce
say thy prayers, and tarewell ...... 1 Henry IV v.
concludes in hearty prajers ........

tall to thy prayers

lic scorns to say his prayer

they have said their prayers, and they - iveny $V$. iii.

$I$ would prevail, if prayers might

good wishes, praise, and prayers

when you make your prayers .........

my humble thanks, my prayers

if a humble prayer may prevail

if my deep prayers eannot appease.

at effect

to hear her prayers for them

a book of prayers on their pillow liny

my prayers on the adverse party $\ldots .$.
turned my feigned prayer on my head

the prayers of holy saints............

ive where their prayers did .........Henry $v I I I$.

make of your prayers one sweet........
my vows and prayers yet are the king's
my prayers are not words duly hinllowed

iny prayers are not words duly hallowed -

almost forgot my prayers to content
slaall have niy prayers, while I shall

my prayers to heaven for you.........

but $m y$ prayers for ever, and for ever

past all comfurts here, but prayers

mistress will remember in my prayers

men's prayers then would seek you ..

$I$ have said my prayers ................

and visit her with my prayers

the prayers of priests, nor times

not accurding to the prayer of the people -

thou barr'st us our prayers to the gods

than pity to our prayers...............

pray to move, prayers would move.Julius Cas sar, iit

hear that prayer of the phople tho

by losing of our prayers...

knee shall bow my prayers to them

undo that prayer, by crying out

prays, and destroys the prayer
tor so bad a prayer as his was ne.

parted with prayers for the provider.
nnd on it said a century of prayers

in bootless prayer have they been.

hernits in their holy prayers..

that, with base prayers, I shopld repent -
which the people's prayers still tall ... Pericles

madam, my thanks and prayers

come, say your prajers speedily

master-reasons, her prayers, her knees

great patron thought ou in my praye

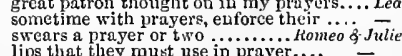

lips that they must use in prayer....

though grant for prayer's sake

tears, nor prayers, shall purchasc out

what's in prayer, but this twofold force

but, $O$ what torm of prayer can serve.

for charitable prayers, shards, flints

prayer [Col.-praying] much castigation... Othello,

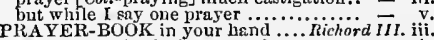

PRAYER-BOOK in your hind ......Richord $\bar{M} I$. iii. miss you morning nor evening prayer -

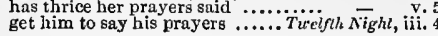

PRAYING for our husbands' $\ldots$. Mer. of Veniee, y. 1
trom praying to purse-taking $\ldots \ldots$. Henry $I V, j$. nay, that's past praying for............ $-\bar{c}$ ii. 4 proying to enrich his wateliful be praying nuns ........... iv. my letters, praying on his side.....Julius Cassar, iv. might I do it, pat, now he is praying... Aamlet, iii.

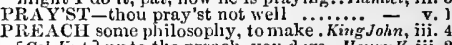
[Col.Knt.] ny to the preach, you dugs..Ilenry I will preach to thee, nark me............. Lear, iv. 6
PREACHED-divinity preached there Pericles, iv. 5 where manners ne'er were preached I Twelfth $N$. iv.

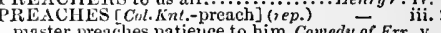
PREACHING to stones ................ Hamlet, iii. PREAD and salt yesterday ........... Hemry $V . \mathrm{v}$. it dues alluy the good precedence. Antnny \& Cleo. ii. PRECEDENT, should a like ........ W'inlor's Talt, ii.

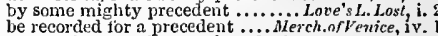
be recorded for a precedent .....Merch,ofVenice, iv.
return the precedent to these iords ... King John, y. be a precedent and witness good.... make them your precedent1 .......3 Heary $V I$. ii. precedent was full as long a doing. Richard III. iii. you a precedent of this commission? Henry VIII. i. grecedent passions do instruet us.. I'imon of Ath. $\dot{i}$. or thy precedent services are ...Anlony \& Cleo. iv. 1 precedent, and lively warrant. Tiins Andronicus, $\mathrm{v}$. gives me proof and precedent of Bedlam. Lear, ii. a voice and precedent of peace
PRECEDING still the fates

of six preceding ancestors, that gem........il's $\bar{w}$ ell, $\mathrm{v}$. PRECEPT, he did slow ........ Dleas. for Mens. iv. I will bestow some precepts on this... All's Hell. iii. $^{2}$ those preccpts cannot be served......2 Henry IV. v. the icy precepts of respect .... Timon of Athens, iv. 3 precepts, that would nake invincible .. Coriol. iv. and these few prccepts, in thy memory. Hamlet, i. 3 and then I preepts gave her, that she ... $\bar{A}$. PRECIOUS creature, I had Tempest, iii. love is still more prccious in itself. Tuo Genpest ini. $V$. ii. 6 of balm, and every precions flower. Nler ry Wives, v. come appareled in more precious habit $-\overline{\text { in }}$, iv. and rare, precions. celestial? ....Mid. N.'s $\mathrm{Dr}$. iil. it adds a precious seeing to ...........

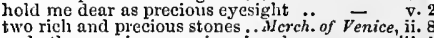
and other precious, precious jewels... thy words are too precious to be .As you Like it, i. more precious than to want ........ $\overline{-}_{\text {is }}$ iii. is the jay more precious than .. Taming of Sh. iv. this jealousy is for a precious creature = i. my father will grant precious things

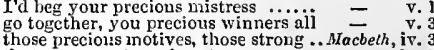
that were most precious to me ...... any annoyance in that precious sense! found it too procious princely for a grave - iv. we hold our time too precious to be... and all the precious liquor spilt .... the prccious jewel of thy home return
this precious stone set in the silver..

the glory of my precious crown....... in - iij. and thy precious rich crown $\ldots \ldots \ldots \ldots . .1$ Henry $1 \%$. if more precious, preserving life in ..... ${ }_{\text {in au urn more precious than........ }}$ r. iv. 4 and set a precious erown upon ...... was it more precious to me tlian 'tis.

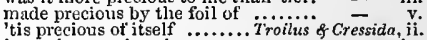
in suel a precions loss far more precious dear tian life........ yellow, glittering, precious gold? .... and leoked upon things lirecious...... Coriolanus, if. my precine most precious linmond. Cymbeline i so precious 'twixt fair and foul? .... what's in't is precious ............... -

he believes it is a thing most precious

ah, you precious pander! .............

said, was precions and cordial to me
such precious deeds in one that promised thought by me a precious thing $\ldots . .$.
returns with precious lading .. Tilus Andronicus, $i$. lie doth wear a precious ring

the most precious square of sense .........

buy this unprized precious maid of me.. that can make vile things precious ....... torget the precious treasure................ this precious book of love............ $=\quad$ i. 


\section{PRE}

PRECIOUS--the precious diadem stole. Hamlel, iii. 4 it sends some preeious instanee of .......

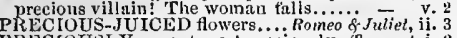
PRECIOUSLY - spent most preciousiy.. Tempest, i. PIECIPICE-precipice for no leap..IIenry VIII. $\mathrm{v}$. PRECIPITATING-down precipititing.. Lear, iv.
PRECIPITATION might down.... Corrolanus, jii. in peril of preeipitation from off the rock - iti. ever preeise in prom ise-keeping.. Neas. for Meas. lord $\mathrm{A}$ ngelo is precise; stands a

but precise villains they ar'

[Knt.] deep as hell. The precise Angelo?

your honour more precise and nice.. $H e$ und PRECISEL Y - say precisel y.... Tho $G$ " " o o therefore, preeisely, ean you earry. N erry ' say preeisely, were not for the eourt. All's We of thinking too precisely on the event. llamlet

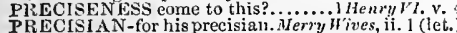
PRE-CONSENT, he did not flo Re PRECOR gelida quallo peens.... Love's L. Lost, PRECURSOR-preeursors o' the dreadful. Tempes, PREDECESSOR $\rightarrow$ of his predeeessors... Haevelh, did to his predecessors part withal.

your great predecessor, king Edward
is worth all your predecessors .......

as your predecessors have, your hon

PREDIC I the line, and the predieament

pitenus predieament! .......
PREDICTION of noble hari these predietious are to the world...Julius Casar, ii. of a prediction I read this other day.......... his humorous predominance. Troilus \& Cressida, ii. 3 PREDOMINANT. When he was .... Ali s Well, strike where 'tis predominant .... Winter's 7 'ale, i. so predominant in your nature.

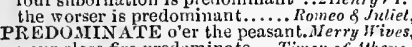
your close fire predominate ... Timon of Atheres,
PREECHES - must be preeches..... Merry Wives, IRE-EMINENCE than fish and. Comedy of Err. ii. PRE-ENPLOYED by lim...

PliEF ACE - a preface of her worthy...1 Henry VI. I will help thee to prefer her to I have access my own love to piefer $=$ iv. any sueh, prefer them hither.. Taming of Shrew study to prefer a peace, if holy
love thee, and prefer thee for it ne'er prefer his injuries to lis prerable presently prefer his suit to Casar. rou must not so far prefer her tore. Cymbeline, that may prefer you to his daughter I will prefer my sons.

before all the world, do I prefe....... Titus Antron. is the first that doth prefer limself? .. Pericles, ii. 2 seeming, do prefer against him

the means I shall then have to prefer them if it be ureferment, to leave a rich. Two Gen af I'er. $\mathrm{i}$. 3 the preferment of the eldest sister. Taming of $S h$, preferment drop on my head . ... Winter's Tale, y, help you to many fair prefermen is. Richard HI. $\mathrm{i}$. gap and trade of more preferments. Henry IIII. v. 1
to any shape of thy preferment..... Cymbeline, i. nor my votee for thy preferment ..... - ii. and true preferment shall tender itself =-

preferment falls on him tlat euts him .. Lear, the long is, our play is preferred... Mid. N's D. this day, and hatl preferred thee.Mer. of venice, ii. 2 altho' in writing I preferred she should be preferred: for what is. because my book preferred me to... - iv, newly preferred from the king's .. Henry VIII. why then prefurred you not your. Timon of Alin. iij. boy, he is preferred by thee to ns

PREFERRETII peaee more than for Hamlet, iv.

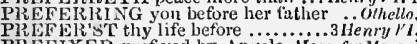

PIL EFIXED-prefixed by Angelo......... the gest prefixed for his parting... Winter's Tale, $i$. the hour prefixed of her delivery. Troilus \& Cress. Iv. PRE-FORMED faculties ............ Julius Cresar, PREG NANCY is made a tapster ...2 Henryl $Y . i$. PREG NAN'T enemy does mueh ... Twelfh Night,
most pregnant and vouchsafed ear .. odours, pregnant, and vouehsafed

You are as pregnant in, as art.... Nleas. for Mteas. $i$. were pregnant by circumstance.. Winter's $\overline{7}$ ale, $v$. 3 are most prompt and preguant. Troilus \& Cress. iv.

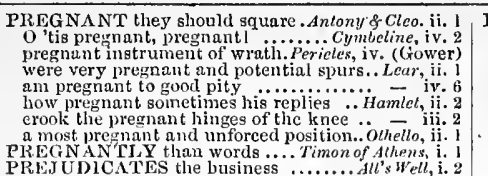
PREJ UDICATES the business ........ All's Wetl, i. breed him some prejudiee ........Henry VIII. i.

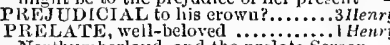

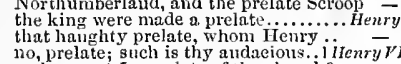
ho, prelate; such is thy audacions

proud prelate, in thy face 1 ............. PREIEDITATED weleomes ...Mid. premeditated and eontrived murder
PREMEDITATION for my purpose
PREMISE-in lieu o' the premises.

the premise observed, thy will.

ulion the premises, but justice
PRENISED flames ot the last d

PRENNEZ misericorde 1 avez pitié.... He

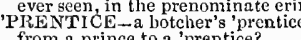

from a prince to a 'prentice?...

fight for ererlit of the 'prentice
PRE-OCCUPIED with what

PPL-ORDINANCE, and first

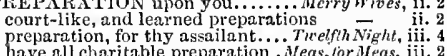

he hath made great preparation
and all the preparation overthro

Wuelt Ado, i. 1

mave not made good preparation...Mer. of fenice,

yould have in formed for preparation... Macbeth,

all preparation for a bloody siege

with strong and mighty preparation. I Henr
of this most dreadful preparation. Heenry $r$.
musters, preparations, should be maintained

give dreadtal note of preparation

to go about my preparation.

lead on this preparation .... Corinlanus, i. 2 (letter) their preparation is to day by sen Anlony \& Cleo. iii. 4 the way to fool their preparation

your preparation can affront no

our preparation stands in expeetation..... - iv. 4 to be a preparation 'gainst the Polack.....

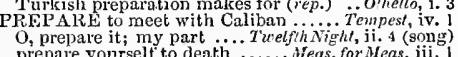
O, prepale it; my part .... Twelfh Night, ii. 4 (song)
prepare yourselt to death $\ldots . .$. . Yeas. for Heas. iii. I
well, go, prepare yourself............ - iv. 2

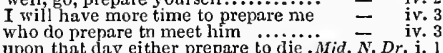
upon that day either prepare to die...Mid. $_{\text {N. Dr. }}$ i. prepare, madam, preparel ......... Love's $L . L$ ost, v. 2
go, bid them prepare $\ldots . \ldots \ldots \ldots \ldots \ldots$
Boyet, prepare; I will away (rep.)... Boyet, prepare; I will away (rep.) .. $\overline{\text { will you prepare for this mask. Merch. of Venice, ii. } 4}$ bid them prepare for dinner (rep.)

a sentenee; eome prepare.

a sentenee; eome prepare......
therefure, prepare thee to eut of
let us prepare some weleome for

go you, and prepare Aliena.....

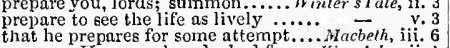
prepare. How mueh unlonked for ... King John, ii. come, boy, prepare yourself...........
when you should be told they do prepare - iv. 1
iv. 2 eoronation: lords, prepare yourselves. Richard fI. iv.

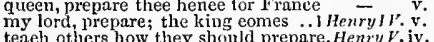

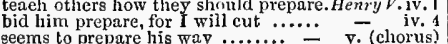

you do prepare to ride unto.

and I'll prepare my tear-stained eye

prepare you, lords, for Edward is

prepare her ear's to hear a

prepare there, the duke is coming...Henry $\bar{V}_{I I I}$. ii.

prepare the ways you have for dignities $\bar{C}_{\text {mut }}$ iij. presently prepare thy grave. Tinon of Alhens, iv. 3 prepare thy brow to frown .......... Coriolanas, iv. 5 bid them prepare within ..........Jutias Casar, ii. prepare the body then, and follow us - iii. 1
prepare to shed them now .......... bid the commanders prepare to lodge - iv. 3 prepare you, generals: the enemy comes - vo noble eyes to weep... Tilus Andron. iii. to prepare this body, like to them........Pericles, i. i
PREPARE for mirth, for mirth becorres Pericles, ii. 3 a present murderer does prepare... - iv. (Guwer) prepare my horses. Ingrutitude

gid my sweet prepare to ehide

prepare her, wife, arainst this ...... = iii. 3

prepare to tollow this fair eorse ......

PREPARED-prepared a rotten carease. Tempest, 3 leavened and prepared choice... Neas. for Meas. $\mathrm{i}$.

he's not prepared for deatij!

and an prepared to die............. - iii. I

be the better prepared for an answer.. MIuch Ado, i. 2 am armed, and well prepared. Ner. of Vrnice, iv. I prepared I was bot for such our waggon is prepared, and time.... - iv. 4 and have prepared great store of. Taming of Sh. iii. 2 but not prepared for this design.. Wninter's Tale, iv.
welcome then, we are prepared....... Kins John, ii. he is prepared; and reason too, he should - V. 2 the champions are prepared .........kichard II. i. 3 and my lieart prepared; the worst is - iii. 2 mow we are well prepared to know ....Henry $V$. i. 2 I am prepared; herc is my keen- ..iHenry $V I . \mathrm{i}$. 2 to a prepared place in the choir .. Henry YIII. iv. 1 for they have not prejared for us... Coriolanus, i. 2 who am prepared against your....... be prepared to know the purposes. Antony \& Cleo. i. our letters are prepared. A proper man = ii. hearing that you prepared for war.. $=$ iii. 6 iii. 7 I am prepared and tull resolved.. Tilus Andron. ii. I with his jurepared sword, he charges ..... Lear, ii. I Tybalt, with his sword prepared... Romeo \& Juliet, $\mathrm{i}$. PREPAREDIY may frame... Anlony\& Clenpatra, v. 1 thou art preparing fire for us .......... King Joriolann, v. preposterous ass! that never.. Tamin of shew, ii. in so preposterous estate as we are. Win'er's Tale, $v .2$ both preposterous; therefore........3 Henry $/ 1$. . y.
preposterous and frantic outrage... Richard $I I I$. il.
sucl preposterous diseoveries! to most preposterous conchusions............ Othello, i.

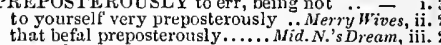
wrought upon thee so preposterously... Hewry $v_{\text {. }}$ ii. PREROGATIFES and laws of the wars - iv. this prerogative of speech $\ldots . . .7$. Twelfth Night, ii. the great prerogative and rite of love.All's $W_{e l l}$, it. me leave to have prerogative. Taming of Shrea, iii. so much from that presogative....... Henry H't. v. on the old prerogative and power.. Coriolanus, iii. 3 PREROGATIVED are they less than... Ohello, iii. 3 a mind presages ne such thift. Nereh.of Venice, $i$. sullen presuge of your own deeay .... King $J_{0 / 2 n} \mathrm{ii.}$ bortives presares and tongues of lieaven - iii. if heart's presages be not vain...... Riehard 1r. ii. 2 credit things that do presage.........Julius Capsar, v. my dreams presage some joyful... Romeo \& on Jiliet, v. the o'erflowing Nilus presageth..Anlony \& Cleo. i. 2 PRE WEen her torks presageth snow ...... Lear, iv. 6 RESCIENCE-by my preseience I find. Tempest, $i .2$

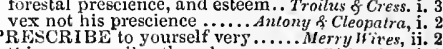
this we preseribe, though no ........... Richard $I I$. i. I preseribe not us our duties............... Lear, j. I PRESCRIP'T of this seroll.. Antony \& Cleopatra, iii. 8

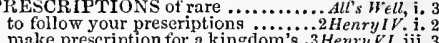
make prescription for a kingdom's..3 Herry $r I$. iii.
I'll go along by your preseription ...Henry VII $\mathrm{i}$. most sovereign preseription in Galen. Coriolanus, ii. and then we have a prescription to die.. Othelto, i. 3
PRESENCE-with thy presenee. Two Gen. of Fer. v. when he approacheth to your presence ${ }_{\text {in my presence still smile.. Fwelfh Night, ii. } 5 \text { (let.) }}^{4}$ iu the presenee of the prioress ..Meas. for Mleas. i. 5
crowd to his presenee, where their ..

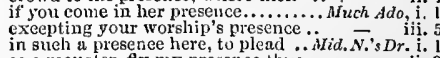
as a mouster, fly my presenee thus. and from thy hated presenee part $\mathbf{I}$ so ii. from the presence of the sun .......... $=$. a donbt, presenee majestieal....... Love's L. Losl, v. 2 party-conted presence of loose love ... ve $v_{\text {enice, iii. }}$ although I speak it in your presenee - iii. for his presence must be the whip yort Like it, i. to came into his presence. 'The king's - v. I 
PRESENCE may well abate ... Taming of Sh. t (ind.) PRESENT-of this present breath.... Love'sL.L. i. I PRESENT-this present summons..IIenry $r$ III.ii. 4 your royal presence I']l adveiture. H'inter's Tale, i. 2 behold the sternness of thred ...... what present hast thou there?........ sir, you shail present before her...... tender your persons to his presence.. - iv. 3 none so fit as to present the nine bear a fair presence, thougl. .......... Comerly of Er. iii.

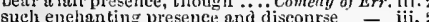
I promised your presence, and the ehain $\bar{z}$ iv. I

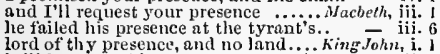
lord of thy presence, and no land.... King $\overline{J_{0}} h h_{\mathrm{n}}$ i. it ill beseems this presenee, to ery aim he shall present Hercules in minority zeal of them which it presents and present the other five the fortune of this present year......... of rerch of Fenice to raise a present sum your proyal prescnees be ruled by me ii. 2 Im debating of my present store her presence would have interrupted - ii. 2 theu call them to onr presence supply your present wants, and take give lim a presentl give him a häter gire me your present to oue master. that holds this present question unto all men by these presents ...As you $\overrightarrow{L i}$ What presence numst not know ...... your presence makes us rich. thou present; but look to it pageants let's present him to the duke, like
mark, what object did presenit itself and therefore take the present time - v. 3 (song) you were in presence then; and $\begin{aligned} & \text { you } \\ & \text { in this royal presence may I speak }\end{aligned}$

any in this noble presenee were.

a traitor in thy presence there

urge her to a present answer baek....

hroeured his leave for present parting
be but your lordship present at his ..

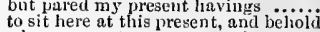

to sit here at this present, and belold
whose present courage may beat. Troilus

your presence is too bold and
so lavish of my presenee been

if $I$ were to live this present hour

$\begin{array}{lll}\text { even in the presenee of the erowned } & - & \text { iii. } 2 \\ \text { my presence, like a robe pontifical ... } & = & \text { iii. } 2 \\ \text { being with his presence glutted .... } & - & \text { jii. } 2\end{array}$

my good lord, he is in presenee here.2 Henry $I \boldsymbol{V}$. iv. 4
not liere in presence. Send tor him.... Henry $V$. i. 2 unless the Dauphin be in presenee Tiere - ii. 4
with onr stately presenee glority .... Henry r. i.
the presenee of a king engenders love

in presence of the kings of Franee ..2 Henry V L. i.

ail in this presence are thy betters

overcome mine ene inies in this presenee?

my suvereign's presence makes me mild =

by these presenee, even the presence of -

may pass into the presence of a king

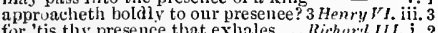

for 'tis thy" presence that exliales ... Richaril III. i 2

to whom in all this presence speaks..

now by present profession.. Taming

I do present you with a man of......

upon entreaty, have a present alms..
siekness, or else present death.........

withont my present vengeance taken

we shall present our services to a fine

I must be present at your couference

though a present reath had been.

$\checkmark 1$ then whet they do in present...

the present eye praises the present objeet

three talents on the present; in future let the presents be worthily entertained -

for some trifling present, you have

$\mathrm{pr}^{\prime}$ y thee be my present partner in

hardly stop the mouth of present dues

nothing doubtiug your present dues -

ii. 2 he las only sent his present occasion

my present friends

ither in hope, or present, I'd exchange - iv.

what lave you now to present unto him?

the present wars devour him ......... Coriolan

he goes upon this present action.

that you not delay the present

to desire the present consul, and last

appreliension of his present portanee
scaling lis present bearing with his past

Mresent me death on the wheel .......

not what is dangerous preseut

enforce the present execution of

no further than this present?

that shall set them in present aetiou

and present $m y$ throat to thee........

I this present, I would not .......... Julius $\bar{C}$ ces
I did present myself even in the oim

he first presents his fire..............

go bid the priests do present sacrifice
and this our present aet, you see we do

and this our present aet, you see we do - ii

not thrived upon the present state .. - i.

what you are doing in the present deeds
what

and there present yourself', and yoir fair-

royalty's repair, for present comfort

as every yreseut time doth boast

present your hand: when she was young -

by any in this presenee, I desire to

no man in the presence, but his....

by my presence miglit have been
most forward in this noble presen

as presenee did present them......

not furnished with the present money

besides this present instance of his rage - iv.

conduct them into our presence.

unless you send some prescnt lielp

[Col.Knt.] yronounee his present deuth . Aacoelh, i.

present fears are less than horribie

to tront this present time

to mend the petty present, $I$ will piece

the present need speaks to atone you

for this is from the present ...........

and present our Alexand:ian revels.. $=$ ii.

material to the tender of our present $\ldots$ Cymbeline, i.

quake in the present winter's state... -

and pervert the present wrath he ....

'fore noble lancius present yourself.

our present numbers be mustered.... =

these present wars shall find I love...

I speak against my present profit ....
were present when she finished .....

ould cease the present power of life - v.

i'the presence he would sny untritlis - iv.?

such flattery now, and in my presence

beyond this ignorant presen

tis present deatli I beg

to the empress' sous pre........

(rive them to jiesent your lordships

iv.

no teeth for the present...............
graeed person ot our Batnquo present

that not in the presence of dreaded.Corinlanus, iii.

most noblel in the presence of ..... Julius Cecsar, jit.

your presence needs must puzzle Antony

not be denied your highnes' presentony

take lim fium our presence

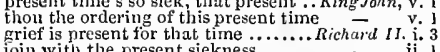

stay your eoming to present themselves -
who is tlue second that presents thimself?

a present murderer does prepare... - iv. (Gower.) join with the present siekness ......
the present benefit which I possess..

the present benefit which I possess ...
ne'er wail their present woes ........

to glad her presence, the senate-house... Pericles,

your preserce ghads our days

other, in this royal presence?

is't not a goodly presenee?

resd them in

show a fair presenee, and put off........... $J_{\text {raliet }}$ iv.

this vault a teasting presence fuil of light

scanter of your malden presenee.

this presente knows, and you must needs

by you invited, do attend your presence, Othello, vi

I'll bring thee to the prentsent business...

he's a present for any Emperor that.

for some of you there nresent

and myself present. as I was

Uid scorn a present that $\mathbf{I}$ sent Tro Gen.of Verona

he must carry for a present to

as a present to mistress Silvia

good enough for sueh a present.

good enly bought many presents.........erry $\bar{w}_{\text {ives }}$

folly of my sonl dares not pre
we'll all present ourselves.

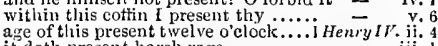

his present want seems more than we

and ruise this present head

this present enterprize set off his head $=$

our present musters grow upon.......

yes, in this present quality of war.

he presents no inark to the enemy

every ininute's instance (present now
from the king, or in the present time

and present exeeution of vur wills

to breed this present peace ....
to York, to present execution

let me in my present wildness die..........

his present, and your pains, we thailk.. Henry $r$.

we'lil give them present audience $\ldots$ prest him with those Paris balls

m'avez appris dès a present.

put me to present pain ..............

your present kindness makes my past

I have this present evening from

why you answer this present summons?

- v. 3

give me some present connsel ...Romeo \& Juliet, iv.

shall fiee thee from this present shame

this present object made probation...... Hamlet, $\mathrm{i}$.

that effect, the present death of Hamlet.

we'll put the matter to the present push

upon some present business of the state...

and to uudertake these present wars......

true advantage never present itself f ...... $_{\text {from }}$

his present reconciliation take .........

PRESEN'TATION of that, lie sloots. As you Like, $\mathrm{v}$. the presentation of but what $I$ was. Richard III.iv. when I presented Ceres ..............? ? ?mpest, iv. I be presented at our tent to us..... Love's L. Lost, v. 2 of blood presented thee inore lideous. King John, iv.

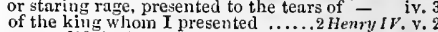
proper life be lere presented . Henry $V$. v. (cliorus) to be presented, by your vietories. .IHemry $V$. iv. I the re is prescnted no monster. Troilus \& Cressidn, iii. 2

presented to my knite his throat ..... Corinlemats, y. 5 presented him a kingly erown.....Jutius Carsar, iii. 2 to enll a present eourt of parliameit.. his pale cliceks, methinks, present...3 Henry $r T$. ii.
frorn whence this present day he is . Richurd III. will take the present at uur liands...

Northumuerland, then present, wept

therefore present to her, as
withholds uny present ald

throngh the clouds behold this present

the eye to flow, we now present .Henr
I was then present; saw them salute

present them; him in eye (rep.).......

eall him to present trial

once more, I present unto your higliness -

to the prejudiee of her present state.

to the prejudiee of her present state..

PRESENTING me a scliedule... Merch of ienice, it.

presently? Ay, with a twink

and presently, I pr'y thee....

presently, all liumbled, kiss ....... Two Ger. of Ver. i.

I'll send him hither to you presently

and then I'll presently attend jou ..
I'll to the aleliouse with you presently
uow presently, I'll give lier...........

to distigsure, or present, the person.
must present wall (rep. $v$. 1$)$
the horued moon present $(r \in p.) \ldots . .$. 


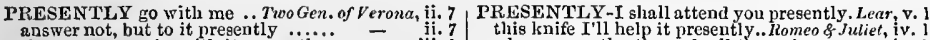
this way comes he with it presentiy into the eity presently $\ldots \ldots \ldots \ldots$............ employ thee in some service presentiy I go presently, and take this ring...... but mount you presently needs speak with you presently ...Merry Ifives, iii. nay, but he'll be here presently...... $\overline{\text { ivel }}$ iv. send one presently to sir Tohy ....... - v. I will presently to saint Luke's. Mear. for $\bar{M}$ eas. iii.

shall be done, good father, presently such $_{\text {ado, }}$ iv. thou wilt be like a lover presently in practice let us put it presently eome, I warrant you, presentl and presently eall the rest of the wate tis well consented; presently away.. and to the cliapel let us presenti

meet presently at the palace... Via. $N$.'s Dream, iv. presently inquire, and so will I... Ner. of 'renice, i. and presently I will be with you.... - i. 3 Bassanio presently will go aboard .. - $\quad$ ii. 6 for this favour, he prestl become - $\quad$ iv. it is meet. I presently set forth. rou and $I$ will thither presently I will here be with thee presently. As you Like it, ii. 6 but presently do thine own fortunes.. All's Well, ji. 3 you presently attend liw further you presently attend his further....
that presently you talke your way for
and 1 will presently pen down my... shall go see your pupils.presently. Taming of Sh. ii. 1 shall fetch the scrivener present

I'll presently acquaint tlie queen. Winter's Tale, ii. 2 quit presently tlie elinpel hee him presently, post to the discharged

against thee preseutly, it thou darest

given his hand, they presently amend. Macbeth, iv. with purpose presently to leave this... we will make for Ireland presently...Richare bid her send me presently a thousand meet me presently at Berkley eastle

since presently your souls must......

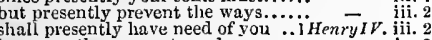

he presently, as greatness knows ..... - iv.

the king will bid you battle presently
shall have letters of me presently ..2 Henryj $I V$. ii. I

you must away to court, sir, presently

good husband, eome home presently.

some of your eouncil presently to sit

presently we'll try: eome, let

and ery - the Dauphin, presently

and ery $\rightarrow$ the Dauphin, present

but we will presently provide for them - v.

'll to the duke of Suffolk presently.2 Henry $V T$. i.

good lord, I'll follow presently...... -

then send for one presently. Sirrah..

I'll call him presently, my noble lord

will make myself a knight presently - iv. 2

marry, presertly. O brave! But is ... $=$ iv. 7

your sword, and dub him presently... - ii.

I will away towards Barnet presently $\overline{\text { var }}$ v.

presently repair to Crosby-place..$R$
unto his prineely brother presently?

if presently you will take hors

[Col.Knt.] resolve you herein presentily - iv. 2 presently the duke said, 'twas the... Henry $V I I u_{\text {. }}$. shall be with you presently ......... and bring his answer presently. Troilus \& Cress. ii. 3 he shall be exeeuted presently.. T'imon of $A l h$. iii. 5 we shall to't presently. I hope...... - iii. 6 Timon, presently prepare thy grave
presently, when you have drawn .. Coriolanus, ii. 3

assemble presently the people hitlier

to-marrow; to-day, presently $\ldots . . .$.

tear him to pieces, do it presently

presently prefer his suit to Cæsar. Jui - v.

'll feteh him prestly l know...

and let us presently go sit in council

of marching to Philippi presently? ..

must Pompey presently be 8onght. Anilony \& Cleo.ji.2

the good gods will mock me p.

my lord desires you presently

my woman hie thee presently $\ldots . .$.

provide me, presently, a riding silit

and bring him to dinner presently ... - iii. 2

be planted presently with horns...

away, and hang bim presently....

go, feteb them hither to us presenti

$1 \mathrm{l}$ bring the body presently........... Pericles, iii.

a word, and I'll have done presently ... - iv. 3

I will seek him, sir, presently ............ Lear,

whieb presently they read; on whose.... - when presently, throngli all thy veins

and presently took post to tell it you that presently they have proclaimed their
and the qneen too, aad that presently.. would speak with you, and presently

let this same be presently perform

by and by a fool, and presently a beasti

PRes, presently: therefore confess thee...

PRESERVATION-our preservation.. Tempest, ii.

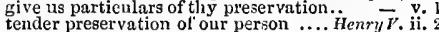

by great preservation we live $\ldots .$. Richarl $M I I$.
require lier times of preservation.. Henry VIII.

those for preservation eased

PRESERVE-that did preserve nei..... Tempest, $i .2$

now good angels, preserve the king!

Which to preserve, is sleep.....

All's Well, $\mathbf{j}$.

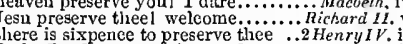

0 the Lord preserve thy good graee! 1 ii. 4 Got pless it and preserve it, as long ...Henvy $r$.

Jesu preserve your royal majesty?

the gods preserve youl

the gods preserve our noble........

the gods preserve you both!
which seeks best to preserve

you eannot preserve it from tainting...

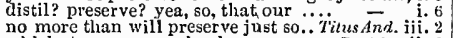

the gods preserve youl (rep. v.
I will preserve myself; ard am

if to preserve this vessel for my iord ..... Oihelin, iv.

prayers from preserved souls

where hast thou been preserved?... Win

rather than life preserved with

men's flesh preserved so whole

a lane, preserved the Britoil

the Britons ......... Cymbelit. ii.

how possibly preserved

irtue preser'ved from fell ....... - v. 3 (Gower)

what canot be preserved when fortune... othello, i, 3 have made preservers of my throne.. Cymbeline,
PRESERVING life in medicine ....2HenryI $y$.

eholsing gall, aud a preserving sweet. Romeo \& Jul.

RESS - would press you down... Two Gen.of Ver.

to press with so little preparat

press me to death with wit..........

doth press to go? what love (rep.). Mid. N's $D r$, iij.

to press a royal merchant... Merchant of
you press me tar, and therefore $I$ will

you press me tar, and therefore $I$ will
$I$ press in here, sir, amongst the ...As

press me not, beseech you, so

I have misused the king's press ..... H Henry IV. v.

I press me none but good householders - iv.

of war, would shake the press, and mak
go, break among the press, and find..

press it to death ............ Troilus

do press among tlie popular throngs. Corinlanis, i. i.

who is it in the press, that calls on. Julius Cicsar, i.

what suitors press to him

he is arddressed; press near, and seeond

nay, press not so upon me.......

for the press of bonts, or pride.

so bold to press heaven in ........ Titus And $\overrightarrow{n n n}$. iv. 3

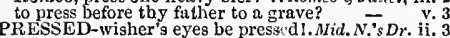

while thou on pressed flowers dost ..

am pressed down with conceit Comedy of Errors, iv.

I am pressed to death, througl

prests.. I Henry $1{ }^{\prime}$. iv.

the gibbets, and pressed the dead bodics - iv. 2
by the king was I pressed forth ....3nlemry $v I$. ii. 5

of York, pressed by his master

pressed in with this caution.........Hen ry r.II. ii.

being pressed to the war, even when

with pressed her heart.

with leaden thoughts been pressed ......... othello, ivi.

in the coffers and in the presses... Werty Wiver's i iii.

of it presses to my memory .........

RESSING to death, whipping .. Meas. for 1 Yeas. v.

PRESS-MONEY-there's your. press-money, Lear, iy.

RESSURE $\rightarrow$ all forms, all pressures past. Ilamlet, i. 5
of the time, his form and pressure ...... which to preserve, is virginity

so the seeks best to preserve it.. Antony \& Cleo. iii. Which, to preserve mine honour

sit, my preserver, by thy patient's........ All's Well, ii. 3

suitors press to speak for right ....3 Henry ${ }^{r} I$. iii.

on his pressed bed lolling .... Troilus \& Cressidn, i. 3
PREST-I am prest unto it ...Merchant of Venice, $\mathrm{i}$. volls dire que volls fait it wous prent lave it prest with more of thine. Romeo \& Jultet, $\mathrm{i}$. PRESTER Jolnn's foot .................Much Aclo, ii. let none presume to wear..... Nerchant of Venice, ii. I do iresume, sir, that you are.........All's W'ell, v.

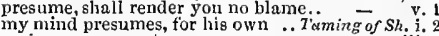
regia, presume not ${ }_{\text {not presume to toueh } a \text { hair of }}$

not presume to toueh a hair of
presume not, that $I$ am the thing

durst not presume to look onee

I dare presume, sweet prince

dare he presume to seom us........3 Henry $V I$. iii.

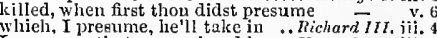

Whieh, I presume, he'll take in ... Pichard III. jii.

this, 1 presume, will wake him...... - ji. 2

as, if it ean, I will presume in you

by the fire, and presume to know ..... Coriolamus, $\mathrm{i}$.

presume too muel upon my love..julius Cargar, iv. 3

Our powers, presuming on their. Troilus \& Cress. iv.

let my presumptions

lose his head for hís presumption

is too mueh presumption on thy part - v. 1

thy son I killed for his presumption All's $^{-}$Vell, i. 3

presumptuous priest! this plaee...... i ilenry VI. iii.

presumptuous dame, ill-nurtured. .2 Hen $\%$ r $r_{T}$. i. i

PREST makes thee presumptuous ...3 Herryli. i.l

PRESURMISE, that in the dole......2 Henry I I i. i

publisher of this pretence. Two Gen. of Verona, iii. )

agrainst the undivalged pretence .........Macbelh, ii. 3

under pretenee to see the queen ..... Henry $Y I I I$. i. I

to keep your great pretences veiled... Coriolanus, i

make pretence of wrong that 1 .............. Pericles, i.

than as a very pretence and purpose.......... Lear, i. 2

but such as shall pretend malieious.j Mlenry II $^{2}$. iv. 1

if you pretend no title? ............

you pretend with that base wreteh... Cymbeline, ii. 3
whom you pretend to honour and... Tilus dndron. i. 1

PRETENDED flight ......... Tu' Gen. of Verna, ii. 6

still pretending the satisfaetion of .. Cymbeline, v. 5
PRE'TEXT to strike at him admits .. Coriolanus, v. 5

PRETTIER fellow of the two ... Mer. of tenice, iii. 4

the prettiest low-born lass ....... Winter's Fale, iv. 3

he has the prettiest love-songs for maids
my prettiest Perdita ................ iv. 3
jv. 3

one of the prettiest touches of ail

it is the prettiest villain .... Troilus \& Cressida, iii. 2

thon wast the prettiest babe....... Romeo \& Juliet, $\mathrm{i}$. 3

slie hath the prettiest sententious of it $\overline{\text { Perona }}$ ii. 4

Lysander riddles very prettily. Mid. N.'s Dream, ii. 3

the king prettily, metlought

hie prettily and aptly taunts ........Riehard III. iti.

PRETTY-a pretty period! .. Two Gen.of Verona, ii. I

why, my pretty youth? $\ldots \ldots \ldots \ldots \ldots \ldots$ is pretty virginity $\bar{F}_{\text {ives, }}$ i.

low does pretty mistress Anne?....... - i.

liad you this pretty weathercoek?.. -

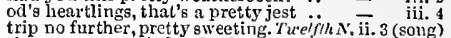

there are pretty orders beginnilg. Mieas. for Meas, ig)

I pretty Isabella, I am pale.

I remember a pretty jest your ........... Much $A d_{0}$, ii.

thus, pretty lady, I am sorry for thy - iv. I

wliat a pretty thing man is $\ldots . . . . . . . .7$. $\quad$ iv.

with pretty and witls swimming ...Mid. N.'s Dr. ii.

pretty and apt. How mean (rep) .... Love's L. Lost, iv. I

pretty, beeause little. Little pretty... - i. 2

thy meaning, pretty ingenions? $\ldots . . . \cdots=$ iv. 2 (epit.)

this pretty; it is well ...............

madam, and pretty nistresses, give ear $=$ v. 2

did pretty Jessiea, like a little .......

you are full of pretty answers.......

where dwell you, pretty youth?

tis pretty, sure, and very probable

there was a pretty redness in his lip

all pretty oaths that are not dangerous

coz, coz, yny pretty little coz

, kir, I have a prefty wit.

these pretty eountry fulks would $\ddot{l}{ }_{i j} \rightarrow$ v. 3 (song)

lie 
PRETTY lady: you must hold twas pretty, tiough a plague.
with a world of pretty, foidd

to be a pretty wise tellow

a wretty peat! 'tis best put fin

the pretty dimples ot his chin

breed thee, pretly, and still rest thine

very pretty bartie! a bey, or a chilil (rep.) -

merry hallar int but ac very pretty one

of excellent discourse; pretty and witty - iii.

my pretty cousin, llessing upon youl . Hacbeth, iv.

all my pretty ones? did you say, all?

what, all my pretty chickens
behold my jretty Arthur more

puts an lis pretty looks, repeat

and make some pretty mateh with. Richard II iv

that pretty Welsh which thon ..... I Henry II

a pretty slight drollery .............

and pretty traps to cateli the petty

the pretty and sweet manner of it...

th pretty plot, well chosen to build.

this pretty lad will prove our Shore's wife hath a pretty foot...

funltless blood of pretty Rutland

iii.

ny pretty consins, you mistake.

I pristhee, pretty York, who told
eradle for such little pretty ones!

the hair, as at lis pretty answer.. Tro

wretty, 'ifaith. IIy lord, I do beseech'

not speak of your nrettyen

sleep kill those pretty eyes ...........

it is a pretty mocking of the life. Timon of $A / k$

uncler thy cloak, pretty Flaminiz

I shall tcll you a pretty tale.

stood pretty dimpled boys.. Antony \& Cleopalra, ii. 2

hast thon tice pretty worm of Nilus

but had most pretty things to say

ii. 3 (song)

her pretty action did ontsell her

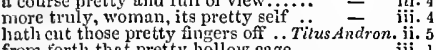

that with his pretty buzzing melody

a pretty moral (rep. ii. 2$)$......................

were as pretty a proportion to live.

Ianent you pretty one? that $\mathbf{I}$ am pretty

now, knt.] think the pretty wrens of

minstrelsy, and pretty din ........... v. 2 (Gower)

how now, my pretty knave? How dost ..... Lear, i. 4

thou wast a pretty fellow, when..........

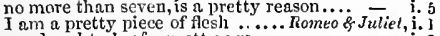

nyy daughter's of a pretty age.......... - i. 3

bitter, pretty fool! (rep.)

hatl a sweet sound. Pretty! (rep.) .. -

how do sort, pretty lady? well ......... Hamlet, iv. 5

pretty Ophelia! indeed, without an onth - iv. 5

nor oath, prevuil not, go ancl see. Winter's Tule, jii. 2

I shall so prevail, to furce him atter..
where how he did prevail, I shane to

where how he did prevnil, I shame to King John a. I
if we prevail, their heads shall .... Richard II. iii. 2

if wishes would prevail with m

Henry $r$ i.

can you suffer hell so to prevail? .....

could not prevail with all their oratory -

admonishments prevail with me .....

whose rightful cause prevails $\ldots . . .2$
malice should prevail, that faultiess
seeing gentle words will not prevail..

seeing gentle words will not
sometime the flood prevails.

humble prayer may prevail.

an upright zeal to right prevails $\ldots .$.
dread curse prevail so much with ..Richard
II I. i. 3

he cannot prevail with 1

his motler, may prevail with him...H

on my knee, prevail in this ...... JuliusCassar, ii. 2

you shall prevail, were it to wo

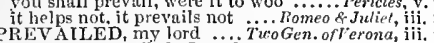

thou last prevalled: I pardon........ - Y. 4

she hath prevailcd with him .Hid. N.'s Dream, iil.

you have prevailed; $\mathrm{I}$ will depart. Comedy of Err.

king of Naples, that prevaile

thus Suffolk hath pravailed

the Daxphin hath prevailed beyond.2. Henry $v x$. $\mathrm{i}$.

O Petcr, thou hast prevailed in right

that lave prevailed upon my bod ${ }^{2}$.

ere so prevailed with me:

dangerously you have with himprevailed

much prevailed oul vour condition. Julius Corsar, ii. ]

to understand you have prevailed..... Cymbeline, $i .5$

hath prevailed on thy too ready hearing!

my practise so prevailed, that I retioned

PREV my empress hath prevail

PREVAILING much in youthful. Comed of ${ }^{2}$ 'I. i.
PREVAIMING-doubt prevailing .... Coriolmus, $\mathrm{i}$. 3 PREVAILMENT in unhardened ... Mid.N.'sDr.

prevent, or so thou, like $\ldots$ w..........

a good hanging prevents a bad .. Tite fflh $N$ ight

prevents the slander of his wife ...A. y/mu Like it, iv.

prevent, resist it, let it not be so...

if God prevent it not, I purpose

to prevent the worst, sir Michael ... H Henry $I V$. iv.

but to prevent the tyrant

too near, if God prevent not..

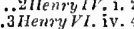

proilus ofith. ii.

then test he may, prevent wild. Timon of Alhens. . .

which to prevent, let Antony, irid Casar -

I must prevent thee, Cimber

so to prevent the time of life

to prevent the fiend, and to kill vermin.. Lear, iii.

est it see more, prevent it................ iii.

desperate which we wonld prevent ...

so shall my anticipation prevent your.. Ifamlet, ii.

to grevent, I have in quick determination - iii.

O plagne right well prevented! ..... Nuch Ado, iiii.
friends had not prevonted me ... Merch of Fenice, i.

which thus she hath prevented........ All's well, iii.

Casar himself conld not have prevented

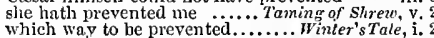

this might have been prevented....... King Jol

o'er myself, prevented from a damned. Henry $V$. ii. 2
but that I am prevented, I slould... Henry $V$.

onglit to be prevented ............ Richard II

too tond, might have prevented this

the gods have well prevented it ....

prevented the ostent of our love...Anlony \& Cleo.

one death might have prevented many - iv, is

how shall this be prevented?................ Pomeo \& Juliet,

but what prevention?................... Henry $v$.

but God be thanked for prevention..... - ii.

orders, preventions, excitements. Troilus \& Cress. i.

orders, preventions, excitements. Troilus \& Cress,
to hide thee from prevention ..... Julius Casar,

for we fear prevention ................

that goes not ont to prey ..............eas. for Meas. i. 4

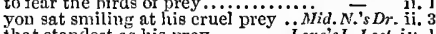

that standest as his prey ........ Love's L. Lost, iv. 1

prey on nothing that doth seem

famous for the creatures of

mous for the creatures of prey...Winter's Tale, iii.

black agents to their prey do rouse ...Hacbeth, iji.

neans, soon preys upon itself ...... Richard II. ii.
not pray to her, but prey on her $\ldots . .1$ HenryI $V$. i. I
the engle England being in prey $\ldots . .$. Henry $V . \mathrm{i} .2$

might have a good prey of $n s$.....

1 Henry I. iv.

as a prey to law, ond shame

thirsting after prey, join with

thou a prey nuto the house of York...3 - venry $\mathrm{v}$.

insulting o'er his prey

to my foes this body must be prey....

that wrens may prey where eagles ...

preys on the issuc of his mother's body

broken faith hath made a prey for worms -

make perforce an aniversal prey. Troilus \& Cress. $\mathrm{i}$.

Nile lave buried them for prey. Antony \& Clco. iij. 11

when valour preys on reason ........

sliali seize this prey out of his

fortl to heasts, and birds of prey

must perforce prey on itself

Lear, iii. 4

in a celestial bed, and prey on gar

PREXED upon the ontward parts

PREYFUL-[Col.] preyful princess. Love's L L L L

drew Prian's cortain in the deadl's 'elt, i. 3 (8on

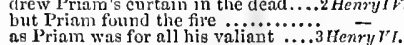

ns l'riam was for all his valiant ....3 Henry $\gamma^{\prime} l$. ii.
Priam's six-gated eity ...... Troilus \& Cress. (proi.

at Priam's royal table do I sit

dread Priam, there is no lady of ....

no more touched thau all Priam's sons

let us to Priam's hall, to greet

with one of Priam's daughters .......
by Priam, and the general state of Troy

as safe as Priam is in Ilion

the youngest son of Priam, a true...

cousin-german to great Priam's keed

forbid me, royal Priam. O Priam.

bastard son of Prian

word will Priam turn to stone
PRIANI-that king Iriam lad .... Tikes Andron. i.

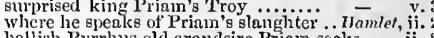
Pyrrish Pyrrhus ald grandsire Priam secks

oi the nilky head of reverend Priam............

SWIArd now falls on Priam............... Priumi, is in y man Tranio ..........
hic steterat Priami, take heed......
PRIA PRIAMUS- of grent Priamus........ Troilus \& Cress. ij. PRIAPUS-to freeze the god Priapus ... Pericles, iv. PRICE-ahatement and low price... Tuelfth Nigh, i. if you hold your lite at any price.... may make what price they will .... Much Ada, ii
what's the price of this inkle?... Love's L. Lost, ji we can afford no more at such a price $-\bar{v}$ his qualities being at this poor price...All's Well, iv. make trivial price of serious things.

heve bought me at a common price.. - joyed since the price of oats ... and happy news ol price ............2Henry $y .4 .4$ my body pay the price of it............ Menry $V$. ii for pix of little price ............... - iii. if he overhold his price so much .... - ii. and we'll have corn at our own price. Coriolan your plice $o$ ' the consulship? The price
at the price of one fair word..............

her own priee proclnims how .......... cymbeline, i. jewels purehased at an easy price. Titus Andron. iii. ]
what's her price, Boult? I cannot be ..Pericles, iv. 3 what's her price, Boult? I tannot be ...Pericles, iv. who now the price of his dear biood. $\not$ Romeo \& $J u l$. will be of more price, being spoke behind - iv. PRICK great price for a small vice $\ldots . . . \ldots$ - iv. my duty prieks me on...... Two Gen.of terona, iii. will you prick $t t$ with your eye?....... let the mark have a prick in t.........
sthe's too hard for you at pricks, sir...

cannot prick out five such .......... if you prick us, do we not bleed?.Mer. of Venice, iii.
love's prick, and Rosalind. As you Like it, jii. 2 (ver.) leave our thorns to prick ourselves ...All's Well, iv. to prick the sides of my intent Toming of Shrere, iii. 2 go, prick thy face, and over-red ..... . - v. which he pricks and wounds with ...King John, v. to know, what pricks you on to take - ii. pricks me on. Yea, but low (sep.)... Henry IV. very well said. Priek him (rep.)

prick the woman's tailor well

come, prick me Bull-calt till he $\ldots . .$. . I would prick your guts a little ...... - ii. an evening at the noontide prick ...... 3 Henry $V t$. i. to prick tliy finger, though to wound

scruple, and prick, on certain........Henry $\bar{v} I I I$. ii. al though small pricks to their ... Troilus \& Cress. $\mathbf{i}$. to prick us to redress? ............. JuliusCesar, ii

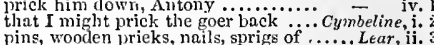

pins, wooden prieks, nails, sprigs of ....... Lear, ii. and it pricks like thorn....

prick nowe for pricking ................. Posom lodge, to prick and sting her .... Hamlet, i. and pricked a pretty..Love's L.Losi, iv. 2 (epitnpi) forty fancies pricked in't for. Taming or shrew, iii.
hath pricked down Bardolph .....2 Llenryy $l v$. ii. I was pricked well enougl before.

dost the iii.

pricked on by public wrongs ....... IIIenry $V x$. iji. 2 will you be pricked in number ...Julius Ca'sar, iii. 1 his voice who should be pricked to die

pricked from the lazy finger ..... Romeo \& Juliel, i. thereto pricked on by a most emulate .. Hamlel, i. pricked to it by loolish honesty ..... Othello, iii. 3
PRICKET-'twas a pricket (rep.).. Love'sL.Losi, jv. 2 the deer the princess killed, a pricket - iv. 2 (enit.) or pricket sore, or else, sorel $\ldots . .$. - iv. 2 (epit.) by the pricling of my thumbs......... Nacbelh, iv. 1 yoll might leave pricking it for pity. Coriolanus,
prick love for pricking.......... homeo of Juliel, PRICK-SONG-as you sing prick-song - in - ii. 4 PRIDE-this pride of hers... Two Gen.ofVerona, iit. that mathre all thy pride $\ldots \ldots$... Tuelffh $\Lambda^{*} i g h t$, iii.
no man liear me,) I take pride... Neas. for Meas. ii. advance their pride against that ..... Miuch Adn, iii. and maiden pride, farewell $1 . . . . .$. - ii.

iii. 3 and maiden pride, all pride is willing pride $\ldots . . .$. ... Love'sL.Lost, ji. in his eye pride expressed $\ldots \ldots . . . .$. my pride fell with my fortunes .....̈s you $\overline{\text { Like }}$ it, $\mathrm{i}$. who cries out on pride, that can

and the greatest of my pride is

fly pride, says the 
PRIDE-towering in her pride of place ...Nacbelh, ii. 4 PRIEST-the protector, saucy pricst?.1 Henry/ $V I$. iii. 1 eagle-winged pride of sky-uspiring.. Richard II. the pride of kingly sway troun

the pride of kingly eway from

now, by God's motlıci, priest."

Beaufort, that false pricst..

$\vec{r}$ VI. ii.

kingly doom, and sentence of his pride = v.

and pridc of their contention did....1 HenryI

priests pray tor enemies ............

coz, of this young Percy's pride? $\ldots . .$.

wont of goveruncut, pride, lianchtin

now tlieir pride and mettle is asleep
all sorts take a pride to gird at me.

their fores the full pride of France.

very infants prattle of tlay pride

$\vec{H}$ v. (cliorus)

re escoped the pride of France....

and froun the pride of Gallia reseued

proved, let's die in pride . ㄲ..........

iv. i.

pride went before, ambition follows hiin-

suppress the pride of Suftiolk

for $I$ cannot ilatter thee in pride $\ldots . . .$. .

at Bcoufort's pride at Som rold

thas Eleanor's pride dies in irer.

and allay this thy abortive pride

in tous ot all but thy pride?

finlls in leight of ant his pride.

to bear the pride upon them

this priest has no pride in hin?

with arromancy, spleen, and pride...

my high-blown pride at leugth brok

than in the pride and salt scol'n ....

pride alowe must tarre the mastiffs

pride is his own glass, his own (rep.).

but with a pride that quarrels

I'll pheeze his pride; let me go...

betweell your strangenoss and his pride =

pride hath no other glass to show (rep.) =

into another's pride, while pride is

which looks like pride, is courtes

which looks like pride, is courtesy $: \ddot{ } \quad \overline{\text { iv. }}$
to castigate thy pride, twerc well. Timon of $A$ h. iv. 3
pride and wrath would confound thee

especially iu pride. And toppin

enforce his pride, and his old hite...

let thy mother rather feel tliy pride

but owe thy pride thyself

o'ercome with pride, ambitious past

Coriolan 'twas pride, which out of daily

and took some pride to do myself $t$ this

or for the press of boats, or pride..... Cym
change of prides, disdain, nice longings

with arms our eneraies' pride

and pride so great, the name of heip

and with strained pride, to come betwixt

to tall and blast her pride! ...........

whose easy-borrowed pride dwells ...... $\overline{\text { suliel }}$ i. 4

and 'tis much pride, for fair without.

pricked on by a most emulate pride ..... Hainlct, i. 1 as loving his own pride and purposes .... Othello, i. 1 pride that pulls the country down $-\overline{-}$

quality, pride, pomp, and circumstance
as salt as wolves in pride, and fools as

PIRIDGE-at the pridge (rep.)

speak with him from the pridge

speak with him from the pridge 3 .

now I want chamberlain? (rep.). Richara 11 . iil. blind priest, like the cldest son.... Henry $\bar{V} I I r$. ii.

and learised priest, cardinal Campeius

thou art a proud traitor, priest .......

Helenus is a priest ............ T'ro

and thy brother Troilus a priest...

lug your priests and servants.. Timon of . Ihens, iv.

nor sight of priests in holy vestments

our very priests must beeome mockers

swear priests, and cowards........... Julius

live like Diana's priests............... Cymbeline

priest and holy water are so near.. Tilus $A \bar{n}$ dron.

part a baclielor from the priest
make all olr swearers priests...

when my maiden priests are met... - y.

When priests are more in word than .... Lear, ili.
tcll thee, churlish priest, a ministering... Hamlet, y.

tly priesthood saves thy life .......3 Henry VI. VI. i.
PRIEST-LIKE, thou hast cleansed..

than in our priest-like fasts

PRIG, for my life, prig...

Pericles, iii.

PRINE-and Prospero the primc duke... Tempest,

my prime request, which $Y$ do last ......

is crowned with the prine... As you Like il, v. 3 (song)

cropped before you come to prime ..Kichard II. v.

the golden prime of this swet....... Richard III. i. 2

that from the prime creation

thy prime of manhood, daring ..... $\quad$ - $\begin{array}{r}\text { iv. } 4 \\ \text { in } 3\end{array}$

were they as prime as goats, as hot .... Othello, ini. 3
PRIMER-there is no primer busiuess. Henry VIII. i. 2

I foreswore myself at primero.... NTerry Wives, iv. 5

PRIMIEST creature that's paragon'd, Henry VIII. it, \&

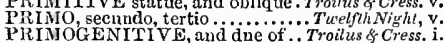

PRIMROSES, that die unmarxied. Winler's Tale, iv. 3

that go the primrose way to the ........Macbeth, ii. 3

look pale as primrose, witl $\ldots \ldots \ldots 2$ Henry VI. ii. 2

like tliy face, pale primrose $\ldots . . . . . . . \quad-\quad$ iv. 2

PRIMROSE-BED the were wont to lie.Mid.N.'sDr.

PRIMY - in the youth of primy nature... Hamlel,
PRINCE-Kiug and prince at prayers .. Tempest,

and a prince of power.

in my condition, $\mathbf{a}$ prince, $\ldots$ rirn...........

a living prince docs now speak to thee....

know, worthy prince, sir
with the wild prince and Poins ...Merry Wives, iii. 2

visit both prince and people .....Meas. far.Meas. $\mathrm{i}$.

O worthy prince, dishowour not .
O prince, I conjure thee, as thou

believe it, royal prince, if he
noble prince, as there comes light.....

then good prince, no longer session

your friar is now your prince

reconciled to the priuce your brother..., Nuch $\overrightarrow{c^{\prime}}$ Ado, $\overrightarrow{\mathrm{i}}$

the prince discovered to Claudio

the prince, your brother, is royally

if the prince do solicit you ....

he is the prince's jester (rep.)

for the prince liath got your liero....

the prince's fool! ha! it may be

go yon to the prince your brother.

to the prince and Clandio, (rep. iii. 1)

ha! the prince and monsieur Love!..

so says the prince, and my new-trothed

being chosen for the prince's watch

stand in the prince's name (rep.)
none of the prince's subjects (rep.)

to present the prince's own person (rep.)

not without the prince be willing

not without the prince be willin
how the prince, Claudio ( rep.

the prince, the count, signior Berediek =

swcet prince, you learn me (rep.)....
is this the prince? is this the prince.

would the two princes lie? $\ldots \ldots i \ldots$. 3 .

your daughter here the princes left for

very much unto the prince and Claudio
princes and counties! surely, a princely

I charge you, in the prince's name ... -

the prince's officer, coxcomb ........

so shall the prince, and all of them...

sweet prince, let me go no further...

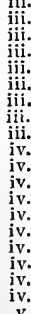

iii.
iii. I
iiti. 3
iii. 3
iii. 3
iii. 3
iii. 3
iii. 3
iii. 4
iv. 1
iv.
iv.
iv.
iv. 1
iv.
iv.
iv. 2
iv. 2
iv. 2
v.
.

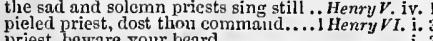
all the priests and friars in my realm $\quad$ - i. 3
I gave a noble to the priest

the word, and I will he his priest

PRINAI,-from the primal state.... Antony \& Cleo. $\mathrm{i}$

the prime man of the state? .......Henry $\overline{F H I}$. iii. 2

PRINCE-I thank you, prinees, for my.Much Ado, v. I so are the prince and Claudio $(r e p$.$) ..$

good-norrow prinee; good-molrow

prince, thou art sad: get thee a wifc

dread prince of plackets $\ldots \ldots \ldots \ldots$......

men's cottages, princes' palaces.. Mer.

there is the Neapolitan prince ......

yourselt, renowned prince, then stood

caskets to this noble prince.

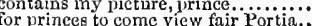

there, take it, prince, and if my form

fuirly spoke hy solne beloved prince

the cost of princes on univortliy ...As you Like it, ii. 7

prince is that? The Plack Priuce $(r e p$.$) - iv. 5$

he is the prince of the world ......... $\overline{\text { iv }} \overline{\text { iv }}$.

you so fond of your young prince.. Winter's Tale, $\mathrm{j}$,

to a fine new prince, one of these.... =

leave out betwixt the prince aud beggar! -

the prince your son, with mere

of the young prince, whose honourable -

three days since I saw the prince....

knew'st this was the prince.

the prince himself is about a piece

to do the prince my master good ....

quitted with this young prince .........

the audience of kings and princes ...

and then the prince, my brother.

report to the prince my master

the kings and princes, our kindred... $=$ - v.

princes, would they, may not .... Comedy of Err. i. 1

justice, sweet prince, against this...

namely, this young prince ...........

young prinees, close your hands

aood-morrow, little prinee (rep.)

no conscience to destroy a prince...

yet, believe me, prince, $\ldots$ am not glad

we of is my prince the Dauphin?...

my noble prince, with other princes...

the precious safety of my prince ..... Richard II.

in him a royal prince ..................

you have misled a prince...........

as he is a prince, is just

as he is a prince, is just ..............

princes, and noble lords, what

some two days since 1 saw the prince

a eonquat for a pringuks

leave the prince and me alone

that the true prince may $\ldots \ldots . . . . . .$.
$2 n^{\prime}$ the prince and Poins be not two

turn upon the true priace? (rep.)....

the court and princes of my blood

the prince is a Jack, a sneak-cup...

but as thou art prince, I fear thee

became him like a prince indeed.

ot any prince, so wild, at liberty ....

if the prince put thee into my service

the juvenal, the prince your master

the youthful prince. The young (rep.

the ear that the prince gave you (rep.)

this to the prince; this to the earl

when the prince broke thy head

why, a prince should not be so loosel

$\vec{J} \circ h n$,

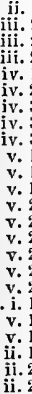

iv. 1

iv.

v. 5

ii. 3

iii.

iii. 3

how many good young princes would all the priests and friars in my realm
presumptuons priest! this place...... rom a prinee to a prentice?
the princc once set a dish of appe-johns 二
will be the prinee, and master Poirs the which the prince admits him (rep.) the prince, lord Jolin and duke of

as a false favorite doth his prince...... where is the prince your brother? (rep.)

the prince will, in the perfectuess of

be patient, princes (rep.) ............

the prince hath ta'en it hence $\ldots . .$. .

$I$ found the prince in the next $. \ldots .$. .

here comes the ptince. Grood-1norrow

and princes, all, believe me, $I$ bescecl

no prince, nor peer, shall have

for a stage, princes to act ...... Heury $r$. $\overrightarrow{\mathrm{i}}$. (chorus)

unele's, Edward the biack prince..... sirrah, what humour is the prince of?
why does the prince love him so then? 


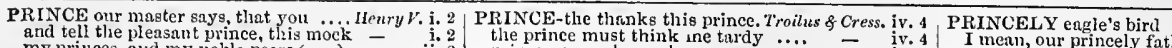
and, princes, look you strongly arm. and all our prin you stron like to the prinee of fiends

up, prinecs; and with spirit of honour high dukes, great princes, barous, lords = lord constable, and princes all

as any prince in the world $\ldots \ldots \ldots . . . .$. of my larly, he's a gallant prince.... to norse we to the princes

God be wi' you princes all!

for many of our princes (woe the while!) their peasant limbs in blood of princes ot prinees, in this uumber, and nobles so are you, prinees English (rep.)

bout on princes, or stay here

look'st to command the prince...... himself king, and suppress the pri

as princes do their courts when.......
suffer such a prince, so kind a father sweet prince, an' if your grace mark regard this dying prince, the valiant dismay not, princes, at this accident my gracious prince, and hononrable
hear him, noble prince! And this when foreign princes sliall be certified for princes should be free.

the Christian prince, king Henry unto the prince's heart of Calydon

and thou a prince, protector of this land a prince, and ruler of the laad (rep.) and princes' courts be filled with my for thy prisoner is a prince, the duke putting down kings and princes ....

you love your prince and country is this uato the priuce your son?...... that is spuken like a toward prince. is far beyond a prince's delicates... and thou no mole art prince with after that wise prinee, Heary the.... renowned prince, how shall poor Henry this noble queen and prince (rep.) you lave rid this sweet young prince and yours, as to this prince! $\ldots . . . .$. that brave prince, Edward, her....

golden prime of this sweet pri
princes liave but their titles.

which of you, if you were a prince... 3 son a begsing prince what beggar pities not? you cloud y princes, your son.... trou cloudy princes, and heart-sorrowing meet so few should fetch the priace whocver journeys to the prince... queen's proud kindred from the prince with all my heart to see the priace.. how doth the prince? (rep. iv. welcome, sweet prince (vep.) this prince hath neither claimed it. the prince my brother hath outgrow the God keep the prince froin all the any time, recourse unto the princes this prince is not an Edward! would this virtuous prince take ou. of virtue for a christian prinee most gracious prince, lend favoinrabi whom our manners call -the princs call them again, sweet prince .......
leart's love, to greet the tender prince to gratulate the gentle princes there sullen plarfellow for tender prince ah, my poor princes! ah, my tender. the slaughter of the prince that owed the wronged souls of butchered priing embassadors from foreign princes like a most royal prince, restored... work us all from princes into pages
wisdom above all priaces, in committ a prince most prudeat................. reckoned one the wisest prince, that. or else to foreign princes, Ego et Rex that sweet aspect of princes, a ad thei ever ranking himself with princes... thanks, that gave us such a prince. a p prince may be beholden to...... the princes orgulous brave Troilus! the prince of chivalry? princes, what grief hath set (rep.).... a prince called Hector ............... kings, princes, lordsl if the.......... now, princes, for the service give us a prince of blood, a sor of..... let him be seat, great princes and, princes all, lay negligent

\section{ii. 2
ii. 4 princes, eaough, so please you ........ -
welcome, princes all. So now, fair prince - ii. 4 you are moved, prince; let us depart iii. 5 liave with you, prince: my courteou}

courage, princes! great Achilles.

iii. 7 stricken by death of priaces ...Julius Ces iii. 7 the greatest prince o' the world....... Antony $8-\bar{C}$ 列 of courts, of prines, of the tricks to prince it, much beyond the trick.. yet bury him as a prince Hy out, and show them princes bora. hreathe not where princes are these gentle princes $A$ most uncivil one most worthy prince os yours your servant, princes: good my lord content thee, prince; $I$ will restore... this prince in justice seizeth but

i. 4 to jut upon a prince's riglat?

ii. 5 rouse the prince; and ring a hunter's the wandering prince and Dido cnce made many princes thither frame. Pericles you sometime famous princes

therefore instantly this prince nutust die prince, pardon me, or strike me. tart in princes' frowns.

and servant for a prince, who by (rep.) how many worthy princes' bloods

a subject's shine, I a true prince good prince, having all lost good prince, having all lost $\ldots$

there are princes and knights come from for princes are a model . i........... so priaces their renown, if not respected
princes sit, like stars, about his throne
and princes, not doing so $\ldots \ldots \ldots \ldots . .$. princes, it is too late to talk of love.. that e'er was prince's clitld the princes, thince, the fair-betrothed thus Kent, o minces, bids you all älicu a man a prince by him a hene........ 'gainst this higli illustrious prince vorthy prince, I know it well.... the sentence of your moved prince till the prince came, who parted.....

the prince expressly hath forbid this

this gentleman, the prince's near ally

the prince will doom thee death ...

o noble prince, I can discover all.

ii. 2 [Col. Knl. o prince, o cousin, lussband = justice, which thou, prince, must give

what is the prince's doom?

what is the prince s doom? (rep.)...
but the kind prince, taking thy part
beg pardon of the prince, and call

beg pardon of the prince, and call a

ii. 4
iii.
in safety, tifl the prince come lither

lord Hamlet is a prince ont of thy.

good night, sweet prince; and fightis

that thou so many princes, at a shot
PRINCE-LIKE-nothing prince-.like.
PRINCELY-hid my princely trunk
princely [Knt.-precise] Angelo?. Neos.

[Col. Knt.] most forward in this princely my princely father, then had wars in mean, our princely father, duke ... - ii. and kiss your princely nephew princely Buckingham (rep.ii. 1)... Richard III. i. when that our priacely father York = and, princely peers, a happy time among this pricely heap, if any here

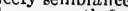
are dear to princely Richerd not thy beauteous princely daughter madam he was ly Richmond now? .. $\bar{V}$ iv. sends you his princely commendations of his great grace and princely care..
all princely graces, that mould up

Menelaus' princely brother's.. Troilus \& Cress. iv. I that now refused most princely gifts Coriolanns, i. 9 have fallen into a princely hand..An'ony\& Clen. y. the suits of princely fellows.......... - iii. our foe was prine two princely boyst - iv. Arviractus, your younger princely son princely shall be thy nsare every way. Tilus And $\nabla$. gracions in those princely eyes of thine

gracions in those princely eyes of thine
to have his princely paws pared .... I thought it princely charity to grieve... Perinles, i. to give her princely training $. . . . \cdots \cdots .$. i. i. 3 princely [Col.Knt.-roble] parentage Roinen \& Jul. iii. his only heir a princess ........ Mial. N.'s Dream, iii. servant's name, fair princess...... Tu.eifih Night, iii. therefore perpend, my princess ........ ${ }_{\text {vainly comes the }}$ v. fair princess, weicome (rep.).......... = dear priacess, were not his requests.. - ii.

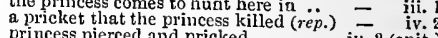
iv. 2 (epit.) to congratulate the priacess at her... present the princess, sweet chuck... before the princess; I say, none so What would you with the priacess?.
the princess bids you tell, how many where is the princess? .............

and this, the princess did I give....... fair princess, you have lost (rep.)... As you Like it, i. the princess' gentlewoman, confesses and your fast $\mathrm{np}$ the princess.... the hadas of your fresh princess... with his princess (rep.) ............... she lifted the princess from the earti princess, hearing of her mother's statue = holds hand witl any princess............. king $\bar{J}_{0 h n}$, ii. de princess. The princess is the better. Henry $V$. v. 2 the rather, gentle princess, because I - v v. say, gentle princess, would you not... Henry rI. v. 3 [Col.Knt.] she is a royal princess ... Richard III. iv. 4 Katharine, the princess dowa........̈Henry $\bar{\Gamma}$ Ill iv. 4 from Ampthill, where the princess lay make way there for the princessi... an aged princess; muny days shall. = v. and fittiug for a princess.... Antony \& Clenpatra, v. 2 the gentleman, the queea and princess be not angry, most mighty princess... shall think is good? The princess.... - ii. 3 a lady, the princess of his conntry ...
the bracelet of the truest princess as ot a most virtuous princess ket a princess to equal any single $\ldots$.... - iv. 4 kind and dear princessl................. Lear, iv. PRINCESSES [Col. Knt.-priacess] call As ynu Like it, i.
PRINCCIPAL of all the deer ........3 Henry VI, ii. a moiety of the principal .....ivereh. of Fenice iv. give me my principal, and let me go

the principal evils (rep.) . . ........As you Like it, iij.

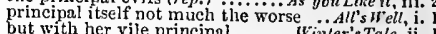
the very principals did seem 0 to rend ... W'ericles, iji.

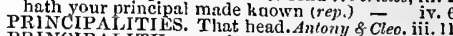
PRINCIPALITIES. That head. Antony \& Cleo. iii. il the first human principle I would...2 Herry IV. iv.

Which of this princely train call ye... Henry created princely dukc of York

the princely Clarles of France $\ldots . . .$. thou princely leader of our 'English
bcanty's princely majesty is such...

bcanty's princely majesty is such.....
gained thy daughter princely libcrty

\begin{tabular}{c|l} 
i. 3 & upon thy princely warrant, I descend \\
i. 3 & to be the princely bride of such a lord \\
iii. & no priacely commendations to my king?
\end{tabular}

iii. 1 no priacely commendations to my king? - v

iii. 3 the princely Warwick, and the Nevils

unto this princely duke of York $\ldots .3$ Henry $v 1 . \overline{1}$.
.1 PRINGS goot discretions with it .......Nerry Wives, $\mathrm{i}$. prings me pread and salt yestcrday ...Henry $V$. in print, for in priat $I$ found it. Two Gcn of rer. he will print them out of doubt... Merry inives, i. wear the print of it, and sigh....... with your print impressed................ Mue's L L. Lost, ii. we win do it, sir, in print ........... - ii althougl the print be little...... Winter's Tale, ii. 


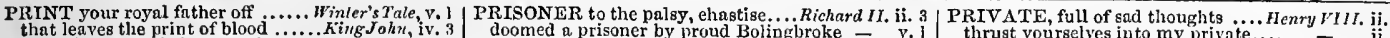

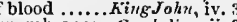
wear the print of his remenabrance...Cymbeline, ii.
to print thy sorrows plain .. Titus dindronicus, iv. PRINTED-is printed in her blood?.. Muth Ado, iv. I

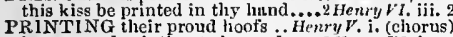
hast caused printing to be used ...2 Henry II. iv. PRINTLiCSS-printless foot do chnse... Tempest, y.

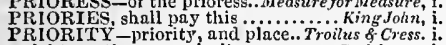
right worthy you priority ........... Coriolanus, i. right worthy you priority ............. Cor tolanis, PRISER-priser of the linmorous.... As you like it, it. PRISON-more than a prison through my prison once a day belioid..

space enough have $I$ in such a prison.

to close prison he commanded. TuroGen. of Ver. iii. i

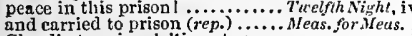

Claudio to prisoul 'tis not

hear me to prison, where I am

not to be weary with you, he's in prison =

not to be weary with you, he's in prison
the afticted spirits here in the prison
take him to prison, officer ..........

art going to prison, Pompey

commend me to the prison .......

away with lier to prison (rep.)

here is in our prison a common.......
borne himself penitently in prison?

evermore had the liberty of the prison

here in the prison, father, ther
an offeerl to prison with her

an officerl to prison with them at the prison

away witi him to prison (rep.

I met you at the prison.......

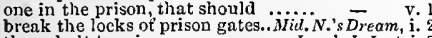

thou shalt to prison ................. Love's L. Lost, i.

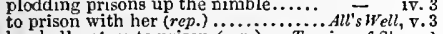
be shall not go to prison (rep.).....Taming of Sh. y. away with her to prison..........Winter's Tale, if. the keeper of the prison, call to

to prison till it eome ........ Comedy of Errors, iv. 1

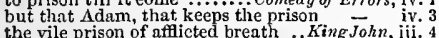
the vile prison of afflicted breath
go I were out of prison, and kept

this is the prison; what is he

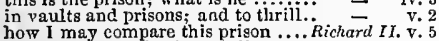
horrl may compars ans prison...

had the most of them out of prison. 1 Henry $I V$. iv. send to prison the immediate .....2 HenryIV. v. 2 base durance, and contagious prison

our wretches fettered in our prisons . Henry $F$.i. 2 in

in prison hast thou spent
hell our prison is, but tell me....

doomed a prisoner by proud Bolinglonroke 11. ii. of prisoners, Hotspur took .....

those prisoners in your highness' name -

I did deny no prisoners.

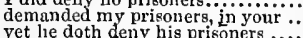

send me your prisoners with the

he will, forsooth, have all iny prisoners

that are your prisoners,-I'll kee

once more to your Scottish prisoners

of prisoners' ransom, and of soldiers sla

the hulk sir Jolnn is prisone

Edward's tame with prisoner kin

into Rouen bring him our prisoner..
with me for twenty English prisoner

with me for twenty English p

to cut his prisoner's throat

what prisoners of good sort are taken

is took prisoner, and lord Scales

low wert thou landled, being prisoner? Henry $/ \%$ i.

the duke of Bedford had a prisoner

art thou prisoner. Prisonerl to whom?

was he not in England prisoner?

there surprised, and taken prisoners

to know what prisoners thou hast

for prisoners ask'st tliou? hell our

keeping them prisoners und
is she not here thy prisoner?
I perceive, $I$ am thy prisone

see, thy daughter prisoner. To whom?

lord cardinal, he is your prisoner..2He

naster, this prisoner freely give I thee

open the gnols, and let out the prisoners

your prisoner to your palace gite ..3 Henry

my brother, is prisoner to the bishop

king is Edward's prisoner........

is prisoner lord, as prisoners must

ir Thomas Vanghan prisoners

come, bring forth the prisoners

stayed me a prisoner in my chamb....

Whole time I was my ehamber's prisoner

conveyed to the Tower a prisoner.

you have a Trojan prisoner ..Troil

and takes his valour prisoner. Timon of Ahens, iii.

I saw him prisoner; but then

a noble prisoner! Roon, ho! tell Anton

you are my prisoner, but your gaoler. Cymbeline, i.

takes prisoner the wild motion of....

bring your prisoner to the king

though then our prisoners with.

give us the proudest prisoner. Titus $\ddot{A}$ ndro

iny sword, my cliariot, and my ph

ransomless here we set our prisoners free

hath prisoner held, fettered in amorous

then am I the prisoner, and his bed - iv.

my soldiers, prisoners, atrimony

a poor prisoner in his twisted gyves. $\ddot{R} o m e o$ \& $\bar{J}_{u l}$. ii.

takes prisoner Pyrrlius' ear ............. Hamlet, ii.

you shall close prisoner rest

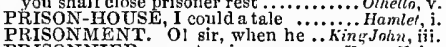
PRISONNIER; nerntmoins.....

PRISTINE wars of the Roman

to sound and pristine health ..........Macbeth, $\mathrm{ii}$.
PRIVACY - fie! privacy? fie! my privaey I have strong (rep.). Troilus \& Cress. ii . let me enjoy my private ......... Tu'elfih Night, lie is a devil in private brawi

in is a devil in private brabble did we.

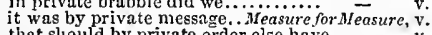

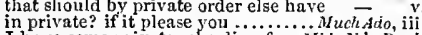
I lave some private sclooling for.... Mid, N.'s Dr. i.

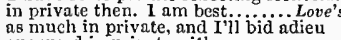

one word in private with you ......

therein tax any private party? .......

but in respect that it is private $\ldots . . .$.
desires some private speech with

desires some private speech with you $A l l s$ ' Well, ii

haply, in private.............. Comedy of liorors

whose private with me, of the

with some few private frienda...

[Col.Knt.] some private conference... H Henry $I \mathrm{~V}$. ii

cannot put him to a private soldier.2 HenryIf: iii.

I shall be sent for in private to lim

that a poor and private displeasure ... Mrenry $r$. is.

that private men enjoy? (rep.) $\ldots \ldots \ldots$ in private will I talk with thee $\ldots \ldots$ iv.

your private grudge, my lord of York

privilege of a private man?

in tlis private plot, be we the first...2 inenry $I$, ii.

myself will lead a private life......3 Henry $V I$. iv.

no man sliall have private............ lichard III. i.

let's think in private more .......... thrust yourselves int to my private.

first, I began in private witl you

to withdraw into your private cliamiber

ij.

both in his private conscience.

being but a private man again

for my privute part .......... Troilus \& Cressida, ii.

and, with private soul, did in great .. - -

should fall for private faul ts int. Timon of $\bar{A}$ thens, $\mathrm{v}$

which shall be yours in private .... Coriolanus, ji. 3

regard tor lis private friends (rep....3) - v.

we'll hear nauglit from Rome in private - $\quad$ v. 3

but for your private satisfaction ...Julizs Casar, ji.

what private griefs they lave, alas .

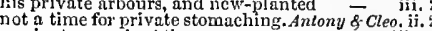

a private man in Athens

in private, if you please to give me.... Cymbeline, v. 5

controller of our private steps! ... Tilus Andron. ii. 3

partakes her private actions to your .... Pericles, i. 1

public war, or private treason..........

come, bring ine to some private place

let me ask lne to some privatc place...- iv. 6

and private in his chamber pens, Romeo \& Juliet i

wivendraw into some private place.... $\overline{\text { Homlet }, \text { i. }}$ ii.

faith, her privates we ....................

manage private and domestie qual'rel ... Othello, ii. 3

What, to kiss in privatc?................ - iv.

speak it privately, go ........Merchant of renice, ii.

we'll pass the business privately. Taming of Sh. iv. 4
she hath privately, twice or thrice. Winter's Tale, v. 2

he hears naught privately ....Troilus \& Cressida, i. 3

PRIVILEGE for thy departure. TuoGen. of Fer. iti. ]

you nuns no further privilcges ... Meas. for Meas. i.

bcg the ancient privilege of Athens. Nid.N.'sDr. i.

a privilege, never to see me more $\ldots . . . \quad$ - iii.

privilege I have with the parents. Love's L. lost, iv. 2

nadst thou not the privilege of.......... All'sl'ell, ii. 3

the child-bed privilege denied ...Winter's Tale, iii. 2

do bear their privilege on earth ........ King John, i.

sir, sir, impatience hath his privilege $-\overline{\text { iv. }}$

presuming on an ague's privilege, dar'st - ii.

liast lost thy princely privilege .....ivenry $I \%$. iii. 2

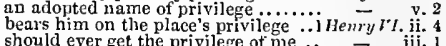

warranteth hy law to be thy privil

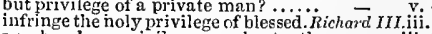

you break no privilege nor charter there - iii. 1

men's privilege of speaking first. Troiluts \&. Cress.iij.2

all bond and privilege of nature, break! - v. 3

nor lionour shall shape privilese $\ldots . . ., \bar{L}_{\text {ear, }}$ iv.

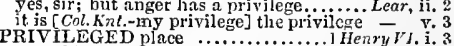

am a king, and privileged to speak...3 Henry $\nu_{1}$. ii. 2

the laws of war you are privileged.. Hen y y VII, $\mathrm{i} .4$
lie is a privileged man .......Troilus \& Cressida, ii. 3 let me be privileged by my piace

they may, cum privilegio. wear..... Henr of $V I$. iv. 4 PRIVILY, I'll privily away........ Neas. for Heas. i. 1 privily deals with our cardinal .... Henry ${ }^{\prime} / 1 \%$.

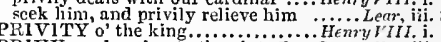
PRIVY-made privy to the plot.T...... Gen. of Ver. iit.

comes to the privy coffer of. Merchant of lenice, iv.
privg to this their late escape(rep.). Minter's Tale, ii told me what privy marks I.... Comedy of Err. iii. his face is lucifer's privy kitelien ..2HenryIV. ii. were not prives to those foults

yet the king not privy to my drift...3 Henry $^{-}$iii.

to take some privy order to draw.. Rishnard I1l. iii.

ready i' the privy chamber ........ Henry $l^{\prime} I I I$. i.

sheets are privy to your wishes .. Antony \& Cleo. i. 2 if thou art privy to thy country's fate.. Hamlel, $i$. I too light winning nake my prize lighit - Tempest, i.

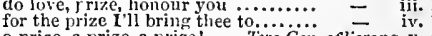
a prize, a prize, a prize! .... Tuo Gen. of erona, $v$.

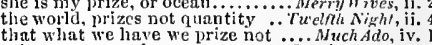
prizc you yourselves............... Lore's L. Losi, y. onc of two contending in $a$ jrize .... T'll never wrestle for prize more ... As you Like it, i. the I prize it as I weigh (rep.) .. Winter's I ale, iii. 2 would not prize them, without herlove - iv. 3 outfaced you from your prize........... ii. shall bring this prize in very easily.2Honry $I V$. iji. I
sender, doth he prize you at .......... Henry $\dot{V}$, ii. 4
Arthur ta'en prisoner? divers dear... King John, iii. brieved, that Arthur is his prisoner?
gris 
PRIZE, fit fur the devil's gracel

bring forth the soldiers of our

in laying the prize aboard

nis lord, a prize, a prize!

PROCE ED-hear now how I did proeed.? Ihamlet, y. 2 PROCLAIMS how she esteemed ...... Cymbeline, i.

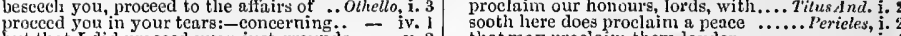
put that I did proceed upon just grounds - v. 2 sooth here does proclaim a peace

proclaims you to be a creature of sale...

it is war's prize to take all ............3 Henry $F I$. i. 4 .

made prize and purchase ot his ... lichard $\bar{I} I$.

men prize the thing ungaine

faveure bht home nnble prize .........

favour, prizes of aceident as oft......

but I do prize it at iny love.... Timon nf Athens, v.

that do prize their hours at ............ Coriolanus, $\mathrm{i}$.

whose loves I prize as the dead ........

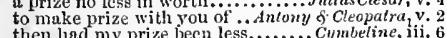

then lad my prize been less......... Cymbetine, ili. 6

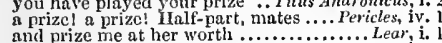

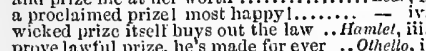

prove lawfil prize, he's made for ever..
or his good nature prizes the virtue that

or his good nature prizes the virtue that
to see how he prizes the foolish woman.

PRIZED my lady's favour ......... Tuelfih Night, ji.

a wit, as she is prized to have ...... Wuch Ado, iii.

which you prized richer than .. Troilus \& Cress. ii.
to her own worth she sliall be prized

are prized by their masters .... Timon of Athens, i. 1

than he hath hereto prized them at. Coriolanus, it. 2

with Antonius prized so slight?...Aniony s.

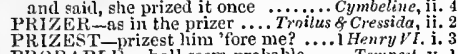

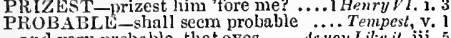

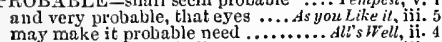

two or three probable lies

of all these signs were probabie....... ${ }_{\text {Hen }} \bar{y} \boldsymbol{V} / . \mathrm{iii.} .2$

how probable, I do not know ...... Coriolam 2 , iv. 6
most probable, that so she died...Antony \& cleo. v. 2

it may be probahle, she lost it ....... Cymbeline, ii. 4

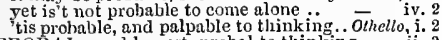

PROBAl, and honest, probal to thinking - ii. 3

I, in probation of a sisterhood ... Meas. for Mfeas. v. 1

with his oath, and all probation........ Macbelh, iit. i

tor more probation, I can with ease.. Cymbeline, v. 5
this present object made prolation ..... Hameled, i. 1
that the probation bear no hinge....... Othello, iii, 3

PHOCEED-no nore, proceed (rep. . . Tempesi, iti. 2

I was much unwilling to proceed in

well; proceed.........................

that I may proceed in my speech. Tuelfth Night,
from thy fate, it sliould proceed. Neas. forNeas. iit.

from thy fate, it slionld proceed
we shall procced with Angelo

wefore your time. Proceed (rep.).....

heard more, proceed accordingly $\ldots$ Much $\bar{A}$ do, iii. 2
part I am tor, and proceed (rep.) ...Mid.N.'s Dr. i. 2

proceed, moon..............

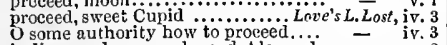

is dismayed: proceed, good Alexander $=$ v. 2

impugn you, as you do proceed...Wer.of Venice, iv. 1

andience, good madam. Procecd.. As you Like il, iui. 2

when virtuous things procee

proceded well, to stop ail gocd ... Love's L. Lost, $\mathfrak{i}$.

why you proceeded not against these... Hainlet, iv.

straituess of his proceeding

for such proceeding I am charged withal $\overrightarrow{\text { IJeas. }}$
PROCESS-the needless process by...Nezs.for

to speak, such was the process ........... Othello, i.

1 said, a gown. Proceed. With a small

since we to openly proceed...... Winter's Tale, iii.
thcrefore, proced, but yet licar this
the

the sesslons shall proceed; this is thore

proceetl, Solinus, to procure my....... Conedy of Err.

we will proced no further in this ....Macbeth, i.

so we sliall proceed without susp

we uray you to proced and justiy ${ }^{2}$ Henry $I V$ iv.

if thon proced in this thy insolence. Henry Vi.i.
atter Humplirey, how he proceeds ..2 Henry VI.

I pray you all, yrocced no straigh

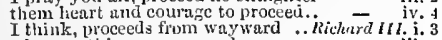

where nothing ean procee viliain'... - iii.

proceed this rashly in the villatis..

frum this larly may proced a gem ..

be't so:-Procecd. Say, Henry king of
should proceed to put me oft, and take
tit this royal session do proceed.......

it fits ye thus proceed, or else $n$

hefore we proceed any tiurther ........

but it proceeds, or comes, from them

proceed, Cominits. I slaall lack voice

and temperately proceed to what you

proceed by process; lest parties....

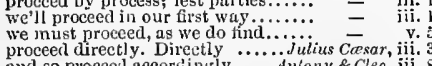

and so proced accordingly ......... Antony \& Cleo. iit.

find you need it not. Proceed ...... Cymbeline, ii.

her lips in openiug it. Procest.......

we nught proceed to cancel of .......... Proricles,

if you violcntiy proceed against him.

and proceed i' the sway of your own will - - iv.

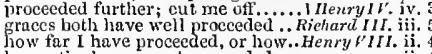
by partieular consent procecded.

tell you what hath proceeded....... Jutius Cresur,

when I strugk him, have thus proceeded - iii.

having thus far proceedcd $\ldots \ldots \ldots \ldots$. Cymb

PRECER-quick proceeders. T'aming of Sh. iv.

an engine fit for my proceeding?

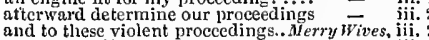

and to these violent proccedings. Nierry Wives, iii.

to stop all good proceeding ...... Love's L. Lost $\mathrm{i}$.

haste as your own good proceeding of . Al's Well, it. 1

doth push on this proceeding ..... Winter's Tale, if.

a false creation, proceeding from the.. NIacbeth, ii.

merciless procceding by these French. King John, ii.

Whe world to your proceedings?......

unurged faith to your proceedings ... - v.

and mere dislike of our procecdings - iv.

is this proceeding just and $\ldots \ldots \ldots$ I $^{2}$ HenryI $V$. iv.

faults, proceeding on distemper ...... Henry $l$. 1 i. 2

by our proceeding in hostility.

What plain proceedings are more ..2 Henry ${ }^{r} I$. 11.2

a feigned friend to our proceedings.3 Henry $V I$. iv.

of good luck to my proceedin

of equal friendship and proceeding.....

ontrary proceedings are all unfolded - iii. 2

inform them of our proccedings ..... Coriola nus, ii.

testimony of her foul proceedings ... Titus Aul. v. 3

to such proceeding who cver but his ... Pericles, iv.
necessity will call discreet proceeding ..... Lear, $\mathbf{i}$. ancicnt of war on our proeedings.

in your hates' proceeding ...... Romeo \& Juliet, iii.

in patience our proceeding be......... Hamlel,

long process could not arbitrate... Love's $L$. Lost,

no other advantage in the process .... All's Well

by law and process of great nature. Winter's Tale, ii.

finish the process of his sandy..... II Henry VI. i

lest that the process of thy kindness - iv

course and process of this time

the process of your speech ........

proced by process; lest parties ..... Coriolamus, iii.

is by a forged process of iny death

may'st not coldly set our sovereign process - ii.

by his antliority I will proclaim it.....

warped looks proclaim what store her.

Lear, ii.

hat's calm, proclaims me bastard ....... =

poison hroclaim was maduess .............

WOCLAINID: Detimes... Measure for Measure, iv. contrary to thy established proclaimed - Lost, i.

it was proclaimed a year's inprisonment - -1 . published and proclaimed it openly. Tain.of Sh. iv. the by -gone day proclaimed .......... Finter's Tale, i. on every post proelaimed a strumpet.. - iii. his tears proclaimed his parting with her - v. your lordslip was proclaimed traitor - ii. 3 was he not proclaimed by Richard ... I Hen $y I V$. i. joined with anl enemy proclaimed .....Henry $r$. i. 2 and be it death proclaimed thro' our host - iv. 8 1 proclaimed a coward through ....2 Henry VT.iv. Edwalt thou be proclaimed in every ...3 Henry $/ T$. ii. well-adviscd triend proclaimed..... Richard WII. iv. 7 art proclaimed a fool, I think .. Troilus \&-Cress. ii. his sons be there prodlaimed ..... Aniony $\& \overline{\text { Cleo. }}$ iii. 6 I heard myself proclaimed; and, by the.. Lear, it. a proclaimed prizel most happy!

that presently they have proclaimed.... Hamlet, ii. PROCLAIMETH, as he comes along. 2 .. Othetlo, ii. 2 PROCLAMATION that you are T'u'o Gen, of t'er. ini. with the proclamation (rep.) ..... Meas.forMeas, $\mathrm{j}$. give him a better proclamation....... find it out by proclamation ..... Nier. of Venice, iv. 1 against the proclamation of thy passion. $A$ ' ' ' $^{2}$ ell, i. 3 thesc proclamations, so forcing ... Winter's Tale, iii.

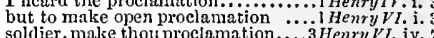
soldier, malse thou proclamation....3 Henry VI. iv. 7 such proclamation hath been made Richord $I I$. iv. lear'n me the proclamation (rep.) Troilus \& Cress. ii. the tenor of the proclamation......... - it. witl proclamations ....Titus Andron. 1. the bloody proclamation to escape.......... Lear, y. 3 the bloody proclamation to escape......... Lear, v.
PRO-CONSUL: and to you ….... Cymbeline, ii. .
PROCRASTINATE his lifeless end.Com. of Err. i. PROCREANTS alone, and shut $\ldots$........ Ohello, iv, 2 pendant bed, and procreant cradie ....... Nacbeth, i. 6 PROCR US was so true (rep.). .... Nid.. N.'s Dreom, v. Rroculeius. Anlony \& Cleo, iv. $]$ my name is Proculeius. Antony did sell - v. Proculeius, what thou hast done thy ... - - ven 2

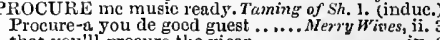
that you'll procure the vicar .......... - iv. 6 that such sorrow I prochre ............ Solinus, to procure my fall .... Comedly of Error's, i.
our arrest, procure your sureties ... Richard II. iv. our arrest, procure your sureties ... Rroche this fat rogue a chargc..1 Heriry $I V$. ii. sir, you should.procure him bettex ..2 HenryI . i. and procure that lady Margaret do... and procure that lady Margaret do could not procure me any .2 Henry $v l$. ij. minds procure knaves as corrupt... Henry VIII. v. acid to precure safc conduct .. Troilus \& Cress. iij. one that I'll proenre to conc.... Romeo \& Suliet, ii. Desceustomed catsc procures her hither? - iii. Desdemona procure me some access .. Olhello, iii.
PROCURED his leave for present ....All's $W^{\prime}$ ell, ji. have procured thee, Jack, a cliarge.. I HenryIV.iii. the voices that we have proeurcd . Coriolants, iii. 3 PRODIG.AL-story ot the prodigal. Merry Wives, iv.
he's a very fool, and a prodigal .. Tuelfh Night, $\mathrm{i}$. be now as lrodigal of all dear grace Love's $L$. Lost, ii. and spend his prodigal wits in bootless $-\bar{v}$ v. to feed upon the prodigal christian... a prouligal doth she return ........... a prodigal, who dare scarce show his
what prodigal por tion have I spent. As you $\bar{L}$ ike it,
i. a motion of thic prodigal son .....Winter's Tale, iv. was killed tor the prodigal .. Comedy of Errors, iv. 3
the tongne's office should be prodigal. Richard II. $\mathrm{i} .3$ with olpression of their prodigal weight - iii. hundred and fifty tattered prodigals.lllenry $I V$ iv. 2 or the story of the prodigal .......2 Henry $I V$.i. thou tassel of a prodignl's pirse. Troilus \& Cress. v. how many prodigal bits have.. Timon of Athens, ii. I, that I was no prodigal

the elariest maid is prodigal enoughi ... Hamlet, iv. I will proclaim my nane ahout the field and to proclaim it civilly, were like
hatl sent me to proclaim the truth.. 
PRODIGALITY of nature .......... Richard III. i. 2 PRUDIGALLY gave them all to youl. Love's L. L. ii. these prodigies do so conjointly..... iulius Ceesar, i. 3 these prodigies do so con disturbed with prodigices on earti..... Fitus Andron. $\mathrm{i}$. PRODIGIOUS son ...........TwoGen. of V'tona, ii. nor murk prodictious, such as are...Mid. $N$.'s $D r_{\text {. y. }}$ prodigious, patehed with foul moles. King John, iii. prodigious, and uutimety hrought ... Richard $M I$. i. yet prodigious srown, and fearfill.. Julins Cresar, i. prodigious birth of love it is to ne... Romeo of Jul

PRODIGIOUSLY be crossed $\ldots . . .$. King Johm, iii.
PRODIGY my soul brought forth her prodigy. . Richard $I I$. ii. that valiant crook-back prodigy ....3 Henry $b$ i. i. PRODITOR-most usurping proditor.1 Henry VI. i. you can produce aquittances .... Love's L. Lost, ii. I we must produce for an interpreter but loatli am to produce so bad

than they slould not produce fair. Winter's $\bar{T}_{a l e}$,i. 1 produce the prisoner

produce the prisoner

I can produce a will that bars...

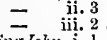

my reasonable part produces reason.

which they produce from Pharanond... Henry ${ }^{\prime}$.i.

produce the grand sum of his sins . Henry VIII. iti.

that I may produce his body to .....Julius Cesar, ini.

ay, though t!lou didst produce my very .. Lear, ii. I can prodnce a champio

PRODUCED (as, if I stay, I sla

iHenry VI. i.

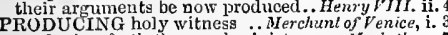

producing forth the cruel ministers...Macbeth, v. 7

PROFACE! what you want in meat.. 2 Henry $1 V$ '.

but, in the less, foul profanation .....

to any other's, profanation ......... Twelfh Night, i. 5
PROF DNE-in shape profane .... M Merry Wives, iv.

profaue my lips on thy toot.. Love'sL.L. iv. 1 (letter)

let nost noble eye protane a tear ......... nichard $11 . \mathrm{i}$.

should so profane the word, that iaught

an ing

anless he do prolane, steal, or usurp

80 idly to prof une the precious time...2HenryIV. ii. 4

so old, and so profase ......................

profane fellow 1 wert thou the son of.Cymbeline, ii.

if I profane with my unworthy .. Romeo \& Juliet, i. 5

should profane the service of the dead... Hambel,

own gained knowledge slould profane

a most profane aud 1

had his great name profaned witl... i Hen Hena, iv. your own dignity so much profaned. 2 Henry $I V \cdot \mathrm{v} .2$

thy george, profaned, hath lost his ä - - iv let,

PROF ANENESS'gainst thine.....Winter's Tale, iii.

PROF ANERS of this neiglibour-stained Roin. \& Jul. i.1

protess requital to a hair's breadth. Merry Wives,

protess requital to a hair's breadth. Nerry Wives, iv.
by the saint whom I profess..... Meas. for Meus. iv.

I profess curing it by counsel ....... ds you Like il, iit. 2

whether dost thou profess thyself..... - iv.

sinee you do profess to be a suitor. Taming of $\$$ h. i. 2

prefess myself your loyal servant. Winter's Tale, ii.

let me hear what you profess....

go we profess oursel ves to be.............. nacbeth, iv. 1

for I profess not talking ............... HenryIV

I do profess, you speak not like..... Heary

for, 1 profess, you have it (rep.)...... - iii. 2

profess [Col. Kut. - protest $]$ to do't.. Timon of Ath. iv. 3

I profess myself in banqueting....... Julius Casar,

but I now profess myself the .........

but, profess, had that was weli worth

that. I profess myself an enemy

$\overrightarrow{\text { Lear, i. }}$ i.

I do profess to be no less than $\mathbf{I}$ seem

meh a one do 1 profess myself .......... Othello, i.

to the public ear profused the contrary

bein' a professed tyrant to their sex...Much Ado, i. I

a inan which ever professed ....... Winters Tule, i. 2

a that you are thieves professed.Timon of Altens, iv. 3

to your professed bosoms I commit lim . Lear, i. 1

I have professed me thy friend.......... Ulhello, ii 3

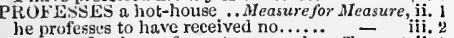
fCol.Knl.] only professes to persuade...Tempest, ii. ! le professes not keeping of oaths ...All's liell, iv, 3 he protesses not answering ... Troilles \& Cressida, ni. PROF LSSION, a tinker.. Tamini.......... of Shircer, 2 (induc. against the hair of your protessions. Merry Wives, ii. 3

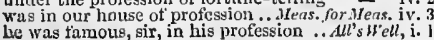

ROFESSION-greatest of his profession $A l l^{\prime} W_{e} l_{1}$ i. 3 year's, profession, wisdom, and conktancy $\bar{r}$ ii. 1 constant to my profession....

to have let in some of all professions ..... Macbeth, ii. 3 mo the profession some grace...... i HenryI . i1. be profession's sacred froin abo

than your high protession spiritual.

(ill. almost charmed ne from my profession

without the sign of your profession?.Jul. Casar, i have sulklued me, in my profession?. Cymbeline, v. 2 do mer is our profession any trade.... Pericles, iv. 3 long have you beeu of this profession?

makes our profession as it were to stink

oath, and my profession: I protest..... Lear, $y$ ROF ESSORS of on's profession

the zeal of all professors els

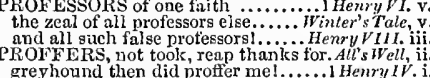
in France, proffers his only danghter.1 Henry $V I . \mathrm{v}$. 1 and for the proffer of my lord.

daily she was bound to proffer.......

he nay my proffer
ROFFERED offer

the proffered means of succou

proffered him their oaths

this proffered benefit of dignity .... Iie

refuse not, mighty lord, this proffered

PROFICI ENT in one quarter of

erves in offices that profit us.....

and my profit on't is ...............

profit in the knowledge of myself. Twelfh Night, $\mathrm{v}$.

ere tlis rinde beast will profit

nor profits you a jot

no more profit of their shining........ Love's $\bar{L}$. Lost. i. 1

daughters profit very greatly under..

since that the trade, and profit of.... of

the soil, the profit, and this kind of..

if that an eye may profit by a tongue
no profit grows, where is no .. Tuming of

now, mistress, profit you in what ..... ${ }^{-}$iving iv. 2

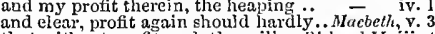

that without profit suck the soil's. Richard II. iii. 4

against the state and profit of this land

the camp, and profits will accrue...... Henry $V^{\prime}$.

do tend the profit profit's sake? the wind, that profits nobody $\ldots . . .3$ Henry $V I$. ii.

where high profts might come home

and the protit of the state........... ili. 2

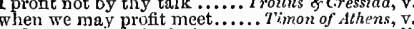

so find we profit, by losing.... Antony \& Cleopatra,ii.

tis not my profit that does lead

for danger where there's noprofit

I speak against my present profit .... $\quad$ - iv.

so soon, to yield thee so much profit ...Pericles, iv.

despise profit, where you have most gain

thought the profils of my deatl $\ldots \ldots \ldots \ldots$. . Lear, ii. 1

the supply and profit of our hope......... Ho

that hath in it no profit but the name

a snipe, butt for my sport and profit.......

peeuliar profit to your own person

I thank you for this profit ............... - iii. 3

ay; if you dare do jourself a profit ...... - iv.

go estimable, profitable neitller. Herch. of Venice, i. 3
the seareh, sir, was profitable .........All's Well, $1 \mathrm{i} .4$

ever-running year with profitable..... Heury $V$. iv. I
PROFI'TABLY removed ............... Othello, i. I

I might answer thee profitably. Timonof Athens, ii. 2
PROFITED in strange coneealments.1 Henry $I V$, iii. 1

hath not the boy profited? .........2 Hemry I $V$. ii. 1
PROFITING-in profiting by them 1 ieas. for Meas, ij. 4

the ears of profiting................ Henry $I V$.

and wage, a danger profitless $\ldots . . . \ldots$.... Ohello,

he is in most profound earnest ......... Mlach Ado. $\mathrm{v}$.

profound Solomon to tune a jig.. Love's L. Lost, iv. 3

vilely compilet, profound simplicity

gravity, protonnd conceit..... Merchant of $V$

magician, most profoutd in his art. As you Like it $\mathrm{v}$.

or the profound seas hide in .... Winter's Tale, iv.

such protound respects do pull you. King Joh

holy, and profound, than mine own. Coriolenus, iit. 3

matter in these sighs: these profound heares $=$ iv,

PROFOUNDEST - to the protoundest pit!

PROFOUNDE Y
PROG -so profound y

sons of your progenitors, go ........ hienryl. iv.

PROG grent progenitors had conquercd? - v. 4

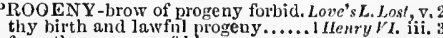

from birth and lawfin progeny of kingeng...

the whip of your bragged prod

PloG NOSTICATION uroclgin...

be not a fruittul prognostication ...Aniony s Cleo. i.

and all the progress more and less .....All's I'ell,

progress to the ocean

his golden progress in the east....... Henry 1 H.

iewing his progress through .......2 Henryl $\mathrm{V}$. iil.

' the progress of this business....... Henry VIII. ii.

the protress both of my life and office

cannot by the progress of the stars. Julius Cessar, ii.

how a king may go a progress through. Hamlet, iv.

PROGRESSION, hath miscarried . Love's L. Lost,
PROHIBIT God prohibit it ......... Mueh Ado

PROHIBITIUN so divine, that........... Cymbeline, jii.

always bending towards their project.

now does my project gath

no shave nor project of af.............. Mruch

my project may deceive me

with project of a power mucl

our projeet's life this sliape...

his projects to accomplish, my best... Corio it.

cannot project mine own cause .. Antony \& Cleo. $\mathrm{v}$.

PROJECTION -niggardly projection...Henty Horl, it. 7

PROLIXIOUS blushes ......Mecusure for Measure, y.

ROLIXITY, or crossing ... Merehan tof

the date is out of such prolixity... Romeo \& Juliet,
PROLOGUE of our comedy ...... Alerry Wives,

whereof what's past is prologue ....... T'empesh, ii.

well, we will have such a prologne.. - iii.

therefure, another prologue must teil

he hath rid his prologue, $\mathrm{li}$

played upon this prologue, like a child

a prologue vilely penned............ Love's $\bar{L}$. Lost, v.

than to see the lord the prologue... As you Like il, v.

.

who, prologue like, your lumble... Henry $V$. i. (c.

is made prologue to their play ...2 Henry $V_{\text {I. }}$.ii.

nor no without-book prologue... Romeo \& Juliet i.

and prologue to the omen coming on.... Hamlet, 1 .

seems a prologue, or the posy of a ring?.. - iij.

or 1 could make a prologue to my braing $=$ - v.

obscure prologue to the history of lust.. Othello,

PROLONG a while the traitor's life ... 3 Henry II I $^{\mathrm{i}}$.

but prolong his hour! ......... Timon of Athens, iii. 1
bnt prolongs thy sickly days........... Hamlet, ifi. 3

was my life prolonged......... Cornedy of Errors i.

Would be, were the day prolonged. Richard $1 I$. iii.

PROMETHEAN fre (rep.) ....... Love'sL.Iost, iv.

know not where is that Promethean heat. Othello, v.

PROMIS-que vous l'avez promis ....Henry $V$. iv.

it is my promise, and they expect .... Tempest, i.

and pronise you calm seas ............. of $\bar{F}$ er. iv.

have you reeeived no promise ..... Merry Hives, ii. 2

he promise me to bring ne........ - jii.

not by my cousent, I promise you ..
build upon a tool ish woman's promise

then to hreat made promise to the .. $\overline{\bar{N}}$ iv. 6

notling of that wonderful promise.. 二 iii.

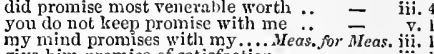

give him promise of satisfaction $\ldots . .$. - $=$ iii.

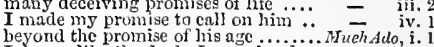

I do not like thy look, I promise thice - . iv

I fear it, I lromise you (rep.) ....... -

if thou keep promisc. I shall cond.Mer. of $\bar{F}$ enice, ii. 3

which this promise carries .......... - ii. ?

than dost promise aught, thy plainness - iif.

promise last, I got a promise of this
therefore, I promise you, I fear you

or I, I pronise thee

an hour of myises in love (reg.).... - j. 2

break one jot of your promise $\ldots . . . .$. - iv.

me censure, and keen your promisc.it - iv.

you miglit excusc his broken pronise $\overline{\bar{s}}$ iv.

where most it pronises; and oft it.... 1 - 1 help, what do you pronise me?..

to whom I promise a coun terpoize..$\quad$ = ii.

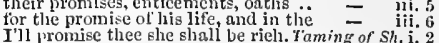

and will not promise her to any man now, I promise you, you have showed - i. 2

by your firm promise; G remio is.... -
I promise you, I should be arguing 
PROMISE-of the grentest promise. Winter's Tule, i. breach of promise to the Poreupin

keep the word of promise to our ear

is this rour promise? go to hold... King John iv.

as thou read'st thy promise past.... Richard $I$.

these promises are fuir, the purtics.

in the name of God, I promise here

knows at what time to vromise.

ealing the air on promise of supply..2 Hemry $I V^{-} \mathrm{i}$.

and to promise you a better......... - (epil.)

as most debtors do, promise intinitely - (cpil.

butween the promise of his greener ilays

now to promise; do but now promise

thy promises are like Aldonis'

my lord of York, I promise you

performance of your promises

promise them such rewards a

with proinise of his sister.............

cinim that promise at your grace's linu

my due by promise, for which your

and promise them success and victory

my life, that promises more thousands

I cannot promise, but that you sha

his promises were, as he then was

jet now plomises upon this land

could promise to himselt a tirought...

and promtse, like Btabbler the hound

I promise you, my lord, you moved.

his prom me friendship (rep.) ........
promise me
only I will promise him an excellent

to promise is most courtly an

his expedition promises preseat approneh -

it is your former promise.

either his gracious promise, which

is this the promise that you m

of any promise that hath passed .....

Show and promise of the promises.

the way which promises assurance..

which promises royal peril ........

your pleustre, and my promise

and on promise to see your grace...

unlike our eourtiers, as good as prom

my word and promise to the emperor. Titus

and mine, I promise you; were't not
fill lis aged ear with golden promises

I promise you, the effects (rep. iil. 4 ).

even in their promise, as it is a making. Hamlet, $i .3$
come now, your promise. What promise. Othello, iii.t
love and fluttery, not ont of my promise - iv.

PROMISE-BREACH, thereon ... Weas, for Mens. v. I Worse than a promise-brenker ...... Coriol stus, i.

PROM[SED-what thou hast promised... Tempest, i.

promised by ber friends un to.. Tu'o Gen. of

that sir Hugh promised to me
well, I promised you a dinne

for so I have promised, and I

but he has promised me, as he
and for thitt $I$ promised you

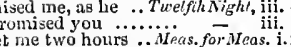
duke's time, le promised her 1

for that her promised proportions

I promised to ent all of lis killin
Cfaudio promised by, his hour

have proinisel to study three years. Love's L. Lost, i. 2

that you to-day proinised to t

do all this that he hath promised

I have proinised to make all this....

his hirhness hath promised me to do it

do you kuow he promised me marriage?

I promised to enquire careitully .. Tumi
hath promised me to help me to another

hath promised me to help me to anotlie
I promised, we would be contributors

greater sum than I have promised .. _

prom you all he promised you .........

come, you promised me a tawdry lace

thtter I hive done what I promised?.. - iv.

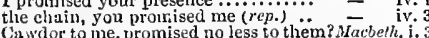

ot wlial greatness is promised thee - i. 5 (letter)

of what greatness is promised thed
shalt be what thou art promised

as the weird womeo promised .......... $\overline{\text { lath }}$ iit. I

you promised, when you parted ..... Richard 1 , if. 2 pay themised you redress of these

here, I promised you, I would be ........ (epil.) of his youtli promised it not ............. Irenry $r . \hat{\mathrm{i}}$. promised to wear it in his cap (rep.).. - iv. delays my promised supply of horsemen
which I promised should be delivered

Which o promised should be delivered
this they have promised, to show ....2Henry $/$ t. i.
promised knightlood to our forward.s Henry Vi. it. you have promised I shall possess. Richurd $1 /$ I. iv. 3 graee in mind of what you promised me - iv. the emperor paid ere he promised . Henry VIII. i. 1 they promised me eterual happiness..

so rich advantage of a promised glory

messa se, and by promised means.. Timon of

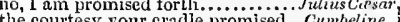

one that promised naught but beggary -

I promiscd your promised love.....

promised to be wived to fair ...Pericles, v. $\overline{2}$ (Gower)

is this the promised end?................ Lear, y. 3

the conveyance of $n$ promised mireh .. Itsanket

you promised ine to wed ............... iv. 5 (song)

PROMISE-KEEPING. Besides ............tens. for Meas. i. 2

never promiseth, but he means to ... Ki Henry $l V$. v. 4

which promiseth successful tortune..3 3 Henry $V I$. ii. 2

as promising her marriage, and things $\overline{\text { Winler's Tale, iv. } 3}$

to go fetch a chand, promising to. Comedy of 'Err.
promising is the very air o' the time. Tim. of $A l \%$.

promising to pay our wonted tribute. Cynbeline, v. 5 RUMONTURY have I made shake...TTempest, y. I since once I sat upon a promontory. Mid. $N$. Dr. ii. 2
one that stands upon a promontory.3 Henry VI. iit. 2 mountain, or blue promontory.. Artony \& Cleo. iv. 12 earth, scems to me a steril promontiry. Hamlet, ii. 2

none will sweat, bnt for promotion. As you Like il, ii. 3
honours, and promotions, as she .... King John, ii. great promotions are daily given to ligh promotions and great dign

the high promotion of his grace of.. Henry $V^{2} I I I . \mathrm{v} .2$

you sought was-her promotion . Romeo \& Juliet, iv. 5
PRONPT-goes on as my soul prompts.. Tempest, i. 2

prompt me, plain and looly innocence . 1 iit. 1

prompt us to have merey on him. Twelfh Night, ili.

story, that I may prompt them. Henry $V$. v. (chorus)

prompts my tongue to speak ......... Richard $I I I$. i. 2

the Grecians are inost prompt and ... - iv. 4
for a towardly prompt spirit...Timon of Athens, iii. I

ready when time shall prompt them. Cor

the matter which your heart prompts
come, come, we'll prompt you $\ldots . . .$.

I am prompt to lay my crown.. Anlony \& Cleo. iii. 11

prompt me, that my tongue may.... Cymbeline, ini.

prompt me, that my tongue may.. Titus Andron. v.

a natural and prompt alacrity

ROAPCED by your present trouble. Twethh N. Hi.

when I have prompted you .... Timon of A Ahens, ii. 2

prompted to iny revenge by heaven .... Huniet, ii. a

PROMPTER - after the prompter.. Romeo \& Jutiet, 1. \&
have known it without a prompter....... Olhello, i. 2

PROMPCING me how fair young. Hero. Huch . Ado, i. 1
prompting eyes of beauteous tutors. Love's L. L. iv. 3

prompting eyes of beauteous tutors. Love's L. Le. iv. 3

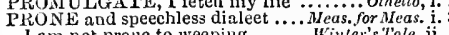

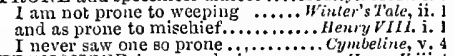

I never saW one so prone................ Cymbeline, v. 4
PRUNONCER-je ne vondrois prononcer. Henry $V$. iii.

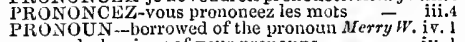

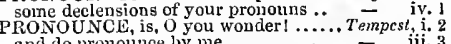

and do pronounce by me .............

pronounce a sentence on your. ...Mleas. for.Meas.

det, when he should pronounce, debt
prosonnce that sentenee then ou me As yru Like

pronounce thee a

to our great grief, we pronounce

pronounce it for me, sir, to all

my tongue did ne'er pronounce

with some unwillingness pronounce. Richard ini. I

in every languare I prooounce..2 Henry IV. (induc.)

I do provounee him in that very

as't please foun'self pronounce their

if what I now pronounce, you have . ${ }_{\text {wedo bere pronounce, non the part. }}$ iifi. 2

we do lere pronounce, upon the part. Coriolan $u s$, iii. 1

pronounee the begrary of hrononnee, by the very truth

do herc prononnee, by the Augustus Caesar
that I am to pronounce Augar's name pronounce I 'gainst

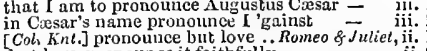

dost love, pronounce it faithfully

I am tame, sir; pronounce............. Hamlet, iiti. 2

sentences, and well pronounced ...Mer.ofVenice, i.

the pardon, that I late prononnced here - iv. I

whose condemnation is pronounced...Henry

who prononnced the bitter senteice. Richard III. i.

Hastings lind pronouneed your part

his tale pronounced shall bury his .. Coriolanus, v,
RONOUNCED-have pronounced... Titus.And. iii. tate would treason have propounced ... Humlet, ii. I pray you, as I pronounced it to you.... - iit. at this badge, promouncing - thit ..... Henry ${ }^{\prime}$. iv. by pronouncing of some doubtful plirase. Hutulet, i. well leave a proof, by that......... Merry Wives, iv.

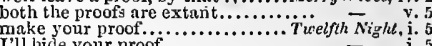
for 'tis a vulgar proof, thiat very oft... $\quad$ - iii. than ever proof itself would have.... - iii. the proof of his valour $\overline{\bar{M}}_{\text {eas. }}$ iii. sir, it is a mystery. Proof

this is an aceident of hourly proof ...... hat proof slail I make of that? Pioof - ii. if you, in your own proof have :..... $\quad$ - iv. 1 I urge this olildhood proof ... Aferchant of $\bar{v}$ eniee, $\bar{i}$. I rou have seen cruel proof of this ...As you Like it, i. that riug a thousand proof

to the proof; as moun tains are ... Taming of $S h$. î. nll $\mathrm{my}$ pains is sorted to no proof ivinter's $\bar{T}$ ale, iii. 3 am proot against that titie ........... -. iv, no credit, were not the proof so nigh

apt in proof, confronted bim with ...... Macbeth, i. add proot unto my armour ............Riehard II. i. 3 as for proof now; a purse of gold ....2 HenryIV.i. gentle exercise and proof of arms..... demure boys come to any proof...... Henry $_{\text {vI. i. }}$ iv.
this proof $I$ 'll of thy valour make ... mark but this, for proof.............. $\begin{array}{ll}\text { in algument and proof of which contrnet - } & \text { v. } \\ \text { argues proof of your accustomed .... } & \text { v. }\end{array}$ coat is of proof $\ldots \ldots \ldots \ldots \ldots 2 \mathrm{Henry} V \mathrm{Vl}$. iv. armed in proof, and led by shallow ... Riehard 11 . v. proofs as clear, as founts in July ....̈̈ Henry $i$ rIr. i. examinations, proofs, confessions of $\quad-$ ii. I Troilus will stand to the proof... Troilus \& Cress. i.

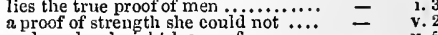
and am her knight by proof $\ldots \ldots . . . . . . \quad$ v. and set me on the proof......... Timon of Athens, ii. 2
whose proof, nor yells of mothers .... with hearts more proofs than ghieldis. Coriolanus, $\mathrm{i}$. but 'tis a common proof, that .... JuliusCcesar, ii. I Thave made strong proof of $\mathrm{my}$ the proof of it will turn to redder .... or his own proof, what woman is ..... Cymbeline, let proof speak. His majesty bids...

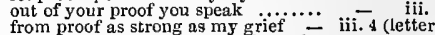
from proof as strong as my grief - ii. 4 (letter)
breast stepped before targe of proof... returned with simular proof enough $\quad-$ v. gives me proof ald precedent of ........... Lear in thy just proof, repeals ............... I'll put it in proof ...................... iv. ive $_{\text {so }} 6$ in strong proof of chastity well armed - i. and I am proof against their enmity $\overline{\bar{c}}$ ii. forged for proof eterne, with less ...... Hamlel, ii. but now the time gives it proof ......... my love is, proof hath made you know .. - iii.

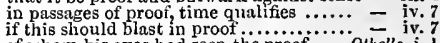
of whom his eyes had seen the proof ...... otkello, +.1 to vouch this is no proof $\ldots \ldots \ldots \ldots \ldots \ldots$ - i. 3 I theak noot yet of proof.................. strong as proofs of Holy writ ............ give me the ocular proof ........

help to thicken other proofs $\ldots \ldots \ldots \ldots \ldots$ 二 I will make proof of thine .......... ROP - of my age, my yery prop. Mler: of Veniee, ii.
or a hovel-post, a staff, or a prop? When you do take the prop that doth - iv
duke of York, our prop to lean upon. 3 Henry $V I$. two props of virtue for a christiau. Richard III. iut. 7 so much as but to prop him? $\ldots . . . \ldots$. Cymbeline, i. 6
but for this virgin that doth prop it up. Pericles, iv. 6 the ratifiers and props of every word .. Hamlel, iv. 5
PRUPAGATE with any braneh or....All's Well, ii. I to propagate their states.......... Timn of . Iliens, an issue I might propagate ............ Pericles, PROPAGATION of a dower.........Meas. for Mecs. i. 3 PRUPEND to you in resolution.. Troilus or Cress. il. 2
PROPEANSON - wings to my propension - ii. 2 men hang and drown their proper scives - ii. for he's a proper man...... Two Gen. of Verona, iv.
is like to reap a proper man .... Tweinh Night, iii. and at my proper cost ................. are not thioe own so proper. Measure for Measure, i. that ravin down their proper bane...
the mere effusion of thy proper loins
pursue faults proper to himself...... and in the witaess of his proper ear... $=\mathbf{v}$.

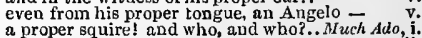
he is a very proper man ............. out at a window? a proper sayingl.. - iv. 
PROPER man, as one shall see .. Mid.N.'sDream, i. 2 PROPHESIED to me many years...2 Henry $I$. . iv. 4 PROSPECT-within the prospect

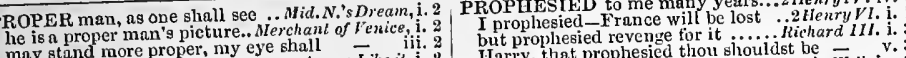

may stand more proper, my

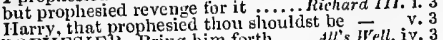
three proper young men ...............

she sees herself more proper

PROPIESIER. Bring him forth ....All's Well, iv. he'll make a proper man . which your prophet, the Nazarite in his proper strenm o'erflows himself whrophet. I, madam; and I speak ..All's Well, i. 3 liere's th prophet, that 1 brought..... King John, iv. i in

a proper stripling, and an annorous Taming of

I am a prople

with a prophet's eye, seen how his

and lean-looked prophets whisper ".i Henry $V 1$. i.

o proper stuffl this is the very

... Macbeth,

no prophet will I trust, il she prove

the prophets, and apostles

die, prophet, in thy spech.........

-

solne proper nian, 1 hope $\ldots \ldots . . . . . . . .2$ Klenry $1 V$.

and that I an a proper fellow.

a proper gentive, and most proper shape

do justice on my proper son........... $v . \quad$ v. (chorus) 等

a prophet, weep what it for be talse

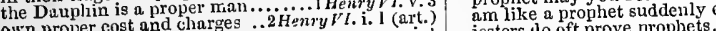

own proper cost and charges

jesters do oft prove prophets........

the eye and prospeet of your town...

acbeth, $\mathbf{i}$

to bring them to that prospect

iry VI. iii. 2

on Prosper fall, and make him

'empesi,

pronouneed the name of Prosper

heaven prosper the right $1 .$.

prosper well in this, and tho

prosper well in this, and thou .... Trelfh Night, i.
knitteth souls, and prospers loves... Mid. N.' Dr. i.
and seen our wishes prosper...Merch. of Venice, iti.

prosper you, sweet sirl your prosper.

as your good this for iveness, prosuer may.... Richard $I I . \mathrm{v}$.

bless you, and prosper your affuirs.2 Henry $I V$. iii. 2

prosper this realus, ke

but prosper better tlian the

so prosper I, as I swear perfeet

ns I intend to prosper, and repent

every trade, we shall ne

triumph in thy glorious prophetess! 3 . $-\bar{d}$ III. i.

many $n$ pound of mine own

the man is a proper man $\ldots \ldots \ldots \ldots . . .$. Richard $111 . \mathrm{i}$.

to be a marveht want her proper limbs............. Henry $\overline{V I I I . i .}$ ii.

a proper title of' a peace.

ROPHETIC-such proplietic greeting?.Nacbeth

speak, with a prophetie spirit ........ King John, ili. 2

o my prophetic soull my unele

.

grow; 1 prospex; now, gods ...........

fairies, and gods, prosper it with theel .. Wives, iv. 5

the issue of your proper wisdoms .... - ii

one that means his proper harm

as proper men as ever trod upon

couceptions only proper to

in her prophetic fury sewed the work...

PROSPERED sinee I Iarswore taste......... Pericles, i.

and is so propletically proud. Troilus \& Cress. iii.

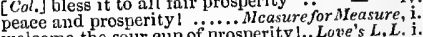

welcome the sour eup of prosperity $1 .$. Love's $L . L .1$.

prost's prosperity lies in the ear........

PROPON'TICK and the Hellespont .... Othelln, Hii.

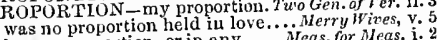

into the purse of rers in prosperity ...Richard 11 . iv. 1 now prosperity begins to mellow...Richard $I I J$. iv. saw'st them, when 1 had prosperity. Tim. of Ath. iv, gentleman, prosperity be thy pagel.. Coriolanus, $\mathrm{i}$. getitioned all the gods for my prosperity

synod about thy particular prosperity .. $\overline{\text { othello, ii. }}$.

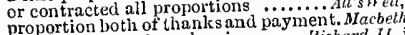

and due proportion, sliowing ....... Rich
time is broke, and no proportion kept!

power was in the first proportion $\ldots 1$ Henry $I V$. iv

lay down our proportions to defend.

PROSPERO, master of a full poor cell .. Tempesi, i.

and Prospero the prime duke .............

'gainst all proportion, didst bring in

must proportion the losses we have borne - iii. 6

against all proportion of suhjection... Henry $_{\text {V1 }}$, ii.

and least proportion of humanity

bear that proportion to my flesh $\ldots . .2$ Henry $r J$. i.

in courage, courtship, and propor

the just proportion of my sorrow?....i - iv.

must bear the same proportion .....Henry VIII. v. 1

course, proportion, season, form...

the past proportion ow proportion
pretty a proportion to ive quietl

pretty a proportior to ive quietly ....Pericles, iv. 3

and full proportion, are all made out ..Hainlet. i. 2

PROPORTIONED to our cause.. Aniany \& Clea. iv. 13

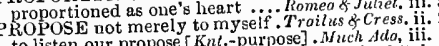

to listen our propose [Knt.-purpose]
when fear proposes the safety $\ldots . . .$.

did first propose; his highmess hath.

the wager which we we pon......2 Henry $V$. v.

whilst I propose the self-same.......3 Henry

propose the onth, my lord ..............

wherein the toged consuls ean propos

PROPOSED for the deserver!, Traitus \& Cressida, ii for the gain proposed elroked ........2 Ilenry $I V$. thy benuty is proposed my fee....... Richard at many leisures I proposed....Timan of Alhens, we eould arrive the pourself proposed....... Le
that portion which you
$[$ Knt. . how proposed, sir, I pray you?... Hamle
not to affect many proposed matches .. Othell, [Knt. $]$ how proposed, sir, I pray you?.. Hamtel, iv.
not to affect many proposed matehes .. Othelle, iii. 3
PROPOSER could charge you withal . Hamlel, ii. 2

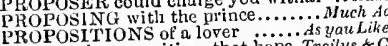
the ample proposition, that hope. Troilus \& Cress.
PROPOUNDED him ............... Henry PROPPED by aneestry, whose grace. Ilenry ${ }^{\prime} I I$ II. $\mathrm{i} .1$

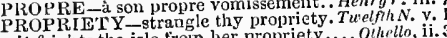

it frights the isle from her propriety .... Othello, ii. 3
PROPUG A TION is in one .... Trailus \& Cress. ii. 2

PROROGUE his honour ..... Antony s Cleopatra, ii.

sustenanee, but to prorognting ...Romiea

nothing may prorogue it, on TionJalius Casar
PROSCRIPTION-and proseriptiony

proscription, and bilis of outlawr

and by that order of proscription

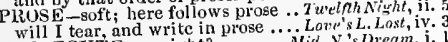

will I tear, and write in prose ....... War. N.'s Dream, i. the king severely proseeute against .Richinrd T. iv.
will proseeute, by good adviee . Tilus.Andran. iv.

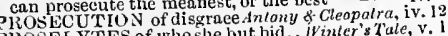

PROSELYTES of who she but bid.. Winler's Tale, v.
PROSERPINA, for the flowers now iv.

is at Proserpina's beauty ......... Trailns \& Cress, il.
PROSPECT of my hopes ....... Twirht, iii.

but how ghoukd Prospero be living

if thou beest Prospero, give us ........

Prospero his dukedom, in a poor isle .... - iv

she hath prosperous art wherfection

a prayer they may prove prosperous $-\bar{v}$ iii.

play upon tliy prosperous helm.........All's

a prosperous south-wind friendly.... $\bar{E}_{\text {rrars, }}, \mathrm{i}$.

by prosperous voyages I of ten. Camedy of Errars, $i$.

hath been both grave and prosperous $\overline{\text { good }}$ cause make thee prosperousl ... Richard 1I. i.

good cause make thee prosperous .i Henry $I V$. iii. I

our oaths well kept and prospers made himn prosperous...

prosperous be thy life, in peace .......

plenty, and fair prosperous and ever. Hertry VIII. v.

proteetion of the prosperous gods.. Timan of $A t h$. v.

with most prosperous approbation .. Coriolanus, if.

may'st thou prove prosperousl..............

the gods make her prosperous! ........

strong and prosperous in this ..Ramteo \& Juliet, iv.

be prosperous: and tarewell, good ear...... Othella, i. 3
[Col.Knt.] ] lend your prosperous ent
PROSPEROUSLY I have atternpted.Coriolanus, y. 5

conld not so prosperously be delivered... Hamlet, ii.
PROSTITUTE our past-eure malady... All's ' ell, ii.

prostitute me to the bosest groor...... Pericles, iv.

this prostrate and exterior bending! 2 Henry $l v$ 'iv.

look graeious on thy prostrate thrail. Henry $V I$. i.

be you prostrate, and grovel on ......... He Hasar, iii.

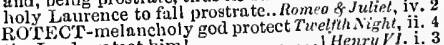
the Lord protect him protect our .....2 Hewry VI. i.

marry, the lord protcet him.

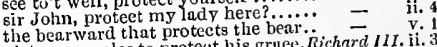

virtwous uncles to protem that kinirly - iv. 1

your long coat, mijest, protects.....

God protect thee!..........

the inw protects not ns $\ldots \ldots \ldots i \ldots . . . . .$. Pericles, i.
the gods of Greeet protect you

that you protect this course, and put it..$\overline{\text { Lear, }}$ i.
that should be to be protected like a clild Trelfh Nigh i, i. PROTECTION of his son........... TwelfhNigh,
leave me to mine own proteetion. Mer. af Venice, v. to its own protection, and tavour.. Wintcr's Tale, ii. whose protcetion is most divinely.

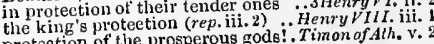

into the eye and prospect of his soul ...Much.Ado, iv.

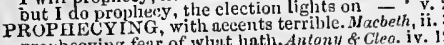

prophecying fear of whut hath. Antony \& Clea. iv. I
PROpHESLED, if a gallows were on .. Tempest, v. 
PROTECTION-babe to hig protection. Cynbeline, i. 1 PIUTESTATION-your protestation. Winter's 7 . iv. 3 PROUD-made him proud with...... Richard Il. V. please you to take them in protection? meet both welcome and protcetion

the proud soul ne'er pays (rep.) $\ldots . .$. .. Henry $I V$. i. ROTEC'TOP answer you so the lord proteetor? (rep.) not protector of the king or realin PlaTESTED-kissed, protested ...Merry Wires, iii. eon tempt of this proud king 二 $\quad$ i. 3 PRo'TESTING oath on oath ... Taming of Shrew, ii. think on thy Proteus, when thou.... because he is protector of the realm. is not his groee protector to the king? my lord proteetor yield and now, my lord jroteetor (rep.).... my lord protetor, so it please your...2 IIenry VI. there goes olur protector in a rage he'll be proteetor; Or thou, or I ( $r e j$.) and the proteetor's wife (rep.i.3 my lord proteetor will come this way Suftulk, and not iny lord protector

wings of our protector's grace, begin

i. 3 sweet Proteus, no; now let us

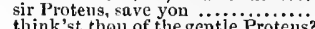
think'st thour of the gentle Proteus? and sent, 1 think, from Proteus....... I bid the base for Protens. $\ldots . . . . . . .$. was Proteus written down ........ forlorn Proteus, passionate Prote
'twas of his nephew Proteus twas of his nephew Proteus with said that rrotens, your sir Protens, your father ealls for you you have learned, like sir Proteus.. yon clid at sir Protens for going ... sir Protens, yoll are staid

going with sir Protcus to

oe proteetor of his excellence? (rep.).

ny lord protector will, I doubt it no a sorry brcaktast for my lord proteetor
my lord proteetor's hawks do tower so perniciuls protector, dangerous pecr protector, see to't well ............... Eleanor, the protector's wilfe .......... so $\mathrm{my}^{\prime}$ lord proteetor, by this menns.

Fenry will to himself protector le...

and thou a prince, protector of this land being proteetor, stayed the soldiers' pay Humplyrey for the king's proteetor? but 1 it be proteetor over hind......... the dnke is made protector of the realm we have left proteetors of the king

I make you both protector's of this länd

concluded, lie slinll be protector? my lord proteetor needs will have it so lord protector? [Col. Knt, -duke of Gloster.] thou proteetor of this damned strumpet -

not as protector, steward, substitute

I mean, the lord protector

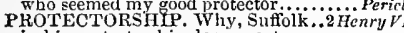
in his protectorship, levy trent

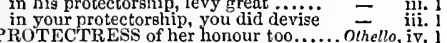
ROTEST true loyalty ....... Two Gen. of Verona, I do protest, that I liave

for, I protest, mine (rep.).................erry Wive protests to my hisband, he is now here my lores I do protest hurt you.

my lord, I do protest

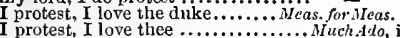
I was about to protest, $\mathrm{I}$ ioved you

that none is left to protest

or on Diana's altar to protest ....Mid.N.'s 's $\overline{\text { Dream, }}$, i. I protest, I love to hear him lie..... Love'sL. Lost, 1 protest a $a$ world of torments tliough protest, by this white clore

a wrotest, the sehoolmaster is execeding I protest, her frown might kill ... As you Like no, I protest, I know not the coittents Al's $^{-}$ that, I protest, I simply am

my meaning in't, I protest, was very - iv. 3

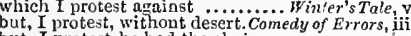
but, I protest, he had the chain ... that even now protcst their first .... Macbeth, iii. I do protest, I never loved myself $\cdots_{\text {King John, }}$, ii. 2 lords, I protest, my sonl is fullof of . Richard $I I$. ii. Euch protest of pcppler-cingerbread. 1 Hen ry $I \%$. iii. 1 for I protest, we are well fortified .... i Henry ${ }^{\prime}$ I. iv. 2 I bere protest, in sight of heaven ...3 Henry VI. I here protest, upon my part, shail be $I$ do protest, was it more preeious
yet, I protest, were $I$ alone .. Troilus \&. yet I protest, for his right noble...Timon of sth iiji. 2 [Col. knt.i protest to dot like workmen on nine honour herc I by leave. Julius Cresar, iii. I do protest, were never better fed .... 'Pericles, ii. Thetest to thee, pretty one

I protest, - mangre thy strength, youth .. Lear, v. protest; which as I take it, is ........ lady doth protest too much, methinks. Hamlet, ili. 2

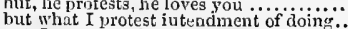

yet, I protest, I have dealt most direeti $\ddot{y}$ 二 iv. they are stuffed with protestations .. of iv. 4 but say their protestation over... Lnove's L. Losl, i.
many protestations to murry...All'sWell, v. 3 (petit.

how now, sir Proteus? (rep. iv. 2 and $\ddot{v} .2$ )

our purses shall be proud, our..... proud control of fierce and bloody
their proud contempt that bent

swell'st thou, prond heart?
to make the basc eartly proud with...

\section{welcome dear Protelis!
ay, Proteus, but that life...}

O gentle Proteus, love's a migitity iord

gaod Proteus, go with me...........

perfection to sir Pring Proteus

tili Proteus make return

if Protens like your journey...........

warrant me weleome to my Proteus..

did govern Proteus' birth

now tell me, Proteus ............

and, Proteus, we dare trust

sweet Proteus, my direetion-giver.

this sir Proteus, that we talk on (rep.)

where lies sir Proteu
alas, poor Protens!

alas, poor Protens! ....................

tlinks that Proteus hath forsook her

sir Proteus, what says Silvia .......

than have false Protens resene me
I do detest false perjured Proteus.

when Protens cannot love where.....

all men but Protens . ...............

Proteus, I am sorry I must............
O Proteus, let tlitis hatiit make

come, Proteus; 'tis your penan

change shapes, with Protens ......3 Henry $v 1$. vii. 2 PROTRACTIVE trials of great Jove Troil.s. Cress. i. 3 Bo great a favour growing proud.. Two Gen.ofVer. so great a favour growing pro
forward, proud, disobedieat.

she is proud

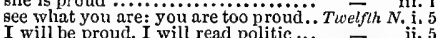
how apt the poor wit to read politic ...

O, but man, proud man 1 ............eas. for Mleas. ii. 2 like favonrites, made proud by prinees

and mine that $I$ was proud on

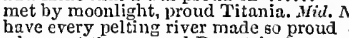

where art thou, proud Demetrius?

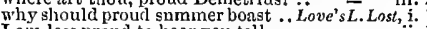

prond of employment, willingly $I$ go

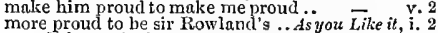

proud, fantastical, apish, shallow...

glow of seorn and proud disdain ....

must you be therefore proud ..........
no, faith, proud mistress, hope not

and be not proud; thouth all the

nor the courtier's, whieh is proud

calls me proud; , nnd, that she could not
peevish, proud, idle, made of self-love

making them proud of his hnmility.

take her hand, proud scornful boy

find what it is to be proud of thy

peremptory as slee proud-minded. Taming of $S h$. iv. this prond disdainful haggard.....

not meanly proud of two such............ Conedy of Err. i.

like a prond river peering o'er his

to be proud; for grief is proud...

and the prond day, attended with.
O death, made proud with pure.

lic at the proud foot of a conqueror...

he fires the proud tops of the eastirn
chid'st me well. Proud Bolinginroke

on yon proud man, shoulu take......

being over prond witl sap and blood

traitor to proud Hereford's king

a prisoner by proud Bolingbroke

lower than his proud steed's neck.

posting on in Bolingbroke's proud joy
so proud that Bolingbroke wes ou his thou proud [Knt,-haughty] Scot....

than those proud titles thou hast...

printiug their proud loufs in the \#...2HenryIV. $\mathrm{i}$.

like to men proud of destruetion

no, thou proud drean, that play'st..

now am I like that proud insulting ship -

against proud Somerset, and William =

Who in proud heart coth stop my....
heart with proud desire of hold-faeed

with a proud, majestical, high seorn

with a proud, majestical, high seorn
with such a proud commanding spirit

as stout, and proud, as he were lord.:
show of love to proud duke Humphrey

i. 1 nor shall proud Lancaster usurp ....

ii. 2 as that proud dame, the lord .........

1 it was, prond Frenchwomn

against this proud protector

did follow thy proud ehariot whei...

thouloud, peremptory, and unlike

and lofty proud eneroaching tyranny

marehing hitherward in proud array

and be proud of thy victory: tell Kent

proud northern lord, Clifford of $\ldots . . . .=$ v

\begin{tabular}{l|l} 
ii. 7 & to our merey, proud Plait tagenet...... \\
iii. 1 & I would assay, proud queen $($ rep. $)$
\end{tabular}

iii. I that doth oft make women proud...

many more proung que

thy minions, proud insuiting boyi...

while prond ambitious Edward......

proud setter up and puller do

like a subject, proud ambitious......

my proud heart sues, and prompts., Richard III.

hate not you for her proud arrogance

to part the of his proud adversaries

and brothers, haught and proud

now thy proud neck bears half my...
thy age confirmed, proud, subtle, sly

pur your proul prou, proubtle, sly

pur yonr proud horses harr ......... $\bar{H}$ that $\bar{V}$ v.

I find at sueh proud rate .............

thou art a proud traitor, priest. Proud - iii.

were he not proud, we all should ....

sick of prond heart; you may cali...
why should a man be proud?

he that is proud, eats np himseif ....

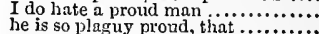

an' he be proud wioud, that..

if lie were proud? Or covetons of ....

a burden whieh I an proud to bear

so prophetically proud of a heroicai

discredit the blessed gods, proud mau

hark? Proud Diomed, believe I come

thou art proud, Apermantus.... Timon of Athens,

feasts are too prond to give thanks to

when I have laid proud A thy occasions =

whereof thy proud ehild, arrogani $\mathrm{man}$

art thou proud yet? ay, that 1 am not - iv. 3

pays himself with being proud ....... Coriolanus,, i.

his mother, and to be partly proud.

he is a lion that $I$ am proud to hinit

was ever man so proud as is this....

too proud to be fo valiant..............
you blame Mireins for being proud?

unmeriting, proud, violent, testy ....
you nust be saying, Narcius is proud

youl nust be saying, Marcius is proud -

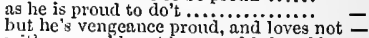

with a proud heart he wore his humble

fret, till your proud heart break.. Jillius Cossar
f.

and make thy fortures prond ... Antony \& Cleo ii.

and make denth proud to take us....

the story prout cleor

a mole, right proud of that mosi $\ldots . . . . .6$.

proud Saturnine, interrupter of the good -

how prout I am of thee, and of thy gifts -

farewcll, proud Romel till Incius come 二

make proud Saturnine and his empress -

to pluck proud Lueius from the

I know thee well for our prout empress =

i. 2

Thetis, being proud, swallowed. Pericles iv, 4.2 prose him set not thy sweet heart ou proud array... = iii. a scrving-man. proud in lieart and anind $=$ iii.

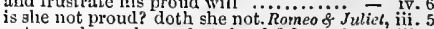
not proud, you lave: but thankfull (rep.) - iii. 5 the proud man's contunely ......... Hamlet, iii.: I 


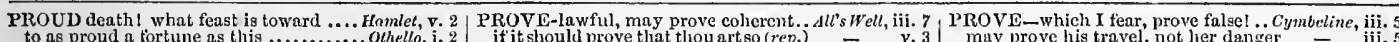
to as proud a fortune as this ............... Othello, i. 2 she that was ever fair, and never prond... - ii.
PROUDER-of prouder stuff than that. Much $A$ do, iii. wonld be pronder of the work. Merch. nf Venice, iil. 4
may well meet a prouder five........ King John, v. 1 may well imeet a prouder foe ......... King John, v.

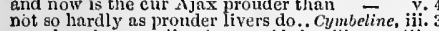
prouder, than rustling in umpniti-tor silk - iii. 3 mine action on the proudest he.. Taming of Sh. iii. 2 and the proudest of you all shali find - iv. 1 amaze the proudest of you all. the proudest peer in the realm $\ldots . .2$ Henry ${ }^{\prime} I$. iv. 7 any he the proudest of thy sort....... now let me see the proudest he .... Herry VIII. v. give us the proudest prisoner of ...T'Titus indron. i. 2 will rouse the proudest panther in...

PROUD-HEARTED Warwick

PROUDLIER even to my person ....

PROUDLY, if I perceive the love .......Mrch Ado, ii. 3 birthrights proudly on their backs... King John, ii. I
so proudly, as if he disdained ...... Riehard II. $\mathbf{v} .5$ let me speak prondly; tell the if it should prove that thou art so (rep.) fairer prove your lonour, than in not plain, and prove untrue.
deeds slati prove. And that I know, he'll prove a jade my dunghter prove a good (rep.). tis like you'll prove a jolly surly. and may you prove, sir, master of...

sweet dear, prove mistress of my .....

if you seek to prove, $I$ dare not

if it prove she's otherwise, I'll keep...

if this prove true, they'll pay for't ... o' the jonrney prove succcssful to the
fairy gold, boy, and 'twill prove so... and the shearers prove sheep, let me will prove so, sir, to my power (rep.) you may nrove it by my long ears...

with my sword I'll prove the lie.......... Aacbeth the which if he can prove, a' pops me. King Joh one must prove greatest; while they cause to prove my saying true

and prove a deadly bloodshed but a jest do not prove me so; set, I am none.. my lite shall prove it true

I say, and will in battle pro

to prove myselt a loyal gentlem

to prove, by heaven's grace (rep.).....

and these stones prove armed soldiers

to prove it on thee to the extremest..
division prove that ever fell upon...

division prove that ever fel

well hath prayed, and prove you true

(for recreation sake) prove a fulse.

to prove that true, needs no more....

shall the son of England prove a thie

which, to prove fruit, hope gives not.2 Henry $I V$. i.

prove that ever I dress my self handsome -

I doubt, prove mine own marring

needs prove a good soldier-breeder

(epilogue)

pray God, she prove not masculine.

Inean to prove this lady's courtesy

i Henry Vi. v.

give me leave to prove you a fool....
for still we prove much in our vows

I will prove it legitimate, sir ........

otten prove rough and unhospitable

how vile an idol proves this godl.....
prove true, imagination, $O$ prove true

but prove a chief offender in

ii. 1
ii. 2
ii. 4

prove them, and I lie open to the

and prove the period of their tyrann

this spark will prove a raging fre

warrant thee, if dreams prove true .

HerryVI. i. 3

the world, will prove a coekney ..... -

prove it hefore these varlets (rep. thon wicked Hannibal

and prove a shrewil Cæasar to you.... - ii.

I'll prove a tyrant to him $\ldots . . . . . . .$.

but yet, sir, I would prove ............

proofs for sin, thou wilt prove this ...
with a prayer they may prove prosperous -

do prove my occupation a mystery

this may prove worse than hanging.
prove, that ever I lose more blood ..

prove, that ever lilt prove a notable argument

this may prove food to my displeasure
sliall we go prove wliat's to be done?

lest I sliould prove the mother of fool

if it prove so, then loving goes by....
are like to prove a goodly commodity

omy father, prove youl that any man

I'll prove it on his body, if he dare ...
he may prove more fond on her ....
badge of faith, to prove them true?..

badge of faith, to prove them
to prove him false, that says

to prove him false, that says

wo far blameless proves my e.t.......

oaths and laws will prove an idle. Love's L. Lost, $\mathrm{i}$

to prove yon a cypher................

for you'll prove perjured, if you muke

to thee three will 1 pro

where $I$ will prove those verses to be

but I will prove, thou being

I'll prove her fair, or talk ti

love's touruc proves dninty Bacclius

none at all in anght proves excellent

may prove prata will prove fools.

to prove, by wit, worth in simplicity

it may prove an ox ................

Pompey proves the best worth
we to ourselves prove false

We to oursel ves prove false ..........
I lear, he will prove the weping. $\overline{Y e r}$. of $\bar{V}$ n

to prove whose blood is reddest

prove it so, let fortune go to heli

iu hope he'll prove a widower (rep.iv. i)

Mony not prove inferior to yourself

will prove our country's bliss....

determined to prove a villain....

Richard III. i.

here you urge, to prove us

I prove a needless eoward!

prove me, my gracious lord............

witlı him, as I prove true to sou

will our tiends prove all true? .......
shall prove not well disposed
the French would prove perfidious.

the French would prove perficlious

you can report, and prove it too.

honest men, (pray God, ye prove soi.)

not reformed, may prove pernicious.

to the proof, if you'll prove it so.......

I'll prove [Kut.-pawn] this truth ....

allow us as wc prove ................

expressly proves, - that no man.....
will, sure, prove ominous to the day

I may never prove so fond. Timon of thth

so it may prove an arrument of laughtur

I should prove so base. to sue...........

now prove grod seconds

shall i' the field prove flaterers......

may prove as benefits to tliee......

and that to prove more fortumes

which will not prove a whip ........

good fith, I'll prove him, speed how

it proves not so; their battles are...Jutius $\bar{C}_{c}$ sa

sister; provo sucli a wile as nyy

prove this a prosperous day

my courage prove my title! ...........
this proves me base; if slie first incet

expected to prove so wortlyy

she'll prove olt eats, and dogs.........
wlien to my good lord I prove untrue

that this will prove a war ........... v. 3 true to thee, were to prove false..... - iii. 5

so, if I prove a good repast to tlie...

and prove it in thy feeling .............

thou have me prove myself
to prove thou hast a true-divining

to prove thou hast a true-divining ...
which I wish may prove more stern.

wave I wish may prove more stern.. $\overline{\text { pricles, } \mathrm{i} \text {. }}$

prove awfui botl in deed .........

prove that I cannot, take me lome.

mere defeets prove vur commodities ...... Lear, iv. I

on the way may prove effects..........................

iii. I that will prove what is avouched there...

jesters do oft prove proplets $\ldots . . . . . . . . .=v$.

and prove my title thine

if none appear to prove upon thy..........
I'll prove [Knt.-make] it on thy heart...

to prove upon thy heart, whereto I speak
must this humour prove ........ komeo o Juliet,

swear'st, thou mayst prove faise .... -

T'll prove more true than those...

thy love prove likewise variable .....
may prove a beanteous flower wheu

may prove a beanteous flower whew
this alliance may so hapuy prove....

proves thee far and wide a broad goose

wax pout

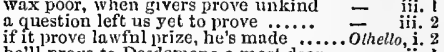

he'll prove to Desdemona a most dear - ii. I

if I do prove her haggard, though that - iii.

be sure thou prove my love a whore..
or at the least, so prove it, that

each drop she falls would prove.......

would I knew, that stroke would prove - iv. I

ROVED the sliding of .............eas.for.Meas. ii. 4
masters, it is proved already that..... A (uch Ado, iv. 2

as shall be proved upon thee by good = iv. 2

and, if you proved it, I'll repay.. Love'sL.L.Losl, ii. I

proved again on my side!...........$\quad$ iv.

how art thou proved Judas?............

if it be proved against an alien ...... of enter iv. 1

rare and proped effects, such as his..... All's Well, i. 3
would all this time lave proved..Comedy of Err. ii. 2

confessed, and proved, have overthrown Macbeth, i. 3

these words now proved a prophecy? 2 Henry $1 V$. iji.

commendable proved, let's die in ... I Henry VI. iv. 6

that e'er I proved thee filse.......2Henry VI. iii.

as Humplurey, proved by reasons.... - iii.

mighat happily have proved far worse
it will be proved to thy face..........

seeing thou hast proved so unuatinal.3 Henry $v f_{\text {. }}$ i. 1

this proved Edward's love ............. is not proved wortl a blackberry Troilus \& Cress. $v$.
has been proved; if $I$ were a liuge.. Timon of Ath $\mathrm{i}$. has been proved; if I were a liuge.. Timon of Ath. i. 2
as if lie had but proved an 2 rgument seeing he had proved himself a man... Coriolanus, i. 3 he proved best man i' the field

as shall be proved upon you?........

you have seen aud proved a tairer. Antony $\delta$. Cleo.i. 2

description proved ns unspeaking sots $-v, 5$

said, 'tis so, when it proved other'tise?.. Hamlet,ii. 2

too much proved, that, with devotion's.. - iji. I

to have proved most royally $\dddot{2} \ldots \ldots \ldots \ldots$.

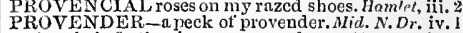
give their fasting horses provender . Henry $V$ iv. 2 have their provender tied to ......... Henryli, i. 2 master's ass, tor nanght but provender ... Othello, i. I PROVER-demand of the prover. Troilus\& Cress. let the proverb go with me

and thereof comes the proverb. Tü Gen of $r$ er. iij.

and the eountry proverbs known......... Wuch Ado, v. 1

ald proverb is very well parted...Ner. of Venice, ii. 2

might we lay the old proverb to... Hinter's 7ale, ii. 3
liave at yon with a proverb.. Comedy of Errors, iii. 1

the hare of whom the proverb goes... King John, ii. I

never yet a breaker of proverbs....... IJenry I I i i.

I wili eap that proverb with (rep.).. - iii.

the ancicnt proverb will be eftected.2. Jenry $r$ r $t$. iii.

grass grows, - the proverb is something. Flamlet, iti.

PROVEREED with a grandsire .. Romeo \& Juliet, i. 4 ROVIEXIT-me pompe provesit alex .Pericles, ii. 2

I'll provide you a chain ..............Merry Hircs, v.

you sirrah, provide your block...Micas. for Meas. iv. 2

to provide for bet ter times to come

provide this messenger

to horse agaiu; go, go, provide..........

provide the fcast, father, and bidi. Taming of $\overline{\text { Sha }}$. ij.

as seafaring men provide for .. Comody of Errors, i. I 
PROVIDE-his wisdom can provide....Macbeth, iij. 6 . PROVOKED by him, you cannot .... Coriolanus, v. ${ }^{5}$ PUBLISH the occasion of our arms ...2 HenryIV. i. 3 get thee home, provide some carts ... Richturd $I I$. ii. 2
provide us all things necessary

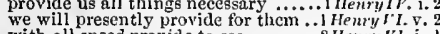
with all speed provide to see
I'll provide his executioner

provide me soldiers, lords, whiles.

art malcontent? I will provide

provide for thine own future.

二 iii.

Pandar to provide this gear?. Troilus \& Cressida, iii. he commands us to provide .... Timon of Athens, $\mathrm{T}$. provide more piereing statuites......... Coriolanus, i. provide your going .......... Antony s clenpatra, iti. provide the proper paltreys.. Titus.Andr

we'll sure provide: thon shalt have .....Perieles, ii we will ourselves provide

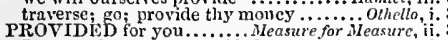
I cannot be so soon provided...Two Gen. of Ver. $\mathrm{i}$. provided that you do mo outrages..... . . - iv. 1 immediately provided in that case... Mid.

to have her love, provided that you

two things provided nore

it is my only suit; provided, that.......

provided, that he win her
provided, that when he's rem

he was provided to do us good

lie that's coming must be provided for... Nacbelh,

provided that, my banislime

and find me worse provided .........

shall all be very well provided tor.

Richard $I I$. iil

we are therefore provided.

Henry $r$, iii.

I myself am not so well provided.. Riehard III.

the gods themselyes have provided. Timon of $A ! k$.

I pry thee let us be provided to show

I shall say I have provided for him. . - v. I

provided, I have your comm

nor ain provided for your fit weicome.... Lear, ii.

Whensoever, provided I be so able as .. Hanlet,

but by immortal providence. she's mine

providence that's in a watchful. Troilus \& Cress. iii. 3

stay the providence of some high...Julius Ccesar, v.
whose providence should have kept ... Hamlet, iv. shocial providence in the fall of a sparrow - v.
PROVIDENT in peril ......... Twelfh Night, i. to be as provident as fear may teach .. Henry $V$. ii. PROVIDENTIY caters for the.....As you Like
PROVIDER-prnyers for the provider. Cymbeline. PROVIDER-prnyers for the provider. Cymbeline, iil. 6
PROVINCE-the province with. Meas. for Meas. iii. 2 as he had lost some province.......Winter's Tale.

these five provinces, with her to thee. King John, ii. 2
and Blanch those provinces? .........

be extirped from our proviuces $\ldots \ldots$. $H_{\epsilon}-\overline{r y} V I$. iii. 3

those provinces these arms of .........2 Henry $V_{I .}$ i.
upon their towns and provinces......3 Henry $V I . \mathrm{i}$.

n province I will give thee...Antony of
kissed away kingdoms and provinces

and so inflict our province.

PROVINCIAL-here provideial............ fers. for

made provision for her following Comedy of Err.

for our gold we may provision have... Pericles, $v$.

such provision as our intents will need?

for provision to shield thee from diseases

that will some provision give thee

sliall be short in our provision .. Roineo \& Jutiet, iv. 2

PROVISO, and exception............... 1 Henry IV.i. 3
PIROVOCATION-a parley of provocation. Othelto ji. 3

come a tempest of provocation ..... Merry Wives, v. 5 this ecstacy may now provoke them to - iii. 3

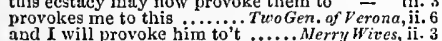
and good provoke to harm........... Neas. for Meus. iv not for that which you provolse...... things does drink especially provoke?... Macbelh, ii. 3
it provokes, and uuprovokes (rep.) .... oppressed child, religiously provolkes. King John, ii. I Why, did you not provoke me?

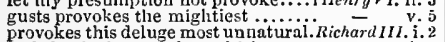
and thy fault, provoke us hither

your goodness, since you provoke... Henry $\bar{V} I I I$. iii. our gentle flame provokes itselt ... Timnn of Ath. i. 1 for le did provoke me with ........... Cymbeline, v. 5 and her to incest did provoke

that to provoke in lim, are niany........ Lear, iv. wilt thou provoke me? then have. Romeo o. Juliet, $\mathrm{v}$ provoke him, that he may: for, even.... Ohello, ii. 1 nor heady-rash, provoke with raging. Com.of Err. y 1 except I be provoked? no, my good. I Henry $/ X$. iii. I
my lord, I was provoked by him ....

my lord, I was provoked by him ....
stomachis be provoked to wilful.....
I was provoked by her slanderous... ivichard inI. i. 2 thou wast provoked by thy bloody mind and not provoked by any suitor else..

the king, provoked to't by the queen... $=$ i. ii. provoked ly my offence .. Anlony \& Cleopatra, iv. PROVOKER - is a great provokcr.........Macbeth, ii. 3

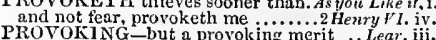
PROV s'uryy and provoking terms ou provols'st thyself to cast ..2 Henry ir.

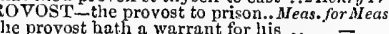
where is the provost? (rep.iv. 3 and v. 1 ) now, what's the matter, provost?
provost! so I think you are (rep.) provost, a word witl you (rep.).......

of the night brother Angelo will not -

this is a gentle provost: seldom, when

there is written in your hrow, provost

the provost. he shall bear them

the provost knows our purpose and our

first, provost, let me bail these

po with him, provost $\ldots$ post, how came it, cia.........

proclaim it, provost, round about...

PROWESS confirmed in the...

nor should thy prowess want praise... Henry $V I$.

Who by his prowess conquered all..3 Henty VI. iii.
PRUDENCE-this sir Prudence .......Tempest, ii.

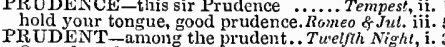
O prudent disciplinel from nortli to. King Jolin, ii. that seem like prudent helps ....... Coriolanus, iii. I
PRUNE-for a dish of stewed prunes. Heryy Wives, i. reverence, ) for stewed prunes

and longing, as I said, for prunes.... - ii. four pound of prunes. which makes lim prune himself....

faith in thee than in a stewed prua

his upon mouldy stewed prunes ${ }^{2}$ Henry $I F$. ii. PUNING-in prnning me? .... Love's L. Lost, iv. PRUN'ST-prun'st a rotten tree....As ypu Like il, it. 3 PRY-have cause to pry int to this. Taming of sh. iii. I

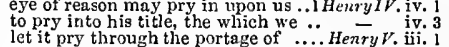
let it pry through the portage of .... Henry V. iii.
to pry into the secrets of the state ..2Henry VI. i.
look back, and pry ou every side.. Richord III. iii. look back, and pry ou every side.. Richord IIr. iii.

PRY'D me through the crevice ...Titus Andron.

he sings psalms to hornpipes ....Winter's Tale, iv

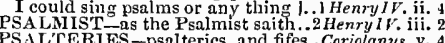
PTISICK-Whoreson ptisick (rep.). Troitus \& Cress. v. 3
PTOLEMLE' pyramises are very. Antony \& Cloo ii. 7 craves the circle of the Ptolemies.....
PTOLENY -1 or the $q$ ueen of Ptolemy

\section{to tumble on the bed of Ptolemy....
to Ptolemy he assigned Syria, Cilicia
PUBLIC-to make us public sport...Me}

thut the body public be a horse... Meas. for Meas. lord Angelo hath to the public ear
yield you forth to public thanls

yield you forth to public thanks ..... he shall endure such public shame... Love's L. Lost, i. your head into the public street. Mer. of Venice, ii.
so near our public conrt ...........As youLike exempt from public haunt, finds

we are to speak in public ......... Winter's ${ }^{\top}$ ale, ii.
at chiefest stern of public weal ....... 1 Henry VI. to be a public spectacie to all......

together, for the public good

cost a mass of public treasury

defacers of a public peace ..........Henry $\overline{v H}$ II. $v$

to your public laws at heeviest

you slall find, no public
a toe to the public weal.

the severity of the public power

public rensons shail be rendered...

forty paces throngh the public street.Ant. $\bar{s} \mathrm{Cleo}$. ii. made his will, and read it to public ear

not by a public minister of justice

eirher by public war, or private treason. Pericles

in the public haunt of men .... Romes

PUBLICAN - a fawning publican. $N$

I am bound to euter publiciy...... Nieas. for for Wivess, iv.

perchar,ce, publicly she'll be asliamed - - v.

beheaded publicly for his offence. Comedy of Err. $v$.

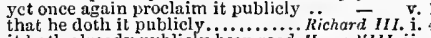
it liath already publicly been read. Henry r $^{\prime}$ III. ii. of gold were publicly enthroned.Antony \& Cleo. iii. 6 Marcus Justeius, Publicola ..... Antony \& Cleo. ili.
PUBLISH-boldly publish her.... T'walfh Night, ii. and pullish it, that she is dead......... Much Ado, iv. publish his commendation. Mer. of Venice, iv. I (let.
when of ourselves we publisll them ... All's Well, $i$. she could not publish more.. Troilus \& Crensido, v.
publish we this peace to all our ..... Cymbeline, v. TUBLISHED daughters' several .......... Lear, i. that you thus have publishcd mo. Winter's Tale, ii. if he be guilty, as 'tis published...2 Henry VI. iil. 2 darest marriage shall be published. Henry Ylll, iii. PUBLISIER of this pretence.. ? wo Ger. of F'cr. Iii. PUBLING a truth? ...... Troilus \& Cressida, v look where Publius is come (rep.). JuliusCasar, that Publius Cimber may (rep.)......

Publius, good cheer, there is no harm

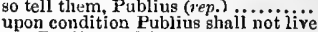

no Publius and Sempronius. Titus $A n d$

O Publins, is not this a heavy ease ..

Publius, Publius, what hast thou donc?

when Publius shot, the bull being galled 二

Publius, come hith

therefore bind them, gentle Publius...

PUCELLE, [see JOAN], if thy name... nenry VI. i. 2

Pucelle or puzzel, dolphio or dogtisli

but what's that Pucelle, whom they

entered Pucelle, and her practisants

yet, Pucelle, hold thy peace.......

sperk, Pucelle, and enchant him.....

Pucelle hath bravely played her part $\bar{T}$ ili.

my gentle Puck, come hither......... - ii. gentle Puck, take this transformed...

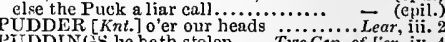
UD his guts are made of puddings... Merry Wives, ii. that killed lusty Pudding $\dddot{3}$ nay, as the pudding to his skin...... for 'Meas. iv.

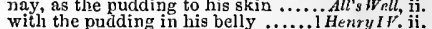
he'll yield the crow a pudding one..... Henry $r$. ii. blessed pudding! didst thou not sce her. Olhello, ii.
PUDDLE, sink; whose filth ........2Henry YI. iv gilded puddle which beasts would...2niony \& cleo.i. hath puddied his clear spirit ........... Othello, iii. PUER ITIA so rosy with a ho..................... admbeline, ii. and puff to win a vulgar station .... Coriolanus, ii.

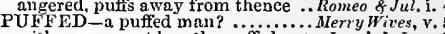
with your sweet breaths puffed out... Love's L.L. v. the sea, puffed up with winds.. Taming of Shrew, i. great, and puffed up with this ....... Henry $I V$. iv. 3
the cholic of puffed Aquilon. Troilis \& Cressida, jv. arrogant man, is puffed......... Timon of Athens, iv. like a puffed and reckless libertine .....Hamlel 1 i. with divine ambition puffed, makes ....̈ - inello, iii. PUFFING with wind ............... As you Like it, iii. 5 powerful fan, puffing at all ... Troilus \& Cressida, i.
PUGGING tooth on edge ... Winler's Tale, iv, (song the power and puissance of the king.2 Henry IV. i. 3 come against us in full puissance....

and make imaginary puissance. Henry $V$. $\overline{\mathrm{i}}$. (chorvs) let us deliver our puissance into $\ldots .$.
arrived to, pith, and puissance $\ldots-$ iti. (chorus) but that my puissance holds it up ... whose puissance on either side ....R Richard $1 I I . \mathrm{v}$.
PUISSANT arm renew their........... Henry $V . j$. and my thrice puissant liege is in...... - i. supplie, mon très puissant seigneus... queed is coming with a puissant host.3Henry VI. ii. at Daintry, with a puissant troop .... - v. western coast rideth a puissant army. Rich. III. iv. mighty, and most puissant Crsar.Julius Casar, iif. I PUKE-STOCKING, caddis-garter . . Henry $I V$, ji. PUKING in the nurse's arms....... As you Like it, ii. 7
PULCHER. Polecats! there are ... Merry Wives, iv. 1 ULING, like a beggar...... T'u'o Gen.of Verona, ii. he, like a puling cuckold ...... Troilus \& Cress. iv. 1 to have a wretched puling fool.. Romeo \& Juliet, iii. 5
PULL thee by the lesser lerg doth back ward pull our slow $\ldots . . . \ldots$..... All's $W$ ell, $\mathrm{i}$. for thou hast to pull at a smack ..... $\overline{\text { Shrew, ii. I }}$ ne'er pull your hat upon your brows... Macbeth, iv. 3 applaud again: pull't off, 1 say

I pull in resolution; and begin .......

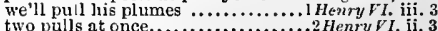
now go some and puli down .......... iv. 7 and pull her out of Acheron .... Titus Andron. iv. 3 pull off my boots ....................... Lear, iv. 6

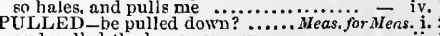
and pulled the law upon you.......... other had pulfed out thy tongue ...As youLike it, i.
hath pulled fair England down $\ldots . .2$ Henry Vi. i. I
unless his teeth be pulled out....... 
PULLED-that pulled me down.... Henry $F 11$. iii. 2 youl pulled me by the cloak......... Julius Cassnr. i. 2 PULLER down of kings!...........3 Henuly $/ 2$. iii. 3 PULLING scarfs of Casar's images.JuliusCiesar, i. PUL'I'-some to the common pulpits

go to the pulpit, Brutus. And Cassilis I will nyself into the pulpit first

and you sliall speak in the same pulpit - iii. thy pulse beats, as of flesh. so strive upon your puls.

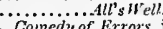
feeling nuy pulse, and with no face .. commandment on the pulse of life?. King Joln, iv. 2 have you a working pulse?

no pulse shall teep his natural.......... of Juliet, iv.

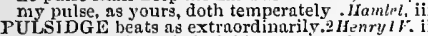
PUMIMEI of Cosar's faulchion .... Love's L. Lost, PMP-new ribhons to your pumps. Nid. N. sD
and Gabriel's pumps were all . Taming of sheer, then is my pump well flowered.. then my pump well fowered... Romeo \& Juliet, ii. 4 PUMPION-gross watery pumpion . Mierry $\overline{\text { Vives, iii. } 3}$ PIN-would pun thee into shivers. Troilus \& Cress. $\mathrm{ii}$. PUNISH my life. must either punish me, not ....Neas. for Weas. v. I

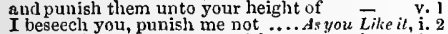

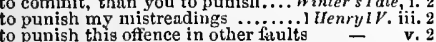
to punish you by the heels ..........2 Henry I $r . \mathrm{i}$. ? highness, and yet punish too.............. Henry $V$. ii. 2 nav before, or God will punish me.Henry ${ }^{\prime} / I I$. as if you were a god to punish pou puish him, where he.

to punish me for what you... Antony\& Clcopatra ii. 5 comes to punisl us, and we purish it ${ }_{\text {punish that before, that he would punish }}$ Pericles, 1.22 seemed so content to punish them - v. 3 (Gorrer) punish me with this, and this with me. Humlet, iif. PUNISHED - austerely punislied you . Tempest, iv. 1 have punished me with.......Two Gen.orl'crona, ii. 4 thou shalt be heavily punished ... Love's L.Lost, i. 2 they are not punished and cured. As you Lize it, iit. 2 let me be punished, that have..

is not to be punished by him ........ $-\bar{J}_{0 h \eta}$ iv. 3 thou shalt be punished for thus frigliting - iii. let him be punished, sovercign ......... Henry

so that here men ase put iv. 1 not be punished with my thwarting.3 Henry $V^{\prime}$ I. iv. 6 to one whom they had punished.... Coriolamus, v. I ohe's punished for her truth

erces, i. 2 and stocked, pmisislied, and imprisoned... - iii. 4 who are punished ere they have done. shall be pardoned, and some punished

I am punished with $\Omega$ sore distraction.. Hamlet.

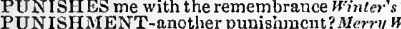

and not the punishment ..........Meas. for.Jeas. i. 4

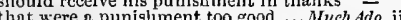
let it be remembered in liis punishment I'll devise thee brave punisinients

the meed of punishment ..Love's L. Lost, i $\overline{1}$ V. 4 broke, deserve not punishment - iv. 3 (verses) punislument that women bear... Comedy of Errors, i. I

gave them condlign punishment ...2 2 Henry $V^{\prime}$ liii. the foulness is the punishment.... Henry VIII. deserve more: a punishment too ..... Cymbeline, $i$. knowing 'tis a punishment, or trial'

punislument itself, and all my treason

- v. 5

punishment for his most wieked life..Tilus.And.y. 3 judicious punishment! 'twas this flesi ... Lear, iii. n punishment more in policy than in ... olvello, ii. 3 UNK is one of Cupid's carriers..... Merry Wives, ii. my lord, she may be a punk ......Meas. for.Meas. v. French crown for your tafteta punk... All's $\overline{\text { We }}$ el, ii. passado! the punto reverso! … Romeo \& Juliel, if. DUN $\mathrm{U}$-twenty of these puny lies. Mrer. of I'enice, ii. 4 as a puny tilter, that spurs his ...As you Like it, iii. 4 a puny subjeet strikes at thy great.. KichardIl. iii. 2
while I question my puny drawer..I Henryl $V$. ii. 4 with stones, in puny battle slay mc. Coriolanus, iv. 4

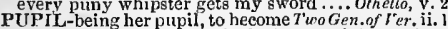
father's of a certain pupil of mine Love's $\dot{i}$. Lost, iv. 2 shall go see your pupils presentiy Taining of sh. ii. I which calls me pupil or hath read.

king Henry be $\mathrm{a}$ pupil still ........... 2 Henry $V 1$ i. 3 his pupil age man-entered thus

Criolanus, il. that pupils lacks pupil long? .....erymbeline, l. not for loving, pupil mine ........ Romeo \& Juli 't, ii.
PUPIL-LIKE, take thy correction .. Richart II. y. I puppet, you? Puppet! why so?.Mid.N.'s Drmam, iij. and marry him to a puppet ...... Taming of $S h$. i. 2 a plappet of me. Why, true (rep.) intony \& Cloo, iv. 3 take vanity the puppet's part nqrainst .... Lear, ii. 2 UPI'IES - $a$ bitchs bliud puppies. Werry Wiv'

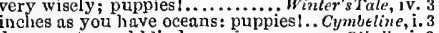
inches as you have oceans: puppiesl... Cymbeline, i. 3 UPPY - brought up of a puppy. Two Gen of Ver.iv. stroke lim as rently as a puppy....2 HenryIV. ii. Roman disciplines, thin is $n$ puppy ... Herryy $V$. with you prescntly, good master puppy - v. 3 PUPPY-HEADED monster............ Tempest, ii. purl the cat is grey.......................... are to this business purblind....... that any purblind eye may find .... M Henry nick-riame for lier purblind son. Romeo \& jutiet, ii worse fools, to purchase mocking.Love's L.Lost, v. finer than you could purchase ... As you Like il, iti. 2 purchase again the sight of dear Sicilia purchase me anotlier dry basting ... Coin. of
purchase corrupted pardon of a man King .0 the difference is, purchase of a henvy

I sent thee fortli to purchase honour. Richn
shalt have a share in our purchase... I Henryl of wildfire, there's no purchase in money nily, hapl y, purchase him a box ..... - - iv. enough to purchase such another.

they purchase great alliance?

I will purchase with mg duteous.... Richard ${ }_{\text {III. ii. } 1}$ which she sliall purchase with still.

I should purchase the day before. Timon of $\mathrm{Ath}$. iii. 2 will purchase us a good opinion ...Julius Ceesar, ii. I wough to purcliase what you.... Antony \& Cleo. v. purchase us thy lasting friends. Tilusind. sought the purchase of a glorious benuty vouch him no more of his purchases.... Hamlet, $\mathrm{v}$. purchasse made, the fruits are to ens
PRCHASED-worthily purclaased $I$ have purchascd at an infinite ..Mcrry I'ives, ii. this is his pardon; purchased by such

pain purchased, doth inherit pain.. Love

purchased by the merit of the. Merch. of 1 enice, ii. for what in me was purchased $\ldots$. . Winter's purchased at a superfluous rate! ..... Henry $V I I I$, i. jevels purchased at an easy price. Tituts Andron. PURCHASETH-merit purchascth.. Mrch Allo, iii.
PURCHASING the semblance... Mer. of Venice, iit. pains for purehasing but trouble.... Cymbeline, ii. 3 pains for purehasing but troubent and pure ........ Tempest,
the - but iunocent
the rocks of pure gold ........ Two Gen. of Verona,
pure messemgers sent ..............

in thy pure bosom rest them

pure hands beld np.......

thou vow'dst pure chastity .........

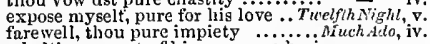
a halting sonnet of lis own pure brain

this princess of pure white

a goddess; pure, pure idolntry .........

yet as pure as the unsullied lil

what follows is pure innocence........... of $\bar{V}$ enice, $\mathrm{i}$. than with safety of a pure blush .. As you Like it, i. with pure love, and troubled brain ... su' $\bar{w}$ red iv. 3 in pure white robes, like very.......... - iifi. against my soul's pure truth.Comedy af Errors, jii. vith our pure hom as soor

with our pure honours, nor attend ...

his pure brain (which some suppose...

see now, whether pure fear.

as pure as sin with baptism

though, in pure truth, it was corrupt

he is pure air and fire

he is pure air and fire................
Pucelle whom they term so pure?

thy cheeks blukh for pure shame ....

a pure unspotted heart

for'sonth, she is a virgin pure

God knows, of pure devotion..........
alas, sir, we did it for pure need

need $\cdots . .$. ii,

on pure heart's love, to greet........ Richard III. Iv.

if', witl $]_{2}$ pure [Kut,-dear] heart's love

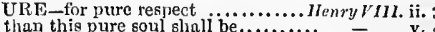
tlat praise, sole pure, transcends. Troilus \& Cress, i. 3 grenses lis pure mind, that from... Timon of $A t h$. iti. 3 stand by tliee, are pure ............ the finest part of pure love...Antory \& Cleopntra, i. 2 opinion you had of lier pure honour. Cymbeline, ii. 4 the pure surprise nnd fear made me ... Pericles, iii. pure Piana! I bless thee for thy houseliolds' rancour to pure love........... Lenr, it. 4 even it pure and vestal modesty be they as pure as grace, as infinite .... ITamlel , i. 4 as cliaste as ice, is pure as snow.
of metais base, shows itself pure in simple and pure soul I come to you ... on onello i. pure grief shore his old thread in twain... - iii. 3 PURELY - strained purely from. Troilus \& Cress. iv. 5
PURER-where should he find it purer. King John, ii. 2 bird that flies i' the purer air! ........ Pericles, iv. 6 PUREST treasure mortal times ....... Richard il.i. I defiler of Hymen's purest bed...Timon of Athens, iv. 3 by the frost from purest snow ...... Coriolnnus, v. 3 URGATION did consist in words. As you Like it, $i$. let lim put me to my purgation ..... to the guilt, or the purgation ...W'in'er's Tale, iii. 2 for me to put him to his purgation .... Hamlel, iii. 2
PURGATIVE drug, would scour these. Aracbeth, v. 3 PURGATORY, torture, hell itself. Romeo \&-Juliel, iii. 3 I should venture purgatory for't $\ldots \ldots$. Olhello, iv. 3 to purge him of that humour.......Winter's Tale, ii. aboard a new ship to purge melancholy - iv. in our country's purge, ench drop ..... Macbelh, $\mathrm{v}$.

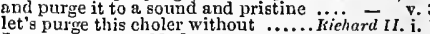
I can purge myself of many ........... Henry $\mathrm{I} V$. iii. purge the obstructions, which begin.2 Henry $I{ }^{\prime}$.jv. purge you of your scum..... $\ldots \ldots \ldots . . . . .-$ iv. wliereof you cannot easily purge ...2 Henry $V I$. iii. 1 from his bosom purge this black .... then, to purge his fear .............3 Henry $r I$. v. 6 hoping to purge himself with words. Coriolnnus, v. 5 purge by any desperate change ...Antony \& Cleo, i. 3 to impeach and purge myself.... Romeo \& Juliet, $v$. Jou $E D$ the air of pestilence .....Twelfth $N i g h t, \mathrm{i}$. ere human statufe purged the gentle... Macoeth, iii. certain king purged and deposed .....King John, ii. 2 these hands, so lately purged of blood - iii. my soul is purged from grudging ..... Fichard 11. i. i. jour rage would not be purged.Antony s Cleo. iv. 1 by yours, my sin is purged

are burnt and purged aw

Hamlet, i. 5 URG ING thick amber ................. Hanalet, ji. PURIFIFS itself, and turng to grace... Lone's L. L. v. PURITAN-is a kind of puritan.... Tiuelfth $\mathrm{Night, \textrm {ii }}$.

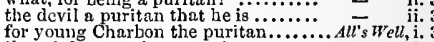
though honesty be no puritan ....... $-\bar{F}_{\text {inter's }}$ ale, iv. she would make a puritan of the devil. Perieles, iy. 6
PURITY - the ward of her purity... Merry Wives, ii. pure impiety, and impious purity $i .$. Much ddo, iv. sully the purity and whiteness of... Winter's Tale, i. shall give a holiness, a purity...........ing $\overline{J o h n}$, iv. 3 such a winnowed purity in love. Troilus ơ Cress. iii.

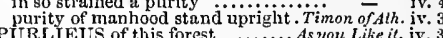
PURLIEUS of this forest ........... As you Like it, iv
PURPLE, blue, and white......... As erry Wives, now purple with love's wound .Mid. $N$.'s Dream,ii.

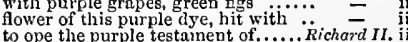
to ope the purple testament of....... Richard II. iit. 3
and Dives that lived in purple $\ldots .$. Henry $I V . \mathrm{iii} .3$ with purple falchion, painted to .....3 Henry $V_{1 . \mathrm{i}}$. 4 his purple blood riglit well resembles - ii. may such purple tears be always shed $-\bar{l}$
did drain the purple sap from l:er . Nichard $I I I$. iv. whilst your purple hands do reek.Jutizus Cosar, iij. the purple violets, and marigolds....... Perieles, iv. purple fountains issuing thom ... Romeo \& Juliet, i. nettles, daisies, and long purples ........ Hamlet, iv.
PURPL tD hands, dyed in ......... King John, ii.
PURPLE-HUED malt-worms ...... Henry $1 V$. ii. PURPLE-IN-GRAIN benrd ............. N' 's Dream, i. 2 PURPORT-a look so piteous in purport. Irmlet, ii. I

the ministers for the purpose hurried how yon the purpose cherish ......... forego the purpose that you resolved the sole drift of my purpose doth .... - iii. to make my purpose switt. . Two Gen. of Verona, ii. 6
here's the ladder for the gurpose .... 


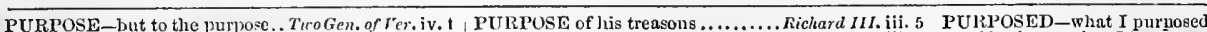

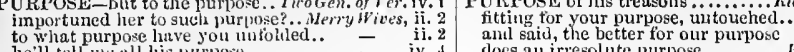

assist me in my purpose
the purpose why, is here

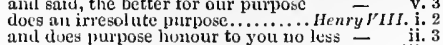

I kuew of your purpose.

and dues purpose hunour to you no less

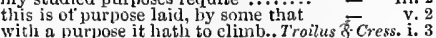

What's thint to the purpose?

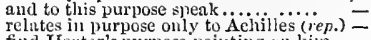

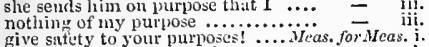

find Ifector's purpose pointing ou lim =

'twas not ny purpose thus to beg a kiss =
we'll exeeute your purpose, and put on =

the speech we liad to such al purpose

lis purpose meets you; 'twas to bring

it power eliange purpose, whist our

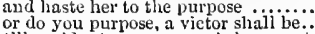

to the purpose; whint was done

till aceident, or purpose, bring you to't

my words cxuress ny purpose

thi" : sted quite from ny great purpose
it is the purpose, that makes (rep.)

and most pernicious purposel.

hat never the purpose to eorrupt lieer
the provost knows our purpose .......

ii. 4 it is the purpose, that makes (rep.).

he says, to veil full purvose............

but we will know tlis purpose

every tongue, to every purpose! $\ldots \ldots .$.

but, sinee it serves my purpose
did retire, to will our purpose.....

did retire, to will our purpose........

than lave limu hold that purpose....
of the people, our purpose to them..

people sin upon purpose, thint thiey......Auch $A d o$, ii.

to speak plain, and to the purpose..
as hushed on jurpose to graee harmony
二

a $K n t$.$] lide lier, to listen our purpose$

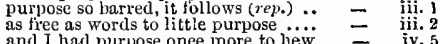

sinee I do plirpose to marry

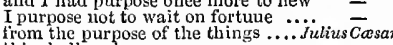

this slatl makne our purpose necessary

to read the purpose of my eoming. Love's $L . L$
more for praise, than purpose.........

more for praise, than pulpose ........
I will have an apology for that purpose

I fear, our purpose is diseovered....

falls shrewdly to the purpose........

and purpose now to lead you to our.

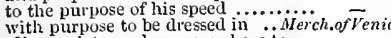

have notice what we purpose. ....Antony
sorry to give breathing to my purpose

prepared to know the purposes I bear

my purposes do dras me much.

all my plots, and purposes how to

our written purposes before us sent...

timelier than my purpose, hither...

my purpose was not to bave seen you

possessed your grace of what I purpose

for the intent and purpose of the law $=$ iv.

notice of my brother's purpose .... As you Like il,

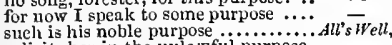

sueh is his noble purpose ..............
solicits her in the uula wful purpose

solicits her in the
now I see the bottom of your purpose
is to kuow straiglat our purpose......

a brave arminy and full of purpose ...
we purpose her no shame...........

bereave yourself of my good purpose

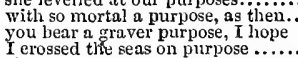

is to kuow straight our purpose...... $=$ iv. 1

their foree, their purposes; nay $\ldots \ldots$.

come, come, to the purpose: did he love
ou purpose trimmed up.... Taming of Sh. $\overline{2}$ (induc.)
ond

never spokest to better purpose.... Wint
but onee before $I$ spolke to the purpose

albeit he comes on angry purpose now

sine lath my letter for the purpose
whereuuto $I$ never purpose return?

my purpose would prove well

out, sword, and to a sore purpose
of late, of tlisis war's purpuse?

nor wheu she purposes return...

I lave spoke to the purpose twice....

that you do ehauge this purpose ....

as I hove purpose to put you to't

hear yatiently my purpose

nay, nay to the purpose

dreading that her purpose was of .

away he posts witli unclaste ptupose
a fitment for the purnose I then followed

oble elange that I have purposed ; King John, iv.

what was purposed coneerniug hi.

it is a purposed thing, and grows ... Coriolanus vii porar i. 2 which time she purposed, by wateling Cymbeline, $i$. your purposed low eorrection is sueh

so an I purposed: where is my lord of ...

let my diselaiming fron a purposed evil mlet, iv.

PURPOSELY on others

his own conduet, purposely to......As you Like it, $\mathrm{v}$.

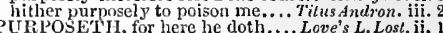

he purposeth to Atliens .....Antony \& Cleopatru, iii. I

PURSE-overtake your slow purse. Two Gen.ofler. i.

open your purse, that the money
of her purse she shall not .............

here, youth, there is my purse

you piek master Slender's purse
the rule of her lnusband's purse

or money in his purse

there's my purse

he eannot ercep into a lialipenny purse

hold, sir, here'

why 1 your purse? .................

denied me mine own purse ........... nuch $\bar{y}_{\text {and }}$, ii.

and moncy enough in ths purse.......

purse, my person, my extremest... Merer of Venice, i.

help to waste his borrowed purse....

you have no money in your purse... 4 s you $\overline{\text { ik }}$ eit ii.

take this purse of gold, and let me...All's Well, iil.

bold thee, there's my purse ............

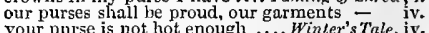

Your purse is not hot enough . ... Wineer's Tale, iv.

to geld a codpieee of a purse............

most of their festival purses

Thad not lef a purse nlive in the....

there is a purse of duets .... Comedy of Eirors

the desk, the purse $\ldots \ldots \ldots . .$.
to her tor a purse of dueats?

this purse of dueats $I$ reeeived.

in to the purse of rich prosperity ......king $\bar{g}$ olnn, v.

for we, that take purses, go ........... Henry $I V$.

a purse of gold most resolutely.
riding to 1 london with fat purses

I will stuff your purses full of .......

variest no more from pieking of purses

prove a

provat money is in iny purse?

I not purpose it. I think, Camillo...

fits the purpose passing well.. Titus Andron

purpose to inake men glorious.. Pericles, i. (Gower)

madam, it this you purpose as you speak $=$ iii. $_{\text {iii. }}^{2}$

and told thee to what porpose. Comedy of Errors, iv.

on purpose shut the doors against.... . . $\overline{\text { sacbeth }}$,
shake $\mathrm{my}$ f fill purpose, nor keep peaee

to-morrow, -as he purposes...........
and had a purpose to be his purveyor

infirm of purpose; give me the daggers
the flighry purpose never is o'ertook

Diana a soldier to thy purpose

make tlrem aequaiuted with your........ purpose

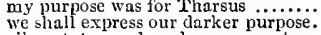

oily art, to speak and purpose not
mistaking his purpose, it would make.

all dirction, purpose, course intent
the better aet of purposes mistook...
a p iii. 1
iii. 3

a passion hateful to ny purposes

pretence and purpose of unkindness
to understand niy purposes aright

suspend thy purpose, if thou didst

opposite I stood to his unnatural purpo
nake your own purpose, how iu nuy ....

and I did purpose, boy, with the
to sound the purposes of al] their

between liis purpose and his conseience

the practice and the purpose of the kin
they saw we lad a purpose of defenee

they saw we had a purpose of defe
with purpose presently to leave .......

never by advised purpose meet......
to what purpose dost thou hoard

Was no purpose in them of this ren
good sir, to the purpose. Who put
tronsport her purposs by rord?

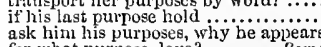

for what purpose, love? ........ Rome

be honourable, thy purpose marriage

a grey eye or so, but not to the purpose

anything, but to the purpose................

against this consumptiou of the purse
your uses both in purse and person.

better than a penmy in purse ...... $=\mathrm{v}$.

for a foreign purse, so sell his......... Henry $V$. ii.

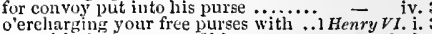

not witl' tle leamness of his purse....2 Heary $V I$. i.

it made me onee restore a purse of gold -

there is my purse, to eure that blow..

thou, trumpet, there's my purse. Troilus \& $\overline{\text { Cress. iv. }}$

thou tassel of a prodigal's purse, thou! $\overline{\text { ther }}$ will he know his purse .... Timon of $\overline{\mathrm{A}}$ thens,
nor

kept his eredit with his purse.
winter' in lord Timon's purse.

jike enpty purses pieked ..............

in your despite, upon your purse?
give me thy hand, here's my purse

an empty purse, there was no nooney

purse and brain bothe empty

the purse too liglit, being drawn .... Fe

open this purse, and take what it contains. Lear, iii.

lere, take this purse, thiou whom

here, friend, is nnother purse

heavy ease, your purse in a ligit

and drive lis purpose on to these delighit
so overdone is tront the purpose of playin

purpose is but the slave to memory
the passion ending, doth the purpose lose

to whet thy almost blunted purpose

so is it, if thou knew'st our purposes
for the purpose, I'll anoint my sword

our purpose may hold there: but stay

if thou answer'st me not to the purpose
and the king lold his purpose, I will win

I am eonstant to my purposes
in this upsloot, purposes mistook falien...

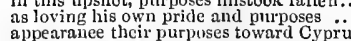

appearanee thir purpuses toward Cyprus
thie better slall my purpose work on hin

swift of foot, outran my purpose

ill at ease, unfit for mine own purposes..
if it be not for some purpose of import.

1 mean, purpose, couraye, and valour

for a speeial purpose whieh wrought .....
PURPOSE-CHANGER, that sly .... King Joth, ii. PURPOSED-truer than you purposed. Tempest, ii. 1
have purposed to forbid sir .. Twio Gen. of Ver. iii.

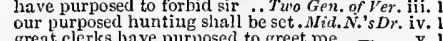

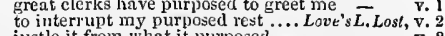
justle it from what it purposed ........
turn his back, and purposed so ...

villain, take my purse; if ever

$\mathrm{l}$ had $\mathrm{my}$ father's simet in my purs....Hamlet, $\mathrm{i}$. 3

lis purse is empty already; all his golden $\bar{z}$ v.

put money in thy purse (rep.) .......... - i. 3

l ever inake nry fool niy purse

contrnit and purse thy brow together....

I had rather have lost my purse full of... -

PURSE-BEARER, and leave .... Tuetfin Night, iii. 3
PUIRED up his heart upon the ...Antony \&cleo. ii. 2 PURSENT-every one pursents , Love's L. Lost, v.

PURSUE, up with your fights....... Nerry Wives, it

when substance love pursues

and fying what pursues $\ldots \ldots \ldots \ldots . . .$. - i.

e'er since pursue me.............. Twelfth ${ }_{\text {Night, }}$.

nay, pursue him now: lest ......... = iij.

pursue him, and entreat limn to...... - $\overline{\text { our }}$

your sense pursues not mine

lie should pursue faults proper to.....

will he to-morrotw nithursue us.MIid. N.'sDream, i.

will he, to-morrow nitht, pursue her
she shall pursue it with the soul of love $-\quad$ i. premeditation for my purposel ....3 Henry $V J$. iii.

for lis purpose in the corouation.... 


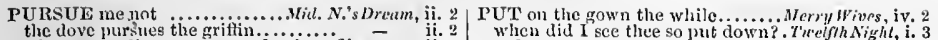
when cowardice jursues, ani valour flics I pray thee, pursue sentence...Merch, of l'enice, iv. pursue me as you draw your bow. Tuming of sh. your love pursues a banished ....... Richari III. drums, pursue the scattered stray..21Imry $V$. iv. 2 let us pursuc him, ere the writs $\ldots .2$. Henry ${ }^{2}$. sonie troops pursuc the bloody-minded $\bar{M}$
before the boar pursues, were to .. Kichart $\overline{I I} I$. that one by one pursue...... Troilus \& Cressida, all extrenity pursue each other?

pursue we lum on kne

pursue vour life, nnd live aje with... - v. v pursue him to his honse............ Coviolanus, iii. I fortune pursue thce! bring him...

I will pursue her even to 'A ugustris'. Cym teline, ii have formal. Titus Androm pursue him, hol go after ............... will they pursue the quality no londer. - ii. and hence, pursue me lasting strife

myself the erying fellow did pursuc .... Othello, Hed her, as love hath pursued...Merry W. ii. whither we pursued them .......... Womedy of Errors. author hath pursued the story ... Henry $F . v .2$ (cho.) pursued the horsemen of the north ..3 Henry /l. i.

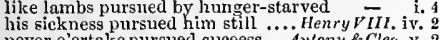
never o'ertake pursued success .. Anto
she hath pursued conclusions infinite so the revenge alone pursued mel .. Cymbeline, iv.
is he pursued? ay, my good lord, he is.... Lear, it. pursued my humour, not pursuing. Romeo \& Jul. i. 1 can vengeance be pursued further than

father siain, pursued my life ........... Hamlet,
PURSUERS

PURSUING that that fies. Merry Wives, $[\mathrm{Col}$.] mistrust pursuing danger..................

not pirsuirg his, and gladly
PURSUIT would be but vain Coriolanns, PURSUIT would be but vain set forth in your pursirt ......... Twelfh Night, now, have you left pursuit?

retreat, and cease our hot pursuit ...1 Henry $V^{\prime}$. i1. and Northumberland's purs

weak we are, and cannot shun pursuit $\quad$ - ii. 3 for deatl doth hold us in pursuit

pursuit, where he did mean no....Richard III. iii. all my force, pursut, and policy ..... now I repent I told the pursuivant. Richard $I I I$. iii. 4 send out a pursuivant at arms ...... v. 3

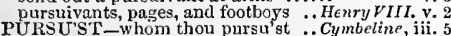
howsoever thou pursu'st this act .......... Hamlet, i. 5
PURSY insolence shall break.... Timon of A/hens, v. 5 in the fatness of these pursy times .... Hamlet, iii. PURUS-vita, scelerisque purus.
PURVEYOI - to be his purveyor

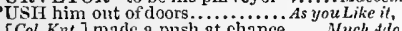
[Col. Knt.] made a push at chance ....Much Ado, $\mathrm{v}$ doth push ou this proccedin
will you not push her out?

will you not push her out?

and one that will push me.......... - ii. 3 upon this push, to trouble your joys $\begin{aligned} & \text { iv. } 3 \\ & \text { v. } 3\end{aligned}$ anis pusl will chcer stools to push destruction, and perpetual ...King John, v. 7 stand the push of every beardless ... HenryI $\nu$. iii. 2 a head to push against the kingdom - iv. I did push it out of further question ....Henry $v$. we may as well push against Paul's. Henvy $\overline{r I I I . \mathrm{i} . \mathrm{s}}$ to stand the pusln and enmity ... Troilus \& Cress. ii. and sudden push gives them

than tarry till they push us.............. Pericles, $\mathrm{v}$.

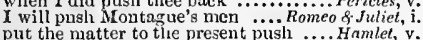

put the matter to the present push .... Hamlet, v.
PUSHED out your gates .............. Coriolanus, v

PUSIIES 'gainst our heart........... Winter's Tale, ii.
PUSII-PIN_-play at push-pin .... Love's L. Lost, iv.

PUSILLAN LII I'TY and cowardice..2 HenryIV. i

and to him put the mang.

your story put hea viness in me...... put thy sut ord uselt upon

as when we pat them on first in $\mathrm{A}$ fric 'twould put me to my slipper might put this ancient mors do you put tricks upon us ...........

even here I will put off $m y$ hope......

your ryc-straw latsput on

put off that gown, Trinculo...........
as when you first put ont to sea......
put forth their sons to seek.. Tugo Gen. ofverona, i. 3 see to pit on your hose

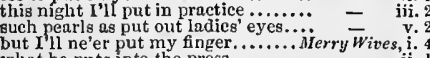

what he puts into the press

yet $X$ cannot put out us two $\ldots . . . . .$. .

and hath threatened to pnt me into

a quart of sack; put $\pi$ toast in't....

otherwise, he inight put on a lat....

kept torcther, and put to uso.

he put his liand behind him

which cunning times put on to. unless yon see cantary jut me down..

put me into good fincling! ...........

that you shonld put your lord into
men of suels constiney put to sea....
prit thyself into the trick of....

put thyseIf into the trick of
thou hast put him in sucl

to put fire in yom

to put firc in your heart

put thysclf minto the trick of............

my young soldier, put tip your iron

I prythee, put on this gown
well, l'll put it on, and $x$...

put your grace in your pocket

may put you in mind.

put strange speech upon me

induced me to the semblance $I$ put on

to put on ycllow stocking

tlicy put forth to steal

a wisc burgher put in for them.

now prits the drowsy and neglected..

why do you put these sayings upon me?

if it be sound, or hollowly put

the merricet was put dow

till eating and drinking be put down

put not yourself in to amazement.....

to rise and be put to deatl

and put your trial in the viliain's

yea, and a case to put it into $\ldots$ in

that puts the world into her person.

you have put him down (rep.)

to put a strange tace on his own

and can put tliem to mending

masters; put your torehes out

et us hence, and put on other weeds

this put a girdle round about

your vows, to her and me, put in two

scriteling loud, puts the wretel $2 . .$. .

which put together, is, in manner.. Love's $\bar{L}$. Lost,

to put in practice that which each

here, sweet, put up this................

finely put on! (rop...........

the ladies and liave put him down!

I could put thec in comfort

presence majestical would put him out

that put A rmado's page out (rep.)

I will not be put out of countenance

we have put thee in countenance (rep.)

put the liveries to by us..

out the liveries to making... iserchant of te

rather to put on your boldest....

the scarfed bark puts from he

and when she put it on, she made me

which he will pat on us, as pigeons.
whe

I'll put myself in poor and ineau.

so you may put a man in your...

Tere to put good meat into...

when he put it into his moutli ...

therefore put you in your best arroy

and lim put me to my pur

the duke hath put on a religions....... life

and put you in the catilogue of those

I shall now put you to the height of

nay, put ne tin't, I warrunt you

but puts it off by a compelled.

nay, my good lord, put him to't

in iny certainty, put myself into

and wouls not put my reputation now

Y'll put another rin

I pray you, sir, put it inp again.......

if $I$ put any tricks upon 'em .......

I put you to the use of your own
dost thou put tupon me at once

that slie would never put it from

rings put upos his fingers... Taming of

we could at once put us in readiness

puts my apparel and my (rep.)

$O$ put me in thy books

to my chamber, put on elothes of mine

to puit on better ere he go to cliurel...

ii. 5 (letter)

- iii. i

PUT-you put me of with limber.. Wixter's Tale, i. 2

may a free fuce put on ...............
of the world sonetime pits forth....

tlat puts to before her trothin-plight...

to put apart these your attendants

forced baseness which he lias put upon't? -

shall help to put him i' the grounc.

the rogue, that put me into this apparel =

I'll not put the dibble in earth

no I have purpose to put you to't ....

good man; luts him off, slighte......

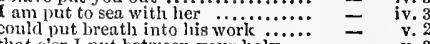

to put the finger in een your holy..... $\overrightarrow{ }$ Err

know not what use to put her to .... - iij. 2

(rep.)

that you would put me to this sliame

wad hoisted sail. and put to sea to-day

you shall put this night's.

what not put upon his spungy.............

which puts upon them suspicion
when first they put the name of.

and put a barren sceptre in

put rancours in the vessel of

enchanting all that you put in
do $\mathrm{I}$ put up that womanly defence

I put mysself to thy direction

about their necks, put on with 11.1.
the powers above purt on their....

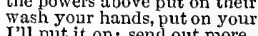

come, put mine armour on

put we on industrious soldiership....... - v. 3

and put the same iuto young $\ldots \ldots \ldots \ldots \ldots k \overline{K i n g} \overrightarrow{J_{0} h n}$, $\mathrm{i}$. I

hath put himself in and and

hath put himself in arms ...

and put my creballs in thy ....... - ii. 2

and down with me; puts on his pretty $=$ iit.

will you put out mine ejes! (rep.) .. $\quad$ iv. 1

whatever torment you do put me to.

sword is bright, sir: put it up (rep.)..

and put on the dauntless spirit of....

up once again; put spirit in the.

put we our quarrel to the will ...... Richard II. i. 2

now open, put into his liands

the true nau's put to death....

put on sullen black incontinent $\ldots . . .$. 二 v. 3

o put down Richard, that sweet ....1 Henry ${ }^{r}$. i. 3

how a plain tale slall put you dow

to put him me from my faith ...... - iii.

where hateful death put on his ......2 Hen $_{2}{ }_{y} I V . j$.

if the prince put thee into my service

had as lief they would put ratsbane..

I put thee now to thy book-oath ......

put on two leather jerkins (rep.ii. 4)

alas, alas! put up your naked weapons

put me a caliver into Wart's land ..

have put us in these ill-besceming

peace pnts fortli her olive

and put the world s whole strength...

accusing it, I jut it on my head.......

dceply put the fashion on, and wear it

and lowrt but

to put forth my rightful

good Bardolpl, put thy nose

put my liand into the bed............

our scions put in wild and savage stock

erowns for convoy put into his purse

France, put up her lovely visage?....

with hair, put forth disordered twigs
marry, if you would put me to verses

po put a golden sceptre in...

put forth thy hand

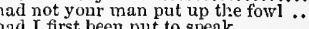

2 Heny VI

put the Enghishmen unto the sword

and Henry put apart in

the elder of them, being put to nur...

a power be raised to put them down

v. 3

to seek to put me down, and reign ...3 Henry $\mathrm{V}$

in justice puts his armour on ...........

well, well, put up your sword (....... Richard III.

let me put in your minds

grace to put it in my mind

and put meckness in thy breast........

it slould be put to no arjparent ....... 


\section{PUT}

PUT-those enemies are put to death. Richard 111. iii. 2 PUT my elouted brogues from off.... Cymbeline, how Edward put to death a eitizen.

these both put by, a poor petitiuner.

unless thou couldst put on some

put in her tender heart the ...........

\begin{tabular}{l|l} 
iii. 5 & but to put those powers in motion ... \\
iii. 7 & I never had lived to put on this...... \\
iv. 2 & gods, put the strength o' the Leonati
\end{tabular}

you have put me into rhym

as I could put into them

he candidatus then, and put it on... Titus $\bar{A}$ tron.

for shame, put np...................

sweat to put a tyrant down ........... =

even this instant cloud puts on...

lave put off the spinsters, carders...

nature puts me to a heavy task.

into monstrous habits put the graces

would have put his knife into him
put the king tiom these sad thoughts

targets, to put off the shame

sliould proeeed to put me ot $\ldots$ is put in anger

come, put it on, keep thee warm.

if put upon you, make the

Pericles,

sopposin you, make the ............

put my sick calse into his hands....

as yours was put into you...ili........

some spirit put this japer in

made me put this main secret.

while it is lint, I'll put it ro the issne

when we first put this dangerous $\ldots$

put turth toward Phrygia. Troilus \& Cressida, (prol.)

puts me her white hand to $\ldots$ th.........

put this withered brawn were put $[$ Col.Kut..........

I know not, $\mathrm{it}$ is put to lottery

savage strangeness he puts on.
we'll put you i' the fills............

put on a form of strangewess

wherein he puts alins tor

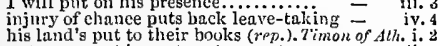

put on a most importmate asprec....

your steward puts me off. my lord

when my indisposition put you baek

I would have put my wealth into 0 ."
he that has no louse to put lis head in

put in now, Titus. My lord

they have e'en put my breath

nay, put all your hands: not one

put up thy gold; go on

put armour on thine ears....

will put thy shirt on warm?

if thou didst put this sour-cold

as common bruit doth put it

Anfidins, that will put you to $\because t \ldots \ldots$.

put your shields before your heart

we'll put you (like one that means.

nor on him put the napless vesture...

shall not want, if he be put upon't... -

for I cannot put on the gown.

put them not to't: pras sou ..........

this muting were better put in hazar

who puts his shall, his popular shall

shall it be put to that? The gods....

I would have had you put your power
I would put mine armour on, which I
else would put you to your fortune..

you have put me now to such a part

wut him to eholer straight ..........

whom we have put in prison ........

be quiet; put up your sword

do you now put on your best attire?.ju

he put it by it the band

searfs off Crear's images, are put to..

however he puts on this tardy form.

I grant, we put a sting in him ......

first time ever Casar put it on ...

have put to death a hundred

I put it in the poeket of my gown....

put on my brows this wreath

then put my tires and mantles......

but Mark Antony put me to some

and put garlands on thy head

to put yourself under his shroud... ...

good fellow, put thine iron on

go, put on thy detences
they have put forth tbe haven

they have put forth tbe
put eolour in thy cheek.

put eolour in thy cheek.
put off my helmet to my

put your cliildren to that destruction

put we i' the roll of eonquest

go, put it to the haste...............

should have been put together with so

'faith, yes, to be put to the arbitrement

winning will put any man into eourage -

you puttme to forget a lady's manners

here did put the yoke ppon us

and puts himself in posture that .....

and make me put into eon tempt .....

fortune, put them into my handl...
and put us to our answer............

iii. 1 put me to present pain; lest this.

seek you to put up that letter?

put on what weary negligence you

why, to put his head in; not to give.

'tis they have put him on the old man's

and put upon him such a deal of man.

when slie put them $i^{\prime}$ the paste alive

who put my man i' the stocks?
he hath put himself from rest

going to put out the

h'll put it in proof.................

I pr'y thee, put them off. Pardon $\mathrm{me}$

put up your swords (rep.). . .

Romeo

give me a case to put my visage

gentle Mercutio, put thy rapier ap

let me be put tu death; I am content
who, to put thee from thy heaviness

who, to put thee from thy heaviness

we may put up our pipes (rep. ?

we may put up our pipes (rep. ....

put put it out for I would not wili

[Col. Knl.] put not anotlier sin upon m

as so 'tis put on me, and that in way....

i. (Gower)

4 (Gower)

v. (Gow.)

put money in thy purse (rep.)

slie puts her tongue a little in her heart. O gentle lady, do not put me to' $\mathrm{d}$........
did justly put on the vouch of very mali yet that $I$ put the Moor at least into every man put himself into tritumph the trust Othello puts him in ........... well, the general were put in mind
shame, put by this barbarous brawl.

shame, put by this barbarous brawl.....
she'll help to put you in your place agr

devils will their blackest sins put on

then put up your pipes in your bag.

and will upon the iustant pnt thee to't

a triek to put me from my suit ............

and put in every honest hand a whip

to put up in peace what already I have

your good rapier bare, and put it home.

but once put out thire, thou

PUTREFIED eore, so fair without. Troil.

Henry less. $v$

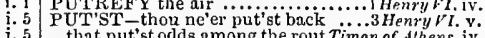
that put'st odds among the rout Timon of Alhens, iv.
and put'st down thine own breeehes ...... Lear, $\mathrm{i}$.
3 PUTTER; your pelly is all (rep.)... Merry Wives, v.

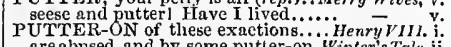
iii. aUTTER-OU' $\mathrm{T}$ on five for one ......... Tempest, iii. iii. 3 PUTTEST [Knt.] up thy fortune. Rnineo o thuliel, iii. iii. 4 with the swiftness of putting nn... Tuelfy Wives, ii . by putting on the destined livery. Meas,for Meas.
for putting the hand in the pocket... and put it on by your allowanee

he that has a house to put his head in...

PE-CORNER - to Pye-corner......2 Henry $1 V$. ii.

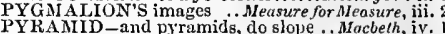

by certain seales i' the pyramid..Aniony \& Cleo. ii.

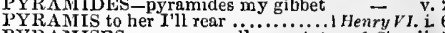
PYRAMISES are very goodly.......... Antony \& Cleo. ii. for Pyramus. What is Pyramus?..... -

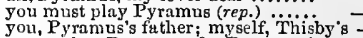

PYRENEAN, and the river Po,$\ldots$.... King John, $\mathrm{j}$.

not there reside, to put my fother in it is the lady that Pyranins must love -
ah, I'Tyramus, my lover dear... no part but Pyramus: for Pyramus is of Pyramus and Thisby (rep.) $\ldots$..... that 1 Pyramus am not Pyramis ... for Pyramus and Thisby, says the story shall Pyramus and Thishy whisper

Pyramns, you begin: When you have

a stranger Pyramus than e'er played

most radiant Pyramus, most lily-wlite -
I'll meet thee, Pyramus, at Ninny's

Pyramus, enter; your eue is past..... -

who Pyramus presented, in their....

my next is. most fair Pyramus ..... =

sixpence a day for playing Pyramus ( $r e p.)=$

for Pyramus therein doth kill himself

anon comes Pyramus (rep.)

which the lovers, Pyramus and Thisby

for parting my fair Pyramus and me

and wound the pap of Pyramns......

not use a long one, for such a Pyramus

o Pyramus, arise, speak, spenk.......

did shine the moon on Pyramus.. Titus anutron, ii

the rugged Pyrrhus (rep.)..............Hamlet, ii. nnequal matehed, Pyrrhus at Priam drives takes prisoner Pyrrbus' ear .............

so, atter Pyrrhus' panse, aroused ...........

- ii. 2

PYTHAGORAS conceming ......T Telfth $N i g h t$, iv.

shalt hold the opinion of P $y$ thagoras
hold opinion with Pythagoras ...Mer.of $V_{\epsilon n}^{-}$ice, iv. i

be-rlnymed sinee Pythagoras' time.As you Like, iii. 2

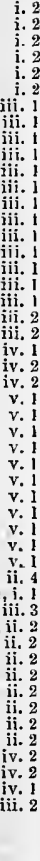

QUADR ANGLE, I come to talk ...2 Henry VI. j. 3 QUAFF carouses to our mistress' .. Taming of Sh. i. 2

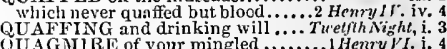
WAGMIRE of your mingled ........... Hemry $V I$ i. 4

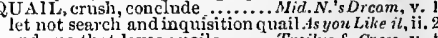
and one that loves quails ..... Troilus $\delta$ Cress. $\gamma$.

spirits quail to remember............ Cymbeline, v. 5 courage in their quailing breasts....3 Henry VI, ii. but fur a fine, quaint, graceful .......Much Ado, iii. and wonders at our quaint spirits.... tell quaint lies, how honourable. Mer. of Venice, jii. more quaint, more pleasing, nor more - iv. show how quaint an orator youz are.2 Henry $V I$ ii QUAINTLY writ............ TroGen. of I'erona, ii. a ladder, quaintly made of cords..... to carve out dials quaintly, point, 3 Henry $/ 1$. ii. with your fine faneies quaintly. Pericles, iij.(Gower)
but breathe his faults so quaintly...... Hamlet, ji. 1 QUAKE, lest thon a feverous life. Meas. for Meas. iii. thou wilt quake for this sloortly........Much d do,

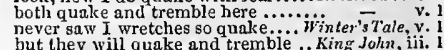
but when he meant to quail and shake that quaint in green she shall .....ïcry Wives, $\mathrm{iv}$. 


\section{QUA}

QUE

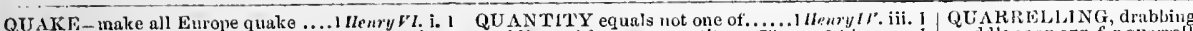

that made all lrance to quake ....2 Hemyll iv, 8 yon deposcd, you quake like rebels? Richarllill. i. thou quake, and chinnge thy colour? quake in the pres'unt winter's state.. Cymbeline, ii. 4 Miakes the foul oftenders quake...

see how the subjeet quakes

Pericles, iii. 2

day would quake to look on

Hamlet, iii.

and, gladiy quaked, hear more....... Coriolanus, $i$, QUALICITIUN shall toine into no.. Othello, 8) qualified as your charities ..... Winler's Tale, ii. 8) qualified as your charities.
by you only to be qualified.

chaste, constant, qualified, and less... Cymbeline, $\mathrm{i}$. some little time hath qualified the lieat... Lear, men are fit for, $I$ am qualitied in...

and that was eraftily qualified too.......... öhello, ii. 3 QUALIFIES the spark and fire of it.... Hamle QUALIFY the fire's extreme TwoGen.of J'erona,
to enforce, or qualify the laws ... Meas. for Meas. to enforce, or qualify the laws ...Meas. for Meas. iv.
spurs on his power to qualify in others - iv.
all this amazement call I qualify ....An $u$ rh $A d_{0}, \mathrm{v}$. al this amazement can quat pains to qualify his. Mer... fr Jenice, ta'en great pains to qualify his. bad cause, to qualify the sume?.. 7'roilus \& Cress. QUALIFY ING dross ......... Troilus \& Cressidn, iv. QUALITE-de bune qualite and qualities beseeming such. Tro $G$ more qualities than a water-spaniel

end ued with worthy qualities

for I have many ill qualities .......... so I admiring of his qualities...Mid.N.'s Dream all gentleman-like qualities....... As you Like $i$ mind carries virtuous qualities

ouly where qualities were level

his qualities being at this poor price

her wondrous qualities, and mild. Taming of Sh.ii.

to your strength, and qualities.....2 Henry IV v.

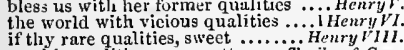

nor his qualities; - no matter..... Troilus \& Cress. i.

cost, in qualities of the best .... Timon of Alhens,

and note the qualities of veople... Antony the adeo.

a shop of all the qualities that man...

no further necessity of qualities can make - iv. 3

[Knl.] for qualities are so weighed ........ Lear, $\mathrm{i}$.

and their true qualities ........ Romeo \& Juliel, ii.

QUALITY -Ariel, and all his quality.. Tempest, $i$.

it is the quality o' the elimate.......... $\overline{\text { do }}$ in our quality much want.. Two Gen. of

of what quality was your love
your office, and your quality
the quality of persons

the quality of persons ............... eifh Night, iii. I the quality of the time, and quarrel

what quality are they of'. Measure for Mersure, ii.

the quality of mercy is not stroined

no oue good quality worthy your....A $A l$ 's $\bar{w}$ ell, iii. 6

hath love uo quality? if the quick ... King John, iv. $\frac{2}{7}$

becruaty and har of our attempt.

yes, in this present quality of war ..2 Henry $I V$. i. as might hold sortanee with his qualit

concurring both in name and quality

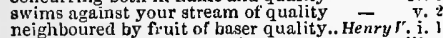

neighboured by fi'uit of baser quality.
I know thy quality. AIontjoy ......
quality eall you me? Construe me..

quality eall you me? Construe me.

have lost their quality; and that this $=$ iv.

hitting a grosser quality, is cried ...Henry $r I I I$. $\mathrm{i}$.

the whole quality wherefore...Troilus \& Cress. jv.

as of grave and austere quality. Timon of Athens, i.

the quality of lord Timon's fury? ${ }_{\text {scolds against the quality of the flesh }}-\quad$ iii. 6
iv. 3

and beasts, from quality and kind.Julius $\overline{\text { Casar, }}$ i. 3

fuculties, to monstrous quality ....... - i.

trom the true quality with that which

whose quality, going on ..... Anlony \& Cleopatra, i. 2

the quality of her passion shall......

a beggar without more quality ........ Cynnbeline, i. 5

to a stranger of his quality................. Lear, i. 5

more composition and fieree quality

you know the fiery quality of the duke.

what quality? Why Gloster, Gloster

if any man of quality, or degree - v. 3 (herald)

your name? your quality? and why .... Hamlel, it. 3

will they pursue the quality no longer

二 ii. 2

come, give us a taste of your quality .... - ii. 2

even to the very quality of my lord .... othello, i. 3

to the general, nor any man of quality.

and all quality, pride, pomp .............. he called me? Qualm pethaps...... Love's L. Lost, v. some sudden qualm liath struck
QUALMISH at the smell of leek

2 Henry $\mathrm{Vi}$. $\mathrm{i}$. QUANDO-quanclo pecus omne : Tove's $L$. Lost, iv. QUANTITIES-sawed into quantities.2HenrylV. V. ho is not quantity enough for that... Love's $L . L$. $v$. thou rag, thou quantity, thou .. Tamink of Sh. iv. soldiers witla great quantity ... Timon of Ah/uns, v. ith loves aljove their quant set on some quantity of barren........ Ilumlet, iii. women's fenr and love hold quantity.....

with all their quantity of love make up

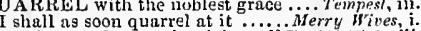
the time, and quarrel, might well T'uelfh $\mathrm{N}_{\mathrm{g} g} \mathrm{~h}$, iii. that put quarrels purposely on others

I have his horse to take up the quarrel
better bethought him of lis quarrel

and let no quarrel, nor no brawl

lady Beatrice hath a quarrel to you... Much $A d o$, ii .

and in the managing of quarrels you

do not quarrel with us, good old man

a quarrel, ho, already?........ Ilerchant of $T^{\circ}$

the unhappy subject of these quariels

sudden aad quick in quarrel

Thave had four quarrels, and like to
found the quarrel was upon (rep.)..

$O$ sir, we quarrel in print, by

holy seems the quarrel upon your....All's $\bar{w}$ ell, iii.

though the nature of our quarrel. Taming of Sh. i.

for in a quarrel, since I came as

we will compound this quarrel $\ldots \ldots . .$. -

lis damned quarrel [Col. Knt.-quarry] . Nacbelh, i. 2

be like our warranted quarrel!

our people quarrel with obedience ...KingJohn, v. I

and put lis cause and quarrel to .....

and wh is the quarrel; for

fined for aneient quarrels, and quite $\overline{\text { now }}$ i.

wow you piek a quarrel to beguile.. 1 Henry $I V$. iti.

derives from heaven his quarrel $\ldots .2$ Heni? $l \%$.

I make my quarrel in particular .....

the quarrel of a true inlieritor daily grew to quarrel, and to bloodshed

busy giddy minds with foreigu guarrels

being just, and his quarrel ionourable

in now the king's quarrel.

I will make it my quarrel

we have French quarrels enough ......
prabbles, and quarrels, and dissentions

all griefs, and quarrels, into lo

this quarrel will drink blood......... i Henry $\overline{V l}$.ii.

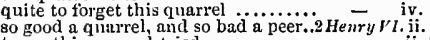

to good a quarrel, and so bad a peer..2 Henry $r l$ ii.

armed that hath his quarrel just.......
what is your quarrel? $(r e p$.$) ii.$

and in that quarrel use it to the death -

because in quarrel of the house of York
my quarrel, and this English queen's
iit.
ii.. 3
is

it is a quarrel most ummatural

in quarrel of the house nf Laneaster.

take not the quarrel from his powerful - i. 4

yet if that quarrel, fortune, do divorce - ii. 3

and that's the quarrel.... Troilus \& Cress. (prologue)

of those this quarrel would excite? ..

a good quariel, to draw emulous

worth that hangs upon our quarrel... $\quad$ - ii. 3

the quarrel's most ominous to us....

had we no quarrel else to Rome.... Coriotanus, iv.

quarrel no more, but be prepared... Antony \& \&leo. i.

my quarrel was not al together stight. $C_{y}-\overline{n b e l i n e}$,

in wrongful quarrel you (rep.).... Tilus dudron. j. 2

maintain sueh a quarrel openly?

such quarrels may be bronched...

to back thy quarrels, whatsae'er ..... =

that fought Rome's quarrel out..
do hourly carp and quarrel

bold in the quarrel's right

speak, yet, low grew your quarreil...... - ii. 1

1

and the best quarrels, in the heat .........

quarrel is between our masters ... Romeo \& Juliel, $\mathrm{i}$.

guarrel, I will back thee

do you quarrel, sir? Quarrel, sir? no

in a good quarrel, and the law on

quarrel with a man that liatl (rep.)

an' I wert so apt to quarrel as thou art - iii. I

beware of entrance to a quarrel

greatly to find quarrel in a straw.......

to manauge private and domesticenee... olhello, ii. 3

a quarrel, but nothing wherefore

QUARR El.LED with a man for. Romeo $\&$-Julie', iii. I

QUARRELLING - hath in quarreiling - i. 3

could right himself with quarrelling. Much $A d o$, v. I

quarrelling upon the head of valour Tinon of $d$ ih.iii.s adrlle as an egg, for quarrelling.

QUARRELLOUS as the wease ...... Cymbelin iji.

QUARRIES, rocks, and hilts whose heuds. othellu,

UARRY eries on havock .............. Hamlet.

[Col.Kut.] ]is darnned quarry smiling..

I'l make a quarry with thousands. Coriolanus, i.

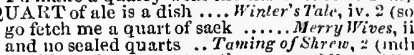

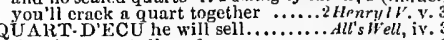

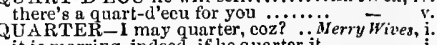

if he lias a quarter of your coat

within a quarter of an hour......... - iv.

in elamour quarter old ...Measure for Measure, iii.

again into his native quarter...........All's " well, iii. 6

not paarters, halt yard, quarter. Taming of sh.

not past three quarters of a mile. dead

keep fair quarter with his bed l... Comedy of Err. ii.

blow, all the quarters that they know...Nacbe/h, $\mathrm{i}$.

continue in this a quarter of an hour .... $-\mathrm{v}$.

keep good quarter, and good care.... KingJohn, v.

not quarter of an hour, that i can ... Henryll. ii. 4

once or $t$ wice in a quarter bear out ...
take you one qunrter into France.... Hen ry $r . \mathrm{i}$.

had all your quarters been as safely. Henny VI. ii. I

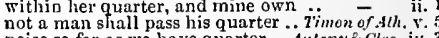

noise so far as we have quarter..Anlony \& Clen. iy. 3

even now, in quarter, and in terms like. Othello, ii.
QUARTERED in her heart l ........ KingJohn, ii.

drawn, and quartered, there should be - iing

where is Iord Stanley quartered.... Richard $\mathbf{M I I}$.
Strand, where she was quartered ... Henry VIII.

thousands of these quartered slaves.. Coriolanus, $\mathrm{i}$.

behold their infants quartered....JuliusCesar, iit.

this night in Sardis to be quartered .. sword quartered the world.. Antony \& Cleo. iv. $12_{2}$

behold their quartered fires ....... Cymbeline, iv. 4

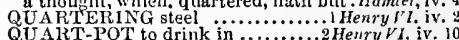

QUASI-master person, quasi pers-on. Love $s$ L. L. iv.

QUAT-I have rubbed this young quat... Othello, v. I

as a scolding quean to a wrangling ...All's W'll, ij.

thow the quean in the ehangling ... All's ${ }^{2}$ ell, ij.

QUEAS-te captum queas ninimo.7aming of sh. i

who, queasy with tis insolence .. An'ony \& Cleo, ii. 1

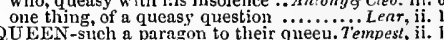

your daughter, who is now queen.... - ij. I

the queen o' the sky ...............

do now attend the queen?
highest queen of state.....

highest queen of state.....

pale qneen of night I swear ...TwoGen. of Ver. iv.

must quesent of all the fairy queen ..... Merry Wives, jv.

our radiant queen hates stuts.......... $\overline{\text { that }} \overline{\mathrm{N}} \mathrm{y} h t, \mathrm{v}$

and his funcy's queen .................. N. $\overline{\text { Drid. }}$ Dream,

I serve the fairy queen, to dew .......

the queen come not within his sight

eome not near our fairy queen .....

to my queen, and beg her Indian boy

first I will release the fairy queen...

wake you, my sweet queen ..........

$\overline{\text { ii. }} 3$ (80)

Aquítain; a dowry for a queen ... Lov

one of the strange queen's lords (rep.)

O queen of queens, how far dost - iv. 3 (verses

your thouglits, my gentle queen.Mjer. of fenice, 11.

thrice-crowned queen of night ... As you Like it.

save you, fair queen. And you...........

as Anna to the queen of Carthage. Taming of $S$

tongueted,

your queen and I are devils

at the good queen's entreaty (rep.)...

will take again your queen ..........

have touehed his queen forbiddenly

and comfort the gracious queen.......

call the queen again .................

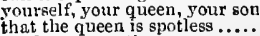

conduct me to the queen

the queen reeeives muel comfort.....

my best obedience to the queen......

I'l presently acquaint the queen of
I'll to the queen; please you, come..

if 't please the queen to sen

more, alas, than the queen' ilifer.....

good queen. Good queen! (rep.)....... 


\section{QUE}

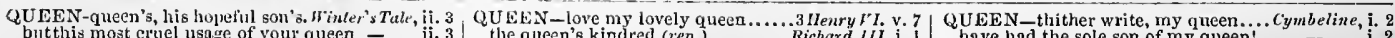
but this most cruel usage of your queen that the queen appen ine queen

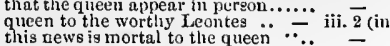

the queen's kindred (rep.)............ Richard III. new woo my queen; recall the good my practice; queen his tortunes here the love I bore your queen ........... dend bodies of my queen, and son... petty rods, and you tlie queen on't petty all your acts are queens ........ she is the queen of curds and to rejoice, the former queen is well? looked upon my queen's full eyes... to choose you a queen.

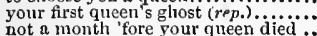
not a month 'fore your queen died are going to see the queen's picture.. lady, dear queen, that ended when $\mathbf{i}$

the queen, that bore thee... we are the queen's abjects, and must thau a great queen, with this condition = have I in being England's queen ....

ere you were queen, ay, or your

iii. 2 being the queen thereot (rep.) $1 . . .$. . thyselt a queen, for me that was a que mother, wite, nor Encland's qucen..

iv. 1 poor painted queen (rep. iv. 4) $\ldots . . .$. iv. 3 'tis the queen and her allies, that stir to my sovereign king, and queen....
guilty kindied of the queen looked pole provoked to't by the queen, devised to part the queen's proud kindred and queen your mother, and your persuade the queen to send the duke
the kiudred of the queen, must die.. the suggestion of the queen's allies. reverend looker-on of two fair queens
to be crowned Richard's royal queeu wife, nor England's counted queen.. that save the queen! (rep. iv.

a queen in jest, only to fill the thou may'st be a queen .............. King $\vec{J}_{o h n}$,

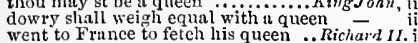
come on, our queen; to-morrow

then, thrice gracions queen

why is he not with the queen?.......

the beauty of a fitir queen's cheeks.

you say, the queen is at your house.

remembrance of a weeping queen.

resting for her true king's queen.

good sometime queen, prepare thee..

Knt. $]$ my queen to France; trom whence -
weep not, sweet queen convey my trist tul quen

to pray for the queen ........2 Henry $t_{\text {. }}$ (epilngue)

and 1 call you, iny queen .................

the kings and queens of France..... i Henry $r$. . i.

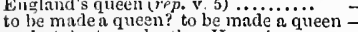

undertake to make thee Henry's queen

his queen, and not to seek a queen to - v, 5

the fairest queen that ever king...

entertainment to my princely quicen

where kings and queens mre crowne

the king aidd queen do me:m to hawk

in court do take her for the queen first -

peace, good qucen; and whet not on these-

now is Henry king, and Margaret queen -

nor the king, nor the queen...........

Margaret our queen, do seek subversion
be a queen, and crowned with infamy!
poisonous ton, and kill thy forlorngueen

ungentle queen, to call him gentle..

eease, ge: atle queen, these execrations
thy lips, that kissed the queen ......

message from the queen to France

until the queen lis mistress bury it.
the qucen that living held him dear

Somerset eomes with the queen.....
the queen, this day, here holds her

and queen of sad mischance

praying nuns, not weeping queens.

your daughter is made queen.

she shall be a high and mighty que

the queen hith hartily consented
under pretence to see the queen.

the emperor, the queen's great nephew

the qucen shall be acquainted forthwith -

I would not be a queen (rep.).....

old as $\mathrm{I}$ am, to queen

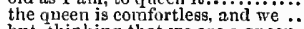

but, thinking that we are a queen

the queen is obstinate, stubborn .... -

some of these, the queen is put in anger -

atginst the person of the good queen

your highness, tlie queen being absent -

to a creature of the queen's, lady Anne -

Kutlizrine no more shall be called, queen -

the late queen's gentlewoman

viewed in open, as lis queen, going...

stand close, the queen is comin

all the royal makings of a queen.

went on each sicle of the queen?

the queen's in labomr, they say.....
from the queen what is the news?

remember the estate of nyy poor queen 二

sir, your queen desires your visitation

and the queen. A hundred marks! -

ye minst all see the queen, and sh

Menelaus' queen, with wanton. Troil. \& Cress. he bronght a Grecian queen

especially to it to the ransacked queen especially to you, fair queen! .......

I have business to my lord, dear queen

well, sweet queen (rep.)

now by the jealons queen of heaven. Coriotam tii.

let us tell the queen these news......

be patient, gentle queen, and 1 will stay

poor queen i how love ti me ....

the army of the qucen (rep. i. 4)

I would assay, proud queen (rep.) $\ldots$....

Clifford, and the queen; who crowned

St. Alban's to intercept the queen
looked full gently on his warlike

we fled; the king un to the queen queen -

the proud insulting queen, with cilifford -

the cueen is coming with a puissant

love to go whither the queen intend

pursue the bloody-minded queen
ask the lady Bona for thy queen

ask the lady Bona for thy

my queen, and son (rep.) ..............

my queen: say that king Edward

I am too mean to be your queen

you cavil, widow: I did mean, my

no more, for thou shalt be my queen

why, say, tair queen, whence springs

renowned queen, with patience calm

and why not queen? because thy.
no more art prince, than she is que

you yourself, our quondain queen

that our fair queen and mistress smiles -

thy help to this distressed queen?...

my quarrel, and this English queen'

queen and prince shall fullow (rep.)

iny wite, and England's queen...

raise my state to title of a quee
but what said Henry's queen?

but what said Henry's queen? .......

the queen rrom France hath brought

that the gueen hat h raised in Gallia

the queen is valued thirty thousand

as I am Egypt's queen, thou .... Antony \& Cle

come, my queen; last night you

that you praised so to the queen?.

I must from this enchanting queen..

I must from this enchanting queen..

now, my dearest queen, - - Pray you..

most sweet queen,-Nay, pray you.

hear me, queen: the strong necessity

she's dead, my queen: look here

ii. 5 nor the queen of Ptolemy more womanl

last thing he did, dear queen, he kissed

ay, dread queen. Where? Madam

Cyprus, Lyclia, absolinte queen
do, most dear queen. Dol.........

the queen, iny lurd, the queen

the queen, of andience, nor desire

the queen shall then have courtesy

and my g meen's a squire more tight

let the queen know of our guests ....
and the queen, whose heart, I thought

I come, my queen: Eros

my queen and bros have, by their...

the queen my mistress, confined

would have a queen his beggar..

royal queen! OClenpatra! thou art (rep.) -

as for the queen, f'll take her to my

good queen, let us entreat you ......
no, dear queen; for we intend so to..

twas, his queen, his queen! $\ldots . . . .$. ...

the queen nualam, desires your

i. 3 or she, that bore you, was no queen....

because of the queen my mother ....

attend the queen, and us ..............

come, our queen. If she he up......... -

I had it trom the queen................

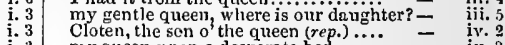

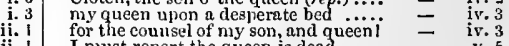

I must report the queen is dead...... - $\mathrm{v}$.

ii. 2 I had it trom the queen

one thing which the queen cortessed

the queen, sir, very oft importuned me

we were dissuaded by our wicked quen -

eldest son of this distressed queen.. Tilus Andron. i. 2

clear up, fair queen (rep.)..............

v. what tis to let a queen kneel in the...

queen [Col.Knt.-nymph], this syren...

believe me, queen, your swarth ......

like Tarquin and his queen...........

confederate with the queen, and her

would youl represent our queen arigh

welcome, dread queen; weleome ....

come, queen o' the feast..................

makes her.. …... ii. 3

how, Lychorida, how does my queen?.. - iii. I

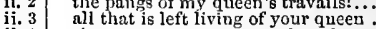

ii. 3 sir, your queen must overboard........ - iii. I

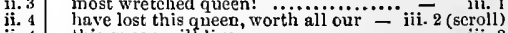

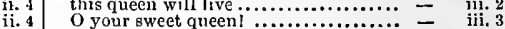

ii. 4 his woeful quecn leave at Ëphess....... iv. (Gower)

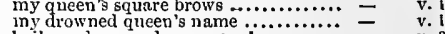

ii. 4
ii. 4 hail, mudlam, and my queen $1 . \ldots \ldots \ldots \ldots$.

iii. 2 yet there, my queen, we'll celebrate ....

queen of us, of ours, and our frir France . Lear, $i$ pieree the queen to any demonstration ... - iv. 3 she was a queen over her passion ........ - iv. 3 though that the queen on special cause..

our sometime sister, now our queen ...... Hamlet, i. 2 my most seeming virtuous queen ..........

or my dear majesty your queen here

the good king and queen (rep.) $\ldots . . .$. alone entreat him the queen, your mother, in most great ... my lord, the queen would speak with you 二 iii. 2 nine own ambition, and my queen .......

the queen, yo's husband s fother's 's

for who, that's but a queen, fair, sober

this to your mijesty; this to the queen

the queen, the courtiers.

the king, and queen, and ail are coming

the queen desires you, to use some gentle

the queen carouses to thy fortune

hook to the queen there, ho!................

UELC queen, adieu! you that look pale - v.

quail, erush, conclude, and quelll...Nid.N.'sDr.

the guilt of our great quell?............. Macbeth,

to quell the rebels, and their .........2Henry $\nu I$. v.

your activity maj defent and quell. Timon of $A$ l $h$. iv.

quench the wonder of her infamy ... Much Ado, iv.

satiety seek to quench his thirst.. Taming of Sh. j.
the thing, she took to quench it.. Winlers Tale, jv.

might quench the zeal of all professors $\overline{\text { puench }}$

puddled mire to quench the liair. Comerly of $\mathrm{Er} r \mathrm{v}$ and quench his fiery indignation ..... suftered, zivers cannot quench ........ sap of reason you would quench......Henry VIII. i. to que low's dew quench!

the way to kindle, not to quench ..... Coriolanus, iii. lonk thee, here's water to quench it... think, in time she will not quench .. Cymbelme, to blow at fire, in hope to quencis it .... Pericles, quench thy nimble, thy sulphurous $-\bar{c}$ iil. quench the fire, the room is grown .... Othello, ii. if I quench thee, thou flaming minister ... $\overline{\text { y. }}$. quenched in the chaste beams ........id. N. Dream, ii. Hesperus hath quenched his sleepy ... All's Well, ii what hath quenched them, hath ....... Macbeli, it. blushes of hers must be quenched $\ldots$..Pericles, iv. QUENCIIING my familiar smile.. Twethih Night, ii. 
QUENCHI,ESS fury to more rage...3 llenry $r^{r} l$ i. 4 QUESTION-asked the quetion ... Timon of Ath. ii. UU ER - labour in the quern ..... Meas. Jor Meas, iv. Jasons come in quest of lier... Merchant of íenice, $\mathbf{i}$. company in the quest of him .... Comedy of Err. i. in quest of them, unlarppy, lose myself should go in quest ut beauty.......... King John, ii. 2 what lawful quest have given ...... kichurd $I I T$. i. 4 expence, can stend the quest ...Pericles, iii. (Gower) or cease your quest of love? ............... Lear, i hath sent about three several quet. QUESTANT shrinks, hes that quiction ... . Tempesi, j. 2 Quere ceuse mure qucstions............... $\overline{\text { Mervy }}$ Wives, $\mathbf{i}$. disarm them, and let them question

my daughter will I question how she - iil. does hal'm to niy wit. No question Tuelfh Nighl, i.

past question; tor thou see'st ......... -

that you call in question the continuanceand that question's out of thy part

in any constant question ...........

out of questiou, "tis DFaria's hand

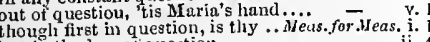

but in the loss of question $\ldots . . . . . . .$.

give me leave to question.

政

send for lim, and question him jourself

for, out of questiou, you were born.

a commodity in question, I warrant

let me but move one question to your

question? why, an lour in clamour

in the true course of all the question

Which ont of question, thesires. Mid. N.'s $\bar{D}$ ream, $\mathrm{j}$.

Irernil, question yonr desires.

therefore, be out of hoye, of question - iii. 2

was it then to ask the questions.

that spur me artion, 00 it is somet...

and out of question,

making question of my uttermost......

and I no question make, to have it

fie! wliat a question's that, it thou

think you question with the Jcw.

you nuy as well sue question with ... -

I'll stay no longer question.......

one of you question yond max......... you like

to question you about your fortunes

whence you have studicd your questir

and had me giddiuess of it in question

after some question with

\author{
= $\quad$ iii. 7
}

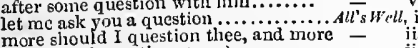

that fits all questions (rep.)....

I will be a fuol in question ............

ask questions, and siug; pick lis teeth

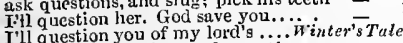

I'll question you of my lord's ....

than question how 'tis born............

have sume question in question......

has these poor men shall we try it?. Comedy of $\bar{E}$ r

a question

a burned in desire to question them..

and question this most lloody piece

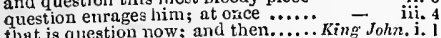

says question; $I$, sweet sir, at yours (rep.)
the haste was hot in question......... Henry $I V$.

directly to this question that $I$ ask.

licncetorth question me wlither I go
while I question my puny drawer..

a questiuu not to be asker

may breed a kind of question in our

staying no longer question $\ldots \ldots \ldots \ldots 2$ Henr

the question then, lord Hastings .....

question surveyors; know our own ...

I muse you make so slight a qucstion

question your royal thoughts

push it out of further question ........

no known quarrel, were in q

himself to question our dclay..........

heard somc question "tween you twa

out of questions too, and ambiguitie

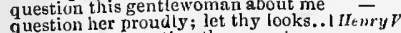

ask me what question thou canst ....

question, iny lords, no further $\ldots \ldots .$.

make answer to such questions

I'll think upon the questions........

no question of that;

to question of his apjyrehel.

withl your clioler question ..............

induce you to the question on't? .... - ij.

gour highness, the question did at first -

this is her question (rep.). .... Iroitus \& Cressid

sword was drawil about thow in hand

the clisecline the whole question.......

not move the question uf our place..

no question. Will you subscribe ....

'tis like, he'll question me ..........

during all question of the gentle truce

to answer such a question, stand again QUESTION-asked the question ... Timon of Ath. ii. 2
make I as little quetion, as he is .. Coriolonus, ii. I
no question asked lim by any .......
lis nature, there's the question.... Jutius Casar, ii. 1

the question of his death is enrolied

in Egvpt might be my question... Antony \& Cleo. ii. 2

besides this gentleman in question ... Cymbeline, $\mathrm{j}$. doctor, thou ask'st me such a question

questiun me turther to question of your king's ...... Pericles, i. 3 $I^{\prime} d$ lave it come to qucstion; if he dislike.. Lear, i. 3 one thing, of a queasy question........

made she no verbal question?

particular broils are not to question

employment will not bear question....

stay not to question, for the watch is..

was, and is, the question of these wars

encompassment and drift of question

et me question more in particulor

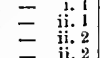

the player went to cuffs in the question.

niggard of question; but, of our demand

some necessary question of the play be.

for 'tis a question left us yet to prove

go, you question with a wicked tongue...
will not debate the question of this strai

to eartl, that 1 must call' $t$ in question

when you are asked this question next

so jump upon this bloody question ...

with more facile question bear it ........

make questions, and by them answer....

now will I question Cassio of $B$ ia

QUESTIONABLE shape...........

Hamlet 3

county, where this is questioned...

so o'ergrown camnot be questioner.

Henry YIII, i.

of my life cymbeline,

QUESTIUN iNG, that reason........... As you Like it,

questionless, with her sweet harmony..Pericles, y. I

QULUBUS-equinuctial of Queubus T'welfh Night, it. 3
QUlCK-be quick, thuu wert best ...... Tempest, i. 2

not show him where the quick freshes

I am struck to the quick ........

but you have a quick wit.

more than quick words.

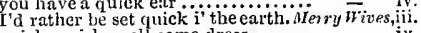

quick, quick, well come dress.

ay, come, quic

how quick and fresh art thon!... Twelfh Night, i.

hence is of so quick condition .... ifeas. for Meas. $\mathrm{i}$.

hence thee quick aw wy offence lis quick cele.......

quick, despatcl, and send the head..

that in despite of his quick wit....... Much Ato, fi.

v.

the ear moore quick of appreliension.

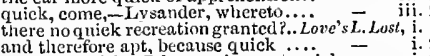

an eel is quick. I do say thou art quick -

you must not be so quick............

quick venew of wit: snip, snap, quick

ole's quick; the child brags in her
for Jaquenctta that is quick by him.

quick, quick, I pray thee, draw ....IIer.

for I long to see quick Cupid's nost.. $\overrightarrow{\text { ii. }}$

it the quick fire of youth light $\ldots . . . . . . .4 l^{\prime} s \|^{\prime} e l l$, iv. 2

quick proceeders, nuarry ! now. Taming of Shrow, iv. 2

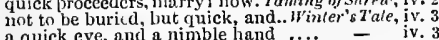

would it touch thee to the quick... Comedy af Err. ii. 2

quick is mine car, to liear of good .. Richard 11 .

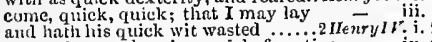

and hath his quick wit wasted .....2 IIenryII iv.

mercy that was quick in us but late .. Henry 1 . ji.

in the quick forge and working

in the quick forge and working $-v$. (chorus)

this speedy and quick appearance.... i Henry $V I$. v. 3

this speedy and quick appearance .. Henry

my cye's too quick, my lieart .......3 Henry I'I. iii.

his grace with quick and merry words

wold, dull clouds, to my quick curses !

bold, qiuck, ingenious, for ward......

reasons are too slatlow and too quick

would give it quick consideration... Henry $V I I I . \mathrm{i}$.

n woman of quick sense ...Troilus \& Cressida, iv. out of our question wipe linn

hers cestion of cordesia, and her father

he questioncd me; for I saw her.

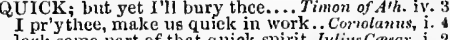

jack some part of that quick spirit. Julins Casar, i.

when our quick winds jie stiil ........ Antony \& $\overline{\text { cleo }}$.

requires our quick remove from

f)r quick accumulation of renown

quick, quick, good hands. Hold, wo.....

yare, yorc, good lrns, quick.......... - v. 2

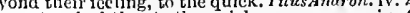

Thave touched thee to the quick

the air is quick there, picrcil
tor the guds arc quick uf ear

some provision give thee quick conduct...Lear, iii. 6

nimble stroke of quick, eross lightning?

O true apothecaryl thy drugs are quick - y. 3

I have, in quick determination, thus set - iii.

for the dead, and not fur the quick...... - iv,

pile yourck lie, sir; 'twill away again ..

be buricd quick with lier', and so will $I$.

love's quicle pants in Desdemona's arms

whom I trasli for his quick lunting .....

QUICK-ANSWERED, saucy ...... Cymbeline, iij. 4
QUICK-CONCEIVING discontents... Henry Ir' i. 3
UICK -quickens what's dead.... Tempest, iji. I

quicken lis embraced lieaviness... . . . Ter.of $\nu^{\prime}$ enice, ii.

quicken a rock, and make you dance. $A l l^{\prime}$ Well, ii.

poesy use, to quicken you .... Taming of Shrew, $\mathrm{j}$.

to quicken your incrcase ..............

quicken with kissing; had my .......... Lear, iij.

is fated to us, when we do quicken.... Othello, iij. 3

QUICKENED-the mind is quickened. Henry $V$ iv. 1

QUICKEN With youthfol spleen..... Henry H'l. iv. 6

Hyperion's quickening fire... T'imon of Athens, iv. 3

QUICKEST-on qur quickest decrees..All's Well, v. 3

QUICKLIER-will be quicklier blown up - i.

and quickly shot of ......... Tuo Gen. of Verona, ii.

you'd quickly lam to know..........
there dwelts one mistress Quickly...

le au mon pocket; depeche, quickly
my nursh -a Qnickly telt me so.......

quickly, quickiy; is the buck-basket

in Datchet-mead; quickly, come...0.

break their talk, mistrcss Quickly ..

here's mistress Quickly, eir $\ldots \ldots . . .$. .

oley him: quickly, despatch ...........

and despatch it quickly $\ldots . . . \ldots \ldots \ldots$.....

how quickly the wrong side may be

do it quickly; I'll call sir Toby......

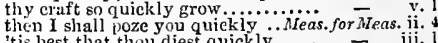

'is best that thou diest quickly $\because \ddot{1}$ -

he must awake, ind that quickly too $\overline{-}$ iv. 3

thou wouldst not quickly die $\ldots$....Mnch Mdo. iv. I

for your reason! quickly, sir ... Love's L. Lost, $v .2$

and 1 'll be with thee quickly..... As you Like it, ji. 6

who is it? quickly, alyd spenk apace $\begin{aligned} & \text { iji. } 2 \\ & \text { the lioness, who quickly fell before him }-\end{aligned}$

quiekly were dissolved from my live.. All's $W_{\text {ell, }} \mathrm{i} . \mathrm{g}$

that she may quickly come........... $\overline{\text { vo }}$ sh. 3

let them come in; but quiekly. Winter's Tre, iv. 3

there well it were done quickly .......

keep it not from me, quickly let me have - ir.

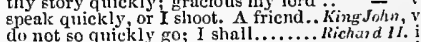

six winters? they are quickly gone...

low quickly should this arm of mine - ii.

you took occasion to be quiekly woocd -

at the suit of mistress Quickly ......2 Henry $I F$ :

and call me gossip Quickly? $\ldots$ ?..... -

neighhour Quickly, says he, receive = ii.

how quickly maturc falls into revolt $=$

the quondam Quickly for the only she -

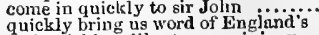

and quickly will return an injury

I should quickly leap into a wifc.... - iv.

pen, fl that you come not quickly ... Henry $\mathrm{Fl}$. i.

and will quickly yield: madam.......

we'll quickly hoise duke Humphrey.2 Henry VI. i. 
QUICKLY-yonr doublet quiekly ..2Henry $r l$ ii. wonder will be quiekly worn....

a staff is quicki $y$ found to beit $a$ dos

a staf is quickly found to heatt a dog -

bit her hide him quickly troin the duke - v. i

is slain, they'll quickly fly ..........3 lle

ind that will quickly dry

a little fire is quickly trodden out....

at hand, and you shall quiekly know

well quickly rouse the traitors in.....

wliance quickly shall call home.... Richard

vou may guess quickly what ........Ienry Vlit. ii.

how quickly wherc it gone?.... Timon of Athens, ji. and four shall quickly draw out ..... Coriolanus, i.
bring in the banquet quickly ...... Antony \& Cleo.
I an quickly ill, and well .......... bring me word quiekly $\ldots \ldots \ldots \ldots . . . .7$ - ii. 5 he could so quickly eut tic Tonian sea he'll quickly fly iny friendship too.. Cymbeli will quickly melt thy life away.. Titus Andron, iii. ay, she quickly pooped him

feel your power quickly.........................

Lear, iv.

send quickly down to tame these vile...
quickly send, be brief in it, to the eastle

he'll strike, and quickly too; he's dead

strike quickly, being moved (rep.) Ro Ro

weapon should quickly have been out

to a numnery, gia and quickiy too.... Hninlet,

power, how quickly should you speed?. Othello,

and you might quickly make it right.....

QUICK-RAISIDD power

QU ICKSAND of deceit?..............3 Henry

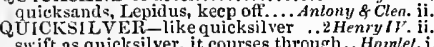

SUIft as quicksilver, it courses through.. Hninl
QUICK-WITTD folks?..... Taming of Shrem,
QUID FOR QUO-but quid for quo.i Henry VI.

QU IDDI'S now, his quillets ............. Hmmle

QUiE' $[-a$ I hope for quiet days...... Tenpest

my king, be quiet (rep.)

sice is much out of quiet.

Tierry Wives

Jove would ne'er be quiet... Mieusure for $N$ ensure,

a man may live as quiet in hell.

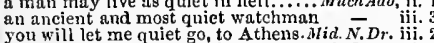

and therefore I can be quiet ....... Love's L. Lost,. .

into so quiet and so sweet a style As you Like

he hath got a quiet cateh

father, be quiet; he shall stay.....

let them go, a couple of quiet ones ... $=$ iii. $\frac{2}{2}$

and love, and quiet life, and awful rule $\overline{ }$

thought to fill his grave in quict. Yinter's $T_{\text {ale }}$

I will depart in quiet

be quiet, people (rep.)

never at quiet! what are you?

Macbet" ii. 3

nay, one quiet breath of rest

KingJokn, îi. 4

truth hath a quiet breast

might from our quiet confines
as quiet as thy father's skull

fie upon this quiet lite $1 . \ldots \ldots \ldots \ldots . . . . . .$.

the lag-end of my life with quiet hou

good captain Peesel, be

from our most quiet sphere by

descend with better quiet, better opinion

could not keep quiet in his conscience. Henry

a killing tongue, and a quiet sword..

quict thy cudgel! thou dost sce, I eat
sleep upon their quiet beds...........
now, quiet soul, depart when

quiet yourselves, $I$ pray, and be at peacc

sweet aunt, be quiet thy greatest help is quiet...........

may enjoy such quiet walks.

hou livest.3 Henry Vl. i i

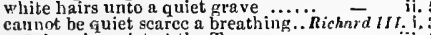

not sleep in quiet at the Tower

God give you quiet rest to-nighti...

quiet un troubled soul (rep.).......... $=$ v.

never slept a quiet hour with thee .̈ienry $\bar{V}$ III ii. 2

as well for your own quiet

a still and quiet conscience ............

good wench, let's sit down quiet...

if quiet all, be quiet

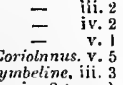

quiet consummation have

quiet consummation have ......... - iv. 2 (song
silould sleep), can breed me quicti..... Pericles, $\mathrm{i}$.

be quiet tren, as men should be

quiet and gentle thy conditions!..

senfarer, I would it would be quiet .........
disturbed the quiet of our streets. Roineo $\xi$ Julie

be quiet, or-more light (rep.).

upon receipt thereof, soon sleep in quiet $\overline{-}$ hame you had quiet guard?............

please you to give quiet pass through

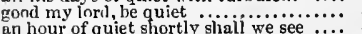

an hour of quiet shortly sliall we see .....

of spiric so still and quiet

practising upon his peace and quiet.......
QUIET-must have his quiet course .... Othello, iv. QUIE'TLY enjoy your hope

that he should quietly reign

Henry

let me pass quietly ....................... of sthens, iii.

quarrels must be quietly debated.Titus Andron.

to live quietly, and so give over ....... Pericles,

QUIETNESS of spirit, the very ...Mer. of I'enice.

stablish quietness on every side ..... i Henry $V I$. v.

I would have peace and quietness 3 roilus o $C$ Cress. ii. peace and quietness o' the people .. Coriolnnus, iv. $O$, quietness, lady! she is dead to 0 .. - iv. 13

QUIETUS make with a bare bodkin? .. Humlet, iii. deliver our supplications in the quill..2 Hemy $V 1.1 .3$ like quills upon the fretful porcupine... Hamlet, $\mathrm{i}$.

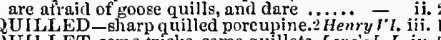
these nice sharp quillets of the law ..1Henry $V$. i. ii. 4 do not stand on quillets ............ Henry VI. iii. uor sound his quillets sliriliy........... pr'y thee, keep up thy quillets...

Othello, iii.

QUINT-blown Jack? how now, quilt? QUINCE [see PETER]

they call for dates and quinces . Romeo \& Juliet, iv.
QUINTAYN, a mere lifeless .........As you Like it, what is this quintessence of dust? ....... Hantet, ii. QUINTUS Publius and Quintus ... Coriolmnus, no quips now, Pistol qu.

slall quips, and sentences

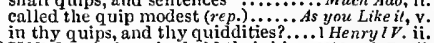
in thy quips, and thy quiddities?.... Henry $l \mathrm{~V}$. ii.
QUIREplaced a quire of such enticing birds. 2 Henry $V I$. i. 3

nur cage we make a quire
QUIRED with my drum

Cyinbeline, iii.

QUIRK -a man of that quirk ..... Tuelfih Night, iii. I some odd quirks and remnants of wit. Much Ado, ii. 3 ehe lias me her quirks, her reasong...... Pericles, iv. 6 QUIT-very rats instinctively had quit it. \%'empest, i. 2 and quit the vessel

or that we quit this place ............... your master quits you their own part, and with ........ Teas. for Meas. ii. 4 I quit them all

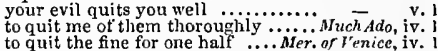
till thou canst quit thee by ......... As you Like it, iii. I never harmed me, here I quit him....All's Well, v.
Hortensio will be quit with thee. Taming of Sh. iii. forbear; quit presently the chapel. Winter's Tale, v. 3 quit the penalty and to ransom.. Comedy of Err.i.

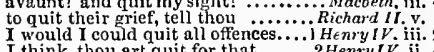

I think, thou art quit for that

dies this year, is quit for the next..... Gen $^{-} \mathrm{V}$ iii.
God quit you in lis mercyl

have you quit the mines?

- iii. 2

let us quit all, and give our vineyards = ifi. 5

at all ad ventures, so we were quit here $\overline{-}$ jv. 1
many wonld the peaceful city quit

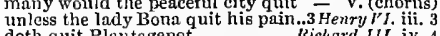

doth quit Plantagenet

children's chitdren quit it in your age z iv. 4

God safely quit lier of her burden..Henry VIII. v. I

to be full quit of those my banishers. Coriola

and say Gol quit you! be familiar.

as he shall like, to quit me ...........

contradiction you shall now be quit.

let's quit this ground, and smoke
to quit the bloody wrongs upon...

...Tilus Andron

now quit you well: yield; cone before ... Lear

to quit this horrid act

and quit the house on purpose $\ldots \ldots \ldots \ldots . . . . .7$ iv. 2

to quit him with this arm? pains... Romea o Jul. ii.

or quit in answer of the third

omittance is no quittance............ As your Like it, it.

rendering fnint quittance, wearied ..2 Henry $I . i .1$ than quittance of desert and merit

exceeding all use of quittance...

i HenryVI. ii.

UIT'EING with this young prince... W'inter's Tale, v. I

QUIVER-all his quiver in Venice.... Much Ado, i. 1

leaves quiver in the cooling wind. Titus Anuron. ii.

cvery part ahout ne quivers ..... Romeo \&-Juliet, ii.
QUIV ERING thigh.................

QUOIFS and stomalhers .. Irinter's Tale, iv. 3 (song and heree, thou sickly quoif $\ldots . . .$. .2 Henryll UOL' him down, Bardolph, like....2 Hemry $l^{\prime}$. ii. 4
QUONDAM carpet-mongers ..........Much Ado, v. 2

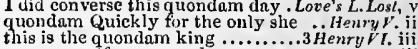
you yourself, our quondam queen

your quondam wife swears still. Troilus of Cress. iv. nority , Love's L.L. v. own margent did qoote such amazes. Love'ser. it. we did not quote them so ............. eye doth quote deformities?...... Romeo \& Juliel, $\mathrm{i}$. morked, for a most perfidious slave ..All's Well, v. marked, quoted, and signed to do ... King John, iv. and qudgment, I had not quoted lim ... Hamlet, ii. QUO'TH-quoth hel that a monster ... Tempest, iii. quoth I, you mean (rep.) .. Turo Gen. of I'erona, iv.
air, quoth he, thy clheeks.. Love's L. Losl, iv. 3 (ver.) did they, quoth you? who sees ..... - iv. veal, quoth the Dutelimain no point, quoth I; my servant ........ $\overline{\text { poor }} \overline{\text { dike }}$ it, vuot. poor deer, quotli he (rep.)............ ys you Like it, ii. ool, quoth I; no, six, quoth he (rep.) - i. let me not live, quoth he, after my....All's $W$ ell, i. this tair face the cause, quoth slic.. - i. 3 (song) frets call you these? quoth she...

ay, by gogs-wouns, quoth he (rep.)... - iii. give me, quoth i: aroint thee, witch! ... Mocbeth, i. 3 at hand, quoth pick-purse.............. Richenty $I V$.

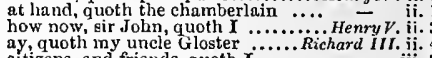

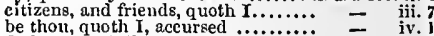
O thus, quoth Dighton (rep. $3 . . . . . . . .$. - iv. if, quoth lie. I for this had been...... ilenry $V_{H I 1}, \mathrm{i}$. I do. quoth be, perceive, my king is - iii. my incorporate friends, quoth he ... Coriolnnus, i. . good friend, quoth he, say ... Anlony \& Cleapatra, i. wilt thou not, Jule? quoth he.... Komeo of Juliel, l. yea, quoth my husband, fallest ........ $=$ i. quoth she, before you tumbled... Hamlet, iv. 5 (song)
QUOTH'A-humour of it, quoth'a.. Merry Wives, ii. one in ten, quoth'a! an' we might ......All's Well, i. ah, sirral, quoth'a, - we shall ........ Henry Hen $1 \mathrm{r}$. sweet, quoth' $a$ ! sweet sink : Troilus के Cressida, $\mathrm{y} .1$ die, quoth'a? now gods forbid! ......... I Pricles, yi. 1 for himself to mar, quoth'a?.... Rnmeo \& Juliet, ii.
QUJO'TIDIAN of love upon him ...As ynu Like it, $\mathrm{iii}$ of a burning quotidian tertian......... Henry $\nu$. ii. 1

RABATO-other rabato were better...Much Allo, iij. 4 $R A B B I T-l i k e$ a rabbit on a spit.. Love's $L$. Lost, ii. I
for parsley to stuft a rablbit .. Taming of Shrew, iv. 4 away, you whrreson rabbit, awayl..2 Henry $I V$. ii. RABBLE-bring the rablle, o'er whom. Tempest, iv, 1 a rabble more of vile confederates. Comedy of Err, $v$. baited with the rabble's curse .......... Macbeth, y. 7
and followed witl a rnbble .......2 Henry $V 1$. ii.

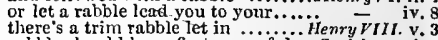
there's a trim rabble let in ........ Henry VIII. v. 3 and make the rabble call our cares..

and your disordered the rabble

the rabble call him lord .................. Hamlear, iv, 5

ACE-but thy vile race.............. T'empest, i.

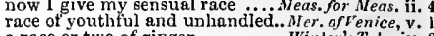
a race or two of ginger $\ldots \ldots \ldots \ldots \ldots$ Winler's Tale, iv. 2 the minions of their race, turned............acbeth, ii. unto the drowsy race of night ....... King John, iil. 3
never of the Nevils' noble race ...2 Henry $r$. iii. 2

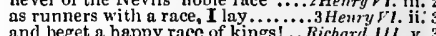
to the whole race of mankind.. Timon of Alhens, iv. 1 so pnor, but was a race of heaven. Anlony \& Cleo. i. 3 forborne the getting of a lawful race iii. 11 upon a valiant race, thy harsh ...... Cymbelime, v.
lacks she none of noble race.... Pericles, $v$. (Gowcr) RACK - I'll rack thee with old cramps.. Tempest, $i$. and rack thee in their fanciesi............ for Meas. iv. take him hence; to the rack with him

why, then we rack the vali...

I live upon the rack $(r e p$.$) .. Merchuni or V$ Ado, iv. I

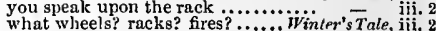
or all the racks in the world.......... HerryI 1 . ii. 4 like a man new haled from the rack.1 Henry $V i$. ii. 5 a thought, the rack dislimns ...Antony \& Cleo. iv. it

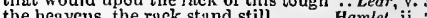
thou last set me ou the rack

$R A C K E D$ set me on the rack Jihelto, iii. 3 that shall be racked, the commons hast thou racked .....2 Henry ${ }^{2} l^{\prime}$ i say, he be taken, racked, and tortured

RACKERS of orthography ........... Love's $L$. when we have matched our rackets ...Herry $l$;. i. 


\section{RAC}

IRACKING - with the racking elouds. 3 Henry $V^{\prime} I$. ii. I IRADIANCE-in his briglit radiance ...All's Well, $\mathbf{i}$. 1R.ADIANT queen hates sluts ....... Merry W'ives, v. 5
most radiant, exquisite, and ...... Twelfh most radiant P Pramus. ..... Midid.N's Dream, ii. to hide me from the radiant sun .... Cymbeline, $\mathrm{i}$. he is entered his radiant roof ..........
his favour with the radiant $\mathrm{Cymbline}$

though to a raoiant angel linked
RADISI - I am a bunch of radish 二 $\quad$ v. Hamlel, i. . RAFT_on the fatal raft?...... Comedy of Errors, y. you rac rou bageate.

you rag, you baggage ................ awas, thou rag, thou quantity .. Taming nf Sh. iv. pluck but off these rags...........Winter's Tale, iv. 2
need of more rags to lay on thee..... iv. 2
her rags, and the tallow in them. Comedy of Brr. iit. 2 surely, master, not a rag of money

of old death out of his rags Suffolk, muffled up in rags! ( 7 rep.)..2 2 Henty VI, iv. thou rag of howour! thou thy father, that poor rag ....... Ti . whose rags shamed gilded arms arm it in rags, a pigmy's stra

to very rags, to spitit the ears of the....... Hamlet, iii. RAGAMUF FINS where they are.... HenryI . . the fire's extreme rage .... T'wolien. of Verona, $\mathrm{ij}$. 7 impatiently doth rage

of his rage, skill, furs, and ........ Twelnh Night, iii. in his rage and his wrath give preceptial medieine to rage ..... $-\mathrm{v}$.

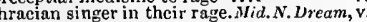
lion rough in wildest rage doth roar.

food for his rage, repasture for ... Love's L. Lost, iv, the very tyranny and rage of lis. $M$ Mer.offenice, iv. so stockish, hard, and full of rage ... how it rages, how it takes up.... Winter's Tale, iii. this present instance of his rage. Comedy of Err.iv. 3 and did not $I$ in rage depart from

all in rage, to-day came to my

brake into extremity of rage

any thing his rage did like........... Macbeth, iv. ghal we rive the signal to our rage..King John, ii. and, in their rage, 1 having hold

a rage, whose heat hath this

thy rage shall burn thee up ....

for my rage was blind, and foul.

or staring rage presented to.............

lest $r$, by marking of your rage, forget - iv.

the Dauphin rages at our very $\ldots \ldots . . .6$ Richard $1 . . .1$.

rage must be withstood..

being raged, do rage the more.

to enjoy by rage and war...........

the rage be his, while on

with rage to be o'erpowered...

when $I$ was dry with rage

it doth present harsh rage

before the Douglas rage $\ldots . .2 \mathrm{Henry} i v$. (induction)

guarded with rage, and coun ten ance

when rage and hot blood are

and make thee rage; thy Doll ...... - v. -5

thy rage, abate thy manly rage (rep.)
in his rages. and his furies .........

and with wild rage, yerk out their... - iv. 7

and left us to the rage of France... I Henry VI. iv. 6
and warlike rage, beat down Alengon
die not with Frenchmen's rage ......
iv. 6
iv. 6

commence rougln deeds of rage

fury, and great rage of heart

there goes our protector in a rage ...2 Henry $l^{\prime} l$. $i$.

and stop the rage betime

and stop the

thy worcis move rage, and not remorse - $\begin{gathered}\text { iv. } 1 \\ \text { who, in rage, forgets aged contusions }\end{gathered}$

your quenchless fury to more rage ...

sind when the rage? why

whiles the foe doth rage.................

and Warwick rages like a chafed bulI

that was in thy rage: speak

love, the devil, and my rage ........

AGE, provoked by him and rage, and foam, to be exalted...Julius $\bar{C}$ assar their servants to an act of rage

thy peace, for moving and rage ....... when one so great berins to rage

thou mine ancestor, thy rage

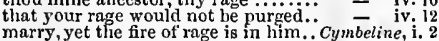

what his rage can do on me..........

go in, and cheer the kin, $r$; he rages nor the furious winter's rages .....
if the winds rage, doth not 2 (song)
the emperor, in his rage, witi doom ... till that his rage and anger be forgot

could I rage and roar as doth the sea

to rage the city turn .............
till the speed of his rage goes slower

the king is in high rage..............

with eyeless rage, catch in their
crack your cheeks! rage! blow

when the foul fiend rages, eats ....

not to a rage; patience and sorrow

could beguile the tyrant's rage

the great rage, you see, is cured

continuance of their parents' rage. Rom. \& $J u \bar{l}$. (prol.)

quench the fire of your pernicious rag

and, in this rage, with some great.

in rage, strikes wide...

asleep, or in his rage $\ldots \ldots \ldots \ldots . . . . . .$.

how much I had to do to calm his rage

as men in rage strike those that wish

$A G E D$, do rage the more

tant so rageth in him. Lear, i. 2

with great ragged hurns ............ Merry ifives,

overweathered ribs, and ragged... Mer. of Veniee, ii. 6 a wretched ragged man, o'ergrown ...
were ragged, old, and beggarly ... I'aming of $S h$. iv. 1

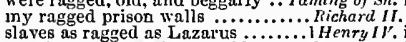

slaves as ragged as Lazarus $\ldots . . . . . . .24$
ten times more dishonourable ragged
worm-enten hold of ragged stone..2 Henry $I V$.

worm-eaten hold of ragged stone

you see what a ragged appearance

that 1 will beg a ragged and forestalled $\bar{v} \mathbf{v}$

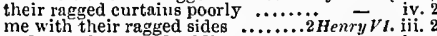

and sent the ragged soldiers

chained to the ragged staff

Richard, but a ragged fatal roc on the ragged stones beat forth ... - $\mathbf{v}$ ragged misery [Col. Knt.-thy back ]. Romeo \&. Jul. y. I
RAGGEDNESS, defend you from ........ Lear, iii. 4 RAGGED'ST hour that time.

2 Henryll $r$. i.

the raging rocks, with shivering. Mid.N.'s Dream, i. time it is, when raging war is done... $\bar{v}$, v. provoked with raging ire

more furious raging broils........

whetp of Talbot's, raging wood ......
this spark will prove a raging fire..2 ${ }_{\text {Hen }}{ }^{\prime}$ I. iij.

1 should be raging mad, and ery out _ iii. 2 eveu where his raging eye what $r$ aging of the sea? roilus \& Cressida, i. of $\bar{A}$ hens, raging hattery upon shores of.. Pericles, jw. 4 (Gower raging with thy tears ........... Romeo \& Juliet, iii.
to cool our raging motions, our carnal ... Othello, i to cool our raging motions, our carnal ... Othello, $\mathrm{j}$. RAGOZZINE, a most notoriou ...Meas. for Meas. iv. 3 With the visage of Ragozine.........

RAIED with the yellows ....... Taming of Streas, iii. though he do nothing but rail .... Tirelfh Night, i. he rails, even there ............ Herchant of Venice, $\mathrm{i}$. till thou canst rail the seal ........... we two will rail against

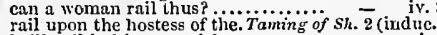
rail upon the hostess of the

say, that she rail

and rails, and swears, and rates

did not her kitchen-maid rail .. Comedy of $\bar{E}_{\mathrm{r}}$ iv. why rail I on this commodity?....... King John, ii. I will rail, and say, there is no ........
why do $I$ rail on thee, since thou .... in all despite might rail at him .....3 3lenry rl. ii. 6 rail on the Lord's anointed....

you i' the camlet, get up o' the rail. Henry 'III.

rails on our state of war ...... Troilus
I sliall sooner rail thee into wit .......

proclamation, and he rails upon

good Thersites, come in and rail

an' you begin to rail on society. Timon of $\overline{\text { ath }}$

such may rail ayainst great... this tiger-footed rage, when it shall..
with Aufidius, rages upon our territories -

wot to allay my rages and revenges.. iv. 6
v. 3
and let me rail so high, that .........
RAIL-winds that sailors rail at

that I might rail at lim to ease... TilusAndron. ii.

see how yon' justice rails upon yon'...

'faith, I must, she'll rail in the street ..... $-\bar{n}_{0}$ iv.

AILED-and railed at me. TwoGen. of Verona, iii.

railed at herself, that she should be... Nuch sdo, ii.

because 1 have railcd so long against

thou hast railed on thysclf.........As y'su Like it, i.

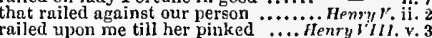

ould beat him, whilst he railed. “Troinus\& Cress ii

being down, insulted, railed, and put i... Lear, ii. 2
RAILER-likeness of this railer here.3 Henry ${ }^{\prime} I$. y. 5

RAILEST-grumblest and railest. Troilus \& Cress. ii.

why railest thou on thy birth ... Romeo \& Juliet, iii. 3

RAILING - nor no railing in........ Twelf call you this railing? ................ As you Like it, iv. 3 were hindered by thy railing .......... a railing wife; worse than........... Henry $I T^{2}$. iii.

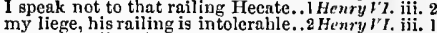
n seurvy railing knave....... Troilus \& Cressida, v. what raiment will your.... Taming of Sh. 2 (induc.) ne'er ask me what raiment I'll wear - 2 (induc.) yea, all my raiment, to my petticoat - ii. wear them like his raiment . Timon of Ahens, iil. RAIN-heavens rain grace on that ..... Tempest, iii. let the sky rain potatoes ........... Merry Wivcs, y. 5 the wind and the rain (rep.) ...... the rain it raineth every dav (rep.) - v. 1 (song) drowned $\mathrm{i}$ the last rain?... Measure for Meosure, iii.

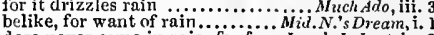
dare never come in rain, for fear.Love's L.Lost, iv. 3 in measure rain thy joy.... Alerchant of l'enice, iii. droppeth, as the gentle rain from hearen - iv. pufting with wind and rain? ...........

clamorous than a parrot against rain - iv. rain a shower of commanded Taming of Sh. $\bar{l}$ (induc.) it will be rain to-night ............... iii.

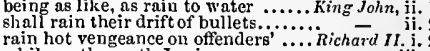
while on the earth I rain my ........... to rain upon remembrance............2 Henry $I V$. ii. to watch in darkness, rain and cold... i Henry $v s$. ii. nor let the rain of heaven wet........2 Henry $V I$. iji. 2 when the rage allays, the rain begins.3 Henry i t i. and mucls rain wears the marble..... rain, to lay this wind......... Troilus \& Cressida, iv. like conies atter rain, and revei ..... Coriolanns, iv. a shower of rain as well as Jove. Antony $\delta$ Cleo. i. unrelenting flint to drops of rain . Titus Andron. ii. befriend thee more with rain ......... inericles. wind, rain, and thunder, remember.... Pericles, 1 . the to and fro conflieting wind and rain... - iii. spit, fire! spout, rain! nor rain, wind.... - iii. z
sucl groans of roaring wind and rain... heiglh ho, the wind and the rain... - iii. $\overline{2}$ (song for the rain it raineth every day.. - iii. 2 (song you have seen sunshine and rain at once $=$ iv. when the rain came to wet me once...... $-\overline{\text { iv. }}$ is there not rain enough in the swect.. Hamlet, iii,

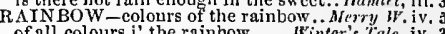
another hue unto the rainbow .... Winter's Tale, iv AIN ED-of blood, rained from...... Richard It. iii. my power rained honour............ Henry r III. . . and in his grave rained many... Hamlet, iv 5 (song) RAINETH every day (r.p.).. Tuetifh sight, $y .1$ (son:for the rain it raineth every day .. Leur, iii. 2 (song
RAINING the tears of lamentation. Love's l. Lost.y. RAIN-WATER-than this rain-water .. Leor, iii. with rainy marching in the painful ... Henry $r$, iv. mine eyes were rainy like to his.. Tiins.Andron. v. I
RAISE up the organs of her........ Merry Wives, v, s be gar, I'll raise all Windsor.......... fer $-\bar{M}_{\text {eas. }} \mathrm{v}$. to raise a present sum............ Merch. of Yerice, $\mathrm{i}$. instantly raise up the gross of ...... - i. will raise the price of hogs (rep.)...... powe up such a storm, that mortal. Trming of Sh. i. for this business will raise us all. Winler's Thle. ii. and raise the power of France upon. King John, iii. [Col.] if you raise this house ........ Richard 11 . iv
if thou hove power to raise lim.... Herry $1 \%$. jii. and raise this present liead ........... Hen.
raise your highness such a miglity sum. Henry

rais your heady to raise so great a siege.. - ii. 3 from her llood raise uy issue to me.... a great power to raise the siege........ - i. to advance or raisc myself

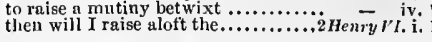


RAISE, we will make fast ..............2 Henry $f^{\prime} l$. i. 4
shouldst raise so great a power without and raise his so great a pover without to raise my state to titte of a queen.

sun shall raise his car above

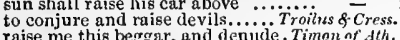

raise me this beggar, and dentide. Thun ath in.

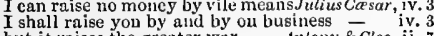

but it raises the grcuter war ......Aniony \& Cleo. ii.

I'll raise the prepination of a war $\because$ witu

the Goths, and raise an army there Thusdndron. ini.1

first framed flesh to raise my fortunes ... Lear, iv.

raise a spirit in lis mistress' circle.
I conjure but only to raise up him

the Capplets, raise up the in intagucs
for $I$ will raise her statue in pure gold

for I will raise her statue in pure gold

get more tapers; raise all my kindred... Olhello, $i$. RAISED in me an undergoing stomacl. Tempest

whith outcries raised the duke $\ldots$ iser.... of $V$ enice,

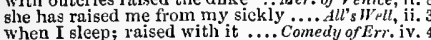
when 1 sleep; raised with.

until a power be raised to put.....

that raised him to the crown $\ldots \ldots . .3$ Henry $V I$, iii. by him, that raised me to this .......Richard IIt. i. who first raised head against........Henry $\vec{F} / 1$.

whose hand las raised me $\ldots \ldots . . . . . . .$.
of learning, that he raised in you $\ldots$ ii. deserves an heir more raised.... Timon of Athens, i. raised only, that the weaker

raiscd by your populous troops.........

than is the stone whereof'tis raised

moke raised [Col. Knzt.-made] with. Romeo \& Jul.

he raised a sigls so piteous and profound. Hamlet

lead to the Sagittary the raised search... Othello,
the raised fatlier, and his friends........

many of the consuls, raised, and met

many of the consuls, raised, nor doth
hath raised me from med; noor
look if my gentle love be not raised up

RAISIN-as many of raisins....... Winler's Tale, iv

RAISING this sea-storm?

must answer for your raising
till, raising of more aid

our heads by raising of a liead
raising up wicked spirits from

in your hearts, there will he rake for it. Henry $V$. ii. 4

our pikes, ere we bccome rakes........Coriolanus, i.

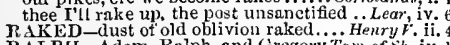

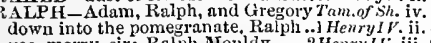

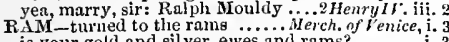
is your gold and sil ver, ewes and rams? a crooked-pated, old, cuckoldly ram,

but the fight of two rams, and Cxsar's - v.

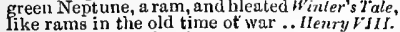

so that the ram, that batters.. Troilus \& Cressida, i. 3

be the ram, to batter the fortress. Antony \& Clea. iii. 22

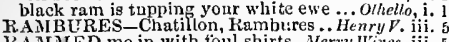

RAMNED me in with toul shirts... Merry Wives, iii.
have we rammed up our gates against. King Johth, i.

RAMP-vaulting variable ramps .... Cymbetine RAMPANT bear chained to the

RAMPING-thou, a ramping fool..

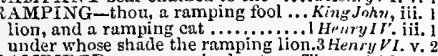

RAMPIRED-Our rampired gates... Timon of Allh v. 5

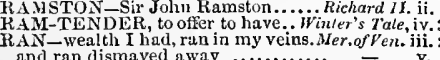

and ran dismayed away ............ how the horses ran awa ....Taming of Shrew, iv. 1 that 1 , alnazed, ran from her..

your wife, now ran from you ........

immediately ran hither to your grace

there ran a rumour of many ............
bloody looks, raul fearfully among..

and still ran and roared, as ever

you ran away upon instinet

faith, I ran when I saw others run

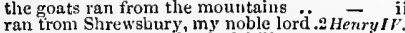
when your ran away by Gadshill

that he ran mad, and died

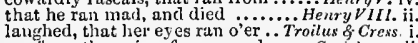

ran

ran Cassins' dagger through

that ran through Cxesar's bowels.

of 'troy ran mad through sorrow. TitusAndron.

he ran this way. and leaped this. Romeo \& Juliel ii

which way ranl he? There hies that.

$[K n t$.$] and they ran well on horseback. Hamlet.$

ran it through, eveu from my boyish days. Othello, i.

the fresh streams run by her......
RANCOROUS outrage of your.. Comedy of 3 (songs)
Errors, i. 1 respecting whint a rancorous inind..2 Henry $V J$. iii.
be scoured in his rancorous leart....
must

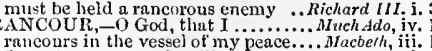

raneours in the vessel of my peace....... Macbeth, itit.
from the rancour of a villain......... Richerd $i I . \mathrm{i}$.

rancour will out: proud prelate.......2 Henry $r t_{\text {. i. }}$.

the brokell rancour of your ligh .... Richard 11 . ii.

stab of rancour I misdoubt ............

RANDON-I writ tit random.. Two Tentof Verrana, ii.

RANGE le did range the town....... Trelfhh Night, iv.

his affection, ranges evenly with mine. Much. Ado, ii. 22

wherein you range under this

in the battle range about

all, whice yet distinutly rers

Henryl'LII. ii. 3

whose several rod tramyy range on. Jutius Casar, ii,

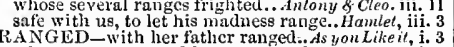

where most trade of danger ranged... 2 llenryy $I V$
arch of the ranged empire fall! .. Antony \& Cleo.

arch of the ranged empire fall! . Antony \& Cleo. i.

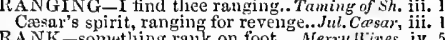

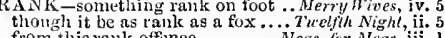

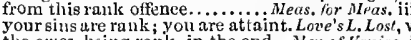

the ewes, being rank, in the end... Mer'of of 'tenice, 1.3

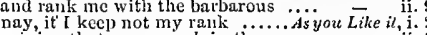

opinion thit grows rank in them.....

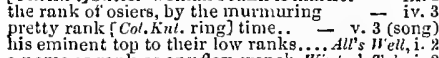

a name as rank as any flax-wench. Winler's Tale, $\mathrm{i}$.

in the stout Norweyan ratks ............Macbeth i. i.

from forth the ranks of many
well-beeenning ranks marcli

what rank diseases grow
to diet rank minds, sick of

to diet rank minds, sick of ...........

why, all our ranks are broke
hemlock, and rank fumitory

Rich ard $r I$ i.

all uncorrected, rank, conceives by

our ranks are broke, and ruin rest.$_{3}$. -1 to rank our chosent trutl with
ha! what, so rank? Al, ha!
he's a rank weed, sir Thomas....

when rank Thersites opes lis.
how rank soever rounded in

maturity blown up in rank Achilies

made of our rank feud int...............

bring in tliy ranks. but leave . Timon of $\overline{\text { ththens }}$ iv. in ranks; and squadrons, and right.JuliusCersar, ii. 2 that tuassailable holds on his rank..
be let blood, who else is rank..........

and his well-paid ranks, that ......... breaths, rank of gross diet.

would he had been one of my ravi.... Cymbeline, ii. in rank and not to be endured riots....... Lear, i. stands in some rank of praise
yours in the ranks of deatl.....

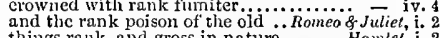

things rank, and gross in nature.......... Hamlet, i. 2

of the best rank and station, are most.....
none so rznk as may dishonour him

thou mixture rank, of midnight weeds... $=$ iii. 1

o, my otrence is rank, it smells... $\ldots . .$.

whiles rank corruption, mining all
$[K n t$.$] o'er the weeds to make then$

[Knt.] o'er the weeds to make them rank $=\mathrm{ini}_{\mathrm{ij}} 4$

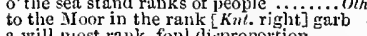

a will most rank, fonl disproportion .... - iii. 3

ANKED-as tiirly rauked .... Mid. N.'s Dream, i, J

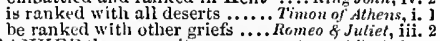

RANKER than my wit..............As yon Like
weeds, to makc them ranker [Kint.rank] Ha

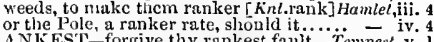
there was the rankst cotnpound . Merry Wives,

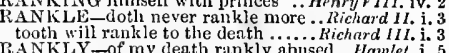

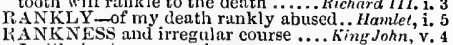
I will physic your rankness

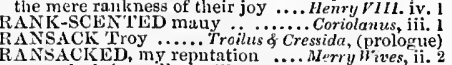
ransacked the peiler's silken ........'Mrtinter's Tale, iv.

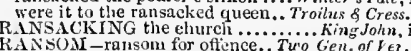

in ransom, and free pardon ..... Meas. for Meas. $\mathrm{ii} .4$

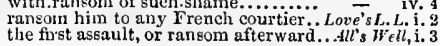

with ranks of toreign lowers
and fill up ler enemies' rank

ow rank soever rounded in ....Troilus \& Cress. i.
LiANSOM -can never ransom nature...All's Well, ii. ransom, ransom; do not hide mine eyes
the penalty, and to ransom lim... Comedy of $E_{x p}$

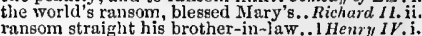
to ransom hoine revolted Nortimer...

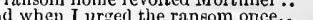

he said, he would not ransom Mortimer

prisoners' ransom, and of soldiers siä there without ransom to lie forfeited

or achievement, offer us his ransom.. Henry $\nu$. what willing ransom he will give....
consider of his ransom ............

my ransom, is this frail and worthless my ransom tben will soon be levied

come thoul no more for ransom (rep.)
du give to me egrcgious ransom.....

and for his ransom, he will give you

ranson? comest thou again for ransom?

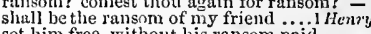

set him free, without his ransom paid
what ransom must I pay before I pass? =

that is her ranson, I deliver her $\ldots . .$.
words were ransom for their faut. 2 Henry

the world slall not be ranson for....
make their ransom on the sand......

what is my ranom on the sand

take ransom, let him live ...

as for these whose ransom $\ldots$ we have set

the ransom of my bold attenpt .... Richard III. v.

ransomend hid the ransom .......... Timon of dithens, $\mathrm{i}$.

men did ransom lives of me..... Antony \& Cleo. iti. i

but our lives nay be aalled ranso...... Cymbeline, v.

be the ransom tor their fiult .... Tilus.Andron. iii.

use me well; you slinli have ransom .... Lear, iv.
can ransom me into his love again ... ot hello, iit.

RANSOMISD-a world ransomed... Wincer's Tale, v. so should lie be sure to be ransomed.. Henry $V$. ransomed and we ne'er the wiser.

rasomed, and we ne er the wiser.....

a B Briton horn, let him be ransomed... Cymbeline, v.

ransomless here we set our prisonc..... Henty $1 \%$. v. RAN'ST-and yet thou ran'st away... Henry $\$$ \% ${ }^{\prime}$. ii.

WANT-I'll rant as wela as thion

Hamlet,

RAN'TNG host of the Garter........Merry Wives,

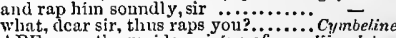

RAPE upon the muiden virtue of ....... King Joline,

for rapes and ravishments he parailicls. All's irell, Ehanl repent tlis rape. Rape, eall... TilusAndron. i. fitted by kind for rape and villany .

made for murders, and for rapes

for villains marked witl rape

talk of murders, rapes, and massacres

hloody murder, or detested rape......

a villain that hath done a rape.

Rape is the other's name
RAPIE1 - hat ard rapier in

take-a your' rapier (rep. ii. m) cell ..... Tempest, v.

hath good slkill in his rapier............ rapier, scabbard, and all ............... Night, iii. the rapier and dagger man ............... foas. for $\bar{M}_{\text {eas. }}$. iv. 3 do excel thee in my rapier ....... L.ove'sL.Lost, i. rust. rapier! be still, dr'uml...........

forged, with ny rapier's point........ Richard IJ. iv.
give me my rapier, boy............. Henry IV. ii.

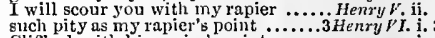
Clifford, with his rapier's point ..........
sheathed iny rapier in his hosom. Titus Andron. it. the tadpole on my rapier's point
fetch me my rapier, boy ........... gentle Mercutio, put thy rapier up ... spit his body upon a rapier's point.$\ddot{\text { thips }}$ - iv. for your rapicr most especial .........

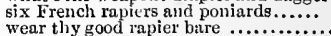

RAPINE and Murder (rep.)...... Titus..... Andronicullo, $v$. $v$.

good Rapine, stab him .......
RAPPED 'em o the coxcombs

APT - that he scems rapt withal ........sfacbelh, i. 3

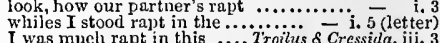

fou are rapt, sir, in some work.. Timen of Alhens, i.

I'm rapt, and cannot cover the .......

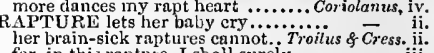

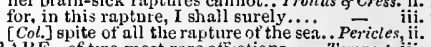

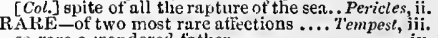

so rare a wondered father..............
some rare note-worthy object ... Tuo Gen.of $\mathrm{rer}$. i . makes a rare turkey-cock of him. Ticelfh Night, that youth's a rare courtier: $\ldots \ldots \ldots \ldots=$ wiil you are a rare parrot-teacher.......... Mnch $A d o, i .1$ 


\section{RAR}

RARE-Vulcsn a rare earpenter? ....... Aruch.Aclo, i. I RASCAL_arrant eounterfeit raseal

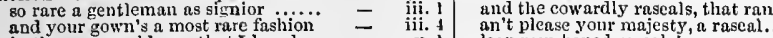
in the rare semblanee that $I$ loved $\ddot{\text { in }}-$ v. I divine, and rare, prceious $\ldots . .$. Alid.N. soream, il. 2 are talent1.......... Love's L. Losl, iv. 2 a rase taleatl Love'sL.Losl, iv. 2

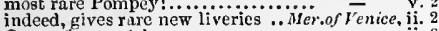
O rare tortune! here comes............ $\overline{\text { ii. }} 2$ were man as rare as of rare and proved effects, sueh as .......Allys well, i. 3 in so rare-1 know not

none rare, my lord $\dddot{3}$ a............. a

a daugliter of most rare note .........

performed by that rare Italian master - - v. 2 and so beeome a rare hangmain

nothing pleasetl but rare aceidents..

$O$ rare $i$ lie doth it as like one.........

their censure of these rare reports..

for his rare suecess in arms ...........

your wondrous rare description.

if thy rare speaker, to nationenryllit. i. 2 if thy rare qualities, sweet gentleness there's Achilles, a rire engineer.Traihus oress. ji. 3 his eom posure must be rare.. Anlouij ó Cleopatra, $\mathrm{i}$.

O rare for Antony! IIer gentlewomen

lived in court (which rare it is to do).

a touch more rare subdues all

in the cleetion of a sir so rare.........

'tis plate, of rare device; and jewels.

that what's else rare, is choked .

a most rare boy, of thelancholy! ....

a book? O rare one! be not, as is ou

fair ereature, rare as you seem to

is not this strange? Most rare...

can be valued, rieh or rare ..........

no cataplasm so rare, eollected

doth not my wit become me rarel $\%$ inuch Ado, iii.

I could play Ercles ravely ..... Hid. N.'s $\overline{\text { Dream }}$ ii. 4 thy offices, so rarely kind

how rarely does it mcet with.. Timon of Alhens, iv. rarely, rarely: he that uubuckles Antony \& Cleo.iv, 4 O rarely base! good queen ...........

be so rarely and exactly whought

ruAENESS - and won by

such dearth, and rareness, as, to make... Hamlet ii.

IARER-the rarer action is in virtue

as our rarer monsters are.

a rarer spirit never did steer

Why, 'tis the rarest argument of.........All's Well, ii. 3

he is simply the all womed

than any the rarest of our ladies.

forget that rarest treasure

amongst the rarest of good one

this is the rarest dream that $e^{\prime}$

n't please your majesty, a raseal.

the harvest which that rasial sowed

the rascal people, thirsting after

leave your noise anon, ye raseals ...

you rascal! Peace, tool; I have.. Troitus

those erafty swearing rascals, - that stale -

no, no; I am a rasenl; a scurvy .......

turn rascul; hndst thou weal
raseal thieves, liere's gold.

rascal thieves, here's gold.............

thou rascal, that alt worst in blood. Cort

from rascals worse than they.

to lock sueli raseal counters fror

here comes a ftatiering raseal.

no, nor thy tailor, raseal, who is thy

a knave; a rascal, an eater of brokc

draw, you rascal: you come with (rep.).

you coward y raseal, nature disclaims
thou raseal beadle, liold thy bloody hand

a dull and muddy-mettled raseal...

youl rogue! you raseal! What's the ..... Othello,
to lash the raseal naked through the world

RASCALLIEST, sweet young prince.1 Henry $I V$.

RASCAL-LIKE-not rascal-like.... Henry $/$ I. iv.

rascally sheep-biter come

ingenious, foolisl, rascally knave .......Alt's $W$ ell

away, you rascally Althea's dream

you poor, base, rascally, eheating

a rascally slave! I will toss

what an arrant, raseally, beggarly ... Henry $\boldsymbol{V}$. iv.

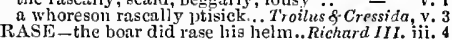

RASED-boar had rased of his helm - iii. 2

as fiom thenee sorrow were ever rased.. Pericles, i. 1

lest I might be too rash...... Hea

not rather make rash remonstron

tarry, rash wanton; am not I.. Mid.. N.'s s - rexm, ii.

our rash fiults make trivial.

that with no rash potion, but........ Winter's Tale, $\overline{\mathrm{i}}$.

rash, ineonsiderate, fiery voluntaries _. King John, ii.

his rash fieree blaze of riot. ....

jesters, and rash bavin wits ......... Henry IV

be not so rash; take ransom........2 Itenry $\mathrm{V}^{\mathrm{V}}$

not rash, like

will be as rash in the repeat.

and room to your rash choler?.

fear not slander, humour, which....... - iv.

was it well done of rash Virginins. Titus dndran. $\mathrm{v}$.

when the rash moorls on

$[\mathrm{Col}$. $]$ his anointed flesh rash boarishi......

wlint a rasl, too unadvised $\ldots$...Rmeo o Juliet, ii.

thou, wretehed, rash, intruding fool

not splenetive and ras.

why do you sueak so startingly and ras.

thou art rash as fire, to say that she was
is this rash and most unfortunate man?

o far, that the rarity redeems him..... All's well, iv.

sorrow would be a rarity most beloved... Lear,

RASCAL-this wide-chopped raseal .... Tempes

your coney-catching raseals ....... Herry $W$
what a damned epicurean rascal is this! -

haing him, dishonest raseall

O you panderly rascals! .........
delight in sucli a barren raseal

二 iii. 3

words are very rascals, since bonds.

why laugh you at such a barren rascal? -

here comes the rascal (rep.) .....Mras. for Heas.

why, you bald-pated, lying rascal! .

I'd poison that vile rasesl ............All's Well, iti.

while she did call me-raseal fiddler

bring along these raseal knaves with
go, raseals, go, and feteh my supper

stretch-mouthed raceal would .............

talk we of these traitorly rascals

peace, je fat-kidneyed rascal

if the rascal have not given m.

zounds, an' I were now by this rascal

that raseal hath good mettle (rep.)...

this oily rascal is known as well.....

Ihoreson, impudent, embossed rascal

rascal, is that all the comfort (rep.

hang lim, swagrering rase

you bottle-ale raseal! you basket-hiit

I cannot endure such a fistian raseal

the raseal is gone: ah, you whoreson

yes, sir; the rascal's drunk; you have

thon damned tripe-visaged rascal ...

come, you thin thing; come, you raseal! -

rascals! [Col. Knt.-son dogs!] .......
sud a knave, and a rascal? what isi]

\section{$\mathbf{R}$}

RASH-LEVIED oals for mon the con

RASULY in the villain's death

and Talbot, too rnshly plotted...... i Hen ry $r^{\prime}$ I. iv. my general and exceptless rashness.. - Timon of Alh. iii. were well deserved of rashness .. Aulony \& Cle

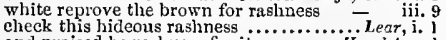
and praised be rashness for it ................ Hamlet, v. 1

tall fellows skip like rats

like rats that ravin down ..........Meas. for Meas. $\mathrm{i}$.

house be tronbled with a rat...Nerch. of fenice, iv.

and, like a rat withont a tail ................ Iacbeth, i. 3

poor rats, liad hanged themselves .. Richard III. v.

take these rats thitlier, to gnaw

she is served as I would serve a rat... Cymbeline, v.

like rats, oft bite the holy cords $\ldots . . . \ldots . .$. Lear, i.
swallows the old rat, and the ditch-dog..

rats, and such small deer ......... - iii. $\overline{4}$ (song)

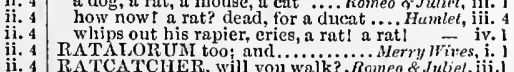

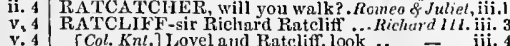
Col. Knt.] I ovel and Ratcliff, look...
they are friends Ratcliff, and I ovel..
RASHNESS that I ever yet. Two Gen, of Verona, iii. I

showed too much the rashness
a better soldier, than rashness.....

a better soldier, than rashness......... Henry $V$. iii.

a dog, a rat, a mouse, a eat .... Romeo of Juliert, iif.
RTCIIFF, eome hither; post to .. MichardIII. iv.

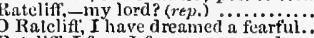

Ratcliff, I fear, I fear, -nay, good....
ATL-o'erprised all popular cate....

and, in my rate, slie too

and, in my rate, sle too ................. - ii.

whose rates are either rich ........... - ii.

a spirit, of no common rate .......id. N.'s Dream, iii.

brings down the rate of usance ....... - i.

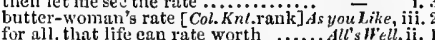

for all, that life ean rate worth.

she reckoned it at her life:
subdued me to her rate

subdued me to her rate..............

and rails, and swears, and rates. Taming of Sh. iv.

five hundred at the rate $\ldots \ldots \ldots . . . . . .2$ HenryIr. iv.

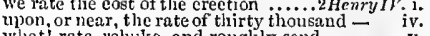

what! rate, rebuke, and rouglily send -

why do you rate my lord of Suflolk.2 Henry F' $^{\prime}$. iii. 2

rate me at what thou wilt, thou...... - iv. 1

go rate thy minions, proud ............

purehnsed at a superfluous ratei...... Ilen ry $r$ r $11 . \mathrm{i}$. I

I find at suell proud rate ............

for corn at their own rates ............ Coriolanus, i. I

one of them rates all that is won and Jost - iii. 9

thy adulteries, rates and revenges .. Cymbetine, v. 4

to blame, my lord, to rate ler so. Romeo suliet, iji. 5
no figure at such rate be set, as that..

your entreatments at a highier rate .... Hamlet, i. 3

RATED-conneil, rated them at... Love's L. Losl, v.

if thou be'si rated by thy estimation
affection is not rated from the. Taming of Shrew, i. 1

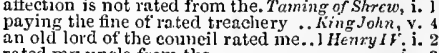

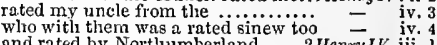

who witl them was a rated sinew too - ind rated by Nortlumberland $\ldots 2$ Ifenry $I V$. jii. 1

thus upbraided, chid, and rated at..2 Hemry $V$. iii.

might liave so rated my expense ..... -

we had not rated him lis part ... Antomy \& Cleo. iii. 6

noble lard be rated for sauciness.. Titus Andron. ii. 3

RATIFIED-are only numbers ratified

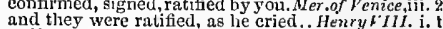

well ratified by law, and herald'y........ Hamlel, i. 1

RATIFIERS and props of every word .... - iv. 5

with lim above to ratify the work..... Macbeth, iii. 6

our peace we'll ratify; seal

RATING-yet, dcar lady, rating.......... of Venice, ii.

loss of virginity is rational increase.... All's Well, i.
RATSBANE-lave put ratsbane in .

a ATBANE-have put ratsbane in ...2 HenryIV.'

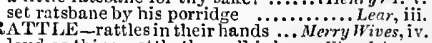

loud as thine, rattle the welkin's..... King John,
$R \Lambda^{\prime} T$ 'TLING-dread rattling thunder.. Tempest,

as from the rattling tongue of ....Mid.N. Dream, 1.1

he was as rattling thunder .............

with dead men's rattling bones.. Rameo \& Juliel, iv. I
RAUGHT not to five weeks ...... Lnve'sL. Lost, iv.

in the face, rauglit me his hand $\ldots . \ldots$. Hemy $V$ iv. 6

that ranght at mountains witli........3 Henry $V^{\prime} I$. $\mathrm{i}$. 4

hand of death hath raught lim... Antony \& Cleo.iv. 9
RAVE-does he rave? .......... Tuetflh Night, iii. 4

stamp, rave, and fret, that I may ....3 Heury VI. i. 4

that he raves in saying nothing. Troitus \& Cress. iii. 3
and rave and cry for tood .... Tilus Andron icus, $\mathrm{v} .3$

the madness wherein now he raves .... Homlet, ii.

RAVED_could so far have raved.... Cymbeline, iv.

make you to ravel all this matter out... Hamtet, ii
RAVELLED-the ravelled sleeve of eare

RAVELLED-the ravelled sleeve of eare. Mlacbeth, ii.

young ravens must have food....... Mery'y Hives, $\mathrm{i}$.

not clan ge a raven for a dove?... BIs. N. N.Dream, ii. 3

an amber-coloured raven was..... Lore s $s$. Lost, iv.

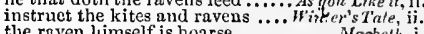

as dotl a raven on a sick-falien ............ King Johnth, iv. 3

and a moulten raven, a conching ...3 Henryll'. ii. I

now to sing a raven's note

the raven rooked her on the ........3 Henry $\mathrm{VI}$ v. i

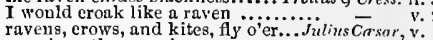

nuy bare the raven's eye............. Cymbetine, ii.

the raven doth not hatch a lark ....

some say, that ravens foster forlorn.

new snow on a raven's back.... Romeo \& Juliet, iiii.

the croaking raven doth bellow for.... Hong ing ii

as doth the raven o'er the infeeted house. Othetlo, iv,

RAVEN-COLOURED love.... Tilus A ndronicus, ii.
RAVENING first the lamb........... Cymbeline, $\mathrm{i}$. 

RAVENOUS-starved and ravenous. Mer. of Ven. iv. I
8weets comfort his ravenous sense... Richarl It. iii. 2 I wish some ravenous wolf had.

he is equal ravenous, as he is subtle. Henry VIII. $\mathrm{i}$. as ravenous fislies, do a vessel follow -

this ravenous tiger, this accursed.. Titus Andron. $y$. is sufe arrived at Ravenspurs

weary way from Ravenspurg to Cöswold -

is gone to Ravenspurg (rep.)

you and he came back to Ravenspurg. 1 Henry 1 r. i. 3 from France set foot at Ravenspurs.

being thus arrived from Ravenspurg. 3 Henry $\mathrm{LV}$. iv.

better 'twere, I met the ravin lion.....Ail's IVell, iii. 2

RAVINED-gulf, of the ravined sait sea

RAVIST, like encharting harmony .. Love's $L_{\text {. }} L_{\text {. i. }}$

ravish doters with a false aspect......

able to ravish any dull conceit ....... i Henry $r$ iv. 3

her sight did ravish ...............2 Henry $l^{\prime} 1$. i.

wives? ravislı our daughters? ....... Richar,l IIL. v. 3

holp to ravish your own daughters.. Coriolnn $u$, iv. 6
suit upon my back, will I ravish ... Cymbeline, iii. 5

ravish a maid, or plot the way,... TitusA ndron. v.

these hairs, which thou dost ravish from. Lenr, iit. 7

$\mathrm{R} A V I S H E D$-now is his soul ravished!. IFuch.Ado, ii. 3

from Perigenia, whom he ravislied?.Mid. $N$. Dr. ii.

younger hearings are quite ravished. Love's L $L$. ii. I

the ravished Helen ......Troilus \&. Cressida, (prol.)
ent thy tongue and ravished (rep. v. 1j.Titus And. ii. 5

ent thy tongue and ravished (rep. v.

sweet girl, ravished, and wronged...

whey it were who ravished

whom they have ravished $\ldots . . . . . .$.

iv.

stah him; he is a ravisher ... Tilus,4ndronicus, v.

with ravishiog division to her lute.. 1 Henryll 1 . ii

$R A W$ - this raw rheumatic day? Merry Wires, ii

nose looks red and raw ..... Love's L. Lost, v. 2 (solig)
a thousand raw tricks...... Merchant of Venice, iii. 4

thou art raw .................... As you Like it,

raw as he is, and in the hottest .. Winter's Trete, iv. 3

being tender, raw, and young ...... Richard The

Richard III, $\mathrm{v}$.

upon a raw and gusty day

may not be raw in her entertainment.. Pericles, iv.

yet but raw neither, in respect of ..........

RAW-COLD rascals!

RAWER-our more rawer breatli? ........ Hamlet, v.

RAWNESS left jou wite ............llacbeth, iv.

with those clear rays which.......... I Henry VI. i. 2

take up the rays of the beneficial ... Henry VIII. $\mathrm{i}$.

for, in her ray and briglitness. . Trnilus \& Cress. $\mathrm{i}$.

as in thy red rays thou dost sink..Julius Casar,

RAYED-ever man so rayed?... Taning of Shrew, iv. I

raze ont the written troubles...

Macbeth, v.

to raze one title of your honour...........ichade II, ii.

and to raze out rotten opinion.....2 Henryi $V$.

raze their faction, and their family. Tilus, Andron. i.
$\mathrm{RAZEJ}-$ ay, that he razed ....... Meas. for Mreas.

lousehold coat, razed out my impress Richard II. iii. I that the Britons have razed out

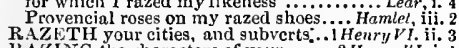
RAZING the characters of your ......2 Henry $l^{\prime} I_{\text {. }} \mathrm{i}$. RAZOR-as is the razor's edge

fourteen years no razor touched ........Pericles, v.

RAZORABLE-be rough and razorable. Tempest, it

REACH - I cannot reach so high. Two Gen. of Ver. $i$.

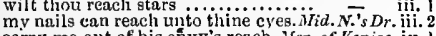

carry me ont of his envy's reach. \$ler. of Venice, iv.

sliould not laugh, if I could reach. Finter's Trite

and boundless reach of mercy

King John, iv.

from forth thy reach he would have.

reach at the glorious gold.

above the reach or compan.

which I must reach unto $\ldots . . . \cdots . .$. Richard 111 i. i.

wlat cnvy reacli you? ........... Henry $\vec{V}$ III. ii. ?

reach a chair; $\rightarrow$ so, -now, methinks..

a mountain ceder, reach hï branclies

true, there's all the reach of it.. Troilus \&. Oress.

one may reach deep enough .. Timon af Athens, iii.

racls me thy hand, that I may help..

thine cye presunes to regch, all thy.

when canst thou reach it? $\ldots \ldots \ldots \ldots \ldots$. . . i ii.

madam, from the reach of these Romeo \& Jnliet,
thus do we of wisclom and of reach .... Ilamle, $\mathrm{ii}$ ninr to larger reash, than to suspicion.

REACiIES at the moon ...........2 Henry $\overline{r_{I}}$. iij.
REACHES of our aouls?

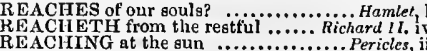

great men have reaching hands......... Pericles, ii.

$D$ it over............... Two Gen, of Verona

read your fortuoe in your ey

thou canst not read ( $(r e p$.$) .).$

iii.

here read, read; perceive how I .......... $\bar{w}_{i v e s}$ i.

, I have read it; it is heresy

here's the challenge, read it

do but read

to read him by his form

open it, and read it (rep.) ..............
no madam, I do but read madness
read i' thy riglit wits $($ rep. $) .. . . .$.

read i' thy right wits (rep.)........... $\overline{\text { being }}$ often read, grown feared ... $\mathbf{v e a s . ~}$

if $I$ read it not truly... .

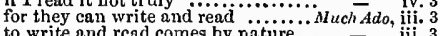

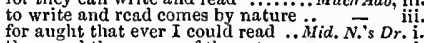

then read the names of the actors...

I read as much, as from the rattling

let me read the sume..............

vouchsafe to read the purpose of $\ldots y$

we will read it, I swear ..............

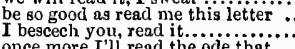

once more I'll read the ode that

let this letter be read

Biron, read it over ...................
I'll read the writing....
a schedule? I will read it............

fore is a letter, read it at you read for certain

teaching all that read. . As you Like it, iii. 2 (verses)

rou shall read it in - many........

sending $\mathrm{me}$

All

shall I read it to you?...........

nay, I'll read it first, by your............ $\overline{-}$

what will you read to her? (rep.).

that never rcad so far to know .....
give me leave to read philosophy...

give me leave to read philosophy
yet read the gamut of Hortensio

you read? what, master, read you?.

that e'er was heard, or read....... Wi

read the indictment

nor read the secrets in't ........

break up the seals, and read

yet I can read waiting-gentlewoman in

and read, as 'twere, my daughter's eyes

and let her read it in your looks

and when lie reads thy perso

where men may read strange matters

do sou not read some tokens

King Joh

who hath read, or heard, of an

read here, young Arthur: how now.

can you not read it? is it not

but that you read these accusations. Richar.d $I$

to reat a lecture of them?

I'll read enough, when $I$ do see..............

that glass, and therein will I read
read not iny name there ..............

I'll read you matter deep.

pee what they be, read them

for therein should we read

at market-crosses, read in churches..

I cannot read them now $\ldots \ldots \ldots . . . .$.

have you read o er the letters.......

for you shall read, that my great....

whis same is yours; rend them read you there, that hath

which you shall read in your own losses -

as I have read in the clironicles

that every one may read........... Henry VI. ii.

that 1 can read no further, 3 never read but $E$ Engiand'...

John Southwell, read you; and

he can write and read, and cast account

but stay, I'll read it over once again

may be to-day read o'er in Panl's.. Richard I1L. iii.

I read in his looks matter .........

commission from Rome is read

wheren was read, how that $\ldots . . . .7 .0$.

read o er this; and, after, this; ant then

you may read the rest $\ldots \ldots \ldots \ldots . . . . .$.

from her shall read the perfect.......

a book of sport thou'lt read me o'er

let me read. A whoreson ptisick .....
read me the superscription.... Timon of Athens,

canst not read? No.................. - ii.
READ-this tomb I cannot read. Timon of Alhens, y. 4 say, we read lectures to you......... Coriolanus, ii. having mead it bid themis rame...

whing read it bid them repair.

he reads much; he is a great ............ Julizus $\overrightarrow{C a}$ if thou read this, $O$ casar, thou them -

reari this schedule. Trebonius doth...

delay not, Casar; read it instantly.

I do not mean to read $\dddot{2}$ the will; read it, Mark Antony.....

gentle friends, I must not read it.....

bonk of secrecy, a little I can rea....... Anton

leisure, read the garboils she awaked
my Octavia, read not my blemishes

hy Octavia, read not my blemishes

his will, and read it to public ear .... $\overrightarrow{\text { iil. }} 4$

nay be truly read, what kind of man. Cymbeline, i.

have read three hours then ......... - ii. ?

read, and tell me how far 'tis........

this story the world may read in me

and read, be henceforth treacberous

who is't can read a woman?

stories ....Tilus Andron. iii.

alt read, when mine .... - iii.

and I have road, than she hath read * - iv.

but thou art deeper read........... 二 iv.

odvinia, shall I read? this is.........

I read it in the grammar ..............

read the conclueion, then; which read

which makes me pale to read it? 2 prediction I read this otlier da...

a prediction I read this ot

slie took them, read them in my presence

read. What, with the mar

stay till I have read the letter

and read out this. Sound, trumpet

where I may read, who passed

can you read anything

stay, fellow, I can read .................

and recks not his own read.

we'll read, anewer, and think upon this

the matter that you read

read on this book.........

reave it at more leisure..........

you shall yourself read in the bitter letter -

READER-every ticlslish reader. Troifus \& Cress. iv.

readiest way to make the werich.... Richard III.

is the readiest man to kill him.. Timon of Athens, $\mathrm{i}$

RADILY be stopped................2 Ilenry $V I . v$.

I thought, by your readiness in.. Meas. for Heas.

page's suit she lath in readiness... Mer. nf Venice, ii.

at once put us in readiness......... Taming of $S h$. i.

ships already are in readiness ....... i Henry VI, iii.

deceived, we are in readiness .........

herc, my lord, in readiness .... Timon of thens

joyful to hear of their readiness.... Coviolanus iv.

your ships; they are here in readiness

vet it will come: the readiness is all Titus And. i.

READING-you reading there?.. Twa Fen. of Ver, $\mathrm{i}$.

cozened all the hosts of Readings....... Merry $\bar{W}_{i v e s, \text { iv. }}$

uncle's feading aload to him.... Twelfh $\mathrm{Nig}$,

writ it, and was reading it over...... - ii.

for your writing and reading, let that -

read, to reason against readingl Love's $L_{L}$. Los

whs.t, Longaville! and reading! listen

here comes my sister, reading

such as his reading, and manif

on the reading it, he changed

wrest, or bow your reading

what interrupt his rending ... Troilus \& Cressido,

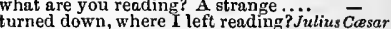

she hath been reading iate ........... Cymbeline,
what paper were you reading? ........... Lear

sadly, the poor wreteh comes reading.......... Hainlel,

i. 4 READY - make yourself ready............ Tempesi,

I am ready now .........................

madam, dinner's ready ......Two Gen. of Verona, i. almost ready to wrangle with....

my heart is ready to crack with.

are you ready, sir? ...................

I'll get 'em all three ready

be ready, Claudio, for your. Miensure for Measure

go to your knees, and make ready 
READY-atory rendy for your ear...Meas.for Mleas, iv. 1 he made five marks, ready money

block, sirralı? Very rendy, sir.......... tis time you were ready ........... - iii. I will wait upon them,

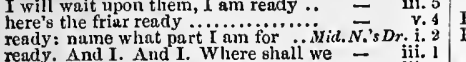
here, villain, drawn and ready

where's Pcas-blossom? Ready (rep.) - iv.

supper be ready at farthest by he's ready at the door: he comes.....

I have them rearly

I have it ready for thee; here it is $\ldots$. $\quad$ iv. 1

ready, sir; but his will hath in it....... you Like it, i. 2

procure me music ready.... Taming of sh. $\bar{i}$ (induc.)

be ready straight (rep.)

each in his office ready at thy....

there's fire ready; and therefore, good

is supper ready, the house trimmed..

all ready, and therefore, I pray thee

are they all ready? (rep.).............

bid Bianca make her ready straight

to bid the priest be rearly to

my hand is ready mo it do

my ships are ready, and my people. Winter's Tale, $\mathrm{i}$.

when ready to leap out of himself.....

I laid their daggers ready, he could not

all ready at a point

our power is ready; our laek is

a drum is ready traeed, that si........ King John, ii.

be ready, as your lives shall answer.

(hese home alarm

Glendower is not ready yet

go make ready breakfast

o make ready breakfast .............

as ready as a borrower's cap .........

if. not, we ready are to try

with a ready guess, declare....

his powers are not yet ready .........

ready they were to shoot me

ii.

and ready are the appellant

our army's rendy; eome, we'll after..3 Henry $V I$. i. 10

I am ready to put armour on (rep. iv. 1) - iii. 3

your horse stands ready at the park at hand, ready to firht ...............
ready to cateh each other by the
are all things ready for that royal time? -

ready, with every nod, to tumble..

is ink and paper ready? It is

banquet ready i' the privy chamber

when they were ready to set out..

we are ready to use our utin
is he ready to come abroad?

more ready to cry ont........ Troilus \& Cressida, ii.

she's making her ready, she'll come

this ohallenge; Ajux is ready

my lord! is the lady ready?.

let us make ready st

ready for his friends.................... Tin

pray, is my lord ready to come forth?

but Rome was ready to answer us...

ready, when time shall prompt them

I lave; 'tis ready, here. Have you..

strong, and ready for this hint ......
have you an army ready, say you?..

your city is ready to flame in .........

ready, gods, with all your thunderbolts

our army lies, ready to give up the ginost -

your commissiou's ready ... Antony \& Cleopatra

go, make thee ready; our letters are

he shall in time be ready

your lady's person: is she ready?..... Cymbelin

ready in gibes, quick-answered.......

ready for death ? Over-roasted (rep.)

if you be ready for that, you are well

they shall be ready at your .. Titus

and see them ready 'gainst their ....

the reast is rear the way of life.

are ready now, to eat those little

are the knights ready to begin ..........

return the:n, we are readly; and our 0 hatehes, canlked and bitumed ready

go, get it ready. How now, what art tho
are the horses ready? Ready, my lord.

are the horses ready? Ready, my lord

where both fire and tood is ready ..........

and they are ready to-morrow

to dissolve........ $\bar{z}$

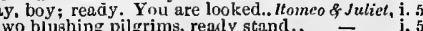

will you be ready? do you like this.

is the bride ready to go to churcli? (rep.) -
READY-make you ready. How now..Hamlet, iii. 2
be the players ready? $\Lambda y$, my lord ...... - iii. 2 be the players ready? Ay, my lord $\ldots \ldots . .$.
the bark is ready, and the wind at heip.. - iv. 3

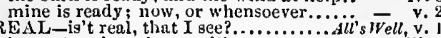
it must omit real neessities ....... Coriolanus, iii. truth of all this realm is fied to ...... King John, iv ere thou fy the realm ................ Kichuard $I ., \mathrm{i} .3$ enforced to farm our royal realm ....

of Wiltshire hath the realm in farm

to rid the realm of this pernicious blot?

though he divide the realm, and give

and barons of the realm pereeived

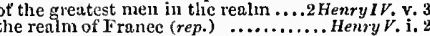

to command the prinee and realm...i Henry $V I$. i. I

prosper this realm, keep it from

protector of the realm (rep.) .........

applauded through the realm of France

of your arrival in this realm

i. 6

the realm of France? (rep. iv, 7 )

the realms of England and France

loss of all the realin of France

both her, the king, and realin.....

us to labour for the realm ......
the realms of England, France.

not second woman in the realm

peers and nobles of the realm have.. =

to be your regent in the realin of France -

[Col.] govern England's realm

staff, sir, and the king his realm

sums of money throngh the realm $\ldots .$.

all the realm shall be in eommon.

burn all the records of the realm

eorrupted the youth of the realn

the proudest peer in the realm

is made protcetor of the reaim

his realm a slaughter-house.

wear the garland of the realm

danger whieh my realms stood $\mathrm{i}$

flling the whole realm, by your .. - ii. 4

rould set whole renlms on fire... Timon of $A t h$. iii. 3

then shall the realm of Albion ........... Lear, iii. 2

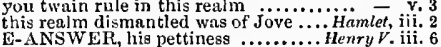

RE-ANSWER, his pettiness ........... Hlenry $V$. iii. 6

our coru's to reap, for yet our ...Mleas. for. Heas. iv. 1
they that reap, must sleat. As you Like it, iii. 2 (verses)

the man that the main harvest reaps

proffers, not took, reap thanks......... All's Well, ii. I

little vantage sliall I reap thereby ...Kichardll. i. 3

as now $I$ reap at thy too ............3 Henvy $V_{1}$. i.

labours thou shalt reap the gain .....

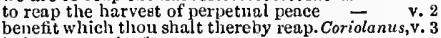

holp to reap the fame $\ldots \ldots \ldots \ldots \ldots \ldots \ldots$..........

$R E A P^{2} E D-$ reaped no eorn ........ Love's $L$. Lost, iv. 3

anger's this? how lave I reaped it? Henry $V 111$.

REAPER-2re muletecrs, reapers. Anlony \& Cleo. iij. 7

REAPING-grew the more by reaping - Tempest, ij.

I do rear up her boy $\ldots \ldots \ldots$...... Wid.N.'s Dream, ii.

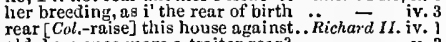

pyramis to her I'll rear

rear it in the place your

OHenry HI. i. 6

the first that rears your hand .....Julius Cosar, iii.

a coffin I will rear, and make.Titus Andronicus, $\gamma$.

kecp you in the rear of your affection ... Hamlet, i. 3
REARED witl gtronger blood.......Winter's Tale, i. 2

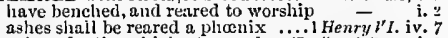

veins of actions highest reared :Troilus \& Cress. i. 3

his reared arm crested the world. Antony \& Cleo. $\mathrm{v}$.

reared aloft the bloody battleaxe.. T'itus Andron.

REAR-MICE - war with rear-miec.Mid.N.'s Dr. ii. 3

ever in the rearward of the fashion. 2 Henry $I V$. iii.

rearward following 'Tybalt's deatli. Romeo \& $J$ ul. iii. 2

REASON for raising this sea-storm .... Tempest, i.

would not infect his reasoll?

yet with my nobler reason, 'gningt...........

that mantle their clearer reason
that they devour their reason.

him best. Your reason?

no other but a woman's reaso

have I not reasou to preter

reasonless, to reason thus?
that's the reason I love him
R DASON-my rcuson's light.

above the reason but I slial.

1 sliall do that that is reason

your request, eousin, in any reason

ask ne no reason why I love you ..

though love use reason for his... - ii. I (letter

reason, you rogue, reason

the tceth of all rybme and reason.

If you liave reason, be brie

Tuelfih $\overline{N i g h t}_{\mathrm{i}} \mathrm{\textrm {i }}$.

thy exquisite reason, dear knighit?

reason for't, but I have reason good.

thy reason, man?

I am loath to prove reason with them

nor wit, nor reason, ean my passion

do not extort thy reasons from

thy reason, dear venom, give thy reason

pon the oatlis of judgment and reason

and wrangle with my reason

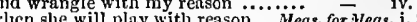

stor this action...

reason thus with life $\ldots$ in all reason sho..........

he shows his reason for that

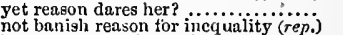

you slould hear reason $\ldots \ldots \ldots \ldots \ldots . . . . M \overline{c h} A d o, \mathbf{i}$.

it freely... - iv.

ne'er weigh more reasons in her balance - $\quad$ v. I

no, no more than reason (rep.) $\ldots \ldots . . .,-$ v. 4

by his reason swayed (rep.) ......Mid.N.'s Dream, ii. 3

you should have little reason for that $=$ iii.

reason and love keep little company - iii.

in all reason, we must stay the time

v. i

he's read, to reason against reading! Love's $L$. Lost,

had small reason for

against the reason of white and red..

gainst some reason, in my breast...

all liberal renson I will yield unto...

your reasons at dinner have been....

know the reason; lady, why (rep.).

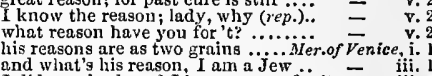

I did, my lord, null I have reason for it -

should be more than reason: but if she =

as there is no firm reason to be iji... = iv. I

the reason is, your spirits are attentive - $-\bar{L}$ tull to rcason of sueh goddesses.. As you Like

eome, lame me with reasons $\ldots . . . . .$. .

by reason of his absence.............

for not being at court? Your reason...

aeither rhyme nor reason ean ......

ou have great rettson to be sad.....

the reason - $\mathbf{y}$

tell me thy renson why thou wilt marry $A \overline{u_{s}} W_{e} u, \overline{\mathrm{j}} .4$

worship's reason? Faith, madom, (rep.) - i. 3

good my lord, the reasons of our state $=$ iii.

too strong for reason's torce .............

I hope, this reason stands .. Taming of $S h . \overline{2}$ (induc.)

iny reusons are both good and weighty
for what reason, I beseech you?(rep.)

I see no reason, but supposed Lueentio

having no other reason, but that his - ii.

my reason, haply, more, to bandy.... $\rightarrow$ v.

for some other reasons, my grave sir - iv. 3

if $m y$ reason will thereto be obedient $($ rep. $)-$ iv. 3

as monstrous to our human reason .. - v.

is neither rhyme nor reason ..........

your reasoll? Lest it make you...... - ii.

but your reason was not substantini = ii.

the reason of this strange restraint ...

how fondly dost thou reason?........ -

the reason that I gather he js mad...$=$ iv.

past thought of human reason..... , - v.

and the reeeipt of reason a limbcek.... - . .

violent love outran the pauser reason

for sundry weighty reasons
have I not reason, beldams....

the flight so runs against all reason... $=$ iii.

produces reuson liow I may be

strong reasons make strong aetions...

some reasons of this double coronation

and not oul manners, reason now (rep.)

iii. 4
iii. 4
iv. 2

teach thy necessity to reason thus ... Richard II. i. 3
what was his reason? he was not .... 


\section{REA}

REASON-liave I not reason........ Richard 11. iii. 2 REASON_not to ask the reason why .... Pericles, $i$. for some reasons I would not $(r e p$.$) ...$ I see no reason, why thou shouldst..1 HenryIV. fort which, for divers reasons, which $\dddot{i}$ will 二 whither I go, nor reason whereabout = yonr reason; what sayst thou (rep.). reason on compulsioo! if reasous were traetable to any honest reason

any other reason than to set me off. .2 Ife

than to set me off..2 Ifenry $W_{\text {. }} \mathrm{i}$.

many thousand froni me all (rep.)

now do I see he hud some reason for it

wer reason to lerselt is only known....

quirks, her reasorts, her master-reasons

quirks, her reasons, her master-reas.

ean reason it thus and thus, yet.....

add snch reasons of your own, as maj.

the reason why the seven stars (rep.)

those that mingle reason with your
rcason not the need: our basest

lie has some reason, clse lie could not hes

reason iu gone back

then reason wills, our liearts should

the in madnest

niee, and wanton reason, shall

hear him but reason in divinity

for your own reasons turn into .......

when he sees reason of fears, as we do

always reason themselves out again.

the reason moved these warlike ......

stay yct, hear reason; Edmind

mo other reason, but because ...Rom

do you know the reason of this histe

nature's tears are reason's merriment

I see no reason, if I wear this rose...

by reason ot his adversary's odds ...

there's reason lie should be displeased.2 HenryVI. $\mathrm{i}$.

show some reason $(r e p$.$) ..............$

bet ter reasons can supplan

hath more reason for his death ........

proved by reasons, to my liege .......

the reason of tliese arms (rep. v

but I have reasons strong and foreilie 3 -

and reasou too; who should suceeed

this reason may suffice

to reason most absurd; whose eommon

down the pales and forts of reason ....

miglit deprive your sovereignty of reason

which reason and sanity could not so...

for, by my fay, I cannot reason.

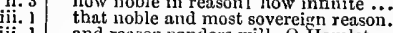

iij. 1 and reason panders will. O Hamlet.

god-like reason to fust in us unused ....

for two speeial reasons; which may to you
what is the reason that you use me thus?

What is the reason that you use me thus?
the reason of this terrible summons?

with such loud reason to the Cyprus wars

then $t$ is but reason, that $I$ be released

and his brothers, un to renson......

had I not reason, think ye, to........

for divers unknown reasons .......

you we'll reason with him.........

what a sliarp-provided wit he reasons!

thou know'st our reasons urge

and tell him all otur reasons ........

your reasons are too shallow (rep.)

Treat reason; why? lest I revenge
let your reason with your choler

if your reason with your choler

this eamnot be, by no assay of reison

but we have reason, to cool our raging

iu our common rcason, (save that, they.

give me a living reason, slie's disloyal

whieb I have greater reason to believe

I will hear further reason for this.

many sharp reasons to defeat the law

thorny points ot my alleged reasons

yet he has given me satisfying reasons...

you sliall find me reaso

upon any reasonable demands

it he be of any reasonable

to be known a reasonable creature.....Much $\mathrm{Adl}$, $\mathrm{i}$.

I have a reasonable good ear ... Mid. N.'s Dream, iv.

out of all reason able matel

incapable of reasonable affiirs?...

my reasonable part produces

out of all reasomable compass

King John, ivi.

what merit's in that reason... Troilus

gway of his affairs with reasons.

and reason flies the objeet of all harm.

wings of reason to his heels.

nay, if we talk of reason, let's ......

that no diseourse of reason

the reasons, you allege, do more ......

the reason why we aseribe it to him

I have strong reasous (rep.)...........

with reasonable swiftness, add mor

yet a reasonnale mery reasonable great

iii. 6

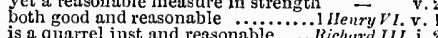

where reason can revolt withont $($ rep. $)$

no reason can folund his state...... The

one that knows what belongs to reaso
in manacles, then reason safely $\ldots .$. .
I'll give my reasons, more worthier..

I'll give my reasons, more worthier.

reason; because they then less need.

revenges, with your colder reasons....

move him more than can our reason

does reason our petition with more..
bnry his reasons with his body

these are their reasons .............

swayed more than his reason

and reason to my love is liable

that you shall give me reasons .......

our reasons are so full of good regard

puhlic reasons shall be rendered of..

and men have lost their reason!

methinks, there is much reason in

no doubt, with reasons answer you
your reason? This it is: 'tis better

good reasons, must, of foree, give place

if you ean, your reason? .... Antony \&
thongh my reason sits in the wiod ..

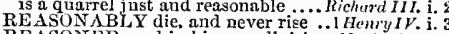

REASONED, and in his own division. Wuch 1 do, v. 1

why is this reasoned? Combine togetlier.. Leer, v.
REASONING witl yourself?... TwoGen.f l' ler. it.

reasoning is not in the taslio.... ...Ner. of Venice, i. 2 proffer is absurd and reasonless ....1 Henry $V$. v.
REAVE her of what should stead........All's $W$ ell $\mathrm{v}$. to reave the orphan of his patrimony.2. Herry $V l$. v. 1
REBATE and blunt his natural. Neats. for

woukd make lis will lord of his reaso

When valour preys on reason...

not very siek, since $I$ can reason of it

love's reason's without reason; the bie

my tather hath a reason for't

REBECK-you, Hughl Rubeek?..Romeo \& Jultie, jv. 5 but a fonl contending rebel. .T. Taming of Shrew, y. 2

personal ventnre in the rebel's fight

ine the rebel with hidden lielp

now for the rebels, which stand out.. Richard

though rchels wound thee with.......

no reason $I$, since on your lives

that the rebels have consumed with $\overline{-}$

Donglas, and the English rebels, inet -

- iii. 2 he calle us rebels, traitors?

and rebels arms triumph in massacres1

a very valiant rebel of the name ..... - v. 4 even with the rebels' blood..2 Henry $I V$. (induction)
do not the rebels need soldiers? ...... says that whieh his flesli rebels against -

but, for you, rebels rebels with.

a famous rebel art thon, Colevile

till these relsels, now afoot .....

if any rebel or vain spirit ot mine
to wilful disobedience, and rebel?

that rebels there are up and put ... Henry $F r$. iv.

your grace to the rebels' supplication?

great reason that my noble lord be

but yet let reason, think you, to look

and wilt thou lave a reason for this

your reason, mighty lord?

a reason, mighty, strong, and effeetua

these Kentish rebels (rep.)

defend the city from the rebels........ =

to quell the rebels, and their complices

you quake like rebels?

REBEL-6afe-eondueting the rcbels. Richard III. iv.

to beat down flock to the rebels and tliei

think, thy slave man rebels. . Timon of Athens, iv. 3

so rebel to judgment ......... Antony \& Cleopatra i.

and not to be a rebel to her stät

and the natures of their lords rebels.......... Pear, ii.
youth to itself rebels, though none else.. Hamlet, i.

devil here that eommonly rebels ...... Othello, iif.

lhe body's members rebelled agrainst. Coriolanus, i.

R E B T

REBELLION of a cod

now, Grod delay onr rebellion ...........All's Well, $^{\mathrm{j} v}$.

who, in rebellion with himsclf .... Winter's Talc, i. 2

is in thyself rebellion to thyself .... King John, iii.
rebellion, flat rebellion: Will't not be? - iii.

unthread the rude eye of rebellion ..

cherish rebellion, and are rebels all.. - -

falter under foul rebellion's arms....

thus ever did rebellion find rebuke.

the flame of bold rebellion even .... Henry $\bar{I} V$. (ind.)

he told me, that rebellion had bad luck -

worse than the name of rebellion caide

if that rebellinn came like itsell ${ }^{*}$....

of forged rebellion with a seal divitie

bringing rebellion bronclied on

't was by rebellion against his king ...3 Henry VI. $\mathrm{f}$.)

almost appears in loud rebellion.... Henry VIII. $\mathbf{i}$.

of this most wise rebellion ...........

in a rebellion, when what's not meet - ifi,

REBELLIOUS liquors in my blood.. ds you Like, ii.

point against point rebellious

rebellious earth have any resting .....Richard II. $v$.

he yoketh your rebellious necks ....1 IIenry $l^{\prime} I$. ii.

rebellious hinds, the filth and......... 2 IIenry $r$. v.

rebellious snbjeets, enemies to peaee... Romeo \& Jul. i.

rehellious hell, if thou cunst mutine .... - - iii.

REBOUND of yours, a grief.. Antony \& Cleopotrn. $v$. REBUKE-rebukes, and manners. Merry Wives, ij

rebnlie me not tor that which you. Love's L. Lost, v.

does not the stone rebuke me .... Winter's Tale, v.

why bear you these rebnkes .. Comedy of Errors, v.

not Gaunt's rebukes, nor England '...Kichord II. ii.

rebuke and dread correction ........ 1 Henry $I V . v$.

rebuke and eheck was the reward ..2HenryIV. iv.

forestalled this dear and deep rebuke

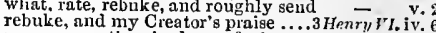

murmurers, there's places of rebuke. Henry FIII. ji.

pluck reproof and rebıke from....... Coriolanus, ii.

thebuke, which might have weli....... Antony \& $\overline{C l}_{\text {Cleo }}$ iii. 7

slie's a lady so tender of rebukes.....

of this great vast, rebuke these surges.. Perictes, iii.

receives rebuke from Norway $\ldots \ldots \ldots \ldots$. Hamlet, ii.

the best of you shall sink in my rebuke
REBUKED, as, it is said ............... Hacbeth, iii. 1

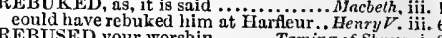

RECALL the good Camillo $\ldots \ldots$ Taming of Shreu, $\mathrm{i}$.

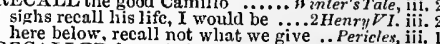

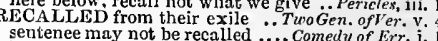

if Henry were recalled to life again...1 Hen of Err. i.

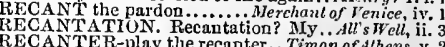

RECANTER-play the recanter.. Timon of Athens, y. 2

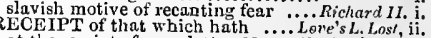

at the reeeipt of your letter.Mer. oflenice, iv. 1 (let.)

many receipts he gave me

thon didst deny the gold's receipt. Comedly of Err. ii.

the receipt of reason a limbeck only..... Ancheth, i. ?

parts of that reeeipt I liad for $\ldots . .$. . Richard II. i.

parts that envied his receipt...... . Henry VIII. ii.

upon receipt thereof, soon sleep. Romeo \& Juliel, ii

he receives eomfort like cold porridge... Tempest, ii.

did in your name reeeive it.. TwoGen. of Verona, $i$.

onee again $I$ do reeeive thee honest

receive it so his youth wili aptly reeeive it .........

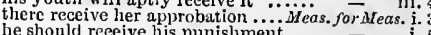

which he is most glad to receive

be glad to reeeive some instruction...

reeeive the meed of receives letters.

reantime reed of punishment. Loce'sL.L.i.l (let.)

receive fair speechless messages...Mer. of $\overline{\text { Venice }}, \dot{i}$.

by note, to give, and to receive $\ldots . . .$.
than to receive three thousand ducat 
IECEIVE-will patiently reeeive... As you Like it, ii. 7

good duke receive thy daughter.. "- v. 4 (verse) we here receive it a certainty .........A Al's $W^{2}$ ell, i. our hearts receive your warnings... = i. i a second time receive the confirmition - ii. 3 my wish receive, which great love grant I - il. 3 would never receive the ring ngam i... $\overline{\text { the }}$ Tule, ii. or newer torture must I receive......

do not reccive affliction at my

which I receive much better than .. - iif. 2

receives not thy nose court-odour....

I shall receive the money for.

part is to receive our duties

part is to receive our dutics

列 7

and receive free honours, all which

receive what eheer you may

to receive at once the benefit

and Derby, receive thy lance.......

noble Mortimer receive so many ....i i Henry $l r^{\prime}$ i.

there receive money, and order for - - iii. 3

says he, reeeive those that are civil

t:ake heed what ginests you receive (re

receive the sectet whispers..... Heury $\nu^{\prime}$. iv. (chorus)

French Englishnen, receive each other! - v. ${ }^{2}$

if thou receive me for thy warli first receive the sum

sooner will receive, than give......

receive the sentence of the law...

as others would ambitiously receive

thou didst receive the sacrament ..Richardill. $\mathrm{i} .4$

and, pray, receive them nobly ...... Henry rrss. i. 4

from a dying man receive as certaiu

receive him, aud see him sate

receive him, and see him sate .........

sloll receive of us in duty rives.....

shall receive of us in duty gives.......

and periaps, receive much honour.

in kissing, do you render, or receive? - iv. 5

the gives, it he receives ........... Timo

let the war receive't in valiant gore

that I receive the general food

receive that natural competene

benetit, which you receive ........

receive you in with all kind love...julius Cas

he did receive his letters, and is coming

shall receive the benefit of his dying

follow me, and receive it.... Anlony 9 Clenpalr

we must receive him according to

receive it from me,

receive it friendly...........

or receive us for barbarous ...........

receive him then to favour, Saturnine

they humbly at my teet receive $\ldots$.

basou that receives your

let him receive no sustenance....

expound now, or receive your sentence... Pericles,

wouldst tremble to receive thyselt

graciously, I will thankfully receive

ghall receive such pay as thy desires

then must we look to receive from his age, $\bar{L} e$ ar

my sister may receive it much mo

receive attendance from those.

I'll receive him gladly, but not ........... Ju Tice ii. 4

your isitaluk from Norway .

receives rebuke from Norway .............

admit no messengers,

did players recive you well?

I pray you, now receive them.

I will receive it, sir, with all diligence

I do receive your offered love like

as I am bound, receive it from ine

RECEIVED a second lite

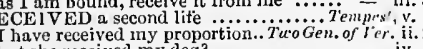

but she reeeived my dog? .............. $\bar{W}_{\text {ives }}$

I am sure, I have received non

I am sure, I have received none

having received wrong by some person -

I have received from her another

I have received from her another .....
received, and bid deliver to our age..
the foppery into a received belief....
iv. 5
iv. 4

to be received plain, $\mathrm{I}$ 'il speak

he professes to have received no.

that lie had received a thousand .......Much $A d n$, iv.

(as neither have) received sum. Love's L. Lost, i

you shall be so received, as you sha

whope, whicli you recived of me. Afer. of Fenic

itself 28 'tis received

the influence of the most received star

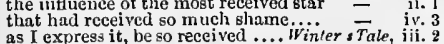

asder, or what is now reeeived...

more than the stripes I have received -

received no gold (rep. iv. 4) .. Comedy of Errors, ii.

of him received the ehain $\ldots . . . . . . . .$. .

the king hath frappily received .......... Marbelh,

will it not be received, when we have.. -

and is received of the most pious Edward $-\overline{\text { iti. }}$
London hath received, like a kind ... Kings John, v.
hath received eight thousand nobles. Richard $11 . \mathrm{i}$.
ECEIVED the sacrament

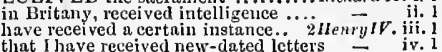

作

and from his coffers received the golden - ii.

War'wick received deep scars in

within this half hour, hath received
the sea received it; and so, I wished

therury VI. ii.

who at his hands received my life.... - ii.

this day received a traitor's.........Henry ${ }^{\prime}$

my conscience first received a tender

I have received much honour..........

let them he received, not without.. Timo

that c'er received gift from him

you liave received your griefs

from whoin I have received not only

you have received many wounds

like his that hatli received au almsi

this we received; and each in eitluer

how he received you, let me be ...Juliu

us Casar, iv. 2

how mine re

and have now received his accusations

so soon as I have received it.

having received the punislment.....

and be received for the emperor's he

who hath received you at fortun

and received this hur' you see, striving.

I have received a letter this night

and of him, that ever ear received

but how hath she received his love?...
but it was, (as I received it, and otlie

he received them of him that brought

I thought you had received some bodi

slie has received them, and returned me

RECEIVER-make him
RECEIVEST thy full peti

...mbline, $\mathrm{i}$.

RECEIVE'TH as the sea

Tuelfh Nigh $_{\mathrm{s}} \mathrm{i}$.

such receiving as shall become... Wir:ier's Tule, iv.

hoofs i' the recciving carth ..... Henry $V^{\prime}$
my lips, and receiving the bad air.Julius
RECEPTACLE of my joys .... T'ilus Anc

RECEPTACLE of my joys .... Titus
out of this tell devouring receptacle.

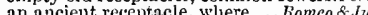

an ancient receptacle, where .. homeo \& Juliet, iv.

RECIPROCAL vows be remembered. Lear, iv. 6 (let.

RECITERAI-je reciterai à vous ....Henry $V$. ii.

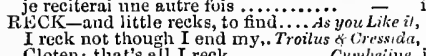

Cloten: that's all I reck..

and recks not his own read ..........
RECKLES as little what . Tü Gen. of
RECKS-the love of reckless Silvia

careless, reckless, and fearles

so flies the reckless shepherd from ...3 Herry $V I$. Y.

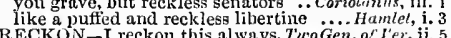

whereof I reckon the casting torth. Winter's Tale, iii. 5

beture we reckon with your several ...Mucheth, v.
if you could tell how to reckon ...... Henry $V$.iv.

I have no more to reckon $\ldots .$. rimon of Athen

whom we reckon ourselves to be . Cyjmbclime,
have not art to reckon my groans. Hamlet, ii. 2 (let.)

RECKONED it at her life's rate

was reckoned one the wisest prince. Henry $V I I I$ i

in the love that can be reckoned.. $A$ nlony \& c cleo i.

aECK ON ING, he is more sli......... Taming of Sh. iv. 1
to the end of the reckoning .... Meas. for Meas. v. 1

to the end of the reckoning ....Mreas. for deas. v.

here comc other rcckonings ............

get your living by reckoning, sir .....

a great reckoning in a little room. $A s$

the parcel of a reckoning. I am not yet - ii.

in reckoning up the several devils

in thy pocket but tavern reckonings

a trim reckoning! who hath it? ....

wit wasted in giving reckonings ....2 Hewry

the sense of reckoning, if opposed.....

to set down her reckuning .. Troilus \& Cressidla, iti.

how goes our rcckoning? ...... Timon of $A ! h$ th

of honourable reckoning are you. Rome

in number, though in reckoning non

0 weary reckoning ! Pardon me ....... Othello, iii.

RECLAIM - tlie tyrant oft rechams..2 Henry VI. V

wayward girl is so reclaimed ... Vismeo \& Juliet, iv. 2
RECLUSIVE and religious life

and of love outh, iv.

his recognizances, his fitres, his double...Hamlet, v. that twenty-three ycars

that way recoll upon me ............
nature may recoil, in an imperious ...
scnses to recoil, and start, when......

or like an overeliarged gun, recoil... 2 iienry, $\bar{r}$. iit.

FEcoILING to her better judgment ... Othello, ii.

RECOLLEC all that may men approve. Pericles, ii.

RECO.MFORTED through the gates.. Coriolanus, v.

RECOMFORTURE. Shall I go win. Richard illip.

we recolnmend to you, tribunes............ Coriolanels, ij.

With his free duty, recommends you thus. Ohello,

not myself, lacks recompense .... Tuelfth $\mathrm{Nighi}$, iv,

not myself, lacks recompense .... Twelfh Nigh

and, in recompense, desire my dog again -

in recompense whereof, he hath $\dddot{\text { co... }}$. for $\bar{M}_{\text {eas }}$. ii.

do not reconpense me, in making me

no, truly, but in friendly recompense $\overrightarrow{ }-\overrightarrow{\text { v. }}$,

that is study's god-like recompense...Love's $L . L . \mathrm{i}$.

cannot recompense me better ....As you Like it, ii. 3

labour to recompense your love.......All s $\vec{N}$ ell, iv.

as recompense of our dear services. Winler's Tale, ii. 3

he means to recompense the pains ........ King John, $\mathrm{y}$.

thy true love's recompense (rep.) ... Richard 1. il.

rny body shall pay recompense.

aloud to call for recompense. Troilus \& Crcssida, iii.3

we for recumpense have praised ..Timon of $\mathrm{Ath}$. . . .

our dinner will not recompense this - iii.

the corn was not our recomponse .. Coriolanus, iii.

your reeompense is still that ......... Cymbeline, ni. 3

RECONPENSED as thought on.. Winler's Tale, iv.

love could be but recompensed...T Tuelfh Night, i.
his father's wrongs be recompensed.1 Henry $V I$. jii.

his father's wrongs be recompensed.1 Henry ' $I$. jii. 1
RECONClLE me to Polixcnes.... Winter's Tale, iii. 2

'tis hard to reconcile. Well, nore.....Mllacbeth, iv. 3

to reconcile you all unto the king..2 Henry $V I$. iv. 8

I hope, shall reconcile them all ....3 ilenry ${ }^{\prime} I$. i. 1

our suit is, that you reconcile, them.. Coriolanus, v. 3

unto your eyes I'll rcconcile.. Pericles, iv 4 (Gow.)

reconcile your friende............ Romeo \& Jutiel, iii.
RECONClLED to the prince pour

we are reconciled, and the first view...All's W Well, v.

and reconeiled king, my bruther. H'inter's Tale, iv. I

king John hath reconciled himself ... King John, iv.

York and Lancaster are reconeiled..3Henry VI.

reconciled your friends and you.. Titus Andron, $\hat{\mathrm{i}}$.

RECONCILER-your reconeiler! Antony \& Cleo. ili.

RECORD-and record way foes.. Two Gen. af Jer v.

that record is lively in my soult.. Twelfih Night, $\mathrm{y}$.

whose fine stands in record ......Aeas. for Mcas. ii.

record it with your lighli and worthy

that he do record a gift ..... Merchant of Venice, iv.

if thy offences were upon record .... - iv.

a countryman of ours, records ......

burn all the records of the realm...2Henry 'I. iv.

abstract and record of tedious dajs... - iv.

and, on rcord, left them the lieir' .. - v.

whereof we have record, trial. . Troilus \& Cress, i. 3

caniot be! we have record .......... Conolanus, iv. 6

got upon me a nobleness in record

the record of what injurie

as record of fair act

Cymbeline, tii.

all trivial fond records, nll saws of ...Hamlet, $\mathrm{i}$.

make a recordation to my soul.. Trailus \& Cress..
RECORDED-the recorded law... Mcas. for Meas.

that are recorded in this schediule. Lave's L.Lost. $\mathrm{i}$.

'twill be recorded fur a precedent. Mer.ofVenice, iv

to the last sylluble of recorded time ..Macbeth, y.
my soul recurded the history .... Richard 1II. iii.

my soul recurded the history .... Richard 111 . iit. 5

and have our two wagers recorded...Cymbeline, $\mathrm{i}$.

spoke to, but by the rceorder ...Richard III. iij.

cone, the recorders. For ir the king ... Hamtel, iil.

you shall recount their particular .......Turh desto, iv.

lct us recount our dreanis ....Mid.N.'sDreum, iv.
by the world I recount no fable .. Love's L.Losi, v.

that some plain man recount their ..

I pr'ythee, recount some of them. As you Like it, iii.

should recount oulr baleful news....3 Henry V7. ii.

I shall recount hereafter ............ Juliuscasar, $;$.

recounts most horrid sights seen by.. $-\vec{n}_{\text {ii. }}$ i.

sit, sir, $\mathrm{I}$ will recount it; but see ....... 1'ericles, $\mathrm{v}$.

recount. I do hesecels thee............. iv. 7 (letter

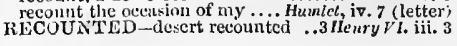


RECOUNTING - which in recounting .... Lenr, v. 3 1:ECOUNTMENTS had most kindly As you Like, iv
IECOU RSE - recourse to her ... TwoGen. of Ver. iii. to give me recourse to him

any time, recourse unto the princes. Richard lll, iii.

u'ergalled with recourse of tears. Troilus $\&$ Cress. v. 3
RECUVER that, we are sure.. TucoGen. of Verona, v.

it 1 can recover him (rep.)............. Tempest, ii. 2

the wine in my bottle wili recover him - ii. 2

if I cannot recover the shore

Tiuelfh $\mathbf{N i g h t , \text { ii. } 3}$ he might yet recover, and prove...Mid.N.'sDr. v. 1 look, he recovers. 1 would I were. As you Like it, iv. 3
who then recover; say, thou art mine..Alt's Well,iv. 2 the will recor; and, perad venture, may recover .... Kinty.lohn, v. lower, princes, for the king recovers.2Henry $I F$. iv. 4 he will recover without physic

might recover what was lost.......

i Henry 1 . ii. 5 we might recover all our loss.... come on then; he 1 recover them. Jutius Casar, i. do seldom or hever recover.

to nature, that can recover him

Perictes, iii. 2 but to recover of us, by strong hand .... Hamlel, $\mathrm{i}$. you go about to recover the wind
he shall recover his wits there

arc ways to recover the general again..... RECUVERABLE. I fear ...... T'imon of $\ddot{A}$ thens, iii. kill him whom you have recovered ...Twelfth $\mathrm{N}$. ii. i brief, I recovered him; bound up. As you Like it, iv. 3 not to be recovered (rep.) ............. - iii. 6 it is to be recovered

$I$ would swear, I recovered

recovered again with aquæ-vitæ........ Winler's $T_{u l e}$ iv. 1

recovered is the town of Orleans.....1 Henry $I . \mathrm{i}$.

lost, and recovered in a day againi...

nor grieve that Rouen is so recovered
recovered your ancient freedom ....2 by good appliance was recovered........ Pericles, iii. 2

lookl Thaisa is recovered...

how came you thus recovered

I have here recovered from the iioor

RECOVERIES -his recoveries (rep.).

undertake the recovery of this drum

witls fine and recovery $\ldots . . . \ldots \ldots$.... Merry W'ives, ip. 2

bear him home for his recovery

grief that they are past recovery ....2 Henry $r^{\prime \prime} 1 . \mathrm{i}$.

use means for her recovery ..........3Henry $F^{\prime}$. v. 5

oinit that bears recovery's name

and the recovery of his recoveries........

RECREANT; come, thou child.Mid. N. is Dreant, iii.

a call's skin on those recreant (rep.). King John, iij.

a caitiff recreant to my cousin Hereford 1 -

to be found false and recreant $($ rep. $) ..$
in thy teeth, most recreant coward $\ldots 2$ Henry $I V$. i. 3
I say, distrustful recreants!

I say, distrustful recreants! ........ Henry $r i$ i.

a mere recreant prove ......... Troilics CCressida, $\mathrm{i} .^{3}$

as a foreign recreant, be led

hear me, recreantl on thine alleginne.....

RECREATE-recreatc Jourselves. Julizs Casar, iii. 2 is there no quick recreation granted?

and we will to our recreation ......... shed there, shall be my recreation...Winter's $T$. iii. sweet recreation barred ...... Comedy of Errors, v. for your best health and recreation. Richard WII. iii. R.ECTIFY-rectify our knowledge.....

as to rectify what is unsettied.......

Tempest, v.

RECTOR of the place

RECTORSHIP of judginent

RECURE, we heartily solicit

he in the red face had it

red and white Nature's own

like the red rose on triumphant ...Mreasur fleasure, iv. white and red (rep.) $\ldots \ldots \ldots \ldots \ldots$......... Love's L. Lost, i. and therefore red, that would avoid

Marian's nose looks red and raw

than there is between red wine.. Mer. of l'enice, (solig) the red glow of scorn and proud. As you Like it, iii. more usty red than that

gartered with a red and blue.Tan..... for the red blood reicns... Winier, $\%$ ate - iv. and let's be red with mirth looked he or red, or pale.............. and white, red spirits, and grey......... iv. 1 (song)

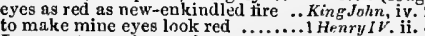
I warrant you, is as red as any rose.2 Henry rr. ii.

sometimes blue, and sometimes red........ Hcrny $V$. iij. 6

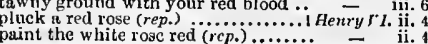

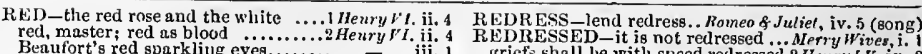

book in his pocket, witl red letters in't - iii.

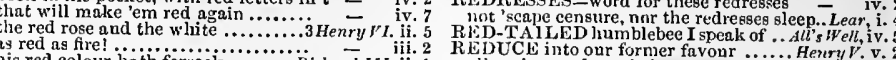

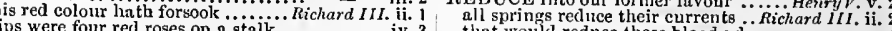

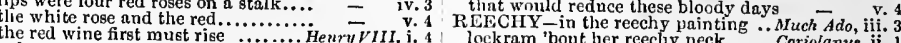
red murrain o' thy jade's tricksi Troilus \& Cress. ij. in characters as red as Mars ........ - v. 2 REED then like reeds, not hair....... Hamlet, iii. 1 backs red, and faces pale $\ldots \ldots . . . . \ldots . .$. . Coriolanus, i. 4 winter's drops from eaves of reed - v.

wis eyes our red weapons o'er our...Julius Case as in thy red rays thou dost sink ( $($ tep.)

cheeks look red as Titan's face ... Tilus Andron. ii.

to have a thousand with red burning... Pericles, iv.

pale, or red? Nay, very pale............. Hamle

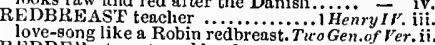
REDDER - turn to redder drops .... Julius Copser. it. REDDEST-whose blood is reddest. Her.of Venice, i and foamy mouth did 1 redeem...... to redeem lim, give up (rep.)........... redeem your brother from the angry

did redeem the virgin tribute so far, that the rarity redeems him . A Al's Well, iv wanting gilders to redeem their... Comedy of Er. sent you money to redeem yon

broken wing, redeem son, as they .....King $J_{0} k_{n}$, iii. to redeem a traitor home? wherein you may redeem your

so he, that doth redeem her thence...

but my going, nothing can redeem it. 2 Henry iii. weening to redeem, and have ...... I Henry VI. but redeem the passage of your agei ${ }_{\text {from }}$ y Redeemer to redeem ine. Richard $I L L$ ii. redeem my brothers both from death. Titus And. iii. a chance that does redeen all sorrows

REDEE come to redeem me?..... Romeo \& Juliet, iv. thou hast redeemed thy lost opinion.1 Henry $1 \mathrm{~V}$. day have you redeemed your $0 \ldots . . .$. Henry $y^{\prime} I$. i. whom he redeemed from prison.. Timon of Ath. iii. seals and symbols of redeemed sin........ Othello, ii. 6 precious image of our dear Redeemer RED EEMING him, should die ...Meas. for $\bar{M}$ eas. ii.
redeeming time, when men think...1 Henry $I V$. i.

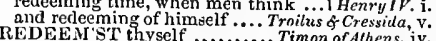
I huve longed long authorities... Meas. forMeas. iv. REDEMIPTION-toul redemption Meas. for Meas. ii. You bid me seek redemption
into everlasting redemption

send him, mistress, redemption.........Muched of Erro, iv. damned without redemption?........ Richard II. iii. as his soul's redemption is by the ..3 Henry $/ I$. ii.
[Col. $]$ hope to have redemption ....Richard III. i. of my redemption thence, and portance.. Othello, i. RED-FACED; by the means whereof.. Henry V. ili. 2 RED-HOT with drinking

were red-hot steel, to sear me to .. King John, iv. REDIME te captum quam queas... Taming of Sh. i.

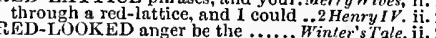
REDNESS-pretty redness in his lip. As you Like, ii.
RED-NOSE innkeeper of Dain try ..1 HenryIr. jv.

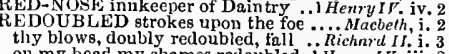
tly blows, doubly redoubled, fall . Richnrel II. i. 3 to render them redoubted most meet... Merch of Venice, iii. lord regent, and redoubted Burgund ... Richard $I I$. iii. 3

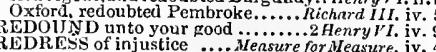
or wring redress from you.
good night to your redress

good night to your redress

and, what I can, redress................Macbeth, iv. 3 means of succour and now ......... kichurd II. ii.

I beseech you, I may have redres....2 Henry $I V$.

no need of any such redress..........

no way canst thou turn thee for redi. Henry $r$ iv. ii. not a iman comes for redress of thee.3 Henry $V I$, vii. seek how to redress their harms...... - v. nse the wars as thy redress .... Timon of Athens, v. be factious for redress of all these... Julius Casar, i. 3 speak, strike, redress! (rep.).

to prick us to redress? what otier..... - ii. that Crasar, and his senate, must redress? - iii. I to have found a safe redress ............... Lenr, i. among the trembling reeds.

i Henry $1 \mathrm{~V}$. i.

thad as lief have a reed that .... Antony s-Cleo. ii. 7

RE-EDIFIED. Is it upon record? .. Rchard III. iii. 1 WEEK I have sumptnously re-edified.. Tit us.And.i.2 saw sighe reek from you ........... Love's L. Lost, iv. as reek o' the rotten fens .......... Coriolanus, iii. purple hands do reek and smoke...JuliusCasar, iii. hath made you reek as a sacrifice.... Cymbeline, i. 3 their honours reeking up to heaven ..Henry $F^{\prime}$. iv. in your faces your reeking villany.. Timon of dth. iii. came there a reeking post, stewed......... Lear, ii. REEKY shanks, and yellow ...Romeo \& Juliet, iv. make my very house reel to-night... Coriolanus, ii. to reel the streets at noon .......... Antony \& Cleo. i.
drink thou; increase the reels........ like a drumkard reels from.............. o o Juliet, ii. REELING-Trinculo is reeling ripe..... Tempest, i. depart reeling with too much drink. Cymbeline, v. RE-ENFORCEMENT struck Corioli. Coriolan us, ii. REFELLED me, and how I replied, Meas. for Meas. v. I do refer me to the oracle ...... Win'er's Tale, iii.

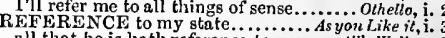
nll that he is lath reference to your.....All's $s$ oll, $\mathrm{y}$. 3

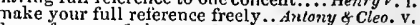
due reference of place, and exhibition ... 0thello, i. 3
REFERRED me to the coming...Macbeli, i. 5 (lette: hath referred herself unto a poor .... Cymbeline, i. 1 to gild refined gold, to paint the lily. King,Jolin, iv. 8ouls refined should slow so heinous. Richard II. iv. reflect upon him accordingly . Cymbeline, i. 7 (letter reflect on Rome, as Titan s rays ... Titus Andron. i.
REFLECTING gems, that wooed.... Richari $I I L$. REFLECTION shipwrecking storms...... Macbeth, i. what he owes, but by reflection. Troilus \& $\&$-Cress. iit. sees not itself, but by reflection ....Julius Casar, i. 2 we hear you do reform yourselves. .2 Henry $I V . \mathrm{V}$. REFORMITION-your reformation. Love's $L . L$. $L$. v. reformation, glittering o'er my fault. 1 Henry $I V$. i. is brave, and vows reformation ..... Henry VI. iv. which reformation must be sudden ... - ven. ver. 2 REFORMIED-they are reformed. Two Gen.of Fer. v.
hatli reformed signior Leonato........ Nuch Ado, v. departed thy penitent reformed ........inter's Tale, $\mathbf{i}$. not reformed, may prove pernicious. Ilenry $Y H I T . \mathrm{v}$. 2

reformed that indifferently with us.... Hamlet, iii.

ask me if $I$ can refrain from love........ King Jobth, ii. 3 scarce I can refrain the execution ...3 Herry $r$ ri. ii. 2
refrain to-niglit; nnd that shall lend .. Hamlet, ii. 4 refrain from the excess of liughter.... Olhello, iv. I to refresh the mind of man ... Taming of Shretr, ii. you wenry those that refresh us... Winler's Tale, iv. 3 shall we refresh us, sir, upon your .....Pericles, v. REFRESHING sliowers .............. Tempest, iv. 1 and would have reft the fishers....... Conedy of Err. i. for his case was like, reft of bis brother - i.

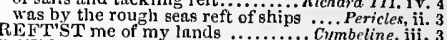
REFUGE-I'll for refuge struiglit.... Cymbeline, iii. 3 in the stocks, refuge their shame....
$0^{\prime}$ er the walls for refuge in the field i Henry $Y$ I. ii. 2 imagine what would be her refuge .. their latest refuge was to send him. Coriolants, y. 3

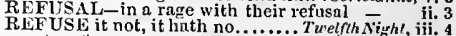
as to retuse so rure a gentleman .....Much Ado, iii. I if I refuse to wed Demetrius.....Mid. N.'s $\overline{D r e a m}, i$. i nor refuse whom I dislike ...Merchant of Venice, refuse to perform your father's will (rep.) did refuse three thousand ducats of me - i. 2 if you do refuse to marry me $\ldots$ As ynu Like it, v. $\mathrm{v}$ if thou refuse, and wilt encounter. Winter's Tale, ii. 3

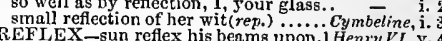
pale reflex of Cynthia's brow ... Romeo \& Juliel, jii. 
REFUSE-Own doors refuse .. Cminedy of Errors, iii. I
that would refuse so fuir an oftered..

being none of lis, refuse him ......... King John, i.

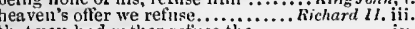
that you had rather refise the $\ldots . . .$. . refusc not, mighty lord, this. if your refuse it, as in love and zeal... - iii. 7 if you refuse your aid in this...

which they did refuse, and canni.....

erown, which he did thrice refuse.Julius $\overline{C a s n}$, iif. refuse to drink iny dear sons'. . T

which if you shall refuse, when $1 . . . .$. . Pericles, deny thy father, and retuse .... Roineo \& Julict, REFUSED it in the open court.......... Oherch of it ine open court.Merch. ni ny which I woudd have refused

er........ in vaulting sea refused to drown me...2Henry $V I$. since you refused the Grecians'. Troilus \& Cress. I that now refused most princely..... Coriolanus, and still as he refused it, tlie.

refused the crown (rep.)

Pericles, $\mathrm{i}$

or else, refusing me, to wed this .......... Tempes Like it shall fall you for refusing him ..Anlony $f$ Cleo. have shook off the resal thoughts still enjoy thy regal dignity ........ i Henry $r I . v$.
point-blank of our jurisdiction regal.2 Henry $Y$. .
and this the regal seat and this the regal seat

impale hin with the regal crown?

shaken Edward from the regal seat.

in time, to bless a regal throne

wore their crownets regal.. Troilus \& Cressid

and Regan, his duchess, will be here with

i' the haste, and Regan with him.....

nor I, assure thee, Regan

beloved Regan, thy sister's naught (rep.)

nerer, Regan (rep.) Re...........

I can stay with Regan, I, and my....

with five and twenty, Re

O Regnn, Goneril! your old kind father....

Regaln, I bleed apac

and regard of such a tather. 7 twa Gen. Tempest and regard of such a tather. Tw

after a demure travel of regord

with an austere regard of contronl

you throw a strauge regard upnn me
vail your regard upon a wronged. Neas. for $M$ Icn

your niece regards ine with an eye ... MuchAto

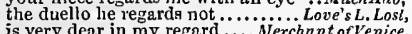

is very dear in my regard..... Merchnnt of lenice,

no attendanee? no regard? no duty?.

better by my regard, but killed.... Winter's Tale, i.

- iii.

in regard of me, he shortens

Richard II

in mutiny with wit's regard

in the strects, and no man regards it.l
sick in the world's regard, wretched

so little regard in these costermonger. 2 Henry II

full of grace, and fair regard ........... Henry $V$.

and in regard of causes now in hand

that regards nor God nor king ...... Hcnry $_{V}$ I. $\mathrm{i}$.

ere we go, regard this dying prince... - iii.

a thing of no regard, king

in regard king Henry gives............

this way, Henry, and regard them not.3 Henry VI. i. I
when did he regard the stamp .....Henry VIII. iii.

when did he regard the stamp ....Henry VITI. iij.

lay negligent and Inose regard upon him -

most abject in regard, and dear in

not to give regard to you ...... Timon of $\overrightarrow{\text { Athens }}$ iii.

to aw aken his regard for his ........

full of regard, and honour.............

is still that I regard it not $. . \ldots \ldots . . . . . c_{y}$ mbetine, ii. as he regards his aged father's life. Titus Andron. $v$. in the most exact regard support .......... such regards of safety, and allowance....... Hamlet, ii. 2 with this regard, their currents turn awry in which regard thongh I do hate him ... Othello, i. and the aerial blue, an indistinct regard

REGARDED in her sumbright. Two Gen. of Ver. iii.

but I regarded him not; and yet he..
beard, not regarded; seen, but with

small eurs are not regarded........

not resarded in handyeraftsmen ..

lee how I regarded Cuius Cassius.... Torinlanus, v. REGARNFULIY? Art tlou.. Timon nf Alhens, iv. REGARDING that she is my...Two Gen. of Ver. iii. REGENT-regent of love-rhymes. Love's $L$. Lost, ii: wert thou regent of the world ....... Richard Il. il. the most glorions regent of this land - ii.

\begin{abstract}
to he our regent in these parts
the regent conquers, and the Frenchimen - iv. 6

lord regent, I do greet your...........

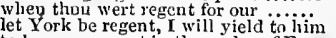

to be your regent in the realm of France -

regent 0 'er the French (rep.)

had been the regent there $(r e p.) \quad \ldots . \quad$ - iii.

the regent malle in Mitylene.... - v. 2 (Gower)
\end{abstract}

REGIA - Priumi regia celsa senis. Tamint of $\mathrm{Sh}$. iit. 3

regia, bearing niy port (rep.) .........

I know you are the Muskos' regiment

appointments, all our regiments .....King Jokn, ii.

his regiment lies lialf a mile at least

to Stanley's regiment; bid him bring

COAINA regina - v. 3

REG ION-'twixt which regions there... Tempest, ii.

sle is a region in Guiara.

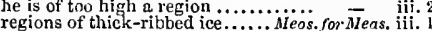

every region near seemed ali one.Mid. N's $\mathrm{Dr}$
to other regionst France is ............All's 'tell,

and a region loved as he loves............ner's Tal,

from every region, apes of ...........2Henry I $b i$ i

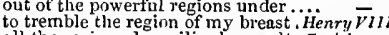

to tremble the region of my breast. Henry $\bar{V}$ ill

keep the fills and upper regions ...Julius Casar, v.

you petty spirits of region low.......... $-\overline{\text { Titus }} \bar{A}$ d. v.

when you come to Pluta's region ..Tilus And. iv.

bourn to bourn, region to region - iv. 4 (Gower)
invade the region of ny heart ..........

the airy region stream so bright. Romeo o. Juliet, ii. 2

should have fatted all the region kite.... it.

that dwell in every region of lis face.. O/hello, iv.
REG ISTER of your own .......... Merry Wives, ii.

me in register a master-leaver... Antony \& Cleo. iv.
REGISTERED upon our brazen ... Love's L. Lost, i.

your pains are registered where every...Macbelh, $\mathrm{i}$.

those many registered in promise Troilus \& Cress. iti. 3

this seizure, and this kind regreet?... King John, iii.

shall not regreet our fair dominions...

REGRESS-have egress and regress. llerry Wives, ii. I REGUERDONED with so mueh as

REGULAR - of regular justice.. Timon of Alhens, v. 5

convenient place for our rehear'sal. Mid. N.'sDr. iii. t

there will we rehearse (rep.) "...Mïi.⿲丿丨.'s Dream, i. ?

every mother's son, and reliearse your $\quad$ were met together to rehearse a play
iii. 2

first, rehearse this song by rote.......

may move thee pardon to rehearse. Richard II.

verhatim to rehearse the method ..1 Henry VI.
REHEARSED, I must confess.. Nrid.N.'sD Dream,

danger formerly by me rehearsed. Mer. of 'enice
defects I have hefore rehearsed .. Taming of $S h$.

REIGN-what folly reigus in as I Tro Gen. of l'er.

fortunc reigns in gifts of:................ As you Like
have J politicly hegun my reign. Taming of Sh.

liappy star, reign now! …........ Hinler's Tale, $i$.

red blood reigus in the winter's pale $-\overline{\text { iv }} .2$ (song)

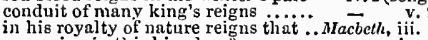

ever reign in this kingdom
than such a one to reign

where we do reign, we wili alone..........

to check his reign, lut they.........

one England brnok a double reign...i Henry $I$

tor all min in all bosoms

year o' the last king's reign was $\ldots . .$. . Henry v. i. 1

the time Edward the third did reign. 1 Henry VI. i.

Monmouth first began to reign (rep.)

should reign among professors of one

in the reign of Bolingbroke

in time to come, I hope to reign.....

wine this tirst year of our reign......

uncurable dliscomfit reigns in tlie

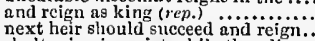

shalt reign in quiet while thon lives

to put me duwn, and reign thyself ...

as thou slialt reign but by their......

a thousand ouths, to reign one year
what is pomp, rule, reign, but ......

Edward stilt lives, and reigns ......... Richard II $I$.

good grace his son shall reign $\ldots . .$.
no douht, us happy by his relgn $\ldots . .$.
son shall never reign our king $\ldots$

that reigns in galled eyes of wecping you may reign in them now 1 ...... Cymbeline, v. o

for his peaceable reign, and good....

to rule, and how to reign, we thus submit - ii.

son and daughter shall in Tyrus reign

then slecp doth reign ...Ramea $s$

now reigns here a very, very-peacock. Hamlet, iii.

death, reigned as ling $\ldots \ldots \ldots \ldots \ldots$.

a springhalt reigued among them ...Henry ${ }^{\prime}$ III. i. 3

that there had reigned by many...... - is - i.

(till Lincina reigned) nnture this dowry. Pericles, i.

to try her skill, Reignier stand thou as -

Alcncon, Reiunis that think'st to

see, Reignier, see, tloy danghter

thanks, Reignier, happy for so .......
Reignier of France, I give thee .....
farewell, Reiguierl set this diamond

farewell, Reiguierl set this diamond
but Reignier, king of Naples ........

while Reignier sooner will receive $\because . \quad \vec{v} \quad$ v.

the poor king Reignier whose large...

$R$ EIGNING-at this hour reigning there. Tempest, iii. 3

REIGNOLD [Col.-Reginald] W'inter's Tale, iv. (cho.)

EIN - dalliance too much the rein ...Tempest, iv. 1

for pills to cool the reins..........Merry Wives, iji. 5

give my sensual race the rein ... Theas. for Meas. ii.

rein thy tongue. I must (rep.) $\ldots$... Love's L, Lnst, y.

giving reins and spurs to my free..... Richard $I I . \mathrm{i} .1$

what rein can hold licentious .......... Henry $\nu$, iii. 3

bears his head in such anding rein ...Richard III. ii.

give your disposition the reins $\ldots \ldots \ldots$ Coriolanus, ii. 1

REINED-he cannot be reined again . Coriolonus, iii. 3

REINFORCEMENT, or we perish. Trail. \& Cress. v.

REITERATE, were sin as deep as. Winter's Tule, i. 2
$R E J E C T-$ this you will reject her. Love's L. Lost, v. 2

REJOICE to hear the solemn curfew.... Tempest, v.

rejoice in the boy's correction... Two Gen. ofver. iii. 1

rejoice in the boy's correction...TwoGen. ofVer. iii. 1
my husband will not rejoice so..... Merry Wives, $v .3$

professed to make him rejoice ... Mileas. for MIeas, iii. 2

as to rejoice at friends but newly.. Love's L. Last, v.

of my estate, to rejoice in yours ...As ymu Like it, i. 2

rejoice, the former queen is wall... Winler's Tale, $\mathrm{v}$.

brother there, rejoice with him... Comedy nf Err. $\because$

rejoice now at this happy news ....2 HenryI $\mathrm{V}$. iv.

more rejoice at the discovery of $\ldots$......henry $\mathrm{P}$ ii.

rabble, that rejoice to see my tears..2 Henryll.ii. 4

not one that rejoices in ......... Timon of Athens, v.

you'll rejoice that he is thus cut off

and to rejoice in his triumph (rep.). Julius Casar, $\mathrm{i}$.

as he was fortunate, I rejoice at it.... - in splendour of mine own. Rnineo \& Juliet. i. 2

REJOICED dleliverance more ......... Cymbeline, $v$.

REJOICIN G at nothing can be more.. Tempest,

rejoicing to see anotlier merry.. Meas. for Mleas. iif.

nur company piece the rejoicing?. Whiter's Tale, $v, 2$
lose the dues of rejoicing ....... Macbeth, $\mathrm{j} .5$ (letter)

REJOICINGLY, and I'll be merry . Cymbeline, iii. I

REJOINDURE, forcibly prevents. Troiluse $\bar{C}_{\text {ress. }}$ iv.

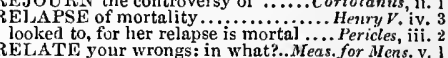

shall relate, in high-born words ... Love'sL. Losi, i. I

to relate the manner, were, on the..... Macbeth, iv. 3

special pardon, dare not relate.........3 Henry $V I$. iy. 1

with bold spirit relate what you.......

relates in purpose only to Aclilles. rrnil. $_{\text {\& }}$ Cress. i. 3

I will relnte; action may....... Prericles, iil. (Gower)

this heavy act with heavy heart relate..... v.

hatis full relation to the penalty......... Terer. of rest, v. I

hath full relation to the penalty. Mer. of Fenice, iv. I

were you present at this relation? Winter's Tale, v. 2
when at the relation of the queen's death - v. 2

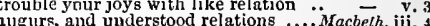

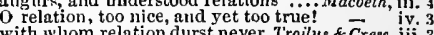

with whom relation durst never. Troilus \& Cress. iii. 3

my sensss eredit thy relation .......... Pericles, y. I

RELEASE-bndge, till you release...

Tempesl, v.

but release me from my bands ...... - (epilogue)

release iny brother ..........Measne for Neasure, v.

but first I will release the fairy queen

RELEASED him, Isabel .. Measure for Mard II. iv, I

got'st thou to be released?............ I Henry $i$ i. i. 


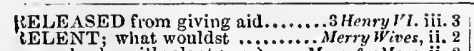
may be, he will relent (rep.)......... ifeas. for Meas. ii. 2 relent, sweet Hermia ............ Mid. N.'s Dream, i. shake the head, relent, and sigh .Mer. of Yenicc, iii.
tears, and will not once relent? ....1Henry VI. iii. tears, and will not once relent? ing lord of Winchester, releut or nature makes me suddenly relent - iii. 3
vonld it not enforce them to relent..2 Henry $V_{\text {I. }}$ iv. 4 and therefore yet relent, and savo my life - iv. 7
will ye relent, and yield to mercy (rep.) - iv. relent, and save your souls (rep.) . Richard MII. i. fierce Andronicus would not relent Tilus

RELENTING passengers ........2 Henry $V I$. iii. relentiog fool, and shullow........ Richard III.;iv. We do bury the incensing relics of
we

we do bury the incensing relies of it -
stains, relics, and cognizance...... Julins Casar, ii.
RELIEF-I will give him some relief.. Tempest, a gentleman you send relicf. Merchant of Venice, iii. wherever sorrow is, reliet would As you Like il, iit. 5
on the relicf ot this oppressed chila.. King John, ii. I and to relief of lazars, and weak age ..Henry $r . i$. if Frunce can yield reliet and my reliet must not be tosied... Timon of $A t h$. neither want my means for thy reliefCymbeline, iii. relief among Rome's cremies. Titus Andronicus, v. 3 for this relief much thanks ............. Hamlet, i. I and my relief must be-tuloathe her.... Othello, ii. 3

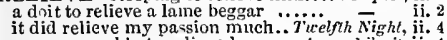
were more able to relieve her .....As you hike il,ii. 4
by this token I would relieve her .....All's Well, v. 3 by this token I would relieve her ..... All's Well,
helpless patience wouldst relieve. Comedy of Err. with purpose to relieve and follow .... Herry ri. i. 1 ere thou relieve the beggar .... Timnn of Athens, iv. 3 surfeits on, would relieve us

and did relieve me, to sec this........ Cymbeline, v. 5 to relieve them of their henvy load

such kindness must relieve me:
seek him, and privily relieve him

RELLEVED by prayer.......... Te ......Lern relieved him with such sanctity.. Tu'tlfih Nigh!, iti. 4 they relieved us humancly.

who are in this relieved, but not .... - v. where they should be relieved .... Cymbeline, ii 6 neighboured, pitied, and relieved, as thom. Lear, i. I the king my old master must be relieved -

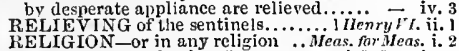
RELIGION-or in any religion ...Meas. for Meas. i. 2
it is religion, to be thus torsworn., Lnve's L. Lost, iv. 3 in religion, what damned error. Mor. of lenice, iii. their hearts are severed in religion

it is religion, that doth make

name not religion, for thou lovest...... Henry VI. i.

religion groans at it .................. Thon of Athens, iii.

religion to tlie gods, peace, justice.

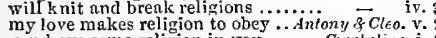
sou have some religion in you ....... Cymbeline, $i$ and swect religion makes $a$ rhapsorly.. Haintet. iii.

meeting with an old relifious man...

hath put on a religious life $\ldots . . . . . . .$. .

in some reclusive and religious life.. Much . Indian-like, religims in mine error ... All's Well, $\mathrm{i}$. thy love's to me religious ................
religious strength of sacred vows.... $\overline{k i n g}$, ii. 3
, iii. 1 cloister thee in some religious house. Richard 1. $\mathbf{y}$. seem they rcligious?

my lord should be religious, and know

when holy and devout religious men $\bar{F}_{\text {thy religious truti, and modesty ... Henry }}$

I know youl wise, religious

only good and wise, but most religious $\bar{T}_{\text {rigions }}$. iv for $1 \mathrm{know}$ thou art religious. Tilus A udronice RELIGIOUSLY; and, as a certain. Love's L. Ln kiss not more religiously .........As ym Like it,
oppressed child, religiously provokes. KingJohn, in his name, religionsly demand

our souls religiously confirm thy words $-\overline{-}$,

religiously they ask a sacrifice. Titus Andronicus,

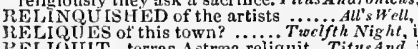

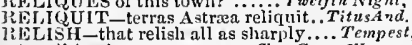

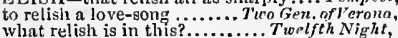
what relish is in this?............ Twolfth Night, iv. relish it with a good observance. As you Like it, iti.
or will not, relish as truth.........Winter'sTale, ii. I have no relish of them ............... Macbeti, iv. some relish of the saltness of time....2 Henryl $\mathrm{V}$.
be of the same relish as ours are $\ldots \ldots$ Henry $V$. iv now I begin to relish thy advice. Troilus \& Cress. the imaginary relish is so sweet...... here contained relish of love........ Cymbeline, iii. 2
RELISH-but we shall relish of it..... Hamlet, iii. ) । You may rclish him more in the soldier. O'hello, ii.
RELISIEED-not have relisised.... Winter's Tale, $\mathbf{2} .2$ RE-IIVI:-this dead queen re-lives? cricles, vii. 3 RELY upon it till my tale be heard.Men. for Mea. v patient, on thee stilt rely ...............All's Well, he doth rely on none ........ Troilus \& Cressida, RELYING on your lordship's.. Tivo Gen. of Ver

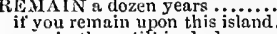

remain thou still in darkness...

Táelfh Night,

beize one comtort should remain ... Much $A d o, i$. and but one visor remains.................. ii. I thon shalt remain here whether ...Mid.N.'s Dr. iii. it is home returned, there to remain there remains unpaid a handred... Love's L. Lost $_{\text {. it. }}$. nothing remains, but that I kindle.
where remains he? how parted le and there remains some scar of let his nobility remain in his

by his autinity he remains here

to remain witls me till they meet.... - iv. 5

nought remains but so; redime te. Triming of Sh.i. and remain, as he says, your pawn

our poor malice remains in danger

what else remains to do, according

from where you do remain, let paper

I do remain as neutre; so fare you

where now remains a sweet reversion.1 Henry IV.iv. 1 then this remains; that we divide $\because$. for you shall remain with us.....

but there remains a scruple in

and there it doth remain the saddest. 3 Henry ${ }_{\text {r. }}$. ii.

what now remains (rep. iv. 7).........
percmptory Warwick now remains..
and thou shalt still remain the duke

to Kimbolton, where she remains.. Henry $\overline{V I L S}$ i

the re to remain, till the king's further

what remains will hardly stop. Timon

and remain 2 beast with the

it did remain $\mathrm{i}^{\top}$ the mirlst $o^{\prime}$ the body.

fetch him off, or make remain alike

it then remains, that yoll do speak

remains, that, in the official marks..

that shall remain a poison (rep.)

you so remain. And so are like to do

while $I$ remain above the ground

only that name remains $\ldots . . . . . . . .$.

the people will remain uncertain

poor remains of friends, rest on this

heart remains in use with you.... Antony of

remuin in't, as thou may'st

that we remain your friend..............

remain, remain thou here while

if she remain unsednced .............

bold, her honour will remain lers

that remains loyal to his vow

are not well; remain here in the cave

behold the poor remains .......Titus Andronicus

shall this hair of mine remain..........Pericles,

remain this ample third of our fair.........

not in this land shall he remain uncaught $=$ ii.

if both remain alive.......................

thou shalt remain full two and fort

bend you to remain here in the cheer.

and now remains, that we find out

remains, and the remainder thus

bad berins, and worse remains behind.

of myself, and what remains is hestiol.

fort governor remains the censure $=$ v.

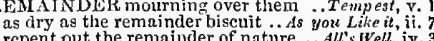

cut the entail from all remainders ... All'sell, iv. 3

upon remainder of a dear aceount \#Richard it $\mathrm{i}$.

the remainder viands we do not..... Troilus o Cress. ii. 2

slender ort of his remaincler .. Tinon of Alhens, iv. 3

poor remainder of Andronici will. Titus Andron. v,

and the remainder, that shall still dcpend. Lear,

it remains, and the remainder thus .... Hrmlet, ii.
IEEMAINED until this time .. Comedy of Errors, iv.
REMAINED nuscorched ..........JulinsCasar, i. 3

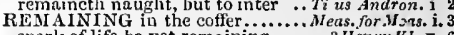

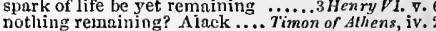
remaining now in Gaslia? .......... Cymbeline, jii. 7 remaining so long a poor unknown...
REAIARKABLE in single oppositions

nothing lett remarkable beneath. Anlony \& Cleo.iv. 13 REMEDLATE', in the good man............. Hear, iv. REMEDIED, to your pollic laws. Timon of $A$ thens, y. 5 REuE DI to her some remedies for life .....Winter's Tnle, iii. 2

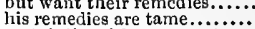
certainties eitlier are past remedics ... Cymbeline, i. 7 seeking to give losses their remedies ....... Lear, ii. I

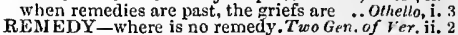
there is no remedy ...............Merry Wives, $i .3$ must send her your page, no remedy

stand not amazed: lere is no remedy $\quad$ wcll, what remedy? Fenton …..... v. if it will not, what remedy? ....... T'wefth Night, i. 5
there's no remedy, sil (rep.).........
hut there's no rcmedy (rep.) .....Meas. for Meas. ii. 4 maiden, no remedy ....

found out the remedy $\ldots \ldots \ldots \ldots \ldots . . . . . . .$.

no remedy? None, but sucl a remedy = in doing good; a remedy presents itself

nay, it there be no remedy for it .....

if not a present remedy, yet a patient be by, beg of her for remedy ...Mid.N.'s:Dream, iii. 3

or absence, soon shall remedy........ - iii. 2

though 5 et I know no wise remedy... As you Like, $\mathrm{i}$.

the reason, but they sought the remedy $=$ iii. 2

amongst the remedy, there is a remedy.All's $W e l l, i$. 3

there is no remedy

shall cease without your remedy ..... - $\quad$ iv. 3

I know my remedy .... Taming of Shrero, $\overline{1}$ (induc.)

no remedy (rep. $\nabla$. 1)............ Winter's Tale, iv. 3

is there no remedy. None, but ...... King John, iv. 1

since there's no rencdy, I mean to...i Henry $V I$. ii.

this Rome shall remed

yes, there is remecly enough, my lord
I will remedy this gear ere long ....2 Henry $r l$ iij.

I did steer toward this remedy ..... IIenry IIII. it.

entreaties will render you no remedy - Y. I

must then to the Greciane? No remedy - iv.

there's no remedy; nuless, by not.. Cmiolamis, iil.
knowing, the remedy then born...... Cymbeline, $\mathrm{i}$.

the harder heart! alack, no remedy ! - iii. 4

careful remedy (rep.) ........ Titus dndranicus, iv. 3 to the friar, to know his remedy. Romeo o Juliet, iii. what thou, speak'st speak not of remedy

opened, lies within our remedy $\ldots \ldots \ldots . . . .$. Hamlel, ii. 2 but there's no remedy , 'tis the curse of ..OHello, i. 1
REMEMBER wliom thou hast aboard.. Tempest, i. I

canst thou remember a time ...........

I pray thee, remember, I have .........

the ditty does remember my drowned

no woman's face remember.............

rcmeinber first to possess his books....

but, remember, for that's my business $=$ iii. 3

tiat you remember not................ of $\bar{V}$ er. iv.

thongh I cannot remember what.....Merry $\bar{W}_{\text {ives, }}$ mistress Page, remember you your..... =

remember, william; focative is $\ldots . .$. =

remember, son sleoder, my daughter = iv.

and rememiber your parts............

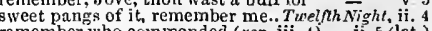
remember who commended (rep. iii. 4) - ii. 5 (let.) tho remember .....................

and yet, alas, now I remember me.. = v.

but do you remcmber? ................

rcmember now my brother............ - jv.

I remember you, sir, by the somid of $=$

to Hero. I rcmember. I can, at any -

I remember a pretty jest your daugliter -

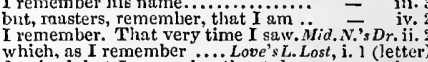
deccived, but I remember the style.. - iv. beseech thee remember thy courtesy $\overline{-}$ I remember him well; and i remember $\bar{T}$, must not learn me how to remember I remember, when I was in love (rep.) can you remember any of the principal - 
REAIEMBER a saying: the fool ...As you Like it, v. I REMIEMBER thine eyes well enough ....Lear, iv. 6 REMFMBRANCER of her

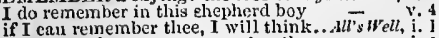
when thou liast none, remember thy ... - i. you remember the daughter of this lord? - v. 3 signior Bnptista may remember me ${ }^{\prime}$ iv. 4 I'il not remember you of mine.. "Inter's Tale, iii. 2
and remember well, I mentioned - iv. (elourus) and remember well, I mentioned - iv. (elionus) reincmber, stoned, and flayed alive...
whilst I remember her, aud her virtues that followed should be, remember inin beseech you, sir, remember since you - v. I you remember me (rep.). ......Comedy of Errors, y. threescore and ten I can remember well - ii. 4

I cannot but remomber suel things were $\bar{L}_{\bar{n}}$ iv. 3 if ever I remenber to be holy....... What I intend tor thee, remenber....

yet I remember, when I was in France not so quickly go; I shall remenuber. Richard on will but iemer me, what a deal.

brielly thissclt remember; the swor as the skill I have remembers not remember thy swashing blow.... Romeo \& Juliet, $\mathbf{i}$. remember it well: 'tis since. I do remember an apotheeary ....... must I remember? why, she would and remember well what I have said.... emember thee? Ay, thou poor ghost (rep.) I remember, one said, there were no...

pray you, love, remenber: and there is.

I beseech you, remenher-Nay, good...

on my bed my wedding sheets, remembie

REMENBERED by don Pedro...........Much if you be remembered (rep.) ..... Mens. for Jfeas. ii. marry, well remembered ...Merchant of Venice, ii. 8 now I ain remembered, seomed at me

my liege, remernber who you are.... it doth remember me the nore

I do remember well, the very time...

to my good use, I remembered ... Winter's Tnle, iv. but not remembered io thy epitaph!. 1 IIenryI $V_{\text {. v. }} 4$ my liumble diuty remembered, I will not yet I well remember the favour of the remember, as thou read st, thy promise $-\bar{r}$ IV I remenber, whember ne, his name is as I before remembered, all our state.
their flowing eups freshly remembered Henry $V$. iv. 3 if your majesties is remembered of it - it -7 if I had been remembered, I eould. Hichnrd III. ii. which craves to be remembered Timon of Alhens, ii. 2 to remember so weak a eomposition.2 Ilenry/ $I$. ii. I do now remember the noor do not bid me remember mine end you, cousin Nevil, as I may remember I remember at Mile-eod Green....... I do remember him at Clement's-ins not to remember, not to have patieo do you not remember, a' saw a flea ... Hen

but he'll remember, with advantages

I do remember it; and here take leave

porter, remember what $I$ gave in chars

porter, remember how my father said.

my lords, remember where we ale
fond man! remember that thou hasi

remember what the Lord hath done

I remember it to my grief

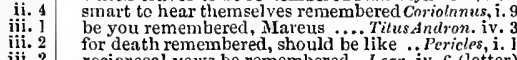

recioroeal vows be remembered.. Lear, iv. 6 (letter) thy orisons be all my sins remembered Hamlet, iij. '
RHIIENBERING how I cried........... T'empest, i. 2 remembering that my love to .. Two Gen. of l'er. ii. 6 by remembering you, 'tis past.. Henry $V$. v. (chorus)
remembering how $I$ love thy .... Rnmeo \& Juliet, ii. REMEABER'ST aught ere thou eamest. Tempest, 1.2 o but remember this another day.

I will never more remember our former

I do remember me; Henry, the sixth

remember Margaret was a proplietess

remember whom you are to cope withal

you remember how under $m$

I yet remember some of these articles

something over to remember me by.

remember me in all humility unto ...

my good inistress will remember in.

remember your brother's excuse. Troil

will you remember? Remember? yes

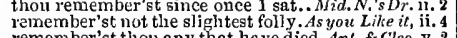

pleased the gods remember?.... T'in

wlicl is from my remembranee

this lord of wcak remembranee............ = i. how sharp the point of this remembrance - v. joep this remembranee for thy. Two Gen. of Ver. ii. 2 emembranee to-morrow on the lousy.

$\begin{array}{ll}\text { iii. } 3 & \text { I pray you, have your remembranee } \\ \text { iv, } 2 & \text { an abstraet for the remembrance of }\end{array}$

lasting, in her sad remembrance of. iv. 2

my remembrance is fiee and clear fr

iii. 4 irom my remembrance clearly banished $\overline{\text { and }}$ v.

that lies in woe, in remembranee of. . take some remembranee of us ...Ner. of t'enice, iv.

and now I remember me, my lord...

and to remember with honours like

remember, iny name is Menenius. ..

if you'd ask, remember this before...

noble man still to remember wrongs?
he no more remembers his mother now

I shall remember: whien Cæasar....Julius $\bar{c}$

more foolery yet, if I could remember

but all remember what you have said

grace his remembrance more tha........ All s s -

prace good remembranee, sir, lies richer in -

from the time of his remembrance

REMFRCIMENS; et je $\mathrm{m}$

Cymbeline, i. 6 my lord, that we are too remi......Meas. for Meas. iv. 2

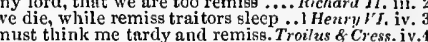
must think me tardy and remiss. Troilus \& Cress. iv.

FMISSION for my folly past . . TwoGen.of $V^{\prime} r$ r. i. 2

find an ant remission in myself... Neas. for Mcas.v.

REMISSNESS new-conceived..... Aicas. for Aleas, it.

REMIT their sancy sweetness ......... - ii

of either; I remit both twain....... Love's L. Losl, v. 2

remit these young men's heinous. Tilus Andron. i. 2

some odd quirks and rembants of wit. Much Ado,ii. 3

thou quantity, thou remnant. Taming of Shrew, iv. 3

to you the remnant northward

leave these remnants of of that royal Richard III. i. 2

remnants of packtliread ............... Romeo \& Juliel, v. I EMORSE-remorse and nature ...... Tempest, v. I mitigation or remorse of voice? ...Tuelfh Night, ii. 3 touehed with that remorse as ...Meas. for Meas. ii. 2 my sisterly remor'se confutes berse....Much Ado, iv. and remorse, more strange ..... Merch. of tenice, iv. 1
pleasure, and your own remorse ... As you Like it, i. 3 pity, and remorse, eool and congeal...King John, ii. 2 presented to the tears of soft remorse
like rivers of remorse and in noeency what says monsieur Remorse? ....... Henry IV. i. 2 moved with remorse of ............. Henry Vl. v. 4 I feel remorse in myself with ........ of them would have stirred up remorge - ved a kind of remorse in me ...... Richard III. i. 4 kind, effeminate remorse, which we.. - iii. work some touches of remorse?........ Troilus s $\overline{\text { Cress. }}$ ii. 2 and mince it sans remorse .... Timon of . Athens, iy. 3 it disjoins remorse from power ....Julius Casnr, ii. 1 lese remorse than Pyrrhns bleeding ..... Hamlet, ii. 2

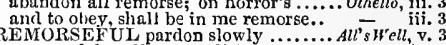
gauly, blabbing, and remorseful day. 2 Henry ${ }^{\prime} l$ i. iv. which never sled remorseful tear ..Richurd III. i. 2
REMORSELESS, have they borne ..2 Henry IT. iii. obdirate, flinty, rough, remorseless... 3 Henry I $I$. i. 4 remote from all the pleasures ...... Love's L. Lost, v. to some remote and desert place... Winler's Tale, grace the gentry of u land remote.... King John, v.

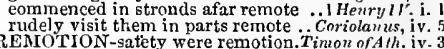
remotion of the duke and her is praetise.. Lear, it. I must remove some thousand of ..... in our remove, be thou at full ... Meas. for Mcas. i. O come, let us remove ................ Lsove's L. Lost, Like it, iti. four or five removes, come short ............... $l^{\prime} \times W_{e} h$, v. 3 moved you hither, remove you henee - ii. once remove the root of his opinion ... - ii. 3 betimes remove the means that ........ Macbeth, iv. punishes me with the remembrance. Winter's $T$. jv. 1 till Birnam wood remove to Dunsinane - v. 3 grace, and remembrance, be to you both - iv. 3 nor the rcmembranee of his most

my evils conjured to remembrance:

my young remembranee cannot ........ Io
let your remembranee apply to Banquo.. keep it safe for our remembrance.... King John, v. 2

I remember the first time ever $\ldots \ldots$.

to remember that the present .....An'z-y \& Cleo I remember now how he's employed

we sliall remember as things but done

you do remember this stain $\ldots \ldots . . .$. Cymbeline

remember, gir, my liege, the kings you

though he came our eoemy, remember

and iny false spirits quail to remember

wemember boys, I poured forth, Tilics $A \overline{n d}$ ron. i

to remember what he does.......Pericles, ii. (Gower)

remember earthy man is but a substance

you'll remember from whence your had

thine oath, remember; tliou hast sworn

now, as I ean remember, by my troth

ever sinee I ean remember .............

can you remember what I called the man

remember him hereafter as my...........

remember what I have said........

remembers what we are come abo

writ in remembranee, more than.... Richard Ir. ii. 1

in the remembrarice of a weeping queen - iii. 4

history his loss to new remembrance - iv. 1
with this remembrance, - that you use

awake remembramce of these valiant ... Men ry $V$, i. 2

wilt this from iny remembrance ..... Richard $1 I I$. ii. 1

the sad remembranee of those wrongs

$\begin{array}{ll}\text { ay, if your self semembrance wrong } & \\ \text { in the remembranee of so fair a dream } & \text { iv. } 4 \\ \text { remembrance of my father-in-law. Ienry } \bar{Y} \text { III. } & \text { iii. } 3\end{array}$

位.

not cumber your better remembrance - iii. 6

his remembranee lay in Egypt ...Antony of Cleo. i. 5

wear the print of his remembranec.. Cymbeline, ii. 3

whose remembrance is yet fresh in their -
praise be given to your remembranee

Julius Casar, (whose remembrance yet
not wore hin from my remembrance

romembrance of my fatiner's death... Titus And. iit. I

by her own most clear remembrance ... Pericles, v. 3

such thanks as fits a king's remembranee - ii. 2

my lord, I have remembrances of yours

there's rosemary, that's for remem

I do remember now: henceforth I'll ..... $=$ iv. 6 some remembrance; no, in good troth..... Ohlello, iii. 4

O nation, that thou couldst removel. King fohn, v.

remove these tedions stumbling-biokiks Henry $r r_{\text {. }}$ i. 2

are only to remove from thee the duke - iv.

your ill-will, and so remove it......... Richard 111 . i. 3

the remove bring up your army .... Coriolanus, i.

requires our quick remove from...An'ony \& Cleo $\mathrm{i}$.

no purpose in them of this remove ....... Lear, ii.

gnod counsel may the cause remove

remove the court-cupboard; look to..

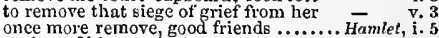

anthor of his own just remove ........... $-\overline{\text { iv. }} 5$

cannot remove, nor choke, the strong....
REMOVED-fron I

a twenty years removed thing..... Tuelffh Night, v.

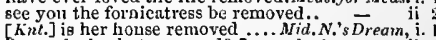

(those clonds removed) upon our.Love's L.Lost, i. 3 mountains may be removed ..... Asyon Like it, iii. could purchase in so removed a dwelling - iii. 2
upon a lie seveu times removed ...... your inelining cannot be removed ...... All's $\overline{W e l l}$, iii. $t$ when he's removed, sour highness. Winter's Tale, $i$

to him, thongh removed fifty times.. - i.

visited that removed house...........

on this removed issue, pligued for .. -

that is removed by a staff of France... - ii. 2 removed Falstaft"s Liorse $(r \in p.) \ldots \ldots$.... Henry $I V$ ii. 1 


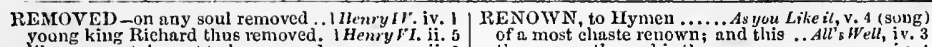
Young king Richard thus removed.
like a mountain, not to be removed. Henry - ii.
who removed, earl Surrey, was sent. Henry 1 ii. who removed,earl Surrey, was sert. Henry $I I I$.ii. ole was removed to Kirnbolton, where
with blood removerl but little.. Romeo \& juliel. iii. it waves you to a more removed ground. Hamiet, $i$. impediment most profl tably removed .. Olk REMOVING-thy uncle is removing .1 Henry $V i$. ii. 5 removin of Cassio. How do you (rep.).. Othello, iv. 2 REMUNERATE. So Bassianus ... Tilus Andron i. look to his remuneration (rep.)....... remuneration? What is a remuneration? - iii. 1 better than remuneration (rep.)

hold there is the very remuneration thou didst then rend thy faith..TuoGen of Fer. v. 4 and snore, nud read apparel ont.. Ner. of $I$ 'enice, ii. 5 and to rend our own soldier

f conld rend bars of steel .............

to rend his limbs asunder.

these nails should rend that

we must not rend our subjects.... Henry VIII i.

rend and deracinate the unity . Troilus \& Cress. i. 3

whose rage doth rend like........... Coriolanus, iii. 1

the very principals did scem to rend ... 1'ericles, iii. 2

RENDER-shall I render y'ou............. Hameas. for Mreas,

nothing unless you render her again. Much Ado, iv.

my love shall render lim ....... iid..N.'s $\overline{\text { Dream, i. }}$ iv.

Ill make her render up her page to me - ii.

speech reuder we no grace...........Love's L. Lost, y. 2

see thou render this into $\mathrm{my}$

doth teach us all to render the deeds

what merey can you render him

to render it, upon his death, unto .... - iv. 1

and he renders me beggarly thanks.

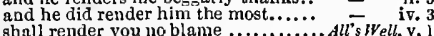

shall reuder vengeance and revenge...Richard 11 . iv.

the nearest grace it renders you..... Henry $V$. iif. I

give us leave freely to render what.... Henry $V . \mathrm{i} .2$

if my tather render fair reply

which renders good tor bad ...........Richard III. i. 2

to render up the great seal present tly

if entreatie thill

and there to render him, for tlie enfreed -

in kissing, do you render, or receive? -

ratber than render back, out with

to make their sorrowed render.

and city, we render you the tenth ... Cori

render me worthy of this noble...Julius

let each man render me lis bloody hand - iii.

Cæsar will I render my legions. Antony \& Cleo. iif. \&

report should render him hourly to

may drive us to a render where.

take no stricter render of me ........

that this

my tributary tears I render

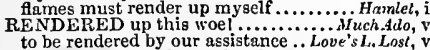

no firm reason to be rendered... Merck.

whereof the king is rendered

rendered sueh aspect as cloudy

rendered such aspect as ploud

a fearful battle rendered jou in ...... Henry $r$.

a mock apt to be rendered.........Julius Casar,

public reasons shall be rendered of ...

she rendered life, thy name so.. Antony \& Cleo. iv.

RENDELING-rendering none? Mer. of Venice,
rendering faint quittance

RENDEZVOUS, a home to fiy unto.i Henryl

my rest, that is the rendezvous of it

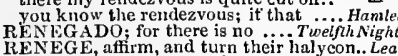

reneges [Knt.-reneagues] All temper. Ant. \& Cleo i.

RENEW-did renew old Ason. Merch. of Venice,

puissant arm renew their feats

his image, aud renew his glories! ..3 Henry 'I. i.

doth renew swifter than hlood.. Troilus \& Cress. iii

but then renew $\mathrm{I}$ eonld not .. Timon of Athens, iv.

and I'll renew me in his fall......... Coriolanus, v.

would not even renew me.. Cymbel.

presence still renew his sorrowa.. Tilus andron. v.

RENEWED fire to our extincted spirits. Olhello, ii.
our old acquaintanee he renewed. .2 Henry $\mathrm{I} \%$. iit

our old acquaintanee he renewed ..2 Henry $I$ Y. iti.
part, shame, part, spirit renewed..... Cymbeline, v.
ENOUNCE all confidence........... Hen y $Y$ i. i.

renounce your soil, give sheep............

this world $I$ do renounce; and, in your. Lear,

were't to renounce his baptism ........ Othello, ii.
RENOUNCEMENT, an immortai. Aleas. for Neos. i.

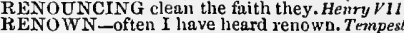

that do remow u this city?........ Tuelfh Nishl, iii. the course, the end is the renown... to win renown even in the jays

as your renown, let me no more...

admiring thy renown, by me

by breath of her renown

the charneters of your renown $\ldots . . . .2$ Henry $v_{I}$, i. 1

no men born to renow' by

if renown made it not stis.

quick aceumulation of renown......... Cortony \& Cleo. iit. wounding his belief in her renown... Cymbeline, $v$ every virtue gives renown to men! .... Pericles, i. such strong renown as time shall never

he was a wight of high renown... Othelio, ii. $\overline{3}$ (song) a noble and renowned brother... Meas. for N/eas. iii. in marrying the renowned Claudio.. Much Ado, renowned Pompey! ................. Love's L. Lost, v. rom every coast renowned suitors...Mer. of Ven.. . yourself, renowned prince..............
renowned for grave citizens $\overline{\text { Sh }}$ rew Katharina Miuola, renowned in Pad

your most renowned uncle .. Comedy of Errors, v. renowned duke, vouchsafe to take..

lift up thy brow, remowned Salisbury

their birth, renowned for their deeds. Richard 11 . ii. he got against renowned Douglas.. 1 Henry $1 V$ iii.
most remowned, hath eat thy bearer. 2 Henry $l V$. iv and eourage, that renowned them

the title of this most renowned duke.

renow ned queen, with patience caim

renowned priuce, liow shall poor Hen

renowned for hardy and undoubted
father-in-law, renowned Warwick. Ric

sir Walter Herbert, a renowned soldier
upon him, Ajax renowned.. Troilus \& $C$ r

renowned Coriolanus! Weleome (rep.). . C

your own renowned knowledge.

and renowned be thy grave.

renowned Lueius, from our troops....

knight of Sparta, my renowned father Pericles, ii.
that is renowned for faith?

REN' the fairest house in it. Measure for Measure, ii.

what, did these rent lines show... Lave's $L_{\text {. Lost, iy }}$

lean, rent, and beggared by... Merchanl of Venice, ii.

manors, rents, revenues, I forego ... Richard II.

torn and rent my very heart ...

see, what a rent the envious........Julius Ces

rent off thy silver hair ...... Tilus.Andronicus, iii.

REPAID a lundred thousand ............... Lear

poorest service is repaid with. Taming of Shrew, iv.

ill art thou repaid tor that good. Tilus Andron. iii.

repair me with thy presence

signior Benedick, repair to Leonato's. Mnch Ado,

all to Athens back again repair. Mid. N. Wreain, jv.

and when they repair, blow like sweet - v. 2

repair thy wit, good youth, or it.Mer. of lenice, iv. 1
it much repairs me to talk of............Al's Well, i. 2

for royalty's repair, for present... Winter's Tale,
look of his would soon repair... Comedy of Err.

bid her repair to our solemnity.

bid him repair to us to Ely-house...Richard II. ij.

with direction to repair to Ravenspurg - - ii. 3

and new repair, our towns of war .... Henry

repairs him with oecasion?........2Henry VI. v.

hither will our friends repair to us

hear no news of his repair? Now .....
repair to Crosby-place (rep. i.3).... Hichard III. i.

times to replair our nature with..... Henry $v 11 \mathrm{I}$. v

repair to me next morning ....... Timon of Athens, ii.

again, repair to the senate-house ..Coriolanus, ij.

your number, repair to the Capitol.

repair to Pompey's poreh (rep.)..... Julius Casar, i.

that shouldst repair my youth

sense repairs itselt by rest ..............

bid him repair to me, and bring. Ti/ns. $A$ Andronicus, v.

givest me somew hat to repair myself... Pericles, ii.

here he does but repair it. I know.. $\quad$ - iv.

let this kiss repair those violent harm... Lear, iv.

repair thou to me with as inuch. Hamlet, iv. 6 (lett.)

plies Desdemona to repair his fortines.. Othello, ii.
walking on the works, repair there to me - ii. a theme of honour ond rebown.. $\dddot{T}$ roilizs \& $\overline{C r}$ ess. ii.

while he, renowned noble gentleman
LEPAlRED witl knots ..... Tuming or Shrew. iii. 2 REPAIRING; ever ont of frame... Love's $L$. Loxt, iii. opposites of such repairing nature ..2 Henry 'l $\mathbf{v}$. REPAST - before the repast ......... Love's $L$. Losi, iv. go, and get me oome repast .. Taining of Shreu, iv. peliean, repast them with my blood ... Hanlet, iv. REPASTURE for his den ......... Love'; s. Lost, iv. REPAY that money will be .............Merry Wives, 7 . if you repay tne not on such a day.Mer. af venice, $\mathrm{i}$. Richard III. ii. and is it thus? repays he my

but hon of Alhens, $\mathrm{i}$.

REPAY iNG what we took from... Twelnh Night, jii.

EPEAL was suppliant ....TwoGent. of Verona, ii

the banished Bolingbroke repeais .... Richard II. it. 2

I will repeal thee, or, be well assured.2Henry VI. iii.

repeal daily any wholesome act .... Coriolanus, 1.

wrust forth a cause for thy repeal...

repeal him with the welcome of his.. -

an immediate freedom of repeal...Julius Casar, iii.

in thy just proof, repeals, and reconciles.. Lear, iii.

REPE ALED-thou hast repealed.......All's $W$ ell, ii.

my banishment repealed, and lands. ilichard 11 . iii.

that act of parliament be repealed . .3IIeñry rt. i.

REPEALING of my banished ....Julius Casor, jii.

please you, rcpeat their names...Two Gen.... of Ver. i.

if you repeat them (rep.).............. Muce's $L$ Ado, $v$.

for $\mathbf{I}$ the ballad will repeat .......... All's $W$ ell, i. 3 (song

lis pretty looks, repeats his words.. King John, iii.

may repeat and history his loss ......2 Henryl $l . .$. iv.

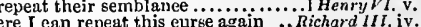

repest your will, and take it......... Henry $V I L I$.

am right sorry to repeat what follows - v.

of help grew odious to repeat
like him's untutored to repeat

sir, it would be too tedious to repeat.

Cymbeline, $\mathbf{i}$.

too mean to have her name repeated. All's Well, iit.

for viee repeated, is like the wandering...Pericles, $\mathrm{i}$.

EPE T'ST upon thyself

REP EPENT-death I much repent. TwoGen. of Ver. iv. why neer repent it, if it.............. repent you, fair one, of the sin ... Neas. for Neas. ii. confess it, and repent it, father (rep.)

yet did repent me after more advice... - , v. do repent the tedious minutes.. Mid.N.'s Dream, ii. 3
that you shoold here repent you ... - v. I (prol.) never did repent for doing good.. Mier. of Verice, iii.

hen I'll repent, and wish, for all that

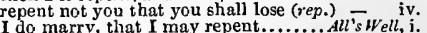

cannot yet find in my heart to repent - ii.

1 would repent out the remainder of $\bar{T}$ iv. to know them, I do repent ............. Nocbeth, ii. then we shall repent each drop ......... King John, ii.

they burn in indignation; i repent...

well, I'll repent, and that suddenly.i Henry $I V$.

then I sliall have no strengtli to repent - iii.

and the young lion repents .........2 HenryI $V . i$.

and $f$ repent my fault, more than ..... Henry $r$. ii.

England shall repent his folly

that vice in me; I must repent ....... and I repent my part thereof ...... Richard 11\%. $\mathrm{i}$. 1 repent me that the duke is slain.

I now repent I told the pursuivant...

intend to prosper, and repent! ..... ${ }^{-}$iv.

yes. Then I repent not ........ Timon of Alhens, i. almost all repent in their election ... Coriolanus, ii.

repent, that e'er thy tongue Anlony \& Cleopatra, ii.

I repent me mueb, that so I harried him - iij.

let him repent thou wast not ........

saved the noble Imogen to repent ..Cymbeline, v.

must I repent? I eannot do it better
thy faction shall repent this rape... Tilus Andron. $\mathrm{i}$.

I do repent it from my very soul .... $\overline{\text { I }}$ - ve v. v.

woe, that too late repents.................... Lear, i.

that I must repent to be just! ............

to repent the sin of disobedient .........

when one ean not repent?..........

for this same ford, I do repent

t..Othello, iii.

anlawful solicita you...... - iii.

REPENTANCE is not satisfied. T repont of $\bar{v}$ er. $\mathbf{v}$.

and then comes repentance ............ Much Ado, ii.

the other with curreut repentance ...2 Henry $1 V$. ii.

and true repentanee of all your denr.. Henry $V$. ii. 


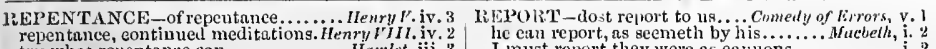
try wlat repentance ean

ve with my repentant tear.... King John.iv. CPEN'TLD o'er his doom. Measure for Measure, ii. 2 too dear, howe'er repented after.

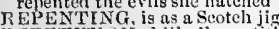

Al's Well, iii. 7

REPETITIUN - kill all repetition

luch trlo, ii. 1

, in a woman's ear ...... cry aim to these ill-tuned repetitions King John, repetition of what thou hast marred. Richard III. with surplus, to tire in repetition whose repetition will be dogged with

and give then repetitim to the life .... Pericles

repetition of my Romeo's name... Romeos fult the world repine... Henry ${ }^{\prime}$.

REPINED-gratis, you repined

Coriolanus, iii. 1

REPLANT Henry in his form
KEPLENISHED villain in the

his intellect is not replenished $\ldots$... Lne's L. Lost, iv.
replenished sweet work of nature.. RichardIII iv.

IEPLETE with mocks .............. Love's L. Lost

thy estate, a balunce more replete....A A Il's $W^{\prime} e l$, ii.

all Franee will be replete with

so full replete witl choice

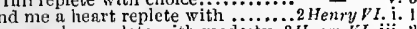

do armue her replete with modesty .3 Henry FI. iii.

liear the replication of your souuds. Julus Caesar, i. 1

What replication should be made...... Hamlet, iv. 2

RERLIED-the boy replied ..... There's L. Lost, v.

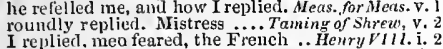

I replied, meo feared, the French ..Henry VIII.

t:uuntingly replied to the discont
he replied it was a bare petition

she replied it strould be better.... Äniony $\bar{s}$ Cleo. it.

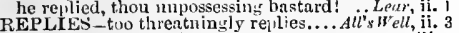
he replies, thunks, Agamemnon Troilus \&-Cress. iii. nor muke replies of loathmess..... Antony \& Cleo. iii. pregnant sometimes his replies are!.... Hamlet, ii. ? the Moor renlies, that he, you hurt,
REPLY - could not a gain reply

what reply, ha? what say'st ..Meas. for . Meas. iii. 2 thus, expecting thy reply. Love's $L$. L wst, iv. I (letter) the reply ehurlish (rep.) ........... As you Like it, $\mathrm{v}$. for a reply, at ieast. if you inake.. Winter's

and make reply without a tong

Michard II. ii. 3

not now be troubled with reply ........ I HenrylV. $\mathrm{v}$.

not undergo this sneap without reply

reply not to me with a fool-born jest

give me hearing what I shall reply . i Henry ${ }^{\prime}$ ). iii. 1

and stand not to reply

fa.........Richard AlT. i.

I pause for a reply. None, Brutus. Julius Casar, iii. 2

I conld reply: if we should serve.Antony \& Cleo. ifi. 7

reply not, do not answer me ..... $k$ why, 'tis a loving and a fair reply

Hamlel, i.

of our demands, most free in his reply. .. - iii. I
REPLXING, yielded to bear the . Richarid

replying slurilly to the well-tuned. Titus Andron. ii.

JEPLY'ST-Odaly thou reply'st!. Romeo \&.Juliet, ii. 5

if in Naples I should report this now.. - jit.

by yourown report, a linguist

by your own report, a linguist ........
now, the report goes................. Wires, i.
unless it be to report your lord's..Twelfh Night, ii.

report of valour (rep.
get thiiemselves a good report after......
hath blistered her report ... Measure for Neasure, ii. 3

shall stifle in your own report .......

if I may live to report you ..........

volumes of report run with these......
marvellous little belholden to your reports - iv.

not better than he, by her own report

ere you make that my report.

foremost in report through Italy........Much $\bar{A} d o$, iii.

they have committed false report...., - $v$,

and cawing at the gun's report.

is my report, to his great worthine $\ldots$ s. Love'si. L. L. i.

if $\mathrm{my}$ gossip report be an honcsh... Mer. of tenice, ii

report speaks goldenly of his profit. As you Like it, i.
if you like, upon report, the soil ....
whon he reports to le a great magieian - v.

and observe his reports for me ......... All's Well,

I shall report it so ............... ii. 2 (letter)

rumour may report my flight

suffice ourzelves with the report of it

serves the count, reports but coarsely

not daring the reports of my tongue.

such pestiferous reports of men

report whicl $I$ so of thave heard...

by report I know him well ........... -

and now $I$ find report a very liar.....

why does the world report, that Kate

I shall report, for most it cau be hated to rejort it

the report of her is extenderl more....

upon his own report, and I helieve it

by their own report, sir, hath danced

whieh I shall report, will bear no eredit

which lnmes report to follow it.

your good repurt to the prince my....

I must report they were as eamlons.......
who did report that very frankly ....... i. 2
i. 4

learned lyy the perfeetest report $\ldots-\cdots \cdots$ i. 5 (letter)

but ent perceive no truth in your report - $v$.

which I will not report after ber

bring we no more reports.................

I should report that which I say
for ere thou cunst report I will.
these dngyed spies witil false repo

throw this report on their incen
report of tashions in proud Italy

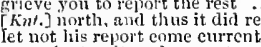

such as fear the report of a ealive

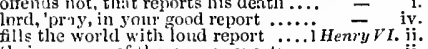

I see, report is fubulous and talse.... $=$ ii. 3

report whit speceh forbears.......... Henry $/ L I$. iv. 1

of Salislury, who ean report of him..

so near as men report ................ kichard 11 i. i. 3

[Col. Knt.] ] as grieves me to report

flatter my sorrows with report of it $\ldots$ - iv.

you ean report, and prove it too.....H

who shinl report he has $\mathrm{n}$ better wife

me under this report-bring.. Trmilus \& Cressida, it

certain: Aleibiades reports it

are his files as full as thy report?

then his good report sliould have been

half an hour since bronght my report

fear lesser lis person than an ill report
but l'll report it, where senators sliall

more eruel to your yood report
of no better report than a horsedreneh

into their estimation and report

to report otherwise, were a malice...

whom we have put in prison, reports
nothing bitt his report: (rep.)........

you must report to the Volseian lord

yes, nerey, if you report, him truly
thrusting this report into his ears. Julius

than almanteks can report...

my learning from some true repoits
lest my remembrance suffer ill report

triumphant lady, if report be square

I made no sueh report; he's bound.

let me report to him rour sweet.

lhis I'll report, dear lady.

makes a very good relwrt o, the.......

a thing too bad for bad report........ Cymbel

without contradietion, suffer the report -

by history, report, or his own..........

who is as tiar from thy report ....
to try your taking a false report

to try your taking a false report .....
your good report. I Iow! my good (rep.)

so likely to report themselves..

aet report should render lim hourly

that I must report ye my master's

experienee, $O$ thon disprovest reporti
son to the quecu, after his own report

as men report, thou orphan's father art

ask of whence you are: repnrt it

a physicinn would this report become?

that my report is just, aud full of. Tilus $A$ drawn by report, adventurous by desire.

our paragon to all reports, thus blasted

report what a sojourner we have

gives a good report to a number...

report thy parentage

all my reports go witl the modest tritt

more than tears, with that report. Ro
of your own renortagninst yourself

than their ill report while you live.

gave you such a masterly report

report me und my eause aright ....

where the aim reports, "tis oft with

if you do find me foul in her report.

more of this matter ean I not report

enquire him out, and he edified

and your reports have set the murder on

REPOKTED by this gentleman ... Mets. for. Ieas. $v$

as you then reported him to be?....... as ancient writers do report

his elothes made a false report of him

have report low 'tis abroad.............
men's reports give him much wronged

making just report of how unnaturail

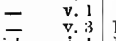

ERORTLD - which was reported
I have heard lier reported to be.

it is reported, inighty sovereign

wept whell it was reported . $0 . . .$.

it is reported, thou didst cat........

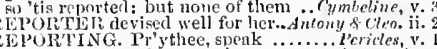

mer emeern me the reporting.

hEl'OR'ST-as thou report

Percy's deatl, ere thou repirt'
REPOSAl-wonld the reposal

Ii EPOSH - this is a strange repese...

we stood here securing you

fitith and hononr 1 repose...Tino Gen. of rerona, iv.3

to repose him here .... Taming of Shrew. ) (indne.

good repose, the whilel ...............

give thy repse to the tot sea-loy. 2 Henry $l V$. iii. give thy repose to the wet sea-boy..2 Henry
so subth with a king's repose........ Henry $V_{\text {. iv. }}$ iv.
we will repose us here: to-morrow..2 Henry li.

on thy fortune I repose myself ....3 lewry $r$. iv.

shall rejose you at the Tower ....Richard III, iii.

ere we do repose us, we will write... Corrolnuss, i. 9

good-night, and good repose.......Jalius Carsar, iv.

readiest cliampions, repose you here..'Tilus dni.

and Rome s servitors, repose in fame

shake off the golden slumber of repose. Perirles,

tempest; repose you thore.

ance repose.

sport and repose lock from me, day

R.POSETH all his confidence

breaks seasnns, and reposing hours.... Alts sich, $i$

6 his right eheek reposing on ......... Gmmedine, iv.

9 REPIEIIEND-do not repreliend. nit $N, \bar{D}$ r. (c)il

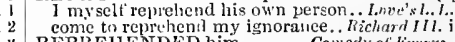

2 REPREHENDED him ¥........ Comedly of

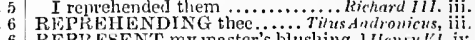
REPI ESEN'T my master's blushing . Ifeny $V^{\prime}$ l. iv. would you represent our queen. .. Titus A mirwn. that in his repricve, longer ........Meas. for.3leas. i .

4 some pardon, or reprieve ............

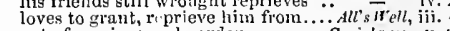

ii. 2 send thy tolcen of remieve

5 REPRISAL-rich reprisal is so nigh.i Henry $1 t^{\circ}$

ii. 5 that name with any just repronch

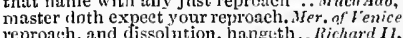

reproach, and dissolution, hangeromel. Hen'y $v$. ii. \&

reproaeh and everlasting shame sits..

or else reproach be Talbot's greatest

in confintation of whiel rude reproach
defice your honour with reproach?

i. 7 defice your honour with seproach 7 reselue thee from this reproach?

$\begin{array}{ll}\text { i. } 7 & \text { for I am but reproach................ } \\ \text { ii. } 3 & \text { courts be filied with my reproach.... } \\ \text { ii. } 1 & \text { to eonelude, reproach, and beqgary } \ldots\end{array}$

iii. 3 fo eonelude, reproach, and beggar'y reproach, attend the sequel.. Ris:har III. iii.

wiit. 4
iii. 5 or die with this repronch .... Tritus . Anironicus, iv.

even thus all guiltless meet reproach ... Olh llo iv.

on the rearward of reproaches ....... Mueh Ado, iv.

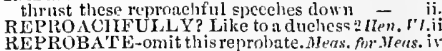

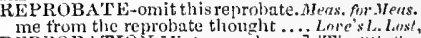

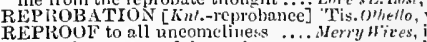

pass with a reproof the easicr .........

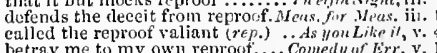

betray me to my own reprorst.... Comedly of Err. v. 1

the taste of danger and reproof ........ - iii. I

as, in reproof of many tales ............

your reproof is something too round..Henry $\mathbf{Y}$. iv. 1
to speak in your reproof ......... Richard 111 . iit. 7
cannot brook the accent of reproof ..

in the reproof of ehance lies .. Troilit: \& Cressida, $\mathrm{i}$.

shall set out for reproof, fall.... T'imon of t'sens, $\mathrm{v}$.

pluek reproof and rebllke from every.Coriolanus, ii.

whereas reproof, obedient, and in order.. Pericles i. 2

it is reported that he has taken rrp.)
so hot a shrew as she's reported?. Iaming of Sh, iv. something in me that reproves my frult - iii.

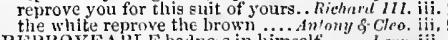

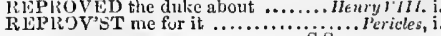

reprove my allegalion, if you can ... Hewry $/$ H iii. I

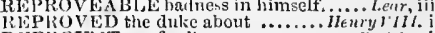


REPUGN-he did repugn the truth.. I lenry r. $I$. iv REPUGNAN'T to emmand

\section{whatever slie. \\ .. Tempest,}

with obstinate repulse, to slay.

received in the repulse of Tarquin.

a repulse; thougl your attempt.....

REPIRCHASED with to make

REPUTATION was disvalood ....3 Ilenry't

other men, of slender reputation. Twotien. of Ver.

keep the haviour of reputition..... if erry $\bar{F}_{\text {ives }}$

her purity, her reputation, her marriare

my reputation gnaw'n at . . $\ldots \ldots \ldots . . . . .11$

and his friend's reputation ............

wrong the reputation of your asation

you will lose your reputation

gour reputation therefore shall not

would not put ny reputation now

upon my reputation and eredit .
reputation is with the duke (rep.)

war agaiust your reputation.. Comedy of Errors, iti.

this tuluches me in reputation

is spotless reputation; that away...

for her reputation through the world

in the effect of your reputation....

his reputation is as arrant villain

case thy reputation in thy tent.

his reputatiou touned to death $T$. iii.

I have offended repet death... Fimon of $A$ th. iii.

your eonfidence, than her reputation. Cymbetine, i.

reputation stained with Tybalt's. Romeo \& Juliel, iti.

in reputation and profit, was better .... Humlet, ii.

that you unlace your reputation tha

reptutation, reputation, reputation! ( $r e p$.)

voly have lost no reputation at all, .......
RPUTE you ever the patron .... Taming of

EPUTE you ever the patron .... Taming of $\overline{s h}$. iv.

how will the world repute me...Two Gen,ofy'
of good repute (rep. $\mathrm{i} .2$ ) . . Lnie's L. Lost, $\mathrm{i}$. I

he reputes me a cannon: and the bullet - iit. I

do rcpute his grace the rightful leir. 2 Henry $r . v$.

our dearest repute witl their..... Troilus \& Cress. $i$.

toes 1 do repute you every one. Titus A ndronicus, i. 2

which Rome reputes to be a heinous sin

unless you repute yourself such a loser.. Othello, ii. 3

without desert so well reputed. Fio Gen. of ter. ii. 4

I am not so reputed: it is the

yet his brother is reputed one of

tise reputed son of Cœur-de-lion
the earl of Hereford was reputed.

WEPUTELESS banishmute mor

REPUTING of his high descent
REQUEST - my prime request.

Ail's Well, iv.

at thy

request me, to importune you ... Tino

you writ them, sir, at my request
so far from granting tliy request
upon your request, cousin

I will marry her, sir, at your request

and requests your company ......... $\overline{\text { at }}$ int ii. 3

grant me another rcquest................

novelty is only in request.

upon figer was not much in request

upon his mere request, (being come to
I am to entreat you, request you ...

or I would request, requcst you .. Mid.N.'s Dr, i.

were not his request so far from.Love's $L$. Lost, ii.

to fill up your grace's request.... Mer.of $V^{\prime}$ enice, ivi. 1 (letter)

to hil up your grace's request ..... is a iv. 1 (lett
more at your request than to
answer the time of request

liberty is all that I request................All's $W^{\prime}$ ell, $\mathbf{i}$.

did you not request to have it cut? there necessity in your request

there necessity in your request.... Hinter
at my request he would not. Hermione

this your request is al together just..
tis in request. I can tell your

tis in request. I can tell, you ........

at your request, my father will grant

hear and grant jou your requests $\ldots . .$.
heartily request the enfranchisemeat

by me, requests your present straight

countenance at his friend's request...2 Henry It

at my desircs. and my requests......
but your request sliall make me

wilt say, ay, to my request.

3tenry $V I$.

at my request, see that forthwith.....
not easily won to our requests ..... Richard. III.
iv. 31.3
iii. 7

what says your lord to my request?

lend favourable ear to our reqliests...
shuns your high request.........
[Knt.] late request that you did sound me

says your highness to my just request

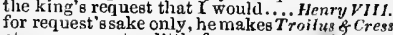

at your request, a little from

rcquest do these men play? (rep.).....
REQUEST-have what he requests Troitus \& Cress, iii.3
farke tliy requests to thy triend .. Timon of Ath. i. I

let the request be fifty talents........

we do request your lindest ears

custom of request you have discliculars -

we did request it; we are the greater

to both it stands in like request?

heius now in no request of his country

if he be dieted to my request.

if you fail in our request (rep.)

say, my request's injonst, nucl s

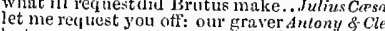

but, as you request, yourselfs slall ..

he las cos his requerts; and to thee sues

your grace but in a small request....

thic emperor requests a parley ...Tilus Anmon. iv.
before thou didst rcquest it

give me one poor request..................
of eame it by request, and sucl fair

Hamlet, i.

'tisdone, at your request: but let her live - ii. 3

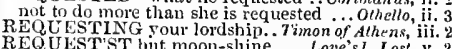

$R E Q U L S T S T$
at unee, what is moon-shine $\ldots .$. Love's L. Lost,

RE-QUICKENED what in flesh was. Coriolanus,

REQUIRE my dukedom of thee.

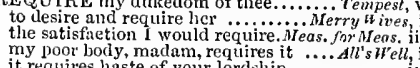

you see, my plight requires it .... Winter's Tale, ii.

more than this deed does requirel.....

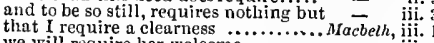

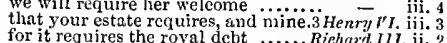

for it requires the royal dcbt ...... Richard III. i

requires slow pace at first

twill require a strong faitl to conceal it

I require your highn require a respite

nature does rcquire lier times of ......

which will require your answ

it requires swift foot ...........

he will require them, as if he
once, if he do require our voices.

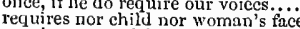

requires our quick remove from ... Antont

in our name, what slie regupt.....

slall I say to Casar, what you require = iij. 10

the quality of her passion sliall require $\overline{\bar{T}}$. $\mathrm{y} .1$

kind nature doth require it so.

if you require a little space for
will your require iu preseat dowe
we do require tliem of you

Pericles, iv.

and her tather, requires a fitter place

this hand of yours requires a sequester

Othello,

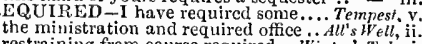

restraining from course required

it is required, you do awake your - iii.

he owes, will be required of me... Comedy of Err. iv.

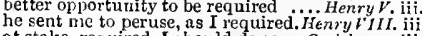

at stake, required, I should do so .. Corinlanus,

return was most required, and nccessary . Lear, iv.

REQUIRETII-case requireth haste.3Henry $I^{\prime}$, iv.

REQUIRING with a plausible .. Meas. for Meas. iii. $)$
nor fetch in firing, at requiring. Tempest, ii. 2 (song)
theat if requing

that, if requiring tail, he will $\ldots \ldots \ldots$ Henry $V$. ii. 4

liath all those requisites in him ......... Othello, ii. 1
REQUIT - which lath requit it $\ldots . .$. Tempest, iii. 3

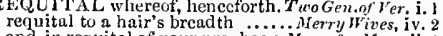

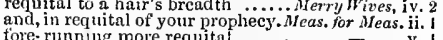

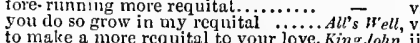

onr state's defective for requital love. King John,
REQUITE-I will requite you with..... Tompost

which to requite, command me.Two Gen of 'er.

fool, I'll requite it in the........ Turelfih Night iv,

I do with an eye of love requite her

find $I$ will most kindly requite... Merchan of you Like $i$.

and, to requite you further, I will As you Lik's Well, iil. 5
for his life, and I will thee requite. . Henryl.

for his life, and I will thee requite ... Henryl: iil.

I will requite tliy forwarlness

and, see, how he requites me!

3Henryli. iv.

no doubt, he will requite it.......... Henry /1hl. ji.

could my otudied purposes requite ...
that I'll requite it last? ....... Timon of Athens, iii.

and wealth to requite me, by making

the gods requite your love $\ldots . \ldots .$. Coriotanns,

hic will requite your wrongs .........

Rome requites with foul contempt.....
the gods requite lis elarity l...Perieles, iii. 2 (scroli)
WQUITE your loves; so, fare yon ...... Hamlet, i. 2 of practise, requite him tor your father..
let lieaven requite it with the serpent's. Othello, iv. 7 REQUITED-it must be requited ..... Much Ado, ii. 3 but I requited him for his lie ...........Macbelh, ii. a work, allel how jll requited!.. Troilus \& Cress. RE-SALU'NE his country with lithe. Coriolanus, iy. I will not re-salute the strcets of Rome Ecescuc you from lim.. Tu'oGen.of $\vec{V}$ er. sir, that did reseue me............ Täelfth $\overline{\text { ighht }}$ v. without rescue, in the first assault.....All's W'ell, $\mathrm{i}$. rescue thy mistress if thou he.Taming of Shrew, $\mathrm{iii}$. 8 uffer then to make a rescue? Comedy of Errors, iv. resete tlose breathing lives to dic .. King John, if. 2 in the hollonrable rescue, and defence a rescul rescue that thou

apur to the rescie! (rep.) .........2 HenryIV looks for rescuc, you, his false hopes

to destroy, came in ; he is ta'en.....

and Somerset brouglit rescue in iness thou rescue lim from foul ...2Henry VI. ii. rescue, my lord of Norfolk (rep.) ...Richard III, v. 4 your comfort makes the reseue...... Antoriolanus, iii. in the rescue of Lavinia ...... Titus Andronicus i. no rescue? what, a prisoner? I am even. $\bar{L}$ Lear, iv.

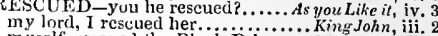
myself, rescued the Black Prince..... Richard s, ii. and resened thec from death ........ - iv. 6 from the pride of Gallia rescued thee - iv. in the end being rescued, I have ...... Henry $V I$. iii. the bishop's huntsmen reseued him.3 Henry $V i$. iv. 6 jirates came and rescued me ............ Richard IIr. ii.

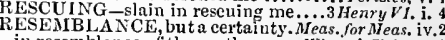
and his resemblance, being not ... Richard IIJ. iii. 7 RESEM BLE something in me .....Tu Tulf/h Night, it. somewhat doth resemble you. Taming of Shree, iv. in speech he doth resemble .........2IJenry $V t$. iji. how well resembles it the prime of...3 Henry $V i$. it. his purple blood right well resembles up and down slie doth resemble thee. Fitus And. nor the iuward man resembles that it.. Hamlet, ii. RESEMBLED ray father as he slept

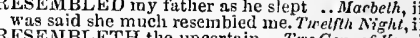
RESEMBLETH the uncertain .. Two Gen. of Ver. $i$. a counterfeit resembling majesty ... King John, iii. I to make some reservation of your wrongs

making not reservation of yourselves Coriolanus, with reservation of a hundred knights.... Lear, $i$. kept a reservation to be fullowed with $\ddot{\text { RSER }}$ - not yours to reserve.. Tuel ii. reserve them till a merrier.... Comedy of Errors, i. but reserve still to give. Timon of Athens, iii. 6 (gracc) should reservely reserve it............ reserve that excellent complexion ......Pericles, iv

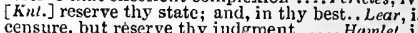
that she reserves it evermore about her. Othello, iii. ESERVED-have reserved alive. Neas,for Meas. v.
her deserving is a reserved honesty...All's Well, iii. her deserving is a reserved honesty... Au's W'ell, iii. 5 the other part reserved I by consent... Richard if. $\mathrm{i}$.

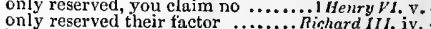
have reserved to myself nothing. Antony \& Cleo. v. 2 not what you have reserved, nor what $\overline{\text { y. }}$ n) ways rcserved my holy duty ...... Cymbeline, thus lovingly reserved the cordial. Titus Andron nay, he reserved a blanket, else we ...... Lear, jii. RESIDE-there reside, to make me.... Tempest, iii. at the moated grange resides this...

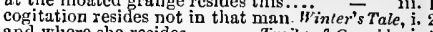
and where she resides ........ Troilus \& Cressida, 1 . endless jar justice reside

a kind of self resides with you ........ I would not there reside, to put my ..... Oihello, $\mathrm{i}$.

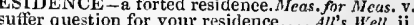
that to their everlasting residence... King John, ii. whose procreation, residenee... Timon of athens, iv. 3
my residenee in Rome, at one ..... Cymbelinc, i. 2

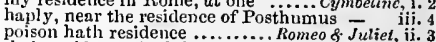
their residence, both in reputation ....Hamlet, ii. 2 RESIDFN' $\mathrm{T}$-resident in France: .i Henry YI.'iji. 4 be resident in men like one another. 3 Henry $Y$ T. v. 6 that thou residing here, goest yet....An/ony \& Cleo. i. no more than my residing here at.... - ij. 2 wilt thou resign them and resign ....... 2empest, y. 
RESIGN-and I resign my gage...... Richard 11 , i. I R RSOLV i itself into a dew ! you hind becu willing to resion

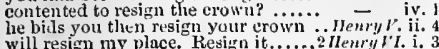
will resign my place. Resign it......2 Ilenry rl. i. 3 as willingly do I the sume resifin.

to resign his crown (rep.)

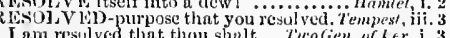
fam resislved that, thou shat full resolved to take a wif

but I am rcsolved un two points.... Tevelyh Night, $\mathrm{i} .5$ and now is he resolved to die ... Mreas. firr.leas, iti. 2 I here resign my goverument to thee - iv. 6 resign thy chair, and, where I stand

for 1 , thy resolved patient................ll's $W_{e}$ th, ii. firmly an resolved you know (rep.). Taming of sh. i 1 for my part, In resign unto your... Kichard $M$. Ni. yield up rule, resign my life .. Titus Andronicus, i. we will resign, during the life of

irremovable, resolved for flight .. Hinter's Tale, iv. 3 we are rcsalved, my lord..............Macbeth, iij. 1 from a resolved and houourable war - ii. 2 he was not so resolved, when last ...RicharriII. ii. 3 we wouls be rolved correction no....2 now are we well resolved ........... - i. 2 are we certainly resolved to draw

I $\mathrm{nm}$ resolved for death, or dignity ...2Henry $V I$. v. 1 I ain resolved to bear a grcater storm $-\overline{3}$, v. 1 by him that made us all, I am resolved - ii. 2 I firmly am resolved, yon shall

resolved to meet all perils.

myself resolved upon a course.......... they, madam, stand resolved....... Tilus ndron. i. 2 I am prepared and full l'solved than could his war resisted.. Antony \& Clenpalra, i. 4 RESISTIN ${ }^{2}$ of this rcsisting town ... King Joh that the resolute acting of your...Meas. finr. Heas, ii. most resolute Pumpey? ......... Love's L. Lost, $\mathrm{v}$. thou art resolved? I an resolyed... RESOLVEDLY more leisure most resolute Pumpey. $\ldots$ he..... Love s L. Lnst, v. be bloody, bold, and resolute ........ Hacbeth, iv. but al ways resolute in most not resolute, unless so much …..... Henry $V I$, iii. and therefore ain I bold and resolute - iv. I ready to figlht; therefore be resolute ${ }_{\text {I thought thou hadst been resolute. Richard }}$ III. i. 4 I thought thou hadst been resolute. Richard Int.

sharked up a list of landless resolutes..Haintet
RESOLUTELY; his meaning is good . Alerry $W$. a purse of gold most resolutely $\ldots \ldots . .1$ Henry $/ V$ i. RESULUTION tietch from. Neasure for Measure, iii. do not satisty your resolution with hopes $-\overrightarrow{\text { iii. }}$ your resolution cannot hold ..... Winter's Tale, iv. 3 I pull in resolution ....................Macbeth, $v$. the dauntless spirit of resolution how high a pitch his resolution soars! Richard II. $\mathrm{i}$. resolution thus fobbed as it is........ Henry IV . i. 2 how terrible in constaut resolution....Henry V. be it with resolution then to fight RESOLVETH from his figure King John, v. 4 ESORT of gentlemen ..... Two Gen. of jerona, i. 2 why then I would resort to her.

often resort unt th this geutlewoman? - iv. 2
but shall all our houses of resort.. Meas. for Mcas i. 2 cause ot my son's resort thither... Winter's Tale, iv. 1 what men of name resort to him?... Richard 111. iv. 5 have had resort to you

to be a place of such resort

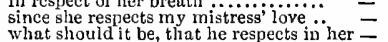
what should it be, that he respects iv her -
though you respect not aught........ in love, who respects friends?

so wide of his own respect.

that, iu some respects, makes

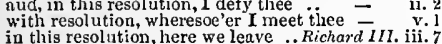
in this resolation, here we leave ...Richard 1 RI. iii. 7 I propend to you in resolution .... Troilus \& 8 Cress. if. 22 breaking his oath and resolution..... Coriolanus, y. and let us swear our resolution..... Julius Casar, ii. 1
my resolutiou, and my hauds ... Antony \& Cleo. iv. 13
no friend, but resolution, and the briefest - iv. I3 no friend, but resolution, and the briefest - ives i. but that my resolution helps me..... myself, to be in a due resolution ............ Lear, i. 2 native hue of resolution is sicklied o'er. Hamlel, iii. 1 and fix most firm thy resolution.......... Othello, $v .1$ I am now going to resolve him... Meas, for Meus. but this shall absolutely resolve you - ii.
suddenly resolye me in my suit ... Love'sL. Lost, ii. shall we resolve to woo these girls.... resolve the propositions of a lover. As you Like it, iii. 3 resolves [Col.-resolved] to carry her ..All's $\mathrm{Well}$, iii. 7 nor is your firm resolve unkwown ...

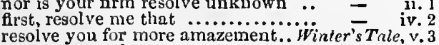
resolve yourselves apart ............... Narebeth, ii. 1

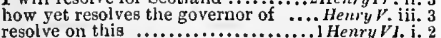

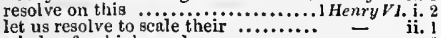

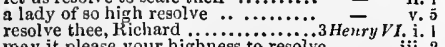
may it please your highness to resolve - iii. 2 and Alontague, resolve my doubt..... I will resolve your grace $\ldots \ldots \ldots \ldots$ Richard $I I T$. iv. 2 theo resolve me whe'r you will, or no

is there no respect of place......... Tivelfh $\vec{N}_{i g h t}$, ii.

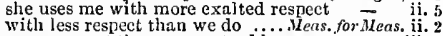
more respect than a perpetual honour
persuade yourself that I respect you? respect to your great place!

Would have daffed all otlier respects... Much $A d o$,
it's but a nightgown in respect of yours else misgrafted, in respect of years... Wid. $\vec{N} \cdot{ }^{\prime} s D_{r}$. and she respects me as her only son.. for you, in my respect, are all.

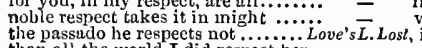
than ali the world I did respect her. was but a Trojan, in respect of thi you have too inuch respect upon. $i l e s$
talk with respect, and swear but now talk with respect, and swear but now

attend them with respect and duty..
in respect of itself it is a good life $(r e)$

in respect of a good piece of flesh

forc me, I speak in respect $\ldots . . . . . .$.

hold me no more in your respect

he is not for your lordship's respect...

respice finem, respect your end.. Comed of $\bar{E}$

takes from his high respect ............ Il acteth,

to tread down fair respect..............

uch profound respects do pull you on = iii. I

that good respect I have of th

humuur than advised respect

compulsiun, and a brave respect! ...

and this respect besides, for that $m \dot{y}$

with honour and respect may take ... liquid surge resolves the moor. Trimon of Athens, iv. 3 and so must you resolve .......Tilus Andronicus, ii. I resolve me this; was it well done . ...
as you will live, resolve it you. Pericles, i. 1 (riddle) as you will live, resolve it you. Pericles, i. I (riddle)
resolve your angry father................ 1 i. 5 he can resolve you (rep.)

resolve me, with all modest haste........... Lear, ii. 4 and prosperous iu this resolve,.. Romeo \& juliet, iv. I

there so respect how vile........ Richard 11 . ii.

lost that title of respect, which form - ...1 Henry $1 V, \mathrm{i} .3$

in respect of the love I bear

your temper in a high respect...

vouchsafe me hearing, and respect

the respect of likely peril fenred

in respect of poverty; but liow I
RESPECT-respeets, $\mathbf{I}$ grant, $\mathbf{I}$ cannot .2 HenryI $\%$,

delivered with yoor respete...........

thothin that I respect and neu neer - - v.

talt fellow, that respects his reputation - i.

bul the respeets thereof are nice .... - iit.

for pure respect.

as you respect the common gord.

yet should find resucet for what

out of dear respect, his royal self
well, well, nyy lords, respect him

observance or respect of any

let me not slame respect
deny him, in respect of his

the icy precepts of respret.

with a respect more tender

our neeks, they respect not us

sir, in respect of a fine workman .......

many of the best respect in Rome

with conrtesy, and with respect enough

thou art a fellow of good respect not

dauther

is dearer in

in more respect than my noble

in that respect then, like a loving. Tilus Andron, v. 3

sliall not be more dear to my respect.....

it is mingled with respects [Kul.-regards]. Lear, i. 1

since that respects of fortune are

but, in respect of that, I would fain....
you shall do small respect, , liow too

you shall do small respect, blow too

to do upon respect such violent o

the which if thou respect .........Romeo of Juliet, i. 5

in onc respect I'll thy assistant he .. - ii.

nre base respects of thrift, but noite of . Hamlel, iii. 2

such things clse of quality and respect...

his worthiness dues challenge much respect- ii. I

comforts of sudden respect and acquittance- iv.

a more respected person than any -

she was respected with him betore..

I respected witl her ( rep. $^{\text {. }}$ )

is not then respected for what.......

princes their renown, if not respected.. Pericles, ii. 2

I am mean, indced, respecting.... T' Thinier's Tale, v. I

respecting this our marriage with. Henry $V^{\prime} I$. iit. 1

respecting this our marringe with.. Henry/l11. ii.

tis too r'espective, and too sociable .. Kint Jolin,

RESPECTIVELY welcome... Timon of dhers. Hi.

RESPEC'T'ST not spilling Edward's . Richard II. ii.

RESPICE fincm, respect your.... Comedy of Err. iv.

I crave but fourdays' respite...........

after some respite, will return........ Henry $V I$ iv. 1

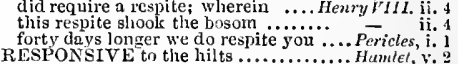

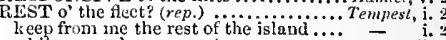

while you take your rest ...............

for all the rest they'll take suggestion

I needs must rest nt

and away with the rest

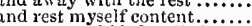

whery man shift for all the rest $\ldots \ldots \ldots$

Proteus, as of all the rest? .. Two Gen. of terona,

and there I'll rest...

and there $\mathrm{I}$ 'll rest......................

above thc rest, we parley

and so, good rest..

him and the restefs rest.............

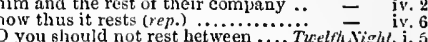

let all the rest give place ..............

Theat the rest of the anatorny.

a woman as the rest goes......

all the rest from their functions.......eas. for $\overline{\text { Huleas. }}$. .

there rest; your partner, as I hear ...

thy best of rest is sieep.....

fairer than honest: rest you weil $\ldots . . .$. presently call the rest of the watch...Much $A$ do, ivi.

the rest I'll give to be to you ...Wid.N.'s Dream, i.

now name the rest of the players.....

set your heart at rest, the fniry ......

w'cll rest $\mathbf{u}$, Hermia, if you think

upon this bank will rest iny head

sleep give thee all his rest! 
REST, let liou, moun-shine this is the greutest error of ail the re wore to that, Biron, and to the rest.. Lov'e's L. L. i.

by the rest thint have no head.

for the rest of the wortisies?.

to interrupt my purposed ro

flitter up these powers of mine with rest -

and merer rest, but ecek the wronry .. -

and thankfulty rest clebtor

rest you fair, good sirni

is my boy (God rent his soul!) nlive..

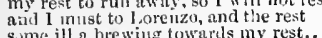

some itt a brewing towarks my rest
where are all the rest? "tis nibe

it we ure like you in the rest

the rest, stami all aloot

no rest be interposer 'twixt us .......

bring us where we may rest ourselves - ii.

God res. Wilt thou s

God rest you merry. sir........................

the reat have worn me out with .....

set up your rest "gainst remedy....

but rest ungluestioned weteonte...

I cun create the rest virtue.

let the rest go. Ny honour's at........ $\overrightarrow{\text { Ii. }}$ i. 3

one thing more rests, that thyself...

and me amoug the rest; an' it you ${ }^{\circ}$ -

he jest, then ull the rest was so ....... -

Wint let it rest; now, Licio, to you.

the rest were ragged, old, and beggariy =

and let the mustard rest

at 1 in in among the rest ..........

...Winter's Tale, ji. 1

a moiety of my rest might come..... $=$ ii. 3

he tonk goud rest to-night ......... =

or that youth would sleep ont the rest

wipe not out the rest of thy services
so drew the rest of the herd to me.

he that sets up his rest to do $\ldots \ldots \ldots . . . .7$.

life-preserving rest to be disturbed Coin. of

in viewing o'er the rest o the.........
the rest is labour, which is not used

heaped up to them, we rest your hermits

What, sir, not yet at rest?

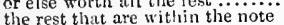

heaven rest them now

that keep her froin lier rest

anci all the rest, so grossly led

one quiet breath of rest: a sceptre

humour rests hy you only to be...

and body to their lasting rest.............

cardinat Pandist is fur evermore

to itself do rest but true

as for the rest appealed....

grieve you to report the re

shatl all rest uuder gage .......

my self a traitor with the rest......
here let ns rest, if this rebellifous

the rest let sorrow say

the rest rests sound; this, let alone (rep.) -

the rest rests sound; this, letal

rest of that consorted crew

the rest, demanded my prisoners...... Hen $\overline{\text { Hry } I V}$

with all the rest retold, may

sirrah, Falstuff und the rest.....

and unbound the rest, and then
him keep witl, the rest banish

the rest w with up abuve.

and rest your gentle head upon

better part of ours are full of rest...

and all the rest to whom they are...

all the rest turned on themselves...

an old man, you should give me

because the rest of thy low ............

booked with the rest of this dayis......

to all the rest of this little kingdom.
lest rest, and lying still, might make

as I have done thie rest of my

that is my rest, that is the rende
gets him to rest, crammed with

gets him to rest, crammed with .....
the rest are, princes, barons, lords ...

let that one artiele, rank with the rest

aud rest your minds in pcace!.....

naught rests for me in this tumultuon

and now there rests no other shift

let dying Nortimer here rest himself

the rest, I wish thee gather.

as will the rest, so willeth..............

as will the rest, so willeth.............
but nuto thee, Alencon, and ilie rest

Dauphin, and the rest, will be but ruled -

Charles, and the rest (rep.v.4) $\ldots$ p....
pardon me, princely Henry, and the rest -

nay, let it rest where it beran.
REST-lord protector, and the
but let it rest; other affair

for lucre of the rest unvanquished

I rest perplexel with a thmsand

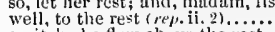

a pitch slie flew above the rest
sivercign lady, with the rest

sivereign lady, with tle rest .........
tizat 110 mul slioulel clisturb your rest

I eamot rest, until the white rose

and the rest, whom we have left......

the rest stum all aloof, and bark.

for all the rest is held at sueh...

needs must $I$ rest awhile

hours must 1 take my rest ........
Lichard, Warisick, and the rest

that rests in me to do 31.

against your majesty than all the res

to rest mistrustful where

and now what rests, but, in night'..........

lie and take his natural rest

guess thoul the rest ..................... lord Hastings, and the rest (rep. iv. 7)
Richmond with the rest shall down..

till Gud please to send the rest

liere at the palnee will I rest awhile..

that he will seduee the rest.

if the rest his soull $\ldots \ldots \ldots \ldots \ldots . . . . .$.

for this, amongst the rest, was l ordaine

thy turn is next; and then the rest

and now what rests, but that we .....

ill rest betide the chamber

God give your grace good rest

perpetual rest [ Col.Knt. ne'er elanging nig nigh

et Northampton they do rest to-night

the rest, that love nie, rise

ever since hath held mine eyes from rest -

where peace and rest lie with me!.;

foes to $\mathrm{my}$ rest, and my sweet sleep

rest thy unrest on England's lawfin

hide my bones, not rest them here!

nor, night, thy rest! ...........

Gud give yon quiet rest to-night!

banguet ere they rest, I think ......

you may read the rest.

and all the rest are countesses.........

her traee sat down to rest awhile

so may he rest......

Trest your servant $\ldots . . . . .$.

and all the rest so laughed

but mark Troilus above the re

my rest and negligence befiriend
rest, sword; thou hast thy fill.

beckoned from the rest below

argument of langhter to the r.
the rest of your fees, $O$ gods.....

the rest of your tees, $\mathrm{O}$ gods

like labour with the rest .......

the rest slall bear the business .......

devise with thee where thou shalt rest

all the rest look like a ehidden train.ju

under leave of Brutus, and the rest

are full of rest, defence, and nimbleness

we with niggard with a little rest

young bloods look for a time of rest.

that 1 may rest assured

remains of friends, rest on this rock.

so, call the field to rest ..............

with the armed rest, courtiers of

and the rest that fell aw uy

is warmed by the rest, and takes

the factor for the rest, have done

go in, and re

when all the rest do nothing

to the shining synod of the rest

and rest upon your never-withering

Alarbus goes to rest $\ldots \ldots \ldots \ldots$ Tilus Andronicus, i.

in peace and honour, rest you here irep.

he rests not in this tomb

hopes more heaven than rests in thee

enlled it from among the rest

but let her rest in her unrest

our law, as dangerous as the

the rest, (hark in thine ear).............

for him to make his rest...

till then, rest your debtor

marshal the rest, as they deserve

if in his grave he rest...

enry rIII. i.

i. 1
ir. 1
v.
i

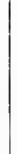

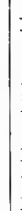

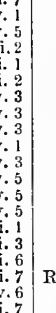

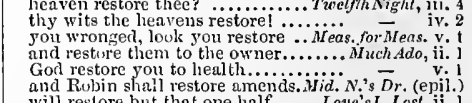

and Robin shall restore amends. Hid. N.'s Dr. (epil.

and restore yourselves into .. ...... HenryI H. .

it made me once restore a purse ....Richard. III. i.

eaptain's brain restores his heart. Anlony \& Cleo. ii

hearen restore me! would I were.... Cymbeline, i.
restore to thee the people's hearts.. Titus

traitor, restore Lavinia to the emperor - i.

I ean again thy former light restore...... o'hello.

that you are well restored, my lordy all their lands restored to them ...

noble lord restored to health.. Taming of Sh. I (ind.)

we joy to see your wit restored $\ldots . . .2 \frac{2}{2}$ (indue

restored again to all his land .......

were youn not restored to all the duke

of nur restored love, and amity ......

either to be restored to my blood .... - iij.

been long blind, and now restored?..2 Henry rI. ii.

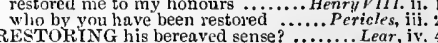

RESTORING his bereaved sense? .......... Lear, iy

when men restrain their breatl $\ldots . .1$ Henry $I V$, ii.

could restrain the stiff-borne action...2 Henry $I V$. .

would restrain the oue, distain ....Richard III. v.

to chain up and restrain the poor.... Coriolanus,
RESTRAINED means, to make.. Meas. far Veess.

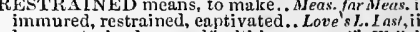

have restrained yourself within .......All's Well, ii.

being restrained to keep him .... Taming of Sh. ii

by the eormorant belly be restrained. Coriolanus

the gods make up the rest upon yon ... $_{\text {and }}$ - iii.

and make the rest malleable .........

my lawful pleasure she restrained .. Cymbeline, i.
should have lim thus restrained........... Lear, ii.2 
IEESTRALNED the riots of your followers... Lear, ii. \& IRETLE. I - sund the retreat

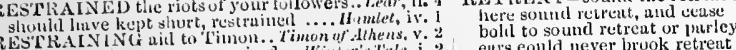
restrainitu from eourse required ... Win'er's T'ate, i. 2

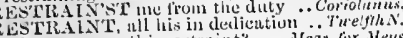
whence cuntes this restraint? ......Meas. the inmoderate uste turns to restrain wishing n mure strict restraint ul

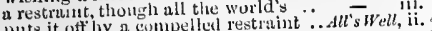
puts it on by a eompened restrit.

my engerness with her restraint...... . Those restim me of restraint..

plucks the muzcle of restrain.

Alleary it

put upon you wint restinint and....

throwtng restraint upon us; ur say....... ESU AlE-100 resumes no care. Thon of alhens, in 1tay, nother, resume that sp

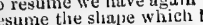

RESU TI D wain the purt I ZESITRREC'IIONS! Give when she...Hery Hives, RL-SURVEY - better heed to re-survey, Henry ¿ET.AILS his wares at wakes...... Love's L. Lost more than he haply may retail......2 Hemry I to whom will rettil my cond

REXAIN to an posterity $\ldots \ldots \ldots \ldots$..... winer did we not retaiu much. Comedy of Errors, $\mathrm{i}$. retau but privilege of ...........

only we still retate the retain?

so oft have boasted to retain?

retain that dear perfeetion.........Romeo \& Julie, ii. 2 be pardoned, and nume the olic Romedy of Er

the duke retained him his.......... HenryVIT.

iREA INING but a quantity of lik....... othetlo, j. RE-TENTIUN-tley lauk retention. Tweifh Nigh, ii.

without retention, or restraint ...... . . . Lear, $\mathrm{v}$.
king to some retention and appointed ...

RETENTIVE euemy, my gaol? .. Timon of Ath. iii.

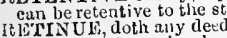

but other of your insolent retiune ......... Leur, i.

RETIRE into my cell...............

thence retire me to ing shilan........ - v.

coluurs of my love and not retire. Merry wives, iii. I

retire yourself iuto some eov

retire we to our chumber..............Macbet/2, $\mathrm{il}$. 2

with a blessert and unvered retire ...

fight eoluly, and retire themselves .

their owa ground in faint retire .... - y.

of sallies, and retires; of trenelres ... Henry

he is enforced to retire, and the duk

troun

our Euylish troops retire

retire intu your trenches

if thou retire, the Dauphin ........... $\overline{H e n r y}$ FI.

graciuus lord, retire to did retire.....3 He, ry $V I$

ne'er till now, his senudal of retire

that eries, retire, if Wurvick bid ....

furced to retire by fury of the wind ... $\bar{F}$ ii

with fiery trunclieon iny retire.......

thou dust miscall retire: I do not fly
[Col.] a retire upon our Grecinu part

$[\mathrm{Col}$.$] a retire upun our Grecinu$
give me leave to retire inyself

he that retires, r'll take him fur

and did retice, to win our purpose

retire to your clianber?.... Antony $\dot{s}_{\text {Cleopal }}$

retire, we have engaged ourselves

they do retire. Well beat eld $\ldots . . .6$ iv. 7

a retire; anon, a rout, collfusion..

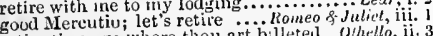

retire thee; go where thou art billeted

RETIRED-buing so retired o'erprized.. Tempes he is of late much retired from.. Wintcr's Tule, iv. 1

you are retired, as if you were ........ $\mathrm{king}$ John

like a bated and retired fooder.

retired himself to I taly

whereupon he is retired, to ripe......

whis he but retired to make him....2 Henry $V$ i.

or is he but retired to make retired me to as wastul

hearing you were retired.

mest retired hath lier lite been

llerullit. iv. lest your retiremeat do amaze your $\ddot{.}$, or $\bar{M}$ e any retirement, any seruestrution..... Henry his retirennent, marvellous distempered. Hamt
RETIRING lrom the siege of Urleans. 1 Herey

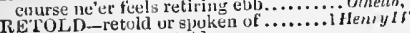

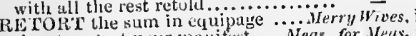

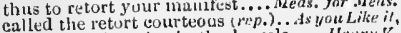

I do returt the solus in thy bowels.... Henry

and they returt that heat aruin. Troilus fo Cress,

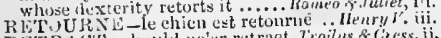

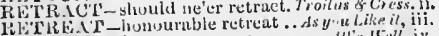
in a retseut, he vutrums any ......... All's Hell,

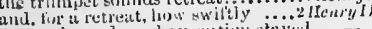
reticat is uniule and cxecution stajed
Henry iii.

atre conld never brook retrent ......3Henyy

ETluGit.1DE-lie was retrograde ...All's We

RETURN_prosper well in our return... Tempest,

ant return or e'er your pulse ........... of rerona

when possibly I ean, I will return

till l'roteus muke returis

return, and make thy.

or ae'er return again into my sight..

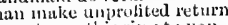

glie returns this rimg to you, sir..

by this gentleman till my return....
if ever he return (rep.) ... Measue for Neasure

but it ever the duke return........... -

contents of this is the return of the duke -

tis he that sent me of the duke's return -

happy return be to your royal graect

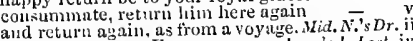

we will returu to France.

but to return to the verses $\ldots \ldots \ldots \ldots$
will they returtu? They will, they will

if they roturn in their own shapes ...

I do expect return of thirice..

and return all in an hour.............
perhaps, I will ret urn immediately..

merke some speed of his return

until my lord's retturn (rep)..........

he left a protuise to return again..... $\overline{\text { s }} \mathrm{W}$ ell, $\mathrm{i}$.

iwhich never returns us thank

till their own seorn return to them ...

return you hitiler? $\Lambda y$, madain..

come, let's return aguin, and suffice

but retu'n with an iuvention $\ldots$.....

or return again intu France? ........

your son was upou his return home

and thou retiarn unexperienced. Tuming
will we return unto thy tuther's house

for our home return; miswilling.. Come

if $[$ return, $I$ shall be prost indeed....

thyu didst retulu from him.........

or else you nuy return without...

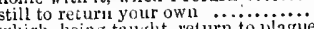

which, being taught, return to plarge

ay madam; but returns a

may suou return to this our suffe

to iny home I will no more retu

if that war return from France........

our colours do return in those same

$O$ fair return of hanislied majesty

and retnrn, for 1 must use tliee.

return the preculent to these lords again -

I will not returu till my attempt ....
and instantly returu with ine astain
buth return back to tineir chairs .... Richard II.

while we return these dukes

never to return breathe I arainst....

spent, return with welcome home.....

bid time return, and thou shalt have

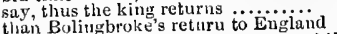

did return to be deposed ............

shall I roturn this answer to the
surety for a safe return again........

as you return, visit iny hourse...

as I retarn, 1 will fetch off these

he iniglit return to vasty 'Cartar.

nnd retura your mock in second

at his return into London ..............

and quielly will return an injury....

return thce, therefore, with a flood of

cone, come; return; return,

respite, will return to Calais a

for, till you to retum, I rest

illen

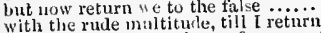

when I return with vietory from ....

uncssen er, return in post..............

stuy till W.arick mule returu?

and then return lansenting

go, return unto thy lurd..................

sitall return beturc your lurdalip
E'TURN und tell his grnce........ Richard H/T. iii.

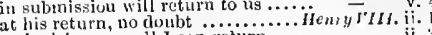

and wislses, are all I can retur.

pr's thee return! with thy approach

but my ort, when returns Cranmer?

furns in peace wot reh ill.... Timon of athens, $\mathrm{i}$

I do return those talents ............

you liave bid me rcturn so much.

but now return, and with their faint

honour to yuu, upon his good returus

then the lot retirns to thine own

please thee to rcturn with us ..........

let us return, atd strain what nea

till my lord return frum the wars ..Corioh

henee, before tile tag return?

what must retur' I do? Retum to the tribuines

I'll return consul; or never trust to..

say that MIarcins return me

you must relura: ols genteral will

so return to you, and nothing else?.Jntims Corstr,

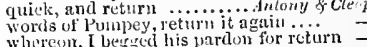

wherem, I beysed his pardon for return

I shall return once more tu hiss......
we must return to the colurt of guard

lend my dianond till your return....
return the cannot, nor continue where

made the speediness of your returu.

our hence-yoing, and our retuin

may'st thon wander, safe returm again

his boily's hostage for his return

why gone, nor when she puryoses return -

a lef of Rome shnll not returu

returns the goot $A$ ndronicus......... Tilus Antron.

true joy for his return to liome (reps)

alsd re

so thou ne'er return, unless thou say ... Pericles, i.

till youl return to us, peaseful........

in our haven, and then return to ns......

my message mut return from whence

find retira, lshall with ag

find, and will unto return, you siall .....

yotir nust $x$ will be dead ere you return

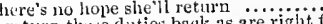

1 return those duties back as are right fit.. Lear, i.

wet you retore; und from huuting ..................

to our sister you do make return (rep.)

retus'n to her? and fifty inen (rep. ......
retarn, and for:e their scantesl courtesy

retarn, and forte the worst returns to laughter .................

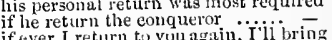

if ever I return to you ngitin, I ll bring

in heir splseres till they return . Romeo

how shall that faith retmin ag:tit...

ready to go, but never to return......
dist return to pry in what $I$ further

leave and fitvour to return to France....

most fuir return of greetings, and desire

and my return, shall be the end of my

my sodden and more strange retur

to what buse uses we may riturn

bade him anon return, and here sseak....

sil', I obey the mund ate, ar.d will retura.

if she will returm me my jewels............
Othetlo and Desdemona return again

RETURNED-minion is returned again Tempest, iv. 1

see it be returntd; or else.... Tu. Gen.of rerona,

of the conut Orsino's is returned ..... $\overline{-}_{\text {eas. }}$ iii.

we ttilk of, were returned as

would he were returned!......

he is returued; and as pleasant as

dun Pedro is returned to seek you...

I am returned, and that war-thonghts $\overrightarrow{-}$

my herald is returuel

Love's L. Losi, iii.

is my naster yet returne

fir our words: are they returned?

and but even now ret urned; 1 have not - v.

the good of our returned fortune...Asyoulike it,

thou urt returnet so sion? (rep).).. Comedy of Ers

nor the slave returnel, that in sucl

to that end am I returned ...........

uot those in emmissisn yet returisel? . Macbeth,

whtil it had returned these terms.... Richerd $I_{\text {. }} \mathrm{i}$.

my unsle is retnrneds deliver up ...11err'y 1

is returned with some diseminfort.....2

nud an wer wis returned that he $\ddot{\text { anin }}-$

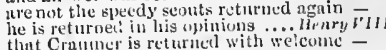




\section{RET}

REV

RETURNED her thanks in

that Paris is returnel hom

... Ierry VIII. v.

to have her baek returmed............

I returned you an enpty

as Cominius is returned, nnikeard......

hail, lords, I am returned your soldier

that I returned with simular proof.. C

honour and with fortune is returned

these mischiefs be returned agaiu.
Built's returnerl. Now, sir, hast
the old min forth: he is returned

was this lefure the king returned?

resternight returned my letter.. Komea \& .nuliet, v.

which had returned to the inheritane

if he be now returned, as checking at....

and I returned the rather for that...... Othello, ii. 3

returned me expeetations and conior.

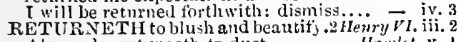

Alexanter rcturneth to dust ....
RETURNING $\rightarrow$ I am returning

All's Well, iv. 3

returning were as tedions as go o

are done, and Casar is returning

REUNITED to the erown of France.....Henry $V . \mathrm{i}$. now reveals hefore tis ripe ..... Ta Thelfh Night, v. 1 we still see them reveal themseives... All's W'ell, iv. 3 madam. I have a seeret to reveal...

till the heavens reveal the damned.. Tilus And. iv.
reveal how thou at sea didst lose...... Perieles, v, 2

no: you will reveal it. Not I ............. Hnmlet, i. 5

REVEALED-she re vealed herself ...ikenry $r I$ ii. 3

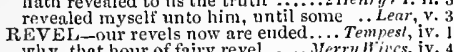

why, that hour of fairy revel .... Nerry Hiwes, iv. 4

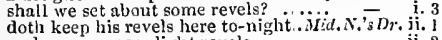
and see our moonlight $r$

in nightly revels, and new joility.... 二 v. v.

for revels, danees, masks ........ Love's L. Lost, iv.

to the fenst, revel and dom the best

the saffron face revel and feast.. Comedy af Err. iv. 4

drink, dance, revel the night ......2 Henry $1 \mathrm{l}$. iv. 4

roul eannot revel into dukedoms ........ Henry $h^{\prime}$ i. 2

revel in the entrails of my lambs... Richard hir. iv. 4

entrent an bour of revels with thein. Henry VIII. i. 4

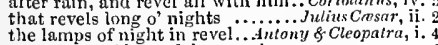

present our Alexandrian revels ........ Titus Andran. v.

which looks for other revels ........... Pericles, ii. 3

date with this night's revels ............. Romea \& Juliet, $i .4$

being our kinsman, if we revel mileh

where joy most revels, grief dot/ 1 most

and revels his addi.tion leads him

what, man! 'tis a night of reveis ......... - ii.

With joy, revel, pleasure, and applause... - ii. 3 that revelled in our parliament ....3 Hen'y ${ }^{\prime} 3 . \mathrm{i}$.

tather revelled in the heart of France - ii. 2

the revellers are entering ................ Wuch Adn, ii.

we is ealled the Briton revelier......... Cy mbeline, $\mathrm{i}$.
REVELLING-have revelling to-night. Mach .Ado, $\mathrm{i}$.

with triumph, and with revelling...Mid.N.'s Dr. i.
still revelling, like lords, till all ..2 Henry $\mathrm{FI}$.

REVELRY - our rustie revelry ..... As you Like it, v. 4

as in revenge of thy ingratitude. Two Gen.

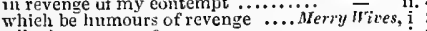

wilt thou revenge?

to be revenge on this same ...........

nursue him with any further revenge?

rather plick on laughter than

revenges to your heart..... Measure for

have ta'en revenge, by so receivi

and so dies my revenge

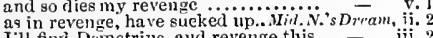

It will feed my revenge ..... Merchant of Jenice, $^{-}$iii.

wrong us, shill we nut revenge?
what is his thumility? revenge

by ehristian example? why, revenge

and no satisfaetion, no revenge......

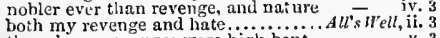

though my revenges were high bent.. $-\bar{y}$.

why, his revenges must in that be. Winter s $T$ ale

the very thought of my revenge

with eyes of pity, not revenge! ......
to bloody thouglits, and to revenge.

thom may'st revenge:--O slave! ......Macbeth, iii.

revenges burn in them; fur their.....

justice, and revenge on you $\ldots . . . . .$.
where revenge dicin paint the fearful..

lay it open, th urge on revenge
giving it the worship ot reviuge

REV FNG E-ofliee for thee of revenge.. Kint John,
let heaven revenge; for I may never. Richard II. but not revenge thee dead

revenge the jeering, and disdained ... IIPury ${ }^{\prime}$ iv. $\mathrm{i}$.

a king that will revenge lord Stafford's - v.

ajptest way for satety, and revenge ...2

ronse up reveige from ebon den with

our person, seek we no reveng

thy grout, in earnest of revenge

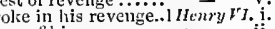

how shine it like seomet of revenge.

hut deeds, revenge this truason!.......

my death's revenge, thy youth

my death's revenge, thy youth ........
not who they sting in his revenge..2ilenry $F$.
thercfure, to revenge it, slalt thou die

if he revenge it not, yet will his firien
think theretore on revenge, and eease

both have vowerl revenge on him ...

as shall revenge his death............

were not revenge, suffieient for me

lest in revenge thereof, sith God is .".

a bird that will revenge upon
blows, and revenge for mel

withhold revenge, dear Gud

iven me measure of revenge

I will revenge his wrong to lady Bon

I will revenge his wrong to lady Eona
but seek revenge on Edward's mockery

nor forwayd of revenge, though they -

revenge his death! (rep.)........... Rich

God will revenge it (rep. ii. 2 ) $3 \ldots \ldots$.

even for revenge inock my destruction?

I revenge. What? Myself on mysell?

menaeed revenge upon the eardinal. Elenry $1 / J I$. $\mathrm{i}$

pleasure, and revenge, have ears. Troilus \& $\bar{C}$ ress. ii.

and that's reve shall hide uur $\ldots$..... - v.

to revenge is no valour, but to bear.

let us revenge this wi th our pikes

for thy revenge, wreneh up thy power

revenge thine own partieular wrungs

vows revenge as spaeious, as between

though I owe my revenge properly

my exile, sweet as ny revenge I.

to allay my rages and revenges .......

revenge; about, seek, burn, fire, kill

we'll revenge his death

revenge yourselves alone on Cassius.
revenge it: I dedicate nyself .......

revenges, hers; ambitions, eovetings

and $I$ 'll be merry in my revenge

so the revenge alone pursued mel

would, revenges, that possible strength

opportunity of sharp revenge upon. Tilus Andra

basely put it up without revenge?

blood and revenge are hammering in

revenge it, as you love your mother's

Which way shall I find revenge's

to heaven she heaves them for revenge

will have diseovered tor revenge ${ }_{\text {reve }}$

will not revenge: revenge the lieaven

$f$ you will have revenge from hell

I am Revenge, sent from below ( $($ rep. $)$

Revenge, whieh makes the foul (rep.)

o sweet Revenge, now do I eome...

he firmly takes me for Revenge......

Revenge now goes to lay a eomplot (rep.) -
ealls herself Revenge, and (links me mad-

ealls herself Revenge, and (hinks me mad

the gods revenge it upon me and mine.

I will have my revenge. ere I depart

the revenges we are bound to take

the king, anl to revenge thine eyes...

but newiy entertained revenge. Romeo \& Juliel

revenge his foul and most nnnatural

may sweep to my revenge........................

prompted to my revenge by heaven and

this is hire and saliary, not revenge.

is't writ in your revenge, that, sweepstak

persualle revenge, it eould not move thus

but $m y$ revenge will eonse...........

revenge shoula stir me most to my revenge

let us be conjunctive in our revenge ....

revenge being nigh, bade her wrong
but partly led to diet my revenge...

ton ponr, too weak fur my revenge!.......

some graee, yet have we some revenge

and sweet revelge grows harsh .................
REV ENGED on Eglamour.. Two Gen. of Verma, v. let's be revenged on him .............. -
detect my wite, be revenged on Falstaf
on whom to-night I will be revenged wenged on the whole pack of you. TuelnhNithi, flnuts me, and l'll be revenged ...Taming of Sh. ii.

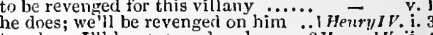
tear her: I'll be revenged on her ...2Henryll. ii. 4 but we will be revenged suffieiently... Henry $/$ l. j. not, heavens, be revenged on mel.... 3 Henry $V l$. revenged may she be on that hatefil
be thuu revenged on men, and let me live

how shall Boin be revenged $\ldots \ldots \ldots$.... I would I were, to be revenged........ Richard III. $\mathrm{i}$. revenged on Pivers, Vuughan, Grey $\ddot{\text { enru }} \overline{V u}$ i. 3 to be revenged on hill be revenged; revenge...... Jutius Crensar, iij. 2 when I am revenged upon iny ... Antony \& Cleo. iv 10 revengedil how should I be revenged? - i. I'll be revenged: his neanest garment? = ii. nay, indeed, to be revenged npon her
I fear, 'twill be revenged ............ ii.. 5 I am sed to Rome and Saturnime, Tizsandron. iij. I am sent to be reveryed on him ....
worse than Progne I will be revenged the king now bears will be revenged .... Lear, iii.

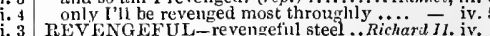
stay thy revengeful hand ........... our devotion with revengefui arms?.3... thy revengeful heart eannot forgive. Hichard III. i. my revengoful serviees may prove... Coriolanus, iv. 5 with revengeful war take wreak. Titus Andror, iv. 3 I am very proud, revengeful, ambitious. Hamlet, iii. I

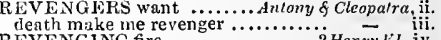
REVENGING fire $\because \ldots \ldots \ldots \ldots \ldots \ldots \ldots \ldots \ldots$ Henry $V_{I}$ iv. REVENGING LY enteebles me ........... Cymbeline, v. 2 withering out a young man's revenue. Mid. N.Dr.i. a dowager of great revenue ............ in beard is a younger brother's revenue

my revenue is the silly eheat ..... W'inter's Tale,

witeheraft with revenue elserish ..... Kimg John, iii.

the revenue whereof shall furnish ... Richard 11 . ii.

barely in title, not in revenue...

manors, rents, revenues, I forego .....

the ripe revenue and due of birth. Richard III. iij. for the wide world's revenue.. Trailus \& Cressida, ii. 2 that we detain all his revenue ...Aulony \& Cleo. iii. 6 a revenue of any king's in Europe ..Cymbrline, ii. 3 the sway, revenue, exeention of the rest .. Lear, i. I
enjoy half his revenue for ever (rep.) - i. 2 (letter) and the son manage his revenue

from thee, that no revenue hast ........Haniet, iii. 2 REVERBS no hollowness ................. Lear, i. 1 that shall reverberate all as loud .... KingJohn, v. 2 like an areh, reverberates ... 7 rot ins \& Cressida, saving your honour's reverenee...Meas. far Meas. ii. hide fiimselt in such reverence ....... Wuch Ado, ii. 3 saving your reverenee, a husband...iling - ivi. I $\mathrm{am}$ foreed to lay my reverenee by ..

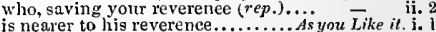
is nearer to his reverence............ As you Like it. i. reverenee of the grave wearers ... Winter's Tnle, iii. without he say, sir reverenee.... Comedy ark'r. iii. the fair reverenee of your lighness... kiehard il. i. I not reverenee, makes thee to exeept.

flesh ani blood with solemn reverene

of holy reverenee, who, I eannot learn - iii. 3 that lie is (saving your reverenee) ..1 Henry IV.ii. 4 but you misuse the reverence of your - iv. 2 of what your reverenee shall incite ...Henry $\mathrm{V}$. i.

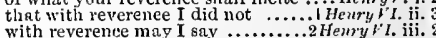

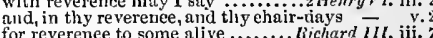
for reverence to some alive ......... Wichard 111. iii. ? deserve we no more reverenee?...... admired reverenee in a slave .. Tiinon nf Athens, v. love, good thoughts, and reverenee.Julius casar, iii. saving reverence of the word ....... Cymbeline, iv. I yet reverenee, (that angel of the world) 二 iv. 2 adlorest and hast in reverenee .... Titus Andron. v. do not look for reverence, but for love... J the sun, for them to reverenee ......... $-\overline{\text { it. }}$ this poliey, and reverenee of age reverenee tlie hoad-lugged bear wotild liejk = iv. sisters have in thy reverenee made play and trifle with your reverence....... Ohello, i. 1 REVERENCED like a blessed saint. 1 Henry $v$. iii. 3 
REVERENCED for their lawful . REV iRliND gentleman.

Merry Wryex, iti. 4 a sad face, a reverend carriage... Tunclith Night, iii. A a most thank tiul nul reverend youth . Much idio, v. I

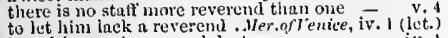
here 'tis, misst reverend doetor

all is done in reverend eure of lier Taining of Sh.iv. I pereeive, thnu art a reverend f

by law, as well as reverend age........ to see a reverend syracusan.. Comedy of Errors, sle is virtuons and a reverend lady.

good reverend father $(\mathrm{rep})$............ King John, goome reverend room, more thain ....... Richard il.

ancient lords and reverend bishops.

to liave a reverend enre of your........

reverend father, and these noble

and twenty reverent bishops ........... Ilenry $I$.

within, with two right reverend fathers

revereud cardiual (rep.).

nry FIII. i.

weleome, most learned rever

these reverend futhers (rep.) $\ldots$........

your pleasures with me, reverend lords?

two reverend eardinal virtues

eome, reverend father's, bestow you

what two revereod bishops were those

where the reverend abbot, with all his

and thou most reverend ......... T'ro

most reverend Nestor, 1 ame gind to

by two of their most reverend senate

gay you are reverend grave inen .....

therefore, please you, most reveren ii.

0 reverend tribunes! gentle nged men!

eome, thou reverend man of Rome

hail, reverend sir! the gords preserve
reverend appearer, no; I threw her.

reverend appearer, no; I threw her.

old and reverend, you should be wise...... Lear i. 4

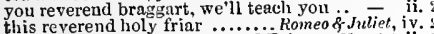

on the milky head of reverend Priam... Hamiel,

most reverend signior, do you know

most potent, grave, and $r$

Timon of $A$ then

REVERENT-very reverent sport. Love's L. Lost

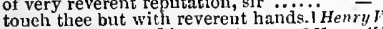
the reverent eare, I bear unto my..2 Henry !

if ancient sorrow be most reverent. Richard 11. iv. 4 how may I reverently worship thee..1 Henry I hold thee reverently.............3 Henry REVERSE-thy stoek, thy reverse. Merity
reverse the doom of death.... Tizus $A$ ndro

reverse thy doom [ $K u t$.-reserve thy state]. Lear

reverse a prince's doom

REVERSION-in reverion lis..

tis in reversion that I do possess

now rerfection in reversion shall. Troilus \& Cress.

REVERSO-the pun to reversol. . Romeo \& Juliel,

Would have reverted to my bow again. Hamlet,

REVILE-revile me there? .. Comedy of Errors

REVIl,ED-she herself reviled you

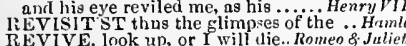

REVIVE, look up, or I will the.. Romen \&. Juliet,
air by whieh he should revive...Meas. for Meas.

air by which he should revive.. Meas. for Mea
is prepared, and time revives us ....Al $\mathrm{s}^{\prime}$ Well

is prepared, and time revive it, boy. King John,
with my breath I ean revive
by death, revives two greater ......2 Henry I

and never shall revive

I should revive the soldiers liearts.... he doth revive again; madain...;
how thy words revive my lieart!

3 Henry

words revive my drooping thouglits

shall after revive (rep. v. 5 )..Cymbeline, v. 4 (scroil)
ret he revives; what are you, sir? ....... Lear, iv.

Jet he revives; what are you, sir? .....Lear, iv.

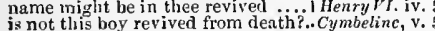

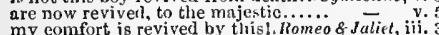

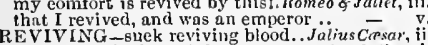
to be more fresh, reviving $\ldots . . . \ldots$. Cymletinu, all revoke your ignorant eleetion

and revoke your sudden approbation
revoke thy gift; or, whilst I ean vent

REVOKED_tlis slall not he revokerl..... - -

REVOLT and elinuge your mind. T' w' Gen.ufier, iii.

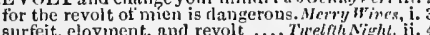
as gravity's revolt to wantoniess.. Lore's l.. Lost, v. to corrupt hin to a revolt ....All's Wrell, iv. 3 (not how minutely revolts uploraid hi

and less have given him the revolt ...... ofoul revolt of Freneh incoustancy' matter of revolt, and wrath
REVOLT-ne'er strined with revolt.. King John, i oeek a blaster of eontenumed revolt

lou ingrute rcvolt your hloody .......

I tear, revoit on Hereford's side.... Richerd $I t$. revnlt our subjeets? that we cannot nenry $^{-}$

quick! $y$ nature fulls into revolit......

ar this revolt of thine, methinks

the stout Parisians do revoit

the king is mereitul, if you revoit..2 2 inenry
all will revolt from me, and turn...3 Henry

hou wilt revolt, and fly to him ....3iehend ill

if I revolt, off goes young George's

doth daily make revolt in iny. Tiinon of sthens,

their mutinies and revolts wherein

all the remious do smilingly revolt

and flush youtl revolt: no vessel.. Antony \& Clco,

Alexas did revolt; and went to .......

at one time eneomiter sneh revolt

by thy revolt, O husland, sliall he ..
for barbarous and umatural revolts

and will revolt from $m$.

now, my thoughts revolt; for he's

revolts from true birth........... Romea \& Julie,

with treacherous revolt turn to another -

made a gross revolt

REVOLTED-our revolted wives........... in ires

that hive revolted wives

to younger brothers, revolted tapsters

France is revolted from the...

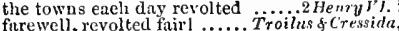

the kings that lave revolited.....Antouy \& Cleo.

when men revolted shall upon record

REVOLTING - on her revolting som. King Joh

the revolting [Col.-revolted] faetion.

seonrge the bad revolting stars

the false revolting Normans.......2 Henry/

revolutions; these are berot ..... Lone'sL. Losi,

pleasure, by revolution lowering. Antony of Cle

REVOL $\nabla \mathrm{E}$ what tales................. Cymbeline,

I may revolve and ruminate ......... Henry $y$

REVOI VING this will teach thee.. Richard III.

REWARD with plagues $\ldots$.? TwrGen. of Verona,

nothing but the reward of a villain .. Much sito
is old dog my reward? mast true .. As yme Lile

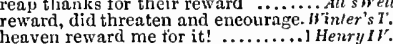

henven reward me tor it! ........... Henry 1

reward: he that rewards me, God (rep.) -

never liave yon tasted our reward.. I Henry ' $'$.

the post, in hop? of his reward

follow us for thy reward

I will reward you for this venturous

have a thousand crowns for his reward -

we give thee for reward a thousand ...

promise them such rewards as victors

there's thy reward; be gone.........

reward, when the deed's doue (rep.) Richard 11 v.

opens his purse, to give us our reward

proclained reward to lim that hing

in time will find tleeir fit rewards.. Henry $\bar{F} \mid I I$

be received, not witlout fair reward

you gods, reward them!.............

a fellow thist will with downg them ...

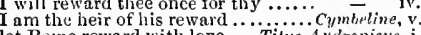

let Rome reward with love....Titus $A$ thronicus, i

for thy reward among the nettl

heaven's sliaft, but sin had his

lust the due alud just rews

take thy reward: five days we do..
the gods rewarl your kindness!...

fortune's buffets and rewards has

conntenance, his rewards, his authorities
thank me. love me, and reward me .... otheth

REW ARD FD-but light $]_{y}$ rewarded. Lore's $L$. Lnst

REV am I thus rewarded?

RFIVARBING my dependaits .... Inve'sL. Lis' RE-YVOliD-I the mutter will re-word.. Hamlet,
REX Anglize, et hæres Franeix .........Henry

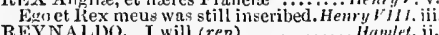
Rlo you mark this, Reynaldo?
RII

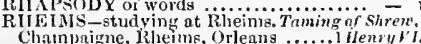
Charles iscrowned king in Rluein

RllENISII-glass of Rlichish wine, Mitr.of Fen
there is between red wine and Rltenish

he drains his draughts of Rlienish down. $\bar{H}_{1}$

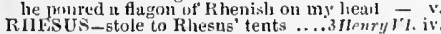

IRIL'TORIC, diselosed with eyes .. Love's L.. L.ost, ii. I

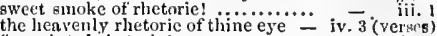
fie, paintel rlietorie

practise rhetorie in your eommon. Tuming of Sh $i$. 1

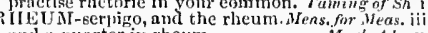

and $n$ cinrter in rheum.............Much Ado

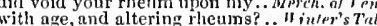
the salt rheum that ran between. Conedy of Err.iij. how now, foolish rilieunl

villany is not withont such a rheum

a waked the sleeping rhemi........... Richard $I$.

at a few drops of women's rheum

he was troullicd with a rleum ... Aniony \& Cloo.

I lave a salt and sullen rheum offends. Othello,

The a salt and sullen rheum offends. Olhetlo,

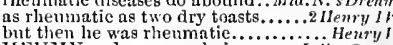

RIIEITMY and unpurged oir

RHINUCEROS, or tlie Hyrcan tige
RIIODES-the proot, at Rhodes

preparation makes for Rhodes ( $r e p$.).

RHODOPE'S, or Memphis' of Ri

RHUBARB, enua, or what yurgative...Machelh

winge eomposed rlyymes sliould ......

the teetly of all rlyyme and reason.......

no rliyme to lady but baby $($ rep. $) \ldots \ldots$.

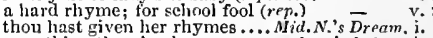

something then in rhyme ........... Love's L.Lost,

assist ine, solne extemporal god of rhyme -

taught me to rlyyme (rep.) ...........

I heard your guilty rliymes...........

see me write a thing in rhyme? .......

his prodigal wits in bootless rhy we
nor woo in rhyme, like a blind ....

I'll rliyme you so, eight y'ears ....... v. v. as your rlyymes speak? weither rhyme

is neitlier rinsme nor reason .. Comediy of Errors. ii. 2

that eau rlayme themselves iuto ladies'. Herry $V$ r.

a rliyme is but a ballad ............... ${ }_{\text {wien their rhy }}$. y. ${ }^{2}$

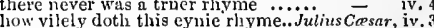

will yuu rhyme upon't, and vent it.. Cymbeline, $v .3$

yon have put me into rhyme .........
wit's inore ripe, aceept my rliyme... Pericles.
i. (Guw.)

post on the lame feet of my rhyme - iv. (Gow.)

speak bnt one rliyme, and I am satisfied - ii. i

R.HYNED - you might have rhymed .. Ilam/et, iii. 2 RHY MERS ballad us out o tune..Anlany \& Cleo. v. 2
RHY not born under a rhyming planet .... Murh Ado, v. 2

what news on the Rialto? (rep. iii. 1) .. - i. in the Rialto you have rated ne dare searce sliow lis head on the Rialio - ji. RIB-barred up with ribs of iron! ......Auch Ado, iv. dainty bits make rieh the ribs ...... Love's L. Lost, i.

every finger I have with my ribs .... - ii.

with over-weathered ribs, and ragged - ii. 6

broke three of his ribs ..............As you Like $i,, i$.

my seated heart knoek at my ribs.......Nacheth, i. 3 finty ribs of his eontemptnous eity... KingJohn, ii. 2 the fat ribs of pence milst by the ..... through the flinty ribs of this .......... unless you eall three fingers on the ribs - iv. like a rib of steel $\ldots \ldots \ldots \ldots \ldots \ldots \ldots .2$ Henry $I V$. ii. to have yerked him here under the ribs.. Olhello What ribs of oak, when mountains..-1
RIBALD-the ribald erows .. Troilus \& Cressida, iv. RIBALD-the ribald erows . Troilus \& Cressida, iv.
RIBALD-RID nag of Egypt . .... Antony \& Cleo. ii.

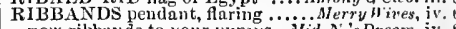
new ribbands to jour punils...Mid.N.'s Drenm, iv. lath ribbards of all the colours.. Winter's Tate, iv. bondage of eertain riblands and gloves - iv. 3 now shnes witly old ribband? .. Romeo \& Jutiet, iii. a very riblsand in the eap of youth ....Ham $e^{2}$, iv. 7 RIBBED and paled in

inter's 111 . iv.

RIClI-witl rich garmcuts.............. Tempess, i, 2 into something riel and strange....... Tempess, i. 2 (song) I ratity this ny rich gift ..............

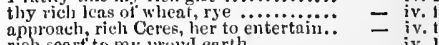
rieh fearf to my lyoul earth .......... and I as rich in having

the rich and por (rep. ii. i)........... iserry Wives, $\mathrm{j}$. 3 supphire, pearl, and rich emhroidery
wlyen the rieh goldeu shaft ...... Tuelmh .Nigh, 
RICH-love-thonghts lie rich, when. Twelfh Nighl, i.

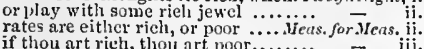
if thou art rieh, thoit art poor.

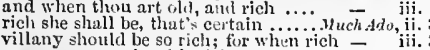

mav counterpoise this rich and precions - iv. I

auth a rich fellow enough, go to ......

from a voya re, ricli with merchandize

with the rich worth of your yirginity

deny your love, so rieh within lis soul $\overline{-}$ iit.

we sliall be rieh ere we depart

no richer than rich tafteta.

our dity is so rich, so intinite

and rich things but poor (rep.)

and rich burgliers of the flood.........

never so rich a gem was set.

two rich and precions stones

gifts of rich value; yet I have ........

ath a ship of rich lading "reckedon = iii. I

ten thousind times more rich

and a rich matt that hath not.......

is to have rich eyes, and poor hands

art rich? Faith, sir, so, so ....

thongh many of tic rich are damncd...All's $H^{r} e l l$.

no legacy is so rich as honest

his ring he holds most rich in choice = iii. 7

thongls her father be very rich. $\dddot{T}$ aming of $\overrightarrow{\text { shrew, }} \mathrm{i}$.

she sliall be rich, and very rich.

if thou know one rich enougl to be

within rich Pisa's walls, as any one - ii.

yet standing in rich place.........

the rich stake drawn, and takest ....

then mike your garden rich in

his garments are rich, but lie wears.. $=\quad \begin{aligned} & \text { iv. } 3 \\ & \text { iv. } 3\end{aligned}$

is unt so rich in worth as benuty...

declining their rich aspect to. Conedy of Errors, iii. 2

and the rich Last to boot ......

make her rich in titles, honours

and this rich fair town we malke

and this rich fair tow

ing John, ii. 2

but to be rich; and being rie........

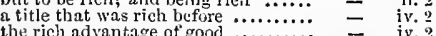

into the purse of rich prosperity $\ldots . .$. . $=$ ichard $U$ y.

shall know what men are rich

Sour presence makes us rich
rich meri look sad, and raffi:

to Canterbury witly ricls offerings...... Henry $I V$. i.

and thy precions rich crown

to rob ine of so rich a bittom here...

to set so ricls a main on the nice.

to hear this rich rcprisul is ...........

such are the rich, that have.

like a rich armonr worn $\ldots . .$.

your chronicle as rich wit prai....

of gallant youth in our rich fields

seck a queen to make lin

from the rich cardiual and, like rich langings in....

than doth a rich einbroidered

treasure, rich stuff's, and ornaments

til a ricli cliair of state

if he ln the rich shall have more. Troilus $8 \cdot$ Cress. 1 .

lies, rich in virtue, and unmingled

and doth think it rich to hear

not worth in me such rich beholding

crams his rieh thievery up

'timen's nod.

happy, and has left me ricl

fich men sin, and I cat root

as if your lord shonld wear rich jewels =

thus part we rich in sorrow........

rich, only to be wretehed

and as rich men deal gift, expecting

go, live rich, and happy; but thus

Jet ricli conceit tanglit thee.

act estabiished arainst the rich......

were not so rich a jewcl.

made rich with the inost noble...Julius Cresar,

bequeathing it, as a rich legacy....... - iii.
rieh in his father's honour ...Antony Cleopalra, $i$.

and hitil rich pearls upon thee ......

and the rich cron of sea and land..... Cy neline, i. 7

jewels of rich and exquisite form.

so bravely done, su rich, that it...

your means abroad you linve me, rich

no wonler when rich ones scarce.....

Laviction shou!d he rich in. Winere? - v v

I can conpure our rieh misers to ........ Pericles, if.

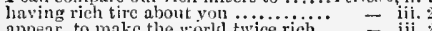

appear, to make the worlk twice ricb.

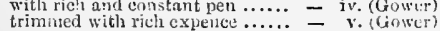

RICH_you make more rich to owc? .... Pericles, $v .1$

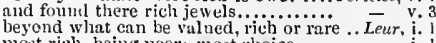
most rieh, being poor; most choic

o slie is ricly in beanty $\ldots \ldots \ldots \ldots$..... Pom a ricls jewel in an Ethiop's enr (rep.) on the fair dnughter of rich Camnlet eonceit, morc rich in matter than but love's shadows are so rich in joy?
attords no law to make the rich atiords no law to make the rich rich, not yitudy; for the a laparel of rich made the things more rich

spend youl rich opinion for the nrove. and content, is rici, and rich enough $\because-$ iii and finds them perfeet Pichard... I am thy gramlam, Richard, call .... and come, Pichard; we must speed. king linichard Conr.-de-lion was thy shall say, when Richard me begot sir Richard, what think you? have yo was brutglit to Richard but even. now before king Rich:trd, in his royal.... true to king Richard's throne thrugh Richard iny life's eounsel the son of Riehard earl of Arundel. as my sweet Richard; yet, again. God for his Richard hath in heavenly king Richard lies within the limits.. doth kiss king Rielsard's hand king Richard and inyself shonld meet mirk king Richard how he looks (rep.)
Riclard leave to live till Richard die? upright judge of nuble Richard...
that is not Richard's subject?...

fetch hither Richard, that in commo thou king Richard's tomb (lep.)
what is my Richnrd botly in shape

and rubbish on king Richard's liead alas, poor Richard! where ricles ... thant is lost, for being Richard's friend and love to Richard is a strange broocl

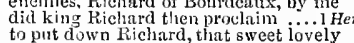
to put down Richard, that s weet lovely was Richard then when I from France
inust not know, sir Richard, the liheral mnst not know, sir Richard, the liheral
the blood of fair king Richard ......2 thy glintton bosom of the royal Fichard since Richard, ant Northumberland even to the eyes of Richard, gave him king Richard miglat create a perfect our late king, Richard, being infeeted
Riclard carl of (rep. ii. 2).... Henry $V$. I Richard's body liave interred new sinis still for Richard's soul......
sir Rieharrl Ketley, Davy Gain.

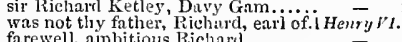
Ricliard Plantagenet (rep.).

since then hath Richard been obscured nephew, late despised Rich:ard (rep.) young king Richard thus removed great reason to do Richard right .....
that Riclard be restored to his (rep.) if Richard will be true, not that alone rise Riehard, like a truc Plantagene
and so thrive Richard, as thy foes well didst thou Richard, to suppress that Richard, duke of York ......... Richard was murdered tris only so for lichard, the first son's heir...... marriec Richard, earl of Gambid Richard shall live to make the earl.
I thank you, lichord: God know's Richind, hath best deserved of all ...3 resolve thee, Richard; clain the English
and that's Ricluard, duke of York ... for Rich:urd, in thic view of many lords ditl Richarl make a lane to me. did retire, Richard cried, change?. Rieliard, I bear thy naric, I'll velige uor now my scanilnl, Richaril, dost. now, Richard, I am witli thee here alon come York, and Richard, Wurwick
your brother Richard marked him Richarl, I will ereate thee duke (rep.)
there is no kingdom then for Richard

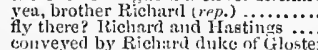
now, brother Richand, Jorl IIastings and, Rich:ud, do not fiown ulyon ny
ald Richard, but a ringed fatal.... holk, liehard, hold, fir we have done hard-favmred Richard? Richaril.. where's Ricluard gone? To London..
vea, Riehard, when 1 know .........
RICLAIR-trust of Richard Gloster.Richard III. i. 3 Richard! Ina? I call thee not ...... till Richard wear the garland of the princely Richard, and to Buckingliam Richard the second here was hacked

standing by when Richard stabbed..

then eursed she Richard: O remember = God save Richard, England's (rep.)
your wisdom, and your love to Richard crowned Richard's royal quecn....... wo thou to Richard, and good angels go thou to Richiard, and good angels Richard yet lives, hell's bep.

for my daughters, Richard, they sioil not be Riclarel that liath done all this as long as liell, and Richard, likes of it
will not king licluard let me speak.. in Richard's bosm (rep.)............

Fichard, thy wife, that wretcher.... -

and Richard fails in height of all....
Richard loves Richarcl; that is, I am I whose bodies Richard murderea .... - v. to act npon the nsirner Ricliard ... Henry

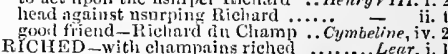
RICIEP than innfeency......... Meas. for Meus. iti. 2 beanties no richer than rich taffeta. Love's L. Losl, v. 2 no richer than lis honour........ N'inter's Tale, iii. whose veins bound richer blood ....Kins John, ii. 2

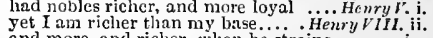

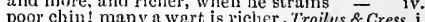
which yon prized ripher than sea.... and I am here no rieher in return, Timon of dth. ii. 2 than Plutus' nine, riclier than gold.Jul. Cresar, iv. 3 richer, than doinu nothiıg for a babe. Cymbeline, iij. 3 richer [Kut.-ponderous] than $\ldots \ldots \ldots$ torigue ... Lear, i. wistom should show itself more rieher. Hamlet, iii. threw a pearl uway, richer than all his.. orhello, v. RICIAS-of riches, or of poverty ....... Tempest, ii. and slow riches ready to

honour, riches, marriage blessing...... in iii.

riclies are these poor habiliments. Tur Gen.of $Y$ er. iv. and 'tis the very riches of thyself...Merry Wives, jii.

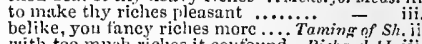
with too much riches it contound.. Richord 11 , iij.
that's all the riches I got in his ...... Ilenry ${ }^{\prime}$. ii.

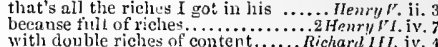
not firs all the riches under heaven. Heury VIII. ii. as place, riches, favour, prizes.. Troilus \& Cress. iii. ? riches point to misery and contempt? - iv. 2 who was, indeed the riches of it ... Cymbeline, iii. 4 my riches to the earth from ............. Pericles, i. greater tlian nobleness and riches.... the riches of the ship is come on shore i.. olkello, ii. 1 but riches, fineless, is as poor as winter - iii. 3
RICHEST-in love's richest book ..Mid. $\Delta$.'s Dr. ii. 3 the richest beauties on thic earth! . Love's L. Lost, v. astonish the survey of richest eyes.... All's Well, v.
will hang npon my richest robes ....2Henry VI. ii. 4 pins leer richest lockram 'bout her... Coriolanus, ii. RICII-JEW ELLED enter of Darius... Henry Pl. i. 6 RICHILY for the practice.............Much Ado, $v$. in Bchmont is a lady riehly left. Merch, of Venice, a vessel of our country, richly franglit

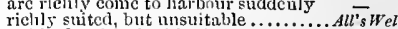
richly furnislied with plate...Taming of shew, ii.

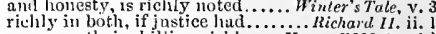
see :way their shillins riclily ....Henry III. (prol.) docs pay thy litbour riehly ...Antony \& Cleo. iv. 12 poor solitier, that so ricluly fouglit ... Cymbeline, $\mathrm{i}$. jewcl-like, and eased as richly ….... Pericles, v. Bretagne and earl ut Richmond ..... King John, ii. countess Richmond, good my live witl? Richum

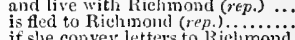
Riehmond should be kine, when (rep.) not live long after I saw Richmond.. Mirton is Hed to Richmond ........ Ely with Richmond troubles me $\ldots .$.
that Richinumd is tleir adiniral Richmond is on the seas wouldst be gone tu join with Richinond Riclunomr, in Dorsetshire, sent out.ity tell Richnond this from me; that ... where is princely lijchmond now?

continually fur Riehmond's good ....

be cheerful, kichmond (rep.

sleep, Richmonh, sleep in perce.......

in proof, and led by shallow li.ichmm

Gund-morr.nw, Riehmond. 'Cry you mer 


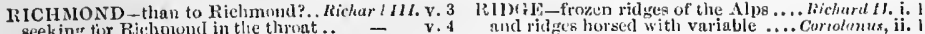
seekintr fir Richomont in the throut. I think, there be six Rielmumbls $\ldots$... onow, tet Riehmond and klizubeth $=$ v. 4 RID-the red plugue rid you .............Tempest, i. 2 that I will sue to be rid of it ...Weas. Jor Meess. iil. I thank God you are rid of a knave... Wnch.tdo, iii. 3 he hath rid his grologle, like... init. Taming of $\mathrm{Sh}$. $\mathrm{i}$. ard rid the holse of her; com

then we are rid of Licio...

to be so rid o' the business sTale, ivi. 3 to inend it or be rid ou't..............1/acbeth, iii. ! to rid the realin of this pernicio

no triend, will rid me of this .

king's friend, and will rid his foe I cannot rid my hand

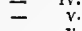

quickly rid the world, to rid us

fur willing ness rids way .............

you have rid this swect young princel $\bar{d}$. no doutbt, shortly be rid of me 3 and soon I'tl rid yout from the feir

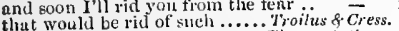
beasts, to be rid of the men

rid me these villuins from.............

blessed, that Rome is rid of him...Julius Cesar,

are rid like mudmenthrough.........

that rids our dous of languish?

get her ravished, or be rid of her

\author{
ricles,
}

let her, who would be rill of $\lim . \ldots \ldots$. Letr, v.

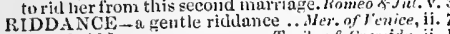
a gnol riduance
RIDDEN with a We........... Troilus \& Cressida, ii.

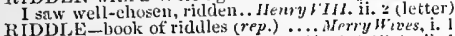
a tustian riddle! $\ldots . . . . . . . . .$. . Twelgh Nizht, $\mathrm{ii}$. mueh upon this riddie runs..... Mers. For Mras. ii

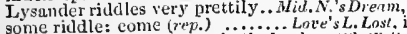
some riddle: eome (rep.) ....... Love's L. Lost, it. so there's my riddle, vile tliat's dead... All's rell, v.

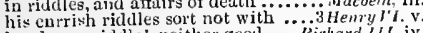
heyday, a riddle! neither gnod ....Tichard W. (Gower 0 ho! 1 know the riddle: I will go.......... Lear, $y$

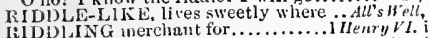

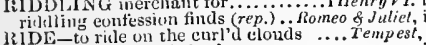
and ride upon their backs..

Ill ride home to-morrow............ tivelfth $\mathrm{Night}$, i. ride your horse as well as I ride you $\overline{\text { it }}$

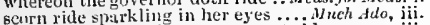
two men ricle of a horse, one must ride - that ride upon the violent .............Alt's $w_{\text {ell }}$, iii. or wit thin ride? youre a vessel rides fist by

true; she ristes me, and I long. Comedly of Errors, ii. but hie rides well

rite you this afterio

inf futed be the air whereon they ride $-{ }_{\text {iv }}$ iv.
fur I will ride, as frr as land ........ Richard II. $\mathrm{i}$.

Where rides bot to rile as fast...

houley lord ride with us tu-morrow...

for tliey ride up and down on her.

eome, wilt thou see me ride?

the devil rides upou a tidd estici.

thirty miles to ride yet ere dinuer-time

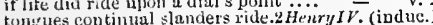

tongues contina' nights, like....... - ii. and rides the wild mare with thie boys

get on thy buots, we'l ride all nitght

a sovertign's sovereign to ride ou ..... Henry

Henry 5 . iil. 7

ride thou unto the horsemen

pripare to ride unto St. Alban $3 . . . . . .2 .2$ Henry $r I . i$

thou didst ride in triumph through...

timu dost ride on a fisot-clutl

will we ride through the streets....... iv.

still rirle in triumph over all........3 Henry $r$ J. iii. hirses hard, an ride in blood........ swore to ride befure him to tice fisld.

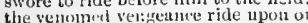

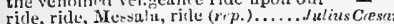

ridie on the pants tribmphing.....Antony 8 . Cleo.

of miles may we well side 'twixt ...'ymbeline, iii. whose breatle rides on the pusting winds $\rightarrow$ ii.

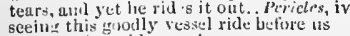

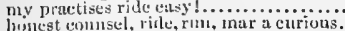

l.ear, i. ride more than thou goest...

to ride on a bay trot ting liorse over.

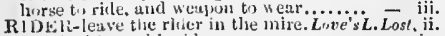
the tired horse his ritler ............. $\overline{\text { iv. }}$ to tliut end riclers dearly lired .....As you Like it, i.

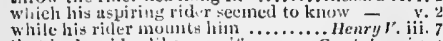
that had a rid

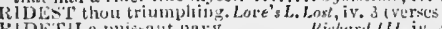
RIDite of the gallows ................. Henylit.

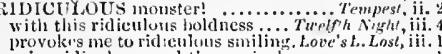
ain, ritliculous, and thrusonical

and their romrla carriare su ridiculous

how many actions most ridieulous. As you Like il, i

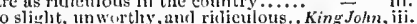

s wasteful, and richiculous excess....

they be never so ridichioits

ridenlous und awkward action... Trnilus \&. Cress. i.

RintNo on the balls of mine ...Merch. of Yrenice, iii.

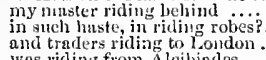

King John, i.

"ere you but riding forth to air..

provide me, presently waring........

against whose shore riding, her
RIDING-RODS, ny arms sucl

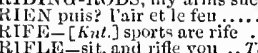

RIFLW - sit, and rifle you $\because{ }_{\text {Two }}$ Gen. of

Cymbeline

iii.
iti.
.

IFT-between which rift imprisoned .. Tempes!, $i$.

your ears should ritt to heur me.. Wrinter's Tele.
slain men should solder up the rift. Ant. \& Cleo. it

RIFTED Jove's stout uak............. Tempest, y.

RIG - hath made me rig my navy...4nlony de Clen, ii. 6
RiGGED-not rigged, nor tackle........ Tempest, i. 2

bravely rigged as when we ............

RlGGISH -bless lier, when she is riggish - ithens, ii.

RIGIT-I nin right glad that he's so.. Tempest, iji. 3 ani be a boy right out

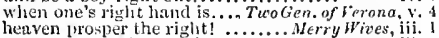

thun hast the right arehed bent....... - iii. 3

who hath got the riglit Anne?........

thou'rt in the right .

right noble is his blood

read i' thy right wits (rep.) $\ldots \ldots \ldots \ldots . . . .$.
but to do myself much right......

in the risht (rep.) ........... Measure for.Measure, ii. 1

thou $r$ in the right, giric...........

hooking both right rind wrong to..

it is the riglit of it...................

nothinger goes risht

company of the right noble Cle......... $=\overrightarrow{\text { ach }}$ Ado, $v$

I will do myself the riglit to trust none

call ag the right master const:alble ...

the right husband, and the right wife -

deserve of me that would right her
if he could right himselt with quarreling -

you say not right, old man $\ldots \ldots \ldots . . .$.

rirht, says size, a great gross one...... =

give lier the right you should have...

ell my right tif her 1 do estate . . . .

slzonld not I then prosecute my right

to try whose riglit, or thine or nine

this the eranoy is, right tand sinister

and God defend the riglit.

we will give up our right in Aquitain

watehed that it may sill go right?

aparkle still the righis Prometheription of our sport

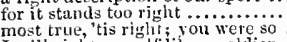

I will right myself like a soldier

of that fault, right joy ful of your .....

bars me the right of voluntary cluosing -

I am right loath to go............

it 1 do choose the rigint

between the owher and their rights

geasoncu are to their right praise $\ldots$..

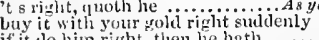

if it to him right, then he hatis...

thou art right welconc as thy ........

an that's the right virtue of the

to ent of his goods: riont, nany...

I would not have ny right Rosaliud

I slould have been a woinan by right

aml it wns his grent right to be so ....

righe, so 1 say (rep.).................. thine ow fort mes thac obedient right a right [Col,-1 write] guml creature

cver do thee all rights of survice......
which are their own right by the iaw

but lis right clecek is worn bare..... what in us hiath seemed ridiculous .. $-v$ v.

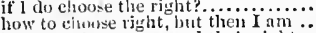

LiIGIIT-dome this right, heur ine. Toming of Sh. i. 2 the rase is right; "tis the loase.

the right vincentis (rsp. iv. 1 and $v . i)$

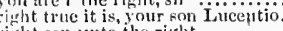

rifht $\mathrm{som}$ unto the right............

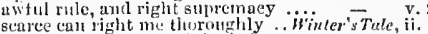

Ipun the carth of its right father.... - iii. 3

go on the riglit liand .................. iv.

ight, sir, I'll teli you when.......... - iii.

dunied you had in him no right $\ldots$...

the right valiant Banino walked

would be humls wiplifted in my riglit

your riglt nolle sun, leurl our........

thy nephew, ant right royal soverejen -

ulion the richt and party of her son?

our right, for 11s. Your strong (rep.)

shadowing their right under you.......

who would not do thee right? .....

and the right thou hast in France ...
bring that right in peace $\ldots \ldots . . . . . .$.
England was Geffrey's right, and this

an' I eatcin you right; sirrah ........

in right of Arthur do I cluim of thee

and rights of this oppresced boy

and in his right, we hold this town....

shath the eurrent of our right run on?

in her right we came n................

when law ean do no right .............

you, in the right of lady Blanch ....
in right you hold, why then .......

the fife, the riglit, and truth of ail $\dddot{3}$.
for the health and physic of our right

on our actiuns set the name of riglit.

of death the face of

newness, that intends old right......

that nove in sour ritzlit splieres.

as thy cause is right, so be ........ Richard II. j. 3

by my seat's right royal majesty

right; yon say true; as Ilereford

rights tway, ind take from time $(r e p$.$) -$

if justice liad her right ...........

stnuls your grace ynon, to do him light 二

to find out right with wrong $\ldots \ldots \ldots .$.

for heaven still guartls tle right

cotsin is right welcome hithe
will add right worthy guins

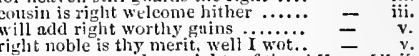

my treasures, and my rights of thee. Ilenry $r$. ii.

of no rivlt, nor colour like to right.. $=$ jii.

no furtlier than your new-fulien rigit = vil

he doth not do it right ................ - iii.

your noble and right well-remembered - iv. 1

our most just and right desires jo... - iv.

then plain and right, must my ..... - iv.

you are right, justice, and you weigh $-\bar{v} .8$ (cong)

o that riglit should thus overeome ...

whose right snits not in native .......

mav I with right and conscience, make -

and fire to win your right............ -

int the right of your great predecessor $=$ i.

riglit ill disposed, in brawl ........ - iv. (choris)

aav, that's right, but why his goot.. - iv. 7

right joyous are we to beliold ........

it think he held the right

vield the otlier in the right opinion...

in the right of Richard Plantagenet.

Talbot, and Englind's right?

proud Lanenster usurp ny right $\ldots . .2$ Henry $r$ i. i.

by toree, and not hy right

thon hast prevuiled in right

emme he right now to sing ............

comeg York, to claim his right

in justice and true right express iti..

I menn to take pussession of niy right

is the right, and therefine pardon me

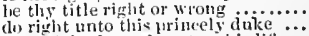

your right depends not on his life....

lyere's to right our gentle-learted $k$ ing whether onr right haliant father

drew thy sworl in right.....

if that be right, whiteh w:rwick (rep.)

forple blowd right well resembles.... 


\section{RIG}

RIGHT-press to spcak for right ....3 Heary on his right, asking a wile for Lid ward that did ever fenee the right Henry from his untive right me but right, und you must ail confess for 'tis iny right, und Iienry but istre. an upriglit zenl to riglit prevuil

usurp'si my lather's ight and mine -

and, no dunbt, right royul............. Richard II sorrow that I hive, by ristit is jours decked in thy rights, as tion art stilied = right, as blow in linryest ........... I'il win our aneient right in Frunce? being the right idea of your fintier .. with two right reverend fathel's...... thy devotion, and right christiall zeal the right and tortune of his happy say, that right for riglit hath dimined if that right were right, the slanghter in the name of he was $i$ ' the right

the right reverend eardinal of York. Henry do me right and justiee .............. has made that riglit use of it still in thy right hand earry gentie as, let them love their rights a right good hushund, am right sorry to repeat whint follows and am right glad to eateh this good

foree slowild be right (rep.) . Trotizs tis Nestor riglit! now twixt right and wronts............... my Cressid in right great exchunge.

firno the weleome, sir; ere we depart .... you'll suic, in giving him his right .. why, this hits riglat.........iï. his right nobie mind, ill nstriuus virtue though his right arm might purehase wrong, right; base, noble; old, young I will make thee do thy right nature
right worthy you priurity right wurthy you priority

'tis right. It was his word .......... he's right noble: let him

i' the risht and strength o' tie com....... rights by rights touler...

coine ou my right hand.............. Julius Cesor. you have right weli eonceited......... I undy speak riglit on upon the right liand $1, \mathrm{keep}$ thou...... I think, I and i' the right ... Antony of cheopatra, iii. go on; riglit roya

like a right gipsy, most right

lies a mule, riphy, hath roud of that

and am right sorry, that $I$ must

right, with honour to muintuin

and am right glad, te is not. .

patrons of iny right, defend the justice ritus $A$ und.i. ben thupitol and seuate's right

been thus forward in my right ......
right und serviee of their noble eouitry -

Kumuns, do me right ................

to jut upon a prince's right!...... ...

hund shill right your mother: 8 ivrong

my soul to right your w rongs.

this poor righi hand of mine

in Horaee; right, you have it

daughter with his uwn riglit hand

like a pour man's right in the la

[Kanl.] event right for marriage fight

rititit noble Burgundy when she wist

bold in the quarrel's right.....

your itraees are right welcome.
when every ease in law is right

gave her dear rights to lais...

deur love, and our aged father's right

pray that the right inuy thrive

iu iny rights, by him iuvested .......

yon, to your rights; with boot

right glad f an, le was not....... knomo
a righit grood marksinan! and she's turr
then here I hit it right

pink tor flower. Kitht. Winy

why, right; you are in the right.

by the rights ot our fellowship, by the.

you buy riplit, sir: o' Ml onday inor'
am I not i the right, old Jephtha?

you kuow riglit well, you did

this euartesy is not of the right breed

with your grief, or you deny me right

your lordisip is right welcume back

Your bonnet to his right use; 'tis for.
liave some rights of nemory .........

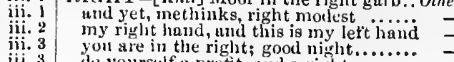

. 4 JIGITT-Dik WV quekly make it riglit . iv. 3

Ro help yous fashion as I do

aftuirs as righteous: but all

recorded by the righteous gods.... Timon of dith. iv.

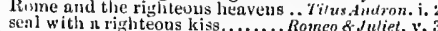

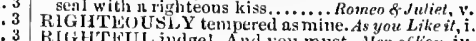

RiGHTHUL judgel And you must.. Her.orten.iv.

to put furtli of a rightiful king

iii. 5 luboured to plant the rightful heir.... Hemy Hent.ii.

Charles, the rightful king of Franee - iv. I lett.
right fin heir untu the Enirlisl erown.

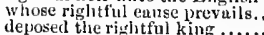

deposed the rightfol king ...............
that shanl sulite our rightful sovereign

for $1 \mathrm{am}$ rightful heir unto the crown - iv. 2

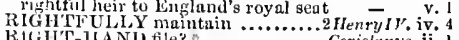
RIGIITLY -to be Englished.......... Coriolumes, ii. I to be saved by believing riglitly.. "uetgh Night, iti. 2

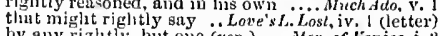
by any rightly, but one (rep.).... Ner. of Venice, i. 2 to our rose of youth rightly belong.....All's $\boldsymbol{V}_{e}$ ell, $\mathrm{i}$. 3 you may be rightly just, whatever ....Horbeth, iv. 3
rightly gazed upon, show nothing ...Richard Ii. ii. 2 rightly gazed upon, show nothing .. Richard II. ii. 2
if rightly taken. No, if riglitly taken. Hen'y $I V$ ii. 4 if I be measured rightly ..........2 Hem $I^{\prime} J^{\prime}$. he telis you rightly. Ye tell me...Henry $\bar{v}^{\prime} / J$.

digest things rightly, tuuehing ........ Coriolmm

to inform you rightly both what.. Anlony \&. Cleo. $\mathrm{i}$.

thou hast been rightly hones

by the holy gads, I emmot righitly....
think'st, and hast most rightly gaid

think'st, and hast most rightly said ....... Lear,

riphtly to be great, is, not to $s 1$ ir.....

iij. 1 RluHT-VAilaNT lord must not.T'mil.f Cress.

RIGOL-from this golden rigol hath.2 Henryl $\mathbf{Y}$.

lave senled his rigorous statutes. Comedy of Err 'arpeian roek with rigorous han
RIGORUUSLY effused, will er:

RGOUR-the rigour of the statute. Mreasenry $I T$.

I tell you, 'tis rigour, and not law Winter's Tale, iil.

as rigonr of tempestuous gusts ...... Henry ${ }^{\prime} I$.

eominon fenr of Clifford's rigour.....3 Henryl's.

whom the rigour of our state forced ....... Lear, $v$.

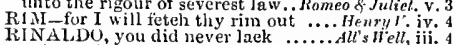

Write, write, thinaldo, to this unwortliy - iij. 4
RIND-luath sourest rind. As you Like il, iii. 2 (verses)

within the infunt rind of this ...Romeos \&uliet, ii. 2

and take this ring with thee...Two Gien, of

well, give her tlant ring

this ring I gave him $\ldots \ldots \ldots . . . . .$.
he sends your ladyship this ring

a ring to madum sily

give my sweet Nan this ring ..........

like to the Garter's eompass, in a ring

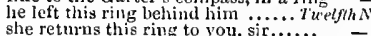

she took the ring of me.

none of my lord's ring!

a ring in chas

thin the bell ringst of your rings .. - v.

with bracelets of thy hair, rings ... Mid $\lambda .5 \mathrm{l} r \mathrm{r}$.

a death's fiee in a ring.............. Lore's L. Lost. $v$. let us all ring faney's knell ...... - in when

bit when this ring parts from

the deares: ring in Ventee will $i$ give

good sir, this ring was given me ....
how well I have deserved this ring

let him liave the ring (rep.)........

if I ean get my husband's ring...

that they did wive the rings away...

I guve iny love a ring, and made.

lust the ring detending it (rep.)

hath not the ring upon it, it is gone.

to whom 1 gave the ring (rep.)

the virtue of the ring (oep.)...
but some woman had the ring

und begged the ring (rep.) ..........

swear to keep this ring ................
for by this ring the doetor lay with me

as keeping sute Neris*a's ring.........

[Col.Knt.] the only pretly ring time - 1.3 (song)

their fiery toreher his diurual ring ...All's W'oll, ii.

a rints the ring (rep.

this ling he hibls in must rich
RING-that ring, l'll lend it thee ....All's Hell, iv. liere, toke uny ring: mine hoitse $\ldots . .$.
when back uguin this rimg shall be... I'll put ancither ring; that, whut.... sueh of ring as this, the last ......... this ring urs nine; and, when I ...... and woild never reeeive tie............ than I have in this ring: 'twas mine if you sliall prove this ring wio.. behuld this ring, wlisse high

the hat li that ring (o ep.)

setul for your ring (rep.) ............

the jeweller that owes the ring ......

sweet clothes, ring and upon. Taming of Sh. I (ind. 3

runs fastest, gets the ring............ -

and eaps, and golden rings, with rnffs

ings, of his, that Panlina knows. Win'er's Ta

you not hear it ring?...... Comedy of Errors,

give me the ring of minc (rep.).......

my ring, the ring 1 saw upon his..... - iv.

snatched that ring. Tis true (rep. $).$. -

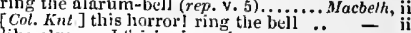

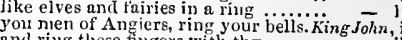

and ring these fingers with thy .......

that ring was eopper (rep.) ......... I Henry $I V$.

the merry bells ring to thine ear....
why ring not ont the bells

why ring not ont the bells

and mine sliall ring thy dire ..........

vouelisafe to wear this ring

look, how this ring cneompasseth ..... $\bar{Y}$ i.

by virtue of that ring, i take ........... - venry

when that a ring of Greeks have. T....

then make a ring about the........Jutius Carsor, iii. 2

a ring; stand round ................ Cymbeline, i. 5

not withstandiur, I fear not my ring - i.

the moiety of my estate to your ring $\quad-\quad$ i. 5

my ring 1 hold dear as my finger....

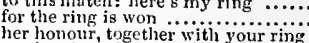

my hand, and ring, is yours .........

take your ring angain (rep.)

may reniler of whom he had ihis ring

win this ring by hers and mine adinitery -

but, youl ring first; and here........

and ring a luninter's peal, that ail. Tilustnetron, ii.

no mommentul beil shnll ring her..... - ii.

my tather, gave you sueh a ring ....... Pericles, v.

my father with his; and she will tell ..... Lear, iit.

thy old grouns ring yet in my ... Romeo \& Jutiet, i.. 3

herc, sir, a ring she bid me give you $\quad$ - iii.

a preions ring; a ring that I must . Famlet,

is this a prologue, or the yosy of a ring?

RING-CARRIER! The troop is past.......il's 's'

PINGING in the king's affairs...... Henry 12 . iy.

RINGLEADER and head of all this..2 Henry $V I$. ji.

dance our -green-sour linglets........Tempest, y.

RING-WOOD at thy leels ...........Merry Wines, ii.
RINSING-did break i' the rinsing.. Henry VIII.

IOT - it is a riot (rep.)

no fear of Gut in a riot (rep.).........

and make a riot on the gentle brow. King John, iji.

feree blaze of riot cannot last $\ldots .$. . . R phard it. ii.

see riot and dishonour stain the ...... rfemy $i v$. $\mathrm{i}$.

withhold thy rints, what widt thou $(r c p)-$. iv

and the feeder of $m y$ riots ...............

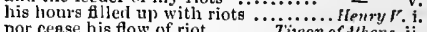

and drown themselves in riot! ...... -

plunged thyseif in general riot ......

in runk and not to be endured riots ......... Lear, $i$.

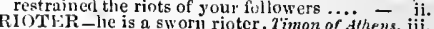

fi. OTING in Alexandria..... An/ony \& Clenpa'ra, ii. shall it eharm thy riotous tongue ..2 Henry $V t$, iv. slew tu day a riotous gentleman ...Richord $I I I$. it.
with riutrus feeders; when our. Timon of

rintous madness, to be entangled. Aulniny \& rleo. $\mathrm{i}$. his kuights gow riotous, and himself .... Lear, i. 3

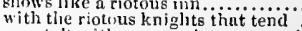

goes to't with a more riotous uppetite..... R.IP-sir rip thy heart to fiud it .........imbelinet, iv. 5 We'd rip thein liearts $\ldots \ldots \ldots \ldots \ldots \ldots \ldots \ldots$. Lear iv, 6
RIPE-Trineulo is reeling ripe ........ Tempest, v. I 
RIPE-but his judgment ripe TroGen. nfrerona, ii , I RISE, nnd fude! he shall be lord of .. Cymbeline, $y$

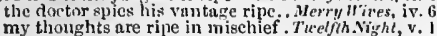
my thoughts are ripe in mischich

not ripe until their season

(rep. vid N.Dream, ii 3

how in show thy lip

how miny splorts ure ripe $[$ kint.-rife $]$, v. I to supply the ripe wants of,.... inereh. of fenice, i. we rifle und rine, and then ........As you bike is, you'll be rotten ere you be hatf ripe

bestows himself like a rile sister

a ripe age: is thy name

thenterstale, $\mathbf{i}$.

to ripe the bloom that promiseti.......... King Jnethn, ii

lis passion is so ripe, it needs must.. - iv.

rrow ripe in fortune.

when time is ripe.

: HenryIt: i.

before tliy hour be ripe?

2 Henryll $v^{r}$

of his youth, ripe for exploits

... Henryl. i.

anll thy sins be ripe, and then hurl. Richard 11 ii. i. 3

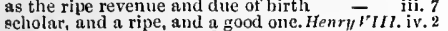

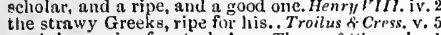
on dthens, ripe for stroke!.... Timon of Athens, iv.

that they are in a ripe aptness

Cortolanus, iv. 3

his face sours ripe grapes

when wit's nore ripe, necept.... Pericles, $i$. (Gower)

ripe $[$ Knt.-right] for marriage fight - iv. (Gower)
smites, that played on her ripe lip........ Lear, iv. 3

an exploit, now ripe in my dev

blossmm first, will tirst be ripe ........... Othell, ij.

RIPELY -it fits us therefore, ripely... Cymbetine, iii. RIPEN - which eller days shall ripen kichard II. ii. 3

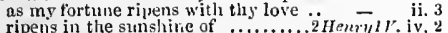
berries thrive, and ripen best

inlony Cleopatra, ii.

ripen loneysuckles, ripened by the sun ...Minchsith time once ripened to my will.

in his full and ripenetl years.........
RIPENESS - ripeness is all; come on

which time shall bring to ripeness.. Heury IrII. $\mathrm{v}$. by summer's ripening breati............ Romes \& Juliet, ii. 2 RIPEIR and more lusty red .......... As you Like it, iii. 5 now humble as the ripest mulverry. Coriolrnus, ii. 2 RIPING-very riping of the time

I must be ripped: to pieces with $m$

from me was Postluminus ripped.....

RISE-tlie humour rises

...........Merry $W^{\prime}$

go to hed when she list, rise when she list

you must rise and be hanged (rep.)... for.Meas. i. I desire her to rise

rise, Grumio, rise..........

Taming of Shreve iii.

C...Winter's Trie, iv

as from your graves rise up...

gentlemen, rise, his highness is .......

that rises like the issue of

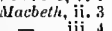

that rises like the issue of .............

I have seen her rise from her bed rise

that rise thus nimbly by

a pardon, ere I rise, or speak

rise up, gool aunt $\ldots \ldots . .$.
would giadly rise, $\mathrm{r}$ know

never give to ro him wrong

gallantly armed,-rise fro

why may not he rise as weil as $I$ ?

no more from this obedience rise

doth rife and fall between thy

Pericles,

rise, pr'ytlee, rise (rep.i. 1)
being topped, they higher ri

this day I"ll rise, or elec ald ill to $\mathrm{ili}$

now, blessing on thee, rige

二 v. i

(Wisea, whe oul doth tall.

fonl deeds will rise, thonth ail the earth.

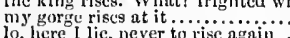

lo, here I lic, never to rise again

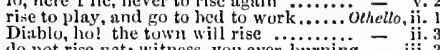

- v.

RISEN-prophetess, new risen up
the otler sille o' the city is risen

ur griefs are risen to the top

RISETIl froun a feast, witl... Me

rning $=$ iii. 3

Ihe rising of the mountain-toot. Tingen. of rer. v.

Lear, ii.

strew the footsteps of iny rising

and, rising so again, when I slail
shall see us risiug in our throne.

shall see us rising in our throne...

from the rising of the lark to the

hating thee, are rising up in arm

iich- iii.

and stop the rising of hlood-suck

excellent in art, and still so ri
they are rising, they are rising

RITE-and holy ritc be ministered

till love have all his rites.

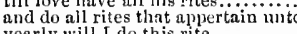

after that the holy rites are ended

to observe the rite of Hay ..... Wid. $\ddot{n}$.'s $D$

we will begin these rites .............As you $\mathrm{l}$.

the great prerogutive and rite of love..Al"s $W^{\prime} e l$, , i

the rites of marrage shall be.

and all the rites of knighthood else... Richurt 1 ,

[Cot.] release all duties, rites

do $w \mathrm{c}$ : Ill holy rites; let there

give us leisure for these rites of

Cassar shall have all true rites
all respect and rites of burial

how we have performed our Roman rites -

shall we eorsummate our spousal rites

no funeral rite, nol man in

my obsequies, and true love's rite's?.

follow? and with such maimed rites!

$[K u /$.$] she is allowed her virgin rites$
and the rites ol war, speak londly

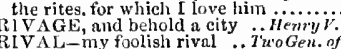

Henryll:v.
Henryl iv.

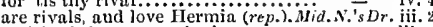

and lead these testy rivals so astray

to hold a rival olace with one ot . Mer. of

be happy rivals in Bianca's love.. Taming of sh. i.

and rivals in my love (rep.).......... $\bar{y}_{\text {thens, }}$ i. 2

great rivals in our youngest daugh ter's . Lenr, i. 1

RIVALITY, would not let...Antony s clenparn, iii. 5
RIVALLED fee-simple of the.... Troilus 5 Cress. v. I

RIVAL-HATING envy, set yon on........... Lear, i. 1.

with a sigl, would rive in twain. Troilus of Cress.

a bolt that should but rive an onk .. Corinlamus, v, 3

soul and body rive not more ... Antony s. Cleo. iv.

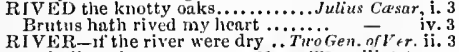

to shallow rivers (rep.).....Merry "Mves, iii. 1 (song)

he hath boen thrown into the rivers.. for iv.

have every pelting river made...ivil.N.'s Dream, ii. 2

the Pyrenenn, and the river Po

like rivers of remorse and inmocenc

let iny kingdom's rivers take their ${ }^{2}$ v v. 7

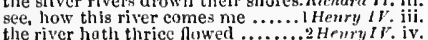

beyond the river Sala, in the...

Heury $i$ i.

he hat passed the river Somme ......

beyond the river we'll encamp ourselves
there is a river in Masedon (rep.).....

why, brother Rivers, are you yet......3 thenry r., jv.

beng suffered, rivers camot queneh $-\overline{\text { iv }}$

and, Rivers, 80 were ynu

Rivers, nnd Dorset, you were stinder....

Rivers, Yaughan (rep. iit. 2 and iv. 4) =

IRivers, and II astings, tulse ench other's

my uncle Rivers talked how 1

her uncle Clarence, her uncle Rivers

We rise betime, and go io it with ......
I pray you, rise; rise, Egypt .......

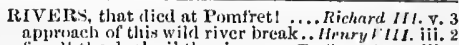
for all the dueks i the river ...Troilus of C'ress. iii.

I send it through the rivers of your... Corintanue i.

upon the river of Cyolnus ...Antony of Cleopulra, ii.
we'll to the river: there, ny monsic..

poor trilutiary rivers as sweet fislt. .. Cymbeline, iv.

a crimson river of warm bithot. Thins, Androwicus, ii.

RIVE'T-clowing rivets up....... Ilenry $r$ iv. (chol.

shake in and wut the rive

I mine eses will rivet to his face........ Itanter, iii.

bave on their riveted trim ........ Mer.of s'enice, $v$.

RIVO says the drunk my memory? .... Cipmbeline, ii

IROAD-futher at the roal expects. Tico fien of

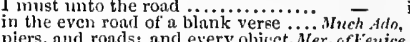

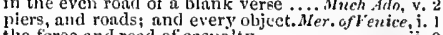

the force and road of ensualty

living on the common roud?.......... yon Like it, ii.

now is lying in Marscilles' roal... Tamin of $s h$. ii.

In nll London Road for fleas ........ Illemry $1 \mathrm{~V}$. ii.

Dull Tearslicet should he some rond.2 Iemy $I V$ ii.

who will make road upon us

to make road upon's a he

to make road upon's again $\ldots . . . .$. Coriotanus, iti.

I am ont of the rond of rutting

ROAD-WAY better than thine .......... Henry $1 \%$ ii.

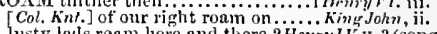

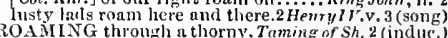

where are you roaming? .. Tiethh Night, it. 3 (song)

Kint.] the poor phrase, roaming it thus.. Hemlet, $\mathrm{i}$.

ROAN - rode on roan Barbary 1 ...... Richard 1l. v.

a roan, a (erol)-ear, is it not? (rep. ....
give my roan horse a drench .......

moke thee roal, waters in this

hark, the a whole herd of lions

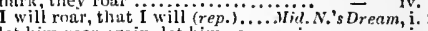

roar you no gently as any (rop.)......

grunt, and rots, and burn, like horse

now willest rage doth roar

二 $\quad$ iii.

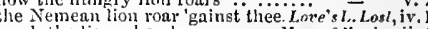
mock the lion when he roars .......Mer. of tenice, ii. make our gricts and clamour roar..... Mocbeth, i. for you hear the lion roar............. King John, ii. if the devil come and roar for them. I Hem? I I i. till he roar arain roar.

makes him roar these accusations.... Henry $r$ r. iii. trenble when the lion roars.......2.2 Henry ${ }^{2}$. jii. you rogue, is this a place to roar in?. Henry $H$ LII. $\mathrm{v}$. but, 1 fear they'll roar lim in and roars as doth the lion in

Coriolamus, iv.

the sea, it it could so roar to $m$

tonld I rage and roar ns doth the sen ..Pericles, iti.

to the sea, and hears it roar beneatin

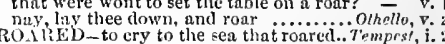

well ruared. lion. Well run ....... Miti.N.'s Dr. v.

roared, and the sea mocked (rep.).i.iuter's Talm,iii.

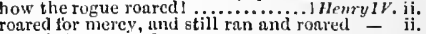

roared the sen, ail trunipet-clangor.2 Henryll $\mathrm{V}$.

the forest tremble when they roared. 3 Hhry $1 \%$. y.

eertain of your brethren roared

torrent roared, and we dia buffet .. Jutius Carsar i.

should he roared in dismal hell... Romeo of Julie?, ili.

ROARiNG-crucks of sulphurous roaring

even to roaring: come $\ldots$ and the azure vanlt set roaring war

for it is notling but roaring.... Miti....'s Dream, i.

both roaring louder than the sea. Winter's tale, ii.

spurns back the ucean's roaring tides. K'ing John, ii.

talks as fumiliarly of roaring hions $\ddot{~}$
so, by a roaring tempest on the flood

n current, ruarmg lomb ............... this rouring devil i the old play ...Henry ${ }^{\prime}$. iy.

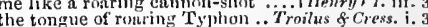
and ot it roarine for Truilus

and, in roning for a chumber-......... Coridlamms, ii.

he cricd almost to roaring... Automy \& Cleopalra, iil.

lad not apprehension of raaring terrors - iv.

who, with roaling voiccs, strike.......... Lenr,

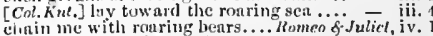

ennt tigers or the ronring sen ......
ROAST-yobeth, i.

nothing but roait malt-wornis.

illitity IV ii.

luke that rules the ronst $\ldots . . . . . . . . .$.

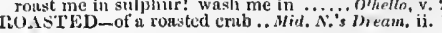




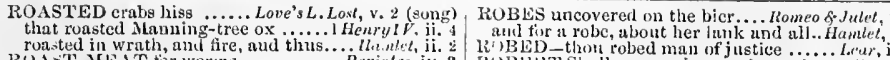
roasted in wrath, and fire, dids - 2h carriage to rob luve from ally... slie robs thee of tiny manc

he, tinut perforce robs lions of

must I rob the law? Yunr sword

beat our wateh anpy mother s name?

wio, I rob? I it thiet?".

shali rob those men that

if you and I do not rob tisen

1 am uecurst to rob in that

ere I'll rob a tout furticer.....

now, could thou and $I$ rob the thieves

to rob me of so rich a buttum liere

rob me the exeliequer the tirst

revel the niglit, rob, murder........2.2 Henry 1 Dot eaules' blood, but rob beehis'es

to come to rob my ground

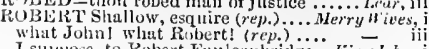
I sulpyose to Robert Funlcoubridge... Kin and I hand his, sir Rohcrt lis, like him guid old sir Rohert's wife's eldest son sir Rubert Wuterton, and Francis.. Riekard II. ii. 1 am $\mathrm{R}$ bert shalluw, sir (rep.) ....2 Hewyl $\mathrm{V}$. iit. excuse me, master Robert Shallow (rep.) -

and ruis his temples of the diadem.

ohould rob ny bed-mate of my.

he slays more than your rob

attraction robs the vast

away; rob one another ..............

Cominius.........

will rub you of a great deal
they rob the Hybla bees

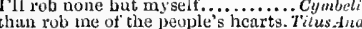

so should I rob my swect sons of their.

that rob the bee of her honey

nu, uo, 1 will rob 'Tellus of her
that robs thee of thy goodness

how conceit may rob tine treasury

he robs himselt, thar spends a bootless...

robs me or that, which not enricltes him
ROEBED-these three have robbed me..?

ROLBED-these three fiave robbed me.. 1
the kuight may be robbed......... Herry

I am robbed, sir, and beate

that robbed the lion of his

if he have robbed these mee

0 Harry, thou last robbed ni...... Henry $I V$. it. 4

1 never rubbed the soldiers of their $2 \ddot{H}_{c n r y} V I$.

have robbed ny strong-knit siue...... .

for where $\mathbf{L}$ am robbed and bound.. Henry VIII. ii.

hat ls robbed many beasts of.. Troilus \& Cressida,

she has robbed me of my sword. Anlony \& Cleo. iv. 1 .

$I$ robbed his wound of $i$

that robbed Audrouicus of his. Fitus Andro

zounds, sir, you are robbed; for shame. Olhello,

the robbed, that smiles, steals somethi

RJBBERS range abroad unseen .... Richard $\bar{I} I$, iit.

be assailed by robbers, and die in ..... Henry $r^{\circ}$ iv. 1

with robbers so o'er-matched.

bold ........ ii. 6

large-handed robber's your grave.. Timon of $t$ th. iv.

for supporting robbers; shall we...Julias Casar,

thou art a robber, a law'-breaker
with robber's' hands, my lospitabl

ROBBEKY have authority

have in this robbery lost thr.

for the robbery, lad, low is............ Henry $I V$. ii. 4

of peace with pillage and rolsbery

I'il grace thee with that robbery..... Coridtenns, v. 5

but by the robbing of the balished.. Rick of ler. il.

to be executed for robbiag a church... Henry $V$. iii. 6

unless by robbing of your friends ..2Henry VI iv. 8

what tell'st thue me of robbing?

ROBE'ST-robb'st me of a moiety ..Ait's Well, iii. 2

nor the judge's robe, become...... Meas. jor.Heas.

exchunge for rags? robes.. Love '. SL.Lost, iv. I llutter)

disguised in sober rubes, to

in pure white rubes, like very

sure, this robe of minc dues change.

these robes are not gentlemin bora ... sta $\overline{a c b e t h}, \mathrm{i}$

lest our uld robes sit easier

like a giant's rube upoil a dwarfish.....

that lion's rohe, that did disrobe (rep.)

putting on so new a fashioned robe

my presence, like a robe pontifical

.

they'll be in fresiter robes.

these disgractiol wailiug robesi........ Henry $\nu^{\prime} I$. i.

thy scarlet robes, as a child s..........

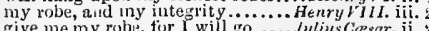

give me iny robe, for 1 will go ..... fulius Capsar, ii. 2
when old robes are worn out ....dntony s Cleo. i.

give me my robe, put on my erown. n

vive me my robes; 1 am wild in wn

rubes, and turred gowns, hide all ......... Lear, iv.
IROB N N, I say ..................... Merry Wives, . v.

love-song like a rubin-redbreast. T.... Gen. of ter.ii. 1

hey Rubin, jolly hobin ......... Tuelfh

Robin Starveling, the tailor (rep.) ....ivd.
called Rubin Good-lellow.............
bie therefore, Rohin, overcast the night

welcome, good Robin ...............

and Robin slatl restore amends.

live like the old Robm Hoot....... As you Like it. $\mathrm{i}$.

nnd hud Rohin Night-work by old.2 Henry IV. ili.

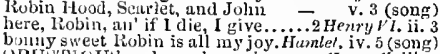

RUBUSTiOUs and rough conjing on.. Henry $V$. iii. 7

henr a rubnstions peri wir-puted fellow Hamlet, iii.
ROCH LSTER-to-night in Rochester... I Henry $V . \mathrm{i}$.

RUCHFORD, one of her highne
ROCK-sty me in this liard rou.

deservediy contined into this roek

a ragged, fearful, hanging rock.. Ti...... Ge. of $\bar{v}$ ii.

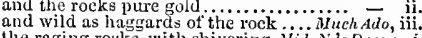

the raging rocks, with shivering. $M i d . N$.'s Dream,

me straiglat of dangerous rocks ...Mer. of $\overline{V e n i c e}$

toucl of merchant-narring rocks................

quicken a rock iii. encountered by a mighty rock. Comedy of Lrors, ii. I

Macbeth, iji. 4

mountains and rocks $(r e p$.)

iting John, ii. 2

and roek his brains in cradie of.

our stern galled rock operhang.

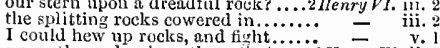

the ship splits on the rock.........

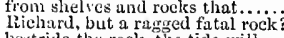

bestride the rock, the tide will

Waves, with sands, and rocks .........

as strong as shore of rock..............

bear him to the rock (rep.)
the Tarpeian rock (rep. iii. 2)

to the rock with him: to the rock.....

preciptation from off the rock Tarpeian - iti. 3

of triends, rest on this rock.

a pendaut rock, a forked ............tony of Cleo. iv. 12
paled in with rocks unscaleable .... Cymbeline, iu. 1

cracked as easily 'gainst our rocks ...
we house i' the roek, yet use thee....
this rock, and these demesues........

into the creek behind our rock

I pr'y thee, to our rock

thiuk, that you are upon a rock.

sea hinth ont upon a rock... Titus Androntens, iii.

run on the dashing rocks thy............. Pe \& Julet $t, \mathrm{v} .3$

rough quarries, rocks, and hilis who....

gittered rocks, and congregated sand

RoCKY-steril, and roeky hard...

all to pieces on thy roek y bosoly

in titue the rod becomes more...

the rod had been made (

I'll whip thee with a rod...

kiss the rod; and fiwn on rage

ventreance and the lod of heave

Whe earl of Surrey, with the rod....

the rod, and bird of peace............

he hatli whipued with ruds...... . Autous o r.teo.

When thou galest them the rod ........... Lenr,
RODE on roan Barbary (rep.)

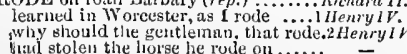

hith stolen the horse he rode on.

helter-skelter have I rode to thee.... $-\overline{-}$

who rom Calais $\ldots \ldots \ldots \ldots \ldots .1$ Henry VI. iv.

When they rode trom London ....Richarl III. iti.

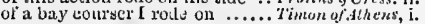

bure scalp of Robin Hood's fat friar.

my cellar is in a rock by the sea-side.

eat rocks, tame tigers ....... Troiluts of Cressida, iii. 2

stand as firm as roeky momntain

as I rode trom Calais liugli-one thent rude to his exceution. (ymbeline, $\mathrm{iii}$.
thit not attend him as we rocle?.. Romea \& Juliet, $\mathrm{y}$. my nume is Ruderigo (rep.).

have you not read, Roderigo, of some

you, Poderign! come, sir, I nin tor yains

do you hear, Roderigo? Whliat say you? ".

now, ny sick tool, Lodcrigo, whom love

Row now, Roderigo? (rep.) ..........

give me thy hand Roderigo (rep.).........
live Rinderiro, he calls me to a restitutio

Roderigu? no: yes sure (rep.) $\ldots \ldots \ldots \ldots . .$.
sct on in the dark by Roderigo

alled Roderiro. Roderigo killed! .

the pocket of the slain Roderi

tiute is, besides, in Roderigo's letter ....

RODOR IGO; my father was

Trelfh Night, ii.

ay, flceter than the roe.. Thining of .jue s L. Lost, v.

without his roe, like a dried ..... Tromeo \& frestie? vii.

ROGER Bulingliroke, the conjurer? ...2lenry VI.j.

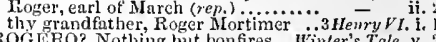

ROG UE-rogues, hence, avaunt!...... Merry Wives, i. 3

French thrift, you rogues.

such a drawling, affecting rogue.......

very rogites, now they be out .........

reasoll, you roguc (rep.)..............

hang him, mechanical salt-butter rognel -

peace, you rogue, no more o' that. Twelnth Nigh

here's an over-weening rogue!

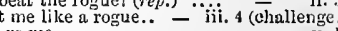

I hate a drunken rogue...........

away, you rogue, away (rep.) ........... preas. for $\vec{M}$ eas. iv.

once to behold, rogue (rep.) ...... Love's L. Lost, v.

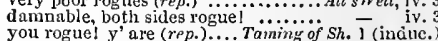

you roguel y'are $(r \rho p$.$) .... Taming of Sh. 1$ (inatuc.

off with my boots, you rogues (rep.)

come hirher, you rogue; what, have you
he settled only in rogue; some call. Winter's

that's the rogue that put me

not a more cowardly rogue in ail ....

an old sheep-whistling rogue $\ldots \ldots \ldots$.

that this same fat rogue will tell us... Henry $1 \mathrm{~V} . \mathrm{i}$.

hanging for killing that rogue .......
bewitched with the rogne's company

and to leave these rogues, I am....

out, you rogue, shall I be your ostler?

you lie, you rogue; 't

what a frosty-spiritcd rogue is this?

away you rogue; dost thou not hear

give me a cup of sack, rogue (rep.).

you rogue, they were bound

two rogues in buckram (rep.)......

plays the rogue with out the play. .2 great toe. .2 in $I V$. i.

thou bastardly rogue! (rep.) .........

away, you mouldy rogue, away!

ah, you sweet little rogue, yonl ( $($ rep. $)$

I will toss the rogue in a blankct....

you blue-bottle rog the l you filthy....
come, you rogue, come!' bring me to

away, you rogue. By my troth......... Henry $V$.

why, tis a gull, a tool, a rogue $\ldots . . . . .$. Henry ifi.

male varlet, you rogue' what's . Troilus o Cress. v.

would I could mect that rogue Diomeds -

railing knave; a very filthy rogue ..
whut's become of the wenching rogues?

poor rognes, and usurers' men! .. rimon of th

compounded thee, poor rogue........ - iv.

tuad! Rogue, rogue, rogue! I am sick - iv.

you dissentious rogues, that ......... Coriolanus, i. go to hell amoug the rogues ........Julius Cassar, i.

fisting of each rogne thy ear is liable.. I ericles, iv.

superserviceable, finical rogue............. Lear, ii.

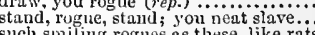

witli swine, and rogues furlorn ..........

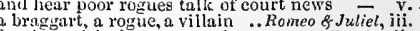

a rogue says here......... Hamlel, ii.

a pestilence and pensant siave am I?

you rogne! you rascall what's ......... Othello, ii.

dost thou pratc, roguel Nay, good ........ - ii.

some busy aud insinuatiug rogue........
ROGULRY to be found $\overline{1} \mathrm{~V}$ iv.

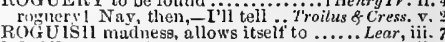

ROISTING eliallenge sent.... Troiluts of Cressida, ii.

as the cye doth roll to every....... Love's L.Lost, v.

$1 \mathrm{am}$ not in the roll of common ..... I Henry $I V$.iii.

the roll? where's the roll? (rep.) ..2 Hemry $V$. jii. 2
which rolls, and rolls, and rolls...... Henry $V$. ili. 6 
ROLL-he's male master o' the rolls. He ury VIII. v. 1 put we $i^{\prime}$ the roll of eonquest ..... Antony dicleo. v. 2
are fatul then, when yonr cyes roll so ... Othello, y. 2 RULLbD in a flowering bank ......2 2lenry I. Hii. 1 lies rolfed in the cheerful sin .... Thas dmitron. in a tiue frenzy rolliug, doth ..Mid, N.'s Dretm, v.

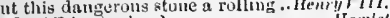

RiNAGE in the lund.................... Inanled, i. I the face of an old Romm coin ....Lnee's L. Lost, y. 2 ancient Runan honour more. Merchant a like a Roman conqueror Roman Luerece for her chastity... Taming of shi. ii. why should I play tho Roman fool ..... Machelh, v. but the ontside of the lioman Brutus., Henry $V$, ii. look you, of the IRoman disciplines the pristine wars of the Romans a Ruman sworler, and a banditto ...2 Henry $r$ I. iv. 1 as lift them against the Koman state. Corichanus, i. I Lartius, a must valiant Roman

Aufidius, piercing our Romans

we arc come off like Romans ........
the Roman gods, lead their successes to the Roman camp conduct us ....... I would, I werea Roman; for I can not he bestrid an o'erpressed liom not Romans, as they are not ........ Ind am a homall; and my services are I would not be a Doman, of all nations I hope to see Romans as cheaj as .... are entered in the loman territories do they stili fly to the Roman? do not say for that, forgive our homans did tend to save the Romans the Romans, this we received ........ shouting Romans, make the sun dance

that bade the Romans mark him...Julius $C a$ he is a nobla Roman, and well given whiso's there? A Ruman

that should be in a Roman, you do want for Romans now have thewes and limbs the lomaus are but sheep (rep.) .... which every noble Roman beirs of yuu which every noble Roman betrs of yuu Wrop of blood, that every Roman bears drop of blood, that every Roman bear it a our Roman actors do. by all the gods that Romans bow before lusty Romans came smiling (rep.) nor to no Romank else ............... thy master is a wise and valiant Roma Romans, countrymen, and lovers! hear so rude, that would not be a Roran? you gentle Romans,-Peace, ho! (rep.) to every Roman citizen he gives .... and bay the moon, thin sucil a te it forth now, as you are a Roman (rep.)...... all take note.. where never Romanl shall tak

this is a Ruman's part: come ......... Romans, yet ere night we shall ....... on the sudien a Roman thongint... Antony \& $\mathrm{Cle}$

the nll-houlured, honest, Roman Brutus the hearts of Romans serve your enil
to the Roman boy she hath sold me. a Roman, by a Roman valiantly ...

let's do it after the high Roman fashion join his honour, agitinst the Romans. Cym to etnploy you towards this Roman

or look upon our komans, whose.... till the injurious Romans did extort my hody's marked with Roman sword some Roman courtezan

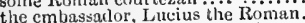

he hath not applared before the Roin es biri, the Roman eagle .. mecess to the Roman hust

the Roman emperor's letters ...i.....

with a supply of lioman geutlemen

when they hear the Roman horses neigh fall on me, by the hands of Rumans! or we are Romans, and will give you the Britus, the Roman [Cot.Knt,-Briton] the slaughter herc made by the liuman a Rumats; who hach not now been.... desire to live, for all he be a Rumau. you look like Ru Runan with a Rumains heart can... liarm, though he frave served a lisina he is a Roman; no more kin to me $\ddot{3}$ to Cesar, and to the Roinall empire. the Riman cagle, from aouth to west let a Roman and a British ensign...

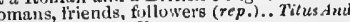
in electim for the lioman empery

stamans, make way (rep.) ............ querorwe have performetl our lioman rites Romans, do me right (rep.) ...........
suum euique is our Roman justice.

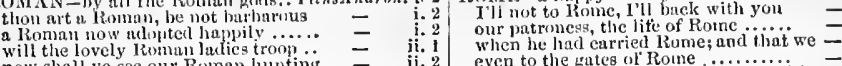
now slall ye see our Roman lunting what Romall lord it was durst do... pray the Ruman god s, emfound you both 二 uthousand Roman dames at such.... with my knite curved in Roman letters
the loman emperor greets you all .. what suy you, Romaus? (rep.) ...... squeak and gibber in the Roman street. . Ifa

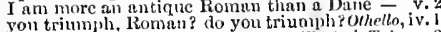
RoNA NO-,Julio Romen

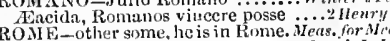
njoined him in liome for want a young doctor of Rume .Mler, of lenice, iv. iv. 1 your city lume (I say, your city) to his trilutaries follow him to Rome.... Julius great Pompey pass the strcets of Rome many of the best respect in Rome is it liome indeed, and room cnough to kcep his state in Rome, as easily.. to repute himself a son of Rome nane opinion that Rome lolls of hibbish shall liome, etc. Speak, strike, redress! (hath the o Rome! I make thee promise...... foul of mel hall suck most boldest and best hearts of Pome that I have room with Rome pity to the general wrong of Rome.

\section{of a licavy curse rrom Rome}

i. 10 the great metropolis and see of Rome $=\quad$ v. 2 to-night within seven leagues of Home lere is a mourning Rome (rep.).

slew $\mathrm{my}$ best lover for the good of Riome we are blessed, that Rome is rid of him there's not a nobler man in Rome should move the stones of Rome. Octaviue is already come to Rome... like madmen through the gates of Rime 二 and carry him to Rume, äd set....... Henry rI. i.

v. 7 by whose virtue (the court of Rome

v. 3 the whule consistory of Rome

is stolen tricks of Rome...

speedily I wish to hear from riome...

the sun of Rome is set! ...............

news, my good lord, from Rome...Anlony \& Cleo. let Rome in Tiber melt! $\ldots \ldots . . . . .$.
who thrns speaks of lim at Rome....
name Cleoputra as slie's called in irome name Cleopatra as slie's called in liome =

in all you writ to Rome $\ldots \ldots \ldots \ldots . . . .$. our contriving friends in Ronne......

quickly drive him to home.........

is every hour in Home expected ...

whicome to $\mathrm{m}$ residing here at Home.

despiteful Rome cast on my noble.".

to send measures of wheat to Rome.

in fear, though you were born in Roine = this will l carry to Rome. And I this = Rome unust know the value of her own

xe will write to Rome of our success
send us to Rome the best ............. that must he hostages for Rome .... (alias, fools) as any in Rome welcome to Rome. renow red (rep.)...

but our Rome will cast upon thee...

when 'Tarquin made head for Rome

this paltering becomes not Rome...

our renowned Rome, whose gratitude -

and sack great Rome with Romans.

beloved of all the trales in Rome....
the honoured gods keep Rome in snfety the honoured gods keep Rome from Rome all seasoned office but since he hath served well for Rol

never more to enter our Rone gates

all tracics in Rome, and occupntions and for Roine's good: F'll tell thee what the wounds that he does bear tor Rome

what's the news in Rome? ..........

there hath been in Rome strange .... to be whooped out ut Rome.......

had we no qunrrel clse to Rome

thongis not for Rome itself ä.....

and sowle the porter ot Rome gates. and Rome sits safe and still witho

列

let Rome be thus in formed a.........

you are come a market-maid to lome

'tis sajk in Rome, that Photimus ....

while he was yet in lome, his power

I my pilluw lelt unpressed in Rome

for her life in Rome would be eternal

shouting varletry of censuring Rome
shalt be shown in Rome, as well as I

shalt be shown in Rome, as whel as I
and then to Rome: come, Dolabella
my residence in Rome, at one........

madam, a nobic gentleman of Rome -

so like you, sir, embassadors from lome -
granted Rome a tribute, yearly......

when was she missecl? he is in Rome?

but what from lome? The senate

it was in Rome (accursed the mansio

good my lurd of Rome call forth

ware the imperial diadem of Rome T.
graciuus in the eyes of roval Rome..

good and great deserts to Rome...

goodertook this cause of Rome.

returncd bleeding to Rome (rep.).....

Rome. be as just and gracions unto me Rome"s best champion, successful in hrought to yoke, the enemerious in thy mourting trite joy for his return to Rome (rep.) let Rome reward with love $\dddot{.} . . . . .$. we are bronght to Rome, to beantify loud 'larums welcome them to Rome Rome's readiest chumpions, repose ..
Rome's best citizens applatud (rep. .. triumpher in the eyes of Rome! $\ldots$ be gond to Rome, they charged him have brollght a trembling upon Rome
that home can make asainst then .. and the nobility of Rome are his . I think, he'lit of to i' the tire of burning Rume. Why, so racked for Rune, to make coals cheay your love can to for line, thour

his eye red as 'twuuld burn Rome

v. 5 from liome. You may not pass, you you'll see your Rome cmbraced with
heard your general talk of Rome.... then you shouli hate Roine, as he does therenter and conjure thee to pardon Rome.... before the walls of lzome tom a crackel heart I have sent to Rome the Volsces plough Rome, and harrow eyes are not the same I wore in Rome the moon of Rome; chaste as the icicle capitulate again with Rome's mcchitnics we'll hear naught from Rome in private = so we will home to Rome............

to set a hend on healless Rome ......

peopic of Rome, and neoyle's tribumes

reflect on Rome, as Titan's rays $\ldots . .$.
Rume's roynl mist ress, mistress of $m y$ in sight of lione, to Suturnine ......

well worthy lome's imperial lort formet = eomest not to be male a scorn in Rome none else in izome to make a stale of ruttle in the commonwealth of lome

v. 3 and will create thec empress of Rome I will not re-silute the streets of Rome

v. 3 but soldicrs, and Ronc's survitors

v. 3 dishonoured by my sons in Roosel.

of andden thus alvanced in liume?

but let the laws of Rome determine all

a friend to thee, and Rome .......... 
ROME and the righteous heavens .. Titus antron. i. 2 ROMEO cries, and then down .. Romeo \& Julit, jii. 3 ROOT of hemlock, digged i' the dark ...Macbeth, iv, the gods of Rome forefend, I sliould be which Rome reputes to be a heinous that will charm Rome's Saturnine... = or know ye not, in Roine how firtous Rome's royal empress, unfurnished of in Rome's great quarrei shed.

Rome could afford no tribune like. for they linve tonglit for liome to do Rome service, are but vain .... of your hands hath not detended Rome when my father was in Kume........ bad bonyent to the yoke a happy star led us to Rome.............. and statcly Rome's disgruce.

shall smoke for it in Rome $\ldots \ldots \ldots$. . . in ungrateful Rome: ah, Rume! take wreik on liome for this.

an emperor of Rome thus overborne to fly about the streets of Rome! .... thyself should govern Rome and me Rome never had more cause

so may'st thou the giddy men of $\mathbf{R}$ ome Rome lath done you any scath signify ingratetul Rome requites with foul. wlint's the news from trom Boine

cound about the wicked streets of Rome learls towards kome a baod of warlike that I repair to Rome, 1 am content for league, and good to Romc........ people, and sons of Rome, by uproar spenk, Rotne's dear friend; as erst. spenk, Roune's dear friend; as erst ... that foright Rome's quarrel out..... thon reverend inan of Rome.

all hail; Rome's royal emperori ( $(r e p$.

may I govern so, to heal Rume's harm
must high and palmy state of liome....

when Ruscius was an actor in Rome ... Hamle what saduess lengthens Romeo's hours?
this is nut Romeo, he's some other where nay, gentle Romeo, we must have you his nume is Romeo, and a Montagne now homeo is beloved, and loves Romeo! humours! madman! passion! = [Col.] O Romeo! that she were o Romeo, Romeo! wherefore (rep.). Bo Ruineo would, were he not liome
Romeo, doff thy name; and for that art thou not Romeo, and a Muntague? gentle Romeo, if thou dost love...

hist, Roineo, hist! O fur a falconer's of iny Romeo's name [ Knt,-lRomeo] Roineo hath not been in bed to-night where the devil stonld this Romeo be alas, poor Romeo, he is already deadi here comes Romeo, here comes Rom
signior Romeo, bon jour! there's ... now art thon komeo; now art thou Roineo, will you come to your fau (rep.) = doth not rosemary and Romeo begin come, what not he; though his tace Rumeo sliall thank thee, daughter. Mlercntio, thou consort'st with Romeo Romeo, the hate I bear thee, can affurd Romeo, away, be gonel the citizens

whom Romeo's hand did slay; Rom Romeo he cries aloud, buld triends! by and by cumes back tu komeu as he tell, did korveo turn and fly not Riomeo let Romeo heoce in haste, else ...... Romeo leap to these arms, untalked of come, Romeo! come, thou day in night 1 -
black-browed night, give me my Ruineo Romeo eau, though beaven cannot (rep.) thou and Komeo press one heavy bier! = Romeo banished; Romeo (rep.) did Romeo's hand shed Tybalt's biood? = slame come to Romeol Blistered be Romeo, Juliet, all slaio, all dead (rep.) for Romeo is exiled: he made you fo not Romeo, take my maidenhead! your Romeo will be here at night.... your Rorneo will be here at night luok on her, but Romeo may not ( $r$ ep.) in carrion flies, than Romeo ......... one knocks; good Romeo, hide thyself who's there? Romeo, arise! thou w
my lady's lord? where is Romeo?

\section{i. 2 ere 1 again beliold my Romeo ....... \\ ii. I I never shall be satisfied with Romeo $_{\text {ii. }}$ \\ ii. 1 it shall be Romeo, whom you know
ii. 3 fitith, lsere tis: Romeo is banished Romeo's a dishclout to him God joined my heart and Romeo..... this hand, by thee to Romeo sealed. Romeo bear thee hence to Mantua \\ ii. 1 because he murried me betise to Romeo? - thie time that Romeo come to redecin iny cousin's ghost sucling out Rumeo what says Romeo? or, if his mind who bare iny letter then to Romeo?. who is it? liomeo. IIow long liath he that my master slew hitn. Romeo? ! O pale! what else? what, Paris - Where's is my Pomeo? I hear some noise - the people in the street ury- $\because$ Romeo the consty Paris slain; and Romeo dead - Romen, there dead, was husband (rep.) - melumtime I writ to Romeo, that he.. noble Paris, and true Romeo, dead}

than this of Juliet and her Romeo

RUNYUN - pulecat, you ronyonf.. Merry Wives,

v. 2 witeh! the rump-ted ronyon cries..... Macbeth

v. 3 but by the hoily rood (rep.) ...... Richard III. iil.

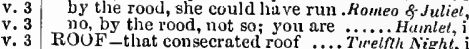
ROU F-that consecrated roof .... Tireifh Nigh, $\mathrm{i}$ $v .3$ thy visor is Philemon's roof............ Hiluch ado, ii. v. 3 thil my very roof was dry... Merchant of r'enice, iji. my tongue to the roof of my.. Taining of Shrew, iv. Richard II. iv. masous building roofs of gold Henry, thatch your poor thin roof with......imonry 1 . ii. 3 to bring the roof to the foundation. Coriolanus, iii. 1 the roof o' the chamber ............ Cymbeline, ii. their thoughts do hit the roofs of palaces is is ents radiant roof...

gondly buildings left $w$ ithout a roof ... Pericles, ii. 4 this majestical roof fretted with golden. Hamlet, ii. i. I ROOFED-our country's hooour roofed. Hacbeth, iii. ii. 2 and rooks, brought forth the sceretest. Hucbelh, iii. ii. 2 RUOKY -wing to the rooky wood ..... Macbeth, iii. ii. 2 RooM-if room enough .................. Tempest, $i$. ii. 2 becuuse it is an open room... Measure for Measure, ii.

ii.

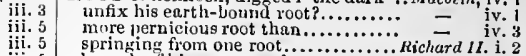
iii. 5 branching from one root................ Richard II. i. $\begin{array}{ll}\text { I will go root away the noisome ...... } & =\text { i } \\ \text { iii. } 5 & \text { arc plueked up, root and all ......... } \\ \text { iii. } 5 & \text { not find a ground to root upron..... }\end{array}$ iii. 5 hide tha a groumd to root ujpon......2 HenryI $V$. iii. iv. a and rank fumitory, doth ront upon .... Hen - i iv. 1 root lim op who dares

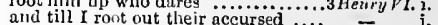
the axe to thy usurping root ... wherenf the rout was fixed in must by the roots be hewn up........ - ₹. branches, when the root is gone? ...Richard III. ii. 2 though we lave it with a root ..... Herry bips his root, and then he falls, as I do - iii. will be blown up by the root 1 ... Troilus \& $\overline{C r}_{\text {ress. }}$ iv. rich men sin, and I eat root. Timon of $A$ th. i. 2 (grace) shows to al little oil, and root

v. 3 thy plenteous bosom one poor rooti... a root-dear thanks! bekold, the eartl hath roots. can you eat roots, and drink cold water? caut rizing to the root o' the tongue.. doth root up his country's peace...... a root of ancient envy heart ....... Coriolunus, ii. shoots my very heart at root ........... I canoot delve him to the root ........ Cymbeliue, i. I untwine his perishing root nuthing roots us, but the viliany....... on herries, and on roots, and feed ..... - iv. 2 which fence the roots they grow by..... Pericles, i. 2 she that sets seeds and roots of shame.. $\overrightarrow{C o l}$.$] iv.$ as if he plucked upkisses by the roots... Othello, iii. 3 and there rooted betwixt thcm......... Allinter's Wole, i from the memory a rooted sorrow........ Aracbeth, v. 3 affiance were deeply rooted.......... Cymbeline, $\mathrm{i}$. and patience, rooted in him both but time hath rooted out my $\ldots \ldots \ldots . .$. Pericies, v. I
ROOTEDLY - hate him, as rootediy ROOTETH from the city's side...Roineo \& Juliet, i. 1 ROOTING - abortive, rooting hog! .. Richard III. i. 3 make the rope of his destiny ............. - i. I [Col. Knt.] I see, that men make ropes. All's well, iv. and buy a rope's end (rep.).... Comedy of Errors, iv. money for the rope (rep.)

sent for nothing but a ropel ..........

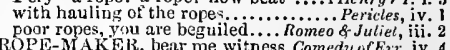
ROPERY ROPING-not hang like roping icicles. Hemry $I$. iii.
ROSALIND-if Rosalind, the duke's As you Like it, $\mathrm{i}$. 1 pray thee, Rosalind, sweet my coz why Rosalind; Cupid have mercy....

hath not? Rosalind lacks then the love no jewel is like Rosalind (rep.).. - iii. 2 (verses) let him seek out Rosalind (rep.) - iii. 2 (verses) thus Rosalind of many parts.... - iii. 2 (verses) with carving Rosalind ou their barks = deifying the name of Rosalind ....... = Rosalind is so admired? I swear (rep.) = and happiness, dear Rosalind! (rep.) my rosalind is virtunus (rep.l $\ldots . . .$. an' I were your verv very Rosalind... not have my right Rosalind of this mind be your Rosalind in a more coming-on have to wife this Rosalind? (rep.).... ilfe for these two hours, Rosalind, I will most unworthy of her you call Rosalind youth, he callis his Rosalind (rep.).. = cried, in fainting, upon Rosalind ..... how you excnse my brother, Rosalind cannot serve your turn for Rosalind? and to and $\mathrm{I}$ for Rosalind. And $\mathrm{I}$ for no (rep.) is you love Posalind meet............ = in sight, you are $m y$ Rosalind........... $\bar{a}$ v. (versess and Rosaline they call her ......... hand of the most beauteous lady Rosaline who sees the heavenly Rosaline........
but Rosaline, you have a favour (rep.) but Rosaine, yout have a favour (rep.) Rosaline, what did the Russian whisper
my fair niece Rosaline ..... Romeo \& Juliet. $\mathrm{i} .2$ (note)
sups the fair Rosaliue............... 


\section{ROS}

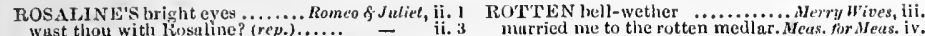

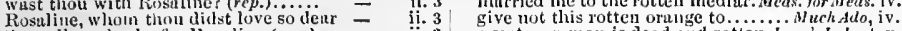

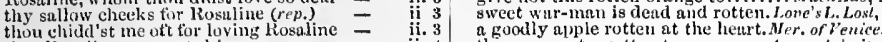

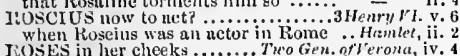

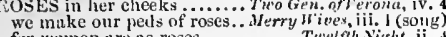
for womzen are ns

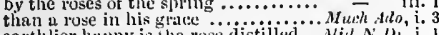
earthlier halppy is the rose distilled ...Mill.N.Di. i. how clanee the roses there do tade in the tresh laty of the erimson rose.

like the red rose on triasiphunt brier

no doubt, they rose un early, to observe _- iv.

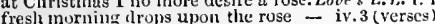
blow like sweet roses in the summer. masked ure roses in their bud.

angels vailing clouds, or roses slept together, rose at a! instant

he that sweetest rose will find

to our rose of youth rightly helor

helong.....All's s' (v'll, i. 3

as mornintr roses newly washed.. Taming of Sh, ii.

as sweet as damnsk roses.. Winter's Tule, iv. 3 (song

with the half-blown rose

do not see, my fair rose witier......... Bichard $1 \%$.

that sirect lovely rose, and plant..

but we rose both at an instant

is as red as any rose

pluck a white rose (rep.)

Henry $\mathrm{N}^{\mathrm{V}}$.

IIIenry Ir:

rose, with Plantugellet (rep.

-

verdiet on the white rose sille.

do paint the white rose red

rose a cauker, Somerset? (rep.)

friends to wear my bleeding roses...
this pale and angry rose, as cognizance
upou thy narty wear this rose........

upou thy narty ween this rose.............

upbraidud me about the rose

raise aloft the milk-white rose

he rose against him, being his

the red $c$ ose and the white arc...

wither one rose and let the othe
were four red roses on a stalk

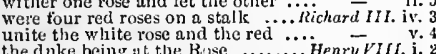

bufore the sun rose............ Troilu: \& cressider i.

why Brutus rose against Ciesar ..Julius Cassr, iii. 2

he wears the rose of yonth

you shall see a rose (rep.)

Pericles, iv. 6

her art sisters the natural roses...... $-v$ (Gower)
tlint which we eall a rose........Romeo \& juliet, ii.

the roses in thy lips and cheeks shall

of pack thread, and old cakes of roses - v.

expectaney and rose of the fair state ... Hanlet, jii. i

two Proveneial roses on my razed shoes.. - iii. 2

up lie rose, and donned his elothie

o rose of Alayl dear maid, kind ......... iv.

WOSE-CHEEKED youtli to .... Timon of Alhens, iv.

ROSED over with the virgin c...Timson of .. Henry $V$.

and tall between thy rosed lips ... Titus Andron.

ROSE-LIPPED eleru

my dish of elantity with rosemary ..... Pericles, iv.

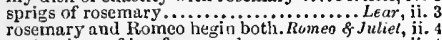
sententious of $i t_{\text {, }}$ of you and rosemary

rosemary, that's for remembrance $\ldots$...Ham

ROSE W

KOSSE - the worthy thane of Rosse.........Macbeli, $\mathrm{i} .2$

the lurds of Rosse, Beaumoud

ROSY -did it with a pudency so rosy... Cymbeline, ii. 5

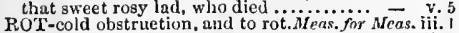
rot and rot, and thereby hangs..... As you Like it, ii. 7 make't thy question, and go rot!

thy love-springs rot?........ Comedy of Errors, iii. I may my liands rot off and never ... Richard Il. iv. members rot but by de thy lips rut off! (rep.) .......... Timon of Alhens, iv. is to rot itself with motion..... Anlony \& cleopatra, i. and their tongues rot, that speak ..... Cymbeline, ii. 3 the south-fog rot him!.............. Cymbeline, ii. a man may rot even here $\ldots \ldots \ldots \ldots \ldots . . . .$. Lenr,, . fat weed that rots [Col.-roots man lie i the earth ere he rot?..... - v. tet her rot, and perish, and be damned.. Othello, iv.

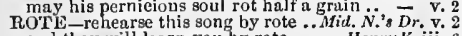
and they will learn you by rote ........ Ifenry $\mathrm{V}$. iii. thy love did read by rote........... Romeo \& Juliet, ii. ROIED-words that are but roted .. Coriolanu, iii. ROTHER - [Col.] ] lards the rother's. Timan of Ath. iv.
ROTTED-green corn hath rotted.. Muth. N.'s Dr. ii. the other rotted with delicions feed.Tilus $A$ nd. $\mathrm{iv}$. ROTTEN-a rotten carcass of a boat ..... Tempest, i. a goodly apple rotten at the hemrt. Aer. of leace

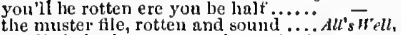
the muster file, rotten and sound ....A Al's Well, which is rotten, as ever wak.

that shakes the rotten earcass

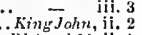

rotten parcliment bonds

King John, ii.

never did bare ald rotten policy ....... liftury $f$ the unguided days, and rotten times.2HenryI $V . \mathrm{i}$. their heads crushed like rotten apples. Ienry ${ }^{\prime}$ hung their rotten coffins up in ......3Henr?!ll. i. 3 drop into the rotten month of death. Richard III rotten disenses of the sonth. . Troilus o C Cressida
from the earth rotten liumidity.. Timon of Ath. shall lift up their rotten privi

lience, rotten thing, or 1 shall shake

like a twist of rotten silk

trust not to rotten planks... Antony \& Cleopatrn, iii. 7

are even as goud as rotten ...........Perictes, iv. 3 enforee thy rotten jaws to open.. Romeo \& Juliet,
something is rutten in the state of ...... Hamle 'taith, it' he be not rotten before he die
RU'TTENNESS-sound rottenness!.. K

ROTTING - mighty, rotting together
ROTINDITY o the worldi

ROUEN bring lam our prisoner.

Lear,

you shall stay with us in Rouen

is Paris lost? is Rouen yielded up?.. I Henry

and we be lords and rulers over Ronen

now livien, I'll slake thy buiwark
onee again we'll sleep sceure in $R$, ueu

thit joineth Rouen unto her

see his exequies fulfilled in Rouen

nor grieve that Rouen is so recovered
ROUGEMONT: at which name. . Richard

ROUGH-ehins be roumh and razorable.

are very ill-favoured rough things. Nerry Wive prove rongh and unhospitable.. Twelfth Night, iii. 3 when lion rough in wildest rage. my father's rough and envious..... ds you Like $i l, \mathrm{i}$. were she as rough as are the.

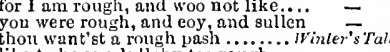

like to have a lullaby too rough $\ldots . .$. .

a lie; you are rougli and hairy

demeaned himself rough, rude

vigour and rough trowu of war.

'...King John, iii. for justice, and rough chastisement..R Richard $U$ iv. those rough rug-he:uded kerns

all the water in the rough rude sea.. $=$ ii. 3

to so rough a course to come ........2 Herry $1 \%$. ii.

even way unto my rough affuirs

we slall be winnowed with so $r$
soldier, rough and hard of heart.

oldier, rough and hard of heart....... Ienrin $V$. in robustious and rough comi

our tongue is rough, eoz .

with rough, and all unable pen.......

and makes the senses rough

beard made rougli and rugged.

tongue is stern and rough, used to

Clifford, rough Northumberland ....3 3 Henry

finty, rough, remorseless; bidst th

though the rough wind say, no

ough eradle for such little pretty. Richard $I J$. iv

and the rough brake that virtue.... Henry VIII.

eome, you have been too rongli(rep.) Co

a little angry for my so rough nsuge.

and yet as rough, their royal blood
till the rongh seas, that spare not....

through the rough seams of the waterg

they were too rough, that threw her

the rough and woelul musie that...

it follows, I am rougl and lecher

ugh for nature to eudure

so tyrannous and rough in prooft Romeo of Juliel,

it love be rough with you, be rough

to smooth that rough touch with.

deserts iclle, rough quarries, rocks ...... ortsello, $\mathrm{i}$. and rougli-cast, doth present wall...'s bream, iii. what, all anort? Rouen has..... but this rongh magic I here abjure. like a rough cult; he knows not..1id.. N.'s Dream, v. 1

their rough earriage so ridieulous. Loze's L. Lust,

and by what rougl enforcement you. All's Well,
she's too rough for me ............ Taming of $S h$.

ay, but not rough enough

in their rough rough work ....... Timon of Athen
ROUGII-C AST, and this stnne... Mid.N.'s Drenm, v. I do not take his rongler aceents for. Corivalanus, iif. 3 dicl deign the roughest berry .... Antony \& Cleo. i. 4 ROUGII. Y - not be roughly used. Tielifh Night, iii. as roughly as my modesty.... Comedy of krrors, v. 1 justles roughly by al time of... Troilus \& Cress. iv. 4 roughly a wake, I here proclaim wa...... v. y. ioUND-a round hose, madam. Two Gfn. of Ver. ii. 7 wear a great round beard............Mery Wives, i. 4 walk round about an oak (rep. v. . s).. - iv. round with eye-oftending brine ...Tuelfin Nighe, i. sir. Toby, I must be round with you.. - - ii. with restless violence round about

proclaim it, provost, round about . . round about ber tomb they go .... - v. 3 (somg) patiently dance it onr round...Mid..$\dot{N}$ 's Drean, ii. I'll put a girdle round about the earth - ii. like round and orient pearls

'tis a good rose in France ...Merchant of Venice, i. 2 have their round haunches gored.. ds you Like it, ii. 3 the big round tears coursed one another

many-colonred Iris, rounds thine eye. $A l^{\prime}{ }^{-}$Well, i. 3

round with all my wanton .. Tuming of Sh. I (iild.)

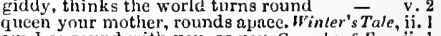

am I so round witl you, as you.Conedy of Err. ii. I

from the golden round, which fate .... Macbelh. i.
we'll drink a measure the table round - iii.

the round and top of sovereignty?..... $\quad$ - iv.

while you perform your antique round - iv. 1
skirr the country round; lang .........

that rounds the mortal temples,... Richard $1 I$, iii. 2
why. you whoreson round man!...1 Henry $V$. ii. 4

at the round table, by a sea-coal fire 2 Henryl $V$. i.

theur reproof is something too round.. Henry $v$. ii. was round eneompassed and set ....i Henry ${ }_{1}$. $\mathrm{j}$. my body round engirt witl misery.
that gold must round engirt these..

be round impaled with a glorious.

that must round my brow......... dichar - ini. iv. 2

health, gentlemen, let it go round... Henry JII. i. oxpeetation whirls me round. Troilus \& Cressida. iii. with ynur weapons round about...... $\overline{\text { v. }}$ I must be round with him, now be ... Thon athens, once attains the utmost round ...... Julius Casar, i1. I time is eome round, and, where $\ddot{I}$ did - v. 3 the world go round! (rep.). Antony $\&$ Cleo. $\overline{\mathrm{ii}} .7$ (song) or round? Round even to faul tiness $\quad$ the round world should have shook $\quad$ ii. 3 the round world should have shook the a scroll; and written round about?... Titus $\overline{A n d}$. iv. 2 we'll live so round and safe ............... Pericles, i. 2 yravished the regions round $\ldots . .$. .... iii. (Gower I went round to work, and my young. Hamlet, ii. 2 and bowl the round nave down......... - ii. 2 enrt gone round Neptune's salt wash.... being thus benetted round with villanies $-\bar{v}$ round unvarnished tale detiver.othello, $\mathrm{i}$. 3 and on every hand, enwheel thee round! - ii. RouNDED-is rounded with a sleep .. Tempest, iv. had rounded with coronet of. Wid. N.'s Dream, iv.
own soldier) rounded in the ear ...King John, ii. soever rounded in with danger.. Troilus frects. $\mathrm{f}$. ROUNDEL-come, now a roundel...Nid.N.'s Dr. ii. 3
ROUNDER-somewhat rounder. Fwo Gen. of $F^{\prime} \mathrm{cr}$. y. 2 ROUNDEST-in the roundest manner 2 . lear, j. ROUNDLY-we elap into't roundly. As you Like it,
shall I then come roumdly to thee. I'amung of Sh. shall I then come roumdly to thee. I'ammg of $\mathrm{sh}^{\mathrm{j}} \mathrm{j}$. 2 at the first so roundly

that runs so roundly in thy head .... Richard ${ }_{11}$. ii. well, how then? roundly, ronidly $\ldots$...HentryI $I$. j. any thing, indeed, and roundly too. 2 Henry 1 r. jii. and fell so roundly to a large . Troilus \& Cress. iii. ROUND-WONBLD - grew round-wombed.. Lear, i. .
ROUSE the night-ow] in a cateh .. Turelfht. rouse up a brave miud ....... Acrchant of ${ }^{2}$ enice, ii.
hiaek agents to their prey do rouse.... Afacbeth, iii. would at a dismal treatise rouse ....... and rouse from sleep that fell ........ King John, iii. to rouse lis wrongs, and ehase .......

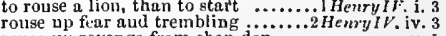
ronse up revenge from ebon den........ when I do rouse me in my throne.... yn, rouse thy vaunting veins

and ronse him at the name of Crispian - iv. 3 we'll quickly rolse the traitors......3Henry ${ }^{\prime} l$. v. I
to rouse a Greeian that is true ...Troilus \& Cress. i. 3 
ROUSE-sweet, rouse yourself .. Troilus $\delta$ Cress. iii. 3
rouse him, and give him note of...... rouse him, and give him note of...... cleorratra, and rouse the prinee .......... Titus andronicus, ij.

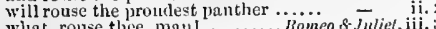
what, rouse thee, man! $1 . . . . . . .$. Romeo of Juliet, iii. 3
on 'Thurseday early will i rouse you.. - iv.

the king's rouse the henven shali bruit.. Fromle', i. there o'ertook in his rouse

call up her finther; rouse him............ Olhello

TOUSED up with boisterous.

and both roused in their seat

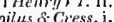

roused with raye, with rige doth. Troilus

by the lark, hatl rousel the ribald

hase roused his drowsy blood ..........

roused to the eneounter, or whether ....... Lear, ii.

a roused ve igeance sets him new ....... Humlet, ii.
roUSILLON, my good lord..............

the count Rousilon eannot be ny..... -

you companion to the comnt Rousilion?

no, come thou home, Rousilion.

colut liousillon; know you suel: a ouje? -

tell the eount Rousillon and my brother -

whint will count Rousillou do then?..

the captain of his horse, count kousilion =

in behulf of the count Ronsillon?

is the count Ronsillon a widower - v. -3 (petit.)

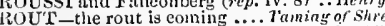

the eommon ront against your.. Cumedy of Lir. iii. i

in base and abjeet routs, led on by ..2Henry $I V$. iv. I

clieering a rout of rebels with you

Aleneon, and that traitorous rout ... $\mathrm{Henry}^{\prime}$

ringleader and head

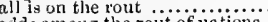

inds among the rout of nations.

in banqueting to all the rout

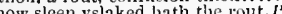

to know how

ROUTED - whither the routed ay dulony or $\mathrm{Cle}$, in

ROVE w'j one that's yet ...

lioVING thieves serve the great...

the first row of the pious elianson

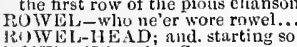

ROWL. ND and to Crassus...........2 Heas for $\mathrm{H}$ IF $\mathrm{i}$.

sir Rowland de Bois (rep. i. 2 ) ......... As you Like

my father loved sir Rowland as his soul -

with old sir Rowland's youngest son

the good sir Rowland's son, as you

the revenue that was old sir Rowland's =

the second son of old sir liowland ...

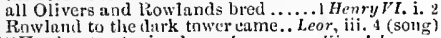

RUY-shout unt, vire le roy !........... King John, v.

notre très cher filz IIenry roy d'Angleterre - v.

shall catch your ruyal flet.

shall catch your royal fleet

to leave our royal court...

sport royul, I warrant you.......... Trenthth $\bar{N}$ ghht, ii.

your royul grate! (rrp.) ..............

heliee it, royal prinee, if he be.........
and I have heurd your royal ear abised

wait on your royal walks....... Hiil. N.'s Dream, v.

into the royal hand of the king ... Love's L. Last,
royal filtrer (rep, v. 2) ..............

royal fiuger (rep. $v, 2)$
of thy royal swect breath as wili $\ldots . . . .$.

peace of mind, most royal complementi

enough to press a royal merchant.... $-\bar{c}$ iv. 1

for 'tis the royal disposition of ...As you Like i',

eat no grapes, my royal tox? (rep.).

entreating from your royal thoughits
to ehnose trom forth the royal blood of

stay, royal sir, the jeweller...........

dignities, and royal neeessities ..Win
of your royal presenee r'll adventure

fior ever earned a royal husband

we call: my royal liege, he is not

a fellow of the royal bed, wlich

sir, royal sir, forgive a foolish....

must know the royal fool tho

print your royal futher off

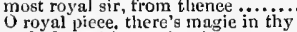

and of poy there's magie in thy $\ddot{0}$

frum our royal master, thanks

most royal sir.

my royal lord, you do not give

grace us with your royal company?.

thy royal father was a most.

your royal preparation makes us

uephew, and right roys sovereign

or add a royal number to the dead

why stand these royal fronts a inuzed

your royal presenees be ruled by me

this royal hand and mineare newly kn

to elap this royal bargain up of ptate
but tinat your royal pluasure.......... RUYAL-nt his most royul root ..... kic
befure king lieliard, in his royai lists?
thy fortune in this loyal fight! ......

chy on our rojal sword your

this royal throne of royal realin.....

this teeming womb of royal king........

chasing the royal blood, with fiury

re borne, in him a royal prinee

tlue poserssion of a roya bea

do thee fitsour witls niy royal hands

to his most royal person: hither ....

upon thy royal grandsire's bontes

the possession of thy royal hand

worst in this royal presence may

hatli eat bread from my royal hand..

camest not of the blood royai...

as mueh as will make him a royai ma.

between that royal field of.

were our royal faith's martyrs.

O my royal futher! My sovereign

up, vanity! down, royal state! ......

and happiness to my royal tather!

to spurn at your most royal ima
question your royal thoughts ...

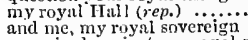

and me, my royal sovereign ..............

upon his royal tiace

upon his royal tace $\ldots \ldots \ldots \ldots \ldots \ldots \ldots$

this bar and royal interview .......

faee to face, and royal eye to eye
before this royal view, what rub.

my royal eonsin, teach you our prin

and, for your royal birth ...............
to Paris, royal Cliaries of France
if

if hippy England s royal king
in ilenry's royal name, as dep
may be England's royal queen

may be Entrland's ruyal queen ....

Jesu preserve your royal majesty!

come about your royal person (rep

is slander to your royal dignity....

in eare of your inost royal person .....
to spoil the city, and your royal court

heir to England's royal seat

royal commanders be in readine

my royal father, cheer these noble

be crowned England's royal king

reet the thy royal person i.......

wherefore else guard we his royal tent

over-muel consumed his roy

remnant of tiat ruyal blood.

and, no doubt, right royal

warn them to his royal presence $\ldots . .$.

but kin, of his ow ral disposition

to be so flouted in this roya presence?

it requires the royal debt it lent you

in the seat royal of this famous isie?

speak, when is the royal day ( $r e p$. )

tile lineal glory of your royal hous..

her royal stock graft with ignoble.

take to your royal self this protfered

then I salute you with this royal title

no more sons of the royal blood

fair, royal and graeious..........

a royal battle mitht be won and $7 . .$.

suceceders of each royal house .....

here was royal to the disposiug of ... II enry $\bar{V} I I$

like a most royal prince, restored i...

re come to know your royal pleasure
it's fit this royal session do ...........

thanks to God for sueh a roval lady..

your royal graees, sliowerud on me

toward the king, my ever royal master

a royal train, believe me
she had all the royal maki

my roynl nepliew, and your ua

angela fly o'er thy royul head....

to your roval grace, and the good queen

this roval infuit, (heaven still move

here forbid me, royal Priam

noble, worthy, roy ul Timon
royal eheer, 1 warrant yon

a most royal one.

minded him, lrow joyal tivas to pardon

mighty, bold, royal, and loving .Julins

O royal Casar! Hear me with patience
royal weneh! she made great .... Antony

royal weneh! she mad
go on; rigint royal.

go on; right royal .................
knew'st the royal oceupation?

which promises royal peril .........

ressl

belield of eyes again so royait.......... cherd II. i. 2 ROYAL-of so many royal kings.. Antony \& Clco. v. 2 i. 3 heing royal, took her own way ........ for she's fuir and royal ............ - iii. his royal bird prunes the immortal wing 二 and one that had a rnyal lover

the lons and v. Rome's royal mistress (rep. ii. 3) .... - i. the boy lie is of ruyal blood....

altiane's royal emperort.

royal Antiochns (on what canse $\ldots . .$. . Pericles

a prince of Macedon, my royal father...

preserve you! hait, hail, royal sir!

royal Leur, whom I have ever (rep.)

jardon ne, rovai sir

you are a royal one, and we obey you...

very gait did prophecy a royal nobleness

let not the royal bed of Denmaris

found, Horatio, a ruyal knavery

the ear-piercing fife, the royal banner .... Olinello, i.

ROYAIAZE his blood, I spilt......... Richiard $I I I$. i. 3 Winuch $A d$, $^{\prime}$

to have you royally appointed ........ iv. the castie royally is manned (rep.). Richard 11 . iii. to answer royally in our defences ...... Henry $V$ ii. and let us binquet royally ............ Henry Vi, i. to have proved most royally............ Hamlet, v. dominations, roynlties, and rights ... King Johre, the roy alties and rights of banished. Richard 11 . ii. my rights and royalties plucked from

than for his lineal royalties, and to beg -

ROYALCY - outward faee of royalty.... Tempest,

I have stayed to tire your royalty. Winler's Tale, i.

for royalty's repair, for present .......

to the suceeeding royalty he leaves..... - iv.

high royalty was ne'er plueked off.. King Jolkn, iv. 2

stranger biood, to foreign royalt...

for thus lis royalty dotli speak...... - v.

his high blood's rnyalty (rep.) ....... Richard $1 / . \mathrm{i}$.

mingled his royalty with capering... Hemry $I r^{\prime}$. iti.

that same royalty he wears...........

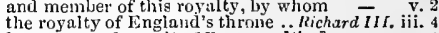
long-usurped royalty [Knt.-royalties] - - y. that your royalty holds idleness... Antony \& Clen. i. frame them to royalty unlearned... Cymbeline, iv. agilinst the royalty of her fatles your..... Lear, ii. RU B-you rub the sore, when you .... Tempest, ii. rub your ehain witll erums....... ..... to leare no rubs, nor botelues . look how she rubs her huuds each little rub, out of the path.......... the world is full of rubs, and that.. Nichurd II, iii. every rub is smoothed on .............. Henry $r$. ji. Whitt rub, or what imped iment .......... the least rub in your furtuues.......IIenzy $1711 . \mathrm{ii}$. so, so, rub onl, and kiss the .......... - jii. deserved this so dishonoured rub... Coriolanas, iii. tak, there's the rub; for in that sleep ... Isamlet, 111.

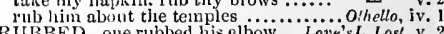
will not be rubbed, nor stopped ........ 1 huve rubbed this young quat almost... othello, v. that rubling the poor itel of your .. Coriolames, $\mathrm{i}$. Richaid Il. v. What rubbish, and what offal...... Julize Cessar, i. RUBIED - with the rubied eherry, Pericles, v. (Gow.) those be rubies, fairy favours... Mid. N.'s Dream, ii. embellished with rubies ... Comedy of Lmors, iii. rubies unparagoned, how dearly .... Cymbeline, it. 2 RUBY - natural ruby of your cheeks .. ilacbeth, iii. dio ope their ruby lips...........Julius Cesar, iii. I
RUDDER-and turn the rudder... Antony \& Cleo. jii.

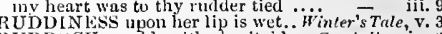
RUDDiCK would, with claritable... Cymbeline, iv. RUDE-that rude umeivil that visit. Julius Cassar, ii. from the rude sea's enraged ..... Turelsh

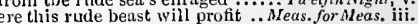
whiles 1 persuade that rude wreteh.. that the rude sea grew eivil at...Mid.N.'s Dream ji. a crew of patehes, rude meehanieals

why are you grown so rude? ......... that, like a rude andi savage man of

which the rude muititude call

too rude, and bold of vojce... Merchant of $\overline{t e n i c e}$ v. for the poor rude world hath not her $\overline{\text { iii. } 5}$

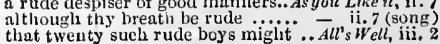


RUDR, and willly

by and loy, rule fishermen of Corint

atit on thee, lute man! thoul dost.... kinir $\bar{J}$

harboned in their rulde cireum

in rude hatsh-sounding rhymes

howsoever rude exteriorly, is yet....

unthrend the rude eye of $r$

left ro slinpeless and so rurle.......... $\bar{y}$

go to the rule ribs of thit ruse sect

how clures thy harsh rule tunfuc...

where rude misgovernet hands. .

What means death in this rude assailt? -

was by the rule liands of that

the rude scene may end .....

he gave it like a rude prinee ........

to tlie wet scaboy in an hour so rude

to

protehil Henry

with the rude multitude

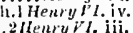

the commons, rude un polished hir

and peasants, rude and mereiless

if one so rude, nut of so mean.

this seene of rude impaticnee?

rute ragged nurse! old sullen

to use so rude belıaviour: go to

ye rude slaves, leave your taping....

peace, rude sounds i fools on both.

rude, in sooth: in gooul sootin, very rude

with the rude brevity and discharge

who is hure so rude that would ... Julus

by this rude place we live in ...... Cymbeline,

the dlust which the rude wind biows ..... Lear,

make lappy my rude hand.

as welt as lierbs, graee, and rude wil

my blood for your rucle brawls doth

iu noise so rude aqaiust me?

rude am I in my speeel, and littlo

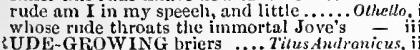

liUDELIEST welcomerl t

IIUDELY - yet you began ruilely......... Tuetfh Nigh

I, that an rudely stamperl.

rudeiy beguiles our lips of ail

or rudely visit tliem in part

do rudeness; do enmel appeared $\ldots$ Treetfo Nigh

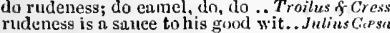

rudeness is a sauce to his good wit... Julins Gir
whose rudeness answered my steps.. Cymhetine

the calneity of my ruler powers. Troilus \& $C$

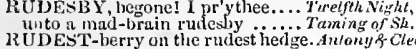

as the rudest wind, that by the top.. Cymbeline,

RUDIMIENTS of art.......... Tuming of Shreen
been tutored in the rudiments of.. As you Like

been tutored in the rudiments of.. As you Like
RUE the time that clogs................ Macbelh,

for you there's rosemary, and rue. Winter's Tale, iv
Franee thou shalt rue (rep) ......... King Jahth, iii.

nought slall make us rue

ril set a bank of rue irep.

France, thou shalt rue th

pent up, rue my sliane.

rit.......3 Iserivy

you and him to rue at the other...... Richard 111 . iii.

all the land will rue it

Titus, rue the tears 1 sher ...............

may wear your rue with a differcue

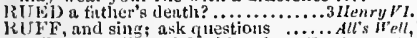

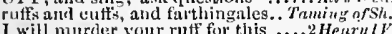

I will murder your rutf for this

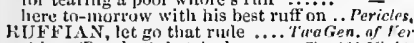

this ruffian hath botshed up....... Tueetrik Night, i

a rufhan st her claunler-window ...Much Ado, iv.

rullian lust should be contanimate?. Can. of kir

well, rutfi:u, I must poeket up thy.. King Jo/n, ii

and ruffians dance and leap

lienryll:

whis tuke the ruftian lillow's by

lase you a rutliatu, that will swear

onear like a rufian, and demean

this to die in ruthiail lattle?

but let the ruffiu lureas onee..... Troilus \& Cre

make eurl'd-pute ruflings balk. Timnu of Atheis

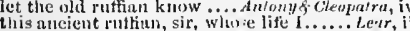

serviec, you think we are ruthiaus

ITUFick up your spirits

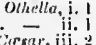

ruth: in the commonwealti of Remne. Titus fuid

and the bleak wints do sorely rutle..

hiospitnble fowours you shumld not ruffle

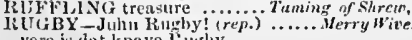

Julan liugby, and you are $\mathbf{j}$ ick izugby

Rughy, buillez me soine paper $\ldots .$. ...

Juck kugby t come to the court! (rep.)..................

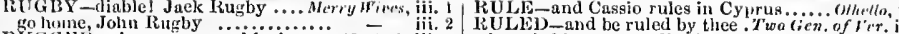

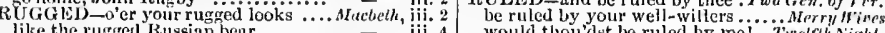
like the ruggetl Russian benr.

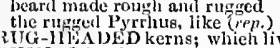
Menzyrt. iii.

presage the ruin of your love $^{2}$

as henvens forfeud! your ruin

for ruin's yasteful entranean .. Camedly of lir $r$

before this ruin of sweet life

bawl out the ruins of thy linen

wh:use ruin you three souglit...

what ruin happened in revenge
by wasting ruin of the cruel toe

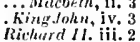

gruin of the

tendering my ruin, and assailed

itriryli: ii.

Henryli.ii.

come, thou new ruin of old

and utter tuin of the house of $y$

are broke, and ruin follows us . .

ah ine, I ee the ruin of my housel. Kichard 111 . ii. i

and all the ruins of distressfu

desolation, ruin, and decay ...........

and weigh thee down to ruin, shame
out of ruins, made my name once.. He

as if ruin leaped trom his eyes

in every thing may bring my ruin!.

anpect of prines, and their ruin where heant to ruin, pitifil.

and furmicss ruin of oblivion.........

fed the wing of the state

in heaps and piles of ruin..........

eome all to ruin.

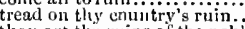

tholl art the ruing of the noblest...

this mortal house 1 'll ruin.

bow this feeble ruin to the earth....C. Cymbetine, iv. a

will soon to ruin fill ................... l'rricles, ii. a

attends the boisterous ruin

Ifamiet, iii. 3

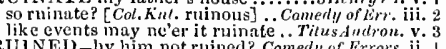

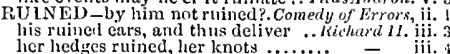

expectation of thy time is ruined ... Henry IV. ili.

eaptail of this ruined band .. Henry $r$ iv. (ehorus)

but my fall, and that that ruined ine

implements of a ruined house.. Timan of thens,

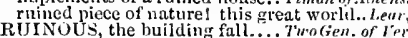

why, no, yon ruinous butt ...Troilus \& Cressidn, v. I despised and ruinous man .... Timon of Athens. iv. 3 to gaze upon a ruinous monastery

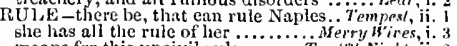

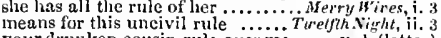

yourdrunken cousin rule over me - v. I (letter)
yet in sueh rule, that ........ Merchant of rinice, iv.
tis a ruinst the rule of nature

tris arainst the rale of nature ........Allis shell, $\mathrm{i}$.

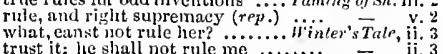

trust it; lie shall not rule me .......... - ii. 3

out of limit, and true rule............ 1 lienry ll. iv. 3

if your own rule be true ..............

ct senses rute; the word is

myduess rules in brainsick men $\ldots . . .1$ Henry $r$ r. iv.

mude the king; but $I$ witl rule hot $h_{1} .$. henry $r$. iv.

new-made duke that rules the roas.

obey, that know not how to rule

and rule multitudes (rep.)

thou shalt rule no mare o er him ...... - v.

serupulous with now awhile.....3 Hem'y/l. ii. 3

pomp, rile, reis'n, but eatrth

luly, you knw no rules of eliarity.... kichard III., .2

his rule were true, he slould be gracions - ii.

and lovinte, may his rule be! ............ v. 3

the specialty of rule hatl been ...........

if there le rule in unity itself

Why rule you not their teetli

thy lenther apron, and thy rule? ....julins $\vec{C}$ ersar, i.

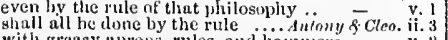

with greasy nprons, rules, and hammers - v. 2

yield up rule, resign my life

your rule direct to any

we will rlivest $11 \mathrm{~s}$, hath of $\mathrm{ru}$

delay by rule of knighthonl
yont twain rule in this realin

yout wain rule in this realin
cutpurse of the em thire and

arginst all rules of nat ure.

eegrins iny safter ruides to rule .......... - ii. would thou'dst be ruled by mei... Tuclshinight, iv.

tre ruled by him ............... Meus. fur Mets.

to be ruled by my conscienee

ngainst you, be ruled by me. Comedy of Errors,

your' royal presences be ruled

be thou ruled by me.................

and the rest will be but ruied................

hath this lovely face ruled
if you'll be ruled by lim

when be ruled by lim

were they to be ruled, and not to rule

cannot rule, nor ever will be ruled.. Cor g cress. ii

prythee now, go and be ruled

if Cassius might have ruled

my lord, be ruled by me, be won... Y'ilus Antron. i.

be ruled, and led hy some diseretion......... Lear, ii.

buled by ne, forget to think of her.. Hoineo \& $J u$, i.

lenceforward I am ever ruled by you

be ruled, you shall not go $\ldots \ldots \ldots \ldots \ldots \ldots$ Hamlet, i.
will you be ruled by me?

my lord, I will be ruled ...............

but, sir, be you ruled by me ............... othello, ii. ?

as doth a ruler witll unlaw ful ...........

a prinee, and ruler of the land ...... - ji.

on any ground that I an ruler of

Whom lieaven ereated for thy ruler. $=$. ve

UMBLE-rumble thy belly-fulli ....... Lerr, iii.

UMINATE-you may ruminate. Tu'o Gen. of ' 'er.

then she ruminates, then slk........Merry Hives, $\mathrm{ii}$.
ruminate the morning's danger.. Henry $V$. iv. (clu.)

revolve and ruminate my grief..... I Ifenry ill.

revolve and ruminate himself. Troilus \& Cressida $\mathrm{ii}$.

ruminates, like a hostess, that hath no - iil,

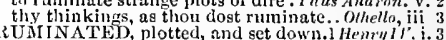

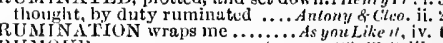

UNOUR-rumour nay' report iny ...At's lliel, it.

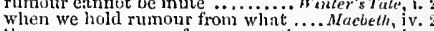

there ran a l'umour of many wortliy

possessed with rumours, full of .......

the noise and rumour of the ficld ....

and who but Rumour, who but only $\mathrm{I}^{-}$(indue.

Rimnour is a pipe blown by surmises = (indue.

from Rumour's tongues they bring

my lord; Rumour doth double

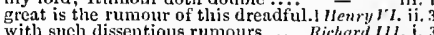

rumour it abroad, that Anne my wife - iv.

straight to stop the rumour.........Ifenry /"III. ii. I

does the rumour hold for true ..........

let every feeble rumour shake you. Caviolan 1 s, iii. :

belike, 'tis lyut a rumour ..Aniony \& Cleopatru, iv.

and it is rumoured, Cominius.. Coriolanu

RUMP-With his fat rump.... Trathes \& $\mathrm{Cr}$
RUM

do so near the bottoun run

Trinculo, run into no further danger...

the tears run down his beard.

rlun, boy, run, run, and seek
thou must run to him

makes him run througli ali....

if you run the nutiook's hin.
I will run no base humnoll.

run in here, good young man......

n womau would run throught fir.

fly, run, hue and ery, villain!

when night-dogs run, all surts

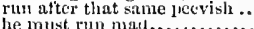

huw runs the strenm?

for long, run by the hideous law. Weas. for

inueh upon this riddle runs tio wisdom -

and the taker runs presentis mud..... nuch dito

You will never run mad, niece ......

runs not this specels like iron tlirnugh

Whase names yet run smootlily in.. . .

l'll rui from thee, and litle me.

run when you will, the story .........
beasts tluat nucet me, run away for fiear

and run througla fire 1 will, fir thy..

are longer thingh tom rum away

well rner, Thisbe. Weil slione, nioon 

RUN by the triple Hecate's ..... Mid. N.' Dream,
well run, dice! there's half....... Aave's L.Last, this carcer, been run.

run away for shame. Alisande.

for it runs against Hector. .

see the sandy hour-class run ... iferchi. of Venice

to run from this Jew (rep.)

take the start, run away

I will run; fiucornd runining ..........

to run a:ray, so I will not rest (rep.)

go, Gratiano, run and overtake 1 in

did run trom Venice, as far as ......
disgrace well as he shall ruu into.:As $\overline{\text { Lik }}$

disgrace well as he shall ruu into. As
that ever love did make thee run into

we that are true lovers, run into strange

run, run, Orlando; carvc, on every..

nan rums his erring pilgrimage

pour alfection in, it runs out

run into $m y$ lord's displeasure $(r e p$.$) ..$

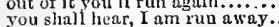

it he run away (rep.) .............
have I run into this dainger

no pace, but runs wliere he will.......

he that runs fastest, gets the ring. T
with no greater a ruin but ray head.

whith the bowl should run, and not

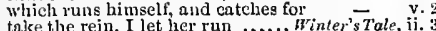

and then run mad, indeed; stark mad!

and spit at him, he'd have run .......
sinec my desires ruu not befure.....
run from her by her own light...emedy of ${ }^{\prime} r$. iv.

a man would run for life.

now yound that runs counter

rum, master, rum; tor God'............

the bour runs through the roughest

flight so runs against all reaso

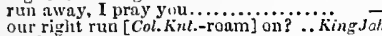

made to run even, upon even...

when we have run su ill?

but slowly; run more fust
torage, and run to meet displen

forage, and run to meet displ
calmly run on in obedience.

even so mist I ruu on .......

that runs so roundly in thy head $($ rep. $)$

and that my fortune runs against

but my time runs nosting ou in

I coulu run as fast as thou caust?

I run when I saw others run

that runs o'luorseback up a hill ....
good mettle in him; he will not run

the snuug and silver Treut slanll run

and runs me up with like advantage
and then he runs straight and cven

my danghter will run mad (rep.)...
I run before king Ilarry's ..2 Hen

1 run betore king llarry's $.2 \mathrm{Hen}^{\prime} \mathrm{l} / \mathrm{V}$. (induction)

this Feeble, the womts s tailor, ruin off?

which way the stream of time doth run - iv.

by the ycar: thus runs the bill .......
that renowned them runs in your.

strcams run [Col. $\mathrm{K}^{\prime} t$. neet] in one

that run befure our business

the king hatle run bad humours

seem to threaten, runs fiar betore them

any apprehension, they would run a

foolish curs! that run winking into..

if thou spy'st any, run, and bring ...115enry

we erying run away $\ldots \ldots . . . .$.
sheep run not half so timorous

and run a tilt at death within

glass, that now bevius to run

Ishrink, and rum away
commonwealth hath daily rui...

over this stool, and run away

orer this stool, and run a way.........
made me laugh to see the viliain run

smootl runs the water, where

and as the dam runs lowing $\dddot{3}$ rum.

run, go, help, help! o llenry

run nothing but claret

mounted, ran their horse to deati

swiftly as the posts could run...

to see the nimutes how they run

but yet I ran befure ny liorse.

what weed st thou run so many

mounts the liquer till it run o'er...

(for so run the conditions,) leave

whicn he has run his course, and sleep.

did lier eyes run o'er too?

my mother's blood runs on the dexter

these two may run lead'st first

I saw him run after a gilded but terfy

how have you run from slaves.......
where he did run reeking o'er the lives

Where he did run reeking o'er the lives
I'll run away till I am ligger .......
run to your tionses, tall upon...... Jutius

run to your houses, tall upon.
when hie doth run his course...

augmented, would run to these.........

a hundred spouts, did run pure blood
IU UN to the Capitol, and nothing ..JuliusCars
run, Lucins, and commend me to my lordrun lence, proclaim, cry it about....

to wind, to stop, to run directly on

my life is run fis compasy

from this country shall Pindarus rui

that it rins over even at his eyes

I held the sword, and he did run on it

nay, then I'll run: what mean... Anton

run one before, and let the queen...

broke it, it would have run all

that rum i' the clock's behulf .........

let the time run on, to good, or bad.

run like swallows o'er the plain ... Fitus Andran

may run into that sink.

now our sands are almost run.

ride, run, mar a curious tale .... great whicel runs down

the knave turns fool, that runs a way
unbonneted he runs, and bids what.

unbonneted he ruis, and bids what.
and the creature run from the cur?.

run, run, $O$ run-To who my lord
how? turn thy hack, and run? ..

she could have run and waddled ....

and slow; they stumble, that run fast

nay, if thy wits run the wilu-goose.

that runs lolling up and down ....
stand up; run to my study: by and by

shall ruin a culd and drowsy humour

mortals, hearing them, run mad
that you run mad, seeing that she

a madmau's mercy bade thee run ar

now at once run on the dashing......

go, tell the prince, run to the Capulet

aud all run with open outcr
run barefoot up and down.....

and fates, do so contrary $r$

thiss runs the world away $\ldots \ldots . .$.

this lapwing runs away with the sliel.

poor lacly! she'll run mad, when she...

tountain from the which my cu
Emilin, run you to the citadel

Emilin, run you to the citadel
RUNAGATE, what doth he there?
than that runagate to your bed

than that runagate to your
find those rumagates (rep.)

that same banished runagate $\ldots \ldots \ldots$ Romea o Juliel, iii. 5

RUNAWAY, thou coward art thou.MIid.N.'s Dr. iii.

close night doth play the runaway. Ner.af renice, ii. 6
bring arain these fool isli runaways. As you Like it, ii.

that wc are most lof ty runaway's..... Henry $V$. Hii. 5 runaways [Col. Knt. unawares] eyes. Rnn. \& Jul. jii.
RUNG-since the curfew rung ... Meas. for Meas. iv.

hath rung night's yawning peal....... Macketh, iii. the market-bell is rung ........... Henry $V I$.
his knell rung out, his judgment ... Henry $V_{I I I}$ his knell rung out, his judgment .. Henry the curtew bell hath rung Romes \& Juliet,

'tis sport to maul a runner. Antany $\&$-Cleopatra, iv RUNNING of one glass........... Winter's Tale scorn rumbing with thy heels, Merchant of Tenice, ii. books in the running brooks.......As you Like it, if.

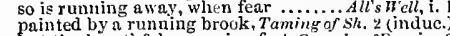
lost thy breath? by running fast. Camedy of Err. iv. argument shall be, thy running

lo pramed in running to devour

makes a still-stand, running peitlier 2 Henry IV. i.

makes a still-stand, runing tore the king .....Henry $v$, iv. I they both came swiftly running ..... Illenry Vi. ii. 2 this course, which you are running liere the which you were now running o
the rumning banquet of two beadles

that tub both filled and runuing

you shall get it by runniu
RUN'ST toward him still

NT toward him still .... Veasurefir..... Lear, iv.

where run'st thou so fast?

if thou art moved, thou run'st a way. Romeo \& Jul. i.
RUPTURE that you may easily. Meas. for Meas. ii.

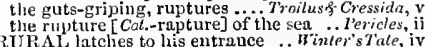

here is a rural tellow....... Antony \& Cleopatr

USII - will rush int the the state. Merch of lenice, iv.
from forth a sa w-pit rush at once. Merry l'ircs,

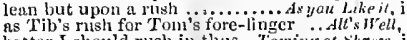

better I should rush in thus. Jaming of shew, iti.

please tu call it a rush candle ......... $\div$. $\rightarrow$ iv.

a rush, a hair, a drop of blood, Comedy of Errars, i

may rosh, and seize us.

King John, ,ii.

the bosom of the ground, rush forth..

a rush will be a beam to hatig...

we will rush on them

Henry'

do rugl upon us as their iung.....

i Henry

rish all to piees on thy rocky ...Richard 11 . jv.

the rush that lies betore him....Antony \& Cleo. iii. s
to rush into the seeret loouse of death

man but a rush against Othello's breast. Othello, v.

and uncivil arms be rutslied upon!. Richard II. i

and rushed into the bowels of the.... Henry VI.
RUSLIED aside the law......... Romeo \&. Juliet, iii. 3 RUSlIES-in which cage of rushes. As you Like it, iit. upon the wanton rushes lay hews down oaks with rushes
we have but pinned with rus

1 Heury IV. iii.

did softly press the rushes ........... Cymbeline, ii. 2 tickle the senseless rushes with....... Romeo \& Juliet,$j .4$ fatal points, and twixt them rushes..
RUSIING in their houses...... Coined of $\overline{E r r o r s}_{\text {rii. }}$ i. cones rushing on this woeful ....... Iichardi II. it. lest that the people, rushing on us.julius Ciesar, iii. as rusling out of doors ............... grcat sea of joys rushing upon me........ Fericles, y. I

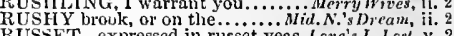
RUSSET-expressed in russet yeas. Laze's $L$. l.aul, $v$. the morn in risset mantle clad $\ldots$ TSSET-PATED clioughs....... Humlet, RUSS IA-jast out a night in Russia. Meas. for. Meas. ii. he is with the emperor of Russia..... the emperor of Russia was my ..Winler's Tale, 11.2
RUSSIAN-Muscovites or Russians. Lave's L. Losl, v. 2 RUSSIAN-Muscovites or Russians. Laze
of Russians left us but of late (rep.)... what did the Russian whisper in your

like the rugged Russinn bear in to the mouth of a Russian bear.......Hemy $V$. rust, sword! cool blushes! ..............All's Well, iv.

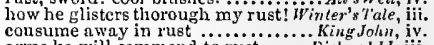
arms lie will commend to rust......... Richard 11 . better to be eaten to death witli rust.2Herry $I V$. .
while that the coulter rusts............ Henry $V . v$. while that the coulter rust

but to rust iron, increase tailors........ Corialnzus, iv. 5 let his armour rust until this day .....Pericles, ii. there rust; and let me die......... Romeo \& Julit, v. 3 swords, for the dew will rust them ...... Othello, i. 2 RUSTIC-our rustic revelry..........As you Like it, v.

how now, rustics?...........

Rith rustie mountainee

Cymoeline, iv.

RUSTLE-I hear his straw rustle. Meas. for Mleas. iy nur the rustling of silks................. Lear, iii. manae rusty busty sword...Taming of Shreu, iii. with the rusty curb of old father .....1 Henry $I V$. $\mathrm{i}$. truce is rusty grown.......... Trailus \& Cressida like a rusty mail in monumental..... for, by his rusty outside, he appear.

do they grow rusty? Nay, their........ Hamlet, work, rein them from ruth ... Troilus \& Cressida, the nobility lay aside their rutis. .... Corialanus, spur them to ruthful work ... Trnilus \& Cressida, $\mathrm{v}$, RUTHILESS thing is this in him. Meas. for Meas, iii. 2 massacre, and ruthless slaugliters ... Henry $Y I$. $v$ as his ruthless arm, with downigiit..3 Henry $V$. . see, ruthless queen (rep. ii. l)....

more than with ruthless waves

of ruthless [Col.-rutbful] butchery. Richard 111 . iv by pardoning Rutland, my transgressing - -1 a tear can fall for Rutland's death?...

tenrs are my swcet Rutland's obsequies

of sweet young Rutland, by rough .

twas you that killed young Rutland

and this for Rutland; both bound

that slew thy brother Ruthand .......

thou pitied'st Rutland, I will pity thee

and young Rutland could not satisfy - ii.

the faultiess blood of pretty Rutland

Thad a Rutland too, throu holp'st to $\quad$ i iv. 4 RUT-TINIE-me a cool rut-time....̈ierry $\bar{w}$ ires, v. 5 RUTTING - out of the road of rutting..Pericles, iv. 5
RUT'ISH-for all that, very ruttish...All's I'ell, iv. 3 RYE-rich leas of wheat, rye, barley .. Tempest, iv. lietwcen the acres of the rye. As you Like it, v. 3 (song)
RYL-STRA WV-your rye-straw bnts ... T'empest, iv. I

SABBATH-by our holy Sabbath. Mer.of Jenice, iv. ] eome the next Sabbath ........... lichurd 111. iii. in his life, banners sable........

he, whose sable arms, black as his purpose - ii.

for I'll lave a suit of gubles $\dddot{2} \ldots \ldots \ldots . . . \%$ ii. 2

A BLE-COLOURED inelanclioly Lozc's L. L.i. i (let.)

liatl druwned lis tongue in sack......

that hath drunk so much sack as...

this cun sack, and drinking do .......... ii. T (letter)

a pottle of burnt sack to give

and let burnt sack be the issue.

and let burnt sack be the is
go fetel me a quart of sack.
let ine pour in some sack... ii. I (letter)

二 


\section{$\mathrm{SAC}$}

[ 643 ]

$\mathrm{SAF}$

SACK_Go brew me a pottle of sack. Merry Mives, iij. s

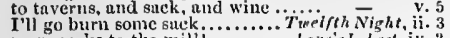
more sucks to the milh! ........... lore's L. Lost, iv. 3

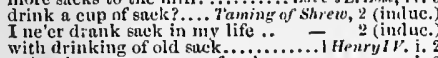

let a cup of sack be my poison

give me a cup of sack (rep.)

fiere's lime in this suck too (rep)....

that huge bomburd of aack.

but to taste sack, and dlink it?

sack, two gallons, $6 s$. $8 d$. (rep.)

to the sack thert thom hrot drini

fill me a buttle of sack; our soldiers

there's that will sack a eity..........
and leave sack, and ljve cieauly

new silk, and old sack ............

Pistol, I charge you with a cup of suek

conie, give's some sack (rep.)

in the wenpon is nothing, without sack

potations, and addict theinselves to

I lave drunk too much sack at supper

they say, he cried out of suck

be engraved the sack of Orleans....

our sacks shall be a mean to sack.

burifk to you in a cup of sack ...2 Henryl' l. ii. 3

sack great Rome with Romans

Timmm th Alicens, v.

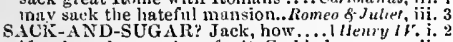

if satk-and-sugar he a fault, Go

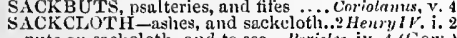

puts on sackeloth, and to sea... l'ericles, iv, 4 (Gow.)

SACK LiRSON loose $t$ wenty times ...Merry Wives, i. 1

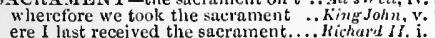

not only take the sacrament to bury

of them here have tu'en the sacrament

French have ta.en the sacrament ... Henry ${ }^{\prime \prime} /$. iv.

as we have ta'en the sacrament

in tleir so sacred patlis he dares. Werry wiver, iii.

on every sacre

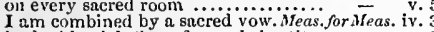

in dnuble violation of sacred thastity

lie hates our sacred nation...Merchanl of 'énice.

that sacred pity liath engendered.A ymu lilie it, ii,
sacred, and sweet, was all I saw ... I aning of Sh. i.

0 my most sacred lady

to sacred Delphos, to Apoilo's temple

for he the sacred lionour of limself.

whose person

whose person, so sacred as it is ......

justice, most sacred duke .... Coinedy of

the sacred storeluouse of his

the free breatli of a sacred kint?

all religious strength of sacred vows - ini.

nearness to our sacred blood

full of Edward's sacred blood

can gripe the sacred handle of

mine own tongue deny my sacred state

dust was thrown upon his sacred head

first, to thy sacred state wisl I all
his angels, guard your sacred tllron

my protession's sacred from above

holy sal's of sacred writ; his study .2Henry Vl. i.

from the sacred ashes of her honour...

inake sacred even his stirrup... Timon of Alhens,

their napkins in his sacred blood. .ulius Cassur, iil. 2
see where be the sacred vials ....Anlonty \& Cleo. i. 3

the honour's sacred which he $\mathrm{tali}_{\mathrm{ks}}$ on - ii.

0 sacred receptacle of my joys .... Titus Andron

our empress then, with her soured wit

all compress in your saered breast!...... Pericles, i. 2

thy sacred pliysie shall receive ............

unite commutual in most sacred basds. Hiamlet, iii.

S.ICRIFICE your tears ....Tu'o Gen, of Verona, $\mathrm{ili}$. sacrifice the lamb that I do luve. Tarelsh Nighi, v. stund tor sacrifice, the rest aloof.Mcr. of eniee, iii. 2 the sacrificel how ceremonious.. Minter's Tale, iii. they come like suerifices............. Hen Holl W.iv. 1 the back is sucriftee to the load ..... Henry VIIL.i. onc sweet sacrifice, and lift my soul ${ }_{\text {tears, and love's tull sucrifice }} \vec{T}_{\text {roilus }}$ C ress. ere the first sacrifice, within this luur spotted livers in the sacrifice

muy give you thank ful sacrifice! .....

bis the pricts do

give the ods a thaukful sacrifice. ./ulius Crsar, ii.

huth mude you reek as a sacrifice.... Cymbelene,

the temple with our sacrifles $\ldots . . .$. . Tilus And. i

religiously they ask a sacrifice

to suve your brother from the sacrifice

do upon mine altar saerifiee..

upon such socrifices, my Cordelio ........ Lear, v.
SACRLFICES of our enmity

a mirder, which I thought ..... Romeo of Jutiet, SCRIFICED his dutgliter.

Rismeo \&. Julie

SACRIFICERS, but not buteliers... Juliu. Cosar, ii. SACRIFICIAL whisperings in his .. 'Timonif' d $h$. i.

entrails feed the sacrificing fire. Gitust thdron. i. 2

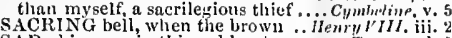

SAD-his arms in this sad knot

servant, you are sad

fiul we sad und solitary

in her sad remembrance

...... $=$ iit.

where sad true lover neer find my - i. i. 4 (sung

he is sad and civil. and suit

if sad and inerry malness $\ldots \ldots \ldots$.

as a sall fuce, a reverend carriage .... - iii. 4

is it sarl, and few words . Mersure for Measure, $\mathrm{jii}$. 2
speak you this with a sad brow? .... Much Ado, i.

why are you thus out of measure sad?

linust in hand, in sad confereoce

wherefore are you sad? Not sad

the count is neitler sad, nor sick.

she is never sad, but when she
if he be sad, he wants money.

pluck up, ny heart, and be sail:

prince, tlinu art sud; get thee.

counterfeit sad looks, make

in silence sarl, trify we ufter the

would go near to make a man look sal
that he will look sad.............. Lime

he made her melanelioly...... snd,

why looks your highmess sad?

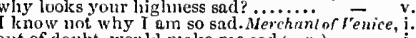

Antunio is sad to think upon his.

iny nerciandize makes me not sad..

a part, and mine a sad one

like one well studied in a sad ostent

speak sad brow, and true maid

good to be sad and say nothing

your experience makes you sad.

O that liad! how sad a passage tis! ... Alts $W^{\top}$

shail sad Apollo weep ....Taming of Sh. 2 (induc.

sad, shall't be? As merry (rep.).... Winter's Tale, it.

and sad tires in a mile-a ....... gentlemen are in sud tali

sad stories of my own mislaps ... Comedy of $E$

you are sad, signior Balthezar.

heavy, sour, sad, and much. much

the is and and possionate at your.

be these sad signs confirmers of...

cousin, look not sad; thy grandan.

nobody should be sad but $I$....

would be as sad as night

see fear, and sad distrust

to see so sad an liour as th

thy sad aspect hath from .....

my death's sad tale may yet.

cannot but be sad; so lieavy sad

rich men look sad, and ruffians

that my sad look should grace

nt that sad stop, my lord, where rude

did spend a sad and bloody hon

yea, there thou makest me sad

I could be sad, and sald indeed to

and a jest with a sad brow

yet be sad, good bruthers ( $r$.

get be sad, good brothers investing lank-lean... He

where the sad and solemn p
sud tidings bring I to you

re sad, your cheer apyalled .......... Henry $r$. i. 1

dream this night dot!n make me sad...2 Henry ${ }^{\circ} J_{\text {. j. } 2}$

with sad unlelpful tears ...........

our hope but sad despair; onr rand
sud [Cot.-nian, for the loss of the

likes it not, for she looks sad...

the sad story of my father's death .. Wichard W1. i. 2

in that sod time, my manly eyes

in their deatl's ead story .......

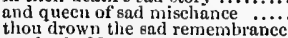

my lord of Surrey, why liok ye so sui

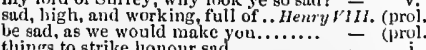

you would say sumething that is sed

full of sad thughits and tronliles a...

pow sad he looksl sure, he is .........

my soul grows sad with trouble

play me that sad note I named

priv to make a sweet lady sal.. Troilis \& Cress. ii

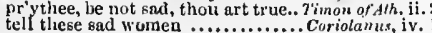

$S A D$-that Cjesar tooks so sad

after thrt, le cume, thus sad, away?
the ruddly drops that visit my sad leart $=$ i.
the charnetery of my sad brows......

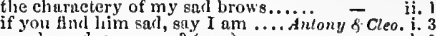

Was he sad, or merry? (rep.)

liray you, luok not snd, nor muke.

call to me all my sad captains

I never saw him sad

wherefore looks't thou sud, wheo. Tilus.dudron. ii.

and my soul's sad tears.

thus in this strange and sad habiliment

that so my sal deerees may fly

kllow thon, sad man, I am liot ......

to love-sick Dido's sad attenting ear

sad Andronei, have done with woes

did moek sad fools -eyed in

I have followed your sail steps.....

the weight of this sad time

louk'st thou sad? though news be sad

more talk of thcse sad thitiss

more talk of these sad things $: \ldots \ldots$. $-\bar{y}^{-}$v. 3

methinks, yoll are sadder ............Much Alo, iii. I

SADDEST-telling the saddest tale. Widid. N.s Dr. ii.

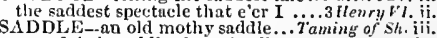

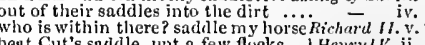

beut Cut's saddle, put a few flacks... i Hem'y/V. ji.

a wa mardolpl; ; saddle my luorse .....

or by vanlting into my saddle witli.... Henry r. v. 2

darkness and devils! saddle my horses..... Lfar, i. 4

SADDJ,ER for my mistress' (rcp.)...Comedy of Err. i. 2

SAD-FACED men, people and sons. Ti/us dn'hon.y.

SADLY - bound sadly home for Nipies... . Tempest.i. 2

when you looked sadly, it was.. Two Gen of Ver. ii. I
the eonference wus sadly burne....... Much Adn, ii. 3

look so sadly on my son?

march sadly after; grace my

Auch Adr, ii. 3

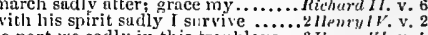

so part we sadly in this troublows...3 Henryl' v.

approach sudly, and go away'(rep.) 7imn of $A / h$. ii.

sit sing sadly greet you our vietory?.. Cymbeline, v.

but sadly teli me, who ........... Romes \&. Jntiel, i. I

yet le looks saclly, and prays the jioor. Othello, ii. I
SADNESS is witlout lingit.

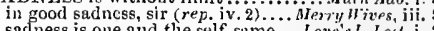

part sadness and melancholy............

a want-wit sadness makes of me........ of tenice, i. 1

so fnll of uomannerly sadness ..........

is a most humorous sadness...

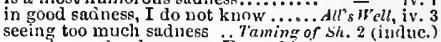

now, in tood sadness, son Petruehio...

you mix your sadness witl? some fear. 2 Henry $l y .2$

fute turns to sudden sadness... Froilus \& Cressida, $\mathbf{j}$.

he did incline to sadness ........... Cymbeline, i.
which are often the sadness of parting

sadness lengthens Romeo's hours? liomeo of Juliet, i.

tell me in sarluess, whio sle is (rep.).

fell into a sadness, then into a fust ..... Hamet. i. ?
SAFE-but are they, Ariel, safe?....... Tcmpes

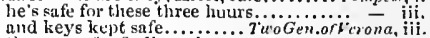

the man of safe diseretion........... Meas. for. $M_{\text {teas }}$

heaven keep your lionour safe 1.

that you keep Costard safe........ Love's L. Lost, $i$,

in kecling sale Nerissin's ring..........

Wurm at home, secure and safe ......

in what safe place you liave bestuwed

is laid un safe at not sufe.

see him safe conveyed lome

long that we were safe and ......... - iv.

Banquo's safe? A y, my goot lord. safe - iii.

the friends we iniss, were sufte nurived

hold himself sufe iu his prisonment. King Jnhn, iii.

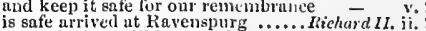

ail sonls that will be sufe, fly

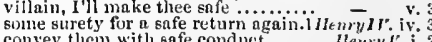

to Frunce shall we convey you safe - -.. ji. (ulurns)

where they would be safe, thiey purioin - iv.

and eomes safe home, will stand ....

set this diumond sufe in golden,......

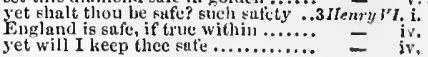




\section{$\mathrm{SAF}$}

S.II

SAFE-what safe means the crown .. 3 Hurury $r$ I. iv. we are not safe, Clarenee (rep.) .... Richurl /II. i. who think themselves as safe as tho

you sleeping safe, they

a sure and safe one, though thy ........ see him safe i' the Tow

to procure safe cunduet (rep.).

the as safe as Prid

and keep your honours safe

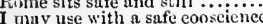

safe, Antony; Britus is safe enou

keco this mau snfe, rive him all

with you should safe iny going

that thou depart'st lience safe.

sting, or neration, I am s.fe

to have llien in safe stowage

O Imogen, safe mny'st thou wander

my jorse is tied ap safe............

and gratulate his safe return... Tims.

with my sword I'll keep this door safe

safte out of fortume's shot

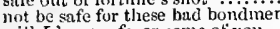

will I keep safe, or some of you

so we may all be safe

then is all safe, the ane him sife.

to line found a sate hes

'tis politie, and safe, to let him keep.

hap more to-night safe 'seape the king! -

what safe and nicely I miglit well delay

nor stands it safe with us .............. Hamtel, iii. .

to keep those many many bodies sa

to be direet and honest, is not safe

are his wits safe? is he not light of bain? - iv. 1

AFED the bringer........Autony \& Cleopatra, iv.

S.AFEGUARD nf your honour................

to safeguard thine own life.

in safeguard ot their brood

if sale do fight in safeguard of your. Richard $1 / \mathrm{I}$. $v$. 3

on safeguard he eame to me......... Coriolunus, iii. 1

sateguarl of what that want

safe] $y$ in harbour is the .......
go safely on to seek thy son

Tempest, $\mathrm{i}$.

that we have safely found

running out, that was safely within. Lnv's $l$. $l$. iii.

I might safely be arimitted ...........

to keep lilm safely till his day.

bath safely fought to-day

all your quarters heen as safely jeept. Henry $V I$. ii.

and safely hronght to Iover...

waft ine safely eross the Cliannel ...2He

God safely quit aner of govern bone.3 Henry $v I$ in.

might go one way, and safely...

then reason safely with you

clucked thee to the wars, and safely -

sufely, I think: 'twas a eontention

and might so safely, had it been .....

safely stowed,-But soft, what noise?... llamlet, iv. 2

$[k n i$.$] go safely on................................$

go safely by the divine Desdemona

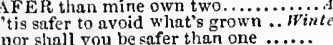

's Woll, it,

nor shall you be safer than

Trte, i.

'tis safer to be that whieh we destroy - iii. 2

a fely shatl he be upon the sandy (rep.) 2Hen.VI. i. 4

but the sater, when 'tis haeked

finds sater footing than blind. Trrailus \& Cress. iit. 2

their meat, ant: suter for

safer triumph is this funeral pomp. Titus dudion. i. 2

fenr too fur. Safer than trust...

the safer sense will ue'er aecommodate... $-\overline{\text { iv. } 6}$

throws a nore safer voice on you .......

IFEST-with your safest haste...... As you Like il, i. 3

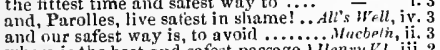

enry Vl. iij. 2

her life is safest only in hel birth.. Richort : II. iv. 4

to take the safest oecasion by the front. Othell

SAFLTIES-but mine own safeties ......7netreth, iv. 3

Which uitl as mueh safety you... Thelfth
that I eannot pursue with aly safety

no less, with wit and satety............

give safety to your purposes1........ens. for
you sball find your safety manifested

let me in safety raise me from ....... -

e"er shall it in safety rest ...... Mid.. N.'s Dream,

to embraee your own safety, nnd give

when fear proposes the safety $\ldots$ Woile, Ail. 2 (indict.)

in safety here, where we are $\ldots . . . \ldots$....

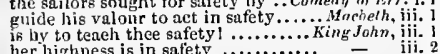

her your fair safe ty; $;$ so I kis

stceps his safety in true blood $(\boldsymbol{r}$ ep. $)$
your safety, for the which myself...
AFETY - to safety, and retura.......
it is our safety, and we must embrime

to seek sweet safety out in vaults.... _ hake the peaee and safety of our......

to seek onit this head of safety

醇

we were enfurced, for safety sake...

What I have done, nuy safety urged me $-{ }^{2}$ v 5

niming at their safety, fly from.....

the aptest way for safety

form, to hold our safety

that sealds with safety

the peace and safety of your person....

all my fame for a pot of alc, and saftity

for his safuty there I'll best devise

I tender so the safety of my liege.

such safety finds the trembling lamb.

strength and safety of our country

and in ourselves, our safet 7 lies......

my person's safety (rep.iii. 5) ....... Richarel III. i. 1

and only in that safuty died her ..... ilen.

provide for thine own future safety.

every man shall eat in safety under.. v. 4

ean found his.tate in safety ..Timonof Alhens, ii.

all thy safety were

gods keep Rome in satety.

no Rome of safety for Oetavius ..Julius Casar, iii. I

seek your honour, with your safety.

the worthy Leonatus is in safety

pawn mine honour for their safety

stand on hostage for his safet

thy safety being the motive.......

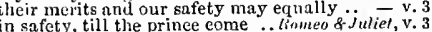

safety [Kut-sanctity] and the lienlt $l_{1}$.. Hamlet, $\mathrm{i}$.

best eafety lies in fear; youtls to itself..

thine espeeial satety, which we do tender - iv. 3

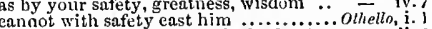

and on the eonrt and guard of safity!...

whose vilianous saffron would have... Al's 'Fell, iv. 5

companion witl the saffron face. Conedy of Err. iy. 4

all you sage counsellors, hence I....2 2 Henry $1 \%$, iv. 4

de most sage demoiselle dat is

and sage, grave men, sinee you
how's this? some more; be sage

how's this? some more; be sage ....... Pericles, $\mathrm{i}$

AGITTAlRY appals our numbers. Troilus \& Cress.

send for the lady to the Sagittary, and let -

what if he lad said, widower.....

widow Dido, said you? ........

why, I said nothing

honest lord, thon hast said well

you said our work should cease.

said she nothing?........................

you have said, sir.........................

ear there be more said? ................

said I well (rep.ii. I and

by gar,' tis good; vell said

weli said. brazen faee (rep.

has thrice her prayers said ............

what is to be said to him, lady? ... Taelfh Nis

though it was snid she mueh

what ean be soid?

what ean be said?...............

but to be sairl, an honest man
very wittily said to a niece
well said, niaster parson.

thati hast said to me a thousand

ay, well said (rep.) ........

I'd fain have said, a maid!

demies all that you have said ..........

thon art said to have $\Omega$ stubborn soul

your higliness said even now .....

for it is said, God sends a curst eo

this was signior Benedick tluat said

when I said, I would die a baehelor
well said, i faith neighbour Verges

I might have said, no part of it.....

I said, thou hailst a fille wit (rep.)

and said, slieg

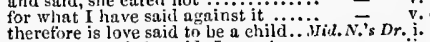

then how ean it he said, I an alone

as may well be said, beeomes ......
this is he my master said, despiseil

I sail, the deer wils not ..... ...Lare's L. Lost. iv.

so they say, the fuol said, and so say I - iv. tendering the precious safety of....... Richarel If i. i. I

longing as I said (rep.).

thou hast said enough
AID-lord Longaville said, I came. Lnve's L. Lost, v. 2

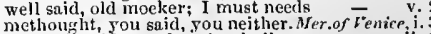
and well said too; for who shall go.. - it. 9 welt said; that was laid on with .. As you Lik ier them again, said with weeping

ell saidt thon look'st cheerly ..... you have said; but whether wisely. may said he? how lookerl he? it is said, many a man knows.

he said, mine eyes were black

it may be said of him, that Cupid....
if I said his beard was not ent well..

if I said his beard was not ent
if you sairl so, then I said so

there's little ean be said in 't ..........

when I said, a mother, methourht...

so would I have said (rep.) ...........
what should be said? if thon canst .

you should have said, sir, before a knave -

hve or six thousand horse, I said ....

between them, as I said; but more

well said, naster; muml....... T'aming of Shrew

so said, so done, is well.

what will be said? what mockery

what said the weaeb, when lie

to satisfy you in what I have said

as I have said, great difference..... Winter's Trale, $i$.

when you have said, she g............

I have saicl, she's an adultress (rep.)

when I have said, cry, woe! the queen

and said, his name was Antigonus ...

how often said, my dignity

so 'tis said, sir; nbout his son

sir, you yourself have said, and writ so =

have, in vain, said many a prayer ... $\overline{\text { Ther }}$ v.

may be said to be on equivoeator .....Macbeth, $\mathrm{ji}$.

'tis sajd, they eat each other (rep. iii. I) - ii.

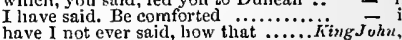

if thou hadst said him liow

when I have said, make an

O let it not be said! (rep.)

who was he that said king John....

[knt.] what I said my life shall

all is said; his tongue is now

all that may be sworn or said

what thou hast said, is fnlse .........

painted imarery, had snid

and what said the gallant? $\ldots \ldots \ldots \ldots . .$.
for more is to be said, and to be done.1 Henry 1

why, that's well said .................
answered indirectly, as I said $\ldots \ldots . .$.
whate ver Ifarry Perey then liad said

he said, he wonld not ransom Mortime

an, ay, he said four. These four eame

and I said, I heard jour graee say so

you said so. Yea; if he said ........

well said, my noble Scot: if speaking

well said, Hal! to it Hal! for........

said he, young Harry Percy's spur..
before you said,--iet us niake liend..

he said, sir, the w'ater itself was......

what said master Dumbieton about..

as I am a gentlemas; nay, you said so

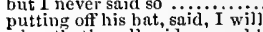

putting of his bat, said, I wil] .....

would bless you to hear what he said

well said, in faith, sir (rep.)

which salique, as $\mathbf{f}$ said, $\ldots \ldots \ldots \ldots \ldots$

and said, tliey were devils intarnate

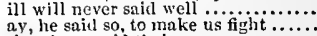

they have said their prayers $\ldots \ldots \ldots$....

here, said they, is the terror of ......

maintain what I have said is true..

lest it be saidl, speak, sirrah

and thus I said, thou maiden yoiti 1 .

'tis said, the stout Parisians $\ldots \ldots . . . . \%$.

my master said, that he was ........

well said, my masters; and weleome all -

who said, Simpeox, come; come. offer

why that's well said (rep. iii, $z$ ) $\ldots .$.

had I but said, I would have kept ...
true; and yet it is said, Iabour in...

nay, it shall ne'er be snid, while ....

you said so much before..............3 $\mathrm{Hl}_{e}$
tis better said than done, $\mathrm{my}$ gracious

but what said lady Bona (rep.

he would have said, the king .........

look, what I have said I will avouch 
SAID, dear brother, live, and be ....Richard 111 . ii. I SAID_and yet said, now I may

you said, that idle weets are fast....

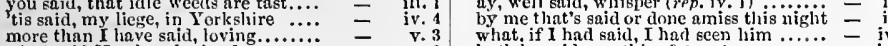
lunmberund.... lath he said any thing?

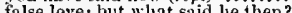
liere nor there. I she said so; I must necds report the trut it may be sinid, it renclies firr ............ whe said so; I must nechls you have snid well (rrp.) .......... burnt that tongue, than said so... so said her woman; and that her... nothing what ean be said against me
gaid I tor this, the girl is like to him? said I tor this, the girl is

you have botlı said well

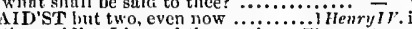

I think thou snid'st thou hadst

SAII, nor tackle, sail, nor mast

and sail so expeditio

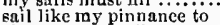

elap on more sails; purs

Trives, $\mathrm{i}$.

I have said my prayers; and devil ..

well said, my lord! well, you say so

when they have said, as false........

I said, good-morrow, Aja

that I have said to some ..............

well said, adversityl and what need

well said, whetstone. I shall

heavens, have I said, the bounty... Timon of $A t h$.

as you have said (rep. iii. 2)
tis said, he gave unte (rep.)

they said, they were an-hungry

false Trojan under sail was seen ...Mid. $N$.'sDr. i. I

and sail upon the sails

the ship is under sail................. Love's L. Lost, v.
your argosies with portiy sail ..... Aler. of JPenice, $\mathrm{i}$.

and ragged sails, lean, rent....

than to be under sail

I saw Bassinio minder sail (rep.)

been very slow of sail $\ldots \ldots \ldots$
had hoisted sail, and prit to sea
but in a sieve I'll thither sail

a whole armado of convicted sail

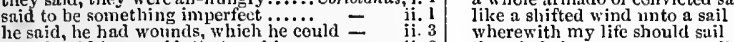

.... F orrors, $\mathrm{i}$

Macbeth, i.

the wind sit sore upon our sail

you should have said, that, as his $\ddot{0}$

he liath said enough. He las spoken

let what is ineet, be said, it must be

well said, noble woman: before he

I have heard it said, the fittest

may be said to be a ravislier

When I said banisl him, I said..

I ever said, we were i' the wrong .....

he said, 'twas folly, for one poor grain

'twas very faintly he said, kise......

I say to you, as I was said to, away

Ciusar said to me, darest thou...........

what you have said, I will consider.
whut said he, when he came unto.

he said, if he had done, or said, anything -

it shall be said, his judgment ruled.

I said, an elder soldier, not a better.

you said, the enemy would not.

I liave said (rep. iii. 2) ........Antony $\&$ Cleopotro

to say, as I said then! but, come
well said. And friends with Caesa

well said. And friends with Caes.

you have said, sir. We looked not

and, as I said before, that which is .

well said; eome on (rep. iv. 4)

and sliow my sail of greatness

now doth a sail, filled with a frettin

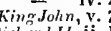

of sails, and tackling reft........... Richard $I I T$. jv.

hoised sall, and made his eourse again - iv

with full eonsent belly'd his sails

- ii.

as waves before a vessel under sail ... Coriolanus, ii.

purple the sails, and so perfumed.Anlonys-Cleo. ii.

not fear us, Pompey, with thy sails.

hoists sails, aud flies

forgive my fearful sails! $\ldots \ldots \ldots . . . . .$.

$\begin{array}{ll} & \text { iii. } \% \\ =\quad \text { iii. } 8 \\ \text { iii. } 9\end{array}$

and question'dst every sail

sail ...........

a portly sail of slips make hitherward.

horse, and sail, and high expence

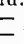

Pericles, i. 4

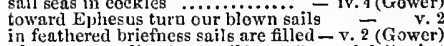

of iny course, direet my sail! ..... Rom

a sail, a sail, a sail!

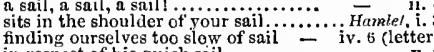

in respect of his quiek sail .................

the heaven and the main, descry a sail

a sail, a sail, a sail! (rep.) ...............

my boat sails freely, both with wind

6 (letter)

if you but said so (rep.) \#......... Cymb

and, as I said, there is no more.......

for 'tis said, a woman's fituess

二

he said, he was gentle (rep.)

if Pisanio have, said she, given................

to wait, said I? to wanton with... Tilus And

to her brother which I said to thee

tell her, this I said: weke, weke!

very sea-mark of my utmost sail

ALED in to the north of my lady"s...Tirelsh $N$. iii.

from Epidamnum had we sailed.Comedy of Err.

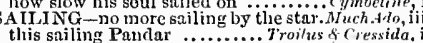

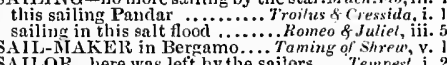

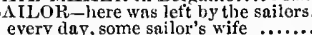

every day, some sailor's wife

which the sailors lieaved over-board

r-board .... ii.

since before Noal was a sailor......... - iii. 2

I spoke with some of the sailors that

the sailors sought for safety by our. Comed $y$ of Frr. $i$.
a sailor's wife lad oliesnuts ............ Waebeth

I'll drown more sailors than the.....3

and half our sailor's swallowed

he a drunkeal ... Richard IIJ. iii.

as a sallor breaks a biseuit ..7 Troilus \&-Cressida,

cried, good seamen, to the sailors........' Iericles, jv

sailors, sir; they say, they have letters... namlet, iv. 6

as 'tis agid, the bo every thing I said,

saying o'er what $I$ have said before. Romeo of $J u l$. i.

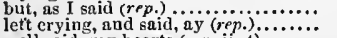

well sair, my hearts (rep. ii. 4)
when she said-Tybalt's dead.....

and well said; a merry whoreson!

musie straight, for so he said lie would
to myself I said, an' if a man did need

what said my man, when my letossed

married Juliet: said he not so?

remember what I have said to you .........

well said, old mole!................... -

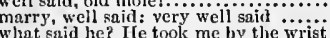

that I have positively said, 'tis so.....

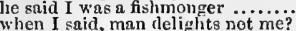

When I said, man delights not me?

I remember, one said, there were no
need not tell us what lord I 1 amlet said

by and by is easily saill................

what said slie to youl Get nuere taper
SAINT-is she not a heavenly saint? TwoGen.of Ver.ii.d
and saint Nicholas be tliy............

at saint Gregory's well ...

yes, by saint Aune $\ldots \ldots . . .$.

the rotarsts of

os with a saint

great men may jest with sain

that, to eatcl a saint, $w$ ith sain ts dost

I will presently to saint I,uke's........

by the saint whom I profess.........

away to saint Peter for the lieavens... sherh dilo, ii.

saint Valentine is past .......... Wint. N'.'s Dream, i
saint Cupid, then! und, soldiers.. Jore's L.Lost,

saint Denis to saint Cupidi 1

saint George's lialt clietk in..........
if he have the condition of a saint. i. 3 sailors, my lord, they say: I saw them not - iv. 7
i. 5 SAIN-that hatl tofore been sain.. Love's L. Lost, iii. 1

his mortal hreathing saint - ii
S.IINT-would rex a saint.... Taming of Shrew, iii. 2
the enrriage of a looly saint.. Comedy of Errors, iii. 2

by all the saints in heaven

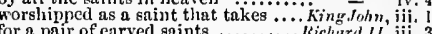

for a pair of enrved saint

pray continually to their saints.

revereneed like a blessed saint

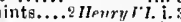

swcet saint, for charity, be not so ...Richard 111. i. 2

that dead saint whiel then I wecpin

fiends roar, saint

the prayers of holy saints, and wronged $-\bar{v}$ v. 3

thy saints for aye be crowned.. Timon of A hlhens, v.

then, dear saint, let lips do

saints do not move, though grant

my name, dear saint, is hateful to ....

saints in your injuries, devils being .... Othella, ii.

between saint Alban's and London... Henry $1 \mathrm{r}$. iv. 2

to ride unto saint Alban's (rep.) $\ldots . . . .2$ Hemy $V i$. i. 2

a blind man at saint Alban's

the masters of saint Aiban'

saint Alban's battle, won by famous

marehed towards saint Albau's (

I met at saint Alban's last.

Margaret's battle the this lady's ..... Fichord iij. 2

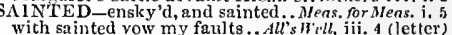

her sainted spirit again possess ...W'inter's Tale, v. 1

fatlier, was a most sainted king $\ldots \ldots$...Macboth, iv. 3
SAINT EDNIUND'S-BURY; it is ... King John, iv. 3

upon the altar at saint Edmund's-Bury $-\overline{\text { val }} \mathbf{4}$

thy meekness saint-like ........... Henry rthi. ii.

SAINt-like, cast her fair eyes to henven $\vec{J}_{\text {S }}$ iv.

and as a certnin father saitl ...... Love's $L$. Lost, iv.

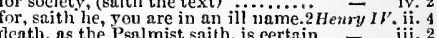

thus saith the duke, thus hath ....Richard 11r. iii. 7

and, as he saitl, so say we all.. Titus dndronicus, y.

for my sake, read it over.... Tu oGen.of Ierona, ii.

this, for my duty's sake . sake(rep.) -

for your friend's sake.

ay Silvia-for your sake...

for thy sweet mistress' sake (rep.).....

the world a stranger for thy sake

for your daughter's sake $\ldots \ldots . . . . . . .3$.

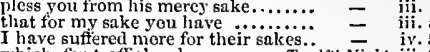

whieh, for traffic's sake.......... Trelffh $\overline{N i g h t, ~ i i i . ~} 3$

he will fight with you for his oath sake - iii.
will for liis honour's sake, have one..

Will for lis honour's sake, have one...
for his sake, did I expose myself ....

she yet wears for his sake. Mleasure for Measure, iii. I

you must pardon for Mariana's sake $\quad$ - $v$ iv.

so would not $\mathbf{I}$, for your own sake $\ldots$...Iucth $A d o$, ii.

for his sake! (rep.) ................

if you spite it for my sn ke..............

for my sake, my dear, lie further.... $=$ - ii. 3

tell true, even for my sake $\ldots \ldots \ldots \ldots \ldots$, $\quad$ i ii..

or my sake but one loving kiss..... Lote's L. Lost, it. I

only for praise' sake, whien they $\ldots . .$. =

for wisdom's sake, a word that (...... $=$ 二 jv.

or women's sake, by' wiom we .....

of my trust, or for my sake.. Merchant of Fenice.

slubber not business for my sake sake

mothing else, for God's sake .........

or your own sake, to embrace ....

fiate him not, for my sake.............

we have stayed her for your sake.....

and wish for her sake, nore tian for

for fashion sake, I thank you too.....

would, for the king's sake, he were...All's Wrell, $\mathbf{i}$.

to have friends for my wife.s sake..... $=$ i.

never do you wrong for your own sake
I would it were hell--pains for tliysake

and, for the contents' sake, are sorry
to bear it for your worthy sake $\ldots . . .$.

Gor's sake, a, pot of small ale.. Taining of $\overline{S h} .2$ (ind.)

not for my sake, but for your master's
and he for your goot sake.............

you are welcome for his sake

all for my master's sake, Lueentin

embrace her for her beauty's sake... 
SAKE-sireet father, for my sake.. Taming of Sh. V. I SALISBURY-I'll be a Salislury ....1 Henry VI. i. 4 SALVATION-of his salvation

for both our sakes, I would that wori the sake of thein thou sorrowest... Comedy of Err. $\mathrm{i}$.

for God's sake, holk (rep. ii. 1)

wealth"s sake, nse her withi... $=$ ili. 2

and, fir thitt Einglaml's sakc

for heavell's sake, Hubert, let......... Bichurd 4 iv.

for Gnd s sake, let me in $\ldots \ldots \ldots \ldots$....

for sport sake, are entent to

tor their own credit sake, make..... - i. -

for safet s sake, torls (rep. iy. 3 and v. 4) = ii. 4

yet for God's sake, go not (rep. ii. 4$) .2$ nenryI $\vec{y}_{\text {ii. }} 3$

Fen, for iny sake, even to the eyes for - iii. 1

or to dance for your sake, Kate ...... Itemryl. v. 2
for their sake, in your fair minds
for v.2 (chioris)

and for alliance' sake, declare.

trust thee, but for profit's sal

for God's sake, let him hake have I slyed many

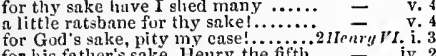

for his sake pity me; lest..........

my office, for my tather's sake

the willow garland for his sake (rep.iv 1)

for Gral's sake, henee (rep. i. 3) ...Richurd ILI. i.

it were mortal poison, for tlyy saike!..

ahinst my soml, for Ldward's sake..

二

he for his tather's sake so loves...

i. 4

av, and for her sake, marlest quick.

for gonduess' sake (rep. iii. 1) .. Henry $V \overline{I I}$. (proi.)

for their poor mistress' sake

take heed, for heaven's sake, take.

to love her for her mother's suke...... =

for request'e silke only, he makes.

why then, for Venis sake, give.......

in part for his sake move

for $m y$ wounds' sake, to give ...... Co

for my sake, stay here with....... Julius Casar, iii. 2

for Brutus' snke (rep.) great Julius bleed for justice

great Julius bleed for justice salke!.. - iv. 3

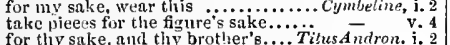

for thy sake, and thy brot!er

even firc his suke am I pitiless ........
and, for our futher's sake, and inotior's

dearly for thy mother's sake ......... - v.

for the sake of it, be manly, and talse..

the one the other porisoned for my sake
though grant fur prityer's sake... Romeo

for whose dear sake thon wast but lately $=$ iii. 3

for your sake, jewel; I am glad.......... othello, i. 3

thil.Knt.] he desires you, for love's sake

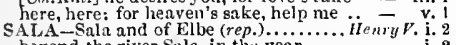
beyond the river Sala, in the year..... - i.
SALAMANDER of yours with fire... 1 inenry $I F$. iii. 3
SALARY - this is hire and salary SAlARY-this is hire and salary

to things ot sale a seller's prcise

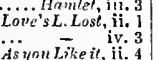

are now on sale, and at our ........

thy sale of offices, and towns......
the other is not a thing for sale

proelaims you to the for sale ....... Cymbeline, i. $\mathrm{i}$

whose sale is present death....... Romeo \&.fulief,

I saw him enter such a house of sale ... Hamlel, ii,

VAIERIO-[Kn'-SOLANIO]

but meeting with Salerio by the way

rour hand, Salerio; what's the

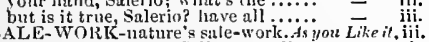

$\triangle A L I C A M-i n$ terram Salicun mulieres. Henry $\nu$. $\mathrm{i}$.

SALIQUE-the law Salique (rep.)..... -
in Saligue land (rep.).............
SALISBURY -stay yet.jord Salisbury kingJohn,

lord Bigot, and lord Salisbury
stand hiek, lorl salisbury, stand ljaek

cries out upon the name of Salishing

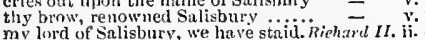

aid $S$. is oury is gone to meet the kilug - iii. 3

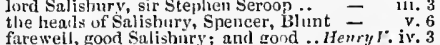

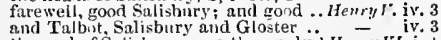

the earl of Salisbury eraveth supp

Salisbury is a desperate homicide

speak, Sulishury; ut least if thou canst

in thirteen battles Salisbury
vet livent thou. Salisbury?

if Salisbury wants merey at thy häids?

Satisbury, eleer thy spirit with this
hear, how dyiıg Salisbury doth groan nev me salisbury into his tent.

ll colishury to make his testament

would I were to die with Salisburyl

the sadishury: for thee, and for ....

Salisury, and (rop. i. 3 and i. 4$) \ldots . .$.
brave Yurk, Salisbury, and victorious

then, father Salisbury, kneel we botl

stay, Sallsbury, with the rurle multit

from the king, my lord of Sulisbury

go, Salishury, and tell them all trom me -

old salisbury, sliame to thy silver hair

of Sulisbury, who can report of him

post to Salisbury (rep.).............. Rich

who, being at Salisbury, made suit
SALLAD-pick a thousand sallads

the sweet-marjoram of the sallad

or nick a sallad another while.
salliarl was born to do me gond $(r$

and now the word sallad inust serve me

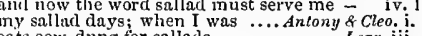

eats eow-dung for sallads.................. Lear, iij.

SALI, ND-IIBRB-not the sallad-herbs All'sWell, iv. 5

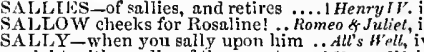

might with a sally of the very town.i Henryl.

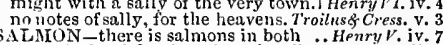

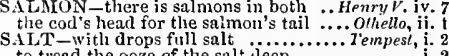

the ooze of the salt leep

it is more than the salt .......

the salt fish is an old coat .....................
we have some salt of our youth

and salt waves fresh in love!.....T.....

whose salt imagination yet ..... Meas. far Meas. $y$

not with salt tears: if' so.......Mid. N.'s Dream, ii.

now, hy the salt wave of the....... Love's $L$. Lo*l, v. 1

by the salt rheum that ran .. Comedy of Errors, ifi.
of the ravined salt sca shark............ Macbeth, iv.

the salt in them is hot $\ldots \ldots \ldots \ldots \ldots \ldots$............ King John, v.

[Col.Knt.] streams meet in one salt sea.

be made a nourish of salt tears ....... i Henrry $r$. i.

With tears as salt as sea (rop.).....2 Henry VI. iil. 2
from mine have drawn salt tears ... Richard III. i. 2

the spiee and salt that season. Troilus \& Cressida, i. 2

i. 3
with the salt of broken tears .........
make use of thy salt hours.... Timon of Athens, iv. 3

resolves the moon into salt tears
the beaclied verge of the salt flood

given up, for certain drops of salt

would make a man, a man of sait, to use. Lenr, iv.

sailing in this salt flood ........ lomeo \& Juliel, iii. 5

gone round Neptune's snlt wash

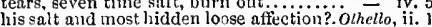

as salt as wolves in pride...............

her snit tenrs fell from her......... iv. 3 (song)
ALT-BUTTER rogue! .......... nerry kives, ii. 2

SAITER -thy tears are salter than.. Corinlanus, iv. 1

AI'TIER-call themselves saitiers. Vinter's Tale, iv. 3

SALTNESS- of saltness of time.

ALT-W ATER-with salt-water....... Tempest, ii.
already sir with salt-water ....... Ticelfh Night, ii.

notable pirate! thou salt-water thief! - v.

find us in our salt-water girdle .... Tymbeline, iii. 1
how much salt-water thrown away. Rrmeo \& Jul. ii. 3 most

speak ny salutation in their minds. Macbeth, $\mathrm{v}$. lout shouts and salutations irom ... 1 HenryIV. iii.

hath twice done salntation ........ Richard III. v.

from Goneril his mistress, salutations.... Lear, ii.

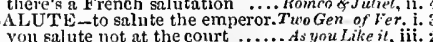

vont salute not at the court ...... As ynu Like it, iit.

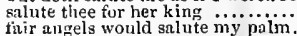

dear earth, I do salute thee with.

we do salute you (rep.) the bolder to salu te my king

Richard $J$ i. iii.

that shall solute our righ

I salnte you with this royal title.. Richard $\overline{1} 11$. iii.

saw them salute on horscback........ denry - III. i. i

it this salute lis grace salute

salutes each other with etach ... Troilus \& Cress. iii. 3

searce have leigure to salute you ....

of his fortunes he salutes thee.. An/ony \& Clen. iii. 10

the golden sun salutes the morn... Tilus Andron. ii. 1

i. 4 let us wilute him, or know what ......Pericles, ii,

i. 4 SALU'TETH-feminine saluteth us... Love's L. L. iv.

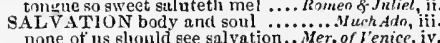

4 take it already upon their salvation... Al Henry $1 \%$, ij. 3 aet that has no relish of salvation in't... Harlet, iii. 3 that wilfully seeks her own salvation?
SALVE-no salve in the mail (rep.).. Love's L.L. take salve for l'envoy (rep.)

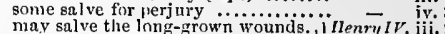
to provide a salve for any sore......3 Henry $\mathrm{Fl}$. iv. 6 you may salve so, not what is ........ Corinlanus, iti. 6 A ANPIIIRE-one that gathers samphire.. Lenr, ivg SAMPLE to the youngest ................mbelime, $i$.

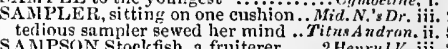
SAMPSON Stockfish, a fruiterer ....2 Henryl $V$. ii Samsoni istrong; jointerl Samson!... Love's L. Who was Samson's love, my dear Moth? -
methinks, Samson had small reason
zet Samson was so tempted

for none but Samsons and Göliasses.... Henry rI. i.

I am not Samson, nor sir Guy .... Henry hII. v. AACTA majestas! who would not..2 lleniry' $I$. y. ont of all sanctified limit.

be sanctified by the luekiest. stars in... .

no swords but what are sanctified ...2Henring $I V$. ir. 4 so helpme every spirit sanetified......... Hamlel, $\mathrm{i}$. ANCTIFIES himself with's hand... Coriolrmus, iv. with zealous feryour sanetify.... - iii. 4 (lctter) and snnctify the numbers ... Troitits \& Cressidn, jii. ANCTIMONIOUS ceremonies may ...Tempest, iv. like the sanctimonious pirate.... Meas. for Meas. i.
SANCTIMONY, she aceomplished..... All's Well, iv. be sanetimony, if sanctimony be. Troilus of Cress. $v .2$

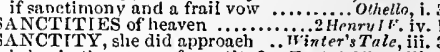
is he, iul the name of sanctity? .. Thelfinth Night, iii. as full of sanetity as the tonch of .As you Like it, iit. 4 such sanctity hath heaven given ..... Macbcth, iv. 3 my sanetity will to my sense bend no... Pericles, v. SANCTUARIZE-murder sanetualize.... - iv. we desire to raze the sanctuary... Meas. for Mlleas. ii. as quiet in hell, as in a sanctuary .... Mrtuch Adlo, ii. he took this place for sanctury.. Comedy of Err. v. my boy, we will to sanctuary ....... Richard 1ii. ii brother York, have taken sanetuary

the holy privilege of blessed sanctuary! -

you break not sanctuary in seizing him
sanctuary men; but sanctiary children

ga thou to sanetuary, and good thenghts - iv.

An -unto these yellow sands ... Tempest, i. 2 (song)

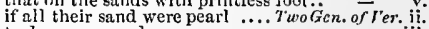

to dance on sands

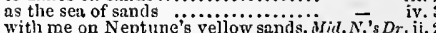
docked in sand, vailing her ..... Merch of 'fenice, are all as faise as stairs of sand ....... three nights ago on Goodwin sands ...King John, v. is numbering sands, or drinking ......Richard $n$ R turn the sinds into eloquent...........Henry $V$. jii. roeks cowered in the sinking sands.2 Henry $V$. iij.

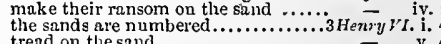
tread on the sand .................. my lord Sands, you are one $($ rep.) ... Menry
with sands that will not bear ...... Cymbeline, jii. nimbler than the sands that rin ...... - iifmueline, one sand another not more resembles
blow these sands, like Sibyl's leaves.. Tilus.t ntl. iv. now our sands are almost run.Pericles, $\nabla$. 2 (Gower) here in the sands, thee I'll rake up ...... Lear, iv. and staff, and his sandal shoon.. Hainlet, iv. 5 (song) and staff, and his sandal shoon .. Hainlet, iv. 5 (song) nlack, sir, I am sand-blind .......... SANDY-not see the sandy hour-glass. Merof t'en. i. the process of his sandy hour ...... i Herry 1 I. IV. $^{2}$

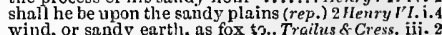
wind, or sandy earth, as fox $\$$... Trailus $\&$ Cress. iit.

SANDY-BOT'TOMED Severn ....... HenrylV. iii. the sanguine eolour of the leaves... i Henry a mole, a sanguine star; it wns...... Cymbeline, v. ye sanguine, shallow-hearted boys!... Titus And. iv. ANITY-renson and sanity conld not.. Hamlel, ii. 2 I do, sans question ...................... sans crack or faw. Sans sans, I pray you Like it, ii. 7 sans teeth, sairs eyes, sans taste, sans
sans fuble, she herself reviled .. Comedy of $\bar{E} r$ r. iv. 7 come, come; sans compliment ....... King John, v. 6 sans clieck, to good and bad.. Troitus \& Cressida, i. nnd mince it sans remorse ...T Timon of Alhens, iv. sane of sense, sans witeheraft could not.. O/hello, i. 3

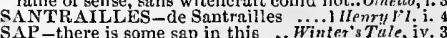
infect thy sap, and live on thy .. Comedy af Err. ii. infect thy sap, and live on thy ... Comedy af Err. ii.
over proud with sap and blood .... Richarl II. iii. 


\section{SAP}

SAP-leaves, that want their sap? .. Richard $11 \%$ ii. 2 SATISFICD-be bet ter satisfied . did druin the purple sap from........ - - iv. 4 it with the sill drink the sap............. i. 2 by the confux of meeting sap. Troiluz \& Cressida, i. 3 there's sap in't yet .............. Antony \& Cleo. iii. il disbrancl from lier muterial sap......... Lear, iv. 2 SAP-CONSU AING winter's drizzled.Com, of thr. v. SAPLENT, sir, sit here: now you

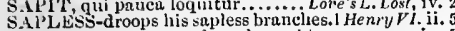
SAheu sapiess age, and wenk unable.

SAl'LING - like a blasted supling... Kichar I 111 iil.

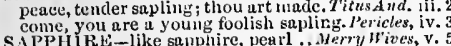
SAPPHIRE-like sapphire, pearl ...Merry Irives, v. 5 SARACLN Turks, aud Strucens ... Richard 11. iv. SARACEN - Turks, and saracens . . Kichard $W$. ii. SARDIANS-here of the Sardians.. Julius Cresar, iv. 3 SARDINIA-ot Sieily, Sardinia...Antony \& Cleo. ii. th eurning from Sardis, on our former

nt Sardis, once; and, this last night.. - vear 5
S.IRUMI-if I had you upon Sarum plain.. Leer, ii. 2
. SAT-I have sat in the stocks...Tro Gen. of 'er.iv. 4
when as I sat in Pabylon ... Merry Wives, iit. 1 ( (song)

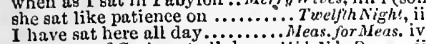
the shape of Corin sat all day......Hid.N.'s Dream, and sat with me on Neptune's ......

since once I sat upon a promontory...

and you sat smiling at his cruel prey, $\overrightarrow{\text { ii. } 3}$ patience have I sat, to see ...... Love's L. L.ost, iv. 3 if thou hast not sat as I do now ...
sat at any good man's feast (rep.)

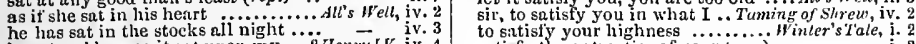

till sutisfied that fair queen Lsabel ..... Menry $V$. i. my suul slaall then be sutisfied yet, so my fancy may be satisficed .... and uc'er be satisfict? (rep.) ......... I am satis. dear God, with our. not there at once and tully satisfied. Henry ${ }^{\prime} / 1 I$. ii. 4 to suy how far you satisfied me
have satisfied the king for his di

second voice we'll not be satisfiet. Trnilus \& Cress. ii. 3 without cause will he be satistied Julius

he shall be sutisfied; und, by ny honour
the son of Cresar you should be satisfied

we will be satisfied; let us be satisfied

if he be at hand, I shall be satisfed

In further yet you will be satisfied........

one rhyme, and I am satisfied.... Ro
let me be satisfied, is't good or bricl?

as dearly as mine uwn, be satisfied

whit be satisficd. Indced, I never (rep.) - jii. 5

how may the duke be therewith satisfied.. Othelln, i.2

would, I were satisfied! ( $r p p$.) W..........

in.the interim, came in, and satisfied him - v. 2 SA'TISFIES-most sle satisfies ....Antony \&

let us satisfy our eyes.............. Twerry Hives, iv Night, iit. 3

do not satisfy your resolution........... for Meas. iii. 1

and yet, to satisfy this good old man...Nuch Ado, y.

satisty me so...................... Love's L. Lost, ii. I

how troublesonie it sat upon my ...̈ Henry $I V$ iv. 4 as if allegiance in their bosoms sat..

sir, to satisfy you in what I .. Tuming of Shrew, iv. 2

satisfy the entreuties of your (rep.) .
shall satisfy your father. Happy be you - i. 2
iv. 3

to satist'y my remembrance........... Kacbelh,

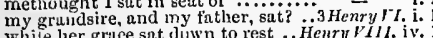

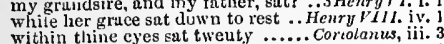

Whave sathe cyes

and satisty the poor woman

partly, to satisfy my opinion

young Kutland could not satisfy ...3 Henry $1 \cdot$. $I$. ii.

there have sat the live-long day .....Julius Cosar, i.

at the feet, sat Casarion, whom

Pillicock sat on Pillicock's bill............. Lear, iii. I

sat me down; devised a new commission. Humlet, v.
the poor soul sat sighing by .... Othello, iv. 3 (song)

SATAN-as slanderous as Satan? ... Merry Wives, v.

play at cherry -pit with sat

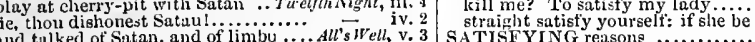

that is enough to satisfy the senate.Julius Cresar, ii.

my letters before did satisfy you... Antony\& Cleo.

will this description satisfy him

satisfy me home, what is becom

let them satisfy their lust on thee.
kill me? To satisfy my lady $\ldots \ldots .$.

Sutan, avoid! I charge thee (rep.).Com. of Err. iv.3 I clurge thee Sitim, housed wath.. i Henry $I V$.

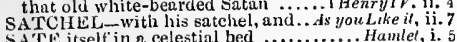

SATE itself in $n$ celestial bed $\ldots \ldots \ldots \ldots \ldots$ Hamlet, i. 5 SATIATE yet unsatisfied desir.

SATIETY seeks to quench ......... Taming of Sh. i. 1

a mere satiety of cummendations... Timon of dth

SATLN-of peach-coloured sutwi..Meas. for Meas.
Dumbleton about the satin for iny ..2 Henry 1 ,

two and twenty yards of sat

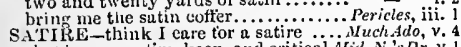
that is some sutire, keen, and critical irid. $N$.'s $D r$ r. a satire against the suttiless u
SATIRIC $L$ rogue says liere

S.IIS quod sutticit.................

SATS aCION at her hands?... Merry Wives,

we may suon our sutistaction have. Meas. for dieas. i. 1

the satssfuction 1 would require
give him promise of satisfaction

give him promise of satista

v. 2 (note)

and no satisfaction, no revenge... Mer. af Fenice, iij. I she ceased, in heavy satistaction ........ Alter's The, present satistaction, or Ill at ach. Comedy of Err.iv.1 to give me ample satisfiuetion fur
we shall inuke full satistaction.

make any pussible satistaction ....2 Henry $\overline{I V}$. (cpil.) king Lewis his satisfaction, all appenr . lienry $V$.i. 2
fur the satistaction, look you, of ny mind - jii. 2 fur the satistuetion, look you, of my mind
but a weak and worthless satisfaction

but a weak and worthless satisfaction
how eanst thou make me satislution

it you seek for further satisfying........... FTURDAY we will return to ... Love's $L$.

A'TURN-born under Suturn.
Saturn and Venus this year in
well have warmed old Saturn

to. Saturn, Caius, not to Saturnine..... -

proud Saturnine, interrupter or the good

long live our emperor Saturnine!

to make a stale of, but Saturnine?....

sent by the heavens for prince Saturnive

receive him then to favour. Saturnine

that will charm Rome's Saturuine
revenged on Rome and Saturnine.

or slunk not Saturnine, as Turquin ers

vengeunce on the traitor Saturnine

my gracions lord, iny lovely Saturnine

ay, and as good as Saturninus may ...

make proud saturninus and his empress

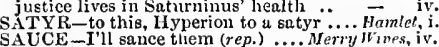
no sauce that can be devised to it......Mhuch tho, jv. 1

is to have honey a sauce to sugar.
I'll sauce her witl bitter words.

the sauce to meat is ceremony.
would be as a sauce to make me...

Would be as a sauce to make me.
$a$ eapon $2 s .2 d$. Snuce, $4 d$......

come, there is sauee for it
morc satee to your leek?

no other satisfaction do I crave...... Henry $\nu l$. ii.

$U$ worthy satisfaction! ..... Troilus \& Cressida, ii.

for your private satisfaction........ Julius Casar, ii.

dogl I give him satislaction?......... Cymbeline, ii. t

stifl pretending the satisfaction of her - v.
let hnt make treble satisfaction..7'itus Andron. v.

auricular assurunce have your satisfaetion. Lear, i.

what satisfaction canst thou have. Romeo \& Juliet, ii. 2
that we call uurs, to you in satisfaction. Hamtel, iv. 5

that we call uurs, to you in satisfaction. Hamter, iv. 5

but tur a satistaction of my trought...... - iii. 3

give you aatistaction, you may lave it .. - iii. 3

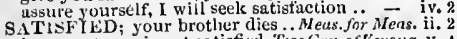
by repentunce is not satisficd. TwoGen.of Verona, v. 4 I camot be thus satistied..............erry I'ives, ii. I isell satisfied; and 1 (rep.).....Merch. of Venice, i You are not satisfied of these eventy... as you shall well be gatisfied.. Taming of Shrew, iti.

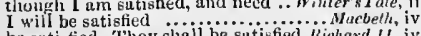
sauce his palate witli thy

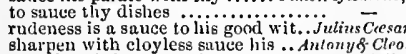
sweeting; it is a most shary suuce. Rnoneo \& Julio, ii.

his folly sauced with discretion... Troilus \& Cress. i.

and sanced our broths, as Juno had...Cymbetine, iv. 2

SAUCLRS-let her out in sauecrs .. Love's L. Lost, iv.

displayed so saucily ayninst your ..... King - John
SAUCINESS, and boyisla troops $\ldots \ldots$. he thinks is a patent for his sauciness. All's well, sauciness will jest upon my love. Comedy of Err
impudent sauciness trom you (rep.)..2 Heary $1 \mathrm{~V}$. noble lord be rated for sancincss. Titus Autron.

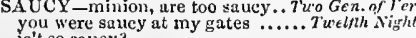

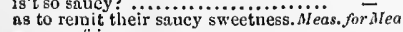
a saucy friar, a very ecurvy

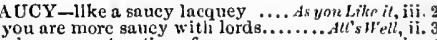

you are more saucy with lords................

bound in to sauey doubts and fenrs .. Morbeth, iii. beldams, as you are, faney, and overbolel? - iij. against these saucy walls............. king John, ii. barking of your saucy tongic.....

you are a saucy tellow

where's then the saucy boat ... Troilus $\&$. Cisssida, $\mathrm{i}$

thou sancy fellow? (rep.

shonid I find them so saircy....

hance, suncy emuch lictors will cateh at us

a saucy stranger, in his court

saucy too blunt, and saucy.............. A $\overline{\text { Titus }}$. v.

dotli affect a saucy roughness ............ Lear, ii.

whint saucy merclant was this?.......

have done you bold and saucy wrongs .. O/hello, i.

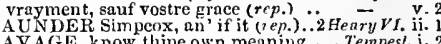

put trieks upon us with savages ..... Tempest, ii. 2

a savage jcalonsy that sometimes. Twelfh Night, v.

that rage in savage sensuality......... ${ }_{\text {a rude and savage man of } 1 \text {. }}$ oste iv.

his lines would ravish savage ears ... - iv.

savage eyes turned to a morlest ......... or of tenice, v. yield any thing suvage, I will ....As zou Like it, ii. 6 a savage clamour? wcll may $\mathbf{1}$... Min/er's Tale, iii. tame the savage spirit of wild .............ning John, v. savage, and inhuman creature

put in wild and savage stock.....

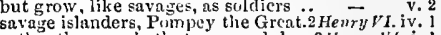
rather than made that savage duke. 3Hemry ${ }^{\prime} l$. i. I where his raging cye, or savage heart

here tend the savage strangenes. Troilus \& Cress. ii. fie, savage, fie! Hector, thien 'tis wars - vimon of $A / h$. were this a savage spectacle ....Jnilius Carsar. iii. for I have savage causc.............. 'tis some savage hold: I were best... Cymbeline, iii. 6 ghe should have bcen, by savage cieon. Pericles, v. by and by, breaks out to savage mariness othello,iv. 1 SAVAGELY-babes, savagely slanghtered. Mach. iv.
SAVAGENESS ir, unrecluimed blugd castmg their savageness aside .... W'inler's 7 nle, ii. She will sing the savageness out of a bear! Ghello, iv.
SAVAGERY - the wildest savagery...King Jnhr, iv. SAVAGE-WIID; more ferce.... . Romeo \& Juliet, v. 3 SAVE-[sec-GOD]
save fur the son that she did ..........Tempest, i. 2 true; save means to
save his najesty!...

save from my glass, mine own

save our graces!

to snye your ship from wreck......... Her ry "lives, i.

by gar, he has save his soul...

save you, master (rep. iii. 1)..........

a thousand thousand sirlis to snve - ii 4 (son

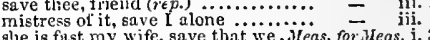

sle is fast my wife, save thit we...ieas, for.Meas. i. 3
this gentleman, whom I would save

bave your honourt (rep.) $\ldots \ldots \ldots \ldots$ -

no earthly mean to save hin

as, to save a head, to cleave...

no word to save tlice ................

to save me from the clanger............

save that his riotous youth .......... - iv.

labouring to save his life $\ldots \ldots \ldots \ldots$. $\ldots$.

save this of liers, tramed lify thy villany -

nnd partly to save your life...........'s - pream, iii.

ever worl, save base authority

a wild of nothing, save of joy

many men to save their gifte

or. of renice, iiii. 2

save $y^{*} 0 u$, fair queen

sense saves another way ........... = ii. 1

as I would have had it, save, that he $=$ = iii.

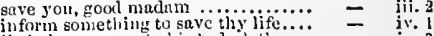

little liarm, save to his bed-clotjics...
shull lia't; save your word ......... iv. 3
y. 2

to sure my life (rep.).......... Taning of Shrew i.

to suve both, farcwell, our brotlier.'inter's Tale, i. 2

and save your thanks: how save you?
to save this bastard's life (rep.)......
to save the innoecult: any thing $\ldots$ i.

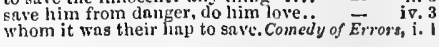




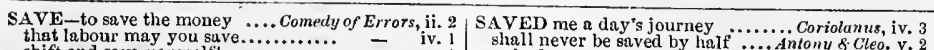
hift and save yourself!

deep sears to save thy life.

I see a friend will save my life

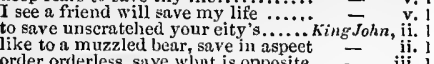

order orderless, suve whint is opposite

o save me, Inuhert, snve mel my eyes - iv.

as grief, save bidlding farewell to.....

husband he is gone tu suye far off.

no sign, save men's opiniu

bequeath, save our deposed bodies

no, if a seot would save his soul

to save our herds hy raising of .....

to save the blood ou eitlier side...

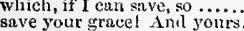

save you, sir John! Welcome.

and heaven save your majestyl...

sove, that there was not

save ceremony, save general ceremony?

he prays you to save his life

save the phrase is a little variation.

what thou canst to save our lion
to save myself by flight (rep.)

to save a paltry lite, and slay

the swan her downy eygnets save....

to save your subjects from

if you mean to save yoursel
to save his life, the common

yet relent, and save my lite.

thy priesthool saves thy life

to save at least the heir .............
fly, lords, and save yourselves

fy, lords, and save yourselve

save that, for reverence to some alive
to save her life, I'll say she is not so

to save her life, I'll say she is not

and save me so much talking

I'll save you that labour, sir

save such as do revolve ......

save these men's looks ...................

gave thee, Tinnon. Now, thieves.. Tim

but all, save thee, I tell with eurses.
tis not to save labour, nor that...

not one amongst us, save yourself

save you, sir. And you. Direct

did tend to save the Romans

sir, if you'd save your life, fly to

every plaee, save here in Italy

ali the eunspirators, save only he...

save when command to your........... Cymbeline, ii. 3

nuthing saves the wager you have...

never bestrid a horse, save oue

from the troops, and save thy'seif...

may save, but to look baek in frown

the whule world sliall not save him.

all o'erjoyed, save these in bonds.

to save yuur brother from the

save thou the ehild (rep. v. I) $\ldots . . .$.
to save my boy, to nourish, and brin

to save my boy, to nourish, and bring

save that [Col.Knt.-'say'd yet] (rep.)

and save poor me, the weaker

sall feeling else, save what beats there

eouldst thou save nothing? didst thou

this save $\left[\mathrm{K} n l_{\text {, }}\right.$-sir] reverence love Romeo \& Juliet, $\mathrm{j}$.

good thou, save me a pieee of ma

sudit stauds, who knows, save heaven? Hamlet, iii. 3

save me, and hover o'er me with your

can save the thing lord; the oee

save that, they say, the warrs must ...... Öhello, iii. 3

that I may save my speech: do but....................

for you, mistress,

for you, mistres, save you your labour.. $\overline{\text { ver }}$.
AVED-saved from drowning. T'u Gene of
that you yourself are saved ...... T'uelfih Night, i.

and that poor number saved with you
you might have saved me my pains

that means to be saved by believing

that honour, saved, may upon asking
by this, is your brother saved... Neas.

by this, is your brother saved .. Neas,

a

my beauty will be saved by merit. Love's L. Lost, iv.

I shall be saved by my husband. Her. of Venice, iii.

liis youttiful hose well saved

thau hast not saved one drop.

All's $\bar{W}_{\text {ell }}$, iv. 3

if men were to be saved by merit.

thou hast saved me a thousand....

better part. I have saved my life of $=\quad \begin{gathered}\text { v. } \\ \text { v. }\end{gathered}$

and a many poor men's lives saved . Henry $V$. iv. 1 all these are saved, if thou ............

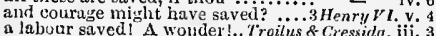
you have saved my longing.... Timon of Alhens, i. I so had you saved the noble Imogen.. Cymbeline, $v$. I honours to have saved their careases? begged for him, saved him from despair... Lear, v. 3 and there be souls must not be saved .. Oolhello, ii. the lieuterant is to And so do I too

ho, as I shall be savel. Is it possible?

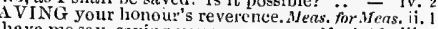

have me say, saving your reverenee...Ifuch ddo, iit.

saving your tale; Petruchio

saving yuur merry lmumour.. Com

saving his dialogue of compliment .. King John iv.

saving your majesty's manhoud.

Hew? $\mathrm{Hen} \mathrm{V}$.

whieh gifts (saving your mineing). Henry 1 rII.ii. 3

I swore thee, saving of thy life

saving reverenee of the wurd

mbeline, iv.

AVORY, marjoram

..Wvint

that

this savours not mueh of distraetion

those freekles live their savours Mid.N.

seeking sweet savours from this häeful - iii.

I sinell surect savours... Taming of Sh. 2 (induction) something savours of tyranny ........

savours of a slanghter-house.........

you savour too much of your yout

[Knt.] who, not used to hunger's savour $P$

tilths savour but themselves savour vilely - iv. 6

SAVOURING of wit, poetry ................ Leare's iv. Lost, iy. 2
SAVUURY-what's homely, savoury. Cymteline, ii. 6

to make the matter savoliry .............IIamlel, ii.

AVOY-and putl down the Savoy ..21henry $/ 1$.

supposing that they saw the king's....

this is the third man that e'er I saw..

I saw him beat the surges

the very instant that I saw you......

if $\{$ should say, I saw sueh islanders...

and since I saw the

since I saw you last.

saw you my master?

you never saw her sinee ...........

which of you saw sir E'glamour.

saw you my daughte

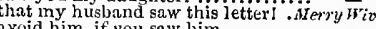

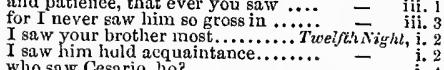

(

I saw him put down the other day ...

I Iaw thee late at the eount Or.........

I think I saw your wisdom there.

marly, I saw your niece

a couplet or two of most sage saws

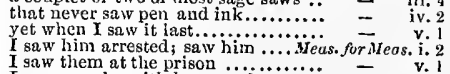

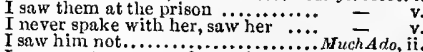

I never yet saw man, liow wise........... - iit.

shame her with wholn, saw afar off

I saw the duchess of Milan's gown

God saw him when he was hid......;

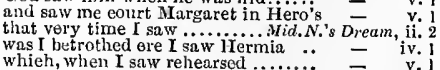

whieh, when I saw rehearsed ........

ton little of that good I saw, is my

that all eyes saw his eyes enehanted

he eame, saw, and overeame (rep.) - iv. I letter)

saw sighs reek from you

my lord Biron, before I saw you.

coughing drowns the parson's saw $\cdots-\overline{v .2}$ (song)

I saw Bassanio (rep

you saw the nistress, $i$ beheld the

and saw the lion's shadow ere himseif

betore ever he saw those pancakes... As

possible, that no man saw them?

of her chamber, saw her a-bed .......

full of wise saws and moderl........

who you saw sitting by me.

now t tind thy saw of might $\ldots \ldots . . .$.

the ferst time that $I$ ever saw him . that he is (saving your reverence)

and patienee, that ever you saw

in Normaudy sow I this........... Love's L. Lost, if.
AW-methought you saw a serpent ...All's Well, i. 3 I saw upon lier fillger ................

she never saw it........................

I saw the man to-day, if man one ... $-v$ v.

never were, nor no man ever saw. Tam. of sh. 2 (ind.)

sawes, I silw sweet benuty in her ...

'Tranio, I saw her corul lips to move

and sweet, was all I saw in her......

if they saw some trundrous mon
I never saw a hetter fashioned

you saw my master wink and laugh

ancl saw rnyself unbreeched ..........ivin

I saw his heart in his fuce

lnever saw I men seour so on .........

I never saw the heavens so dim......

sinee I saw my country....

three days since I suw thie prince....

never saw I wretches so quake....

We saw not that which ny daufinter

for what sher, as thought, dead

I never saw her till this time. . Comedy of $\overline{E r}$

faith, $I$ saw it not; but $I$ felt it...

you raw, they speok his finger

God he knows, I saw not

these people saw the chain about .....
I never caw the ehain, so help

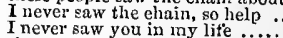

I never saw my last..

I never saw my father in

spoke with one that saw him die........ Mavere

if I stand hou the weird sisters?

for that I saw the tyrant's power

I saw a smith stand with .................

that never saw the giant world..........

two days since I saw the prinee...

faith, I ran when I saw otliers $\mathrm{xun}$

I saw young FIarry, with

I did, I saw him dead, breathiess...

when he saw the fortune of the....

how is this derived? saw you

I saw him break Skogan's head ....

never saw him but once in the .....

he saw me, and yielded...............

who saw the duke of Clarence?.....
for after I saw him fumble

a' saw a flea stiek upon Bardolpli's.

never anybody saw it, but his .........

who ever saw the like?

till now we never saw your faee .....

holy saws of sacred writ; his study

I saw not better sport these seven....

I man, that ne'er saw in his life before

struek those that I never baw.....

King John, iv. 5

Richard II. v.

二 iv.

2 Henry $I V$.

I saw him in the battle range ........3 3 Henry $V I$. ii.

queen Narraret say thy murderous. Rich - ii.

saw you the king to-day, my lord of

since last I saw him

I saw good strawberries in your...........

not live long after I saw Riehmond..

who saw the sun to-day? ............

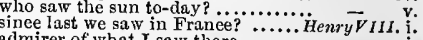

then present, saw them salute

'twas said, they saw but one

I saw well ehosen ridden before ..... i.

or sorry, as I saw it inclined........

every eye saw them, envy and base...
saw you the eardinal?

vou saw the ceremany?

suel joy I never sa w befo.

saw ye none enter, since I slept? $(r e p$.

ay, if I ever saw him before

he ne'er saw three and twenty

we saw him at the opening of his.....

sinee first I saw yourself and Diomed

I saw them speak together..... Timon of $\overline{\text { tulhems. }}$ iv.

I saw him run after a gilded ........ Coriolanus, i.

I saw our party to their trenches ....

there's a letter for you; saw it........

nith all praise I point at, saw lim fight
no; no man saw 'em. Ile said........

saw you Aufidius? On safe-guard hë $^{\circ}=$

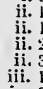

more beard, when I last saw you ... - iv.

$\begin{array}{ll}\text { ii. } 7 & \text { first uny wedded mistress saw bestride } \\ \text { iii. a } & \text { you saw his chariot but appear.... Jutius Cresor, } \\ \text { iii. } & \text { I saw Nlark Antony ofter him }\end{array}$

why, saw you auy thing more.

they saw men, ull in fire, walk .......

she dreamt to-niglit sle saw my statua - 

SAW-noble Casar saw him stub . Julius

saw you my lord? No, lady

I saw the treasons pinted

there saw you labouring for hini....

since I saw you last, there is a ehange

mul saw her led between her brother

I never saw an action of such slane

for when sle saw, (which never slu

never saw I figures so likcly

carve, and sinw, und overcune....

I saw him not these many

long is it since I saw him ............

whnse face 1 uever saw

I never saw one so prone.........

I never saw sueli noble

but we saw him dead $\ldots \ldots \ldots \ldots \ldots$
dismal'st day is this, thit er i saw...
low many women saw this child $(r e p$.

when I saw the porpus
I never saw so huge a billow,

I never saw so huge a billow, cir ....

I saw you lately; when you cn
when saw you my fathir last?

when he saw my best alarumed.......

that must approve the common saw

I stumbled when I saw

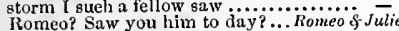

ne'er saw her match, sinee first ( $r e p$.)

for I ne'er saw true beanty till
for the world, they saw thee her

I saw no man nee you at his ........

I saw the wound, 1 saw it with"

that e'er time saw in lasting ........

I saw her laid low in her kindred's..

I saw him once, he wils a gooilly king

thel suw you not his fuee

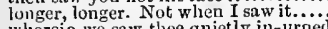

wherein we saw thee quietly in-urned

all saws of books, all forms oi...........

I saw him enter sueh a house of sale

since I saw thee last (rep.)

nor do not saw the air too mueh with......

8:tilors, niy lord, they say: I saw the

I saw it not, thought it not..........

I naw it not, thourstitis before

thongh I slould swear $I$ saw it

but then I saw no harm...........

I saw my handkerchiet in

S.AWED into quantities

never saw'st good manners ( $t$ ep.). ...... "I'empest, i.

what did he, when thou saw'st him? -1 iii.

saw'st thou not, boy, how ... Taming of Sh. I (indluc.)

saw'st thou the prinee Florizel .. Winler's Tale, i
saw'st thou him enter at...... Comedy of Errars,

saw'st thou him enter at.... . Comedy of Errars,
since thou saw'st thine own knee? .. IIenry I'.

since thou saw'st thine ow n knee?...R Renry lii.

and say, thou saw'st me not ...

thou saw'st them, when I had ...... - iv. 3

and trimmed her as thou saw'st .. Tilusandron. v.

S.AXONY-duke of Saxony's neplew. Mer. of I'enice, i.

I say or of our way, 1 say

say, how thou liast disposed

Tempest, $\mathrm{i}$.

dull thing. I say so .................

eome forth, I say ...................

and say, what thou see st yond

wonld it not say, he lies?

what is it thou didst say?

pr'ythee, say on........................

say, this were death that now ........

any bisiness that we say befits the hour -

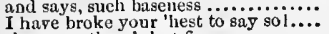

they say, there's but five.

I say, by sorcery he got this isie.......

didst thou not say, he lied?

I say to-nights: no more..............

in what thou hadst to say.............

before you ean say, come and

say again, where didst thou ...........

I did say so, whien first

say, my spirit, llow fures .............

patienee says, it is past her cure...

and say how thou cal

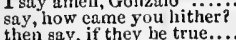

yet writers say (rep.) ........

... Tuo Gen. of Veron

i say shie did nod (rep.)

bay, trom whom? (rep.)

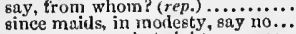

vou may say whiat sights you see......

what say you to a letter ......

they say, that love hath not

and the hostess say ..........

if he say ay, it will (rep 1 say to thee

whatever slie doth sa

whatever she doth say .............

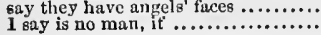

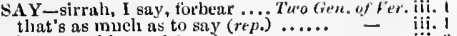
but say, this weed (rep.)

gay ay, and be the captain

say, thint she be..........

I have heard thee any...................

out with the dor, say's ore $(r e p)$.
ant whit says slie to my (rep.)

a way, I say stay'st thou to..........

what say's silvia to my suit? (rep.)...

now I dare nut suy I liave

I heard eay he was out-run............

slice, I say! patrea pauca.

I will say, marry trap ..................

for my part, I say, the gentleman...

was, as they say, cashiered

what says my bully-rook

and, to tory boy, say

how say you? 01 should

Joln, what Joln, I say!

what should i say to him?

yet, I say, I conld show.

eavalero-justice, I say

well on : Mistress Ford, you say.

your worship says very true $\ldots \ldots . .$. .

but what says she

why, you say well ...................

let tren say, 'tis grussly done.

iet then say, 'tis throssly done .......

some say, that though she appear......

what sap you to't, sir John?

I say, I shall be witl her betwe

they say, the jealous wittolly

who says, this is improvident jealousy

what eays my Asculapius

what say you to young master Fenton? =

thou art a traitor to say so

and, say thou art this and that......

thou might'st as well say, I love...

Bardolph, I say-Here, sir

my hushand says, my son profits

why, wife I say

empty the basket, i say.

let them say of me, as jealous.

you sny, he hath been thrown

what says she, I pray sir? (rep.).....................

go; say the wonian told me so....
inay i be so bold to say so, sir?
do not say, they be fled ...........

long enough to say my prayers.

they say, there is divinity in odd.....

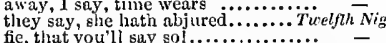

fie, that you'll suy sol................

say, I do speak witl her

that say, thou art a man you be bold to say

for what says Quinapalus?

therefore, I say again, take lier

that's as much as to say, I wear

give me fiaith, say 1 ...........

I can say little more than i

have $y$ ou no more

faith, so they say . ...................

say, that some lady, as perhaps

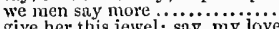

peace, I say

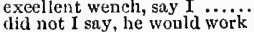

nay, but say true, does it........

so thou may'st say the king.

I might say, element

east thy humble slough, says sine...

do you know what you say?

for more than I'll say.

get him to say his prayers........

0 , say so, and so be!

as to say, a eareful man

what hoa, I say, peace in this (rep.).

advise yoth what you say $\ldots \ldots \ldots \ldots .$.
what say you, sir? (rep.iv. 3 and $\mathrm{v}$. i)

but as yon say, let your.

nnd say-thrice weleome $\dddot{2}$ the........

or sav, tis not your seal

you ean suly none of this .....................

call hither, I say, bid come..............

nay, not as one wouli say,

was, as they say, plueked down.........

I say, sir, I will flutest (rep.)

eonstable wlat say you to it?

come to pass, siby, lompey toli
AY - to hin, I say ........ Heasnre for

ean speak against the thing I Euy.
as for you, say what you cant .........

what says any brother?

say to thyselt, - from their

go; say I sent thee thither
some say, he is with (rep.)

I say to thee again (rep.)
say tlut I said so; firewel

little have y'ou to say

puinting sir, I lave hen

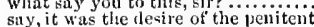

if you liave anything to say to me

may, by this token, 1 desire his

but they say, the duke will.

he says, to veil full purpose.

what would you say?
and say by whose advice thion

and say by whose ardvice thou

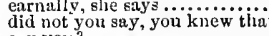

say you? .........................

hold up your liands, say nothing

they say, best men are inoulded..

and say you will be mine............

says nothing... ATuch $\bar{A} d 0$,

and say, get you to heaven, Bentrice

look sweetly, and say nothing .......

I may say so, when I please (rep.)

I say my prayers aloud

by my faith, you say honestiy $\ldots \ldots . . . .$.

your grace may well say 1 have lost $_{\text {it }}$

and all grace say anen to

for I have heard my daughter say

sn your daughter says: shall I, says she -

I measure him, says she

iny daughter says so

and hear what he will say $\ldots$

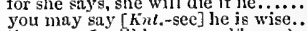

Jou may say [Knt.-see] he is wise...

that's as much as to say, any pains..

so says the prince, and my new-trothed

tell her of it; near what she will say

so say $\mathbf{1}$; methinks (rep.) ...............

as much as to say, the sweet youth's

I could say she were worse; think you

so will you say, when you have seen

you may say, they are not the men..

tush! I may as well say, the fool's ..

your eousin will say so....

O, that exceeds, they say............

I think, you would have me say

it pleases your worship to say so
fain know what you have to say

as they suy, when the age is in ......

say; it' I have known her, you'll say

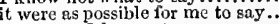

that says, 1 love not you

I must say, she is dead ........

marry, sir, we say we are none

what heard you him say else?

Isay, thou hast belied mine innocent

most euriously, say, ny knite's naught

true, says she, a fine (rp.) .........

they say he wears a key in his ear

what say you Hermia? be advised... is

Puter Quinee, say what the ptay

that I will make the duke say

if Hermia meant to say, Iy'sander ..

do not say so, Lysander, say not so.

and reason says you are the worthie

and let the prologue seem to say (rep.)

what suy you. Bottom?

to say, to swear, I love tliee.

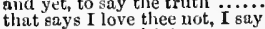

if thou say so, withulaw

in earnest, shall $\mathbf{I}$ say?

and know not what to say ............

or say, sweet love, what the forester

1 cannot truly say how I

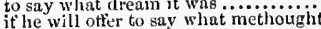

you must sny, paragon .............

say, what abridgment have you ....

he says, thiey can do nothing

all that I liave to kay is.

I ema but say" their protestation ....... Love's $\bar{L}$. Lost,

let ine say, no (rep.) $\ldots \ldots \ldots \ldots \ldots \ldots . .$.
wetl, say 1 an; why shouli wroud ...

for thint angel knowled ge you ean sny

whith saly youl, lords? why, this was

but if he say it is so, he is............
with this I passion to say wherewith - i. I (let.) 


\section{SAY}

SAY-sirral,, what say you to this?.. Love's L. Lost, i. I SAY-though I say I am n magician. As you Like il, v. 2 SAY-be but about to say (rep.).... Winter's Tale, ii. I

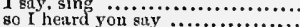

and therefore, I will say nothing................

they say so most, that most his........ my why that he, or wr.

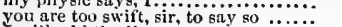

Will add the l'envoy; say the ino...

first praise me, and again, say, no?

a mark, says my ladvl

but. onne beme, say I (rep.)....

somic say. a sore; but

as Hornce says in lis.

so said, and so say I

ah mel says one; O Jovet

what will Biron say, when

say, can you fast?

, should say, doub

nt the fingers' ends, as they say.

bay, none so fit as to present.

what would they, say they?

slie says you havc it, and you may (rep.) -

say y'ou so? frir lord .........

I say, they shall not come............
if your ladyship would say, thanks..

your nose says, no, you are not

prepare, I say :-I thank you

no words that smooth-faced wooers say =

what says Maria?.................

yon say, it wearies you.

Ierchant oflenice,

and leap, and say, you are merry....

When sliall we laugh? say when? ..

as o should say (rep. i. 2)

how say you by the French lord.......

what say you then to Faulconbridge

say notling to hin

and you say, slinlock, directly ......

what should I say? slionld I not say

whispering humbleness, say this

I say. to buy his favour, I extend...

my conseience says, no

vin! says the fiend $(r e p$.$) ...$

his father, though I say it

or as you would say, in pla

as one wonld say, to serve ...........

and sigh, and say, amen; use all .....

why, Jessica, I say! ............

before me, sirralı; say, I will come...

what says that tool of Hagar's off sprin

what says the golden chest? hat

thou wilt say anon, he is some

as they say, if my gossip report

I say my daughter is my flesh and biood -

mine own, I would say; but if mine
then be bold to say, Bassanio's dcad

my husband, Launcelot, what you say

good sweet, say thy opinion,

but, say, it is my humour..

sliall I say to you, let them he free.

ay, so he says. Do you confess.
ay, his breast; so says tlie bond

merchant, have you any thing to say?

say, how I loved you, spenk m

in which predicament, I say, thou

what dost thou say? I am content

what should I say, sweet lady?.......

let me go, I say.

they say, he is already (rep.

say what thou canst, I'll go

I smile, and say, this is no flattery...

peace, I say; good even to you, friend

when that I say, the city-womp.

come in, and say, that $I$ mean he

that says, his bravery is not on

but forbear, I say; he dies ......

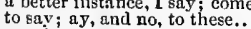

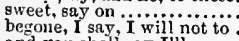

and you shali say rll prove .......

say, that you love me not; but say not

they say you are a melancholy...

good to be sad, and say nothing

what would $y$ on say to me now

I take some joy to say you are

sny, sister? Pray thee, marry us (rep.)

then you must say, I take the

say a day, without the ever.....
he might say, wit whither wilt

marry, to say, she came to seek.

how say you now? is it not past

I say, she never did in .......

and say this to her; that if she

but asy with me, I love Aliena; say

hut say with me, I love Aliena; say
Insomuch, I say, I know yon are ... now oft did you say, his beard

he would a, sny thy prayers............An's $w^{-}$

for they you of this gentlewoman?

I say, I any your mother (rep.)

to say, thou dost not; thereiore teli..

cry you loud, I say, farewell ........
they sav, our Frcich lack language

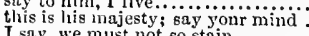

kiss his liand, and say nothing....

to say precisely, were not for

have you, I say, an answe

so I say. That gave him out $(\mathrm{rep}$.

you saly well; so would I have (rep.)

that I may say in the default...

as rou say, why, I bay nothing (rep.)

nor dare I say, 'tis miny

therefore dare not say what $\mathrm{I}$ think.

for ever gone. Do not say so

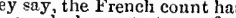

but, you say, she's honem for

what shall I say I have done?

and say, I got them in exploit

and to say, it was in stratagem

my clothes, and say I was stripped ...

then recover: say, thou art mine

could not be her office to say, is come

he can sny nothing of me

what will you say withont em?....

the duke is stron sav no more

I will say true, or thereabouts

poor rogues I pray you say

a dumb innoect that could not sa....

and say, a soldier, Dian, told thee -

but little more to say, sir, to his honesty

what say yon to his expertness in...

and, as he says, is mndded withal.

ii. 2 this I must say, -but first I...............

ii. 2 I blush to say it, he won me ....... v, 3 (petition)

ii. 2 unless thou can'st say they are

ii. 2 this ring, you say was yours?

this it says, when from my ...........

say, what is it your honour (rep.) ... - induc.)

if she say $I$ am not fourteen pence...

say, thou wilt walk (rep.) ..........

they say, that I have dreamed.

I say a husband. I say, a devil ........

how say you, signor Glemio?

bene troyato may $\mathrm{I}$........

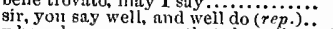

when she comes; say, that she rail (rep.) -

I know not what to sny

amen, say we; we will be witnesses

say, signor Gremio, what

didst says Lucentio to this ( $r$.

didst thou not say he comes?

let all the world say no, I'll $\dddot{k}$ eep

a bridegroom, say you? ...............

and sooth to say, in countennnce

as who should say, if I slould sleep

how say you to a fat tipe...

have endured me say my mind

I say unto thee, I bid thean maste.

this is true that I say

it shall be what o' clock I say it

pardon me in what I have to say

I say, it is the moon that

say as he says, or we shall never go

go his mother says, and I may believe

I sny, he shall go to prison $\ldots . . . .$. .

then thou wert best say, that $\mathbf{I}$

a hasty-witted body would say

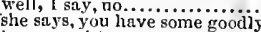

to your mistress; say (rep.)

I know not what to say............... Winter's Tale, $\mathrm{i}$.

say this to him, he's beat from

but let him say so then

ghmild yet say, sir no going...

they say, $i t^{\prime}$ 's a copy out of mine

are to this business purblind: say

then say, my wife's a hobby-horse

say, it be: 'tis true............

yet black brows, they say, to say you did mistake

much comfort in't, says, my poor.....

encounter witl som your good queen

wolves and bears, they say, casting ...

since what I am to say, must....

searce boot me to say not guil

say no more; howe'er tlie business

patience to you, and I'll say notling

that Time himself it is a sea....

say to me, when Eaws't thon

man they say, that from

what would he say? or trep.) .....

most constant, though destiny say, uo

which, youl say, adds to nature

ii. 3 this youth should say, twere weil

ii. 3 he says, he loves my daughter!......

ii. 5 which the wenches say is a rallima

ii. 5 but, my daughter, say yon the like..

iii. 5 I 5 cannot say, tis pity shall not........

who, I may, 'tis pity slie lacks.....

who, I may say, is no honest man
for a pheasant; say you have none :.

some say he shall be stoned............

as I may say, even blessed

sorely, to say $I$ did

his princess, say you, with him?......

whom he loves, (he bade me say so).

could not say, if the importance .....

I would fain say, bleed tears.
to say, one would speak to her

to say, one would speak to her
you were best say, these robes

you may say it, hut not swear it .....

and franklins say it, I'll

behold; and say, tis wel...............

and may say, indeed, thou art $\ldots . . \quad-\quad v$.

well, Syracusan, say, in brief.. Comedy.of E $\overline{F r}_{r}$

they say, this town is fuil of

say, is your tardy master ..............

they say, every why hath a wherefore

for your master, say he dines forth..

not hours: say that illingered

say what you will, sir......

you wrong me much to say

have you not leard men say

and says, God give you good resti...

the pride,

fly pride, says the peacock
how bay you now? is not

sir, sooth to say, you did not

say. wherefore thou didst lock (rep.)

say, woman, didst thou so? ............

$I$ am advised what $I$ say

you say, he dimed at

brave friendl say to the king $\ldots \ldots \ldots \ldots \ldots$.

af

say from whence you owe.

thou'rt mad to to say

foolish thought, to say a sorry sight

I could not say, amen, when they (rep.

as they say, lamentings heard (rep.)

rumk of man hood, say it

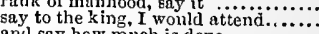
and say how much is done

they say, blood will have biood...

only, I say, things have been....

as who should say, if it plea.

his speech, but say thou naught

this great king may kindly say...

did you say, all? O hell-kite

have you heard her say?

some say, he's mad; others

pull't off, I say; what rhubarb.

which I soy I saw, but know...........

they say,

now say, Chatillon, what would

who, as you say, took pning ...

no sir, says question

who lives and dares but say

what England says, say briefly

I have but this to say, that he's not..

let it be so; say, where will zou

not complete, to $\$ n y$, be is not she.

i. 2 wliat say these young ones? (rep.)

i. 2 in wisdom slaall vouchsafe to say....

thou dost but sny, 'tis so

thou darest not say so, viliain ...........

what slould he say, but tus the ........
know not what to say. What (rep.) 
SAY - to say what good respect I ... Kinu John iii, 3 SAY - a mar is, as they Bay .......... AY-to say what good respect well, L'll not sas what 1 intend I ay, the kills will wot say, 10 .... I hive to say witl you ................. cive methe iron I

whiclı as they sny (rep.)

whereon, he says, by heaven, I thiink

dicl not the prophet say, thint

he flatly says, he'll not lay ....

I suy a kain, if Lewis do wilu

naught at all to say: first.....

besides I say, nud will (rep).........
our doctors say, this is no time

what shall I say? to safeguard

and the king's, say who thou nit ....

go say, I sent thee forth to .....

go say, say, what store of partiin.

$\boldsymbol{O}$ but, they say, the tongue

he, that no more must say ...............

right, you say true: as Hereford's...

What says he now? Nay,

but I dare not say how near........

cousin, I would say; pray, pardon mo

reply to aught you say $7 . . . . . . . . . .$.

uncle, you say, the queen is at $\ldots . .$. .

how can you say to me, I am a king?

say, Stroop, where lies our uncle

what say you now? what comiort....

to say, king Richard: alack

Northumberland, say, thus the king

what says king Bolingbrok

then I must not say, no .............

why dost tlion sny king Richard .....

yet, what 1 say, is true ..................

whilst I say, he lies, and lies, and lies

the king! will no man say, amen?...

say that again; the say of my

the rest let sorrow say ...........

for tivere, they say (rep.)

nay, do not say-stand up ...........

in Frencl, king; say, pardonnez moy

as who should say,

the devil, that told me, i did well, sars

majesty, I should say, for grace.

and let men say, we be men of ......

were, as he says,

therefore, I say,-peace cousin, say no

you say true: why, what a cand

happy man be his dole, say I........

and you so? say you so? his wife, fie upon.....

a plague of all cowards, I say

and theu say, it was iu fight?........

he says, he comes from your fat.

but, to say, I know more harm if

I have mucl to say in the behalf .....

who shall say me nay? would say, where? which is Bolingo....

and what say you to this? Perey

like a dog, it he would say so ........

and I said, I heard your grace say so

our purposes; what say you to
and the shirt, to say the truth.

why say your so? looks he not

to-night, say I. Come, come ...........

this is not well: what say you to

that triendship: say tliy prayers... .

deliver what you will, for reward....

what shall I say you are? ...........2 Henry 1

say, Morton, didst thou come from $\ddot{\text { th }}$ -

yet for all this, say not that Perey's

if he be slain, say so; the tongue ...

yet did you say, - go forth

what says the doetor to my water?.

and yet he will not stick to say.....

why sir, did I say you were

if you say I am any other than......

for you hear not what I say to you..

for you hear not what I say to you...
if $\mathrm{I}$ did say of wax, my grorth ${ }^{3} \ldots \ldots .$.
if you will needs say, $I$ am $\ldots \ldots \ldots .$.

if you will nal, what say you to it?....

and slie says, up and down the town

court'sy, and say nothiug, he is virtuou

louy to you, i vo desire.

the worst that they can say of $m e$ is

but they say, there is some of

how comes that? says he

ere one ean say, what's this:

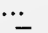

as they suy, the emptier vessel ......

I ain the worse, when one say's, swagger -

I ain the worse, when one say's, swagger -

they say, Poins has a good wit . .

what satys the almanack to that? ....

way, the bishop and Northumberlind

I dare say, my cousin William is .:
I may say to you, we knew where ..

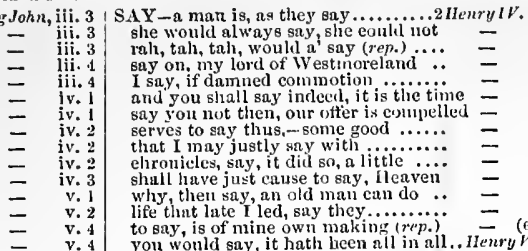

i. 4

i. 1
i. 1
i. 2

you wonld sny, it hath heen all in al .

the prince onr master says $. \ldots \ldots . . .$.

and some say, knives have edges

i. 3 hear me, hear me what I say ........

i. 3 they say, he cried out of sack...

but unwholesome tood, they say
thereliore I say, 'tis meet we all.

thus says my king; and, if your .....

therefore he scorns to say his pray

what say you? will you yield

and plainiy say, our inctile

ii. 3 tlus says my king: say thou to Henry =

for, to say the sooth (though 'tis no..

I will not say so, for fear I should

You may as well say, that's a valiant

I dare say, you love him not so iil

if ever thou come to me and say ....

what's to say? a very little lith
and say, to-morrow is (rep.)

he says, his name is - master Fer with a feeble gripe, says, dear

your majesty says very true

you say very true, seald knave

what says she, fair one? (rep.) ........

but directly to say, I love you ( $\mathrm{rep})$.

if not, to say to thee, that I shall die

and say-Harry of England, I am.

before they are married, would she say? -

v. 3 why no, I say, distrustfui recrearts!

as who should say, when I ami......

a maid, they say, a maid! and be so

how say you, madam? Are you now

and say withal, I think he held

for his craven heart, any thus.

and aay you are well waried

why didst thou say, of late

stay, stay, I say! (rep.)......
when Gloster says the word

to say the truth, this fact

my lorl, how say you? are you
say, gentlemen, what makes

the world will say (rep.)......

as who shnuld say, had death............

who art thou? say, that I may honour

vouchsate to listen what $\mathrm{i}$ say

how say you, madam; are you .....

to say the truth, it is your $\ldots . . . . . .$.

be gone, I say; for, till yon do return

and so says York, for he hati greatest

I dare not say, from the ricl ........

they say, a crafty knave doe was...

my lord of Suffolk say, is this.........

say, inan, were these thy words?

unele, what shall we say to this law?

I'll sily, I am dnke IIumplurey'

and say, I w ronged the dike ..........
well, my lord, to say so much. I say

and 'twixt each groan, say - who's

my lord of Sutfoik, say as you think

say but the word, and 1 whl be.

say, he be taken, racked

will make him say, I move..........

say we intend to try his grace to-clay

forbear, I say; their touch affrights..

did seem to say, seek not $\ldots$ lo...
say, if thou darest, proud

with reverence may I say

i. 3 and say $\rightarrow$ it was thy mother..............

they say, by him the good ditke

well, I say, it was never merry.

as much as to say, ns, let the .......

sume say, the bee stings; but hay with him, I say; hang him...

but, I say 'tis true; the elder.

we'll have the lord Say's head

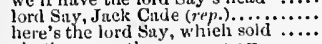

ah, thow say, thou serge, nay you of Kent? Nothing

as who should say, I'll be even

take him away, Isay, and strike .....

what say ye, countrymen? will ye rolent
lis cap, and say, God save his majesty!

to say, if that the bastard boy

gay, what news with thee?
his sous, he suys, slaall give thei
I myself heard the king say
S.AY-1 kay, come for th and fight ....2 seury i 1. v. 2

.........3 Henry VI. i. 1

v. and say, alas, it wns a pitcons dcedl.ii

anr dukedom, throne will kinglom s เy

if for the last, say-Ay, and to

v. 3 say, lleury, shall I have my riglit...

nor hears us what we say ...............

for wise men say, it is the wisest ....

sav, what art thou, that talk'st of....

wilt say, ay, to my request (rep.)....

and so I say, I'll cut tlie causes.

i. well, say there is no kingdom ......

i. 2

I hoer have often heard him say .....

she eould say little less ....

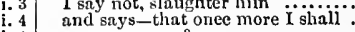

ay, say you so? ..................

say Warwiek was our anehor

ugh wind say

iii. 5 what I should say, my tears gainsay

away, I say; I charge ye, bear her ...

my lord, I should say rather

I have of eu heard my mother say...

to say the truth, so Judas kissed

about $a$ propheey, which says, that... Richard $I L U$ v.

and says, a wizard told him..

we say, that Shore's wife

how say you, sir?.

say, I slew them not ....................

say then, iny peace is madel

prayer will scarcely say amen .......

and say, poor MIargaret was..........

he'll siy, 'twas done cowardy (rep.)
the fee, and tell him what I say......

therefore I say, with noble (rep.)....

they say, my son of York.

but say, my lord, it were not registered

so young, they say, do ne'er live long
what say you, uncle? I say, without

I must not say so....................

so it should seem by that $\dddot{i}$ have to say

besides, he says, there are two ......

pray God, I say, I prove a needless.

yet who so bold, but says, he sees it not?

how now? what say the citizens?.

as $I$ ean say nay to thee for...

what says your lord (rep.)

God defend his graee should say us riay -

you say, that Edward (rep.) ........

ere mer ean say, - God save the queen!

say on, my loving lora (rep.)

say, have $I$ thy eonsent, that
say, it is done, and I will love

what gay's your lighness to my

that I may live to say, the $\mathrm{dog}$

kneels, and says-God save the queen?

strike, I sny; - ci ther be patient

1 say amen to her. stay, madam

3 which, say to her, did ilrain the purple

what where I best to say?

or shall t say, her uncle?....

to arm me: leave me, I say ......

what says lord Stanley? will he

say, amen, to all (rep.)..............

men might sav, till this time $\ldots . . . . .$.
I say again, there is no English soni =
say not, treasonoos. To tlie king I'll say"t -

they say, they are devised by you

that oft, says he, hath sent to ne....

say, lord Cliamberlain, they have....

what say they? such a one ..........

and must needs say, a noble one ....

who's there, I say? how dare you...

they will not stick to say, yoll ......

I'll to the king, and say, I spoke with

say, are you not stronger than you wer

your speaking, and to say fo no more

that's to say, meant to reetify .......

break up the eourt: I say, set on

they whed me say so, madam

(I dare say, without vain-ylury)

iv. 7 a kind of good deed, to say well.....

iv. 8 say, withat, if ymu are bomm trep....

tlieir coronets say so; these are stars

$3 !$ man living cuuld say, this is my wi
$i$ the presence lie would say untrutlis

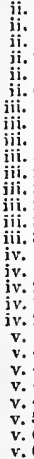

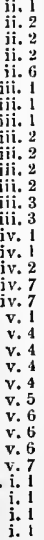

i.

i. 3

i. 4

ii. 2

iii.

iii.

ii.

iii. 2

v. 4

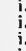


$\mathrm{SAT}$, his long trouble now is as they say, spirits do (rep.).

Henry VIIJ. iv. 2 SAY then; 'tis true, I ought 8

I would say, thou liest, unto thee....

Coriolanus, iii. 3 SAY, I wonld die

and yet my conscicnce say

is the queen delivered? say, ay

I could say more, hut reverence.

norst of ull this table say so............

I have a little yet to say $\ldots$

f thee which say thus

they'll say, 'tis naught

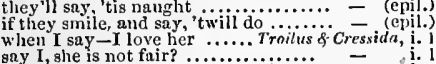

v. 1 you were used to say (1,ep.).

they say, she's mad. They have

power to say so to my husbaud ...

列

that sha!t say, yea, to thy desires.

one cannot tell how to say tlat...

say, thwack our general? I do not say

Ihave heard him say so himself

he'll go, he says, and sowle the porte.

let me liave war, say I ............

they say, hc is a very man (rep.) ....

go he says here. True, he was

to say truth, brown and not browa (rep.)

who will, as they say

say one of yonr watches.

as Uly'sses sny's (rep.) ................

say so,-did not the general run then

I say, the proclamation ...............

thus once again says Nestor from ....

Mector, what say you to't....

then, I say, well may we fight ......

it she that lays thee out, says, thou...

$X$ shall say so to him

Achilles bids me say,-he is...

if you do say - we think is a.........

what should I say? Ile is so

well, you say so in fits ................

what says my sweet queen?

Why shonld you say-Cressid

as what envy can say worst

yea, let them say, to stick.

which, you say, live to come in......

as who should say-there were wit..

what say you to'

is he here, say you? ...................

some say, the Genius so cries, come 1
be thou true, say I, to fashion........

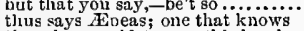

that thou conldst say - this hand

they say, he keeps a Trojan drab

what sass slie there? Wo.............

What sass slle there?
Trate, hay 1 where's Troilus (rep.)
Fat me what $I$ say! ...........

mark what $I$ say .....................

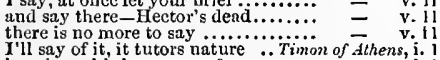

imprisoned is he, say you? there's none can truly say, he....

there's none can truly say, he gives ..
they say, my lords, that ira furor ...

I have one word to say to you...
Caphis, hol Caphis, I say

I am proud, say, that my occasions....

nothing doubting, says he?

and say, thou saw'st me not

one of iny greatest afflictions, say.....

why, I say, my lords

what shouli I say to yon?...............

and say, this man's a flatterer?
I flatter not; but say, thou art....
I'll say, thou hast gold ..........

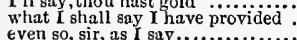

Even so, sir, as I say....................

but say to A thens, Timon...

to say, thou'It enter tiriendiy

can be content to say, it was

you must in no way say, he is.........

they say, poor suitors have strong.
(this says the belty) mark me......

what say you to't? It was an answer

they say, the city (rep.)...

yet, they say, all the yarn she spun.

say, has our general met the enemy?

shall say, against their hearts.........

no more, $I$ say; for that I have not

I cannot say, your worships have...

this, as you say, suggested at some

threc, they say; but 'tis thought of every -

let me say I how 1 got them

I say, if he would incline ...............

your good voice, sir; what say you?.

I would be consul, says he

say, you chose him (rep.)

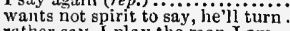

rather say, I play the man I am

have heard you say, honour and poliey

now, say you will, and go about it ...

when they hear me say, it shall......

II I say fine, cry fine

peace, I say (rep.)....................

but. as I say, such is become a soldie
I huve not the fuce to say, besecch you

say not, we brought it

well, and say that Marcius returu........

with his unkindness? say 't be so? ..

lis tiar (as you say, you lave.

back, I say, go, lest I let forth

I sny to you. as I was said to

in my stead, say, would you have

move the people with what he would say -

say no more; here come the lords

I am but, as you would say ........... Julius $\bar{C}$.

our elilers say, the barren, touched in
when Cæsar says, do this, it is performed

when could they say, till now.........

you and I have heard our fatliers say

what you have to say, I will with
did Cicero say auy thing?

let not men say, thesc are their...

a wake, I say; what Lucius!

awake, I say; what Lucius! .....

what suy the augurers?

and he shall say, you are not weil ...

Mark Antony shall say, I am not well fher you have heard what 1 ca

for some one to say, break up........

say, I am merry: come to me (rep.)

say, I love Brutus, and I honour (rep.) =

alas! what shall I say?

the enemies of Cæsar shall say this..

and say, you do't by our permission

bid me say to you hy word of mouth

to him I say, that Brutns' love .......

let us hear what Antony can say
Brutus says, he was ambitious (

Brutus says, he was ambitious (rep.)
I heard him say, Brotus and Cassius

wisely I say, I am a bachelor (rep.).

I am. I say, you are not

$y^{t}$ on did, I care not

what says my general? ...............

what says my lord? Why this ......

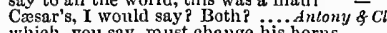

which, you sny, must change his horns

An tony, thou wouldst say, - $O$ my lord

what says the married woman?

and say, the tears belong to Egypt.

all the east, bay thou, shall call...

I should say myself offended ........

you must but say, I could not help it
say not so, Agrippa (rep.)

say to me, whose fortunes slall rise

I say again, thy spirit is all afraid
get thee gone; say to Ventidius

ind say, $a h$, ha! you're caught...

if thou say so, villain (rep.)...

what say you? hence, horrible

if thou anain say, yes....

say in mine ear: what is't?
what's elsc to say? Be jolly, lords

ho, says a'! there's my cap ........

ii. would you praise Cesar, say,-Cæesar

do not say so, my lord

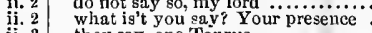

ii. 3 they say, one Taurus ...................

ii. 3 none but friends: say boldly

shall I say to Casar (rep.)

and say, God quit youl..

look, thour say, he makes me ........

peace, I say, what slould this mean?

iii. 2 and they say we shall embattle.

\begin{tabular}{l|l} 
iii. 2 & say, that the last I spoke was.... \\
iii. 3 & let me say, before I strike this...
\end{tabular}

I say, o Cassar, Antony is clead.

wc'thear him, what he says .........
go, and say, we purpose her no sliame
bring us what she says, aud how ..... and, to say the truth, so rlid ver.

but do not $8 a$, for that, forgive our.

say, my request's unjust, and spurn

and my auguring hope says, it wili.

we use to sny, the dead are well

\begin{tabular}{l|l} 
ii. 3 & fall not a tear, I say; one of \\
ii. 3 & will yicld us up. He says so
\end{tabular}

say, that I wish he never fiul.

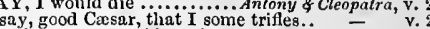

iv. I but he that will all that the..........

that I may say, the gods themselres

but had most pretty things to say .... Cymbeline

will my lord say so? ay, madam ....

I was about to say, enjoy your

O happy Leonatus! I inay say

why, so I say. Did yout hear

but that you shall not say i yieid.....

I do not say, I am one .......................

we do say then to Casar.

say, and speak thiek ............
say she'll home to her father

there's no more to say; occessible...

son, I say, fullow the $\mathrm{kin}$

which, as I say, to vex her, I will...

if it be sin to say so, sir

'd say me heard you sar love's...

say, what thou art; why I. should yield =

say, where shall's lay jim?..............

v. 3
$v .3$ say his name, good friend.....................

v. 3
v. 4 I will not sar! Thy name? Fidele ....

o say Y. Amen. No rerson I...

pr'ythee, say. First, she confessed.....

thou may'st say, and prove it in thy

nor wherefore, to say, live, boy

that diamond uponl your finger, say

Onever say hereafter, wut too good..

crown him, and say-long live our. Tilus Andron

I say no more, nor wish no less ......

2 away, I say; now by the gods.....

the power that some say (rep.)

ii. I shail I say, 'tis so? O that I knew

ii. 2 and let ine say, that never wept before

O say thou for her, who hath done..

and that you'll say, erc balf an hour

ii. 2 as for my sons, say, I account .......

iii. I licard my grandsire say full of t...

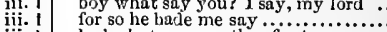

lacks but your mother for to say ame

as who should say, old lad, $I$ ain ....

iii. 1 what shall $\mathbf{Y}$ say nuto the empress?...

iii. 2 what says Jupiter? (rep.) ............

iii. 2 as who wonld say, in Rome no justice

iii. 2 as he eaith, so say we all with him...

iv. 3 I say, thy child shall live

what canst thou say all thi

what canst thou say all this........

and say, $I$ an Revenge, seut from .

where, they say, he keeps $\ldots \ldots . . . . . .$.

what say you, boys? (rep.) ..........
what say you, Romans? have we

if you say, we shall, lo, hand in hand

tell you what mine anthors say. Pericles, i. (

say, is it doue? my lord, 'tis done.........

nor boots it me to say, I honour him..

and will not say, he wants it

what, Patch-breech, I sayl wirat say you

snys to them, if king Pericles .... … iii, (Gower)

hiles I say a priestly fareweli to her..

i. 3 mariner, say what coast this is?........

, you say well. But I much marvel.

al ! says one, wiit thou?

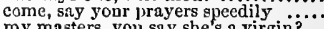

therefore say what a paragon she is....

Whe died by night; 1 'll say so

as for Perieles, what should he say?...

thou would'st say. Your honom' (rep.)

was it not thus? what say you ........

than to sar, my mother's aid push

you have heard me say, when...

shall we say, doth love us most

what can our second daughter.

fhey say, they love you, all?

what say you to the lady? love is not.................

and, is I say, retire with ve to say

him that is wise, and says little

your face bids me thoure? Call ........

your face bids me, though you say nothing -

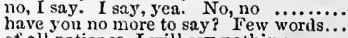

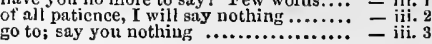


SAY-he says his name's poor Tom say's sulm, mum, ha nu nothny, dol phin

bind him, I say. Hlard, laurd

Idd suy, I hat eyes agstin! ...........

$O$ gods! who is't ean saly, $I$ atn at

is not, so long as we ean say of..............

to sny ny and ung

hone does oftend, none, I say, none ...... - iv.

your wite (so I wonld say), and your - iv. 6 (let.)

know not what to sny; i will not sweur

they say, Eigar his humishet son

mark, I suy, instuntly; and carry it so ... $=\mathrm{v}$.

Bay thou, nu: this sworl, this ari
some say of breeding breathes.

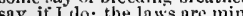

you look as you had something more to say $-v$.

he knows not what he says ..............

my master ealls, and I must not say, no.

is the Inw on our side, it" I say, ny? Romen o

my sword, I say! old Iontague is eome

my lord, what say you to my suit?.

to them say, my house and welcome

ye shy hili leave erying, and say, ay ...

I pray thee, nurse, suy I

what say yon, can ynu love.............

and to say truth, Verona brags of

she spenks, yet sine say's nothing $\dddot{\text { ini }}$
I know, thou wilt say, ay; and I wil
they say, Jove lauglis; $O$ rentle Rome

and be perverse, and say thee nay

ere one can say, it fightens ..

you say mell as to say, such i....i.

what she bade me say, I will keep to

as they say, it were a
go to; I say, you shal

did you ne'er hear say, two ma.......

when I say so, she looks as male

brenth to say to ine, that thou art

whyt says he of our marriage? (rep.)

what says he of our marriage? (rep.)

say thou but I, and that bare yowel

be mereiful, say-deatl.

do not say-banjslumen

and what says my eoneealcd $\dddot{l}$ ad $y$

she says nothing, sir, but weeps

but what say yon to Thursay?
I'll say, yon grey is not the morning;

some say, the lark (rep.)

stuffed (as they say) with honourable

you say, you do not know the lady's

where, as they say, at some hours in

why, love, I say! madain! swectheart!
what say you, Simon Catling? (rep.)

I know not what to say...

the singer: I will say for you.........

what says Romeo? or, if his mind be

then say at onee what thou dost know.

Kormeo's man? "what ean he say in

tley say, you spirits oft walk (rep.).

what says Polonilis? He hath, my lori

I wonld not hear your enemy say so

then if he says, he loves ynu .......

earrying, I say, the stamp of oin

say, why is this? wherefore? ............
I say, a way: go on,-Inll fillow thee

I say, away: goon, - l'll fillow thee ...
how say you then; would heurt of nan. but yon may siy, unt well

alout to say? by the mass, I was (rep.)

and, as yon say, there was he gaming.

or, rather say, the cause of this defe

for the satirieal rogue says here

Eay you? nay, then I lave an eye of you

by your smiling, you seem to say sn....

will they not say afterwaris

for they say, an old man is twiee $a$ ehiid

prythee. say on (rep.).....

to say we end the heart-ach ..................

(as I may say) whirlwind of your passion

plaved onee in the university', you say?

played onee in the nothersity , you say?
I will say, my my and by is easily said

I will say so. By and hy is easily said

why yet I live to say, this thing's to ilo...
says, she liears, there's trieks i' the world

say you? nay, pray you, mark
they say, the owl was a baker's daughter

ask you, what it meant, say you this.....

they say, he made a goud end .........

sailors, my lord, they say .......................

in a postseript here, he says, alone

in a postscript here, he says,

the scripture says, Adam digged

now thot elost ill, to say, the gallows is.....

this question next, say, a gravemaker.

to be in't, and say it is thine

very strangely, they say $\ldots \ldots \ldots \ldots \ldots . . . .$.

but as I say, spacious in the possession

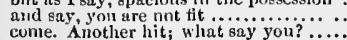

AY you so? eome on..................... llamle hust heard me say, my dauglater is not I say again, lath mnule a gross revolt ... litters say, a humbel ant seven ballies.......... low say you by this change?

in your own purt, ean you say to this?

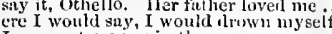

I sny, put money in thy purse ..........

you have little eause to say so.

you say yolt, Cassio? .................

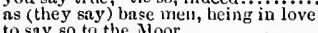

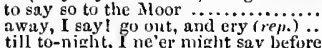

I may siny so in this respeet

and what's he then, that says-I $\mathrm{I}$ play

but, as they say, to hear m

save that, they suy, the wars must

why, say, they are vile and fail....

to say-my wife is fair, feerls well

dost thon say so? she did deceive .......

like the mines of sulphur. I did say so
whut slaall I say? where's satisfaction?

what slanll I say? where's satis

patience, I say; your mind, pering....

I lare not say, he Jies anywhere

for me to say a soldier lies ( $r e p$.

saj you? It is not lost; but what rep.

we say, lie on her, when they belie her

I say, but mark his gesture (rep.)....

pr'y thee, say true...............

and she's obedient, as you say, obedicnt

she says enough; yet she's a simple ( $r e p$.

I eannot say, whore, it does ablior me

by this hand, I say, it is very seurvy

he says, he will retirm ineontinent

if you sny so, I hope you will not kill me

Lord have merey on inel I say, amen

ay. II 'll not say so. No, his mouth 1 ...

you heard her say herselt, it was not I ...

my husband fay, that she was false?

if he say so, may his pernieious sonl

did yon say, with Cassie?.............

set you down this; and say, besides.

what mean you by that saying?

for saying so, there's gold ......... The

ear tell thee where that saying was born $\mathrm{Nght}$, i. 2

anil the old snying is ............

put these sayings upon ne?

if their singing answer your bayin

out at a winclow? a proper saying!

must speak through, saying thus...Mid.N. s Dr. iii.

loy saying, that a Costard was broken

eome upon thee with an old saying
reputed wise, for sitying nothing.

ny meaning, in snying he is a gnod

temlits me, saying to me, Gobbo
and steeh odl sayings, the sisters

while grace is saying, hood mine.....

the ancient saying is no heresy.......

pulled out thy tnngue for saying so... $s$ s $y$ jou $\bar{L}$ ike

that shall civil say ings show, some.
for all tlue old gentleman's sayng

I do now rememher a suying .......

you would believe my saying .... Hüter's Ta

gou wound believe my saying..... moner's Tale, ii. goflsinith here denies that saying.. Com, of Err. v.

not dend, for all your saying.............nacbeth, iv.
to prove my saying true ............ Kins John, ii.

the heavy time; saying, what laek you? - iv. I

art an unjust man in saying so ... Henry I $r$ iii. 3

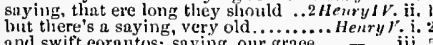

and swift eorantos; saying, our graee

eornc, tis a foolish suying: your re]
but the saying is true, the enpty ...

saying - the sangaine eolour of $\ldots .$. . H Henry $V_{s}$. iv.

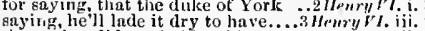

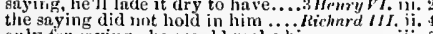
only for suying-he would make his son

in saying it, you shull but say the truth $=$ iij. 7 but, saying, thus, instead of oil.. Froilus \& Cress. $\mathrm{i}$. he raves in saying nothing

as the goodly saying is, $O$ heer

fleet of saying is quite ont of use.. Timon of $\mathrm{dth}$.

yet you must be saying, Mareius is. Corintmus, ii
to have't with saying, gout-morrow

mueh reason in his suyings ....... Julinescesar, iii.

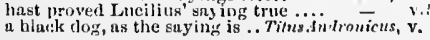

S. IYING-have exeuse, with saying.... Pericles, ii. 3 cold as a snow-ball; saying his priyers - iv. 6 mav give his saying deed which is . . what thoul suy'st? ........... T'o Gen.oflerona, ii. what say'st thou? (rep. iv. 4) ..........

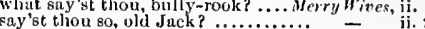
whent een nine and ten, say'st thou? . - iii. say'st thou, that house is dark?

say'st thon to this ture (rep.) .. ïreas. for Merex. iij. thon' being, (as thou say'st thou art). Muth s do, i. ha, hal what siy'st thou?...........ove's L. Lost, jii. ha; - what say'st thou? ..... Werchant of renice, iiti.
as thou say'st, chiarged my brother. As you Like it, $i$. by iny troth thou say'st true

thou say'st well: I do now remember - v.

what say'st thou to her?................Al's Welt, v. ?

no, say'st me so, friend :.................. of of Shrew', $i$.

why, thou say'st true; it is a paltry

a maiden, as thou say'st he is.'.

thou villain, what say'st tlou?... Comedy of Er. iv.

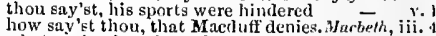
What siy'st thou, boy? look in...... King John, ii. Philip, what say st thou to the cardinali
of Norfolk, what say'st thou to this? Richord II. i. I of Nortolk, what say'st thou to this? Rekord $/$ i. I
thou, now a dying, say'st-thou flatter'st - i. I
thou say"st well (rep.) ….......... Henry $r$. i. 2

what say'st, my lady? What is it.....

what say'st thou to this? (rep.)..... - ii. 4

the mass, lad, thou say'st true (rep. iii. 3$)=$ ii. 4

mass, thou say'st true: the prince ..2 Henry/l', ji. A say'st thou me so? is that a ton ........ Henry $r$. iv. 4 what say'st thou then to my love! (rep.) - v. 2
what say'st thou, man, hefore dead ... Henry VI. i. I what say'st thou, Claries? (rep. v. 4) - iii. 3 what say'st thou, MIajesty! (rep.)....2 Henry $v 1$. i. ? what say'st thou? did the duke..... - i. 3

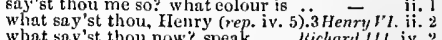
what say'st thou now'? speak .... kichard /Il. iv. 2 what say's thou? ha! to pray for her - v. what say'st thou to me now?.......Julins Corsser, if. thon say'st; and thou say'st ..... Antony \& Cleo. ji. these wars; and say'st, it is not fit ... - iii. what is't, thou any'st? I say, O Cæsar - v.

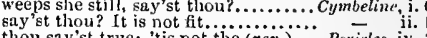
thou say'st truc; 'tis not the (rep........ Perictes, iv. thou say'st, the king grows mad ......... - iii. himself; what say'et thou to him? (rep.) - y. 3 and say'st thou (rep. nit. 5) $\ldots$ onomeo of Jutiel ha, ha, boy, say'st thou so? art thuu.... Hamlel, $\mathrm{i}$.

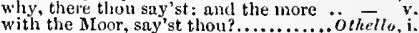

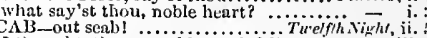
I thought, there would a seab foliow. Nuch Ado, iji. 3 thou'rt a good se:tb: hold ...........2 Henry $/ V$. iii. opinion, make yourselves scubs? .... Coriolanus, i. it is in my seablard; shall I draw it? Whush sdo, v.

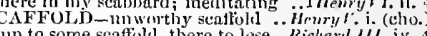

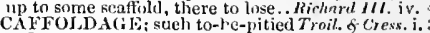
ALD-thiat scalds with sufety ....2Henryll. iv. the raseally, seald, begirarly, lousy.....
will you be so gont, scalil knave (rep.) water to scald sureh chickens... add to the number that many seald thee - iii. mine own tears do scald like molten lead. Lear iv ALDE-sealfed with iny vinlent. Kins John, v. huruing, sealiling, steneh, consumptioul..Lear, a feather will turn the seale... Troosen of Mers. or Meas. iv, put in two scales, will even weigh. Mid. N's Dr. iii. joizing $\mathbf{n s}$ in her defeetive seale ....All's "ell, ii. in both seales against either seale .....Macbuth, ii.

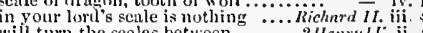
wint the seales hetween let us resolve to senle their the cause ill justice' cqual senles........

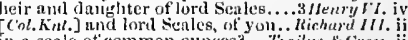
1 will venture to seale $t$ a little more. Coriolumus, $i$. by certain senles i' the pyramidl.. Antony s' Cl'n ii. 7 in those erystal sentes, let there.. Romo of fulie', till our seale burn the bean

hacl not one seale of reason to pisise ....... othello, i.

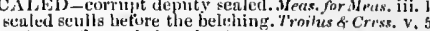
a cistern tor sealed snakes!. Antory \& Cleupalra, ii.

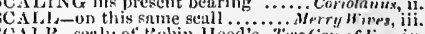

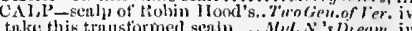
thin and huirless sculps aguinst... Mithurh 11 . iii. 2 


\section{SCA}

SCAIY - a suly gnuntlet now.

SCANBLE-to tug, and scamble..... King John iv

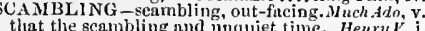
I get thee with scunbling, and thou

SCANEL, [Col. Knit.] Young scanels
SCAN-that makes us seun the outwo

to scun this theses us sem the outward. Pericles, SCANDAL once cali touch ................. Othello, for Meas, iii. 3 iu a tomb where never scandal slept. . Itw' Atito do set a scandal on my sex. ...Yid.N.'s Drean, ii. 2 nut without some scandal

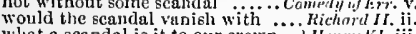
tlyy scandal were not wiped uway ...2 HenrylVT. ii. his scandal of retire (rep.)........3 Hency's. ii. I

und after scindal them

lid scandal many a holy tear.

often dout, to lis own scandal............. Hamlet.

You nnust not put anotlere seandail on lim
SCANDALED-standuled company

SCANDALIZED, and fOH

it will make me scandalizcd. Twa Gen.ufverona, ii.

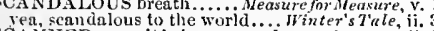

acted, ere they may be scanned....... Macter

that would be scanned; a villain ikitis. Hrombet, iit.

ther -bcant this excess ...Mer

Ecants us with a single fannished. Troilus \& 8 Cress. iv.

seant not my cups; and ma
than she to seant her duty

to scenst my fizes, and in comclusion.

to scant my sizes, and, in co
and she shall scant show we

he's fat, and scailt of breath. ...

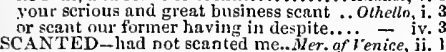

he hath scanted men in hair.. Canedy of Errars,
rou have obedience scanted, and well .... Lear

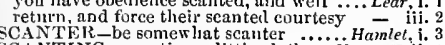

SCANTING - scanting a little cloth $\ldots$. Heary $y$. ii. 4

SCANTLY - spoke seantly of ime. Antany \& \& Clen.

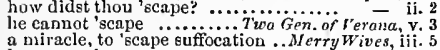

he cannot'scape me

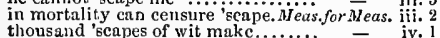

scape

now to' 'scape the serpent's tongue. $M i d . N$. Dr. (epii)

to 'beape drowning thr
here are simple 'scapes

and not one vessel 'scape tiie dreudful $=$ iii. 2

else how thou slouldst 'scape.....As yau Like it, iii. 2

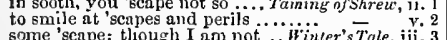

sorne 'scape; though $I$ anz
if he 'scape, heaven forgive

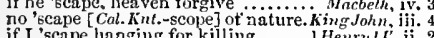
if I scape hanging for killing ....... Henry $1 \%$. ii. 2

how 'scapes he agues, in the dev

thougl l could 'scape shot-free.

thy despite, shall 'scape mortalit
hut if we haply 'scape, (as w'ell

Henry IV ii.

fly, to "acape their handel.............

2 Hewryl. v. 2

Whould he scape Hector fair ... Troilus 8 . Cressida it. 3

and so 'seane hanging

thou shouldst not 'Ecape me here .. Corialanus, i;

some innocents 'scape not.. Antany \&.Cleopalra, ii. 5
and so I slaall 'scape w'hipping .......... Pericles, ii. 1

to 'seape his hands, whleer I was like
Mrarina thus the brotliel 'scapes

Marias thus the hrotliel 'scapes

the fault would not 'scape
the villain shall not 'ceape

(Gower)

while I may 'scape, I will preserve.

false justicer, why hast thou let her scape? ii. 3

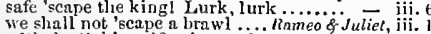
with death himself to 'scape from it ... Hamlet, iv.
virtuc itself 'scapes not calumnious ... and who shall 'scape whinping?

and scape deteeting, I will pay the thef = iii. 2

BCAPED-T have not 'scaped drowning. Tempest, ij. 2

two Neapolitans 'scaped! .7............ W - ii.

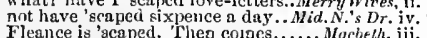

I have 'scaped by miracle

andl glad we 'scaped so weil

father 'scaperl; or' whether he (rep.).3 Heury Hi. iv. or, had he 'scaperl, methlinks, we sliould

he 'scaped the linnd, to perish on.......... P'er icles, i. 3

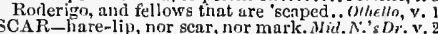
there remains some sear of it .....As you Like il, iii.
honour but of danger wins a scar....All's s'ell, iii.

whether there be a scar uncler it .....
a scar nobly got, or a noble scar $\ldots$ iv
deep scars to save thy life.... iv deep scars to save thy life ..... Comedy af Errors.
capable of wounds, and scara........ Henryl H.
and blow his sears, and say and ghow his sears, and say ........... Henry $P$
patches will $I$ get unto these scars.... patches will $\mathrm{I}$ get unto these scars....
received deep scars in France........
show. $\mathrm{i}$.

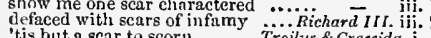
SCAlR-boasting show their scars.. Trailus f-Cress. i
show them the unaching scars...... Carialunus,

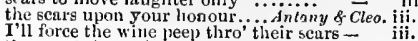
Thorec the wine peep thro their sca
thon and those thy scars had onee

of Clotens hasl cver scar for

Cymbeline, $\mathrm{v}$

my scal's of sor witow in his heart. Tifuss.tndran. iv.

in jests at scars, that never fclt... Romeo of Juliet, ii. 2

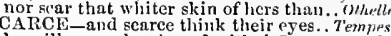

he will scarce be pleased withal.
going will scarce serve the turn.

his mother's milk were scarce out. Tiutelfhs

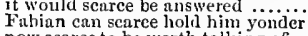

now scaree to be worth talking of

I would scarce trust myself, thoughi.. Much Ado,

an attending star, bearce seen.....Lave's $L$.Last, iv, 3

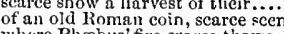

revercnce) are scarce cater-cousing.

she scarce makes honest

or I will sun spenk to thank

and that thou art scarce worth

three great oatlis would scarce mak

scarce ean right me thoroughly
it sliall searce boot me to say.

there's scarce a maid westward, but.

scare any joy did ever so long live.
scarce could understand it (rep.). Cunedy

of welcome makes scaree one dainty dish - iii. where therds are scarce, they are... Marcbeth, iv. villain! thy lips are scarce wiped ...Pichard II I I i i. scarce blood enough in all their...... Henry $V$. iv.
full scarce six thousand in ......... of Gloster, scarce himself, that bears.2 Henry $r T$. ii.
scarce can I speak, my choler........ moist can I speak, my choler...

scaree I can refinin the execution

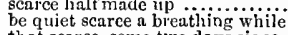

that scarce, some two days since
starnp of honour is searce cirrent

sturip of honour is scarce cirrent.....
when scarcc tlic blood was well washed

You have scarce time to steal from.
if he live, will searce he gentlemen

- iii.

my lord, I scarce have leisure.
call scarce entreat you to be odd

entertainment. I scarce know

and birth, scaree is dividant .........

grants scarce distinction ...Aniony of Cleopalra, iii.
thanks, and scarce can spare them

she can scarce be there yet .......

beiog scarce made up, I mean....

the odds is, that we garce

have scarce strength left to
we could scarce lielp ourselv.

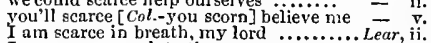

I an scarce in breath, my lord ............ Lear, ii. 2

for many miles about tleere's...............

was then scarce friends with him

show scarce so gross as beetles.

we scarce thought us blesscd.... Ramea \& Juctiel, ivii.

nnd dare scurce come thither ............ Ilamlet, ji.

first, are scarce found to distaste ........ oithello, iji. 3

O slie was foul! I searce did know you
CCARCEE-BEARDED Cæsar lave. Antory

CA RCE-COLD conqueror ........... I Henry, $I t$. iv.

of this yet sitarce-cod batte ......... Tymbeline, y.5

scarcely have coveted what was.........
of thia forest, searcely off a mile...2

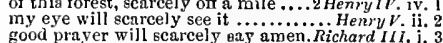

you acarcely have the hcarts to tell..

armour on, which I can scarcely bear ... Carial. iit.

like me, he'll scarcely look on' t.... Cymbetine, iiit. 6

of your person it would searcely allay .... Lear, i. .

which scarcely keeps thec warra

yet glanec by, and searcely bruise.

scareely heara of this his nephew's........ H

forbid such searcity of youth!... Treilks \& 'Cressida, i. 3

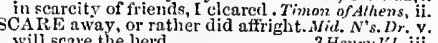

a word scare Troy out of itseif. Troilus 8 Cress. $y .11$

noise fid seare ne from the tomb. Ramea \& Juliet, y. 3

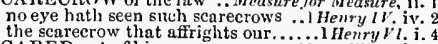

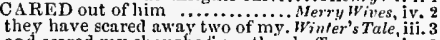

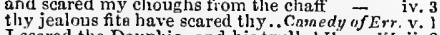

I scared the Dauphin, and his trull..I Henry VI. ii. 2

scared [ Cal.-scarred] the moon
SCARED-been scared out of lis good wits. Lear, iv. 1 CAliF to my proud eart

he a lieutenant's scarf? you must...Murh Ado, iii.

sce thee wear thy heart in a scarf. ds yout Lite in

yet the scarfs, and the banncrets....... All's Well, that jack-an-apes with in thy scarf

in the knot of livs scarf

with scarf, scart, that has .......... scalf ul the tender eye of double. Taming ar Sh. iv. 3 maids their scarfs and handikerchiefs. Corialonus, ii.

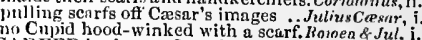
CAlRFED bark puts from her.... Ner. of renice, il.

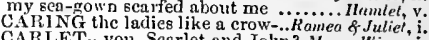
a velvet hose a searlet and neace to scarlet indignation

drinking deep, dying scarlet ............. Henryl IV it:

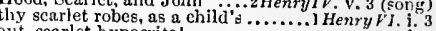
out, searlet hypocrite! ............... thus jaded by n piece of scarlet .......
mast, the brier's scarlet lhips .. Timon of ${ }^{2}$ ithens, iv. they'll be in scariet straight ....Rnmen \& Juliet, ii. CARRE- [Col.Kne.] in such a scarry...All's $H^{-}$ell,
, him deep, and scarred lis henrt.. Titus Andront. could not procure me an ............ King John, them that have done scath to us ..... Richnrd III. $\mathrm{i}$.

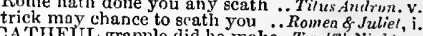

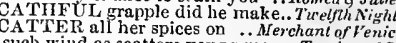
sucls willd as seatters young men.. Tarning of Sh.

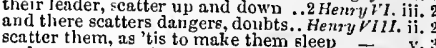
and ooze scatters his grain .......Anlany \& $\overline{\text { Cleo }}$.

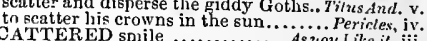
lis plausive words he scatte........ As you L Like it, in

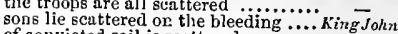
of convieted sail is scattered .

pursue the scattered stroy.... i HenryIV

pursue the scattered stray .........2 Hemryly. shalt not dread the scattered foe .....3 Henry VI. scattered in the bottom of the sea.... Richard 11 i. army is dispersed and scattered

iloughed for, sowed and cattered... Cariolan $_{\text {se }}$, iii. to knit again this scattered corn

a powcr into this scattered kingdom.......... I.ear, iii, scattered to make up a show .....Romea sf fuliet, $y$.
SCATTERING and unsure observance.. Olhello, iii. SCELERA-lentue nudis scelera?.. Tilus Andron. jv. SCENE-Falstaff hath a great scene....... that's the scene that I would see. ....Aluch Ada, a tedious hrief scene of young .............. s .

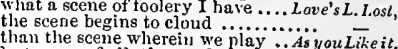
thant the scene wherein we play .... As you Like it,
last scene of all, that ends this . A
give my seene such growing. Winter's Tale, iv. (

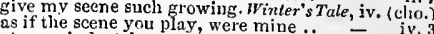
at your industrious scenes and acts... King $\bar{J}_{\text {o } h n, ~}$, ij our scene is altered, from a serious...... - vehard IT. iii. thic rude scene may end...............2 Henny $I V$. i. to behold the swelling scencl ... Henry $V$. $\overline{\mathrm{i}}$. (chori and the scene is now transported - ii. (cliorns) iil (chorns)
our swift scenc flies, in motion.... what scene of deatl thatl battle fly - iv. (chorus what means this scene of rude ...... Richard IIl. ii. woe's scenle, world's shanie

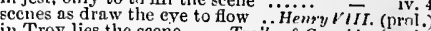
in Troy lies the scene .... Troilus \& Cressida, (priti.) might act the woman in the scene..... Cariolanus, ii.

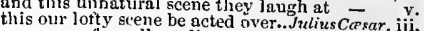
one scene of excellent dissembling sntony \& Clen i. our fast-growing scene must ...Pericles, iv. (Gower) while our seenes [Kint-tears]

Where we lay our scele ....... Romen \& Juliet, (prol. cene und vidalule, or must act aloue - iv. well digested in the suenes, set down

- ii. CENT - lie is now at a cold scent.. Turelith Nighl, ii picked out the dullest scent. Taming of Sh. I (ind inc.)
neethinks, I scent the morning air ....... Hamtet, $i$. ay, by my sceptre .................. of l'enice, iv. thou a sceptre's beir.................Winle's's 'ale, iv. put a harren sceptre in my gripe........... Mac beth, iii. a sceptre, snatched with an unruly King $\bar{J}_{n} h n$ nuw by my sceptre's a we I make
the dust that hides our seeptre's gilt 
SCEPTRE--handle of our sceptre .. Richard 11. iij. 3 SCIATICAS, linnckilns i' the palm Troilus $\downarrow$ Cress. v. 1 .

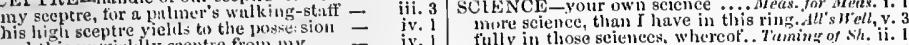

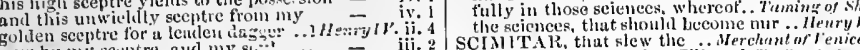

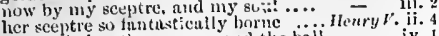
nest the baln, the seepure, nnd the baif - iv. to

to put a golden sceptre in

SCIMITAR, that slew the ... Merchent of lenice, ii. I which with ny seimitar. I'll coul. Frmilus o Cres.
he dlies upon iny seimitar's sharp. Tifus dudrom. SCION-narly a gentler scion tn... Irinerr's T'at

CISS IRS nicks lim.......... Comen'y of Error

SCOliE-henten with pure senff.

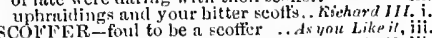

bere is a hand to loold a seeptre up ... a septre, or un eartly sepilis the aw ful sceptre troin his fist

thy sceptre wrung fiom the

to

to ming the thet bears the sic

a cress

a mure laver list of scejtres

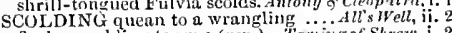

at such atnd such a sconce ............ Hemy $V$. iij. 6

populous city will yield mal it, IIoratio..
thou art a scholar, speak to it
as you are friends, scholars, and soldiers

as you are friends, scholars, and soldiers - i. 5

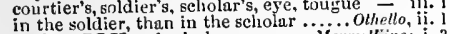

SCHOLARLY and wisely

SCHOOL-my young man here to school -

how now sir Hugh? No school to-dav? $\overline{\text { tight. iit. }}$

for school, fool, a babbling rhyme... Much filo

when slie went to school........ Mid. N.'s Drenm,

and the help of school; and wit's own

I lave discontinued school ... Nerch. of I"enice, iii.

brother Jaques he keeps at school. As you
creeping like snail unwillingly to school

creeping like snail unwilled of ......All's $\mid r^{\prime}, l l$, i.

no breeching scholar in the schools. Tam, of $S h$. iii.

as willingly as e'er 1 came from school $-\overrightarrow{\text { iii. }} 2$

I pray you, schnol yoursel

2HeurylV. iv. 2

I have \& whole school of tongues

murdcrous Machiavel to school..... Henry I I. iii. 2

in schools, and brotherhoods.. Tritusf Cressidn,

and schools should fail for priyate

that we two went to school togetier

we'll set thee to school to an ant.

toward school with heavv looks. Romeo \& Juli

guing hack to school in Wittenberg .... Hamlet $\mathrm{i}$.

SCiIOOL-BOY that lad lost

the flat transgression of a schionl-bny. Much dito,

motion of a school-boy's tongue.. Love's likest,

big enougls to bear a schiool-boy's. Winter's Tale,
whom, like a school-boy, you may. . I Itenry $V^{\prime}$.

whom, like a school-boy, you may

a peevish school-boy worthless of. Julius Corster,

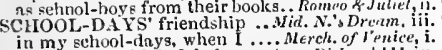

school-davs, frightful, desperate ... Richart III.

CliOOLED, and yet lcarned .......As you Like it

twere good, he were schooled. Thming of silveu",

well, I am schooled; good mannes.

SCHOOR,FELLWW, whom I will .... Homlet, iil.

sCIIOOLING private seliooling.Mid.N.'s Dream, i.

SCHOOL-MAIIS change their

CHOOLMASTER, made thee more...? ?'enpest, $\mathrm{i}$

marry, master schoolmaster .... Lone's l. Lost,

seloolmasters will I keep within. Tuming of

to get her cunning sclinolmasters ....ike -

as a schoolmaster well seen in music

ahout a uchnolmaster for fair Bianea

my fellow schoolmaster doth watch

than look upon his schoolmaster .... Coriolanus.

Cæesar, 'tis his schnolmaster.........

unworthy I, to be her schoolmaster.... lericles, ii.

pr'y thee, nuncle, keep a schoolmaster

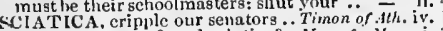

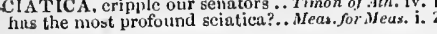

threc or four serc haid lis sc

entertain a seore or two of.......... Richard 11I.

SCORED-have you scorcl me? Well .... $\overrightarrow{.}$

O, what a denl of yeorn looks... that scions, put in wild and savi

scuff on, vile fieud, and shmineless

CULD - hear them scold than figlit. Merry H'ives, ii.

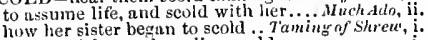

she is an irksome brawling scold

thou unadviscel seold, I can produce. King John, ii.

take away this captive scold ..........3 Hemry $V I . \mathrm{v}$.
more, or scold it out of him........ Henry VIII.

the flamen, that scolds against. Timon of dithens, iv. 3

that ever I was forced to scold.

for her scolding tongue (rep.).. Taming of Shrew, i. 2

she would think scolding would do...
away this scolding crook-back...... 3 lienry $V$ r. v. 5

the seolding winds have rived ...... Julius Casar, i. 3

in your seonce. Sconce, eall you it? - ii. 2

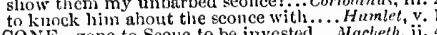

will you to Scone? No. cousin ...... - ii.

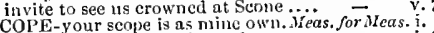

so evcry scope by the in

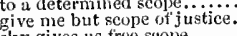

gky gives us free seope ...........
[Col. Knl.] no scope of nature...

I do know tle seope and warrait limito. John, iii. 4

no further seopc, than for his ....... Richard 11 . iii. 3

scope to beat, since foes have scope to $-\bar{V}$ iij. 3

even of his natural scope, when
give him line and scopi t till

offender grutited scope of spec.

may have some scope to beat.

2 Henrylli. iv.

COR N-will prove an idte seorn ...Love's L. Losl, i.

ocor

how will he scorn? how will he....

will henr your idle scorns, continue.

the red to mak of scorn and proud

take thou un scorn, to wear

not a thing to luugh to senrn...

if the seorn of your brisht eys

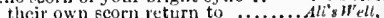

lut one that seorn to live in .. Taming of shre

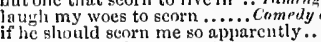

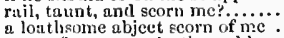

spurn fate, scom death, and licar
laurl to scory the power of man

lauph to ecom $w$ the power of
wili latugl: a siege to scorn......

weapons langh to scorn

which seoris a modern invocation

your daring tongue seorns to ........

charge inc? I seorn you, seurv
low? yout fat fool, I scorn you

with scorn shoved from the court.... - ii.

cause to eurse the Datphlin's scor....... terery $v . i$.

scorn, and defiance; slight regard......

therefore he scorns to say his pray'ers

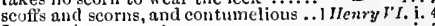

I scorn thy strength; go, go.

thy scorns this way, Plantagenet (rep.)

and take fonl scorn, to fawn on.

whieh laughest us here to scorn

will scorn theal, him

in her heart she seorns our poverty ...2IIenry rI. $^{\text {v. } 3}$

the unbility think seorn to go in $\ldots . .3$ uenry $r l$ iv.

aud, after many scorns inany foul ".

presume to scorn us in this mamer?

setting your scorns, and your mislike $-\overline{\text { iv. }}$.

Michard IMI. i.

and with thy seorns drew'st rivers ....

the wind, and scorns the sun

as 'twere in scorn of eyes

injury, to scorn his curse
to mitigate the scorn he giv.

to trunt and scorn you thus

"tis coneeived to scope.......... Timon of

making your wills the scope of justice - v

when you will it slahl have seope. Julus Casar, $r, j$.

witlin her scope of choice ........ Romeo \& Juliet,

in the gross and scope of mine npinion.
more than the seope of these dilated

nn anchor's checr in prison be my seope! $\overline{\text { Tit }}$
CORCH me up like a burning glass. Merry Wives, $\mathrm{i}$

to scorch your face, and to.... Comedy of Errors,

to scorch your face, an newburned. King John, iii. 1

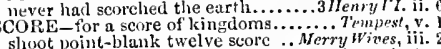

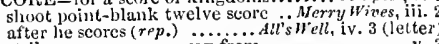

strikes some scores awny from ........- v.

call him half a score knave

for she will score ytur fault upon..... Comedy of Frr.

iillacbelh,

seore a pint of bastard in.

will be a mareh of twelve senre......

$i^{+}$the clout at twel ve score.

all shall eat and drink on my senre.

no other books but the scorc and ...

without a seore of villaius Timon of Ath. iii. 6 (
let us score tleir backs ....Anthny \& Cle'tpntra

speak, how many score of milc

more than two teus to a score

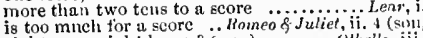

eight score eight hours? (rep.)
strike off this score of absence

$\mathrm{SCORN}$ is bonght with groans
she did scorn a present titat

slie did scorn a prosent tita
a woman sometimes scorme

a woman solnetimes scor
fior scorn at first makes

if thou scorn our courte

let me sustain no scorn

the argument of his own scorn. $\ldots \ldots \ldots$.... Much
have so oft enrountered him with seorn

'tis very possible lie'll scorn it .......

condemued for pride and scorn so much?=-

I scorn that with my hecls

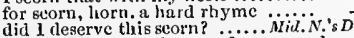

that I should woo in scorn? seorn and

I scorn you not; it secms thut (rep.)

as in scorn, to follnw me

sweet, do nnt seorn her so...

in her behall' that scorns your services

think no scorn to meet at Ninus' tomb 'tis but a scar to seorn

the pride and salt scorn of his ey.es ..

winged thus swift with scorn ......

whit, does the cuckold scortu mic?... - iii.

I scorn thy meat; ' twould choke.. Timon of $A t h$.

the grenter ecorns the lesser ..........

sliall scorn him further trial than....

Fortune knows, we scorn her .....Anlony \& Cleo. iii,

wear mine, are titles but of seorn .... $\quad$ - v.

geck and scorn o' the nther's villany?

not to be me, scorns ine ..............

in scorn to thee sent hack............ - i

in that it scorns to bear unother hue . Fericles, ii. 4

[Col.] you scorn believe me ............ o o Juliet, i. i

scom at our solemnity (rep.) .........

a martinl scom, with one hand beats $\overline{-}$ iti.

her own future, scorn her own imagc.. ouetlo, jii.

for the time of scorn to point his slow.... iv. $\overline{3}$ (soug)

CORN'DST our brain's flow.

CORNED - hath slandered, scorved....Much Ath, ix.

mocked at my gajus, scorned ...Mer. of l'trice, iii.

liearts that scorned to scrve ............. -

the kitchen-vestal scorned you.. Conedy, of Frr. iv.

to be so baited, sconicd, and stomed..... Richardlil. i. 3

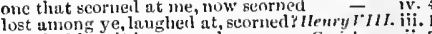

how in his suit he scorned ynu...... Corinfmns, ii. 3

nll poperty was scorned, and pride......Perirles, i.

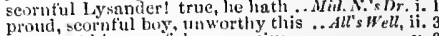
contempt his scoriful perspective....
dort not scornful glances from.... Tring of $s h$. v. d:irt not scornful glances from.... Taming of sh. v.
thou senrniul page, there lie thy part. Cymbeline, v. bilinding flames into her seornful esesl .. Lear, ii. 4 but snys, he used us scornfully....... Curiolamus, ii. join witl men in scorning your ..Mid.N. 's Dr. iii. join with men and seen thec scorning . Troilus \& Cress. iv. seorninge the base degrees by which.Julius Capsar,
Elunrpest hlow, Antiochus, scorning ..... Perieles, Ci)leN'sT thou at sir Robert? ........

ACOlil'lON-full of scorpious is my ..... Alacbrth, iii. 
SCORPION-as a scorpion to her sight... Cymbeline, y. CoT -ever vatiant and approved scot. llenery $\mathrm{l}$. i. those same noble Scots, $\ldots \ldots \ldots . . . . .$.

a Scot of them; no, if a Scot would save 二

that spriglitly Seot of Seots, Douglas

well said my noble Scot..............

as you, my lord, or any seot that lives -

I was mot born a yielder, thou proud scot

hold up thy head, vile Scot, or thou...

hot termagant scot had paid me scot

the noble scot, lord Douglas

furious Scot, the bloody Dougias...2 Henry $I V . \mathrm{i}, \mathrm{i}$

of English, and of Scots, are by the

against the Scot, who will make

but that the Seot on his unfurnished

as a stray, the king of Scots.

the wersel Scot comes snerking......

and the Seots captain, captain Jamy

the king of scots is crowned......... Henry rt. iv. SCOTCH-is as a scotch jig (vep.; ....Much delo. ii.
SCOTCHED-have scotched the snake. Macbeth, iii. he seotehed aud notched him like... Coriolanus, iv.

SCOTCIIES-room for six scotches.Antony s-Clen. iy. mark, king of Scotland, mark...........

ns if it telt with Scotland, and yelled

yet do not fear; Scotland hath $\ldots \ldots . . .$.

have banislied me from Scotlan

your eye in Scotland wonld create

hail, king of Scotland k king ot

the first that ever Scotland in

mean for powers in Scotland (rep.) ...
son in Scotland being thus employed

the banks of England, Scotland, Walc

lord Mortimer of Scotlankl hath sent

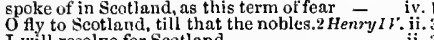

to ripe his growing fortunes, to scotiand

to ripe his growing fortunes, to Scotland -

from Seotland am I stolen..............

Scotland, hath will to help

Henry now lives in Scotland ............

COTTISH-of the Scottish lord

once more to your Scottisl prisoners. I Henry IV, i. 3

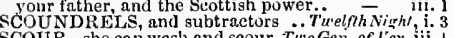

COUR-she can wash and scour. Two Gen. of $l^{\prime} e$ '

I wash, wring, brew, bake, scour
look you scour with juice of balm

never saw I men scour so on ......
would scour these English hence?

shall scour my shame with it

I will scour you witl my rapier

Tinter's Tale, $\mathrm{i}$. Macbeth,

this day, to scour it in the dust

than to be scoured to nothing with ..2Henrylli.

shall be scoured in his rancorous....2 llenry VI. iii.

revengement and a scourge for m.
will scourge with haughty arms..

with them scourge the bad revoiting. 1 Henry $V I$. i. I

an $I$ to be the English scourg

to scourge you tor this apprehension
terror, and their bloody scourget ....

the Frencinmen's only scourse

Naples, England's bloody scourge! ..2 Henry $r$ iv. 7

whit scourge for perjury can this ... Kichard 1II. i.

to scourge the ingratitude that ..Antony \& Cleo. ii. 6

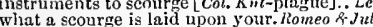

What a scourge is laid upon your. Romeo sumet

the otfender's seourge is weighed
SCOURGED-whipped and scourg

vet nature finds itself scourged by the 1 HenryII. i. 3

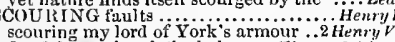

scouring my lord of York's armour ..2 Henry VI. i. 3
fearlul scouring doth clioke .... Timon of Athens, $\mathrm{Y} .3$

fearlul scouring doth clioke .... Timon of Athens, v. 3
scout' me for him at the ........ Tuetfih Night, iii. 4

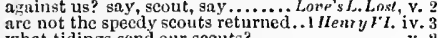

what tidings send our scouts? .........

our scouts have fiund the arlventure

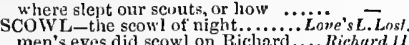

men's eyes did scowl on Richard.... Richurd II. v.

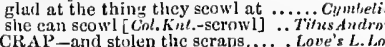

CRAP - and stolen the seraps..... Love's L.Losk, v. 1
those scraps are good deeds past. Troilus f Cress. iii. 3
the frarments, scraps, the bits........

colll dishes, with scraps o' the court... Cymbeline, ii. 3

if it be but to serape the figures. . Merry ilites, iv. a trenclier! he scrape a trencher!. Romeo \&-Juliel, i. 5
SCRAPED one out of the table..... Meas. for Meas. $\mathbf{i} .2$ you will be scraped out of the $\ldots . .$. Love's L. Lost, v.
of fair king Ricliard, scraped from ..2 Herry $1 v . \mathrm{i}$. SCRAPING futher's' gold ............ Richurd II. v.
SCRATCH - tailor might scratel. Tempest, ii. 2 (song)

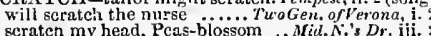
but to help cavalero Cobweb to scrateh - iii. do but tickle me, I must scrateh

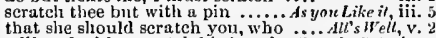

will nake him scratch his bcard. Hinter's Tate, iv.
a shalluw scratch should drive...... Herery $I F$. v.
SCRATCH your heads

and scratch my praised eheeks.. Troilus of Cress. iv.

I canne seratch my licad i' the sun. Coriolenus, ii. scratch it [Col. Knl.-search] out of the... Pericles ay, ay, $n$ scrntch, a scratch

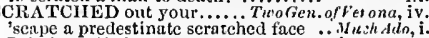

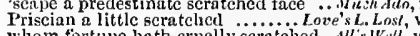

Whom forture hath cruelly scratched.. All s Wed , v.

them you scratched your head ..... Julins Cresnr, ii.

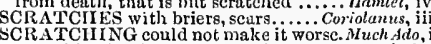

scratching her legs....... Taming of Sherew, 2 (ind inc.
and I had the seratching of thee. Troilus \& Cress. ii. I and I had the scratching of thee. Troilus \& Cress. ii. I strange screams of death

SCREECH-OWL aye be called. Troilus \& Cress. v. II
SCREEN-to have no screen between .. Tcmpest, i. ? your leafy screens thrown down .........Mucheth, y. 6 SCREENED and stood between ..........Hamlet, iit. 4

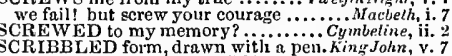

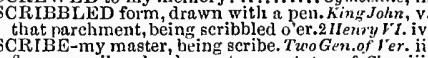
CRIBE-my master, being scribe. Two Gen.of Jer. ii.
figures, scribes, bards, poets .... Anlnny \& Cleo. iii.
will let thee, play the scribe .... Tilus A ndron. ii. will let thee, play the seribe

SCRIP-according to the serip.

yet with serip and scrippage........ As you Like it, iii.

CRIPTURES of the loyal Leonatuscymbeline, iij.

the devil can cite scripture for his. Mer. of Venice, i.
with a piece of scripture, tell them... Richard III. $\mathrm{i}$.

minderstand the scripture? (rep.) ........Humlet, v. 1

CRITCH-OWL, scritching loud
the time when scriteh-owls cry

hoding seritch-owls make the concert - iii. 2

that fatal scritch-owl to our house. 3 3 Henry r. ii. 6

SCROLL of every man's name ... Mid.N.'s Dreain, i.

eall forth your actors by the scroll ... - i. 2

here's the scroll, the continent

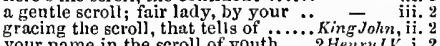

your name in the scroll of youth ..... 2 Henry IV. i. 2

accept this seroll, most gracious.... Hen ry FI. ii1.

give the king this fatal plotted seroll. Titus.And. ii. 3

sweet scrolls to fly about the street

CROOP, where lies our uncle ......Richard $I I$. iii. 2

sir Stephen Scroop; besides a clergyman - ii. 3
the lord Scroop, 1 speak not.......... I Hen $r y$ I $V^{\prime}$ i. 3

this to my cousin Scroop

lord Scroop of Masham (rep. ii. 2).ilenry $r$. ii. (cho.)

though Canibridge, Scroop, and Grey

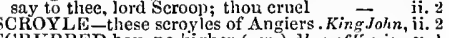

CRUBBED boy, no figher (rep.). Her. of i enice, v. I

if I lose a scruple of this sport.... Tuetrithight. ii. .

no dram of a siruple (rep.)........... - - iri.

have to do with any scruple

twentieth part of one pour scruple.....Mnch $A d d$,

and I will not bate thee a scruple.... All's 'I'ell, ii.

fears and scruples shake us ..............Macbeth, ii. 3

former scruple in our strong-harred.. King John, it. 2

uncleanly scruple! fear not you .... Rickard iv. !

a scruplc, or indeed, a scruple itself..2 Henry $I V$. i. 2

but there remains a seruple in...... Henry VI. v. 3

cornmitting freely your scruple to the -

lail any sertuple in your way.........

and the king's late scruple ............

for every scruple of her contaminated

or wotch, made scruple of his praise.. Cymbelen

or some craven scruple of thinking too. Hamtel, iv.
SChUPULOUS-with scrupnions wit?.3 Henry $I$. iv.

powers breed scrupulous faction. Anfony \& Cleo. i. 3
sCUFFLE-in the scuffes of great fights - i. I

and yellow chapless scults .....Romeo \& \& Jutiet, iv.

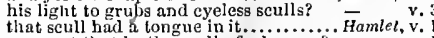

nny not that be the scull of a lawyer?.

this same scull, sir, was Yorick's scnll1.

SCULLION-away you scullion!
like a very drab, a scullion!

CUM - frotl and scum, thou liest...

purge you of your scum the filth and scum of Kent

a scum of Bretagnes, uul base ...... Richaril lit. $\mathrm{v}$.

SCURRIL-breaks seurril jests. Tritus \& Cressida, i.

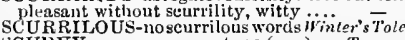

SCURVY - a very scurvy tune (rep.).... Tempesi, ii. 2

a most scurvy mons

geurvy jack-a-nape priest (rep. ii. 3$)_{\text {iverry }}$ Wives, i.

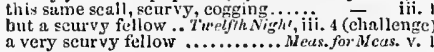

CURVY, nor a temporary meduler.. Nea. for Mea. y.

courtesice alone, they are scurvy ones

1 scorn you, scurvy companion ...2.2Henry $l V$. ii.

you scurvy, lousy knave $(r c p$.$) ......... Henry \nu$.

thou scurvy, valiant ass l $\ldots .$. Troilus \& Cress. it

that same scurvy doting foolis $\mathrm{h}$.........

am a roscal, a seurvy reiling knave

dike a scurvy politician, seem ......Lear, iv.

scurvy knavel I an none of his .. Romeo \& Jul. ii. base notorious knave, some scurvy fellow - iv. by this hand, I say, it is very scurvy ow - iv. and laid good 'scuse upon your ecstacy. Olhello, iv. CUT - my doe with the black scut?.Merry Wives, $v$. CU'TCHEON plain declares ....... Love'sL. Lost,
honour is a mere scutcheon scutcheons, and your signs of conquest $A n t . \&$ Cleo. $\mathrm{v}$

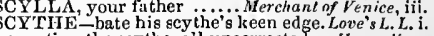
wanting the scythe, all uncorrected...Henry $V^{\prime}$. v. even with his pestilent scythc.. Antony \& Cleo. iii. i SCYTIIA half so barbarous. . Tilus Andronicus, i. the barbarous Seythian, or he that.......... Lear, i.

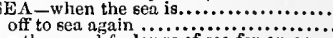

a thonsand furlongs of sea for an acre

but that the sea, mounting
I would have sunk the sea

bore us some leagues to sea

to cry to the sea that roar'd to us.......

and hear the last of our sea sorrow..... ut doth sufph o' the sea mest, i.

sea nymphs lourly ring his $\mathrm{kneili..}=$ i. 2 (song being as thcy were, drenched in the sea
sowing the kernels of it in the sea ....

rom whom we were all sen swallowed then to sea, boys, and let her ...... - ii. $2(\mathrm{smm})$ and the sea mocks our $\ldots \ldots \ldots \ldots \ldots \ldots . . .6$ the never surfeited sea hath $\ldots . . . . . . . . .$. 二 exposed unto the sea ................. twixt the green sea and the $\ldots . . . . . .$. . as when we first put ont to sea and promise you calm seas...

and drench'd me in the sea... Two Gen, of Verona, as twenty seas, if all

why, it is at sea

ns the sea of sands

Thy never to sea again ............Merry Wives, ii. thy capacity receiveth as the sea.. Tuelfh Nighl, $i$. you took me from the breach of the sea =

men of such constancy put to sea...

is all as hungry as the sea $\ldots . . . \ldots \ldots . . . \quad=$ ii. the great soldier, who miscarried at sea?

on the bcached margent of the sea.Mid.N.'s $\mathrm{Dr}$. iv. a wind too great might do at sea

in the narrow seas (rep. iii. 1)...

guiled sliorc to a most dangerous sea

flow as hugely as the sea...........Asyou $\overline{L i k e}$ it, ii. have 1 not heard the sea, putfed .... gain, or perish on the scas..

by sea, and by land; but 1 am not (rep.) -

I wisl you a wave o' the sea
or the profound seas lide in

I am put to sca with her $\ldots . . . \ldots \ldots . . .$. . $\overline{\text { the }}$

in earth, in sca, in sky ..............

and wild watery seas,
for he is bound to sea

and put to sen to-day

by wreck at sea? (rep.)

........... Alacbeth, i.

the ravined salt sea shark

lin'ge lengtlis of scas and slio

the sea enraged is not half so

upon this side the sea (except

in rage deat as the sea, hasty ........

precious stone set in the silver sea

after late tossing on the brenking seas?

in the rough rude sea ean wash.

clipped in with the sen that

we ventured on such dangerous seas..2 Henryl it. $\mathrm{i}$. melt itself ioto the sea!.

nnd ebb back to the sea.................

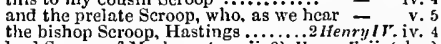

ike to ason for raising this sea storm? shall no inore to sen, to sea...... - ii. 2 (song)

one foot in sea, and one on shore. Much Ado, ii. 3 (8nilir) have sucked up from the sea contagious

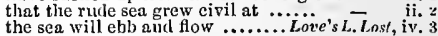

the pageants of the sea ..............

great seas have dried, when miracles.. All's Welli. ii. 2}


SE A-the ooze and bottom of the se resth streams run in one self sea...

chinrming the narrow stus

buttoms through the furruwed sea...

Herryr. i. 2

ii. (clio.)
iii. 2

it is a theme as flustut as the sed ....

- iv.

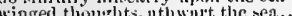

v. (eho.)

out-voice the dcep-monthed sea.... - v. (clio.)

iii. 1

and in that sen of bloor.

to the fortme of the nea

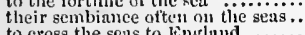

to eross the sens to England

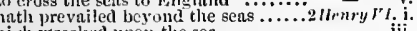

nigh wreeked upon the sea ...............
vantting sen rctusul to drown me

with tears as sa!t as sea thronglt.

with tears as salt as sea throngh $\ldots$.
the sea receivel it; and so. I wished

二

the sea receivel it; and so, I wisl

should make a start o'er seas...

Fanlconbrirlge eommands the narrow seas

like n mighty sea foreed by the tide

the self-sume sen forced to

sled seas of tears, and ne'er $\ldots \ldots . .$.
slall Warwick eut the sea to France

slinll cross the sen, to effect.

Ill cross the sen, to effect.............

shall cross the seas, and bid filse

with Grod, and with the seas .......

passed, and now repassed the seas

my sea shall suck them dry

adil water to the sea ..............

and thyself, the sea, whose envious

all scattered in the hottom of the sea.

b:rrst to belch it in the sea

a bark to brook no mighty sea

on the seas. There let lim sink (rep.)

what makes he upon the seas?

these stragglers oer the seas ag.

even the billows of the sea.

many sunmers iu a sea of giory

the sea beiug smooth

what raging of the sea? ................

richer than sea and land?.

when we vow to weep scas ...........

we must all part into this sea of air.
where the light foam of tlue sea may

attraction robs the vast sea......

the sea's a thief, whose liquid.

the sea's a thief, whose liquid.........
entombed upon the very liem o the sen
he waxed like n sea; nud ........... Coriolo

such as yon, a sea and land fuil...

by sea, and land, in every place.

on stich a full sea are we now........

Ponpey is strong at sen

make the sca serve them

both what by set and land.

love me, and the sea is mine.

by sea he is an absolute maste
we'll speak with thee at sen

I must rid all the sea of pirat

at sea, I think. We have, sir ........

so quickly cut the Ioninn sea.......

will fight with him by sen (rep.).

refusing him at sea, being prepnred $(\dot{r} c p$.$) -$

Publicola, and Ceelius, are for se.

till we have done at sea ............

the myrtle leaf to his grand sea

by sea and land I II fight: or I wiil

their preparation is to-day by sea

order the rea is given ................. crop of sea and land.... Cymbline

from Gallia I erossed the scas ......
on our terrible seas, like egg-shells.

on our terrible seas, like egg-shells.
if you are sick at sea, or stomach-

the imperious scas breen mon

af ter your will, have erossed the sea

would make me spurn the sea .......

environed with a wilderness of 'sea ..

I am the sea: hark, how her sighs (rep.)

liappily, you may find her in the sea

until his very downfal in the sea
the land, to perish on the seas.......

of late, earth, sea, and air

put forth to seas, where wher men

the sea hath cast me on the rocks (rep.)

I marvel how the fiehes live in the sea

till the rough scas, that spare not.....

spite of all the rupture of the sen

was by the rough seas reft of slips.
by miefortune of the seas liat been

Ileap into the seas, where's ............

lyer nurse, she takes, and so to se

the sen works high, the wind.
with us at sea it still hath been...

with us at sea it still hath been.
standing bleak upon the sea.

pven now diri the sea toss upon...

it the sea's stomach be o'ercinarged.....
did the sea cast it up?

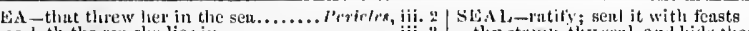

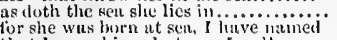

that l was whipped nt sen, I well
wreath of tluwers, ere the sea mar

endired a sea that almost burst

sail scas in evekles..............

he puts on sackeloth, und to sca

serve after a long voy'ate at sea
where we left liim, on the sea

for I was born at sca. At sea?

lest this grent sea of joys rushing ...... - $v_{\text {. }}$

how thon nt sea ditlst lose

thy nurclen at the ses, and callerl Mirina

rth into the sea

if thy flight lay toward the raging sea

as matl as the vexed sea

lark, do you hear the sen?

ant waved like the enridged sea..........

the fish lives in the sea .............
shore washed with the furthest sea...
my hounty is as boundless as the sea

my hounty is as boundless as the sea

I hark, a sca, a wind: for still $\ldots \ldots \ldots$

empty tigers, or the roaring sea .....
whether in sea or fire, in earth or air

beetles o'er his base into the sea?.....

looks an many fathorns to the sea..............

haply, the seas, and conntries different.
mad as the sea, and wind, when both.

ere we were two days old at sea
and conitine tor the sea's worth

and conitine tor the sea's worth $\ldots . . .$.
from the Cape can you discern at sea?

from the Cape can you discern at sea?

the Noor himselt"s at sea, and is in fiil

for I have lost him on a dangerous seal

the great contention of the sen nind sises

- $\quad$ iii. 5

like to tlye Pontick sen, whose icy current

more rell than anguish, hulger, or the sea! -

SEA-BANK - the wild sea-lanks.. Aer. arJevinc, $v$.
the sea-hank with certain Venctians..Othello, iv. SEA-CAP-let seaboy in an hour so.2 henryll. iii. $\mathrm{E} A-\mathrm{COAL}$-end of a sea-eoal fire ... Merry Hives,
Oatcalce, sir, or George Sen-coal .... Much Aro,

come hither, neiglibour Sea-coal

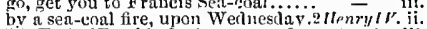

SEN-FARER-this fresl new sea-farer. Pericles, iii.

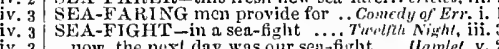
now, the next day was our seat-fight.... In amlet, v. and seal the bargain

break the seal for once.....

or' say, 'tis not your seal.......

Trögen.... of terona, i. 3

v.

here is the hand and seal of the duke - iv.

which $I$ had rather seal with my death

ii. 1 pure white, this seal of bliss!. Wiil.N's Dream, iii.

to a nntary, seal me there your ... Her. of Venice.

I'll seal to sueh a bond (rep.)
you shnll not seal to such.......

to seal love's hondy new made

till thou can'st rail the seal from off
by him seal up thy mind. - iv you Like il, iv. 3 (letter)

it is the show and seal of nature's .... All' sell

not dared to break the holy seal. Winter's Tule, iii. 2

break up the seals, and read

afterwards sealit, ani again return ...Mracbeth, v,

here is your hand and seal for ...... . - ivent iv. 2

the man in seal of death.

what seal is that, that langs without

we'll hut seal, and then to horse ... IIen $\overline{y /} J \mathrm{r}$. iii. i

giddy mast seal up the shiphoy's

rebellion with a seal divine

and sliortly will the broken seals of perjury .... - iv. 3

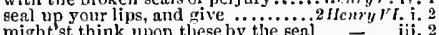

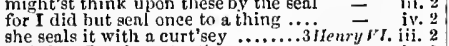

she seals it witly a curt'sey
and thus I seal my truth

I seal upon the lips of this

with my hand I seal my tr.

Bnto your ence......

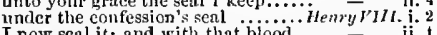

under your hands and seals.

render up the great seal presenti

render up the great seal presently ask with suels a vinlence -

to earry into Flanders the great seal

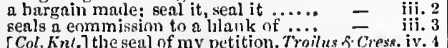

[Col. Knl.] the seal of my petition. Troilus f. Cress. iv. 4 seal what I end withall?

together with the seal o the senate....

with the seal of Casar (rep.)....... Julius resar, iii.

geal then. and nll is done ...........

to seal the acelser's lips
feal with n righteous kiss

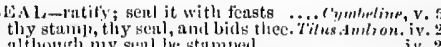

your humls and lips numst seal

.

to rive them on - y. 3

cvery god did scen to set his seal.

must your eonscience my acquittance scul - iv.

all seals and symbinls of redecmed sii..... inhetho, ii. 3

F...LED-or sums in sealed bags. Merry Wires, iti.

thut's sealed in approbation...

a tererch of lenice,

a sealed bag, two sealed bags of llucats - ii.

by Alollo's great divine sealed up. W'intr's Tale, iti.1

have setler his rigorons statutes. Comedly of Srr.

which bein: realed interehangeabio.i Hewry $I \mathrm{l}$.

hast sealed up my expectation.....2Hen - Hy $I F$. iv.

with blood he sealed a testament ..... Ilenry $V$ iv. 6
the conquest fully been sealed up ... Herry $V$. i. I

now thon art scaled the son..........

that wast sealed in thy nativity.... Richard III. i.
till we have sealel thy full desire. Timnof Ath. v.

I found this paper thus sealed up. Jutins Crosar, ii. 1

written and scaled between 128 .. Antony \& Clco, ni.

his sealed commission, left in trust ..... Pericles, i. 3

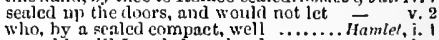

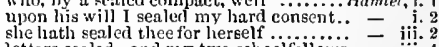

letters sealed: and my two sehool fellows - iii.

for every thing is sealed and done $\ldots . . .$.
how was this scaled? Why, even in......
SEAIED-UP' contsel.

bronglit this sealed-up oracle ....W'inter's Tale', iit. 2

SEALING the injury of tongues. Winter's Tiule, $\mathrm{i}$.

the other three are esealing.......Anlony \& Cloo. iii. 2

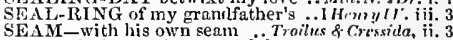

through the rough seams of the waters. Pericles, ii.

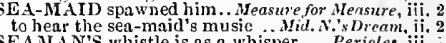

SEA-MIARG wh, steril. and rock $y$-lhard . Tempest, iv.

and very sea-mark of my utmust sail.. O/hello, v.
and

and very sea-mark of my utmost sail. .Ohello, v. 2

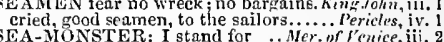

in a child, than the sea-mnnster!........... I.rnr, i. 4 SAR-calummy will sear virtue.. Whiner's 7ale, ii. 1

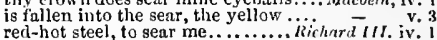

red-hot steel, to sear me............ Richard $t I l$. iv
and sear up my embracements ...... Clymbeline,

the sea mocks our frustrate seareh ..... Tempest, ii.

and thus I searel it with .. Ture Gen. of Verona, i.

and my assurance bids me

to search for a gentlemau.

search, seck, find ont ..........

see the issue of his search............... $=$ iii. 3

to search the house for bis wife's love and did he search tor yon...........

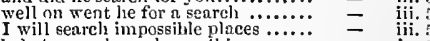

help to seareh my house this ......... - iv.

once more search with me

search Windsor castle, elves ........

with him to search Bastanio's ship.. - ii. s

a thing of his own searcl............Asyon $\vec{L}$ ike it. i. I

not to flnd that her search implies ......Al's ' $\|^{\prime}$ ell, i. 3

the scareh, sir, was profitable.

should go in searel of $y$ irtue

they arc come to search the hol

search his pockets. What hast
search out thy wit for scerct.

to seareh the secret treasons of

King, Ioln, ii. 2

guarded! and the seareh so slow .... Cymbeline, i. I

go, and search. You have ahnsed - ii. 3

and honour; which dies i' the scarch $=\quad$ iii. 3

dost thon searel my mound.. Titus, $m$ udronicns, ii. 4

[Col. Knt.] search out of the calendar... ['prictes, ii. I

of Pericles the carcful seareh by

seareh every nere in the higli grown $\ldots . .$. t.eur. iv. 4
infold me from the search of cyes. Romeo \& Jut. iii, 3

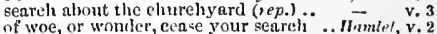

lead to the Sngittary the raised search ... Ohello, i. 1 several quests, to search you out ........ iv - i.

the last time he searched tior him.... - iv. 2

who, inwari scarehed, have livers. Ver.oflenice, iii. 2

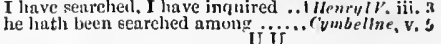


SEARCIIERS of the town ......Rnmen of Jule SEARC1LES to the bottom of ..... Troilus \& Cress. ii. a men the searehin wound

a marvellous searching wine.

Richurd II. iii.

my own searching eyes shall

searehing the wimlow for a flint ... Julins Carsar, ii.

[icl.] uftem readl onaten's name seared

that seared tle wings of my sweet...3 Heurur

[Knt.] in these seared hope

SEA-ROOM, an the brine and clond

SEA-SALT tears

who LK, think ............. Love's L. Los,

who began to be mueh sea-sick.

rocks thy sen-sick wenry bark l.. Romeo \& Julie

政,

we set ori, Camillo, to the sea-sice.

he hath despatched to the sea-side ... King Jol

to the sea-side straightway. Antony ơ Cieoputra,

SEASON-past the mid season........... Tempert i. and of the season too, it shall .............. Irines, fii. 3 all this, to season a brother

we kill the fowl of seus $m$........

frame the season for your nwn iiarvest. Much ddo. i.

which thay seasin give to her fiul

we see the setsons altcr ......... hid. $N$ 's Dream, ii.

are not rife until their season ......

and wit the season, and olserve.

whell mercy seasons justice. Mes chan' of

low many things by season seasoned - v.

of Adum, the seasons'difference ..Asyou Like it, ij.

I am not a dny of season.................

these jests are out of season. . Comedy of Error

any nan thus beaten ont of season? - ii. 2

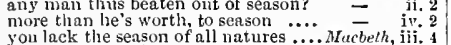

best knows the fits o' the season

would have done at the same season.i. Henry $I F$. iv.

not a soldier of this seasnn's stamp

health in very happy season....

und joys abound, as seasons fleet ...2 2 Hen

for a sea son after, conld not believe. Richarit ir ii.

tor so the senson bids is be

spice and salt that senson a mail..........

proportion, season, form, office

and the season can yield it.... Timon of tithens, iii. 6

season the slaves for tuhs.............

tell you at some meeter season.... Antony \& Clro. v.

honest wills, which seasons comfort.. Cymbeline
with aptness of the season ...........

with aptness of the season

wrom south of sucli a season

to see this gracious season.

thus out of season; threading

se: son love, that of it doth not taste!. Rom. oful. ii. 3

season your admiration for a while

my blessing season this in thee

as you dians near the season, wherein

as you may season it in the char
dire tily seasons him his enemy

confederate season, else no creature ....
E.ASONED with a graeious voice. Mer.of renice, iit. 2
be seasoned with such viands? ...... 2 iv. 1

many things by season seasnned are -... - iv. 1

so seasoned with your faithful love.RichardIII. iii.
from Rome all seasoned office...... Coriolanus, iii.

he is fit and seasoned for his passage?.. Humlet,

who newly in the seat, that it.......1reas. for Meas. i. 3

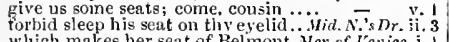

Which makes her seat of Belmont. Mer. of renice, i.
this castle bath a pleasant seat .......... Macbeth i.

thray you, keep seat...........................

now by my seat's right royal.

against tly seat: bith young...........
and in this seat of peace, tumultuous

thou live in Richard's sent to sit

my soull thy seat is mp on hirh $\ldots . .$.
tliat Holmedon and this seat of ours..

that Holinedon and this seat of ours..1 Henry

vaulted with such ease into

struck me in my very seat of judgment

so soon did loae his seat.

to the crown and seat of France.

never valued this poor seat of England

fi) $r$ your great seats, now quit.

phlose low vassol seat the Alps..........
hoise duke Fiumphrey from his seat..2 Henry $r$ ii. 5

I sat in seat of majesty

heir to England's royal seat

shoulder do I build my seat

my seat .......

and the seat of England's true-unointed - iii. 3

force the tyrant from his seat by war
shaken Ed ward from the reanl seat

have we swept suspicion from our seat

honour, state, and seat, is due to me. Richor

in the seat royal of this famouts.

the supreme seat, the throne majestical -

canst rield a melancholy seat SEAT-nt thy godlike seat......... Troilus f. Cross. i. 3

e debase the nature of our seats...

et Crevar seat lim sure ...............ulius $\bar{C}$ cesar, $\mathbf{j}$.

fhrows befure thy seat a humble heart

whilst the wheeled seat of

my throme's a seat for basenes

for this, from stiller seats we can

onproach the imperial we

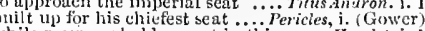

he gre $w$ unto his seat

lusty Noor hath leaped into my seat.... othello, ii.

and make my seated heart knock ... Aerch. of lenice, $i$

before I see thee seated in that .........

and see hin seated in the segal throne - ivi.

now $n \mathrm{~m}$ I seated as my soul delights $\overline{\text { being seaterl, and domestio boils.. Richard } 11 \text {. ji. } 7}$

assistance, is king lichard seated

so, now you are fairly seated $\ldots$.

what a grace was seated on this brow..Hamlet, iii.
SEA-TOST-the sea-tost prince..Pericles, iii (Ciow.)

SEA-IVALI,ED garden .............lichard II. ii. 4

of the A'TER shalt thou drink ......... Tempest, $\dot{j}$. 2

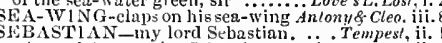

what miglut, worthy sebastian (rep..).....

thou'rt pinched for't now, Sebastian

Sebastian is thy name? .... Tuw Gen

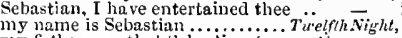

my father was that sebastian (rep.v. i)

he ramed Sebastian, done good feature

Sebastian are you? (rep)

ECOND-1'vastian so many ..........All strel,

received a second lite, and secoud father

and these are of the second edition.....

the second mads him............. Trwelfh $n$ ight, i. 5

the nurse of second woe ..Measure for Mpastere, $\mathrm{ii}$.
thus to second grief against pourselt... Much Ado, $\mathrm{v}$.

the first and second eause will nint. Lore's $L$. Los;, i. 2

the second, silver, which this ...

to be the lowry of a second head

so he served a second, ard so.............

you shall not entreat him to 2 se

the second, the quip modest........

I am the second sim of 0

from me, I bury a second husbind ....... Alt's $w^{\prime} e l l, \mathrm{i}$.

our widower's second marriage-day...

the secontl, and the third, nine.... Taming of Sh. i

good uny lords, be sccond to me .......

urging it the second time to me... Co
highly beloved, second to none that ...

who lies $i$ 'the second clamber?

great Nature's second course

our point of second meeting

being but the second generation

a second tall of cursed man?

or base secund means, the cords

that I am a second brother.

to second non attempt (rep.)

the second property of your excellent

your workings in a second body .......

in second accent of his ordnance

a second Hector for his grim aspect... 1 Henry $r I$, ji.

the second, William of Hatfield

York in arms, to second him

now begins a second storm to rise ...3Hernry $r^{\prime} t$. iij.
Richard the second here was...... Richard 111 . iit.

by the second hour in the morning

our cardinal, to sccond all his plot. $H$

I believe, his secund marriage shall.

on him ereet a sccond hope ............

I will the stcond time. as I would buy $-\overline{\text { iv. }}$

now prove good seconds ............. Co

shamed me in your condemned seconds
three-pence to a second day of audience

the second nume of men

fond of no secund broot wili............

what was the second noise

press near, and seeond him ......... - vii. I

by the second hour $\mathrm{i}^{\mathrm{s}}$ the morn...Aniony $\&$ Cleo. iv. 9

where's Dulabella, to second Proculcius? - - vy

to enjoy a second night of suclisweet - ii.

that is the second thing that I have.. -

if seconds had answered him

is the seeond that presents limi............

and cursed be lie that will not secolid it..
SECOND_what says our seeond daughter.. Lear i. no seconds? all myself? why this would... in is the operation of the second cup

are happy in this second match.......

to rid her from this second marriage

in second luse second time come to...... - ii. , that second marriace move a second time $I$ kill $\mathrm{my}$ liusband dead ...

a back, or second, that migit hold 政 and compel her to some scoond choice... - ii. hazard such a place, as his own seeond $\ddot{0}=$ ji. 3 I will be near to second your attempt ... $\overline{-}$ iv. 2

in question, is thy secondary .......... Meas. for $y /$ hes. $\mathrm{i}$. so doubly seconded with will.... Troilus \& Cress. i. the slave's report is scconded ........ Coriulumes, iv. 6 provost, for thy care, and secrecy. Meas, for M/eas. requires notling but secreey .... Winter's Tale, iji. the business asketh silent secrecy.....2 Henry but with advice, and silent secrecy $\ldots$ - ii. scececy, to defend mine honesty. Troilus \& Cress. i. her private actions to your secrec y .... Pericles. in dreadlul secrecy impart they did ...... Hanterices, $;$. secrecy to the king and queen moult no

no, in riespite of sense, and secrecy, uopeg - iii. unto the seeret nameless friend. Tư Gen. of Ver. ii. get such a secret from me

some secrets to confer about

wherein thou must be secret ....... - iii.

the book even of my secret soul ... Twetfh $\bar{N}$ ight,

to give me secret harbour...............

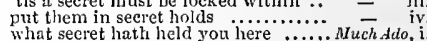

what secret hath held you here
I can be secret as a duml man

a thousand times in secret

other men's secrets, I beseech you. Love's $\bar{L}$. Lost iv.

under the left pap: i' faith, secrets ...
wretched fools'secrets heedfully o'ereye $=$

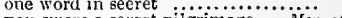

you swore a secret pilgrimage......... of of $\bar{v}$ enice, $i$.

a seeret and villanous contriver ...As you $\bar{L}$ ilis it, $\mathrm{i}$.

diseovered the secrets of your aring... - iv.

art to me as seeret and as dear.... Taming of $S h_{\text {. }} \mathrm{i}$. 1

to whistle off these seerets.............

thou to me thy secrets tell........... - iv. 3 (song)

those secret things, all but what $\ldots$...jel $~$
sir, there lies such secrets in this fardel

will have fulfilled their secret purposes
the finder-out of this secret ...........

how now, you secret, black ...............Macbeth, iv. I
deaf pillows will diseharge their secrets

lis secret murders sticking on by any secret course thy hateful life.King John, iii. 2

by any secret course thy hateful life. King John, iii.
stay, and be scret, and myself will. Richard II. ii.

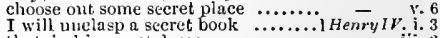

that, in his secret doom.............. He - iii. 2

seeret whispers of each otier's. Henry $V$. iv. (choris)
through a secret gate of iron bars $\ldots . . .1$ Henry $V 1 . i .4$
se

seareh ont thy wit for secret policies - iit.

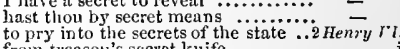

God's secret jud lyment .................

and live alone as secret as I may .....

advertised him by secret means.....3 Henry $1 \%$ iv. 5

if seeret powers suggest but trutli... = iv.

as for another secret close intent ..... Richard 111. $\mathrm{i}$.

the secret mischiefs that I set $\ldots \ldots \ldots . . . . . \quad$ i.

the history of all her secret thoughts
the secret is so weighty ............. Henry $\bar{v}$ III. ii.

to know the secret of your eunference - ii. 3

this main secret in the packet ...... = iii.

the secrets of nature have not.. Troilus \& Cress. iv. 2

other bnnd, than secret Romans ..Jnlizes Capsar, then should I know this secret

and not my husband's secrets? $\ldots . . .$.
shall partake the secrets of my lieart

the seeret house of death. An louy cloopatra ii.

this secret will force lim............ Cymbetine, ji.

nav, the secrets of the grave heart.... $_{\text {'ll have this seeret from thy }}$ - iii.

some marks of secret ou her person...

not trust the air with seerets.......... P' ivericles, $\mathrm{i}$. he might know nome of his secrets....

have secret feet in some of our best ports Lear, iii. 1

all blesfed secrets, all you un published - iv.

give leave' a while, we must talk in sccret - 
SECRET-in the seeret night .... Roneo of Juliet, ii. 4 is your man seeret? did you ne er.... . I I themlet, i. 5 but you'll be sceret, - ay, by lienven in the secret parts of fortme?

her and most.. - ii.

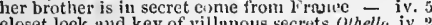

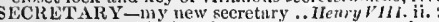
lreferrel from the king's secretary
and the king's seeretary; further, sir

heliness, master secretary (rep.) .... - v. HCRET-FALSE: what need $\ldots$ Camedy of lir. jii. HClRE'TLY - eomes so seeretly? ...Merry Hives, iv. let her awhile be secretly kept in ...Mnch Ado, iv. I will deal in this as seeretly, and justly

did whisper often very secretly .... Mid.N.'s Dr. y.

give1, sir, seerctly to understand... As you $L$

she secretly o'erheard your dauglite

sliall seeretly into the bosom ereen...1Henryll.

were best to do it secretly, alone.... Richard Th

secretly to greet the empress' friends. Titus.dnd. i

SliCT-all seets, all ages smack.. Neas. for . Neas.
would she bugin a seet ........... Winier's'Tule, wo is all her seet; ant they onee.

a fuvourer of this new sect?...

2 Henry IV. ii. 1
Heury VIIT. $\mathrm{y} .2$

packs and seets of great ones

Krt.] as he in his peculiar sect.

Ilamlet, i. 3

that rou eall-love, to be a sect, or seion. Othello, i. 3
SLCTARY-yolt are a sectary ...... Henry VIII. liave you been a seetary astronomical?.... Lear, i.

SiCUNDO-primo, secundo, tertio. Turelfh Night, y
SECURE-Page be a secure fool.... Merry Wives, ii.

Page is an ass, a seemre ass ........
for $\mathrm{n}$ secure and wilftal Actron

for a secure and wilful Actaon ....... - iii.

to nake societies secure... Measure for Measure,

secure and eonfilent from foreign ...King John, ii.

sleep donbtless, and secure, thut Hubert - iv.

open the door, secure, fool-hardy

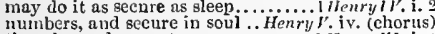

they deemed me not secure...

might the Frenehmen ase seeure.

we'll sleep seenre in Rouen........

and to seeure us by what we can....2 Henry $V t . \mathrm{y}$.

which secure and sweetly he enjoys. 3 Hrary $V I$. ii.

there shall I rest secnre from force . Pirllar iv it

but that I know our state secure..... - jii.

I myelf seenre in grace and favour $-\overline{\text { iij. }}$ is

is surety, surety secure ...... Irnilus \& Cressida, $\mathrm{ii}^{2}{ }^{2}$

to the mountains; there seenre us...Cymbeline,

seeure from worldly chianees .. Titus
sits aloft, secure of lhnnder's crack

he's more secure to keep it shut....

our mean seeures us; and our mere....... Leur, iv.

upon my secure hour thy unele sto

heaven seenre himl so be

thus, not jealous, nor secure; I would not - - othello, i. 3

to lip a wanton in a secure eouch......... iv. 1

stand seeurely on their battlements.. King John,

my lord; securely I espy virtue...

like IIeetor; bnt secnrely done.. Troilus\& Cress.

wars, whilst you gecurely slept.. Titas Andron.

SECURING-here securing your repose. Tempest, $\mathrm{ii}$.
SECUKITY enongh, to make ...Meas. for Neas. $\mathrm{ii}$.

all know, security is mortals' chicfest. Macbeth,

through our seeurity, gro

he liked not the seeurity ............2 HenryIV.

merey, but too much seeurity

and made our footstool of security...3 Henry $y i$.

fnir leave, and large security.. Troilus Cressida, $\mathrm{i}$.

friendship, without security ... Tim
yonr reverend ages love security

and hazard, from firm security.. Aniony \& $\overline{\text { Cleo. iii. } 7}$

now will he creep into sedges......... Wuch Aito,

now will he creep into sedges........ Mhach Aio, ii.
Cytherea all in sedges lid.. Taming of $\$$. 2.2 (induc.)

as tle waving sedges play with ... $\bar{T}^{2} 2$ (induc.

SEDGY gentle Severn's sedgy bank...1 Herry $1 V_{\text {. }}$

and heaped sedition on lise erown ...3 Henry/'l, ji. 2

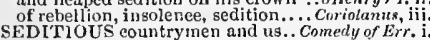

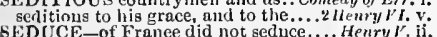

SEDUCE - of France did not sednce..... Henry $Y$.

that he will seduce the rest
thint have the power so to

SEDUCED hy thy flattery.. TwoGen. of i erona,

yet was Solomon so seduced ....... Love's L. Lost, i .

many a muid hath heen sedueed ......Ati's Well, iii.

1 was sedueed to make room for ..... King John, i.

or how are they seduced, that we ...31/enry I'l. y.

go firm, that cannot he seduecd? ..Jutius Carar, i

SEDUCER-a seducer flourishes. $A u^{\prime} \& W e l l, v .3$ (petit.) SEDUCING-sedueing so my friends. Coriolamus, y.

I haye no ambition to see a goodlier man -

I ne'er again sliall see her

methinks, I kee it in thy face..........

ten to see a dead Indian

when she sees me work...............

where I have hope to see the ....

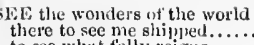

to see whut folly reigns......

et's see your soun'

I see, you have a month is mind

you nuy say what sights you sce

see things too, although

let me see rep. jv. 4 and

not an eye that sees your and still I Eee her beautifii.

il you love her, you cnmot sce her............

what should 1 see then

could not see to garter his liose $(r e p$.

conld not see to wipe iny shues.

but see how I lay the dust

to see sueh lovers, Thurio.

let me see thy eloak

thon eanst not see thy love

and see the gentleman you

when didst thou see me heav.

didst thou ever sce me do such a trick?

see, where she comes
is this I see and lieal.

let us see honest master Page............

fidd to see your worship's weli (rep.)

let me see tliee frotli and lime

and see if you ean see my master.....

let me see...............................

go in with us, and see

come and sce the piet

to see thee fight to see thee (rep.)

I I see a sword out

now I see, you'll be a courtier

I asn sick, till I see her

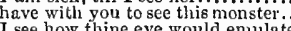

I see whow thine eye would enulate.

she shall not see me.

let me see't, let me see't
your shall see sport ano

see the issue of his seareh...

I see 'tis an honest wom

it would yearn your lieart to see it

I see, you are obsequious in

now he shall see his own foolery

see but the issue of my jealousy

you cannot see a white spot.

Herve's oak, and yon shall see wonders

as you see, like a poor old man

when you see your time....

when you see your time

see yout these, husband?

cannot you see but marry boys?

eyes did̆ see Olivia first

so long as I eould see...

thea let mine eyes not see!

unless you see canary put me

let me see thee caper

he sliall see none to fea

now you see, sir, how your fooling.

I see what your face

I see what you are $\ldots \ldots \ldots \ldots \ldots \ldots \ldots$.

disgnise, I see, thou art a wickedness

did yon never see the pieture...
let ine see, let me see. let me see

you might see more detraetion.

see thee ever eross-gartered (rep. iii.

if you will then see the frnits (rep.).
if

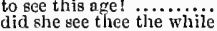

as plain as I see you now

hall we go see the see you.

first, go see your lodging

do you not see youn nove liam.

but see, but see

give ground, if you see him finrious.

come, let's see the event

he sees thee not.

till I see his brains

let the see his letter $($ rep. $)$

and let me see tree in thy

see him delivered, in thy

lience slinll we see, if
I'll see what I can do..

we see it: bat what we do not see......

gee that Claudio be execnted ...

doth your honour sec any harn.

see you, the fornicatress be

to let me see them

and sce how he goes abont

rather rejoicing to see another iwerr.

yet sinee I see you fearful..............

see, this be done, and sent

to see thine eyes so red

we are glad to see you.

SEE-let the subject see, to make ... Meas.for Meas, $\mathrm{v}$,

let's sce thy fice yon shali see how I iil.................

methinks, I see a quiekeping in...

and see our pleasure lierein cxceuted

I ean see yet without spectaele

shull I never see a baehelor or

here you may see Benedici

and thou shalt sce how

I hope to sec you one day fitted....

I can see a ehureli by daylight

where's the eount? did you see him?

and bring them ther eliam

to see a good armour

see you where Benedick hath hid...

[ $\mathrm{kn}$.] of quarrels you may see he is wise -

that's the seene that I would see

to see the fish cut with her golden

if you dare not trust that you entered -

if you dare not trust that you gee....

for I can not see liow sleeping ........

yon'll see he, shall laek no barns ....

God help us! it is a world to seei....

all you that see her ..................

see, see; here comes the man we went

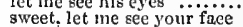

he no more shall see my face $\ldots$ irid. $N$,'s Dream, i.

before the time I did Lysander see

in their gold eoats spots you gee.

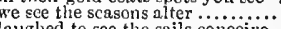

and see our moonlight revels

but I night see young Cupid's fiery

next live creature thiat it sees...

When I do see your face

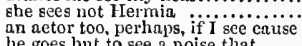

why do I ree on thee? (rep.)

I see their knavery

hy some illusion see thou bring.

I see you all are bent to set

never diu desire to see thee more

you see how simple and how fond

see, as thy face by dayliglit see

methinks, I gee these things with

one sees more devils than vast heli

all as frantic, sees Helen's beauty

Ilove not to see wretehednes

yon shall see no such thing .........

you shall see, it will fall pat

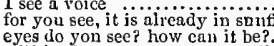

will it please you to see the epilogue

not to see a woman in that term ... Love's $\bar{L}$. Lost, $\mathrm{i}$.

let's see the penalty...

but I would see his own person.....................

did I see that low-spirited swain
my lord Biron see lim delivered o'er

if ever I do see the merry days .......

some shall see-what sliall some see?

impatient to speak and not see

what then, do you see?

let me see a fat l'en roy....

to her white hand see thon do commend $=$

see; wly dirn he see? to ovaved....

to see him walk before a lady......

to see him in a school.

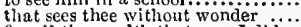

for all the wealth that eve

the king your mote did tee ..............
see a king transformed to a gwat? (rep.)

When shall yon see nie write
who sees the heavenly Rosaline

my foot, and her face see .....................

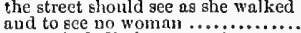

we see in ladies' eyes (rep.)

an angel shalt thou see

to sce a lady's fiuce

see where he enmes! ..................
soft, let us see; write,

tokens on you do $I$ see ................

for Alisander, allas, you sce, how tis

do you not see, Pompey is ............

not sec the sandy hour-glass........ Her

for gught I see, they are as sick....

and, let me see (rep.) asick.......

see to $\mathrm{my}$ house, left in ..................

sce these letters delivered....

than his feliows: see it done
well, we sliall see your bearing

well, we slall see your bearing .......
at supper slinlt thou see Lorenzo.... 
SEE-not have my father see me...Mer. of V'enice, ii. 3 SEE-yon yet ever see Baptista's .. Taming nf Sh. i. 2 SEE-Up, up, and see the great doom'B...Macketh, ii. 3 W will not say, you shall see and lovers tunnot see the pretiy......... blush to see me thus transtormed.... let's see once more this saying. as o'er a brook, to see fuir Portia... for I long to see quick Curpid's post.
I slall ne ver soe my gold again. see [ Col, $\mathrm{knt}$.-fee] ne an offieer and yon sliall see tis pruthased by whether what I toe do true you see me, lord Bassanio, where.... you shall see how mueh I was..... if' I might but see ............... see thou render this into ny

we'll see our husbands befure they (rep.) none of us should see sal

that thou shalt see the differene

I see sir, you are liberal in offer:

did you see master ] orenzo, nnd mistress that liglit we see, is burning

we did not see the candle ............... nothing is good, I see, without respect

your bed until I see the ring (rep.)...

I see myself,-Nark you but that! (rep.)-
I hote, I shall see an end of him...As you Like herein, I see, thou lorest me not with your ladyships, you may see the end longs to see this broken music. shall we see this wrestling (rep.)....

spe:k to him, ladies; see if yon ean..
I eannot hear of any that did see her but what is, come see, and in my....
here shall he see no enemy (rep.) here shall he see no enemy (rep.)

let ine see wherein my tongue hath.

shall see thy virtue witnessed every to see my ewes graze, and my lambs and when shalt thou see him again? pity to see sueh a sight ............... that you see dwell where she. I would tain see this meeting I am very glad to see you $\ldots$ will see a pageant trul I see no more in you than of you she sees herself more.......... your own land, to see other me for, see, love hath made thee..... how it grieves me to see thee

to see no pastime, I................

than to see the lord

ii. 5 nay, now I see, she is your treasure.

ii. 6 you shall go see your pupils presentiy 0 let ine see thee walk whereby I see thy heauty... I'll see thee hanged on Sunday (rep.) tis a world to see, how tame I see no reuson, but supposed Kieentio where I an, and sees you there.

ee not your bride in these..

I see, a womant of this

Peter, didst ever see the like?

see, how they kiss and eoturt

I see she's like to have neither. say thou wilt see the tailor paid and wander go along, and see the truth hereof... the ehureh o' your yes, marry sif see thy master's.. see the end of this controversy (rep.) I eharge you, see, that he be........ see, wher'e she eomes; and brings..... you shall see, as I have said ........... Winter's Tale he longs to see lis son,

at once see good and evil

to see atike mine who may'st see plainly, as heaven sees for, you see, my plight requires it and see her, no further trust her. fourteen they shall not see I see't, and feel't, as you feel doing (rep.) to see his nobleness! eoneeiving go, see how he fures: fie, fie!

and see it irstantly consumed
to sce this bastard $k$ neel and call. that he diel but see the flatness. and see what death is doing go and see; if you can bring if the ner shalt see thy wite

but see how it chates, how it rages (rep.) I'll go see if the bear be gone from let me see; every 'leven weth

to see his work, so noble, viliely.......

see, your guests approach; address

you see, sweet maid, we marry

that thou no more shalt see this lep.

for all the sun sees, or the

I mean not to see him any $m$.

whom I so mueh thirst to see........

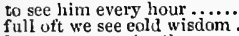

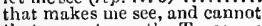

that mean to see the Tusean serv

now I see the mystery of your.....

and thine eyes see it so grossly shown

the last monarehy), see, that you co

if you will see her (rep.) ....

I see things may serve long....
and see, who shuns thy love
two days ere I shall see you

wo days ere $I$ shall see

when you see my son, to teil him

when

when your lordship sees ............

a fair ereature; will you go see her?

now I see the bottom of your ( $\tau e p$.

I see that men make hopes

he still see them reveal themselves..

have him see his eompany anatomized

or let me see my death]...

I hope I shall see him ere I $\mathrm{I}$ die....

let us go see your son, I pray you
sinee you're like to see the kiug

sinee you re like to see the kiug

cries to see what's done

cries to see what's done ...............

now, pray you, let me see

more than to see this

is t real, that I see?.............

my dear mother, do I see you living...

see, doth he breathe? .. Taming of
sirrah, go see what trumpet tis ...

and see hitn dressed in all suit

to see this despatched with all

I see, I hear, I speak

how we joy to see your wit.......

well, we'll see ' $t$; come, madam.

in the other's silenee I do see maid

but seel while idly I stood

to see my friends in Padua.........
(for aught $I$ see, two aud thirty

am eome abroad to see the world .....

I will not sleep, Hores

here's no knaveryl see; to beguile...

see that at any hand; and see you read no-
good disy and and tong, to see .......... methinks, I see Leontes...

joy to see her in your arms ............

the stars, I see will kiss...............

that onee, I see, by your good father

you'll swear, you see, there is such

see you these elothea? say, you see

are going to see the queen's picture

to see the life as lively moeked

see, my lord, would you not deem.

a love to see, I hazarded the loss. Comedy of $E$

and when they see time, they'll go.

I see, the jewel, best enameled

see, here he eomes ( $r e p$. iv. 1) .........

I am glad to see you in this.

and therefore, see thou do it .........

to see it they'll disdain me!

I see, a man here needs not.

but soft, I see the goldsmith

I pray you, see him presently

chain, I pray you let me see it

delight to see a wretclied man

master doetor, see him safe

I see, these witehes are afraid.

see, where they come; we will....

my liege, as I do see your graee

I see, a triend will save my life...

I see thy age and dangers make

to this fortune that you see 1

I see, we still did meet ...............

I see by you, I am a sweet-faeed (rep.) Ma

let not light see my block

that may keen knife see not.

never shall sun that morrow seei.......

a dagger, which I see before me ........

and yet I see thee still ( $r \rho p$.)
see, aud then speak yourselves to be honest, I see fortune would...

preserved myself to see the issue

I see my son Antipho............. \begin{tabular}{l|l} 
ii. 1 why, see you not? is't known \\
ii. 1 & wetl, may you see things well
\end{tabular}

sce, they encounter thee

pr'y thee, see tliere! beholdi looki

ny hittle spirit, see, sits in

I'll see no more; and yet

and some I see, that twofold bails......

ay, now, I see, 'tis true

when shalt thou see thy

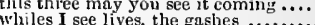

liere may you see the gashes

and yet, by these I see, so great..

see a yiel dinite to see us crowned .....

whe looks of Franee. King Jakn, ii. 2

all I see in you is worthy love (rep.)

gliall never see it but................

now shall I see thy love.

ere our coming see thou shoke..........

couldst see me without eyes ...

now see the issue of your penee! ....

methinks, I see this hurly all on

see else yourself; there is no malice

ont of my sight, and never see me...

although you see, that you do see?.

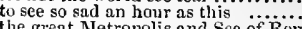

for 1 do see the eruel and see of Rome

of speed to see your majesty

when he sees onrselves well

who when he sees the hour

shall good old York there see

of thine eyes see thy grieved heart....

our kinsman come to see his friends

and see thee ill. Now, He that (rep.)

to see this business: to-morrow........

we see the wind sit sor

we see the very wreck $\ldots \ldots \ldots \ldots . . . .$.

ne'er see joy, that breaks that oath (iep.) -

see then delivered over to ............

my lord Northumherland, see them

shall see us rising in our throne ....

sweet love, I see, changing his
well, well, I see I talk but idly.

my unpleased eye see your eourtesy

full of tears, I caunot see...

but they ean see a sort of traitors....

when ido see the very book ........
ha! let's sec: 'tis very true, my grief

I see your brows are full of discontent but soft, but see, or rather do not see pale? let me see the writing

sinee I did see him last

I see some sparkles of a better hope

and never see day that the happy sees

praise of him, see riot and dishonour

I see no reason why thon sliouldst .

see a good amendment of life ......

fight longer than he sees reason........

for I see danger and disobedienee...

to see him slime so brisk ..........

thy lantern, to see my gelding in...

let me see some more

ha! you shall see now, in very.....................

suel as we see when men restrain .

let me see-about Miehaelin

didst thou never see 'T'itan kis

you eare not who sees your back

my lard, do you see these meteors?.

harlotry players, as I ever see

let's see what they be.

the earth shook to see the heavens.

see, how this river eomes me $.17 . .$. .

which hath desired to see thee more

1 never see thy taee

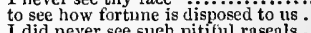

Hal, if thou see me down.

why, then I see a very valiant ......

but eyes and nobody sees my and by

see, what a ready tongue suspicion...2 Henry $I V$ 1 see a strange confession in

yet cannot he see, though he

wait close, I will not see him glad to see your lordship abroad

.

and when we see the figure

to see his fatleer bring up his.

and see if thou canst find out..........

and whether I shall ever see thee again

I'll see her damned first ...

see now, whether pure fear
II. $\mathrm{i}$.

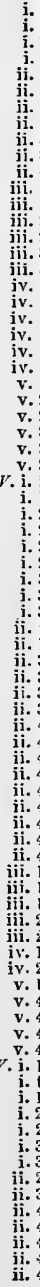

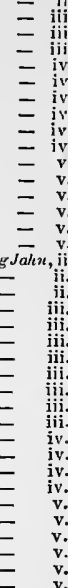




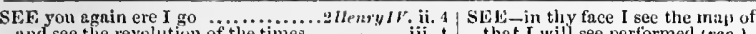
and see the revolution of the times. to sce the beachy girdle of the $\ldots . . .$. demil see, see! he drew a good bow. I ain glad to see you well (rep.)...... lct me see them, I beseech you (, ep.)

yea, marry, let us see Bull-calt.......

I siall never see such a fellow...... I do see the buttom of J ustiee Slmllow we

we see which way the stream of......

than now to see you here

where is he? let me see lim

see, eons, what thinge you are

I am glad to see your worshi

too see the semblable colierenie...........

o you shall see him laugh, till his .

and never shall you see, that I .

live to see a son of mine

nay, you shnll see mine orehard.

liope to see London once $(r e p$.$) .....$

zeal I had to see him (rep.)...

to see performed the tenur ..........

that you see them printing ....Henry ${ }^{\prime}$. i. (chorus)

what see you in those papers

see you, my prinees, and my noble..

my eye my scareely see it...

\section{$=$
$=$
$=$
$=$
$=$
$=$
$=$
$=$}

iii. 2
iii. 2
iii. 2
iii. 2
iiii. 2
iii. 2
iii. 2
iii. 2
iii. 2
iv.
iv.
iv.
iv.
iv. 4
iv. 4
v.
v.
v.
v.
v.
v. 2
v. 2
v. 3
v. 3
v. 5
v. 5
orus)
orus)
i.

ii. 2

ou see, this elinse is hotly followed

and therein see a siege ...........

look to see the blind and blowdy soidier =

when he sliall see our army

but I diul see him do gallant service

as you shall see in a summer's day ..

his folly, see his weaknes

each battle sees the other's umbered - - iv. (elio.)

yet sit and see; minding true

wherefore when he sees reason of tears

outlive that day to see his greatness.

if I live to see it (rep.).

never sees horrid night

if I can see my glove in his eap........

if he be perjured, see you now

I would fain see the man, that has

see it onee; an' please Got (rep.)

and, solemnly, see him set on to...

till I see him once agaiu

thou dost see, I eat

when you talke oeeasior to see ieeks

ghall see advantrgeable for $\ldots \ldots . . . .$.

when they see not what they do..

who cannot see many a fitir Freneli eity

you see them perspeetively......
when he sees me go back one

blessed with, which you see....

see the eoast eleared, and then we.....

watched, if I could see them

for aught I see, this eity must

nay then, $I$ see, our wars will $\ldots . .$.
$I$ see, report is fabulous and false

I laugh to see your lady ship

and see what eates yon have

will see his burial better than...

as, see the bishop be nut overborne

you see whut mischief, and what

or 1 woull see lis heart out, ere the.

see here, my friends, and loving

see, noble Charles! the beacon

but see his exequies fulfilled .........

see, see, the pining malad $y$ of France

see then, thou fight'st agaiust

when thou shalt see, I'll ineet...

I see no reason, if I wear

no simple man that gees this $\ldots \ldots \ldots . . . . .$.

that see thee now well-eoloured $(r e p$.
years did not Talbot see his son......

see, where he lies inhearsed

my lord protector, see them guarde...

sce, Reirnier, see, thy daughter prison
to see her coronation be performed ...

in thy face 1 see thy fury

we'll see these things effeeted

let me see them: Whint is thine ......

I doubt it not, see you well guerdosed

see your trinkets here all fortheoming

to see how Gurl in all his ereatures...

protector, sec to't well, proteet yourself

et did he never see ..................

Gloster, see here the tainture .........

I see no reasnn, why a ling..

to sce this quarrel tried (rep.).

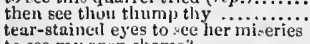

to seo my open shame?

to see rny tears, and hear my

I long to see my prison

yet thou slanlt not sce me blusla...... that I will see performed ("

seeing him, I see my life in denth

and sees fist by a buteher.

see, how the pangs of deati.

I see them, I see them! 1 .................

I see them lording it (rep.)

to see if I enn eat grass ........
see if thou eanst outface me....

see Buckinghain (rep.) $\ldots . . . . . .$.

and we will live to the hottum of ....

and we will live to see
before $I$ see thice seated

if once they see them spread

I'll see your grace; till then
be feed. I see, tu make me sport.

see, ruthless queen, a hapless father's

to see how inly sorrow gripes.

or do $I$ see three suns? .............

see, seel they join embrnee
$O$, never, shall $\mathbf{I}$ see more joy

live to see a sunslinine day

thereby to see the nicutes low

but let me see: is this our fueman's

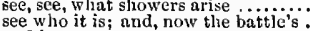

and he nor sees, nor hears as
first will! I see the coronation

to see these honours in $\ldots . .$.

to liear and see, her plaints ...........

see, that he be eonveyed unto the ...

and ste where comes the breeder of

nay, then 1 see, that Edward

see that forthwith duke Edward.

and see lim seated in the regal throne
sce, where the huntsmen stand

till I see them here, by doubtfiul.

see, how the surly Warwiek.........

my heart to see your forwardiness...

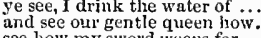

sec how my sword weeps for.............

O gentlemer, see, seel dead Henry's

with all expedient duty see you...

to see you are become so penitent...

then present, wept to see it ...............

and see another, as $I$ see thee

and see how he requites me!

cane too lag to see him buried

I did not see your graee..........

look to see a troublous world

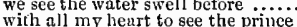

ah me, I see the ruin of my house!
$\mathrm{I}$ see, as in a map, the end of all........

0 then, 1 see, you'll part

where, he shall see, the boar wiji use

but yet, sou see, how soon tlue day

I an glad to see your honour.........

ii. 3 he longs to see your hearl.....

he is, and see, hi brings the may ur

yet who so bold, but says, he sees it not?

eannot see this palpable device? (rep.)

see where his graee stands 'twee

and youl may partly sec, how far

father's mother, I will see them

the king is angry; see, he gnaws

and see what now thou art

the earl to see me in my tent.

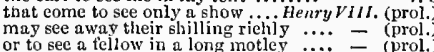

think, ye see the very nersons

but $X$ can see his pride peep

when we see each grain of gravel.

under pretence to see the quieen
to see you ta'en from liberty.

to see you ta'en from liberty
yet see, when these so noble.

as far as $Y$ see, all the tood our

may be wise, and never see the Louvre

and see the nobite ruinced bur

is coming; see the barge be ready....

these aifairs see this main end
my Wolsey, see it furnislicd...

why, this it is; see, seel

we slaall see him for if, in arehibishop

ant no man sce me more ............

my has a nobleman want manners

ii. 1
ii. 3 sent from the king to see you
this fillow let me ne'er see agai

and this mornine see youl do almen

I see your end, tis my uuguing ....

ii. 4 and see him safe i' the Tuwer.

ii. 1 nuw lct me see the proudest

there's sime of $y \mathrm{c}, \mathrm{l}$ see, mor.
the common volee, $\mathrm{I}$ see, is

you see the poor remainde

when mever mighe to see a chine a.....

4

i. 2

iii. 2 iii. $t$ many day's slildren sluull see .

I shall desire to see what this chili.

iii. 2 tell her, the next time $I$ see her... Troilus $\delta$ Cress. $\mathrm{i}$.

iii. 2 all the vole, to see the battle

do you know a man, if you see him?

here we inay see most bravely.......

mark Troilus; you shall see ano.
it he see me, you shall see him

iv. 10 if he see me, you shall see him
iv. 10
you shatl see. If lie do the rieh

fouk you yonder, do you see? ........

in 'Troilus thousand fuld I see thain.

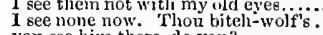

You see him there, do you?

but I'll see some issue of my

and let's see your picture.................

they never see truly

see, we fuols! why haved

married there where it may see itself

now slall we sec to-morrow
to see these Grecian lords?

ii. 5 I see, my reputation is at stake.

ii. 6 to see great ileetor in his

you shall gee the pageant

see, hol who's that there
ii. 1 good unele, go and see......

2 we see it, we see it; how now, jamlis?

iii. 2 when sliall we see again: ................

when shall I see yon? I will corrupt

iv. 3 ent witl thee, and see your kniglits.

iv. 5 and see me at my tent....

\begin{tabular}{c|c} 
iv. 6 \\
v. 1
\end{tabular} there, where we see the lights......

v. with my heart the other eye cloth see

I would fain see them meet ............

now do I sce thee: ha!

to pray Achilles see us

you see tlis confluence (rep.)

2 ay, to see meat fill kn1aves

2 you see ny lord, how ample
3 see them well entert

3

lia! now $x$ see thould sou at Corintls.

, bood hap, yonder's my lord (repr.)

I see 110 sense for $t^{\prime \prime}$, but his ....

well I'll never then was a....

what else to do, 1 'll see thee again...

let us first see perce in

see thon man, and let me ve'er see thiee

you shall see him a palm

men may see't the better

ii. 4 hear him eog, see him dissembic.............

see what I do deliver out to each

see, our best elders

thou shalt see me onee more

see him pluck Aufidius down by

I am glad to see your ladyship

he had rather see the swords

see, they have shut him in ..........

wherein you see me smeared
if you see this in the map of

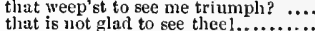

I have lived to see inherited my very

sights are spectaeled to see him .......

ceen the dumb earnestness to see him

lets them plainly see't ................

when you now see, he had rather.

were you ignorant to see't?

hardy in our ages see their baniers

we see, have sided, in his heliaif

do you see, )witom you have banisiled

but when they sliall see,

go see this rumourer wli........

to see your wives dishonoured

tis a spell, you see, ot muleh
to see the son, the luusbant

the see son, the husbank .......

see you yond' cuign o' the tapitul...

to see Ciesar, and to rujuie
to see great $P$ ompey pass

see, whe'r their basest metal

before me, let me see lits titee ...........
will you go see the order of the eourse?

can you see your tace? ( $\mathrm{rc} / \mathrm{s})$.
thut you might sce your shad

since you know you cambot see youirself = 


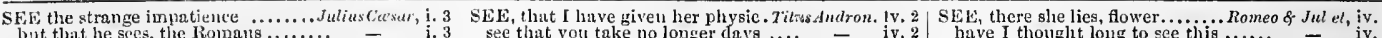
but that he sees, the Romans

ere diny, see Brutus at that

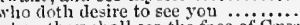

when they shall see the finee of C:
to see him pass on to the Capitol

tu see him pass on to the Capitol
yur see we do; yet see you but

to sce thy Antony making his

Aarum, I sce, thou wilt not trust...

now let me see your arehery

to see thy noble unele thus distract?

bee you do it bravely.

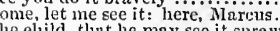

tlic eliild, thint he may see it slrawl.

ous all did sec, that on the iuperea

see, winat a rent the enviou

as you sec. With traitors .............

tet me go eye conld mever see such

let me see, let me see ............

shalt see ne at Philippi $(r e p$.
I will see thee at Philippi then
clidst thou see any thing?.............

to sce my best friend ta'cn before.....

than you slabl see me pay .........

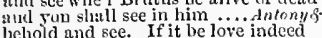

to see a liandsome man loose-wived

we see how mortal an unkindness
where is he? I did not see liim (vep.)

where is he? I did not see lien, and where slie died.

see when, and where slie died........

you may see, Lepidis, and hencefort

Where we see, the taney out- $w^{\circ}$ ork
I see't in my motion, liave it not

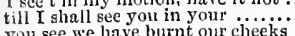

yon see we have burnt onr cheeks.

I'li see you by and Ly

sec you here, sir ..................

I see, men's judgments are

see, my women! (rep. iv. 13)

sond $I$ see still, a diminution in

see $i t$ be done; and feast the arny

haply, yout shall not see me more

Wak, let's see if other watcl
let's see how't will give off'...

that thon couldst see my wars $(r e p)$.

before the sun shall see us ....
tiny uprise shall I see no more.

sumetime, we see a elond

when I should see behind me.........

see, here he comes, and 1 must ply.

and see them ready 'gainst their mother -

and see the a mbush of our friends be

see justice done to in the

see where she comes, appareled like.....Peri

and tlie sore eyes see elear to stop

now do $I$ see he had some reason for $i$

see if 'twill teach us to forget our....

but see what leaven ean do!

nan, pray see me buried ...

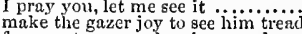

for men to see, and seeing wonder at

see, not a man in private conferene

I'll see you wed; then, with what

my wedded lord, I ne'er shall see again

but l'll see further; perhaps for this piee, yon see; if you like lier

and swore he would see her to-morrow

shadows see them nove awlile - iv. 4 (Gower)

I am glad to see your lomour...

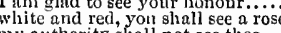

wy authority shall not see thee...

may we not see him thea?

hut see. I am prevented.

at Ephesis the temple see............. $v .2 \overline{\text { (Gower }}^{v}$

may we see them? Great sir

see better, Lear; and let me still.....

youl see how full of changes bis age is

I see the husiness:-let nie, if not.

shalt see, thy other daughter will

on any shoulder tliat I see before.

nothing almost sees miracles
shall see their children lind

1 am glad to see your highnes.

where you shall see how hardiy

and see what I can show in th.

you see how easily she may....

I might see but such another mant

and I shall see some squeaking.

I'll never see it: for, I am su

dost thou not see my baby at iny

to sec performed the dreaded act

do nolabella, see high order i....

in the world that I may see again

ro see my lord aboard

but, I see, yon have some religion

eyes to see tlis vaulted arch .....

and on promise to see your

to see the enclosed lights

I see her yet; her pretty action.....

I see betire me, man, nor bere

a profit from all things we see .......

ne'er longed my mother to see

nay, be brief; I see into thy end ....

there shail slle see my valour.......

I see, a man's life is a tedious one

hit sec, thy brother. This Cloten...

stark, as you see: thus smiling ......
Great griefs, I see, medicine the less.
let's see the boy's thee ..............

you see, not wore him from....

to see the way of blindness!

I sce a thing bitter to me as death
pence, penee] see further (rep.)

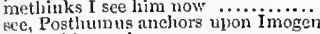

to see this grraeious season ...........

see, lord and see his slipwreek, and his .....

ree our Roman hunting (rep.

dichested vale, you see, it is
yulur glory, to see her tears

sec, that you make her sure

more than mine eje can see $\ldots$

nind see s fearsul sight or what hole is here ..............

tunrs, whieh now you see filling
see. thy two sun's heads; tliy warlike

let me see what task I have

no more see one another

if you shall see Cordelia, (as fear not

then comes the time wholives to see $t$

that sees his son a gentleman before lim

I'll see their trial first

Regan, see what breeds ahout her heart

becsuse I wonld not see thy eruel nails.

but I sliall see the winged vengeance....

if you see vengeance

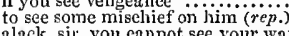

might I but live to see thee in my touch

i. 7 that will not see because he dotb not

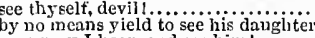

ii. 4 soon may I licar, and see him! ...................

when I do stare, see, how the subject

see how this world goes (rep.).

see how you justice rails upon ........

seem to see the things thou dost not

let us see: leave, gentle wax

with pity, to see another thus

the great rage, you see, is cured in jim

sliul never see his pardon..........

shall we not see these daughter

I'll sie that straight

o, see, see! And my poor fool...................

we that are young, shall riever see so imuch

carly walking did I see your son. Romeo of Juli

without eyes, see pathways

ean you read anything yon can see?

to see now, how a jest shall

un' I might live to see thee married once -

$O$ then, I see, queen Mrab hatl

ii. 3 see, how she leans her cheek upon

ii. 4 if Isee octusion in a good quarrel.

doth weep to see his grandsire's heaviness

I see, thou art not for my company

cee how sivift she conies (rep.)

there is that she desires to see

anil see their blood, or die with....

let's see; integer vite, scelerisqui.

as lief see a toad, a very toud as see him

see, thou know'st me not

that ever I should live to see thee dead! then I see that msdmen have no ears -

see how he will take it at your hands

but now I see this one is one too .....

let me see the eonnty .................

ha! let me sce her: out, ala ?

v. 2 have I thought long to see this

I see that thou art poor; hold thier.

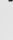

iv. 3 see thou del iver it to my lord and.... -

iv.

to see thy son and heir more early down

look, and thou shalt see

gee, what a scourge is laid upon.......

I eame to see your father's stinerail....

it was to see my mother's wedding
vy 3 myther, - methiuks I see my fat

see you now; your bait of falseliood

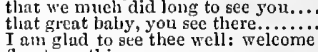

fly at any thing we see .......................

let me see; let me see (rep.iv. 7 )....
but, as we often see, against some.

if the gods themselves did see her then

to heur and see the matter.

see, unsees, we may of their encounter....

now see that noble and most sovereiga

seen what I have seen, see what I see!
[Knt. to see a robustions perriwig-pated

II I could see the puppets dailyio

$O$, the recolders: let me see one...........

do you see yonder clond, that's almost

see, what a gritee was seated on this brow

there I see such black and grained spots

send thither to see; if your messenger

I see a cherub that sees them

do you see this, O God?

beg leave to see your kingly eyes

and tint I see in 7 (letter)

passages of proof $\ldots . . .-$ iv.

a Col.Knt.] let me see. Alas poor Yoricki

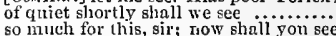

I see the portraiture of his; I'll count

whst part a gentleman would see........
this is too heavy, let me see anotlier

this is too heavy, let une see ano
she suoons to sce them bleed....

trenchery! see it out

what is it, yon would see? if anght

minds, what you see them her.

1 did not see you; welcome, gentle...

and thou shalt see an answernble...

let me see now; to get his place (rep.)

see for the news. Good aneient you are.

as my content, to see you here before me

didst thou not see her pacldle with the

and do but see his vice .................

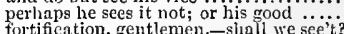

no, Iago, I'li gee before I doult...
they do let heaven sce the vranks.

I see, this hath a little dashed sour spirit but, I do see yon are moved (rep.)
we see in all things nature tends. doubthess, sees and knows more.

cast) so prove

if ever mortal eyes do see them bolster...

it is improsible, yon should see this......

yet we see nothing done; she may be...

now do I see 'tis true: look here Iago

to lave him see me womaned ...........

if I shall see you soon (rep.) ...........

well, I may chanee to see you .......

and to sec how he prizes the foolish

glad to see you, signior.

lct me see your eyes; look in my face.

why, now 1 sce there's mettle in thee.

see, and smell, and have their palates

do you see, gentleme!1? Nay, guiltines

though you do see me weaponed

for seed... Meas. fin

he'd sow it with nettle sced............ Tempest, from the true seed of honour? .......... of Yentice, ii. slip to us from foreign secds ..........Ait's Well, i. if you can look into the seeds of time .. Aracboli , i. the sced [ Cul.-seeds] of Banquo kings! $-\bar{y} I Y$. would, of thut seed, grow to a greate

saw his heroieal seed, and smiled ....Henry

to great Priam's seed ...... Troilus \&. Cressidn, i she that sets secds and roots of sliame.. Pericles, iv.
bladders, and musty seeds....... Romeo \& Juliet, $v$.

iii. 1 unweeded garden, that grows to seed ...Honlet, $\mathrm{i}$.

iii. 2 SELDED pride that hath to ... Troilus \& Cressida, i.

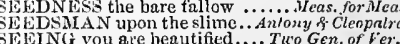
SELING you are beautified.... Tuo Gen. of Ver. seeing her go through the streets.. Merry Wives, iv.
that one man, seeing how much.... Hhech dao, ji. it doth impair the seeing sense.Mid.N.'s Dream, $\mathrm{i}$ adds a precious sceing to the eye.. Love's L. Losl, iv but suddenly secing Orlando...... ss you Like it, iv. 
SEEING, you should love her? ....As yon like it, v. 2 seeing too muel sadness Tam of Sh. 2 (induc.) 1, seeing this, came theuce for very... iijter's Tale, ii. knew no more but seeing, could not - v. 2 to see, and in thee seding con........

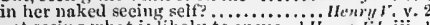
not seeing what is likely to ensue.. I Henry $\%$. iii. seeing the deed is meritorious......2 henry $F$ h iii. for seeing him, I see my life in deatl

well, seeing gentle words will not...

secing iguorntee is the curse of God

aral.3Henrylli.

the seeing the he thut mule

then, seeing 'twas he

Hemy $\vec{v}$

rou must be seving christening? ?.... - v. that seeing reason leads, finds.. Trailus $\delta^{\circ} \mathrm{Cr}$ 'ss, eeing his repntation tonehe ... or, seeing it, of such childisl

know'st ine, and secing the, dost not

secing thin death, n neeessury ent.
seeing those beads of sorrow stand
the seeing these effects will be

men at ...tericles, $\mathrm{ii}$.

e before us

- vear,

sir, in fine, seeing how loutlily opposite .. Lear ii.

weep ye now, seeing she (rep.)... Konco of Julie, iv.

else no ereature seeing; thou mixture

seeing the worst, which late on hopes .. Othello, i. 3

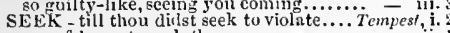

go safely on to seek thy son..

I'll seek him deeper than e'er

hereafter, and seek for grace

I seek my master, and my master seeks -

to seek preferment out

sec his way to seek out yon? .........

as seek to quench the fire (rep.)

run, run, and scek

gone to seck his do

I will seek out Falstaif

search, seek, find ont

vet seek my father's love, stili seek it

I seek you a better husband

well he's not here I seek for

if I find not here I see

that he did seek the love of

Tirelfitin

Go thou and seek the coroner....

seek him out, and play the ture ....

he did range the town to seek me ozit

I find, I seek to die

rou bid me seek redemption

come you to seek the inmb

and seek not to alter me

whom you sent me to see

shall we go seek Benediek

here comes the man we werit to seek

to seek you both. We have been (rep.)

to seek new friends and stranger

1 must go seek some dew-drot
and he shall seek thy love

and seek through this grove $\ldots$ i.....

these lovers seek a place to fight ....

to seek the light of truth........... Lo

thau seck a dispensation for his oath

I sue, I seek a witel a woman , $\dddot{2}$...

that want itself doth seek.

make him fawn, and beg, and seek.

are forfeit, seek not to undo us

but seek the w'eary beds of peopic...

you shall seek all lay ere you...

I have sent twenty out to seek for...

re have been up and down to seek him.

be content, and seek no new

. iii. 3

he seek to soften that, (than whieh...

let $\mathrm{my}$ father seek another heir.........

and do not seek to take your change

to seek my unele.....................

and I'll go seck the duke...............

go, seek him; tell him, I would ....

seek him with candle.

to seek a living in our territory ......

thim scek out Rosalind

g.he came to seek you there $\ldots . \ldots \ldots . . .$.

that seeks not to find that her ...........

Guestant shrinks, find what you seel

this discovery; seek these suitors

with satiety seeks to queneh his... Taming of $\mathrm{s}$

to seek their fortumes fiurther than.

$[\mathrm{Col}$.] the iee, to do this seek

or seek for rule supremuey...

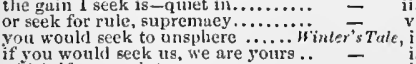

whieh if you seck to prove $\ldots \ldots \ldots . . .$.
wuld fright me with, I seek; to

i'll not seek far, (for him, I partly

toreed me to seck delay' fir them Co
to seck thy lich liy beneficial help.
SEWK-in the occun seeks another. Cont dy of Err. i. 2 SEEk him ont: if in his .
to go seek this slave

in sent to seek his master.

or else I shall seek my

in fithess. seek to hic

jeek to know no more .........

sir Robert's son, that you scek so? ..... kingr. inth

to seek the beauteors eye of
do not seek to stuff my hend

going to seck the grave of Arthinr....

l will seek them ont $\ldots \ldots \ldots \ldots \ldots \ldots . .$.
shall they seek the liom in his ilen?.
should seek a plaster in eontemmed.

should seek a plaster in eontemised
to seek sweet safety out in varits.

to seek sweet safety out in valits...
seek out king John; and fall before.

straight let us seek, or straitht ....

since thou dost seek to kilt my

seek you to seize, and gripe
yet seek no shelter to avoid

and $1 \mathrm{am}$ eome to seek that name

I'll go seek him ......................

what honour dost thou seek

or it we two boys, seek Perey ........

go, seek him ont: is he so hiasty.

our person, seek we no revenge

tell thy king, I do not seck him now

we would not seek a buttle as we are
$n \mathrm{r}$, or more tlan we should seek alter

absenee, seek throngis your eamp.
lray thee, go seck lim, and bring

lray thee, go seck lim, and bring

and seek how we may prejudice

and not to seek a queen to make
the golden mark I seek to hit

the golden mark 1 seek to hit .....2 Henry $V /$.

nor never seck prevention of thy .....

scek not a seorpion's nest.........

I seek not to wax great by others

and seek for sorrow with thy spectacles? -

in eruelty will I seek out my fame...

they reek revenge, and therefore.

to seek to put me down................

that seeks to make them foes

through these wounds to seek out thee =

came to seek you out .................

but seek revenge on Edward's moekury

unless they seek for hatred at.
I seek for thee, that Warwick.

and seek their rut to redress their

and seek their ruin that usurped .....

never seek for aid out of himself..... Herry rIII, i. 2

let him not seek't of us .......

seek the king: that sun, 1 pray.

men's yrayers then w ould seek you... - v.

seeks his praise more than he.... Troilus \& $\mathrm{Cr}$.

O, let not virtue seek remuneration
that doth seek her (not makiug

that doth seek her (not makiug.
half IIeetor comes to seek this.

lechery eats itself. I'll seek them.....

strike; this is the man I seek

and seek about for eases

who seeks for better of thee...... Timon of Alhens,

whose pions breath seeks to convert you -

why dost thou seek me out?...........

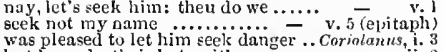

but he seeks their hate with 1 wish I had a cause to seek him

to seek a singie man...

than seek the end of one

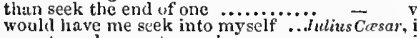

gonle to seek you at your
seek none, conspiraey

that's all $I$ seek; and am moreover.

about, - seek, - burn,--ire, - - kjl

come, seck the eonspirutors ..........

seek him, Titinius: whilst I go

seek him, and bring him lather...Aniony $\bar{s}$ Cleo. $\mathrm{j}$.

nay, pray you, seek no colour . .

or else he seeks out us.

who seeks, and will not take

I will seek some way to leave him.....

I will go seek some ditch
of Ciesar seek your homour

but if you seek to lay on me a tinger

if you seek for further sutisfying

Which he, to seck of me again.

only seems to seek out dange

would geek us througl, and put us to

seek fur danger where there's no profit

and meet the time, as it seeks $119 . . .$.

lienec to seek my lovely
to seck her as a bedicllow
0 , seek not to entrap, my gracious lo.... Perictes, ii.

your ludy sceks my life ................. iv.

overboard thrown me to seek my inotlier

why so eurnestly seek you to puiti....

go, sirrah, seek him; f'll apprehend

Edmund seek him out; wind

my fintlier's godson seek your life?

that, sir, which scrves and sueks for thit
fie on this storm! I will go seek the kimg

I will seek $[\mathrm{Kn}$. -look] him and privily.

seek thine own ease; this tempe

ventured to eome and seek $y$

his duughters seek his denth ..........

disposition made him seek

seek out the villuin Gloster $; p . . . . . .$.

seek, seek for him; lest his mgoverned

not stir one fiot to seek a foe .... Liomeo o Jutiat

giri, seck happy niglats to happy days

vain to seek him here, that means not

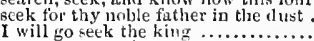

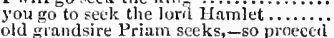

go, seek him ont, speak fair .............

seek him i' the other plaee yoursel.

go seek him there. Ile will stay
that wilfully seeks her own salva

whieli seek out assurance in that ......

here eomes another troop to seek for you

seek him, bid him eome hither

I will go seek him: Cassio, walk here...

and scek to effeet it to my utter

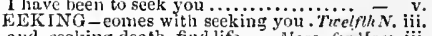
and, seeking death, find life ...... Heas for Hous, iii, t light secking light, doth light $\mathrm{t}$..... Love's L. Lost, i. ।

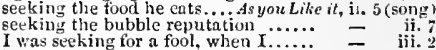

lose none, in seeking to augment it $\ldots$. Mucheth, ij. I

am hot with haste in seeking you .. Kint John, iv, 3

sceking a way, and straying from..3 Herry $F$. iii. seeking for Hichmond in the thront. Richard III. V.4 been sceking you this hour...... Troilus \& Cress. v. 2 What's their seeking? For eorn at ..Coriolanus, i. 1

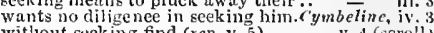

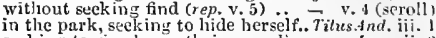
seeking to give losses their remedies....... Lear, ii. t2 cousin's gliost sceking out Romeo. Krmeo \&, ful, iv. 3 why seek'st thou me?........Mir. N.'s Iream, iii. 2
thon seek'st the greatness that ...2 HenryIV. iv. I tell me whom thou seek'st $\ldots, \ldots \ldots$. Wenry $v i$ iv. 7 EEL-wise gods seel our eyes inlony of Cleo. iii. 11

rather seel [Col. Knt.-seal] my lips.... to seel [Col.-seal] her father's eyes ........ - iii. 3
SEELING night, searf up the tender ..Macth, iii. : SEEIY - and sir Bennet Seely ...... Bieharet II, v. 6 thougli this island seem to be desert .. Tempest ii.

our gurments seem dow as fresl.

whose every unbit seems to ery out... w -

seem eo. Seem you that your ... Tico Gen. of $r$ er. ii. 4 what seem I, that I nn not? ........ - ii. 4

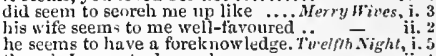

though I seem to drown her

and she, mistaken, fecms to dote on ine - ii. !

than love that would seem hid .....̈ = iii.

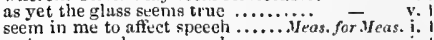

with mails to seem the lapwing ....

or seem so, eruftily . .................

which seems th litile fouler than it is

as some rould seem to be.

that which but seems unlike

may seem as sliy, as grave
where it seenis hid rep.)

do with your injurics us seeling yoü best

my liking miglit ton sudden seem.... Iuch Ado. $\mathrm{i}$

lowsoever it seems neem to pity the lady; ic seems

all matter clse scems weak

where his collyiees secuns as miss....

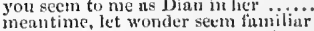

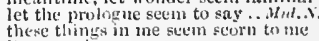

it seems thit you senily me.

he will seem to break lowse..........
all this deribion shatl scem at ircuin 
slitims to me now as the.

these thimgs secun small.

When every thing secns douhle...

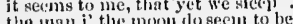

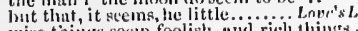

wise things seem foolish, ank rich things

shrullil seem then, that

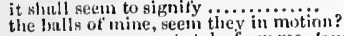

culuntemunce seens to take from me..1s y ous

sem more virtunus, when she is gone

not to seen senseless of the

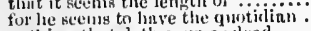

mothing that doth seem as thead...

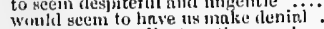

shall secm expenlient on tle now-lworn

nyy respeets no better than they scein
lusy secms the quarrel upon ynur

so confidently se'ms to wuilertake

it would not seem to

for we must not seem to inderstand

so we seem to know, is to know

you must seem very politie
only to seem to deserve well

only to seem to deserve well
thisugh time seem so adverse

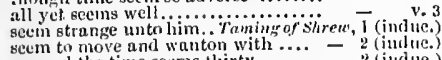

ay, unl the time seems llirty

thron, it secem, thant enl! st fur. ...

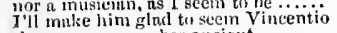

sir, you scem a sober aneicnt

juinee, as we do seen to be of ours

I will seem friendly ns thou hust

than sucli as most seem yours

who leust will seem to hlu so

ns my tule now scems to it.........
a powr humble swain, as 1 secin now

anthing she does, or secuns, but smac

it shoull seem, hath sometime loved

the young swain seems to wash ......
for she sucnis a mistress to most that

he sexns to he the more noble in being

for you seun to be honest plain men

he secms to be of wreat muthisrity ...

in the chase it sceins of this fnir eouple

nothing so aged, as this seems

the very life seems warm upon

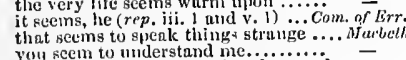

and feem to fear things that do sound

thint he seem rapt withal........
doth seem to have thee crowised

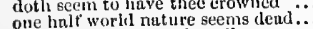

for it must seem their guilt....

will seen as pure as snow.........

ankl yet scem eold, the time you
violeut sorsow seems n modern

to seen thus washing her huntls

one of greatest note suems bruited

not of one mother, then, it seems ...

intent yinst neds seem horrible

makes it scem like rivers of.

it seems, you know not the
the uglier seem the ctouds
shatl I seem erest-falien..

show he did seem to dive into their

low he did scem to dive into thert

in me, it seems, it will make ...

it seems then the tidings $3 . .$. ....

his present want seems more than

secms to weep over his country's.
for nothing can seem foul to those

shall seem the more reasonat

pust, and to eome, seum hest

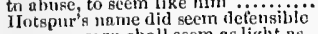

even oor erru shall scem as light as.

even our errin shat scem as ind
his inust seem thins to tlie world.
be secms indifferent: or, rather.

liww dirl this offer seem received

grwin they urave and learned? $\left(r, \ldots p_{0}\right)$

and so fincly bolted, ilidst thon seem

when what they secin to threntiy

Spiriferd with wine, seem trot
big Mlurs seenas baikrupt...

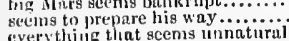

everything that scems linnation
thongh he seem, with forgen

gn seans this gorgenus beallty..........

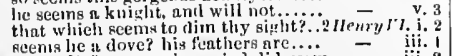

but well-tore-warning wind did seem

glinild seem to curse and bra

3Henry ${ }^{\mathrm{iii}} \mathrm{i}$.

they join, embrace, anil seem to kiss

the time shall not seem tections.

more than fsem, and beems, as may bescem

hut now may seem as wise ...........
nit whom you seem to have sin tonder

and seen a saint, when most 1 .....Riehnt HIT. i. 3

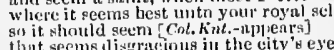

c:an muke acen pleusing to her .......

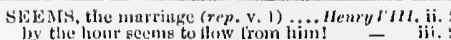
by the hour seems to buw lrom him! seen all aflined and kin...... Troilus f Crreside

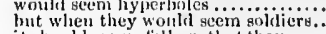

it shoulk seem, Jellow, thut thou ...

that which seems tle wound to kil

Intil to neem won; but I was won

that seems a slceping.... Timon of Ailiens i. 2 (grace)

and it shanll seem by the sum, yon.
as lie made it seem in the trinl of....

our gutes, which yet seem shut.....
wond scen but inulest: therefine ..

now to secm to alfet the mailice.
nul this shall seen, as purtly 'tiv.

be that you secm, truly yrum

vuy's, that secm like prutent heips.

to seem the same you are not.......
let us seem lumbler atter it is flone.

whose double bosoms secm to wear

true, which they so seem to fear.......
although it scms, nud so he thinks..

although it semns, nud so he thinks..
he would not seem to kunw me......

dotunt ns you seem to be? can you.

tell me not wherein I seem unnaturnl

nut after fecm to shide tliem

it secms to me nost strunge that.

diel this in Casar seen ambitivus?

their shadows seem a eunopy

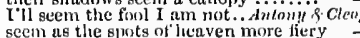

jenlousies, whieh now seem great...

whore wind did scent to glow......
make ne slo, seems mueh unequal

make me slo, seems mueh unequal
t'ie hourl that scems to tie their....

for what you secun to fear..............
fir he seems proul and disdainfii.

that Antony may seem to spend

still geem, as does the king

that, it secms, much loves .......
ymu clo seem to know something

so secm, as if you were iuppired......
that I should seem to lnck humanity

our Britain seems as of it, but

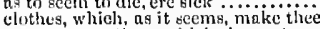

may aecm to those whi

fin, it seems, they erave to be

the time secms long; their bluod...

it seems, come from the fliers

n. very fintal pluee it seems to me

and seem to weep with me......
henls do scem to speak to me.

liow courtesy would seem to eco
whose arm feems fiur too short

wo fear, when tyrants seem to $k$ i..."....

he scems a stranger: but his present

the viands that 1 eat do seem unsavour

very principals did seem to rend .....

mark mc; you must seem to do....

where mir scenes seem to live twould secm like lies disdained in.

to points that seem impossible

for yet he seems to dunbt ..........

it did al wnys sem so to $118 . . . . .$.

draw; scem to defend yourself

being weak, seem so; if, till

this seems a fuir (leserving

light and portable my puin seems now

and goodiness to the vile seem vile.

proper deformity secins not in the

seem to see the things thou dost not

wretehed though I seem, I can produce.

nh me! sarl hours secm long .... Komeo $\vec{s}$ Jutiet.

[Col.] it seems she haugs upon ........

it it be, why secms it so partical
scemar, marlan! Nay it is (rep.).

scems, maslam! Nay it is (rep.)..........

shat they may teem the thints of lilerty

as it did seem to shntter all his bulk

it seems [Col.-by heaven] it is as proper..

though by your smiling, you ssem to ssy

and there did seem in lim a kind of
you would seem to know my stops

every god did seem to set his seul...

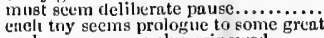

perhaps, seem mueh unsinewed.....

whom now, it scenis, your speeial mandinte

thinks men himest, that but scem to be so

the chiding billow reens to pelt the cloud

and action, make the hours seem short.

his bed shall seem a school, his board

men fhould be whit they seem (rrp.)
thant be not, would they might seem non

thint be not, would they might seen

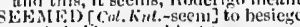

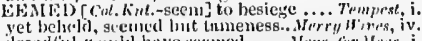

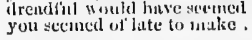

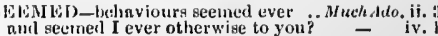

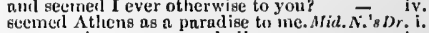
every region near fecued all one..... in us hath seenael ridiculous .... Lnvers $L$, Lnst v. and seemed to ask him sops as he. Trming of Sh. iii.
they have secmed to be together.. Winter's Fule, $i$. they seemed alinost, with staring .....

thint, it seemed, sorrow wept to

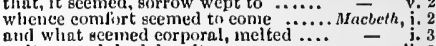

that words stemed buried

that words seemed buried ...........kichart $I I . \mathrm{i}$

his nspiring ricler scemed to know .. - v v.

lis tasking? scemesl it in eontempt?.1 HenryIY, v. 2

their weupons only seemed on our side - i.

it seemer in me, but as an honour

mortified in him, scemed to die too.... Henry $\nu_{\text {. }}$.

thongh we scemerl dead, we did but slece - iii. 6

it. fecmed, npperrel to Rone ........ Coriolnons, i. 2

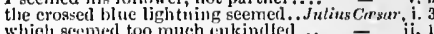

Which secmesl to teil them ...Anlonjo \&lcopatra. i.

yet my mother secmed the Bian..... Cymbline, it. s.

the ginful finticer seemed not to strike... l'erieles, i. 2

niglit, who seemerl iny good proteetor

it seened, she was n glueen over her...... Lear, iv.

seemed not to know what guests $\ldots . . . .6=$ - v.

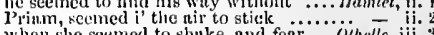

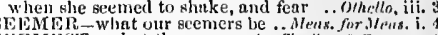

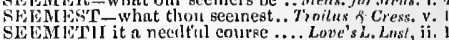

so sensible scemeth their confirenee.

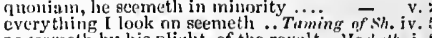

ns seemelh by his plight, of the revolt ., shacbeth, $i$.

ends not when it seceneth done ....... Wichen il II. i.

what to your wisdoms seemeth

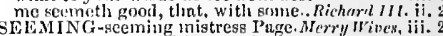

wiser souls to thy inistress Page. Mer'y Hibes, ini.

seeming, seeming - I will proelaim thee -

showed him a seeming warrant for it

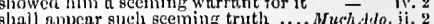

nut on thy scemingl I will write.....

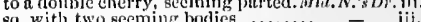

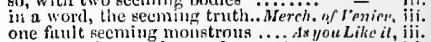

than secming the lover of any otlier
benr your borly more seeming,

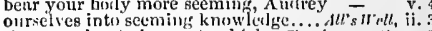

that seeming to be most, which .. Timing of sh. v.

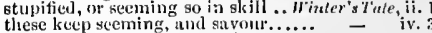

the trutli of your own secming

pour snull! seeming as burdenied....... Comedy of kir. $i$

essentially mad, withont seeming so.l llenryll: $\mathrm{ii}$. this seeming brow of justice...

there is no seeming merey in the k.i.

by seeming tolkl, or eareless of his ..2IIenry $I V$. i

borrow not that fuce of sceming
writ me down after my reeming

in secming to augment it, wastes it?.Ileury r.ll, i.

is conelsed in seeming gladness...T. Torilus $\&$ Crens. i. and o'er-wrosted secining lie acts thy - i.

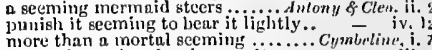
nore than a nortul sceming $\ldots . . .$. . Cymbrtine it. not seeming so worthy as thy birti... = iv.

that thouglit her like her seening ... =

within that little. seeming substrice ....tear, $\mathrm{j}$.

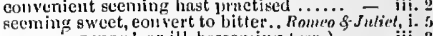

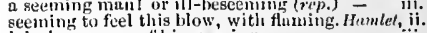
not 1 tor love and duty, but recming fo... onthetho, i. poor likelihoods of moclern seeming .... = the thing I aln, by secming otherwise... $=$ ii. mere form of eivil and lumane seeming - ii.

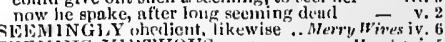

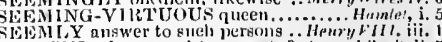

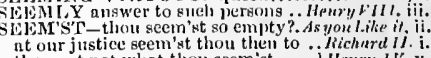

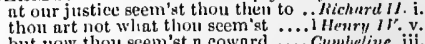
but now thou seem'st n eoward .... Cymbeline, iii.
and thou seem'st a palaee for the..... lepirtes, $y$. to what thou justly seem'st..... Rinmen of hulier, iii. slekN-having seen but him and Calibur. Tempest, $i$. $I$ have secn thee in her

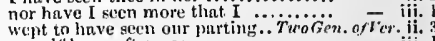
my'selt' have often seen

if Silvia be not secn? ............... ii

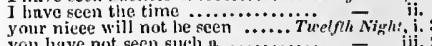

Tuelfth Night i. 3

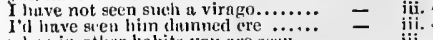

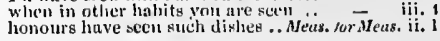



SWEN, when, after execution .....Mcus.for Mcas, ii.

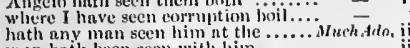

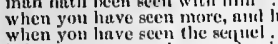

- iii.

wis neen enongh: you shouli wear $\overline{-}$ ii

fulse Trojun under snil wos seen ...Mill.x.'s Dr. i. I

and half his tiue must be seen tirough - iif.

what visions lanve I seenl....

iv. i

where I have scen them shiver tidi lionk $\overline{-}$

nnd not be keen to wink ut' nll .... Lone's $L$.

if any man be seen to talk with.......

duys of desolation thit I hinve seen .

searee seen a lith

that hath seen the worlit

a smaller hair than may be seen
of an old loman coin, fenrce seen

I liave seen the day of wrong

in a gondola were seen together........ of of $\bar{r}$ e

yet I have not seen so likely an.......
and seen vur wishes prosper, to ery..

was not to have seen you here

have seem eruel proof of this man's...ts you

the we hinve seen better days.

then, to have reen mueh, anil to

this seen, Orlando diti approneh

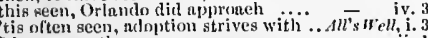

I linve seen those wars ...............

sir, I heve seen you in the eourt

not yet leen seen in any house ..

would Katlarine had never seen him

son of inine, whiels long $I$ huve not seen -

I have seen them int tire clt
have not yom seen, Chinillo

as lie hud seen't, ar been an ....

I have seen a latiy's nose that
I have drank, antl seen the spicle

I have drunk, antl seen the spicler.
I have scen two suein sights, by sea..

it hatl seen very hot service.

pliay as I have seen them do in
give way to what's seen now

give way to what's seen now
to say, you have seen a hetter.

to say, you have seen a hetter........

whish was to be seen, eamot be spoken -

if all the world could have seen it.

be seen at ans syraensan morts

as they had seen me, with these

I lney seen linurs drentifinl, mind things
in England, I liave seen him do .......

is ance seen to smile .................

I have seen her rise from her bed
that I have seen inhubit in thuse.

that I have seen inhabit in those.
five inoons were seen tomight..

five moons were seen to-night.
than had I seen the vauity top

some npparent danger seen in him....Richurd 1J. i.

prophet's eye, seen hoow his son's s.n.
more's not scen; or if it he, 'tis with

here shortly shall be seen, in the ....

that lienorible diny shall ne'er be seen

apprent guilt be seen in them

of homour in thee liave I seen seen -

n. virtue that was never seen in you.i. Henryt

by heing selflom seen, I eould

ne'er seen, mit wondered at ..........
go when lie liml oecasion to be keen.

no eye hatls seen steh seare-crows

let. it be seen to-morrow in ...........

and not ourfelves be scent $\ldots . . . .$.

you have not seen a hulk better...

what we have seen the seven stars.
o, if this were seen, the humpiest...

that thou hadst scen that this (rep.

O the days that we have seen

SWlin-you have feen him open't. Honry Jlll. ii there is seen the baby tigure

that thou last mol meen the
liave you feen ny cousin?

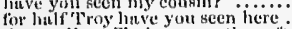

thou gallant Trojum, seen thee ait

[Knt.] and seen thee seorning forfeits

and I have seen the pumse ...........
linve I seen, lint this thy cominteonise

I lave seen the timse-I ponter.

I have nut seen you long ....... Timon of $\bar{s}$ he

that mem eyes have seen the foot.
is not my laril seen yet? Not yet

we have seell better days

it will be seen to morrow

nasy be alshorred turther timi...........

I have before time seen him thus

Thave seen the dumb men throng
thriec six I have seen und heard of

upon yourselves whut you have secri me

whin you have sech him tho......

and talked of nore thin seen

those muims of slame seen tliromylh..

I linve seen tempests, whin the .....

of as have seen strange sights.

that we have heard and scen (r......

there are no eomets seen; the heavens
Oetavius, I have scen mire days than

for 1 have scen more yeurs, $I$ ain sure

yon have secn and provel a fairer
I Jiave seen lier die twenty times

woukd I hand never seen her

I have seen thee fight, when i

mal not to be seen to move in t $\ldots \ldots . .$. .

thou hast seen these signs........

Inve seen him in lirituin (rep.)

if she well lyefore others I linve sech

not seen the most precions dianomel

we have seen nothing: we are bcastly

not seen of have not seen these two day

eivility not ween from other

into erutely, than hive seen this...

1 have not ween hin so pictured

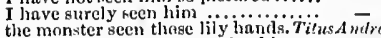

had I but seen thy pieture in this

was ever seen emperno of Rome
whieh [ have scen thee enrefiul

and seen with mistful eyes

and seen the desolation of your ............
the whieh, I hepe, shall ne'er be scen....

here lave you scen a mighty king

his queen and dnughter, seen....

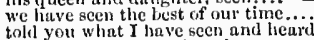

when they are seen almised

iii. 4 I have not seen him this two diay

1 have seen drumkarts do more.

what hath been seen, either in shitili

full oft 'tis seen, our ment sectires us ....

go fir eannut be seen or heard.

thou hast seen a furmer's dog ..............

whave seen the day, with my goon biting

fhe lath not seen the elunge of .

I have seen the day, that I have worn

too early scen unk uown, and known

put it out, for I wonld not be Reen

Truaded sifht twice seen of us (reps.)

impart what we have seen to niglit

Or. cver I hat seen that day, Iloratio
jt was as I have seen it in his lite...

never make known what you have scen

there sech, licave hima away ....ii...

well, thingli never seen betore

never to speak if this that you have sech

when I had seen this lint love on the wing

nll woe! hal seen the molsled ingeel

who this hut scen, with tomgue i

the plyit. the a devil

there be players tlint I have eeen play

it is a dumnel gliost that we have scen

and of 'tis secsi, the wicked prize itself

my good lord what have I keen to-niglat
I hitve seen myself, and served against

'twill not le seen iil him the

I hitve secn you loth: but sinee he's

of whm his cyes had seen the proof

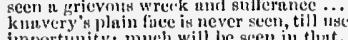

importusity; mueh will be seen iu thut

you not sometimes sech n hnmlkerehict
would to heaven, that I had never scen

I have feent the entmon, when it hath...

her lonour is an essence that's not seen

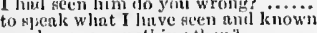

you have seen uothing then?

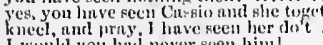

I wonla you hui never seen him

I linve seen the fluy, thint, with this libitie

jiliti: $=$ =

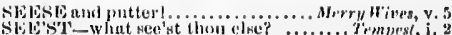

ath suy what then the whe?

this gnilus which then sce'st.

sec'st thou here, this is .............. of Teron

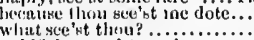

nn' if thou sec'st iny hio.

if thou sec'st her' lefore nne

IIsery rimes, in.

for thon see'st, it will not $\ldots$ som an ever thou see'st lim

thout sec'st, theou wieked varlet... Meas, for Mens, ii. I

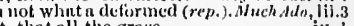

thou see st, that all the graee

what thin see'st, when thou
thou sce'st, these lovers seek

see'st thou this sweet sight?

beholdest, surveyent, ol' sce'st. Lone's $L$. L.t. I (lelter)

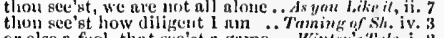

or else a fuol, that fee'st a gume ...Winter's 'ule, i. 2

mark, and perform it; (fece st thou?)
see'st thon not the air of tlie eourt

thousecht the henvens.

int thut thou see'st thy wretelied

thon rec'st, I have morc fleth
thon sce'rt, I am pareificd; btili

thou see'st with peril I hinve.......

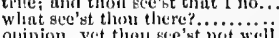

- i

Illenry riti.

Opinion, yet then see'st not weil $\ldots . .$.

the lnw, thou sec'st. hatls jufiged the - ii, 3

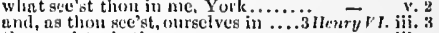

thou pee'st what's janst .....

dichuret III i.

see'st not tliy luss in transturination?. Tim. of dth.iy.3

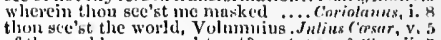

of the worlt, mno; see'st nest? ... Autony \& Cleo. ii. 7

when thon, see good letlow?

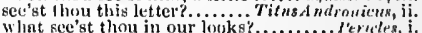

ree'st then this oliget, kent? ................erer, v.

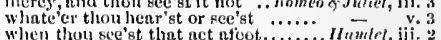

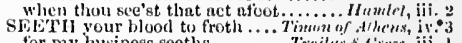

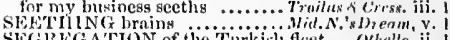

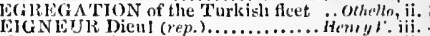

devant les seigneurs de Franee..........

très distingué seigneur d'Aunleterre
$O$ seigneur! je jowr est perdu

lassez, mon seigneur, l nissez, iaise...

supplie, mon tres puissant seigneur.. - v.

the lady I nust seize upon?...........Murh dido, y. 4

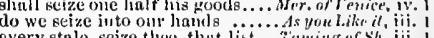

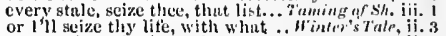

may rush, and seize us? ............. Macbeth, ii. 3

I will surprise; seize lpon Fife......

it you do wrongrully reize l lerefiord's

we seize into our linhls, his phate.
brenthing; seize it. if thou durest

here eousin, seize the erown $\ldots \ldots \ldots$. iv. 1 lisel of the soil eone to scize me ...2nenryly. iv. 10

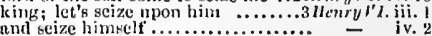
seize on the shame-fiked ifenry...... - iv.

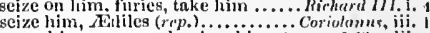

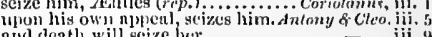
and deatl will seize her ........... seize my own, my true betrothed.. Tituss atrm, i. ghall fesze this prey out of his ....... and thy virtues here 1 seize npon ............ Lent, $i$. you we first seize on $\ldots$................ which shall seize ench vita? spirit.

devils themselves hlonld fent ta seize ... O/hrllo, iv. 2

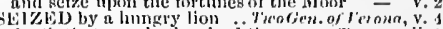
something seized his wisherl ability. W'inter's $T$. ansuther shipl had seized on us . Comedy of kir rur Johin hath scized Arthur hath seized the wastelinl $k$ in
Ifenry the fourth, seized on livil seized nom their tow ( iii.

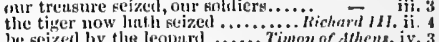
flecp hath seized no wholiy.......... Cymbeline, ii. 3

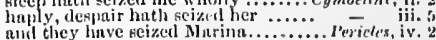

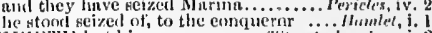

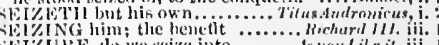

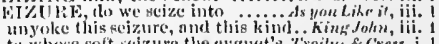
to whose soft seizure the eygnet's. Froilus ore cres.

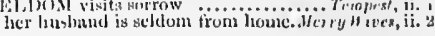


SEI.DOM when the steeled gaoler.. Alea.for Mra. iv.
which very seldom lies ........... Love'sL. Lost, ii. his majesty seldom fears merit of service is seldom attribute

such in telligenee hath seldom failer

good now, say so but seldom

they are seldom spent in vain ......... Richard II, ii.

by being seldom seen, I could not

so my state, seldom, but sumptuous

seldom, when the bee doth leave ...2 Henry

are otten suoke, and seldom meant.2 Henryl IV. iv.

preserverl so whole, do seldom win

th is, that seldom kings enjoy .......3 Henry $\boldsymbol{l}^{\prime} t$. iii.

yet hasty marriage seldom proveth well
by'r lady, seldom comes the better. Richar

God lie knows, selilom or uer

$\mathbf{n}$ soldlier, therefore seldom rich. Timon of dithens, $i$.

not seldom, nor no slight cheeks

which doth seldom play the recanter

seluom he smiles ...................Julizes $\overline{C_{C} s a r}, \mathrm{i} .2$ do seldom or never recover............ dntony \& Clen. v. men been, there's seldom ease...

have seltiom gold for sounding.. Roraeo \& $l$.

SELD-SHOWN flamens do press.
SELECT and generous, chief in ti

though thanks to all, I must select .... Irtmelet,

speak the truth, Selencus. Madam ...

the ingratitude of this Seleucus does

firbear. Seleueus, be it known.

二 $\quad$ v.

SELF-ADMISSION. Wliy will.. Froilus $\&$ Cress ii

SFLF-AFFAIRS, my mind did. Wid. N S Dream, i.

SELF-AFF RIGHTED, tremble.... Richard $I$, iij.

SELF-ASSUMPTION greater ...Troilus \& Cress. ii. 3

SELF-BOLN hour to plant ... Finter's Tule, iv. (clo.)

SERT- peace with selt-borm arms.... Richard YI. ii. 3
SELF-BOUNT, be abused; look to't . Othello, iii. 3

FIF-CIIARITY be some times a vice.. Othello, ii. 3

SELF-CONIPARISONS point against ...Nacbeth, i. 2

SEISF-COVERED thing, for shame
SWLF-DANGER, you should tread .

SELF-DRAWING web, he gives.... Henry HIIT. i.

SELF-ENDEARED-so self-endeared. Much Ado, iji.

SELF-EXPLICATrON; put thyself.. Cymbeline i.

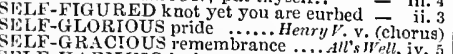

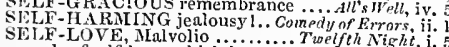

made of self-love, whieh is the most ... All's it'elh

self-love, my liege is not so vile

dedicate to war, hath no self-love
SLLF-LOV ING, and affecting

SELF-LOVING, and affecting

2Henryl.

ST-MOULD that fashione

SELF-NEGLECTING From our hrother $H e n$,

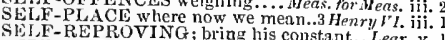

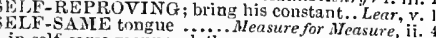

in self-same manner doth accuse

one and the self-same thing.
self-same flight the self-same.

with gelf-same kindness wel...

the self-same sun that shines.... Waming of $S h \mathrm{v}$.

and in the self-same inn ....... Comedy of Error

to the self-same tune, and word

for self-same wind, that I should

like the self-same sea foreed to retio $\mathrm{Henry} \mathrm{V}$

are birds of self-same feather.........

propose the self-saine words to thee =

the self-same name, but one of better

for the self-same heaven, that frowns

whose self-same mettle, whereof thy

the self-same gorls, that armed.... Titus

this is a fellow of the self-same colour
SFLF-SLAUGHTER a prollibition.

fixed his canon "gainst self-slaughter

SEIF-SOVEREI iNT only o. Lore's L. Los
SLIF-SUBDUED; and, in the fleshment

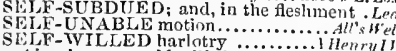

EIF-TVIL LED harlotry
Ajax is grown self-willed

a peevigh self-willed harlotry ... Romen \& Julie

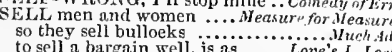

to sell a bargain well, $\ldots$ is a............... Love $L$. L

I will never biy and sell out of this

buy with you, sell with you ........... of of Fenice

in your ear, sell when yon ean ...ds you Like it,

he will sell the fee simple of his.......All's $\mathrm{W}_{e} \mathrm{ll}_{\text {, iv. }}$

you'll buy 'em to sell again

yet sell your face for five pence.......... King Joh in

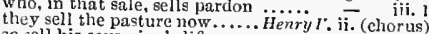

sa sell his sovereign's life.

achieve me. and then sell my bones

hat once dia sell the lion's skin .... $\quad$ - iv. 3

sell every man his life

iulenry $r$ r. iij. 2

or sell my title for a glorious grave...Ifury $V I$. iii. 1
ELL - merchantlike I sell revenge ..2 IIenry VI, iv.
does buy and sell his honour........ Wenry IIIl. i. perclunce, they'll sell; ;f not .... Troilhs \& Cress. i. mint commend what we intend to sell

as those, wich oll'selves ........... - iv. if I would sell my horse

a mother should not sell him

to sell and sell with groats; to

and sell the miglity space of our

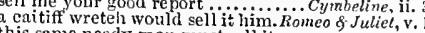

this same needy man must sell it me

may'st not sell; I sell thee poison...

ELLER'S praise belongs my land.... Othello,

SLLLING the dukedom of iIaine ...2Penry IT. iv. 1

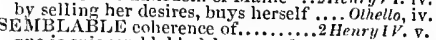

que je suis semblable a les anges? ..... Henry v v. v. 2

his semblable is his mirror import Ant.\& Cleo. $\mathrm{iii}$.

SENBLLABLY furnished like the....... Hen Henlet, v.

another NCE-your own semblar

ind ueed me to the semblanee Twelf

ight, v.l rlet.

to be cozened with the semblance...

in the rare semblance that I loved

the semblance of my soul ..... Her

one in semblanee, besidesances ..ds you Lile it, $\mathrm{i}$.

sinipboy's semblunee hatl disguised . King Johr, iv.

from glistering seniblances of piet $J$

wit eheerful semblance

of ashy semblance, mengre, on $\ldots . \overline{1}$ Henry $r$ r. $v$.

mirrors of his princely semblance.. Richord III. ii. 2

path, thy native semblance on..... Jutius Casar, ii.

apcechless tongues, and semblance pale. Pericles,

by the semblanee of their white flags.

an ill-beseeming semblance for.. Komeo \& Jatict, $\mathrm{i}$.

SEMICI RCLE, or half-moon...... Thinier's 'Tale, ii. I

EMII-CIRCLED farthingale........ Merry Wines, ifi. 3

this godless, this Semiramis .... Titus Antron. ii.

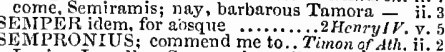

Lueius, Lucullus, Sempronius; ail ... $\frac{-11 i .4}{4}$

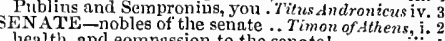

health, and eompassion to the senatel

that the usuring senate pours ug

pluck the grave wrinkled senate from

is not unknown to the senate........

- iii. 5

is the senate possessed of this?

the senate has letters from the gene....
the senate, Coriolanus, are well pieased
you anon do meet the senate

nourish "gainst nur senate (rep.)

digest the senate's courtesy?

you are sent for to the senate

together with the seal o' the senate.

to call me to your senate, I'll...

that is enough to satisfy the senate. Iulits $\overline{C P s}$

break up the senate till another time

that Casar and his senate, must redress?

Roman gentlemen by the senate sent -

he by the senate is accited ....Titus Andror

but libelling against the sente.

the senate hath sent about three....

Olluello

[Knt.] do in duties to the senate

ENATE-UOUSE? There ............... Torio

myself agnin, repair to the sennte-house
are going all to the senate-house.....
Mark Antony to the senate-house-Julius $C$

I come to fetch you to the senate-house

rum to the senate-house; stay not to

ENATORS of the antique $\ldots$ Henry $\because$. v. (ehor

go you, sir, to the sentiors, (of wiom

cripple our senators, that their limbs

the senator shall bear eont
with senators of the beneh

the senntors, with one eonsent of love

as you malign our senators........... Cori

the senators of Rome are this good belly -

I heard a senator speak it.............

you grave, but reckless senators $\ldots . .$.

your snn, these senators, the nobles

those senators that al ways favoured him -

the senntors, patricians (rep. iv. $7 \&$ \& $v .4$ ) -

asked him by any of the senators.

the senators to-morrow mean to e....

bear my greeting to the senators .... -

penple, and senators! be not alfiginted
SENATORS-seventy senators ....JuliusCasar, iv. 3 to you all three, the senators ..... Antony \& Cleo. ii. the tyrant custom. Thost fhrave senalt ...

the duke and senators of Venice greet you - iv.

I must go send some better............ Tcrogesen, ii.

Whicher were I best to send him?...

Eend her another; neve

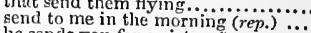

he sends you for a picture?

more sliame for him that he sends it me -

sir IIngh send-a you?

to send your little page (rep.

shall we send that foolish enr........

what honest send thee good fortunei

and did he seut you botll these......

send to Falstnff straight (hey'll

send me a eool rut tight (rep.)

God send you, sir, a speedy ........ Turelfth $\bar{N}_{i g h t, \mathrm{j}}$

haist need send for more money $($ rep. $)$ -

I did send, nfter the last enchantment

send ministers to ments

send one presently to sir $_{\text {Toby }} \ldots \ldots \ldots$.......

send after the duke, and appeal ..... - i.

and send the liead to Angelo $\ldots . . . . .$. - iv.

he eends a warrant for my poor.......

God sends a curst cow short horns (rep.) - ii.

if he send me no liusband............

that you ean devise to send me on

and send her home again without

but God send every one their heart's $=$ iii.

the king your father sends (rep.).. Love's $\bar{L}$. Lost, ii.

marry, sir, youl must send the ass.....

this will I send; and something el....

true a gentleman you send relief $\dddot{m}$ iser. of

an not well; send the deed after ... of Tenice, jii.

send to his hrother; fetch that..... As you Lithe it,

he sends this bloody napkin .......... $=$ ii. 2

God send him well! the court's ......Al's 'Well, j. I

or I wonld send them to the Turks.. $=$ - ii. 3

Til send her to my house (rep.)

God send her quickly! (rep.).

send forth your nmorous token....

iii. 5

will lose a husband, send for your ring $=$ v. 3

or shall I send my dinughter Kate. Taming of S

send for your danghter by your.

Gol send' 'em good slipping.

at first when he doth send for lier....

sir, my mistress sends you word

will, sir, that you send for me?

Jove send her queen to send ..... Winter's $\bar{T}_{\text {al }}$

at friend, can send lis brotlier spirit!

send some other messenger .. Comctly of Errors....

a purse of duents; let her send it .....

nor send him forth, mistres

imless you send some present help

reust send those that we bury .......... Nocbeth

[Col. Knt.] I'll send my prayers with himl -

Seyton, send sent: doctor, the thane

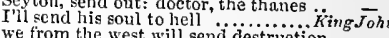

we from the west will send destruetion -

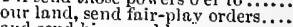

and send him word by me

and send them after to supply.

.... Fichard $I$

tell her, I send to her my kind $\ldots . . . .$.
trumpet send the breath of parle....

and sends allegiance, and true faith

and send defiance to the traitor......

and send him many years of.

and send the hearers weeping to their

banish us uoth, and send the king

sendls ne word, I shall have none $\because$ i Henry

send me your prisoners with the ... -

cume and roar for them, I will not send =

I slanl send you written, be assured

antl send lim hack again to my mother

faith, I'll send him packing. Now, sirs =

a shorter time shall send me

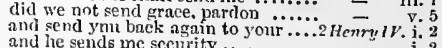

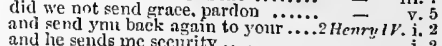


SEND_heaven send the prince a our nftuirs, and send us peacel

and semil discovers forth, to know....

roughly send to prison the immedinte

send tor him, good uncle .........

whom she did send to France......

he therefore sends you, meeter tor

he sends you this inost memornble

as send preepts to the were send to know what...

shall we go send them dimner

from Ettian $I$ intend to se

sliall send between the red

I camnot send then now; this...

I tid send for thee, to tutor.....

what tidings send our scuit

to send such peevish tokens...

and send for his manter with

then send for one presently...........

send suecours, lords, and stop tie ra.

to send me packing with send thy soul to hell, pernicious

and send thy soul to hell, jer.
the cummons send you word

could send sueh message to their.

I'll senil some holy bishop to

I will send you Matthew Grigh

tell him, I'll send duke Edmuk .....

and sends the proor well-pleas

send thee Warwick, stuch a messenger.3 Jentry $r$
of Norfolk sends you word by me....

of Norfolk sends you word by 1

sends me a paper to persuate......

and the hady Bond, send to him
we'll sent him hence to Brituny

we'll semt him henee to Brituny
till Goit please to send the rest

tis not the king thint sends yon to...

thint inade him sertly send thy soul...

that holp to send him thither..........

makes him to send; that thereby

lie sends you not to murder me....

tis he that sends us to destroy

may send forth plenteous tear

send straight for him, let him $\ldots \ldots .$.
nersuatle the queen to send the duke

persulate the quil [riol. Kut.-certifies your]

sends youl worll
therefure he sends to know your

hie sends you this tood news ....

l'll send sorne packing, that yet......

buy souls, and send them thither ....

send to her, by the man that slew hicr

send her a letter of thy noble

gend out a purstivant at arms .......

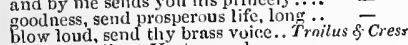

that the gallant $\amalg$ ector sends.......

that the gallant Ilector sends.

to send senil the fool to Ajax.

might send that Greekish....

bid 'em send o' the instant

and does he send to me! $\mathrm{T}$
sends now tor money (rep.)

where wouldst thou send it? .......

I thank them; and would send the

and send forth us, to make thend thy gentle beart

I send it throngh the rivers of $\ldots . . .$. .

if I do send. dispe the hest

and to send for 'Titus Lartins.....

we shall not send o'er the vast .......

their latest refuge wns to send him

incenses them to send destruction
bid Antonius send word to you.....

scnd such drealful heralds to.........

send Mark Antony to the senate-house

shall Cresar send a lie?

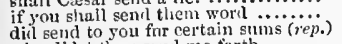

why didst thou send me forth.

and to Thassos send his body .......

to great Egypt sends this treasure

send so thick? Who's born (rep.)

to send measures of wheat to pome

when hither he sends so poor a pinion

the boy Cresar send this grizzled head

and send to darkness all that.

Fo, Eros, send his treasure after.......
and send lim wort yom are dead

and senr lim work yom are dead
ditl slie send thee? Now, my lord

Casar scuds greeting to the quecn

and send clilil ren will he sent before

W'll drink the words you send........

s will make boli to send them to you

send your truuk to me; it sluall sife

send the arrearages, or look upon ï.. -

may he, she plucked it ofl, to send it

tlyou, king, send out for turturers...

send thee by me, their tribune.. Titus $d$ nitron

your hand, and send it to the king (

Illl send the emperor iny hand......

presents, that I intend to send them
and sends the weapons wruplued about

and sends the weapons wrupned about
basely insinuate, and send uy gifts.

basely insinuate, ant send uy gifts
the empress sends it thee.............

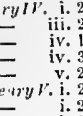

SEND the nidwife presently.. Tilus Andronicus, iv. 2
but l'luto sends you word .......... torend down justice for to wreak.........

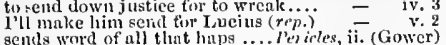
tur every gratz' wnuld sendt a caterviliar

I will send fir aud ncar, thint ahi

i. 2 and not send back my messenls

\begin{tabular}{l|l} 
iii. 3 & send quickly down to \\
iii. 5 & a century seud torth
\end{tabular}

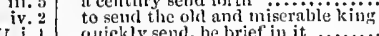

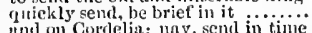

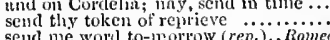

$\therefore$ - ii. 4

ii.

shatl? I word to thec? At the huur of nine -

nine, when I lid send the nurse

send thy man away ...................
and says, God send ne no need of theet

with the other scnds it back to Tylutlt

not keep him long, hint scmi

unless that husband send it $\mathrm{m}$....

seud for the county go tell liim

iii. 2 I could not send it, herc it is agnin....

till I conveniently could seod to
sends out arrests on lortinbras

that she sends you to prison hither?
if she find him not, to England send him

if she find him not, to england
in he:wen; send thither to see...

mnst send thee lience with fiery.

he sends to know if your pleasure.

I do beseech you send for the l

I'll seod her to you prescntly...

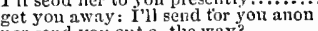

hor send you out o the way? ne..........

send for the man, and ask hiin

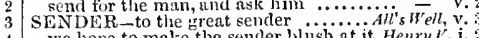

4 not misbecome the mighty sender.... - ii. I

2 SENDETH forth to skirmish ......... Chenry H' i. i.

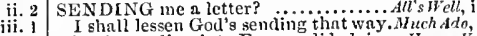

iii. 2 lntely sending into France, did claim. Henry ${ }^{2}$. i. 2

iii. 2
iii. 2 he's ever sending: how shali I...Timon of $A$ th. iit. 2

iii. 4
iv. 4 for sending me abont, to eatel ... Romeo \& Juliel, ii. 5

did provoke our hasty seoding ........... Hamlet, ii.
iv. 4
this sudden sending him awny mist ...

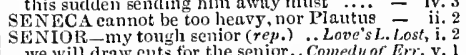

we will draw cuts tor the senior. . Cnmed ly of Err. v. I
SEN IOR-JUNIOR, giant-dwart .. Lore'sL. Losl, iii. I

SENIORY - the bevefit ot seniory... Richard 11 . iv. 4

SENNA-what rluburl, scini, or what.. Afacbreth, v. 3

SE'NNIGIIT-be but a sc'nnight... As yout Like it, ili.
anticipates our thoughts, a se'noight's.. Onhello, ji.

SENSE- hath such senses as we have.

their thenses l'l restor

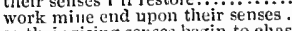

so their rising senses hegin to e

been justled from youl' senses ........ of $\bar{r}^{\circ}$ r. iv. 4

it is his five senses $\ldots \ldots \ldots \ldots . . .$.

ii 1

call all your =enses to you

denial I would find no sense ...... TwelfhNisht, i. 5

disputes well with my semse..........
vet have I the henefit of my senses - v. I (letter)

and motims of the sense ... H

so that, in the beastliest sense.

and 'tis such sense, that my sense hreeds =

more betray our sense than woman's

your ecnse pursues not mine
the sense of death is most in

with danterous sense, might, in.......

slie spenks this in the infirmity of sense

madoess hatlo the odiest in trance of ense

against all sense you do importune .. $\overline{\text { v. }}$ v

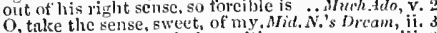

their sense, thus wenk, lost with...

doth impair the secing sense

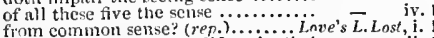

all sensts to that scinse did make their

all his scnses were locked in lis eye.
make passionute my sense of hearing

make passionate my sense of hearing

bestow on me the sense of hearing..

dimensions, senses, altections...Merch, of tenice,

that weiols their pains in sense.

whose alprehensive senses all but

they tolsched not any stranger sense

now tor all sense 'tis gross, you lo

when help prst sense we deem o...̈ = ii.

=

no skill in scnse to make distinction - ii.

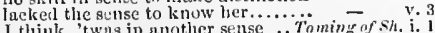

and yet you miss my cense; I incan .. — v.

and in no sense is meet, or aniable

that your senses, unintelligent.... Whiter ${ }^{\circ}$ Tule, $i$.
SENSE-surprised my sense .......Winter's Tule, iii. I
if not, ny senses, better lilensed .... - iv. 3

all their other senses stuek in ears

work for the otlier senses

no settled serises of the world ........ - . v.

establish him in his true sense again - iv.

itself unto our gentle senses

ny, but their sense is shut

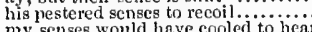

palter with us in a double sense

v. 7

sweets eomfort his ravenons sense... Nirharn 11 . iii.

in comm senses in forgetfulne

in common semse, erow vs.........

let senses rule; the word is....

whose sense have bit humant

- iv.

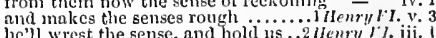

ay, but, I fear me, in another sense..

spirit of sense lard as the palm.. Troilus of Cress. i. 1

to et his sense on the attentive...

this shape of sensc assumes............
dost thou think I have no sense

to suck ill the sense of fear

so sweet that it enchants my sense

that most pure spirit of sense........
give as soft attachment to thy senses

$=\quad \mathrm{ii}$.

a woman of quiek sense $\ldots . . . \ldots . . . .3$ iv - iv. 5

I ree no kense for't, hut his occasions - iii. 3

gan pierce his ready senes fall

awake your senses, that you may.juliuscipsar, iii. 2

et the adjacent wharfs. Antony \&-Cleo. ii. 2

you take me in tondolorous a sense... Cymbeline, iv. 2

stupiry and tull the sense awiile..... - i. 6

and man's o'tr-laboured eense repairs = ii.

to the smothering of the sense .......

ere wildness vanquish my staider senses - iii. 4

speaking such as sense cannot untie - v

is so frum sense in hardness............. Pericles, $\mathrm{i} .1$

it smells most sweetly in my eense..... - iii. 2

and make my senses eredit thy relation

the most precious square of 'sense

pierce every sense abont thee! .........

doth from my scnses take all feeling

ninght yet have balmed thy broken
in the restoriug his bereaved sease?

why then, sour other senses grow

how stiff is my vile sense, that $I . . . . . .$.

the untuned and jarring senses, 0 wind ip - iv.

slays all senses witls the heart ....... - ii.

your worship, in that sense, may cail - iii. 1

the most vulgar thing to sense.......... Hamles

Fense, sure, you have, else, conld you not $=$ iii.

nor sense to cestacy was ne'er so thralical = iii.

a sickly part of one true sense eould not

who all sense doth ent of habit's devil

prower thereof may give thee sense....

y but hialf sense

burn ont the sense and virtne of mine eyel - iv.

from the scise of all civility

I'll refer me to all things of sense

I do approve in feartinl sense .........

in the bitter letter, after your own sense

have

$[K n$.] there is more seuse in that than in

have you a soul, or sense? God be wi' you

even to that sense of pain...............

mine ears, or any sense, lelighted them

their wives have sense like them ...

sich noble sense of thy t'riend's wrong

for, in my sense, 'tis liappiness to die ....

0 thou senseless form! .............. iv. 4

and excecding gousensend fit man. Iruch

made senseless things begin to do... Wil. N.s s l r iij. 2

to estecm n senseless help, when ielp.Al's H'cll, ii. I

senseless villain! tood lfortensio. Tamin of sh. i it was senseless; 'twas nothing. Winter s whr. iv. mock not my senseless conjuration. Richard II. iii. :

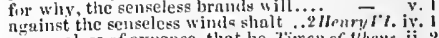
so senseless of expense, that he. Timon of thens, ii.

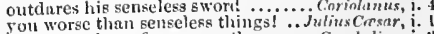
I am senseless of your wrath ........... cymbcline, i. scuscless linen! limppicr therein than 11 二 i. senseiess bauble, nurt thou a teodury' for 二 iii.

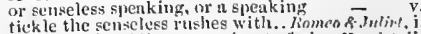
then senseless Ilim, secnint to fech ... Hamlet, it, 2 


\section{SEN}

SFNSFLESS, that glould give us ...... llamlel, v. 2 SENT-and hath sent post haste.
SENSELESS-OBSTINATEyou are too senseless-obstinate.... Richarl III. iij. 'twas a goor sensible fellow Tempest, ii. sensible warm motion to bee

the sensible Benediek (rep. v. 1) .......Mnch Ato, i. . being sensible, should curse agrin. Mit. N.'s or. v only sensible in the duller marts.. so sensible seemeth their confirence

with affetion wondrous sensible.Mer. of Tenice, ii he bringeth sensible regrcets ....... - ii. 9 you are sensible, and yet you iniss

thon art sensible in notling.. Comedy of Lrrors, iv. 2 fital vision, sensible to feeling not mad, but sensible of grief....

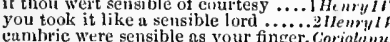
King Johli, iii. sensible, out sares his as your finger.

yet his liand

without the censible and true ovouch

How a seusible man, by and by a tool .. otictlo, i. 1

sensibly ficd of that self-blomd....

nm most sensibly in grief for it......... Ilambet, iv. 5

kinsible as the lorutisla sting itself $d s$ you $L$ ihe it, ii. 7

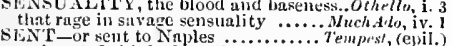

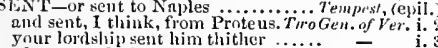

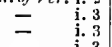

shall be sent after thee

I was sent to call the

sent from lis heart .............

for they are sent by me...

the inessage I am sent on.

the ring you sent to silvia

my wife hath sent to him

let him be sent for to-murrow

my master Slender, sent to her

were you sent hither to praise me?.Tuelfin Night

Iny sent thee sixpence for thy

have sent after him

i sent for thee upon a sad occasion.

that I am not sent for yon? (rep.)....

we have sent to the deputy .....Meas. for Neas. iii. 2

my lord hath sent you this note...... - iv. 2

have Claudio's head sent me by five - iv. 2 (note)
and sent according to command ....

hatli yet the deputy sent my

bis bead is off, and sent-to Angelo

was sent to by my brother
was

et him be sent for

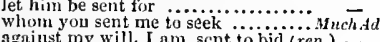

against my with, I am sent to bid (rep.)

her fuiry sent to bear him to

have you scint to Bottom's lous

have sent to thee, to receive. Love's $\ddot{L}$. Lost, $\overline{\mathrm{i}}$. I (let.)

and sent me from Don Armath

the fool sent it, and the lady

but what was sent to yon fion fair

these pearls, to me sent Longaville

sent twenty out to seek ....Merchant of

whom I have sent for to determine... -

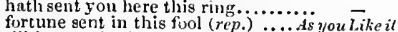

till heaven hath sent me fortune ....

he sent ine word (rep.) ..............

sent you a daughter-in-law
Jumo, seot him forth from

but I sent to lier, by this same

Thave letters sent me, that set.
or sent it us upon liẹ great

that owes the ring, is sent for

ind sent hefore to make a fire

the foolish knave I sent betore?....

Tr's Tale,

my master. hath sent for me ........

sent by the king your father to greet
in such liaste I sent to seek his. Coraedy of Err. iv. 3
sinte at first I sent bim from .........

yolur mistress sent to have me

sinee you sent me hence....
slie sent for you by Dromio

she sent for you by Dromio ............
whos sent whole armadas of carracks
u ship you sent me to................

the gold you sent ine for (rep.).

have you that I sent you for?..........

that I was sent for nothing............

get him bound, and sent him home.
and sent him iny peasant home......

I sent you money, sir, to be.

we are sent to give thee...........

to gain our place. have sent to peace $=$ iii.

the king hath sent for you..............

audience; I am sent to under (nol)

sudience; I am sent to speak
go $b 4, I$, seut thee forth to

the lorses your lordslip sent for

they have sent me such a man.

that the rods sent not corn

he sent in yonmg llarry percy, sent from iny

why am I sent fur to a king (

to Loudon sent the hearts of $($ rep. $p$. .

but l have sent for him to.
aud huth sent for you to line.

have I sent him hootless hoime

Insrd AIortimer of Scotland hath sent

Gawsey hath for succour sent, and

whom hath sent out a speedy power....

I looked he shonld have gent ine

Sir Joln, I sunt for you before

you worli not come when $I$ sent for
Isent for you, when there were.....
if'I

if I be not sent nway post.....

powers that you nlready have eent fouth =

we have sent forth already

I sent your grace the pnrcels .........

tell him who hath sent me after hi

the messengers sent from the dauph

bitter noek you sent his majesty....
by his fatlier seut about merelandis

who hath sent thee now? Tlie Constable

hundreds ling we sent

a vision sent to her from heaven

we sent unto the Temple

.

York should have sent? Whither

he might have sent, and had the horse

and she sent over of the kius sent?

we'll see thee sent aw ay ........
sent his poor queen to France.

pay in France, and never sent it

that Somerset be sent as regent thither

sent from a sort of tinkers to the king

sent the ragged soldiers wounded hom

he was lately sent from sour $\ldots$....

sent from your brotler, Marquis

be sent for to return from.

have they sent it for her rausoin?.....

sent before my time into this ......Richard $\overrightarrow{\text { III. }}$.

to be sent to the Tower............ $=$ i. 3

marry, we were sent for to the just....

I have sent for these strawberries....

the reason we bave sent for you

yesternight by Catesby

in Dorsetshixe, sent out a boa

commissions sent down among
hatl sent to me, wishing me

he sent command to the lord

hatl sent one general tongue

papers of state he sent me to peruse.

you sent ine ileputy fiur king .....

item, you sent a large commission

a gentleman, sent from the king

caused you write, yet sent away?

by her woman I sent your miessage

that was sent to me from the eouncil

to the port of Athens sent Troilus \& $C$

$[\mathrm{Col}$.] we sent our messengers.

let lim be sent, great pinces...

let one be sert to pray Achilies..........

bas sent your loonur two brace. Timon of $\bar{s}$ th

and 1 am sent expressly to your Jordslip-

mistonk him, and sent to me, $i$ should

only sent his present oceasion .....

he hath sent me an carnest...

when he sent to borrow of me....

he sent to ine, sir,--here he esmes.
lordship this other day sent to me

if you hath sent but two hours.

cause of Pear, we sent thee treusure

to a cruel war I sent him........

you are sent for to the Capitol

for thy suke, and would have sent it

meet to be sent on errands.

have not sent his powerful.

Antony sent to her, invited her Anto \& Cleopu

our written purposes before us sent how you take the offers we have sent

hath of ter thee scnt all thy treasure

my mistress sent me to thee........
SlinT too slow a messenger.. Anony of Cleopa,$a$, v.
tinere's Dolubella sent from Casar ..

letter that I have sent her. Cymbeline, iii. 2 (Ictur.

Thave sent Cloten's elotpole down

Roman gentlemen, by the senate eent

sent by the lieavens for prince....

so many enemies shall not be seit. ...

in seorn to thee sent back.

hath sent by me the goodliest..
what hath he sent her?

Revenge, sent from below (rep.)...

art thou sent tis me, to be a tormeut..

I am sent to be revenged on him

O, here is the lad $y$ that I sent for

by some incensed trod sent hither...

iuto the world betore he was sent for.....

employment I was sent to you

to whose hands have you sent the

with him I sent the queen

I um sent to find those persons .............. of Julied, v.

hath sent a letter to his father's house

Gool had sent [Col.Knl,-lent] us but this
but sent to my accont with all ......... Hamlel, i. 5

he sent out to suppress his nepliew's...... -

were you not sent fir (rip.) ..............

whether you were sent for, or no? (rep.).. = ii

we have closely sent for Hamlet hither... - iii. I

affliction of spirit hath sent me to you $:$. - iii.

Thave sent to seek him, and to find the - - iv. 3

and sent into England (rep.)

the gallies have sent a dozen sequent...... othello, i.

and your noble self, I am sure, is sent for $=$ i.

shall think to be sent after me $\ldots . . . \ldots . . .$. 二 i

meant to have sent this damned villain...
SENTENCE- of his five sentences

a sentence is but a cheveril glove. Trelfh Night, iji. 1

under your sentence? yea.

pronounce a sentence on your brother's

as cruel as the sentence that you .....
immediate sentence then, and sequent

shall quips, and sentences, and these. Mruch $.4 d o$, ii. 3 sir, I will pronounce your sentence. Love's L. Lost, i. I good sentenees, and well pronounced.Mer.ofl ent $^{\prime}, \mathrm{i}$. 2 must needs give sentenee 'grainst the

I pray thee, pursue sentence.

a sentence; come. prepare..............

or at evury sent sentence then .....ds you Like il, i. 3

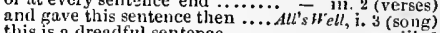

this is a dreadful sentence .......... tii. 2

a hen yy sentence, my most suvereign. Kiehard 11 . i. 3 after our sentence, 'plaining comes...

and in the sentenee iny own life .....

can give sentence on his king

cold considerance, sentence me......... Hen $^{2} I V$ v. v. 6 to steal his sweet and honey'd sentences. Herry i i i i hear your sentenec; you have conspired - yi. 2
receive the sentence of the law......2 $\|_{e n} y r$. ii. 3 write in the dust this sentence ......3 $\mathrm{Hem}_{\mathrm{y}} \mathrm{VI}$. v. of what we chance to sentence .... Coriolan III, i. black senteuce and proscription

youl leaned unto his sentence.

Cymberine, iv.

sentence on this execrable wreteh. Titus Antdran v. expotind now, ar receive your sentence.. Pericles,

sentence of your moved prince .. Romeo $\ldots$ sultiet,

pronounce this sentence then .........

fay a scintence, which as a grise, or step... Othello, i.

he bears the sentence well (rep.)

SENTENCWD; tis toolate ...... Meas. for.Mras, ii.

and he that got it, sentenced .........

if he chusce to fiil, he hath sentenced
than $A$ ngelo who liath sentenced lim

he's sentenced; no more liearing ... Coriolanus, iii. 3

SEN'Throats are sentenced, and stay ...

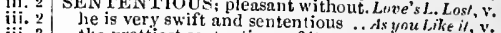
the prettiost sententious of it....Romeo of Jutiel, ii. alarumed by lis sentinel, the wolf ..... Macheth, i. the fixed sentinels almost receive. Honry ${ }^{\prime}$. iv . (cho.

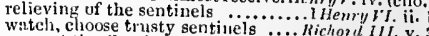
eorrupt the Greciun sentinels.. Trinitus of Cress. iv. v. 5 SWNTST-sent'st the emperor.... Tilus.tudron, iii. to separnte tle husband and...Comedy of Errors it. a man cau no more separate age $\ldots . . .2$ Hehr?! $W . i$. SEPARA'TED fortune sliail keep us \&. Tressida, v.

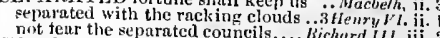
SEPARATHON, as may well be.ivid.N.'sDieam, ii. made separation of their soejety ... Wimler's Tale, $i$. onr separation so abides $\ldots$... Anomy of cleopatra, i.

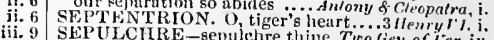
by pangs of death and sepulehre. Twelfh Night, iii. this firail sepuldire of our flesh...... Richard th. i. 


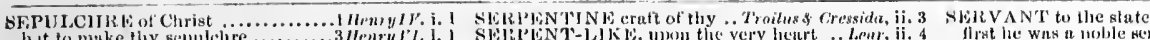

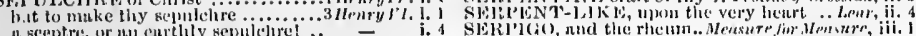
a eceptre. or $ы$ enthly нерuld lire

sweet boy, slithl be thy sejulteit

likened of to kingly sepulehres..... $-{ }^{2}$ v. 2

Why the seminge, wherem we snw .... llamet,

SEQUEL-I guess the sequel \# Fo...... of fer, ii. I

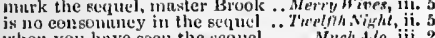

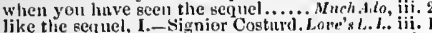

like the sequel, 1.- signior Costurd. Love's L. I. iii. I
the sequel by that went betiore. ('omedy of tirrors, i. I

and then, in serinel, all, aceording to.. Henry

murk how well the fequel hangs.. Nicharil IIt. iii. 6

nitend the sequel of your imposition . numb

but is there no sotinel at the hecls of . Mnmict, ini. 2

by thir sequence and suceession? ...Rizhard II.

in the sequence of degree ...... Timon of.sthens,

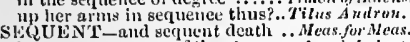

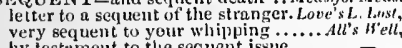

hy testument to the seruent issue .... - v. 3

in my sequent protestution.. Troilus \& Cressida, iv. 4

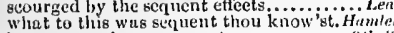

What to this wus serqent thou know'st.

SLQUESTLR - a scquester from liberty .. ii. 4

why are you sequestered from all. Tilus Aulron. ii. 3

SELUESTIRATIN from open

fouthiseme sequestration huve I

slalt sce an unswerable sequestration ... (vikelto

SERE-erooked, old, and sere.. Comedy of Errors,

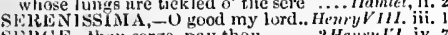

silkG E-thon serge, nay thon ....2.2 HenryIT.

und thet, and a sergennt in the way

ay sir, the sergeant of the band .......

hindered by the sergeant, to tarr

this is the sergeant, who, like........... Macberh, iv.

sergeant, you shall: thus are poor ... Henry!'l,

us this fell sergeunt, deatl, is striet in.. llamlel, v.

SERioUs-serfuns than my ctstom.... Tempest, ji.

un serious business, craving quiek. Love'sL. Lost, ii. a very serious bnsiness calls on liin..

price of serious things we have $\rightarrow$ v.

grafted in iny serious trust......... Winler's ' late i. 2

a common o!' my serious hours. Comedy or lirrors, ii. 2

there's nothing serious in mortality ...Mncbeth, it. 3

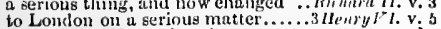

a wcighty and a seriuns brow

he did it witl a serions minti........

line wing -2

intending olher scrious matters... Fhon of Alh. ii. 2

to use thce with a serious industry.. Cymbeline, iii. 5

words with that whieh is so serions.. . Pericles, iv. 6

what serious contemplation are yout in? .. Le: $u r, i, 2$

fritll, he is posted hence on serious matler - iv
O heavy lightness! serious vanity l. lloraen of $J u$.

but lend thy serious hearing to what ...llumlet, $\mathrm{i}$.

your serions and great business scalit . othello,
SLRIOUSLY - Ceres whisper seriously. Tempest, i

seriuusly I inay convey my thuughts. $d l^{\prime}$ ' $W^{2}, l i$,

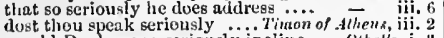

would Desdemona seriously ineline ..... Ohello, i.

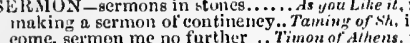

eome, sermon me no further... Timon of Aihens,
SERPENT-a serpent by the tongue. Wuch Ado, to pluck this erawling serpent from. Mid.N.Dr. ij. 3

than thine, thon serpent, never adder
slake thee trom me, ike a serpent

now to 'senpe the serpent's tongtse .. - (epii.)

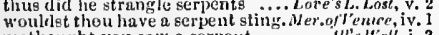

metlionght youv saw a serpent ........ All's s'eth, i. 3

acbeth, i.

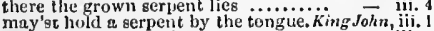

he is a very serpeut in my way.......
what serpent hath surt 11 . iii. 3
iii. 4

a serpent that will sting thee ......... - v. 3

atfrights me, as a serpent's sting .21lenry VI. iii. 2

were there a serpent seell, with forked
such tell serpents as finlse Suttiolk is

frightf'al as the serpent'y hiss

the lurking serpent's mortal sting?...3 henry $V r$. it. 2 I will a serpent when he hisses.. Troilus f Cress. y. I not Afrie owns a serpent, I abhor ..Corintanses, i. lhink him as a serpent's egg ....... Jutius Casar, where's my serpent of old Nile? .....

you have strange serpents there

your serpent of Egypt is hred now

it knife, drugs, serpents, have eige...

glarner than a serpent's tooth it is.

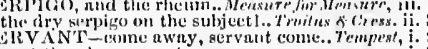

wast then her servuut.

my brother's servants were then

my imlustrious servant Ariel!

gir Valeutine and servant...

and so good-morrow, servant.......

servant. Mistress

whes is that, servant?

too mentu a servant to linve $n$ io .

enterluin him for your aervant

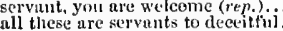

inyzelf do want my servant's fortine

your servant, und your friend
when a inan's servint shall.

would do this for their servant?

respet uot auglit your servant doth

us ever servant shall eome in

I shall be glasl to be your survant.

let me be your servant..........

Cesario is your grevant's ualue

my servant sir! 'twas never merry...

your servint's servant is your servant

so did l abuse, myself, my servant

and suits well for a servant with

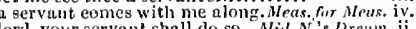

, your servant shall do so...Mid. N.'s lietun, ii.

your sorut straight was mute.... Love's L. toost, v.

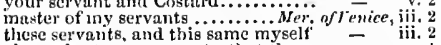

give order to my servants, that they
let me be your servant.............As you Like it, ii.
in your thoughts be servants to you!..All's Well, i.

in your thonghts be servants to you!.. All's $H^{\prime} e l$, i. 1

I his servant live, and will his vassal
hose of thy sleeves? do other servants sol二

am your most obedient servant

yeu never had a servant, to whose trust

makes your servants droop. Tanaing of $\mathrm{Sh} . \overline{2}$ (indue.)

how thy servants do attend on thee $=2$ (indiue.)

most trusty gervant, well approver

was it fit for a servant to use his

trusty, pleasant servant Grumi

send for your daughter by your servant

that offer to heat my servant ........

if I lad cervauted a servant, grafted.

account ine not your servant...

myself your loyal servant ......

both dame and servant; welevmed ail

bid the servants spread for dinner. Comed

for servants must their masters mind

elildren, and servants; which do but... Macheth, i.

your servants ever have theirs $\ldots$ will beeame the servant to defect

wife, children, servants, ail that coinid

on earth hath been thy servant still.. kin $J_{0 h n}$ iv.

household servants fied with him .. Richaril Il, ii.

frontier of a servant hrow.........

look to thy servants, cherish thy guests

here eonies my servant Travers.......
could better command his servants..

or if a servant nnder lis master's ......

of his son, nor the master of his servant

thy humble servant vow s obedience

this is my servant; hear him.....

calls yout forth, survant in arms. $3 . .$.

hatle witness of his servant's muliec. 2 Ifenry $V$

the servant of this armourer, my lords
it thy poor devoted servant may ... Miehard 111 .

sovereign, of my servant s life .......

heing my sworl servant.

for suecour to his servant Bannister - ii.

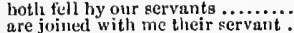

learned unl well-beloved servant...

peacemakers, friends, and servants.

brought the king to be your servant

I rest your eervant

were the servants to this chosen infuint

proud to be his servant, Paris.. Troilus
unworthy to be ealled lier servant...

go, go, my servant, tuke theu 'Troiliis

to present slaves and servants.. Titan

thou hast a servant nameri Lucilius

one Varro's servant, my good lord ..

hound servante, steal!

priests and servants from your sides

an homest poor gervant of yours......
rather be their servant in my way..

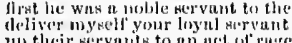

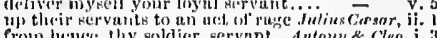

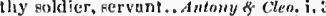

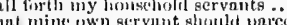

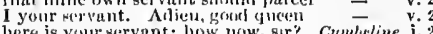

here is y yur servant: how now, sir?.. Cymbetine, i. 2

thut luth more kings his servants

lyon art no seryant of thy nuther's..

will play the cook, and servant..

iii. 1

goud servant dees not all commanis

m am $8 / m$ asul servant to your will

I'll not berenve you of your servant

give me my servant forth $\ldots . . . .$.

who stoeked my servant? $\dddot{R}$ e.................

those thnt sle calls servants, or from mine? - if. 4

this trusty servant shail pass between us = iv.

glain by his servunt, goine to put out

and your aflectionate servant, Goncril - iv. $\overline{6}$ (let.)

your servant Kent: where is your servant - v. 3

the servants of your adver'sary ... liomeo of Julint, i.

go, your scrvants tend. Farewell, (jhelia - j.

servants of the duke, and my lieutenant. othello, i. 2

GRVANTLO to

SERVAN'T-NAID, than a great ..... Richarl LII. i. 3

LileV li-and serves in oflices that profit. Tempest, $i$. 2

bit the mistress which I serve........ - iji. I

and l'll serve thee ine................

less than a pound sinhl serve me. TwoGen.of ler. i. :

will scrve the turn? (rep.)

and serves for wnges .....

iiii. I

will searce serve the turn........... $\quad$ that will serve the turn.............

on my worl, it will serve him.... Harry llives, iv. 2
one of you does not serve heaven fecl - jv. 5

none but llerne the hunter serve your - v.

Sir $J$ ohm Fulstaff, serve Got $\ldots . . . \ldots \%$.

I'll serve this dnke . ................. - i.

if that this simple syliogism will serve

to serve this noble eount ............ - v

one that serves a had woman.... Meas. for Meas. ii.

shall we serve heaven wilh less......

let your renson serve to make........

will it serve fur any nodel to bitili.... Mnch - i. 3

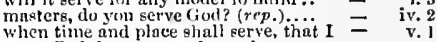

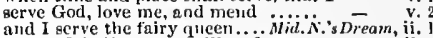

one turf shall serve as pillow for ..... -

I have enough to serve mine own turn $-\overline{\text { iii. }}$

and second eanse will not serve my turn - i.

I am bound to serve

a little scratched; 'twill serve .......

I'll serve thee true and faith fility.....

if I serve not him, I will run......... - ii.

if I serve the Jew any longer ..........

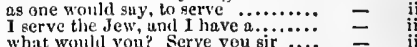

what woull you? Serve you sir $\ldots .$. - ii.

I am sorry, that your leisure serves.. - - iij.

that 's"'nse serves many nien to...... $\overline{\text { iv }}$ iv

nn' you rerve me such another triek - iv.

my iustruetion shall serve to...........Al's $W^{\prime} e l l$,

it may well serve a nursery to $\ldots . . . .$. i - i. 2

at your bilding, serve your mujesty..

of being eaptives before you serve
an answer will serve all mien $(r e p$.

may serve long, but not serve ever.

why, there 't serves well again.......
whom I serve ahove, is ny masic

he's gone to serve the duke of F'lorenec

a gentleman that serves the eount....

of ny garments would serve the turn
hardly serve, thoirgh I swore I leaped

ny, so you serve us, till we gerve you.

it' I cannot serve you, I can serve as great

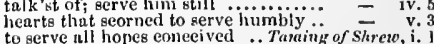

as you find your stommeli serves you

and serve it thus to me, that love....

conning down the hill, will serve

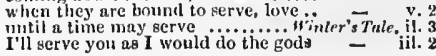


SERVE-to serve my turn........ Winter's Thle, iv many fond fools serve mal jealousy! - ii. cun entreut all hour to serve ........... Macbeth, ii. nne serve with lim but eonstruined - v. will serve to strangle thee .......... King John, iv. 3 must I not serve a long................
which serves it in the ofliee of $i$ wili hinth power enough to serve sur tur. if he serve God, wo'll serve him to
Which serves as paste and cover to Whieh serves as paste and cove not so mueh as will serve to

not so mueh as will serve to

how long hast thou to serve, Francis?

the powers of us may serve so great..

it shall serve among wits of no

for, to serve bravely, is to comle....

no inun's too good to serve his plinee

when tilie shill terve, to show

there is no excuse shull serve ........

this Davy serves yoll for gool use.

but when time shall berve, there....

and an serve yon with hearts erente
thongh they wonld serve ne, could not

I wurrant you, when time is serve ..

numler whit eaptain serve you? .......
moy slutll not serve; I will have forty

I proy you to serve Grot, and keep you

the ery of Talhot serves me fir $n$.

break it when your pleas

but yet, it shall not serve

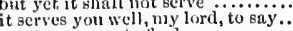

mist serve me to fech on ......

filhed, our wnrts will gerve

ald learn awhile to ecrve .............

ant, us oecasion serves, this noble queen

if fintune serve me, I'll requite......

to serve me well (rep.)

ghame serves thy life, sud doti thy

when they slould serve their sovereion = iv.

and Danger serves among them.... Ilenry IIII. $\mathrm{i}$.

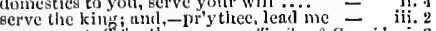

Eerves ths stuff lor these ....... Weree

I serve thee not. Well, go to (rep.

a fool, to serve sinch a fol.............

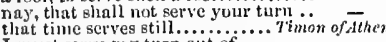

I must serve my turn out of $\ldots . . . . .$. .

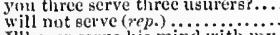

I'll ever serve his mind with iny

still serve him with my life

I must serve him so troo.

true, when the day serves.....

will the time scrve to tell?

a little he! s will serve: tor once

how youngly he began to serve
I think, 'twill serve. if he ent ....

the day serves well for them now

no, I serve not thy master..........
serve with thy trencher: licuee.

make my misery serve thy turn

to destroy the Vulsecs whom yoll serve
when it serves for the buse matter...

yun serve Oetavius Caesal, do you not?

mist tnke the enrrent when it serves - iv. 3

make the lady whoin you scrve

every time serves for the matter

a fame, when him we serve's away
the leurts ot liomans serve your end

it we should serve with horse and mures

effers which serve not for his vantage -

youll serve unnther maste

aral our advantage serves for a fuir.

how fit his garments scrve mel

all goot, serve trinly, never find....

she is served as I wonlu serve a rat.

to serve our Roman euptive?
will serve our long interrogutrie

to serve, and to deserve my mistress.'Titus ${ }^{\prime}$ nd. it

snitels or so would serve your turns
there serve your lust, slianlowed from

my hand will serve the turn....

let it serve to ransom m

liy turn to serve our lust

duy serves not light more faitliful........ periel iv.

gerve the great pirate Valdes ...........
fiith, she would serve after a loug voyage $=$ iv. 6

where $n$ man may serve eeven years.......
serve by indenture to the common 6
iv. 6

if thou eanst serve where thinu dost.

to serve him truly, that will put

follow me, thou shalt serve ine.

I shall serve you, sir, truly

I serve you madam: your gruees......... = ii.

which serves and seeks for gain...

when time shall serve, let but...

I serve as good 4 man as you .... Romeo \& Jitiet, $\mathrm{i}$. tis enough, 'twill serve......... - iil. all these woes slutl se ve for sweet. 0 - iii.s lo hamed in the command of the rerviceiv. 1 lunt that the merit of serviee is seldom -

whereto serves merey lut to confronit.. Ilamle, What torm of prayer cun serve my turn? do thee ull rights of serviee ........... a foul, sir, at a woman's eervice (rep.) - iv. phyers that ofler service to. Taining of $S h .1$ (indue. for me to lave his serviee, look you

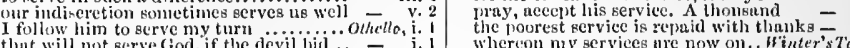
that will not serse God, if the devil hid .
in lieaven, but whut serve fur the thumder I'll put my fortunes to your serviee reesent our ferviees to n fine new.... and then for the land service, to see wipe not ont the rest of thy services
with thee the very' serviees thou liast that I have eyes inder my serviee. which served me us tit

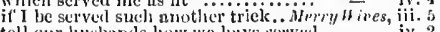
tell our husbands how we huve served - iv. 2

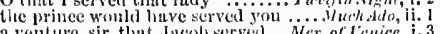
a venture, sir, that Jacola served ... Mer. of fenice bi 3

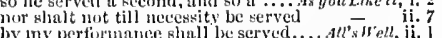

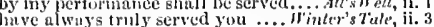
I have served primee Florizel

I have served him frotn the hour.......

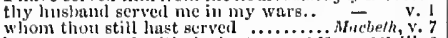
have you served with the best .......2 Iffew'yIJ. iii. 2

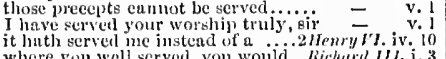
where gou well servel, you would.. lichurt III. i. 3 hind I but served ny God with (rep.) - iii. 2 of inine, hinth served me long ... Timon of A/tens, i. ay, wonlal they served us! (rep.) … served his designments in mine own

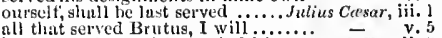

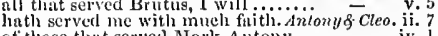
of those that served Mark Antony ."

not as you served the eause ...........

served, who best was worthy to be served - v. 1 Whom he served with glory..........
thourh he have served in Roman

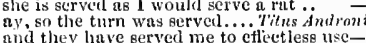

and they have served me to eflectless use- iij. I
servel the lust of my mistress's heart.... Lear, iij. 4 I lave served you ever sinee I was.

and is it not well served in to $a$ sweet

I have seen myself, and scrved against. Hounlet, iv. 7

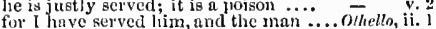

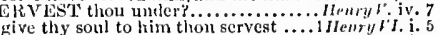

thrm ervest me, and I'll love thee

.....Lear, i. 4
Iem?l'I. Hij. 1
..Tempesl, i. 2

ELVICL-done thee worthy

no use of service .....................

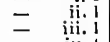

your nst servico did worthily perform - iv.

all this serviee have I dome...

commend their service to his...Two Gen. of fer. $\mathrm{i}$.

lose thy servies: and in losing thy surviee-

and the master, and the service? .....

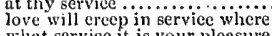

employ thee in sone service presentily

madoy this sone servec prescerty - iv. 4

now they be nut of serviec .......... Merry inives,

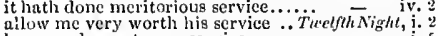
here, madam, at your service $\ldots . \ldots \ldots$
she that would alter serviees with and most humble survice......

miglit do me golden serviee.

and, for your service done him......

eycs almost ont in the service ...NIcas. for Mias, j.

he knew the serviee, and that $\ldots . . . .$. - iii. 2

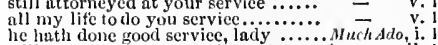
will your grace commund me uny service, - ii. I witl eruel puin, to do you serviee

and duty in his service perishing .....

Dumain was at my service, and his.

was tor my service born...........

muose some serviec on me for

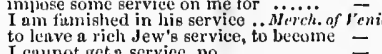

I cuinot get a scrviec, no.

in love and service to you evermore - ii.

turning these jests out of service, let us -

I'll do the service of a youuger man.

servite nf the antiqle world, whel service-

dis choke their serviec up even with..
all mute of twith and serviee .......

that mean to see the Tusenu service
look far into the service of the time.

service is nu heritage: and I think...
and nuy service, ever whilat I live... it hatl seen vury hot serviee.............

you have lieard of my poor serviees

if I Jast in this service...... Comedy of Errors, it. at his hands for my serviec, but blows - iv. 4 my service nnt the loyalty I owe....... Macbeth, i. 4 for 'tis my limited service.............. $=$. i. at your service, sir, - no, sir............. King John, i. i ulyon your onth of serviee to the Pope
to offer service to your enemy ...... do bequenth my faithlinl services..... to offer serviec to the dluke of Ilerefird - ii. I tender you my service ........... - ii. 3 to more approved service and desert $=$ = iii. 3 as my true serviee shall deserve... - iif. 3

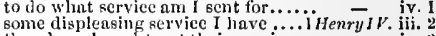
they have bought out their serviees..2 - ivenry $r$. 2 grince put thee into my service.....2 Henry11. i.

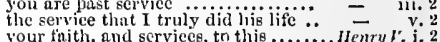
your thith, and serviees, th this ......... Henry
so serviec shall witl stceled simew... to do your grace inecssant serviees..$=\overline{\text { I }}$ ii. all the riches I got in lis service .... there is very excellent service enmmitted - iii but 1 did sce him do gallant service - iij. 6 when they purpose their services.... - - iv. I an lonourrable padge of the serve..... $=$ iv. 7 yowr fuithiful aerviee, and your toil...
gome serviee to duke Intmohrey's..2newry $r$ iii. : created knight for his gond service... and such a piece of service will you do - your legs did better serviee than....3 Henry your highness' service. What service - iii. purchase service for so good ....... Riehar $\bar{d} \| I I$. my sovereign, for my service donel.. are at my service, like enfored smiles repays he my deep service with such

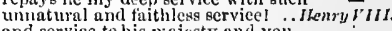
his service and his comsel ........... our utmost studies in your service. thy hopeful serviee perish too........ the king shall liave my serviee ........ first, mfne own service to your graee
for liis love and service, go to him... when you slould do service............

to nake the service greater than .... took a truee, and did him service.... to do youl scrvice, $\mathrm{am}$ beenmie ........ desert in service, love, frientiship.... cornmend uny service to her beauty.. - iii. with thanks, und service, for whose hielp heart is ever ut your servifee, my lord h' as done fair service, and slain in fight Boner gnt another service.

come to off'cr you our serviee ........ ean do, we'll do, to do youl service . to gratify his noble service

still my life, und serviees .............. Ifot them in my country"s service. they necr did service fur't

this kiud of service did not deserve = the warlike serviee he fias done..... what do you prate of service? ay; tis un honester ecrvice, than to the painfin service, the extreme dangers -
my revenget'ul services may prove .. and seck some better serviec $\ldots . . . .$. our steeds for present service neigh..
nud turn tliem out of service....... commencl my service to my sovercign = iv. 6 there ot your to lord Timnt ..... Timon of Althens,

and my serviees are, as you are, ngainst = I'll do his evuntry service .......... = 
Slity ICE-to do the ervice ....... Coriolinus,

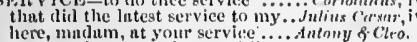
eommands our servies on whilo.

there 1 deny my lund ker vite ..........

In reed thut will do me no servieo

urevail under the service of $n$ elitidi.

thut I might do you serviee...........

nitarried to your pool erviec
lunve puid my het ter service

or thy preedent ferviees are nii.....

the last serviee tlunt I shall comminnd

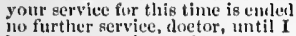

let me my serviee tender on your.

mut take this gervice 1 huve dime....
mulke deninls inerense your serviees

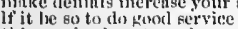

this serviee is not service, so lieing done

desire his scrvice, tell him wherein..

flrst service thou thost me (rrpe)

nlike eonversunt in genera
that promise nolle servies

ery out for service, try many, ail gool

and, leaving o his service, follow you
the king lutth unt deserved my serviee

he lirags his service as it be........

the service, that yom tlire

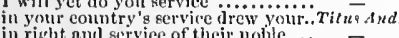

all the service I requive of them is

to do lome serviee, ure hit vain ....
ean do no serviee on her sorrowful.

tho me some serviec, ere $x$ eome.......

in her unholy serviee.......... ierities,

my services to your lordslip..........
to thy law my gerviees nee boimil.

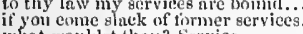

Whint woullust thon? Serviec

What serviecs eanst thou din?

womldst be a buwd, in way of yood serviec

his dengliter spenk; commund her serviec

hut better scrviee hinve I never done

to theo a woman's serviecs are die.......

and did him service improper for $n$ siave

to lay our serviee freely at your feet......

coming, to offer you service

do the king best serviee in the end

is but variable service; two dist

we should profune the service of the deai

it did me yeomnn's service; wilt thon .. =

tis the eurse of serviec; proferment gocs,
throwing but shows of service ont their.

because we eome to do you serviec.

lack iniquity sometines, to do me service =

my services, which I lave done

my general will forget my love and serviee =

to wronget Othello s servicel.

that neither service past, nor present...

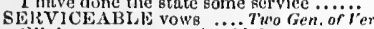

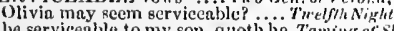
he serviceable to my son, quothi he. Taming of sh never let me be contuted servieenble. Cymmetime, iii.

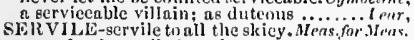

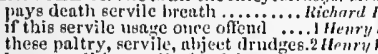

kecp us all in servile fearfulncss ., Mllinus Corster, [Col. Knt.] and servile thungta

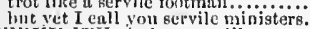

She

Servilius! you are kindly met, sir .
thoul speak seriously, Servilius" (rep.)

Oheres Servilius; now we slanil (rep.)

SERVING-serving of bceks

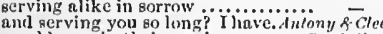

Woill you, in their serving ......... Cymbeline
SERVING-ClRFATU

SERVING-CREATURES dagger. Romeo fitul. iv
SERVING-MAN, a fresh tapster ...Merxy Wiwes,

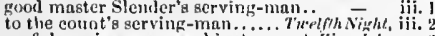

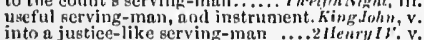

he is your serving-man, ant your

a ferving-mann, prond in lieart and inind. Leerr

Int uninst diacarded ervint -... Taming of sh,

SWRVITEVR-votre servitenr.. Tirelfh Night, it

SliRViTUR - thus are poor serviters.iilenry $Y$.

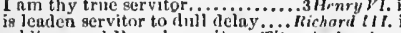
soldiers, and Rome's servitors. Filines A ndronicus,

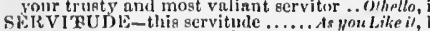
this servitude mukes you kecp. Comedy of Lrrors, lis prinees and his peers to servitutle.. Henry' $P^{\prime}$ ii.

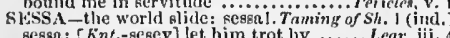
sess; [ Knt.-serey\} let him trot lyy ....... Iear, iii. do le, de de. Sessa. Come, mareli to wakes - iii.
stissION" gummon a gesion, that we may... Winter's Tale,

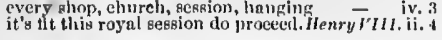

Rssion-you sha! lold your rension .... Lear, v,

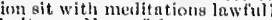
SFSTOS -it was, llero of sestos ...1s y/an like it, iv. set all heerts

nor set n murk so bionisy
I'll ket thee free fur this

trille are they set

them sets ofl

the sinn will ket, hiefire I

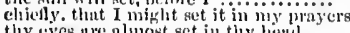

thy cyes une almost set in thy hich

ifney were set in lis tail

and the nzure viult set ron ring wi....

set Cnlibnan and his comprn

let your indulgenre sut me free

that set together is $\left(r^{\prime} p^{\prime}, w_{2}\right)$

Your ind y'thil, enll set.

then may I set the worli.

that set this dow montong....

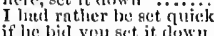

if he bisl you set it down
set slown the busket, villn

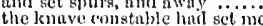

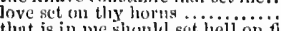

yourselves in orler set

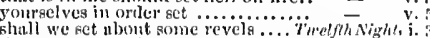

that erow so at these set kind of fiols
in women's waxen licarts to set their

in women's waxen hearts to set their
wilt thon set thy foot o' my neek? ..

have youn not sct mine honour.

Bet em down; go, ubmit

Rul, conscquently, sets dowii the

set hipon Aguti-check a notialyle

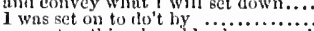

you set notling by a bloody cioxconib

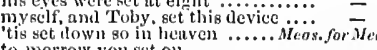

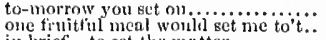

some one lath set yout om

antl to set on this wretelsed wo........ Iiere

mighltier member, that sets them (rep.)

and sct thens in iny firrelearl....

only get the len'ned writer to set iown

hut when shinll we ket the savage bull's
but did my brother set thee oun to this?

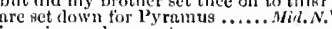

is, as in moekery, set.

your wrongs do set a scaudal on.
w'ba would set his wit to so fooliti

you all ure lent to set usuingt me.

have youl uot set $L$ yeander

only purposed liunting shall he ret aside

thy liberty, set thee from durance. Lor'e's L. Tost iv. iii. king Coplietra set eye upon

so, were there a patcls set on learning

well, set tliee dlswn, sorrow!

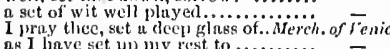

was set in worse tlian gold

it is mect, $[$ presently set foit $t$.

I set fortli ns soon as you.

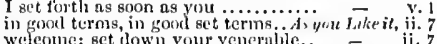

and I bet lim every day to woo me.

to set her hefore your eyes to-morrow -

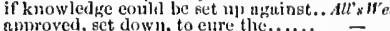

approved, set down, to eure the......
fince your get up your rent 'gainst....

thon wert hest pet thy lower
shoots at him, I get him there

myself embrace, to set lim
feecl it, sct down sharply

so euriotsly he had set this coninterfitit

shall I set town your answer 6o? (rep.)

if not so, until the sun he set. Faming of Sh. 2 (indi.)

we sct his youngest frre for......

the elder, ket the younger free
and you the set of books; you shitil go

and you the set of bonks; yo
age, set fioot under tly table

fuirly set down in studs .........
Baptista; set your counteriaic.

Baptista; set your connterance...... - iv, i

as nine own eourac lutve set down. irinter's $T$

hast set on thy wife to this

doth set my pugging tosth on

in earth to get one slip of them

doleful matter, merrily set dow

thiss we ret on, Curnillo, to the .......

ghtll be be set against a briek wall.

hic heaven sets apies upon us.

ere the weary sun set in
ghall I set in my staf?

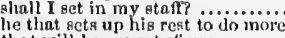

that will be ere sit of sun...........

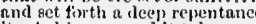

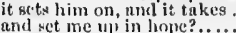

Slict - thut I would get my life on any...Nucbeth, iii.

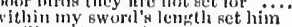
will set down whint eomes.......... -

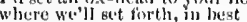

the rich, blond of lings is set oin ini

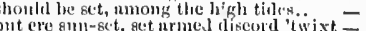

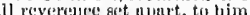

angons set thou at liberty.........

"twixt tusodrendent buttles set

he Alereury, net fint intler

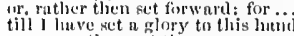

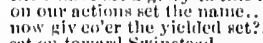

set mi towarll swinstend

methontht, was loth to set

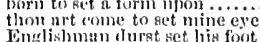

dares him to set forwerd to the figit.

wherean tlan art to set the precious

moeks at it, and sets it li,

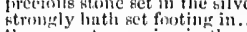

thy sinn fets weeping int

my jewels, for us set of beind.

my jewels, for set on

sikeness, set to dress this wirden

in this shee, 1 "ll set in bank

who sets me cise? ly licaven.....

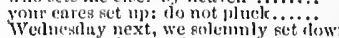

intervilangealily set down their lanuls

ere thy linul did sct it flown

and do set the worrl itserf ang

of the eharge set down lint ............

why, we will ket forth before ........

but we'll sct nopm them
which lanth no fuil to sct it oif
whe

did set forth upon his Irish expedition

you, that set the erown nulon.
ruminated, plotted, and set dow

some of the'm, set fiorwarcl nlrenuly

I will set forward to night (rep.)
we four set upon some dozen ......

sn w yout fintr set on four $\left(r^{2} p\right.$. $)$.

well, here 1 num set ....................

and that would set my teetl nothing

when I from France set finot nt .......

Wednesday next, Jlarry, you sluull se

to set the exact wealth of ull onr states

the king himself in person is set forth

on tleir answer, we will get on them

Esperance! Percy 1 and set on

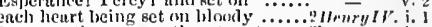

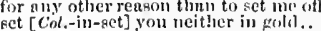

then set your knighlitlond and your.:

do you set down your nnme

yo itruw our numbers, and set on?

I know thou wast set on to this.........

why then, eover, ant set them

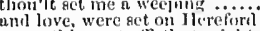

every thing set off, that might

in God's nume then, set forwari .....

for that fet it $n$-work

and rets it in aet and nse.

get me the erown mpon ny ...............
to have a son set your iseerees at

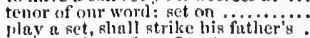

play a act, shndl strike his futlicer's...
the king is set from London.

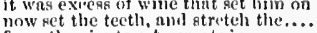

from the rise to set, sweats in

solemuly, see him set on to Londion -

enrompassecl and set upon

pikcs to set hefure his nerchers.
their nrma are set, like clucks

thinge are get in order liere.....
which oblonguy set hars before

and get this unneeustomed flah

antl set your knee nerinst my

ond set upon our loostint enemy....

w.hen Tnibot harth set fisoting....

they get hin free, without his

lort bithop, set the erown np

York act him on to flght (rep.)....

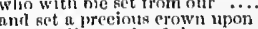

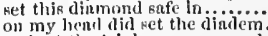

on my hend did set the diadem.
and sit the triple crown npon his..

when troy wne get on froents

were set to guturd the chiseken

were set to footing on this unkind....

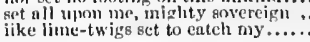




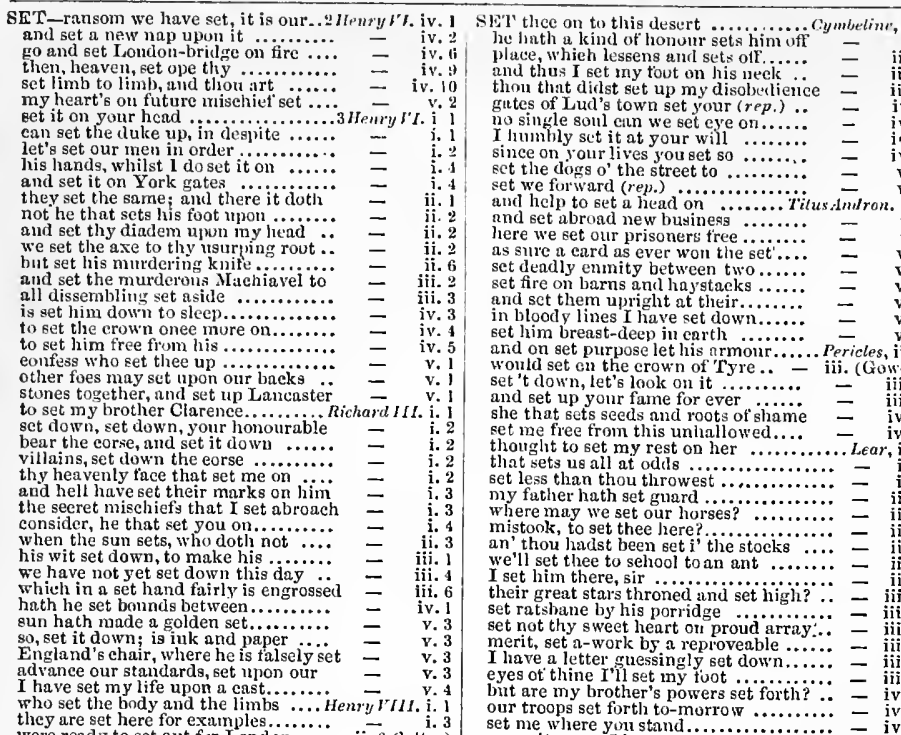
Who set the body and the limbs.... Henry were ready to set out for London envy and base opinion set against me when she set foting here...
we have scen him set himsif we have seen him set himself .... that sun, I pray, may never set ........
and set me lower; 1 have not long grief hath set the jaundice

to set his sense on the

will you set your wit to a $\mathrm{t}$

should set the very wings

but her brain to set down her.
but

get them down for sluttisls spoilis.....

that cause sets up with

they set me up, in policy
how the sun begins to set

how earnestly are rou get a...........

set this in your painted elotls .......

fair ladies, set a fair fashion o... Timon and set me on the proof

and set mine eyes at fluw

the villanies of man will set hiin clear

would set whole realms on fire

set them dow horrible traitors

and by thy virtue set them into...

before prond Athens he's set dow

set but thy foot against our ..........

whom you yoursel ves shal

he did so set his teeth and tear it .....

are set down before their city.....

duties, as $I$ have set them down....

set up the bloody flag against ali

as to set dogs on sheep

have you not set them on?

the people are abused; set on

procured, set down by the poil?

that shall set them in present action

and set down, as best tho

set at upper end o' the tahil.

and then I'll set upon him

to morrow set down our host
thou hast set thy mercy and thy

thou hast set thy mercy and thy
set him befure me, let me see.

and I will in one eve, and death . ....

set this up with wax of mine

set on your foot; and with a heart...

set a huge mountain 'tween my.....

bid him set on his powers betimes.

compelled to set upon one battle

Cassing day is set; the sun of $\ldots$ rep.....

and Fla vius, set our battles on ...... shall set thee ou triumphant chariots

whieh is set betwixt us, as the ......

set we our squadrons on you

but now lil set my teeth.
and set thee by Jove's side

sueh a spacious mirror's set before him

had set betwixt two elarming worls. Cymbeline,
we will have these things set down

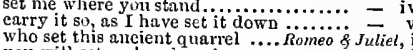
ing heart's dear love is set on.

on hers, so hers is set or mine st:y not till the wateh be set $(r e p$. $)$.

When the sinn sets, the air doth drizzle

the county Paris hath set up his rest
here will I set up my everlasting rest

no figure at sucli rate be set ...........
set your entreatments at a ligher rate.
W'TTLE-shall on them settle ......All's W' Well, iii. 1 eun settle the henrt of Antony ...Antony \& \&leor.ji. 2

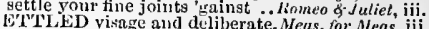
heon some settled low content .. As you Like it, ii. more ponderous and settled project.. no settled senses of the world enn....

I am settled, and bend up each

difference of yourt settled hate
which, bcfore eold and settled.

Richurd IH,

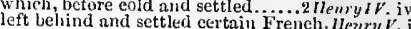

continuance in a settled place ......1 Hemry VI. ii how the blood is settled in his fart....

no, he's settled, not to come off... Hemry

her blood is settled, and her.... Tomeo \& Juliet, iv.

SETTLEST admired reverenee.. Timon of of thetel, iv. SET TIING -till further settling. ....... Lear, iv.
SETT'ST-thon sett'st on thy wife. Winier's Tale ii.

sett'st onth to oath.
that sett'st the word itseif a.......... King John

after God, thou sett'st me free......3 Henry VI iv.
SEVEN-by seven o'cloek .. Turo Gen.orl'terona, iti. and seven hundred pounds (rep.). . Merry Wives, i. of even groats in mill-sixpences
me have stay six or seven

till seven years heat................ Tuelfi $\bar{N}_{i g h}$ seven of my people, . Witti a.......... obent
seven year and a half, sir... Measure for youl say, seven years together?

and six of some six or seven.......

or of the deadly winters more respect

lans been a vile thief this the least - i is her house remote seven leagues...Mid.N.'s Dr. $\mathrm{i}$. fire seven times tried (rep.). Mer, of Ven. ii. 9 (scroll I was seven of the nine oays out...... it seems the length of seven years...

upon a lie scven times removed......

for twice seven yen justices could not $\overline{-}$ v. you will set coek-n-loopl. ........... o sulee, i.

it shall be now some seven o'eloek..

it shall be seven, ere I go to..........

these seven yen; a race, or two.... inter's Tale, iv.

作 but seven years since, in Syracusa.... - v. Edward's seven sons (rep.) ….......... Richard it, i. every thing is left at six and seven .. i Henry $1 P$.i. i. 2 some six or seven fresh men set....... $=$ all their or seven points in my target (rep.) =

with a thought, seven of the eleven...

that I did not this seven year before
not above seven times a week........

earl of Westmoreland, seven thousand

seven groats and two pence..........2Henry 1 seven walled towns the seven stars. $\ddot{H}_{\text {enry }}$ ii. this seven years did not Talbot....... better sport these seven searsida... -. ii. in England, seven halt-penny loaves = ii. after seven years' siege ....... Troilus of Cressida $\mathrm{v}$. six or seven times honoured........... \& Cressida $\mathrm{i} .3$ he was wont to shine at seven. Timon of Athens, iifi. an estate of seven years' health .... Coriolenus, î if I could shake off but one seven ye.

some six or seven, who did hide...Julitus Cresar within seven leagues of Rome

a gamester at five, or at seven?...

the seven stars are no years for ....... - iv. been Tom's food for seven long year - $\because$ iii. 4 (soar, $i .5$ tears seven time salt burn out my letters say, a hundred and seven..... Othello, i. world for four times sad seven years' pith

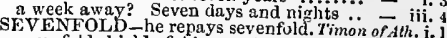
sevenfold shield of Ajax ..Antony $\&$ Cleoparira, iv 12

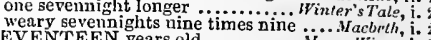
nine se EN years old..............Merry Wives, i. from seventeen years till now ......As you Like it, ii. 3 at seventeen years, many their fortunes - it it, ii. 3 seventeen poniards are at thy bosom...All's Well, iv. 1 hrint of seventeen battles sinee.... Coriolanus, Was upon the seventh cause (rep.). As ynuLike it, v. the seventh, the lie direct.

a seventh! Inl see no more..............Aactioth,

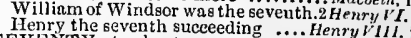

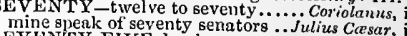
SEVENTY-FIVE drachmas SEVER-severs day from night....... Tüelfih Night, vii. at the gun's report sever themseives.Mid.N.Dr. Dii. who can sever love from charity? Love'sL. Lost, iv. 3 their several kinds have done.

with strange and several noises........

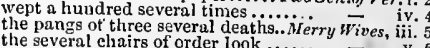
instalment, coat, and several crest... $=\quad$ v. 5 


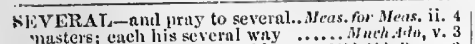

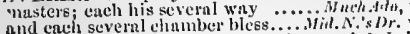

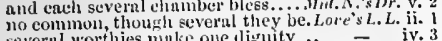
severul worthies mike one lignity

into his severn nistress (rep.t.......

diver serence Horn me out with several applications. Al's "leth, $i$. severnls, of heat-piece extruordiutury. Hinter's $T$. i. at several posterns, elear them ....

he sings seieral tunes, filster than

in the divisjou of euch several crime. ways usurpingly these several titles. King John, i. to order several powers to

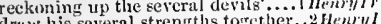
aruw heverticle herein redresser

paw unto their several countie

the severals, and umhidden phssares ... Hen'y $r$.

many arrows, loosed several wuys ... - -

here you maintain several taction

to your severnl dwelling-pilaces

your several suits have heen considered -

the several colours we do wear.

with every several pleasure in .....

dismiss yon to your several eount
I lo not like these several couneil
eael leader to his several charse

eaeh leater to his several charse
siveral tongues, and every tongue

the several pareels of his plate.....IHenry $\bar{r}$ III. iii.

severals and generals of trinee.... Troilas of Ciess. $\mathrm{i} .3$

our several livnours all engnged

upon our joint and several dignities $\overline{-}$

toneh them with several tortunes

the Volsces with two several powers -

in several hands $(r e p$.$) ..............$

guilty of a severat bastardy.........

two several times by night

twenty several messengers ............ Antony of Cleo. $\mathrm{j}$.

have every day a several sreeting.....

gather their severa virtues ......... Cymbetine,

felt several years, and wanting breath

knikhts unto their several lodgings.. iv - ii. 3

to publish our dauth ters; severa! dowers...

the several messenters from hemee attend

[Kut.] every several lineament ...Romeo \& Jiliet, i. 3

SEVERALLY entreat him Troilus $\ddot{\&}$ Cressida, iv. 5 I will despateh you severally.. Timon of A'tens, ii. 2 the counterehange is severally in all. Cymbeline, $v .5$ SEVERE-lord Angelo is severe... Neas. for Me: O just, but severt law! .................
brotlier justice have 1 found so severe

should be as holy as severe ........... - iii. 2 eyes severe, and seard of formant...... lleicry $V I$ y come, you are too severe a moraler

EVERED-here are severed lips. Ner. of f'enice, iii. 2 how'er their hearts are severed

Tempest, v.

heard me severed from my bliss... Coinedy of El.

the kiug hatl severed you and prince.2 Henry/IV. i. 2

no more ean I be severed from....... Henry $r$. iv. 5

but severed in a pale clear-shining

that I should wisl them severed ....

our severed navy too have knit. Antony \& Cleo. ii. I

by uproar severed, like a flight..... Tius andron. v. 3
ny thoughts be severed from iny griefs .. Lear, iv. 6

my thoughts be severed from my griefs. . Lear, iv.

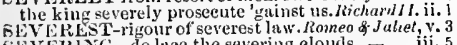
SEVERING-dollace the severing elouds - iji. 5 pLinging as soul and body's severing. Menry Whereon to practiee your severit trial than the sererity or the public. Coriolumus, iii.

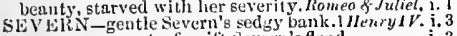
npon agreement, of swift severn's flood
of $\mathrm{W}$ ye, anl sandy-hottomed Severu

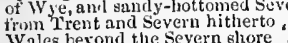

till he have crossed the Scvern $\ldots .$. Cymbcline, iii. 5 SEW-item, she ean sew .... Two Gen. of I'erom, iii. I I said loose-bodied rown, sew me. Taming of Sh. iv. 3
I'll sew nether-stoeks, and mend.... I Henry $1 \%$. ii. 4 I can sing, weave, sew, und clance.......'tericles, iv. 6 SEWVD-eut ont, and sewed up ..Thmmg of sh. iv.

could have better sewed than Philomel - ii. 5 iü licr lrophetic fury sewed the work. ometho, iil. 4 oll reeptacles, common sewers ......Perisles, iv. 6 in lord, as I was sewing in my closct.. Hamlet, if sEX-I do not know one of my sex...T'empest, iii. I

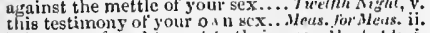

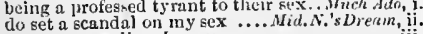
do set a scandal on my sex ............ she - iij. you have simply misused our sex ....

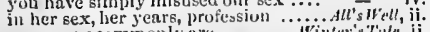
as our sex commonly wre.......... Winters Then, ii.

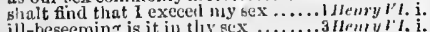
ill-beseeming is it ill poor our sex! this fiult .. Troilus of Cressida, $\mathrm{v}$.

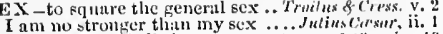
I an no stronger thisu my sex

'id ehan shamed our sex

Lx'roN-a cushion for the sceton!.. Alach dilo, iv. where's the sexton? let him write....
loy this time our sexton hath reformed

signior Lemato, and the sexton too..

that bald sexton' 'Tine, is it as he .. King.John, iii. i but, muster, if That ben the sexton ... yeric/es, ii. I have been kexton here, mus, and boy
ixTUS [see ponIPELS]

SEYMOUR-Berkiey, :und Seymonr... Richarl II. ii. 3 SIXTON: I am siek at heart (rep.)

five me iny staff: Seyton, send out .....ïi Night, v.

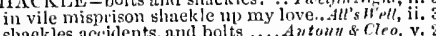
HADE-revellurs, and shades of night. Werry $1{ }^{\prime}$. v. 5 trip we after the night's shade.

tarrying in mulberry sha

sweet leaves, ghade foll y............
under the eool slade of a syearore
toward that shade I inight behold....

the shade of melancholy hourtys As you Like it.

under which busln's shade, a lioness.. -

let us seck out some desolate sliade . Michar 1 , iv. $\mathrm{i}$.

wander throngh the shade of night

under the sweet shade of your

and the gloomy shade of death

for in the shade of death I shall

a sweeter sliade to shephierds

sleep under a fresh tree's shade...

illenry Wr. i.

iHenvyli, v.

to shade: alis! alas! witness (2:per

nut flies flel under shade .....

ere in onr own house $I$ do shinde

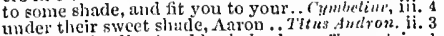

IIADOW the dismissed bachelor low

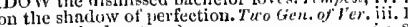

I am but a sladow (rep.) .............

become you well, to worship shailows
better fit his ehamber, than this shatow

come, shadow, eome, and take this (rem) - iv. 4

Love like a shadow flies .............herry ives, i.

all shadow and silence in it .....Meas. fir Meas. iti. i

believe nie, king of shadows, 1 mistook

the best in this kind are but

will feuee with his own sliadow......... of $\bar{F}$ enice, i.

that shadows kiss (rep.)...........

saw the lion's shadow ere himself....

tis but the slindow of a wife you see...All's H'pll, $v$.

that ereep like shadows by him... "Winter's Tale, ii.

horrible shadow we une demart.

thereby shall we shadow the numbers

life's but a walking shaclow

the shadow of myself formed $(r e p . . . .$. King $\bar{J}$ ohn, ii.

of a grief hatil twenty shadows

step into the shadow of these trees

the shadow of your sorrow hath (rep.

thau thou the shadow of succession

so many of his shadows thou linst

but shadows, and the shows

let ne see; Simon Shadow! ...

where's Siladow? Here, sir. Shadow

Shalow will serve for summe

Bull-ealf, Feble, and Shadow .......

in shadow of such greatness!

thy shadow hath been thrall.

I an but shadow of myself (rep.).

mist he be then as shadow of himselt? - v parted but the shadow with his hand.3 lleary $y^{\prime}$ i. parteding indeed: thou but tire shadow
true kinglow
lite a double shadow to Henry's body

spy my slindow in the sun........... Kichard $11 \mathrm{iv} . \mathrm{i}$

that l may see my shadow as i pras
a sladow like an angel, witl bright

a sladow like an angel, with bright
poor shadow, painted queen ........

poor shadow, printed queen $\ldots$ ii $\%$ (iep.)

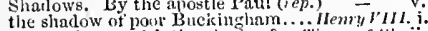

dost clialogue with thy shadow?

within tlee shadow of your power.

.

their shadows seem a eanopy most ... J - v. I

a mangled shadow; perchu

eondemning shadows quite

the shadows be not nonaypeased ... Fitum the

to eppease their groaning sladows that

a elieekerer shadow on the gromm

takes false shadows for true substa

that with the shadow of his wings

he will come in our shadow, to seat

Lear's shadow? I would learn that

to course his own elindow tur a tiai

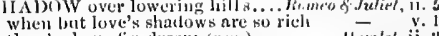

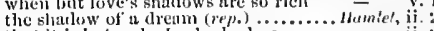

that it is but a shaulow"s shalow,........... - ii

fustian with one's own shadow? ........ Othello, ii.

Ghadowed fiom heaven's cye.. Tilas A mismirus, $\mathrm{j}$.

sladowing their right under.......... King Jofh, it.

shaslowy firests and with ehamiains ..... Lear, $i$

- iu shady eloister newcd .. Nit. N s. Wr

SIIAFALTS to Procrus (rep.) ... Miti. N.'s W, pam, v.

when the rich golden shaft ........ Twelfeh Night, i.

Cupid's fiery sliatt quoneherl ...Mid. N.'s bream,

this murderous shat't that's shist ........ Mu berth,

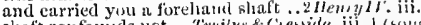

shoot all your slafts into the .... Tiaks dudron. iv.

your shatts of fortune, thougl they...

等

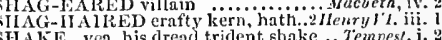

sliake it off; come on trident shake .. Tempes, i. 2

shake off siumber, and bewar

promontory have I made sliake.

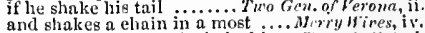

till the pangs of death shake him... Tuelfh Night, i. s

be pleased that $I$ shake off these......

fants may shake our trames ...Miets. for Meas. ii.

eome, you shake the head at so long.

might sliake off fifty .....

hear how he will slake me ul) ......As you Litie it, i.

I eould shake them of my eout........

whilst I can shake my sword (i......... - iv.

that shake not, though they blow. Taming of Sh. ii.

as whirlwinds shake fair buds ........ inter's Tule, $i$.

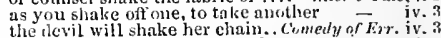

fintastical, shakes so my single state... Nacbelh, $j$.

visitings of nature sliake my tell

awake! shake off this downy sleep.

fears and sertuples shake $u$

never shake thy gory locks at me

never sagg with doubt, nor shake with -

as tha ses the rotenk them ofi.

see thou shake the bazs of hoardii

passion would I shate the world ....

ii. 4

to thrill, and shake, even at

if then we shall shake off our .....

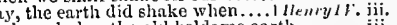

llake the pence ond safety of our ert

fecl, masters, low I slake

unfasten so, and shake a friend....... - i .

prepartion make all Gallia shake .... Heury 1. i.

air shakes them passing shake for it - iv.

Rouen, 1'll shake thy bulwarks ....illenry $r l$ iii.

shake he his weapon at us ........

but 1 must shake fair weathe
hope to shake king Henry's

have meng blats to sluke them..... kichard 114.

look on us, and sluke your head ..... $\bar{F}$ ij.

her foes shake like a field of benten.. $\overline{-}$ - Y.

which slatl shake him more thin

that slightily shakes lis parting....

to shake off my triend when he. Tit

but they do shake tlreir heads, and
let's shake our heads, and say, :s 't

thou malest thine enemies shalie...

or I shall shake thy bones out it

feeble rumour shake your hearts! .... -

constrains them weep and shake with far -

Ghake of their steril eurse........Jula
did shake: 'tis true, this god did shake

tor we will slake him morse...

I can shake off ut pleasu, e ..............

Murens britns, will 1 she with you

sw caring sliake the throned gods..Anlony \& cir

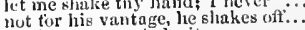

no ehance may shake it...

slake thou to look on't.........
even here do we shake haini.

meant to qua il and

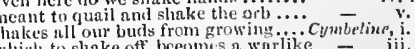

Which to shake off, beeomes a warlike - iii.

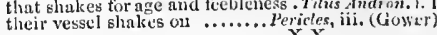
$\mathrm{X}$ 
SII AKE ofl the golden slumber of repose. Perictes, iii. 2 SIIAM Fa-mueh shame ... Twelfh Night, v. I (ietter) SILANIE-O perdurable shamel

to shake ull eures and business from ....... Lear, i. t benr the shame most patiently... Meas. for.Meas. ii. 3 and shake in picees the heart of his,

has broughit you to this slumm

it. 3 be sliort; else, sliame will be too long

power to sliake my manhood this.

cre I'd yield any body uj to shiane... $\quad$ ii. 4 the shame hercof will make me......

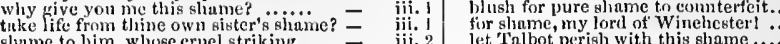

slume to him, whose ernel striking.

twice treble simme on Angelo $\ldots \ldots . .$.

upon your chin, l'd slake it on this quinrel二

in your sights, shinke paticntly my $\ldots \ldots . .$. . iv.

shake, quoth the dove-lionse .... Romeo of Juliet, i.

so hurrilly to shuke our disposition ...... Ihumlet, i. 4

that we ehake humls, anel purt ..........

it is not worls that sliake ne thas

with ransom of suel slame...........

sliame to the duke of burrundy.....

in the world, his shame in $y$ mu ........

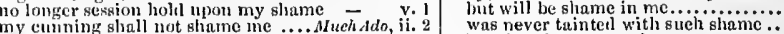

I shoulel wed, there will I shame lier -

shame her with what he saw over-night -

cvery carthly thing ery shame uponi... ier? -

spirits were stronger than thy slianes

a thousund innocent sliames in angel

dough he do shake me oll tis liggurly

do you shake at thint? Ile sting
bloutly passion shakes your

11 K KD you, sir, and eried .......... Trmpest, ij. foundation of the etrth thinkeilike.

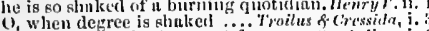

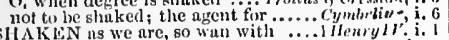
lave shaken Eelward from the regal.3 Ilenry ${ }^{\prime}$

so the life, that died with sliame..... v. how can'st thou thus, fiur shame. Aid. N. Ireo mailen shinme, no touch of bashe

yielding resenes thee from shanciliove's $\bar{L}$. Lost, $\mathrm{i}$. such public shame ns tho rest........
stunds in utninder of eternal shame

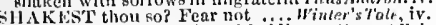

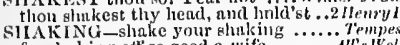

to desire that, were a sham

you were born to in shame!

Ilacbeth is ripe for shaking, ani tioc. Nacbeth mnke a shaking fever in your walls. Kingr
what clost thon mean by sliaking of thy -

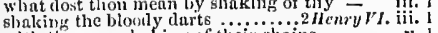
sith the very shuking of their chinins
of the sea? shanking of enrth.. Troilus \& cressida, i. 3 slakking the bloody fingers of thy. Jutius Casur

at last th little shaking of mine arm ..... Hamlet, ij. 1 SIlALES and huks nt' men.
SILALOW [sce ROBER'T]

this is a very shallow monster........ Tempest, ii. ome shullow story of deep love. Trino Gen. of $\mathrm{i}$ er. think's thou, 1 am so shallow.

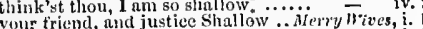
for iny venison, master Slanllow ( $r$.

as my eousin Shallow snys (rep).

to shullow rivers, to whose (rep.) $\cdots-$ iii. l (song) there comes my master, mnster Shallow knod master Slindlow, let him woo (rep.)
the shore was shelvy and shallow....

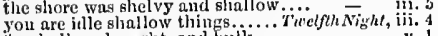
your are itlle sliallow things.ik

langhech int sucle shallow fillies ....... Aruch delo, ii. 3 these shallow fools have brought to light -
that shallow vassul......... l,ove's L. Lost, i. 1 (letter) und to what end their sliallow sliows

which shallow latghing hearers give to $\bar{g}$ v. 2 the sound of shallow foppery enter... shnulow, shallow; a better

most slablow mant (rep.)................

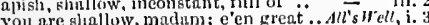

as he that leuves a shallow plash.. Taming of sh. i.

you tre a shallow cowardiy lind ..1 heury I $r$. ii. 3

amblert up and down with shallow jesters

a good shallow young felow......... Imenry $I F$. .ii. 4

good-mnrrow giod cousin Shailow (rep)

which is justice Shallow?

Shallow; deep, master Sliallow (rep.)
slie could not abide master Shallow

I do see the bottom of justice slialiow -

too shit's-stovestings, muen too shallow =

if I had a suit to master Shallow

I would curry with master Shaliow...

I come, master Shallow, I eome (rep.)

master Shanllow, my lord Shallow (rep.) =

muster Shallow, I owe you (rep
unlettered, rnde, and shullow
will savour but of slanllow wit.

will savour but of shallow wit.....
gitldy, shallow, humorous youth

gome shallow spirit of juslgment.....inenry vr. ii. 4

your judgment, which being shaliow3 isenry $r$ t. iv. incupable, and shallow innocents... Nichard
bis fears are slaallow, wanting instance -

your reasons are too sliullow ...

athd shullow changing - womnn

and led by shallow lichmond ...... - v. 3

how many shallow bauble houts. Troilus of Cress? i.

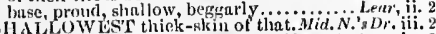

SHALLOW SIlALI,OWLY dill you these arms..2Henry SilADLBLES of the parliament
ns summer flics are in the shambles.

the more shame for him that my sha......

well mocked, deprt away witl. ...... -

Biron, they will shame us .........

the more shame for you, Judlas
forget the shames thint you liave.

liolil a candle to my shames? .........

I was hot shame myself to give.......

$O$ for shame, firl shame, lie mit .. As
gome of my shame; if you will know

I come of my shame; if you will know - iv. 3

divalgel shame-tradueed by odiois. $A l \bar{l}^{\prime} \mathrm{H}_{\mathrm{T}}$ ell, ii.

that haul reeeived so much shame...

and, Purolles, live snfest is shamel..

to this ghame of purs? No shame bint
doff this habit, ghame to your cstate

doff this habit, ghame to your
enme thence for very gliame

if thou necount'st it shame, layy it..

what she should shame to know herelf

and fixed the sliame on $t$ in himelf

as you were past all shan
unto our shame perpetual

which will shame you to give hị....

and corruption doth it slame. Comedy or livr

thy own shame's orntor.......
sluame hat $n$ bastard fam

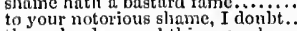

these slanders, and this opent sha
it is no shame; the fellow finds....

put me to this shame and troubie

the charge, the slame, the impris
for these deep slames, and great

but I sliane to wear $n$ lieart so white.. Nucbe

shame itself! why do you make suel faces? fie, for shamel Blood hath been

thou dost shame thy mother .........
how lie dial prevail, I slume to speak

this ilay of shamo, oppression, perj iury

doff it for shame, nnd hang...........

eould find some pattern of our slinme

slinme liath spoiled the sweet (rep.).

and 'tis shame, thant greatness should

to do a deed of shame, this murder.

deep shame had struek me dumb .....
this is the bloodicst shame, the wildest

to do ine sliame, I'll strike theo dend

and eyeless nistht have done me slame

destruetion ald perpetuul slıame... v.

but not my shane; the one ......... Richarel $11 . \mathrm{j}$. i

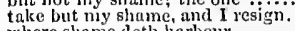

where shame doth harbour....

thy reals he wonld have laid thy shame -

it were a shame, to let this lani

live in thy shame, but die not shame

afore heaven, 'tis shame, sueh wrom
woutid it not slame thee, in so fitir

spend inine honour with his shame

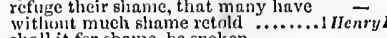

ghall it for shame, be spoken .........

from this npen and apparent sliame?

to shame the devil; by telling (rep.)
and but for shame, in such a porley

shall scour my slume with it.........

on my head my shames redoubled!.

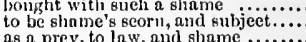

as a prey, to law, and shame

to ece my open shame? $73 . \ldots . \ldots . . . .$.

mailed up in slunre, with paoers ...

and blusts not at my shame ...........

liast heen conduet of my shame.

n shame take all $(r e p$.$) ..............$

thereby of ten thonsand shames.....

were't not a shame, that, whilst you
old Salisbury, shame to thy silver hair

and shame thine honourable age with

for shame! in dinty bend thy knee (rep.)
shame and contiusion! all is on the..

for sliame, awayl Can we outrun....

Islame to hear thee speak

were shame enough to shmine thiee...

ah what a slanme were this!..........

for slame, leave llenry, and eall ....

the last with slame? shame oin jimself

Why, twere perpetual shnme ..........
hie thee to hell for shame .......... III.

foul shame upon youl you have ....
for shame, if not for eharity $(r r p) \ldots$

life my sliame, and in my shame stili

why and I see iny shame in

world s shame, grave's due by ..........

shame serves thy life, and dotli tliy.
eonvey me to the block of sliame.

thee down to ruin, slame, and deathi

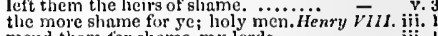

mend them for slame, my lords .... -

they would shame to make me wait else
forbear, for shame, my lords ........

why, what a shame was this? ........ -

the dislain and shame whereof....... Troilus \& Cress. $\mathrm{j}$.

peace, for shame, peaec! mark him ...
and think them shames, which are..

and think them shames, which are .
our homour and our shame, in this ..

for a fool's will shrame it .............

to your great worths, and shane to nie

to your great worthis, and slane to me

to shame the zenl of my petition

let me rot shane resict

ignomy and shame pursue thy life...

I nm e'en sick of shame ..... Timon of Athens, jii. 6

shame, that they wanted ennning.... -

light on you, you sliames of Romel... Co
never slanme to hear wlint you have..

thosc unams of shame seen through

and cannot live but to thy shame...

the tribunes cannot do't for shame...

may'st prove to shame unvnlnerable

let us shame him with our knees...
to the Antiates, than shame to the

which was your shanse, by this unhoily

for shame, you generals; what do you - Jours Casar, it.

clse so thy elieck pays sliame .....Antony $\bar{s}$ Cleo.. .1

I never saw an action of sucli sliame -

he is unqualitied with very shame..
I convey my shame out of thine cyes

twas a shame no less than was lis loss - iii. 1

for shame, transform us not to women

his fuce subrlued to penetrative sliame

ocasar, what a wounding sliame is this - vv.

with slame the first that cver..... Cymbeline, iii.

to shame the guise o the world ......
living to die with lengthened sliame

for preservation eased, or shume .....

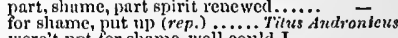

were't not for shame, well could I....

will make it thy face for shamel

our empress' shame, and stately iome's =

irl should not survive her shot beg

shame with thee; and witl thy sho...

the targets, to put off the sliame......... Ferieles

is it $\mathrm{n}$ shame to get when we are olat......

for your bride goes to that with slame ...

did grace the shame of those that....2 Henry $\mathrm{l} / \mathrm{i}$.

a shame to be on any side lut one (rept

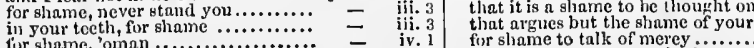

seeds and roots of shame and iniquity.....

iv.

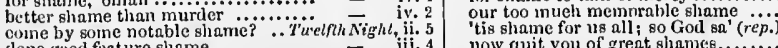

at last shame them derides..................

now quit you of great sliames........
reproacl and everlasting sliame sits 
SIIAME whieh here it sufters. let slame eome when it will

for slume, bemouster not thy finatu..... - ii. sisters! sliame of lulies! sisters I ....... = iv. a sovereign shame so clbnws him $\ldots . . .$. - iv. 3

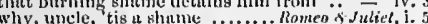
more light, more light, for sliane.....

of her chicek wonld shme those stars

gentlemen, for slame forbear this ostrage -

shame come to Rumeo! Blistered be
born to shame; upon his brow $\left(r r^{\prime} p.\right)$

like denth to ehide awny this sliame

aliall tice the from this present shume

for shame, hring Juliet forth (rep. )..
to do some villanons shame to the dead

nbonrd, ahourd, firr shime; the wind sits. I

lie'tl not sliame to tell you what it mean

sinme, where is thy blush? rebelious

prochim no shame, when the eompulsi

let shine for shamel young and

I will gutin nothing but imy shame ...... Hamelet, v. zounds, sir, you are robbed for sliame... Othetlo, i. 1 genertit speaks to your; hold, for shamel

all kitnds of sores, and shanes

net of slume a thousand times eommited - $\mathrm{v}$.

ull, n11, ery shmme agninst ine

AND, yout are overthrow ...M.r.

why then you are nterly shandi

huve him publiely she shat (rep.)

anl shamed life a hatefind ....... Meas, for Mers, iii.

is but one shamed that was never..As yon Like it, $\mathrm{i}$.

my slamed life in his disitonour lies. Richard II. v. have slumed me in your eondemued. Coriolanus, i. 8 ay, thou art slumeil

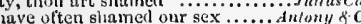

whose rags slamed gilded a........... Cymbritine

our mother is tor ever shamed ..Tilus.jedron. iv

will be shamel [ $K$ rt.-nshumed] for

silive

tis a bluslyinr slame-faced spirit ....Richarl lit. $\mathrm{i}$.

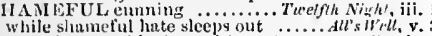

wehold in me this slametial sport. Conedly of Err. iv.

it is the shamelul wrork of llubert's. Kiny John,

lath made a shameful eonguest.... Rirhard $I I$. ii.

cass 1 bear this shamefinl yoke?

by slarneful murder of a gniltess king - iv.

you do me shameful itijury ......... Kichard III. i. 3
through the sluametul field .... Trrilus \& Cress. v. II

worthy slameful ehcek it were...Antony \& Cleo. iv. 4

two pasties of your shamelind henls. . f'itus duil. v. 2

not to behold this shameful lodging

SIIA MEF ULLY surprised ............ Hewry!ri. ii. I

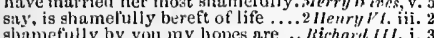

SIIAMELLSS thrown on me... Co

beastly, sliameless transformation ...i Henry i

wert thou not shameless

to make this shrirneless eallat $k$
and shameless Warwick, peace

grew shameless desperate

SIIAME-PROOF, my lord
SIIAMI'S to aeknowled re

shttus'st thou not, knowing wiencomedy of E'r

eonspiratcy! sham'st thou to slow. futites Cresn"

sham'st the musie of sweet news. konco

SII ANK - for lis slurunk shank....ds you Lik more than my slianks, and wrists
or I'll so earbonado your shank

with reeky slanks, and yellow. hoine o... Lear

SHAP'L-with a human shape

go, take this shape ..................

nor cun imaginution firm a shape

sueh sliapes, suclı gesture.............

thy ghape invisible retain thou stili.

as in his shape .......................

and alore false shapes $\ldots . .$. .

woment to ehunge their shapes ...... $=\quad$ iv.

whild meet him in this shape .......erry Wives, iv.

but le'll come, and in this shape ....

he dares to tread, in shape proline

in the shape of 4 woman (rep.)

only shape thon thy silenee............

the shape of lis leg, the mame

and lut it keep one shape ....... Meos. for $\overrightarrow{M e r}$

nor take no slupe nor projeet of .....Murvid do, jii.

for shape, for bearing, arganent .... -

in better shape than I can lay ...... - iv.

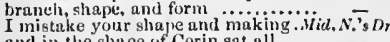

and in the shape of Corin sat all .....

the poet's pen tur

the poet's pen turng them to sliapes..
to make an ill shrpe gord (rep.)... Love's 2. Lo
flgures, shapes, shyects, ideat ........

the shape of love's 'Tyburn that hang

rol. disflgure not his shape

and sliape his serviee wholly to...

again be here in their own shapes $($ rep. $)$ -
IIAPE-full of strange slianes

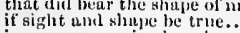

in nanners, ns in shupe!

have taken the slaupeg ol beasto.

both in mint, and in my shape. "Coment s' Tale, iy.

take any shaue but that.......

an if my brother had my slinpe..... King John, i.

finds shalies of erief, more thun .... kichary 11 . ii.

in shuse and mfinl transformed.

and shape of likedihood the

Wits fiull of fiery hasues.

let time shape, und there an eni.....

nimble, fiery, am delestable sliapes.

when I do shape, in furms

than may be gatlierced by thy shape.
my sluape. Chinged to o worser shape

no slinpe but his ean pleas.

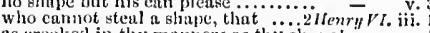

to shape my legs of an murequal size.3henry

ehange slapes with licteds....

conldst put on sone other shupe

Kichara III. ii. 2

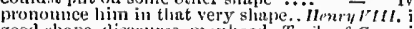

goon shaje, diseourse, mun

gifts, natures, shapes, severais

my time to bring it to some shape
this shape of sense assumes .................

but shupes and forms of slanghter

in all shapes, that man goes up. Tinao

that you work not in holier shapes

that hear the shapes of

work so mueh upon your shape
that shupes this monstrons appar

and destroyed in sueh a shane

to any slmpe of thy preferment
I know the sliape of his leg.

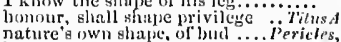

nature a ow shape, of hid .... Perict

as generous, and my shape as true ....

take the lusest and most poorest shape

a womin's shape doth shield thee........
she cumes in slapie no biguer than. liome

thy shape, thy love, thy wit (rep.)
thy noble shape but a form of wax.

that ormumeut to shape and love....

thourh lewduess court it in a slape

power to assume a pleasing shape
imagination to give them slape

in furrery of slinpes and trieks

may fit us to onr shape

a divinity that shapes our ends................

my hopes clo shape him tor the goverio...

oft my jealousy shupes

not shaped for sportive tricks

it is shaped, sir, like itself?

the inore it, sir, like itself...Antony \& cleopn

like PLESS idled u

left' so siapeless and so rucle

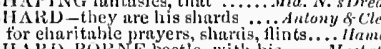

for eharitable prayers, sharis, glints.... Hamle

IIARDE D bectle in a sufer hold.

share damuation together

no one so true dic share it. shall share the goid of our.......... As. for Meas. ii. 2 goodness shatre with thy birth-right ..All's $\|^{\prime} c l l, \mathrm{i}$ of all-but my shure of the teast... Timing $\overrightarrow{\text { of }} \mathrm{sh}$. $\mathrm{v}$ and every onessinall shares wit.....

but in it shares some wor

nity, let us share thy thourhts....... Rirhe

let us share, and then to horke

let

the greater slare of honour.......

methinks, whild ahare from me
Walter Whitmore, is thy share

thy share thereof' is small

share $[K a h,-$ wear $]$ with him

and share the air with us?

we'll have tera shares.

of nyy

one of the three to share it?

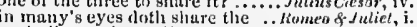

go shall you share thl that he

SIIARED - we two have shared $\ldots \ldots \ldots$; Inumiet, iii.

while all is shared, and all is horne..2 Hemry $r l$.

on youl love; shured daungers with you. Ohw lln, iii.

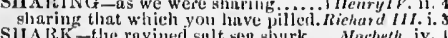
SIIARK-the ravined sult sea shurk ... Macbeth, iv.

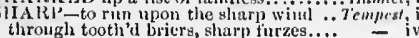

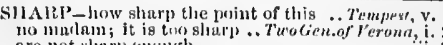

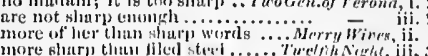

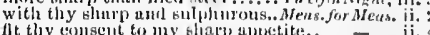

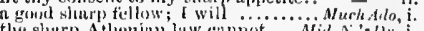

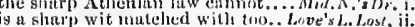
lanve been slaarp and eentertiou.

thrust thy shary wil quite through

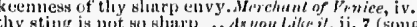

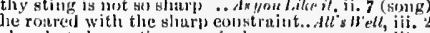
ah, what shorpt stings are in her

ambe as swect as siarpl: we must

my fitem now is slarp...... Trening of shren iv.

fiery ville and sinnp) diseourtie be Comedy of $h$

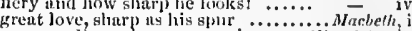

my sword s as shurp as your's ....... King John,
this day as sharp to them as thorn.. Kichend Hi.

his nose way us blarp as a jen ........ lseury $r$. ji.

insteat whereof, shnrp stakes........

in these niee sinn rp (quillets of...... - ii.

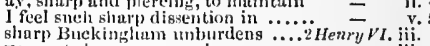

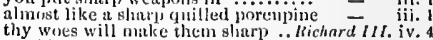

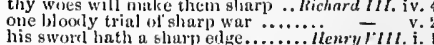

his sword hath a sharp edge......... Henry r $t 11$. i.

bitt the sharp thorny points of ..... = ii.

by your gnod thvour, too sliarp...... $\quad$ - v

you bite so sharp at reasons.. Troilus of Cressida, it.

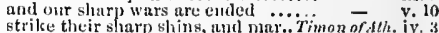

do not please sharp fate to.Amony \& Cteopat a, iv. i

with thy sharls teeth this knot ......

puinted him as sharp as my needle... -

opportunity of sharp tortmre........ revenge.. Titus sndronicus, i. 2

we'll be as slarp with you ........... - i.

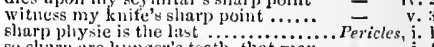

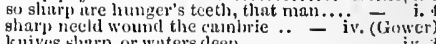

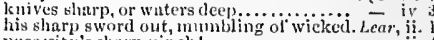

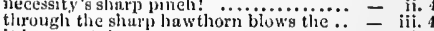

it is a most sliarp sauce...........howeo \& Jutict, ii.

sharp misery had worn hion to the benes - v.

though inelination be as slarry as will. Hamle. iii.

shurpen with eloyless sance his ... Antouy \& C'rw. ii. I

iARPER-whose sting is sluryer. W'iuter's talt, ii.

in thee no sharpes spur? ............. Richarel 11 i.

swceter to yon, that liase n sharper... Cymbeline, iii.
whose ellge is slan']er than the sword

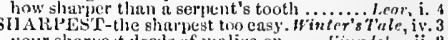
your sharpest deeds of mnlice on .... King John, ii. 2 I wait the shapest blow, Autioehins ..... Perictes, i. I

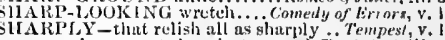
swagrering aecent sharply twanded. Firelrith $N$, iti.

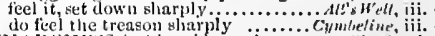

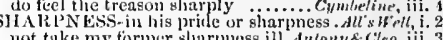
hy thuse that ficel their sharpness ..........ear v. 3 SHARP-PROVIDLD wit he reasons - iti. I

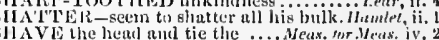

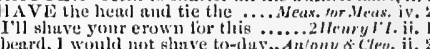

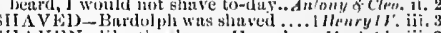

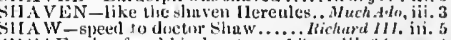

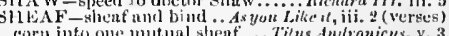

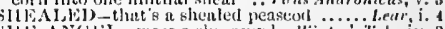

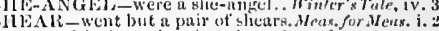
slume with shenrs lus thrend ... Mit. N.'s bream, v. I

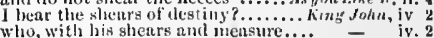

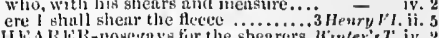
IILARLilinoseray fur the shearers. Henter's $T$. iv. nud the shearers prove sheep, let me. - iv. 2 SIIEATI-yout shenth, you bowease. I Henry $1 \%$ : iv. 4 cre thou slcep in thy shenth........2 Henry $V^{\prime} t$. iv. ${ }^{10}$ this is thy sheuth...................hmen of Jutied, y. 3 ctlge, 1 sheatlie andin undecled........... Iacbrth, v. 7

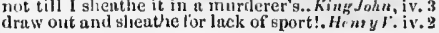




\section{SHE}

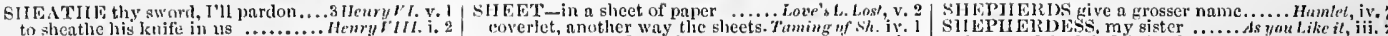
to sheathe his knife in us ..........Hermilli. $\mathrm{i}$. slieathe your da:fer..

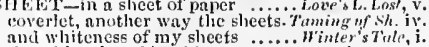
the wlite slicet bleaching on........ - iv. 2 (sing my tratfic is slueet

put thy nosc between his sheet.

suw him fumble with the slieets

will not be shifted with my slicet

look on the sheet

the your sheets... dutony \& Clen.

When snow the pasture sheets........

fresh lily and, betwixt enlu sheets .. Cymbeline, i.

suel sheets ot fire.

got tween the lawful sheets $\ldots \ldots \ldots \ldots . . . .1 \%$

salch dexterity to ineestuous slieets!

for-and a shrouding sheet........

well, happiness to their sheets

I have lail those sheets you bale me

shronit me in one of those same sheet

HIEFTED dead did squeak ...........Homlel, $\mathrm{i}$

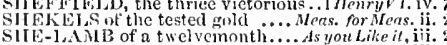

SICEIF the preeious diadem stole \%.... Hamled, iit. 4

and kill him in the shel

thy eorse, lying with simple shelis..... J'ericles, iii.
how mu oyster makes his shell? .......... Lert, i,

this lapwing runs away with the sheli...Hamlet, y.

seek elielter, pack! …................. Terry lives, i. 2

under the shelter of your honour

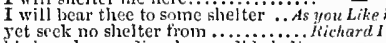

lis broad-spreading leaves did sheiter - ili. A

prove a shelter' to thy friends .......2 Henry ir iv. 4

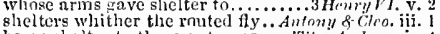

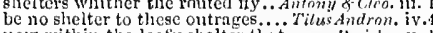

How within the leafy shelter that .......'erieles,
the gods to their dear shelter take thee.... Lear,

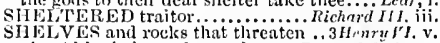

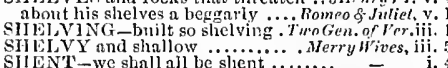

I am shent for speaking to you... Firelfh $N \overline{i g h t}$, iv. I am shent for speaking to your .. Twelfih Night,
he shent [Col.-we sent] our .. Troilus \& Cressida,
how we are shent for keeping your . Coriolantes,

how in my words soever she be shent. Hramel, iii.

that my master is a slicpherr (rep.).. - i. i f i l

the shepherd seeks the sheep (rep.).
for finder follow the shepheril (rep.)

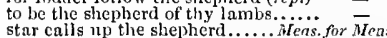

star calls up the shepherd....... ireas. for Meas. iv. 2
than lark to shepherd's ear.... Mird. N.'s Drean

than lark to shepherd's ear .... Mird. N.'s Dream, i, 1
when shepherds pipe on.... Love's L. Lost, v. 2 (song)
Dhen

Dick the slepherd blows his nail - y. 2 (solng)

the skilful shepherd peeled me. Merch of J'enice, i. 3
alas, poor shepherdl searehing ...As you Like il, ii. 4

alas, poor shepherd searehing . As you Lile

I pr'ythee, shepherd, if that love, or gold-
I am shepherd to another man (rep.)

shepherd's life, master Touchstone? (rep.
plilosophy in thee, shepherd? (rep.)
thou art in a parious state, slicpherd
if tourtiers were shepherds..........

mend the instanee, sliepherd

devil himself will have no sheplierds

shepherl, go off a little (rep.).........

you footish shepherd, wherefore ro you

so, take her to thee, shepherd
dead shephord! now I find thy

well, shepherd, well, this is a let ter... - - ii. 5
art thou god to sheplierd turned

alas, poor sliepherd; do you pit

and here live and die n sliepher

goorl sheplierd, tet this youtl

goon sheplierd, tetl this youth .....

in this sheplierd boy some lively inchese -

a sheplierd's daughter, and what - iv. (ehorus)

have some question with the slieplier.

give you ont an unstained shepherd
pray, good sheplserd, what fail (rep)

pray, good sheplserd, what taik (rop.

a sheplyerd's daunhter. It that sheplierd -

0 , that's the ease of the encpherd's son

heart the old slieplaerd deliver $(r$.

now he linanks the old sliepherd, which -
this avounches the slieplierd'e son .....

and in the view of the sheplierd.......

by birth a sheplieril's dinghter.....

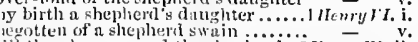

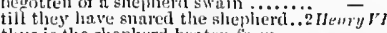

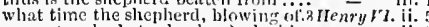

a sweeter shale to shipliderds, linkiug - ii. 5

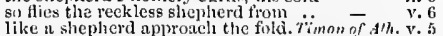

the shepherd knows not thunder

as the wolf does of the shepherds

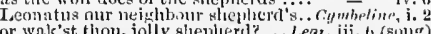
the proul distainfil shepheriess that come, sister: shepherdess, lnok on him Shepherdess, (a finir one ore you. Winter's Tale, iv.

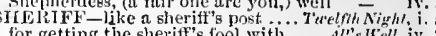

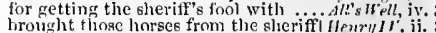
the sheriff.' with a most monstrous (rep.) - ji. eall in the sheriff. Now, master sherift and, sheriff, I will engage my word ... we'l take her from the sicriff ........ and, master sheriff, let not lier penance
sheriff, farewell, and better than $\mathbf{I}$.. HERRIs-excellent sherris is ........
but the slervis wnrms it, nud nikes and this valour comes of sherris......

and good store of lertile sheris
SHEFRIS-s $A C K$ hatl a two-fold

IIE-WOLF-8he-wolf of France ...... 3 Jen $\overline{n r y}$ iv. 3

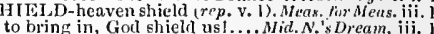

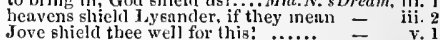
witl targe and shield, did make...... Lore's 2. Los , v. 2 God shield, youmean it not! .........All's I'e h, i. I throw my warlike shield ............Marbelh, v. shield thee from Warwick's frown..3Hen'y $Y$ l. iv. whose honour heaven shieid from... Herry rJil. your shieids before your hearts (rep.). Corialanus, i. i given your enemy your shicld

than Telamon fir his shield ...̈ntony \& $\overline{C l} c o$. iv. il the evenfold shield of Ajax....... marks upon his battered shield....... hath been a shield 'twixt me ant denth. Pericles, ii. a waman's shape doth shich tie...

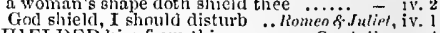
SHI CLDED him from this ........... Cymbeline, v. I must coney - catch; I must slift....... Tempery trives, thy eomplexion shifts to strange. Heas. for Mers. iij.

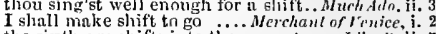
the sixth age shifts into the....... As you Like it, ii.

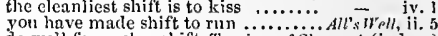
you have made shift to run .......... All's Irell, ii. 5
do well for such a shif t. Taning of shrew, 1 (induc.)

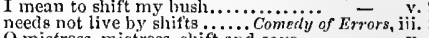
O mistress, mistress, shift a... save ... of leave-taking, but shift away .......... if I'Jl make other slift; you'tl be ....2 Henry $1 /$. ii. 1 have marle a slift to cat not to have patienec to shifi.....

unto Southampton do we sluilt ...jenry $\mathrm{F}_{\text {ii }}$ (eho.) rests no other shift but this .......... l lienry ivi. ii.

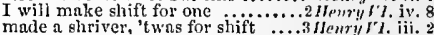
fortune in her shift and change ... Timon of $A i h$. i. 1 palter in the slifts of lowness ...Aninuy \& cleo. iit. 9 should we shift estates, yours would.

1 would advise you to slift a slirt... ymbeline, to shift his being, is to exchange....... - i.

that foreed us to this shift! .. Jitusandrnnicus, iv. taught me to shift into a madman's zags.. Lear, $\mathrm{v}$. he sluift a trenclierl he scraye.... Romeo \&.Juliet, GIIFTED-shifter ont of thy trie.... Mind sulo, iii. 3

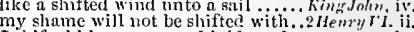
I shiftel him away, and laid good ..... (othello, iv. IIILLING-cost me two slinllings... Merry l'ives i. I had rather than forty slillin

five fhilliugs to ons on't, witl ainy Mhe pound and odd shillings ......... Winler.s darcst not stand for ten shillings.... JJen y $1 \%$. cight shillings and sixpenee $01 \cdots \cdots$ -

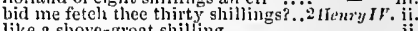
like a shove-groat shilling $\ldots \ldots \ldots \ldots . . . \cdots=$ - ii. you'll pay me the eight shillings I.... Uenry. V. ij. I

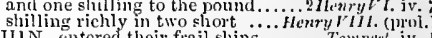
I N - entered their frail shing......... Tempe'st, iv bauks, shonlders, sides, and shins ..... - v. over the threshold and broke my shin - iii. till there be more matter in the shili $\overline{\text { in }}$ iii. strike their sharp shins ....... Timon of Athens, iv. fur your broken shin ............. Nomen of suliet, i. because they shine on thee?
then did the sum on dunghill shine Bremy - ives. my stars shine darkly over me .. Tu'clfh Nighe, it shines every where

and heavens so shine that............... slanll shine from tar, and make... Nid. N.'s Drean may shine in at the ensement........ and yonder shines Aurorn's harbingel 


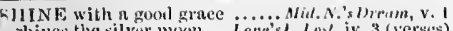

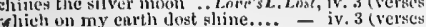
flich on my enrth dost sline..

the sun, that muketlr wll things sline?

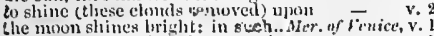

so shines a good deen in a nuturgty

a substitule shines brightly as a

and genelly shines the moont.. Taming of Shrete, iv.

slines sa hro sht. I k e

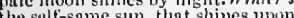

when the sun shines, let foulish.. Comedy of Rrr. ii. 2

shall shine on all deservers ............ Anacbeth i.

upen thee, Mruebeth, their speceices sline

your spirits sline througl you

warms you here, sliall sline on me... Richard 11. i. 3

he hom sline so brisk .........

wlien it sines selcloin in adnich

of his wife shines through it

shine then. Thine's too thick to shine

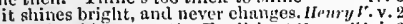

lute, dis he sline upon the Englishe 1 id

to shine on my contemptible

now shine it like a eomet of revenge

half-faced sum, striving to shine,

and who shines now, but llemry's

shime out, fair sun, 'till I have

disilains to shine; for, hy the book

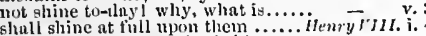

Ghall sline at full upon them

he wis wont to sline at seven. 7inon of sheris, iii.

if, after two days' shine, Athens

Ilyperion's quickening fire doth shine - - iv.

for he would ghime on those that make

thy lustre thickens, when lhe slines by

slie slines not unon fools, lest the
hath Britain all the sun that shine

by this sun that shines, I'Il thither

which ghines here in the west....

let desert in pure electiou sline ... Ti
bright, and shine in pearl and gold..

here never slines the sun ...

doth shine upon the dead man

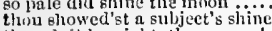

thougl it be night, the moon shines.

SHIN

profit from their shining niglits ... L.ene's $L$. Lost, satehel, and slining morning fice....ts you Like il, so clear, so slining, and so evide

with shining cheekered

Henryll.

the dimming of our shining star.... Richard $11 \mathrm{l}$.

when his virtues shining upon. T Toilus o Cress.

cry to the shining synod of the rcst.. (ymbeline,

show you, shining at this feast .. Romeo f Jutiet, i.

SHIN - the night is shiny... Antony \& Cl'opatra, i
SIIIP-thougl the ship were no stronger. I empest,

the good slip so have swallowed.

I bonrded the king's ship (rep.)
sately in harbour is the king's shi

sately in harbour is the king's ship
that they saw the king's ship wreck'

to the king's ship,

the next, our ship ...................

I'll bring you to your slip....

to save your ship from wreek

with my naster's ship?

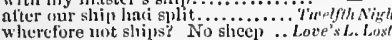

the ship is muler sail .....

my ships eome home a month

Merof of ten

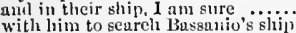

the ship was under snit

the ship was under sut?.............

hatl a ship of rich lading wrocked on

nuny a tall ship lie buried

the end is, he linth lost a ship.

my ships have all misearried $\ldots . .$.
that my ships are safely come to rind

your ships ure staicl at Venice. . Trming or sh iv 1

my sliprsare ready, and my peopile. H'inter's Fule, $i$.

1 eyent them evele th their ships.

our ship lintl touelsed nuon the deserts -

now the ship boring the moon

lut to maks an end of the ship...... - iii. 3

gone abourd a new stipl to prorge... iv.

two shigs frome fiar nukkinerise

but ere the slips ermlit necet by twice

onr hel liful ship, was aplitted ii

unother ship, hud seized on us........

the ship is in her trim

is there ning slip puts fintin.

with enche

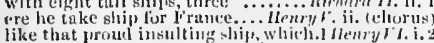

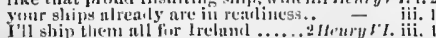

like to a Nhip), thut, having 'reaperl

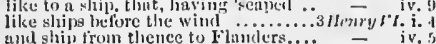

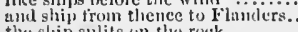

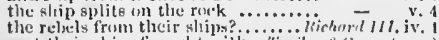

sent their shipts litught witi... Thoilus s cress. (pro.)

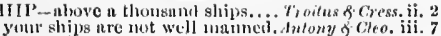

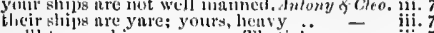
we'll to our sling; why, my Thetis

the mumber of the shipis behold

possess you of that ship thel trensure

witl slips negions, muy

wifto

with yuur ships: they are here .......

a portly suil of ships make hit herwarl...
let not oux ships ans mumber of $\left(r c^{\prime} p.\right)$

for ourselt, ourt ships, and men

reft of ships and men (rep st.

and down the poor slipip drives $(r p, \ldots)-$.

well-sailing ships, and bennteons - iv - iii. Lysmachls our Tyrian ship espies - v. (Gow.) but we will slip him lienee llomlet, iv. they got wlear of our ship........

the slip is hero put in, 2 Ycronese

the riches of the ship is come on shore.. - ii. 1

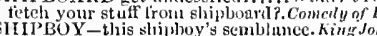

scal up the slipboy's eyes.........2 uenry $/ V$. iji. Fil AI AN-i' the shipman's card ....... Macbeth, i. 3 IIPMEN do the hurrienwo call. Troilus $\&$ Cress. v. he is slipped already

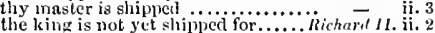
would thou wert shipped to heli.... Tituts.tmhon. i 2 emperor may lave shipled her hence $-\overline{\text { ive }}$ iv. 3 hath shipped me into the land... Himile, v. 1 (song)

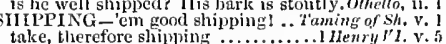
take, therefore shiplping .............. henry "l. y.

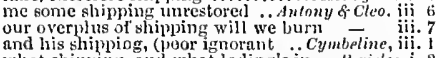
what shipping, and what lading's in ...'cerieles, $i$.

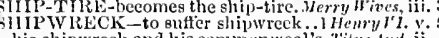
his shipwreck and his eommon weal's. T'inw dut. my shipwreek's now no ill, since

shipwreeked upon a kingiom ......Henturlll. iii.

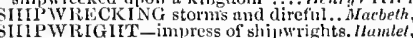
the shipwright, or the earpenter? (rep.).

IIIRLEX-the spirits of shiriey.

IIRT-foul shirts and smoeks ...Merry Irives, iii.

I will not combat in my slir

truth of it is, I have no shirt........... - . ${ }^{\prime}$.

and the shirt, to say the truth

I take but two slints out witli me
to bear the inventory of thy shirts

to bear tle inventory of thy shirts

will put thy shirt on warm? ... Timinn of Athens

I would advise you to shitt a slint ... C'ymbetine

six shirts to his berly biore to ride

two, two $n$ sliert,

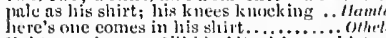

liglst gentlemen; l'n bim, it witlimy shirt

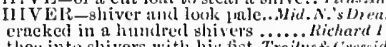

thee into shivers with his fist. Troiduso' Cressidu, ii.

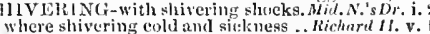
the deptlis and sho:ils of lighen time.... Afucbeth $i$.

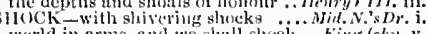

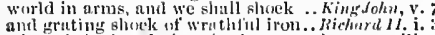

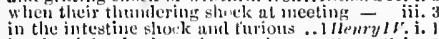

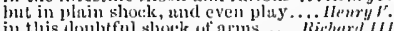

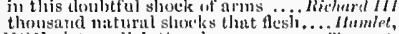

IIOL-let me lick thy shoe ........... Tempest,

see to wipe my shocs

this shere is my father (rips)

thlis left shoe is my mother
this sloe with the luote in it

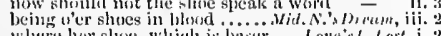

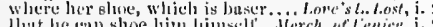

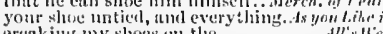

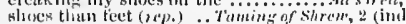

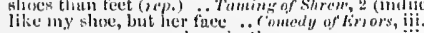

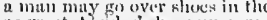

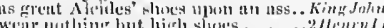

l kiss lis olity shoc, and from

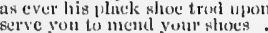

our shoses is not so gisut...

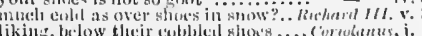

IIOLi-n surgeon to oll shoes

to wear mit their ghoes, the
let not the crenking of dhe

to slue " troos? of horse with falt.

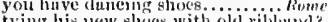

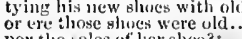

two Proveneinl roses on my razed sine

AlOSING, and plougli-irons

IIofN AkER shmid medile.

tupe, glova, slsoe-tye, bracelc
silog oft? I would liave you

shall we thog oft? the king wil

When the moon shone, we dich.... Aser'of teen:
that e'er the sun shone briglit on. Hinter's T,

like licathen gools, slione down the.. Hrmry rlli. $\mathrm{i}$

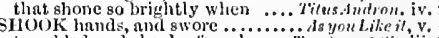

trembled and slook; for why ... Thminzof of $\$$ h, iii.
shouk hands, as over a vast ...... Hinler's Tale, i.

ne'er shook hamds, nur lade firewell ... Mactiefh, $i$.

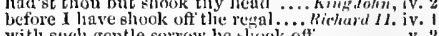

witl such gentle sorrow he sliwok oft - v.

and shook off by him, from whom ... Henry/

this distemperature, in lossim biook $=$ iij.

hath shook, and trembled at the .......Henry ${ }^{\prime}$ i. 2
your mistress shem dlly shook your hack - iii. 7

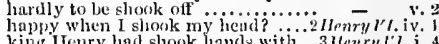

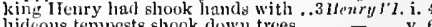

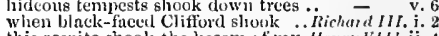

this respite shook the bosom if my.Henry VIII.ii. 4

Irom the lion's mane, be shook. Troilhes \& Cress. iii. his eonquering banner slook .... shtony \& Cleo. i. should have shook jions into eivi i street $-\bar{y}-$ i. i
shook down my mellow hangings.. Cymbeline, iii. shook, as the earih did quatie ......... Pericles, jij.

there she shook the holy water firom ....L. Lar, iv. fet our beard be sloook with danger.... Hamlet, iv. 7 and staff, and his samdal slrooll. Homlet, iv, s. (song) and staff, and his sandal shoon. Homlet, iv, 5 (song) a cunnon will shoot point-lilank. .Herry Wir w, iit.

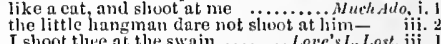
I shoot thee at the swain .......... Lore's L.Lost, fij. you may make the faircst shoot (rep.) - iv. thus will I save my eredit in the liout $=$ iv.
indeed, a' monst shoot nearer, or lw.ll to shoot another arrow that (rep.).sIer. of Fenice, $i$. of that, he shoots his wit .........dsym Like it, v. and watehed the time to sluot ....... pasli, and the shoots that 1 hure... Minlar's Tule, Anstria and France shoot in each.... - ii. sueak quiekly, or I shoot...

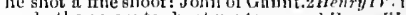
realy they were to shoot me to.
mighit shoot them at your finees

to show forth thauder so hoth may shoot. That enunot be.3 /ewry $r$. iij and so my shoot is list

power this eye shoots forth! .... Timan of silhens $i$.

which sorrow sluots out of the. Antony is Clem, iv.

you were as gned to shoot nguinst. Filus Andron. iv.

I do not bill the thunder-luturer shont ...... Lear, if.

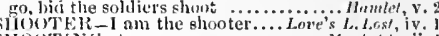

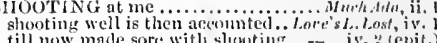
till now made sorc with slowting - iv. o (egit.)

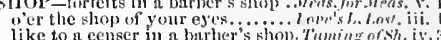

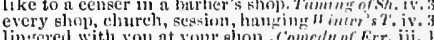
linecred with you at your ohop. Conedy of Err. iii.

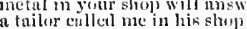

compelled to shut our shops...

licmk open shops: nothing ent

our trudesnen singing in their shiols

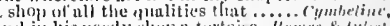

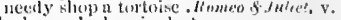

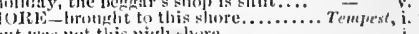

good urus in linsty strokes to the showe - i. i

huve indensed the sens und sluges....

fill the reasomable slures ..........

who must strunfely, upm this shire

a drier death on blore ...... Trogen. ar t wom,

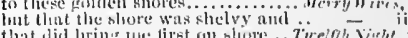

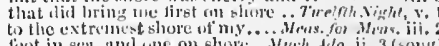

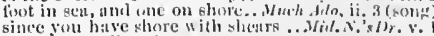

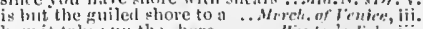

now it takes $n 1$ the thore ...... Hinter's linte, jii. 

SHORE-waters, undreamed shores, Winter's Tule, iv. 3
if he think it fit to shore them again
I h

I have from your Sieilian slures

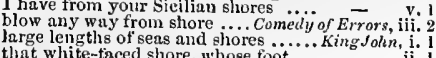

that white-taced shore, whose foot

two such shores to two such streums

grapple tliee unto a pagan shore...
whose rocky shore beats back the

sliortly mean to touch our northern.

Will serve for a short holding

who was sliot, whodisgraced ......... HenryV. iii.

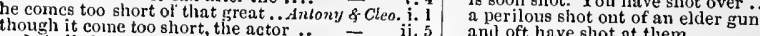

- iv.

or I stinll short my word .............. Cymbeline, i. . $\quad$ with shot or with at them

but, in slort timort farewell

you are very short witl us.......... Titus Andron. i.

a guard of chosen slot I had.

and I abide your sliot $I$ had................ i.

far too short to hit me here ............. Pericles, i. 2
and longest leagues make short - iv. 4 (Gower)
only slie comes too slort

Wales berond the Severn shore

gave him welcome to the sliore

all vengeance comes too short

the aim of every dangerous shot... fichard $J I$, iv. loose shot, delivered such...........Herr.y $V^{\prime \prime l J} . \mathrm{v}$. the hourly sliot of aner bolt of nothing, shot at nothing...... Cymbetine, $\mathrm{i}$.

my lile will be too short ...........

which, having, makes them sliort. Romeo \& $\overline{\text { suliet }}$ iv.

I woulil have made it short.

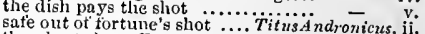

thou hast slot off one of Taurus' whese the high shore of this....... Henry

no fuoting on this unkind shore? ".enenry $V I$. iii.

blow towards England's blessed shore

and we will make short work

when Publius shot, the bull being

when from the shore the tempest....

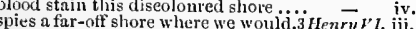

betwixt the king and inistress Shore. Richard III.

that Shore's wife hath a pretty foot

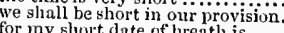

for my short date of breatl is .........

striking too sliort at Greeks ................

with sighs shot through ............... ive 4 (Gower)

sliot through the ear as if that name, shot from the deadly - ii. 4 out of the shot and danger of desire.... Hamlet, that insorts his poisoned slot

it will be short that i have shot my arrow o'er....
at a shot, so bloodily hast struck?
they do discharge their shot of cour

give inistress Shore one gentle kiss

his conversation with Shore's wife
hither

after he once fell in with mistress shore

to the shore [Col.Knt.-our slores]

sent out a hoat un to the shore.

and aetion, make the hours seem short. omello, it.

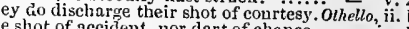
the shot of accident, nor dart of chance.. - iv. HORTEN - to Aliee Shortcake .Merry Wives, i. but shorten thy Iife one wcek.......... 'Temperter's Tul, iv. sljorten my days thou my son's....... Richard $I I$. i. 3 to shorten you, fnr talcaust with SHOUGH-curs, shougls, water-rugs... Macbelh, iii.
SHOULDER to my leel .... basket on your slioulders (rep. Taming of shere.
they took ine on their should $W$. iit. 3 they took ine on their shoulders .... = iii. 5 heaveo shorten Harry's happ $y$ life...2 Henry $I V$. v.

eonirerce from dividable shores.. Troilus their bosoms higher than tlie shores.

a pale, a shore, confines thy

made in her concave shores? ....... ft
do kiss the most exalted shores of all

to be known, shortens my made inteut .. Lear, iv. ?

I'Il try you o the sliore ......iniony $\&$. Cleopatra, ii.

the varying shore o' the world

grew'st unto the sliores ot the haven.... Cymbeline,

descried, upon our neighbouring shore. A Pericles.

washed me from shore to shore

shipwreck, driven upon this shore

and men, and cast upon this shore

even to the edge $o^{7}$ the shore

raging battery upon sliores of

being on shore, honouring of Neptnne's..

o'erbear the shores of my mortal

retresh us, sir, upon your shor

this lady was tlirown upon this sliore..... - $\quad$ v. 2

SORTENED, for she hath
so her torture may be shortene

iruchAdo, iij.

we shall be shortened in our aim

IIIenry VI. v. HORTER-longer, or shorter ....... Heas Herry PI. iv. 6 shorter [Col-smaller] is his daughter. As you Like, i. 2
a shorter time shall send $\ldots \ldots \ldots \ldots$. Henry IV. iii. I

your way is slorter .......... Anlony \& Cleopatra, ii. 4 unless things be cut shorter

a shorter journey to your desires ...... othello, ii.
SHORTEST of day................. Richard $11 . \mathrm{v}$.
SHORT-GRASSED green? ............ Tempest, iv.

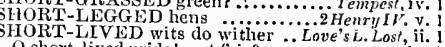

O short-lived pride! not fair?........
tHoRTLY shall all my labours end .. Tempest, iv. iv.
tide will shortly fill..................

leisure, which shall be shortiy ........
who shortly also died ...........

wonld I very sliortly see thee there ... if my passion chauge not shortly ..... MuchAdo, i.

thou wilt quake for this shortly

it will go near to be thought so shortly

shall not shortly lave a rasher. Mer.
I shall grow jealous of you shortly.

of wit will shortly turn into silence

we shall have shortly discord in...As you Like it, ii. 5

bycks, shoulders, sides. and shins

so tickle on thy slioulders .............. not have his liead on her shoulders... Much ddo, i. lier shoulder is with child......... Love's L. Lost, iv. 3 and clapped him on the shoulder soulder - v. I but what lights o' my shoulders. 1 Ier.of venice, iij. 1 of princes on unw orthy shoulders? As you Like it, ii. ? Cupid hath clapped him o' tbe shoulder, $\bar{c}$ iv.
on his shonlder, and his ......... Hinter's

marks upon my shoulders ............. I shall seek my wit in my shonlders - $\quad$ ii. as the mark on my sloulder, the mole

I have it ou my shoulder ............. King John laid my knighthood on my shoulder. Richard $L . \mathrm{i}$. from thy unreverend shoulders...... straight enough iu the shoulders

witll two poin ts on your shoulder?..2 Henry $I r^{\prime}$ ii. that never had the ache iu his sioniders bear them on their shoulders ......... Henry and from iny shoulders crack $\ldots . .$. ... i Henry $v_{i} . \mathrm{i}$. weak his headers, overborne with ......

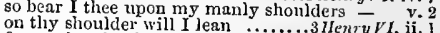

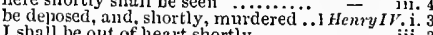
then to the inns of court shortly.....2 Henry $\mathrm{V} V$.iii. 3 and shortly will I seal with him

gates, or I'll shut thee out sliortly

u widower, shortly (rep.................2Henry VI. ii. 4 I shortly mind to leave you ........ no doubt, shortly be rid of me be dead write to me very

or shortly after this world hä........Henry
shortly, I believe his second marriage

give away thyself in paper shortly. T

thon wilt be thronged to shortly and shortly comes to harvest .......... Anlony \& Cleo. ii. 7 thou'lt catch cold shortly................. Lear, i. cut short all intermission........ added years to his short banishment. Richurd II. i. it that come short, our substith for our time of stay is short sliall make their way seem short the way being short, and piece the way

word is short, but not so sliort as swcet
o, let the hours be short .............

in sliort time after, he deposed...

but, in short spuce it rain
miglit draw short breath

reath to-day....

satin fur my short cloak, and slops?....

your wind short? your chin double?

take up the English short

We should have none shortly ..Komeo \& fuliel, iii. 1
must leave thee, love, and shortly too..Hamlet, iii. you shortly shall hear more

you shortly shall hear more..............

to him shortly as bitter as coloquintida...othello

he's well, and will be shortly here

HORTNESS of the time can .............. plain ness, and your shortness..... Taming of Sh. iv. gecond night of such sweet sliortness. Cymbeline, ii.
SHORT-WINDED accents of new.... IHenry IV. brevity in breath; short-winded ...2 IlenryIV.
some certain shot be paid .............. -

for one shot of five pe

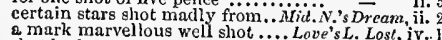

shot by heaven!...

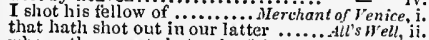

where, thon wast shot at by fair eyes All's $\boldsymbol{W}^{\prime} \mathrm{ell}$, ii.

to all that shot and missed

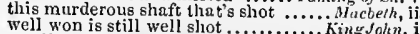

a volley of our needless shot

King John, i. and, to he short, for not appearance... = we will be short with you.............
we come short of our suppose.... Truilus \& $\&$ ress. her breatin as short as a vew-ta en...

for on thy shoulder do I build my seat - it.

upon my gniltless shouldera.......... Richard 1 III. $\mathbf{j}$. you should bear me on your shoulders

from these shoulders, these ruined

from Cupid's shoulder pluck bis. Troil

clap the Tubber A jax pluck bis. Troilus \& Cress. iii.

i'the shoulder, and i' the left arm.. Corintanns, iii. to run, and thow the Anchises beur. JuliusCepsar, i, now is growing upon thy shoulders. Cymbeline, iv. on any shoulder that I see before me ..... Lear, ii. with his head over his shoulder turned . Hamlet, i. heads do grow beneatl their shoulders.. othelio, $\mathrm{i}$. SHOULDER-BLADE is out ... Winter's Tate, iv. SHOULDER-CLAPPER, one that Comedy of Err.iv. SHOULDDRED in the swallowing. Reehard J11. iii.

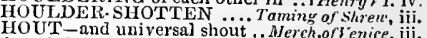
HoUT - and universal shout ... Nerch.of senire,
lieard these islanders shont out....... King Johr lond shouts and salutations from .... Henry $2 \%$. ii. whose shouts and claps This had .2 2 HenryIV.iv. my lord! what shonts are these? ..3Henry ${ }^{\prime} I$. iv. applause, and cheerful shout .....Riehard lil. iii. 7 hark t what shout is that?.. Troilus \& Cressida, v. $\}$ what shouts are these? the other ... Coriolanis, i with their caps and shouts; I tions ha! what shout is this? shall I never - ii. you not made a universal shout $\ldots . .$. Julius $_{\text {Casar, }}, \overrightarrow{\text { v }}$ another general shout! I do believe - i. and harkl they shout for joy........ $=\mathbf{v}$. didst thou not hear their shouts?.....

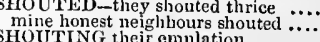
HOUTING their emulation .......... Coriol
and the slsouting Romans, make tlie sum and the shouting Romans, make tlie sum aud then the people fell a shouting ... up to the shouting plebeians..Antory \& clea. iv. 10

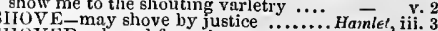
HOVED-shoved fiom the court $\ldots 2$ Henryle, $1 \nu^{\prime}$. iv. 


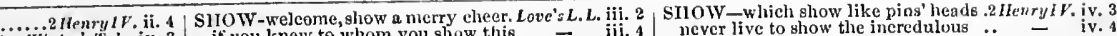
in dust., Hinter's'Tale, iv. 3 if you knew to whom you show this about the sconce with a dirty shovel... Hamlet, v. $\quad$ wilt thou show the whole wealth.... SIIOVEL-BOARDS, that cost inc ....Merry Wives, or fright mew thee every fiertile inch $($ rep.) ghow thee a jay's nest

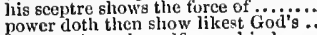
fortune shows hersclf more kind ....

I pray you show my youth old.

this visitation shows it

I'll not show him where the

dear Cetia, I show morc mirth .....As you $\bar{L}$ ike

thou wilt show more bright, and secm

$=$
$=$
$\bar{I}$
$=$

hose ought to show itself courrageous
hatli ta'en from me the slow of smooth
that shall civil sayings show .... - iii.

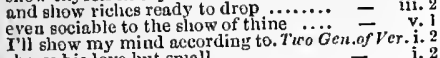

to it, and Ill olow it you.......

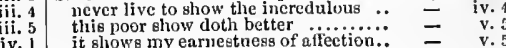

ghows his love but snial

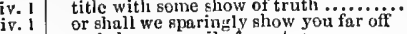

lenry $r . \mathrm{i}$.

that the contents will show...

I feared to sliow my father...........

i. 3 now show the wound mine eye ......

iv. 2 and show my sail of greatness........

good corporal Nym, show the valour
oir, you show great mercy, if you $\ldots$.

glow men dutiful? why,

i. 3

show us here the mettle

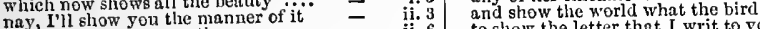

shows Jolia but a swarthy ..........

than I shall show to be.......

to show the letter that I writ to you

ii. 7

he may show what outward cournge

and your fair show shall suck away

and your fair show shall enck away

and show his scars, and say

I will some mercy show.................

that will I show you presently.

and

it is the show and seal of nature's iruth

and make a show of love to pro

and show thee all the treasure ......

I have to sliow to the contrary (rep.) - i1. I I will show myself highly fed.........

give him a show of comfort in his suit $\begin{aligned} & \text { - ii. } 1 \\ & \text { he is not show his fice ............. }\end{aligned}$

(rep.) $\ldots . . . . .$. = i.

I will show you a monster..........

and show itself, attire me how

in his simple slow he harbours.

and Gloster's sliow beguiles him

that shows him wortlig death.

humble wife may show. Taming of $\ddot{S} h$. 1 (indnetion)

we'll sliow thee lo, as slie was.

msster, some show, to welcome...

to ohow how quaint an orator.

show no colour for my extremity....

without the sliow of both

I'll show you here at large ............ - iv. 6

and show rou the pictire.....

am bold to show myself a forward .

soldiers, show what cruelty ye can $\ldots$.
now show yourselves men, t $t$ is for liberty $\quad$ iv. 2

mountain top the cedar shows $\ldots . . . .3$.

show thy descent by gazing 'sainst.... - ii. I

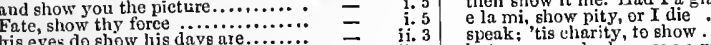

ii. 4 but your words show you a madmä

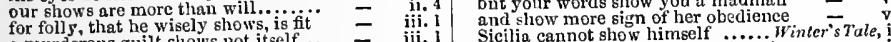

a murderous guilt shows not itself ...

Sicilia cannot show himself .......Winter's Tale,

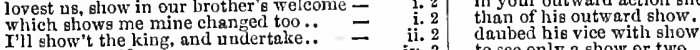

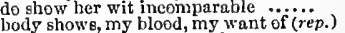

mirtlufol comic sbows, euch as.......

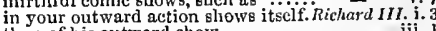

to sce only a show or two ......IIenry $\overline{T I I}$. (prol.)

to show myself a glass ..............
this shows a sound affection

with such a sliow as fool and fight is ... - (prol.)

why dost thou show me thus............ feas. for $\overline{\text { Mlleas.. }}$ i. 3

not sinow your face; or if you show ..

all that you speak shows fair

only to show his pomp as well in France
would show a worse sin than .........

woul a thing,- you cannot show me...

ynu'll show a little honesty ............
celebration of this day witl shows

show the inside of your purse to the

which nature shows above her breeding

show me how, good father ..........

$\begin{array}{ll}\text { iv. } 3 & \text { silence, it the more shows off your ... } \\ \text { iv. } & \text { I have your hand to show ... Comedy of Errors, iii. } 3 \\ \text { iv. } & \text { rith some show of blindness ........ }\end{array}$

I'll show your grace the strangest

$\begin{aligned} & \text { he shows his reason for that } \ldots . . . . . \\ & \text { first, let her show her face } \ldots \ldots . . .\end{aligned}-\begin{array}{r}\text { iv. } \\ \text { v. }\end{array} \mid \begin{aligned} & \text { with some show of blindness } \\ & \text { the arm, show us the sleeve. }\end{aligned}$

I will not show my face, untii

thou show not, than our earth"s........
look what I iije.

that indeed which outwardly ye show

and show us to be watchers; be not..

to show an unfelt sorrow.

that joy could not show itself modest..
a good cover, they show well out ward
must not make the full slow of this..

he shows me where the bachelors sit.

shows it his companion.

or show the glory of our art?.

show me hriefly how..................

he doth, indeed, show some pparks...

which will be merely a dumb show...

I'll show thee some attires...

as to show a child his new coat ........

I will show you eoough .

to let him show himself what be is

that shows, thou nrt nnconinimed

these exterior shows? - iv.

that possession would not allow us..̈̈hip? - iv.
is there any way to show such friendship
and show him their examination .... iv. 2

show outward hideousness, and speak

marry, I caunot show it in rlyme ..... ${ }_{\text {nat }} . \overline{-}$

$O$ how ripe in show thy lips

as men you are in show ...............

never so little show of love to her....

show our simple skill, that is

by their show, you shall know ali - v. 1 (prol.)

rou wonder at this show; but wonder

chow ! how! show! show his eyes on

filthy hags! why do you show me this? =

a glass, which shows me many more

and show like those you are

tyrant, show the show and gaze o' the time... - v.

I will show thee to my kin ......... King Jo

most of all show evil; what have
does show the mood of a much

show boldness, and aspiring confidence

temper cost thou show in this

show me the very wound of ....

slow now your mended faiths ....... Richard 11. v.

do remain, let paper show,$\ldots \ldots . . .$. .

ghow me thy humble heart ...........

to show the world I am a gentlcman

duty tenderly shali show....

if we be not, show us the liand ....

and slow fair duty to his majesty
tears, show their love, but want

fair sun that shows me where.

should show so lieinous, black
that it may show me what a face.

$\begin{array}{ll}\text { iv. } 2 & \text { a plot, shall show us all a merry ..... } \\ \text { iv. } 3 & \text { what we are slows us but this ..... } \\ \text { iv. } 3 & \text { I may not show it. I will be satisfici }\end{array}$

lovely, wall, show me thy chink $\because \because$ Lver $^{\prime} \bar{L}$. Lost, $\mathrm{i}$

then it was to show my akill

ostentare, to ghow, as it were will....

heaven show his face ............
did these rent lines show some

bcarce show a harvest of their.

that show

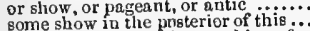

vouclisafe to show the sunshine

but in visors, show their faecs?

their shallow shows, and prologue

to grace it with such slow ...........

to have one slow worse than

treasou that my haste forbids me show

and groans, show minutes, times

shall show more goodly .................
to show the line, and the jredieanent

valour's show, and valour's worth...

the unworthiest shows as fairly $3 . . .$.
like merchants, show our foulest ware

[Knt.] yet to show shall slow the better

I let him show us a cause......

wherenpon, I will slow you a chamber

show not their mealy wings.................

what thinks bov

such as boasting show their scars ....

thon boy-queller, show thy face i.....

the fire $i$ the flint sliows not.... Timon of $\bar{A}$ th

to show lord Timon, that mean eyes

when dinner's done, show me this
as this pomp shows to a little oil ....

to show them entertainment

to show him what a beggar his .......

I'll show you how to observe $a . . . .$.

mark, how strange it shows, Timon.

that which i sliow, heaven lnows

curse all; show charity to none....
it will show honestly in us

\begin{tabular}{r|r} 
ii. 2 \\
iii. 3 \\
ii. 1 \\
ii. 3
\end{tabular}

they noeds we'll slow 'em in deeds.

where he would show most luve......

if these shows be not out ward.........

slow them the unaching sear

I hinve wounds to show you, which shall -

which he conld show in private......

to show bare hends in congregatious

you will rather show our general $\because .$.

large temples with the slows of peace

which show like graves i' the holy :
and car: show from Rome her enemics'

and car: show from Ronc her
would slow tliee but a fool.

durst not (look you, sir) slow.

go home, and show no sign of fear...

and I'll show thee a precedent

v. 2 and slow it a fair pair of hecls

v. 2 and can show it you here

though sometimes it show greatness

that shows the ignorant a kind.

in the end of our show $\ldots \ldots \ldots \ldots . . . . . .3$. af $\bar{r}$ en

who enn converse with a dumb show?

this kindncss will I slow: go with ..

there they show something

stoops not to shows of dross...........

to show how costly summer was at

dare scarce show his head on the laialto -

so may the outward shows

and the shows of men, to fight

i. 3 doth it not slow vilely in me ........

ii. 7 that show a weak mind and an able.

ii. 9 was then sir Dagonct in Arthur's show

to show in articles; which, long ere this

obscures the will show you his estate

sliall show itself more openly herente

if you do not all sliow like gilt .....

unproperly show duty, as mistaken.".

may show like all yourself $\ldots . . . . . .$.

that gentleness, and show of love ...Jiliu

forgets the slows of love to other me.

and sutterance show us womanish....

sham'st thou to show thy dingeron

let me a little show it................

show the reason of our Cresar's desth

and let me show you him that made

make gallaut show and pronise of ."

ge, show your elaves, how choleric

much cuforced, shows a liasty spar 
\$HOW -eomes on in gallant show..Julins Casar, v. I SHOW ED him a seeming warrant. Meas, frr Meas. iv.

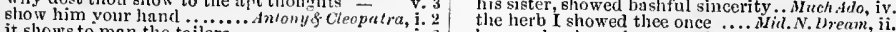
it shows to man the tailors
lid show ourselves i the fiejic.....

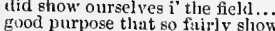

good purpose thant so fairly show.
sliow lis the way, sir (rep. ii. 7 )

she shows a body rather than a life.".

already show me the way of yielding

and to be stuged to thic slinw

not the imperious show ot

and see what $Y$ ean show in this

show me to the shonting varletry

in solemn show, attend this...

would show the Britons cold

shows much more his own coneeiving

to show less sovereignty than the
to show what coast thy sluggisl
and show them prinees borm

gore valour in me than my habits show -

sliow thy spite on mortal flies.

with other spritely shows of mine...

let him show his skill in

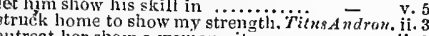

elitreat her show a woman pity...

in dumb shows pass the remainde.

now let me show a brotlier's lov
I'll show thee wondrous things.

slow me a murderer $(r p p$.$) ............$

the trumpets show, the emperor

show us wherein, and from the place

to show his sorrow, would in sitch

who makes the futirest show.........
6low you those in troubles reign...

I'll show the virtue I have borne

whieh shows that beauty hath his
mean better than his outward show

every worth in show commends

what's dumb in show, $\mathbf{1}$ 'll plain

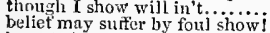

born to lonour, show it now
what shows, what minstrelss

shows like a riotous inn .....................

small respeet, show too bold malice.

at poinc to show the

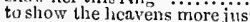

fiee things, and happy shows, behiud...

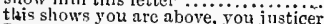

I would sliow what party $\mathrm{Y}$ do follow.

show searee so gross as beetles

I will show myself a tyrant

slrow me mistress that is pasfing fui
her face with some that I shall show

will show you, shining (rep.)

show a fair presenee, and put off thes

which mannerly dee, and put off thes

substance of divinest show !...........
some grief shows muel of love (rep.)

he will show thee where tliey are.

so shalt thou show me friendship.

sun, for surrow, will not show his head

to offer it the show of violeuce ...............
and all things will we show our duty.

to show my duty in your eoronati

tlant within, which passeth show

it shows a will most ineorreet to hen

show rae the steep and thorny way .......
of that die which their investments siow

the glow worm shows the matin to be nea

I tell you, must show fairly ont ward

the pious ehanson will show you more

that show of sueh an exercise may col
aloue entreat him to show lis grief...
nothing but inexplicable dumb show

to sliow virtue her own feature

and shows a most pitiful ambition in ....

belike this show imports the argutnent

this show meant? (rep.)

to show, he ll not shame to teji you

mineral of metals base, shows itself pur

nothing, but to show you how a king

shows no eause without why the ma! dic
to show yourself in deed your father's son

to show yourself in deed your
that shows his hoar leaves in

zounds, show me what thou'lt $\ddot{d o}$

tlie field, but here shows mucit amiss.....

throwing but slows of service on their.

I must show out a flag and sign ....
gives me this bold show of eourtesy

one unperfectness shows me another

at first with heavenly shows, as I do no
thou dost love me, show me thy thoug

show the love and duty that I bear you

pranks they dare not show their lusisbne

courage, and valoutr, this night show it

show you such a necessity in his deatl

this nct shows horrible and grim

my mistress showed me thee

rou have showed ine the........ mpest, i.

kiudness gou have showed mise... Twerry Wives, ii. 3

and showed, thou mak'st some tender - v.

it better slowed with you........2 Henry $I V$ iv. 2

there wat neessity belonged... Timon of

When I have showed the unfitness

and showers of oaths did melt.. Mid. N.'s Drean,

a shower of commanded tears. Taming of Sh. I (ind.) the her' I showed thee once .... Mitl. N. Lream, ii.
he was, he showed a monnting ... Love's L. Lost, jv. till this man showed thee?

- v. 2 thou show'st a noble vessel .......... Richard II. i. v. 2 have more than thou show'

one of them slowed me a ring .. Mer. or Fenice, iii. ? Wlien thou show'st thee in a cliid

a king of slureds and they vented..... Coriolanus,

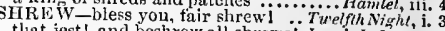

tliat jest! and beshrew all shrewsi. Love's L. Lose, v. 2

like a little shrew, slauder lier. Merch. of Fenice, $\mathrm{v}$.

a shrew of thy impatient huniour of storeu,

is she so hot a shrew as she'

how to tame a shrew (rep. iv. 2 )

to you they have showed some truth $:$ - ii.

new reaped, showed like a ftubbl

that have showed themselves lume ... Hewry $l^{\prime}$. i.

how showed his tasking? Seemed it payment, showed unto my father. yourself, you showed your judgment - iv. in courtesy showed me the eastle.... Kichard III. ii that stood, showed like a mine .....Henry $\overline{\text { H }}$ III. i. hath showed him gold ................

thoit hast the veriest shrew of them all

but liast tamed a curst shrew

wome a slirew, you first .. Comedy of Errors, v.

SHREW_'slirew my heart 2 Henry IV. v. 3 (song)

shrew me, if I would lose it for..... Ch Ch

prove a shrew'd Cæasar to you .....Meas. for.Meas. ii.

or else

she is keen and shrewd ................

and a shrewd unhappy gaj]ows too...... Love's $\bar{L}$. Lost, $\mathrm{iit} .2$

there are some shrewd eontents... Mer.of Venice, iii.

that have endured shrewd days ... ds you Like il, y.

a shrewd knave, and an unhappy.......

should have showed us his marked in't - iii.

wherein they showed most valour

alt boats alike showed mastership

and therein showed like enemios

though I showed sourly to him) once

Wish thee to a shrewd ill-favoured wife

as eurst and shrewd as Soerates'

ah, foul shrewd new'sl............... i.

to lift shrewd steel against our..........King John, y.

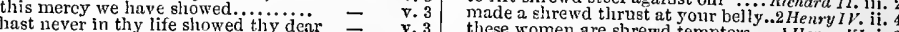

you showed your teeth like apes ..Julins $\overline{C r e s a r}$, v. 3 these women are shrewd tempters ...1 Henry VI. i.

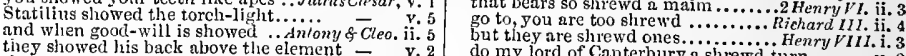

the mountain top Pisanio showed.. Cymbeline, iij. 6 he has a shrewd wit, I can tell ... Troilus \& $\bar{C}_{\text {ress. }}$. .2

the very gods showed me a vision..... - iv. 2 fiod of him a shrewd eontriver....Julius Casar, ii. I

gnod sooth, it showed well in youl. TilusAndron. ii.

so muel duty as my mother showed .... othello ii.

HOWED'ST a suljeet's shine........... Pericles, i. 2

SHOWER-refreshing showers.

this shower sing in the wind $\ldots \ldots \ldots$. . . Tempest, iv.

dust with showers of blood

faster than spring-time shower......2 IIen $r y V$

sunshive brewed a shower for

I shower a weleome on you

as sun, and showers, there hind .. - iii.

one eloud of winter showers ... Timon of Alhens, v. ii.

and the eommons made a slower ... Coriolanus, it.

I'll set thee in a shower of gold......

Apri] shall with all bis shower

With true-love showers
sHOWERED on me dail

SHOWERING on your head

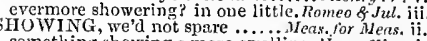

snmething showing a more sweiling. Mier art ore. i.

showing, as in a model, our firm ...R Richard $1 \mathrm{IJ}$. Hi.

lest he, by showing it, should .........Henry ro iv.

by showing [Knt,-shall show]. Troilus o Cressidn

for showing me again the eyes.

seal your knowledge with showing then -

koft society, and great showiug ........ Hamlet, $v$

and sir Hugh hath slown himself.ilerry H'ives, ji. 3

your receiving, enongh is shown. Trelfh Night, iii. I
in rour waking shall be shown ... Mid. N.'s Dr. iif. 2 and fears by pale-wlite shown..... Love's L. Lost, i. 2 so grossly shown in thy behaviours ... All's Well, i. 3

in babes hatl judgment shown

his valour, slrown upon our crests ... i Henry $\vec{r} V$. v. 5

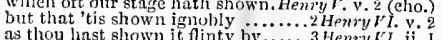

as thou hinst slown it flinty by.......3 Henry HI. ii. I
he had shown it in his looks ...... Rickard III. iii. 4

shown ot full their royal minds .... Henry VIII. iv.

goodness, sorry ere 'tis shown .. Timon of Athens
when I might have shown myselt' ..

now we have shown our power .... Coriolanus, iv. 2

be shown for poors i diminutives.... Antong Cleo. iv. 8

have shown to thee sueh a declining

shalt be shown in Rome, as well as I

to keep it slat, than shown $\ldots \ldots \ldots \ldots . . . .$.
whom the gods have shown their power
where shall be shown you all was found

whiere shall be shown you all was found - v.

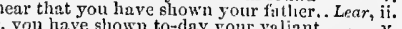

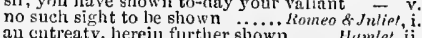

'tis a shrewd doubt, thongh it be but a.. Othello, iii. 3
SHREWDYY passed upon thee you apprehend passing shrewdi. .....Much Ado, yi. 1

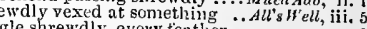
'tis shrewdly ebbed, to say ...... Winter's Tnle, v. 1 mistress shrewdly shook your back ...Henry $V$. jit. 7 my fame is shrewdly gored.. Troilus \& Cressida, iii. 7 the air bites shrewdiy; it is very cold .. Hamlet, i. 4 SHREWDNESS ot policy too ...Antony of Cleo. ii. 2

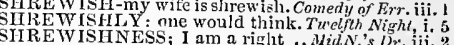
SHREWSEURY. My father $\ldots . \ldots . .$. Hentry $1 V$. iit. eleventh of this month at Sluewsbury - iii. for, sir, at Shrewsbury, as $X$ am truly $=\quad$ iv. a bloody field by Shrewsbury $(r m p.) \ddot{2}$ Henry $\bar{l} V$. (ind. certain news from Slirewsbury (rep.)

sinee done good service at Shrewshury
before yonr expedition to Shrewsluury

your day's service at Shrewsbury t...
was young

prease at Shrewsbury

lord Talbot carl of Slirewsbury .... Ihenry $r$. iji. 1 SHRIEK-that they should shriek ...Wid. N's Dr. i. 2 then I'd shriek, that ever, your ears.. groans, and shrieks that rent the ...... Nacbeth, iv. What noise? what sliriek is this?. Troilus \& Cress. ii. lady shrieks, and well-a-nearl.. Pericles, iii. (Gower) what sliould it be that they so sluriek SIRRIEK ED-so eried and shrieked... Nerry $\bar{W}$ ives, $\mathrm{v}$. and he shrieked ont aloud........... hichard IIt. i. 4

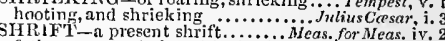
futher now hath done lis shrift.....3 Henry IJ. jii. by thy stay, to liear true shrift .Romeo \& Juliet, i. I eonfession finds but ridkling slurift .. - ii got leave to go to shrift to-day ...... - ii. seem a sehool, his board a shrift ....... othello, iii. 3 slirill echoes from the .. T Taming of Shrew, 2 (jndue.)

With this shrill addition ............ Henry ${ }^{\prime}{ }^{\prime}$. ii. poor Andromache slurilis Jier..... Henrnilus s. Cress. $\mathrm{y} .3$

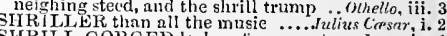
SHRILL-GORGED lark so tar eannot.... I ear, iv. 6 SHRILL-SOUNDING throat awake.... Hnmlet, i. is she shrill-tongued, or low? madam - iii. 3 I RULI Y-quillets sliriliy.... Trinnn of Athens, is. 3 replying shrilly to the well-tuved. Titus dndron. ii. 3
SHR IMP - a ehild, a shrimp ....... Love's L. Lost, $\mathrm{v} .2$ SHIRIMP-a ehild, a shrimp ....... Love's L. Lost, . 2
this weak and writhled shrimp .... I I Ienry VI. it. 3

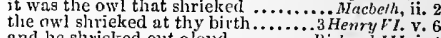


SIIRINE, this mortnl..........erechunt of Fanice, ii. ?

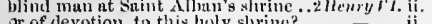
or of devotion, to this hoty slirine?

aming the shrine of Vemus ......... Cymbetine,

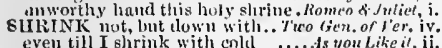
even till I shrink with cold .....As you Like i, ngainst this fire to 1 shrink uj....... King John, v. 7 that he shall slirink under my lichurd IV. ii. when he pereeived ine shrink. to shrink mine arm up like a... Henryl'l. iv. 5 a friend will not shicink from him. Henry VIJ. iv. 1 and his estatc shrinks from him l'imon of thens, iif. 2 ground slarinks before his trealing.. Corrolenus,

getested life not slirink thereat. Titus A nirou.
sIIIRINKING for distress, but ..... I Henry $\%$. 'Troy shrinkiug [Col-slırieking] 7 roilus \&-cress. and the shrinking sinves of winter.. Cymbeline,
SilRIVE me tlian wive ne .. Merchant of renice,

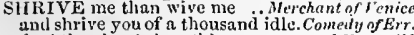

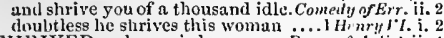
SILRIVED and narried.

SIIRIVELED up their bodies............. Pericles, ii.

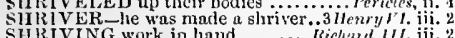
SHRIVING work in hand

SHIROUD, till the dregs of the storm ... Tempest, ii. my shroud of white …..T' selfh $N$ ight, if. 4 (song)

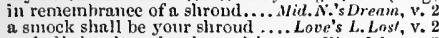
and all the slirouds wherewith........ King John, v. brnke we'll shroud oursclves ......3 Henry I'I. ili. 1
how to shroud yourselt from cinemies? - iv. 3 of Eroun

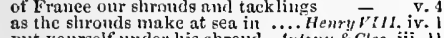
put yourself under his shroud......niny \& Cleo. iit. il with a dead man in his shroud.. Romeo of Juliet, iv. I lies festering in his shroud $\ldots . . . . . .$. - iv. 3 gliroud as the mountain snow.. Hamlet, iv. 5 (song) shroud me in one of those same shcets, othello, iv. 3
siltroUDED in this bush ......... Love's L. Lost,iv. honour may be shrouded ii a hearse. Rieharnllil. i. never shrouded any lout lazars.. Troilus \&-Cress. ii. 3
shrouded in eloth of state; bulmed..... l'erieles, iii. 2

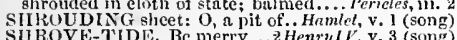
SHROVE-TUESDAY, a morris for ...Al's Well, ii. SIIRUB-here's neither bush, nor shrub. Tempest, ii. 2 mine arm np like a withered shrub.3 Henry 1 . ini. 2 We are but shrubs, yo cedars we... Tihus. Indron. iv. 3
sIIRUG - with a patient slurug ... Merch, of I'pnice, i. 3 the shrug, the hum, or ha (rep.)... Winter's Tale, ii. attend, and slirug, i' the end, admire. Coreolanus, i. 9
slikUG'ST thou, malice? $\ldots \ldots \ldots \ldots \ldots$ Tempest SIIRUNK-for his slurunk slank ......... Tou Like it, ii. 7 one of you will prove a shrunk pannel - iii. 3 shrunk to this little mensure. a man shrunk up with cold

borrowed likeness of shrunk denth. Romeo \& Jul. iv. I

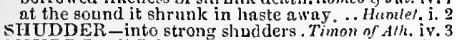
SIIUDDERING fear, and........Merch. offenice, iii. 2

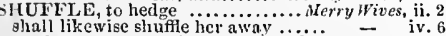
olıall likewise shuffle her away ....

sLond master, must shmffle for ilself. Combeline, v. 5 we have ghuffled off this mortal coil . Wamlet, iti. there is no shuffling, there the aetion... Haute $t_{\text {, iii. } 3}$

sr with a little slanming your may........, - iv. 7 coth evitate and shum a thonsand...Merry ives, y. 5

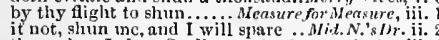
thus when I shun Scylla .. Merchant of terice, iii. who duth ambition shun ... As you Like it, ii. 5 (song)
who shuns thy !ove, shuns all his love. All'silelt, ii. who shuns thy love, shuns all his love. All shun your house. Taming of Sh. 2 (ind.)

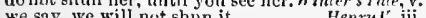
let him, whun

I would not shun their firry Henryl. iit to shun the danger tliat his soul... Richari $1 I I$. my desert unmeritable, shuns your. von cannot shnn yourself ....... Troitus \&. Cress. iii. like beasts which you shui beastly .. Cymbeline,
by flight I'll ghus the danger .......... Pericles, by flight I'll shun the danger thou'dst shum a bear

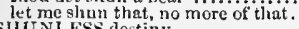
SIIUNNEi) the fire Two Ge... Coriolanus, it. 2 that I ever yet have shunnci........... of terom, ii. the mouse ne'er shunned the cat ..... Curistrnux, shumnel to go even with what ...... Ciymbeline, ghunned my abliorred sneicty ........... L.pur, ghunned who gladly fled from me.kmmen fulipt, i. silu NNING-I advise your shuming. Sli hear, the Volsces slumning lim

"lempest,

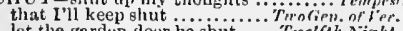

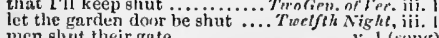
men shut their gate.................. awny this villnin; shut him up .. Love's L. Lost, i. 2 whiles we slunt the gate non one...Ver.of Finice, $\mathrm{i}$. who shut their coward gates on........ gon t.ike it, iii. 5

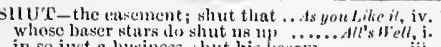

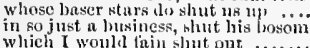

so grieving, tlunt he shuts up. Winter's Tol

own doors being slut aguiust. Comedy of Li, roms,

upon me the Enilky cloor's werd

the abluess shuts the gates on $\mathrm{ns}$

asuinst his murderer shut the ino.........

and shut up in muasurcless cuntent.

shint the door: there somes

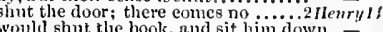
of mercy slabl be all shut up

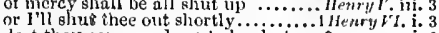
lost thot command me to be sliut out?

compelled to shut our slops ........

lialberds did shut mp his passage..

shut the gates for safety of oursclves
must not be shut, but in the night

政.

minds of all sliould be shut up ....Troilus S Cress. i. 3

let's shut our gates, and sleep.

to those have shint him uy....... Thinon of athers, $\mathrm{i}$.

all the wealth I have, shut up in thee

our gates, which yet scem shut they.....

hence, and shut your gates ipon us.

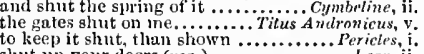

shut up your doors (rep.)

shut your mouth, dame, or with

slints up his rind dars.

shut up in prison kept withont.......

or those cyes shut, that make thee

or slut ne niglitly in a charnel-ionise

denth when lie shuts up the day of lite

holiday, the beggar's shop is shut...
let tlye doors be shut unon him

as if thou then had'st shut op in thy..... Hnmell, iii.

\section{leave procreants alome and slut the...}

SHUTTLE-life is a shuttle..........Merry Wives, v. I

niay seen as sluy, as grave ….......

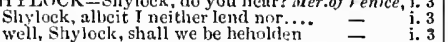

you say, Shylock, we would have...

Shylock, thy master, spoke with (rep.)

difference rifold Sliylock and Bassanio

Shylock, for his part, knew the bird

Shylock, the world thinks, and I thïn

and old Shylock (rep.) ...............

have by some surgeon, Shylnck .......

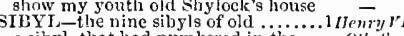

a sibyl, that had numbered in the .... Ohello, iij. 4

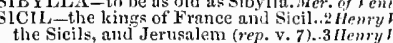

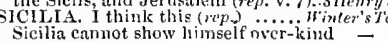

what means Sicilia? Hc Homething..

lementes, king of Sicilia.

of that fatal country Sicilio...........

and lay asice the thoughts of Sicilia.

make for Sicilia; and tlie'c present....
I shall review Sicilia; for whose sight

have I here touched Sicilia.........

Sicilia, and Jerusalem ....2Henry Fi. i. T (arlicles)

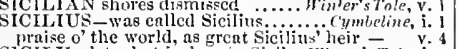

praise o' the world, as grcat Sicilins' heir-'
lCILY- let what is dear in Sicily. M'inter's $T$ al
unr shall appear in Sicily, - my lord

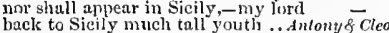

you have made me otter of sicily

having in Sicily Sextus Pninceius.

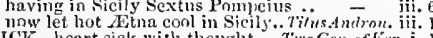

when I was siek, you gave me.

I am sick. till l sce her
rou are sick of sclf-love

Y an sick or not at home

I told him you were siek

that longing $I$ have been sick for......

at this instant he is sick, my lord ......

liow then, sick? Neither (rep.).

how Benediek is sick in torve witi

dn you speak in the sick tune?.......

by my troth, I am sick

nrt thou sick, or angry?

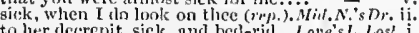

is the fonl sick? sick at the lientit....

that the lnver, sick to death .... - iv. 3 (verses)

bear with tne, I am sick .

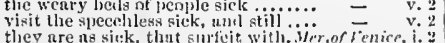

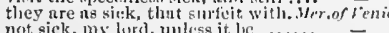

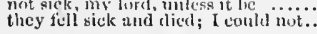

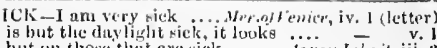

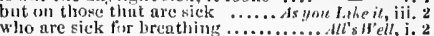
licr eyc is sick on't; l dlscerve her now -

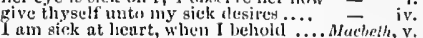

nnt so sick, my lord, us ghe is......... - v. 3

far 1 am sick, nurl crpable of fears ...King Johen, iii, I

but you at your siuk service $\ldots . . . .$. .

linkes anuth opinion sick, and truth
the child himself felt he was sick ....

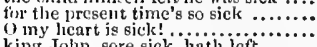

king John, sore sick, hath loft

not sick, althongh I have to do ....... nitinard II.

can sick men pliny so nic

now comes the sick hom tiout

yick and blunter with somm it......

ick. Zumads! how has (rep.)

sick now! Droop now! this sickness - iv.

would have male me sick, heing sick.2 Henryl

I heard say, your lordship was sick..

their fathers being so sick as yours.

inwardly, that my father is so sick.

though that be sick, it dies not

rank ninds, sick of happliness

should these good news make me sick?

if he be sick with joy, he will...
poor kinglom, sick with civil...

poor kinglom, sick with civil...

he is very sick, and would to beil ......Henry $r$. ii.

his soldiers sick, and famished.

do as evcry sick man in his bed....... - iv.

in his litter, siek, came to.......... litenry rl. ivi. 2

with weeping, sick with groans ....2 Ifenry $V l$. iii. 2

my wife is very gricvons siek (rep.). Richort III.iv. 2

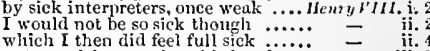

put my síck cause in to his liands....

0 Grittith, sick to death: my legs.... = iv.

he fell sick suddenly, and grew so ill
thank ye, she will be sick else ......

unless they are drunk, sick ... troilus \& Cressida, i. 2

the enterprizc is sick!

that is sick of his superior $\ldots \ldots \ldots \ldots .7=$ i.

not sick. Yes, lion sick, sick of biroud = ii.

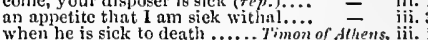

weep their cliambers, are not sick....

I am sick of tlant gricf too .......... =

hang his poison in the siek $\mathrm{air} \ldots \ldots \ldots$. $\quad$ - iv. 3

that nature being sick of man's......

nor sanctiary, heing naked, siek .... Corintanus, i. 1

some drink, Titinius, as a sick giri.julizu $\bar{C}$ etsar, j. 2

you bare some sick offence within...

here is a sick man, tliut would..... - i.

mak, he is sick. Sliall Casar scrit.....

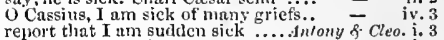

I an sick, and sulen. I am sorry ... - i. 3

with pity, that doth make me sick .... Cymbeline, i. 7

if you are sick at fea ..................

as to secun to die, ere sick............... = iv.

I nm not very sick since I can reason
$\mathrm{nm}$ sick still; licart-sick: Pisanio..

pray, be not sick, for you must be .... - iv.

than one that's sick w' the gout ....... =

sny, I am sick: if y'ou come slick

sick, $U$ sick t if not, l'll ne'er tri

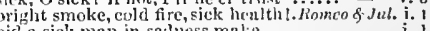

who is alrendy sick anul pale with grief - i. !

vestal lirery is but sick and gren.... - ii.

youl te be siek to morrow for this .... - iv.

here in this city risitin\& the sick ....

was sick alminst to doou'seday .......... -

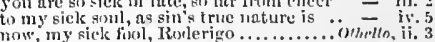

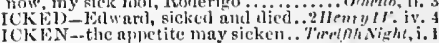
that his enul sicken nut.... Mewsure for Yrensure, ii. 4 the more one sickens, the worse... s yon L,kit, iit. 2 cven till destruction icken, answer .....uscbelh, iv. 1

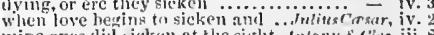

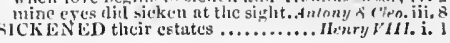




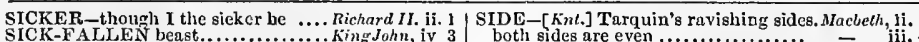
SICK-FALLEN beast................. KingJohn, iv 3 SICKLI IED o'er with the pale cast ....... Hamlet, jii. SICKLINESS-to wayward sickliness. Rirhard II. ii. then, if sickly ears, dea fed with ... Love sL. Lost, y. 2 she has raised me from ny siekly bed. All'swel, ii. 3 wear our health but sickly in h and henee, thou sickly quoif $\ldots \ldots \ldots \ldots$. $\ldots$ Henry $I V$ i. I

the king is sickly, weak, and ...... Richard III. i. is this thy vow unto my sickly heart

this siekly land might solace as before
for he went sickly forth ............Julius Cesar, ii. 4

as we were sickly prey $\ldots \ldots \ldots \ldots \ldots \ldots$. the indisposed and sielly fit for the .... $L$ ear, ii pliysie lout proloogs tlyg siekly days ... Hamlet, iii. 3 but a sickly part of one true sense ....... iif. 4 or sickness did lay siege to it.....ilid. N.'s Dream, i. siekness is catching: $O$, were favour

hut like in sickness, did I loath.....

go, sickness as thou art! ..........

thess, or else. Taming of Shrem iv.

thicre is a siekness which puts some. Winter's ?ale, a sickness caught of me, and yet I well

'tis a sickness, denying thee any tbing

we feared, his siekness was past eurc. KingJohn, iv.

O vanity of sickness! ficrce extreme

join with the present sickness that.. Richard 11. ii.

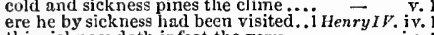

this siekness doth infect the very .....

your father's sickness is a maim to us

nith the siekness of Northumwerland

till his friend sickness hath determin
siekness growing upon our soldiers ..

政

fitter for sickness, and for crazy age, $\mathrm{I}_{\text {Henry }} V I$. iii. 2

a grievous sickness took him $\ldots \ldots . .2 \mathrm{2H}$

procecds from wayward siekness ...Richard III. i. 3

had the king in his last sickness .... Henry $V^{\prime} I I$. i. 2

eagerly his sickness pursued him ......

the nature of the siekness found.. Troilus \& Cress. i. 3

of any power to expel siekness. Timon of Ath. iii.

whielı argues a great sickness in his..

my long sickness of liealth, and living $\overline{-}$

I here discard my siekness

upon what sickness? Impatient of m

her length of sickness, with what.Antony \& Cleo. i. 2

nat siekness should detain me ....... ii. 2

bid my woman feign a sicknes

this siekness grows upon m

that so his sickness, age, and impotence. Hamlet, ii.

it warms the very siekuess in my heart

SICYUN how the news? (rep.). Anlony \& Cleopatra, $\vec{i}$.

ulere died she? In Sicyon $\ldots . . . . . .$.
SICINIUS-Junius Brutus, Sicinius ... Cor

what, ho! Sieinius, Brutus, Corjolanus - iii. I

speak, good Sicinius. Hlcar me. people $-\bar{W}_{\text {iices, }}$ i.

elose by the Thames' side.

I will kcep my sides to myself.......
backs, shoulders, sides, aid shins ....

Taurus? that's sides and heart ...Twelfh Nigh, i. 3

how quiekly the wrong side may be

drew on my side; but in eonclusion...

ingrateful boy there, by your side.

angcl on the outward side! ............. for $\bar{M}_{\text {eqs. }}$ iii. 1

whose western side is with a vineyurd - iv. 1

it keeps on the windy side of eare........ u $u c h$ Ado, ii.

turns she every man the wrong side out
dost thou wear tliy wit by thy side?

often hath she gossippied by my side.Mid. $\bar{N}$. Dr. ii.

then by your side no bed-room .

and the Athenian wornan by lis side

as if uur hands, our sides, volees ....

Armatho o' the king side

and his page o' t'other side.

writ on both sides the leaf

this side is Hiems' winter .............. $=\quad v_{2} \cdot 2$

but my gentle vessel's side...Merchant of renice
never sliull you lie by Portia's side...

see this broken music in his sides?. As vou Like

and pouch on side; his Jouthfut

apurs lis horse but on one side

二 $\begin{array}{r}\text { iii. } 2 \\ \text { iii. } 4 \\ \text { ' } v e l l, \text { ii. } 3\end{array}$

damnable, both sides rogue .............. - iv. 3

sit by my side, and let the.. Taining of Sh. 2 (ioduc.)
our eake's dough on both sides..............
eracks his gorge, his sides ........ Winter's Tale, ii. 1

eracks his gorge, his sides .................

sometimes her head on one side....
you had been by the ship side $\ldots . .$. - iii. 3

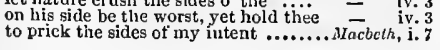

both sides are even.... brother by the mother's.............

ut of one sidc her lappy minion.

strong upon the stronger side

spoke like thunder on my side?

which is the side that $I$ must go

on that side shanl I lose..................

upon our sides it uever shall be...

laod will let rie, by your side.

revolt on Hereford's side: sir
where one on his side fights

tly irom my side; for time ...........

二

ondst fice side to the othcr turning

with like advantage on the other side

and ou this north side win this cape

against the panting sides of his poor. 2 Henry $I V . i$. a shame to be on any side but on

and by his bloody side, yoke-fellow...Henry $y$.

did he sline upou the English side...

Henry ri. i. 1

appears so naked on my side

upon whose side the fewest roses

my verdiet on the white rose side.

on my side so against your will ......

witnessing the truth on our side

come, side by side together

fight by thy father's side

and 'stablish quietness on

gently on thy tender side.

is the shepherd beaten from thy side

dash me with their ragged side

were by his side; sometime...........

God on our side doubt not of

and both sides fiercely fought

she, on his left side, eraving aid

and sit thee by our side: yield not

come thou the forest siae.............

give my voice on Richard's side

and pry on every side, tremble and start -

but on thy side I may not be too

good angels fight on Piehmond's side

whose puissance on either side

are slain on either side?

whieh breaks the sides of loyalty ....Henry $\bar{v} 11$

to the water side I must conduct

on one and otherside, Trojan. Troilus \&

fools on both sides I Helen must
whose weak untimbered sides but

whose weak untimber

expectance here from both the sides

pasture lards the brothers' sides. Timo

the one side must have bale.

side faetions, and give out eonjeetural

know you on which side they.
on both sides more respect

these are a side, that would be gind.

and each, in either side give thee

be strong upon my sidel ...............

orchards on this side Tiber...

praying on his side, because $\mathrm{I}$...

one another in the sides of C
the legions on the other side

the legions on the other side ..........
the sides of nature will not sustain.
thou liast a sister by the motler's side $\quad$ i.

on each side her, stood pretty.
O Antony, stay not by his side.

as loud as his strong sides can $\ldots \ldots$. $\ldots i$ squadrons on yon' side o' the hil

our squadrons on yon' side $0^{3}$ the hili
on our side like the tokened pestilence

look out o' the other side your
and set thee by Jove's side

had been tables by lis side

can my sides hold to think, that man

on either side I come to speod my breath -

stand by my side, you ( $r e p$.

unon the-rapier by your side.... Titus Andro

he's your brother by the surer side

and by his side his fruit of

abuts against the island's si

pared thy wit o' both sides.

lis eyes on either side his
$O$ sides, you are too tougl.

your houseless heads, and unfed sides

of equity, bench by his side.

I bad turned the wrong side ou to save the blood on eitlier side

tive flower-de-luces on eaeh side

and on all sides the authority allowed

priests and servants from your sides

$O$ eleave, my sides! lieart.
S1DE-liardly sliall I carry out my side.... Lear, $v$.
the common bosum on his side ......... take the law of our sides (rep.); . Romeo $\&$ Jutiet, $\mathbf{i}$. westward rooteth from the city's side a good quarrel, and the law on my side coming from this ehurehtord side.

for so this side of our known world $\ldots . . . \overline{\text { Ham }}$

been muel to do on both sides ........... -

if we could carry a eannon by our sides

- $\quad$ v. 2

they bleed on both sides: how is it.........

messengers are here about my side ..... Othello, i.

turned almost tlie wrong side outward .. = ii.

slie might lie by an emperor's side $\ldots \ldots . .$.
turaed your wit the seamy side without - iv.

hang my head all at one side, and sing.. - iv.

ay, ay $\mathrm{O}$, lay me by my mistress' side!.. - v.

SIDE-PIERCING sighti “Nature; 3 nove . Lear, iv. 6

SIDE-SLEEVES, and skirts ruund . . Nuch Ado, iij. 4

SIEGE of this moon-calf................

upon the very siege of justice ... Nleas. for Meas. iv. 2 or siekness did lay siege to it ... Nid.N.'s Dream, i. 1
lays down his wanton siege before ..Al's Well, iit. 7 will laugh a siege to scorn preparation for siege, and stir....... King John, ii. and his siege is now against the....... beats back the envious siege of....... Richard $I I$, ii. 7 girding with grievous siege, eastles .... Henry $V$. i. 2 to whom the order of the siege is given - iii.

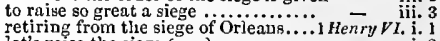
ret's raise the siege (rep.) ............ - i.

tear down, than forsake the siege.....

to raise this tedious siege

a great power to raise the siege........

horselnen, that were levied for this siege - iv. 3

after seven year's' siege, yet Troy. Troitus \& Cress, $\mathrm{i}$. to whom all sores lay siege .. Tinon of Athens, iv. 3
been to me as fearful as a sicge .... Cymbeline, iii. 4 she will not stay the siege of ...... Romeo \& Juliet, i. i to remove that siege of grict from her regard, of the unwortsiest siege.... Homlet, iv. 7 the battles, sieges, fortunes, that I have... - i. 3 SIENNA'S brother .................. Cymbeline, iv. 2

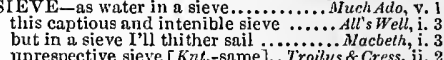

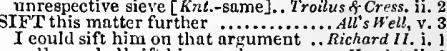
well, we shall sift him: welcome ...... Hamlet, ii.
SIFTED - thy thought were sifted ...i Henry VI. ii. SIGEIA tellus (rep.).......... I aming of Shrew, cooling of the air with sighs............... Tempest, witls leart-sore sighs......... Tiwo Gen.of Verona, $\dot{\mathrm{i}}$. to sigh, like a sehool-boy ............. drive the boat with my sighs ...........
and daily heart-sore sighs $\ldots . . . \cdots \cdots$ sad siglis, deep groans $\ldots . . . \ldots \ldots . . .$.

you sacrifice your tears, your sighs ...
to that l'll sigh and weep.............

with sighs of fire.................... Twelfh $\bar{N}$ ight, i. a thousand thousand sighs to save - ii. 4 (song) thus advises thee, that sighs for.. - ii. 5 (letter) and sigh away Sundays ................Much $1 d 0, \mathrm{i}$. sight no more, ladies, sigl no more - ii. 3 (song) then sigi not so, but let them go

what? sigh for the tootlinacli?

she eoneluded with a sigh, thou wast -

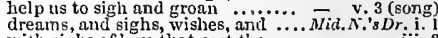
with sighs of love that cost the ........ sigli a note, and sitrg a note......... - iii. sweet welkin, I must sigh in thy fac

a very beadle to a hunorous sigh.....

and I to sigh for her! to watch fur lier

love, write, sigh; pray, sue, and groan

saw sighs reek from you
of sighs, of groans. of sorro

and sigh, and say, amen; use all . Mler.of Venice, $\ddot{i i}$. no sighs but $o^{\prime}$ my breathing.$\ldots \ldots$ - $\quad$ iii. 1

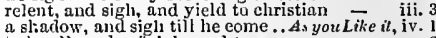

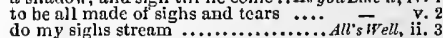

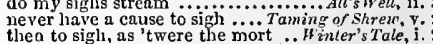
thea to sigl, as 'twere the mort . Hinler's Tale, i. the earcer of langhter with a sigh?

and do sigh at each his needless ....
thou dost but sigh, that thou no more where sighs, and groans, and surieks... Macbeth, iv.
what a sigh is there? my heart will sigh, when $\mathrm{r} . \ldots \ldots \ldots \ldots$........ Richard $I I_{\text {i }}$ i. 3 our sighs, and they, shall lodge.

with sighs, they jar their watches.....

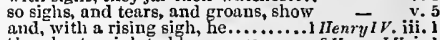
thou hast a sigh to blow away .......2 Henryl $V$. i.

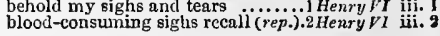




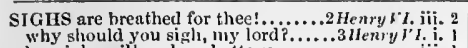
her sighs will nake a battery............
blood-suck $=$ iing sigls. lest with my sighs and many an old man's sigh ........

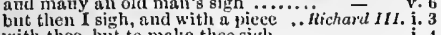
with thee, hut to make thee sigls .... - i. as wedged with a sigh ......... Trnilns of Cressida, i. I why sigh you so profoundly? with so many thousand sions did........

and siglis, and takes my glo

out of your gutes with sighls ........... Coriolantes, v. winds und waters, sighs and tear.s.... dutony of Cleo. i. then shall the sighs of Octavia

lie furnaces the thick sighs from hin. Cymbetine, i. 7 Winilin witl a sigh (rep)

gmiling with a sigh (rep.)

twiee o'er, I'll weep, and sigh.

or with our sigls we'll breathe ... Tilus Andron. iv.

hark, how her sighs do blowl.

my sea be moved with her sighs

with sighs shot through ..............

with a sigh like Tom o Bediam

$\overline{7}$ iii. 2

a smoke raised with the fune of sigls

appear thou in the likeness of a sigh

the sun not yet thy sinds, thy sigh

\&. Juliet, $\mathbf{j}$.

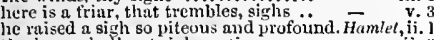

the lover shall not sigh gratis.

never alone did the king sigh

is like a spendthrift sigh

for my prins a world of sigh

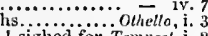
ghed his soul tow'ard the Greeian Mer.of i"en, $\mathrm{y}$. i sighed upon a midnight pillow . As you Like it, ii. 4

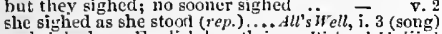
and sighed my English breath in ... Richard II. iji. sighed forth proverbs................. Coriolanus, $\mathrm{i}$. never man sighed truer breati 1 ......... and sighed, and kissed

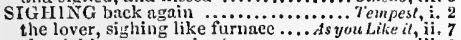
the lover, sing minute.

a plague of sighing and griefi......... Herry $I V$. ii. 4 hecame sighing mister the

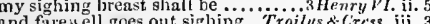
and sighing, with your arms....... Jutius Cossar, ii. I wound it with sigling, girl ... Titus Audronecus, iii. 2

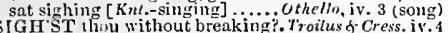
SIGHT hut mine .................... Tempest, i. 2 here's a goodly sight return no more into my siglit .. TuoGen, of b'er, j. 2 you may say what sights you see

or ne'er return agrain into my sight

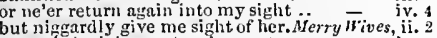
upon their sight, we two in great .... - iv. 4 fivour to the youth in rour sight ouly _ iu my sight she uses thee kindly - iii. 4 (ehali.)

out of my sight!
stiek it in their ehildren's sight........ Areas. for Meas. i. 4 nature vever in the sight [ [ ol. Knt.-fight]

as bring me to the sight of lsabelia.

you shall not be admitted to his sight - iv. 3 the sight whereof, I thiok....

we must starie our sigh

corne not within his sight

nis sight...........

so, at his sight away his fellows fly

the love-juice on some true-love's sight

true delight in the sight of thy furmer

gee'st thou this sweet sight?.

I trust to taste of truest 'Thisby's sight - iv.

wear the favours most in simht.........

be pity to see sueh a sight............

the acenstumed sight of deatl makes

none could be so abused in sight as he

that loved not at fir'st sight

never eome in my sight more ........

be out of the sight of Orlands

in sight, you are my daughter ( $r e p$.

if sight and slape be true, why then $-\bar{v}$.

the city we shall bese all whe cisht

and at the lather to our sirht

whose sudder sight liath thralled.....

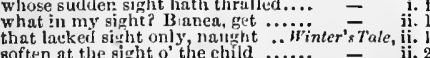

not ten at the sight o the chid

here's a sight for thee; look thee....

feteh me to the sight of hitn .....
will he endure your sight as yet

purehase the sight again of dear, $\ldots$. =

for whose siglit I have a woman's longing-

and show our strange sichts

then have you lost a sighit, which

and in our siunt, they three were. Cönedy

and that will elear your sight ........

semsible to feeliog, as to sight?
SIGIIT. A foolish thought (rew.)....

sweep him trom my sight $\ldots \ldots \ldots \ldots . . .$.

you can behold sueh sights, and $\mathrm{k}$ seep

whint sights, my lord?................

but no more sights! where are

and amazed my sight; I think .....

1 cannot brook thy siglit

how of the siglit of means to do

out of my sight, and never see
crest-fallen in my father's sight

anointed in his sight, hath eaused...

to endure the sight of day

you will, so I were from your

but is aweary of thy eommon si

to fly out of your sight, and ruis.

his dimensions to any thick sight $\ldots$...2Hen -13

sparkling through sighits of

and now my sight fails, and my brain

upon thy siglist, my wrorldily

rearlful will not be, as was his sight.i Henry $t^{\prime}$ i.

the sight will mueh delight thee

by sight of these our baleful ........

her sight clid ravish; but her

abase our sight so low, as to

hath reecived his sight ; a man

althougl by his sight his sin be.
sight niay distinguish of eolours

sight niay distinguish of colours $\dddot{2}$ in siglit of God, and us, your guilt ig

take henee that traitor from our sigh

kill the imnoeent gazer with thy sirit

my earnest-gaping sight of thy laud's

and in thy sight to die, what were

even iu their wives iud children's sight -

the sight of me is odlious in their eyes

even at this sight, my heart.

the sight of any of the house of York.3 Heñyltr. i.

the see this sight, it irks my very soul

mine own lanil with my wislaful sight

I here protest, in sight of heaver
out of my sisht! thou dost infeet

what makest thou in my sight

what siglits of ugly death....

draw the brats of Clarenee out of sigist

then bring me to their sights .......
blind siglit, poor mortal living ghost

disgracious in your sight [Col.Knl.-cye]

pageants, and sights of honour

pageants, and siglits of honour $\ldots$...Hen

'll show your grace the strangest sight
Argus, all eyes and no sight.. Iroilus

through the sight I bear in things

sing any man at first sight...........

most hingrily on your sight .........

and the bleared sights are spectaeled Coriolan 2
down stretch below the beam of sight

take up the olasses of my sight

thy sight, which should make our eyes - v.

three of us have seen strange sighti...

most horrid sights seen by the Hatel
O most bloody sight 1 we will be .....

my sight was ever thiek

mine eyes did sieken at the sight Antony of Cleo. iii.

a heavy sight! I am dying, Egy

was as a senrpion to her sight.

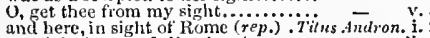

my sight is very dull, whate'er....... -

ever eye, with sight, made heart lament -
and see a fearfill sight of blood and death
for such a s!ght will blind ...........

made thee handless in thy father's sightit?

with this dear sight struek pale......

and be this dismal sight the elosing

fon, get thee from my sight ............

how desirous of our sight they ar

aloud they not their sights perpet

to glad the sight, and not so mueh

supposing once more put your siglat -...

hence, and avoid my sight

out of my sight! see hetter, I ear.

a but, val'et, trom my sight! .........

and the defieient sight topple down.

and, in your sights, shake patiently

flou side-piereing sight

fly sines leciner in my sight .............

a gight most pitiful in the meanest
the sight of the tlenth-praetised duke
this is a dull sight: are you not $k$ ent?

wo such sight to be show'n......... Romes of Jutiet,

forswear it sight l lor 1 ne'er $82 \mathrm{w}$

one short ininute gives one in lier sight
ont

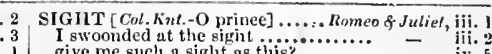

give me such a sighit as this?

pitiful sight! liere lies the county sian - iv. 5

(t) 3

and vanished from our sorlit

have hitherto concealed this sightit

or looked uyon this love with idle sight.

fecling without sight. enrs without han
twould be a sight indeed, if oue coukd

where is this sight? .....................

such a sight as this beeomes the.

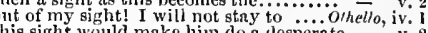

GHT ED like the basilisk........ Winter's Tnle i. a

GHop all sight-holes.1 Henry $I V^{\prime}$. iv.

horsed upon the sightless couriers of the Macteth, i. 5

unpleasing blnts, und sightless stains. King John, jii.

SIGIIT-OUTRUNNING were not .... Ternpest,

aign me a present pardon for.....Mleas. for Mer. ii. $\mathbf{2}$

let the sign of blind cupid

rather die than give any sign of..

iii. 2

boy, what sign is it, when a man .. Love's L. Lost, iv.

a great sign, sir, that he will.......... - i.

until the twelve colestinl sigos lave..

deed after me, and I will sign it. Mer. of venice, iv.

in sign whereof, please ye we ... Taming of $\overline{s h r e s c}, \mathrm{i}$.

and slinw more sign of her obedicnee -

$\begin{array}{lll}\text { though he does bear some signs .. "Winter's Tale, ii. } \\ \text { till, from one sirn of dolour to another } & \text { v. } 2\end{array}$

but signs of nobleness, like stars ....... Macbeth, i. 4

it were a good sign that I fhould ........... iv.

be these sad signs confirmers of ..... King John, iii.

with signs of war about his aged.... Richard 11 . ii.

these signs forerun the denth ......... -

leaving me no sign, save men's ...... = for tis a sign of love; and love to...

and dials the signs of leaping-houses. 1 Henryll $1 \mathrm{i}$.

smooth, like unto the sign of the leg.2 Henry $1 \%$ : ii. 4

the signs of war advanee .............. Henry $v$, ii.

in sign whereof (rep.iii. 4 )

- ii. 4

give me signs of future aceidentsi.....

It's sign of plighted fuath been libcril $\ldots \ldots \ldots . .$.

make my image but an alehouse sigu -

with tull as many signs of clendly....

wh, what a mign it is of evil life $\ldots . . . .$. -

no better sign of a brave mind

underneath an alehouse' paltry sign - iv

in open hand in sigh of love........3 Ifenry $/ \%$. iv.

slurieked nt tliy birth, an evil sign...... - v.

in sign of league and amity with..... Richard IIt. $\mathrm{i}$.

a sign of dignity, a breath, a bubble - iv.

you sign your place and calling . Ilenry 11 in. ii.

in sigu of what you are, not to ....... Chriolanus, i. 9

without the sign of your profession? Julius $\bar{C}$ arsar.

gave sign fur me to leave you ........ - ii.

it signs well, does it not? ...........

t!ou hast seen these signs.............

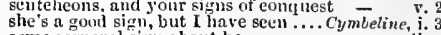

some eorporal sign about her ........ - ii.

these are no venereal signs.... Titus andronicus, ii.

sce, how with signs and tokens ...... - ij.

or make some sign how I may do

thaterstand her signs

I ean interpret all her nartyred signs

nor kneel, nor make a sign ...........

ye aleliouse painted signs! $\ldots . . . . . .$.

bitt if my frosty signs and ehajs of age - v.

a flag and sign of love, whielt is $(r \mu p.) \ldots$ Othello, i.

attending but the signal to our rage.. King John, ij.

atending but the signn to begin ...... Richarl $M$. i. 3

in signal of my love to the $\ldots \ldots \ldots$.... Henry l' l. ji.

give signal to the fight (rep. v. 4) ...3 3 Henry r. i. ii.

stir not until the signal............. Julins Corsar, v.

quated, ankl signed, to do a decil of. . Kinus John, iv. 2

signed in thy slobl, and crimsoned. Julius Carsar, iii. I

to them to use your signet .... Timon of Alhens, ii.

I hai my tather's signet in my purse ...llamlet, v. 2

SIGNIEUIR Dew sliould be $(r e p$.$) ....... Henry r$. iv.

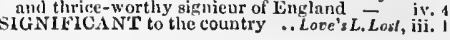




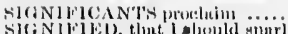

114eury'te

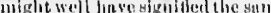

3llemrylli, $y$

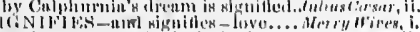

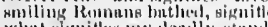

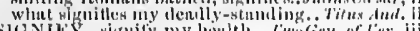

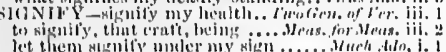

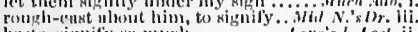

luste, nignily po mue?

thane's l. loost,

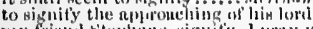

my friend steplumn, signity, 1 proy you

bif fure, to signify thecir combling ......

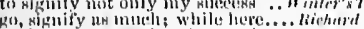

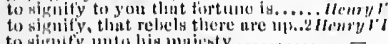

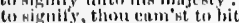

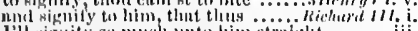

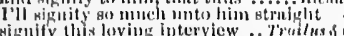

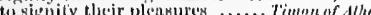

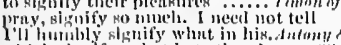

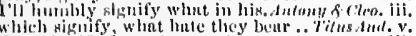

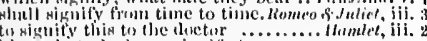

his nexjesty lonte me signify

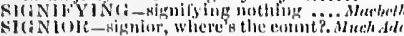

buy, - Signior. In my elunber-winlow

shlil सignion,

now, signhir! Whint news? (rrp.)....

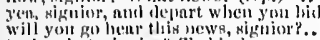

to do whet, niption? To bind ine

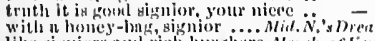

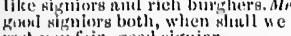

rest youl firir, goot si

good signior, tuke the atranger..........

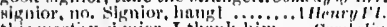

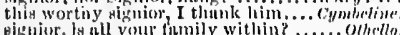

signior, it is the Mloor: Down with him

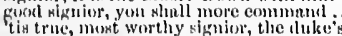

weicenc, gentlo sigrior; we luckerl your

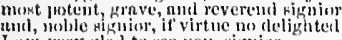

Intm very glat to sce you, signior

sicNolitis - through all the fignerice. Trm

you lave feel ungun my sipuotis

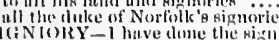

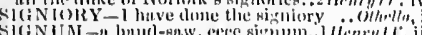

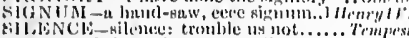

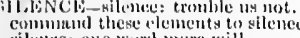

filenes one wort more will

年

the nifhth's dem silence wiil

lixt your nutnew; silenee, your airy.

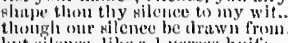

but tilenee, like $n$ laterece knife.

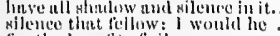

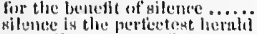

your silenee most oflently me

gilence, a while: jastoin, tnke ot

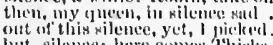

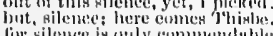

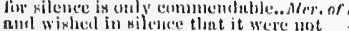

will alturtly turn inte silent:

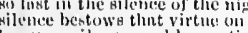

ler very nilenes, and ler patien.

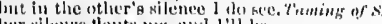

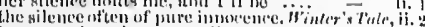

ili perstm here in eonirt: Hilence?

silenes, goul mother; hear the

silkence, no more; go elosecly in

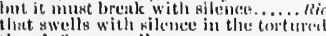

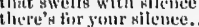

luw doth ny goud enusii

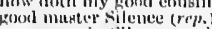

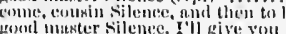

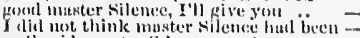

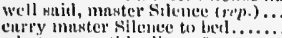

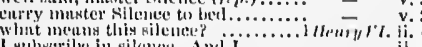

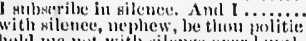

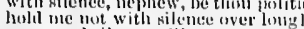

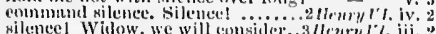

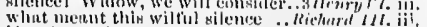

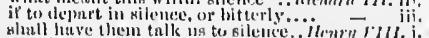

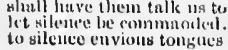

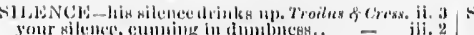
lont we in siltsee hosla this

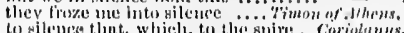

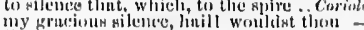

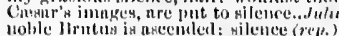

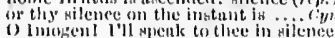

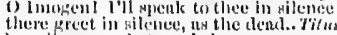

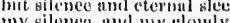

thon I swent wy pouly melancholy?

let it be tennlble in your silenee stili....

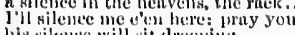

Jik sillente will sit trooping

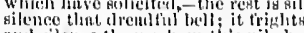

num tilone thuse whom this vile broin

Itambet,

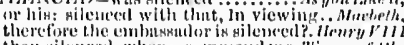

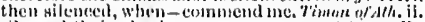

pilment their plenters.

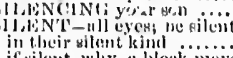

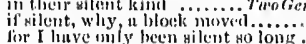

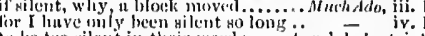

to be tor silent in their worls no....

this lesert silent les?

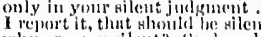

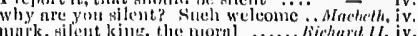

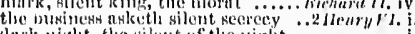

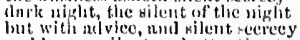

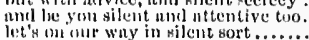

the sweet sileny murn of sort........ - iv.

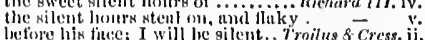

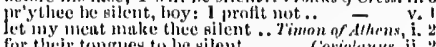

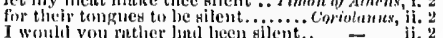

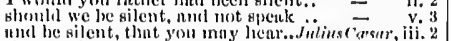

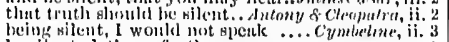

to silent; let's gee fiurther

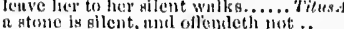

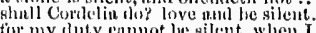

how silent is this towns low! inuriert

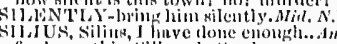

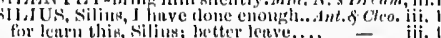

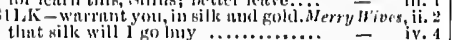

with sluetu'x his threut of wilis

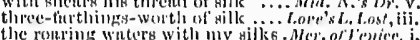

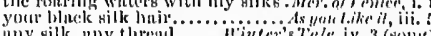

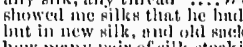

how muny puir of silk stocking

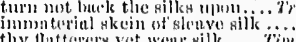

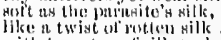

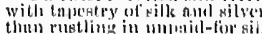

her inkle, nilk, twin with the ribibed

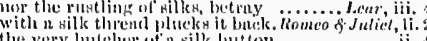

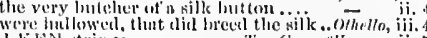

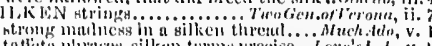

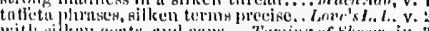

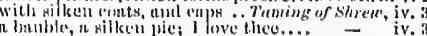

willeen cloublett in yelyet hoset

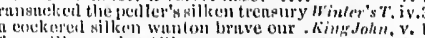

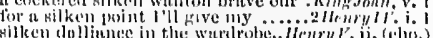

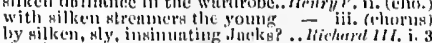

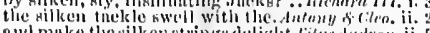

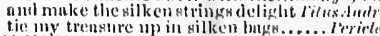

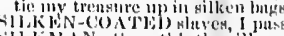

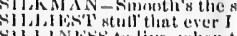

sild N Nise to live, when

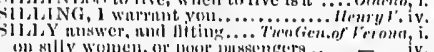

... Mnit. N.'slmercum, v.

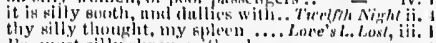

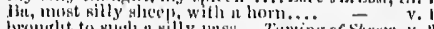

brought to such at willy pess . Temming ar sharem, vo

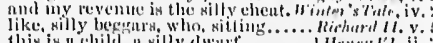

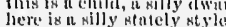

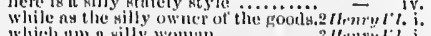

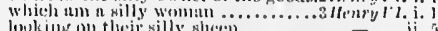

at silly time to suke preseription

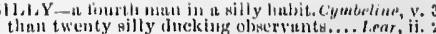

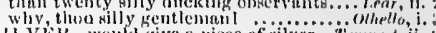
11.V bitt-woult give a piee of silver... Tempest, ii:

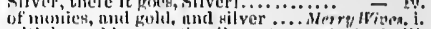

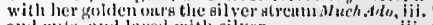

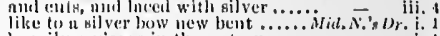
nor whines the kilver moon. Love'si..iost, iv. 3 (ver.)

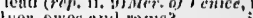
thic eceoul, gilver, which this promise

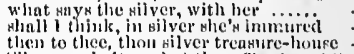

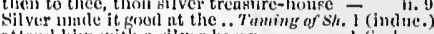

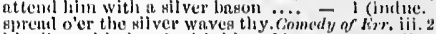

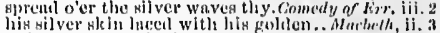

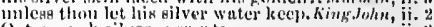

of two suets silver currents.

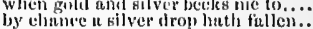

stone set in the silver sent

which makes the silver rivers trown - iii. 2

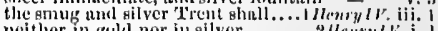

neither in guld nor in gilver ai

fithers taken liy the silver lieardi..... Henry

troubles the silver suring where ....2uleneys $i$. iv. 1

nhame to thy silver hatir, thou muil.

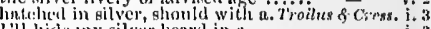

Tll hide tny silver bentl in $n$........

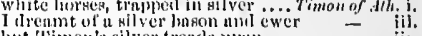

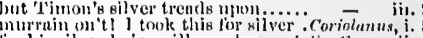

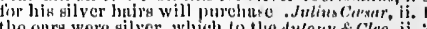
with tnuestry of allk when silver two winking euprids of' silver, eneli on ill bolld nud silver rather tum to dirts - iii. is

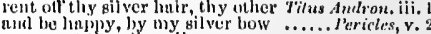

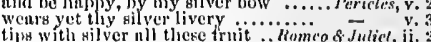
low gilver aweet soum, lovers' tonyues nutuie, with her silver sound (rep).

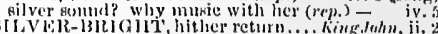

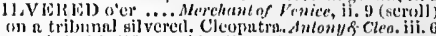

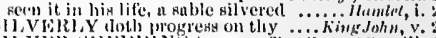

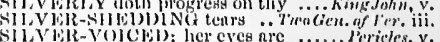

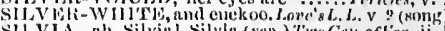

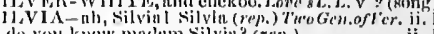

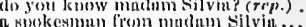

now, dhumglter Silvitu, you

tolue f rlenk to your.

for Julin, silvin .

niming at silvia ns ne...

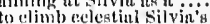

de harbour with my silvin njgltly.

inut silvin is mingedt

exeept he lyy silvin in the nighit (r.....

for meerel silvini

if silvia huve forrwo.......................

as then lovest silvin, thongh ........

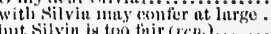

who is silvis? what is alde? (rep.......

政

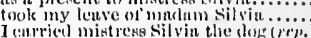

lis som do love your latly silvin (repe)

Whint Silvin nt l'atriek's cell

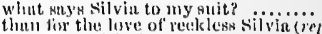

rephir not with tlyy presenece, silvia..

decliver un riget to mulume silvia (i......

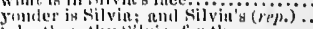

thke then thy silvin, fir then

Silviun, tlie time was, thet 1 hated

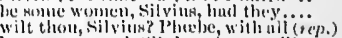

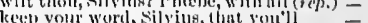

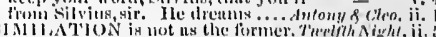

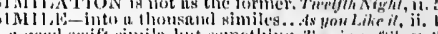

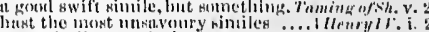

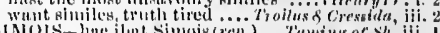

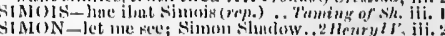

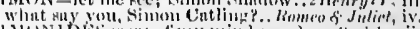

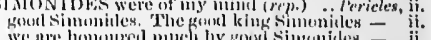
rent mermento

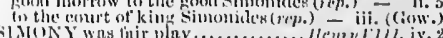

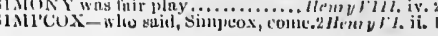




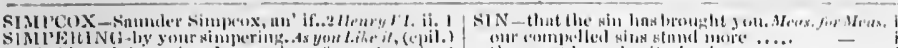

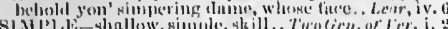
for, withost you were:

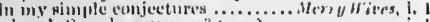
where's Simple, 1 my mitn?

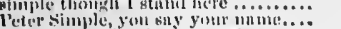

klere in some silumples in my elonet.

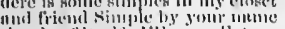

simple ef itaclit l'll nom pullet-sperim

in the simple stllee of line .

We are simple min; we thin mit

tir my simple trie jull inent?

Thtrhathl, i. 3

to wituens sinple vistue

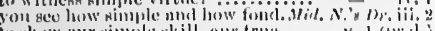

a ment siluple elowril

lliss is a gitt thut I ling

ive, simple, simple - iv. 2

mut wenchesi you have simple wits.

is a simple erming in fir one mut

here nere nimple seripjes

there is no vite sos simple, liut issiume

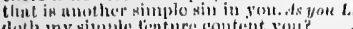

deth iny simple fenture eontent your

empminnded of miny simples,

have llow 11 from simple noure.

there's a wimple juttumg all

I num a simple nutil; and therein

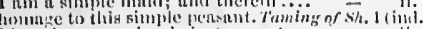

There bestow a simple instriment

that women are sos simple to ofler war

nworu brother, usery simple genilemin!

nre we, that ne not pimple me

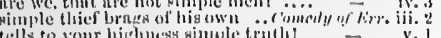

mine iron; it is as simple onte.

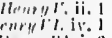

mi) simple mak that seen ..............

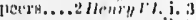

and in lis simple show he lumbrome.

so mony simple wothls glomble protish

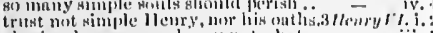

nh, simple men, yeur kinsw not whia

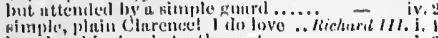

limt thes his simple trith mist.

I lo heweep to many gimplo gully.

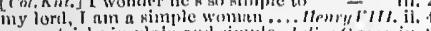
are 30 trick in plnim and simble

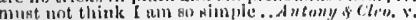
it simple sountrymun, thut he

In simple nollow thing

lint harsh, molsle. simple, molling ... pe $\bar{c}$ jii. I tre unaty simples oneratise.

raile upon yom' simple thief.

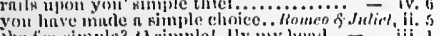

the fac-simple? o simple? Hy my heat

think trice ove neter, simple molesty

understatuling nimple and nusc:looled

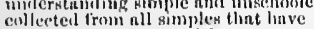

in simple nmil pure soul a enme to you

a minple fawd, that enmot any as mach

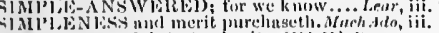

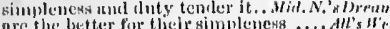

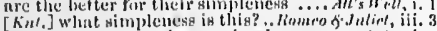

iis vour voice to nesist my simpleness.... Othello, $i$.

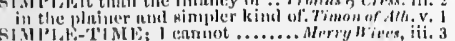

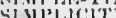

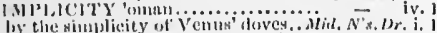

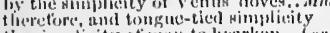

the simplicity nt mun to henrk

twice gom simplicity, bis buetns!..... - iv,

vile s Tyburt that hongs up piloplieity

by wit, wortls in aimplicity

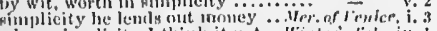

Whenge simplieity think it mo.

cufel meres gimplicity .............. iv. 4

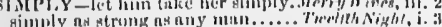

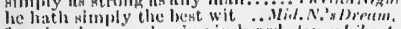

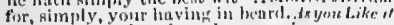
yeil have simplly misused our $8 \mathrm{x} \mathrm{x}$ in

I protent, I singily nne a mail.

. Alisuritl, il. 3

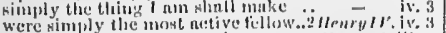

he is, simply, the most astive ......... Itemy'

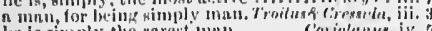

Giditidit proot enough

Cymbeline, $y$,

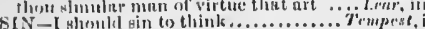

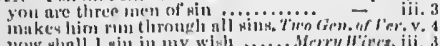

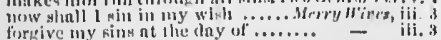

forpive my kins nt lie day

lenven librgive onr finst

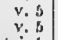

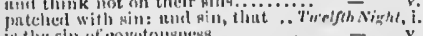

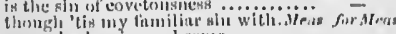

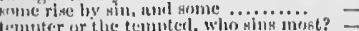

gompler or tie on to sin in loving vlituo...

you, fitir one, of the sin you curry?

ii. there not be a durrity in sin $\left(r+p^{2}\right)$

thy нin's

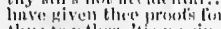

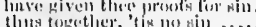

purehased bis surth

ami penple sin 11 is

coll cumbing sin: corere it nelf.

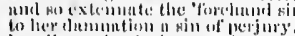

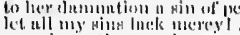

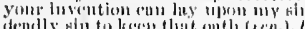

do not enll it bin in me ...

I that lodel it min lo brenk ...

iil itselit an sill, thins

it is a sill to be $n$ mocker.... bereheml of $f$

nlack, what heinous sin is

thes siles of the futhere net

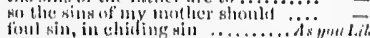

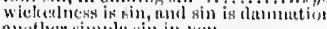

the most inlihisited sin in the re........

only sin mul hellish obstintury the

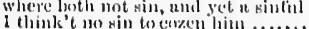

were sin as deep as thant

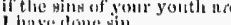

strels like libertie...........

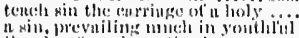

of evory sing that has th nus

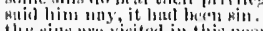

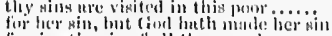

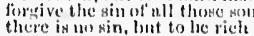

norios parley with wilt.

for I nim ntifled ivild this smell of sii

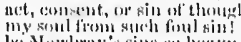

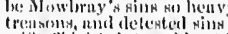

Belt'-nfli ighifell, tremble at

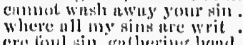

cre loul sin, gudherigg hend...

more sims, fist this forkivenes

'tik no sin for a man to lab

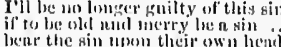

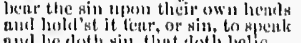

that tiont sin, Ruthering hend

the oldest kins the newest kinil.

is not so vile n sin, as self-neglecting.

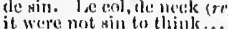

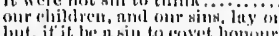

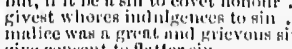

pive cosisent tor fluter sis

fir find sule

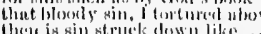

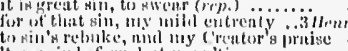

"Lwns nin before, but now 't

"Lis sin to flutter, guod was ...........

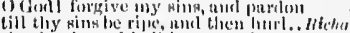

siin, clenth, mal heli have ret the ir

for in that gin he is as deces.

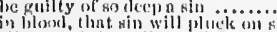

all Heycrul sits, all used in en:

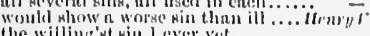

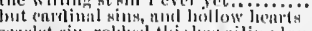

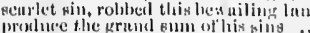

prodlute the grand bum of

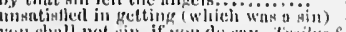

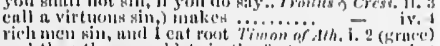

uncl tlen thou wouldat shet the fibter.

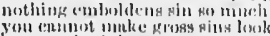

I grunt, is sin's xerement gitst

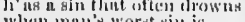

When intus worst nin is

I vin in enverine fin mbility

As it were sin tis clomldet.

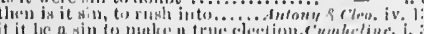

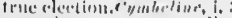

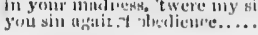

sare it is no siz

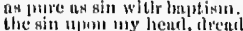

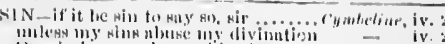

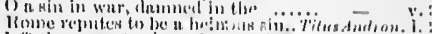

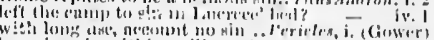

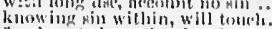

liaw love to hene the sins they live

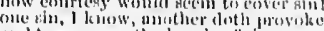

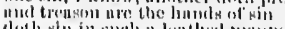

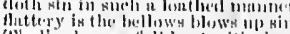

'Phaljugteme fiall bent with sin

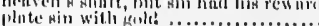

ii. ifinver)

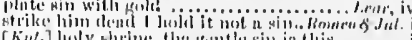

[Kat.] lowly whrine, the gentle sin in this

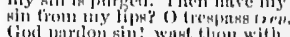

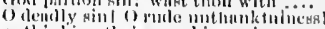

us thinking their own kises sin

is it more shi-to wisld lue thas for

thom know'st, is cross mot timll of

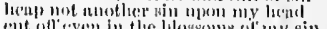

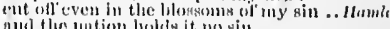

le nll my sins rementered ...

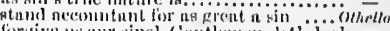

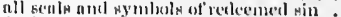

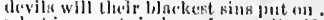

Whint ignorunt pin lanve I committed?

think on thy wing. They are love

en

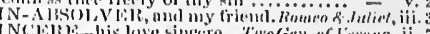

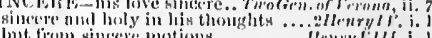

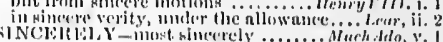

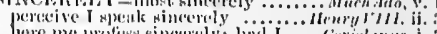

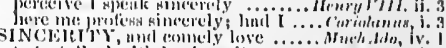

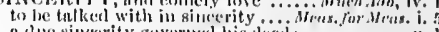
al ane sinererity governel his decels.....

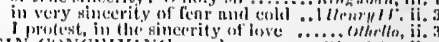

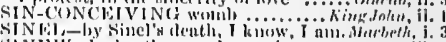

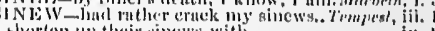

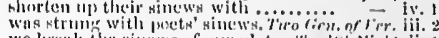

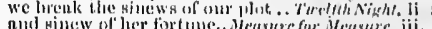

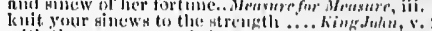

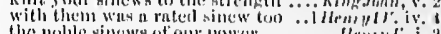
the nolile sinewa no on power

slaill with steclerl sinews toil

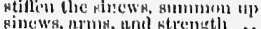

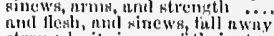

- iii.

8o slualt thom sinew lestle thene lumis - ii. it

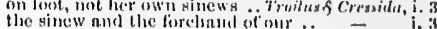

prent den of your wit lic's in your sinews - ii. i

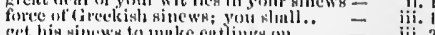

get his mincks to muke cutfings on .. - iit.

let grow thy pinews till their knit... -

liers lies thy hent, tlay sinews, and thy - $\quad v$.

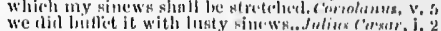

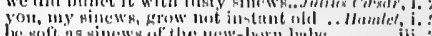

SIN ENW

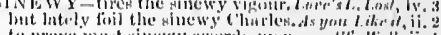

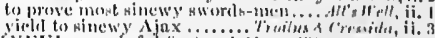

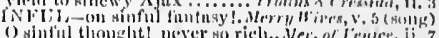

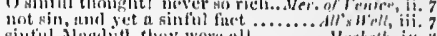

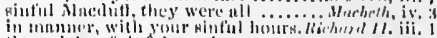

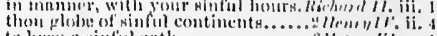

to kicele a mintiul osuth

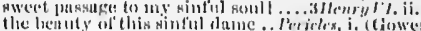

the sinfint hinther scemesl not............

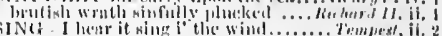

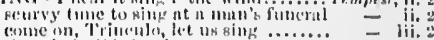

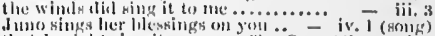

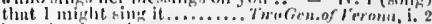

bent sing it to the ture

Nor you will pin: it ait

vat in you sing let us bing.

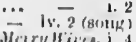

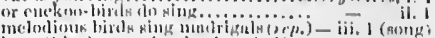

lienr thin shower sing in the windl.. - iii.

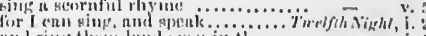

thil sint thein lombl cwen in tlic..... - 1 .

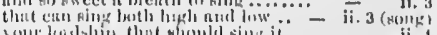

iis: pr'sthee, sing ............... 


\section{SIN}

SING-decreed not to sing in my cage... Much Ado, i. 3 I will but teach them to in my I pray thee, sing, and let me woo sing no more ditties, sing no noer do you sing it, and I'll danee it sing it to lier bones; smg it to-night sound, and sing your solemn hymn. sing me now asleep: then to your. sing in our sweet lullaby.......... and I will sing, that they shall hear and sing, while thou on pressed flowers sing, and dance it trippingly a........ will we sing and bless this place. the bircls have any eause to sing ...... Love's $L$ igh a note aut sing a note. that sings heaven's praise with wnch nay, he ean sing a menn most meant niglitly sings the cuekoo, enekoo. if a throstle sing, he falls straiglit. Mer.of i ienice, $^{2}$. when the bagpipe sings i' the no

the erow doth sing as sweetly as the

if she should sing by day, when every I do desire you to sing (rep.)......As

and I'll sing it. Thus it goes....

heigh-hol sing, heigh-ho. unto the - ii. ii. 7 I would sing my song without a

then sing him lrome; take thou...

when birds do sing, ley ding

-hiles a wedloek-fiymn we sing v. 3 (song) Fond cuekoo sings by kind ..... Ali'sirell, $\overline{\mathrm{i} .} 3$ (song) air sing: mend the ruff, and sing (rep.) tured his bounty to sing happiness....

and now she sings in heaven

caged nightingales do sing. Taming of Sh. $\overline{2}$ (in glie sings as sweetly as a a sing it

birds. O how they sing ....Winter's

and he sings psalms to hornpipes.. when yon sing gnng, and danee her turn -

your affuirs, to sing them too

your affairs, to sing them too $1 . .$.

why, he sings them over us they

she sings it; 'tis in request (rep.) ......

and now about the canlaron sin

of frailty, sings his soul and body.

where mounting lurks should sing

malam, I'll sing. 'Tis well, that

[Col.Knt.] and I conld sing, wou

she will sing the song that pleaseth yon

I'll sit, and hear her sing (rcp.).

eome, sing. I will not sing. "Tis the

in the hauneh of winter sings........

I heard a bird so sing, whose musie..

as bird doth sing on bough $\ldots . . . . . .$. Henry $V$. iji. 2

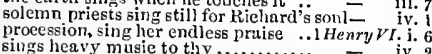

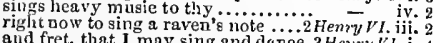

aing. and disperse them, if thou

bow themselves, when lie did sing - Henry - iii. l (song)

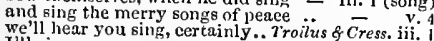

I'll sing you a song now

Greekish girls shall tripping sir......

she will sing, nor lieel the high......

full merrily the humble-bee doth sing - v.

pray you, daughter, Eing; or express. Curriolans, $\mathrm{i}$.

not now to hear the sing or . Aniony \& Cleopalra, i.

I sing but after you. MI sallad days
then the boy shall sing:

cast, write, sing, number, ho

the crickets sing, and man's. ....

the lark at heaven's gate sings...... Cymbrline, ii.

bird, and sing our bondage

how angel-like he sings! .............

Cadwal, I cannot sing; I'll weep..... - iv. suffers little birde to sing

to sing a song of old was sun.$\ldots \ldots \ldots$

to hearran old man sing.

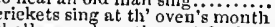
hall we go hear the vestals sing? - iii. (Gover)

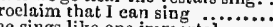

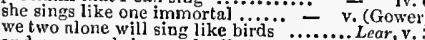
and pray, and sing, and tell old tales...... Lear, v. that birds would ging, and think. Romeo öJutiel, ii. he fights as you sing prick-sons

nightly she siogs on yon pomegranate

it is the lark, that sings so out of tune

no longer than they can sing

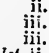
a tongue in the sings at grave-making - v. v. to sing a requiem, and sueh rest to her

and flights of angels sing thee to thy rest! $=\nabla$. $O$, slie will sing the savags nnd dances. Othello, iji.
STNG and sing it like poor Earbara .... Othello, iv. 3
sing all a green willow (rep.)...... - iv. 3 (soug tlunder-bolts, singe my white head! $\ldots$ Henry FII. i. whose beard they lieve singed ... Merchant of Fenice, ii. 9 SINGEING his pute against the burning. Limitet, v. an ill singer, my lord

Mici... Mrterth sto, ii.

you nre the singer; I will say... Romeo \& Jelim,

SINGETII all nergt long ................ Hamlet, i. if their singing answer your saying... Much dilo,

I meau in singing; but in loving

6wallowed love with singing love...Hore's $\bar{L}$. $L$. ii. I

suppuse the singing birds musicians. Riekard II. $\mathrm{i}$.

surveys the singing masons buildiug ...Henr? $F$

young, sir, to love a woman for singing ...Leas, i.

her furtune, and she died singing it ...0thello, iv.

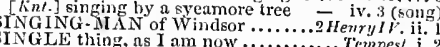

INGLE thing, ns I am now

a double heart for his single one......... Much ddo $_{\text {, }} \mathrm{y}$.

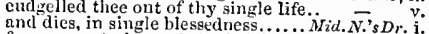

for aye, austerity and single life

we single

seal me there your single bond ... Mer.

single man theretore blessed? ...Ner. of renice, i.

to the wars; she to her single sorrow.. All's Well, ii. 3
but the plain single vow

one single word. You beg a single penny $=$ iv. v.

were poor and single business.

in single opposition, han

try furtune with him in to hand ...1 Henry $W^{3}, \mathrm{i} .3$

eliallenged you to single fight

your wit single? and every part ......2 Henry $1 \mathrm{~V}$. $\mathrm{i}$.

single combat, in convenien t place ..IIIenry/ I. i.

nuy, Warwiek, single out some

thought to sten the single tent.

pomp was single; but now narred...Hen $\bar{y}_{\text {VIII. }}$ v.

I speak it with a single jeart.

ains, enn these my single arms... Troilus \&

his fitir worth, and single ehivalry

thon stand'st single, thon art rot $\ddot{r}$ -

apart, all single and alone

actions would grow wondrous single. Coriolan

every one of us has a single honour..
were there but this single plot to lose

o seek a single man; and lose........ - iv. 1

but for my single self............... Julius Carsas, i.

this great war in single fight l......... - iv. 4

remarkable in single oppositions...... Cymbelin

with his own single hand le'd take

equal any single crown $\because \ldots$ the earth

trust to thy single virtue ................. Leor, v. 3

the single and peeuliur life is bound ... Hamlet, iii. 3

thev come not single spies........
SINGLED from the barbarous

how he singled Clifford forth...

3llenryVI. ii.

singled forth to try experiments ... Tiins 4 ndron.

SINGLEN ESS-the singleness! . . Romeo \& Juliet ii.

NGLY, ean be mantifested............ Nerry Wives,

he must fight singly to-morrow. Troilus o Cress, iv.

world be sungly counterpoised... Timon af fhens, iv. 3

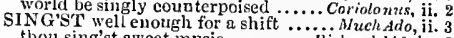

SINGULAR and clroice epithet....... Love's L.Losi

so singular in eneh particular ... ivinter's Tale,

of singular integrity and lea........2 Henry $1 \mathrm{r}$. iii. 2

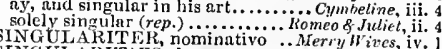

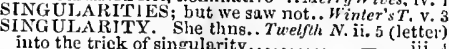

into the trick of singularity
more than lis singularity.

more than lis singularity $\ldots \ldots \ldots \ldots \ldots$. Coriolanu

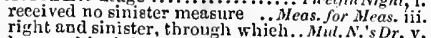

here on his sinister chi ek

'tis no sinister, nor no a wlkward

SINK-have you a mind to sink?

All sileth, ii.

let's all sink with the king ...

why doth it not then our eye-idds siak?

till he sink into his grave ..............Mnich $A d o$, ii. 1

arebery, sink in apple of his eve.......

to think that I would sink it liere...... Alu's Well, $Y .3$

why sinks that cnuldron? .............. of Jrrors, iii, 2

our eountry sinks beneath the yoke...
whilst my gross flesh sinks dow ward. Richard $1 I . v .5$
INK-or sink or swim; send danger..1 Henry I $V_{\text {. i. } 3}$ kennel, puddle, sink; whose filth $\ldots$. ... Henry $V$. iii. 5 sand; w wy, there you quiekly sink..3 Heny $r i$. v. I let it sink me, even as be the seas.. Richard III. iy. but where they mean to sink ye

a load would sink a navy........ - ii.

now, Troy, sink down; here ijes .... Troilus \& Cress, v. 1 furtnnes mong lis friends can sink 7 imon of $A t h$. ii. who is the sink o' the boly $\ldots . . . \cdots$. iii. gink, my knee i' the eartli ............... Coriolanus, i. deeeitful jndes, sink in the trial........ keep off them, for you sink........Anlony \& Cleo out of breath, and sinks most lamentabls my loavy point to sink for food ..... Cymbeline, iii. 8 mny run into that sink.......... Titus Andron. iii. here many sink, yet those whieh see..... Perieles, $i$. sink in it, should you burden love..Rnmeo \& Jul. iv. SINK-A-PACE: what dost thon mean. Othello, ii.

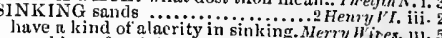
ore blows for sinking under tliem.. Coriolures, 11. must leave thee to thy sinking.. Artoriy \& Cleo. iii. I INNED - if thou hast sini....... Tomedy of Errors, i. I have then sinned against lisis... ... Much Ado, v. if you firt sinned witl us .............. Winter's ' Tale, a man, more sinned against, than sinning. Lear, iii. so much a sinner, to be a ........ Treitrh Night, $\mathrm{y}$. I eross me fur a sinner a.......... forbear to judge. for we are sinners. 2 Henry $V 1$. ii. 3
which is too weak to be a sinner. Timon of guilty deeds to sinner's' minds.. Romen o. Juliet, iit. WINNING-simed against, than siminig.. Lear, iji. 1 I N IN - a Sinon, take another Troy .3 Henry $\% 1$. iii. tell us, what Sinoung did seandal l. Cymbeline, iii. IP-so muel as sip on a eup with. Merry Wires, $\mathrm{ii}$.

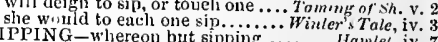
II - you are most a tht to pluy the sir in... Othello, ii. 7 which do eall thee sire.... Mleasure for Mersure, iij. honour's born, and is not ilke the sire. All's Wetl, ij. 3 a child shall get a sire, if I fuil .. Toming or $\mathrm{sh}$. ii. I make their sire stoop with .........kekerd II. iii. 4 whiles that his monntain sire ...........Henry $j$.ii. 4 neither like thy sire nor dim of .... 3henry and graeed thy poor sire with

compelled, been butcher to the sire...Richard IrI. v. erutch from thy oll limping sire.. P'imon of all. iv. 1 like the sire for ever being good ...7. Titus dntron. $v$. IRRAH-be king of the isle, sirral ? .. I Tempest, $\mathrm{v}$.

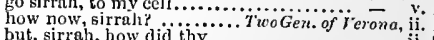
but, sirrah, how did thy $\ldots . . . . . . .$. . ii. go, sirral, for all you are iny man... Siserry wixes, do you call your knight's name, simrah? - iii.

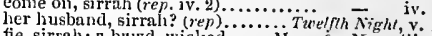
sirrmh, bring Barnardine $(r c p.) . . . . ..)=$ iv. yon, sirrah, thnt knew me for a fuol... $=$ v. $v$. sirrah? I no a gentleman (rep.).... Anuch ddo, iv. Quare Costard 1 will enfranchise thee - ii. girrah, go betore (rep.ii. $5 \&$ iii.5).Mer. of Fenice,

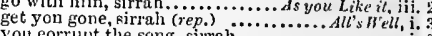

on eorrupt the song, sirrah $\ldots . . . .$. - i.

sirrah, your loui and master's narried

pray yout: eome, sirrab.......... - ii.

tell me but, sirrah, tell me tine...... - $v$ v.

co, sirrab, take them to (rep.). Taming of Sh. 1 (iuduc)

bit, sirrah, not tor my sake, but trith, sirrah, an' you'll not knoek (rep.) $^{-}$

sirral, lead these gentlemen to my...

sirrali, young gamester, your futher.

sirrah, I will not bear these braves of

sirrah, get you hence, and bid my

eome, sirrah, let's away (rep.v.2)

irrah. Grumio, go to your mistres...

y.

but sirrel, you shall bmy

sirraln, what say yon?

irrah, a word: attend those men...... Maebeth, jii.

sirral, speak, what doth move (rep)..... $\overline{\text { ing Joln }}$ iv. 


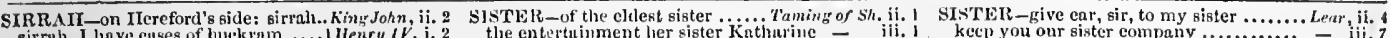
irrnh, 1 have enses of buekiam ..... Henry $t V$. i.

girrals, eurrier, what time $(r, p.) . . . . .$. .

sirrali Jack, thy horse stands...

the entertuinment lier sister Katisurine

help to dre'ss your sister's chamber " "1

tet Biunen take her sister's room

the sister to my wife, this geatlewoman

brother Petriehio,-sister Katharina
where is jour sister, and Jlortensio's wie二

where is your sister, and Ilortensio's wife-
it has an elder sister, ur I mistake. Winters $T$

it has an elder sister, or I mistake. Winter
what will this sister of mine do with

have more in 'em than you'd think, sister

nor my sister; we are gone elac......

my nisstress, and her sister.... Comenty

if so, be pntient, sister.................

sister, you know, he promised
wont to use my sister tlus?...

wont to use my sister thus?...........

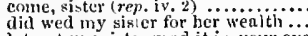

let not my sister reud it in your eye

your weeping sister is no wife of mine

drown me in thy sister's flood of tears

my sister so. 'Thy sister's sister (rpp.)

my sister is, or clse should be (rep.
I'll feteh iny sister, to ret her.........

but her fuir sister, possessed witl.
go fetch it, sister, this I wonder....

go bear him hence; sister, go you

he, alul my sister, to-day dil dise
my wife, her sister, and a rabjle

fair gentle woman, her sister here

she now shall be my sister, not
where hast tlou been, sister?

the weird sisters hand in land

these weird sisters saluted me....

of the three weird sisters to you.....

unto the weird sisters; more they

come, sisters, eheer we up

saw you the weird sisters? ...........

to Plasliy, to my sister Gloster.

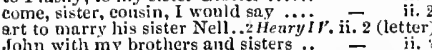

must I marry your sister?

untwine the sisters threel............ ne $\bar{r}$ ry. $r .4$

will you, fair sister, go with

marrying my sister, that thy.......... i Herry ${ }^{\prime}$ l. ii. s

his eldest sister, Anne, my mother..2 Ilenry l't. ii.

thy fair sister, to kngland s kin

of his love unto our sister Bonna.
now sister, let us hear your firm

our sister shall be Edward's..........

to eall king Ed ward's widow, sister...kichard III. i. i

sister, have comfort: all of us have .

for my sister, and her princely sons...

to Bona, sister to the king of $F$

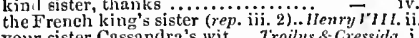

your I a sister were a grace ........... -

had I a sister were a graee ..............

二

pence, sister, peace ..................

great Heetor's sister did Achilles win

I would therefore, my sister had had no -

I lad a sister, whom the blind

that mude my sister thirteen years..

a sister?-you are slie.

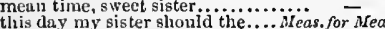

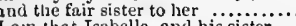

I an that Isabella, and his si hatll he a sister?

one Isabel a sister ${ }^{2}$ des...........

that you, lis sister, finding

than that a sister, by redeeming him

beture his sister should her body stoop

look, signior, here's your sister
now, siyter, what's the eomiort?

sweet sister, let me live.................

word, young sister, but one wor

lath pasc between you and your sister =

let me ask iny sister pardon
of Mlariana the sister of Frederick

of Mlariana the sister of Frederistied vessel the dowry of

am the sister of one Clnudio

the of ntleman should be her sister... Nuch llo $_{0}$, iii.

to live a barren sister all your life.... Sid. $\overline{N .}$ 's $\mathrm{nr}$. i.

the sisters' vows, the hours that we.

$\mathrm{U}$ sisters three, come, come to me.... - v.

he killed your sister ................ove's L.Lnst, v.

sisters thrce, and sueh branehes... Mer.nf J'enice, ii.

than the natural bond of sisters ...As you

here cones my sister, reading....

come, sister, will you go? (rep. iii. $\ldots$ )

come, sister, you shal be the priest..

what do you say, sister? Pray thee.

my father's sister's son $\ldots \ldots . . . \ldots . .$.
here, sister; armed, and bloody in

and sisters, of the hold-door trade.....
below thy sister's or'b infect ...'Timoniaf athens, iv. 3

the noble sister of Publico

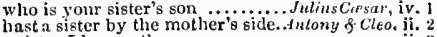

a sister I hequeath you ...........

Cresar's sister is calierl Octavin

sister, prove such a wife as my tiroughts -

110, my most wronged sister.....

sister, weleome $($ rep.) ................

teudering our sister's honour .... Titusd nitron. i. 2

gentle sister, who hath marty red thee? -

see, bow my wretched sister sobs

farevell, Lavinia, ny noble sister.

they eut thy sister's tongue.

they it werc that ravished our sister

I am made of that self metal as my sister.. Lear, i. I

a third more opulent thru your

I sliall never marry like my sisters

bid farcwcll to your sistcrs ..........
and, like a sister, am most iontl

aister, it is not a little I have to say.

he always loved our

I'll write straight to $\mathrm{my}$ sister

I have writ to my sist

have you writ tliat letter to my sister?

from my sister been well informed

so hath our sister, of difference

meswengers from our sister and the $\mathrm{kin}$

self-same colour our sister speaks of

beloved liegan, thy sister's numbt

Were not his sister; can't no other. $d i t$ sister, content you in my....... T'saing of Slurew, $;$. her elder sister is so eurst and shrewd

good sister, wrong me not...

to our sister you do make return...

return sou to my siste

I know't, my sisters: this approves.

if you affeet him, sister, here $I$....... fiurewoll our sister company.

nor thy fierce sister in his anointed........ - iii. 7 cried, sister's! sisters! slame of ladiesl (rep.) - iv. 3 your sister is the better soldier $\ldots \ldots . . .$. . that my two sisurs be in thy

for your sisters have, as I do rememher. do you not love ny sister? ................

than that sister should loosen him (rep.)

sister, you'll go with u

see these daughters, and these sisters?...........

for your claim fuir anter these sisters?...

and her sister by her is poisooed

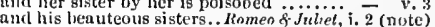

our sometime sister, now our queen ... Ilamlet,

and, sister as the winds give henefit

fear it, my dear sister; aur kecp you

kind sister, sweet Ophelia?

a sister driven into desperate terms
your' sister's drownell Isertes

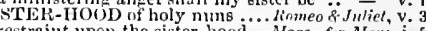

restraint upon the sister-hood.... Meas. fur Meus. $i$.

$I$, in probation of a sister-hond ....... $\overline{\bar{y}}$. v.

a nun of winter"s sister-houd ........ As you Like it, iii.

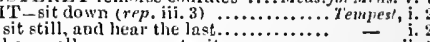

how well my garments sit ipon me.... - i.

while I sit lazy by ................. = iit.

sit, then, and talk with her............ - iv.

we'll make you sit

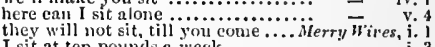

I sit at ten pounds a week ............ ivelfhNight. i. 5

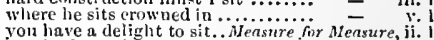

you have a delight to sit... Meastre for Measure, ii. I

git you down: well horrow............
I know, sits at your heart...........

he shows me where the bachelors sit...Much $\bar{A}$ do, ii.

I may sit in a eorner ...................

is t possible? sits the wind in.........
slie will sit you, - you heard my $\ldots \ldots .$.
and there will she sit in her smoek..

go sit here upon tise ehureh-bench .. - iii. 3

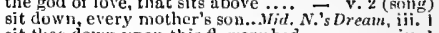

well, sit you out: go home

well, sit you out : go home ........ Love si.. Lost, $\mathrm{i}$.
sit dinwn to that nourishment .... - i. 1 (letter)

like ndemi-god here sit I in the sky

and birds sit brooding in the snow $-\bar{v} \cdot 2$ (song)

to know where sits the wind .....Mer. of Venice, i. I
sits like liis grandisire cut in

the keen appetite that he sits down... - i. 1

here will we sit: and let the sound... $=$ v.

sit, Jessica; look, how the floor...... $\overline{\text { low }}$.

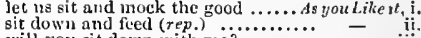

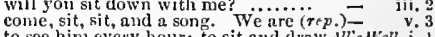

to see hin every hour; to sit and draw sll's well, i. i

coldest, and despa:r nost sits [Coli-fits] $=$ ii.

sit, my preserver, by thy patient's ... - ii. 3

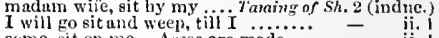

come, sit on me. Asses are made ... $\quad$ - ii.

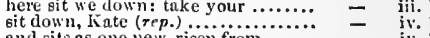

sit down; fir now we sit to elat $($ rep.) - v v.

they sit conferring by the parlour . H.
prny you, sit by us, and tell's a ... Hinter's Tale, ii. I

or sit down at the hatch ...............

raized with it, when 1 sit .............. Waebeth, ii.

you know your own degrees, sit down - iij. 4

may it plense your highiness sit?.....

sit, worthy friends; my lord ........ - iij.

pray you, sit still ; You have $\ldots . . .$. = iii.

nud e'er since, sits on his horschack kung $\bar{J}_{\text {ohn }}$, ii.

here I and sorrow sit; here is my.....
thut I might sit all night ............

and I will sit as quiet as a lamb......

and in his turcheal site $\mathrm{n}$ lure-ribibed - iv.

O, sit my husbant's wrontrs on...... Richarl H. i. 2

woe doth the heavier sit

We see the wind sit sore upon........

treasons sits fair for news to go .......

let

and there the nutie sits, seoffin.......

and who sits here that is not Rieliard's

nimlats, sit by the fire with good...... - $\mathrm{v}_{\mathrm{.}}$.

and you sit down? and uncle......... i Hen $\overline{\text { wy }} I r$. iii. I 
SIT_I'll sit and hear her sing ...... I llenry $/ \Gamma^{\prime}$, iii. I SIT-whercfore should he sit here? Mirs shall on his altar sit........... sit on my knee, Doll: a rascal and sit him down and die

let me have him to sit uuder that man, that sits within a...... no, I will sit and wated here by. lo, here it sits, which Heaven. w here it sits Ilarry, sit thou by wated garment, majesty, sits not so ea... now, sit down, sit down ( rep.).

Joul sit upon their throne..

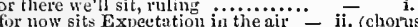
there must you sit; and thence .. - ii. (chorus) now sits the wind fitir, and we .......
that sits in leart grief and uneasiness

by their wateluful fires nit patiently - iv. (chorus) the throue see; minding true...

their horseruen sit like fixed

to sit with ns onee more

nud sit like a jack-a-napes never of

and sit at chietest stern of public ...

so York must sit, and ret and bite...2 Henry r. i. I

madan, sit you, and fear not.

nurderous tyranny sits, in grim majesty

look where the sturdy rebel sits

lie durst not sit there, had your.

where now he sits, write up

laudis summa sit ista tue l.

on this molelinll will I sit $\left(\mathrm{rep}_{\mathrm{j}}\right)$

liere sits a king more woeful tha

sit down with us (rep.)................

and sit you fast ( $r e p$. $v$.

to sit awd weep but k.

onee more we sit in Englaind i.......

Col.] pr y thee; sit by me awlilie ... Rith

one nigh!t as we did sit at supper

and victory sit on thy helm (rep.).

we sit, or sit state statues only ...

sit by us, you shall hear this was.

pray, sit bctween these ladies....

ill he a judge, that no king...

whilst I sit meditating on

good wenel,. let's sit down quiet

1 am very sorry to sit here at

gond man, sit down: now let

when we sit idly in the sun...

sit. gods upon your throne

the fellow, that sits next.......

for policy sits above eonseience.

if there sit twelve women at

sliall sit and pant in your great.

sit, Coriolanus (rep.) ............................

than idly sit to hear my nothing

and Rome sits safe and still......

$y$ tell you, he does sit in gold.

the glorious gods sit in hourly
he sits in his state as a thing

he sits in his state, as a thin
the bird of night did sit...

$O$, lie sits high in all the people'

let us presently go sit in eouncil

now sit we elose about this tape
sit thce down, Clitus: slaying

upon your sword sit laureled.....

to sit and keep the turis of tippling
stands he, or sits he? or does he walk?

mark Antony in Eryst sits al dinver

sit. Sit, sir

sit, and some wine: $a$ heal th to

though my reason sits in the wine.

let me sit down: OJuno!............

Casar gits down in Alexandria

he sits 'mongst men, like a deseended $C y m b$.

and sits aloft, fecure of thunder's... Titus.tndron.

it fis ant nefas, till i find

Aarni, let us sit (rep.) ..............

so, eo, now sit; and look, you eat $n$.

sit down, swect niece (rep.)............

but yonder sits the emperor....

all did sit to knit in her their

sit down, sit dowu $\ldots \ldots \ldots \ldots$
sits here, like beauty' $\mathrm{ehild}$

hat, sit, sir; sit (rep. v. 1)

melancholy

we sit too loug on trifle

please youl sit and bark erown

she would sit stili and weep

Knt.] pray you, let us sit togeti.... = v.

canst not smile as the nind sits........... Leur, i.

six years we bonis, that

full scarce six thousand in you are of the enmmissious sit you tep...

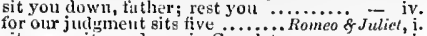

sit, nay, sit, good eousin Capiliet

the stains duth sit of an old tear.

they camnot sit at ense on the old ....

let the nurse this night sit up..........
bosom's lord sits lightity in his thro

sit down awhile; and let us once (rep.). Lamlet, i.

of Iamlet sits stuiling to my heart...... - i. 2

the wind sits iu the shoulder

o'er whiels his melancholy sits on brood

come eome, and sit you down (rep. we

lis silence will sit drooping.

in session sit with ineditations Iawfili?.OLhello, iii. 3

the easier, sith yoll yourself know.Merry wives, ii.

sith that the justice of your title ....

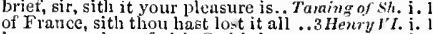

in revenge thereof, sith God is just ... -

sith every aetion that hath.

not I, my lord, sith true nobility... Titus sndron. $\mathrm{v}$.

and, sith there is no justiee in earth

sith that both charge and danged
sith I have cause, and will i.
sith you have heard, and with

Lear, ii. 4

sith you have heard, and with ..........

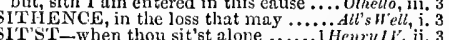

a moral fool, sit'st still, and ery'st ....... Lear, iv

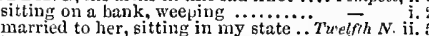

ii. 5 marred to her, sitting in my state... Twelfh $N$. ii.

he, sir, sitting, as I say ............Meas. forkeas, ii.

manor house, sitting with her .... Love's
holds his poli-ax sittiug on a elose-stool

Who you saw sitting by me on ...As you Like 1l, iii. 4

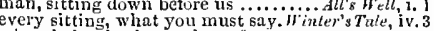

Who, sitting in the stocks, refuge ..Michard I i. v, 5

for every honour sitting on hi

here, sit ting upon Loodon-ston

2 Henry $1 \mathrm{iij} .2$

long sitting to determine noo

sitting in the suy under.

is there no pity sitting in the clouds gnilty creatures, sitting at a play iii.

glilty creatures, sitting at a play ...... Hamlet, ii. 2
SITU ATE-know where it is situate. Love's L. Lost, $i .2$

nothing situate under heaven's. Comedy of Err. ii. I

that the situations, look you, is both.. Henry $r$. iv. 7
sIWARD-aad warlike Siward......... Macbeth, jii. 6

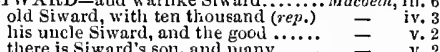

there is Siward's son, and niany $\ldots .$. . Termpest, i. 2

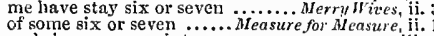

and six or seven winters more $\ldots \ldots \ldots$.

at six o' clock the morning

pay him six thousand (rep.)

poor world is almost six thousand..... you tike il

some six months sinee, my lord .....

of six preceding ancestors, that gen

to the pail, six score fat oxen .... Taming of Sh. ii.

one girt six times pieced .............

absence was not six montlus old ... Comerly of Err. $i$.

six frozen winters spent $\ldots \ldots \ldots \ldots \ldots$. kichard 1 . . i. 3

i. 3
i. 3
i. 3
ii. 2

every thing is left at six and seven....
lie that kills me some six or seven...

some six or seven fresh men set.......
when he was not six and twenty strong

the wearing out of six fashion

Henry r.

in wh six thousand strong

some six miles off the duke

thou obey'dst thirty and six year..3 Henry $V^{\prime} l$. ii.

six or seven thousand is their...... Richard III. v. 3

Dunstable, six miles off from

six or seven times honoured..... Troilus \& Cress. iii.

on forfeiture, my lord, six weeks.. Timon nf Ath. ii. 2

ice six I have zeen.

six of his labours yon'd have done .. - iv. 1

O that I had him, with six Aufidiuses - $\quad$ iv. 5

some six or seven, who did hide ...Julius Casar, ii. 1
six kiugs already show me the way. Ant. \& Cleo. iii. 8

yet room for six seotehes mo

can it be six miles yet? .............. Cyrabetine, iv.

eome not, in twice six moous ...'ericles iii. (Gower)

some five or six and thirty of

Inmlet, v. ?

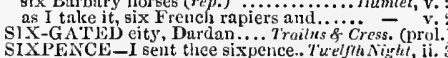

SIXPENCE-there is sixpenee lin you. Tretfih $N$. ii. gath he lost sixpence a day (rep.). MFid. N.'s Dr, iv. 0 , sixpence, that I lad ......... Comedy of Errors, i. eiglt shillings and sixpence.......... Illenry $1 V^{\prime}$ shall never earm sixjlence out of it ..2llenry $\mathbf{~} \boldsymbol{H}$. j. held them sixpence all too dear. Uthello, $\overline{\mathrm{it}} 3$ (song) XPENNY strikers................ Henry lr. ii. I have to night despatehed sixteen ..Ali's'l'ell, iv. 3 'er sixteen years (rep, v. 3)...Winter's $T$. iv. (chorus) sixteen, ut least, my lord ..........1Henry $I \nu$, i. but sixteen hundred mercenaries ......Henry $r$. iv. 8 I have been begging sixteen ycars... Ienry III. ii. 3 son of sixteen, bluck the lined.... T'imon of $A$ th iv. at sixteen years, when Tarquin .... Coriolumus, il. 2 fome dozen or sixteeu lines ........... Hamlel, ii. the sixth of July : your loving friend... Muchest,, $\mathrm{i}$. sixth and lastly, they have belied (rep.) - v. vor
alout the sixth hour .... Love's L. Lost, i. i (ietter) the sixth age shifts into the ........ As you Like a, ii.

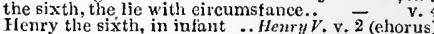
IIteny, of that name the sixih! ....1 Henry' 1 . iv. 1 maresial to Henry the sixth ....... iv. the sixth was Thomas of Woodstoek.2 Henry ''l. ii.
how Henry the sixth hath lost ....3 Henry'l. iii. 3 when Ienry the sixth (rep.iv. 2 )...3ichard 1li. ii. 3 sixtll part of his substance (rep.).... Henry VIII. i. 3 at the six th hour of moln, at noon ... Cymbeline, i. and what's the sixth and iast............. Perieles, ii. and, on the sixth, to turu thy hatcd baek... Lear, $i$. I have sixty sails, Casar none ... Antony \& Cleo. iii. 7 from sixteen years of age to sixty .... Cymbetine, iv. for any mouth of this age's size... Merny you Wives, iii. be any answer of most monstrous size dulike it, iil. or woman, of all sizes.

my legs of an unequal size..........3 Henry l'l. iii. by lis large and portly size... Troitus \& Cressida, iv. ingratitude with any size of .. Timon of $d$ thens, $v .1$ our size of sorrow, proportioued.Anlony of Cleo. iv. 13 it's past the size of dreaming ......... to Ecant my sizes, and, in eonciusiou .... Leur, ii. 4 SKEIN-Mith a skein of thread ... Romeo s. Juliet, ii. 4
. Taming of Sh. iv. 3 KIES-besides the groves, the skies.Mid. $N$.'s $D r$. iv. artillery thunder in the skies? .... Taraing of Sh. i. 2 the skies grimly, and threaten.. Mrin/er's Tale, iii. the wrathful skies gallow the very ....... Lear, iii. contention of the sea and skies parted...Othello, il. KYLFU L-is quiek, skilful, and. Tuelfh Nigh, iii.

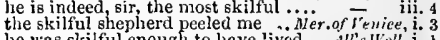
he was skilful enough to lave lived . Aill's Well, i.
allowed the skiful pilot's cliarge? and skilful to their strength .... Troilus \& (ress. the skilful conserved of maidens' hearts. Olhello, iii.
SKILFULLY_speak'st skilfuliy.. Lnve' sL.L ost, ii. SKILL-my shallow, simple skill. Twotien. of i er. $\mathrm{i}$. to compass her I'll use my skill ....... skill, fury, and impetuosity ..... Tuetfh Night, iij. youth, strength, skill, and wrath.... so it skills not mueh when ............ with me, and I will use your skill...Muchsdo, i.
would teach my smiles sueh skill!...ivid.N:'sDr. i. toncling now the point of humian skill - ii. 3 to show our simple skill, our true $\overline{\text { ve }}$ v. I (19rol. dart thy skill at me $\ldots . . . \ldots \ldots \ldots \ldots \ldots$...... whose skill was almost as great .........All's Well, more than my father's skill ........

needs must intimate skill iufiuite

I have not mucl skill in grass or stupified, or seeming so in skill. $\%_{1}{ }^{\circ}$ '"r's 's'ule, ii. I think, you have as little skill to fear - iv. I would my skill were subject .... Richard Il, ivi. 4 so offend, to make offenee a skili...... Herry $1 \%$. i. so that skill in the weapon is .....2 Henryl $\mathrm{r}$. iv. first, to tly her skill, Reignier ....... Henryll. i. lad I sufficient skill to ntter tlem

it skills not greatly who impugus..2Henry $r$ I. jii. it skils not grcatily who impugus..2Henry ${ }^{\prime} I$. ini. a easque composed by Vulean's skill $\overline{-}_{\text {hath }}$ v. smiled at their linek of skili .......... Cymbeline, ii. yet 'tis greater skill in a true.......... - ii, witl the little skill I lagve...... Tilus.... Andronicus, ii. this Philoten contends in skili.. P'ericles, iv. (Guw.)
my utmost skill in his recovery ...... v. and all the skill I have renenibcrs not .. L.cor, iv. thy skill be more to blazon it .. Romeo f. Juliel, ii. with all our majesty and skili ........... - iv

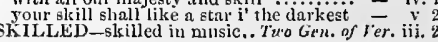




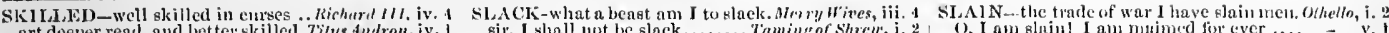

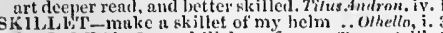
SKII.L-LEsS-I an skill-less of ...... Tempest, iti. I being kill-less in these parts .. Tierifh $\mathrm{Night, \textrm {ij }}$. 3

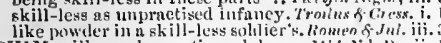
SkIN milk; ant sometimes labun:...Mid.A.'sDr. ii.

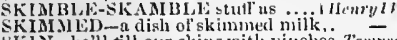
Skin-lie'll fill our skins witl pinehes. Tempest, jy. your skins are whold .......... as the skin befween his lrows ....... Much dite, iii. his teather skin, and humls. As you Like it. iv. ? (song) nay, as the pudding to lis skin ........Al's wrll, ii. beense his painted skin emintents. Taming of sh ant tear the stainet skin wh

if the skin were purchntent......... - iti. till 1 sheath it in a murkerer's skin. Kim, John,

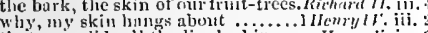
thit unce dial sell the lion's skin the skin is goot for your proken.

gir, I whall nut be slack.
if thoit be slack, I'll tiplit.

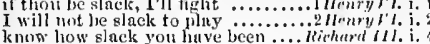

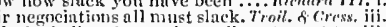
sluek the bulins there; thriu wile glack! that $I$ counine was go sluek.....

if you come slack of former ecrvices

I um uotlíu slow to slack his linste.....

say that thicy slack their duties ...... ohthth, iv. 3

SIACKN ESS-behind-haul slackbess. Himt's 's\% v. lust of men, to taunt at slackness.. Ant. \& 6 it thoul hast bla in 1 sganter in lis. Mrit

filds his trusty' Thisby's maintle siai

thuse that MItuebeth fiath slain

i' thon he'st slain, and with

King $J_{i} / h_{n}, \mathrm{iii}$

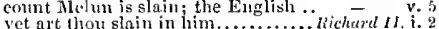

sume slain in war; some liaunted

二 iii. 2

one sear eharnetered on thy skin...

- iii.

the skin of an inmoeent lamb should = iv.

Whose skin's a kecper's fee $\ldots \ldots \ldots . .3 H e n r y$ r

and on their skins, as on the bark. Tilus.tudron. v.

sturin invades uts to the skin

it will but skiu and film the uleerous.. Homlet, iii.

thant whiter skin of hers than snow .... Ohello,

skiNNY-laring upon her skimny Jips.. Marbeth, i. 3

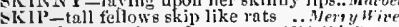

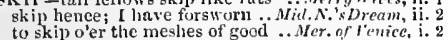

let tot tly sword skip one..... Timon of dhens, iv.

and skip when thou point'st out?.

tliey skil from stem to stern.
I woult lave made them skip...

SKIFPED-skipped from sixtecn........... Lear, v. 3 SkIPPER, stamil back; 'tis nge. Taming of Shrew,

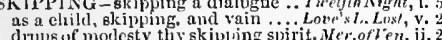
compelled tluese skin

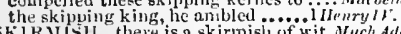
Skl RAlsil there is a skimish of wit. Much Aten, i.

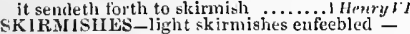
SKIRK-skirr the country romit and make them skirr away, as swifi. Hrwy ${ }^{\prime}$. and skirts round, underborme with...Muck delo, and skirts round, underborne with...Muck Ado, tii. 4 and to the skirts of this wild wood.... - v. sew me in the skirts of it .... Tuming of Shrew, iv. 3
hatt: in the skirts of Norway .......... Hamlel, i. I SKIKTED-and skirted page

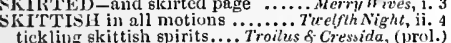
tick ling skittish spirits.... Troilus o
sume men ereep in skittish fortune

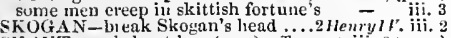
SKUUT -and skout 'em (rep.).. Teinpest, iii. 2 (song) SKULKING-skulking in eorners?. Winler's T'te, i. boil'd within thy

woild within thy skull .............. the sknll that bred them...Merchanit of ienice, iii. 2 of quiet as thy lather's skult .....i. Richard Tr. iv. some lay in dead men's skulls .... Richard M. 1. 4 were to issue out of one skull ...... Corinlamus, ii. 3
sKY - the sky, it seems .............. T'cmpest, i. 2

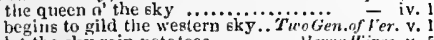
begins to gild the western $6 \mathrm{ky}$... Tu. as glorinusly as the Venno of the sky

nyy soul is in the sky .................
the sky, the welkin, the heaven... Lave's L. Lost, iv. 2 like a demi-foid here sit I in the sky the sky changes when they...........

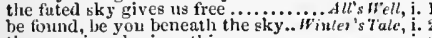
the eovering sky is nothing.......

in earth, in sca, in sky ...... Comedy of Errors, ii. I hanners flout the sky ... Macbeth. i. 2 now, by the eky that hangs........... King John, ij. 2 no mutnral exhalation in the sky....

so foul a sky clcars not without

the more titr ant erystal is the sky.. kichard $n, \mathrm{iv}$. by the complexion of the sky......... iii. 2 in the clear $6 \mathrm{ky}$ of fame.........2 HrnryII. iv. 3 and yet my sky shall not want...

winged through the litlier sk 5 .

and when the dusky sky begun to..2 Henry' 1 , iii. in a pale clear-shining sky $3 \ldots \ldots . .3$ Hcrury VI. ii. I the sky doth frown and lower upon

wider than the sky and earth .. Troilus \& Cress. v. this disturberl sky is not to wajk in. Jnlinsceesar, i.

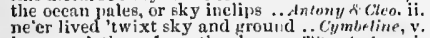
incense, doth perfome the sky

the wink, and persecutions of the sky ... Lear, ii.

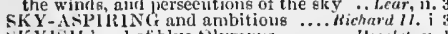
SKYISH head of blue t)lymus
SKY-PLANTED, hatters all

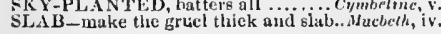

feat, and be sian; wo worse
be ta'en, or slain, we hear no
rumson, and of solchiers elain.

three knimlits sold our party sl....

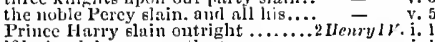

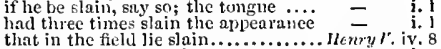

i Henryliti.

our comntry, slain our citizens
he is ta'en, or slain; for fly

revenge my death, if $I$ be slain

witness for me, being slain
ours, now bloody Talbot's si

from France, or else be slain ..............

- iv. 4

is Jack Cude slain? (rep.)

O I am slain! famine, ayd no (rin).

is't Cade that I have elain?.........

is eithorls of common soldicrs slain..3 Henry $\mathrm{Fl}$. i. )

but, when the rluke is slain..........

atlo are slui

had he been glain, we sliould have

noble dinke of York was elitin (rep.).

Rutland, by young Cliftiord slain....

sir. Jolin Grey, was slain

nyy soverefgil slain? (rep.)
lis suljects slain, his statutes

[Col.kut.] say, they are not slain .... Richoril HI. i.

and slain by Edward's hand .........

broken, nor my brother slain .........

the tyrant bcing slain; if you do
his horse is slain, and all on foot

what men of 11 me are slain

a Tiojan hath been slain.... Troilus \& $C$

Achilles hath the miahty Hilcetor siain

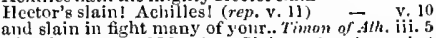

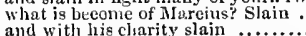

fools, whose children he hath sjain

he is slain, O Julins Cxsar, thou... dulius Casar, v. 3

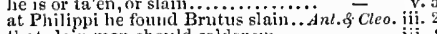

that slain men should solder up

go tell him I have slain myself.....

that here by inountaineers lies slain. Cymbeline, iv, 2

since I wrote him, Imogen was alain = iv, 3

some, slain before; some, dying ....... =

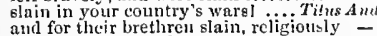

in field, s]airi manfully in arms......
quarel you have slinin your son (rep.)

quarrel you haye slatin your som

nowe basely slain in brawls ........

slain in Cupid's wars ...........
ravished, mukt by me be slain

ravished, mukt by me be slain ..........

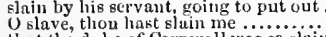

that the duke of Cornwall was so slain

Acrcutio slain! away to heaven. Romeo
eitizens are up and $\mathrm{x}$ ybalt sluin (rep.)

lies the man eiain by young Romeo.

if he le slain, say, $I$ : or if not, no.....

would have slain; and Tybalt's (rep.)

hath slain ten thousand 'íybalts

hast thou slnin Tybalt? wilt thou slity

Tybait being slain so late, it lmay....

0 I ain shin! if thon he nereiliul...

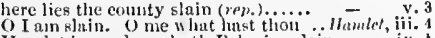

IImulet in madnese liath I'olunim

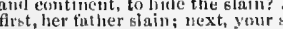

he, which linth your noble finther whin that in the field lie slain...

but Jove was never slain, as thou.......

rejent me that the dnke is slain
ns if that I hatd slain my cousins

Patroclus ta'en, or slain.

why hast thou slain thiue only

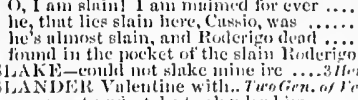

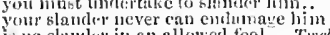

in the sirlut, to do a lowed fool.. Tuelfh Night,

yrur action of elanter too.

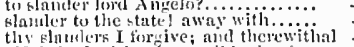

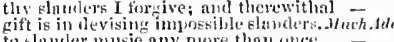

I'l] devise some houest slanders to stain

disl emitirm any slander that don John

unceyered slanler, umitigated

deprive :and slander go antick] y

Eecoudarily, they are slanders

incensed me to slamder the latly Hero. Mverh Ado,

my lord, but whiles lier slander lived

prevents the slaurler of his wife. As you likn'u, iv.

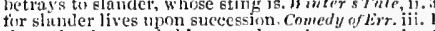

these slanders, and this open shamel - iv. 4
told this slinder of his blecrl ......... Richard H. i. I

to the soul with slauler's yenomed...

a deed of slander, with thy fatai hiand - v.

and he slanders thee most grosely... Henry $I S$. iij.

do me no slander, Douglas .......... iv ${ }^{-}$iv. 3

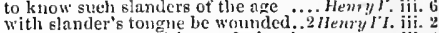

that slanders me with nurder's crimson - iii 2
is slander to your roynl dignity......

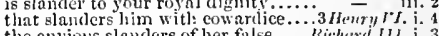

thou slander of thy mother's heavy... - i,

0 , do not slander lim, for he is kind - i. 4

slander myselt, as false to Edward's. -

that slander, sir, is fomd a truth .. Iirnry / lll. ij.

gall coilss slanders like a mint... Troilus a coess. ?.

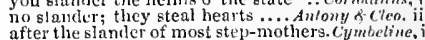

a to longings, slanders, mutability - -

wo, 'tis slaniler; whose edge is slarper

this vipermus elander enter.
slanders $\leqslant 0$ lier judgenent

whom not to slander, outsweetened not - iii.

fur not slander, censure rash .... - iv. 2 (sotg)

wher slanders do not live in tongues .... hear, iii.
stained with Tybalt's slander... homeo \& Juliet, iit.

that is nn slander, sir, that is a trath - iv. 1

so slander any moment's leisure ..........
slanders, sir; for the satirical rogue says.

so, haply, slander, whose whisper........ - iv.

if thou dost slauder lier, and torture me. Olhello, iii. the purest of their wives is fonl as slander

Eome office, liave not devised this slander - iv:

hatli slundered, scorned, dishonoured. Much drla, iv.

she is slandered, she is undune

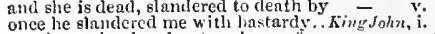

you have slandered nature in my form - iv.

and thou hast slandered it....... Romen \& Jals', is.

call not me slanderer ...................

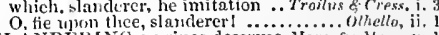

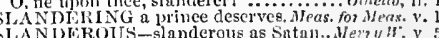

up in the slanderous tongue? ...Mras for . Meas, iii.

death by slanderous tomgues. . Much dido, 1.3 (ferili)

olanderous to thy mother's womb... King. Inht, iii.

enll him, a slanderous eoward .......kicherd $i l$.

the attainder of lis glanderous lips . Bichard $M$, i

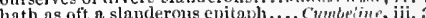

hath as oft a slanderons epitaph.... Cymterimen, iit.

and slish, and slash, like to.. Taming of Shrer, iv. 3

torgueless, slaughter' a thousand... Winter's Thte, $\mathrm{i}$,

in the dying elaughter of their foes........... Juhn, ii.

with slanghiter coupled to the name

overstraincd witly slnughter's vencil
have sold your king to slaughiter....... Menry r.

have done this slanghter; heside..... - iv.

of loss, or

and ruthless slaughters, as aic daily

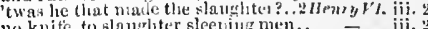

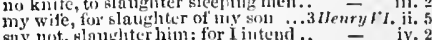

ay, and for nuch more slanghter ufter - iv.

unworthy slaughter upun others .. Richort [II. i. .

provede te a drunken slaughter.....

firm all the slatylyters, wretch, that - iv.

(col kini?

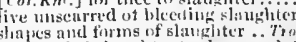

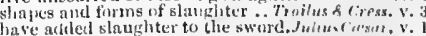

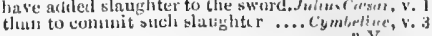


SLAUGITTER is here made by with slaughter of you their captives
stand peerless by this slaughter. Pericles, iv. (Gower) a piece of slaughter the sin and noun. - iv. 4 death hath made this slaughter - iv. A (Gower) should sure to the slaughter, if my eap.... Lean, i. 4 where he speaks of Pring's slatght

SLAUGHTERED-snvagely slauglitered..nucb. iv 3 be kept with rlitughtereil men? ... King John, ill. wounds of slanghtered Englishmen - iii. 3 the mof the ilyeury our bodies slanghtered by thy fues. only slaughtered by the ireful arm. thiy Edwarel, to thy slaughtered sou. Fichard II $\mathrm{L}$. $\mathrm{i}$. whose parents thou last slaughtered

slanghtered thuse that were the nuews

be slaughtered in the streets.
like to a slanghtered lamb.

is iRomeo slaurhteretl? ................

villain lives which slanghtered him
his body that hath slaughtercd him

a lantern, slaughtered youth, for

Sl.AUGITERIER-slatugh terer duth.i HenryV1. ii. 5 to the blooly slanghter-louse......2 Henry $V^{\prime} t$. jii. 1 been in thine own slaughter house his realm in slaughter-house 3 Henry VI. $\mathrm{Y} .4$

to bear me to the slaughter-house. hie thee from this slanghter-louse .
SL IUGHTERING hands, and keepiHenry $V$. iv. I SLAUGHTERIAN to all my kin ..3 Henry Vi. i. 4 the slaughterman of twenty ......... Cymbrline, v.

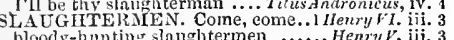
bloody-hunting slanghtermen ....... Henry $V$. ii. 3
SLAUGHT'ROUS thoughts............ Macheth, v. 5
SLAVE-my slare, as thou report'st..... Tempesi, i. 2 SLA VE-my slare, as thou report'st.
well visit Caliban my slave (rep.).

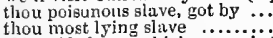
abhorr'd slave; which any print so slave; heneel to $_{\text {to }}$ it

and slaves they are to

an unmannerly siave...

a slave, that, still an end

hang 'em, slaves! I do uot think... Merry $\overrightarrow{F i v e s, ~ i i . ~ I ~}$ art thou the slave, that with the.

upon tire world'e baser slaves .......ove's L.Lo emne, you transsressing slave; nway

many a purchased slave......ie, to live and die her slave .As you bike it, iii. 2 (ver.) what a past-saving slave is this!

quoted tur a must perfidious slave

a hondmaid and a slave of me... Taning of $S$

jolt-heads, and unmannered sla

a tross luut, a mindless sia

protess ourselves to be the slaves of chance

what mistress, slave, hisst thou?

tor go seek this slave; 1 greatly .....

back again, thou slave, and fetch (rep.)

the heedful slave is wandered fort
thus grossly with your slave.

thou drunken slave, I sent the

hie thee, slave, begone ........

till he fiacel the slave; and ne

that were the slaves of drink

liar aud slavel Let me endure

where is that Blave, tily brother? ....
thou slave, thou wreteh, thou coward

to be utterded by slave, that take

am I Rome's slave? what penn

he did throw away on slaves....

and sovereignty, a slave; proud majesty

not the first of furtume's slaves

what a slave art thou, to huek .......

slaves as ragged as Lazarus......

but thoughts the slave of life...

a raseally slave! I will toss the

bragging slave! the rogue fled...
base is the slave that pays ...

base is the slave that pays ...............

so soundly as the wretched slave..;

whilst by a slave, no gentler than

for they are hair-brained slaves

fly from your oft-subdued slaves ....

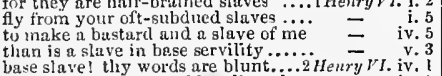

a Pom

as tor these silken-coated slaves .... $\overline{\text { and }}$, devilish slave, by thee ........

and, devilish slave, by thee $\ldots \ldots \ldots . . . R$

in thy nativity the slave of nature...

slave, i have set my life upo
obedienee is a slave to each

ye rude staves, leave your gaping....
LAVE-a alave, whuse gall coing
any wic, like a burbarian sla
and the act a slave to limit..

turn, slave, and figlit. What art thou?

have slaves, and pensants, this night

my breath from me, the slaves

cap and knee slaves, vapours.

slaves, and fools, pluek the grave.....

this yeliow olave will kn

thon art a slave, whom Fortune's....

beastl Slav'e! Toad! Rogue, rogue

think, thy slave man rebels.

ye came ror gold, ye slaves ...........

run from slaves that apes wonld beat

these base slaves, ere yet the fight
where is that sluve, which toid me

first budger die the other's slave ....

0 slaves, I ean tell you news ..........

there is i slave, whom we ha

thie slave's report is zeeonded

buy! o slave! pardon me, lords.

a conmon slave, (you know him

go, show your slaves how choleric

eall the slave ngain; thomgh I am

O slave, of no more trinst than
slave, soul- less villnin, dog

mechanie slaves witl greasy aprons

what slave art thor? $(r$.

and the slminking slaves of winter.

slaves, the strides they vietors made
look, how the blaek slave smiles. Titus and

come on, you thick-lipped slave ...

say, wall-eyed slave, whither wouldst
unhallowed slave! sirs, help .........

why eame not the slave baek to me..........
you whoreson dog! yon slave! you eurl

oue-trunk-inheriting slave ..................

strike, you slave; stand, rogue, stand'(rep.)

this is a slave whose easy-borrowed......

rather to be slave and sumpter to this

here I stand, your slave, a poor, infirm

lust-dieted inan that slaves your ordinance...

let go, slave, or thou dies
slave, thou hast slain me

slave, thou hast slain me $\ldots . . . \ldots \ldots \ldots$

I killed the slave that was a langing the -

that shows thee a weak slave

let mischance be slave to patience....

what a rogue and peasant slave am $\ddot{I} !$.. Ham

that is uot passiou's slave, and I will wear

purpose is but the slave to memory
a slave, that is not twentieth part

not bound is not twentieth part $\ldots \ldots \ldots-$ iii. 4

and has been slave to thousands $\ldots . . . . .2-$ jii. 3

$O$ that the slave had forty thousand lives!

some eoggitug cozening slave $\ldots$ murlerous slave 1 o villain $\ldots$......

same villain, for tis a damined slave

O eursed, eursed slave

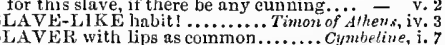

to live in slavery to the nobility....2. Hentry 1 . iv. 8

to live in slavery to the nobility.....2Hentry 1 i. iv. 8

by the insolent foe, and sold to slavery ... Onello, i. 3

the slavish motive of reanting fear... Richard $I$. $\mathrm{i}$. 1

a thing more slavish did I ne'er .... Cymbeline

away with slavish weeds...... Titus Andronicus, ii. I

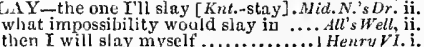

to slay thy brother Abel (rep.

to sliy your sovereign, and destroy...

sland on quilets how to slay him........

why wilt thu slay me? ............3 Henry $F I$. i.

foulest deed, to slay that babe ....... Richard ill. i. 3

and he slays more than you rob........imon of $t h$. iv. 3

in puny battle slay me ...............

for I will slav ho does

must ur for Britons slay us

their use, and slay ns after .......... iv.

to slay his daughter with his own right $\overrightarrow{\text { wat }}$ y 3

whom Romeo's hand did sla

thou slay thyself? and slay thy lady

to another, this sliall slay them both

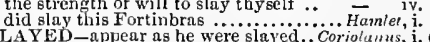

SLAYED-appear as he were slayed.. Coriolams, i.

SLAYETH [Knt.-stayeti] me....Mid.N.Wream, ii.

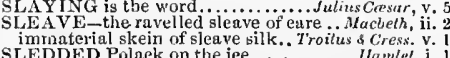

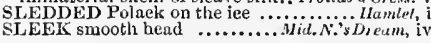

SLEEK-lord, sleek your regged looks .1/nctreth, iii.

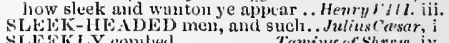
SLESKLY combed............ Taming of Shrrw, iv. SLEEP-thou art inclined to sleep ...... Temmst, go sleep, and hear us ................ and thou speak'st out of thy sleep....
thou let'st thy for ture sleep-die ratier as he that sleeps here, swin

a sleep were this for your advancenient i' the afternoon to sleep............... long sleep, will make me sleep a........ our little life is rounded with a sleep we were dead of sleep .................. elased sleep from my enthralled eyes dhe dotli talk in lier sleep......

so she sleep not in her talk .......... ere she sleep, has thrice lier prayers.

sleep she as sound as eareles.

but those as sleep, and think ........
thus to drean, still let me sleepl. Tuetrith

endeavour tizyself to sleep............. -

years we bave let sleep

an after-dinner's sleep, dreaming....

as fast locked up in sleep, as gnilitiess

dreadfully, but as a drunken sleep .

may sleep the sounder all

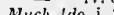

ohe is never sad, but when she sleeps - ii.

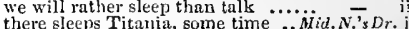

sleep give thee all his rest

let love forbid sleep his seat on thy...

while thou on pressed flowers dost sleep if thou hast slain Lysander in his sleep that bankrupt sleep doth sorrow owe

and sleep that sometime sluts up.

on the ground, sleep sound

of sleep come upon me. Sleep thou

than common sleep, of all these......

to sleep by hate, and tear no enmity?

half 'slecp, half waking.........

that yet we sleep, we dream then, to sleep but three hours in ... Love's

not to see ladies, study, fast, not sleep

sleep and snore, and rend apparel out

how sweet the moon-light sleeps upon

I'll go sleep if I can; if I cannot... Asyou Like

for they sleep between termi and term =

till he when thou art inclined

and is gone forth to sleep: look. .......

to beguile two hours in a sleep

eat and drink, and sleep as soft as....

sleeps out the afternoon

sleep so soundly raming of Sh. 1 (indne.)

or wilt thou sleep? we'll have...... - 22(induc.)

I will not sleep, IIortensio, tiil I see her -

if I fhould sleep of sleep; with oaths

thereuld sleep, or ent, 'twere ...... - iv. 3

whieh to preserve is sleep .............

his appetite, his sleep, and down-right

I come to bring him sleep

that presses bim from sleep............

I sleep out the thought of it ...... iii.

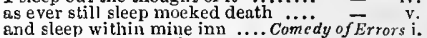

or sleep I now, and think $I$ hear .....

wis sleeps were hindered by thy......

on day, nor sleep on night .........

when in swinish sleep their..........

wieked dreams abuse the curtained sleep-

there's one did laugh in his sleep.... -

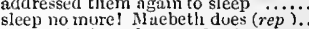

nuse-painting, sleep, and urine.......

equivocates him in a sleep

and sleep in the afflietion of these

atful fever, he sleeps well ............

of all natures, sleep, Come we'il to sieep -

of drink, and thralls of sleep?

and sleep in spite our nigh

the benefit of in a most fast sleep....

those which have walked in their sleep

from sleep that fell anatomy ....... king Jo

pretty child, sleep donbtless, and secure - - iv.

peace shall go sleep with Turks

may do it as seeure as sleep.....

(n)

so bestirr'd thee in thy sleep

there let him sleep till day .............
on your cyelids erown the god of sleep

\section{ii: i} .2 iii. 1 


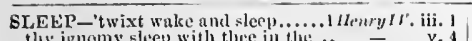

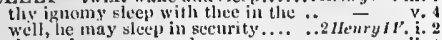
the mndeserver muy slets.............. - ii. why rather, slect) liest thou ith.... oour father is ilisposed to sleer sleepl with it now y yet not so ......... this sleep is sound indeed: this is in sleep doth suppose my sleep my death?... lanve broke their sleep with thonght men muge slcep, nut they may have cun sleep. so soumly as the wretelud and all ming sleeps in Elysium

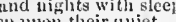
omed axuln we'll slecp seene in Roven while remiss traitors sleep it my slecp by good saint siba........ your highiness should intend to slcep Worm might make the sleep etermal

the more need to slecp now then slcep in thy gheath

ere thou slcep in thy glieath

by this, is set lim down to sleep

Whe hant me in my sleep

no sleep elose up that deally eje

atah hinin us he sleeps?

I slall not sleen in quiet ä tlie rower

from you, Catesby, ere we sleel?

caisnit thy master sleep the tellious

did I clijoy the golden dew of sleep..

the sons of Eclward sleep in Abraliam's =

When didst thou sleep, whien such
furbear to sleep the night, and fast

fotit emnfurt thee in thy sleep .....

Richnond, slecp in peace, and wake

quiet soul, sleep thou a quiet slcep...

the sweetest slecp, and fitirest bod

und sleeps in blessings ..............

and she, sleep in their praves.

to make them sleep on MLay-day.

nor slith this peace sleep

with wanton Paris sleeps... Troili...

tanier than sleep, fonder than

let Achilles sleep. Light boats

sleep kill tlose pretty eyes

nanghty man, let it sleep? .......... -

sleep upon it, and let the foes. Timnn

for here it sliceps, and does uo hired..

nor slcep, nor sanctuary ...

as patient as the midnirht sleep......

broke their sleep to take the one

down together in my sleep

and snch as sleep onights

LFEP-golden slcep doth reign.. Rome f Jutien, upon receipt thercot; sum slece

pennyworths now: slect for a week
if I may trust the fluttering eye of blecp

her birly sloeps in Cunpl's momument

death, contngion, and uninatural slect

do not slece, but let ne hear trom

to sleep, no more ;-mul, by a sleen, to sis

to die; - to sleep:-to sleepl peruhaue
in that gleep of death what dreums.......

day with sleep. Slcep roek thy....

while some must slecl; thus runs $\ldots . .$.
a knuvish speech sleeps ju a foolish ear

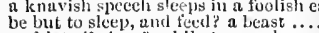

and let all sleep? while to my shame...

of figliting, that would not let

of hy go to-berl, and slcel?. I will
find it still, when I have list to slo

'tis evermore the prolugue to his sle

shall ever medicine thee to that sweet sleep

that in their sleeps will mut ter this.

In ElePE I lienrd him say thouse?

the ground whereon these sicepers. Mith. Tempest, $v$.

demincly wake the slcepers

LEEPING-left Uivia slecping... Tirelfh Night, ii.

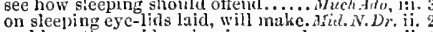

and here the maitlen sleeping sound

she was in her thull and sleeping ?inu

I took him sleeping, that is funisled too-
have stolen away from sleeping IIerniu?-

have stolen away trom sleeping lleriniu?
nud hast thou killed him siecping?..
thut I sleeping here was found ......

that I sleeping here was foun

lay sleeping on his buek: aboit his...

when that the sleeping num should stir
all proofs sleeping else ........... Winter's

or in hell? eleping or waking?... Comedy nf $L$, iị. 2

the sleeping, and the dead, are but.....hacbelh, ii.

sweltered venom sleeping got.............

aw aked the sleeping rleum ....... richa

some siceping killed; all nurdered.

a kind of sleoping in the blood...

2Henryli

wike not a slceping wol

when I am sleeping with my aneestors

nlike? Sleeping, or waking, mut $\mathrm{L} . .1$ Henry $/ \mathrm{H}$. $\mathrm{ii}$.

sleeping neglection doth betray....

in sleeping on your beds!

by subtility, sleepins, or waking..... Henry'r. iii. I

he"ll say, we stabbed him sleejing.. Richard III. i. A

nut sleeping, to engross his idle body

you sleeping sale, they bring you.

wished the sleeping of this business. H.noy VII

not Agamemnon's sleeping hour.. 'Troil. f Cress. i. 3

that seems a sleeping .. Timon of Ailiens, i. 2 (gruec)

pity"s slecping; strange times

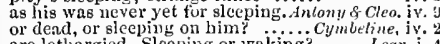

are lethargied. Slecping or waking? ....... Lear,

so tutored by my art, a sleeping potion

thus was $Y$, sleeping, by a brother'

as the sleeping soldiers in the alarn

IIeetor, thou sleep'st; awake ... Troilus \& $C_{i}$

therefore thou slecp'st so sound.

sleep'st thou, or wak'st thou .......
SLEEPY - it is a sleepy language

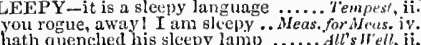

he will give you sleepy drinks.....iriules's T'ul,

we will give you stepy arinks....

and smear the sleeply "orooms with binud $\overline{-}$ it.

mulled, deaf́, sleepy, insensible

this is a sleepy tume.

SLEEVE unbuttoncd, your shoe...... Cy you hilike it,

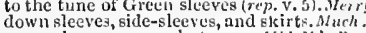

some, sleeves; some, lints ....Mid.N.'s Dream,

by this jewel on her leeve

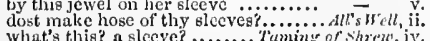

with a trunk slceve (rep.).........

will fasten on this sleeve of thine. Cumculy of Err.ii. 2

like a herald's eoat without sleeves... inemy $r y$. iv.

then win he strip his steeve $\ldots \ldots \ldots \ldots$.......

Wear this sleeve. And you this. Troilus
here, Diomed, keep this slecve ......

you look upon that sleeve; behold

that alecere is mine, that lie'll bear

lose my arn, or win my slece .....

young knave's sleeve of T'roy
with the sleeve, litek to the

Boft ! here eome sleeve, and tivitier...

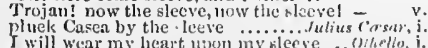

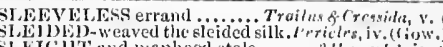

1.FI(ill and nanlrool to to

siculer, I broke your houl

did you piek master Slender' burse

cousin Almulum slender (rep.).....

and cke eavalero Slender ..............

good master Slender's servinto-mun
Anne I'age and my consin Slender

master Slcuder would speak a

eome, snu Slender; in $(r, p, \forall .2) . .$.

marter sichuer is let the buy's liay

that slender, thougl well landed

from naster slevder (rep.) ............

to slip uway with slender.

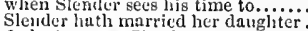

Jeshu! master Slender, caunot you

your waist, mistrese, were as slemler tore's

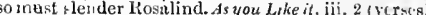

bazel-twig is straight and slender. Taming of $S \%$, ii.

your nider warning, you're like to $(r e p$.) - i -

some slender ort of his remainder. Timan of Ath. it.

how would he linut his slender.. Tilus dudron. iii. 2

SLENDERER - my waist slenderer ...2ulenryl $\psi^{\prime}$ i. 2

I.EPT - thou hast slept well, awake! ........ Tempesi, i.

been dead though it hath slept ...Weas. for Meas. ii. we still have flept together............ As yuc Like it, i. 3

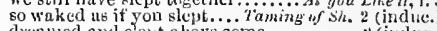
dreaned and slept a tove oome.. - 2 (induc. lise night she slept not

growing as you had rlejt betweon - inler's Tale, ii. he sle,t not for my urging it.. Come $\bar{L} y$ of Jirrors, v.

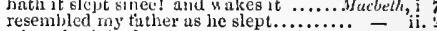
where hath ii slept? ................... John, iv. our title still had slept..............3 Herry $V i$. ii. Where slept our seonts, or how .......
sluade the ranping lion slept...$\cdots$

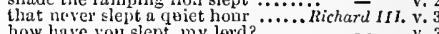
that so lung have slept upon ......... Hen $\bar{y} \bar{V} 111$. ii. to heaven, and slept in pentee ........ - iv. saw ye none enter, since I slept? .... - iv. such as slept within the sladow...Timan of $\mathrm{Ath}$. v. against Cesar, I have not slept ..... Julrusccesur. ii. Thave slewt, my lord, already......... - ir.

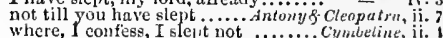
I lave not slept onse wink............... - iii. as I slept, methooght, great Jupiter..

wars, whilst you securely slept... Titus dudron. iit. wake the king? he hath slept long ....... - iv. I slept the ncxt niglut well ............ othpllo, iii.

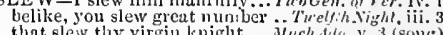
scimitar, that slew the Soply...Merch. of renice, ii. with his own hand he slew the ....... Alt's II'ell, iii.

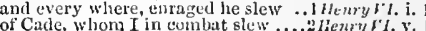
art thou the man that slew lizu?..... -

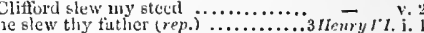

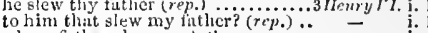
whose fither slew ny tuther ........ - i. the land that slew thy brother....... hand to hand I slew in fight $\ldots \ldots \ldots$. who slew to-dlay a riotous genticinan

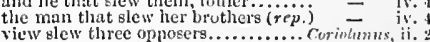
ns lie was a mbitious, I slew him...... Huliuscarsar, iii. I slew the cowart, and did take it .. $-\mathrm{v}$ the story; I slew him there $\ldots . .$. . Cymbelinc, $v$.

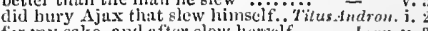
for my sake, and after blew herscif ...... lewr, y. 3 Romeo slew Tybalt, llomeo (rep.) ... $\quad$ - vij. 1 and that my nuster : lew lim ....... kill thee, and thou glew'st Tybult. Rmmeo \& Jal. iii. 3

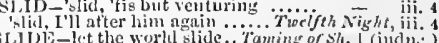

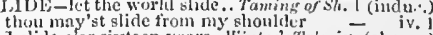
1 slicle oer sixteen years.. Winter's Tale, iv, (ehorus)
the fool slides o'er the ice .. Troilus of Cressich, iii.

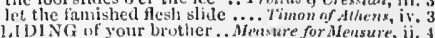
1,11) NG of your brother... Mensure for Mensure, ii. 4 


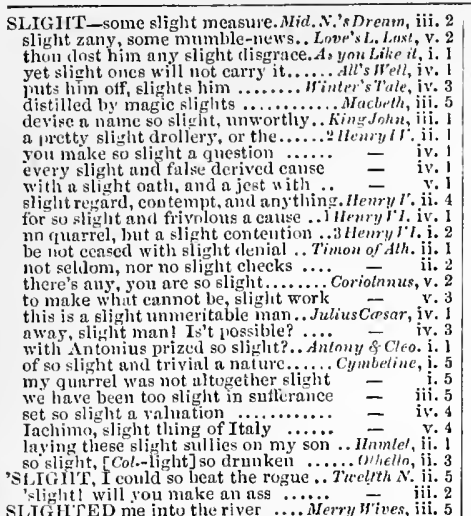

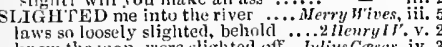
knew the man, were slighted of
SIIGITTEST-slightest errand

yea, even the sligintest worship.

LIGI'TLY - are but slightly basted ... Much ddn, i so slightly with rour wife's......3erch of tenice, v. gone slightly o'cr low steps

Henryllill. ii.

some elifhtly touched, some falling. Cymbeline, $y$

so slightly valued in his messenger ....... Lear, ii.
slightiv timbered for so loud a wind ... Hamlet, iv.

SITGIITNESS-unstable slightness. Cor

Sl.ILY-slily glided towards your

slily stole away, and left his men ..3
keceivc more slity than Ulysses could

the king was slily fingered from . $\dddot{R}_{R}-\mathrm{v}$.

slily crept into his human powers.

upon the slime and ooze seatters $\ldots .$.
these fig-leaves have sline upon them

with niry slime left on them. Titus.

SLIIIY - slimy bottom of the deep .. Richard III

pierce their slimy jaws .... Antony
sLiNG-from the old Assyrian sling

to sutfer the slings and arrows ........ Hamlet, iii.

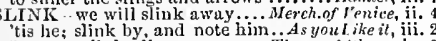

tortunes slink all away ...... Timon of dhens,

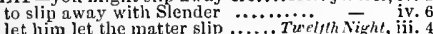

[Knt.] years we have let slip....... Musure for Measure

such a warped slip of wildernc

should slip so grossly, both in

without any slips of prolixity. Nerch. of t'enice

with intended glides did slip.....As you Like it, iv.

a native slip to us from fore ign seeds... All s i ell, i.

and let the world slip . Tammg of Shrew, 2 (induc.)

gall of goat, and slips of yew.............

game's afoot, thou still let'st slip..... Henry $I$
stand like greyhounds in the slips.... Herry $V$.

fair slips of sucli a stock.

was graft with crab-tree slips.........

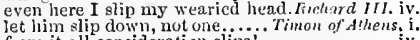

to let him slip at will

cry havock, and let slip the dogs... Juitius Cepsa

we'll slip you for at scason............ Cymbeline, iv. 3 brave slip, sprung from the...

the slip, sir, the slip; can you .......... seo s. Iutiet, ii. 4 so they do nothing, 'tis a venial slip..

SLIPPED me like his greylound
and that you slipped not with an

had slipped our claim until another... Henry VI. ii.

thou wouldst not have slipped..

the bonds of heaven are slpped.......

I.IPPIER-put me to my slipper ...... Tempest, $\mathrm{T}$.

1 do adore thy sweet grase
where are my slippers?

where are my slippers?
standing on slippers, (which his.... Kins John,
SLIPPEREED-slippered pantaloon. As you Like $i$,

LIPPELY - my wife is slippery?.
that stands upon a slippery place

that stands upon a slippery place .. King Jolen,
clamours in the slippery clouda ...2 Hemry $1 \%$.

being slippery standers (rep.).. . Troitus \& Cress. iit. 3

of glib and slippery creatures

stands on such slippery gromnd ... Jultiuk Cresar, iij. 1

our slippery people (whnse Iove... Autony \& Cleo. i. 2

as slippery, as the Gordian knot.... Cymbeline
or so slippery, that the fear's as bad

slippery [Knt.-slipper] and subtle .... othello, ii. I

SLIPSIIOD-thy wit shall not go slipshod.. I,ear,
SLIPT like him .............

SLISH and slash iike to a censer... Taming of sh. iv.
SIIVER anil disbranch from

nu envimus sliver broke.............
SIIVE

........ lear

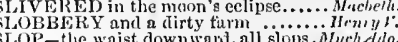
dOP-the waist downitart, all slops. Much ddn

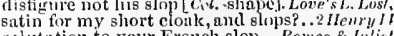

salutition to your Frencls slop.. Romeo of Julie

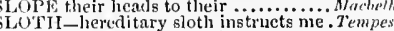

by their own fear, or sloth.

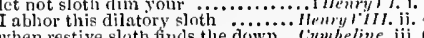

When restive sloth finds the down ... cymbeline, iii.

Ton

OUGII -in a slough of mire .... Nerry $b$

with casted slough, and fresh
with shining checkered slong

SI,OVENLY, unliandsome corse

SLOVENRY - worn us into slovenry.... Henry

- the man i' the moon's too slow. Tempest,

cannnt overtake your slow pu

she is slow in words (rep.) ....

t makes me have a slow heart

everend earriage, a slow tongue. Tueffh $N_{i g} h l$, ii

how slow this old mnon wanes!

slow in pursuit, but matched in

I say, lend is slow........................

other slow arts entirely keen.....

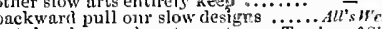

unt slow in speech, yet sweet as .. Taining of Sh. it.

for being slow in thy hot office .............

is slow to overtake thee ................. Ifacbeth, $\mathrm{i}$.

the swift, the slow, the subtle...

and creep the ne'er so slow, yet it.. King.Jnhn, iii.

you are as slow, as hot lord Percy ... Ri hem l/ I\%. iij. I

away, ny lord, you are slow

their suits witli slow delays.

recuires slow lince at first

as the bear, slow as the elephin

hath sent- as slow as another

search so slow, that contd not trace.

how slow his soul sailed on
but, thougln slow, are fleadl

man, could never go so slow

hou art too slow to do thy master.

wisely, and slow; they stumble.. Romen \& Iutie

unwieldy, slow, heavy and pale as lead -

I am nothing slow, to slack his haste

wrung from me my slow leave.
goes slow and stately by them

finding ourselves too slow of sail

to point his slow unmoving finger at .. Othelln, iv.

SLOWED-why it should be slowed. Romeo of Iul
SLOWER foot came on ............ Mens. for Hea

till the speet of his rage goes slower
SLOW-GAITED-very slow-gaited.
SLOWLY - bringing wood in slow'ly
for though he comes slowly .......As

will come on very slowly

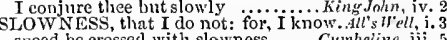

speed be crossed with slowness..... Cymbeline, iii. 5
SLOW -WINGED turtle! .... Taming of Shrew, ii.

slubber the gloss of your new fortunes . Othello, i. 3

Sl,UG-thou snail, thou slug .. Comedy of Errors, ii. 2

SLUG-ABED I why, love, I say I lionen \& /nlict, iv. 5
SLUGGARD [Col.-coward] majesty!. Richard II. ii. 2

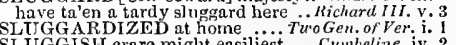

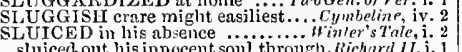

sluiced out his innocent soul throngh, Rich ret II. i. 1

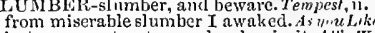

thought this was so, and no slumber. Winter's T. iii. 3

in thy faint slumbers, I by thee .... Wemry $I$

the ports of slumber open wide $\ldots \ldots$. .

suffered in that harmful slumber..2Henry Vi. iii. 2

but like a pleasant slumber in thy lap? - - iil. 2

lest leaden slumber peize me down

not wake him in his glumber ...... Henrytrilt. i. I

are for dreams and slumbers.. Troilus \& Cressith, ii. 2
the honey heavy dew of slumber...Julius Casar, ii. 1

O murderous sl nmber! lay'st thon ..Cymbeline, i

possess a golden slumber....... Titus A ndronicus, ii. 3

possess a gald ilumber in eternai sleep!

then wost not slumber: see, thy two sons'

if heaven slumber, while their creatures. Per
shake off the golden slumber of repose -

thick slumber hangs ou mine eyelids

SIUABERED here....... Mid.N.'sDred... Othello, ii.

SI.U MBRY agitation, besides.............. Mnebrth,

SLUNK not Saturnine, as Tarquin. Tilus Audrm. iv.
SLUT-radiant queen hates sluts ... Merry Ifive's, v.
STUT-honesty upon a foul slut.. As you tike it, jii. 3 I am not a slut, though I thank....

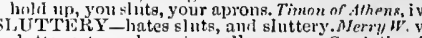

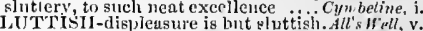
sluttis') spoils of npportunity .. Troilus \& ('ress. iv.

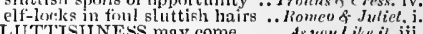
LY - by some sly triek...... TwoGen. of feronn, ii. the slys are no rngues.. Taming of shrrw, I (induc.) old sly's son of Burton-heath....... 2 - 2 (induc. that sly devil, that broker ........... King John, ii. [Cint. Knt.] the sly slow hours slinil .... Richard 'i. $\mathrm{i}$. silken, sly, insimuating Jacks? Richurd wi i. proucl, sibtle, sly, and bloody.......... a sly and constant kuave.

sly frantic wreteh, that holp'st... Tiims Auiron. iv my f of this vice . ........ Measurefor Mensure, ii. my' father did sometling smack .Mer.nr' 'enice, ii. now he hath a smack of all neiglibouriag but smack a clasnorous smack .. Taming of Sh. iit. thcy smack of homeur both; go.......... Mucbeth, i. doth not smack of observation (rep.). King John, siath yet smome smack of age in youl..2 Henry Ir'. i. 2 SWACKING of every sin that lias a..... Macteth, iv.
SMALL in pasture............ Tu. Gen. of ferona, show's his love hut smail ....

were ynu banished for so smali a fault? a thy sinall pipe is as the......... Tuelfin Night, $\mathbf{j}$. to make my small elses coats........ by his seem small light and undistinguishablesmall have comtinual plodder' ..... Lnve's $\overline{L . L o s t}$. mo, lie is best ind ined in the sniall.

no, lye is best indlued in the sniall..... here's a small trifle of wive ... Merch. of t"rnice, it.
and, a fter some small space...... As yor Like it, iv. the small acquaintance, my sudden $-v$. a pot of small ale $\ldots \ldots$.... Tamisg of Sh

at home, where small expericnee grows

with a small compassed cape....... iv. 3 (note) fastened him unto a small, spare. Comedy of Err. i. that none so smill advantage shail.,King John, iii. then, feeling what small things are.,- iv. incaged in 80 smell a verge. and that small model of the harren...

by small and small to lengthen out the 二 it is a matter of emall censequenee..

that with our small conjunetinn ... I Henry $I \%$. iv. a kingdom for it was too small a bound

in me, to desire small heer (rep.) $\ldots{ }^{2}$ Henry $I V$. Ii. small time, but, in that small

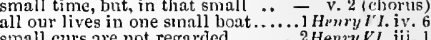
denther curs are not regarded........2 HenryVI. uii. mall things make base men proud...

this small inheritance, my fither.....

thy share thereof is small fa.......3 Henryyl. i.

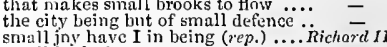

small herbs have graee ..............

in just proportion our small power... - iv

a haberdasher's wife of small wit....

but small thanks for my linbour. Troilus $\&$. Cress.

things small as nothing, for requests

received some small kindnesses from ${ }_{\text {if }}$ youll hestow a small (of what you Coriolnn

and small inferior veins, from me....

a pipe small as an eumben $\ldots$ small thing would make it flame

but small to greater matters (rep.) Antony \& Cleo. ii. but I have seen small reflection....... Cymbeline, i. 3 entreat your grace but in small request - i. grind their bones to a a ........... Tius $\overline{\text { iv. }}$ iv. ghed yet some small drops from...... . Pericles, iii. 3 with fingers, lons, small, white as -... Pericles, iv. (Gower O. most small fault, how ugly ............ Lear, i. a small spark, all the rest of his $\ldots . . . . . .4=$ iii. almost too omall for sicht.... nnd the small gilded fly does jecher in... - iv. through tatteresl clothes small vices do... $=$ iv. 6 a suall grey-coaterl gnat ......... Romen \& Juliet, i. rind of this small [ Col. Knt.......... Reak flower the tears have got small victory by that - iv. small annexment, petty consequence . Hawlet, iii. suckle fools, and chronicle small beer.. Othello, ii.
by that small hurt, hast cashiered Cassio - ii. 'tis a great price, for a small vice........ iv $\bar{T}$ iv. a smaller hail than may be seen.. lnve's L. Lost, v. $[\mathrm{Col}$.$] the smailer is his daughter..As you Like it, i. 2$
much smaller than the smallest $\ldots . .2 \mathrm{Hen} / \mathrm{I} / \mathrm{i}, 3$ 


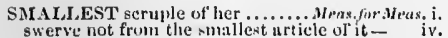
swerve not from the smallest article ol it

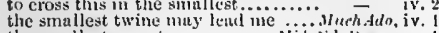
the smal lest moostrous mouse...Mit....'s 1 , entm, v.

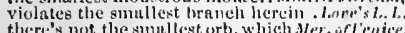

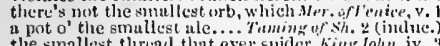
the smallest tlreal that ever spider. King John, iv. the smullest insed of this vow .... Ilemyll?

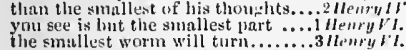
the smo brenk the smallest particle.julins Corsar,

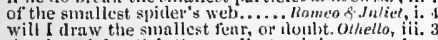
that he might stick the smallest opinien - iv. 2 SII A ILNESS of a pmat to air

SHALTalthongh he smant, not to seem...As you Like if, hath nut made me smart

as smart us lizards' stings

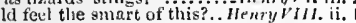
thon eanst not ease thy smart .. thoilus o. Cress, iv. and they smart to liear thenselves.. Coriolan,

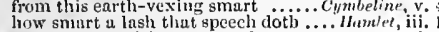
S.IARTING, with my wounds .......illenry tr.i.

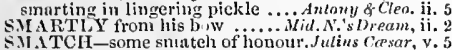
SHATTER with your gossips. . Romeo o Ju S.IEARED with captivity

my glory smeared in dust and blood I SHenry $V$ t. wherein you see me smeared
dlyead and black complexion

s.llead and black complexion smeared.. Mtumter, ii. a very ancient and fish-like sniel.

munster, 1 do sme!l all horse-priss.....

actuainted with the smell. Two Gen. of l'ernn

he smells April and Min

and smell like Bucklersbury iil...... - iii. 3

rankest compound of villanums sineli

I excell a mun of middle earth ........ I smell al device ......

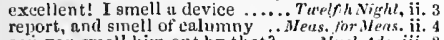
eni youl gmell him ont by that?.... Muchtdo, iii. I am stufferl, cousin, I camnot smell - jii. 4 I smell false I,atin; innghill tor

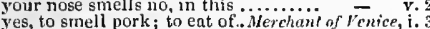

thou losest thy old smell............ As you l,ike il, i. 2

smell somewhat strong of her strong....Hl's Well, $v$. ?

if it smells so strong as thou.

mine eyes smell onioos, I siall

smell this business with a sense...Wiuler's Tale, ii.

I smell the trick of it................

to smell out work for the other senses - iv. 3

here's the smell of the blood still.

stifled with this smell of sin

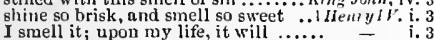

is as bad as to smell a fox $\ldots \ldots \ldots \ldots$. Henryl $V_{\text {i. }} 2$

the smell whereof shall breerl a piagne

I am qualmish at the smell of leek . - v. 1

with whose sweet mell the air shall.2Heary I'l. i. 1

the ear, taste, touch, sineli...

the feast smells well: but I......... Coriolonus, iv. 5

with knaves that smell of sweat... Antous \& Cle ii. I

wreath wus sulplusurous to smell

counsel, lad, smells of no cowardice.. Tilus And, ii ,

soft, soft! it smells most sweetly...

do you smell a tanlt ..................

lot can amell him that's stinking

I smell the blood of a British main ….. $-\mathrm{ii.}_{4}$

and let him smell his

it smells of mortality ...................

the first time that we smell the nir....... iv. 6

what with loathsome smells

my offenee is rank, it smells to jieaven. Hamle', iv. 3

firh one may smell, in such, a will .. ("helto, iii. 3

they see, anl smell, and have their paiates.

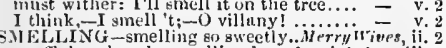

rest,

(l)

dreams he of strelling ont a suit. Romeo of Juliet, $\mathrm{i}$.

huthds or eyes, smelling sans all

IItumlet, iii. 1

MIETL'S $T-a n d$ smell'st so sweet

Tempert, iv.

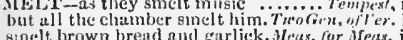

sinelt brown bread and garlick. Metex, for Heas.

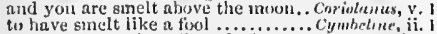

I found them, there I ameit them out .. Lear, iv. 6

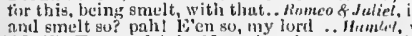

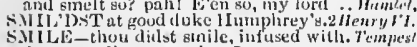

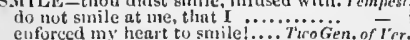

bestow thy fawning suiles on

tw make your grace to staile
quenching my raniliar snile.
thy smiles betome thee weil

thy suniles bitome thee $1 "$ eil
in my presente still sunile

I will smile, I will du crery

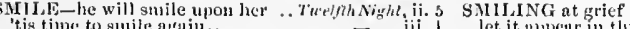

lie dines smile lis fatee into mo..........

if' slue do, he'll sulite, and take't ....

he dots nothing but smile

thit thou therelsy mus'st smile

an' $\mathrm{y}$ 'ou smile not, he's gagged

ro you not smile at this

and smile nt to man's jests....

if such a one will smile, and stroke

each my smiles such skill! ......Mid.. .2 strean

aftliction may one day smile atriti.

the fluwer that smiles on every one

thut smijes his elicek in year

cnforce the pained impotent to sntile - v

ghow their teeth in way of smilc....uer. of fenice, $i$.

with cold. I smile, and say

thint for eominte a-night to jaine Sunile

ull of tears, fill of smin

fevonr of the king, suile upon this .. All's rell,

pity his distress in my smiles of eunifurt - v.

you should smile, lie grow s. Taming of Sh. 1 (ind.)

making at pructised aniles as in .... H'inler's tale,

lis sniles; the very mould and finme

there's dlaggers in men's smiles .......

Is onee sem to smile ....................

mit swords I smile at, wegpon
troops, the kim: doth smile at

witli the craft' of smiles.

her tears, and smiles in meeting

still combating with tears and similes

under the sinile of safet

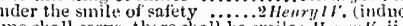
and smile upon his fingers' eurls

good-morrow with a nodest smile..

vietors, upon us he smiles ...........
with Jis hand, and sniles on me

valour makes me smile at the

vor boyl he similes, trethink

shise smile and crown, like to $\mathrm{Aeli} i l \mathrm{l}$ s

miles, and says, his Edward is installed

peers of Frunce shonlil smile at thit

uneeo and mistress smiles at her news

speak fair, smile in men's faces .....

at my serviee, like entiorced smiles.

shall make me smile in France.......

I stood not in the smile of heaven.. Henr

betwixt that smile we would asivire to
troins that waited upon my smiles..

if' they smile, and say, 'twill do, I know

this sigh in wrinkle of u smile..Troilus of

0 , he smiles valiantly...........

to send their sniles belore them to.

welcome ever smiles, and fitrewell

your tlirones, ankl smile at Troy!....

but rather one that smiles .... Timun of $\bar{s}$ the

whuse dimpled smiles from ${ }_{\text {gla }}$

with a kind of smite, which n

senators shall mingle tears with siniles

bid me fitrewell, and smile

seldom he smiles; and smiles in ....jul

could be moved to snile at anythiug

lide it in sniles and afiability .....
for, look, he smiles, and Casar doth

some, that smile, have in their heart

do ineet aguin, why we sliall smile (rep.)

suminer news, smile to't before ....C Cy

in plensing smiles such murderons. T'itus

stars that frown, lani us a snile.

canst not smile as the wind sits

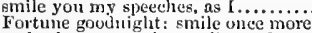

and rain nt once; her smiles and t'ur.

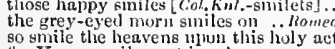

tor Venus smiles not in a louse......

to move the heavens to smile upon my

oeension amilcs upon a seeond leave

the robherl, that smiles steals something. (om

lase it nust so lung as we can smile

ay, smile upon lier, do fl..................

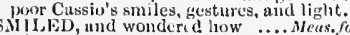

whose minceries are to be smiled it.

and still he fmiled, dut talked

und smiled to see him mangie....

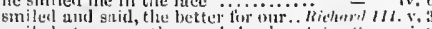

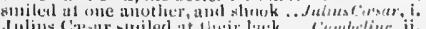

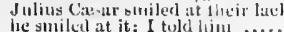

but it me me in tlsy smili

then cant'st in smiling, 31 .

sat smiliug at lis cencl prey

provokes me to ridicalous smili

a villuiu with a smiling bleck.

I would, while it was

the murriage-berl of smilingr peace.

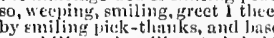

on a hill stuod smiling, to be
thon smiling while he

with smiling plenty, and fuir

I think his sniling lecomes hi

most smiling, smochlh, detested. Timon of

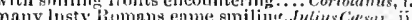

many lusty liomans enme smiling.

dimplcd boys, like smiling Cupids. Awlo

and smiling extremity out of net

such smiling rugues as these.

of Hamlet sits smiling to my jie............

viluin, villain, smiling, damned villain! - is

IILINGLY revolt ................. Corolemes, iv. 6

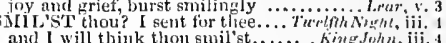

smil'st upon the stroke that ...... Romp's \& Jutie', iii.

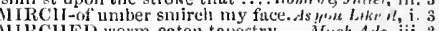

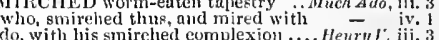

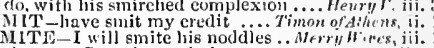

the next Casturion smite!

it smites me beneath the fall .......... of $\bar{T}_{e r i e}$ v.

I saw a smith sturd with his........ King Jolu, iv. 2

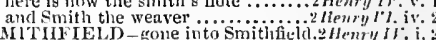

che witeh in Smithficld slall be ....2 Henry 17 . ii.

but get you to Smith field, and gather - iv. 4

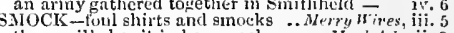

there will slie sit in lier smock .......Wuch d do, ii. 3

bleach their summer smucks....... - v. 2 (soung)

the turehorse to a smock ..................Alv's itell, ii.

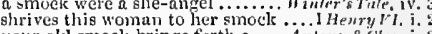

your old smock brings forth a.... Antony foclen. i. 2

ill. starred wenchl pale as thiy snoek!. Whello, $v .2$

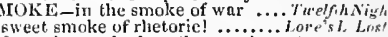

from the smoke into the smotlier... s s you like

they legin to smoke me ................All's s'el,

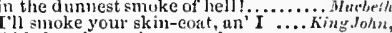

filded up in smoke, to nrake a

smokes about the lurming erest..... - ii.

so bees with smoke and doves ........ Inenryli. i. 5

smoke, ankl lukewarm water.. Timon of $A$ thens, ii. 6

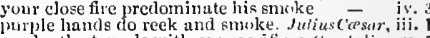

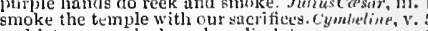

and let our crooked smokes climls to $-\bar{y}$

sone of you shall smoke for it ...... - is.

that bluody knife? "Tis hot, it smokes.... Litur.

bright smoke, cald fire, sick health. Romeo of $J$ ul i.

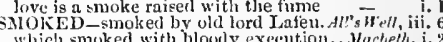

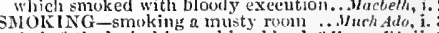

their fetlocks in lis sunoking blood..3Henry $r$.

that we with shtoking swords may . Cor iolamus, i.

worse than a suloky house ........ ll Heny $/ \%$. iii.

to the fire-eycu maid ot smoky war..

unlustrous us the smoky tight .......'('ymleline,

SIOOTII-is not mure smoutl

with such a smoutli, disereet ........ -

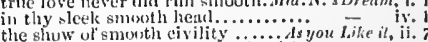

politie with my fricul, snototi with

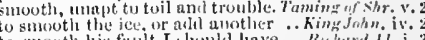

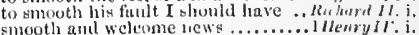

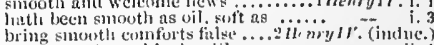

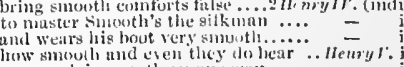

crery 1 mb is shootls on wir way .... -

and my condition is not snooth ......

smonth rums the water, where the

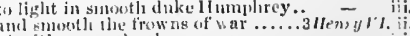

his tille, sungetlis the wrongr...... - is. 
SMnOTI-in men's fines, smooth ..Richard III. i. 3 SNATCIED with an unruly hand ..FingJohn, iii. A his pr:ee looks cheer

the sea beillg smooth, how many. Troilus $\bar{\delta}$ (ross. i. 3

most suiling, sment! , lle tested. Tim

Ewclli with stinf str fine : $11, \mathrm{cl}$ smoth

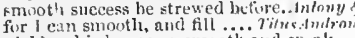

yiclir to his hunour, si

yeut to strike but smouth

smoutl crery passion, that in the ni.......

to smooth that rongh toleh witli. Fom
whit tonge shall smootls thy name

loatlisome erust, all my smooth body
to bear all smooth and evel, this sudd

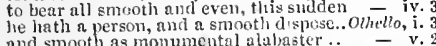

and smooth as monumental atulsaster
hath smoothed his wrinkled front ... Ri

is smootled by that below
iforTH-TACE Woocs

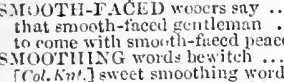

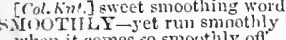

When it comes so smouthly of
JUUTII ESS, her very silene

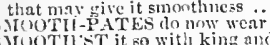

MIOOTH -TONG UE, Spruish-

rays have smote the night of dey
rages

rediles smote? onrselves resisted. . Corrotenus, iij. dog, and smote him-thus

Simmlet, i. 1

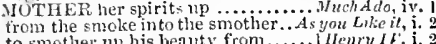

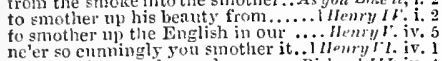

ne'er so cunningly you smother it...11lom
let's smother my dimned sont ..... Riclarr

girow worse, to smother it..

that tumetion is smothered in surmise.

Emothered it within my munting ..

the vapour of my glory smothered
we smothered the most repjenished

smothered in their dusky graves .... $=\quad$ iv. 4

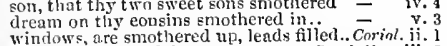

S.MOTHEiING of the sense .......... Cymbeline, iii.

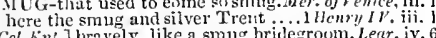

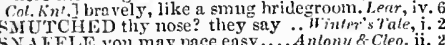

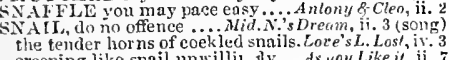

the tender horns of coekled snails. Love'sL. Lost, ix.

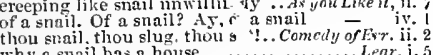

why a snail has a house

sinail-meed Ajax arm to

F.AKE throws her enameilied .... Mid

You spotted snakes, with double
exit shall be strangling a smake

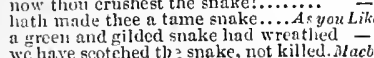

fill.t of a fenns s s. .ke................

snakes, in my hed-biood warmed.

with fell Aleeto's snake ............

you hut warm the staryed snak
like a fury crowncd with snak

a eistern for scaled snakest........... - ii.

a thousand hissing snakes.

a thousand hissing snakes .........

AAKY golden loeks........ Merchant of te

of nature, qut I may snan at him ...2

AAIPED of with two old men.........Much Ado.

W. RE the nimlle marmozet.

that fled the snare of watchfin..
where's Snare. 0 lord $($ rep. $)$.

yea, good master Snare (rep.)

iflices, master Frang and mastc

the snares of war to tangle the

by snares, by subtility, sleepin

fill, I fear, our toes the snare... Timon of $\overline{\text { th }}$ thens,

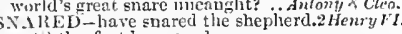

SNAPI, suarl, and bite, and play.....3 Henry $r$.

SALLTL in the gentle eyes of..... King.lohn,

N.ARLANG - were you snarling all.. Wichard II

to snateh words from my tongue.. L.ove's $L$. Lost.

as now arsain to snatel our paim ... King John,

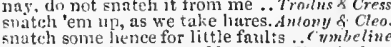

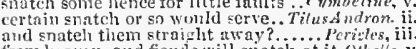

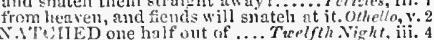

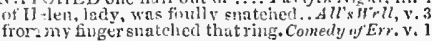

an honour snateled with hoisternis.? Henry II: iv.

nealh hath snatehed my luzslundi.. Rictured III.

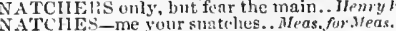

pale fire slie slatelies from the sun Timon of $.11 \%$. iv. 3 Enatehcs in his voiee, and birst of.. Cymbrime, iv. NATCIING-they'll be snatehing

NE.1K not away, sir, fur the .... Meas. for Mers. v. 1 If
NEAK-CING-a sncak-cuin?

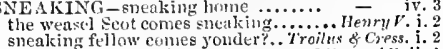

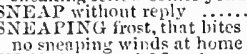

no sneraing winds at hon

SNL1't tue, but a snip! and away. Love'sL.Lost, iii.

here's sulp, ami nip, and cut $\ldots$. Taming of $\mathrm{Sh}$ iv. 3

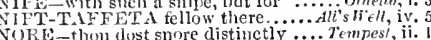

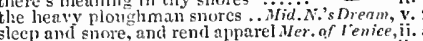
do nock their eland rend apparel

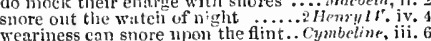

but snores, the holise nbont.... Perieles, iit. (Gower)

NORING-here do snoring lie.. Tempest, ii. I (song)

arice; awake the enerting citizens with . Hhello,
NoUT the tinker (rep. iv, 1).... Mid.N.'s Dream,

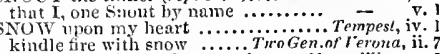

kissing-comtits, and snow eringoes.Merry H'res, v. 5
high Taurs's now, fanned with...Mrd.N.'sDr. Hii.

high Taurns' snow, fanned with.

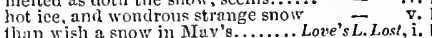

and lirds sit brooding in the snow - vow 2 (song)

't:'een snow and fire, as ...Nerchant of renice, jii.?

dare not shake the snow from...........All's sell, iv. 3

as white as driven snnw...
or the fannerl snow, that's bulted ....
winter's drizzled snow ........ Comedy of Er.rors, iv. 1

winter's drizzled snow ...........

or, as a little snow, tumbled , were a noekery king

colrl snow melts with the sun'

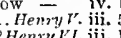

so mueh eold as over shoes in snow?

doth thaw the eonsecrnted snow

when snow the pasture sheets......... Antory of Cleo

as chaste as unsumned snor .........Cymbeline, it.

snow to their eolder moorls

between her forks presageth snow.....

ven's back tomeo \&. Intiet, iii.

as pure as snow, thou shat

his shroud as the mountain snow - - iv. 5 (song)
his beard was as white as snow ...

that whiter skin of hers than snow ..... Othello, $v$.
thow-BALIS for pills to eool...Mery Wives, ij.

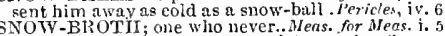

SNOW-WLITE pen the .. Love'sL.L.ost, i. 1 (letter)

snow-white hand of the most beauteous - iv.

SNOWY dove trooping ..............Rnmeo \& J J uliet,

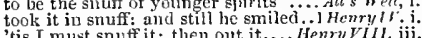

'tis I must snnff it; then out it.... Henry VIII. iii.

and solace i' the diungeon by a snuff?.

my snuff; and loathed part of nature

a kind of wiek, or snuff, that will ...... Hamlet, iv
NU FFED up love by sinelling . Lnve's L. Lnst, ii

UG the joiner (rep. iii. 1 \& v. 1).Mid.N.'s Dreat,
$\mathrm{AKS}$ up the king's countenanee..... Humnet,

OAK LNG, wil] draw in more......... Hinter s Tal

sink, and soaking in, drow the. Tims sndron. iii.

the kite soar with unbloodied beak?.2henry $r$. ii

and goar with them above a...... Bomeo \& Juliet, i.

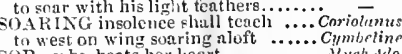

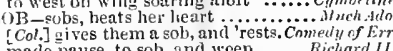

made pause, to sob, and weep ...... Richard

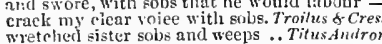

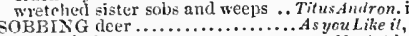

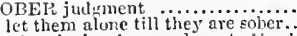

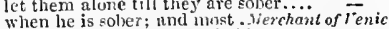

if I do not put on a sober habit

enter my sober house...
but some sober brow wili biess it

speak'st thou in sober meanings ......

disglused in sober rohes, to oldi.... T'aning of

sir. you scem a soher uncient gentleman
sober virtue, ycars, and modesty. Comedy a $/ E$ there's meaning in thy snores

wallow naked in Deember snow...... Richard II. i.

the light, by taking it in snuff.... Love's L. Lost,
to be the suuft of younger sjirits ....All's Well,

how high a pitelh his resulution soars nichxid $I$.

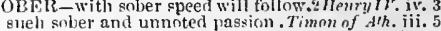

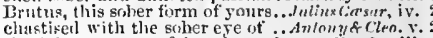
that's but a queen, fair, solser, wise.... Hamlet, iii. SOBERLY dirl mount a termagant. An'ony \& Clen, i. SOBRIE'Y - behaviour nnd Eubiety Taming of sh. i. the sobriety of it, and the mnlesty ...Men it $t$. iv. SOCIABLE to the show of thine ....... Timplest. v. and too saeiable for your ennverginn... hing.Joln, i. can he not be sneiable? ...... Troilus \& creasida, ii. is no comfurt to one not sociable ...Cymbelini, iy. now art thou sociable, now art.. Romen \& Juliet, ii.
SOCIETIES-my wild societies .. Merry Wimes, to make soeieties seeure... Mrosure for Mra.ure, iii.
he ablhorred all feaste, soeieties .. Timon of dhl. iv. that he enehants societies unto him...Cymbrline, $i$. alijure for of her soeiety be not afraid. Tempest, iv. I beseecle your society ( $r$ cp. $)$..... iove's L. Lost, iv. the corner-eap of soevety, the shape..

in love's grief desir'st society......... leave, - the society, which in the boorish abanton the suciety of this female.... $\bar{T}_{\text {male, }} \mathrm{v}$. malle separate of their snciety ...Wh'ters Tale, i. ourself will mingle with soeiety ....

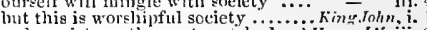
rude snciety as thou art matched ... i Henry I $H^{\prime}$. iii. 2 with the portieipation of soeiety....2 Henr? $I V . v$. they are a sweet society of fair ones. Henry an you legin to rail on society.. Timon of $\mathrm{d} / \mathrm{hen}$, $\mathrm{i}$. our soeiety with thankfulness $0-1 i$. 6 (grace) society is no enmfurt to one not ....Cymbeline, iv. shunned $\mathrm{mr}$ abhorred soeiety ............. Lear, v.

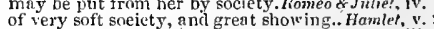
sOCK-smoeks, socks, foul stockings. Merny Wives, iii. soD-twice sod simplicity..... Love's L.. oost iv. SODDEN-can sodden water, a direncli. Hen,y $r^{\prime}$ iji. sodden business! there's a stewed. Troil. \& Cress. iii.
they are sn pitifully sodelen ........... Pericles, jv. SODDEN-WITTED lord $t . .$. Troilus $\$$ Cressida, ii. SUE' $\mathrm{ER}-$ tongue soe'er spenks false ... King.Iolhn, iv.
how mean soe'er, that have their .... Cymbeline, $i$. what villany soe'cr 1 bid thee do ..... Cymbeline i. ii. how st range or odd soe'er I bear unysclf. Hnmlet, $\mathrm{i}$. 5 SOEVER - what eomplexion soever. Merry "ires, iv. of what vnlidity and piteh soever.. Treelfh Nigh, how low soever the matter, I hope. Lore's L. Lost, of what degree soever, with his

how rank soever rounded in Troilins \& Cressida i. how in my words soever she be shent... Hamlet, iii. so-FOR'TH-Sieilia is a so-forth .. Winter's ' " $i_{e}, i$, a dish of earaways, and so-forth SoF' $\mathrm{\text {vich }}$-soft, a brotheli, or so-forth

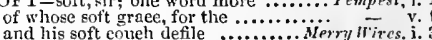

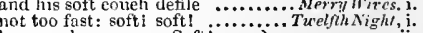
by your leave, wax. Soft! (rep.)...... - ii. so tar benenth your soft and tender.. for we are soft as our complexions ... dost fear the soft and tender fork....

but coft and low, remember now .... - - iv.

thronging soft and delieate desires.....Much sdo, $\mathrm{i}$. sott and tair, friar: whieh is Beatriee? - v. hut soft; what nymphs are these?.. Mid. N.'s Dr. iv. 1 love's feeling is more soft, and sersible - iv. Eoft, let us see; write, Lord have $\dddot{2}$ but soft: how many montlss do $\overline{\text { seniee, }}$ i. 2 I'll not be mede a soft and dill-eyed

beds be made as soft as yours........
soft! the Jew sliall have all (rep.)...

soft stillness, and the nighit, become $-\bar{y}$. soft! comes he not here? ......... As youlitile il, iii. with soft low tongue .. Taming of Shrew, I (indive.) Itcel soft things; upon my life .

soft, son! Sir, by your leave

but, soft! what eompany is..........

why are our bodles solt, and weak

you may ride us, with one soft kiss. I'inter's To

this hand, as soft as dove's down

soft, swain, a while, 'besceeh youl....

$O$ soft, sir, hold rou still ............ of Errors, ii. 2

windy breath of soft petitions .........King John, ii.

to the tears of soft remrrse ..........

smooth as oil, soft as young ........... I Henry IV. i.

lut, suft, I pray you (rep. ii. 1 and v. $^{4}$ ) $-i$.

in your nower, suft sileneing your....

tolieh her soft mouth, and mareh .... Henvy $v$.ii.

a goorl sof pillow for that good white - iv. 1 but, soft! I think slie eomes ........2 Henry $V$ l. ii. women are soft, mild, pitiful .........3 shoull not deal in her soft laws....... Richard 1 Iii. $\mathrm{i}$. or End ward's soft and pitiful ......... Richard $I I$. i.
but soft, lacre eome my executioners 


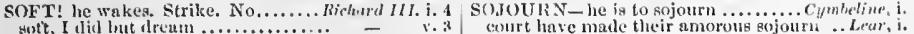

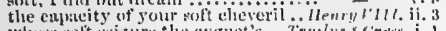

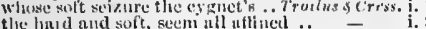
the haid and sofe, seen all uthined sult iufancy, that wisthing etunst ant give us soft atturluncut to yet, soft: lleetor, I kuke my leuve suft! here eome sleeve, and tolher soft, take thy physic first ....T whuse foft injeression interprets whlt: who compession .

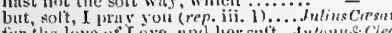

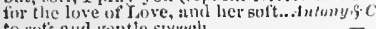
to sutt and gentle speceli ............. tlue bets i' the enst uru soft .......... our sunt as air. as gentie ...............

soft, suft; we but indefence

in trosit cupa sutt beds, sweet worils

a stone is sot as

soril sec how busily slie turns .......

but, soft, mcthinks.

sotit, here he comes: I must dis emble. Perictes, ii.

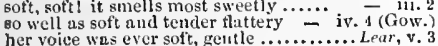

her voice was ever soft, gentle ............. Lear, v.
suft. I will go alous; an if y'oul.. Romeo of Jutiet, i.

suft, thil go al light an though yonder

but, soft: whut duy is this?

sott, tuke me witis you, tuke me

stratagems upon so soft a subjeet.

soft you, now! the frir Ophelin

surt; now to my nother, $\rightarrow$ licart

but soft, what noise? (rep. v. I)

sott, let me see; we ll make..................

of very soft society, and great showing

0 come iv, Emilia: soft, by and by

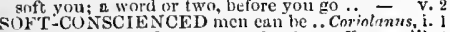

SOFTEN stet and stones.... TuoGen..nf Veronn, iii. 2

by your fair prayer to soften ......Meas, for Yeas. i. 5

how he may foften at the sighit... Mer.of

that grief softens the mind

Cleopatra, 6often thy waned liph..Anlany \& Cleo. ii.

tears tell from her, and softened. othello, iv. 3 (song) SOFTER and sweeter than.. Tuming of Sh. 2 (induc no lady of more softer bowe

SOFTEST-the frailest and softest. As yon Like it, their softest touch as smart as

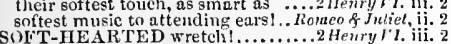

like-HEARTED wreteli!..

SUF"TLY-tread softly (rep.)

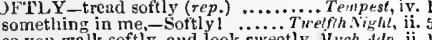

so you walk softly, and look sweetly. Inkch sto, ii.

though he go as softly as toot cain. As you Like it. iii. 2

sottly, my inasters! if jou be...... Taming of Sh. i. 2

softly and swiftly. sir; for the priest - v. I

Iwill tell it softly: yon crick

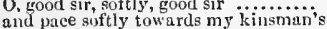

speak of tly; y yonder, as I think.. Comedy of Err. v. some other chamber: softly, pray ..2 Henry $l F$ iv. 4 speak softly; or tixc loss I Henryll. i. I

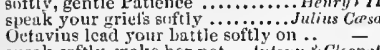
Jutizts Casar, iv.

speak softly, wake her not... Antony Cleopulra. $y$

pruy you walk softly, do not heat ..... I'ericles,

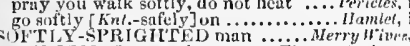

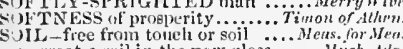

as great a soil in the new gloss........ Huch dedo,

of terra, the soil, the land, the euril...
the soil, the profit and this kind...As you l.ikr

the soil, the profit and this kimd...As you likrit,

suks the soil's tertility frum wholesome -

the thirsty Erimys of this eisil...... IIenry 1

of ach suil betwixt that Hotuedion.

the finttest stril to w'ceds

tir all the soil of the aeliciement

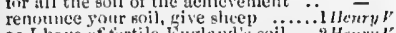

as I have of fertile angland's goil...2.2 Henry $\mathrm{I}^{\prime}$.

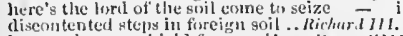

hononr henven thield from sollt..... Hem y llit.

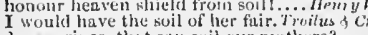

dome, prinee, that eats suil our nuthers?

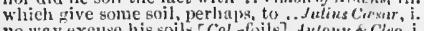

no way exeuse his soily [Col,-foils $]$. Antony $\delta$ Cloro.

must not roil (Col.-fuil] the precious. Cymbeline.

with swioiah phrase, soil our ajelition

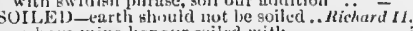
or have mine honour soiled with

when we have soliled them.... Troilis \& Crenside, $\mathrm{i}$

a thing a litkle suiled i' the working....... il ramlet,

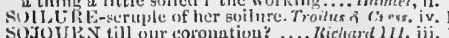

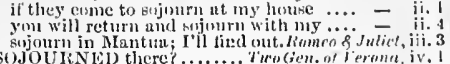

but, th guest-wise, sojutirned.

sorrow strange past me solace.. Lnve s L. L.ov, iv.

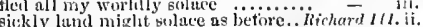

huzards still huve been your onlace. Corrola

solace i' the dungem by a snut'?

one thing to rejoiec and solace in. Romeno. Julim,

the boy lath sold him a bargatill... Love's L. Latsh, iii.

you luve sold vour ow 7 jands ...............

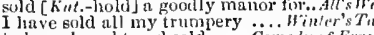

to be so bouglit and soid .... Comedy of Erro

have sold their fortunes at their ........king $\left.J_{1}\right)_{h y}$, it. I

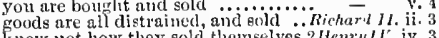

know not how they sold themselves.2Henryl ${ }^{\prime}$,

you would have sold your ling to .....Ilenry $r^{\prime}$ ii. 2

think, I had sold my farm to buy..... -

from bought and bold lord Talbot.....

lands are bargained fur and soli $\ldots \ldots$.... Heury $/ l$. i. 1

Anjon and Naine were sold to Frnee
jedlar's daugliter, and sold many laeco

geven halt-penny ioaves sold firr a pent
the lord Say, whiel gold the towns

I sold not iraine, I lost not

have sold their lives unto the hio......

master is bought and sold... Richard III. v. 3 (ecroill)

bonght and sold among those of. Troilus \& Crpss. ii. 1

all my land be eold

last sold me to this novice .... Antany

to the Roman boy she hath sold me.

things that roerehants sold ......... - v. 2

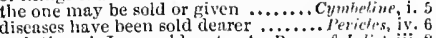

and, thongh I mm sold, not yet...Romeo \& Juliet, iii.

by the insolent foe, and sold to slavery... Ohello, i. 3

I'd not have sold lier for it

SOLDAT-car ee soldat icy est dispose. Henry $y$. iv. 4

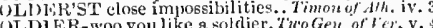

SOLDIER-woo you like a soldier. T'wo Gen of ler. v.
if the love of a Buldier can., Merry Wives, it. 1 (letter)

you were good soldiers, and tall .....

money is a good soldier, sir...........

come, my young soldier, put up ..... Me $-1 v$.

I never heard any soldier dislike it...
which in the soldier is flat blaspluemy

which in the soldier is flat blaspliemy
Frederick, the great soldier, who....

good soldier too, lady. And a $\left(r p^{2}\right)$.
1 looked upon her with a soldier's ey
like an honest menn, and a soldier....

like an honest man, and a sold soldier's in the...

as it is base for a soldicis to love... Love's $\bar{L}$. Lost ii.

and, soldiers, to the freld?, that

gentiemen, and soldiers, pardon me.

and I will right myself like a soldier

a stholar, and a soldier, that .Merchant of rinich,

you have somer stallentered soldiers, to retur

your lordship thinks not lim a soldier

and to be a soldier? Such is ly noble

and to rend our own soldicrs

between the fool and the soldier?

antl say, a soldier, Dian, told thee

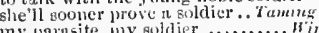

my partsite, iny soldier

a better soldier, nune that Christendom

fic! a soldier unil actart?

gcese, villain? Soluiers, sir ..............

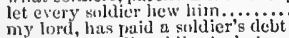

wh the che

a solutier by the hoswour-giviug liand...king John,

I :m a solclier, and now bound to....

the swords of soldiers are nis teeth ..

to the fir la as God's own sullier

been sworn my soldier? liddling
lirave soldier, parton me, that any

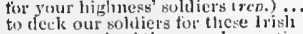

prove urmed soldiers, cret ler native

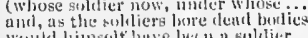

of suldiers slain, suld all the current

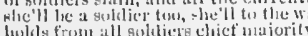

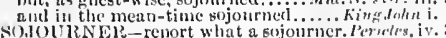

(1) I. the thlorions phant. Sol .... Troilus

sell thee poison, thou hast soli me none

nor the soldier's, which is ambitious

to talk witli the young noble soldier

who, hike a ront! and lsardy soldier .... . Nart

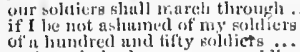

such ns, indeed, were never soldiers.

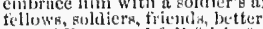

our soliliers stand full diaily tor.

thin did our soldiers, aimi the rchels neted ast

to lilke s'ldiert up in thecoun

a soldier is better aceommoduteil tlian

le's like to be a coli soldier.........

Barilolpli, give the soldiers coate.

and my lit fle soldier there, be merry

as I min as soldier (rep. iii. 3)

and hind -

yct my soldies's suldiers in their

yct my soldieg's are in my command -
the blind and blondy soldier witl tist

sickness growing upon our soldlers.

under the form of a soldier.

advantage is a better soldier . .ji....

the parcicular endings of his soldicers
try it ont witl all mingrot ted solitiers

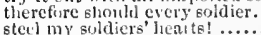

tud niy poor suldiers tell ma... yct c...

now, soldiers, march an ay; and liow
in which array (burate soldier) doth

then every soldier kill his prisolicrs.
hath cancel every solditer to ent his.

soldier, you must cone to the king (r

as lie was a soldier, he would wera
is it fit this aoliticr keep his unth?.

cnl hin hither to me, soluier

il that the soldier strike lim

give me thy glove, soldier; look.
like savage, as soldiers will......

to trach a soldier terms, Eucl as $\ldots \ldots$.

take a soldier; take a soldier, take

among the soldiers this is nuttered...1 Henry I

ten thuusand sildiers with me......

if any noisc, or suldier, you perteive

to gather our soldicrs, scattered.

for suldiers' stomach always serve.

I should reviye the soldiers' hearts.

a braver soldier never couched lance

soldiers, adieu! I have what 1 would

gentleneen, and soldiers, that in thio

more like a soldier, than a man
fur solitier's pay in Franee (rep.).
wever robbed the soldicrs of their

provicle me soldier's, lords, whiles I.

provirte me soldier's, hords, whil

bring forth the soldiers of our pirize.

and sent the rngged soldiers wouts.

soldiers, defer the spoil of the esty....

soldiers, this llav luve you reduened

soldiers, I thank you all: disperse

the swords of common suldiers slain
soldier's, stay, and lodge by me this.

soldier's, stay, and lodge by me the have truops of soldiers at

and I'li keep London witlin ne soldier

for solders should have tossea me.

soldier's, away with him $\mathrm{l}_{1}$...........

that robbed my soldiers of their.
our soldiers, like the niglit-owl's lizz

our soldiers, like the nighit-uwl's liz

with aid of soldicrs to this necdful .
our coldiers jut to flicht ............

bunds uf ehosen soldiers, rii undertal

these soldiers slanll be levieti, and tho his solliers lurking in the towns abon

that leerry is nu soldier ............

or die a soldier, as I lived u

llerbert a renowned soldie

the army, checring $11 p$ the eoloiers.

I will lead forth my suldier's to the ph

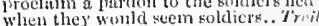

but we ure foldiers; and muy that rold i

he was a soldier gond; but, by b
that this grent Enllier may his

thou art in soldier, therefore .... Timon

there's gold to pry thy soldiers

enriehed pror straggliag soliliers with

thun wast a soldier even to Cuto's wisl

nay, my good sellitirer, upr ray gentle

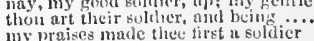

you lind hin like us aldier........

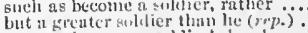

$\bar{z}$

$=$

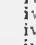

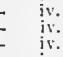

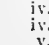

$$
\text { i. }
$$


SOLDIERS use lim as the grace

the tribunes nte no soltiers..

IuIn the soldiers

thee o' the elietest soldicrs; itil be one

I :m a soldier, I, vlder in prantice

You say, you are a better soldier

weary his solkliers, doing himself offence -

and leeding from our soldier's hands

most like a soldier, ordered honourably

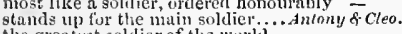

I go frum heme, thy soldier, servint

wits borne so like n soldier ...........

thou art a soldier only; speak no more -

how far'st thou, soldier: Well; and well -

let's ha't, good soldier. Come ...... -

ambition, the soldier's virtue, rather

that without which a soldier, and his

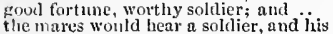

how now, worthy soldierl o noble.

to-morrow, soldier, by sea and land..

and the soldier that hos this mornio....

un more a soldier; brutiven piees go

the soldier's pole is fallen; young boys
nht soldier! how goes it here?
lyis fa........

his father and I were soldiers together

this attempt I'm soldier' to, and will
he shall be interred, as soldiers ean

the shall be interred, as soldiers ean.

that the poor soldier, that so rieh

the forlorn soldier, that so nobly fought -

I an, sir, the soldier that did compnny $=$

none but soldliers, and Rome's servitors

a hulter, soldiers; hang lim on.....

very well beeome a soldier's dane

but be a soldier to thy purpose

your sister is the better soldier
to't luxnry, pell-mell, for I lack

take thou my soldliers, prisoners ........
for thy soldiers, all levied in my name

driveth v'er a soldier's meek. my name

1), farewell, honest soltier: who hath .

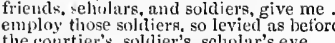

the courtier's, soldier's, scholar's eye
as the slcenng soluliers in the alarm

like a soldier, to the stage; for he was...

the soldiers' musie, and the

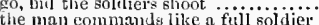

you may relish him more in the soldier.

not past a pint, as I am a soldic

koldier's a man, a lite's bit a span $(r$
he is a soldier fit to stand by Ciesar.

or liss than trutl, thut art no soldier.

"tis the suldier"s life, to have their balmy

itself sustain unon a seldier's thig

UIDDIER-IIKEDER: shall not thou. Herry

be andlier-like word, and a yord..? Memry II

to the possibility of thy soldiership.
more of his soldiership I lnow not

and put we on industrious soldiership.. Marle

kniyhthood and my soldiership aside. 2 Henry I

snldiership is twiee the other twain...
throw thway the absolute soldierslip

withont practiee, is all his soldiersh

(i), - the sole drift of my purpose

th - the sole dift of my purpose .... Tempest

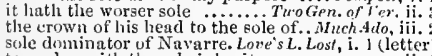

to parley with the sole inlere tor $\ldots$...

not on thy sole, but on thy soul.Mer.

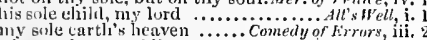

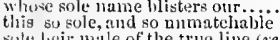

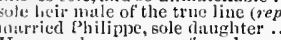

Itenry, sole pussessor of my love
Inim she slanll be sole vietress

thint praise. sole pure.

ant affecting one sole thimone

inled, sir, a mender of bad soles...J Ju $\theta^{\prime}$ the world ........

he purposet to his wife...... An sole

is whe sole thild to the kin

liave had the sole son of my queeut

lancing sloves, with nimble soles

when the single sole of it is worn

nor the soles of her shoe?

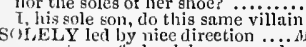

great way tool, solely a eoward........All's si'el,

left solely heir to all his lands .. Taming of s's, $\mathrm{i}$

sulely sovereign sway and masterdom

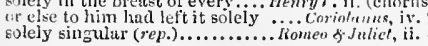

SOLEMN temples, the great globe

a solemm air, mut the best.

and sing your solemn hymn

their folly, passion's solemn
ancl an old, in solemn talk.....

.. Ttretfin Night, v.

the solemn feast stall more

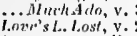

al though betore the solemn priest.

s.till's lichli, $\mathrm{ij}$.

of whom he liatl taken a solemn leave - ii. 3

an eyesure to our solemn testival. Taming of sh. iii. 2

in solemn synods been deereed .. Comedy of Err. i. 1

we hold a solemun supper, sir
bend sueh solemn hrows on me

bend sueh solemn hrows on me?

in solemn shatles of endess night ...Richard il. i,

stil and solenun priests solemn still

here we entertain a solemn peaee . iHenry li.

sworn with a solemn tongne!

and broke lis solemn vow $($ rep $)$.

our army shall, in solemn show...Antony $\bar{s}$ C

solemm things should answer (rep.). Cymbeline, iv.

even at thy solemn feast, I will brio

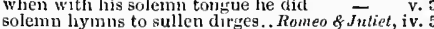

nor customary suits of solemn blaek... Hamlel,

we'll make a solemu wagct on ......... $\overline{\text { oth }} \overline{\text { iv }}$ iv. $\mathrm{v}$

SOLFMINESS ont o'door............. Coriolamar, i. 3

OLFMNITY. Aud as we walk. TwoGen. of Ver. y. 4

here in grace of our solennity...Mid.
we"tl liolli a feast in great solemuity

a fortnight hold we this solcmuity

won by rareness, such solemnity

won by rareness, such solemnity ...1 1/entry I' '. iii. 2

seorn at our solemnity? (rep.).... Romeo o. Jutiet, i.

to murder, murder our solemnity? ..

solemuize this day, the glorious sun. King, John, iii. I

Jaques Fauleonbridge solemnized. Love Tempest, v. 1

our nuptial rites be solemnized...Mer. of Venice, ii. 9

and the day it is solemnized ....As you Lilie

this marriage to be solemnized

SOLENNLY, dance in

Golemnly set down our coronation.. Richard II. iv. I

solemnly, see him set on to .... Henry $V^{\prime}$ v. (ehorus)

after I have solemnly interred....... Richard hI.
he solemnly had sworn, that ...... Henry III.

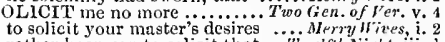

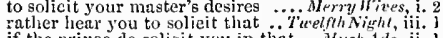

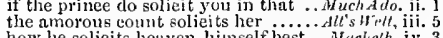

how he soljeits heaven, himself best ... Macbeth, iv. 3

mure solicit me, slian your exclaims Richarl II. i.

we heartily solicit your graeious..

did solicit you in free contempt

frame yourself to orderly solicits...... Cymbeline, ii. 3

we will solieit heaven ....... Tilus Andronicus, iv. 3

heaven and graee, solieit for it straight.. Othello, v.

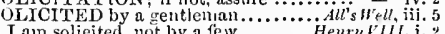

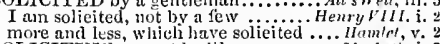

OLICITING eannot be ill................. Hacbeth, i. 3

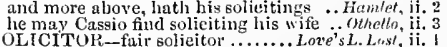

for thy solieitur shall rather die ....... Othello, iii. 3

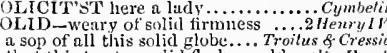

a sop of all this solid globe... Troilus \& Cressich,
that this too too solid flesh would melt. Homile

whose solid virtue the shot of aceident. Othello
OLIDAIRES for thee ........ Timon of Athers,

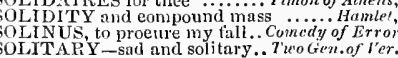

in respect that it is solitary........ As you Like it,
sox,ONON - Solomon so seduced .. Love's L. Los

and profomint solomin to tune

OLUA -ad imprimendum solnm. Taming of $\mathrm{Sh}$.

the solus in thy most marvellous (rep.)
I do returt the solus in thy bowels....

I do returt the solus in thy bowels...

didst thou not hear womebody?

to erzen somehody in this eity

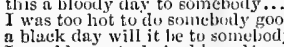

a black day will it lie to someljody

go to the gate; somebody knoeks...Julins Crssa

red rose, with young somerset

Somerset, where is your argument? (rep) -

proud Somerset, and Willian Poole

whieh somerset hatls offered to my

against my lord, the duke of Somerset
will not this malice, somerset, he left?

cuusins both, of Vork and Somerset

my plerige. accept it, Somerset $\ldots . .$.
ineline to Sumcrsct, thian York....
SOMERSET-lord of Somerset, wnite .1 Hewry VI.iv. 1 he wears the bandge of Somverset ........ inble York and Somerset ( $r$ rrp.iv. 7 )

consin of Sumerset, juin yon with (rep.) Somerset, Bnckingham, and grumbling or Somerset, or York, all'y one to me if Somerset be unworthy of the piaee

my lord of Somerset will keep 's ' 7 .)
let Somerset be regent o'er the Freneh

cume, Somer'set, we'll see thec sent away -

at Somerset's ambition, at Buekinghum -

that Somerset be sent as regent........

the duke of Somerst, wioni lie terms

Somerset, we will conmit thee thither -

to remove proud Somerset from the king -

the duke of Somerset is in the Tower

to henve the traitur. Snmerset from lience -

how now, is Somerset at liberty?... =

shall 1 endure the siglit of Sonverset?

graee dend, my lord of Sumerset?

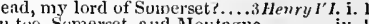

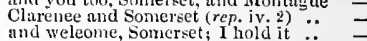

my lord of Somerset (rep. iv. 6) .......

and Somerset, witli Oxford, flerl to her -

and Somer'set another goodly mast?..

for Somerset, off with his suilty head

three dinkes of Somerset, threefold ..

OMIETHING riel an:d strange.. T'mmest, i. 2 (song)

but he's something stain'd with grief.. - i.

't the name of something hily, sir ....

my will is something sorted............. Gen of Fer. i. 3

he is something peevisls that way... Nerry ir ices, i.

which hath something emboldeneel me -

good hearts, devise something

are something rank on foot..........

make that resemble something in me Thel Nigh , ij,

1 do eare for something............. $\quad$ - iii.

there's something in me, that ......

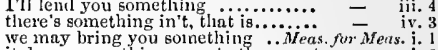

we may bring you soinething .. Meas. for Metss. i.

something too erablied that way, friar = iij.

happily, you something know ....... $\overline{\text { ive }}$ iv.

of something nearly that eoncerns . Mid. $N " s, D s, \mathrm{i}$. 1

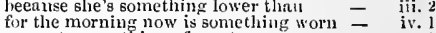

grows to something of great eonstaney
something then in rhyme ......... Love's L. Lnst, i. I

I will sometling afiect the letter..... - iv.

and something else more plain ......

my father did somethingr smack ( $(\mathrm{rep}$. $)$ - ii.

there they fliow something too liberal - ii. 2

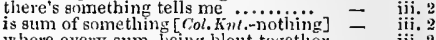

Where every sum, being blent togetlier - iii. 2

tarry a little there is something else - iv. 1

or something that nature gave ..As you Like it,

something that hatll a reference to my

but it grows sometling stale with me -
and if I loring thee not something to eat -

your aceent is something finer tlian.. -

for every passion sometling, and tor no - iii.

sonrething browner than Judas's .... - iil.
I sliall devise something

it concerns you somethlug to know it... All's sell, i. 3 a good traveller is homething than my

sometling, and searee so mueh......

he's shrewhly vexed at something ...

thou may'st inform something to save

there is something in't that stings his $=$ iv.

but something hard of hearing. Taming of shrem, ii.

may'st cu-join with something....... if inter's Tale, $\mathrm{i}$.

something before her time, delivered

please you eome something uearer ... -

weak-linged tancy), something savo.
diseover, something sare, even tlien..

but smacks of something greater than

he tells her something, that makes her

your heurt is full of something .......

that I may eall thee something more

wants but something to be a reasonabl
being sonething gently eonsidered ..

took something gond to make a......

of something, wilclly by us perfinmed
hath oomething seized his wished uoility

eomes it not something neur?........ -

tis give you nothing for sometling ...

there is something in the wind ...... 

SOMETIIING-fetth me something. Com.oftir. iif.

and solvetring wieked this way enmes...... - iv.

but something you nay deserve of him.. - Iv. 3

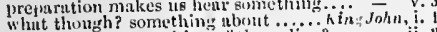

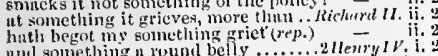

out the sudilen, something ill

devise something to do thyself good $\overline{-} \mathrm{V}$.

yom reprout is something tor romind.. Aenry . v. I

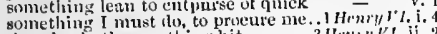

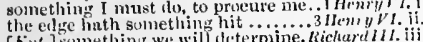

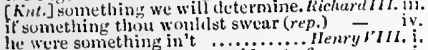

there's sometling nore wonld out of
num something spoke in choler, ill ${ }_{\text {when you weruld say something that is }}$

he is vexed at sumething ( $r p$.

my gutests; something lent command

bie lungs the lip at something.. Thinilns

no: but something mat at something

Yll give you sumething el

Thave bcell sometimes there

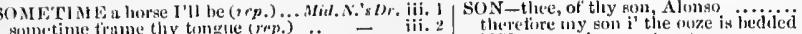

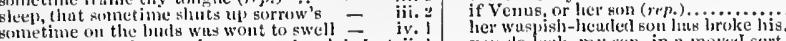

whut though? something nomit not something of the policy?

let it do something my grood loril $\ldots$ 二 iv.

find out something not worth in

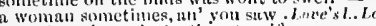
sonctime throngl the thireat as if you

and so it is, sometimes; glory grow's..

(by the world) o(metime to lean myon

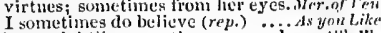

how mightily, sometimes, we make ...All's W'th, iv. 3

sometimes unore ftet than . Taming of Sh. 2 (induc.)

quarts ; sometime, you wonld eull ii,

how sonietimes nuture will betray'

comes a ereature, sometimea her head

pors souls! sometimes to see 'em ....
it should seem, hath sometime loved

honest, I $\mathrm{am}$ so sometimes by ehunee

that I tumiliarly sometines ... Comb or froms, ii.

took up uny lers sometimes, yet I. .

to do good, sometime, aecounted .........

didy sometimes lotother's wife nometime ery, nil haii

gond sometime foren, presale the.

to look upou iny sometimes maste

I etumot ehoose: sometimes he .....
though sometimes it show greatness

but sumething hath been aniss....
tluat I might love thee sonething

suid to be something impe
but this is something odd

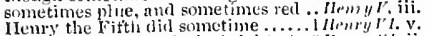

tow rourh, something too rough..........

by his fuce that there was sonething

und lis, find something in hi

yet something leuds ne forth ....Jinting

and sothin it is I would

thus sometimes, lath the brightest... Henry $/$. ii. I

sometime lhe tilke as it (rep.)

Jove sonctime went disgrised

which someting they have used . ...3
sometime the flood prevails; and then

as sometime Margaret did ......... lirh

sometimes our brother's wife....... Henry $\bar{l}^{2}$ III. ij.

stars, indeet; and, sometimes, faling - iv. 1

sometimes we are devils to inirselves

sometime, it appears like (rep.) .. Timon of $-d t h$. ii.

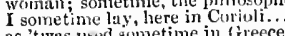

as 'twas used sometime in Greece.

nay, sometimes, like to a bowl upon

and talk to you sometimes?.

sir. sometimes, when he is not..........

will sumetimes divile me from........ - ji. 3

nay, sometime, limus both thier".

the somes like our jud mme

Belarius whom you sometime banixhed

with fog, ns sometime elonds.
youl sometime famous princes............

fur it was sonetime target to a king

as thou my sometime dunghter
and, sometime, $I$ am whipped for holding

sometime with lunatic bans, som

who sometime, in lis better tune

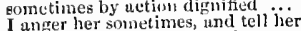

I anger her sometimes, and tell her.
buried Dewnark didl sumetimes na

our sometime sister, now our q

you know, sonctimes he walks. ......

our indiecretion sonnetimes serves us
1 lick iniquity sometimes, to do me

unless selt-ehurity be sometimes a vice.

the best sometimes torget: though Cussio

vou not sometimes seen a landkcrelict = iii. 3

SOMEW HAT ronnder ...... Thro Gen, nf
here is a letter will say somewliat. Merry

here is a letter will say some What.Merry l'imes, iv.
tuld somewhat of my tale ........Meas. fur. Weus.

that's somewhat madly sioken ....... of

these foolish drops do somewhat.inr. of enice, ii. :3

and smell sumewlut strong of her.... All ste ch, v.

are grown somew hit light, we are ...kichurd 1 . . i.

vell, somewhat we must do: eeme

say, an old man (an do somewhat ..2 Henry If. v. 3

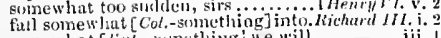

somewhat $\left[\mathrm{K}^{\prime \prime \prime \prime},-\mathrm{s}\right.$ -

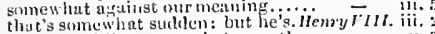

there is a fellow somewhiat near the..

vere mot semewhint

Titus, huid

some what doth she ment....... see, Lueius

then giv'st me soncwhat to repuir .... l'ericles,

from this time, le somewhat sennter....
from

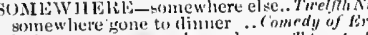

somewhere gone to limier ...

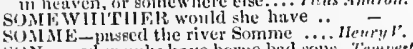

SOMME-mesed the river Somme .... Ifenry

the king's son, I'erdinand (rep.).

ses, Caliban her som

the duke of Milan, and his brave son.....

und give it his son for un alple

fur coming thence, my som is
wa have luet your som, i teme

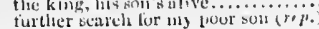

you do louk, my sim, in n moved sort.

my dear son fesdinund (rep.).

his neplew Protus, your son.

lint forth their sons to see

hath he not a bon? (rep.)

for thou art Merol's son

we son of my grand the bisther of women

come, sun slender (rep.

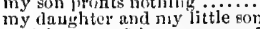

son! how now? how now, son? (rept)

as if thy eldest son slimild be a fool..

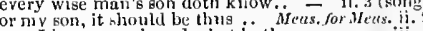

son, I have over-heard what hath fion - iij.

liath Leona to any fon, ny lord ........ A ech.dulo, i.

where is my cousin, your son?

too like iny lady's eidest son

ndamls sons are my trethren....

Aot till Monday, my dear son........ -

slie respeets me as her muly son. Mul.N.'s Dream,

for their stins ure well tutored..... J ore's L. lose, iv.

Mchercle, if their sons be ingeniuus - iv.

but a joor man's son.............. - ii. 2

a will tell you news of your soln......

your son that is, your child that (rep.) 二 ii.

go, father, with thy son.............. - ii.

son of sir liowlund (rep. i. 2 \& i. 3). ds yon like il, $\mathrm{i}$.

an old man, and his three sons

betore know'n this young man liis non

that you should love his son dearly?

got the son-yet not the son (rep)

in delivering my son from me ........

her matter wa:, she loved your son

sour son, were not my

my lord your son made me to thinik

be you the sons of worthy Frenehmen -

an' they werc sons of nime, I'd have son-

to muke yoursclt a son out of my... - ii. 3

well, thou hast a son, shall take.... ii ii. 3

your son will not be killed so....

I only heur, your son was run

he was my son: but $\mathrm{I}$ do wash

my son corruts a well-deriva......

the duke's eldest son; that Esealus.

from son to son, some tour or five...

your son was misicd (rep.)

against your solk, there is no $1 . \ldots . .$.

yoniter's my lord your son (i $e p$.)

conte on, my son, in whom iny

son, on my life, I have seen her

lylayel a farmer's eldest son Taming of $\$ 4.1$ (indue,

be survicenlile to my sou quoth he

old Antunio's son (rep. ii. 1) ..........

of Pisa, sir; son to Vincentio (rpp.

sot't, son! sir by your leave

my son Lucentio nade me (renter

the deeciving futher of a deecittul son

now, by ny mother's son.....

the happier for thy son, and now by law

to see thy honest son, who will

to see thy honest son, who will
vollr son was beloved in Palun

my son and my servant spendi ali...

$0, \mathrm{my}$ son, my son! tell me, thou.....

lives my suectest son! $\ldots . . . . . . . .$.

rithit som minto the right fincentio ${ }^{\circ}=$

the blosel o' the prinee iny son ...... -

eren for your son's sake; and, therelyy
Yurusclf, your queen, your son ......

his hopetil sons, his bube's..........

bodies of my theen, and son

yet I'tl tasry till my sum eome $\ldots . .$. .

saw'st thom the prinee l'lorizul my son?

the andle that plucksour som thitlier (rep) -

reason, my son, should choose (iep.)

whon son I dare not cul .

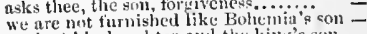

peainst lis deturliter and the kine's son -

he would not etll me son

his sem that shemild huve inaried....

lias $t$ lic old andin e'cr a son, tir ...... 


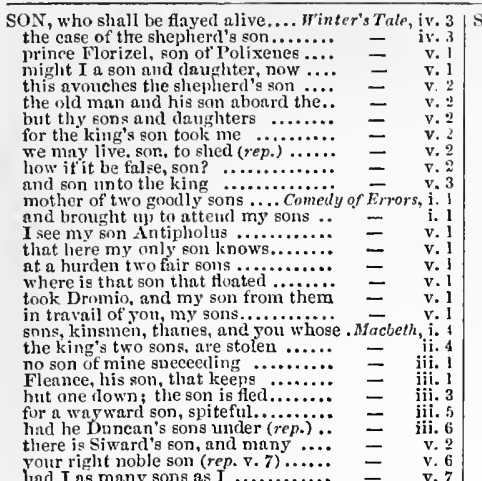

had I as many sons as I ...........

and elclest son, as I suppose.....

the son and heir to that same...

and this son like him............

son, had of your father claimed this son -

his son; England was Geffrey's right -

thy usurping son. Ont, insolent ...

my bed was ever to thy son a

that barg the title of thy son ............

son to the elder brother of this man

whose sons lie scattered on the
Bon, list to this conjunction....

thr princely son, can in this

and makes your con a shadow

command thy son and daughter

where is the and her son? tell me....

look so sadly on $m y$ son?.............

young Arthnr is $m$ y son, and he....

mad, I should forget my son

these hands enuld so redeem $\mathrm{my}$ son

that never had a son ...

my Arthur, my fair son l ............

Geffrey's son? $\mathrm{No}$, indeed (rep.
many a poor man's son would

the sons and children of this isl

Henry Hereford, thy bold son

duke of Norfalk, you your son

duke of Norfalk, you your son
throw down, my son, the dnke
Edward's seven sons, whereof

Edward's seven sons, whereof

four years of $\mathrm{my}$ son's exile.

death not let me see my son

thy son is banished upon good

come, come, my son, I'll bring ......
world's ransom, hlessed Mary's son..

world's ransom, hlessed MIary's son.:

brother to great Edward's son (rep.)

his heir a well-deserving son?

for now his son is duke .................

the son of Piehard earl of Arundel ...

your son was gone before I came ....

you have a son, Aumerl

of mothers' sons shall ill ............

have we more sons? or are we

phere he far son from .......

a bastard, not thy son son..........

a bastard, not thy son

toll of my unthifty fon?...............

blot in thy digressing son.

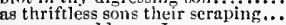

come. my nld son; I pray .............

so blest a son; a son, who is..........
for never a king's son in Christendom

for never a king's son in Christendom
of this fault, and not my son $\ldots . . . .$. .
your departure with your son........

your ceparture with your son....

your son in Scotland heing thus

to my horse; good king's son

and yet the son of a womanl ..........

a king's son! If I do not beat thee...

are villains and the sons of dark ness

that thou art my son, I have

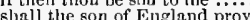

be hold to tell you, that I nm your son

with lim my son, Iord Joho ot Lancaster-

the son of ntter darkness ..............

good householders, y'eomen's sons....

my brother, and his son, that brongli

the treacherous lahour of yonr son ...
the fortine of my lord, your son $1 . .2$ Henry

sir John, is prisoner to you

four son have not the liay.

wouldst say, your son did thus

caunot think, my lord, sour son is dead -
SON-Fdwurd, to thy slaughtered son. Riehard MII. i. 2

ON-of blows, your son might drop ... IIfnry
my loud your son had ouly bnt the corps -

my lord your son had ouly bn

that her eldest sou is like you.....
knight to the son of the king .... ii. 2 (letter)

two lionours lost; yours and your son's

my pror sou, ot 'Tewkeshuryl

a liusband, and a son, thou ow'st to ine

son, that now is prince of Wales (rep.)

when iny son was stubbed with

ha! a bastard son of the kic.'s?... ...

whose son art thou? II $y$ motier's son
so the son of the temale is the shadow

whereou this IIydra son of war ......

Humphrey, my son of Gloster
prince Jolin, your son, dotll kiss

see, sous, what things rou ure!

to invest their sons with arts

Heaven knows, my son, by thy

to have a son John; but healt

the tather, and propose a son...

yourself $\mathrm{kn}$ by a son disdained $\mathrm{.}$....

live to see a son of mine offind you.

iij. 2 witness my son, now in the shade....

bowels of thy sovereign's son

blessed his three sons with his
if you were a prince's son, being

O Clarenee, my unhappy son!
he ls my son. ay, and therein iny.

he ls my son. ay, and therein my....
Edward, my lord, thy son, our king.

of the young prince your son

gond grace lis son shall refon

and the queen's sons, and brothers ..

th and down my snne were tost.
when Riehard stabbed hel son

my sister, and her princely sons

he would make his son heir to .....
that Edward is your brotlier's soir

mother to a many son

the ehild, wour brother's son (rcp......

letters from me to my son in
Stanley, he is your wife's son

the son of Clarence have I penved ...

the sons of Edward sleep in............
Harry died, and my sweet son ......

where be thy two sons?

gmother my damned son (rep.) .........

death of my poor sons, and brothers?
and little Ned Plantagenet, his son?

art thou my son? ....................

I have no more sons of the royal ....

is but, a son being king ..............

Dorset sour son, that, with a fearmin

my sni George Stanley is franked .

and thy fair son Edward, Vaughan..

Edward's unhappy sons do bid thee

slaughtered his own son, the son

now his son, Henry the eighth ...... Henry $\bar{T} 11$

like the eldest son of fort une $\ldots \ldots \ldots . . . \quad$ ii.

sperr up the sons of Troy .... Troilus \& Cress. (proil.)

- i. 3

penee, son; and show son? (rep.)

i. 3

had seven sons; the first. Edward

ii. 2
ii. 2 makes many Thetis' sons .............
ii.

no mnre touched than all Priam's sons

or step-dame to her son..............

a son of Priam, in change of him ....

now, great Thetis' son! ................
emulation hath a thousand sons ....

the youngest son of Priam ............

a bastard son of Priam's..............

if the son of a whore fight for $\ldots \ldots \ldots$....

who all thy human sons dothi hate.

twixt natural son and sire!

it my son were my hushand

tender-bodied, and the only son of $\mathrm{my}$

good report should have been my sov

how does your little son? .....

o' my word, the father's son

wherein he gives my son the wliole...

and motliers that lack sons

Numa's daughter's son, who, after...

your son, these senators, the nobles..

I pr'y thee now, my son (rep.) ......
your son will, or exceed the common

my first son, whither wilt thou go?.

I would $m y$ son were in Arahia.....

as if he were son and heir.

cannot offiee me from my son Coriolanus -

o my son! my son! thou art preparing -

to your corrected son? then iet........

the son, the husband, and the fätier

for nvsselt, sol, I purpose not........

speak to me, son; thou hast affected

but, firr your son, believe it $\ldots . . . . .$.
he killed my son; my daurliter....

to repute limself a son of Rome......julius $\bar{C}_{c}$

brave son, derived from honutrable..

who is your sister's son, Mark An tony

I am the son of Mlarens Cato, ho! (rep.)

may'st be homonred being Cato's son
all his dignities, ujnn his son ....Antony \&

having a son,

bear the king's son's borly before.....

whom they eall my father's so

eonquered Egypt for my son

he purposed to his wife's sole sor

iv question, two other sons (rep.) ...

have had the sole son of my queen !..

ny lord your sundrew on ny master

your son's my father's friend ........

his nuster, and enemy to my son,....
bring me word, she loves my son ....

to boot, my son, who shall take...

and thou, son Clarenee, shalt stir ...

what says my loving son?...

Thope, she hath a son fur $\mathrm{me}$

thy son 1 killed for his presurnition

not lived to kill a con of mine.

and the prinee his son, are gone.......

our dear son, when you have given...

ycs, and a gentlewoman's son .........
wert thou the son of Jupiter .......

son, let your mother cind.
thicy are sous to the king. 
SON, I say, follow the king..

how now, my son? "T'is eertain......

'that they had been my father's sonsi

he was in queen's son, boys ..........

he was an queen's son, boys $\ldots$..........

now for the eomnsel of my sol

gons, we'll higher to the mountains.

the old man and his sons were angel

eince, Jupiter, our son is grool......

your low-laid son our gonthend will.

to work her son into the adoption...

my sons, I must, fir mine own part.

for the nursing of thy sons (rep.).

and think they are my bons...........

hut graeions sir, lere are sour

Arvira a pair sour younger princely son

point thy two fons fort

Titusdindromicus

fever Bassianus Casar's son.........

with his sons, a terror to our foes (re.)

of hy suffier'st thou thy sous.

Why suffer'st thou thy solns........

the eldest son of this distressed queen

tenrs in passion for her son;

think my son to be as dear ...................

ginare my flrst-born son........

to this your son is marked

rest sou here, nyy gnns (rep. .........

crente your emperor's eldest son

quarrel you have slain your son ....

are any sons of minc: my sons

to banily with thy lawless sons ....

to bartuons son. No, toolish ( $r e p) \ldots . .$. .

amwortly brother, and unworthy sons

wise Laertes' son did graciousiy plead

be dishonoured by my sons in Romc!

own hand did slay to whom (rep.)

gons, let it be your charre, us it is ours

thy sons make pillage of her chastity

I'il go fetch thy solis to back thy

this is at withess that not sons alike.

rob my sw eet sons of their fee

farewell, my sons: see, that you inak

farewell, my sons: see, that you mak

the unhapily son of old Andronicus..

fell fault ot my accursed sons.

fear not thy eons, they shall .......

be pitiful to my coodemned sons....

niy son's sweet bloud (rep.)..........

to death my wretched song (rep.)
if thon love thy sons, let HIarcus

lither both thy sons alive .........

as for my sons, suy, I account of .

to have thy sons with thee ...........

tliy otiler banished son, struck

with more care read to her sons.......

the lustt'ul sons of 'Tumora performs

carry trom me to the empress' sons.

tor juy the emperor hath a son

thy and 1 will have tine vind..

the wilful soos of old Androniens...

of sorrow for his valiant sous

as it' his traitorols sons .............

but he will not entreat his son for us

twas her two sons (rep.) ..............

for his hand, he had his two sotts head

like the end tor Lucius, his son (rep.) .....

can the son's eye belioid his father

people, and sons of Pome, by uniroar

as I nm son and servant to your will

that would be son to great Antiuchus..

lie's fatlier, son, and liusband

show s, we'll joy in such a soli..........

where now his son's a gliw-worm ....

our son and daughter silall in
is nit this your son, my lord?

a son fir her cradle, ere she...................

hut $l$ have, sir, a sull, and you, our $(r$

our soll of Corn bers sons be yours

my eon Edgar ( $r p p^{\prime}$. iv. 1 )

that sons at perfect age $\ldots \ldots \ldots \ldots \ldots \ldots \ldots$

as ward to the son, aud the son mona.

burd eruckel between son aud filtler.

and the son and heir ot it mongref lifich

your soll and daughter (reft) .........

Had a son, low

to his sisn, for he's inad

my sos eame then utu my mind ......

[rof. Knt.] bless thee, foot ma
of the loyal service of lits son

where was his fon, when they iliil trike

Gioster's bastard sim (rep. is. 7 )
tlicy aay, Ed tarar his baoisicd som

my name is Litgar, and thy tather's sm

early walking thin see your som. hom

trom light steals hone my heavy son

his son was hut it waril ............. \begin{tabular}{l|l} 
iii. 5 & SON-omly son of your great encin \\
nicknume for her purblint som
\end{tabular}

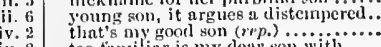

iv. 2 too thmiliar is my den. son with

iv. 3 acquint her here of my smm Paris' love

v. 4 son, the night before thy wedaling-diis

v. 3 to sce tliy son and heir numre early...

my cousin Ilanlet and my son $\ldots . .$.

that which dearest tuther hears his so

that they do know my son, come you...

to visit my too much changed son
and source of all your son's disten

and source of all your son's distemner

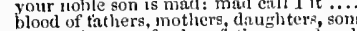

that I the son of a dear father numlered

O wonderful son, that ean so astonisis

do you not come your tarrly son to chide

o gentle son, upon the heat and flame of

where is your son? bestow this pluce

next, your son rone

show yourtelf in deed your father's son.

omy son! what them

set some watch over your son...

SON

throngh our proper son stood in your.

but a mean to fill sour song

book of sougs and somnets here

Merry

rush nt onec with some diffused gong $\bar{F}_{\text {irwh }}$ iv

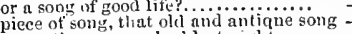

i. 2 come, the song we hall last night ..... for $\overline{\text { Ners. }}$

i. 2 a man take yon, to go in thear that song again

i. 2 with songts of woe, rount abont .. - v. 3 (song)

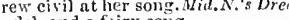

ii. 3 now a rouncled, and a fairy song

if. 3 first, rehearse this song by rote...... - v.

ii. 3 like a blind harner's song ........ Love's L. Lost, v.

are harsh afeer the songs of Änolio - ve 2 (son

suck melaneboly out of a song .

here was he merry, hearing of a song

I would sing my song without a
have you no song, forester, for this

come, sit, sit, and a song

to hear suclt a foolish song
you corrupt the song, sirrah

purifying o the song; would $\mathrm{G}$ od would

sold $\mathrm{n}$ goodly manor for a song

and songs composed to her unworthiness

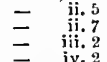

I's ilell, i. 3

and songs com posed to her Hintertinte iv. 2 (son.

iii. 1 would sing her song, and dance her

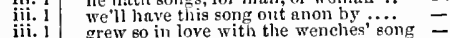

grew so in love with the wenches' song
but my sir's song, and the nothing of it

sing the song that pleaseth .........

come, Kate, I'il have your song
come, sing me a bawdy song ..........

a merry song. come: it grows $3 \ldots \ldots$ 2 Henry $t r$ ii.

iv. 2 owlsl nothing but songs of death?. Richard JII. iv. 4

iv. 4 and sing the merry songs of peace to

iv. 4 Jet thy gong be love .................

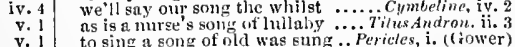

v. to sing a song of old was sung ... Percles, i. (rower)

v. 2 too credent ear you list lis songs......... Ham/st, i. 3

your songs? your flashes of merriment ... ounello, i. 3

a more cxtyuisite song than the other..... - ii. 3

she had a song of - willow, an old.
that song, to night, will not o firom

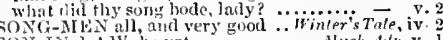

I will buy me a son-in-law in a fair. An's irrli, v. 3 we hear not of our som-in-law ... 'aming of sh. iii.
then cmluraces lis son-in-law .... W'inter's 'Tale, $v$. this your son-in-law nut son unto the - y. 3 and his son-in-law, jIortimer ...... H Herm/r. ii.

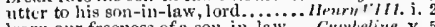
learn our frceness of a sou-in-law . Finmheline, v.
a valiant son-in-law thou slat death is my son-in-law, death.. Romeo 8 trutiet, iv. 5
your son-in-law is far more fair than ... Orhello, i. 3

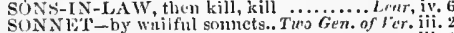
I have a somnet will serve .......... Herntrires, i. I
my book of songs sund sonnets here. my book of songs and sonnets here. Arerry Nires, will you then write ine a sonnet in...Wuch Ado, $\mathrm{v}$. hath one o' my sonmets alrealy ... Lnre's L. Lost, iv. 3 dis never sonnet for her sake corripile
will you give me a copy ot the sonnct. All's ivell, iv. 3

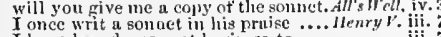

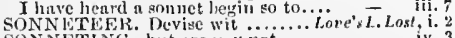
SONNETJNG hut are you not ....... of rence,

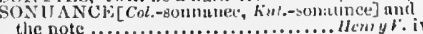

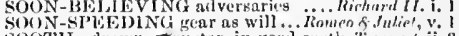

in sooth, I wonli miter, in food sibth. Trmpres, ii.

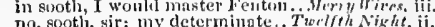

in sonth, thon wast in ver'y

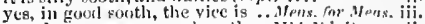

scoth ... Hith.

yes, sootli: and so du

in govol, I know not why I a

but in good sooth, are you lie thiut....

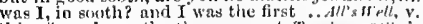

in sootli, you 'ecupe not so

in food sooth, even thus ........... - iii.

he looks like sooth ...................

sootl to say, you dld not dine. Comerly of Errors, iv, 3

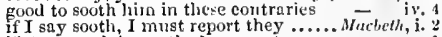

it thy Eneceh be soith, I care not

in sooth, good triend, your thather

no, in good sooth; the fire is dend.... - iv !

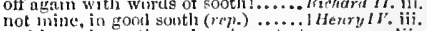

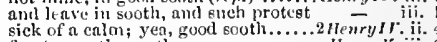

for, to say the sooth .................. Henryl. iii. 6

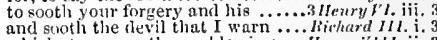

which, to say sooth, are blessings... Henry 111. ii.

rude, in sootly; in gond sooth, very intius Cosar iii. I

south, la, $X^{\prime} l 1$ help............ Aniony \& Cleopatra, iv.
good sooth, $X$ care not tor you ........... Pericles, i.

when signiur Sooth here does proci...... Pericles, i.

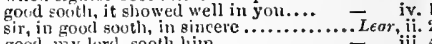

grood, my lord, sooth litn ........... . othello, iii. 3

in snotl, you are to blame ............... ini. 1

OOTIIER-the tongues of soothers... Henry Il,iv. I

made all of fulse-faced eoothing

I say arain, in soothing them, we.... - iij, i

SOOTIISA X-yon cannot soothsay. Antnny \& Cleo. i. 2

the sootlisayer that you praised ... Antony \& Cleo. i.

soothsayer. Tour will?
call forth your sootlisayer.

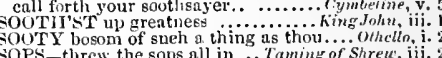

to ask lim sols as he was drinking.

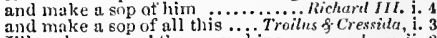

I'll muke a sop of the moonshine .........ear. ii. OPIISTICA'ED: thou art the thing Lear, iii.

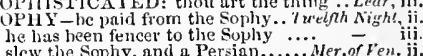

slew the Sophy, and a Persian........... Her.of Fen. ii.
SORCER.ER, that hy his cunning ....Tempest, iii.
dark-working sorcerers, that . Comedy of Err i.

conjurers, and sorcerers, that, atiaid. Henry/r. i.

ORCERESs-are all, a souceress. Comedy of Err.iv. 3
that witeh, that damned sorceress... I Henryl $l$. iii. 2 bring fortli that sorceress, condemned - v. by art, and haleful sorcery............ i $H_{r}-m_{r} l \cdot I$, ii. by art, and the sore, when you should.. Thropest, ji. upm a sole injunction .............

for to strange sores strangely they ... Anch Atlo, iv.

punt 1 to sore, then sorei (rrp.) - Lost, iv. 2 (enitupil all the enbossed sores, and beaded. As yma L,kr it, ii. 7

Four sorrow was too sore laid on" "Hinter'stale, $y$.

this knave rould go sore .... Comedy of Errors, ii.
cacl dity's life, sure labour's bath ..... Maeteth, ii.

such in sore of time should seek.............. King John,

they say, king fo'm, sore sick

Richaud [1.

see the wiul sit sore mpon our sails .̈

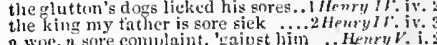

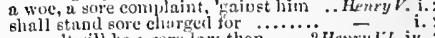

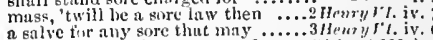

you not with this sore shony?....... kichnral III i

thon green sarenet flap for a ore eye - v.

nature, to whom all sores lay sicerc. Timon of $\mathrm{Alh}$. iv.3

and sore blows for sinking

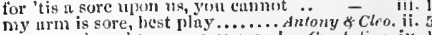

ont, fword, and to a sore purpose! .. C'ymbeline. iv.

and the sore eyes gee clear .......

thombin the confliet he sore lretween....... tear, iit.

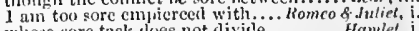

Whose sore task dres not divitle

your water is a sore derayer ut your .... $-v$.
how $L$ am punished with a sore distraction $-v$ 
S)RE-all kinds of sores, and shames . Othello, iv. SOREL jumps from thicket (rep.) Love's $i$. $L$. iv.'.(epit.)

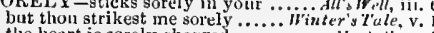
the heart is sorely charged

I do accnse myself so sorcly .............. Hirtony \& cleo, iv. and the bleak winds do sorely rittle .... Lear, ii. 4 SORER-to lapse in fulncss is sorer..Cymbetine, iii. SORRIER-I am the sorrier SORliILST fancies your companions... Mucbeth, weigh our sorrow with our eonfort....

is nothing, but heart's sorrow

let rriet of sorrow, and dismay

let grief and sorrow still embrue......

a puck of sorrows, which .....

aurl that's her cause of sorro

it' in thonght $I$ telt not her very sorrow - iv.

your sorrow hath eaten up my ....ïierry $\overline{\text { Wives, }}$ iv.

be so nbandoned to her sorrow.... Trelilh Night, i.

that such sorrow I procure ...........

cry-surrow wag! and hem, when he

those that wring under the load of sorrow-

so sorrow's heaviness doth heavier.. Mid.N. ${ }_{r}$, iii

that sometime shuts up sorrow's eye $\quad-\quad$ iii. 2

sit thee down, sorruw! ( $r p$. iv. 3). Love's L Lost, i ,

let not the clond of sorrow justle it... $=$ v. 2

now at our sorrows pale .......... As you Like

do sorrow at ny grict' iu love (rep.).. - iii. 5

a sorrow, than to have (rep.) ........

to the wars, she to her single sorrow - ii. 3

and sorrow bids me speuk ...........

my husband's sorrow by his woe .i.̈.

and lead me to these surrow日....... - iji.

I never saw a vessel of like sorrow

performed a salnt-like sorrow; no tault

were joy, or sorrow; but in the

it seemed, sorrow wept to take ieave
'twixt joy aud sorrow, was fouglit in

your surrow was too sore lajd on

no sorrow, but killed itself mue
utter what my sorrow gives me

utter what my sorrow gives ine ... Comedy of $\bar{E}$ r.

which of these sorrows is he suljject

hide themselves in drops of sorruv

iv. 3 .

nor oilr strong sorrow on the foot...

new sorrows strike heaven on the fice

where violent sorrow seems a modern
give sorrow words: the grief

from the memory a rooted sorrow....

your cause of sorrow must not be.
he's worth more sorrow, und that

to believe this sorrow (rep.) ......... Kin

I will instluet ny sorrows to be prinut

aud not sorrow. Thou art not lioly.

now will canker sorrow eat my

to all our sorrows, and cre lowg

for sorrow ends not when it seex...

to seek ont sorrow that dwells .......

fir giarling sorrow liath less power

scemed buried in my sorrow's grave

sume unborn sorrow, ripe in fortune's

Hulingbroke my sorrow's dismai lieir

we to woe, and sorrow to sorrow juined -

write sorrow on the bosom ut the
surrow and grief of heart makes

surrow and grief of heart make

remember me the nore of sorrow (rep.) -

kecp thy sorrow in my breast

give surrow leave a while to tutor.....
hath sorrow struck so many blows (rep.)

your hearts of sorrow, mant your eyes of

ill woolng sorrow let's be briet

adien; the rest let sorrow say ........

firom me all ostentation of surrow
since sudden sorrow, scrvee to

and heavy sorrow's of the blood

deep dementour in great sorrow .....

burow not that face of reening borrow
burrow so royally in yous alyenrs ....

burrow so royally in you alyenrs .... i heury $r$

sorrow and grief have vanquished ail.
thy head with sorrow to the

sinrow would solace, and mine afe.

with sorrow suares relenting passengers $\overrightarrow{-}$

but to make my sorrow greater?
mischanee, and sorrow, go along

increase, niuc for wo, go along

and seek fur sorrow with thy spectacles?

and I witle grief and sorrow, to the court -

to see how inly sorrow' gripes his sou

much is your sorrow; mine, is ten ...

on true sorrow: and see (rep.) . .....
tiall of sorrow and heart's diseontent

but I snall turn his jest to sorrow
SORROW-what sorrow can beful thee. 3 Henry $r \%$ iv. 1
my fear to hope, my s mrows unto joys iv
these sorrows could not thence this sorrow that I have, by right

still live my surrow's raget ..........

sorrow breaks seasulns, nnd reposing

my soul is inll of sorrow ............

interest have I in thy sorrow

I am your sorrow's nurse.

drown desperate sorrow in dead .....

eighty odd years uf sorrow have I scen

if ancient sorrow be most reverent

if sorrow can adnit society.

the $j$ ust proportion of my sorrow?

flatter my sorrows with reprort of it

for wholn you bid like sorrow.

our mistress sorrows we were pitying

to betray you any way to sorrow .....
the burden of my sorrows fall upon $\mathrm{ye}$

we are to cure such sorrows.......

but that time offered sorrow

meditutions, tears, and sorrows, he rave

and hing their heads with sorrow.... -

but sorruw, that is couched in ..Troilus \& Cress. i. 1

tlins part we rich in sorr

the sorrow that delivers us this

and shake with fear and sorro

seeing thosc beads of sorrow

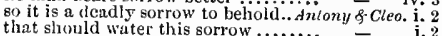

which sorrow shoots out of the mind

I do escape thic sorrow of Antony's death

our size of sorrow, proportioned...

lament nor sorrow at; but please

took suel, sorrow, that he quit being

for notes of sorrow, out of tune

recount your sorrows to a stone......
bring consuming sorrow to thine age

witness the sorrow that their sister..

is not my sorrow deep, having no...

besides, this sorrow is an enemy $\ldots .$.

how now, has sorrow made thee dote

of 'Troy ran mad througl sorrow....

and so beguile thy sorrow, till the...

guide thy pen to print thy sorrows

gliaken with sorrows in ungrateful

what an' if' his sorrow's are past

the effects of sorrow for his valiant

now begin our sorrows to approach ..

let not your sorrow die, though

witness all sorrow, that I know

presence still renew his sorrows .......
with thy shame, thy father's sorrow die?
as from thence sorrow were cyer rased.

to slow his sorrow would correct himselt

olir sorrows do sound deep into the air
speak out thy sorrows which thou bring'

one sorrow never comes but brings

nor come we to add sorrow to.

the calse of your king's sorrow

ald I for sorrow sung ............

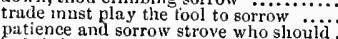

patience and sorrow strove who should

by the art of known and feeling sorrow

ingenious feeling of my huge sorrows!

to sorrow seplit my heart, it ever

redeem all sorrows that ever I have feit.

parting is sucl sweet sorrow .. Romeo of Jutie

With sorrow chide us not!

what sorrow eraves acquain tanee......

which heavy sorrow makes them apt

ry sorrow drinks our bluod

the sun, for sorrow, will not show

that we with wisest sorrow think

more in sorrow than in anger.

O Gertrudi Gertlude, when sorrows
or are you like the painting of a sor

or are yuu like the painting of a sorrow
whose phrase of sorrow coujures tlie.

with sorrow 1 embrace my furtune

bears both the sentence and the sorrow.

no age, nor known no sorrow

neither service past, nor preseit

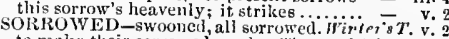

to make their sorrowcd render. Timow of $A$ thens, v. 2

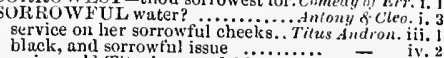

go into old Titns' sorrowful house...........

sorrowful drops upon thy blood-stained -

SORROW-WRREATHEN knot.. Titus Andron. iii. I
I Am sorry that for my sake....... Merry Hivers, iii. 4

I would be sorry, sir, but the .... Tivelfin Night,

I am solry, madam, I have

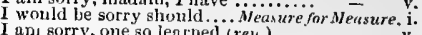

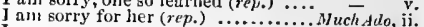

I am sorry you must hear $($ rep. $)$

$m_{y}$ heart is sorry for your daughter's

. 2 I an sorry, madam; for the mew Lore's

I am sorry, thou wit

I am sorry for thce, thou art

Inn sorry, firat your leisure ........ $\bar{c}$ iv.

suke, are sorry for our pains

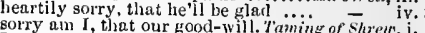

I never wislyed to see you sorry. Winter's Tule, $^{\prime}$

am sorry for't; all taulte I make...

$1 \mathrm{am}$ but sorry, not afeard ..........

$1 \mathrm{~mm}$ sorry, nust sorry, you have..

and as sorry, your choice is not so rich - v.

I am sorry, sir, that I have (rep.). Comedy of Err. v.

the plaee of death and sorry execution - Y.

I am sorry I should force you $\ldots . . .2$. Menry $l \mathrm{~V}$. i.

sorry am I, his numbers are

for $\mathrm{I} \mathrm{am}$ sorry, that with revere....... Ilenry $\nu_{.}$iif

a sorry breakfast tor my lowl

sorry I am to hear what I have...... - ii.

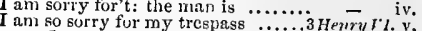

sorry I am, ny noble cousin.........3icharel 11 . . iii.

I am sorry to heir this of him

sorry that the duke of Buck ingham

I am sorry for't: so are a number.

noble lady, I am sorry, my interrity

and am right sorry to repeat what

he is inuch sorry, if any thing. Troilu \& Cressidn, ii. 3

recanting goodness, sorry ere 'tis .. Timon of dth. i. 2

I am sorry, when he sent to borrow

Iv.

siall be sorry for. You have (repelves - vetiusc.pert iv.

I'm full sorry, that he approves... dutony \& Cleo. $i$.

I am sorry to give breatlung to $\mathrm{my}$.

and be thou sorry to follow $\mathrm{C}$...........

I am mich sorry, sir, you put me ..

I am sorry, Cymbeline, that I ...... - iii. 1

I'm sorry for't; not seeming .........

sorry that you have paid too (rep.)

I am sorry for't, my lord (rep.).....

I an sorry, then, fou have so lost...
I am sorry for thee, friend ............

one part in my heart that's sorry jet.......

only sorry he had no otler deatils-man

- iv. 6

I am sorry, - what lind you

I am sorry, that witli better heed...

are very sorry, gcod Horntio

om sorry for yy for What, in your... orhello, i.

I am very sorry that you are not weil

[Knt.] I have a salt and sorry rhen....

1 am sorry, that $I$ am deceived in him...

am sorry, to find you thins ............

SOR' $\mathrm{C}$ some sorry neither; 1 d have the live $-\mathrm{v}$.

in a sort. 'That sort was weil fislied .. Tempest, ii.

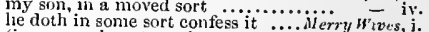

(in any such sort, as they say)

in many sort of mased

in many sorts of music

Tirelfin Night, i.

give notice to such men of sort and suit Aleas. iii.

if it eort not well you may conceni.... iruch dde, $i$

I am glad that ail things sort so wcil
thick-skin of that barren sort. Mid. N.'s Dream, iii.

many in sort, rising and cawin

noue, of noble sort, wonld so offend.

bo war we are spirits of another sort .....

there are a sort of men, whore..... Lone'sl.t.ost,

by some other sort than your......... -

of ali sorts enelunitingly beloved... is you $\bar{L}$ ike $i t$.

With musics of all sorts, and songs ...All's I"ell, iii. ?

some sort, sir; but though my case.. IFinter's $T$, iv.

opinions from all sorts of people .........Macbeth, i.

the they can see a sort of trators .. Kichard $I l$. iv.

and in some sort it jumps with ...... 1 IIenry IV.

men of all sorts take a pride

to spirits of vile sort

二 $\quad$ iv. 1

a' did in some sort, indeed

it sorts well with your fierceness

to sort vur nobles from our common.

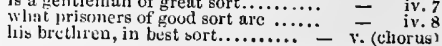




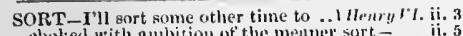
hokerl with anbition of the meaner' sort -

iii. 2 站. sort how it will, 1 shall have ........2 Ilenry t't. i. a sort of numgty persmis, lewilly.... sent from a sert of inkers to why then it sorts, brave warriors ...3!lentyl. ii. any he the protelest of thy sort. let son ollr way in sitent sort. discharce the commen sort with pay but I will sert a piteliy thy but, it" chol surt it so, "tis more

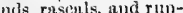
(ts.... hrohus os isaw the surt to fight with.

yet, in a sort, leehery eut $i$ itseif in lieustly sort, (dragired through and tendunce all sorts of hearts

Rnd, in sime sort, these wats

pourself in a inore comfinrtable

in some sort, may be stid to la

........ $\overline{\text { uldins }} \bar{c}$ and suriles iu sucli a surt, as if ie noeket -

as it were, iu surt, or limitation...... voiees and mpplatise of every sort . Tit

cume, otlue surts offend ns well as we. Pericls especinlly of the younger sort? ........ - iv.

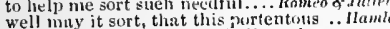
for the younger sort to lack diverution."

I will uot sort you with the rest ....... - ii. 2 SoRT.ANCE witl his quality .......2 Henyl $r_{\text {. iv. }}$ SORTED with his wish ...... Two Gen. of 'eronn, i. 3 all my pains is sorted to no proot. Tuming of sh. iv. 3 before it was ill sorted

hatl sorted out a sudigen diny .......... SoRTiUs, one of my plaee in tyrin. Antony \& Cleo iit. I have you make-a de sot of us! ...iferry I'imes, iil. how jow, sot?

sot, did'st see Dick sureon, sot? thou strail, thou slug, thou sut l Comediy of Err deseription proved us unsireak soto that your honour menss. Tas. of sh. 1 (indue.) SOTTISII; and impatienee

SUUCED 1 am a soueed gurnet.... I Heary 1 . soUGll her help.................... Trmpest, v. 1 I have sought to mateh my. Tuo Gen of Terona, iii. 1
love sught is good, but given . . Twelfh Nirht, iii. I lave suught is good, bought iny love, which I ...Ver. of V'enice,

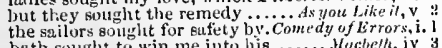
hath sought to win me into his ........huchelh, iv a it love ambitious sought a mateho

or straight we shall be sought

a partial slander suught 1 to nvoid
that sought at $O x$ ford thy dire

sought to entrap me by

have not sought the duy of this $(r \mathrm{rep}) \quad-\mathrm{Y}$.

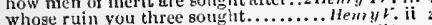

whose ruin you three sotight.....

that sought to be eneompassed.....

bint those, that souglit it $\ldots . .$.

to those ment that songht him.

vet sought the very way to euteh .... Corrolanns, fii. I here's tile book I sought for so...

Pompey presently be sought .....Aolony \& Cleo.

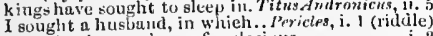

I songlit the purehase of a glorious

ainee thuu last sought to ninke us break.. lear

lie soughit my life, but lutely .......... - jii.

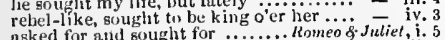
nsked for and sought for ......... Romeo o Jntie the most you sought was-her jromotion-

SUUGHT'ST to hirder ......Antony of Cloopatra, $v$

SUUL_poor soule, they perished.

the freighting souls within
there is 110 soul, no, not so

not a soul but felt a fever......

it goes on as my soul prompts it ....... -

and the fair soul herself weigh 'd ......

never any with so full soul $\ldots \ldots \ldots \ldots . \cdots$ 二 iii. )

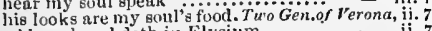

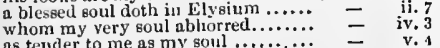

as teuder to me as my soul ............

that the folly of my soul dares not ..

by gar, he lias save hi

二 ii. 3

pless my soull how füil (rep.)........ - iij. I

us $\mathrm{I}$ am a christians soul .............

his boul is in hell, madonna (rep)

your brother's soul being in lieaven

and eall upon my sonl within.........
will draw threc suuls out of one weaver

mature pranks heril, attracts iny soul - ii.

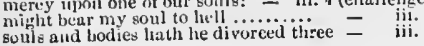

SOUI, the perlition of roul

reshew his sond for me.

the susul of our tranduni

for thounh niy sum disputes weil

and too doulinful soul mus live ut jence

ollut recend is lively il my sosul!

keep ts truc in soul as doth....

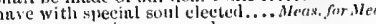

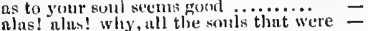

prayers trom preserved sulls

and tie the wiser souls to thy

than my sonl. I tulk not of your..... soil

r'll take it as a peril to my soul $(r c \mu)$.

but grace. being the soul of your

poor noul, slie speaks this in tlie

but 0 , pom souls, come you to seck
thon art said to have a stubborn soul

now is this soul ravished ..............

oliunld hatle souls wut of men's bodie

eufer salvat ton hucty and son

i charge you, on your souls, to utte

and unemstrailed soul give

not knit my sonl to an approved

into the eye und prospetet of his suli

as your soul should with your bouly

as 1 hase a tholght, or a soul........

by my soul, nor $I$ (rel.)...............

my boul ennsents not to give....Mid.N.'s Drea

pursue it with the soul of love

pretty soul! she chrst not lie........

and extort a poor soul's patienee...

so rieh within his soul, and temde.

my life, my soul, fair Helena!

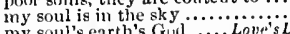

unlettered small-knowing soul

by my sweet soul, I mean .........

by my soul, a swain! a most

What, my soul, verses?

all ignurant that soul, that sees.

mirtl connot is

an evil soul, produeing holy... We
is ny boy (God rest his souit) ali

she be plucet in my constant soul.

by Portia's side with an unquict soul

the semblunce of my soul....

but on thy soul, harsin Jew
that sonls of animals infuse

rom the wallows did his tell soil theet

glaull I lay perjury upon my soul?

sighed lis sonl toward the Grecian

sweet soul, Jet's in, and there expect

sueh harmony is in immortal souls.

by my soul, nowoman had it (rep.).

my soul upon the forfeit ...........

loved sir Rullund as his sol

the souls of friend and friend ....... iii. 2 (verses)

he divine forfeit of his soul upon oath

but fair soul, in your fine franie .....
that she. poor sonl, knows not. Taming of shren,

on thy soul's peril, and thy body's.

how the poor souls roared, and the

alack, poor soul! thou hast need ....

now appear) soul vexed, besin. and..

her part, poor soulf seeming.. Comeriy of $\mathrm{Er}$

my soul should sue as al voente for the
with intelleetual sense and souls....

a w retehed soul, bruiked with....

against my soul's pure truth

earries poor souls to liell.

ponr distressed soul!

so betal ny soul, as this is failse.......

to half a soul, and to a notion.......... Macbeth,

Bath fo, thy roul s fight .

a erew of wretehed souls, that ........

deatls of thy soul] those liner. cheeks.

my sonil is too much elin

by my soul, I tlink, his fathe

forgive the sin of all those sotuls.

by disjuining hands, hell lose a soui

the conjumetion of our inward souls

there is a soul cunnts thee

a grave unto a sonl; holding ail
now that their sonls are top finil

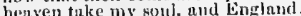

from whore obulience 1 forbid $\mathrm{my}$ sonl =-

our souls religiounly entinto thy worils =

all you whuse wisl ablior the.

upon my soul (rep. vo I and v. 2)
OU1_-love of soul, to stranger hlood.. King John, v

biown uj by tempest of the soil

and purt this lody and my soul....

whish some surinose the goul's fruil

sings his soul and borly to thei

and then my soul siall wait on theo

I have a kind soul, that wonld ......

or my alivilue soul answer it in ..... Richurd 11 ,

slinced ont his innoeent soul through -

firmness of my moright soul ail

piered to the soul with slander 6.

0 God defiul my soul from .....

one of our konls had wandered

look, what thy soul holds dear

this land of sucli dear souls...........

and my inward soul (rep.) $\ldots . . . . .$.

now liath my sont lronklit forth....

vex your souls ( wioee presently (rep.)
that heaven will take our souls

all sonils that will be safe.............

arain nucurse their sonls..................

lave toru their souls, by thrting

his fure soul unto his eaptain (rep.)

who with willing sonl atlopts....

the souls of men may deem.....

with silence in the tortured soui.........

letrn, gond soul, to think our .......

with heart, and soul, and all heside
the fimale to my soul; my soul......

nount, mount, my sonil thy seat

my sonl is full of woe, that hlond
abont thy sond, that thon sold'st...

which the proud soul ne'er pays
who, on my soul, hath wilfully.

and let my sunl want merey .......

would save his soul, he sliall not ....

the soul of every man prophetieally
by ny seejtre, and my sonl to hoot.

and dear a trust on any suul removed

the very lottum, and the sunl of hop

there is many a soml shall pay

no, by my soul; I never in my

I do respect thee as my soul

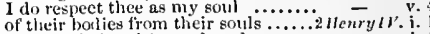

lint, for their spirits and souls

Perey was the man nearest my soul

[Col.] upont my sou], my lord ........

inniartinl condinet of my sou

of indigent fuint souls, past ............

and his soul shall stand sore eharged

knew'st the very bottom of my enul

a black soul burning in liell-fire

on the poor souls, fior whom

I love and honour with $\mathrm{my}$ soul

and see ure in soul, the confident

but every subjeet's soul is his ow

whir it one souls, our debts...

sing still fur Riehard's suul.

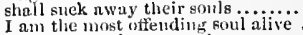

that their souls may nuke ...........

more glininus star thy soul will .... I lienry l $^{\prime}$

paicl my vow unto his sonl ............

and, by my sout, this pale and angry

enours my goul shall then be satisted

no whr, befal tly partine soul! .......

now, aniet soul. depart w hen heaven

musie to thy timorous soul ...

merey on hrave Talliot's soul...

of earthily blessingrs to iny soul

in merey so deal with my smi.....

poor soull God's goodness luth been

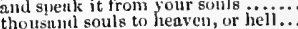

labour to perswade my soul...

for, with his som, fted all

and sent thy soul to hell, pernieiou

the fererets oxile, my soul's treasure?

here comlul I breuthe my roul into

thou either turn my flying soml ...

set to cutch my winged soul?
strong sicge unto this wreteli.

pence to his soul (rep. v. 2) ..........

fare with your depurted sunls?

the meorifuered soul ot Cule

misht thrust thy sonl to hell ........

a seeptre shull it have, have 1 a mil
it grieves uny soul to leuve thet .....

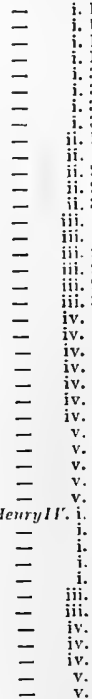

二 iii.

- v.

ii. 


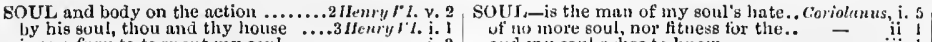
is as a fury to torment my sinnl ...... my soul to heaven, my blood. my soul flies through these wounds... now iny soul's palace is become. it irks my very soul ehain iny soul to thine. aweet passage to my sinful sould my body's Whose soul is that which takes lier. and, by my sout, if this riglit hand.. and thou, poor soul, art then forsal. and yet, between my soul's desire. lips keep in nyy sout uwliile t

now an I seated as niy sonl delights

to tright the souls of fearful ..........Rich

dorto niy soull here Clurence

his soul thou

in thy soul's [Col. Knt,-fual] thioat.

and let the soul tirth that adoretir

of conscience still begnaw thy soul?

kept iu my soul, and would not let.

that there did greet my stranger soul

now give evidevee agaiust my soul.

charted us from his soul to love

that holy feeling in thy soul....

yet to thy owu soul so blind.

more ind save your souls .......

by heaven, ny soul is purged lrom

with whom my soul is any jot

how the pour soul did forsake

speak unto myself for him, poor soul

our swift-winged souls may catel.

the danger that his soul divines

wherein my soul reeorded the history

to enrich his watchful suul ..........

against miy conscieuce aud

go, go, poor snul (rep.) ...............

no more than with my soul I mourn

if yet your gentle souls fly in

to buy sumls, and send them thither

in the soth of Laward's children

from my soul, I love thy (rep.)...

and imany a christian soul, dentir..

if that your moody discontented soul
this $\Lambda$ il-souls day to my tearful soul

I do commend my watehful soul ...

let me sit heavy on thy soul (rep.).
for the wronged souls of butchered

and let thy soul despair!

quiet untroubled soul, aw ake, awake

thou, quict soul, sleep thou a quiet.

and, if I die, no soul will pity me...

nethought, the souls of all that I had

struck more terror to the soul of Jicha

holy saints, and wronged souls...

babbling dreams affright our soul

antere is no English soul mo

on my soul, I'll speak but truth

and, till my soul forsuke me

he dives into the king's soul

panging as sout and body's scvering.

from my soul refuse you fur my juage

syeak this with us free a soul as I doi

upon my soul, two reverend cardiutal

and throw it from their soul

by my suul, your long coat, pric

sir, as I have a soul, she is an angel

true beauty of the soul, for honesty.

wisls cliristian peuce to souls departed

win straying souls with nodesty

than this pure suul shalt be...

joy's suul lics in the doing....
sisul and only spirit, ia whom
have snul in such a kind ..............

have snul in such a kind

every lithe soul, 'mongst many......

like a strange soul upon the

my very soul of counsel

in the soul of state $\ldots \ldots \ldots \ldots \ldots \ldots$...........

no blood, no soul so near me
by my soul, fair Greek, if $"$ 'e

witl private soul, did in great

a recordation to my soul ut cvery.....

if beuty have a soul, this is not (rep.)

within my soul there doth commence

so eternal und so fixel a soul.

upon iny soul, 'tis truc, sir

why, this is the world's soul .

only speak from your distracted sou

jou souls of geese; that bear the .... Corivianus, i. 4

v. 3 of no more soul, nor fituess for the.

we hive supulur sonls thon in.

crieu, a as, good soult and furgave..Jutius Cersur, i.

sulliriug souls that welcome wrongs

i. pour soull his eyes are red as fire...............

come such divition 'tween our soulsi

come stich division 'tween ou' Boulsi -

the sisul and body rive not more ....

Where souls do cuach on flow
low stow his sonl sailed on

wuld torce the tieler's soul to the.... Cymbet

no sinule soul enn we wet ey there

siuts that fly back warils! stand.

their good sonls may be appetsed ....
latest tireweth to their funls....... Titus $A$ ul

Tamorn, the empress of my sou

for, by my Boul, were there worse

whose souls are nivt corrupted...

that which gives my soul the (rep.)
will have his soul black like his....

swene unto my sonl to right your....

to vex the father's soul withal (rep.)
I dorepent it from my very soul

with a sonl emboldened with the

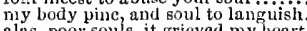

alus, poor sonls, it gricved my hear

some covering for this naked soul...

thou art a soul in bliss

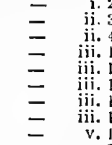

ii. I friends of my soul, you twain rule ...

his soull a' was a niary mi......

I liave a soul of lead ...................

so thrive my soul-a thousand
i. 2 it is my soul, that calls upon

ii. 2 it is my soul, that calls npone........

iii. 2 for Nercutio's soul is but a little way

how is't, my soul? let's talk, it is not
ii. 7 God! I have an ill-divining soul..

iii. 7 by my soul, I'll ne'er acknowledge

iv. from my soul too; or else beshrew

iv. 4 my soull, and not my cliild

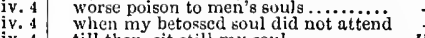

$v, 4$ the inward service of the mind and soui...

grapple them to thy soul with hooks

iv. 4 thoughts bey ond the reaches of our souls

and, for my soul wliat ean it do to that.

o, my prophetic soul! my uncle! .........

nor let thy soul contrive aguinst thy
as I hold my sonl, both to my God.....
since brevity is the soul of wit ...........

to the celestial, and my soul's idol

could furce his soul so to his own eoncei

there's something in his soul, o'er which

v. 3 o, it offends me to the soul, to hear......

v. 3 evell with the yery comment of thy soul

tonge and sonl in this be hypocrite

o, limed soul, that, struggling to be fre

and that his soul may be as danned

contrution plucks the very soul

ii. 3 step beiwcen her and her figliting soul

ii. 1 not that flattering unction to your soul

my soul is foll of discord, and dismay.

iii. 1 to my sick suul, as sin's true nature is

God forey on his soull ( $r$ me $p$.) $\because$ jointl

jointly labour with your soul to give

but, rest her soul, she's dead

iv. 1 to her as to peace-parted

iv. 2 I take him to be a soul of great article

these fellows have some soul

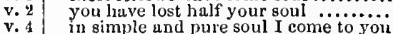

for their souls, another of his fathoin

my title and my perfect soul, shall
fair question as sonl to soul aftordet

I am glad at soul I have no other child

iii. I heaven defend your gnod souls ............

iii. 2 o, my soul's joy! if after every tempest.

iii. 3 my soul hath her content so absolute

iv. 1 nothing ean or shall content my soui.

iv. 4 for his own rage, holds his soul light.

iv. 5 his soul is so enfettered to her love ......

I wonder in my sonl what you could its
perdition catch my soul, but I do love

is the immediate jewel of their souls

good heaven, the souls of all my tribc

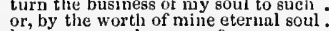

have you a soul, or sense?.... $7 \ldots \ldots \ldots$

a kind of men so loose of soul, that in...

arraigning his unkindness with my sou
but jealons souls will not be answered

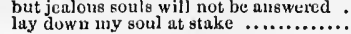

SoIrL-in some part of my soul a drop.. Othe!ln, iv. the poor sonl sat sighing by ...... - iv. 3 (song)

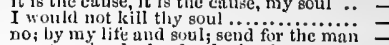
sweet soul, take heed, take heed of periury may his pernicious soul rot lualf a graiu

so come my soul to blise as I spenk true... this look of thine will hurl my guul lion Why lie huth thits enswared my soul and

OUL-CURER, and body-culer.... Mlerry Wives, ii. 6

o) II . FEARIN G clamours lave ..... King John, ii.

SOUL-KL,LING witclies that.. Comedynf Errors, i. 2 nor no sound that the earth owes...... Tempest, i. bear witness to this sound $\ldots . . . . . . . \quad$ i. full of noises, sounds, and sweet airs
the sound is going away; let's follow it shapes, such gesture, and such sound iii. deepur than did ever plummet sousd
but 0 how oddly will it sound

and inure diversity if sounds ............ Amaimou sounds well .............. ep slowposed fanices pinch finn sound - iv. [Knt.] sound that breatlies npon.. TwetfhNight, i. as the maiden's oryan; shrill and somil - i. 4
full of crror; I am sound ... Medsure for Mensure, i. 2 but so sound, as things that........... if it be sound, or hollowly put on.....

by the sound of your voice $\ldots \ldots \ldots . . . .1$

converting all your sounds of...1uckiddo, $\bar{i}$. 3 (song) sound, and sing your solemn hymn... - iii. making it momentary as a suund ....Ail. N.'sDr. i. 1

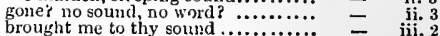
on the gruund, slecp sound $\ldots \ldots \ldots \ldots . . . .7$ - iii. 2 a sound, but not in government...... $\Rightarrow \quad$ iv. 1 will bear the lowest sound ............. the trumpet sounds; be maskeil...... - v. 2 the some to thee is sound of........... of $\overline{V_{e}}$ nice, let not the sound of shallow foppery

let music sound, while he doth ......

are those dnlleet sounds in break of ...

and let the sounds of music creep....

but hear perchance, a trumpet sound
moved witl concord of sweet sounds

methinks, it sounds much sweeter ..

pipes and whistles in his somd ... As you Like it,

as clcan as a sound shecp's heart.....

his powerful sound, within an organ - ii.

a dulcet and a heavenly sound. Taming of $\overline{S h}$. I (ind.)

see what trumpet 'tis that sounds... -1 (indue.)

as ever oak, or stone, was sound.. Winter's Tale, ii. 3

and sound ones too (rep) .............

I tell you, 'twill sound harshily...... - iv. 4

things that do sound so fair? ........... Macbeth, it.

possess them with the give a sound.... $=$ iv.

purge it to a sound and pristine heulth 二 $\quad$ v. 3

that gave the sound of words ......... king John, iii.

and harmful sound of words $\ldots . . . . .$. 二

stench! sound rottenness! arise ..... 二 二 ii.

makes sound opinion sick $\ldots \ldots \ldots . .$. .

as thine; sound but anotlicr........... ickard $r ı$.

sound trumpets; and set forward $(r e p$.$) -$

with other flattering sounds $\ldots \ldots \ldots$....

tongue sound this unpleasing news?

now, sir, the sound, that tellow........

that bears a frosty sound ........... i Heury $I V$. iv.

souud all the lot'y instruments ........
the trampet soumds retreat . $\ldots . . . .$.

and his coffers sound with hollow....

where nothing but the sound of.......

to sound the botton of the after-tines

$y$ th not so sound, and half so dcelly

my voiee sha!l sound as you do prompt

order give to sounds conffused. IIenry $r$. iit. (choris)

firn and sound of heart, of buxom.... - iii.

of either army stilly sounds ...... - iv. (chom us)

empty vesscl makes the greatcst sound - iv.

sound, sound alarum $\ldots \ldots \ldots \ldots \ldots \ldots . .1$ Henry VI. i.

whilst any trump did sonnd ........ -

hark 1 by the sound of drum $\ldots . . . \cdots \cdot \ldots$.

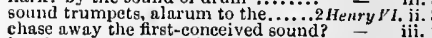

the first-conceived sound?

to sound retreat or parley.............. 
SUUNJ)- letty soumls to ecuse!

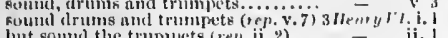

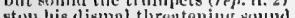

stup lis dismal thenteming sombl

to the walls, and somet a purle

their conrsers nt the trumpet's soluid

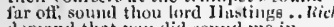

denment that you did somel me

cull for some men of kound direction

jook that uny staves be sound

somin, drims and irumpets, holaly.

the trumpets somed (ep. s. 3) 3...henry

ye are not sound. Not sound? Not sound
as mueh no one gouml eullecl of tour

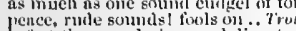

lence, rude sommels fixols on ..
inferet the sound pine, and dive

dialogue and somul 'twixt his

in our ishands sount her trump

lio! hid my trumpet soundl No notes

the 'rojus trumpets somd the like

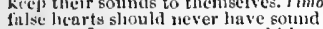

[Ciol. Knt.] no reason can sound his state -

so harsily on the truminet s sound

nor sound his quillets siritis

sound to this cowrentend inseivious

(10, sound thy trumet in the

In know the sound of Murcius' tonghe

()) let me elip you in urms us sound

which you protune, never somud more

rougher accents for malieirus soutud

and liarsh in sound to thine

the replicution of your sounds ....... Juliu

what of Cicero? slanl "e sound him?

therefore thou sleep'st so somind "......

to somind more sweetly in grent Cxsar's

sound, and be hangerl, senum out.

may strike their sumis together.....
hnrk, Polydore, it somuls! hut what.

who ever yet could sound thy lrot toml

here's no sound jest I the old.
gin sound the ocean, and east

giv sound the ocenn, and east ...

our sorrows do sound deep into .....
which nuke a gumd, but killed are

every one with claps 'gan sound.

glie made more sound by hiurting it

resirters stand upon sound legs...

rarest sounds! do ye not hear?

sickly fit for the sumd mun.............

bleed st not; speak st; art sumi ........
hetrs that, whicht can distinguish sound

let the trumpet sound (1ep. v. 3)

let him appeur at the third sound - v. 3 (heruli)

sonnd. Aguin. Again. Ask hitn his......

interance yet 1 k fow the hon'.

hrief sounds determine of my weal..

trumpet sound the general tioom!

low sound is she asleepl I neella

mecause silver hatl a sweet sound (rep.) iv. 5 (song)

if thou liust any sound, or use of yoiee..

and at the sound it slurunk in haste uway -

to sound what stop she please

you wonld sound me from my lowest note - ii

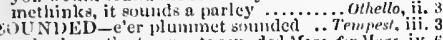
twice have the trumpets smunded Mcas. for Mo

but it eannot be sinnded .........Axyon

and thy beauly sinumed, yet not. Taming of Sh. ii. lave sounded the very basc string ... H Hew'y $/ Y^{\prime}$. $\mathrm{ii}_{\text {. }}$ the trumpets lave sounded twixc....2 Hen!n! ! is Guafticr, heing riglitly sumded..2 Henry

Epoke. which sounded like a ctnnon.3 Inemy II. y. Cutesby latis sounded liastings in our

somuled all the depths and shouls. Henry $\bar{T} T I$, iii. mathe be somuder nore than yours. Intias Casur,

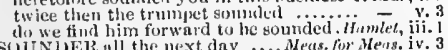
SoUN1)ER ull the uext day .... Meas.for Meas. iv. 3 a more sonnder instane .......... SOUNDEST judgments in .... Trnilus

the best ming sounclest of his time hinth

so far from sounding and ilikenvery. liomeo of Jul.i. linve seldom gold fior sombling

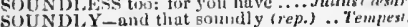

let them be hunted souudly...

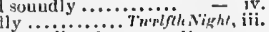
I had swinged him sounily. Mecasure for vedaure, v. I say, knock no here sou

and rap him sondly, sir f..............

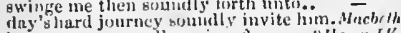
huve you us boundly swingen ......2/lenryly can elecp so soumbly as tlice wretched. Hewryl. if you will love me noumelfy with your $-\bar{y}$ y go, effect this business somudly . Richard III. iif.

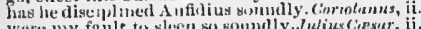
Were my faule to sleep so komndly.Julius Copser, ii. I luve it, and soundly too...... Romeo \& Juliet, iii.
SilN

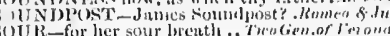
cleome tlie sour cup of prosperity 1 . Lamp's $L$..

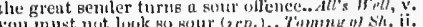

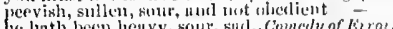
fic lath becn helvy, sour, sul...tomedy of biross, y. 1

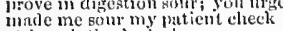

nlthough thy look a be sour .....

of rue, sutr herb of "gruce; ric..

delivered me to my sunr enso.......

liow sour sweet musie is, when ......

of conscience, and sour meluneholy ä n,

let me embruec these sonur nd

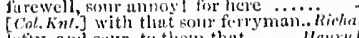

Intty, and sour, to them that ........llenry f'thl. iv.

lips, let sour worrls go li

the tartness of his face sours ripe ... Corioh $m, s$, v.

to sour vour liapyiness, I must.

11' sour woe delight in in fillowship....

my dear son with such sour eompang
with me in sour mistortume's book

- vy

oUnd E-flown from simple sourees...Alit's Well, ii. I

the very souree of it is stoppcd....

quell the solurec of atl cretion

and poison it in the source. Antony \& Cleopn/ra, iit.11 the head and son're of all your son's...... $\overrightarrow{\text { ii. } 2}$ OURED-lad soured themselves. W'inler's Tule, i. 2 to the sourest and most ileadly .... Wirchard II. iii. 2

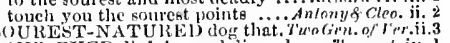
OUR-EYED dislnin, and discord .... Trmpesl, iv. 1
URLY-I showed sourly to him ... Coriolitms, v. 3

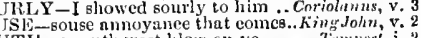

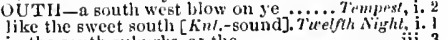

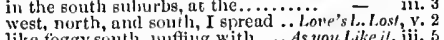
west, north, and south, I spread ... Horte's l.koss, y. 2 a knoeking at the south entry, ........Mrrbirh, our thunder from the south, shall ...king John, ii. 2 eross it from the nerth to south.

by smith and e!st, is to my part
like the south borne with black

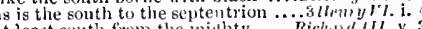

at least solth fom the mighty .....Richurd HI. v.

ull the contagion of the south lighte..Co

I pray you (tis south the eity mills)

enst, west, north, sonth; and their .jus $\bar{c}$, it. 3

the ehiminey is south the ehamber
winged from the spungy south

from solith to west oli wing sonring...

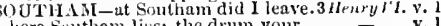

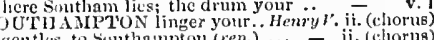

gentles, to sonthampen (rep.)....

as Bevis of Somtlimunton fitl upon..2llmryvl, ii. 3

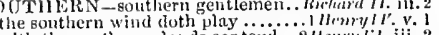

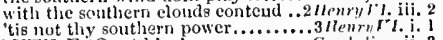

SoUTll-Fog rot him! .............. Cymbeline, ii. 3

GUTH-SEA sliscovery .......... As ton likrit, iji. 2

at liberty, 'twould sure, southward. Coriolums, ii. 3

at the White llart, in Sonthwark... - iv. \&

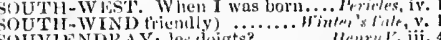

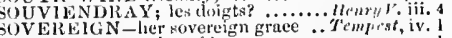

I have her ooveris aid

I search it with a sovereign kiss. Two Grm. of Fir. i.

these sovereian tbrohes, are ali ...TiralfhNizh, i.

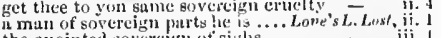

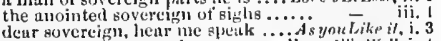

goddess, anel a sovereign, a cuunscillor. All's $I^{\prime}$ ell, i.

o'er whom both sovereign pow

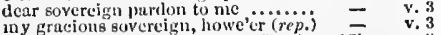

thy head, tly yovereigm; one.. Taming of Shrrew, v. 2

to hear my sovereign inistresg .... Ninfer's Talt, i, 2

our sovereignl lord the kim .... -

what, sovereign sir. I did not well....
sueh a gentle sovereign grace .. Comedy of Frr. iii.

give solcly oovereing sway

to dew the sovereign flower $\ldots \ldots \ldots \ldots \ldots$.........

right roynl sovereign What fullows.. king John, i.

to any sovereign state througliout.... - . 11 .

(Bo please my sovereign) ere 1 move..

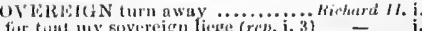

1 throw, slient soverejon, ut thy

lat ine kias roy bovereigo's linend

for Gud, his soverejgit, ant himselt'.

the oms's no sovercign, whom brith.

in linving armo against thy govereign

feed not thy govercign's fies, my genti

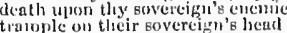

tranple on their bovereigh s head
ont house, my sovereign liege $(r e j$,

have charge, and sovereigis trust

my sovereign lord, efieer up yourecif

thes hear me, grasious sovereign (rep.) -

sin 1 oun my hetuld dreal sovereign

and me, my royslied, sovereign

hut not my houry, parkerk, sovereign... -

for usovereign to reason on (rep.)...

commend nyy service to my sovereign

kiss her as my sovereign queen .......

the kiug, thy sovereign, is not quite
to slay your sovereign, and destroy...

this scrill, most gracious sovereign..

my gracisus sovereign, as I rode $(r e p$.

hath he furgot he is his sovereign? .

Ilenry ${ }^{\prime} I$.

should he then protiet our sovereiga -

Whes thw wert regent for our sovereign -

fonte our rightful sovereign with ..

meuns to frume our sovereign's faii..

no, no, my sovereign; Gloster is a man

elear from treason to my sovereign.

prescrve my sovereign from (rep.).

eomfort, my sovereign! graetous Henry -

mighty govereign, that goor (rep.).. -

that my sovereign's prescree makes

spenk. Buatiort. to thy sovereign $($ rep. $)$

wed let my sovereign, virtuonis Henry

it my feet; I am thy' sovereign.......3 Henry $V I$.

hombur me as thy kisig and soyerelgn

but fiar nifit to be a sovereien .......

my lord and sovercign, and thy' vowed

their true sovereign whom they inust

ay, gi'neious sovereign; they are so

then is my sovereign Elain?

challouge nothing of their sovercims

it shall be done, my sovereign, with all

ny, now my sovereign speaketh iike

my sovereign, with the loving eitiza

IIenry, your sovereigh, is prisoner to

the bowels of thy sovereign son.....

bood-morrow to my soverejgu kilig...

my sovercign lord, I ito beseceh your

a boom my sovereign, for my service,
the forfeit, sovereign. of my servant's

my thought's sovereign: the weary way -

commulul me, us my sovereign

my grueious sovereign. Give

say, $I$, her sovereign, am her subject low -

most mighty suvereigu (rep.) ......... -

my graeious sovereign, now in ......

where of iny sovercign would liave nute -

and thy marts sorereign and pioms else

dread soverizin, how mish are we ( rep.) -

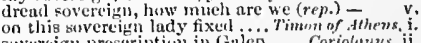

anvercigh preseription in Gulco..... Corinlenns, i1.

Bovereign of Ligypt, haill Jlow mueh - i.

she is deut too. our soverestn........

with tear's as sovereign ats the biond.

sweet sovercign, lense us .............. rymentine, i. 2

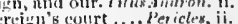

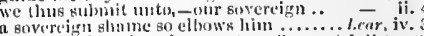

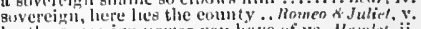

by the sovereign power you have of us.
that noble und most sovereigu reuson

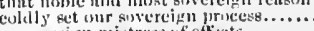

nowereign mintrces of efticts .............. olhello, $\mathrm{i}$.

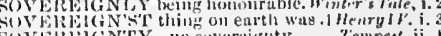
SOVERLIGNTY-10 sovereignty ....Tempent, ii.

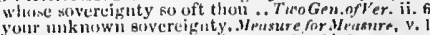
your ments not to give sovereighty. Wid.N. ribeas i.l 


\section{SOV}

SOVIRREIGNTYY do meet ........ Love's L.L.os haa colleeted for general sorereignty... All's Hell, sovereignty will fall upes Macbet

down fair respect of sovereignty ..... King John, and sovereignty, a slave.....

Richard ll.

or my hege s sovercignty. 2 Henrut

perfections challenge sovereignt

on hinself the sovereignty thereot. Richard $I I I$.

on himself the sovereignty thiereof

bear the golden yoke of sovere

your subject, lonthes such sovereignty

ninute with words of soyereig

eminence, wealth, sovereignty...

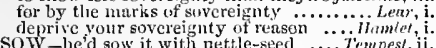

for yet our ty the's to sow.. Nensure for.Meusur

pour in sow's blood, that hath ........1herelh, iv. I

8liall we sow the headland.

suein sorrows, not to sow them ......Wenry

sow all the Atheuian bosoms.

if we will plant nettles or sow lettrice .. Orhello, i.

allons! Allons! Sowed cuckle .... Torely's

harvest which that rascal sowed
plouthed for, sowed and scatte

a criss as if it had becn sowed

a criss as if it had becn sowed!

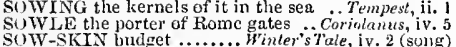

SOWTER-Sewter will cry upon't. T'uelfh, Night, ii. 5

'twixt which regions there is soine space

a space whose cvery cubit

a blank space for differcnt names......

after some small space ..........

within what space hep'st theu my

attend upon the coming space

for the whele space that's iu...

within that space, you may

if after three days' space

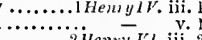

world's large spaces canmet. a time]. Rich.Jli. iv.

no spsce of earth shall sunder

sell the mighty space of our

'tis a space for further ti'nel

make space enoughl between

if you require a litlle space for pray.. Cymbelise

dearer than eyesight, space and liberty.... Lear,

no less in space, validity, and pleasure
und istinguisled space of woman's will

to-morrow, or at further space

count myself a king of infinite space ...... Hamlet, ii. 2

gour pleasures in a spacieus plenty...... All's W' Wactl, ii. 1

the spacious werld cannot again...... Richard III. i. 2

thy spacious and dilated parts .. Troilus \& Cress, ii. 3

and yet the spacious breadth of this - v. 2

few words, but spacious in effect... Timon orinianus, iv. 6

when such a spacious mirror's set. Antony \& Cleo. v.
walks are wide and spacious.. Titus.Andronicus, ii.

walks are wide and spacious... Titus.Andronicus, ii.

I sav, spacious in the pessession of dirt. Ilantel.

dig with mattock, and witil spade... Tilus And.

aud this spade from him ......... Romeo \& fuliet, v.

come; my spade........................ Hamlet,

$a$ pick-axe, and a spadc, a spade, for $\rightarrow$ v. 1 (song)
SPAIN-refined travellcr of Spain.. Love's $L$. Lost, i. )

many a knight from tawny Spain

Spaiu? Faith, I saw it not .... Comedy of Err. iii.

to the hot breath of Spain

that daughter there of Spain

King, John, ii.

subdue the greatest part of Siain .......Henry $V$. iii. 6

ky ny friends in Spain advised

had a fever when lhe was in Spain...Julins $\bar{C}_{c s a r}$ ii. $\bar{i}$

a swerd of Spain, the ice-brook's temper. Ohello, v. 2
SPAKE-is that, that spake? .. 7'u Gen, of Ver. iv. 2

ay, you spake in Latin then too ... Merry Wives,

I spake with the old woman .......... - iv. 5

there spake my brother ... Measure for

I never apake with her, saw her ....
weuld answer, I spake net true ...

Would answer, I spake not true ...As you hike it, v. 4

Epake you not these words ..... Taming of Shrew, i.

spake he so doubtfully

when spake I such a word?

unless I spake, lookcd, touched....... $\quad$ - i.. 2

I never spake with her in all my life $\bar{y}_{\text {when I spake darkly what I......... King Jolsn, iv. } 2}$

there, methinks, an angel spake.....

thouglit the very window suake...

he spake it twice, and urged it twice $=$ v.

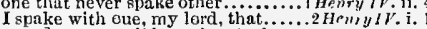

[Kut.] upou my life, spake at ad venture _- I.
PAKE unto the crown, as having ..2 HinryIV. iv. 4

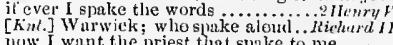
God hant the priest tiat spake to me -

spake one the lctst word not a word - iii. 7 about that which the bishop spikk.

ever spake against yeur libertics,

spake you of Cessar? ..............

the lint she slake was Antony $\mathrm{i}$....

the last that he spake to thee?

Julius Casut

In that he spake too far

spake you with him

swore as many oaths as i spake words

I spake, I sjakc it to iny face your lord. Romeo o

I spake of mest disastrous chances ...... Oolhelio,

she that I spake of .......

and even but new he spake.

thou spak'st it.Richard

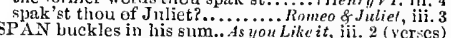

rem spiritual leisure a brief spanl. Henry $I^{\prime} I I T$, iii.

spans and inches so diminutive. T'oilus $\&$ Cress. ii. 2
whe hath outstretehed his span.. Timon of $A$ th. v. 4

a life's but a span .............. othello, ii. 3 (song)

SPANGLE heaven witl . ..... Traning of Shrew,

whe stuck and spangled you with. Timon of $A / h$,

too nuch edds for a Spaniard's rapier. $L$
this Armade is a Spaniard, that keejs

fig me, like the bragring Spaniard..2 He

iard's by bou a ii.

use me $-I$ an your spaniel... Mid. $N$

Where's my spaniel Troilus?. Taming

you play the spaniel, and thinls.....Hen

curt'sies, and base spaniel fawning. Iuling Cresar, jii.

hound or spaniel, bracl, or ly $\mathrm{m} . . . \ldots$........ Lear, ivi.

PAN IEL-LIKE, the mere sle. TwoGen of Ier. iv. 10

PANISH-breaking of my Spanish .. All's Well, iv. 1

Spanisli plades of health

SPANISH-POUCH, O lord, sir.
SPANNED-my life is spanned

PARE-I pr'y thee, sljare

bpare him, spare him; he's not.... Tuesplon Night, ii. 3

wc'd not sparc heavell, as we

we will spare for no wit,

and I will spare your liaunts ........ Mid $N . \bar{s}$ iii. 5 it sheuld none spare that come ....Love's $l$. Lost, ii. as it is a spare life, of flesh

he that ears my land, spares my tcum. A ll's Well, $\mathrm{i}$.

the rather will I spare my praises

is content to spare thiee yet

thy mete-yard, and spare not me. Taining of $s h$ iv.

sir, spare yeur threats...

fastened lim unto a smail spare... Comerly of $\overline{E r r}$. $\mathrm{i}$.

Orether...

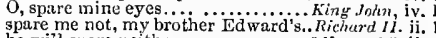

he will spare neither woman........2 Herry $I V$.

or are they spare in diet

or are they spare in diet
spare for no faggets, let there...

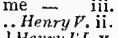

spare none, but stuch as ge in clouted

spare England, for it is your native..

York not our ald imen spares $\ldots . . . .$. - iv. 8

tell him and his friends on oath ....3 Henry $F$ I. if. 6

$O$, spare my guiltless wife...

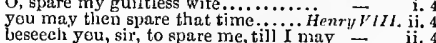

you'd spare your speons; you shall.

he'll spare nonc. Good morrore, sir - v.

spare not the babe. whose dimpled

spare your oaths, I'll trust to.

he will not spare to gird the

ay, spare us nnt; say, we read........
aveid so soon as that spare Cassius..

I pray you, sparc me ...........

spare your aritlimetic: never c........

and spare ne blood beside

then, spare not the old father...........
that $I$ have on you, is to spare yoi

spare my first-born son spare yol .

can better spare my hloed thin

agree between you; I will spare...

the rough seas, that spare not any me... Pericles, $i$.

spare ny. grey beurd, you wagtail? ...... Lear, ii.

geod Angelica: spare net for cost... Romeo \& Jul. iv.

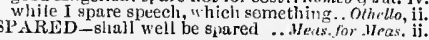

PARED-that may best he spared ..KingJohn, v. 7

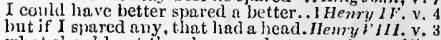

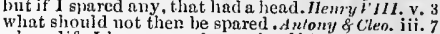
Whose life $I$ have sparcd, at suit of lis.... Lear, ii. at sparing linit to my tonguc...... lichlurt IIT. iii. 7 in him sparing would show a worse. Henry rill. $\mathrm{i}$. in that fparing makes huge waste. Romeo of Irtiel, i. I

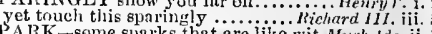
'ARK $\rightarrow$ seme sparks that arc like wit. Much ddo, ji.
tis not his fault; the spark ...........All's $t$ ell, ii. geed sparks and lust rous, a word ....... All's 1 ell, ii. extraet one spark of evil ................ Henry $t$. thlood 110 spark of he a raging tie..2 Henry $Y$ l. iii.

if any spark of life be yet remaining that lath onc sparis of fire. Troilus \& Cresside, ii. those sparks of life that should ..... Juluusciesur, puinted with lumimbered sprarks...

to hide the sparks of nature ......... Cymbeline, iij.

is flattered, but a spark ................... tericles, [Knt.] that spurk gives lieat.

cnkindle all the sparks of nature......... lear, iii.

time qualifies the spark and fire of it ... ilamiet, iv.

to sparklc in the spirits of $\mathrm{my}$.... Love's L. Lost, iv.

perchance, will sparkle in your eyce. King John, iv.

mine cyes should sparkle like the...2 Hemary $1 \%$ I. $\mathrm{iii}$.

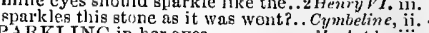

their eyes of fire sparkling through... Nucheddo, iii.

his sparkling cyes replete with ..... Hemry HI.

viands sparkling in a golden cup ...3 Henry $\mathrm{YI}$. ii.

a fire sparking in lovers tears ... Inomeo \& Juliet i.

PARROW-but play with sparrews .. Tempest, iv.

the finch, the sparrew Mid. N. 'sDram, iii. I (soni

providently eatcrs tor the sparrow. $d$, you likr it, ii.

yes; as sparrows, eagles; or the hare . Mlurheth,
Plilip? sparrow James, there's tey's. King John.

pistal kills a sparrow flying

the cuckoo's bird, useth the eparrow:

nine sparrews for a penuy (rep.). Troilus of Cres

as short as a new-tacn sparrow......

the hedge sparrow fed the cuckeo so long.. Lear,

SPARTA-with hounds of Sparta .. Mia. N.'s Dr.

in Crete. in Sparta, nur in Thessaly.

a kniglit of Sparta, ny renewned....... Perieles, ii. O Spartan deg, more fell thär anguish SPAVINS, raied with ........ Tuming of Shrew, iii. before, the slavin, a spring halt .... Hrnry ${ }^{\prime} / 1 / .1$. SPAWNED him $\ldots \ldots . . . \ldots$ Measure for Mersure, $\mathrm{jii}$. PPE

PEAK te the mariners

Nericles, ii.

speak; tell me $3 . \ldots . . . . .$.

took pains to make thee speak .........

to hear thee speak of Naples .........

why speaks iny father so ungently? ..

few in millions can speuk like us.......

if but one of his pockets could speak .

and time to speak it in

do yeu not hear me speal

now is to speak well of his friend .......

hear my soul speak

if I speak true; if holiowly.....

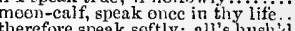

does now speak to thec

the devil speaks in him ..................

to speak puling, like a beggar . Tu... Gen. of $\bar{v}$

it cannot speak; for truth

the shoe speak a word for weeping...

heds not a tear, nor speaks a word...

Silvia, I speak to you................

then speak the truth by lier...........

can nothing speak?....................

but sinall I hear him speak?...........

to that I'll speak, to that

where to speak with madam Silvia..

look up

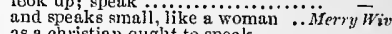

as a christion ought to speak

jou must spcak pessitable
spenk scholarly and wisely

de intend vat $i$ speak?

Genk-a your tale $\because \ldots . . . . . . . .$.

alas; he sueaks but for histress....

believe it, I’age; lie speaks sense ....

a woman would sleak with you (rep.)
would you speak witl me? anpest, i.

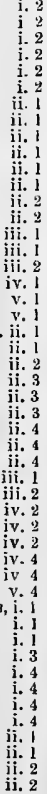




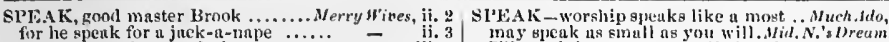

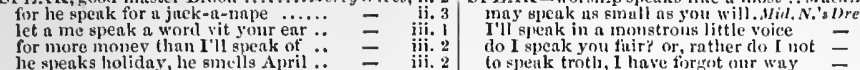
he speaks looliday, he smells April wmuld needs speak with you presentiy speak louler (rep. iv. 2) ............ master slender would speak a worl spenk to mistress luge .............. liere's mistress Quickly, sir, to spenk to spenk with the gentlemen; thes spenk eome to speak with sir Jolm Faigtaff he'll apeak like an Anthropophnginian speak from thy lungsmilitary feak well of them, warletto

yet hear me speak: assist me in

speak I like lierne the liunter

lie that speaks to them shall die ..... Tuelfin and spenks three or four langunges. say, I lo speak with her, my lord much desires to spenk with ynu... he spenks nothing but madman...... yond young fellow swears he will speak he shall not speak with me.......... but he'll speak with you (rep.)

and he speaks very shrewishly

speak to ine, I shall answer for her..

for she did speak in starts distractedily thou dost speak masterly ............

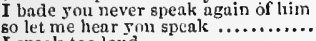
I speak too lond

ret I'll spenk to him ............... how hollow the fiend speaks within him -
la you, an' ron speak jll of the devil la You, an' Fou speak ill of the deril

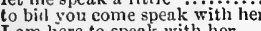
my lord would spisak my duty my lord wonld sprak, my

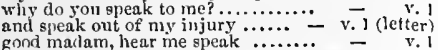
do I speak feelingly now? ... Mreas what, but to sueak of. would offend... may your graee spenk of it?

I speak not as desiring more

if you speak, you must not show (rep.)

why dost thou not speal, Elbow

glie speaks, and 'tis sueh sense.

that 1 desire t, hear her sense .......

for renn speak against

I'll spcak more gross ..........

we speak not what we mean

bring them to speak, where I may....

and $\mathrm{I}$ ean speak to lim. I will open

let me hear you speak further $\ldots \ldots . .$. .

have you not hast, sir; and speak apaee

therefure you spenk unskilfully

since ynu know not what you speak

to speak so indireetly, I am loth ....

it peradventure he speak a spenk, an' it' you hear; spenk, of all loves aleak, Py ramns; 'Thisby', stand forth why, you niust not spenk that yet yoli syeak all your purt at once

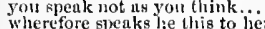

speak; how low an 1 ? ............. let her alone, spenk not of Itelen,
prond Demetrits? Speak thou now:

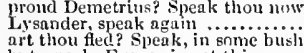
art thou fled? Speak, in snme busli?
but, spenk, Ertens; is not this....... for truly would I speak, and now $\mathrm{I}$ io thint these lovers speak of ............. not enongl to speak, but to speak true I wonder if the lion be to speak.....
desire lime and hair to spenk better? o Pyramus, nrise, speak, spenk. witli yourself to speak, -a majd ...
this word shall speak for me, I ain this word shall speak for me, I am
it is the manner of a man to speuk $i n$ it is the manner of a man to speuk th
speak youn this in my proise, master? he speaks the mere contrary, srosses all impatient to speak and not see. but to speak that in wor when tongues spenk sweetiy......... the I may speak of thee as the traycller loth as to spenk, dout, fine, when he..... thus must thou speak, and tims thy fenr not thou, but speak audaciously how how? speak to be understood........... mawlam, sperk true; it is not so.....

speak for youreelves, my wit is a
he speaks not like a man of God

a conqueror, and afeard to spenk

will speak their mind in some other

spenk, brave llector; we are ........

if they sliould speak, would al most.

for Gratiano never lets me speak

prest unto it: therefore, speak

may I speak with Antonio? ....

one speak for both ; whit would you

ancak it privately, go ....................

I speak tno long; but 'tis to peize.

only my blooil speaks to you in $\mathrm{my}$.

speak not agninst my bond....

I prny thee, hear me speak ............

madam, although I speak it in $y^{\prime}$ our
and speak, between the cliange of..

and speak of frays, like a fine

and so now I spenk my agitation...

offend'st thy lungs to speak so lond.
loved you, speak me fair in death..

loved you, speak me fair in death.
sir, I would speak with you: I'll bee

speak not so grossly: you are all

report spenks goldenly of his profit. As you Like it

or to speak-more properly, stays me.

the duke's wrestler, here to speal

I speak but brotlierly of him .........

now is your time; opeak loud ......

and she will speak most hitterly

yoor sotsl, she speaks this in the

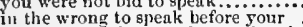

in the wrong to speak before your
friar Lodowick, that she speaks of?..

let her show her fuee, and atter, speak

I would speak with her: pray you ..

speak not you to him, till we

let him speak no more

say nothing, I'll speak ail

have me speak after my custom .......

I pray thee, speak in sibcr jullgment

you speak this to fetch me in (rep.).

speak low, if rou speak love

she speaks poniarcls, ancl every word

speak, conis, tis your cue .......

Bneak, causin; or, if you eannot.
and let not him speak, neither
I was born to speak all mirth.

he was wont to speak plai

these are very crotehets that he spenks

that the white-bearded fellow speaks it

why you speak truth: I never yet ...

his heart thiriks, his tongrie speaks..

eight or nine wise worly to speak to you -

for what I would sperik of

you speak like an aneient and most

never speak; we charge you, let 119.

how now! to you speuk in the sick..

gnimman Verges, sir, speaks a little.
that he dotls sireak so wile? (rep.)

I know not: it' liey speak but truth

and bil him speak of maticnee ( $\mathrm{mp}$.)

a peak oif half a dozent danjernis worda

shet I must speak: eloose your revenge

that fonls may not sjieak wisely

why, this that I speak of

speak to him, laclies; see if you can.

I cannot speuk to her, yet she urged

you to conceive, than me to speak of

and her patience, sleak to the peopie

give me leave to spenk my mind

speak yoln so gently? pardon me

I scaree can speak to thank you
quiekly, and speak apnee: I would

speak sad brow, and true maid........

when I think. I must spenk

I will speak to him like a saney

unele of mine tanght me to speak.....
so much in love as your rhymes flienk?

writes brave verses, speaks brave words

when he that apeaks them pleases.

you were better spcak first $\ldots \ldots \ldots . .$.
have heard him speak of that same.

(for now I speak to snme purpose) .

I speak not this, that you sliould bear
who do sou speak to, why blame

how ealled you the inan you speak of. $1\left\|T_{s}\right\|^{\circ} \mathrm{el}$ to speak on the part of virginity

and I speak the trutli the next winy.

to speak. Sirrah, tell my (rep.)

in their kind they spenk it

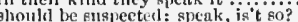

epeak truly, to go to Paris? $\left(r c n_{0}\right)$..

speak, and move under the intluence

in thee oorce hlessed susirit doth spenk fore me I spe:ak in respeet in sour fair eyes, butiore I speak

is it not a language, I suenk

that which I durst not speal

bint to speak of him as niy kijenkus.

Al's Well, ii

ii. 2 spenk what terrible lunguage yri......

ii. 3 not to know what we speak to .....

iii. 1 understand thee, and can shenk thy

nay. I'lt speuk that which you will.

iii. 1 cet down,-lor l'll speak trut

iii. 2 we shall sienk of you there...........

and the muster I fueak of, ever keeps
to slieak in the hehalf of my drumbler

to speak a truth: an I that (rep)

is this the man you speak of ? .......

more than I'll speak. But wilt (rep.)
ill will to speak of, therctice (rep.)

and if he eliance to spenk.. Taming of Sh. I (induc.)

vee, Thear, I speak; I smoll

never spenk of atl that time?

and if you speak me fair, Ill tell...

that are poor petitioners, fincak to.

mute, and will int speak a word.

and now, Petruclsio, speak.

to speak the ceremonial rites
way to stand, to lnok, to speal

now let him spenk; "tis elisyity.
leave to spe:ik; and speak I will

look, whiat I fpeak, or do, or think

is liere at the door to speak with him

verily, I speak it in the freedom.. "Nin

tongue-tied our queen? Speak you..

now, while I speals this, holds lis

and speak to me as it' I were a hahy

speak for her, is a far off guilty (rep.)

it is for you re speak, not

even sinee it could speak, from a........

you speak a langunge thit I

I'Jl speak of her' no more, nor of

thou didst speak but well...........

to speak of Perditn, now grown

which then will speak; thiat you mist

I cannot speak so well, nothing so

i. 3 ean he eneak? hear? know man

ii. 2 spenk, ere thou diest. I cnnnot speak

bosom there, and speak his very heart

all, that yoll spenk, shows fair .....

where's Bohemia? speak .............

I speak anazedly; and

as often as they speak ............

but yet sneak; first you, my liege...

to speak, I am eontent to hear $(\mathrm{rm})$
pertain to life, let her speak too........
helives, though vet slie sleuk not

I to speak my griefs unspenkable..

Eav, didst thou speak with him?

to me she spenks

tonk sweet, speak fair, become

sueh a one as a man may not speak of

didst speak him fair?..............

speak softly; yonder, as I think

draw near to me, 111 speak to him

operk freely, Sy raensan, what

lie spenks tome; In ymour

2 seems to speak things strange

to me if you ean; what are you?

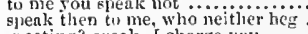

greeting? speal, I charge you
here, as we do speak about?..

whot, can the devil speak true

let 11 s speak our free hearts each to

the eriekets ery: did not you spenk?

do not bid the speak (rep.) .....

and heart spenk, they are nelcome.

f rruy you, flenk not.....

more shitl they speak: fur now I.....

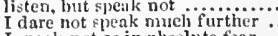

be tit to govern, speals.........

that speak him full of grnce ........

the grief does not speak, whispers
linrk, she speaks: [ will set down

I think, but dare not fpeak ....

make all our trumpets spenk

$$
\text { 三 }
$$




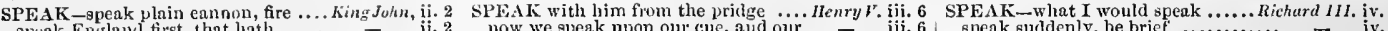
speak England first, that hath ...... - ii. 2 now we speak npon our cue, and ou or, if you will (to sleak more lroperly)

makes harmful all that speak of $i \mathrm{it} .$. that a man slould speak those words

speak, with a prophetic spirit (

nor wince, not speak $a$ word
any tongue, spenk it of what it wiil.

anil he, that speaks, doth gripe .......

I an sent to speak; ny holy lord...

thus lis royalty doth sleals in me

me leave to spenk. No, r will sleak..

the king yet s1)uks (rep. v. 7)....... - v. $\quad$ v. 6

and the accused, fretly pleak.......

of Cheshu Clirist, slleak lower ( $r e p$.)

by my troth, i will speak my eonscience -

iv. I belore I positively speak in this............

iv. they could not speak; und so I left...

iv. 1 you speak too bitterly $(r . \ldots.) \ldots \ldots . . . . .$.

iv. 3 I must speak [Cnl.Knt.-talk] a word

let ne speak speaks, that fonght with

I speak but in the figures ind

beeause he exould not spenk Englisi in

thou ean'st speak no better Linglish...

opeak, ny fair, and fairly, I pray thee

iv. 7 Richard let me spenk with him?

v. some good means to speak with him

speak freely. First (rep.) .............. ienry $v$

who, though I speak it betore lijs fae

v. 2 on ny soul, I'll speak speak aught?

you ean speak the Freneh tongre.....

beeause they speak no Linglish $\ldots . . .$.

ench

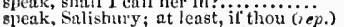

the uohle ruined man you speak of.

and, if he speak of Buekingham $\dddot{i}$ fell

what my tongue speaks, my ........

speak truly, on the knightliood (rep.)

nay, kpeak thy mind (rep.) ........... -

for heaven's sake, speak eomfortable

and bicls ne sleak of nothing but

strive to speak big, and clap their.

speak sweetly, man, al though thy

let $u$ man speak again to alter
speak to his gentle hearing kind

so poorly, and to speak so lair?

he doth atteud to spenk with you.....

these ill tidings; spenk, thou wrete....

now Bagot, freely speak thy

presence may I speak (rep.

presence may I speak (rep.)..........

before I freely speak my mind

fur love, speak trenson to thy face? ..

speak it in French, kiug

thine eye begins to sperk

if a man should speak truly

gpeak unto Talbot; nay, look np....

and so loath to speak, in dumb

i.
i. 4 every tongue spenks them, and every true
ii. 2 not to speak of; I would not be so siek

lest it be said, steak, sirraht....
I speak not to that railing....

perceive I speak sincerely, and high

voue
lord cardinal, to you I apeak

speak, Pueelle; and encliant

let thy humble handmaid speak (rep.)

you speak not like yourself

before his highmess shall speak in....

I speak my good loril cardinal ......

speak to thy father ere thou

he speaks witl such a proud

our seonts? I pr'ytlice, speak

would they speak with me? they willed

would all other women eould speak this

speak in Fnglish; here are some (rep.)

speak, Winchester; for boiling

he did speak them to me in the....

let me speak myself, since virtue...

speak on, sir; I dare your worat ....

till thou speak, thou shalt not pass.

I have no power to speak, sir.

f ealnot stay to speak. Art thou

but shall I speak my conseience?

losers may jave leave to spea

was dumb, and could not speak a word

every word, you speak in his behalf
go, speak not to me; even now ......

it is thy sovereign speaks to thee...

gleak, eaptain, shall I stab.

heur you speak of Hortimer (rep.)

to you, good people, that I speaik
that speaks, he knows not what?

wipeak jot this in estimation.......... -

speak terms of manage to thy bourding

if you speak in jest, or no?

and, to speak truth

away with himl he speaks Latin (. ep.)

speak, sirs: how was it?..............

hear me speak hut tlis. Mark ......

for I inust spenk in passion ...........

now I do not spcak to thee in
then peremptorily I speak it

dost thou speak like a king? ...........

as oft us Luneaster doth speak of you
I think, there is no man speaks better

speak it in Welsh. I can speak Engli

the business that I eome to speak

he speaks most vilely of you .........

you speak it ont of fear, aud cold heart

I pr'y thee, speak; we will not trust...

I speal of peaee while eovert enmity - (ind

to speak so true at first?.............. he speaks not ' ; seak?

give mir, speak it to us. As well ....

to hear me spenk his good now

Christendom sliall ever speak his virtise

now, sir, you speak of two the most..

have ventured to speak my mind

I grieve at what $I$ speal

geak to the business, master secretary

let me speak, sir, for Heaven now...

I speak no more

pray you, speak no more to me ......

my lord would instantly speak with you -

hear what Ulysses syeaks (rep.). ....

then to speak. Spealk frankly as the wind -

to this purpose speak: kings, prinees
speak then thou unsalted leaven, speak -

I shall speak as much as thou ...... -

searee ean I speak, my choler.

Paris, you speak like one...

Patroclus, I'll speak with nobody...

sponk speak blasphemy ere bid.....

leave to speak. Plantagenet shall speak -

I sliame to hear thee sveak

gentle Mrargaret, and hear me spealk

hear me speak lefore I die

spenk thou, Northumberland..........
York cannot speak, unless he wear..

by your leave I speak it .............
O speak no more! for I have heard.

O speak no more! for I have heard.
that I shonld speak withal, is kindly

bear thy glories, makes me speak.

O I eaunot speak! Ay, erook ...........

Ong-tongued Warwick? dare you speak?-

or sin, to speak a truth (rep.) .........

you must speale louder, my master...

sir, my lord would speak with you

your life, to come speak with me
I pray you all, speak plainly your

you speak as having power to........

for those that eonld speak low

nay, if he do nothing but speak nothing -

do not speak like a ceath's head

how vilely did youl speuk of me even

did speuk these world, now proved.

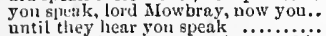

of them all spenks any other word but
shall better speak of you than you.

shall better speak of you than
speak lower, prinees (rep.)

I never thought to hear you speak again -

is able to spcak for himself ................

well, you must now speak sir John...

are a king, speak in your atate

live to speak my finther's words....

which king, Bezonian, speak or die?

I speak the truth; when Pistol lic

the things I speak, are just ....

elatef justice, speak to that vain man

speak? My king! my Jovel I speak

1 cannot now sleak: I will hear .....

before the Frenchman speak a $a$ word

speak, my lord, and we will hear $(r e p$.
with fuli mouth, speak free!y of our

more of you: this the Daluphin speaks
the dilke of Gloster would speak witl

therefore, go speak, the duke will....i
tpeak, captain, for his life, aud I wili

am a king, and privileged to spenk

before his face I speak the words

tongue no more sliall speak. ...

speak, Clifford, dost thou know (rep.)

press to speak for righit......

I speak no more than what $m y$

tongue-tied sorrows leave to speak

hear me speak, before you answer

Montague, speak freely what you think

apeak suddenly, my lurds, are we.

tu the Tower; let him not speak

glues ny lips, and will not let me speak -

this speak I lords, to let you understand -

ward heard her speak these words

for every word I speak, ye see...

lorenee, I will not hear them speak

the gallant, let us hear him speak $:$.

speak like a sulject, proud

an' it I speak; and I will sueak. (rep.) - v.

we come to speak with him (rep.)

and speaks not to himself, but with

why do you not speak to her?

what tritli can sieak truest

I sliall surely apeak the thing $\mathrm{I} . . .$. .

because it shall not speak of your ..

comes the gencral to spenk with me?

sinee she eould speak, she hath not..

import him much, to speak with me

I speak not, be thou true, as fearin

hear why I speak it, love.............

nay, her foot speaks; her ...........

What are you up here? ho, speak .....

one eannot speak a word, but .......

do not speak of flight, of fear ...... $=$ v. I

I saw them speak together

he speaks the common tongue $($ rep. $)$

than you can with modesty sjeak

that what he spenks is all in lebt....

speak to 'em, fool. Now do you.......

use, as I with you anon

ingeriously I the speak...

neer speak, or think, that Timon's...

dout thou speak seriously, Servilins?

who ean speak hroader than le that

7ou ouly spenk from your distraeted

if I speak ike a eaptain ............

what art thou there? Speak............
speak not, begone. Hast thou goid jet

speak truth: you are honest men...

you would speak with Timon (rep.).

look ont, and speak to triend

and prompts my tongue to spenk ....

his graee speaks cheerfully

flatter, and speak [knt.-look] fair.....

speak, and be hanged I for each .....

we speak in vain. But yet

and made us spenk like friends.....

I would speak witl clarenee

and how deadly dost thou speak $\ldots . .$. .

who's here? Epeak, hol no answer? ..

hear me speak. Speak, speak.

not a manl wunld speak, nor I (reps)
in Gorl's name, speak, when is the royal

speak, and look baek, and pry on every

had youl heard the traitor speak $(r e)$.

or bitterly to speak in wour reprone.

therefore, to speak, and to avoid thie first hay, but syeak not malieiously

the mat ter? speak, I pray you .......

make the belly smile as well as speak

doubt not that; I speak trom eertainties

when you speak best unto the purpose 


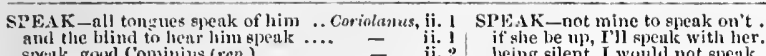

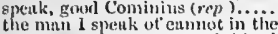
let me say, I enumot speak him home thint you do speak to the people...... into those womnds, ank speak for the apenk to them, I pray you now..... my specel, and $I$ will speak't again you speak o' the people, as if' $\ldots . .$. . one, that speaks thus, their voiee?.... I cunnot speak: you, tribunes of (rep.) gpenk, spenk, Epeak. Fut a re at point eonlin he not apenk them fair $\dddot{0 . . . . . .}$ speak briefly then; for we are peremptorystool uj to spenk of peace, or war .
when extremities speak. I have heard it lics $Y$ (cu on to speak to the people.. go with us; speak fair: you may. even as she speaks, why, all then he speaks what's in his heart first, heur me speak (rep.). when he speaks not like ne eitizen....... and heard him speals, beating your. woulk speak that-We know (rep.) why speak'st not? Speak, man ...... should from yon elnud speak divine if he coyed to hear Cominiug speak.
come to speak with Coriolanus (rep.) I would not spenk with him till after Micnenius, I will not hear thee speak speak to me, son (rep.) speak you: he cares nnt fur your (rep.) and then I'll speak a little

peace, both, and hear me spenk (rep.) the drum, that it speak mourntully.. peace, hol Cresar speaks. Caiphio... cry, Casar, speak; Casar is turned what sny'st thou to me now? epeak. by the eloak; would you speak
it you please to speak with me it you please to speak with me you speak to Casea; and to such ...... to speak truth of Cresar, I have not. speak, atrike, redress! Brutus (rep.) that would speak with you. Caius speak, hands, tor me. Et tu, Brute? do not eonsent, that Antony speak... what Autony shall speak, I will (rep.) but speak all good you ean devise...
and you shall speak in the same pulpit and you shall speak in the same pulpit if any, speak, for lim have $I$ ( $r e p$.$) .$ peace, silencel Brutus speaks....... coine I to speak in Cresar's funeral I speak not to disprove what Brutus but here I am to speak what $x$ he begins again to speak
public leave to speak of him public leave to speak of hin
I only speak right on ........... and bid them sueak for me me. eountrymen; yet hear me speak Cassius, be eontent: speak your grief that you are Brutus that speak this. hcar me, for I will speak

nine speak of seventy senators......

gleak to me, what thou art ..........

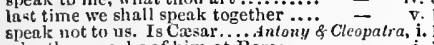

who this speaks or him at home...

speak to me home, minee not the....

from sieyon how the new

and spe.iks as lond ns his o............

thime honour that I sperk it now...

Iepidus, let him speal

the present need speaks to atone you a sullier only, speak no more (rep.). give me leave, Casar, - speak (rep,).. the word of no woman hearl speak. gpeik this no more. To none but ... pity me, Churmian, but do and hear ine speak a word

what it speaks think speak esst, urite, sing, number diulst hear her sjeuk? is she (rep.) their tongwes rot, that speak against speak not against it; I will not stay go to hitn, madam: speak to him. approach and speak. Sueh as I an...
his very netion speaks in every powc his very netion speaks in every pow

let's ppeak th het's hear him (rep.) a wake, awo, seak their to us ..... nnd let me spenk a little. No, let ( $r e p$. I will speak what you shall please .
let him speak, nyy lord, upou lis peril to my peril, speak that which is not
$O$ coinlitst thou gpeakl that I might. Eleak softly, walce her not.............
you sperk him fur. I do exteril ..... you sperk him fur. I do extenl ..... Cymbeline

I pray you, speak with me .........
gou speak of him when he was less

these letters that he spreaks of and there spenk to great Casar. speak in the order of his funeral I will hear Brutus speak atand, ho! sperk the word along

thine honour, that $I$ spenk it now.... pity me, Charmian, but (lo not speak let proof spenk. llis niajesty bids.

saty, nhil spenk thick; (love's......
speak, how many seore of miles

sut of your prost you speak

what shoth we speak of, whin we

spenk, man; thy tongue mny

I speak not vut of weak surmikes

talk thy tongne weary; speak (rep.)

Epenk, or thy silenee on the in
if any thing that's civil, spenk.....

so far as thou wilt speak
I dare speak it to mysejt

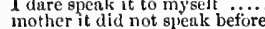

we'll speak it then ...............

the ruiu speaks, that sometime
U Imogen! I'll speak to thee in

I Imogen! f'll speak to thee in silence

speak, wilt have him live ......

walk with me; speak freely.....

on, speak to him. Mr

of lim that best could speak

wilt thou not spenk to me....
fear is from me, I'll spenk t

that $\mathbf{I}$ was he, speak, Iachimo..

low fair the tribune speaks.... Tilus And speak, queen of Goths, dost thoul applaud
doth nature speak. Speak thou no more doth nature speak. Speak thou no more

not dissembled, speaks his grief

there speak, and strike, brave boys.

I will not hear her speak ..............

speak, brother, lnst thou hir. thee.....

let them not speak a word, the guild

speak, gentle niece, what ster

why dost not speak to me................
sliall I speak for thee? shali I sny

slatl I speak for thee? shall
no tribure hears you speak

spenk, my Lavinia (rep.)

ol brother suenk with possibiiti....

these heads do seem to speak to me.

would'st thou spenk with u

why dost not speak? what deaf?.

vex thy soul to hear what I shall sieals

smooth, and speak him fair, and tarry let them not speak a word (rep.)

say, if should let you spe
speak. Rome's dear friend

speak, Rome's dear friend $\ldots \ldots . . . .$.
will throb and weep to hear him speak $^{2}$

now is my turn to spe

I eannot speak to him for weep.

leave to speak, freely I'll speak

doth speak sufficiently, he's gone

speak out thy sorrows whieh thou bring

what need sjeak I

ean any way speak in his just eommend

and I can speak ot the disturbanees

you purpose as you speak.

she has a goou face, speaks we

aut

he will not spenk to any (rep.)

she speaks, my lord, that, may be

mine ear, go not till he spenk.

pr'vtlice speak; fillaeness eannot (rep.)

of Mitylene, speaks nobly of her

like him you speak, like him yon are

[Col.Knl.] what shall Cordelia speal

[Col.Knl.] what shall Cordelia speak
desrest Regan, wife to Cornwall? speak

that duty shali have dread to speak.

to sperk and purpose not (rep.

bring you to hear my lnrd spea

oceasions, and I shall, that I may spenk

tell my daughter I would spcak with her

if I steak like myself in this

does Lear walk thiss? speak thus?

ii. 3 the shame it celf doth spenk for in

ii. 5 what is your difference? speak (rrp.)

ii. 6 he must speak truth .......................

self-same eulour nur sister speaks nf ...

deny to speak with me? they are siek?

iii. 3 epeak with the duke of Cornwall (rep.)

iii. 7 I'd speak with them; now, present

speak 'gainst so great a number?

and speak it agnin, my lord; no niore.....

I'll speak a prophey cre I gn.............
neither to speak of him, entreat for hini

she mist not gleak why slue.

sent the mplitic kling? speak

I speak in understandling; you are
liear yout, sir? sneak! thus mighit ....

a miracle: speak yet araini ....

he wakes; sperk to hin.

ut thes apenk the Iruth, do you not in

sir. you speak nobly y....

thy heart, whereto I speak, thou lie t...
Cymbeline, i. 7 | SPFAK. O aave him, save him

Previcles, $\mathrm{v} . \mathrm{s}$

hit speak your on; yon look na you.

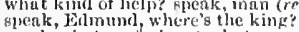

apenk what we teel, not what we onght .,$-\bar{v}$

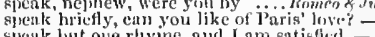

speak to my goseip Venus one fair word -

speak to my gossip Venlus one fair word -
sle speaks, jet slie says nothing $(r r p)$

$O$. speale agnin, bright angeil

mire, or shall $\mathrm{L}$ epeak at this?

is hoarse, and nay mot speak aloud...

and will speak more in a miunte than

speak, good, good nurse, speak

k to them -

that speaks but Romeo's name, speriks

speak well of him that lilled (rep.).

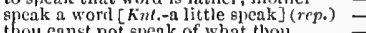

thou eanst not spenk of what thou

then migrtat'st thion speak ...............

speak not, reply not, do not answer $\ddot{m e}$

I speak no treason (rep.) $\ldots . . . . . . . .$.
talk not to me, for I'll not speak a word -

be not so long to speak: I long to die
what thou speak'st, sleak not of remedy -

my tongue, und will not let me spenk -

let us hear Bernarelo sieak of this

speak to [Col. Knt.-question] it (rep.)...
by heaven, I clinrge thee, speak (rep.)

speak of it. stay a vou, 0 s.

it was about to spenk when the eock erew -

stund dumb and spetk not to him

to motion, like as it would epeak

I'll speak to it, thnugh hell itself siouid

it will not speak; then I will foilow it

sleak, I am bound to hear

speak of this thut you have seen (rep.)

it we list to speak; or, there be ...........
Inosed out of lyell, to speak of hormrs...

I'll speak to him again: what do your re

eome, come, nay speak ....................

Where he speaks of Priam's slauglit

will speak with most miraculous or...

speak the epech

not to speak it profanely, that, neither

speak no more than is set down for the

sou desires to speak with you ( $r e p$.

I will speak daggers to her, bit use non

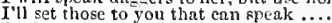

speak to her, IJamlet How is it witli you

to whom do you speak this?

your trespass, hut my madness, speaks

go, scek hin ont; s]ienk furr, and bring

I will not sjeak with her

at straws, speaks things in donlit...

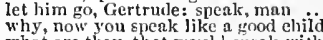

why, now you spenk like a gnod ehild

what are they, that would speak with me? - iv. 6

I will spenk to this fellow

indeed, to speak feelingly of

lordslup speaks most intallihly of him

if his fitness speaks, mine is ready

let the kettle to the trumpet speak
let me speak, to the yet unknowing

of that I shall have also enuse to syeak

and the rites of war, speak loudly for him

mittle of this, great world ean I speak

but, Othello, speak : did you by indireet -

it was my hint to spenk..................

when I did speak of some distressful

sane Cassio, - though he speak of eonfort lie speaks home, madnm

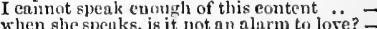

when she spenks, is it not an alarm to lo
well cnough, and speak well enough .

well chough, and speak well enough
hold, holdit the general speaks to you

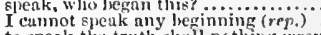

I cumnot speak any leginning (rep.) ...

clrunk? anil speak parrot?

and she spenks for you stoutly

have time to speuk ynur hosom fieriy
why, stay, and here me speak. Mlutam

I npeak not yet nl proset.

in position, ilintinetly speak ot ber

[knt.] Why do $y$ on speak so faintly

Ii.
ii.
ii.
ii.
ii.
ii.
ii.
ii.
ii.
iii.
jii.
iii.
iii.
iii.
iii.
iij.
iij.
iii.
iii.
jii.
iv.
jv.
iv.

\section{i.}

. speak to me: if there be any goorl (rep.)

you cannot speak of reason to the Dane

you speak like a green girl

O spenk of that; that do I long to hear 


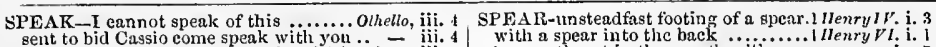
do you speak so startingly and rasli? (rep.) - iit. 4 I would on great occasion speak with you to speak what $Y$ liave seen and known did I but speak thy deeds.

speak withiu door. O fye upon him! it does abhor me, now I spenk the word..
he spenks well. I know a lady in Venic

guiltiness will speak, though tongne

like she comes to speak of Cassio's deati.

she'll sure spenk to my wife

speak again I Sweet Desden

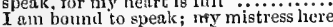

let me have leave to speak

no, I will speak as liberal as the air

my soul to bliss, as I speak true .......

and speak with ine, or, naked as $I$ an

speak of me as I am; notling extenuat

then mast you speak of one, that loved
SPEAKER-kill the speaker's heart..L

stay, you imperteet speakers .....

the speaker in his parliament.

what! a speaker is but a prit
who shall be the spenker?

who shull be the spenker? $\ldots . . . . .$.

ather speaker of $11 \mathrm{y}$ living actions

to be a speaker free........... Troilus \& Cressida, iv.

hercafter, but I am truest speaker ..Cymbelin, v. 5

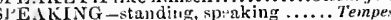

little speaking shows his love..Tino Gen of ter. i. 2

if speaking, why, a vane blown ..... Much

angry with me, matain, speaking

do not wrest true speaking, I'll off

speaking of her foulness, washed it

I'll have no speaking; I will...Merch,of I'enice, iii. 3

innneenee persuades. when spenking. Hinte's $T$. ii. 2

my first fulse speaking was this ...... Macbeth

to death, through want of speaking!

and, spcaking it, he wistly looked

and speaking thick, which nature.

brave deatin by speaking, whether..iHenery VI. iv.

to unthink your speaking, and to.. Henry VIII. ii. 4

trusted for spuaking false in that.....

speaking is for beggars: he wenrs his

by friendshing by deeds, and deedless in his

please me wi:ls speaking to in

consuming it with speaking! .........
Cresar), speaking of Brulus ......
wlo rated him for speaking well of

wh to rated him for speaking well uf..

he s speaking now, or murmuring. Anlony \& Cleo. i.

or senseless speaking, or a speaking..

will think me speaking, though $I$ swcar.

they'll have me whipped for speaking
strange celiads, and most speaking louks

past speaking of in a king

my cause, in speaking for myself ........

so speaking as I think loud, or tainting.. - ii.

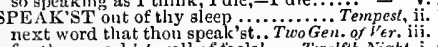

for thou speak'st well of toolsi.... Tu'elfth Night, i. 5

there thou speak'st reason; nay......Much Ado, $v$.

thou speak'st ariglit; I am that. Mid. N.'
an old l.ve-monger, and speak'st. Love's

and thereupon thou speak'st, the fairest

thou speak'st it well: go, fither...Mer.of

then, how'soe'er thou speak'st, 'monlg - iii.

thou speak'st wiser, than thou art.
speuk'st thou in sober meanings?.

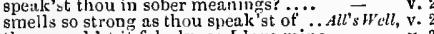

thou speak'st it falsely, as I love mine

thou speak'st truth: no more such. Winter's
thou spenk'st false in both .. Comedy of $E$,

thou speak'st with all thy

if thou speak'st false, upon the nex

I'll prove the lie thou speak'st ....
that wliat thon speak'st may move

thmu sperk'st asif $\mathbf{I}$ would deuy .....

why speak'st thou not? what

in vain thou speak'st, poor boy

no leprosy, but what thom speak'st

that speak'st with every longue.
though thou speak'st truth (rtp.)

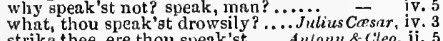

strike thee, ere thou speak'st

Aulony \& cleo. ii.

thou weep'st, and speak'st ........... C'ymbeline, v.

thou speak'st like a physician..........
thou speak'st like him's untutored

and thou spe:k'st in hetter phrase
bleed'st not, speak'st; art sound

Lear, iv.

speak'st thou trom thy heart?...Romeo $\&$ Juliet, iii.

if what thou speak'st, speak not of

that handkerchief thou speak'st of........ Othelln, y,
SPEAR-slander's venomed spear .... Richard 11 .

husband's wrongs on Hereford's spe

if I be gored with Mowbray's spear.. he was thrust in the mouth with a spear - iv. 7 like to Achilles' opear, is able a special virtue, for then

special suspicion of Falstafi"s......... have a special care of him ....... Trelfth Night, iii. 4 we have with special soul elected.Meas. for Meas. i. from lord Angelo by special charfe. in special business from his holiness
hold you ever to our special drift ...

not by night mastered, but by speciai. L.ove's L.L.i
from special officers of Charles......

some certain special honou

what place muke you special

ay, when the special thing is well
clond, without our special wond

take special care my greetinos barbeth,

hath drawn the special head of all... Henry $I V$.

ordained his special governor..........

'tis my special hope, that you will elear
without your special pardon......... Henry ${ }^{\prime} I$.

without your special pardon........3 henry

for whom we stand a special party. Tit

to the earth some special good liomeo \& Lear, iv.

with this special observance, that you.. Hamlet, iit. 2

there is a special providence in the fall

raise some special officers of niglit .......
your special mandate, for the state affiirs

he dropecial mand for a special purpose.
SPECIALLY to be aclieved

to lubour and effect one thing specially
SPECIALTIES are bound .............

PECLALTY of rule hath been . Troilus \& Cress. $\mathrm{i}$.

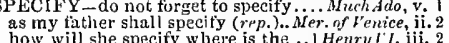

how will she specify where is the ..1 Henry I'I. iii. 2
SPECIOUSLY for master Feoton... Merry Wives, iii. 4

specionsly ore of them ............. - iv iv

I can see yet withont spectacles ....... Huch ido

with spectacles on nose, and pouc

to be a public spectacle to all

them blind and dusky spectacles

$O$ barbarous and bloody specticle

seek firr sorrow with thy spectacles?
the saddest spectacle that e'er I.

o piteous spcctacle! O bloody times!

what a pair of spectacles is lere! Troilas $\delta \cdot \overrightarrow{\text { Cress. iv }}$.

else were this a savage specticle...Julins Corsar, iij. 1

partition spectacle! O noble Cæsar

nothing, I shall not need spectacle

SPECTACLED to see him? ................

SPECTATOR-to take spectators.

imagine me, gentle spectators .....
prove a good repast to the spectators

quantity of barren spectators to laugh. Hanlet, $i 1$.

SPECTATORSHIP, and cruell
SPECULATION in those eyes

took stand for idle speculation

Macbeth,

speculation turns not to itself. Troilis

the spies and speculations intelligent
SPECULATIVE their unsure hopes

\& Cress. iii.

my apeculative and active instruments.. Othello, i.

be gone, sir, you are sped. Mer. ofi entice, ii. 9 (scroll)

of wind galis, sped with spavins. Taming of Sh. iii. 2

are narried, but you two are sped

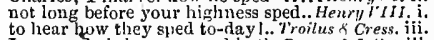

I am sped: is he gone, and hatli. Romeo of Juliet,

than lie appears by specch

joath to cast away my speecli...

that I may proceed in my speech

I will on witls my speech in your prisise

give me this prerogative of spech
put strange speech upon $\mathrm{me}$

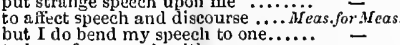

to have free speech with yoir .........

by and by have some speech with $y$
there was some speech of marriage

runs not this speech like iron tluroughi. . Fuch d do v

by helping me to the speech of Beatrice $-\bar{r}$, v.

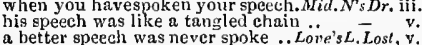

a better speech was never spoke. .. Loi

nor to their penued speecli rencler we

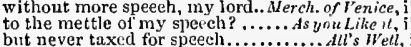

bis epitaph, as in your roya speech......

by the fair grace and speech of the poor $\overline{-}$
but slow in ppeech, yet sweet as .. Taming of Sh. ii. PECLAL-these special marks.. Two Gen. of' 're

had you a special warrant

a special deed of gift, after his

let specialies be theretore draw.

how I have sped among the ....
Charles; I marvel how lie sped

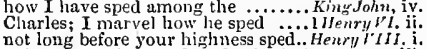

near to the speech we had to such

dcsires some private speech witl you
PEECH-all this goodly spech '.. Taming of Sh. ii.

on my faith, deserves ligh speech. Winler's Tale, li.
i' the boldness of your speech........
gasping to begin some speech, her eyes $=$

if I mny come to the speech of him..

the was speech in their dumbness.: - v. 2

hear lis

be not a niggard of your speech.......... - iv.

having no witness to confirm my speech $\quad$ - v. 1

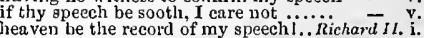

reins and spurs to my free speech.

should be the first word ot thy speech - v. 3

and here is my speech: stand ...... Henry $I V$. ii. 4

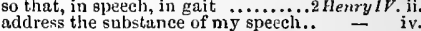

out of the speech of peace..........

moist impediments un to my speech...

strength of speech is utterly denied..

my speech; my fear is your (rep.)....
if you look for a good speech now... (cpil.)
and my speech entreats, that I may.. Hen' $V$. $v$.

his deeds exceed all speech ........... i Heury Vi. i.

with sudden and extemporal speecil

but her grace in speech, her woras ..2Hewry $r . . i$.

thy head for this thy traitor's speech $=$ ii.

in specch he doth resemble; by this

iii.

for this one speech, lord Hastings...3. Henry $r$ l. iv. 10

die, prophet, in thy speech............

every day it would infect his speech .. - i.

what was the speech amongst the ....
speecli fir truce, success, or loss.. Troilus $\& \overline{C r}$.ess. i.

give pardon to my speech............. -

witness the process of your speecil ...

this was my speech, and 'I will speak't

in your funeral speech blame us...Julius Ccesar,

after my speech is ended

nor the power of tending to Cresar's.:

this speech were else your last .......

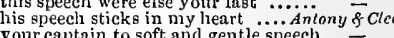

your eaptain to soft and gentle speech
your speech is passion: but, pray you

if he mislike my speecls, and what is

my speech of insultment ended on his - iii.

unfold a dangerous speech, though .... $v$.

a corrupted mind, thy speech liad al tered

the inore she gives them speech ...........

makes breatls poor, and speech unable ..... Lear, i.

accents borrow, that can ny speecli diffice

with curst speech I threatened to

wear this; spare speech; decline

if my speech offend a noble leart.

this speech of yours hath moved me ...

what, shall this speech be spoke... Romeo \& Juliet, $\mathrm{i}$.

we'll have a speech straight ............

a speech once, but it was never acted

a speech of some dozen or sixteen lines

a speech of some dozen or sixteen lines

how smart a lash that speech doth give..

speak the speech, I pray you, as I

do not itself unkenuel in oue speech

n kmavish speech sleeps in a foolish ear

I have a speech of fire that tain would

your patience in our last night's speech.

rude ain I in my speech, and little .......

let me have speech with you ............................

being in speech, there tomes a fellow

is free of speech, sings, plays, and dance

not to strain my speech to grosser issue

my speech should fall into such vile

speech so faint? [Knt.-speak so faintly].
of his displeasure, for my free speecl 1 .

that I may save my speech

my knees, what doth your speech import

villanous speeches of the dulse ...Meas. fer prest, ii.

by the nose, for thy speeches?..........

construe my speeches better ...... Love's L. Lost,, .

thy speeches will bring me to .....Winier's Tale, $y$.

upon thee, Nacbeth, their speeches ... Narbeth,

my former speeches have bot hit your $\ldots$.

not my speeches that you do mislike. 2 Henry $Y I$. i.

or certain speeches uttered by the..Henry III, ii.

Lours, lives, speeches spent .............

w am the master of my speeches ..Julius Casar.

forbear sharp speeches to her ......... - ii.

thrust these reproach ful speeches. Tilus $A$ id dron. ii. I

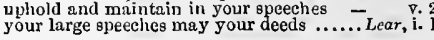


SPEECIIES-my speches, as I were a fool? Lear, ii. 2 sl'pestilent sliceches of his tintlicr's dentli. Hamlet, ir. would afford my specechloss visor.. iove's L. Lost, v, visit the speechless sick, and stil..... no $\bar{r}$ rnice, $\mathrm{i}$.

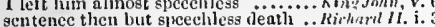
sentenec then but spleechless deat
thus, with his speechless hand

thus, with his speechless hand ... . Coriolnums, v. for his fortunes ull lie spechless .... C'ymbeline i. spell thee with specehless tongues....... P'erimles, the hold winds spceehless, and the orb... Hamlet, ii
sPEED-make soced from hence. Two Gcn. of Ver. SPEED-minke spced from hen
saint Nicholas be thy spred

Faint Nicholas be thy specd.

ghall know how I speed (rep.iit

fitter place; and that with speed. $\dddot{M}$ eis. for $\bar{M}$ eas.

best appointment make all speed

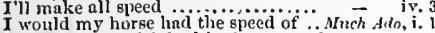

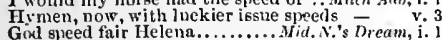

speed to catch the tigcr: bootless spcedi - it speeds too fast. 'twill tire ....... Love's L. Lost, ii. 1

to the purpose of his spcer

but go with speed to some forlorn....

lie would make some syeed of his.Mer.

with imagined speed unto the tranect....

madam, $\mathbf{I}$ go with all convenient spect

whicli speed, we hope, the better for

Hcrcules be thy speed, young man. As you Like it, i. 2

ride upon the violent speed of fire..... - iit.

if you speed well in it, the duke..... $=$ iii.

which, if it speed, is wicked meaning 二 iit.

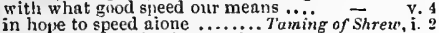

woo, and happy be thy spe...i $\ldots . .$. - ii.

how speed you with my danghter? ...
it were impossible, I should spced amiss $\overline{\text { ii, I }}$ ii. I
much eontempt, speeds from me... Hinter's Tale, i. 2

tlieir speed hath been beyond...

'tis good speed; foretels, the great....
and fear of the queen's speed, is gone

Blossom, speed thee welli................
and witli speed so pace to speak

fortune speed us! thus we set on

by your good father's speed, wil
curried with more speed before

my fullows had the speed of him Comedy of Err.

we must speed for France

in this action of swift speed.....

speed then, to take advantage of

so hot a speed with such ndvice.

withhold thy speed, dreadfal

time shall teach me speed...............
that child, anil follow me with speed

that child, anil follow me with

with all good speed at Plashy

Gril speed him well, and had the
with all swift specd you must

with all swift specd you must
come yourself with speed to us
no little reason bids us speed

no little reason bids us spe

good manners he your speed

thy looks are full of speed . ............

prevent the worst, sir Michael, speed

arm, arm, with speed: and fellows
beud you, with your dearest speed

alsuost forspent with spreed ........

fites with grentest speed; so did.
and make fricnds with speed

and make friends with speed
make good spect: how many

these griefs shall be with speed redressed -

and we with sober speed will follow you

despatch us with all speed, lest...
the herald? speed him hence

the herald? speed him hence ..........
bestow yourself with speed .........
St. Dennis be iny spreed!) donc vostre G d speed the parliament! ....... Henry $V^{\prime}$. iii. 2 stay not to expostulatc, make speed.3Henry VI. ii. 5 your brothers to go speed clsewherc..

th return from France with spced (rep.) -

neighbours, God speed give you

with all speed to doctnr Sliaw

an honest tale speeds best.

the devil speet him! no man's........ ilenry $\overrightarrow{I^{\prime} M}$. i. $\mathrm{i}$

with great spced of judgment..... Troilus o Cress. i. 3

once denied, will hardly spced. Timon of Alhens, iii. 2

thy conntry, speed thee straight.

forget not. in your apeed, Antonius, $J_{\text {nulits }} \bar{C}_{\text {ensar }}$

let the gods so speed me, as I love

post back $x^{\prime}$ ith speed, and tell lim

post back with speed, and tell him

this lool's spect be erossed with,... Cymobeline, iii.

shall you spcedl in y'our journey's end

offend you then that hoth slould speed?

if this letter spect, and my invention....
till the speerl ot his rage goes slower

to make your speed to Dover

sir, specd ynu: whut's your
l'll send a friar with speel.

ii ? Rnines.......

so that my speed to Muntua was stayed

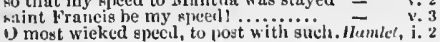

SPEED-ghall with speed to Englund .. IIumlet, iii. I SPEND your adver turous wnth.

Bullt, nnend thou that in the tow

I'ericles, il. 4

cries haste, tud speetl must answer it...... O!hello, $i$.

our thouglats, and hitepy spece...

our thoughits, a sennight's spect
how quiekly should you speed?

EED ID - be specded well .....Meas. for Me

SPEEDIER course than lingering .. . Tims $A$ Th

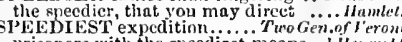

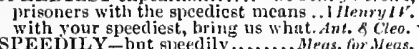

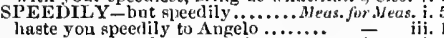

my duty, speedily to acakaint you..... All's trell, $\mathrm{i}$.

go, spcedily, and bring again the count - ve $1 \mathrm{v}$.

or liitlierwards intended syeedily.

let us take a muster speedily

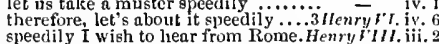

but nust be lookerl to speedily

come, say your prayers speedily ........ Pcrieles, iv. I

nether erimes so speedily can vcrge! ....

P'EEDING? nay, then...............

got a specding trick to lny down.... Henry rII1, i. 3
all for speeding do thicir best ......... Pericles, ii. 3

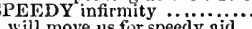

All'slithli, i. 5

ware, pleasant, speedy, the time is. Winter's T'ale, iii.

some speedy messenger bid her...... King John, ii. 2

and hath sent out a speedy power .2 Henryl i, i.

you speedy helpers, that are

his speedy and quick appearane

your company for speedy eounsel...3 Henry $r /$

prays your speedy payment ... Timonof Alhens,

if your diligence be not speedy, $\mathrm{I}$ shall be. Lear

eraves a speedy answer

devise his speedy tnking off

with speedy lielp doth lend.Romeo \&.Jui. iv. $\overline{5}$ (song) SPELL-or else our spell is marted ...... Tempest,

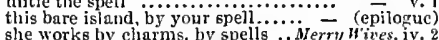
she works by charms, by spells ...Merry Hives, iv.
hat she would spell him backward ...Mueh Ado, iii. never harm, nor spell ....... Mid.N.'s s)r, ii. 3 (song and your spells provide ................Macbeth, iii.

ye charming spells and leriapts ...... H Henryl't. v. 3

tis a spell that is out

als, thou suell! avaunt.... power . . Coriol

and corrapted by spells and medicincs of jul. ii. 3

SPELI,-STOPP'D-you are spell-stopp'd. Tempest, $\mathrm{V}$.

SPELT back ward witl the horn
SPENCER, Blunt, and Kent

SPEND his yontli at liome $(r e p$.
that thou shalt spend some time

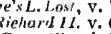

and spends whint lic borrows

spend it at thy will: hut now

the .... Othello, i.

and direction, to spend witlithess grief

and spent your rich oplinion, for the raine - ii.

at home; spend his manly marrnw in. All'x Wrul, ii. 3

where thinu spend st tly time

is like a spendthrift sigh

and suent our hours thgether.

I am a gentlenian that have

surely, suit ill apent, and laboin

the hours that we have spent

I know not what's spent in tile.... L Lovere's L. Lost, ii.

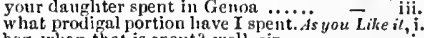

ere, whe have thy youthfu! wages sucnt

ill music we have spent all hour.. Tanaing of Sh. iii.

if ever you have spent tinie worse - iv. (clioris)

as two spent swimmers, thit do........ Macbeth, $\mathrm{i}$.

nought's had, all's spent, where...........

to be speat with such a bral,bler ......

six frozen winters spent, return.

thiey are seldom spent in vain........ and all, old Lancaster hatlı sieni... $\quad$ ii. I

spent not tlat whieh his triumpliant $\quad$

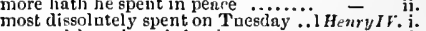

spent with crying-bring in......... - i.

it is time you were spent. Spent! .... $\overrightarrow{\text { iii. }}$

hast thou spent a pilgrimage .......

think it but a minnte spent in slort - iii,

cancellcd, and lis trcasure spent ....3 Henry I'l. Y.
happy, indeerl, as we have suent ... Ricrard III. ii.

thougli we have spent our harvest... -

eleven hours I live spent to

lives, speccles spent, thus once.. Troilus \& Cress. ii.

in her defence...

how have we spent this morning?

when all's spent, he'd he crossed. Timinn of thens

my lord hath spent of Timou's wealtl -

and, thy fury spent, confounded be

our lamp is spent, it's out..Antony $\hat{\theta}$ Clenpatra, iv.

lmost spent with liunger,

lis trials well are spent

ten years are spent, since first... Titus

Whose ynthth was spent in dangerous iii.

stale and hoar erc it be spent..... Romeo o o juliet, ii.

mine shall be slent, when theirs are dry - iii.

he means to spend his time awlile.. - ii.

I spend in talking to thee........... $\overrightarrow{M e r r y}_{\text {ives, }}$ ii. 2

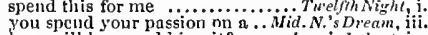

how will he spend his wit? ..............

and spend his prodigal wits in boot.

a twclvemontli shall you spend....

and hercin spend but time...Alerchant of renice, i.

if he would spend lis power ........

moncy that he spends in tiring.. Comedy of Err.

this night I'll spend unto a dismal-fatal - iii.

more sorrow, and that inll gpend for him

six years, that be hath to spe.

did win what he ditl spend

and he shall spend mine lionnur

we may boldly spend upon the .......

coward dogs most spend their monthis.Henry $r$. ii. 4

we may as bootless spend our vain.
in fretting spend lis gall .............

in lis bosom spend my latie

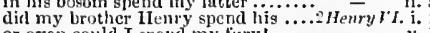

and spend her strengtl with

in tlevotion spend my latter days.......

aud men ne'cr spend their fury on

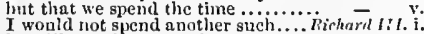

lie will spend his mouth .... Trnilies \& Cressidin,

and spend our flatteries, to drin

io more th reckon, he to spend

my money is almost spent; 1 hia

othelln, ji.

ERALACETI, for an inward briise.I llen,wl\%.

PERle up the sons of Troy ...Tromlus \& Ciess. (proil.
PHELE-the moon out of her spliere.. Temprast, ii.

than mosic from the spheres ... Treplfih, itghe, iii.

shot madly from their splieres ...... - ii.

Venus in her glimmering splsere .....
have shortly discord in the splueres. As yon Like it, ii.

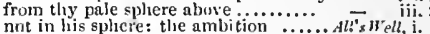

nut in his sphicre: the ambition ....... Alis shell,

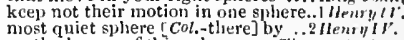

to be called intro a huge spliere...A Anouy 8 . Cleo.

burn the great sphere lho mnvest in!

the music ot the sylueres list,

twinkle in their spheres till .... Romeo \& Juliel, ii.

a yriace out of thy splhere spht.Knt.-..... Ham - ii.

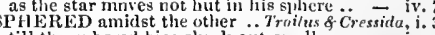

till thy ophered bias eleek out-swell
SPIIER ICAL, like a globe.... Comedy or Errars, iii.

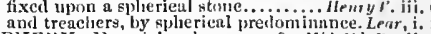

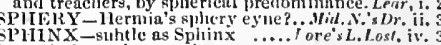

PICE-her spices on the strcam....Mer of i enice. i

I must go buy spiees for onr ......... - iv.

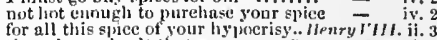

the spice and salt that scasen... Froilus d Criss. i. 2

as he hath spices of them al

bid Nest 1 r bring me spires ...............'Pericles, iij.

anil fetel more spices, nurse spictions

than spend o townend the tim

may seem to spend his fury

PICED-in tle striced Imliun air.. Mhid N.'s Dr. ii.

spend that kiss, which is my liearen - v.

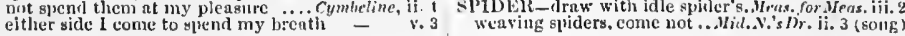


SPIDER-plays the spider.

Merch. of lenice, $\mathrm{iji}$. the crip a spider steeped

thread trat , and seen the spider..... ing $^{-}{ }^{\prime}$ in. but let thy spiders, that suck up .... Richavd 11 . busy than the labouring spider ....2.21enry strew'st thou sugar on tliat bntiled spider to hels me curse that botted spider $\because$ - iv. 4 deliver a fiy from a spider..... Troilus \& Cressida, ii. of the smallest spider's web...... Komeo s Jut
SPIDER-LIKE, out of his self-.... Henry $V^{\prime}$. SPIED - hath spied him already. Mid. N.'s Lream. spied a hlossom, passing

llis $H_{e}$ ell, $\mathrm{jii}$. but at lust I spied an aucient..... Taming of $\mathrm{S}$. at last, I pied his eyes............2HenryIV. ii. the white hair that Helen spiel...
the fire is spied iu populous eities

SPIES-if these be true suies which i.... Ohello, I am attended by some splies. Tiro Gen. of ferona,

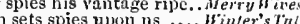
I'll fill these dogred spies with........ King John, and epies a fur-off sliore where

spies of the Volices beld me

s beguiled all spies.................... \& Coroolanus, 1. are to France the spies and speculatious. Lear, iii.

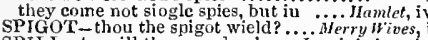
SPIGLT-thou the spigot wield?..... Merry W'ives to spill mine enemies' blood......... King John, ii that spills another............ Timon ... Henry 1. if. well spill the blood that has ... Antony of Cleo. iv. all germens spill at once $\ldots . . . . . \ldots \ldots$..... Lear, SPILLED of niy dear kinsman l.. Romeno \&. Juluel, iil SPILLING Edward's blood.......... Richure II. it. I

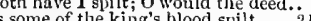

is some of the king's blood spilt ....2 Henry IJ' ii. thou know'st, unjustly must be.... spilt! Rarl 11 iji.

spills itself. in fearing to be spilt ...... Hamlet, iv. 5
SPILTH-wept with drunken spilti. Timon of $d ?$, ii.

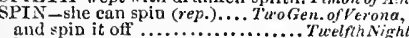
and spin it off ................... TwelfthNight SPINII-the regiment of the Spinit ..All's Wetl, ii. I
SPINNERS, hence ....... Arid N.'sDream, ii. 3 (song) made of long spimers legs........ komeo \& Juliet, i.
SPINSTERS and tlue knitters.... Twelfth Night, if. have put off the spinsters, carders .. Henyl ${ }^{\prime \prime I} i$. i. SPIRE - the spire and top of praises.. Coriolunus, my brave spirit! (rep.) ............... T'empest, i. thon wast a spirit too delicate

what is't? a spirit? (rpp.).
spirit, fine spirit, I'll free thee

if the ill spirit have so fuir a loine ......

nor I; my spirits are nimble
his spirits hear me, and yet.

here comes a spirit of lis.

nor hath not one spirit to command

to the dulling of my spirits....

now'gins to bite the spirits.

may I be bold to think these spirit

spirits, which by mine art (rep.)
apirit, we must prepare to muet

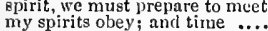

sily my spirit, how fureg

dost thou think so, spirit? ( $($ rep. $)$

my tricksy spirit! (rep.)

now $I$ want spirits to enforce.

who then? lis spirit? .... Tü Gen. of Verona, ii.

I do applaud thy spir

the spirit of wautonness is

juu have heard of such a spirit

dis-lion the spirit, and moek.

as I am a true spirit, weleome!

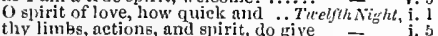

and the spirit of humours intimate.

let thy biood and spirit embrace.

a spirit I am. insleed

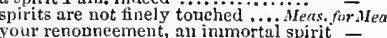

to visit the aftlicted spirits here in

and the delighted spirit, to bathe in $"$ "

spirit to do any thing tliat appears
heaven give your spirits comfort?..

and wholsomest spirits of the nighit..

hat epirit's possesserl with haste ....

by my own spirit; for I should flout him -

hath a very contemptible spirit .....
spirits are as coy and wild as haggards

mas, but his jesting spirit .............

thius to lierht, smother her spirits up.
thouglat $\mathrm{I}$ thy spirits were stronger

whose spirits toil in trere stron

the pert and nimbie spirit of nirth..... isd.

firewe]l, thou lob of spirits ..........

too mueh the harred of my spiritit.

Ind woluders at our quaint spirits

that thou shalt like an airy spirit $g^{\circ}$
PIRIT-low now, mad spirit?.Mid.N.'s
damned spirite all, that in cross-ways but we are spirits of another sort when a man of great spirits grows... Love's $\bar{L}$. Lost it

chirit grows heavy in love

foulisll extravagant spirit, tull of forms

nimble, stirring spirit she might

heavenly spirits, vouchsafe nut to

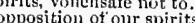

to cloke a gibing spirit, whose influence -

of modesty thy skipping spirit ... Mer. of te

are with more spirit ehy manly spirit

is no bar to stop the foreign spirits

giddy in spirit, still gazing, and in doubt

that her gentle spirit comrnits itself.

of manner's, suncl of spirit

with a quietness of spirit ............

shalt see the difference of our spirit..

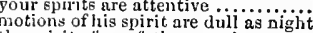

the spirit of my father (rep.) ........ As you
your spirits are too bold for your years

an unquestionable spirit

to be the snuffi of youm to yoir........

in thee some blessed spirit doth spenk

must we of a most facinorious spirit

to sparkle in the spirits of $m$

be infused with so foul a spirit ! Taming of $\overrightarrow{\text { Sh}} .2$ (in

woo her with some spirit when she..

if she liad not a spirit to resist .......
pluck uj thy spirits, look cheerfuily

nnd our weak spirits ne'er beell ... Win

send her a better guiding spiriti

some powerfinl spirit iustruct

I would your spirit were ens.

woukl make her sainted spirit again

took tles spirits, standing like..........

and which the spirit? ................ Fomedy of Frrors,

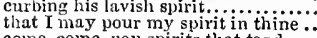

your spirits bhine through terd....

my little spirit, see, sits in

black spirits, and white; red spirits -

thou art too like the spirit of Banquo

the vpirits that know all mortal

and fits the momiting spirit

whose laboured spirits, forwearied in

fiery kindled spirits! . ..............

or if that surly spirit, melanclioly

holding the eternal spirit, agaiu

of hetven hatl blown his spirit out....

the spirit of the time shall teach

the damutless spirit of resolntion.

and fiesh lis spirit in a warlike

tame the savage spirit of wild war

culled these fiery spirits from.

put spirit in the French...........
is, a bold spirit in a loy al breast
whose youthitul spirit, in me.

Whose youthtul spirit, in me
I have a thousand spirits io

have the spirit of persuasion

thy spirit within thee hath been ....

I can call spirits trom the vasty

as full of spirit as the mouth of 1 Iay

I did not think thee lord of such a spirit

the spirits of Slirley, Stafford, Blunt

your spirit is too true, your fears.....2 Henry $I V . i$.

hut let onc spirit of tlie first-born.

that his firward spirit would lift

praetised upon the easy yielding spirit

and the spirits of the wise sit in.

you do diraw ny spirits from me.

dove and very blessed spirit of peace

believe me, I am passiog light in spi
and inland petty spirits. muster me

whisper onusic to my weary spirit.

and inwarl duteous spirit teacheth.

of his men's epirits and his

their spirits are so married in.
strike sail to spirits of vile sortl.

bold, just, and impartial spirit

and with his spirit sally I survive ...

to envelope and eontain celcstial spirits

neeter for your spirit, this tuin of...

thy spirits are niost tall

constant in spirit, not swerviog
bend up every spirit to his full. iii. SPIRIT-your spirlt: and, upon this .. Henry $V$. iii.
nud, with spirit of honour edged .... $O$ brave spirit l Via

conjure of the spirit of love in t...

spying his tudaunted epirit ........

Salisbury, cheer thy splirit with
She hat

practise and converse with spirits....

Rome slallow spirit of judgment ....
undaunted spirit in a dying hreast

invineible unconquered spirit.

drencl his over-mounting spirit

ny spirit can no longer beur these

nay eleer ont drooping spirits ......

anl ye elosice spirits that admonish.

ye fumiliar spirits, that are culled...

had ain your spirits now witl
lad to do with wieked spirits

a spirit rizised from deptll of ........2 IIenry $v r . \mathrm{y}$.

a woman of an inviucible spirit $\ldots$.

raisility up wickcd spirits from under

last thou not spirit to curse thit.

inspired with the spirit of putting down -

aghit, winged witl...3Henry $Y I$. i. I

my lord, cheera, fal of spirit..... - i.

a woman of this valiant spirit should

of like spirit to limself.............

bid a blashng shance-facen spirit.. Richard 11 . i.

yet so much is my poverty of spirit ${ }^{\circ} \quad$ - iii. 7

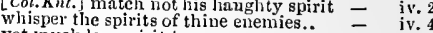

yet inuch less spirit to curse $\ldots \ldots . .$. .

clanlienged the noble spirits to arms. Henry $r 11 \%$. $\mathrm{i}$.

aud with bold soirit relate what .....

a noble epirit, as yours was put......

came spirit pnt this paper in $\ldots \ldots \ldots . .$. .

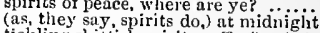

and spirit of sense hard as the palm..

soul and only spirit, in whom

that most pure spirit of sense........

speak it in my spirit and honou

her wanton spirits look out at evely

whereout Hector's great epirit flew ..

liey-day, spirits and fires! ..........

all these spirits thy power hatly. Timon of $\overline{\mathrm{A}}$ the

tis a spirit; sometime, it appears like

to thirteen, this spirit walks in......

every flatterer's spirit [ Col. Knt,-sport]

and noble fury, and tair spirit, seeing.

$O$ abhorred spirits! not all the whips

express in thee thy latter spirits ....

death, that dark spirit in's nerv..... Coriolan

gtraight his doubled spirit re-quickened =

are out of, with a gentler spirit.....

wants not spirit to say, he'll turn

if he cau thereto frame his gpirit....

extremity was the trier of the spirits

resube that spirit, when yol

Erotus part of that quick spirit.......... Julius $\bar{C}_{\text {cesar }}$

scorned his spirit that could be moved

governed with our mother's spirits....

retentive to the strength of spirit....

the insuppressive mettle of our spirits

the spirit of Casar; and in (rep.)....

with uatired spirits, and formal .....

antl master spirits of this age .........

it then thy spirit look upon us now

an Antony would ruffe ni your spirits

motion governed by my spirit .......

what thou art rhy evil spirit Brutus -

ill spirit, I would hold more talk witls

thy spirit walks abroad, and turus our

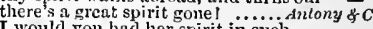

I would you had her spirit in suck.

thy spirit is all afraid to govern

and make thy spirits all of comfort!

but it would worm hispremacy .

like the spirit of a youth that....

now, my spirit is going; I can no more

a rarer spirit never did steer humanity

show the cinders of my spirits throngli

the loeking no the spirits a time

his spirits fly olit into my story

most willing spirits that promise
part, shame, part, spirit renewed

no voore, you petty spirits of region low

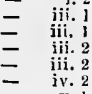

(prologue)

=

iii. 2

iv.

iv.

v.

ii. 2

iii.

iii.

\section{i. \\ iii.}


SPIRIT-spirits quail to remember .. Cymbetine, v. 5 SPITE-time and spite dare bring then eheer thy spirit: for know... Tilu

- v. neither plesin the Pericles, i. over-pre

and of how eowed it spirit.............

munele, here's a spirit ( $r$ rp.)

would streteh thy spirits up into the air

let not my worser spurit tempt me

you are a spirit 1 linuw.

and niy best spirits are bent to prove

to raise a spirit in his mistress . Komeo o-Juliet ii. 1

that a allnet spirit hach aspired. ...

thou did'st bower the spirit of a fiend

ghall seize each vital spirit

hours in the night spirits resort......

an unceustomed spirit lifts me above

they suy, you spirits oft wak in death

they say, no spirit dares stir abroal

this spirit dumb to us, will speak.

my father's spirit in armsl all is not well

be thou a spirit of health, or goblin ........

I am thy father's spirit; do

rest, rest, pertat I have seen, may be

(ns he is very potent with such spirits)

but thy good spirits, to feed, and elothe

my spirits grow dull, and fain I

in most great aftietion of spl [ Knt..........

that spirit, upon at your your spirits wildly peep

whose spirit, with divine ambition puffed

with all diligenee of spirit.

poison quite o"er-erows my spirits

iny spirit, and my plaee, have in them.. Othello,

of spirit so still and quiet, that her inotion

give renewed hre to our extirits, that hold their....

Othou invisible spirit of wine

I bear you with franker spirit

1 see, this hath a lithle dashed your spirits

his spirits gloonld hunt after new faneies

so help me every spirit sanctified

hath pndal hill thy unprepar...

I would not kill thy

SPIRITING-do my spiriting.......... Henry $V$. iii. SPIRIT SPIRIT-STIRRING drum ............... Othelln, iii. 3 upon our spiritual eonvocation tonehing thy spiritual function ....... Henry $I^{\prime} I$. than your high profession spicit
and fixed on spiritual object

\section{senrce time to steal from spiritual}

\section{SPIRT up so suddenly into}

\author{
二 iii. 2
}

IT-she epit in his face ... Measure for Measure, ii.

made Hereules have turned spit ..... Mueh Ado , ii. I
like a rabbit on a spit............. Love's L. Lost, iii. I spit [Knt.-spet] upon me on Wednesday

to spit [ $\left[\mathrm{h} n t_{\text {- }}-\mathrm{spet}\right]$ on thee again......

whose ambitions head spits in the face

weep for him, then spit at him . .As

spit in the hole, man ........ Taming of

looked big and spit at him

the pis falls from the spit

would st thon not epit al me

KingJohn, ji.

dety him, and I spit at lim..

and spit it bleeding, in his high. ...

and spit upon him, whilst I suy.

I would I might never spit white

the Alps dotll spit and void

why dost thious spit at me?........

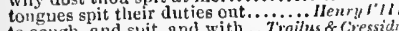

clean enough to 8pit upon

wives with spits, nuld boys with stone

spit, and tlurow stones, east mire .... Cu

a jig, prepured to the spit....Titus Andronicuv, iv.

Wilt thon spit all thyself? . . 7 .

epit, firel spout, rain! .......................

spit his body upon u rapier's point. Komen \& Jut. iv. that my Nell is dead in the spital......

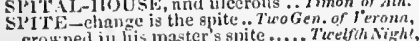
to spite a raven's heart within ....... MuchAda, v. if you spite it tior my gake, I will spite - Ospite! too old (rep.iii.: \& v.l).Mil..N.'s

this false sport in spite

and revelute this spite .................. the more lik spite uppears Thinitur of Shrete, $U$ spite of spites! we talk with. Comedy of Error unthing but to spite my wile

he dist ine pone.

we dhat I do, to spite the world ..........Maebeth, iii. and sleep in spitc of thut:der

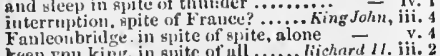

keep you king, in sjitc of all ...... lichard $1 /$. iif.
this is the deadly spite that angers... Henry $1 \%$. iit.

who in spite, put stutf to so friensls, in spite of the, shull wear.

in spite of Burgimaly, and all his...

the spite of man previlideth nguinst ..211enry $r$.

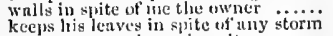
for shume, spenk net in silte

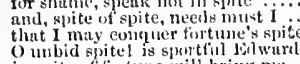

in spite of fortune will bring me.. flenryllil. iii,

luek, in very spite of eumning. Troilus of

live jo all the spite of wreaktul............

but in mere spite, to be fill

and spite of all the rupture of the... Cymbeline, y

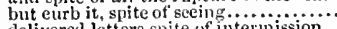

tlourishes his blade in spite of me. Inme

that is hither eome in spite ............

bad enough, before their spite........

O eursed spite! that erer I wos born

and she-in spite of nature, of years........

the spite of hell, the fiend's areld-moek

PITEFUL-son, spiteful, and wrathful. Wacbeth,

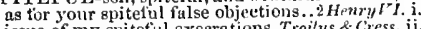

issue of my spiteful execrations. Trilus \& Cress. ji.
SPITTED-intants spitted upon pikes.Henry $l^{\prime}$. iii. 3

SPITTING - hawking, or spitting. As $y m h$

with our splicens, would .Mensure for Heasure, ji. 2

that in a spleen, unfolds both...Nid. N.'s Drenm,

thy silly thought, my spleen .... Love's

eonceived of spleen, and born ....As $y / m$ L Like it, iv.

the over-merry spleen f. Taming of Shrew, I (indue.)

fierce dratrons' spleens; have sold

or teael thy hasty spteen to do me.

ant spleen of spiced to see your mujest

inclination, and the start of

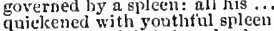

my soliliers of their hated spleen.

inspire us with the spleen ot fier
youl eharge not in your spleen.

Youl eharge not in your spleen

a)royaney, spleen, and pride.

as might offend the weakest spleen

performance of our heaving spleens..

it is a eause rorthy my spleen. Timon of Alhens,

digest the venom of your spleen ...JuliusCasar,

ereate her ehild of spleen................... Lear i. i.

Four are all in all in spleen, nothing..... Othello, iv.
SPLEENFUL sons this trull.. Titus Andronich, ii. 3

SPLEENY - a spleeny Iutheran .. Henry VIII. iii.

SPLENDID - their splendid nuting.2 fenry his preeious eye...... Kins John, iii. I

to rcjoice in splendur of mine awn.. Romeo \&.Iat,
SPLENETIVE-not splenetive and rash.Hnmlet,

SPLINTED-but lntely splinted . Richard III. ii.

scared the moon with splinters?..... Coriolanus,

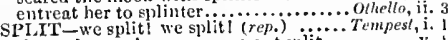

three glasses sinee, we gave out split

to tear a eat in, to make ail split ... Mid.N.'sDr.i.

bosoms, split my breust

when he shall split thy very heart... itichard $111 . \mathrm{i}$. 3

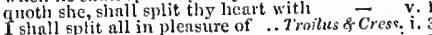

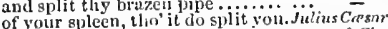

mine own tongue splits what it.. Anemy \& Clen, ii. .

him safe, is wreeked and split.

let sorrow split my heart, if ever .......... . .enr, $\mathrm{y}, 3$

to split the ears of the groundlings.... Hambet, iit.

do't pot, thou split'st thine own... N'inter's 'ate,

so eracked and splitted

even as a splitted bark; so sunkler..2llenry

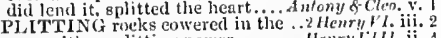

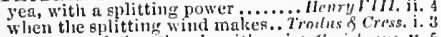

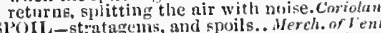

in the spoil of her and spoils

only it spoils the pleasure of the....... Muebeth

thou dost shame thant bloody spoil... King dokn,

company, hath been the spoil of me
spuil [Cnt.-tear, Knt,-tuitut] und husock. Itenry

like a miser, spoil lis cur

the enraged foldiers in their spoil

deadly murder, spoil, and vilatily

londen me with many spuils......

dnth frumt thee with nopuresit spoil... -

to spoil the city, anl your roy'ul...

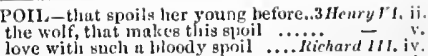

and spoil your nobler sout

to the wanton of opil of portinity. . Troilns of Crerss

to the wantun spoil of pliab

our spoils he kicked at: und looked = ji...

the noil, got on thie Antintes..........
we leskedl for no less spoil, thial glory

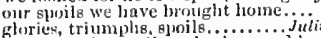

figned in thy spoil, unl erimsoned in

lis soldiers fell to enoil, whils

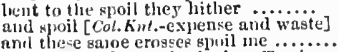

UILliD, and-yonder lie is .. Taming of Shren,

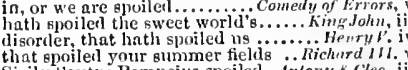

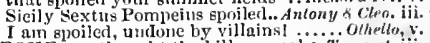

SPOKE-methought the billows spoke. $T_{\text {empest, }}$ i

fairly spoke, sit then, and talk

that it is spoke in liate .... Tư Gen.nf Vernna, iii.

I have spoke; let him follow

The spoke; let him flow -

as it were, spoke the prolngue ...... - iii.

I have spoke with ler................

thou hast spoke for us, Maloina....... i.

if it be honest you have epoke ... Meas. for

and one that hath spoke most .......

you, indeed, spoke so of him....
what you have spoke, I pardon

I spoke it but according to the trick ..

not to be spolse of; there is not.

not what she did, when she epoke to me -

not what she did, when slie Epoke to me $\overline{\text { Dream. }}$.

more than ever won:en spoke .......... ${ }^{\prime}$ I have fur barbarism spoke more.. Love's

I spoke it, tender juven

but, while 'tis spoke, eaeh turn away

vice $y$ on should have spoke...........

we have not spoke us $y$ et of.......

I spoke with some of the sailors
after some oration fairly spolke by

after some oration fairly spoke by $\because-$ - iii.

would not have spoke such a word. Als you $\bar{L}$ ike it. $\mathrm{i}$.

the youth that spoke to me erewhile? - iii.

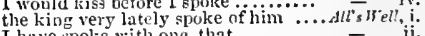

I have spolse with one, that...........
of what $\{$ spoke, unpitied let me

fiom you, spoke with the king .......

and show you the lass I spoke of

lave you spoke? All that he is hath

I liave spoke the truth

virtues spoke of, and thy beanty... Taming of $f$. ii.

splke like th oflicer.................

you neyer spoke what did become ..

but I lave hnl moke, even since it.. - iij.

was it not yesterday we spoke together?... - iii.

slue lins spoke what she should not .......

hast thou not spoke like tisunder.

and ne'er hare spuke a lnving word.. =

whoever spoke it, it is true, my lord..
what I have spoke, or thou eanst... Richard 11. .

he liears Owen Glendower spuke of.1 Henry $I V$. ii

not such a work speke of in seotland

spoke your deservings like a chroniel

and spoke it on purpose, to try my

ere $y$, whth grief had spoke ..........

Nym thou last apoke the riclit .....

what lie has spoke to me, thint is well - iii.

tis resolntely spoke. Nut restivte...

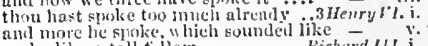

sperke like a tall tillow ............. Richard III i.

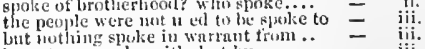

be not you spoke with, but ly $\ldots . . .$. - iij.

words spoke by a lioly nonk ....... Henry IIIl.

that, what lie spoke, my chapliain to no -

for 1 wiss spoke to, with sir llew
mueh lie spoke, and learsedly

unil somethiug sproke in ehol

nnd sny. I spoke with you ..........
I have suoke long: he pleased yourself

anens tairly, flusil be spoke

every syllable that luere was apoke .. $-\bar{v}$.

thit's well ploke. Commenil me....

in view; but huve nnt spoke yet ..... Coriahnus, $\mathrm{i}$.

there's wondrous things aloke of his $=$ ii.
spoke he of ne? Ile did, wy lord .... 


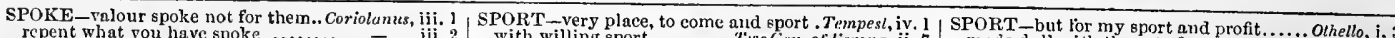

with willing sport........... Tuofen. of lerona, ij, ach word thou hast spoke hati

it is spoke freely out of many mouths

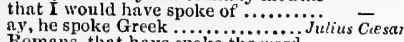

Romans, that have spoke tlie....... word..

I alone, till Antony hinve spoke

when I spoke that, I was ill-temperei

that what I wonld have spoke.... Antony

parthily spoke, Mecanas

touched with what is spoke; for 'tis

would we hand spoke togctherl $\ldots .$.

have dome, and not have spolse on't

spoke scantily of me: when perfurce

Whilst he stood up and spoke, he was

I will tell you what our sport shail be

you shall have sport $\ldots \ldots . . .$.
why then make sport at $n$.

iii. 2 you shall sec sport anon $\ldots . . . \ldots \ldots$

from their sport to make

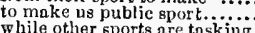

heaven prosper our sport!..
and laugh this sport o'er by.

and laugh this sport o'er by
that danger shail seem spo
sport royal, I warrant you

I have spoke already, and it is provi

I have spoke this, to know if your...
being, as it is, mich spoke of .....

perehanee he spoke not................

but she spoke it dying, I would not.

sport royal, I warrant you

which, to be epolke, would torture thee

I have spoke it, and I did it............ $\overline{-}$

then see the fruits of the sport
this

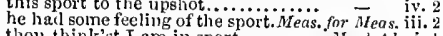

thou think'st I am in sport
lie would but make a pport of

the sport will be, when they hold

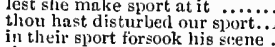

in their sport forsook his scene
that must needs be sport alone

patience, all to make you sport

this sport, well carried, shall be

this their jangling I esteem a spoit...

if our sport had gone forward

how many sports are ripe.

he should have struck, not spolke....... Pe

unless you can find sport in thiei...

too late have spoke and done..............
spoke with how manifold and strong .

this is the letter how? $\ldots$.....

swain, and he be, to take what.......

and one that makes sport to the pribce

very reverent sport, truly.

there's no such sport, as sport by sport

demanded, ere you had spoke so far ..... - iv.

Epeech be spoke for our excuse?.. Romeo \& Juliel, i.

faintly spoke after the prompter

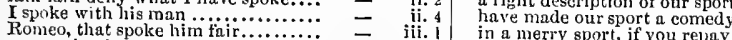

forestal our sport, to make us....

a right description of our sport, my iord

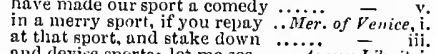

more priee, beng spoke hehind your $\overline{7}$ iv.

brenk all the sprokes and fellies from $\ldots . . . .$.

to whose huge spokes ten thousand ......

spoke sucli seurvy and provoking te.

when I have spoke of you dispraising]

what is spoke cones from $\mathrm{m}$

all that's spoke is marred................

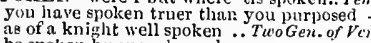

be of a knight well spoken.

made dull witly the act of sport.

each man to what sport and revels $\mathrm{his}$...

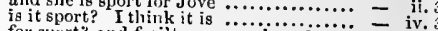

I pr'ythee, do, to make sport withal

what slall be our sport then

you have lost mneli good sport. Sport?

breaking of ribs was sport for ladies

make you some sport with the tox....

iii. 3 SPor sport? and frailty, ns men have? $\ldots \ldots$. iv.

$\begin{array}{ll}\text { Verona, i. } 2 & \text { for I have some with thee } \\ & \end{array}$

for I have some sport in hand... Taming of $\overline{S h} .1$ (ind.)

spiken with the wonan (rep.)........ilerry wines, iv.

why, that's spoken Jike an honest..... Mach Ado,

why, that's spoken ike an hon
are these things spoken? (rep.)
they have spoken untruths.......

then is spoken; fare you

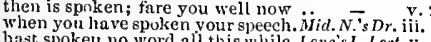

I have spoken better of this while. Love's L. Lost,

to your sworn counsel I have spoken

whien you h:nve spoken it, 'tis dead

thon hast spoken all al ready

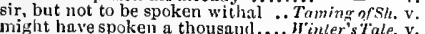

to be seen, cannot be spoken of

what sliould be spoken here

am as I liave spoke

what is this? sport? ...............' "inler's Tale, ii.

let foolisli gnats make sport...Comedy of $\overline{E r}$

sliall buy this sport as dear as all.

thou say'st his sports were hindered

in food, in sport, and life-preserving

no, misery makcs sport to mock.... Richand 11.

what sport shall we devise here

no dancing, girl; some other sport
the moral of this sport
to sport would be as tediou....................

to sport would be as tedious $\ldots \ldots \ldots \ldots$ ir Henry $I$ iv. i. 2
blows, and grouns applaud our sport

the which, for sport sake, are content

be chaste, and Dian sportfuil..... Thelfth Night, y.

out the worst that must be spoken. Richard II. iii.

much shmine, retold or spoken of

shame, be spoken in these days.......

by this liglit, I am well spoken of ..2 Henry $l v$. ii.

correction of bragging be it spoken.

well hast thou spoken, cousin ....... Henry $l$. $v_{\text {. }}$

why, that is spoken like a toward prince -
his grace hatli spoken well ........

tis nobly spokcu; take notice, iords
fair spoken, and persuading: lufty.

'tis most nobly spoken..........

he has spoken like a traitor ........ Corr

tis spokent well; were we betore. Antony \& Cleo.

tis nobly' spoken. If it might plea

wonld undergo w'hat's spinken

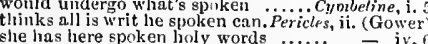

for this three montlis hath not spoken to

have you not spoken 'gainst the duke of.. Lear, ii, i

methinks, your are better spoiken

loou hast spoken riglit, 'tis true..

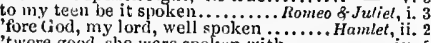

'twere good, she were spoken witli..........

sPokESM AN from madam Silvia Tuo Gen. of Ver.i.i.

never spokest to better purpose ... Tretfih $N$ ight, ii. 5

res, thoul spokest well of me .. Timon of Alhens, ip. 3
SPOUN-I litve no long spoon ....... Tempest ii, spoon meat, or hespeak a long spoon. Com. . . . E Err. iv. 3 put but a litile water in a spoon .... King.John, iv.

you'd spare your spoons ..........HenryVIII. v.

thaden sporis, irons of a dujt........ Coriolanns, $\mathrm{i}$.
leaden
PORTS-some sports are paiuful .... Tempest, iii.

and up with riots, banquets, sports ...Hcury $r$ i.

anto a peaceful comic sport........... i i Henry $r i$. iv.

so suddenly, we liad had more sport
think it but a minute epent in sport

feed, I see, to make me suort.......

hours must I sport myself .............

limbs of this great sport together .... Hem $\bar{y}$ rIII.
liark! what good sport is out of.. Troilus of Crest.

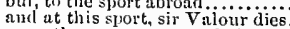

more than your sport and plessure

let's liave some sport with rem.

[Col. Knt.] piece is every ftatterer's spor

lie is given to sports, to wildness... Jut

what sport to-night?......... Antony $s$.
drums him from his sport ..........

'tis sport to mats a runner ...........

here's sport, indeed! how heavy

make not, sir, your lass your sport...

now, for our momtain sport...... .

chariots let us have, and to our sport. Tituss
beind. ii. 2 intercepted in your sport

being intercepted in your sport

thy griefs their sports, thy resolution

twas trim sport for them that had

when 1 told the empress of this sport

makes my patst miserics sport.

poort at his mnking ....... Lew they kill us for their sport

unlooked for sport, comes weli .............

away, begone; the spert is at the best

make malicious sport in mincing with. $\boldsymbol{H}$
sport and repose lock fiom me, day, and

for'tis the sport to have the engineer...

thongh't be a sportful combat. Timilus \& Cressida, i.

SPORTIVE-from the soorlive court... All's 's' IV. iv.

not in a sportive humour now. Comedly ar Errors, i.

SPOT-you can not see a white spot. Herry I'ives, iv.

the drowgy east with spots of grey.....Mruch Ado, v.

not be one spot of love in't .......As ynuLike it, iii.

yet here's a spot ................... Allucheth, v.

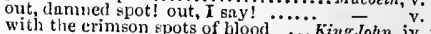

upm the spot of this cnforced cause -

Fea, but not cliange their spots....... Richas d $11 . \cdot \mathrm{i}$. I

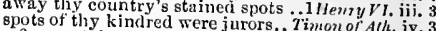

a fine spot, in good faith ............ Coriolanus, $\mathrm{i}$

look, with a spot I damn liim........ Julius Casar, i.

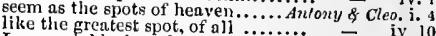

I bee such black and grained spots...... Famtet, iij. 4

affird, is, spotless reputation ......... litichard it i.

be his cause never so spotless .......... Herry l'. iv.

to force a spotless virgin's chastity .2llenry ri. v. I

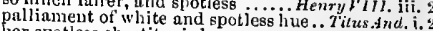

SPOTIED and inconstant man...Mid..N.'s $\overline{\text { Dreom, }}$ v. you spotted snakes, with double.. - ii 3 (song)

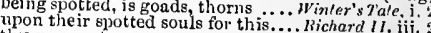
thy garments are not spotted witi ...lichord III. $\mathrm{i}$. spotted livers in the sacrifice .... Troilus \& Cress. $v$. spotted, de, let die the spottcd.. T'imm of Alhens, v.

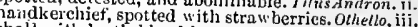

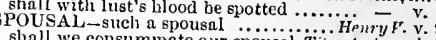
shall we consummate our spousal. Titus Amiron. i.
POUSE of any noble gentleman.. Taming of kind embracements of my sponse. Comedy of $\mathrm{Sh}$. iv.

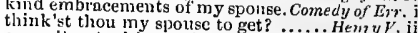

commit not with man's sworn spouse..... Lear, jii.
SPOUT-eyes became two sponts.. Winter's came to spout agninst your town.... KingJothi, $\mathrm{ii}$. not the dreadful blood $\ldots$ Troilus \& Cressida, iv. a fountain. with a hundred spouts.Julins Ceesar, i. a conduit with three issuing spouts.. Tirus And. it.

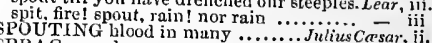

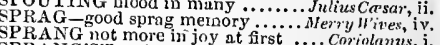
SPRANG'S'T-W'lence thou surang $\ldots$... Cortinlamzs, i. SPRAT - tell me what a sprat you.....Al's Well, iii. SPRAWL'ST thou, take that to end...3 Heury PRAY - two fast-growing sprays ...Richard Il. iji. shall a few sprays of us ................ Henry $V$ iii.

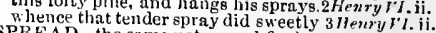
masters, spread sourselves....... Mid....'s Dreana, i. she is spread of lutering might..... love's $L$. Lost, $v$. bid the servants spread for dimner. Comedy of Err. ii. spread o'er the silver waves thy .... spread his colours, boy, in thy behalé.King John, ii. good air: spread, Davy, spread.......2 Henyy $I V$ v. his arms spread wider than .......... Henry $\mathrm{Vi}$. i. of my name 'mongst them was spread - i.
the 'Talbot, witl lis colours spread..
and with colours spread marelied....3 Hemry $r$ ii. once they see them spread: and spread another spread on his breast.........Henry VIII. i. it is spread in general name.. Troilus \& Cressida, with thy banners spread ....... Timon of dihens dust in others' eyes, to spread itseiff Coriofames, iij. whan fime had spread their cursed ..... Pericles, 1. France spreads his banners in our $\ldots . .$. Lear, iv. 3 ere he can spread his sweet leaves. Romen \& Juliet, $\mathrm{i}$. I do not spread the compost on the weeds. Hamlet, iii.

her clotlies sprend wide ..............
SPRE A DING-till, by broad spreading.। Henry $r l$ iv. 7 SPRIG I -nails, sprigs ot rosemary ............ Lear, ii. 3 SPRIGHTED with a fool; friglited .......... Cyear, ii. 3
SPRIGHTF IILY and bold, stays ... iuctare 3

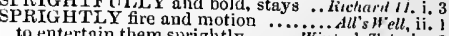
to entertain them sprightly ..............iter's Tale, iv. 3 be surightly, tor you fall 'mongst ... Cymbeline, iif.
SPRING - the fresl1 springs ............ Tempest, I'll show thee the best springs spring come to you at the farthest $-{ }^{2}$ iv. $\overline{1}$ (song) by the roses of the spring ......? T welnh Night, ii. 1 the middle summer's spriog ......ilid. N.'sDream, ii

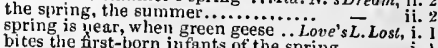
whence doth spring the true ........ - iv. 3 
SPRING-this Ver, the spring .... Love's L. Lost, y 2 the spring time, the only ...As yon like it, v. 3 (song)
aweet lovers love the spring........ v - v (song) hal some flowers o the spring ... Winter's Tile, iv. 3 welcume hither, as is the spring...... - y. 1 even in the spring of love (rep.). Comedy nflirr. iii. 2 so from that spring whence comfort..... M and four wanton springs, enil in $\mathrm{n}$ word currents that spring from one …... - iii. 3 he that suftered this disorlered spring the green lap of the new-come sprin

(iurewell, thou latter of time, lest ym che the the as in an early spring, we see.

aled in the spring of day

that shall first epring, and be most.... Henry $l$ ii. 4 firing crestless yeomen from so dech

from whence you spring by linen

now 'tis the spring, and w'ceds are...2 IIer'y $\%$. iii.

the purest spring is not so free

that center spray did aweetly spring

no hopeful branch may spring

Whence springs this deep despair...... all springs reduce their curre

lightly have a forward spring......... . ii. I (song)

straight, springs out into tist gait.... $\&$ Cressida, i. ${ }^{2}$ ?

and P'll spring up in his tears Troilus \& Cressida, i.

and what stock he springs of......... Cmriolamss, ii. 3

and in his spring became a harvest .. Cymbeline, $i$. I

and in his spring beca it and slut the spring of

at those springs on chaliced fowers - ii. 3 (song)

liere stands the spring whom.. Tilus A

(v) vering

apparcled like the spring, graces......

who withered in her spring

the inain grief of all springs from....

rood effects may spring from words of love. Lear, i. i

never spring a babe to lonour her!

back to your native spring....... Rnme o \&uliet, iii.

and know their spring, their head .. - v. 3

galls the infants of the spring $\ldots . . . . .$. Hamlet, $i .3$

it springs allike the spring that turneth wood.

snd unpolluted fesh may violets spring! $\overline{\text { v. }}$, I

ny, springes, to catcl woodcoeks.........Hamlel, i. 3

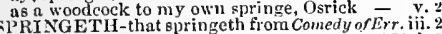

SPiY NGING trom une root ..........Richtw II. i. 2

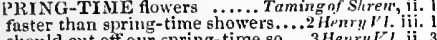

sliould cut off our spring-time so ..3 Henry Fl. ii. 3

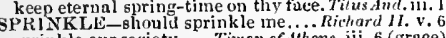

sprink le our society.... Timon of

aby distemper sprinkle cool patience.. Hrmlet, iii. 4
thy
sPRITE-sweet sprites, the burden. Tempest, i. 2 (sollg)

an' if they be not sprites .............
that shrewd and knavish sprite.Mid.N.

evers one lets forth his sprite .

and fairy sprite, hop as liwht as ......
quintessence of every sprite. As you Like it, ii. 2 (ver.)

quintessenee of every sprite. As ?ou Like il, iii. 2 (ver.)
I have one ot sprites and goblins.. Winler's Tale, ii. I

to fright me with your sprites......

owls, anl elvish sprites ...... Comedy of Errors, ii.
and walk like sprites, to countenauce... Macteth, ii.

and walk like sprites, to countenta

if she were frayed with a sprite. Troilus 8 . Cress. iv.

SPRITEFUL noble gentleman ....... King John iv.
SPRITELY brethren ........ Trouius \& Cressida, ii it's spritely, waking, audible ....... Coriolamus, iv. once for thy spritely comfort....

anil with our spritely port make.

sPR()UT-grow and spront as high ...2ly,nry $1 \%$

liyperbules, spruce affectation.

now, my spruce compunions.. Taming of Shren, with lile he never more sprung up ... Hewryl

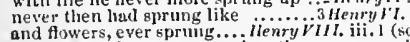
again, there is sprung up a heretic

that instunt, like a babe sprung up.
unmanly melancluoly sprumg from.

unmanly melancholy sprung from . - iv

brave slip, sprung from the ireat Tilus Anilron.

of lis grief sprung from neglected love. Hormlet, ij

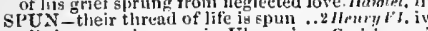

all the rarn slie spun in Uly sses ${ }^{4} . .$. Corinlanis.

besides, tu he demanded of a spinnet... Humier,

take you me for a epunge, my lori?

SPUNGY April at thy hest hetrims... Tempent, iv. what not put upon his spungy officers... Muclueth, mure spungy to suck in the sense. Troilus o Cress. winged from the spungy south to . ' 'ymbrline iv.
SPUlt-and by the spurs pluck'd up.... Tempest. $\nabla$. they spur their expedition.. T'ro Gen. of I'ryna, v. did spur me forth uway............ Nerry Wiv's, iv. 5 lets it straight feel the spur....... Meas. for Meus. i. 3 he spurs on hity power to qualify ..... that spurs his horse but on ........As you like it, iit.
PUR-boots and spurs and all

in usurping his splars solong

counsel hud, shall stop, or spur

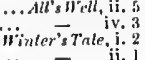

wich is another pur to my repar

Iharp as his spur, jath ho helit to prick the sicles

now spurs the linted travelier.....

giving reius and spurs to my free

Riehard II. i.

betimes, that spurs ton fast betimes.....

and spur thee on with full as many

lpon his horse; finur, post; and get.
Harry Perey's spur was cold (rep.)..

Harry Perey's spur was
of Hotspur, cold spur?

from lielmet to the spur, ali biood

spur to the resene of the noble..
lier fume can need no spurs

spur your proud horses hard

and spur them, till they obey.
spur to valiant and magno

as hot as Perseus, spur thy
spur them to ruthful work

with that spur as he would to

may spur on my juurney to. Timon nf linens,

what need we any spur, hut our...Juliks Cars

they should endure the bloody spur..

and hide thy gpurs in him

make to him on the spur: yet he spurs

what both you spur and stop

both, mingle their spurs together

if to that my nature need a spur
spurs to make thee seek it...

switch und spurs (rep.)

and splir mr flnli revenge!
SPUR-GALI.ED, and tired

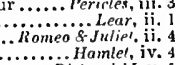

RTO-one captain Spurio..............Alla's Well,

let me see; Spurio a hundred and fifty $\overline{\text { Th }}$ iv. 3
PURN-she spurns my love ...TrnGen. of ler. iv. 2

as your spaniel, spurn me........ Mid.
who even but now did spurn me witl

to strike me, spurn me, nay, to kill.

as you spurn a stranger

gain, to spurn thee too .............

do spirn me thus? you spiminn m.

spit at me, and spurn at me........

wo wilfully dost spurn; and, force

to spurn at your most ruyal image.

spum in pieces posts of adamant
wben he might spurn lim witl

and spurn upon thee, beggar

Macbelh, iii.

spurno

2 Herrylr. v.

og, or I'll spurn tliee hence

thit bears not one spurn to
unjust, and spurn ne back

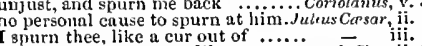

or I'll spurn thine eyes like......... Antony \&

spurn her home to her tuther

would make me spurn the sen ......... -

gi yes my soul the greatest gpurn.Tilu

and the spurns that patient merit

spurns enviously at straws; speak
SPULNED me sucli a clay.... Merr

SPRRLD-will not be spurred. T wo Gen of ler. v.

ne'er spurred their coursers at ......3 H Herry I'I. v. 7

after him, came, spurring lard ......2 Jmary $W$. i.

and mar men's spurring ...... Timon of Althens, iv.

but I may spy more fresh .. Tuo Gern. Orl'erona,

I spy a great peard under.

I spy comfort; I cry, bail................. for Mess. ii

n.lien they him spy, us wild geese...Milil.N.'s Dr. iii.

and $I$ am to spy lier thronth thic wall

with the perfect spy o' the time
w death. I spy life peering.............

trouble $y^{\prime}$ on, if 1 miny spr them.....

and, wlien i spy alvantage

I spy a lilack, suspieious ..............

to spy [Col. Knt.-see] my shadow ... Nichard IIK, i.

takes upon her to spy a white .... Troilus of Cress. i. 2

I suy. You spy! what do you spy? ...

cunnot smell out, he may spy into......

I do spy a kind of hope, which eraves - iv. 1

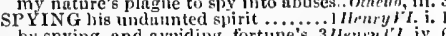

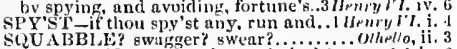

SQUADLON-are squalrons pitehed.iileury I. iv.

in rauks, and :quadrons

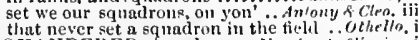

QUANDERED a broad ......... Herehani ofl'enire, i.

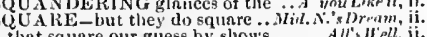

that square our guess by sliow's

the work about the square on't

swarm ahout our squite ef bnttle.... Hetirg

it is not equare, to take ........ Timor arth thens,

thiey should square between
lady, if report be square to her
SQUARE-not kept nyy square ...Antony \&.Cleo. if. 3
lo practiee hud in the brave squares - iii. 9

no practiee hut in the brave fquares
mine honcaty, and $\mathbf{l}$, begin to kquare

such fonls, to square lor this?.. Titus.lut

how l'raisticly i square iny

my queen' 8 ind the most precions square of

that ever I had aquared me to thy.
SQUARER - no young gquarer now

SQUAI'ST thy lite aceorting

SQUASII-as a squash is before..... Therefor .Heas. v.

commend me to mistress Squusl1.. Mid.N.'s Dr. iii.
this kernel, this squash, this ...... W'inler's T're, i.

did Equrak and gihber in the Ruman .. Ifamlwi,

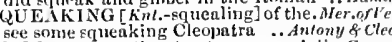

see smine fquenking cleops

UUETE a Cotsivo

QUINY at me? no, do tliy worst

it proper squirel and who, ant who?...Whet sdo.

then rich with $\mathrm{my}$ young squire...Mid.N.'ADr. it.

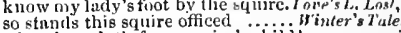

a bearing-cloth for a squire's ehild!
twelve fiut and a half liy the squire.

makes thee a landed squire.

18, that are squires of the night's....1 Henry $I V^{\prime}$.

four fisot by the squire further ...... - ii.

and barons. knights, and squires ....IIen $r y V$. iv.

make you to-day a squire of low degree $-\bar{v} F$. $v$.

my queen's a squire more tighit. Antony \& Cleo. iv.

a squire's cloth, a pantler ........ Cymbetane, i.

no squire in debt, nor no poor kniglit.... $-\bar{f}_{\text {iif. }}$

SQUIRE-L1KE, pension beg to keep...... Lear, ii.

that shall seek the squirrel's hoard. Mid.N. Dr. iv.

made by tile joiner squirrel ..... Romen \&. Juliet, i.

puniards, and every word stabs............1/nch Atro, ii.

and his rnshed stabs looked jike...

call me coward, I'll stals thee ......... i HenryII'. ii.

to stab at lialf an hour of

shame! let's stab ourselves

slall I stab the forlorn swain?
stab poniards in our flesh.

what, shall we stab him as

Henry $\mathrm{V}$

hang tlem, or stab them, drown.. Timon of . Ath. $v$.

that dide Crsar saw him stab....Jalius Casar, iii.

thear them on .. Tilus a ndronicus, v.

stab him, he's a murlerer (rep.) .... of rerana, i

wild Half-can that stabled Pots. Meas for Meas.

he stabbed me in mine own house..2 llenry 1 '.

that stubbed thy father York.

Intar your

stabbet by the selr-same hand that.ilichard III.

twrs I that stabbed young Edward.

wleen my sun was stabberl with hiloody

stabbed me in the tield by Tewksbur

when Richnrd stabbe!t her son .....

he is deacl, that stabled my Edward

whose dagrers have stabbed Cesa

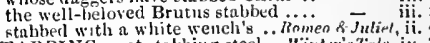

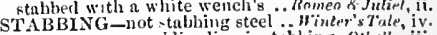

fur me to say a soldier lics,

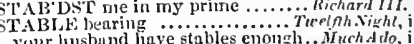

Your husbund liave stables enongh...Muchdido, iti.

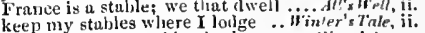

in litter of your stable plumk

a poor groom of thy stuble, king ..... - v

see my geluling in the stable (rep.) .. Inenryl 1 , it.

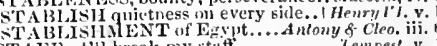

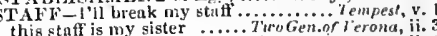

my staff understands nie $(r c p$.

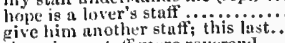

there is no statf nuore reverenil........ Wuch Allo, $v$.

let me henr a statf, u stunza.........ere's L. Lost, iv.

or a huvel-post, or a staff........... - ii. 2

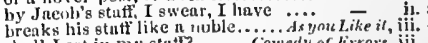

ghull I sct in my statt? ....... Comedy of hrors, iii.

give me my staff; seyton................ Macbeth, y.

broke his staff, antl resigned his ..... Richard $I I$. ii.
broken his stuff of office, and dispersed

no long st tff, sixplenuy strikers....... i Henry $I \%$. ii.

fior you, my staft of office did 1

liuig nom the staff he threw
this gtatf mine oftice-lyalge...

give up thy stats (rep.)
noble Ilenry' is my stuti 
STAFF of honour raught ..........2 Henry VI. ii. 3 STAJNED-how they are stained. Titus Andron. iii. 1 STAMPED with your foot ....

a staff is quickly toond to beat a dog: ind fain to go with a staff we have no stuff, no stay! .......... we have no staff, no stay! .........3 3 Henry I"I. ii. I
should make a staff to lean ujot ..Aml. \& Cleo. iii. il broken a stuft, or so; so let it pass ... Perictes, ii. 3
hy his cockle hat and staff....... Mnmiet, iv. 5 (song) TAF FORD dear to-day hath boight. I Heny $V$. v. 3 will reventre loril Stafforl's death...

the spirits of shitley. Stalford. Bluut - v. shall with us; Staftiord, take her ...2 Henry ${ }^{\prime} I$. i. 4 and lord stafford, all a-breast (rep.).3Henry r. iv.

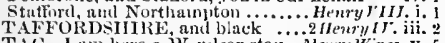
TAG-I un here a iW nulsor stag.. Merry Wives, v.
a poor sequestered stag, that from. As you Like it, ii. 8 ift as brentled stags . Taming of stireu', 2 (induc.) and desperate stags, turn on......... Henry $I^{\prime} I$. iv.
vea, like the stag, when snow ..... Antony \& Cleo.

they shonld take him for a stag... . Titus Andron. ii. 3 not like to stage me to their eyes.Meas. for Meas. i. I

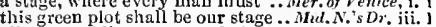
on this stage, (where we oftenders. Winter's Tale, y. 1 aet, threaten his bloorly stinge a well-graced actor leaves the stage...Richard $I I$. v. 2 this world no longer be a stage $\ldots \ldots 2 H e n r y I F . i .1$ a kingdoun for a stage, princes.. Henry $r^{\prime}$. $i$. (chorus) supplying every stage with .......... Aniony \& $\bar{C}$ Cleo. iii. 6 imagination hold this stage ........... Pericles, iii. (Gower) teach you the stages of oar story - iv. 4 (Gower) eome to this great stage of fool

two hours' traffic of our stage. Romeo \& Juliel, (prol.) and so berattle the commou stages .....Hamlet, ii, 2 high on a stage be placed to the view

bear $\mathrm{Hamlct}$ fike a soldier, to the stage -

STAGED to the show ....... An'ony \& Cleopalro, iii. II
STAGGER-fills it up, I stagger in. Mers. for Heas. i. 3

TAGGER-fills it up, I stagger in. Aleos. - for Heas. i. 3
fearful heart, stagger in this ....As youLike it, iii. 3 into the staggers, and the careless ....All's W ell, ii. 3 fire, that staggers thus my person ...Richard II. v. 5 how colne the stagger me ..........Henry VIII. ii. 4

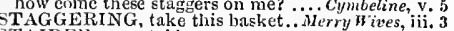
STAIDER-my, staider senscs

honest slanders to stain my cousin... Much Ada, iit. with bloody moutlt did stain ...HAid.N.'s Dream, $\mathbf{y}$.

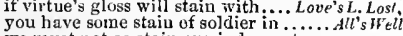
we must not so stain our jndgment.

such ado to make vo stain a stain .. Wirters $T$. ii. 2 stain your own witl oily painting ... the blots and stains of right.

and sightless stains, lame, foolis.

to stain the track of his bright .... kichard II. iii. to stain the temper of my knightly.. - iv. leaves behind $a$ stain upon

and stains my favours in.

whose temper I intend to .............

to wive ench maked curtle-ax a stain. stsin to thy eountrymen! ...... Henry fliglit can

charge shall clear thee from that stain -

all the impure blots and this ......2.2 Henry VI.

currupt her manners, staiu her beauty
he carries some stain of it .... Troilus \& Cressidh

stains the glory in that happy ..... Timon of $A(h)$,

only suffering stain by biw $\ldots . . . \ldots .$. . Coriolunus,
stain all your edges on me

but do not stain the even virtue of $J_{u l i}$ ins Cessar, ii.

of a war shall stain your brother.A ntony \& $\bar{c}$ leo. iit.

this stain upon her (rep.)........... Cymbetine,

and stain the sun with to

water-drops, stain my man's cheeks ..... Lear, iii.

her breath will mist or stain the stone

which stains the stony entrance of th

STAINED-but he's

with salt water

as she that he hath stained? Yeasurefordieasure,

What, stained with blood .......Mid. N.'s Dream, v.

this handkerchief was stained.... As youlike it, iv. 3

and tear the stained skin off ...... Comeely of $\mathrm{Err}$.
back to the stained ficld ............ King John

ne'er stained with revolt

stained the beanty of a fair ............. Bichar: 1 II. iii.

with the king's blood stained the lking's - - v.
from his horse, stained with......... Ilenry $r$. i.

but to stand stained witil travel ....2 Henrr $/ V$ v. 5

wasl away thy conntry's staiued ...i Henry $/$. iii. 3

stained with the guiltless blood

cliaps be stained witli crimson blood

I stained this napkin with (rep.) ....3 Henry $Y I$. i. 4

bend y thy stainer na me....... Troilus \& $\bar{C}_{\text {ress. }}$
Whom you have staned with mud

regutation stained with Tybalt's. Romeo

ow I have stained the childhood of

miNls-let me lining thee to Staines. Hemlet

PANING - in any staining act.......All's $W^{\prime}$ ell, ;ii.

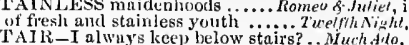

the stairs, as lie treads on then ... Love's L.Lost

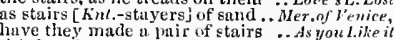

this has been some stair work .. Winter's Tale,
when she was gone down stairs ....2Lenry 1 .

thrust lim down stair

as common as the stairs that

as you go up the stairs into the jolbyeo \&. Homlet, ii.

set mer paunch lim with a stake. Tempest, iii.

set mine honour at the stake.... Tuelfh Night, ini.
I

what, and stake down? (rep.).Merch. of 'enice, iif. 2

my honour's at the stake .............All's W'ell,

they have tied me to a stakc

when thou comest to the stake

iHanry

pitel upon the fatal stake

two stake ny twenry VI. v. 1 and my friends, at stake, required. Coriolanus, iii.

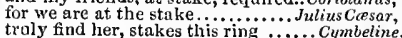

the inurderous coward to the stake........ Lener,

I am tied to the stake.

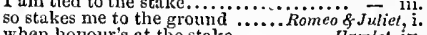

lay down my soul at stake....

Olkello,

ha! is he dis stale to catch these thieves. Tempest,

to

link my dear friend to a common stale

a proverb never stale in thrifty... Mer. ofleni

to make a stale of me amongst. Taming of Shrew, i. I

make stale the glistering of.. Winter's Tale, iv. (cho.)

poor I am but his stale ...... Comedy of Errors, ii.

so stale and cheap to vulgar ....... . i Henry $I V$. iij. 2
you basket-hilt stale juggler........2HenryIV. ii. 4

none else to make a stale, but me?..3 Henry ${ }^{\prime} t$. iit. [Knl.] makes stale the morning.. Troilus \& Cress.

must not so stale his palm

that stale old mouse-eaten dry

or did use to stale with ordinary ...Julius Carsar, j.

nor custom stale her infinite

we could not stale together in ...... - v.

poor I am stale, a garment out of ... Cymbeline, iii. 4

within a dull, stalc. tired bed.

that is something stale and bonr. Rameo of Juliet, ii. 4

STALED-and staled by other men.JuliusCasor,

STALEN ESS. O sir! a courtesy .......Perieles, v. 1

and stalk in blood to our possession?. King John, ii. 1

lips were four red roses on a stalk.. Richard III.

why, he stallss up and down like..... Cressida, iii.

comes that which grows to the staik.. Pericles, iv. 6
see! it stalks away. Stay, speak ....... Hamlet, i.

With martial stalk hatl he gone by .... Like il, i. 1

leave me; stall this in your bosom ...All's. Wrelt, i. 3

fat oxen standing in my stalls. 'Frming of shrete, ii. I

broke their stills, flung out $\ldots . . . \ldots$. Macbeth, ii. 4

stalls, bulks, windows, are ............. Coriolumus, ii. I

STALLING of an ox? ................ As you Like it, i. I

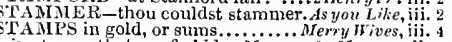

in stamps that are forbid... Measure for Meo:

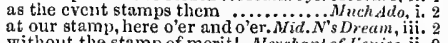

at our stamp, here o'er and o'er. Mid. N's Dream, iit. 2

nor stamp, nor stare, nor fret. Taming of

lianging a golden stamp about

a. boldicr of this season's stamp

under my feet I stamp thy

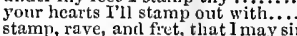

stamp, rave, and fet, that I may sing.
how Lewis stamps as he wcre nettled

when did he regard the stamy ....Henrard $Y H . \mathrm{i}$. 3

would one day stamp upon me. Timon of Alhens,

methinks, I see him stamp thus .... Coriolunus, i. 3

his sword (death's stamp) where it

they weigli not every stamp $\ldots . . . .$. Cymbeline, r. 4
hath upon bim still that natural stamp - v. 5

stamp, thy seal, and bids thee .. Titus Andron. iv. 2

let it stamp wrinkles in her brow $\ldots$........ Lear, i.

use almost ean change the stamp of nature- iii. 4

can stamp and counterfeit ad vantages. Othello, $\mathrm{ii}$.
TAMPED-figure be stamped ..Neas. for Meas. $\mathrm{i}$.

tigure of an angel stamped in gold... Mer. of ren. ii. ?

for why, he stamped, and swore. Taming of Sh. iii.
them for it with stamped coin .. Winter's Tale, iv.

to be stamped on the king's eoin ... Henry lilil. ii. not wltere wheu I was stamped........ Cymbeline, ii. nyy seal be stamped in lis tuce ...Tilus Androne.

that stand 'twixt me and MLilan

hest stand upon our guard

r's thee stand further off (repinculo

i will stand to, and feed (rep.) ........

there stand, for you are ...............

I stand affected to her

when it stands well with him (rep.)

what I stand in need of ................

fellows in effectnal force...

staud, sir, and tirow us

pence, stand aside!

here she stands; take brit................

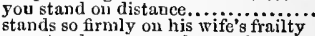

you stand uoon your honour $1 . . . . . . . .$.

I stand wholly for you

never stand you had rather $\ldots \ldots \ldots . .$.

that it nay stand, till the perpetual.

have I lived to stand at the taunt...

stard not amazed: here is no...

stand your awhile aloof.................. Ticelfih $\bar{N} i g h$

stand at her doors, and tell.
he'll stand at your door like

he'll stand at your door like ........

stands by thy tabor, if thy tabor stand

stand here, make a good show on't .

you stand amazcd, but be of comfort

they shall stand for seed ................ for $\overline{\text { Measure }}$

which else would stand under grievous

stends at a guard with evvy

but as we stand in rear.

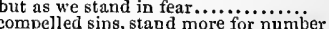

et, as the matter now stands number -

richer thau inuocency, stands for the

grace to stind, and virtue go

I have found you out a stand most fit

his integrity stands without blemish

strong statutes stand like the forfeits
stand up, I say, I have bethought

stand I condemned for pride and ... isuch $\bar{A} d$

if he will not staud wlien be is bidäen

stand thee close then under this (rep.)

I staud dishonoured, that liave gone....

Leonsto, stand I here? is this the prince?

well, stand aside. 'Fore God, they .

ere stand a pair of honourable men

tand fortl, Demetrius (rep.) .. Mid.N.'s $\overline{\text { Drea }}$

the fold stands empty in the

one, aloof, stand sentinel .............

tand close; this is the same (rep.).

and darest not stand, nor look ne

pray you all, stand up

hall not in their issue stanon points

edict shull strongly stand in force......ove's $\bar{L}$. $L$.

in the least degree, stands in attainder
must stand and play the murderer in?

a stand, where you may make ......

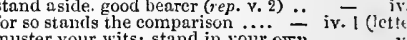

muster your wits; stand in your own

that you stand forfeit, being those ...

of the wortly; but I am to stand for lim-

if it stand, as you yourself stiji....... or of $\overline{v_{e}}$

pray you, sir, stand up; I am sure

there stand the caskets, aoble prince
many then sirould cover, that stand bare!-

and the rest, stand all aloof ........

I stand for sacrifice, the rest aloof...

so, thrice fair lady, stand I,
where I stancl, such ss I am

where I stancl, such ss I am ........
that only to stand high in your.....

madam, it is, so you stand pleased...

that stand in better place.

but since he stands obdurate ........

yon may as well go stand upon.....

and old Shylock, hoth stand forti..............

you stand wititin his danger

and stand indebted, over and above

and here he stands; I dare be sworn

now I'll stand to it, the pancakes . Ats you Like

and that which here stands up........ is but -

I pray thee, if it staud with honesty

my stster, reading; stand aside.......

of this forest, stands a sheep-cote....

iii.

iii. 3

i.

ii. 


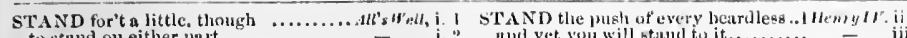
to stund on either part

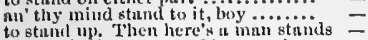
to stinith up. Then here's a mun stands
at my bitlding, yous could so stanul up my dear futher's gift st:1ntls chict .... nowle bent ot in differences set thy lower part where thy nose stands = stanci num more off, lut give thyself..

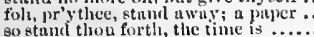

in thy evidenes; therefore stand aside stauls: for my excuse (reph). Tinning of sh. 2 (induc thus it stands; ler elder sister (rep, i. 2)

ald she stind him bot a tittle

as for my putron (stand youl so nssured)

Bianca, stantl aside: poor girl

whinen he stands whise I am; and sees

and here she stands, towchl lier whocver =

knows not which wny to stand .......
what I have said; stand by, aud murk

I pray' you, let it stand

I pray you, stund good fittier to me....

with either prart's agreement stand?
pr'ythe' Kate, let's stund nside ....

so st:mnds this squire officed..

What case stund $I$ in? I must

I dure not stand by ; nor shall.........
I will stand ' $t$ wixt you und danger..

for, as the ease now stands, it is.......
and ouly that I stand fior I alppeal.

my life stands in the level of your ..

llow now, canst stand? Softly........

O lady fortune, stand you a aspicious

we stand upon our manner

as le'll stand, and read, as 'twere....

but, O the thorns we stand upont....
then stind till he be three quaters.

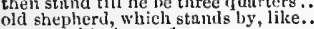

and stand in hope of answ

as now it coldly stands ...............

then all stund still; or those...........

stunds on tricks when $Y$ an $\ldots$.........

they stand nt the door, mast
yoli stand here in tlie cold

of her body stands Ireland?............
thun I stand debted to this gertleman

than I stand debted to this gentleman
how it stinds u pon my credit........

presently, if thou darest stand

present stand by me, fear notling

stay, stand apart; I know not.

and, to be king, stands not within......

makes him stand to, and not stan.

it should not stand in thy posterity...

then stnnd with us: the west $\ldots . . .1$
stand to't. It will be rain to-nigit

stand to't. It will be rain to

good night: stand uot upon the order...

but why stands Nacbeth thus
let this pernicious lour stand aye

let this pernicious hour stand ase
by his own interdict stands accursed

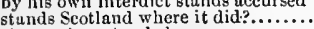

observe her, stand close ................

belold where stands the usurper's......

it holds, stands young Plantagenet.... King Joh

stund in his face, to contradict his

command the rest to stand

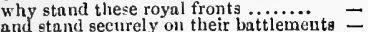

and stand securely onl the
or, if it must stand still

or, if it must stand still................

Lewis, stand tast: the devil ter
a churchyard where we stand

and he, that stands upon a slippery..

that Jolum muy stand, then Arthur

and look thou stand witlin (rep.).....
I will stind stone-still: for heaven's

doth make a stand at whint.

I saw a smith stand with his .......

stind back, loril salisbury (rep.).

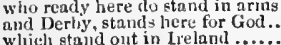

which stand ont in lieland ............
unr uncle Gaunt did stind possessed

wherein the king stands genernily

there stands the custle, by yon tifi...

comes to years, stands for my bounty

on what condition stands it...........

permits sour grace upunn.............

staml bare and naked, trembling ....

thit stands upon thy royal a........

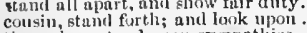

thy valour stand upone sympratlices.

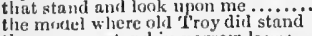

they suy, as stind in narrow lanty .

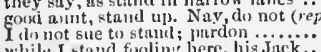

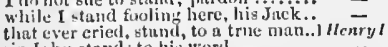

sir John stands to his word ...........
if thou darest not stand tor ten shiling $=$

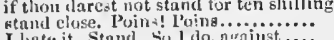

I late it. Stancl. Sol do, ngainst...

do horse thend in sume ly

do thou stand fior my father.

my spevects: stund aside, nobilitity.....

du thisu stund fur me, and I'll play ..
und liere I stand: judge, my ....... nuld yet you will stand to it............
l'ercy stimds on high;

but stand ugainst ns like aut encmy .

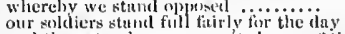

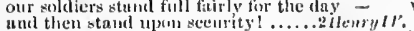

n lusty ycomnn? will a' staut tot?... -

studd fron hin, tellow; is heredire...

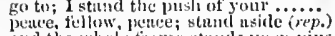

and the whole frame stends upan ping

stant, my lerrls; and send discovers..

so the question strunds, liricfly.........
of what conditions we sluth stand upon

our peace slanll stund as firm as rocky

wherefi,re stands our army stilli? (rep.)

to caurt, stand my guod lort, "pray.

stand from him, give him air ...

you stand in culdest expeetation
stand here hy me $(r e p)$.

but to stind stained witl tiavei................

Fracious lord, stund tor your own......
let another lialf stand laughing by .

and his solt shall stand sore chin
though the truth ot it stands oft

bade the stand up, gave thee no $\ldots .$.

you stmal upont the rivage .....

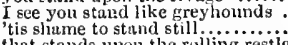

thint stands unout the rolling restiess

and such anuther neighbour, stand..
well placed; there stands your fricnd

well placed, there stands your fricnd
touk stand tor itlle speculntion

will stanl a tip-toe when this day

castle called, that stands hard by?

stand awny, captain Gower...........

and noue durst stand him ............
Reignier, stand thou as Dauphin....

stanu back, you lords, and give us icave

stand back, thuu manifest (rep.)

north gatc; lor there stand lorts
and stands non the hunour of his

and stands unont the hunour of lis.

therefure, stand up; and, for these

stands with the snares of war.

the help of une stands me in little...

shall our condition stand? It shall.

ktands on a tickle point..............

well, so it stands; and this,

than where cast les mounted stand (rep.) =

stand by, my masters, bring him $\lim _{\text {I }} . .$.
I an not able to stand alone (rep.).

I am not able to stand al

whose beam stands sure, whose......

there let it stand, where it best ....

and do not stand on quillets

sirs, stand apart; the king sliall
look, look it stands

se should stand in fetr of fire.

it his heatd will stand steadier on ....

thus stainds my state, 'twixt Carle....

boldly stand, and front him to his fuce

shall I stand, and thou sit in my...

make him stand upon this molehilii..

the rest stand all aloo

here $I$ stand, to answer thee

there thy mother stands; fur, weil i wot

why stand we like sott-hearted......

it witls thy will it stands ...

pillars, that will stand to us ..............

in the place your covert will we malke our stand

where now we nean to stand

like one that stands upon a promontory

many lives stund between me and home -

that thuu shouldst stand, while Lewis

to stand aside, while I use fiurtier

that you stand pensive, as hath.

brother Richard, will you stand by us

kinew til what estate ine stand

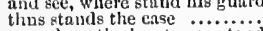

see, where the huntsmen stand ....

why stand you in a duult?

take leave, and stanl not to reply....

stand we in food array; tor they
yonder stands the thorny wood

and, where I stiend, kneel thon

my' lorl, stand back, sunl let (rep.)... $R$

resgairing, Bhalt them stend excused
they that stand high, have many...

my lunir doth stand on cusl to hear.

we will not stanci to prate $\ldots . . . . . .$.

how he doth stand aticeted to onr .

and stund het ween two churelanene.

Bee wherc lis gruce stants 'twcen tw'o
stand all apart: cousin of Buckinghtan than stand uncovered to the vuigar.

your horse st and youl thins close...

wlicefore stand you on niee points?
TAND-it stands me mich upon .. Richard 11 . i.

drops stund on my trcombling fle eli

mul I will statud the hazurd ot the die

if we shall staul still, in fear onir .. Henry $Y$ ' $H$.

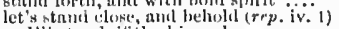

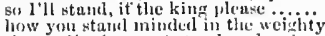

the s:ardininl cusnots stand under tlacin

ariel stand unshuke ne yours

stand tliese puor people's triend......

there's busie standis under noure....

stand un, gond Conterloury (rep.

the pood stants on is my trith.

and behosde thut chair stund empty...

muly stinl forth tiu'e to face

all that stand abinut lim are.........

he stands there, like a mortar-piece
you great felluw staul close uy......

stand up, lord. With this kis

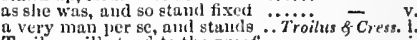

Troilus will stand to the proof ......

yet Troy wals staud; sith cvery ...

tenty do stund hollow upun...

in onr weakness st tunde [Knt.-lives].

and to stand firm by hunour .......

must not be, nor goudly llion staud.

the walls will stind till they fail ....

Achilles stumils i' the entrance of....

I stand condemned tiur this

a stride and a stand: ruminates....

go, gentle knitht, stand by our $\mathrm{Ajax}$

now how youder city stands $\ldots . . .1 \%$
there they stand yet; and modestiy

stand fair, 1 pray thee (rep.)
stand where the torcls may not

stand where the trich may not .......

Diomed, stand fist, and wear a eastle

and I do stand encragcd to many Grecks =

the gools with safety stand about theel =

and stands colossus-wise, waving his

stand, stand, thou Greek (rep.)

stand, hol yet are we masters of $\dddot{\text { Timon of }}$ - v. $i$

in purity of manlood stand upriglit - iv.

gout 5 keepers of the cannat tand.

unust thou veceds staul for it villain."

feeblint such as stand not in .......... Coriolanus, i.

if you'll stand fast, we'll beat...

neither foolish in our stand

and stand upon my cummonon part.

When he shall stand for his place...

were he to stand for consul (rep. v. S)

how many stand for consulshi is? $2 . .$.
put on the gown, stand naked .....

put on the gown, stand baked .......
do not stand upon't: we recummend

bot to come by him where he stands

pray you now, if it may stand with

the Volsces stand but as at first ....

or let us stand to our authority......

stand fast; we have as many yriend

to huth it stands in like request?

latey stand in their ancient strengtio

stand I before the here........................

but they stund bat d befire him

stand and go lnck. You guard....

but stimu, as if a man were

und pray you stund to me in this cause.........

stumd, Aufidius, aucl tronlle not ....

stund close a whije, tiur here comies.

blanl liume staul under one man's.
the hight eust stands, as thic Capitol

he will stind very stront with us ....

buy, stand aside: Cains Ligarius o...

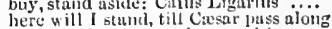

I gu tu take my ftaml. to set himl...

stund fast torgetluct, lest some ...........

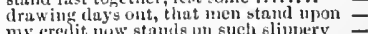

my eretit now" stands un such slippery

seeing thuse bends of sorrow staind ii

he slould stanid one of tlic thiree

stund liere. Give the word (rep.) ...

do stand lut in a firected affiction .....

they stumi, and wonld bave purley $\left(r r^{\prime} p_{0}\right)$

the gods to diny stumel friendly ......

ghit int ure minglit stamd ul, and suy

to weet we stand up peerless........Antony $\bar{\delta}$ Clea. i.

pray you, stand finther trom ne....... 
STAND the buffet with knaves ..... An'l, stnuds he, or sits he? or does lie walk?
great Pompey would stand, and make were't not that we stand up against.. that stands upon the swell at fuil. ah, stand by. The queen, my lord.. our landmen will stand up ........... stand close, and list to him .......... where yonder pine dotli stand......... the villy stand the varying shore... stand you! you liave land enough ... in eonstaney, you think, stands so safe thint thou mayst stand to enjoy thy. their deer to the stand of the stealer which stands as Neptune's park
yet the traitor stands in worse. when thon hast ta'en thy stand

stand, staud! we have (lep.) ............. fouls where they mude the stand?.... who dares not stand his foe

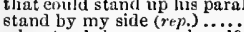
stand by my side $(r e p$,$) ....$
why stands he so perplexed

I stand on fira: eome to the niatter whom we stand a speeisl party. Tit then, madam, stand resolved

in readiness for Hymeneus stand ...... young men's heinous faults: stand up for now I stand as one npon a rock here stands my other son stand by roe, Lucius; do not feas. and if he stand on lostuge for his. Where Rape, and Murder, stand liere stands the spring whom yo
stand all aloof; but, unele, dras there let him stand, and rave and cry before thee stauds this fair Hesperides.. they here stand martyrs, slaio in C thus knit, a kingdom ever stands. and Tyrus stands in a litigions peace stand peerless by this slaughter .
besides, the sore terms we stand upon who stand $i$ ' the gaps to teaeh passion stands for truc old woe? bo stand alcof for more serious wooing my temple stands in Ephesus

sir, there she stands; if anght within....

respeets, thist stand aloof from the entire wherefure should I stand in the plague of
now. gods, stand up for bastards!........ cerve where thou dost stand eond emoed..... may stand by the fire and stink

why one's nose stands in the midale to stand his anspieious mistres

tha, rogne, stand; you neat,slave, strike ulder that I sce

not b.ing tire worst, stands in some rank. here $I$ stand, your slave, a poor .....

how do you, sir? stand you not 80 amazed to defend him, stand in assured los

and I must stand the course

a peasant stand up thus!

here's the place: stand siili

your leys? you staml. Too weil, too wei the main desery stands on the liourly that I stand up, and have ingenions for nuy stute stands on me to defend..... immediacy may well stand up ......... to be valiant is - to stand to it....Roineo
of that liouse shall move me to stand feel, white $I$ ana able to stand may stand in number, thourh in for theu she eould stand alone stands your disposition to be married? I'll wateli lier place of stand ready stand to smooth that rougin.

letting it there stand till she

let me stand here till thoul...

to have thee still stand there........... who stand so muelt on the new form minute than he will stand to in .... atand not amazed the prinee will door stand up; run to my study (rep.).... rise and stand; why should you fail and liere stands all your state.

jueund day stands tiptoe on ........... this is well: starid up.......

henee, and stand aloof (rep.) .......... 1 ans allost aliaid to stand alone. nay, answer me; stand and unfold.... I think, I hear them: stand, hol pon whose influenee Nevtune stand.... do, if it will not stand $\ldots . . . . . . . . . . . .$. eael particular laiir to stand on end

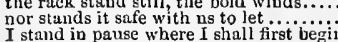
I stand in pause where $I$ shall first begin
and, how his audit stauds, who knows.
STAND-starts up, and stands on end .. Hamlet, iii. 4
how starid I then, that have a father .... - iv, 4 how stand I then, that have a fatlice to this point I stand, - that here stands the man. mood: if the man... - iv. makes them stand like wonder-woun think thee, stand me now upou? his crib shall stand at the king's mess... in my terins ot honour, I stand aloof .... hola 1 stand therel signior, it is the $\mathrm{H}$. that it stands not in such warlike braee. to death, stand in bold eure.................... on tlie brow o' the sea stand ranks who stands so eminently in the degree of I stand accountant for as great a sin I can stand well enough, and speak well fit to stand by Casar and give direetion. and the eondition of this country stands he shatl in stranganess stand no stand you awhile, apart.

come, stand not amazed at

there stand I in much peril ....

TTAN stand I in much peril

if you list; he's no standard

advance your standards, and

standard $T$ you shall bear my standard. Richarel advance your standards, draw your $(r e p)-$. v. 3 S'TANDEP-BY to lear my ......... Winter's Tale, $\mathrm{i}$. you were standers-by, and so wast thou

saud to some nyy standers-by ... Troilus \& Cress. iv. it is not for any standers-by ........ Cyinbeline, ii. I here standeth Thomas Mowbray ..... Richard II. i. lord Hastings, standeth thus. well; I am standing water ..............
brooks, standing lakes, and groves
tis with hin e'en standing water. 'tis with him e'en standing water.. Tielfin Night, $\mathrm{i}$. and mantle, like a standing pond.Mer.of Irerice, the danger is in standing to t......... All's Well, standing in riel place, I nultiply .. Winter
will continue the standing of his body will continue the standing of his body for life - iii. touk the spirits, standing like stone... King. $\bar{J}_{0 h n}$, iv. 2 king of snow, standing before ........ Richurd II. iv
shall there be gallows standiug in ... Heury $I V$. you bow-ease, you vile standing tuck on mountain standing, up in $\ldots . . . \ldots$ Henry $V$.
standing naked on a monntsin $\ldots . .2$ Herry $V I$. surmised whilst thou art stunding by - ii graee speaks his own standing!. Timon of dthens, $\mathrm{i}$. the eause, sir, of my standing here... Coriolantu, ii. into love, standing your triendly lord standing ever'y faw, and saving talk not of standing; Publius.... Julins $_{\text {Carsar, }}$, vi. 1

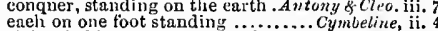
right glad he is not standing here.....
standing bleak upon the sea.......... Pericles, iii. 5 things standing thus nnkuown ...... Hamlet. v. 2

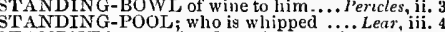
STAND'ST between her father's. Nid. N. S Drear, int. 4 thon lamb, that stand'st us his .. Love's L. Los', iv. I that shwws me where thou stand'st. Richard II iv. 1 stand'st thou still, and hear'st sueh. 1 Henry $I l^{\prime}$. ji.
in that very line, Harry, stand'st thou - ifi. what stand'st thou idle here?..

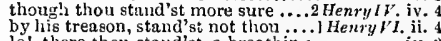
$10 !$ there thou stand'st, a breathing - iv, stand 'st thou aloof upon comparison? $\overline{\text { not }}$, v. 4 art thou stiff! stand 'st oit? ........... Coriolanus, i. । in what ease thou stand'st .... of hanging - . v. 2 thit stand st so for Posthumus! ...Cymbeline, iii. 5 STANLFY, in the isle of Man ....2Henry $/$ I. ii. 3 and sir John Stanley is appoiuted now - ii. 4 Stanley I pr'ythee, go (rep.) ........
sir William Stanley, leave off to $\ldots$ ii. Stanley, I will requite thy forwardness - iv.
lords of Buekingham and Stanley.. Richard 111 . good my lord of Stanley ( $r e p$.

to Stanley, Hastings Bueking what think'st thon then of Stanley?
one from lord Stanley. What is't o'eloe [Col.Kn'.] eannot my lord Stanley sleep now, lord stanley? what's the news? Stanley, he is your wife's son (rep.) Stanley, he is your wife's oon (rep.)
chsnged; Stanley, what news with you? your 80n, George Stanley (rep. iv. s)
sir William Stanley; Oxtord, redoubted our tather Stanley lines of tair eomfort where is lord Stanley quartered

at arms to Stanlev's regiment.

call up lord Stanley (rep.) ............. STG and takingl iv. 5 STAR.CROSSED lovers take.. Romeo \& Juliet, (proi. v. 2 STARE-you in this strange stare? .... Tempese, iii. 3 nor stamp, nor stare, nor fret. Tainizer of Sllrew, iii. that he stares and looks so wildly?.. Richard $11 . \mathrm{V}$ gasp, and stare, and cateh the wir ..2 Henry $V I$. iii. and children, stare, cry ont, and run - iii.

STANZA-a staff, a stanza, a verse. Love's $L$. Lost, iy. 2
stanza; call you them stanzas? ..AsyouLike il, ii. 5 staples, and corresponsive...... Troilus sov' Cress. (prol. TAR-upon a most auspieious star .... Tempes i trucr stars did govern

by welkin, and her starl

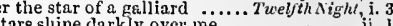

Iny stars I am above thee........ - ji. 5 (letter) look the pofolding star cali............ slie would infect to the north star.... Much Ado, ii. there's no more was a star danced

certain stars shot madly from...Mid.N.'s Dream ii. give a name to every fixed star...... Love's $\bar{L}$. Lost, i. pardon me, my stars

and these thy stars to shine

thus pour the stars down plingues.....

whose bave a bright partieular star ..All's Well,

yon were bort minder a eharitable star

by the luekiest stars in heaven .......

my homely stars have failed to equal

it shall be moon, or star... .. Taming of Shrew,

whom favourahle stars allot.............. $\overline{\text { Winter's Tale }}$ iv

seek to unsphere the stars with oaths

by eaeh partienlar star in heaven......

stars, very stars, snd all eyes else....

like stars, shall shine on all............. Macbeth, i.

stars, hide your fires!........

now, now, you stars, that ............ like a shooting star, fall to $\ldots \ldots \ldots \ldots$. - ii. go by the moon and seven stars....... whatl we have seen the seven stars. 2 Henry $y$. Hi. stars, or suns, upon it? Stars......... Henry $V$. iii.
lived this star of England ...... v. 2 (chorus) scourge the bad revolting stars ....... Henry VI. i briglit star of Venus, fallev down.....

what lowering star now envies ....2. $n$ nenry $V_{I}$ iti. tew men rightly temper with the stars $-\bar{y}$. iv. and fortune of our shining star ...Richard 11 . hi. at their births good etars were opposite $\overline{\bar{H}}$ iv. or like a star dis-orbed? ....... Troilus o $\%$ Cressida, ii. farewells as be stars in heaven .......
on the hungry beaeh fillip the stars. Coriolanus, is not in our stars, but in ourselves..Julius Casar, but I am eonstant as the northern star - iii. moon of the star's give light to. Antony \& Cleo. iii. when my good stars, that were....... that our stars, unreconcilabie.......... that knew the stars .............. Cymbeline, tii. o inlay heaven with star

was't not a happy star led us... Titus...tndronicus, iv. save yon field of stars, they here......... Pericles, i. ye angry stars of hearen! wind, rain like stars, about his throne.... her better stars brought.......... - v. the sun, the moon, and the stars........... Leor, $\mathrm{i}$. hud the maidenliest star iv the firmament the reason why the seven star's are $\ldots \ldots .$. - i.

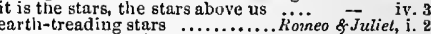
consequenee, yet hanging in the stars of her eheek would shame those stars $=$ ii. 2 thien I defy you, stars! thou knowest $=\quad$ v. 1 the yoke of inauspieious stars ......
when yon same star, that's wcstirard ... Hamlet, i. I as, stars with trains of fire and dews

being nature's livery, or fortune's star.... - i.

doubt thou, the stars are fire...... - i. 2 (letter) as the star moves not but in his......... - ii. moves not but in his.

TANNYEL checks at it! ......... Tüeifh Nitht, $\bar{i}_{i} .5$ 
STARE-when a madman stares? .. Jntius Cirsur, iv. 3 my blowl cold, and my hair to stare?

thint makes thice stare thits?

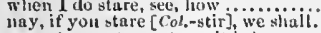

we sliali..... onthello is

ars: it is true........ y. y.

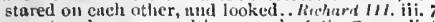
You starcd upon me witls unpentle. Julius Corsar, ii. nightly sings the etmrint ow!. Lere's l. L.ost, $v$, ge song wich staring on une ancher h.... Ninter's Tok or stariug rage, presented to the .... Kinn John, jv. 3 staring full glustly like a strungled.2 llemyli. ii. that werich is sturk moul.

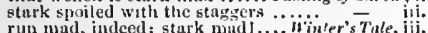
run mad, indeed; stark mudl..... Hinler's Tale, iti. all matel, or stark limt ...... Comedy of Exrork, v. lay ine stark naked, und let.

stark, as you sce: thus smiling ....... Cymbeline, i

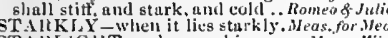

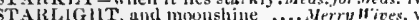

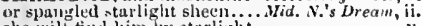

STAR-LLKE-shall star-like rise .....̈enry YIII. STARLING shall be taught to enenk... III STARRED must uuluckily ....... Hinlers sule, Hii. STAkRY welkin eover thou anou... Nirl.N

Aou have the start ot ime.

did speak in sturts distracteili...... Tirelgth $\overline{x i g}^{\circ} h t$, ii. witl an obedient start, make iut .....
appuritions start into her face ...... $\bar{A}$ do, iv. 1 apparitions start into her face...... Nuch Ado, iv. what's an muther, thant you start at it?.All's siell, i. every fentler sturts you

she stirs; start tot; lier actions

if your husbaul sturt some other. Comedy or Ey

Rood sir, why do you start; and seem
$\mathrm{U}$ these flaws, and starts. (impostors

a fourch? Start, cyes! What.

thoughts, cannot once start me

do but stait an echo with...

a lion, than to start a hare ........
you start a way, and lend no ear

and start so otten when thon sit'st

in the slips, strnining upon the start.

in the slips, straining upon
mangling by sturts the full.

from nyy side to sturt into..........
when I start, the envious people

ankl start at wagging ol' a stra

he bites his lip, and starts

Richari III iii.

than starts i' the way lief, r. the the

so get the start of the majestic

kings would start furth Anony

and, by starts, his fretted fortunes

at which he sturts, and wakes....

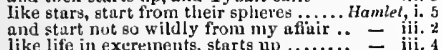

like life in excrements, starts up .

now fear $L_{\text {, this will give it start again } . .} \overline{\text { ive }}$ iv.

STARTED owe poor leart of minc. Tirelfih Nimht, iv.

at which name, I started. ........ Richard I

then a way she started to denl with ...... Lear, iv.

and then it started, like a guilty thing.. Hamie', $\mathrm{H}$
STARTING-mar all with this starting. Hacbrth,

starting so, he seemed in sumning ..2 Henry $1 \%$, $i$

starting thence away to wh

after this trumge starting froin your. Cymbeline

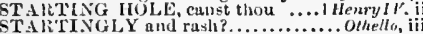

STARTLE-Would startle at thia.. As ynotike il iv. startles und frights eonsideration ... King John, iv. 2 I'll startle you worse than

know'st how thou dost startle me .....

this, which startles in our pars? . Itomen of Juliet, v. 3

SAR'ST'-why start'st thin? ....2/leny'rI. i STAKVE misst starve our sight. Hid. N's. Is eam ghe did starve the general purld.. Lere'st. Lost, they that starve with aothing... Mrich. of lence barren inountains let him starve ..... llenryI

your grace may starve. perhaps..... Henry $r$ I. iii. he had better starve, than but .....ilenry III. v. 2 here starve we out the night. Troilus \& Cressida, $v$. 11 and starve your supple joints?. .. T'mounf Athens, i. and so shall starve with fecting

nay, then thou wilt starve sure.

w.lio starves the ears she feeds........... $-\overline{L e r r}$, v. 3

'ericles, ii.

STARVFD the ruses......... Trofien. of Prona, iv. bloody, star ved

mam staryed for meut giddy ... Taming o shuetr. v.

mountains starved [Col.starve] .... I lienryl IV.

in iny panulers are quite starved

this sane starved justice hath done.: llenry $l r$. iii.

ay, come you starved bloodlioand....

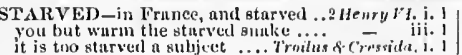

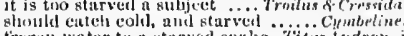

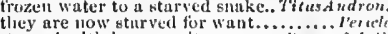

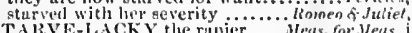
STARVE-LACKY the rapier........hrers for. Meas i

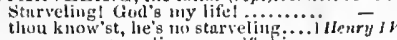
away, you starveling, you elf-skin

STARVETI in thy eyes ......... Romen of Jutie

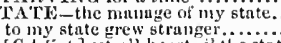

Col. Knt.] set nill

highest queen of state, great ...........

iny state leing galled with .........lery lives, iit.

do guide the statt...................

yet my state is well (rep.) ........... Tiviffh

my state is desperate for my mast

sitting in my statc ................

tang arguments of state (rep.

with the danger of my state. Meastie. for Measure,

the state, whoweon I stueried

and iny juace i' the state

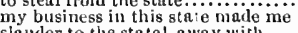

slander to the statel away with.......

which maintained so pulitic a state
in the stite of hononuble marriage.

still doth tend upon iny state.. Shid. N.'s Drean, iii. 1

gainst the kingly stute of youth

would I o'erswhy his state, that he...

full of courtslip, and ut state....

keep some state in thy exit

when I told you my state was.iverch. of $v_{e-n i c}$

duth irnpeach the freedom of the state

from out the stute of hellish cruelty?

pluck eomniscration of his state from

will rush into the state

thou anst he haned at the st:te's charre-

comes to the general state, which
ay, for the state, not for An tonio

and then his statc enpties itself

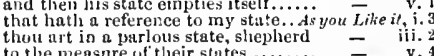

disclose the state of your atrection .....
whose state is sueh, that cannot ehoose

any trumeli ur imnge of thy state.

and my state that way is dangerous

were iny state far wor er than. Taming of shreo

exchange uny state with Tranio...
made mure homely than thy state

of your own stute take care.......... $=$ iv. 3

you's pity not the statc, nor ...... Winer of ray state: what.Comedy of Errors.

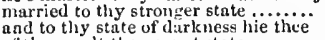

of the revolt the newest state ...

acterth, i. 2

are to your throne and state, childre....

we shall have catse of state

二 i. 4

thoustess keeps her state. ...

二 iii. 3

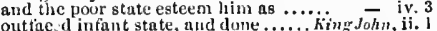

this wild counsel, miglity state? smacks

and to the state of my great $\ldots . . . .$. .

and my statc is braved, even at...

to any sovercign state throughont...

the lineal state and plory ............. as, praiser of his stute

thy state of litw is hondslave

yew agninst thy state.

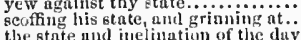

the state und irselination of the
they'll talk of state; for every

that thy state might be no wor

my glories and iny state depose.....

own tonguc deny my sacred state.
against tic state and profit of this.

a suhject; state, a preasant...

think onr former state a hapily

whose state and honour I for lye ailow -

the concord of my state and time...
first, to thy sacred state wish I all.

this chair sluall be iny state ........
thy state is tuken for a juint-stool

and so my state, seldoun, but

earded horstate ming ed his roynity

more worthy interest to the state...

in the state of iouvecuev, Alaui ticll

I would the state of tinic hul fliret

the exaet wealtit of all our stutey

tasked the whole stute ...............

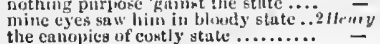

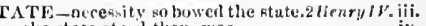
us the state stom them, was.....
down, royal stutil ull you suge.

lonk too nenr wats my itute.

ninge with the state of floods..

great bady of our state may fo .

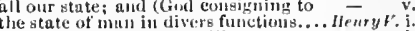

I will kecp my state; be ike
with what great state he heard

whose state ac many had .........

change of tince and states, brandish
blessed hapdid ne'er vetal our state.

licly state is tomeled so near. State.

iny lords, the states of Christendom

pillars of the state, to you ...........

pry into the secrets of the state ......

dangerously aguinst your state...

used according to your state (rep.)...

that touk our state unon lim to frece

misehau'e unto my state by Suffolk'

thus stands my state, 'twixt Cade

even in the eliair of state! (rep.) …3

should lament thy niserable state

sweet widow, by iny state I swea

replant llenry is his forner statc

to raise my state to title of a queen

my captive state tis liberty

my waned state for Henry'

hy hour, state, and seat, is

and seat, is due...Richard $I I I$ i.

what new's, in this our tottering stite? - iii.

but that I know our state secure .... $=$ iii. 2

and supposed their states were sure..

your stite of tortune, and your due

I am unfit for st: te and majesty.... - i

urge the necessity and state of times $\overline{\bar{l}}$ iv.

takes nutice....

in aught pertains to the state........

or sit state statues only...............

or Clotharius, they keep state
that trick of stute was a deep....

my' state now will but mock me ...

to the prejudice of her present state
bearing a state of mighty moment

to wear our mortul state to come ....
papers of state he sent me to peruse.

papers of state lie sent me

the prime man of the state?

and che profit of the state.

the king's will, or the state's allowaice

in a rich chair of state, opposing

with the eame full state paced

know you not how your state stunds

who holds his state at door ..........

a general taint of the whole state
kindling such a combustion in the state

married calm of states quite.. I roilus $\$$ Cressid

rails on our state ut war ai noble state, to caili upon

all his state of war ................

and mighty states characterless a......

providence tlat's in a watchtiul state

by Primm, and the general state of Troy =

hail, all the state of Greece ..........

to propanate their stotes

never niay thint state or furtunc.ii....

fly so beyond his state ..............

fully laik aty state before ine

even to the state's best health

when neighlour states, but for tiis.

best state, contentless, hath............

youl slander the lielms o' the state

rather our state's defective for requital =

a petty servant to the state ..........

fer the ruin of the state................

even when the mavel of the state.
love the fundamental yart of stnte

berenves the stute of that interrity

liur the whole stute, f would put ....

our state thinks not so ..............

he is, and feasts the nobles ol the state

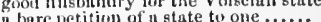

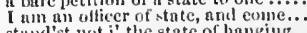

stund'st mot i' the state of hanging.

iwn from the state, nor jurivale triends

lue sits in his stute, as a thing

you lorrls and heads of the stinte.

untu some monstruns siate

aud tie state of man, like to 


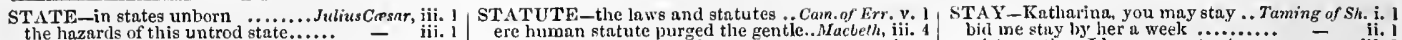
to younc Octavins of the state of things - iij: the time state made frends. Antany $\&$ Cleor not thrived upon the present state. taught us from the prinal siate did praetise on iny state in attiunds in place of 'sreater kings, queens, and states for your lunour and your state....Titus Andron. $\mathrm{i}$. to order well the stute from the dujected state wherein he is... Pericles, ii. not to be a rebel to her state

hearing of yuur maelancholy state.... $K w i$.$] reserve thy state; and, in thy best.. Lear, \mathrm{i}$ fiuc tiune liom this enormous state.

deuth on my state

t!at discerns your state better. decrees, and statutes, I deny ...... Richard Il. iv. statutes cancelled, and his treasure...3 Hemry $V I$. provide more piereing statutcs daily. Corialum with his statutes, his reengnizances .... Hamlet, v. TAUNCH-hold us staunch my tears stauneh the eartll's.. T'itus Ant ronicu, in. TAV Covs avariee, that, were 1.Macbeth, iv. hired to bear their staves ...............Macleth, v. 7
their armed sta ves in charge ...... Henry $V$. iv. 1 such bearded hermits ${ }^{+}$stave look that my staves be sound ........... Kichard $11 \mathrm{v} . \mathrm{v}$. amaze the welkin with your broken staves! $-\overline{1}$, strike at the heaven with your staves, Coriolanus, STAY-concluding, stay, not yet ....... Ternpest, no more of stay; to-morrow that tide will stay me lovger then stay at home ................ that stays to bear my.

stay with me awhile .....

thy master stays for the come coz; we stay for you $(r e p.) \ldots . .$. Merry Wive lie will not stay long ............ heve I not stay for him. come, we stry too long ............

to stay for me at ehure.

but stay, I smell a man

I'll stay a munth longer

O stay and hear ..........

stay : I pl'y ihee, tell me
I'll not stay a jot longer

I conld not stay hehind you

signior Fabian, stay you
Cesario, lusband, stay

stay a little while ((rep. ii.3 \& v.1).Mieas. for Mea

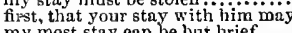

my most stay ean be but brief .....

there he must stay, until the officer.

and tell him where I stay.

shall stay here at the least a month... Much $A d$ I uo but stay till four marriage......

an offence to stay a man against his

O stay but till then

there will I stay for thee

inid.

within this wood intend you stay?

[Knt] one I'll stay, the other stayeth

I will not stay tly questions

stay, though thon kill me, sweet
stay, on thy peril; I alone will go

stry thou but here a while ...........

why should he stay, whom love doth

stay, gentle Helena; henr my........
nor longer stay in your eurst company

but stay; $O$ spite! but mark

make no stay; meet me all by

and, to the state, this heav $y^{\prime}$ act.......... $-{ }^{\circ}$. 2 with your stately and air-braying tower

the time with stately triumph

like the stately Phobe 'mongst... Tilus dndran i. and stately Rome's disgrace.............. Hamlet, i.

parasite, my soldier, statesman .. iVinter's Tale, i.
STATESHEN-shal our statesmen he .. Othello, STATILIUS showed the toreh-light.Julicus Cosar STATION in the file .................. Hacieth, in the unshrinking station where he
puff to win a vulgar station....... Carialan
take up some other station; here's no take up some other station; here's no $-\overline{-}$ and her stank and station are most select. Hamlati. n Etation like the herald Mercury ....... - iii. A

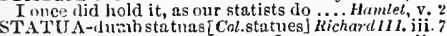
suw my sta'va [Cal.Knt.-statue]...Julius Corser,

base of Pompey's statua [Col.Knt.-statue]
STATUE in thy stead ...... TwaGen. of Ver

with any man that knows the statues Wueh Ado, iji. of her niother's statue (rep. v. 3).. Wuter's Tule, v, 2 to see the statue of our queen
the statue is but newly fixed

I'll make the statue nove indeed. we'll set thy statue in some....... Henry $r^{\prime} l$. iii. 3
ereet lis statue then, and worship .2 Henry $r^{\prime} I$ iii. the primitive statue, and objique. Trailus ơ Cress. v. cold statues of the youth

nohles bended, as to Jove's statue.... Cariolanus, $i$ with wax upon old Brutus statue...

statue sjouting bluod in many pipes
give him a statue with his ancesturs

a statue, than a breather ...Antony \& Cleopatra, iii. 3 gilld his statue glorious .........Pericles, ii. (Gower)
will raise her statue in pure gold. Romeo $\&$.Juliet, $v .3$

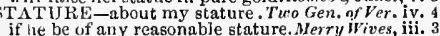
if he be of any reasonable stature. Merry Wives, iti. 3 the the wes, the stature, buik .......2 HenryI $F$. iii. 2 her stature to an inch.................. Perieles, v. fillows close the rigour of the statute

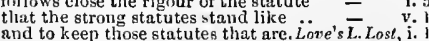
and to keep those statutes that are. Love s L. Lost, according to the statute of the town. and stay here in your court ....... Loves s $\bar{L}$. Lost, $\mathrm{i}$.

prove perjured, if you make me stry

stay not thy compliment; I forgive.

so shall we stay, moeking intended.

nay, why dost thou stry?

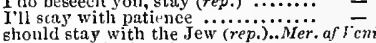

mates by this time for us stay

our friends all stay for you

to stay you from election.

shall e'er be guilty of my stay ......
which stays for us at the park gate.

I'll stay no longer question ...........

more properly, staya me at home... As

thit either tou stay behind him...

you must, if you stay here

let us now stay and see it............

and never stays to greet him $\ldots . . .$.

let me stay the growth of li
who stays it still withal?

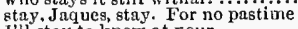

I'il stay to know at your...................

that you will stay behind us!.....

Itay; the king-Use a more.

stay; the king-U se a more ...........

sliall I stay here to do't? ...........

and will stay upon your leisure $\ldots . .$. .

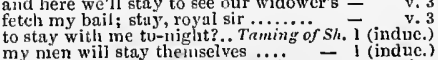

my nen will stay themselves ... - 1 (induc.)
O stay, slave; I must employ thee...

and let the traitors stay.

nyy lord here stays witlout
I stay here on my bond........ mistress, then I have eause to stay ..

I stayer fortude stays him from ....

ruther go than stay: and, honest......

let us entreat yon stay (rep.)...

so shall you stay till you bave

the tailor stay's thy leisure ...........

to stay him not too long $\ldots \ldots . . . . .$.
stay, officer; he shall not go to ........

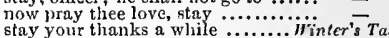
no longer stay. One seven-nighit longer -

my stay, to you a charge $\ldots \ldots \ldots . . . . .$.

you'll stay? No, madam (rep.) .......

this great sir will yet stay longer.....

he would not stay at your petitions..
how came it, that he did stay?

Bohemia stays lere longer. Ha? Stays

that wilt not stay her tongue ........ -

cherish it, to make it stay there........

why, they stay at door, sir .......

st ay there, Dromio, till I eome ......... ivedy af iv. 3

and her sister, stay for you ...........

made me stay thus loog

bound to sen and stays but $f$

wind and tide stays for this gentiem in

what ship of Epidammum stays for me?

faith, stay here this night..............

am Dromio; pray, let me stay

stay, you imperfect spenkers, teli me... ... $\overrightarrow{\overline{a c} b e}$ we stay upon your leisure

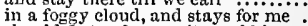

should 1 stay longer, it would be

iv. 3

rouchsafe a while to stay, and I shail

here's a stay, that shakes the rotten

your grace slall stay behind course...

no vile hold to stay him up...........

stay yet, lord Salisbury; $\Gamma^{\prime} l l$
to die, and go, as die, and stay

one poor string to stay it by

I do but stay behind, to do.

as much good stay with thee........... Richard II. i. ?

and buld, stays but the summons...;

stay, the king hatl thrown

for our time of stay is shor

but that they stay the first ..........
fearing to do sc, stay, and be seeret.

stay yet nnother day, thou ...........

but stay, here come the gardeners

yet still witl me they stay

stay thy revengeful hand.

here is 110 longer stay. If thou love me $\bar{v}$ v.

Whill entay, and pause awhile.I Henry

and only stays but to behold

pray you, stay a little, my lord

for God's sake, cousin, stay tili äil .

persuaded you to stay at home? ...2 $\mathrm{Henr}^{-} \mathrm{v}$

a dozen captains stay at door........ -

have a desire to stay witl my friends

where is he that will not stay so long

I stay too long by thee ...............

stay but a little; for my cioud ........

doth the man of war stay all nighit...

if he stay in France. To-morrow....

you shall stay with us in Rouen ....

ing friends, and all things stay for me

why do you stay so long, my lords ..

I stay but for my guard.

I nust stay with the lacqueys .........

the princes, or stay here with us?

stay, stay thy hands (rep. iii. 1)....... 1 Henr $y$ r

fily do you let them sta.

troops retire I cannot stay them....

stay, my lord Talbot; for my........

whose strengthiess stay is numb ....

if we both stay, we both are sure (rep.)

no hope that ever I will stay $. .10 . .$.
stay, go, do what you will, the $1 \mathrm{ike} .$.

an if more, we hazard by thy stay.....

stay. my lord legate; you shall ....

$O$ stay 1 have no power (rep.)
if $I$ longer stay, we shall begin

if $x$ longer stay, we shall begin ......2 Henry $\nu$

my stay, my guide, and lantern $\ldots \ldots$.

I cannot stay to spenk $\ldots . . . \cdots \cdots \cdots$.

stay, Salisbury, with the rude 
STAY, Whitmone; for thy prisoner

but stay, I'll real it over once again

in this city will I stay

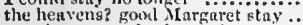
stny by me, my lords; nmel (rep.) ..... let's stuy withim this house .......... gentle queeni, anil I will stay.

stuy gentle Margaret, and hear .... gon bdward, thom wilt stay with me but, stay; what news? ............... here must I stay, and here my life nay, stay; let's licar the orisons. retire, if Worwick bid lim stay. stay ne no lowater lreaming of ren that clurst make yout stay

stay, Edwarl. No, wrangliig (rep.) to tly that will not stay...

death rould stay these rutlifil deeds! nay, stay not to expostialate

not that I fear to stay, but love.
IIl staly above the liili, so both.

let's stay till he be past........

the nore we stay, the stronger $\left(r^{2}\right.$.

why stay we now? (rep, iv. 5) ......

I stay not for the love of Elward

stay, or thou diest

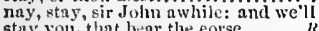

stay you, that bear the eorse

struck we, that thought to stay him

gentle keeper, stay [cot.-sit] by me.

lay, I priythee, stay a little; I hope
this will out, ant then I must not sta

what stay haxl I (rep) ............

let not us two stay at home......................

stuy, I will go with you

but ling I eunnot stuy there.............

like enough, tor I stay dimer there

costay him from the fall of...

stay yet; look bilek, with me...

yoll, sir Walter Ilerbert, stay with me

stay, my lord, and let your reason.. It

my barge stays; your lordship shail

to stay the judginent o' the divorce.

stay, where's your eommissiolt, lords?

stay, good my lords, I have....

you must stay the cooling too.... Troilu

no, sir; he stays for you to conduct.

with venomous wights she stays

lialf Ileetor stays at home

honour, or go, or stay
I pr'ythee, stay (rep.)

I pr'y thee, stay (rep.).
why stay we then?

your guard, stays to condoct youl hoine

now if thou lose thy stay

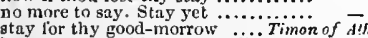

let re stay at thine own peril .....

if Timon stay at hom

are more valiant, that stay at home

will not reeompense tlis long stay

stay, I will lencl thee money .....

nay, stay thou out for enruest $\ldots . .$.
O let me stay, and eomfort you $(7 \cdot p$. $)$

stay not, all, in vuin................ v. 5 (epitapi

why stay we prating here ............ Coriolanus,

ere stay behmil this bisiness

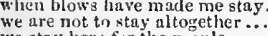

we stay here for the people ..............
than stay, past doubt, for ureater

than stay, past doubt, for freater ....
peace, peace, peace; stay, hold, peace

you sliall stay tivo: I wonld (rep.)

Why stav we to be haited with

stay; whenee are to

uyon execution

stay for me in Ponney's porel .....Juliusce

if lie should stay at home to-(lay for fiear
thy humour, I will stity at home (rep.)

my wife, stays me at houne

stay not to answer me, but get (rep.)

yet, stay a while (rpp. iif. 2$)$.......
for my sake, stay here with Antony

stay, hol and let us hear Murk trep.

nutling but deatl shall stav" ine.

to stay the providence of somine
Strato, stay thou by thy lord ....

yon inist not stay here linnger.........

he stays upon your will $\ldots \ldots \ldots . . . .$.

I will not stay belind. Nay, I läe

I must stay his time. To flatter

to the city, shall stry with

stay for me: where sonls rlo
what should I stuy-in this wili..... world?

noy, stay a little: where you but .... Cymire

st.ıv, cimme not in; but that it...

brother, stay here: are we not brotiere? -

I'll stay till hasty P'slydore return
atay, sir king: tlij man in better

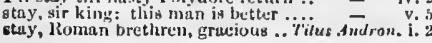

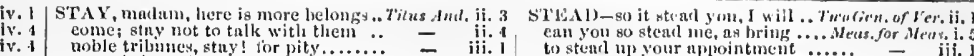

stay, tatler; fin that noble liund

now, stily yomr strite

stiny, murlerus villainst

may you stind inc?

you imust needls stay a tim

in......... steal

your graces redrest in my steal - iv. I (teter

of whut shonlis steal lier most? ...... - Y.

let Rulje und Mlurder stay with me.. - $\quad$ v. 2

stay your coming to present theinselve.s. $-\bar{r}$ ricles, it. 2

we flo our loneing stny, to hisur.

yoll are the man must stent us ali ...

gise sheep in lions' stend .........

and minister in their ptemls!

let me not stay a jot fine dimuer...

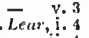

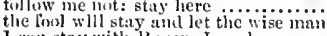

l cin stay with liewan, I, and my

ii. 1 entreat him loy nomeans to stay .......

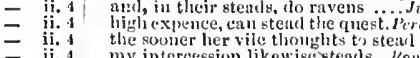

my interecesion likewise steads.. linmes o 3 . Jufiel, ji. 3

ii. 2 stiy with us; tlic ways are dangerous.

ii. 3 stiy yet, heur reason: Elmund, I arre....

STEADED-since have steaded muel. ... Tomprs', i. 2

STLALby line and level (rep.)

as the morning steals upon the wight... Tempest

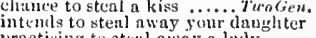

thou wert so happy by thy stay... Rompo o. Juliet,

she will not stay the sierte of lovin

iractiting to steil away a lud

to steal at a minute's res

stay, fellow; I can real .........

stay but a little, I will eome again

ant, stay, goorl nurse, belind...

ean you not stay owhile?

and rll stay the ciremnstance

there stays a husbumd to make you...
you slazll not stay alone, till holy clureh

why dist thou stiny?

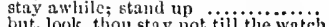

gone and live, or stay und die........

1 hinve more eare to stay, thom will to

stuy, Tybalt, stay! Romco, I eomel -

tarry for the niouroers, and stay dinner

I will still stuy ; ive, awd hereafter

stay to louk on his intents. Stay tion

stay not to question, for the wateh ..
I dlare stay no longer

star, speak; speak (rep.) ............... Itamter, i.

I pray thee, stay with us, go not ......... - i. 3

grod madam, stay awhile............... - ii. 2

my mother stays: this physic but prolongs

who shall stay you? my wili, not aii..................

but stay, what noise? how now, sweet...

stay, give the grinding of the axe

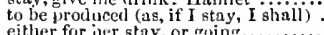

her wrong stay, and her tispleasure fly

I will not stay to offend you $\ldots$.................

stay you, good gentlemen; look you pale
sT.YYED-you are stayed for

he hath stayed for a better
thou hast stayed so long

thou hast stayed so long .........

thine eye hatli stavel upon .......... Trelf $\vec{N}_{i g h t}$, ii. you have stayed me in a happy hour..Much dilo,
stayed the oklds by adding tuur...Love's L. Lost,

here they stayed an hour $\ldots \ldots \ldots \ldots \ldots$.......

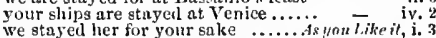

we stayed her for your sake ......As $y$ inn

would they has stayed !.......
whose leisure I have stared

whose leisure I have stajed ............... Juhn, ii.

we have stayed ten days.............Fichor' JI, is made, and exeution stayes

thro' the chamber where we stayed ...
she should have stnyed in France....2

that I have stayel so long

protector, stinged the soldier's pay

never wonld have stayed in Fraiee ..

an untimely ugue stayed me.

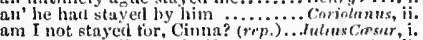

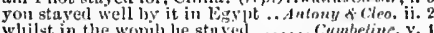

hast stayed us here too lony... Tilus dadranicus, it. 3

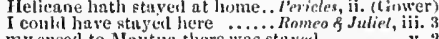

my speed to Mnntua there was staycd
friar John, was stayed hy necident ..

very like; stuyed it long? .............. IInntet, $\mathrm{i}$.

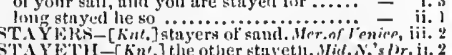

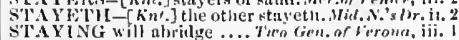

no longer stuying but to give .... Meas for Meus.

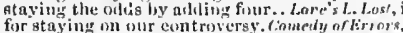

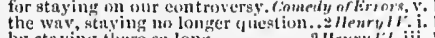

by atnying there sol lon:

the is stnying a gentleman, sent...ienre

Stygiau bauks stay iug fur waftuge. Irnil. . Cress, ifi.2

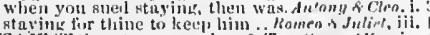

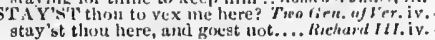

steal! Foli; a fieo for the phinase!

thou shalt not steal?

they prat firth tos steal

to steal frum the state, and usur...

and steal out of your connany . . .....

through $A$ thens' gates have we devisd

the honey-logss steal from

is blessing, if men steal it ow $\ldots$... $\bar{c}$ iii.

cxeept to steal your thoughts ....... - ii.

did Jessica steal from the wealtly Jew $\vec{v}$ v. I

and mysclt, did steal behind him ....

on 11 butl did haggisle age steal on ... Ath's We $h_{\text {, }} \mathrm{i}$.

steal away havely (rep.) $\ldots \ldots . . . . . .$.
most fnin wound steal what law does

he will steal, sir, an egg out it

foot of time steals ere we can

methinks, to steal our marriage... Fanning of sh. jii. 2

strange he thus should steal upon us

whieh steals itselt, whi........ Counedy af Errors, iv.

unless le do prufine, steal, or usurp. Virtharthi. iii.

under whose comntemanee we steal .. I lleury I $t$. i.

we stenl as iu a eastle, euck-sure

from whom you now must stent

as a cat to steal eream. I thitik, to steal

shall we stenl erean. It thitk, to steal - iv.

steal his sweet and huney'd sentenees.. Hemry $i$ i.

they will steal any thing, and call it

Englan! will I steal, and there I'll steal - iv.

when be would steal the lamb ...2 II'ury $V^{\prime}$. iii.

who earmot steal a slupe .....

stand you thus close, tor steal.

thought to steal the single ten ........

deceit shoull steal such gentie slinies -

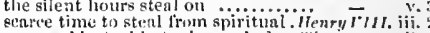

bomil servants, steall.............. - iv.

will he sten out of his wholesome.Jutitus $\overrightarrow{C r s s}$. ii.

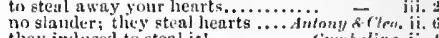

they ir:dued to steal it!............. ymbeline it

of a ent loaf to steal a shive........ Tilus Anelron. it.

which rlid steal the eyes of youns ... Prrirtes, iv.

she steal love's sweet bait from... - i. 5 (cliorus

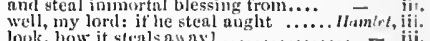

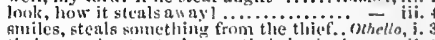

their moutlis, to steal thay the? brunsi- - ii.

that he would steal away so guilty-like.. - iji.

Whastenls my" purse, st cals trasl $\ldots \ldots \ldots$ - ii.

lie bergacd of me to steal it

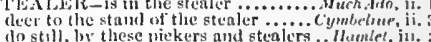

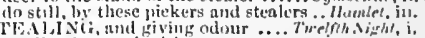

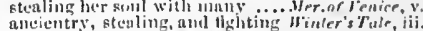
a piee of iniguity : stenling a wuy . . B - is.

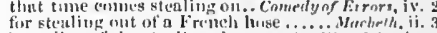

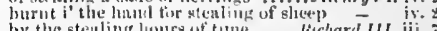

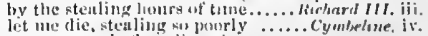
unom my end of atenling tluem ......... Trar. iv.

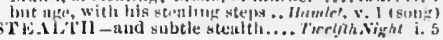

his eonmianion, and he stenls it ... bicl her stcal ittin the pleaclied bower -

that stenl the power tosteal both his - iii.

por thief, I'll steal nway $\ldots . . . . .$.
he will steal himselt into a imang ...

want golil, steal bint a beggar's dug. T'imon of dih. $\mathrm{ii}$.

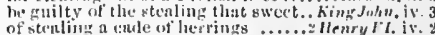




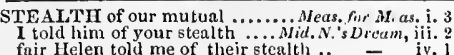

STEEP and thoiny way to heaven.
STEEP-DOWN gulfs of liquid fire

like elsc where, do it by stealth. Comedy of $\overline{\text { Corr. }}$ iii. 2 makes it worse than siealth

in the lusty stealth of natmre
fox in stealth, wolf in greediness

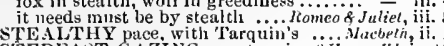

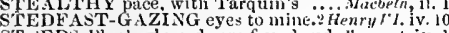
ST 2 EDS-l'hobus's:edds are fuumdered. Iempest, iv. I

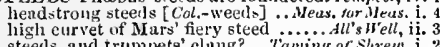
steeds, and trumpets' clant

his barbed steeds to stable

momted upon a lot and fiery steed.

of manage to thy bonuding steed ...i llenry $I \%$. ii:

low threatens steed

and their wounlel steeds frerve..

Clifford slew my steed

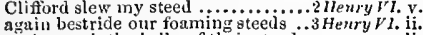

nusiernenth the belly of their
should eheck thy fiery stecd

from thence the Thrician fatal steeds

instead of molunting barbed steeds.. Richard III. i. present the fair steed to my iady Cressid

our steed the leg 0 general, here is the steed............

my noble steed, known to the camp

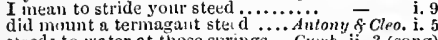
steeds to water at those springs... Cymb ii. 3 (song) steeds to water at those springs. . Cymb

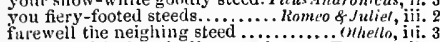
STELL - with this obedient steel ......... Tempest, it. for she's as hard as steel....

could soften steel mind stones
and by my' side wear steel?

and by my' side w
with wit or steel?

nore sharp than filed steel.

for my heart is true as steel.

....̈nerry Nives, i. 3

and puking-sticks of steel. Winter's rale, iv. 3 (sung)

with stamped coin, riot stabbing steel - iv. 3
and my heart of steel ......... Comedy of Errors, iii. 2

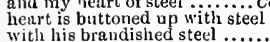

Alactieth, i.

nor steel. nor poison, malice

King John, ii. 2

with thy blessings steel my lan

stcel. and hearts harder tinan steel

never brandish more revengefin steel - iv.

crush our old himbs in ungentle steel. Aerry

like a rib of steel, to make

sparkling through sights of steel

Goud of battlesi steel my sold

Hen $\bar{y}$. iii.

I coutd rend bars of steel ..................

Hentyri. $\mathrm{i}$.

bloody hounds with heads of stee].

or never, steel thy fearful
though locked up in steel.

makes clifford mourn in steel

throw away our coats of steel.

were thy heart as hard as steel

fortune, steel thy melting heart

and bteod, to sear me to the brain?
as the long divorce of steel falls.

as the long divorce of steel falls.... Hichard Henry HIII.

or give me ribs of steel t............ Troil

more obey, thin to the edge

as true as stcel, as plantage .......

or like a gate of steel fronting $\ldots \ldots \ldots$

when steel grows soft as

trail your steel pikes

to steel with valour the meiting ....... Jilius $\overline{C a s}$ sar,, v.

as he piucked his cursed steel away.

leave thee now, like a man of steel. Ant. \& Cleo. iv.

a thoroughf fare for steel (rep). ........ Cymbetin

Marcus, steel to the very back.

slieathing the steel in my at venturous

of this neighbour-stained stee

my' man's as true as steel

in my temper softened valour's steel

with piercing steel at bold Mercutio's

to thy soul with hooks of steel ........... Hamlet, i.

the flinty and stcel couch of war... as iii.

STEELED-the steeled gaoler... Meas. for. Meas. iv.

from his metal was his party stecled.2 Henry i $V . i$.

shall with steeled sinews toil.

give me ny steeled coat

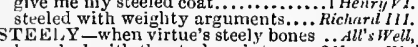
broalied with the steely point ........3 Henry $V I$. ii.

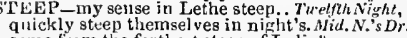
come from the farthest steep of Indiu?

against the steep uprising of

my lord, I will steep this letter.

King Lost, iv.

steep my senses in forgetfulnes.

promounce the steep 'Tarpeian..

2 Hemylr.ii.

Henry

acar the sea?. Lear, iv, have stceped their galls in honey a napkin steeped in the harm

wind hath steeped onr seuse in

cliurch, stceple, bells, and all (rep.

till you have drenched our steeple

a seeming mermaid steers.

this is a sten ot that vietorions.

they skip from stem to stern

step furth mine advocate .......

that is a step, on whiel 1 must

which with usurping steps do....

let's step into the shadow of these

step aside, and Ill show thce...

steps me a little ligher than
we should not step too far till

vengeance tend upon your steps!
children, but one step below ......

children, but one step below .......

where others tell steps with

sir, step you forth; give answer..

my lord, to step out of these dreary

controuller of our private steps!
whose deligbtful steps slaall mak

action, or dishonoured step.........

would step trom this to this?

or' step-dame to her son and a step-dame false

O Stephano, two Neapolitans (rep.

Wilt come? $\mathrm{king}$ Stephano! O peer! (rep.)

is not this Stepliano, my drat shake off their steril curse
Hamlet, i. 3 STERILITY_her womb convey sterility! Lenr, i. in the cap a spider steeped. Hinter's $r$. ii. Nacbeth, ii.

thy father, stecped in Rutland's blood

Paris too? and steeped in blood?.... Romeo o Jutiet, v.

steeped nue in veverty steeped.......... Humle' ${ }^{2}$ ii.

TEEPLE-topples down steeples ..1 Hewry 1\%' iii.

like youthful steers unyoked ......2 Hemry $I^{\prime}$, iv.

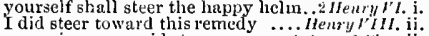

STEERAGE-with his steerage........... $\overline{\text { Pericles, iv. }}$ (Gower)

STEERED-boats that are not steered. Cymbetine, iv. 3

STEERING with due course townd .... Othello, i. 3
STEILED-quenched the stelled fires ..... L'ar, iji. 7

sweet stem from York's great stock... H Henry $r$. ii. ii.

STENCH -thou odoriferous stencli!. . Kintus Cosur, it.

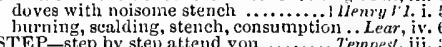

with his teeble steps........ Firo Ger... Ternpest,

each weary step, till the last step

step in to the chamber, sir John .......

lit the ground you step on ....... Tuetfhh Nighl, iii.

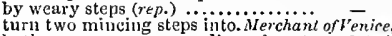

hath many a weary step limped $\ldots A, y \omega u L t i+$ it, ii. 7

deadly divorce step bitween me ......Adl's $w$ ell, v.

leave you to your graver steps ..... Winter's Fale, i.

Nacbeth,, $\mathrm{i}$.

snarl ad vantage sliall step forti............. $J$ John, iii. 4

wherein we step after a stranger ma.....

of thy weary steps esteem a foil.......Rich

and thy steps, no more thau a delightíul

we'll consecrate the steps that Ajax

so please you, step asidc.

woutd step trom this to this? $\ldots . . . \ldots \ldots$..... Hanlet, iii.

but age, with his stealing steps.... - v. 1 (song)

sir, this as arise, or step, may help ...... Olhello,

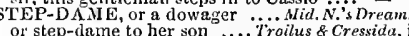

a father by thy step-dame governed
STEPHANO-wlile Stepliano breath

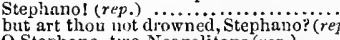

Stephano is my name (rep.)................

STEPHEN Sly, and old John. Taning of sh. 2 (ind u.

Steplen Langton, ehosen archbishop. King John, iii.
sir Stephen Seroot) ............... Richard $I I$. iii. 3

God, and saint Stephen, give.Titus Andronicus, iv.

king Stephen was a worthy peer. Othello, ii. 3 (song

STEPPED thus far in .......... Taming of Shrew, i.
the prince of Wales stepped forth .I Henry $I V . v$.

if well, he stepped hefore me ...... Hen'y $r M I$.

by whose deatle he's stepped into. Timon of $d t h$.
blood, hath stepped into the law ....

Whose naked breast stepped before .. Cymbeline,
STEPPING o'er the bounds of .. limeo \& Juliet,

STEPT-I am in blood stepit in so far... Afucbeth, iii. 4
STEPII-sea-marge, steril, and rock $y$. Tempes: he hath ilke lean, steril, and bare ...2 Hemy $1 \%$

seems to me a steril promonitory.......... Hamlet,
either to have it steril with idleuess .... Ochello,
TERLING yet in England ........ Richard 11. iv.

for true pay, which are not sterling ..... Ilamlet

TERN-not have been so stern...Meas. for Meus. ii.

for you are cold and stern.............All's Well, iv.

he hath a stern look, but a gentle .... Kirro John, iv

the very hand of stern injustice......

with child by the stem tyrant..2 Menry $1 \%$. (indue.)

why look you still so stern and tragical? -

decls of rage, antl stern impatience $.{ }^{-}-$iv 7

some stern untutored churl........

stern F's imperial tongue is stcrn.... - iv.

thou stern, obdiratc, flinty, rough ... - i.

our stern alarums changed done ..... .

Thave seen thee stern, and thon ...Coriolanus, iv,

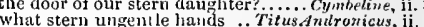

more stern and bloody than

at thy gate lowled that stem time......... Lear, iii.

TERNAGE of this navy ........ Henry $V$. iii. (cliorus)

should be made of sterner stuff...Juliuscersar, iii.

which gives the sternest good-night ... Nacbeth, ii.
STERNNESS of lis presence?

TTERAT-hic steterat (rep.).. Titmmg of sh. iii.

he would unto the stews............. Richard li. v.

to mart as in a Romish stew ........ Cymopline, $\mathrm{i}$.

art any more than a stewarl?....... - ii.

his captain, steward, deputy elect... Michard Ml. iv.

I am furtune's steward............2 Henry I $F^{\prime} . v$.

as protector, steward, substitute .. Richard 1II. ii1
claims to be higl stewara (rep.) .. Henry W11I. iv

the god of gold, is but his steward.. Timon of Ath.

go to my steward. Please it your .... =

ha! is not that his steward nuffled so? =

hear you, master steward, where's

have gold, I'll be his steward still....

as your steward still. Had a steward -

and he is a steward. How fain would

gave unto his steward a mighty sun
it is the false steward, thint stole his .Hamlet. iv.
STEWARDSIIIP, and all the ...... Kichard 11 . ii.

dismiseed us from our stcwardship... - i i

TEWED-a dish of stewed prunes. Nivr

for stewed prunes..........Measire for

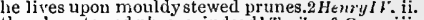
there's a stewed phrase, indeed! Troilus \& Cress. iii.

a reeking post, stewed in his haste......... Lear, ii.

TICK-disarm thee with this stick ..... Tempest, i.

I'll bear him no more sticks

on whose nature nature can never stick - iv.

a cod-piece to stick pins on .......... - ij.

only to stick it in their children's. Meas. for Meas. 1 .
am a kind of burr, I shall stick.... - iv.

and so deep stieks it in my ........ - v.

this drum sticks sorely in your

our fears in Banquo stick deep

I durst not stick a rose.....................

and yet he will not stick to say........ King John,

the knave will stick by thee,$\ldots . . .$. . v.

and stick it in thy eap $\ldots \ldots \ldots \ldots \ldots$. - - iv.

they will not stick to say, you........

to stick the heart of falsehood ......

feather sticls in his own wing.. Timon of dithens, ii.

opinion, that so sticks on Marcius ...Coriolenus, i.

his speech sticks in my heart. Antony \& Cleopalra, i. 5

rapped 'em on the coxeomb witli a stick.. Lear, ii. 4

flesly stick [ $\mathrm{Col}$-rash] boarish fangs...... $-\overline{\text { iii. }}$

scened i the air to stick ................ Ilamlet, ii.

like fruit unripe, sticks on the tree........ - iii. 2

will nothing stick our person to arraign

he might stick the smallest opinion.... Olhello, iv.

the slime that sticks on filthy deeds ....in $\overline{\text { Theth }}$ v.

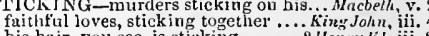

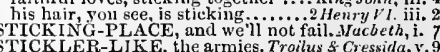
STICKLER-LIKE, the armies. Troilus f Cressida, v.9
STICK'S' $\mathrm{C}$ a dagger in me .. ANerchant of l'enice, iij. 1 the countenance of stern ..........s sou Lilie $t, \mathrm{ii}$

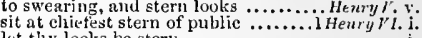

nurder, stern murder, in the direst.

STERVED, Knl. $]$ and ravenous... Mler. of ' '

let me see thee a steward still.......... ii. (letter)

dicposition stieks me at heart ...... As you Like it i. 2

thy leg a stick, compared with ........ - iv 10 


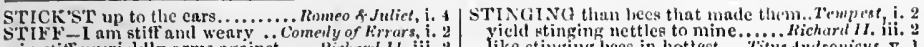
in stiti unwieldly arms agrinst .... Nichari 11 , ii. 2 with stiff unbowed knee

at sea in a stiff tempest as lour.

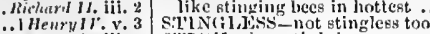

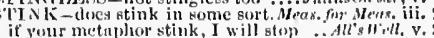

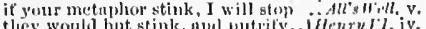
for his breath stinks with eatin

mofesfion as it were to stink a

may stank by the fire and stink $\ldots . \ldots \ldots$. lear, i.

with stinking elothes that fretted., herry " wiw

now as chenp as stinking mackarel..1 llenry/r. ii. 1

stinking, and ty-blown, lies here ... Henry r't iv.

people, log their stinking lireathe..

when you enst your stinking, grent
such a deal of stinking lorath

that's fel with stinking tullow

and let the stinking cliler, grief...... -

TIN INT-not stint our necessary ....herry VIIT. i. mulke pence stint war.......... Trimon of Aliens,

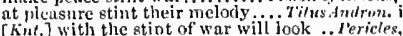
[knt.] with the stint of war will look .1'ericles, i. 2 and stint thou too, I lray thee ... Romeo of Juliel, i. 3 wouli I night never stir............. Mer my irines, $\mathrm{v} .5$

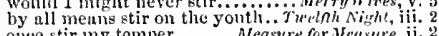

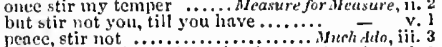

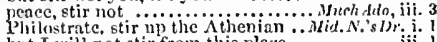
but I will not stir from this place... the now will I tir this gamester......... As you Like ih, i. 1 when that the sleeping mun sionoild stir $\overline{\text { a }}$ iv. 3

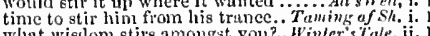
what wislom stirs amongst you?.. Hinler's Fule, ii. I than all thy woes can stir ......... done thee, stir afresh within me .... I'll fill your grave up; stir; nay
you perceive, glue stirs; start not....

wili determine this before I I... Comedy of

erown me, without my stir ..............unachelh, i.

might never stir from off this piace... King John,

wlio dares not stir by day

betir them op aganst a nighticr task

or stir thy foot or teach thy.......... and what stir keeps gool old Yoric ... He - ii. 3 unapt to stir at these indignities

o the bloot more stirs, to rouse...

I could not stir, hut, like a contet....

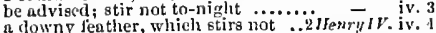

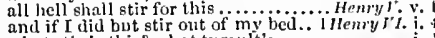
what stir is this? what tumult's

no, stir not, for your lives;
nor stir at pothing, till tlite nxe
I will stir up in

I will stir up in England som

revenge his death, before I st
shalt stir, in Suffulk, Norfolk.

mat thee, if thou stir abroat .........

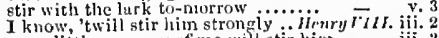

some little memery of me will stir him - iii.

more stirs against, both in hell push against I'unl's, as stir them -

the eyc, thatl what not stirs..... Troilns g cress, in.

if renow'n inecle it not stir ........... Coriolcmis, i. 3

ot hinat, for which the people stir.....
there is no stir, or walking in $\bar{c}$ iii. 1
.

stir up their servants to all act of (....)

if I were disunsel to stir your liearts - iti. :

let me not stir you uy to

know meantine of atirs abroai.

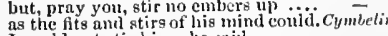

I eonld not atir him: he suit

stif a nutiliy in the mildest.. Filus ind ronich

fecl you, men must gtir soln to........ - iv.

her beanty stir up the lewilly-inelined

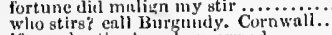

if you dis stir abroud. go arued.

fir these daugliters'

to move, is - to stir; and to be............... on Jutice

thon shalt not stir one f'sot tw seek.

cone, stir, stir, stir! the s(rond ences

tle laily stirs. $O$ comtiortulble frial

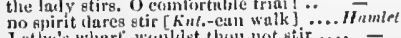

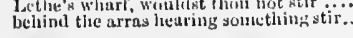

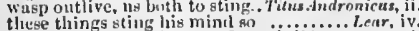
serpent thue did sting thy father's life . Ilamlet,
bosom lolge, to priek and sting her ...... -
TIR without grent argument ........... Hanalet, iv.

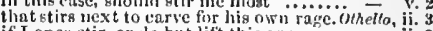
if onee gtir, or do but lift this arm .... - ij, louk, he stirs: du vou withdraw you

[Col.] buy, if you + tir, we shall lienr...... -

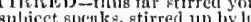

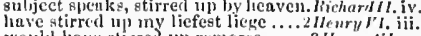
would have stirsed up remorse...... 3 Henry l't. v. 5

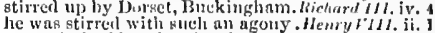
never desired it to be stirred.......... Brutuf, are you stirred so carly ...Julus Coryar, ii, the senate liatl stirred up...

fountaik stirred with wind riscs Andronisus ii. ele, you mailly were stirred up ....... Hamlit, iv. 7 lial neighbour makes us carly stirrers. Herry $F$. iv. ATRRRETI not................... Romen \& J Jutiet, ii. TSRlA I G -in stirring love ...Mil. N.'s Dream, ji, nor no ill luek stirring .... Nercrant of lenice, now in the stirring paesage. . Comedty of Errors, iij. is the kin" stirint, worthy thane?..... - ii. 3 an $A$ té, stirring him to blool............ King $\overline{J o h} n$, ii. i

eowards, there's no equity stirring... i Henry $\boldsymbol{W}$. ii. for stirrine un my eubjects ............. Henry F'. v. 5 Hector was kt tirring early .... Trailus of Cressidu, i. 2 where there is wit stirring, and leave - ij. I we shall have a stirrint world .... Coriolanus, that our stirring ean..........A nlony \& Cleopalra, ji. 1 quiet guard? Not a mouse stirring....... Hamlet i. i attends the general's wife, be stirring... Othello, iit. STIRRUPS of no kinelred ..... Taming af shrem, iii. to hold my atirrup, nor to tnke....... make saced even his stirrup.... jimon of dihens, i. I STITCIERY - lay aside your stitelicery - i. 3

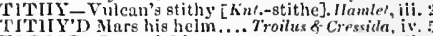
TOCCADOEs, and I know not.....Very Hires, ii.

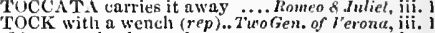
I have sat in the stceks............... ivery - ivives, ii. 3

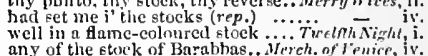

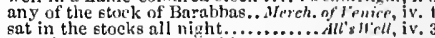
already, the stocks cary litio.

$\begin{array}{ll}\text { lys disaster of settiug in the stocks .. } & \text { iv. } 3 \\ \text { r the stueks, ir anywhere, so I may } & \text { iv. } 3\end{array}$ a pair of stoeks, you rogue!. Taming of Sh. $\overline{1}$ (indue.) nor no stocks, I pray; or so devet

and in the stoeks avouch... Winier's Tale, iv. 2 (song) pair of stock in the tow

who, sitting in the stocks the true line and stoek of Cliarles........ Nenry ${ }^{2 . i .2}$ $\mathfrak{a}$ stem of that vietorions st ock
put in wili nnd sarage stoek sweet stem from York's great stock... Henry $r$. iit.

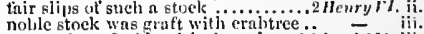
corruption of a blemished stock .. Wichard III. iii. though from a lumble stock...... Vienry $\bar{r} \| l l$. is.? but for the stoek, sir 'Thomas, I wish nnd what stoek he springs of ..... Coriolanus, ii. like one i' the stoeks ................... be jointed to the old stoek (rep, s, s) - v. 4 (scroili) nur thee, nor any of thy stoek. Tilus andronicus, if 2 luteli furth the stoeks, ho! (rep.).............ear, ii. bring a way the stoeks.................. not i'the stocks, fool ............. who put my man i' the stereks? (rep) ... STUCKlis-who stoeked iny servait? ..... Leur, ii. stoekel, muished, and inprisoned ....... - iii. you stock-fish-o for breath to utter. i Henryl ii.

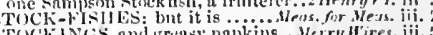

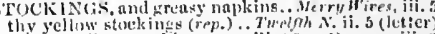

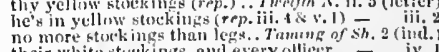
their white stuckinge, ant every ollieer - iv.

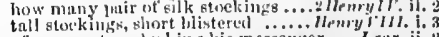
of my umster, stecking his messenter .... Lear, ii.

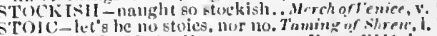
Toklist. and binriliner........ how my father stole two gece........... Wry Wires, iii. warily. I stole into a nelihbour ...ove'sL.Lose.v. the gentloum that lately stule...iver. of rence, iv. 


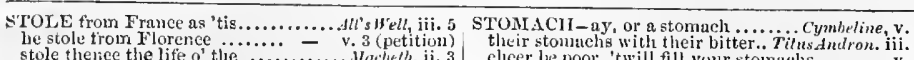
stole theriee the life o' thie Bardolph stole a lute wease... in Culitis theg stole a fire-shovel
he slity stole awny, and left his i manliood stole to Khesus' tent two years old, I stole these babes stole into the cuvert of the woorl....... Romeo s. Jutien upom my secure liour thy uncle stole...
from a glicif the precious tliadlem stole

that stole his master's daught
sToI.

SOI.EN-tlus be stolen alwa
for puddings he liatli stolen.

the other nutirrel was stulen from

hatli from nature stolen a man.

my stay' nuet be stolen out
Juve stolen his lird's nest

have a anre that your bills be not stoly

writ in my consin's hand. stolen tro

stolen the impressim of her fintasy
a lovely buy, stolen from an Indian.

a lovely buy, stolen from an Indi

they were stolen into this wood.

woill he have stolen away from sleepin:t -

they would have stolen away

God's my life! stolen hence, and left

stolen the seraps................... Lore's

rich theuts stolen from me..Mer. of l'enice, $j$.

a titir colcur, or expresscd it stolen mis $^{-}$ii.

Tranio stulen your elothes? (rep.). Taming of

or, villain, thou hast stoleu buth. Comedy of $E$. W

are stolen away and fled.

Worcester is stolen away to-nigit.... Inen ry $1 \%$. ii.

to say the trith, stolen from my ho

thon hast stolen that, which after...

was by a beggar-woman stolen away.

from Sevtlaud am I stolen $\ldots . . .$.
ne'er have stolen the breech from...

ne'er have stolen the breech from....
oidd ends, stolen forth of holy writ.

Cordius, stolen forth of loly writ.

stolen what we do tear to (rep.) Hervilus / $/ 11$. iii.

a composture stolen from general. 7 im on of $\mathrm{Ath}$. iv. 3

stolen name Coriolanus in Corioli?. Corio

why tave Jenu stolen upon us ...Antony \& Cleo. iii.

till they had stolea our jewel.

from tlicir mursery were stolen ........

being corrupted, hath stolen it from her -

good troth, I have stolen naing

yor.

and whel I have stolen upon these..

luth stolen him home to bed. .Romeo

Thomeo fuliel, ii.

is abused, stolen from me, and corrupted. othello i. 3

Just stolen it from her? No, fuith.........
senee liad $I$ of her stolen hours of just

robbed. not wanting what is stolen
S'IOLCST a cup of saek eighteen ...

STOMICII-an undergoing stomacl.

igainst the stomaeh of my sense

my stomae! is not con

kill your stomach on your meat. Two Gen.of $v^{\prime}, \mathrm{iii} .3$

eat when I have stomaeh.....

of his quick wit and his queasy stomach -

you have no stomaeh, si pritior.........

I shall do it on a full stomach .... Love's L. Lost, i. 2
your stomachs are too yourg
done, sir; they have all stomad......

it goes much against my stomaci.....

it goes much against my stomaci...s you Like it, iii.

old man loves money with no strmach

why, if you have a stomaeh to't $\ldots$...

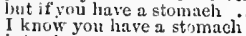

I know you have a stomacl

then vail your stomachs

stumaeh: you have no stomach,....... Comedy of Err. ...2

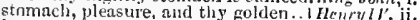

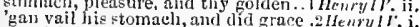
she either gives a stumach, and no food

not offend one stomach witla our. Hemry $r^{\prime}$. ii. (elo.) villany goes again-t my weak stomach

which bath no stomaeh to this figlit

nobles should such stmuachs bear!

how will their grudging stomachs be

so do your stonachs, lords.........2 Henry Y's. ii. I

goodness is poison to thy stomacli. Henry $\overline{5}$ ivi. 10

to arms, that hath a strmach ... Froilus s $\bar{C}$ ress. ii. 1

my little stomach to the war......... - iji. 3

where my stomach finds meat. Timos of dthens, iv,

gives men stonach to digest his....Julius fiasar,

wars, when you have stomachs.

if you must bclieve, stomach not all on o Cleo. ii.

stomachs'will make what's homely. Cymbeline, iii. elicer be poor, 'twill fill your stomachs - - v. 3

and sharpens well the stomach

answer trom a tull-fluwing stomach........ Lear, v, 3

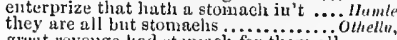

STreit revenge had stomuel for them all - v.

store be stomaphers to my heart f..Cymbeline, iii. ${ }^{q}$

STOMACH-QVALMED at land.... Cymbeline, iii.

against the bruising stones

he is a stone, a very pebble stone

i. 3

conld soften stelel and stone

a stone. And what is a stone, William? $\overline{-}_{\text {iv }}$ iv.

clear stunes [Col. Kint.-stories] towards

is more to bread that stone ........Meus. for Meas.

eracking the stones of the foresa

and this stouse, doth show that I

curst be thy stones for thit...

and see the holy edifice of stone ... 1 ier of

she hath the stones upon her ........

llis stontes, his daugliter, and his ducat

Orpheus drew trecs, stoncs, and flouds

sermons in stone, and good in

able to breathe life into a stone

slie brousht stune jugs .... Tan
urass, nor stone, nor parchimen

All's Well, ii

as ever oulk, or stone, was sound

not a counterfeit stone, not a ribaud
clide me, dear stone; that I may ...

wrought you, (for the stone is mine)

be stoue no more: approach

er's Tale, $i$.

toad, that under coldest stone.

those sleeping stones, thiat as a w'.

limito of yon lime aud stone

heraped from Ponfiet stones

ï.. iii.

make

and they were as eold as any stone ...Henry $\nu^{\prime}$.i. 3

is fixed non a spherical stone

as swift as stones enforced firom...

digged stones out of the ground....
stomes! stones! 0 my good lords

their pockets full of pebble stone

my heart is turned to stone ............

to lime the stones together............
beat the stones nbout thine arg

inestimabie stones, unvalued jewel ... Richard - v. 1

pity, you ancient stones, those tender
toolish sorrow bids your stones farew

a base foul stone, made precious by . $-\overline{\text { v. }}$

have worn the stones of Troy 7 roilin \& Crusida.

the fall of every Phrygian stone will

a word will Priam turn to stone

gives us dianomls, next day stones of Athens, i. 2

Ian sorry, I shall lose a stone by thee - $\quad$ iv. 6

and boys with stomes, in puny battle

you are not stones, but men 1 o......

and the twimned stones upon

sparkles this stone as it was won.

sparkles this stone as it was wont....
the stone's too hard to come by $\ldots . . .$.
spit, and throw stones, cast nuire $\ldots .$.
the gods throw stones of sulphur....
ii. 4
v. 5
v. 5

Jour sorrows to a stone (rep.) ...Tïus Andron. iii. t

and on the ragged stones beat

in vegetives, in metals, stone

more lard than is the stone wher

you are men ot stones; had I your

in herbs, plants, stones, and thei

[Col. Kut.] thy canoyy is dust and stones

Them.Hamlet, iii. 4

(sung)

no, my lieart is turned to stone

- iv, is (sung)

are there no stones in heaven, but est

STONE-BUW-O, fur a stone-bow. Tuelfti Night, ii.

STUNED-he shall be stoned ...Winter 'Tule, iv, 3

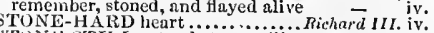

a stone. And whut is a stone ivilianery

does not the stone rebuke me (rep.)

this pred ofices, untrodden ston

I am not made of stone.

thy knee bussing the stones........... - Coriolanus, i. 1

and the tirst stuue drop in my neek $\quad$ ine ii. 11

as big as a young cockrel's stonc. Romeo of Juliet,
TONY - a stony adversary...Merchant of lence, iv. 1

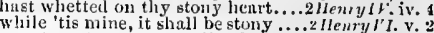
nor stony tower, nor walls of .........julius Cesur, i. 3 even like a stony image, cold .........Titus,t mironi. iii. which stains the stong entrance of ... Fomeo fuliet, it. STONY-STRATFORD; and at...... Richard 11i. ii. OOD-whiles we stood here seeuring. T'mpest, ii. Whose heads stood in their breasts?..

and thou hast strangely stood the test - iv. stovd it next to death $\ldots \ldots \ldots \ldots \ldots \ldots \ldots$. distant time stood, as it were.....Meas. for Mers. $\mathrm{ji}$. you have of late stood out against.... MuchAdo, $\mathrm{i}$. or else it stood upon the choice of.......

stood now within the pretty flouret's N. $^{2}$ Dr. 1 . then stood as fair, as any eoner..Ner. of Tenice, ii. that liave stood by, and geen our.... - iii. stood on the extreme Dido with .... and therefore atood lamely in the verse - iii. as she stood, with that (rep.).....All's Well, $\overline{\mathrm{i}} .3$ (aong) and thouglit I stood encared: but to

and idly I stood idly looking on. Taming of $S h, \dot{i}$. might thus have stood, begetting.. I'inter's Tale, $v$. thius gle stood, even with sueh........ I guess, it stood in her clinin.. Comedy of Errors, iii. doubtfully it stood; as two ............ Macbeth, it. whiles I stood rapt in the wonder -..... i. 5 (letter.) I stood and heard them; but they .... - ii. 2 that so stood out againgt the holy ..... King Jnhn, y. thus long have we stood to wateh .. Richart II. iii. an as the state stood then, was............ Ifenry $I V$. what terms the enemy stood on.......... Henry tho mieely urged, be stood upon...... the whole army stood agazed......... Heriry $r$, i. liny angry guardant stood alone........ I stood vpon the whist 1 , his forlorn... Henry $v$. in our voidling lobby hast thou stood $=$ iv. and stood against them as the hope..3 Henry VI. ii. I

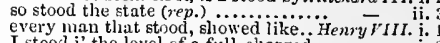
I stood i' the level of a full-eliarged - i. metliourth I stood not in the snile - - ii. 4 which my realms stood in by this.... We have stood here observing him that hath thus stood for his country.Coriolanus, ii. 2 when we stood up about the corn.... - ii. 2 yon liave stood your limitation...

no less than what he stood for

stood $\mathrm{np}$ tr speak of peace, or war.

when Mareius stood for Rome......

franehises, whereon you stood

you that stood so much upon niglit havd on eeremonies ....... - ii. 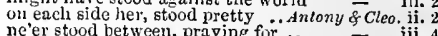 ne'er stood between, praying for .... - iii. she stood, and spake; I found her .. $\quad$ v tremblingly she stood, and on ....... this minion stood upon her ehastity - ii. 3 and stood between her and her fortunes $\overline{-}$ iv.

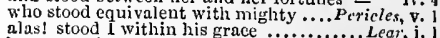
here stood he in the flark.........

opposite I stood to his unnaturai

shoutd have below, methought........ $=$ iv. 6

his lands, which he stood seiscd of...... IIantel, iv. 7

as a painted tyrant, Pyrrhus stood ........ - ji. where late the diadem stood

hath screened aud stood between much... - iii. 4 where each seeond stood heir to the first. o!nello, iv. 7 thongh onr proper son stood in your action - i. 3 STOOL and a cushion for the sextonl yuch do iit. 4 for three-foot stool mistaketh me...Mid.N. $s D r$. ii. Moldle with a three-legged stool . Taninis of Sh. i. I
all's done, you look but on a stool..... Alacbeth, iii. nnd push us from our stools

leap me over this stool, and run a...2 Henry $F I$. ii till he leap over that same stool .... - ii. thou stool tor a witchi...... Troilus \& Cressida, ii. I each man to his stool ......... Timon of Alhers, iji. when on my three-foot stool I sit .. Cymbeline.

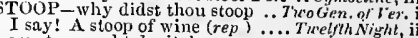
we stoop and take it, because...... Theas. for Mleas. ii. her body stoop to such abliorred pollution a golden mind stoops not to ..... Lovers L. Lost, i and, till she stoop, she must ..... Tamirg of Sh. iv. [Col. Knt.] makes his owner stoop ... King John, iii. I 


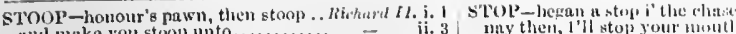
nutl nuke you stool? unto.

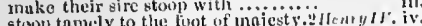
I will stoop and lumble my when they stoop, they stoop witi....... Ucur's $r$, iv. a strniglit back will stoon. on the king communds me stoop.... intenryl'r, iti. stnop then, and set your knee

I'll either make thice stoop....

wilt thoil not stoap?

dumted now? now will ye stoop? ....

ratiser let my heal stoop to the blec.

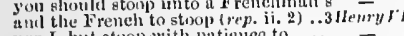

mor I, but step with patienee to ....

stool, Romans, stoop and let ( $(r)$.).Julins Corstr, iii.

humotir to stoop in sucli $\Omega$ cuse

stony, buys: this gate instruets .... Cy mbetene.
and inake him stoop to the vale .....

and make him stoop to the

at thy mercy shall they stoop and kneel -

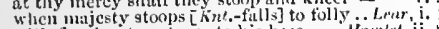

with flaming $t: p$ stoops to

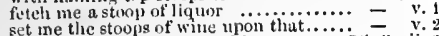

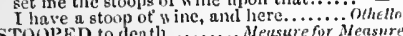

STOOPED to teath ........ Mensurefor Measure, v.

have stooped niy neck under your.. Ritharil II. iii. I

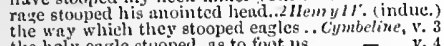

the holy eagle stuoped, as to foot $118 .$.
STOOPING-to most ignoble stoopiog .. Tempest, i. 2

as stooping to relieve him

if it be worth stooping for ......... Wrelfh wirht, ii.

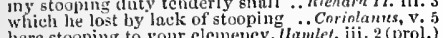

here stooping to your
s. $0 H^{\prime}$-there sir, ston

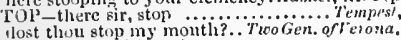

stop there; I'll have her
let me stop this way first

and so stop the air

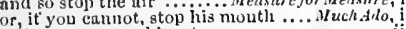
ancl now governed hy stops

pence, I will stop your

he kmows not the stop..........Mill.N.'s Drean
these be the stops that himder .... Leve's L.J.ost

these be the stops that himd

but stop my house's ears...

is no bar to stop the fureign.

come, the full stop his wounds, jest he do

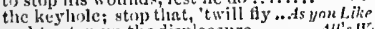

and to stop up thic displeasure...........A $\ell^{\prime} s W^{\prime} t^{\prime} l$,

you need not stoply gour nose (rep.). .

that stops ing way in padun.?

counsel had, shall stop, or spor me. ivinter

Bohemia stops his ears, and threatenis $\overrightarrow{\vec{r}}$

stop in your wind, sir; tell
I'll stop nine ears against

you stup our way with such.......

stop up the access and passnge..............

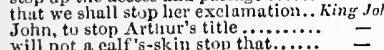

will not a ealf's-skin stop tha
and stop this gap of breatl

yea, without stup, didst let $\ldots \ldots \ldots \ldots .$.
to stop their marehes, fure we are....
so run on, and even so stop ..........

but stop no wrinkie in his .............

one kiss shall stop our moutlis

at that sad stop, my lord .......... i inenry $I r$. ii.

and stop all sight-holes, every lo

of all the word, must liave a stop....

which of you will stop the

to stop mine car indeed.

as ofter to stop it with security

which hezin to stop our very veins

nnd sir, do your mean to stop an

turn hear, and stop pursuit ........
stops the mouths of all tind-fuvits

heart doth stop' my enrnet

rexation almost stops my breath

tos stop effosion of our Cirristian b] ood

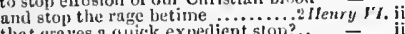

that eraves a fuick expentent stop?.. - iii. 1

with thy lips to stop my month

why stops my lord? shall I not lieii

and stops my tongre. While henrt is $=$ iii. 3

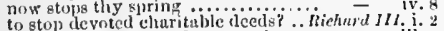
then aguin begin, and stop again...

untired, and stops he now fur breuth

to stop all hopes, whose grow

stops on a sualden, looks upor

stops on a surdaen, looks upon

....ieny $\bar{t}$ thl. iv.

but stop their moutis with stubi..... - iti. 2

will stop the eye of 1 [elet's .. Troilus \& Cressidn, ii. 1

of comiscl: stop my month ............. - iii. 2

hinder me, slioula stop my way...... - v. 3

nin eare, no stop! so Renseless... Timon of Athen

whoso pleas the nouth.

ii. 2

wholl

Con iolunus, iii.

and stop those maims of slinus.

to stop, to rut directly on ............ Juilius Cursur. iv.

may they stop their nose. Antomy \& Cleopalra, iij. I

nnd send to durkness all that stop ine
what both you spur und stop ........ Cymbeline, $\mathrm{i}$.

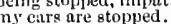

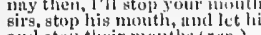

ami stop their months (rep.)......

he'll tup the course by which.

what! do you stop

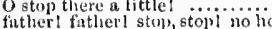

fitherl fathel stop, stopl no help? $(r / p)$.
stop her therel arms, arme, sword, tirel.

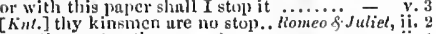

stop there, stop there (rep.) .............

stop thy unluallowed toil, vile $\ldots \ldots . .$.
stay anil speak: stop it, Niarecilis

to sound what stop she $p^{3 l \text { lase }}$

look you, these are the stops .......

yout woulal seem to know iny atop

minht strp a hole to keep the wind uwuy $-\vec{y}$,

jet's teach ourselves that honourthlic stop -

sueh an answer would stop them ail
therefore these stops of thine tright me

heaven stops the nose at it .............

imperiments than twenty times yoir stop -

being

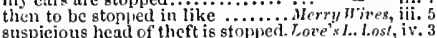

suspicions head of theft is stopped. Love sl.. l.ost, iy. 3

her ear is stopped with dlust

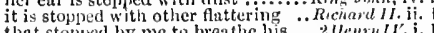

what stopped by me to breathe his....2 Ilrury IY'i. I

may readily be stopped

lasth stopped the passage where thy...3 Henry $r i$. i. 3

I have not stopped mine ears

[Col.Km.] flod stopped in my o...il... Riehard $11 \%$. i. 4

villain stopped .....

which stopped onr mouths.. Lenvy ïill. ii. 2 (letter)

he stopped the flier $\ldots \ldots \ldots \ldots \ldots \ldots$ Coritumus, il. 2

like an oven stopped, doth burn.. Tilus Jutron. ii. 5

which now arc midway stopped .......... l'ericles, y. 1

of my sun's exile hath stopped ... Rnmeo \& Jutiet, v. 3
no, his mouth is stupped, houest Iago .. Othello, v. 2

indeed, these hanits have newly stopped

stopping my greedy car with their...2llenryl\%'i.

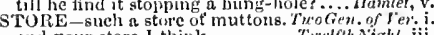

nind your store I think

thint to your hnge store wire........ Love's L. Lost, v.

I have better news in store for you .. $\overline{\text { ind }}$, v. I

lie bade me store up, as a triple eye ...Ali's II'ell, ii.

aid me with that sture of power.

grent store of wedding eheer .... Taming of Sh. Hii. 2

that thou call'st for such storc.. Comedy of Err. iii. 1

I would, your store were here

a pound of mine own proper stor.

1 Hewry $1 \mathrm{~V}$.ii. 2

nor store of treasons to augment

with store of childish drops...................

have any grievous plague in 8 to..... Richard III. i.

(ve shall have great store of room ... Henry $\vec{F} I I$.

an hour's tnlk good, and good store.

1 do appoint him store of provender...

we have store to do't, and they... Antony \& Clen. iv. 1

nothing doubt, yolt liave store
sons of mine hast thou in store.

sons of mine hast thou in store...

proclaim what store her heart is made of: L eir, iij.

witlt beauty dies licr store.......... liomeo of Juliet, i. I
and you among the store, one more...

would store the worli they played for... Ohello, iv,
STORED-king so stored with friends. King John,

they say, the eity is well storel.

no one fuult, but stored with all

this glorions casket stored with
their tables were stored full.

are storel with corn, to make.

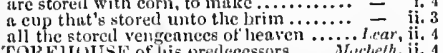

COJELIIUUSE of his predsecssors

locense I am the storchouse, ant thic

to give forth the corn o the storuhouse - iii.

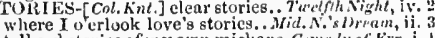

tell sad stories of my own misliaps. Comedy of $\mathbf{E r r}$. i. !

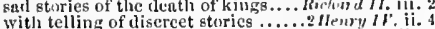

Fo rearl with thee sal storic's.. Tilus.dudronicus, iif. 2

for raising this sea storm?...

aud another storm lrewing

the storm is come again? $\ldots \ldots \ldots . . .$.
till the drcgs of the storm be past?

it the storm over-blown
for feur of the storm

a................

1 will move storms, I will conlole... iid $\mathrm{A}$.

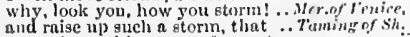

cirvusing to his mates atter a storm - iii. ?

to wateh the niglit in stornm, the deny $\overrightarrow{\vec{b}}$, $y$.

still winter in storm perpetital

the storm begins; poor wretel
seafaring meu provide for storny. Comely of Err. i. ]
TOlRM-mhi

chara not without as storm

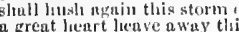

bint sudilen storms are short

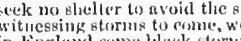

in lingland some black etorm
stoof ision the liatehes in the

stonl worn the liatehes in the st
resciver! to benr a greater storin

jis leaves in spite of any storm

bering a sceond storm to rise

"yainst foreign storms than any

king lidward inl lia time of sturin.

every clond engenders not a storin

untimely storne make men ex
swell before a boisterous storn

Grow is terrible sturm that

an old nutu, troken with the.........

when the sum dothi light a storm. Troilus \& Cress i i

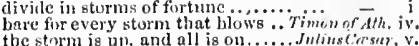

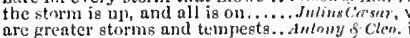

the discanlying of this pelieted sturm

for our reposc, shall hear a storm.... - iv.

here are no stoms, no noise, but... Thus sudinn. i.

with a liapy storm they were surmisad =

one hour's storm will drown ........ = ii.

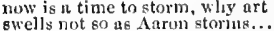

or grass beat down with storms.

thon, storm, thon! venomously wilt

do not ussist the storm: here's all......
is like n lasting storm, whirring .......

to rain, and leave thee in the storm
let us witludraw, 'twill be a storm

counscls well: come ont o the storm
fie on this storm! I will go seek

contentious storm invades us to thic
bide the pelting of this pitiless storm

the sch, with sucht in storm as his bare....
the last niwht's storm I such a fellow sow

what? i' the storm? i' the night?

kinsman? wherefore storm you so?
what storm is this, that hlows 80

ngainst some storm, a silenee

vinence and stor'm of fortunes............ onhellin,

if yoll give o'er to stormy passion.

a torbulcnt and stormy night

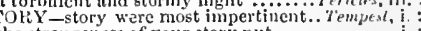

the strangencss of your story put

a most strange story

the story uf my life ond the

I long to hear the story of your life.

the story of your loves discover

painted about with the story of ... Mierry Hires, iv.

sir, niake me not your story ..... Me'ts.
who lath a story ready fur your car

to twist so fine a story?

8lie liere deny the story that is lyriti
the story sliall be changed

gays the story, din talk tlirough

but all the story of the night
to tell this story, that you

which makes her story true...

the story then goes fnlse, you thre

from point to point this story know

acgins his morning story right ........

thy story quickly, Gracious my loril.

it appears so by the story
or the story of the prodital

author will continue the story

this story shall the good man

thin hine not thed the stery....

tell'st the lieny story right.

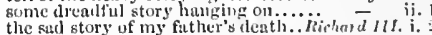

as index to flic story we late

very persons ol our noble story......... Henry r $\overline{l l}$, (proi

(tis an old stery, ) that would not be

I fear, the story of his anger

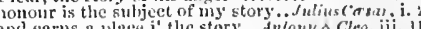

and their story is no less ln pity.......

rather than atory him in his
and the contente o' the story

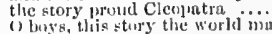

bis mirits fly out into my story.

demand the of thy story, so f

the story of that hateful liurning....Thus.tudron. v.

teneh you the stages of our story - iv. I(iow.)

intorn homest humse, our story singe

tell thy stury; if thine consics
to the buttoin of your story.

fir the lneks in the golden stinly... Remeo of fulicl, $\mathrm{i}$. 3

fo fortificd ugainst our story............. humlet, $\mathrm{i}$. i

the story is extant, and written in very.. -
thy breatl in pait, to tell my story .... 


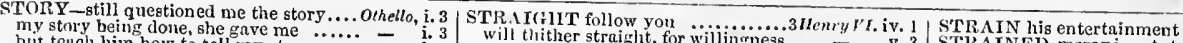

but tench hing dowe, she gave me

Ingo beckons how to tell my story.....

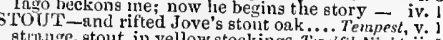
strunge, stout, in yellow stockings. Ticelfin. Nithht, ii. 5 his waser in the stont Norwey

his oWner stuut [Col. Knt .-stoop]
dreadful pomp of stout invasion!

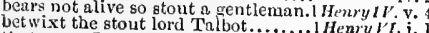
thut stont Pendrugon, in his lit

tlie stout Parisians do revolt

of (iall, and proud, as he were lord...2 Henry

that us Ulysses, and stont Diomede..

aise stout eaptain, and persuaded. - iv my hardy, stout, resolved mates? .. Richard III i. plnck stout men's pillows from. Timnn of thens. iv. hiss, correcting thy stout heart.... Coriolonus, iii. part them. whs stout Tylualt slinin of Juliet, iii. STOU'TER clampion never .......

his bark is stontly tinibered....

3 Henryl

FOU'TNESS_-dangerous stmitness.

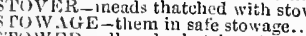

safely stowed, but soft, what noise?

Where last thou stowed my daught

Tempest, i.

Hamlet, iv. 2

STlRAGGLER-whip these stragglers. Richard IIt, v. 3

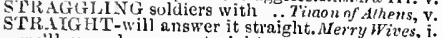

we'll come dress you straigh

go, send for Falstafi straight

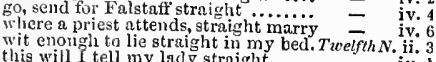
lets it straight teel the spux ....... Meas. for Meas. iv.

tos be most straiglat in

he will come straiglit

I will be with thee straighit.......Mid. N.'s Dream, iii. 2 my servant straiglit was mute.......... Love's $L_{\text {. L L }}$ iv.

lo, le is tilting straight! .............

he falls straight a capering

I will go and purse the ducats straight -

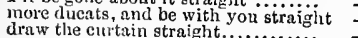

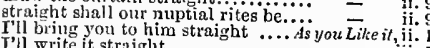

into what straithts of fortune slie is...

is to know straight our purpose.......All's $W^{\prime}$ ell, ii.

straiglit, and with a low. Taming of shrew, $\bar{i}$ (induc.)

we will fetch thee straight, Adonis -2 (induc.)
like the laazel-twig is straiglot

grumble? I'll be with you stroight...

and let us straiglit to him...........

bid Biacca make her ready straight...

straight the shrug, the hum, or ha. $w^{\prime}$

he straight declined, drooped, took it

take it up strat

straight, obedient to the stream... Coinedy of $E$.

put ont, then straight away
villain, hie thee straight

bear it straight; and bring

straight after, did I meet lit

!l call upon you straight.

did he not straight, in pious rage...........

requests your presence straiglst...... King $J o h n$, it. I

and you are so straight

straight let us seek, or straight we shall

I'll finr refuge straight to Bristol $\ldots$

command a mirror hither straight

ransom straight his brother-in-law..1 Henry

witlont their ransom straight

I will bnck him straight

you are straight enough in the shoulders -

yet straight they shail be here

and some straiglit decrees, that lie...

wilt thither straight, for willingnes
Oxford? to I lammes' castle straight

abuut your business straight...

you straight are on your $k$ nees ........

that straight shall post to Ludlow...
firr by his face straight shall you know

r'll signify so much unto him straight

you must straight to Westminster

I will despatch it straight............

straight to stop the rumour ...........ienry $\bar{V}$

straiglit, springs out into fast gait....
go we to him straight ........ Troilus \& cres

she'll come straight $\ldots . . . \ldots \ldots \ldots . .$.

travels in a straight so narrow...............

let us make ready straight

his credlent it struight starts you

it foals me, straight, and able horses

then straight his doubled spirit ....

and straight disclaim their tongues?

put him to choler straight

will I straiglit to visit him .....

e must straight make heal

a hasty spark, and straight is cold again
thant thon wilt kill me straight

whither straiglit $I$ will lead you.

I'tl bring thee word straight...

but, to owe such straight arms ...

that the straiglit pass was damme...

make a fire straight
should and with ..... Tilussandron

straight will I bring you, or else die

home enough, and tis there straight

and snatch them straight away?

but straight must cast thee scarcely.

arench it open straight; if the sea's 0.

their meiny, straight took horge

I will arraign them straight .................

none o' the best: I'll tell youl sti.:
I'tl see that straight. That from
I beseeh Fou follow

,you, follow strajght.... Romeo \& Juliet, $\mathrm{i}$.

o'er ladies' lips, who straight on kisses

by her fine foot, straight leo

county will be let straight at any news -

county will be liere with music straight

it would dispatch Fou straight

aud bring it straight unto my cell

be will come straight; look, you lay home

will be with you straight

straiglat satisfy yourgelf: if she be in....

I will come to thee straight.

a little while, he will recover straight...

heaven and grace, solicit for it straight

STRAIGHFED for a reply to.... Winter's Tale, iv.

STRAIGHTEST plant

STRAIGHTLY given in charge ..... hichurd IIi. i.

STRAIGHT-PIGH'T Minerva
STRAIGHTWAY et liberty

waked, and straightway loved an ass

and straightway give thy soul to way?

like friends, will straiglitway go ... Julius Carsar iv.

to the sea-side straightway .... Anlony \& $\&$ Cleo. iji. 9
art straiglitway with the fiends.

TRA I N of strutting Chanticlere. Tempest, $\mathrm{i} .2$ (song)

un would, all of the sume strain were in

that strain again: it had.

he is of a noble strain, of ajproved . WinchAdo, ii. 1
strangely they strain the cure

let it answer every strain for strain.

love is full of unbefitting strains.. Love's L. Lost, v.

and strain their cheeks to idle......... King Lou

you struin too far; 1 , ratlier .......... HenryI I . iv.

my thoughts to any strain of pride.2Henry $[F$. iv. 4

when he strains that lady

make no strain, but that $A$ chililes Trailus \& Cress. i. .

so degenerate a strain as this.

I do liot strain at the position

the struin of man's bred out
praise his most vicious strai

and strain what other means is left

affected the fine strains of honour - v. 2

touch thy instrument a strain .... Jalius Cons, v.

wert the noblest of thy struin...

sweats, strains his young nerves...... Cymbeline, iij. 3

Onoble strain 10 worthiness of nature! - ii. 4

have shown to day your valiant strain ... Lear, v. 3

a man may strain curtesy..... Roneo \& Juliet, ij.

strain my speech to grosser issues....... Olhello, iii.

nuless false Suffolk straight be done to - ii.

and write bome for it straight ....... I have strumed, to appear thus.. Winier's Trie, iit. struined passion doth you wrong...2Henry $l \%$. $\mathrm{i}$. love thee in so strained a purity. Froilus 8. Cress. iv. and with strained pride, to come betwixt.. Lear, iv.

4 t rained from that fair use....... homeo o juliet, ii. TR AINING-more straining on. H'inter's Tale, iv. 3
in the slips, straining upon the start..Henry $f^{2}$. iii. in the slips, strnining unon the start..Henty $F_{\text {with }}$.ii. 1 straining harkh discurds......... Romen \& Juliet, iti. knees he kissed the Cretan strand.. Tamaing of Sh. $i$. STRANGE-by acident of Strand.. Heriry I'lll. v. 3 in to something rich and strange.. - . Tempest, $\mathrm{i} .22$
what strange fisl 2 (song) what strange fish hath macle

what a strange drowsiness posesses them
this is a strange repose, to be asleep......

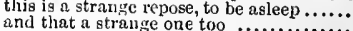

any strunge beast there inakes a man....

misery acquaints a man with strange....

gnod life, and observation strange.

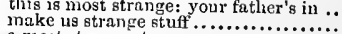

a most strange story

they strengthen from strange to stranger

with strange and several noises ...........

as strange $a$ thing as e'er I looked on...........

she makes it strange ........ Tuo Gen. of verong v.

strange things in liand, thing of this...Merry Wives, $v$.

this is strange! who hath got Brook 1

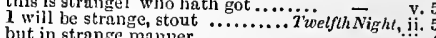

this is strange mamer ............. - iii.

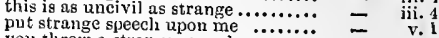

yout throw a stranife regard upon me
thy complexion shifts to strange. Meas. for $\bar{M}$ e

upon him, sir, a strange pick-lock

the signet is not strange to you
receives letters of strange tenor

I should not think it strange $\ldots . . . \cdots .$.

most bitterly, and strange. Most strange -

is it not strange? that Angelo's a (rep.) =

nay, it is ten thmes strange......

be is sick, my lord, of a strange fever

this is a strange abuse .............

just so many gtrange dishes .......

is it not strange that sheep's guts should

there is some strange misprision

dreain $I$ on this strange conrse

fur to strange sores strangely they

is not that strange? As strange as the

some such strunge bull lcaped your.

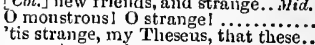

tis strange, my Theseus, that these...
more strange than true ...............
but, howsoever, strange, and admirable

but, howsoever, strange, and admirable -
and wonarous strange snow..........
one of the strange queen's lords... Love's $\overline{L . L}$

one of the strange queen's lords... Love's $L$.
moon-like men, of strange inconstancy

with some strange pastime solace....

opinion, and strange without heresy

this begging is not strange ...........

"lath framed strange fellows... Merehant of $\overline{F e}$

so strange, outrageous, and so variable

of a strange wature is the suit you.....

by what strange acciden $i$ I chanced...

rua into strange eapers .............. you Like

full of strange oaths, and bearded like

that ends this strange eventful

what strange effect would they work - iv. 3 jut.

a pair of very strange beasts

impossible be strange attempts........... Alt's Well,

nay 'tis strange, 'tis very str'ange
strange is it, that our bjoods

is not this a strance fellow

lot, $O$ strange men! that cain....

why ao you look so strange npon.....

beateu laeem strange unto. Toming of Sh. I (induc.)

will you be so strange? sorry am I.. -2 (induc.

that with a wife, were strange

this is strange!....................Winter's $T$.

a by strange furtune it came........ - ii.

and show our strange sights........... - iv. 3

still $t$ is strange, lie thus should steal $-\mathrm{v}$.

ook straoge, and frown the one ... Conged

being strange to me, that undividable

the reason of this strange restraint...

why, this is strange; go call

lave written strange defeatures in....

you owe this strange intellige........

did'st make strange images of de?

but 'tis strange; and of teutimesth

whon lim like our strange garments
1.
1.
.
.
1
1
1
1
1
1
5
5
4
1
1
1
1
2
2
2
6
1
1
1
1
1
2
3
3
3
2
1
1
1
4
1
1
1
1
2
3
3
2
2
1
8
1

iv. 1 3 


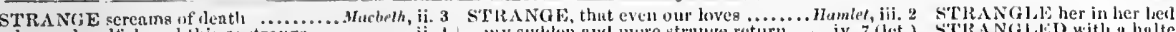
hours dreadrul, tuul thiug a straige a thime most strange nhat tertmin......

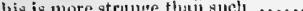
- if. I my subletin ast mure strume returi

'twas strange, 'twas passing strunge .... Othello, i. 3 this is more strunge than s

strangel crery inostriste cupis until

lunt's strunge. I clurst, wy lord, to wager

you ruake ine strange even to the.

my strunge and selt-uluse is the

with this strange virtue, he huth

TIANGE-DISIMstio time

PliANGELY - vanished strangely ...
aul theu hast strumely stoxl the tegt

tis strunget to think how inneli........

aul thou hast stratnely stowd the teat
who most strangely, upon this gloore

[Cnl. Knt. $]_{8 t r o n g}$ retsons make stra]

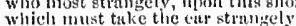

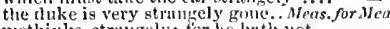

nethinks, strumgely; for he lunth not

O misehief straligely thwarting! .... Afuch de, iif
to strange sores, strumgely they strain - iv.

tis strange, thut dentlishonlal sing
is a strunge bronch in this all......

in thy toce strange metions

comnend it stringely to som

but strangely visitul people

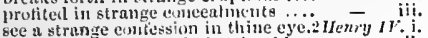

is it not strange that desire sliould

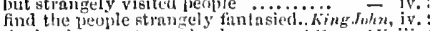

his eompanions, like a strange tonghe

the herds were stranguly elamolous. I fenry

tis so strange, thint, though the truth.. Iten'y $F^{r}$. ii. lort Strange of Blackmere.

or at lenst strangily neulected?
most strangely. 0 how, how?

woven so stringuly in one piece.

'tis wontrous strange, the like yet ...3 Hen

yol'd think it strange if I should mury - - iii. 2

now are altued strangely with ine

you are strangely tronlisesome to.....

it is a day turned strnugely

this is strange to me. Ilow tastes it?

a strange tongne makes my carrse $\left(r^{\prime \prime} \mu\right.$. $)$

sume strange emmotion is in trange postures we have seen

or lave we some strange Indian, with

dugiged with two strange followers. Troin
set lie loves himself: is it not strange?

or strange, ur self-afficted?

like a strange goul upon ..............

triumph, strangely furnishet....

TuANGLAD with a halter
shmll le st rangled on the gut

Othello, in.

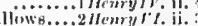

he hus rtrangled his language

atrunglet ere my humco con
STIR N

STRANGI,ING a smake.

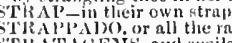

ThATCGEAls, amb howils

think your nysstery in strutugen

and to say, it was in strutare

it will be un excellent stratage

When without strutagem, hut in l, laill. Hem
Denuis bless this hapjyy gtratagen! I Hewry

to tatir thee in strntarem

any time, to graee my atratugems.. Fichuri Mll. ii.

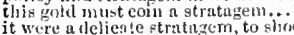

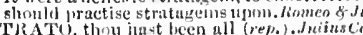

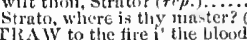

very strungely, they say (rep.)
STRANGFNES of yom story pit

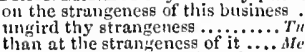

the strangeness of his al tered

the strangeness of his nl tered ........ Henry $r l$. iii.

betwcen your strangeness and his

this is ahove all strangeness............. Lear, jv.

a strange fellow here writes
this is not stranire, Uig-s

miny see itsulf: this is not strange at all

a tight of this strange nature

what strange, which manimbli... Timon of

STRA in strangeness stand no further

Oihello, iil.

Wow to observe a strange event

mark, how stralige it show

strange, anusual blood, when inals's

fortmes am unlearned and strange.;

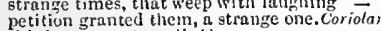

petis is strange (rrp.ii. I)

youth are a puir of strange ones........

tell you most strange things from Rome -

a strange one as ever I looked on ....

tell my master what a stran

here's a strange alteration: ............

to see the strange impatienee

as these strange eruitions ar.

have seen strange sights ...........

iliat, inethinks, is strange.

they strengthen from strange to stranger

and already you are no stratim

which to a stranger, unguided

tranger [Col.strange] companies...Mrid.N.'s Dr. i.

a strnnger Pyrain us than e'er play'ed

what would these strungers? know their
sinee you are strangers, and eome here

the four strangers seek for you ....Mer.

Neriasa, cheer yon stranger; bid her

the commolity that strangers have with - iifi.

she is dead, and by strange manner..

for he hath laid strange courtesies

from the barge a strange invisible ...

tluere's strange news come, sir ......

is't not strange, Canidius, that from
strange, thut his power sliould be...

strange, that his power sliould be...
of nothing strange abont the streets?

ay; is't nut strange? Do you he
give uff: Content: 'tis strange

all strange and terrible events are

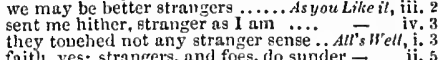

faith, $y$ es: stranger's, and foes, do sunder -
band of strangers $i$ the adversary's..

you walk like a stranger...... Taming of Shrew, ii. I

being a stranger in this city here.....

thus strangers may be haled and abused
we being strangers liere ..... Comedy of $\bar{B}$
take the stranger to my houge .......

take the stranger to my hous.

that he was a stranger here

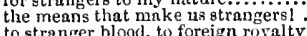

after a stranger mareh upon her .... KingJohn, v.

the stranger paths of banishment $\cdots$... Richard $I I$.

$O$ had it been a stranger, not my elild

and strange it is, that nature must

to vie strange forms with fulley
how soc'er 'tis strange, or that...

I am a stranger here, in Glostershire - ii. 3
to make us strangers to his looks .... HenrylV i i. 3
strangers in court do take her fur ....2 Henry VI. i. 3

there did greet my stranifer sotil

needs deserve all strangers' loves

Richard lll. i.
Herry llil.

loth think, she las strange lingering

he is strange and peevish

I am something eurious, being strange

he's a strange felluw himsetion.

Wet still it's strange, what cloten's being

Yis strange: nor hear 1 from $m y$.....

this was strange elance, a narrow

fuing on ugly munster, 'tis strange... -

after this strange starting trom your orbs -

thus in this strange and sal hubiliment

ti) runinate strange plots of dire.

'twas very strange. And yet but just ...

is not this strange? Nost rare......

his uffuce, honcity! atrange! strange!

[Knt.] $U$ strange and fastened villain!

Ihave liearl strante news. If it be true

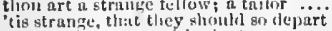

the url of our weessities is strange

hliere is some strange thing towar

blie gave strange coiliarla, and inost

strange nuture. ... Romeo \& Jntiel,

more cunning to tre st range ( $r m p$.).

aflicted with these strange flieg......

strangedrean! that gives a detud man

'tis strunge. This, twice before .........

lookes some strunge eruptim to our state -

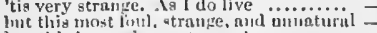

how strange or ould secer I bear nibself

it io sut very strange: tor my uncle is ..

poor ladyl she's a stranger now again

to be acknainted with this stranger..

how may a strunger to those.. Troilus of Cressidn,

we ure bint strangers to hity ......... Cymbeline, $i$.

I thank him, makes no stianger of me -

none a stranger there so merr

a saucy stranger, in tis eont

Who told you of this stranger? $\ldots . . . .$. .

by a strunger? no: he hathi, enjoyed lier - ii.

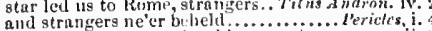

he sems a strunger; but his pre ent

vudo a stranger knight to lie so bold

ghe'll werl the stranger knight, or never

and your affeetions on a stranger.

Where $I$ am but a stranger ............

my child is yet a struiger in the world

the strangers all ure grone ........

as $n$ stranger give it weleome ..........Hanlet, i

nill extrav his ear a stranger to thy thmughto - ii .

TRANGERLD with our oath, take her idfar, i.

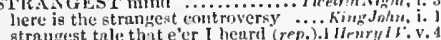

strow your graee the strungest siglit. Henry?lll. $\mathrm{v}$

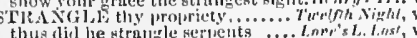

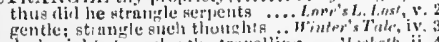

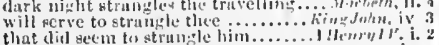

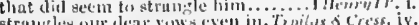

I hear his straw rustle ........

pipe on oaten struw:

no! life. I prize it not a stra

and stu1t me out with struiv

for oatlis are straws ..........

a wisp of stritw were worth

eurn, then after burn the siraw

where is this straw, my fellow?

a ligny's straw doth pieree

not selmate the question of

not delinte the question of this straw.. Hamtel, iv.

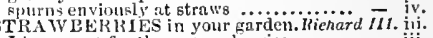

handkerchief, spotted with stra wberries. Othello. iit. 3

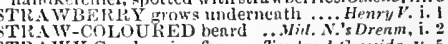

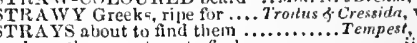

whom thus we stray to find............

hy many winding nooks he stray . H $\bar{Y}$ ii. 7

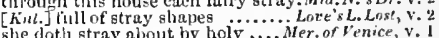

she doth stray abont by holy ........... Richard li. i.

pursue the seattered stray...

and impounded as a stray.

comes to reize me for a stray.

clo - iv. 10

and if Jove stray, who dares say .......... Perielrs, i. I

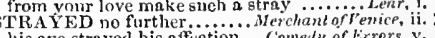

his eye strayed his aftuetion .. Cinmedy of Errors, $v$.

STRAYING from the way.

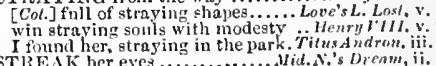

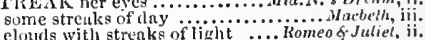

elourls witls streaks of light .... Komeo of Juhet. ii.
what envious streaks do lace $\ldots . . . .$.

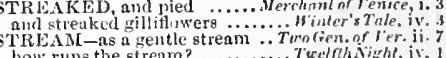

the very strenm of his life............ Heas. for Meas. iii.

with lacr gollem oars the silver strenm, Wuch dido, iii. I

gollt his galt-green streams.....Mid....'sDrenm, iii

golden, glittering streams, I trust to

all her spiees on the stream
my eye slinll be the stream

weeping in the iti.

to furswear the full stream ot ......... - iii.

by the murmurimg ntream left on your II's $^{2}$ iv.

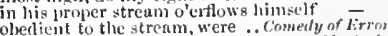

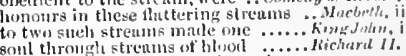

sont througth streums of hlyor

from whene this sitean through

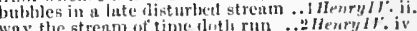

way the stream of time rlith ry

as mnny freslo stremms ruy in one self . Ileny, $r$ i.

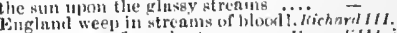

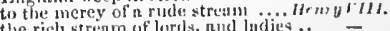

ont the stream of his dispone .... Trnilus f- 'ress.

gainst the stream of virtue the... Timon of .f's. iv

hefore the stresm o' the people

till the lowest etreain sis kins

us fast as ther strem finth thy hikend - it

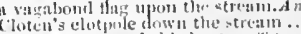

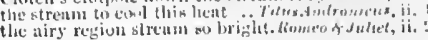


STREAM-leaves in the giassy strenm.. Hamlet, iv. 7 STRENGT11-and not our strength ... Ienry $V$. iv. 7 sails freely, buth with wind ind streain. ot

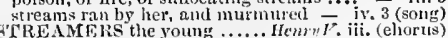

STREAMING the ensign of............. Rirhnre 11. iv.

THEE'T-hard by, at street end ....Merry Wives, iv. 2

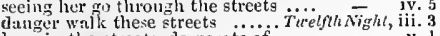

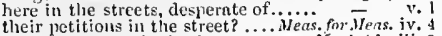

also malke no noise in the streets.....irnch dito,

if the streets were pared

the street slwull see as she waiked . . iv. 3

Jew did utter in the streets........... of ii. 8

he met the duke in the strect.........

are not, in the milst of the atreet?

my master stays in the street. Comedy
when in the streets he meets ........
tull her, I am arrested in the street..

he hurricd throurly the stree

in the street I met lim

from forth the streets of Poinfret.........ing John

in the streets ilo prophesy upo

dead, and east into the street
when I bulield in London st

the other day in the street ..........

Richarl It v.

a eomnanion io the emmmon streets
lic lath done about Turnbull street

and burquet in the open streets

Itenryrt. i. 6

she curlure the flinty streets

2 Hemryri.i.

ride in trimmph throngli the st

will we ride through the streets......

lurding it in London streets, crying.

iv. 7

dissentious numbers pestering streets

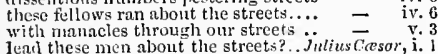

great Pompey pass the streets of Pome

walk up and down the streets..

no stir, or walking in the streets ....

from the streets of home the Trirguin

did sluriek, and squeal abo

here the street is marrow

urge you your petitions in the street?
moelaim, cry it about the strcets....

gis yon in to the other street, and part
thirough the streets of Rome? .........

we'll wander thro' the street.

to reel the streets at noon
forty paces througla the polit

foring strimge abnit the street. .

set the dogs o' the street to bay me... Cymbeline, v.

the streets of 1Rme (rep. iv. 4 and $\mathrm{v} .2$ )

to strets of queen kneel in the streets.

strewed herself cven in the streets

the quiet of our streets (rep.) ....Rnm

forbid this bandying in Verona streets

beg, starve, die i' the streets, for : ...

the peryle in the street cry-Romeo
squeak and gibber in the Roman streets.

proclsim him in the street: ; incense... othello,

fuith I must, slie'tl rail in the street else

what strength I have's mine ow.1.. - (epilogue)

by strength drives out anoth
what youth, strength, skill

adviee my strength ean give

it is exeellent to have a giant's strength $\overline{-}$ ii. 2

thy threats have no inore strength. Mid, N.'s Dr. iii.

and he liad an exeellent strength. Love s L. Lost, i.

to try with him the strength of ... As you Like it, i.

the little strength that I have

a char'ge too heavy for my strength.... All's $\bar{w}$ ell, iii.

of what strength they are a-fost... - iv. 3 (note)
strength as weak, our wealsness...Taming of $s h$. v.

I have got strength of limit.......Winter's $T$. ale, iii.

and ampler strength than most have

and ampler strength than most have

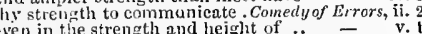

yout lo unbend your noble strengil

our eastle's strength will laugh

slabl help to give him strength.

dissever your united strength

thy fortine, and thy strength

with all religious strength of sacred

二 $\mathrm{v}$.

your sinews to the strength of mine.

KingJohn, ii.

hath left thee so mueh strength .... Rirhnral sr v.

strength, gives, in your wenkness, strengtli -- it.

not with such strength denied

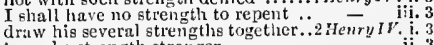

to make strength strouger
to his furmer strength ma........

we want a little personal strength
put the workd's whole strengtl into one

put the workd's whole strength
that strength of speech is utter
according to your strength

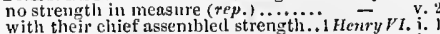

Where is my strength, my valour

sincern thy strength....................

what is the trust or strength of foolish

seven walled towns of strength .......

princely leader of our English strength

to try' his strength, fursaketh yet
Ireland cone I with my strength

and was by strength subdued

my strong-knit sinews of their strength

nor strength to holk out flight.....

unless my land and strength eoild.

or than for strength and safety of our

my want of strength, my sick heart.

give more strength to that which hith

assistance, and your strength, must by
and his rash-levied strength ...... Rich

the greatest strength and power he
the king's name is a tower of strengti

skiltal to their strength, fierce to. Troilus

stands, not in lier stren

the lioly strength of their eoinmand.....

a wroof of strength she could not publish -

they stand in their ancient strength..

thy eomintry's strength and weakness
is all the poliey, strength, and defence

strengtlis by strengths, do fail.

with more strength than thou hast

retentive to the strength of spirit

the liated, grown to strength

our strength is all gone into lieavine...

that possible strength might meet...

that possible strength might meet....
put the strength o the Leonati in ne.

renew thy strength ...................

led my eountry's strength sucessfuily

struel: home to show my strength.

nor I no strength to climb without

sn much strength in us as will reve

Whose wisdom's strength ean bear it.:.
scarce strength left to give them burial

conterring them on younger st

to descry the strengtir o' the enemy

friendly haud put strength enough to

gives strength to make it fly $\ldots$. Rom
fill, when there's no strength in men
hast the strength of will to siay thysel
love, give ine strength, and strength

love, give ine strength, and strength
if you had the strength of twenty men

with all the streagth and armols

and strength, and means, to do't
STRENQT'LN from strange to

in arms you strengthen it with yours Kiner

poliey strengthen thenselves $\ldots . . . .3$ Henry $r i . j$. 2

to strengthen that holy duty ....... Hertry $\bar{r}^{\prime}$ III. v. 2

to strengthen that impatience ...... 1uliusCassar, ii. 1

and the gods strengthen thee! ....... lericles, iv. 6

strengthen your patience in our last.... Hamlet, v.
STRENGTHENED with what apology.All's "'ell,ii.

strengthened by interchaogenient $\%$ Felf $/ \mathrm{N}$.
kind reds are mightily strengthened.2 Henry $\mathrm{W}$. .

would more hightily strengthened.2 senry 1 . ji. 2

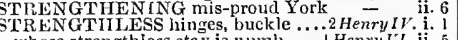

whose strengthiess stay is numb .... I Henry rl. ii.
STRETCH-dare no more stretcli. .ileas. for Mleas. $\mathrm{v}$.

did streteh his leathern eoat $¥ \because \ldots$. . As you Like it

what! will the line stretch out...
so far as my eoin would stretch.

ho far as my coin would stretch

stretch the nostril wide ................

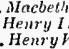

come, streteh thy ehest, and let. Froilus \& Cress. iv. 5

the preeipitation might down stretch

may well stretch so far, as to ........ Julius $\overline{\text { Car }}$ snr, ii. I

ahmost stretel the sides o' the world. Cymbeline, ii.

that stretch their dittes nicely .......... Lear, ii

of this tough worid streteh him out longer -

I stretch it out for that word..... Romeo o Juliet, ii.
STRETCHED His yoke ........Mid.N.'s Dream, ii.

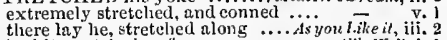

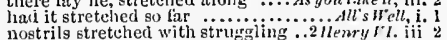

nostrils etretehed with strusing..2ichnly $r$. ii

stretched him, and, with one hand...leary $F^{\prime}$ ijt.

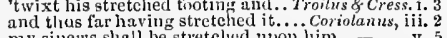

I in conquest stretched mine arm...JuluesCasor, ii.

and our best means stretehed out .... . re icles, $\mathrm{v}$. aud spend all the strength thou liast

i' the riglit and strengtlio' thie common

what's lis strength by land

wrestle with you in my strength of love

here is the guess of their true strength
STRETCHED-OUT life ...... Trouins \& Crassida, i. 3 and it atretelies beyond you and it atretches beyond you .........Ienry VII, $\mathrm{j}$. STRETCHING of a span. As you $L$ ike it, iii. 2 (verses) MTRETCH-NioUTHED ruscal .. Winfer's Tule, iv, TRE IV good lack, oughes, sh1...... Merry Wires, v.
sweet friend, to strew lijin o'er... Winter's Tale, iv. sweet friend, to strew hiin o'er...Winter's Tale, iv.
for it shall strew the footsteps........ King $J_{0} h, \mathrm{j}$. that strew the green lap of strew me over with maiden

ienry FIIt. iv.

you now strew flowers in his way..... Jutinolanus, v. shall, which we upon poll strew .... Cymbetine, i. to strew thy green with flowere ........ P'r ricles, iv.
witl flowers I strew thy briclal bed. Romeo \& Jul. v [Col.Kn/.] to strew thy grave and weep - v. he came with fowers to strew his lady's $=$ v. She may strew dangerous conjectures.. Hamtet, iv. TREWED-1 have stre wet it in. Ntas for Meas. i.
whose delay, is strewed witls sweets ...Als, Well, ii. rushes strewed, eobwebs swept. "Taming of Shrew, iv. the presenee strewed ............... Richard $I I . i$. 3 strewed with husks and formi........... Troil. \& Cress. iv. 5 smooth success be strewed before. Antony \& Cleo.i. 3 had found gold strewed o' the flnor.. Cymbetine, iii. 6 and weeds $\mathrm{T}$ have strewed his grave.. ${ }_{\text {for riches, strewed herself even in ...... Pericles, } i \text {. }}$ and not have strewed thy grave..........Ihmlet, v. 1 ar'e strewings fittest for graves......... Cymblyline, iv.

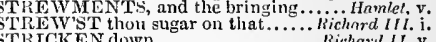
the clock hath stricken ti............. Richard 11. v. like a deer, stricken by many princes - iii. we have strict statuteg

wishing a more strict restraint ........... $O$ me, with what striet patience......
this strict eourt of Venice must... iter. $\overline{r e n i c e, ~ i v . ~}$ I was too strict, to make mine ....... Richard II. i. is my strict tast, I mean ............. nithery - ii. I

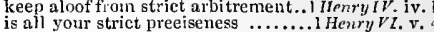
sueh striet and severe covenants ..... - v. for litw is strict, and war is notling.. - iii. by the tenor of our strict ediet....

what the strict fates had pleased

this same striet and most observant ..... Ilamlet,

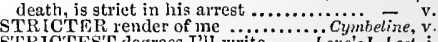
STRIC'TES' $\Gamma$ degrees I'll write .... Love's L. Lost i. STRICTURE, and tim abstinence... Mlea. Poricles, ii. 5

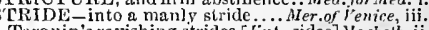
Tarquin's ravishing strides $[$ Knill-sides $]$ Macheh, ii. every stride he makes upon my ....... - i - iii. on the moment follow his strides .. Timon of $A$ ih. 1 mean to stride your steed........... Coriolamus,
not dares to stride a limit .......... Cymbeline, $\mathrm{ji}$ slaves, the stricies they vietors made...
TRID NG above anl other strifes .... Measure for Mleirsurm, iii. above an other strifes ..... Measure for Meisure, ini.
I shall end this strife war is no strife to the dark house .....All's Well, $\mathrm{ii}$ with strite to please yout ...........

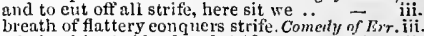
stirring him to blood and strife...... King John, ii. in peace, die free from strife ........ Richard II. . . 6
rests for me in this tumultuous strife.1 Henry VI. i. mucle Gloster, mitigate this strife... - iii. । let me be umpire of this doubtfui strife $=$ iv. 1 betrayed to fortune by your strife.... $=$ iv. of discord and eontinual strife? ...... my lords, let me compound this strife.2 IIenry $Y$ t. ii.1

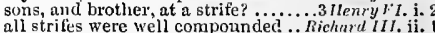
half stints their strife before.. Troilus \& Cressida, iv.

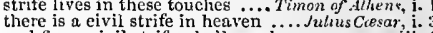
and fierce civil strife, shall eumber... - iti. be nothing of our strife ....Antorny \& Cleopatra, 1 now, stay your strite ......... Titusandronticus, iii.

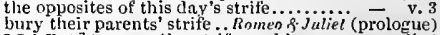
[Col.Knt.] to cease tliy strife, and leave - ii. twenty of them fought in this black strife - iii.
pursue me lasting strife, if, once ...... Hamtet, iii. pursue me lasting strife, if, once ...... Hamet, iii, but darest not strike

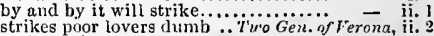
strike? Whom wouidst thou strike?.. - iii. 1 let him not strike the old woman...Merry $\bar{W}_{i x}$ s, iv. 2

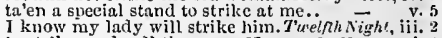
to strike, and gall them..... Afeusure for Mleasure, $i$. 4 in the ambusli of my name, strike hone - i.

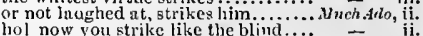
of repronches, stike at thy life...... $\quad$ iv. 1 
STRIKE up, pipers................... 1uch didu, y.

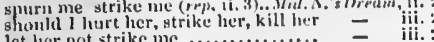

and atrike more dead than eommon

and she strikes at the brow i........... flokls, where noble lellows strik

ditl'st lnve her, strikes some seures ... - v. I'll cuff you, if you strike ugat .. Taming of $\mathrm{sh}$. ii. If you strike me, you are no gentleman $\vec{r}$.

will strike where tis pretlent nostril

that nuy strike the clullest nos

come on, strike up (rep.) ...........

a thont a mesenger. Com of Err.

und now the elock strikes onc........ Wacketh, ii.

she strike upon the hell .....

Who dik strike out the light?

I cunnot strike at wretehel keries

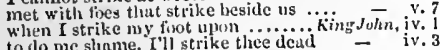

strike up the drums (rep.).............. Richard $I$.

a puny subject strikes at th

and they shull strike your childien

strike him, Aumerle. Poor boy.

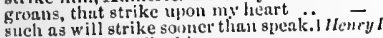

now cannot I strike hit

strike; lown with them
strike up our drum*, pursu

strike up our drum, pursute

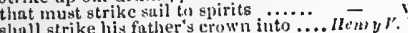

yea, strikc the Dauphin hlind.

Gotl's nrm strike with

I will strike it out soundly.......

I will strike it out soundly..........
if that the soldier strike him $\ldots \ldots \ldots \ldots$.
I promised to strike him.

I, indeed, thou lromiserl'st to strike $=$ iv.

fike clocks, still to strike on

should strike sucl, terror to his enemies

Ii. i. 3

she shall not strike dlame Eleanor. 2llenry t. i.

on our long-boat s side strike on his hean

strike off his head presently (rep.) ..311enry IT. ii.

since we have bermin to strike..

since we have begun to strike.....

now Bfargaret inust strike her sail

strike now, or else the iron cool
go low a sail, to strike to thee..

Ill strike thee to my foot

with lightning strike the mürdere... -

basilisks to strike thee dean

soitl he wakes. Strikc. No \#..... Whike

well, let it strike. Why, let ii strikel - iv.

trumpets I strike alarum, drums! (rep.) $-\vec{F}^{2}$ iv.

tops ataing trikes his hrea-t hard .

rude sou should strike his futner. Troilus \& $\bar{C}$ Cress. $\mathrm{i}$.

how many hands shall strike

thou canst strikc, canst tho

thou shouldst strike him their.

whall strike amazement to their...... - ii.

strike not a stroke, but keep yourselvcs -

strike, tellow's, strike;

strike a free march to Troy .

strike me the counterfeit inutron

strike their sharp shine, and mar.

strike up the drum toward

we but offend him. strike ...........

each otlier's leceh: let our drtims strike

may as well strike at the heaven

w'e shall ever strike till one can.

strike all trades in lione

let the nutinous winds strike..........

I know it: and iny pretext bistrikc at $-\bar{y}_{\text {speak, strike red ress! }}$

entreated then to speak, and

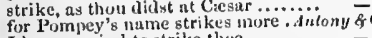

I have a mind to strike thec .........

that they strike a meaner than myelf

strike the vesgels, hol here who
strike not by land; kecp wh

I'll strike, anil cry, take all........

may strike their sounls together
before I strike this blerudy gtroke

shull 1 strike now? Now, Eros ......

let him that loves me, strike itre

your cuuse doth strike my licart

strikes life into loy speech

where, if thon feur tos atrike...........

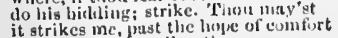

firness, which strikes the eyc

the gods do mean to strike tine $t$ ' .....

and strike her strike, brave boys.

some planet strike me diun

thou canst not strike it thinl to.

what dost thou strike at. Mlareus.

or strike me, If you pletse.

Reeinerl not to strike, but smoriti

IIelieanus, strike ame, honourel kir...
rRIKR-dial my father strike ........... lecur strike, you shuve: stumb, roguc, stum $\left(e \mu_{0}\right)$ he dies, thant strikes nguits

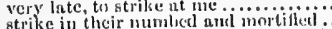

strike her young hones, you tuking uir.

strike the sight of the cleatli-prust ised

let the drum atrike, num girove wy title

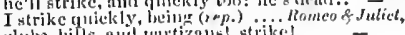

clubs, bills, and purtizans strike!

to strike lime dentl I lwhld it mot a sin $\overline{-}$ in

then no plancts strike, no fuiry takes

strike on the tinder, liol give ure a t:lier $^{2}$

with his truneheon may strike at yom in rage strike those that wish

time, strike oll this score of absel

whint, strike his wite? Faitl, that wo

or, say, they strike ns, ur seaut our former -

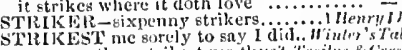

no sense, thou strikest ne thus?
thou strikest as slow as another

thou strikest not me, 'tis Che ar. duifomys clico. iv. 12

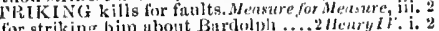

as he is striking holds his intuut

his sword did ne'er leave striking.... I Hen'y) $l$. i. A

striking in our enuntry's canse .....

TRlNG - up in silken string ... TüGen. of ler.ii. 7

with ille sphider's strings most. Hras, for Mreas. iit. 2

good strings to your beards ....Mral. Ns Dream, iv.

time broke in a disordered string .. Wicherd 11. y. 5

when soch strings jur, what hope....2 Rewryl. ii.

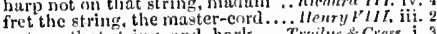

untune that atrinu, und, hark .. Truilus Cress. i. $^{2}$

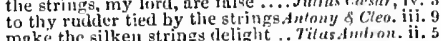

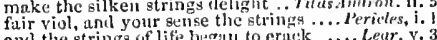

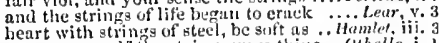

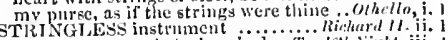

STlP your sword stark naked .. Twrerth Nirht, iti. I

the church, would they strip from us... Meny, $\nu_{\text {. }}$ I

then will he strip his
strip thine own buck

such tricks as these strip yoil out of....... ohellen, ii. 1 more thon the stripes I huve.

who wears $\mathrm{my}$ stripes impressed
hence with tliy stripes, begonc

STRIPLING - a proper stripling
a handsome stripling too: I wis

Ter'sule, iv. 2

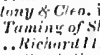

STR1PPED-there stripped himsclf. is tymul lilis ic, iv. 3

glie stripped it from her arm..............

that stripped her from his benediction ... Lear, iy. 3

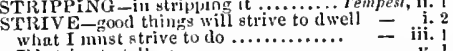

What I mist strive to do.

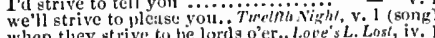

when they strive to he lords

wherc zeal strives to content

sostrive upon your pulise.

二

oo strive upon yove in vain, strive agains
I lor will strive to do't (rop.).

we'll strive to hear it for your.

strive mishtily, but ent and Irink. Fitming of Sh. i.

to strive for thite which resteth in my

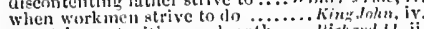

nor strive not with your bienth .....hichard li. ii. 1

with womes's voies, strive to sleak = iii. 2

that 1 may strive to kill it .......... v. 1

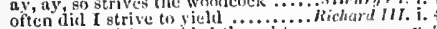

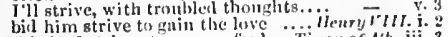

this lord strives to appear toul...Timon of dth. iii. 3

stream of virtue they may strive $\ldots$.....

filly strives to make it self

that it clid strive in work

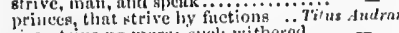

sirs, strive no more: sucl withered..

Burgundy, strive to be interested.

strives in his little werla of man .......... in - ii. I

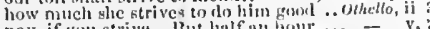

nay, if youm strive, - l3ut half an homr..

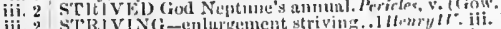

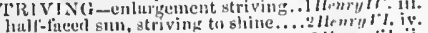

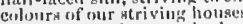

striving to moke an sigly slecd Timnn af, shens, iti

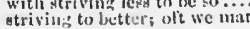

STRIVING to approhend him

Lenar, ii. 1

TRIV

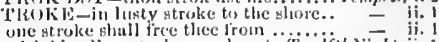

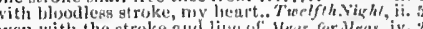

the unsiting postern with these btrokes - iv

gmilc, and stroke lis beturl

a. youl love strokes, sor jest

but certain is iste strokes imi

and with loostroke of mine.

the vilest strike, that ever wall-eyeri

wele mise is the stroke of theatl
you may stroke lifm as gently

he thit strikes the first atruke

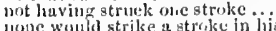

Mirtard II.

llenry $r$

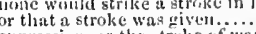

oppression, or the strike of wo

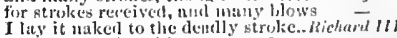

upen the stroke of finur (rep v 3 ).

thon kcep'st the stroke betwixe thy.

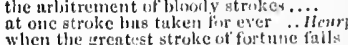

when the grcatest stroke of fortune fails - ii.

their strife betore their strolece begin - iv

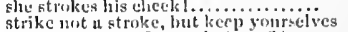

on Athens, ripe for strike!.... Timon of thens, iv.

fiece anm terrible only in strokes...... Coriolsans,

oppusing laws s ith strokes ......... = iii.

tis fond to wail inc vituble strokes

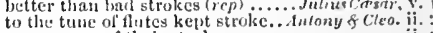

as anorms of their strokes ...........

ant give me snfliein struke-for death

by some mortal stroke she do defeat us
the strolsc of deatl is ns a fover's pinche

that wouls are strokes, and strokes.. Cymbetime, ifi.

the stroke of this yet ararce-eld inattle

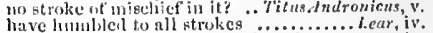

but not witheut that harmiful stroke..... - iv

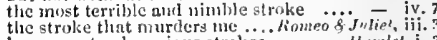

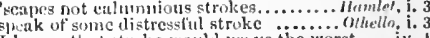

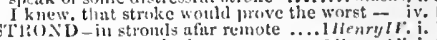

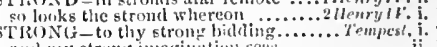

and my strone inaginationsees

and one so stranc that could...

like $a$ strong distillatim..............

to a stron' mast, that liverl

simply as strong as any man.

the beating of so strong a pission

some two thousand string, or so
whose strong corruption fillialits

the strong stmil swe elling cril of

that the strong statutes stamilike

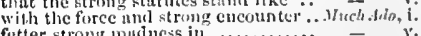

fetter strong muduess in $\ldots \ldots \ldots \ldots \ldots$......

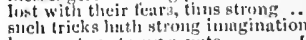

hears wot so stromg no wote........ Lore'nl. Luet

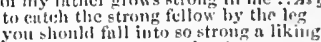

iwherefore are you gentle, string ...

let gentleness my strong enfircement be

being strong at heart, he sent me

my rensons in'c mest strung

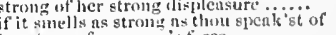

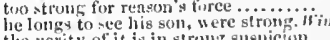

if by strung land you uflit . Comelly verrors, iii.

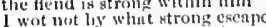

and his sulject, strung loth agninst....... Mnctelh, $\mathrm{i}$.

heing tero strong for him nor our strong sorrow on the fisot.....

make strong themselves by ill

strong posstession, and our riglit (r..... . . King

till yuur strong hund sluthl help...i... -

iil any breast of atrong unthority ..... =

in love, os strong in both ............

nut niek strong inatier of revelt

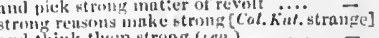

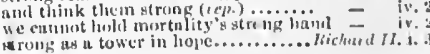


STRONG and great, in sulstance ... Richard II. iii. 2 tie thee to my strong eorrection

eracking the strong warrant of an oath for kome strong purpose, stceled

makes one pardon strong

our tortunes in our own strong a rms.1 Henry

seven thousand strong, is marching .

with strong and mighty preparation

When he was not six and twenty string
but wislom to make strong aqainst

nothing

we are a body strong enough

and the artibishop, are stron

HenryI $J^{r}$. j.

are fifty thousand strons
young, strong, and of good

good friends.

our armour all as strong..............

think we king Harry strong........

my pains, and strong endeavours..

二 iii. 1

and strong enough to issue out

i Henry l'

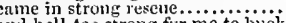

and hell too etrong fur me to buekle
the strong noison that I botight $\ldots .2$ Hen

Bargulns, the strong Illy rian pirate.

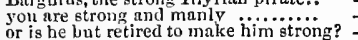

be more weak, and I more strong.

I have reasons strong and forcible ...3 $\mathrm{Henr}^{-}$

stroog, I would not shm their

is thirty thousand strong (rep.,$\quad 3 . .$. .

will be full as strong as ours

to keep the strong in awe (rep.)

make my volicl as strong a

the strong course of iny anthority.

the strong course of my ant ority....

within whose strong if

strong as the axletree on which hearen

good arms, strong joints, true swords

to steel a strong opinion to themselves
but it was a strong composure ......

but it was a strong composure
you are as strong, as valiant

my privacy, I have strong reasong.

in a sense as strong as that which

an esperanee so obstinately strong

$O$ instanee! strong as Pluto
that makes strong the vow

till their knots be strong .............

terribly swear into strong gi.....

marrow, in the hearer strong, eries

etrong breaths, they shall kno

unaking parties strong, aod feebling

'tis fit you make strong party........

more strong than are upon you yet.

you make the weak most strong

he will stand very strong with us.

$U$ constaney, be strong upon my side

your voiee shall be as strong as any man's

more strong than traitors' arms.....

for I am armed so strong in honesty

have made themselves so stron

these strong Eryptian fetters. Antoni... \& Cleopa

the strong necessity of time commands -

there's a strong feliow, Mena.. Whiy?

as loud as his strong sides can volle

o'er your content these strong necessities -

not, in their best fortunes, strong...

in her strong toil of grace............

but from proof as to be believed.... Cymbeline

weak with toil, yet strong in
more strong, not beneath him

hath yoked a nation stro

is not your city strong? ..............

a reason, mighty, strung, and effectual

and we are strong in earnest.......... -

such strong renown as time sliali never =

a strong wind will blow it to pieces..

will be strong with us for giving over
manifold and strong a bond the child .... Leer,

strong [Knt.-strange] and fastened villain -

and the strong lance of justice.
with his strong arms be fastened

i1 strony proof of eliastity ....... Romeo \&

be strong and prosperous in this resol

strong liand, and terms compulsatory

stronger guilt defeats niy strong intent.

inust not we put the strong law on him.

being strong on both sides they are strong - iv.

a jealonsy so strong that judgment eannot

with any strong or vehenent importunity - iii.

confirmations strong as proofs of Holy Wr

the strong conception, that I do groan

SCRONG-BASliD pronontory have I..
STRONGEl-the ship were no stronger

made to be 110 stronger..... Neasure for Moas

made to
that is thy spirits were stronger.
that is strouger made, which was...

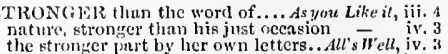

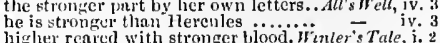
higher reared with stronger blood. Winler's Tale, i. 2
or stronger for your need. Hark ..... iv married to thy stronger state. Conesly of Errors, ii. 2

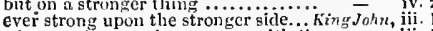
wliat motive may be stronger with thee - iii.

grow stronger for the breaking

the

when we arow stronger, then we'll.

more stronger to direct you than....Henry l' 117 . i. I

are you not stronger than you were?

ears a

am not of stronger earth than others

be stronger than thy continent. Aniony

a voucher, stronger than ever law ...

our kinglom is stronger than it w

gives heat and stronger glowing......... Pericles, i.2

stronger tlim either the mason (rrp.)...

ynur love slall grow stronger ............ Othello, ii. the strongest oaths are straw ............ iv. 1 by Cupid's strongest bow ...... Nid. N.'s Dream, i. 1 $\mathrm{know}$ the strongest and surest way. Richard 1 . ini.
strongest nerves, and small inferior.. Coriolamus, $\mathrm{i}$. to use our strongest hands... Antomy \& Cleopatra, i. I in wealsest bodies strongest works ..... Hambel. ifi.

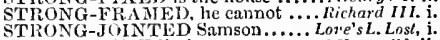

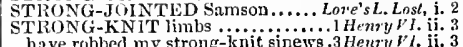
have rohbed my strong-knit sinews 3 Henry $y$ lii.
SCRONGLY-that works lim strongly. Tempest,iv. your eharm so strongly works thein

now are too strongly embattled ...Merry wives, ii. shall strongly stand in force ....... Love's L. Lost, i. each to other hath so strongly sworn Fre i. I my rememlurance the more strongly.

great Dunsinane he strongly fortifies
which was so strougly urged ..........

an strongly guarded; cousin, look not

who strongly hath set footing ....... Richard II. ii. 2

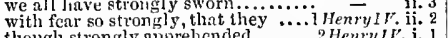
thougl strongly apprehended........2 Henry/ . i. I fortify it strongly 'gainst the Frencl - iii. 3 atrongly throngh my fixed tecth ..2 Henry IrI. iii. 2 I know', 'twill stir him strongly........ - iii. 2 do strougly speak to us ........... Antony \& Cleo. i. 2 be looked to speedily, and strongly... suspects, ret strongly [Knt-fondly] ioves! - iii. 3 STRONG-WINGED NIereury.. Antony \& Cleo. iv. 13 STROVE to show her merit............. All's stell, i. I patienec and sorrow strove who should ... Lear, iv.
sTrow STROYED in dislonour ..Aatony \& Cleopatra, iij.

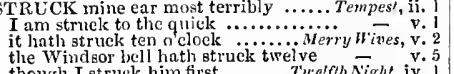

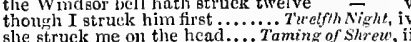
myself am struck in years .............. of shrew, ii. I that had strlick anointed kings ... Hinter's Tale, i. 2 so, come, help; well struck
whom I myscif struck down

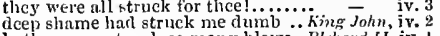
hath sorrow struck so many blows. Rhihard II. iv. 1 worse than a struek fowl

death hath not struck so fa

fow ard, struck his armed hee

and struck me in my very seat of...

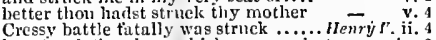
has struek the glove which your inajesty _ iv. not having strick nne stroke.
and thy ehcek's side struck off

dicl somnd, or drinm stronek up

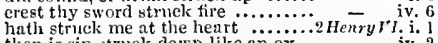

then is sin struck down like an ox..
oft have 1 struek those that (rep.) .3 iv. 2
iv. 7

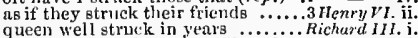

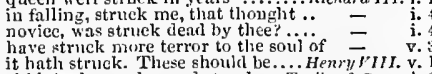
chite Andromache, and struek ...Troitus of Cress. i. enped llector in the hottle, and struek
shall be struck ofl; Ifeetor...........

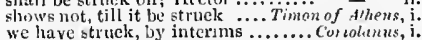

SRUCK -the alarnm were struck .. Coriolanus, ii. 2 a sndden re-enforcement struck Corioli fortme's blows, when most struek lome you shatl lave the drum struck up... and I nm struek with sorrow $\ldots \ldots \ldots$ strack but thus mieh show of fire... Julius $\bar{C}$ e that did love Casar when I struck him
that struck the toremost mao of all..

behind, struck Casar on the neck...

a Roman thought hath struck him Aniony $\bar{s}$ Cl now, darting Parthia, art thour struck
while I struck the lean and wrinkled nine ear, therein false struck ...... Cymbeline, and struck me, wretelh, more worth" struek down soine mortally..........
nnr tiel him, where he struck nnr teel him, where he struck
the elock that struek the linur

thou hast struck unon my crest...Tïius $A \overline{n d}$ and this for me, struck home to show

light struck pule and bloodle

I'll not be struck, my lord.

...... Lear, $\mathrm{i}$.

but new struek nine $\ldots \ldots \ldots \ldots \ldots \ldots \ldots \ldots$ Romeo o. Juliet, i. 1 tis now struck twelve: get thee to bed . Hamlet, i. I no, it is struck. Indeed? I heard it not

been struek so to the soul, that presently
your behaviour hath struck her into....

my head shonld be struek off

at a shot, so bloodily hast struck?........ the cluck hath strueken twelve. Comedy of Errors, i. 2 thonght to have strucken him with. Coriolanus, iv. 5
Casar, 'tis strucken eight ......... Julins Cersor, he, that is strucken blind, cannot. Romeo \& Juliet, i. t
why, let the strucken deer go weep ..... Hamlet, jii. STRUCK'ST thou one blow in .....2 Henry $Y I_{1}$ iv. 7

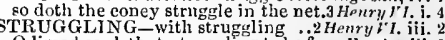

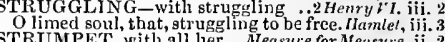
by the strumpet all her ...Measure for Meastere, ii. 2 a strumpet's boldness, a divulged ..... All's $W e l l$, ii. 1 great king, I am no strumpet............ Winter's $T$. iit. 2

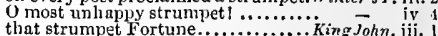
chastise this higli-minded strumpet...1Henry $V_{7.1 .5}$

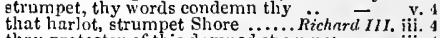
thou protector of this damned strumpet - iii. transformed into a strumpet's fool. Anlony \& Cleo.i. hath played the strumpet... Cymbeline, iii. 4 (letter) and bid that strumpet, your.. Titus Andronicus, v. 2

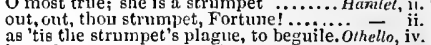
impudent strumpett (rep.) .............. - iv. be-not to be a strumpet, I am none
strumpet, I come: forth of my heart

strumpet, I come: forth of my heart ....
O notable strumpet! Cassio, may you...
fye upon thee, strumpct! I am no strum

fye upon thee, strumpct! I am no strumpet

Ont strumpet weep'st thou for him $\left(r \epsilon p\right.$.) $\overline{-}_{2}$ y.

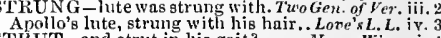
TRUT - and strut in his gait?........ Nerry Hines, i. 4 to strut before a wanton ambling .......Michard III, $\mathrm{i}$. While we strut to our confusion. Antony \& Cleo. iii. II Britons strut with courage $\ldots . . . .$. Cymbeline, iij.
TRUTTED - linve so strutted, and ..... Hamlet, iii.
TRUT'TING Chanticlere andTTING Chanticlere ..... Tempest, i. 2 (sone to kindle - like a otubble land ........ I Hemry $1, \mathrm{i}$. to kindle their dry stubble.......... Coriolumus, ii. that I may appear stubborn.... Twelfh Nigh, iii. 4 art said to liave a stubborn sonl.. Meas. for Meas. v. due to me, to stnbborm har'shness .. Mid. N.'s Dr. i. i stubhurn Turks, and Tartars. Merchant of enere, iv. a stublorn will to please

authority be a stubborn bear.... Hinter's Tale, iv.

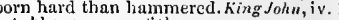
as the sepulehre in stubborn Jew ry..Richarn $I I$. ii. created with a stublorn outside .......hen'y ${ }^{\prime}$. v. have I seen this stubborn Cade ...2 Henry $/ 1$. iji. I

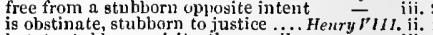
is obstinate, stubborn to justice .... Herry $/ 1 /$. for your stubhorn answer about the.

stop their months with stubborn bits $\vec{C}$ give advantage to stubborn critics

you stulbborn ancient knave ................. Lum, ii. with this more stubborn and boisterous. 0 the lio, i. STUBDOR -C1 ASTE against all. Troilus of Cress. i. TU BBOR N T he did repugn the ..1 Henry $1 I_{\text {. iv }}$ a conrse of impinus stublornness ...... Hamlet, $\mathrm{i}$. STUCK all with yew........ T'uelfhi Night, ii, 4 (6ong) taloe eyes are stinck upon thee!... Meas. for Meas. iv. I
two piteh balls stuek in her face.. Lore's L. Lost, iii. ।

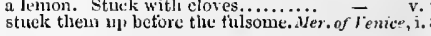




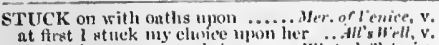
their other senses st uek it car . . Minter's Tule, and nment stuek in my throat ......... Wusceth, it stuck ulfem him, nes the allaryit it st uek upon him, as the Hemyly. ii. who stuck ant spmuglel you... Timo the limmolf stuck tuth to eall us

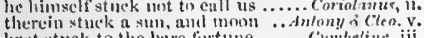

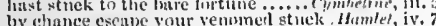
strek-1N-gives me the stwek-ill. Twelfh wigh,

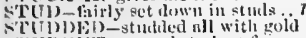

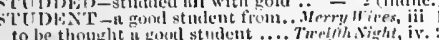

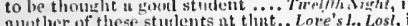
aneriauns stwent! leurn her by heart

nerfigent stwent! ledrol her byeart little more than I linve stulied ...Tweth Nigh, the stnte, whereon I studiesl. Measure for Veasire, $\mathrm{ii}$. have stmitied eight or nine wise words. Murh.fdn, iii. ? here is three studied, ere yon'll..... Lore's L. Lost, i. like one well stmiction a sal....... Mex. of tim 5ou huve studical your question.

what studied torments, tyrunt ... Hinler's inte as one that hath been stutied in his.... Marbrth shimuld not be so loosely studied ....2/enrylt

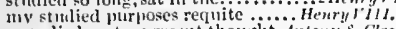
It st tulietl, not a jresent thouritit. intony \& Cleo. ii. au well studicel for a liberal.

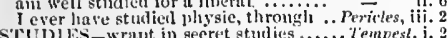

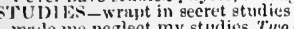
Tempest, for interim to out studies.

stulies my lady? mistress, look on .. of many desperutc studies by his ...As you Like il after his studies, or his usual pain?.. and them bend their best studies.... King John, iv. who strulies,

all atudies here $I$ sulemuly defy

prince but studies his conpautions...2 Henry/r. jv.

all your stullies make ine a curse... Ifenry $h$ ll

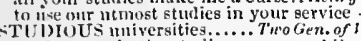

vet he wary in thy stud

sTuby -those being all ny study ........ Tempest you make me study of th

iny fitclier is hurd at study

anil study help for that

I took great pains to study it..........

profits of the mind, study and....... Mleas. for all he were, I would burn my study... Nuch Allo, i.

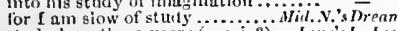
study here three yenrs (rep. i. 2) . Love's L. Lost, not to see ladies, study, fast (rep. iv. 3)
I only swore to study with your graee what is the eid of study?

is study's godlike recompense (rrp.)

to stutly where I well may dine (rep.)

it study's gain be thus (rep.

the straps that hinter study quite (rep.)

stuly is like the heaven's glorious sun

hosthdy now it is too late

so stuly evermmre is overshiot (rep.)..

why, sir. is this such a piece of stivily?

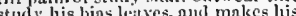

you have vowed tos study. Jords $(r p p$.)

found the ground of study's excellence

nutl stuily ton, the enoser of your

becauke he cannot study.

then I'll study how to die..........

it is my study to seem derpiteful.....

in brief, sir, study what you most..

where did youl study all this goodly.
to thee, stall be my sturly........ Winter's $\bar{T}$ ate,

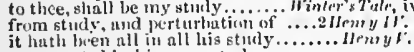

never noted in him any study ......

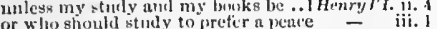

fltter is my atuily und my books .....

nor hos to stuly for the feople's

to stuily fashions to acluri

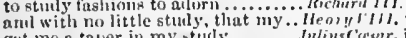

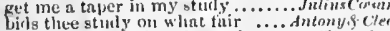

knock at his ntuly, where, they say...'Titus $A$ nd.

a)l my sturly be trin notetivt? ........ - v.2

let your fully be, to content your jord

learned Thelian: : What is your sturly?.... $=$ iii.

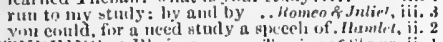

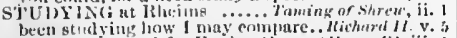

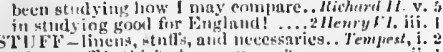

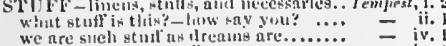

muke 118 strange stmil .....................

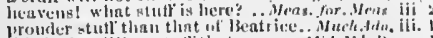

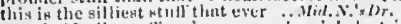

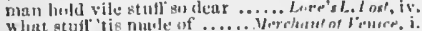

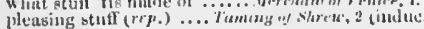

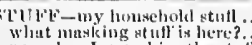

no orter, I gate him the stuil

for parsley to stutt' a rablibit

awny, to get our silull aluare

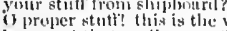

bosing of thent grerihus st utt.

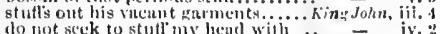

truitur's nume stutl a the throsit

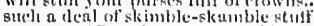

wlint stutr witt linve a kirtie

there's in him stett that put

rich stufts, and ornament s of linusehold

you ure finl of henvenly stuft.

at his fusty stulf, the lurge

perves as stitit for these two ...........

swells with stuti so fine and smoutis

as tustuff a botcher's eushion

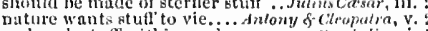

and sue h stuff witlin, endows

moulded the stuff 80 fair

or else such stuft is muturen tongen

did empoumd fis her a eertain
the stuth we hise, a strons wint

it will stuff his slispicion more fuil

was no sucls stutl in my thonglits
if it be made of penctrable stulf

that we are inde of stiutl so thut anil divit

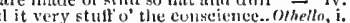

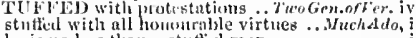

lie is 10 less than a stufter minn.

I am stullich e.

in ivory coffers I luve stufted my. Taming nfsh, ii. I

eleanse the striffil bosom of $t$.

my arms such eclskins stuffed.

not seen a hulk letter stuffed....
When we have stutled these pipres

When we have stutled these pipes

stuffel (as they say) with ......

horribly stufted with epithets of wir... Ohe

STUFF LNG, - well, we tre all nortal...Much dro, $\mathrm{i}$.
stulling the enrs of mon with ..2Hcnryll. (indile.

stumble witl hanste in his eyesight.. Love's L. Lost, ii.l

it grows dark, he many stumble

her run; but she'll nut stumble... irïiver's Tole, ii.

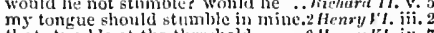

my fonteloth horse dicl sturuble ....Wiehand III. iit. 4

they stumble, that rum fist ...Mmmo \& Jntiet, ii. a

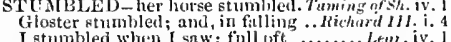

I stumbled when i saw'; full if

my oll feet stumbled at gray

S'TUMB]ING-frem stumbling... Taining of sh. iii. 2

befire the stumblity night dic

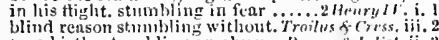

true lirth, stumblime on abuse.. Rnmen \& Julict, ii.

TTU1P-while thas

and, if thy stmmis will let thet. Fitudndronicus, ii. 5

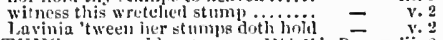

TUNG-Hever uader stmig ...Whil.N.'s Dreum, iii.

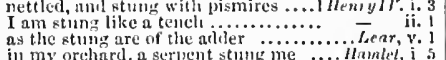

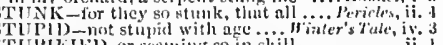

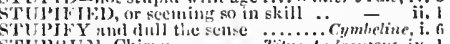

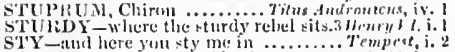

S'Y ${ }^{2}$ ind here you st $y$ me in ........... Tempert, i.

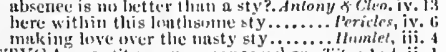

STYG. - per styora, per manes velion... Tifus.tnit. ii. I

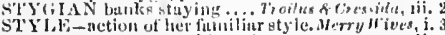

ant I will aggrusute his style

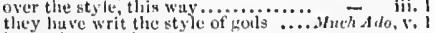

in to higlt at style, Nargare

th the ofyle shill pive us eave.......... Lore's L. lo

into so quiet and so sweet a style......

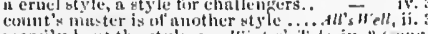

merrily licut the at yle-a .. Winter's thite, iv. 2 (sumg)

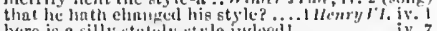

hore is a silly stalely otgle in

whose larke style ngrees not

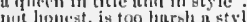

intlintele nuil gute, horseway

nrivit.

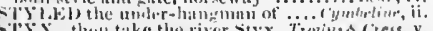

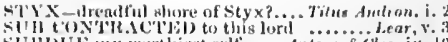

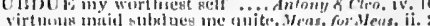

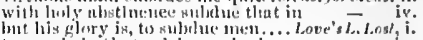
to nuy lutly that sublue日 a loril........

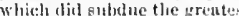

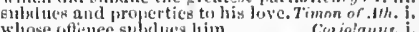

whose oflece subl nes him

resist, sublue him st hus peri ..............

cunrstes sulbdue wmil poism this youmg

Is the greater, thent I num subluet
is the

botli parties nobly ure sululued

lumds thisu hast at once sublucd.

ancl was by strength subilued.

hants your finther was sublued

illenry

Cesar, thum hast subdued his.. Antony o cleo. Bii. I

his face subrlued to jenctrative slume

comlal have subdued nature to such...... I.pit, iii.

my heart's subdhed even to the very...... of thello,

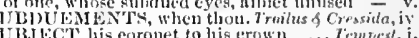

be sulject to no sizht but inis.

nll the subjects that you liaye...

to be thy trie follicet..................

I'll swear myse-If thy sulijert.
the pow monster'y my sabject

I am subject to a ty riat

tenche ubrond.

and : 111 I now a subjeet for then? Tren, nf ler. ii.

and am as subjeet to heat, as butter.. - iii.

and pray to everal suljects .....Mens. for Meas.

the grenter file of the subijet hold... =

lis sulject am I mit, nor here provineial -

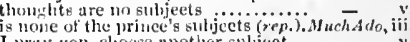

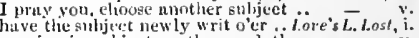

sarying in subjects as the eye doth ..

true subjects bisw to a new-erowned

will subjeet me to the matice .... As you Like it, $\mathrm{ji}$.

such ifuty as the subject owes ...... Tuming of st. $v$.

physies the sulpjeet................

allegiance of a truc subject.... -... iii. $_{2}$ (indli:t.

Camillo a trtie sulijeet............

which of these sorrows is ine subject to?

it was the suljeet of my theme .......

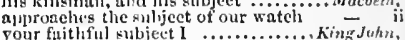

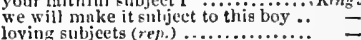

we are the king of lisgland's sulijecte

let me lave no suljucet cuemies...... =

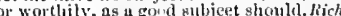

the devotion of a subjeet's love ...... -

our situte, wur suljects, or our iand

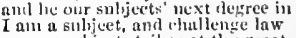

a puyy subjeet strikes at thy great

my subjects, for a pair of earvel

subjects' fect may hourly tramjle
nyy akill were suljuct to thy eurse

what subject can give sentenec (rep.)

protul mat jesty, at sulijed a

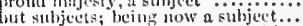

tu. Lolingloke are we suorm suljects

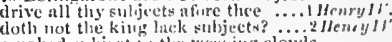

a nakcd subject io the weeling elouds
we are time's sulingets, antl time bids

very lard!y, upm puch a subject.

thentsinel of my pourest suljeets are

the subjcets of his substitute $3 . . .$. .

and a fumous true sullijet tnok him..

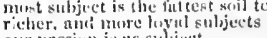

our pussien is as sulject ............

never elid futhtinl suljeet more ........

we, his subjects lave in wonder foumd
the subjects we have lost ............

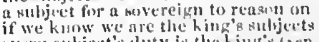

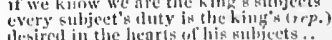

his suljeet s, mil his loyal fricuds.. inenry

like true sulijeets

th him homage ne vibeilicut silligict

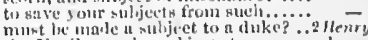

more ferileare thy subjects to emminand -

neither anhjert, weslth, nor linete'm.. 
SUBJECT-being a subject as I am..2 Henry ' J. v. an too mean a subject for

so grieved for subjects' woe

we his subjects, sworn in all ( $(r . . p$.

you were sworn true subjects unto ine

soon performed, bccanse I ann a subject

ram a subject fit to jest withal

列

is every loyn subject nught to do

his subjects sluin

for stirring up my subjects

spenk'like a subject.......

.......... Riehart III. $\mathrm{i}$.

Your queen, and you my subjects....
live eneh of you the subjects to his hate
or, like obedient subjects, follow ...

the sabject traitor this day had pletter?

Tyrrel, and your urost obedient subject

am her subject. But sle, your subject

that yolur subjects are in great g.

most like a careful subject

would be served before a subject

jea, subject to your countenance
to be hontest, and live a subject?.

outspezks possession of a subject.

a loyal and obedient suriject

a poor and humble suliect to a subject

it is too starved a sulije:t tor ni

where II lell is the subject

now the dry serpigo on the subject.

now the dry serpigo on the subjectl.. - ii. 3

that puor rag, nulst be thy subject.
tlat were not subject to a benst?

that were not subject to a benst? .....
sueh ridiculous subjects as yon are..Carinlanus, ij.
honour is the subject of my story..Julius Cessar,

hoids idleness your subject .........Antony \& Clen. $\mathrm{i}$.

commanuls I should be sulject io

hadst great king, a subject, who

we this peace to all our subjects.

grsces her subjects ...............
resist, and subjects punjsied

to princes, and to subjects joys

thou showd'st a subject's shine......

since from his subjects he gains.

if thu be as loer, and in

see how the subject quakes

to peace. Romeo \&

are all made out of his subject

he himself is subject to his birtl

subjected tribute to commanding love $k \dot{i}$ ing Johm i

greatness, subjected [Col. Knt.-subject]. $H_{\text {r }}$

and true suljection cverlastingly

all parts of his subjection loyally

I'll bring you in subjection

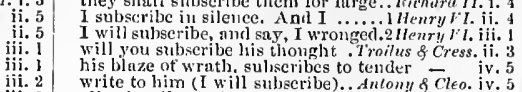

iii. 2 all subscribe to thy atlvice .. Titus Anetronicus,

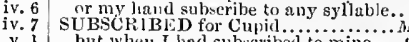

but when I had suberibed to mine ...All's ' 'ell, v.

subseribed [ Knt.-prescribed] his now

iolutue

all cruels else stibseribed

subseribed it; gave't the impression....
SUBSClRIPTION; why then let fall.....

ii. 2 SUDSEQUENT rolumes...... Troilis \& Cressida, i. 3

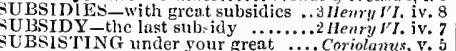

SUSTANCE that I have gre. Tho Gen...
the substance of your perfect self (rep.)

the substance of your pertect self (rep.)
my substance sliould be etatue in

he is of substanee good .............

with the finger of my substance

ry

far the substance ot my praise.

ier.of venice

in the substance or the division of ilie - iji.

substance valued at the lighiest.. Come dy of Err. $i$.

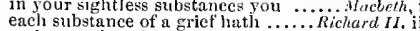

and great, in substance, and in friend

of one substance bred, did lately ....1 Henry $I V^{r}$.

hath put all my substance in to that.2HearyIV. ii.

but not much of the father's substance
tenor and substance, thus-here doth lie

acldress the substance of my speecli.

then have I substance too. No, no, I am -

deceived, my substance is not liere... - ii.

these are his substance, sinews, arms $=$ ii. 3

can the substance of ten thousand. Richord ' $I$. i.

each the sixtli part of his snbstance. Henry Jili. $^{2}$.

you have sent inumerable substance

poul and substance of us all . Frome

takes false shadows for true substances -

within that little, seeming substance........ Lear, i.

hast heavy substance, bleed'st not ...... Jiviel, iv.
as thin substance as the air ....... Romen \& Jutiol

brags of his substance, not of ornament - ii.

despised snbstance of divinest show
doth all the noble snbstance often dont..

for the very substance of the ambitious.. - ii. 2
SUBSTANTIAL things! .........Meas, fm Meas. iii. 2

your reason was not subtantial Comed of orrors, ii.

flattering sweet to be substantial...Rnenen s.Jul. ii.
SUBSTITU'TE-this substitute. Meas. for Neas. $\mathrm{iii}$.

to him, and to his substitutes

momun here agrainst our substitutel.

most wrongfully accused your substitinte - v
a substitute shimes brighitly as. Nerch. of ienice, v. I

substitute. his deputy anointed .... Richard II, i.

the subjects of his substicute

our substitutes in absence well invested - iv.

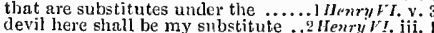

as protector, steward, substitute.. Hichard III. iii. 7

I left belind an ancient substitite

and thougl we have there n substitute.. othelio, i. 3

substituted in the place of mine .. Tilas tredron. iv. 2
SUBSTITUTION and executing ....... Tenpest, i. 2

eommend this kind submission

in all submission and hunility

vile submission! à la stoccata ... Romeo of Juli

a low submissive reverence. Taming of sh. I (ind

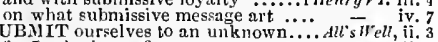

for I submit my fancy to your .......

unvess he do submit himself to Rome - iije -1

do submit me to your highness

he shall submit, or I wilt wever

and submit thyself, thou shalt be.

inemy VI. iii. 1

cubmits her to thy might . Anle

UBTILTY, sleeping, or waking

the king's subtilty, to have my life..... I'erictes, ii. 5

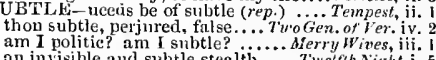

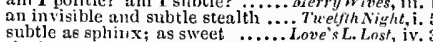

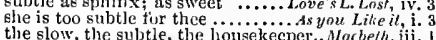

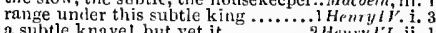

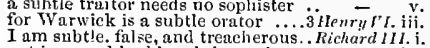

not incensed by his subtle mother
proud, subtle, sly, and bloody

proid, subtle, sly, and blood

too fine, too subtle potent...... Troilus \& Cress. iti.

nor play at subtle games ............

the subtle blood of the grape... Timo

bolder, thongh not so subtle.........

like to a boul not so subte...... Coriolanus, $\mathrm{i}$. 10

as subtle masters do, stir up their...

that the subtle queen of Goths. Titns.tndyronicus i. 3

what subtle hole is this, whose moutl
whier subtle Greeks surprised kiog..

a slippery und subtle knave..........

this is a sibtle whore, u cluset lock

Otkello, $\mathrm{i}$

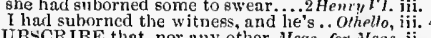

to which I thus subseribe .. Trrofien. of I Eroma, v, or I will subscribe him a coward ..... Nitch Ado, v.

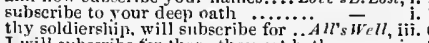
I will subscribe for thee; thou art botl - iv.
UBURBS of Vienua (rep.) ..........eas. for Heas. $\mathfrak{i}$. the English have the suburbs won ... Henry rs. it. in the sulurbs close intrenched.......
faitliful tiricnds o' the suburbs? .... Henry
VIII. dwell I hut in the suburbs of your...Jnline Casar, ii. UBVElT -and subverts your towns.l llenry $I_{I}$.i. UCCLDANT-mulieres ne succedant.. He Hry $V$, i.

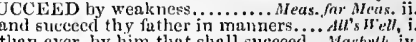
than ever, by lim that shall succecd.... Wacbu/h, no womall slall succeed in Salique .... Henry $r$. i. did this king suececd; whose state . $-r$ v. evermore suceeds barren winter .... next heir should sneceed and reign ...3 Ilenry $V I$. i.
be king, why should not I succeed? who slould snceed the fatlrer ...... what was past, what might succeed....Pericles, $\mathrm{i}$. that may succied as mis meritor.

effects he writes of, succeed umbapility ..... Lear, like to this succeeds in unknown fitte ... Othello, ii.

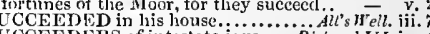
UCCEEDERS of intestate joys............ Richard III. iv.

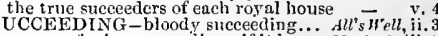
no son of mine succeeding: if it be so.. Nacbelh, iii. to the succecding royalty he leaves .. michard II. i. succecding his father Bolingbroke ..Whenry $F^{\prime} t$. if.
snecceding ages have re-edified .. Richard JII. ifi. IIenry the seventh succeding .....Henry FIII.ii. succeeding from so fair a tree ..........Pevicles, i. of thy success in love ................. and doubt not uut success will ....... Much Ado, iv. Will be glad of our success.. Nerchant of Venice, iii.

the bottom of his success in't

cannot greatty condemn our sucress - iii.

by an abstract of success ............ $=$ iv. not only my suceess in Lybia........ the news of thy success: and when he... Macbeth, $\mathrm{j}$. they met me in the day of success....$-\overline{\text { i. } 5}$ (let.) catch, with his surcease, success........ and so, sucess of mischief shall ....2Henry ${ }_{\text {doth }}$ not wish suecess and conquest. ...Henry $r$. ii. she promised, and assured success..... i Henry $r i . i$. for his rave 1 voces in arms

sucess unto our valiant general.

I not now have the like suecess? .....

whether twas report of her success.. - ii.

the queen hath best suceess.........

appear by caward's good success.... - iii. drean of ets success of bloody wars

success, or loss, what is, or is not. Troilus $8 \cdot$ Cress,

for the success, although particular.

in fear of bad success

tickled with good success ............

ere long have knowledge of my success -

my success hatl done this deed (rep.)

smooth snccess be strewed ...Antorey of Cleopatra. i. sir, good successI Farewell ..........

never o'crtake pursued success .......

success to the Roman host .......... - iv.

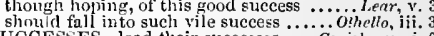

in our well-fuund successes ........... Coriolanus, i.
ii.
UCCESSFUL words than you. Tamming of

prove as sucessful to the quecn.. Winier's Tale, iii. give successful end to this debate ..2 Hrnryll.
which promiseth successful fortune. 3 Henry $V I$. successtul in the battles ...... Titus.tulronicus, $\mathrm{i}$. welcome, nephews, from successfill wars -
UCCESSFULYY-looks successfully 'tis my hope to end successtilly. Taming of $s h$. my comitry's strength successfiuly. Tilussudron. $i$.

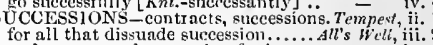
and a perpetual snceessions for it ...... from ny succession wipe me, father! - iv. by fair sequence and succession?.... Richard II. ii. I
thon, the shadow of sucession ....IH Hury $I V$. iii. thon, the shadow of succession .... H H Hry l V ii. and that succession be determined ... $\quad$ - ii. $t$ to the sncession of new days.. Timnn of Athens, ii. 2 for him, and his sncession, granted. Cymbetine, iii. I exclaing against their own succession?.. Hamlel, ii. 2

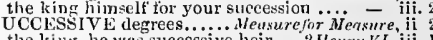
the king, he was successive heir...2 2Henryl VI, iii. that whicls four successive kings in .... llamlet, v. UCCESSIVELY from age to age... Richard ill. iij.

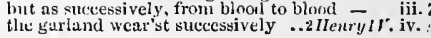


suCCEsson-his sucessors, gone... Wery l'ires, i. I so his sucessor was like to be.... Wher s Tilf i. . sflceUUR-and fuints for succour. As yon like il, ii.

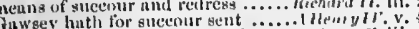

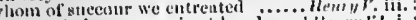

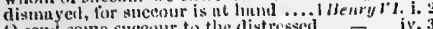
0 semi soine sucenr to the distressed - iv. the levied suctours that should ....... G.M1, our hopse, will suecour $11 . . . . . .$. .

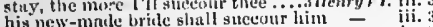
his new-male brite shall sucedur him

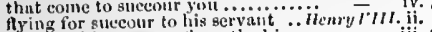
fur from his suceour, troun the king.. - iii,

truncheoneers deas to her stlecoltr

revolt from me, to suceour him ...

StClI-A-ONE, that praised (rrp.)

SUCk-the sun sucks up from bogs
where the bee sueks, there suck $I$.

l'ericles, i.

snck ineluncholy out of a sings (rep.).

Therio

vol (sum

the suck the swets of sivect

they'll suck our breath, or pinch. Comedly of kirr.ii.

I have given suck, nud know how

why then I suck my tecth

spiders, thint snck uy, thy
that without profit suck

nut so sucks her princely eg............ nin

titir show sluil suek nway

as I suck blond, I will some....

droncs suek nut eingles' blood

iny sea shull suek titem dry

more spunsy to suck in

go, suck the subtle blood of ... Timtont of sthens,

nisd suek up the lumour

from youl great kome shinl suck.......

but suck them up to the top-mast... Cymbirhire, iit.

SUCK'DS'T-thou suck dist leer breast. I Inenry rI. v.

thou suck'dst it from me .......... Coriohurtes, ii.

sUCKLD my verdure out on't.......... Trmpest, 1 .

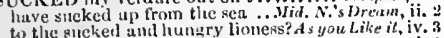

when Itertor's grandsire sucked.. Troilus $f$ Cresa. $i$.

thou hualst sucked wisdom f.....

death that hath sucked the honey

sucked the hroney of his music vows ...

SUCK [NG - ns any sucking dove..... Mid.

as waters to the sueling of a gulf ....Hent?

in the noutli of every sucking bube. I Henry l?

as is the suck int dove, or harmless. 2 Henry $l^{\prime} l$.

WUCKI,E-she did suckle If fector

to slickle forols aud thronicle small becr. (thello, i. i DDEN - then let us both be sudden.. Tempest, ii.

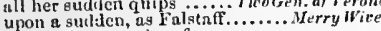
the sudden surprise of my powers ..... $\overline{\text { to }}$ v. 5 my liking might too sudelen seem ......MuchAio, $i$. 1 and sudden breaking uot of mirth. Love's $L$. Los', the sudden hand of death close ..... on such a sudden, you shonld fall. As you Lit in sudden wosing, nor her sudden.

therc was never ailything so sudder

ghould of a sudilen tuke suth hold
whose suitden sigitit hath thralled

and sudden, tells us, "tis not .......

false, deeeitful, surlitell, malicious...
therefore 1 will he suthlen ........
better arm you to this sudden time

better arm you to this sudden

to make my end too suchitin
ou gome great sudiden haste

on the suflun, something ill

since sullien sorrow, serves to say

and as suchlen as fliw's emgealed

never was sueh a sulden sehwlar
gome sudisten inisclijef may a rise

for fear of suldien dieath

this suduen mischief never eould

roused on the sudilen frum their

as I with sutilen and extemporal

one sudhen focape lis sudden fighi

somewhat too suctlen, sir .....

come sudden qualin hath struck

some sudden quam hath struck ....2llenry ri. i. I

makes you in this sullen changr?..3 Herry $r$ iv. iv

lee's sirdden, if a thing comes in

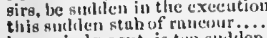

iichard 1 I. j. 3

in $m y$ jurlginent, is the sudden.

Richard H. v. III+nryl

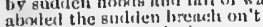

what sudllell unger's this? Jinw have I =

that's somuwhat suthlen: bit he's

her rrace is niterel on the sulften?

ever $g(x)=\mathrm{nt}$ suditen commendations....

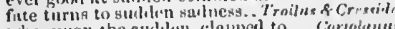

who, upon the sidhlen, clajped to .ii
on the sulden, I warrint him crinuit

with a sulden, re-enforeement at rinck

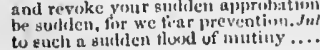

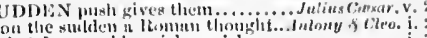
that I am sullilen sick : quick

and on the suldes drengerl....

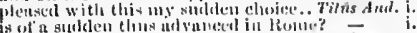

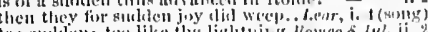

on a suldede, onc lintis wonnedro me

let us hence; 1 : thith on suthen hinste

lineh serted coun an sudten ifing of jey

full ah, in this son sucleden busiues

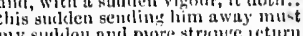

iny sultell nui nore strumte ictur!

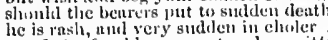

等

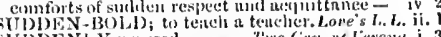

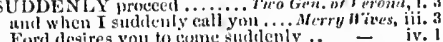

Ford desires you to come suddenly . . - iv. I

suddenly resolve me in my (rop.). Lore's $L$. Lost, ii. 1

yet do not suldenly, for it muty.
richly come to harboor suddeuly

gninst che lady will sudclenly

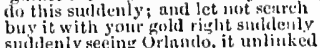

Flurentincs, will sudden'y surprise...Ams $\bar{\nu}^{\prime} \mathrm{cl}$, ivi.

mateh clapped up so suddeny? .. Anmm of sh. ii. I

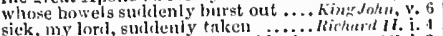

tirge is ripe, (which will be suddeinly.

spint up so suddenty ints the clontis.

we will, suclitenly, pass our aceejst... - v. 2

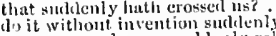

cr mature makes me sudrenly relent
sullenly made bim from my side..

suth be autdenly surprised by blovidy
mats put ups the fowl so suldenly

but suditenly to nominate them all
thint's nor suddenly to be performerl.

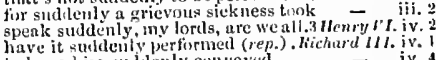

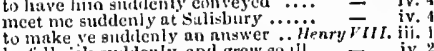

he tell sick suddenly, and grew so jil - iv,

when suddenly a file of boys beliuil

iny yc all by the heels, nnd suddenly $\overline{-}$ v. 3

like a prophet sululenly enrapt.

it cume in too sudcleuly; let it die ... Cymbetime, i.

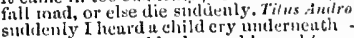

surprised him suldenly; aud broting

come, let's have hir ul
full sudilenly he fled.

is sin suddenly gone back know you.

suddenty contrive the ncans of neeting. Hanlet. ii.

UE-my mnater sues to her. Two Gen. of lerona, i. 1

when ingiders ane, men give .......Meus.yur. Meas. i. 5

that banish what they sti. for.

tos sue to live, I find, I scek
that I will sue to lie rid of it
I sue! I seek a wifel ..........

Love'sL. Lost

\section{sigh, pray, sue, and cor}

thint forfeit, being those that

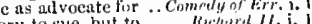

we were not bornt to sue, but to...... huth - ii.

denied to sue roy livery here ........ - $\quad$ v. ?

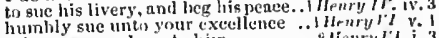

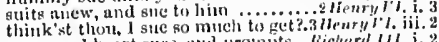

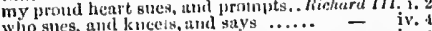

being stcal to, one thite hmmbly sues - iv.

nor weet, as when desirc rlid suc.. Troilus retess. i.

decays the thing we suc for....... Antony g. cleo. ii.

to thee sues to let him breathe .......
she shall not sue umluearl...........

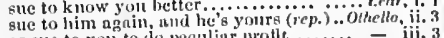

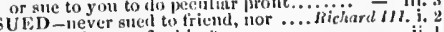

who sued to me for him? $\ldots . . . . . . .$. - ii.

for one being aned to one thint........

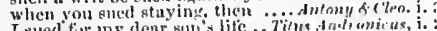

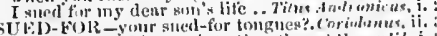

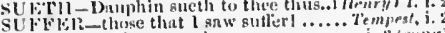

but doth sulfer a sen-change.....

than I would sutfer the flewh-fly

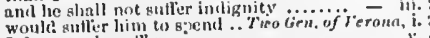

Ido av truty sulfer ..................

thate autfer surfeit, clovinent .... Tirelgh Night, ii.

that sutfers umbler probutim ........ Mersuse

or eloc let hisu sutfer
UFFER-they shoulal muller salvation. Much d do, iii. make these, thut fly whtend yon, sufter

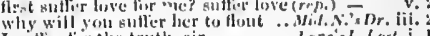

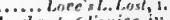

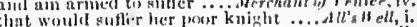

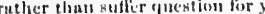

yet must saffer sonethitug in uny

whose nge and hosurer both sisfer.....

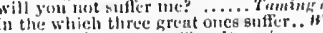

settled project may witler alteration...
wot he alue shall sutfer what wit ean

forcune sould mot sufler me.......... $\vec{x}$ iv. witt thon suflic them to make ...... - iv.

that suttier in exposure, let $118, \ldots \ldots \ldots$. . Nercbeth, ii.

both the worlds suffer, cre we........... - ii.

tenter duty make me outlit wrong?. Hichard li. ii.

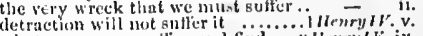

what wrongs we suller, and find..... Henrys iv.

can you suffer hell so to prevait...... I llenry $/ \%$. i.

and sutfer you to brentlec in .........

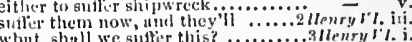

What, shatl we sulfier this? ...........3litenryl $l . \mathrm{i}$.

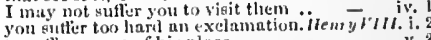

to sufler an man of his plued ..........

the king will sutter but the little finger -

5oullt ne'er be gond, nor suffiter others - i

sutker us to fumish $\ldots \ldots \ldots \ldots \ldots \ldots \ldots$.

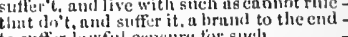

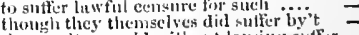

thant verity' would without lapsing suffer -

it

lest ny remembrance suffer ill report - ii.

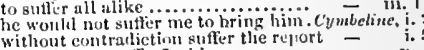

why did you suffer Iachimo...........
with a llomuns s licart can suffer ....

suffer thy brother Murcus to inter. Titus Andron. $\mathrm{i}$.

the engle suffers little birds...........

see how beliet may suffer ...... - ....... Lear, ii.

my duty eannot suffer to obey $\ldots \ldots \ldots \ldots . . .$. - iii.

who alone suffers, suffers most $i$ ithe mind - ii. 6

my gond brother suffer you to do it? ... o Juliet, ii. 2

ince. or no, that thus he suffers for .... llamed, iii.

suffer the flings and arrows of out rageons
onc. in sulfering all, thut sutfers notling

r else shall he suffer not thinking onl

why dres he suffer this rude knnve.....

grief with me; I suttier with hiun.....

no weapon, and perfo ce must suffer For in corproral sufferance finds a pang .. - ii. 1

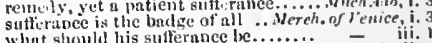
what should his suffernace le......... the scemine suflerances that you..... I Henry It: v. 1

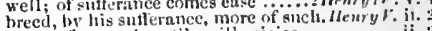
I in sifferanec heartily will rejoice.. $=$ ii. 2 weaklucse, and ndnire our sntferance 3 'tis a suttierance, panging as soul. . Wrenryllil. ii. your last service was sufferance

did eommence in stflerance .. Timon of stheus, iv. 3 ant breatled our sufferance vain

in suthority a aranst all noble sufferance our yoke nud sufferance slow us ...Julaus Corsur. i. 3

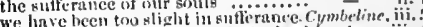

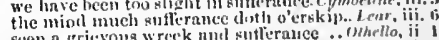

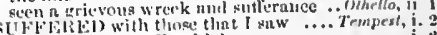
joind to their suftiresl linlour

he bul sutfercel for"t (rep.). Troo sutlered the pangs of three neverni deatlis fur my rake you have sittlered all this - ii. nnd have not they suttererl? .......... why have you sutlered me to bx.. Trelgh sight, $v$

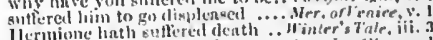

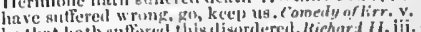

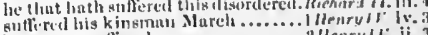

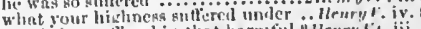

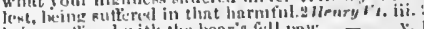

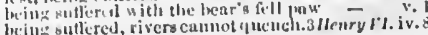


SUFFERED-the pain you suffered Ilenry V/1l. iv. 2
Greeks and Trojnns suffered. Troilus \& Cressidn, iv. 1 your jewel hatl suftered........ Timan of Alhens, $\mathrm{i}$. the one part suffered, the othier will. Coriolanus, $i$ ii. for which he sutfered death

and suffered ny command . Antomy s. Cleopatra, iv. that I suffered, was all the harm o Cymbelin, iv. and I have suffered nenr him.

hath power, but as it is suffere

I suffered much extremity for love that my youth suffered.

\section{SUFFERING I have foolishly suffired}

Ohello, i.

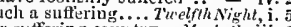

in suffering thus thy brother to be... Richard II i. 6

suftering so the eauses of our wreck.

for sutfering flesh to be eaten........2 Henry $I F$. ii.

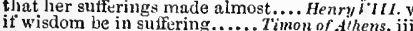

Four suffering in this dearth ........ Coriolanus, i. 1

with only suffering stain by him

and cruelicr in sutfering

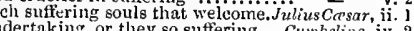

thine honour from thy sufferin

in suffering all, that suffers nothing..... Lear, iv. 2

SUFER's more of mortal grief\& .... Henry $V$. iv. I

Why suffer'st thou thy sons.... Titus Andronicus, i.
SUFFICE thee, mistress (rep.). Merry Wives, ii. 1 (ict.)

it shall suffice mee at which. Merry Wives, i1. I

to know thee sliall suffice.

if that will not suffice (rep.)............ let it suffice thee, that $\mathrm{I}$ trust ..... As yon Like il, i. few words sutfice: and, therefore.. Taming of $\mathrm{Sh}, \mathrm{\textrm {i }} .2$ let that suffice: I have trusted.... Winter's Tale, i. 2

this reasoll may suffice

it suffices me, thou art ....... Troilus \& Cresside, ii. 3

let it suffice the greatness of your,..... Pericles, ii. I

myself I dare: let that suftice you?.... othello, iị. 4 iny knightly stonach is sufficed...... King John, i. larsh to bear; sufficeth, I am come. Taming of shrew sufficeth, that I have maintains ...2 Henry $\bar{l}^{r}$. but it sufficeth, that Brutus leads..2Henry $/$ I. iv 10 sufficeth, that the day will end

sufficeth, a Roman with a Roman's.... Cymbeline, sufficeth not, that we are brought.. Titus Audiron. nor sufficiency, to be so moral............. Much ddo a substitute of most allowed sufficiency. Olhello, ii.

a substitute of most allowed sufticieney... Othello, $\mathrm{i}$. in your ward sufficient......... Mleasure for Measure, the most sufficient of your parish

the man is, motwithstanding sufficer. of Fenice, my daughter a sufficient dower. Tamint $\bar{s}$

and some sufficient honest witnesses

here half a dozen sufficient men?

shall be a wall sufficient to defend.

Were not sufficient to contain it ....1 Henry VI. ii.

(had I sufficient skill to utter them)

were not revenge sufficient for $\ldots \ldots . . .3$ Henry $V^{V} T_{\text {. i. }}$

a sufficient briber for his life.. Timon of Athens,

never meet a more sufficient man...... Ohello,

our full senate call all in all sufficient? $\overline{\text { WUth }}$, iv.

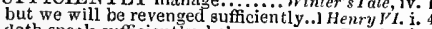

doth speak sufficiently, he's gone ......Pericles, i. 3
SUFFICING strokes for ...A ntony \&cteopalra, iv. 12

SUFFICIT-satis quod sufficit .... Love's L. Lost,
SUFFIGANCE-it shall be suffiganee.Huch Ado,

SUFFIGANCE-it shall be suffigance. Huch Ado, iji. 5
SUFOCATE-his windpipe suftocatc. Henry'
Suffulk's duke, may he be suffocate..2 Henry 6

when degree is suffucate
SUFFOCATING strean

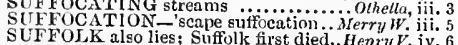
tarry, dear cousin suffolk!

and over Suffilk's neck he thirew ihis

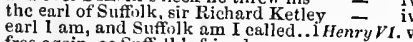

free again, as Suffulk's friend

Suftolk, what remedy? I am

speaks Suffolk as lie thinks?

that Suffirlk doth not flatter............
glall Suffolk ever have of Margaret..
but, Suffolk, stay; thou nay'st not..

my noble lord of sufficlk

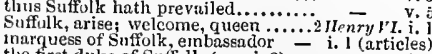

the first duke of Suffolk (rep. i. 2),. .0$)$
Suffill, the new-made duke (rep.i.

tor Suffolk's duke, may be be........

with the duke of Suffolk (rep.)

the pride of Suffolk, and the cardinal

Suftiolk concluded on the articles....

this is the duke of Suffolk, and not my $=$ T. i.

:ny lord of Suffulk, say, is this the givise -

t'll tell thee. Suffolk, why I am for unmeet

what mean'st thon, Suffolk? teil me

await the duke of Suffolk (rep.).:

wivk at the duke of Suffolk's iusulence my lord of Suffolk, Buckinglam ....
well, Suffiolk. [Knt.-Sutfolk's duke].
and Suftolk's clourly brow his .....

thricc-noble Suffolk suffolk (rep,)

run to my lord of Suffulk; let him know -

doth my lord of Suffolk comfort me?

why do you rate iny lurd of Suffolk thus? -

hy Suffempted Suttulk's tongue and the curdinal Beaufort's

ale you the butcher, Suffolk?...

Suffolk dare him twenty thousand

unto my state hy Suftblk's means

and let thy Suffilk take his heavy leave -

enough, sweet Suffolk (rep.)

so Suffulk liad thy heavenly company

omitting Suffolk's exile, my soul's.

come, Suffolk, I must waft' thee.....

and Sutfolk dies by pirates

and mourning for Suffulk's death?

is gone, now Suftulk is decensed alive

Suftulk, now of Kent (rep. iv. 8)

at primero with the duke of Suffolk

I ask your voices, and your sufirages. Tilus And.

threw the people's suffrages on him - iv. 3

forbear your suffrages; if that you ....Pericles, ii. 4
SUGAR-and sugar of the best .... Merry

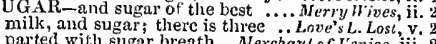

parted with sugar breath ... Nerchant of I'enice, iii. 2
to have Jioney a sancc to sugar ...As yont Lilie it, iii. 3

three pound of sugar

give thee this bath been as sugar .. Richard II. ii.

to what end lie gave me the sugar... Henry $I V$. ii. 4

for the sugar thou gavest me

more eloquence in a sugar touch ......... Henry $V$. y. ${ }^{2}$

We do sugar o'er the devil himself ..... Hamlel, ijl. 1

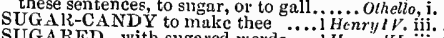

UGARED - with sugared words...

thy poison with such sugared words.2 Herry $Y$ i.jii.

but followed the sugared game. Timon of Athens, iii.

SUGARSOP, and the rest....... Taming of . Shrew, iv.

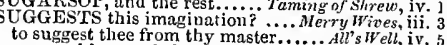

suggest his soon-believing ......

devils, that suggest by treasong ......... Henry $Y$. . ii.

if secret powers suggest but truth ...3 Henry VI. iv. 6

we must suggest our master

do suggest at first with heaveniy shows. Othello, ii. 3
SUGGLSTED-is soon sugrested

these faults, suggested us to make. Loye's L. Lost, y.

hath suggested thee to make ...... Richard 11. iii.

SUGGESTION as a cat laps milk....... Tempest ii.

suggestions are to others, as to me. Love $e^{t} s$ L. Lost iv.

those suggestions for the young earl.. All's Well, in.

against these giddy loose suggestious. King John, ii

herein misled by your suggestion

mingled with yenour sliggestion ... I Henry $I \mathrm{~V}$.

by the suggestion of the queen's ...Richard III. iii.

one, that by suggestion tied all.....Hertry VIII. iv
to thy suggestion, plot, and damned....... Leor, ii.

UIT-low to grant suits

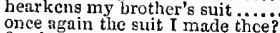

for thy wrongful suit ....... Turo Gen.of Yerone iil.

my master's suit will be but cold .....
what says Silvia to my suit?......

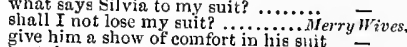

give him a show of comfort in his suit

and humblest suit cannot attain

my suit then is desperate ............

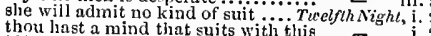

would you undertake another suit...

二 ii. 5

and suits well tor a servant.......... = iii.

an assume both form and suit

well, what's your suit? .....1 Ieasurefor.Measure, ii.

you, granting of my suit .....

for some tour suits of pence-p

give notice to suel men of sort and suit -
your suit's unprofitalle; stand up

the firet suit is bot and hasty .........Much $A d$

doth commence his suit to her ..........

surely, suit ill spent, and labour
whose wrongs do suit with mine

suddenly resolve suit with mine .... -

L.Losl, ii.

Biron did swear himself out of all suit $=$ v.

for my great suit so easily obtained

what humble shit attends tliy ......... $\quad$ v.$z$

trouble you with no more suit...Merch. of Venice, $\mathrm{i}$.

monies is your mit: what should I suy -

I have a suit to you. suit........... iii. I what page's suit she lath in readiness of Fenice, ii.

farc yul well; your suit is cold .. - is. 7 (scroll) of a strange nature is the suit you follow

we will make it our suit to ........... ds you Like il,

more snits you to conceive, $\ldots . . . .$. .

that I did suit me all points like...

it is my only suit; provided that you

you lisp, and wear strange suits......

by aily token of presumptuous suit. .. All's

sir, will you hear my suit?

if this suit be won

be ready with a costiy suit........... $\bar{T}$ (cpiil.

dressed in all suits like a lady....

to effuct your suits, here is man....... Winler's tale, i.

arrest him at my suit .................

that in an honest guit nigi...........

at whose suit. I know not at whose suit -

and gives 'em suits of durance...

whose suit is he carrested at?

which now suits with it at................ Macteth, iv.

the suit which you demand is gone

lords, to grant the commons' suit?... Richard 11 iv. 1

for obtaining of suits? (rep.)

two rugues in buckram suit

at the suit of mistress Quiekly........2 Henry $1 \mathrm{H}$. ii. 4

by no suit gain our andience

If had a suit to master Shallow.....

whose right suit not in native

suits, and give their t'ssting hor words = iv. 2

my lord, despy suit ...............

your scveral suits lave been... .1 Henry $V I$. ii.

she will derly thy grait

answer makes your grace unto my suit? $=\quad$ v. 3

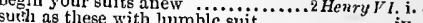

I have suit with humblc suit....

her suit is now, to repossess

dhe well, to graut ber suit ............. - iii.

widow, we will consider of your suit

then no sadness of iny suit..........

her suit is granted for her lis at and end

nor posted uff their suit su with........... -

not you spoke with, but by mighty suit

in no worldily suit would be be moved

if to reprove you for this suit of yours

whe'r you aecept our suit, or no ......

weet prince, accept their suit

half your suit never name to us....

made suit to come in his presence...

for any suit of pounds...

have a suit which you must not deny me -

stubbol'n-chaste againgt all suit.. Troilhs \& $\bar{C}$ r

but by the suit o, the 'll suit ...Timon of '1hens, ii.

how in his suit he seorned you...... Corrolamus, ii.

mine ears against your suits are.......

resh e the general suit of Rome

our suit is, that you reconcile them.....

hrutust some suit to Casar....... Julius Ca'sor,

.

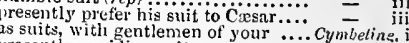

presently, a ridiug suit of your ..... cymbetine.

contempt the suits of princely feliows

fetel that suit hither .................

suit myself as does a Briton penso...

二

and this suit I make that you bed $\overline{\text { vitus }}$ v.

and at my stit, sweet, pardon (rep.)

ashore, I liave another suit

who hath had three stits to $\mathrm{bis}$ back...... Lear, ii.

what say your to my suit?.........komeo $\&$ Juliet, in.

thy suit [ Col. Knh-strife] and leave me - i. 4

nor eustomary suits of solem: black

but the trappings and the suits of woe ... - i.

bers of unholy

I'll have a the vord...

personal suit to make me his licu..........

every thing he does with Cassio; suit

nay, when I have a suit, wherein I mean

a trick, to put me from my suit...

by their own inportmena stit

1.

UITABLE tigr destruction Timon of $A i h, \ldots$ ini. $b$ (grace) 
SUITRD to his watery tomb ..... Twethh Nipht, v. I

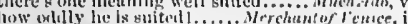
how" ortily he is sutint

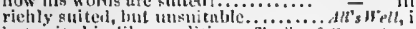
but suited in like conditions. Truilus of Cress. (prol.) he thetter anited: these weeds ure ......... Lear, iy.

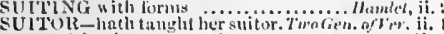

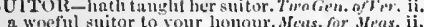
ahe lint troubled with a pernicious snitor ........nnch.the. $\mathrm{i}$. Whe is the suitur? who is the suitor? prineely suitos's that are alrenily eome? $\overline{\text { ing }}$ i. 2 scek these suitors; gos, sjeudily ......All's Weth, $v$, shall wot be anmoycil witl suitors. Tomims of $\mathrm{Sh}$.
and ocher more suitors to her, anil rivals sle may mure suiturs have, ani me she keens from all aceess of suitor

mofess to be th suitor.

of nll thy suitors, here 1 eharge the

make myself $n$ stitor to your ila ughter

your ncighbour, and was suitor tirst -

in age, is ahe become the suitor ... Hinter's Tuld, $Y$. 1 will not be yeur snitor ............2 lenryl. ii. not proviked hy nuy suitor else ..... Richard Iil. i. 3 longer kneel, I um a suitor ........... Nenry r'lll. i. humble suitor to your rirtucs. Timon of .Hher,
they say, noor suitors have strong .. Coriolonus, and my

and as a suitor will I five him...

what Ciesar doth, whtat suitors press common suitors, will erowd a fecble

and $\mathrm{nm}$ moreover suitor, that I may

we are suitors to their throur a foolisin suitor to a wedded lady ..... Cymbetme, no licretics burned, but wenehes' suitors. Lew, iii. suiturs following, und not look belipisl. Oth aud aecels no other suitor but his likings
I have been talking with $\mathrm{n}$ suitor here.

I have been talking with n suitor here . . - iii. SULLEN-peevisl, sullen, frowarl Two Gen.ofl to eope him in these sullen fits...As you Like were rough, and coy and sullen. Taming of Sh. ji, I sullen presage of your own deeny .... King John, thou eanst with sullen sorrow ....... kicharl 18 . the sullen prssare of thy weary steps

and put on sallen black incontinent = bright metal on a sullen ground ..... IIfenryl! eres fixed to the sullen eirth ........2 Henry $\mathrm{F}^{2}$

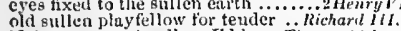
if thou wert not sisllen, I'd be .. Timon of Athens, I un sick, and sullen.........Antory \& Cleopitra, $i$ solemn hymms to sullen dirges change

a salt and sullen [ $K{ }^{\prime} n$,-sorry] rheum .. Ohello, iii. SUL, LIED-Talbot hath sullied ..... Henrylt iv SULA,

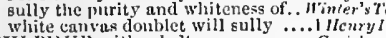
White canvas donblet will sully
suldPll Coriolanus,
Cynabeline, the golls throw stones of sulphir Orhello, iii. 3 roust me in sulpes of sulphur

roust me insulphurl waslt me in sleep-down thy sharp and sulphurous boit ............. for . Mpos. this nimble, thy oul phurous flashe sulphurous and thonght-exeenting tlere is the sulphurous pit, hurning...... SUICT.N-three ficlds of sultan... Mer. of renice, ii.

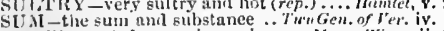
I will retart the sum in equipuge... Merry Wives, ii. or sums in sealed lagg

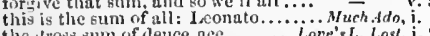
the 'ross sum of deuce nee ......... love's L. Losi, all entire sum, disbursed by my father (als itcither bat ve), receivet that sum.

gurudu acens cune sum umbre runinat quin raise a present sum

as are expressed.

lad lieen the very s111n of my confersion

the full sum of me is sum cit sumething -

what sum oses he the . Few?...........

yea, twise the stmin; if that will not

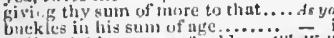

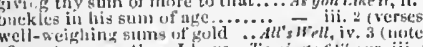

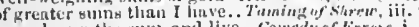
to make up the smon, and live.. even just the sum, that I ........... dislaure the sun on the receipt...... - iv. eolyent to pas this sunt for me will pay the sum for hisin (iep.) this is the very sim of all fiaii
the sums 1 have eollected shail sulseribe them for lavge autns for what fum? Lt is inore than to give a greater sun than ever. sucli un mality sun, as uever.
MI - the sim is poid

traus of nill our nonwer is.

receive the sun of mency..........

lay great sums of money thrensis

the sum of all I 'mu; I have

the grind sum of his sins.

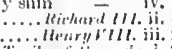

will you with eounters suim............

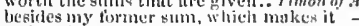

rather then the wrorth of thriec the sum

preferret you not your suma ant bilis

ent iny henrt in sums.

hetps and sums of love sund wiii

for eertain sume of golld, which you, dulinest:

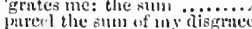

overbiy's me nlmost the sum

it sums up thousmols in a tri

I eamot of this, hromglit hither. I'erish's, iii. (Cxow

our sun of parts did not togetier .... Nanlet, iv. 7

of' love make up nyy sum

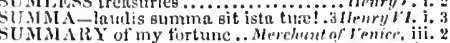
liave the simmary of all our

SUADIEl-nfter summer, merrily Fempest, $\bar{v}$. l soly cre summer tomes, or euckoo-burds...lerry

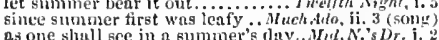
as one slutil sce in a summer"'s day...khid.

chaplet of swet summer buts

the spring, the summer, the ehilding

why' shonld prond summer boast...Love's L. Lost, $i$.

weet roses in this summer atr ....... $-\bar{v}_{2}$ (song) to show how eostly summer was. Ler. of lenice, ii. 9 hy the same winter and summer as.

the mending of higlwways in summer - w. this coming summer, the king of ... Winter'st'ale, i. nre summer songs for me aud my

not yet on summer's death, nor on
these are flowers ot middle sumner

lylow away, so many summers, dry

five summers have 1 spent in... Comedy of Frrors, i.

like a summer's clond. wi thout our........ Hucter, jii. 4

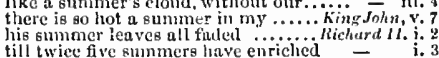

till lwiee five summers have enriclied

luy the sumner's dust with showers.

sliall lodire the summer corn $\ldots \ldots \ldots . .$. - iii. 3 fir queen iu a summer's bower ..... - ii. I thou art a summer bird, which ever in - iv. as elear as is the summer's sun .......

ns you shall see in a summer's day.

as you shall desire in a summer's day

expect saint Murtiu's summer ....... I llmury I"I. i.

summer's parehing heat, to conquer... nud, after summer, ever more suceeeds

like fo the summer's eorn by tempest - iii.

swarm like swmmer flies (rep.) .....

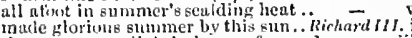

short summers lightly hive a forward

which, in their summer benuty, kissed

that spoiled your summer helds

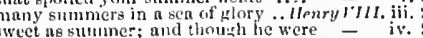

mealy wings, hut to the aummer. Trisilus s cress, iii. a

boys pursuing summer hattertlies.. Cormitans, iv. 6

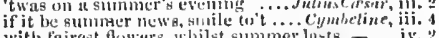

lout to be stial het ammucrs tanlines

trees, though sumber, wet forlern. Th

bees in hottest smumer's duy ....... -

summers youltger $[k n /$ hunger

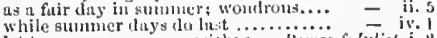

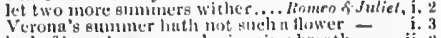

bul of iove, loy summer"s ripenisng breutl $=$ ii. 2

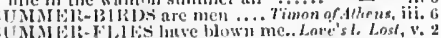

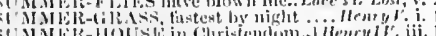

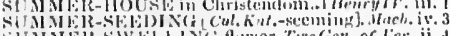

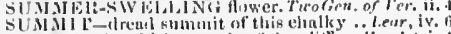

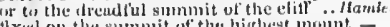

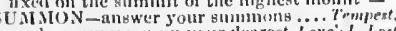

madam, summon np your dearest. l.ove + l., l.nst, li. 1

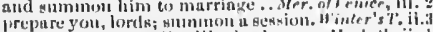

a heavy summons lies like lem. ........stacbrth, ii.
U M MIUN-Hack Ifecates summons.. Macbeth, lii. 2 sone trumpet sumbon hither ....... king John, li. What lesty trimpet thes cloth sumnom us? - v. 2 the sinew日, summon ul, the blood .... Ifeuryl. iii. I slummon a parley, we will talk ...l/kenry rl. iii. 3

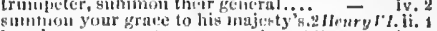
k nock onse more, to summon tlem.3Hrary rl. iv. to make this present summons......ll, ary r'lit. ii.

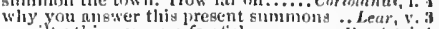
a guilty thing ujon a feartul summong.. Hhatre $j$. anc reasin of this terrible sumnoms?

1,AJUNED me hither nind aie simmoned to meit ano intemens, ji.3 Uair

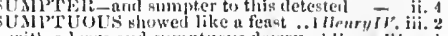

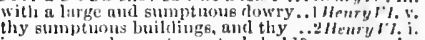

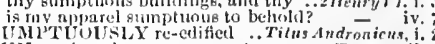
UN-unless the sun were post ........ Trimprst, it. the infections thant the sun sueks bedimmerl the noon-tide sun shows all the henuty of the sun.
now I worship a celestial sun.. 二 iil. i - ii. 6 sturn did the suo on dunghill shine. ifrmy Wires, i. 3 have 1 laid my brain in the sun $\ldots \ldots$.. .

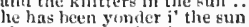
thant the orb, like the sun .......... - iji. 1 ly'int by the violet, in the sun ..........

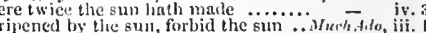

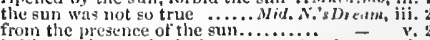

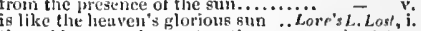
the golden sun gives not to those... - iv. 3 (ver.) but then no sun must shine......... - iv. 3 o'tis the sun, that maketh ail

that you get the sun of them ......... as the day is when the sun is hid

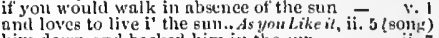
him down and baskerd him in
of the night is lack of the sun....

I the night is lack of the sun........ ere twiee the horses of the sun shall until the sun be set.... Taming of shirer, $\overline{2}$ (indinc.) and as the sun breaks ihrough .....

the moon! the sun; it is nut ....... blessed sun. Thien Grid he blesseil (rep.) - iv.

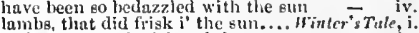
and as many of raisins $0^{\circ}$ the sun.... that goes to bed witli the sun ....... - iv. 3 for all the sun sces, or the close..... - iv. 3 the sun looking with a south ward $\ldots$. that e'er the sum shome bright $\mathrm{mm} \ldots . .$. . $\overline{\text { Errors, }}$. at length the sun, gazing upon ....... - i. I ere the weary smm set in the west

your beams, fair sun, being by ...... - iii, as whenee the sun 'gins his reflection... - i. 2 never shall sisn thnt morrow see?

shall have no sun to ripe the blowm... king John, ii. becomes a sun, and makes your.......
the glorious sun stays in his course..

the sun's o"ercunt with blood

fieble, and tany wenriel sun

the sum of heuren, methought

the sun, that warms you here ....... live

the sun sets weening in the lowly... =

by that fuir sun thet show

treacherous ear from sus to fun ....

thant like the smin, tid mak

and the blessed sun himself a fair ... II/cnryll:

[Cot. Kw.] at the sweut tale of thie sin?

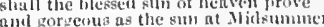

worse thum the sun in Marels.

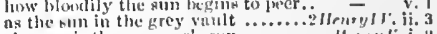

Clear as is the simmints sum

$n \times$ in bespite, the sun lowk prie $\ldots .$.

like the sun, his libernl tye ....... - iv, (ehoruk)

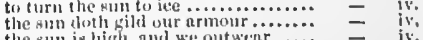

the sun is high, ant we outwets ....

is the sun and moun: or ratier, the vin - von

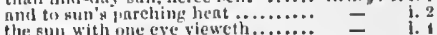

as plays the sus upon the kiusi.... 


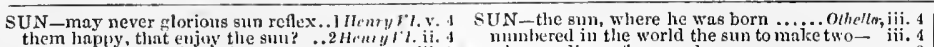
them happy, that enjuy the sum?
melts witlitive sui's hot beans.

like to the glorious sun's transpar

like the sun 'gainst glass .................
aclvance with our half-faced sun

her farewell of the glorious sun?

three suns? Three glorious s
one lamp, one light, one sun

, on $\ldots$.......

thy descent by gazing 'gainst the sun

nnd Ldward's sun is clunde

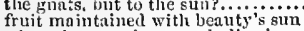

when the morning sun shall raise

as piercing as the mili-day sun

the sum, that seared the wings ...... Richarel III. i.

to spy my shadow in the sun .......
all the world is cheered by the sim

all the world is cheered by the sun ...
shine out, fuir sun, till I have

and seorns the sinn. And turns the su

When the sun sets, who doth not ....

Who saw the sun to-day? Not $1 \ldots .$.
the sun will not be seen to-day......
those suns of glory, those two

when these suns (for so they $\mathrm{p}$
the rays of the beneficial sun....

by darkening my elear sun

so many courses of the sun enthroned

as sun, and showers, there had

no sun shall ever usher forth ....

that sun, I pray, may never set1 ..... -

wherever the briglit sun of heavels.. - iv.

the sun doth light the storm.

before tlie sun rose, le was

hy the first hour of the sun

as sun to day, as turtle to........

a thousand complete courses of tie...

the sun borrows of the moon

in mass by the almighty
how the sun begins to set

the vail and darkening of the sun

doors against a settins sun .... Timon

there were no suns to borrow of...

there were no suns to borrow of......

fire slie suatches from the sun
thon sun, that comfort'st, burn!

sun, lide thy beams

upon the ice, or hailstone in the sun. Coriolan

scrateh my head i' the sun ...........

as I know the sun is fire $\ldots \ldots \ldots \ldots \ldots$.....

as I point my sword, the sun suises

as I point my sword, the sun arises.

by the of home is setion of your su.

U sure thy uprise shall I see.....

o thou sun, burn the great splzere

therein stuck a sun, and moon
behold the sun with as firtn eyes

to hide me from the radiant sun

if Cresar can hide the sun from us...
one score, "twixt sun and sun, madi.

one score, 'twixt sun and sun, madam
withount good-morrow to the sun ...

hath Britain all the sun that shines?
fear no more the heat $0^{\prime}$ the sun...

by this sun that shines

to look upon the holy sun....

and in the beams o' the sun so vanished

as when the golden sun salutes.... 't'itus.sndron.

lies rolling in the cheerful sun.

here never shincs the sun....................
sweet tidings of the sum's uprise?

and stain the sur? with fog .......

is the sun dimmed, that guats ........

black $\boldsymbol{E}$ thiop, reaching at the sun
and he the suit, for them to reveren

to seatter his erowns in the sun........

the sun and moon ne'er lnoked upon:.
by the sacredl radiance of the sun

these late eclipses in the sun and moon.

benediction eornest to the warm suin.

drawn by the powerful sun, to fall.

were all the letters suns, I could not see
hour before the worshipped sun.. Rmme

so soon as the all-cheering sun should

the all-seeing sun ne'er saw her match

sitting in the sum under the dnye-hou
and Juliet is the sun! arise, fair sun

now ere the sun advance his ........

the sun not yet thy sighs from heaven
faster glide than the sun's beams.

now is the sun upnn the highmost hill

and pay no worship to the garish sun

some meteor that the sun exlales.
when the sun sets, the air doth drizzl

the sun, for sorrow, will not show

SUN1BEAll-in the sumbeams Cymbeline, iv. SUNBEAMED eyes (rep.) SUN-BLIFIIT eye
SUN-BURNED sieklem
and 1 am sul-burned

of terona,

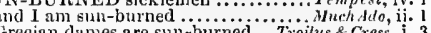

SUN-BUlRNING-not worth sun-burning. Hen, $V$. v. i. 1 SUNDAY-and sigh away Sumdays..... MuchAdo, i. Ii. 6
Ii. will to Venice; Sunday comes apace
Iill be married o' Sunday

Sunday next, you know, my daughter
now, on the Sundiny following .......

now, on the Sunday following ....... as Ilelers is on Sunday........ Troitus \& Cre'ssidn, i. 1

1
i. 2 we may call it herb of grace o' Sumdays.

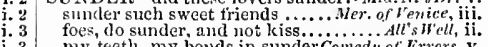

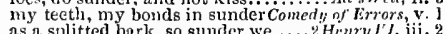

the seu that sunders him ............3 Herry VI. iii. 2

to sunder them that yoke so weli...

sunder his that was thine enemy?.. Romeo o Jut. v.
SUNDERED? shall we part......... As ynu Like it i.

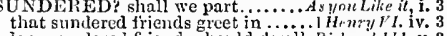
long sundered friends slould dweil. Richard lit. v. 3 fur sumdry weighty renson

more sundry ways than ever $\ldots \ldots \ldots \ldots$........ ive 3

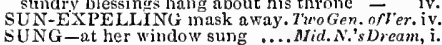

to be sung by an Athenian
indeed, and sung lamentably

indeed, and sung lamentably ........ïinter's Tale, iv. 3

and sung this ballad against .......... $\overline{\text { hing }} \overline{\text { John }}$, iv. 2

aven now he sung............

sung those tunes to the over-scutclied.2 Henry $J V^{\text {iiii.2 }}$

let there be sung Non nobis .......... Ilenry $v$. iv. 8

in dismal discords sung

together sung Te deum.

ïenry $\bar{T} 11$ iv.

sung thee aslee

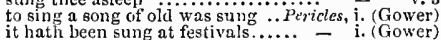

or when to the lit te slie sung

Lear, $\mathbf{j}$. 4 (song)

UNK-I would have sunk the sea........ Tennest, i. 2

and sunk, on Goodwin sands ........ King John, v. 5

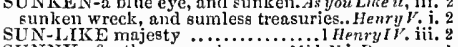

UNNY - for thy

her sunn

a sunny look of his would $\ldots$...... Comedy of Eirrors, ii.

SUN-RISING-before sun-rising ... Richard III.. .3

SUNSET, set armed discord...

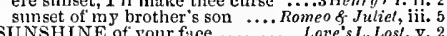

SUNSH INE of jour fuce ........... Love's L. Lost, v. 2

many years of sumsline days!...... Richard II, iv.

in the sunshine of his favour ......2 Henry $1 \mathrm{~V}$. iv.

then that sunshine brewed a shower

when we saw our sunshine made.... ii. 2

UUP-dine, sul, and sleep ....... Tro Gen. of fer. ii. 4

I am fain to dine and sup with. Meas. for Meas. iv.

in's belly than will sup a flea .... Love's L. Lost, v. 2

but sup them well...... Taming of Shrew, 1 (induc.)

in Eastcheap; there I'll sup

whill you sup wips he?

sup any women with him?

for yu shall sup withrow nigit

you'll surely snp in hell

come, let us sup betimes

1 will not sup to-night

wou must not know where he simps

you'll sup with me?................

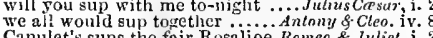

Capulet's sups the fair Rosalioe. Romeo \& Juliet

I do entreat that we may sup together... - iv. I

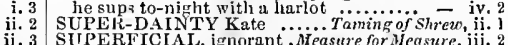

ii. 3 SUPERFICIAL, ignorant. Mfeaste for Heasure, iii.

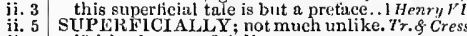

ii. 5 'faitl, sir, superficially

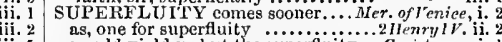

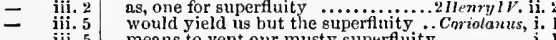

means to vent our musty superfluity - i. 1
SUPERELUOUS

that superfluous case, that hid....Love'sL.Lost, v. 2 wisdom waiting on superfluous folly .. All's I' 'ell, i. was once superfluols; you were erowned superthous branches we lop a way ... Richard $I l$. iii. shuuldst be superfluous to demand ${ }^{2}$ Herry $I^{\prime}$. dout them with superfluous courage..Henry $V^{\prime}$ iv. so wo ghall the mountains toucl so would I ha' done, by yonder sun - iv. 5 (song
other things grow fair against the snn.. Othello, ii. 3 so many journeys may the sun and moon
UPRRFI,UOUS laciueys and nur.... Hen'y ${ }^{T . \text { iv. }}$

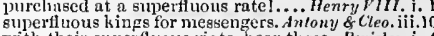
with their superfluous riots, hear these...Perieles, $\mathbf{j}$. in the poorest tling super fluous ........... Lear, ii. gives me superfluts as denth!............. Hamlet, iv. SUPERFLUOUSLY; and 'twere more. henry $V$. iii. 7 SUPERFLUX-shake the superflux to . Lear, iii. SUPERNAI, juldge, that stirs ......... King Jolin, ii. supermatural soliciting cannot be ii ...MAabeth, i. 3
SUPERPRAISE my parts, when ...Mid.N.'s Dr. ii. 2 SUPERIPRAISE my parts, when ...Nidi.N.'s Dr. iit.

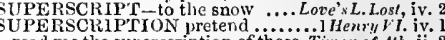
read me the superscription of these. Timon of Ath. ii.
SUPERSERVICEABLE, fical .......... Lear, ii. SUPERSERVICEABLE, fnical .......... Lear, ii. 2

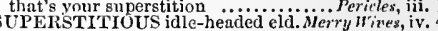

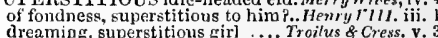
lie is sujerstitious grown of late ... Jultius Caresar, it. superstitinusly doth swear to the gods.. Pericles, iv. SU PER VISE the canzonet ................... that, on the supervise, no leisure bated. Hamlet, $v .2$
SUPERVISOR, [Col.Knl.-supervision]. . Ohello, ii. UPPED-lie has almost supped .......... Macbeth, i. 7

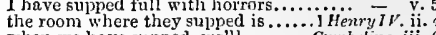
when we have supped, we'll ......... Cymbetine, jit. 6

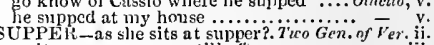
wait upon your grace till after supper of - il.
I will not fail him at sulper........... Much Ado, I came yonder from a great supper... . Much Ado was not count John here at supper?...

the fool will ent no supper that night which is ealled supper..... Love's L. Lost, i, 1 (letter) supper be ready at the farthest...Mer. of Venice, ii. I am bid forth to supper. Jessica.... - ii. cinners, and suppers, and sleeping As you Like it, iii. 2
supper ready, the house trimmed. Taming of Sh. iv. I go, and feteh my supper in ..........

we hold a solemn supper, sir........... Macbeth, iii. the time, 'twixt this and supper .......... - - iii. come home with me to supper....... Richard 11. iv. hesbuttoning thee after supper $\ldots . . .1$ Henry IV. 1 . will tell us, when we meet at supper company, last night at supper ...... sack after supper, $2 s .6 d \ldots \ldots \ldots \ldots \ldots$. Doll Tearaheet meet you at supper?.
we steal upon tliem, Ned, at supper

made after supper of a clieese-paring

Thave drunk too much sack at supper - Y.3 make a bloody supper in the Tower...3 Herry r't. v. 5 as we did sit at supper............. Nichard 111 .

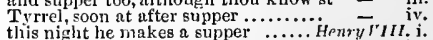
tlis night he makes a supper ....... Henry r'III. i. 3 come agaiu to supper to him.. Timon of Alhens, iii. and $y$ esternight, at supper ..........Julius Cresar, ii. I invited her to supper ............... Julony \& Cleopatra, ii. let's to supper; cume, and drown .... $-\overline{\text { iv. }}$ we'll go to supper i' the morning ........ Lerr, iji. supper served up, you called .........
supper is done, and we shall come .. slue will indite him to some supper $:$. = ii. at supper. At supper? Where? ...... Hamlet, iv. 3 being tull of supper, and distempering ... Olnello, i. shall't be to niglit at supper?..........

low these instruments eummon to supper! - iv.
SUPPER-TIML-ere supper-time ....? we will visit you g.t supper-time. Mer.of fenice, ii. 2 and twill be supper-time.... Taming of Shreu, iv. 3 a hundred crowns since supper-time.. we will keep ourself till supper-time...Macbeth, iii. now it is supper-time in Orleans .... I Herry $\% I . \mathrm{i} .4$ it is now high supper-time...$\ldots \ldots$ Othello, iv.
SUPPING - thou me of supping? Comedy of Err.iv. 3 UPPLANT your brotlier Prospero.... Tempesl, ij. I you did supplant good Prospero ....... we must supplant those rough....... Riehord 11 . ii. I
if hetter rcasons can supplant ......2 Henr? Vl, iii. I and so supplant us for ingratitude. Titus And ron. i. 2
SUPPLE-tribute of his supple knee...Richard If. i. 4 I'il make him supple ......... Thoilas ó Cressida, ij. 3 for supple knees feed arroganee...... deprived of supple goverument.. Bnmes f.lutiet, iv. I we have surpler souls than in our .. Coriolumes, $y$ SUPPLIANCE of a minute ............... Hamlet, i. 3 and speech of the poor suppliant what shrill-voiced suppliant makes. Richard II. v. 3 what a humble suppliant lord...... Rishard $I I I$. i. scandaled the suppliants for ....... Coriolants, iii. 1
make it like a humble supptiant. TilusAndron. iv. 3 


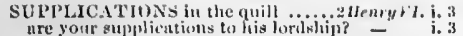
ure your supplicutions to his orileslip? your grate th the rebels sulplicution?

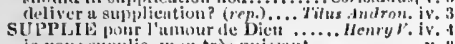
je vous mupplie, mon tres puistu.

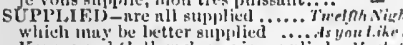

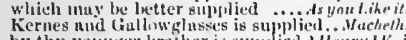

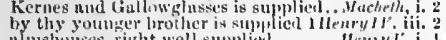
nlmshouses, right well suppliet.

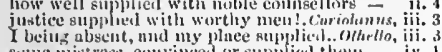

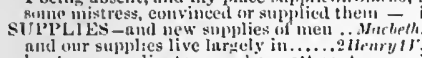
we have supplies to scemul our attempt -
tis their tresh supplics. It is a duy.. Cymbeliu

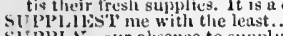

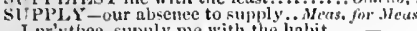
I pr'ythee, supply me with the liabit
did suphly thice at thy garden-lyouse
yet, to supply the rifie wants of... Jer of Fenice, yet, to supply the ripe wants of...Mer.

to supply the places at the table.. Fumin

you sliufl supply the bridegroow's place - iij. tor the great supply, that wis......... King
your supply, wheli you bave wisher

send them after to supply our wants. Richart 11 i luoks he not for supply? So do we.. I llewrylt: iv. 3 for the whieh supply, admit me. Henryl. i. (ehorus) eraveth supply and hardly kecjs his.l lienry rt. i. I my promised supply of horsenten

let this supily the room ...........

shall follow with a fresh silp
lody, and supply his plnee

but fiud supply immedinte ............ Timo on dithens, iv. 6 to use them toward a supply of molley to sulply lis ins linour to sulluly.

nor hing lie with him to supply his lite

with supply us easily.

政 sinply the place lor your labour..l.eur, iv. fi (letter supply it with one gender of lierbs.

SUPPIX-INT-must be supplynut.. ('ymbeline, iii. 7 SUPPIYYIENT-nor supplymeat ... Cymbeline, iii.

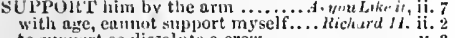

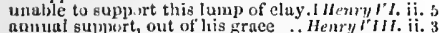
bute to support hin ofter. ediets for usury, to support usurers. Coriol

support the wirships of their name

durest thon support a published traitor?

alack, too weak the eontliet to sumport?.. - v. I a lieuvy interim slall support ........ Othello, i. 3

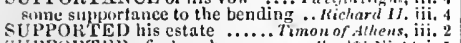

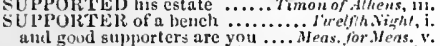
that no supperter but the huge firm, King John, iii. 1 SUPPUS SU I'PUSE-they suppose is drowned... Tempes', and 80 , suppose, am I...... Tueo Gent. of lerona, iv. and he sujpposes me travelled to..... Mens. for Me rs. since, I suppose, we are made to.
and do suppurse, what hath been and do supporse, what hath been
thint he blanll suppose no other

Whom lie supposes to be a friar

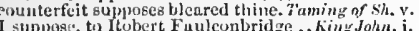
I suppose, th lobert Fuluconbridge ... Kint John, suppose the soul's frail IIwelling-houve

supnose, deveuring pestilenee liangs. Richard II, i.

if you suppose, us fearing you....... i ifenty/s, iif. )

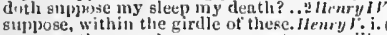
suppose, withill the girdle of these. Hemy r. i. (elio.)
suppose, that you have seen (rop.)

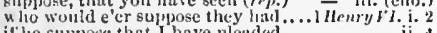

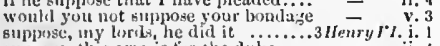
suppose, this arm is fir the duke....

suppose, they take off che witlout

suppowe, that I aln now my ........... as little joy you may suppose in me

emine short of our sulphese so fur.. Troslus f Cress. i. 3 though they suppose nue mad.. Tilns, twh onchus, v, 2

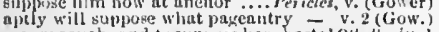

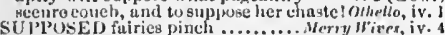
I'll be supposed upoo a book..........

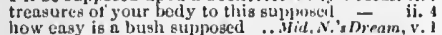

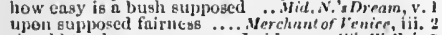
sluuld tender your supposed atd........Al' ow ell, i. supposed Lucentio inust foct (rep.). Faning or sh. ii. supposel hy the comnan rout .. Comedy of Rrr. iii. supposed sincere and holy .........2 thenryly. i. . vainly I supposed, the fuly l,and $\because$ - iv. iflly anplosed the founder of this la w... thenry b' i.

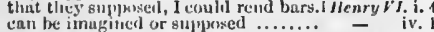
co tcrmed of our supposel tather ...2henry riv. iv. 2

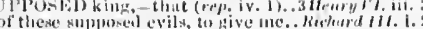
mul supused their states were sure... ii -

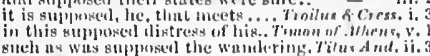

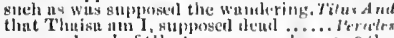

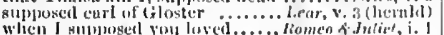

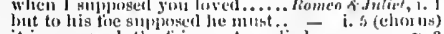

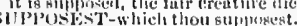

sulvosing that they saw the

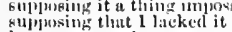

in your pisposing one nure pit.

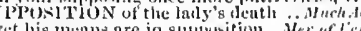

yot his means nre in stppumition.

in that florious slppon

lichurl, to suypres thy

to suppress his further gait herein

n'mls. i.

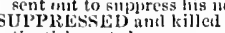

or himselt, be quite sup
oIPPRESLIT wroms

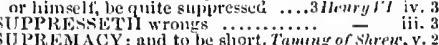

under him, that grent siupretnacy

thy finl supremaey thou knew
diii vail their erowns to his sul

SUI'lREA le-are supreme he!d

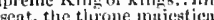

neither supreme, how soon conflusion

my supreme erown of gric.

URA NCE that thou art Revenge. Filus dntron.

lest I surcease to honour mise own. Corinhtums,

natural prog ress, but furvegse .. Roneo of fuliet, iv. 1

and sure, it waits unon some goil.

mest sure, the goddess on whiom

for lie is, sure, i' the island $\ldots \ldots \ldots \ldots \ldots . \cdots$ - if.

nay, sure I think, she.................. of verona, ii.

you wonld sure deceive
sure at I live, lie nad

we are sure enough

I am sure vou eannot give.............

lor different names (sure more) .......

I'll be sure to keep hin above deek..
meed, I am stare, I have reecived noide

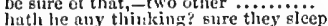

sure he is by this, or will be presently

fuirer things than polecats, sure $\ldots . .$.
but are yeu sure of your lusband now?

in my house I nm sure he

all his purpose sure, he'll come........

sure, ene of you does not serve

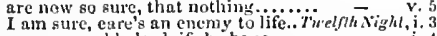

sure, my noble lord, if she be so
aud i, that in sure I laek thee.

sure, you have some hideeus matter

she loves me, sure; the enuning ....

lie is sure prossessed.

I nm sure no man hath.

srt thou sure of this? I atr too sure....

precise villains they are, that I am sure

have, sure, more inck of reneon ........ -

I an sure, your know him (rep.)....

no, sure, my lord, my motlier erietl.

knavery camet, entre, hicle limself in

sure, I think so; and theretion

sure, sure, such carping is not

yea, as sure as I have a thought.

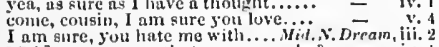

[Col.] are you sure that we nre awata?

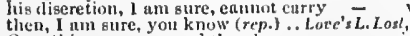

$O$, nothin so sure; nud thereby

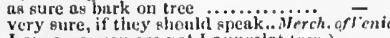

I atn anre, you are not launcelot (rep.) -

why, I un sure, if he forfit, tioui

fir I am sure, you ean wish none....

I $\operatorname{am}$ sure, the cluke will never grant

and yet, I am sure, you are not satisfled -

as sure I think dlid never tank love so you

go, he sure, will Itosntimi.........
I an sure, you ne not prigoner...

tis pretty, sure, and very probalile.

nor, $I$ an sure, there is no force

but sure, he's proud; anul yet his
nud his hund. Sure, it is hers.
Iili, motlice flogl toward.

coml, I ma sure, as many as have good -

and eive where ghe in sure to lube ....All's

nul thiuk I know most sure, ny art

urecrtain life and sure deatl .......

aim gure, thy finther drank wine..

I nin sure, the younger of oil niture

Whit, I am fure, he know not.....
but fure, he jo the prinee of the worli

I unsure. 1 saw her wear it

but, sure, that lart was .... Taming of sh

a gite very grateful, 1 am sore of $i$

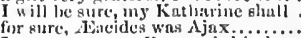

I am sure, swcet Kate, this kindo....

tell hin, you are sure, nll in .......

a lustnril, so sure as this beard's grey

pret y oue; sure, some seape .........

for then we are sure they ase true.

sure, when I slanl see this gentlemuin

for, I am sore, my licart wept blond

gure my master is horn-mad (rep.)

sure ones then.

sure, these are but ima riunry wiles..

anon, I am sure, the duke............

and sure, unless you semd bome...

I an sure, you both of you ( $r \in p_{0}$.).

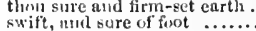

I'll nike assuranee dou

what she sliould not, I ani........... of thit and. he sure, I eount onyself in......... Nirhard $I I$. ii. 3 Jut, be sure, I will from .............1/enryl $\%$ two, I am sure, I have paid ...........
the parties sne, and our indiction..

and, as sure as day: and givest ......
so should I be sure to be heart-burned I nusure, the never learnol.....

but inine, I am sure, tluu art....

I am sure he is, to the hearing

eoment upon a sure foumdation.
gord marter Fing

gord mater Fung, hold him sur
fe sure means lovevity in breath

eertain, 'tis eestain; very sure, very sure -

stand'st moge sure thau I could do .. - iv.

sure, we thank you, mo learned löd̈.. Itrury $r$.

nay, sure, le's not in hell.......... = iii.

which I an sure will hang upon ..... Z

to thy dear eost, be sure $\ldots \ldots . .$.

'tis sure they fulld some place...

am sure, 1 scarcd the Danphin

so sure I swear, to gat the town.

hoth stay, we both are sure to die...

I'll be the first sure

whose benum stands sure, whose....

ns, sure, it shortly will .............

poor clicken shoula be sure of death

ter, sure, my thoushts do hourly

the king hath kent lim, sure $\ldots . . . . .3$ - $v$

take 11 . We nre sure to die

nay, he thou sure, I'll wel

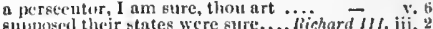

but kure, I tiar, we shall ue'er .......

fer. 1 um kure, the cmperor $3 .$.

lin, sure. there's no converting of thit'm

be sure, you be not loose .............

how sad he lowks! sure, lie is mich

a sure and safe one, though thy...

the citizens, I am sure, have

antl, sure, those men are happy.
sure, you know me? Yes,

I mmi sure, thon hust a eruel natire:

than malice; I nm sure in me

I and sure, he is not lleetor .. Troilus of Cresside,

but. I nu sure, none; vileks.......... = iii.

ghe was nut, sure. Must sure she wa

my drenst will aure prove onimous

now to guaril hure tlicir master .. Jim

as your waiting, 'fwere kure enough

baushedl 'tis 80, lie sure of it...

ever donbt, though ne'er so sure .....

cleal, surc; and this his prave.........

our gond wills: a sure destruetion...
nt liberty, $t$ inulal sure, suutliward.

wliy, so hie did. I am sure.

hice slotl, sure ou't ii. I 3

ii. 3

V. 3

ii. 2

iv. 2

i. 1

3 3

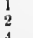

iii.

v. 4 3

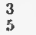
i. 3

iii. 2 ivi. 5 i. 3 
SURE-thou sure, when he shall come. Coriolanus, iv. 7 SURELY -he is, he's surcly dem ....3Hemry $l^{\prime \prime}$ ii. 6 sure, if y'ou would be your country's

thiat thought them sure of you

let Cxsar seat him sure; for me.

and, $I$ an sture, it did not lie there.

as I am sure they do, bear tire

sure, the boy heurd me ......................

seen more years, I am sure, thun ${ }^{2}$

nay, I an sure it is, Volumnins

thou art sure to lose; nnd, of that. \#wiony $\bar{s}$

if he do, sure he cannot weep.....

pestilenee, where denth is sure $\ldots \ldots . .$.
to bc sure of that, I will ask Antony

for, I $\mathrm{mm}$ sure, thongh you can guess

I am sure, uny nails are strouger...

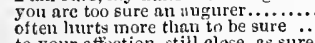

to your affection, still close, as sure...

zou did mistake him, sure.

but, be sure, no less beloved........... =
than be curel by the sure pliysieian
which I am sure you do not know...

Which I am sure you do not know

I am sure, hairgine's the way of winking -

so is as you your tather's.............
sure as death I swore, I wonld .... Titus and
we will make that sure: come, mistress -

see, that you make her sure...
but, sure, some Tereus hatl

'tis sure enough, an' you knew how....

you are a beaiteous hlossom, sure...
as sure a card as cver won the set...

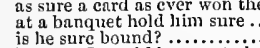

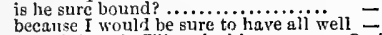

pistol's length, T'll make him sure

to break one, will sure crack one

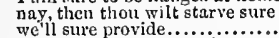

we hire he provide...................

sure all's eftectless

how sure you are my ilaugliter

since, I am sure, my love's more

sure, her offence must be of sucli

or waking? ha! sure, 'tis not so...

I am sure, is kind and comfort
slould sure to the slaughter

I ant sure ou't, not a word

not love her husband; $I$ am sure of that

most sure, and vulgar............................

that he will sure run mad .....Romeo \&

[kat.] sure wit. Follow me this jest now -
I am sure, I have in my whole five..

\section{so sure a draught [Col. Knt.-dram]}

so will you, I am sure, that you love me -

for, I am sure, you have your hanils, $\overrightarrow{\text { I }}$

sure I am, two men there are not living
policy so sure as it hath used to do

sure, dear friends, my thanks are to

sure, you have, else could you not
sure, he, that made us with such

thongh nothing sure, yet much unhappil

but, sure, the bravery of his grief
it is as sure as you are lionlerigo

but thou must needs be sure

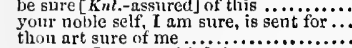

no, sure, I camnot think it

surc, he fills it up with great ability......

be sure thou prove my love a whore $\left({ }_{\mathrm{rep}}\right.$. $)$ -

I am sure, it was your wife's ........
sure, there's some wonder in this.

I pr'ythee, doso: somzthing, sure, of stat

ply Desdemona well, and you are sure of

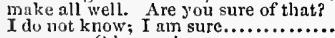

yes, sure; O lieaven! ................

if she come in, she'll sure speak to my wife $=\quad$ v. 2
sure, he has killed his wife ..............

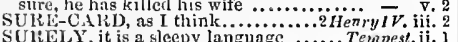

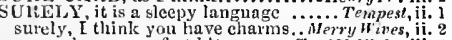

as surely as your feet hit ......... Tue elfh Nisht, iii. 4

you do wrong lim surely.....

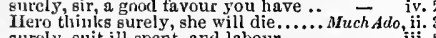

Iurely, stit ill spent, and labour ........ -

surely, a priucely testimon

a swcet gallant, surely!............... - iv.

surely, affected her for her wit ........ Love's $\bar{L}$. Lost, $\mathrm{i}$.

none are so eurely caught, when they

youtll is surely in their company...ds you Like it, ii.
ay. surely, mere the truth ...........All's swell, iit.

a good matter, surely.. Taning of Shreu, i. 1 (induc.)

in gate and counterance surely like

in gate and counterance surely like
hut, swrely, master, not a rag ut: Comedy of Err. iv.
they will surely to us no larms......

shalt so surely tie thy now unsured... King John, ii.

that sal I surely do.

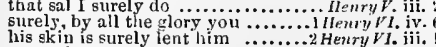

his skin is surely ient him .........2 Herry VI. iji. I

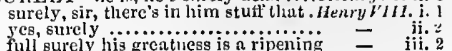
devil was amongst them, I think, surely

I slall surely speak the thing.. Truilus \& Cress. Iji. 3

else, surely, his had equalled.. Timon of

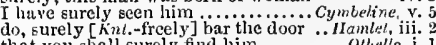

that you shall surely find him ........... Ohetho,

yet, surety, Cassio, I believe, received.....
URER bind, this knot of amity ..... Jienry $r$.

you are no surer, no, than is

SUREST-strongest and surest way... Richard 11 . iii. 3

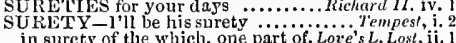

in surety of the which, one part of. Love's L. Lost,ii. 1

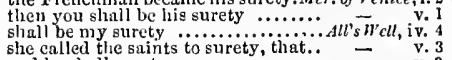

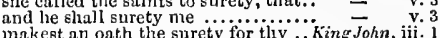

makest an oath the surety for thy ... King John, iji. 1
what surety of the world, what hope - iv.
giv'st such sarcenet surety for....... I Henry $1 \mathrm{~V}$. iii. 1

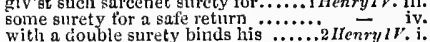

that for my surety will refuse $\ldots$.....

of peace is surety, surety secure...... - ii. 2

we'll surety him $\ldots \ldots \ldots \ldots \ldots \ldots$.
in that kind, will do, as if for surety ..... outhello, i. 3

URFEIT-make me surfeit .. TuroGen. of fer. iii. 1

that suffer surfeit, cloyment...... Turelfh Night, ii. 4

as a surfeit of the sweetest things...Mid.N.'s Dr. it. 3

so thou, my surfeit, and my heresy

make it less, for fear I surfeit....

as one that surfeits thinking on..... Herry $V I$. iii. 2

to cure thy o'er-night's surfeit? ... Timon of Ath. iv. 3

what authority surfeits on ..........

too full of the war's' surfeits...

full surfeits, and the drymess of ....Antony 8 Cleo. i. 4

the surfeited grooms do mock $\ldots . . \ldots \ldots$. Mucbeth, ii. 2

my hopes, not surfeited to death........ Othello, ii.
SULFEITER-amorous surfeiter.A Alony \& Cleo. it.
SURFEITING, the appetite may.. Trelfth Night, $\mathrm{i}$.

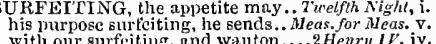

With our surfeitillg, and want on ...2 Henry I .ip.

SURFELT-SWELLED, so old, and

and breasted the surge most swoln ........ fi. fives, it. 5

the blind waves, and surges ...... Tuvelfih Night, v.

of the rude imperious surge .........2 Henry i $\mathrm{V}$. iii. ।
breasting the lofty surge...... Henry $\mathrm{V}$. iii. (cliorus)

whose liquid surge resolves

the turbulent surge shall cover

egg-shells moved upon their surges Cymbeline,

when some envious surge will in. Tilus. Andron. iii. 1
rebuke these surges, which wasl both. Pericles, lii. I

the murmuring surge, that on the....... Lear, iv. 6

SURGEN-the love of Grod, a surgeon. Twelfth $N$. v.

didst sce Dick Surgeon, sot?

with the help of a surgeon ....Mid.N.'s Dream, v.
have by gome surgeon, Sliylock. . Mer. of Ienire, iv. 1

go, get him surgeons .................Mactelh, i.

some, crying for a surceon.......... Henry $V$. iv.

opinion shall be surgeon to my hurt.i henry $V$. ii. 4

surgeon's box, or the patient's . Troilus \& Cress. v. 1
I am indeed, sir, a surgeon to old .. JuliusCcesar, i. I

deal withal, and defy the surgeon? .... Perieles, iv. 6
let me have a surgeon, I am cut to ...... Lear, iv.

go, villain, fetch a surgeon....... Romeo $\&$. Juliel, iii.

O help! hol lightl a surgeon!
I'll fetch the general's surgeon

UURERE-dilueulo surgere ..... Tueifin Night, ii. 3 the mere despair of surgery, lie cures... Macbeth, iv. 3 honour hath no skill iu surgery ..... i Hen'y $11 . \mathrm{v}$. and to surgery bravely

SURLY with servants $\left(\right.$ rep. iii. $\left._{1}\right)$. Tivelfih $N$. ii. 5 (let.) you'll prove a jolly surly groom.. Taming of Sh. iii. ? justice, with his surly hum.

the surly Gloster's governance.........2 Henry VI. i.

ay, or surly borne? ........... Troilus of Cressida, ii.

would have galled lis........... nature..Coriolanus, ii.

Went surly by, without annoying .. Julins Capsar, i:

that function is smothered in surmise... Macbeth, $\mathrm{i}$.
blown by surmises, jealonsies ..2 HenryIV. (ind ice

expectation, and surmise of aids

or wrong surmise, liold me a foe ... Richard HII. ii.

not out of weak surmises .... Cymbeline, iti. 4 (let.
whereat it tremhles by surmise ... Titus Andron. ii.

me this: now gather, and surmise .... Hawuet, ii. open perils surest answere

witl a double surety binds his ......2Henry IV. i.
for surety of our leagues $\ldots \ldots \ldots \ldots$ Henry $V$. v.
shall be the surety for their traitor ...2Henry $V I$. v.

the sick hour that his surfeit made... Richard if. ii. 2

often the surfeit of oul own behaviour .... Lear, i. 2

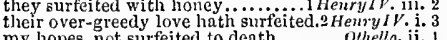

SURMISES, matching thy inferenee .... othello, iii. 3
SUllMISED whilst thou art .......2 that gave't surmised blape ... Troilus \& Cressida, i. 3
the HOUN'TS our labour

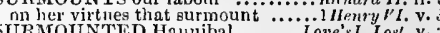
SURMOUNTED Hamibal.......... Love' L. Lost, v. are requited but with that surname.. $-\overrightarrow{\text { iv. }}$ iv. Andronicus, surnamed Pius ... Tilus Andranicus, $\mathrm{i}$. SUPPASSING the common URPLUS of your grace With surplus, to tire in repetitiou... Hinter's Tale, v. surprise her wit gower's .......... Merry Wires, v.

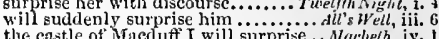
the castle of Hiccluft I will surprise... Alacbeth, iv. lay cheir heads together, to surprise.2 Henry $V 1$. we may surprise and taknd him.... - iv. surprise me to the very brink... Timon of Athens, v. surprise and fear made me to quit ..... Pericles, iii. 2
SURPRISED with all ................ Tempest, iii. l be surprised: muster your wits .. Love's L. Lost, v. was beguiled and surprised. Taming of Sh. 2 (induc.) your castle is surprised: your wife..... Mlacieth, iv. in this adventure hath gurprised ..... i Henry $\mathrm{J} V$. $\mathrm{i}$. were there sururised and surprised... Henry hoth be suddenly surprised

their governors, suxprised our forts... Henry $_{V I}$. iv by lis foe surprised at unawares...3 Hen $y=$ iv. low easily slie may be surprised. Anlony \& Cleo. v. with a happy storm they were surprised - ii. 3 $\mathrm{I}$ an surprised with an uncouth fear - ii. wert thou thus surprised, sweet girl..

Greeks surprised king Priam's T'roy

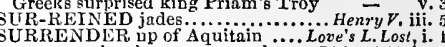
cominon view he may surrender ... Richard 1I. 1v. this last surrender of his will but offend th importing the surrender of those lands ... Hamlet, I dare meet Surrey in a wilderness .. - iv. the earls of Surrey and of Warwick. 2 Henry IV.iii. 1 lord of Surrey, why look ye so sad?.. RieiardIIi, v. 3 saddle white Surrey for the field.

and what said Surrey then?

earl Surrey was sent thither ........... Henry $\bar{v} I I 1 . \mathrm{v}$. forty hours Surrey durst better have

a bounder man than Surrey can be ..
and that the earl of Surrey, with the rod

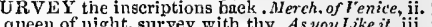
queen of night, survey with thy. As you Like it, iii. 2 that takes survey of all the world ... Hemry IV. v.

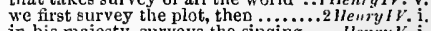
I his majesty, surveys the singing.... Henry and to survey the bodies of the dead.I Henry VI. iv. 7 survey his dead and eartliy image..2 Hem'y 1. ii.

hake but an interior survey........ upon a just survey, take Titus'. Titus Andronieus, i. SURVEYEST, or see'st ..... Love $\%$. L L L t, i. I (letter) SURVEYOR-question surveyors.......Macbrth, i. make the fox surveyor of the fold? 2 Henry 1 . ii my surveyor is false: the o'er-great
you were tle duke's surveyor, and lost appeared against him, his surveyor $\dddot{H}^{-}, \bar{G}$ be it that she survive me .... Taming of Shrer, it. if 'Talbot but survive thy treachery. 1 Henry $\%$ ? ii that survive, let Rome reward. Titus a udronicis, the noblest that survives, the eldest.. yon that survive, and you that slcep

SURVIVOR hir of her shame........... the survivor bound in filial obligation.. Mamlet,

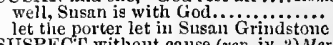
if you suspect me in anse (rep. iv. 2) Nlerry Wives, if I rather will suspect the sun ........ $=$ iv. 4 you may suspect him, by virtue ....... Much $\bar{A} d o$, iii. 3 dost thon not suspect my place? (rep.) ${ }^{\prime}$ iv. leat she suspect, as he does, her... Winter's Tole, ii. within the compass ol' suspect. Comedy of Err urs, iji. I do slispect thee very grievously ... King John, iv. thon dost suspect, that i have been ... Kichirard.1\%.
he will suspect us still, and find .... Heury $1 \%$. as the suspect is great, would make..2 Henry $V I$. $i$. that yet suspeet no pcril, will not.

if $\mathrm{my}$ suspect be false. forgive mo.

then you, belike, suspect these noblemen will suspect, 'twas he that made

never have yout in suspect.............

draw me in these vile suspects........ Riehard III. $\mathrm{i}$. froin all attainder of traitor

froin all attainder of suspect $\ldots . . . .$. .

my noble cousin should suspect me..

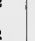


SUSPECT my humbandry in whinse hrenst donbth nul suiject.

whet still eomes where an estate.. - iv. 3

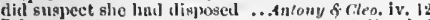

I do suspcet yuu, mnilun ............. Ciymterline, i. 6

if he surpect 1 may dielsonour him ..... Iterirles, j.

harms, that he enspeets none...............herst, i.

I lo suspeet the lusty Monr hath lemped. Othella ii. I

Yet doubts; sugpects, yet atrongly lovet

if. liaply. you my fintlue do silpuet.

male you to surinet me with the Moor

may you suapect who they should be

suSPECTFD-shoulu he surpected

ho would have suspected an aubui....

olinion sick, and truth suspected ... Kinn John,

I give enuse to be suspectesl of mo:e.. Cymb
suspected of your earringe from the conrt

rise 4

and a smonth dispose, to be suspected ... oithello, $\mathrm{i}$.

SInt a smonth dispose, to be suspected .. Olhello, i.

suspend thy purpose, if thou didst ......... i. 4

SUSPICION of the decd.

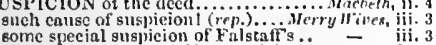

another cxperiment of his suspicion

lie will wear his enj with suspicion?... N/

nothing of his ill-ta'en, suspicion!. Wint

lier honour true, than your susplejon

too much believed mine own suspieion

the verity of it is in strong suspicion

we sliall proceel without suspicion.. Richard UL iv.

euspicion shall be all stuck lull of ... l Hemry Ir. $\mathrm{y}$.

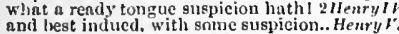

in York this breeds suspicion.

he may acquit him of suspicion!

the guilty 3 Henry

yet

intending deep suspicion: ghastly looks -

never yet hranded with suspicion?.. - ii.

to answer their suspicion with their. Titus And. ii. 4
it will stuff his suspicion more fully .... Lear, iii. 5

a great suspicion; stay the friar.Rume

Lear, iii.

bring for th the parties of suspicion

for mere suspicion in thut kind

nor to larger rench, than to suspicion...

USPICIOUS head of theft ......Lnne's L.l.osh iv.

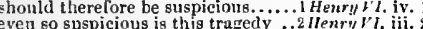

spy a hlack, suspicious, threatening. 3 Henry $l y . y$.

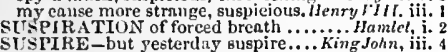

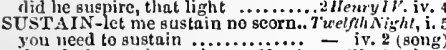

you need to sustain ............. iv. 2 (song)

ghould sustain the bound and high ..A Al's Well, ii.

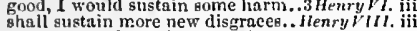

doth sustain in life's uncertain. Timan of Athens,

sites of nature will not

well then, sustain me $\ldots \ldots \ldots \ldots \ldots \ldots$ - ii. 9

if she sustain him and lis hundred ..... Lear, i.

entreat for him, nor any way sustain him - iii.

this realm, and the gored state sustain..

a letter never lid sustain itsel[ upon .... othell, 1.

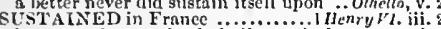

by yon to he sustained, shall our abode .. Lear, i.
stisT.

SUSTLNAXCE - no sustenanee.... Titus Audron. v.

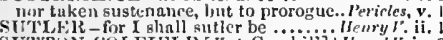

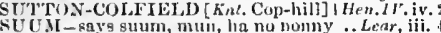

SU UM-Rays sum, mun, ha nu bumy . Letar, iii. SWA BBLIR, the boatswain and I. Tempest, ii, 2 (hong)
no, gool swabber; 1 am to lull . . Tuelfihsight, i.

CI, () TS. Ifarly, lye"s a sceond time. Itamlet, ii. 2 SWAGGER - it he swayger, let him........ Mhella, ii. I am the Horse, when one says-swagger - i
will he swngger liimself out.... Trotius of Crss.

swager? swenr? and diecourse fustian. Olhella, ii. 3

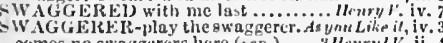

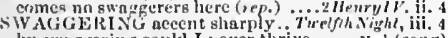
ly swaggering coult I never thrive - v. 1 (Bong)

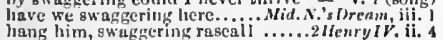
while, to have swaggering now (rep.)

and the awagnering ulp-siring rewis .... Ilambet, $\mathrm{i}$. (ling clierish thy forlorn swain

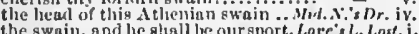
hat low's irited swain (rep )

give enlurarement to the gwain

Guch ent

I shomt thee at the swain ............

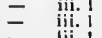

this swain, becsuee of his great himb

the swain, Pompey the Great.........

too liglit for such a swuin as you. Taming of $\mathrm{Sh}$. $\mathrm{ji}$.
WW AIN-you pearant swaln!. Tumoing af Shrow, IV a poor humble swain, as I seemin now

whet fnir swain is this, which tlanees

low prettily the young swain see

like a ledge-Lroru swnin that
hegotten of $\mathrm{a}$ slicplierd kw win

obseare and lowly swain.......

no better than a homely

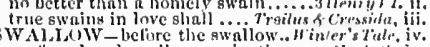

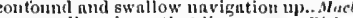

now swallow down that lic
do you think me a swallow

and swnllow my aword like a
nud swallow me ulive, where

kid swallow up his lif

as thou dost swallow up this good.... kiehar

lct prisons swallnw them, lebts.

swallows have built in Cleopatra's.Ant. \& Cleo. iv. io

will in his brinisl bowels swallow him -

as swift as swallow flies.

swallows the old rat, and tie diteh-dog.. Lenr, iii. it engluts and swallow's other sorrow's ... Othelia, i. 3 nnd wide revenge swallow them up...... - iif. 3 from whom we were all sea swallowed - ii. I as if Ihad swallowed snow-balls...Merry mires, in. you swallowed love with singing. Love'sL. Lasl, jii.

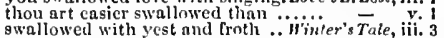
daily swallowed by men's eyes ..... H Hry chewed, swallowed, and digested ..... Henry $1 \%$ ii 2 our sailors swallowed in the flood?..3 Henry $r^{*}$. v. 4 that swallowed so oluch treasure .. Mrnyy III. i.
oblivion swallowed cities up. Troilus \& Cressidn, iii. 2 at tendants absent, swallowed fire. Jutius Casar, iv. 3 if they had swallowed poison..... A ntony fo Cleo. $\mathrm{v}$. they've swallowed the whole parish. . .'ericles, ii. because he slould have swallowed me too - ii. ]
swallowet some part o' the carth - iv. 4 (Gower) hath swallowed all my hopes .... Romeo of Jutiet, i. 2
first mouthed, to be last swnllowed..... Hnmlel, iv. 2 WALLOWING a tajlor's news ....King John, iv. 2
your gight, for fear of swallowing ... HewrylV. v. for swallowing the treasure ........2henry I. iv. I procecd by swallowing that ......... Cymteline, iit. 5 WAMI ashore, man. like a duck ...... Tempest, ii. 2 I swam, ere I eould recover the shore.. scarce think you have swam in ... As y/oulike il, iv. 1

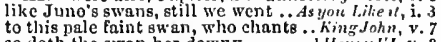

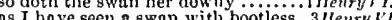
the swan's down feather .. Anlony \& Cleopoly in a great pool, a swan's nest .......Cymbeline, iii. 4 mnke thee think thyswan a crow. Hameo \& Julict, i. 2 I will play the swan, and die in music.. Ghello, y. 2 WARE they were his faneies ......2 Henry $W^{\prime}$. iii. 2
Brutus sware for Lnerece rape .. Tilus Andron. iv. I thenatore do swarm upon him...Maebeth, i. 2 swarm about our squares of hattle..... Henry $l$. iv. 2 people swarm like summer flies .....3 Henry Vi. ii. 6 people by number swarm to us ....... plebejans swarming at their licels. Henry $r_{\text {. v. (cho.) }}$
SIVART, like my glioe, but her..Camedy of Err. iii. 2 crooked, swart, pronligious, patehed. Ki"ly Jahn, iif. I

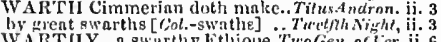

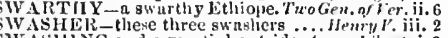

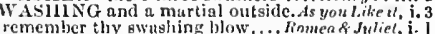
remember thy owushing blow .... Rmmea \& Juliel, i. I

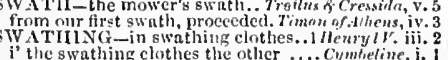

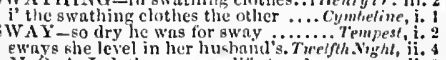
eways she level in her hushaid 's. Trelfth. Noht, ji. N, O, $A, I$, doth sway my lite (rep.)
not thy passion, sway in this uneivil ii.
she could not sway lier housc........ iv. and to behold his swity ..... Mensure for Measu

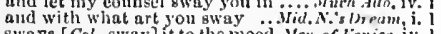
swass [Cols-swny] it to the mood. Ver. of lenice, iv.] that my full life doth sway....... . is you $L \overline{i k}$ it, iil. 2 supremucy, and sway, when they. Taming of sh, y. 2
you would bear some sway .. Comedy of tirrors, ii. I onvercign sway and masterlom..........hucbelh,

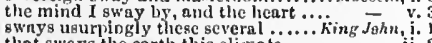
that swnys the earth this climate.

this swny of motion, this commodity = it. kingly sway from out my heart.... Rirhard $I l$.

ghall lose his sway

let us sway on, nnd free them.........2nenty

because nu one should sway but he. i Hewry $* t$
SWAY-now sways it this wny (rep.).3/lenry $/ \%$, ii. s

thou art worthy of the sway

inighty fur thy place nntl swa

naught but humnur sways liim

poteney, and sway o' the atnte.

when all the sway of eterth shate

made me man, and sway in

who oways, not as it hath yower.

and groceet i' the swoy nf your ow'.... wit

and proceet i' the sway nf your own will - i

WAYED-his reason swayed... Witi.N.'s $I$ ?

swayed in the back

mueh lave swayed your majesty's.. Whewry I':

minds swaycd by $\in$ yes, are full..

when his affections swayed more.. Julius $C$

Wu W W ING more upon our part ... point - iii.

TVAR-cvery drop of water swear.... \% ' empest, i.

swear to that; kiss the hook (rep.).....

I'll swear myself thy subject (rep.) $\ldots . .$. = ii.

or be not. I'll not swear............... or - - yerona, ii.

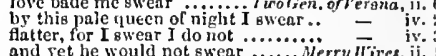
for he swears, he'll turn me away... - iii. 3 and swears, he was carried out ...... = iv

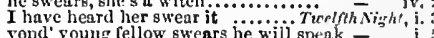
Yond' young fellow swears he will speak -

we men say more, swear more

by imnocence I swear, and by $m y . . .$. .

by heaven I swear I tender dearly

would make

I swcar. I will not swear. Measure for Measure, jii.

though they would swear down each

as I have leard him swear himse.

I dare swear he in no liypocrite

if you swear, my lord. you shall

yet will he swear, he loves

she'd swear, the gentleman should be

would you not swear, all sou that be

do swear by it, and eat it. I will swear -

that only tells a lie and swears it .... her -

for they did swear you did .............. and necze, and swenr a merrier hour

to say, to swear, I love thee..........

swear by that which I will lose for thee -
but as yet, I swear, I cannot .........

I will swear to study go .............. Love's $\vec{L} . L$

swear me to this, and I will ne'er say, no-
we will read it, I swear

and how most sweetly a $;$ wili swearl

heven Jave wowld swear, Juno but -

which such a zcal did swear?
that I may swear, beauty doth

what you first did swear onto........

it is not swear himele ont of all suit

it is not so, I swear; we have had...

though Nestor swear the jest. Herchant of $\bar{F}$

swear, that I have a poor pennywortl
by my tove, I swear, the best regarded

or swear bctore you choose

doth offer to swear upnis a hook.

and swear but now and then .........

aiwear, have no mind of leasting

cvery one doth swear, that conice to...

I have heard lim sprear, to Tuhal..

men shall swear, I have discontimued

wid young Lorenzo swenr lie loved he

by yonder moon, I swear, youl do...

ant swear, Ilost the ring defending

and thant $w^{\prime}$ hich you did swear to kcep

swent by your touble sclf, ant there"s

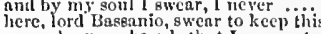

fiere, lord Baseanio, swenr to keep this

but if $y$ nit swenr by than that is not..
und in that kind, swears you do mor

I swear to thee, youth, by the white

but why dill he swear lic would comic

you have heard him swear downright

lie hath been a courtier, he swears ..

to swenr, nnd to forswe

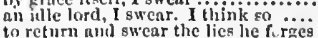

I would swear, 1 recoverel it

thint we swear not by but take

to awear by him whom I protest

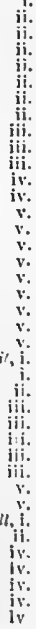

i.

ost, i. i 

SWEAR-when he swears oaths. Al's Wrll, iv. 3 (letter')
and he'll swear to't; I'll swear.

one shull swear slie blceds.. Taning of sh, 2 (ind ne. I swear I'll cuff you, if you stliku...

and rails, and swenrs, nivl rates....

you thut durst swear that jou

swear, this is the right Vincentio. Swcar

I dure not swear it. Then thon ......

with ail confidence lie swears..
swear his thought orer by cucli

swear his thouglit orex by cnch

swear by this sword (rep. iii. 2) ......
I swear to do this: thongh a present

all this, we gwent. Brenk up.

I'll swear tor 'em. This is the prettiest

will you swear never to marry $\ldots . . .$. .

Fou hear, you'll swear yous sce, there is - v.

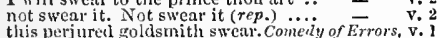

an equivoeatur, that could swear....... Bacbeth, ii. 3

why, one that swears and lies..........

all be hanged, that swear and lie?

to bra sul stompend su.............

to brag, alid stamp, and swear, upon

illbeit we swear a voluntary zeal

by that sword I swear, which gentiy. Richarll $11 . \mathrm{i}$.

swe:rr by the duty that you owe.

I swear, and $Y$, to keep all this....

by the lonourable tomb he swears ...

this swears he, as he is a prince.
[Col.] vows unbrolie that swe

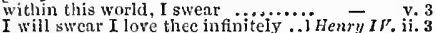

and swear it was the bloorl of truc men

sot swear like a comsort-mat mate, like a lady.
I would swear by thy face

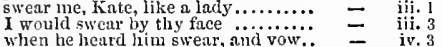

When he heard him swear, and vow..

yea, aly I'll swear I killed him......

he swears, thour art to upou.

and swear's with a good grace.

and sweat here by tize honour

anil I dare swear, you borrow not....

now, by this liand I swcar, I scor

let us swear that you are wurth......

they slali have none, I swear, but these -

I eat, and eat, I swear. Eat, I pray you -

not enough leek to swear by got them in the Giilin wars -

and swear, I got them in the Gallin wars
I lure not swear, thou lovest me ....

so snre I swear, to get the town.......Henry $\overrightarrow{F I}$. iij.

vantage, every one will swear

thon wilt swear to pay him.

then swear allewiance to his............
swear like a ruffitu, and demean

to swear talse allegatious to o'erthro
by his majesty I swear, whose far
but when I swear, it is irrevocable..

but they jointly swear, to spoil......
to swew unto a sin, but greater sin...
over him that swears.................

Cliffordl swear as thou wa.............

you know not what you swear.

by my state I swear to thee........
heard him say, and swear, that...

heard him say, and swear, that..

a suan cunnot swear, but it

not your hatred, swear your iove

as I truly swcar the like

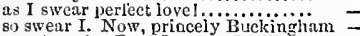

now by saint Paul I swear, I will not

I swear. By nothing; for this is no onth
wouldst swear to be believed, swear then

what canst thou swear by now?

you would swear directly, their very..... He

verily, I swear, 'tis better to be lowly
I swear again, I would not be a queen

as corrupt to swear against you? .....

I swear, to you, I think, ILelen... T....

all lovers swear now to performance

your

your gnondam wife swears still by ..

I litl swear patience. You shith
the gods have heard me swear

sweir against objects; put armour Timo

sweir against objects; put armour

I'll swear, 'tis a very pretty boy ....
I heard him swear, were he to stand

and let ns swear our resolution....Jutius
swear priests, and cowards, and men

unto ball causes swear such creatures

cr I could make him swear the shes..
would undergo what's spoken $I$ swear

when a geutlcman is disp
still, I sivear, I love you

if you swear still, your reeompense...

he swears; by Jupiter he swears ....

it you will swcar you have

In swear by all the Roman gods .... Titus A $\bar{n}$ rirom.

to lome I swear, if Saturnine ndvance

and swear unto my soul to right your
and swear with me, as with the woful
SWEAl- - unless thou awear to me. Tihes
swenr that he shall, and then I (rep.)

which by that god he swears ...
cren by iny god, I swear to thee

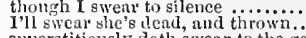

superstitiousiy doth swear to the gods

he swears never to wasin his face - - iv. 1 (Gowcr)

and swears site'ti never stint $\ldots . . . \ldots \ldots \ldots$ iv. 4 (Gower

swear not; commit not with man's.

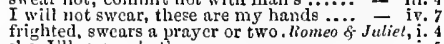

she, I'll swear, hatli corns

lady by yonder blessed moon I swear

o swear not by the moon, the inconstaut

swear by? do not swear at all $(p \rho p$.$) ..$

and when I do, I swear, it shall be Romeo - iil. 5
but swear't. In faith, my lord, not I..... Hamlet, i. 5

upon my sword, indeed, Swear (rep.)...

Swagger? swenr? and discourse fustian. Olhello, ii. 3

I swear, 'tis better to be much abnsed.

beds, which the y dare swear peculinr.....
believed in Venice, though I should swea

come, swear it, damn thyself (rep.) ....... - iv. 2

the liars and swearers are fools $(\ddot{r e p}$.). Macbeth, iv.

sWEARING to gentlemen ............Perry Fives, if.

drinkings, and swearings, and starings - v. 5
nay, let me alone tor swearing ... Twetfth Night, iif. 4
and all those swearings kecp as......

some other way than swearing by it.musch Ado, jv. I

swearing, till my very roor was.Mer. of

we shall have old swearing, that they $\overline{\text { Like }}$ iv.

swearing, that we are mere usurpers of ii.

swearing allegiance and the love .... King John, v. 1

some, sweariug; some, crying for.....

to swearing, and stern looks, diffusd
swearing, that you withhold his..

swearing, that yoll with hold his.

all swerang swearing rascals .. Troilts \& Cress. v.

though you in swenring shalke the. Antony \& Cleo. $\mathrm{i}$.

vows, which break themselves in swearing
must take me up for swearing ...... Cymbeline, i.

no swearing. If you will swear

fencing, swearing, quarrelïing, drabbing $\overline{H a}$ met, ii.

at ganing, swearing; or about some act
at

for thoul swear'st to me, thou art........ Tempest, youlike it, iii. 3

what thou swear'st, against (rep.)... King John, iii. 1

thou swcar'st thy gods in vain

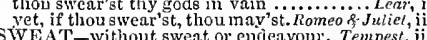

what with the sweat, what with .Meas, Jor Meas. it.

the ploughman lost his sweat...Mid. N. s Dream, it. 2

for wooing here, until I sweat. Merch. of Veniee, iii. 2

why sweat they under burdens? ....

where none will sweat, but for promotion

do not your courtier's hands sweat

as angry boar, chafed with sweat. Taining of $S^{\text {iit. }}$ ?

she sweats, a man nay go.... Comedy of Errors,

of our armour here we sweat.......

Nacbeth, ii. 3

are liable, sweat in this busine

Falstaft sweats to death, and lards...i Henry $I V$. ii.

I mean not to sweat extraurdinarily.2 Hemry $I V$ i. 2

or shall I sweat for you? If I do sweat
Falstaff shall die of a sweat...

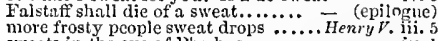

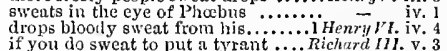

if you do sweat to put a tyrant ...... Richard nh. v.
and sweat of thousand filiends .. Henry VIII. proi.

did ainost sweat to bear

such an agony, he swent extremely

I have sweat to see his honour Timon 6 ; Cress. v.

政

and saved your husband so wuch sweat -

to make mine eyes to sweat compassion - v. 3

if arguing make us swent, the proof .

With knaves that sinell of sweat... Antony \& Cleo.

the sweat of industry would dry .... Cymbeline, iii. 3

a chilling sweat o'er-runs my. Tilus Andronicus, ii.
at this time, we sweat, and bleed ......... Lear, v.

to grunt and sweat under a weary life...... Hamlet, iij. 1

in the rank sweat of an enseamed bed

hie sweats not to overthrow your
SWEATEN-grcase, that's sweaten

bareheader, and blowing ......... Aierry Wives, iii. 3

and sweating with desire to see lim - . - v. 5

'tis swcating labour, to bear such. Antony $\delta$. Cleo

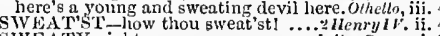

SIVEATY night-caps ............... Jutizs Casar, i.

this sweaty haste doth make the night. . Hamlet, $\mathrm{i}$.
SWEEP-manly swcep the sky.Mid.N.'s Dream, iti.

ears that swcep away the morning
to sweep the dust behind the door..

quoth Jaques, sweep on, yon fat...... As you Like it, $\overline{\text { y. }}$. 1

power sweep him froin my sight........ Macbeth, iii. I

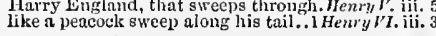

SWEEPS it through the court .......2nenry VI. i. 3
kissed the queen, ghall sweep the ground - iv. klaat must \&ucep the court clean .... - iv.

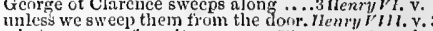
what a sweep of vanity comes.. Timon of thens, i. that will sweep your way for you. dntony \& Clen. iii.? of love, may sweep to my revenge ....... llamlet, i. they muat sweep my way, and marshai 7 . ii. 4 SIVELPSTAKE, you will draw both .. Hamlet, iv. with its sweet air

twas a sweet marriage

by sweet mistress weeps

fill of noises, sounds, and sireet......

marvellous sweet music

no swcet aspersion slail the heavens

sweet lord, you play ine filse.........

sweet Vances of thy hon

sweet Proteus, no (rep. iii. 2) ..........

passionate Proteus, to the sweet Juilia

hear sweet discourse, converse.

sweet lovel swect lines! sweet lifel

yourself, sweet lady (rep.)

sweet, exeept not any

forswear not thyself, sweet youth....

fores

he liath a sweet mouth

with some sweet concer

thect complaining grievance ..

sweet lads, let me rake it

for thy sweet mistress' sak

- iv.

how now, sweet Frank?..............

the sweet woman leads an ili life.....

sweet sir Jolnn! (rep.iv. 2$) \ldots . . . .$.

to him, sweet Nan (rep.)

must iny sweet Nan preseii

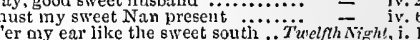

tis $n$ nt so sweet now ............... =

to sweet beds of flower

sweet sir Andrew

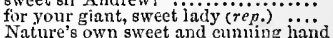

and so sweet $a$ breath to sing .........

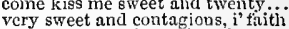

sweet sir Toby, be patient for........

not a flower, ant a flower sweet....

sweet lady, ho, ho....................

we do know the sweet Roman hind

pardon me, sweet one, even for .......

give up your body to such sweet. Meus. for $\overline{M r e a}$

that's bitter to sweet end

sweet Isabel, take my part (rep.) .... v $\overline{-}$ v.

$O$ sweet Benerlick! Goul give me ...... Mueh Ado, ji.

of the false swcet bait that

the sweet youth's in love

swect prince, you learn me (rep. $\ldots \ldots$

if this styeet lady lie not guiltless here
what offence, sweet Beatrice? (rep.)..

a sweet gallant, surely!

you have killed a swect lady (rep.).

pray thee, sweet mistress Margaret

sweet Beatrice, wouldst thou come.

why then she's mine: sweet, let me see, -

and she, sweet lady, dotes...............

catch your tonguc's sweet melody

of their council sweet [Col.-swelled]
farewell, sweet nlayfellow

she never had sô sweet a changeling

hobgoblin call you, and swect puck

chaplet of sweet summer buds is .....
sweet musk-roses, and with eglantine

a sweet Athenian lady is in love ....

sing in our sweet lullaby.......... -

sweet friend; thy love nc'er alter (rep.)

through fire I will, tor thy sweet sake

deserve sweet look from Demetrius

onlious savours sweet (rep.) ..........

left sweet Pyramus traoslated these

sweet, do not scorn her so.............

soine music, iny sweet love? (rop.).

soine music, iny sweet love? (rop.)

he woodbine, the swcet honey-suckle

see'st thou this sweet sight?..........

wake yon, my sweet queen ..........

he is a very paramour, for a s.

oswect bully Bottom! (rep.)
for we are to utter sweet breath......

to hear them say, it is a sweet conied

why, gentle sweet, you shall see ....

anon comes Pyramus, sweet youth ..

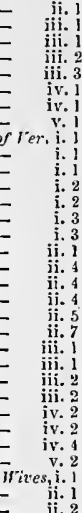

$=\quad$ i.$$
\text { i. }
$$

$$
\text { 三 }
$$$$
\text { ii. }
$$ 


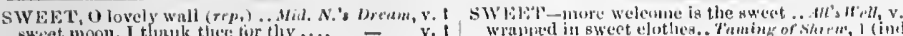

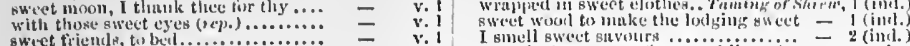

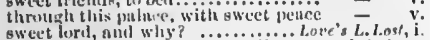
tor thy nore sweet understinding - i. I (letter) by thy sweet grace's willecer $\ldots \ldots . . .$.
at the least of thy sweet notiee.... i. 1 (letter) menst sweet Ilereules! ................. owect inveration of a chll

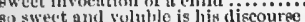
she is il most surect laly (rep.) .....

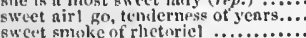

by thy tinvour, swect welkin

li, my sweet soul, I mean, sitting

liiy sweet ounce of nian's tleshl....

1) sweet gnerilm! (rep.)

?' my troth most sweet jests!

in music, and sweet flre..

sweet clown. sureeter

9 weet a kiss the golluen

in love 1 es

6)

let her ont in saucers: sweet nuij]rision! =

youth so apt to pluck a sweet.... - iv. 3

and Ethiops of their swcet complexion as sweet, and musicul, ns bright $\because \ldots$

a sweet tuch, a quick venew of wit.

at your sweet pleasure (rep.) .....

but sweet heart, let that pass (rep.)

the prinecss, swect eluck ............

sweet hearts, we shall be rich (rep.).

holkl, tnke thou this, my sweet

there's laalf a dozen

let it not be sweet...............

with your swcet breaths puffed out.

blow like sweet roses in this summer

their damask sweet eomn

a blister on his sweet tongic...

all liail, sweet mulain (rep)

fair gentle sweet, your wit makes....

of thy royal swett brenth as will

my fair, sweet, honey monareh....

and so, adieu, sweet Jude

sweet lord Longaville .............................

sweet royalty, bestow on me.

alore thy sweet grace's slipper
sweet bloods, I both nay and will

Ay, swcet my lord .................

for her sweet love three years'.........

you wonla be, sweet madain ...ir rech.

6 weet friends, your patience for......

80 nre you, sweet, even in the lovely

sweet. adieu! I'li keep my oath ....

in April never eame so swect .........

sweet Portin, wcleume (rep.) .
sweet Bassanio, my ships have

good sweet, say thy opinion..........
when the sweet wind did gently kiss

sweet soul, let's in......................

bow sweel the inoonition

never merry, when I hear sweet nusic

by the sweet power of music .........

not moved with eonenrd of sweet sounds

what shoulil I say, 6wect lady? (rep.)

sweet doetor, you shall be my.

gseet masters, be putient............
I pruy thee, liosaliml, sweet $\mathrm{my} \mathrm{coz}$

therelure, niy sweet liose

shall he part, swcet girl? ............

sweet are the uses of adversity ....

into so quict and 80 swect o style

O my swet master

unto the sweet bird's tirong

I must Epeak. Sweet, say on

enme, sweet $\Lambda$ ultrey

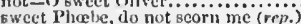

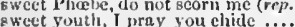

riva

the ford of sweet and bitier.........

Ganymede? aweet (innymede?

sweet lovers love the sjring.........

food faces, or s sect breatlis, will

Giay, his sweet disaster.

say oweet lord that yon will .......

owect practiser, thy physie $i$ wiil try

when your sweet seif wis got

When your sweet seif was got .......

by love's ofn sweet collstratic

a wite, and so sweet a latly..........

that ean guel sweet nie make of ....

and be as sweet us shar, IIcleu that's deal, was a gweet crontion
I smell sweet suvestrs .......

the love 1 licar iny sweet lsmeth (rep.)

and sweet wenty in lier fitce

and tell me now, sweet fricml.

yet sweet us nuring-time flowers
marry.

farewell, sweet masters, botl

and marry sweet Biuned (rep.) ......

ii. most patient, swect, ant virtusus wife $=$ iii.

good sweet Kate, be merry ( $f$ ep).

sure, sweet Kate (rrp.iv. 5 and v. 1 )

fuir, and fresh, and swect, whither away

[Col. Knt.] lives my sweet soir? '.

What not, thant's sweet and hal:py...
sweet villain! most dearest! ......

why, my sweet lord? You'll kiss

the sucet birds, $O$ how the

a root-man, bwet sir (rep.)

and, my sweet friend, to strew bin

whin you spenk, sweet, l'd huve

gloves, as sweet as dninask roses ....

rith a sweet fillow to't?

O sweet Paulina, make me

mistress hath thy sweet aspect.

train me not, sweet mermaid

as good to wink, sweet love.

v. 2 and my sweet hope's aim .....

the purse; sweet riow, make hasto.

1 now, good

I should pour the sweet milk ot

gotue sweet oblivious

to deliver swect, sweet, sweet poison

jath spoiled the sweet world's taste

corruption of a swect eliald's death

stenling that sweet breath which

v. 2 to seck sweet safuty ont in vauits...

O my sweet sir, news fitting

to make the end most sweet

draws the swect infant brenth

as the last taste of sweets, is 3 o sweet a guest as my swcet

so your sweet majesty, lonking awry

the hard way sweet and delectable

nor with thy sweets comfort his

sweet love, I see, elanging his

of that sweet way I was in to........

I am sworm, brother, sweet, to grim .ïn -

ohe came adorned hither like sweet II

is ehort, but not so short as sweet...

how sour sweet music is, whic

I pray thee, sweet wag $(r e p$.)

of the tavern a most sweet we

rasenlliest, -sweet young prinec

good-morrow, sweet Hal; what says

now, my good sweet honcy lord i....

aod smell so swcet, and talk so

tell me, sweet lord, what is't that

bit, sweet Ned,-to sweeten

that melted at the sweet tale

how now my sweet erenture of bomi.....

weep not, sweet quecn, for trickling

makes Welsh as sweet as dittics

O ny sweet beef, I must still be

England tid aveet reversion .......

I will take it as a swect disgrace ...2.2Jenry $1 \mathrm{~V}$. i.

I thank your pretty sweet wit for it

alus, sircet wite, my honour
bad my swect ifary had but

sweet knight, I kiss thy neif (rrp, v. 3)

ah, you swect litte rogne, you! .......

well, sweet Jack, have n eare of thy'sel

my lords: sweet prince, spo

from every fluwer the virtumi........

sweet prinees, what I did, I tlid in

sweet sir, sit; I'll be with you anom.

now comes in the sweet of the niglit

the sweet shaile of your government

use teuits, swe te justicc, sweet prince, a ninst...

for his sweet life's loss

Enipland' 6 ground, farewell, swect soil

captain Pistol: not here, sweet capi.nin

Goll snve thee, iny xurect bin?

steal his sweet and honey
SWF Fi:T-anil aweet majesty

thrry, sweet soul, tor tain

the pretty nind sweet man 3 if it.

sweet enlargement doth tisuis

declare, sweet betn from fork

for, aweet prinec (rop.iv. !).

tirrive me, combtry, anl sueet

and this is mine; swet IIenry

sweet madam, give me hetriug (r.....

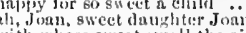

with whose sweet sncll the ai

wit! eweet reheursal ot my mor

sweet annt, be riniet; "twas a a waint...

sweet York, begin; and it thy eluim
good York; sweet Somerset, be still.

enough, sweet sulfolk (rep.) .......

slave, murledel sweet Tully .......

sweet Warwick (rrp.ii. 6 ) .............

pardon me, sweet sorn; the enrl ot.".

sweet Cliftorl, heur me (rep.)........

dipp'st in blood of my sweet boy ....

sweet duke of York, ons prou ti) i cun

give swect passage to my sinful goul

how sweet? how lovely' gives not

su'cet hoy, shall be thy sepul
with thec, good sweet Fxiter

6wcet widow, by my stute I ewenr

if thou be there, sweet brother...........

sweet rest his soul! fly, lords

meet with joy in sweet Jerusalem

low eweet a plant have you .........
you have rid this sweet young prined

sweet Clurence, do thou do it
hapless malc to one sweet biril

hapless malc to one sucet birl ......

upon the lips of this sweet babe......

live one hour in yonrs sweet busom ... -

never came poison from so eneet a place -

could never learm sweet soutling word

the golden prime of this sweet prince
beeause sweet flowere are slow .......

welcorne, eweet prince (rep.) ..........

6o swect is zealous contemplation .

nnd my' sweet sicep's disturber's.
thou sing'st ewect music; hark.

the most replenished eweet wark

flowers, new-appcaring swects I......

that thy two sweet sons sinotherel

sep from her sweet brother's bod

aequaint the prineess with the sweet

sweet Blunt, make some good means

they are a sweet society of this ones.

sivect ladies, will it please yout sit? (rep.) -

sweet partner, I must not yet forsake -

tolenve so sweet a beltellow?........

than 'tis sweet at first to acquire.....

rare qualities, sweet gentleness ..... - ii.

in sweet musie is such art....

that sought hin, swert as suim

sweet IPndidurus, - pray you, s.jenk Tro

good niee, do; sweet nieec Cressirlu

ever knew love got so sweet, as $\mathrm{n}$.h

thou art of swect composure ........

make a sweet lady sad is a sour online

hy my troth, sweet lorl (rep.)

sweet Ilelen, I must woo you.....
sweet, above thnught I love you

thic imatinary retsh is a

esplies my sweet larly in.........

sweet, bit me hold my tongtue

alheit sweet nusic issues the
your leave, swcet Cressid?

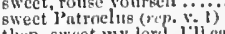

tleen, sweet my lord, 1 il cal

so nenr me, as the sweet Troilius

weicome to the (irceks, sweet iaily (rep.) =

shat! I, sweet lord, be bound to $y(s)$.

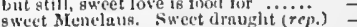

sweet fir, you lionour nic

now, ny sweet gunrilinn .

suect honcy (ireck (rep). ............
of sally, for the heavens. sweet brither

swet honey and sweet inites tozether

iii. 
SWEET-resemble swcet instrumevts. Tim.nf $A t h$. pardon him, sweet Tymandra...

proceeded the sweet degrce

good-day to you. Sweet madam

come, good swect lady

most sweet voices! ( $r e p$. .)

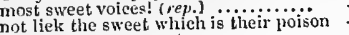

I pr'y thee now, swcet son........

lune, as my exile, sweet as my revenge

good friends, sweet friends, let me not

show you sweet Casar's wounts . . .

that cannot go, sweet Isis, I beseech

most sweet queen,-Nay, pray you..

youl have lieard on't, sweet?..........

melt their sweets on blossoming Casar

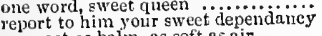

as sweet as balm, as soft as air ......

of leigers fur her sweet ...................

a wondertil sweet air, with admirnble

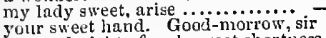

a seeand night of such sweet sh

the sweet view on't might well ......
poor tributary rivers as swect fish....

not wagging his swect head? $\ldots . . . . .$.

in tresli eups, soft beds, sweet words.
from her his dearest onle, sweet Innogen
more swreet than our blessed fields.

more sweet than ond blessed
that sweet rosy lad who died

sweet eell of yirtue and nobility.... T
sweet nercy is nobility's true badge

thanks, sweet Lavinia ...............

there lie thy bones, sweet inutius....

nnd at my suit, sweet, pardon what..
come, eome, sweet emperor (rep.)...

nat be denicl: sweet heart. look back

under their sweet shade, Aaron. 3 aird

ah ny sweet Moor, sweeter to me ....

sweet lirils, eutreat her hear ne

so should i rob inv sweet sons of

sweet liuntsman, Bassianus 'tis ..
call for sweet water, wash thy hands

those sweet ornaments, whose.....
which that sweet tongue hath made..

my sons' sweet blnod will make.

like a sewet melodious bird (rep.)...

thut gives sweet titings of

bear thou my han

alas, sweet aunt.

sweet poetry, and Tuli y's orator

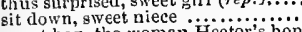

sweet bos, the woman Heetor's hope

sweet blowse, you are a bea

sweet scrolls to fly about ...............

now, sweet emperor, be blithe again

so sweet a death as hanging presently

both her sweet hands, her tonglie (rep.)

to make's entranee more sweet for your sweet musie this last nicht.....

Oyvur sweet queen! that the strict.....

with her sweet harmony and

bitter fool anl a sweet fool! (rep.)

if your swect sway allow obedienee.......

broke them in the sweet face of heaven

farewell, sweet lord, and sister

bless thy siveet eyes, they bleed...

now, sweet lord, you know the goodnes

a elyking gall, and a preserving sweet

seeming sweet, eonvert to bitter gall
steal love's sweet bait from ....

extremities with extremes sweet $\overrightarrow{ }$

by any other name would smell as sy

lowk thau but swcet, and Iood-night! this bud of love.

as sweet repose and rest com

sweet Mantague, he true ...........

how silver sweet sound lovers' tongu

my sweet $[$ Col.-dear, Knt.-madam $\}$.

parting is such sweet sorrow, that I.

Eleep aud peace, so sweet to rest

early tongue so swect saluteth me?

woukd handy her to my sweet

now, gool sweet nurse (rep.) .........
thou shamest the music of gweet news

$O$ sweet $J$ uliet, thy beauty hath made

mortal paradise of such sweet flesh?.

bid my sweet prepare to chide ....

say, the lark makes sweet division ...
shall serve for sweet discourses in opj

shall serve for sweet discourses in oup
sweet my mother, east me not away!

live an unstained wife to my sweet lo

beenuse silver hath a sweet sound....

how sweet is love itself possessed

sweet tamb [Col. Knl.-O woe $]$ i....

$f_{\text {tis sweet and commenditble in your. }}^{\text {Col. Knt. }}$ as wholesome as sweet, and by very much sweet Gurtrule, leave us too ........... o, help him, you swcet heavens! .... like swect bells jangled, out ot tur.

rain enough in the sweet heavens.

sweet religion makes a rhapsody of

$O$ 'tis most sweet, when in one line ......

alas, sweet lady, what imports this song

arded all with sweet flowe

dear mand, kind sister, sweet öphelia

for bonny sweet Robin is all my joy

what noise? how now, sweet

good-morrow, sweet lord! how dost thou

thy bride-bed to have decked, sweet mai

sweet lord, if your lordslip were at leisure

good-night, sweet prince; and flights of.

U my sweet, I prattle out of fashio

do you justiee. O sweet England
not now, sweet Desdemona (rep.)

ii. 3 the sooner, sweet, for you ....................

ever medicine thee to that sweet sieep

cry o sweet ereature! and then kiss ne

i' fith, sweet love, I was eoming ....7\%...

I know not, sweet [ Kut.,-neither]

a fair woman! a sweet woman!

smell'st so sweet, that the sense aehes at

he that is yours, sweet lady. I have

O my dear Cassio! my sweet Cassio

so sweet woul, take heed, take heed

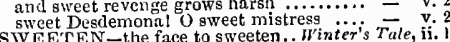

ii. 3 of Arabia will not sweeten this little ..Macbeth, v. to sweeten which name of Ned.......... Henry $r$.ii. 4 nor sweeten talk, nor play at

I'll sweeten thy sad grave

sweeten with thy breath this................ Learoo \& juliel, ii. 6

SWEETENED with the hope........ Richard 11 . il. 3

\begin{tabular}{r|r} 
ii. 5 & shall thereby be the sweeter. Mensure for. Mensure, iii. 1 \\
iii. 1 & sweet elown, sweeter fool ........ Love's L. Lost, iv. 3 \\
ii. & it
\end{tabular}

it sounds much sweeter than by...Mer. of Venice. $v$. I
softer and sweeter than .... Taming of Sh. 2 (induc.)

for slie is sweeter than perfiume itself

and sweeter than the kernels

sweeter than the lids of Juno's eyes. Minter's $T$. iv.

the luaw thorn bush a sweeter shade..3 Henry $v i$. ii.

a sweeter and a lovelier gentleman... Richard $11 /$. $\mathrm{i}$.

sweeter to you, that have a sharper. Cymbeline, iii.
Moor, sweeter to me than life! . Titus Andron.

Moor, sweeter to me than life . Thtis Andron. 1i. 3

O the world hath not a sweeter creature $\bar{v}$,

sle is the sweetest lady that ever I ...Much A Alo, $i$. I

sweeter fool, sweetest lady 1 ....... Love's L. Losl, iv.

with sweetest touches pie

sweetest nut hath sourest.. As you Like it, iii. 2 (ver.)
he that sweetest rose will find

my sweetest [Col. Knt.-sweet] son? Taming of sh. v.

\section{destroyed the sweetest companion.}

of sweets, is sweetest last ...........

now comes in the sweetest morsel ..2 HenryIV. ii.

lulled with sounds of sweetest melody? - r $V l$ iii.

the sweetest sleep, and fairest....... Richard III. v.

sourest points witl sweetest terms... Ant.\& Clen.

and sweetest, fairest, as I my poor...
0 sweetest, fairest lily! my brother.

two of the sweetest companions in ... Pericles, i.

the fairest, swectest, and best ... - iv. 4 (Gower)

the sweetest honey is loathsome in his

upon the sweetest flower of all the tield

SWEET-FACED man

I am a sweet-ticed youth ..... Comedy of Errors

Pare is come with me, sweetheart

what is the matter sweetheart? (rep.). All's 'well, ii.

take your sweetheart's hat ....... Winler's Tale,

ii. 5

sweetheort, I were ummanneriy ....... Ienry $F 111$ i.

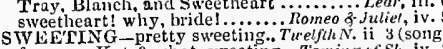

iii. 2 Stwes my Kate? what, sweeting.. Taming of Sh. iv. 3 ay, marry, sweeting, if we conld $\ldots 1$ Heury $Y$ 't iit.

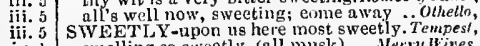
smelling so sweetly, (all musk) .. Merny Wives, ii.
so sweetily were forsworn. Mleas. for Meas. iv. I (song) how sweetly do you minister to love... Much.4do, and look sweetly, and say nothing ... $\quad$ - iv. aad how most sweetly a' will swear!
WETLY - are sweetly varied .. Love's l. Lost, iv. 2 the crow doth sing as sweetly... Merch. of Venice, $\nabla$. my eon version so sweetly tates.. As you Like ir. sings as sweetly as a nightingale... Taming of $S$..., ij. speak sweetly, man, although thy.. Rieharil 11 . iii. that erst brnught sweetly forth........ Henry $V$. v. words sweetly plaeed, and modlestly.1 Henry $r i$.
which seeure and sweetly he enjoy s.3 Henry $V i$. that tender spray did sweetly spring sweeth in fore unto her fair life'. Michard I11. iy sweetly, in all the rest showed ....Henry W11I. i more sweetly in great Cresar's ear. JulizisCosur, iij. o trespass sweetly uryed! $\ldots . . . .$. Romeo \& Jnliet, i. . SWELT-MARJORAN of the sallad..All s/lel, iv. with sweet-meats tain ted are ..... Romeo \& Juli to loathe the taste of sweetness ... I Iiemry $1 /$. infeeted the sweetness of affiance! .... Henry $r$. tuned too sharp in sweetness ...Troilus \& Cress. ili. 2 and drown me with their sweetness..... erectes, v. SWEET-SAVOUR.ED in thy.. Comedy of Errors, ii. SWELL,understanding begins to swell. Fernpest, v.

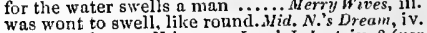
the tears that swell in me.. Love's L. Lost, iv. 3 (ver.) where great additions swell ........... All's Well, ii. 3 secmed to eome, discomfort swells .....Maetiel $h$,i. above his limits swells the ruge .....Richard with silence in the tortured - iv. or swell my thoughts to any strain..2 Henry $1 Y$. iv. and swell so much the higler ......3 Henry $V_{1}$ i. they swell, and grow as terrible ...Henry I'll. iii. I unless it swell past liiding.... T roilus \& Cressida not to swell our spirit ........ T'imo
why, thy verse swells with stuff so

y the ambitious oeean swell .... Julius $\overline{C a s a y}$, i. 3 swell, billow; and swim, bark! ....... $\overline{\text { any }} \overline{\mathrm{C}}$ leo the silken taekle swell with stands upon the swell at full of tide here no envy swells, here grow no. Titus Antron iy. how this mother swells up tow ard.......... Lenr, ii. or' swell the curled waters 'bove ......... swell, bnsom, with thy fraught, tor 'tis of - iit.
SWELLED-I had been swelledl Merry Wines, it. [Col.] of their connsel swelled .. Mid.N.'s Dream, i.
the tide swelled up into its height ..2 HenrylV. ii. and Cydnus swelled above the banis. Cymbeline, made barren the swelled boast of him - . shor evit of ny...... Nea sure for Measure, as are the swelling Adriatic seas. Taming of sh. i. to the swelling act of the implerial ..... Macbeh, i. the sweiling difference of your settled. Richard $I I$. $\mathrm{i}$. down from these swelling heavens..1 Hentyl $\mathrm{V}$. iii.) comes swelling like a tirkey-cock (rep.) - v. hatle allayed their swelling griefs ...3 Henty Vl. iy swelling wrong-incensed peers .... Richnrd HI. ii. appear by external swelling ..... Antony \& Cleo. v.

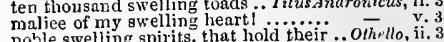
noble swelling spirits, that hold their .. Othrllo, ii. WWLTERED venom sleeping got..... Marbeth, iv. J SWENO, the Norway's king............ in shreer, iv. thus liave we swept suspicion from..3 Henry rli. v. 7 that ever madem the smallest.. Meas. Hor ritas. iv. or swerve a liair from truth.. Trooilus \& Cressida, iii. but alas, I swerve many dream ..... Cymbeline,
SWERVING with the blood . ........ Henry $r$. a most unnoble swerving ... Antony \& Cleopatra, ii,
SWIFT-this swift business I must .... Tempest, by the swift course of time ..TwoGen.of Verona, to make my purpose swift ............... for Meas. iij. make a swift return ............... = having so swift and cxeellent a wit., Mluch Ado, iii. swift as a shadow, short as any. Mid.N.'s Dream, for night's swift dragons cut ......... you are too switt, sir, to say so ...... -

ean look as swift as yours. Nerchant of renice, iii. extremest verge of the swif brook..As you Like it, ii. he is very swift and sententions .... $\bar{T} \overline{.}$ (indue.)

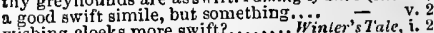
Wishing cloeks more awift?.......... to me, or my swift passage, that I - iv. (chorns) beanteons and swift, the minions of .. Nacbeth, ii. I

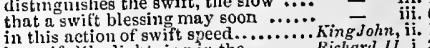
in this action of swift speed...

with all swift speed you must.......... upon agreement, of swift Severn's ... Henry $I V$. i. with all swift despatch to line ......... Hertry $V$. ii. 
SWIFT-our swif secene nes .. Itrnry r: jii. (ehorus) lavoltns lighl, nul owilit cornentus

as swifr as stoncs entorect rion. v. (chorus)

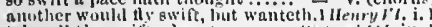
take all the awift advantage ....... Ithehard III. iv. true loupe is awift, and thies wion

wingeth thus swift with seori .

lighe boats sail swift, theough

give me switt transportmnce $\ldots . . . . . .=-$ iii.

wlugs more monentury swift tlian... - iv.

foblins swift as frellzy thoughts ..... peple ingrossed by swiff impr.... its swift llought brenk it not

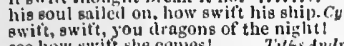

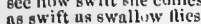

thy vengeful wagtron swifi uwn

make swife the pangs of my queen.". . Pericles,

our posts slunll be swift. and intelli..ent... Lear, iii.

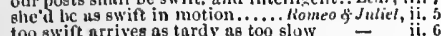

too swift arrives as tardy as too slow

O mischiefl thou art swift to enter
with wings as gwift as meditation

that, awiti as quicksilver, it cour'es.

IIamlel, i. s

hie, sivift of foot, outran my purpose.

Uithe $\overline{l l l}$, ii. 3

abrut the wood go swifter than the wind

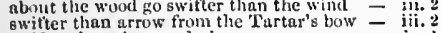

swifur than the wandering moon..

wind, thonglit, swifter things.... Love's $L$. I. I.st, v. with swifter splecu than powder .... King John, ii. that arrows fled not swifter toward..2 Hemry $1 V$. i. 1 come oft and on, gwifter than he ....
swifter than blood deeays. . Troilus \& Cressidu, iili. . caused our swifter eonposition .... Coringltutus, iii.

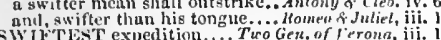
with the swiftest wing of speed .........All's IIelt, iii., with thiftest wing of recompe

....Macteth, i. 4 the swiftest har ts have posted you... Cymbeline, ii.

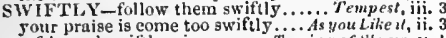

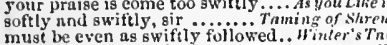

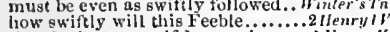

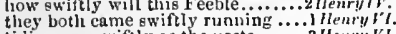

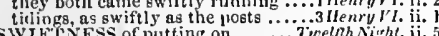

sWIFTNESS of putting on .... Fivetrh Night, i

with reasonable swithess, add more. Mllenry

the liarm of unscanoed swiflnes.

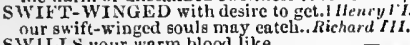

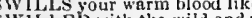

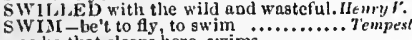
as he that sleeps here, ewims

I ean swim like a duck (rep.)

the Leviathan ean sxim a leagne.Mid.N.'sDrenm,

which swims against your gtream ...2 Henryl

labour swim atainst the tide .........3 Henry ri. i. a

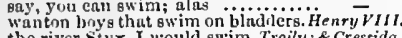

the river Styx, I would swim. Troilus of Cressida,
swims with filts of lead.............. Coriolanus,

swinls with fils of lead ..........
flood, and swim to yonder point?

thig is a naughty night to swim
swring

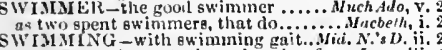

Lear, iii. 4 swiNE cai all the dratt swimming frog...Lect

pearl enough for a swine Merry Hives, iv. 2

killiog swine. Sister, where thou? to hug witll swine; to sceks swect .... King John,

a baser temple than where swine... Timna or $A$ h h. v. $\mathrm{v}$

linvel thee with swine, and rogues forlorn. tent

SWINE-IIERI's, that linve made. Win'er's Tinle

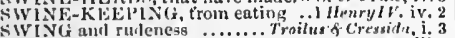

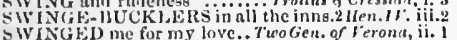
SWINGED me for my love. Two Gen. of terond

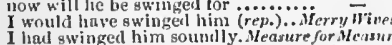

Shad swinged him sountly. Measure for Heashre,

lit. Genrge, that ewingel the dragon. Kins ohn,

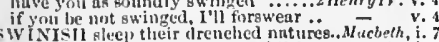

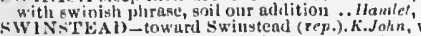

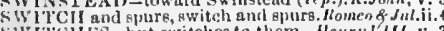

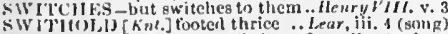

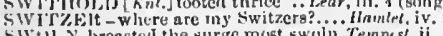

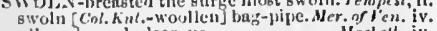

nll swoln and ulecrout.................. Macheth, iv. that $8 w^{*}$ oln pareel of dropsies............ interny? whilse the lig year, 8 woln withi....... Herv Ir. (ind nic.)

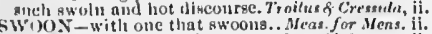

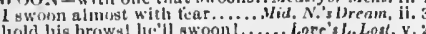

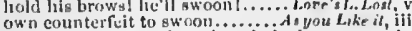

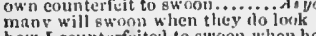

how [ enunterfeitel to swon when he -

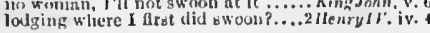

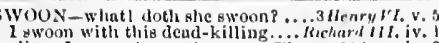
alive; 1 swown to sec theo...... Tinoon of dtherns, iv. 3 entse, do you think, 1 have to swoon? What did Cxsur awom? lle fell... Jalitus Cersar, i. she skoons to see them bleed ........... Hamlet, r. SWOON ED, all borrowest ............ "inter's Tiale, y. 2

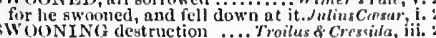

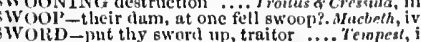
folony, gword, pike, knifi

of whon your swords arc tempered

your swords are now to

二

it is petter that triends is the swo......

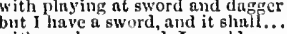

witly my long sword, I would.
which I with sword will open

if 1 sec a sword out

what, the sword and tie word

lay their swords to pawn

or strip 5our sword atark (rep.)...... J treln

put ul, your sword (rep.)

tempt me further, draw thy s

you drew your sword upon me ........

he, who the sword of heaven will bear

by my sword, Beatriec, thou ..........

my liand meant nothing to my sword
give us the swords, we liave bucklers

must draw a gword to kill himself

we will do no harm witl our swords

out, sword, and wound the pap......
conic trusty sword; cone, blade

if drnwing my swrord ngainst...

at my serviee, and his sword .........

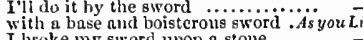

I broke my sword upon a stol
I biush, and hide my sirord..

we measured swords, and parted

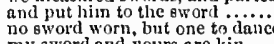

my sword and yours are lin
it was this very sword entrencita

whilst $I$ ean shake my sword

that his sword can never win ......

rust, sword! cool, blushe

an old rusty sword ta'en out of... Taming of $s h$ ifi..

sting is by this sword, thou wilt

slaall swcar won this sword of justice - ii. 3

and eome with naked swords.Comedy of Errors, iv. 4

these witclese are afraid ot sive his sword away: bind

with drawn swords, met us again........

I drew my sword on you

never didet thou draw thy swo.il on

give me my sword; who's there........

$\overline{=}$

give to the edge o' the sword his wife.

hold fast the mortal sword

or wear it on my sword, yct

be this the whetstone of your aword
within my sword's length set lim

within my sword's length set lim
with my sword I'll prove the lie

with ny sword I'll prove the lie
but swords I smile at. weapons

and dic ou mine own aword?

my voiec is in $m s$ sword....

desiring thee to lay nside the sword..... king Joh

that lift their swords in such $n$ just

with unhacked swords, and helmet

the sw-ords of soldiers, are lisis teeth

Your sword is bright, sir; put it up.....
Y think, my oword's as sliarp a. yours.

put up thy sword betime $\ldots$.............

my right sword 1 sweur, whicl gently

there shall your swords and latees ...
ploughed up with neighbours' swords

lay on our myal sword your

and friculls their lefpeful swords ....

lie so lieavy on my eword, that

leaning lupon my sword, came .......
my 6 word hacked like $\mathrm{n}$ lankt-saw

to hack thy sworl as thou hast done
how eanne Fnlataff's swooril so haeked?

thou hadst firc and sword on thy side

anil here draw I a sword, who

this sword lath ended him

pr'ytice, lend thy eword. o llal

thou get st not my sword; but take.

worse than thy sword my flesh ......
haut thou fleslies thy maidens swird

hast thou fleshed thy maiclen sword
make him cat a piece of ny sword

Wrath of nohle llotspur's sw'ord.2 Henry
whose well-lubouring sword had three

five me nyy aword, and cloak........

by dint of sword, have since
SWORDS whieh must decide it

draw no swords but what hre

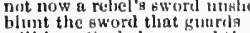

still beur the bulanee and the swiri.

we beartuined sword that $y^{\circ}$ in luve

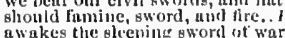

give edge unto the swords lliat
with blootl anul sword and fir

With blood, and sword, and fic
lides a swerd from litits unto.

cullure cold us another man's sword
valour of in man, and put up thy sword

by this swort I will. Sword is an oath

and sword and sliceld, in bloody ficld

a killing tongue, and a quict sword ..

come to the arbitrement of eword

the sword, the mace, the erown

mennged shat thou be by this my oword

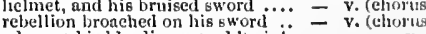

advance his bleceding sword twixt $-y \cdot \overline{2}$ (d)irns)

.

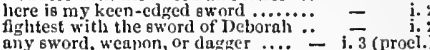

his sword did ne'er lea ve striking

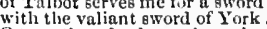

O turn thy edged sword another way

lets fall his sword before your highines
stouter champion never handled aword

that, who so draws a sword, tis

till with thy warlike sword ...

erest thy sword struek fire..........

the sword of Orleans hath not.....
his bloody sword he brandislied....

flugh his puny sword in Fredelimein'

and girt thice with the sword ....
my sword should alhed hot blood

proud proteetor, with my sword

and that my sword be staincd with

put the Englislimen unto the sword

but here's a vengeful sword, rusted.

broke be ny sword, my arms torn

come, and get thee a eword

neither aword nor fire $\{r e p$.$) ............$

we will have the mayor's sword bor
Eouls should perish by the swordt

hath ny sword therefore broke through

that have a sword, and set am ready

Exwallow my sword like a great pin

gword, I will hallow thee for this ...........

thy body in with my sword.

cxeept a sword, or sceptre to balanee

so let it help me now aqninst thy sword

sword, hold thy now ang

nuw, by my sword, well hast thou

by the swords of commonon sol
our swords shall plead it in

our swords shall piead it iu minj ot...

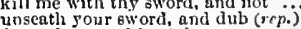

draw thy sword in right

the third, if this sword hind .........

see, how my sword wecps for ........

Clifford shook lis sword at him .....
I lend thee tlis slarp-pointed sword

take up the sword agan (rep.
with the hilts of thy sword

O that's the sword to it? $\ldots \ldots \ldots \ldots . . . .$.
is the sword uoswared? is tilie king dead?

is a thousand swords [Col. Knt.-men]

and

draw your wilting swords...............

our eonecicnee, swords mir law.....

my sword i' the life-hlood of thee else

those with sworts? Swords? miy thin

his sword is bloodicd, and his helm.
llector's sword hnd lacked a minster

strung joints, true swords ...........

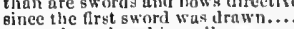

a sworl emploged is perilous.

beliohs cart to dure, or and a swort....

he should eat swinris first

if to my sworil his fate be not.

stami at merey of my swort ........
whercin my swort has not injeresire

linond hy my mortal sword le drained

my sword slould bite it..............

than shall my prompted si...... finilin

vengeance ride upon our swords ....

with your true sworcl ilrawn

rest, sworsi; thes hant thy fil].........

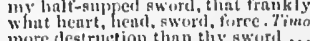

but for tliy sword and tort tule

let not thy sword skip onc 
STVORD - thy trenehant sword. Timon of Alhens, iv. ? | SWORD-purpose, I'll anoint my sword.Ilamlel, iv. 7 SWORN-unswear faith sworn ...... King John. iij. 1

and shakes his threateuing sword.

than hew to't with thy sword

let ane use my sworri, I'd mike

at Greeitu siords eontending .......
he lial rather see the sworts, ani hear

he liaw rather see tlie sworls, and hic
that we with smoking swords may

ontclares lis senseless sword

elarms misguide thy npposers' swords
tilling the air witls swords advanced

make you a sword of me?............

equal foree, (true sword to sworil).

he lurched all swords o' the garland

his sword (death's stamp) where it..
of ten he had met you, sword to sword

dnwn witl that sword; tribume
sinee he eould draw a sword ...
lis gnol sword in his hand ...

his gnol sword in his hand ...........
here I clip the anvil of my sword..

aehieve as snon as draw his sword

all the swords in Italy could not....
let him feel your sword, which we

to use my law ful swordi...........

be quiet, put 11) your swords ......

here, as I point my sword, the sum
to the elbows, and besmear our swo

to the elbows, and besmear our sword
as those your swords, made rieh

to you our swords have leaden point

slaughter to the sword of traitors

not born to die on Brutus' sword

with this good sword, that ran

come, Cassius' sworl, and find Titinius' -

and turns onr swords in onr proper..

I held the sword, and he did run on it

ghines o'er with eivil swords. An/ony \& Cleop

now, by my sword, - And target ....

eause enough to draw their sword
that drew their swords with you

I did not think to draw my sword

great Cesar lay his sword to bed ....
whilst I wore his sword Philippan .

if 'twill tie un tlay diseontented swrird
with Parthian blood tliy sword is wirm

with Parthian blood thy swordion
his sword, grants searee distinction
do you misdoubt this sword, and these

kept his sword even like a danrer..

kept his sword even like a danrer

and that my sword, mide weak.......

flie has robbed me of my sword

I, that with my sword quartered

elraw that thy lonest sword (rep.

this sword but shown to Casar
this is his sword, I robbed his w

this is his sword, I robbed his wo
died with their swords in hand

to be put to tle arbitrement of swords

goul shall answer me with your sw

to master Caesar's sword (rep.) .....
my boty's marked with loman s

what shall I need to draw my sword?

whose edge is sharper than the
look! I draw the sword myselt

best draw my sword; and if (rep.)

with lis own sword, which lie dir wave

threatened our prisoners with the swor

came to me with his sword drann

suceessive title wtl ynur swords .. Titus. 4 nd
where he eirenmseribed with his sword

given me leave to sheathe my sworl
and, with our swords, upon a pile of

araw your swords, and shea the them not -

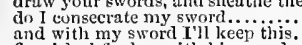

and with my sword I'll keep this....

and that iny sword upon thee shail,.

give me a sword, I'll eltop off ny .....

this sword shall prove, he's honou
his sharp sword out, numbling ...

his sharp sword out, numbling .......
with his prepared sword. he charges

such a sinve as this shondd wear a sword

give me thy sword; a jensant............

bending his sword to his great master....
the sword is out that must destroy thee.
tender-minded does not become a sworc

dender-minced dhy sworl; that, if my speeel.

clespite thy victor sword, and fire-new

this sword, this arm, and my best spirits
this sword of mine slall give them instint

this sword of mine sliall give them it

put up your swords (rep.)......... Romeo

fiery Tybalt, with his sword preparcd

than twenty of their swords $\ldots . . .$.

will you pluek your sword out .....

upon my sword. We have sworn (rep.)..

his antique sword, rebellious to his

for, lo! his sword which was declining

than Pyrrhus' bleeding sword now fulls.;

scholar's eye, tongue sword .............

lip, sword: and know tholl a more horrid
looks raw and red after the Danish sword
no trophy, sword, nor hatchinent

no trophy, sword, nor hatchinent
you may choose a sword unbated

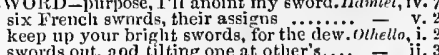
swords out. and tilting one at other's.

following him with determined sword

he that you followed with your sword?

forth, my sword; he dies .................

二 ii. 33

i. 6 I care not for thy sword; I'll make thee

9 every puny whipster gets my sword.......

ii. 2 and this good sword, I have mate my wit =

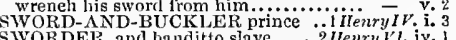

iii. 1 SWORDEP, and banditto slave ... 2uenry

ii. 1 to the shnw against a sworder. Anfony \& Cleo. iji. II

SWORDSMEN - sinewy swordsmen. . All's " Iell, ii. I

SWORE he would marry ber to-night. Mrtch Ado, ii. I
swore he would meet lier as he was..

be swore he would never marry

for he swore a thing to me

swore that you were almost sick (rep.)
no judgment, when to her I swore. $\bar{F}_{i l}$, v. 4

swore, to stud y with your grace .. Love's L. Lost, i.

you swore to that, Biron, and to the rest -

sir, then I swore in jest-what is .....
keep what I have swore [Col.-sworne]
and swore, a better speech was never

and swore, a better speech was never
madam, he swore, that he did hold me

I never swore this lady sueh an oath

v.

and swore lie would pay him again..

you swore to me, when I did give... - i. 2

shook hands, and swore brothers ${ }^{-1}$ s you Like it, i. 2

though I swore I leaped from..........Alls $\bar{w}_{e l l}$,

swore so loud, that, all amazed.. Taming of sh. ili. 2
he stamped, and swore, as if the vicar

how he swore; how she prayed

Dromio; swore, I was assured .. Comedly of $\overrightarrow{\mathrm{C}} \mathrm{rr}$.

swore he, that he was a stranger (rep.) - iv. 2

swore the devil his true liegeman ...i Hen'y $I V$.ii. 4

swore little, diced, not above

you swore to us, and you

to this we swore our aid.............. =

Whe swore consent to your succession. 3 Henry

and swore, with sobs, that he wonld. Richard lif

that swore to ride before him .......

swore, they saw men, all in fire ......JuliusCesar, i. 3
then $I$ swore thee, saving of thy life.

and swore, with his own single hand $C_{y}$ mbeline, iii. 3

but, that he swore to take our lives?

and swore, if $I$ diseovered not.

truest prineess, that ever swore her faith 二

sure as death I swore [Knt.-sware]. Titzs.Andron. i.

swore a would see her to-morrow ....Pericles, jy. 3

iii. 4 he swore, had neither motion, guard ... Inamlet, i

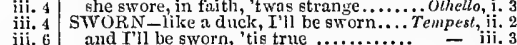

nay, I'll be sworn I have . Tü........ of vernna, iv. 4

n'll be sworn (rep. ii. 2 and iii. 3 )...Merry Wives, $\mathrm{i}$.

that I would have sworn his disposition

sir Toby will be sworn.

I'll be sworn thou art.

and thy sworu enemy

may, in the sworn twelve

iii. 4 (challenge)

every month a new sworn brother... Mruch Ado, i.

thoughl I had sworn the eontrary....

though, I'll be sworn (rep. v. 4).....

I would have sworn it had, my lorcl

have swo for three years terrn.. Lnve's L. Lost, i.

I have already sworn, that is, to live

laving sworn too hard-a-keeping oath

eael to other hath so strongly sworm

eael to other hath so strongly sw
dear lady, I have sworn an oath
my hand is sworn, ne'er to pluek

or, keeping what is sworn,

the king is my love sworn,

since when, 1 ll be sworn, lie wore
be sworn, if thon be Launcelot...

I have sworn an oath, that I wili....

lave I sworn, to lave the due

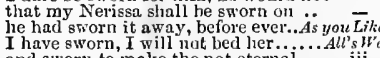

and sworn to make the not eternal

bow have I sworn? "Tis not........

how my sworn friend, and then .......ंinter's $T a$

thereon lis execution sworn ........

I dare be sworn: these dangerous...

so attired: sworn, I think, to show...
which we two have sworn shall come

hast eworn mp love to be (rep.) ... iv. 3 (song

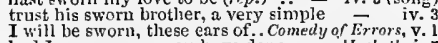

had I so sworn, as you liave done ........ Sulubeth, i. .
been sworn ny soldier? ............. king Johnt, iii. I is sworn againet thyself, and may not be - iii.

I have sworn to do it; and with hot
yet am I sworn, and I dicl purpose ..

yet am I sworn, and I did purpose ... = iv. I

neglected my sworn duty in that case. Richard $I I$. i. I

we all have strongly sworn to $\ldots \ldots . .$. - ii. 3

whiel I have sworn to weed ......... $=$ ii.

I am sworn be sworn or eaid........ $\rightarrow \quad$ iii. 3

to Bolingbroke are we sworn subjects $\bar{E}$ sirrah, I am sworn brother to ....... InenryIV. ii. 3 120, I'll be sworn; I make (rep. .......

no, I'll be sworn; unless you call.... - iv.

whom I have weekly sworn to marry.2 Henryl $I Y$. i. 1

as if he had been sworn brother (rep.) - iji.

and sworn unto the practises of Franee -

as two yolke-devils sworn to either's $=$ ii.

have sworn to take him a box o' the ear - iv.

your oaths to IIenry sworn ...........11 Ienry Vt. i.

a dreadful oath, sworn with........2 Henry $V^{\prime} l$ iii.
Jaek Cade hatlis sworn to have thy head - iv.

true allegiance sworn (rep.)..........

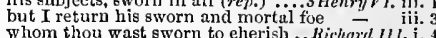

Whom thou wast sworn to eherish ...Richard

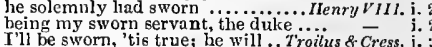

I'll be sworn, 'tis true; he will...Troilus \& Cress

now to her, that you have sworn to me -

to keep an oath that I have sworn ..

you have sworn patienee .............

he is a sworn rioter: h'as a sin.......

true? I'll be sworn they are true $\ldots . .$.
I will, sir, flatter my sworn brothe:..

what may be swown by, both divine..

friends now fast sworn, whose

our general has sworn you out of ......

I dare be sworn, you were.............

madam, as thereto sworn by your.... \& - .

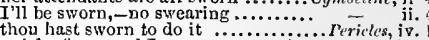

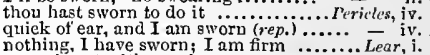

nothing, I have sworn; I am firm ......... Lear, i.

to both these sisters have I sworu my lore

be but sworn my love, and I'li no longer -

thy dear love, sworn, but hollow perjury - ii.

I lave eworn't. My lord, my lord....... Hamlel, $\mathrm{i} .5$

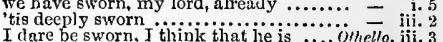

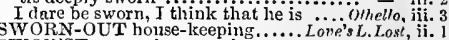

SWOR'ST-onee thou swor'st....... L M Lave, for L. Lost, il.

what sinee thou swor'st, is sworn .. King John, ii.
swor'st thou not then to do this. An/ony \& Clen. iv.

WOUNDED almost at my pleasing... Titus And. $v$.

YBIL, and ang about his head .. llomeo of Juliel, i.

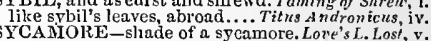

underneath the grove of syeamore. Lore's L. Lost, va

sat sighing by a syeamore tree ... Oihello, iv. 3 (song)

which Syeorax could not again undo

by Syeorna my mother.

but only Syeorax my dan, and she

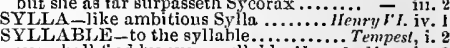

you shall tind by every syllable. ileas.... for Meas. ir. 3

yelled out like syllable of dolour......... Macbeth, iv.

to the last syllable of reeorded time....... $\overline{V I}$ no, i.

of every sylloble that here

with the major part of your syllables. Coriolanis,, ii.

syllables of no allowanee $\ldots . . . . . . . .$. . pericles, ii.

I will believe you by the syllable

if thou deny'st the least syilable of ........ Lear, ii.

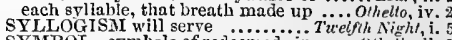

SYMBOL-symbols of redeemed sin ... Othelln, ii.

SYMIPATHIES, there is my gnge.... Richard $I I$. i

with the loser's let it sympathise ..... Inenry/V.

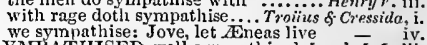

sympathised one day's error .. Comedy of L'trors, $\mathrm{v}$.

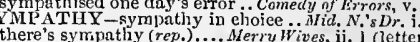
Would you desire better sympathy? - ii. I letter) if sympathy of love unite

whelh I'll keep, if but for sympathy. Cymbeline, v.
what a symputhy of woe is this!. 7 .

O woeful sympathy!............. Romeo \& Juliet, iifi.

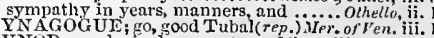


sFouls been deereed

sit in hourly gy ment aboit tijy

Comedy of Rrr. i. cry to thic ghining synul of thic rest.. Cymletinc Yil.

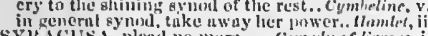
SYli.ACUSA, pleal no mure.... Comerly of lirrors,

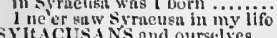
at any syrneusan murts and tiniro $i$ rep.) $=$ a Syrausall merehant (rep. v. I)

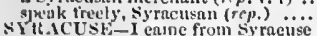

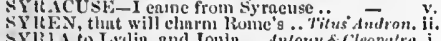

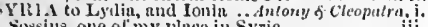
Sossius, one ol my plnee in Syria
inale tier of lower syria, Cy

in $P^{2}$ tolemy lie assigned Syrin Cilieia

Citsar through asigncasyria, Citieia

the tiurest in all syria
syllup-with wholesome

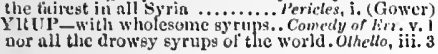

\section{T.}

TABER-the knight witl my talser. Nerry Wives, iv. 4 under the duke's table

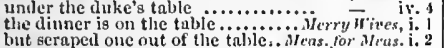

to gratify the tnlle with a grace. Love's L. Lost,

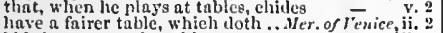

bid them cover the tnble, ser

and weleome to our table $\ldots \ldots \ldots . . .3$ you Like it it. 5

in our hemrt's table; heart, too eapable. All's Weth i.

to supply the places at the tuble ....

at upper end o' the tathle, now .. Ininter s.ats, iv.

drink a measure the table roind

the table's full. Here is a plaee
general joy of the whole table

give to our tnbles meat ${ }_{\text {in }}$ the futtering table of her eye.......

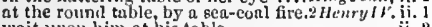
lispin" to his master's old tables...

will he wipe his tables elean

loth from thy table. Meenry.

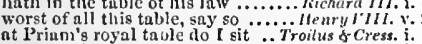

Richard III. i.

to my table so man y meals ............
uxelas? the tables of their thoiglit

let lim lave a table by himsels. Timon of 4 thens,

all pleased from thy table rise

a perfecter gituer for the table

act at upper enl o' the tubie

and grant of the whole table $\ldots . . . . .$.

yet you clasp young Cupil's tables. Cymbetine, iv. 7

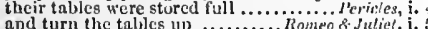

and turn the tables up .......... Romeo \& Juliet

clans me his sword upon the table
coldly furaish forth the marriage tables. Inamlet, i. 2

from the table of my memor

my tables, meet it is, I set it do i.

God be at your table! Conceit upon

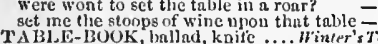

if I hai played the desk, or table-book. I Iamlet

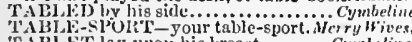

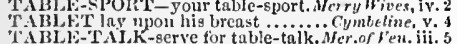

'TABOR-then I bent iny tabor ........ Tempest,

dost thou live by thy tabor?............ Tempest, iv.
gtands by thy tabor, if thy tubor stands - iii. rather licar the tabor and the pipe.......uch diso, it. or I will play on the tabor.......... inve's L. Lost

dance again after a tabor.......... Winter's Tale, iv. 3 antl fifeg tubors, and cym a talor.

T.Alsuli Elt -I conld sec this talorer.... Terapest, iti. TABOUIt INE-lond the tabourincs. Troil. of Cress. iv. 5

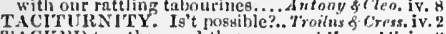
TACKLI) together, and throw........ Henry!?. iv. 2 the tackle of my lacart is eracked....... King John, v, 7 upon the hentuen taekle .i.....Henry '. it. (chorus) thro the the silken tackle swell with

ond from the laclder tackle waslieal ott" \& \& Clro. ii. 2 I'ICKL t:D-like a tneklerl stair.. Nomeo o Juliet, ii.

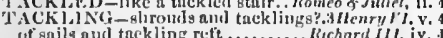

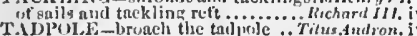

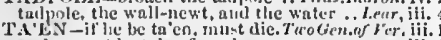
nud cannot be ta'en from lier......... ifien. I'll huve my hraine ta co out ..... Werry si

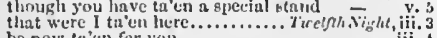
be now ta'en for you .............. - iii.

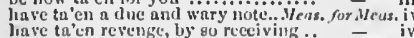

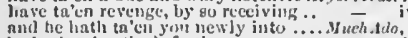

lie liath ta'en the liffectim ..........

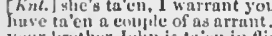

Your lernther Jolin is ta' en in dighit...

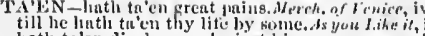

lath ta'en displeasure 'Euinst lis.

from the limster's aim bud ta'en a liurt -

liath ta'culrom me lie show of..

und luw was that ta'en up?....

where is no nlensure tr'en ..... Taming of shrem,

well ta'cu, and like a buzard.

an old rusty sword ta'en out of .

nay, 1 have ta'cn your napping

nind afluarel ta'en from me

I thoughit to lave ta en you ........ Carnedy of $E$.

and 1 whs ta'en for lsim, and he for 1 ac

Arthur ta'en prisoner? llivers denr.

mand was robled and ta'en away

madam, there is order ta'en fi,

be ta'en, or slnim, we hear not.
if I be tu'un, I'll 'peach fur this

jour of us here have ta'en a thousand

aceorling to our threcfoll order ta'un
great Doustas; ta'en him once......

preat Doturlas; ta'en him once
his corruption being ta'en from in

the prince hath ta'en it licnee........ - iv. I

their stings and teetl newly tach ont $-\bar{c}$ iv. 4

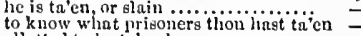

allotted to be ta'en by me.............

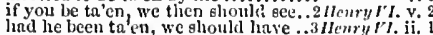

be not ta'en tardy by unwise..........ich

as we lave ta'en a tardy sluggard her

to see you ta'en from liberty ........ ien

to Rome, hath ta'en no leare.........

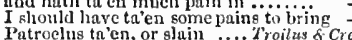

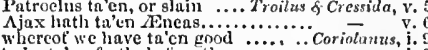

th be ta'ca forth, betore the commoin

you should have ta.c.................

he's ta'en: and, hark! tlicy shouit...ju

my best friend to'en before iny face

he is, or ta'en, or slain

ta'en the treasure of her honour.....

When thou hast ta'en thy stand....
I have ta'en his head from lim.

lisme art gone, and ta'en thy wages -

if you ghould have ta'en vengeance on

a prisoner, the noblest ta'e

Ihaving ta'en the forfeit............

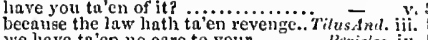

We have ta'en no care to your

he and his dougliter ta en!

let me be ta'en, let me be put... Romen \&...Julict, iii. 5

tewards hast ta'en with equal thank

if IIamjet from limselt be ta'en away.. - ii. 2

that I have ta'en away this old man's ..omello, i.

of you dispraisingly hatli ta'en your part $=$ iii. 3

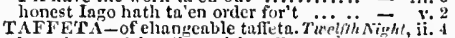

beanties no richer than rich taftu.

tafleta plirases, silkeu terms precise..

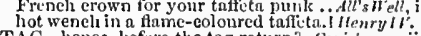

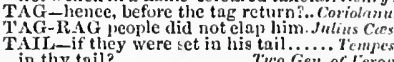

if he shake lis trii

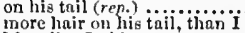

more hair on his tail, than I ........

in your tail? nay, come agnin .......

and, like a rat without a tail, $Y$ i i ilo ...Macbeth,

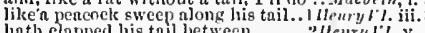

tic his borly to my horse's tnil

and at the inurderer's horse's

once subdined in nrmed tinil.....
fenr this bedy luatli a tail mo

with iny mother unler the clragon's tail.. l.enr, i. 2

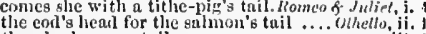

therelyy hanga a tail.

secresy of thine shall be $a$ taijor... Merry is ires. iti. 3

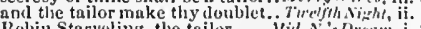

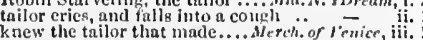

knew the tailor that made....... Aerch. of fenice, iti.

a very goos tailus. I

the tuilor stuys thiy leisure gone....... of stuminte

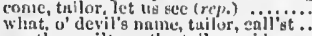

say thou wilt see the tallor pais

tailor, I'll pay thee for thy gow

nil Englisli tailor cone hillier

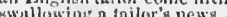

CAILOR's yard, you whenth

a woman's tailor, fir (top.

if lue hud been a man's tailor irep..... - iii.

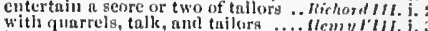

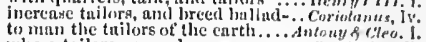

whore tailors are as denr as yonirs .. Cymbertine, it.

nn, nor thy tailor, rascal, who is thy

my tailor male them not.............

dikelaims in thee; a tailor made thee
$n$ tailor make a man? $\Lambda y, a$ tailor,

when nobles are their tailors' tuturs

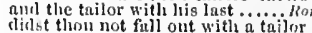

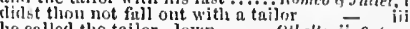

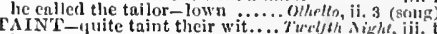

lest the deviee take air, and taint....

or any taint of vice, whose

liere abjure the tajnts and blames......... Macbeth, iv.

I camnot taint with tear................. v.

tover yet taint with love............ Illenry II. v.

I will not taint my month with

in taint of our best man ...... Troilus \& Cresside, i. 3

suhtly taints even then when we.... - iii. 3

his taint and honours waged....... Corintants, iv. 7

to taiat his nobler lieart and brain ... Cymbeline, v.

taint not thy mind, nor let thy goij ........ ilamier,

that they may seem the taints of liberty or ${ }^{-}$ii.

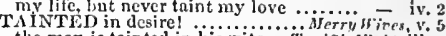

the man is tainted in his rits .........elfh Night, iii.

Whether thou art tainted, or flec. Meus. for Meas. $\mathrm{i}$.

give to laer fonl tainted fleshl!......... Wueh stlo, iv.

flea so tainted and corrunt .......̈.

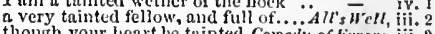

thongh your heart be tuinted. Conedy of lirrors, nit. 2

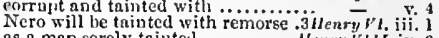

as a man sorely taintchl............henry rit. iv. 2

brenths with swcetweats tainted . Kmmeo of jaliet, i. 1

you cannot preserve it from thinting. Cymbeline, $\mathbf{j}$.

Fncaking too lond, or tainting his ....... othello, ii.

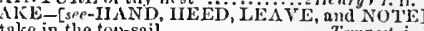

they would not take jier life

go, take this shape .....................

good lord, how you take it

conspirney his time doth take..........

as I take it, an ague.....................

and mueh less tnke, what.........

and take his bottle from him
do I bo? take thou that.........

and the devil take your fingers.

if thou beest a devil, take't as thou list

oxe my douge will we tuke thoroughly

if I slowld take a displeasure.

'gainst my fury do I tike part

had plotted with them to take myili:

to take this drunliard for a gud

where you slinll take your rest.

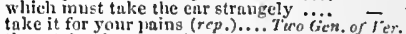

there take the pajer
best to take then? ul

lest lie should take excejtions

a eloud takes all awny

and yot take this again

here take yout this

to who will take her in

take no repulsc, whatever

my davghter takes his going ..........

have you anytling to take to?

I take your ofler, and will
sir Protent, as I tuke it

one that tnkes unon lim to be $a$ dug

to take a tinult yton me..............

and take this shangw wo we

and yet she takes excytions
take but jossession of fier witl

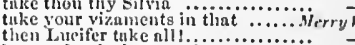

then Lueifer tuke all 1................

take-a your rulier (rr $p$, ii, 3 )

say what she will, take all, pay ali...
lake all, or half, for cusing nie ......

well, I will takc him

it lie take her, let him take hier simpily

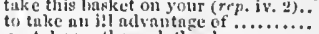

Eo, take up these elothes Jicie. 
TAKE away these chalices..........Merry Wives, iii. 5 TAKE-we will take some care .... Love'sL.Lost, v. 2 TAKE away this dish ....... Taming of Shrew, iv. 3

ghe does so take on with her men....

I will now take the lecher

come, come, take it up

will you take up your wife's clothes?

where we may take lim

and takes the cuttle...................

come, will this wood take fire?

I will never take you for my love...

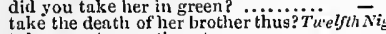

takes great exceptions to your ......

are they like to take dust

take the fool away (rep.)

take away the lady $(r e p$.$) .............$

I protest, $\mathrm{I}$ take these wise men $\ldots .$.

is to take those things for bird

lie takes on him to understand

to tell me how he the

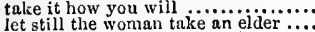

I take pleasure in singing, sir.

does not Toby take you a blow

and take't for a great favo

lest the device take air and taint.........

lob noh, is his word, give't, or take't

I have his horse to take up the quarre

take him away; he knows

take, and give back, affiirs

let your bounty take a nap

take thy fortunes up

farewell, and take ner..

take thy commission ....................

we stoop and take it ................

will take order for the drabs

and take the shame with joy ........
(let no man hear me) I take pride ...

to take away a life true...............

to take life from thine own....

take my defianee: die; perishi........

to take this poor maid from the world
and sir, we take him to be a thief too

take him to prison, officer

if you take it not patiently $\ldots \ldots \ldots . . .$.

take, oh take those lips away

take then this your companiou

she'll take the enterprize upon $\ldots$......

for, as I take it, it is almost day ....

take him hence; to the rack

sweet Isabel, take my part .......

and pray thee, take this mercy.

takc him to prison; and see our.....

and take her hearing prisoner with.

be meant to take the present time
impossible you slould take true roo

therefore I will even take sixpence.

who, as I take it, have stolen his

count, take of me my daugliter.
but ril take my oath on it

but Yli take my oath on it....

than you take pains to thank me.....

you take pleasure then a

any pains that $I$ take for $y o$

nor take no shape nor project.

nor take no shape nor project.........................

take their examination yourself ....

o fato, take not away thy heavy ....

as I dare take a serpent by the tongue
no, that you shall not, till you take her

no, that you shall not,

take time to pause: and, by the next.....Mil..

you must take Thisby on you .........
take pains; be perfect, adieu.......
take this charm off from lier sight $($ rep. $)$

take this charm off from lier sight (rep.) -

do it for thy truc love take....
0 take the sense, sweet (rep.)

O take the sense, sweet (rep.) .........
when I did him at this advantage take

when I did him at this advantage his function takes...

though you take her part (rep.)......

that every man sliould take hig own.

that every man silunla take his own.

Robin, take off this liead .....

and take your places, ladies

noble respect takes it in might $\ldots \ldots \ldots$.

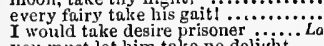

you must let him take no delight....

take away this villain

to take him at his word.................
take this kes, give enlargement $\ldots$.
doth the inconsiderate take salve for

doth the inconsiderate take salve for
good my glass, take this for telling

hold, take thou this my sweet.........

so shall Biron take me for Rosalinc.
fuir lord-take that for your fair lail

fuir lord-take that tor your fair laily

but that you take what doth to you.
but take it, sir, again ............... take away the conqueror,

master, let me take you a button-hole $\overline{\vec{F}}$. v I think, I may take his bond ..........

iv. 4 for when did friend sinip take ........

yon must take your chance...

use your legs, take the start

pray thee, take pain to allay with .

how I shall take her from her father;

i. 3 there, take it, prince, and if my form

take what wife you will to bed

\author{
v. 2
}

take it up unto thy master's use $1 . .$. .

take you assurance of her.

to the clurrch; take the priest.......

- iv.

will you take eggs for money?

i. 1 to take again your queen...

ii. 2 take the boy to you; he so tronbles...

he would not toke it .................

ii. 2 to laughter as I take it $7 \ldots \ldots \ldots \ldots . . . . .$.

ii. 4 for present vengeance, take it on her

unless he take the course that you ..

when she will take the rein ..........

take this same letter, and use thou ail

you are welcome, take your place...

him that gives, and him that takes

ii. 4 take then tliy bond, take thou thy

$\begin{array}{ll}\text { ii. } 4 & \text { I take this offer then } \\ \text { ii. } 5 & \text { doth the Jew panse? }\end{array}$

dake my life, and all, pardon not

iii. 4 take my house, when you do tike (rep.)

iii. 4 tril take this ring from you (rep.)

since you do take it, love, so much

wii. 4 would take aught hat the two rings.

iv, 3 countenance seems to take from me. As $_{\text {s you }}$ Like

but the same tradition takes not

that all the beholders take his part.

you will take littlc delight in it.......
they take the part of a better.........

do not seek to take your change.

ii. I and bid him take that for coning...............

and bid him take that for coming....

I pr'y thee take the cork out $\ldots . .$.

ii. 4 but take a taste of ny finding lim...

which I take to be either a fool

will I take upon me to wash $\ldots$ wot take her on gift of any.....

lore him; take his offer

so, take her to thee, shepherd .......

You might tuke occasion to kise some joy to say you are

I take thee Rosalind, tor wife (rep.

never take her withont her (rep.
take thou no scorn, to wear

will the faithful offer take of me....
will you talse him by the arm?

well then, take a good heart

therefore take the present time....

to take that that no man else

purposely to take his brother.........
the tyranny of her sorrows takes all

once more, take her hence (rep.) ....

and played, to take spectators ...... - iii.

her hence; her lieart is

take your patience to you ...........

how it takes up the shore..........

now take upon me, in the

or take away with thee ..............

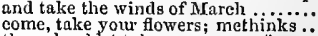

come, take your flowers; methinks...
thou shouldst talke no money of me..

that does take your mind from .......

of your own state take care...

the cheek, but rot take in the mind

I cannot with conscience take it ....

some eovert; take your sweetheart's hat -

husband take by my consent... - v.

gaoler, take him to thy custody...Coinedy of Err. i.

mang a man would take you

will, not, sir, I'll take my heel

serve him so, he takes it ill ..........

as take from me thyself, and not ....

and as a bed I'll take thee ...........

take the stranger to my house (rep.)
that takes pity onl deca yed men......

that takes pity onl decayed men.......

for God's sake, take a house

whilst to take order for ...........

if he can take you, to scorch ...........

vouclisafe to take the pains to $\cdots \cdots .$. - v.

that takes the reason prisoner?.......... Macteth, i.

and take my milk for gall .............

and take the present horror from......

it sets him on, and it takes him off ....

whose cxecution takes your enemy

that they take place, when virtue's

our wonder too, or take off thine
I dare not say I takc you, but $I$

young Bertram, take her, she is

a sou shall take this disgrace off

that yon will take your instant $\mathrm{A}$.

presently yon take your way for

and would you take the letter of her?

we'll take your offer kindly $\ldots \ldots . . .$.
take this purse of gold, and let $\mathrm{me}$.
but take the Highest to witness......

here, take my ring; mine house ......

that he might take a measure of

bid him drop gold, and take it ......

after lebts, take it before .........

take any shape but that ..............

and take a bond of fate.............

if you will take a thomely man's

nd would not take their pourt?

unlock her closet, take forth paper....

marry, as I take it, to foutsilion....

let's take the instant by the forward

pleases you to take it so.............

lend her away, I do not like her (rep.)

I take him for the better dog.. Taming of

go, sirrah, take them to the buttery

iii. 2 and take a lodging, fit to en tertain

iii. 2 would take her with all faults $\ldots . . .$.

I had as lief take lier dowry with....

uncase thce; take my coloured hat..

take your papers too, and let me

therefore Kate, take this of me

a buzzard take thce? (rep. ...........

good masters, take it not nnkindiy..

Bianca, take him for thy lord ... -

stooped again to take it up.....

now take them up, quoth he .....

iii.
iii.
iv, and let Bianea take han than I will take cold

my stirrup, nor to take my horse?

v. 2 you plnck ing foot awry: take

$\begin{array}{ll}\text { v. } 2 & \text { there take it to you, trenchers ...... } \\ \text { v. } 2 & \text { and here I take the like unfeigned ... } \\ \text { v. } 2 & \text { take in your love, and then let me alone }\end{array}$

thit you take upon you as you...... - then take my king's defiance ........... King $\overline{\text { Joln }}$

brother, take you my land, I'll take my -

that will take pains to blow

I'll take that burden from your back

henven shall take in nature of a fee

makes it take liead from all ..........

his words do take possession of .......

heaven take my soul, and England...

take again from this my hand

and make you take the hatch..

who did he take it? who did

with honour and respect may take

as to take up mine honour's pawn ...Richard

take honour from me, and my life

and take an oath with thee..............

take take

take special care my greetings

thould take it off again with words...

forbear, thou shalt not take it up.

I take [Col. Knl.-task] the earth

you shall not only take the sacrainent

inine, and thus I take thy heart ....

take effeninate hoy, takes on the poin

the devil take Henry of Lancaster.
take hence the rest, and give them : with my vexed spirits I eannot take

how easy dost thou take alt England up 1 -

T take it up and by that sword

to take advantage of the absent......
= i.

- ii

- iii.

Z ii.

- iv.

二 iv

- iv.

v. 6

iii. 1

iv. 3

iv. 3
v. 1
v. 3

v. 2
v. 4
v. 6

i.
i.
i.
ii.
ii.
ii.
iii.
iii.
iii.
iii.
iv.
iv.
iv.
v.
v.
v.
v.
v.
y.




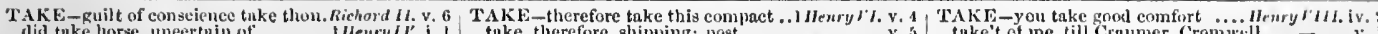
did tuke horse, uneertuin of where slubll we take n purse to.no...... the devil take suell eozeners! ......... each takes his fellow for .....

i. 2 therefore I will take the Nevils'

ii. 2 in court ilo take her for the queen shall he clie, and take lis and (rep.). and tuke this drab away ............. what is $t$ thint takes from thee they take it ulreaty uipm their..... prove uthief, and take purses? ...... as min the other sisle it takes from yout shall I not take mine ense in ......... come, let us take a muster speedily. take it for thy lubour; and it it $(r e p$.) now forsooth, takes on him to reform thut he slath take the odls of his ....
will they take the oller of our grace will they take the ollur of our gtace or take auny the it advised but take my pistol, if thou wilt that takes survey of all the worli..... ulien, and take thy praike with thee I will take it as a sweet disgrace....... men of ull sorts take a pricle to gird.. he woukl not take his bend and yours will take me withent weighing... I take but two shirts ont with a third must take up as............. to take soldiers up in eounties that takes upon him not to conecive merriment, it you take not the heat
whin take the ruftin billows by ....

nud I will take suel order, that thy take not on me here as a phy'sician ilien take my lord of Westmorelind I take your princely word tor. they tuke their courses cast. or else a fenst, and takes away........ I pruy you, tuke me up, and bear put it in thy nind, to take it hence as men take diseases, ene ef another I take it there is but two ways
I woulil not take a knghthood let us take any man's herses

to the Flect: take all his company..... hear you s on; take them away whereof take youl one quarter ...........
ere he take ship for France........
ior I can take, and Pistol's cock is ..

and to take merey on the poor sonls look you, if you take the matter.... men ot llarfleur, take pity of your town and I will take up that with ........ I will take thee a box on the enr.... I take thee in the king's compan take from them now the sense the banner from a trumpet take and I the erowns will tul

and takes him by the beard....

Philip of Macedon, as I take it .... to take the tales out of my mouti. take a trumpet, herall; ride theu.. your majesty takes no scorn to,$\ldots \ldots$. have sworn to take him a hox o' thi
wlich your majesty is take out of Which your majesty is take out of .1. Takeecly yel. take it for your own fault or tuke thut praise finy thiner when you take occasion to see leeks. in truth, you shall take it $\ldots$........ and take witl you frue power $\ldots . .$. . cunst love me for this, take me (rep.) dear Kute, take a fellow of pluin moicty, take the word of $u$ king and take fler, latir son; and from her... we'll take your outh, and all the ireer of Aujus dith take his pirt.......... golliers with me I will tuke. she tukes upon her hravely

girs, take your places, aml he vigilain Jaik'st a trup th take iny life ...... your borlslipip takes us then for fools ausl dare net take up arms like ... now will we take some orker.......... the rest, will take thee in their arm and in our corunution take $y$ our liluce in witness, take se that............... muth less to tiske occasion from persumle you tuke a better eourgc

aud take foul BCor", to fakin

pauke, und take thy hreath

ko, take their bexdies hence

then take iny soul; my borl $y$, soni

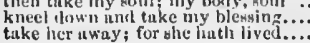

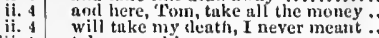

take awny his weapon

iv. 1 we'tl take her from the sheritf ......... to take her with him to the isle

iv. 2 I pr'y the go, and take me hence...
iv. 3 sirs, tuke away the duke, and guard

iv. 1 sirs, tuke away the duke, and guard
v. 1 and as the butelier takes awny

v. 1 ere you ean take due erders.

v. 1 noble York take thou all this

v. 3 whiles I take erder for mine

I take it kindly; yet, be well

v. Jords, take your places; and, I pray

let thy suffolk take his heavy

be net so rasla: take ransou

that king Edward take the

like a Sinon, take another Troy

where I must take like sea

if Warwick take us, we are

and take the great-grown traito

come, Warwiek, take the time.

take alvay this captive seeld (rep.)

if heaven will take the.

to take is not to give

and take deep traiters for thy denrest

take the devil in thy mind

take not the quarrel from his...

take that, and that; if all this

take thou the fue, and tell him

I fear thy justiee will tuke hoid

that you tuke with untliank fulness.

if presently you will take liorse.....

to take some privy erder to draw.

this virtuous priun take in......

to take on you the eliarse and kingl

take to your reyal self this proffercd

besceeh you, tuke it not amiss

and take thy office frem thee.

take all the swift advantige

if I did take the kingtlom.

some ene take order, Buckingl 1 im

we must beth give and tak

troublet thonghts, to take a ninj

arlse, and take place by us

there, I take it, they may ............

and pruy them take their pleasures.

find out, and he will take it..........

to take you out, nnd not to kiss yell.

to take your good graee frem ine?

take thy lute, weneh; iny soul

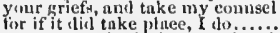

take notice, lords he lias a loyal

n way, if it take right, in spite

there take an inventory of al

you cime to take your stund here...
I take it, she that carrics ul ...... i. 3 take this fellow in. and send tir...........

2 away, take horje Come, Dargaret

take him away, and behead him ( $\left.r p_{\text {. }}\right)$
nnd take up commodities upon our bills

I mean to take possession of .........3 Hen ry

i. 2

you me take

you tuke a preesipice tor no leap......
I take it, by all voices, that fortiwiti.

I take ny eange ent of the pripes .....

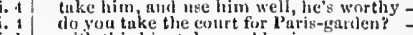

I with this kiss luke my blessing .......

ii. 3 some come to take tlicir ense ........... - (epii.

i. 3 gertdess, he should take his chioiec

tinke but degree uxay

lie basle me take a trumpet

I takoever you take nim to be, he

if the te-day a wife. and my election

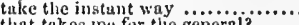

that takes ine for tlic generni? .......

the devil take Antenori.

deitics, - take thee from me ............

both take and give .......................

seen thee pause, and take tliy l,......

take and take aguin such preposterou

and siglıs, antl takes my glove...........

he, that takes tliat, must take my licart

bitt now you have it, take it...........

a buruing devil take them ...........

shouldst then take the river styx....

the devil take thee, coward!............

I'll take geed breath: rest, swerd .....

take it fur thy lubour ........ Timon

I take all and your eeveral visitations

I go, sir: take the bunds along .......

no counsel, take no warning hy iny..

must I take the cure upen me?

take down th' interest into their

for, take it on my sonl, my lori

surprise and take him at eur plensure

eaeh man take his stand ............

and take his thanks, that yet

tear me, take me, and tlie geds....

take uly valeur prisoner $\ldots \ldots . . . . . . .$.

soft, take thy physie first

take thon that toe, with multiplying

let caeh tak fortune by the arm

Ill take the peld thou givest me ......

take the bridge quite away

mend my comnauy, take aw ay thy....

here, take: the gods eut of my nisery
wish I, yon take much pains to mend

you'll take it ill. Misst thankfully.

to take the eaptainslip, theu shalt ..

let lim take't at worst

to take ber in her heart...............

therefore, take with thee my most henvy

takc up the rays of the benefieial ...Heary I'I

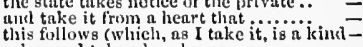

repeat your will, and take it

we shoulk take root here where we sit

one would take it, that nevur saw.....

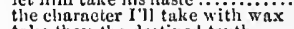

it is net square, to take, on those

whose coune will on the way in tak...

take the rats thither, to griaw .......

to take in many towns

I'll take him for a Volsce.

take eonvenient numbers to nake....

my heart eonsent to take a bribe...

if

take to soll, as your prelecessors have

take the one by t'other

no; take more: what may lie sworn by

that would take from you all your.

thtu to take in a town witl..........
schoolboy's tears take up the glasses

do not take his rougher aceents.......

yout take it ell rough?

contrived to take from lome

take iny prayers with you.

to tuke oll power from the neipile...........

yon take my purt from $y^{\circ}$ ou, sir ......

take ul some other stution

tule our friensly senutors by

take the one hulf of ny commission

who takes it by avereignty of

his own impaticue tokes from irifilius -

take hins up: help three o'the........ -

gool Cinna. take this pulper.......... Juthus Cas

I go to take iny stamk, to see him......

Anteny, here take yon Castar's hedy

le would not take the erown

truitors' housey: take up the billy

then take we down his lom

Inil we must take the current when

nint good boy

and did take it from lim take.... take my cap. Jupiter, and I thank thice

be'st a IRomnn, take it firth

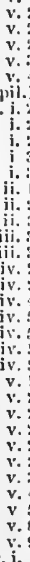

i.

i.

iii. ? 3

iii.

iii.

iii.

iv.

iv. 3
iv. 3
iv. 3

iv. 3

v. 2

Y. 3

$s, i$.

i. 2

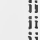


TAKE-did I lake thee prisoner .Julius Carsar, v. 3 TAKE-here take your place....

here, take thou the hilts; and,

shall ever take alive the noble Britus

Octavius, then take him to follow thee
take in that kingdom ....... Antony s

to take the wile of a man.............

I should take you for idlenes

I learn, you take things ill........

take Antony Uctavia to his wife
take no offence, that I would not

take no offence, thint I would not....

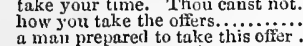

a man prepared to take

here they might take two thieves.....

I shall tike it, sir; we have nsed....

they take the flow o' the Nile by ....
who seeks, and will not take when ..

you take from me a great part

thou must not take my former take from lis heart, take from $\mathrm{his}$.

the fonian sea, and take in Toryne?

laden with gold; take that (rep.)

friend, or take his jife there.

take hence this Jack (rep.).............

to let a tellow that will take
I'll strike; and cry, take all

now the witch take me, if $I$

snatch 'em np, as we take hares

snatch em np, as we take hares

wht him take thee, and hoist thee......

and hring me how he takes my death

good sirs, take heart....................

if thou please to take me to thee ....

and take a queen wortli many

take to you no hard thonghts.......

take thou no eare, it shall

and take the last warnith of $\ldots \ldots \ldots .$.

take up her bed; and bear he

take it, heart; but keep it tili..........

is encled; take your own way.....

but take it for thy labour....
take it: it is an earnest ......

who shall take notice of thee .........

which, if he take shasl the

and takes it thankfully...............

take my power i' the court for yours

to take them in protection?...

must take me up for swearing

take not away the taper $\ldots \ldots . . . \ldots \ldots$

he cannot cloose but take this ser
liere, take this too; it is a basilisk

and thke your ring again; 'tis not ..̈

which then they had to take from os

as would take in some virtuc

take me in his dominion ..........

they take for natural father

luay take off some extremity .......

v. 3 take I your wish, I leap into the seas

who takes offence at that wonld make
their doom, will take the crown...

'ericles, ii. 3 TAKSES prisoner Pyrrhus' ear .......... Hamlet, ii.

is in your bounty; take them in ........

why, I should take it; for it cannot be...

or to take arms against a sea of troubles
patient merit of the unworthy takes

patient merit of the unworthy takes
their perfume lost, talke these again

i. 2 take in your arms this piece

5 take from my heart all thankfuiness!

a groaning to take oft my edge ...............

livery will I take me to, and never..

good Iforatio, I'll take the trlost's word

to take him in the purging of hi
for tliy hetter; take thy fortune

takes off the rose from the fair

Boult, take you the nuarks of liei.....

O take her lome, mistress,
(to take your imagination)

that we may take it thence ...........

$\begin{array}{rr}\text { yon must take some paims . . ......... } & \text { iv. } 6 \\ \text { how's this? we must take another course } & \text { iv. } 6\end{array}$

the devil take thy sonll................

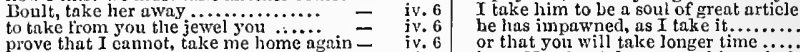

ii. 7 to take lrom you the jewel you ........

take tlys reward: five clays we do...

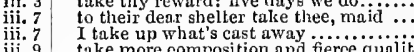

take more composition and fierce quiniti =

liere, Inamlet, take my napkin, rub thy.

take up the bodies: such a sight $\ldots \ldots$.......

nor doth the general care take hold on me

good Brabantio, take up this ningled...

eannot be preserved when fortune takes
whereof I take this, that you call-love..

he takes her by the palm: ay, well said..

to take the safest occasion by the front..

the and take the fool with thee

take you some company, and away.....

set guard to take my brotlier

his present reconciliation take $\ldots$.............

gou dake no notice; nor build you; take mine office.....

take it, and do' $t$ : and leave me for thi

take vantage, heavy eyes .................

to take the indisposed and sickly

send down, and take my part

to take it; I must take ont the whole...

I must take out the work? (rep.)........

takes aw ay with him the fair Desdemona

you may take him at your pleasure.

and take what it contains.......

$v .2$
$v .2$
$v .2$
$v$ take physic, pomp, expose thyself.

.2 rood, my lord, take this offer ...........

that the open air; telke it thankfully .... = iii.

man of jnstice, take thy place

this is Othello's ancient, as I take it ....

TAKEN-you have taken it wiselier... Tempest, ii. 1

on whom my pains humanely taken .

I was taken up for laying.

and have taken him by the chain.......

I have taken great pains........... Tuelfin Night, i.

his very genius hath token

his very genius hath taken ...........

being taken up of these men's bills... Much Ado, iii. 3

and taken following her into the park - L i. i.

to be taken with a wench (rep.) .......

'erhs taken with aquenetta.....

to be cut off and taken in what.. Nierch. of Tenice, i. 3

man's flesh, taken from a man

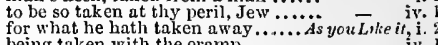

being taken with the cramp............

that he has taken their greatest .... - jii.

he's bravely taken here; he stole $\ldots . .$.
of whom he hath taken a solemn....

his confession is taken, and it shail.. = iv.

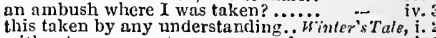

Without my present vengeance taken

if you had not taken youreell witli...

have taken treasure trom her lips

can take no greater wound ...........

madam, we must take a sliort farewell

in savage, take, or lewd: hol
single hand he'd take us in

swore to take, our lives? .............
by the top doth take the mountain pine -

wilt take thy chance with me?

it' each of you would take this course =

within my bosom takes off my manhood -

take no stricter render of me ........

for Inogen's dear life take mine ...

take pieces for the figure's sake......

our son is good, take off his miseries =

that take apon them to know; or: take

and take him from our presence

take Titus' part, and so suppiant... Titus.And

take up this good old man $\ldots \ldots \ldots$.......

brave boys, and take your turns

this letter? take it up, I pray thee

they slould take him for a star .......
Andronicus limself did take it $u p$

come, brother, take a head

he takes false sladows for true ( $r e p$.

and take choice of all my library...

see that you take no longer

take wreak on liome for this

to take up a matter of braw $\ldots$........

he firmly takes me for levenge .....

I take them, Chiron, and Demetrius

good uncle, take you in this barbarous

draw nigh, and take your places ....

power to take thy life

treason, will take away you

why, do ye take it, and the gods gite

iii.
iii.
iii.
iv
iv.
iv
iv.
iv
v
v
v.
v.
v.

let us take the law of our sides

take thou some new infection to

that he lielps not to trke a...........

and the longer liver take all!.

while my prayer's effect I bake
take all myself. I take thee

and I will take thy word

as I take it, is a gentlemanlike offer

Peter, take my tan, and go before.

now, Tybalt, take the villain back ngain -

could not take truce villain back a

take him and cut him out in little stars =

death, not Roneo, take my maidlenheral -

bid him cone to take his last farewell

take me with yon, take me with you

take thou this phial, being then in bed -

you take your pennywortlis now

ay, let the county take you in your hed -

- ii. 1 but break it, and take this. My poverty -

brit, chiefly, to take thenee from $\mathrm{h}$.

take thou that: live, and be prosperous

arms, take your last embrace! .......

will not let belief take hold of him

and this, I take it, is the main motive
no fairy takes, nor witch hath power to

take thy fair liour, Laertes .................

peevish opposition take it to heart?

take each man's censure, but rescrve .....

you must not take for fire $\ldots \ldots \ldots \ldots \ldots$. $\ldots \ldots$.

indeed, it takes from our aclievements...

take corruption from that particular

of falschood takes his carp of truti

take this trom this, it this be otherwise...

you cannot, sir, take anytling thut I wili =

wont to take such delight in ............ three were taken up by fishermen. Conedy of Err, i.

are takeu by the tide, these Lincoin... king John, v. 6

sick, my lord; suddenly taken....... Richicur $1 i$. $\mathrm{i}$.

hand of that welshan take...

and wert taken with the manner

if rightly taken. No, if riglitly taken

hatll in reason taken from mo

youl have taken up, under........

valour, taken sir John Colevile...... - iv. 3

your fathers taken by the silver

nothing taken but paid for

Talhot is taken, whom we wont ...... Hemry $\begin{array}{r}\text { iv. } 1.8 \\ \text { T. }\end{array}$

there surprised, and taken prisoners - iv.

say, he be taken, racked, and tortured - iii.

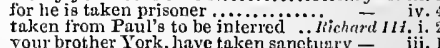

you brother lork, have taken sanehing

the duke of Buckingham is taken . ileny r"a iv. ii.

out of pity, taken a lond would sink - iii.

if Troy be not taken till these ... Troilus o $\bar{C}$ ress. ii.

since I have taken such pains
I'll be taken too, or bring limm of.

might well be taken troun the people. Coriolim

he was not taken well; he har not.... julius cirsur

but there's no heed to he taken of them

which, taken at the floou, leads on ..

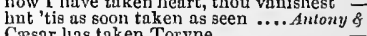

Cosar lias taken Toryne

o cleopatra! thou art taken, queeni = iv. 13

be vraised! Lucius is taken!......... Cymbeline, v.

till the fresh taste be taken from. Titus sndron. iii.

must have your maidenhead takeu off. pericles, iv. 6 
T.IKLi. anstenanee, but to prorogne.... I'ericles, v. nor feur will to be tuken

it he tw tuken, lie slinll never imore

then wile be taken: atay uwhile, Komeo of Juliet, iii. 3 lelight ant dole-tnken to wife fiave taken mote of it; the age is grow.... - in thoul rAkEli-tlie taker runs presently mud. ifuchaldo, $\mathrm{i}$. the life-wenry tuker may tult . Rome of Juliet, v.

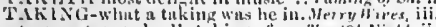
to repurt your lurd's tuking of.... Thetph Night, it.

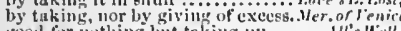

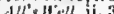
from forenee, taking no leave - v. 3 (netition takiug note of thy ahhorred ajpect.. King dohn, iv. for taking go the lueal, yeur whole.. Richtrull. ii. 3 the manner of their thking muv appear _ vo thoronght with them in lunest taking. for taking their mume's upkn you betore

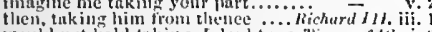
would not hold tnking, I eloubt me. Timon of. $1 / \mathrm{h}, \mathrm{i}$ taking their leuves of

tuking bribes here of the Sartians. Juliasctersar, iv. (1) tuking Antony's course should we le taking leave as

for taking theggar witliont....

taking advantuge of enur report.

for tnking one's part that is out of

vigilunee, does not attend my taking

whirlwinds, star-blusting, and taking

Well Worth a poor man's taking.......
the kind prince, taking thy part. lioine

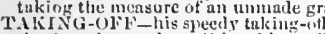

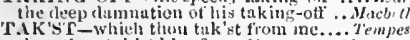

than thou tak st him for ... Mrersure for Mtowsure,

if thou tak'at more, or less... Nerchantaf lenice.

tak'zt it all for jest

it thou tak'st un the princess.

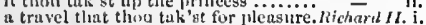

thut even here thou tak'st, as fron

if thour tuk'st leave, thou wert

whatsoe'er thou tak'st me tor

thou tak'st up thou know'st not

lord Tabot and the Freneh (rep.)

wliere valiant Talbot, abuve human

a Talbot a calbot! eried out umain
thrust Tulbot with a spear into ......

is'Talbot slain? (rep.iv. 7 ).

'Tallot is taken, whim we wont

Talbot, iny life, my joy, again

speak unto Talbot; nay, look nip ...

2seend, hrive Til bot; we will fol iow

'ts thought, lord Talbot, when the fi

call ye the warlike Talbot, firr his
here is the Tulbot; who would Ejxcek

here is the Tulbot; w
80 is lord Tallot eome

it this the Tallot, so mueh (rip.i.iii.i)

stay, iny lord Tulhot: for my ludy

to certify her. 'Talbot'a here......

aught but Talbot's shadluw (rrp.) ...
vietorions Talbot l pariou my abure

nor misconstrue the mint of 'raltot

or clse let Talbot perish with .........

it' Talbut do bot thusiter

for Tullot means no gord iness........

loril Tallot, do not so etistionour me

will you fly, and leave lord t'alhot? (ref.

Warlike nul martial Talbut. Burgume -

What wills loril Talhot, jleaseth
let fratitic 'Tulbot triumpt tor awilic

to lease the 'Tnihot, and to follow us

there geres the Talbot, with his col:mar
when Talbot bath see footing onee...

when Talbot hath set roting onee ...

lord Talthot there shali talk with.

Englixh, J (s) in 'Talbret (rep.).

to thrlit with ' Talbot: os lie marehei.

rentiwned Talbot doth expeet........ =

fircwell Tultwot, Franee, and Enginid's -

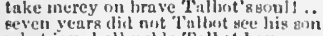

what joy shall noble Talbot have....

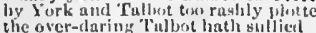

the over-daring Tulbot hath sullicel
that. Talbut dead, great lork 1uiglat

that, Talbut deat, great Jork miglit

T:aibot perislictli by your reffult ....

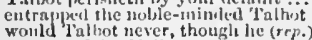

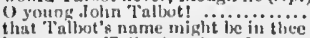

is my name Talbot? and am I your son? -

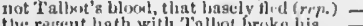

the regent hath with ' Jallot broke his.

clistet firece from Tallsot, my tirave boy

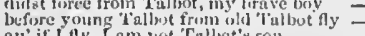

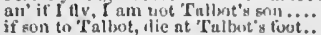

young Talbot's valour nuke's nut..

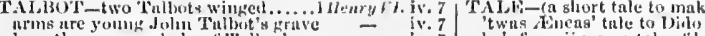

how the young whelp of 'T'ulhot's.

valiant horet T'ulbut, earl of sincewaliuryl =

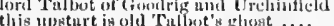

will be ours, now blontl 'Tulbet's slain

trust, the phost of Thlhot is not there

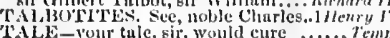

my tule urovokes thint yulestion

trouble him noy more in his tale

I'll tell no talus.

my tiules of love,

speak $-a$ your tale............

there is an old tale goes.......

this tale of Jerne the hunter........ -

pretty tules of the duke...Measure for hisum

rely upon it till of iny tale

ike the old tale, ny lord .............. Vuch dolo,

strong eneounter of my amorous tile

that tells a lieavy tale tor him

and now torwari with thy tale .....

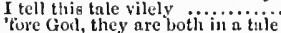

eould ever hear by tale or history "..ivia.

tolling the saddest tale,

ayed ears play truant at liis

and wherry the tale and siailes not. iver. of

this beginniog with an old tale.

and rot, and thereby hangs a tale....

feel a tale, not to hear a tale (rep.)

tell thou the tale; but hudst thou....

says, thos she conceives her tale.

and tell's a tale. Merry, or

as my tale now secms to it.

is solike an old tale (rep). v. 3) ....... v. 2

thiek as tale, thy praisea in lia ...........Macteth, i.

your tale must be, how he employed. King

tell o'er thy tale agnin

not all thy former tale........

as an aneient tale new told

as bill me tell my tale in

as bit me tell my tale in ..............

liath but a heavier tale to say......

madam, we'll tell tales

and let them tell thee tales of wofit

no man en ter till my tale lre done.

tell your tale, for rove toine

that Jis tale to me may be

melted at the sweet tale of

how a plain tale sliall put

in reproof of many tules devise

this is the strangest tale that

to take the tales out of my munth. $v$.

approach not ere my tale tie done ...illenry ri.

I glould lave told your frace

tale to Inake, we at St. Alban's ...3nlewry ri.ji.

iverdili. 7

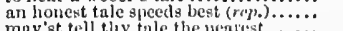

a sereral tale, and every tale conicmins

in sceking tales, and intormations. Herny r.111.v.

you shall tell me anoth
to end a tale of lengtl

I shall tell you a juetty öale

tois tulu pronum

though in his tale lie death....

truth would be but taleg $(2 p)$.
thou wonlust have told this tul

the tale of rereus.....................
revolve what tales I lave tril you

to tell this tale of mine

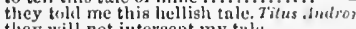

they wil! not intereept my tul

merry with aome pleasing tale

this is the tragie tule of $I^{3}$ tilome

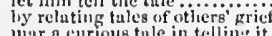

litar a c"urious tule in telling

and tell old tales, unil langh

list abrief tale; ant, when tis tolit.

could tell a whispering tule...

my tate againkt the huir (rep.) $\ldots$.....

fonger than the tule thon dust exeme

is not so long us is a tedious tule .... 'turi- a sliort tale to make) fell inte... Marmet, ii.

a round unvarnislate tale deliver

I think, this tale would win mer dai...... Othetlo, i

whereby liangs a tule, sir? Anrry, sir... = iii.

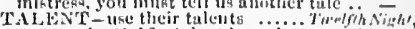

a rare talents If a talent be a cluw...Lote's..... iv.

fle talents is his debt.................... Thon of Athens,

I the talents on the present..........

let the request be fifty talents.

o the instant a thousand talents to ine -

anil instant oceasion to use fffy tulcuts -

cannot wunt fifty-five liundreil tajents

cannot wunt fifty-five hundred tajents - iii.

I eount his, leyond all talents ...... Cpmbelinc, i.

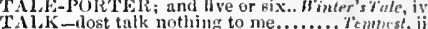

and does not talk after the wigest...

sit then, and talk with her $\ldots . \ldots \ldots \ldots$.

when you tulk of war................

break their talk, inistress Quickly

why, does he talk ot' him?

master lienton, talk not to mie.

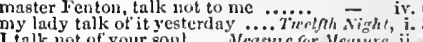

you

I would the duke, we talk

come, talk not of her; you siinii...

because you talk of woring.....

now you talk of a sheet of praper

my talk to thee must be $\ldots \ldots \ldots \ldots .$.
for tlie watch to babble anil to tilik.

for the watch to babble and to

last night, talk with a ruffian........

the wateh heart them talk of une..

well talk witl Nhargaret ...........

if any man be seen to talk with we...Leve's L. L.ost, i.

we will talk no more of thi withal..

come, come, you talk greasily.

with visages displaved, to taik, nud greet -

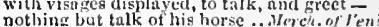

sell with you, talk with you ..........

talk with respect, and swear .......

my father sue me talk with thee... - ii.

what taik you of the posy $\ldots \ldots \ldots \ldots$.

a young man, and an old, in soleman talk -

never talk to me, I will weep...
but wliat talk we of fathers....

thou canst talk of live so well

a loevish hoy: yet le talks of your goud fiatlier...

I halk talk of you lnst ni.lit ...........

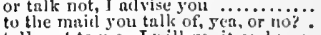

talk not to ne; I will go sit and wecp
Katharipe, tlat do talk of me ......

yours, if you talk of tails

but what talk I of this?....

if you talk of a wonder.

to irate and talk for life............. irinter

all fongres to talk their hitterest .... -

and the gentlemen are in sal talk .... - iv.

I licard them talk of a firdel.......

your town, as te vour talk .... Comerly of krrors, ii.

who talke within there?

witt thow still talk?

lung those that talk of fiar............... Murbeth, $v$.

he talks to me, that never hai ........ kitk - iii.

it I talk to him, with his $\ldots \ldots \ldots \ldots . .$.
amil when they talk of him $\ldots \ldots \ldots \ldots$.

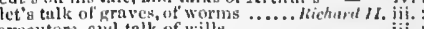

executors, and talk of wills......... - iii.

they'ji talk of state................ $=$ iii: 4

amonets much other talk.

talk so like a wnitink-gentlewomail... nenryll. i.

I will talk to yoll, when $\ldots \ldots . . . . .$. - i.

talk not of dying: I aln ont of tiar...

I talk not of his mujesty ............ -

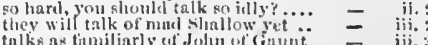

talks ax timiliarly cit Jolm of cinmint
is all too henvy to aulnit nuch taik.. 
TALK-when we talk of horses.. Henry $V$. i. (chorus) TALKED of the whore of Babylon ....Ilerry $V$. ii. 3 TANE and most familiar to .. Truilus \& Cressida, iii. 3

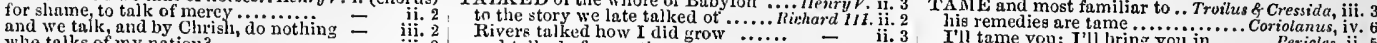

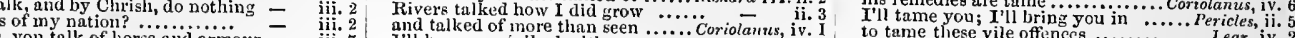
constable, you talk of horse anil armour = iji. 7 . I'll have you $i$ ilked with anou......

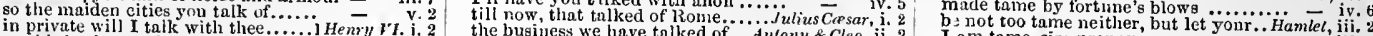
methinks, is very long in talk $\ldots \ldots$ - $\quad$ j. 2 the business we have talked of . Antony \& Cleo. i. bold verdict enter talk with lords?.. - iij. 1 daund and have talked; and more ... lear, iv. talk like the vulgar sort of market-men 二 iii. 2 not to be talked on. yet they are past a parley, we will talk with him...... - iii. 3 therefore have I little talked ofe past

lord Talbot there shall talk with.... - jv. 1 good gentlemen, he hath much talked.. Jamlet, the hey-day in the blood is $\ldots \ldots \ldots . . . . . .$. - iii. I'll watch him tame, and talk him out. Othello, iji.

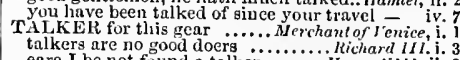
he talks at random

he tulks ot wood $1 . . . . . . .$. lady wheretore talk you so? ......... v. Henry llll. ii. 2 pleasure is to talk with him ........ - ii. I fiom thy naster thou talkest of thou talkest of an admirable....

talkest thou to me of the langman? : ilienry 1 ?

that talkest of kings and queens?

talkest thou to me of ifs? thou art...Richard III. iii. witlout those means thon talkest. Timon of Ath. iv. 3
peace; thou talkest of nothing .. Romeo \& Juliet, $i$. ALKING-be will be talking

we were talking, that our garments..
without any more talking

I spend in talking to thee

scarce to be wortla talking of ${ }^{2}$. Two Gen, of $\overline{\text { Ver. }}$ iv. 2 I wouder that you will still be taiking: MuchAde i. for she thath been too long a talking ot ${ }^{\prime}$

because I would be talking of her..... you Like it, iv. 1 no longer with idle talking

Baptista is safe, talking with... Taining of shrew, iv.4

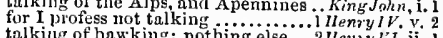

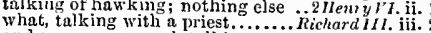

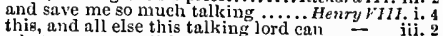
what were you talking of (rep.).. Troilus \& Cress. $\mathrm{i}$. no more talking on't; let it be done... Coriolanus, i. the general, and his wife, are talking ... Othello, iii. the other day, talking on the sen-bank

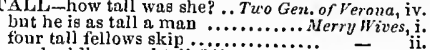

I talk of yon; why did you wish come, what talk you of it Murcius?

their talk at table, and their thanks

heard your general talk of Rom

not let yon eat, nor talk, nor sleep.Julius $\overline{\text { Cassar }}$ and talk you sometimes? ............. talk not of standin

do not talk of lim, bit as a property of night is crept upon our talk. ......

we must out and talk. Mrark Antony

sacred, which he talks on now .. Ant
and we shill talk before we fight...

and we shill talk before we fight
if idle talk will once be necessary

never talk on't: she hath been
we'll talk of that hereatter

talk thy tongue weary; spenc

a way, and talk not $\ldots \ldots . .$.
stay not to talk with them

that thus dost talk in signs: ...........

to talk of hands; lest we rememb
how franticly I square my talk!

now talk at pleasure of your safety.

I am come to talk witl thee .

how can I grace my talk.
thon wouldst talk with me

too late to talk of love

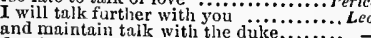

first let me talk with this philosoplier

I'll talk a word with this sum

phat rogues talk of court news (rep.)......

leave awhile, we must talk in seeret
the very theme I came to talk of ....

true, I talk of dreams; which are....

this wind you talk of blows us .......

talk here in the public haunt of men

it prevalls not, talk no more

let's talk, it is not day ..............

hearing him talk of Juliet, to thinik

as to give words or talk with the Jord

mpon the talk of the poisoning

about her, to kiss, and talk to

if tall, a lance ill-headed.......... Twelfth Night, i.

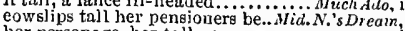

ser personage, her tall personage...

of many a tall ship lie buried. Merch of $V^{-}$ice iii I am more than common tall ....As you Like it i.

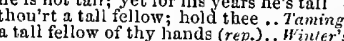

with cight tall thy hands (rep.)... Winter's Tale, v.

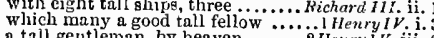
a tall gentleman, by heaven

and welcome, my tall fellow: cone

are shrews, both short and tall $\ldots . . .-\overline{\mathrm{v} .} 3$ (song) spoke like a tall fellow

in tennis, and tall stoekings

Richard llit. $\mathrm{ii}$. 1 Henry VIII. i.

earry back to Sicily mueh tall youth

is she as tall as me? She is not, madam - iif. 3

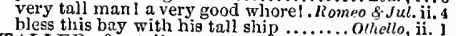
TALIER - few taller are so young... Lowe's 2 . Lost, v. a taller man than I will take. Taming of Shrew, iv. I
TALLEST - and the tallest (rep.)..Lore's L. Lost, iv. I ALLOW - to piss my tallow?........ Werry Wives, v eall in ribs; call in tallow $\ldots \ldots \ldots \ldots . .1$ Herry $1 r^{\prime}$.

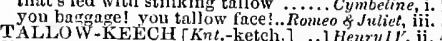
TALLY-but the score and the taliy.2Henry ${ }^{2}$. iiv. a kite? where are his talons? ....... 2 Henry $V I$. do peck the falcon's piercing tajons...3 Hernvy $V_{I} \mathrm{~s}$. TAN -the tevil and his tam
muke tirers tame.

shall not make me tame.... Two Gen, of verona, ii

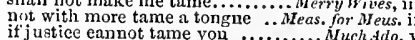

you are a tame man, gol ..........idi. N.'s Dream, iii.

Tath made thee a tame snake .. As ynu Like it,
I liave kept of them tame, and know. All's Well,

I am lie am born to tame, you..... Taming of $S h$.

winter tames man, woman

how to tame a shrew (rep. iv. 2)

make us as fat as tame things ..... Winter's Tale and make them tame to their $\ldots . .$. ... King John, iv. and tame the savage spirit of wild..... not of such tame patience boast

lions make leopards tam

who, ne'er so tame, so cherislied........ hostess; a tame cheater, he ......... 2 Henry $I V$. makes wild grief tame. my tongue. ilichard 11I. iv. those, that tame will horses .......Henry VIII. . two eurs shall tame each other.. Troilus of Cress. i. 3 eat rocks, tame tigers................ $\quad$ - iii. 2 last tumed old master ...... Tuming of Shrew, iv. and tamed the king, and made $\ldots \ldots$.... AMELY to the foot piece... Troilus \& Cressida, iv. 1 if we live thus tamely, to be thus.. Henry $r$ III. iij. TAMIENESS-seemed but tameness......... Lear, ivives, iv. TAMER than sleep, fonder than.. Troilus \& Cress i. TAMING my wild heart to thy ......... Much Ado, jii. TAMORA, the queen of Goths (rep.).. Titus And. $\mathrm{i}$. I choose thee, Tammora, for my bride of if ever Tumora were gracious in .... now elimbetli Tamora Olympus' top hark, Tamora, the empress of my soul Semiramis, nay, barbarous Tamora! o Tamoral thou bear'st (rep.) here, Tamora, though grieved with... this letter? Tamora, was it the like? for thy self, and that's for Tamora... the lustful sons of 'Tamora performers high-witted Tumora to gloze witli ai if Tamora entreat him then he will.
and be a venged on cursed Tamora.. our proud empress, mighty Tamora. of this was Tamora delivered...........

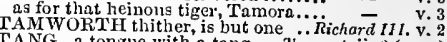
TANG-a tongue with a tang .. 2 iempest, ii. 2 (song) tang arguments (rep. iii. 4).. Tirelfh Night, ii. 5 (let.) slie means to tangle my eyes..... As you like it, iit. 5 the snares of war to tangle thee .... Henry ${ }^{2}$. iv. TANGLED-like a tangled ehoin... Mid. N.'s Dr. v. I
my king is tangled in affection.... Henry VIH1. iii. 2 my king is tangled in affection.... Henry VII1. iii. TANLING-hot summer's tanlings.. Cymbeline, iv. TANNER-the tanner of Wingham.2Henryl'1. iv. 2 TANQUA tanill last you nine year ...... Hamlel, $v$.

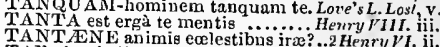

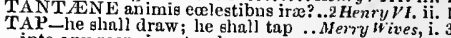
into any room in a tap bouse .... Meas. for Mers. ii. tap for tap, and so part fair .......2 Henry IV. ii. TAPEIS on their heads ............. Aerry Fives, iv. 4

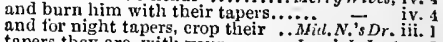
tapers they are, witll your .......... Lore's L. Lost, y. my inch of taper will be burnt ........ Richard It. $\mathrm{i}$. ate me a taper in my study ........ Coriobanus, 1. tet me a taper in my study $\ldots . . . . J u l i u s$ Casar, ii.
the taper burneth in your eloset .... now sit we close about this taper bice

low ill this taper burns!

take not away the taper

and tapers bure taper bows ........... - ii. by taper in some monument...... - ii. give ne a taper; call of all all my people., $\overline{\text { othellso, }}$ i. TAPER-LIGHT to seek ............ Kinu John, iv. waste it for yon, like taper-liglit. $P$ ericles, i. (Gower)
TAPESTRIES-fty-bitten tapestries .2 Henry $I V$. ii. TAPESTRIES-fty-bitten tapestries .2 Henry IV. ii. I hangings all of Ty rian tapestry. ... Taming of Sh. ii. the tapestry of my dinish tapestry. Com.of Err. iv. it wns hanged with tapestry of silk .. Cymbeline, ii. TAPSTER is a good trade .............. Rerry Wives, i. withered serving-man, a fresh tapster $-{ }^{\prime}$. What's to do here, Thomas Tapster?
he sir? a tapster, $\operatorname{sir}(r e p.) \quad \ldots \ldots \ldots \ldots$. not have you acquainted with tapsters to me, master tapster; what's (rep.)
eolour it in being a tapster.

it fitteth the spirit of a tapster......... Love's L. Lo than the word of a tapster ......... As you Like il, iij.
revol ted tapsters and ostlers..... pregolted tapsters and ostlers. 2 Herryl $\dot{V}$

indeed, a tapster's arithmetic. Troilus \& Cressidn, i. 2 like tapsters, that bid welcome. Timon of Alhens, iv.
TAR-savour of tar nor of pitch.. T $\rho$ mpesi, ii. 2 (solng) and would you have us kiss tar?.As you Like il, iii.

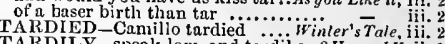
TARDILY-speak low, and tardily..2Henryl ${ }^{2}$. ii. 3 TARDINESS $-a$ tardiness in nature ........ Lear, i. say, is your tardy moster now. Comedy of Errors, ii. still our tardy a aish nation limps .. Michard II. ii. some tardy tricks of yours will ....2 2 Henry IV. iv. be not ta'en tardy by unwise that you have ta'en a tardy sluggard
o my lord, you are tardy ........... Henry $r$ HII. i. 4 


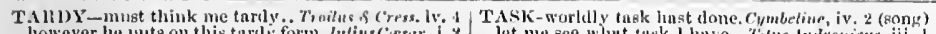
however lue puts on this tarly form. Ju/ins Ciasure

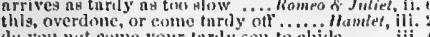

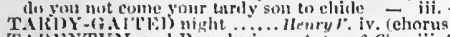

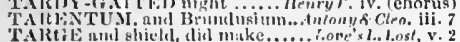
TAltiE mini ghield, dicl muke.

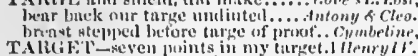

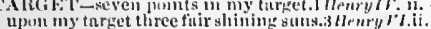
apull iny target three

a lusise of turgets............

pow by ury ou

sword. Buld target ...tintony of Cle

anci tine taryots, to putet off the shaine.

it was sometime tunget to a kis.

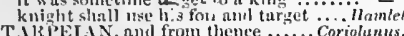

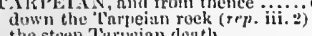

precipitation from otf the rock Turpeian

T.LRoUIN's ruvishing serides ........ Wucheth we reecived in the repulse of Turquin. Coriato
when 'Turquin male a head tor liome

Taryuin's self he met, nud struck

not the expulsion of the Taryinus

streets of Rome the Tariuin thive. Juliss Casar,

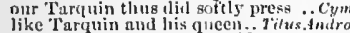

r.ilike-thet doth ture, as Thr lim

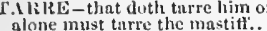

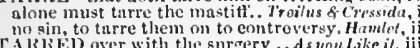

TAlisidek-of my tarriance. Ts you Like it, iii.

TAlied-I not tarried? (rep.). Trothes of Cress.

and then you wunld have tarriei.....

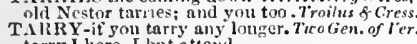
tarry I here, I but atteud............

turry you a lictle-a while....

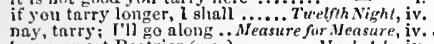
tary, swect Beatriee (rep.)............... Hech A do, iv. I tarry, rash wanton: am not I...MFil. N.'s Dream, and tarry for the comfort of the day

tarry a little; there is sumething else

tarry, Jew; the law hath yet an

I'll tarry no longer with you .....As you Like it, iii. if yoll will tarry, holy pilyrim .........th sile ell, iii. will therefore tarry, in despite ${ }^{2}{ }^{2}-2$ (induc.) I elafe you, if I tarry; let me go

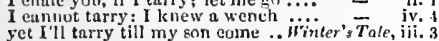
to tarry fur the hoy, Delay ...Comedy nf Brrors, iv. 3 tarry at home, and be hanged (rel.)..1Henty I $P$. i.

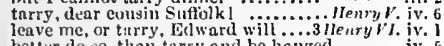
better do so, than tarry and be hanged - iv. tarry the grimding (rep.)......Traitus of Cressid but you nust tarry the leavening....

tarry; you men will nerer tarry

than tarry till thev push us ......... tarr tary ther push us ........ Jutuse Cessar, your lubber's lengtl again, tarry

muncle Lear, tarry, and take the fool

liere; tarry for the mumers ...Romen \& Iutiet, iv. strealn, there it no turrying here .... Troilus $\ldots$. Cressida, lord, fly; there is no tarryinj liere. Julius Cipar,
T.IRT-why so tart a favour. dutny o. Clenpatra, unother way, the news is not su tart ..... Lear,
TARTAR-a Buthenian Tartar..... Nerry ives,

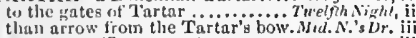
out, tawny Tartar, ou! ?............. iii. 2 throum flinty Tartur'6 bosom ........ All's 'H' no, he's in Turtar limbo...... Co.nedily of Eo rot

return to vasiy Tartar huck

Menry!

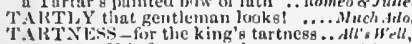
TASK Ariel, and all his quality ......... Trmposi this my meall task would be .... but has a rongher tank in liand ..........Much deto, $\mathrm{i}$. i) there are barren tasks, too hiard.. Lone'sL. Losi, i. but now to task the tasker
nuil your task sliall be, with nil...

a heavier task eould not lave.. Comedy of Ërors. ngainst a mightier task ............ King John
tink the free breatl of a sacred king? the task he undertakes is

an easy takk it is, to win $\ldots \ldots \ldots \ldots$. $\ldots i k e$

nay, task me to my worl .......... I HenryIV to lay tak will i. I have performeil my task

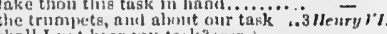
shall I unt hear iny task? (rep.)......
the long day's tusk is done. Anluny of Cleopatra, iv.

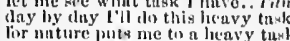

the danger of the tusk you nulettake .. d'erictes, i. 1

null klare not tusk my weakneas

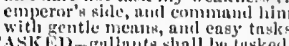

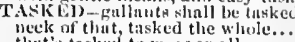

thint y tasked to mow or all .......... Comolrues, $\mathrm{i}$.

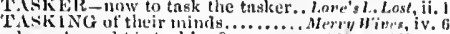

low sluwed his tnsking?

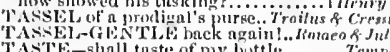

As'TE- shall taste of ny buttle...... T
will't please you taste of w'hut is jiere?

taste your lege, sir ( $m p$

mind of uny jullowi...............

eome to my lumtural taste, now

$x$ trust to taste [Col.-take] of trued

which we of tinste antl leeling are. Love's L. Losh, iv.

pruves dainty Bacehus gross in tuste

rob it of some taste of tedioniness.....

out, tuol! For a taste ...................

take a taste of my finding him

taste of these conserves.. Tuning of Shrew; $\overline{2}$ (indue.

to tnste of thy most worst?

has a taste as sweet as nny cordial

sweet-savoured in tliy taste. . Comedy of Frrors, ii. 2
I have alnost forgot the taste of ....... Meschelh, v.

spoiled the sweet world's taste.

tnke it?

and he to taste tieir fruits of duty

taste of it first, as thon art wont

witlout the taste of danger

$\left[\mathrm{Col}^{2}\right]$ come. let me taste my horse...

shall to the king taste of this action.

taste the due meet for re
this bitter taste $y$ ield his

fiter the taste of much correction

shall take, shall taste our mis mercy

that we may taste of your wine.

gall, the daintiest that the taste?

let them not live to tnste this

the Trojans taste our dearest

.......Rich

when that the watery palate tastes.

as in way of taste, to give me

full perffet that I taste

hatis

taste lurd 'Timoli's bounty? ...... Timon of $\overrightarrow{\text { thens }}$

the car, taste, tonch, smell, all pleased

caudle thy morning taste, to cure

frentest tnste most palates thei

the valiant never tnste of deatly..... Julino
go in, and taste some wine witli me...

go in, and taste some wine taste, is lepidus but so

Phall be assured to taste of too........

for they shall taste our confort

to taste the fruit of yon eelestial...

inventions to delighit the taste

prosperitics so largely taste ............

muat neets taste his tolly

all friends elall tnate the wa

when it did taste the wormwo

in the taste confounds the ajpetite

CASTED-never have you tasted . .ijenry'th.

pruise us as we nre tasted.... Troilus $\&$ Cress redu, ii
l never tasted Timon in my life. Timon of $\mathrm{Alh}$, ii

often of your open bounty tasted....

being trated, slays all senses with. Re. Cymro of Juliet, ii.

pioncers and all, hid tastell her sweet . Othetha,

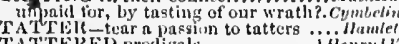

TAT'TERED prodignls............. I tenry

tuttered [Col.-tattering Kint,-totiering king Joh

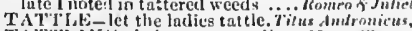

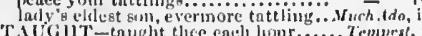

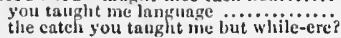

taste with a distempered appetite. Ticetictio

things aweet to taste, prove in ....... Richard II. i.

as the last taste of sweets, is swectes

began to loathe the taste of 8 weetiness

as an will taste ns like this

conce, give us a taste of your quality .. llämie

ilurough tatteren elothice small viees..... dear,

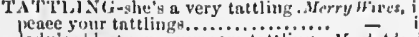

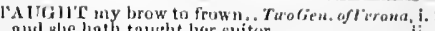

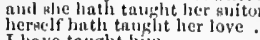

I have tanght him

ray thi

tuught lisn $t$ o fitce me out of

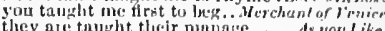

I an not tnosht to muke nny thing

I eould have taught my love to take
unele nf nine tauglit ine to speak..

he taught me how to know a m

or were you taught to find me?

than hath been cumpht liy any

who taught you this? I learned it. Wirn/er's Tale

which, heing taught, return to plugne... Nactseth,

yon taight me how to know the face. King John,

that taughit me craft to comnterfeit.. Michard Jl.

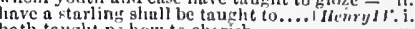

hath taught $\mathrm{n}$ s how to eherieh

he fins a fingl that touglit thien me...

poor mune of York hath tauglit you $2 A_{1+n, y}{ }^{*} I$, iv.

that taught his son the oflice

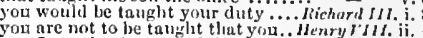

say, I taught thee, say. Wolsey...

he nust be tuught and troined . Timon of $\mathrm{A} / \mathrm{h} . \mathrm{V}$

it hath been tainght us from. .... Autony s cle teo,

learn, being tnught, forbearance ..... Cymbeline,

where I was taught us manly dutics

her wrath, she trught it thee. Tilus Ändronicus,

who hath taught my frnil mortality..... l'ericles, $i$

tauglat me to shift into a madman's ragrs Lear,
TAUN'r-at the taunt of one .......

talnt him witlr the licence of ink. Terelfh . Night, iii.

scorns, and contumelious tnunts ..... Henry VI. $\mathrm{i}$.

thee to taunt his valinnt age

many foul taunts, they took

of those gross taunt $I$ often lia..... - ii.

he prettily and nptly taunt hase...Richard 111 . i.

to taunt and scorn you so opprourionsily - ii.

nay, but his taunts. Being moved.. Coriolanus, i.

and with tannts did gibe my missive

TAUN'CED-taunted her ......Nirl.N.'s Drean, iv.

[Col.J taunted, seorned and baited... Kichara IS $\mathrm{i}$. .

TAUNTING letter.................. ds you Like it, iii.

TA URISS? 'Taurus? 'That's sides .. Turelfh, Night, i.

they say, one Tumrns. Well l know...Ant \& Clen. iii.

shot off one of 'Taurus' liorns.... Titus dnds on.

A AVERN - me to the taverl............. Je, ry Wives,

and to taverns, and sack.

is not $m y$ hostess of the tavern (rep.s.l Henrys

'tis going to the king's tavern a.... -

in thy joeket but tavern reckonings =

knocking at thic taverns, und asking.2 Henry $1 \%$

what plyysie the tavern aflurds ..... I/lenry 1. ii

make it more like a tuls.

enters the eonfines of a tavern... Romeo o. Jutim, i

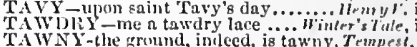

out, tawny Tartar, out! ........ Mid. N's, Dream, iii.

many a knight from tawiy Spain. Love's L. J.ost, $\mathrm{j}$.

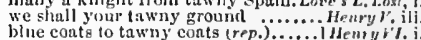

b?

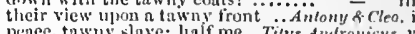

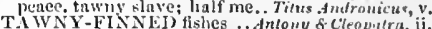

TAX-when it doth tax itscif ..... Meas, for Meas.

to tnx hitn with imbstice?..............

good my lori, tax not so bald a voice.. -

ghall tax my ferts of little........... $\overrightarrow{\text { and }}$

they tax our poliey, and call it. Troulus

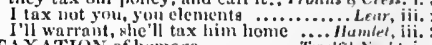

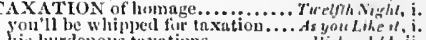

upon these tnxations, the elothiers...lleury Jui i. taxation! wherein? and what taxation? -

raXED their whole rex............ As you like it, iit.

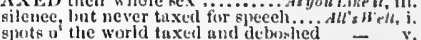

traluced, nnd taxed of other nntions .. Humble

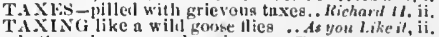

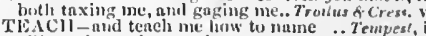

I'll teach you how to llow ............

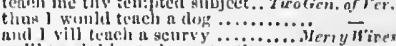

we'll tearl him to knuw tiurties........ - ii.

we'll teard him to know tirtles......
juu do ill to teaets tine clitd such.... 
TEACII-I will teaeh the children. Werm Hires, iv. 4 TEACIING-manrer of his teaching. Tam. of Sh. iv. 2 teach her tlie way yo....................... niy lure is thine to teaeli; t

teach you how to humour your cousin

then let us teael our trial patien

would teach hy smiles sucli skiji

to teneh a teacher ill besecmeth me...... It

did they teacle him ther

teach us owet malau, for.........

I can easier teach twenty whist.

than the fond eye doth teaels

the villany yout teach me, I will

doth teacli me answers for deliver

you teach une how a be:tgar should

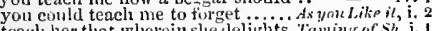

bowed her hand, to teach her fingering

to teach you gamut in a briefer...... - iii. 1

mistress to most that teach ....WWinter's Tate

tench sin the carriage of a holy

and teneh your ears to listen with

herein I teaeh you, how you .............

...........tucleth, $i$.

at mine hostess' door, teacli us some.

is by to teach thee safety

of the time shall teach me speed

or teach thy hasty spleen to do

teach thy necessity to reason this

tlay tongue to teaeh, pardor

dost thou teach pardon pardon to

why, I can teneh you, cousin

in nature, teael the act of order

as proviclent as fear may teac

and teach them how to war! .......

to teach others how they should

shall the good man teach his son

will you vouchsafe to teach a solilier

cousin, teach you our princess English

my lord, teach your cousin to coul
if you will teach her to know my

maintain the thing you teaeh.

a am Gioster, teaeh me to forget.....

teach not thy lip such seorn....

to fiatter...

and teach me how to queen (rep.)

jou, that best should teach us. ...ifenry $\vec{V}$ IuI v

ont of love I teach............ Trooilus \& Cresside,

insolence shall teach the people ..... Coriol

by my body"s action, teach my mind

a ereature that I teach to figh

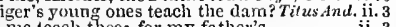

teach her not thus to for my fathe

I'll teach thee another eourse.

let me teach you how to knit again.

and your goodaess teach me credit

who stand i' the gaps to teaeh you

but can you teach all this you speak of?

sirrah, I'll teach thee a speecin

no, lad; tench me. That lord

we'll teach you-sir, I am too oili to.

teach me how I should forget... lromeo of Juliet, i. i

thou eanst not teach me to forget

we'll teaeh you to torches to burn …. . Namlet, i. 5

we'leall you to dridk deep, ere you.

thit you must teach me

but sliould teach os, there's a divinily.. v. 2

let's teach ourselves that houcurable stop 二 ii.

a knave! teach me my duty!.

those, that do teach young babes........

EACHLR - to teaeh a teacher ill... Lome'sL. Los, iv. 1

turn tailor, or be redbreast te
and instruct treat teacliers.

poor fools believe false teacher.

EACHES him to hick and to hack Merry Wires, iv. in the world, teaches sueh beauty. Love's L. Lost, iv. Yes, yes, he teaehes boys the horir-buok $\overline{\text { henice, }}$, I. I Nerissa teaches me what to believe.

and teaches me to kill or hang........ King John, iii. nature teaches beasts to know
want teaclies me to think on.

Coriolnans, ij.

thou teachest like a fool $\ldots \ldots$ Anlony \& Clenpatra, i. 3 thou teachest me, o valiant Eros .... - iv. 1 TEACHETI thee that thou .......Asyou like it $i$

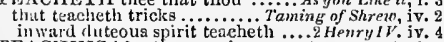
TEACHING him the practice ..... Tuelfih Night, i. to follow mine own teacling. Merckantof Venice, i. teachint all that read ...Asyoulike il, iii. 2 (verses)
utidertake the teaching......... Tuming of Shrew, i. 1 of tercling and of learning instantly

by the triple Ileeate's team ..... Alid...

Al's H'dl, $_{\text {i: }}$

TEARS rum down his beard.

to tear such loving words 1.. Tuo Gen. of l'erona,

nay, not the tide of tear.

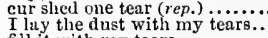

fill it with my tears...

with niglitly tears

lis tears, pure messengers

whieh some call tears.......

you sacritiee you: tears

and with your tears moist it again...

whicli I so lively acted with my tear

with fertile tears, with groans .... Tuelfh

my master's tears to you deplore.....

him will I tear out of that

left her in her tears, and dried.......... for. $\vec{M}$ eas. iii

and he, a marble to her tear

beats her heart, tears lier hair..

Much ARo, i.

the ge lands shall tear her

your over-kindness doth wring tears $=$ iv.

What will ask some tears in the true.

or a part to tear a cat in .............
not with salt tears: if so, my eyes

to conjure tearia up in a poor

like tenrs, that did their own

but more merry tears the passion.

do but behold the tears that swell - iv. 3 (verses)

thou wilt keep my tears for glasses

3 (verses)

your tears, there is no certain

tears exhibit my of lamentation....

his eye being big with tears.......... - ii.

aud almost with tears $\dddot{\mathrm{I}}$ speak it...... s $_{\text {you }}$ Like it, $\mathrm{i}$. I

I should have given him tears

augmenting it with tears................

said with weeping tears, wear.

from your eyelids wiped a

full of tears, full of smiles.............
that tears do not beeome a man...
tears our recountments had most kindly $=\quad$ iii.
iv. 3

all made of sighs and tears

All's Well, $\mathbf{i}$.

and find your salt tears' head...

we drown our gain in tears!

bid him shed tears....... Taming of Shrew, $\overrightarrow{1}$ (induc.)

a shower of commanded tear $\ldots . . .$.
the blood and tears are drawn $\ldots \ldots$ l (induc.)
aud till the tears, that she hath sied $=2$ (induc.)

and tears, shed there, sliail be $\mathrm{my}$...

for their joy waded in tear's.

would fain say, bleed tear

the first gentleman-iike tears.

and tear the stained skin off

in thy sister's flood of tear's .........

that tears shall drown the wind......

the two delinquents tear.

in tender womanish tear.

would drink my tears, and queneh hiis

hath melted at a lady's tears

knows not how to do

profane a tear fur me, if $\mathrm{I}$ be

our hollow parting witli a tear

glazed with blinding tears, divides

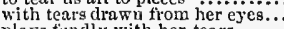

plays fondly with her tear'

ind tears the clousy

foul weatlicr with despised tears ....

some pretty match with shedding tears? -

never borrow uny tear of tiee....

here did slie drop a tear $\ldots . . . . . . .$.

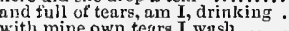

this is his unele's teachiug .............. Henry/r. i. I

your teacling and your ehupluins. Henry $\vec{r} J 11$, v. 2

TEAN of horse shall not.... TwoGen. of rerona, iii. !

before the heaveuly-harnessed team. iH

and derision never come in te

through tears of mine..... Love'sL. Lost, iv. $\overline{3}$ (verses)

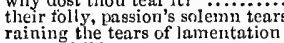

burns worse than tears

whose daughter his tears proclaimed

our tears are not yet brewred,

mucli work for tears in man

some virtue in my tears..............
TEARS-mine eyes are full of tears.. Richard II. iv. of gurrow, und your eyes ot tears

still eombating with tears and smiles

may tear a passage through prayers

in eleansing thicm from tears

so sighs, and teurs, and gronns

for tears do stop the flood-gates.......

not in clrink, but in tears..........
or I will tear the reckoning from...

with tears of innoceney ................

he hath a tear for pity ...............

wasling with kindly tears lis $\ldots . .$. .

let all the tears thit slould bedew.

but for my tears, the moist ............
shall convert those tears, by nimier

$[\mathrm{Col}$.$] to tear and havoek nore than$

urns lie the widows tears ...........

more contrite teare, than from it ....... - iv.

and gave ne up to tears $\ldots \ldots . . . \ldots \ldots$.

were our tears wanting to this

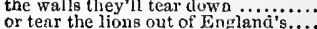

my sighs and tears, and will not once

ghalt rue this treason with thy tears
with a flood of tears, and wash away

to tear the garter from thy

hot blood, mine eyes no tears........... 2 Henry $r$.

mine eyes are full of tears $\ldots \ldots \ldots \ldots . . .2$ Henry $F$ -

rejoice to see my tears, and hear my
witness my tears, I cannot stay......

for I should melt at an otlender's tears

might liquid tears, or heart-offending

an ocean ot salt tears through

by violence teal him from your............
dew it with my mournful tear

the southern clouds contend in tears

prayers and tears have moved me....

pears virginal shall be to me ....

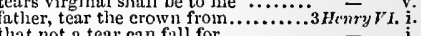

these tears are my sweet Rutland'...

hardly ean I check my eyes from tears -

and I with tears do wash the blood..

shed tears; yea, even my toes ( $r e p$.).

flames, that tears would quench ....

tears, then for babes; blows

my tear's shall wipe away these...

be blind with tears, and break

shed seas of tears, and ne'er be

her plaints, her brinish tears

wet my cheeks with artificial tears.

cause as fills mine eyes with tears ...

for this I draw in many a tea

with my siglis or tears I blast.

thy tears would wash this congealed

my tears gainsay; for every word ....

from mine have drawn salt tears ...Richaril 11

whieh never shed remorseful tear....

wet his grave with my repentät tears

in ler mouth, tears in lier eyes......

aid you witl our kindred tears? ....

send forth plenteous tears to drown...

pour all your tears, I am ......

myseif have many tears to wash .....

I would, these dewy tears were from
think it well, let fall a lcar ....Henr

a tomb of orphans' tears wept on 'eml

I did not think to shed a tear........

strangled his lang uage in lis tears ...

weaker than a woman's tear.. Troilus \& Cressida, $\mathrm{i}$.

vows, gifts, tears, and love's filil sacrifice -

practise your eyes witl tears.

tear my bright hair, and serutch

where are my tears? rain to ling

o'ergalied with recourse of tears $\ldots \ldots$ - iv.

gods fall Timon of $A$ th. iit.

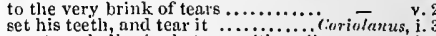

senators shall mingle tcars witl snilea -

come, leave your tears; a brief..... .

thy tears are salter than a younger..

to tear with thunder the wride.

but at his nurse's tears he whined

name him not, thou boy of tears

tear him to pieces, do it presentisy

thep your tear's into the channel.. Julius $\bar{c}$ cesa

if you have tears, prepare to slied.....
tear him to pieces, he's a conspirator 


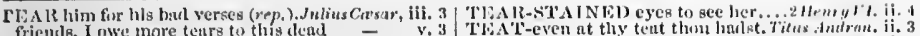

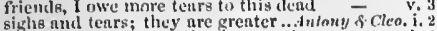
and indeed, the teur live in nuil siny, the tears belong to ligs pt. and the tears of it nre wet........... with juyful tenrs wish the emgenlinent lanent, witls tears as sovereigni........ ditl seandlul many a holy tetur.........

my tenrs, thint fill, prove holy water

the tears I shed, $n$ mother's tea

my tributary tenrs I render.........

with tears of joy shed on the earth

no man shel tears for noble Mutius!

rour glory, to sec her tears

I poureci forth tears in vain

whole munths of tears thy futier's cyes?

these bitter tears, which now yon seo

my soul's sad tears; let my tears.

miy terrs are now prevailing orators

receive my tenrs, and seem to w'(e)

no liands, to wije awny thy tenrs.

a brine-pit with our bitter tenrs

thy napkin cunnot drink a tear of inine

Yith his true tears nil bewet $\ldots . .$.
if any nower pities wretched tears

if any power pities wretehed teas
with her eontumal tears beeome

with tier eonthichal tears beeon

make

that all the tears that thy poor a $y^{\prime}: 8$

tho lamenting forl in sea-salt tears

male of tenrs, and tenrs will quii:kly

hetuld his tears, and lnughed so heartily -

owners queneh them with their tears =

fur whom my tears have mnic me bilind -

but flonds of tears will dr

onr fither's thara despised

to slied alisequious tears upon $\dddot{3 i s}$ trunk -

toar for tear, and loving kiss for kiss

my tears will els,ke me, if I ope...

to sicak, help me with tears .....

to uld sorrow to your tenr

0 , in tears, Lyehorila, no tears

and higgeet tears o'ershowered
which his mortal vessel tenrs

[Knl.] while our tenrs must play $\bar{y}-\mathrm{i}$

with cadent tears tret elaminels in

What these liot tenrs, which breal.

tears his white hair

ns this mouth ehnuld tear this hand

nny lears begin to take lis part ...........

to dislocate and tear thilled down her

iles and tears were like....

of the enrth, spring witl my tears!

my mourning, and importan

that milic

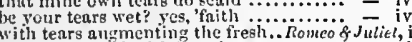

a sea nourished witl lover's tears.

then turn tears to fires

writcea. I would tear the word

else would I tear the eave where

stuin doth sit of an old tear that is no

linck, foulish tears, lack to your untive

w'ash they his wounds with tears?

then mightst thon tear thy hair

thy tears ner wors mish.

thy tears nre womanish...............
wral hitn from his grave witl tears?

what, still in tears?

do chb and low with tears?...............

raging with thy tears, and they with

to stop the irundation of her tears.

is muelı abused with tears! the tear

more than tears, with that repurt ...

dry un your tears, and stick

yet nuture's tenrs are renson's........

by henven, I will tear thee joint ....

like Niobe, all tear

the salt of must unrigliteous tears ha.

colour, anid has tears in's ey'es (rep.)

perriwig-patel fellow tear a pasion

tears, perchance, for blood

teurs, seven times salt, hurn out

in his grave roined many a

therefore I tirhid my tears i..........

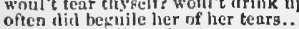

I'll tear hex ull to pieces

the enrth could teen with women's tears

procesl you in your tears................

her salt tears fill from her ......... -

I must weep, lut they are erucl tears
alrop tears as fuat as the Aralvian trees. chard IIIt. iv. 2 rbillist the Thracian.

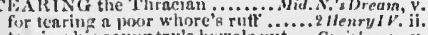
tearing his eounntry's bowels vit .. Coriolatas, v. 3 in the midst a teuring grom ...Anlony, ficho, iv. 19

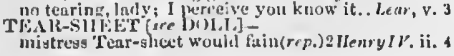

sucker wiselon fiom thy tent.... thomeo of Julime, $i$. 3

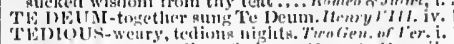

ii. ! grown feared and tedions

nejuhbours, you are tedinus.

it I were as tedions as a king..........

0 long and terlious nirht, ahute

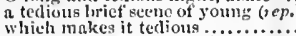

not in the court, it is terlious
what tedious homily of loye

no luxten of heary tedions ne........ - iif. 2

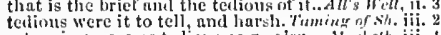

ii. 5 returning were as tedious as go o'er...Marich, iij.

every tedions stride I make will

grief latly kept a tedious last

in winter's tedious nights, sit by ....
thinking his prattle to be tedious ....

sport would be as tedioms as to work

he's as tedions as a tired horse

to rnise this tedious siege

these tedious stumbling-blocks

weaves tedions sanros to trnp.

bet ter to be brief, thinn tedious.

.... $=$ iii. i ije

brief, then tediotis........ Richard lit. i.

cannot thy master sleep the teclion.

and record of tedinus days, rest tliy.. - iv.

nway, thon tetions rogle! .... Timon of dmens, iv.

in a telling samed her .. Tilus Andron.

v. 2 pray ; but be not telious ..............

so tedious is this day, as is...... Romeo o Juhet, iii.

these tedious old fools! ................. VIamlet, ii. 2

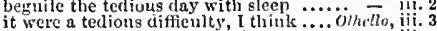

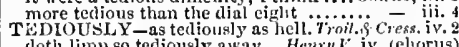

TEDIOUS limeso tediously away .. Henry V. iv. (eliorus)

TEDIOUSNESS-all thy tediousness. Wrech Ado, iii. 5
rob it of some taste of tediousncss. Merof lence, iii. 3

mieh beguiled the tediousness.

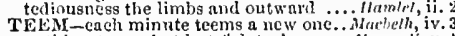

nothing tecms but hatetul doeks....... Heury $t_{\text {. }} .1$

infinite breast, teems, and

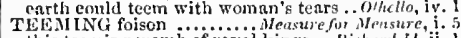

this tcening womb of royal kings ... Nichurel $/ J$. ii.

oft the teming carth is with a kindinenryIV.iii.

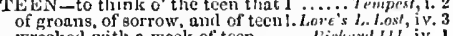

wreeked witls a week of teen ...... kichurfl IIJ. iv. I

and yet to my teen be it spoken... liome

item, she hath no teeth (rep.). Two Gen, of 'rer. iii. i

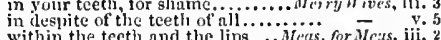

within the teeth and the lips .......... for . Vcass. iii.

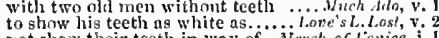

rot show their teeth in way of... Nerch af lenice, i.

sans tecth, sans eyes, sans taste...

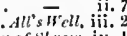

lips might freeze to my tecth. $\because$ amin of shen', iv.

by the pieking on's teeth ........ Winh'r's Tule, iv. 3

till gnawing with my teeth iny bonds - - vi i

why then I lic present

my teeth shall tear the slavish
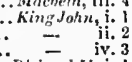

ith my teeth, and lips ..

sct iny teeth nothing on edge

stings and teeth newly ta'en out

the solus in thy teeti, and in thy.

now set the teeth, and stretch

we'll fall to it with our teetl....
atrongly through my fixeri teet

strongly through iny fixed teetb ..2uncary

thruet his hond butel out ........ iv. 7

teeth hadst thou in thy head

Jeau bless us, he is born witls teetiii.

that had his teeth before his ey'es.. Lichure 111 . iv.

daring the event to the teetl

he did so set his teeth, and te
and kewp their teeth elean
why rule you not their teetli

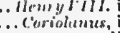

out of the teeth of emulation

to east into my teeth

you showerl your tecth like anes.....

1will give the hurl we in your teet

took't, or did it from by tecth.

with thy sharp tecth this knot

haml grawing with thy teeth...... Til
hand. Awcet wench, between thy tee

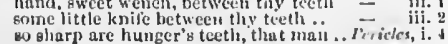

his teclions measures with

if she must teem, erente her ehild .......... Lear, i. 4

of soldiers arc his teeth, his iang

hint now, I'll set my tecth, and seivi

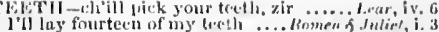

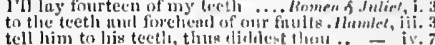

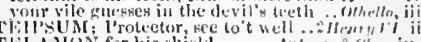

WI, MON for lis shich

rELi, tell your piteong licatt...

of any thing the imare trill mo

then tell nie it this mislit be

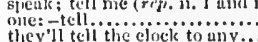

I eun tedl you, and thint...

you eannot thll who'y your friend

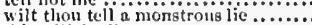

this will [ te]l my master...

I'd at live to tell you.

tell me, lo you know (r

now tejl me, how

I tell thee, my mast

nnd tell me some gord ....
tell ne. good my ford (rep.).

tell ne, good my lurd
now tell no, Proteus
I will not tell myself

tell me this; who begot the

why didst not tell me sooner.

tell us this ......................

and tells you, eurrish think

tell hin from me, one intia.

I'll tell you as we finss along

shall tell you nother taje

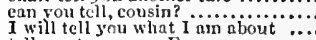

tell master parson Einns ...............

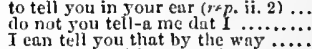

tell your worship more of the wnrt.

I will tell you what our siort.....

and tell him my name is Brools

and she bade me ted your worship...

but, I pray thee, tell me this ........

I will tell yous sir, if you wi...........

you would toll me of a nuses of porritge

I eannot tell what the rlickens .......

everlasting liberty, if I tell you of it

go tell thy master, I am alone.

I come before to tell sol.

and tells me 'tis a thing

may be, he tells you true ............

they cnin talyou how things go .....
well, I will visit her; tell lier so (rmp.)

shall we tell our liusbands

alls he tell the trut

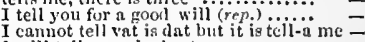

1 will tell you: he beat nie...........

I'll tell you all, master mil

tell her, master Slender linth

What need you tell me that?

and tell them, there thy fixed finit. Firel/h

either tell me where thou hast lecen

tell him. he shall not speak will we

I pray you, tell mie

to tell me how he takes it

tell him, I'll none of it .............

$m y$ lady' bade me tell you....

tell 11 something of hin

you eannot love her, you teili hic.....

diell not I tell you

would make me tell them

this will I tell nu louly straiglit.

tell me how thy lady dae

but tell me true (rep.)...............

now my toes tell me phinty

- vive

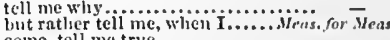

come, tell me true ................. -

'll tell him of you .....

d would tell what twere to be .......

and you teli me that he shall

diil I tell this, who would believe ine?

1'll tell him yet of Angelo's requent

can $y$ (n) tell me of nny?

that lie hath foreed me to tell him. 


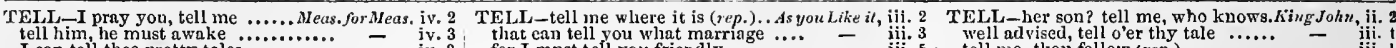
I can tell thee pretty tales

and tell him where I stay

besides, he tells me, that if ................

than you must expect of me to tcli' ...Much Auo, $\mathrm{i}$.

for I mnst tell you friendly ..........

- iiv. 5

well advised, tell o'er thy tale .......

I'll tell thee, Aliena. I cannot

I do not shame to tell you what I....

I pray thee, tell me truly how thou.

I pray you, tell your brother how....

thll tell thee wim this tale rrep.

he tells us, Arthur is deceased

as bid me tell my tale in ...............

there, tell the king, he may.........

good sheplierd, tell this youth what

to tell us Cupid is a good hare-fiuder

and tell him I will not fail him...

and tell fair Hero I am Clandio.......

go you, and tell lier of it ................

to tell you true, $I$ eounterfeit him

will you not tell me who told you so?

n'll tell him what you say

my cousin tells him in his ear ......

and I will tell you my drift .........

spare not to tell him, that

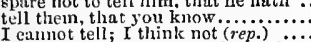

you heard my daugliter tell you liow

my dlanghter tells us al

tell me thy reason why thou wilt ..

and tell thee what: thou art ....

sirrah, tell my gentlewoman, I would

by the hand, and tell her, she is thine

I must tell thee, sirrah $\ldots \ldots \ldots \ldots$......

here they come, will tell you more

to tell him, that his sword ean

go tell the count Roussillon and $\mathrm{my}$

go tell the count Roussillon and $\mathrm{m}$

I will tell you a thing, but you...

and I tell thee so before, because

and I was about to tell yout.........

t'll never tell you....................

tell himedick of her love? Never teli him

and tell her, $\mathbf{I}$ and Ursula walk in ..

did they bid you tell her of it, madain
but who dare tell her so? if I should

yet tell her of it; hear what she $\ddot{3}$ indeed that tells a lien vy tale for

I came hitier to tell you ...............

that only tells a lie, and swears it

my soul doth tell me, IIero is belied

but I must tell thee plainly

I pray thee now, tell me (rep.).........

I tell you, sirs, it you should smile - indue.

I'll tell you largely of fair Hero's....

I'll tell thee wliat, prince................

do I not in plainest truth tell you ..

for more better assurance, tell them

another prologue must tell, he is not

for auglit that I can tell ( $r e p$.$) ........$

did not you tell me, I should know.

and in our flight, tell me how.....

for, if I tell you, I am no

ali that $I$ will tell you, is, this

to tell you, that the lantera is .........

tell me precisely of what complexion

I witl tell thee wonders

I am less proud to hear you teil my

tell him, the doughter of the king
but tell me; low was there a Costard

will tell you sensibly

tell me thy mind: for I have...

iii I I eannot tell (rep. iv. 3 and iv. 4).

tell me thine first...................

iii. 2 he tells you flatly wlint his mind is...

iii. 3 tell me her father's name... tell you what, sir,-an' si

iv. I I'll tell you news indifferent

if I may be bold, tell me ..............

and tell them both, these are their

then tell me, if I get your daughter's =

for I tell you, father, I am ...

why then, I'll tell her plain

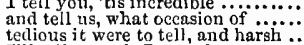

tedious it were to tell, and you, sir Iucentio...............

good Grumio, tell me, how goes

I tell thee, Kate, 'twas burn

now tell me, I pray (rep.) ............

iny tongue will tell the anger.
I tell tlee, I, that thou hast

if you will, tell what hath ............

I pray you, tell signior Lucentio...

my son! tell me, thou villain (rep.).

I charge you, tell these headotrong

to tell he longs to see his son

I pr'ythee, tell ne; cram us

sit by tel and tell's a tai

I will tell it softly, yon erickets ......

now, my liege, tell me whä ilessings

I tell you, 'tis rigour, and not law.

he tells her something, that makes

faster than you'll tell money

thou to me thy secrets tell.

i. 3 tell him, toward Swinstead .............

a monk, I tell you; a resolved ........

tell me, moreover, hast thou .......... Richard 1I. $\mathrm{i}$.

I had forgot to tell your lordship....

let me tell you this; I have had

worse thas $I$ have power to tell.

and tell sad stories of the death......

tell Bolinghroke, (for yon

madar tel well tell tales tidings

and let them tell thee taies of...........

you would tell the rest, when weeping

recover breatli; tell us how near ....

now, sir, the sound, that tells what hour -

bootless tis to tell you, we will go .... Henryl

in the court, I can tell you ..........

I tell thee, he durst as well have ....

good uncle, tell pour talc ..............

heard him tell it to one of his company -

hang him! let him tell the king ......

tell me, sweet lord, what is't that....

an if thou wilt not tell me all ......

and tell me flatly 1 am no $\ldots . . . . . . .$.

I tell thee what (rep. iij. 1) ............

come, tell us your reason

tell met in you on compulsion

but, tell me,

give me leave to tell you onee again

tell truth, and sliame the devil ......

shall I tell you, eousin?

o, tell me, good Dumain

for sir, to tell you plain......................

shall I tell you a thing? the princess bids you tell, how ma.....

tell her, wc measure them by weary
but teil not me; I know ... Merchan

Inl tell thee more of this another....

well, tell me now, what lauly

to-day promised to tell me of

pray you, tell me this; if

I tell thee lady, this aspect of mine..

can yout tell me whether one (rep.)

you may tell every finger I have

I must teds tell thee all...

who are you? 'Tell me, for more.....

you were best to tell Antonio what

tell me once more what title thou
tell $u s$, do you hear, whetler Antonio

there's something tells me (but it is not
tell me, where is fancy bred......

I pray you, tell me low my good.....

and tell quaint lies (rep.).............

I'll tell thee all my whiole .........

he tells me flatly, there is no $\ldots \ldots \ldots$.

tell her the process of Antonio"s end

and so, I pray you, tell him..........

can you, teli, if Rosalind .............. As you $\overline{\text { Like }}$ it,

I'll tell thee, Charles, it is ...........

I can tell who should down..........

I pray you, tell me this (rep.................

but I ean tell you, that of late $\ldots . .$. ..

go, seek hin'; tell him, I would speak

fie on theel I can tell what thou...

go to my erve and tell me $\ldots \ldots \ldots . .$.
velhemence, tell me who it is $(r e p$.

I'll tell you who time ambles.........

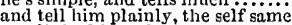

to tell the king of this escape

but to tell the king she's a changeling =

tell me, (for you seem to be honest

and tell me, for what dull part ....... -

to tell sad stories of my own .. Comedy of $\overrightarrow{E r}$

tell me this, I pray (rep.) ..............

this jest? I pray you, master, tell me?
ghall I tell you, why? Ay, sir.........

would tell you what I think ..........

right, sir, Ill tell you when

can you tell for whose sake?

and tell her, in the desk (rep.)

and tell his wife, that, being.

I tell you, 'twill sound harshly...

still did I tell him it was vile

but she tells to your highness.

but telt me yet, dost thou (rep.)

I cannot tell; I, to this fortune

you imperfect speakers, tell me........

sir, can you tell where lie

v. 2 good tather, tell her, that she.............

than men would tell their children.

be bold to tell rou that I am your so

prive heard the prince tell him .....

the king, I ean tell you, looks for....

but tell me, Jack, whose fellows are

so tell your cousin, and bring me....

lord Douglas, go you and tell him so

tell me, tell me, how show

because some tell me that thoi $(r e p$.

find no boy's play here, I can tell you

did you not tell me, this fat man .....

my lord, $\mathbf{r}$ ll tell you what ..........

tell thou thy earl, his divination....

tells them he doth bestride ...........

boy, tell him I am deaf...............

and give me leave to tell you .........

I cann tell you me of it?

the rest the paper telis

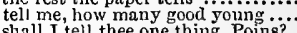

never tell me; pour ancient surager.

now he said so, I cas tell whereupon

I tell thee what, corporal Bardolph.

will you tell me, master Shallow...

witlin my bosom tells me, that no.

canst thou tell that? With Poins....

the good news yet? Tell it him ......

and tell lim who hath sent me......

I'll tell thee what, thou (rep.).......

plainness, tell us the Dauphin's mind tell him, he hath made a mateh ...

I cannot tell; things must be as

and tell the legions, I can uever

to the minesi tell you the duke...

I will be so bold as to tell you ...

I will tell him my mind

tean tell your majesty, he is ........

and tell thy king, I do not seek (rep.)

I tell thee, constable, my mistress

tell him, I'll knock his leek...........

if you could tell how to reckon

and my poor soldiers tell me

tell him, my fury shall abate ...........

I tell you, captain (rep.) $\ldots \ldots \ldots \ldots . .$. .

tell me, (if your art can tell so

tongm thou still hast served, teli thee... - v.

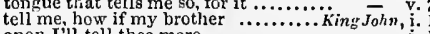

and $I$ tell you, deserves as well...... 


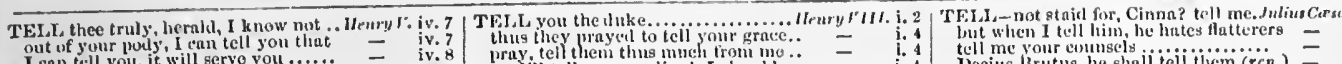

to tell how nany is killed?

I will tell you. nom fris a

and then 1 will tell him a littie pice.

I emunot tell vint is (rep.)

I will tell thee in irench..........

have a surving faitl within me, tells me -

therefore tell me, most fair Katharine

I'll tell y'oumore at large..........

theretore tell her, I retarn grent

I tell you, malain, were
liut teil me, keeper fiep.)

or, l'll tell you, curilinul, I shoulal

年

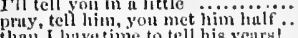

thau I lave time to tell his yeury

v. 2 he tells you riphitly. Ye tell me wlitt

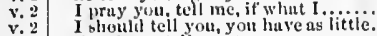

that I can tell you too

ns I walk thither, I'll teil ye romore

I'll tell thee ny discnse.

tell me how he died.

tell him in deuth i, i...... bi.......

my tenter yenrs can tell .

bit to tell you, that we are hicre
but tell me whom thou seek st

how eanst thou tell, she will

tirst, let me tell you whon .....

let me tell you, it will ne'er be well.

toll me, and I Il requite it

this day, sir, (I may tell it you) $\ldots$. .

$=$
$=$
$=$
$=$
$=$
$=$
$=$
$=$

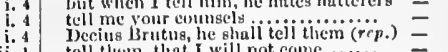

ii. I tell them, that I will not come .i...

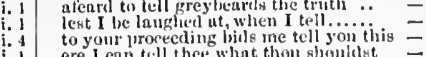

ii. 1 ere 1 cart tell thee what thou shoutclst =

ii. 2 tell him, so plilease him eome ( $p$ p. $)$

I tell you that, which you $(r e p)$

let me tell you, Cnssilis .................
tell me true. Then like a Romun (rep.)

to tell thee, thou shalt see mic.......

tell me what tlam notest,.............. =

if it be love inilect, tell me how... Antony sf cle

nuy, come, tell fras hers ............

who tells me trite, though in ..........
seemed to tell them, his remenilirance

I will tell $y$ mu: the barge she sat in.

but let ill tidings tell themselves ....
be plensed to tedt us, (for this .......

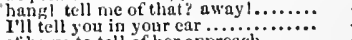

of horse to tell of her approach .......

I tell again: tell him, he wears (cep.) -

good boy, tell him I come............

I tell you, expects performance......

toll me, what fate awaits

good follow, tell us liere

my conscience tells me..............

to tell my love unto his dumb

go, i nm sent to tell his majesty

fo, tell this heavy message ..........

go to, tell the king trom me...........

tell me, whereio I have offended mosi?

eun wish, or tongue can tell...........

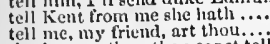

that's more than thou eanst

i tell him of Nestor, one that wrs

will tell him, that my lady ..........

anil tell you what I say of him

hath none, that tells him so?
then, tell me, Patroclus (rep.).

then, tell me, Patroclus (rep.)
go and tell him, we corne $(r e p$.

they are burs, I can tell yo
to him. Patroclus; tell him

and till me, noble Diomed (rep.)

tell me, sweet unele, what's.

tell you the tndy what she is ......

why tell you me of moderation?
lut I ean tell, that in cach grace
I tell thee, lord of Greee (rep.)

all me, may not a king adopt

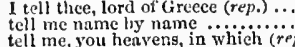

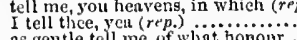

let us tell the queen these news.

and tell him privily of our intent

I cume to tell you things sinee

tell our devotion with reveugeful....

Clifford, tell me, didst thou.

whiles Warwick tells his titi

tell me then, have you not ............

chililren hast thou, widow? tell me (rep.) -

I'll tell you how these lands are....

I can tell you both, her suit is granted

queen Alarguret, and tell thy grief

with my tongue to tell

you tell a pedigree of $\ldots \ldots \ldots \ldots . . . .$.
now, Warwiek, tell me $($ rep. $) .. . . .$.

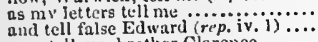

now tell me, brother Clare

tell me some renson, why.

in brief, tell me their wurds............

tell me, if you love Warwick more..

and tell me who is vietor, Yurk.......

I tell ye all, I am your better..........

I'Il tell you what, I think.
I tell thee, fellow, he that.

when tevils tell the truth!

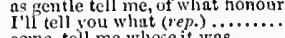

eome, tell me whose it was

ii. I by herself, I will not tell you..............

iii. 1
iii. 1 to tell thee-that this day i
and tell you them at night

and tell you them at right ......

tell her, I have ehastised . $i$ m.......

understand me not, that tell me so...

else I should tell him ........... Timon of thens

but tell him, sirrah, my uses ery.....

yout $\mathrm{I}$ can tell you one thing, my lo...

I tell you, denied, my lord ..........

I need not tell him that; he knows.

tell out iny blood.......
I'll tell you more ano

I'l tell you more anon ......
if thou wilt, tell them there

but, tell me true, for I must ever doubt

tell him of an intent that's coming ..

and, tell him, Timun speaks it

and tell them, that, to ease them of..

tell my frienils, teli $\Lambda$ thens.

your triends, tell them your feats

they eannot tell; look grimly
go tell him I lave sluin my celf

our Cxesar tells, I am conqueror.

to tell them, that this worlel..........

Antony did tell me of you, bade......

you must tell him (rep.)..............

when boys, or women, tell their drenn

I am loath to tell you what I wrould
i tell you this: Cesar througli Syrio.

for her physicion tlls

but pray you, tell me, is she sole $\ldots . .$. cymbe
ere I could tell him, how I woukt think -

I'll tell thee, on the instant ........

tell thy mistress how the cnse..........

rcail, and tell me how far 'tis thither -

tell me how Wales was made so happy

and tell the warlike fents............

when rich ones searee tell true

to the sen, and tell the fishes

shant not return to tell what erows

Ill tell you, sir, in private ..........

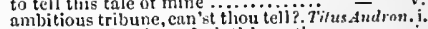

tell me. Andronicus, doth this motion

ii. 2 - I tell you, lords, you do but plot.......

womanhoud denies my tongue to tell

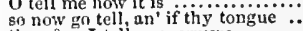

therefore I tell my sorrows ............

nor tongue, to tell me who hit
tell him it was a bant that

iv. 3 to bid Ancas tell the tale twice

tell me, rlid you see Aaron

I tell you, yuunglings, not ....

tell the empress from me (rep.)......

tell him, it is for justive.

I shall tcll you a pretty tale

I tell tree, homicide, these mails...

sir, I shall tell you (rep.)

tell him, and spure not ..................

with a piece of scripture tell them

my Iord? I pray you, tell me....

nfraicl. methinks, to hear you tell it

duke of Gloster, and tell him so
but while one would tell twenty

the hearts to tell ine 80

tell Valeria, we are fit to ...
I'll tell you exeellent news.

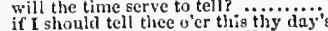

the augurer tells me, we shall.........

that tell, yon have good faces...

tell him, when that our princely .....

gnoul Grandans, tell us, is our tather

not she, I eunnot tell who told rue

that he comes unt to tell us........
l'll tull youl what, my cousin.

tell him all our reasons (rep.) ......
tell him his fears are shallow (rep.).

I tell thee, man (rep.) ........

great preservation we live to $i e j i$ it you

will them. how Eliward (rep.)

tell him, iny tolf, the mayor aiti......

once more return and tell his sraee..

I camnut tell, if to depart in

tell o'er your woes arain by viewing

tell ine, thou villain-slave (rcp.) ....

tell her, thou mudest away (ri'p.)...

tell me your highness pleasisre.....
when thou may'st tell thy tule .....

then, tell me, what makes lie.........

tell Richmoad this from me .........

tell me, where is princely kiclimond

tell him the queen hath heartily ....
tell me, how fares our loving nother?

tell the elock there

tell us his ticeds trep.

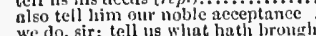

we do, sir: tell us What hath hrongh

tell those trichls they have ehese...
tell me of eurn! this was my sucech

grant that, and tell me, in peine

tell these sad wosnen, 'tis fond.

iii. 2 I'll tell the shat; yet go............

tell you most strange things

iii.s
iii. 5 frythee, tell my master what thee, we have a pow'er

I camnot till how to term it ( $r$
O slaves, I eas tell you news

iii. 7 Oslaves, I ean tell you new

I tell you, he does sit in gold

iv. 3 I tell thece, fellow, the general is my....

lins he dined, tan'st thum tell?........

thit eannot tell what he would have

go tell the lorels of the eity

sir, I cummot tell, we must proceed

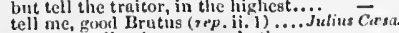

iv. 5 tell me, goorl, what you and other men

tell you what hath procecled ..........

I rather tell thee what is to be fearel

tell me truly what thon think'st....

as well he liauret as tell the manner

nay, an' I tell yuu that, I'll ne'er....

I eannot tell, what ficaven...........
wliere otliers tell shej witla me..... 
TEI, - thou canst tell, why one's nose eaust tell how an oyster makes... pr'ythee, if thou love me, tell me danglisters, as thou canst tell in a year tell the hot duke (rep.) nor tell tales of thee to lighi-judigiug she will tell who your fellow is

when usurers tell their gold i'the
I'll tell thee, frieud, I am almost true to tell thee, the grief hath true to tell thee, the grief hath and tells me, Nero is an angler in tell me what more thou know'st of thy death and business I can teil ... tell me-but truly - but then speak toll old tales, and laugh at

I'll tell son straight .................. be's a good fellow; I can tell you that tell me in sadness, who she is ........ and tell thee? Groaln?

now I'll tell you without asising .... taith 1 can telier age unto an loir conld tell a whispering tale in ..... will.you tell me that? his son was I know not how to tell thee who I am how camest thou hither, tell me? ... to crave, and my dear hap to tel I'll tell thee, ere thou ask ( $r^{e p} p$. $\ldots .$. ean any of you tell me where $I$ may bnt first let me tell se, if ye slould. i'faith I will teil her as much. I will tell her, sir, that sou do protes tell her that Paris is the properer man news be sad, yet tell them merrily tell me, holy friar (rep.) ............... I'll tell my lary sou will come.... tell her, slie shall be married $\ldots \ldots . .$. tell him so yourself and see how he.. go in, and tell my lady I am gone go in, and tell me thet thou (rep. O give me! tell me not of fear. took post to tell it you tell me, good my friend, what torch.. go, tell the prince, run to the Capulet' good now, sit down, and tell n

eannon to the clouds shall tell ................ moderate liaste might tell a hundred... but tell, why thy canonized bones good my lord, tell it. No; you will .... from the grave, to tell us this............. an honest ghost, that let me teii you...... I must tell you that, before uny daughter I will tell you why; so shall my I proplieey, he comes to tell me......... you need not tell us what lord IIamle he'll not shame to tell you what it mean and tell you what I know ................ tell him, bis pranks have been too tell us where tis $(r e p$. $)$.......... tell me, Saertes, why thou art this.... of them I have mueh to tell thee but tell me, why you proceeded not...... I tell thee, slie is, therefore, make tell me that, and nnyoke (rep.) ...... camnot you tell that? every fool can tell and tell her, let her paint an incl thick pr'y thee, Horatio, tell me one thing .... as 'twere, I cannot tell low

in pain, to tell iny story

so tell him, with the occurrents $(r e p) .$. tush, never tell me, I take it mnels.. I am one sir, that comes to tell

very moment that he bade me tell it but teach him how to tell my story.... first, I must tell thee this -Desdemona. he shall tell me, I am a drunkir teli her, there's one Cassio entreats her........ Whien shall he come? tell me, Othello tell me but this, have you not

to tell you where he lodges, is to tell you tell him, I have moved my lord in his for I will make him tell the tale ............. now he telts, how she plueked lim to... I cnnnot tell: those, that do teach In tell you, 'tis not very well ............. mistress, you must tell us another tale
tell my lord and lady what has happed tell my lord and lady what has liapped
but did you ever tell him, she was false TELLER-infeets the teller... Antony \& Cleopats $a$ to you in telfing her nind.. Tira Gen. of J'erona, $\mathrm{i}$.
TELLING you then, if you be .. Meas. for Mefs. ii. the wisest aut, telling the saddest. Bid. $N$.'s $D$. ii. telling the bushes that thou look'st. my glass, talse this for telling trie will have no telling. Come on. Tuming of $s /$ iv. gardener, for tellillg me this ..... Richund lt. teling me, the sovereign'st thing....1 Henryl a iness of vinegar; telling $1 \mathrm{~s}$, she had.. for telling but her dream? ..........2 Iterry $r$ I. j. you me with telling of the king? ... Richard Li. last longer telling than thy kindne one, that telling true under him ..... Coriolam the praise of it by telling ...Anlouy \& Clespuirn, ii. telling you that $I$ am poor of thunks. Cymbetine, a enrious tole in telling it....

and telling her fantnstieal lies..... the s thou me of black ............... Ollevello, ii. thou tell'st me, there is murder.. As you like it, iii. what tell'st thou me of supping? Comedy of Err. yet tell'st thou not, how thou it thou tell'st the heavy story this thour tell'st me (rep.) ....
thou tell'st the world it is not more unlike tlian this thou tell'st ... Cymbeline,

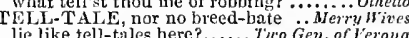
we are no tell-tales, madam .

i. 1 hear these tell-tale romen ral

There is no fleering tell-tale
therLU -
nLigeia tellus (rep.)

i. 5 no, no, I will rob Tellus of her weed ... Perictes, iv. TEMIt Waslx, and Tellus' orbed ground .. Humlet, once stir my temper; but this...Meas. for Heus. ii.
poison of that lies in you to temper... Iuch Ada, ii. yon know your father's temper ... Winter's Tale, iv.

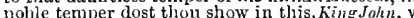
the temper of my knightly sword... Richord 11. iv . he holds your temper in a ligh $\ldots . .1$ ldenzy $I V$. ii . whose temper I intend to stain what inan of good temper would........... his temper, therefore, inust be well of
the fellow of this temper, Kate........... a fellow of this temper, Kate. which bears the better temper.... few men rightly teinner with tempers [Col.-tempts] him to this ..Richard III. i. a gentle, noble temper, a soul as whom the tempers and the minds. Troilus of Cress, i. his com fortable temper has.... Timon of $A$ thens, iti. you keep a eonstant temper ......... Coriotantus, v. of brother's temper do reeeive yo reneges all temper; and is become. Antony \& Cleo, $\mathrm{i}, 1$
patient after the noble temper ...... Cymbeline, $\mathrm{ii}$. 3 to temper poisons for her

and temper him, with all the ar

that you lose, to temper clay...

temper softened valour's steel. be mad - i. to bear a poison, I would temper it.

TEMIPERALITY; your pulsidge....2 Henryl $1 \%$. .

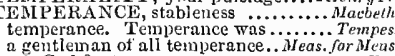
ask God for temperance......... ... Henryllil. i. be remed again to temperance...... Corioln temperanee, ladyl Sir, I will eat no I doubt not of his temjerance. must acquire and beset a temperance...... Hambeat, iii. but temperate as the morn............... Tempes of shes, ii amazed, temperate, and furious, loval... Macbe pause, or be inore temperate.......
suen temperate order in so fierce

lath been too cold and temperate...

of grace .... Henry $\mathrm{Y}$. ii TEMPERATELX keep time ......... Hamlet, iii. he eannot temperately transport..... Coriolanus, ii.
and temperately proceed to what you - iii. TEN, temperately; your promise $\ldots .$. . Tempest, iii. lack of tempered judgment after. Mleos, for Meas so righteonsly tempered as mine... As you Like it, are better tempered to attend....

from the best tempered courage.

but he, that tempered thee, bidle.

and your brain so tempered. Troilus o. Crenry $l$. i. when was my lord so ungentiy tempered thy disposition better tempered.. Ramea of Jutie it is poison tempered by himself......Hamlet, $\mathrm{v} .2$ tempering extremities., Romeo \& Juliel, i. 5 (chorus)
TEMPEST that I bade thee ............. Tempest, $\mathrm{i}$. when first I raised the tempest

tempest, I trow, threw this whale....... let there eome a tempest of provocation - v from the tempest of mine eyes ...Mid.N. Dream, i TEMPEST on the flood $\ldots \ldots \ldots \ldots \ldots . . .$.
eincture ean hold out this tempest $\ldots$, iii. 4 blown up by tempest of the soul .... = v. this lowering tempest............... Richard $I I$. i. such crimson tempest ahoull be.... . iii. a tempest, and a blusteriog day ...1 Henryl $V^{\prime}$. v. I in fierce tempest is lie comin

this fell tempest shall not cease....2 Henry $V I$. iii. from the shore the tempest beat us buck - jii. summer's corn by tempest lodged ... $=$ iii. keep thee from the tompest of the field 二 v. the windy tempest of my heart ....3 Henry $V I$. ii. then began the tempest to my soul! Pichard III. $\mathrm{i}$. navy is dispersed by tempest ......... nake at sea in a stiff tempest as lowd - iv.
wind and tempest of her trown .. Troilus \& Cress. i. seen tempests, when the scolding...Julias Casar, i. go through a tempest dropping firc... - i. 3 dies in tempest of thy angry frown. Vitus \&ndion. i. 2 to ealm this tempest whirling in ....... $\overline{\text { pericles }}$ i. disgorges such a tempest forth.......... iii. (Guver) born in a tempest, when my mother
bears a tempest, which his mortal - iv. $\overline{4}$ (Gower) did yon not name a tempest, a birth ... Lear, iii. the tempest in my mind doth from my ... - iii. this tempest will not give me leave ....... - iii. the desperate tempest hatli so banged.... Othello, ii. I tempests thenselves, high seas.......... - ii. if after every tempest come suel ealms - ii.
TENLPEST-TOST-shall be tempest-tost. Nfrcbeth, i. overset thy tempest-tost body . Rnmeo \& Juliet, iii.
TEMPESTUUUS gusts provokes ....। Hem. $r$.

and higl tempestuous gusts .. Tiins Andronicus, $v$. corper.. Tempes, gorgeous palaces, the solemn temples \#. $-\overline{\text { ninch }}$, iij. ay, in the temple, in the town.Mrid.N.'s Dieam, if. for in the temple, hy and by with $u \dot{s}=$ iv. and he did bid us follow to the temple

the duke is coming from the temple

first forward to the temple............ for here we have no temple............. Hou Like it, iii. the temple muelt surpassing $\ldots . . . . .6$ inter's Tale, ii. the temple liaunting martlet

the lord's anointed temple, and stole ... - ii. rounds the mortal temples of a king. Richard $I$ r. iii. within their eliefest temple $\ldots . \ldots .1$ Herry $V I$. ii. adorn his temples with a coronet

and roh his temples of the diadem ...3 HenryVI. i. 4 the tender temples of my ehild.... Richard IIT. iv. 4

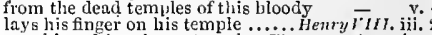
worshipped in a baser temple...Timon of Athens, iv. throng our large temples witli...... Cariolanus, iii. your temples burned in their cement

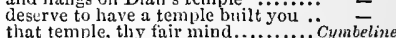
that it would fly from so divine a temple and in our temple was he inarried ... and smoke the temple with our saerifices and in the temple of great Jupiter ... Diana's temple is not distant far........ P'erintes, iii. 4 my temple stands in Ephesus. at Elhesus, the temple see .......... v. 2 (Gower) placed her here in Diana's temple (rep.) - v.

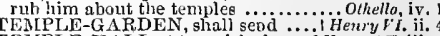
TEMPLE-HALL at two o'eloek ....1 Henrv 1 V. iii, TEMPOPAL royalties he thinks......... Tempest, $i$. dhe force of temporal power ...Merch. of Venice, iv. is this an lour for temporal affairs? Henry IIII. ii. cliildren temporal fathers do appease. Cymbeline, v. TEMIPORALX meddler .... Meusure for Measure, $\mathrm{v}$. will not reln porize witl? my entreaties. King $J n h n, v$. temporize with my affection. Troilus of Cressida, jv. TEMPURIZER, that canst.......... Finter's Tale, $i$. TE 1 PT - do not if thou darest tempt me further... nor doth she tempt .......... Meuszire for-Measure, ii. tempt not too much the hatred.1/id. N. s Dream, ii. at mine elbow; and tempts me. Merch of Y'erice, ii. 2 but durst not tempt a minister ... Winter's Tale, ii. did he tempt thee so? .................. persuasion did he tempt thy love? .. - iv, 2 nor tempt the danger of my true...... King John, iii. and tempt us not to bear above our...

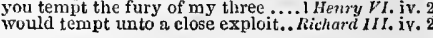




\section{TEMI}

TEMPT him to angthing .......... Richar III. iv. 2 | TEN-how ten thousand gouls... ay, if the devil tempt thee to do good - iv. \& therchy of tent thusund slam

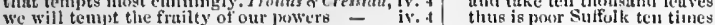

awe will teme the fruity of our low'irs ant tempt not yet the bruslies...... - v.

tor a whore, he tempto jnegment...

thus is poor Sulfuik ten times...

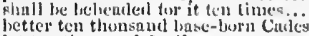

let ton thusnat devils come

and give ne but the ten meuls

and ten to one is no impenel of...

tuin duys ago I lruwner the se new.

will cost ten thousant lives to-day

1 , nnd ten thousand is this ivekiess

that wonlin be a ten day

ten to one, you'll meet

and tent times more beloved ........̈.

unun the stroke of ten...........

my heart is ten times lighter than

fire substance of ten thoustich

wisls him ten tathom deep

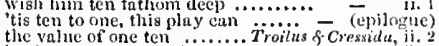

lend me ten thousand cyes

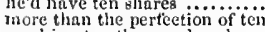

2llery/l. iji. I THNDER_swear I tender denrly.. T

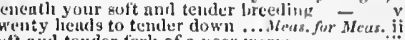

hut that lier tender bhame will not

if alne slould make tender of laer

if for his tender liere I make.

I an such a tender ass, if iny inir

when simpleness nnd duty tender

my tender juvenaly (rep.) .........
whiels we may noninate tenter

than are the tender hor th of euekled

to offices of tender courtesy 1 tender it for him in

which I tender dearly, though I siy

coul I tender dearly', though I gay,

you slioutel tender your sulposed aid. A
I come to tender it, and ny mpliance

and expose those tender limbs of thine

will be too ehill and tender.

eome short to tender it herseif

tender well my hounds. Tnming of shreer, $\overline{1}$ (ind uc.)

yet Samson was so temptcd ....... Lore's $L$. Last,

miglit so have tempted him as yo

mine ear huth tempted judgment 3 tenry

from my cabin tempted me to walk.
ghnil I be tempted of the devil thus?

but be not teinpted.

erucking ten thousand cirrbs

never tencler lady hath borne

thns so tender o'cr his follie

\section{theng so tender...}

where he is aboard, tender your persons

or pile ten hils on the Turpeian ....

being barbered ten times o'

well deserved ten times as
fur in every ten that they

I will lay you ten thousand.

my ten thousand ducats are
above ten thousund meaner
ten, ehased by one, ore now

ten, ehased by one, are now ..........

ten thousand swelling toads, as maun

that I cannot do ten thousand mure

more than two tens to a score

five and twenty, ten, or five...

ten times faster gide than

linth slain ten thonsand Tybaits ..... Hamlet, ii. 2
pisked out of ten [Kut,-two] thousand. Ha

pitked out of ten [Kut,-two] thousand .
we shall obey, were she ten times our..

fall ten times treble on that eursed head

nine or ten times I had thought to lave. othello, $i$

ten eomandments. ueas. for

hold out in year together

ten times loutler than

nine or ten times net ten o'eloek: our genernl enst - ij. 3

may, it is ten times strange $(r . \ldots p.) . . .$. .

it eost me ten niglits' watchings.......

TENANTS, friends, and neighbouring. Her. H $\%$. iii. ?

and now will he lie ten nights awake

yours is worth ten on't

be thy tenants, and thy followers?.hichard Ml. iv. 4

I have bcen your tenant (rep.) ............ Lear, iv.

ten ten words long (rep.) ...MMil.N.'s Dream,

being ten times undervalued to......

TENAN'CIUS-titles ly Tenantius .. Cymbeline, $\mathrm{i}$.

to give ten throusand timas

I $w$ give ten bound to pay it ten times....

thion aliouldst have had ten more

Withiu these ten days if that thon.
it is ten o'clock; thus may we see...

may be tent times found .

there's y'et one good in ten (rep.)..
as fit as ten grmats is for the hand.

ns fit as ten grinats is for the hand...

love her ten times more than
fueed it witls a eard of ten

tis ter to one it inaimed you.

a thousand knces, ten thousand........

no are between ten and three nuil twenty - iif.

ten thousaud lollars to our general ... Ilacbch, i. 2

threescore and ten I ean remember...

whth thousalsd warlike nien (rep.)

to that drog ten thourand wiry ..... king John, iij. 4

a jeหtel in a ten times barred-up...... nichard

a jeหret a ten times barred-up..... nichard 11. i.

we have staid ten days, anil hurdily.

in peace, ten thousand blondy crowut - ii. 3

clenprest of us is ten groats too dear..

darest not stund for ten shiling..........

threescore usu ten miles afiot withi ine

some etight, or ten. Zound s! ........
ten times manre dishonourable ragged

wherein the fortme of ten thousund

let it be ten ponul, if thon canst...

and ten times better than the nine

tis nist ten years gone, ginee .........

and here is four I Iarry ten shillings

near vur person by teis mile

the Mraves stood temnteas
TENCH. I ike a teneh?

.i.ïnenrylt

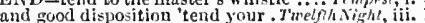

and tend on no mnn's business

Lysander, whereto tends all this?...

sieh rude boys might tend upon

you spirits that tend on
where tloing tends to ill

who didst thon leave to tend hi

they tend the erown

any thing that tends to inughto..................

any ehoice, teods to God's glory
do tend the profit of the land

vengenuee tend upon your stejs

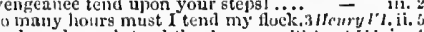

and giod angels tend thee I

lend the savage strungentss .... Troilus

that our request did teod ta.........

tend me to-night (rep.)..... Aniony s. Cliopet,

commant to your disnission tends.. Cymbeline

that tends to viee in min ............... Tim - itus. ii.

knights that touk upon my futlec:

[Km.] sommands, tends, service $\ldots \ldots . . .$.

- ii. 4

go, your servants tend

his affeetims do not that wny tend
hitherto thoth love or: fortume tend

the assoeiates tend, and every thing

some tender money to me . Conardy of

shnll not die so muth we tender hi

and know how tender 'tis, to loy
searf up the tender eye of pitiful

Nimg Juhn, iv.

how long shall tender duty muke...Pichard 11 . ii.

and priek my tender patienee ...... - ii. I

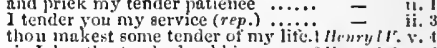

sir John, thy tender lambkin now ...2hlurg/ $l$.

our kingdom's safety must so tender - - ij. 2

ny tender years can tel] ...

doth close his tender dying eyes

my tender years, and let us not.....

a virgin from her tender infineg
my tender youth was never yet.

doth sut my tender feet ...

I tenler so the sntety of $m y$ liege.....
for their tender loving care .......... iii. I

in protection of their fender ones ..3 Henry $/ I_{\text {. ii. } 2}$

frum whence that tender spray ...... = - ii. 6

whom you stem to have so tender eare? - iv. to
ns well I tender you, and all of.... Richard III. ii.

the tender prinee would fain (rep, iv. I)
thie tender love 1 beur your graee ....

those tender babes, whom envy hath
old sullen pluytellow for tender princes

ah, nuy tender bubes 1 my unblown

soever laneed their tender hearts

scem pleasing to her tender years?

grueed the tender tempies of my
two tender bedicllows tor dist

I tender not tlyy beanteons prineeli...

thy brother tender George be exectited

kind of my obedience I should teniler

you tender more your persm's honour
the tender leaves ot hope, to-morrow

subseribes to tender objeets............

tepder dowil their servees to lind.. Timon of dit. $\mathrm{i}$.

we tender our loves to bim with

let me my scrvice tender on ........ Cariohme lije iii,

to the tender of ounder on your lips. Cyutcline, $i$. 7

those duties whieh you tender to her

she's a lacly so teuder of rebuks

by a piece of tender air $(r c p, r .5)$

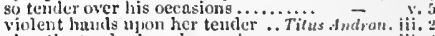

alus, the fender hos, in passion .......
peace, tender gapling; thou nrt inide
thy brother In

thy brother Anleus tenders on thy lins

nor will you tender less ................

in tender thing. Is lose a temler.. Roing

that rough toweli with a tender kiss..

which name i tender as dearly as min
a desperate tender of my eliilit's love

in her fortunu's fender, to answer....

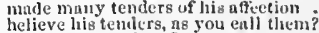

helieve his tenlers, ns you eall tit
tn'cn these tenders for true pay

tender yourself more dearl
you'll tenter me a fool

thine cerpecial snfety, whieli we.............

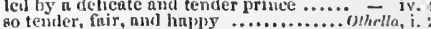

TiNisfik, and delicate temperance.... Tenpes!, ij.

eontent tender your own good fortunc?
whom once aguin I tender to thy hind

your affections would become tender

your afrections wond become tenter

the young and tender wit is.

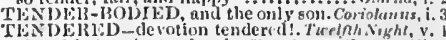

knowing thint tender youth. Treofien.aflerona, iii.

churlish teet she tendered.. Tirafien. of Finoma, iij.

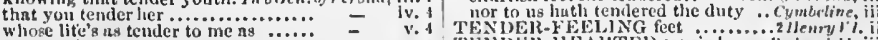

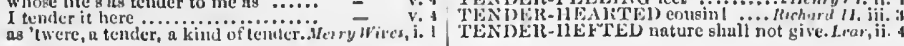


TENDERING their own worth.... Lore's L. Los' ii. subject's love, tendering the precious. Richarill his majesty, tendering my person's... Richard ili. i.

TENDERIY-so tenderly ofticious, H'inter's Tale i

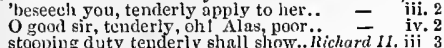

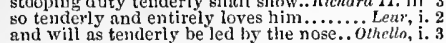
TENDER-NIINDED does not becom

TENDERNE

etch from flowery tenderness?. Meas. Pr Mpas. iii. the tenderness of her nature became. All's ' ell, iv.

these fail rites of tenderness.........

we know your tenderness of heart. Richard III. ii . with tenlerness and mild compassion $-\bar{v}$ iv. 3 not of a woman's tenderness to be ... Coriolomus, v.

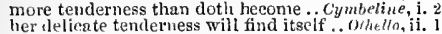

TENDRR-SNELLING knight..... Love's L.Lost, v. 2 TENDER'ST thou that paper
TENDING-give him tending thoughts tending to ambition (rep.). Richard II. $\mathrm{v}$. all tending to the good of their .... Coriolanus,

his speech tending to Casar's glories - iti.
TENEDos they come...... Iroilus \& Cressida, (prol. TEN EMENT, or pelting farm ...... Rielinrd II. if. I

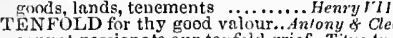

cannot passionate our tenfold grief.. Titus And. iii. the faitl they have in tenni

there falling out at tennis ............. Hamlet, ii. What trensure, uncle? Temnis-balls.... Henry $r$. T LNOR-the tenor of them doth. Fu...... Pericles, ii. receives letters of strange tenor.. Neas, for Meas. iv. 2
doth warrant the ten or of my book... Nuch delo, iv. it is paid according to the tenor.. Mer. offeniee, jv. is 't not the tenor of his orneie..... Wint my good lord, I guess their tenor cold intent, tenor and sulsstarice. performed the tenor of our word..... whose tenor was, -were he evil ....Henry $V I I i$. v. the tenor of the proclamation ...Troilus \& Cress, ii. letters of the self'-same tenor .....JulinsCasar, iv. 3
their tenor good, I trust ........... Cymbeline, ii. 4

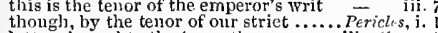
thougl, by the tenor of our striet ....... Pericles, 1 . for them in their tents ........... Love's L. Lost, iv. should be presented at our tent to us..

gone to her tent: please it your. toward the Greeian tents..... Nerchonl of I'enice, $v$.
when we bring him to our tents....All's Well, other letters, in my ten

costly apparel, tents, and canopies. Taming of Sh. ii. passionate at your highness' tent.... King John, ii. of trenches, tents, of pallisadoes .... Hexry/ $\%$ it. at my tent the Douglas is that I saw in your tent to-nighit........ Henry $V$. iij. and from the tents, the armourers - iv. (chorus) from tent to tent, let him ery .... - iv. (ehorus) away all that was in the king's tent and bring him to my tent ............. Henry VI. i. will go into his highness', tent ..... Henryli.iv. guard we his royal tent, but to ...... here pitch our tcnts, even here in.. Richard iv. up with my tent; here will I lie (rep.) some ink and paper in my tent
the earl to see me in my tent in to my tent, the air is raw and coid come to my tent and help to arm me under our tents I'll play............... caine to my tent and cried-on! victoryl man found on my tent this morning $-\overline{-}$ and in his tent lies mocking

keeps his tent like him .............. Is this great Agamemion's tent voice througl all these lazy tents...

lord nf Greece, from tent to tent

ere I colne any more to your tents?. the tent that thent that seares to we saw him at tlie opening of his tent go you and greet him in his tent stands $i^{\prime}$ the entranee of his tent thy reputation in thy tent to cunarmed to my tent my fumous cousin to our Grecian tents and see me at my tent peers of Greece, go to my tent.........
'T'SNT-at Menelaus' tent.... Trnilus \& $C$ after we part from $A$ gatmemnon's tent
who kceps the tent now? come, Thersites, help to trim my tent
he goes to Calelias' tent (rep.).........

Achilles see us at our tent

you vile abominable tents $\ldots \ldots \ldots \ldots . \cdots=\quad$ v. 10

so, to our tent: where, ere we (rep.)...

you cannot tent yourself: begone.... mile hefore his tent fall dow

a summer's evening, in his tent .
then in my tent, Cissius, enlarge

let no man come to our tent

here in the tent. What, thou speak st

sleep on eushions in iny tent (rep.) .̈.

are those my tents, where I pereen

within my tent his bones to-night

at thy tent is now, un

go with me to my tent ..................

bottom tirat.........

I shall attend you presentiy at .. Titus andron. $\mathrm{i}$.

convey her to my tent: come hither

TENTED -action in the tented field

TENTH of mankind would hang ... W .... Ohello,

aiso king Lewis the tenth, who was

among the people gather up a teuth

lost so many tentlls of ours

take chou the destined tent

and eity, we render you the teixth, a tenth, letting them...

if on the tenth day following...

TENT-ROYAL of their emper.

TERCEL-falcon as the tercel ... Troilizis \& Cress. $\mathrm{i}$

TEREUS the tale of Tereus ....... Cymbeline a craftier Tereus hast thon met....

treats of Tereus' treason, and his
TERM-the terms of my honour

and in such alligant terms .......

terms! Names! Amaimon sounds.

and reeolleeted terms, of these.... T

in terms so bloody

and the terms for common justice. Meas. for Neas, $\mathrm{j}$. 1

hear IIargaret term me Boruchio...

nor I cannot woo in festival terms

for three years' term to live (rep.)...

as, not to sce a woman in that term.

silken terms precise, three-piled

this twelvemonth term from day

in terms of ehoice $\mathbf{I}$ am not solely

in plain terms, gone to heave

which to term in gross, is an unlessoned

delended it with any terms of zeal

thood terms, in goou set terms . As

without all terms of pity....

with twenty such vile terms.

thus in plain terms: your father ......

villain than terms ean give thee out ... Blacbeth, $v$.

oly equal terms to give him

many holiday and lady terms

speak terms of manage to thy

of innocency, and terms of zeal...

I should meet upon sueh terms as now

with the happiest terms I have .......

upon sueh large terms, and so $\mathrm{Kii}^{2} H$
so, hike gruss terms, the prince wil.

(which is four terms, or two aetions)

I Ecorn the term; nor shall my
as I may, in fair terms (rep.)

what terms the enemy stood on ....

vouchsafe to teach a solklier terms

we have consented to all terms of

Pueelle, whom they term so pure?

other vile and ignominious terms....

salute my king with ruder term

invent as bitter-searching terms

be not too rough in terms...

brave me with these sauey terms?

8o anery at these abject terms...
break out into terms of rage!

to he thus bold in terms $\ldots . . . \ldots \ldots \ldots$. .

in plain terms [Col. Knt.-plaiuly to leer]

with terms unsquared, which, from..
on terms of ba.e eompulsion?........

should enlar itse if to wratlifil term

I caunot tell how to term it.

to close in torm of friendship.... Jitius Carsar, ii.

sourest points with sweetest terms anfony \& clen. ii.
but pay me terms of honnur ........

hut pay me terma or homur.

as long a term as yet we have
or loss of that, you term her frail..
TERM-afterwards in other terms ... Cymbeline, iii. 1 and mollis aer we term it mulier ..... nil the bitterest terms that... and nil the bitterest terms that .. Titus Andron. ii. 3
besides, the sore terms we stand upon .Pericles, iv. 3 parted you in good terms? finds, and dotage terms so $\ldots \ldots \ldots \ldots \ldots .$. - ii. 4 not stay the sicge of loving terms. Romeo \& Juliet, i. and expire the term of a dexpised lite

by strong hand, and terms compulsatnry. $\bar{I}_{a m l e l}, \hat{\mathrm{i}}$. for some term to do obsequious sorrow

I would not in plain terms, from this.

doomed for a certain term to walk $\ldots . . .$. the terms of our estate may not endire.. - iii. 3 but in my terms of honour, $I$ stand aloof $=$ v. 2 whether $I$ in any just term am.......... othello, $i$. suel scurvy and provoking terms against $=$ i.

such despite and heavy terms upon her.

TER I G

termagant [Col.Knt.-arm-gaunt] steed Ant. \& Clen.i.5

whipped for o'erdoing Termagant ..... Hamlet, iit.
TERAIED, si:, the grod ............... Tempest, v. termed them mereiless to us l... Comedy of $E$ rrors s. i. John Cade, so termed of our supposed $=$ iv. 2

by the sign thereof, was termed so. Richard 11 . ijf.

TERMINATIONS, there were no $\ldots .$. Much Ado, ii. 1

'tis bona terra, mala gens ..........2 Henry II. iv. 7

TERRAM Salicam mulieres ne .......... Herry $V_{1} \mathrm{i}$.

TERRAS Astrae reliquit ....... Tilus Andron. iv

TERRENE-our terrene moon ...Antony \& Cleo.

give me thy hand, terrestrial ........Merry Wives, iii.

terrible oath enth human hearing ... Tempest, $\mathrm{i}$.

were a terrible as her terminations.. Much Ado, ii.
that so terrible shows in the wreek. . All's Well, jii.

speak what terrible language you will $\overrightarrow{\text { Nacbeth, }}$ i.

corporal agent to this terrible feat .. - i. 7

aceents terrible, of dire combustion.. - iii.

too terrible for the ear .............. Bichard $I I$, iii.

my name were not so terrible to......2 Hen'y $1 \mathrm{~V}$. i.

how terrible in constant resolution ... Henry $\nu$. ii.

a terrible and terrible aspect........

death's approacl is seen so terrible!.2 Henry VI.iij.

such terrible impression made....... Richard III. i. 4
and grow as terrible as storms .... Henry IIII. iii.

and grow as terrible as storms .... Henry ITIII. iij.

not fierce and terrible only in strokes. Coriolanus, i. 4

blondy, fiery, and most terrible ....Julius Casar, i. 3

all strange end terrible events...Antony o Cleo.jv.

on our terrible seas, like egg-shells . Cymbeline, iii.

that terrible despateh of it into your........ Lear, $i$.

in the most terrible and nimble stroke ... $-\overline{\text { iv }}$.

[Cnl.] act sinows terrible and grim.......

an' you should do it too terribly Mid. N.'s Dream, i.
ynu'll swear, terribly swear...Timon of Athens, iv.

TERRITORIES - my territories. Tu'o Gen, of ier.iii.

the cirele of his territories.............

we banish you our territories ........... Richard II. $\mathrm{i}$.

more than half the Gallian territories

interest in those territories is .....2 Henry VI. iil.

prepared against your territorics .. Coriolanus, iv.

TERRITOR Y -in our territory ......... you Like it, jii. interest of territory, eares of state ......... Lear, $i$. ERROR - be terrors in him …............ Lear, i. breed no terror int the youth ..... iretfh $\lambda_{i g h t}$, iti. their pereh, and not their ferror....... = to our perjury to ndd more terror. Love's L.Lost, $\mathrm{v} .2$ that we make trifles of terrors ..........All's $W^{\prime}$ cll, ii. 3
both joy, and terror, of gond. Hinter's Tale, iv, (cho.) thou hate and terror to prosperity... King $\bar{J}$ ohn. iii. 4 th no less terror than ............ Rickard 1 . iii. divorce this terror from my heart? said they, is the terror of the Fremel. and what a terror he had been to .... - ij. strike such terror to his ellemies ... - ii. snur kingdom's terror and black .... = iv. all the foul terrors in dark-seated ...2 Ienry $V I$. iji. so lull of dismal terror was $\ldots \ldots \ldots$ Richard $11 I$. j.

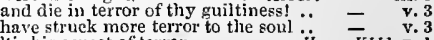
'tis his aspect of terror ............. Henry $\bar{v}$ III. v. pence, plenty, love, truth, terror $\cdots$. unaceustomed terror of this night. Jutius Cassr, ii. not apprehension of roaring terrors. Cymbeline, iv. his sons, a terror to our foes .. Tilus Antronicus, $\mathrm{i}$. hut they shall be the terrors of tle earth .. Lear, ii. it is the cowish terror of his spirit.....
liath more terror in his look.... Romeo \& Juliet, iij. together with the terror ot tie place - ive 3 
TERTIO-primo, seeundo, tertio.. Teethh Night, v.

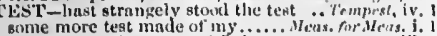
hring me to the test, and $Y$ the inatcer. Mumlort, ii

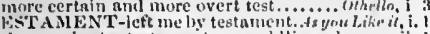
thou makest a testament as worklling din - il. 1 eonferred by testament to the sequent Al's H'Pll, v. 3 purple testament of bleed ing war .. KichardII. ii. a testament of noble-ending love Salisbury to muke his testaine

a kind of will, or testument....?

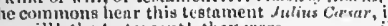

the will! the testament! they were..

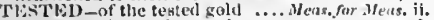

Tis

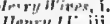

hold, there's a tester tir thee ......2 Ilenry I
WSTELNED me; in requital .. Turo Gen, of 1

ristry your bounty .............. in or sh. iv. 3 ean testify slie was the first

are alive at this day to testify

would testify, to emrich mi

hrenth, shall testify thou livest. Linmeo of Julich, iv.

TESTIMON ILS against his worth.... for - v. I

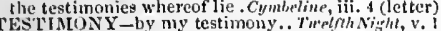
this testimuny of your own kex. Veas, for sleas. ii. a princely testimony, and goodiy........unch the testimony of a gool conscie

there is ton great testimony in ...As you l,ike it, iv. 3

alla by other warranted testimony ...di's sel. the testiming on

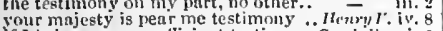

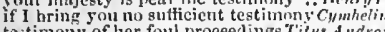

testimony" of her foul proceedings 'I'tus $A$ udrou.

lerive from him better testimnny

TF.TI.N ESS-power of his testiness............ear, i. 2

TH lead these testy rivals sonstrny.Mid.N.'s Dream, iii. 2 furls the testy gentleman so hot...Nichard FII. iii. 1 proud, violent, testy magistrutes .... Carinlumis, ii. and test $y$ wrath eould never be lier..... Pericle's,

TETCII Y and wayward was tíy... Richaril $/ 1$ l. and he's ns tetchy to be wooed. Troilus of Crrssicia, i. 1 to see it tetchy, and tall out.

TETHER may he walk

.. Ramea of Julict, i.

detter. Trifius of Cress.

which we disdain should tetter us.. Coriolamms, iit

TEVII - the tevil and his tam! ........... Hery "ives, i i

as goot a gentleman as

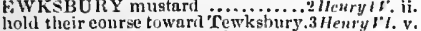

in my angry mood at Tewksbury...Rich

my poor son, at Tewksbury.

in the ficll by Tewksbury (rep.ii. i) - i. 4

ill my prine of youth at Tewksbury
TEXT_what is your text? (rep.) .. Terelsh. Night, i. 5 you are now out of your text........ Wuch $A d v$, i. 5 . 1 for society (saith the text) is i... Love'sL. Los

and certes, the text most infailibly

fair as a text $\mathbf{B}$ in a enny-bon

your exposition on the holy text ....2 Henry Ir. iv. 2

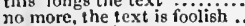

Pericles, ii. (Gower)

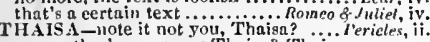

my mother's nane was Thaisu? Thaisa
diil wed the fair Thaisa, at Pen tapolis

look 1 Thaisa is reenvered. Tha..........

embrace him dear Thaisa, this is hi.....

HALIRD you're of our chamber (rpo

Thaliard, adieu! tili Pericles lse deal..

Lord Thaliaril from Antinchus is nelcom

how 'Thaliard eame full bent i.... it. (Gower)

to be thrown in to the Thames? (rep.)

pour in some sack to the Thames watel - iii. as 1 have been into the Thames.

Ilenry $\nu_{\text {. iv. } 1}$

throw them into Thames

inleurylidiv.

most worthy thane (rep. ii. 2 and ii. 3) - i.

who was the thane, lives yet

sons, kinsmen, thanes, auil you

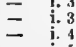

our thane is eoming. one of iny

then fy, false thanes, anl mingle..

dinetor, the thanes flo from me

my thanes and kiusmen, lienceforth

TIIANK-give thanks yon have lives .. Tempess,

heavens thank you to

may thank yourself for this great los....

thank you; wondrous hea

come with o thought; I thiarik you......

1 thank thee for that jest

your brumty, I thank yon................ ofrofrerona, iv.

I thank you, yem su inged me........

we thank the giver.................

I thank thee for thine hones.

I thauk you for your ount
IIANK yu for your mure. $T$ elirishth thanks is gond enough
she thunks you

1 thank you, mailain

aud slic shall thunk

thank your grnce .............

[(ol. Kut.] and 1 think vou al ........Merry Thiu

Bir I thank you. Sir I thatk youl

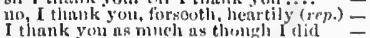

I lad ruther walk here, I thank you

I thank thee fort that lommonr.

than I do with her. I thmenk hegi.....

goth bot lich slie thanks

I thank you for it: I thank you fior that -

ne er malle my will yet, I think lat
I thank thee; and I pray thee, once

[ thank your wort pray

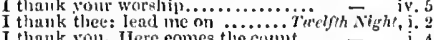

I thank you for your putins.....

Jove, I thank thee ..................

both thanks and use ........Mersure for $M c^{2} a$

I thank youn: fare you weil $($ (rep. i. 3)

reecive his punishnent in thanks.... -

ay sir, whom, I thank heaven........

Iliank you, good Potmpey

most holy sir, I thank you

I thank you for this eomiont

more than thanks and good fortime.

I thank thee, Varrins; thon hast ...

thaiks yooll forth to public tlianks

thanks, provost, for thy eare

I thank your: 1 am not of mas

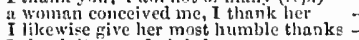

1 thank it. poor fool, it kecps on

fair Beatrice, I thank you ..........
for those thanks, than you take irep.)

is as easy as thithks $\ldots \ldots \ldots \ldots \ldots \ldots$.......

ani thank Goll you are rirl of a knave

yes, I thank Gra, I am as homest....

your many enurtesies, I tlank you (rep.) =

thanks to you all, and leare 18.

thanks, grood Egets .............

if I ha te thanks, it is a dear exp
mine ear. I thank it, brought me

to give them thanks for nothing

I thank thee tor thy sunny berin

I thank your worship..............

and thank you too; for soeietr

nay, I have verses too, I thank Biron

I thank him, is my dear ..............

I thank you, graeious lords, fur all

eoming so short of thanks for my.
shall I say, I thank your, gentle wif

I thank ny fortme for it.... Merchiant of $t$

thanks, i'fuith; for silence is ouly.

even for that I thank sou..........

1 thank thee, good Tubal; good news
I thank your loordship (rep.) $\ldots . . . .$.

I thank you fur your wish, anili......

would give $y$ ou little thanks for that

I thank thee, Jew, for tenehing me. .
Charles, I thank thee for thy love. As yon I.

let us go thank him, and encourage him

I thank it; more, I pr'y thee (........

if ever I thank any man, I'll thing $\mathrm{k}$ you -

when a man thanks me hentily.

but I give heaven thinks, and make no 二

Thank ye, and he blessed (rep.)
sleuk to thank you for myself

I thunk you tor your company $\left(\right.$ rip. $\left._{j}\right)$

and I thank God (rep, v. I ........

alld thank heaven; fastin.

my thanks and duty are your majesty's -

1 thank you for your honesi eare...

we thank you, maiten; but may not

such thunks I give, as one near
reul, thanks for their reward

thank henven for you

llinks, kir; all the rest is mite.....

I thank you, ant will stay. ...

I limbly thank you (rep iv. 3

to thank hoth heaven and me

bothing, hot let him have thank

and anawer, thanks: I tnly am.
but I thank nyy Gowl, it holts yet

rather make you thank your paits

go. I lhank thee; wait on me hom

We thank your honour . Tinning

thon'dst thank me lute a littl

Lil give lier tlauks, us though slic bid

\section{iv.
iv.
iv.
iv.
v.
i.
i.
i.
i.
i.
i.
i.
i.
i.
i.
ii.
iii.
iii.
iii.
iv.
iv.
i.
i.
i.
i.
i
.}

TIIANK- and thank your both. Taaing of Sherer,

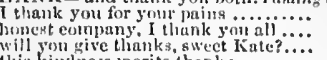

thorest scrvice is remain with thanks

foorest scrvice is repait with

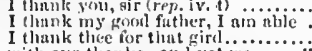

witl onr tlanks: and yet we .... Win'er's rete

gtay your thanks awhile (rep.)

The thiuks the

I thank him, I hare liome .... Comeily of

well, sir, I thank you. 'Thäik me, sir?

five me thanks for kind tosec

fint he, 1 thank him, gnawell in...

minch thanks for my gorwl clicer...

proportion both of thanks and pinyme.....

thanks, air; the like to you! ................

thunks to your majesty.....

with their hearts thanks...

for thy good caution, thinnks

so thanks to all at one...

I give heaven thanks, I wris not like...... King Jolu.

with all my heart I thank thec for.

$O$ heaven! I thank you, llubert

that wonld give you thanks.

I thank my liege, that, in re.r.

with, thanks my countrymen.........

I thank thee, gentle Perey (rep, v, 6)

evermore thanks, the exchequer...........

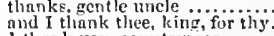

1 thank you, emintrymen

Evtors. I thank the not

to thank God on (rep.)

I thank fim, that lic eite.

I'll thunk myself tor doing these.

'ou niay thank the muniet time... . - v.

yed; I thank your jretty skcet

thy father is to give me thanks for it

I thank yon; I must a dozen mile

二 ii.

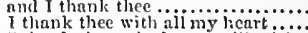

I thank thee: the kwave will sticjr.

sure, we thank you, my learrice lord

deliver so: thanks to your highness

upon his knees, a thousand than
thanks, good my countryman

yon thank love for my blindness

thanks. gentle sir (rep. $\ldots$ if 2 i...............

regilerdomed with so much as thank

thanks, Reirstier, happy for so sweet
I give thee kingly thanks.............

we thank you all (rep.)...

thanks, unele Winchester .........

I human God, nnd saint Alban......

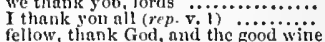

fellow, thank God, nnd the good wine

I thank thee, Margaret.

sir, I thank God, I have hecr so weil

with thanks, and pardon to you aii.".

thinnk thee, Cliftord.

thanke, gentle Nortolk, stay by me...

my lenve, with many eliousand thariks

my humble thanks (rep. iii. 3) ......

elivefly therefore I thank Goll, and thee

thanks, good Nontgomery (rep.) ....

with no and thinnks, and let's away

thanks, noble Clarenee ( $r e p$.).

let him tliank ne, thint hol? ?

I thank you, good my lurd (rep.)

I thank you, gentle unele.........

I thank your honour.............

I thmik his araee, I know he loves

thanks, gentle citichs, and from

kind sister, thunks ..................

how do thank thee, that this carnni

my lieart's leve, 1 do thank thee for it

I ihank your grace, healthful

and give thanks to yoo that ehoked it

thank your niajesty

and thank your lordship ........

a lowl may holil ny thanks.

thunks, my good lorit chmmberlaii...

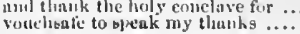

ivi. 1

iv. 3

i. 2

v. 3

i. 2 


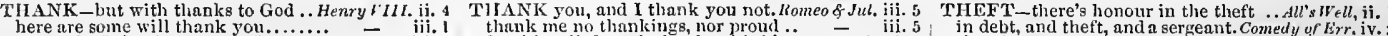
here are some will thank you......... nothing render but allegiant thanks and, no doubt, ghall thank you ....... I thank you, sir; had I not known I thank you, honest lord

who returned her thanks in............

I thank you, you are always ins

in daily thanks, that gave $u s$.

I thank ye heartily (rep.)

she must thank ye, she wili be sick el

but small thanks for my labour...7

I thank you for that; it my lord

often have you thanks therefore ....
and he replies, thanks, $\Delta$ ramemnon

save the thanks this prinee expects

by Mars lis gaumtlet, thanks i $\ldots . . .$. .

aecept distrneted thanks .............

doubled, with thanks, and service....

too lrondevice, I am to thank you for it

with more than common thanks I will

how shail I thank him, think'st thou?

the gods require our the

a root, thanks $I$ nust roi..........

I thank them; and would send them

thou shat be met with thanls

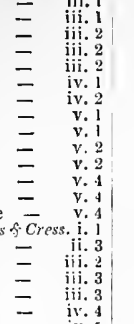

for this relief much thanks proud ... - iii.

this affair nong: for all, onr thanks ...

thanks, Rosencrantz, and gentle

I am even poor in thanks; but I thaik...

my thatks are too dear, a hulfpenny ....

hist ta.en with equal thanks .............

aud so I thiank you for yonr yood colnsel - iii.

I thank you: keep the donr

thank your lordship, tis very hot.

the ability of life to thank youk

umbly I thank your grace: l.......... - v.

thanks to the valiant of this warlike isie - Othello, $\mathrm{i}$. 3

make the Moor thank me, love me........

Thumbly thank you for't: I never knew

not with vain thanks, but witli acepptance

I humbly thank your ladyship (refi, iv. 3)

TIIANKED- he is to be thanked.. Tuelfih $i$

nilieh, God be thanked, hurt not ......Mnch dich

I thank you, madam, wive welcome.

find hou, madam; wire welcome..

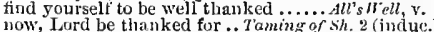

but, lieaven be thanked, it

God be thanked for these rebels.

Gud God be thanked for prevention....Herry $V$.ii. 2

till I have thed, trede is no need... Richard 111. iii.

I thank your ladyship .............. -

a eer tain number, though thanks to all
we thank the gols, onr Rome hatl ..

I thank you, general; but cannot...

howbeit, I thank you: I mean to $\ddot{\text { take }}$.

he is wounded, I thank the gods for't

both to thank, and to remember

thank yom, sir, farewell. O world.

must have that thanks from Rome

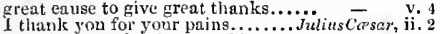

now, Brutus, thank yourselt...

I thank thee, Brutns, that thou liast

weleume to Rome. Thank yon...

humbly, sir, I thank you .............

and thanks tu you, that ealled me

thanks to my lord: the Jove of powe

thank you all; for dounty-handed

and Jove natke me thankfull... Tuelfh wight, iii. 4
I will live to be thankful to thee fur't

\begin{tabular}{l|l} 
i. 9 & a most thank ful and reverend youtl. Much $A d o$ \\
ii. 1 that we thankful should be ....... Love'sL. Lost,
\end{tabular}

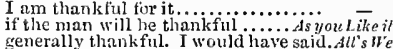

get am I thankful; if my heart.......

yer the whiel I sliall continue thankful $=$ v.

to be more thankful to thee.......Winter's 'lale, iv.

and ye shall find me thankfil.....

may give you thankful sacrifice! ...... Coriolanus, i.

i will most thankful be ....... Titus Andronticus,

by your fancy's thankful boon. Pericles, v. 2 (Gower)

THANKF UILY rest debtor for. Merch

this ring $I$ do accept nost thanlifully - iv. 2

most thankfully, ny lord (rep. v.l) Timon of $A t h$. i. 2

night be used more thankfully.

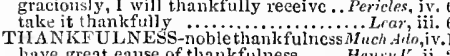

as I will kneel to him with thanks

I thank you, sir: know you ..........

thank your highness ( $r c p$. v, 5 ) .....

this worthy sigaior, I thank hiln

my liumble thanks. I had almost forgot -

I thank you for your pains.

the thanks I give, is telling you (rep.) -

sir, (I thank her,) that: shc stripped
thus defied, I thank thee for myself

to the best I Amen: I thank thee...

thanks, royal sir: my emper

and thanks to stay and eat it.........

thank the man that gave them the

where, (thank the gods1) they grow

I thank you: by yon bush? (rep.iv. 3)

ne'er thank thy master; live ......... Titus $A \overline{n d}$

thanks, gentle tribune (rep.) ........

I rive thee thanks in part of thy deserts =

thanks, noble 'Titus, father of my lifel -

thanks, sweet Lavinia: Romans .... Hord =

I humbly thank him, and 1 thank you -

thanks, gentle Romans; may I govern
Antiochus, I thank thee, wlio hath

1 thank thee for it (rep, ii. I)

I thank you, sir. Hark you, my friend

thanks, fortune, yet, that after all $\not 3$ ij

we thank your graee. Yet pause a whil
I thank him. Wishing it so much (rep.)

he thanks your graee; names limself..

thanks, gentlemen, to all; all have done
I thank thee; Mariner, say what coast

madam, my thanks and prayers.

ny recompense is thanks, that's all

thank the holy gods, as loud as thunder

and whom to thank, besides the gods.

I thank thee, fellow; thou servest me
now my friendly knave, I thank the

now my friendly knave, I thank the

for him I thank your graee..............

Gloster, I live to thank thee for the love

I thank you, sir: that's all (rep.) ..........

pray you undo this button: thank you, sir! -

wiy then I thank you all (rep.)... Rnmeo \& Juliet,

shall thank thee, dauditer, for us $(r e p$.
ghe gives you thauks (rcp.).......... have great eause of thankfulness

next, accept my thankfulnes

THANKINGS to you both.

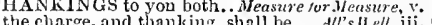

traced the thankings of a king ....... Cymbeline, v.
thank me no thankings, nor ..Romeo \& Jutius,

TIIANKLESS natures-() abliorred. Timon of Aih. v.

shed for my tirankless country

THAN KSGIVING befure meat ... Meas, for hear, i.

TIIARBOROUGH-grace's tharborough

Tharsus, o'er which I have government

the miser of Tharsus may be theirs
is still at Thargus $($ rep. $)$..........

we ale near Tharsus. Thither, gentle

at Tharsus. and by Cleon (rep. v. 3 ) -

brought this king to Tharsus $(r \in p)-$. iv. 4 (Gover

my tither, clid in Tharsus leave me...... - $v$

not dead at 'Tharsus, as she should have.

TriAssos send his body JuliusCarsar, v.

THATCH-upoa our houses' thatch ... Henryl' jii. 5
thatch your poor thin roofs .. Timon of Athens, iv. THATCHED-thatched with stover. .. Tempest, iv. then your visor should be thatehed ...Mnch Ado, ii. That I was duller than a great thawerry Muches, iij. 5 fire scaree thaws the icicles... Merchant of lenice, ii. come by a fire to thaw me.... Taming of Shrew, iv. I thaw, and resolve itself into a dew! .... Hamlel, be thawed from the true quality... JuliusCasar, iii. THLATRE-and universai theatre. As yoa Like it, ii. ? as in a theatre, whence they gape.... King John, ii. 2
as in a theatre, the eyes of men ....Richard II. as in a theatre, the eyes of men

Richard 11 , v.

that done, repair to Pompey's tileatre - i.

o'erweigh a whole theatre of others .. Hamlet, iii.
TiEBAN-with thissame learned Theban, Lear, iii

THEF T-his thefts were too open ...Merry.'s'smes, $\mathrm{i}$. society with thankfulness. Timon of Ath. iii. 6 (grace) there's warrant in that theft which. ..Mlacheth, ii. 3 for thy thett hath alrealy ........... Henry 1 .'.iv. 2 useth it to patronage his theft...... Henryl'l. iii. O thet most base............. to use violent thefte................... . . . $\mathrm{v}$. for there is boundless theft in. Timon of athens, iv. rough power have unchiceked theft ... - iv.

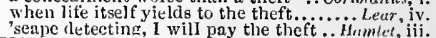
THEME-liave just our theme of woe...Ten vell, I am your theme.

ay, that's the theme.......... Twelfoh Nisht, $\mathrm{ji}$. part of his theme, but nothing.... Hinter's Tale, $\mathrm{i}$. is colder than that theme............. of Errors, ii. ? it was the subjeet of my theme ....... the theme of honour's tongue. $\ldots \ldots$.. Ilenry I $F^{\prime}$. it is a theme as flucit as................ Henry $V_{\text {. }}$ ( is a theme of honour and renown. Truilus of Cress, ii. not theme of all our storns! ....... - iv. 5 apt, without a theme, for depravation gieater themes for insurrection's.... Eleor. ii. his gentieman theme for you. Aniony \& clen. ii. and when a soldier was the theme... handle not the theme, to talk .. Tilus Andron. iii. he eounes, and I must ply my theme - v. whose eornmun theme is death........... Hamlit, $i$.

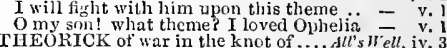

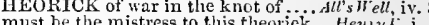

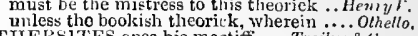
TIEISITES opes his mastiff.... Troilhus \& Cress. $\mathrm{i}$. Thersites-Agamennon-how if he $(r \in p)-$. mistress Thersites! thou slowldst strike good words, Thersites. What's the...

what, with me too, Thersites? .......

who's there? Thersites? Good Thersites -

Thersites, my lord. Where, where?.

proceed,'Thersites. Agamemnon (rep.)

who? Thersites? He. Then wili $\mathrm{Ajax}$

go eall Thersites hither, sweet Patroelu here comes Thersites. How now, thou

come, come, Thersites, help to trim
what I would be, if I were not Thersites -

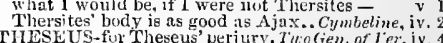
hippy be Theseus, our remowned...Mid. N.'s $D r$. $\mathrm{i}$. to Theseug must be wedded............ intended for great 'Theseus' muptial-day dance in duke 'Theseus' honse …ํ.. strange, my Theseus, that these lovers =

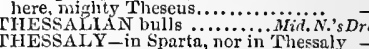
the boar of Thessaly was never. Anton? \& Cleo. iv. 1 HETIS-the gentle Thetis .T Troitus \& Cressida, i. Achilles' horse makes many Thetis' sons - i. now, grcat Thetis' son?............. ou s - iij. Thet is, being proud (rep.) ..Fericles, iv. 4 (Gower)
TIIE W ES, the stature, bulk ........2Henry $/ r$. iii. liave thewes and limbs like to ....... Julius Caesar, i. daes not grow alone in thewes, and bulk. Hamlet, $j$ floor of heaven is thiek inlaid ...iter. nf Perpice, i. thiek, thick, spare not me ..............tl's Wrll, thiek, bereft of beauty ........ Ta ming of Shrew, v.
thoughts that would thiek my.....Winter's tate as thicks as tale, thy praises in .......... Macbeth, $\mathrm{i}$. make thiek my blood, stop up

muke the gruel thiek and slab .......... and made it heary, thick ..........kingJohn, iii. wit is a thick as 'Tewtsbury must... Hen'y 11 . ii. his dimensions to any thiek sight were = jii. was ordained so thick, to heave ....... thick as thought could make them.Henry lis. fall thick in blessings on herl........ where you pereeive them thick ........ Julins $\bar{C} \bar{c}^{\prime} s a r, \mathrm{i}$.

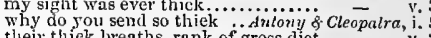
dissolve thick cloud, and rain........ say, and speak thick (love's counselior - Cymbeline, i. anon, a rout, eoufusion thiek .......... strike flat the thick rotundity $\ldots \ldots \ldots \ldots$. Lar, iii. thiek and inwholesome in their thoughts - Hamlet, ii. let her paint an inch thick

FHICK-COMING funcies .................. lustre thickens, when he shines..Antony \& Clco. $\overline{\text { ii. }} 3$ 
TIICKFN other nroofs

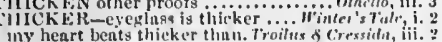

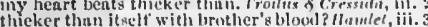
rillekes't and the tallest (rep.). Lore', L. Lust, iv.

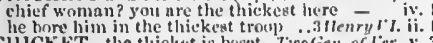

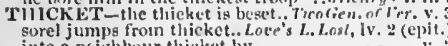
into a nejghtour thicket by ............ this ehictest thicket of the park. \%3llenry/rJ. iv. the hart Aehilles keeps thicket.. Troilus o cress, ii. Tilck-crisow bruke We'll shroun.3 hemry 7 . ii

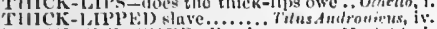

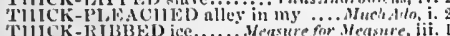

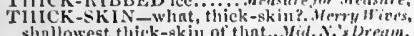

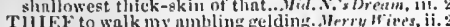

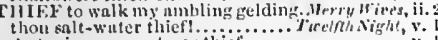

Antonio never yet was thic

he the the have thief or tro eniltier we take him to be a thict too true mus's apparel tits your thief (rep.) - iv. 2 too bie for your thict; your thief tlit?

it you meet a thief, you mpy suझpcet. Wuch do, iii. 3 if we know him to he a thief .

it you do tnke a thicf, is, to let ......

a deformed thief this fashion is! (rep.)

you thict of love! what have slid. a true man, or a thief, that ....... Lnve's 1. Losi, iv.

cith a thief to the anth

like n timorous thief, most inin

with the durk, porr thief, I ll steni

what simple thice brags of his. Comediy of Errors, iii.

a giant's robe unon, a dwartish thief..... Mncbrth, $y .2$

so when this thief, this traitor .... Kictard Il,

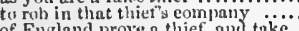

of England prove a thief, a

$U$ for a fine thiet, of the age.

weleome, my little tiny thief?........ Henrylr y.

and, like a thief, to eome to rob..... - iv. In

the thief doth fear ench bush........3 Hew.y I. y. 6

as ever hangman terved thiff.. Timon of

go, strong thief, when
the sum's a thief (rep.)

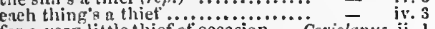

for a very little thief of oceation..... Coriolmm. ni. I

a cunning thief, or a that way

and eave the thief; nay (rep.)

a villain; yield thee, thief $\ldots \ldots \ldots . . .$. .

egregious murderer, thief, anytling

than myself, a saerilegious th

die he like a thief, that robs $\ldots . . .$.

pinion him like a thief, bring him .......

yon' justice rails upon yon' Eimple thief

Othou foul thief, where hast thou stowed

steals something from the thicf...

TIIEF-STOLEN, as my two brothers..... Cymbetine, i. 7

YIIFVES- stak to eateh these thieves. Fempest, iv. 1 for thieves do font by vight .........Nerny Wires, thieves for their robbery have

to play the thieves for wives. Nerchimi of /inice, ii. 6 provoketh thieves sooner than goll. As you Like i, i. 3 We're heset with thicves...... Tatning nf Shrer, iii. 2 thieves are not judged, but the

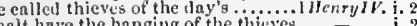

when thieves en mot be true

When thieves entmot be
the thiteres have bound ...

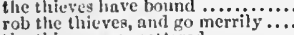

the thisves are gcattered $\ldots . . . . . . .$.

do you think 1 kecp thieves .

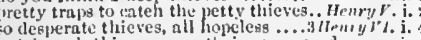
so triumph thieves upon their eonquered

itus \& Cress. ii.

(imon of. Ith. iv. 3

thices. Soldiers, not thieveg (rep.).. - iv. 3

that you are thieves,

all that you meet are thicves........ - iv. 3

aA thieves to kes ro lose

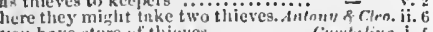
you have store of thicves ............ Ciymbth line i. 5

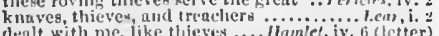

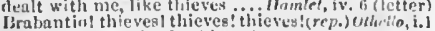

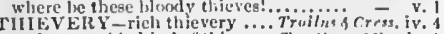
an honournble kind of thievery. Trofinthar ber. iv. 1 exnmple you with thievery .... Timon af , thens, iv. 3 TIIIE ISI living on the eommon ...A, tyut l,ke it, ii. 3

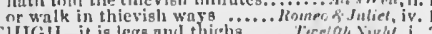

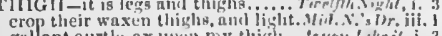
gullant eurtle-ax unom ny thigh ... is you tike it, $i .3$ a ncw wound in your thigh $(r<\mu)$....

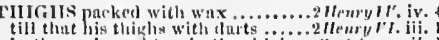

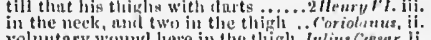
roluntary womed here in the thigh.Jnlins Cerser. li.

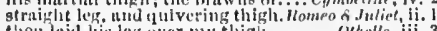
then lnit lisis le over my thigh itself sugtuin nym an soldier's thigh.

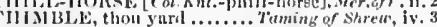
fluger le nrmet in a thimble ......... - iv. 3

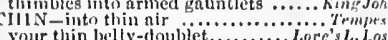
Yanril loolging, and thin weeds, nip not beurd grew thin and hungeriy... Thaniug of $S h$. ii. like tioliave a thin and sleude

it your guments were thin .. Comeily of Error

we will not line his thin bestuinet

have arned their thin and hairless... isicharal 11 . iii. 2

to forswear thin potations.

so thin, that life looks through

thou thin man in a euser?

hls eolu thin drink out of his "...

iv. 4

give himselt, nll thin and nakeil...3ichenry IIi ii.

they nre too thin nnd base to hitle... Henry rill. v. 2

(pow perdut) with this thin helm? ...... Leew, iv.

whieh is as thin of substmee .... knmeo of Jut

thill hibits, and poor likelihoeds........ Ohhello, i. 3

The $\rightarrow$ rown furze, any thin

thou liest, malimant

for one tlinis slie diil

one thind or other .................

I might cull him a thing divine.

a single thing, ns I am now weil with't

here is every thing advantageous to life

I would by contraries execute all thing

these be tine things, an'

let you helieve things ecrtain ..........

and think of cach thing well

what things are these, iny lord Aintonito

this is as strmge a thing ns e'er .........

are all these thing pereeived in me?

no impression of the thing it wa......

forgs for every thing that he ........

of another thing she may

three things that women higlil

exeels cach mortal thing.

niways plny but one thing?

a dor at all thing

1id the thing you wot of

I will do a grester thing than thit

never need to understand any thing

there's no sueh thing in me

shinll it be eo? Any thing

tells me, tis n thing impossibie........

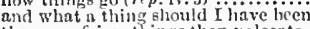

there are fairer things than poleeats
I would not have things cool ........

I lad other things to have spoken

wherefore are these things lifi? . . Treetfhis

any thing that's menled, is but patched -

and one thing more; that you be...

any thing eonstantly hut a time-plenser -

their business might be every thing.

you have not scent sueh at thimg a

havlly forhear hurling things ot him

nme the things of tame .............

you are idile shinliow things..........

ally thing

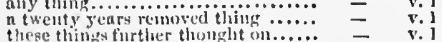

thege thiniss turther thonght on......

as thimge thit are

one thing to he tempted, Eacalus (rip.)

jast cure of the thing you wot ot ....

for those thing s that make her .......

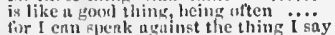

I romething lo excuse the thing I hate I do lose a things that newe lust

sinirit to do any thing thri............

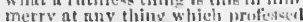

pund'rouanand substantiul thines!.

if nuy thing thll ter yot upunt this.....
TIING-these thinge should be.. Mens. for wrat. Iv.

clist you sucls a thing?

iv. 3

sueht a depenteney of thing on thing - v.

there is a mensure in every thing ..... Aneth dito, ii.

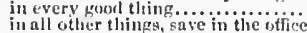

you look to those things I told you or
to linve all things unswer my nind

will I enthavour any thing

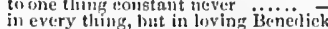

nny thimg to-niktht why I sliould not

it is the simly thing for a qualin

are thee things spoken?

and these things are true .............

these thing, enme thus to light.......
coth not every turthly thiug ery eliame

ns strange us the thin I know nut.

eome, bits me do any thing for theec...

for he swore a thing to me on Mondluy

they have veritiod unjust things...............

in any thing thint I lo know by her.

or melis that all thinges gort 60 well

thing things eune to confusion. vili. $x$.'s 7

the sext thing w lien ghe waking ( $r . p_{0}$.

wake when some vile thing is near

as a surfeit of the sweetest things

nunong laclics, is n most dreadiul thing

low, I am no such thing
but the re is two hard things

then there is another thing...........

from yicklers all things cateh

jow can these tlings in ne seem.

and ull things slatl be peace

how eame these things to pass?

I see these things with parted eye (rep.)

in, Gont hlese us! a thing of nought ...

the forms of things unknown ......

fur never any thing can he amiss.....
gentle sweet, you shall see no sueli thing -

till truth make all things plisin ........

things lid and barred, ymu mean... Inee's L. Lost, i.

but like of exel thing, that in season

one and the self-sane thing, dear imp

do one thing for me thit 1 shall....

not be perjured, 'tis a hateful things.
when shall you see me write a thing

to things of sale a seller's prnise

thint maketh all things
shall I tell you a thing?

wind, thonght. swifter things.

makes wire things fnolsh (rep.).....

that such a thing, bechunecu ... Nerch, of Fenice, $i$

I will do nny thing, Nerissn, ere I

a these things being boursht, and orderly

all things that are, are with more.

men enforeed do speak any thing.

the half of any thing that this same

liear other things: Jorenzo.

the things they do not love? (rep.).

merchant, have you any thing to say?

wrant me two things, I pray you......

how many things by season.

a thing stuck on with onths...

to urge the thing held as a eeremony?

nnd we will answer ull things faitlifully

num nt tanglit to make nny thing.

in that it is a thing of his own senreh

so fuir and exeellent

nith good in every thing

nssuredly, the thing is to be sold ....

yjeln any lling anvage, I will.......

tint all thiugs lutel been savare bere

gnne eyes, sans taste, smas erery thin

every thing nhomit you demonstrntiug

tor no passion truly any thing ......

is it a true thing?

the liese thing in him is his............

can one glesire too muel of a good thing? -

being the thing I an

never my thing no sudficn

that $I$ teus do atring is to

have leer und dentl were luth $\ldots . . . . .$.

nu ill-fuvoured thing gir, but miuns -

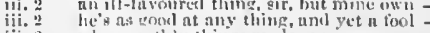

hen carthly thinge made ceveli

we: met, nud the e things fln
will jou any thing with it?

\section{(}

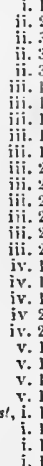

iii. 2

iv: 3

iv. 3

,. 1

v. 2

i. 2

iii. 6 


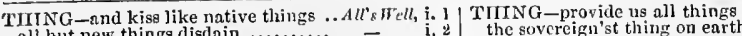
all but new things disdain ......... I see things may serve long, but not and fumiliar thing supernitural when virtuous things proceed. bat for two things. What two things? in every thing $I$ wait upon his will.. these things shall be done, sir .... are not the things they go under never trust my judgment in any thing a will tell you a thing, but you must let every thing in him by wearing.

I could encure any hing before $\ldots . . .1$ simply the thing I am simply the thing 1 am .

price of serious things we liave

that will speals any thing? .......

the name, and not the thing ........ I feel soft things; upon my

one thing more rests, that thyself.

supposing it a thing impossib

learning what a thing it is $\ldots \ldots \ldots$. when the the thing thit feeds their tury rings, and things, and fine array .... and all things that belong to house. and all things answerable to this my ass, iny any thing: and here

and every thing in order?

and ail things neat? All things is ready or any thing thou wilt .......... things aud cuffs, and farthingales, and tha... that every thing I look on seemeth... ${ }^{-}{ }^{-} T$ women say so, that will say any thing make possible, things hings to my heart to do a thing, where I the issue doubted and $I$ remain a pinehed thing thou thing, which I'll not cal any thing. my lord, that my do not repent of these things ........ thum the poor thing is liere............

it thou'lt see a thing to talk on.......

to the freshest things now reigning

denying thee any thing; a death .... me

have money, or any thing $I$ want...

nor any thing to any, if $I$ be not

and the thing she took to quench $i t$

so she does any thing, though I.....

or a very pleasant thing indeed....

cleliver, things known betwixt us...

and we may do any thing extempore

any thing that is fitting to be known

lonked on, sueh goodly things as you?

will grant precious things, as trifles.

there's a time for all things.

sure, in a thing falsing ...

but on a stronger thing; a chain

that seems to speak things strange

anci seem to fear things that do.......

were such things here, as we .........
was wrought with things forgotten

the dearest thing he owed.....................

there's no sueh thing; it is ...........

to think so brainsickly of things ...

of three things. What three thing

horses, (a thine most strange and certain

may you see things well done.

and all things else, that might

the trame of things diejoint.

good things of day berin to.......

things, bad begun, make

can such things be, and overco.....

can slich things be, and overco

jour charms, and every thing beside...

only, I say, things have bee

yet my heart throbs to know one thing

things at the worst will cease .......

and un welcome things at once .........

cannot but remember such the

but constrained things, whose..........

liaving no external thing to lose
all things begun come to ill end

arrainst the thing thou swear'st

I hall a thing to say; but I will...
feeling what small things are...

all things, that you should use ......

things sweet to taste, prove.............
more than things long past ..........
divicles one thing entire to many...

which, for things true, weeps things

and every thing 18 left at six and

things past redress, are now with

thou little better thing than earth ...

from a eerious thing, and now changed
as thoughts of thiugs divine .........

for in every thing, the purpose ii. 1 thou wilt not tell me all things true

ii. 3 there is a thing, Harry, which thou

wherein villanous, but in all things

for some things trul wherein my

ii. 5 gn, you thing, go. Say, what thing?

iii. 6 may do any tling. laob me the (rep.)

things, incleed, you have articulated

and as the thing that's heavy in itseif

not able to invent any thing that tend

to the hearing of any thing good....

if thandish any thing but my botte..

wit will make use of any thing

seem best; things present, worst .....

lie's an infinitive thing upon ms score
one thing, Poins? Yes; and let it $(r e p$.

and those two things, I confess

of the main ehance of things as yet..

such things become the hateh ......

are these things then necessities?...

which is an excellent thing

to do any thing about her, when I

what thing in horrour, had my

there is a thing within my bosom...

some good thing comes to-morrow.

when every thing is ended, then ....

see, sons, what things you are

as things acquainted and familiar to us

if thou want'st any thing, and will not

you thin thing; come you roscal!....

presume not, that I an the thing I Was
where, for any thing I know, Falstaff..

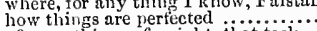

of some things of weight, that task

that many things having full

things must be as they may

and any thing that may not nisbeeome

they will steal any thing, and

thou makest use of any thing

minding true things, by what .....
some soul of goodness in things evil.

charitably dispose of any thing........

sueh outward things dwell not in ....

af he durst steal any thing adventurously

for there is figures in all things.

why and wherefore in all things

if I owe you any thing, I will pay.

any thing in, or ont of, our demands

his glass for the love of any thing he

after that things are set in order.

maintain the thing you teach $\ldots$.....

that, for a toy, a thing of no regard.

tush! that's a wooden thing

straight a thing impossible
we'll see these things effected...

wouldst any thing with me?

see the lists and all things fit...

for things are often spoke...............

are all things well, aecording as ...

are all things well, aecording as $\ldots$...

judgest all things, stay my thoughta

small things make base men proud

is not this a lamentalite thing.

and henceforward all things sibail

as all things shall redound .........

pay, and every thing you wish

how sweet a thing it is to wear
that things ill-got had ever bad

no wrong, but every thing is right

never will I undertake the thing

why, 'tis a happy thing to be the

ay, that's the first thing that we

if a thing eornes in his head...

partake of any thing we say $\ldots . . . . .$.

creeping venomed thing that thing to despath this thing?

llow going to despateh this thing?

it is a dangerous thing ( $r \rho p$.)

in common

in weightier things you'll say a beggar

'tis a vile thing to die, my gracious lord -

are all things ready for the ropal time?

if to have done the thing your gave in

yet one thing more, good captain

a thing devised by the enemy.

things now, that bear a weirhi.......

the traet of every thing would by a..

order gave each thing view ..........

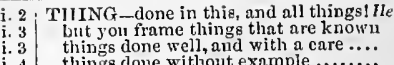

things done well, and with a care...

things dome without example

pledge it me

every thing that heard him play.. - iii.

i. 2 if ye be any thing but churehmen's.. -

iii. 3 ye appear in erery thing may......... -

such things have been done............

this happy child, did I get any thing -

the joints of every thing (rep.)
well, cousin, I told you a thing

swords? any thing, he cares not.....

2 men prize the thing ungained more..

2 why, then, the thing of courage......

then every thing includes....

of things to come at large....

thou thing of no bowels, thou

unworthy of $a$ thing so stoien.

sweh things as might offend.....

it any thing more than your sport

things small as nothing, for......

gpeak the thing I shall repent

through the sight I hear in things

no man is the lord of any thing......

what things again most dear

remumeration for the thing it was

made and moulded of things past....

since things in motion soo

dise thing he means to kill de........

deeeived, I think of no such thing...

drawing all things to it ......

that a thing inseparate divides ......

and what one thing, what another ..

in every thing illegitimate!.

a thing slipped idly from me ... Timon of $\bar{A}$ the

that few things loves better

but I congs o from him ............

as I understand how all things go .

believe't, that we'll do any thing for gold =

but men, men are the things themselves =

more things like men? eat

each thing s a thief, the laws

what viler thing upon the earth... .

digest things rightly touching the ...

wesides, if things go well, opinion.

tell me one thing that I shall ask you

in troth, there's wondrous things spok

only there is one thing wanting......

he was a thing of blod, whosed en

if we give you any thing, we hope to.

have done many things, some less ...

of all things upon the enrth............

hence, rotten thing, or I shall shake

things created to buy and sell with

tell you most strange things from Pom

from yon cloud speak divine things.

between the youngest and oldest thing

he leads them like a thing made by..

you are goodly things, you voices

that he bears all things fairly....

not to be other than one thing .......
for such things as you, I ean scarce

the things, I have forsworn to grant

you will not grant us any thing... .

he's more than a creeping thing...

as a thing made for Alexander than senseless things $i$

by reflection, by some otler things

in awe of such a thing as I myself

to hear, and answer sueh high thing

could be moved to smile at any thivg

did Cicero say any thing?

shakes like a thing unfirm?..........

they are portentous thiugs unto the.

they are portentous things unto the..

why all these things change, from ... -

so vile a thing as Cxsar? ............ -

no eolour for the thing he is......... =

will never follow any thing that

will strive with things impossible..

besides the things that we have....

these things are beyond all use .......

al me, how weak a thing the heart ... =

to young Oetavius of the state of things

in this mood will give us any thing..

things unluckily charge my fantasy

things unluckily charge my fantasy
listen great things: Brutus and Cassius =

to wish things done, undone ,....... =

every thing is well. Grod-night .....
art thou any thing? art thou some god
didst thou see any thing? .............
. 
TIING-eredit things that do of men the things that are not? alas. thou hast misconstrued cvery thing -

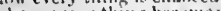

Whout eve thing most any thing. Alexus, ntmost.

thinges thut ure putst ure done

in emb thing give him way.

whom these thimgs camot blemish....

last thing he did, ibenr queen

deenys the thing we sue firr.

for vile:t things beente themsioes...

whramises are very.guoully things...dile? -

this erenture's no suteh thit the

I have une thing more to ask him

Rud things ont waril do il row .........

fir the things he spenks moy concert

the brenking of or arent a thing sliould

twilo that thing thut emils nit
ax things but doue by etumes

as things hit dolle hy ethine

things of such alignity us we

for things that others do

flad nt the thing they seowl at

is a thing $t$, o hai for bad report

(1), thislowal thing. thou shouldst repair

thou frulish thing! they were aytin

bit hial most pretty things to sny...

those things I bid yous do, get them.

we will have these things aet dowil...

depender an a things that leans

tis the the

more vexed at any thing in the warth

with everv thing that pretty him.

this is a thing which you minlit from a prutit from all things we sec

in simple and low thimes, to prince it

wisnla he interpreted a thing perplexed

n thing the most distlained of fort

a thing more made of malice.......

l torget to $\mathrm{s}$. him one thing........

this is $t$ le second thinc that $Y$.

if ang thing that s eivi, spleak ....

nutl liase things sire buse

n thing more stavisls ditl i ne..........

frum one bat thing to worse

all solemn things should answer

what thing is it, that I never .....

rather to wormler at the things you heur

'ionngst his foes, $n$ thing of pity

such noble fury in so poor th thing

this one thing only I will entreat.

the same deal thing alive

any thing that's due to all

a!l the abhorred thing o' thic carthi...
wins not thouglit by me a yreeions thing

wns not thought by ne a preeions thing =

and every thing in readiness.. Titus $A$.

when every thing doth make a gheeful

and one thing more the the beholil the thing

O wondroms thing! hw ensiy.........

thou shnit the emploverl in theye thing

now, whent $\Omega$ thing it is to be an ass?

and hast a thing within thee, calied..

have done a thinsunt! rirendfut things

the thing the which is fing intered be as they may

let me ask one thing. Whut do you

who thourlyt of such a thing? ....

here is a thing ton yome for ..........

canst not do a thing i' the world ...

ilisl yon ever (lream of siele a thing?

I'll dn any thing now that is virtious

tell ine one thing first. Conne (rep.)

do nny thing but this thon dine

no neerlful thing omittel

corsmit a thing so tnonstroil.

to linge on leer for any thing ............

clee "ill take the thing she bess

no furtlier witls any thing you know

I huve one thing. of a queusy quiestio

nre in the prores thing supertluses

I will do smelt thing -what they ure
that things nitat whange, or ecose

commend a flar thing to you

things that here niplit, luve not.....

that ean make vile things irreious

there is some strange thing toward ......

thmin nrt the thing ituelf................

leaving frest thimen, asst haply shows...

allows itself $\mathrm{t}$ any thing $\ldots$..............

thon changet ant setf-enveres thing ....

there things sting itis mind so venomitusly
what thinz was that which proted frun.

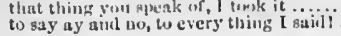

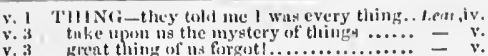

and low, nn exectlent thing in womm... - v.

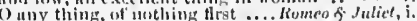
cun your redilaty thing you gee?

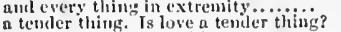

whine they do clrean things true

unwasien tion, tis n foul thim

wly, is not this a lumentable thing.

thou wast never with inc for uny thing

it were an ill thing to be otlered

a little prating thing, 0 there's.

every unsorthy thing, live here in.

tirings have follen out, sir, so .........

things, that fo heur them tolel

things for the eook sir............

bit one thing to rejoice anil solace in

uncl all things change tlien....

put this in any lituluid thing you will

much I fear some ill unlucky thing

to huve more t:alls of these sail thin

what, has this thing appeared ngnin

a fruity thing upon a fearful summon

the most valgar thing to sense

things rank und gross in nature ............

firm of the thing, each word made true

there are more things in heaven and eai

t:ake from me auy thing that $I$ will.

Ruy thing-but to the purpose

it alpears no other thing to me......

fly at any thind we see ..............

mot more ngly to the thing that helps it..

ns malle the things more riely.......

firr any thing so overdone is from.........

ten thousand lesser tlangs are mortised

the king is $a$ thing $-a$ thing, my lord?

nnd every thing is bent for Engtand

live to say, this thing's to do .........

spenks things in doubt, tlint carr

iv. 1 of itself after the thing it loves ...

Wisdom, all things else, you maioly ....
or is it some abire? and no such thing?

ean save the thing from denth

$\mathrm{pr}^{\prime} y$ thee, Horatio, tell me one thing....

if your mind dislike any thing ....

things standing this unknow

v. 4 sir, I will answer any thing

Rotcrigo, of some such thing?

the sooty bosom of sueh a thing as thio...

of country, credit, every thing, to fall

thiese things to henr, would Destemena.

but I do heguile the thing I am

Which thing to do-if this poor trash

ir place, that dres those things

ii. 3 though other things grow fair ...........

two things are to be done, my wife must

never nny thing but 5our true ecrvant

tor sueh things, in a ialse disloyal knave

Whereinto foul things sometimes intrude
we sce, in all things nature tends.........

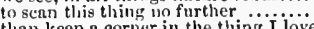

a thing for you. $A$ thing lor me? (rep.)

call any thing be made of this?

men's nutures wrangle with inferiorthings-
hath he said any thing? Ile hnth, my lord

and wcep not; all things shull be we

nn old thing 'twas, but it expressed...
the world is a luge thing: "tis a grcat

marry. I would not do suith a thing

Why noy thing: an homonirable nurderer $=$ -

my henrt bleerls to think .........

I should fin tin think but nolily

I think, he will carry this island home

I lo think, a king; I would, not sol.

when I shall think, or Pllobits' steeds

may I he bold to think these spirits?.

I rnther think you lave not somghit.....

if I lid think. sir, I were well nwake.

num think of each thing well

thillk on thy ['rotens, winen.

of inany gool I thinik him best

I think him so, heenuse \& think him so

of all the rest, I think, best loves ye.

and sent, I think, from Proteus...
I think, your lordship is not (rep.

I ean harlly think you iny nuster.

rou think ton much of so much juins?

Think, Crab my dog

antiug think, no other treasure.

nuy, sure I think, she holds

nuy, slire I think, she hillts
if you thuk so, then
IIINR my patienee mare. Thofien, uf Venom, iil.

ti) think that she is by

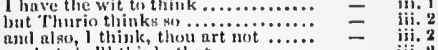

ay, lut she'll think, that ........... -

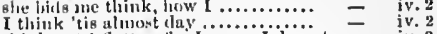

think nt i finter, pir fowear I do not

but think yion my grict.

not no, I think wlie lives

she thinks flunt l'rotens (repor.

when she did think iny master

to think upon thy works
I think, if I had such a tire

and think thee worthy ........

o v.t

a flimk my cousin meunt well... Herry H'i

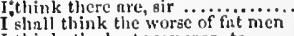

I thisk, the best weny were t

do you think there is truth in them?

I lo not think the knight....

and I think he hath appointed ......

gurely, Itlink you the elinring .....

and what they think in

I think, if your husbunds were dead

I think, I shail drink in pipe-wine..

and bid her think what a man is..... =

I think you have killed.............

by yeta mil no, I think the oman..... =

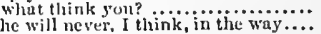

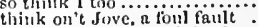

the fintest, I think, i' the forest...

and think not on their sing....

I think, we have watehed you
do vom think, though we would...

I think, to repay that money

$\mathrm{v} .5$
$\mathrm{v} . \mathrm{v} . \mathrm{v}$

What think yon, sailors?...............

why I think so; I am not such .......

and I think, I huve the hack triek

I did think, hy the extel

those wits, that think they hinve the

whe would thimk his is fool, Mntrilyio?

but I think, it rather consists of......

dost thou think, beenuse thou...........

so crammed, as he thinks, with...

I think it well, my lord.

what slould I think on't .............

for him, I think not on hin

that tyrantous heart can think?

that you do thiok, youn are not .....

then think you right: I am not...

I think, oxen and wainroles ennnot

Ind rour store, I think, is not tor...

den nut think I am mad

mut I would not have yon to think

I think you set nuthing by ..........

think of me as you plense .......... - v. 1 (letter)

what figure of us think you he ...Meas.for. Yeas. $i$.

nor do $I$ think the man of $\ldots \ldots \ldots . . .$.

for, I think, thou never wast where.

I think, or in nuy religion

I think, I have done msseif w........

and never think of it ....
which. I think, is a very iil house...

I think no less .......................

what's o'clock, think yon? ..........

I do think that you might parion ...

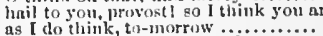

pray anil think, I think ani pray.....

think you I ean $\ddot{n}$ resolintion feteli

dost thou think, Clumbo..........

if you think well to enrry this .....

co thou but think what tis to cram

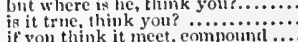

your true man thinks it big cnoigh.

your thief thinks it little enomgh

you will think yom have mate no.

nul I think, forty more

(l) we jest now, thlnk you?

I shoulla not think it stron?

who thinks, lie knows, that he (rrp)

marry, sir, i think, if you hamelled..

which I did thiuk witli slower foot.. 
TIIINK, a due sincerity .... Measure for Measure, I think, this is your daughter

come, eome; do you think I do not know but did you think, the prince would

i' faith, lady, I think your blazon....

I think, I told your lordship, a year his snit to her he thinks not wortlyy

I did never think that lady wonld have

Ihould think this a gull but thit.

were it good, think you? liero think -

were it good, think your? Hero thmks

I did not think I slould live till I were -

for what his lieart thinks, his toyou

5ou may think, I love you not

think you of a worse title, and 1 will

may this be so? I will not think it

first, who think you the most desartiess

nay, by'r lady, that I think (rep.)

I think, you would have me say

none, I think, an' it be the right .....

you may think. perehnee, that I think =

I eannot think, if I would think iny

dend, I think; help unele; Ilero! .....

think you in your soul, the eount

I think he be angry indeed $\ldots \ldots \ldots$, $\ldots$,

in spite of your heart, I think; alas!

how long is that, think you?

I must entreat your pains, I think

I think, he thinks upon the savage bull -

dost thou think, I care for a satire .

1 will think nothing to any purpot
I dicl think to have beaten thee

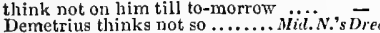

therefore I think I am not in the night -

we'll rest us, Hermia, if you think if

if you think I come hither as a lion
why should you think that I should

you speak not as yon think, it cannot be -

you, perhaps, may think, becanse.

think no more of this night's aecidents

do not you think, the duke was here

that you should think, we come not

did these lovers think no scorn to ....

thoi art my love, I think. Think

think but this (and all is mended)

I think seorn to sigh ................

doth the wise think them other?

I know not, but I think, it was not he

no thought ean think, nor tongue
I think no less; dost thou not wish

will they not, think you, hang

but this, I thick, when they are...... =

to think me worthy of Pompion....

but $\mathbf{I}$ should think of shallows.. $u$ Ierch of $\bar{F}$

the thought to think on this

sad to think apon his merchandise..

what think you of the Seottish ior

as I think, so was he ealled ......

I think, I may take his bond

think, you are my son (rep.)

to think sn base a thpught

or shall I think, in silver she's

I think they eall tlie plaee

that thinks he hatla done weil ii...........

makes me think, that this Antovio

our husbands before they think of us

for truly, I think, yon are danmed..

Ithink the best graee of wit

the world thinks, and $I$ think so too

I pray you, think you question with

and, I think, the nightingale, if she...

whieh I think is within me $\ldots . . .$.

to think my poverty is treaeherouls...

for I think, you have no money in yo

I think of as many matters as he....

I think he be transformed into

of what we think against the
dost thou think though I am

dost thou think though I am
when I think, I must speak

I think it was made of Atalanta

he thinks himself too soon there ....
do you think so? yes: I think he is.

I to think him as eoneave as

hut I think he is not in .............

that I shall think it a most plunteou

think not I love him, though I ask.

searce think you have swam ........

or I should think my honesty ranker

I will think yon the most pathetienl
I verily did think that her old gloves
THINK-would think this was w
the fool doth think he is wise

the fool doth think he is wise.......

I shall think my brother happy...... - v.

Ithink not on my father ............

notorious liar, think him a great way

I will think of thee at court

I especially think under \Iar's........

when he was retrograde, I think (rep.)

and, I think, I shall never have the..
than, I think; she wished me.......

made me to think of this; else Paris

but, think you, Helen, if you should

I think, sir, you can eat none.........

lately whipped, sir, I think....

fore God, I think so

I did think thee, for two ordinaries...

I think, thou wast ereated for men

with what apology you think may

I think so. Why, do you not know him?

dare not say what $I$ think of it......

think upon patienee; pray you ....

you eame, I think, from Franee?...

do you think, I am so far deeeived...

if you think your mystery in........

he most think us some band of

and this disgnise, I think

and what think ron he linth........

or whether he thinks, it were not....

I think, I have his let ter

whieh he thinks is a patent for his...

than for to think that I would

I think she has: certain it is

I think thee now some eornmon .......

I think lie cannot clioose........

as he shall think, by omr trine...

iii. 2 al though, thould think seolding would do it the think you, a little din can

so I pray you all to think yourselves
I think, she'll sooner prove a soldier

that thinks with oaths to face

I know, you think to dine with......

as thou shalt think on prating .....

conceit is deeper than you think fol

let's see, I think, 'tis now some

I think, I shall command your

pray, what clo you think is his name?

gidu, thinks the world turns $\ldots . . .$.

I think, this eoming summer

and little thinks she has been sluiced

and 'tis powerful, think it, from east

that man, that does not think it ....

dost think, I am so muddy.

by

lie thinks, nay, with all

leave me; and think apon my biddin

Whieh not to have done, 1 thinl

or I o'erween to think so....

I think it not uneasy to get

sworn, I think, to show inyself a glass

I think, they are given to men of....

I think so too; for never gazed

I think, there is not half a kiss

you'd think, sister. AF, good (rep.).

is it true, think you? $\ldots \ldots \ldots \ldots \ldots \ldots \ldots$

I not purpose it. I think, Camillo..

I meeds must think it honesty

please to think I love the king

I think, afflietion may subdue the eheek

think you so, sir? Not he alone......

if he think it fit to shore them again

and so still think if the wrong I I Oi. -

and think me still no gentleman born
fancy may think anon it moves (rep.)

fancy may think anon it moves (rep.)
make me to think so twenty years

but then you'll think, (which I protest

I think, the meat wants that.. Comedy of

and think I hear all this

I think, thou art, in mind ........

teaeh me, dear ereature, how to think

and, I think, if my breast had not ...

time, I think, to trudge.

ah! but I think him better ............

one that thinks a man al ways.

I think, he brings the money ........

youder, as I think, he walks
, v.:

by this, I think, I lad; I never. Comedy of Err. v.

from whenee, I think, you are come $=$

I think it be, sir; I deny it not ......

think upon what hath chameed ...... Mracleth

I am at raid to think what I ...........

and, I think, being too strong for him

have died with them they think on? ..
think of this, good peers, but as........

when now I think you ean behold

and I do think, that had he Dimean's

I think, our country sinks beneath....

and but dare not speak ............

his will to get me father

will I not thiuk of home ..............

I believe, you think them false......

by my troth, I think, thon lovest....

or' madly think, a babe of elonts ....

nay. you may think, my love........

nay. $y^{\prime}$ ou may think, my love.......

think you, 1 bear the shears of ......

sir Riehard, what think you? Have you -

by heaven, I think, my sword's.

I did not think the king so stored....

I did not think the king so stored....

I did not think to be so sad............

Iubert, I think. Thou bast a perfeet

and other lords, if yon think meet .. - v. 7

think not, the king did bonish ...... -

honour and ailegianee cannot think (rep.) -

and thonglh you think, that all......

'twill make me think, the world

amen, if heaven do think him me

to think our former state a happ

though shalt think, though he divide

by and by, think that $I$ am unkinged

What think you, eoz, of this young ... HenryIV, v.

when men think least I will .........

always think him in our debt (rep.)

I think, this be the most villanous ...

I think, you are more beliolden to ...

I shall think the better of myself....

and as I think his portend?.......

I think it is good-more some fifty

$I$ think, there is no man speaks......

do not think so, you shall not $\ldots \ldots$.....

never see thy fane, but I think on
if I did not think thou hadst been

do you tlink, sir Joln? ? do you think

dost thoul think, I't fear thee as I ..

and think how sueh an appreliension =

our joints are whole. As heart ean think -

ii. 3 that you would think, that I had a.. -

iii. 2 I think, to steal erenm, indeed ....... -

eonsin, I think, thon art entamoured -

I did not think thee lord of sueh and, think not, Perey, to share with me

I eannot think, my lord, your son ..2 Henry I

I think, we are a body strong enougji

what would'st thou think of me ....

fellow to think as every man thinks

do you think I would deny her? (rep.)

I lid not think, thou wast within

for the which, I think, thou wilt howl =

where, I think, they will talk of mad
two of sir Jolnn Falstaff's men, as I think-

master Sure-card, as I think ........ -

I think, it is my lord of Westmoreland -

mighit so much as think yon enemies

do you think me a swailow, an arrow

I think he's gone to hunt, my lord..

almost, my liege, to think you were

and hear, I think, the very latest....

indeed, I think, the young king love
sits not so easy on me as ynu think

you are, I think, assured I love you not

by'r lady, I think a' be; but goodman
puissanee: think, when we talk ... Heary $\bar{V}$. 1 (eho.

puissanee: think, the lour, I wink, is talk

give me jour thoughts; think you not -

there's not, I think, a subjeet, thint sito -

but though we think so, it is no matter

think we laing Harry strong

$\begin{array}{ll}\text { iv. } 2 & \text { by Cheshu, I think (rep.)........... } \\ \text { iv. } 3 & \text { eaptain Mraemorrig, I think, look yon } \\ \text { iv. } 4 & \text { I shall think you do not use me .... iii. }\end{array}$

I think, in my very eon seienee......
for my part, I think the dluke.......

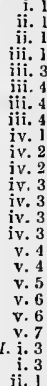

iii. 2

iii. 4

v. 1

i. 2

i. 3

ii.

ii. 


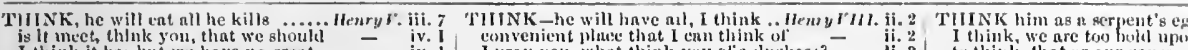
I think it les hut we have no great what thinks lie of (nur estute?.........

to you, I think, the king is bat...... I think, he would not wish limsciïny not to-lay, think nut upon the faule ghall think themselves aemrsed ....

into the humls of (ns he thinks) …. whint think you, tenptnin Fluellen?

do you think I'll he forsworn?

thou wouldst think. I link sold .......

a thind mun thinks, withont.

I think, ly some okd gimmuls ......

then will think "lpon a

to think that you have aurbit bui....

umbl linink me himoured to teast

Withal, I think he held the right.
think not. nitho' in writing I

I think, the euke of Burguady....

I think her old fumiliar is asleep.

I think, this upsturt is old Tailioi

I think, I have you fist; tuchain.

glreaks Snffulk as lie tlioke?

iv. I I Iray you, what think you of a iluchess? -

iv. it fints me to think whit follows.... -

nul think net at ull uf friesel to truth

ji. 3 to think, that or our cause

ii. 3 I think, he will stund very sirong......

their eoming, ow

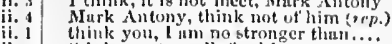

iv, 1 yrn $y$, think us those owe protes

think yon to walk firth

Ither, hy this he is ................

to think upon the purt of businus

when he tlinks; fosd easy num

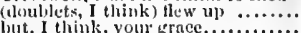

Int, I think, your grace.

for I mist think of that

I think, your highness snw this.

do $y$ rou think, my loris, the king

ii. 3 and think with wagging of your

onte think his place heeomes 7 Ti....

of lirutus yeurns to think yioni ....

he'll think your nother elicsur bears

think of murehing to Philipui (rep.)

left realing? llere it is, I think...

I think, it is the weaknegs of mine...

when think youl that the sword

I think, she knows not well

as I think, it was by the eardina

heldame, I think, we watehed you

how think you by that? were it ....

and would ye not think thent euming

for, I think, I lave taken ny last ..

hit, soft! I think s!le comes ........ -

tor whilst I lhink I am thy mirried

I think, I should have wild your

what are they, that think it?

suy sa yout think, and speak it frrm

nut a thonglit, but thinks on lignity
and thinks lie, that the ehirping of

and think it but a minute sjent

that thou nightst think upon the
what, think yon much to poy.

What, think yon miteh to my $\ldots . . . .$.
the nobility think scorn to go in

I think, he latll a very fair w

iii. I let none think flatery $\ldots \ldots . . . \ldots \ldots . . . .$.

this lay, no man think he has bunness

I think, Ifelen loves him bet ter..
I think, his sniling beeomes him

to think how she tiokled his chin

I tola you a thing yesterdny; think on't
I think he went not forth to (lay ....

and think [Col-call] them shounce

and loth think it rich to hear........ -

and wake him to the mnswer. think you? -

und, I think, this word sallet $\ldots . .$.

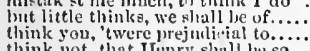

think not, that IItenry shall he so

da but think, how sweet at thing

I think, it eites us, brother to the....

their power, I think, is thirty thimsand =

1 think his unilerstancling is heref

I think, he means to beg a elild of her -

you'd think it strange ..............

tell him planly what I think

sperk frcely what you think ...........

say mot muel, but think the m
helike. he thinks me IJenry

else might I think, that Clarene.....

and tintik, perehance, they'll scll

dost thou think, I have no sence

ii. thou art proclaimed a fool, I think

ii. 3 lest, merehance, he think we dare not

ii. 4 we think him over-proud

What he thinks he is (rrp.) $\ldots \ldots \ldots$....

iii. 1 what think you of this man

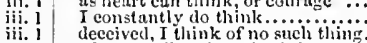

I eonstantly do think.................

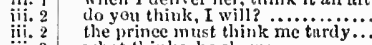

iii. 2 what thinks, he shows $\ldots \ldots \ldots \ldots . . . . .2$.

and modesty, I think, the tinil of urery =

think, we had mothi...................

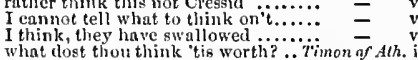

should think ourselves for ever perfect

you think, none but your sheets.

I the think, there is mette in denth.

Why should I think, you can be mine
vouchsufed tis think he had jartners

I must not think, there are evils
lack blood to think on't, nnd flusli

jou think of lim too mivel .........

aud think, what Vinus did with MIn
think on me, thut an with Plicebus'

think on me, that am with Plicebus'
MLenas, I die not think, this antorens

I think, nut moved by Antony $\ldots . .$. .

II think them every one an Antisny

I did net think, fir, to have mo

I think, the poliey of that purpose
i think so too: but y'ou slall fucl.

1 think, thou'rt mail: the matter?

althongl thou think me joor, I am.

I think so, Charmian: (lull of tongrie

by llerculce, I think, I am i the right

Cessur must think, when on or wo...

he thinks, being twenty tinies.

think you, there was, or might

you must think this, look you ......

though, I thusk, the king be turuelsed. Cymboline,

I would tlink on him, at ecrtin liours

safely, I think: 'twas a confention

will contancy, you think, stands so Eafe

she doth think, she has strange

lost thou think, in time slie...

think what a chance thon ( $\tau_{e p .}$.)

can my gides hold to think, that mian.

if he fhall think it fit. a saney stranger
not easily, I think. You are a fuol

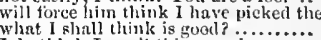

I do think I san 't this morning.....
and, I think. he'1l grant the tribute.

wateh there, and tn think on him?

I grieve narself, to think, when ....

and I think so back wardly of me

iii. 2 ay, and I think, one business does

what do you think the hour? .........

I camnot think, but your age has $\ldots$ in

I should think so

and I not renson, think ye.....

by henvel, I think, there is no....... Richart 11

fonler than heart ean think theo

which, I think, proceetls from way whed

and think no harm, but thus his ....

[Col. Knt.] will not think hut ticy aseend -

think you my unele did dissemibie...

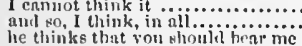

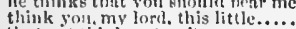

thine yet think not on't

wha think themset ves as safe
think you, but that I know our.

yonr grace, we tlink, should soonest

what! think yon we are 'Turk

I think, the dluke will not be snoke...

yon might haply think, tongue-tied

think now what I would epreak

mentime, but think how I may do...

menntime, bint think how I may do.

iny dnughter's mother thinks it
what thiuk yon of it matian?.

think, how thou stultidst ine in my

think on the Tower, and me...........

think ugon Grey ( $r$ ing $)$

and think nur wrongs in ïielinal's.

think on lort llnstiags and alcepair
in the battle think on Buekingham.

I think, there be six lichunond a....
may, if they think it wetl ....... Hern

may if they think it wetl .......Henry rist. (1)

think, you see them great, and followed

grievingly I think, the pence

to think an Englials eourtier .....
I think, would better pleave tlicm.

I do not think, lie fenrs tenth

as all think, for this business
I think, you hrove hit the mat

leı's thiuk in private more ...........

think it a bustard, wiom the oracle..

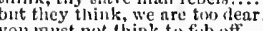

you mist not think

prythee, think there's livers out

fetter true? Sir, as I think

OJould think thee an honcst man

now, I think on thee, my hunger,

fhir youth, think us no elurrls

thou art a way, I think, to liberty

I thin he wismlal clinge plaees with

so, think of your estate

nor dirl vou think it fiolly I have

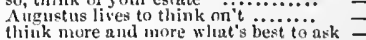

I do not think-where is the enemy?

if any think, brave death ont weiglis

ii. 2 woulist do sn, I think, should we...

ii. 2 What I think, I utter; and spend my

iii. I make ns think, rather our state's

iij. 2 think you so? which way, do you juilge

desire them to think num you. Think

you must think, if we give you .......

do you think, that his econtempt

iii. 5 I think, 'twill sers', if he en! .....

your name, 1 think, is Adrian

nm the man, I think, that siali......

clost mot think me for the mnin .....

iv i more in him than I could think

I think, he is: lint a greater............

so he thinks, and is no less alyurent

think you he"ll enrry liome? ......

I think, he'll hear me: yet to bite his

think to front his revenges with......

enuse, to you think, I have to swoen?

I ean searee think there's any........

thus ehanged, makcs you think so

think witic thyself, huw more . ......

tost thou think l'll gruee thee with.

and other men, think of this tife

he thinks ton muel: sueh men nre ..

that he could not but think her bond

think, that you are unon a rock.....

think they are my sons, are none....

think yout mut how diangerous........

that thinks of me so nbjectly .........

have I pot reason, think you, in inok

that woc is me to think ujon

I dis think we nre not brought so low

1 think, she merns, that there ......

he thinks, with Juve in heaven.....

that hiserdy minul. I think

am! yet, I think, fev eonse within ..

think denth no humurd $\ldots . \ldots \ldots \ldots \ldots$.... Perich

will think me speaking tho' I swear... -

happily may think ure ...............

enthing to think an, but ensioing blenth

wnint teaches me to think on ...........

my laugliter, sir, thinks very well ul you

or think. muy be as grent in blourl ....

be it ns you think meet...............

as I think, I liave brought II)...

I think, I Henll have something......... $=$ iv.

I think, you'll turn a ehilal aggin.......
that thisk the petty w rens of Thareis

to think st whint notile otrain........

think his pilot thught ....... - iv. A (Gower)

ancl think you now are nll ...... - iv. + (ciouer) 


\section{THI}

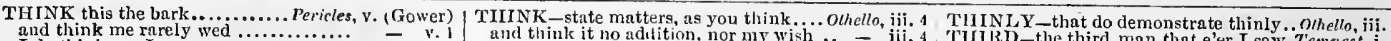
- v. 1 and think it no adilition, nor my wish

I think thou sajilst thou hadst

it may be, you think me an impostor think, every benrded fellow .............

think our father will hene

I would fuin think it were not

think you so? If your honour jidge

the

dost thou think, if I would stand.

Regan, I think you are (rep.) ............

alas, poor roguel I think, i' faith

\begin{tabular}{c|c} 
- iv. & where every third thought shall \\
- iv. & whip him out, says the third..7
\end{tabular}

for, as I think, they do eommand ham

if you think otleer, remove your thought

[Knt.] nay, I think, it is seurvy .......

I think thon woultist uot (rep.)

I do not think. there is nny such woman

I do think, it is their hushands' faults
I think it is; and dotl affeetion (rep.)

nust be content to think you old........
you think, I'll weep; no, I'll not weep

Iet's think that, and fix most firm thy

let's think ' $t$ unsafe to come in to $\ldots . . . .$.

think on thy sins. They are loves
I think upon't; - I think, - I smell't

he, that will think to live till he

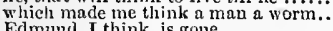

think that the clearest gods

I think this lady to be my child cordel

so sjeaking as I think, I die .....

ay, so I think. He knows not what ......

and 'tis not hard, I think, for men ... Romeo

TIINKING on it, makes me

thinking me remiss in mine......... Merry wives, jii.

ere we may tlink her ripe to be a bride

to think it should leave crying

well, think of marriage now .........

marry, that, I think, be young Petruchio -
would sing, and think it were not night -

thou nay st think my haviour ligh

doth she not think me an old murderer

I think, she will be ruled in all respects

I think it best you married with ....

as you think fic to furnish me

gives a dead man leave to think think upon these gone; let them....

think upon these gone; let them $\ldots . .$.

of Jnliet, to think it was so?....

not thinking 1 had been myseif...... Mlueh d

and a third drowns him ............ Trelfh Night,

and let the fool make a third drink.

the thisd pays for all.

a third is fled, that had a hand ........Much ddo, v. then, for the third part of a minute. Mid. N.'s Dr. ii. the third he eqpered,

he hath a third at Mexico...Mercnani of Feniee, $\vec{i}$.

the third possessor; ay, he was the third -

wept for the death of a third husband

served the seeond, and so the third... As

one that lies three thirds, and uses ...Al's Well, y.

third, or fourth, or fifth.. Taming of Shrete, l (indue.) and the third, nine, and some five.

my third comfort, starred most

a third is like the former................ Machell, iv. perforce a third must take ............ anr every third word a lie

Edward the third (rep.ii. 4).

and the third sir Thomas Grey....... Henry...

I would think my heart out of thinking -
cost (thinking that I mean him)... As you Like il, ii.
I ean live no

mariam, I was thinking with wh

third hour of drowsy mornin

i. (eliorns)

nation's orew in dismal thinkings

a third man thinks, withont ......... Henry VI. i.

hird som to the third Edward (rep.ii. s) -

Ed ward the third, my lords (rep. $). .$. Henry $v$.

thinking on fantastic summer's heat

York ciains it from the third (rep.)

two of you; the devil make a third!

and thon shalt be the third, if this ... slenry r iii.

to look on you, thinking you dead..2 Henrylr. iv.

I think, I hear them: stand, hol .....

whose musie, to my thinking, please

dishonoured, and the third usurped. Kicharilll.

he eomes day, comes a frost ......H Hry $V I H I$. jii.

he eomes the third time home...... Coriolanus, ii.

he offered it the third time (rep.i...... Julius Cessar,

the third o' the world (rep.ii. 7).. Antony \& Cleo. ji.

so the poor third is up, till deati.....

the third is, that thon wilt be ..... Cymbeline, jii. 5

connsel, when the third's a way... Titus.4ndron. iv.

and what's the third? The third .......Perieles, ij.

to draw a third more opmient ............... - i.

two daughters' dowers digest this third.. - - i.

let hin appear at the third sonnd $-\ddot{v}_{3}$ 3 (heraidd) one, two, and the tliird in your . Romeo s. Juliet, ii. 4
the third night, kept the watel. ......... Isamlel, i. in answer of the third exchange $\ldots \ldots \ldots .$. - v.

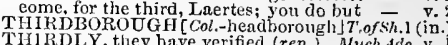
TII RST-and more thir:ts after....... All's Well, vii. satiety seeks to quench his thirst... Taming of sh. $i$. and him, we thirst, and all to ail dost thou thirst, base Trojan........... Henry $V$.. . 1

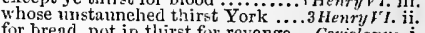
for bread, not in thirst fur revenge .. Corinlarus, i. when they are thirsty, fools would...Love's L.L. v. 2 none so dry or thirety will deign. Taming of Sh. v. no more the thirsty my heart is thirsty for that noble. Julius Cesar, iv. to be thir ty after tottering honour ..Pericles, iii. 2 maids of thirteen do of puppy dogs ... King Jnhn, ii fom tourseore to thirteen $\ldots \ldots \ldots$... I Henry Vi. i. filom fourseore to thirteen ...Timon of Alhens, ii. 2 TIIRTIETH of May............... Hamlet, iii. 2 THIRTY leagues, off and on ........... Tempest, iii. 2 between fourteen and five and thirty. Much A do, iii. 3

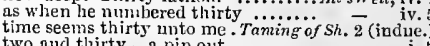
two and thirty, - a pip out o 3 ......... king $\bar{J}_{\text {ohn }}$, ii. low thirty, at least he fouglit ........ Hemryl Hi. i. thou, and I, have thirty miles to ride yet- ii. to thirty thousand. Forty let it be ..2 or near, the rate of thirty thousand.. = thirty thousand strong (rep. v. 3) ...3 Henry VI. a band of thirty thousand men ....... - ii.

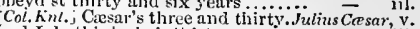
and I do think she's thirty. Aniony \&-Cleopalra, iii. five or six and thirty of his knights...... Lear, iii. by'r hady, thirty years ........... Romeos \& fuliet, i. full thrty times hath Phœbus' eart ...Hamlet, iii. sexton here, man and hoy, thirty years.. - iii. of thirt? sail, and now do they re-stem.. Othello, i. TIII RTY-ONE sweltered venom ........... TIIISBE must be answered .... Mid. N.'s Dream, of young Py ramus, and lis love Thisbe but silenee: here comes Thisbe

Well rm, Thisbe. Well shone .......

before Thisbe eomes hack and finds her
which Pyramus, which Thisbe, is the and hanged himself in Thisbe's garter 
TyIsBle fenfully dertrip........Mereh of lenire

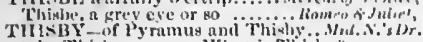
tnke Thistly on you. Wint in Thisby? -

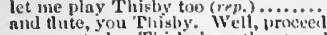
you muse play Thistys's mother ( $r e p$. eomedy of l'yrumus and 'Thisby (rep.) Thishy, stanil tirth. Thisby

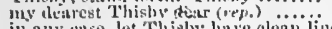

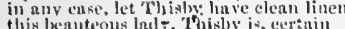
the trusty lhishy. euning tirst (rop) Thisliy tarrying in mulberry slanle. I fiur my "Thisby's orimuise is forgot!

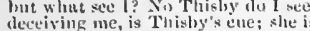
hear my Thisly's face. Thisbly:

to taste of truest 'llisby'g siglit...

thins Thishy ends; ndien, atien, atlien

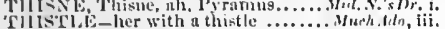

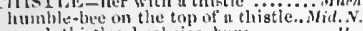

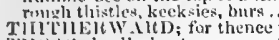
ryo.ss, dendly hurt

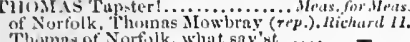

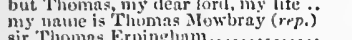
sir Thomps Erpinglimus... page to Thomus Mowbray............. Mil

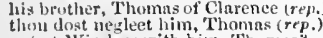
not at Winuls with him, Thome?

sir Thoma Grey knight of .... Ilenry I' lend me thy cloak, sir 'Thomas sir Thomus Garerave (rep) arainst my macter, Thomng Hiorner. the sixth, wat Thomas of Womistoek sir Thumes Lovel, and lord marciuis

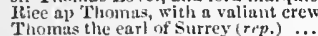

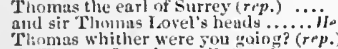
Thinmas whither were sou woing
sir Theumas I.ovel (rep. ii. I and

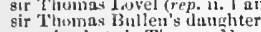
next is, that sir Thomas Mlore is chio Thumas Crumbell: a man in mueh .

TII1) MI Iltohy - prieking gins and thoo........ Tempest, iv. with a busla of thoris anil a lanteris lor briers and thoriss at their appare

hingek the from thy thiorn.. $L$.
this thorn doth to our rinse of

you barcly leave our thurn.

shall have leaves as well as thior

is goats sthorns, nettles, tails of
but, (1) the thorns we stiuul wuon

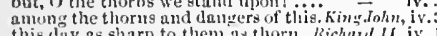
and plant this thorn, this enuker

a red rose from oft' this thorn with ...illtenry $r$.

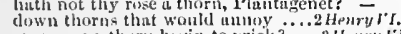

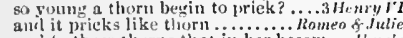
and to these tluorns that iit her bosom .. Humict

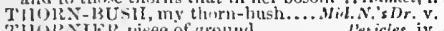
milolinl:k piee of gronent the thiorny point of hare distress...ds yout Like ih, ii.

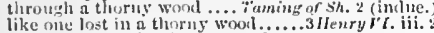
yonder stands the therny wood ......... the steen and thorny way to heaven .....llamel, i.

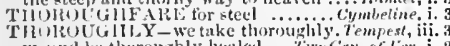

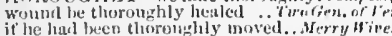
my lord, we'll do it thuronglily ...Meds. for. Meats.

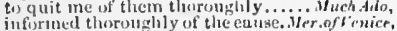
that would thorougfly woun lier .. Taming of sh pew

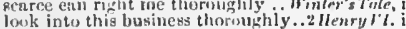
we shall beat you thoroughly

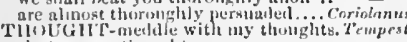

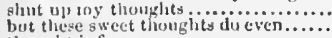

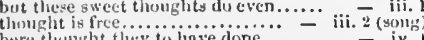

here thusurht thicy to have done...

eome with a thomght
thy thouglats l cleave to

I do bo to the

ner buath ? hat one

nhere every thirel thenghi bhisii ie....

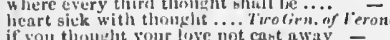

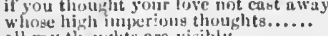

all my timughtits are visibly

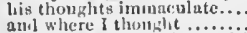

and where e thonklic ............

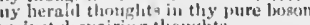

agithint de her fromg thomghts

thut lis elianging thouglits forget....

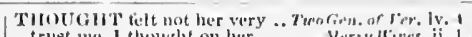

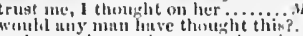

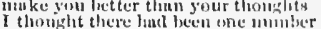

a hetter selosiar, than I thoughe he was

iii. 1 that likewise have we thought upen

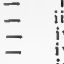

iii:

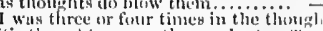

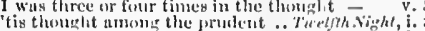

now sir, thonght is free: I prony you

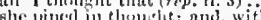

firr his thanglits. would they were bilinks -

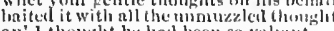

to be thiongint a good student

my themglits are ripe in misthief

these things liurther thought on

froin whom we thought it me.

I thought, by your rendiness in......

incertith thonghts intogine luwwling

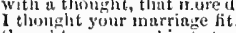

thoughits are no sulpjeets (rep.)

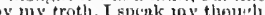

it is pisst the infinite of thonghtit.......
I would have thonght her syirit litul been-

yoll are thunglit here tu be the most

and thought they, Mlargaret was J lero?

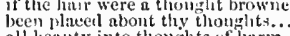

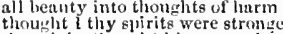

though he thought his aceusation trin

as sure as I have a thought, or a soul

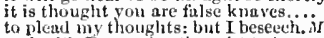

and with Denetrins thought te have

ns thourglite, ant dreums, and sights.

which is thought fit, through all Atlien

thought you lord of more tric

from the reprobate fhought of it... $L$
most maculate thoughts, master ...

your own good thonghts exeuse me...

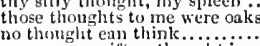

I thought to these thinge eyes annery. hiv

bullet s, wind, thought, swifter .......
when I thought whint harm. Mrrchint of

shall I have the thought to think

exeept to stenl your thonglits.

heaven, and thy thoughts,
to think so base a thought

O sinfil thought never so rici........

and employ your ehiefest thoughts.

a maitlen liath no tongue but thought

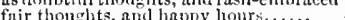

and then, 'tis thought thou'lt showe

Would be thought no better a musieian
not with your hard thoughts

Sol motel as in a thounght monborn ....

Ithought, that all things had beeli...
my thesughty I'll eliaracter ...........

there was no thought of pleasing you

ant I thouglat no less.................

that was begot of thonght, eonceived
I thouthtit, thy heart harl been wounder

one of them thought bitt of an if ....

lies richer in your thoughts, than on

from the conversation of my thoinglits

I may convey uny thoughts in this.

w'as in my nobler thouglits most base

80 soon th 1 themglte lie wonld

whose though th noure trolly libosur to

trusting of the eozencd though lits defiles the heavens lave thonght weil on thice

a mure mble thouglat upon mine

swur honour, than in ny thouratio it lies!

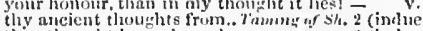

they thusurtht it gorol you hear a -2 (indue.)

bend thenghts and wits to achieve her

or yourr thouglits can gues.

tis themght, your deer does huld yoin

that thought there wns no more helhinul -

eares in me thourhts thant woulls thick or thought, for cogitation resiles not

nor eycen norears, ner themplith ....

with thonghts so qunlifted an

fie, no thunght of him; the very thoight = to blowely thonglits, and to revenge. .. througlat this was an, and uog shumber

lay asigle the thoughts of silia

1 alewe out the thousht of it

with these forecd thoughts, I priytice

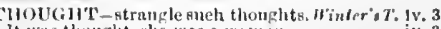
It was thought, yle was a womant....
by the pattern of mine own theoughits 1 that thught to flll hig grave in qulet

have you thoughe on a place

faster than thouglit, or time

if $\{$ thonkht it were not a pieee

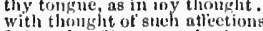

I thought of her, even in these laciks

1 thought slie harl some great matter
if I humt thought the sight of my poos

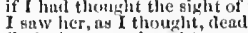

Corinth, as we thought (rep.)... Conedily of Erro

- iii. I

belike you thought our love ........

past thought of human reason ...... - v. I

this have 1 thought good to deliver tice

that tenul on mortal themglits ..............
restrain in me the eurserl thoughts

a fiulish thoughlat, to say a sorry sighit...

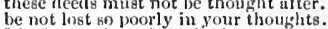

I hail thonth tht ts have let in some.

al ways thought, thut I require

using those thoughtst which shouliti

speeches have but hit your thoughts

Who cannut wast the thoughts.

to erown ny thoughts with acts (rep.).

was once theughit honest ...........

recho why thoughts to thy good.......

thouglits speculative their unsure..............

familiar to my slumglit'rous thouglits

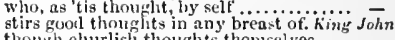

thongh ehurlish thoughts themselves

into thy bosom pour my thouglits.....
it mukes the eourse of thouglits to feteh

fly, like thou'ht, from thetm to me ...

eould thought, without this object.

eonsent, or siti of thougbt, be guilty..

the remnant of my thouglits in peaee

thou hast a perfeit thought .......... $=$

as of a thonthe of ill in lim ......... Richard II. i.

with lhim go these thoughty.......... =

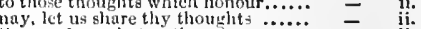

thy words are liat ns thougints.

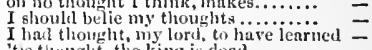

'tis thouglit. the kimg is deal ........ =

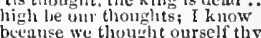

the lieary thoup hit of eare?

slivok off the regal thonghts wherewith $=$

I thourht, you had been willing .....
would have thought the very window

still brecting thoughlyts (rep.).

the good thoughts of the world again

With a thought, severn of the eleven..

majesty's good tluonghts a way from mel =

it will be thought by some that kinow -

I thought your honour had alreadly been =

is thought with ehilu by the stern.2 Henry $\bar{T} r$. (ind.)

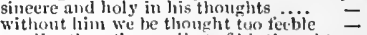

snaller than the smalle tof his thoughts -

that it is as slan ane to be thoughit on... =

I hasl thoniflit. weariness clurst not.

it would be wery man's thoughit (rep.) =

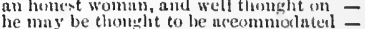

nelmittance to a thought of ficar...j.

mastion, the expenlition of thought?

I never thouglit to hear you speak

-

or swell my thioughts to any strain.

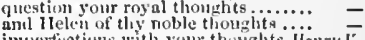

imprerfectiuns with your thunghts. ilenry $\bar{r}$. i. (elio.)

it must he thoughts thint now.

that tukk our thouglite, enneerning

aml all things thought upou, that ingy =

let every mun mow task fhis thought

but it will he thonglt we keep ...... =

pive me yonr thoughts: think you nut -

of no less celerity than thought ..
work, work, sour thoughts

lest a should be thouglit a eowneril .. - - iii.

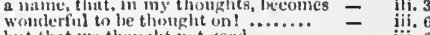

I thum

not toll his thought to the kins? $\ldots$ - iv.

upen your winged thoughts..... - v. (che.) 
THOUGFT-a pace hath thought. Nenry ${ }^{\prime} \cdot v$. (cho.) ( THOUGIIT-I thought to erush him.. Coriolanus,
forge and working louse of thought

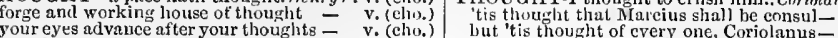
you thought hecruse he could not speak avouch the thoughts of your heart

Tilbot, above humain thought and to make us no better thought of Ihat thought to have strucken him but I thought there was more in lim
to my person, than I thought lie would that thought them sure of you ....... my thoughts are whirled ........... I thought, I should have seen soine.. proclaim your thoughts; let him grudge one thought against your.... sweet prince, he thought no harm for I al ways thought, it was both.... of love unite our thoughts .........2Henvy canker of ambitious tlour

or comjnss of thy thought?..........
I thought, king Ienry liad resembled never said nor thought any such matter I thought as mitch; he'd he ahove and thoughts beat on a crown he had thollght to hinve murdered is it but thoughit so? what are they steel thy learful thoughts, and chang colnes thought on thought (rep.) as being thought to contradiet your. my thoughts do hourly prophec and thought thee happy when I sliool from harbouring foul deceitful thouglits I thought, you would never have given more kingly in my thoughts

fur be the thought of this from ....... and in thy thought o'er-run $m$ and very well-appointed, as I thought as inght yon did revive my drooping thoughts... not 1: my thoughts aim at a further after many moody thoughts, at last I thought, at least, he would have said I thought no

the thought of them would have stirred it follows in lis thought that tis very grievous to be thouglit upor: from my heart the thought thoreoft. well thought upon, I have it here etruck me, that thought to stay hin I thought, thou hadst been resol lis fault was thought, and yet his my thoughts' sovereign; the wear' $\mathrm{W}$ way and shali be thought most fit the history of all her secret thoughts bad dealing must be seen in thouglit the mildness of your sleepy thoug!nt of all his thoughts [Col. Knt.-degree] having no more thought of what thou devotion, holy though with trouhled thoughts, to take a $\mathrm{na}$. perform beyond thought's compass. Ienry the very thought of this fair company full of sad thoughts and troubles.... put the king from these sad thoughts to remove these thoughts from you.
lience I took a thought, this was a holy men I thonght ye, upon my soul she now begs, that little thought, whe I had thought, they had parted (rep.) Cressid comes into my thouglits. Troilus figure of the thought that gave't .... vould they but fat their thoughts whom Aristotle thought unfit to will you subscribe his thought, nnd say = matter of the world enter his thought hot thoughts, and hot thouglits (rep.) thoughts were like unbridled cliidion to angle for your thoughts $\ldots \ldots \ldots . . .$. . keeps place with tlought (rep.).......
call my thought a certain knowide who, in your thoughts, merite fai more momentary swift than thoigh unclasp the tables of their thougits. nor dignifies an impair thouglit with thou art thought to be Achilles' mail goblins swift as frenzy thought assuranee blese your thoughte? Timo upon that lords be thought a fool what's to be thouglit of him? who have tlought on gpecial dignitie hath been thought on in this state ..
disdain as much beyond our thouglits how I lave thought of this, and of these none of you have thought of him

love, good thoughts, and reverence ... to fasten in our thonglits that they have here again, even with a thought in a general lionest thought, and commonworser thoughts heavens mend!...Antony \& a Roman thought hath struck him thy freer thoughts may not fiy forth not a present thought, by duty ruminatedsuch a wife as my thoughts make thee -
ii. I will their good thoughts call fron him iii. 1 abused beyond the nark of thought 二 ii. 2 I lad thought, to have held it poor... if swift thought break it $1+$ ot $\ldots \ldots$. . and finish all foul thonghts......... even with a thought the rack dislimn
whose heart, I thought I had........ but please your thoughts, in feedin

where mine his thoughts did kindle
you do extend these thoughts of horror

nake not your thoughts your prisons

such thoughts, and such: or I could... 'tis thought, one of Leonatus' friends that I thought her as chaste lust and rank thoughts, hers, hers werc, in his time, thought false....... and thought to have hedgred, or bought

'tis thouglit, the old man and his son that thought her like her seeming

i. 2 was not thought by me a precious thing until we thought he died .

speaks to calm my thoughts!.. Tiizs

and fit thy thoughts to mount aloft.

'tis thought you have a goodly gift

are not corrupted as tis thought !...

if I sliould be thought thy son

f will learn thy thought; in thy

a mutiny in the mildest thought

commander of my thonglits, calm thee =

being credilous in this mad thought

her thoughts the king of every virtne
of any other thought but faithfulness....

now, my thoughts revol

punished thot ne'er thought offe sad...

I thought it princely charity

thouglit naught too curious........
I tlouglit as much. One sorrow

pay you with unthankful ness in thought

never did thought of mine levy offence.

my actions are as noble as my thouglits

who thought of such a thing?

sooner her vile tlioughts to stead

think his pilot thought (rep.)

her father turn our thoughts aga

no more but what my thonghts did ...... (Gower)

and thought to set my reat on her

great patron thought on in my prayers.
bat thought, by making this well know

if they not thought the profits

which I best thought it fit to answe

since his coming forth is thought of....... - iv. 3

bear free and patient thouglats

so should my thoughts be severed.

that thought abuses you...

what, in ill thoughts again?...............
sir, I thought it fit to send the old

well thought on; take my sword .........

I thought thy disposition hetter

arelessly-

I will not entertain so bad a thought I thought long to see this morning's face above the ground with cheerful thoughits -

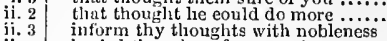
huried thouglits of great value ....Julius $\vec{C}$ Inever thought him worse shall be thought put on for villony.. I thought you would not back again

for many years thought dead wife. We scarce thought us blessed ii. 1 in wh GHT-thought did but forerun. Romeo \& Jul.v.

thy thoughts and wishes bend again

thy thoughts no tongue (rep.)........

as meditation, or the thoughts of love...

there was no such stuff in ny thoughts

sicklied o'er with the pale cust of though
than I have thoughts to put them in ....

thought some of nature's journeymen

that's a fair thought to lie between.....

our thoughts are ours, their ends none.

thoughts liack, hands apt, drugs fit ....

my thoughts remce and course of thoug

a thought, which, quartered, hath but o.

the words up fit to their own thoughts
the

he thonght, though nothing sure.

thoughts. A document in madness (rep.)

thouglit and affliction, passion, hell itsel

so far he topped my thought, that I...

I thought, thy bride-bed to have decked

go tliou decer most generous thoughts...

I had thought to have yerked him here.

if we make thought of this, we must not

ay, so 1 thought..................................

and it is thought abroad, that 'twixt my

to the history of lust and foul thought.....

thought whereot doth, like a poisonour....

I thought you had received some bodily

of my thought; no further harm (rep.).

dost love me, show me thy thought ...

thy worst of thouglits the worst of words

mak'st his ear a stranger to thy thought

or wisclom, to let you know

lie thought, "twas witcheraft

vile success as my thoughts aim not at ..

let me proportion, thoughits un natural .

I saw it not, thought it not

could almost read the thoughts of people

with leaden thoughts been pressed ......

in discourse of ther, remove your though

a murder, which I thought a sacrifice...

I told him what I thought

but thought he had no weapon $\ldots . . . \ldots \ldots$. v.

THOUGIT-EXECU'TING fires ........ Lear, jii. 2

THOUGITFUY, to invest the

All's Well, ii

thought'st thy griefs might equal......... Pericles, $\mathrm{v}$.

.

a thousand! thousend!

a thousand twangling instruments... - iii.

a thousand times it answers. Tuo Gen. of Feron

a thousand good-morror

command a thousand times a..........

shalt liave five thousand welcomes ...

twenty thousand soul-coufirming oaths

a thousand oaths, an ocean

a thousand times good-morrow .......

a thousand more mischances ........

rend thy faith into a tlionsand oaths

two thousand, fair woman ...........

and a thousand other her defences

a thousand fragrant posies (rep.)...

as I will desire among five thousand

though twenty thousand worthier come

the

a thousand thousan sighs to save - ii. 4 .

for a pension of thousauds to be paid

a the two thousand strong, or

thou hast said to me a thousarid time

to three thousand collars a year times

was worth five thousand of you all ..

lie hid more thousand deaths $\ldots . . . . .$.

pray a thousand prayers for thy deatlx
have paid for the nursing a thousand

thousaud 'scapes of wit make thee ... - it.

it will cost him a thousand pound .... Much Ado

tore the letter into a thousand halfpence -

Don John, a thousand ducats (rep.iv. 2) -

fea, and 'twere and times good-night -

a thousand times in secret ..........

a thousand innocent shames in unge

pieree a hundred thousand hearts. Mid ${ }^{*}$ iv. ?

three thousand times within tlis.

a hundred thousand crowns (rep.)

hatl been five thousand years a boy

compared to twenty thousand fairs.

some thonsand verses of a faithful

three thousand ducats $(r e p$.)
cust me $t$ wo thousand dueats $(r e p$.$) ...$ 


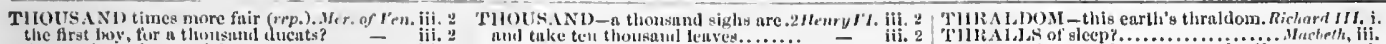
the first loy, fior a tholsisul (lucuts?

for me three themsand duents..........

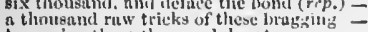

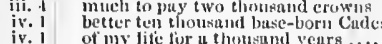
to give ten thousant duents to

in lieu whereol, thee (housund durats did refuse three thousand cluents of the but a pour thousand erowise $(r e p)$. . ds you $\bar{t}$ ih o yes, into a thinsand similey ...... you are a thousund times a properer is almost six thousanil ycars uld .... your moter huve a thomsund lover. to pass a thousnnd mothinge with .... five or six thousund ( $\mathrm{eps}$. .......... we mny jick a thousnimel sninds. thint ring's a thrusand proofs ......... burs a thousand harins.. Taming of a thousand thanks, signior Gremio.. tweity thousand erowns (rep. v, 2). two thousand lueats by the year (iep.)
lic'll woo a thousank, point the day thousunds more that fo befure it.... slinghters a thousaud, whiting up meny a thousand of us luve if I could exmmple of thousand I liave lorked on thousands........... a thonsmul knces ten thousand years forty thoosand lathom above wnter. a thousand marks (rep.i.2, ii. \& \& ii. i) shrive you of a thousand idle pranks ten thousund rlollars to our gencrni use. have offer of goodly thousands ten thousand warlike men (reps)
there is ten thonsand-Geese, villaii? twice tirted thousund hearts.......
full thirty thousand murks of Eiglish possessed with a thousand wrongs train ten thousand Euglish. told of a many thousund warlike. I'll find at thousand shift s to get....... feast upon whole thousands of the Freneh received cight thousand notsles give tloce firr rew ard a thousand mi.... I'l break a thousund outlis, to reis: she is haril by witla twenty thousani for a thusasud causes, I wonlid jrolon thirty thousand strong $(r+p, v, 3) \ldots$ with a band of thirty thousand men men have broke their fnst were worth a thousand erowns, to make
will erst ten thousand lives to duy.. a thousun lives must wither........ my leuve, with many thotisand thank with live thousund men, shall eross numy a chousund, which now mistrust a thousand feartul wrecks; a thousand six or seven thousand is their utmost
conseience hath a thousand several. the substance of ten thousund colclier

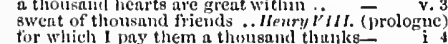

i. 2 for which I pay them a thesusand thunksthat promises more thousands .......
whose bright faces cast thouzani lienms one christening will beget a thousand a thoosand thousand blessings, which more in T'roilus thousand folil i

nongst many thousand dismes 3 io. lend me tent thousand ey ce. ........

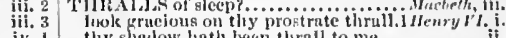

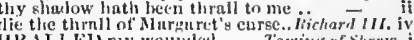
scuec to certucy was ne'er so thrulled

in TilltisiI Truilun

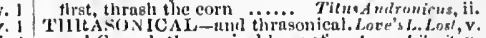
nud Creanc's thrasonical lorag ot .. As you Like it, $v$.

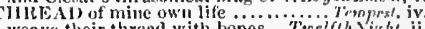
weave their thread with bonges in a silken thread.....Much.th, cut thread and thrum............Mid.N.'sl ream, v. he iraweth out the thireal of .............. Tre's L. L.ost, liest, thou thrend, thon thimble. Thenims of niarry, kir, with needle and thread... - iv. 3 ally silk, any threnal ...... Ininter's Tule iv 3 iv. smallest threal that ever spider .... King John, iv. a carnel to threal the postern. Bardolph's vital threat be eut.......
his thread of life had not so soon their thrend of life is spun ............ degtinics do cut his thread of life grief shore his old thread in twain TIIILEAD-13ARE juggler .... Cinmedy of Krrors, v. so he had nced, for tis thread-bare..2Henry $V I$. iv.
TIIREADEN sails ............Jenry $V$. iii. (chorus) THIRADING dark-eyed niglit ............. Tear, ii.

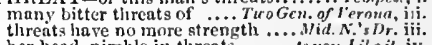
her head, nimble in threats .......... As you Lihe it. iv sir, spare your thrents
whiles I threat, he lives

no more than he that threats............ King John, frowns, words, and tlireats, shall ......3 Henry th $\begin{aligned} \text { ii. } 2 & \text { thonsand complete courses of the sun! } \\ \text { iii. } 3 & \text { with so many thonsand sighs did buy } \\ \text { iit. } 4 & \text { there is a thou sand IIeetory in the fiel }\end{aligned}$ iii. 4 there is a thousand Heetors in the fiel
iii. 4 tise common: a thousand moral rimon
iv. 2
that eharitable title from thongands that eharitable title from thousands thonsand to Vurro; and to sidore (rep.) -
o' the instant a thousand talents to me tive thousand erowns, my lord ( $(\mathrm{rep}$. thousand flutterers sit within thy crown you pluck a thousand dangers (rep.) send me presently uthousand pound on his side tights, thousmnis will fly the ranks ol many thousand Freneh
liave twelve thousand highting men! the blood of twenty thousund men ten thousand bloody crowny

a thousand spirits in one brcast ( did inelve thousand, none and a thousanit of lis peoplc

give thee for it a thousand pound (rep.) finve tu'en a thousund pound.......

and $\mathrm{n}$ thousand bluc-mips more......

hang in the nir a thousund leagues..
a hundred thoutuml relocls die in thi

thou hust savel me a thousand marks thousand pount. Sirrmt, des I owe (rep.) to thirty thousand. Forty let it be the furtune of ten thousund men .... your lorelship lend me thousand pournd to five and twenty thensand men (rep.) bat many thonsand reusans hold me many theusund of my prorest suljects and Northimberiand are fifty thousand or mar, the rate of thirty tlousand thou hid'st a thousand daggers in... I would have bestowed the thousund I owe you a thousand pound

let me have the humdred of ing thinnisundmito a thousand parts divide . Alemy
six thousund atd two hundred good a thousund pourds by the year. on may a thessand uctions, onec a fout for a many thousand widows ghull .. thousands weep, more than thid hat they have full threescore thols mind
but one ten thesumand of those nen thou hast unwished ftve thousand nie upon his knech, a thousank thanks. eight thousand and timul hundred... in these wn thenasnd they liuve lost scarce six thousand iu his troop ten thousand soldiere wit. a thousand souly to death...... ten thousnd French have triet and tainterl with a thousand vices... an' if it harl a thourand lives ........

perplexel with a thousand eares..... for thoumands inore, that yet snesuect.2 Ifenry $F^{\prime}$ with twenty thousand kis-es, and io dare him twenty thousand times
thereby of ten thousand shames

a thonsand pieces. $A$ thousand pieces! with thousanits of these quartercd slaves -

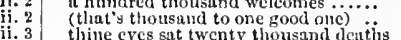
iii. 3 thine cyes sat twenty thousand denths
iii. 2 a thousnd welcomes! and more a fricndfor ten thousand of your throats I'd not live uthousand years, I shall not.Jultus CC
ten thousnd harras, more than... Antony of and thousands more nt ecmblable.
hy land, and our twelve thoorsind horse a thoussand, sir, early though it be ... lay you ten thousand ducats (rep.)... C yearly three thonsand pounds

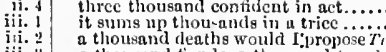

a thousand tiends, a thousand (rep.)
iii. 3
warderl him from thousand dangers

we had a thousand Roman domcs

would she for twenty tinusand mor

I have done a thoussand drcadtul thing

that I camot do ten thotsand more

i. 3 show me a thousnd, that lave slone the
ii. 1 and have a thousand times more cause
ii.

ii. 3
iii. 1 ten thourand, worse thnn eyer ye
a thousund doubts how I might

iiii. ? three or fuur thousand clicquins

batcd one doit of a thousund pieces....
break into a hundred thousanl flaws

to have a thousand with red burini
he land a tlongsand noscs, horns...

an'

thousand times good night! a thousu
to chy lady. Ay a thousanel times..

hath slain tent thinusand Tybults...

above compare go niany thousand times? gives him three thousand crowns......
one man picked nut of ten thousaid

one man picked out of ten thousand
and the tliotsand natural shocks that

the ghost's word for a thousand pound

ten thinusand lesser thinge are mortised
two thousand spuls, and twenty thousand

imminent death of $t$ wenty thousand men

for that frame outtives a thoussand tenan

forty thousand brothers could not

and has heen sluve to thoorands
that the slave had forty thousand lives!

a thousand, a thonsand times: ald then

Iv. 1 act of shame a thouqand times enmmitted
lv. 2 TIIOUSAND-FOLD more care to.....3/frnry

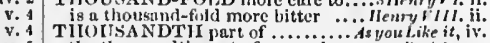

Y. 5 the thousandth part of my condurance... l'ericters. $v$.

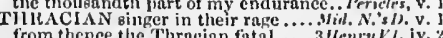

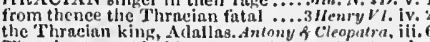

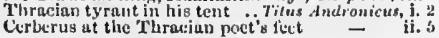

how I seorn his worthless threats! ". Riehard 111 . $\mathrm{i}$.

cvery one did threat to-morrow's.... hearing the surges threat....... Timon of dhens, iv. no terror, Cassius, in your threats.Juliusciesar, iv.
very wisely, threat betore you sting..

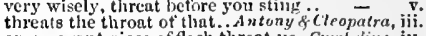
an arrogant picce of flesh threat us.. Cymbeline, iv.
grown, to threat your friends? .... Titusdndron. $\mathrm{j}$. and threat me, I shall never …..... - iii. helm thy slayer begins threats $\ldots \ldots . . . .$. . Lear, iv. TilREATEN-though the scas threaten. Tempest, with the twigs that threaten them ... All's " well, iii. dill threntell ant eneourase him.. W'ister's Tule, iii. and threaten present bitsters........̈ 二 vith man's net, threaten his bloody stage ...Nacbelh, ii.

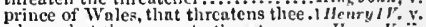
when what ticy scem to threaten .... Henry $F$. ji. steed threatens steed, in high .... .... iv. (ehorus) that threaten us with wreek ........3/tenry Fl. v. to threaten me witl death, is most... kichard Th. i. stute, whose numbers threaten ...Anlony \& cleo. i. as loud as thunder threatens us ....... Hamalet, iii. TIREATENED to put ne into ... Merry Wices, iii. threntenet me to strike me your eity's threntened ehecks......... King John, ii. that threatened me, ne'er looked...julins Cosar, ii. have threatenel our prisollers with.. Cymbeline, $y$. as no less is threntened me, the king ..... nnl threntered ne with deuth ........ THIREATENES, than dost............ of tenice, iii. unknit that threatening unkink.. Tuming of sh. v. pity from our threatening locks.. Cometly of Err. i. therefore thy threntening eolours now - v. the noise of threntening arum...... Richard 1l. iii. with such a cruel threntening look ...3 al hack, suspieious, threatening cloud not endure ull threntenings?.. Timnn of Alikens, iii. nr pitying, threatening the other..... Coriotanus, i. cxalted with the threatening clowits.Juluuversur, i.

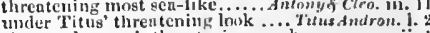
nbove pmle envy's thruatening jeach $=$ ii. with all his threatelling band of ..... . . Famlet, ii.

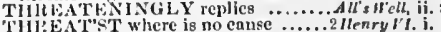
Tilite thum wast not nut three years. Tenpest, $\mathrm{i}$. this obelient stecl, three incles
lic's ante for tiese three hours

we nre liurce of them

you are three men of sin ..........

ali three of them are desierate.......

who tluree lours since were wreeked

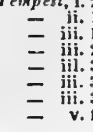


THEE-cannot be three hour Which but three glasses sinc

these three have robbed me..............

ing that women .. Two Ges.of Verona, iii. 2 three or four of bis blind brothers.... - iv. 4 the company of three or four ........ $\quad$ iv.

these three hundred years ............

there is but three skirts for yourseli

there is three umpires

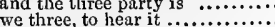

I keep but three men and $\mathrm{a}$ boy

three veneys for a dish of

for three reprieves for yol

in three linndred pounds a yeari $\ldots \ldots$.

the pangs of three several deaths....

alas, three of master Ford's brothe

and three or four more ot their ......

there is three cousin Germans

I was three or four times in.............

not three hours travel from ....... Twe

nind speaks three or four languages.

he speaks three or four thengages

did you never see the picture of we three?

will draw three souls out of one weaver -

and three merry men we be ......

having been three montlis malried

I'll get 'em all three ready

souls and bodies hath he divoleed three -

put you in mind, one, two, three

to three thousand dollars a year. Neas. for Meas. i. 2

withine these three days his beds.

let me bail these gentle three.............
be was not three leagues off when $\mathrm{I} . . . M$
rather than bold three words' couference

if you three will but minister

yet but three? come, ooe more...

three and three, we'll hold a feast
two or three lords and ladies more

this long age of three hours mor...

the thrice three Mruses mourning

so shaters three, corne, come to me....

have sworn fol three years' (rep.).. Lo

to sleep but three lours in the night

penance of each three years' day (rep.)

penance of each three years day (rep.)
to to thousand tímes within this tluree

all those three; I was seen with her.

I have promised to study thrce years

now here is three studied (rep.)

or the three or the two; or one .......

of such a ballud some three ages sinc

glalil out-wear three years, no woman

all those three I will prove ...........

still at odds, being but three

for thiree farthings: three fartilings...

carc a pin if the uther three were in

all three of you, to be thus much

a beam do fiad in each of three $\mathrm{.....}$

I will plny three myself

and sugar; there is three .............

on those three; they are infected $\ldots . .$. .

and three times thrice (rep.) ........

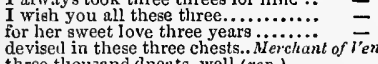

three thousand dacats, well (rep.)

for three months. For three (rep.)
of thrice three times the value

that won three fields of saltan

the sisters three, and eneh branches

one of these three contains her

three thousand ducats (rep. iv. i $i$ i v. 1 ) =

some three or fonr of you, go give him

there you shall find, three of you

an old man, and his three sons.......

the eldest of the three wrestled with

ribs, that there

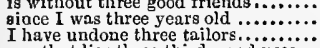

one that lies three thirds, and uses...All ${ }^{-} \bar{v}_{\mathrm{W}}$

two or three probable lies..........

witlin these three hours 'twill be...

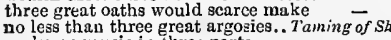

make no music in three parts ....

widow in three inches?

widow, ere the yard, three quarters, half yard

thou yard, three quarters, half yard
ever since he was three years old .....
we three are married, but you two

was when three crabbed months ... $\boldsymbol{w}_{\text {inuler's }}$ Tale

in the which three, great ones suffer...

I have three daughters; the eldest

between ten and three and twenty
sir, it is three days sinec $I$ saw

sir, it is three days since I saw
three pound of sugar; five pound

iii. 1

$\mathrm{v} .2$
$\mathrm{v} .2$
TIIREE-past three quartere of a mile. $W$

three carters, three shepherds, three

these four threes of herdsmen (rep.)

not the worst of the three, but jumps

things known betwixt us three .......

they three were taken up...... Comedy of Er
three quarters, that is, an ell and (rep.) -
ainonit to three odd ducats more....

when shall we three ineet again....

I dreamt last night of the three weird.

provoker of three things. What three.

'tis two or three, my lord

within this three mile may you

in a frenzy died three dilys...

are wrecked three nightits ago

come the three corners of the world...
tliree parts of that receipt I had ....Richard II. v.

we three are thy selt; and,

be not vain, we three here part.

manned with three hundred men....

tliree Judases, each one thrice.... ...

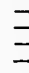

this full thee months, since I did see.. - v.

brought three hundred marks ........
three or four loggerleads, amongst three

three or four loggerlieads, amongst three
there live not thitee good men..........
if there were not two or three and fifty

if there were not two or three and fifty

would have it, three misbegotten kna

in this robbery, lost three liundred ..
three times hath Henry Bolingbroke

divided it into three limits, very equally -

that I borrowed, three or four time

three or four bonds of forty pound ...
soldiers, three hundred and odd pounds

unless you call three fingers on ......

three knights upon our party

three times slain the appearance

I was born about three of the
do brawl, are in three heads
king in three divided ...............

I have three pound to free iIouldy

and three eorrupted men....... Henry

and we'll be all three sworn brothers

ruin you three [Col. Knt.-have] sought
God, God! three or four times

three swasher's (rep.)

and sold it for three halfpence

legs did march three Frenchmen

i. 2 by three and twenty thousand....

these three days have I watched
the fury of iny three attendants.

now we three bave spoke it

but three days longer, on the pain ...

iii. and three times thrice by thee..............

iii. I seen him whipped thrce market

the loss of those three lurds torments.3 Henry $r /$. three times did Richard make

or do I see three suns? Three (

nay, bear three dangliters....

three dukes of Somerset, threefold

blessed his three sons with

v. 2 alas! you three, on me, your

v. 2 three times to-day my foot-eloth horse

kinsmen of mine, three at the least...Henry ${ }^{2}$ iII. $\mathrm{i}$.

and, three nights after thi

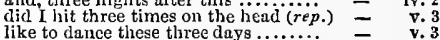

like to dance these three days ..........

he ne'er sa:v three and twenty
with my three drops of blood

ii. 1 may make them three ........

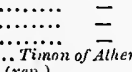

you three serve the present.....Timan of Althens, i. 1

all the the solidares for thee..........

three? Humph! it shows but little

yes, mine's three thousand crcwus

to wheel three or four miles about

i. 2
iii. 2 within these three hours, 'Tullus
are three, that Rome should dote

three, thiey say; but 'tis thought of

i' the consul's view, slew three opposer

by ones, by twos, and by threes.......

help, three o' the ehiefest soldiers.......

three parts of him is ours already....

the clock hatl stricken three .........

till Casar's three and twenty wounds

'tis three o'clock; and, Romans, yet

let me be narried to three kings... Ant
then three kings I had newly feasted

to you all three, the senators alone

gone; the other three are sealing

three in Egynt canuot make better note

withe in the

i. 2
$T$. iv. 2 THREE-I have read three hours .... Cymbeline, ii.

yearly three thousand pounds

at three, and two years old

these three, three thousand confide....

for three performers are the file

the service, that you thiree have done

a mother to the birth of three?

your three motives to the battle

$\begin{array}{lll} & \text { v. } \\ \text { did company these three in poor } \ldots . . & - & \text { v. } 5\end{array}$

we have but poor tliree, and they can.. I'erieles, iv.

three or four thousand chequins

who for this three months hath not.

hal here's three of us are हophisticatedi

all three now marry in an instapt

three civil brawls bred of an airy. Roi..

till twelve is three long bours ........

bell hatl rung, 'tis three o' clock ....

within this three loours will fair

three thousand crowns in annual fee .. Hamlet, $\mathrm{ii}$.

and, ever, three parts coward ............ - iv.

these three years I have taken note of it $\ldots$ v.

i the eartly three and twenty years

ii. 4 he shall not exceed you three lits.......................

二

iii. I not kissed your three fingers so oft

but let it not exced thebela

within these three days let me hear the

TH 3 THREE-FARTHINGS-WORTH... Love's L. L. ii.

provokes me to this threefold perjur
with threfold love I wish you

according to love 1 wish you .... Love's L. Lost. $\mathrm{v}$.

threefold vengeance tend upon .....2 2 tenry $V I$. iii.

Somerset, threefold renowned for $\ldots . .3$ Henry $V 1 . \mathrm{v}$.

on me, threefold distressed....... Riehard $\bar{I} I I$. ii.

is it fit, the threefold world should.JuliusCosar, iy.
THREE-FOO' stool mistaketh me.MIid.N.'s Dr.ii.

when on my three-foot stool I sit .. Cymbeline, iti. s
THREE-HEADED canus ........ Love's L.Lost, v.

3 THREE-INCH-three-incl fooli i.Tanine of $T^{\prime}$, v.

fillip me with a tluree-man beetle! ..2 Henry $I \nu . \mathrm{i}$.

THREE-PENCE bowed would hear. Ant. \& Cleo. iv. 6

a dish of some three-pence. Measure for Measure, ii.

after three-pence a bay

the controversy of three-pence to $\mathrm{a}$... Corinlanus, ii.

in my time, wore three-pile ....... Winter's Tule, iv

.

never see a ba and ten I can remember.Mracbelh, ii.

is threescore and ten miles afoot ..... I Henry IV.ii. fighting men they have full theseescore. Henry $V$. iv

pedigree of threescore and two years.3 HenryVI. iii.s

THRESHER with a flail

cur over your thresliold .....Merchant nf Venice, i. that stumble at the threshold .......3 Henry VI. iv.

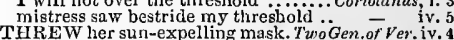
threw this whale, with so many ... Merry ivives, ii. they threw me off; from behind....... which Charles in a moment threw. As you Like "i, i.
he threw his eye aside, and, mark.... coatained the name of her that threw. $A l^{\prime}, \bar{w}$ Well, v. goes false, you threw it him out.......
the sops all in the sexton's face .. Traming of Sh. iii. 2 threw off his spirit, his appetite ...Winler's Tale, ii. they threw on him great pails. Comedy of Errors, v. from windows tops threw dust...... Re hard $1 \%$. v. upon the staff he threw: then threw - iv. he threw his wounded arm $\ldots \ldots \ldots \ldots$ Henry $V$. iv.
threw it towards thy land .......... threw it towards thy land ...........2. Henryl'I. ini.
they threw their caps as they would.. Coriolartus i as nauy coxcombs as you threw caps - iv. threw up their sweaty night-caps..Julius Casar, i.
what time I threw the people's...Titus Audron. iv. 3 threw him ashore, to give ....... Pericles, ii. (Gower) I threw her o'er-board, with these....... - iii. threw him on my father ................. Lear, v. 3 like the base Judean, threw a peari a way. Othello, y. 2
TIIREW'ST dust upon his goodly ....2 Heury $V$. i. 3 THPICE double ass was I ............... Tempost, v twice or thrice in that last article.... not been thrice in my company! ... Nerry Wives, ii. if thou thou'st him some thrice....... Twelsh $\overline{N i g h t}_{\text {, iii. }}$

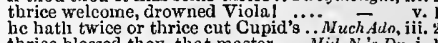
thrice blessed they, that master.....Miii.N.'s Dr. $\mathrm{i}$. the thrice three Muses mournin

how many is one thrice told? ... Love's L. L.ost, i. 2
three studied, ere you'll thrice wink

three times thrice is nine (rep.)....... 


\section{THR}

THIRICE-'acape Irowning thrice, Mer.of fenice, ii. 2 TILli IVE well, I'l) vimit the 8o, thriec fair Ruly, stamel there's thriee thy uoney wficeil (rep.)

and seck to thirive by that which lus

Wive, ank thrivel Winowell, kind

live, and thrivel linetwell, kind
enterprize to-tlay nuy tlurive (iep.).

jt to molrow our navy thrive

letting them thrive again on

lia contirts thrive, hits trials
I lonpe, sir, if you thrive, you

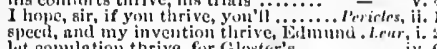

let eopulation thrive, for Gloster'
if ever thou wilt thire, lumy my boily

pray that the right may the

so thrive my soul, $-\mathrm{a}$ thousand... Lingeng \& Juliet,

do well thrive hy them, and, when

THRrVED - as linve not thrived ...Anlony \& - cten. $i$.

So he has thrived, that he is ..Pericles, v.: (iower)
rulliviNG-miss a thriving issue. Hinter's Tale, ii.

go I, a jolly thriving woocr......... Hichurl III. iv. 3

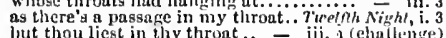

with an out-stretelied throat..... Neas. for Meas. ii. 4

a pox o' your throats!............... iv. 3

sometime through the thront..............

not take this hand from thy throat. As you tike il, $\mathrm{i}$.

minto the sweet bird's throat...... - ii. 5 (song)

that it did, sir, i' the very

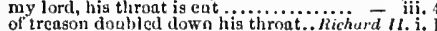

passage of thy throat, thou liest I

ent the villains' throats; ahl
I had ticl in my throat if I hat

nay have their throats alroot them.... Hew?

in thy teeth, and in thy thront

I will eut thy throut, one time ........

$\bar{z}$

there is throats to be eat, and wor

fetch thy rim out at thy throat ........
for I will cut his throut..............
every soldier to eut his prisoner's throat

every soldier to eut his prisoner s throat -
wetll cut the throats of those we have

that's a lie in thy throat

my part thereof into thy thro

Heñy VI. i. i

eut both the villains' throat
and iniquity's throat cut lik

next his throat unto the buteher's ...3 Henry I'l. ve

to eateh each other by the throat

thy gaard, I'll cut thy throat .. Truilus f Cress. iv. 4
with harness on their throats.. Timon of Athens, i.

quietly eat their thronts without...

eut yoor tristers' throat,

pronounced thy throat shinli e
cut throats; break open shops....

while you have throats to answ

beto:e the reverend'st throat in $A$ theng

my throat of war be turned...

and present my throat to th.
fisting eacli other's thront..

fisting each other's thront..............
our thronts are senteneed, and sitay

for ten thousand of your throats
presented to my knife his throat

presented to my knife his throat

and offered them his throat to eut.. Juliu

down thy ill-uttering throat

We have used our throata in Egy th ..
when we are put off, fall to their thronts

threats the throat of that hig

hath eat her throat already ......... Cy
which he did wave againat my thront

in their thronts that have committed

and now prepare your throats

I can vent clamour from

ot eut tine forcign throats..

his loity ankl shrill-soanding thirinat...

gives me the lie i' the throat, a
to eut his thront i' thie cluurch.

tuke thy fugers from my thiont

whose rule throats the immortal Jove.... he lies there, were to lie in my own thront - iii. I
I took by the throat the circumeised don - v. vour liente will throb ant weep... Finustudron. v. 3

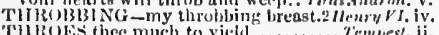
gave to me inuly a gronnin throe.

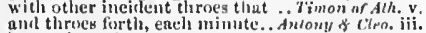
lut touk me in my throes.....

wix' throne

these sovereign thrones

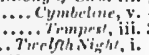

honoured for his busning thirone....

we have left our throne without.

a mosiety of the throne, a great

draw our throne iuto nine ne-cote?

't wixt your throne and his liteasurel
are to vour throne anil state

are to vour throne and state ois.
of the hapy throme, and fail of.

truest issile of thy throne.

here 18 mv throrie, bial kings enme......

leat thy foot to binglumil's throne

true tuking licharel's throme

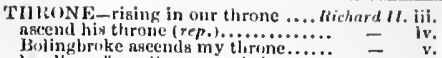

headling from the ushiricul thene...

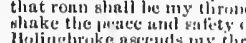

his anuels, asterd

and bervices, to this inpurial throne

heir, you sit apon their thront ......
do rouse me in the throne of Franed

the throme he sits an, nor tlie tiale.
heatlong from his thione...........

my aitvanement to the throne

honoralile peace attenul thy th
that josed an esrthly throne

that joged an eurthly throne .........
that throne which now the house of 3 -

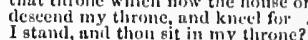

thant I will leave my kintiy thirne?..

and ilukedom, throne and kingdom say =

Eee him seated in the regal ilirene

likely, in time to blegs a regal throne

the innocent and awless throne.

the the royalty of Englasal's throne

sit, gools utpon your thrones. I rnilus d eressidn

this throne, this Fortaoe, and thit.. Timon of thith. $\mathrm{i}$.

and afleeting one sole tlirone

opmleut throne throne in ........... -

whiles we are sultors to their throne..

like a burnishet] throne, lmirned on ..

pursae lier even to Augustus' thirone

have made preservers of my throne.. -

like stars, about his throne, and he....l'erictes.

bronght to knee his throne .............. lene, ii.

bosom"s lor'l sits lightly in his throne o Jule?,

the most immediate to our throne...... Haralet, 1 .

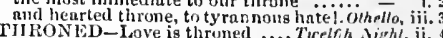

TIIRON ED-I Love is thruned .... Tirelfi, Night, i

it heemmes the throned monareh. Mer. of lenire,

feigned Fortme to be throued .. Tinan of, Jhens,

fwearing shatse the throned goda...Antony of Cleo.

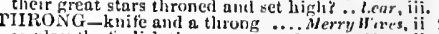
so play the toolish throngs..........Meas. for Meas. ii. they throng who shall buy first... " Finier's? The, iv. in their throng and press to that ins of frrmx,

nor the throng of words thint........2 Heury $1 \%$..

up the Euglish in oar throngs ........... Henry $l^{\prime}$

Iil to the throng; let life be short
to the shore throng many doubthil. Bichard
III. iv.

in caeh degree, throng to the bar .i.̈.

did throng, and pressed in with this

societies, and throngs of men!.. Timon of thens, iv.

the damb men popular th rongs

throng our large temples with

fellow, come trom the throng
the throng that follows Ceesar

Wh to shortly (rep.). . Timonof of thens, iv.

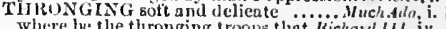

There lk the thronging troops that Kichayd III. iv. 1

if a throstle sing, he finils straight. Mer. of yeuice, $\mathrm{i}$.

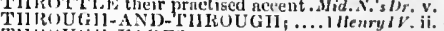

THlioUUil-FAR ES now...... Werchant or tente, ii.

will do his commission throughty .. Cymbelme, ii

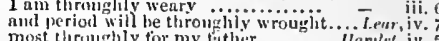

Tilkow thy tor my mither.......... Ilantet, iv.

and throw os that your raging sea .. - i.

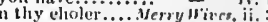

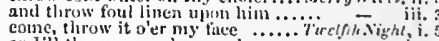

or I'll throw your linger der.......
no more muey ont of me at this tirow

yous throw a strange regard ujon we -

I'd tawn it linw tor your deliverance.

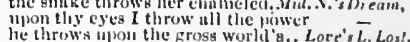

ahate a throw nt nos'min..............
but if they will not, throw away

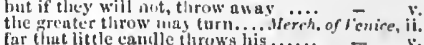

not one to throw at a thing............ you toke is, $i$. 3

mineiples do not thow from you .... . a the ii. I

or I will throw thece troun wing renre.....

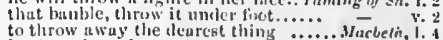

in the primmed entraila throw

giblet, throw into the llane.........
froun her hed, throw leer nighigewin.

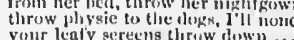

your lealy sereens tliruw down
before my borly I throw ny warlike. 
TIIROW thine eye on yon .......... King John, to throw a perfume on the violet there I throw my gage (rep.)..... ived there I throw my gage (rep.) what reverence he did throw away with a mortal touch throw death throw a way reapect, tradition....... by heaven, I'll throw at all here do I throw down this.........
behaviour I throw off, and pay THRUSII and the jay ....Winter's Tale, iv. 2 (song) will thrust himself into secrets. TwoGen.of Ver. ii thrust from the company of we would have thrust our virtue..... thrust upon them (rep. iii. 4) .. Tuelfh $N$. ii. 5 (let. an thou wilt needs thrust thy beck ...Moich Ada, i. nor thrust your head into.......... Lerchane of Venice, ii. what advice shall thrust upon thee ...All's We $h$, cannot thrust myself into this.. Taming of Shreed, i. minute of his being thrusts against... Nacbelh, ifi. thrnst but thesc men away .........KingJohn, and thrust thyself into their companies

had falsely thrust upon contrary

thou shal thrust thy hand as dee

to thrust his iey fingers in my

the world thrust forth a vanity ......

I am eiglat times thrust through....

but I am thrust upon it.

I care not for his thrust

call thrust me from a level consideration -

thrust him down stairs; I cannot endure Col.] you might have thrust him .....

thrust in between the paction

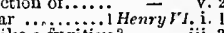

and thon be thrust out, like a fugitive? - iii. 3 for he was thrust in the mouth $\ldots \ldots \ldots$ 二 iv. 7

thrust thy body in with my sword $(r e p$.) - iv 10
seek to thrust you out by force......3 Henry 1 l. i. to thrust his hand between his ........ have thee thrust me out of doors. Timon of Alhens,i. 2 if the time thrust forth a cause ..... Coriolanus, thrusts forth his horns again ........

withal, thrust these reproachful.. Tilus Andron. ii. go, thrust him out at gatts .............. Lenr, iil. 7 and thrust his maids to the wail $\ldots . .$. .

w cre interchanging thrusts and
an envious tlu'ust from Ty balt

close together, at blow, and thrust

that thrust had been enemy indeed.". THRUSTING forth his paw .......... Richard $I I . \mathrm{v}$. we are evil in, by a divine thrusting on ... Lenr, i. THUMB - that worthy's thumb..... Love
with lis finger and his thumb, cried.

With I have a pilot's thumb.

by the pricking of my thumbs

between my finger and my thumb...2 Henry ${ }^{\prime}$.

with his finger and his thumb .... Corioianus,

with your fingers and thumb

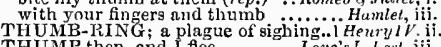
THUMP then, and I fiee...

thump. Thumpl then see (rep.)

then thus I thump it down.. Titus Andronis Vil. if. MPED, and, on record, left....Richard $I I T$. v.

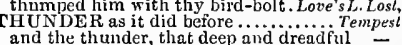
the dread rattling thunder have I given wwith groans that thunder love.... Thetrh Nigh
great men thunder as Jove...... Meas. for Meas.

a diseord, such sweet thunder...) Vid.....'s Dream, thy voice his dreadful thunder.. Love's L. Lost, and heaven's artillery thunder........... of shrew's $\overline{\text { rate }}$ i. in tliunder, lightning, or in rain?. storms and direful thunders brea

and sleep in spite of thunder ............ our thunder from the south.

spoke like thunder on my side?

and mock the deep-moutled thunder

fall like or

in thunder, and in earthquake............ Heary ${ }^{\prime}$

it Talbot do but thunder, rain wili ..

to shoot forth thunder upon these..2 $\mathrm{H}_{r}$ r

thy voice is thunder, but thy looks...Richard III.

these are the yonths that thunder.. Hen'y $I I I$.

by hinn that thunders, thou hast

knows not thunder from a tabor ..... Coriolanus

a shower, and thunder, with their coips

or Jove for his power to thunder ....

that thunders, lightens, opens graves.Jul $\vec{C}$ cesar favours, by' Jove that thundersi Antony \& Clev. ii he was as rattling thunder.

he came in thunder; his celestial..... Cymbeline, $v$.
secure of thunder's erack....Titns $A$. udranicus, ii secure of thunder's erack ....Titns Andranichs, it
thunder above, and deeps bejow . l'ericles, ii. (Gow wind, rain, and tiunder, remember.

deafening, thy dreadful thunders.

thiunder shall not so awake...

as loud as thunder threatens us ..........

and thoudall $[k n t .-$ the thimder bend ... Lear, ii.
THUNDER-rain, wind, thunder, fire.... Lear, iii. 2 what is the cause of thunder?

when the thunder wonld not peace a..... against the deep dread-bolted thunder?.. = iv. 7 bruit again, respeaking earthly thunder. Hamlet, i. so loud, and thunders in the inclex?... - ii. in heaven, but what serve for thumder?.. Othello, y, THUNDER-BEARER shoot, nor tell tales. Lear, ij. 4 liath lately suffered by a thunder-holt. Tempest, ii. gods, with all your thunder-bults.Julius casar, iv. scape not tl:e thunder-bolt. Antony \& Cleopalra, ij. Conriers to oak-cleaving thunder-bolts . Lear, ji. TIIUNDER-DAR'TER of Olympus. Troil.\& Cress. 1 i. TIUUNDERER, whose bolt ............ Cymbeline, v. 4 TIIUNDER-LIKE pereussion of thy. Coriolanus, i. 4 THUNDER-MASTER show thy spile Cymbelme, v.4 the all-dreaded thunder-stone. Cymireline, iv.2 (song)
THUNDER-S'TROKE. What might...

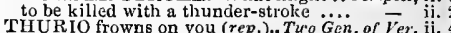
sin Thurio borrows his wit .......... and you, sir Thurio (rep.) $\ldots \ldots \ldots \ldots . . . . .$. blunt 'Thmrio's dell proceediog....... sir Thurio, give us leave
to bestow her on Thurio

to match my friend, sir Thurio...... between sir Thurio and my danghter and love sir Thurio? (rep.)...........
you, sir Thurio, are not sharp enough I must he unjust to Thurio (rep.)..... ay, gentle Thurio ................... Thurio give back, or e............... $-\mathbf{v}$. 2 HURSDAY; or indeed, Francis ....... Henrry $I V$ ii. 4

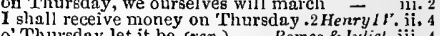
say you to Thursday? My lord (rep.) - Julie, iii. early next Thursday morn (rep.)

get thee to church o' Thursday

1 do not use to jest; 'Thursday is near = iit. no, not till Thursday; there is time $=$ iv. wont to thwack our general (rep.)... Coriolanes, iv. 5
THWART ne in my mood? .. Camedy of Errors, ij. 2 did draw bias and thwart.... Troilus \& Cressida, $\mathbf{i}$. and he a tliwart disnatured torment ....... Lear,i. nation, thwarted my bargains. Merch of I enice, iii. I an thwarted quite from my. Troilus \& Cressidn, v, THWARTING-strangely thwarting! M Much Ado, iii. punished with my thwarting stars..3 Hemry $\% l$. iv. 6
lesser had been the thwartiags .... Corialanus, iii. 2 thwarking the wayward seas.. Pericles, it. 4 (Gower)
TIIYME-the wild thyme blows. Mid.N.'s Dream, ii. set hyssop, and weed up thyme $1 . \ldots . .$. Olhello, i. 3 THY name; make thine own edict. Aul. \& Cleo. iij. I comes enquiring fur his tib.............'lericles, iv. I would they of were in Tiber! ...........
that Tiber trembled underneath
iit draw them to Tiber banks; and weep

the troubled Tiber elafing with ....

orehards, on this side Tiber........... TIBERIO-heir ot old Tiberio..... Romea \& Juliet, TICED-have 'ticed me hither. Tilus Andranicus, ii. TICK in a sheep, than such a. Troilts \& Cressida, iii. if ny hair do hut tickle me..... Mird.N.'s Dierm, if you tickle us, do we yot laugh? Mer.of lentce, nay, I'll tiekle ye for a young prince - it.

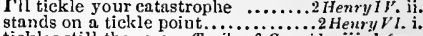
tiekles still the sore... Troilus \& Cressida, iii. 1 (song) po'll tickle it for his concupy

can tickle where she wounds! $\ldots \ldots \ldots$. Cymbeline,, 1.2 tickle the senseless rushes........... Romeo \& Jutiet, i. 4 ICKLED you othergates .......... Twelfth Nighi, v. she's tickled now; her fume can ....2Henry $V I$. how she tiekled his ehin ....... Troilut \& Cressida, a nature, tickled with good sucess.. Cariolanus, $\mathrm{i}$. whose lungs are tickled o' the sere ....Hamlel, as bad as die with tickling ........... Much Adv, ít gentleman, tiekling commodity .... King John, ii. tickling skittish gpirits ... Troilus \& Cress. (prologue) tickling a narson's nose.......... Rt,mea of Juliet, i. 'I'ICK-TACK-a game of tick-tack. Meas. for Meas. IDE-the washing of ten tides ......... Tempest and the approaching tide will

tide is now; nay, not the tide... Fuo Gen. of Fer that tide will stay me..........

you will lose the tide (rep.
what's the unkindest tid

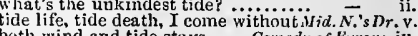
both wind and tide stays .... Comedy of Error's iv. 
TIDE-the ccean's romring tides that mpen the swelling tide... among the high titles, in the are taken by tho ticke.... may turu the ticle of fenrin many turn the ticle of fenriul ns with the ticle swelled ull
the title of blood in me hath like the tide into a breach cen at turningo' the ticle to be washed of the next tide..........
nor the tide of pomp that bents...... iv.
wouli en nonlu eall forth her howimg tides.. mightiest hulk against the tide
lnbour swim agnilist the tide fureed by the ticle to combot fured by the tixle to combat ........ both wind nuld title (rop.iv. 3 and $v .1)=$ iii. 3 low gets the tide in? as muili........ of this action rode on his tide ... business, the tide whereot let in the tille of knaves........... more .. iti. ever livel in the tide of times.....

there is a tide in the affuirs of men

litequeying the varying tide.

narks the waxing tille grow wave Tilus sntron. iii. I TIIINGS-glad with these tidings. Very lines, iv. that 1 may drink thy tidiugs. bring these tidings to this lair

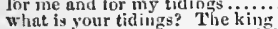

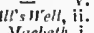

enme hillaer to tronsport the ticking

the tidings come, that they are all .. King John, iv.

fildy with these ill tiditgs............

we hear no tillings fiom the king...

tubest the tidings of enlanity
York's, that tell blnek tislings

cam'st thou by these ill titlings?

that's the worst tidings that I hear

what good tidlings eome with you?

what good titlings eome with you?

good ticling $x_{\text {, }}$ my lord Hastings.......

end tidiugs bring $I$ to $y$ ou out of

these ticlings would eall furth

what titlings send our seonts?

health and glad tidings, to your majestyl - iv. the happy tidings of lis goos cseape 3 alenry $r$. ji. tidings, us swiftly as the posts eould run

despiteful tidings! O nopleasing news!

to bear this tidings to the hloody king - iv. I

to bear this tidings to the hloody king - jv.
the tidlings that I bring will make.. IIenry r IIt. v.

the gods loless you tor your tidings... Coriularus, v.
with her death that tidings came... Sulias Corsur, iv.

these tidings will well comfort Cassius

as ticlings of this sight

ram thon thy fruitiul ticlings....... intony \& $\overline{\text { cteo. }}$ ii. 5

to trumpet such good tidings?

but let ill tidings tell themselve

but it is a tidings to wash the eyes

but it is a tiangs to wash the eyce . - v. 1

promise to yield me often tidings

no tidings of him? Ile hath been

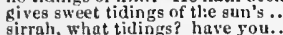

these tidings nip me

and, fur my tidings, gave me twenty

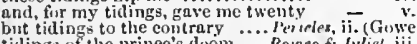

tidings of the prinec's doom..... Rosne of Juliel, iii. a

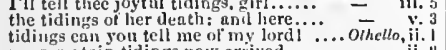

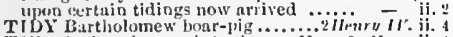

TIE-tie the wirer souls to tliy................. for.

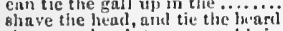

tic up my love's tongte, und ling. Mid. N.'s Dr. iii. i

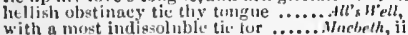

thorl shalt fo surely tie thy now ..... Kims John,

to tie thee to my strong eorreetinn... Kirhw I'Jl tie them in the wood

eume, tie his boly to my horse.......... Henrilus f cress.

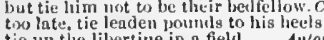

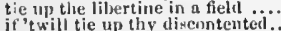

that scems to tic their friendship.

With one that tics his points? ........

or tie my treasure up in silken bagz.. P'erieles, iii. ? whieh tio him to an nnswer............. Lear, iv. TIED-if the thed were lost ....... Turotirn. of I lumkindlest tied that erer any man tied
w'liy, he that's ticd here............. I am tied to be obedient ................ Taing of sthreve, where you were timl in duty ....... Winter's Tale, v. I

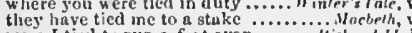

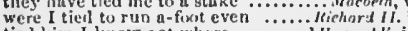
were I tiel to run a-fikit even ........kichard 11.

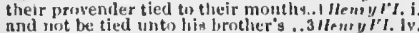

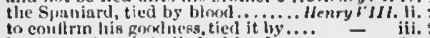

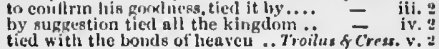

Tle. U-rudier thed by the strings. Antony 8 C:lro. iii. 9

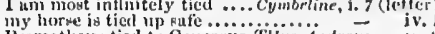
Promethems tied tw Cumeasus. she lath, so strielly tied her hures are tied hy the heads .............. Lear, ii.

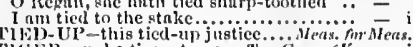

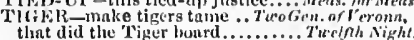

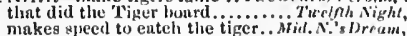

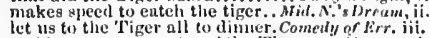
to Aleppon gone, master o' the Tiger ..... Machelh, i. 3 or the thereto a tiger's elauriron

a fusting tiger safer by the teoth.

imitate the action of the tiner
O, tiger's heart, wrupjer in a

than tigers of IIyreania
the tiger will be mild, whic

the tiger now hath seized the.
by the brize than by the tiger.

by the brize than by the tiger...
tame tigers; thioking it harder

go grent with tirers, dragons .. Timon - iii.

thtan there is milk in a mnle tiger ... Curiolanus, $\mathrm{y}$.

when did the tiger's young once.. Tilus dnd, on. ii.

a wilderness of tigers? tigers mist
this ravenons tiger, this aecursed

as for that lieinous tiger. Tamora...

empty tigers, or the ruaring sca.. Romeo \& . Julic iv.

TIGER-FOOTED rage, when it

a squire more tight at this.. Antony s cleopolro, iv

he will elapper-elaw thee tightly

TIKE-ay, sir Tike; who more?

or bobtuil tike, or trundle-tail

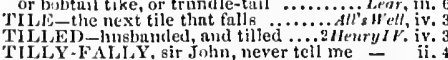

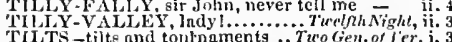

\section{mnmmets, and to tilt with lips}

ran'st a tilt in honour of

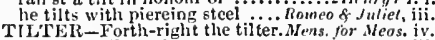

as a puny tilter, that spurs .......As you Like it, iii.

expresseth his full tilth and.ANeusure for. Measure,
TILTING - he is tilting straight l. Love'sL. Lost

of his heart's meters tilting.. Comcdy of lirrors,

tilting one at other's brenst ........... Ohello, ii. 3
TILT-YARD -once in the tilt-yard.2ileny $I V$. iii.

Tis stukly is his tilt-yard, aud his love...2

bark, and part o' the timber........ Herry rith. i. 2
TiJiBERED-too slightly timbered tor.. Hamlet, iv. 7

his bark is stoutly timbered, and his.... Ohello, ii.
TIME- tis time I should inform thee ... Tempest,

ean'st thou remember a time before

in the dark baek ward and abysm of time?

as, at that time, through all...........

whint is the time o' the day?

before the time be out? ...............

witlin whiel time she died

why, in gond time

and time to speak it in ..........

in the noon, when time was

and many a time the harmony

give me the lie unother time

after a lictie time. I'll beat

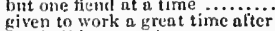

we shall lose onr time.

at which time, niy lord

wherefore Wuste 1 time tucomsel. Tro.... Gen.ofi $\bar{v}$

is it nenr dimber time?

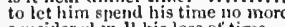

eonsidered well his loss of time

and in good time

thint thou shate spend some time

a thousand times it ansurers,

a thousand times as muel
or else for want of idle time...

why muse you, sir? 'tis dinner time

nnd donc too, or this tim

be means to spend his time awhile .

for that food so long a time .........

the fushion of the time is changed

will give thee time to leave.
time is the nurse and breeder.

the time now serves not to

a little time will melt her (rep.
for this time I spend in talking

a thousand times good-morrow

any a thonsand times

a hundred several times..............

to come lecore their time ......

and have done any time there...........

seen sackerson loose twenty times

lie kept not timie
[MF-holing time of my beanty,..Meny Wines, i].

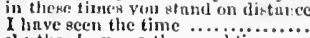

slic thanks you a thourini tiones

so much of your time in excliange.

for at that time the jeulons ...........

use your patience: in pood time

the last time lie nearehed for him

as they ditl last time .................

and in that time, shalt master

from time to time I hure nequainfed

this is the third time.

away 1 say, time wears.

still pinch him to your time............

'tis time I were choked with a piece.

"tis not that time of noon time in

tis not that time of noon $\ldots \ldots . .$.

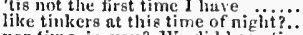

nor time, in you? We dicl keen tim

most britk and gidely-paced times

ynu waste the trensure of your time

the quality of' persons, and the tinie

upibraids me with the waste of time

albeit the quality of the time

whiles yon beguile the time....

the time goes hy; away

what time we will onr eelebration ke....

of place, time, fortune, do cohere

thou tee st said to

you shall from this time be

time and our eoneernings shiali .....ïeas. for yeos.

no? a dozen tinses at lenst....

in time tlie rod becomes more mocked

as blossoming time, that from.

which at that very distant time stood

so, for this ime, Fompey

ou had continued in it some time

ten times louler than beanty eouli...

ma, call us ten times frail $\ldots \ldots . . . . .$.

in good time ( $r$ 'p. v. 1) $\ldots \ldots \ldots \ldots \ldots$.......

that the time nay have all shadow.

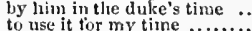

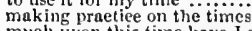

I promised

you bluall have your full time of

an unlaw ful bawd, time out of mind

neither in time, matter, or other ....

and I will liave more time to pre.....

nizht, in the times to eome..........

gainst the troth of time, and razure

now is your time, spenk lond ........

to , it is ten times strunge

and with rinened time, unfoid

well, he in time may come to elear.

with such a time when l'll depose

for better times to eoure.

but fitter time for that

to take the prescint time by the top.

if you he not wooed in good time.....

t'inie goes on eristches, till love

and a time too brief too, to hinve all.

for she'll he up twenty times n nigii

bids ine a thousand times gosd-niglit

'tis titue you were ready ...............

"twere a thonsand times [Col.-poumet]

time batly not yet so dried this bloon

by this time oir ecxton latli refurmed

when time and place shalt: erve 0 ö...

will quickly dream nw ny the time...Mid.N:'sD

take time to pause: nnd by the ....
butiore the time I dicl I Jysander see

before the time I did laysander se

a time that lovers flights doth
that very time I saw (but thou

chicl Ure hasty-fonted time for parting

how khall we hegulle the lnzy time

tis almost fairy time. I Itear, we sliall

spite of eormornat devouring time. Lore's $\bar{L}$. $L$.

ht in hir place and time............. -

the time when? (rep.) ............. - i. (letter

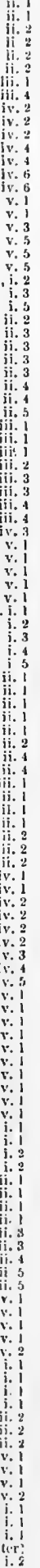


TIME-at that time was there .... Love's l.. Lost, ii. I TIME-'tis time to stir him from .. Taming of Sh. i. 1 whit time $\Omega^{\prime}$ day?

as much mor..........

or spend a minute's time in pruning

the shortness of the time can shape

the time shall be omitted that (rep

some entertaiument of time.

ats nbserve the times, and spend his

and fair time of day

three times thrice is nine (rep.) ......

the extreme parts of time extrenely

sakes have we neglectcd tinic

a time, methiuks, too short to mak

lut the time is long................

st rulige fellows in her tim.

whirein my time, something too

and lierein spend but time, to wind.

ii) your futher's time, a Venetian .....

luany a time and of t, in the Rialto..

another time you called me dog.

of thrice three times the vulue .....
o ten times faster Venus' pigeon

mates by this time for us stay

beiug ten times undervalued
stay the very riping of the time.

stay the very riping of the time
the chaff and ruin of the times

the fire seven times tried (rep.)

tis now no time to vent our love (rep.) -

lave I not in my time heari

I love her ten times more than e.....

to hours, nor'pointed times, but learn =

in time I mas believe, yet I .........

ne firt six times pieced

this doth fili the time

to the fashion, and the time.............

and titue it is, when raging.........

conty times so much $\ldots . . . . . . .$.

wood part the time between's then .

something before her time, delivered

until a time may serve ..............

the time is worth the nse on't........
w liave landed in ill time; the slies
I did in time collect myself...........

in the time collect myself...

I witness to the times that ( $\mathrm{rep}$.)

and in my time, wore three-pile ....

that might become your time of day

'tis time to part them

for this time, though fuil of our

at this time he will allow no....

$O$ thi'se naughty times put

but 'tis to peize the time .............

twenty times myself; a thousals (rep.) -

it is now our time, that liave stood

even at that time I may be....

the petty debt twenty tinies over.

many that have at times made ......

waste no time in waste the time together

to pay it ten times o'er, on forfeit...

we trifle time; I pray thee, pursue

but musie tor the time doth change. .4 is you $\overline{l i}$

it is the first time that ever I heard....

you will try in time, in despite...

if you ont-stay the time, upon.... .

devise the fittest time, and safest way -
thou art not for the fashion of these times-

willingiy could waste ny time in

and neglect the ereeping liours of time

and one man in his time plays $; \ldots \ldots$

ask me, what time o' day............

time travels in divers paces (rep.)

then they perceive not how time moves -

at which time would $\mathbf{I}$, being but

that time, come not near me

a thousand times a properer man....

a thousand times a properer man...

and in all this time there was not...

men have died from time to time....

we shall find a time, Audrey

time, the only pretty rank time.....

and therefore takc the present time

we kept time, we lost not our ti

the first time that I ever saw...

upon a lie seven times removed.

generally is at all times good

may be ten times found.

answer the time of request......................

and at this time, his tongue obeyed...

might be a copy to these younger times =

or four and twenty times the pilot's

if I break time, or finch in

the choice of thy own time; for I ....
I play the noble liouscwife with the time -
thast hath shot out in our latter tines

h second time receive the confirmation

love made your fortunes twenty time claims

which, as your dne, time claim

holds not colour with the time, nor does -

delivers me to fill the time

the time and place, witl this deceit.

'twill be time enough to go home...

that, what in time proceeds ...........

some other times, we drown our gain

from the time of his remembranee..
time was, I did lim a desired office.

the time will bring on summer

is prepared, and time revives us

though time seems so adverse.

and watched the time

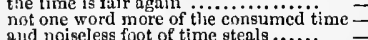

credit with them at that time........

come to me in happy time.. Taming of sh. 1 (induc.)

luever speak of all that time? $\ldots . .$.
the time scems thirty unto ne (rep.) -2 (induc.)

fur h friends as time in Padia.

guch friends as time in Padia faster than thought, or time

so that in this time of lethargy.......

thoug the time that the $m$ m

would have done the time more benefit

which waits upon worn times.

siace you owed no more to tim

been 60 any time these four hours...

tis time; descend; be stone no more

in this wide gap of time

time is their master (rep.) ..............

in good time, sir, what's that? to jegt in good time; there's a time (rep.) 二

the time was once, when thou unurged $=$

$r$ for this time, sir

why at this time the doors are.

'tis time, I think, to trudge.......

but twenty times you have...

'tis time, that I were gone

tlat time comes stealing o

renained until this time, free.

bear my wealth at any time
with Time's deformed liand lave....

know my voicel O Time's extremityl

weary sevenuights, nine times ni.

can look into the seeds of time

and at more time, the interim luving

to beguile the time, losk like the time

upon this bank and shoal of time.....

nor time, nor place, did then adhere

if you wonld grant the time

if you wonld grant the time $\ldots \ldots . . . .$.

come in time; lave napking ..........

new hatelied to the woeful time lived a blessed time

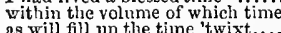

as will fill up the time tw

ii. 1 let evary man be master of liis time tili

with the perfect spy o' the time..

ii. 2 but, in best time, we will .......

ii. 3 i' the olden time, ere liuman

the times have been, that..............

you'll rue the time thut clors me......

Harper cries: 'tis time; 'tis time
pay his breath to time, and mortal

time, thou anticipat'st

but cruel are the time

the time you may so linod-wink

at no time broke my faith.

now is the time of help

what, at any tine, have you lieard

would have been a time for such $a$ word

the last ayllable of recorded time ......

to be the show and gaze o' the time...

the time is free: I see thee ...........

plauted newly witls the time

in measure, time, and place...............

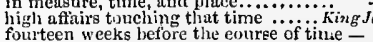

he is but a bastard to the time
lave given lim time to lank

lave given lim time to lankl

and this hand of time sliall traw.... as every present tíme doth boast

the time approaclies, that will
TIME-that time, have we rammed ... King John, ij. which till this time my tongue

fit it with some better time [Knt.-tune] =

and creep time ne'er so sln

cheered up the heovy time

being urged at a time unseasonable..

the spirit of the time shall terch

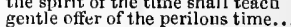

the yet unbegotten sin of times...

be the present time's so sick

thou the nrdering of this present $t$ im.

that such a sore of time shonld seek

such is the infection of the time...

armi you to the sudden time...

$O$, let us pay the time but...

purest treasure mortal times o.........

in a ten times barred-np .............

by this time, had the king

bring their times about, my oil-diried

thon canst help time to furrow $\ldots \ldots .$.
for a time. Joy absent, grief (rep.).

long time have I watched....

his time is spent, our pilgrimg.........

and take from time his charters

and tís time, I trow

for our time of stay is short

advantage of the absent time.............

bid time return, and thon shalt.......

for time return, and thou shalt......

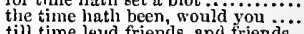

we at time of year do wound

in that dead time when Gloster's.....

that very time, $I$ heard you say......

twenty times thou liest .................

many a time liath banished Norfoik

the time shall not be many honrs....

my teeming date drunk up with time?

were he twenty times my son.........
keep time: how sour sweet music $(\mathrm{rcp}$.

'tis time thou wert away ............

what time of duy is it, lad? (rep.)....

reckoning many a time and oft.....

abuses of the time want conotenance

redeeming time, when men a time, with all the rest........

times they breathed, and three times
fill up clronicles in time to come

yet time serves, wherein you ........

in Riehard's time, what do you eaii..

till lie hath found a time to pay
when time is ripe (which will be

sirrah carrier, what time do you nean

any time this two and twenty years

the time itself unsorted....

I am eight times thrust through $3 . .$.

maj'vel where thon spend'st thy tini

three times lath Henry Bolinghroke

a shorter time shall send me to you

expectation of thy time is ruined.....

for the time will eome, that I shail...

the slightest worslip of his time ....

not ahove seven times a week ......

any time this two and thirty years.

to be sick, in such a justling time? ...

I would the state of time had first been -

faith, sir John, 'tis more tlan time.

know at what time to promise ....

misehief to the unborn times?

did I break in Richard's tim?

the dangers of the time; you swore...

What witl the injuries of a wanton time
starving for a time of pell-mell havock

and find a time to punish this offerice

never shall a the time of hife is short

what, is't a time to jest and dally now

life time's fool; and time, that takes

the times are wild; contention ........

to dignify the times, since Casar's ..

this I shall have time enough to mourn

tis more than time: and, my most.

lordshipgood time nf day: I am glad

the uncuiet time for your quiet

little regard in thesc coster-monger times -

as the times do brawl

what trust is in these times? ........

we are time's subjects, and time bids
your place, your time, and business?

so sick as yours at this time is?.

play the fool with the time...........

thie time was, father, that you ........

the time was, father, that you ...... iii. 3 


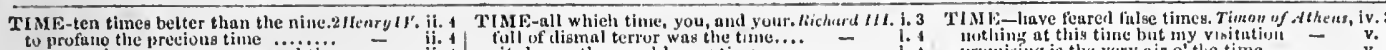

wenty-nine yenrs, come peasciul tiinio ve the revolinim of the times unke

clic time uhall come, tlus did he (rep.)

fivetelling this same time's comblition

the nature of the times sleecasetl

beome the hateh nud brool of time.

tis the more time theu wert used..

let time sliape, and there an end....

when way the stream of time doth ra

the condition of these times to lay

the times to their neeessities (rep.)

tho time misortered doth..............

rutten times, that you sliall look upon

will, in the perfectness of time, cast.

ime's doting chronieles, say (rep.)

for now a time is eome to mukk.....

to weleome the coudition of the thine

$O$ if $Y$ lad had time to have mude...

jumping o'er times ............. lenr.
the stumbling and uaguiet time did.

than ever at one time the elergy

there was not time euough

at one time bring in to all

their throsts abuut them at that tini

I will cut your throat, one time or other

God, Godl three or four times $\ldots$ iny custom

nuw be welghs time, even to

it is no time to diseourse $\ldots . . . . . . . . .$. .

I warrant you, when time is served.
'tis not the first time you were ......

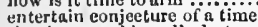

the time was blessedly lost

if the time were eouvenient..........

aud time hath wora us into glovenry
liad ten times more yalour .........

the exeuse of time, of numb lii. 1 ited up a thaterror was the tinc.

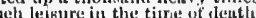

and in good time (rep. iii. I und iv. $i$ ) are all thiug reacly for tint royi tiul

iii.

iii. ! my usulse tor

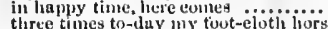

1 proplsecy the fearfil'st tine tos the

iii. 2 ut any time, to graee my strutugcms

iv. I
iv. I your mectest vantuge of the time.

lave any time recourse untu.

nelluwed by the stealing hours of time

the corruptiou of alousing time

iv. 1 could not at that time, have told ine

iv. 1 propheey, the time would come

iv. A the ruins of distresstul times repaired

v. 3 teu times double gail of

v. 5 herenfter time, for time part

not by tirne to eome (rep.)...........

where and what time your inajesty..

i. 2 my heart is ten times lighter thau

ii. i nucls about cock-shut time, from....

ii. advantage will deeeive the time.

ii. 3 why, then 'tis time to arm, sind give

ii. 4 enfurcement of the time forbils iv

iii. 2

whole time I was my ehaunber'........

till this time, pomp was singl

heard him at any tiue speak aughit?

I remember of sueh a time

tis time to give them phy

longer than I have time to teil i i.......

wheu old time shall leud him to

a most unfit time to disturb him

by this time, I kuow your bark.

you may then spare that tim

currse and procesy of this tian

I will be bold with time, and you

let me have time, and counsel, for

the ofter of this time, I callut promise

you liave scaree time to steal

nutury onces l lave a time; a time to

nuth

ike rams in the old time of war.....

the times, and titles, now are

times to repair our nature witli (rep.)

may find rood time, and live ......

with thiel the time will load him ...
we triffe time away; I long $\ldots . . . . . .$.

which time shall briug to ripeness

for this play at this time, is only ....

the next time I see lier

be you my time to bring it to

fame, in time to expeoce.

for this time will i take my leave.

the advantage of the time prompt

all that time, nequaintanee

time hath, my lurd, a wallet

to envious and ealumniating time

an effeminate mna iu time of action

bitter dispositivu of the time will ...

justles ronglily by all time of pause..

anjurious time now, with a rolber

walked hand io hand with time.

arlitrator, time, will one day end it

I will the seeond time, as I wuuld

when many times the enjitive...........

and, at that time, berpeuth you.......

near? why then another time I ii hiea

his days aod times are past

the time is unnareeable to this ......

wherefore, ere this time, had you not
at many times 1 brought in my ....

yet now's a time, the greates

luve found a time and ofe then

if the time....

that this is no time to lend money

it pleases time, and fortune, to lic

might purchuse his ow'n tine.

the govol time of day to yon,

treneher-friends, time's flies, eaj and

time lats as

there is no time so miscrable

unest with thins time's buis

strange times, tliat ween witi taughing

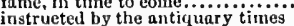

unthing at this time but my vinitution

prothising is the very air o tle time
at all timea alike men are not (omp.

filled the time witl all licentious

iii. 4 now the time is flush, when ..........

ii.. 1 and, from this time, for what he clid

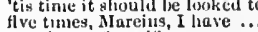

in whieh time, I will nuke a lip

and 'twas time for hitn too, l'll wair.

at some time when lis soaring (rep.)

is content to spend the time, to cund it

the Just on antique time would lie...

wlich will in time broak ope the

the violent fit o' the time cruves

iv. 4 and when such time they have

Y. 3 from time to time elsviten agaiust

\begin{tabular}{l|l}
$v .3$ & the fittest time tu currupt a \\
$v_{3}$ & a hundred times liath broke
\end{tabular}

v. 3 beat me out twelve several tines...........

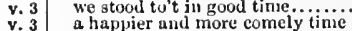

v. 4 in tlie interpretation of the time

yct one time be did call me

the interpretution of fill time may

keep your name living to time .....

that so sliort a time can alter ...........

many a time and oft have you

alw of these times. L Eliall reenunt

and this time is like to lay to hum....

every time gentler tban other

then he oftered it the third time (rep.)

for this time I will leave you ........

indeed, it is a strange-disposed lime

'tis time to part. But it is
'

O what a time have $y^{\prime}$ out cherse out

eowirds die many tiones betiore ......

brenk up the senate till antotlier time

'tis but the time, and drawing days..

aluridged his time of learing death

how many times shull Casar bled in

in suels a time as this, it is not .....

young bloods look fur a time of rest.

the very last time we shall.

60 to prevent the time of life..........

I slall find time, Cassias, I sliall (vep.)

two several times by night

wilt thou bestow thy time with ne?

let's not confuund the time with $A$ uron

I have seen her die twenty times o...

in time we hate that which we of ted

strong necessity of time coniminils...

to confound sueh time, that drums

tu frout the lwain did sho

sleep out this greal gap of time, uiy...

like to the time o the $y$ ear between...

a time for private stomaching (rep.)

being barbered ten times o'er....

all whieh time, before the gouls my.

that long time have been burren...

take your time. 'Tlion ean'se not.....

well deserved ten times as mucl.

the time shull not ont-go iny thinking

be younot troubled with the tine ...

with uew' tle time's м ith labour.

to try thy eloqueuce, now "tis time...

and ut this tine most easy 'tis .......

1 must stay his time

bcing twenty times ot het ter furtine

the tume of unisersal peuee is near .

and time is at lis periul

he sladl in time be realy

all the learnings that

flis pent leman at that time vouchin.....

witli live times so muels cunversation

Your service for this time id ended

in time sle will wot

tive times redecmed trom death.

klusuld at one time eneunter suchi..

I have outsturod my titue.

onc, two, three,-time, timei ......... tii.
iii.
it will in time win upon nuwer

ii. s unl, at all times, to undereret

one time will owe anothe

you shall have time to wransle in

who in the wars of the tine............ dymbertine,

v.

i. 10

i.

ii.

ii.

iii.

iii.

iv.

iv.

iv. 6

v. 1

i.

i. 3
ii. 1
ii. 1

ii. 1

ii.

iii.

iii.

iii.

iv. 3

$\mathrm{v} .3$
$\mathrm{v} .3$

vi.j

i. 3

i. 3

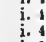

i.

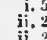

ii. 2

ii. $\frac{2}{3}$

ii. 5

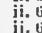

ii. 7

iii. 7

iii. i9

iii. 11

iv. 2

iv. 12

guxnl time of day unto (rep. I. 3 )
num twenty times made trutise

in sliat sail time, my manly eyes....
tis time to speuk, niy pains are.... 
T1ME-gome more time must wear ..Cymbeline, ii. $3 \mid$ TIME-monse-hnt in your time.Romeos Juliet, iv. 4 TIMON-thee, worthy Timon (rep.). Timon of Ath. i.

ceened the Dian of that time

stronger than it was at that time ....

the gup that we should make in time

than in all the fore-end of my time...

were, in his time, thought false......

but to win time to lose so bad.

all that good time will give no

but from this time forth $\ldots \ldots . . . . .$.

she said upon a time, (the bitterness

and the time of their despatch

in the advantage of the time

but time hath nothing blurred

make good time with hin

su time into

ha

the time's tronblesome; we'll slip you

and meet the time, as it seeks us ....

in such a time, nothing becoming you

waste their time upon our note
the time seems long; their blood

the time seems long; their blood

in which time she purposed, by

and in time when she had fitted you

et the time run on, to good.

upon a timc (unliappy was
but in sloort time, an offices.

but nor the time, nor place

at dead time of the night ...............

make us wondered at in time to come

now is a time to storm; why art .....
chanced in the times of old.......

what time I thres the people's

till time beget some careful.

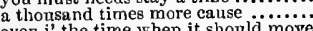

even i' the time when it should move

many a time he danced thee on......

played upon before your time ..........

tis time to fear, when tyrant

I see that time's the king of men..................

if in which time expired ................

aud time that is so briefly spent...

nor have I time to give thee hallo

strong renown as time shall

carry winged time post

not worthe we waste and ............

advanced in time to gr'eat....

a second time within these arms

a second time within these arms it....

time shall unfold what plaited cunnin

world bitter to the best of our times

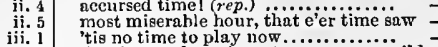

iii. 2 the time and my intents are savage-wild -

as the timc and place doth make .... -

iii. q some hour before his time............ $\overline{\text { Hamlet }}$ v.

iii. 4 so hallowed and so gracious is the time...

iii. 5 and for this time of meeting, thus much

iii. 5
iii. 5
iime both in time, form of the thing..........

given private time to yon.............

at such times seeing me, never shall
the time is out of joint; $O$ cursed spite

the time is out of joint; o cursed

as to expend your time with us a while.

and time is time, were nothing but (rep.

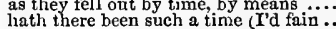

at such a time I'll loose my ........

haply, he's the second time come $\ldots \ldots . . .$.

bear the whips and scorns of time

some time a paradox, but now the time.

ond the very age and body of the time

full thirty times hath Phœbus' cart...

have times twelve thirties been........

drugs fit, and time agreeing ..........
we shall obey, were she ten times.

tis now the very witchirg time of night

lapsed in time and passion, lets go by....

in the fatness of these pursy times

iii. 2
iv. 3 chief good, and market of his time .....

\begin{tabular}{l|l} 
iv. & tears, seven times salt, burn out \\
iv. 3 & love is begun by time, and that \\
v. 3 & time qualifies the spark and fire of it
\end{tabular}

v. 3 convenience, both of time and menns

which time, she chanted snatches
O the time, for, ah, my behove, $O$

in's time a great buyer of land

borne me on lis back a thousand time

it is the breathing time of day

only got the tune of the time......

in happy time. The queen desires you

but till that time, I do receive your....

in good time, must his lientenant be.

what's to come of my despised time...

nine or ten times I had thought $\ldots . . .$.
till fit time of law, and course of direct

in councill in this time of night?

with thee: We must obey the time

many events in the womb of time.

W whipe

which the time shall more favourably

on some odd time of his infirmity........

as the time, the place, and the condition

man living, may be drunk at some time

in happy time, Iago. You have not been

some other time. But shall't be shortly

I pray thee, name the time; but let.

aud many a time, when $I$ have spoken

hath a hundred times wooed me

a man, that all his time, hatl founded
than the dial eight score times?

in a more continuate time, strike off

and leave me for this tim

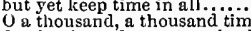

for the time of scorn to point his slow

what place? what time? what form?

the act of shame a thousand times ....

more impediments than twenty times
from this time forth I never will speak

the time, the place, the torture ........

TIMED with dying cries .............. Coriolanus, ii. TIMELESS-your timeless grave. Two Gen.of Ver.
bloody office of his timeless end..... Richord II. behold office of his timeless end.... Richord II. duke Humphrey's timeless deatb ...2 Henry ${ }^{\prime} I$. ii. for their parents' timeless death ...3 Henry VI. v. complot of this timeless tragedy.. Titus Andron. ii. 4

power, time means to meet $\ldots \ldots . .$.

keeps time, distance, and proportion

which ten times faster glide tlian.....

till we can find a time to blaze

hundred thousand times more joy

not had time to move our daughter..

these times of woe afford nout to to wo

comes well in such a needful time ...

madam, in happy time, what day ....

on Thursday, sir? the time is very sibort we must entreat the time alone...

out of thy long-experienced time ..... -

shall be much unfurnished for this ti
tili Thursday; there is time enough
I wake before the time that Romeo.. iv. 5 thou giv'st so long. Timon, I fear me

and haste you to lord Timon (rep.)...

this is to lord Timon (rep.) $\ldots \ldots . . .$.

who is not Timon's? (rep.) ..........

one of lord Timon's men? (rep.iii. 4) -

who, the lord Timon? (rep.) .......

as you said, Timon is slırunk, indeed -

Timon has been this lord's father (rep.) =

winter in lord Timon's purse .........

this is Timon's last; who stuck......

the quality of lord 'Timon's fury?...

lord 'Timon's mad. $I$ feel 't upon ....

and grant, as Timon grows, his hate

yet do our hearts wear Timon's livery
for Timon's sake, let's yet be fellows

yea, himself, Timon disdains

the noble Timon to this change? $(r e p$.
little gold of late, brave Timon

ay, Timon, and have cause .........

wive us some gold, good Timon

farewell 'Timon; if I thrive weli .....

and have forgot that cver Timon was

where liest o'nights, Timon?
with the bensts? Ay, Timon

then, 'Timon, presently prepare.

eat, 'limon, and abhor them .
save thee, Timols. Now, thieves?

hail, worthy Timon! Our late.

wonld speak with Timon (rep.) ......;

worthy Timon,-Of none but such (rep.) -

lack of Timon's aid, hath sense (rep.) $=$

Timon hath made his everlasting (rep.) -

much hazard, if they bring not Timon

no talk of Timon, nothing of him....

so did we woo transformed Timon

those enemies of Timon's, and mine own - v v

here lie I, Timon; wlio, alive .. - v. 5 (epitaph)

TIMOR - gelidus timor occupat artus.2 Herry ${ }^{\prime} l$ iv.

TIMOROUS-like a timorons thief.... All's JFell, ii.

nusic to thy timorous goul

of England's timorous deer.

ah, timorous wretcht thor hast $\ldots \ldots$ 3IIenry $r I . \mathrm{i}$.

with like timorous accent, and dire yell.othello

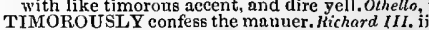

with his tinet gilded thee thelying .... All's 'Well, v.

with blue of heaven's own tinct

as will not leave their tinct............ Hamlet, iii.

if you can bring tineture ....... IVinter's Tale, ii

TINDER-strike on the tinder ............ Othello, i.

TINDER-BOX - of this tinder-box...Merry Wives, i.

TINDER-LIKE upon tno trivial ..... Coriolamus, ii.

Tom Suout, the tinker (rep. iv. i)...Mid.N.'s Dr. i.

present profession a tinker?.. Toming of Sh. 2 (ind.)

and not a tiuker, nor Cliristophero Sly $\overrightarrow{2}$ (ind.)
if tinkers may have leave. Winter's rale, iv. 2 (song)

and married a tinker's wife within .j - iv.

drink with any tinker $\ldots \ldots \ldots \ldots \ldots \ldots$ Henry $I V$. ii.
sent from a sort of tinkers.........2 Henry $V I$. iii.

TINSEL-with a blueish tinsel .......Mrch Ado, iii.

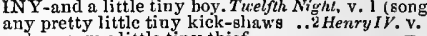

we that has a little tiny wit...........

If -we'll tip thy horns with gold ..... Much Ado, v.

that tips with silver all these ...Romeo \& Juliel, ii.

TIPPED - than one tipped with hor'.. Much Ado, v. TIPSY - of the tipsy Bacchanals.Mid.N.'sDream, v. TIP-TOE-Will stand a tip-toe when.. HenryV.iv. stands tip-toe on the misty ....Romeo \&. Juliet, ii
TIRE - if I had such a tire... Two Gen. of Perona, iv.

any tire of Venetian admittance...Mlerry / 'ives. iii.

tire the hearer with a book of words... Much $d d o$, i.

that yet would never tire (rep.).Mid.N. Dream, iii.

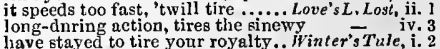
your sad tires in a mile-a ......... he tires betimes, that spurs .......... Richard ll. ii. tire on the flesh of me, and of my....3 Herry $I$ i. i

his way, self-mettle tires him ....... Henry $I^{\prime} I I$.. .

with surplus, to tire in repetition.... Coriolanus, i.

laving rich tire about you, should at..Pericles, iii.

TiRED out of breath ............ T weifith Night, iii. the tired borse his rider.................ove'sL. Lost, iv. fie, fie on all tired jadesl .... Taming of Shrew, iv.
my horse is tired; my master........ my horse is tired; my master........ tired majesty did make thee ofer.. and when thou hast tired thyself ...inenry $I \nu$.ii. as tedious as is a tired horse $\ldots . . . . .$. . nen $r y v$.ii. I 
TIlzED-truth tired with itcration. Troil. \& Cress. iii. yeu, my nemury is tired

of 'Tiber dicl i the tired Casar......... Jutius Corsar, i. I have tired myself; and for two.. Cyrabeline, iil.

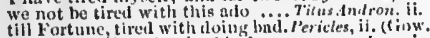
within a lull, stale, tireel bed

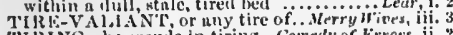
TIl ING-he spends in tiring. . Comedly of krrors, ii.

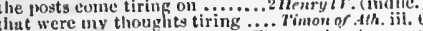
witness the tiring day......... Tims smlronicm, $v .2$ TiRRA-LIRiR elants..... Winser's Fule, iv, 2 (song)

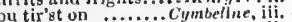

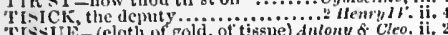
"TIs UE E-(elotl of gold, of tissue) Aniony of Clco. ii. IITAN kiss a dish of butter? (rep.) IHenryl toueh of common-kissing Titan.... Cymbeline, Rome, as Titan's rays .... Titus Andronicus, i. 2 作 NTINIA-proud Titania.........Mid.N"s. Dreum for slume, Titania, glance at my. should Titania crosa her Uberon.. where sleeps 'Titania, oome time I wouder, if 'Titnuia be awaked. (ao it eame to lass) 'Titunia wak
now, my Titania; whe your

TiTif of a hir was never lost...... i Hepry erery tithe soul, mongst many. Tino of thens TITIE.PIG-a tithe-pig's tail ... Roneo \& Juliet, TITINIUS, as a sick girl ...........Julius Caes. Lucius and Titinius guard our door. Lueilius nod Titimius, bid the forl-night, Titinus: noble, noble stund fast. Titintus: we must out O. look, Titinius, look (rep.)... Titinius, if than lovest me (tep.) ..... it is but ehnnge. Titinius; for Uetavius Eeek lim, Titinius; whil I I go to .. Cassius' sword, and find 'Titinius' heart Titiaius mourning it. 'Titinius' face hrave Titiniug! look, whe re have Trint diest as brnvely as Titidi he iustice of your title to him........... liis dressings, eharaet s, titles, forms...

tho uader that worse title, and I wil yicld thy crazed title to my certain ...Mirl.N.J, as an appertirent title to your ... Love's L. Lust. to have his title live in $\Delta$ quitain. a title to Phobe, to Luna, to the onec more what title thou dost.......er. of that I had a title good enough to .... - it

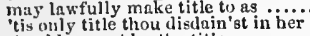
should go, not by the titie ................. to which to be arcat part of your title... a title for a maid, of all titlcs. Taming a title for a maid, of all torely kiss? that vulgars give bold titles

I am proof against that title $\ldots . . . .$.
u'ith his former title greet Macheth by which title, befure, these weir his mansion, and his titles, in
thy title is affeered! fare thee now does he feel his title hang usurpingly these several titles......... King John that bars the title of thy son whose title they armit, Arthur's or to verify our title with their lives and make ler rich in titles, lonou (having so great a title to be more prince) to guard a title that was rich ............
ardich an immortal title to sour crowa! barelv in title: not in revenue ........ must flnd that title in your tongue... to raze one title of your lonour
ti) be brief, left I his title out .......

have no name, no title,

Inst that title of respect which $i$ ije

Nortimer doth stir about his title

militury, title elapital

to pry into his title, the which

a bormwed title hast thon bo

of his true titles to some certain witls opening titles miscreate ... make elaim and titie to the erown to fine bis title with some show ...... king Pepin's title, and IIngh Capet's in right and title of the female their erooked titleg usurped from the fareed title running 'fore the king Minrtimers, in whom the title rested.I mnonify'rt with ail cleae title citlier accept the title thou usurjist.. nithough in glorions tities he excel. cleliver up ny title in the queen ....2 9our grace's titte whall he multiplicd ain I a qucen in titic and in style. craving your opinjon of my title ... umber the title of Inha Moitimer... the title of this most renowned duke
CICLE to the crown? (rem.) my title's wenk; tell me be thy title right ar wrong .
write up his title with 118 orpin bear's the title of a kin ur title still laml slept $\ldots \ldots \ldots \ldots \ldots$. Whiles Warwick tells his title..... misehunee hut is trou my title down. usurus tle regul title

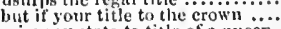
rilise my stute to title of a Itwer
but as this title honours me. fioret our title tis the erown. fight, if you pretend no title? prinees have but their titles for ......hichors $\overline{\text { iv }}$ i. between their titles, and low nane
us I had title in thy noble husbundi that might have kept that title salute you with this royal title from that kingly title than is the doting title of a mother under what title shall I woo to wail the title as her motler doth...

but liow long shall that title, cver, linst

a proper title of a peure $\ldots \ldots$ howned he fis title to the

to hear that load of title? ............

Wilingly that noble tite your the times, and titles, now are altered

few of you degcrve that tit

and lordship are my titles...Tria.... . Cressitla, ii cliaritable title from thousands.... Tim

give them title, knee, and approbation
wlyere gentry, title, wisdom cannot. Cori

name my cournge, prove my titlel. Aintony \& Cleo.

bou may wear her in title yours

plead my successive title witi your.................

be, as your titles witness, imperious.

first, Bir, ill pray, what is your tite?

charms in it, whose title more..

strike, and prove my tite thine........... me title, and my perfect soul, shall .... Othell TITLED goddess; and worth it, with.. Alt's W'ell,
as amply titled as Achilles is .. Troilts \& Cress. TITLE-IEAF, foretels the nature ..2urnry 1 . TITLEL ESS, till he had for bet

TITTE.PAG TITTE-TATTIING before all our. Hinter's
TITUS [see ANDRONICUS ard 1.ARTIUS] your young nephew Titus lost... Tuelfh Night, gnod-morrow, Titus and Ifort
lut in now. Titus. NIy lord

then, valiant Titus, take convenient

as is the wind: deliver lim, Titus

thy noble brother Titus, and his sons

graeious conqueror, vietorious Titus

graioe-noble Titus, spare iny first-born
to tremble under Titus' tlirentening look
to trent

honour live lord Titus long! (rep.)

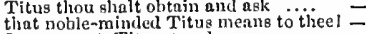

for an onget, Titus, to advanee

thanks. nohle Titus (rep.) .........

no, Titus, no; the emperor needs....

Titus, whien wert thou wont to walk

nohle genticman, lord Titus hero $\ldots i i$

take 'Titus' yart, and so supplant

rise, Titus, rise; my empress hath
Titis, I am ineorporate in llome

Tiens, I am ineorporate in lione
le it so, Titus, mnd gramerey too

Titus, prepare thy noble eyes to

goon 'Titus, dry thine eyes ..........

becomes not 'Titus' brother

but, 'litus, I have touched the.

Titus, I am come to talk with

my brother! 'tis gad Titus ealle.......
whieh the careful 'Titus hath ordaine

the villain is alive in Titus' house

go, go into olu' 'Titus' sorrow ful house

like the trat, urly, and venomous, As you the ii.

adders' heals, and trad

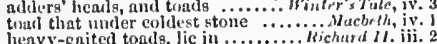

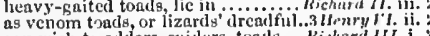

enn wish to adders, gpriders, tonds .. Kichard $I I I$, i. 2

never limg poison on a fouler ton

poisonong hunch-backed toad

I linte the engenclering of toads.

engenders thic hisck tond...... Timon of Atheus, iv.

slave! Toarl! Rogite, roguc, rogut t.

were't tond, or adcler, spider......... Cymb

aq Inathanue as a toad amongst..

the thai, the tadpole, the wall-newt ....t.rar, iil.

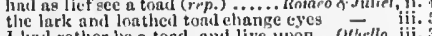

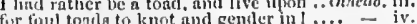

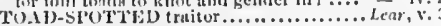

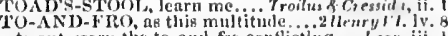
To $\Delta S^{\prime} \Gamma-1 u t$ a tos int monc but guel toaste an! butt

2 1lenryli: il. is rlueumntic as two dry toast: Ireny $r$.ji.

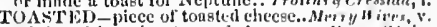

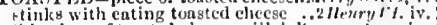

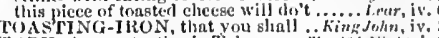
TOB Y - by my troth, sir Toby.......? Juclith Nisht, i. ride hame to-morrow, eir 'T'oby (rep.)

if' sir 'Toby would leave trinking.

gir Tobs, madam, your kinstunu

gool rir'Toby (rep. ii. 3 and wit. 4 )...

sir' 'T'uby, there you lie ......

to ask for my kinsman 'Tuby ..........

Tohy approaches; court'sicis there $t$, me -
and does not Toby take you a blow..

cousin Toby (r.p.iii. 4) will baftle gir Tuby, I

this is a dear manakin to you, sir ioby =

sir Toby, my lady prays you to look

hold Toby; on thy life $\ldots . . . . .$.

Bonos dies, sir 'Toby $\ldots$ sir Thiby

and has given sir Toby' a blowl

I was set on to dlo't by eir 'T'oby'...

Ohe's drunk, sir Toby, an hour.....

I'll help you, sir Toby to.

myself, and Toby, set this device (rep.). U-DAY - so mueh sack ä I to-diny?.. Tenpest, iii.

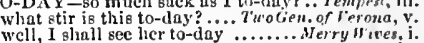

no school to-day? No....

was to-day with my lady ...............

to-day, my lord ...................... -

inquired for me here to-day?....... aseas.for Meas. iv. Ifrill not die to-day tor any man's... as, to be a Dutchman to-day ......... are you yet determined to-day to marry $=$ I do dine to-dny at the father's
a fairer facc not washed to-day

a fairer facc not washed to-day

that you to-dny promised to tall...M.
must measure t wenty miles to-diy.

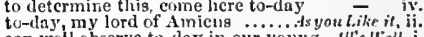

can well observe to-day in our young... Al's $1{ }^{2}$ ell, $i$.

1 saw the man to-day, if man ..........

will your honour wenr to-lay? $\ldots . .-2$ (induc.)

you think to dine with inc to-thy

I will not go to-day (rep. iv. 3 ) .......

slie cat no ment to-day ............... -

such a day to-morrow as to-day 3. inter's Tre

penitent for your default to-day.. Coraedy of $\mathrm{E}$

not dined to-day. Nor to-day here.

been Dromio to-day in my place $\ldots$

he told to-lay at dinner

loek me forth to-duy, and why dost.

all in rage, to-day cane to $m$

and my toster, to-dny dia ilie.........

of you two did cline with me to-day?

goes the king from henec to-day? ........ucbeth, ii.

once more to-day weit inet...............

let not to-morrow then ensue to-ilay

your lordship: to-clay, as I came by

llenryll.

I om a ryos if loukiled to-dlay?.. - ii.

enrl of Westmoreland set forth to-ilay - iii.

no man night draw short breath to-day

Staftord dear to-day hath houghit
not etruek so fat a deer to-day

if thou eubowel me to-day
upon our party slain to-dus.

shown upon our erests to-day.

to-tlay might $I$, lunging on ..........

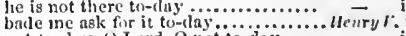

net to-duy, O cord, o not to-day ....
Erencli gullants, shall to-day draw out -

in E,ngland, that bo no work to-ilay!

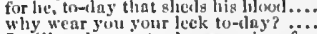

I will make you to-day a equire of . .i Freneh, then deatf had dicd to-day... is intend to try his grace to-ding......... any thou canst conjure up to-diay.....
to thrive to-day, it gities ny boul.. 


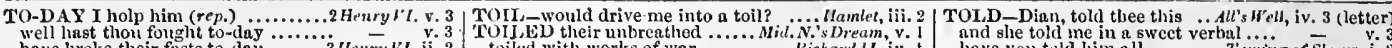

have broke their fasts to-day.

whil cost ten thousand lives to-day ...

why louks your groec so heavily to-disy?

whu slew to-dny a riotous gentleman

to-duy the lorils you talk of are lehended -

to-day shalt thou bchold a sulject die

three times to-day my foot-cloth horse

how mine enemies, to-day at Pumfret

I am not in the giving vein to-day

who suw the sun to-duy? Not $I$.

the sun will not be seeu to-day ........

not shine to-day? why, what is that

to-day, the French, all elinquant ... Henry

to-day he puts forth the tender leaves - iii.

guod sport is out of town to-davi ....

fixed, to-day was moved: lie elid

who said he came hurt home to-d
I think he went not fortl to-day

I take to-day a wife, and my

who's a-field to-dny? Hectur.......

I long to hear liow they sped to-day

and do not fight to-day (rep.)..........

I am to-duy i' the voin of chivalry
I'll stand, to-day, for thee, and ne.

I would not have you fight to-day..

and will uot arm to-day; whercunon
who hath done to-day mad und fautastic-

though 1 end my life to-day .........

hitnted with his honour to-day. Tmon of dhens, ii.

to-morrow; to-day; presently

yon have jrayed well to-day

proceeded, wortly note, to-day.....

tell us what hath chanced to-day
will come forth to-day, or no ........
holl him from the Capitol to-day

stir out of your house to-day (rep.)

stny at home to-day for fear (rep.).

that I will not come to-day (rep.).

remember that you eall on me to-dain

your enterplize to-day may thrire
tongoe had not offended so to-day

if you thare fight to-day, come to
tho gods to-day stand friendly

the gods to-day stand friendly

政

that thou couldst see my wars to-day

the blood that has to-dny escaped...

lie hath tought to-day, is if a god

their preparation is to-day by sea.

what I have lost to-liny at bowls ...

we'll hont no more to-day, nor seek

to-day, how many would have given - iv. 2

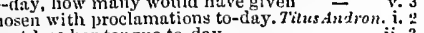

your liusband from his hounds to-diay!

you have slowis to-day your valiant .... Lear, v. 3

saw you him to-dav?............ Romeo \& Juliel, $i$.

Eot leave to go to shrift to-day? I have - ii. 5

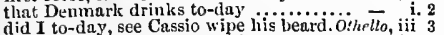

TOE-each one tripping on

from toe to crown he'll fill.

ont o' the toe like a parish top ........

as my toes look through. Taming of Shrem, 2 (induc.)

ere of newt, and toe of frog

plays the rogue with my grent toe.... 2 Henry $y$ iv.

the mother's, from the top to toe.. Richard III. iii.

grandsires had nails on their toes. Troilus \& Cress. il.

fie rises on the toe: that spirit

the great toc of this assembly? (rep.). Coriolanus, $\mathrm{i}$.

the man that makes lis toe what.. Lear, iii, 2 (song)

that have their tocs unplagned KRomeo \& Juliel, i. 5
from top to toe? My lord, from head.... Ilamlet, i. 2

the toe of the peasant eomes so near

theurt is thou tofore hast beeu! T Titus Lost, iii.

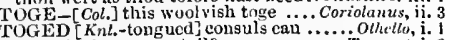

TOGED [Knl-tongued con
TO1L-is there more toil?

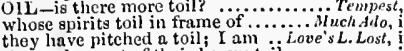

show a harvest of their heavy toil..... - iv. 3

to toil and trouble in the world. . Taming of Sh. $\mathrm{v}$.

double, double toil and trouble (rep.). Mrrebeth,
this toil of ours should be a work of.. King John,

after auch bloody toil, we bid good-night - v.

dry with rage, and extreme to

yost corporal toil, a linudred

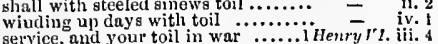

service, and your toil in war wa.... Henry t'2, iii.

forspeut with toil, as runuers

not used to toil, did almost

Henty III. $\mathrm{i}$.

their observant toil ........... Troilus \& Cressidta, i.

in her strong toil of grace ...Anlony \&. Clenpatra

the toil of the war, a pain

I am weak with toil, set strong.........

puts himsclf unto the shipmas s toil Prericles, i. 3

the drudge, and toil in $y$ or

su nigitity toils the subject. toiled with works of war
like a brother toll

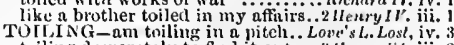

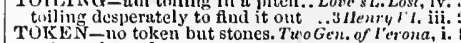

to leave her token.

and, on that token, the inaid..........

say, by this token, I desire his .........

enticements, oatlis, tokens, and all...

tokens und letters which she did re-send -

may token to the futore our pust

by this token I would relieve her

in tokeu of which duty, if he please

or seud ine by some token ..Comedy of Errors,

do you not read some tokens of ....... Kingr Joh

may bear tlose tokens home

2 Henry $1 \mathrm{~V}$

loving token to his mijesty?

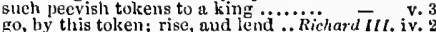

gives token of a goodly day to-morrow

a token from Troilus (rep.) ... Troilas \& Cressida, i.

token from her doughter

give me some token for the surety .. - v.

or any token of thine hunour.. Timon of Alhens,

by tokens, send such drealful ...... JulinsCarsar,

some uobler token I have kept ...Antony \& $C$ C
with tokens, thus, and thus ....... Cymbelin

with signs aud tokens she can scowi.... Tilus $A$ nd. ii.

send thy token of reprieve................ Leut,

but she so loves the token, (for he ...... Humlel, ii.

this is some token from a newer friend.

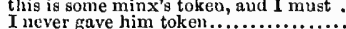

- iv. 1

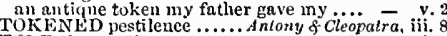
TOLD the no lies

as I told thee be

I thonght to have told thee of it ........

I told you, sir, they were ............ - iv.

Launce, his man, told me..............

I could have told you more...........

murry, as I told you before.

I told you, sir, my laughter

as you told me you had appointed?
I told him you were sick (rep.) ... Tivelfth $\mathrm{N}$

The has been told so ......

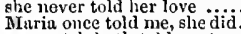

slie first told me, thou wast mad

lie hath not told us ot the eaptain ..... - v.

say, Pompcy told you 80 ............... for Meas. ii. I

you live told me too many.......

there was a tiriar told me of this mai -

her nother hath many times told ......Much Ado, i.

any wit, that told you this?.........

will you not tell me who told you so?

I toli him, and I think, I told him true -

she told me, not thinking I laad

will you look to those things I told you -

what was it you told me of to-ilay?..

a pretty jest your daugliter told us of

I was told you were in a cousumption,

my lurl, tair Helen told me..........

that have 1 told my love, in glory...

it will fall pat as 1 told you...

of midnight liath told twelve...........

I told you; my lord............
then of one is easily toli

told our intents betore, whici..........

even so; my tale is tolit...............
for the which, as l told you...Mercinant of $\bar{v}$ e

three monthe, yout told me 60.

often liave you lsead that told

who told me,-in the narrow sens.

ii. 7 (seri.i

thought upon Antonio, when lie told =

I treely told your, all the wealth

when I told you my state $(r e p$.).

when the tale is told, bid her be.

have told you of good wrestling $\ldots A s$
thou hadst told me of another father

you told me, you salute not at the

I lold him of as good as he

my triends told me as mucli

math told the thievish minute

I have told my neiglibour .............

my notler told me just liow ........
I have told your lordship already. and she told me in a swect verbal .....

twas told me, you were rough

as I told you befure, simois..........

I lold you, I, he was a frantic .....

nay is told you, your sold you of ...

nay, it told you, your son was beloved -

's 7 ale, ii. 2

it was told me, I slould be rich....... - ii. 3

I told you what wee, how I wns cozened - iv. 3

how of tem have I told you ..1.....

were it lut told you, should be ......

ay, ay, he told his mind upon. Comedy af Rrrors, ii.

and told thee to whnt purpose

a mad tale, lie told to-day at

what I told you then, I hope

two truths are told, og a

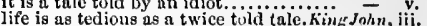

and told me, Hubert should put out - iv.

when you should be told they do prepare - iv. $\quad$ iv. 2

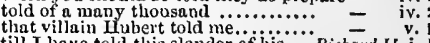

till I have told this slander of his ... Richard II. i. I

you told me, you would tell

the clevil that told me, I did well .....

that I told you yesternight

these nine in buckram, that I toli thice

so I told lim, my lord; and I anid ...

I told him gently of our grievanees

would have told him, half his 'Proy'
whereby I told thee, they were ill.

and told him, there were five ........

I was told that by one that knows .. Ifenry $r$. iit.

he liatl not told his thought .........

thou couldst have better told ......2nenry $/ \dot{T}$. ii.

the duke lantls told the truth

I think, I should have told your grace's -
and told me, that by Water I ghould die -

till all were told, the words would ...3 Henry $I$.

yout told not, how Heary the sixth .

Itold your majesty as much ........ - iii.

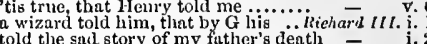

told the sad story of my futher's deatl

good uncle Gloster told me (rep.)....

pretty York, who told thee this? .....

my grandam told me, he was.........

have told me, I beinir by, that $I$ should

because a bard of Irelaidd tola me once

speeds best, being plainly told ...........

your highness told me, I should post - iv.

I told my lord the duke............Henry $\bar{v}$ ins. i.

1 told your grace, they would talk anon - i.

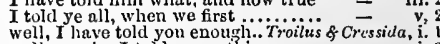

well, cousin, I told you a thing...... \&

this shall be told our lovers........... =

wherein you told, how Diomed $3 . . .3$.

dined with him, and told him (rep.) $=$ - iij.

while they have told their money.... - iii.

thou wast told thus ..................

which told ne -

fruith, sir, if you had told as many $\ldots$.

as I told you, he put it by once .....Julius casar i.

forgot the will I told you of .......... $\overline{\text { f }}$ Cleo. i.

so Fulvia told me: 1 pr'y thee.

my news I might have told hereafter

I have told hin, Lepidus was........ - iii.

thou wiuld'st havo told this tale tor

who told you of this stranger?

revolve what tales $\mathrm{I}$ have told you...

two berrars told me, I conld not $\ldots .$.

they told me, here, at dead tinic. Titus dndron. ii. 3
no snoner had they told this (rep.)..

she langherl, and told the Moor...... $=$ iv. 3

many a matter hath he told to thiee...

liis riddle told not, lost..........'Pericles, $\mathrm{i}$. (Gower)

if you have told Dimna's altar true ... $\quad-$ Lear, i. 3

I inve told youl whint Ihave seen

I told him of the army (rep.). . .

and told me, I liad turned the

aud told me I had white hairs
they told me I was cvery thing

and, when 'tis told, 0 that iny heirt

i. 2 ii. 4

(3)

1
4
2
7
1
1
2
1

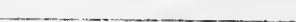


ToI,I)-firat to last tolu him my pilgrhage l.rar, v. told the most pitcous (ulo of feir.........

I thiak, lie tolil nie, l’aris oliould

(iy told ine, he liath very oft

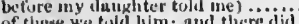

are he told him; and there did

- iii. I

I have tolil the oftun, and I re-tell thee. Othello I. 3

iill the belt lauth told elever.

二 iii. 3

ahe told low tord thee, he was of noy

she told her, while slie kept it

ay, 'twas he that tolld ine first

I told him whut I thought; and toli iio

youl tild a lie; an odious, damnet lie.

\section{- iv. 2}

tol.

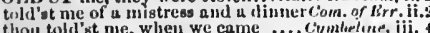

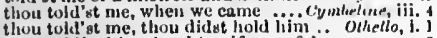
thous told'st him that his wife was fulio

THEEDO, this is purposed........... Henry VIII. i. . chou didot make toleruble veut of tliy..All'a "llil, ii. 3 TU1, - in a fnir, und toll him

solul ty the or toll in our dominions. King John, hi. elocks do toll, und the third hour. lirary $f_{\text {. iv. (cho.) }}$

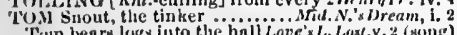

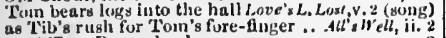
as 'Tib's rusli for Tom's fure-

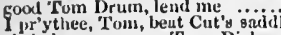

elíristian names, as Tom, Dick.

and here, Tum, take all the money...2 Ifeñy $V$ ii. 4

with an sigh like 'Tom o' Berlla.

poor 'T'urlygood! yoor Toin! $\ldots$............

bless thy five witsl Tom's a-eold (rep.)
do poor Tum some cliarity, whom tlie..

phor Tom, tlant eats the owimning frog

liave leen Tum's food for Beven long

liaunts poor Tom iu the yoiee of (rep.)
'Tont will throw lis liend at them (rep.)

foor Tom, thy jorn is dry .......

'tis poor niud Tomp. And worse

juor 'Jum hath heen geared out of

thy urm; poor 'Tom ghull lead thet... = jv.

TysiB-suited to his watery tomb. J weirth Night, v.

in a tornb where never scandal
hang lier an epitaph on her tomb

lis uwn tomb ere he dice

hang thou there ujon the tomb... - v. 3 (seroil)

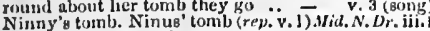

a toinb must eover tly sweet eyes.....

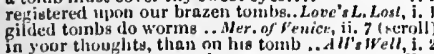

debauched on every tomb

is the tomb of honoured bones indeeri

by the honomrable tomb he sweurs.. Itichard It. iii. 3

thou king Kieliard's tomb, and not

in lis tomb great grundsire's tomb, from

Yll erect a tomb wlyerein his .........

mother s bloped in Gloster's tomb?....2 IIenry $l^{\prime} l$. iii. 2

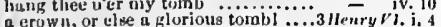

a erowll, or tiave a tomb of orphans' tears. Henry I'lit. iii.

what's on this tonds $I$ caimnot read.

with femule tairies will his tomil

Coriolunus, iv.

thy tomb with blool. Tilus.

lo! at this tornb my tributary teurs

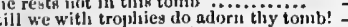

by my futher's reverencl tomb. I vow

the tomb where grief should seep
diviree nue from thy motlier's tomi

that's nature's nother, ie dier tomb. Wingeo f.

as one rleurl in the bottom of a tomb

when I an laid in to the tomb.

swet tomb! [Col, knt.-U woe]

witls fumeral praises do nlorn tliy tomb =

ogen the tumb, lay ne with Juliet

fic to open tlese deal inen's winhs

a toise dis! beure ne from the tomb.

ane with light to ope the tombs
wilich is not tomb enougli, and

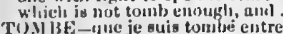

Toly 13E-tyle je suis tornbe entre...

Toil bI, liss. with no rencmbrance

to-suinrow be in readinese to go $\left(r e p_{1}\right)$

let lim les ocin

I do invite you to-murrow moriing.. - ji.

will he tip-nurrow at court ...........

will esine this way tu-inorrow

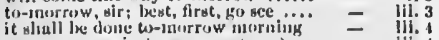

you, come aruin to-murrow (rep.) . -111 .

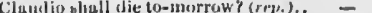

Cluntio sliull die to-morraw? (rent)

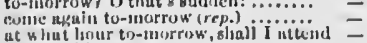

as I dot think, to-morrow ...........

ns I lear, wuat die to-thorrow (rep.)

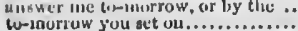

TO-MolthoW-ilient to-norrow. Mras. for Me realy Clandio, for your denth to-jnorr

if Clandio die to-morrow, wr nu? (rep.) latl you to-morrow in your exeention by eight to-inerrow the minst le inule
but le must lie to-inorrow? the duke eomes lonne to-morrow (iejp, to-morrow, iny lord; time got's on ... Mach d do Why, every day; to-morrow; eone

your lordship to be nurried to-moirow? -

if you love her then, to-morrow weal her -

Why I sluould not marry ber to-morrow
for the weddiog bejing there to-morrow

to-morrow morniug eone you to my

until to-morrow morning, lords .... $=$

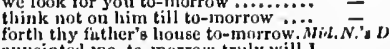

ajpointed ine, to-norrow truly wili 1

to-morrow night when Plawbe duth

to coll them by to-morrow might $\ldots$...

to-morrow you shall have a sight. L

the

siare a pound of flesli to-morrow. Mer, of Fenice, jii. 1

what you wrestle to-morrow before tha -

to-morrow, sir, I wrestle for my credit 二

they shall be married to-morrow..... =

why then, to-morrow I eannot serve

to set her before your eyes to-morrow

to-morrow meet me all torether

I'll be married to-morrow (rep.) .....

begoue to-morrow: and be sure of this

to-morrow I'll to the wars, slse to b.
they fell: to-morrow to the field ...

he will be here to-morrow, or I .......

and if I die to-morrow, this is liers .
know, to-morrow is the wedding-duy

be, nor to-morrow, nor till I please..

miny thee for thy gow to

very sooth, to-morrow. Wëli part

cory soth, to-morrow. We't part .. $\quad$ i. 2

that tu-morrow you will bring.. Conedy of krr. iii. 1

to-rnorrow, - as he purposes.............

but of that to-morrow: when, therewithul -

get thice gone; to morrow we'll liear ....

o-morrow and

let not to-morrow then ensue ....... Alichard II. ji.

to-morro:v next we will for lreland..

shull we take a purse to-morrow .....

tin-1norrow niphit in Eusteheap (rep.)
ride with us to-morrow; 1 huve a jest

will I set furth, to-morrow you......

wutels to-nisht, pruy to-morrow

thod wilt be horribly ehid to-morrow

ts-morrow, eousin Perey, you and I

Jack, meet me to-morrow i' the 'Ternple

likc enough, you dn; to-morrow, gool

powder me, and eat me too, to-

thou shalt have a eaj) to-morrew

some good thing eomes to-morrow
to-morrow shuli you know our in

to-morrow for the murch are we ....

some of them will

I will trot to-njorrow a mile

we shnll find to-moorrow they liave only -

to-morrow, the king lisnself will be..

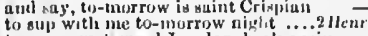

to-morrow, tisward Iondon. bick ànitis -

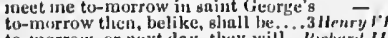

tommorrow or next day, they will. Micharil It i

for we to-morrow hold divider counsels

alversaries to-morrisw are let blexd..

to-marrow in my judgment is uo, sulden-

the visit lim to-morrow, or next day.

bisorrow may it please yont to be

I lie to-night; but wiliere, to-morrow

fur, lorils, to-morrow is a buky day..

pives taken of a goodly day to-morraw -

with the lurk tomorrow, gentle Norlinlk -

white Saricy for the flitd w-morrow

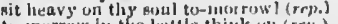

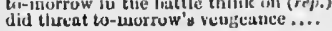

(1)-Noltuow, they made Isritain.

to- morrow blossoms, a nd bears ligs

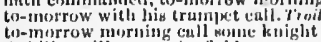

Achilles will not to the flelil to-minruw
to-morrow, we must with ull our maju

an' you take leave till th-morrow.....
if lector will to-morrow be miswered

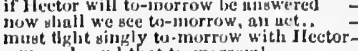

mast thglis singly to-morrow w
a wound; und that to-morrow

I'il flght with thee to-1norrow............

to-morrow, do I meet thee, tell as death -

jny great purpose ln to-morrow's battle

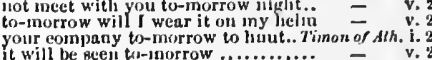

to-morrow; to-day; iresentiy.......... Coriolanus, iv.

will you dine with me to-morrow? Juliu Catsur

senators to-morrow menen to catubli-h =

is not to-morrow, boy, the ides of Alureh? - ii.

hope of better deeds to-morrow ...Anlony \& Cleo. iv.

that to-morrow the last of many battles -

to-norrow, nollier, by sea and land..

I hope well of to-morrow

to-morrow is the day ................

to-morrow', before the aun shali see us - iv.

this night; I must aboard to-morrow. Cymbeline, i.

comes to Mrilford II aven to-murrow

to-norrow, yield up rule ...... Tilus Andranicus, i.

and to-morrow is her birtlday ........ pericles, ii.

to-norrow, with his betst ruff on ....

and swore he would gec lier tu-morrow - iv. 3

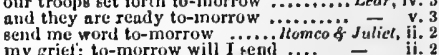

at whint oclock to-morrow shall I send -

ask for me to-morrow, and you thall

and know ber mind early to-inorrtw

this knnt knit up, to-morrow morning

we'll to church to-morrow ...........

belioveful for our state to-morraw

you'll be sick to-morrow for thit.

to-enorrow elall I beg leave to see

are of tlis t(t)-norrow.... Oihello, $i$.

to-morrow, with aur carliest, let me have $=$ ii. 3

why then, to-morrow night t................ - iii.

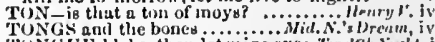

ONGUE blubs, then let mine ey"es. Frelfh Night, i.

thy tomgue, thy face, tliy in the tongues

lier eyce hail lost her tongue tongue tang argaments (rep. iii. i) -

ii. 5 (letter)

it hatl no longue to vex you

and the tomgue of loss.................. rempext, i..

who, with cloven tonkues............ - $\overline{\text { ii. }} 2$ (son

the harmony of their tongues hinth .. - iii.

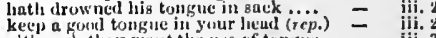

no tongue, au eyes; be silent ........ - iv.

fice. fle, unreverend tomguei........... - ii. 6

thut man that hath as tongue (rep.)...
liberul. Of lier tongue slic cunnot...

lave you the tongotn? $\ldots \ldots \ldots \ldots \ldots \ldots$.

live in tliy tongue and laeurt ..........e fos. for.leo.

tomgue far from lieart.................
with more tame a tongue desire it

not sound a thouglat upmon your tongue

hearing not my tonglie, ullihors un ..

Tave no torggue but one

tic the gntl uy in the slund rous turigue? -

the tange of Iraluel ..................

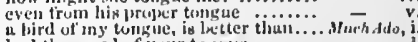

hut the speed of yonr tonk the ........

if thou be sos slarewil of thy tongue .

1 cunnot endure my latly 'Tongue....

tongue is the clapjer (rep.) ............

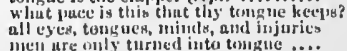

me'l ure only turned inta tomigne
take a nerpent by the tougae

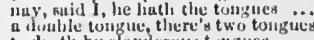

your toulges ytect uir molu 
TONGUE should catch (rep.).....Mid.N.'s Drenm, i. I spotted snakes, with double tongue for with doubler tongue than thine.. enswers trom my geotle tongue? sometime frame tliy tongue his tongue to conceive, nor his lieart as from the rattling to

tonirue, not a word: come.........

the iron tongue of midnight hath told - v.

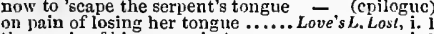

and my mother's tongue assist mei.'.

by base sale of chapmen's tongues

his tair tongue (conceit's expositor)

hy adding a tongue which I know

jig off a tune at the tongue's end...

when tongues speak sweetly, then ...

well learned is that tongne, that well

nor tongue of mortal tell . ..........

love's tongue proves dain ty Bacchns

his tongue filed, his eye amb

you have a double tongue withiu...

the tongues of mocking wenclies are

a blister on his sweet tongue, with

the motion of a school-boy's tongue

lurd Longaville, reign thy tongue...

news I bring, is heavy in my tollgue

and the world's large tongue proclaims

never in the tongue of him that........

in a neat's tongne dived..................

I have ne'er a tongue in my head...

tears exhibit my tongue: most ......
I'll swear that $I$ do know your tongue

a maiden hath no tongue, but thougb

no power in the tongue of man to......

hangs these weiglits upon my tongue?

that will not, hold your tongues

wherein my tongue hath wronged him

tongues I'll hang on every tree.. - iii. $\overline{2}$ (verscs)

cry, holla! to thy toligue........ - i iii. 2 (verses) unless yon take her without her tongue -

that flattering tongue of yours won me $=$ iv. I

an eye may profit by a tongre .......

his tongue obeyed his hand...............

and hellish obstinacy tie thy tong

a man's tongue shakes out h

my tongue is too fool-hard

and can speak thy tongue.........

low tongue, and lowly .... Taning of $\dot{S} h .1$ (induc.)

bear the penance of her tonguc?

in Padua for lier scolding tongue (re

do you tell me of a woman's tongue =

in nis tongue. Whose tongue? Your

my tongne to the roof of my mouth

and charm her chattering tongue.... $=$ iv. 2

there is no tongue that moves .......Winter's Tale, i. $\mathrm{i}$.

for sealing the injury of tongues $\ldots . .$.

a cll use that tongue I have: i

that wilt not stay her tongue.......

thiat wilt not stay her tongue..........

clamour your tongues, and not a word - iii. 2

it is as hitter upon thy tongue ......

your eye, will have your tongue too

be not thy tongue thy own shame's..

my tongue, though not my hed

thongh my tongue do curse.

so cracked and splitted my poor tongue

with the valour of my to

your hand, your tonme.

why do we hold our tongt,

both with eye and tongue

wool of bat, and tongue of $\mathrm{dog} . . . . .$.

whose sole name blisters our tongues

let not your ears despise my tongue

and braggart with my tongue

accursed be that tongue that tells

gives the bastinado with his tongure.

gives the

the law forbid my tongue to cursel.

may'st hold a serpent by the tongue

which till this time my tongue did ne'er -

with his iron tongue and brazen $\ldots$

without a tongue, using conceit alone

presages, and tongues of heaven $\ldots . .$. .

hold your tongue (rep.)

the utterance of a brace of tongues

cut ont my tongue, so I may keep

hut this from rumour's tongue

can give audience to any tongue
TONGUE shall hukh again this ...... KingJohn, v, l | TONGUE-wag his tongue in censure. Henry VIII. $\mathrm{i}$. and let the tongue of wur plcad

that know'st my tongue so well

breaking from thy tongne, should ïsape $\overline{-}$

clamour of two eager tongues.

ere my tongue shall wound.....

which robs my tongue from me

whereto thy tongue a party verdict.

gave leave to my unwilling tongue.

that my tongue should so profane

the tongues of dying men enforce

his tongue is now a stringless instrumen

disburdened with a liberal tougue

whe double the your tongue.

discomfort guides my tongue

than can my care-tuned tongue dejiver

my tongue hath but a heavier ......

that e'er this tongue of mine.

bow dares thy harsh rude tongue.....

your daring tongue scorns to unsay

heev mine own tongue deny my

while all tongues cried-God save thee

no joyful tongue gave him his welcome

to speak, thy tongue to teach

what my tongue darcs not ...........

and clocks the tongues of bawds
whose tongue shall ask me for one

no more bint one tongue for all

forbade my tongue to speak of Mortimer -

thine ear to no tongue but thine own?
gave the tomgue a helpful ornament

gave the tongue a helpful ornament
for thy tongue makes Welsh as sweet

I defy the tongues of sootleers........

your praises with a princely tongne.

hand of death lies on my tongue....

my tongues continual slanders.. 2 Henry $I \bar{V}$. (induc

from Rumour's tongues they bring.

the fire, ere he his tongue.

see what a ready tongue suspicion hath

and his tongue sounds ever after....

may his tongue be hotter $!$...........

the harsh and hoisterous tongue of war? -

and your tongue divine to a loud ....;

delivered o'er to the voice (the tongue)

if my tongue cannot entreat yoi.

my tongue is weary; when my legs are

turn the sands in to eloquent tongues

brokenly witl your English tongue

these fellows of infinite tongue

will hang upon my tongue like

than in the tongues of the French

our tongue is rongh, coz; and my ....
shrewd tempters with their tongues.. Henry VI. i.

and yet thy tongue will not confess.

cet bars before my tongue..........

I see, must hold his tongue ....

with envious carping tongue

enchantress, hold thy tongue

confounds the tongue, and makes..... = v.

and fret, and bite his tongue $\ldots \ldots \ldots 2$ Henry $V I . \mathrm{i} .1$

thabnrdens with his tongue the envious -

my heart accordeth with my tongue
with slander's tongue be wounded.

tempted Suffolk's tongue (rep.iv. 1 )

a serpent seen, with forked tongue...

shall it charm thy riotous tongue....
that speaks witly the tongue of an enemy -

this tongue hath parleyed unto foreign -

he has a familiar under his ton

and wish, or tongue can tell...........

and bite thy tongue, that slanders ...3Henry $V$

story hanging on thy tongue?

nor can my tongue unload my heart's

give no limits to my tongue

thou hast thy mother's tongue

to let thy tongue detect thy.........

and his ill-boding tongue no more.

and with my tongue, while heart is

or I will charm your tongue

a passing pleasing tongue ..............

Richard v.

was provoked by her slanderons tongu

my tongue conld never learn sweet.

and prompta my tongue to

to $n$ se our hands, and not our tongue

have I a tongue to doom my (rep)

a sparing limit to my tongue

woe-wearied tongue is still and mute

my tongue should to thy ears.........
several tongues, and every tongue ... $\begin{array}{ll}v .2 & \text { which action's self was tongue to ..... } \\ v .2 & \text { tongues spit their duties out }\end{array}$

if I am traduced by tongue

you can speak the Frcneh tongue.....

every tongue sjicaks them, and every

the general tongue unto us...........

were tried by every tongue, every

a strange tongue makes my cause :-

i. 3 every good tongue blesses.............

ii. to silence envious ton tongue $\ldots . . .$. - iii. 2

ii. $\quad$ stands under more calumnious tongues -

wagging of your tongue to win me.

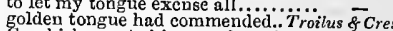

iii. 2 Greekish ears to his experienced tongue -

iii. 2 I shall cut out your tongue..........

sweet, bid me hold my tongue

iii. 3 he wears his tongue in his arms ....

iv. 1 and deedless in his tongue a......... -

. he speaks the common tongue... Timon of $A / h$

I would, my tongue could rot tliem off! -

$v .2$
$v, 3$
$v .3$

3 the tongue our trumpeter................ Coriolan

i. 1 all tongues speak of him .............

i. 2 that for their tongues to be silent.......

i. 3 to put our tongues into those wounds

i. 3 cannot bring my tongue to such a pace =

ii. 1 but mock, bestow your sued-for tongues? -

iv. 1 the tongues o' the common mouth ...

${ }_{2}$ pluck out the multitudinous tongue

your worthy rage into your tongue.

words that are but roted in vent .... -

must I with my base tongue .........

never trust to what my tongue......

in thy lying tongue both nimbers...

ii. 2 and that tongue of his, that bade ... Julius Ceesar,

good-morrow from a feeble tongue... -

the voice and utterance of my tongue
put a tongue in every wound of Cæsar

put a tongue in every wound of Cæsar
this tongue had not offended so to-day
for Brutns' tongue

for Brutus' tongue hath almost ended $\overline{-}$

never have tongue to charge me .....

a host of tongues; but let $\mathrm{i} i$

repent, that e'er thy tongue hath so

mine own tongue splits what .........

their tongues rot. that speak against

this is but a custom in your tongue ... Cymbeline,

to my tongue, charms this report out
we'll try witli tongue too $\ldots \ldots . . . .$.

will to ears, and tongues, $\ldots \ldots$ theme....

whose tongue outvenoms all the worms

talk thy tongue weary; speak .......

or else such stuff as madmen tongue

ly thine own tongue thou art.

that thunder'st with thy tongue... Tïus Andron

the palace full of tongues, o

that womanhood denies my tongue....

she hath no tongue to call....

detect him, cut thy tongue $\ldots . . . . .$. -

she but lost her tongue, and in a.....

with their tongues doon men to death

or shall we bite our tongues.

their stomaclis with their bitter to......

both ear and heart obey my tongue..

torment you with my bitter tongue $i$.

her tongue, and that, more dear (rep.)

cut away her tongue, and they, 'twas

with his solemn tongue he did discourse -

tcll thee with speechless tongues ...... Pericles, $\mathbf{v}$.

give experience tongue; they do abuse ...

our tongues and sorrows do anger

[Ool.Kni.] till tongues fetch breath that..

to give my tongue that heat ................

more richer than my tongue

such a tongue that $I$ am glad ................

whan slanders do not live in tongnes

that thy tongue some say of breeding ..... - v. 3
had I your tongues and eyes, I'd use $\ldots . . .3 \overline{-}$ v. 3
words of that tongue's utterance. Romeo \& Juliel, ii. 2 over the king in his tongue.

. your good tongue, more than ........ - v.

the voice and utterance of my tongue -

hearts, tongues, figures, scribes, bards

nor tongue to tell me who hath .......

let us, that have our tongues

strnck me with her tongue.......... 
TONGUE [Col,-voiev] moro hourse.. Komea o-Jud.

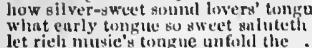

owifue thu his tongut. his agilu arm every tungue, that sfraks luit lomeo's what tongue sluall smooth thy num hold your tongue, good prurlence $\ldots$. with that same tongue which she hath ties un my tongue, nut will not let me give it an unlerstanding, but no tongue give thy thoughts no tongue, nor my.... cunds the tongue row

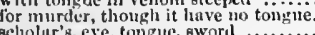
acholur's, eye, tongue, oworil

let the trippingly on the tongue ......... iny tomye und soul in this be hyporite an idle tourue Go, go, you guestion (rep.) darest wag thy tongue in noise so rude... enps, hands, and tongnes, appla

clant sull haul ut tonume in it, and eould. thure are no tongues else for's turn

as of her tongue she of bestows on me...

tonfue at will, und yet was never lowi

I hul ralher liave this tongue ent from

will speak, though tongues were out of $u$

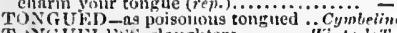

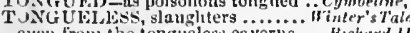

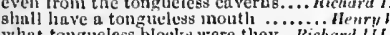

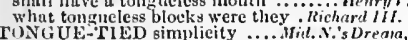
Tong

tongue-tied our queen?
since you are tongue-tied

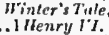

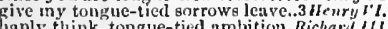
if so, thell be not tongue-tied

grant all tongue-tied maidens... Truilus \& Cress.

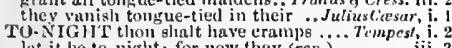
let it be to-night; for now they (rep.).. 1 wave dreamed to-night .......... iii. 3 once to-niglit. give my sw.

to-vight at licrue's oak

the matter will be known to-night.

on whom to-night I will be revenged

be patient for tornight ............... Tet

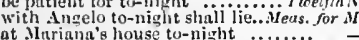

go but with me to-night, you shall see -

there is a grent eoil to-night .........

our wntelh to-night, exeepting your.

sing it to-night: to-morrow morning

to-11iglit, I take my lenve

dist! kecp his revels here to-night... Mid..$\overline{.}$ s. Dr. ii.

hung themselves to-night? ....... Love'sL. Lost, v.

his master will he here to-nitht... Mer.

I do funst to-night my liest-esteemed

I har to-night; yout shall not rage (rep.) -

to sup to-nigltt with my new muster

I ditl liream of morey bngz to-night

no masque to-night, the wind is

pertormed to-night: the solemul feast. All's

my lord will go away to-night whe away to-night?

and to-linht, when should take...

why then, to-night let us assay our plot =

that my snat will be here to-niglit....

to stzy with me to-nightit?.. Taning of Shrew, I (ivd.)

is't pusuible, you will nway to-niglit? -

slept nit, nor tomight slue shall not

lie tirok gow rest torny ght; 'tis hoped

mulam, he hath not slent to-night . .
hurbour int this town tor-night .. Conedy of $r$ r.

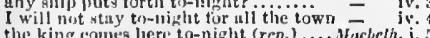

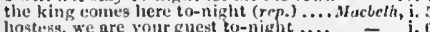

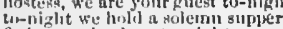

To-N1ciln' pray to-morrow .........

Hewy $1 \%$ ii. 1 we'll to suten-colllelel tu-nicht

[knt.] we must nway all to-night...

二 iv.2

yen, or to-nipht. Content. 'To-nicine

hestow himself to-night in his trute..2 Henry $W$. If.

I must a clozen mile to-night.

sir, you shall not uway t
we will uljonrd to-night

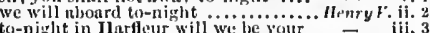

that I saw in your tent to-niglut.... Z ii. 7

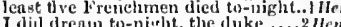

you shall sup with Jesu Clirist to-nighe - - v.

at Northampton they do rest to-night
to-night the boar had rased off his hela

to-night the boar had rased off hill I lie to-nightit; but where

I will not suy to-night; give ne some

I will play no more to-niglit ...... Herty 5 tr vi

Troilus lodges there to-nigit . ......

fell as death, tornight, all frends....

Diomed dloth fenst with him to-night

bluad with Greekish wine to-right .. - v.

silver basom and ewer to-night. Thnon of Athens, iii.
we sluall have news to-night........ Cariolumes,

We slinll have news to-night ........ Cariol
I will make my very house reel to-night -
it is decreed, he clies to-night .........

wiil you suj with me to-night ......... Julius $\bar{C}_{\text {cesar, }}$ i. 2

but hever tili to-night, uever till now

nor earth. have been at pence to-nisht

he lies to-night within seven leagues

I dreamt to-night, thut I did ti-ast .

to lodge their companies to-nighit
red rays thou dost sink to-niglit

my tent his bones to-night shall lie...

to-niglit, we'll wander through...... -

and to-night I ll foree the wine peep

ny good fellows, winit on me to-night

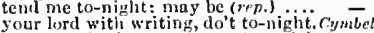

stranger, that's come to court to-night?
l'll wim to-night of him: eome, go ..

nay certainly to-nicht; tor look

to-niglt to-light: but mistress do you

I'll bring home some to-night .........

and the king gone to-night! $\ldots \ldots . . .$.
will be here witll him to-night (rep.)

worthy areh aud patron, comes to-niglit

wlat will inap more to-night ............ $\overline{-}$

thou hast heard me speak to-night

satisfuction east thou have to-nighit?

weo hath not been in hed to-niglit

I'll not to bed to-night

I will henee to-night ................

foot wandere this way to-night ......

my liege, my wife is dead to-niglit

whas this thing appenred nguin to-night?

hold you the wrateh to-niglit?

Whatsoever else slant hap to-oight

the king doth wake to-night .............

there is a play to-night before the king

my good lord, what have I scen to-nighi?

I.ll fuve him henee to-night

your eounsel and your help to-night

ou mast henee to-night. To-night

wateh you to-niglit; for tlie eommand

not to-night, good Ingo

that which he linthe cup to-night

to Desdemona linth to-night earoused

have I to-night flustered with flewwing eups

been to-niglit exeectlingly well eudgeled

to-night at supper? No, not to-nigli

an' you'll eome to supper to-night

air, to-night, I do entreat that we may .

he sups to-night with a hurlot ..........

luve you prayed to-niglt, Pesdemonn?.

Touk pains to make thee spenk

....... Temperst

g't $y$ oul took up so gingerly? T'iro

winen I tork my leave

I took't upon mine houour.

I will set forward to-night... with tongue in venom steeperl... possible to understuud in another tonizue

he swore he would marry ler to-night

to-night I"ll mourn with Hero

to he under sail, and gone to-nighit...

hnse his company to-sightit ........

she'll not come down to-night ......
to-night she's mewerl up to her beaviness

I will wateh to-night; perhaps twili waik

je to-night, hath boardet a lund entuck, othello,

Iiclaci, look you to the guard tominght

song, to-night, will not go frum my mind
Toh) me on their shouldere ....... Alerry Wres, iii. 5
upu my life then you tork the wrong - v.

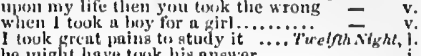
oneme hour befire yon took me from... = she took the ring of me.

in repaying what we took from tiem

that trok the l'heenix...

We took him for a coward .............

might the vantuye best have took

I took no more pains for those (rep.). Much A do, ii.

they are not the men you took thin for

a ecrtain aim he touk ot a fair ..... Nid....'s Dr. iv.

I took him slecping, that is....

that I tonk in the park with ........... Lnve's L. Lost, i.

Ialway took three threes for nine..... -

that took sone pains in writing...... - $\mathrm{v}$.

your highmess took his dukedom....... ds you like it, i.

whase words all ears took eajtive.... $=$ - v.

the Inst that ere I took her leave ....
touk some care to get her euming. Taming of $\mathrm{Sh}$.

the mad-brained bridegroom took him -

he took the brisle about the neek .....

declined, drooped, took it decpiy.... - ii. 3

all that are, took something good.... = iv.

from thy admiring daughter touk the - v.

alluring beanty took from my. Comedy of Errors, ii.

tuok perforee my ring awny (rep.iv. 4 ) - iv.

fit of madness took liin.

and took deep sears to save thy life.

by foree took Dromiu and my son . 0 . Machelh, ii.

and violent hands took off her liti ... - - - vol

advantage of his absence took the king -

as you bay, took pains to get

mily know wherefore we took the.....

Percy here at Holmedon took....... -

came there, took it in sny again........

but took all their seveu points in..... $=$ ii.

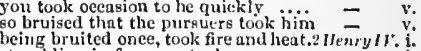

being bruited once, took fire and heat.2 fenry $1 \%$.

and you took it like a sensible lord

wlio took it rom nuy pillow

basis by took stand fur idle ..............
for had you been as I took you for

and he first took exeeptions nt...........

I took ye for my lord protector.
that you took bribes of France.

i took a eostly jewel from my neck.

thy mother took into her blamefiil

sutidenly a grierous sickiless took him

we took him setting of boy"s eopies ..
took odds to eombat a poor famisheri

I took an oath that he should quictly.3 - iv. in

they took lis head and llenry's chair =

when he took a hegrar to his bed ....

to the man thint took him

thing I took the vantage of

Vichard $I I T$.

took he upon him, withont the ....... ilenry r m ii. $i$.

for telling how I took the biow... Troilus $\bar{f}$ Cress.

(old wranglers,) took a trute.

some single vantilges youl took. Timon of $A \overline{t h}_{\mathrm{t}} \mathrm{ns}$,

as I trok not of the place

a inurrain on't! I touk this for silver. Coriolan

and took what lay before them.

I tiok him; made him joint-seryant
ant took some pride to do myself this

where. I lanve trok them ul, ....... Julins $\overrightarrow{C a r}$

therefore i tonk your hanels ............

took it too eagerly : hit soldiciers...... -

he not touk t [ knt.-looket]]. Anfany o-Cleopatra, iii.

being royal, took her own way ......
touk gneh sorrow, that he guit ...... cymbelin

which he took, as we do air

when he tonk lenve of my lariy......
or bought, whut 1 have took ....... this took your brother's life

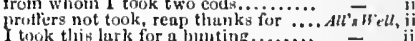

though I took for a bltuting.

for the king's hon took me) who began - v.

forkooth, took on him as a conjurer.. $=$ - v.

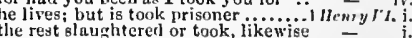

henee I took a thought ... reason - ii. 2 (lciter)

Where it lid mark, it took.......

they took thec for their mother......

2

I diil not think to be si, sal to-nighit
goxl quarter, and gonel care to-niglit 
TOOK-you tonk his life ........ Cymbeline, iv. 2 TOP-branch that's only green at top ...Per icles, ii. 2 TORN to pieces with a bear

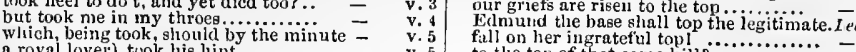
a.royal lover, tuok his hint.

king imto lim took the enemy'tistindran. v. with wlom the fither liking took took some displensure at hin your lord has took himself t took it in rage, thougle calmed thom the the use of mine

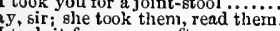
in took it for a man; of ten............ ny name took their discharge....... the sin that they rave took........... presently took post to tell it you. we took this mattock and this spad he took me by the wrist, and held. he took my father grossly, full of bread I took thee for thy better; take thy........
which I observing, took once a pliant $\mathrm{I}$, beiog here, took' t up: look, here it

I, beiag here, took' $t$ up: look, here it is - iii. 3
took you for that cunning whore of Venice - iv. 2
I tonk by the throat the circumcised dog

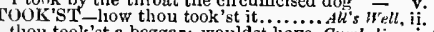
thou took'st a beggar; wouldst liave Cymbeline, $\mathrm{i}$.
TOOL - the great tool come to court. Hemry some coiner witl his tools made. take you to your tools draw thy tool here comes two...Romeo \& Juliet iv. 3 TOOTH-gainst the tooth of time. $M$ Cos. Hainiet, iv. thy tootl is not so keen ... As you Like il, ii. 7 (song) with ne'er a tooth in her liead. Taminer of Shrec, $\mathrm{i}$ set my pugging tooth on edge Winter's T: iv. 2 (song) in danger of her former tooth .......... I acbeth, iii. scale of dragon, tooth of wolf

poison for the age's tooth .............

fell sorrow liat ever chewed with a tooth...... more poisons than the every rankle.

your colt's tooth is not cast pet. food for fortune's tooth... Trailus \& Cressill i i. tuotl that poisons if it bite.

by treason's tooth bare-gnawn $\ldots \ldots \ldots \ldots . . . . .$.
being troubled with a raging tooth $\ldots \ldots$ othello, iii. 3 what? sigli for the tooth-ach?

yet is this no charm for the tooth-ach

he that sleeps feels not tire tooth-ach

TOOTHED briers, sharp furzes

rooril-PICK-and the tooth-

ToOtonth-pick at my worship's mess.. King Joik played truant, and whipped top ...... Terry West, out o' the toe like a parish top

that skins the vice o' the top

to take the present time by the top red-lipped humblebee on the top.Mid. N.'s Adla, $\mathrm{i}$. up to the mountain's top, and mark N. iv. on the top of the mountain? .......Love's L.Lnst, v. to wag their high tops....... Merchanl of Venice, iv. bowed his eininent top to their...........All's Well, j. 2 to bear a schoolboy's top ............ Winter's Tale, ii. 1 the roud and top of sovereignty?......

this is the very top, the height ....... King John, iv. 3 had I seen the vaulty top of heaven $K i n g J o h n$, iv. 3 from windows' tops threw

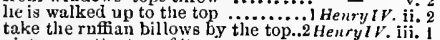
pieture on the top of it ............. iv. 3

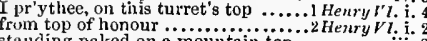
standing naked on a mountain top.. as oo a mountain top the cedar

whose top branch overpeered Jove's. 3 Henry $V I$. v. weok chimney's top

binildeth in the cedar's to all the mother's, from the top to toe ikichard IIL. i. 3 Whose wanton tops do buss.. Troilus o Cressida, iv. which to the spite and top of praises. Coriolans, i. I

as one would set up a top.

yea, to chimney tops, your infunts... Julius Casar, i. whose top to climb is certain ....... Cymbeline, iii. iy the top doth tals

Wliat trunk is here, witliout his top?

climb the higherat promontory to..

cimb the highest promontory top
lu unore but as the tous of irees to the top of that same hill?

make much more, and top extren....

tiptoe on these frut-tree tops ... Romeo oै Juliet, ii. from top to toe?

out on the top of the question.... cried in the top of mine

to the toping top stoops to his base

they fool me to the top of my bent

TopAS_sir Topas the curate (rep.) Tiueifin Night, sir Topas, sir Topa................

dark? As hell, sir Topas (rep-)

TOPe sir Topas, sir; but that's all one

their souls are top-full of offenc.

TOP-GALLANT of my joy must. Romeo Koshn, iii. 4

TO-PINCH the unclean knight..... Nerry Wives, iv.

TOPLESS deputation he puts on...Troilus \& Cress. i.

on the top-mast, the yards
and Montague our top-mast

ToPPED, they ligher rise ................ Pericles, i. 4
lie topped [Knt.-passed] my thought ... Humlet

TOPPING all others in boostio

though eastles topples she

and topples down steeples.

Hlacbeth

seem to rend, and all to topple......... Pericles, iii. 2

TOP-PROUD fellow (whom from ...Her. Lear, iv, 6

TOP-SAIL-take in the top-sail

ORCH-Hymen's torch be i lighted....

dies the dusky torch of Mortime
by thrusting out a torcl 2 from

by thrusting out a torel from
this is the happy wedding torcl

the burning torch in yonder tur

follow his torch, he goes to ..Trailies \& Cressida, v. I

since the torch is out..... Antorty \& Cleopatr. v.

give me a torch, that's turned ..........Perictes, i. 2

give me thy torch, boy: hence...........

what, with a torch! muffle me $\ldots . . .$. .

there, where the torch doth burn

fair Jessica shall be my torchbearer.....

for you must be my torchbearer...... - ii.

TORCHEl his diurnal ring ...........All's Well, ii.

put your torches out torches do. Meas. for Meas. i. marks in links and torches............ Mach Ad do, y. 3 to burn this night with torclies..

fy, brother; torches! torches.

good-night: more torches there

TORCH-STAVES in their hands
CORE-sle tore the letter in to ...

to see how the hear tore out lis...........Much Ada, ij. I tore them from their bonds ...... King Jole, iii. 3
I tore it from the traitor's bosom ... Richiard II. v. 3 ToRMENT I did free thee? (rep.) ....... Tempest, i. and to torment me, for bringing

do not torment me (rep.)....

all torment, trouble, wonder

foul mischance torment me.

shc never will; that's her tormeot ...MTuch $A d a$ iv

till I torment the poor lady worse

a world of torments though I I....Move's $N$ 's. $D r$, ii.

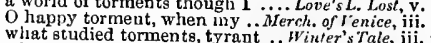
whatever torment you do put me to.King John, iv. those tliree lords torment my heart..3 Henry $V I$. i. as a fury to torment my soul

furment myself to catch (rep.)

chice, take lim to your tormentsl... Richard III. i. 4 in torment and in agony. And cume

thy dullness would torment thee.. Timon of Ath. vv. then be a torment to lier contempt.. Cymbeline, iii. to torment which torments me.

to be a torment to mine caer.e.

a thwart disnatured torment to heri.

to herl ......Lear,

art thou, that dost torment me thus?

to live, when to live is a tormeut........ Olhello, i. 3

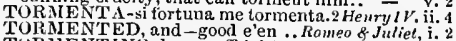

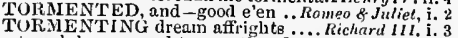

to sulplumous ard tormenting flames .. Hamlet, i.

TORMEN'T'ST me ere I comc to heli Richard 11 .ii.

Tolfulk, thou torment'st thyself'...2 Henry/l. iii. 2

and our faith not tom ............ Love's L. Las, iv.
the lioness bad torn sumc flesh...As you Like it, iv, 3 suck them up to the top-mast..

that which now torments me i....... -

cunning cruelty, that can torment him.............. from my own wiudows tor'....... Winter's Tale, v.
fo. Richur'd $1 \%$. iii. France shonld have torn and rent ...2 Henry $\mathrm{rl}$. i. my arms torn and defaced, and $1 . .$. - iv. not being torn a pieces ............Henry $\bar{\nu}$ III. v. thongh thy tackle's torn .......... Coriolanus, iv. is torn from forth that pretty..... Tilus Andron. iii. TOR RENT of occut of the earth...Rnmeo \& Ju $l$.

the torrent roared; and we did........ Julitus Ccesnr, i.

for in the very torrent, tempest ........ Hnmlet, iit. 2
TORTIVE and errant from his .. Troilus \& Cress i . OR' TOISE-come forth, thou tortoise!. Tempesst, $\mathrm{i}$. in his ncedy shop a tortoise hung. Romeo of Juliel, $v$.

hate me, torture me to death.........Much Ada, iv.

Biron I'll torture ere I go .............. Lave's L. Lost, . . with vilest torture let my life .........All's 'Well, ii. he calls for the tortures; what wili . ${ }_{\text {anter's }}{ }^{2}$ ale iv. what old, or newer torture must $\bar{I}$. the tortures he shall feel, will break $\ddot{b}^{-} \quad$ iii. than on the torture of the miud ........Maebeth, iii. want pains enough to torture me! .. - iv. with Erebus and tortures vile also..2 Heury $r$. ii. that so her torture may be .......... lleny $r i, v$. Jou go about to torture me in vain..2 2 Henry $r \%$. ii. and to were torture more thin grievous lingering - iii. 2

O torture me no more, I will confe....

while we devise fell tortures for ....3 Henry VI. ii. 6
to torture thee the more .......... Richard $111 . \mathrm{iv}, 4$ or hang, or torture, as he shail.änlony \& Cleo. iij. I1 from thee by a sharp torture........... Cymbeline, iv. 3 bitter torture sliall winnow .......... $\quad$ - $\begin{array}{r}\text { iv. } 4 \\ \text { thou'l } 5\end{array}$ on pain of torture, from those . . Romeo \& $\bar{J}_{\text {uliet }}$, i. 5 this torture should be roared in dismal - iji. 2 'tis torture, and not mercy; heaven is - iii. 3 the place, the torture, -0 enforce it! ..... Ohello, iii. 3 and our parting is a tortured body . . All's ${ }^{2}$ ell, $\mathrm{ii}$. with silence in the tortired soul ...Richard $I I$. iv. 1 tortured above the felon.........2 Henry VI .ii. I play the torturer by smail and

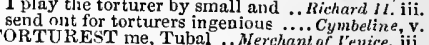
Ol'TURING-a torturing hour?.. Nid. N.'sD?. TOMY never heard of torturing pain. Tilus Aud. ii. he is descried; Cresar has taken Toryne - ii.
TO-SPEND it so unneighbourly! .... King John, v. OSS - tut, tut, good enough to toss... J Henry I $\%$, iv. I will toss the rogue in a blanket ..2 Henryl $V$. ii. now did the sea toss upon our shore... Pericles, back do I toss these treasons
ToSSED-as yon are tossed witi have tossed me on their pikes must not be tossed and turned. Timon of Athens, ii. billow, sir, as tossed it upon shore .... Pericles, iii. TOSSETH - that she tosseth so? . Tilus Andron. iv. after late tossing on the breaking.. Riclard II. $\mathrm{ji}$. TOSS-POTS still had drunken.. Twelnh $N$. v I (song) from coast to coast is tost .............. [Cal.] on the sea, tumbled and tost - v. (Gower
TOTAL - tlierein to a total ... Trailus s Cressida, now is he total gules; lorridiy tricksd . Hamlet, ii. 2 TOTALLY_mistake the truth totally.. F'empest, ii. ] TOTTERED [Col.-tattered] battlements Rieh.l I . ii ii. [Knt.] wound our tottering colours.....All's Well, i. in this our tottering state?........ Richard IIL. 1ii. thirsty after tottering honour ......... l'ericles, iii.
roUCH me, and speak to me a touel, a feeling of their affictions. tonch me not; I am Dot Stephano. the inly touch of love ....TwoGen. of Verona, i. whose golden touch could gofte...... - ii. take that rude uncivil touch......... touch me his finger-end ............Merry $\bar{W}$ ives, $v$ so excellent a tonch of modesty ....Tuelfh Night, $\mathrm{ii}$. to touch fortune's fingers ........ - ii. 5 (letter) Ry, toucl him: there s the rein....ineas. for Meas. ii. particular scandal orice can touch

as free from touch or suil with lie

they that toncls pitch will be defiled.Mruch $A$ do. iif. brave touch! could not a worm. Mid.N.'sDr. jii. one day in a week to touch no food... Love's L. L. i. $\mathrm{i}$. durst poet touch a pen to write

a sweet touch, a quick venew of $i$.

seape the dreadful touch of. Merchane $\nu^{-}$anice, v. I will not touch a bit ................. Asyou tike it, ii. ? as the touch of holy bread

in the most bitter touch ot surrow $\ldots . .$. . All's $w_{\text {ell, }}$ i. do not tunch my lord! $\ldots \ldots \ldots \ldots \ldots . .$. - iii. herc she stands, touch her whinever of Shrew, iii they slial not touch thce, Kate..... - 


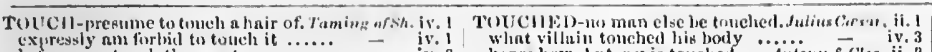
hetore you touch the ment

to: sip, or truch one ilrept of

others tousch, yet often touching........

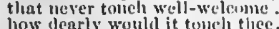

nothing ceint timel' him furtlier

he waints the naturnl touch

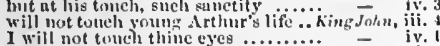

as to touch the lists.

knows nu touch to tiinc....

dnred nonce to forech n dust of Englanil'e

nay with a mortnl touch throw

emult never touch the ground ....... I/

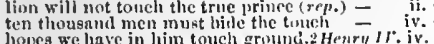

touch her sof mouth, and march....... Hecury 1 : ii. 3

tonch of flarty in the night...

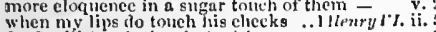

for I wili temeh thec but with,.

anl dare not tonel his own ...........2
their touch affrights me, as in serpients

sinart as lizaril's

but knows some touch of pity ....... Michard III. i. $^{2}$

to tonch his growt th nearer

Yct touch this s graringly

mand am, 1 have a touch, to try if....

and his blessings touch me alike....ttenry $r$ I

or touch of her good person?

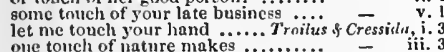

one touch of natnre makes............

here is a touch: is't good? .............

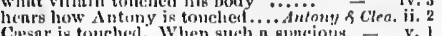

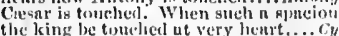

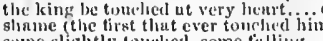

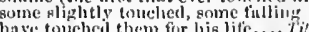

1 have touchell thee to the quick...

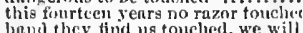

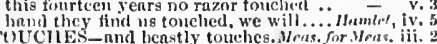

the touches of swect harmony ... Mer. of i ienice, v. 1

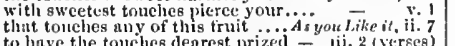

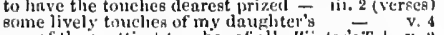

me of the pretticst touches of all. Mrinter's Tale, y. 2

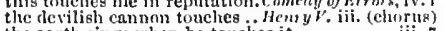

thic earth sings when he touclics it . . Richard 13. ii. 7

souches me decper than you...

work some touches of remorsc?. Troiltes \& Cress. ii. 2

strite lives in these touches $\ldots$. Timan of athens, i.

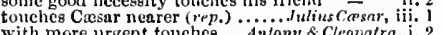
with more urgent tonchce ... Antony \& Clenpatra, i. 2 that touches this my first-torn ... Titiussutron. iv. 2 tremble, touches us not with nity ......... Lear, v. 3

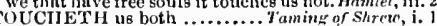
the quarrel toucheth none but...... I Henry l'li. iv. far as toucheth iny particular... Trailus ơ Cress, ii. 2

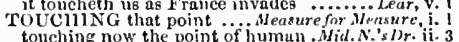
touching now the point of human . Midl; N's s r r. ii. 3 little boy, as touching the hit it? (rep.)

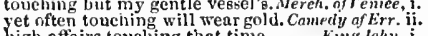
high affitirs toucling that time ....... King saln, his grace at large, as thuching France. Hen
touehing our person, seek we no revenge as partly touching or concerning the

as touching the dircetion of the military - $r$ iili. 2 and touching the duke of York

articles be drawn touchung the jointure - iii. 3

as touch ing Richmond ............ Richard IIIT. v.

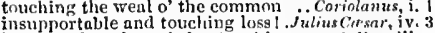
listory of my knowledget tonching . Cymbeline, iii. 5

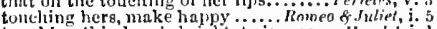
touching this dreaded siglit, twice reen .. Hawlel, j.

something touching the lord I Ian
touching this vision herc,-it is

Filcenk of ramfort, touching the Turk ish. Othrllo, ii. I this sliephererl's iffe, master Touelietone? -

not a whit' Touchstonel................ Pericles TOU UG II sevior. Wliy tough (rep.)...Love's L.Losit, i. 2

thy tough commixtures melt

$O$ silles, yon are too tough! ................ Lear, it. 4

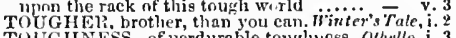

TUURAINE, Mnine (rep. it. 1 and ii. z), King Jahn, i. 1

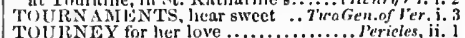

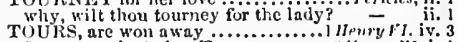

famous ancicnt eity, rours............2 Henry

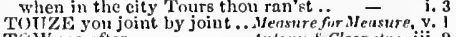

Tolv me after ............. Anlong d Clenputre, iil. 9

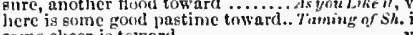

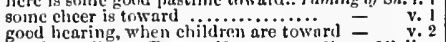

good hearing, when childrem are toward - 5 .... y. 2

spoken like a tow'ard prince
here's a noble feast toward...

I pereeive, four feusts are townrl, futony of Clea. ii. 6

liuse you heard of no likely wars toward. Lear

there is some strnnge thing tor
nuglat, sir, of a battle toward

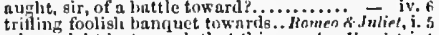

whut miglat loc toward, that this swecaty. Nlanter, $i$. I

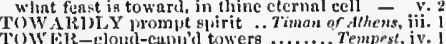

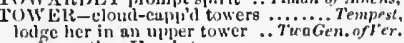

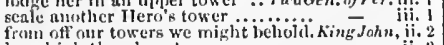

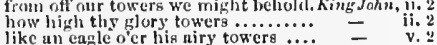

like an eagle ocr his niry towers ....

convey him to the Toucr

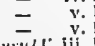

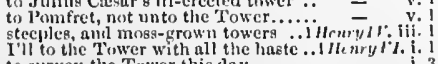
to anrvey the Tower this dny ........
hath here distrained the 'Tower to his

hath here distrained the 'Tower to his
have armotir here out of the 'Tower.

in yonder twwer, to overneer $\ldots . . . .$.

at Iondon-hridge, ns at the Tow'er?

thrinsting out a toreh from yonder to
sour statcly and air-Lraving towers my nnme liath touehed jour ears.....
barren, tonched in this looly chuse... when the navcl of the atute was tonclied - ii.
TOW k'1R-linwks dn tower 80 well....2 Hewry $r /$. ii. I ail ne your honour from the tow if you cent hurn down the ?'iswer ton

the duke of somerset is in the Tow ow

he lie espryesell unto the 'T'ower.

llene with him to the Tower.

you Tower, the Tower 1 owe Ned

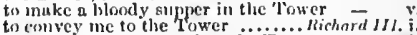

sluall he new cliristened in the Tower
the king that sends you to the Tower

the king that sends you to the T-we
ecund Lirel Jlastings to the Towe

dinre ailsenture to be sent to the rower

I hid hroken from the Tower.
I thall repose you at the Tower

I do not like the Tower, of any pinec

at the 'Tower, and weleome you (rep.)
shall not slcep in quict at the Tower

on them, to I into the Trow

summon him to-morrow to the Tower toward the to the rowcr...

then was I going priboncr to the Tower =

she's wandering to the Tower.........

nock, with me, unto the Towe.....

1 mean those bustards in the Tower

the chaplain of the 'Tower liath buried
the king's name is a tower of strength

tlink on the Tower, and me
tlyy cousins smothered in the Tower

you shall to tlete Tower (rep.). Tower

to make your , I thoughts our, I world have

you be commitied to the 'tower...

conveyed to the Tower a prisoner....

must needs to the Totrer, ny lords?

and see him fafe i' the Tower ..... Henry/III. v.

yon towcrs, whose wanton tops $\ldots . . . . .6$ ives

these great towers, trophies.... Timon of Athens, v.

nor stony tower, nor walls of jeaten

Whild Rowland to the dark tower. Heenr, iii. 4 (songt

off the battlements of yonder tower komeo \& Jnl. iv.

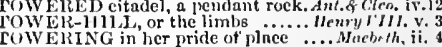
did put me into a towering passion ....... Hamlel, va 2 be there bears i' the town? Which of 'yn know Ford of this triwn? = i. there is a gentlewoman in this town $=$

go you through the town to Frogmore
and every way but the town way....

there is $n$ frientl of mine cone to town - iv. 5

the forest better than the torm? .......

witls viewing of the town............. $=\underset{\text { iti. } 3}{\text { jv. } 3}$

range the town to seck me out
when came he to this town?

to a captain in this town $\ldots \ldots \ldots . . . . . .3$.

league without the town (rep. i. 2)...Mid.s.'s Dr. i.

I am feared in field and town..........

a walled town is more worchier... As yau Like ii, itii, 3

Hymen peoples every town (rcp) - v.4 (sumg)

thy mildncsg praised in e...... Taming town..

bear my enuntenance in the town....
no trafic to cmir allverse towns. Comedy of Frro

to the statute of the town, dies ere .. -

walk with me ahout the tuxw?

this town is full of cezenage ........

and u lair of stocks in the town? $\ldots . .$. = iii.

not harbnur in this towin to-night .: $=$

I have snme business in the town ....
I will not atay to-night fur all the town =

the laws and statutco of this town....

the brows of this resisting town ..

we'll lay het're this town our royal

are expedient to this town, his forec

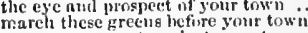

we come to spout agnings your town
and in his right, we hollt this town.

we hold our town fur neithe

hy this pecish town, turn th
drift of bullcts on this town

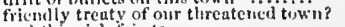

afripht my ton ns with dreailfiil..... = iv.

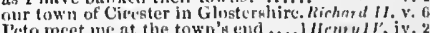

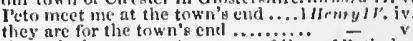

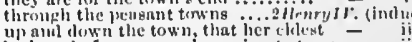
lie heard of your grace's enming to town =

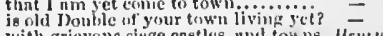

with grievous siege castles, nut towns.. Hew y 
TOWN-new repair, our towns of war.. Henry $V$. ii. 4
I would have blowed up the town the town is beseeched.....

the town sounds a parley .............

resolves the governor of the town

we yield our town, and $\mathrm{lives}$.........
what call you the town's name

or the loss of those great tow 5 .

what towns of any moment...

master-gunner am I of this town

on the lute, beholding the towns bur

the bells thronghout the town?....

centre of this cursed town

either to get the town again, or die

in this late betrayed town

take some order in the town ........

and seven walled towns of strength.

re of all the towns

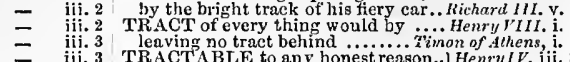

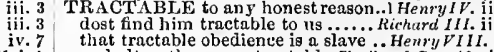

and al together more tractable. Troil

i.
i. 2 bnt I ghall find them tractable enough. Pericles, iv.
i. -2 TRADE -

and $I$ will trade to them both....

i. 4 if $y$ our trade be to her ................

1. 6 you need not change your trade...Nens. for Meas. i. 2

ii. 2 the trade, Pompey? is it a lawful trade? -

ii. 3 not whipt out of his trade!

iii. 2 your hangman is a more penitent trade

iii. 2 I will instruct thee in my trade.

iii.

in any of our towns of garrison.......

beadles io your town, and things .....

my lord. whole town to fiy
the towns each day revolted

the towns each day revolted .........
and, throughout every town, proclaim

sold the towns in France (rep.) .........

and seized upon their towns $\ldots \ldots$. 11.2 )

in the towns as they do march along
lurking in the towns about..........

lodge in towns about him.

for Edward will defend the toirn......

wilt thou leave the town, and figlit?

tirited ont of all towns and cities ...Richard III. i.

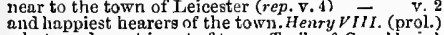

what good sport is out of town. Troilus \& Cressida, i.

that pertly front your town...

go in, and cheer the town .............

to this coward and lascivious town ...

to take in many towns, ere ........... Coriolanus,

summon the town. How far off........

call thither all the officers of the town

the town is ta'en! 'Twill be delivered
for they had so vilely yielded the town
than to take in a town with geatle...

my love's upon this enemy

your native town yown .............

since that the trade and profit of. $M$

common ferry that trades to Venice

steeped in the colours of their trade

some way of common trade ........ Richard $I I$.

what trade art thou, Feeble

stands in the gap and trade of more. Henry ${ }^{\prime} I I$
sisters, of the hold-door trade.. Troilus \& Cress.

mysteris the hold-door trade... Troilus of Cress.

to make $a$ whore forswear her trade.

an enemy, and give over my trade.

pestilence strike all trades in Rome

trade, sir, that I hope I may use

food of us that trade in love .....Aniony \& Cleo. i

to be used in every trade

I cannot be offended with my trade.

but two hours at the trade $\ldots \ldots . . . .$.

二

bad is the trade must play the fool $\ldots . .$. - iv. 1

lnave you any further trade with us? .. Hamlet, iii.

thougii in the trade of war I have slain... othello,

TRADED in it, makes it seem........ King John,

TRADE-FALLEN; the canicer's of... Henry/ ${ }^{\prime}$. iv.

peruse the traders, gaze upon... Comedy of Errors, i.

it went the hackside the town

on the gates of Lud's town set (rep.)

so through Lud's town march

is welcome to our town and us .....

Boult, spend thou that in the town....

whe poor distressed Lear is i' the towin...

for the wealth of all this town .. Romeo

there's a nobleman in town, one Paris

the searchers of the town, suspecting

as lief the town crier spoke my lines:
MIarcus Luechese, is be not in town?

the town is empty; on the brow o' the

diablo, ho! the towo will rise...

the town might fall in fright

look with care about the town
how silent is this town! ho!

how silent is this townt ho!
TOWN-GATES on his back

TOW N-GATES on his back ............. Lev L. Lost, i. TOW NSMEN yet admit? ..............King John, ii.

come the townsmen on procession ..2 HenryVl,
Toys as little by such toys.. TwoGen.ofVerona,
I do not like dese toy's ............. Merry Wives,

silence you airy toys

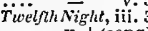

a foolish thing was but a toy........ $\vec{v}$ I (song)

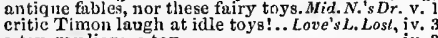

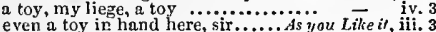

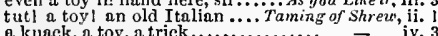

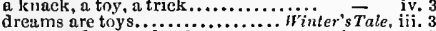

any toys for your liead..................... iv. 3 (song)

James, there's toys abroad
shall we fall foul tor toys?

for a toy, a thing of no regard

being but a toy, which is no grief.....

lamenting toys, is jollity for apes .. Cymbeline, iv.

if no unconstant toy ....................... Hamlet, i. 3

the very place puts toys of desperntion

toy seens prologue to some great amiss... 二 iv. ivg

nor no jealous toy, conerning you .......

TRACE this alley up and down .........Mich Ado, iji.

to trace the forests wild.......... Mid.N. N. 's Dream,

souls that trace his line $\ldots . . . . . . . . \ldots \ldots$ Macbeth,

all my joy trace the conjunctioni... Henry FIII. iii.

so slow, that condd not trace them! .. Cymbeline,

the traces, of the smallest......... Romeo \& Julict, $\hat{i}$.

why may not imagination trace......... Hamlet, v.
and, who else would trace him ........
TRAIl ST thou the puissant pike?.... Hemry $r$. to bear my lady's train .... Two Gen. of Verona, and in her train there is a gentie iady $-\frac{\text { Lost }}{\text { iij }}$

his train? Camillo with him?.

my best train $I$ liave from your...

by many of these trains hath

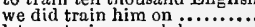

luenry ${ }^{2}, \mathrm{v}$

which trains march by us...........2

and take away his train

the Dauphin, and his train

the very train of her worst wearing..2 Henry $V I$. i. 3

with some little train (rep.)......... Richard III. ii.
honour's train is longer than his ... Henry VIII. ii.

a royal train, believe me

she that carries up the train

you to offend you ..Troilus \& Cressida, v.

sequestered from all your train?. Tilus Andran.

my train are men of choice ................ Lear,

comes with so small a train [Knt.-number] -

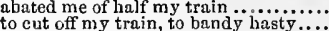

dismissing half your train, come then

as, stars with trains of fire and dews...... Hrant

RAINED me like a peasant ....... As you Like il,

I was trained up in the English.... I Henry $I V$. i

he first trained to the wars.

for that cause I trained thee

he was never trained up in arms .... Richard $I I J$. v.

he must be taught, and trained ...Julizuscasar, iv.

thongh trained up thus meanly ...... Cy

strong, trained up in arms .... Tilus Andronicus, $\mathrm{i}$.

I traincd thy brethren to that guileful - v.

youthful, and nobly trained.... Romeo \& Juliet, iii.

to give her princely training............ Pericles, iit.

I doubt not but thy training hath been - iv.

put thy sword up, traitor

and justify you traitors................

thou art a traitor [Col. Knl,-tyravt] Merry Wines, iii.

ourd let the traitors stay............ Love's L.Lost, iv

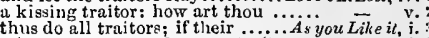

mistrust cannot make me a traitor ... - i

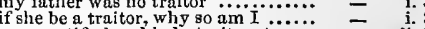

are sanctified and holy traitors to you $\overline{\text { a }}$

a traitor you do look like $($ rep. $) .. . .$. .. All s

merely our own traitors ..............

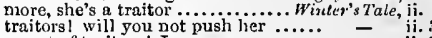

a nest of traitors! I am none

thou, traitor, hast set on thy wife.....

by that most disloyal traitor the thane.Macbeih, $\mathrm{j}$.

our fears do make us traitore ........ - iv.

when we are traitors, and do not $\ldots . .$. -

alraitor, mother? Ay, that he (rep.)...

doth espy hinself love's traitor........... King John iv.

tholl art a traitor and a miscreant ... Rickard 1I.

if I he traitor or unjustly fight!

consequently, like a traitor coward...

a recreant and most degenerate traito

upon this overweening traitor's foot

a traitor to my God, iny king (rep.)..

that he's a traitor, foul and dangerous -

the rest of the revolting faction traitors? -

your love pursues a banislied traitor

I am no traitor's uncle; and that word -

this thief, this traitor, Bolingbroke.

to come at traitors' calls, and do them
is a foul traitor to proud Hereford's..

can see a sort of trai tors liere .......

villain! traitor! slave! What is

thou hast a traitor in thy presence

I tore it from the traitor's bosom
the traitor lives, the true man

old digs once more a traitor rear?....

to Oxfurd, or where er these traitors are -

I'll be a traitor then, when thou ..... Henry $I V$

to redeem a traitor home? ............

I do arrest thee, traitor, of high ....2. Henry I

some guard these traitors to...

your name, a traitor your degree.....

to dub thee with the name of traitor

'sblud, an arrant traitor, as any

I am no traitor. That's a lie

here is a villain and a traitor.

traitors have never other company

to die for treason, but no traitor

I am louted by a traitor villain.....

by forfeiting a traitor and a cowar

we die, while remiss traitors sleep 


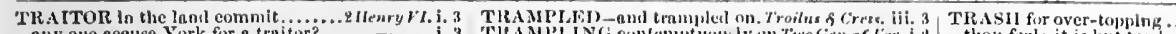

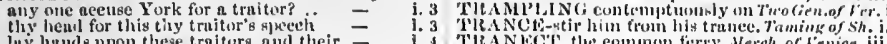

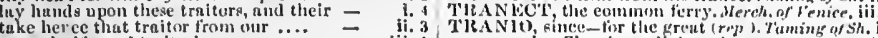
take herec that traitor from our .... whis's utraitor, tiloster he is none he's a villnin, and a traitor. proclaim them traitors that nie uj......... Jorl Sny, the traitors hate thec joinity join with the truitor; and they jointly is the trator Cade surjorised? ........ of sumerset, whom he terms a to heave the traitor somerset from present your grace a truitur's hem. no, nor canst not rule a truitor O moustrous traitor! I nrrest the olney, audaeious truitor; kneel the surety for their trintor finther... wliy, what a brood of truiturs hitwe we thy kills, and thou a jillse-heart traitor = a subtle truitur neels no sophister a traitor to the crown (rep.)

iii. Eramercies, Trunis, well dost tlas

iv. 2 o Tranio, till I finud it to be trie (rep.)

iv. 2 Tranio, I Buw her coral lips to move

iv. 1 Tranto stich

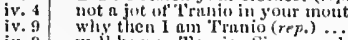

iv. W Well begun, 'Tranio. Sir a work

iv. 90 Prianli, is my man Tranio, regia

Trunio, son jest (rep.)

years old and lis name is-Tranio

v. where is that clamned villain, "Trunio

exeliange my state with 'Trauio (rep.)

gignior Tralio, this bird youl 7 Tranio hits you now. I thank tice

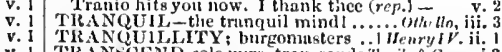

ThANSCEN D-80le pure, transcends ?'rail of Cress. i.3

TRANSFIGUIRED go togetlier. Mlid

TRANSFOtial me to a piece of clueese... Nerry w, love may trarisfurm

prolong a while the traitor sifie

off with the traitnr's head, and rear it

hat durst the traitor breatlie out so..

that Eilward be pronounced a traitor

take the great-grown traitur unaw

we'll quickly rouse the traiturs in....

which, truitor, thou wouldst lia se in

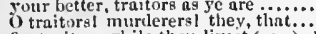

for truitors while thou livest (rep. I...Ric

tilou art a traitor: off with his head

the head of that ignoble traitor......

the covert'st sheltered traitor that ever
the subtle traitor this day had plotted

to warn fulse traitors from the like..
would have had you heard tie traitor

would have had you heard the traito
be brief, when traitors brave the field

to him, that brings the traitor in?..

transform me then

iv. transfurm us not to women

beaty or ate transform you from whut ...ecar,

and applanse, trans form ourselvesty. Famiet, ii

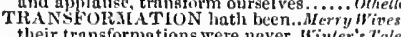

beastly, shameless transformation ..1 Menry II

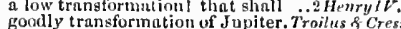

lot thy loss in transformation?

You lieard of Ilumlet's transformation.. Hamlet, ii. how I luve been transformed ..... Merry $W_{i} \mathrm{Dr}$. transformed: four woodeoek $3 . . .$. Love's L.Losi, to see a king transformed to a gnat 1 iv. iv. gee me thus transformed to a boy. Mer. of reniec,ii.
he be transformed into a beast.... As yna Like it, ii. I ain transformed, inaster.... Comedy of Error she had transformed me to a curtnil-rlog
both in shape atrd minul transfurmed. both in shape and minul transformed. lichard $11 . \mathrm{v}$. eome ngain transformed to orient:. Nichard $I I I$. iv. did we woo traneformed Timon

pillar of the world transformed ... Antony \& Cleo.

TRANSGRESSED against his valour. All's Hell,

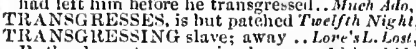

Rutlapd, my tranggressing boy ..... Kichard 1l.

or iny false trunsgression.... Trofien. of "erona, ji. make a trust a transgression? (rip.j - ii. 1 for our rucle transgression some litir. Love's $L$. L. L. v.
not my tranggression to my eharge... King.John,

a traitor to the people. How! Traitor?

eall me their traitorl thon injurions

tell tle traitor, in the lighest (rep.).
the fates with traitors do contrive..

they were traitors: honourable men!
iugratitude, more strong than traitor'

ingratitude, more strong than traitor
murred, as you see. with traitors

O traitors, villains! 0 most bloody

let not a traitor live

with the brands fire the traitors houses

the sword of traitors. Cas shr (rep).

men' 8 vows are women's traitors I... Cymbeline,

yet the traitor stands in worse ......

whot of liin? he is a banished traitor

I know not how, a traitor.

Tirusinds

traitur, restore lavinia

traitor, if home have law........

and vengeanee on the traitor Sationi

Inhuman traiturs, you enustrained

traitor, thou liest. Traitor! (rep.)
that ealls me traitor. I return the lie

to eourse his own shadow for a truiter

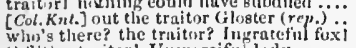

0 thithy traitorl Unuereiful lady

go white, and sueh a traitor! . .............

do chance to liear of tliat

darest thou support a publishici traitor?

he is that names me traitor, villsim-lice.

thy fect, a most toud-spottel traitur

the traitor murderer live might lia ve.... - v. traiturs enstected to clog thic guilticess... Othello, ii. reatrui

traitorous Warwick, with the men .2 Henry rl. iii.

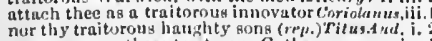
sevenge upon these traiturans Goth

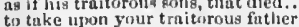
with eraitorons gifts, (I) wickerl wit

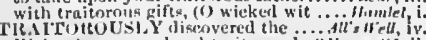
Jieharil was inurderel traiturousiy. II umplirey traiturously is murdereil thoul hast most traitorously eorrupted

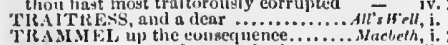
TRAMMFI up the colsequence..........Wacteth, i. RA.MPLA,-steps do tranjle tliee .. Wirharid
heurly trample on their sovereign's head -

\section{TRANSILVANIAN iB dead
TRANSLATE the stubborn}

make thee away, translate thy lite

can with ease translate it to my will. King John, ii.

trauslnte his maliee towards you

foree of honesty can translate beality..Hamlet, iii.

TiiANSLA'ED Jier well ..............Mery hives, i. 3

to be to $y^{\text {no }}$ translated; $O$ teach ...vid.N.'s $D r_{\text {i }}$. 1
bless theel thou art translated ......

TRANSMIGRATES. What eolonr, Ant. \& Cleo ii. 7

TRANSPAREN'T a barriendoes Thelfih Wight, iv.

through the transparcut bosom Lote's $L$. L. L iv. 3 (ver.)

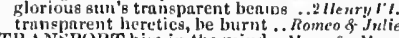

TRANSPORT him in the mind...

When I eame hither to transport ....Macheth, iv.

mipht not you transport her purposes.... Lear,

to lis blank transports his posoncel shotifinale, iv.

alinost so far tratsperted, thint he'll think -
thy letters have trunsported me .........nuebeth,
the

transported shall be at hight feetivnlis lise
shall be transportel presently to Frnuee

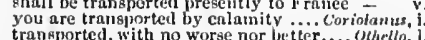

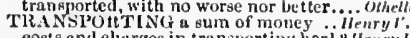

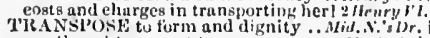

my thonghts eannot transpose.......... Mastielh,

ThAl'-I will way, inarry trap........... Mrry Hites,

pretty traps tueateh the petty .......... Henyy is.

lail'st a traj to take my life ....... i ilruy $/ ?$ l. iij.

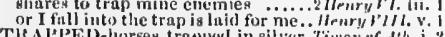

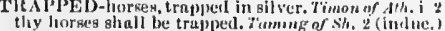

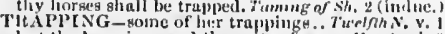

thus translate him to me .... Troilns \& Cressidu, left sweet Pyramus translated there - jii.

TIANSPOR CANCE to those fields. T'ruil. OC Cr.

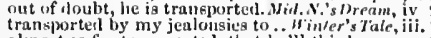

the seene is now trunsported ...Mnry I'. it. (elioru

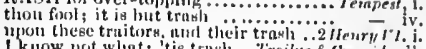

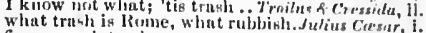

for so much trash, us may

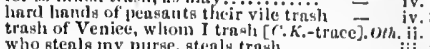

who steals iny purse, stealy trash ....... - iii.

TRAVAll look for grenter hirth .....Murk sion. ju our will whieli travails in thy good ....At's wall. Ii. is all our travail turued to you. Compllyofkr. ve

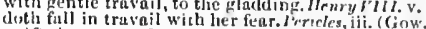

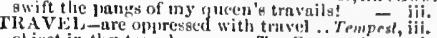

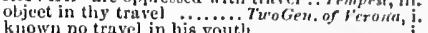
whither travel you.

my youthful travel lierein

not three liours travel trom tili..........

what night befall your travel.

in man of travel, thut liath seen ... Love's L. Lost, v.

maids as we are, to travel frirti..........

would he not le a eunforl to our truvel? - i,

maid with travel mueh oppressed.... $=$ ii.

sundry contemplation of my travel.

sad, and to travel for it too........

make tolerable vent of thy travel....... Ali's Well, ii.

travel yout fur on ............ Taming of shrese, iv.

for witl long travel I am stift and weary -

a travel that thou takest for pleasure. Richard $I I$. i. .

if I travel but four foot by ........... Ifenry $/ \%$. ji. 3

but to stand stained witl travel ......2 Henryll: v.

I met in travel tuward his........... H Hemry t 7 iv.

those types of travel ................. Henry I'Iil.

loss of time. travel, expence........... Tro

fur of timene, travel, expence.......... - ii.

With what the discreavel for..... Timon of Alhens, v, 1

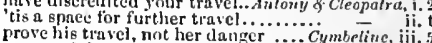

grove his travel, not her clanger .... Cymbeline, iti.

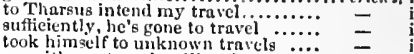

look himself to unknown travels $\ldots \ldots . .$.
we with our travels will enteavour it
how ehanees it they travel? .............. Ihamter, ii.

talked of sinee your travel muel ......... iv. iv.

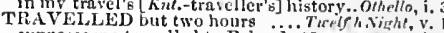

supposes me travelled to Poland...Mear. for.Meas. i

of our travelled galinnts.............lem

he, and myself, have travelicrl.. Tinos of Athens,

I have watched and travelled hard .......Lear, ii.

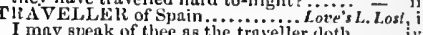

the sinewy vigour of the traveller...

travellers ne'er did lie................. Tempest, iii.

the travellers do fenr so mueh.. Tro fien.ofler. jv.

master Slioe-tye the great traveller.. - iy.

but travellers must be cootent ... As you Like it, ii.

furewell, molsieur travelier ha.......

and no true traveller: you are nore. Al's "Well. ii. 3

like pleasant travellers ...... Taining no sherme, iv.

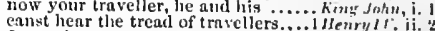

I was then a young traveller .......... Cymbeline, $i$.

from whose bontru no truveiler returns bumlet, ii. I

TRAVELLING inlong this const .. Lore's L.J.ost,

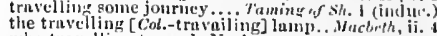

who travellitig towards York

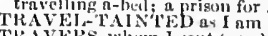

Cunthard II, y.

the gent. whom 1 sent (rep) $\ldots . .$. - i. 1

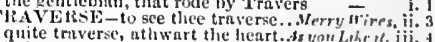

liold, Wurt, traverse; thu thus ...2Henrylt: iii.

TIA VElitED arms ........... Timon of Athens, 1.

TRAY. Blaneh, and Sweetheart ............ Lewr, ij

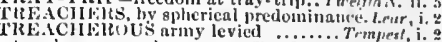

treacherous man! ............ Tiro Gert. of Ironni, v.

thee by' some treaeherous device...... As you hake ot,

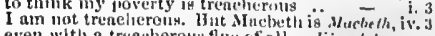

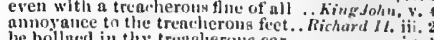

coyal father of a treacherous ear...

the treacherous hubour of your son ... i denem

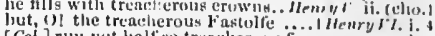

[Col.] run nut halt wo trenidierous from -

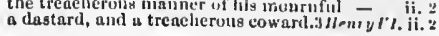




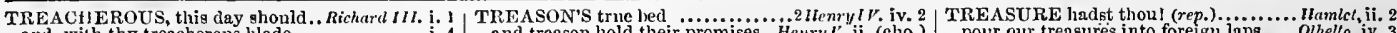

and, with thy treacherous blade.......

read. be henceforth treacheroufl guile

treacherons linel that will... Tilus Anilron, iv.

out, treacherous villain! thon call'st ..... lear, jii. 7

. Iecherous .... Hamlet, $\mathrm{ii}$.

the treacherous instrument is in thy liand $-\mathbf{v}$.

TREACHFROUSLY hast thou ....3 Henry $V '$ ' ii. 1

TREACHERX used to Val the

fla se vantage, or base treachery........ $\bar{F}_{\text {ives, }}$ iv. I

is composed and framed of trcacliery. Which Adn, v. 1

lest that the treachery of the two. Winter's Tale,
$\mathrm{O}$ treachery! fly, Good Fleance, fy ...Macbeth,

young fry of treachery? ................

paying the fine of rated treachery... King John, v. 4

what treachery is Jerel Why, what is it - y. 2

whant treachery was used? (rep.)........ i Henry $r i$. . . 1

and for thy treacleery, what's more.. - iii. 1

o monstrous treacheryl can this be so

falsehood, and hy treachery.....

2 HIenry VI. i, 2

that fear their subjects' treachery?...3 Henry $V$ l. ii. 5

hol Gowness, treachery, and all ruinovis.

of Gloster's treachery, and of the loyal

let the door be locked: treachery! .......

from this world with treachery $\ldots \ldots \ldots$....

pray you, tread softly ................... iv wives, iv. 4

we tread upon, and uever think.. Neas. fur Meas. ii. I

for Jack of tread ...............Mid.N.'s Dream, ii. 2

which is basest, doth tread........... i.ove's $\bar{L}$. Lost, i. 2

were much too dainty for such treadl

when turtles tread, and rooks $. . . \cdot-\overrightarrow{v .2}$ (song)

a kinder gentleman treads not ...̈irer. of Ienice, ii. 8

when I shall tread upon the tyrant's...3/ucheth, iv.

we tread in warlike marel these ..... King John

to tread down fair respect of $\ldots$.....

this foot of mine doth tread...........

but tread the stranger paths of ......... nichard ri. i. 3
for on my heart they tread ..........

you tread npon my patience

we live to tread on of travellers

by this heavenly ground $1 \ldots \ldots \ldots \ldots . .2$ tread on HenryI $^{2}$

tread them with her tender-feeling..2 Henry $\Gamma^{\prime} \boldsymbol{I}$. ii.

bid me be advised low I tread

tread it under foot with all contempt - v. I

go, tread the patl that thon............. Richard $I I I$. i. I

shadow which he treads on at noon.. Coriolanus, i. 1

his knee, and tread upon his neck.

than to tread, (trust to't, thou ...

he shall not tread on me $\ldots . . . \ldots \ldots . . .$.
tread not upon him; masters aii.....
bids me tread no more npon't ...

bids me tread no more npon't .
are young; I'll tread tliese fiats

you should tread a course pretty and full

make the gazer joy to see him tread ... Pericles, ii.

lieel of limping winter treads... Romeo .. Juar, ii.

no foot upon the cliurchyard tread ..

the primrose path of dalliance treads ...
one woe doth tread upon another's heel..

TREADING on his lieels

Tround shrinks hefore lis treading... Coriolanus, v. 4

TREASON, felony, sword, pike .......... Trmpest, ji.

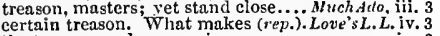

certain treason. What makes (reason, and you, go in peace

twas treason, he said ..................

coufess what treason there is.

coufess what treason there is...... Ifer. of Fenice, iii. 2
that ngly treason of mistruet........
'tween snow and fire, as treason $\ldots . .$.

fit for treasons, stratagems, and spoils

the common course of all treasnns

arraigrted of high treason .. Winter's. $\dddot{T}_{\text {.i. }} 2$ (indict.

very frankly he confessed his treasons

whorderl and treason! Bamquo for

二 ii. 3

to appeal each other of high treason....Richard $J l . i .1$

such terms of treason doubled

confess thy treasons, ere thou fil

rebellion, and detested treason .......

mis treasons will sit blusling

upon my land, is dangerous trcas

ot capital trcason we arrest you ...... =

speak treason to thy face? $\ldots . . . . . .$.
the treason that my haste forbids....

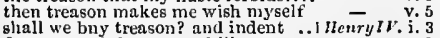

for trensun is but trusted like.........
treason: and you, lord $($ rep.)........ and treason hold their promises... Henry $l^{\prime}$.

to wait on treason, and on murder

why thou sliouldst do no treason...

I arrest thee of high treason (rep.)

but it is no English treason, to

will give his treason payment.

treason contagious treason come to ligjit -

condemned to die for treason...

hut decds, revenge this treason 1

how ill we brook his treas
and ugly treasons, lurk...

treason, falsehood, and by treaciery

doth accuse jis master of high treason

hold! I confess, I confess treason .....

our royal person

arrest thee of high treason liere.......

nor store of treasons to angment

royal person from treason s secret $\mathrm{kn}$ ife =

henceforward, it shall be treason for any -

of capital treason' gainst the king

neitler by treason, nor hostility.

mistrust, and treason wait on him

mistrust, and treason wait on him

search the secret treasons of the world - v.

we speak no treason, man .......... Richard $l 11$. i.

manner and the purpose of his treasons

puppy to the old dam, treason....... Henry $\overline{V I I I . i .}$

the treasons of his master he shail

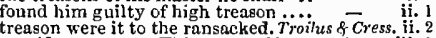

manifest treason. Thinsack.

Whilst bloody treason flourished.. Julius Casar, iii.

O treason! madam, I trust, not so...

do feel the treason, sharply $\ldots . . . . . . C_{y m b}$

beaten for loyalty excited me to treason

urke no treaso, here no envy .... Tilus Andron.

treats of 'Tereus' treason, and his rape

that I may this treason find

poison and treasoue, treason; villanie

or private treason, will take away

in palaces, treason.

O leavens! that this treason were not .. -

the overture of thy treasons to ns........

thy heinous, manifest, and many treasons

back do I toss these treasons to thy hiead

otate would treason have promounc

namlet.ii. 2

treason can but peep to what it would...

venom, to thy work. Treason l treasoni = vo

TREASONABLE abuses ... Neasure for Neasure,

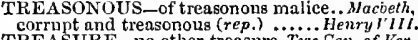

TREASURE-170 other treasure. Two Ge

waste the treasure of your time... ?uelfh Night, ii.

the treasures of your body ........MPas. for Nicas. ii.

casketed my treasure, given order....... All's Well, $\mathrm{i}$.

she is your treasure, she must have.

have taken treasure from her lips. Winter's Tale, v. 1

though the treasure of nature's

for all the treasure that thine uncle. King John,

given purest treasure mortal times

your spirit, this tun of treasure..........Henry $v$. $i$.

a crown, the treasure of thy heart ..2 Henry $V I$. ij. 1

Sifrolk's exile, my soul's treasure?

I'll give thee England's treasure.

our treasure seized, our soldiers....3 3 Hen $r y \mathrm{VI}$. iil.

cancelled, and his treasure spent

thither bcar your treasure ........

Richard IIt. $\mathrm{ii}$.

his treasure, rich stuffs, and ornaments - iii.

it is noised, he hath a mass of treasure

the treasnre, in this field achieved ... Coriolanus, i.

increase, and treasure of my loins ..Coriolanus, i.

this treasure of an oyster..... Antony \& Cleopatr

my treasure's in the larbour, take it
possess you of that ship and treasure

gir, his chests and treasure he has not

go, Eros, send his trensure after...

after thee sent all thy treasure....
and ta'cn the treasure of her hon

that rarest treasure of your cheek. Cymbeline, ii. 2

dispose this treasure in mine.... Tilus Andron. iv. 2

or tie my treasure up in silken bags .. l'ericles, iii.

besides this treasure for a fee..... - iii. 2 (seroll)
torget the precions treasure...... Romeo \& Juliet, i.

forget the precions treasure ....... Romeo \& J Juliet, i.
in thy life extorted treasure in.......... Ilumbet, i. pour nur trensurres into forepgin laps ...... Ollamelct, ii.
TREASURE-IIOUSE; tell me once Ner. of $V_{e}$, ii. 9 TREASURER; let bim speak.....Antony \& Cleo. $\mathrm{A}$ TREASURIES_-oumless trensuries .....lienry $V . \mathrm{j}$. the pedler's silken treasury

cost a mass of public treasury

the treasury of everlasting joy I........ i. TREAT - conceit may rob the treasury of life. Lear, iv. 6 treats of happiness by virtue... Taming of shiew,

and treats of Tereus' treason. Titus Andronicus, iv. TREATIES-send humble treaties Aniony \& Cleo, ii.
TREATISE - with a longer treatise ...Much Alo, $\mathrm{i}$. TREATY of our threatened tows

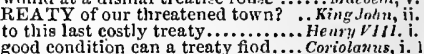

we are convented upon a pleasing treaty -

ne'er be made this treaty .....Anitony \& Cleo, ii. 5

deBLE-trcbles thee o'er ............. Tempest, ii.

twice trehle shame on Angelo .......

six thousand, and then trehle ... Mer. of Fenice, iii. 2

ofiel the treble jars $\ldots . . . . .$. Taming of Shrew, iii.

the case of a treble hautboy........2 Hcnry $I V$. iit.

slanll double gild his treble guilt

our battalia trebles that acconnt.. Richard $I I S$, v.

let him make treble satisfaction.. Tilus Ardron. v. I

calls and trebles their confusion ....... Pericles, jy. 1

Treble woe fall ten times treble on ..... $\bar{F}$. v.

TREBLE-SINEWED, hearted .A nlony \& Cleo. iii. II

this is Trebonins. He is welcome.....

what, Trebonius I I have an hour

Trebonius doth desire yon to oll. - ii. 3 (paper) Trebonius knows lise time o'er-read - iii.

not least in love, yours, good Trebonius - iit.

a mutincer, the next tree............. = iii. 2

ono, two, tree, four, come for? .........

six or seven, two, tree hours

our measure ronud ahout the tree ... - v. climbing trees in the Hesperides?... Love's L.L. iv. 3 as sure as bark on tree ............. - v. on every tree, mocks married men
wind did gently kiss the trees. Merch.of renice, $\mathrm{v}$. Orpheus drew trees, stones, and floods

find tongues in trees, books in.... As you Like $i l$, it.

thon prunest a rotten tree, that caumot $\overline{\text { ii. } 5 \text { (soing) }}$ (ii. 3

the duke will drink under this tree..

these trees slanll be my hook

carve on every tree, the fair..........
on a tree. Truly, the tree yields bad

tongues I'll liang on every tree -

$I$ tound lim under a tree.

mar be callerl Jove's tree .............

hangs the verses on the trees..... .

despatch us here under this tree.....

to move, and trees to spea

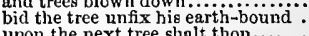

the castle, by yon tuft of trees.....

into the shadow of these trees ......

roses are cropped from the tree...... Heary $r ?$ H. ii.

what, and wouldst climb a tree?

a grove of cypress trees

hideous teave's spreading tree.

the fruit of such a goodly tree

that I love the tree from whence

tike trees bedashed with rain

tre royal tree hath left us royal .... -

made trees, and the mountain part. Henry Fllli.i. 2

will these mossed trees, that have. Timon of $d$ th. iv. 3

I have a tree, which grows here in

ere my tree hath felt the axe .......... ilius Casar, ii.

barks of trees thou browsed st...... An/ony \& Cleo. i. 4

the trees by the way should have borne - iii. 6

or blue promontory with trees upon't $\overline{-}-$ iv. 12

my sonl, till the tree diel

bury so much gold under a tree...Titus Andron. ii. 3

the trees, though summer, set forlorn - ii. 3

the pit, and this the elder tree

hang him on this tree

skins, as on the bark of trees

the fruit of you celestial tree $\ldots \ldots \ldots . . .$. Pericles, $\mathrm{i}$.

no more but as the tops of trees.........

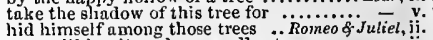

now will he sit under a medlar tree.. she sings on yon pomegranate tree.. ii

like fruit unripe, sticks on the tree ..... Hamlet, iii. 2
sat sighing by a sycamore tree ... Othello, iv. 3 (song
I'll smell it on the tree .................. v. 


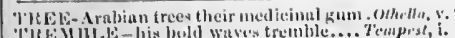

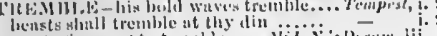

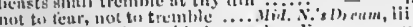
weth cunke nud tremble here, when lim -

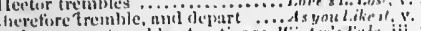
anel tyrumy tre lile nt patience. ivinter even no.s l tremble th thillk, y'enr thther luw he trumbles in his eestaley t.. Cometly uf lirr. iv.

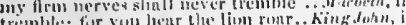
tremble: fur youl hemr the fim this day.

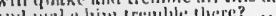

with tuschins treublus Rirkted II. ji.

elliotrinlitul, cremble at his sin

illewryl

our lle the encle dial tromble

As my lieart shoth tremble to lufolt .2 henry

but grent ment temble, when ........

mude ble liorest tremble when they

whint, duy you trembe? ......... Hooks

tremble and start nt waysing of......

trathe tre

purt of men to ferr niul tremble...

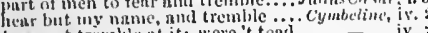

I eanunt trimble nt it: were 't toad.

Iremble still witl fear

to tremble under Titus' tiireatening... Titus.snd.i.

stemps and trembles at her frown

whereat it trembles by surmis.

geen those lily hamt tremble to recive

tremble; thust wrotel, that hast within... Lear, iit.

makcs us tremble, hint touches us 1 sot

fre tremble

Iuratio? you tremble, nut look pule ... Hamet, $i$.

that lowk pale und (remble an this ehunce

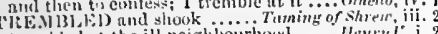

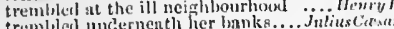

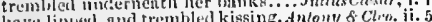

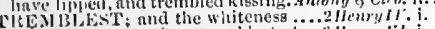

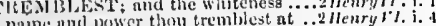
wime

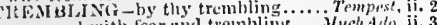

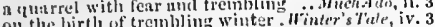

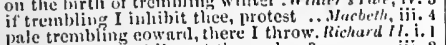
pase inked, trembling at themselves?

fearfully ainong the trembliug reds..1 Henryll', i. 3 trembling even at the nume of

2Hentylt: iv. 3

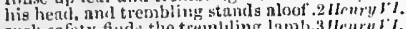
with trunbling wings mislowbteth. . Rishard III.j.

stuml on my trembling fles $\ldots .$. ... a trembling contributiond
brouglit $a$ trembling upon cerrins my trembling juints
It

l'ltE.I $)$ R cordis on ine

Autony f cluo. v.

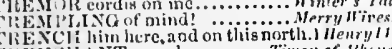

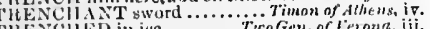

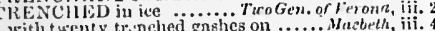

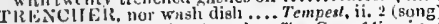
but he steps me to her trenelier. Tro Gen.of 1 er. iv. 1 hofling a trencher, jesting merrily? Lone's l.. l.. v. there take it to you, trenchers.

thun oue whicht liolds a trenelicr. Timon of the

than one which holds a truedier. ... Carisham

upon dew Cte ar's trencher .... Antony \&. Clon. iii. il

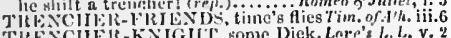

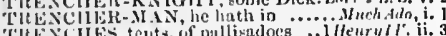

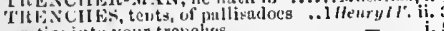

as they ts to our trenches fullowed... Coriolanus,

nur varty to their trenchea drisen

they hail beat $y$ ou to your trenelies?

TRENCIII YG war chamel........... Henryt

nurthward, iyine nft from 'Frent

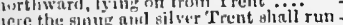

cume, yuin sluall have Treme turnet ...

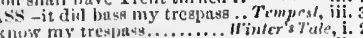

if any be, the treamsa of the quacen

more penitenee thin done trespass. . un - v.

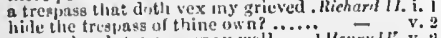
my nephew's trespass may well .... I lienryll. v.

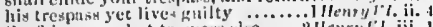

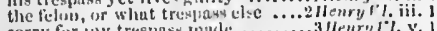

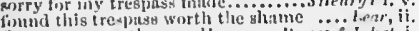

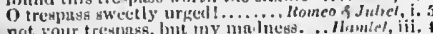

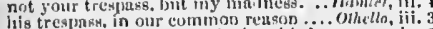
e'er my will did treapass "gninst his love ive

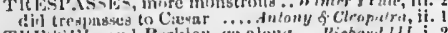

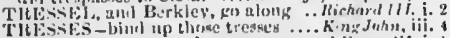
lirandish your erystal trestes .......... llienry it. i.

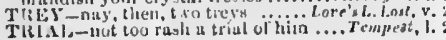

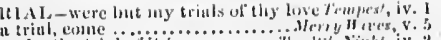

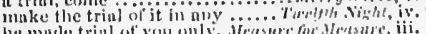

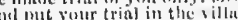

but l't iny trinl lie mine own......

Finrsely believe this withont trinl.

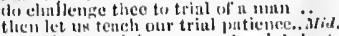

bliculet un tench on

but blut it bear this trial, mul last ..

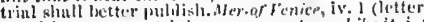

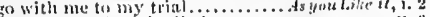

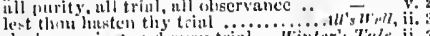

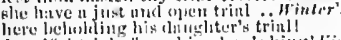

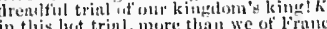

in this live trial, more than we or

order the triat, mathin, and logen $\ldots$

We will ontore his trin]

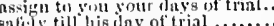

wage an instunt trial with the king.juenryll iv.

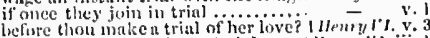
intil your tiutluer tine of triul

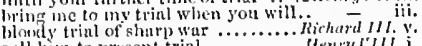

call him to present trial.

ind without thent fill.

I hal my trinl, nul, must ieeds sny

the trinl just and moble ............ =

duke of Buekingluam came frum his trial -

till better trial of you

nemst for his trinl, and frir.

the protraetive trials of great Jove

yet in the triat much ofuninl.......

lnw slaul seorn him further trial

deceitfin janles, sink in the trial Julius

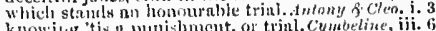

his trials weil are slent. .............. Lear, iii. 6

I'll sce their trial tirst .................. - iit.

and it would ene to immediate trinl.. Ilamied, v.?

olpositim of your lerson in trit
dlin but blow them to their trinl

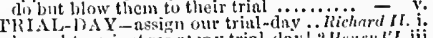

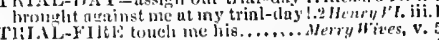

NRIB, trib, faries; eme (rep.).........

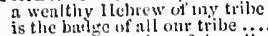

here emos another of the tribe....

have yon enllected them by trilice? (c)oriolanns, iii, 3

call all your trilese torether.

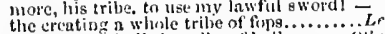

my wits, nid all the trilic of hell

- ili. 3

a pentl away, rither than all his tribe . witl my pigeons to the tritural.. Tutus and on. iv. 3 TIIIBUNE-five tribunes, to detend..

when we were elosen tribume

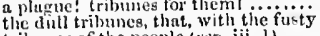

tribunes of the people (rep. iit.

and the tribunes endue you with

tribmes, give way; he slinll to ........

and make me your fellow tribine

the prople do witli these balld tribines?

trilmes, patricisns, citizens! whot lio!

tribumes, heur me but in word ( $(r e p$.$) .$

$y$ ca, the two tribunce, but now 't

She woble tribunes are the people.

if by the tribunes' lenve, and yours.

retarn tis the tribmes ..............

nway, the tribunes llo attend you.

thou inj urious tribune!.............

in the power of ut the tribunes ......

the gons preserve our nolsie tribunes

the tribunes canot do't far slame

the tribmes are no soldiers............

of tribunes such as you, a sea and limel =

and to $y$ w the trilunes, for this..... (ivmbrtin

tribunes! nul me n pour sompetitor

tlannks, gentle erilune, noble turother

send thee by me, their tribune, mol their -

proud sut nmbitious tribune, eftnst thou -

tribumes, I th:mk you: and this puit I

no, firs]ish tribune, no; 110 gon of min

the tribane and lis neplews kncel

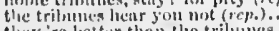

ty.y 're better than the tritumea ....

tribunes with their tongerses doom ino
Tilbusen in lia losth

IIIIII)

your trilutury dirans belo

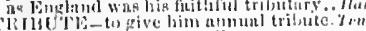

1 klow not luw mueli tribnte.

as ut tribute, west as a fee..............

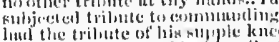

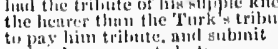

tupay him tribute. and

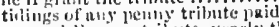

grantel lanne a tribute, jearly thire =

eome, there' no mere tribute to be praid -

trimite for light: c else, sir, no mo

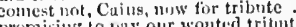

them thein, the tribute thut I owe. Titus andmn

his mujesty shill have tribute ot me .. Hemter, ii.

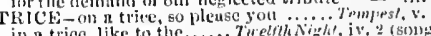

in a trice, like to the..... Treethy

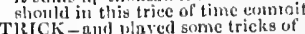

l.eril, $\mathrm{j}$.

do yon lunt trieks upot ns
nse you in such anotler triek

by some sly trick .......... Tho

ever sec me do fuch a trick?
godjy company for this tick.
that were a triek, indectl...

and we will yet have nume trick
if 1 be served sneh ansther trick

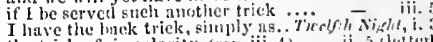

the trick of singularity (rep. iii.4) - ii. s (letter

would he for the momentary trick be - iti.

it was n mul funtastienl triek of him = ili.

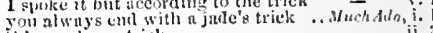

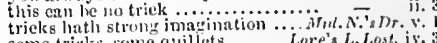

some tricks, some quililet $8 \ldots \ldots$ Love's L. Lost, iv. 3

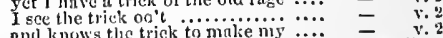

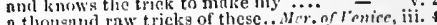

serve me sneli another trick ....... As yun like i i iv.

too ealnable uf erery line ant triek of... Atl's

without any tricks (rep;)
tricks he hath lad in

a tumbling trick? No .. Taming of Sh. 2 (indue.)

ce'll rail in lis rope trieks .........

a knack, a toy, a triek................. - iv ${ }^{-}$iv 3

n very trick for them to play nit.....

the trick of his frown, his forchead.

I smell the triek of it ............... iv.

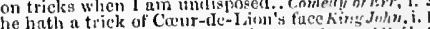

I know a trick worth two of thint ... Inemylt:

二 ii.

with hicfly, a yillanous tiek of......

always yet the trick of our Englisin..2 2 enry

thes trick up with new-tancd oati..... Hrary $y^{\prime}$. iii.

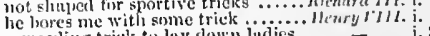

a specliug trick to lay down ludies...

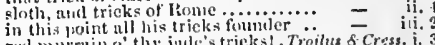

red murruin o' tlyy jutde's trieks! . Troilus of Cress. i.

and what necd these trieks?.......... - v v

as good a trick as cver hamgman... Timonofan. it.

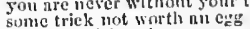

the very trick on th...............

itis onc of throse odd tricks

of prinees, of the tricks in war...... inmte tinc, iii.

iii. 3 much beyom the trick of others ....judranicus,

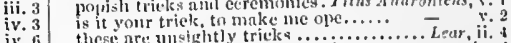

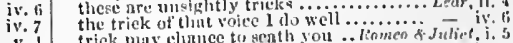

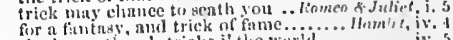

slie hears, there's tricks i' the world .....
in forgery of slianes und trieks ......... iv.

but yct it is

his teuuneg, nutl his triek w?

if such tricks th these strip you out of ... othelln, ii.

this is a triek, to fut me from my suit... =

2 how ermes this trick upon him?......... inamet, it. 2

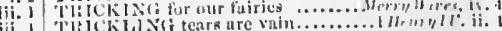

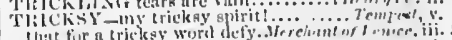

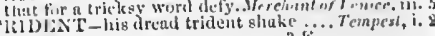

$3 \mathrm{E}$ 


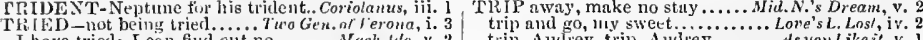
I hase tried; I ean find nit no ...... Mach-the, y. seven times tried this irep.) ....... - ii. 9 seroil first tried our soldier'ship: in your silent julgment tried being tomelied, ind tried, proves. court, to see this quarrel tried disdainful to be tried by it .... We might have tried lord Lieins... Timon of $\mathrm{A}$ th. jii. his spirit, and tried his inclination. he's a tried and valinnt soldier.. gold, that's by the touehstone tried. still been trich a holy man their aeloption tried, grapple them to .. Hamle TRIER-Was the trier of spirits

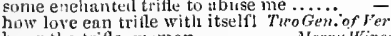
lung the trifle, w' whan

dispense with trifles

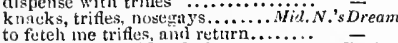
here's a sinall trifle of wives ... Merch. of $\overline{T e r i c e}$ alus, it is a tritle; I will not.
but is trifle neither, in good

bit a trifle neither, in good....
that we make trifles of terrors.

a snapper-up of unconsiderert trifies

she prizes loot such trifles as these are
grant precious things, as trifles.....

which he eounts but in trifle....

as 'twerc a eareless trifle a trifle, some eightpentur matter for a trifle, that was bought his tyranny tor trifles $\ldots$.............. my lord, in trifle of our love ..... Timon of $\overrightarrow{\text { Athens, }}, \mathrm{i} .2$ and such like trifles, nothing eomparing - iii. 2 some lady trifles have reserved ...Antony \& Cleo. v. so, in our trifles 1 still win of you.... Cymbeline, i. 2 we sit too long on trifles ................ Pericles, ii. 3 himselt upbrids us on every trifle:.
why I do trifle thus with his despair

I feared he did? but trifie

play and trifle with your reverenee.

Hrmle/, ii.

than ing as air, are, to the jealous.

'IlliFLED former knowings

TRIFLER-away, away, your triflerl.1 luenry $1 \mathrm{H}$.

for ene trifling respeet .................. Rerry llives.

for some trifling present, vou... Timon of Alhens,
we have a trifling foolish banquet.. Romen \& Jutl.

Iramlet, and the trifling of his tayou

TIIGON, his man, be not lisping ...2 Henry I $b^{\prime}$. ii. 4

TRIML - where we, in all her trim ....... Tempest,

turned into tongue, and trim ones...Wush ddo, iv.

trim gallants, full ot eourtship.... Love's L. Lost,

come like sacritices in their trim

air. A trim reckoning! who hath...

oul hearts are in the trim ..........
will have of these trim valitie

there's a trim rabble let in

Troilus \& Cressida, iv.

I give him, with all his trim

have on their rivetetl trim...Antony \& Cleopalra, iv.

your laboursome and dainty trims.. Citmmeline, iii.

another's $q$ liss to trim them by ......... Pericles, $i$.

Cupid, he that shot so trim .... Romes
go and trim her up; l'll go and ehat

CRIMII,Y ll:essed, tresh as

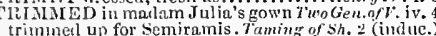
he home trimned, rushes strew

han not so trimmed and dressed ..Rickard II. iii. 4 and being now trimmed in thine nwn.2 Hen

trimmed like a younker, praneing ..3 heur: /' $I$ i

and trimmed her as thou sawest.. Tihes
slic was waslied, and eut, and trimmed

slic was waslied, and eut, and trimmed
banmers sable, trimmel witl rich. Pericles, v. (Gow.)

trimmed in forms and visages of duty ... Oihello, i. c:Lil thing up the diadem.. Antony \& Cleopatra, v. "e'll see your trinkets herc all .....2 Henter's Tule, iv. if uny be Trinenlo's legs (rep.)

Trineulo, the king and ail (rep.

Trineuls keep a gnod tongne in your head Will stand, and so shall Trincul

and Trinemlo and thyself shall be (rep.)

eome on, Trineulo, let us sing

put off that gown, Trineulo..

trip, Audrey, trip, Anul................s yon Like it, v. 1 to trip the eourse of law ...........2nenry Ir. exeellent in making tadies trip........... Pericles, fi. 3 PRIPARTITE are drawn .......... Herry

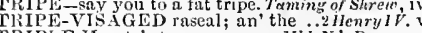
RIPLE Heeate's team ........Mid.N.'s Dream, bade me store up, as a triple eye ....All's Well, the triple pillar of the world, Antony \& Cleopatra, $\mathrm{i}$

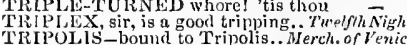

cast a a ay, coming from Tripolis ....

Tripolis, from MIexico, and England

ThLIPPED up the wrestler's heels.. ds $y$ ou of Sh. iv. we gatler, you have tripperl sinee. Winter's Tale, i. lor trippped neither; you base football ... Lear, i. 4 since 1 tripped up thy heels $\ldots . . . . . . . . . .1$ - ii. 2

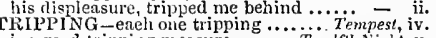
is a good tripping measurc............ Tuelfh Night, the Greekish girls shall tripping. Troilus \& Cress. iii.s as I pronounced it to you, trippingly.. llamlel, ifi. as I pronounced it to you, trippingly .. lambel, iit. 2 TRIVUN of the minnows? .......... Coriolanus, iii. art thou led in trimph? .. Measurefor Measure, iit.

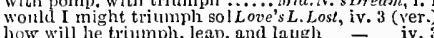
how will he triumph, leap, and laugh - iv. 3 triumph thus upon my misery 1. Taming of $S h$. iv. 3
men did triumph in my faee ...... Richard II. ili. 2 should grace the tritmph of great

hold those justs and triumple?

'gainst the triumph day ...............

of these triumplis hell at oxford ..... 0 Henry $I J$. iii. rebels' arms triumph in massaeresi.. - v. Tulbot triumph for a while..........

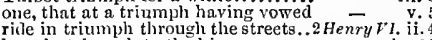
bear in trimmph to the ling ........ to triumph, like nu Amazonian trull

still ride in triumph over all mischance

triumph. Henry, in thy day of doom

yet set down this day of triumph " Rich

will triumph o'er iny person

and to rejoiee in lis triumpl

and to rejoiee in his triumpl ........

thy ennquests, glories, trimmphs, spoil
with triumph home unto lis house..

to be led in triumph through the.

and blemish Cesar's triumph

my glory unto an enemy's triumpli

he'll lead me then in triamph?

the matter? triunphs for nothing

but safer triumph is this funeral

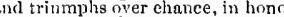

thou in triumph long hath prisoner.
knights realy to begin the triumph?

in honour of whose birtl these tri

triumph die; like fire and powder. Fomeo \& $\bar{J} u l$. ii.

bray out the triuminh of his pledge...... Hameled, $\mathrm{i}$.

do you triumph, Roman? do you triumplly?
TRIUAPIIANT hifer ......... Mid. N.'s Dre

bound in with the triumphant sea.. Richard li. ij.

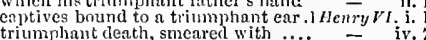

to Lonclon with trimmphant mareh.3 Henry / I. ii. 6

would be so trimpliant us I am?

the gods, and make triumphant fires. Coriolouns.

bi:e's a most triumphant lady ...Aniony \& Cleo. ii. 2

bury thee in a triumphant grave. Romeo \& J J uliet, v.

duke Thesens' house triumphantiy i Mid.N.'s Dr.iv.

are at hand triumplantly displayed. Kimg John, ii. \&

Antony's hath triumphed on.........tony \& cteo, iv. is

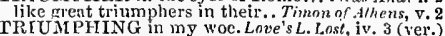

trinmphing, how mine enemies ..Richard IIl. iii. 4

TRICHYIRATE should be deposed

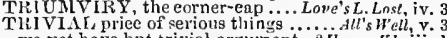
we yet have but trivial argument...2 Henry VI.

thereof are nice nnd trivial

Richurt $11 \mathrm{l}$.

we dehate our trivial differenee....... Anlony, \& Clen. ii.

of so slight and trivial a nature....... C. Cymbeline, i.

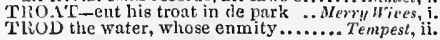

TlROD on neut's leather............... Tempest, ii. I hive trod a measure .............. and been thus trod down......... Michard 11. ii. as ever his plaek sloe trod upon....... Henry f. iv. I had never trod this English ..... Henry VIII. that onee troa the ways of glory I trol upon a worm against my will .Jus Casar, TRODDEN--in the troiden paths... As youLike it, i. the more it is trodden on ............ Henryl He. ii. stnined uobility lies trodden on....... worm wili turn, being trodden on ...3 TROILUS-Cressida to this Troilus Tuelfth Night, iii. I Troilus the first employer of panders. MruchAdo, v. 2 Troilus had his brains dashed out. As yon Like, iv. Where's my spaniel Troilus?.. Taming of Shrew, iv. how now, prince Troilus? (rep.). . ... Troilus will not eome far behind (rep.) Troilus, for a hrown favour (rep.) commended Troilus for a eopper nose $=$ Helen loves 'Troilns, - Troilus will (rep.) bait mark Troilus above the rest (rep.) $=$ Troilus? I'll sliow you Troilus (rep.)

brave Troilus! ( $r e n$ )

live and die $i^{\prime}$ the eyes of Troil us $(r e p$.

ay, a token from Troilus ..............
more in Troilus thousand fold $\mathbf{I}$ see

now, youtlifill Troilus, do not ......

with Paris from the prinee Troilus...

your brother Troilns, - M $y$ lord ....... prinec Troilus, Inave loved rou (rep.)

approve their trutlis by Troilus

my brother Troilns lodges there ....

is not prinee Troilus here? ............

so near me, as the sweet Troilus (rep.)

good my brother Troilus, tell you (rep.)

from Troilus too? From Troy and Troilus

be com -

be nnt mnved, prinee Croilus

they eull him Troilus; and on him...

most yrineely Troilus: there Dinmed

may worthy Troilis he half at tuclice

no, faith, young Troilus (rep.) . . T....

take thou Troilus' horse, present.....

and at it, roaring for Troilus $($ rep. $)$..

yea, Trnilus? O well fought $\ldots$ Troilines - v.

RROJ AN-fn]se Trojan uniler sail. Alid. N. ' $\&$ Dream, i.

was hut a Trojan in respeet ...... Love's L. Losh, v.

unless you play the honest Trojan .

witl there are other Trojuns than .l llenry ', ii.

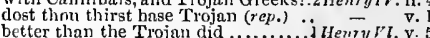

Trojan, and Antenoricles. Troilus \& Cress. (prologne

and other side, Trojan and Greek - (prologite)

each Trojan, that is master of his

this T'rojall seorns us; or the men

peaee,'Trojan, lay thy finger on thy lips! -

in view of Trowans alid of Greeks...

for liere the Trojans tarte our.......

art here put to thrasl Trojans ........

not wisli a dirop ot'Trojan hiood .....

I wonld, he were a Tiojan!.........
of us. Trujan? make demand (rep.).

weight, a Trujan hatl been slain...

Greeks and 'T'rojans suffered death

the Trojans' trumpet. Yonde

what Trnjan is that same that ......

thy commixtion Greek and Trojan.

Greein all, and this is Trojan

I have, thou of our Trojan part ...

there's many a Greek and Trnjan dead

how nay, he keeps a Trojan drab...

how now, Trojan? Diomed-no, no

that that same young Trojan ass....

now for thy whore, Trojanl now....

I have ehastised the amorous 'Trojan

the Trojan trumpets sound the like
along the field I will the Trojan trail

fike the Trojan horse, war-stuffed....... Pericles, $i$.

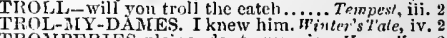
TROAIPERIES-pleines des tromperies. .H" Hry $V$. $v$ I second thee; in liave dispersed ....Tempest, i.

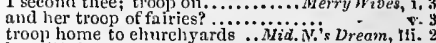

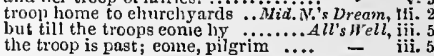


'TROOI' of Florentines..... the troop are all reattered ................. is not the buly. Comstance in this trong

ancisess, unil boyisle trouss, the king

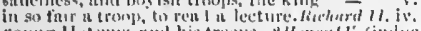

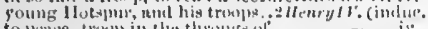

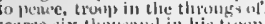

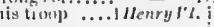

drives buck uur trouns

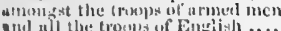

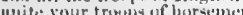

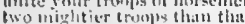

through the count with tr(x)ps of

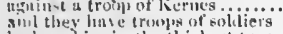

lie bre him in the thickest thoml...

all waether wo sur troops ............

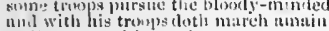

thi 1) itutry, with un puissnut twill.

such troups of citizens to come

Where be the thronging tropls

n liwhile truop of strangers..

the mable troops that waited

ahlessed t:on] invite me to a banciuct

to let the tron puss furiy . . .........

whint suy the other troos

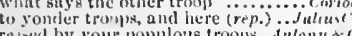

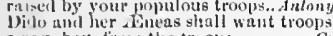

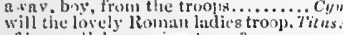

of her well-hesemting troos?

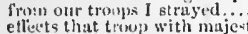

oitr tronjos act firth to-morrow

here conkes another troop to $80 \mathrm{ek}$ for $y$ on

furcaell the plumed troon [Knl-trnopin.. - ii.

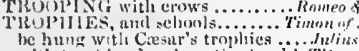

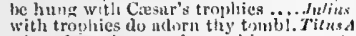

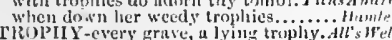

giving full trophy, sigual

and worn as a memuiable iroply.... - v. (clisilis)

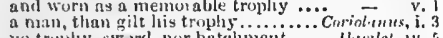

mo truphy, sworl, nor hatehiment.....

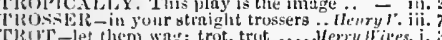

CkUT-let then wa; trot, trit

hy my trut, 1 tarry (rep. iv, 5 ) .........

who time trots withal (rep.)......... As you but

lie trots harl with a young masid

he trnts the air; the earth sings....... llewer

would trot as well, were some

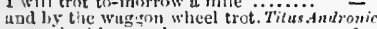

sessa; let his trot by ............... Lem

two bisoms, nind one troth (rép.).

and wet break iny trith

newer break men s troth ..............

fitith and truth, strainet purely. Troilu, of Cor,

luabaul that dirl e'er plight trotlt . Clmmbetace, $\mathrm{i}$.

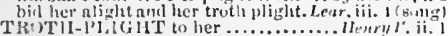

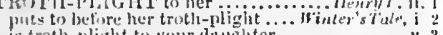

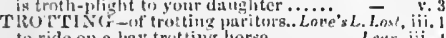

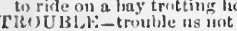

wh you t onible was I then to $y$

if you troub e him any more

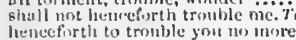

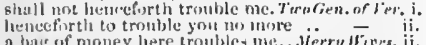

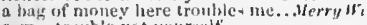

firc tive anole not yourself

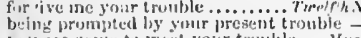

bull ire

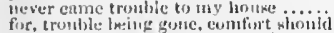

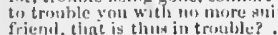

to toul ant trouble in the worla ... Tsmou like it, ii. 7

to you a charge, mul trouthle...... Irinker'stinte, i

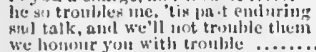

tin trouble your juy witl like reläion

but troubles of the unrriuge bed. Comedy of

le: gone, sir. ant not tronble $y$ osu ..... -

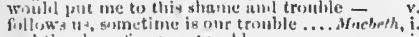

and thank us tir your troulile

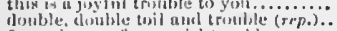

for a charm ot guwertiul troutle....... - iv.

raze out the written tronbles of ........

benone, and trunble you no mure ... kirchati

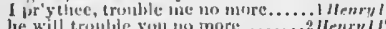

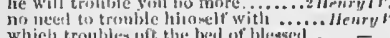

which troubles if the lyed of blegsed 


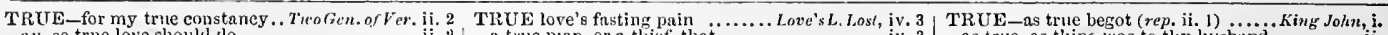
ay, 60 true love should ilo. her true perfection.

a true devoted pilgrim is

when I protest true loy alty to lier.....

I witl mike true

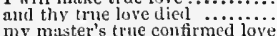

but eamnot be true servant

'tis true, such pearls as put $(\ddot{r}$ p.............

'tis trut; $O$ herven! were man

as I despise une that is not true......

thit is ruy true himi...

by me, thine own true knight

aun this is truc. I like not $(r e j$. $)$

a true man, or a thiet, that

true, true; we are fult .................

as true we are, as flesh and blood

it rejoiecth my iutellect true wit...

the number's true; and, were.......

mudam, spetk true; it is not so.....

for how can this be trme, that you....

must truc, 'tis right; you were so....

trak, and it was enjoined him in ....

for ever to be true to those that mike

true, mad:m; lie, of all the men. Aier. of $\overline{\text { verice }}$

this is my true begutten fatlier?

wise, fuil, ant true, shall slue be

be gleaned from the true seed of

your worlhip says very true
is it not true, master Page? (rep.

have you been trile to us?

may be, lie tells you true

tis ohl but true, still swine eat

my intelligenee is true $1 . . . .$.

true, madam: and to comfort ......... Tiee

your true love's eoming that can -

your trine love's coming thitt can

such as I am, all true lovers are

no one so trie did share it
where sad true lover ne'er find

they are as true of heart as we

nay, but say true; does it work.
it is with me as the ver's true son

nothing but this, your true love $\ldots .$.
prove true, imasination, O prove true

prove true, ima

from iny true place in sour favour

as yet the glass seems true

keep as true in soul, as doth

upon a true contract, I got...Measure for Men

it is true. I would not-though

from his true meant design

is this true? (rep. iii. 2 ).

come, tell me trise.

but with true 1 ray ers...............

to the law upon that pain. True

my false o'erweights your true
anil I know this to he true (rep. $\mathrm{iii} .2$

true man's almarel fits your thicf (rep.)

your true man thinks it big enough
if they be true, if not true, none

have heard me in my true eomplaint

as true as it is strange (rep.)....

and hide the false, seems true....

what he doth know is true, and filse

as this is true, let me in safety

my simple true julgment? (

impossible you should take true ro

to tell you true, I counterfeit lim

and I think I told him true, that

'tis true incleed; so your daughter $($ rep $)$ -

there's no true drop of blood in lim

are you good men and true?

virtue of your office, to be uo true mone

tis very true .......................

do not wrest true speaking

and these things are true (rep.).

thoigh he thought his aceu

noth out what was true ..........

in a fafso quarrel there is no true valom

as it appears in the true course

tis most true. And I do with an eye

the course of true love never did run

if then true lovers have been ever...

in the true performing of

do it for thy true love tak

I thought you lord of more trie....

as true as truest horse (rep.)

the sim was not so true unto the day

sorne true love turned, and not (rep.)

to prove them true?

tlou takest true cleliglit in .............

and will for evermure be true to $\mathrm{it}$.

more strange than true ...............

to eantent you, our true intent is.

not enough to speak, but to speak trie
not Shafnlus to Proerus w'as so true.

true; and a goose for lis discretion.

he is, in telling true, but so so ..........

for trie it is, I was taken with (rep.)

base vilgar do eall, three. Tru

make tender of to thy true worthiness

true, and I for a plantain (rep.)....

trise, that thoun art beauteous .....
tis true indeed; the collusion

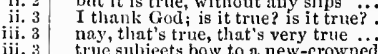

iii. 3 true suljeets bow to a new-crowned

and then I told you tive

but is it true, Salerio? have al

you have a noble and a true coneeit

how true a gentleman you seod relief

'tis very true: $O$ wise nnd upright judgel

and neer a true one ...............

most true, I have lost my teeth ...As you I

high eommendation, true applause..

we thas true a lover as ever sighed

true it is that we have seen bette...

sir, I am a true labourer ...........

speak sad brow, and true maid.

then there is no true lover in......

the pale eomplexion of true love

if $y$ ou be a true lover, hence
nay, 'tis true: there was never

I spake not true: this is ealled

in sight and shmpe be true, why them

this to be true I lo enente.

that your true faith dotti merit

as we do trust the $y^{\prime} l$ end, in true ielights -

if it be trine, that gnod wine (rep.) - (epilor v.

knew the trise minute when

which mert fill true silall find...

therefure tell me true (rep.).

there do muster true gait

a vagalond, and no true travelier.....

and ever sliall witl true observaince seek -

whiel mal that in story true, ever

tell me true, I charge you..............
by our true diligence . . Triming of $\mathrm{sh} .1$ (ind uction)

tis very trine; thon did st it exeenche - 1 (imdne.)

till I found it to be trite, I never

to change true rules for oud $\ldots . .$.
why, thou say'st true $(r$ ep. $) .. . .$.

but is this true? or is it else.

I would that word were true.

fuir looks, and true obedienee........... $=7$.

say it be, 'tis trite. No, no, my lord.

if I had servants true about me

all's crue, in my true opinion?

if this prove true, they'll pay for $\dddot{t}$. .

to have her honour true, than your..

and allegiance of a true subject

as claste, as true, as I am now

that's true enough; though 'tis...
Camitho a true subjeet, Leontes

very true, sir; lie, sir, he; that's.

your youth, and the true blood.....
for then we are sure they are trie...

is it true, think you? very true (rop.)

true, too true, my lord; if. one by une

my true Paulina, we silall not murry

this news, whiel is ealleal to w

nost true; if ever truth were pregni...

as lonest a true fellow as any is ....

ne'er so false, a true gentleman ma

the almanaek of my true date
and truee with thy true bed...

'tis true (rep. v. I) and true he swore, though

cstablish him in his true sense again

upon my lite, I tel you trie

true, worthy Banquo .

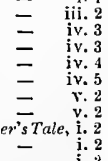

so please you it is true

true, my lor

impostors to true fear

ay, now, I see, "tis true ......

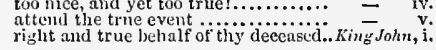

not true in love?

to the true and exact performe

I will say true (rep.)

ricrlis true, that I say; an' I had... as true, as thine wan to thy lusbind

whether thy tale be true. As truc a

trove my rayine tr

amity, true love, between our

gentle brow of true sincerity?

like all counsel, true reilress........

if that be true, I shali see my

stecps his salety in true blood...

this true; to hurt his master...

the clanger of my true defence.
be possiblel may this be truel

since it is true that I must

sliould 'seape the true aequaintaince

and true subjeetion everlastingly ....

my life shall prove it true ............ Richard 11. $\mathrm{i}$.

speak like a lrue knisht

there lives, or dies, true to king .......

Christian service, and true elivalry

God things true, weeps thing
for thing

O madnm, 'tis too true .............

allegiance, and true frith of heart

as my true service slatl deserve........

yet what I eay, is true $\ldots \ldots \ldots \ldots \ldots \ldots$.......

Aumerle is guilty of my true appeal

then true nobleness would learn ....

tis very trne, my grief lies all $\ldots . .$.
thus nimbly hy a true king's fali $\ldots . .$.

any resting for her true king's queen

against them both, my true joints bended 二

ours of true zeal and deep integrity ... -

mercs, which true prayers ought to have -
lath jrayed, and prove you true .....

to hear my truc time broke ........... - v.

thou sny'st true, lad... industrious ... Int'mery $I T$. i.

that ever cried, stand, to a true ma....

the true prinee may, (for recreation..

you say true (rep.)

purchase, as 1 am a true man .........

when thieves cannot be true...

the thieves have bound the trie men

our friends true tund eonstant.........

Will not tell me all things true $\ldots . .$.

swear it was the blood of true men ...

thou sayest true ( $r e p$. iii. 3)..........

never eall a true piece of gold ........

for a true face, and good conscience.

for some things true, wherein .........

find pardon on my true submission.

now as I am a true woman

they tell thee true...............

hut the true and perfeet image ......

to speak so true at first? ........2.2Henry $/ F^{-}$. (indue.)

false, worse than true wrongs ........ - (iuchue.

your spirit is too true your fears.

your spirit is ton true, your fears ...

that true valour is turned bear-herd

'tis very true (rep. iv. 1) $\ldots . \ldots \ldots . . .$.
wrenching the true cause the false way

limself to-night in his true eolours.

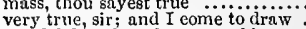

eareful friend, and a true subject....

in his true, iative, and most proper..

acquitted by a true substantial form
true obedience, of this madness eured

worse, if your own rule be true

treason's true bed, and yielder up....

and a famous true subjeet took him...

my most true and in ward du teous.

it may with thee in true pence live...

and a true lover of the holy cliurcli...

of his true titles to some certain $\ldots . .$.
of the true line and stock of Charles

very old and true, if that you will

and true repentance of all your.

from him the uative and true ehalienger -

in the true tliseiplines of the wars.$\ddot{~}$

minding true things, by what....

Gloster, "tis true, that we are in great

when the true and ancient prerogatife

but the saying is true; the empty....

you say very true, scald knave.

in true English, I love thiee, Käte.....

appear in his true likeness (rep.)

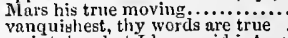

maintain what $I$ have said is true

a true Plantagenet (rep. iii. 1) ......

true; and thou see'st, that I no issue

and, like true subjects, sons of.... . 


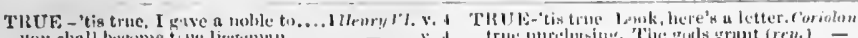
you alaall berence t: vie liegentin

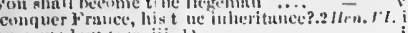

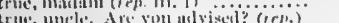

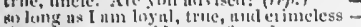

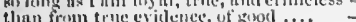

cood Waryeick, tis tou true. irue nolility is ex.met iruin fo.......... true; anl yet it is snich ( $\left.r r^{2}\right)$. aguinst thy onth ant true ullegine never live lut true unto his liege?. If Jrenus prove true ..............

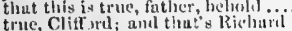
trefore a true and law winl maisistrate. so true men yickl, with robtsers we are true subjects to the king. how true he kequs the wiml? .......... impatienee wuitcth on true sorruw. is Elw'trd your true kin!? henceforth 1 am thy true ser is safe, it true within itself?.......... and their true sovereign, whom they to hold your trie oldedienee...........
God help Montugue, its he proves truel and be truc king inteed

true beir to the Englisle erown...........

true, my gord lord; 1 know you

and iny Troy's true lope

if the rest be true whirh $\mathbf{1} \ldots \ldots \ldots \ldots$

incleed, 'tis true, thut Ilenry twhl... if king Edward be as true and just.. hichand III. i. please to hide in this true brent

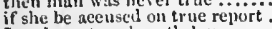
I sual iny true heart's love

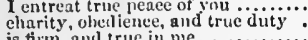

ay, sir, it is too true; Giod help.

ay, gir, it is too true; Gowd help rite were true, he should he...

my master's licirs in true tleseent.

[Col.Kul.] true computation of the time -

truc ornaments to know a helly man

true, nohle prinee. () bitter (rep.)...

true, when avisked grfee mak
bear her my trme love's kiss

o true, givil Catesby; bill him

with him, as I prove trike to you

will our friends prove tll trite?

will our iriends piove all trite? $\ldots . . .$.

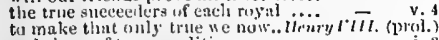

a. these of true embition .....

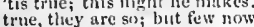

most truc, these news are every

atul every true heatt weeps lime
been to you a true and liumble wifi

and, like he: true nolility, she has..

a wife, a true 'ne? a

primaunce, youl hive fomm trile

sin noble, and so true a master?

tis very true (rep, v l) .....

with a true hetst, ant brother-lowe (rep.)

as true thou tell at me....... Troil
true, he was so; I know the eause

to saly the truth, trie ant not t

I'll be sworm, 'tis truc; lie will weep

liea the true prisof of inel.

strong joints, true swurds.

a Greclant t!nt is true in love

tur the volee of nuy true derivini
be true to my laril: if lie thiseh

who shitl be true to us .................

but, alas, I am true as trit
true swains in love olhull

as true as steel. as plantage to

na trine as Trimlins shill eress.

youll he so true tio lime to b.

and is it true, that I mant gar irom Triny?

ive thas but true of hemrt, - I true!

I speak not, be thou true (rep.).....

but, I'll be true (rep.)....
pluin and true. the........

tis true, that yon are smel, and he

goll of Prism, it frule knizht.

it is true. Ifo! bitl nty trumb

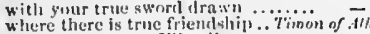

will tell yus truc. I'll rall an you

you tell we true. If won sumpeet ...

thou art true, und lubest.

upus my nonl, tis true, sir .........

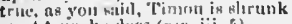

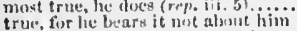

en miscrahle, but u man may le true

lial I a stew arel no true, sis just, and now -

lout tell me trie, (fin I mitst ever d uulst -

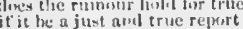

true; w'ien the thy surves

fur eatis trute wiril a lilis

care fur use trule, inulecell.............. romiat

true is it, my ineorphomte frienilis

Mareins, tip true, that yom lave ....

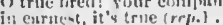

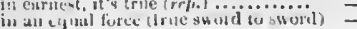

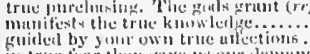

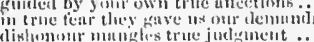

say then: tis truc trep. iv.

true, so I m. T'my you, poor gentlema

tis trie; if he were prition

would be ghat to have this trut.... which

telling true mider him, must sul
nut ny true lip hath virgined

art thou eertuin this is true?

if you have writ your un!m

in the theatre, $t$ am nu trise mian

wonld emsider the true entuse .....

and sluw yourotves true Itomm

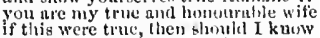

thawed from the true guality.........
of this untrod state, with all true fuitl

of this untrod state, with all true fuith
ditl love thee, Casar, 0 'tis true......

Ciesar shall have all true rites

make your vunting line............

as you are a Rommin. tell me true...

no man, but lie was true to me

hast proved Lucilius saying true....
who tells me true, thougl, .. dulony Cleop

you cau be mine, and trine ..........

and give true erite nee true reports

bit twelve per'suns there; is this true?

he hatli spoken true

all men's fates are true (rep.).

the news is true, iny lord

I tell you trie: best that youi.........

to went all your true follisu ers out ..

it it be a sin to minke a ti ue eleetion

f this be true (rep.)........

luturg both thief' and titu man....

sinee the true life on't was (rep.)

greater skillin a true hate

took pity from most true wreteliednes

not be a villain, but do me true service

and true preferment shall tender

anl be true. Thou bilddest

when rich ones senree teli iiv.....

tis true. Come on then, and remove

I dare be bound be's true ..........

you have no true debitor and ereditor

to boast were neitler true nor nudest

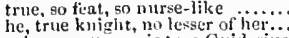

prince, as yours, is true Guileriu.

nerey is nobility's true lnulge

sitis true nobility wartants these

mis true; the riven doth not (rew

with his true tears all be-wet....

as true n dog as ever tomglit at head.

grave witnesses of true cxperience

brownem their enmity in my true tear

liammel as he is, to witness this is true

the lnet true duties of thy moble son!

n suljoct's shine. I a true jorinee

0 'tis too true. But see whint heaven....

is not this true? Unr enceks and hollow

in comrse of trine delight thath...........

stands for trite old wor! ........

in my true hent to fibl, she to

the trie blank of thine eye .......................

have we whipperl fur spenkinu tive

if it he trure, all vengeulue comes...

but, for true need, - youl leavens

true. my gond boy: come, bring

true to tell thee, the grief lusth

here is the giness of their true strength

esme on. Anl that's trie two ........

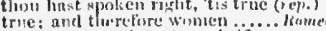

by thy atay, to lear true shrift......

while they ho cloen things true

fur I ne"er sau trac beanty tili

my true lowe frut that

sive

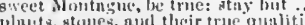

phult, stanes, and their true qualiti

that lust is trute. tle swerter re:t thengly 1 cantinot nutce true war

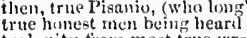

the or filse, it hiath mance thee carl

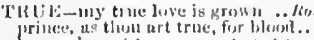

prince, we thun art true, for blawh....

\section{ii}

iii, I give this rillf tumy true kitigldt....

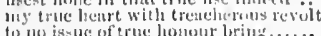

ny" what duses, and true lose".

(1) true upotlucary t thy dluts o.....

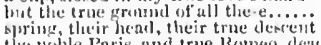

the nohle Paris, and true limme, deth

withent the sensible and true avoucli

entel worrl mate true aud grood

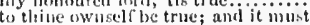

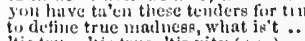

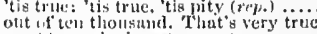

mist true, slie is a strumpet
but your iews is not true.

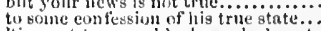

tis most true; gnd he bencebed me to

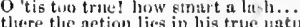

there the action lies in his true uature.

as sin's true nature is, each toy

imsinitehel brow of my true mutlier

like a good eliikd, anil a true gentlemain

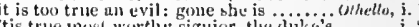

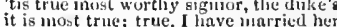

I know not, if 't be true; but $I$, fir nore

nuw! is this true? The ship is liere put in

you say true; 'tis so, indeed ................
though true ailvantage never present itscif -

tholf true anvantage never present itsen-

it's true, good licutenant...............

looks nut ou his evils? is not this true?

now do I sece tis true; look here........ - iii.

my nolle Nloor is true of mind .......... - iii.

indeeill is't true? mort veritable ........ - iii.

prythec, say true. I am a very vilinin... = - iv.

yom true and loyal wife. Come, swear it - iv.

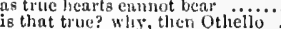

is that true? why, thicn Othello

she wits hearenly true! .................

it is truc, imuced, 'tis a strange truth

my soul $u$ lyis., ns 1 spenk true ......... $=\bar{F}$.

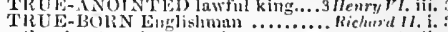

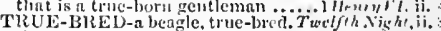

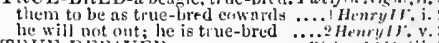

TRUE-DERIVED eomrse ..........Richurd I1. iii.

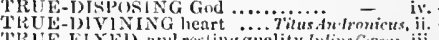

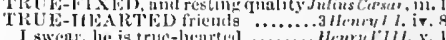

nolle ani true-hearted kent banished! . . Lam,

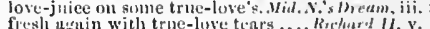

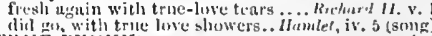

TRUE-PENNY" e me on.

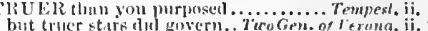

it is not tricer lie is Angelo......... Mreses. for . Meas. $\because$

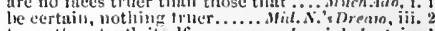

trice than truth it selt............. Lore"s L... L.nsl, iv.

far truer spoke, than meant..........2 inerury 1. iii.

kill a fitl tiver love; to hoth........ Richard 1II. i.

triest, not truer thun Troilus

there never wus a truer rhyme.

poor stewarl wear a truer grief... Firmon of .th. iv.

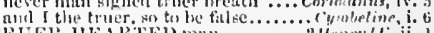

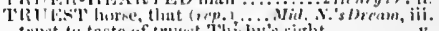

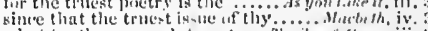

Wlint truth ean whalk truest.... Troilers of (ress. iii.

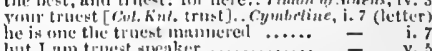

the bracelet of tile truest princese.....

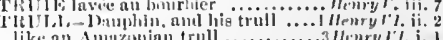

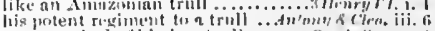

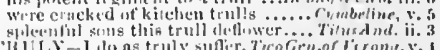

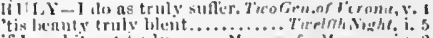

if I real it nut truly ....... Weasme for llecure, iv. 2

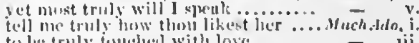

tiil her alswer truly (op.)

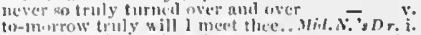

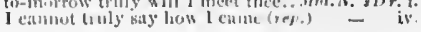




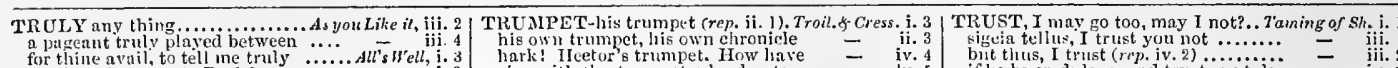

a pareant truly played between ..... speak truly, to go to Paris?

Inay truly say it is a novelty ....

and tell me truly too ......... Taming of Shrew, v. 5

this is put furth too truly l .........
we have always truly scrved you...

ne have always truly scrved you..... iii. 2 (orucle)
his innocent babe truly begotten - ii.

what I am truly, is thine ............. Muchet $h$, iv. 3

to give obedienee where 'tis truly owed $\bar{J}_{0}$

not umiss, when it is truly done

truiy speaks; who speaks not truly lies $=$ iv. 3

speak truly, on this knighithood
and, as I tiuly fight, defend me

demond thut truly which thon

if a man elould spent truly $\ldots . . . . .$.

as I am trily given to understand

thou hadst truly borne hetwixt
I have gervel your wos sip trul

serviee that I truly did his life

in every branef tivily demonstrative.. Hen

a.s duly, but not as truly, as birk ....
I tell thee truly, heratul, I know not $\quad$ iii. 2
iv. 7

and I thine, most truly falsely.......

more truly now may this be ....... Henry l. i. 2

I'l! see it truly dome, my lord of York - in the 19

as I truly swear the like! ........... Richmd HI. if.

as you are truly notle, as you respeet - jii.

never so truly liapps, my good Cronwell -

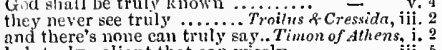

he's truly valiant that can wiscly .. coriolanus, i.
grateful to us that give yout truly
Tou seem, truly your eountry's friend - ii.

jou seem, truly your eountry's friend

ay, merey, if you report him truly, you were best...

ant briefiy, wisely, anil truly.........

kept, and truly yielded you

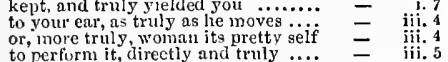

if Pisanio have mapped it truly .......
serve truly, never find sueh another

than I did truly find he

to serve him truly, that will put me.............

I shall serve you, sir, truly, however clse
tell me,-but truly,-but then speak .....

not trity in their hearts......... Romen \& Jutiel, ii.

truly to speak, sir, and with no addition - iv. 4

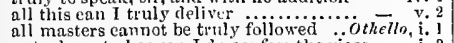

as truly as to heaven I dr entifess the viees -

if he be not one that truly lnves y
heavind dotli truly know it (rep.)
TRUMP_any trump did sound ..

TRUMP-any trump did sound .........iliemry Ir iv.

in one islands sound her trump. Troitus of Cress. iii. 3

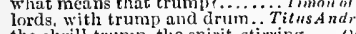

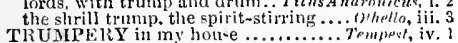

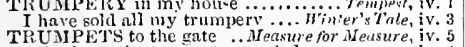

twice have the trumpets sominded

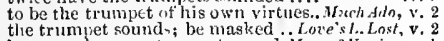

hear perclunce a trumpet somd..Mer. of Fenice, v

is at hand; I lacar his trumpet........

you may know by their trumpets! .. dill's

what trumpet 'tis that sounds. Taming of
neighing steeds, ansl trumpet's clang?

anger be the trumpet any more.

that suels a hideous trumpet

make all our trumpets speak

some trumpet summon hither .......

our trumpet ealled yon to this gentle
ghall braying trumpets, and loud....

shall braying trumpets, and loud....
what lusty trumpet this dotl suminon

what lusty trumpet thus dnth summon - v $-v^{-}$

sound trumpets; and set forward (rep.)
harsh-resounding trumpets' dreadful

through brazen trumpet fend.....

play the trumpet to his purp
the trumpet sounds retreat

tongue dlisine to a loud trumiet ...2Hen
the loud trumpet blowing them together

the loud trumpet blowing them

the trumpet sound the retreat.......... Het

and the trumpet ealls us to the breac
trumpets solund the tucket sonuanes
the banner from a trumpet take....

the banner from a trumplet take .....

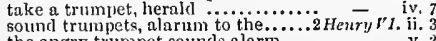

the angry trumpet sounds aln rm
now let the general trumpet blow

sounl, drums and trumpets

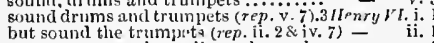

but sound the trumpita (rep. il. $2 \&$ iv.
go, trumpet, to the walls, and sound

their eourser's at the trumpet's soum
[Col.Knl] the trumpluet sounds. ...R;

a flonis il, trumpets! ftrike

sound, drums and trumpets ..........

we lave frightel witle nir irmanpets.

what trumpet? look, Alenelaus. "ro

trumpet, blew loud. semil thy bruss give witls thy trumpet a loud note.

thou trumpet, there's my purse.......
no trrumpet answers. "T's but early.

the Trojaus' trumpet (rep, v. 9 ).

it is true. IIo! bid my trumpet souvid!

what trumpet's that? .......... Ti

thy ti umpet in the market-plaee
when dimms tmil trampets shall

the trumpets. These are the ushers..

trumpets, sack huts. psulteries, and fifes
trumpet such gond thilings? Antony \& Cleopat

these trumpets, Autes! what! ........ - ii

the trumpets sliow, the emperor

to trumpet finth my infany.

L

what trumpet's that? I know't, my sister

let the trumpet sound (rep. v. 3)

at the third sound of the trumpet

- v. 1

upunt this cail o' the trumpet.
rest fur ever: trumpets, speak.

3 (hernid)

twiee then the trumpet sounded $\ldots \ldots \ldots . . . . . \mathrm{v}$.

thit is the trumpet to the morn ........ Hamlet, i.

kcttle-drum and trumpet thus bray out

to the trumpet apeak, the trumpet to.....

the Noor, I know lis trumpet
what trumpet is that same?..

TRUMPET-CLANGOR soumds.......

TRUMPETER, summon their ...... I Henry $I^{\circ} l$.
trumpeters of our unlawful intents?.All's $W^{\prime}$ ell,

the tongue our trumpeter....
trumpeters, with brazen din

ininny \& Cleo. iv. 8

TRUMPET-TONGUED, against ...... Macbeth, i. 7
TRUNCHEON, nor the judge's ... Meas. for Meas. ii. 2

they would truncheon you out.....2 Henrylt' it. 4

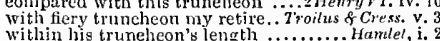

with lis truncheon may strike at yout... Othello, ii.

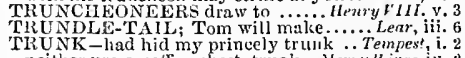

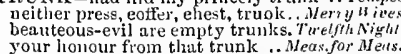

your hollour from that trunk ... Meas. for Meth

with a trunk sleeve... Taming of Shrew, iv. 3 (note)
that lies enclosed in this trunk.... Winter's Tale, i. 2

trunk work, sume behind.door work - King - ii.

with that trunk of lum truns.

from this bare withered trunk.
is this firail and worthless trunk

is this frail and worthless t
unto his dumb deaf trunk

.1HewryIV.i

leaving thy trunk tor erows

Henryl iii. 6

whose bare unhoused trunks. Timon or f

wherein this trunk was framed...... Corinlaturs, v. 3

sencl your trunk to me ................

to the trunk again, and shut

muke his dead trunk pillow ... Tilus...ndronicus, ii.

shed obequivus tears unon this trunk

trimk may be discharged of .... Romeo o. juliet. $\mathrm{v}$.

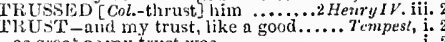

as great as my trust was a..........

we dire trust you int this kind ...... - ii.

I must never trust thee more .........

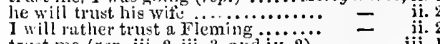

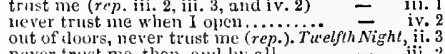

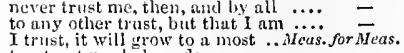

trixt not my huly order............ - iv.

amil on my trust, a man thit never..

I will do myeelf the riglit tis trust none
well, niece, 1 trust, you will be ruled

neynciate for itself, and tiust no agent

I will never trest my expectation.

if you dare not trust that you see...

trust not my age, my reverenee.......

to trust tlic opportunity of night

trust me, sweet, out of tlis silenee

trust to taste of truest Thisby's sight.. = v v.

O! never will I trust to speeehes.. Love's L. Lost, v.

your oath 1 will not trust...............

to please his grandam, never trust me
not fruntie (us I do trust I num not).As you Like it, $\mathrm{i}$.

suthec thee, that I trust thee not

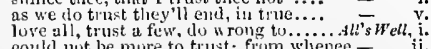

could not be mure to trust ; from whenee -

trust lim nut in matter of heavy

never trust my judrment in any th

I will never trist it man agai

to whose trist yont husines

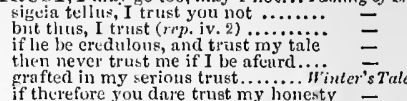

if therefore you dare trust my honesty
to see you sorry; now, I trust. I shall

and see her, no further trust lier

if she dares trust me with her

and, after that, trust to thee

and trust, lis sworn hruther, a ver....

I will trut you: walk before twwald
not being a tall fellow, trust me not

trust me, were it not (rep.v. 1) Comed or v

trust so great ......

well holp up, that trusts to you.......

skipping inernes to truat their liecle.... Aracbelh, i.

I buit an alreolnte trust

and damned, all those that trust thiem

rust aceordingly, kind eitizens ..... King $\overline{J o h} n$, it.

I trinst we shall, if not fill up.........

trust not those cumining waters of....

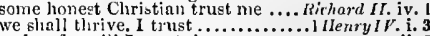

and so far will i trust thee .............

so dangerous and dear a trust on any -

sou live deceived our trust

we will not trust our eyes.

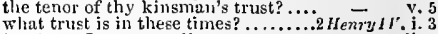

trust me, I am exceeding weary .....

is bold, to trust these traiturs........... Henry $r$. ii.

pitcll and pay; trust none: for oatlis..
I will never trutt his word after $\ldots . .$.

the which, I trust, shall witness live... $=$ iv.

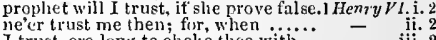

I trust, erc lons to ehoke thee with...

not trust thee, but for profit's sake..

Talbut; I Il no longer trust thee ....

$=$ jii.

I trist, the ghost of Thot

trust not the Kentish rebels (rep.)...2 Ilemry $r$, iv.

and trust not simple Henry.......... - i. 2

trust me, my lord, all hitherto

for trust not him that hatl onee ......

endeavours to trust to himself

trust the mockery of unquiet slumbers

I will not trust you, sir .............

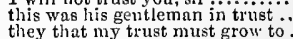

they that my trust must grow to... Aenry $V I I I$ i.

trust to me, Ulysses........... Troilus \& Cressila, i. i

I will no more trust him when he leers

I will, la; never trust me else.......

to trust man on bis oath or bond .. - i. 2 (arace)

trust not the pliysieian; his antido...

ne'er a one of you but trusts a knave

hang yel trust ye? with every

have placed their men of trusi? ......
are the Antiates, of tlieir best trust ..

or never trust to what my tongue...

to tread (trust to 't, thou shinlt mot)... in - v. 3

maulam, I trust. not 60

entertainment. bint no lronourable tivust

barle me trust you; but I do not ......

of t10 more trust than love that's hire

in sucin lonour as you have trust in

[Col.kmt.] as you value your trust

of thee, duserves thy trist
their tenor good, I trist

pray you. trust me here.

a roodl yuds and their trust... Titres.tudronicus, i.

Ill trust, by leisure, him that ........

thou wilt not trust the air.

left in trust with me, dotlis speak

snfer than trust; let me still.

the reposal of any trust,

deep trust we shall nueli need

I will lay trust upon thee ..........................

if' not, I'll ne'er trust poison

trust to thy single virtue.

eman, I'll prove...komen $\&$ Jutiet

there's no t: ust, no fuith, no honesty - iii.

trust to't, bethink you, I'll not be

it I may trust the flattering eye of sleep

to desperatiun turn my trust and liope!.

the trust, the offiee, I do hold of you

a man lie is of lionesty, and trust...

trust , ine, I eould do much ( (rep.)

TLUSTED-be trusted now.. TuoGen. of $\bar{V}$ erona, v.

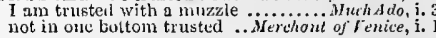




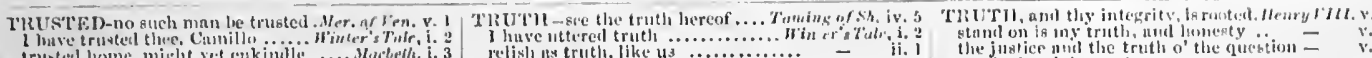

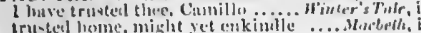
tru-bet liome, might yet cukinile

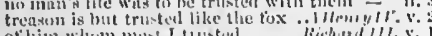
ot him whom mmst I t insted

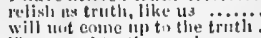

it the good truth were known
will have the truth

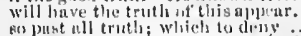

fust thou demt touth? Av, my loril

there is no truth at all $i^{\prime}$ the cracl

the wistim is not to le trusterl

llemvilll. it

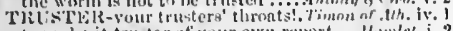

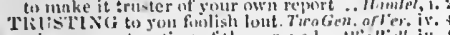

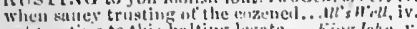
not trusting to this halting lesnte ..kimgdohn y. 2

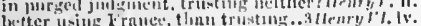

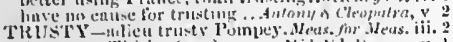

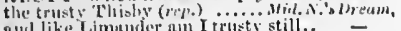
aul like Limuder num I trusty still..
cumt, trusty sworal; come, blide ....

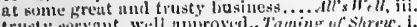
trusty sereant, Weth thprosed.. Taming of shere,

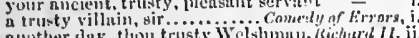

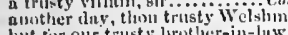
but tor our trusty lrother-in-luw .... - v. like to a trusty sunire .............. illenry Ir. iv. I ehouse trusty sentinels $\ldots . . . \ldots . .$. lich

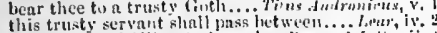

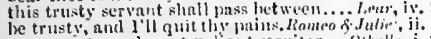

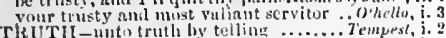
rkUTII-Mito truth by tellion

whell mot the trath; which I receive

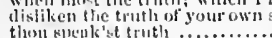

if ever truth were piengint ioy

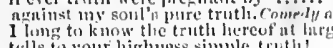

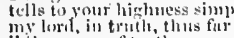

of dirtkuess tell us trutlis

two trutlas nre tolil .......

emmencing in a tritli? ...........

if there come truth from them

to thy go de trints and lionour

pereeive no truth in your reno
the fiend, thut lies like truth

the certain knowledre of that tritit...

but truth is truth..................

the truth is then most done..

thy truth agninst an oatis: the trusti

opinion sick, auul truth suspected ...

that lhou tor truth givest out

the right, umb trutli of all this realiz....

die lueve, and live hence by trutli?... - iv.

the truth you speak dittl lnck

their eyes do oinets of truth.

then speak the truth by the

a harel mpinion of his truth ..........

trinth hatli $n$ quict brenst

so help yon truth and heaven! .....

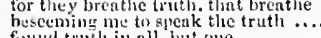

the trutls of whin we

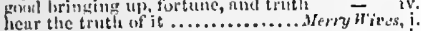

in trutl sir, she is protity...............

goue to the truth if lis words......
do you think there is trutly in thein?

you haye churus, las res, in truth

and till he tell the trutl

the truth of what we ure shows

it they sneak more or less than trutli.i Henry

is not the truth, the trutin?
he would swear truth out of Finglini

telling truth; tell truth, ant slyame

neither faith, truth. 110r womanlinod
trutls in thee, than in a drawn fiex

the trith being known,

honour, truth, ant cuery thing... Firelfu. $\overline{\text { inght, }}$ iii. I

one truch. and that no woman h

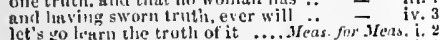

and vet, to sny the truth.

fewlless ant trith tis tinis.

I hope here be truths (rep.)..........

that uppears nut foul in the trath...

there is ge:arec truth enough alive $\ddot{1}$

Ior trut! is truth to thie end.

to mnke the truth appear ..............

as there is sense in truth, and truth.

Muchduo, ii. 2

they have the truth of this frotn Hero
tis a trutl., I ean bear them witueas

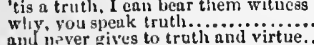

and you

no room for faith, trutl, nor honesty

if speaking truth, in this fine age

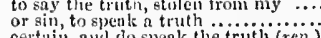

well, the truthi is, sir Johin (rep.)

my grow th wonld approve the truth
the truth is, porverty hath distiacted

in very truth, do I (rep. iii. 2).........

to speak truth, it very well becomes $y^{\prime}$

king Cophetua know the truth thereos

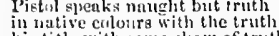

in native crilonirs with the truth
his title with some sliow of trut
though the trutli of it stands off

in good truth, the poet is nake.

frumed of the firm truth of valonir....
verily, and in truth, you shall titke it

no man answer in a ease of truth

Had show ot truth can cumsing sin .

hollil against her maitlen trut

if they speak lut trinth of her........

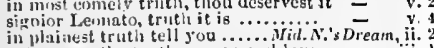

yet, to say the truth, ren fon and love

in their nati vity all troth appears
when truth kilts truth. ...............

when truth kills truth ..................
till truth make all things piain

the trutl is so: and this the eranny is

Mo, in truth sir, he should not .......

Isutir fior the truth, sir

if thwe hearr! is truth .............

it is so: trith is truth. A th yonr waist

ay, in trintli, my lind ; trim g:1l!uts.

the nuked trutin of it is, I

the tiuth anpears so muled on

suppose that t have nleaderl truij

muntam the party of the trith ....

wituessing the fruth on our sille

to suly slie tritth (yep. v. 4).

stubbormy lie did remign the truth.

the truth and innoence of thio poor

I suy no nore thun truth .............

ti) speak truth, thon deservest no lese

but, to comedale with tritth
tell me fur trith the mensure of....

both fill of trutl, I make king

in sign of truth, I kiss your..........

to say the truth so Jut as kissed

truth will come to light (r.p.) ........

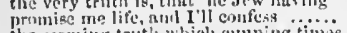

the seeming truth which cum

thant inaliee hears down truth ........

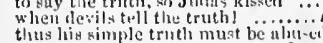

methinks the truth slatild live from

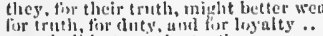

you sluti but say the trutli....

lie said the truth: tund what sail.....

tin the last of thy love to me werc.ds mon tint

there is no truty in him..............

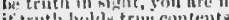

numl I epenk the truth the wext wity

the slow unil senal of unt ore'e truti.

that truth slonld be su-peeter

If will tell truth ......................... this hat been trutli, sir

иве a knevil truth to pass a thio.....

ay bltety. merce the truth

to rank our chinen truth with suc

On my soul, l'll spectk bint trinsli

slanter, sir, is timud a truth now .....

in trith. I'luen yous are weukly min

as muels as youl hinve done ny' triti

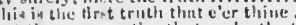

not the inauy soptho, thint make the truth -

apeak truth. IIe'd very uen the triti

a tritlics a truth, the ruguet are.....

you would think trith were a fool .

bits to sputak a truth....

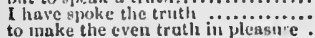

if you speak instli, fist t?

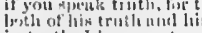

iut the way ot luylty nul i......

and do justice for truth, salce, nowi i

out 'f thy homest thith tuplay the

with thy religiose truth, whl molesty

that'w the plinin truth ...........

trutit bhill nurse her......

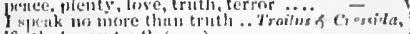

futh, tosay struth (rop.) $\ldots \ldots \ldots \ldots . . .$.

is this in way tis' trut

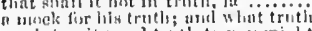

my integrity nut trith to yom misht

approve their tritilis by 'Troilus.

after all compurisms of truth, as truat

or swere n linir from truth.

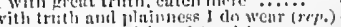

ie ind publiahing a truth?

justiec, trut!, clumestic uw
sicuk truth, you are hontest

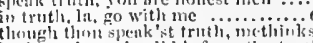

et lim alone; be did inforni tle trut

nis allowatce, to your hosini trith

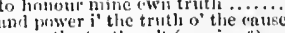

tiassy the truth on't (opp. iv. 6)....

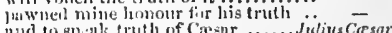

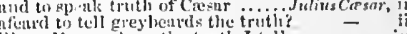

like at lonsan hear the truth $I$ tell . . $\bar{g}$ iv.

that trith should be silent, I had...

truiths wuild be but tales (rep.)

rent the trutlaim the truth $\ldots . .$. - iv.

by the very truth of it. I enre no......

iruth, where semblanec; love, where -

unent he love. mend truth, and vowi...

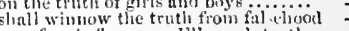

now fear is l'tum me, I'lt spenk t in!

now the flaitors, a the the truth!. Thus Andron. iv.

now youl huve heard the iritio $\ldots \ldots \ldots$.

fir the erowed ernts to dwell in......

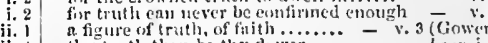

thy truth then he thy dower .............. le le i.

truth's a dog that must to kennd ii...... - i

be simple-nnswered, for we kisow the truth - iii.

als my repinta go with the moncst fruth

maintain my troth nut lonowe tirmly... - v

t) say truih. Verom bruga of him.. Rrmen of Jul. i.

this is the truth, or let Bervolio wie

[Cal. Knt.] the fla!tering truth of te.ep - iv.

of the truth hercin this juesent aljocet .. Ilamiel, $i$.

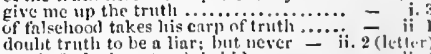
doulut truth to be a liar: but neser - it. 2 (1) iter will you ha' the truth on't? If this hat.. - ro

mone of l'se than tritth, thon ant no sc. litier-

spenk the trith shall nothing wrong hin = ii. with nanght bat truts: I lase wated = iv.

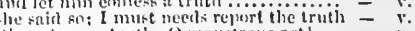
Wl $Y^{r}-t$, try with main-eourse........ Tempes? i. I will try the ................... - iii

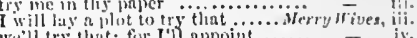

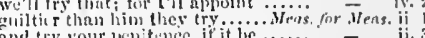
and try your lent nec. if it he
to toy lice orations furtume.

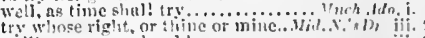

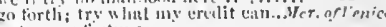

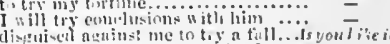

Gith bion the stremuth of .

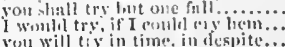

you will time in time ind and and ...

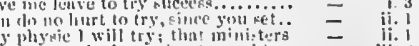

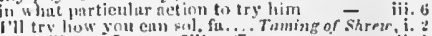

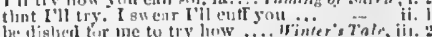

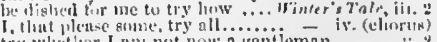

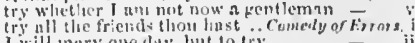
thill mary one diys, but to try..... 


\section{TRY}

TRY_yet Y uill try the last .. Blacbeth, v. 7 TUMULTUOUS strife

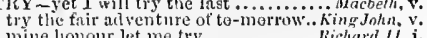

mow slall lie try his friunts.....

lac repealca the his honoul

- iv. 2

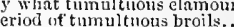
TUN - witl so many tums of nil a tum of man is tliy companion .... Henryl'ti. i. 3 The of Cyprus us beguile TRK of Cyprus us beguile ............ Othello, i. 3 the ' iurk with a minst mighty prepraration tempest hath so bunged the Turks

the 'Purks are drowned, how do our old are we turned Turks; and to ourselves do

let the end try the man

...Hcury r. i.

- 1.3 TUN1)ISI- with a tundisi Criolanus, jv. 5 first let them try themsel ves.

on furpase, to try my natienee.

to try with it, as with an enemy

con tiry it out with all unspotted
fi"st, to try her" skill, Reirnier

MIeas. for Meas.

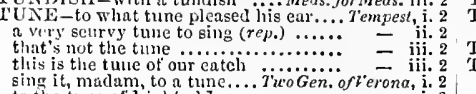

my conrage try by combat $\ldots \ldots . . . . .$.
mesently well try: eome, let's away

and then we'll try wliat these

sud try if they can gnim your

to the tune of lighit o' love
too heavy for so linht a tune

kecp tune there still

I lo not like this tune

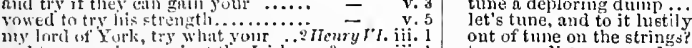

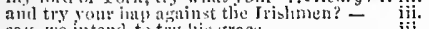

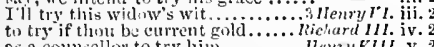

ns a coumsellor to try him...

tune my distresses, and reeord ......

[Col.] out o' tune?

and play the tune tije whilie

if it be anght to tlic old (ntre ..........

spenk in the sick tune? (rep.) ........ Farch Ado, iii. 4

serye for the writing, nor the tune. Love's L.Lost, i. 2

to jig off' a tune at the tongite's end.

and keep not too long in one tume $\because{ }^{\circ} \quad$ -

and protound Solomon to tune a jig $\overline{\text { iv. }}$, 3

thou bring'st me out of tune

and both in a tune, like two gipsie... $=$ iv. 2

in tune? that will be never (rep.) 7aming of Sh. iii.

he sings several tunes, faster ... Winters

use an scuris

and goes to the tume of, two maids

we liad the tune on't a montli ago...

till he had both tume and words.....
to the self-same tune, and words

to the self-same tune, and words
this tune [Knt.-time] goes manly
r Knt.- fit it with some better tune

and sung tou filthy tones

and sung those tumes to

as lond, and to as many tunes ...... Henry III. iv.
in this tnue, is lie? (rep.).... Troilus s.Cressida, iii. 3

stancl with the tumc of your voices ... Coriolanus, ii. 3

this is a sleepy tume ..............Juthis Cassar, iv. 3

to the tune of flutes kept ...Antony \& Cleopatra, ii. 2

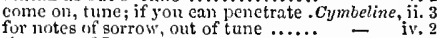

the tume of Imogen! . .............

do tume the harmony of this penee ... $\overline{\text { Dericles, }}$ v. 5

sometime, in his better tine, remembers.. Jear, iv. 3

like swect bells jangled, out of thine...Hamet,

only got the tune of the time ............. $\overline{0}$, v. 2

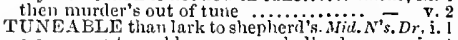
a ery more tmealle was never hollaed

TUNED lis bounty to sing ..........All's $\bar{w}^{\prime}+l$, iv. 3 w 11 be done, cre you have tuned Tamina of Sh, iii. I
tumed in the self-same key .. Troilus \& Cressida, i. 3

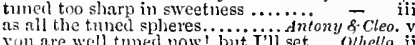

y ture well tmed now! but I'll set .. Ohello, ii.

UNIS-Clurilel to the king of Tunis.. Tempest, ii.

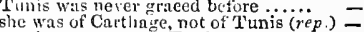

as when we were at Tunis $\ldots \ldots \ldots . .$.

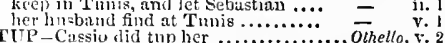

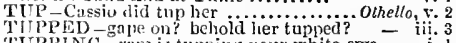

TIPPING-rum is tupping your white ewe

TrRbiNED Tuk beat a Venetian ... Olhello, v. 2

TURBUIANCE-blood t turbulenee. Troil. \& Cr. v. 3

been a turbulent and sturmy night ... I'erictrs, iii.

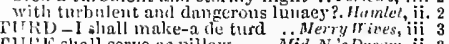

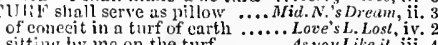

sitting thy me on the turf ........... As you Like it, iii.
Puter Turf, and Jenr,... Taining of Shrew, 2 (induc.)

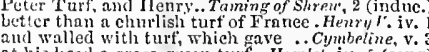
aul walled with turf, which rave .. Cymbeline, v. 3
at his heat a grass-green turf.. Hamlel, iv. 5 (song)

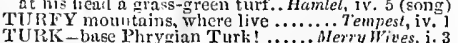

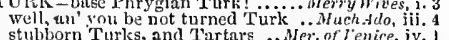
stubborn Turks, and Tartars ... Ner. of lemice, iv. I
defies me, like Turk to Christian. As ynu Like it, iv. 3 defies me, like Turk to Christian. As you Like it, iy. 3
or send them to the Turks to ......... All's W' $W^{\prime}$, ji, 3 or send them to the Turks to ........All's W' Well, ii. 3
nose of 'l'urk, and Tartar's lips .......Macbelh, iv. go sleep with ' l'urlss and infidel $\ldots . .$. Richard $I 1$. iv. Tosleep with 'lurks and infidels $\ldots$ regory never did sueh deeds.i Henry $J V$ iv. 1 to the hearer than the Turk's.....2 Hemry IV iii. 2
and take the Turk by the beard? ....Henry $V$. Y. 2 the Turk, that two and fifty ..... Henny r. iv. 7 think you we are Turks or infidele?.Rich. III. iii. 5 out-paramourel the Turk: fulse of...... Lear, iii. rest of my fortunes turn Turk with me. Hamlet, iti. must not think, the Turk is so unskilful
TURKEY enshinns bossed with. Taming of Shre

TURKEY-COCK of him with. Taming of Shreu, ii. 1 a turkey-enck. "Tis no matter (oep.) Henry $?$. v. U lik ISH tapestry $\ldots . . . \ldots \ldots$ Comedy of Errors, like Turkish mute, slall have........... Henry $V . i$. Turkish fleet (rep. ii. l and ii. 2) ......... Ohello, i. Turkish prejaration mukes for Rhodes..
toureling the Tnrk ish lose,-yet lie looks

TURLYGOOD-poor Turlygood! ........ Lear, ii. 3 TURMOILED in the turnoil. TwoGen. of Jer. it. 7 TURN-do not turn me abont............ Tempest, if., 2 I'll turn my merey out of doors $\ldots \ldots \ldots .$. .

or I'll turn you out of my kiigdiom..... and turn lier out to who

as thine will serve the turn? (rep.).

a somet that will serve the turn ....

turns me to shame ......

I ghall turn your liead ou

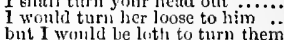

turn another in to the rcgister..

fer he swears, he'll turn me away....

no more turn me to him

and turn him to no

and

but llerne the hunter serve y. ur turn?

- ii. 3

often good turns are shnffled off......

immoderate use turns to restraint Meas. for.Meas, i. 3

rurn you the key, and know his.

you will turn good husband now

a feather will turn the seale

to use me for your own turn $\ldots \ldots \ldots . .$.

you have no intent to turn husband... Much

soturns she every man the wrong .. - iii. 1

to turn all beatity into thoughts ..... — iv.

if he be he knows how to turn iijs girdle -

turn melancholy forth to funerals... Mid. $\bar{N}$ :'

for, bear, fire, at every tim ....... =

I have enough to serve mine own turn
enstern wind, turns to a crow........

mows upon me, when tim my back
turns into jellow gold his salt-green

a mote will turn the balance.........

not serve your turn, sir (rep.).... Lnve's L.. Lost, i.

for I am sure, I sholl turn sonneticer

the other turns to n nirth-moving jest -
day would tom to niwht

her fin vour turns the fishion.

each turn away her face

and turn it to a jest..............
we will turn it finely off, si
purifies itself, and turns to

purifies itself, and turns to g/ace....

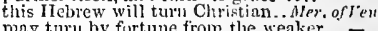

turn up on your right hand.............

unless the devil himself turn Jew....

turn you where your lady is .....

could turn eo mucl the constitution
and turn two mineing steps finto ....

of wit will shortly turn into silenee.

naty, if the seale do turn but in .......

Col. Sul. ]et ine turn monster..... As you Lihe il, i.

that any man turn ass ............. $=$ ii. 5 (song) or turn thou no mme to seek.

and turn lim going the turn his inck............

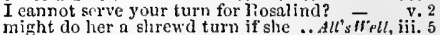
might do her a shrewd turn if she .. All's "Pll, iit.

to the great sender tmms a sour........ - v

for her turn; weli-real in poetry...Talning of Sh. i. 2

and thanktul fur good tirns

well tit him to our turn. and he.....

down the hill, will serve the tur

my best bluod tarn to an infected. ïinter's Tale, i.

turn then my fresh reputation to

great Apnlo, turn all to the best!. - iv. (chorus)

sing lier song, and dance her turn.... - iv.

f could frame to serve my turn.......

turn,

we in your motion turn .... Comedy of Errors, iiji. 2

$a^{\prime}$ turns baek for very fear

hath he not reason to turn back

stay licre still, and turn witeh ..... $=$ iv. 
TIRN-messenger turns me his lnek...M wheth, ili. ! t!rm, liell-houml, turn, or'all ure then turn your tirees firm this....... King Jot

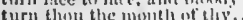
nuy ruther turin this chy isit.........

anil thum shalt turn to sishes

Thome Minbray, do 1 turn

let my soverigan tirn awhy....

hath power enongh to serve niir iiiri

his property, turns to the sourest
and 1 will turn thy falsthool tu thy

nay, if 1 turn mine cyes upon

mince thate tnirns one, or hoth.......

to turn true main, anil to leave

shouhl I turin upon the trie prince?

in the realm; hurns lienl ugainst.

moly turn the tinle of tearful tinetion.

to turn und wimi n fiery I'wasus...

it pleasel your majesty to turn your

now the bishop turns insurrection

wonlal turn their own perfection to ailuse -

it her fenthers turn hack in any

will turn the seales between

ant tirn all to a merriment.

now disth it turn, and eb

turm him to any eause of ............... he

turn heat, and stop pursuit.

and on your head tirms he

thy ......

torn the sands into eluquent tongles

ant turn them out of servile ......

so dirl he turn, and over suffolk

is turn away the tiat knipht with
well, hawd will I turn, and something

ablick beart will turn whit

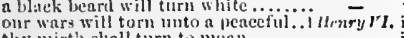

tiuril not thy scorng this man.

Ili turn my part thereof into

turn thy ediged sworil anutlier

dure like a Frenchmati; turn, and tiurn =

enust thou tion thee fior realress......

turn ent the blondy hrmeds ....i.

aurd turn afain unto the warlike

namigst them, if they turn to us ...
wijl nothing turn your nurclenting

thou turn aw:iy, and h de thy fince?.?

or turn our st the fires of them ups

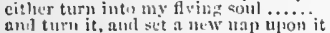

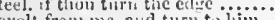

revolt from me, nind tirns to him ...3

to the eager foe turit back.

never onee again turn baek.

then "twas iny turt to $11 \mathrm{y}$.

none but I shall turn his jest..........

Clarewee, thy turn is next ..........

ril turn yon fellow in hin siave....

aul torn you all yeur hatral now ...

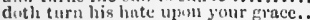

this war thou turn a emingeror.

tom turn their own points on the

they tarn to viciunt turms.............

gom of fortune, turns what he

you turn the gond we otler (rep. $)$.

you and I nust walk a turn togetlier

Goxl turn their licarts rever somph

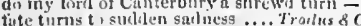

we tarn not hack the silks

that shall nut serve yimir tyri

dheth turn oh! oh! to ha! ha! he! - ii. I (som.

fir aprecslation turns mot to it

louk, huw thy eye turns palet.

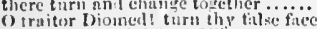

turn, sluve, ancl tight what art thou?

a worl will p'riam t+irn to stone

I must serve my turn ont of . Tin

slould it thrive, and turn bo nutriment

I will liok youl oll a gerrd turn

matrons, turn ineminent ...........

tis mont jut that thou turn ruseai..

It almost curns my dantectous nuture

I'll meet you nt the turn ........

Othat you conlif turn your eyes

I know not where to turn............

lie'll turn your enrrent in

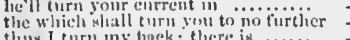

thins ? tirn iny laek: there

$U$ worll. thy slipery turns!

notke my mirery serve thy turn
aftel turns up the white of the eye

some news is eune, thist turnv their.

ainl turn the sirege ef it "1y+4

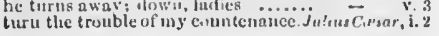

TII:X yome hidden worthinew

the ellimber-uphourd turns his the

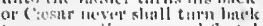

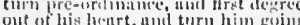

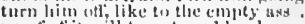

prouf of it will turn to redeler drops.

my sword, mut turn away thy tiuec

now enrn ble oftte mat devotion...

and kepe the lurn of tippling with..
for what fued turn? lor the licet turn

tulu your displeasure tlat way.....

in his ntuminations, turns yout of

ily, and turn the rulder; to
friende. I turn rou not alwy

tirn from me thes that neible

never eount tl:e turns............

ull rold and silver ratlece turn tio dirt

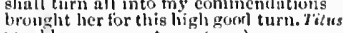

would serve your turns (rep.)....

urave hoys, and take your turns
suek'dst from ber, did turn to marbi

my hand will serve the turn .........

thint I may turn me to each one of you

how busily sle turns the

enn never turne ouran's blick leg....

[Col. hint.] with him, till I turn aguin
now is my turn to sjeak.............

now is my turn to speak
then Ill turn eraver too

nor did ill turn to any living creature.

she meant thee a good trirn ............
I think, you'll tinn a child again...

to her father turn our thoughts...

I pray you, tman your eyer again ........

to rage the city turn ............

to turn thy liated back upon

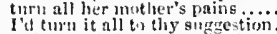

and turn their haleyon leaks witi..... - ii.

smile onec more; turn thy whech

ne the kurns the key tw the poor ...............

und turn his sleen to wakc....... - iii. $\overrightarrow{2}$ (song

this coll night will turil us all to fools

ghod porter, turn the key......

women will all turn

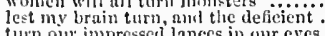

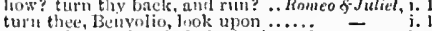

turn gildy, anil lie holp by baekward =

turn the tubles up, and quecrici tio fire -

turn back, dull eartli, nnd find tiy.....

virtue it self turns vice, being nisapplicd -

therefore tarm, and draw...

turus deadly point to point.........

witl treacherons revoli tiurn is another

their eturrents lum awry, and lose .....Ham

to desperation tirn my trust and hope!.
if the rest of my furtumes turn 'lurk

form of prayer ean serve my turn?

the turns to fuvenr, and to prettimess
I am to do a goer timn for them

iv. G (letteris

no tonghes else for's turn ...............

when I shull turn the business of iny soul = iii. 3

make her turn: sir, she ean turu (rop.)

make thy complexion there!.............

pray you, tirm the key, and kecp...... -

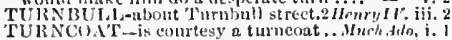

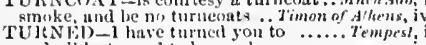

and all be terned to burnucles .........

tender wit is turned to fistly. TiroGenof leven
I have turned away my other.... Nerny Hive

turned my duughtior into green .......

or to be turnell a way .................

yon gull Malvolio is turned beathen

have male I Jerenles have turned spit.
anul now is he turneil orthographer..

Oday untowntily tirmed

and inen ine only turned in: to timgue

never su trily turned over and over.
turned her oliedicuce, which is due.

that he hall turned u hegrepinto

true bere turnet, and not a false tirned

as wit turnetl foul: filly, in wishoni.. Lore's

the funrth burned on the toc

that ever turnol their laneks to $(r c p)$.

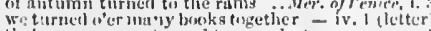

thele suvape cyes turned th a modest gaze

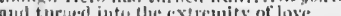

art toun god to slepherd turnet? - iv. 3 thetaer)
TIIRNE1) atl a flrat gromble wi

was turned into a eold dislo

bitice turuc in nuture

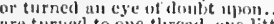

ure turned to one threal, one little

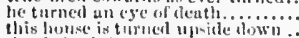

thy futher's beand in tinned ulite

licar a bruzen eandlleatiek turned...

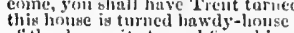

of the doy quite turned trom him - iii.

fir solut Umfievile turnesl me back .2Henryls'. i.

af the rest turncel on tilemselves

hinve your turned him out of derors.

is turited intis a jutice-like surving - man -

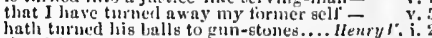

hath turned his balls to gun-stones.... Lenry $I^{\prime} \mathrm{i}$.

mine eyelalls into bullicts turned... inenry $\nu^{\prime} 1$. iv.

travail turned to this etlect?

thou mayst be turned to hobuails.... - iv. in

my heart is turnet to store.......... - . . . ?

and turned my captive state to liberty - is.

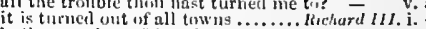

hatli turmed my feigned pray.

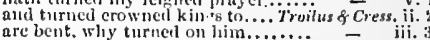

my mind is now thrred where....... $=$ iii.

mustrimet be tossed and whe ... Jimon of $A$ ther

my throat of war be turued ........ Cortulanns, iii.

lie turned me about with his ...........

sicak, Cosar is turned to hear.... Jalius Cosur, i.

liave to mine own turned enemy ..... $\overrightarrow{-}$

1 am sorry it is turncel to o drinking of Cleopatra, ii.

and then have turnet mine cye....... Cymbeline, $i$.

nost enldest that ever turnesl iij ace = ii.

nll turned to heresy? away, away 0 = iii.

it is a day turned strangely: or hetimes = iv.

which could have turned i distaff....

sonne, turned coward but by exumple
being all to dolours turned?..........

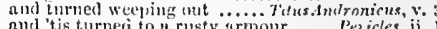

torch. that's torned unsige arour....... Pes icles, ii. I

I lind turned the w rony side out ........... $\overrightarrow{\text { tear, }}_{\mathrm{iv}}$

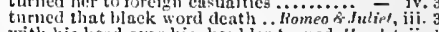

with his heal over his shonlder turned. Humlet, ii.

imperims cosar, dead, and turned to clay - ii.

the foul practice hath turned itself on me - v.

love hins turned almost the wroug side.. Othello, ii.

are we turned Torks?..................

thrned your wit the seamy side without - iv.

she turnet to folly, and she was a whore - v. 2
TURNED-FORTI, be it known.. Titus Andron. v. 3

'LTRETIl wood to stone ............. Hamlet, iy. I will leave them at the next turning.juch sto, $i$. with turning up your cyelids.... Lore's L. Los?, iii.

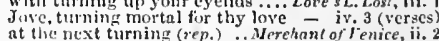
turnint his face, he put his hand .... - ii. turning these jests out of service..... ds you Lihe it, i. he slyould have old turning the key ...Mactieth, ii. rheme- turning distitcous torture... King John, in. simls by turning them from us.... Richard 1 l, iii. 3

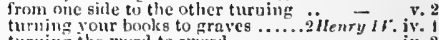
turning the wurd to sword ........... - iv.

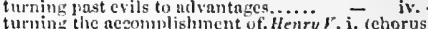

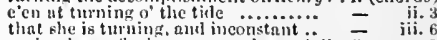
ensigu he re of mine wa turning .. Julins Capor, y. 3

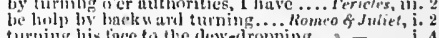

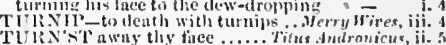

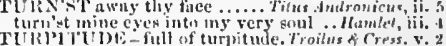

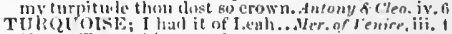

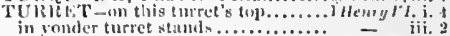

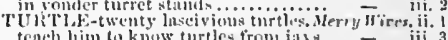
tench lim to know turtles from jas
will there turtles los gonc?........ Lore's L. Lost, iv. 3 When turtles treat, that rooks .... - v. 2 (semp) so turtles pmir, that never......... Hinles ' Tule, iv. 3 1, an old turte, will wing me........ riscl.

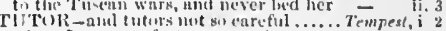
what, I ray, my fort my tuturt......... Tempest,

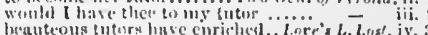
these are their tuturs: bid them... Tanming of sh. ii. 1 
TUTOR-a while to tutor me to this. Richard Il: iv. 1 TWENTY cnnsciences, that stand the tutor and the fueder ot my .......2 leneryll,

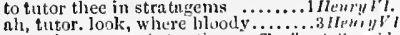
ant nssinego may tintor thee . Troilus of feaven be thy tutor,

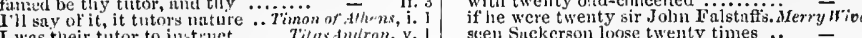

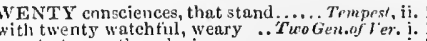

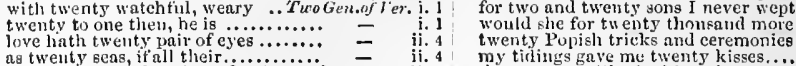

TWENTX-buried one and twenty. Titus Andron. i. 2

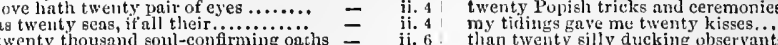
than twenty silly ducking observants

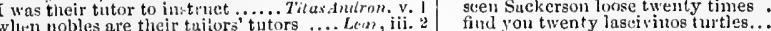

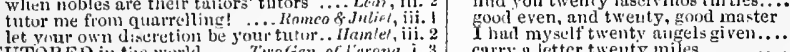

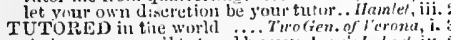
their sons are well tutured by $y$

carry a letter twenty miles
though twenty themation worthier
nad twenty glow woms shall unr

and twenty glow woms shall u

等

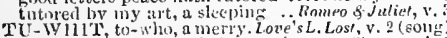

and iwenty pounds of money
kies me sweet and twenty.....

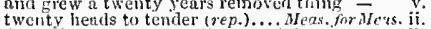

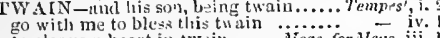

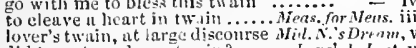

did lie unt send yout train

I reinit both twain. I sew .......... of renire,

'tis bartrained 'twixt nis twaill. Fismiry

what liave we twain forgo

for a dark liour, or twuin.

Nucbeth, iit.

dotl not pardon twain, but makes $\because$ Henry

was broke in twuin; by whom

we twain will go into his highness' ... Henry

yout twain of all the rest. nre near.. 3 trenry $/ 7$, iv.

initation of these twain

divide cternity in twain

for she'll be up twenty times a night. Miach
there's not oue wise man among twenty

am compared to twenty thus and Love's L. Lost, v. 2

twenty what were good (rep.) .... Mfer.of Fenicc, i.

I have sent twenty out to seek for

he trebled twenty times myself.....

thim twenty times the value of

the petty debt twenty times over

wenty of these puny lies I'il tell...

there twenty brothers betwixt us.. As $y_{0} \bar{L}$ Like

so near our public cont so twenty mites
and twenty such. What say'st thou?

five and twenty, sir ...................

love made your fortunes twenty tim

the dor for twenty pound

a gory emulation 'twixt us twain....

tis time we twain did slaow ontrselves

wars 'twixt you twain would be as if

could not out-peer these twain

tweenty cared nigfitiugales do sing.. - 2 (induc.)

twenty more snch names asd men..

.

gone five and twenty years (r.....) Romeo \& Ju

thine eye, than twenty of their swords

and twenty sucl Jacks

it beats as it world fall in iwcrity jijeces

some twenty of them fonght (rep.)...
with twenty liundred thousard limes

go hire nue twenty cunning cooks....

the strength of twenty men...........

give twcity, forty fifty, a hundred .... Hamlet, ii. inminent deatl of twenty thousaud uncn $=$ iv.

yon i' the earth three and twenty years.
thee known, though I lost twenty jives. othello, v.

inpediments than trenty tinses your stop $-\bar{v}$.

nd us twaius, that, striking in our... Cymbeline,

bite the holy co:ds in twain which are ...

hence a mile or twitin, is the
which twain liate brought $i$

yon twain rule in this realm .............

that hand that cut thy yout? in twain - v, 3

mischance between us twain 1

Hamlel, iii.

pure grief slore his old thread in twain. O/hello, y. 2

pirre grief shore his old thead in twain. Oinello, y. 2

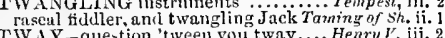

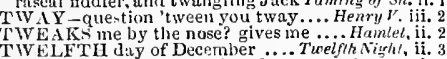

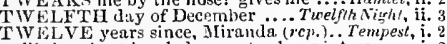

till thou hast howled away twelve winters-
shoot point-blank twelve score...Merry Wives,

shoot point-blank twelve score

just twixt twelve and one (rep.) $\ldots$

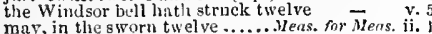

betwixt twatye and oue?

of midnight hath told twelve... Miri.. N.'s Dreat

mintil the twelve celestial signs .. Love's L. Low

let it be more than Alcides' twe
and twelve tight galley's: these I

and twelve tight galley's: these I. …

but jumps twelve fout and
the elock hatli strueken $t$ tre

and she goes duwn at twelve ........... Macbeth, $j$ i.

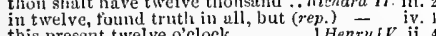

this present twelve o'clock........
will be a marcli of twelve seur

some twelve days hence our generai $\quad$ -

clapped i' the clout at twelve score..

bore it twelve letrryss, and sold it for - iii. - if

fift fortresaes, twulve cities.
we lost twelve hundred mea

if there sit twel ce woment. Timow of $i$ ih Henry $r$. $i$.

beat me out $t$ welve several times.. Curiolanus, iv.

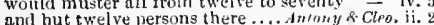

by land and our twelve thousand hor

one twelve moons more slit'll wear

my twelve months are expired ........ - iii.

some twelve or fonrteen moonshines....... Lea

from uine till twelve is three

'tis now struck twelve; get thee to berl.. Hamle', $\mathrm{i}$

twixt elevelus

about the world have times twi we thirties - ii.

be liatli laisl, on twelve for nine...

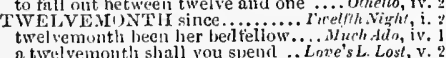

Othello, iv.

a twelvemontli shall you spend ...

at the twelvemont'l's end, l'll chan;se

anu sivelvemontli? well befil what (rep.)

witli twenty such vile terms

tricks eleven and twenty long.....

twenty crowns. Twenty urowns!...

but twenty times so much upon my
their losses twenty thousand erowns

their losses twent thousand erowns
between ten and tiree ard wenty
two and twenty. humt this weather?

made me four and twenty nosegnys for

make me to think so twenty years ...

no, not these twenty years ............

twenty years liave I been patron

TWLN'Y.NINE year

with twenty mortul mirders on

I can buy me twenty at any

of a grief hath twenty sludows ....

[Col.] name twenty thousand nam

to answer twenty thousaud suel

were he twenty times iny son, I would

two and twenty knights, balked in ...
nuy time these two and twenty years
lent you, four and twenty pout .....

thief, of the age of two tha trent $y$

and if it make twenty, take them all

have gent me two and twenty yards.2 HenryI

let it be but twenty nobles ..........

are $t$ wenty weak and wearied post

four hundred one and twenty years.

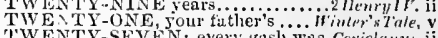

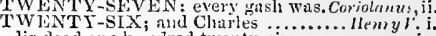

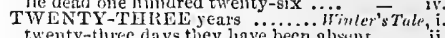

twenty-threc days they lave becr absent - ii. 3
TWVICE, and cry so so

or e'er your pulse twice beat

one dear son, shall I twice lose $\ldots \ldots \ldots$. of $\bar{c}$ crona,

who askel them once or twice..... Mrrry Wives,

twice treble shame on Angelo ... ileas. for Mets. :1i.

did show me the way twice

twice have the trumpets sotnded .....

he hath twice or thrice cut Cuygid's...
twice snd simplicity, bis coctus!.. Love's L. L.ost, i
offending twice as much

and so adieu; twice to your visor.....

have a serpent sti

yea, twice the sum twice did he tmom his hick.

twice did he tmin his hack ...........

ere twice in mork and occidental.....

who, for twice seven years, hath....

and rwice as much, whate'er thou.....

I have spoke to the purpose twice....; -

bolted by the northern blasts twice o'er -
for once, or twice, I was about to speak -

privately, twice or thrice a day ...... =

nor twice, but twenty times............

in every point twiee done

life is as tedious as a twice tolu tale - iii.

mueh more than twice all this ...... - iji.

twice for one step I'll grnan............
twice saying pardon, doth not pardon

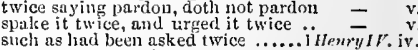

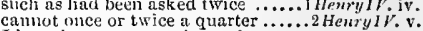

I have been merry twice and unce.

who twice a day their withered laands. Henry $V$. iv

wirn me for tinenty linglish misone...?

at this gentleman twice or thrice

ald twice by awk ward wiod fiom...2 Henry ${ }^{\prime} I$. is.

baws, twice two fur one $\ldots . . . \ldots \ldots$. 3 hichry $/ l . \mathrm{i}$.

whithers, i.

and I twe twe times reven biahops.'2

with twenty thusand kisses .......

rour loving uncle. twenty times his

male us joy one and twenty fifteens

five men to twenty .................

thun to accumplish twenty golden; ..

but while one would tell trenty
rolul were as good as twenty or:

trold were as good as twenty oritor
kisg you twenty will a breath.

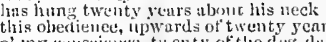

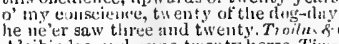

he neer saw three and twenty. T
Aleibiales, nnd some twenty hor
which makes it five nond twenty.

my hor:e, aml buy twenty more betio

no asseably of twenty be without

expecting in rcturu twenty for one? iit. 6 (grnce)

burn like twenty torelies juinetl i.

he thut euts off twenty venrs of life..

I have sidu Juc die twenty times.Aninuy \& Cleo.

ay, madum, twenty several nesetegers

twenty times of bettur fortune (rep.)

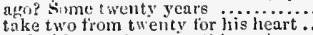

and, this twenty yeurs, this rock ....
ea:s one the slanghticrman of tweity

eas:h one the slanglicerman of twenty
these twenty yenrs hitye I trained up

betray i she-lamb of a twelvemanth - iit.

our purpose is a twelvemonth old.... Hewry

a twelvemonth longer, let me then ..
that fnr this twelcensonth, sile'll not

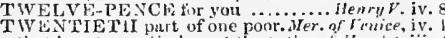

that's twice. How should that be? ..

I.ll make a journey twice as far ..... Cymbelin

from oft our ciast, twice beaten....
sucl as $\mathrm{I}$ ean, twice o'cr, I'll weep

an old main twice a boy.....

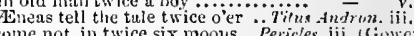

(Gowe)

I had ratber than twice the wortil ......

fuith hice so many have a command..

twice then the trumpet sounded.

this dreaded sight, twice seen of us...... ifrmb

thin, twice belore, and jump at this....

nav, tis twice two month, my jord......

Wre the thrcatering twigs ......Meas. for Meas i.

I must go look ms twigs ................

supportance to the bending twigs ...Riclurd 1 . iii.

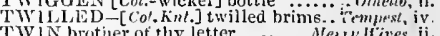
TWIN brotier of thy letter............ Merry Wives, $\mathrm{ii}$.

is not mose twin than these ........ Tinetih Night, v. one of thic other twins was bound.

and the twin Dromio, all were ......................

who twin, as 'twere, in love............ Coriolames, iv.

silk, twin with the ruby elerry. Pericles, $v$. (Gower) 
TwIN-13)ll with greaties TWiNk mat leut me (1) let me twine mine arms

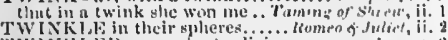

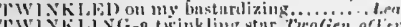

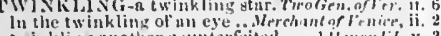

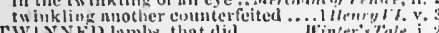

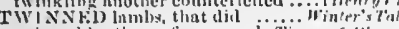
iwinuerl lrothers of one wemb. Timon of dhens, Rnd the twimntd toney upon ......... Cymberlin

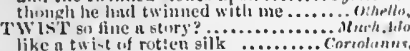
like n twi-t of rot:en silk
TWISTED from lier woub

Corinlant

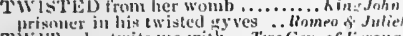

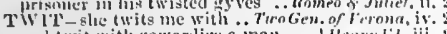

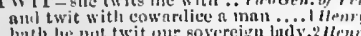

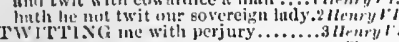

Twu-set lier two courses.

at leust two glinsses

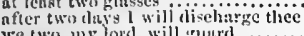

ree two, my had, will guat

four legs, and two voiets

encounter vit two most rue...............

if the other twing bus bind like us

a turn or two I'll walk

two of these fiellows your .................

delitrernte a sling or tw

to you tu o thrusand ...............
whiere have you been ihese two days

unless thou hudet two. . .
pity $t w 0$ such friends shouid

pity two such friends should .........

cost me two slmorls ond wiore

in the witint two yards about ..........

I vill mit all his two stones
when he would put has two

a wuril or $t$ wo? Two tlonsenili, fitir..

one, two, tree, fuur, eolne for?
six or stien, two, tree hours

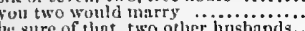

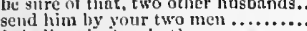

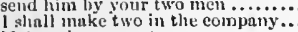

if there he one or two....................

hir Johy linlstnff from my two mistreses -

low many numbers is in nouns? Try

re tro will still be the ninister

we two in grent anazedness

from the two purtics, forooth

we two nust go torether
I ain resolved on twro pusing

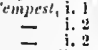

tivo fuults, Ndudminu, that drink.....

item, two hifs indifferent $r$

some two thuusand strons. or so

s eouplet or two of mont sage sa w.....

an ounce or two of this malapert blon

mat you in snind; one, two thiree

I have travelled but two lours

one hubit, and two person
nin apple eleft in two

promised to met me two liwe.........

within two hours..................
have a thief or twn, giiltie

two notoriuth lecendiactors

sir, we lane but two in the lasuse

ant free paitlon, are of $t$ wo houses.

a word or two with clandio...................

fince, of two usuries, the merriest.....

within these two days he will be here

but break a comparison or two on ine

out $I$, with your t two heldis

in the shape of two esmirres at onte

nand then the two bears will net bite

two of thent dich, the priste aud Claudio =

nu' two men rille wr a horre............

eomprelimiter wo aspiei

wonhl the two princes lie? ...........

two of then hase the rery bent...

lie shall kill two of

two nonses strarped uff witli tio...........

there's at double t'mingue, there's to in.

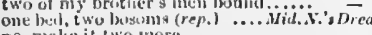

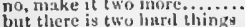

then will two nt one wers one.....

put in two seales whe even weigh

like two ortilleiul sivls

two lovely berritus musided on one (rep.) $=$

two of the fir at, like eents.

two of beth kinds makes ip foir......

I has rather lave a lumalfiul, wr two.

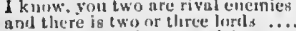

down het ween the tho nelighthours

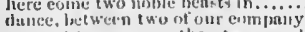

ainesuit th one uere than two .....

and stusly' three yeurs int two wrorily.

with two liteh balls sluek in lier face

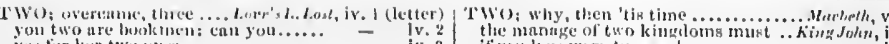

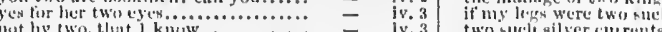

$v, 1$ the finly of two dewerts (rep.)

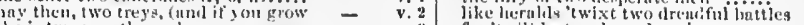

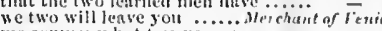

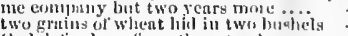

Genl dictital me from these two

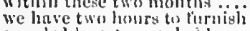

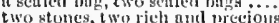

but 1 go nway witis two.................

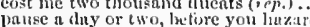

Eome suoutis or two, bufire

like one of two conteriding
tliere is a monastery two miles ofl.

the prettier fillow of the tiro ...........

and turn two mincing stejs into

lay two carthly women.

in elirintening thon slatt hive in

grnut me two things, I pray you

thlke anght but the two rir

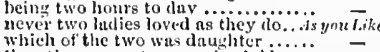

then there were two eousins luid iny
from whum I took two cods.........

like the encomber of two dug-n
opluresed with wo wetak cvils

and we $t$ wo will rail against our
for these two hurt's, Rosalind (re

by two o'clock I will be will

is it not past two o'elork? .............

but the fight of two rams ai........
eone two of the banished

like two gipsies on a horse

is but fur two months vieturajed........

sich ilifference betwixt their two extites -

that clare lenve two togetler

snfer than mine own two, more......

think thee, for two ordinaries.

I we:e but two hours younger .....

'twill be two days cre 1 ghall see you =

betwcen two soldiers and my younc lady
elay upon you two or three probublu lics

to beguile two hours in a sleep .......
sir, his wife, sone two months sinee

sir, his wife, some two months since
and Gratii two humdred nuld finty enel

a eheck of two pile and a half

yet for a nigit or two .. Traming of sherew, 2 (induc.)

as many diseuses as two and tity

he that has the two fair daugh

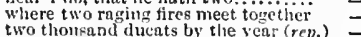

brides twa ducats by the year (rep.)

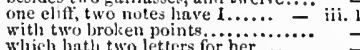

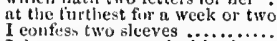

I dare assure you, sir, tis almost two

as those two ey's become that........

latve at $y$ ou for a bitter jest or two

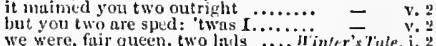

my lord the verier wang o the two? ...

we two will walk, my lord ..........
anti will, by twos, and threes, ut several

lest that the treneliery of the two ....

her eyes beeume twro spouts; the fury

they have searel awny two of

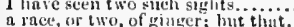

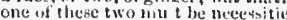

Hhich we two luse sworn shull conie

1 will bring these (wo inoles

meeting of the two kings?

jaytial mother of two goodly sons. Cume

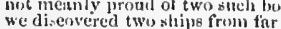

sure, Lueian, it is two o oelock

at two hands with me, nnd thut iny iwo =

for tun; and sound ones to

in Ephlesus. 1 um but two huurs oili

it was two ere I left lim

graw wed in two my corls

gee two hubbunts, or inine e.............

bore thee at a burien two fnir soung

these two Antipholus' these (wo (rep.)

as two spent uwimuners, tibat do.

two truths are told .......................

his two chamberlains will i with.
thoee sleepy two ut his own chaml

there are two lendsed togetleer....

the two delinute nts tear

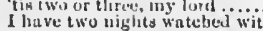

fur (will be two lonue dny jumer

De che

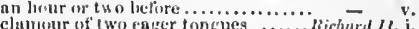

ne like two inen that vow......

there lies two kinnmen, nigged ....

that owes two buckets filling no............

my lort, snme two days since I Bity.

twio of the dangerer $1+$ consorted trniture

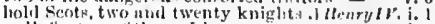

weel, for two of them, 1 know.

I think, it be two oclnek ...

Inty time these two and twenty years
and

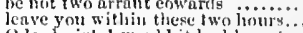

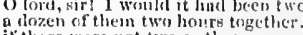

if there were not two or three.......

Thave peppered two of them;

Fo, two mere already

eleven buek ram men grown onitififirol

I think it he two o'cliek. .......

I'll nway witlin these two hours.

of the neye of two and twenty....

at twi'n s'clock $i$ ' the afternoon

nnil the half shirt is two napkina.....
I have two boys, feek Perey, and tiyssclf

wo Eturs keep nut their motion.

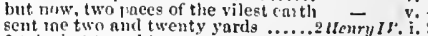

I take but two shirts out ........... =
geven gronty and two. I can get vin..

hring a resene or two: thou wo t
and those two things. 1 couffess

and hose two things. 1 eonfess........ -

put on two feather jerkins ( $r \in p$. ii.4)

yout two never meet, but you fili.....

whist, with two points on your

and, in two years after, were they
here come two of air.Jnhn Falstiff's men

here is two more ealled than your ...

revives two phenter ther's two ston

which is fint terno or two aetiong.

there is hint two ways, either to utter

there hath been $n$ man or two la
it will he two o'clock ere they

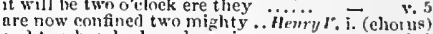

and two hund red fond esquire

fir ne ver two snrli kingdoms .........

ns two yoke derils, sworn to eitler's

I have huilt two chantries

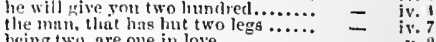

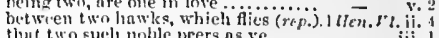

whom. two hours since. I met in

two Talpota, winged through ........

axl tho turo countipe I will ......

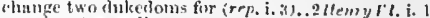

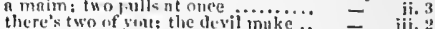

event thes two fripuls condemned.... $=$

thes have bern iu thece two days.... - is.

by her he land two elildiren.......... - iv.

to the etnke my two hrave benrs...... = y.

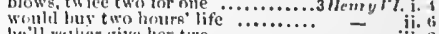

he $l l$ ritlier give her two ............ = iii.

of threc core and two yeurs.......... = iij. $\frac{2}{3}$

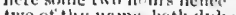

two Clitlirds, as the father anil (i.....)

with them, the two lrave bears..... $=$ - v.

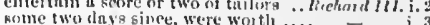

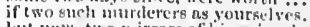

lat now", two mirenre of livis princely"

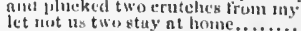

n cust at two humb old: 'twis tuii tivo =

muralize or two your inglimess.

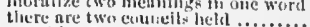

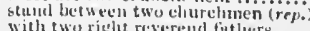

with twe right reverend fintliers
meditating with t wo deep diving

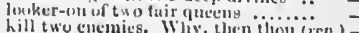

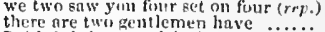

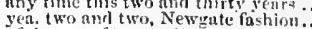

as rlammatie as two dry ton
gir Jolm, with two bulliets

whant's a joint of mutton or $t$ wo in

were discovered two nightier troops ii. 1

i. 3

i. 4

i. 1

ii. 1

3
.3
3

2

2

i. 2

i. 4

i. 1

i. 2

vi

5

i. 1

i. 2

.7

1
. .3
.

7

1

$i$
2
7
$i$

5
2
3

ii. 3
v. 1
v.

i. 2

ii.

ii. 4

iiii.

iii. ?

iii. 7

iv: 


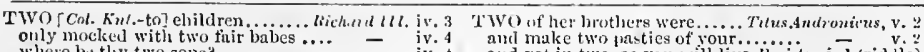
that thy twy two soms? ..................

which now, tro tencler leblfllows.

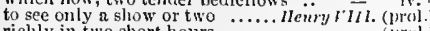

two short hours

those two lights of men, met in

the two kings, equal in lustre.....

confessor to one or two of tili...............

two women placed together makes

two equal men: the queen shal
the two great ctrdinals wait

two reverend cardinal virtue

till Cranmer, Cromwell, her two hiand

you spenk ot' two the most remarked

yolt sliall have two noble partners

slall hold you play these two montin

and sleep an act or two............ ("pilog

is the better min of the two........ Troilus o
[Col.Kut.] but two and fifty hiairs(rep.)

between the two moist elements

as stuff for these two to make........

are dogged with two strange fullower
two curs sliall tame each other ......

two traded pilots 'twixt the

not taken till these two molernine it

none of him, they two are twain ....

we two, that with so man
these two may run inad.

Hector compiny an honr or two......

shall sumder our two hates...

some two months hence my

sent your honour two braee of.. Timon of $\bar{A}$ then

it turns in less than two niglits.

if, after two days' shine, Athens ....

once lived to see two honest men?.

and you this, but two in eompany

thou art, two villains shall not be :

by two ot their most reverend semate
you two are old men; tell me one

that you two have not in alundance?

do you two know how you are censure

in the neck, and two in the thigh....

by ones, by twos, and by threes.

bear of wounds two dozen add

when two authorities are up, neitier

best if tlien; ; yea, the two
l'd erave a word or two...

the Volsces with two several po.......

grain or two, to lenve umburnt (rep.)
there's two or three of us have

some two months hence...

we were two lions littered .......
that one of two had ways you...

touch thy instrument a strain or two?

two mighty eagles fell

two several times by night

that we two weut to seliool tingether

equality of two domestic power's...Antony $\&$. Cl

Fou'tl win two day's upon me......

my heart parted betwixt two friends

tend me to-night two hours

in question, two other sons .......... Cymbeline
he had two sons (if this be worti $\ldots$.

I had set betwixt two charming words

and by such two, that wonld .......

and have our two wagers rceorded

thief-stolen, as my two brothers ....
twixt two such shes, wonld cliatter.

two creatures, heartily

eannot take two from twent

one, two, three,-time, tim
were two winking eupids .

were two winking eupids

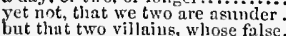

to him the other two shall ministe.

at three, and two pears old

I have not seen thiese two do ys.........

and for two nights together have....

two bewgars told me, 1 could not mis
blazon'st in these two priucely boys!

he, with two stripling

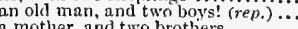

that two of us are as good

these two ynumg gentlemen...

and 1 must lose two of the sweetest.

I liave got two worlds by't

court can fenst two brides.......... Tilus...

not tlee lifference of a year, or two
broad awake two hours anil more.

broad awake two hours anil more.
these two have 'ticed me hither.....

these two have 'ticed me hit
two of thy whelps, fell eurs
bare of lice two

twe tranehes?

for two and (wenty' soms I never we

shiall distil from these two ancient urus

to resew: my two brothers from...
to ramsom iny two nepliews from

the heads of thy two noble sons (rep.
tor these two heads ilo seem to sue:t

for these two heals ilo seem to spe:ik
two may keep counsel, when .........

'twas her two sons (pp.)
he had his two sons' heads

he had his two sons' heads ......

Eet deanly emmity hetween two ......
[Col. Knt.] provide thice two proper
know you thesc two? ................. and yet. in two as you will live........ may the two litter darken. hurt in purtin: iwo that foughit... Cy two......

I liave not sem him this two days

has banished two of his daughters

I had two coxcombs, and two daugliters

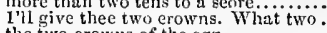

is it two days ago since $I$

thongh they had been but $t$ wo hours

witls two pernieious danglaters joined...

hast thou given all to thy two duughters

cries in Tom's belly for two white herrin

his eyes were two full moons

we two alone will sing like birds

'twixt $t$ wo extremes of passion

the fatal loins of these two foes .... Juliet, (prol.

is now the two hours' traffie ..........

two of the house of the Montagues

swears a prayer or two, and sleeps

was but a ward two years ago...

my lips, two blushing pilgrim

two of the fairest stars in all ........

one, two, and the third in your bosom

a saill ' $T$ wo, two; a shirt, and a smoe

her fan's the fairer of the two...

holy church incorporate two in one..

holy eliurch incor'torate two in one.

who is living if those two are gove?.

a friend, or two; for hark you........

hath lain these two day's buried......

what we two nights Jave seen

- (prol.)

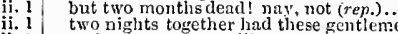

ii. I make thy two eyes, like stars, start from

ii. 3 [Wul.] one man pickerl out of two thous.... -

wwo hours. Nay, 'tis twice two monthi...

die two months ago, and not furgotten yet

with two Pruvencial roses

presentment of two brotlers ..........

when in one line two crafts directly ....

ere we were two days old at sea

two months since, here wis a gentleman

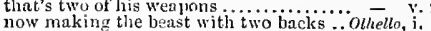

and mine, two hundred: but though they - i

two things are to he done ...............

'tis not a year or $t$ wo, shows us a man.

two or three groans; it is a heavy night.

$a$ word or two, before you go......

WofOI,D and treble secptres

ye violate a twofild narriage

...ilacbell, iv.

Eack hath a twofold operation........ Henry $\mathrm{l} \mathrm{V}$. iv. 3

TWV-HAND sword ...............2 Henty

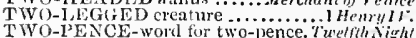

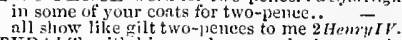
TYBALT, with his sword prepared.. liome of dil,

Tybalt, the kinsinan ot old Capnlet.

iii. 3 Tylmalt, the reason that i have to love =

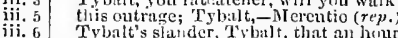

iii. 6 here emmes the furious Tybalt back again-

citizens are up, and 'Tybalt slinin (rep.) -

there lies thut Tybalt. Up, sir, go,.$*$
Tybait, ny cunsin! O ny brotier's

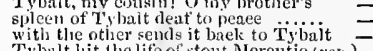

Tylualt hit the life of stme Nereutio (rep.)

Romeo slew Tybalt, Rumuo mu it not -

Tybalt, Tybult, the hest friend (rrp.)

Tyliait is gone, and Romeo banished

did Roneo"s hand shed Tybalt's blood?

that 'Tybalt would have slain (rep.)..

Tybalc is dead, and komen-hanished

when slie sain- $T$ 'ylalt's dend........

father, mother, 'Tybalt, liower, Julict

then starts np, and 'Tybalt calls
hast thou slain Tybalt? wilt thou

Tybalt would kifl thee (rep.).......

she luved lier kinsman Tybalt denri,
hark you, Tybalt being slain so late if fortune brag of two she loved .............

two thousand souls, and tweity thousand

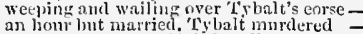

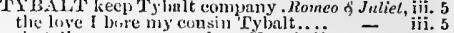
that dim nnomument where Tybalt lies
she weeps fur Tybalt's deatl she weeps fur Tybalt's death ......... 'Iybnit, liest thou there in thy bloody = marriage-dav, was Tybalt's dooms-day -

nyBd not for Tybalt, Juliet pined $\ldots$. $\overline{\text { nove's }}$ v. 3

TYING thine ear to no tongue....... lllenry $I$, i. 3 not article tying him to aught....... Corinlmus, ii. 3 tring her duty, beauty, wit, and fortunes. (Jlhello, i. 1
TYMANDRA? Yes. Be a whore.. Timon of $A t h$. iv. pYardon him, sweet Tymandra ......... Plirynia and Tymandra had gold of him $-v$ v.
TYMBRI A, Jlas, Chetas .. Troilus \& Cressida, (prol.)

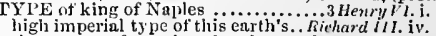
these types of travel, and understand llenry Flil. $\mathrm{i}$. TYPIION'S broud ............ Titus.tudronicus, iv. ${ }^{2}$ TXRANNICAL power (rep. .......... Coriolanus, iii. 3 TYRANNISE on unreprievable .......... King fohn, v. 7 that thus doth tyramnise breast. Tilns Andron. in. TYRANNOUS heart can tlink?. Tuelfth Night, iii. 1 but it is tyrannous to use it ..... Meas. for Meas. ji. 2 then were he tyrannous; but this being - iv. 2 let us be cleared of being tyrannous - jii. the tyrannous breatlood act ....Rerchard iv. 3

ii. 2 I knew lim tyramous; and tyrants' I'ericles, $\mathbf{i} .2^{2}$

and let this tyrannous knight take hold . Iear, iii. 4 so tyrannous and rough in proot!. Momen \& . Iut. i.

learted throme, to tyrannous hate! .... Ohello, iij. 3
PYRRANNY be in his place Me'asure for Meusure, i. 3

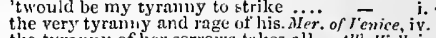

the ty ramling of her sorrows takes all ...All's I"ell, $\mathrm{i}$. and tyranny tremble at patienee ..... - iij. thy tyranny together working with.. $=$ iii.

intemperance in nature is a tyranny - - iv. 3

Wed the snares of wateliful tyranny..

that tyramny, which never quaffed ... i fenry $\nu^{\prime}$ iv. 4

hast by tyraung, these many years.. I Henry $V I$. ij.
was nothin. less tlian bloody tyranny

was nothing less tlian bloody tyranny

England was defimed by tyrainy..... Henry ${ }^{\prime} 1$.

'y/l. iii. 1 thy eyelalls murderous tyranny sits - iii.

insulting tyraniny besins to jut..... Richard III. ii.

vis tyranny for tr.fles............. - ii.

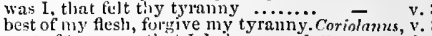

part of tyranny, that $I$ do bear.... Julias Cepsur;

thry teat thon hadst thy tyramy......

smiles such murderous tyramny...... - ii.

in the oppression of aged tyranny .Lear, i. 2 (letter)

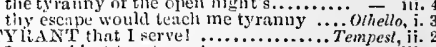

lim subject to a tyrant

[Col. int.] art a tyrant to say so.........

the marble-breasted twrant, still.. Tuetfih.vight, v. of late to make the luw a tyrant. Meas. fur Meas. ii. make mercy swear, and play tie tyrant $=$ in.
being a professed ty rant to their sex?..15uch dan, Pyrumus? a liner, or a tyrat??.Mid. N's Drean,

yet my ehiet humour is for a tyrant.

plint in tyrants mild humility ...Loire'sL. l.ost, iv. tyrant duke unto a tyrant brother. As you Like $i t, \mathrm{i}$.

called tyrants. butchers, murderers!

minrk how the tyrunt writes .......... were I a tyrint where were her life?.. studied torments, tyrant, hast for me? but, $O$ thou tyrant! do not repent.... his presenee at the tyrant's feust.......Macbrih, iii. this tyom this tyrant holds ........

space that's in the tyrant's grasp $\ldots . . .=$

with an untitled tyruntbloody-seuptred -

fir that I has not but tercd at........ -

what does the tyrant?.................
but the confident tyrant keeps $\ldots . . .$.

do we but find the tyrant's power....

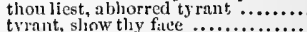

the tyrant's people on both sides .....

al me! this tyrant tever burris ......... King John, v.

eliild by the stern tyrant wnr..2 Henryll: (indue.)

we are no tylant, but a christian king.. Hewry $r$. i

for how that the tyrant oft reclams..2Henryl . y.

to prove lim tyrant, this reason

force the tyrant from his seat $\ldots \ldots \ldots . . \quad$ iii.

tyrnnts themselves wept when it.... Kichard III. i. 
TYR.IN'T, แni a homicite to put n tyrunt downd (rmp.

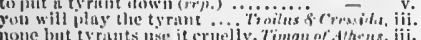

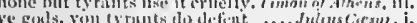
"liy should Cresser be a tyrant thein?

-

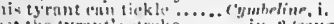
the Thracinu trenut in his tent .. ?- it. 2 (song to fell, when ty rallts teem tol hi

and fien the thrant, whuse cither

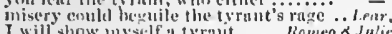

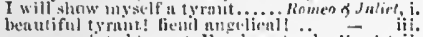

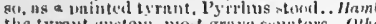

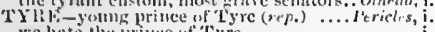

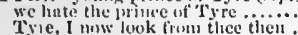
sos, this is $T$, re: und this is the co

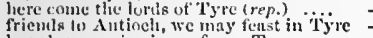
hearl your misericy as fir as Tyre ...... ii.

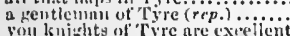

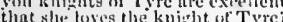

nt lust trom Tyre (1'aine answering

淐. (Gow.)

he must heme: de depret to Ty're... 二

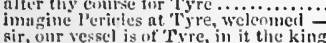

sir, our vessel is of Tyre, in it the king

I here entutess mysclf the king of $T y$

Then I lic tly frum Tyre.

mur Tyrian ship espies.....

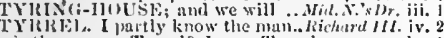
is tly, name-Tyrrel? James Tyrrel

kind Ty rrclt and I lappy in thy (rpp.)
eome to me, Tyrrcl, sion at after sulper $=$
iv. 3
iv. 3

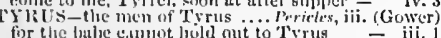

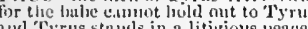

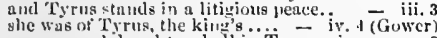
ontr fen and ilanghter slall in Ty rus reign - v. 3

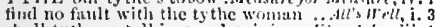
shat twentieth part the tythe of

TY'THNG-from tything to tyeiniug..... Lear, iii.

$\mathrm{U}$

IRIQUE - hic ct ull:que?

(11)

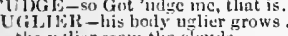

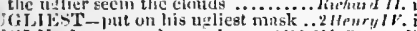

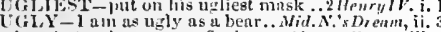

hut that ugly treas on of inistrust.Mer.

like the tont, ngly und venomous. ds syou Lite

wert grim, ugly, ant slanderons

there is not yet so unly a fiend

through the foul and moty mis

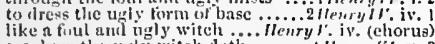

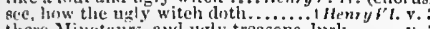
there Mlinotuturs, and ngly treasons, lutrk - v. a lecll of ungly devils!

leutrinl dreuine, of noly sighit

what sighits of usly reath with

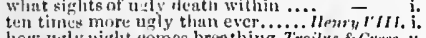

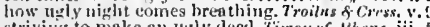

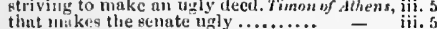

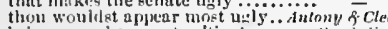
being an ugly monster 'tis strange .. C'ymbeline, $v$

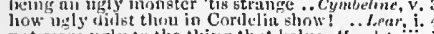
not nore ugly to the thing thut hel $y_{1}$..

leanty in his litc, that mukes me nigly
Ul.cliti of my heart.......... Truins

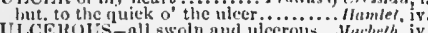
spitul-house, anth utecrous Eures.. Timoa of thth. iv.

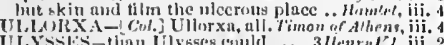
H.Ys.

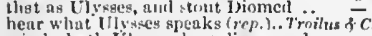

wiscly hath vils gseg leere diecuvered

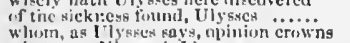

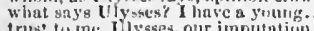

trus: to me. Ulysses, our imputation

Ulygses now I legegin to relieb thy

to sleak with hitin. Nlysues, enter...

lice is Viyses; I'll interrupt hiy (rep.) =

I know y'mur favour, lised Ulysses (rep.) =

my lort Ulygses, teil me, I besecel you =

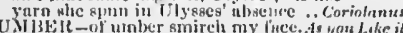

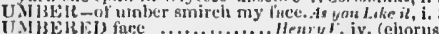

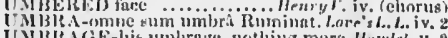

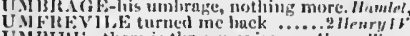

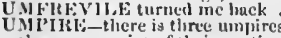

iingryllines

chose as umpure of their muting ...Love'sL. Lost, i.
UMPIBE of men's miseries

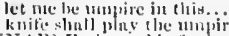

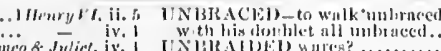

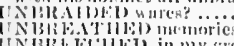

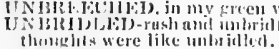

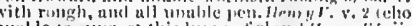

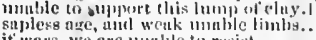

it wars, we are nuable tor resist.........

t)

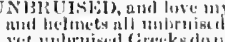

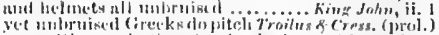

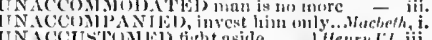

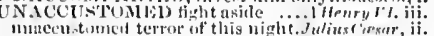

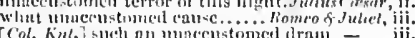

rove with one thut a yet mubrinifed .

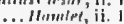

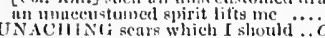

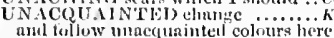

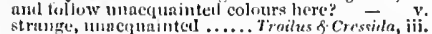

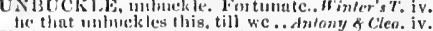

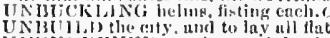

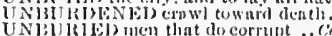

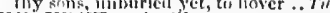

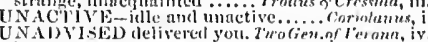

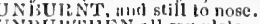

lest unaclsisel youl stain your swords. Kin John, iti.

antl unudvised revel, this unhatioced

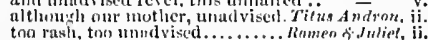

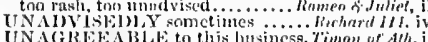

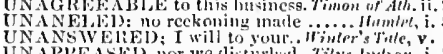

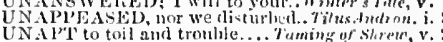

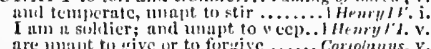

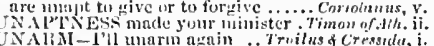

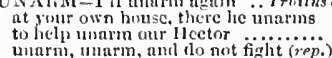

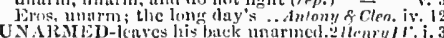

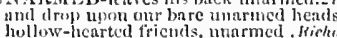

as dubomair, unarmed, as bendirg. Trmilus o Cress,

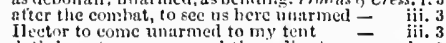

loth long to sce unarmed the valinnt

I am unamedi furego this vantage.

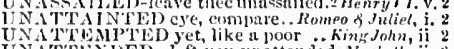

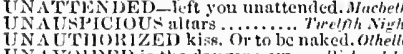

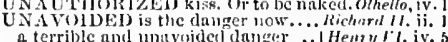

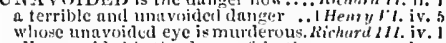

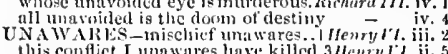
at unawares many beat down ..........

or hy his foc surperised una we

talse tlie great -grown tratitor unawases

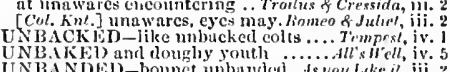

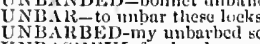

ENB.LSIINUL forchend woo
UNBSTED fire that he did

NBATED fire tlat he did pac.....iler. of l'ence, it.
you muy choose a sword unbatcd....... Hamnet, iv.

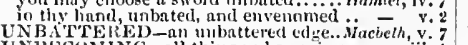

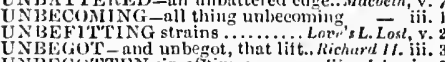

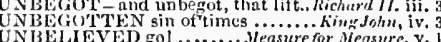

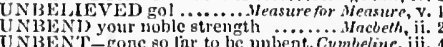

UNBENT-Gone o lar to be unlent. Cymbeline, iij.

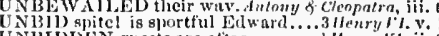

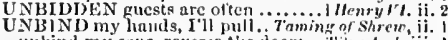

Mnthint my goms, revere tic doom.. Fitus And iij.

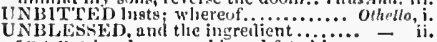

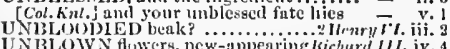

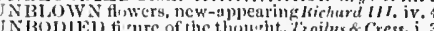

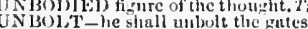

rill unible to you: you sce liow. Fimon of Athene,

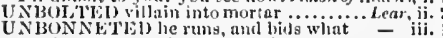

8peak, unlonucted, to as prout if fortune. othello, i.

UN30OK 1811 jealousy must censtrue

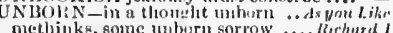

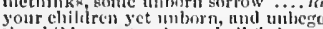

the chilltren set untorn sliall tiel....

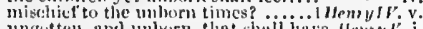

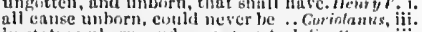

in states unhorn, and neeents y't....julins Cirsar. iii.

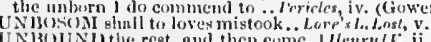

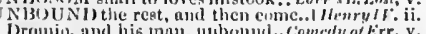

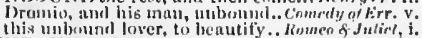

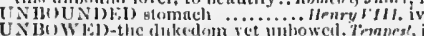

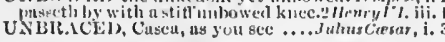

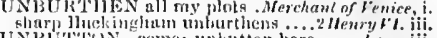

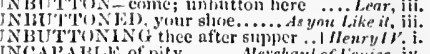
NCAP'ABIS of pity .......Merehani of lenice, jv.

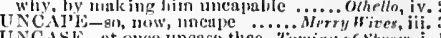
UNCASING for the combat?

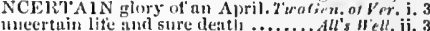

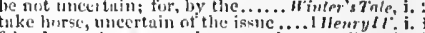

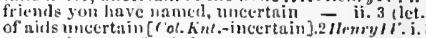
. lichard lill. iv. the cred of war's unestate..... Timon of Ahens, v.

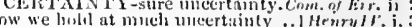

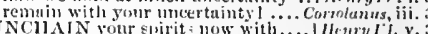
NCHARGE the practice............... Alumlet, iv.
NCHARGEI) ports

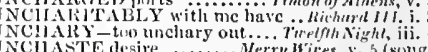
NCHASTE desire .........Mrerywires, sos (song

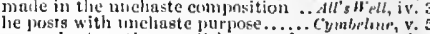

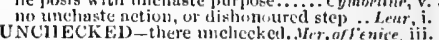

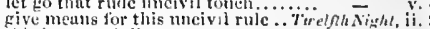
this is as uncivil an strange .......... - tii. you uncivil lady, to whase ........... the uncivil kcrnes of l reladd ......2 Ilenry $V^{\prime} l$. iii. he was a prince. A most uncivil one. Ciymuelne, y.

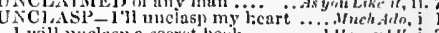
that wide unclasp the tables. Troilus of Cressude, iv. unclass, unelasp; thanks, gentlement. . Perieles, ii. kingly guest unelasped my praetiec Hinter's $T$, iii. NCI,E, called Antenio ............... Tempest, i. uncic cun tell you good jests (rep.......... isern Wires, iii. 4

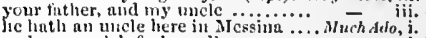
and my w.1.cle's fool, readius n goud toot, uncle, and money (rep.)

1 ery you mercy, uncle ................
licing her uncle and lier muardini....

madlan, you must cone to your uncle
1 will to with thec to tliy uncle's ....

why, then your mele, and the prince $-\quad \checkmark$

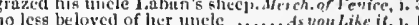

me, utucle? you, cousis

then, dear uncle, never, so inueh .....
to feck oyy uncle. Alas, what dnuyer

nn old religious unste of mine tnught

many desye of my uncle's mark

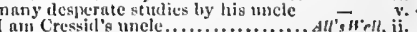

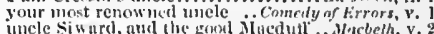

sou, wrothy unele, slahl, with iny .....

my mele's will, in this retwect...... -

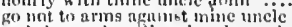

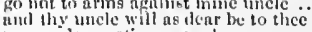

my uncle practifes more hurm ......

政

gowl mele, let this cul where ....... nishard ts. iv.

uncle, evcu in the glasstr (rep.).......

our turele finut diol ktand posscessed

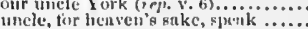

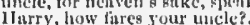

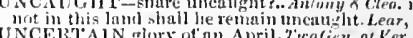
im my uncertain grounds to fail ...... the pleople will remain uncertain ....

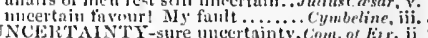

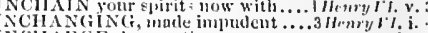

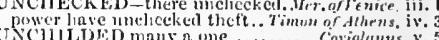

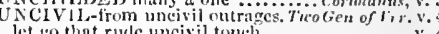

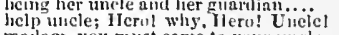

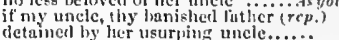


UNCLE-my noble mele! (rep.) .... Richard II. ii. 3 IJNCI nf, my hent of what lies nor uncle me nn umcle: I on no (rep.) my gracious nncle, let me know an offer, uncle, that we will

thancle, you say, the queen is $7 . . . . .$.

thanks, gentle uncle; comc, lords....

mistake not, unele, futlier (rep.)....

uncle, give me your h:und........

what is the matter, uncle? sfea

gond uncle, help to order scveral ...

uncle, fnrewell, and cousin too, adien
this is his uncle's tcaching ...........

here com uncle's tcaching

his uncle kcpt; his une $\dddot{\text { Y }}$ York

good mile, tell your tale.......

my father, my unele, nut myseif?

your uncle Worester's horse came ..

in the morning early shall mine uncle

unele, what news? The ki

mancle's, Edward the llat. $(r p$ iv. 7

what treasure, uncle? Ternis-balls..
umele of Exeter, enlarge $\left(r^{\prime} \eta\right)$.

fur us, dear uncle, the winter coming

ives he, gond uncle? thrice.

unele Exeter, and brother Clarence...

an, noble uncle, thus ignohly (rep.)... H Hen
but nnw thy uncle is removing ......

uncle, would some part of my young
uncles of Gloster, and of Winchester

pray, uncle Gloster (rep. iii. 4 ) ......

fie. uncle Beanfurt! I la ve licard...

and those occasions, mincle, were of..
sent from our uncle dnke of Burgund

ay, marry, uncle (rop.) ...........

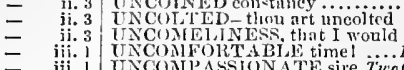

...Coriolnums, iv.

TABI timel 7. Romeo o Juliel, jy.

iii. 2 INCONIPRiDIENSIVE dceps Truilus o Cress

- ii. 3 UNCONFIREABIE baseness .... Mrrichirex, ii.

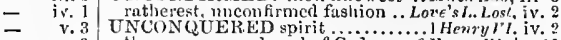

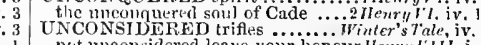

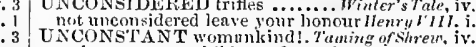

i. 3
i. 3
such unconstant children of ourselves King $J_{0 h}, \mathrm{iii}$.

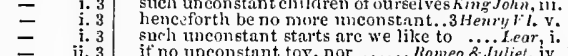

ii. 3 if nn uncomstant toy, nor ...... Romeo \&. Juliet,

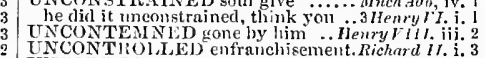

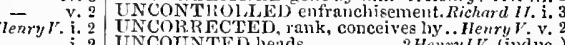

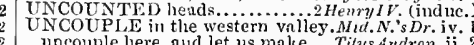

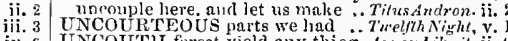

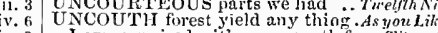

iv. 8 am surprised with an wincouth fear. Tilus Aitd. ii. 4

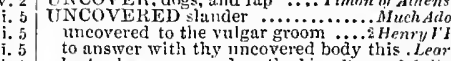

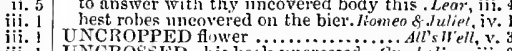

iii. UNCROPPED flower .................. All's II'ell, y.

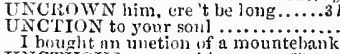

v. UNCTUOUS, greases his pure .. Immorn of dhens, iv.

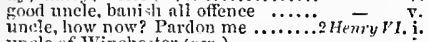

hath of Wincherter (rep.) ........... -

ay, uncle, we will keep it if we cnn... -

good uncle, hide such nialice .........

truith holy uncle, would 'twere come to

call onl uncle to our presence straigh
where is our uncle? what is the ....

your loving uncle, twenty times

sir liugl AIortimer, mine uncles?

my uncles bith are slain in..........

the king my uncle is to blame.

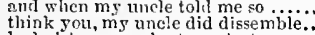

latd virtuous uncles to protect

I could have given my uncle's grace

no, uncle; hint our crosses on the way

want more uncles lieve to welcome me

those uncles, which you want
whant say you, uncle? I say.

I thank you, gentle uncle (rep.)
unele, my brother mocks both vou.

unele, my brother mocks both you

the scorn he gives his
I fear $n$ uncles dead

I fear no uncles dea

UNC

CUCKOLDED; therefore,
CUli

1

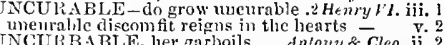

ii. 1 UNCURkENT pay .............. Tuelfh Night; iit. 3

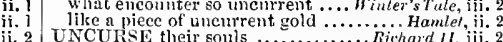

iii. 2 UNCUASE their solls \#...........Richard 11 iii. 2

2
UNDEn

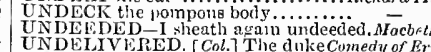

2 UNDERBEAR-lound to nnderbear. King Joln, it

2 UNDERBOIRN E with a blueish

UNDERCREST yont good addition... Coriolanus, i. 9

would I not undergo for one

of work to undergo such ample.

undergo such maiden pilgrimagc ...vili...'s $n D_{r}$. i.

my ability may under
but undergo this fight

mich danger do I undergo tor thice.
is't not 1 , to undergo this charge?

a world of curses indergo

able such a work to unilergo

I will not midergo this sneap

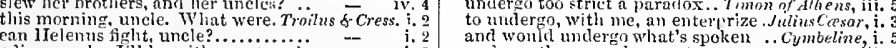

adieu, unele. I'll be with youl $(r e p$.
well, uncle, what fully I commit....

your uncle's worl, and my firm faith

it is your uncle. A pestilicnce on him.

you nauglity mocking uncle!.......

gond uncle, gn and see ............

I will not. uncle: I have forgot......

thille vnele, (famols in Casar's ..... Cymbaline, i
shall thy gond nncle, and thy.

to see thy noble unele thins $\ldots . . . . . .$.
brawl betwixt my uncle and onc....

good nnelc, take you in this

sirs, help our uncle to convey $2 . .$.

my nolile uncle, do you know Röneo of Jutiel

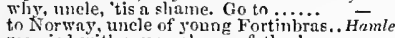

married with my uncle, my futler

upon my secure hour tliy uncle stole....

makes row befure lis unele.

for my uncle is king of Deumark.

murder of my father, before mine uncie

goodnight: but go not to my uncle's bed I searee did know you, uncle ........... Ont UNCLEAN-tle unclesn knight.. Herry Wive an unclean mind carries virtunus fallen into the unclean fishpund

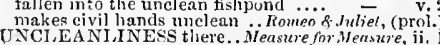
UNCIEANLY-wonld be uncleanly. As you Like, iji. the very uncleanly flux of a "at.....

uncleanly scruple! fear not you..... King Jolin, iv.

but some uncleanly apprelieusions .... othello, iii.
UNCLEANNESS, as she that. UNCLE-FATIER, and ny aut ........ Hamlet, ij. 2
UNCLEYV me quite andergo those employments
UNDERGOES my chay under.

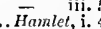

UNDERGOING goldess-like than... Cymbeline, iii.

UNDERGONE - are nobly miergone

molerland corrupted foul injusticc. Richard III.

ITNDER-HANGMA N of his kingrlom Cymbeline, ii, 3

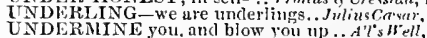

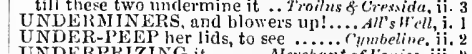

UNDERPPOP this action?

my staff understauds me (vep.) ...... - ii.

stand under, and understund, is ail one - ii. 5
do you understand no?

do you understand me?

never need understand any thing....

for I must let you understand ...... - ii.

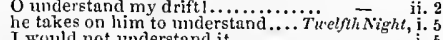

I would not understand it

my legs do better understand me (rep)
this I can let you understand ... Neas. for Meas. iii.
I am inade to
iunderstand, that you..

to make you understund this

fir you must understand...............'s Dream, iit. 2

I nuderstand not what you mean by' this - iii. 2
I understankl you not; iny griet's... Love's L.Lost, v. 2

by tiese badges understand the king

to have you understand me............ of tenice, i.

the duke wis giveu to understand .. $=$ ii. hired me to undermine the d ncliers.
till these two undermine it .. Troilus

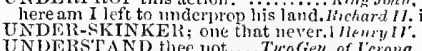

I understand you, sir, 'tis well begged
IDERST AND me well ........ Mer. of Venice, iii. 2
I pray thee, uncerstand a plain man I pray thee, uncersiand a plain man - ivace shull nuderstand, that - ivetter) given, sir, secretly to understank ... As you Like it, i. 1 whut must we muderstams hy this? .. - iv. understand we thin!? Be thou blest ...All's IFel, i. rou understul me? Most fruitfully.. $=$ i. understand it not yourselves $(r p.) . . . . \quad$ = iv. I understand thee, and ean spetk...... $=$ = iv. understand ne? (rep. i. 2 and iv. 2 ). Taming of $S h$. $\mathrm{j}$. 1 unuerstand you this of me, in sooth..
by the way, ] let you understand.... most unlerstand Bohemia stay's...Winter'sTale, i. Ineak a language that I understand not - iii. 2 scarce could understand it (rep.). Comedy of Err. ij. I your liberty. I understund thee not - ii. 2

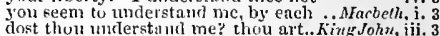
to understand a law; to know....... - iv. 2 French we do not understand ....... Richard Ir. v. 3 let me not understand you then...... I Hewry $1 F$. iii. I understand thy kisses, and thou nine - iii. now I perceive, the devil mnderstatids - iii. I and we understand lim well ............. Henry $V_{\text {jij. }}$ me uriderstand well. NIarrs, if y'u

at large ycur grace shall understand.2 Henry $r$ r. ii. 1 to let you understand, in case .......3 Henry $7 \%$ iv. 4 you shith understand from me.... Richard $I / I$. iv. the kng shalf understand it, presently - v. to men that understand you, words :. we understand not one another. Troilus \& Cress. iji. understand more clear, whiat's pust... - iv. how shall $I$ understand you? .. Timon of $\bar{A}$ hens, $\mathrm{i}$. make his lordship understand ...... - ii. as I understand how all things go .. - iii. I understand the well; and be .... Coriolanus, iv. give me directly to muderstand you.. Cymbeline, $\mathbf{i}$. I yet not unlerstand the case my'self - understand her signs: hal slie.. Titus Andron. iif.

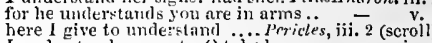
I understand you not. O take her o blame. ivear, i. to understand my puryoses ariglit ...... do not unlerstand yourself so cleariy.... Hamlet, $\mathrm{j}$. I do mit well unclerstand that .......... we would not ander:tand what was most

how dnst thou ui:derstand the seripture?

possitle to mulerstand in another tongue? let orrselves again but underetund....... dost nnderstand the word? my ficnd... $=\mathrm{v}$.

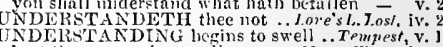
hast thou no underatundings .... Merry Ifives, iv. conveyer? to my understandings, ilcres, for Mieus, iii.

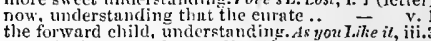
or to tly better understanding, diest.. - ve v. by any unclerstanding late hut thine? - i. nicely charge your understunding soul.Hesery $r . \mathrm{i}$. 1 think lis understanding is bereft..3 Henry $r l$, i. 6 never an understanding friend.. Hmry III. (prol.) ment of some understunding and wisdom - - v. understanding simple and unschonled.... Hamlel, i. give it an understanding, but no ton que... - i. INDERSTAND'S. Why dost. Froilus \&-Cress. iv. NDEKSTUOD none neither, sir... Lore's L. Lost, v. 1
ppcak to be umlerstood .............. is too cumning to be unicrstood...........unch Ado, v.

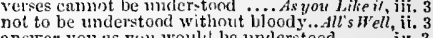
anstre: yout as yull woull he understood - iv. 3

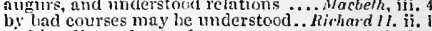

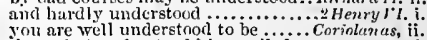
those that understond him smiled....Julius Cassar, $\mathrm{i}$. I have munderstood your lord has took. Pericles, i. 3
UNDERTA'EN to do in his absence. Wimler'sT.

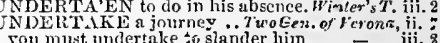
you'I undertake her no nore $\ldots .$. Nerry ITives, iii. 5 I would not undertake her in this. T uel/h Night, i. 3 would you tindertake another suit ..

in tlie interim, modertake one of .....uluch $A d o, \mathrm{ii}$. or undertakes them with a most..

well. I will undertake it......... Mil.... s Drean, i. 2 undereke your ben venuto...... Lone's L. Lost, lv. 2 hand of a solder, I will undertake it - iij. 6 seens to undertake this business.... = iii. 6 
CNDERTAKE the remery..........d/"s Hell, iv. I pom makertale to betruy the Forentine? - iv, nill umelertake to was enres knthimijo

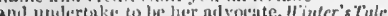

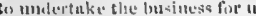

whit you bul ine undertuke

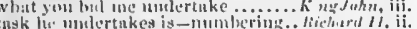

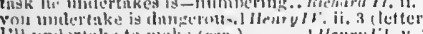
I'll untertake to make (rep.) ...... litenry 1. . v.

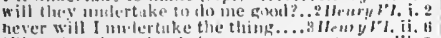
lil undertnke to lund them on our enst - iii. to untertuke the senth of all ...... kwehart IIt. i. ygm my liti, my lutl, l'll mulertuke it - - vi. Who undertnke yiu to your ent .... ii. this shall \& undertake ...... Troillus foressidn, iit.

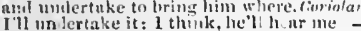
shomul nulertake every cianyanian cymb wherewre then wist nntert:ke it? .. - iii. I

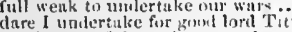
the danger of the t:ak you lunilor

she'll but unlertake a murried life ....

antif will mitertake ath these th teneh - iv. ti

indertike in thiug like aleuth ... Itrmeo s.Julie

that he means no miore to unlertake

to umlertake these present wars ay

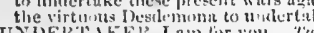

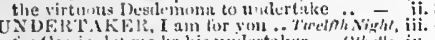

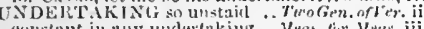

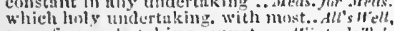

your fice undertaking eannot.... Hinter's Thle,

nothing, but our underiakin

either lie so undertaking, or che $y^{\prime}$.... Cymbotin

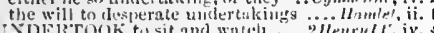

in my minsl, not undertouk.. Verchant of lenice,

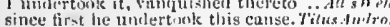

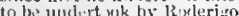

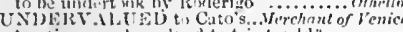

ten times unervalued to tries fuld?

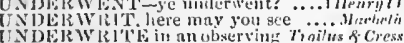

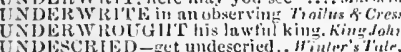

UNDESCRED-get un

this is luterd und nuluserve

gome muleservel liult I Ill find.

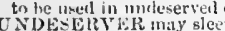

betaped 11 pous me,

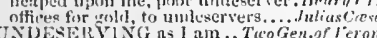

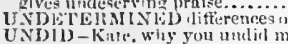

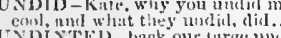

UNDInClid. mystery remaincil undiscovered....ininter's Taie, $\mathrm{y}$.

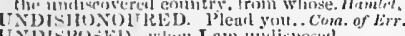

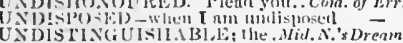

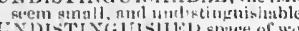

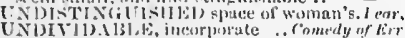

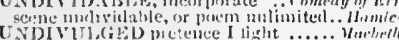

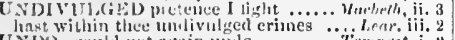

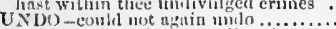

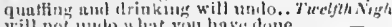

will not Muth what y'su have done ...

to bint mes, or umelo ing

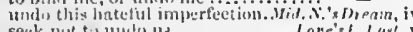

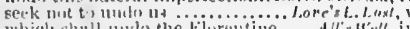

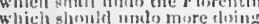

nurk me low 1 will undo mys

goisd speceh now, yont un

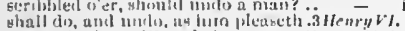

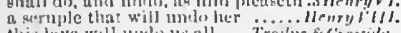

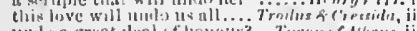

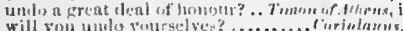
usklis the prayer, by erving............

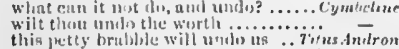

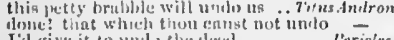
I'il give it to mul, the dest a.........

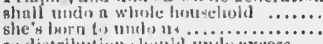

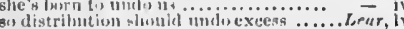

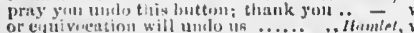
ghe shall undo here eredit witli the silnor. Whello

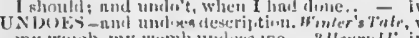

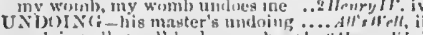

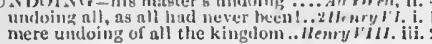

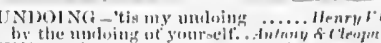

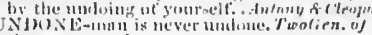

Bir, we ne moldent

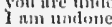

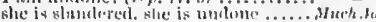

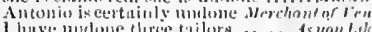

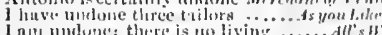

undume, nul tisfeited $t$, cares tur everi

the king, and und hine nin

a pror unit is undone.

I am unduse! I am nombon

even here unchone: I was unt ....

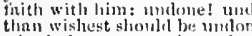

what's dome. eanmut be mulone

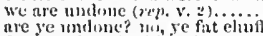

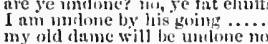

llinu hast ondone tlustione now

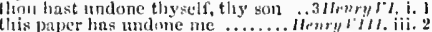

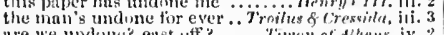

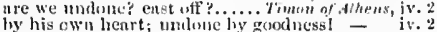

by that $w^{\prime}$ lieh has undone thiee.

a truer orief for his undmet lord

lenves nothing und me ............... -

we are are all undone, maless
yet he hat li left undone that

and be undone by 'em! .....Antony de Clmop th

we are all undone

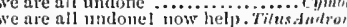

hell hat undone our mistler.

In it be unclone? $O$ biong $2 \pi$.

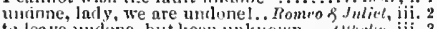

to leave umfone, but kexp unknown ... Whotien, iii. 3

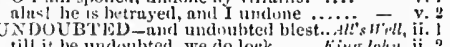

till it be undonbted, we do lock ..... Kimg.tohn, ji. 2

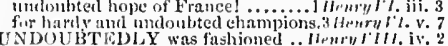

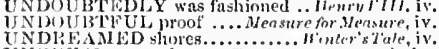

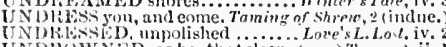

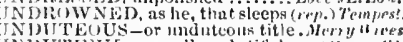

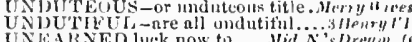

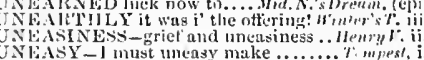

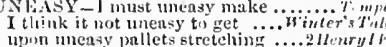

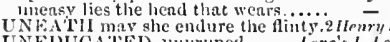

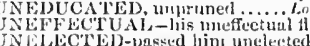

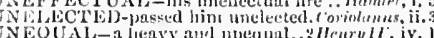

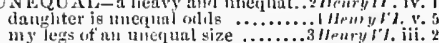

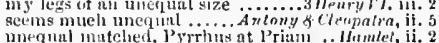

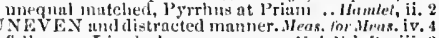

fullet an I in dark meven wr

ant rotheven, anderen ways, draw ont

eight yards of uncven proumd

unevell is the ennrse, Flike it not.... $\overrightarrow{0}$

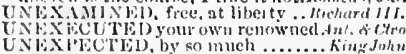

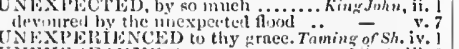

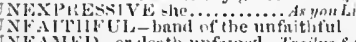

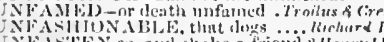

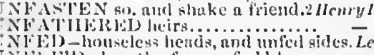

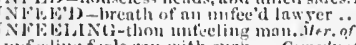

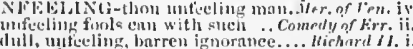

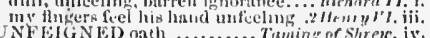

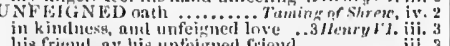

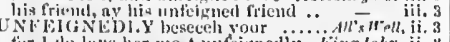
fur 1 do love her mo-t mifejenedly, hing.John, ii.

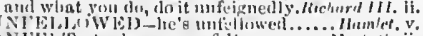

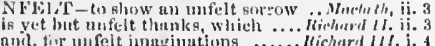

nmi, tir 14 feit imm imations

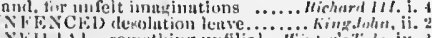

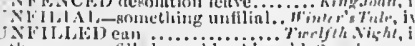

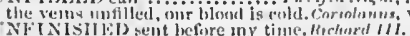

ehinin untinished mncle me stay. Comerly we hir, iti.

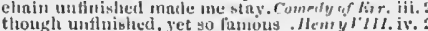

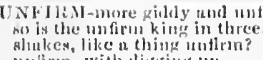

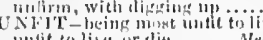

silemill:. i.

indit tolise, or tlie.......... A

but far wailt in be a sovereice.

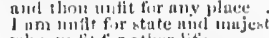

whin, mitic fir other life ......

Trmpest, vii.

thrughit minft to lem morni

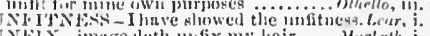

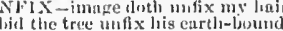

dheking to unfix un enemy.......2.

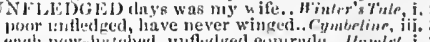

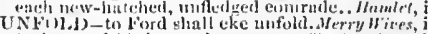

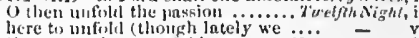

the properties to unfold...............ens, for,yeas,

with ripened time, wiffid the evil....

in a spleen unfulles both henven. Mid.N.'s Dream, i. i

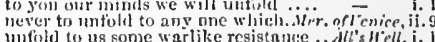

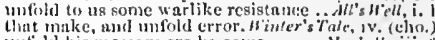

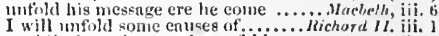

worlilly hss, thon ean st unfold........

jrosperl and would untold our griofs we iv.

my maner's nima. Un fold it .........

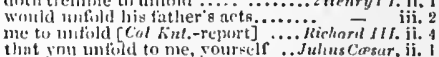

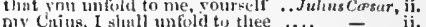

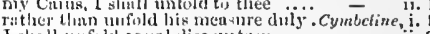

I slinll mufold cqual disenutery $\ldots$.

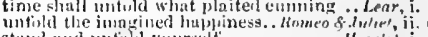

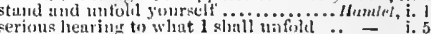

I conlly a tale unfoll, whose lightitest word - i.

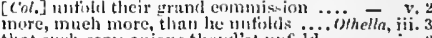

that slech companions thoud'st unfuld ... - iv.

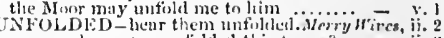

lurpose have you unfolded this to me?

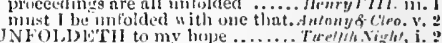

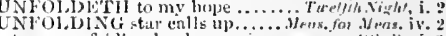

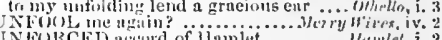

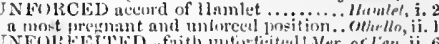

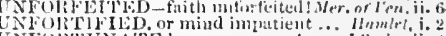

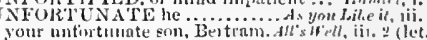

unfortumate souls thint traee his line...llowelly, iv,

unfortluate, I misecd my nins

I was so unfortanutio a beer

more unfortunate than a

be was gentle, but unfortunate

a pour linfortunate begintr

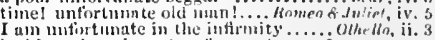

is this rnst and most untertumute ninn? - v

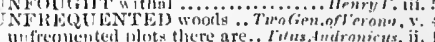

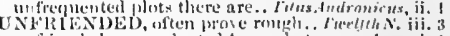

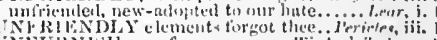

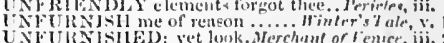

emuty lunlgings, nnd un: furnished ... Richerd 11 . i.

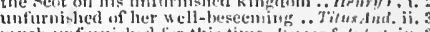

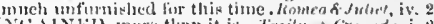

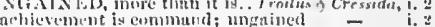

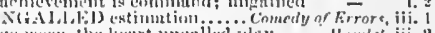

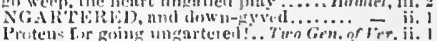

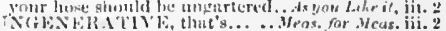

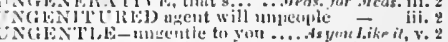

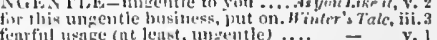

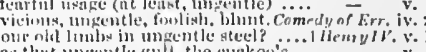

ns that ungentle guli, the cuekov's ...

ungentle queen. (n enll him gentle..2 Itenrylr. iii, 2

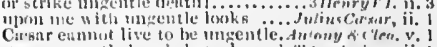

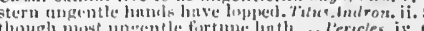

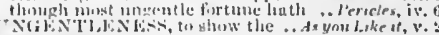

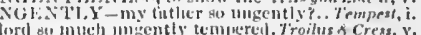

have ingeutly, Brutue, alole from... Jultuscorar

Neillil) thy itrnugenes ........ Threlf h.Vight,

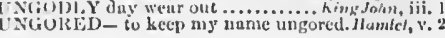




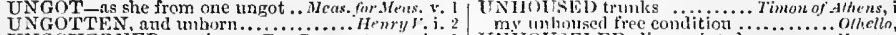

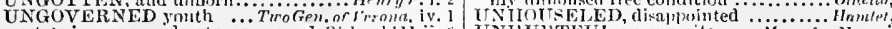
estate is green, and yet ungovernert. ungoverned youth, to wail it in their lest his ungoverned rage dissolve an ungracious motith, is but profane. Nich swear st thou, ungracious hoy? ?...... I I Jen eut off thy most ungracious liend..... Hen peace, you ungracions clannours!. Trool with this ungracions paper strike......... Lear,

UNGRATEFUL maid!

and damnable ungratefuil.

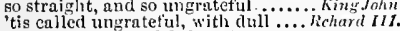

out in an ung ratcfuil slape ! . Fimon of Alhens,

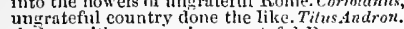
shaken with sorrows in ungrateful hon

INGRAYELY he did fashio

UNGROWN Warrior $\ldots$

to her unguarded nest the weisei scot. Hearyl

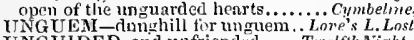
the unguided days, and rotten

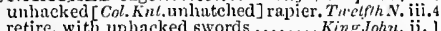

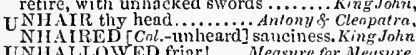

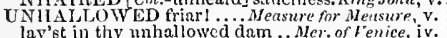
lay'st in thy nuhallowed dam
or unhallowed, what of that?

never day nor nigltt mhlallowed pass. 2 H'nry $r$ this unhallowed and blood-stained ...Titus
your unhallowed diam, like to the earth your unhallowed dam, like to the
inhumann dog! unhallowed slave
free from this unhallowed place

stoi thy nnhallowed toil.
UNHAND me, gentlemen

U NAANDLCD coits ........... Ierchan of fentice

UNHANDSOME-Were unlandsome...NuchAdo it is no more unhandsome . ...Asyman Like 4 , (e) I was (linhandsome warrior as I am) Oothello,

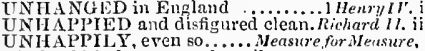

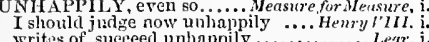
writes of, sueced mnappily ...............ete
nothing sure, yet mneli unhanpily..... Hamlet,

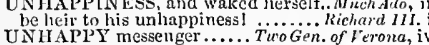
some unhupppy pasenger in chace $\ldots .$.
O miserable, unhappy that $Y$ an! (rep.) unlaappy were you, madam ....

thinu mak'st me most unhappy

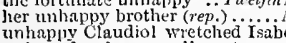

a shrewd unhappy gallows too.... Love's 2 .

$\mathrm{am}$ the unlanpy sulject of these...Mer. of 5

we are not all alone mulhappy

a shrewd knave, and an whhapp

arrned for some umlappp words.. Taming of sh. as $k$ kings are no less unhlappy, their iss

anil that unhappy king, my mastcr.. $O$ most unhappy day! O most unlappy to-day, to-day, unhippy day

ah me, unlappy! to be a queen.....2 2 Herry $I^{\prime \prime}$.

Edward's sinhappy sous do bid thee. I am the most unhappy woman. .. Henry $F^{\prime}$ H. iii. umhappy was the elock that struck... Cymbreti,

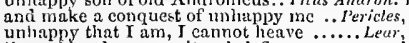
unhinpy that 1 am, I cannot hea

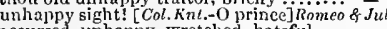
accursed, unhappy, wretched, hatcful O unfappy girlt with the Moor ..........

poor and unhappy brains for drinki

a most unhappy one; I would do much... - = iv..

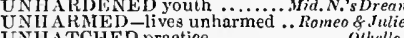

UNHEAlDD, fall on your head

as Cominius is returned, nnheard ... Coriolanus. She shall not sue unheard. Aatony 8 . Cleopatra, iii, 1
whisper in the ears of death, unheard.. Whisper in the ears of death, unh
UNHEART - much unhearts nic
UNIIEDF U1, desperate, and witi unheerlful vows may heedfully. Th

UNHEEDY haste: and therefore ...Mit. N.'s $D r$ N

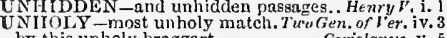
by this unholy braggart .............. Cnriolamus, v.

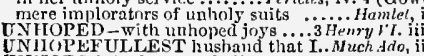

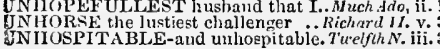

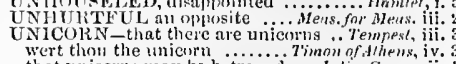

that unicorns may he betrayed.... Jutize Casur,
VNIMI

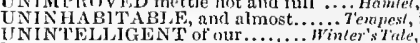
UNIUN-bestrew the mion of your hed. Trmprst this union shall do more ............. King.John, in the cup an union shall he throw...... Hamlet, is the mion here? follow ny moth
UNITE your troops of linrsemen...

of love unite our thonghts
we will unite the white rose

will now unite in your complaints. Hirnry FIII. unite commutual in most saered

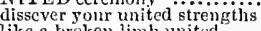

like a hroken limb umited.......

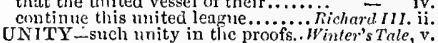
confound all umity on earth $\ldots \ldots . . .$. .... Macbelh, iv. make me happy in your unity
tl:e unity, the king thy brother

the mity and married calm..

mimbeline, $\mathrm{v}$.

WNIVWRSAL plodkling prisons up... Love's L. Losi, iv.

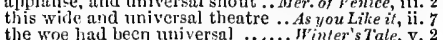
uproar the universal peace, contound. Hacbelh, iv. largess universal, like the sun. Hewry $r$.iv. (chorus) you not made an universal shout.. Julizts Corvar. the time of universal peace is near .. INIVERSE-rif the mniverse .. Hemry r. iv. (cliorus) UNIVERSITY - nt the university. Taming of Sh. v. 1

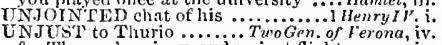
for 'Thescus' perjury, and unjust flighit

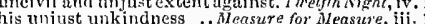
the drike's unjust, thus to retort..

know this purpose: what nujust?... Nruch Atto, v. to oursel ves unjust, destroy onr.......All's $W^{\prime}$ ell, v. in this unjust divorce of us .... Coneriy of Brrons quarrels tujust against the good........... Nacbelh, iv. gage them both in an unjust bchalf. I Henry $I^{\prime}$. $;$. thou art an unjust man in saying so
but discarded unjust servingmen ..

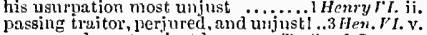
rogue, and most uijnst knave .. Troilus \& Cress. v. say, my request's unjust, and spurn. Coriolan
my'lord. you are unjust be traiton, or unjustly fight? ......... Aichard If. i. the French nnjustly gloze, to be the . Henry I. i. as thou know'st, unjustly must be spilt! - iij.

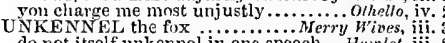
do nnt itself unkennel in one speech... Humlet, iij. 2 called deformed, hut the unkind. Twolfh Night, ifi. my lady is unkind, perdy

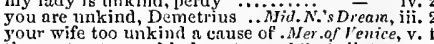
thou art not so unkind 3 As you Like it, ii. 7 (song) that threatening unkind brow... T'aning of Sh
hast no unkind mate to grieve.. Comedy of Err.

last no unkind mate to grieve..

by unkind remembralice! thou

King $J_{o h n}$

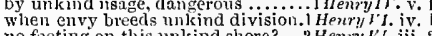

no footing on this minkind shore? ..2 Henry VI. iii. 2 will never be unkind: and so .......

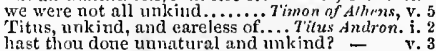

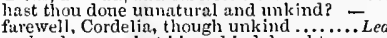
stch a lowness, hut his unkind daughters

What an unkind lrour is guilty.. Romeo \& Juli
wax ponr, when givers prove unkind.. IIamle him and $m y$ lord, an mikind breach ... Ohel
UNKINDEST tied (rep.)... Two Gen. of feror

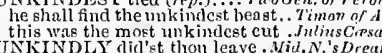
take it not unkindly, pray . Taming of Sheter, if Brutus so unkindly knocked .. Julizs Casar, I take it much unkindly, that thou .... Othello
UNKINDNESS - down ali unkindness. Merry $W$. thy unkindness shall his death. Mfeas. for Meas. his unjust unkindness, that in all reason $-\bar{F}^{\circ}$ in take no unkinglness of his hasty. Taming of Sh, iv. 'twixt his unk indness and lis.... Wimter's Tule,

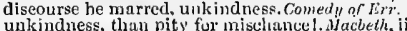

UNKININE-S be like cronked age.. lichard ll. ii.

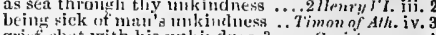
grief-shot with his unk irdness? how mortal an unkinduess i...Jutius Cerser, jv. pretence and purpose of unkindiness..... Lear i. 2 sharp-tuothed unkindness, like a vulture - ii. his you, ymu elements, with unkindluess - iii. arraigning his unkindnces with my.... o.helln, iii. 4

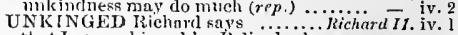

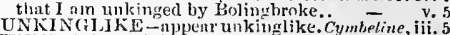
UNKISS the oalh 'twixt ........... lirhard Ii. v.

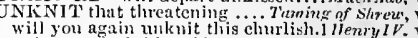
will you again muknit this churlish.1 leemry $l V$. v.
and not unknit himself the noble.. Corrolanus, jy. unknit that sorrow-wrea then .. Titns Andron. ii .
UNKNOWING-yet unknowing world . Hamlet, $\mathrm{v}$. to the milknown beloved I. Tuo Gen, of Veront, iif. I

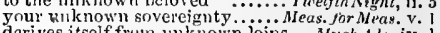
dcrives itself frun mknown ioins . Mruch Allo, iv. not unknown to you, Antonio... Aterch. 's Dream, v. hatli an unknown bot tom...........As you Like is 'tis not unknown to you, madlam .... All's We my father is not all unkiown.. Tenaing of Shrew, i. your firm resolve unknown! to me....
may be, are to me unknown ...... Winter's Tale, iv. bid thesc unkmown friends (rep.)

some ciuse to yon unknown. Comedin of Errors, iji. to make it wander in an mknown field - iii. 2 that he, unknown to me, should be... I am yet miknown to woman ........... Henry $\bar{v}$. iv. 3 my worth unknown, no loss is......... Henry $V_{l}$. iv. are petty faults to fallts unknowt..2 Henry is all nuknown to me, my gracious... our business is not unknow 11 ........ Coriolemes, $i$. the end of it unknown to the beginning - ifon
and accents yet noknown?

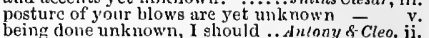
remaining so long a ponr unknown. Cymbeline, iv. 4
and thus, unknown, pitied, or hated - v. 11
to limself unknown (rep. v. 5).... - v. 4 (scroll)

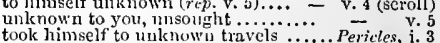
wast not bound to answer an unk nown ... Lear. v. too early seen unknown ......... lisneo \& Juliet, i. 5 things standing thus unknown .......... UNLACE your reputation thus.......... his herl of blackness unlaid ope ......... Pericles, i. 2
UNLA WF UL-an unlawful bawd. Ifeas. forMeas. iv. 2 SNLA WF UL-an unlawful bawd. Neas, for Meas. iv. 2
solicits her in the unlaw'ful purpose... All's Welt, iit. 5 be trumpetcrs of our unlawiul intents?
think it is unlawful business .... Winter's Tale, v. 3 $h$ is affection in unlawful love?.Conedyor $E$ rrors, v. 1 a ruier with unlawful oaths ........ I Henry J'l. v.

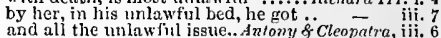
from any other fnul unlawfil touch ... Othetto, iv. repent my unlawful solicitations.......

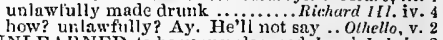
WNLEARNED-to be very mnlearned. Love's L. $L$. iv.

in thy fortunes am unlearned.. Timon of thens, iv. 3 frame them to royalty unlearned .. Cymbetine, iv. 2 UNLESSONED girl, unschooled. Aer. of 'enice, iii. 2
UNIETTERED small-knowing.Love's L.L. i. I (let.) his companies unlettered, rude

UNICENSED of your loves ........ not unlike, sir; th:t may be....... Lovere's L. Lost, unlike art thou to Fortia? .. Merchant of reniee, ji. scnt you hither so unlike.... Taning of Shrew. i how prond, peremptory, and milike.. not unlike, eacli way, to better.... Coriolams, $i$ how muth unlike alt thou Mlark. An/omy \& Cleo. i. male you, unlike all others, chaffless. Cymbeline, i. is more unlike than this thou teli'st $\overline{-}$ v. UNYIKL1, Y - plnt unlikely wonders. Bichard 11. $y$. more unlikely, than to accomplish.3Herry $/$ J. iii. this is unlikely: he and Anfidius .. Corinlames, iv, 6
rNl.M I'TED-or poen unlimited...... Hamlet, ii. 2 UNI.JKED itself. and with .............

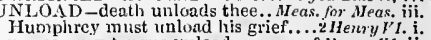
UNLOA DE
UNIOA the gibbets .......... I Henry IV. iv. UNI, AADE
UNILA the gibbets $\ldots \ldots \ldots \ldots$ I Henry IV. iv. NLOCK the little gate ............ Lnve's L. Lost, i. upon her, unlock her oloset . Aferth of eniee, it. and unlock the rivets all .... Troilu. \& Cressida, UNCOCKED to your oceasions... Nerch.of Ienice, UNLOUK ED for is this expedition! .. King John, ii. I
this unlooked for unprepared pounp.. 


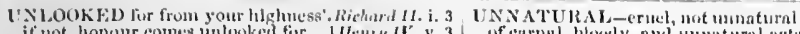

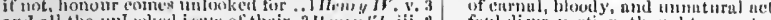
anl anl the imlinolicel isste of

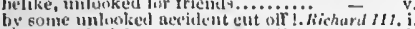

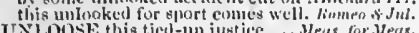

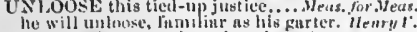

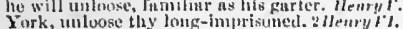

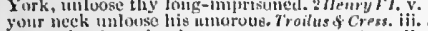
nie tine int rimse t'umlons

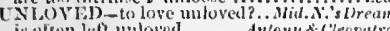

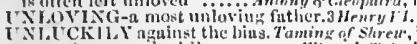

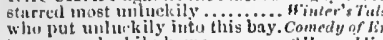
to eome unluekily home.

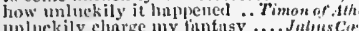

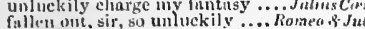

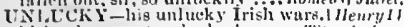
hither in a most unluck $y$ hour .. Titus sultron. ii.

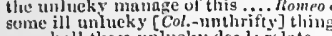

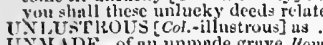

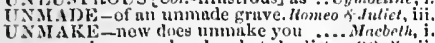

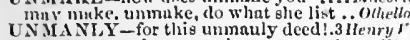

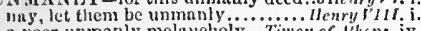

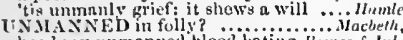

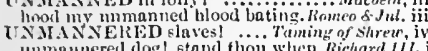

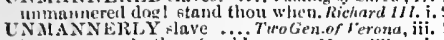

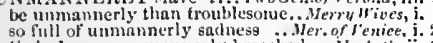

so fill of unminnerly sacthess...W
their duggers unmannerly breechet

this apishi nut unmannerly npproaeh. King John, v.

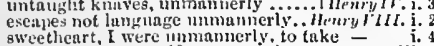

sweetheart, I were nimmannerly.
if $I$ have used my self ummanne:l

my haste maste me unmamerly

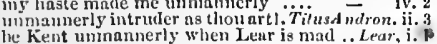

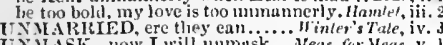

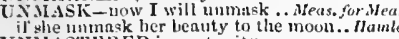

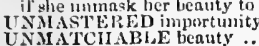

so sole, and su unmatehable.

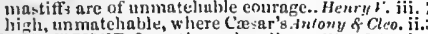

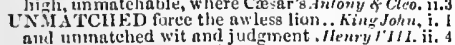
z'al to your unmatehed mind. Tizaon of Alhen

1hat unmontehed furm and fenture
UNAIEASURABLE di tumee ...

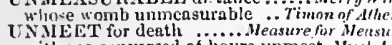

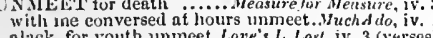
alack, for youth unmeet. Lore's L. Losh, iv. 3 (verses)

is inist unmeet nf any man (rep.

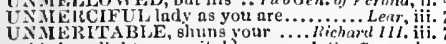

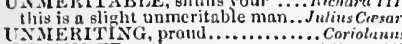

INMERITING, prond...

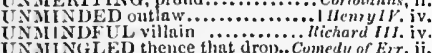

UN NINGLED thence thint dro....... Cumedy of Err. ii.

VNMITIGABLE rage.

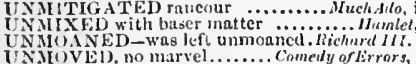

VNIIVVED, no marvel ....... Comedy of lirrors,

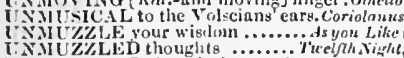

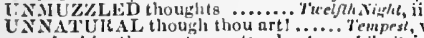

well I know he was munatural........

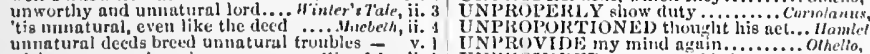

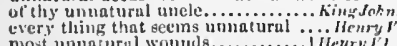

most unnaturul wounuls........

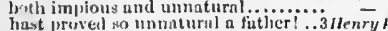

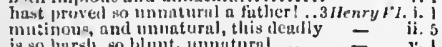

is so hursh, so blutht, unntutural .... Bichard 111 ,

white ngly and minatirul ay

it is a quarrel motut unamatural.

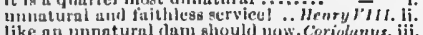

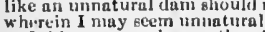

and this unctatural seere they Jaingh at

tur barbarous and unnatural revolts ciymberfine, iv.

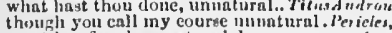

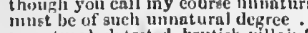

unnatural, detested, brutiah villaini: ......

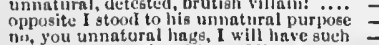

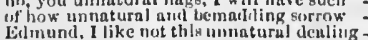

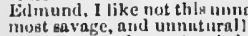

most savage, and unnuturall .............

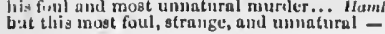

thint deent, s ununaturat, that kills tior

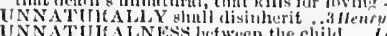

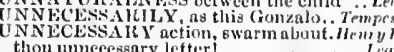

nze is unnecessury; on my knees $I$ beg

TNNELYED tinther rol

NNOBLE swerving ...................

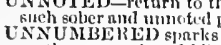

oul the menumbered idle pelibiles eliates.

UNOWED interest of proud-swe

NPATD a liundred

than rustling in unpaicl silk
thut duty lcave unjaid to $y^{\circ}$

UNPANAGONLD unpail fir

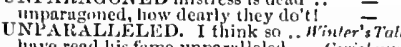

hiture read lis fame unpartlelect ...... Coriot tom

UNPARDONA BLE-too unpardonallile: Heryer.

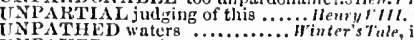

UNPAVED eunuch to boot......

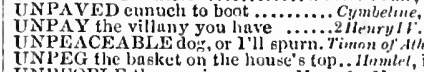

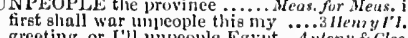

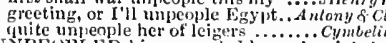

NPEOP LED-his unpeopled house $C$ Core's L. Lost, ii. I for it is umpeopled? .......ds you Litive it, iii. ? (verses)

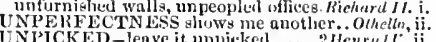

UNPIN me (rep.) $\ldots$

NP'SNKED i' the hee
UNPITLED whirping
unpitied let me die

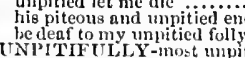

Taning of

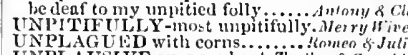

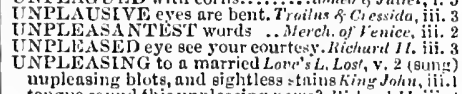

tongue sound this unpleasing news? Hichard ll.
O unplensing news

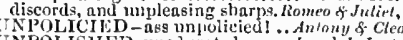

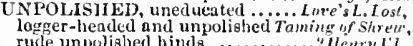

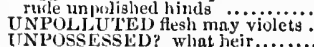

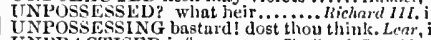
UNPPOSSESSING bastard! dost thou thin
UNPRACTISED infancy

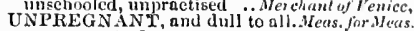

IMPregnant of my cause .............. Hamle, ii.

UNPREPARED, unmeet for ......ive
heing unprepared, our will became
unlooked tor, untrepared pomp ...

when men nre unprepared.... flat, and unpresfitable seem to $m$

ED-piliow left umpressell.Ani.\& Cleo. itii. il

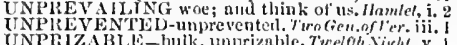

Inprizalle estimutionis

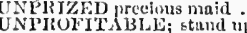

no more of this unprofitalule clint . . I Henryer. ij.

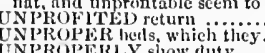

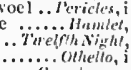

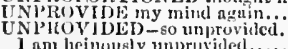

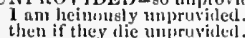

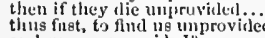

and go os unprovided? ................tichturd int

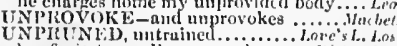

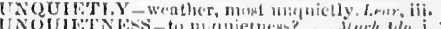

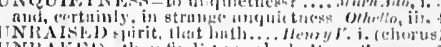

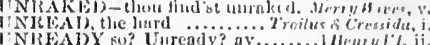
UREAPY no? Unread

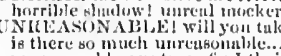

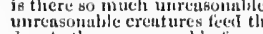

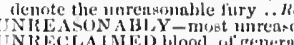

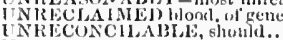

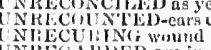

UNREGIS'TliRED in vul

jreful arm of unrelenting clifliord

ns unrelenting flint to drops .. Tht

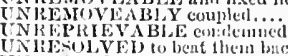

UNRESPECTIYE l.

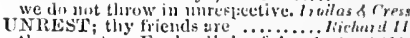

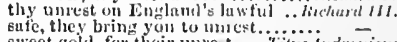

let her rest in locr unrest wwibile .... -

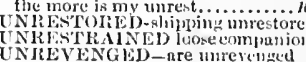

not strik GLD-nre minerenged

UNREVERED Tongt:

umreverend and uninallo,
ay, thou unreverest boy

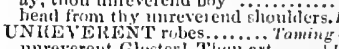

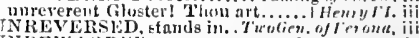

NREWARD LD - not po more arded. Tempesi, iv.

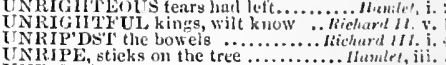

U
$\mathrm{U}$
$\mathrm{U}$
$\mathrm{U}$

UNRIVALLED merit

NROL.LED, and uay name put... Wintritr's Tule, it

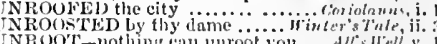

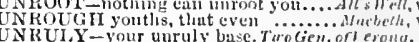

more violent and unruly

but, too unruly deer, he lire
is troubled with unruly luy
the night has been unruly.

syatched with an unruly h..................un beth, ii.

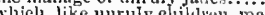

make why, unruly woman

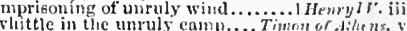

Kruee with the unruly

eye and tongue: unsil

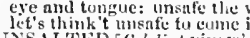

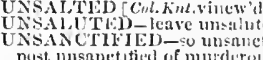

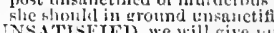

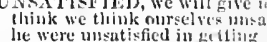

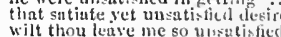

nnd my conse arizlat to the nusati

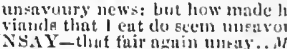

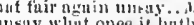

lie said, so he wusar inee

I will hise more or clec umi............

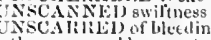

the miscenreal brat.terts of tile w..... 7

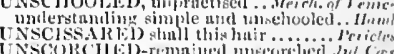

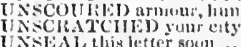

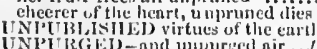

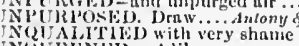

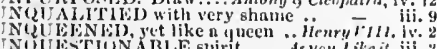

prescintly he dir ungent thicin

UNCUESTHONED mE Firit

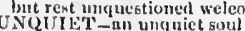
As you Liks it,

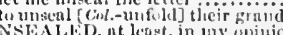

wonld make elec nil the sout

Ali'sil'ell, ii.

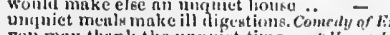

gou muy think the unclutet time

Henty I I

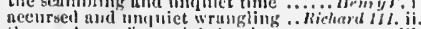

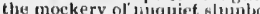

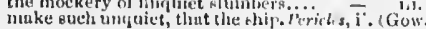

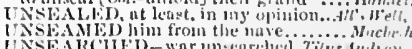

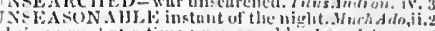

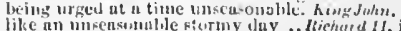

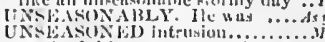
my lurd, tis num miscugonet gointier

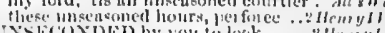
Niscosped by you to look......? 2 Hew 
UTSEDTCED-she remain unseducerl. Cymbelin

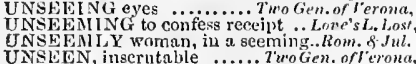

Eit alone, unseen of any .............

inseen, gau passage find. Lore's L.in

y/ears his honnur in a box unse

nis fellow fortlt, unseen

sind robbers range abroal inseen. ....

otlier down, unseen, and full

shidows to the unseen grie

left unseen an wondertul

arms, untalked of and unseen!, Ro

mining all within, infeets unseen.

kills the unseen good old man .........
IINSENINARED, thy freer thouglits

NSEPARABLE-in love unseparable.. Coriol. iv.

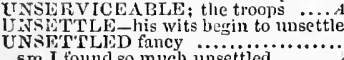

sm I found so much unsettled

he something seems unsettled .... Winte

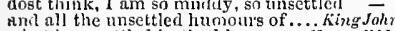

WNiat is unsettled in the

UNSWX On mortal thrii

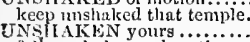

fail, unshaken, when they mellow he... Hawlen,

UNAILPES me quite ...........Mras. for.Meas

NSHEATH your sword (rep.)........
exeentioner, unslieath thy sword

INSlIOUT the noise that banished

UNSIIRINKING station

UNSIIRUBBER down .......

UNSIIUNNED ennsequence
UNSIFTED in sneh perilons

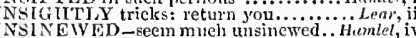

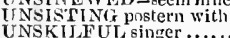

thoug unskilfu w............. Nerry Wives, i

though it make the unskilful laugh ... Hamlet

not think, the Turk is so nnskilful ....... Othelto, $\mathrm{i}$.
UNSKILFUI.LY, or if your.... Meas., for Ners. iii.

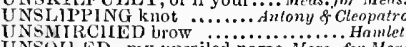

UNSOI1,ED-ny unsoiled name............ Hamer. for Meas. ii.

Uhers not a gad left unsolicited. Titus Ant
there
USORTED; and your whole..1 Henry IF.

NSOUGIIT is betier

yet loath to leave unsonght ..Comedy/n nf

UNSOUND-so unsound a man ... Tuelfik U it h

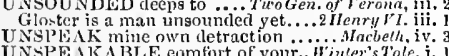

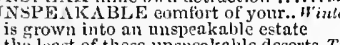

these wrongs, unspeakable, past patience

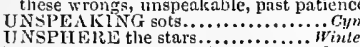

WNSPUK

UNSPOKEN that whieh, to be spolken. Cymbeline
UNSPOT'TED-all nnspotted soldiers.. Henry

a pure unspotted heart

a pure unspotted heart ............... Hentily Henty

a most unspottel lily shall slie pass. Henry VIII.

UNSQUAPED UNerms unsquared .. Troil.\& Cress.

UNSTABLE-to unstable slightness.. Coriolmus, iii. I
UNSTAID a journey? ...... Turo Gen. of Verona, ii. 7
Unstnid and skittish in all motions. Tuelfh N. it. Unstaid and skittish in

inter's?

with a heart full of unstained love ... King Jo

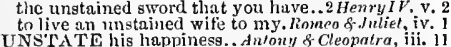

I Would unstate myself, to be in a due .... Lear, i.

UNSTAUNCHED weneh

Richarylli

UNSTA YED - to his unstayed youti. lichard 1, i i. 1

UNSTEADFAST footing of a spear ... Kich
INSTOOPING firmmes of my ..... Rich
UNS'IRINGED-than an mustringed vinl

UNSTRINGED-thay an nustringed vin

UNSUBSTANTIAL air, that I embraee.. Lear, iv.

UNSUITABLE to her disposition.. 'Nelfhk Nizh, ii.

riehly silted, but unsuitable.

All's Well, i.

UNSULIEED lily, I protest $\ldots \ldots \ldots$ Love's L.Losi, y. 2

UivSURE-is still unsure.

the truth thou art unsure to swear... King John, iii. I

giddly and unsure hath he $\ldots \ldots \ldots . . .2$ Henry $1 \%$ i. 3

exposing what is mortal, aljd unsure ... Hainse', iv. 4

INSSURED assirance to the erown .. King John, ii. 2
UNSUSPECTED, eourt her.... Taming nf shrew, i. 2

snd unsuspected II astings

Richard IIl. iii.

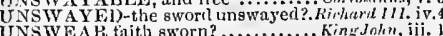

UNSWEAR faith 8 worn?....

Othei's, iv. 1

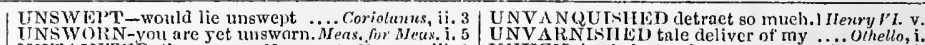

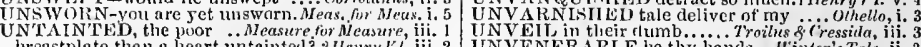
breastplate than a heart uintainterlis.2 Heary $Y$ l. iil

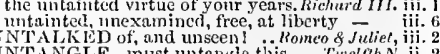

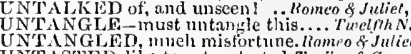
UNTAS'lED-like to rot untasted Trooilus \& Cress.
UNTAUGIT love must needs... Aras. for ileus. he ealled them-untaught knaves to eommand, untaught to plead.... Henry $_{\text {Hen }}$ ' thou mintanght! what manners... Romeo \& Julice

UNTEMPERING effect of my visß
UNTENDER - look untender?....

UNTENDERED-is left untendered........ Cymbeir UNTEN' $\mathrm{N}$ his person ald share. Troilus $\mathrm{Cress}$

UNTEN'TED woundings of a father's $\ldots$... Leur, $i$,

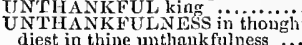
you take with unthankfuluess All's IIell, i. 1 O rude unthankfulness!
UNTIIIN your speaking

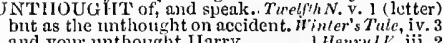
and yomr unt hought I Iar

UNTIIRLAD the rude eyc of ...
UNIIIIFT love did run fiom

given away to upstart unthrift
dirlst thnu cyer know unthrift

us unthrirty to our knowledge UNVENER A BLE be thy hands... Irinter's Tole, ji.
UNVEXED retire ................... King.John, ii. UNVEXED retire ................... King.lohn, ii. I

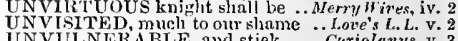
UNVUINERABLE, and stick ..... Crriolnmes, v. 3

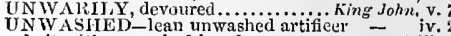

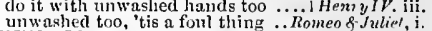
UNW $A T C 1[E D$-not mwatelied go.... Lamlet, iii. UNWED-you to keep nuwerl. Comedy or Lirrors, ii.
UNWEDG EABLE and gnarled. Meus. for Meas. it

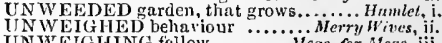
UN WEIGIIING fellow ......... Vers. for stens. iii.

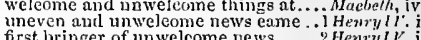
frst bringer of unwelcome ne ws ...2 Henryl $I V$

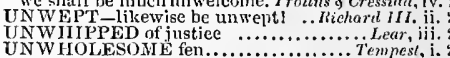
use this unwholesome humidity........... Terry Wives, frut in an unwholesone dish.. Troilus \& Cressita. that made the air unwholesome .... Corialanus, iv. they 're too intwholesome o' canseienee. Pericl's, iv. do not think it so unwholesome UNW IELDY arms against thy ....Richard II. .. Othello.

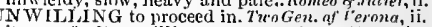
'twas a fault unwilling ...... Tnming of Shrea, iv. home return: mwwilling I agreed. Compdy of Frr. $\mathrm{i}$. gut rather beeause I am unwilling . 2 Henry 1 l $\mathrm{ii}$. iey, cold, unwilling, be thou so too. Richard III.i mnwilling to outlive the good that. Henry ${ }^{\prime} I 11$ i
UNWILIINGLY what 1 command .... Tempest. unwillingly, take them again.. T'woGen, of Fer.
unwillingly I left the ring ... Merchont of Venice, like smail nnwillingly to sehool...As you Like it, ii.

have, and most unwillingly of late. Henry $Y$ II $I$.

dull unwillingness to repay a debt. Aictard 111 . ii. UNW IND her love from.... T To Gen. of verona, iii.

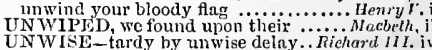
never mind was to be so unwise. Fimon of dhers,

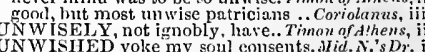
UNWISIIED yoke my soul emsents. Mid.N.'s Dr.
hast unwished tive thonsand men ..... Henry $I^{\prime}$, iv. hast unwished tive thonsand men ....Henry $I$. iv
UNWITTED-planet had unwitted men. Orhelln, i. UN WITTINGLY, or in my rage .. Rickrarl 111. ii.
my ennseience, pit unwittingly?.. Henry 111 . iti. awakens me which now came........ Tempest, i.

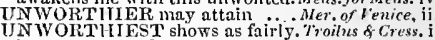
in my regnrl, of the unworthiest siege. Ilamlth, iv. mworthilv thou wast installed.... Henry ${ }^{\prime} ?$ songs composed to her unworthiness... Thl's I eli, iii. as may unwortliness define...Henry $r$. iv. (chorus) the court with thy unworthiness .... Cymbeline,
NWORTHY body as I am..TwoGen.of Veroua,
. mueh he is unworthy so goorl a laxly. Which Aito, a poor unworthy brother of yours...As you Like it, cost of prinees on unworthy shonliers? most unworthy of her ynu cull Rostlind bless this unworthy husband? (rep). $)$ one unworthy all the former.

for onr honour therein unwortliy thee unworthy and ridicul unworthy the - iv. on this unwarthy senffold, to bring. Il eury $t$. i. (cit their bones in an unwortly urn...... left ine prondly, as unworthy fight ... if Somerset be unwortlyy of the place... Henry muworthy though thou art, I'll espe

whose fur unworthy deputy I am ...
were unworthy to behold the same?

unworthy slaughter upon others... Richoril III a poor fallen man, unworthy now...Henryl'lll. iii. thicves, un worthy of a thing.. Troilus of Cressida, ii. as thou unworthy to be enlled her...

to my poor unworthy notice....

of on that unworthy place

ly\& Cleo. iii

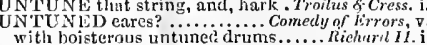
the unturerl and jarring senses

untutored lad, thou art too maliapert...3
speak'st like lim's untintored to repoat

spink 1 in the sisters three

grief, untwine lis perishing root.... Comm
UNURGED wouldst vow that $\ldots$ Cnimedy

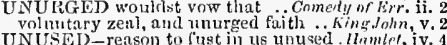

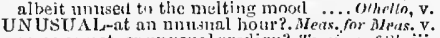

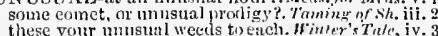

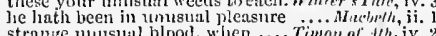
guard, and must unusual vigilance ........ent, ii.

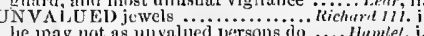
unworthy hrother, and unworthy... ت̈itus.swdron.

unworthy [G.K.-unworthiest] hand. Romeo \&. Iul unworthy thing, live here in heaven

patient merit of the unwortlyy takes .. II $\vec{m}$ lel, iii.

I hold him to be unworthy of his plnce. omella, ii.

UNWIRUNG-our withers are unwrung. Hamlel, iii.
UNYUKE this seizure .............. King John, iij.

ay, tell me that, and ninyolke............ Hamlel

like yonthilul steers myoked .....2 2 Hem? $/ \mathrm{F}$.

the clntk upbraids me .......... Tireijh Night, $\mathrm{ji}$

I did upbraid her, and fall out.Mlid.N.'s Dream, jv. 


\section{UPI3}

8(0:3]

USTE

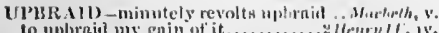

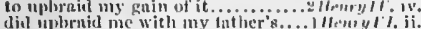
as well nay they uphrabl me

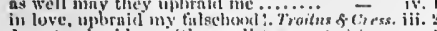

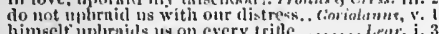

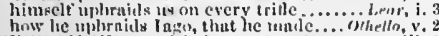

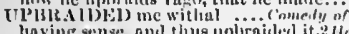

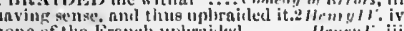
none or the french uphruileel

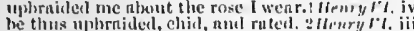

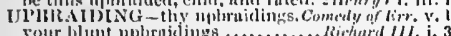

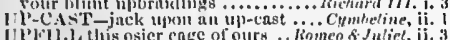

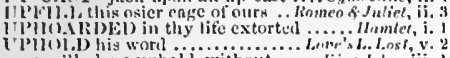

we will alone upholi, withoint...

lime that the enholds,
nilnone upholds the diny

nilnene upholds the dny ..........

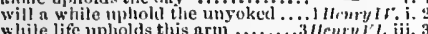

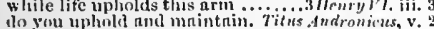

Ilifold, Tht him that thice.

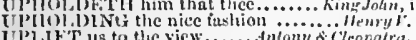

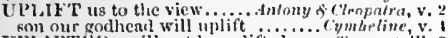

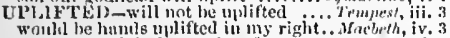
wonthl be hample uplifted in

how were 1 then upliftedl ... Troitus of Cressida, iii.

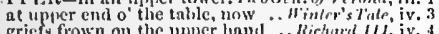
griefs frown on the upper hant .. Nichurd II neiglatururs, the upper terinnily ect it uplere enct o the table

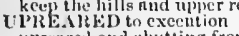

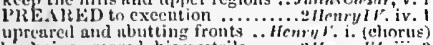
UP'RIGilt? witla his enriage as untight as the ced

0 wise and upright juitgei

firmucs of my upriglt soul .........

nwas, you whoreson lupright rabbit. 2 tleary $1 \%$. it. 2

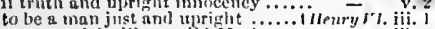
enper upright like n wild Ntoriseo..2 Henry $1 \%$. iit. I

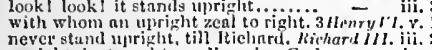

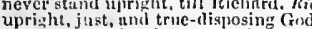

uprighty of manthond stand upriglit. Limon of $A$ th. iv. 3

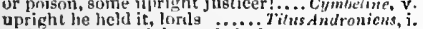
and set thens ulritght at tieir denr

the mon wonld I not leap uprig

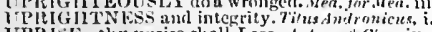

UPIR IsE-thy uprise slanll I see. Anthy $x$ c Cloo. iv. 10

IPRISING of the liill?

PROAl the universnl peace

an uproar, I dare warrant.............illenry $r$ t. iii.

are all in uproar, and dituger serves. I

by untroar bevered, like a fliglit of Titis antron

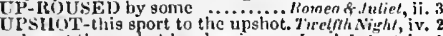
slie get the upshnt by elenving . Lore's L.L Lost, iv.

and, in this upshot, purposes mintook \#IImmlet, $\mathrm{y} \cdot 2$

toreh. that's turned upside-down
UP-STIIRS, and down-stairs

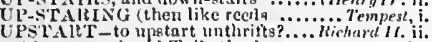

iivenricles, ii. 2

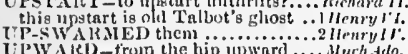

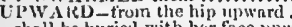

Wrech deto, iii.

ghall be buricl with her face upwarls - - i

what unward lies the stretet....... l.ore's l. tonst, iv. else climb upward to what they were .Macheth, iv.

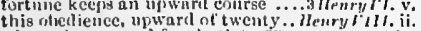

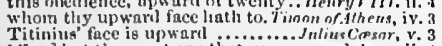

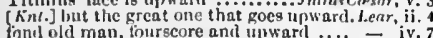
from the extrenest upward of thy heail.

UTellins shall, fur that vast of niglat .. Fempest, 1.3 or fright me with urehin slow's.

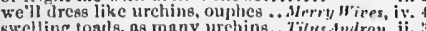

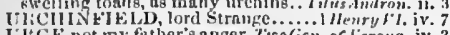

UItGE not iny father's anger. Trofich, ar lerout, iv. tlic motesty to ure the thing lield . of Tenice, i. whichs here we urge in war............. urge them, while their soula nic. lisy it open, to urge on revenge ...... urge it no more, nyy forl ............. iv. then if you urge me further thall....... IIrn ry ry v. to urye his hatred more to Ciarene..... Nichurid III. i. which licre you urge, to prove 118 .... how canst thoun urye Gort's drentfiul they dist urge it still unten the kings. urge tive nerersity and state of timca

litili me to put ofl

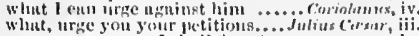
urece ine no nore, I sheth furnct...

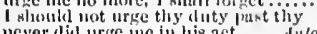

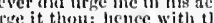

therefure loat then wirge the

to that I'l hirted him; therefore.........

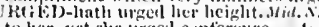

whiler, yet she turged eunfer

so strongly urfecl past nyy' define

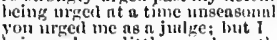

being ue'er so little uryed, another

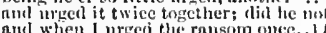

a ehnillenge urged more modestly

my satery urged me to............

ilis bill urged by the conmon

the penee, which you before so urged
nrtieles, ton nicely uryed, be stumf on

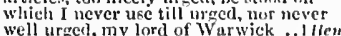

well urgel, my lord of Warwick ...Temy

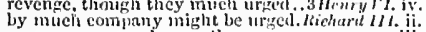

then he was urtesl to tell ms tule itgrin = iii. 7

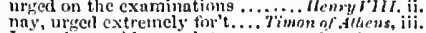

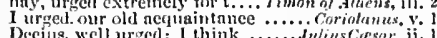

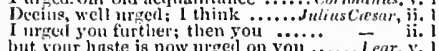

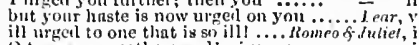

o trespass swectly urgedt give me

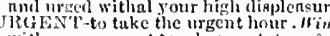

with more urgent touches ...Antomy of Clorpultro

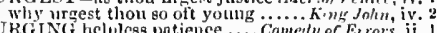

firr urying it the second time to me me

for nyy urging it; at honed, lic fed (rep.)
besides our urging of lier wreck ....

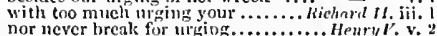

nor never break for uring ............... Heary $t^{\prime}$. v. 2

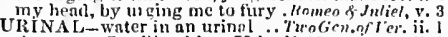

thon nrt a Castilian king, Urinall. Merry Wives, ii. 3

URINE is congcalerl ice ... Mersure for Mensure, iiii, 2

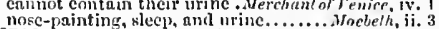

URN-bones in an ulworthy urn .........Henry! He. H.
in an urn more precions

ever herakd diid follow to his urn......Coriolams, v. 5

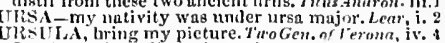

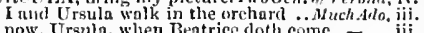

now, Ursula, when Beatrice floth empe
no, trully, Ursula, slic is too dislainful

gooxd Trsula, wake my coutsin ( $r p p$, )

and this to oll mistress Ursuln.

USAGE-the lenst sinister usage .... Tirel
but this nost crucl usace of your. Win'

to the feartul usage (at least, ungentle - valc, v.

your stubhorn usage of the $P^{3}$,

this servile usage anece offend
good usnge and great liberty

I llenrylly v.

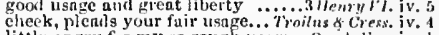

little ungry for my so rougha usnge... Cysmitrelime, iv. I

minecty shall be thy usage

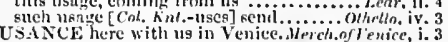

nbout my monics, and my usauces

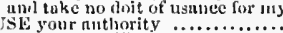

the curth let liberty imake use of
no use of scrvice, of riehes (rep.)

they nlways use to langly at nothi...

nor ennnot, use suclt vigilunec .........

aithough they want the use of tongue
I must use you in suelt nnother tricks.

use me, and my dauthter.

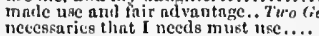

necessarics that I necds must it
to eomplass lier l'll ufe my skill

to eomplass lier l'll ufe my skil
that use thicin to so buse effict

when would yon use it?
I'll use thee kindly for tiv

and will not use a woman lawiessly

how use doth brecll a habit

nse your art of wrooing
1 will uie her as the key

ues your patienec.......

he histh no use of thicm

you use me well, master

there they nlways use to elipeli........

fuiries use Alowers for their

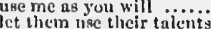

do ufe to elnunt it ...

uses the witls $n$ more exulited respe.....

weth Which slic uecs to sen

my rivlititic, ami put to ise....

that will use the devil limsels bith

hy the inmumlerate

hie (to give fient to ufe

do nothing but nke their ribuse.....

to usc it like n giant
wonld use his heaven

wonle use his heaven for thimitic..

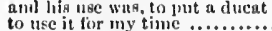

if not, use ling for the preseriot.

oerasiom to ure me for
and I will use your ak ill

use of your discontcent? (rep.)................

and 1 gave liom ure fir i

ne it for my love some otlier......

if yol u'c them. Misrgarci.

to he lised as yout $11 \mathrm{ge}$ your ding?

would not ues a gentle lasy so

slie slonilu not $118 \mathrm{sen}$ a ling gome.

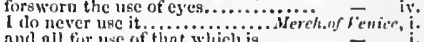

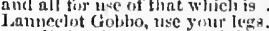

ure all the observanee of eiviluty

and use thou all the endicatour

you may ns well ue question
ho more ofters, use no fintlier

ou usc in abject and in slarisly

it is atill leer use, to let the wretebed

the other half in use, to render it

swect nee lie unes of adversity

which she tiol nee nos she was writing

hey do nse goutl huslics...

rntiler in power thrn use..

uke a more spatuious cercinminy

give us $n$ further use to lie nume.

give me lcave to use the helly.

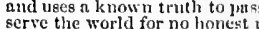

such sweet nse make of whut they

I put you to the life of your

pray you, sir, use the carji as

and use you like n fool

I advise youn use your minnicrs

for $n$ servant to use his
bitl them use them well

minto lly master's usel (rep.).........

slinuld a like langny dothe uec . Winter's Tale, ii.

I'll ufe tlike tongue I lave

the time is worth the use

the name of 'Time, to usc my wings -

thant lie use no scurrileus wirds

to my good ise, I remenbere

an' you use these blows ining

for were you wout to use.

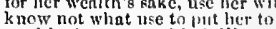

good lnrd, you uec this dnlliance

Ecared thy hussisand froln tlie

dollar's to our peneral usc....

agninst the nse of nature?

but with the aid of use

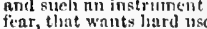

thou com'st to use thy tongue......... -

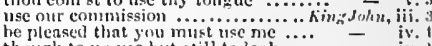

though to no use but atill to look

of note fir inerey-lneking uses ...

return, for I nust lise thee

1 must lose the use of nll ilceeit?

my tongue s use is

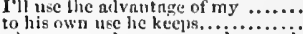

when we need your use and counsel...

us clnotuly men use to their....

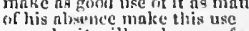

n gond wit will make use of any......

and made lier serve your uses both

but do you use me this, Nuivi?

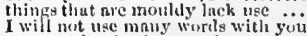

more perfect in tlice use of arms .......

come to 1 in furtlaer use

I will ufe him well (rep.).

that you use the fame with the like.

this layy serves youl tor gool uses.

not nictsuring whut uke we maile.

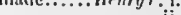

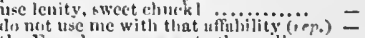

the French: use merery to them all.." =

to use lis goot pleastre. 


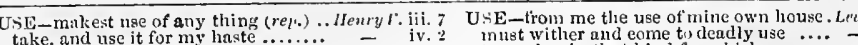
onths which I never use till urged
I'll use, to carrv thee out of this
distrained the Tower to his use... handle, the Tower to his use. use no entreaty, for it is in vain
in that $I$ pray you use her well in that I pray you use her well any groat I hoarded to my use dost thou use to write thy nam is his to 11 se, so Somerset may.... made impudent with nse of evil deeds im that quarrel use it to the leat

2 Henry $r$. ji.

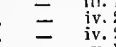
use her honourable. Ay, Edward know 1 not how to nee embnssadors nor how to use your brothers brotherly and, if we use delay, cold biting......

use mealls for her recover

the boar will use us kindily.

princes, use my bahies weili ....

but thit still use of grief makes

use eareful wateh, ehoose trusty

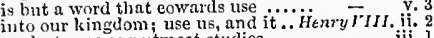
ready to use our utmost studies...

has made that right use of it $\ldots \ldots \ldots . .$.
make use now, and provide for thine

to use so rude behaviour ..........

persuasions to the eontrary fuil not to use =

many hands aud no use

if thou use to beat me...

to use between your strangeness

and denr in use what thinge agai

nay, we must use expostulation

Grecian, thou dost not nse

and uses the traitor Calchas' tent....

to use [Cal.Knt.-count] viole

exeeeding all use of quittanee... Timon

that you wonld onee use onr hearts.

ny uses cry to me, I must serve.

trankly use, as I can bid ....

to them to use your signet ................

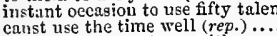

eanst use the time well (rep.).
supply his instant use with so

supply his instant use with so ........

as to use mine own words to him

and none but tyrants use it eruelly.

they love thee not, that use the

make use of thy salt hours ..........

atfeet my manners, and

the deed of saying is quite out of use

for thy best use and wearing

thou wilt use the wars as thy

and I will use the olive with

and let me use ny sword, I'd make...

see how he intends to use the peopl

leads my use of anger, to bet

sis use it, that my revengeful $\ldots . . . .$.
hut your soldiers use him as the grace

he would use me with est

to use my lawful sword! $1 . . . .$.

I may use with a safe conseience
or did use to stale with ordinary

you do want, or else you use not

these things are beyond all use .......
blood and dest

out of use, and staled by other men..

of your philosophy you make no vise

reeording to lise virtue let us use lim

to use our strongest hands

we use to say, the dead are will...
Antony will use lis affection

part of myself; use me well in it

part of myself; use me well hing having made use of him....

that liave no use for trusting

make your best use of this .......
whose use the sword of Casar

yet use thee not so hardly....

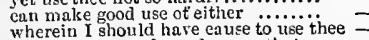

wherein I should have cause to use the
use like note, and words, save that ..

mise like note, and words, sa'e that

such as wink, and will not use tliem

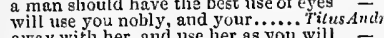

will use you nobly, and your....... Tilns

liave served me to effectless use.....

bit you not use his daughter.

to use as you think needful

to use as you think nith long use, aecount no sin ..........
as holes, $\bar{i}$. (Gower)
as hose are defiled for want of use

to use one language, in each
will you use him kindty?

take her away; use her at thy pleasure

sir, I will use my utmost skill $\ldots . . . .$.
use [ Col.Knt.-love] well our father ........ Lear,

ean vou make no use of nothing ........ -

you would make use of that good wisdoin
thy other daughter will use thee kindly

wherein we must lave use of

fatlier's dog, you should not use me so to use her in that kinkl for which ...... to use his eyes for garden water-pots

no to use them, as we shall find

I'd use them so that heaven's vault beauty too rich tor use ........... Romeo of Julite lips that they must use in prayer

to nse me at his pleasure (rep.)

the dammed use that word in heli....

usest none in

think on't, I do not nse to jest
living here and you no use ot $h$ im

grave, for there must I use thee.......... $\overline{\text { any }}$ to me all the uses of this worla! ................ the need, we have to use you

I swear, I use no art at al

the adventurous knight shall ue $\mathrm{his}$ fuil much better use according to their desert much better: use every man after.

pitiful ambition in the fool that uses it that to the use of actions fair and good

for use almost can eliange the stamp

yet the unshaped use of it doth move

to what base uses we may return

your bon that you use me thus?

to use some gentle entertainmeni.....

do their broken weapons ratler use ...ii
adieu, brave IIoor! use Desdemuna weil

adieu, brave Aloor! use Desdemuna well

I have use for it; go, leave me
is it his use? or did the letters

then, let them use us well; else, let......

USED thee, filth as thou art

treaehery used to

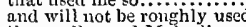

.........

the madly used Mralvolio ......

for he lath not

be used as reunth used so long .......Much Adio, y. be used as you use your dog.......idid.N. sDream,
much better used on Navarre .... Love's L. Losi, much better used on Navarre .... Love s s. Lice, i he usell as creatures of another

hath nains, not used, must by

and better used, rrould make her..... Winter's Tale, iv.

iv. 3 till I have used the approved. Comedy of Errors, v

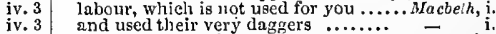

and used their very dagger

hath used rather for sport thain need King John, iv $_{\text {v. }}$

I have used my eredit ( $r e p$.
of greatness to be used on it.

you used us so as thed on it.....

tis the more time thou wert used...2 Henry $I V$. iii.

sword that you have used to bear
for disciplines ought to be used

what treaehery was used?

thus ignobly used, your nephew

Henry $r$ iii.

by seeret means used intercession

there to be used aceording ...........2 Hen

-

stern and rongh, used to eommaud...

hast eaused printing to be used......
they have used witl fearful flight $\ldots 3$ Henry $r J$ iv.

or foe, let him be gently used.........
the people were not used to be....Richard $(1)$. iii.

misused ere 11 sed, by times...

all used in each degree, throng .......

were he evil used, he would outgo

if I have used myself unmanmeris

they were used to bend....... Troilin

he used me kincily; he eried to me... Coriolanus

but says he used us seornfinly

o'erbear what they are issed to bear.

he hath been used ever to eonquer ."
you were used til say extremicy was

you were used to say extremity was
you were used to load me with ......

as they used to do the players in

we have used our throata ... Auton

we have used to eonquer, standing .. Clenpalra,

wight be used mure tlank fully...... Cymbeline

worse than Ylui lomel you have used

by me so used a guest is..................
$[K n t$.$] wino, not tised to hinger's savour$

asks of you, that never used to heg
conseienee to be used in every trade

conseienee to be used in every t
and must be used with eheeks....

I have used it, nuncle, ever sinee.

that going shall be used with feet
let them be well used; for tliey are

they have used their denrest action ..... Homlet,

this only is the witeheraft I have nsed ...
knavery's plain faee is liever seen, till used -

good familiar ereatme, it it be well used -

tis meet I slould be used so... .......... -
he hath-used thee. How? unlawiliy.
USEFUL-or useful eerving-man .....King John most useful for thy eountry..... Antany \& Cleo. iv. I

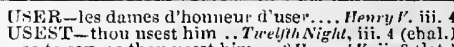
as to say, as thou usest him ..2 Henry $V$. ii. 2 (let. ay, but thour usest to forswear .....3 Henry $P I . Y$.

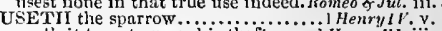
useth it to patromage his theft...... I Henry VI. iii.
it useth an enforeed ceremony....Julius $C_{a}$ sar, iv. the one's tor use, the other useth it .... Othello ii. I these are the ushers oncurs ......... hnve an army for an usher ....... ninony of Cleo. iii. 6 USING those thoughts, which shoild... Macteth, iij.

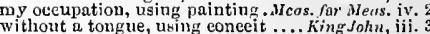
using the names of men ...........2 Heuryl. i. using no other wenpon but his....... Hemry 'll. ii. for well using me? nay, be .......... - iv. 6 unless, by using means, I lame ...... Coriolamus, iv.
USUAL manager of mirth? main flood bate his usual heightit. Mer.of Ventce, iv. his studies, or his usual pain?.... Taming of sh. jii. first, it was usual with him ........Henry $\nu^{\prime} I J$. i. such wanton, wild, and usual slips
USUALLY, so all meu do .......

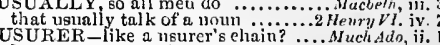
he was wont to eall me usurer.. Nier. of Verice, $\mathrm{iji}$. how a usurer's wife was brought. W'inler's ? ale, iv. 3 bless me from marrying a usurer! . Henry ${ }^{\prime} t$ iv. 3 poor rogues, and nsurers' inen!. Tino on of Alhens, ii. no usurer but has a fool to his servant $=$ ii. ediets for usury, to support usurer.... Coriolanns, $i$. 1 when tisnrers tell ther goid i' the field... Lear, iii.

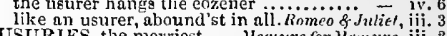
USURIES, the nerriest...... Mensurefor.Hetwate. iii. 3 but know the city's usuries ........ Cymbeline, iii. 3
USURING senate pours ....Timon of Alhens, iii. 5 evvetous, if not a usuring kindness.. ${ }_{\text {USU }}^{-}$iv,
USUP a name thou ow'st not.......... if 1 do not usurp myself, 1 ain.... Tuelfht Nigh', $\mathrm{i}$.

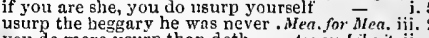
youl do more usurp than doth .....As you Lilie i, $\mathrm{ii}$. wiaek, thou dost usurp authority.... King Jahn, ii. and thine, usurp the doninations..... dinat proud man, that dial usurp his back? doth but usurp the saered .......... I Henr?/ $\bar{r}$ ?.iv. Laneaster usurp my right ..........2 Hemy $V I$. i
now the house of Lancenster usurps..3 Hemry $V$. $\mathrm{i}$. but did usurp the plnce .............. = benst that would usurp their den .....
of York, usurps the regal title ......

thy father Henry did usurp ......... and all the pleasures you usurp.... Richard III. i. thou didst usurp my place $(r e p$,$) .... - i$ usurp upon my watery eyes.. Titus.indronicus, iii deatl may usurp on nature many .... P'e icles, iit. my fool usurps my bed ................. Lear, iv. USURPATION of thy manatural .... King John, ii. finding his usurpation nost unjust. . Henry VI. i to him, and his usurped anthority... King John. ii at the font, but 'tis usurped........ Richard 13 . iv. headlong from the usurped throne ... erooked titles usurped from you ........... his state usurped, his realm .......... Henry/ $r J$ v. their ruin that usurped our right?..... dishonoured, and the third usurped.. - iv endured so long; he but usurped his life... Lear, $v$. thy favour with an usurped beard ....... Othetlo, i.
USURPERS, tyrants, and what's.. As yau like it, ii j stands the usirper's eursed hend ......... . acbeth, v. thou dost call usurper, Frnnee?........ King Johu, ji. that your majesty was an usurper ... 2llenry $/ . \mathrm{i}$. and ealls your graee usurper, tpenly - iv.

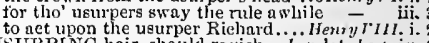

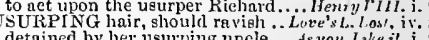
detained by her usurping uncle...As you Like it, $\dot{\mathrm{f}}$. it is dross, usurping ivy, hriar ...Comeily of Err. ii. make answer; - thy usurping soll.... King John, ii. strumpet Fortune, that usurping Join - iii. I do, thou nost usurping proditor ... 1 Henry ${ }^{\prime} l . \mathrm{i}$. in following this usurping Henry ....3 Hemy $r I$. the axe to thy usurping root $\ldots . . . .$. ii. the usurping helnuets of our adversaries! - $-\mathrm{y}$. liend againgt usurping liehard.... Hewry $\overline{r l}$ ll. ii. USULPINGLY these geveral tities ... Kiny John, $\mathrm{j} . \mathrm{J}$ thou usurg'st my father's righ

that usulp'st this time of nigint ........Hamlet, $\mathrm{i}$. male ediets for veury, to suppor t.... Corrolanus, i. UTENSI - - he has brave utensils ..... Tempent, iji. and utensil, labelled to my will ..Twelfh Night, i. 5

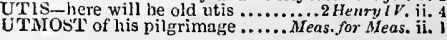




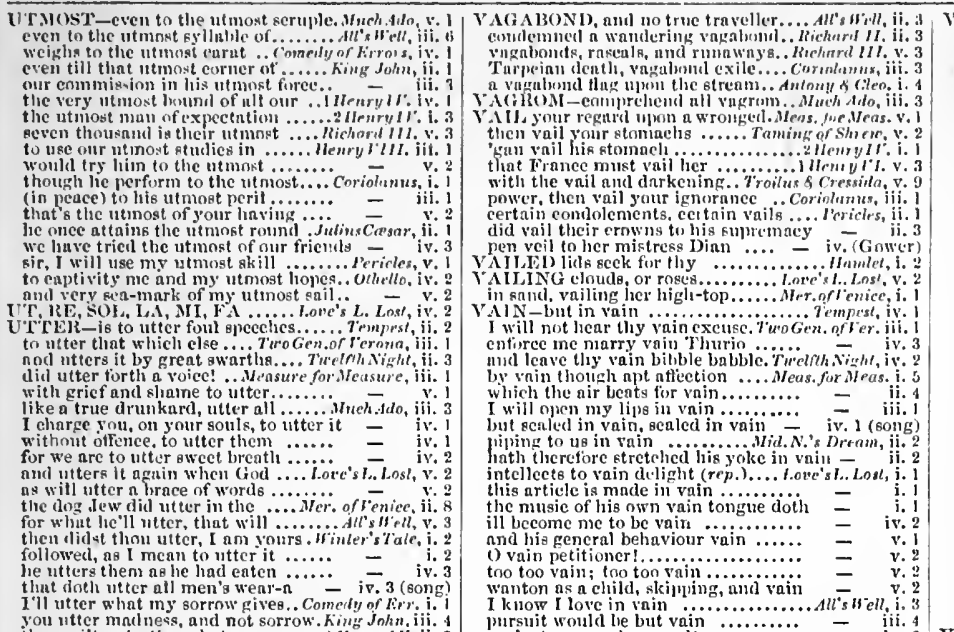

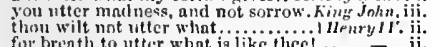

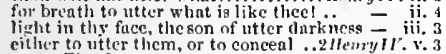
cither to uiter them, or to conceal

cinne, Pistol, utter ninre to me

the utter loss of all the realm.
sulficient skill to ut ter them

ancl utter ruin of the lowe of York... heard him utter to his son-iu-law.. ilenry I'lll. ghould utter, with demure ennfitlence

the words I utter let none think finttery

what I think, I utter

mored by that which he wili iiter. and malice have nower to utter

glad to be constraiucd to utter thi...

hear whint fearful words I utter.. Tiitus dwiron.

iny tongue mny u'ter forth

giter your ernvity our bitter.

deatl to any lie that utters them . hoineo of Jal, iii.

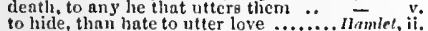

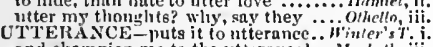

and elampion me to the ut teranee ... Macheth, iij. the utterance of a brace of tongues.. King John, iv. I
with all the gracious utterance .... Rich ard $1 I$. iii. 3 to eloke it in the ntteranee....

to beg the voice and ntternnce....Julizis
nction, nor utterance, nor the power and break my very ntterance ........ Timss Andron. y 3 tongue's utterance [Kut.-uttering]...Nompo \&.Jul, ii.

command to any utterance of
UTTERED-it were so ut tered

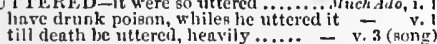
not uttered by liace sale of ......... I liave uttered trutl; which if .... Winter's Taln, $\mathbf{j} .2$
holds but till thy news be uttered.. King Johm,

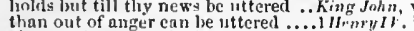
than out of anger ean be uttered $a^{\prime}$ uttered as prave ords at tlic pridge. Henry $V$. iii. a uttered as prave ords at the pridge. Henry glpeches nttcred by the bistnp .... Ifenry PIII. ji. as you have uttered worrls in your. "Wrn -

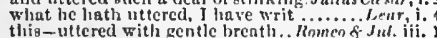
this-uttered with gentle breath... Kmoneo of Jut. ifi.
nnt madnefa, that I have uttered....... Hamlet, iii.

ITTER .'TII piereing elnquenee.. Faming of sh. ii.

UTERING sueh dnect and . Mid. N.'s Bremm, ii.

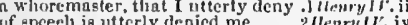
of apceel is utteriy denicd me. territorics utterly bercft yoll...

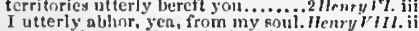
ny, utterly grow from the king's

elemenita farcont thec utterly

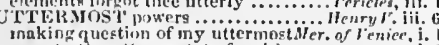
inaking question of ing uttermostiser. of lenice, i.

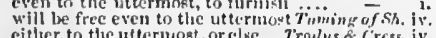

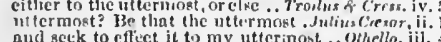

\section{$\nabla$}

VAC.A.YCY - not a minute's vneaney .. Twetmas. v. 1

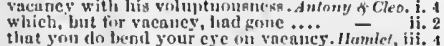

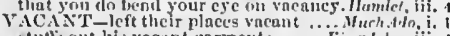

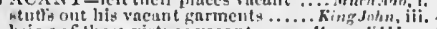

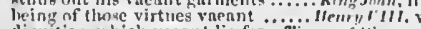

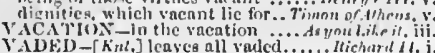

to nilter this, for connsel is but vain

the all in vain are these mean ......

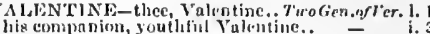
of compendation sent from Valentine gir Valentine, and servant, tro you .. sir Yalentine, $y^{o u r}$ futher" $^{\circ}$ in for Valentine, I neeft net eite......... my zeat to Yalentime is cotd and Ynlentine I like (rep.) and Valentine I'll liald wis enemy
some treachery used to Vulentine enraged, will hanisl. Talenti

to forbid sir Vulentine lier eomna......

fir Valcutine is enmine (rrp.) .....

friend Valentine, ${ }^{n}$ wort

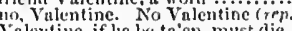

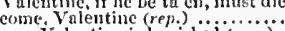

now Vulentine is hanishei $(r c p)$.

forget the love of Valentine (r'p.) ..

alrendy have 1 heen false to Valentin

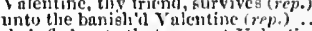

Glie's fed unto that pensant Yalentine

O Vulentine, this 1 endure
withilraw thee, Volentine.

low I love Vulentine...

Valentine! (rep.)................... Sop.)

do uppland thy spirit, Valcntine (rep.) - v

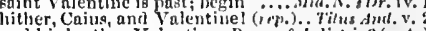
and his brother Valentine. Romeo of $j_{\text {uliet, i. } 2 \text { (note) }}$ 'tis saint Pulentine's day ....... humlet, iv. s (song)

against snur vain assault ................ and huve, in vain, said mang a proyer - v. 3 to be a little vain when ...... Comedy of $E$ ro

is but the vain breath of a enmmon.. King $J_{n h n}$, ii for alt in vain comes counsel.

if lieart's presages be not vain.

infusing lim with self and vain encecit - iii. 2

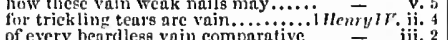

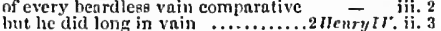

if any reticl or vain spirt

speak to that vain man ........................

by a rnin, giddy, sliallow, lummorous

Epend our vain command upon ....... il tenry $r$.

vou go albont to torture me in vain...2 llenry $\%$ l. it.

swordls were never trawn in vai

iii vain thon speak'st, poor bny

but all in vain; they had no heart $\ddot{\text { vin }}$

vinu flutish of my fortume (rep. iv. 4).Reh. MII. i. 3

vin prophecy of Nieholas Hopkins.lI

myself lave spoke in vain...... Timon of $\bar{A} / \mathrm{hens}, i$.

feusts, jompreat and vain glories?

it is in vain thint you would sperk.....

atay not, all's in vain

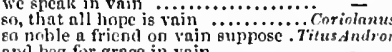

and heg for grace in vain

you lament in vain................

it is in vain; he will not spenk

thos: swear'st thy godls in vain $\ldots 1 \ldots \ldots \ldots$...... Lear, i. 1

and vain it is that we present us to him.. ve velo

we waste our lights in vain ......
begat of nothing but vain funtasy
for tig in vain to geek him here..

Our vain blows malicions nockery....... Tramlet, i. 1

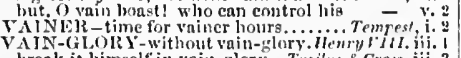
break it himself in vain-glory .. Troilus of Cress. iii. 3

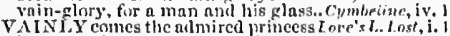

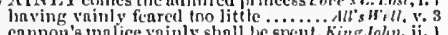
ennnon's mnlice vainly shall he spent. King Jnhn, ii. ]

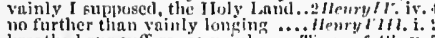

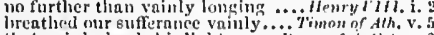
thant vainly ients his light ...... Itomen so Juliet heing tree from vainuess ....... llentry

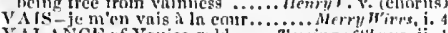

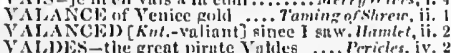

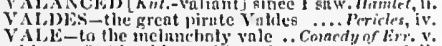
his comfort in this enrthly vale ....2Heny $r$ ? it.

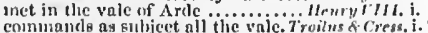

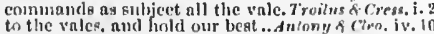
ant make him stong to the vale..... Cymbeline, iv.

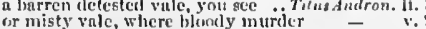
drelined inte the vale of yenrs ......... onhelio iii, 3

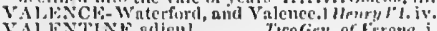
Al.F.
I will be thy tead's-man, Valentine

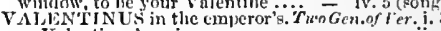

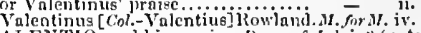
VALENT10, nnd his cousin. IRomeo o Jul. i. 2 (note) AlFRIA-lady Vale rin is come..... Coriolanus, i.

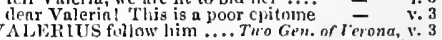

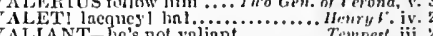
would my valiant master wroili iesiony - Tempest, ii. valiant, wisc, remorseful .. Tu'oGen. of frronn, iv. gnod and valiant $\ldots \ldots \ldots \ldots \ldots \ldots \ldots$. an' I thouglat he had been valiant ...
the valiant licart's not wlipht ...seas. for Meas. ji. thou nrt by no means valinnt.......... with a piece of valinnt dust

lie is now as raliant as Ifercule

huth feared the valiant .... Nerehani of renice, ii. gentle, strong, and raliant?......... As wer like it, it.

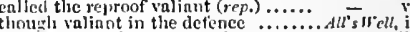
and ot very valinnt approof............ -

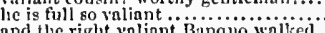
do eall it valiant fury .................

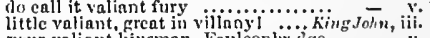
your valiant kimsman, Fauleonbicigc thy soutlful hlond, be valiant ..... lirchand II. i. thint ever valinnt and npprosed Scot. 1 lewrylt.

darest thou be so valinut ...........

I am as valiant as llereules...........

valinut Jack Falstatf (rep.) .............
valiant as a liom, nud womdrous afible

n very valiant rebel of the name .... - v. besme the necents of the valinit ...2llenrylr. ii. 3 you whoreson little valinnt villain

in Englann the most valiant gentlenian that frince Inary is voliant
lie is becone very lint. nnd vinlint remembrance of these valiant dead n very valiant gentleman, i' faitl.

coid blood to Eueh valiant heat?
lic is as valiant as Mink Antony

a vnliant and most expert gentlenain!

of Eingland breeds very valimet crentures -

thine a valiant flea,

lcuve tlicir raliant hones in Finnce....

brave, vuliant, et tris distingue
for I do know Fluellen valiant

where valiant Tulbot (rep. iv. i) ....i Hem I I

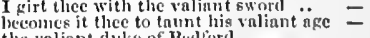
that such a valionst company areflica viliant, and virtunus, full of liaushty fliould we save a valiant genticmun.. where is valiant Jolin? ................. lier vnliant courafe, ant undaunted

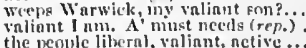

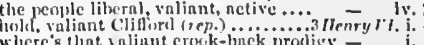
where our right vnliunt father is licenic his nome that valiant duke hath left -

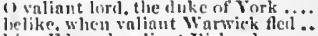
king Elward. valiant Iichard I know thou art valint ............. -

\section{i. 3 \\ ii. 1 \\ ii. 1
ii. 6
ii. 6
ji. $t$
ii. 6 \\ iii. 1

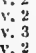 \\ v. 4}

iii. 1

4
4
4

\section{)}

.

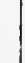


VALIANT-for all his valiant sons..3 post that cane from valiant Oxford?

a woman of this valiant spirit.

be valiant, and give si

young, valiant, wise

with a valiant crew; and many.

to their fiercencss yaliant ..... Troilus \& Ciessida, $i$.

less valiant than thic virgin

he is as valiant as the lion

so to be valiaut, is no praise at ail...

a spur to valiant and nagnanimou

I am yours, you valinnt offspring...

know the whole world, he is as valian

I humbly desire the valiant Ajax....

a valiant Greek, Aucns (rep.iv. 3 ).

health to you, valiant sir, during

to see unarmed the valiaut Hector (

why then, women are more valiant

old, young; coward, valiant ........

thou valiant Mars! thou ever young

Titus Lartius, a most valiant Roma....

then, valiant Titus, take con

otheious, and not valiant ............

the valiant never taste of deat

Brutus is noble, wise, valiant..........

and, uly valiant Casca, yours...

as lie was valiant, I honour him
he's a tried and valiant soldier

Antony is valiant and dejected

thou teachest me, $O$ valiant Eros

thou may'st be valiant in a better

o'erthrow nature, makes it valiant..

upon a valiant race, thy hars

pr'ythee, valiant youth, deny't again

his valiant sons (rep. i. 2 \& iv. 4) ...

a valiunt son-in-law thou shalt enjoy

thy thrice valiant son, who leads towards -

you hive shown to-day pour raliant si.......ear, $\mathrm{v}$

you valiant, is to stand to it .... Romeo \& $-\overline{\text { siet, }} 3$

in brief, the valiant Paris seeks you

in which, our valiant ftamlet.

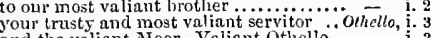

and the valiant Noor. Valiant othel

thanks to the valiant of this warlike isle

I thank you, valiant Cassio. What tidings
if thou be'st valiant as (they say) base.

I am not valiant neither, but every pun

VALTANTLY he took ............... I Henry

keeps the pridge most valiantly $\ldots \ldots$...

lie smiles valiantly. Does he not. Troilus $\&$ C

by a Roman valiantly vanquished..Aut. \& Cleo. iv.

VALIANTNESS was mine

VALIDITY and pitclu snever.... Twelf, $h$ Nigh

whose high respect, and rieh validity. All's ir.

no less in space, valinlity, and bleasure.... Leary. i.

of violent birth, but poor validity ..... Hmolet, iii.

VALLEY - in the western valley ...MTii.N.'s s Dr. iv. I

nay, the valley, the pretty dimples Winter's Tale,

melted snow upon the valleys

I'll meet you in the valleyi....

Henvy

YALOROUSLY as I may ..........

Henty $r^{5}$.

furious knight, and valorous enemy
most brave, valorous, and thrice-wortlry

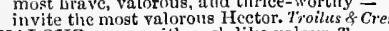

VALOUR-even with such like valour. Tempest,

so full of valour, that they

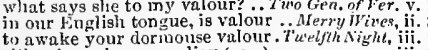

eitlier by valour or policy (rep.)

with woman, than report of valour

a notable report of valour

on others, to taste their valo

in the proof of his valour.............

for bearing, argument, and valour

in a falsc quarrel there is no true vaionr- - .

cowardice pursues, and valour flies. Nid.N. $\overrightarrow{\text { 's }}$ Dr. ii. this lion is a very fox for his valo

his valour cannot curry his (rep.)..... melancholy, valour gives thee place

for valour, is not love a ferement. ier. of Fen ice,

that your valour and tear makes....... All's $W$ ell, $\mathrm{i}$.

and transgressed against his valour..

the great dignity, that his valour hat
his valour, hoocsty, and expertness

to his valour; what is his lonesty?..

like valour's mininn, carvcd out

with the valour of ny tongue all...
VALOUR to act in satct.y............ Macheth, iii. whose valour plucks dead lions by .. King John and my body's valour, in lists, on... if that thy valour stand on sympathies as full of valuur, as nf royal blood.... - v. no more valour in that Poins ....... let them, that sliould reward valou his valour, shown upon our crests.. true valour is turned bear-herd...... and check was the reward of valour and this valour comes of sherris.....

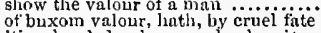

'tis a hooded valour; and, when it..

3 much care and valour in this Welohman -

the vanour of our valour will.

a bounding valour in our Englisl

ten times more valour than this
trophy of pre-deceased valour....

trophy of pre-deceased valour.

my strength, my valour, and my force

noble deeds, as valour's monument

by fimine, not by valour........... = iv. 10

by circumstance, the name of valow

teu to one is no impeach of valour...

'twas not your valour, Clifford, drove

his valour did enrich his wit (rep.). Riehan $\bar{l}$ IlI. iii.

his valour is crished into folly,. Troilus
doth valone's slow, and valour's worth

that knows lis valour, and $\mathrm{k}$ nows no.....

in one man's valour, to stand the push

valour and pride excel themselves

even in the faith of valour, to app

upon the head of valour (rep.). Timon
to revenge is no valour, but to bear.

be such valour in the bearing.

how full of valour did he bear

your valour puts well forth .........

that valour is the ehiefest virtue

contend against thy valour.

done a deed whercat valour will ween

to steel with valour the melting ...Julius $\overline{C a s}$

when valour preys on reaso

tenfold for thy good valour.

peace: not Ceesar's valour hath

there shall she see my valour.

though valour becomes thee weli enough

more valour in me than iny habits

you have so bestirred your valour

temper softened valour's steel ...Roneo \& Juliel, iii.

digressing from the valour of a man

we put on a compelled valour... Hamlel, iv. f $_{\text {(letter) }}$

purposc, conrage, altd valou

you set so slight a valuation

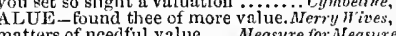

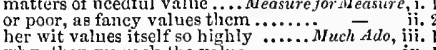

why, then we rack the value ...........

thrice three times the value of.....Mer.of Venice

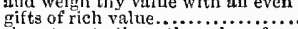

iv. 1

more dcpeods on this, than on the value

who young that time to value her...As ion Like ih, i. 3

of much less value is my compary... Richard IA. $\mathrm{ii}$. 3

and us not vilues the cost that .... Henry VIII.

it valucs not rour asking

more is his life in value with

but value dwells

some better than his value...............

things of like value, differing in......

must know the value of hor

buried thoughts of great valne

rather by her value, than his own

as you value your truest Leonatus

it did strive in workinanship, and value $=$

which of the dukes he values most......... Lear, i.

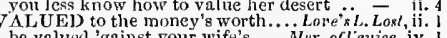

be valued 'gainst your wife's ..... Mler. of 'entice, i
valued at the highest rate .... Cometly of Er Ers,

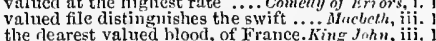

nur business valued. Bome twclve ..1Henry $1 \%$. iii. 2

dispraising praise, valuerl with you $\ddot{\text { heing valued thus, as nuch as would.. Heary } r \text {. i. }}$

We never valuel this.poor seat .......

tis exactly valued........... Antony \& Cleopatra, v.
VALUED-can be valued, rich or rare .... Lear, i. VALU E1.ESS-proves valueless $\ldots .$. King. John,
VALUING-not mine, valuing of her. Much Adn,

VAN-lave revoltcd in the van ...Anlony \& cleo.

VANE blown witla all winds ............nuch

no; 'twas the vane on the honse .....
what vane? what weathercock?.. Lave's L.L Lost, iv.

VANISH like hailstones, go .......... Ner? "Hives,

some state in thy cxit, and vanish. Love's L. Lost,
the scandal vanish with my life .... Rieliard 11 ,

vanigh tongue-tied in their guiltiness.Jul. Cecsar, $;$.

vavish; or I shall give thee .....Antony \& Cleo, iv. io VAN ISFED strangely that you are vanished.................. TrFen. of crona, iit. whither are tliey vanished........... and so he vanished $. . . . \ldots \ldots \ldots .$. . Richand $111 . \mathrm{i}$ face of Casar, they are vanished...Julius Capsar, ii. there vanislied in the sunbeams .... Cymbetine, iv.

a gentler judgment vanished.. Rameo \& $-J_{\text {uliet }}$, iij. 3 away, and vanished from our sight $\because \because$ Hamlet,

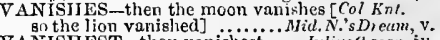

VANISHEST-thon vanishest ...... Julius Cresar, iv. 3

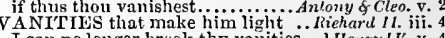
I can no longer brook thy vanities ... Herury $I^{\prime} \cdot \mathrm{v}$. you shall find, his vanities forespent ..Henry $/$ it. we to do in these fierce vanities? .... Henry more worth than empty vanities .... $\overrightarrow{\text { Tempest, iv. }}$ ANITY - some vanity of mine art ...Tempest, iv. the vanity of wretched foolst ...Meas. for Meus. v. o vanity of sickness! fierce............ King John, v. 7 thrust forth a vanity, (so it be new . Richard II. ii. light vanity, insatiate cormorant .... i Henryl $1 \%$ ij. 1

here's no vanity! I am as hot as .... - v. if I were mucli in love with vanity $\ddot{2}$ Henry $I V$. iv. up, vanity! down, royal state! .....2 Henry $/$. iv. matching to his youth and vanity $\ldots$ Hen $y$
stay him from the fall of vanity... Richard $I / 1$. stay him from the fall of vanity... Richard $1 / 1$. iil.
what did this vanity................ Henry $V I 1$. . a sweep of vanity comes this way...Timon of $A$ th. $i$. . and take vanity the puppet's part......... \& Juti, $\mathrm{il}$. yet not full, so light is varity ........

VANQUISH-and vanquish you? ...2 Henry I $^{\prime}$. iv. 8

vanguish my staider senses ......... Cumbeline, iii. elsc a wit by folly vanquished...Two Gen, of $\mathrm{er}$. i. I undertook it, vanquished thereto ...All's 'Well, v, the field, and vanquished his foes... i Henry $r I$. iii. I am vanquisled; these haughty words - iii, be vanquished by a maid............ yhom you lute ranguished, should vanquished him for, hand to (rep.).3Henry $F_{7}$ iv. 10 quite vanquished him ............JuliusCasar, iii. 2
a Roman valiantly vanquished.Antony \& Cleo.iv. ${ }^{3}$
our men be vanquished, ere they do.... Pericles, i. 2 thom art not vanquished, but cozened....... Lear, $\mathrm{v}$. 3

Fortinliras, had he been vanquisher .... Hamlet, $i$. VAN'TAGE of mine own excuse. Two Gen.of Ver. $\mathrm{i}$. without false valtage............... the doctor spies his vantage ripe. Merry may have such vantage on the duk

if not with vantage, as Demetrius'. Nin. $\bar{N}$ 's $s v$. my vantage to exclaim on you...Mer.of V'eniee, iii.

surveying vantage, with furbished.... Macbeth, $\mathrm{i}$.

nor coigne of vantage, but this bird... another way, to our own vantage ...King John, ii. 0 happy vantage of a kneeling kneel - r. if I lave any vantage of ground ...2 Henry $I V$. till time and vantage erave my company - . an cremy of craft and vantage ......Heary $r$. had the forehand and vantage of a king $\vec{H} \cdot$. you that brings no vantages...........2Henry War's prize to take all vantages......3 llenry $l^{\prime} j . i .4$ for he'll take vantages $\ldots \ldots \ldots \ldots \ldots . .$. ich - iii. at your meetest vantage of the time... - jii. 5 I took the vantage of those few..... - $\quad$ iii. 7 all for our vantage; then, in God's name - v. some single vantages you took. Timon of thens, $\mathrm{ii}$. first, to win some vantage $\ldots . . . . .$. Coriolanis, i. lcads my use of anger, to better vantage - iii.

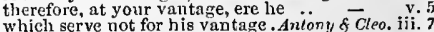
when vantage like a pair of twins ... madam, with his next vantage ...... Cymbeline, i. 4 for my vantage, vantages, that may - vilent take vantagc, heavy eyes, not to behold... Lear, ii. to claim wy vantage doth invite me .... - v. to claim my vantage doth invite me ..... $\overline{-}^{2}$ v. 2 VAPIANS passing the equinoctial. Tuclfth Night, ii. 3 


\section{VAP}

VEN

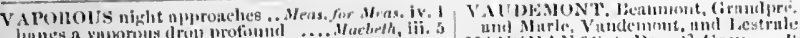

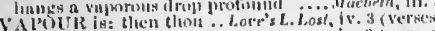

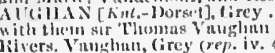

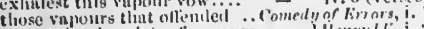

foul and ugly mizts of vapours ....... Whemryll, it.

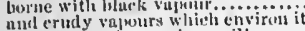

livers. Fumphun, (irey, (rep. iv. A)

enme, Vulgelum, let wa liere cmbraro

think ilm vanishan...

chest, trauk, well, yuult.

Concty o.........

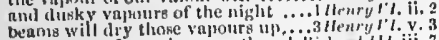

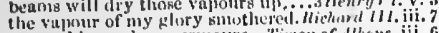

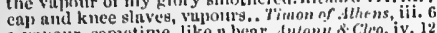

a vapour, sometime, like a bear.

unel pestilent enugregution of vapours.. Waumlet,

und live upota the vauwur of a dungeon, othello, iit.

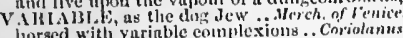

horsed with variable complexions ... Cnmolaming

thy love prove likewise vuriable limmeo \& Julirh, ij. 2

will varinble objects, elunll expel this.. Ih
your leau beghat, is but varinble servico

your leau begate, is but varinble servico $-\overline{\text { iv. }}$

V.IRIATION of eneh soil

kave the parnse is a little variationg

v.ARIst)-it is so varied too

ihe efithets are sweetly varied .....

it sung sweet varicel notes...

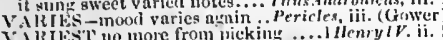

Xlliss no mone from picking ...lllenrylV. ii.

Vili, -dat I vil not for the vurld. Se

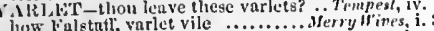

luwg him, dishonest varleti.

prove it befure these varlets ..... Meas. for Meas. ii. thou naughty varlet!.

tell me now, though naighity varlet

away, varletsl draw, Burilofh $\ldots . .2$ Henry $1 \mathrm{~V}$. ii. I a good yarlet, a good varlet (rep.).....

Achilles' male varlet. AIale varlet

abominable varlet, Diomed

turn the dregs of it upon this varlet. Corio - ve thou precious varlet, thy tullor .... Cymbetine, iv. what a brazen-faced variet

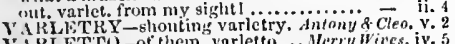

IRIETrO-of thein, varlet

beauty doth varnish age, as if new-horn - iv.

and set a donble varnisli on the fume.. Itumle

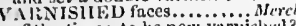

nf the times, to be new virnishted? .. Th ii. 9

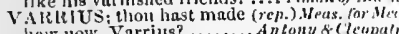

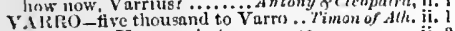
goot even, Varro: what, you eintic.

one Varro's servant. my good lord ...
the like to you, kind Varro .........
Gurro,

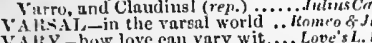

VAliY -how love can vary wit.... Love's L. Lest, iv. 3

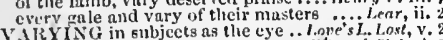
Aul, with his varying childness .. H'inter's Tal

the varying ghore o' the world

is lefe this ynult to lirtug of

eafety ont in vanlts and prisons.

sounded like a cunnon in a vault....3

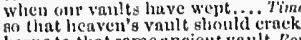

horne to that same uncient ranlt. Ro
shull I not then be stifled in the vante

as in a vault, an ancient reepptael
iil lier kinisred's vault (rep. v. 3 )

makes this vault a feasting prusene

go with me to the vant the...........

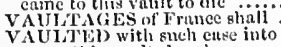

to see this vault such et

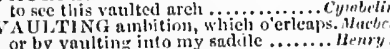

the pretty vaulting sea retased

Whiles he is vanilting variable
VAUTY - in thy vaulty hrows

Bcell the vaulty top of heaven.........
do beat the vaulty henven...

VAUMIOND, Bentii, two hundred ..... Alt's $W_{\text {cll }}$, iv.

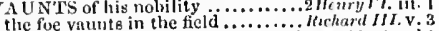

leaps o'er the vaunt ....... Troilus \& Cressidta, (prol.)

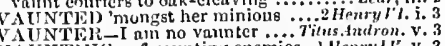

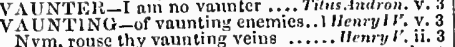

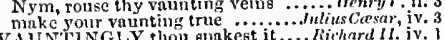

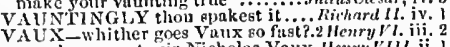

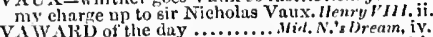

linat are in the vaward of our youth.2 Henry lV. i. 2

I licg the leading of the vuward.
he being in the vaward, (placed.

illenry ivi. i. 3

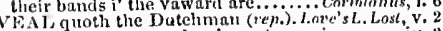

Vipe chi non te vele, ei non te presin - iv.

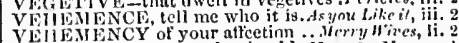

with such velomeney he should. Bretus, for , Me

with what vehemelsey the ocension. Henry lIII. v. I
VEIIENENT-and aves veliement.Mens. or 'Meas. i. I

yet for your vehement onths. Bez
hy long and veliement suit 1 was

by their vehement instigation .......hichord III, iij.

VLIOL_-per niancs yehor .... T'ilus Andranicus, i

give me my veil .i................ Freeth

he says. to veil full purpose ......Meas. far Neas. iv.

dimmed with denth's black veil ......3 Henry I'l.

VEILED-she will veiled walk ... T'wetfh Nighl,
to kcep your great pretences veiled.. Coriolanus,

to keep your great pretences veiled.
onr veiled dames commit the war
if I linve veiled my look. I turn.

if I linve veiled my look, I turn..... Juliuscarsar,
VEII ING an indian lieaity. Merchant of Ienice,

VEIIING an indian leauty . Merchant of tenice,
VEIN-in the veins o' the enrth ........ Tempest,

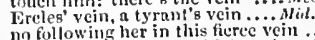

this is the liver vein, which makes.

hood speaks to you in my veins.iger.
nll the wenth 1 lad mu in my veins

all the weulth I lial ron in my

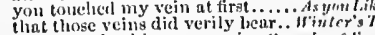

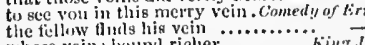

whose veint bouml rieher ...........

tickling uy anul rlown the veing....

pluvs in that infunt's vein

will do it a vein of ensue $\ldots \ldots \ldots \ldots$.

begin to stop our very veins of life..2 lleuryl $W_{\text {ip. }}$

Fonowned them, runs in your veins.

blood enough in nll their sick

to l'aris, in this eonquering vein .. I Menryl't iv

from cold and empity veins .......... Richurd III.

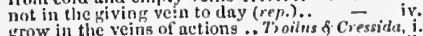

ruls the vein of him ................

every fiblse drop in her bawly veing
I am to-ilny i' the vein of ehivalry

the small inferine veins, from

the veins unflliel, nur biool is cold..

and here my bluest veing to kisa...h

ciul.' with blondy veins, expiceting

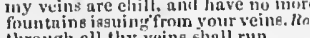

throngh nil thy veins ehall run.

fiuint enlal fene thrills through my veins

vilinerse itself through all the

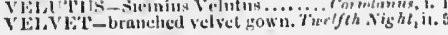

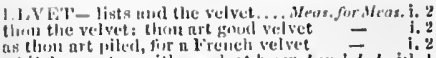

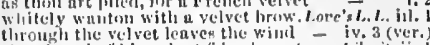

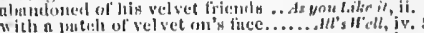
the velvet knows: but 'tis a gothlly (rep) - iv. a velvet dish; fic, tic! 'tis lewd.. 'Fuming of sh. iv. a velvet hose! a seurlet elonk! ....... inter's Tole, i.

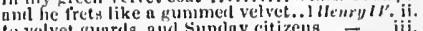

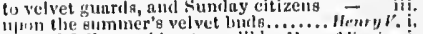

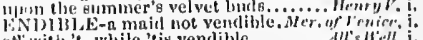

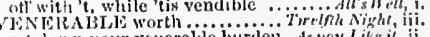

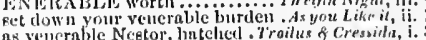
and thent most venerable man $\ldots \ldots .$. C.mmbeline, ii.

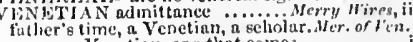
a young Yenctian, one that eomes.. and iny ol,l Ventian friend, salerio? that qhe Venetiun law eamnot impugn on the rea-hank with certuin Yenetian
my lord, has killed o young Venctian my lorde be known to the Venetiun stale.

a turhancd 'T'urk beat a Yenctian ...... VENLY-three veneys for a dish of.Merry Wives, i. I WNGE my Gloster's cleath .......
to 'venge me as I may, and to put have litierty to 'venge this

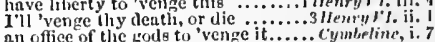
nether erimes 80 speedily ean veange!.... Lear, iv. none but I might venge my ... Romeo of Jutiet, ii. : a vengeanee on't thicte 'tis. Tu'oGen..nf Veroma, ii. 3 di) no vengeanee to me .. As you Like it, iv 3 (litter) a vengeance on your erafty .. Taming of Shrew, ii. 1 my present vengreance taken ....... Minier's Tule, i.

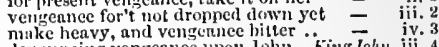

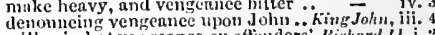
will rain hot vengeance on oftenders ${ }^{*}$. Richard $i$, i. I Eay, and a vengeance tool ......... I Henry 1 . Ii. for the lint venteance and the rod ... usenry ${ }^{\prime}$ ii. $\mathrm{i}$.

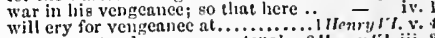
vengeance tend upon your steps I ..2 Ienry rI. iii. 2

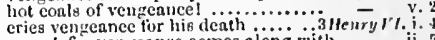
away! for vengeance comes along with - ii. s
shall teel the vengeance of my wrath doing wortlyy vengennce on thyself. llichart 11 : i. for he holds vengeanec in his hand.

and that same vengennee doth he.

vengeance on the head of Richard
sime vengennee on the Greeks.. T,

the vengeusice on the whole eampl
the venomed velageanee ride upon

weeping, eursing, vowing vengeance

What the vengeance, coull lie not speak

O rengennce, vengeancel............
it you should have ta'en vengeance on

ine, Wretch, more worth your vengealiee - ve

vengeanee is in my heart. death in. .. - ii.

and vengennee on me had the traitor Saturnine - iv. 3

hit vergeanec rot yont alt ........

wreakful rengennee on thy foes......

tuke vengeanee of euch kind of men
uithliolif the ventennce that they liad. rerirles, ii.

if' it be trite all vengenece eomes ins sliort. Lear, ij.

all the storch vencteances of heaven fall.. - ii.

I shall see the winget venfeanec overtake - iii.

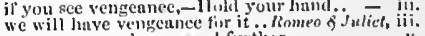

eant vengeance be pursteel furtlier ..... -

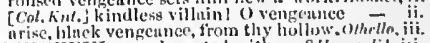

viNGis U s sord, rusted with....2 He

VENAl, do nothing, 'tis a veninl slip. OHello, iv.

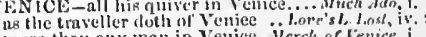

more than any man in Yenice...1erch. of fenice,
what my eredit ean in Ventec do.... -

usance here with us in Venice,$\ldots . .$. .

crediturs in my emmpany to venice.
fur were he ont of Ventise, I enu nake

what's the news from Ychice? .......

atrangers lave with us in Venice....

emmnon ferry which tracles (1) Venice

this atrict court of Vienice must neeili

there is no power in Ventice can alter

of Venice, eonfleate unto llie state (rep.) -

it is enather in the lnws of Cenite.....

diit rill from Venice, as far as .......

I will unto Yenice, to luyy (rep.). Taming of sh.

your shipur are staid ut vinnie

ilsul your futher was at velice

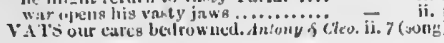


VENICE-at Venice, gave his body, Richarall. iv. this is Venice; my liouse is not a

a noble slip of Venice lantli seen

Thave bronght youl fiom veniee....

and a little more wit, return to Venice.

in Venice they do let heaven see .........

something from Venice. sure

the duke and senators of Venice grcet $y$

for that cunning whore of Venice

and the great messengers of Veniee stay

especiul commission come from Yellice.

and Destemona return again to Verice

VENISON-you ficen he, sir; d

I wished your venison better.

a hot venison pasty to dinner

lie, the go and the renison fir

firt..... Cymbeline, iin.

VENIT-videsne quis venit? ...... Love's $L$.

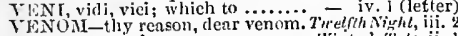

and yet partake no venom ...... Winter's Thite,
the venom clamours of a jealous. Comedy of Err.

that in time will venom breed

\&weltered venom sleeping got ...........
to whose venom somd the open ear. Iichard

fo whe like venom, where no

that suck nip thy venom ............

mingled with renom of

as venom toads, or lizards' dreadfui .3 Henry ${ }^{r} J$

his venom tooth will rankle to ..... Kichar

thirest the venom of your spleen
with tonine in venom steeped.

envenomel too! then, venom
VENONED spear; the which

or any ereeping venomed thing ....Richard

hy cliance esenpe your venomed stuck.. Humlet

VENind-MOUTHED, and I......... Henry lit. i.

witl 2 venomous wights she stays. Troilus \& Cress. iv. 2
and venomous to thine eyes......... Coriolanus, iv. I

poor venomus tool, be angry

venomous malice of my swelling..
reNUMOUSLY wilt thon spit nil

thinus sting his mind so venomonts
VENT-thon didst vent thy groans

in pr'y thee vent thy folig

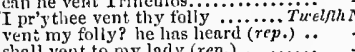

the which he vents in mangled ....... you Like it, ii.

thou ditst make tolerable vent of......All's Well, ii.

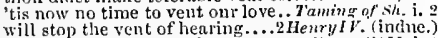

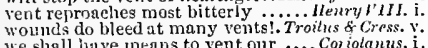

we shall have means to vent our .... Cor iol

waking, nudible, and tinll of vent

a vent of blood, and something

rliyme upon't, and vent it for a mocker

I can vent elamour from my thront

VENTED their complainings

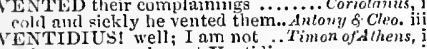

0 by ro means, honest Ventidius...

yn to Ventidius, pr'y thee, be not sad
Ventilius lately buried his father...

now Ventidins is weal thy too.........

entidius..........Antony \& Cleopatra, ii.

say to Ventidius, I would speak (rep

VENTPICLE of memory ........ Lave's L.Lost, iv.

VEN'TURE to depart alone. Turogen, of lcront, iv

misfortulie to my ventures

my vent:ures are not in one bottom
other ventures he hath equandered

other ventures he hath equandered

month or two, betore you vent

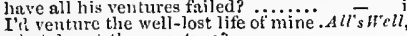

what clarest thou venture? ..........

renture madly on a desperate mart

thon darest venture to be drunk
thy personal venture in the rebeis'

thy personal venture in the rebels

so dare we venture thee, albcit

at a venture [Knt.-adventure]
sinee we are o'erset, venture again

there's a whole merehant's venture..

and so to the venture.

(epii.)
(epil.)

like merchants, ventme trade abroad... Heñ'y $V^{\prime}$

plnms well, that wouldst venture .2 Hewry VI.

the king will venture at it

if' it dn. I'll yenture one heave at him

I would, and yenture maidenhead for't

venture to seale't a little more...... C
ve had ratlier venture $n$ il his limbs for

cesnr, iv.

when it serves, or lose our ventures .Jut, Cosnr, iv.
with diseascd ventures, that play .... ('ymbeline,

if you lare venture in your own behalt . . Lerre, iv.

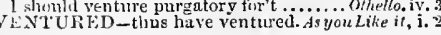

VENTURED-we ventured on such,..2 HenryIr. i. I
I have ventured, like little wanton. Henry VIII. iii. mrselt have ventured to speak

yet have I ventured to come and seek .. Lear, iii. ENTURING-'tis bot ventinring, Merry, Wives, iii.
VEN'TUROUS fairy that shall seek. Mid. N.'s Dr. iv. enterprize more venturous.......... Henry Vl. ii. I

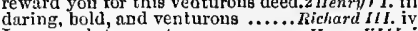
I am much too venturous

Hempest iv.

VENUS, or her son, as thou....

Much illo, iv. 1

the simplieity of Venus' doves. . Mid. N.'s Drean,

yonder Venus in her glimmering splicr

as gloriously as the Venus of the sky
then was Venus like her mother. Love's L. Lost,

fuster Venus' pigeons fly..... Nerehant of Ven
wieked bastard of Venus .......... As you Like

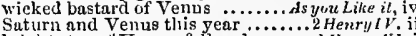

bright star of Venns, fallen down...... Hem Hemy

mortal Venus, the heart-hlood. 7
by Venus' harid I swear, no man

why then, for' Venus' sake, give....

Ewears still by Venus' glove........
his heart inflamed with Verus
what Venus did with Mars .........

laming the shrine of Venus.....

madum, though Venus govern ........ Titus Andron.

Eenk to my gossip Venus ....... Rom

ENUTO-bene venuto, mol to. Truning of Shreur.

Petruchio, I shall be your ben venuto
VER, the spring ................. Love's L.Losh, v. 2

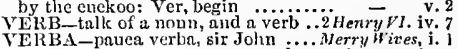

shall not say me nay, pauea verba Lovers L.Lost, iv.

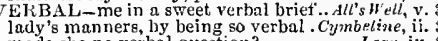

made she no verbal question?.

VERBATINI to rehearse
VERBOSITY finer thun

VERD-in my closet un boitier verd... Nerry LVives, i.

VERDICT-a party verdiet gave ..... hirhard IL.

must your bold verdiet enter talk

have given their verdiet up unto ... Richard $I I I$.
carries the due verdict with it...... Henry $V I I I$.

is't a verdict? No more talking on't. Coriotnums,

VERDUN of Alton, lord Cromwell... Henry VI. iv.
VERDURE-suek'd my verdure out.... Tempest,
i.

Josing his verdure even...... Two Gen.of Firoma, i. I

VERE-tlie lord Aubrey Ve

palabras, neighbour Verges (rep.)..... - iii.

stood on the extremest verge ....As yoth Like il, ij.

incaged in so small a verge $\ldots . \ldots . .$. . - i. - i. 1

the inelusive verge of golden metal. Richard 11I. iv. I
upon the benched verge......... T'imon of $A$ thens, v.

stand $s$ on the very verge of her confine ... Lear, ii. 4

Witinin a foot of the extreme verge ......

there are verier knaves desire to live. Cymbeline, $v 4$
VElliEST antic in the .. T'aming of Shrew, I (induc.)

think thou hast the veriest slirew . - v. 2

but yield me to the veriest hind ....... Cymbeline, v.

truly now may this be verified

Much ddo, v.

unless the adage must be verified.

the common voice, I see, is verified. Henry $V^{\prime} I I . \mathrm{v}$. 9

VERIFY onr title with their lives.... King John, ii. I

VERILY he had been langed. Taogen. of Ver. iv. 4

I verily did think that her old ...As yon Like it. iv.
verily, I speak it in the freedom.. Hinter's Tale, $\mathrm{i}$.

I may, not, verily. Verily! (re

a lady's verily is as potent

by your drend verily, one of them......

yes, verily, and in truth, you shall.... Henry $v^{\prime}$. v. 1

verily, I sweal, 'tis better to be lowly Henry $Y I I I$. ji. 3

VERITABLE; therefore look to't well . Othello, iii. A

VERITE, vous prononeez les mots ..... Henry r. iii.
VERITIES on thee made good ....... Hacbelh, iif.

VERI'TY - was a noise. that's verity..... Tempest, ii.
every syllable, a faitliful verity. Meas. for Mleas, iv

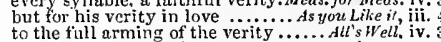

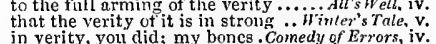

in yerity, you did; my bones. Comedy of Errors, iv.

't would prove the verity of
all the size that verity would

all the size that verity would ...... Coriolanus, v.

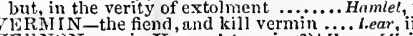

VERNON-colssin Vernon! (rep. iv. 3)I Jenry I $V$. iv.

but there is Mordake, Vernon
to the death, and Vernon too

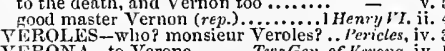

VERONA-to Verona ....... TwoGen. of Verona, iv.

from Verona baulsished $\ldots \ldots$ Verona shall not hold the

Vel.j Verona shall not hold thee....

how do yout all at Verona?

to Padna here, from old Verona!

boin in Verona, old Antonio's son ...
I am a gentleman of Verona, sir .
in fair V(rona (rep. i. 2).. Romeo \& Juliet, (prologue)
in

inade Verona's ancient eitizens....

here iu Verona, ladies of esteem
VERONA'S summer hath not such.. Romeo of Jul. i. 3 to say truth, Verona brags of him

henee from Verona art thou banislaed

there is no world without Veroun walls

news from Verona! how now, Balthaza

VERONESE, [Knt-Veronessa] Alichael . Othello,

VERSE_he writes verees ........... Merry Wires, iii.

in the even rond of a biank verse ..... Nuch dio, v.

feigning voice, verses of feigning. AJid.N.'s D, eam, i.

what, my soul, verses? .................

where I will prove those verses to. be

, I have verses too, I thank Biron - v. 2

I'll give you a verse to this note ... As you Lilie it, ji.

hang there my verse, in witness .... - iii.

the very false gallop of verses.

dids verses would bcar. That's no (rep.)

the rerse, and therefore stood (rep.)..

mar no more of my verses $\ldots \ldots \ldots . .$. .

when a nian's verses cannot be .......

an' you talk in blank verse ..........

sonr verse flowed with her beauty...̈inier's 7 'ale,

if you would put me to verses ......... llenry' '. v.

Troilus shall crown np the verse. Troilus \& Cress. iif. 2

live to have need of such a verse

that happy verse which aptly... Fimon of $\bar{A}$ thens, $i$.

Why, thy verse swells with stuff

for his bad verses, tear him (rep. .).Julius Cesar, iii.

tis a verse in Forace (rep.). Titns Andronicns, iv.
or the blank verse shall halt for't....... Iramiel, ii.

VERSING love to amorous Phillida. Nid. $N$.'s $s$. ii.

VESPER'S pageants ...... Anlony \& Cleopatra iv, i. 1

VESSEL - a brave vessel who had ...... Tempest, i. 2

to any erenture in the vessel .......... - i.

a bawbling vessel was he captain.........

having in that perished vessel... Meas, for Mte tus. jii. so is the weaker vessel ealled. .. Love's $L . L$. i. I (let.)
$I$ keep her as a vessel of thy law's .. i. I (let.) but my gentle vessel's side. . Merchant of
there misearried a yessel of our country

and not one vessel 'seape the dreadful - iij.

believing thee a vessel of too .........All's I'tell, ii. 3

never eaw a vessel of like sorrow. Hinter's 'Tale, iji. 3

I have a vessel rides fast by ...........

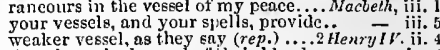

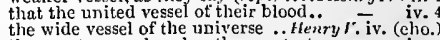
the wide vessel of the universe ..Henry $r$ iv. (cho. do a vessel follow that is new ..... Henry FIII. i. nature's fragile vessel dotli sustain ... v. as waves before a vessel under sail... Cंoriolnnus, ii.

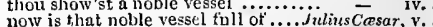
no vessel can peep forth $\ldots$. Anlony \& Cleopatra, $i$ these competitors, are in thy vessel ..
strike the vessels, ho! here is to Casar

to make your vessel nimble ........ Cymbetine, ii. most bravest vessel of the world...... - iv. their vessel shakes on Neptune's which his mortal vessel tears.... - iv. $\$$ (Gower our vesscl is of Tyre, in it the king .... as well to see the vessel thint's come in.. Othello,

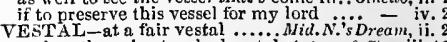
perjure the ne'er-touched vestai, dnilony \& Clen, iji. io a ve tal livery will I take me to ....... lerieles, iii. shall we go hear the vestals sing?...... $-\overline{\text { iv }}$ iv. 5 even in pure and veftal modesty $\ldots$...
VESTMIENTS his affections bait?. Comedy of Err.ii. 3 priests in loly vestments bleeding. Timon of Ath. iv. 3 this mand - from her vesture. Two Gent.of 'erona, ii. put the vapless vesture of humility . Coriolanus, it. I in the essential vesture of creation ..... Othello, ii. VETCHES-rye, barley, vetehes, oats. Tempest, iv. it hath no to vex me here?. Two Gen. of Verona, iv it hath po tongue to vex you. an injurs wonld vex a seint..? that doth vex my grieved sonl ........Richard IS. $\mathrm{i}$. yex not yourselt, nor strive not.

they may vex vour with shot............. il ij. not all these lords do vex me hialf ...2 Henry $V t$. i. if so thon thinkst, vex him with....3 Herry VI. ii. 6

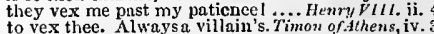
vex not his prescience $\ldots . .$. . Anlony f Cleopatra, i. which, as I say, to vex her, I will. Cymbeline, iii. 'twill vex thy soul to hear what.".

vex not his ghost: O let him pnss!........ Lear, v. vEXATION to your age . TwoGen. of Vierona, ii. vexations were but my trials ....... Tempest, iv.
full of vexation come 1 ........Mid.N.'s Dream, i. but as the fierce vexation of a dreain

do me most insupportable vexation...Al's Well, ii. 


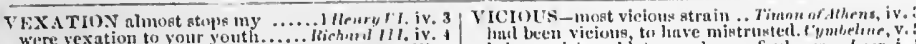

g ve him detersel vexation.

mit yourself with your vexation

Corrolisurs, iij. 3

fo

it is mo vicions liken, murber, or full

for some vicious mole of whe whice.

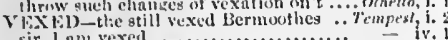
sir, L nn vexed .................iili..

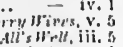
he's shrewilly vexed at something
goul vexed, bugin, alud why to mo.

vexed witl thy in!med iment

with my yexed spirits I ennino

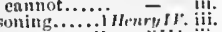

he is vexed it something.......... If

the nobifity are vexed

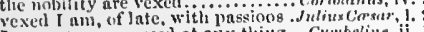

I am not more rexed at any thing.. Cymbeline, ii. 1

as mad as the vexed sea

heing vexel, an sen nourisherl...

, afore dod, r am so vexed .......

my por lwart so for a kinsman vexed - Trar, iii.

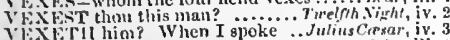

Vixifu the dull ear ................ King Joh

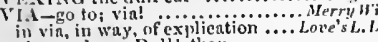

in, Kundman Dolli thou

ericd, vial we will do't, come ........

vial says the flent; Inayl... Nerchant of lenice, ii. 2

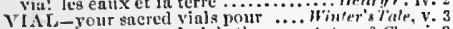

where be the snered vinls thou

the viul $[$ Kut.-viul] enee more
juiee of cursed helienon in a vial

juiee of cursed hehenon in a vial ....... Humlet, i. 5

be scasoned with such viands? ... Mer. of Truic

his vinmds snarkling in a golden....3 Henry $I^{\prime} I$. ii, 5

mur the remainder viants....
still entomeding the vianil

Coriolanus, i. 1

within there, anil our viunds.

Cymiseline, v. 5

onr viands had been poisonedl ....... Cymiseline, v.

viC.1li -proeure the vicar to stay . .ierry Wives, iv. 6

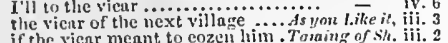

vicE- vour uld vice still.... Tico Gen. of i erons, iii.

liere fullow lier vices

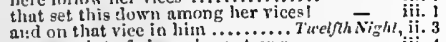

or any taint of viee, whose strong..... - iij. 4

like to the old vice.................

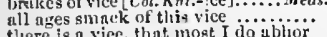

there is a viee, that most I do abtior
tlut skins the vice $0^{t}$ the top ..........

ha! fie these flthy viees! .

a merriment than a viee ...............

elothe a back, from such a filtiy vice

it is too general a vice, and se

the vice is of a grent kindred ..........
to weed my viee, and let his grow!

craft against vice I must apply

when viee nalses merey, nercy's....

vice Y'u should have spose ...... Love's L. Lost, v. 2

there is no viee so simple... Wereherwi of J'enire, iii. 2

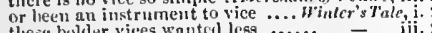

these bolder vices wantel less

apparel viee like virtue's .... Cornediy of Errors, iii,

nwre vices than it had thefore .......... Macbtth, iv. 3
all the purticulars of vice so grafied..

there is ro vire, hut beggary .........King John, ii.

t!at reverem vice. that grey ...... I Hewryll'

a 1 a eome but within my vice..:
okl inen are to this viee of lying!

now is this vicc's dagger become a squire- jii.

now is this vice diuger become a squer

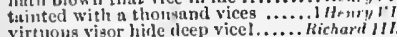

like the formal vice, iniquity.

Fo smonth betaubed his vice with .
what a viec were it in Ajax now. Froilws 8 Cress.ii. 3

ben

brother, you have a vice of merey.....
whut vice is that, goon troilus?.....

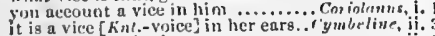
that tends in vice in man.

fin (event to vice they are not eongtaint

changing still one viec, hut of.

for vice repentud, is like the
in vise their law's their will

in vise their law"s their will

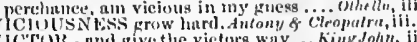

icroll-and give the vieturs way ... King John, ii.

lesign the vietsr'n chivalry

now we are vietors ......................

both theging to be vieturs.

ant tell ine, who is victor, York...... -

the strides they victors maje ......... Cymuletine,

althoush the vietor, we submit to Cxar -

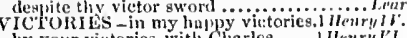

by your victories, with Charles ... Inenry Fl. iv.

Ill pawn my victories ........ Timon of shens,
VIC'TOR IOUs hand be feebled........ Kinn Jeht

a stem of that victorious stock

(leuryli.

brave eaptain, and victorions lordi.

Salisbury, and vietorinas Warwick

and so to arma, vietorious futler
victorious prince of York, before

tound with yicturious wreaths.

three sous with his victorious arm ...

your arms, be praised, victorious fiends - v

IRome, victorious in thy mourning. Titns, sdion.

gracious eonqueror, vietorious 'Titus

VIC'TORY is twice itself, when .........Much $A d o$, i.

the eumblusion is victory.. Lore's L. Lost, iv. 1 (letter

the victory till on us ...................hacbeth, i.

rietory, with little loss, doth play ...King John, ii.

kisslum with a glorious victory....... Richard II. I. 3

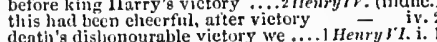

dentin's dislonourable victory we

after this golden day of victory .....
lieavens lave glory for this vietory!

二 iii.

St. George and vietory 1 .......

monument of the victory wili i bear.

God on our side doubt not of victory - iv. 8

return with vietory from the field..... 3 neñyly.

I doubt not, nucle, of our vietory

and cither victory, or else a grave...

to whom God will, there be ilie victory!

then am I sure of vietory

the liarder matched, the greater victury

graced with wreaths of victory

promise them success and victory...hi

should moust witl wings of victory

that we may maise thee in my victory

on! victoryl I promise you ..........

saint George! Riehmoud, and victory
upon them? victory sits on eur luims

be done to him thut vietory

brings a vittory in his pock

you have won a happy vietory to rome

he whined and roared nway your victorv

on my brows this wreath of victory. Julus Cresor,

your sword sit laureled vietory l...Anlony \& Cleo

why so sadly greet you our victory...... Cymbeline

to whom this wreath of vietory I give... Pericle
If you have victory, let the trumpiet ....... Lear,

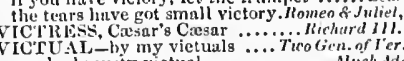

VICTUAI-hy my vietu

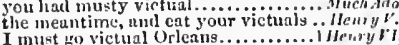

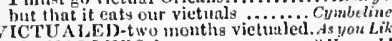

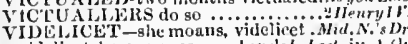

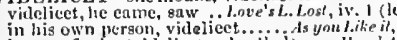

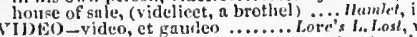

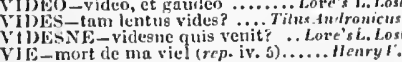

gardez ma vie, et je vous ..............
to vie strange forms with firev... Auiony
c cron.

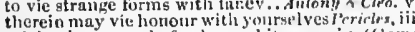

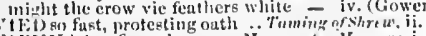

VIENNA he of worth $7 . . .$. Netsurefor Mras

and nerey in Vicnna live in thy

here in Vienna (rrp.ii. I and v. 11 ...

himld out in ticnna ten yeur ........

ns any in Viema, on my word ....... -

riliti-the letter to my view? . Tienfien. of Fir.

beum of her view gilded my foot... Memry Hirrs, slie matle pout ree at amy

u here they view themselves............. fors. Jeas.

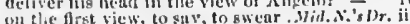

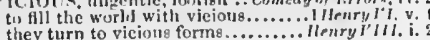

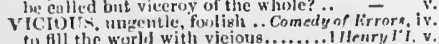

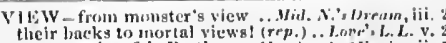

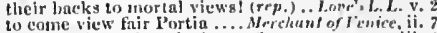

come firth to view the imase ol

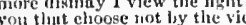

tion - iir, 2 (beroll)

at the flrt view, to you that kno

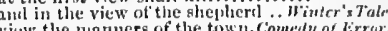

vir and downers of the tow n.

leath within my view, retaining........king John.

lere, in the view of men, I will

to view the sick and tecble piart

is retle to view their buttlo

to view thic fleld in safety..........
hefore tlis rayal view, whint rub

lords, view these letters ............

and view the Frenehmen how they..

protuelor, view the letter sent

I lost fuir Fngland's view, and bii,. .

gracious sovereign, view this body ..

let me view his visage being dead.

in the view of many lorda ...........
curat for blusling, view this face

cunst for blusting, view this face ..... Hichard III. i.
the liopeful nother at the view
delighit to view thy leinous deeds....

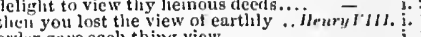

erave leave to view these ladies.........

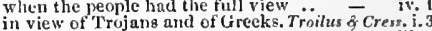

even to my tull of view........

I lave with exact view nerused.....̈ ivy

amorous view on the fair Cressid....

then Aufielius was within my view

would soar above the view of men. Julius Cersar.

and do invite you to my sister's a

and could net endure a further view

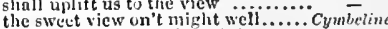

never winged from view o' the nest..

tread a course pretty and full of view

ntine eres are clnyed with vicw.. Titus.dnitron. iii.

countless eyes to view nen's ut.

with blondy views [Cols-veins], expecting - i.

never more to view nor day nor ligit...

love, 80 gentle in lis view......... Romeo \& Julict, $\mathrm{i}$.

thent love, whose view is milffed still

amongst view of many, mive .........

ligh on a stage be placetl to the vicw..
J never did like molestation view on

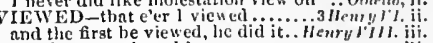

this day was viewed in opes

VIEWWST, beholdest, survesest.Lore s L.L. i. l let.

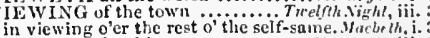

yontl, viewing his progress ........2 thrnryll, iij.

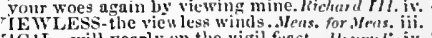

IGIL-will yearly on the vigil feast.. Ih mryl iv.

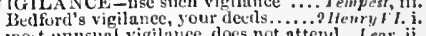

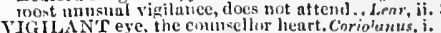

be vigilant [Col.-vigitant?, I besecel...Mnch dith, iii.

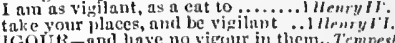

iGOitR-and liave no vigour in them.. Trimpest, i.

with all her double vigour, art.

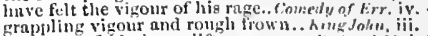

with a twofold virour lift me......... lichord is. i.

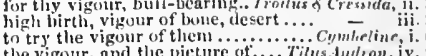

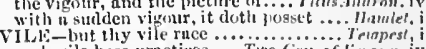

snch vile base practices.... Tiro firnt nf tromen, i

how file ill-tu vourced finilt

vile worm, hou wast o'erlonked Firens, $\overline{\text { inght, }}$ bij.

the vile eonelusion I now hegin. Mers. for . Mers. v.

eonfessed the vile encounters ..........

things base and vile, hithing
wake when fome vile thit:

low 1 th a worl is that vile name

wull, that vile wall (rep.).........

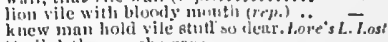

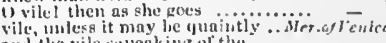

and the vile equenking ol the ..........

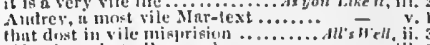

thil dosson that vile rusal

uit ls twenty such vile ters, A. . Taming of Shrere, ii.

with lier snost vile princip'wl...... Hin!er's Tule, ii. 


\section{VIL}

VILE offence, I'll utter what .. Comedy of Errors,
I tell him it was vile and bad ........

and a rabble more of vile conferierates
whom the vile blows and buttets of .. Mneheth. iti.
in such a love, so vile a lout

this vile drawing bias, this sway......

most base and vile concluding peace
by the inerit of vile gold, dross .......

in the vile prison of attlicted

makes nice of no vile hold

Four vile intent must needs...........
both our tougues held vile to name

there's no respect how vile.

of this vile politician, Bolingl.........

privilege with vile participation

but in vile apparel, and send you.....2 Henry

keeping such vile company

with Erebus and tortures vile ilso

why liest thon with the vile

strike sail to spirits of vile sortl

$O$ viper vile! the solins in thy

$O$ braggard vile, and damned furiois

is not so vile a sin, as self-neglecting

four or tive with vile reproach

be he ne'er so vile, this day stiall

of thy vile ontrageons crimes...

senff on, vile fiend, and shameless....

with other vile and ignominious ...
all 'long of this vile traitor Somerse

is more vile, tlian is a slave ..........
wicked and vile; and so her death

wreat men oft lie by vile bezonian

二

iii. 2

- iii.

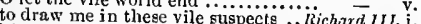

I bade the vile owl go learn me........ Troilus \& $\vec{c}$ ress

you vile abominable tent

recompense have praised the vile... Timon of $A$ th.

to illuminate so vile a thing ....... Coriniamins, i. I

dare the vile contagion of the night?

I can raise no inoney by vile means

hard hands of peasants their vile tras]

when your vile daggers hacked one.

by this vit

thy vile lady! she has robbed.. Antony \& $\overline{c l e o}$.

hence, vile one! Sir, it is you

more clement than vile men
only in killing creatires vile

only in killing creatures vile.

ind their vile vile fault be baked

should therein make me vile.

that can make vile things preciou.

Titus,indroñitus, v.

flesh and blood, my lord, is grown so

out, vile jelly! where is thy lustre now

quickly down to tame these vile offences

low stiff is my vile sense

liy some vile forfeit .......................

calm, lishonourable, yije the earth..

where are the vile beginnerg of this fray?

eontaining such vile matter, so fuiriy

stop thy unhallowed toil, vile Montague

with 1 vile and loathsome crust ............

[ $\mathrm{Knt}$.] damned light to their vile murther

and this vile deed we must

O thou vile king, give me my father

those whom this vile brawl distracted.
iny thoughts? why, say they are vile..
fall into sugh vile sirceess.

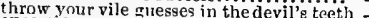

VILE-ESTEEMED [Col.] in fine .... I Henry $r I$. i. 4

an agate very vilely cut ............

vilely compiled, profound......... Love's L. Lost, v. 2

and prologue vilely penned

vilely in the morning (rep.)............

work, so noble, vilely bound un? Winter's Tale,

he speaks most vilely of you
doth it not show vilely in m

how vilely did you speak of me.

how vilely did you speak of me....... - ii.

how vilely doth this eynic rhymel. Coriolanus, iii. 1

duller Britain operate most vilely Cymbeline, v. 5

very doors and windows savour vilely. Pericles, iv. 6
VILENESS - a name; vileness is so.....All's Hell, ii. 3

VIIER thing upon the earth ... Timon of Allieus,
VIILST torture let my life............ All's Well,

the vilest stroke, that ever wail-eyed. King . fohn, iv. 3 two paces of the vilest earth .......IIIEnryIV.v. tor vilest things become ..... Autony \& Cleopntra, ii. 2
VILI-I tell you for good vill
VLLA...Merry Wives, iv. 5 more worthier than a village ......... in - iii. 3 her pale-faced villages with war..... Nichard $I I$. ii. nothing compelled from the viliages. Hervy $V$. iii. f go we in procession to the villag

Will not part with a village of it

等 poor pelting villages, sheep-cotes .......... Lear, ii. VILLAGER-rather be a villager...JuliusCremsar, i. 2 VILLAIN-'tis a villain, sil, I do not .. T'rmpest, ii. I
VILI AIN, forbear .......TwoGen of rerona, iji. these are the villains

peace, villain

gone but to masket, vilain .............. huse and cry, villain, go (rep.)

here cumes the little villain.......... Tirelfth $\overline{\text { Night }}$

thon thyself art a wicked viliain. iii. 4 (challenge)

bint precise villains they are

put your trial in the villain's inovith

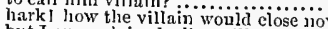

but I am a plain-dealing villain.....
not take pity of her, $x$ am a villail

for when ricl of villaing have need.

most like a liberal villain, confessed

God shonld go before such viliains....

was a villain. Write down (rep.)

villain! thou wilt be condemned into

villain, thon art full of piety

yuu are a villain, I jest not.

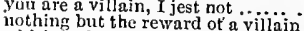

which is the villoin? let

no, not so, villain; thou beliest thyself

here, villain; drawn and ready.MLid.N.'s Dream, iij

villain, thou shalt fist ............ Love's $\bar{L}$. Lost

take away this villain; shut him up

why, villain, thon must know first

二 iii. 1

fair terms, and a villaiu's mind.

the villain Jew with outeries raised.

on me, villain? I am no villain ...As you Like it, i. 8

some villains of my court.............

villain, I say, knock me (rep.). Tamin

you rogues villain!-good Hortensio

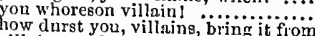

lay hands on the villain

ay hands on the villain

Ofine villain! (rep.) .......

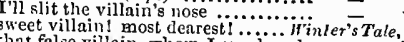

should a villain say so (rep.)

I knew the villain, I would la. nd-dainn

a trusty villain, sir ............ Comedy of $\overline{E_{3}}$

horn-mad, thou villain

villain, thon didst gave thee, villajn?

villain, thon didst deny the gold's

lere's a villain, that would face ine.

to Adriana, villain hie thee

ducats, villain, for a rope?

thou whoreson, senseless villain

dissembling villain, thon spealiest

out on thee, villain

thou art a villain, to impeach..................

a humary lean-faced a villain

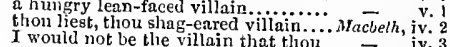

geese, villain? Sold iers, sir that thou

thou bloodier villain thin .....

not say so, villain, for thy life ........ King Joh

second a vil villain, get thee gone! (rep.) -

enongh to stifle such a villain up.

that villain lifubert told me, he did live -

a slanderous coward, and a villain .... Richar

from anse traitor, and injurious viliain -

O villains, vipers, dumned without...

I will nppeach the villain

Wence, villain; never more

villain, I'll make thee safe $\ldots . . . . . . .$.

'Was, villain, ere thy hand did set.....
villain, thy own hand gields tluy deatlı's

an' I do not, $I$ am a villain.

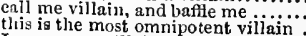

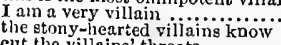

cut the villains' throats

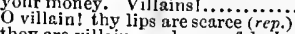

they are villains, and sons of darkness

other injuries but these, $\mathrm{I}$ am a viliain

nay, and the villains march wide $\ldots . .$. .

$O$ thou loneysuckle villain!

if the fat villain have not transforme

villains will make the word captain

than the nine worthies; ah, villain!

thy mother, thou paper-faced villai

he is a craven and a villain elise.......

lis reputation is as arrant a villain..

low now, sir? youl villainl

villains, answer you so the lord........

villilin, thou knowest, the law ......
a plugue upon that villain Somerset.
I am falsely aceut by a traitor villain. I Henry 'l.iv. 3 base dunghill villain, and nechanieal - Ilen'y $V t$. i. langh to see the villain rum away....

this villain here, being captain of.....

he's a villain, and a traitor ............

stand, villain, stand, or I'll fell...

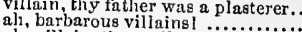

\author{
=
}

二 iv.

stiffe the villain wlose unstauncher. - iv. 10

determined to prove oloody canuibals! - v

villains, set down the corse ...........

a murderous villain, and so still thou art -

thus rashly in the villain's deathay!

they were fleshed villaing.............

dull unmindful villain, why stayest

I am a villain; yet I lie, I an not.

every tale condemns me for a villain

die I a villain then

blow, villain, till thy gphered............

that Greekisl whoremasterly viliain

your lordship's a gondly villain.. Tr - iv.

wheut a score of villains........ - iii. 6 (

whereat a villain's not a welcome guest - 6 iii.

always a villain's office, or a fool's

all villains, that do stand by thee....

to serve in meat to villains

must thou needs stand for a viliain in

assured, that he's a made-up villain

where thon art, two villains shall not be

where one villain is, then him abandon -

they were villains, murderers ....... Coriulius $C_{\text {Conar, }}$

O traitors, viltainsi o most bloody ...

villoins, yon dopched his body..... - iv.

villains, yon did not so, when your...

thon say so, villain, thou kill st. Antony s. Clco.

hence, horrible villain! or I'll spurn - ii

I am alone the villain of the earth ..

the villain would not stand me........ cymbelin

but that two villains, whose false oathe
thou then look'dst Jike a villain ....

vome villain, ay, and singular in....

villain, where is thy lady

all-worthy villain! discover where thy -

even there, thou vildain not be a villain

that vilhain hath mocked me

thou-breaker, a villain; yield thee.

thou villain. Cloten, thou double villain -

that's due to all the villains past
that caused a lesser villain tlian

every villain be called, Postliumu...

what villain was it spoke tliat word?

leave you botl like bloody villains....

stay, murderous villains! will yon.

find them but the empress villain?..

go, dras tle villain hither by

peace, villain, peacel even thus.

O detestable villain! eall'st thou.....

show me a villain that thself! ........

villains, forbear (rep.) $\ldots \ldots \ldots \ldots \ldots$.............

if a king bid a man be a villain

hyld, villaint a thou art a viliain

O villain Leonine, whom thou liast....

wooed a villain to attempt it ........

this villain of mine comes opinion (rep.).. Lear

find out this villain, Eumund

as if we were villains by necessity

some villain hath done me wrong.

now, Edmund, where's the villaini (rep.)

the villain shalened villainl would he

I will tread this unbolted viliain iiito.....

the villnin [Col. Knl,-traitor] Gloster .....

thy villain I Nay the

out, treacherous vil]ain! thou call'st.....

turn out that eyeless villain

villain, take my purse; if ever thou

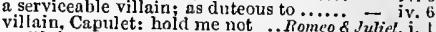

a villain. that is hither come in spite

it fits, when such a viliain is a guest

term than this-tliou art a villain ..

go, villain, fetch a surgeon. Couratre

Togue, a villain, that fights by the book =

a clamned saint, an honourable villain I

villain, didst thon kill my cousin? (rep.) -

the villain liyes which slanghtered (rep.)
tlat same villain, Romeo. Villain.. 


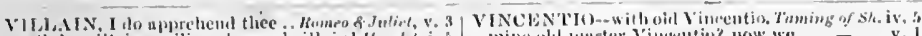

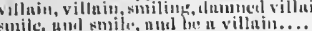
tlueres ne'er a villain, dwelling in ait.... whis calls me villain? loreaks suy jute. law wily villint remeless (rép.).

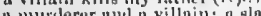
thou net is villain. You nre-11 I am a very villnin else.

ir some eternal villain, fome bu: Inow his gait, tis he;

I am spoiled, molone by vitioing

here's Cassio luyrt by villuims ............ lisprove this villuin, if thou be

previuns villain! 'Tlie wonum falls

tis a notorions villain: tuke you this...

I'll after that same villnin, for 'tis.

bring the villain forth. I look down
i) villain! Host heathenish, and most

meant to have sent this clammed viliain.

remains the ecusure of this hellisl villain
VIIIAIN-I.IKE, I lie; thut eaused . Cymb

vilden me truitor, villain-like he lics .... lrar, v

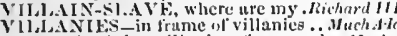

the multiplying villmies at nature do...Wnethe

given me notice of their vilianies...2Hemy r $t$. iit.

vie villunies of man will set lim. Timon of Alh. iit.

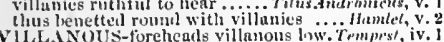

onl reeive this villunons wrons Nerry Whes,

runkest conipound of villanous smels

than the villunous ineoustancy of

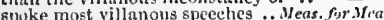

a secret and villanous contriver...As you Like

so young and so villakious this day....

thut villannus saltpet re should

the most villanous house in all.......

a villanous coward: go thy ways

there's villanous news al)road

but elictly, a villanous triek of $\ldots . .$.
whercin villanous, lut in all thing

whercin villanous, lut in all thinge?

company, villanous eompany, hath been -

no villanists lounty hat yet.

my cue is vitlinust melamelioly

to do sume villanous sliame ..... Romeo \& Jaliel, v. 3

that's villanous; and shows a most..... Huntel, iij. 2

U villanous! I have looked upon . . ....
villumous thoughts, Rotlerigo! when these

a closet lock und key of villanons seerets - iv. 2
the Hoor's abused by some most villauous - iv. 2

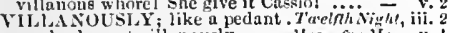

my loril, most villanously 7 iil...heas. for Mea

consent tu act any villany against him

villany, take your rapier

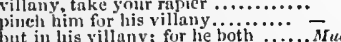

that any villany should be so deir:...

if it were possible any villuny should
hat elietty by my villany, which did

framed hy tiy villany. Aly villany.

nyy viliny ticy lave ullonl reeord.

and fled lie is uyon this villany.............

the villany you teach me.....Merehunt of revice

he hath ont-villnined villany so far . Al's I'ed, iv.

ny, there's the vilany ilila... Taming of shrea, iv. 1

let villany itself forswear 't .i....." Hinter's Tule, i.

fit for blome y villany, apt. liable

for villany is not without gucla rheum -

Fulatafl do, in the days of villang?...

unpay the villang yout have done ...2llouryl $\mathrm{l}$.

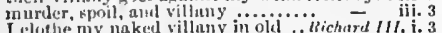

your tinces your recking villany, Timon of dth, iii.

eursed natures, lime direct villuny.

do, villasty, , do, sinee $y^{\circ} \mathrm{min}$ profess to $7 \mathrm{j}^{\circ} \mathrm{t}$

in me, 'tis villuny; in thee Aulony \& Cleopatr
shall be thouglit juit on firr villany . Cymathe

what villany sncer I bid thee do ....
roots us, but the villany of our fears

roots us, but the villany of our fea
und searn o' the onther's villariy?

und searn o' the rother's villury.

ifi. 5

by kind for raur and villany ..... Tilusdudron.

til viltany and veogente consectate

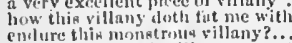

(1) villunyl luil let the ther ine locked .. llismlst, v. 2

.

villany, villany, villany! (rep,)

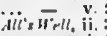

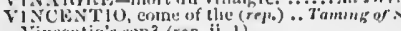

get a futher, called, sinposed Vinceintio -

Fet a futher.

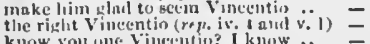

know you inc Vincentlin? 1 know

uny naute is

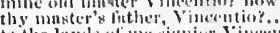

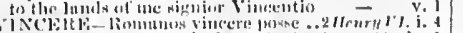

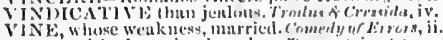
vines, with eluntering lomnelie's. Tompest, ir. I (somg

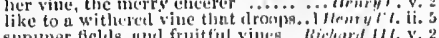

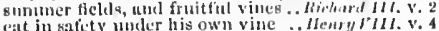
und like a vine grow to him.

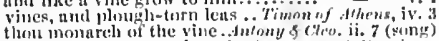

rott, with the incrensing vinet .... ('ty unbline, iv.

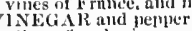

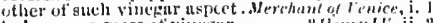

Vis borrow a mess of

VINEXANis lamd, til

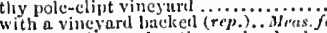

from the vincyard to the garlen leads

s. Henry I', iii. s

VIOl,-than an unstringed vi

you're a fair viol, and your selise ...... Percictes, $i$.

when Viula from her birth ..........

foldet the honour of my ehild.....

that violates the smallest branch... Love's $L$. Lost, i

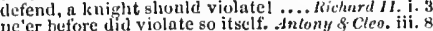

to violute my lady's honour .......... Cymbeline, $v$.

IOLA'TION of sacred ehastity... Meas. fur 31 fas. v. I

but by the violation of ing faith... W'inler's Tate, iv. 3

violation of all faith and troth ....... Henry 1 . . y. 1

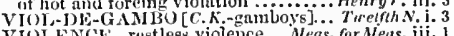

lest your justiee prove violence ... Mturter's Tate, ii. 1

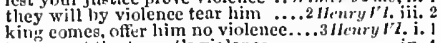
to prevent tie ty rant's violence....... nichardhi. iv. 4 to make an aet of tramic violunce ..... in - ii. 2 you ask with sueh a violence .....Henvy/III. iii. 2

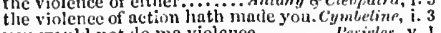
you would not do me violenee ......... Proriteles, v. I to offer it the show of violene.............llamlet, $\mathrm{i}$. $\mathrm{l}$

the violence of either grief or joy ........ = iii. 2 my downriglit violenee and storm ........ Othello, i. 3

IULENT proeeedings.

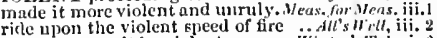

miglity, nust it be violent

his sides, with violent hefte.............

the expedition of iny violeut
upon a will and violent sea.

whiere violent sorrow seents ...........

scalded with my violent motion

ye liale me to a violent death

come violent hands were laid on (ref.) - iij. 2

to use violent thefts, and rob.

proud, violent, testy magistrate

poisonous where the disense is violet

almost inature for the violent breaking

such vinlent hands (rep.) .....Trilus dud

gome violent death they have

waves sor wind more vinlent ....

repair thuse vistent hums ............

violent delights lave violent ende......... $\bar{J}_{n t}$ iv. if

whose violent property foredoes itself.. Uhm

and le most violent author of lis own...

make your bouts more violent to that end - iv. 7

jarted with foul and violent tempest....

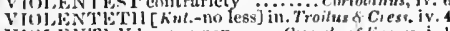

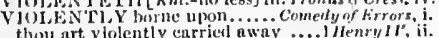

thou art violently curried away .... Inenryll, ii. 4

disehurget of breuth as violently. Haneo g. Jultet, y.

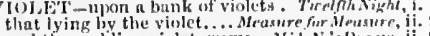

and the nodiling violet (rows... Blit. . S S Dream, ii.

daisies pied, and vinlets bluc. Lore s....ns', v.2 (kong

violet, dim, himt sweeter than.

who are the violeta now

kichmil tiv.

blowing below the violet, not wagging

the purple vollets. aud marigolds ..... Ire irtre, iv. I

a violet in the youth of primy nuture .. Hanklet, i.

and infouluted flesh may violete springi... my blo rly thonghts, with violent fuce .. - iii. 3

the vislet smells to him ................hentyl.

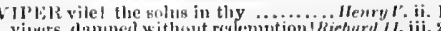
vigers, dumned withisut redemption! Riedard ll. iii.

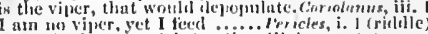

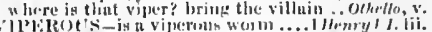
to desputeh this vijerous trait

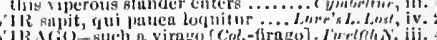

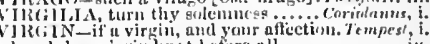
lreil $-i f$ to virgin, and your a
l,er virgin knot before all

white eold virgin snow upon my heart

hay with all virgins

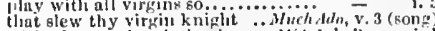

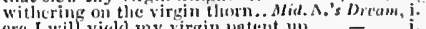

of nolile fort, would so ollewd a virtin

a sirgin. It was so varied (rep.) ... l.ore's l. l.ost, i.

by ihis virpin palm, now kissing 3 .

hist-regariled virgins of our elime

says the silver, with her virgin hue?
when he did redcem the virgin tribute

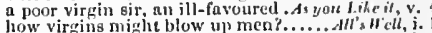

and tliere was never virgin got

is melal to make virgius ...........

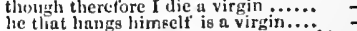

Diann, no qucen of virgins, thot would

a pror unlearned virgin, when

some precepts on this virgin ........ - iii.

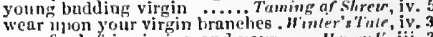

your fyesh fair virgins, and your ....Henty $r$. iii. 3

beguiling virgins with the broken seals - iv.

sweet virgin, for our good ............ Henry $/ \%$. iii.

a virgin from lier tender infine

foree a epotlcss virgin's cliastity..... 2 Henry $\%$. $v$

yet a virgin, a most unspotted lily. Henry III. v. virgins and hoys, niderge and Wrinkled cress. i. let not the virin's check make..'I'imon of $\mathrm{Ath}$. iv.
giving our loly virgins to the stain.. or the virgin volee that babies .... Coriolanus, iji. my masters, you fny she's a virgin? ... = iv. I still my virgin knot will kees.
but for this virgin that doth prop.

thy name, my most kind virgin? ....... Harale! $v$ VIRGIN Al, sliall be to me eren......2 itrury $r$. v. viritinal palms of your taughters ... Corinhums, v.

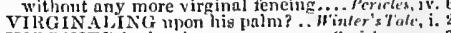
VIRGINED it e'er since $\ldots \ldots \ldots . . .$. Coriolanns, $y$. wnuld yield him my virginity.. seas. fol. Mrtes. in. and made defeat of her virginit y.....Much Atlo, iy.

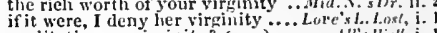
meditating on virginity? (rep.)......... All's liell, $\mathrm{i}$.

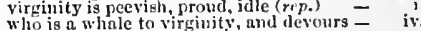
he does think he had not nig virginity - $\bar{y}$. age, with warrant if her virginity .... l'erictes, iv. crnek the glass of lue virumity ........... iv - iv.

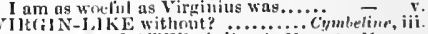

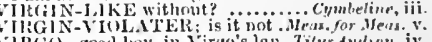

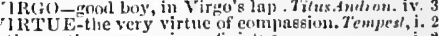
thy mother was a picee nt virtue ..... - i. is in virtue than in vengenuee ........ a sweet virtue in a maid

in specinl virtue, for the

she hath many nameless virtues $(r+\ldots)$.

nake a virtue of necessity $\ldots . . . . . . .$.

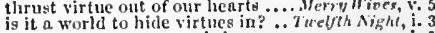

virtue that trangresses, is but.........

good my mouse of virtue, auswer me - i.

virtue is benuty.......................

for if our virtues did not go forth ....

Thelieve to be most strait in virtue.
and some by virtue full.................

from thee; even from thy virtuei..

your virtue hath a lieence in $t$......

liat it beendise a virtue...............

virtue is bold, nnd roolness uever

the whitest virtue strikes...........

grace to ftand, and virtue go ........
null truth in virtue, I an aftianced.

and I know her virtue .......

athe with all hinmomrable virties . s/uch dil

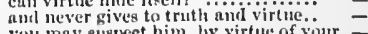

yoll may sugpeet him, hy virtue of your

can blot int llero's virtue

than we fhul the virtue, that pissession
by no inan's virtue, nor sufliciency.. 
VIRTUE-thy particular virtues

the trumpet of his own virtues ...... Mtuch Ado,
your virtue is my privilege....Mid.. N.'s Dream,
thy fair virtue's force periorce doth

and all the faitls, the virtuc of doth..

fair virtue's gloss, (it' virtue's.. .. Lore's L.Lo
of all that virtue love for virtie loved

the virtue of your eye must breal

your nick-name virtuc: vice you slönld

virtue's office never orcaks men's troth

some mark of virtue on his

I miglit in virtues, beauties, livings...

silence bestows that virtue on it, madam -

praise her for lier virtue

virtues, gentle master, are snnctified

slinll see thy virtue witnessed every

not cliange for your best virtue.

virtue is no horn-maker 0 ............

of necessity hold his virtue to it.....

they are vintues and traitors tio

when virtue's stcely bones look bleak

is a virtue of a good wing ..........

thou dislikest of virtue for the name

great additions swell, and virtue none

of your birth and virtue gives you...

reposing too far in his virtie, you

reposing too far in his virtie, whic

if they were not cherished by our virtues -

drunkemness is his best virtue.........

since you lack virtue, I will lose virtues -

by virtue specially to be aclieved....

this virtne, und this moral discipline
thy virtues spoke of, and thy beauty

her new-built virtue and obedience.:
for calumny will sear virtue itseif. Winler's $7^{-}$
when they have approved their virtues -
for which of his virtues it was

there's no virtue whipped was

my name put in the book of virtuei..

that must be i' the virtue of your...

her soher virtue, years ...... Comedy of Er

apparel vice like virtue, $\because$ larbinger.

with this strange virtue, le hat

upon the maideu virtue of the crown.K. King $\overline{J_{0} h}$,
should go in search of virtue ........

in beauty, virtue, hirth

my virtue then shall be, to say.

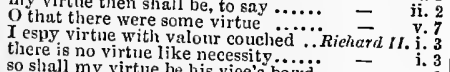

the virtue of this jest will be ..........

is there no virtue extant?

I see virtue in lis looks...............

a virtue that was never seen

virtue is of so little regard

graut that, my yoor virtue, grant.....

it is no hidden virtue of his fathe

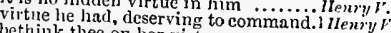

bethink thee on her virtues..........

if she liave forgot honour, and virtue.

virtue is choked with foul ambition
virtue is not regarded in ............

tove, virtne, that doth make them............

love, which virtue hegs, and virt
heauty's image, and thy virtue
root was fixed in rirtue.

the was fixed in rirtue s ground ...

daubed his vice witly sllow of virtue
your bounty, virtue. fair humility

two props of virtire for a christian

pawnel his knigintly virtue

by whose virtue (the court of Rome...

two reverend cardinal virtues.

two reverend cardinal virtues..........

you wrong your virtues with these.

the virtue; his fuults lie open...

Christendom shall ever speak his virtue -

weigl not, being of those virtues vace.

and. by that virtue. no man dare

by virtue of that ring, I take ..........
of wisdom, and fair virtue, than this

witlo all the virtucs that attend ....

is, as a virtue, fixed .......... Troilus \& Cressid

gentleness, virtue, youth, liberality...

a man distilled out of our virt

yet all his virtues, not virtuously...

and your virtues the fairer .............

as when his virtues slining upon.....
o let not virtne scek remunerntion.
in silence hold this virtue well

in silence hold this virtue well ......

as in grateful virtue I am bound. Timon

lumble suitor to your virtues (rep.).

getting his fate aside. of comely virtue
gainst the strcam of virtue they may

ii. 3
ii.. 3
iii. 3
iii. 3
VIRTUE-thy virtue set them into. Timan of All. iv
even to the altitude of his virtuc.

your virtue is, to make him wortliy..

like the virtmes which our divines $3 .$.

who lack not virtue, no, nor lower

the virtue of your name is not here

I know that virtue to be in you.... Jullius $\bar{C} \alpha$

the cliange to virtue, and to wortliness

by the right and virtue of my place...

according to his virtue let us use him

whose virtue, and whose.....4ntony \& alcopa!

let not the nice of virtue ..........
Lord of lords! 0 infinite virtue!

she esteemed him and his virtue
she holds her virtue still

gather their several virtues

compe told this tale for virtue

than they are to their virtues

as wonld take in some virtue.

the virtue which their own conseience

he was as ealm join with my request

the temple of virtue vire

seat, to virtue consecrate ....... Tititus...

sweet ccll of virtue and's best champion

eternal date, for virtue's praisel

virtues will, I hope, reflect on Rome

in fame that died in virtue's

virtue stoops and trembles at her frown

I'll show the virtue I have borne

Iheld it ever, virtuc and cunning were

thou art a piece of than

with other virtues, which $\mathrm{I}$ 'll keep from

thee and thy virtues lere $\mathrm{i}$ beize upon

all essay or taste of my virtue.

his virtue and obedience dnth this

and thou simular man of virtue that

all you unpublished virtues of the earth

trust to thy single virtue

friends shall taste the wages of their.......

many for many virtues excellent.. Romeo

virtue itself tirns vice, being misapplied
doth besmirch the virtue of his will ....

virtue itself 'seapes not calumninu

their virtues else, (be they as pure as grace

your virtues will bring lim to his wanted

Virtue cannot so inoculate our old stock.

salls virtue her own feature

to flaining youprite

forgive me this let virtue be as wax

virtue itself of vice must pardon beg

the sense and virtue of mine it not

my virtue, or my plague, be it either

if virtue nodelighted beauty lack

not in virtue to amend it. Virtue? $\ldots \ldots$ othello, $i$.

prizes the virtue that appears in $\mathrm{Cassio}^{\circ}$

so will I turn her virtue into piteh .......

the big wars, that make ambition virtue

whinse solid virtue the shot of aceident

that is a virtuous mind .. TwoGen. of Verona, iv, 4

the modest wife, the virtuous e........ Merry Hives, i.
what's she? A virtuous maid

yet $I$ suppose him virtuous ...........

a very virtuous maid (rep.).Measure for

as it is virtuous to be constant in any

another virtunis; yet I am well....
virtuous, or I'll never cheapen her

out of all suspicion, she is virtuous

a virtuous bachelor and a maid.... Mid.

whose liqunar lath this virtuous property

i. 5

your father was ever virtuous ..... Ner s.thost, it.

seen more virtmous, when she is ... As you Like it, $\mathrm{i}$,

why are ynu virtuous?

mind corriestind is virtuous

aged honour cites a virtuous yoult

one fair and virtuous mistress fall.

place when virtuous thing ..........

Ali's Well, iv.

a maid too virtuous for the contempt

ii. 3
ii. 3
ii. 3

death of the most virtuous gentlewoman - iii. 2

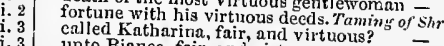

unto Bianca, fair, and virtuous

a virtious and a reverend lady ... Cnmed $\overrightarrow{ }$ iii. 2

a good and virtnous nature may recoil. Wuebelh,jv. 3

and yet there is a virtuous man ..... King Jonry $I V$, iij.

need to be; virtuous enoug

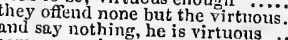

come, you virtuous, is virtuous ....2 2 Henry $3 r$ rii.

virtuous, civil gentlewoman? $($ rep. $) ..$ - ii. 2

from every flower the virtuous swect
VIRTUOUS Joan of Are ........... llenry Fl. ii. 2

gond lords, and virtwous Henry

aliant and virturus, full of haughty

of kings; virtuous, and loly..........

I mean, of virtuous choste inter

nephew, virtuous Henry (rep. $y$. 1) . .

the duke is virtuous, mild

my son my virtuous deeds bejind.... - ii

ii. 1 that virtuons lady Bond ..3 Jenry VI, ii.

v. 5 famed for virtuous (rep.)

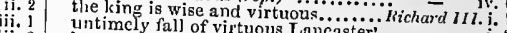

lie was gentie, mild, and Lirtucaster...

virtuous and a christian-like concinsion -

had virtuous uncles to protect vicel

tluis virtuous prince take on himself

virtuous and fair, royal and gracious

he was so virtum, kept him .....

a fool, for he would needs be virtuous

What though I know her virtuous ...
the archbishop's, the virtnous Crannier

to give lier virtuons breeding

O virtuous fight, when riglit... Troilus \& $\overline{\text { Cress. }}$ ivi.

thy honourable virtuous lord.. Timon of Athens, iii.

takes ocasion were not virtuous .... - iii.

account me the more virtuous........ Coriolanus, ii.

lo, thougl it were as virtnous to iie - v.

more fair, virtuous, wise, chaste....... Cymbeline

bal quarrel slain a virtuoughter....

as of a most virtuous princess ... Titus Aa $\bar{a}$ ron. $\mathrm{i}$.

then, as you are virtuous as fair ........ Pericles, ij.

a plot upon her virtuous liusband's lif.. - iv.

virtuous and well-governed youth. Romeo \& Juiiet, iv.

a good Jady, aud a wise, and a virtuous - Juiet,

the virtuous Desdems: where is Jour - ii. 5

by your virtuous meane more virtuous - iii. 3

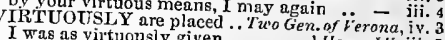

I was as virtuously given .......... I Heriny $/$. iii. 3
not virtuously on his own part.. Trnilus of Cress, ii. 3

that mean virtuously, and yet do so.... Othello, i. 2

SAGE - bears in his visage no... To.... Othello, iv.

satisfy the gise and deliberate..... Meas. for Meas. iii.

show your knave's visage, with ....... $\quad$ - iv.

mine eyes do loath this visage nowl ... N . Dream, $\mathrm{j}$.

with visages displayed, to talk.... Love's $\overline{L . L a s t}, v$.

whose visages do cream and mantle.Mer.of Ven. $\mathrm{i}$.
witi blenred visages come forth

looks in her with an importing visg. ge. All's $^{-} W_{\text {ell. }}$ v.

$m y$ trespass by its own visage .... Hinler's T iale, $\mathrm{x}$.
lides not his visage from

desiring eyes upon his visage $\ldots \ldots \ldots$. nichard $t r . v$.

on the visage of the times ${ }_{\text {put }}$.

and untempering effect of my visnge... Henry $V . v_{\text {. }}$.

let me view his visage being dead....2 Henry $r t$. v. 2

there is more in it than fair visage. ilenry 1 . II. iij. 2
and to behold bis visage .... Troilus \& Cressida,

aspect, a visage of demand... Troilus \& Cressida, iii.

to mask thy monstrous visage!....... Cortius Canus, i. 9

plough thy visnge up with her...Antony \& Cleo. iv. 10 a pla flay thy wolfsh visage ............... Lear, $i .4$ a case to put my visage in ...... Romeo \&.Juliet, i. 2

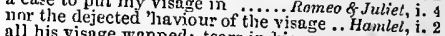
all his visage wanned; tears in lis eyes .. Hamlel, with devotion's visage, and pions action with tristful visage, as agninst... trimmed in forms and visages of duty.... othello, $i$. that was as fresh as Dian's visage......... thou visible god, that solder'st... Timon of thon visible god, that solder'st.. Timon of Athers, iv. 3 though bis actions were not visible.Cymbrline, iii, 4 VISIBLY character'd and................... Lear, iv. the baseless fubric of this vision. .... Tempest, iv. is this a vision? Is this a dream? ........ what visions have I seen 1 ................ 's Dream, iit. $X$ lave had a most rare vision.....

while these visions did appear ...... $-\overline{\text { (enilngue) }}$ to a vision so apparent, rumour... T'inter's Tale, i. which by a vision sent to her from .... Whencheth, ij. and, in a vision tull of najesty...... it was a vision, fair, and fortunate.JuliusCasar, y. the very gods showed me a vision .. Cymbeline, iv. 2 I bless thee for thy vision ............... Pericles, v. 3

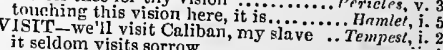
whilst I visit young Ferdinand.......... will visit thee with mine... Tu o Gen. of rerona,. .

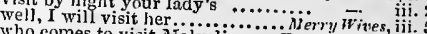

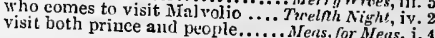




\section{VIS}

VISIT-to visit the a fltieterl s. ere long l'Il visit you n:min. Im going to visit the prisoner...... Iremils visit the ut the lodge o-horrow gliull we visit your hignin chat. but what, cume they to visit we eame to vfsit yoll; and purpose

ve will visit you at supper time is friencls visit his eountrymen. ?

not I, believe ine, thus I'll visit lier.

visit $\mathrm{B}$ oh

to visit the next rom, l'll presentl

and on mine, she should not visit you

onee nday 1 'll visit the eliancl

at supper-tine i'll visit you .. Crumethy of Firrars, iii.

with all good syced at Plaslyy visit...

to entrent your minjesty to visit lim

let'a all go visit him:

means to visit us ................. I Henry $I T$.

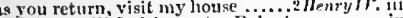

and there will I visit master Rohert.. $r$. iv. (choris)

to visit her poor eastle wiere.......... I idenry $/$ l. ii.

sort some otlier time to visit you ...... Richard JI. iii. 7

to visit him to-morrow

RichardIJ. iii.

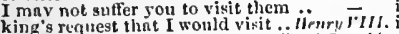

Diomed, visit me no more . Troilus \& cressidn

newly alighted, and come to visit.

lady Valerin is come to visit you...

y'ou must go visit the good larty...

ar rudely visit them in parts

drops that yisit my sad heart

content to visit otlier plnces

When lnst I went to visit her........ Cymbrline, iit.

bou know not why we eame to visit youl. lear, it.

visic hier face too roughly

twixt eleven and twelve, i ili visit you.... - i. 2

before you visit him to nake cnquiry of

to visit my too miseli changed son ......

VIsITATION shows it................ Pempest, vou have lent him visitution ...Meas. for veats. iii. 2 but pence, and gentle visitation ...ate's $L_{-}$l.ost, v to pay Bohemia the visitation .....' Wiater's Tale, i. $\mathrm{i}$

tis a vitation tramell but forced

and in the visitntiou of the winds..2trenry $l Y$. iii.

negleet the visitution of my friends. Rschard $1 / I$. iii.

Wulsey, here makes visitution .....

give thee nightly visitation. Trailus \&. Cressida, iv. and your several visitations ..... nothing at this the bill my receive snch..... Hamlel your visitation shall reeei ve snch.

this visitation is but to whet thy almost dny's aproach look to be visited. Mu. N.'s Dr these lords are visited; y'ou are ... Love's L. J.ost. Y. sloult be visited upon me..Merchant of lenice, iii. s visited that removed house

but strangely visited people, ali swoln. Mucbeth, iv. sins are visiled in this poor elild.... Kiny Joh ere he by siekness had been visited. Thenryly. iv. the gnond patricians must be visited. Corinlauus, no are cone from visiting his mujesty . Richard III. i. apnertainments, visiting of him. Th aitus f' Cress. ii. 3 in this city visiting the sick ...... Kanten t. Juliel, y. 2 ISITUR will not give him o'er so .... Tempest, it. ! from the aceess of gentle visitors! IInter's Tate, i.
this great flood of visitors ...... Timon of Athens, i. this great flood of visiters...... Timon of Ametrs, i. why - mour visor should be thatehed a.hy, then your visor should be...... -

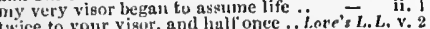
what, was your visur made without.

aftord iny elvecchless visur lialt

or ever, nut in visors, show their frees?

which of the visors was it (rep.).

then, that visor that super to my friend

I lave visors for you all

our visors sece we; on with your visors $=$ i.

against that Vikor; thut Visor is all ilichar $\bar{T}$ III. $\mathrm{ii}$.

no visor does lhecome hlack... I'eriches, iv. 4 (Goner)

a vieor for a vlsor! what care I ... Homeo of Juter,

YIS()It-I,IKE, unchanging ..........3 Henry ['l

Y'TA-tlie word, lux tua vita nilit..... Pericles, it. IT E-integer vitas, seclerisque.. Tilus Aniron. iv. let not Burdolyling vitnl thread be ..... Wenry J'. lii. 6 tune bereft my vital powers........2ilenry $f^{\prime}$. iii. 2 glall scize each vital spirit .......... VITNES - bear vitnes that me ...Merry Mives, ii.

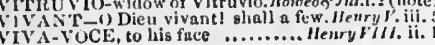

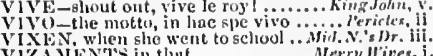

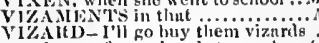

mak our taces vizards to our liearts. Warbeth, iii. IZA IIDED-maskel and vizarded., Merry "W'ives, iv. 6 verree being vizarded a...... Troilus \& Cressida, nud full of eribes nud vloutiug-stoss

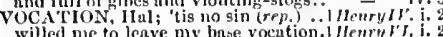
labour in thy vocation

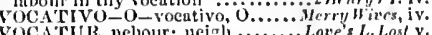
Vorce-1 bhould know that roiee ..... Tempest, ii. four lega, and two voices

his baekwurd voiec is to niter.

to know him by his voice. TroGen. of Vrroma, iv.
the hardest voice of her behaviour. Merry lives, i. 3

let me have thy voice.................

in voices well divulged $\ldots \ldots$

nny mitigation or remorse of roice?..

my matter hath no voiee, lady

to him in thine own voice.

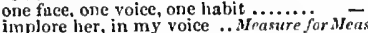

it is a man's voice....................

dit ut ter forth a voice

by the sound of your voice ..........

tax not so bad a voice to slander ......Much Alo, ii. 3

with feigning voice nischief

wanting your fatle, yoice.

my ear should enteh your voice........

but I will aggravate my voice so

our sides, voices, and ninds

forlow ny voice........................

I sce a voice: now wil I to the ........

thy voice his dreadtul thunler

seasoned withl a gracions voice

of man and boy, with a reel voice....

the duke only, gainst all other voice
thint is the voice, or 1 am muel. ......

the cuckoo, by the bad voice .........

$\mathrm{my}$ voice is ranged

and his big manly voice

the only preludes to a bad yoice?

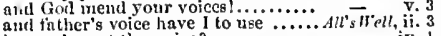

the grace, yoice, gait.... Taming of shrew. 1 (induc.)

thou not know iny voice? (rep.).. Comedy of Rrr. y. 1

I hearl a voice ery, sleep no inorel..... Hacteth, ii. 2

my voice is in my sword

whose voices I desire alnud ..................

thinking lis voice an armed Englishman

政 2

boys, with women's voiees, strive... Michard 11. ii. 2

for my voice, 1 have lo

in a the voice and echo vo.............

the ingagined voice of God himseif

which, delivered o'er to the voice.

hath got the voice in hell

the ditke will hear thy voice

and our voice is inperial

full a voice issue from so cmpty....

haply, a woman's voiec may do fome

having neither the voice

is it you whose voice I hear?

passage of $m y$ poisoned roice

witl one ehecrful voice welcome

mysclf lave heard n voice to eall him so -

that with lis grumbling voiee ......3 3h.nry!

that I'll give my voice th Irichn rd's sicle -
in the duke's behal' l'll give my voiee -

I menn, your voice, for crowning ....

miseries have ernzed ray voice ......

than by a single voice ................. ilenry
wliat warlike voice? and to whint end

your feruple to the voice of Christentom -

linve their free voiees ................ -
voice is now only about lier eoronation -

voice is now only about her
well, the voice goes, madam

by all voiees, that furtha'ith ........

author't pen, or aetor's voice. Trorlus of Cress. (proi.)

lier elicel, her gait, her voice.....

erowns with an imperial voite .......
which with one voiec call Aganemion

sentl thy brass voice tlirougli all

to the voice of any true decision

In secontl voiee we'll not $\ldots 7 . . .$.

theverbates the voice of lions

revek my clur voice with subis

divided by any volice or order........
VoICF-nud voice, which you do. Troins fo Crest. y. 3 in a joint nut corjorate voice.. Timon of dillena

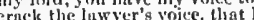

I shall Inck voice; the deede of

sir, the prople must have their

ate you ail reselved to rive your vicen

in giving him our own voices with our =

your gool voice, sir; what suy your

may stand with the tune of your voiecs

therefore give you cur voiecs leart:ly

mont sweet voires! leeter it is to dic

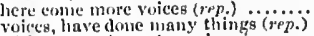

without any honest mnn's vice

worthy voiece! You have stoud

he lias our voices, sir (rep.)

to yield your volees? (rep.) ............

have five hundred voice of that soind
arninst the grain to voice lim eonsul
have I hat ehildren's yoices! (rep.)..

have I hat ehildren's voicest (rep.)

one, that spealss thus, their voice? (rep.) -

of all the voiecs tliat we liave procured

sulmit you to the people's voices

wassed for consul with fuil voice

ly the voice of slaves to be $\ldots . .$.

and pay you for rour voices.

you na goonly things, sou roices

is there no voice more worthy than..

ll he as etrong

ithoice and utteranee of my tonirue

with a monareh's voiee, ery havock
took his voice who slould be prieked

it is not Ciesar's natural voice....

$[k w$.$] it is a voiec in her ears.......$

nor the voice of unpaved ennueh

nor my voice for thy preferment....

our voiees have got the mannish ernek

linve, by commont voice, in elcetion. Tit
I ask your voices, and your suffrages

with voices and appla use of every sort

the eommon voice do ery, it shanl.
druwn her pieture with miy voice....

voice anth fu vour! you are,
the voice of dead 'Thaisa!

beggn rs, who with roaring voices, stijke. . Lenr, ii. 3

poor tom in the voice of u nightingale

I know that roice. IIn! Gonerili........... = iv.

her voice was ever solt, gentle, and low . Z v.

consent and fair aceording voice.. Mameo $\&$ Jutiel, i.

hy his voice, sliould be a Mintagne.

[Col.] make her airy yoice more honise -

clingerl vorees too! since arm (rep.)
slould he tlie voice of friar John

last any sount, or use of voice

to the Dane, and lose your voice $\ldots \ldots$.

thin the main voice of Denn

your voice, like a piece of uneurrenit....

a broken voice, ond his whole function

you huve the voice of the king himsclf

I hnse a voiec and preetlent of pence

on Fortinbras he has my dying voice

whose voice will draw on more .......

a voiec potential as double as the duke's

let me find a charter in your voice

your voices [ Knt.-liave ycur viee] ....
the voiee of Cassio: Iago kerps lis worl

$[\mathrm{K} n t$.] the volce is very ilircfinl $; \ldots \ldots . . .$.

ont. nnil alas! that was my lady's voice - v.

()ID of all profanution............

you, that did voil your rhenth. Ale ch. of Finice,

crell so void is your fin of any dram

doth spit abul void his rlecuu unon

lope you are not the flelel

iltenty

3hemry' l. iii.

mpon whee age we void it un.. Timnn of Alhens, i.

FIDED-Would have voluded thee. Coriolanus, is:

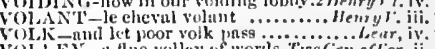

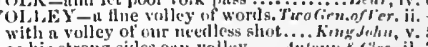

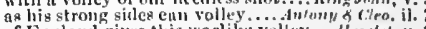

of Entlant gives this warlike volicy . Humtert, v.

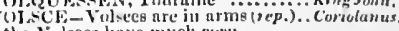

the Voleces sliunning lim

the volsees luwe an nrny lirth....... =

Thies of the Voltees lickl mine in elines

whieh of yu bue is timur visloces?

I eaunot, being a Volkec, be that $i$ nin

having determined of the Volsces....

go then the Vulsees stanel but.........

ditl eure ngninst the Yulster, for thicy $=$

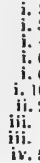


VOLCES with two several powers ... Coriolan the Volsces dare break with us ....... -
let the Volsces plongh Rome, and hiarrow Aufidius, and you Yolsees, mark Thilie the Volrces the Voisces

the Volsees are dislodged, this mercy I fluttered your Volsees in Corioli

a nalAN-from the Volscian state to see Romans an as to the Volseians' Mareius should be joined witl? Volscinne good husbandry for the Volsciun state
my remission lies in Volscian breasts you must report to the Voiscian lords

vol tellow had a Volscian to his mother

say, Voltimand, whet from our brother.

LUBILITY, that you would think. Ali's " Well, iv. 3

then rll eommend her volubility. Taming of $S$.
vor,UBLE is his discourse

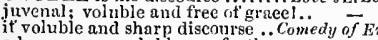

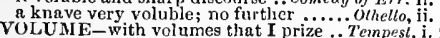

Yolumes of report run with these. Meas. for Mo a eas. iy.

I am for whole volumes in folio ... Love's L. Lost, $\mathrm{i} .2$

within the volume of which tim
this brief into as lunge a volume

have had a volume of firrewells

the nature of a tragic volume.......... Richenriy $I$ H.

wonld make a volume of enticing...1 Henry VI

will bear the knave by the volume.

place upon the volume of your deeds . Cymbeline,

what the volume of young Paris'... Romeo \& Juliet, i. 3

the book and volume of my hrain lie.... Hamlet, i. 5

VOLUMNIA is worth of consuls

Volumnius: thou see'st the world (vep.) - vesar, v. 5

VOLUNTA BY ehoosing .... Merehant ang

themselves in to volun tary exile... As you tike it

heaven be thanked, it is but voluntary

we swear a voluntary zeal............

I serve here voluntary (rep.). Triitus \& Cressida,

me self a voluntary wound here. . . Jullius $\overline{\text { cessar }}$, ii. 1

or volut

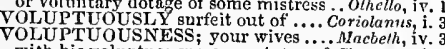

with his voluptnousness.... Anlony \& Cleopatre

VOMIT-eat thy dead vomit

$o^{\prime}$ er-eloyed country vomits forth....... Richard III. $\mathrm{v}$.

slould make desire vomit emptiness. Cymbeline

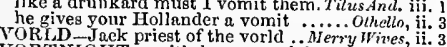

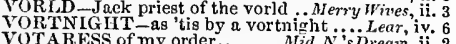

atA the imperial votaress passed on

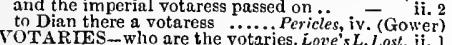

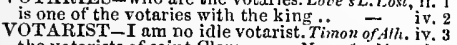

the votarists of saint Clare ......... M eass, for or Afeas. $\mathrm{i}$.

would half have corrupted a votarist... Olhello,
VOTARY to fond desire? .... Tico Gen of Verona

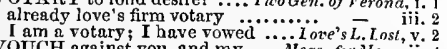

voUCH against you, and my ........ Meas. for ileas.

What law does vouch inine own........All's $\overrightarrow{\mathrm{r}}_{\text {ell }}$,

and make my vouch as strong........ Henry $\boldsymbol{I}^{\prime} I 11$. .

will vouch the truth of it

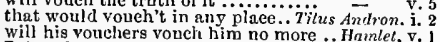

I therefore youch again, that with ....... Othella,,$i .3$

to vouch this, is no proof ; withont more
voueh with me, heaven, I therefore.

put on the very voueh of malice itself

a certainty, vouehed froin on

Teinprst, ii.

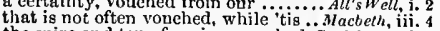

the spire and top of praises vouelicd. Coriolan us, $\mathrm{i}$.

his double vouchers, his recoveries....... Hainlet, vit

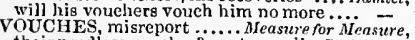

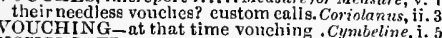

VOUCHSAFE my prayer may know . Cymberine, i. 5

vouchsafe me jet your pict

vhall I vouchsafe your worship.........

and I"ll vouehsafe thee the hearing..

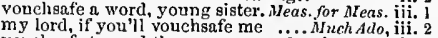
vouehsafe to read the purpose..... Love's L.Losi, ii. heavenly spirits, vouchsafe not to behold -
vonchsafe to show the sunsline (rep.)

vonchsafe to show the sunshine (rep.)
vounchase sorme motion to it (rep.)

will you vouebsafe with me to chinge

that she vouchsafe me audience for

that you vouchsafe in your rieh

mighty duke, vouchsafe me (rep.) Comedy of $E_{r r}$ v. v.

Freneh, amazed, vonchsafe a parle .King John,

great king; vouchsafe a while to stay

if thou vouchsafe theim; bnt, if' not.

if you vouchsafe me hearing ...... i Henryy $l r$. iv.

vouchsufe to those that have not. ileary $r$. v. (elio.)

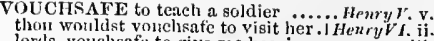
Jords, vouclsafe to give me hearing
larby, vouchsafe to listen what I say

Miar'garet do vouchsofe to come say

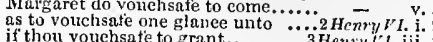

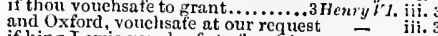

and Oxford, vonchisate at our request
if king Lewis vouehsafe to turnish u

vouchsate, divine perfection (rep.)..Richard III. i.

vannot vouelssafe this burden...

beseeel your lordship, vouehs a..... Henry r'III. ii. 3

will you vourehsate ne a word?. Troithes \& Cress
voucheafe my labour, and long. Timon of Athe

beseech your lonour vouchsafe me a word

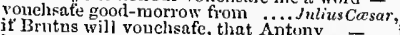

but she vouchsafes no notiee .......... Cymbeline, ii. 3

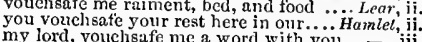

your lordsliph would vouch safe tle answer- v. 2

odours, pregnant, and vouchisafed.
but that you have youelsafed

or vonchsafed to think he had..... Antony \& 8 Cleo. i. 4
yOUCHSAFING here to visit me ....

VOUTSAFE me, look you ............. Ilenry $r$ r iii. 2
VOW-or else good niglt your vowi ... Tempesi, iv. 1

whose vows are, that no ................
unheedfnl vows may

unbeedfnl vows may f.....Tu

Ieceived so many with thy vow......

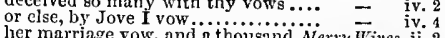

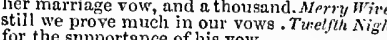

for the supportance of his vow

swallowed bis vows whole

by the vow of mine order

as words could make un vory

or to a vow of single life ........ Miä. N.'s $\overline{D r}$ eat

when $I$ vow, $I$ ween; and vows so boorn

your vows, to her and me, put ......... =

to vow, and swear, and superpraise my $\overline{\text { Navarre hath made a vow }}$ iii...... Love's

vows, for thee broke (rep.)

三...

to break the vow I am enga

a vow to study, lords $(r e p$.
the

and so hold your vow

she made me wow, that 1 s should

her soll with many vows of filth

I am falser than vows made in

sle thought, I dare vow for he
blessing upon your vows $1 . .$.
with sainted vow my fanlts.....

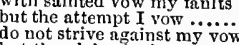

but the plain single vow............

fou give away heaver's vows

for $I$ hy vow am so embodied yours

and here I firmly vow, never..
henceforth I vow it shall be so

you put me off with limber vows "... iriuter's $T_{0}$ jv.

so long I daily vow to use
but it does fulfil niy vow

and made between's by vow

with a deep-divorcing vow?

and vows, if he can take you

all religious strength of sacred vows. King $\overline{\text { Sohn }}$,

that doth make vows ke to

thy latter vows, against thy first

I make a vow, such, a neighbour
Int

that vow a long and weighry pilgrima....
the smallest parcel of this vow ......

and yow to God, he eame but to be

a little higher than his vow made
that he keep his vow and his oath

then keep thy vow, sirrah, when

now have I payed my vow unto .....

vow, Burgundy, hy honour of thy....

he did vow upon his knces...........
gives lorl Warwick for his vow.

is brave and vows reformation.

and vows to erowu himself in.....

to entertain ny vows of thanks....... -

I vow by beaven, these eyes vow to.. _

lord Clifford vows to figlit in $\ldots . . . . . .3$

as if they vow some league invioialle

$I$ vow to God above, I'll never.

and, in this vow, do chain my soui....

assuranee with some friendly vow....

made a solemn vow neve

didst break that vow................... Richard iv.

is this thy vow unto my siekly heart - ii. 1

vows and prayers of love

and their vow is made .... Troilus \& Cressida, (proi.)

world, vows, gifts, tears...............
with truant vows to ber own lips....

when we vow to weep seas .......... $=$ iii. 2
VoW-strangles our dear vows .. Troilus \& Cress. iv.
my major vow lies here this rii let souls guide vows, if , this

gods are deat to hot and peevish vow....

leave their false vows with lim. Timon of Alhens, and vows revenge as spacious as........ Coriolames, $i$.

tempted to intringe my vow in
by all your vows of love (rep.)

vows of women of no more bonda...Antony \& Cleo. $i$. the love, and truth, and yows, wlich I Cymbetine, ii. that remains loyal to his vows, which 1 wen's vows are women's traitors I - iii. upon her nuptial vow, her lo..Titus Andronicus, $\mathrm{i}$. reverend tomb. I vow, they shall be.. =

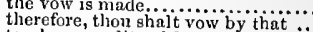
teuch me eredit, withont jour vows ... perieles, iij. let our reciprocal vows be remembered - iv. 6 d det and in that vow, do I live dead ... Romeo \& Juluet, $i$. of thy love's falithful vow for mine ..

and nade exchange of vow ...........

the sonil lends the tongue vows ........ Hamlet,

even with the vow I made to

makes vow before his uncle.

makes marriage vows music vows

if sanctimony and a frail yow, betwixt.. Orhello, $i$.

reverence of a sacred vow I here engage

OWED-when you have vowed ... Nleas. for Meas. i.

hold, ji not to beauty vowedl ..... iove's L.L.Ls' v.

where that you have vowed to study - iv. 3

I have vowed to Jaquenetta to hold - v. v.

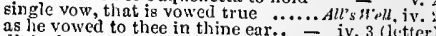

divinely vowed unon the right $\ldots . . .$. Kivg. 3 (lictter
I vowed, hase lsnight, when I..... having vowed to try his strength ..... were vowed duke Humphrey's foes ... - if - 2 sovereign and thy vowed friend .... - iii. 3

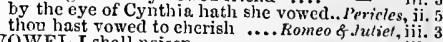

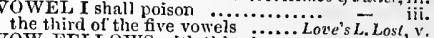

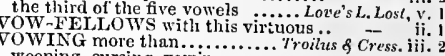

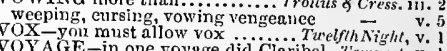
lose thy voyage (rep.) ....... TwoGen. of ternuta, ii. 3 lose the tide, and the voyage ........ my determinate voyngewas mere. Trelfih Nivht, i. i always makes a good voyage of nothing - ii. I mean, she is the list of my voyage -
drawn one to a longer voynge $\ldots \ldots . .$.
that will make a voyage with him that will make a voyage with him.....Mnch Adn, i. I remainder biscuit atter a voyage. As you Lile i, ii. by prosperous voyages I often. Comedy of Frrors,

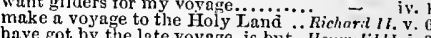
have got by the late voyage, is but... Henry SIII. i. 3 omitted, all the voyage of our ilife.Jnof Alhens, v. if you make your voyage upon her.. Cymbeline, like fragments in hard voyages

would serve after a long voyare at sea I pray yon, to this speedy yoyage .... Hamlet, iii

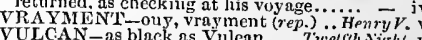
and Vuican a rare carpenter? ........... Much Ado, $\mathrm{i}$. as like as Vulean and his wife.......... Trutuch \& Cress. i. a easque composed by Vulcan's skill yet worn Vnlcan's badge .. Tilus Andron. vil are as foul as Vulean's stithy ........ Hamlet, iii. the base villgral' do call, three..... Love's L, lost, i.

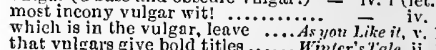
volgar comment will be made. Comedy or $E_{\text {rrors, }}$, iji. leave them as naked as the vulgar air. King John, ii. and eheap to vulgar company ...... Henry H. .ii oo do our vulgar drench their peasant. Herry $r$. iv. stand uneovered to the vulgar groom.2Henry I. $_{\text {. }}$ iv. and puff' to win a vilgar station

no less apparent to the vulgar eye .. _ _ iv. unregistered in vulgar fome...... . nlins C.rsar, most sure, and vulgar: every one hears.. Lecar, iy. 6 as any the most vulgar thing to sense ... Hamlet, $\mathrm{i}$.
familiar, but by no means vulgar. VULGARLY and nersonally...... Aleas for Aleas. v. VILNER ABLE erests ..................Macheth, v. let vulte-cannot be that vuiture in you let vultures gripe thy guts! ......... Merry Wires, i. 3
let vultures vile seize_on his lungs..2 Hevry $\%$, v. 3 


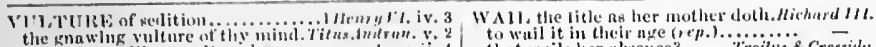

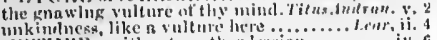

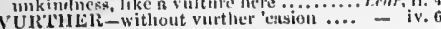

IV

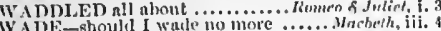

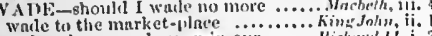

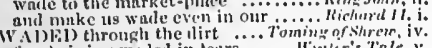

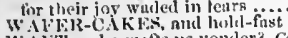

W Ak $\mathrm{T}^{2}$ - who watts us yonder? Comrity of Errnes, ii. hie English bottoms hove watt o'er. . Kinc John, waft me safely cross (rep.)......

sull watt her hence to Frnnce .......... will her ivory hund wafts to her.. Timon of dhe $i$. lunks staving tor watta:c

W.Aping his eyes to the

WAr-why hoy! why wag

let them wh. tre hel givii i......

provoke him to't

let us why then.

ery-8orrow, wrel and hem.

their.... Lnve's L... Lont, v v

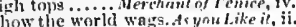

was not my loral the verier wa:

I prny thee, sweet was (rr ${ }^{\prime}$ )

I must confess, nre wres too

merry in hall, when benrels wa....... ail mryl $r$. $i$. durst wng his tongue in cen

bitt wag his finger at the

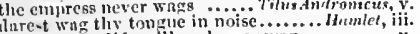

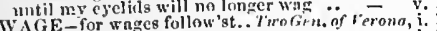

thy master for wnges follows net

Rnil serves for whges ............

and we will mend thy wa

our juraises nre our wages .....
the awless lion could nut wage

to wage m instant trial

top nny of William's wages....

等

$\mathrm{ny}$, and to wrge this bnttle. Antmy f. Clenpalra, iii.

I will wnge against your golt ...

home net gone, nud tren thy wages - iv. 2 (song)

nor the commodity wages not

and clinose to wage agninst the ennity...............

to grake, and wage, a danger profitless

WACED me with his comiten

but he hath waged new wars...

WV $A$ GER_for a good wager, first hewins. 7

dine; the wamer?

I'll hold thee any wager ...Mer

and on the wnger lay two earthl... - iii.

the whel we hill propose

the wa will win my wace better

iwes I won the wager, though you

a wager, they have met.........

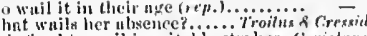

tis temul to winil incvitalile strokes.

lor luence to make me wail ..... lin

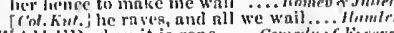

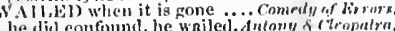

he die emfomd, he wriled. Antony

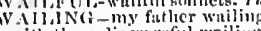

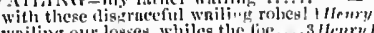

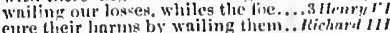

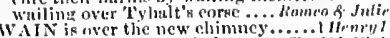

W A Nluples cannot hale ....... Tinelgh Night.

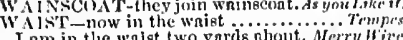

I nm in the waist two yards nhout. Arry Wire

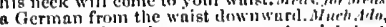

nu' your waist, mistress, Were nas.
girdles for your waist should he fit

a hreast, a wnist, $\mathrm{n}$ leg, $\mathrm{n}$ !iml,

an eagle's talon in the wist.

政

were greater, and my waist flenderer. 2 llenr!! ! ?

ancl buekle in a waist most... Trnilus $\delta$ Cressidion

in the dead wnist [Col, -vist. Knt,-wnste], ilumlt

then you live ahout her waist

I'll wnit whits his plensure.

we'll wait unon yolle grnee

I must wait on myself, mist 1 ? ?........ is erry

will wait on him

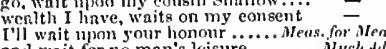

nnd wait for no man's leisure

we'll wait upon your

come, wait non hat o............

more than to us wit on your toyal...

never more in Kussinn hnlit

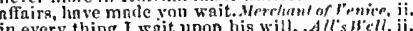

in every thing I wait upon his

Biondelln enmes, he waits on ther.

well, I must wnit, and watcls withiti

which waits upon worn times

you wait on nat ure's misehief .....id .

grod digestinn whit on nplyetife
eonfusion waits (ns doth a rave

my foul shall wait on tlice

sliall wait upon your fath

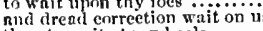

than to wnit nt my heels

wnit close, I will not see him.

and writ upon him at his table...

wonder, to wait on treason .............

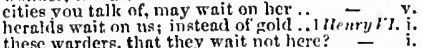

mistrust, and treason wait on him ...3 Hrnryll. ii.

that waits upon your graec?....

I'll wait upon your lordship

eardinnls wait in the presence.....
who waits there? (1,pl.)

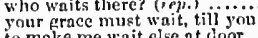

wait liken lousy firnthoy at elianher-ioor?-

Wnit nttendance till youl hear

for which I wait for money

We wait for certnin moncy here,

and I will wait for you.............Juliux (ier

I will not wait jinioned................

I nm not bicl to wait upon her wit doth earthly honour wait

wait upon this new-made enuress
I wait the sharpest blow, Antioelus

no mrn on whom perfections wait

new jor wait on you

- v.3 (Gower)

I must hence to writ $\ldots \ldots . . \ldots \ldots$.... Romes \& Julim

humble and writs upon the judgment

I pray thee, good IIorntio, wait upon hin - y. I

we'll wait ypon yeur lordship ....... (1) (thrllin, iij. ?

often hast thon waited at my cuy ..2 Inenry r. iv.

and duly waited for my coming forth? F iv.

am to hlame to he thus waited for. Julive Casar,

will we. sir; and we']l he waited on. Filus And.
Wil.

WAJTETII on true sorrow..

a thousand, superfunis folly....

a thelsand. Waitipg upon that .. Irinker's lake,

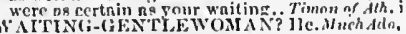

the waiting-gentlewoman to llera..... $\vec{r}$. ii.

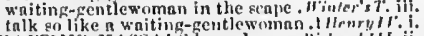

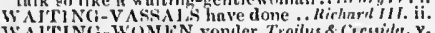

rlianbermaicls and wniting-womel....... lemr, iv.

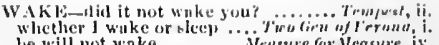

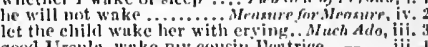
good Irsulu, wake niy cousin mentrice - Bii. we will not wake your paticnee......

wake, when srome vile thing is near..

what anpel wakes me from iny

when ther next wake, all thi
now my titantu, wake you

bial the lututsmen wake ilucm with

at wakes, und wassails, meetiugs lopel los iv.

sleep when he whese? nnd ereco

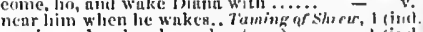

music renty when he wakes $(r+\gamma)$. _ - I (isul

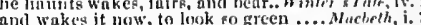

that they did w wke ench other.

whke loinean with thy knocking! ...

to wake our yenee, which in

differenec 'wixt wnke and slecp ... Hewr?/l' iii.

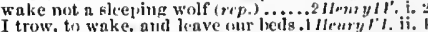

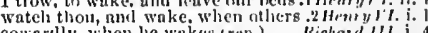

cowardly, when he wakes (rep.)..... Richard

soft! lie wakes. Strike..........

Jienry $\bar{I}$ III. i.

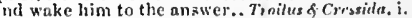

this, I presume, will wake him .......

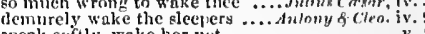

gpenk soiflly, wake her net..............

cven when I wake, it is without me
wake, and find nothing. But, alas

wnke, my

the llam will wake; and, if klie wind - iv.

glecp till I wnke him (rep.)............... i llettir

nnd turn his sleep to wake $\because \ldots . .$. - iii. 2 (sung

come, march to wakes and fairs

he wakes; speak to him

at which he sturts, and wakes................ Jines tuliel, $\mathrm{i}$.

I wnke hefore the time (rep.) ..........

three hours will fair Juliet wake ....

the king doth wake to-night............ In m/el.

to wake, and wnge, a danger protitless othellu.

WAKED after long sleep .............. Fenpest, iii.

that when I wakesl, I eried

have wakel their slecpe

nnd wakel herself with lnughing ........Mrrh wh.

waked, nnd strnightway loved...W/it.. .'s $B$, cum, iii.
nnt, when he wnked, of forec she ....

unto him when lie waked.. Thum of shrein! ! imi.

I $\mathrm{nm}$ waked with it .......... Comedy of Errors, iv.

but necessary you tere waked.....2 2lenry 't. iii.

the busy diny, waked by the lurk. Trnilus 8 . Crexs. iv.

waked half dead with nothing..... r turinlaums, iv.

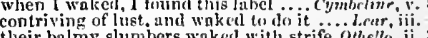

their balmy slumbers waked with strife. Othello, if.

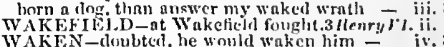

we waken to our esurtry's good .. Nichard III, iii. ?

we wnken to our country s good ... Nichard III, iii.

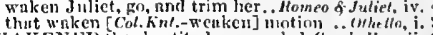

AKEN ED the chast ty he wombde ('ymbrline it.

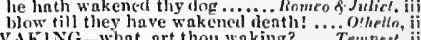

W $\triangle \mathrm{KING}$ - what, art thou waking? ..... Trmpest,
wink'st whiles thou art waking.....

then she waking lonks mpml.... vid.. 's Drenm.

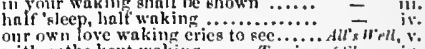

our own loye waking eries to see....... Allswen, v.

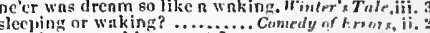

sleeping, or unking, must I........... Hew Hew $^{\prime} l$. ii.

glepitg. or waking. "tis no nutter iow - iii.

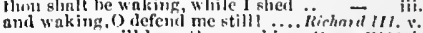

youn nre nne will keep them waking. Hamy lili. i.

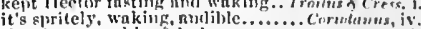

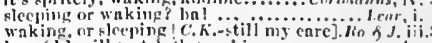

lie anili will watef thy waking

that $I$, on enrly waking what witi ... - iv.

at the prefixent homr of her waking . . Wiat. N's Dr.

now. When thou wak st, witli thine..

or wnk"st lhow, jolly shepherd? .... l. .rar, iii. G (st

post from Wales, lonilen with heavy...1/lowy

though 1 he but prince of Wnles (rep.)

and he of Wnica, that pave $A$ mainzen

nll west ward, Wnles heyenul... Wres

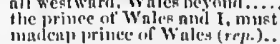

ii. 
W ALFS - to be incaged in Wales.... I urrnry $I V$. iv. 3 prince of Wules (rep. v. 1, v. 2 , nnd v. 4)

with some discomfort from Wales....2 Hen ${ }^{2} 1 V$.

Harry prince of Wales (rep. ii.

comes the king back from Wre youl come from Wales?

the prince of Wales! Where is he?

Edward black prince of Wales ........ Ilenry $r$. ii

the plack prince of Wales, as I lave read - iv:
the Black Prince, prince of Wales ..2llenry VI. ii.

that now is prince of Wales (rep.)

low Wales was made so lappy

W $A$ LK - a turn or two I'll walk ........ Thmpest, iv. 1

to walk alone, like one...... Two Gen.

walk hence with that

and, as we walk along.

I pray you, sir, walk in..................

iii. 1

a thief to walk my ambling gclding

come, come, walk in the park $\ldots . .$. .

walk round about an oak (rep.) ......

she will veiled walk 3 ..................

Malvolio's coming down the

dnes walk about the orb ...........

do not then walk too open

will you walk towards him?

will 't please you walk uside?........... fors. $\overrightarrow{\text { Meas. }}$.

come, we will walk ...................

cone Escalus, you must walk by .....
will your walk about with your (rep.).1/uelt
the walk, especially, when I walk away -

my lord, will you walk? dinner

old signior, walk aside witl me

I will walk up and down here. Mid.N.'sDrcam,

hop in his walks, and gambol in

wait on your royal walk, and wot..... Love's $\overrightarrow{L .}$. Lost,

a gentleman, betook myself to walk

to see him walk before a lady...

talk with you, walk with you... Mereh. of Venice,

yonder, sir, he wallss ............

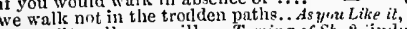

thou wilt walk; we will .. Taming of $S h .2$ indul

methinks, you walk like a strat

let me see thee walk: thou dost.....

may go walk, and give me lcave a whi

we two will walk, my lord.........."

spirits of the dead niay walk again.

walk before toward the sea-side.

will you walk with me abont .Comedy of Er ro

let him wallk from whence le

pleaseth you walk with me dow

yonder, as I think, he walks .......

will you walk in to see their gossiping?

which way they walk, for fear thy ....
and walk like sprites, to countenance

make it their walk .............

by dey, must walk by night

lies in his bed, walks up and down.....

how wildly then walke $\mathrm{m}$

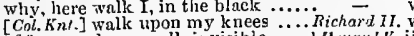

of lern-seed, we walk invisibie

Netl Poins, and I will walk lower

we'll wrlk afoot a while ...........

the rest walk up above

I lo here walk before tliee............. $\mathrm{Henry} / \mathrm{W}$. i.

if you would walk of, I would prick . Ienry $r$. ii.

limn gait walk the whole world

spirits walk, and ghos ts break up....2 Henry $V l$. .

enjoy such quiet walks as these?

3 Heñy

my parks. my walks, my manors .....

to walk wly thither, I'll tell ye more. Henry $/ 11$. iv.

thit walk (as, they say, spirits do)

you and I must walk a turn

walk off. Have you seen.... Troilus \& Cressida, iit.

walk here i the orchard $\ldots$ ynu walk in, wyy lord? (rep........

please you, walk in, my lords.......

as we walk, to our own selves.

will you walk on, my lord?...

to thirteen, this spirit walks in Timon of Athens,

pray you, walk near; I'll speak......

instruet, walk, feel, and mutwall

when he walks, he moves like
not walk, upon a labouring day

not walk, upon a labouring day ....

walk up und down the street

this digturbed sky is not to walk in...

ard is it pliysical to walk unhraced.

think you to walk fortls? you shall $n$

then walk we forth, even to the......

to walk abroad, and recreate yourselve

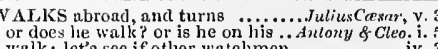
move him to walk this way ......... Cymbeline, i. 2 pray, walk a while. About some.

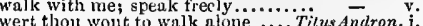
the furest walks are wide and spacious - ii.

let's leave her to her silent walks...

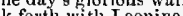

take her by the arm, walk with her........

pray you, walk softly, do not heo.t

and wolk till the firt speak thin

the flslicrmen, that walk upon the bench.

will't please your highuess walk? .........

mind drave me to walk abroad .. Kooneo \&

I will walk myself to county Paris...

you spirits oft walk in death............

Hamlet, i. i

walks o'er the dew of yon high

perbaps 'twill walk again

i. 3
ii. 5 the spirit held his wont to walk $\ldots \ldots \ldots \ldots$ 二
i. 3
i. 4 somctimes he walks four hours together - ii. 2 will you walk ont of the air. my lord?

Opluetia, walk you here: Gracious

sir, I will walk here in the liall.......... - iii. I

Cassio, walk hereabout; if 1 do find ... olkello, iii. 4

will you walk, sir .........................

T will walk by; I would not kill thy - v.

when he would have walked ten mile.Mneh Ado, ii. 3

which, I inean, I walked upon. Lover
sthould see as she walked over liead

lie forth walkerl on his way raming of sh iv. iv. 3

where I the ghost that walked.... Wirter's Tale, v.
Wir.

valiant Banquo walked too late....... Macteth, iii. 6

when was it she last walked?

those which have walked in their sicep - v.

.

you knew, he walked o'er peril

he's walked the way of nature

so long walked hand in hand ...Troilus \& Cress. iv.

you suldculy arose, and walked about - in ${ }_{\text {in }}$ his livery walked crowns. Anlony f Clevpalra, v.

I have walked like a private man. Tilus Andron. iv.

hare walked barefoot to Palcstine .... Hamel othello,

VALK ING in a thick-pleached alley. Mneth Ato, i. besides her walking, and other actual . Wacbelh, v. for your walking invisible

and torches, walking with thee in...... iii. 3

walking from watch to watch. Henry $V$. jv. (chorus)

no stir, or walling in the streets...JuliusCasar,

that craves wary walking $\ldots \ldots \ldots \ldots$.
le's walking in the garlen-this Antony s. Clen.
look, here comes a walking fire........... Lear,

look, here comes a walking fire.......... Lear, i

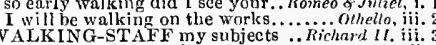

VALI,-raised the wall, and honses too. Tempesl, ij.

hung by the wall so long... Measure for Measure, i. 3

a wall in the great chamber (rep.). ifid.N.'s Dr.

must present wall (rep. $v$. I) $\ldots \ldots . . . .$.
rougli-cast about litm, to signify wali

and through wall's chinks, poor sonls

doth show that 1 am that same wall

Pyramus draws near the wall

thanks courteous wall: Jove shield

$O$ wicked wall (rep.) ..................

and I an to spy her through the wail

I wall, my part discharged so (rep.)

when walls are so wilful to hear without -

ay, and wal! too. No, 1 assure you (rrp.)
when icicles hang by the wall . Love's L.L. v. 2 (song)

the weatlier on the out ward wall. Mer.

within rich Pisa walls, as any one.Toming of Sh. Yi.

be set against a brick wall ...... Wivter's Tale, iv.

our banners on the nutward walls ......Marbeth, v.

thit lath warned us to the wailis?

ron indignation 'guinst your wall

harbourgae witlin your walls.......

of your old-faced walls can hide...

against these supcy walls..............

the wall is high

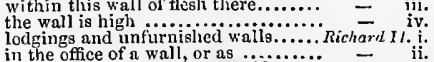

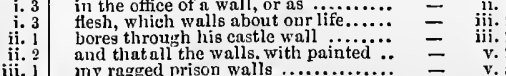

my ragged prison walls

and for thy walls, - a pretty $\ldots \ldots \ldots 2$ Henry I $\mathrm{Y}$. ii. I
WAIL-shall be a wall suficient to .... urury I'. i.
or close the wall up with our English or close the wall up with our English
reverend heads dashed to the walls ..

the walls thiey'll tear down $\ldots . . .$.

in iron walls they deemed.

.1 Herny VI. i. ?

in iron walls they deemed.............

near to the walls, by some apparent...

foothoys do walls for refuge $1 . . . . .$. .

lct's get us from the walls

sit before the walls of Rouen $\ldots . . . . .$.
summon their gencral unto the wail

at your father's castle walls we'li ...

on a brick wall have I climbed ....2illenry $\bar{V} x$. iv.

environed with a brazen wall $\ldots \ldots . . .3$ inen $\bar{r} v \nu l$ iv. 10

to the walls, and sound a parle (rep.)

Catesby, oerlook the walls ............. - iii.

envy liatl immured within your wailst $\overline{\text { ing }}$ ive

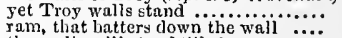

for yonder

back upon thee, $\mathrm{O}$ thou wall $\ldots$ Timon of $\overline{\text { thens, iv. }}$ iv.

both within and out that wali! ...... - iv.

against the walls of Athens.......... $=\quad$ iv.

these walls of our's nere not erected ... Coriolanus, $_{\text {i. }}$

picture-like to liang by the wall $\ldots . .$. ...

we'll hreals our walls, ratlier.......

alone I fought in your Corioli walls".

clinbering the walls to eye him ....

climbed up to walls and battlements.Jui. $\bar{C}_{\text {crsar }}$, i.

nor walls of beaten brass ............

richer than to liang by the walls ....

the why within the city walls .....TitusAndron. i.

I heard a child cry underneath a wail $\quad$ - $\quad$ iv.

dauh the wall of a jakes with 3 him............ Lear, ii.

the walls are thine: witness the world $\ldots .$. 二 iii.

I will take the wall of any man. lromeo 8 . Juliet,

for the wenkest goes to the wall (rep.)

wall, and thrust his maide to the wall

and leaped this orchard wall .........

the orchard walls are high

vliere is no world witlout Verona's walls - iii. 3

patch a wall to expel the winter's flawl Hamle', v.

walled town is more worthier ..... As you Like il, iii. 3

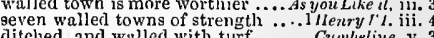

wear out, in a walled prison................ Leas, v.

my lord, a wallet at his back .......... Tempest , iij. 3

ALI,EXED wrath, or staring .... King John, iv. 3

say, wall-eved slave, whither... Titus Andronics, y. I

WALLOON-base Walloon, to win ... i i Herry $1 . \mathrm{i}$.

of Artois, walloon, and Picardy .... - it. I

I may wallow in the lily beds.. Troilus \& Cress. iii. 2
WAINUT-a hollow walnut for ... Merry Wives, iv. 2

WAINUTSHEIL, a knack....... Taming of Sh. iv. 3

and Walter's dagger was not come

gir. Walter Blunt (rep. iv. 3 and v. 3$)_{1}, 1$ Herrry $I Y$.

not so, sir Walter; we'll withdraw... $=$ iv.

such grinning lionour as sir. Walter hath - iv.

Gmalticr, or Walter, which it is...... - iv.

Walter,-Come, Suffolk, I must ..... Whare ${ }_{\text {III }}$ iv. 1

WAN-and wan le looks! .... Comedy of krrors, iv.

so shaken as we are, so wan...........1 Henry $1 r^{\prime}$

WAND-as small as a wand. T'u Gen.of Yerona, ii. 3

pceled me ccrtain wands .... Merchant or Ventice, i.

WANDER-whither wander you?....Mid.N.'s ${ }^{2}$.

I do wander every where .............

how now, wit: Whither wander sou? $\overline{\text { in }}$ i. 2

wander we to see thy houest son. Taming of sh. iv. 5
I wander here and there... Winter's Tinle, iv. ? (song)

and wander up and down .... Comedy of Evors, i. 2

and here we wander in illusions ....

I wander from the jewels that I .... Richard $1 \%$. .

with Cain go wander tluongh

that we may wander o'er this

Hemyr. iv. 7

madum, you wander from the good. Henry l' 111 . iti.

to disorder wander, what plagues. Troilus \& Cress. i.

we'll wander through the streets... Antony \& Cles, i.

safic may'st thon wander, eafe....... Cymbeline, iii.

what cursed foot wanders this ... Romeo \& $\overline{J u l i c l}$ iv.

WANDERED throngh the forest. Turo Gen. af 'Eer

the heedful slave is wandered .. Comedy of Err.

hath faulty wandered, and irregnlari Henry / 1 . ii

he himself wandered away alone.. Riehard III. iv.

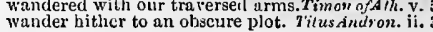




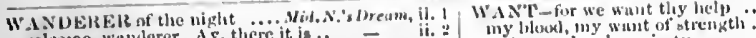

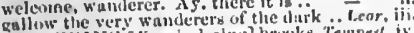

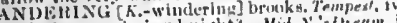
Thlshy? a wanctering knight? sud ftint with wandering iill there. swifter than the wandering moon... vagabond.... Nhchard $i$. whilat we were waskering that wandering kuight so rair

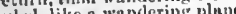
ruled, like as wandering plishet empro my life, the wandering prinee nut Dido.. is like thie waindering wind, b

cunjures the whindering stars .......... Hramlet, y. ANI)-LIKE-as wand-like straight. WANE-this old moon wancs that he is in the wanc:

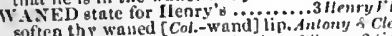

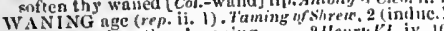
wnx great by otliers waning......2 2tenry $V$ t. iv. 10 the waning of mine enemies

WANNED: $[K n l$ - wnmed $]$ tears in .... Hamlel, if. iv ANT-being drunk, for want of wine. Tempes what I shall ilic to want whint does else want credit ............ - iii. 3 althongh the want shall shun you - iv. I (song) now I want spirits to enforee ........... (epili.) it was for want of money .. TuroGen.aflerona, ii. t or else for want of jule time

never yet did want lis meed

and he wants wit, that wants..........

my'self do wunt my gervant's fortune

in our quality much want ............ for want of company lant it wants inatter to prevent ........... he wants advice ........... Measure for theasure, iv.

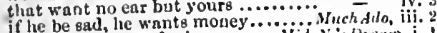
belike, for want of rain ............id.N.'s Diean, i. I stieli as our play wants

the human mortals want their

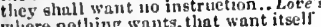

in Rome for want of linen

come sir, it wants a twelvela Verchan

the ripe wants of my rients...nd tak

(wants miney ...As you tike it,

nore preeions than to wall.......iii..... All's $W^{\prime} e l l$,

lic eannot want the best that sid

whose want and whose delny, is strewed

lose my life fir want of langurge ....

to want the bridegronin...............

gou know, there wnnts no junkets.

spites me inare than all thesc wallts

than thus bo want thee.

liave money, or any thing $i$ waint ......

may know yolt shat not want o.....

my elowil. (who want I lave .. Conedy

beillg scanned, want wit in all one

who, all tior w'ant of pruning...

nnil want gilders for my voyage

winc cantiot want the though

he wants the nntural touel

an so ficree a cause, doth want exnmple?

must netds want pheading

let hell want pains eno gh..........

send them after grief, nced friends

reel want ather gemedics

my want of joy: for what thave (re

tus death, through want of speaking

abnses of the time want eounted

I want work. O my s weet flarry .....

his present want scenis more than wo

wever yet did insurteetion -

we want a want in ineah. "ve'll have.... - v. 3

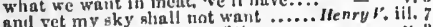

anil yet my ghy for want ol time.

whose want gives growth to ...

no treachers: lint want of men tie.....

if Sallohury wants merey

good-motrow, gallants] want ye corn

Ienry $V$

becanse you waut the grace...........

the herlss fur want of hushandry

I shall not want fale withess $\ldots$......

but yct we want a colonr their lealer, scatter up...

one that surftits thinking on a $w$

that no wnat of resolution in me ....

nor should thy prowess want

thall not want lis part thit wath love's miajesty .......

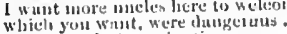

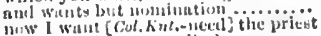

doth wani lier proper limbs..........

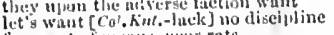

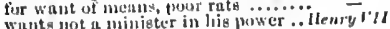

a nobletuan want manters (rep.)

fruilty, and want of wistom ........

and big eompare, want similes. Tritus s.

if [ w'unt gold, steal hut a beggar's. Fimon

bawis between goid and want].

these wants of inine are erownet.

they are at full, want trens
he ennuot wnut for moncy

enunt want fifts-five hundred $($ rep. $)$

the want that makes hin! lean

the mere want of gold

muels do wunt. Your greatest waint (rep.)

want? wlyy want? We eaniot live

for your wants, your suffering $\ldots . .$. Coriolu

to save lukotr, nor that I w'unt love
whicl tiine shall not want, if lie be..

ronts not syirit to say

of what that want might ruin .......

baited with oule that wants her wits?

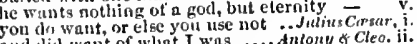

and lid want of what I was .... Antong

but wut will perjure.................
and fiel ticas slinll wait troops...

anl her Encas slinll wait troops.... - iv. ${ }_{2}$

neither want iny means for tily......

there wants no diligenee in secking him -

the want is, but to put those powers

you come in faillt for want of ment.

there are none want eyes
Chison, tlus ears want wit

poor ereatures, want our lity

slanl have like want of pity $\ldots \ldots \ldots . . \overline{\text { Pericles, }} \mathrm{i} .{ }^{4}$

slumber, while their ereatures want

want of use, they are now starved (rep.)

wherein we are not destitute for wan

if for I want that glils and oily art

worth the want ilut jou have wanted .

weary of all, sliall want some. ..........

nu way, and therefore want no eyes

that wants the means to lead it......... iv. $\overline{6}$ (letter

if your will want 110 t. jighit...... Romeo of Juliel, ii.

shows still sonve wunt of wit .

that wanta discourse of reason ...........

will want true eoluur...........................

fin wat of the renired eonvenicuess.

whose want even kills me ...............
WANTED the modesty.......

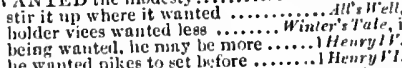

he wunted pilies to set lstore ......... Fithens.

what they wunted elunnily .... Timon of Alnens, it. 2

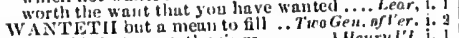

fly swift, but wanteth wings ......... Henery'ti. i.

there wanteth now our brother ........... Hericles, i.

ANTRE your fatler's.

...dsyou tike il, ii. 7

Wunting gilders to redeew their..Comedy of trr.

I'yacton, wanting the manage of

being altogetler wanting, it doth..... is ury : v.

were our tears wanting tanting aid ... - i.

alch a wortly leations wanting food..............

lliv eomeil and eomsent wanting [Cnl. Knt,-without] Richard MI. iit.2

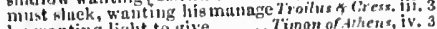

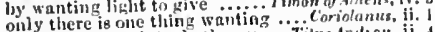

wanting strength to do thee so... Titus Anthous. ii.

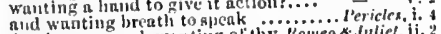

death prorogned, wanting of thy. Knmen f. Juset, y 3

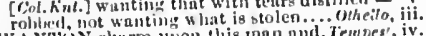

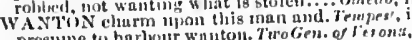

nresume th the wanton lies................

your worklip' a wanton........... Iferm Night,

might muke my sister wanton

the waston sting and motions ... Meas. for Meas.

iny soul to an approved wanton.... Nurf Adn,

IIInzis in the wanton green ............ -

whitely wanton with a velvet ..Lore's L. Losl, lii.

are guards an wanton Cupid's hose.. iv. $\overline{3}$ (versces
ANT'UN as a child, nkitping ....i.ore al. loot, y.

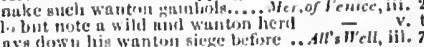

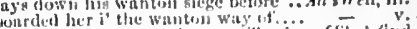

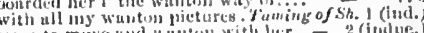
ecen to mase und wanton with lice - 2 (imilue. und then you'd wantrin uill,

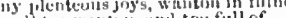
is all too want(b), und toe full of.... King John, iit.

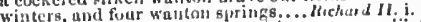
or vilull we play the wuitime with

wo nuke woe wantur with this fond

- v.

at Nirsummer; wanton as youth fil

with the injuries of a wanton tin.

a gunril too wanton fis the heal

and wanton reason, shall, to the king

a

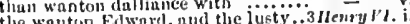

malcling more for walton lust tinn

to sirut ficfore a wantoll ambllng ... dichord IIJ. i.

and purehase of his wanton eye.......

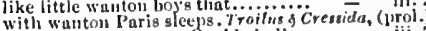

mad the wenk wonton Cupid shali .. -

her wanten spirits look out...........

to the wanton tops do linss ..........

but not go eitizen a wautou ........ Cymbeline, iv. 2

down, wantins, down: "twas her LJother.Lear, ii. 4

as flies to wantom boys .................. Juliet, iv.

yet no further than a wanton's birc

now eomes the wanton blood up in..

sueh wanton, wild, and usunl slips .... llonict.

pineh wanton on your eheck; enll you.. - iii.

witl wantoll dullness any speculative.. Othello, i. 3

not yet marle wanten the night with her - ii.

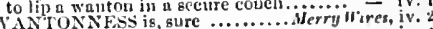

with eodd, than the with wantomess - jv.

as fravity's revalt to wantolness. Lace s Lidosh, viv.

miseonstrued in his wantonness .... \& Cresida, iii. 3

make your wantonness your ignernuce. Hnonet, iii.

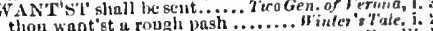

it seuns, thou wast'st hreaking.... Conedy of firr. jii.

if thou want'st a eord, the smalest. .

old, and want'st experienee?..........2 ilsnry ${ }^{\prime} I . v$.

want'st Knl.-want onest? thou ejes...... Lear, iii.

WANT-WIT sadness makes ot me.Mer.of tentce i.
WAPPENED widow wed again .. Timon of Ath. iv.

WAL-the azure vanlt bet roaring war. Tempest,

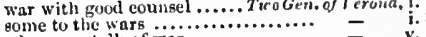

whene to the wass walk of war...................

I bring no overture of war........... - i.

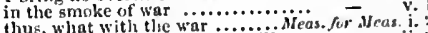

but that I am at war, twixt wili ..... Much Ado, i.

veturned from the wars or no? .......... -

done good service, lady", in these wirs

I liked her ere I went to wars............ -

kar, deatli, or siukness did fay....... -

that thou book'st for wars, and witt not - iij.

that wn ngainst your ownl....... Lore's L. Lost.

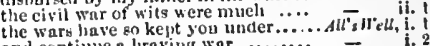

nnd continue a liraving war $\ldots . . . . .$. .

an emhlem of war, here on his $\ddot{3}$ ï

of a man's font: to the warvl (rep.).. =

the tumlamental reason of this war..

the event tht the mone-sparing wnr?..

a disanter of war that Caes liimelf - iii.

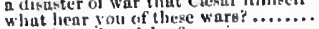

the whole theorick of war in ........ - iv. 3 (nuthes

wur of while and retl within... Taming of shreur, iv.

when rnging uar is done, th tuile .

to otler war where they shimid knecl or Erors, jii.

mulking war igaingt her hair ........
thy husband servet me in my wars.

when I bestril thee in the wars......

mint of war .....

towurds which, nutvance thic wur.... = v.

do bravely in the whr.............. King John,

here lave we war for war...........
fonght the hol, wars in Paleatine.

their rlglit unler your winga of war

in sueh a just and eliaritnlile war...

which here we urge lin war ..........
if thint war return from $F$ raile.

you from ont messengers of war ...
from a reolved and honourable wir 

WAR-and rough frown of war ...... King John, iij. I
war W warl no peacel peace is $(r e p$. and like a civil war, set'st oath. doth dogged war bristle his angry..... hush agitin this storm of war and glister like the god of wa the suvage spirit of wild wer $\ldots \ldots . .$. this business, and maintain this war? craw this gallant head of war. to whip this dwarfish war................ purpose presentily to leave this war thus plated in liabiliments of war we will eurself in person to this wa for these Irish wars (rep. ii. I) in war was never lion raged

\section{三}

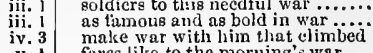
make war with him that wlimbed.... the equal poise of this fils war Whilst lions war, and battle .......... like vivil war, be blind ............. 2 the frowns of war with peaceful .... fall by war's mischance.......... likely to be blest in peace, and war. and we shall have more wars $\ldots . . . .$. in peace, et bold in war
the fatal instrument of $w$ ar.

Nirs have not wasted it........
in peace, than they in wars. threc thonsand men of war ..... fur muney fur these wers? Yurk there, with his men of war?. pale-fuced viliages with war? imke war upon their spotted souls..... some slain in war; some hat and toiled with works of war............. tumultuous wars ghall kin with kin
no more slall trenching war channel no more slanl trenching $w$ ar channe
the edge of war, like an ill-sheathed the edge of war, like an ill-gheathe
bat by the chanee of war; to prove bnt by the chanee of war; to prove...
inurmur tales of iron wars .........
spirit within thee hath been so at war we must all to the wars...

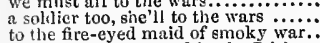
when be was personal in the Irish wor this churlish knot of all abhorred war in his unlucky Irish wars.............. sound all the lofty instruments of war
by the steris tyrant wer $\ldots \ldots \ldots .2$ Henry 1 you cast the event of war. Is there not wars? ....................... yes, in this present quality of war.... go not.to these wars] the time was. thou art going to the wars .......... were these inward wars once out of. thou shait go to the wars in a gown.
harsh adel boisterous tongue of war? harsh a ad boisterous tongue of show a while like fearful war.. this Hydra son of war is born ........ that war, or peace, or both at once ... you awake the sleeping sword of wa for these wars be soon collected ....
doubt not of a fair and lucky war the signs of war ad vance ...... our towns of war, with men of
thongh war, nor no known quart

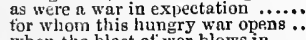
when the blast of war blows in ....... and teaeh them how to warl ..... the disciplines of the war (rep.) in the ancient wars $\ldots$................. of the war, the Roman wars .... and the weather, and the wars ...... now and then goes to the wars.... now and then goes to the wars .....
con perfectly in the phrase of war prerogatifes and laws of the war prerogatifes and laws of the wars.... slall fiud the ceremonies of the wars sume, making the wars their bulwark wur is his beadle, war is his vengeance every soldier in the wars do as every
knowledge and literature in the wars knowledge and literature in the wars I got them in the Gallia wars....

and never war advaoce his bleeding. one wonld have lingering wars ........ nor money, hath he to make war.... one that still motions war. he first trained to the wars ............... our wars will turn unto a peaceful .. in peace, and war! And peace, no a while given truce unto my
scrvice, and your toil in war grown to credit by the wark............ the snares of war to tangle thee..... tutor thee in stratagems of war. of all his wars within the realm...... or the struke of war, ny danghter.... ease jonr country of distressinl war..
will plague thee with incessant wars coin, and people in the wars? .......... your deeds of war, and all our couns ratier than bloody war sha dig a grave to find ont war .......
thus war hath given thee peace $O$ war, thou son of hell ................. he, that is truly dedicate to war........ shall be the war that Henry in dreadful war may'st thou to cease this civil war.
if I claim by open war

\begin{tabular}{l|l} 
ii. & we have had pelting wars, since $\ldots . .$. \\
ii. 3 & still, wars and lechery; nothing eiee
\end{tabular}

\section{grim-visaged war hath smonthed}

though not by war, by surfeit die.....
during the wars of York and Lancaster

that thou wilt war with God

tather then had wars in France.

ii.. 2 your diseipline in war, wisdom.

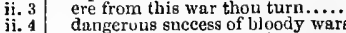

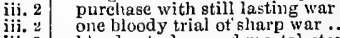

ii. 3 bloody strokes, and mortal-staring war

is named, your wars in France.

by nll the laws of war you are
nnd fears than wars or women lia

like rans in the old time of war . .

ii. 3 'tis but the chance of war............

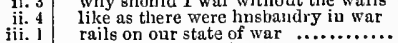

rails on our state of war
as no member of the wnr

bed-work, mappery, closet war ......
and make you plough up the wars

and make you plough up the wars..
hot digestion of this cormorant war..

on those that war for a placket......

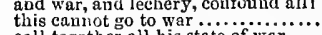

call together all his state of war $\ldots . .$.

in that Ill war with you (rep.).......
my tittle stomacil to the war ......
we have had pelting wars, since

not yet the brushes of the war.........
Hector, then 'tis wars.................

and our sharp wars are ended

the war receive tin valiait gore (rep.)

braggarts of the war derive some pain

beastly, mad-brained war

wilt use the ware as thy redre

make war breed peace (rep.)
if the wars eut us not up

that like nor peace nor war? $\ldots$

\begin{tabular}{l|l} 
ii. 2 & attend upon Cominius to the \\
ii. 4 & the present wars devour bim \\
ii. 4 & to a crue
\end{tabular}

ii. 4 till my lord retnrn from the wars......

and to make it bricf wars

and make.my wars on you

iiii. 1 made an overture for the wars! ....... commit the war of white and damask

\section{iii. 2 than camels in their war}

iii.. 2 being pressed to the war, even when...

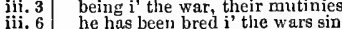

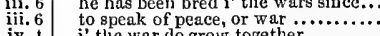
to speak of peace, or war ...

if it be honour, in your wars.

my throat of war be turned.

and not our streets with warl

thon art too full of the wars' eurfeits

"fore my wars have I heard groan

and, pouring war into the bowels of

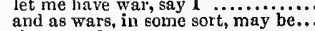

the wars, for my money m..................
was a worthy officer i the war
with the deepest malice of the

with the deepest malice of the war

and stick i' the wars like a great

\begin{tabular}{l|l} 
ii.. 2 & till these wars determine \\
ii. 5 & the end of war's uncertain
\end{tabular}

iii. 4 has clucked thee to the wars......

iv. 1 led your wars, even to the gates......

never admitting counsel o' the war.

poor Brutus, with himself at war...ju

and equadrons, and right form of
quartered with the hands of war

what shonld the wars do with such.
and nusters of the war ...... Antomy and nusters of the war

whose better issue in the wa........

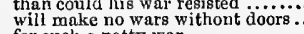

for such a petty war ..................

and brother, made wars upon me ....

and make the wars alike against

attend those wars which fronted
miglit go to wars with the wome

miglit go to wars with the women! .
oit of Egypt, made wars here.......

bnt it raises the greater war between lie hath waged new wars gainst ....

ii. 2 wars 'twixt you twain wonld be ....

ii. 5 use of him in the wars 'gainst Ponpey

ii. 5 levying the kings o' the earth for war

ii. 6 forspoke my being in these wars ....

iij. 3 a charge we bear $\dot{i}^{\prime}$ the war..........

in the brave squares of

iv. 6 that thou couldst see my wars to-dä

iv. 7 determine this great war in single ..

makes only wars on thee ............

whose eye becked forth my wars ....
I made these wars for Egypt ........
withered is the garland of the war

and companion in the front of war..

low hardly I was drawn into this war

who in the wars o' the tim

war, and confusion, in Cæsar? ngme....

thic toil of the war, a pain..............

to undertake our wa againgt

of this war's purpose?

when fearful wars point at $m$

if in your country wars you chance...

and the disorder's such as war were.

we that draw his krives i' the war...

never was a war did cease..............

from weary wars against ........ Titus An

from successful wars, you that survive

jouth was spent in daugerous wars..

i. 2 leave you not a man of war unsearched

and with revengeful war talke........

this to the god of war.

iv

ii. 3 with the ostent of war will look........... Pericles, i.

iii. 2 makes war upon your life ..............

by public war, or private treason .......

if war's, we are unable to resist
go to the wars, would yon? ...

with the ancient of war

With the ancient of war on our proceedings [ $K n$. ] by the law of war, thon wast not... was, and is, the question of these wars .. jon from the Polack wars, and you from and the rites of wur, speak loudly for him $-\overline{-}$ horribly stnffed with epithets of war.... Othello, with such loud reason to the Cyprus' wars though in the trade of war I have slain.. to undertake these present wars

of peace, and he ro to the war, the rites.

news, lords, our wars are dooe

the wars must make examples ont of....

pomig wars, thet make ambition virtuel

WARB. nnd chreumstance of glorious war! $-\overline{\text { iii. }}$

come, warble, come ................ Asyoulike it, ii.

to eaeh word a narhling note

from the ward of her purity ......... rempest, $\mathrm{i}$.

men in your ward sufficient .......... Meas. for Meas. ii.

to say to me, come to my ward

for the best ward of mine lonour. Love's $L . \bar{L}_{\text {ost }}$, iit.

to whom I am now io ward ............All's Wel,

what wards, what blows ............... Henry $I V$.

that kuow'st my old ward

deputy's wife of the ward to thee....

in justice, ward you as his soldiers.Richard III. at what ward you lie ......... Troilus \& Cressida, and at all these wards $\mathrm{i}$ lie.............. if I cannot ward what I would not..... ne'eracquainted with their wards. Timon of Ath. iii. a his son was but a ward two jears. Romeo $\dot{\phi}_{\text {Juliet }}$. $\mathrm{j}$. there are many confines, wards $\ldots \ldots . .$. . Hamlet, WARDED-a hand that warded him. Titus And. ili. WARDER-the warder of the brain .....Nacbeth, $\mathrm{i}$. 7 topple on their warders' heads Richard II. i. 3 the king did throw his warder down. 2 Henry $1 V$. iv. where be these warders, that they $\ldots$. Henry ri. i.
WARDROBE here is for thee! .........Tempest, iv. the yeoman of the wardrobe............. hangman hath no lean ward robe $\ldots . .1$ Henry $I V . i$. dalliance in the wardrnbe lies........... $v$ ry $v . \overline{\text { ii. }}$ (cho.) and retails his wares at wakes .... Love'sL. Lost, v. 2 bas he any unbraided wares? ..... Winter's T'ale, iv. slow our fonlest wares ......Troilus \& Cressida, $\mathrm{i}$ the last that ware [Col.Knt....Tore]. Tilus Andron. than thon art 'ware of (rep......... Love's L. Lost, do him wrong ere you are ware. Troilus \& Cress. iv. has the game: 'ware horns, hol ........ WARIIY I stole into a neighbour.Love's L. Lost, v. 2 


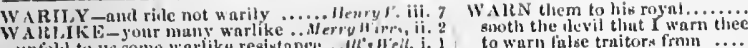

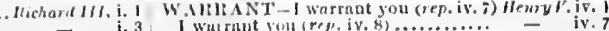

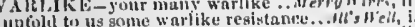
these wro rike principles do not throw whe warlike yrinciples to not throw Nore the warlike smahts with ten thousand warlike men.

I throw my warlike shickla lay on ..... him Jot wolt of a many thousant warlike French is whike. Jolnt anl in his forehen

Vs Vue then sluuld Ulic warlike Ilurry ...lenryl,i. (elio.) invoke his warlike splirit, and your. reeeive ne for thy warlike mate ....ilienry r. i. 2 ot a warlike enterprize more venturous

the warlike 'Talbot (rep. iii, 2) \#...̈

the rensm moved these warlice

t) Bourdeaux, warke lo dord.............

in travel to

mean to warn us at p'lilipipi here....iulius cars

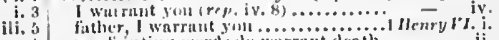

warng iny old age to a sipulelire. Inimen of Julim,

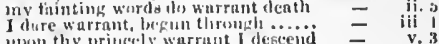

be warned by me thesl.........

ingon thy prithecly warrant

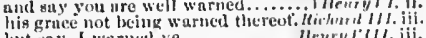

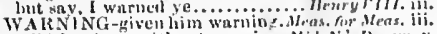

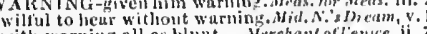

with warning all as blunt ... Werchant of femce, it.

tlint, at so slender warning. . Finaing o

gives waming to all the rest of this.o llearylt:

too snddeo, sirs, the warning is.........

he lath a very fair warniug........2nen

take win warning by my cooling....... iij !

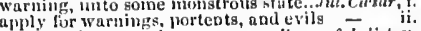

the boy gives warning ........... Romeo folutim,

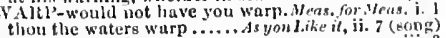

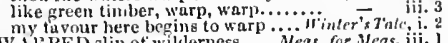

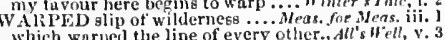

wnother, whose warped lovks proelnim. . Lewr, iii.

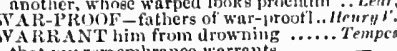

that my romemlyance warrant

no, I warrant you (rep. iv. 1) .........
she will become thy bed, I warrant

will bring us good warrant of ........

his worth is warrant for his welcome

warrant me welcome to my

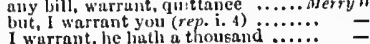

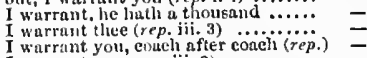

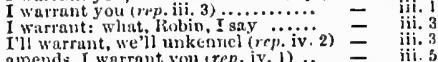

amends, f warrant you (rep.iv. in the warrant of womanhood -

I warrunt, they would whip (rep.)

1 warrant you (rep. it. Sund ficiow.

I warrant there's vinegar and pepner
ay, is it, I warrant him: do but reaul
th ree-pited piece, I warrant thee.Aleas. for Mens. i. I

I warrunt, it is: and thy head ...... -

the provost huth a warraut for hig

by all external warrant

look, here's the warrant, Cluudio ...

showed him a seemiug warrant for it

here you have a warrant to execute.

for, look you, the warrant's eome .....

he sends a warmot for my poor.......

I warrant thee. Claudio, the time..... Much
I'll make her come, I warrant you (rep.)

I warrant, one that knows him not.

wonder not till fusther warrant
bring Defurmed forth, I warrant $(\ddot{r e p}$.)

I warrant, your cousin will say so...

we will spare for no wit, I wrirrant..
doth warrant the tenor of my book..

whiel maiden modesty doth warrant

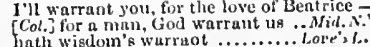

hath wistom's wurraot ........... Lole's l.

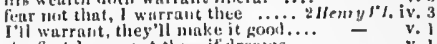

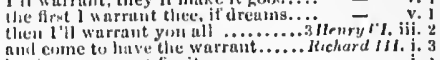

laviug a winrmut for it ....

mothing spyke in warrunt froin litimele = iii.

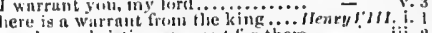

Yun have ehrintion warrant for them o

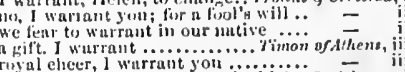

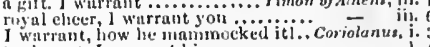

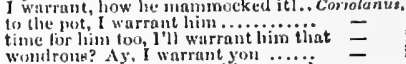

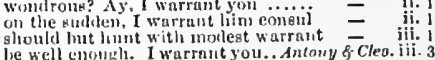

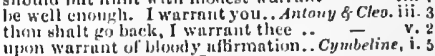

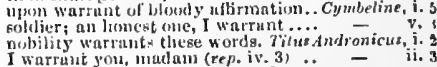

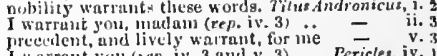

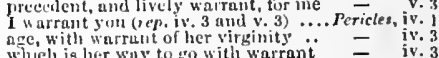

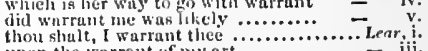

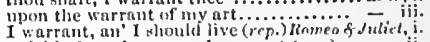

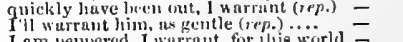

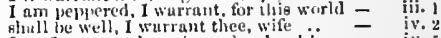

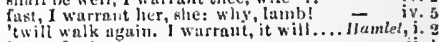

it is a fetch of warrant ................ - ii. 1

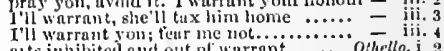

ai ts inhibited and out ol warrnt........... othello, i

I warrait thee: nect me by und by $\ldots .$. - ii. I

[Kul.] I warmut it grieves (rep. iv. 1)...
1 give thee warrant of thy place $\ldots \ldots \ldots$.
iii. 3

if twere no other, -It is but so, I warrant - iv. 2
WAKRANTED need, give. Measurefir Measure, iii 2

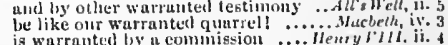

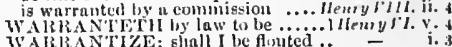

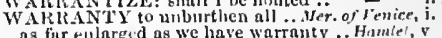

as fur enlarged as we have warrnity... Hamlel, $v$
with sueh general warranty of heaven.. Othella, $v$

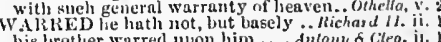

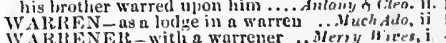

WARILFNElh-with a warrener ...iler, y Hites, i

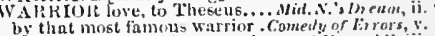

infunt warior in lis cuteririzes ... Inenry $1 V^{\prime}$. iii.

look for of suel an ungrowan warrior - We $r$. iii

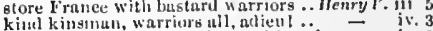

we are but karriurs for the Horking-day - iv.

were no place for llenry's warriors.. - iii. 3

We English warriors not not what ..

no. I warrant your graee........... As you l.ike "l, ii.

Lord warrant us l what fiatures?

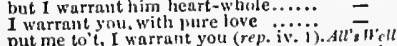

put me to't, I warralit you (rep. iv. 1). All ' lFell, ii.

I warrant hum, Petruchio is Kated . Hinter's Tal

to pass it, laving no warrant...
which is enougli, I'll warrant...

which that he knew, I warrant him.....

the luw go whistle. I warrant (rep.). .
warrant of immediate dleath ... Comrdy of Fror

all my travels warrait me they live.

go muel, noney to warrant thee.....

here's that. $I$ warrunt you, will pay...

under whose warrant, 1 impeach ...... King Joh

there's law and warrant, lady
I hope, your warrant will bear out...

I hope, your warrant will bear out

he shoned his warrant to a triend....

take their humours for a warrant....
to give us warrant from the liand
and warrant limited unto my tongic
I w

I warrant, they liave mate their .. Michard $\$$.

the strong warrnnt of un oatly

with a eundle, I warrant thee .......

I warrant you, that man is not alive
hope gives not so much warrant ...

hope gives not 8 mueh warrant
I warrant you (rep. ii. 2 and ii. 1 ).

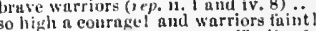

to greet the warriors.......... Frnitiss \& Cressida, iit.

Worthy "arrior welcome to onr tenty - iv.

yet welcome, warriors:

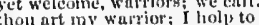

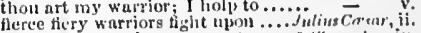

kiss it, my warrior .......... Antony fictenjatia, ic

a hraver warrior, lives not this day Tius.sudran, $i$.

and bring ynu up to be a wartins

my tuir wurriorl ity dear Uthello! .... othello, ii.

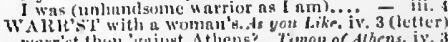

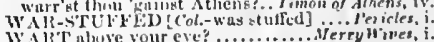

we hud an hour's talk of that wart.

the great wart an my left urn. Comedy of Erroks. iii.

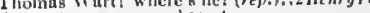

I wenld. Ware miget hare gond

here' wurt youl kee what a rngged

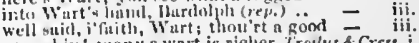

poor chin! many a wart is rielter. Frohlus f Cress, i.

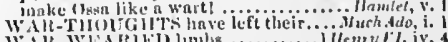

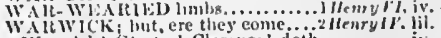

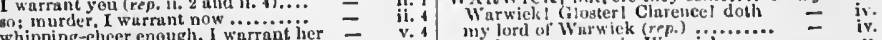

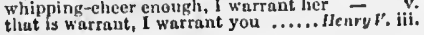

warmth breathes [C.-warm brcthth] ont. Pericles, iii. from the loatlied wirmth whereof Lear, iv. 6 (fetter WAIt.j-lackiug. (Gud warn usf)... ds yauLike il, tv. I

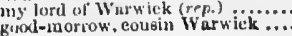


WARWICK and Talbot, Salisbury .... IIenry my lord of Warwick (rep. iv. 8 ).......
follow, good cousin Warwick: if that
Gloster, Warwick, nnd Tuntingdon Gloster, Warwick, and Huntingdon

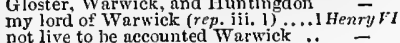
not live to he aecounted Warwick .
Warwick, Warwick! I foresee with gricf
Salisbury, and Warwick (rep.).......2Herny Sal isbury, and Warwick (rep.). Warwick, my valiant son (rep.j....
so God help Warwick, as he loves.. which by main force Warwwick did win and Warwick (rep. i. 4, ii. 2, and v. 1) presence are thy betters, Warwick (rep.) peace, headstrong Warwick $1 . \ldots . . .$. 二 is dead, gond Warw'ick, 'tis too true
gives lord Warwick for his vow? (rep.) 二 gives lord Warwick for his vow? (rep.)
what dares not Warwick, if false.... the traitorous Warwick, with the men
come, Warwick, come goot Warwick come, Warwick, come goorl Warwick
the plincely Warwick, and the Nevils rourselves to matcll lord Warwick $($ rep. $)$ 二 Warwick is huarse with calling thee hold, Warwick, seek thee out some..
what says lord Warwick? shall we.. swret Warwick (rep. ii. 6 )
if Warwick shake lis bells

if Warwick shake his bells ............
power of Warwick, that false peer

and Warwick sorwek (rep) it (rep)

my lord of Warwick (rep.)..........

whet on Warwick to this entcrprize

noble Warwick, Cohham, and the rest 三 lord of Warwick, if we shonld recount
0 Warwick! Warwick! (rep. v. 2)... gentle Warwick? (rep. iii. 3 )

I know it well, lord Warwick (rep.)

I lear great Warwick speak ........

rhy, how now, long-tongued Warwick? -

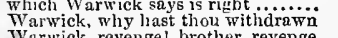

TWarwick, revengel brother, revenge

nay, Warwick, single out some

being the earl of Watrwick's man

and Richard, Warwick, and the rest
shall Warwick cut the sea to France

Ghall Warwick cut the sea to France
Warwick, as ourself;, shall do, and undo =

Warwick, as ourself, shall do, and und
the great commanding Warwick is..

for Warwick is a subtle orator

come to beg; Warwick, to give
whiles Warwick tells his title
welcome brave Warwickl.

me speak, before you answer warwick =

Warwick disannuls great John of Gaunt 二
why, Warwick, cansi thou speak (rep.)

why, Warwick, cansi thou speak (rep.)

conference with Warwick (rep.)

Warwick, this is some post to us

While Warwick frowjls at his.

Warwick, what are thy news? .....

Garwick, these words have turned (rep.)-

Warwick's daughter (rep.

stay till Warwick made return?

Lewis and Warwick (rep.)

your king and Warwick's (rep.).....

is Warwiek friende with MIargaret?

you that love me and Warwick (rep.)

meet Warwick with his foreign power

for Warrick and his friends, God ..

till Warwick, or himself', be quite

if Warwick be so near (rep.) . . ......
Warwick, when we parted last $(r e p$.

pitcled battle against Warwick?

fell Warwick's brother, and

Warwick may lose (rep.). .......
if Warwick take us, we are sure

shield thiee from Warwick's fiow

no, Warwick, thou art wrortlyy (rep..)

consents, if Warwick yield con
Warwick, and his mates (rep.)

where peremptory Warwick now......
honour hears, marcheth from Warwick $=$

how the surly Warwick mans ( $(r p p$.
call Warwick patron, and be peniten

if but by Warwick's gift (rep.)

gallant Warwick, do but (rep.) $\ldots$ W......

wind-changing Warwick now can

trow'st thou. Warwick, that Clarence

trow'st thou, Warwick, that Clarence

for Warwick was a bug (rep.) $\ldots \ldots . .$.
who is victor, York. or Warwick?...

durst amile, when Warwick bent....

Warwick bills you all fareweli ........

say, Warwick was our anchor ........
brave bears, Warwick and Montague

brave bears, Warwick and Nontague -
I'll marry Warwick's youngest.... Richard III. 1.

did forsake his father Warwick, ay..
renowned Warwiek, who cried aloud
did forsake the miglity Wa'wick ....

he lataes me for my father Warwic
WAKWICKSHIP

Wroud lord of Warwicks good lord.. 1 HenryIV.

proud lord of Warwickshire, that..2 2 Henryl VI,

Warwickshire I have true-hearted.3 Henry $F^{\prime}$. iv.
WAR-WORN coats, presenteth. Henry $V$. iv. chorus

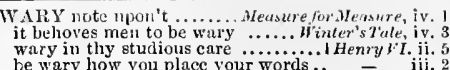
that craves wary walking .........iulius Cesar, $\mathrm{ii}$. day is broke; be warly, look about. Rnmeo \& Jut. iii. and you, the judges, bear a wary eye

hold their honours in a wary distance.

hold their honours in a wary distance... Othello, ii.

WASH -nor wash dish...........Tempest, ji. $\overline{2}$ (sont she can wash and scour...... TuroGen. of Verond and I wash, wring brew $3 \ldots \ldots$ Merr. will wash off gross acquaintance... Tuelfth $\bar{N}^{2} \mathrm{~g} / \mathrm{h}$, i. you let time wash off

when was he wont to wasl his fice?... Huch $A d o$, iji, drops too few to wash hcr clean again ${ }_{\text {to }}$ wash your liver as

forth to wash him in the Hellespont

miglitiness to wash your hands?.. Tam. of $S h . Z$ (ind. come, Kate, and wash, and welcome

seems to wash the hand, was fair.. Winter's Tale, iv. 3 will all great Neptume's ocean wash this Wash your hands put on.............
than we well could wash our hands.King Joth, iji. to wash your blood from off........ Kich

own tears I wash away my balm .....

with Pilate, wash rour hands.

and cannot wash away your $\sin .$.

to wash this blool afgain with....

go, wash thy face, and draw tha....2 HenryI cannot wasl your' majesty's Welsh

ii. $\quad$ wash away thy country's stained ..1 Henry $y$. wash away my woeful monuments .2
do wash the blood away $l^{\prime}$. ii

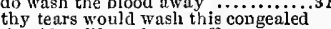

ii. 2 the tide will wash you off .17........... ii. 2 many tears to wash hereafter

ii. 3 will go wash; and when my face... Coriolonns, i.

ii. 4 bid them wash their faces.

ii. 5 stoop then, and wash .....

when I wash my brain ....... Aniony \& Cleopal

to wash tbe cyes of kings

jii. 1 wasli thy hands. Slie hatli

iii. I which wasla both lieaven and hicll

jii.
iii. 1 he swears never to wash his face
wasl they his wounds with tears?

wilt thou wash lim trom his grave..
gone round Neptune's salt wasls...... Haznlet,

to wash it wbite as snow?

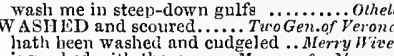

is washed with them........ Aeasure for Measure, thar foulness, washed it with tears

eyes are oftener washed than hers.. Nid. N. 's 's

their colours should be washed

a fairer face not washed to-day

roses newly waslied with dew. Taming of Shren,

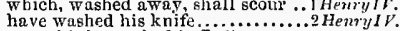
may this be washed in $\mathbf{L}$ eti

is in your conscience washed as pu
look to be washed off the next tide

that washed his father's fortunes.

thy balm washed off, whertwith ...

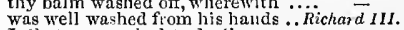

1, that was washed to death...........

ere bloody hands were washed nos.... Cymbelizine

washed me from slicre to shore .....
ne'er come, but $I$ look to be washed

from the ladiler tackle washed off

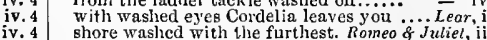
brine lath washed thy sallow clieek o Juliel, ii. brine liath washed thy sallow cheeks

iv. 6 WASHER, and his wringer .........

v. 6 WASHES all the air.............Mid. N's Dream,

these lincoln washes have devoured. King John,

at a brealkfast, waslies his hands..... i inenry $I V$.

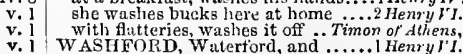

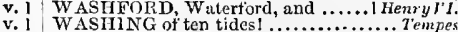

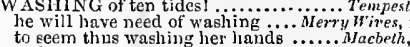
to keem thus washing her lands.......Macbeth, v.

WASP

come, come, you wasp........ Taming of Shreec,

v. 2 Who knows not where a wasp doth $\ldots$.

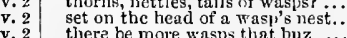

the more wasps that buz .....Henry $\bar{Y} I I I$. ij. WASPISH - and waspish action ...As your Like il, iv. 3 if I be waspisly, best beware .Taming of shrew,

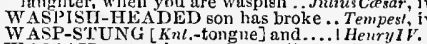
WASSAIL-at wakes, and wassails. Love's L. Lost, with wine and wassail so convince .... Muchellh,

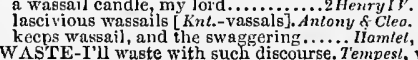

WASTE-wherefure waste I time. Tü Geme or Ver. i. I

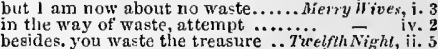
besides. you waste the treasure...Tirelfth Night, ii. as to waste thyself upon.... Measure for Measur arld you but waste your word

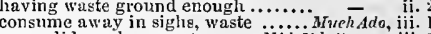
never did mockers waste more .......... than if you had made waste. Merchant of l enice, j. help to waste his borrowerl purse .....
that do converse and wastc the time

waste no time in words .............. willingly could waste my time ...As you Like il, ii. the waste is no wlit lesser.............. Richard II. ii. Whicl waste of idle hours liati...

very slender, and your waste is great.2 Henry $1 \%$. i. may waste the memory.............. enlinkcd to waste and desolation? ." Herry seeming to augment it, wastes it?.. Henry in motion of raging waste? ... Timon of Alnens, ii. so shall he waste his means .......... Juthius Ceresar, iv and wasteg the lamps of nighit..... Antony \& Cleo and they have earned the waste .... cymbetine, iv. by inclies waste you
that I might waste it for you ............. and waste the time, which looks for - ii. thus time we waste, and longest - iv. 4 (Gowcr) that sparing makes huge waste ... Romeo \& Julie', $i$. we waste our lights in vain ............ -

$[\mathrm{Knl}$.$] in the dead waste and middle.... Hamlel, i$. and the niglit grows to waste.......... Oilkello, iiv. WASTED-Was never wusted tiere. Aidid.N.'sDr. ii. 1 then he hath wasted it......... Comedy of Error wars have not wasted it ............ Richard 11 . ii. youth, the more it is wasted ......... i Henry $\bar{l} r$. $\mathrm{ii}$. his quick wit wasted in giving .....2 Henry $1 V^{\prime}$, i. but my lungs are wasted so........... i Henry ${ }^{2}$ iv. ii. 3 would le werc wasted, marrow .....3 Hemry $y^{\prime}$. iii. upon the wasted building ....Titus Andronicus, v. till now some nine moons wasted ...... Ollello

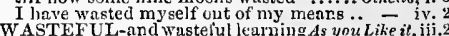
for ruin's wasteful entrance .............Machelh, ii. hath seized the wasteful king......Richard 1 . ini. charged for the wasteful vengence ... Henry $V$. i. retired me to a wasteful cock.. Timon of $A$ lhiens, ii. WASTING lamps some fading. Comedy of Errors, y. by wasting ruin of the cruel foel .....
WATCH - up the watch of his wit... iii. and watch your safety $\ldots . . . \ldots \ldots \ldots \ldots . . .7-$ ii. I'll go watch $\ldots \ldots \ldots \ldots . . . . \ldots \ldots \ldots$. Merry Hives, $i$. pereliance, wind up my wateh .. Tuelsh Night, ii. being chosen for the prince's watch... Much A $d o$, iii. fit man for the constable of the watch - iii. for the watch to babble and talk...... we know wbat belongs to a watch ... = watcha about signior Leonato's door.: = marry sir, our watch to-night (rep.) - iii.5 also, the wateh heard them talk of ... $=$ v. 1 I'll watch Titania when she is.. Mid.N.'s Dream, ii. 2 to watcl tor her! to pray for lierl.... as I will wateh the aim ............... Inl watch as lomg for yoi thien........ = ii. 6 With cat-like watch, when that ... As you Like it, iv. 3 I'll watch you better yet $\ldots \ldots$ Taming of shrew, iii. 1 doth watch Bianca's steps so ........ to watch her, as we watch these $\mathrm{kitës}=$ iv. to wateh the night in storms........... near approaches the subject of our watcla - iii. 3 as 1 diel stand my wateh upon......... be heedful, hence and watch .......... King Johnt, iv. 1
sit all niglit, and watcll with you ..... to watch the feartul bending ....... Richard II. iii. 3 the outward watel whereto my ....... Watch to-night, prav to-morrow .... HenryIr. ii. will sit and watch here by the king..2Henry $I V$. iv. snores out the watch of night ........ = iv. undertook to sit and watch by you . . walking front watch to watch ..... - iv. (chourss) so few, watch such a multitude ....... I Henvy $\boldsymbol{V I}$. i. now, boy, do thou watch
constrained to watch in darkness....... had your watch bean good

. .}




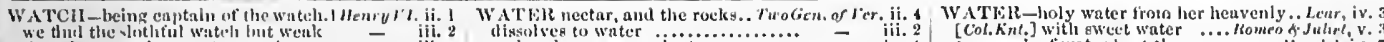

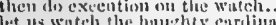

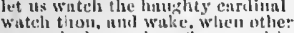
- i.

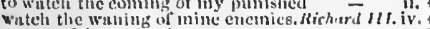
use eareful wateh, choose tristy

and make water against ............. fisl iny gunter wateli; leare me....... - v. I'll watels you tor that (rep.)..... Troilus \& Cress. i. ? therefore I'll watels him till he be ...Coriolanus, vy 1 hurrid sights scenl by the wutel ...tulius Cessur, ii. 2 we witl stand, ant winteh your bleasure $\bar{c}$ iv. 3 to lie in wateh there, nud to think. ' 'ymbelme, iii. I to watch, (pror perd u! ! with this this.... Jecur, iv, eare keeps his watelt in every he anl I will wuteh thy waking frum such watehing now they inglit, I will go eall tlue watelt .. to gijestion, for the wateh is coming then I ran away to call the watel rivals of my watch, bid them make häte Hamlel, i. I to wutch the miuutes of this night

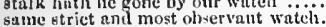

same strict an most ohserwa

eomes urmed through our watch

break we our watel up ......................

the thirl night, kept the wutel

hold gint the wateh tonight? ivedo.

Thiil wateh to-night; perhaps 'twill ....

fur some must watch, while some

give lier good watch, I pray you

set some wateh over yonr s

wateh your ta-night, for the command

we must to the wateh. Not this hour

lie's to wateh; three lads of Cypris ( $r c^{p}$.

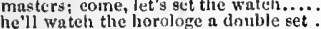

here's a goodly watel, indeerlt

licutemant, I must to the watch ........

I'll watch him tame, and talk him out of

if you will watcli his going thence .....

made him brave me upon the wateh $\ldots . . \vec{V}$, v. 2 WATCII-DOG-Watch-ilogs burk!. Tempest, 2 (8011g) W ATCIIED you now ................ Mtry Hines, y.5 longest wight that e'er $\mathrm{I}$ watched Tirorien of rer.jy. 2 but being watehed thiat it inay

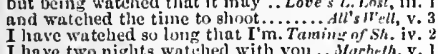

I have two niglits watched with you
England long time liuve I watched

I by thee have watehet, anth hear

we watehed you at un inch.....

Itesty

methinks, you watched her

and watehed him, how he singled...3 Henry rs iii. I in our armours wutehed the winter

you must be watched ere yon.. Troilus \& Cress. iit. watehed for your voiees; for your

frusty nights that I have watehed. Tilus dulron. iii. I have watehed and travelled hard

I have watelied ere nuw all night. Romaeo \& Jul.

npon the platform where we watehed .. Humlet,
WATCHEls of mine own... Tuo Gen. of ierona,

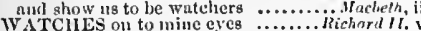

at a thousand watehes (rep.). Troilus o Cressida,
my father watches: $O$ sir, fly this pluce... Leur,

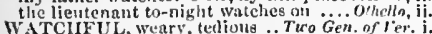

fled the stares of wateliful ty ramny .... Hacbeth, v. 7 in desprite of brouled whteliful day

and like the witeliful minutes to the - iv. by their watehful fres sit .....iveriry 1 . iry

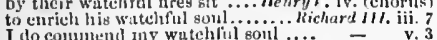
I do commeni iny watehliil sonl

lords, nnd wateluful gentlemen ...... what wntehful cares do inturpose. Julut

V.ATCll SG-ten nights' wat
and slo the effects of wateling

...Wucbeth,

2 Ilenryll. iv.

these chceky are pale for watehing..2 and then it is past watehing . Troilus a cressida, i. by watehing. wepink tentance .....

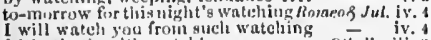
faith, that's with wutehing

W.ITCilMA $N$ to my heart: biit, gond . .llumlet,

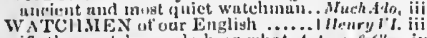

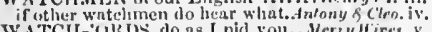
W ATCII-'ollds, do as I pid you... Merry lires, W.ATEk-Cory drop of water swere .. Tempest, put the wild witers in this roar

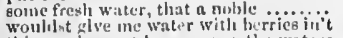
this music erept by me upon the waters he troil the water, whose cumity

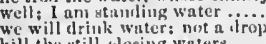

kill the wtill-closing waters............
like the water in un urmal.. Tirogino reno, ii. through hire unt water tior sucla...... = iii.

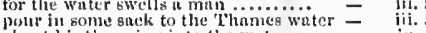

and water onee aduy her elianter. Firelgh Nizht tis with lint so much as muke water

is drowned in treally, sir, with salt wäter =

enrry his water to tlie wise woman

I am for all waters ....................

dine and sup with witer and bron

as prolitless us water in a sicve

my eycs water (rep. v.

hut moon-sline in the water ......... -

the roaring waters with my silks. $M_{i} \cdot r$.

now will I raise the waters....

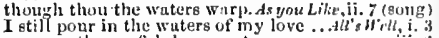
no more than a fisl Inves water...... fire, fire; cast on no vater

some water, here; what ho:

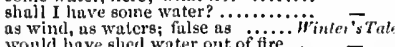

Would have shed water ont of fire

never gazed the moon upon the water

forty thiousand futhom above water..

to ulppathed waters, undreamed sheres -

caught the water, though not the tish

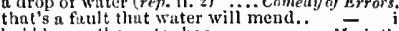

bubbles, as the water has...

go. get some water, and arash.....

as rain to water, or devil to his dam...... King $J_{0 h}$

let his silver wuter keep a penceful

trust not those euming water

commend these waters to those baby

not all the water in the rough........ Richard:

I'll be the yieliling water; the rage..

I rain my waters; on the enrth....

andi water eannot wash away your

there will be a world of water slied

to my water? He said, $\operatorname{sir}(r e j$.)

fureat never appear in him

all the water in Wye eamet

like a circle in the water, w

smooth runs the water, where
told me, that by Water should $\mathrm{I}$.

thine eyes ean water for his denth

adid water to the sea, and give
I drink the water of my eyes

noise of water in mine ears?

we see the water swell hefore.........

to the water side I must cond uct .. Hemry $\bar{r} J I$

fall away like water from ye

their virtues we write in water ........
the bounted waters should lift .. Troilus o.

more dregs than water, if my.....

that I miglit water an ass at it!........

honest water, which ne'er left man

she's ey setting on water tos scald

smoke, and lnkewarm water is your

on grnss, on berries, water,
and drink cold water? nn

our best whter brought $b y . \ldots . . .$.
doth rend like interrisptel watere

stand in thiue, berant to water Jus

cannot enll her winls and wo

shouldst fill with sorrowful water?

a hournished throne. lrumed on

nor what I have dose by water.....

makes it inclistinct as water is in wa ter

to water at those springs .... Cimbelin

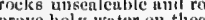

fripest and holy water are so ne......... Fit

eall for sweet water, wash tiy

hath urllect 1 ine

for all the water in the ocenn

whing the waters and the wind .....

thironzh the rongly neams of the water

uld lume

diamonly of $n$ innst pruiked water aplea

wit in the waters thot youl lowe

uwell the eurlel waters "bove tlie muin.

when brewers anar their mult witla wate as fmzatil water to a starved anake
[Col, Knt.] with ewcet water
too mnel of water hat thou

liere lies the water, good
t) this water, and drown himel

t) this water, and drown hinkelf

but if the water eome $t$, him, anl drown $=v_{\text {. }}$

to cust water on thic hurning bear........ Odhello, ii.

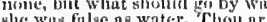

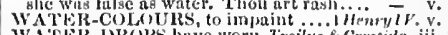

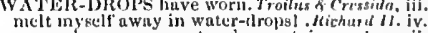

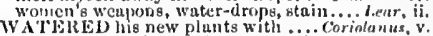

Wua a Spaniarl's moutl so waterei ... I'ereles, iv,

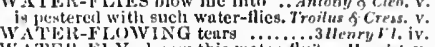

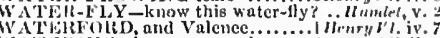

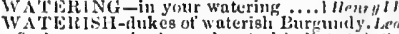

fiecl upon sueh nice and waterish dict. (jthello, iji. :

VATHR-RATS, water-thicves. Merrh. of iemice.

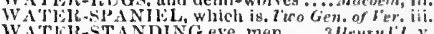

WATER-THEVES, and lund

WATEut N

IVATER-WURK, is worth ...

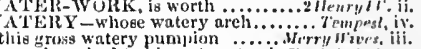

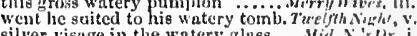

in the chaste beams of the watery mum

the watery kingdom, whose. Mrechont of tence, ii.

the strcum, and watery llcath-hed ... - iii.

ninc changes of the watery star. . Nmter's $t_{a l e} \mathrm{i}$.

and wild watery seus . ....... Comedy of Rrrors, ii.

governed by the wntery noon ...... Kichard lil.ii.

ustrp upon my watery eyes. Titus Andronicu, ii.

thrown him from your watery grave...l'ericlics

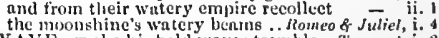

WAV E-make his bold waves trcnible.. Tempest, i. 2

the we the contentitous wares hic kept - i. 2 (song)

hold acquaintance with the waves. Tuelfh Night,

hold acluaintance with the waye

nuw by the salt wave of the ...... Linre's L. Lost, v.

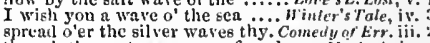

spreal o'er the silver waves thy. Comedy of Err. iii.
though the yesty waves confound .....Macbu'th,

strength with over-matching waves .3 Henry $t i$. i.
let onr bloody eoloure wavel ........

an on bisy to coloure wave

as good to chide the waves

more than with ruthless waves...... =

so minded, wave thus, to cxperess .... Cariolants, $i$.

in our uges see their bamners wave aguin $=$ iij. 1

from the wayes of 'Tiher dia $I$....... Julus Corsur, $\mathrm{i}$.

aword, which he did wave against.. Cymbeline, iv. 2

a koman and a British ensign wave - $\quad$ ws

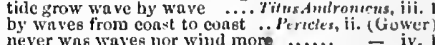

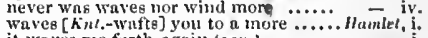

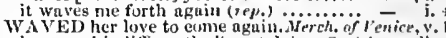

he wavel indifferently thwixt doing. Coviolanus, ii.

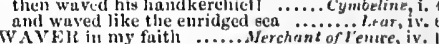

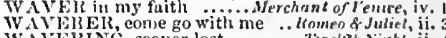

A YRIRING, Bnoner lost ........ Trelt', Nikht, ii.

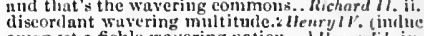

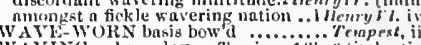

W A ING sedges play .. Tanning of Sh. 2 (induction)

culnesur waving colours on the... Hemyrt. i.

his lyat, thus waving it in seur

wiving our red wh

thill waving, as the flts and stirs of .. ('ymhedue, $i$.

Wie head thins whing "p and drwn ... Hamber it.

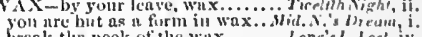

brenk the neek of the wux ...... Lore'sl..l ost, iv.

to make his gallhend wax................

eyen ns a forme of wux resiolveth .... king Johu, $y$

our thighe packed with wax ......... - is

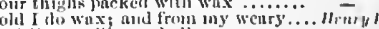

a thil eye will wax holluw

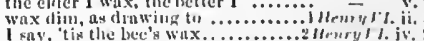

I seek not to wax great bi. otiers.....

nay, then her wax nust melt.........

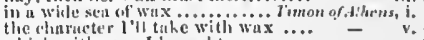

which with wax I bremglit away..... -

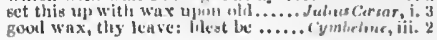


WAX-a stone is goft as wax .... Titus Andron. iii. I doth not the sea wax mad

leave, gentle wax; and, manners......... Lear, iv. Why, he's a man of wax ......... Romeo s Juliet it.

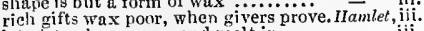
let virtue be as wax, and m. TwoGen..... $\ddot{z}$ erona, iii. the seas waxed calm, and we.. Comedy of Errors the days are waxed shorter.... Timon of $f$ thens, he waxed like a sea; and .......... Coriolanus, ii. with rounds of waxen tapers........Merry Hives. in women's waxen hearts to set.. Twelhh Nid' waxen in their mirth, and nceze... crop their waxen thights, and light them. not worshipped with a waxen epitaph. Henry

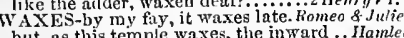
he waxcs desperate with imagination. WAXING - the waxing tide grow. Tilus Anilron. iij. WAY-out of our way and give it way ........................ no hope, that way, is another way in the dark, nut of iny way......... my best way is to crecp under ....

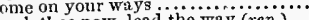
I pr'ythee now, lead the way (rep.).... and your ways............ - iii. that have chalk'd forth the way ...... but $I$, being in the way.....

the way is wearisome.

and this way comes he ............

the best way is, to slander

for the wnys are dangerous

can no way change you.......

he is something peevish

in the way of marriage ............

the best way were to entertain

come a rittle nearer this ways (rep.)

go thy ways (rep. iv. 1)

which way have vou looked

which way have vou looked

you will al so lock that way

yonder he is coming, this way (rep.)

and I will one way or other.....................

nay, keep your way, little rallant

let me stop this way first ........

have you any way to imfool

there is no hetter wiy than ....

well, go thy way

here hes your way $\ldots \ldots \ldots \ldots \ldots$

I will drop in his way some...

I am a foul way ont ..............

there lies your way, due west

and't be any wav, it must

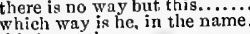

this is not the way....

no way but gentleness tal.

give them way, till he take........

and no way approve his opinion

then lead the way, good father .......

all that offend that way

amen: for I am that way going.........

terch her the way...

admit no other way to save his life

and 'twere the cheaper way.

womething too crabbed that wa........ fria

after the downright way of ereation

he was not inclined that way...

on vour knowled ge find this way?
he did show me the way twice o'er

let me have was, my lord............

that's the way; for women are light

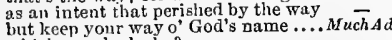

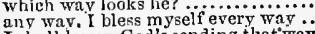

ans wav. I bless myself every way..

you must wear it one way $\ldots . . . .$.

the most peaceable way for you

any way to show such friendship? (rep.) =

some other way than swearing by

you go not the way to examine...

masters; each his several way.......

well, go thy way (rep. iii. 2) .........
to speak troth, I have forgot our way

ay, that way goes the game

coy, that way goes the game within another's way........

fillen aun I in dark uneven way....

be gone, and be all ways away .....

ay, our way to be gone..................

in via, in way, of explication.....
WAY - by the way of progression... Love's L. Losl, i we are much out o' the way

strewing her way with flowers . $\ldots . .$. .

that was the way to make his........

ghe is two months on lier way....

why that's the way to clioke

we will bring you on your way

glow their teeth in way of smile......er. of Fenice, $i$.

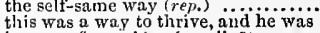

in way of marriage (rep. ii. 9).........

twill be a hard way to hit ...........

meting with Salerio by the way.....

well, you are gone both ways.

where the ways are fair enoug

vay of .....

twill be a mantin in the

As you Like it,

but come your ways (rep. ii. 3)

that's the way to make her scorri.......

as plain as was to parish chutch

as plain as was to parish chutch

and, by the way, you shall tell...

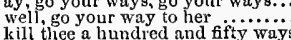

kill thee a hundred and fifty ways

think him a great way fool ...........

nay, conce your way's (rep.

my state that way is dangerous...

they have gone a contrary way

is this the way? (rep.

he can come no other way but by...

how and which way you will

they 11 be for the flowery way

gistrneted clonds give way; 90 stand

.

by none of all these ways, how could

while I nake way from heart.. Tamin

which is the readiest way to the house

the instrument my pate made way

opel, sir, there lies your way

all foul ways! was ever man

another way $I$ have to man my...

this way the coverlet, another way

this, by the way, I let you ........

shail I lead the way? welcome

Petruchio, go thy ways (rep. v. 2 )

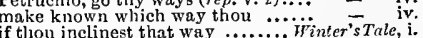

which way to be prevented, if to be..

saw I men seour so on their

or will, that way inciining

to look that way thou wert

home, home, the next way (rep.)

am false of heart that way

jog on, jog on, the footpath way

$=$ i.

i. 3

a way to make us better friends

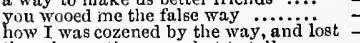

there is no other Way, but to tell .....

give way to what's seen now
meets lie on the way the father.

and mark what way I make ..........

ngainst lis way, my way is now

by the way we met my wife.........

you stop our way with

for in iny way it lies.

to catch the nearest way.....

that nature gives way to in reposei...

marhalst me the way that 1 .

my sters, which way they walk .......
must not be thought after these ways.

the primrose way to the everlasting

and our safest way is, to avoid ....

whear it by the way; but I wili

all causes shall give way ................
something wicked this way comes

each way, and move

and more sundry ways than ever

several crime, acting it many ways....

my way of Jife is fallen into the sear

the way to dusty death

that way the noise is (rep.) .............

give our betters way ................

and give the victors way

Dauphin every way complete...

have turned another way, to oux

he is a very serpent in my way

I have a way to win their loves.......

hy ree, which way you go............

I come best way is, to trenge......

now, no way can I stray
to lie thal way thou goest...
WAY_r'll bring thee on thy way ....Richard II. i. 3

high Hereford on his way? ....
whose way himself will choose

go all which way it will the noble:.

how, or which way, to order these ..

rough uneven way's (rep.)............

toads, lie in their way

prevent the ways to wail

some way of common trade....

and surest way to get.............

this way the king will come $(r e p$.$) .$

know'st the way to plant unrightful

thy way with sighe him hearlong

make way, umruly woman ...........

uncertain of the issue any way

or any way impeach what then......

hold out water in foul way?

we shall lave good trading that way

in the tedious ways of art

'tis the next way to turn tailor......

a mad fellow met me on the way....

if the king have any way your good

to meet you on the way, and kiss ....

if he do come in my way, so..........

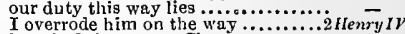

he asked the way to Chester .........

the aptest way for safety

have been well on your way to York =

wrenching the true cause the false way -

as common as the way between.

give even way unto my rough ......
makes a still-stand, ruuning neither way -

let it go whlich way it will, he that ...
we see which way the stream of time

we see which way the stream of time
is open; he is gone this way.........

is open; he is gone this way ...........
oldest sins the newest kind of ways?

and indirect erooked ways, I met...

he's walked the way of nature

I gave bold way to my authority ...

loosed several ways (rep.)..........

every rub is smoothed on our way...

I knew there was but one way .......

in the way of argument, look you.

another neighbour, stand iv our way

and my way shall be paved with .....

geems to prepare his way.......

Fench maid that stands in my way $=$ v.

stood in the way for my wisl (rep.)..

which way, should they first break in? -

turn not thy scorns this way

thy edged sword another way

and no way canst thou turn

and smonth my way upon their....... Henry $r$ I. i.

protector will come this way by and by -

good wine in thy master's way
go, lead the way; I long to see

the way her harmless young one.......

this way fall I to death (rep.)

turn this way, Henry, and regard ...3 Henry V1. i.

now sways it this way (rep.)

no way to fly, nor strength ......

a way, and straying from the way ...

or hew my way out with a bloody axe

let's on our way in silent sort ..........

comes hunting this way to

he make this way (rep.) ..............

thither straight, for willingness rids way -

Think the way, and thou........

the redist way to

then give way dull clouds

for, hy the way, I'll sort occasion.....

(rep.)

reag ere this have met us on the way

gracious pleasure any way therein ...

to meet you on the way

the way to win your daughter (rep.)

tell thy tale the nearest way? if by the way they be not fough

grace chalks successors their way ... Hen

of his own merit makes bis way .....

but when the way was made ........

men of his way should be most liberal

our breach of duty, this way, is business -

pray you, keep your way...

or laid any scruple in your way .....

and that ray I am wife in

and that way $I$ am wife in ...........

betray

betray you any way to sorrow
the way of our profession is.

the way of our profession is..........

aud hedges, his own way; but in ....

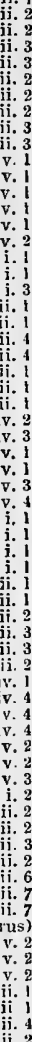


W $A X-$ no way to cure this?

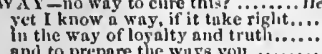

Wolsey, that once trod the way.

found thee a way, out of hig........

ye glanll go my way, which is
of mine own way i know you

of mine own way, i know yoil........

glal, I eune this way so happily

might go one way, and safely.

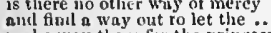

and finul a way out ro let the
muke way there for the princess

shull read the perfeet ways of.

lead the way lordst ye minst. .........
go thy way. If cetor (rep.)

making their way with those ot.....

is this, in way of truth ..............
come your ways, eome your ways

beseecli you, as in way of taste

I will lead the way

if youn give way, or heilge....

it will go one wuy or otice

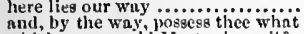

which way wonthl Heetor have it

mnke eruel way through rank

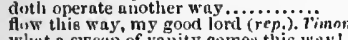

What a sweep of vanity comes this way!

I knew it the most generul way $\ldots . .$.
and muke a clear why to the gods.
fear to eateh it, and give way.........

you that way, and you this, buit iro

you must in no way say

course will on the way it takes

glucked all gaze his way

Ill poteh at him some way...............
ratler be their servant in my way

rather be their servant in my way
make way, they are coming

congent of one direet way should tie

Which wuy, do you judge, my wit
why that way? To lose itself........

Youl must eaquire your wuy

set sought the very way to antel.

and give way the while to unstable.

this is the way to kindle (rep.)
gir, thone cold ways, that seein

gir, thinse cold ways, that seem
it is the humane wis: the other

we'll proceed in our first way.

hast not the soft way, whict

that starts $i$ ' the way before the

keepl on your way. O you're

and have already o'erborne their way

gave way to your elusters.....
kacel the way into lisis meres

and enninot lose your way...

you know the way home again

gave him way in all lis own desires.

aiter your way his tale prongy
now strew flowers in his way

go you down that way (rep.)

6tund you directly in Antonius 'ay

Which ig a great way growing on
this way have you well expounded

seeurity gives way to conspiraey

which way hast thon been?
he draws Mark Antonio out of thie......

spurn thee like a cur out of my way

one of two bad ways you mus
or driven as we point the way

must 1 give way and room to your

you wrong me ever
give lim way (rep.)

Aninny \& clenpa

no way excuse his soils, when we.

entmities may give way to greater.

to greater mutters must give way

your way is sliorter, my purposes....

glow us the way, sir

blow ine which kay

give light to thy fair way

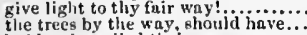

hold unberniled tlieir way

quite forego the way which promises
already show me the way of yielding

that 1 liave lost my way for ever

that will sweep your way for ynil.

I have many other wave to die

It have many other ways to

this was: well said

to the way sle's forced to ........

make way there, - Cerar (rep.)
why, that's the way to forl thici

being toyal, took hier own way

of eany ways to die

knowledge whieh way they weit......

in despair; that way, past grace

or a that way aceomplisied courticer

is eniled, take your own way .........
would chalter this way, anl conterni

is there no way fior men w be $31.1 .$.

nild, by the way, tell me linw Walc

aecessible is none but Ifil frral way
told me, I could not miss my way...

told me, I could not miss my
did make my way long firtti

which is the way? I Ihank you

this way, the Rumanis must or .....

the way which they stouped eagles ryllill, iii. 2 WAY -art a way, I think, to lilerty.. Cynueline
you know not which way you slaali go

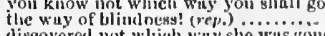

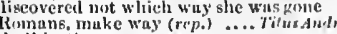

gluntl be thy usuge every way.

purr'st me iny way in Roster

this way of was ht ail, stand you

this winy to death iny wreteleie

Which why shall I find revente's eave?

or plot the way to do it

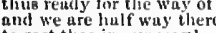

to cant thee in our way !................

go tliy way's (rep, iv.

your thoughts went on my way

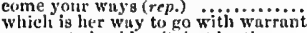

no way to be rid on't. but hy the way

Wolld but give way to enstonic.

come your ways (rep.). .........

any of these ways are better

give him way. Rarest aound
rest nutold: sir, lead the way

your liking a inore worthier way....

tled his way, sir: when by no
a bawd, in way of good service

draw, you raesal, eome your way'

if the wild geese fly that way

tis best to five him way

in whieh your pain that way; $\mathrm{I}^{\mathrm{i}} 1 \mathrm{i}$ tiji...

eivtrat

this way, my lord. With $\mathrm{him}$

his wits late given way to lis iun

let him sulell his way to Dover.

ii..

in the way to Dover (rep.)

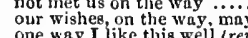

one way I like this well (rep.) .......

gtay with us; the ways are dangerouts.

my bruther's way to the forlenided pluee

thou dost make thy way ...
gliall give them instant way

thall give them ingtant way
the the way to eall hers....
he ran this way, and leapes

go thy way, weneh; serve God

is but a little way above our liend

is but a little way alove our heads
way ran he that killed MIerentio? (rep.)
to light thee on tlyy way to Mantua..

or walk wanders this way to-nighit.......

lead boy; whliels way? Yea, noise

the steep and thoray way to heaven.... Ilant

he seemed to find his way vithout.......

we coted them on the way

and profit, was better both ways

certain players we o'erraught on tie way

bring ho to his wonted way again.

Knt. plny the fool no way but in

his aftections do not that way tend .....
they must sweep my way, and marsial.

come, I will give you way for thesc......

gome one was, some antother

is the next way to draw new

let ler will lave a free way ...............

it is elcan out of the way

these mutualitics so marsinil the wing

what, man! there are ways to recover

ng, that's the way; dull not device..

slcak is it out of the way?

gicare is no other way; 'tls slie............

bring me on the way a little (rep.)....

nor sert yout out o' the way? Never

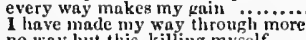

WAYLAID-lave already waylaid

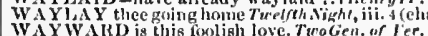
her life to a chis

whining, purblind, way ward hey. Lave's 1 . Lost,
my wife is in a way ward mood Comedy of lirrors

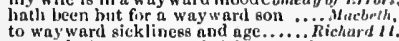

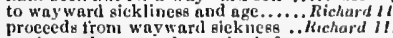

teteliy and way wird was thy infancy

thwarting the wayward seas. l'erecthrs, iv, 4 (Gower)

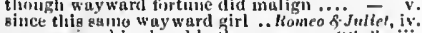

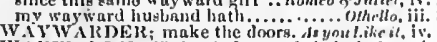

WAYWAlRDNh:ss that infirna and choleric l,ar,

a very weak munster ...............
weak masters thoughi ye be

mule wit with musiling weak. Tiro Geti. of l'erona

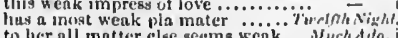

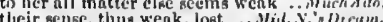

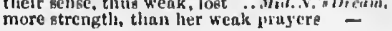

WFAK-a wenk homal holds you ...Mid.N.'s Dr. hil.

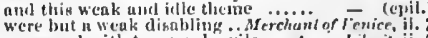

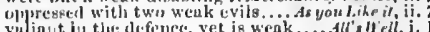

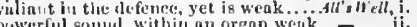
powsermil sommil, withium an organ wetk nul nine aye is weak

but very wesk and une................

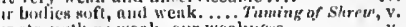

and war weak spirits ne'er been .. Hinter's Tule, i

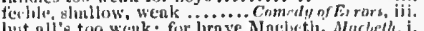
luit ali's too wecuk: for lirave Maciseth. Macbelh, i.

sante wenk winl which enkindietl it. King Jahn,

out of the wenk deor of our fainting

hereanse niy wower is we'nk

weak mell must finll; lor licaven

how these vain wenk vinili ina....... ten

luold as little conuses with weuk tear. I llenry $/$

the power of Peres is tols weak

cun a weak cimpty vescil bear

twenty wenk und wearieci posts

from talling witls so wenk $a$ wind...

of a weak and wigagardly projection.

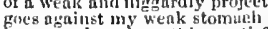

but a weak and worthless eatisfinetion

with army, but a weak and eiekly guturd 二 iii.

aray is grown weak and fuist
helps me, elee I were too weal

this wcak and writhled slirimp

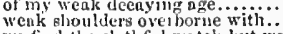

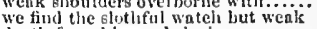

age, aud weak weakle limbs

ny ancient ineantations are too wenk

till lifenry be more wenk

my the s weak. tell ne .............

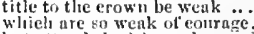

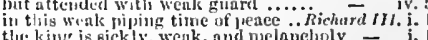
if my weak oratory can from his....... onee wertk oncs, is not ours

tis too weak ever to get a boy
mueht too wenk to opyose you

.

with my weak wit, oud to such men

with these wcak women's feurs ......
whinse weak uotimbered sider

and the weak valton Cupid shal

to a weak and colder palate...........

. Cornhamus, v.

you make the weak noost strung

hegin it with wenk straws

thus to comnnit your wenk condition

ah me, how weak a thing the heart.. -

nade weak by my nfliction .........

mine eyes are wenk; fold down ..... cyynbeline, ii.

that eravens my wenk hand

I an wenk with toil, yet strong....... -

fult weak to unclertake aur wark .... - iii.

morr, infirm, wenk, and lespised nlit inan - iii.

alnek, too weak the conflice to support l - .

from love's weak ehikglists bow........ - i.

any gentlewoman, and very weak denling = ii.

holing a wiak supposal of our worth ... Hambel, i.

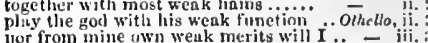

thor from mine uwn weuk merits will $1 .$. 二

either his not dion weak our ... Troilts \& Cressiltr,

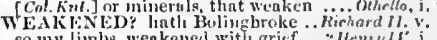

WEAKER-muet weaker than you.... Tempest,

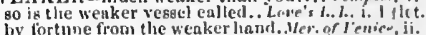
or semuething weuker masters thee. As you l.ike ii, $\mathrm{i}$.

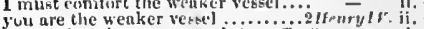
an weaker than a woman's tcar. Troilus a c'ress, $\mathrm{i}$.

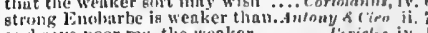

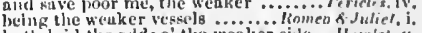

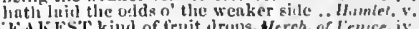

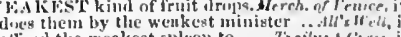
otlienct the wenkest Epleen to .... Thoilus a cic in wrakest bialin's stroume twal

WN.1K-111N(G) finney .............

Whaki, $\rightarrow$ my diseretiun so weak

but weakly ginarlerl where

flenyou ire neakly mate
WLAKNLSS Wlich I feel. ilewrylli. 


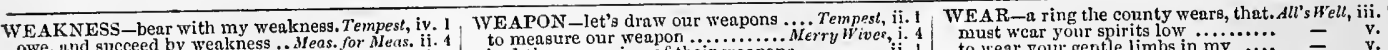

means of wenkncss and debility...As y'u Like it, ii. 3

than I dare blame my weakne

our weakness past compare ... Taming of Shrew, y.

whose weakness, married to thy. Comedy of Err. ii.

straight; weakness possesseth m

gives, in your weakness, strength ...Richard 13 . iii.

see his weakness, and admire our ..... Henry $r$ iii. 6

for weakness, which she entered

bear with her weakness, which

I Hentyl.
Richard VI. v. 4
Ris

rords and wealeness

Troy in our weakness stands.
from my weakness draws my

thy country's strength and wcakness Coriolanu

thy is the weakness of inine eyes ... Julines Cresar,

O noble weaknessl if thicy had ...Antory \& Cl

thenee into a weakness; thence to .... Haml
out of my weukness, and my meincholy

dare not task my weakness wi

WEAl,-purged the gentle weal

Othello, $\mathrm{ii.} 3$

the medicine of the sickly weal

sit at chrefest stern of public weal ...

watchmen of our English weal......

God's glory, and my country's weal

smells from the general weal. Timon of Athens,

touching the weal o' th

a foe to the public weal: ohey

in the tender of a wholesome weal ....

determine of my weal or woe ..Romeo \& Jul

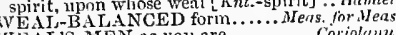

WV EAL'S-MLN as you are $\ldots . . . . \ldots$ Coriolames, il.

and more wealth than faults ( $\mathrm{rep}$.)

I have little wealth to lose ...........

for the wealth of Windsor Cas

to heal it only by his wealth
thy father's wealth was the first

thy father's wealth was the first ....

tor it is all the wealth he hath left ...Much Adn. I.

for all the weal th that ever I

all the weal th $I$ had ran in. Merch

man outlive his wealth, to view

man outlive his wealth, to vlew state.

for halt thy wealth, it is Antonio's.

I once did lend my body for his wetilth. $\overline{\text { Like }}$

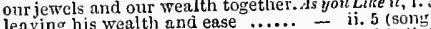

leaving his wealth and ease

honour, and wealth, from me $\ldots \ldots . .$. All's $F e l l$, ii.

as wealth is burden of my wooing... Tam

a merchiant of incomparable weal th..

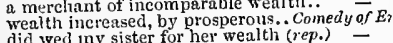

did wed iny sister for her wealth (rep.

hath he mut lost mich wealth by
destroving them for wealth

Mac $\bar{b} e t$

for the wealth of all the world

and were masters or their wealth

to clioose for weal th, and not for

to cloose for wealth, and not diad

or gather wealth. I care not with

been desirous of their wealth

affected eminente, weal th .....
what piles of wenlth hath he

all that world of wealth $I$ have

政

I would not for the wealth of Athens

have put my wealth into donation

who cannot keep his wealtli, must $\ddot{\text { my lord hath spent of 'Cimon's wealth }}$

the latest of my wealth l'li sharc

not wisl to be from wealth exempt

hadst thou wealth again, rasctils ....

take wealth and lives together

you had power and wealth to requite me

and silns of love and wealth, as shitl

"would half my wealth womld buy.

if there were wealth enougl fin....... Cigmhe

I tell you anl her wealth

sum up half $\mathrm{mr}$ sum of wcalth all this town

impo thume of much wealth and peace. Hamle

IVEALTIIEST, that, I protest ......All's s'ell,
IVEALTHILY in Padua (rep.). Taming of Shrew,

WEALTHY Andrew dacked in

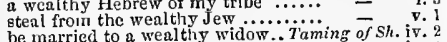

her dowry wealthy, and of worthy birth - iv.

and all the wcalthy kingdoms of ....2 Henry $F I$. i.

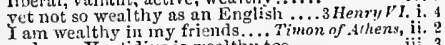

and now Ventidius is wealthy too....

wealthy curled dartings of our nation . Othello, $i$.

I tie ratier wean me trom ..........3 Herry Yl. iv.

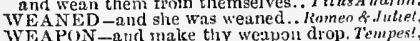

WEA PON-and make thy wedpon
I saw their wenpons drawn. to measure our weapon ...............

had the measuring of their weapons
what weenpons is lie? No weapons, sir

it appear's so, by his wear

keep in your weapon ......................

are dangerous wa

get yourt with the same weapons... Mereh. of Venice,

raw forth thy wenpon....... Taming of shres.

I smile at, weapons lizugh to scorn .... Macteih, v. 7

he doth, if' his weanon be out.

put up your naked weapons

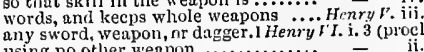

using no other weapon ............ - ii.

his weapons, holy saws of acrert
hnth turned your weapon'日 edge

take away his weapon $\ldots \ldots \ldots \ldots \ldots \ldots$........
you put sliarp weapons in a madman's

your wrathfil weapons drawn here..

lay your weapons down...............
shate he his weapon at us, and pass hy

words will not, then our weapons shall

slall rust mon my weapon ........3 Hen y $r$ I. i. 3

kill me with thy wcapon ............. - y. 6

what, would youl have my weapon with your weapons. Toilhs \& Crew.

wcapons, weapons, weapons! .....

waving our red weapons.

with thy weapon nothing darest... Titus dindron. ii. I

stand st thou with thy weapon drawn

and scnds the weapons wrapped about

with this, my werpon drawn ........ here.

let not women's weapons, water-drops

my naked wcapon is out ......... Romeo \& Juliet,

throw your mistempered weapons ...

heat down their wcapons....

I mean, sir, for his weanon ...........

get weapons, hol and raise some special

Hamlet, $\mathrm{ii}$.

with years, than with your weapons .

in his shirt, with light and weapors ....

he another weapon in this chamber.

hast no weapon, and perforce must sutfio

behold! I have $\Omega$ weapon

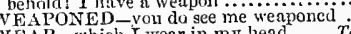

wear out thy youtl in ...... Tho Gen. of rerons,

compass will you wcar your farthingale?
shall I fashion me to wcar a cloak?..

I'll wear a boot to make it ...........

and by my side wear steel.

a way, I say, time wears................ notsh $\bar{N}_{i g h}$

so wears she to him, so oways.

here, wear this jewe for me

keen whips I'd wear as rubies ... Neas. for $\bar{M}$ teas

which she yet wears for his sake ....

he wears lis faith but as the

but he will wear his cap with

what fashion will you wear the garland -

your must wcar is too costly to wear........

let her wear it out with good counsel

and may wear her lieart out first.....

the fashion wears out more apparel..

no, pray thee, gond Meg, l'll wear this
I'l wear nowe but this ...............

God give me joy to wear

win me and wear me ..................

they say, he wears a key in his ear ... -

to wear away this long age ...........

wear his colours like a tumbler's. Love's L. Los

this fuvour thou shalt wear..........
come on then; wear the favours

come ou then; wear the
this jewel did she wear

and that a' weal's next his heart

wear prayer-books in my pocket. Mer.of le

wear yet upon their chins the beards

thetn lightest that wear most of it ...

and wear my dagger with the braver

that you would wear it till your .......

the clerk will ne'er wear hair on .....
gentleman, wear this for me $\bar{L}$ ike.....As you
wears yet a precious jewel ..........

wear these for iny sake

motley's the anly wear! $\ldots . . . . . . . .$.
get that 1 wcar; owe no man........

get that 1 wcar; owe no man .........

and horns to wear (rep ) .......

to sce thee wear thy heart in .........

and tonthpick, which wear not now

and I like tlie wear wcll

it will wear the surplice of humility

for wears his honour in a box must wcar your spirits low ......
to wear your gentle limbs in my

I have seen her wear it (rep.). ........

What appare he will wear.. Taming of
raiment will your honour wear (rep.) -2 (induc.)
where a wasp doth wear his stiug?..

the morning wears, 'tis time....
repair what she will wear in me

gentlewomen wear such caps as...

why he that wears her like her......... inter ${ }^{\top}{ }^{\top}$ Tale, $\mathrm{i}$.

as friendship wears at feasts ...........

ill they wear their plackets ........

and timest, finest wear-a?.........

but he wears them not handsomely - iv.

often touching will wear gold. Comedy of Errors, 1 ,

but I slame to wear a lieart so white... Macbeth, ii

who wear our health but sickiy...

and wears upon lis baby brow

went thou thy wronge.

wer out the day in peace

thou wcar a lion's hide!

for lis sake, wear the detested

might wear, without corrival .....

wasted, the sooner it wears

when $l$ will wear a galment

that same royalty lie wears.........

wear nothing but highl shoes

and wears his boot very smooth....... -

He that wears the crow

and wear it in my heart ............

they could never wear such heavy

do nnt you wear your dagger...

nhis will I also wear in my cap

this will I also wear in my cap .......

no scorn to wcar the leek upon (rep.)

he would wear, if alive .............

here, Fluellen; wear thou this ......

proinised to wcar it in his cap .........

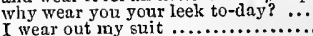

thou shalt wear me, if thou wear m

and not to wear, linande, or use .......

in spite of thee, shall wear

will r upon thy party wear this rose

still wiil I weur the same ..........

ought to wear this ormament .........

in thet he wears the badge of .........

name the several colours we do wear

let thy hor'se wear a cloak..............

shalt wear it as a herald's coat .......

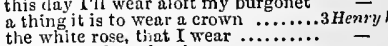

cannot speak, unless he wear $a$ crown

tho' he do wear the crown .............

and much rain wears the marble .....i)

now shall wear the English...........

altho' my head still wear the crown.

framed to wear a crown $\ldots \ldots \ldots \ldots \ldots$........

wear both of tliem, for both ............

too weighty for your grace to wear .

wear their licads, than some (rep.)...

but shall we wear these glor es ......

cum privilegio, wear away

and wear a golden sorrow.............

I feel I am not worthy yet to wear.

who wears his wit in his belly .........

he man may wear it on both sides.

wear this sleeve.......

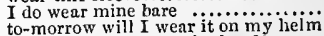

and wear a castle on thy headl .......

it wears, sir, as it grows ........ Timon

and he wears jewels (rep.)

yet do our hearts wear Timon's livery

thy fiatterers yet wear silk

ne'er did poor steward wear $a$ trucr.

Caius Marcius wears this war's....

you wear ont a good wholesome......

double bosoms seem to wear one heart

who wears my stripes impressed on him

truly, sir, to wear out their shoes...Julius $\bar{C}$ ca

and he shall wear his crown, by sea.

where brave Caius, to wear a kerchief?.......
he wears the rose of youth...... Aniowy, $\overrightarrow{C l}$.

he wears the rose of youth.........hlowy sctoo. iii. il
wear all your true followers out..... 


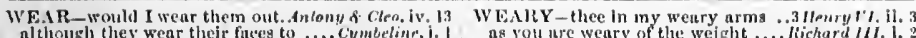
although they wenr their futes to ...... Cymbelinr, i. Sor my sake, went this; it is

must wear the print of his remembianes

now, it you conla wear a mint dal

fortli I wear it no your tenemis

for I wear not my dugter in ..........

my hrother werars thee not the one

he dinth went a precions ring...... ?

mare sle'll wear Diama's livery

O gotkless, wears yet tliy silver livery

Winth that lenrned elonrity aye went

thou must newls wear my exxcon

know not how their wits to wenl.
wear a s work, who wears no homest

lin, ha; look, he weurs erinel garter

then he wenrs woxden nether-stock

fathers, thint wear rags, do m

if you disd wear u heard upon your eliii...

wear this, spure specelt; decl

and we'll wear out, in n wal

and none lut tonls lo wear it prison

will the er wenr out the everlasting fliut

be hanged, sir, if he wear your livery

new rubes, and may not wenr them..

I will wear him in my lieart's cor

you, inay wear your rue with a difterence

you inas wear your rite wis

no you ure weary of the weight

the weary suil hath inade.

lrepgurs, wenry uf their lives.

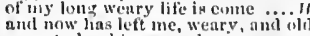

come to luy his wenry buics nmome

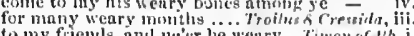

to my friemla, nnil ne'cr be weury

I am weary of this cliarige

longer to live menst werury

waste his menns, weary his soldier.

talk tliy tumpue weary; speuk.

bot weary for the staleness

put in what weary newligence.

wenry of all, shall want Eome.

they nre sick? they ure wetry?

row wenry stale, weary butk l...Romero of blu

to grunt aud sweut under a wesery lite .

whelury rekoning! pare thy hearer.

Wensel hath not steh a deaj of
the wench seot eomes sneakin

the werkef seot eomes snenkin

it i like n weasel (rep.) .................... Hum

it is foul weather in us all (rep.).

twill endure wind and weatlie

fair wenther after you!

maly ean brook the weather that

winter und rongl weatlie...

as the winter to foul weatlie

tis like to be luud wenther...... Winter's?

hart this weatlier? they hare eeared

condured all weatleers. Lay't so.

extremity of wather continuing .....

and make finir weather in your..........

make foul weather with ilespied ... Richard

fie! tlis is hot wenther; gentlemen.2 Ifeny $t V^{\circ}$.

and the weather, and the war

ghake fair weuther yet $\mathrm{a}$ whililo

placed together makes a while ...... -

keeps the wenther of my fute. Troilus \& Cressidu, v.

and left me bare to wentlicr....... Cymbetene, iii. 3

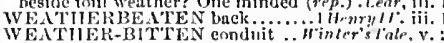

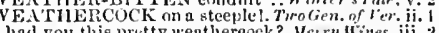

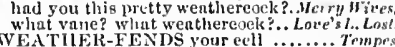

WEATIIFR-FENDS your eell ........ Trmpes

weaves tedious sntres to trap.

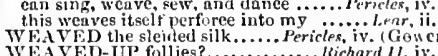

WEAVER's benm

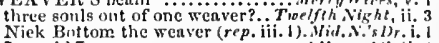
I would I were a wenver

fullers weavers, who, unft for ...llenry rlll. WEAZNND with thy knife .......... Tempest, iii.

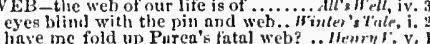

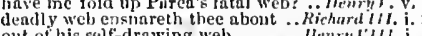
out of his self-drowing web......... Irnry r'll.

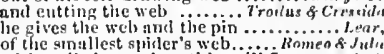
of the sinallest spirler's web....... komen s Juli
with as little a web as this, wiji i ....... Otheth

there's magie int the weh of it........... ne

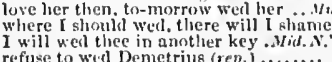

refuse to wed denet would weil me, or else die.i.öre'sl.

Drcember when thry wet..........ts you Like

nur neer weti woman, it you .........

not to wou honour, but to wed it

faire fortune, it you ever well

wno her, wed her, unl beth her. Fimming of stre

I woull not weth her for a mine of

if the deny tu well, I'll erave the ing

to wisle me wed to one laalf humatie...

yet never means to wed where he.....

nanl wed unto us wamen

if you weil my sister fir lier walth...

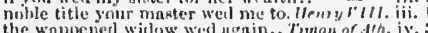

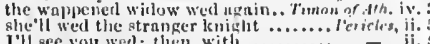

I'll see your wet; then, with

choiee, und think me rnrely wed......

liaply, when I shall wed, that lord....... I.eur, $\mathrm{i}$.
W FD-that I must wed ere he ... Koneo f Juliet, iil. s

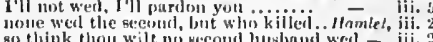

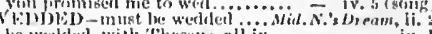

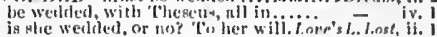

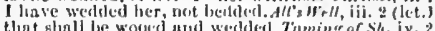
that shall he wored and wedlded. Tuming of sh. Iv. were you wedded you womil ...... Comedy of lirr. $i$

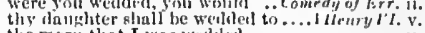
the mornt that I was wetded............ when I tlrst my weilded inistress .. Comirsinnus, is

she's wedded; her liusband lanis
a tholligh suitor to a weddcri lady

why dial you throw your wedded iaily

Whom for the theft i wediler

Pericles, my werkerl lord, I ne'ur ..... Pa

thou art wedded to ealamity .. Momen f Juluel, iii. VEDDING-plums at your wedding.... Werry W'ires,

Wosing, wedding, and repenting
the wedding, mannerly-modert.

very niglat before the iutended we.titing - ii.

I will not to wedding wi' thee ... As you Like it, iii.

let yonr wealding be to-morrow ......
weduling is preat Juno's erown ....

otrer'bt fairly to thy brotlier's weelling -

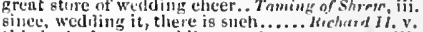

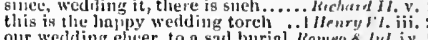

our wedding elicer, to a sasl burial. lomen fo.tul iv.

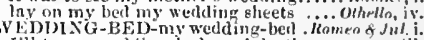

I'll to ny wedring-bed; nuld denth... - iii.

this wedling-day, perhaps, is but...

on his weddfing-diay at ngglit.....Mid...'s Dream, i.

lienee upon your weddling-ilay...jerch of lenice, iij.

that uyoul Sunday is the wedding-day -

to buy apinarel 'gainst the wediling-day =

this is your werlding-day, first were we - iij.

upon thy kedding-day? against.... King John, iit.

against this wedtling-day a..... Womeo g Juliel, iii.

VEDD?

WHDDING-G URMENT on? Taning of Shrew, lv.

WEDGES of gold, great anchors .....richart liti. $\mathrm{i}$.

blunt wedges rive hard knots. Trailus \& C Ceswila, $\mathrm{j}$.

my leart, as wedged with a sight. Trombs \& cress. $\mathrm{i}$.

etrongly wedged up in a bloekhead.. Corratums, it.

so wedluck would be nibibiing....

higli wedlock then be honoured... Ansou Like $\|$, iis.

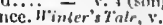

fid after wedlock bear him

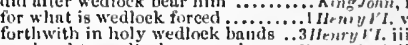

my bond to wedilsek, or my loye

WEDI, CCK-IIY II we sing.............

Weduesday the fourscore of April. H'inter's T'tule, i

that I had a' Wednesdny last... Comedy orlirrwi, i.

on Wednesdny next, we solemnly . Richard $/ 1$, iv.

Oll Weilnestiay next our comeil ...1 HenryI j.

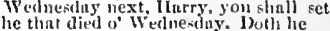

upon Wednesdny in Whitsun-week.oll

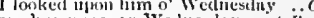

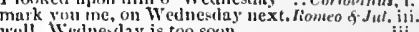

Weiluedneslay is too soun

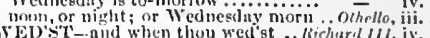

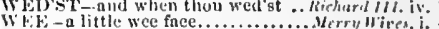
EED - with weels so loathly ......... Temprse, iv. such weeds as may ........ Triogen.

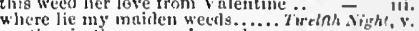

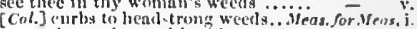

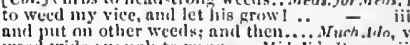

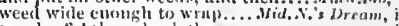

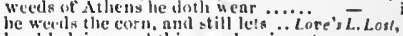
lanrl lenlging, and thin weetls, nip not

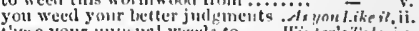
thene your unusual wewla to .... Winser'st'ale, iv.

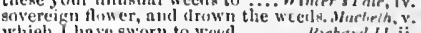
whieh thave sworn to wecd

ruot away the noisome weeds.........

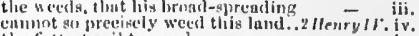

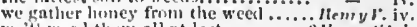

nuil weeds ure shallow rootedi....

...... iii.

nourning weeds are lnitl aside (rep.... iv. 1) iii.

alle sline and grow apace.

idle weeds nee tinst in growth....

he's a rank weetel, sir Thumn

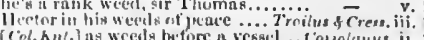


WEED-he wore his humble weeds .. Corinlanus, ii. 3 WEEP-will you have them weep what contempt he wore the humble weer then we bring forth weeds...Antony \& Clenpatra with wild wood-lenves and weeds .. Cymbeline,

victorious in thy mourning weerls!. Tilus Andron, i. way with ovigh weeds, and idle.

but attired in grave weeds, Rome.

nor man in mournful weeds

I will rol Tellus of her weed

and all the idle weeds that grow in

these weeds are memories of those

with

in tattered weeds, witl overwhelmin

than the fat weed that rots itself

do midnight weeds collected

his sables, and his weeds, importing hent

her coronet weeds elambering to hang

. iv. 7

o thnu weed, who art so lovely fair....... Ohello iv,

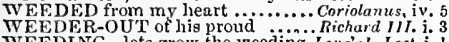

WEFDING -let grow the weeding. Love's L. Lost, i. 1

WEEDY trophies, and herself............ Homlet, iv. ?

I sit at ten pounds a week

they have had my house a week .... - iv.

one day in a week to touch no food. Love's $L$. Lost'

you shall fast a week with bran

but a' must fast tliree days a week
that's not five weeks old as yet?......

and raught not to five weeks .........

at tourseore, it is too late a week. As you Like

and, for a week, escape a great deal...Al's 's'ell, jii. 6

at the furthest for a week or two .... - iv. 2

adventure to borrow of a week.......ंinter's Tale, i. 2

sliorten thy life one week.............
she'll burn a week longer.... Comedy of Errors, ivi. 3

this week he hatli been heavy.

full fourteen weeks before the

turn this day out of the week.
it would be argument for $a$ week.

not above seven times a week

so many weeks ere the poor

Henryll.ii. 2

joy wrecked with a week of teen...Richard $\bar{l}$ llJ. iv. I

a whole week by days ...... Troilus \& Cressida, i

Timon or Ahens, ii.

not be hanged till the next week. Tilus Andron. iv. 3

sleep for a week; for the next...Romeo \& Intiel, iv. 5

what! keep a week away? seven days "Othello,

WEEKLY sworn to marry.

i Henryll. ii.

WEEP - and that he does, I weep
my sweet mistress weeps when she
twill weep for having wcaried you

I am a fool to weep at what I am giad of 二 iii. I

wherefore weep you?..................

well, he weens on

to that l'll sigh and weep.

I made her weep a-good .......

my grave, to weep there... Tiselgin Night, ii. 4 (song)

as make the andels weep ....easure for Measure, i.

how much better is it to weep at joy... Much $A d_{0}$, i. I

yea, and I will weep a while longer.

the bell rings, and the widow weeps

the bell rings, and the widow weeps
look, when I vow, I weep...............

every tear that I do weep. Love's $\mathbf{L}$. Lost, iv. 3 (verses)

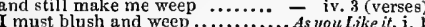

now weep for him, then spit at him As you Like it, i. I

never talk to me, 1 will weep.........

to weep? As good cause as one (rep.)

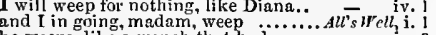

he weeps, like a wench that had ...... - iv. 3

and after weep thejr dust .........

gmell onions, $t$ shall weep anon $\ldots \ldots$
shall sad A pollo weep ... Taming of Shrew, $\overline{2}$ (induc.)

poor girl! she weeps

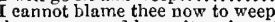

there weep, and leave it erying

1l weep what's left away.... Coinedy of Errors, ii.

if he were dead, you'd wcep for him ...Macbeth, iv.

and there weep our sad bosoms empty

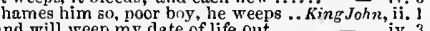

and will weep my date of life out ....

$I$ weep for joy, to stand upon

better wonldst thou weep (rep.)........

in compassion, weep the fire out

weep thou for me in France

weep not, sweet queen ................

my daughter weeps; she will not.

and they weep for thy death

and they weep for thy death

when thousands weep, more than.........
I will weep for thee; for this revolt.

and weep, their gain and loss...

constrains them weep, and shake................... to weep their intermissive miseries .... Hentry $I^{\prime}{ }_{I .}$ it. makes me weep, that thus and unapt to weep, or to exciain

weeps over them, and wrings his

his fortures I will weep ..........

to ween; but who ean eease to weep
woulrist have me weep?................

= veriry VI. i. 1

I cannot weep; lor all my body's

to weep, is to make less the depth...

weep, wretched man, i'll nid ............

where I may weep my fill ............
weeps and says, her Henry is deposed
from the helm, to sit and weep ......

二 $\quad$ iii. 1

my sword weeps for the poor king's..

and he will weep. $A y$, millstones (rep.)

why do you weep so oft?....

tweeps, and so do $I$; I for a Clarence $($ rep. $)$ -

then, haply, will she weep .............

and make poor England weep .......

weep upon his wedding-day $\ldots$ Henry
dare be bold to weep for Buckingham

and every true heart we

sir. I am about to weep..............

my heart weeps to sce lim so little...

look, the good man, weeps!

a propliet, weep what it foresaw.......

when we vow to weep seas, live.

weep out and wandar; -do, do

why dost thou weep? (rep.

that weep with laughing ...............

to make vast Neptune weep for aye...

a deed whereat valour will weep

get thee apart, and weep.............

now you weep; and, I perceive

I could weep my spirit from

to ehide, to laugh, to weep.

sure he cannot weep it back again

Octavia weeps to part from Rome
will Cassar weep? he has a cloud

to make his followers weep

look, they weep; and I, an as

Cleopatra, and weep for my pardon...

the gods themselves do weep!........

that weep this momen lable divorce

I'll weep, and word it with the

twice o'er, I'll weep, and sigh.
when I do weep, they humbly

my tears, and seem to weep with $\mathrm{n}$

perchance, she weeps because they killed -

how my wretehed sister sobs and weeps -

to weep with them that weep doth ease =

weep to see his grandsire's heaviness
will tlirob and weep to hear llim spea

our eyes do weep, till lungs .............

make us weep to hear your fate
[Col.] why do you weep alone?

to weep that you live as you do.

why do you weep? it may' be.....

she would sit still and weep...
they for sudden joy did weep

I'll weep; no, I'll not weep: I have

no, I will weep no more: in such a night

it thin wilt weep my fortunes

ere they shallot, know....

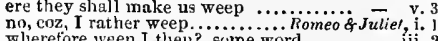

wherefore weep I then? sime word..

weep for sucl a ficling loss ( $r e p$.$) ....$
immoderately she weeps for Tybalt'

thoul hast done so, come weep vith me

and weep ye now, seeing she is arlvanced
[Col. Knt.] to strew tly grave and weep

a friar, that trembles, sighs, and weep

let the strucken deer go weep.

he weeps for what is done...

but I temnot chooge bit weep, to think.:
woult weep? wonlth fight? woul't fast?
do deeds to make heaven weep....... Oth

make lier amends, she weep

why do yon weep? am I the occusion of

do not taik to me, Emilia; I cannot weep

do not weep, do not weep; alas, the dayl

go in, and weep not; all things shail ...

1 mint weep, but they are crucl tears ...

ere I have done wiseping my father's. Tempest, i. 2

my mother weeping ................ - ii.
WEEPING-word for weeping.. TwoGen. of $\mathrm{Ver}$ ii. 3 prove the weeping philosopher .......... Mruch of fenice, take his part with weeping .........As you Like il, my lord, weeping and commenting

I am not prone to weeping ....... Winter's Tale, and with him rises weeping.

and weeping his welcomes torth .... away, and weeping of

your weeping sister is no wife of ...... tliy sun sets weeping

so, weeping, smiling, greet I thee......
digged their graves with weeping eyes?

could weep, would weeping do me gond in the remembranee of a weeping queen -

together weeping, make ane woe .....

when weeping nade you break

in weeping after this untimely bier..

subject to the weeping elouds......2 Henry $1 \mathrm{~V} . \mathrm{j}$.

fall to weeping joys: such is .......2 Henry $r$ i.. $\mathrm{i}$.

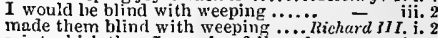

maint them blind with weeping ..... lichard $3 I I$. i.

in galled eyes of weeping souls

praying nuns, not weeping queens.

is arming, weeping, cursing. Troilus \& Cressidn, iv.

or a harlot, for her weeping. Timon of $A$ th. i. 2 (grace)

with laugling, not with weepingl

he cares not for your weeping.............

weeping as fast as they stream.......

are red as fire with weeping .......

and Sinon's weeping did scandal $\ldots . .$. Cymbeline, iii. my wrother, weeping at my woes. Titus Andron. iii. she is the weeping welkin, $I$ the earth - iii. I cannot speak to him for weeping... $=\quad$. 3 a lord, and there $a$ lady weeping ...... Pericles, $\mathrm{i}$. weeping she comes for her old nurse's.. - iv. hath oft delivered weeping ............. Feeping and wailing over................. Beareor, it. Feeping and wailing over....... Romeo \& Juliel, iii.
blubbering and weeping, weeping and - iii. weeping for your cousin's death? .... . Hamlet, iv. 7

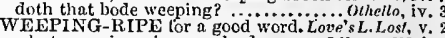

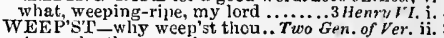
Aumerle, thou weep'st ............ Richar'l II. iii. 3 thou weep'st to make them drink. Timon of Alh. i. thou weep'st, and speak'st........... Cymbeline, v. 5 thou weep'st not so much for ..Romeo \&. Intiet, ivi.
ween'st thou for him to my face? ...... Otherlo, v. 2 WEET the world to weet.... An on . $\%$ Cleopatra, i. I cannot weigh our brother. Mecsure for Measure, ii. go to, gir, you weigh equaliy .........
what they weigh, even to the utmost. Nuch ivo, $^{2}$. 1 shall ne'er weigh more reasons in her - v. weigh oath with oath (rep.) .Mid.N.'s Drcam, iii. I weigh not you (rep.) .............. Love's L. Lost, v. 2 a balance here, to weigh the flesh? .. .- iv. shall weigh thee to the beam $\ldots . . . .$. All's well, ii. 3 word weigh heavy of her I prize it as $\mathbf{I}$ weigh grief.............. Winter's Tale, jii. 2 how mnet your chain weighi.... Conedy of Err. iv. I stuff, which weighs upon the heart? ...Macteth, y. 3
while they weigh so even, we hold ... KingJohn, ii. 2 her dowry shall weigh equal with ..King Jo/m, if. 2 with that odds he weighs king...... Richord 11 . iii. the pnrpose must weigh the folly.... - i. 2 jo more wilt weigh my eyelids...... - iin. I tis best to weigh the enemy more ...... Herry $r$. ii. 4 weigh it but with the grossness.......... Richard $\bar{l}$ III. iii. I weigh it lightly, were it heavier ... $\quad$ and weigh thee down to ruin ....... must weigh out my afflietions ....Henry $r$ III. iii. o'er fie, my brotherl weigh you.. T'roilus \& Cress. ii. each weighs nor less nor more ...... - iv. and make him weigh with her... Timon of $\overline{\text { thens, }}$ iv. I weigh my friend's affection

we with this

I love them os they weigh......... weigh them, it is as heavy ......... JuliusCasar, $j$. how heavy weighs my lordi ........ they weigh not every stamp …....... Cymbeline, , $^{4}$ weigh, what convenience, hoth of ........
WEIGHED-fair soul herself weighed.. 7 , 7 ii. the injuries be justly weighed .... Twelfih $N$ ight, v. would have weighed thy brother. lleas. for Aleas. v. 1

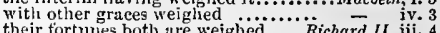
in equal halanee justly weighed ....Richard $I I$. jii. 4 weighed sueh a componnded one? ... Henry HIII. $\mathrm{i}$. I weigled the danger which my realms - ii. wherein he must be weighed rather... Cynteline, i. 5 
WEIG HED-balunee to be weighed. Tilus tnitron. I. ! from whenee nt first slie weighed lier
if both were justly weighed ............. Perieles, $v .1$ If both were justly weighed, for equalities are so wel....... Pericles, v.

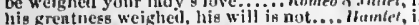

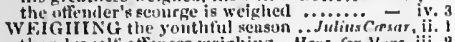
thinn by self-ottenees weiglang.. Mews. for , Mrras, iii. not weigling well the cuil

will tuke me withme weipling

in equnl newle weighing delight ......... Nmmirt, i. ?

V RigIIT-our otfence by weikglit. Meas. for. Yeas i. 3

nil there he my mintter

any heavy weight that he'll enjoin.. - y. i

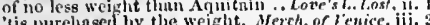

tis purehased by the weight. M.

tovest me not with the full weight....

hamge these weights upon my tongue?
of enlour, weight, and heat

as heavy as niy weight should be. Taming of sh. ii.

with like weiglit of prin

wie nnder their black weighit............ king $\bar{J}_{n h n}$ iii.

the empty hollowness, but weigit ....ticherd il. i. 2

oppression of their protinul weight

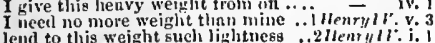
lend to this weight sucli lightne
the weight of a hair will turn.......

the weight af a hair will turn........ de verryl.i. 4

aceording to the weiglit and worthiness - ii. 2

iil bearing weight of govermme

nud heave it shall some weight

still as you are weary of the weight. Richard 11 .

in such a pojnt of weight, sa near. Menry rll, iii. I

there was the weight that pulled

lav all the weiglit ye can upon my... \& - versita, i. 3

toil, the enemies' weight......
the mntch and weiglit of gich

her eoutaminated currion weight .....

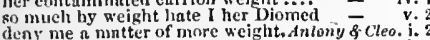

so great weight in his lightness....

the weight we mist convey with ü.. = 二 iif.

you bear it as nuswering to the weight $=$ iv.

so many weights of haseness eannot.cymbetine, iti.5

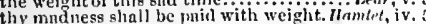

rCol. Knt.] of prize and diffieult weighte ohtello, iii. 3

much weightier thing this work

atend our ueightier jusginent
atend

VEIGITTY

a weighty cnuse of Ine lictween

eye, firr sundry weighty rcasons

is

in this weighty canse (rep. jit. I).....

steeled with weighty arguments....

it is too weighty for your grace to wear - iii. i

a weighty and a serious brow ...Henry $r \overline{\prime \prime}$. (proi.) the secret is so weighty, 'twill require
slall meet about this weighty business

shall meet about this weighty busine

wnrils cannot earry authority so weighty $=$ iij.
wEIRD sisters, hand in hand .......... Macbeth,

these weird sisters sal uted me.

last night of the three weird siser
as the weird women promised

as the weird women promised
unto the weird siaters; more sluali...

snw you the weird sisters? ...........

w EkE, wekel go eries n pig ...Titus.dndrantem, iv.

welcome, my friends nll...

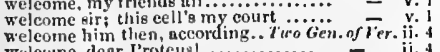

weleome, dear roteus witi..............

his wortl is warrant for his weleome $=$

you are weleome to a wor

onee more, new rervnnt, weleone......

welcome to Alilan

nor never weleome to a place.

nor the weleome to a place.

thou shult liave fave welcome .......... -

warrant me weleome to my Protcus

your grace is ucleome to a mun......

such Brooks are weleume to me.

snu're weleome: whint's yeur wili?..

he s welecme: lleaven prusper

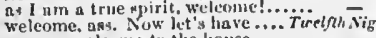

you are veleime to

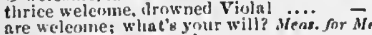

the wish dewcrvin a weleome ........ -

and very weleome. look, signior....

very well met, and welle
weleome! liow noreci?

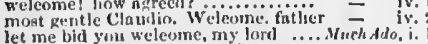
welcome

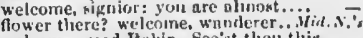

weet me with ireneditnted welcorues
WFLCOMLF-paying me a welenme. Mrit. pieked a weleouse; nint in the modenty prinecss, welenne to the eourt (rep.)

weleone to the wide ficlds too bise..

I will be weleome then ............

you are welenne, sir; ndicit! ( $r$ rp.

welcone, pure wit! thom pintest
welcome. SIerende; but tlint thom.

lith the fith weleome with ...Merche
furewell hent, and weteome frost.

mutl Sulerio, weleome hither .......

hive power to bid you welcome
welcome. So tlo I my lord (rep.)

elwer yun fermager; bid her welesme

your nrewelenne: tnke your plnee

deel will be well weleume to Lurenzo

dent luty, welconte lume (rep.

ir, you are very weleome to onr

you are weleonie not withstnnding
Antonio, you are welcome; and I have

in uny voice most welcome and weleone to our tulie (rep.)

he truly weleome hither (rep.)

nice, welcome thou art to me (rep.

weleome, young man; thau offer

at their leisure: weleome, count

but rest unuruestioned wejeome.

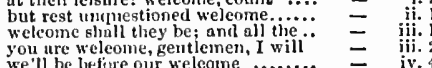

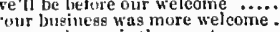

more weleome is the swect ..........
fellows, you are welcome .. Trming of sh. $\overline{1}$ (indue.)

give them friendly weleome every owe - I (induc.)

ply his bonk; weleome his friends

welcome, sir; and he, for your (rep.)

You are passing welcome, itnd so I pray =

youn are welcome, sir. And yet 1 come

sit down, Kate, and welenne: soud!

and wash, nud welcome heartily ...

wou are welcone: travel you far on

slinfl coninand your welcome liere

draw your bow: you are weleome a.ii $\overline{\overrightarrow{1}}$

show in our brother's weleome ...
these unk

welcome to sour sheep-shearing (rep.)

and weeping his weIeomes forth

most dearly welcomel nnd your finir

welcome hither, as is the spring to the
welcome to their slipwrecked... Comedy of

g(ni) will, and $y$ our good weleone here

a talile full of weleome (rep.).........

bil then welcome hither............

welenme hither (rrp. iv. 3) .....
gone before to bid us weleome

to muke society the sweeter woleome

and last, the learty welcome.

tis given with weleome; to feed

our duties did his wcleome pay ......

such welentme and unwelcome things
give him weleone hither.............

let them be welcome then, we are.

will not let me weleome this gom :.

and weleone home again discarded..
what elieer there for weleonie .......

with welcome lome from bunishment

weleme, my lorils; I wot, your love

nor lises. to me welcome you nre $\dddot{3}$.

welesme. my lord (rep, v. 6) W.......it

cousin is right welcome hither .....
preserve thicel ueleome, Bulnghroke

no joyful tongue gave him his welenm

Welcone, my son: who nre the violets

you are weleme; with this alirill

Wernon! weleome, by my sonl (rep;)

we shall be weleome ton; where is his

my tatlier fave him weleome to the.. - iv.

by my trith, weleome to $\mathrm{I}$................

your yeurs very well: weleome.

your guif worship is weleme

Beast affetion of o weleohe, trive.

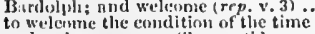

and weleome merry slirove-tide ..
weleome my little tiny tlijef (rep.)

nelome these pleasnit dny

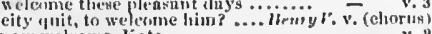

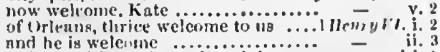

welene, high prince, the mighty

welcune, brave duke! (rep. iit. 1 and v. 3) -

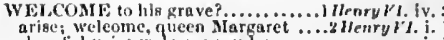
alise; weleome, queen Mlargaret

and welcome all; to this genr ...........

welentue is lanishment, welcome ....

wenme, hrt shmerk.............

wesne, my lorf to this brave ....3

weleone unto Warwick; nud wicleome
but welcome, Clarence (nep. v. 1)...

welcoms, Oxforill for we wunt thy lieln

mow werome more, nind ten times mire -

neleome destruetinn, blooul, and

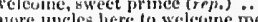

weleome, my lard (rep. iii. 7)

Buckingliam, to weleome tliem ashore

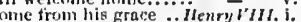

good wine, gool weleume, enum make

you are welesone, my finir fulest

go, give tlien weleone, you ean kp.nk

you're weleone, most learned reverend

in mine arms I bid him velesthe ....

finl the weicome of a noble toe. Troilus $\delta$ crest

weleome ever miles
welcome to Troy! (rep.)

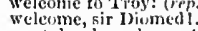

nust denrly weleme to the Greeks...

Achilles bids you welcome $\ldots . . . . . . .$.

as welcome us tu one that would $\ldots$.........

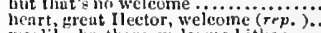

wortly wprior, weleme to vur tente

greit suldier

wele sma branay his weleme know

and welcome, both to those that ge

most weleone, sir (rep.)................

hollow welcones, recanting goinlies

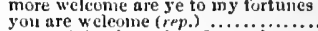

art an Atlieninn; therefore welcome

they are welchme all .................

they are fairly welcome.

none so weleome .....................

yon are very respertively welcome, sir

to nothe, gond bruther $\ldots \ldots \ldots \ldots \ldots$. jii. 6 (gra.

a villain's not a welcome suest ....... -

tupsters, thint bid weleome, to knaves - iv. 3

we nre fit to lial her weleome ......... Coriolanus, i.

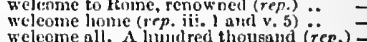

yet weleome, warriors.................

be welcome with this intelligewee.....

a thousand welcomes! ....

the weleome of his mother (rep.) ....

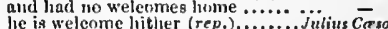

they are all weleume

souls that weleome wrong

weleome, Publius: what, Brutus

Welcome, Mark Antony ..............

glall be as welcome to the eare of Britus -

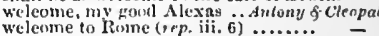

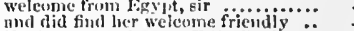

Enobarlua wreme. Fill, till the coip =

ever wclcone to us. W'clcome, lndy $(r e p$.$) -$

gend-mor row tw thee, weleome .......

strange aul terrible events are weleome

Welenne, welromel die, where thou hast -

you ure us welcome, worthy sir (rep. ii. Cymbeline, i. ?

I wns going leme, worthy $\operatorname{sir}$ (rep, ii.

yidkal you: you are very weleome.

thou art welpome, Cains: thy Casar

hus me mine; nll the remuin is, welcome

berre, lial hirn welcome. Were you .. =

amb stleh $n$ welcome as I'd give to him -

most welcomed he spriphtily, for youl

most w eleome, hond notel for thou nit

arisl, weleome, nepliewe, from snecesyful -

welrome, Finilius, what's the news
nol weleome ne to this world's liglit

thicrefore, enmo lown, nul weleone me -

weteme. drend fury, to my wol'ul louse -

you are wele(me ters $(r c p.) \ldots \ldots \ldots$. .

welcome, my graclous lowi (rep.).... = v.

Intioehus is kecleome ...tericles, $i .3$

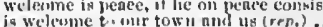

flup-jueks; and thou shalt be welcome

n wrorl, with ine? nnd weleutue.

welcom", finir one! intl unt a goodily

your gracers are right weleme............ Isar, i. 
WELCOME-provided for your fit welcome.lear, ii. 4 WELI_may be, he is not well weet both weleme and protection then, thou unsubstantial air welcome, my lord: I marvel, our......... you are weleome hither. Nor no man..... one more, most wetcome ......... Kaneon \& Jutiet, my horse and welcome on their pleasure gentlemen, welcume! (rep.)......... 败en come death, and welconie! Juliet wills $=$ iii. welcome frim Muntua: what satys ...
weleome, Horatio: welcume, goud ..... Hamlet,, . as a stranger give it welcome... ur well, or ill, us this day's battle............. Lear, ii.
lady, I $\mathrm{nm}$ not well; clse I............... 7 WELSH -the Wetsh devil, Hugh?.. Nerry Wives, $v$. she is not well; convey her to my tent..... malan, I am nut well ................. \& Juliet, iii. 1 run mat, seeing that slie is well......... ulon the cross of a Welsh hook ..... there is mo man speaks better Weilsh speak no English, I no wels......... that pretty Welsh which thou pour's in, if slie be well. Then she is weli loril frumlet? Well well (rep.ii.2) ..... Hamlet, i. 2 Well be with you, gentleme the devil understands Welsh

welcome, deni Rosencrantz and

most welcome hoonel This busines

he that plays the king. sliall be welcome

the applurtcuance of welcome is tashion

weictine: but my uncle-finther

you are weleome, masters (rep.)
hath sent me to you......... Yon are welcome.

is right welcome back to Denmark

the worse welcome: I have charged ...

gond ancient, you are welcome (rep.)

welcume, Yago: we must to the watel
signior; welcome to Cyprus (rep.).

that he's well, and will be sho

why, but you are now well enough
are you not well? I have a pain

WELL-ACCOMPI,ISILED youth. $\dddot{L}$ ove's L. Lost, ii. I

WELI -ACQUAINTED friend.. Comedy of Err.iv.

well-a-ding, we cotild scarce help.
wor and he

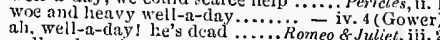

well-a-day, that ever I was born $1 . .$.
WELL-ADVISLD? Known un to iv. 5

so do I ever, being well-advised ..... Richu

my grandsire, well-advised
WELA,

WELL-APPA RFLLED A pril ... Romeo WELL-APPOINTED powers ........2
well-appointed leader fronts us liere?

wclcomed all; served all ........... Ithinter's 7 . weicomed home with it .......Comediy of Lrr

weluom weleomed cCal.-welcon WELCOMTR of glory! ............. Rick iv

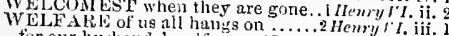
tor our hlysbund's welfare...Merchant of Venice, v.

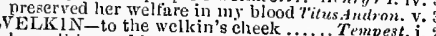
by welkin, and her star! …........... Terry IFest, ives, shall we inake the welkin dance. Tivelfh $N i$

the sturry welkin cover thou anon.....idid.N.'s Dr. iii. 2 the welkin's vicegerent.... Love's L. Lost, i. 1 (letter the sky fayour, sweet welkin, I must

make the welkin answer them

louk on me with your welkin. $T$ aming of Sh. 2 (ind.) mate the welkin's car, ant mock.

and let the welkin roar

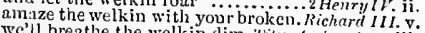
threatening the welkin with his

she is the weeping welkin, I the ear

at saint Gregory's well

um glad tu see your worships weil .... Nerry Wive

coffer, cliest, trunk, weil, vault

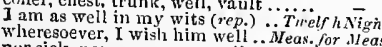

nur sick, nor merry, nur well.

an well; a nother is wise (rep.).......
is my tord well, that he doth speak.
I wish your worship weil; Gorl rest

I wish your worship well; Gorl restore

thave a device to make all

thell me then that he is well ...........

you look not well, signior ... Merchant of Venice,

nor well, unless in mind

I am not well; send the deed

broken limb, shall acquit him weli....

God send him well! the court's
is she well? she is not well (rep.)

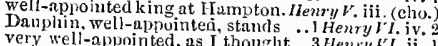

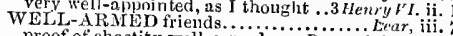

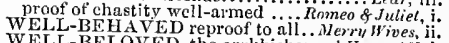

learned and well-beloved servant.. Heriry the well-beloved Brutus stabbed...julius Carsar, jii. 2
WELL-BESEEM ING ranks, march.. I Henry I i. 1 of her well-beseeming troop?

WELL-BLED, and of good name
WELL-CHUSEN bride....

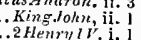

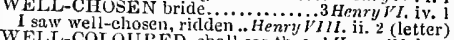
WELL-DEALINGD, shall see thee..1 Herry II. iv. 2

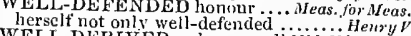

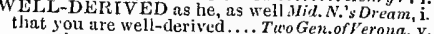

a gentleman, and well-derived ....... v. v. 4

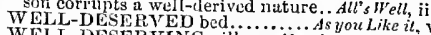
is not his heir a well-descrving son? Richard 11
to any well-deserving fricnd ...... Henry/ $1 V$.
her virtuous, and well-deserving?

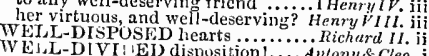
WV ELL-DIVI! EI disposition

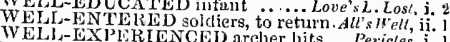
WELL-F A MED lord of

wite seems to ine weli-fiv

be a well-favoured man, is the gift. Tuelfh Night.

you are well-favoured, and your looks. Pericles, iv. WELL-FOREWWARNING wind did.2 Henry ${ }^{\prime}$. iii. 2 WELL-GOVERNED yout

WELl-GALLOWED cause.

is caught of you, that yet are well. (repinter's $T_{a}$ le

ris he well? No, he's in Tartar .. Comelly of $\bar{E} r$.

hpon a thought he will aguin be weii . Macteth,

on hour since I lett lim well (rep.). King John

like buckets, in concealed
would not this ill do well?

this golden crown like a decp........ Reichard $I I$. iii.

well, would have made me sick (rep. $)_{2}$ Heñry $u^{\text {? }}$

air; he'll straight be well.

exceeding well; lis cares are now ali

well, madam, and in heaith

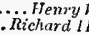

none so ball, but well may be reported

feel full sick, and yet not well ...Henry $\bar{Y} I I I$.

make wells and Niubes of the.. Troilus \& Cress. v.

lis health is well, sir (rep.

I am not well in health ............. Jutius Casar, ii.

he shall say, you are not weil to-day

I am quickiy ill, and well ... Antany socleopat

we we to say, the thead a more wellold..

if not well, tliou shouldst come like..

Antony lives, is well, or friends......

madam, he's well. Well said

I am not so well as I should be.....

WELI, KNOWN body to......2 Heary IF. (induc.)

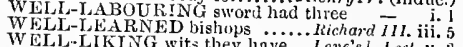

WELL-IOS'T lite of mine.

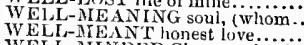

All's Well, $\mathrm{i}$.

WELL-MIN DIDD Clarence, be tho

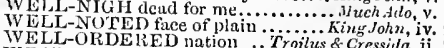

Henry H. $^{\mathrm{iii}}$. WELL-PAID ranks, that ne'er.. Anlony s - Cleo. iji.

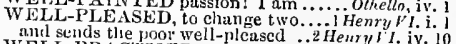
WELL-PRAC'TISED, and wise

WELL-PROPORTIUNED bend ...2Henry 1 . iii.

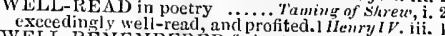
WELL-REMEMBERED futher?

WELL-REPAIM, he is tranked up. Richard III. i. 3

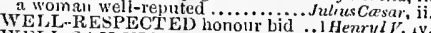

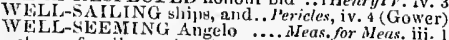
cliaos of well-secming form
WELL-SPOK EN ding

IRomeo of Jutret, i.

i. 5 WELL-SUMAIELED and warm kept...IIenry $\%$ i. are you well? Thanks, madam, weli. $c_{y}$ mbeline,
continues well my lord? doth ill deserve by doing weil

you are not well; remain here $\ldots \ldots$.

sosick I am not, yet I am not weli.
well, or ill, I am bound to

your claughter is not well , ….........

WELI-TUNEI horns ....... I itus dnd rou

WELL-IV A Rl, ANTED cousin .. Mers.for Meas

WELL-WELCUNE to thy hand.Comedy of Err. it.

WELL. W ISII $\mathrm{E} D$ king ..... Weasnere for Measure, $\mathrm{i}$.

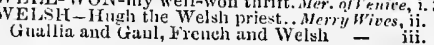

and hear understands Welsh $\ldots . . . .$. .

to the Welsh lacly's bed .............

the french and Welsh baying .........2 HeuryI ${ }^{\prime} . \mathrm{i}$. for I am Welsh, you knuw ............. Henryl i. cannot wash your majesty's Welsh plood WELSHMAN-Hurh, the Welshman. Merry v. thon trusty Welshinan ........... Richard 1t. ii. hands of that Welshman taken ...... HenryIV. i. muel a welshman. Know'st thou..... Henry $r$. iv. wherefure the Valour in this Welshman $\bar{T}$ iv. WLSHALN, hearing thou wert ... Richard II. iii. the Welslmmen did goot service in...... Henry $V$ iii. 3 backed with the hardy Welshmen..3ichard HI. it. WELSHWONEN dome, as may not ... I Henry I $Y$. i. I WENCIL -2.5 an wen to be as .....2 Henry $1 V$. ij. well demanded, wench ............ T'empest, $\mathfrak{i}$. no, wench; it eats and sleeps.......... temperance was a delicate wen... - j.

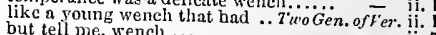
a stock with a wench...................

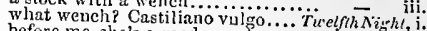
excellent weneh, gay I

to could marry this wench for this.... to him, wench; be will relent ...Meäs. for $\bar{N}$ eas, ii.

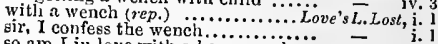

so am $\mathrm{I}$ in love with a base wench ...

Guinever of Britain was a little wench =

and, to begin; for you are a light wench -

the poor wench is cast away

she's a good wench for this... Merchant or $\overline{\text { renice, }}$,it. 2 that wench that had shed her milk. All's Well, iv. by the world, it is a lusty wench .... What said the wench, when he arose

二 why, there's a wencli! corve on ........ - iv. in the habench of excellent. Comedy of Errors, iii. God me make a light wench $\ldots . . . . . .$. - iv. of the tavem a most sweet wench? ... there is not a better wench .........2 $2 \mathrm{Henry} \mathbf{H}$. ij. mays the wench have no worse fortune!
to be tlic pillage of a giglot wench... Hen way to make the wencli amends.... Richard III. when the brown wench lay kissing... Henry VIII. jii. good wench, let's sit down quiet.... wheu I am dead, good wench........ thou must he gone, wench .. Froilus of Cressida, iv. riyal wench! she made....Antony \& cleopatra, ii. swcet wench, between thy teeth. Tilus Andron. iii. I and a wench full grown ....... Pericles, iv. (Gower) gothy way, wench; serve God ...... got thy way, wench; serve God ......

a good wench; give it me ............ othello, iii. 3 WENCHES-mad wellches? (rep. v. 2) Love's L. L. ii. I light wenches may prove plagues.... - iv of moches, arml encounters.

pinsocking wenches are as kee

the lip, as angry wenches will, Taming - v. 2 but getting wenches with child .. Hiner's Tale, iif.

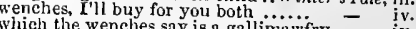
grew so in love with the wenches' song dost thou conjure for wenches.. Comed $y$ of $E$. the wenches say, God damn me...

ou see my when they marry, they get wenches alas! poor weuches, where are now.Henry $\bar{p} I I I$. iii. how many boys and wenches I stood.Jul. Cursur, i. 2 no heretics burned, but wenches suitors. Lear, iii. WENCIING rogues? ......... Troilus \& Cressida, v. WENCH-LIKE words with that .... Cymbeline, iv. to ND you with this letter .... Meas. for Meas. iv. and helpless dothe lovers wend ...MFid. N.'sDr. iii. 2 WENT_as doth Egeon wend.. Conedy of Err. i. liave I done since I upon four legs ... T'empest, ii. brothers and sisters went to $10 \ldots \ldots \ldots \ldots$ Git. of $\overline{r e r}$. v. went you not to lier yesterday..... Merry Wives, $v$. I went to her in white

how chance you went not with i......

a month ago I went from hence

and when she went trom hence .. T'welfh Night, i. 
WENTstill in this fashion ...... Twetnh. vight, iii. . so went lie suiteel to his. .iviros.for Meus. $i$

thint went to sed with the ten....
there went but $n$ pair of gleners

and goonl words went with her na

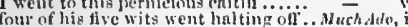

my lord, when yout went onw urd.

I likesl here ere $I_{\text {went }}$ to wars.

away" went Clnutlis enraged i........

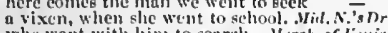

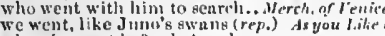

we went, like Jumn's swans (rep.
wherein went he? what makes

wherein went hie? what makes.

went they not quickly

as she went to the gnden............ivinter's Tute

hing knaw not thes it weet or

the senuel by that went before.........

if you went in pain, muster.

take order for the wronirs I went

not eoming thither, I went to seek him

thane of Cnwdor too; went it not so

Inte, friend, ere you went to bed?

sinec his majesty went into the ficio.

gince last I went to Fyn?ce

.....nicharel

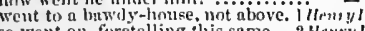
so went on, furetelling this san-

never went with lis fores in

.

(1)

the way her harmless young

in whose time boy's went to spnn-counter =

like to liglitning eame and went....3 Henry

for his hoarling went to hell

went all a foot in summer's...........

$\bar{d} I I l$.

from troop tooper througli .. -

went beyond all man's endencoure. ii

youl went emhassador to the
those thint went an enela side

so went to bed; where engerly

who were those went by? $\ldots$ Troitis

"twas wistoum Paris we

ehanee my hrother Troilus went not?

thie cry went once on thice...

when went there by an age

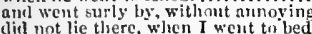

look well, for he went sickly forth...

thint we two went to schonl ............
sinec he went from Egypt ......
$\bar{g} \mathrm{C}$

lise power went out in sush distrath

nnd went to Jewry, on affitirg of

knowlectge which way thcs we

if slee went before others 1 have seen

is it fit. I went tn look upon him?

when last I went to visit her ..........
sinec she went to Milford IInven?

lie weit henee cven now. What does

thiey went henee so soon as they ....

pour thouglits went on my way w........

go, out went the candle, nnd we ........

father that went henee to fnst? .............ear,

that it went hand-in-land even with ... Hamler

nn, I went round to work, nnd iny young

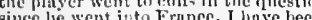

lacked gold, and yet went iever gay.... outhello

went he lience now? Ay, sooth.......... -

he went hence but now, and, certninly... = iii. 3

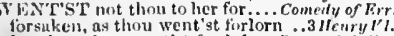

forsuken, as thou went st forlorn...3llenryl'le iij.

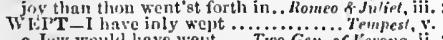

a Jetw wruld have wept.....Tre

moved wept a

moved theresithing wept hitterly.....

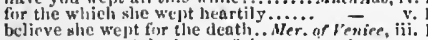

sorrow wept to thke linve of them. Winter's Tale, v.
I am sure my heart bepte blend .....

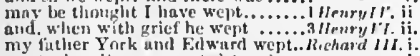

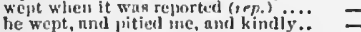

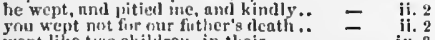

wept like two children, in their
with me, I have weyt

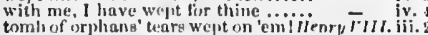

lave shook my head, and we wet. Tonon of thens, ii.

when our vaults linve wejut witis

mor have eriel. Creanr hath wept. Julius Cossar. iil.

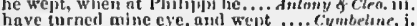

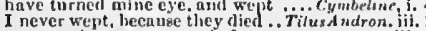

me gay, that never went befure
againat my will, but 1 wept for

we wept after her lieare

Perieles, liv.

WEST $-a$ south weat blow on ye........... Ternpest, $i$.

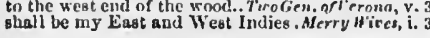

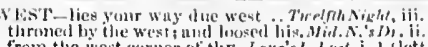
from the irest corner of thy . I. or e's L. Lost, i. I (lett

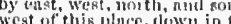

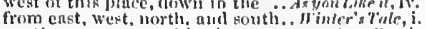

ere the weary sum set in the west...Comedify afterr. $i$.

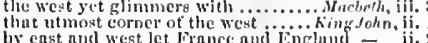

by east nnd west let France ant Englum -

seta weeping in the low send .......

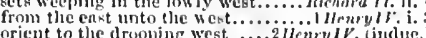

weent of this tiorest, scarcely

kinginms of the west, thice

Henerply

come kniphts fromgest the west

known whether for cast or west. Coriolus

south to this jart of the west w... sonth

from south to to st on wing soaring.

woulh whip you to the west....
cast nnd west. makes us trutide

I nm lat mad nortl nerth west.

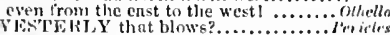

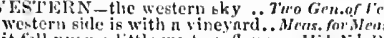

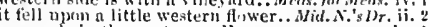

meouple in the western valley
the enst to western Ind.. As ynu

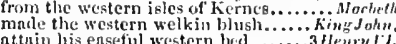

attuin lis ensefiul western bed

nnt nuw sapmon the western slinre. ....hich 1 II.

conspiratur. ubbot of Westminster

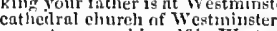

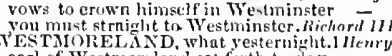

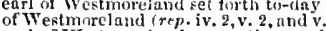

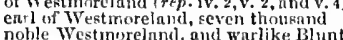

nohd Westmorelnunl, that was cngaged

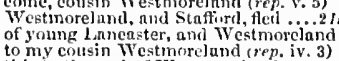

to my consing of Westmorelund ....
this to the enrl of
duke of Lancaster, and Westmorelind

it is my lord of Westmorelind (rep.)
as I told my lurd of We-tmoreland (rep.) $=$

who's here? Westmoreland? .........

my lord of Wettmorelinel

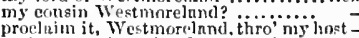

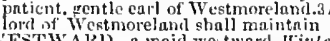

VESTWAlib-R maid westward. "rinder"s $\bar{T}^{\prime}$ le

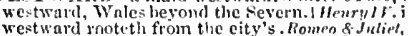

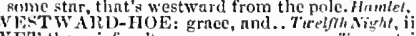

WE' the frief on't ................... Trmpess, ii.

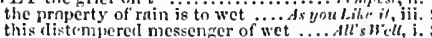

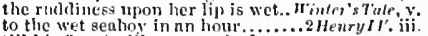

till his face be like $\mathrm{n}$ wct clonk

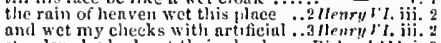

standers.by had wet their elieeks ... Richard $17 i$. $\mathrm{i}$.

and wet his grave with my

and the tars of it re wet ...............

when the rnin eame to wet me onte....... Lear, iv, 6

YETIIF tears wet?.

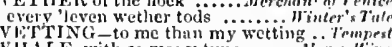

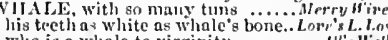

Whio is a whale to virginity

before the belclining whale

such whales have I hend on n' the land -

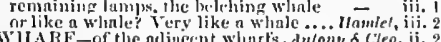

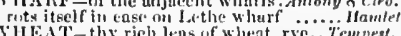

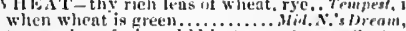

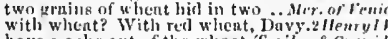

have a eake out of the whirat.'Prrilius o cressid

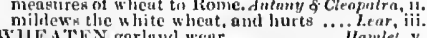

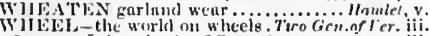

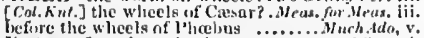

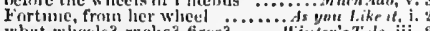

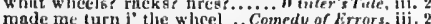

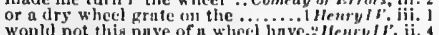

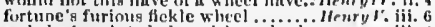
and she is pninted alen with a whicel 1 - iii. 6 are whirler like u potter's wheel o...1 Henrylli. 3

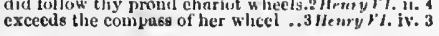

Wulvi,-me where I whel.. Troilus \& Cressida, v. 7

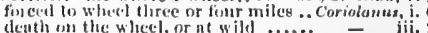

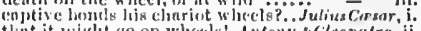

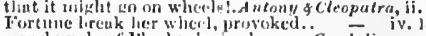

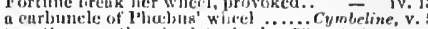
tenr them on thy eliuriot whecle., Titus, nndron.

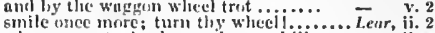
when a great whecil russ ilown n liiii..... -

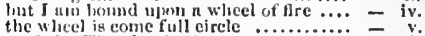

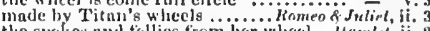
it is a nasgy whet. fixed on

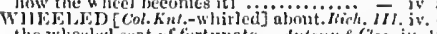

the whecelect rent of tirt unate ... Antony \& clen.i

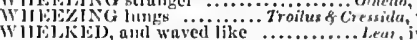

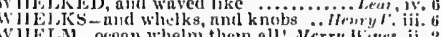

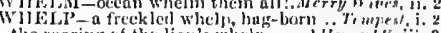

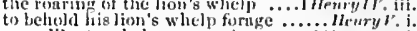

now, like to whelps, we erying.

or an unlicket bear whel h.

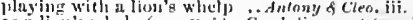

thou, l. conatus art the lion. Cymbeline, v. 4 (Et)

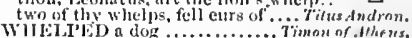

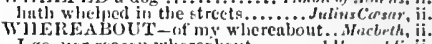

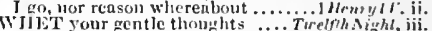

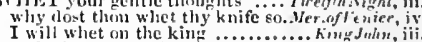

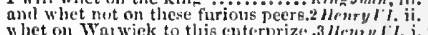

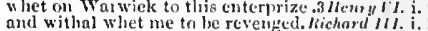

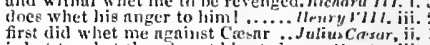

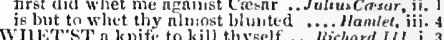

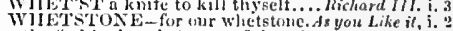

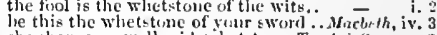

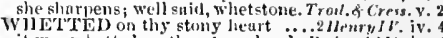

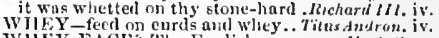

WHIEY -FACE? 'Tlie Ennlish ............ Hactetha,

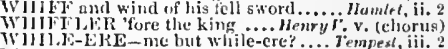

WiIN E nloud for mercy...An'ony 8 Cletparra, iii.

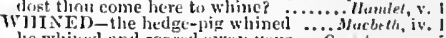

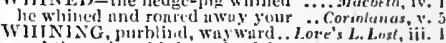

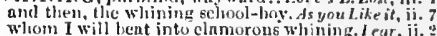

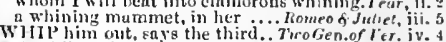

the fellow that whips the dogg (rep.)

they would wling ne with lieir ...ivirry rives, iv.

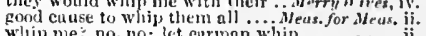

Whip me: no, no; lct cirman whip ...
the impression of keen whins I'd wear

I'll whin you from your fointing fence. Wuch addo,

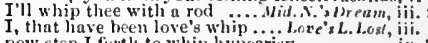

now step I fortl to whip hypoerisy ..
go, whip thy pig ......

go, whip thy gig .................

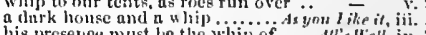

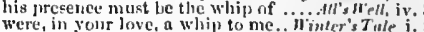

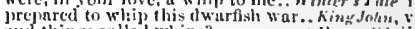

und things ealled whips?
sirrah beudle, whip him tili hie

nay, whip me then; le'll ruthe......

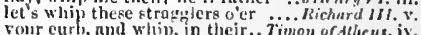

wilt tho

pert all the whins of lieaven

chance to wlip your infornintion.

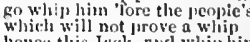

henee this , Inck, nuel whiph him....... - iv.

mon antel starsi whiph him (rep.) .. -

marry, whip thec gosling: I think..... Pericles, iv.

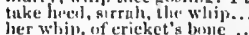

would whip you to the west, and bring o thit

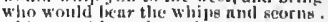

whipls rut his rapicr, eries, a ratl a rat!.

nnd put in every honest hand a witip....

whil me, ye ilcyily fien the a whe.... -

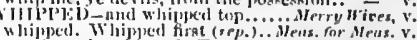

worthy wo lo whitped. To he whipned Much Ado ii.

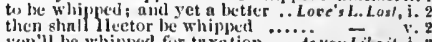
y'un'll be whipped fur taxation........ Ax you Lite it. Yol have them whippecl; or I would

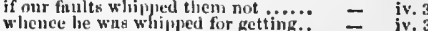
whence he whs whilped for getting..
he glanll be whipyed through the arm

to be whipped at the highth-crose.. Taming of $\mathrm{Sh}^{\mathrm{i}} \mathrm{i}$. 


\section{WHI}

WHIPPED out of the court ( $r e p$.). Winter's Talp. iv. 2

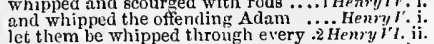
for 1 lave seen him whipped three .̈̈riolanus, iv. 6 shalt be whippell with wire...

you will be whipped. Approach is he whipped? Soundly, my lord

my messenger le hath whipped

all your beggars whipped then? (rep.)
he must be wlipped out. when Lady....

let him be whipped that first finds....

lie, we'll have you whipped...

Whipped for speaking truc (rep.) .........
who is whippel from tything to tything

whipperl nad tormented........... Rong - iii. 4

I Wonld have such a fellow whipped... Hamlel,

WHIPPING-unpitied whipping. Mseos. for Meu

pressing to death, whipping, and hanging
rreat Hercules whipping a gig ... Loves sL..

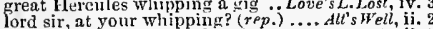

to save yourself from whinping ....2 Henry VIt it. 1

and so 1 shall scape whipping ......... Pericles,

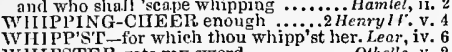
WIIPSTER gets my sword

practiscd nonre the whipstock........... Pericles, WHIP'T-I shall have you whipt . Meas, for Meas
not whipt out of his trade ...........

I whipt me behind the arras

MuchAdo

WIIRL_-justice al ways whirls in. Love'sL.L.Lst,

the fifth did whirl about the other . King John, iv 2

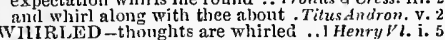

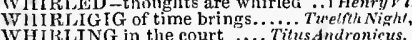

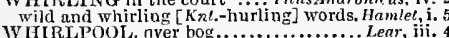

WHIRLWIND bear unto.................... Teerona, i. 2

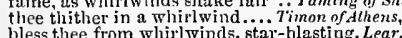

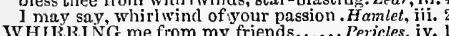

WHIRLING me from my friends...... Pericles,
WHISPER-Juno and Ceres whisper.Tempest,
to

to whisper and conspire against. TuroGen of I'rer, i. 2
we'll whisper o'er a couplet .... Turelfth Nighe, iij.

Whisper her ear, and tell lier..........M. MuchAdo,
Pyranus and 'Thishy whisper.Mid.N.'s Drean,

they are content to whisper.............
did whisper often very secretly

did whisper often very secretly .......
which the fearful lovers are to whisper

the Russian whisper in your ear?.Lo'e's $L$. Lost,

blushcs in my cheeks thus w
I'll wllisper with the general
your follower's $I$ will whisper

yhisper lim in your behalfs

that does not spcak, whispers the $\ldots . .$. Macbeth,
so muchl no eonseience whispers in ... King John

mark, how they whisper: urge theer

will whisper music to my weary

whispers of each other's whers to his pillow

Whisper the spirits of thine enemies. Richurd III, i

Troy come not to whisper him ...Troilus \& Cress. i. 3

never adinitted a private whisper . Coriolanus,
shall they not whisper, lo Cæasar.. JuliusCcesar,

devil whlisper eurses in mine ear.. Titus Andron. v.

is as 2 whisper in the ears of death .... Pericles,
and whispers nine ear, go not till ..

whose whisper o'er the world ' dinmeter

well said, whisper: withl as little a web..

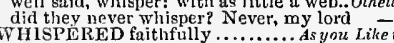

prophets whispered fearful ehange. ... Aichard II

mean, the whispered ones, for they are.. Lear, $\mathrm{j}$.
WIIISPE RING and most guilty.. Meas. for Meas. iv

WIIISPERING and most guilty... Mens. for Meas. i

al ready; whispering, rounding

is whispering nothing? ........
tis well they are whispering

foul whisperings are abroad ............Macbell,

8acrispering tale in a fair lady's $\mathrm{s}$ ear., Roneof Jul.
whist

WhIST - the whld waves whist ... Tempest, i. 2 (Eong) pipes and whistles in his sound whistle Asou Like $i$ it, ii.
to whistle off these secrets........ Winter's Tale, iv. to whistle off theee secrets.......... Winter's Tale, iv. 3
lite the law go whistle, I warrant you
iv. 3

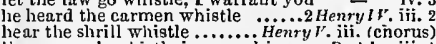
the seaman's whistle is as a whizper ... Pericles, iii. boatswain whistles, the master calls."

sleep out, the rest 1 'll whistle
I have been worth the whistle

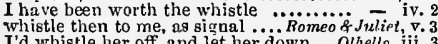
I'd whistle her off, and let her down ow olhello, iij. by his hollow whistling in the leaves.l Henryl 1 did sit alone, whistling to the air. Antony \& cleo. ii. not a whit............................Merry Wives, i. 1

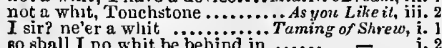
Bo shall $\mathbf{I}$ no whit be behizd in .......
no, not a whit.......................
$[830]$

WHO

HIT-wiste is no whit lesser than .. Richard II. ii. I | WHITE-F ACED shore, whose foot .. King John, ii.

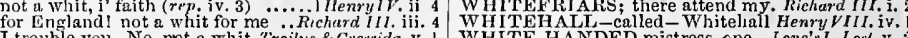

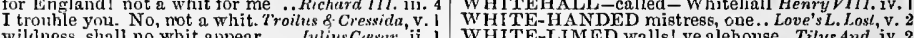

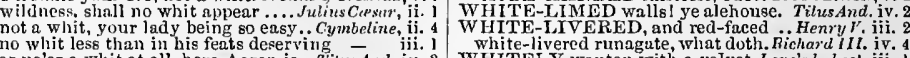
no whit less than in his feats deserving - iii. I or ne' a whit at all, here Aaron is... Titus An no, not a whit; whatl ............ Rameo \& Juliel, iv. 1 sle is as white as a lijy ................. Tempest, iv. white louses do become an old eost well

(and

finely attired in a robe of whit

means she shall be all in white...

I come to her in white

the white will deeipher lier
black, grey, green, and white

flack, grey, green, and white

I went to her in white, and cried ....

my lady has a white hand

WHITELY wanton with a velvet. Love's L. Losl, iii.
WHITENESS so became them. TwaGen. of Ver. iii.

in angel whiteness bear away those... MIuch Ado, iv.

purity and whiteness of ny sheets. Winter's Tale,
but $I$ could find no whiteness. Comedy of Errors, ii.

the whiteness in thy cheek is apter..2Henry ${ }^{\prime}$. $\mathrm{i}$.

lily! and whiter than the sheets! .. Cymbeline, ii.

nor scar that whiter skin of hers........ Olhello, v.

my shroud of white, stuck aii....... - ii. 4 (song)

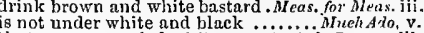

that pure congealed white...Mid. N.'s Dream, iii. 2

immaculate white and red (rep.)... Love's L. Lo

what is she in the white?............. = ii. to show lis teetl as white os whale's - v by this white glove, how white the hand $\overline{-}$

have livers white as milk?

by the white hand of Rosalind ..... let the white death sit on thy cheek...All's Hell, ii. such war of twite and red within her

the wager, though you hit the white

in pure white robes whit

the white sheet bleacling on

wwn as white as driven snow

iv. 2 (song)

by my white beard, rou offer him ...

black spirits and white........... jv. 1 (song)

white bcards have armed their thin. Richard 17 . iii.

thy father's beard is turned white

his white hairs do witness it ........

a whitc beard? a decreasing leg? .... -

i., 2

I would I might never spit white again = i. 2

whose white investments figure...... - iv. 1

left the liver white and pale $\ldots \ldots . .$.
how ill white hairs become a fool $\ldots . .$.
a

by the white hand of my lad $\ddot{y}$

plack beard will turn white.

pluck a white rose with me $($ rep. $) ..$. . i Fenry $V I$. ii.

verdict on the white rose side

dye your white rose in a bloody red..
bctween the red rose and the white... ii. 4

leave me at the White Hart.........2 Henry $r$ I.iv. 8

would bring white hairs unto a quiet - ii. 5
red rose and the white are on his face

saddle white Surrey for the field ..Richard III. v. 3

comparison all whites are ink. Troilus \& Cress. $\mathrm{i}$.

puts ine her white hand to his eloven

to spy a white hair on his clin (rep.)

that white hair is my father

with these your white enchanting

will make black, white....... Tim

the war of white and damask

turns up the white o the eye ........

henceforth, the white hand of a lady
whitc and azure, laced with blue.... Cymbeli

of white and his white beard came to - v. 3

turn a swan's black legs to white .... - ivericles, i. 2

long, small, white as milk.............. iv. (Gower)

might the crow vie featliers white - iv. (Guwer)

tears his white hair.................. Lear, ivi. 1

singe my white lead and thou

millews the white wheat, and hurts

be

so white, and such a traitor

some flax, and whites of ergs, $\ldots \ldots \ldots$ o............

ha! Goneril! with a white beard! .....

these white flakes had challenged........
witl a white wench's black eye. Romeo

they may se wench on

in her excellent white bosom ... Hamlet, it

his beard was as white as snow

ram is tupping your white ewe........... oilelto

find a white that shall her blakness fit

W HITE-BRARDED fellow speaks it. Much $\overline{A d o}$, ii. 3 which makes my whitest part black. Henry VIil. i.

WHITIN(i-TIMI send him by ... Merry Wives, ii. 3

stay. Whitmore; for thy prisoner is..2 Henry VI. iv.

WHITSTERS in Datchet-inead .. Merry Wives, iii. 3

busied with g, Whitsun' morris-dance. Henry $V$. ii.
WHITSUN-WEEK, when the prince.2 Henry $\nu$, ii.

WHITTLE in the unruly eamp. Timon of Alhens, v.
WHIZZING in the air ............. JuliusCresar, if.

[Col.] come whizzing in upon them ....... Lear, iit. 6

let then keep their limbs whole... Merry $W^{\prime} i v e s$, iii.

rovenged on the whole pack........ Treelrh - iight. v. I

swallowed his vows whole. Measure for Meassre, iii.

with a whole army shooting at me ... - ii.

before the wholc congregation ...... $=$ iii.

is our whole dissembly appeared?....

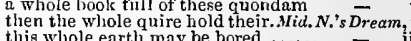

and the whole world again, cannot... - v.

nor is my whole estate upon ...Merch. of Venice, $\mathrm{i}$.

the whole theorick of war in ............All's Well, iv.

of the whole dungy earth......... Winter's $\bar{T}$ ale,

a purse alive in the whole army...... - iv.

who sent whole armadas of........... Macbelh, iij. 4

the general joy of the whole table ...
for the whole space that's in ........

for the dignity of the whole body.... $\mathrm{kin} \overline{\mathrm{J}}$ ohn $\mathrm{v}$.

to stop Arthur's title in the whole... $\quad$ a whole armado of convicted sail ... 2

to teast upon whole thousands of ....
the whole land is full of weeds .... Richard 11 . iii. 4

and your whole plot too light....... - ii. 3 (letter)

the state of time liad first been whole - iv. I

gnes well, yet all our joints are whole - iv.

and now my whole charge consists of - iv. 2

there's a whole merchant's venture. 2 Henry $I V$. iv. 3

of mutt in or two, in a whole Lent?:- $\quad$ and the whole trame stands upon pins

and the whole trame stands upon pins $\quad$ I iii. 2

lion gait walk the whole world ...... Henry $r$. iv. 4

and his whole kinglom unto desolation -

all the whole army stood agazed ..... Henry rI. i.

were the whole frame liere .......... all the whole inheritance I give $\quad$ ii.. 3

called but viceroy of the whole?... .2 .

my lurd, whole towns to fly.........

preserved so whole, do seldom win ..
with a spear, and tis not whole yet
ail the iii.

yea, the wh.ole consistory of Rome...
to bring my whole cause fore his....

these are the whole contents ....... - iv. 2

in the world, with the whole world?.. =

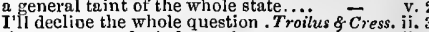

the passage and whole carriage.......

you shall make it whole again ........

makes the whole work

with the whole quality wherefore....

to the

that the whole life of Athens .........

affection common of the whole body . Co

and the shop of the wh.....

where

and grant of the whole table.......... $=$ iiv.

as matter whole you have not ... Antony \& Cleo ii.

roasted whole at a breakfast ......

but his whole action growa not in....
and the horse whole, do you not?...

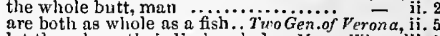

for I $\mathrm{am}$ for whole volumes ........... Love's $\bar{L}$. Lost, $\mathrm{i} .2$

taxed their whole whole weal th of.. $\bar{i}_{\text {. }}$ iil.

the whole world. Comedy of Errors, jii 


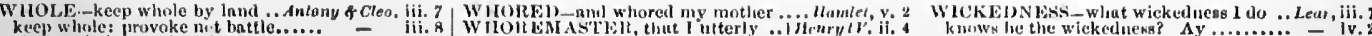

all the whole synot of them!

kiss the honoured gashes whole.......

=

lii.: the whole world er in the whole worla what will wholo mouths of temrs. T all thy whole lienp must atio awnd (swed the whele purish, cliureh ainh undo a whole gonerat ion frep.). ....lear, i. for 1 was come to the wlole depti.... our whole eity is mueli bound to him our whole kingdem the be contrite so the whole ear of Denmark is hy .... [Kut.] roree his soul so to his whole eoneeit o'erweigh a whole thentse of ofliers a whole one. 1: for tlum thost know sir, $n$ whole history. The king, tir in my whole coursc of wooing.

but, for the onthole world (rep.)

WHOLESOME, as in state ................ "ive iv. iv. to the must wholesome physie. Love's L. Lost, i. I (let.)
is not, by mueh so wholesome ......... as wliolesome as tho sweat ............ ao it be wholesome food ........ Taming of shrem, iv. 3 lie linve whiolesome beverage....... I'inler's Tale. $\mathrm{i}$. with wholesome syrups, drugs ... Cumedly af Em sce thy wholesone days agnin? ....... Waetheth,
wholesome eounsel to his instayed . Wichard II.

fertility from wholesome flowers....

and wholesume berries thrive.......
counsel, you'll flik it wholesome

which are not wholesone to those.

and not wholesome to our cause

while it were wholesome, we might...Cariolanus. repeul dnils any wholesoure net

you wear out a good wholesome forenoon he steal out of his wholesome bed... Sulius cassor, ii. so wholesome ns that you vent
how nuw, wholesome hiniguity?.

in the tencer of a wholestme weal.... i... the nights are whulesome: then no the thin and wholesome hlood as wholesome ns sweet, and by very make me a whole usturp immedintely blusting his whlolesone brother.

not meet, nor whotesome to my plaee.

Will wholesome wisdon, he miglit mot but shape his service wholly to tny .. Lore'sL.Ln whiolly. Bir. Who may they to. Wroins cress. iii. mistly depends on your abode... Antony \& Cleo. i. 2 sleep hath seized me wholly ........ Cyrabeline, ii.
w IJOOBUB [Col.Knl.] agninst his, Winter's Tale, iv. WloOP -did not whoop at them ........ Henry $r$. ii. 2 WIIOOPED out of Rome Corinianus, iv. 5

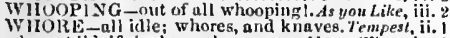
her, ehild, if she be a whore ...... Merry Wives, iv. I ever your fresli whore ....Measurefor Neosure, iii.

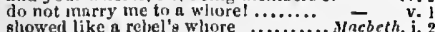
for tearing a poor whore's ruff in ...2ilemy $r$. and the wlures called him mandrake and talketl of the whore of Babylon .. Henryy ii. 3 a euckndd, and a whore...... Troilus of Cressida, it. the heaver for at whore.

my inind is now turued whore

Trojan ass, thut loves the whore tiore

thy whore, Greeiant nnw fir thy whore eommon whore of mankind . Trianon of Athen this fell whore of thine hath
be a whore still! (rpp.).

be a whore atilll (rrp.) ...............

be strong in whore, allure him ......

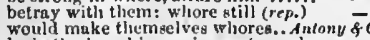

he hath given his empire up to a whore

triple-turned wlyorel tis thou hast.

the name of whore thus denriy ....... Cymbeline, ii.

out, out, you whore! is black so.. Tilus.Ind,an. iy.

leave tliy drink and thy whor

Fortune, that armit whore.............ild

a boy's love, or a whore's oath

a very good whorel why ls not... Hoveas o intirl. ii. 6

must, like a whore, unpaek my........ Intualet, ii.

be sure thou prove my love $n$ whore ... (thetlo, hil. 3 him, and lie huth given it lis k hore.

is a aubtle whore, a closet lock nuil key.

what, not $a$ wliere? No, as I shnll be saved

you for that cunning whore of Venice

he called her, whore a bekgar, In his.

hier friends, to the called-whine? (rep.)

I cannot sny, whore; it soes alhor me

ahe turned to folly, and slie was a whiore
villanoug whorel she give it Cassiol ....

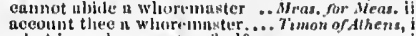

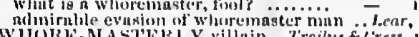
WIIOKL-MASTELLY villain.. Proilts of W' why, thou whoresull ass .... Th. how now, you whoreson peasul
nh, you whorean hognerlicati

you whoreson malthorse drudgel Tan
you whoreson villuin! will you let.
n whortson, beetle-liended, flap-enre Whorefon, senscless villun! .. Comethy of Frrors, iv. whis, you whroresoin rount man! ....

thou whoreson, impuctent, embussed

thon wherent

the whoreson smooth-intes do nuw

into this same whoreson apoplexy

away, you whoreson npriglst rublsit...
ah, you whoreson little vallisut villinin

eome on, you whoreson chops. ........
thou whoreson little tidy Bartholomew

thuu whoreson inal componnd of.

a whoreson cold, sir; a eough, sir

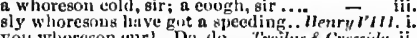

youl whoreson eurl Da, lo... I'roil
a whoreson dog, that shull palter...

you whoreson indiatinguislinble cur, no

these same whoreson devils. Antony \& Clenpat whoresun dog! I gave him satisfuction?

and the whoreson must be acknowledged

a whoreson, gluss-inuzing, supcrservicenble

you whoresou, cullionly barber-monger

a merry whoresont lin, thoul shult. Romeo $\mathrm{A} \cdot J \bar{u}$. iv. decayer of your whioreson deast body ... Ifaniet, v.

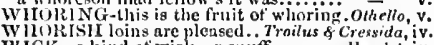

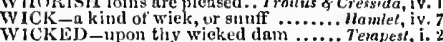
as wieked dew as e'er niy motlier.

for you, most wicked sir $\ldots . . \ldots \ldots \ldots \ldots$.... till the wicked tire of lust.

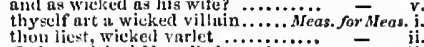

O thou wieked linmil

thou secst thuin wieked
a but a a wieket bawd

a butcked a wieket bawd! ............ - iif. O wieked wall, throogh wlus i see no - v. i thy minners nust be wicked ... fls you 2

have heen, mallum, a wieked erenture...Al's $w^{\prime}$ oll. i. that would unseen be wieked?

I nm assisted liy wicked powers ..... something wieked this way comes ..... a will! a wicked will; n woman

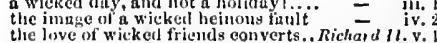
little better thal mie of the wieked...I Ilenry Ir.i. dispratied him before the wieket $\left(r e p_{0}\right)$ a nen.l $r$. ii. 4 of the wicksd? is thine hostess (rep.) - ii. 4 raising up wisked spirits from a.....2 Ienry $V^{\prime}$. ji.

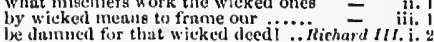
firce the swords of wikked men...... whint a wieked beast was I.... Timon of alhens, iii. 2 takes virtwous copies to be wicked ..
consume you wiekell euitiff lettl dissuaded by our wicked queen ..... Cynabelire, v. about the wicked streets of liome... - v. 2 punishment for his mnst wieked life
for Marima writ by wiokel Dionyza .. Pericles, iv. 4 cruel Cleon, with his wieked wife......
for wieked Cleon, wal his wife.. mumbling of wieked charms ............ Lear, ii. 1 those wiekel ereatures set do look (rep.) $\rightarrow$ it. 0 most wieked speed, to post with such.. Hamlet, i. $O$ wieked wit. and gifts, that liave the

the wicked prize itself buy out the Inw - if 3 with a wieked [Knt -an lifle] tongue ..

upon my sout, a lie a wicked tie.

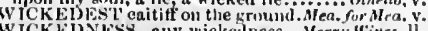

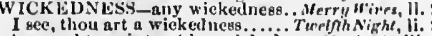

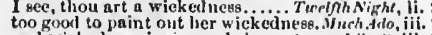
and wiekedness is sin, and sin. As you like it, iii. a talnted fellow, and full wiekesed.

reln can hold licelıtious wickedness ...Uenry $V$. iii. imputation of hia wiek etness, by your rule - iv.
sueh la thy audacloug wickedics .. I lienry $/$. lii.

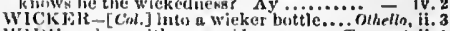
so wite of lis wwit resuet. 8o wille na a bristle muy enter..... Tuelfh night i. that lie doth spenk so wide?............ Aluch ddo, iv. that the wide sen hath drons too few - iv. widte enough to wrup a fairy ....M..... N.'s Dream, ii. weleone tu the wide flelds too base. Love's $\bar{L}$. Lost, ii.

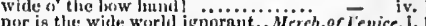

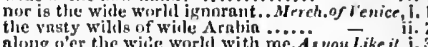
along orer the wilie world with me.
this wide aml universul theatre.

a worla too wide for lis slirunk. und wide havock made for biloody ... King John, it. opely witle your gates, and let young

\section{we in the workl's wide nnuth ......}

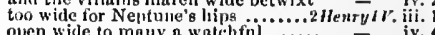
and stretch the nostril wide ............ neury s. iji.

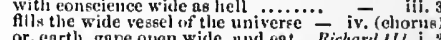
or, eartl, gape open wide, nud ent .. Rirhard III. i.
for the wite worlil's revenuc'.... Troilus \& Cress. ii. no suels natter, you are wide.......... - iii. I

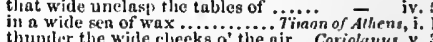
thuntler the wide clieeks of the air . Coriolanus, v. 3 that her wide walks eneompassed.. Julius Carsur, i.
widle arch of the ranged empire ...Antony \& Cleo. $\mathrm{j}$. the wille difference 'twixt amorous ... Cymbelime, v.
the wide world's emperor...... 7 7itwa Andronicus, 1 . the wide world's emperor...... 7itwe Andronicus, i. still, still, far widlel ..................... Lentr, iv.

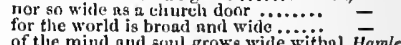

of the mind and soul grows wide withal. Hamlet, $i$. 3 in rage strikes wide..............

nul witle revenge swallow them up...... WIDER than fur other men...

2llentyll, v.

more witler tlaan the sky ..... Troilus \& Cressida, v.

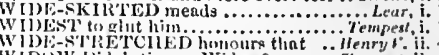

IDUIV Hidu's time. Wirlow? ......... 7'empest,

Miru nul Noples lave nore widuws = ii

a wiclow then?................... neither nnid, widow, nor wife? (rep.).

the bell rings, and the widow weeps... Murh ddo v.

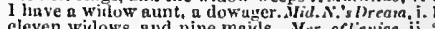
will live as maids and willows...... of be married to a wealthy widuw ... 7 aining of $S h$, iv. to my widow; and if alie be froward

with thy loving widow, feast with....

my widow suys, thus she ponceives ..

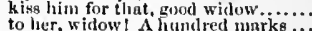

encli new morn, new widnw how i... - v mother's thanks, a widow's thalks ... hing John, ii. mowy a widow's hubbund groveling

a widlow, husbandlese, subject to

my willow eoinfort, and my sorrows the willow's elinmpint, and my sorrows and defenee .. Richard II. i. 2 I am a poor widow of Eastcheap ....2 Henry $/ l^{2}$. ii. and enme I n widow ...................

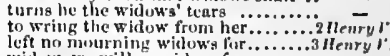

widow we will consider of your...... - jil. ay, widow? then I'll warrant .i...... = - iii. 2 l'll try this widow's wit............. sweet widow, by my stnte............ you covit, widow; l did mean.......... = widuw, go you along oli mait's slyh, nnd niny n wido.... to enll king bol warl's widow, slater.. - i. I innle her widow to a weretin] hed?...

thou nrt a widuw; yet thou art $7 . .$. .

a benuty-waning ani distressed widow

and witlow to urince Arthur.........Henry $\bar{F}$ Irt. ivi. the walle hidow wed ngain. Timon ol Alhens, Ix. tis I that made thy widows.......... Coriolant iv.

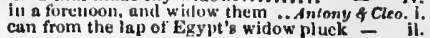

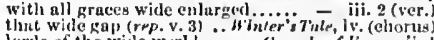

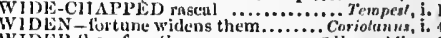
for a many thousnus! widuws shali.

so young", so okl a widow 


\section{WID}

WIDOW-was a widow. Willow but being widow, and my Gloster.......... Lear, iv, to take widow, exrsperates ............ if, once a widow, ever I be wife! ...... Hermlel, iii. 2 TV IDOW-DOLOU P likewise be .... Richard Ill. ii.
WIDOWED and unchilded many.... Coriolanus,
W Tempest, ji. our widower's second marriagethe count Rolssillon a widower -1 y. 3 (petition) prove a widower shortly (rep. An. Anlony flea. ii.

WIDOWHOOD, be it that she.. Taming of Shew, ii.

WIDOW-AIAKER; O and there...... Kinr John, v. 2

his hand to wield a seeptre .........3 Henry $V^{\prime} I$. iv.

more than words can wield the matter ..... Lear, i. i

to wield old partizans, in hands. Romeo \& Juliet, i.
WIEE-farewell, my wife and children. Tempest,

every day, some sailor's wife

I am your wife, if you will

a wonder'd fatler, nnd a wife [Col.-wise]

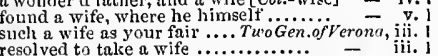

wite, bid these gentlemen weleome...... $\bar{y}^{-}$itives,

Ford's wife (rep; ii. 2 and iii. 5)

another to Page's wife (rep. ii. 2$) \ldots . .$.

love my wife?.......................

he loves your wife (rep.)
this voyage towards my wife.

I do not misdoubt my wite ........

and stands so firmy on his wife's frailty -

good-morrow, good wife

ne fartuous a civil modest wife

for the which his wife seems to $\mathrm{me}$...

and thru shalt lie with his

he will trust his wife, he will not....

than $m y$ wife with herself ............

deteet my wife, and be rere
truly, sir, to see your wife
is your wife at home, indeed?

he pieces-out his wife's inelination...

and now she's going to my wife......

but my wife master doctor.............

your wife is as honest a 'oman

eoine wife, come mistress Page,$\ldots \ldots . .$.

somebody call my wife

what wife, I say $1 . \ldots . . . . . . .$.

the modest wife, the virtuous........

will you take up your wife's cloties?
searched a hollow walnut for his wife's

pardon me, wife: henceforth, do ....

I will never mistrust my wife again

and as wicked as his wife?

desire thee to laugl at my wife ....
she is, by this, doctor Cains' wife

myself would be his wif

your wife is like to reap a proper

than e'er I shall love wif
as well a sister as a wife

she is a a me wo ...Meas. for

my wife sir, who

marry sir, by my wife

what was done to Elbow's wife (rep.)

do the constable's wife any harm?

his wife is a more respected...

he is his wife's head, and I can never

neitlier maid, widow, nor wife? (rep.)

le knew me as a wife...

if Hero would be my wife .............. Much $A d_{0}$,

she were an excellent wife for Benedick

the righit husbanil, and the right wife
when I lived, I was your other wife

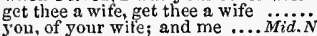

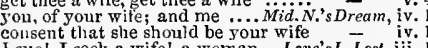

a wife of such wood were felicit $y$

a wife! - a beard, fair liealth

I thank you, gentle wife?...........

Margery your wife, is my mother ...

become a chriftian, and thy loving wife - ii 9 (scroll)

my heart, so thou canst get a wife.

go with me to chureh, and call me wife =

if you thus get my wife into corners

of me, as she is for a wife..............

I am married to a wife, which is as dear

my wife, and all the world your wife would give you little thanks

I have wife would give you little thanks =

was given me by my wife..........

'gainst your wife's commandment

for a light wife doth make

to part so slightly witl your wife's ...

you give your wife too unkind .......

that is the dowry of his wife ....As you Like

for me hereafter to leave my wife.....

have to wife tlis Rosalind? .............
for wife, I take thee. Rosalind, for wife
a wan that liad a wife with sueh a wit
[ 832$]$

W IF

to have triends for my wife's sok. As you Like it, iv he that comforts my wife $($ rep. $)$.......

physicinn's daughter my wife?

dark house, and the detested wite

till I have no wife, I have (rep.)
to this unworthy husband of his wife

to become the wife of a detesting .....

as you owe to your wife.

when his wife's den

shaking off so good a wife.

sir, his wife, some two monthe since

would a wife, mourned for her $3 . .$. .

and I would give his wife my bauble

he lost a wife, whose beanty did
when his wife was dead

look so strange upon your. wife?

turned off $a$ first so noble wife.

I gave it his first wife.

he got his wife with child

but the shadiow of a wife you see

and your humble wife.. Taining of Shrew

where is my wife? Here, noble
are you my wife, and will not..

are you my wife, and will not..

madam wife, they say (rep.)....

to a shrewd ill-tavoured wife?. ......

Petruchio's wife (rep. iii. 2).......

with snch a wife, were strange

dowry shall 1 have with her to wife?

that you toll be thee for niy wife.

and will have Kotherine to $\mathrm{my}$ wife

fatlier, and wife, and gentlemen, adieu

detained you from your wife, and sent

if Katherine shonld be lis wife.....

to kill a wife with kindness...........

the sister to my wife ...................

twenty times so much upoo my wife

your wife send you not a worse.

now where's iny wife? She says.

your sister, and ILortensio's wife?...

the boldness of a wife to her allowing

holds his wife by the arm

not think it,) my wife is slippery?

Bohemia is nothing; my wife is nothing

my stables where I lodge my wife.

he dreads his wife. So, I would....

hast set on thy wife to this ( $r$ ep. $)$

the danghter of a king; our wite ....

ne'er shalt see thy wife Paulina more

when my old wife lived.

how a usurer's wife was brought to..

my son should choose himself a wife

and my wife's, in safety here

as I by thine, a wife.................

my wife and $I$, fixing our eyes on

yonr worship's wife, my mistre
great care to please his wife................

no house, no wife, no mistress.

not Adriana, nor thy wife

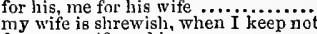

deny my wife end house .............

unvinlated honour of you
my wife, (but, I protest..

notling but to spite my wife

gister is no wife of mine ..............

no hushand yet, nor I no wife $\ldots$.....

doth for a wife ablior $\ldots$ withal ..............

among $m y$ wife and lier confederates

and bid my wife disburse...

give it to my wife, and fetch

and tell his wife, that, being

my wife is coming youder

ife, now....

and the wife

gavest to me to be my wife

Wadet a wife once called Atmilia......

shall be my sister, not my wife

of my wife with your approael

diamond he greets your wife withal

his wife, his babes, and all untortunat

to leave his wife, to leave his babes....

left you wife, and child, (those precions

low does my wife? Why well

your wife, and babes, savagely slaughtered - iv. 3

my wife killed too? I have said...........

than Harry Perey's wife
WIFE and ehildren's ghosts will......... Macbeth, y. 7

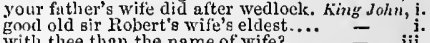
with thee than the name of wife?....

and buss thee as thy wife! ............

right of lady Blaneh your wif

$=$ iil.

thy sometimes brotlier's wife......... Risharar II. $\mathrm{i}$.

my wife [Kint.-queen] to France

政

and says to his wife,-fie upon ......
shall play dame Mlortimer, his wife..

a tired horse, a railing wife.........

(1) wife...

I am an honest man's wife.

the liglituess of his wite shines......

could get me but a wife in the stews - i.

and make me my lady thy wife ....

I pray thee, loving wife, and gentle.

alas, sweet wife, my honour is
his wife doth? Sir, pardon (rep.)

like an offensive wife, that hath

be merry, be merry, my wife's as ail - iv.

here comes ancient Pistol and his wife. Henvy $V$. ii.

I should quickly leap into a wife .... - v.

shall Kute be my wife?

as man and wife, being two

thy wife is proud; she holdeth $\ldots . . . .$. . i Henry $v I$. i.

remember, that thou hast a wife..... - v,

I am unwortliy to be Henry's wife ..

wife and all, from me.

the lord protector's wife (rep. ij. i) ..

buildiugs, and thy wife's oftire 4 ....

his wife, an't like your worslip......

my wite desired some damsons ......

dame Eleanor Cobliam, Gloster's wife

I think I $\mathrm{nm}$ thy married wife......

come wifc, let's in, and learn to

how will my wite, for slaughter $\ldots . .3$ Henvy $r$ iv.

sister, to wife for Edward (rep.)....$\rightarrow$ ini.

shall be wife to the English king.....

on your new wife's son

is it for a wife, thou art malcontent?

eontented with one wife $\ldots . . . \ldots . . . . .7$ iv.

we say, that Shore's wife hath $\ldots \ldots .$.
wife to thy Edward, to thy slaughtered -

if ever he have wife, let her be ......

motwer, wife, nor England's (rep. $\dddot{\text { jiv. }}$ l) =

spare my guiltless wife, and my $\ldots$

wife, love lord Hastiugs, let him kiss

embracements to my wife's allies .....

his conversation with Shore's wife.

and be tlyy wife, (if any be so mad)

that Amne my wife is very grievous.

he is your wife's son .........

and Anne my wire hath bid

O Harry's wife, triumpln not in

for happy wife, a most distressed .....

calls thy beauteous danglater, wife

to his chinluren, or lins wife's allies

thy adversary's wite doth pray for thee

heen totler's wife (rep. ii. 4) ....... He

that I have been your wife, in this..

report he has a better wife

and that way 1 an wife in ...........

this is my wife, there; ali............

I was a chaste wife to my grave

as like as Vulcan and his wife ...Trmilus of $\vec{C}$ r

ake to-day a wife, and

than wife is to the close?

if Helen then be wife to Sparta's.....

your quondain wife swe

liath another, his wife another ........

to

to help to get thee a vite

I am in this, your wife, Jour son......

my dear wife's estimate, her womb's

if you had been the wife of Hercules

farewell, my wife, my mother!

come, my sweet wife, my dearest .....

the fittest time to corrupt a man's wife
his mother and his wife (rep. v. I \& v. 5)

my wife comes foremost............

even he, your wife, this lady, and myself -

his wife is in Corioli, and his child ..

$O$ mother 1 wife! I am glad.

not his wife. You are my true $(r e p) .3 u$,

a woman that lord Brutus took to wile -

reuder me worthy of this noble witel

when C'xar's wite shall meet.

had you your letters from your wife 


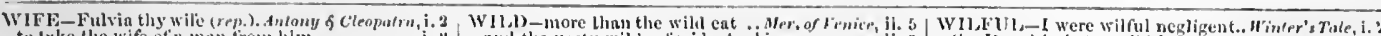

to luke the wife ot a man trom hlm.. your wite, nutl lirother, made wirs Sour wife, natel lirother, made w'urs...
as for my wife, I would y ou hud her

as for my nife, 1 wotst

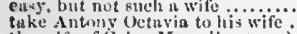

thke Antmig Oetnvia to his wife

who would not huve his wifi 80 ?

gister, prove sule a wife as iny
the wife of Antony shouth have

your wife (etavin, with her modest.

he purposed to his wife's sole son

kecer it till yau wno another wife
so doth my wite the nomparcil

was wife to your plae

my wifel o Imogen, Imo............

I divine, is this most constant wife.

but not to be his wife, tlat is. Tilus And -

true hetrithed love, and now iny wife?

his wife but yesternight was bronght

I mother, wife, and yet his ehili..

that man and wite draw lots ....

nr I will make your, man and wife

Cleon's wife, with envy rare..
wife, tuke her in: instruet her

of a beloved dougliter and a wife

my denrest wife was like this maid

my denrest wife was hike this maid ...
Clcon, with his wicked wite, llid seek.

huw thon at sen didst lose thy wife...

nltar true, this is your wife ............
for wieked Cleon and his wife

denrest Regnn, wife to Cornwall?

tell the duke and his wife..

Your wite, (so I would say, it........

commission from thy wife and me.

his wife and dam hiters (rep.). Rnmeo
stays a husband to make you a wife

when I, thy three hours wife, have

when I, thy three hours wife, have
wife, go you to her cre you go to bed

prepure her, wife, ngainst this .....

take me with yon, wife

wife, we searce thouglit its blesed

and my wife. Thint may be (rep.)

to live an unstained wife to my
shall be well. I warrant thee, wife

nursel wife! what hol what, nurec.

O my love! my wife! deatll that hat

my wife is tend tor-night

there dend, that Romeo's faithful wife

delight and dole-taken to wif

gets the love of Gonzago's wife

the queen, sour husband's brother's wif

is man and wite, man and wife is one.
shouldst have been my Hamlet's wife.

a fellow nlmost damned in a

I erave fit dispesition for my wife,

to his conveyanee I assign

that the is too familiar with inis wife..............

till I am even with him, wife for wife.

our general's wife is now the general

hy wife must move for Cassio ..................

that attends the general's wife

Ingn, to send in to your wife ..........
the general, and his wife, are talking of

was int that Cassio, parted from my' wif

when Cossio left my wife.

to say-roy wife is tuir, teerls ifeli.

lonk to yonr wife: observe her well

get on thy wife to observe..............

to have a foolish wife. O is that all?

with strawberries, in your wife's hand

but if I give my wife a handkerchicf

and is again to enpe your wife

he prizes the foolish waman, your wifel

and see, your wife is with him

your wife, my lord; your true (rep.)

in my wife: iny wife? (rep.).

what wife? I have no wife ....................

(lo with so gowl a wife iCol,-woman]

mure, he has killed his wife! (rep.)......... inore goddexs-like than wife-like. Combeliue. WiGilT-I ken the wight ............. Nerry H'ives, lase fiongarian [ $k$ nt.-Tfungarian] wight!

Armado is a most illustrims wight... Love's L.L.i.

with venomous wiglits bhe staje. Troilus of Cress. iv.

so li, her many a wight did ilie. I'ricles. i. (Gower)

she was a wiglit, - if ever such wight ... othello, ii. I
he was a wiglt of high renown.... - ii. 3 (kong)

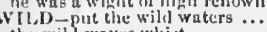

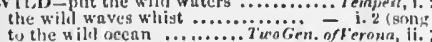

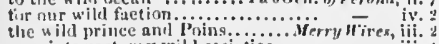

the uild prince and Poins...........erny lT

anil wild lialf-cun that ataliked. Méas. for Meas. iv.

tuming my wild heart to thy loving

teave thee to the meres if wilil ix'ants

a busk wherem the will thyme blow's

as will geere that the crecping.......

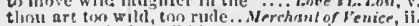

lest, througl thy wild behaviour.... nuld -more than the wild eat . B/er,
turusty wilds of wide $A$ rabiu..

upm the wild sea-banks, anil wa.....

do but note a wild and wantmin hent

my taxing like a wild goone thet.
slirts of this wild wood he cusne

Will you woo this wild cat?... Taming
from a wild cut to a kate eonformulble

there most piteons to be wild.... Wrint

widle wrorld, and wild watery scas Conge

so witleret and so wild in their attire. Aue

turned wild in nature ..............

how like you this wild eounsel

tame the savage spirit of will war

the irregular and wild Glenderser

like a flock of wild geese

will have a wild trick of his ancestors

of any prince, so wild, at libert

the times are wild; contertion.
keep the wild tlotd confined!

and ricles the wild mare with tive boy

and the wilk dog shall flesh his.

swilled with the wild and was

put in will and savage stock .........

unheedful, lesperate, wild adven

as wild Mledea young Absyitus did..2

desperate, wild, and furious ...... Richard $1 / 1$. iv.

use of gricf makes wild grief tar
if I elance to talk a little will

the approneh of this wild river briak

those, that tame wild horse

the wild and womdering flood.. Troilus \& $C_{1}$ essida,

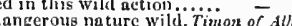

to prevent wild npproaehes wild

or at vild wild Aleibiades' wrat

more than a wild expostiure.............
which before were in wild hurry

go, you wild bed-fellow.......

the wild disguise hath almost

in this wild werld? so fure tie........

the wild motion of mine eye

Ihen with wild wond-leave

shut up your doors, my lord;
now a little fire in a wild field

thy wild aets denote the...........

these are but wild and whirling words ... llamet t. i. 5

such wanton, wild, and usunl slip.

paragons deseription, aod wild fun

parlours, wild eats in your kitehens....

town of war, yet wild, the people's hearts
WIID-DUCk-thin in a wild-luck. I Henry a struck towl, or a hurt will-d luek
wILDLR-with our wileler days........

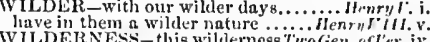

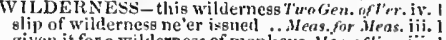
given it for a wilderness of monkeys. Mer. oft en. thou wilt be $\&$ witderness again....2 Heury 11 . iv. 1

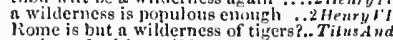
environed with a wilderness of sea

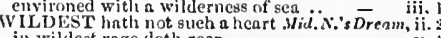

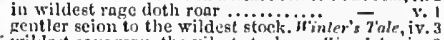

willest savagery, the vilest stroke .. King Jnhn, iv. 3

fearful wihl-towl than your lion...Mit. N.'s l)r.iii.

WIID.(iLESE - so many wili-geese..2 IJeny $1 i$, v

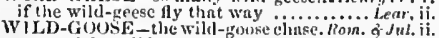

more of the wild-coose in nue of thy wits - ii. A
WILDI,Y - smmething tho wildly...... rempest, iii. I

blowing, and looking wildly.. ...ierzy"lives, ii. 3

guilty to what we willily do
sjeak of anmething. Wrildy by us

rough, rude, and wildiy

how wildly then walks my............ King John, $i$

that he stares and looks so wildly?... Richard I

valeur, that willly yrow in then . Cymbeliur,

nt your eyes your spirits wildly peep.

IILNEAS of his youth

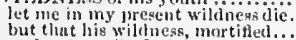

under the veil of wildness $\ldots$ il........

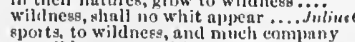

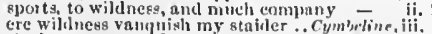

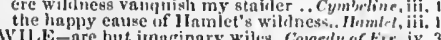

WILE-are but imaginary will's..Comaely of fir. iv.

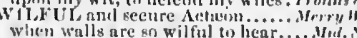

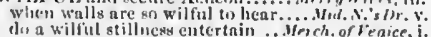
and like a wilful youtl, tlat which.. the ban, hin is tow wiflul nplosite. . King John, y,

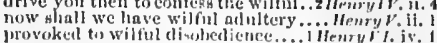

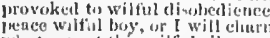

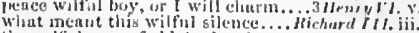

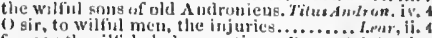

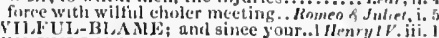

VIJ.EULL X dose spurn

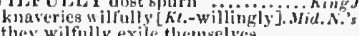

hath wilfinly betrayed the lives.

tlat wilfully sceks her own salvation? Hem v It: i.

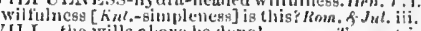

commend their service to his wili \% \%o.... Trmpest,

relying on your lordslitij's will

my will is something gurled
for what I will, I will

that wants resilved will to

opposes ler against my will

my will is even thig.

thant make their wilis their law...............

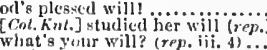

What's your will? (rept. iif. 4)
Got's will, and bis passion of

I ne"cr made my will yet.

wit, and 't be thy will, mit me...... Tutelsh $\mathrm{N}$ iit.

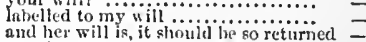

our bhows are more thanl will.

I do assure you, 'tis against my wiil

obedient to your grace's will .......Mers. for Meas.

what's your will? (rep. it. 3 and iji. i)
by yielding up thy body to my wili.

hy yiejding up thy tody to my will

but in the force of his will............suchd do, i.

against, my will, I an sent to bid (rep.)
I would not hang a dog by myy will..

to stay a man against lis will w..... - iij. 3

for I love thee agninst my will ....... -

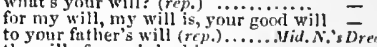

the will of man is by his renson.......

what's your will? Nothing, gond

Egeus, I will overbear your will

humlile-visoged suitors, his ligh wili. $\bar{c}$ iv.

tou blunt o will; whose edge linth (rep.)

by my will. Why, will shall (rep.)..

what's yolir will, sir? whin's your witil?

forsworn, in will, and error ............

will of a living dauchter (rep. .... Ner:

eall you? what is your will?

Bassanio, lord love. if thy will it be!

and enrb this eruel devil of his wiil..

by will, but a joor theusand crow\%.s. - iv

you ghall lave come part of your will

and al togetler against my will ......
ready, sir; but lis will hath in it...

for no ill will I bear sou

$\cdots-\mathrm{ii}$

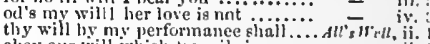

olvey our will whieh travals in 3 ï
what's his will, else? That you vili take
in every thing I wait unon his will

I shall nher lis will: you mist not

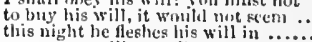

upon your will to sufler................

What's your will? 'That it wili please.

would derive me ill will to gleak of..

what is thy will with her? Tummg of Shr

what is vour to make a stale of

whats

as mine, neninst their will ............ inter's Tale

ant so the king"s will be perfirmed!

in aet, or will, that way inelining

good luek, an't be thy willi............
it is my finther's will, I shonilit take.

oppose agnimst their wills; care lift.

le is the lirille of your will.. Comedy of Enom

thenl let your will nitund on
whint is your will, that 1 should to..

although against my will........

nig' hearl, shall have his wall

and bid my will ayouel it

nerlear, that diil puphe my

to fill up your will, of your will......

le by will hequeathed his linds........... King $\bar{J}$.

than was his will to get me

a will: a wieked will ( $r \mathrm{me}$.).

3 
WILL-uncle's will, in this respect King Joln, ii. 2 translate it to my will; or, if you will
if not fill up the meastire of her will

against her will, in the vile...........

although my will to give is living

our quarrel to the will of heaven..... Richrevd 11.

your will be done: this must

against my will, to do myself.

whore will doth muting with ........

oppose not myself against their wi

so I do, against my will ...........

master sheriff, what's your wili........

and Will Squele, a Cotswold man...2

present execution of our wills to us.

seeming eold, or careless of his

fair reply, $i t$ is against

God's nill

Got's will and his pleasure (rep. v. i)

glsall show me the way to my will

or whose will stands, but mine?

my wide so a a ainst your will (.............

time once ripened to my will ........

as will the rest. so willeth winchl

against her will. Against her willi...2

and, Will, thon shalt have my hammer -

bnt God's will be donel Cold news...

with his soul, heaven, if it be thy will! =

so was his will in lisis old feeble

why now thou hast thy

if God's good will were so

Scotland hath will to help ............

have $\mathrm{my}$ will. And shall have your will =

it was my will, and grant (rep.)...... =

makence to lis so vereign's will? .... - iv. 6

make the jest against his will? .......

their heirs, (God, if thy will be so).... Henry $\bar{V}$ III.

a slave to each incensed will

our laws, and stick them in our wili
his will is most malignant his will is most malignant $\ldots 10 . . .3$. God's willl much bctter she ne'er $\ddot{\text { an }}$

serve your will, as't plense yourself.

thank you both for your good wills.

it's hearen's will; some spirit put

the king's will from his

without the king's will

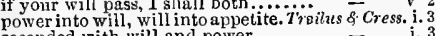

dwells not in particular will

and the will dotes, that is.............

of will and judgment; how may (rep.)

as anple power as I have will ......

to their benumbed wills $\ldots \ldots \ldots$ will.......

that the will is infinite

which his own will shall have.....

between my will and all offences...

ladies? what are their wills?.... Timo

u'itl me? what's your will?

performance is a kind of will

making your wills the scope of

to lct him slip at will .............

not so soon out, as another man's will

what custom wills, in all things

do your will direct me, if it be your......

direct me, if it be your will ...........

he that hath a will to dis..

at his will he may do danger witl...Juline $\overline{C a e}$

the cause is in my will, I will not come

in his closet; tis his will

the will; read it, Mark Antony (rep.)

hearing the will of Casar (rep)......

let me show you him that made the will -

the will I told pou of (rep.)....

I have no will to wander forth $\mathrm{iil}$.

you may do your will, but be's .......

then, with your will go on ..........

durst I have done my will............

soothsayer. Your will? ..... Anlony \& Clenpalr he stays upon your will $3 \ldots \ldots$....

would make his will lord of his reason
Cæsar's will? Hear it apart...........

and cry, your will? have you no ears?

and cry, your will? have you no ears?

a very rebel to my will ................

that have their honest wills.

the cloyed will, that satiate jet...

proceeded but by both your wills.....

after your will, have crossed
[ $834 \cdot]$

WILL_do your best wills, and make.Cymbeline, v. l| WILLING-all as willing as I live ..2 Henry VI. y.

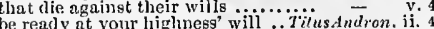

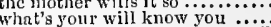

pertorm, it I might have my will w.....

I'll make my will then to your will

in vice their law's their will
can make his will his act

here my father's gift by will ............

then honour be but a goal to my will

frame your will to mine .............

trod upon a worm against my will.

a constant will to publish our daughters'.. Lear,

fallen out with my more leadier wili

quarrel with your great opposeless will

what's your will? Do you bear auglit...

if your will want not ............

proceed i' the sway ot your own will

see pathways to his will .......... Rom
bid a man in sadness make his will..

my will to her consent is but a part..

what is your will? (rep. iii. 3 ) .........
it is my will, the which if thou respect

as well as herbs, grace, and rude will!

and attend our will: mercy but murders

more crie to stny, than will to go

the strencth of will to slay thyself

no more, by crossing their high will..

not $m y$ will cousents (rep.)

upon his will I sealed my hard....

it shows a will most incorrect to heaven.

doth besmirch the virtue of his will ......

will of my most seeming-virtuons queen

and leads the will to desperate

pnzzles the will; and makes us rather

pnzzles the will; and makes us ratier
our wills, and fates, do so contrary run

though inclination be as sharp as will

and reason panders will and will, and strength, and..........

ii. 1 my will, not all the world's

let her will have a free way................

authority of this lics in our will

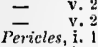

raw your willing swords........... Richard Ili. v.

if they be still, and willing...Henry $F_{I I I}$. (prologue to the earth, willing to leave their

most willing, madam. In which 1 , ${ }_{\text {follows not summer more willing }}$ ivi: willing misery ontlives incertain pomp - iv. this before a willing bondman ........ Corliuscesar, $i$. too much, but thou art willing ........ willing you to demand your.. Titus Andrnnicus, v. God willing, shall not lack ............. Hamlel, $\mathrm{i}$.

WILIINGLY I would (rep. iii. 1). Two Ge f $_{\text {of }} \mathrm{V} V$. and willingly, to do you rest....Twelfh Night, this rude wretch willingly to die

I crave death more willingly than merey -

proud of employment, willingly and willingly could waste my.... Axyou Lik il, ii. as willingly as e'ex I came frum. Tuming of $S h$. iii. ey your command.. Winters Tale, iv.

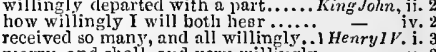
if I come in his, willingly, willigly

and $Y$ accept the combat willingly. $.2 \mathrm{Henry} V \mathrm{VI}$.

as willingly do $\mathrm{t}$ the same resign...

the and wili..3 Henry $r$. i. give ne willingly that noble title. Henty $\overline{Y^{\prime} I I}$. iit. I nor more willingly leaves winter. Timm of $\mathrm{d} / \mathrm{h}$. jii. $\mathrm{G}$ most willingly; but yet my caution. Coriolanus, ii. whint willingly he did confound....ntony \& $\overline{\text { Cleo }}$. iii. willingly; and pawn mine honour... Cymbeline, $\hat{i}$. poor sick Fidele! I'll willingly to him - iv. I will most willingly attend. T'itus Andronicus, which you commit willingly.......... Pericles ne would as willingly give cire. Romeo \& Juliet, that 1 will more willingly part withal ... Hamele WLLLINGNESS-all willingncss ..2 Herry $\bar{r} I$. iij. thither straight, for willingness rids.3 Henry VI. v.
WILLING'ST sin I ever yet ...... Henry VIII. iii. WILLOUGHBY, with all their......... Richard 11 . ii.

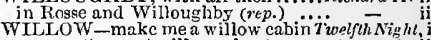
even to the ncxt willow, about your... Aluch tdo, offered him my company to a willow tree wear the willow garland (rep.iv. 1) 3 Henry $V I$, iii. there is a willow grows ascaunt $\ldots . .$. Hamlel, iv. 7 sing all a green willow (rep.) $. \cdots . .$. iv. 3 (song) to get his place, and tu plume up my will had tongue at will, and yet was never loud in such, a will most rank, foul $\ldots$.......... her will, rccoiling to her better judgment

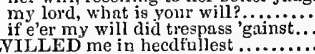
be interred, for so le willed it ............ King $J_{0}$ willed me to leave my base............ K Henry than we are willed. Who willed you?
they willed me say so, madam $\bar{F}_{\text {II }}$. wishes fall out as they're willed Pericles, v. 2 (Gow WILL YIE, NILL HE, hè goes.......... Hamlet, v. come hither, Willinm, hold up ...MerryWives, iv. william, how many numbers .......

is good, William; what is lie, Williain
is the focative case, William? (rep.)...

show me now, William, some declensions -

is thy name, William? William...ds you Like th
do, good William. God rest you ....

William is become a good scholar..2 Henry IF. iii. 2

mean to stop any of William's wages

conntenance William Visor of Woncot

and sir Witliam Glansdale...

here is sir William Luer (rep. $\ldots \ldots \ldots . . .2$.

William of Windsor was the seventh

Hastings, and sir William Stanley .3 Henry $Y$ l. iv.

William lord Hastings (rep. iii. 4). Richard III.

sir William Stanley; Oxford, redoubted

sir William Brandon (rep. v, 4)...... Henry ${ }^{\prime} I 11 . \mathrm{i}$.

WILLYNG as bondage e'er of freedom.Tempest,

with willing sport, to the TwoGen.or Verona, it.

what I am willing to keep in..... Tuelnh Nighl, ii.

my is very willing to bid you fove, the rather by

whiles you are, willing it shal

if yourt a willing ear incline .... Meas. for $M$

not without the prence be whing ... Much Ado

all pride is willing pride

$I$ was as willing to grapple, as he.....

one dend that is willing to be so ...As sou $\bar{L}$ ike

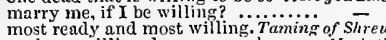

we lave willing dames enough ....... Wachelh,

who with willing soul adopts.

yoll had been willing to rcsign ....... Heñry $r$

could be willing to march on to Calais - and die ill music; willow, willow, willow - v.
WIII, YOU, NIL YOU, I will.. Taming of Sh. ii.

WLiTSHIRE straight bid lim..... Tichard $1 l$. ii

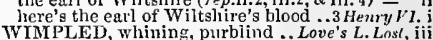

WIN it from me, the lord on't........... Tenpest, i.
I think you'll hardly win her... Two Gen. of $\mathrm{V}$ er. $\mathrm{i}$

your grace win her to fancy lim?....

Win her with gifts, it she

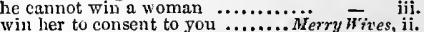

that $I$ should win what you............

this wins him. liver and all ........... Tuelfth $\overline{\text { Night }}$, ii. 5

the good we of might win.. Heosure for Mcasure, i.

such a man will win any woman ....... Much $A d o$, il. and shape to win grace though he.Love'sL. Lost, ii. master, will you win your love with
as thou wilt win my favour.

as tholl wilt win my favour......... and win them too: therefore let...... - iv. 3 to win me, if yon please.............. of $\overline{\text { renice, }}$,i. to win thce, lady; but alas .......... - ij. we shall ne'er win at that sport....... ${ }^{\prime} \bar{w}^{\prime}$ elt, iii. to cozen him, that would unjustly win - iv.

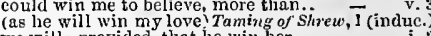
we will; provided, thint he win her ...
tis deeds, must win the prize......
beauteous looks, shall win my love... I will win my wager better yet....i.i. to win ns to our harm $\ldots \ldots \ldots \ldots \ldots \ldots$ Macbeth, i.

win us with lronest trifles..........

may easily win anto - iv.

e'er the coward hand of Frnne can win -

I cannot pray that thou may'st win

政, on that side shall I

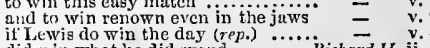

did win what he did spend...

but we must win your grace ........

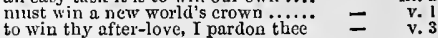
but of danger wins a scar ............ - iii. shall win the wager which we will ... $=$ v.

win you this city witheut stroke..... -

to win this easy match 


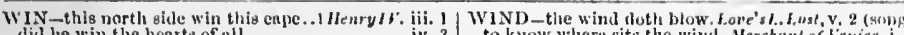
didio win the hearts of all ............. whocter thou he, and thus I win the

that thou might'st win the more ...2henryly. antl fire, to will your right

I can never win a boul 80 easy

dotlo win imuortul fnue

if 1 could win a ludy at lenp-lrog.... $=$ v

to win the Dauphitis graec ...........

l'll $w$ in this lady hargaret.

my self did win them lwoth
by inain foree Warwick disl wi

whied I will win from Frane

preserved so whole, do seliom win

here let us win our riglit

Ill win them, fear it no

no lope to win the dny..............

in eonelusion, wins the king

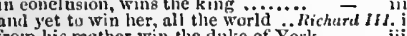

fron his mother win the duke of York
I'll win our aneient riglit in Franee

We sliall ne'er win him to $i$

this is not the way to win your ......
shall I go win iny daugliter .......

a rake, and win tlic dryt.

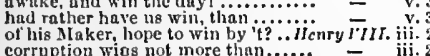

corruption wios not more than...

sir, I did never win of you before

with wagging of your tongue to wiri me

and let them wiu the work

my Cressid then so hard to win?. Troilus \& Cress. iii. 2

bade hint win all

二 $\quad$ v. 3

it will in time win upon power

and did retire, to win our purpose

and puff to win a vulgar station

our wish, which side should win

his encks do win the battle ........... Antous 8 Cleo.

you'll win two days upon me.....

husband win, win brother, prays

as I can win the oftended king

in our trifies I still win of you

I'll win to-night of him: ecme,
Jot, and furious, when you win

so sure to wia tie king, as I am boid

but to win time to lose so bad.

and win this ring by hers and

flid, and win unto return, you

frould win some words of

win your displeasure..... Lear,

I will win for him, if I can; if not ..... Haniet, v. $v^{3}$

I shall wis at the odds; but thou

our son shall wir. He's fat, and seant...

to win the Moor again? (rep.)

what shall I do to wis my lord againi... - iv. 2

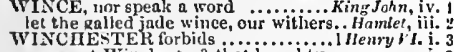

arrogant Winchester? thiat lianghity

Winchester and Gioster (rep. iti. I)..

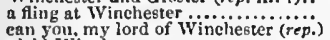

yield Winchester; cxecpt you mean

liere, Winehester, I offur thice my hand =

is my lord ot Winchester installed (rep.)
now Winchester will not suboit. I trow

spenk, Winchester; for boiling choler - v.

uncle of Winchester, I pray (rep.)

my lord of Winehester, I kuow your..

the one, Winchester, (newly preferre

he of Winehester is held no great good

commendations, bislyn of Winchester $\bar{W}_{\text {some }} \mathrm{v} .{ }^{2}$

WIXCUT-ale-wife of Wincot. Taming of Sh. 2 (ind.)

to sigh to the winds, whose pity

thou shalt be as free as mountain winds

I lienr it sing $i$ ' the wind

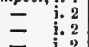

as well wound the loud winds .........

be culm, good wind, blow not .. Two fien. of ver.

if the wind were down................ ii. 3

hear this shower sing in the wind.Merry lives, iii. 2

if my wind were but long enough.....

twill endure wind and wentlice

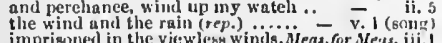

imprisoned in the viewlesy wing

a the wind in that corner?

is bint foul wind, and foul wind is but

ringlets to the whistling wind ...Mid.N.'s $\overline{D r e}$ therefore the winds, piping to us

abutut tle wond go switier than the wind =

funncel with the enstern wind, turn

and I will wind thee in nuy urms ou

the weatlicr, ilat love not the wind. Love's $L$. $L$. Iv.

the wind, all unseen, 'gan
bullets, wiud, thoughit, swifer tbings to know where sits the wiul, Merchan
my wilud, eovling my bruth..........

what harms a wint too grent inighit

for the four winds blow in from

the peril of waters, winds, aubl rocks

erubracel by the strumpet w/mil

sueh winton gambols with the wind

when the sweet wind did gently
elicling of the winter's wiul...........

na lurge a chnrter ne the windi.

heing monnted on the wind .
but-wind away, begone, I

futhing witl wind and rain?

same coxcomb that we liave

gur'ythee, allow the wind ine the wind - iii.

sertges play with wind.. Tuming of shirew, $\overline{2}$ (induc.)

sueh wind as scatters young nen
puffed up with winds, rage like...

fire grows great with little wind

as mountains are for winds, that shiake $\overline{\text { ing }}$ i.

that may blow no sneaping winds ...

as wind, as waters; finlse as.

take the winds of Mlarch with bqauty

with more speed befiore the wini. Co.n.

stop in your wind, sir; tell me this

and words are but wind.

and if the wind blow any way from

melted, as breath into the wind.................

thougli you untie the winds

the adverse winds, whose leisure.......... King Joh

no eommon wind, no enstomed.....

like a slifted wind an

thy threatening colonrs now wind ü........

to make his bleak winds $\mathrm{ki}$.

exeept the north-cast wind

we see the wind sil sore upon.

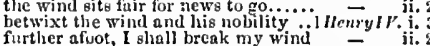

imprisoning of unruly wind within..

wind with suels a deep indent

like estridges, that wing the wind.
to turn and wind a fiery Pegasus...

the southern wind doth play $\ldots \ldots \ldots j$.

naking the wind my postiorse. 2 He

your wind short? your eliv double?

with so rough a wind, that even

what wind blew you bither (rep.).

now sits the wind fair, and we will..... Jenry $r$. if.

the invisible and creeping wind... - iis. (clicrus)

the wind was very high $\ldots \ldots \ldots \ldots \ldots$.

the winds gruw lighl; so do your.....

by awk ward wind from England's.

against the senseless winds sliall gri

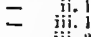

like ships before the wind

for seif-sume wind, that I should speak

of the wind: sometime the flond ( $($ e ej.)

obeying witly ny wind when I do biow =

that moves hoth wind and tide.

to resist both wind and tide...

huve wind and tide thy friend

sirubs from winter's powertul wind...

though the rough wind say no

and dill-dispersed wind of misery........

the splitting wind makes fiexible

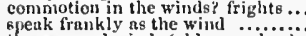

Epeak frankly as the wind ..........
the seas and winds (old wranglers).

ald fetehes her wind so slort........

rain, to luy this wind, or my

even in the fin and wind of your .....

wiul, to wint, there turn and ehatige

lie sliould be free, as is the wind

wind $y^{\prime}$ ourselt into a power ty rannieal =

then let the mytinous winds strike... $=$ v.

and the seolding winds have

to wind, to stop, to run dircetly on

they pass by me as the idle $n$ ind $\ldots$...
blow, wind: Bwell, billow; and swin

whell our quick winds lie still.....Ant

we enmot call her winls and waters
whose wind did seem to glow the..

whose wind did seem to glow the.
the lenst wind i' the world will.

his alfirs come to me on the wind

tlougl my reanon sits in the wint

wheu we shall hear the raia aud wind - the merry wind blows fuir from laind

is the wind in that door, it faith?

3 Henry riv.

infect another ngaingt the wime.
WIND-rlifes on the posting winds.. Cynbeline, ii, to commix with weinds that sailors with the next betefit o' the wind ....

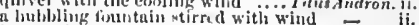
if tic wimls rafe, doth not the sea.. and, ir she wind you once, slic's with and $I$ will have the wind of you....

as pood to slinet ugainst the unid

fenttered by winds and hish tempestueu

fur now the wind begind, to blow.

wind, rain, and thunder, remember.

Whom both the waters and the winl

the wind jo loud, und will not lie tili..

ard the pentlest if the wind cease

is this wind westerly that blows?

when I was born, the wind was north.

a strong wind will blow it to pieees..

hounteons winds, have broughat .

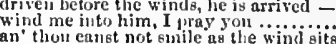

outface the winds, and jerseeutions of

bids the wint bluw the oarly rufte

the to-and-fro eonnicting wind anil rain

nor rain, wind, thunder, fire, are

streh groans of roaring wind and rain.

havithorn blow's the eold wind (rep.).

dint which the rude wind blows

$O$ wind up of this clitid-clinnged fatheri

winds, who nothing lurt witlong wils? - iv.

and more ineunstant than the wind..

a bark, a sea, a wind

the winds, thy sighs

miglit not beteem the winds of he......... Fannet, it.

as the winds give benefit, and emvoy ....
the wind sits in the shoulder of your sail

not to erack the wind of the poor phrase

but with the whiff and wind of his ....

the bold winds speechless $\ldots \ldots . . .$.

as the sea. and wind, when botll contend

tuo slightly timbered for so loud $\mathrm{a}$ wind.

for his death no wind of blame
stop a liole to keep the wind aw

'tis very cold; the wind is northerly.

methinks, the wind hath fpoke ulvid ...

may the winds blow till they huve ......

gails freels, buth with wind and stream
I pray you, called wind instruneuts?

marry, sir, by many a wind instrument.

the bawdy wind, that kisses all it meets.
that knocks?

blow me about in wints! ronst me

WINDED in my forelicad.............

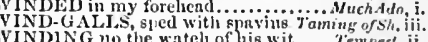

many winding nooks he strays. Tu' Gen. of 'ere ii.

a wretel, winding up days with toil...Hemry iv.

arms of mine shall be thy winding-slieet -
WINDI,ACES, and with assays of bias... Hamles,

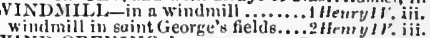
VIND-OBEY ING decp gave any...Comedy of Iir. i. one may enter at her window? ....... of Jer. ii. now must wo to her winulur

it hath bay windows transparent. Tueloh $\mathrm{i}_{\mathrm{i}} \mathrm{hl}$, iv.

priests in the old elurelt windew..... Much ddo, iii.

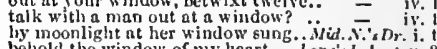

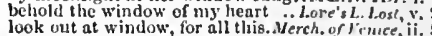
so, my good window of lattice...........All's "Hell, ii. 3 looking out at the window (rep.).. Tansug of sh. v. in at the wiullow, or else o'er ......... King John, i. fromlil not out at winclows, nor at doory - ve from my own windows torn iny..... Michard 11 . iii. 1 would liase thoukht the very winiove

no part of his fuee from the window .2Henry II: ii. 2 lo, in these windows, that let forti... Hethord $1 i l, \mathrm{i}$. ere 1 let full the window of nine eyes - y into the eompassed window .. Troilus f Cressida, i.
bulks, windows, are smothered up.. Corrolanus, ji.

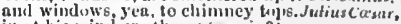
in at his windur s throw (sep, i. 3 )...

sluck diwn formo, whdo s, any thiing - ii.

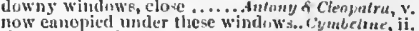
there the window: such the ulormulent - ii.

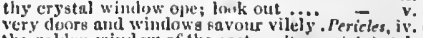
the golden window of the east ... Komeo of Juhes, light througlt yonder window brenk a? then, window, let fluy in, and lot life out -
thy eyes' windows fall, Like death.... 


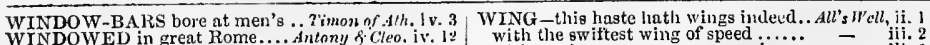

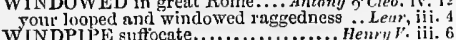
Wv windpipe's dangerons note........... Timon of Ath WIND-S1PAKED surge, with high and.. Othello,

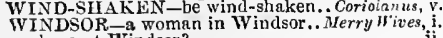
when the court lay at Windsor prayer, as any is in Windsor old Winclsor way, and every way. colning with half Windsor at lis heeels for the wealtll of Windsor Castle....
miotisme a keeper here in Windsor Rud moek him home to Windsor ....
the Windsor bell hsth struck twelve for me, $I$ am lere $a$ Windsor stag.... search W indsor castle, elves, within how like you Windsor wives?........ we'll bring you to Windsor, to one... will hold at Windsor so inform....... HenryIV to humt my lord, at Windsor........

not at Wiudsor with him, Thomas
homin at Windsor, should lose all ... iHenryy William of Windsor was the .......2 Henry ${ }^{\prime} I$. ii.

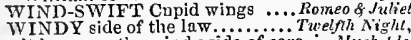
it kceps on the windy side of care $\ldots$. Much did
hy the windy breath of sof petitions. King.Johim hy the windy breath of soft pestions. King.r. windy attornies to their client ....Richard 111 . 1 . nor windy suspiration of forced breatl... Iamlet, i. no usc of metal, corn, or wine, or oil

if all the wine in my
where iny wine is hid.

where iny wine is hid o......... is
where $m y$ hogshead of wine

where liad he wine?

carry the wine in ......................
and in such wine and sugar.

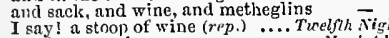

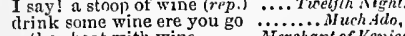

rather heat with wine
set a deep glass of Rlienish wine
betwreen red wine and Rhenish.

between red wine and Rhenish.
as wine comes out of a narrow

fnlser than yows made in wine
titat good wine needs no bush (

I am sure, thy father dranis wine ....

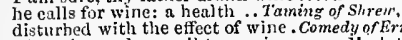
disturbed with the effect of wine. Comedyofrerr.
with wine and wassail to convince .... illacbeth, the wine of life is drawn ail

give re some wine;

by this wine, I'll thrust my knife .-

give master Bardol ph sorne wine

a cup of wioe, sir? (rep. in song).
it was excess of wine that get him
spirited witll wine, seem frosty?

spirited witll wine, seem frosty? taste of your wine, and see..........

good wine in thy master's way........2 Henr.
run nothing but claret wine this first

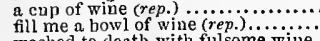

fill me a bovil of wi.t. good wine, good welcome, can.......Henry $\bar{H}$ III. i. 4

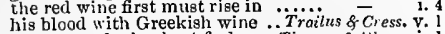
knaves, and wine heat fools.... Timon of Alhens, wept with drunken epilth of wine ...
fill me some wine: and how doea ...

please your lordship herc is the wine

have we no wine here? go we to..... Coriolan

wine, wine, winel what service is herel =

of our blood with wine and feeding.

Lncius a bowl of wine (rep.)

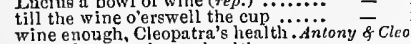

sit, and some wine: a lealt

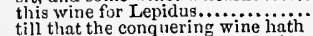

till that the conquering wine hath
Enobarbe is weaker than the wine

some wine, within there, and our viands

give me some wrine and let me .......
we drink this standing-bowl of
wine... Pericles

we drink this standing bowl of wine...Pericles, ii.
wine loved I deeply; dice dearly ....... Lear, iif.

sct me the stoops of wine upon ........ Hamlet, y. 2
the wine she drinks is made of grapes... Ochello, ii. I

I have a stoop of wine, and here without

some wine, hol (rep.). ...................
thou invisible spirit of wine, if thou
come, come, good wine is a good familiar

come, come, good wine is a good familiar $=$ ii.
WING-with thy saffron wings........ Tempest, iv.

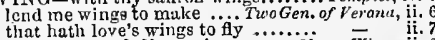
that hath love's wings to dy ........ on the wing of nll occasions ...... Merry Wives, Wings, and no eyes, figure......Midid.N.'s Dream with rear-mice for their leathern wh
and pluck the wings from painted

and batty wings doth ereep...

their conceits have wings ..............ve's L. loost, v.

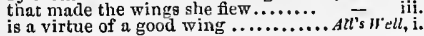

with our horse upon our own wing.
to use my wings. I impute.. Winter's Tale, iv. (clii. 6
ino.) will wing me to some withered .......... makes wing to the rooky wood .......... - iii, and owlet's wing, for a powerful charm

their riglt under your wings of war . King John, ii. our drooping country's hroken wing. Richard ll. it. that wing $[C o l$ Knt-witb] the wind.

but with uimble wing we were enforced $-\bar{y} \boldsymbol{y}$
what wings shall his affections.. .2 . Henry ${ }^{\prime}$

with youthful wings is flown

more feuthers to our wings.

iving iv.

they stoop wich the like wing...

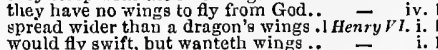

would fyy swift, but wanteth wings .

underneath her wings.

under the wings of our protector.......2 Henry $v^{\prime}$. i. 3

bualies to betray thy wings.....
slow and flagging wings clip

knowledge the wing wherewith we

dares stir a wing, if Warwick shake. 3 Hersry $v$ iv. $\mathrm{i}$.

even with those wings which sometime
they follow us with wings ..........

with trembling wings misdoubteth..

for all his wings, the fowl was .. $\ldots .0$
that senred the wings of my sweet boy
fiery expedition be my wing...... Richard 111.

fiery expedition be my wing ........R

and flies with swallow's wings

should mount with wings of victory

fair company clapped wings to me. H
thy person under their blessed wings
the very wings of reason .... Troilus

the very wings of reason .....
gave wings to $\mathrm{my}$ propension

pluck his painted wiugs, and fily $\ldots . .$.
show not their nealy wings, but to..

show not their mealy wings, but to..
with wings more momentary swift ..
the dragon wing of night o'erspreads

the dragon wing of night o'erspreads - v. 9

he has wings; he's more than ...... Coriolans, ii.

plucked from Cassar's wing ...........JuliusCasar, i. 1

so poor a pinion of his wing ... Aniony f cleo. iii. 10

thine eyes, though they laad wings.

the best featlier of our wing
o for a horse with wingst...

'would I had wings to follow it!......

the king himself of his wings destitite $=$
his royal bird prunes the immortal wing -

from south to west on wing soaring:.

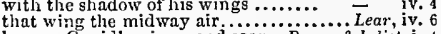

borrow Cupid's wings, and soar............... Leareo of Juliet, i. 4

of the wings of grasshoppers $\ldots \ldots . .$.
with love's light wings did I o erperch

hath the wind-swift Cupid wings.....
for thou wilt lie upon the wings of night $=$ ii.
iit.
with wings as swift as meditation ....... Harnet, i.

and hover o'er me with your wings........ 二 $=$ iii. 4

do all thouglits; they are winged. As you Life ii

the fighes, and the winged fow ls. Comedy of Err ii.

this sealed brief, with winged haste.
with winged heels, as Fnglish.... Henry $V$.

upon your winged tlounghts

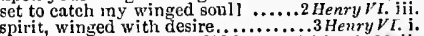

slaall be well winged with our

winged thus swift with scorn. Trailus \& Cressida, ii.

or, winged with tervour of her iove... - iin. 5

the Roman engle, winged from .....
only I carry winged time post .. Pericles, iv. (Gow.)

but I shall see the winged vengeance ... . .

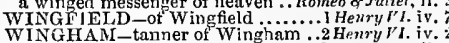

WINK-cannot pierce a wink beyond... Tempest,

although you judge I wink. Two Gen. of Ferana, i.

upon a homely object love can wink

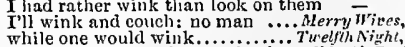

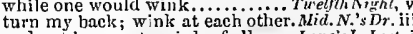

and not be seen to wink of all ..... Lave'sL. Last,

erew you master wink and laugl... Taming of $S$.

give mine enemy a lasting wink.. Winter's Tale, i.

as good to wink, sweet love .. Comedy of Errors, iii. 2

the eje wink at the hand $\ldots . . . . . \ldots \ldots$. Macbelh,
did make beholders wink? $\ldots \ldots \ldots$ ichord II. 1
but $I$. will wink, and hold out mine ... Henry $V^{\prime}$.

but $I$. will wink, and hold out mine ... Henry $r$. if.

I will wink on her to consent...

good boy, wink at me, and say. Timon of A Aliens, iii..

nor wink, nor nod, nor kneei. Titus Andronicus,

that runaways eyes may wink. Romeo \& Juliel,
as her winks, and nods, and gestures .. Hamlet,
iv,

thic nose at it, and the moon winks ..Othello,
WINKED since I saw these ...... Finter's Tale.

and, on the winking of authority

winking, leaped into destruction
that ruo winking into the moutl that a winged Mlercury did bear........3 Henchary 171 , ii

let me see thine eyes: wink now....2 Henry VI. ii. 1

on distemper, shall not be winked at. Henry ${ }^{2}$

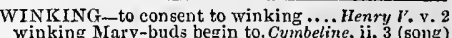
winking Mary-bud begin to. Cymbeline, ii. 3 (solig) am sure, hanging's the way of winking $=$ v. for winking at your discords too. Roines \& Jutiet, vi.3
[Col.Knn.] or given my heart a winking. Hamlel, ii. 2 Wol.Knt.] or given my heart a winking. Hamlel, it.
WINK'ST whiles thou art waking .... Tempest, ii. I WINNER -being a winuer .... Taming ar' Shesew, $\mathrm{v}$. you precious winners all........... Winter's Tule, $y$. beslirew the winners, for they........ Henry Hi. profess myself the winner of her ..... Cymbeline, $j$ ii. is yct to name the winner ..........
both friend and foe, wiuner and loser?. Hamlet,

WINNING make the prize light......... Tempest,

would hazard the winning both of .. Cymbeline,
winning will put any man into courage -

how to lose a winning match .. Romeo \& Juliet, ii

winnows the light away...... Troilus \& Cressida,, i. 3 Inost throughly to be winnowed ....2 Henryy I' iv. iv. of such a winvowed purity . Troilites \& Cressida, iii. 2 the most fond and winnowed opinions. Hambet, v.
WINTER-lowled awny twelve winters. Tempest, like winter's drops from eaves ........ on or $\bar{c}$ cr. vi. 4

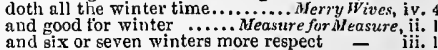

mortals want their winter here......14id.N.'s $D_{r}$. ii. angry winter, clange their wonted $\ddot{\text {, }}$, ii. this side is Hiems, winter............ by the same winter and summer. Hire... of Venice, iii. 1 my age is as a lusty winter, frosty ..- $\overrightarrow{\text { ii }} 5$ (song)

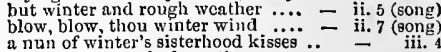
a nun of winter's sisterhood

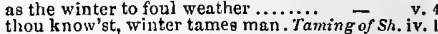
thou nit, thou winter cricket thou . and still winter in storm perpetual..
anlood reigns in the winter's pale...
iv. 2 (song)

and savour, all the winter long
our ages with flowers of winter

nor on the birth of teremhing winter

will bur'n a poland winter.... Cainedy of Errors, iit. a woman's story, at a winter's fire.... Macbeth, iii. none of you will bid the winter come. King John, v.

four lagging winters, and four ......... - i. 3

what is six winters? they are........ $=$ i. 3

in winter's tedious nights, sit by....... as laumorous as winter, and as sudden - iv. ever in the haunch of winter sings ... $-\overline{\text { iv. }}$ "inter's cold, and summer's parching. 2 Henry $V i$. i. barren winter, with his wrathlul $\ldots . .$.
well could I curse away a winter's niglt = that winter lion, who, in rage..........
winter should cut off our spring-time.3 $V I$. cold biting winter mars our......... - iv. 8 fable in a winter's night.............. $=$ v. 5 armour's watched the winter's night.. iciard III. fall, then winter is at hand $\ldots \ldots . . . \ldots \ldots$...
tiil death, that winter, kill it...... $\bar{\nu} I I I . \mathrm{iji}$. take that winter from your lips Troilus \& Cress. iv. 5
one cloud of winter showers.... Timou of Alhens, ij. I fear, 'tis deepest winter in lord .... nor more willingly leaves winter...
with one winter's brush fell from... there was no winter in't... . Antony \& $\&$ Cleapasra, $v$, nor the winter's furious rages. ..... - - iv. 2 (song) and the shrinking slaves of winter goodly summer with your winter mixed

winter's not gone yet, if the wild............. Lear, there's no labouring in the winter......... on the heel of limping winter treads. Rameo \& Jul. i.

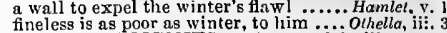
WINTER-GARMENTS must. As yau Like, iii. 2 (ver.) WINTERLY, thou need'st but kcep.. WIPE thou thine eyes ................... Ternpest 1 , i. from my forehend wipe a perjured.. Love's $L . L$. Camillo wipe not out tle rest.... Winter's Tale, iv. from my succession wipe me, fatherl ${ }_{\text {let }}$ we wipe off this honourable dew.. King John iv. $y$.

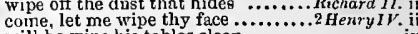
obertience to the king wipes the crine. Henry $V$ iv. do make me wipe off both............3 Henry VI. i. 3 bid the father wipe his eyes......... - i. my tears shal wpenway ............. to wipe out our ingratitude
executed ere they wipe their iips .. Cariolanus, iv. out of our question wipe him .... Antony \& Clea, ii. be cheerdul, wipe thine eyes ........ Cymbeline, iv.
no hands, to wipe away thy tear. Titus Lavinia, I will wipe thy cheeks....

ay her woe!

let me wipe it first..................... Lear, iv.

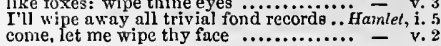


WIPE-see Cnssio wipe his Ienral with.. Othello, jii. 3 WIIED-your eyelids wijed in ten
and wiped our cyes of drops thet and wiped our cyes of dropls thint
linth from my sout wipet the biluck linth from my sout wipet the black ..Marbeth, iv. grief had wiped it from my mind .....2 Henryl $b^{2}$. j. I thy sesndal were not wiped away .2Henry $\%$ i. ii. with our sworl we wiped nway the blot -

this blool be wiped from thy poin

iv. 10 the WiPING-his mailed linud then wiping

W IRE-be whippedl with wire.....Antnny \& Cleo. ii.

WIS-be fooly alive, I wis.Mer. of Ienice, it, 9 (serul $)$ to fear; I wis, it is uot lialt:... Taming of shrew, i. to fear: I wis, it is nour grandun liad

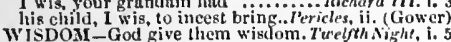
I think I saw your wisdom there... - i ji. I let thy wisdom, not thy passion...

be it as your wisdom will...Neasurefor
thus wisdon wishes to appear more..

runs the wisdom of the world

olow seur wisdom, dnughter, in

pace your wisdom wistlat bood latili.. - iv. 3

my lord, wisdom and love combating. Aluch Ato ii. 3

aid if their wistoms be misled in this

and 'tis not wishlom, thus to secund

what your wisdoms coult not discover
for wisdom's anke, n word that all. Lare's L.Losl, iv. 3

folly, in wisdom lintehed, hath wisdon's

they have the wisdom by their wit

have hy sour wisdon been this day.

now unmuzzle your wisdom ...... As yau Like it

his love and wisdom, approved so t

prefession, wisdom, and constancy ...

Go I leave you te your wisdom

thus your own proper wisdom brings $=$ iv. 2

the wisdom of your duty ....Thming of Shreen, v.

whith wisdom stirs amongst you?. finter's Tale, ii.

long experience of her wistlom.. Comedy nf Err. iii.

hove wisdom, grace, and fear

what distance his wisdom ean provide

his wisdom, er his fear. Wisdom! ..

as little is the wisdom, where $\ldots . . . .$. .

and modest wisdom plueks me from..

what you in wisdom shall vouclasafe. King $^{\prime} \bar{J}_{n} h$, ii.

for wisdom eries out in the streets $\ldots 1$

that wisdom, wisdom to make strong against

disoree not wisdom from your

your wisdom be your guide..........

as your wisdoms best shall see

yclad witly wisdom's majesty $\ldots . .$.

what to your wisloms seemeth be

now is it manheod, wisdom, and $\cdots . . .2$

till then 'tis wisdom to concenl

sir; 'tis a point of wisdom

argues your wisdom, and your love... $=$ - iii. 7

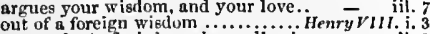

a precedent of wisdom above aij prinecs -

a precedent or wisdom above ali prinets

want of wisdom, 5ou, that best

and wisdom of my council ........... -

count wisdom as no member..... Troilus $\$$ Cress. i. 3

twss wisdom Paris went ...............

the issue of your proper wisdoms rale

the and proise thy

if wisdom be in suffering ..... Timon of sthens, iii. 5

and since the wisdom of their clioice

title, wisdom cannot conclude

alna, my lord, your wisdom is

censure me in jour wisdom.

if heauty. Wis som, modesty. Antony \& Cleopalra, ii, 2

wislum and fortune eombuting...... - iii. 11

whose wlsdom lath her fortune .... Tilus dudron.

for wisdom sees, those men blush not ...Pericles, $i$.

who by thy wisdom mnkest a prince

whose w'sarom s atrength can bear it

to wisclom he's a fool that will not

the businese after yeur own wisdon
though the wisdom of nature can...

linve $y^{\circ}$ th wiadom? so.................

inucli more attasked for wont of risidoin

his ear abused, wisdom bicle fuar

wisdom and goodness to the vile

what can man's wislom do .........

desire her ea!l her wislon to her

in wirdon. I shonld ank thy 11 am

ind his wistlom, hastes our marriage.

in his wistom, hastes our marriage

herein barred your letter wisiloms.

it fits your wisdom so far to belicve it...

your wisulom beat sliall think

your wisdom shonlu sliow itseif mure.........

hath but one pnrt wisdom, nnd, ever

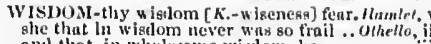
anil that. in wholesome wisdom, he......

[Col.kint.] thint your wisdom from one

WISE-[Col.] woulered father and a wise Tem

not be ehronielelt for wise...............

holy, fair, nnd wise is alto

vulimit, wise, remorscful

convey, the wise it eall
lye is wige, sir: he knew

a wise and patient cluveliman .......

was't not the wise woman of Breniford?

yos tlere a wise woman $\ldots \ldots . . .$.

may lass for a wise man.......... 7 u.el $\Omega \bar{\lambda}^{-}$

iotirmity, that decays the wise.......
I take these wise men that crow so

evcry wise mnn's son doth kuow
this fellow's wise enough to play

this fellow's wise enough to play ....
ns full of labour as a wise man's art

but wise men, folly -fillen ..........
earry his water to the wise womn

earry his water to the wise woman ...
these wise men, that give fouls noney

but that a wise bursher put

here's a wise officer..................

held the duke to be wise. Wise? wlig
one so learned and so wise as you.

another is wise: yet I am well ......

that's certain; wise, or I'll
and she is exeeeding wise.

and in my mind, vers wise ..............

you may sny le is wise; for eitler
ant wise, but for loving me..........

low wisc, how noble, young, hew....

I $\mathrm{nm} n$ wise fellow

the gentleman is wise (rep.)....

there's not one wise man among

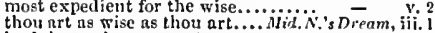

lord, how wise you are! ..............

his ignorance were wise, whicre
do the wise think them other?

what fool is not so wise, to lose.

we are wise girls, to mock our

your wit makes wise things foolish

this proves you wise and rieh..

therefore enly are reputed wise...
one of these same dumb wise men

as his wise mother wrought in his

it is a wise faller, that knows lis....

iike herself, wise, fuir, and true
had you been as wise as bold

had you been ns wise as bold .... - ii. 7 (Eerell)

I know no wise remedy how to noid. As you Lilip, i.

what wise men do foolishly

grows rank in them, that I am wise

if not, the wisc man's folly is.........

learn of the wise, and perpend

but she is wise, or else slie could not

think he is wise, but the wise mon pretty

she is young, wise, fair .............All's $W^{\prime}$ cll, ii.

am I not wise? Yes; keep; you Taning of sh. ii. 3

master, be wise; an' if you give. Comedy af Err. iv. 3

nho can be wise, amazed, temperate ... Macbeth, ii.

are to a wise man ports and happy

it will make wise men mad

I know you wise: but yot

the wise miy make some ............. Henry llenry $1 \%$.

and the spirits of the wise sit in...... - ii. 2

well-proclised wis, or ignornnt..

appear more wise and modest to the

be wise, and cireumspect. What tho'.2 IIen'y $I^{\prime}$

if this fellow be wisc, lie'll never

and, after that wise prinee.

may seem as wise as virtuous...

a wise stont captain, and persuailed.

gany the king is wise, and virtuous..... ilichart III

are seen, wife men put on their clonk

so wise so young, they say, did ne't
full of wise care is this your connsel

an English courtier may he wiac....

exceeding wise, fair pluked

net only gool and u ise, but mn

the wise ant fool, the artist ... Troilus o Cressi

then grent, $\rightarrow$ nnd wike, to hear...

as wise, no lega noble...

lie cumot but he wise.

liut you nre wise; or elee you jove (rep.)

I hive noted the ulwat mine.

but tlun are wire: nut thou lnow: st

more hinhost mow. than wise.

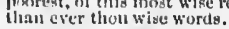

WISE-Brutus is wise (rep. iii. 1 )
thy mater is a wise und vulian

they nre wise, and hortourable.

the wike geds seel our tyes ........

virluous, wike, clinste, constant

reverence, those I fear, tlie wise.

Wise Jaerteg' son did gracionsly. .. Tritusdndron $i$

I jereclve lie was a wise fellow ......... I'ericies, i.

connsellor, most wise in general

to converse with him that is wise

for wise men are grown foppish ....

old, before thou liadst heen wise

Lenr, i.

$4(\operatorname{son}$

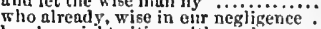

here's a night pities neither wise men

she is too fair, too wise ................... o suliet,

a geod ludy, and a wise, äjd virtuous..

when that wise men have no eses?

de then but call my rcsolution wise.

for wige men know well enough ...... llamlet, iii.

who, that's but a queen, fair, eober, wise $\overrightarrow{\text { pleasure, and most wise consent }}$ iil.

If she be tair and wise, fnirness ond wii
foul pranks which tair and wise ones do

foul pranks which tair and wise ones do

nny, but be wike yet we sec nething done - iii.

$O$ thou art wise, tis certain. Stand you - iv.

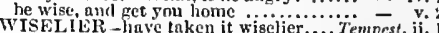

WISEJ,Y - then wisely, good sir, weigh Tempest, ii.

spenk seholarly and wisely ......... Nerry W'ires, i. 3

thist he wisely sliows, is fit

and we must do it wisely..... Measure for. Measurc i. 3

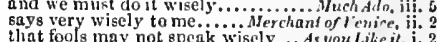

that fools may not speak wisely ... As you Like it, i. 2

a fool doth very wisely hit.........

but whether wisely or no, let the.....

very wisely; pupgles!............ Hinler's Tale, iv.

very wisely, but I regarded him (rep.).i Heury it, i. 2

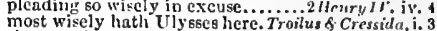

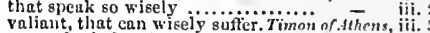

ay, and wisely. $A y$, and truly ..Juliuscarsar, iii. 3

directly, and brietly, wisely, and truly - iii.

would be wisely delnite ............. cymbeline,

wisely toe firr, to merit hliss ..... Rome of Ju'itel,

wery wrill took, i'faitly, wisely, wiseiy
I will; nnd this is wisely done......

You shall do marvelloukly wisely $\ldots . .$. . Ilamlet, $i i$.

one thint loverl not wiscly, but too well . Olhell $\rho, v$.

which is the wiser here? ... Mersureforry Mersure, ii.

and tie the wiser souls to thy false ..
men may grow wiser every day?... As you Like il

men may grow wiser every day ... As you Like il i.

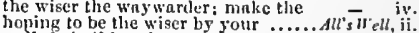

well, I shall be wiser ............... - ii.

might nake onc wiser mad .. Comeily of Errors v.

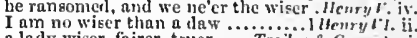

a lady wiker, fairer, truer ...... Troilus of Cresvida,

nre a frientl, and therein the wiser .. Cymbelinc, $j$.
WISEST-not talk after the wisest .... Jempest,

the wisest aunt, telling the ..... Hit....'. 's pream, i.

feat on to entrap the wisest ....Mres of renice, iii.

say, it is the wisest course knew 3 ilenry l.

wiston was a mirror to the wisest. . . il - ii.

wisest Greeinns, pardon ine.. Troths of Cressudn, iv.

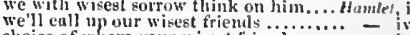

is great in mout rour wisest friends .......

ISII - l wisl mine eyes would ...... Tempest, it.

-

I wisla myedf were mulibied in

wish me partaker in thy .... Tirofien. of Jeruna,

not depenuling on his friendly wish.

you have vour wish ..................

ns much 1 wish nll gooll befortine you

Anne is on wond gor ever..............

even 60 my wieh .......................

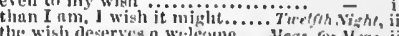

hint wheresocver, I wish him well ..

ant wefl could wisly you har nint found

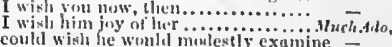

to sibh him wrestle wills atlection 
WISH he had not so nocued her.... Mister?

I wish your worship well ................ I would wish you, or I would request

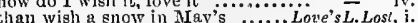

the own wish wish I thee in every

o heavens, I have my wish.........

that I had my wish! And I hed

then wish me better, I will give........

and I will wisl thee nerer more to...

you'll make me wish a sin... Merehani of renice,

rour wish; for I an sure (rep.)

for your wish, and am well (rep.)....

and wigh, for all that, that $I$ had not

the wish would make else an imqu

I should wish it dark, that I were.

a good wish upon youl .............

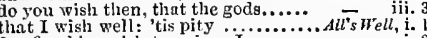

do after him wisl too, sinee

-

so true a fiame of liking, wish chastely

to those that wish him live .......... -

nor would I wish youl; first, give

I will wish him to her fither.. Taming of $\overline{\text { Sh}}$ rew.

to have the next wish after $\ldots$ wish thee to a shrewd ili-faroured -

and I'll not wish thee to her ........

to wisll me wed to one half lunatic...

and $I$ wish, my liege, you had ... Winler's $T_{n} l$

I wonld wish this youth should say.

I wisli you a wave o' the sea
I wish your horses swift.

and wish the estate $0^{\circ}$ the world

I would not wish them to a fairer

lo, uponl thy wish, our messenger

not wish the fortunc thi

cause to wish him dead...

and wish, (so please my sovereign) .... Riekard II. i.

the wish of happy years............ -

makes me wish myself a beggar ....
to thy saered state wisl $I$ all happioess

to thy sacred state wish $I$ all lappioess
though I did wish him dead .........

I eould wish, this tavern were ..... Henryl

as good ns heart can wislt.....

liere doth he wish his person

you wish me health in very...

thy wish was father, Harry................

with an inivard wish you...

that doth not wish sncess ...........

be would not wish himself any where

so ill, to wish lim here alone

I pray thee. wisls not one man ......

thou dost not wish more lielp from ..
likes me better, than to wish us one

stood in the way for my wish.

the rest. I wish thee gather
that Exeter doth wish his day.

.....iHenrylit.

I wish some ravenous wolf ...........

as $I$ do long and wish to be a subject

shall have pay, and every thing you wish

why, now thou hast thy wish

so do I wish the crown, being...

trom those that wish the downfall... - iv. I

than I can wish to adders ........... Riehard $111 . \mathrm{i}$,

preserve better than you would wisli:

those that I can wisli upon the

that thon shalt wisl for me..........

that I slrould wish for the to help me

not fricuderl by his wigh, to your.

wish him ten futlom deep

I conld wish more Chlistians........

yc tell me what you wish for bnth

appears, as I could wish mine enemy

may you be happy in $y$ our wish

speedily 1 wish to hear from Rome...

as you wiblh Christian peace

as yon wish Christian peace

I wisl your highness a quiet nighit ...
would not wish a drop of Trojun. Troilus $s-\bar{C}$ re

'tis Agarnemnon's wish: and great

could wish my best friend at such. Timon of $A t h$

I also wish it to you. I think..........
who wonld not wish to be from......

Who wonld not wish to be from.
I do wish thou wert a dog.....

I'd exchange for this one wish

neither wish I, you take much

I would wish me only lie........

a wigl you much mirth.......

their successes as we wish our own ....

thongh I could wish you were conducted -

I wish no better, than have him hold
to our noble consul wisl we all jor...

to our noble consul wish we all jor.. $\quad$ wish I had a canse to seek him thiere $\quad$ iii. 2

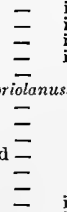

a noble wid you wish me milder?....

may wigh good Marcius home again

yet I wish, sir (I mean, for ynur...
tlougl we had our wish, which side

every one doth wish, youl had ....Julius Cesar,

- ii. 2

I wish, we may: but yet have I a miod - iii.

he comes upon a wish...............

Antony \& Cleopatra

we wish it ours again................ =

I wish. I could be made so mony me...

say that $I$ wish, he never find.........

I wish not so; unless it had been ..... Cynnbeline

wish that warner days would "me...

I wish ye sport. Folz health $\ldots \ldots$ my

I know not how to wish a pair of ...
I say no more, nor wish no less....
a charitable wish, and full of love

a charitable wish, and full of lo
oft have you heard me wish for.

which I wish may prove more stern

I life would wish, and that I ... Peric

I would wish no better office, than...

for his sake, I wish the having of it...

have, and wish but for't into ........ $\vec{\nabla}$ ii.

wish thine enemy to be? $(r . .$.
you wish me well :.....

Fet, let me obtain my wish

I'd wish no better eho

as thy desires ean wish w.........

so will you wish on me, when $. . . . \ldots . .$. Lear, $\mathrm{i}$.

married once, I have my wish ..........

and wish lis mistress were than $\mathrm{kind}$

blistered be thy tongue, for such $a$ wish 1 二

as one's lieart could wish a man

sin, to wish me thus forsworn...........

madam, I wish it may. Ophelia, walk
but wish and beg, your sudden eoming

write from us; wisl [Col. Knt.-to]

I eould well wish courtesy won]d invent

conld leartily wish this had not befallen

nor my wish, to have him see me........
vou did wish, that I would make lier turn
wISIIED - have wishcd a thing. Troo Gen.

I wished your venison better........ Merry

wished to sce thee (rep. iii. 1)...Tuelfh $N$. ii. 5 (let.
nor wished to hold my peace.... Meas. for Meas v.

nor wished to hold my peace..... Neas. for Meas, v.
her shame, that may be wished for.. Much $A d o$, iv.

and if a merry meeting may be wished

sick to dentl, wisherl himself. Love's $L . L$. iv 3 (vor.

wished in silence that it were
this he wished; I, after him

than I think, she wished me

the wished haven of my bliss . Taming of shrew, $v$.

as dice are to be wished ............

by the benefit of his wislied light
whieh you have wished so long....

that wished him on the barren

this matter to the wished end

.... King Err.i.

I wighed this world's eternity

and so, I wished, thy body might....

we wished your lordship here ..... Riehar $\bar{d}$ IIII. iii. 5

wherein $I$ wished to fall by the false

such a man I would have wisbed ...

ever have wished the sleeping of this

I wisled myself a man ...

I have often wished myseli poorer

man was wished to love his enemie

we wished Coriolanus had loved

have wished that noble Brutus
he wifhed, to day our enterprize

was wished, until he were ...Antony \& Cleopatra, i. 4

have wished that Lucius were... Tilus Andron. iy.

she wished she had not heard it (rep.)... Ohello, i.

WISHER'S eyes be pressed! ....Mid. N.'s Dream, il. 3
WISH

wishers were ever fools ..Antony \&-Clenpalra, iv. 13
WISHES-and my good wishes.... Twelfih Nitht, ii. 5

thus wisdom wishes to appear.... Meas. fnr MPas.

and siglas, wishes, and tears, poor ...Mid.N.'s Dr. i.
and seen our wishes prosper... Merch. of Yenice, ifi.

and geen our wishes prospcr... Merch. of Venice, ii. 2

in having what he wish

madam. I lesire your holy wighes......Alls $w_{\text {well, }}^{\mathrm{v} .}$

madars, I lesire, your holy wish

do slutut us up in wishes, might

lie wishes earizestly ....... Winter's Tale, iv. (ehorus)

I will not wish tliy wighes thrive ... King John,
if wishes would prevail with me .... Henry $r$.

Trhat' he, that previl with nes

goy and good wishcs to our ..........
WISIIES towards you honour ......Henry YIII. i. 1
nor my wishes more worth than (rep.) no power to make his wishes good. Timon nf $A t h . \mathrm{i}$. to see inlierited my very wishes .... Coriolanus, $\mathrm{j}$ but your sheets are privy to your wishes - i. fill thy wishes to the brim with...... - iii. il he wishes you all happiness ....... Britons have their wishes in it .......
to your wishes' height advance to your wishes pleasure bring..$P$ Pericles, i. (Gower)
wishes fall out as they're willed our wishes, on the way, may ............ 2 (Gower our wishes, on the way, may ............ Lear, iv.
my thoughts and wishes bend again.... Hamlet, i.
WISHEST should be undone nmmber, thee, that wishest shamei...2Henry VI. ij. I WISHFUL-with me wishful sight..3 Henry $I \%$. iij. WISHING me with him ..... Tuo Gen. of Verona, i. 3 but ratlier wisling a more striet. Aleas. for Meas, i. 5

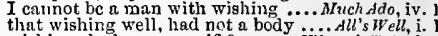
wishing cloeks more swift? ...... Winter's Tale wishing his foot were equal

hath sent to me, wishing me to..... HevryVIII. i. 2 unsavoury, wisling him my meat? . Pericles, ii. WISP-a wisp of straw were worth ..3 Henry $\bar{F}$ l. ji. 2 WISTLY [Col.-wishtly] looked on me. Richard II. y. WIT-Winding up the wateh of his wit. T'empest, ji. I wit shall not go unrewarded ........... youth liave ever homely wits ... Two Gen. of Ve young and tender wit is turned to folly made wit with musing weak ........ but you have a quick wit............. I shall make your wit bankrupt ...... and he wants wit ......................
to lcarn his wit to exchange....... as thou hast lent me wit to ............ and yet I have the wit to think...... that covers the wit, is more than (vep.) by wit or steel ....................Merry $\bar{W}_{i v e s, j .3}$ iv. by wit or steel $\ldots \ldots \ldots \ldots \ldots \ldots \ldots$. $\ldots \ldots$............ I will stare him ont of his wits $\ldots . . .$. . taught me more wit than ever..... . see now, lable dexterity of wit ..........

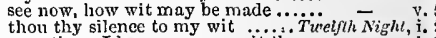
sometimes I have no more wit than
that does laarm to my wit............. neither in estate, years, nor wit........ those wits, that think they have ...... better a witty fool, than a foolish wit = do not think I have wit enougl $1 . .$. thou most cxeellent devil of wit l.... craves a kind of wit quite taint their wit nor wit, nor reath is come the man is tainted in his wits ere 1 will allow of thy wits....... besides your five wits?

I am as well in my wits (rep.) ......

no better in your wits than a fool.....

with wit and safety.

but to thy right wits ......

few of any wit in such matters.......... 'tis wit in them; but, in the less.... thousand 'scapes of wit make thee....

my lord, her wits, I fear me

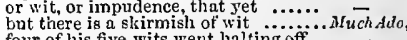

four of his five wits went halting off ..

hath the fellow any wit, that...........

not koow you by your exeellent wit?.

and that I had my good wit out of ....

and the commendation is not in his wit

show some sparks that are like wit....

it is 110 addition to her wit

and remunts of wit broken on me....

and her wit values itself so highly ....

so swift and exeellent a wit, as she is...

doth not ny wit become me rarely?

when the age is in, the wit is orit...

we will spare for no wit, I warrant.....

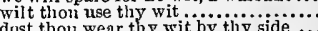

have been beside their wit..............

sir, your wit ambles well ..............

thy wit the other day; I said $(r e p . . . . . . .$.

no, said I, a great wit; right, say's slie..

a good wit; just, said she

thy wit is as quick as the greyhound

a most manly wit, Margaret ..........

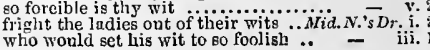




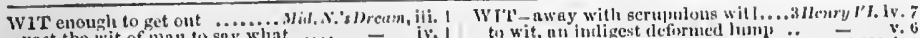

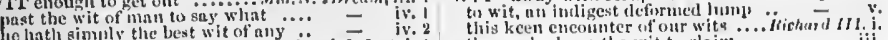

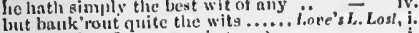

hort bank wout ritite the wits.

for her wit. It wins so, bir (rep.)

my futher's wit, nath a very gool wit....

devise, wit; write pen.

in apenting your wit in the pritise

is a sliarp wit matehed with to

such short-livel wits ilo wither.

for he liuth wit to make an in wing

to win graee t:ought he for his wit.

your wit's too hot, it speeds tou fust.

your wit's toro hot, it gling

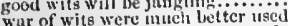

were as slender us iny wit, onc of

nost incony vulgar wit

$o^{\prime} t$ 'other side, that handful of

cru you tell by your wit, wh

well proved wit! by the lord

I'll mark how love can
how will he spent his wit?

n quick venew of wit .......................

it reu lialf femuy purse of wit

a set of wit well plyyed .............

spend his prodignl wits in bonticss .

when they are catclied, an wit

nnd wit's ou'n grice

to prove by wit, wortit iii...

muster your wits; stand in ............

mad wenches; yon have simple wits

well-liking wits they have ..........

O puverty in wit, kimgly-1)

this fellow pecks up wit, as pigcons

he is wit's pedlar: and retnils his

your wit makes wise things foolish

thrust thy sharp wit

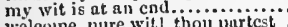

within the mercy of your wit.

all the fierce endenvour of your wit.

hedged me by his wit, to yield...

the wisdom by their wit to

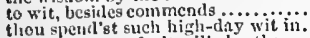

the best praec of wit will sliortly

the whole wcalth of thy wit in

none that thon hast wit cnoug
repair thy wit, good youth

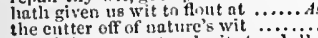

pereeiring our natural wits too diii

whetstone of the wits: low now, wit?

for since the litele wit that

as wit and fortunc will

be 'ware of mine own wit, till I

learned no wit by nature or art......

you have ten courtiy a wit for me...

you have a nimble wit: I Inded witi

think my honesty ranker than my wi

doors upon a woman's wit, and it wiil

such a wit, lie might say, wit, whither

wit going to your neighhour's bed (rep.)

ay, sir, I have a pretty wit.

presentation of that lie shoots his wit

had the wit, which I can well observe. Al!'s $W^{\prime} c l l$,

joy to see your wit restoredl. Taraing

hearing of her beauty, and her wi

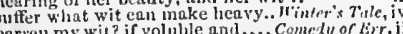

seck my wit in my shouller

he hath given them in wit ............

plain-dealers without wit..............

by all iny wit being seanned, want wit

I knew, he w'as not in his perfect wits

scaresl thy lusliand from the

brought him to his wits ngain.........
all thy wit; and yet, i'fuith, with wit...

all thr wit; and yet, it fuit.

Kirstr.lohs, ii.

mutiny with wit's regard

have fulp maklmen to their wits ....

alut rash cause that wit is in other men.2 llenry 1

and huth his quick wit wasted in

your wit single? and cvery part
thank your pretty swect wit for it

iliank your pretty swect wit for

it shall serve amnng wits of no.

a growl wit. He a pind witl (rep.)

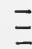

二

the birth becomes excellent wit.

have you your wits? know you ...... H

will savour but of shallow wit

alc-Wasliel wit , $_{\text {, is womlerful }}$

may. the man liatl no wit

leaving their Hity witl their wives..

witl all my wits my pains........

my wit uotrained in any kimi
seturch out tlay wit for seeret jolicie

petareh out thy shit for seeret moliches

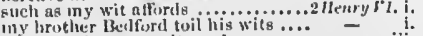

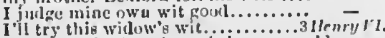

her words do show lier wit inconivarable
he

has not fo much wit-11uy

blese tlay firc wits! ( rep, iii. there who hinge the wit tin chin

enrich lis wit, his wit set low't.....

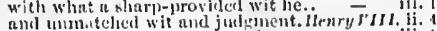

with my weak wit, and to stch meth

lacking wit to make n secm

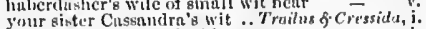

shinl an: hnve his wit thls year...

lie lus a slirewd wit, I can tell you.

upon my wit, to rlefend iny wiles...

somser rail tliee into wit nnd holiness

among those of any wit

what modieums of wit he utteri
who wears lis wit in his belly

will you fat your wit to n fool'

whose wit was mouldy ere

I will keep where there is wit stirring

wit would be ont of farlion...

where is my wit? I know not

fir bentity, wit, high birth

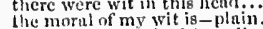

aloula wit lorced with malice (rep)

that I hat no nngry wit to be... Timon of $A$

80 much wit thoulack'st ............

our wits are sin diversly (rep.) ....... Cnriolo

I'l try whether my old wit be in...

baited with one that wants her wits?

is a sutec to his gond wit 3 .......... Int

seen smull reflection of ticr wit .......Cymber

it his wit hal been like him....

upon her wit doth earthy honour. Tine

our enpress, with her sacred wit ...

he, that hail wit, would think that I

lintve so nycrwhelmed his wits

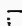

now plcase you wit the epritaph

thou hadst little wit in thy buld crown.

know not how their wits to wetr
last paral thy wit o' both silics.

tliy wit shall not gn sliushod

having more man thas is it about me.

Dy wits begin to turn

the orief hath erozed ny wits.......

trouble liim not, his wits are gune

becn scired ont of his good wits...$$
\begin{array}{r}
\text { i. } 2 \\
-\quad \text { i. } 2 \\
\hline
\end{array}
$$

i. 3 forgive tlice for a witeh . Antory of Clengutra, $\mathrm{i}$.

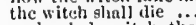

fuch a holy witeh, that hic eneliants..... cunatieline, $i$. 7

nor witr:l hatl, lower to clinerm ........... Hommlet, $i$.

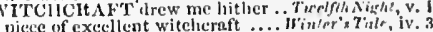

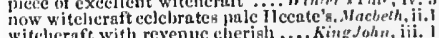

witcheraft with revenuc cherish ..... King fohn, iii. 1

you have witcheraft in your lit. their witelicraft thus linve moriced me - iij.

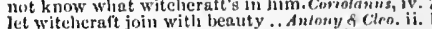
Jet witcheraft join with beauty . Anlony f ctro. it.
no witchernft eliarm thee! .. Cymbetine, iv. 2 (gon!?

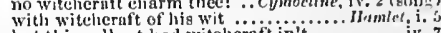
but this gallant had witelicrnft in't........ this only is the witcherat I loave used we work by wit, and not by witelicraft ...

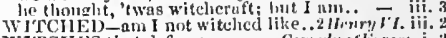
WITCII the that deform ......... Comedy of Lir rors, i. there's none but witches the inhabit.. - ii. tooth of wolf; witelses mumimy .......Macbeth, ive

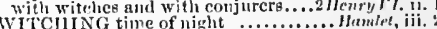

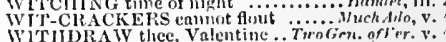
us withdraw together (rep, i. 2 )...Mens. for Meas, i.

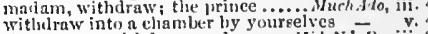
withdraw inton clamber hy yowe.Mlid.N.'s Dr. iii. lullice withdraw; thic gallants are. I.nm's l. last, v. withdraw and weep upon the spot .. King dolen, v. witlulraw with us; and let............ Richard Ii. i. withdraw yourselves, and leave us here -y, r.

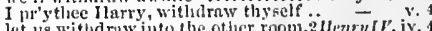
I'll withlraw me and my blooly ...111rwryl. iv.

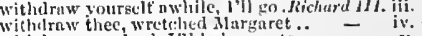
withidraw, my lord, I'll help you to..

to withdraw into your private .... Ifen, y $\bar{T} / l$ l. jii.

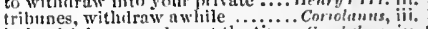
let's withidraw; and incet the time... C'ymbelme, iv. that you withelruw you, and aliate .. Thin

we'll witlidraw into tho gnllery.

let us withoraw, 'twill be a storin
I will withuraw: but this intrugion.

hut 'tis no wit to go. Why, miy ...

pind Ben volio: my wits fail

if thy wits rim the will-goose .....

thy shane, thy love, thy wit $\left(r^{2} p\right.$.

show's still gome want of wit....

past lic compass of my wits

my wit; i will dry-bent you $\left(r r^{2}\right)$

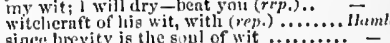

sinet brevity is the sinl of wit

my wit's tlisenserl; but, sur, such aiswer

a yoming mands wits shonld be ns...

harlst thon thy wits, and didet perstade

he slatll recover his wits there

'fith, en with losing his wits

her dity', henuty, wit, and fortuines...

finirucss ankl wit, the one's fir use.....

hack, nlite thereto hite a wit.............

Work by wit, and not hy witeluernti (
the cxecution of his wit, humb, heurt

this is within the compuss al nan's wit.

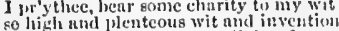

are lits wits safe? is lic not liztit of

that tursicel your wit the scany side.

I'TCIt-the foul witch sycurax $\left(r \cdot p_{0}\right)$. Temprest, $\mathrm{i}$.

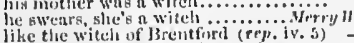

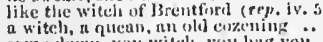

eeme down, you witeh, yeut hig you

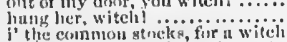

for benuty is a witeh, agutust whose.. Much diln, ii.

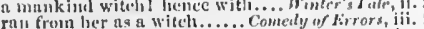

avaunt, thum Hitely! come

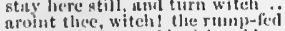

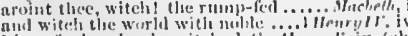

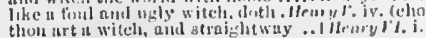

villo

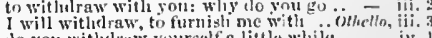

do you witludrin yourscle a little while..

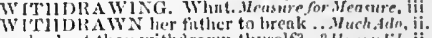

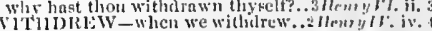

care withdrew me from ....... Froilus $\delta$ Cort ssikla, $v$.

Withtrew to mine own room again .... Humtet. y. do not see, my tuir rose wither ...... Kichurd $11 . .$. a tinir fuec will wither .................1lewy

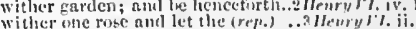

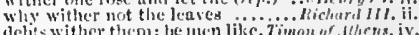
age ennmot witlec leer, nor.. Antomy \& Cicoperta, ii.

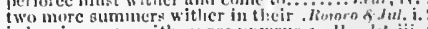
jule winec, our withers nte unwrunb. Hattel, iji. n withered serving-nun $\ldots$..........Werry Hores, i.

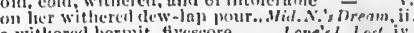

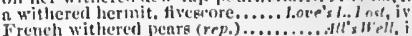

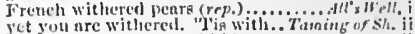

wing me to some withereel bough. Winter'strrle, v.

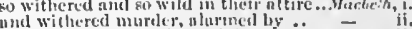

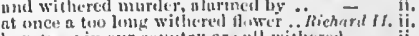

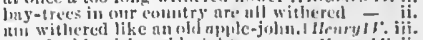
roum, nli, withered luights........

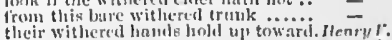

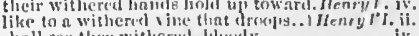

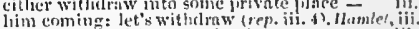

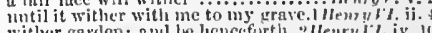

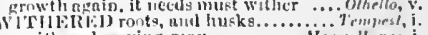
on your ernlty withereil hite!

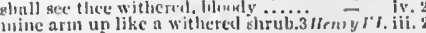



like a blasted sapling, withered up... put this withered brown....... Troilus \& Cressida grieve thee? $O$ withered trut
withered is the

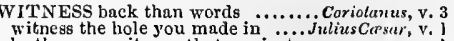
witness the hole you made in .....
be thou ny witness, that, against .

O bear me witness, night . Antony \& Cleopalra, iv. 9 be witness to me, $O$ thou blessed moon and this will witness outwardly ... Cymbeline. ii. 2 as flowers now wither even 80 . Cymbelin as ifathered lily almost withered. Tilus gneh withered herbs as thees are meet - in ii. who withered in her spring of year - iv. 4 (Gow.) wITHERING out a young man's ...Mia. N.'s Dr.

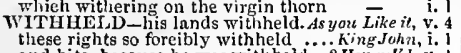
these rights so foreibly withheld .... King Joh his mother was perforee witheld. Richard III. ii. 1
WI'THHOLD-withholds the loved..Mid.N.'sDr. ii. and her witlliolds from me .. Taming of Shrew, i. 2 withold thy speed, dreadful oecasions

conld not withhold thy riot $\ldots \ldots .2$ Henry $I V$. iv. 4 that you withhold his levied host ... H Henry $V I$. iv. 4
withhold revenge, dear God........3 Henry $V I$. ii. that withholds [Col.Knt.-holds off], Richard lll. who should withhold me? . Trailus \& Cressida,
what cause withholds you then .. Jutius Cecsar, What cause with holds you the

I false? thy consciedee witness ......

this is a witness that I am thy son. Titus Andron as your titles witness, imperious...
deeds be witness of my worth .......

witness this wretehed sturnp (rep.)....

witoess the tiring day, and heavy (rep.)

my scars can witness, dumb al though

to wituess this is true: now judge

my daughter, she can witness $i t$

witeess the world, that I create thee .....Lear,

wpon the witness of these gentlemen.... Hamlet, $\mathrm{i}$.

here comes the lady, let her witness it... othello do not rise yet; witness, you ever-burning -

I had suborned the witness, and he?

WITNESSED_virtue witnessed.. As you Like it, iii. 2 hath left a witnessed the rather

the gods withhold mel shall $I$ do that - iv. 1 to withhold the vengeance tliat they...Pericles, ii.
IV ITHOLD [Knt.-Swithold] footed Lear, iii W ITHOUT-BOOK prologue .... Romeo \& Julie WITHSTAND them $\ldots \ldots \ldots \ldots \ldots \ldots . . .2$ Hen?? W ITLESS bravery keeps.... Measure for Measure. a witty mother! witless else her.. Taming of
like witless antieks, one another. Troilus $\&$ Cr

WITNESS-bear witness to this sound. Tempest,
witness lieaven (rep. v. 4) .. Two Gen, of Verona to whom, thyself art witness, I am witness good bringing up

Tyitnes, you do if.. Merry Wives, iv. is this the witness, friar?

this is no witness for lord Angelo.....

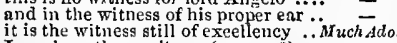
I can bear them witness (rep. $v .2$ )

no farther, till you witnesses above...Tuelf $h N$ Nigh amen, say we: we will be witnesses Tamirg of $S$, ii. and some sufficient honest witnesses, iv. 4

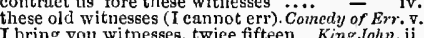
I bring you witnesses, twiee fifteen..King Jahn,

grave witnesses of true experience. Titus A ndro
WITNESSETH than laney's ...Mid.N.'sDrea

Witnesseth thy lowliness ..Love'sL.Loxt, iv. I (letter) as witnessing the truth on our side... Richard llenry $Y$. ii. WIT-OLD-Whieh is wit-old ....... Lave's L. Lost, y.
WIT-SNAPPER are youl ... Nerch. of 'renice, iii.
WITTENBERG, it is most retiograde.... Hamlet, i. stay with us, go not to Wittenberg...

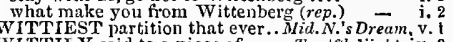
be proved upon thee by good witnes

were as great; be witness this .... Love's L. Lost, producing holy witness, is like ..Mer.
thy thoughts, are witness that thou art
Lorenzo here sloul witness, I

dorenzo here shall witness, I eet forth $\overline{-}$ my verse, in witness of my love ...... one here in eourt eould witness it ..... than words can witness or your thoughts - ii. 1 eres are witness of her lightness

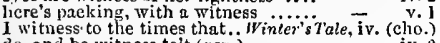
do, and be witness to't (rep.

the world unay witness, that ... Coinedy of Errors,

my two ears ean witness $. \ldots \ldots . . . . .$.
witness with her, that she did (rep.)

witness you, that he is borne about.

thus far I witness with him wi....

can witness with me that it is .

Wash this filthy witness from your....

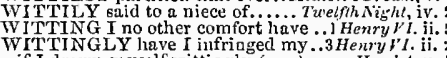

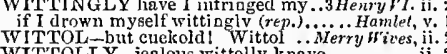

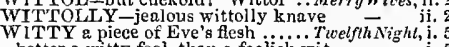

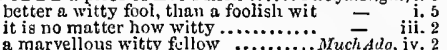

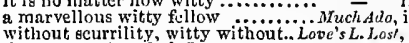

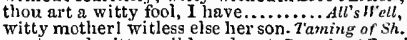
pretty and witty; wild, and, yet. Comedy of Err. iii. I am not only witty in myself .......2 Henryl V. i. 2
witty, courteous, liberal, full of......3 Henry VI. i. 2
deep-revolving witty Buekingham. Richard III. iv, 2

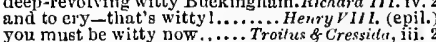
you must be witty now...... Troilus \& Cressidlu, how if ahe be black and witty? ......... Olheito, ii. wives nay be merry, and yet lionest

let our wives yet once again

how like you Windsor wives?

witness against us to damnation1 ... King John, be a preeedent and witness good

1 eame, alas! to wive.......Twetfih Night, $\overrightarrow{\text { v. }} 1$ (song) do not eurst wives hold that .... Love's $L$. Lost, his white hairs do witness it $\ldots \ldots \ldots$ Henry $I J$. witness our too much memorable 2 Henryy $r$ iv. shall witness live in brass of this

should slrive me than wive me...Merch. of renice, i. 2 to play the thie

the rest aloof are the Dardanian wives - iii. 2 fain to be beliolden to your wives for
the sky ehanges when they are wives

wonder, sir, sinee wives are monsters. All's Nell, $r$. to wive, and thrive, as best I may...Taming of Sh. i. brings your froward wives as prisoner

that have revolted wives...........Winter's Tale, $\mathrm{i}$. five or six honest wives that were.... your wives, your daughters .............Mach lenve your ehildren, wives, and you

let wives with child pray, that ......... iii. 1 some poisoned by their wives ...... Richard II. iii. 2 upon the parting of your wives
break with your wives of jour

here come our wives, and let us.

have given them \&way to hakers' wives - iii. 3 leaving their wits with their wives... Henry $r$. ili. 3 some, upon their wives lett poor belirid $=$ iv.

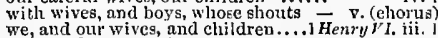
bargain for their wives

and dowries, with their wives...........2 Henry $r_{1 .}$ i. that their wives be as free as ........ - iv. 7 wives for their husbands' rate .....3 3 Henry r I y. 6 servants, duughters, wives, even ..... Richard III. jii. . in enfercentent of the wityes, your wive

nnd blessed with benuteous wives....

Niobes of the maids and wives. Troiltes $\& \overline{c r}$ ess. v. II

WIVES-beat them to their wives .... Coriolanus, i. it ourselves, our wives, and ehild iren ....

on to your

'Tould we had oil suel witare ..JuliusCesar, iii. lip your wives, your triends, teli... how many must murder wives mucli. Cymbeline, v. 1 when my fate would have me wive...... Olhetlo, iii. the purest of their wives is fonl as slander - iv. their husbands' faults, if wives do fall ... - iv. 3 WIVED-manued, horsed, and wived.2 Henry $_{2} \nu . i$. to be wived to fair Marina..... P'ericles, v. 2 (Gower)
good lieutemant, is your general wived?. Olhello, ij. I WIVING goes by destiny. . Nerchant of Fenice, ii. WIZARD - peace, doting wizard. Conedy of Err. i . Wizards know their times

a wizard told him, that by $\mathrm{G}$ his...... Richard $111 . \mathrm{i}$. WOE $-O$ woe the dayl .................... Tempest, $\mathrm{i}$.

our hint of woe is common

have just our theme of woe...

I am woe for't sis

二 $\mathrm{ij}$.

fed upon this woe already ............ -

they waxed pale for woe

and record iny woes

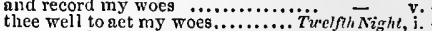

woe mel for what? .................. Tere for Measure, $\mathrm{i}$.

stilt the nurse of see

heaven shield your grace from woe.....
all your sounds of woe...........

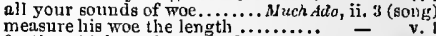

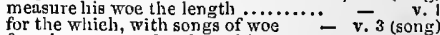

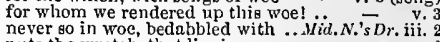

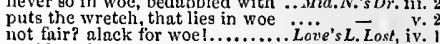

so ridest thou tritumphing in my woe - iv. 3 (ver.)

husband's sorrow by lis woe.. Taming af Shrew, v. 2
woe the while! (rep.) .............Winter's Tale, iii. 2 the woe had been universal............ my woes end likewise with .......... -

liberty is lashed with wo

laugh my woes to scorn...............

but in it shares some woe; though ...... $\overrightarrow{\text { iv. }}$ and leave those woes alone ..........King John, iii. pay the time but needful woe ....... it ends a mortal woe

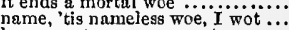

have woe to wne, sorrow to sorrow...
what a tide of woes comes

storms to come, woe, and unrest.....

cry, woe, desiruetion, ruin, loss......

a king woe's slave, shall kingly woe

alack, alaek, for woe, that any

a ehange: woe is forerun witl woe

at London London's king in woe

for telling me this news of woe .......

the woe's to come; the children.....

together weeping, make one woe

we make woe wanton with $\mathrm{my}$ soul is full of woe, that blood.....

words only, but in woes also.............

Henvy $I V$. ii.

are every oue a roe a sore complaint. Henyll: $y .3$

of our prinees (woe the while!) ....... $-{ }^{-}$iv. 7

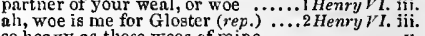

Bo heavy as these woes of mine

to add more measure to your woes

never weep, now melt with woe $\ldots . . . \quad$ - ii.

woe above woe! grief more than ..... - ii

[Cal.Knt.] to over-go thy woes .......Richa,d 111

their woes are pareelled, mine $\ldots . . .$. =

that sliall ery woe for this hereafter

woe, woe, for England? not a whit..

tell o'er your woes agnin by viewing

triumph not in my woes ............

dead happiness with living woe.....

full of state and woe ....... Henry $\%$ III. (prologie

ay, marry, there will be woe indeed

woe upon ye, and all sucl false $\ldots . .$. =

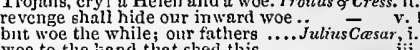
alas, and woe! Let him that ...Antony \& Cleo. iv. conquer Antony; but woe 'tis so!... stands in worse ease of woe ......... Cymbeline, iii. in them have laid this woe here.

I, in mine own woe charmed .........

they have nursed this woe .. Titus And onick

my brother, weeping at my woes ....
what a sympathy of woe is this! .... 


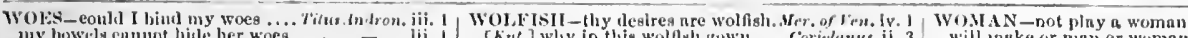

my bowels cunuth hide her woes..... revenge these hitter wees of ours

thou mny of wore, that tlus.

or woe letide thee evermorel.......

arehitect and plotter of these woes.

larms, and wije nway" ler woe!

associnte trients in grief num woe.

luve done with woes; give senten
feelling woe, gripe not it enrthly.
gound deep our woes into the air

onund deep our woes into the a

omit we ail their dole nnt woe .

a heart that even eracks for woel...
changed with this unprofltable noe

wosion stands for true old woel

Woe and henvy well-n-iluy i...

my bidding, or thou livest in woe...

were, that too late repents ....

betters see benring our woes .....

and woes, by wrong imnginntions..........

pound i piteh above duil woe..... finmeo 8 . Juliel,

forgot that name, and that name's we

and thege woes were all for Rosaline

determine of my weal or woe.

these griefs, these wocs, these sorrows

Your tributary drops belong to wo

if sour woe delights in fellow bhip.

no words en that wre sound........
the times of whe atfird no time

these times of whe atfird no tim
more dark and dark our woes

more dlark and dark our woes woes shall serve for

and all these woes shall s

$m y$ lentrt is full of woe ..............

wherent these woes do lie ( $r p p$.)

what further woe eonspires as ainst

for te. Wr was a story of more woe....

to be is straeted in one brow of wue...

but ts trappings and the suits of woe ...
throw to earth this unprevailing woe...

but who, ah woel [Col. Knt.-whis] had seen

one woe doth tread upon another's heel..

trehle wue full ten times treble.

if nught of woe, or wonder, cease your ... $-\mathrm{v}$. I

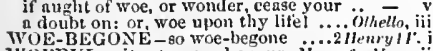

WOEFUL suitor to your honone . „3eas. for Heus. ii.

my woeful self up in a mourning . L'se's s.. I ost, v. 2

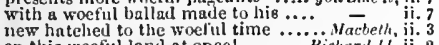

on this woeful land at oneel ........ Kishard 11 . ii.

a woeful pageant have we here beheld

of woefin ages, long ago betid

hase mercy on me, woefil mant $\ldots$ th
hath contrived this woeful tragedyi
thyself hast given her woeful breast!

wash away my woeful monuments.2 Henry ${ }^{\prime} T$. iii.

one thut was a woeful looker-tin $\ldots .3$
for these woefal ebanees, mis-think.

here sits a king more woefin! than you

male her tridow to a woeful bed?
my woeful banishment, conld all

my woeful banishment, conld nl
thou woefin weleomer of glory!.

thou woefin weleomer of glory.......

a woeful Cressid 'mongst.... Troilus f Cressida. iv. I

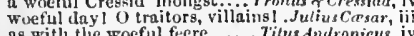

as witl thie woef nll feere
dread fury, to my wo. Tilus

I mut as woeful ns Virginins was .....

his woeful queen leave at liphess $-\overline{\text { iv. (Gower) }}$

if there be more, more woeful, hold it in... Lear, y. 3

$O$ woeful time! Death, that hath ta'en

Woful, wefful, woeful dayl (rep.) . Bichart iv. 5

locked inta the woefullest eask ......2urnoryl. iit.

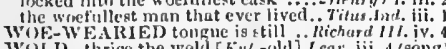

Wois - thrice the wold [ Kut,-old] lent, iii. I (song)

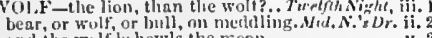

and the woll hrowls the monn .i.... v. 2

thy eurrish spirit governed il woll

a. wolf, nay wores, a fellow .......... Memely of Errors.

a wolf, nay worpe, a tellow .. Comedy of firrors, iv.
alarumed by hit sentinel, tlie wolf ..... Vucbeth, ji.

tooth of wolf; witclies' mummy

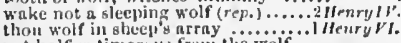

jot half so timorous from the wolf.

1 wish ane ra venerus woll liad..... - v.

and yonder is the wolf, thut maken...

flice the reekless ghephliest from the woulf - $-v$.

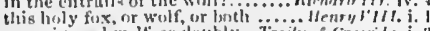

an univeraal wolf, srs denubly. Troilus f. Cresside, i.

as woll' the lifer's ealf, part to ......

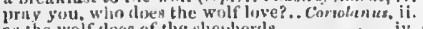

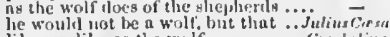

like wrrlike as the wolf ............. ('ymbeline, iii, 3

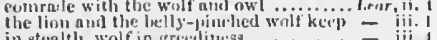

that trusts in the tunesess of a woif..... - iii.

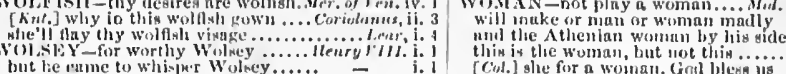

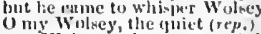

ay, Wolncy, that once trest the wnys

liot to bee a womm (rep). iv. 3) ....

lie seed to talk with a woman (irp.).

wol, lis - did make wolves liow!

the rolves have preyedi and lemik

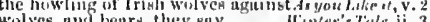

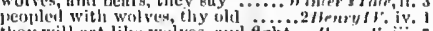

they will eat like wolves, unil fight
orleuns from the Linflish wolves.

Orleuns from the binflish wolves.
the ruvenous wolves (Col.-wolf).

the wotves are gnarling who shal

limb, environed with wolves ........

illenryl

Ieñyri. i.

pursured by hunger-starvel wolve
but worse than wolves of l'rance

afluble wolves, meck bears . Timon of Athens, jii.

dragons, walves, nnd bear

if wolves had at thy gute howici.

Lear,

WOIXISII-RAVENING Tainbi.lioneo $\delta$ Jut

I ue'er saw woman, but only

swect vuderatanding

no weman may upproucli his silent..

a woman sumetimes, an' you kaw lier

are mit you the ehief wounan?........
that was $n$ woman whicn quecn...
n woman I forswore but, I ..

beauty of a womm 's fuee? (rep.)

racher un honest woman's son

be an thoest woman of her word......

be less than an honest woman

av, il a woman live to be a man.

but some woman had the ring........

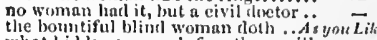

and to ery like a woman

what woman in the city do I natie.

lo you not know 1 an a woman?

is there none here to give the woming

a jroperer man, than slie a woman

ecrtainly, a wommin's thought ruos.....

make the doors upon a wisman's wi

woman's gentle bruin could not drop

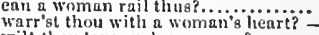

wilt thou tove snch a women? ......

Int the woman luw, and browner thian

he sir, that must marry this womu

gir, here' a hapier womnn...

gir, here a woman would speak ....

would have won nny womnin heart

woman, commend me to her

If never knew a woman so th

boy, go along wirls this wornai

see the hell of having a filse womani

glie's a very tattling woman .........

I sce 'tis an honest womn

foman would run through fire....

build upon a foolishi woman's promise

why, wowan, your husband is in lis

what a woman are youl.

there is no woman's gown big eno......

fut woman of Brentford ( $r$ cp.and iv.

eome you and the old woman flown.

old womant what old woman's that?

think you have killed the poor woman

an old woman, a fat womau (rep.)

hat a fat womanl (rep.).............

Was there $n$ wise woman with thee?

master Brook, like a poor old woman

for all be was in womsn's a prarel..

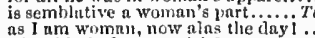

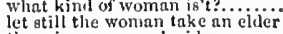

there is no woman's sides ean.

it might he, perlinps, were I a woman

one truth, and that no woman has..

In man's commendation with woman

earry his water to the wise woman ..
were you a woman as the re.t

never shouldst love womnn like to me
let me see thee in thy woman's weels

a woman .................... Neasure fur
but there's a voman witi maid by him

one tliat serves a had womnn

Thank heaven, is an honest woman
ghe had heen n woman eardinally given

and hisonts s ineans?...............

with man, woman, or eliilil...

more betray our sense than womanis

as I love the woman tliat wrongel him

he that you are, that is, a womul.... -

way not mude by man and wotmun ..

to sct on this wretehed womnt lice

know hou this woman (rop.)

and tliou pernicions women, eominet

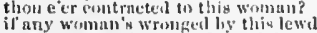

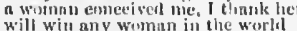

would it not grieve u womm to he

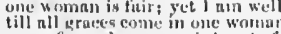

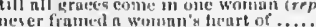

if he be not in live with otone women

it will not hurt a woman

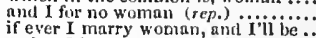

and as I love no woman, and I'll be .

to desire to be a woman of the world

or hnve a woman to your lord.......

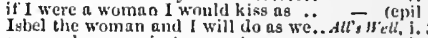

we'd find no fult with the ty the woman -

liave a good woman borm but every..

on the start, eall woman me unto't

a foul, sir, at a woman's serviee......

by this woman here, what know you?

as a gentleman loves a womno

this woman's an easy plove, my

boy lave not a woman's gift.. Tauning of $5 \bar{s}$, I (inil.

ay, the woman's maid of the house $=$ ? (ind.

do you tell me of a womin's tongue.

and a woman's erupyer of velure...

winter tames, man, woman, und beust

a woman moved, is like a fountain.....

even such, a woman oweth to her...

ineh of woman in the worlt (rep.). Hinler's Tule, ii.

the ritshess of a womin

for mun, or womnn, of all sizes

it was thought, slie was a woman i...
for whose sight I have a womun's longing

gook, to make uperfice woman .......
that she is a wontan more wortli tiinn

and wed unto a Wumun........ Cumedy of Er

this woman that I mean ............. -

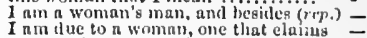

against that woman there

o perjured womm ! they are boti

this woman loeked me out this lay.

come to my womnn's loreasts
ln a womnin enr, would nuries.

a womm'y story. at n winter'y lire
for noue of womin born shall liarm

I am yet unknown to womnn........

whs he nut hern of wumber? (rep, $v, t$ )

may ensils win a woman's ........... king Jok

n woman, nuturally born to feurs.

I am $u$ woman, I'll nut swomn.
not the trial of $\mathrm{n}$ womants war.

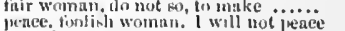

thus fond mad woman (rep.) .......

a woman, nut throe annt, grint $\mathrm{k}$ iing

thou trantic womnn, what fost then.

wh loreak intu this weman's missl .... illentyl

eonstunt you are, but yet a wonnus

bring him out that is liut wouns

neitler: 'tig \& Wounan's fumt

fo to, yom are a woman, go. Whiu I
now, as $\mathrm{I}$ am a true wonian, holloud of

thard II. i. 


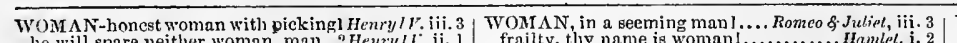
be will spare neither woman, man...2 Heary 1 . for a poor lone woman to bear

the easy yieldling spirit of this woman and sutisfy the poor womn

you are an honest woman, and well

a woman's tailor, sir (rep.)

thou hast done in a woman's petticoat?

well said, good woman's trilorl.......

haply a woman's voice may do some

God's name, I fear no woman........
lie shrives this woman to her smock

woman, do what thon eanst to save our -

a woman, clad in armour, chase

vet hath a woman's kindness over-ruled -

she is a woman, therefore to

second woman in the rcalm

and, being a woman, I wible spirit
to be a woman of invincible
what woman is this? His wife

eall it a woman's fear ...............

fie, coward woman, and soft-hearted -

woman's general; what should we fear?

wrapped in a woman's hide!

geen to bear a woman's fuce ?

Wroned wo wo

for she's a woman to be pitied much

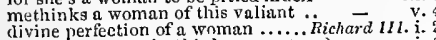

was ever woman in this humour (rep.)

falsc-boding woman, end thy frantic

fool, and shallow changing woman

a woman of less place might ask ...Hen

I am a rnost poor woman, and a stranger

of wisdom o'ertopping woman's power

I am a simple woman, moman, fallen

alas, I am a woman, friendlese, hope

a woman lost among ye, laughed at -

a constan troman to her husband

and to that woman, when she has done -

I am tlie most unhappy woman living

you know, I am a woman, lacking ...

of thy honest truth to play the woman

she is the goodliest woman that ever

but hy her woman i sent your ...
so saiel her woman; and t $]_{1}$ at her

and hit that woman, who eried out

weaker than a woman's tear.. Troilus

saw her look, or any woman

you are such a womanl one know

a woman impulent and nomnish grown

I have a woman's longing, an appetite

lover, elder lurother, and woman... Timon of

because thou art a woman ...........

surely, this man was horn of woman

act the woman in the scene ......... Corio
well said, noble woman; before he...
nay,

not of a woman's tenderness to be (rep.) -

I grant I am a woman (rep.)........J J

a man's mind, but a woman's might

how weak a thing the heart of woman is!
let him marry a woman that .....Antony $s$ Clco.

what says the married woman?

ne'er the word no woman heard speak

a woman with an cumclis played (rep.)

never a woman has a true face

no more, but e'en a woman ..........
and I have nothing of woman in me

honest woman, but something (rep.)

not eat a woman; I know (rep.
he is a man, worth any woman.

his own proof, what woman is

a woman, that bears all down
who's there? my woman Helen?

to Dornthy my woman hie thee.....
go, bid my woman search for a jewel

gond out the woman's part in mel (rep.)

go, bid my woman feign a sickne

more truly, woman's pretty self

more exquisite than lady, ladies, Woman

were you a woman, youth, I should woo -

\section{who is't can read a woman?}

qualities that man loves woman for...
she is a woman, therefore (rep.).. Titus Anu
thou bear'st a womar's face..........

entreat lier show a woman pity.

foltreat her show a woman pity .......

ii.
ii.
ii.
ii.
iii.
iii.
iii.
V.i.
v.

I. i.

i. 2

i. 5
ii. 2
v. 3

i. 4

iii. 2

and fur womanhood, maid Marian may

setting thy womanlood aside, thou art
not he believed tor womanhood! Troilus

twomanhood denies my tong

no grace? no womanhood?

relent

lie never was so womanish

womanish it is to be from thence. Troilus \& Cress.

gufferance show us won

no uuconstant toy, nor womanish fear of Juliet, ii.

Wo unconstrnt toy, lor womanish fear $\overline{\text { Th }}$ iv.

put up that womanly defence $\ldots . . . .$. Naebeth, iv. 2

WONAN-POST is this?

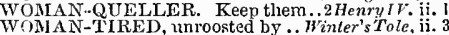

Woll B-good wombs have borne bad ... Tempest, i. 2

from the womb I did participate. Tuelfh Nigh

following licr womb, then rich. Mid. N.'s Dream, ii. 2

child was priconer to the womb.. Winter's Tale, ii. 2

sun sees, or the close earth womb

's womb un timely. Macbsth, v.

from thy sin-coneeiving womb.......

and slanderous to thy mother's womb - iii. 13

ripping up the womb of your dear ...
thiat bed, that womb, that mettle.... Rich $I I . \mathrm{i} .2$

this teeming womb of roy al kings...

ripe in fortune's womb, is coming

in their mother's woin b to chase..... I Hernry I $V_{\text {. }}$. 1

my womb.

the fruit of her womb in w womb...2 Henry/ IF. iv. 3

than I'il shame my mother's womb. He. (clorus)

then the froit within my womb.

forswore me in my motber's womb.3 Henry $V I$. iti. 2

of Ed ward's offspriog in my womb... - iv. 4

my accursed womb, the bed of death.
from forth the kemnel of thy woinb..

thy womb let loose, to ehase us

strangling thee in her accursed womb

in your daughter's womb I bury them

twinned brothers of one womb. Timon of

whose womb unmeasurable.

Whose womb unmeasurable.......... - iv.

and the only son of my womb ....... Coriolanus, $i$.

on thy mother's womb, that brough

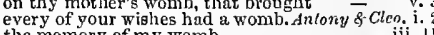

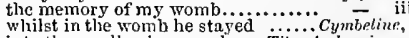

into the swallowing womb.... Tilus

to herald thee from the womb

in to her womb convey sterility 1 womb: and from her womb. Roine

hurry trom the fatal cannon's womb
detestable maw, thou womb of death

are innus events in the woinb of ear

WOMBY vanitages of France...............

WOM EN-four or five women once.

women highly hold in hate .. Tiva Ge

of Fer. iii. 2

how many women would do

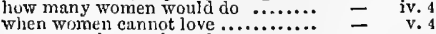

women to ehange their shapcs .........

but women indeed cannot abide em

praised women's modesty..............

that come like women in men's applarel $\overline{\bar{N}}$

in women's waxent hearts to set... welfth Night, ii. 2

for women are as roses ...............

What love women to men may owe .
nay. women are fiail too... Ileasure for Neasure

women! help heaven! men their....
WOMEN were all dead .... Meastre for Mcasure, iv. 3 these poor informal women are no more hath set the women on to (rep.) $i . .$.
that's the way; tor women are light
thou hast suborned these women....

a dear happiness to women

all women shall pardon me.........

more than ever women snoke... Alid. N,'s Dream, i.

these women to forswear

the authors of these women $(r e p.) . . .$.

- iv. 3

mistake in her gifts to women ......As you Like il, i.

and all the men and women merely

in laid to the charge of woment

as boys and women are for the most

re bome women, Silvius, had .. - iii.

the women. I cliarge you (rep.)..
for the love you hear to women.. (epilingue)

between you and the women $\ldots . . . \bar{A} l$ ' (epilowe

do you know these women?............

women are made to bear.......Tuming of Shre
when men and women are alone ....

When men and women are alone ....
kindness in women, not their beantcous

that wornen are so simple to offer....

when women are froward..............

become some women best,........... - ii.

my women may be with me (rep.)

which 'longs to woraen of all fasioion

iii. 2

not women? Women will love her .

you should be women; and yet sour... MLacbeth, $i$

as the weird women promised

it is the cry of women my good lord ${ }_{\text {women and fools, break off your .... King John, ii. I }}$

boys, with women's voices, strive... Riehard II. iii.

sup any women with him?

for the women, -for one of them... - $-\frac{1}{\text { ii. } 4}$

in disdain the German women ......... Hertry $\% . j$.

as ever sou came of women, come in

handle would have him about women - ii.

grandsires, babies, and old women - iii. (chorus) and none but women left to wail ..... Henry VI. i. 1

these women are shrewd tempters

more than in wonien comnionly $\ldots . .2$.

that doth oft malse women proud....3 Henry $r l . \mathrm{i}$. 4

Women are soft, mild, pitiful ....

Edward will use women honourabïy $=$ iii.

women and clildren of so high......

when men are ruled by women ...... kichard $I I I ., \mathrm{j}$.

these tell-tale women rail on the Iord's - iv.

two women placed together makes. IIerry IIII. i.

all other women could speak this with -

virtues with these weak women's fear

ald fearg than wars of women have

some pity upon my wretehed women

come to court, the women so besiege us?

mereiful construction of good women ... (epil.)

comparison beter whe

or that we wonjen had men

they dancel they are rnad wo.nen...Timon of $A t h . \dot{i}$.

why then! women are more valiant - iii. 5
if there sit twelve women at the 6 (gracc)

women nearest; but men, men are .. - iv.

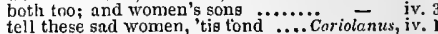

the easy groans of old women..........

at a few drops of women's rheum, $\cdots$...

a hundred ghastly women transforined -

how hard it is for women to keep.....
then, we kill all our women. .

compelling occasion, let women die..

might go to wars with the women!...

other women cloy th' appetites they fced -

leader's led, and we are women's men

see, my women! against the blown rose -

transformed us not to women $\ldots \ldots \ldots$.

help me, my women (rep. iv; is) ....

ah, women, women! look (rep.)

or women, tell their dreams.........
show me, my women, like a queen

very many, men and women too ....

do the gods great harm in their wome

call iny womes : think on my words . Cymbetior,

I know her women are about her...

one of her women (rep. ii. 4) .........

but women must be half-workers?

nen's vows are women's traitors

the handmaids of all women ........
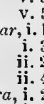

ii.

ii. 5
iii. 4
iii. 4
v. 5 


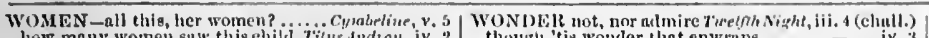

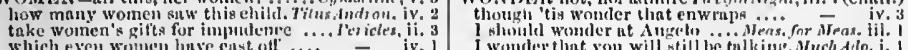

Which even women huse east ort

let not winen's wenpons...........

betrny thy pour hen't to women
women will all turu inonsters

centanrs, though women all ahove ...... - J lv. women grow hy men

making them women of good enrringe

women may fall, when tlier

women fear too much (rep.) ........... llante

fir

flat

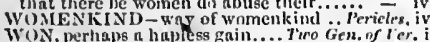

why then a grievous Inbour won

Why then a grievous inbour won,. .3 .

lie won it of me with false dice

and fair Ifero is won

won thy love, doing thee injüi..........irid

nnd won her goul; and she, sweet lady
liave eontinual plodilers ever wom. . I.ove

"tis won, as towns with fire; so won...

unless you may be woul by some... Ver. of $\mathrm{V}$

that won three fleids of Sultan .......

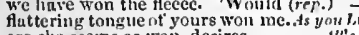

ere she seeins as won, desires

you won a wife of me

a heaven on earth I hive won

hall won, is match well made ...... - iv. 3 (letter)

now sou are doubly won?
if this suit be woul that you

3 (p)etition

(epilngise)

in a twink she won me to her love. Taming of Sh. ii.

the fleld is won. Well, forwart ...i.

twas $I$ won the wnger, though

is he won set? IIelli stay .......... ivintar's Trale, $\mathrm{i}$.

have won his grace to enme ... Comedy or Errors, v.

lost, noble

rell wnu is still well sliot.

eliangerl and won from the

if you had won it, certainly

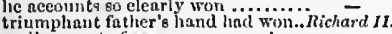

easily won to fawn on any man!

gain of care-by new eare won

all's done; nll's won; here hreathless

proud titles thou hast won of me

not leave till all our own be wo

the king ant

rou should have won them dearer

I would wonder at Angelu .... Mers. Snr Mras in.

lon much wonder, that one nint......

wonder not, till furtleer warrubt

I wouler at it $\ldots$ attired in woinier. I $\mathrm{k}$ know

will quench the wonder of her infum

und wonders at our qualut gpirits.

I wobler, if 'Titanin be awaked

I wonder of their being here togethe

perelmine, you wonder at this sho

I wonder, if the lion be to speak ( $r$ ep.

Nitvarre shall be the wonder...... Love's $\overline{L . L}$.

a wonder, master ; liere...... a Costard...

that sees thee without wonder $\ldots . .$.
by heaven, the wonkler of a morti

二 iii. 1

and wonder, what they were

do wonler, thon naushty gnoler.,yer. af fenice, ii

nine days out of the wouder ........ - iii.

ay, and greater wonders thin tliat

may spund our womker too ..........

spenk that whieh you will wonder $a t$

I wonder, sir, since wives are monsters

make it no wonder; 30 you knew...

here is a wonder, if you talk (rep.)

a boy, or a chitd, I wonder?

enough then for your wonder......

begetting wonder, as you, gracious....

kuch a deal of wonder is broken out..
it i do not wonder, how thou darest.

it the more shows off your wonder

by what wonder you do hit.. Comedy

this I wonder at; that he, unknown

his wonders and his praics
rapt in the wonder of it

without our specine of it

wonder, lady! lo, upon thy wisli.. King Jnhn ii.

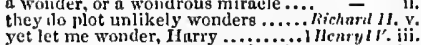

I wunder much, being men of such...

the onute wonder lurketh in men's.... Henry $V$. i.

bring in wonder, to wait on treason..

wonder ot himer found

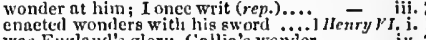

Was England's glor, , ciallia's wonder

eight sliflings I won of your at betting? -

bre Eligm the day is won
bor the sub

Poietiers, and Tours. a re won awa....

stain the honour you have won.

ay all the glory you have win

witls pain have wooed and w

till Fratice be won into the Dunpliin's

but all the lionour Salisbury hath won

for they hine won the brid

nor have we won one foot.............

many a battle have I won in France.3

soon won witl movirg word
tliat now hath won the day.

tliat now hath won the day.

as it was won with blood .............
not be won to aught agningt him ...

and be not easily won to our requests

I will retail my conquest won 1 .....

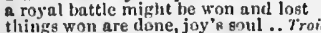

they are constnnt, heing won .......

liard to geem won; but $I$ was won ...

where he hath won with tame

lire those that he lintli won...

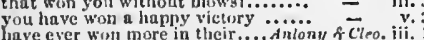

rates nll that is won and lost ..........

for the ring is won yet won: it mi.............

you have won: ict's tollow him.

riled by me, be won at last ......
a woman, therefore may be won

as sure a earl as ever worn the set

think an ton quiekly won ...Jonco \& Julie,

won to his shameful luat the will .......llmale,

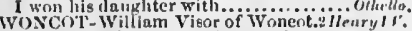

WONDEI? if you be unarle, or not (rep.). Trmpest

that wonders to hear thee sjeak.......

trouble, wonder, and amnzement...

Ot wonter! how many goodly creatio... -

that you will wonder ................

that yous will wonder .................̈erry Jiveres, iv.

at llerne's nak, and you ghill wee womlers

with such estimulule wonder

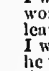

he wonders to whint end jou have

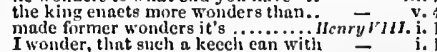

I wonder, that such a keech ean with
who wat enrollerl 'mongst wonders..

ean thy spirit wonder, a great man.
as when the bird of wonder dieg

as when the bird of wonder dieg i
thou spenkest wonders. She slaal be

known? Is that a wonder ... Troilus \& $C$.
n wonder! What? Ajax goes up .....
I wonder now low Jonder city stonds

I wonder now how yonder city stands
I wonder, men dare trust ...... Timon
I wonder on't; he was wnit to shine

monument and wonder of good decds

nuil enst your elf in wouder to see.... Jutiuscirser,

of nll the wonders thit I yet ........

I du wonder, doetor, thou nak'
wliist I am bound to wonder

no wonler, when rieh ones searee teil

not wonder at it: you are made (rew.)

sanguine star; it was a murk of woncler -

to mine eye beyond all wonder ........

by Jove, I wonler, that is king.

itherease our wonder, and set ny your fame -

nis wonder, that thy life and wits........

the woyder is, he hath enlurel so long...

ming selze on the white wonter. lom
I wonder at this lhute; thut I must

it harrows ne with fear and wonter...

it plves me wonder great as my content.
I winder in my soul, what you easlil us

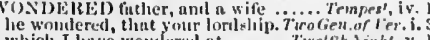

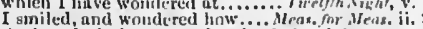

the breed of wits so wontereil at? Ifare's s, Last,

he: may be more wontered at........ Inemy It leave off to wonder why I drew $y^{2}$ ou...

hut I do wonder, his insolence can ...

I wrinder, none of you have $t$

if nught of woe, or wonter, cense your

where's nome wonler in this handkerehief - it.
W(DNI)FRF1)-make thee wondered..3 3lenry IT. 1. be snoked and wondered at ............
the nuidwife wontered, und the women

1 womlered, conld be to rurely ....... Cymbeline, ii.

ne'er beheli, but whe

from his bosk, and it is wouderini.

of that wonlerful promise ...... Sicelgh Night, iii.

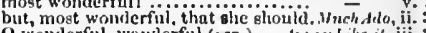

O wonderful, wonlerful (rep.) .. As yem Like it, iii. 2

stark mal, or wontlerful froward.. Taming of Sh. i.

wenderful, what may be u rouglit ... Kims John, jii.

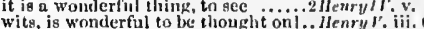

woulderfull Come, go we in processinn - iv, 8

and so young, is wonderful ........... $\overline{-}_{\text {iii. }}$

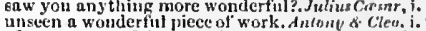

after, $n$ wonterful sweet air ........ Cymbeline, ii.

o wonderfull good ny lorl, tell it...... Isamel, iv.

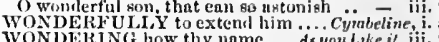

bONDEkING how thy name... As ynilake it iit.

graec equal with wondering. Ninter's Tut, iv. (clio.

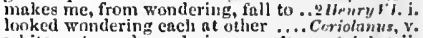

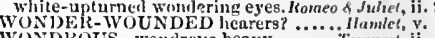

but follow thee, thoul woncl rous main... Ternpest, fi.

hot iee, and wond rous strange snow. Mill. $N:$ 's $\mathrm{Dr}$. v.

that word, of wondrous virtues. Mrtch. of lenice, i.

and found her wondirous eold..........Alls $\|^{\prime} e l l$, iii,

I found you wondrous kimt ...iia.....

is slie a wondrous fat marriage. Coniedy of Err. iiii.

or a wond rous miraele, thic shadow... King John, ii.

other foni ill wondrous notion .........

as a lion, and wondrous uftitsle...... - iij.

and him. $O$ wondrous him! $\ldots . . . .2$ Henryll. 1.

Ilenry with her wondrous prajse .... Inc - v v

tis wondrous strange, the like yet....

brave Oxford, wondrous well heloved - iv. 8

youtrselves wondrous malieious ....... Coriolan $1 s_{4}$ i.

Wondrous things spoke of him (rep.)...

wondrous thingt how easily murder - ii.

fair day in summer; wondrous fuir..... Pericles,

whate er it be, "tis wonlrous heary.....

but this is wondrous strange 1 ............ llamict,. .

or throw him out with wondrolle potency - iji.

'was pitiful, 'twas wondrous pitiful .... Ohello, $i$.
wONDROUSLY to discontent. Timan af.then, iit.

WONT-you were wont, when.. TroGen, of icr. ii.

the lights they were wont to have ....
tales of love were wont to weary

I love him not, as I wns wont .......

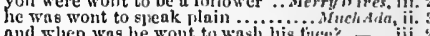

were wont to die, emptying ....Hid...'s Drean, i.

be as thou wast wont to lie $(r p, \% \ldots . .$. , iv.

your worship was wont to tell me. Afereoflence, ii.

than tliey are wont to keep plliged...

your to cucc was wont to lough....

I was wont to lond my sle with... Hinter's Title iv.

were fou wont to use my sisler.. Conedy v lirr. ii.

linglant, that was wout to conquer..... Jichard $M$. ii.

tustc of it first, as thou art wont to do - - wery i. .

intrendienl, wont, through a seerce...

'tis not his wont to be the hindimost.2 Henry I'l. iii.

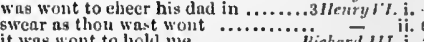

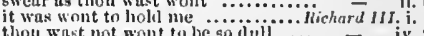

thot wast not wont to be so durl

he was wont to shine at seven. Timan as attens, iij.

was wont to eome home woumled .. Cos iolanus, ii.

"hicn gou were wont to suy.

he thit was wont to thwack

sparkles this stone ae it was wonit. Juliwa creser i.

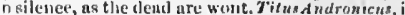

when wert thou wont to walk alone..
affeetion as you were wont..................

ulen were you wont to be so fiiii......

ilamict, i.

even those you were wont to take........
thint were wont to set the table on a roar?

Mluntum, you were wont be civil ...... Othello, it.

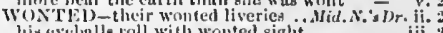

his eyclualls roll with wonted sight ...

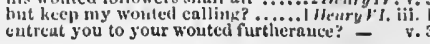


TONTED sleep under a fresh tree's...3 Henry $r$ r. ii. 5 will nut lose her wonted grentness. Ilenry I Ill. iv. promising to pay our wonted tribute. Cymbeline, endeavour keeps in the wonted pas

woo-yet I will woo for him. Two Gen. of Verona, iv.

I'll woo you like a soldier

and thou shalt woo hex

till thon art oble to woo her in....... bourd her, wou her, assail her ....... Tivelfth Nighl, $i$. woo your lady: yet barful strifel (rep.)

for, that 1 woo, thu therefvre

and let me woo no more

and she will die if he woo her

Iuch $A d o, i$. nor I cannot woo in festival terms ...

and were not made to woo .....Mid.

then will two, at once, woo one.

that I should woo in scorn?...........

at Nimus' tomb, there, there to wo

so shall your loves woo contrar

nor woo in rliyme, like a blind

to woo a maid in way of.... Merchant of Yerice, ij. 9

I cume to woo, but I go away .......

with unbashful forehead woo the means -

your poor friends inust woo your...

every day to woo me (rep.).....

come, woo me, woo me:

men are April wien they woo ......

loving, woo? and, wooing, she should - v. urr, but to wed it ....AAll's Well, ii. told me just low he would woo....... undertake to woo curst Katherine .

woo this wild cat? Will

mongst the rest that woo $\ldots$ wo........

rough, and woo 110 t like a babe (rep.)

and woo her witll some spirit when..

moved to woo thee for my wife......

never to woo her mor.

new woo my queen ...........

not the gift to woo in other
when I come to woo ladies

when I come to woo

to woo so fair a dame
deign to woo her little i.

Winter.

deign to woo her little

... i Henry J'I. v. 3

liow canst thou woo her?............
under what title shall $I$ woo for the

aod woo your own destruetion?.... Her

sweet IIelen, I must woo you to .... Timon of Alh. v. 5

keep it till you woo another wife .....

doth woo me oft for my confections?
I ghould woo hard, but be your groom

were it to woo my daughter .......... Pericles, $v$.

but woo her, gentle Paris .......... Romeo

of woe afford no time to woo.

that should be husband, comes to woo

yea, curb, and woo, tor leave to do.... Hamlet, iii.

woOD-fetcli in our wood.....

there s wood enough within

for bringing wood in slowly

and get thee wood enough

like a wood woinan ........ TuoGen. of Verona, ii. 3
to the west end of the wood.........

shindowy desert, unfrequeuted woods $\bar{W}_{\text {will thes, vo }}$ v.

and in the wood, a league (rep.) Hid.N.'sDream, i.

then to the wood, will he, to-morrow
and meet me in the palnce wood ....

how long within this wood intend

they were stolen into this wood.......
wood within this wood, because I cannot -

nor doth this wood lack worlds......

you faint with wandering in the wood

you faint with wandering in the wood

out of this wood do not desire.

about the wood go swifter than.......
tolil him of your stealth unto this wood

belind the wood, seeking sweet savours

when in a wood of Crete $\dddot{I} \ldots \ldots . . .$.

$O$ wood divinel a wife (rep.) .... Love's L. $\vec{L}$

are not these woods more free .... As you

we have no temple but the wood .....
to the skirts of this wild wood he came

to the skirts of this wild wood he came $\overline{\text { varing }}$
and burn sweet wood .. Tarning of Shrew.
randuc.)

roaming through a thorny wood..
nakes wing to the rooky wood 2 (induc.)

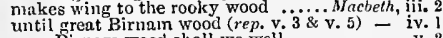

near Birnam wood shall we well ......

what wood is this before us? The wood

methought the wood began to move
and now a wood comes toward

though Birnam wood be come .......... Richard $\bar{u}$ v. and felled my forest woods $\ldots \ldots$... Richard 11 . iii. I'll tie them in the wood ............. I Inenryl $\mathrm{V}$. i. 2
whelp of Talbot's, raging wood.... Henry $V 1$. iv. he talks of wood; it is ............... lost in a thorny wood (rep. v. 4)...... Henryly I. ii. 2 Timon will to the woods ....... Timon of Athens, iv. 1
slame not these woods ..............
WoOD-men like blasted woods. T'imon of Alhens, iv. 3 upon a pile of wond, let's he wh

the woods are ruthless, dreadful

in the rutluless, vast, and gloomy woods $=$ ii. 2 stole into the covert of the wood. Romeo $\&$ Julich, i. I that turneth wood to stone ............. Hamlet, iv. 7 over-canopied with lush woodbine...MAid. N.'sDr.,ji. the wondbine, the sweet honeysuckle
woODBIRDs but to couple now

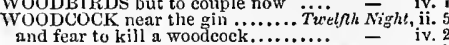
shall I not find a woodcock too? "...... Afrech Ado, v four woodcocks in a dish!......... Love's L. Lost, iv.
we have crught the woodcock 0 this woodeock I what an ass. Taming of Shrew, $i$. ay, ay, so strives the woodcock .......3 Henryl $T$. i. 4

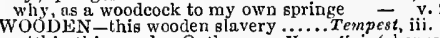
within this wooden $O$, the very. IIenry $V$. i. (chorus) pare his nails with a wooded dagger - ipon a wooden coffin we a.tend ....l Henry VI. tushl that's a wooden thing !

to hear the wooden dialogue.. Troilus \& Cressida, i. 3 pins, wooden pry him a wooden one?.. l'ericles, iv. pins, wooden pricks, nails, sprigs

WOODLAND fellow, sir, that ..........Alls Well, iv. $_{\text {W }}$

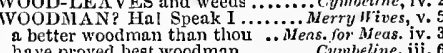
have proved best woodman ......... Cymbeline, iii. 6
WOODMONGER, and buy nothing.... Henry/ ${ }^{7}$. v. WOODVILLE, prizest him 'fore mc?... Henry $V^{\prime}$. Autony Woodville, her brother..... Richard III. i.
[Col. Knt.] Woodvilie, and lord Scales - ii.
WoOED-inotive that I wooed thee.Merry Wives, iii. 4 if you be not wooed in good time..... Nuchado, i. and, as I wooed fur thee to obtain her and, as I wooed fur thee to obtain her - iii. 2 I wooed thee with my sword ...Mid.N.'s Dream, i. I wooed but the sign of she .......... Love's I.. Lost, v. 2 I had as lief be wooed of a snail... As you Like it, iv. 1 you woned the gentlewoman Taming of Sh.

who wooed in haste, and means

means to wed where he hath woo

you wooed me the false way .... Winter's 'Tale, iv.

when first I wooed herl.

when she was young, you wooed her
because he hath not wooed me yet ... King John, ii. 2 to be quickly wooed to gripe ......... I IIenry IF. with pain have wooed and won thereto

ever woman in this humour wooed?
reflecting gems, that wooed the slimy

as tetchy to be wooed to woo.. Troilus \&
though they be long ere they are wooed

loved you well, I wooed you not

occasions might have wooed ...T
arms as sound, as when I wooed

and having wooed a villain to attempt. Pericles, $v$.

did Michael Cassio, when you wooed .. Oolhell a hundred times wooed me to steal

to be her wooer ..........................

since many a wooer doth commence...

that mooth-faced wooers say .... Love'sL.Lost,

whiles we sluut the gate upon one wooer -

daughter liad a tlousand wooer

the bluntest wooer in Christendom.3 Henry ${ }^{\prime} T$. iii. prepare I, a jolly thriving wooer . Richard III. iv. fresh, loved, and delicate wooer. Timon of Alhens,

\section{that she rras holf the wooer}

W OOES you by a figure...... Tu. Gen of Ferona, ii.

he wooes both high and low ....... Merryl Wires,

the prince wooes for himself ......... Much Ado, ii. 1

yet he wopes; yet will he swear........All' $\overline{\text { thell, iii. } 7}$ who wooes even now the frozen.. Romen \& Juliet, i.
WOOF-Arachne's broken woof.. Troilus of Cress. v. WOOING-use your art of wooing... Merry Wive we shall have the freer wooin

wooing, wedding, alsil repenting ......Much $A d o$, ii.

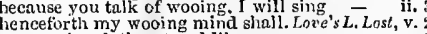
our wooing doth not end like an

for wooing here, until I sweat. Merch. of renice, iti. I remember the wooing of a peas

my sudden wooing, nor her sudden... = v.

I have won, by wooing thee......... Al's ${ }^{r}$ ell, iv.
to begin his wooing, that would.. Taming of $\mathrm{S} / \mathrm{s}$. i. I

is burden of my woing danee

but bear his charge of wooin

but you this case of wooing, a clinid.... =

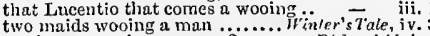

on slaves; wooing poor craftsmen ...Richard II. i.

in wooing sorrow let's be brief....

my wooing is fit for thy understanding. Henry
WOOLNG-for more serious wooing.... Pericles, iv. 6 in my whole course of wooing $\ldots . . \ldots \ldots \ldots$. thello, iii. 3 GLY -smells wooingly here.... Nacbeth, j. wool of lat, and tongue of $\operatorname{dog} . . . . . .$. Mrachelh, iv. the sheep no wool, the cat no perfume .. Lear, iij. 4
wooLLEN-rather lie in the wonllen. Minch Ado, ii. I wont to call them woollen vaseals.. Coriolanus, iii. WOOLLY breedcrs in the act ...Merch. of Yenice, $i$. this fleece of woolly hair that now. Titus Andron. ii. WOOLVISI $-[K$.-wolfish $]$ gown $[C$. -toge $]$. Corial. ii. WORLESTER-at Worcester must his. King John, v. whereon the earl of Worcester hath. Richard 11 . ij. sent from my brother of Worcester .. - ii. this is Worcester, malevolen to ..... Henry
Worcester, get thee gone, for I see danger -
Worcester is stolen away to-nirht

Worcester is stolen away to-night ...
and, uncie Worcester (rep.) ......... I learned in Worcester, as I rode along = your uncle Worcester's horke came but

no, good Worcester, no, we love our..

bear Worcester to the dea th $\ldots . . . . .$. . WORD-thy purposes with words ....... Tempest,

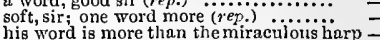
you cram these words in to mine ears...

in terrupt the monster one word further

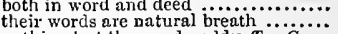

nothing but the word noddy. Two Gen of

to tear such loving words

tis a word or two of commendation...

except an angry word ..............

truth hath better deeds than words...

the shoe speak a word for weeping .

a fine volley of words.................

you have an exchequer of words ....

and, in a word (for far behind

quench the fire of love with word...

his words are bonds, his oaths .......

if she respect not words.

friend Valentine, a wrord ...............

your old viee still ; mistake the word

she is slow in words (rep.) $\ldots . . . . . . .$. .

where your good word cannot

to think upon thy words

to the gentle spirit of moving words

at $a$ word, he hath (rep. ii. 2$)$........Merry Wives,

word of denial in thy labras here (rep.) -

I an at a ward, follow ..............

to speak a good word to mistress .....

gone to the truth of his words

the very hand, the very words ......

vouchsafe your worship a word or two?

a word, monsienr Mnd the word!

let-a me speak a word vit your ear..

and I'll be as good as my word ......

he sent me word to stay within.......

he will seek there on my word (rep.)
to send him word they'll meet .......

you yet shall hold your word

Tüelfth $\overrightarrow{\mathrm{N}}$ ir

will not pass his word for two-pence
my words are as full of peace as ....

by word of mouth (rep. jii. 4).........

they that dally nicely with words ...

indeed, words are very rascals ......

none without words, and words are...
not her fool, but her corrupter of word

hob nob is his word; give't, or tailse'

I'll be as good as my word .............

he has heard that word of some....

and bring me word how thou

one word, good friend: Lucio. a word

I'll send him certain word of my ....

and you but waste your words ......

in the captain's but a cholerick word

I do arrest your words

my words express my purpose.........

provost, a word with you (rep.) $\because \ldots$

no word to save the

vouchsafe a word, young sister (rep.)

and good words went with her name

is it sad, and few words? ............

go to, no more words ............

\section{iii. \\ iv. 3 \\ v. 5}

- ii.

= ii.

it

ii:.

ii:

ii:

ii:

iii.

iii:

iiii:

iv. 4

i.
i. 1
i.
i.

i.:

iii.

ii:

iiii.

iii. 4
iii. 5
iii. 5
iv. 1

iv.

Y. 5
i. 3
i. 5

i. 5

iii.

iii.

iiii.

iii. 4

iv.

i.

i.

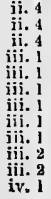




\section{IVOR}

$[845]$

TVOR

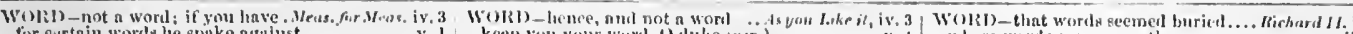
for ecrtain worts

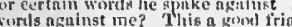
and worls from breath, $a$ a thicre is ... strongly as worel conlil make 11 you friar and you must have a word anon net of many worls, hut 1 thinili........s/uch and tire the hearer with a honk of sordy -

at u word, I an not (rep.)

spenks puninrls, nud every word stoibs

rather thun holil three words' conference -

his words are a yery fintustienl bannuct eight or nine wise words to spenk to y the word is too coot to paint int her

one word sir:

one word sire our wateh sir.......... innintnined the change of worls with slie died upon his words, the iden....

will you not ent your word?

a word in your eur, sir (rep. y. I)

upon with ir and nony with words

spenk off halt $a$ dozen dangerons words only foul words ( $r e p$. )

thon firt

first, o' $\mathrm{my}$ word; therefore, plny

$O$ how thi $u$ word is that vile name

no soumt, no word? Alnck, where..

I ani amnzed at your pussiun

I'll not trust your word.................

some ten words long (rep).

there is nint one word npt .............

tongine not a word: eome, trusty

he sint me work, if $I$ andel his beurl $:$.

Worl ngain, it was not well eut (
l will not

have andience, fur $\mathrm{a}$ worit, or two

his plunsive words he teatterch not.

and hustroms, $\mathrm{n}$ word, good netal

the mere wort's a slave, deburuelied on

a word with you. Four plensure, sir?

you stre not wortli another wor

stings are in her millest worla!
let every word weigh heavy of lie

I lave unt many words $\ldots \ldots . . . . . .$.

are words, and 1 mor contlitions

to hear me one single word

save your worl. Mly nam

whose words than one word then...

not one word inore of the eonsunei

but $n$ word, I pray: thiough............

spake sou not these words pinin

with more suceessful words than

sir, $\Omega$ word ere you wo............

to whint end are all these words?

did slie eros s thee witli a litter word?

armed for some unhappy worls.

and will not speak a word

than words ean witness, or your

I am come to keep my word

therefore have done with words.....

what, not a word? nay then, thou "̈̈'st -

take no unkindness of his hasty word

I would that word wow a madnan

sensls yon word that she is bus

to handy word for word, nuel frown

a man of fire-new words, fushion"s

I hoje in God for high words...

not $n$ words of other men's seerets

the word three, and study three

in such apt nnd grueions words........

we arrest your word: Buyet, you ean
sir, I pray you a word (rep.)

sir, I pray you a word (rep.)
a word with lim but a jest (rep.

of you, to take him at his word...

but to spenk that in words, which his

nnd the word. l'en voy, for a salve?

will never buy and sell out of this word =

thou fellow, a word; who gave thee.

defllel a finul word. Wo

is not thint a good word? $\ldots \ldots \ldots . . . . .$.

averd =

lived long on the alms-basket

the word is well eulled, chose.

thou hast spoken no word all this..... -

one sweet word with the

one word in secret (rep.)

with me tn change

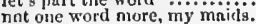

was weeping-ripe tor a good word...

id audienee for one word

to sngteh words frith one linppy word

to snatch words from my tongue

as will utter a brace of words...

honest plain worls liest pierce

$O$ word of finr ! unpleasing to

within this hour bring me word 'tis..

whose every word deserves to taste..
if word, nor onth, prevail, go and see

if word, nor oath, prevail, go and sec

no scurrilous words in his tune..

your tongues; and not a word more

inark tlioll my words; follow ua

know you sliall not want,-one word

pray you, $a$ word. What I do next.

every word, vea, and his son's pranks

when your words are done .... Comed

woutd tilse you at your word, and go

when spike 1 sueh a word?

who every word by all my wit (rep.)

her very works didst thou deliver to

are doubled with an evil word are but

meaning of your word's deceit

hrought youl word an hour since.

his word might hear my wealth....

vouclesafe me speak a word.

so welt thy words become thee
to the self-same tune, and words

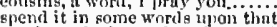

words to the hent of deerls too euld

sirral, a word; atteod those
his leisure for a few worls

thou marvell'st at my words .........

but one word more. He will not

that hring you worl, Nreduff
but I have words, that would be

and, in n wiorul, but eren now. .Merch. ai I

and, lairer than that word,

who brings wortl, the jirinee

his words were. farewell, mistress

be an lionest woman of lier word ....

youl lave hereft ne of all worls.

a few of the impleasantest words....

and every word in it a gaping wound =

low every fuol can jlay upon the word] -

ouly, cover is the word
low his words are suited

an army of tood words.

that fur a tricksy word def

those are the vers worda

the words expressly are, a............

anil I bring woril, my nistress, wili..

we hope, the better fir our words

wulle not have spike such a woril... As $y^{\prime \prime}$ - $L$ i

not n word? Not ure to throw

no, thy words are too preeious

in the grentuess of iny word, you dic

answer me in one worl ...............

is it honest in deed, nul word?

no stronger tlian the woril of ........

spenks lirave words pwears brave...

what eare I fur worits? yet words dio

such Ethiop) words, blacker in ........

give sorrow words; the griet ...........

I linve no words, nyy voiec is in.

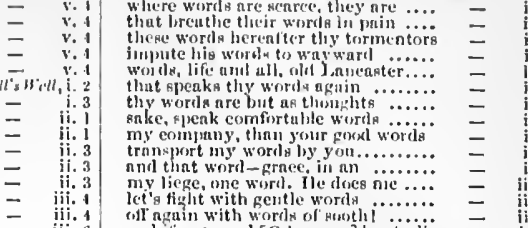

ii.

and if my worl [ $\mathrm{Col}$-name] he sterlin

his workle enme from his mouth.

the word is short, lut not so

et'st the worll it relf naninst the word

those were his worls he spake?

word [ $k$ mt,-faith I itself ngainst (rep.)

and beither my gond word

and Bends me worll. I shall

for keeping thy word with the devil
low muel heter than my word $\mathrm{I}$ am

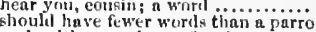

and, with a wort, mit-fueed you....

not in worly only, lut in woes also

both in word and matier.

I will engage iny word to thice

hut marked him not a worl ........

darest thou be as good ns thy word.

rare worls hrave world! Ilostess ...

there is not such a worl spoke of in

and bring me word whut lie will do...

should kcep his word in loring us

sir John Falstuff, a word w'ith you

nor the throng of words that entme.

enme, no more words of it (rep.)

no word to your master.

that you bruke your word

Bardolyh hath bronght woril..........

theserd -

did speak these words, now proved.

I have heurd the worle phrnse, enll

the word with my swort] (rep.) .......

I will not use trany wrords with you

Ihave spoke, at a worl; fare you well
and every thirl word a lie, dutr paid

I take sour prineely word for.

the word of peuce is rentlered...

iii. 1 believe not the word of the uni...

that the moet immorlest word be looked -

but write lier fuir words still in

live to speak my father's worls...

see performed the tenor of our vord
sir. I will be as goon as my word.

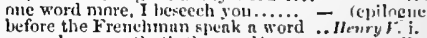

thie le gorde, that's the word

a' hreaks words, and keeps whole.

that men of few wrords ure the best.
but his few bal wrords are matehed..

bring us worel of Eneland's full

I will ncver trukt his wurd after
keep thy word: fure thee well

eannot suit it self in worls in their montiss ns honfeholi....

perpend thy worls, () signieur Dew

upon the ferorls I enme ............

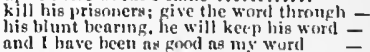

avouch in your deeds any of jour w orls? -

they shout but calm words, folded .. King to

I was never so bethumperl with woril

bint the woril matid, cheats the nenr

for thy world is but the vain brentl.

but this une worll whether thy

envennm him with words.........

shoulil spenk those worits to nid

that gnve the smund of words

cars, and harinfitl sound of words

[Col.] spoiled the swe't wnol's taste

his wnrils do take poser'ssion

nor sicenk a worl, nor lork unin

bitl me tell my tale in express worila

our souls religionsly confirm thy worlds

now keep your holy word. Go meet..

let not my enld worly here arelese .. Vichard

yet one word nore; grief loumletli...

the hnpeless word of. never to.

(n)

thy whirl is eurrent with hing.

shoulal so profane the word

neike the word of a king anl a liaclielor -

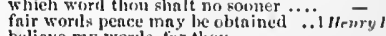

believe my words, for they .........

anguer the with worts are true ...

run and bring me wurd.............

I'll maintnin my words on any

some worils the re frew "twixt....

my fuinting worla slo warrunt

he wary how you thee your words.

let no worla, but deeds, resenge .... -

and enehant him with thy worts.
lewiteliesl me with her words

lewitehel me with her words......
these hangity worls of hars litse

I brenk tily

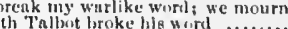

these worily of yours dra

Inuphin? "tis a mere lireneli wo........

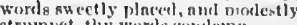

gtrumpet, thy world cumlemn $\ldots . . .2$.

let not lis smootling words be witeli 
WORD-give no words but-muml....2 Henry IrI. i. 2 | WORD-will not keep my word... Troilus of Cress. v. 2 WORD-soft berla, sweet words........ Cymbelize, v. 3 sing, man, were these thy words? hang me, if ever I spake the words or else conelude my words effectual janominious words, thonglo elerkly. say but the word, and I will b
these words content me mueh

was dumb, and could not speak $a$ word thy poison with sutel sugared worts for every word, you speak in his behalf the commons send you word by me.

should stumble in mine word; but.... my words stab him, as he hath (rep.) thy words move rage, and unt

seeing gentle words will not prevail

and such abominable words, as no

I feel remorse in my'self with his words

for more words, whose greatness (rep.)

give due action to my wor one cannot speak a word, but it $\ldots . .$.
words, words, mere words; no matter
my love witli words and errors tîli slie

3 bardou's the word, sir.

shall give their words for him........

if our words, or blows, here let us $1 . . .3$ Henry $V$

row that, words, and threats, shail

Clifford, how thy' words revive

of 'Warwick, hear but one word...
where thy words sliould enter

bandy with thee word for word.

the words would add more anguish...

of Norfolk sends yon word by me...

have done with words, my

these words will cost ten thousand.....

and no more words, till they .........

vex him with eager word

soon won with moving words..........
her words do show lier wit ..........

sweet larlies with my words and looks

that Warwick's words bewitei him not: -

these words have turnerl my hate...

few worls, but sach as I, withont...

these were his very words $($ rep.).........
few words, if you'll not here proelaim
speak gentle words, and humbly bend

if a coward heard her speak these words

for every word I speak, ye see

propose the self-same words to tinee..

Tol plague yon for that word

with thy weapon, not with wordsi ...

and this word, love, which greybeards $\overline{-}$

and even with the word, this hand

his grace witll quick and merry words =

the urging of that word, judgmen

attended to their sugared word

sends you word [Col.Knt.-certifies your] -

thy breath in middle of a word

the eitizens are mum, say not a word

they spake not a word ....................

my words are dull, 0 quicken them

mild and gentle in my words...

政

is but a word that eowards use

our aneient word of conrage fair...

word with you; let there be letteri.

every minute with worls of sovereignty.

the verity of certain words spoke

and your words, domesties to you

and yet words are no deeds.

did crown his word upon you

words eannot earry authority.........

if I Inved many words, lords

to whom he orve these words...

ever double, both in words and me......

understand you, words and weakness

and the words I utter let none think here's yet in the word ........ Troilus \& Cressida

words, vows, gifts, tears, and iove's.

Nestor shall apply thy latest words..

Achilles sliall have word of this intent

a word, my lord. What moves $\dddot{\mathrm{A}} \mathrm{jax}$

friend! you! pray you, a word .......
dear tord, you are fnll of fair words.

will you vouchsafe me a word? .....

nay, I eare not for such words

few words to fair faith ...............

withal, bring word - if Heetor will

gave to me good word, nor look

given so many good words brea

yet matchless; firm of word

when Diomed keeps his word

hark! a word witl you (rep.)...........

your mind be eoupled with your words -

torments, I will not speak a word....

iii. 1 aud, in a word, scare Troy out .......

I have one word to say to you .......

he owes for every word ...............

you gave good words the other day

and turned to me in words, but find

as to use mine own words to $\mathrm{him}$ ?

Flaminiusl sir, a word: pray........

your words have took sueh pains.
not one word more: thus part we...

not one word more: thus part we.

for eaeh true word, a blister!

these words become your
lips, let sour words go by

deseend, and keep your words.

we have ever your good word (rep.).

o' $\mathrm{my}$ word, the father's son,

no; at a word, madam; indeed...

it was his word; O he would miss it

I hope, my words dis-heuehed you
made me sta. I fled from words

no more words, we beseech you.
so shall my lungs coin words till

what's like to be their words

hear me one word: beseech you (rep.)

one word more one word.

ii. 2 with such words that are but roted ii

take in a town witll gentle words

as free as words to little purpose

the word is mildly; pray you, let....
at the price of one tair word $\ldots . . .$.
for Rome, than thou hast spoken words?

than ever thou wise words $\ldots . . . . . .$.
in a word, I also am longer to live

Mareins, Marcius, eaels word thon

iii. 3 as you liave ittered words in your own =

another word, Menenius, I will not hear -

a better witness back than words....

hoping to purge himself with words

that my weak words have strnek

if I would not have taken him at $a$ word to digest his words with better

v. 5 look in the calendar, and bring me word 二 shall I en treat a word?

5 if yorr shall send them word

yes, luring me word, boy (rep.)

sweet words, low-erooked court'sies

to say to yolt by word of mouth.....

marked ye his words? he would
but yesterdtly the word of Cæasar

neitheir wit, nor words, nor worth..

give the word, hol and stand .......
a word, Lucilius (rep. v. 1) ........

the generals wonld have some words

words before blows, is it so ............
words better, as you do. Good words

you give good words: witness
but for your words, they rob

Brutus gave the word too ear

and bring us word auto Oetavius' tent

slaying is the word; it is a deed in

pist a word. What says my lord?.....

our departure, death's the word ...Antony of

Cxsar I bring thee word, Meneerates

you were the word of war............

neter the word of no woman heard

bring me word quiekly (rep.)

and fair words to them. Then so much Pompey, a word. Say in min

what needs more words? good-........

that magieal word of war............

I'll bring thee word straight

and werd it word you are dead

she sent you word she was dead....

one word, sweet queen ..............

I'll drink the words you sen

...... Cymbeli

ii. 3
iif.
bark thee, a word. I do not like heer

iii. i my women; think on my words (rep.)

as 1 have words to bid you

or I shall short my word ........

with admirable rich words to

in posture that aets my words ......

in a word; or else thou art straightwa

at once, at the next word, - no more

saving reverence of the word

iv. 5 thy words, I grant, are bigre

v. 1 play in wench-like words with that..

v. 2 use like note, and words, save that ..

v. 2 I'll weep, and worl it with thee $\ldots$....

\begin{tabular}{l|l} 
v. 2 & and bring me word, how 'tis with her \\
v. 2. & with this word, stand, stand ........
\end{tabular}

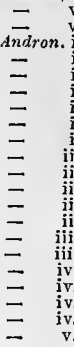

what these words in princely.

these words are razors tó my wounded

that villain was it spoke that word?

my word and promise to the emperor

i. 2 with words, fair looks, and liberality?

i. 2 by foree, if not by words $\ldots . . . . . . .$. .

let them not speak a word

iii. 2 eousin, a word; where is your husbänd? -

iii. 4 dicl not name the word of hands?...

iv. 2 will write these words, and lay ......

v. 2 o' my word, I have written...........

no; not a word? $(r<p, v, 2) \ldots . . . . . .$.

let them not syeak a word ..........

cannot talce you to attend my words - v.

i. 3 prove awful both in deed and word -.... ii. (Gower)

i. 3 sends word of all that haps in Tyre - ii. (Gower) lord Helieane, a word. Witl me? $\ldots . .$. = ii. I never spake bad word, nor ........ - iv. spoken holy words to the lord Lysimn - iv. would win some words of him.......... more than words can wield the matter..... Lear, i. may spring from words of love............. fine word, legitimate! well, my legitimate not a word (rep. brother, a w ord; descend: brother, I say..... . $=$ to baudy hasty words, to seant $\ldots . . . \ldots . .$. 二 priests are more in word than matter $\ldots . .$. - iii. priests are more in word than matter $\ldots . .$. - iii. 2 swore as many oaths as I spake words.... - iii. 4 let me ask you one word in private $\ldots \ldots \ldots=$ - iii. 4 word was still, fie, foh, and fum .. - ii. 4 (song)
not you transport lier purposes by word? they are not men o' their words ............. = iv. 6

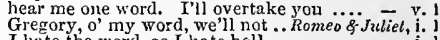
I hate the word, as I hate hell ...... - i. ah, word ill-urged to one that is the constable's own word .............. your nother eraves a word witii you I take thee at thy word .............. tear the word. Hy ears have (rep.)... and I will take tly word

three words, dear homeo ............

I streteh it out for that word-broad pray you, sir, at word: and as I told you but close our hands with holy words

more riel in matter than in words..

a word with one of you (rep.
make it a word and a blow

some word there was, worser than ...
that one word-banislied, hath slain

to speak that word, is father, mother

in that word's death; no words can that -

the dammed use that word in heii....

but speak a word [Knt:-a little speak]

armour to keep off that word .......

talk not to me, for I'li not speak a word =

hast thou not a word of joy a..........

each word marle true and good

as to give words or talk with ............

now to my word; it is adieu, adieu!

given him any hard words of late?

rend, my lord? Words, words, wordsi

and, iny deed to my most painted word

suit the aetion to the word, the word to.

these words are not mine. No, nor mine

Obut she'll keep her word ..............

youehsafe me a word with you ...........

how in my words soever she be shent...

ay, Indy 'twas my word.

sweet religion makes a rhapsody of words

these words like daggers eliter in

but one word more. good lady $\ldots \ldots . . . . .$.

the words up fit to their own thoughts

pray, let us have no words of this

your father's con more than in words? - iv. 6 (let.)

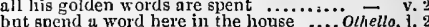

but worils are words; I never yet did henr-

Weigh'st thy words before thou givest them- iii.

it is not words, that shake ine thus (.... 
WORD-abhor me, now I sleuk the word. olkello, iv, for your words, and perfurmanecs ure no doist unelerstunt the word? my firend.... this time forth 1 never will sleuk word. soth roo; a worrl or two before you go $:$. when l wore it at vonr dan wher'y mirriage? of the visors was it, that you wore?. Lore's L. Losf, v. he wore none but a dlish-elout ...... n thy thiner's finther wore it ......... - iv. sim.

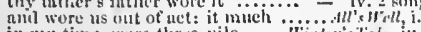
in my time, wore three-pile .... Hinter's late, is. that wore theirerownets resul. Troilus \& Ciess. (proi.) bury with thise thint wore then with a proul heurt he wore his .......
with what eonternt he wore the humble - ii. 3
ii. 3 with what eontemnt he wore the humble - if. 3

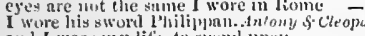
nul I wore my life, to spend up of tus not wore him from my remcin

who neer wore rowel nor iroul ....... [Col. Kat.] that wore the implial. Titus. wore glove' in my eup, served .......... Lew

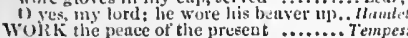
work you, then ......
lint there's more work hint there s more tork the vust of night that they ma........ tite vitst of mighe the now Prosper works upon thee. weeps when she sees ine work

pray you, work not so lin

my high charms work, and thes..... given to work a great time after..... some pussion that works him strungl you said our work should echese..... to work mine end upoin their sernse

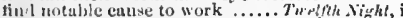
1 know my physic will work with him Nokt, il. 3 does it worly, he whild work it out?

I.it it work ppon him?.................

nud let them work

In will go durkty to wiork with he

n yerr good picee of Wurk ...... Mid.
d.) tlicir work, and they shail have

that work for breud upon Attenitu

men, that do work in Atheny licere

which tlerein works a iniracle

yon would be prouler of the

I lave work in hand that you .....

this is tot fortune's work neither... Äs yon Like

wonld they work in mild aspee

ay hearen silali work it me for thine

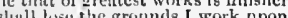

that I will work apriust in

'tis a very execllent fiece of work. Taming of

marry, sir. llow it begins to work.

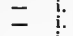

stuir sliould fot work maliciudsy finter

stuir work, some trunk work (rep.).
see his work, so noble, vilely bound ul?

ans the work nbout the square on'l..
to smell out wurk for the other seuses

vields a carcful man work

jimt loreath into lis work, would beguile

this most bloolly piee of work......... Mincbeth, ii. 3

to lenve no rubs, nts boteles, in the

a most miraculous wark in this good.

wil of oars should be a work of thine

much work fis tears in many

make work upom ourstl lecs, for hearen
n diamnerl and a bloodly work........

n diti wiork of uuy huad (rep.).

the wiork br ung hus of this titir work?

but on the outsille of thiy work i..... and twilerl with works of war...

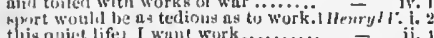

this greal work, (which is, thlmost

luw uble sueh a work to undergo.。
though it do work as strong as

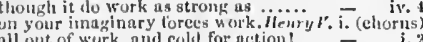

all ont of work, and coll for action!

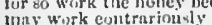

mangle the kork of matiure.

work, work, your thesthts ..........

the wark ish give over; the trumpet

there is not work anus la fur nur

in England thint dis no work to-day'

iul braks of this day $*$ work

fill bereeive low 1 will with

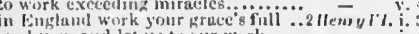

real you. nind let us th our wozk ...

Gind in all wis ertulures work

what miechiefs work the wieked one

ar to work my downfall ...............

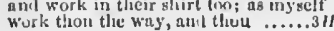

WVORK - ghull we fill to work?

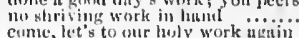

cemle, lets to onr his y work a faim

linw lsolily he works in nll lis

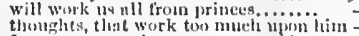

I was set at work anoug my manl
will this work? The king in this...

much weightier thun this wor?

nhashed belabld our works

Troilius

spur thim to ruth titu work, rein

and there lacks work; anon

now is my day's work done

how enruestly are you set a wark....

in this ronglt work, shaped ont......

1 like vour work;
yet lie's but a filthy piece of work

jet lie's but a filtly piece of wor
look in thy last work, where

may kliseases only work upon't? ...

that you work not in holict ohupes...

you have tlone wo:k for me

graves only be inc1:'s works.
whlut work's my countryen

make us cquitk in work

list, what work lie makes among.....

and male whint work I plensed

tell the o'er this thy duy's work....

here's goodly work! I woull they

good work a pair of tribunes

to make what eannot be, slighi work

to get myself into more work

what you woulil work me to, I

let me work: for I ean give his litimour

could it work so much upon your shape

a piece of work, that will make sick

well, to our work

this same day must end that work .

nor my power work without

I have done my work ill, fricuds

fearing sinee how it miglit work

upon him will I first work

do thou work: when thou $\ldots$.......

a picee of work so bravely done......

hut for the ent it works to

having work more plentiful than.....

the things you hear, than to work any
to work her son into the adloption.

there's other work in hand

tut, I have work enougl for you to do

the sea works hight the wind is lund.

disturbunees that nuture work

to du my work with haste.

some pains to work her to your matiage

Ill work the meuns to nake the ti..........

low shall I live, and work, to makel

然 6

[Col. Kul.] tide, time, work, liny
if this mixtore ton not work at a.l]?

bear this work of leaven with patie

in what purticlilar thought to

I went roumk to work, and my young...

will the king heur this piece of work?

tis a knavish piece of yor

eonceit in weakest bodies strminget wo wo

work like the spring that turnetis wood

and thus a while the fit will work o. ji.

then, veumn, to thy work. 'Treason!..

to play, and go to bed to work

We Work ly wit, mil not by witcheraft.

I'll have the work tu'en on

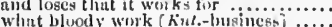

in lier prophetic fury seworl the work.

I like the work well; ere it be

tle who my me tieine, work

I muse take out the work? ( $($ ep.) . .....

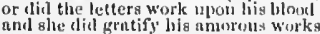

this is thy work: the object polsous bight

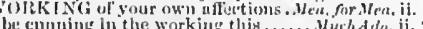

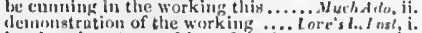
demel to that the working of the hiort

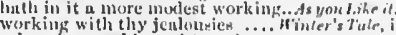

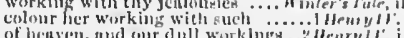
of hewen, whd our dull worklngs.... Henrylt. confund themselves with working.

by whese fell wiarking f Was ilst .....

moek your workings in a keevid bexly - v.

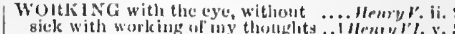

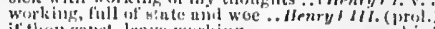
if trou cunst, leuve working ......... - hi. mo less working, than ure swords. Troilut f Cress. $i$. than we cuat do with werklus.......... l'ericles, it. luve you a working mulne?

might in their working de you thit......... t. a thing a little soiked it the working.... Hambet, ii.

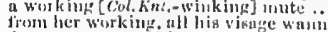

Wenustenents. Wurkine from the heart.. Ohe tho iij, might huve anothar for workingentings you like a, i. plodded like at um for work ink-clays.. Hewy l. I. tout warrisrs for the working-day.

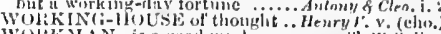

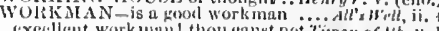

execllent work munl thou ealst not gianu of. $1 / h$. v.

Shouldst ece $n$ workman in't .... Antony feleo, iv.

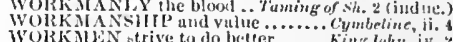

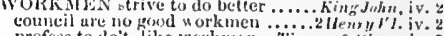

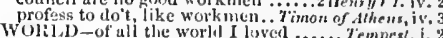

worth what's dearext to the world!.... - ii.

nny companion in the world but you....
beyond anl limit of what else $j^{\prime}$ tic world $=$

to inotrumient this lower world

o bruve now world, that has

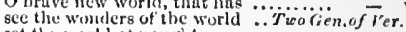

set the world at nought ............... - i.

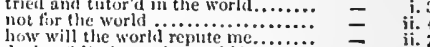

during dinly burn the world?......... $=$ iii.

count the wurld a stranger ............

why, thes, the world's mine oyste... Berry -

as they say, and know the world ....

my som protics nothing in the world = iv.

1 would all the world inight be eozened - iv.

fellow o' the strangest mind in the world -

he that is well hanged in this worid =

and leave the world no enpy ........

more woble thum the world ............

there is no love-bruker in the world

the world, will pleve a enckuey...... - iv.

and the world slatl know it..... - v. l llette

a great while ago the world berun - v. I (somg

but miglit you clotion in the world.

thouglh all the worlel's vastidity you had =

round about the pendant world....... -

we shatl have all the world irink brown-

is the world as it wus mun?

what news abroad is the worlic.

rums the wistom of the world........ -

injurions world! most damned Angelol =

no further than this world ............
the fushion of the world is to avoid .. such

hull not the world one mun ......
will win any woman in the world

that juts thie worid into leer licison.

thes gese every one to the worli bui I

Gnd lielp us! it is a world to see?

I do love nothing in the wrild so weil

Mill.X.'s Dr. i.

- ii.

when alt the world is here to lixik $\because$ = ii.

eante this gentle concerd in the world

liuge army of the worlel's desires .. Lore's L. Lost, $i$.

sliall be the wonder of the world ....

mamer of thest world's thelights

a man in all the world's new faslion

the world wat very guilty of sieli...

lechl precists in the world's esteem.

not for the world, fair mindan

ido nothing in the world bint lie..

fuimst whom the werlil enumst jolid -

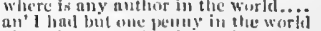

plese lis grace (lye the worlat) mosetime -

that hath seen the womlel but lat.

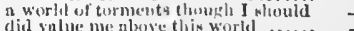

und the wlole world ngmin, cunnot..

when in the world I livenl, I wus (rep.) -

nud the w'urld's large tongue proctaing 
WORI.D-respeet unon the world...Mer. oflenice, $\mathbf{i} .1$
I loold the world but as the world.... I lrold the world but as the world.... - $\quad$ i. 1 liever to taste the pleasures of the world nor is the wile world ignorant

all the world desires lier

he only loyes the world for him......

else nothirg in the world could turn

for the poor rude world liath not ....

and all the world, are not with me.

glines a good deed in a naughty world

for the wealth that the world masters

for they did in the golden world .. As you Like

Eo mueh in the heart of the world...

reigns in gilts of the world, not in

only in the world I fill up a place...

all the world was of my father's mind

in a better world than this, I shall

full of briers is this working-day world! -

What a world is this, when whiat is....

the constant service of the antique world -

quoth he, how the world wags

quoth he, how the world wags ......

disgorge into the general world ....... -

a world too wide for his slirunk

her world, being mounted on.....
rail against our mistress the world ii.
no breather in the world, but myself

forswear the full stream of the world

though all the world could see...... -

the poor world is almost six thousand -

and slow the world what the bind hinth -

lie hath no interest in me in the work

from his enterprize, and fiom the world $\overline{\bar{c}} \mathrm{r}$, v.

good will to go to the vorld, Isbel the

may the world know them?
wonld serve the world so all the yearl

it is a novelty to the world

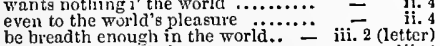

none in the world; but return $\ldots . . .$. .

the greatest obloquy i the world $\ldots .$. 二 $\quad$ iv. 2

greatest in the Christian world shail

he is the prince of the world

all the spots o' the world taxed ..........
let the world slide; Sesss.t. . Taming of $S h . \overline{1}$ (indue.)

the veriest antic in the world .... - I (indus.)

was the fairest ereature in the world - 2 (indne.)

of great traffic through the wurld

eentters young men through the worid =

am come abroad to see the world

now, by the world, it is a lusty .......

yourself and all the world, that talked -

tis a world to see, how tame .......

from all the world, by your firm

now must the world point at poor

the world say no, I'll keep mine (rep.)

how goes the world? A cold world

would all the world, but he, had quite

giddy, thinks the world turns round

js not in the world eitlser malice.... Winter's 7 'ate

none, none i' the world, so soon as

mongst the infinite doings of the world =

Why, then the world, and all that's in't =

for every inel of woman in the world =

as this worlil goes, to paes for honest

yea, scandalons to the world

you wedded all the world.............

if all the world conld have seen it ... -

no settled senses of the world can match -

$\mathrm{I}$ to the world am like a drop of water

lords of the wide world, and wild...

and therefore, to the world's end

how week world is changed with your.

a. week longer than the whole world

wow o'er the one half world nature... . nucuche'

now goes the world, sir, now?

buffets of the world have so ineensed....

both the worlds suffer, ere we...........

and wish the estate o' the worid were... $\quad$ - $\begin{array}{r}\text { iv. } 2 \\ \text { v. } 5\end{array}$

and all the world, upon the right ..... King Jo

from all the thorld, in sooth, he

be a cneen, and i in sooth, he misi

ranmed up our gates against the woild =

world -

mad world! mad kings?

the hias of the world: the worid

with the pleasures of the world ........
with a passion wonld I sluke the world

my food, my all the world $1 . . . . . . . . .$.

the eweet world's [Col,-word's] taste
fresh in this old world! Juhn lays.

for the wealth of all the world

bud world the while! this must

the thorns and dangers of this world

let not the world see fear, and sad....

never saw the giant world enraged ... -

these fiery spirits from the world

the fair play of the world, let me ....

what surety of the worid, what hope

all the cornerly .

what $a$ deal of world $I$ wander............

where doth the world thrust fortl ...

of the world's ransom, blessed
her reputation through the world...

wert thou regent of the world....

but, for thy world, enjoying but ....

to show the world I am a gentleman
the globe, and lights the lower world

as if the world were all dissolved ....

make me think the world is full of .
to thrive in this new world ............

must win a new world's erown

shall not live within this world .......

little world; in humours, like (rep.). .
this hard world, my ragged prison walls -

up his beauty from the world...
in the world's wide montl

that you a world of curses $\ldots$...............

good thoughts of the world again....

this is no world, to play with mamm

a bad world, I say 1 would I were...

for there will be a world of water slied

rare words! brave world! Hostess

so general eurrent through tlie world

comrades, that daffed the world aside
the world with noble horsemanship..

the cankers of a calm world

doth join with all the world in praise

against the world in arms.............

all the poisonous wotions in the world

that takes survey of all the world....

and let this world no longer: be a stage

so openly known to the world

a man's thought in the world keeps..

for all the world, like a forked radish

and put the world's whole strength .

all the world will right finlly maintain

so shall the world perceive, that $\mathbf{i} .$. ...

he must seem thus to the world......

his lion gait walk the whole world...

as any prince in the eurld

and for the world (familiar $t o$ us..........

upon the high shore of this world...

in this best garden of the world...

by which the world's best garden -

all the Talbots in the world, to save
make thee famous through the world

his life unto a world of odd

his fame lives in the world

the world will say-he is no

frowning at the favours of the world?

last breathing in this mortal world?

that e'er Ill look npon the world.....

the world may laugh again...............

slsould be quickly rid the world, to rid

What know I how the world may.....

what is this world? What news are.

proclaimed a coward through the

and exhort all the world to be coward

let the vile world end.

as this the world; whate'er it bodes,
for this world frowns, nnd Edward'

for what is in this world, but grief .

nay, then the world goes hard

otlier pleasure can the world afford?
to aecount this world but liell ......

the secret treasons of the world..

sadil the world witl world

thou camest to bite the world

yet I m not looked on in the ..... brooeh in this all-hating world $\ldots \ldots \ldots$.
up his beauty from the world........

and hanish all the world ............

wounds the world: and who....2 HenryI $\bar{F}$. (induc.

to mock the expectation of the world

fills the world with loud report.......

to fill the world with vicious .........

grim mejesty, to fright the world...

WORLD_and leave the world for me.RichardIII. i.

iv. 3 . as all the world is cheered by the sun

yet to win her, all the world to nothingl -

the spacious world cannot again ....

wown so bad.

troubler of the poor tis world (rep.)

to buy a world of happy days......

they often feel a world of restless .....

all-seeing beaven, what a world is this! -

tears to drown the world:

look to sce a troubly world

not yet dived into the worlel's deceit

lis a reeling world, indeed, my lord

the censures of the carping world....

bad is the world; and all will crime to

will you enfiree me to a world of eares? -

my wife hath bid the world good-night

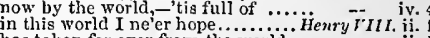

has taken for ever from the world ...

tliat man i' the world, who shall weport -

shortly after this world had aired them

for no dislike $i$ ' the world against...

creature that's paragoned o the world

of wealth I have drawn

and glory of this world, I hate ye....

that yon love the denrest in this world

now is passing out of this world....... -

your state stands i' the world (rep.)..

and fair purgation to the world, than

as may be in the world (rep.i. 3 ). Troilus \& ${ }_{\text {Cr }}$.

else might the world convince of .....

for the wide world's revenue

matter of the world enter his tioughts

know the whole world, he is ........

shall, in the world to come, approve

become as new into the world.........

hell of pain, and world of charge..................

ah, how the poor world is pestered -

how goes the world? (rep. ii. 2 ).. Timon of
how

for th the beggars of the world

is't possible the world glould

wliv this is the world's soul ......

and came in to the world when ........

whom the world voiced so regardfully?

what things in the world canst thou

what wonldst thou do with the world

that beasts may have the world in $\ldots$...

half to half the world by the ears..... Coriolan

as if the world were feverous .........
to all the world, that Cains Mareius

nor fitness for the world tham

cannot in the worla be singly $\ldots . . . .$.

is too noble for the world worl...........

there is a world elsewhere ............

send o'er the vast world, to seek ....

of all men $i$ the world $I$ would have

he is simply the rarest man i' the world

blush, that the world goes well .......

his lorns again into the wo

neither care for the world, nor

there is no man in the world more ...

6o gct the start of the majestic world

he doth bestride the narrow world ..

else the world, too sauey with thie god

know all the world besides, that purt

are to the world in general, as to Casar

so, in the world: 'tis furmished .....j.

O world! thou wast the forest (rep.)

might have stood against the world..

the foremost man of all this world..

Cassius is aweary of the world ......

thou see'st the world, Volnmuius...

say to all the world, this was a man!

pillar of the world transformed ...Antony \&

ji. 3 the sides o' the world may danger

thind, the greatest inldier of the world

the third o' the chorld is the world....

to edge o' the world I woull pursue it

my blemishes in the world's report..

the least wind i' the world will b...

wilt thon be lord of all the world? (rep)

an the man will give thee all the (rep.) -

he bears the third part of the world.. 


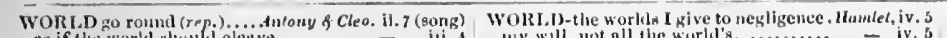

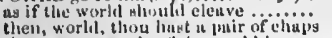

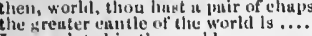
I anis lateil in the worlil

with halt the bulk o' the worlil pilizyed

the three-nookel worthing partic

$U$ thun day o' the worli, cliain

from the world 's great thure une.....

mite lise world rimk me in .......

with my sworl ifuntered the world.

the worship of the whale world lic.
the vurying shore o the worlil......

the grevitest prince o' the world

ghutl I ubide in thix dult worli

the round world thould luse showk

in the name lay a moiety of the worle

uot stall tugether in the whole wor

let the vorha see his nobleness

hale renred arm crested the wort project

and inay, through nil the world

thut tell st the world it is not.......

this jewel in the world, that

aguinat any louly in the world.

should yield the world this assi....... -

people, such that ment upon the world =

almost streteh the sides o' the world

this atory the world any read in me

the:e demeanes, have been my workd
dotit belie all eorners of the world

i' the world's volume our Brituin

that angel of the world, doth muke

are like the pleasures if the world

bruvest vessel of the world struck

to shame the guise o' the world

deserved the praise o the world.....

as is our fangled world, a garment...

does the worly

does the world go roullt? $\ldots . . . .7 \%$.....

the sweetest eornpanjons in the world

I have got two worlds by' $t$

a seeptre to eontroul thie wor

the wide world's empleror.............

all the world, I love lavinia more ( $r$ r

welcome ine to this world s ligit.

who know the world, sce lienven.........
nor tell the world. Antivelius sluti sin

nor tell the world, Antiuelius dutli

lowking for adventures in the world

if in the world he live, we ll scek.
rutcliest welconed to this world..

to make the world twict rich

to make the world twice rich

do a thing $i^{\prime}$ the workl so soun

this world to me is like a lasting

lorit if all this spacious world, 1'l give

to the world and awkwart casting

intur the worlane

malikes the world biter to the best.

this is the excellent loppery or the workd!

munt make a dillurd of the world

all the werld well kns;s:

all the world slaalt - I will ilo gü

strives in his little world ol mun

pourly led? Wurld, world, 0 wurldi

hlis great world shull to weur out

yot you sue how this world sot o

your business of the worlil hatl so un eid

williess the world, that I ereute thee...

What iil the world he it tiat inumes

clitil is yet a strunter in ilie werld...........

her mateli since forst the world begun

guch a murn, as all the world ....

I wuald not for the world (rep.) ....
follow thee uny lord throughinat the world -

as any clout in the varsal world

I any clout in the varsul world i....

that all the world will be in love with
fur the world is brend and wille (rep.)

banished from the world, and world's

all the world to mothing, that lie dures

nure musclers in this louthsume worli

for sig, this side of uar known wor
let the world take note. you are.

let the world take mote. Yor are...

but linat the world's orewn lionco

a the beanty al the world! the purugoii.

the beat ustors in the world, eit tier for

about lie wurld have thince twelve

this worlly is nut for aye
nus otfence in the would

no otfelle flice word a

breatles out contagion ti, thite worlid.

iil lise corrupted carrersta of this work

to give the worlil usaurance if a mant.

whose wininper o'er clic wiorld's liaructe

there's tricks l' the world; and hems.
and wa the world were nuw bat to bogie iii.

iii. 9

which kept the

…. $-v$

to the yet unk woswing worlit, low

julge me the world, if "tis not grods in

little ot this grent world ean f ipeuk

of fortunes muy trumet to the worlig

huve lowked uneun the world tor tour time

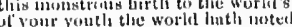

mor all the droway syrups of the world

by the world I think me wite be fiones

lowll catechise tlse world fir liam .......

the world hath not a swecter ereature.

lash the rased naked throught the womid
nut the worid's mass of yanity tould mak

tuke me from this world with treachery

such a dleed for atl the world? (

having the world lor your labour (reps).
as would ature the world they played to

none in the worlel; nor do I know the nen

anwther world of one entire and perfect

for the worls and worldlings basel..2 2 deury

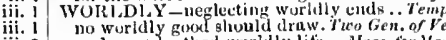

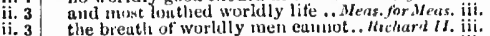

the worst is worldly loss, thou

lust thon not worlilly pleasure ......211

in no worldly suit would he be mosed

being weary of these worldiy bars.. Ju
thy worldly task hast done .. Cymbelin

of worldly matters and direction..........

$\bar{O} t_{1}, l l_{0}$, i. 3

IVORLD-WEARlid tlesh........Romeo o Juliet, v. 3

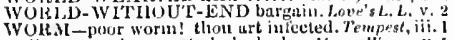

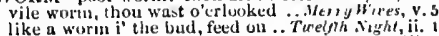

and tender fork of a poor worm. Sfeas. Fur. Is Has, iii

is but a humour, or a worm

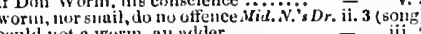

could not a worm, nu ndder.

tius to reprove these worms .... Lave's t.. Lost, iv.

and worms have euteu them........ A you Like il, iv. I

you howard and miable worn

what, with worms and flits? ..............

filsgers with thy houseloold worms ...King John, iii. 4

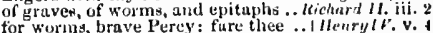

give thee life, unt, the worms...

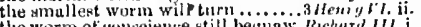

hath made a prey for worm

when I shall dwell with worms ...... Henry Fill. iv. 2

and eyeless venomed worm with ...Timon of.Alh. iv.

hast thou the pretty worm of Nil us...th
makes a very goud report o' the worms

most fallible, the worm's an odd worm

that tle worm will do his ki

there is 110 gouthess in that worn.

outvenoms all the worms of Nile

and the poor worm dothe die fur't

I trod upon a worm agnilst my will
glie made hin roastineat for worms.

thou owest the won no sil

which male me tlink a man a worm.... - iv.

not lialf so big as a round little worm

with worms thut are thy eliamber maits -

worms are e'en at him; your worm.... Hamtet, iv. 3

the worm that hath eat of a king (rep.).. -

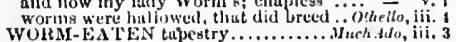

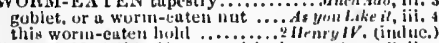

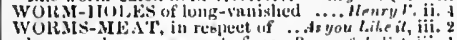

have made Wormb-meat of
WoHS WOOD from your.

did taste the wormwoud on the nipple - i. 3

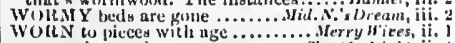

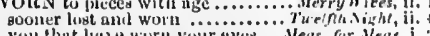

you that liane worn your tyc

the gurland he might liave wori

uch dilo, ii.

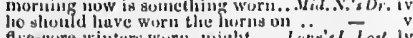

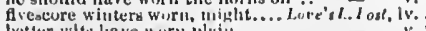

betfer wits have worn pluiil.

ay, and worn in the cap....

and no stiord wors but vile is secure firum worktly chunces....... Titus.tutrost. $i$.

civil dissension is a viperous worm. I llem y 7 . iii.

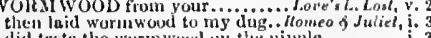

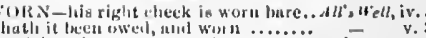

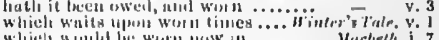

thitl I late weral so thing

fltter (u) be worn in my cup.

like a rich ormour worn in heit

Ilenty il, i.

atud worn na a memisrable trojllig.

womder will de ruickly worn
ftill have wara the peticost

they have worn out Cleristendom

thay are worn, lorel confal, so. . Truilus \& Ciess. iii.

before you hid worn it wut

when olel rides ure worn vit

opinion, by this, worn out

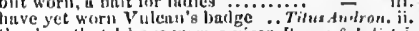

the day, that 1 hinve worn a visor. Komeo \& Juliet, i.

mikery hud worn linis to the bones.

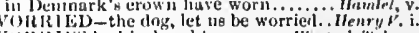

WokRIES he his duugliter......... Winter'strinle, v.

()likY - to worry lumbe, and lap.Riehard IIt, iv.

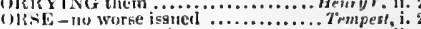

are worse than devils.................

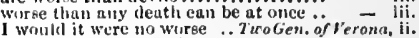

and thut's fur worse than none …....

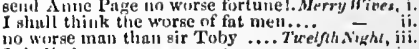

I shall give worse puyment ........... - iv.

and the worse for my triendy (rep.)...

to be worse thatl worst of those. Ifeos. for $\bar{M}_{\text {fur }}$ iii.

still thus, and (hus, still worse!...... - iii.

this may prove worse tluth langing -

ant torment the poor lubly worse .... - ii.

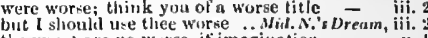

the worst are no worse, if imagination -

thicy are worse fools, to phreliuse... Love'r $L . \bar{L}$ ost, v.

tir have one sliow worse tlian the king's $=$ v.

le is little worse than a man. Merchant of $t^{2}$ esice

whas set in worse tlan gold $\ldots$ wha.....

thint 1 was worse than nothing ......

and whin's worse to tright the animals - ii.

censure, worse thun drunkarels ....... $\overrightarrow{\text { iv }}$ iv.

the prizeipal itself not mueh the worse. All's Nell.

as Sourates' Xorse luek in my life... or a worse... Fuming of $S$.

alus, sir, it is worse for me than ou

neither urt thon the worse fur thi
to like no worse than 1 , sir ..........

your wite send you not a worse.

huted tou, worke than the greatest. Win'er's Thle,

which burns worse than tears drow

you huve spent time worse ere liow $\cdots-$ iv. (eho.)

in making, woree in mind .. Comedy or Errors, iv.

in Tartar limbio. worse tluan heli ...

a wolr, nay worse, in fellow all
nuy, she is worse, slie is the devil.....

and, which is worse, all you have doue - iii.

a nuny foot of lanil the worse ........... king John, $i$.

or thun eanst worse devise..............niehurd Il. i.

but the greuter fecling to the worke..
that is worse: the lord Nortlimberland -

each one tlirice worse than Judusl..

a eoward is worse than a eup of ..... inenty $1{ }^{\prime}$. i

no more, nn more; worse thail the sü =

the report of a caliver, worse thim

to in the worse, suntered his ....

to

it is worse slume to beg than ......... - i.

mul the wench have no wore foitune! = ii.

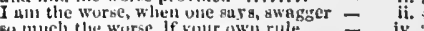

110 worge than they ure back-bitten.. - v.

and which is worse, within thy nusty Menryp. ii. I

entreat lier not the worse........... - ii.

fall, worse flun gall, the flainciest ...

uh hit' a worse than murderer............

thy lose makes the bul-eunser worse $=$ iv.

your feurs are worke. Ilatie I lived... - iii.

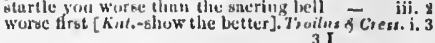


WORSE-know each other worse. Troilus \& Cress.iv. makres it worse than stealth ... Timon of Athens, iii. 4 I am worge than mnd: I have $\ldots . .$.
I hate thee worse. Why? thou fiatier'st - iv. 3 worse than the worst, content........ $-\overline{\text { iv. }} 3$ budge from rasculs worse than they. thate thee worse that a prornise-breaker = and love thee no worse than thy oid you worse than senseless things $1 . . J u l i u s$
we will shake him or worse days endure I never tliought him worse ........... and give him a worse (rep.)...Antony \& no worse a husband than what's worse, must court'sy

stands in worse case of woe........ from one bad thing to worse; rot frenzy re vorse than priests and fa lls with ills, each elder worse ...... more, sir, and worse. She did confess

the worse to her, the better loved. Tïns And keep me from their worse than killing

for worse than Philomel you used (rep.) -

ten thousand, worse than ever yet ...

Grows worse,

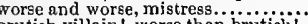

brutish villain! worse than brutisis

my sister may receive it much more worse

and a worse matter than that

an worse than e'er I was .....

and worse I may be yet......

his answer was, the worse

a thousand times the norse

there is th

till better, and worse $\ldots . . . . . . . . \mathrm{Ham}$

had begins, and worse remains behind ... - iii. 4

I am worth no worse a place

the worse welcome; I have ch

witn no worse nor better guard ..........

she's the worse for all this ................

WORS it hath the worser sole...... TwoGen.of I'erona, ii. what worser place can I beg in. Mid. N.'s Dream, my state far worser than it is. . Taming af Shrew, $\mathrm{i}$. your grandam bad a worser match. Richord III. i. 3 worser tholghts heavens mend! . Antony \& Cleo. i. met not my worser spirit tenipt

where the worser is predominant.Romeo $\&$ Jutiet, ii. 3 gome word there was, worser thay

Wor'ser, that you give me the addition. Othello, iv. your worship, sir; or else...T......... Tempest, $\mathbf{v}$ your "Worship, sir; or else.
she that your worship loves?

was this the idol that you worship so?

now I worship a celestia] su

become you well to worsilip shailows
glad to see your worship's well ..... Merry Wives, i. $i$

desires your worship's company. (rep.)

I may not go in without your worship

that it pleases your good worship to ask -

your worship good-morrow (rep. iti. 5)

not 80 , an't please your worthip

your worship says very true (rep.)

lord, lord! your worship's a wanton

ancl she bade me tell your worship.

and hath sent your worship a morning's -

to your worship from mistress Ford

let not your worship think me...Meas, for $\bar{M} e$

workhip's pleasure I should do with this -

woes your worship mean to geld

if your worship will take order.

to your worship's house, gir? ...........

it plcases your worslip to say so ..... Much $A$

as good exclamation on your worship

excepting your worship's presence ...

morning examined betore your worklip -
worship speaks like a most thankful

arrant knave with your worship (rep.)

worship's mercy, heartily (rep. $). .$. Midid.N.'s $D r$.

I will come to your worship to-morrow

like savagcs, may workhip it ..........

your worship's friend, and Launcelot

God bless your worshipl .............

that I would bestow upon your worship -

your worship shall know hy this

calls your worship? (rep.) .......... As you Like it, $\mathrm{i}$.

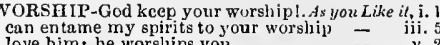
is this all your worship's reason?........

ll's Well,

man has rebused your worslip?

the cap your worship did bespea

she says, your worship means to

our worshp is deceived; the gown...

(a)

your worship had like to have given us - iv.

pay your worship those again.. Comedy of Errors, i.

your worship's wife, my mistress .... . $\vec{J}_{\text {. }}$ i.

be my lord, for I will worship thee

by giving it the worship of revenge.. ${ }_{\text {the }} \overrightarrow{ }\left(V^{\prime}\right.$ iv. 3

give me your worship's good hand...

your gnod worship is welcome

iii. 2

I have served your worship truly

a very little credit with your worship

I am glad to see your worship .......

god-den to your worship there's one $\overline{\text { n }} v$, ii.

reverently worship thee enough? ....1 Henry $V^{\prime} I . \mathbf{i} \cdot{ }^{2}$

$\begin{array}{lr}\text { and worship it, and make my image } & - \\ \text { like brothers, and worship me their lord }-2 & \text { iv. } 2\end{array}$

ay, but give me worship, and quietness $=$ iv. 3

and please your worship, Brackenbury - i.

all the Greeks begin to worship. Troilus \& Cress. iti. 3 baseness, to him that worships. Timon of Athens, iii. I waseness, to him that worships. 7mon his cashiered worghip mutter?
th thee be worshipl and thy saints for

your worships have delivered

good e'en to your worships (rep.).....

thesired their worships to think. Julius Cosar, i. 2

ot those who worship dirty gods.... Cynbcline, iij. 6

your worship, in that sense ..... Romeo o. Juliet, iji. I

and pay no worship to the garish sun $\overline{\text { The }}$ ii. 2

but this is worshipful society ......... King.fohn, i.

accites your most worshipful thought
very worshipful and loving friends. Richard $I I I$ iii. 7

worshipful mutineers, your valonr ...Coriolonus, i. I

WORSHIPPED, kissed, loved.. 7 iwo Gen. of Ver. iv. 4

but God is to be worshipped $\ldots . . . .$. Much Ado, iii.
Lord worshipped might he bei...Mer. of Venice, ii.

and worshipped as a saint ...........King John, ili. I

is worshipped in a baser temple. . . imon of $A^{\prime \prime} h$, $\mathrm{v}$.

an hour befire the worshipped sun. Romeo \& Jul. $\mathrm{i}$. 1
WORSHIPPER-npon his worshipper. All' $* W^{\prime}$ ell, $\mathrm{i}, 3$

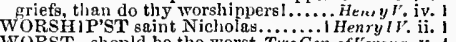

WORST-should be the worst. TüoGen.of J'erona, v. 4

worst thing about him (rep.)........ Meas. for Meas. ji.

that I may know the worst that ......irid. $\bar{N}$.'s Dr. i. I

the worst are no worse, if imagination - y.

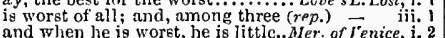

an' the worst fall that ever fell........
therefore, for fear of the worst, $\mathrm{I}$ pray

the workt fnult you have $\ldots . . . .$. . As you like it,
no worse of worst extended

after who comes by the worst............All's Well, ii.

had not Grunsio come by the worst..

and think it not the worst of all

a man, the worst about you ....... Winler's Tale

a man, the worst about you ...........nter's Tale, ii. 3

on his side, be the worst, yet hold thee $=$ iv.

not in the worst rank of manhood ... Macbelh, iji. 1

treason has done his worst $\ldots \ldots \ldots \ldots .$.
by the worst means, the worst $\ldots \ldots \ldots .$.

to hear the worst, then let the worst.King $J_{0 h} n$, iv. 2

tell him so; we know the worst....... Richard 11. iv. 3

the worst is worldly loss ............ - iii. 2

the worst is-death, and deatli will..

to lengthen out the worst that........ $=$ i iii. 2

whose worst was, that the noble $\ldots . . .1$ HenryI $I$ iv. i. ?

that's the worst tidings that I $\ldots . . .$.
and to prevent the worst, sir Michaei

than to be on the worst side

the worst that they can say of $m$

best of gold, art worts of gold........

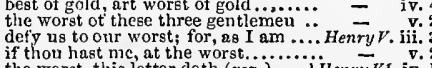

iHenry $V I$. iv.

train of her worst wearing gown .....2 Henry $F I$. i. 3

to prevent the worst, forthwith

Richard III. ii.

what

against the worst may happen
WORST-dare your worst objections. Henry VIII. jii. you may, worst of all this table

to the by, worst of all this table $\ldots . . . \quad v$. What envy can say worst............ - jii. fait 2 , for the worst is filthy..... Timon of Athen when orsc than the worst, content.....

et him take't at worst.

政

come, or what is worst will follow.... Coriolanus,

when thou didst hate him worst...Julius Casar, iv. 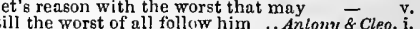 well, what worst? The nature of...... i. the worst of me: so I leave $(r e p.) \quad \ldots$. Cymbeline, ii. liath done to me the wors

the gods do like this worst

be worst, the lowest, and mome $\ldots \ldots$ Lear, ii. the worst returns to laughter........... - iv, hat thou hast blown unto the worst ..... - iv. ho is't can say, I am at the worst? .... - iv. no, do thy wot, so long as we can (rep.) - iv. best meaning, have incurred the worst... $=$ v. 3 yea, is the worst well? yery well. Romeo \& Jutiet, ii. Denmark being one of the worst ....... Hamlet, ii. by seeing the worst, which late on hopes. Othello, i. ignorance! thou praisest the worst best. that stroke would prove the worst $\ldots . .$. - iv. WOR'S'T it on thy horn ….. Troilusis cressidn, v. 2 WORT, and Malmsey..................... Leare, ii. 2 good worts. Good worts! $\ldots \ldots . . . \ldots .$. Merry Wives, . I tis an office of great worth.. TwoGeri. of I'eronu, i. far behind his worth come all the praises according to his worth $\ldots$ worth is warrant for $\mathrm{his}$ wejcome whose worth makes other worthiea.. not worth the name of a christian. now's not worth a pin $\ldots \ldots \ldots \ldots . . .$. bounty, worth, and qualities $\ldots . . . .$. - iii. as you in worth dispraise............. will allow me very worth his service - i.

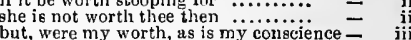
scarce to be worth talking of ........
did promise most venerable worth.. be of worth to undergo such ample .. was worth five thousand of you all... - i. 2 testimonies against his worth and credit - v. her worth, worth yours, I find an apt $\overline{\text { note of mine that's worth........ Much Ado, }}$ your's is wortl ten on't.................... iich - ii. we prize not to the worth, whiles we $\overrightarrow{\text { iv. }}$ with the rich worth of your..... Viel.N.'s the worth of many a knight from. Love's L.Losi, $\mathrm{i}$. less proud to hear you tell my worth - ii. who, tendering their own worth $\ldots . . .=$ - ii. by wit, worth in simplicity ......... - v. even now worth this $(r e p$.$) ...Merchant of Fenice, \bar{i}$. your worth is very dear in my ...... world ignorant of her worth $. . . . \ldots . .$. = it is worth the pains: I ain glad 'tis $\overline{\text { it }}$ il. her worth, being mounted on the - iii. 2 (verses) his head worth a hat, or his chin worth - iij.

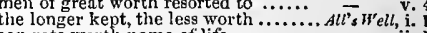
can rate worth name of life...

you are not worth another word ..... dog the heels of worth; he is too $\cdots-$ iii. 4 (letter) or to the worth of the great count.... - iii. esteem hitm worth a dozen .. Taming of Sh. I (ind.) accept them, then their worth is great $\overline{\text { gitale, }}$ ii. he is a woman more worth than .... a man, not worth her pains...

not so rich in worth as beauty

worth the audience of kings and princes whose worth, and honesty, is rielly y.. ring he hath of mine worth forty .. - iv. must not be measured by his worth.... am not worth this coil that's made..King John, ii. your worth, your greatness, and nobility - iv. by the wortls and honour of himself nd to thy worth will add right .... do fow a trick worth two of that..... HenryI\%. ij. seal-ring of my graudfather's worth $=$ iii. 


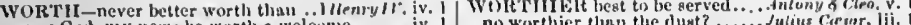
pray Gou, my news he worth a welemo are nnt worth a gooscherry.

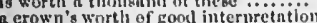
a good lieart's worth gold. of Troy, worth tive of $A$ gainemno...... a gnod seore of ewes may be wortli ten you are worth your breed ing U... Utenry $l^{\circ}$. show me but tlyy worth] whint is all that I can do, is nothing worth whose face is not worth sum-burning my worth unknown, plo los deign to wno her little worth marriage is a matter of more

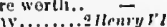
whether your gruce be worth, yea, or wo it is not worth the enjoying........

wenty times his worth, they sny....

and is wor $a$ mali $n$,

a wisp of stra 3renyrti.ii. some two days sinee, were worth.... ihichurd III, $\mathrm{i}$ many other of great fnme and worth
were't worth to know the seeret ... Henry $\bar{V}$ III. more worth than empty ranilies

not worth his serinis considerin

well worth the sceing. Gond sir.......

grows dainty of his worth

avow her beauty and her worth......

and not worth the splinter of $a$ iance.

not worth to 118 , had it our naine.

weigh you the worth and honour.

brnther, she is not worth what

is she werth keeping? why, she is

disgraee to your great worths.........

imagined worth holds in his hinod

something not worth in me sucli rieli

esteem, and ponr in wnrth ........

to her own worth she shatl be prizer

do deeds worth prnis

is not proved worth a bitackberry

dost thou think "tis werth $(r e p) .$.
you have added worth unto't.........

their lege be wnrth the suins that...

I had rather than the worth of thrice
miniless of thy worth, forgetting thy

is not werth the wagging of you

is worth all your predecessors.........

some triek not worth an egh

what is that couresy worth?

and your rlinmer writh the enting...

and his worth, and nur great need

neither wit, nor words, nor worth

but ne'er worth love ........ Antony s \&

take a queen worth many hahes

for it is not worth the feediug.

wnrld it is not worth the lenve-taking

if this be worth your hearing ....

she is not worth our debate.

we count not worth the hanging .....

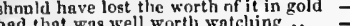

han that was of worth he drawn

than thine owa wortl prefur thee...

wreteh, more worth your vengennee

had it been all the whrth of his ear.

undo the worth thou nrt unpald for

hefit our honour, and pour worth......

this eoet of worth. for it was sometime

ynur wortl in arms, were more thinu.
ginee every wnrth in sliow eirnmends

a show might countervail his worlh

not worth the time of da

rather than twiee the worth nf her

which is not worth a brenkfnst in the.. - iv.

there is anme ne wrth whill cone abone

and prize me at her worth

perforce, should make thee wrth them..

virtue, or worth, in thee make $\ldots . .$.
found this trespass worth the shime

worth the whistle. O (ionerill (rep.)

helps him. take nil my ut warl worth

begears that can enunt their worth. Ramen fo $J_{u}$

a werk supposal of nur worth

he hlmxly, nr he nothing w'ortli! 0.

whase worth, if praines mar go

and ennfine for the sea's worth .............

fortumes afginst any lny wnrth naming

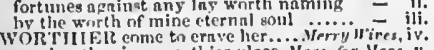

emplor thee in a worthier llace, Verte, for Megi, the nther nutut be held the worthier. Min

renann say youl nre the wortlice main - ii.

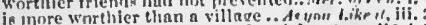

is the wirthier. Ambitions Warwick. 2 Henryly. i.

[Knt.] allnwance as the worthier. Trailus f Cress. ?

nuls wrothice than himaelf liere.......

iny reasons, nore wortlier than ticie no wortlier then the dust? ........ Julins Carme iii. I

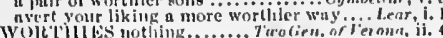

several worthies inke one....... tote's L. losl, iv. lufure her the nine worthics (nep.) ... whill play on the tabor to the urorthes art thou one of the worthies? ........

like to he a good gresence of worth
ant if these four worthies in their

but there are worthies a enming

worthiey, away; the secue beging.

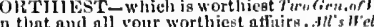

eft his to the worthiest .......... Minter's Tut

whese riglit is worthicst ( $r e p$,

thon worthiest AI areins! Go, goum

worthiest to have eommint subdue my worthiest relf.

only for the most worthiest fit

IILY purelas sed

not now worthily termed them... Cnmmly af Frr.

wherefore the king most worthily.... llenry,

how may he wound, and worthil

deserved worthily of his country

worthily spoke. Meconas ...Antow

worthily, yon would have now sneceed Tilus And.i.

that I may wnrthily note him

is iny report, to his great worthiness

her worthiness that gave the ring.Mer. of

aecording to the weight and wrrth

definee of my lord's wortlinese.... iiirnry

the worthiness of praise distains... Frnilus \& Cress.

In kuow the consul's worthiness.. Coriolanus, ii.

wnrthiness docs challenge much respect. (mhe $l / o$, ji.

welcome to a worthless mistress.

no; that you nre worthless.

be corrupted with my worthlifse

hazard for my worthiess self ...Mesch. of Fruice, ii.

worthless faney, then take.. Taming of Sh. I (induc.)

is this irail and worthless trunk

aloof with worthless emulation
8o worthless peasants bargain

8n worthless peasants bargain......
the daughter of a worthless $k$ in

inenryl. iv.

Forthless of ench honout..... Julinscesar,

citing my worthless prnise.....Ther

what might, wnrthy Sehastinn

worthy his youth and nobleness. Tiro Gen. of $\bar{V}$ er

and worthy estimation

he is as worthy for an empress' love

know, worthy prince, sir Valentine

as many, worthy ladly, to yoursel

and think thee wnrtlyy of ..........

endued with worthy qualities........

and not worthy to toneh.. Firelfih sight, it. 5 (liet

We firly met.. Meass. for Meas

to justify this worthy nohlenin

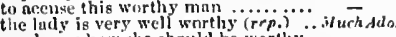

the lady is very weth wnrthy (rrp.)

as heing worthy to be whiplyed...

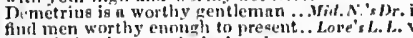

enough for that wortly's thimb

know not the degree of the worth

Pomney proves the best worthy

he will he the ninth wortly..........
furewell. wrorthy tord! a lieavy lieart

the wnrthy knight of Troy .........
remember him worthy of thy praike.

you nre a worthy julge: ynu know

moat werthy gentleman, 1 and $m$

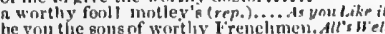

nnil thoul art worthy of it............ -

common speceh given him n wortily jas -

to lear it for your worthy agk

preecpta nu this virgin, worthy the inote

goosl yuality worthy your inribhijis
grace the attempt for a worthy exploit or worthily, ne a good subjicet slmuld.lachard $/$.

whose worthiness would stir it up.....

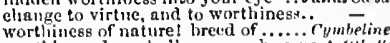

with yeur high and worthy diceds.... -

I nin net wortliy of the wealth

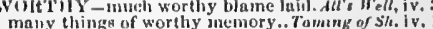
maly thing of worthy memory.. Tomang of $5 \%$. iv

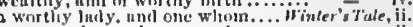
most worthy madlan, your honour.

- iil a pindiot. bonety limeclt to huve a worthy freeling mperial nomareh, thereof most worthy worthy Crunile, what, colsur for my - iv. whe worthy, respecting lier that's gone

Incelonwald, worthy to be a rebei..... Maribeth, $i$.

vnliunt eousin! worthy gentleman!.

worthy thane? (rep. i. 3, ii. 2 ond ii." 3 )

we stay minn.

sit. worthy Banruos lie is fult $\mathrm{BO}$.

my, wortliy inrd, your noble frienile.

of many worthy fellow e that were

wurthy, Macdutr, ant we, sliall tuke

all I see in you is worthy love $\ldots . .$. . King $J_{a h n}$, ii.

will add right worthy gains ....

whercin worthy, but in nothing? . illenryll. ii.

hiut, mnre worthy interest.........

and was a worthy king: huw now ..2 2 teu, $1 b^{\prime}$.

whilat anch a wrorthy leader ........... illenry $r$ i. .

(it I were wirthy to be judge)........

prefice of her worthy praise ...... v - v.

worli.

年

they have been most wortiyy to live...
the worthy gentlemnn did Inse ....3

queen of Englemenn did inse ...3 Henry $/ 2$. iii.

Irom worthy El wurl, king of Albion = iii.

our brcher mate a worthy ehoiee?.. - iv.

nor were not worthy hlame........... - v.

fir doing wortlyy vengeance ......... Richarid III. i.

have hewept a worthy hushand's denth - li.

for worthy" Wolsey, whe cannot err. lenry l'Ill. i.

well wortly the best heir o' the world = ii.

and truly a worthy frient $\ldots \ldots \ldots .$.

and tise him well, he's worthy of it.. - y.

wortly Ilcetor, shie is n theme.. Troilus \& Cress. ii.

I come satisfuetinn wnill it were - ii.

worthy wartior, welcome to our tents $=$ iv.

tis a worthy lord! nay, that's.. Timon of Athens, is

liast feigned him a worthy fellow (rep.)

to thee, worthy Timon (rep. ii. 2, v. i, v. 2)

my worthy friends will you

doubt it not, wortliy lord ...........

worthy A Arsenius Agripin (res, ii. iicoriolanus, i.

right worthy yon prinrity $\ldots . . . \ldots \ldots . . . .$.

my gentle Mnreins, worthy Caius ..

a little of that worthy wrok perforines

Forthy Cominims, speak: nay, keen

noble eunsult worthy yniees!..

ne his worthy deeds did claim ......

put not your wurtliy rage into yeur

done to Itime, that's worthy deatio?

clinirs of justice supplied with worthy

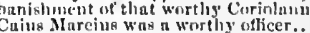

the worthy fellow is our general

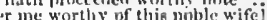

any expluit worthy the nnine of hounur

is there mo voise more wortly tlian.

was worlliy" -

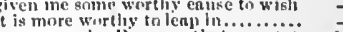

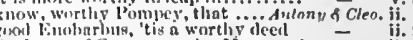

识.

food tortune, wortlyy ooldier (rep. iii. is rebiukahle. and worthy nliamefual eheck -

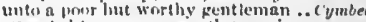

low worthy he is. I will leave to appear -

this worthy klguinr. I thank him....
sutstain whint you're worthy of......

the worthy lewnatua in in snfety

a worthy lellow, nllicit he cones on. 


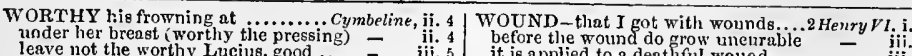
leave not the worthy Lucius, good.. - iil. 5 it is applied to a deathful wound not seeming so worthy as thy birth $\ldots$ why, worthy father, what have we gometime it was a worthy building for the are worthy to inlay heaven
most worthy prinee, as yours, is true most worthy prinee, as yours, is trite
it doth, my worthy lord (rep.).. Titus

presents well worthy Rome's.........

Fiorthy Andronieus, ill art thou repa

how many worthy is the incarnate how many worthy princes' bloods

my worthy areh, aud patron, comes.....

so wortly a gentleman to be ...........

' a trie, most worthy signior ............

Hamiet, i.

king Stephen was a worthy geer

worth Othello, I am were wont be civis

Cassio"s my worthy friend: my lord

(an worthy eause I have to fear-I am)

no more worthy leaven, than thou (re

WOT-the thing you wot of

disosder wonnds where it should guar

iii. 2

through these wounds to seek out thee

add more anguish than the wounds..

upon thy wounds, that kill mine....

and cureless are my wounds

liath been balm to deadly wounds

fast wound about thy e(nal-black hair

dend that made these wounds! ....

the new-healed wound of malice

bind up my wounds, - liave mercy,
with treason wound this fair land's

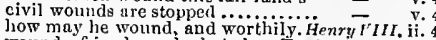
wounds, friends, and what else.. Troilus \& Cress. ij. the wound of peaee is surety.

that which seems the wound to kill - iii. I (song)
tii. I (song)

those wounds heal ill, that men.

I may give the loeal wound a name

box, or the patient's wound........

Patroelus' wounds liave roused

and made plenteous wounds ... Timon

senate pours into Captain's wounds?

the wounds beeome him $\ldots$

past cure of the thing you wot.....Meas. for.Meas. i Ior well I wot, thou runn

and wot not what they are............ Love's L. Lost. iv.

anon, I wot not by what strong. Comedy of Errors,
benevolenees, and I wot not what .. Richard II.

tis a nameless woe, I wot.

I wot, your love pursues

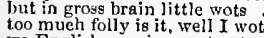

we English warriors wot not

Henry 1 iv.

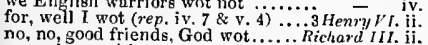

come, have witl you: wot you what

and wot you, what I found there. .Henry $\bar{V} I I I$. iii.

my mother, you wot well....

foll well I wot the ground of. Titio... - iv. 5

by the mill than wots the miller of

brotlier, well I wot, thy napkin canno

I wot well where he is.......... Ron

why, as by lot, God wot, and then .... Hamlet, ij. 2

WOTTING no more than move

WOUND-sometine I am ali wound ... Winter's Tale, iii. 2

as well wound the loud winds

the private wound is deepest

that only urounds by postern ...Mleas. for $\bar{M} \rho \alpha \varsigma_{\text {s. iv. }}$

now purple with Jove's wound...Mid.N.'s Dream,

and wound the pop of Pyramu......

there's an eye, wounds like

in it a gaping wound, issuing. . Merch Love's $L$ Lost, $\mathrm{v}$

to stop his wolmds. lest he

searching of thy wound, I liave........ you Like it, it.

now show the wound mine eve

know the wounds invisihle thit

for then we wound our modesty ........All $\bar{r}_{s} w_{\text {ell }}, \mathrm{i}$.

to wound thy lord thy king .. Taming of Shrew,

meant to hathe in reeking wounds.... Nlacbelh,

beeome thee, as tlyy wounds

peee! the eharm's wound up

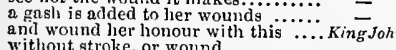

whe inveterate eanker of one wound

and wound our tattered colours elearly -

klow me the very wound of this $\ldots .$.
the whigh lie prieks and wounds with
flrst dicl help to wound itself ........

ere my tongie shall wound mine...... Richard $I$

thougli rebels wound thee with..

the worst of deatli's destroving wound

rained from the woumis of slaughtered

do wonnd the liark, the skin of .....

and wounds the earth, if nothing else

with my wounds heing cold ..........

and wounds, God save the mark l...

working with suel deadly wounds...

long-grown wounds of my intemperance -

or take away the grief of a wound? ..

a new wound in your thigh (rep).

his flesh was eapable of wounds...

I am loth to gall a new-healed wound

as I was washing thy wound, to marry

they were ill for a green wound? .....
let grievons, ghastly, gaping wourds

these wounds I liad on Crispin's day...Henry

yoke-fellow to his honour-owing wounds

wounds I will lend the wrench.

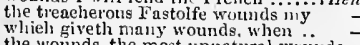

whose wounds become bard-favoured twenty-five wounds upon him

bear of wounds two dozen ourd

he said, he had wounds, which hie

think on the wounds lis body bears

giving myself a voluntary wound.. Julius $\bar{C} c$

over thy wounds now do $I$ propiee

kise dead Cæsar's wounds (rep.) . ....
put a tongue in every wound of Cæasar

till Cæsar's three and twenty wounds

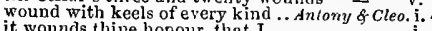

do commit murder in healing wounds

Ihis sword, and these my wounds?

the congealment from your wounds

I robhed his wound of it

can tiekle wliere she wound

ean take no greater wound ...............

dost thou seareh my would

received some unreeuring wound..
sight should make so deep a wound

wound it with sighing, girl...........

our Rome the elvil wour

sharp neeld wound the cambie...... - iv.

I saw the wound, I saw it with ...
wash they his wounds witlı tears

griping grief the heart doth wound
you had received some bodily woun

政, sollo, ii.

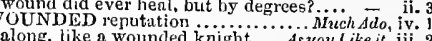

Wounded with the elaw of a lion (rep.)

wounded his daughter...... Taminincer's Tale

wounded to death. Fly, noble $\ldots \ldots$ King John, v. 4
physieians that first wounded thee... Richard II. ii.

neek he threw his wounded arm $\ldots$. Henry $P$. iv. 6

and their wounded steeds fret fetloek -

sent the ragged solaliers wounded hone

wonnded? he was wont to (rep.).... Coriolanus ii.

where is le wounded? (rep.) ........

our Cæsar's vesture wounded? ..Jut

razors to my wounded heart .. Titus .. Cymbeline, it.

mine lionour thon liast wounded..... -

when as the one is wounded .........

not wounding, pity would (rep.). Love'sL. Lost, iv. I
comparisons and wounding flouts.... v.

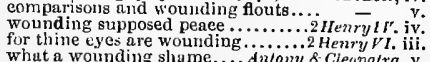

what a wounding shame... Antony \& Cleopntra, v, 2
untented woundings of a father's eurse ... Lear, $\mathrm{i}$. 4

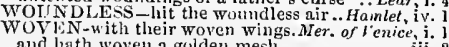

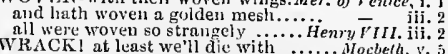
WRACK! at least we'll die with ........ Wocberd,

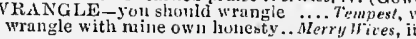

the inaliner is) his wounds to the people -

and entreat them, for my wounds soke

our tongue in to those wounds, and tell ns -

Jook, sir, my wounds; I got them in

I have wounds to slinw you. which shall -

at sears, that never felt a wound Romeo \& Juliet,

either slain, or wonnded dangerous..3 Henry $Y I$. i.

follow the womled chanee Antomy o cleopatra, iii.

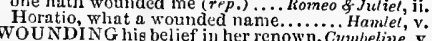

WRA NGLE with my reason

you still wrangle with her ..... Twel/fhNight, iv.

you stuatl have bid them .....Intinus Cassar, iv.

men's natures wrangle with inferior .. Oinello, ifi. seas and winds (old w.ranglers).. Troilus onry ${ }^{\prime}$. WRANGIJING; for thy loving seolding quean to a wrangling knave. All's Wcll, vi. but, wrangling pedant ...... Taming of Shrew, no, wrangling woman .................. Henry $r l$
hear me, you wrangling pirates.... Richard $I I$
aecursed and unquiet wrangling days!

fye, Wrangling queen I.......Antony \& Cleopatra, i. my often rumination wraps me...As . wrap our bodies in blaek mourning 3 Henry $5 \%$. ij.

will in coneenl wrap and fumble. Tilus Andron.

why do we wrap the gentleman in our. Leur, iv

WRAPPED in a paper................. All's Hell, v. wrapped in sweet clothes.. Taming of $S h . \bar{l}$ (ind ue. instead of bullet wrapped in fire..... King John , ii. sends the wenpons wrapped about. Tilus Andron. iv here wrapt up in countenance!.. Neo .. Tempest, RATH - whose wrathe to guard you. I'empes', my wrath slall far exceed. TrroGex. of Veruna, iii. within the measure of my wrath

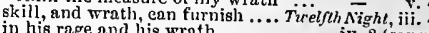
in his rage and his wrath ......... iv. ${ }^{2}$ (so

patiently to bear my wrath.. Merchanl of $l$ enice, ii.

they are in the very wrath of love. As you Like it, $v$.

let me endure your wrath

I am burned up with of onr wrath ....... King John,

strong inatter of revolt, and wrath

the wrath of noble wrath, or staring

(indue )

and his wraths, and his eholers........ Henry $V$. iv.

presumption not provoke thy wrath. I Hen'y $V^{\prime} I$. ii.
but add inerease unto my wrath ..2 Henry VI. iii.

hence, heap of wrath, foul indigested

too mean a subject tor thy broth

Wrath makes him duaf

spark ling for very wrath

sliall feel the vengeanee of ny........
thy cloudy wrath hath in eternal .. Richord

$\overline{-} \bar{r} y$

who, in my wrath, kneeled at my feet

thy bruising irons of wrath.

it foresaw in Hector's wrath.............

wrath would confound thee .. Timon or sithens,

to prevent wild Aleibiades' wrath

whieh makes me sweat with wrath. Curiolan

and wrath o'erwhelmed my pity
or wrath, or eraft, may uet ]

the good gods assuage thy wim.

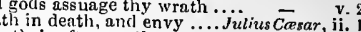

to exense their after wrath.; Antony \& Cleopatra, v.

I am senseless of your wrath

your father's wrath, sliould he take $-\overline{\text { iii. } 2 \text { (jet. }}$ (ji.

by tasting of our wrath? ............ v. -5

o do not les noved to wrath ... TilusAndronicus,

o why should wrath be mite...........

and testy wrath eonld never be her mild Pericles, i. 1

between the dragon and his wrath ......... Lear i.

power shall do a eourtesy to our wratil.

roasted in wrath, and fire, and thus ..... Homlet, ii. 2

to give place to the devil, wrath .......... Othello, ji. 3

WRATHFUL; who, as others do......... Mocbeth, iii. 5

whiles we, God's wrathful agent ...... King John, i. .

as valiant as the wratliful dove......2 Herry 1 . $l^{\prime}$. iii. 2

eyes replete with wratliful fire ,..... $\mathrm{Henry} \mathrm{rl}$, i

with his wrathful nipping cold .......

free us from his Father's wrathful eurse -

your wrathful weapons drawn here
angry, wrathful, and inclined to blood -

enlarge itself to wrathful terms. Troilus of $\bar{C}$

the wrothelt to wrathrul terms. Troilus \& Cress. v.

WRATHFULLY - not wratbfully. Julius Cesar, ii.

WREAK-a heart of wreak in thee... Coriulanus, iv. justice for to wreak our wrongs...... wreak the love I bore my cousin... Romeo of Jul. ivi. hy working wreakful vengeance. Timon of Alhens, iv

WREATH your arms like.. TuoGen.of Verona,

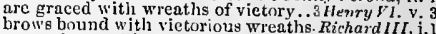

oul my brows this wreath of victory. Julizas Ciesnr, v. to whon this wreath of victory $\mathrm{I}$ give... ${ }^{2}$ ericles, $\mathrm{ij}$.

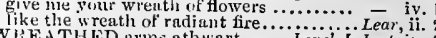

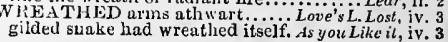




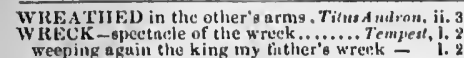
weeping aguin the king my tinther's wret:k the rreek of all my friunty.

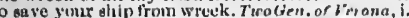
Treenh Nivht, $\mathrm{y}$, have share In this most happy wreck - $v$. suilors that escnped the wreck..Yerch. of lewler, iii. show' in the wreck if maitliom? much wealth by wreck at sen?

mer urging of her wreek at steu

aboured in lis country"

the very wreck thint we must suffie..... Richard $11 . \mathrm{ii}$.

venrsy 1.

with sunken wreek aul gumle

Henry

grew the general wreck and massacre. iv. I (letter)

knavery will be the dilcliess' wreck

commonwenlth hat h daily run to wreek - $W$ i.

cheer them that feur their wron

3 Henry Vi. ii.

lot endure that beanty's wreek....... Richard $\| l, \mathrm{i}, 2$

way, ont of his wrek, to rise in ..ilenry $\bar{T}$ 'Il. iiti.

rejoices in the common wreek.

What wreek diacern you in me ...... Cymbeline

what's thy interest in this snd wreck?

our titore this ehest; tis of snme wreck. Pericte

but trifle, and menut to wreek thice .... Nambet, it.

WRECK ED-kaw the king's ship wreeked Tempert,

behield the king $m$ y tather wrocked

bruther Frederiek was wreeked.Meas. for Meas,

ieh lading wrecked on the narrow.Mer, of b'en, ii ,

a pilut's thuinb, wrecked, ns homeward. lacteth,

are wrecked thrce nights no.

even as men wreeked upon u sand....... heury '.'iv. I

night wreeked npon the sea

hour'y joy wrecked with a wcek ... Richard hit. iv.

[Col.] that have wreeked for liome.. Corinlanu, $v$.

WREN-youngest wren of nine... T'telnih Night, iii,

wen with little quil ...Nid.... Si eam, iil. 1 (song)

the poor wren, the most diminutive... Nacbeth, iv

thit the chirping of a wren

that wrens may perelt where eagles.. Richard III. i.

small a drop of pity as a w
the petty wrens of rharsu

no, the wren goes to $t$, und tic smaii ..... Lear,

noble nature may eateh a wrenche linoon of . Aht

hy revenge, wrench nip thy 1

wrench his ywerd from him

Wrellch his yword from him ...
WRENCHED with an unlinei

Othello, $y$.

like an engine, wrenched iny frain

nrattoek, and the wrenehing iron. Komeo \& J

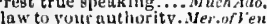
fashion, wrest, or buw your reading..... llevery he'll wrest the sense, and hold 政 Will wrest an alphulhet....... Titus Andronicus, iii.: tiro lavishly wrested his meanin that cer I wrested from the king

yoll wrestle to-mor row before
I'll wever wreatle for prize inore

2neuryltitit.

wrestle witli you in wing strength..tutony \& Cteo. ii. 3

sir, you liave wrestled welt

as he did the day he wrestled?

this wretler aluall clear all

witl, Cliarles, the duke's wrestler (rep.) -

the parte und grueces of the wrestler..

tripped up the wroter s heet

i w o thestling fould have tila you of govd wrestling

linll we wee this wrestling. cousin?

the place appointed for the wrestling

thot the wrotling might not gu furwari =

affectiun

like an Olympiun wrestlin

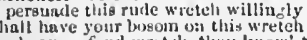

by lieaveu, fund wreteli, thut kuow'st

puts the wreteho flus lices in wo

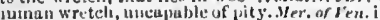

a meacuck wreteh can make..... Taming of sh.

wreteh, that, for thy muther o lault. Winter's 7 .

fic on thee wreteh! "tis jily ... Compily as Errors.

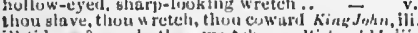
ill tidingu? npeuk, thus wreteh .... Kichard $1 t$. ii orisuns trainst this puor wreteh ...... Uleury $p$ every wretch, pining aubl pulc lefire - iv. such a wetch, wilshing up days with - iv.

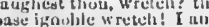

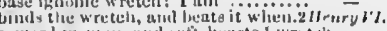

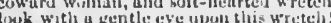
lowk with a gentle eye upoin this ureteh!
lays atrong diefe nuto this wretelis soul

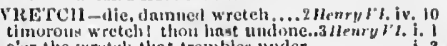
er the wreteli that tremblea under

thint whe, poor wretel, for aric

temples of this blooly wreteh have i

was hy thut wetch bitrayed ....... Ilenry bll. ii. I

potr wreteh! a pwor capocehial.. Troolus chess. iv. 1

thou wretch! despite o'er whelin the

mortal wretch, with tliy shar'] ...Amtony o c che

ani struek me, wreteh, inore worth
whercat, I wreteh! made serniple of

aly frantie wreteh, that holp wh.. Ti
dic, frantic wreteh, for this aeeuraed

sentence on this excernble wreteh.

tremble, thou wretch, that hat withi

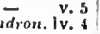

the wreteh, that thou hast bliswn utito...

- Lear, $\mathrm{v}$

the retty wretch left erying .............. \& suliet, iv

disolueticht wretch! I tell thee whint
here lives a cuitiff wrteh would sell

and to decline npon $n$ wreteh $\ldots . . . . .$.

$\overline{\mathrm{H} a m l e t}, \mathrm{i}$

pulled the poor wreteli from her

三 iv.

exeellent wretelet perition enteh iny soul - ii.

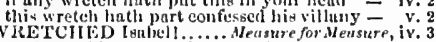

to set on this wretehed wommu here..

and wretched fiols' seerets..............

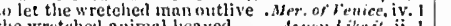
ele are they very wretehed.

and nil ut once, over the wretched?.

I num, my lord, a wretelied Flurentine. $A \|^{\prime}, H^{\prime}$ ell, v. 3

a wretehed soul, bruised in . Comedy of Errors, ii.

there are a crew of wretched songe...... Macbeth, iv. 3

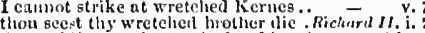

the world'e regard, wretehed and low.1 Henryl $l$.iv.

whint a wretehed and peevish fellow.. Henry $V$. iii.

posterity, await for wretehed years ..1

wretehed sliall Franee be only in.

wretched man 1 be woe for me (rep.).2 Henry
may England eurse my wretclied reign

ah. wretched man! would I lad dierl.3 Henry

makes us wretehed by the deuth ...jichard 11 . i.

thy glury, like uny wretulied self: ....

lighted on pror llastings' wretehed head -

that ever wrctelied age hath louked "1]on -

the wretched, bloorly, and usurping boar -

a little happier than my wretehei.. iienry $\vec{V}_{I I}$

cordial that you bring a writehed lady

how wretehed is that poor nat

some fity upon my wretelied women

rich only to be wretehed; thy great.

lies a wretclied corse of wretched - y. 3 (epitap)

and Cassius is $n$ wretehed crenture.Juliuscipur i.

you shall hid ine, "retelied mun .. Cymbet

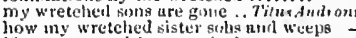

if any puwer pities writeluel teurs...

witncs this wretclied stump.

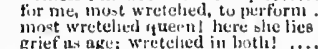

I um wretchet. makes thee the haip

wretshed boy, that dielst consurt. Roune of Juliet, iij,

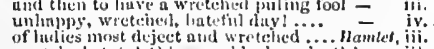

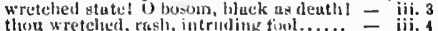

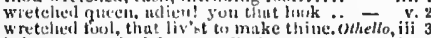

it is my wretehcd fortune. Breblirew....... - iv.

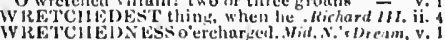

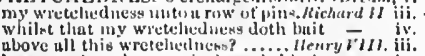

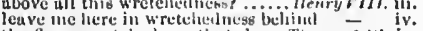

the feree wretehedness that phory. Timon or Ath, iv.

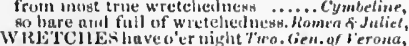

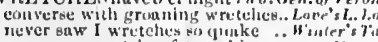

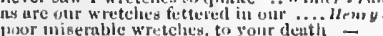

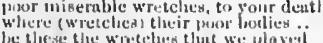

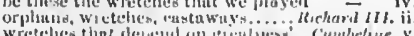

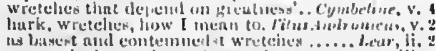

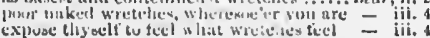

VJING-a hint, tlint wrings mine eyes. Tempest, i.
I warl, wring, brew, luake

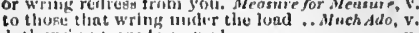

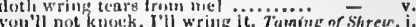
nutl wrighs his liapless hauls........2hem y /'t. i. sring him by the nope .............. - ili. and wrang willow from her enstomed - $-v$.

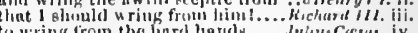
to wring from the haril hasuls ..... Juhus Corsut. iv. uhy doss thou wring thy liaida?.. Koraen of Jut. iil. and lct me wring your heart .......... llamlet, iii. WRINGER - and his wrimger....... Merry Wwr, $i$.

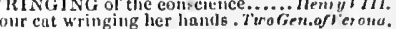

wringing her halls, whoee whiteness $-{ }^{2}$,

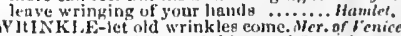

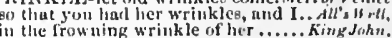

stop no writikle in his pilgrimage.......hthech 1 .

nn deeper wrinkles yet? thath sorrow -

the wrinkles in my browe, now ...3 Henryrl. v.

youth und freslinese wrinkles Apollo's a

you are old. Wrink Wes forbidi.... Automy \& cleo. i.

let it stamp wrinkles in her hirow ..........egr,

and wrinkled tlian. Meas. for,yeas, i.

old, wrinkled, fuded, withered .. Taming of sh. iv.

with wrinkled brows, with nods .... Kims John, iv.

foul wrokled witch, what makert . . $\bar{c}_{\text {milus }}$ i. 3

the grave wrinkled senate.... Timon of dthers, iv.

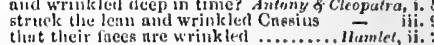

WIIST-doth gripe the hearer's wrist. King John, iv.

more than iny shanks, and wrists ..Cymieline, y.

WRI'T to you in rhyme ..... T'rogen. efrerono,

in one line is his nanie twice writ...

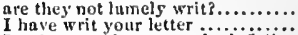

I writ at random, very doubifility

the lines are very quaintly writ.
you wit them, sir, at my request.

you wit them, sir, at my request....

and where it's writ, for my soke......
wliy. she hath not writ to me.......

that's the letter I writ to her friend..

for often you have writ to lier .......
which, being writ to mee ............

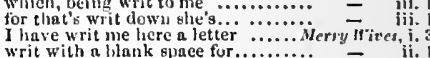

'twas well writ.......................etsh sighe, iii.

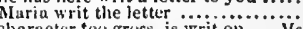

by clanee, nothing of what is writ... - iv.

every letter he hathi writ liath dievonelsed - i

wihen sle lial writ it, and was reading - ii.

have you writ down, that they are none? - iv.

fowever they have writ the style of gols -

if lie thut writ it, hal played ... Mlid...'s Drean

have the sul,jeet new'ly' writ o'er .. Lore's L. Los, i.

III read the ode that l hinve writ ...

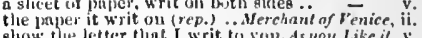

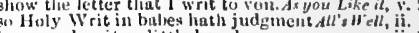

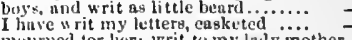

and writ to ine this of her duy.........

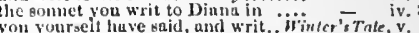

read it? is it nut tair writ?.......... King John,

writ in remembrance, more ......... kichard $I l$.

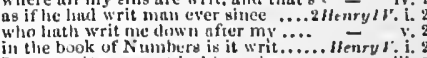

I ouce writ a sonuct in his uraise .... henry 1 i.

holy suive of socred wit .........2llenry $b^{\prime} t . \mathrm{i}$.

my lord, let's see the devil's writ.....
of mine hath writ in thy behnlf..... i.

under the which is writ, lnvitis nubibus -

mur:be lim cre the writs go forth....

there be letters writ to every shi

business I writ w his huliness....... -

you "rit to the pupe ngaimst the king

tiat therefore stich a w'rit be silut

within the reat of pity wit ..?'tmon of thens, iv.

H.une elironicle thus n rit............. - vartolas, v.

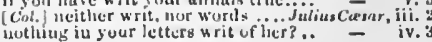


WRIT his honour in the acts ...... Antony \& Cleo. .. I [ WRITE-Cxsar did write for him.Julius Casar, hii, 1 is the tenor of the emperor's writ .. Cymbeline, iij. 7 when I have writ my name without - Titus did ivon. ii. 4 read, my lord, what she hath writ?

thou wilt write to Antony?. Antony \& Cleopatra, iii. speak, cast, write, sing, number..... - iii. 2 bring lim to me where I will write..

the epitaph is for Marina writ.. - iv. 4 (Gower) that he hath writ this to feel my

write to him (I will subseribe)

have you writ that letter to iny

thither write, my queen, and with $\ldots .$. Cymbel

our fither lie hath writ, so hath our sister - ii. $\mathbf{i}$

for my writ is on the life of Lear ........ v. 3

whose namies are here writ

I will write: send your trunk to me

Why should I write this down

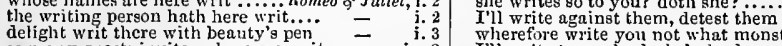

i. 7 and I should wrong it, to lock it in...

so many guests invite as here are writ = iv. 2 I'll write to my lord, she's dead.

$\begin{array}{lll}\text { if his mind be writ, give me........... } & \text { v. } 2 \\ \text { one writ with me in sour misfortine's } & \text { v. } 3 \\ \text { meantime I writ to Romeo, that he } & = & \text { v. } 3\end{array}$

meantime I writ to Romeo, that he...

we have liere writ to Norway .......... Hamlet, i. 2
we did think it writ down in our dity...
for the law of writ, and the liberty......
is't writ in your revenge, that 2

to write, and read, be hencetorth...
write down thy mind, bewray. Tituss
in the dust I write my heart's deep.

in the dust I write my heart's deep..

ist writ in your revenge, that $\ldots \ldots \ldots \ldots-$ iv. 5

WRITE-he writes how happily.

will write these words, and lay it by

because 1 will not do them the wrong.. Much $A$ every man the wrong side on

and now he writes to heaven
had he a hand to write this?

the effects he writes of, succeed unhappily

the effects he writes of, succeed unhappily - i. 2 why should she write to Edmund?

enjoined me to write some lines

any man the write happy, when thou.... $\bar{y}$ v.

I'll write your lad yship another

made you write to yourself?

to write unto her lover....

but I will write again to Mantia

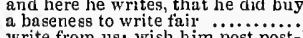

he writes verses, he speaks holiday

not ryite my; proies host poste.

goodly book, made to write wliore upun?

only get the learned writer to set.

write loyal cantons of contemned. Thellh Night, i. 5

I cau write very like my lady

go, write it in a martial hand.........
thougl thou write with a goose pen

I'll haste the writer.

did he write this? Ay, madam ......

write from it, if you can
wic shall write to you

let's write good angel on $\ldots$ will $\mathbf{I}$ write lecters to Angel

in such great letters as they write .......ruch $A d o$ iv. 3

with scorn, write to him that I love him?

when she is beginning to write to him

二 $\quad$ iii. 3

8o immodest to write to one that

but to write and read comes by nature

I will write against

pray write down, Bornchio (rep.).....

write down, prince John a villa

here to write me down an ass

will you then write me a sonnet

I will get Peter gue; and let...Mid. N.'s

strictest degrees Inll write my name...Love's L. L. i.

to the laws at large I write my nane
devise wit; write pen; for I am.......

devise wit; write pen; for I am

I will love, write, sigh, pray, sue
will $I$ tear, and write in prose..

will $I$ tear, and write in prose........

touch a pen to write, until his

live still, and write mine epitaph..Mer.of ven

the iearned Bellario, what he writes

will I Rosalinda write....As you

I'll write to him a very taunting

why writes she so to me?

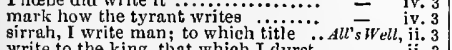

write to the king, that which I durst

besides, their writers eay, king Pepin... Henry

WRITHLED shrimp should strike..... Hamlel Henry $l^{\prime}$ ii. 3

WRITING-is not my writing .... Tuelfh Nigh

would neither serve tor the writing. Love's $L$, Lost, i.

the party writing to the person written

I'll read the writing ...........Merchant of I'enice, ii. 7

that took some pains in writing

with writing love-songs in their. As you Like il, iii.
did use as she was writing of it.....

but your writing now is colder... To wing of Sh. iii.

let me see the writing. My lord...... Richarl II. v.

peruse this writing here, and thou shalt - y. 3

writing their own reproach .. Troilus o Cressida, $\mathrm{i}$.
I was writing of mine epitaph. Timon of Allienz, v.

he sent in writing after me.......... Coriolonus,

still in all my writings....... Antony \& Clenparra, v.

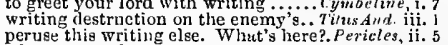

what names the writing person...Romeo \& Jaliet, $\mathrm{i}$.

there is written in your brow ... Tleas. for Aleas, iv.

for here's a paper, written in his...... Buch Ado, iv.

have you the lion's part written? ...Mid.N.'s $\mathrm{Dr}$. i. 2

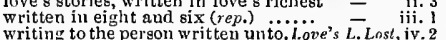

Writing to the person writted unto.i.ove's L.Lnst, iv. 2
there is a written scroll?
more I'll entreat you written to .....Ail's W'Wll, iii. 2

it is written, they appear to.. Comedy of Errurs, iv.
have written strange defeatures......

have written strange defeatures............

having our fair order written down... King John, v.
which I shall send you written ...... Henryl ${ }^{\prime}$.

that are written down old with ........2 Henry $1 \%$ i. 2

whose memory is written on this.

werused what I have written to you? Coriola nus, $v$.

our writ ten purposes betore us sent Antony \& Cleo.ii.

our composition may be written ...
thoug! written in our flesh, we shail

enough written upon this earth.. Titus Anüron.

a scroll; and written round about?

what is written shall be execnted .....

find written in the margin of his eyes

had I it written, I would tear the wo

WRONG-did us but loving wrong ........ T empest, i.

fear, you have done yourself some
with their high wrongs I am struck

entreat thou pardon me ing wrongs...

whose wrong her honour, the proudest

who wrongs him? Marry, thou (rep)

death in guerdon of her wrongs

your wronga do set a scandal ... Ait. N.'s bream, ii.
and blindworms, do no wrong ....

you do me wrong, good sooth ........

right and wrong wave bitter wrong

much wrong, and wrong the reputation

oh pardon, love, this wrong, that sings

you do me now more wrong.... Merch of $\overline{\text { Fen }}$

tor my love, I pray you, wrong me not -

the Jew having done me wrong.......

if you wrong us, shall we not revenge

for, in choosing wrong, I lose your.

doth wrong this shadow in underprizing -

shall I dread, doing no wrong?...... -

a great right, do a little wrong $\because \ldots 3 .$. .

forgive me this enforced wrong .......

Irlust a few, do wrong to none .........All's Well, $\mathrm{i}$.

Ill never do you wrong for your own

the king has done you wrong .........

the does me wrong, my lord ..........

Wrong me not, nor wrong yourself. Taiming of

you do me double wrong to..........

the more my wrong, the more his spite $=$

think of the wrong I did myseif $\ldots$....

can with such wrongs dispense. Coinedy of $\bar{E}$ r

be it my wrong, you are from me (rep.) -

'tis double wrong, to truant with .....

you wrong me much to say so (rep.)

that she hath done thee wrong .........
to take order for the wrongs I weint

beyond imagination is the wrong...

my w'rongs might make one

suffered wrong, go, keep us company

or else it must go wrong with you......

his grandam's w'rongs, and not his.

oppressed with wrongs, and therefore

that law bar no wrong; law cannot

gince law itself is perfect wrong

possessed with a thonsand wrongs

you sliould use to do me wrong

attend the steps of wrong....

honour with such feeble wron

against my will, to do myself this wrong -

duty inake me slufer wrong? ........

look on my wrongs witl an indifterent

to rouse his wrongs, and chase them

liad feeling of my cousin's wrongs ...

from her eyes by your foul wrongs

furbearance from so foul a wrong

to do him wrong, or any way......... HenrylV. i.

whose wrongs in us God pardon .....
you will not pocket up wrong?
seems to weep over his country s....

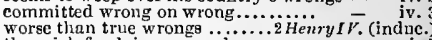

thee ricly for doing me such wrong ...
passion, doth you wrong, my lord ..

the gallows shall have wrong...

o never do his ghost the wrong.............

make thee wrong tlis virtuous......
sir John, do not yourself wrong.

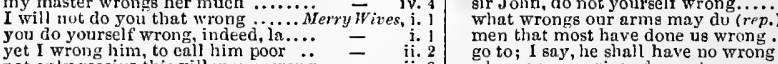

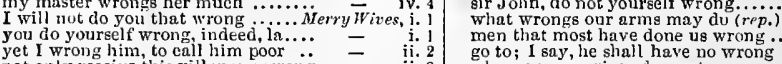

yet I wrong him, to call him poor

not only receive tlis villanous wrong
and by him that does me this wrong

having received wrong hy some person

you wrong yoursclf too mueh .......

you do yourself mighty wroul.....
you wrong me, sir, thus still (rep.)

this wrongs you................................

how quickly the wrong sirle may. T

the wrongs are thou hast done him
who docs do you wron??

certainly, she dive edge unto

plain pocketing up ot wrongs.

and yet I do thee wrong to obedience

e wrong to mind tliee

how much he wrongs his fame

for that she's in a wrong belief ......

his wrong doth equal mine ............

thnu chost then wrong me ... $\ldots \ldots \ldots . .$.

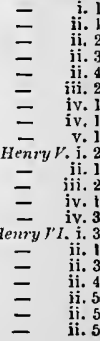




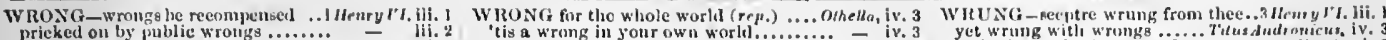
liberty to venge this wrons. lone me wrong. What is that wrong

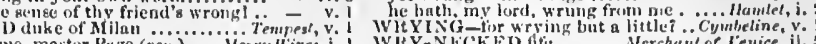
antith he is wronger

ed ............. thou never di

be thy title right or wrong

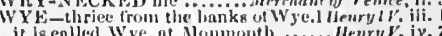
it is enlled Wye, at Molumboth ....... Henry

XANTIPPE, or a worse......... Tuming of Shrew, $\mathrm{i}$,

$\mathbf{Y}$

YARD-the yards and bowaprit

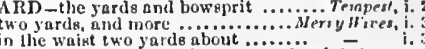

in the waist two yorde about ............

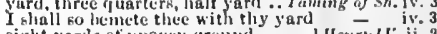
eight rards of uneven gronnd ...... IIfury $/ H^{\prime}$, ii.

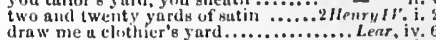
should medille with his yurd ............... Lear. iveo \& Julict. 6 YAlE, yare; take in the top-sail ....... Tom tomet, i. yare, luwer, lawer............. e yare in tliy prepuration ...... Tweifh Night, v. the yo.... Measure for Meosuse, iv. the hangmant thunk for beirg yore. Cleopatra, iit.

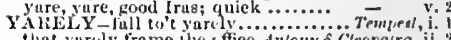

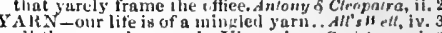
all the yarn she spun in Ilysses'.... Coriolamus. $i$. Y A WN, und y ield your dend .... Huch Aido, v. 3 (song)

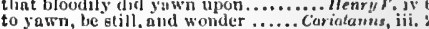
then ehurehyards yawn, and heli .... llarale?, iii. YAWNED, and yieldet up................ Othe Casar, ii.

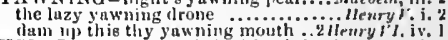

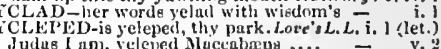

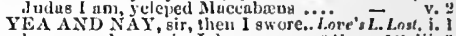

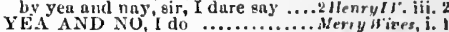

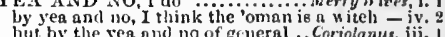

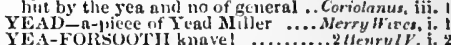

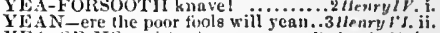

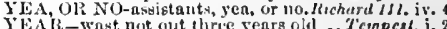
twelve years sinec, Mliranda (rep.).... - i.

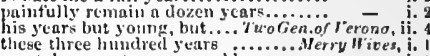

Thertike Eeviteen years old

in three hunil red jound a ..........

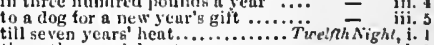
thee thonsand ducats a year......... i. 3 they shall yet helie thy happy ycars - i.
of what personnge and yenrs is he?.. - i. 5 ot' what years i' taith? About your years grew a twenty yeurs ronoved thing.. - v.

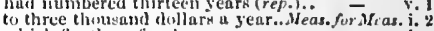
which fiur these fourle'll yeurs ue ... - i. a man of fursecore pound a year ( $r e \ddot{p}$.) hill oot in vicuma tell year

you pay, sevell ycars together? .....

a lowil uf eleven years continuance.

eornound with him ly the year...

one that is a prisencr nine years old..

a mant of Clandio's yenrs ............. he has been a vile thich this seven yenr - jii. 3

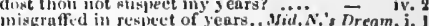
have + worn for three years' term ... Loce'sL.Lost, j. and study here three years (

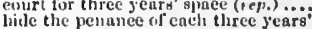

itlin the turm of chree y cars

so to study three yeurs is but short.

Was prcclaimed a year' shull out wear three years............

ffinderness of years; take this ke lwen 1lve throusand 3 ware a boy

that smiles his eheck in years........

for her sweet love three years........

hot two years nore, thou shalt not.

fuber out that year on (rep.

his lack of years be no innedimen..." - iv. lil. I 
YEAR_too bold for your years ....As As you Like $i$ trom seventeell years till now (rep.)... it secms the length of seven yeari...

I pray you chide a year together....

yet for his years hes tall .......

would have lived many a fair year

such garments, and such years ...

I have, sinee I was three years old ..

within ten years it will make itself

would serve the world so all the year

in her sex, her y ears, profession.

these fitteen y'ears you

some fifteen year and more

of Shrew, i (induc

(rep.)

near twenty years ago, in Genr'a

I did recoil twenty three years...

that I slide o'er sixteen years

iv. (chorus)

then comes in the sweet o' the year - iv. 2 (song)

sir, the year growing ancient ..........

the gods do this year connive at us..

a piece many years in doing

to think so twenty years toget

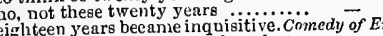

her sober virtue, years, and modesty

I buy a thousand pound a year

I buy a thousand pound a year $\ldots \ldots$.
seven short years, that here.........
but seven years since $\ldots \ldots \ldots \ldots \ldots \ldots$
twenty years have I been patron $\ldots \ldots$

tweaty-five years have I but gone ...

tweaty-tive years have I but

look upon the years of Lewis .......... Richard

many years of happy

language I have learned these forty jears -

too far in years to be a pupil no

number or his banished years plucked =

he shortens four vears of my son'

thou hast nony years to

six years we banish him

fortune is come to years

we at the time of year do wound

planted many years, be judged....

fourteen hundred years ago

if alt the year were playing.....

any time these two and twenty years -

forsooth, five year, and as much

stolest a cup of sack eigliteen years ago -

when I was about thy years, Hal.....

that vanity in years?

any time this two and thirty years..

whilst the ligg yeur, swoln with .2 Hen

so many years outlive performance!

known thee these twenty-nine years

two years after. were they at wars ( $r e p$. $)=$

look well, and bear your years very well -

that's fifts-five year ago .............

as the year had found some mont ths

truly, sir, this eight years; and if 1 ..

we will eat a last year's pippin of.

praise heaven for the mer

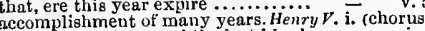

in the eleventh year o the last king'

a thousand pounds by the year......

within the year of our redemption

in the year eight hundred five ......

so the ever-running year with profitable -

throughout the year to chureh
await for wretched years

a wht not onte in forty year

these many years, wasted our country

some part of iny young years might

my tender years ean tol Talbot.

my years are young; and fitter.......

better sport these seven years' .....2Ilenry VI. ui.

why a king of years should be to

my life for a thousand years ........ - iv.

days will finish up the year (rep.)

so many years ere I shall sheer.

monthis, and years, passed over.
of threescore and two years.

obeyd'st thirty and six years ..........
in the duwnfall of his mellowed years

in the duwnfall of his mellowed years

in lis full and ripened years $\ldots . . . .$. .

the untainted virtue of your years ...

her laushful years with your experieuce

seem pleasing to her tender years? $\ddot{H}_{\text {than }}$ I have time to tell his years!. Hen

has hung twenty years about his ueck

a thousand pouud a year (rep.)
YEAR-upward of twenty years .....Henry $r$ III. ii. 4 reigned by many a year hefore ........
shall not have his wit this year.. Troilus \&-Cress. i.
after seven years' siege, yet 'Troy.... after seven years' siege, yet Troy .... for half a liundred years

an estate of seven years health

thou hast years upon thee.............

the youthful season of the year.......ulints $\overline{\text { Casar, ii. }}$.

twenty sears of life, cuts off so many years

for I have seen more years, I am sure.

like to the time o' the year . Antory \& Cleopatra iv. 3 her years, her inclination

that year, indeed, he was troubled...

eldest of them at three years old

thou heapest a year's age on me?

this twenty years, this rock..............

at three, and two years old, I stole

from sixteen yeare of age to sixty

many year's, though croten the ....

for many years thouglit dead .........

ten years are spent, since first he...Ti

five hundred years hath stood.........

not the differenee of a year, or two...

felt several years, and wanting lreat

च- iit. ${ }^{2}$

ve seven years for the loss of a leg

$\begin{array}{r}\text { i.i. } 2 \\ =\quad \text { iii. } 3 \\ \hline\end{array}$

at fourteen years he sought to murde

some year elder than this, who yet...

he hath been out nine years $\ldots \ldots \ldots \ldots \ldots$......

I bave years on my back forty-eight

fools had ne'er less graee in a year

Tom's food for seven long year - iii. 4 (song)

your father's tenant, these fourscore years _ iv.

yenr old I bade her come

of all days in the year (rep.) .........

an' I should live a thousand years.

much upon these years that you are

some five and twenty years; and then

his son was but a ward two years ago

'tis twenty years till then

by this count $I$ shall be much in years

for these many hunilred years, the bones

may outlive his life half a year......

of all the days i' the year, 1 cane to't.

eight year, or nine year (rep.)

you the earth three and twenty year..

you shall more eommand with years...

in spite of nature, of years, of country

the story of my life, from year to year

sympathy in years, manner's, and beauties.

sympathy in years, manner's, and beal
vale of years; yet that's not much

'tis not a year or two show s us a man.

I wonld have bim nine years a killing ... $\bar{A}-$ iv.

the yearly course that brings thi......King John, iii.

five hundred poor I have in yearly

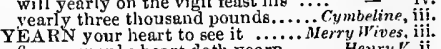

for my manly heart doth yearn ....... Henry $r$. ii.

is dead; and we must yearn therefore

the hesrt of Brutus yearns to $\ldots$...Julius Casar,
YEARN

YEARNING-nn my yearning time ..Pericles,

YEDWARD; if I tarry at home........ Henry I H
YELL the dogs did yell ........... Love's L. Lost,

nor yelis of mothers, maids.... Timon of Athens,

YELIED out like sylable of dolour ... Matbeth, iv.

YEILING [Knt,-yelping] noise .. Tilus Androns. ii. 3
YELLOW-these yellow sands .. Tempest, i. 2 (song)

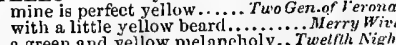

a green and yellow melancholy... Twelfth Night, ii.

sle did commend my yellow stockings

strange, stout, in yellow stockings,$\ddot{\text { iii. }} 2)-$

though yellow in my legs

to put on yellow stocking

on Neptune's yellow sands . $7 . . . . . .$.

these yellow cawslip cheeks, are gone

roied with the yellows, past eure. Taming of shong)

'mongst all colours. no yellow in't. Winler's Tale, it.:

is fallen into the sear, the yellow leaf . Mucbeth, y.

a yurded with yellow, will be. Henry

gold? yellow, glittering, precious. Timon of Ath. iv. 3
this yellow sluve will knit .......... $3 y .3$

this yellow Iachimo, in an hour...... Cymbeline, ii.

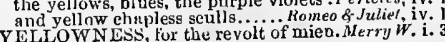

YEIPING kennel of French curs ..I Henry $V I$. iv. 2

where is your yeoman? (rep.)

2 Henryly. ii.

e grace the yeoman, by conversing. 1 Henry $V I$. ii.

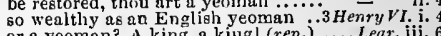
or a yeoman? A king, a kingl (rep.) ..... Lear, iii.

YEOW it did me yeoman's service........ Hamlet, v.

YEOMEN-yeomen's gons .......... Henry $I V$, iv.
good yeomen, whose limbs were made. Hrriry $r$. iij. spring crestless yeomen from so ..... I Henry J $^{\prime}$. ii. YERK out their armed heels............. Henry $V$. iv. ERKED him here under the ribs......... Othello, $\mathrm{i}$. ESTERDAY in this basket..........Merry Wives, iv. went you not to her yesterday, sir.... with a French man yesterday ... Merch.of Verice, ii. I met the duke yesterday, and had .. was it not yesterday we spuke .........Macbeth, iii. that did but yesterday suspire .......King Jolkn, iii. call back yesterday, bid time return. Richard $i l$. iji. 2 enlarge the man committed yesterday. Henry ii. were but yesterday dubbed knights.

prings me pread and salt yesterday...

had heard her talk yesterday.. Troilus \& Cress $d o$ they say, he jesterday coped Hector

I told you a thing yesterday ........
prisoner, ealled Antenor, yesterday took yesterday the bird of night did sit. Julius Casar, i.

of thesterday the word of Cakar.....

1 saw him yesterday, or t'other day.... Hanlet, ij.
sleep which thou owed'st yesterday.... Othello, iii.

this is his seennd fit; he had one yesterday $-\mathrm{i} v$.
YESTERNIGH' $T$, my lord, she ...Meas. for Meas. $\nabla$. alked with you yesternight out at ... iluch Ado, iv. what yesternight maintained the change - iv. of the eharge set down yesternight

for yesternight by Catesby was it...Richard $I I I$. iii. she looked yesternight fairer ..... Troilus \& Cress. i. and yesternight, at supper $\ldots \ldots \ldots$. Julius Corsur, ii. and yesternith returned my letter. Romeo \& $J u$. my lord, I think $I$ saw him yesternight. Hamlet, $\mathrm{i}$. Y FSTX - the yesty waves confound.... Marbeth, iv.

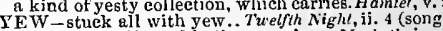
slips of yew slivered in the moon's ...Macbeth, iv. their bows of double-fatal yew...... Richardll. ii . unto the body of a dismal yew.... Titus dudron. it. as I did sleep under this yew-tree here - v. which throes thee mucli to yield ....... - ii. kill the bees, that yield it .... TuoGer... of Verona, $\mathrm{i}$. I'll foree thee y ield to my desire .... and makes mileh-kine yield blood. Merry Fives, iv. Y'd yield my body up to shame...Meas. for Meas. ii ie'd yield them up, betore his sister

and yield me a direct answer........ - .

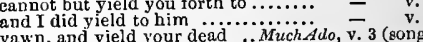
vawn, and yield your dead ...MuchAdo, v. 3 (song) whe I wil yield my virgin poter ere I wh y yolent up

or else the law of Athens yields you up =

y ield you up my part ................

all liberal reason I will yield unto

to yield myself his wife .....Nerchant of Ferice, $\mathrm{ii}$. and yield to christia in tereessors 3 - iii. and therefore I will y ield: give me... $\overline{L i k e}$ iv. ii. it this uncouth torest yield any thing $1 l^{\prime}$ ' $W$ ell, iii. 6 I to her, end go she yields to me Taminu of sh ii. every tod vields - pound and odd. Winter's Tale, iv. 2 I yield all this; but, for some........ - iv. and to your power I'll yield. Comedy of Errors, iii. 2 to yield possession to my holy $\ldots \ldots . .$. . wacbelh, i.

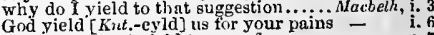
which mist not yield to one of ...... I'll not yield, to kiss the ground ..... that it yields naught, but shame .... - ii. I shall yield up my erown $\ldots . . . \ldots . .$. . yield stinging nettles to mine......... = iii. what, will not this castle yield? ....

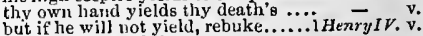
umless thou $\mathrm{r}$ ield thee as my ......... do ye yield, sir? or shall I sweat ..2 HenryIV.iv. 3

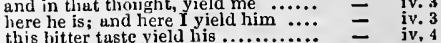

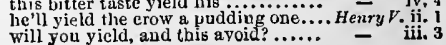




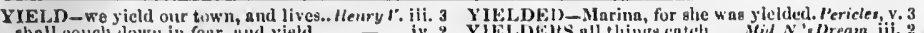
shall conch lown in feur, and yield. siall yield them little, tell ...... yet they do wink, and yield; as love yield day to nighti comets.......... cause hilin once more yicld the ghost I milst not yicld to any rites of...... shall yieid the otter in tine right ... ie slult submit, or I will never yield duke of G loster, I will yicld to thee made me alınost y ichl ipon my knces enowned nobie gentleman, yich is youthful, nud will quickiy yield then yield, my lorels; und licre eonchide be regent I $w$ ill yield to him I yieid to thee, or to the meanest groom and yield to nercy, wilst 'tis offered and all his powers do yield; nad humbly Ill yield myseif to prison

rich to our with not yich $\ldots . . . . .3$ hien 80 true men , ield, with rohbers. hercules inimself inust y icld to odds wilt thou yield the erown? (rep. ere night yield both my life and them I humbly yield puto than $\mathrm{f}$ will yield into..... more than $x$ will yield unto ........ yield unt thy neck to fort

requires, and mine enn yield therefore I y ield thee ny free consent if Warwick yield eonsent.

Burgandy will yield him help .........

inust yield my body to the earti ( $r$ ep.

sheep doth yield his flete

than death cun yield ne here..........hichard $\mathrm{J} I . \mathrm{j}$.

Ilastings will not $y$ ield to ou complots?

I eannot, nor I will not yield to you

as the yield ine not thy light

despairing, yield thy breatli!......... - y. 3

o Priam yield not to him

or yield me this, to slow him ... Timinn nf Athens, $i$.

if money, and the scason. yield me roots

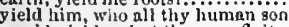

would field us but the superfluity.

common body, to $y$ ield what passes here -

friendliness to yield your voices? ....

have voices, that ean yield them now

all places yield to him ere he sits down

upon the next cncounter, yields

I am ashamed I did yield to them...

yield or thou diest. Only I yield to die

if thou 80 yield him, the
hell never $y$ ield to that

courtesy, so she yield us up?

and the golls yield you for'tl .......

go to him, Dolabella, bid him

which your own eoffers yieldi $\ldots \ldots . . C$

yield up their deer to the stand......

but that you shall not say $x$ yicka

a villuin: yield thee, thief.

yield, rustic mountaineer............

promise to yield me often tidings

but yield me to tlie veriest hind.......
yield up rule, resign my life .. Tilus

y ield ai entrcats, and then let me alone -

yield to his humour, simooth

a substance that mast yield to you....... Perict

therefore briefly yield her;
to yield thee so mueh profit.

wherein my death might yieid her.....

city will yicld many sehol

life would not yield to age

by no means will yield to see his dungiter - iv. 3 when life itself yields to the theft.

nor will it gield to Norway and

iilhelln ivi 5

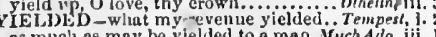

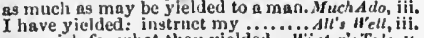
more rich for what they yielded... Winter's Tale, $v_{\text {. }}$ thus have I yielded up into your.... King John, v. now give o'er the yielded bet?

basely ylclded upon eomprimise.... lichard $I I$. ii. Youth yiched up his body to the grave - ite

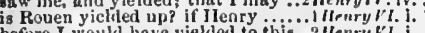
before I would have sielded to this.. 2 thenry $V^{\prime} L$, the king hath yielida unto thy demand

and look to have it yiclded ....... Neshard 11 . iii. not replying. yielded to bear the golden for they had so vilely yielded..

a very little I lave yielded too....... - v. vali. yowned, and ylelded up their dead.Julius Crarar, ii. mine honour was not yielded.

my fleet hath yielded to tise ...... iv.

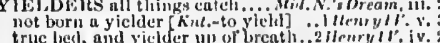
YIELDING up thy body to my ... Aeats for Heas hi.

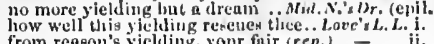
from reason's yiclding, your fair (rep.) - it. n yielding in the looks of France.... King John, ii. practised npon the easy yiching..........

thercforc, paticnty, and yielding
yielding to notlier when it lilow's

dentes the yieluling of her up? Troil

thow me the way of yielding.
her go back, even to the yieldin
hlo

her go back, even to the yiclding .... Cymbetine,

the voice and yielding of thut bud ..

do not these tair yokes becon

needs thrust thy neck into a yok bull doth benr the youke streteleed his yoke in vain ........... do benr an equal yoke of love.Merch. of Venice, iii. ghnll shake off our slavish yoke .... Kichard 11 . i

bring him in obedience to your yoke.1 Henry $\nu I$. can 1 bear this ahameful yoke? ....2 Henry VI. ji. sunder them that yoke so weil together the golden yoke of sovereignty.........ichard $I I$. ivi. 7 rears half my burdence you

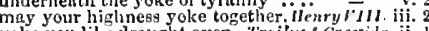
yoke you like draught oxen.. Truilus \& Cressida, i underneath this age's yoke ...........Jutius Cossur, i. 2 our yoke and sufferance show us .... yoke me in my good brotlier's fault.

to yoke the enemies of jiome...... Titus Andron.

to thee, and to thy Roman yoke.

with nged patience bear your yoke

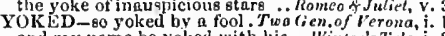

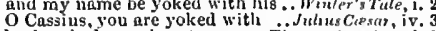
hath yoked a nation strong.... Tilus Andronicus,

YOKE-DEYILS sworn to either's. ......newry $\%$ ii.
YOKE-FELLOWS in arms, let us to Franee - ii. 3 yoke-fellow to his honour-owing wounds - iv. 6 YOKETH your rebellious neeks......ivenry $V$ i. ii. 3 get thee to yon same sovereign ... Ticel/h Night, ii. A

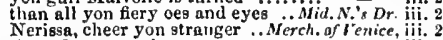
shrewd eontents in yon sume paper. that yon green boy shall have no .. King John, ji.
throw thine eye on yon young boy...
hy yon tuft of trees, manned .......Richard $\|$. ji. the limits of yon lime and stone.

yon island carri,ns, desperate $\ldots \ldots . .$. hill

I'll to yon corner. And I this ...... I wenry $V I$. ii. not yon Diomed, with Calclias'. Trailus \& Cress. iv.

yon towers, whose wanton top:. by yon clouds, let me deser ve...... Corialanus, iii. I and yon grey lines, that fret..........utius Cressnr, ii. I by you bush? pray, low far thither?
as yon grim looks do testify $\ldots . .$. Pericles,
i. (Gower)

yon king's to me, like to my father's

yon knight, methinks, doth sit ...

gee how yon justice rails on yon simple.. J iv. 6

nightly she sings on yon pounegranate

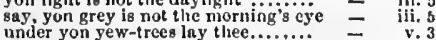

when you same star, that's west wari ... Jamlet, I. 1

YOND' same black cloud (rep.) ......... Tempest, yond huge one, looks like fo............. madam, yond' young fellow ........ Ferry

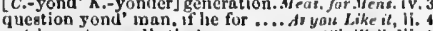

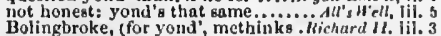
but yond' marn's ever angry.... Timon of dhen, $i$. yond' coign o' the Capitwi; yond" . Coriolanus, $y^{\circ}$ whether yond' troops are friend ..... what torch is youd", that vainily.jiome of Juliel, v. 3 sarage bull doth benr the yolke ...........
whose uuwisjed yoke my soul... will not endure his yoke ........... -

on son proud man ................. - iii. behold yon poor and starved.

is yon despised and ruinous .. Timon of Alhers, iv. yon ribald-rid nag of Egypt ........ to taste the fruit of yon celestial tree.

and you tall anehoring burk
beliold yon simpering dame.
YOND'-by yond' marble heaven ...... Othello, iii. 3
YONIER-what thou Ece'st youder .... Tempest,

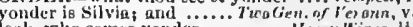
look, who comes yonder......... yonder is a most reverend gentleinain = I came youler at lit ${ }^{2}$ to ............. f'abian eall scarce loold him youder.. - iii

youder mant is carried to prison....

I came youder from a great

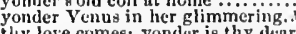

thy love comes; yonder is thy dear.

and yonder bines Aurora's harbin

upon the edge of yonder coppice... Lore sl.. L.ns,

by yonder moon, I swear, you do....

yonder cumes my master............ ds you Like il,

yonder they lie; the poor old man
yonder, sure, tliey are coming

sonder the man?.......inin... ...All', Iretl, iii., yotder he is; deny him ...... Taming ns $\overline{\text { Shrew }}$, y. my wife is coming yonder .......... - iv. demand of yonder ehamplon........ Richard IJ. $\mathrm{j}$. ask yonder knight in arms ........... yonder lie comes; and that arrant ...2 llenry / 5 .ii. re see yotider the beginning of the day in yonder tower, to overpeer

yonder's brave followers, yonder stand

ond yonder is the wolf, that makes...

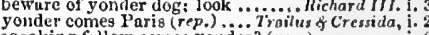
neaking fellow comes yonder? (rep.) yonder comes the troop............. I womler now how yonder city stands

no, youder 'tis; there, where we sce..

then is he yonder, and there the strawy

by good hap, youder's my lord .. Timon of $A$ th. iii. yonder comes a poet, and a paiciter... Coriolan us, i. who's yonder, that does appear as..... Julius $\vec{C}$ esur. and swim to yonder point? .........

lo, yonder; nnd Titinius mourning it - v. 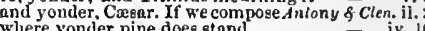 and yonder they east their caps up... - iv. 10 but yonder sits the emperor.. Tit us dndronieus. iv. as youder lady o'er her fellows shows light through yonder window breaks I
lady, by youder blessed moon I awear
lace the severing elouds in youder east from off the battlements of youder east - iii. do you see youder cloud, that's almost. Hamlet, jii. so would I ha' done, by yonder sun - iv. 5 (oong)
but, look I what lightits come yonder?.... Oilicllo, $i$. good my lord, yonder's foul murder ...... volus, poor Yorick! I knew him, Io.....tio - v. be York the next that must be ........ Hichard $I$ here comes the duke of York in.......

here comes the duke of York ........ what power the duke of York had levied regent of this land, the duke of $\dddot{Y}$ ork your uncle York hath joined with good duke of York's that tell black why, York, whet wilt thou do?........ doubt not but to ride as fast as York kind uncle York, the latest news his unele York; - where I firet bowed.l Ienry II: i. the arclibishop. Of York, is't not? . of Seotland, and of York, to join .

the archbishop's grace of York ......

townds York shall bend you......... - Y. what, to York? Call him........... - i. your grace of York, in God to York - if. my lord of York, it better showed ... = iv. ake it, brave York; now, soldiers....... Itenry $t^{\prime}$. Iv. the duke of York commends lim.... - iv. 6 if thou be not then ereated York.... i Henry FI. ii. scet stem from York's grent stock belong unto the house of York ...... with the valiant sword of York....... princely duke of York (rep.) in lionour of my noble Inrd of York as good a men as York. Hark ye.... = cousins lootl, of York and Somerset (rep, ) cousin of York (rep.) $\ldots$ B...........ii 
YORE, and Talbot, foo rashly plotted IHenry VI. iv. 4 | YORK-this little prating York....Richarl III. iii. I great York misht bear the name $\ldots . . .6$ York set lim on, York should have (rep.) York lies; he might have sent had York and Sunerset brought consin of Yurk, we here (rep.) $\ldots$.....2 brother York, the uets in Ireland... and so and Yo saly Yorkst, and fret, and bite. then, York, be st Yurk, to grapple... aud grumbling York (rep. iii. 1) as fur the duke ut York-this late omerset, or Yurk, atl's une to me (rep.) let York be regent, I will yield York is the wurthier (rep.) ............ York is most ummeet of any man Richard duke of Yurk, was rightful because in York $t$ ! tis breeds suspicion my lord of York, to be the post...... sweet York, begin; and if thy claim York claims it tirom thic third their deatlis, it York ean pruphecy make the duke of York a king York, and impious Beaufort, that failse aud dogged Yurk, that reaches at.... ah, Yurk, no man alive (rep.) ..... no more, goul Yurk (rep.)

\section{now York, or never ..........}

nnw, York, or wever $\ldots \ldots \ldots \ldots$ of $y$. and now thic house of York, thrust from Cade, the duke of York hath taught the Guke of York is newly come and now is York in arm

from Ireland thus comes York

York, if thou meunest well

for thousand Yorks he sliall not hide

then, York, untoose thy loug-imprisoned I alrest thee, York,

this is my king, York, I do not mistake then, nobly, Yurk; 'tis tor a crown ... York not our old men spares an infunt of the house of York

battle, won by famous York

possess it, York; for this is thin

unless

thou factious duke of York, descend he made thee duke of York (rep.)....

unto this princely duke of York $\dddot{\text { York }}$ be thou a prey unto the house of York nuto the house of York (rep.)......... the sight of any of the house of York look, York: I stained this oapkin alas, poor York! but that I hate

grieve, to make me merry, York ....

Xork cannot speak, unless he (rep.)

and set it ou York gates (rep.) $\ldots$.....

on the gates of York they set the same duke of York, our prop to lean upon

valiant lord, hut duke of York....

to this brave town of York

to this brave York did level at thy

ah, cousin York! would thy best friends backing of the duke of York

and old York, and yet not satisfied.

for York in justice puts his armour on

is for the duke of York $\dddot{Y}$ that stabbeu thy fatlier

came on the part of York

strengthenung mis-proud York......

no ground un to the house of York

of York. From off the gates of York

didst love York, and I am eon to Yor

York aud young Rutland coutd not

ambitious Edward duke of York

and I the house of York ( $r e p$.$) ....$

my brother archbishop of Yor

farewell, good duke of York

committed to the bishop of York

Edward, at the least, is duke of York

let's harbour here in York

gold their lives unto the house of York

who is victor, York, or Warwick?

like a subject, proud ambitious York]

by this sun ol York; and all the .. Richard

did York's dread curse prevail so much =

diring the wars of York and Lancaster =

my son of York hath almost ..... Jet

I pr'ythee, pretty York, who told.'..

my mother, and my brother York (rep.) Z

to send the duke of York un to his ..

from his mother Win the duke of Yor

here comes the duke of York (rep.).
our cousin, noble lord of York? (rup.) noble York, my princely father......
the prince, thd my yuuirg son of York
I'll salute your grace of Yurk as muther
youmg York he is but boot ........... finrewell, Yurk's wite, and queen of sad thereon engrave, Edw of Yurk is there alive (rep.)

whe wronged heirs of York do pray.

all this divided York and Lancaster $-\bar{v}$. $I I I$.

y York (rep. it. 2)

my lurd of York (rep. iti. h h....̈ York

you mut no more call it York-place

tif of Yorkshire...2 $\mathrm{Hent}$

YoUNG-I'll get thee young sea-mells.Tempest,

Whilst I visit young ferdinund.

how young Leander erossed. wooken.of rerona, $\bar{i}$.

the young and tender wit .....................

his years but yuung, but lis

to hate young Valentine

now, my young guest!

I know the young gentlewoman

would I were young, for your sake..

run in here. good young man.........

you are not young, no more am I .

why, sir, my wife is not young

both young and old.

wlat say you to young master Fenton?

'tis a fair young man.............

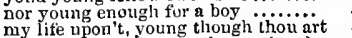

madam, the young gentleman

when your young nephew Titus $\ldots . .$. - v.

vouclisate $a$ word, young sister

first here's young moster Rash

young Dizy, and yount master...

and young Drop-heir that killed $\ldots . .$. iv.

is there no young squarer now

prompting me how fair young Fero is

how noble, young, how rarely featured

what have I done being young ....... -

to call young Claudio to (rep.) ......

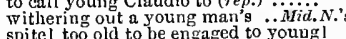

then rich with my young squire ....

I might see young Cupid's fiery shaft

so I, being young, till now ripe not.

a tedious brief scene of young Pyramus

appertaining to thy young days .. Love's $\bar{L}$. Lost

young blood will not obey an old...

your stomachs are too

few taller are so young ................

pluck the young sucking cubs from.

master, young man, you (rep.)

for the young gentleman (rep.)....

young in limbs, in judgment

at your gate a young y enetian

both accoutered like young men....

commend a young and learned doctor

with me a young doctor of Rome -

$O$ wise young judgc, how do $I$.......

O excellent young man!

did young Lorenzo swear he loved her

I'll mar the young clerk's pen .......

many young gentlemen flock to him

your brother is but young and tender

it is the stubbornest young fellow of

as pigeons feed their young...........

thuee proper young men, of excell

alas, he is too young; yet he looks.

young gentlemar, your spirits are to

young sir your reputation shall not

where is this young gallant, that is so

Hercules be thy speed, young man! (rep.) -

whot is the name, young man?...

had I before known this young man

I was too young that time to value.

a young man, and an old, in solemn

here's a young maid with travel muc

that young swain that you saw here

if ladies be but young, and fair .......

here comes young master Gan

it is young Orlando (rep.iv. 3 )

he trots hard with a young maid....

that abuses our young plants with.

truly, young gentlemen, though there
YORK-PLACE, where the feast.... Heury $\bar{\nu} I I I$.

and here young muster Sleuder....

that young start-mp liath all the glory
had got the good-will of this young lady -
YOUNG gentlewoman had a father ....AAl's $\|^{\prime} e l l$, i

young Bertram (rep. $\mathrm{i} i, 3$ ) ..........

for young Charbon the puritan, and old -

wrs young ...

farewell, young lord (rep.) ......

to be young again, if we cuuld.... .

you are tou young, tou happy, and $\ldots$ too

the is young, wire, fair: in tiese ....

twake my young lord to lie a jery .

those sugrestians fur the young earl

he hath jervertud a young pentlewoman -

lor I knew the young count to be.... -

I long to talk with the yourg noble

the young lord did to his majesty...

slie fiels her young onc kick ........ -

eatters young men through the world -

weal the enough, and young $\ldots \ldots \ldots . . . .$.

I have lighted well on this young mau -

give unto you this young scholar....

such a young one. Now, by Suint (rep.) -

I young. And may not young men die -

sirrah, young gamester, your lather

young budding virgin, fair .............inter's $T \alpha$

not crossed the eyes of my young....

are you so fond of your young pripce

thyself, and my young rover, he's

if yuung Doricles do light upon ber

when I was young, and handed love

how prettily tlie young swain seems

and leave this young nan in pawn...

not be so young as was your former.

quitted with this young prince $\ldots . .$.

Whacbelh ii:

we are vet but young in deed.........

will fight, her young ones in lier nest
what, you egg? young fry of treachery?

I am young; but something you ....

kiss the ground before young Malcolm's - v.

stands young Plantagcret; son to ... -

young $\Delta$ rthur, duke of Bretagne (rep.)

is the young Dauphin every way ....

what say the young ones?...

likes us well; young prince.

throw thine eye on yon young .......

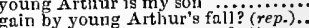

look to't; young lad, come forth .....

read here, young Arthur: how now

both mine eyes? Young boy, I must

young Arthur's death (rep.)

after young Arthur, claim this ....... Ricinard II. $\mathrm{i}$.

for young hot colts, being raged... - ii.

than was that young and prircely.

being tender, raw, and soung.........

Black Prince, that young Mirs of men

I am too roung to be your father.

greedy looks of young and old through

while he, young, wanton, and effeminate $-\quad v$.

young Harry Percy (rep.) $\ldots \ldots \ldots \ldots$ Henry $W . . . .$.

sweet young prince; bept,

what, ye knaves? young men must live

nay, I'll tickle ye for a young prince

wild as young bulls. I saw young Harry

young Hotspur (rep. i. 3) ......2Henryl $/$. . (induc.)

young prince John, and Westmoreland

that young Harry Percy's spur was cold

under the condnct of young Lancaster

the young prince hath misled (rep.)

the capacities of us that are young

and will you yet call yourself young?

and the young lion repents

how he can part young limbs

how many good young prince

e'er a scurvy young boy of them ail

a rood limbed fellow; young, strong

if the young dace be a bait for $7 . .$. .

are there llo young pigeons? $\ldots \ldots \ldots$ - $\ldots$ v.

silken streamers the young...Hevry $v$. iii. (cliorus?

as young as I nm, I have observed ... Henry $F$.

red rose, with young Somerset .......

for that (young king Richard thus

ii. 3 some part of my young years might -

when I was young, (as yet I am not old) -

and ou his son young $J$ ohn $($ rep. $)$...

O young John Talbotl ( $r$ rep. iv. 7 )

iii. 2 young 'T'albot (rep. iv. 7) Fol.....

alas! my years are youns..

as wild NIedea young Absyrtus did 2 Henry $V I$. iii

as wild NIedea young Absyrtus did... 


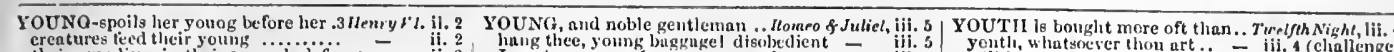

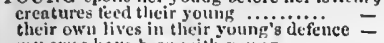
my ewes have been with young...... and his son young lol 1 wrol, and all. gueen antl this young printe ugree.. that young prince bilward murries.
my liege, it is youmg lleury, carl of.. brave young prince! thy fumous $\ldots \ddot{3}$. can so young a thorn begin to pric
lave rid this sweet young yrined liave rill this sweet young yrimed

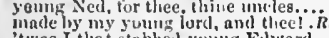
'was I that stabbed young Elward soung, valiant, wisc, and, no doubt. all, he is young: and his minurity of the younig prince your son

from Ludlow the young prinee he
why, ny young consin? it is good when he was youns, so long a growing low, my young York? I pr'ythec let so wlse so young, they sny, do we er -

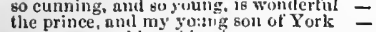
so young, so old nut young Edwark lives: think now what young York he is lut hout

is yount George Stanley' living?

ii. 2 linug thee, young loggugel disolbedient

ii. 2 I an ton young. I prity you, parion me

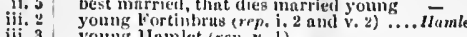

young llamlet (rep. v. I) that he is young........ freeze thy young bluod; make lliy' two cyes being of so young dings bumplit up with.

What? my yuung lady and mistresst....

young men will du't, il they come -

young men will du't, il they come is't possible, a young in

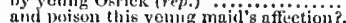

and

mitr; and hath

and offence as $\mathrm{my}$

for there? a yuung and swin a sceining

then yeung nud rose-lipped elerubim .. Z it. a I have rubbes this young quat almost.

mo lurd, las killed a yuung Venctian

lie looks younger than he dia .... Teretfith sight,

younger hearings are quite ravished. Lote's $L, L$. ii.

banished by his younger brother....s
that your yeunger brother, Orlando

I'll to the service of a younger man.

in beard is a younger brother's revenue $\overline{\text { iii. }}$.

to be the snuif of younger spirita ....

they were young, and latudsoune - it.
wo dd not be a yoming count in your way our ehuste loset, his young ilaughter

.8 young und of a noble nodest unture

fair 3 oung maid that yet "tant
inave this young vile nade

ner soung or old, he or she

is very young; mad yet will.

he so young a man, and so old
iave a young conception in $\mathrm{m}$

t much unlike young men

d s not you fulluw the foung lord Päris?

it must grieve youn Pyrrlius no

he soung prince will go mad.
gever did young man fancy w

how mow, young mnn? mean'st.

vish young knare's sleeve

t same young Trujan ass of Troy

is young and apt; our ow

young; enward, valiant

jul ever young, fresil, loved..

reble, and young, when thy first griefs

selp him, young and old!.........

lowliness is young nmbition's .... Julius $\bar{C}$

5oung Uetavius, come (rep.) $\ldots . . . . .$.
I know, young bluods loek for a time

young man, liou eeuldst net dic more

and come, young Cato (rep. v. 4) .....

I must to the yuing man send...Anlony of Cleo.
youog loys, and girls, are levei now
I was then a younig trnveller......... Cymbelin

you elasp young Ciipicl's rables.

your legs are yourn; I'll tread.

strnins his young nerves, and puits ...

all lovers young, all lovets must

young one, inform is of thy fortune

and beget yourt re ribluts. I uever sai.

these two young gentlemen, that eali

let not young Mintius then:.... Tilus An

I da remit, these young men's heinous

when did the tiger's young ones teach

thy sight is young, and thou shatt res

you're a young limitsman, Mnrel

and now, young lorels, whst not

to press heaven in my young days

young prinee of Tyre, you (rep.)

too young fior sueli a vilace...

steal the eyes of young and old ........

come young one, I like the inanner..

did you go to it so young? Were yout

to whose young love the vines of Frane

so young, and so interulerl bo young

not so young, sir, tal lwe a woman for .:
sinee iny young lady's going intu Frane

its heal bit off hy ity young............

strike her young bunes, you tuking airs

strike her youmg bunes,

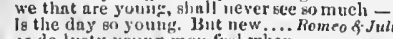

is do lusty young men fee.] wh

a

lany, such a man

soung Multaplue is't? "ris hie...

That, thiok, be yonng Petruelio ..

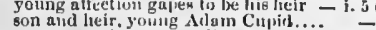
young son, it argute a distemplered head yeung men's lose then lies not truly coine, young waverer, cante gh witli me my the young Roures? I can tell (sep.) the the genteu oman in yoming.

the man, slain by young livmeo .....
as young as I, Juliel thy luve....... if I were but two hours younger, I il beat
the younger of our nature, that surfeit

the younger then is free, and not before

set the younger free for our aeecs.

being younger born, doun he laj

which by thy younger brether is.

sworn to us in your yuunger e
sueceed before the youmter.

KingJohn

sueceed before the younger.........
Clarence will have the younger

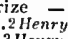

are salter than a younger man

3 Henryl

the younger bother, Cadwa

summers yeunger [ Knt.-hunger's saveur]

conferring them on yeunger strengths $\ldots$... Lear, i. 1

younger than she are happy ....Romeo \& Juliet, i. 2

younger than she are haply $\ldots$.....

common for the yeunger sort to lack ... Hamlet, ii.

yeungest son of sir (rep. i. $2 \& \mathrm{i}$. 3 ). As you Like it,

to bestow my yeungest daughter.. Ta
we set his youngest free for a luusband

indeed liad Baptista's youngest daughter

his youngest duughter (re'p.)

my yeungest boy, and yet my... Conedy of Errors, i. 2

pride dies in her yeungest days ...2 Henry $r$ t. i. 3 though I be youngest, give me leave .3 Henry ' l. i. 2

the youngest son of Priam .. Troilies \&

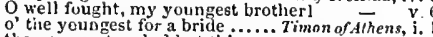

0 ' the youngest for a bride ...... Trimnn of Alhens,
the youngest and oldest thing ....... Coriolamus, $\mathrm{i}$

a sample to the youngest ............... Coriolanumbeline, i.

rivals in our youngest danghter's iove..... Lear, i.

youngest dauhter does net love thee least - i. I

I nm the youngest of tliat name. Romeo \& Jtriet, ii. 4

YOUNGLINGI theu canst not love. Taming or Sh

youngling, learn thou to make some.

will you make a younker of me? ... I Henryly, ii. 6

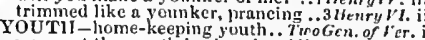

wenr out tly yuuth in sliajeless idleness -
whisper and conspire agninst ny south? -
to spend his youth at heme

known no travel in tis youth.

known no travel in his youth.......
worthy his youth nnd nobleness of birth =
ferswear not thyself, sweet youth....

may heceme a youth of greater

tenter youth is som sliggested

why, niy pretty youth

that I liave need of suel a

glie is beholden to thee sentie yoüiij

here youth, there is my purse.

have some salt of our youth in us....jer

you, youth laf yoll

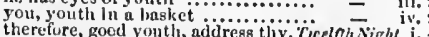

等

I feul this youtli's perfections.

veutli's a stuff will not enc.

sioce the youth of tlie count'

that youth's a rare courtierl ........

good youtl, I will not have you yrep.

by innocence I ewear, and by my youth

slie did show faveur to the youth in your -

you should have langed the youth into

ii. A clallenge me the conit's youth to fight

lii. 1
iii. 3
aud his opposite, the youth, bears... we slatl ne er be younger.7 aming of shrew, iii.

Arviragus, your younger prineejy sen

YoU NGLY - how youngly he began. Coriolanus, i. 3

of fresh and stuinless youth. as I know his youth will aptly receive it - iii. what youth, strength, ekill, and w rath - iii. this yenth that you see houth's a devil

three inenthis this youth hath teoded

pased between this youth and me

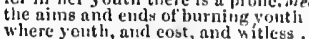

all the youth in the eity?..........

them hast nor youth, nor age........
for all thy hlested south becomes as

nips youth 'i the liend, and follies

that his ristous $y$ onth, with dangerous

a man loves the ment in lifis youth

as inuch as to say, thie sweet youthis

his May of youth, suld hlonm of ....

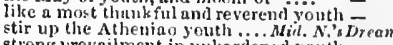

gtrong lrevailment in unhardened youth -

knew of your south, examine well

with a disdainful youth: ansini $7 . . .$. .

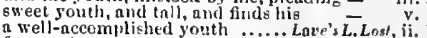

a well-nccemplished youth ...... Lave's L.Lost, ii.
for youth unmeet; youth so ait to - iv. 3 (verses

'gainst the kingly state of yontl

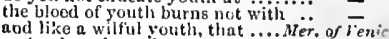

such a hare is muduess the youth..... of -

full of mmanuerly sudness in his youth -

like a fine bragging youth thy wit, good yeuth, or it wili fail ${ }_{0}=$

show my youth old shyloek's house
I gave it to a pouth, a kind of boy
the yonth wil not be entrented ... As you $\overline{L i}$

in pity of the eliallenger's youth ......

try with him the strength of my youth -

that youth is surely in tlieir conurainy

unliappy youth, come not within these -

for in my youth I never did apply . .̈ -

where dwell you, vretty youth (rep. iv. 1) -
who was in his youth an inland man.

I swear to thee, youth, by the white

being but a moonish youth, grieve..

with all my heart, goed youtli $($ rep. iv. 1)

all's brave, that youth mounts, aud fully - iii.

know'st theu the youth that spoke

whether tliat thy youth and kind - iv. 3 (lait.

and to that youth, he ealls his

be of goed clieer, youth: yon a man?

there is a youth hiere in the furcst...

yenth, you have done me much.

youth, thou bear'et $t$ ly father's face...sil's $W^{-}$ell

to our rose of youth rightly belong...

strong passion is impressed in yenth
aged honour eites a virtuous youth..

yeuth, beauty, wisdem, cournge ....

carcless lapse of yeuth and ignornnee

if the quiek fire of youth light net.

unhaked and donglyy youth of a nation -

boarded her i the wilnton way of youth

youth would sleep out the rest .. Winter
if the sins of your youth a re forgiven

I would wisli this youth are forgiven

but that yeur youth, ant the true blood -

wore I the fairest youth that ever

I am a sweet-fueed youth .... Comeity of Ferors,

and hath been frcm his youth....... Wacteth, it.

leng his youth, the rich advantage.. King John, iv.

I do eommit his yeuth to your

had I thy youth, anil cruse...

ecunsel to his unstuyed youth

the open whom youth and ease.

deal mildly with his youth.........

crest of south ngainst your dignity..1 llentryl

yet youth, the more it is wasted...........

abominable mislcader of youth.

wherein my youth hath fuulty.......

it hatli the cxeuse of youth, umi lient

chid lis trunut roucti weith

t!:ou hast roblecil une of my yonih $^{\circ}$

thout are in the un ant your youth ..2nenryl

your name in the serolt of Jouth ....

to approve my routh turthicr.......

Whe happiest youtli, vien ing hin .... -

led on by uf the williness of his youth -

we will our youth lend on to higier

\section{i. 2 \\ ii. 3}

iii 4

iii.

i. -2

ii. 3

iv. 3

r. 
YOUTII-noble image of my youth..2 Henry $l \%$. iv. 4 YOUTH, howe'er distressed........... Cymbeline, iv. 2 YOUTHF UL Troilus, do not these. Troilus\& Cress. ii. 2 O foolish youth! thon seek st. - iv. 4 'lack, good youthl (rep.) the coursea of lis youth promised....... Henry $\nu$. i. in the very May-morn of his youtli.. - i. how nll the youtl of England are shaliow, humorous youth, that fear. matching to his youth and vanity gallant youth in our rich ficlds....... their bodies to the lust of English youth detained me, all my flowering youth.l Henry $r^{\prime} I$. i i. and shall my youth be guility of .... - iv. thy youth, and Englands yet brother Henry spend his youth......2 Henry corrupted the youth of the realm.... - iv. o lose thy $y$ outh in peace $\ldots \ldots \ldots . .$. - : v. like a gallant in the brow of youth . ${ }_{\text {Henry }} I I$. ii. youth take leave, and leave you - iii. what youth is that of whom look in his youth to have him so cut off! die in his youth, your gouth were vexatton to to wail it in their age thou art my good youth, my jage though you did love this youth, I blame nurse, a mother to lis youtli... Titus andronicus, mose youth was spent in dangerous molood

and the picture of my yout f in our youthe we conld pick up...... stamp wrinkles in her brow of youth....... Lear, $\mathrm{i}$ maugre thy strength, youth, place ....... virtuous and well-governedyouth lomeo of Juliet, i. but where unbruised youth with .... - ii. slaughtered youth, for here lies juliet $=$ v. that hand that cut thy youth in twain a violet in the youth of primy nature .. Hamlet, the morn and liquid dew of vouth. youth to itself risele, though none ". that youth and observation copied there the

so neighboured to his youth and himourin my youth $I$ suffered much extremity hy the consonaney of our youth .... form and feature of blown youth .... to fiaming youth let virtue be as wax a very ribband in the cap of youth ... for youth no less bedid weighing the youthful season ....Julius Casar, ii. tab'dst me in my prime of youth.... $\bar{v}_{L I} \mathrm{v}$. these are the youths that thunder... Henry or Cress. i. gentleness, virtue, youth, liberality.. his youth in flood, I'll prove this .... forbid such searcity of yout whose in plight and youth $\ldots . . . .$. the Grearan youtlis are full of quality mac that knows the youth even ...... hiff' ily harness, youth, $\mathbf{Y}$ am......... in sine of the youth siat levity's in youth....... Timon of $\bar{A}$ th the rinds and marrows of our youth ring inm: rose-cheeked youth to the thy youth in different ina witow youth and opulency in pity of our aged, nnd our fouth when youth with comeliness plucked. Coriola are bringing forth our youth and hush youth revolt

for goal of youth

hat shouldst repair my youtli $\ldots . . .$.

my youtl I spent much under him.. can borrow from youth of such a season money, youth? All gold and silver .. vere you a womnn, youth, I should woo know not why I love this youth.... in youth when I did love ......... the property of youth and maidhood .... othello, $\dot{i}$. I abised her delicate youth with drugg.... - i. she must ehange for youth: when she is

the gravity and stillness of your youth.. - ji. YOUTHFUL Valentine...... TwoGen.of Verona, i. the youthful lover now is gone ..... unto a youthful gentleman of worth $\quad$ iii. unto a youthful gentleman of worth - iii. my youthful travel thereir made...̈ and youthful still, in your doublet. $\overline{\text { iver }}$, iii. race of youthful and unhandled.Mer, ofvenice, $\mathrm{v}$. ere we have thy youthrul wages...As you Like it, ii.

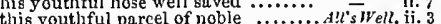
previling mucl in youthful meu Comedy of $\mathrm{Brr} . \mathrm{V}$ your mind is all as youthful as ....Kini John, iii. whose youtliful spirit, in me .......... Richard Il. i. rouse up thy yonthful blood wanton as youthful goats, wilä as...iHenry $I V$. iv. you have misled the youthful prince. 2 Henry I $r$. i. 2 like youthful steers unyoked ....... - iv. with youthful wings is flown ......... Henry is youthful, and will quickly - v. 3 as did the youthful Parts once ...... coldly eyes the southful Pbobus. Troilus \& Cress. i. 3 than youtl ful April shall with all .. Titus And. iij. I and warm soutlful blood .......Romeo \& Juliet, i. met the youthful lord at Laurence' cell - iiv. icles, iii. (Gow.) YSLAKED-10w sleep yslaked hath - ii. (Gow.)

IES-than the fools' zanies.... Tuelfh Night, i. 5 ZANY - some sliwht zany .......... Love's L. Lost, v. 2

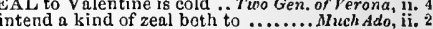
which such a zeal did swear? ............ what zeal, what fury hath

where zeal strives to content

with any terms of zeal....... Merchont or Venice v. 2 queuch the zeal of all professors. I'inler's Tale, of hospitable zeal ......King John, ji. I lest zeal, now melted, by ........... - ii. 2 and freeze up their zeal; the to.. - ii. 2 a voluntary zeal, and unurged faith - v. 2 my cold words here accuse my zeal.. Richard $I I$. . . ours of true zeal, and deep integrity . Hen $\overline{-} I V$, iv. 3 inuocency, and terms of zeal......... Henry 1 - v. whose zeal burns in his nose ........2 Henryl $\mathrm{V}$. $\mathrm{ii.} 4$ under the counterfeited zeal of God.. - iv. 2 woth infer the zeal had to see him.: - Y. thern cool in zeal unto your grace 2 Henry whom an upright zeol to right ...2H Henry devotion, and ritht christian zeali. irichard 11. . v. as in love and zeal, loath to depose ${ }_{\bar{H}}$ iii. 7 and with what zeall for, now he .. Henry $/ I I I$. ii, 2 zeal and obedience he still bore your - iii. I my God with half the zeal I served.. more bright in zeal than .... Troilus \& Cressida, iv. 4

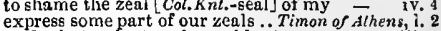
under hot ardent zeal, would set.... - iii. duty and zeal to your unmatehed.... ZEALOUS - , alous his name with zealous fervour. $A$ ii's ' Well, iij, 4 (let.) thy cheek lay I this zealous kiss .... King John, ii. if zealous love should go in seareh of so sweet is zealous contemplation.. Richard III. iii. 7 ZED-thou whoreson zedl $\ldots \ldots \ldots \ldots \ldots$ Lear, ii. 2 ZENELOPHON; [Col.-Penelophon] and he

it way that might ...... Love's L. Lost, iv. I (letter) ZEP

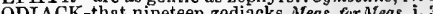
gollops the zodiack in his glistering. Titus And it. Zollops the zodiack in his glistering.. Tilus And. il. ZWAGGERED out of my life ............ Lear, iv. 6

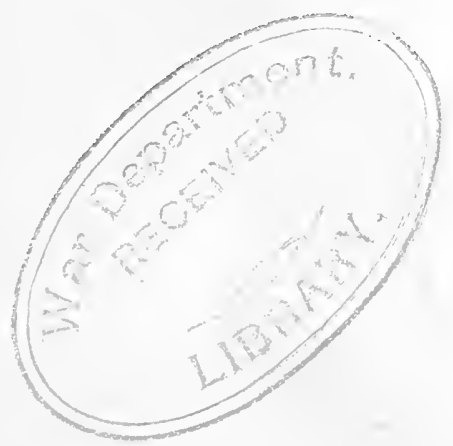

THE ENI.

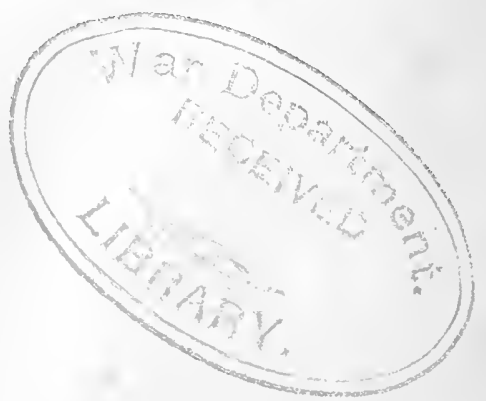




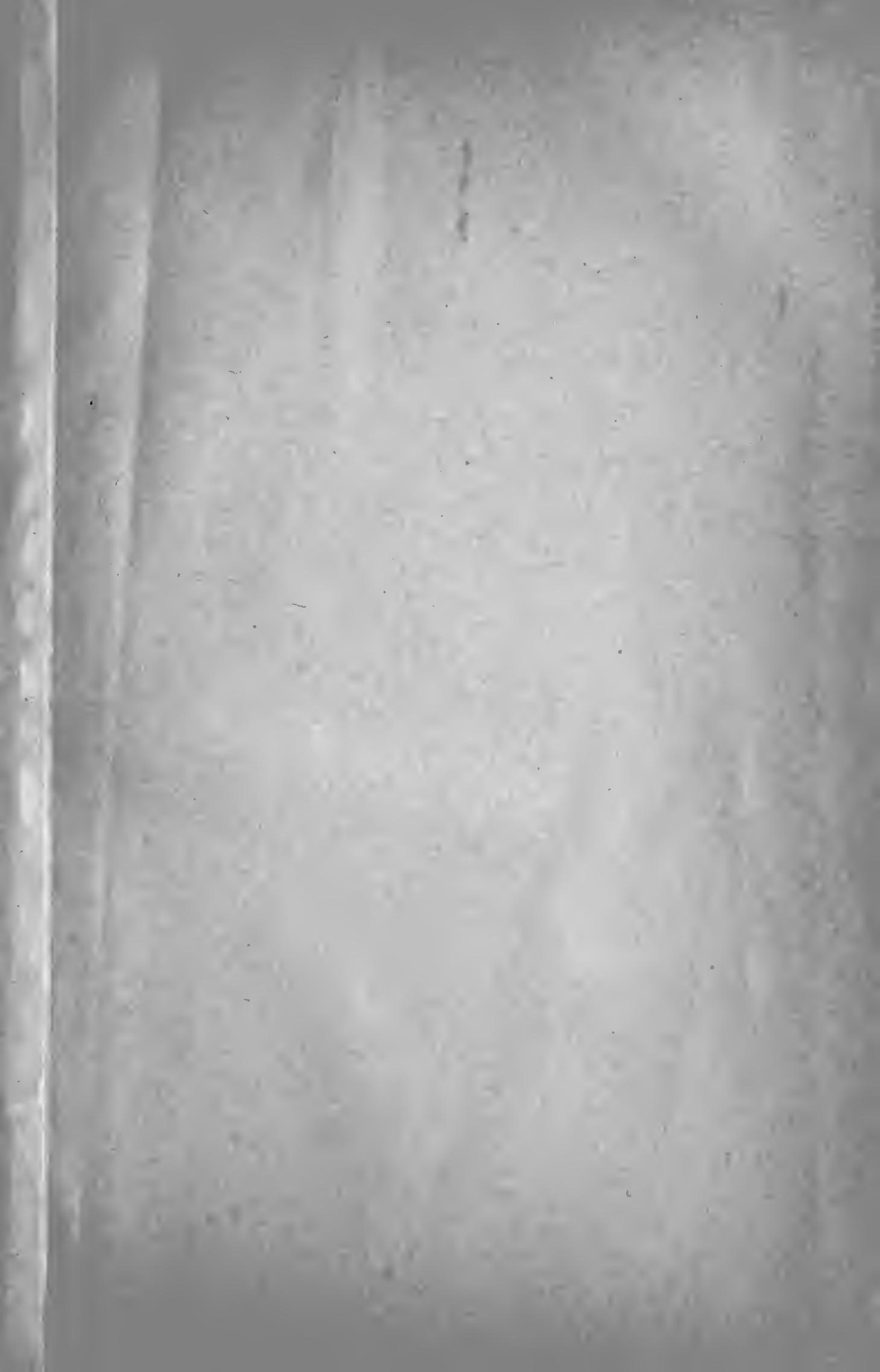




